


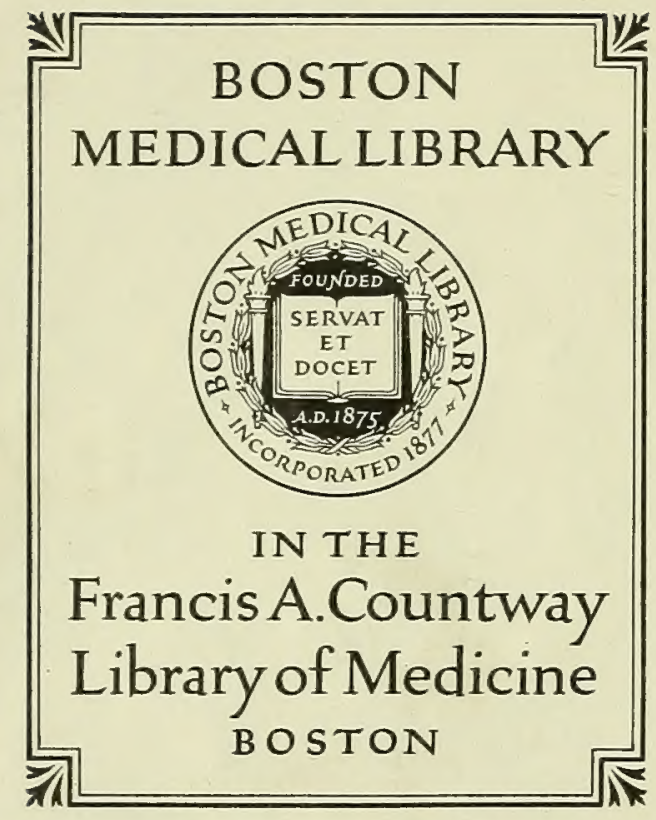


Digitized by the Internet Archive in 2011 with funding from

Open Knowledge Commons and Harvard Medical School 



\section{Petri Andrex}

\section{M \\ A T T H I O L I \\ S E N E N S I S}

Serenifsimi Principis Ferdinandi Archiducis Auftrix \&c. Medici,

COMMENTARII SECVNDO AVCTI,

IN IIBROS SEX PEDACII DIOSCORIDIS A N A Z A R B E I DE E DICA MATERIA.

Adiectis quàm plurimis plantarum, \& animalium imaginibus qua in priore editione non habentur, eodem authore.

HIS ACCESSIT EIVSDEM APOLOGIA ADVERSVS Amathum Iufitanum, quin \& Cenfura in eiufdem enarrationes.

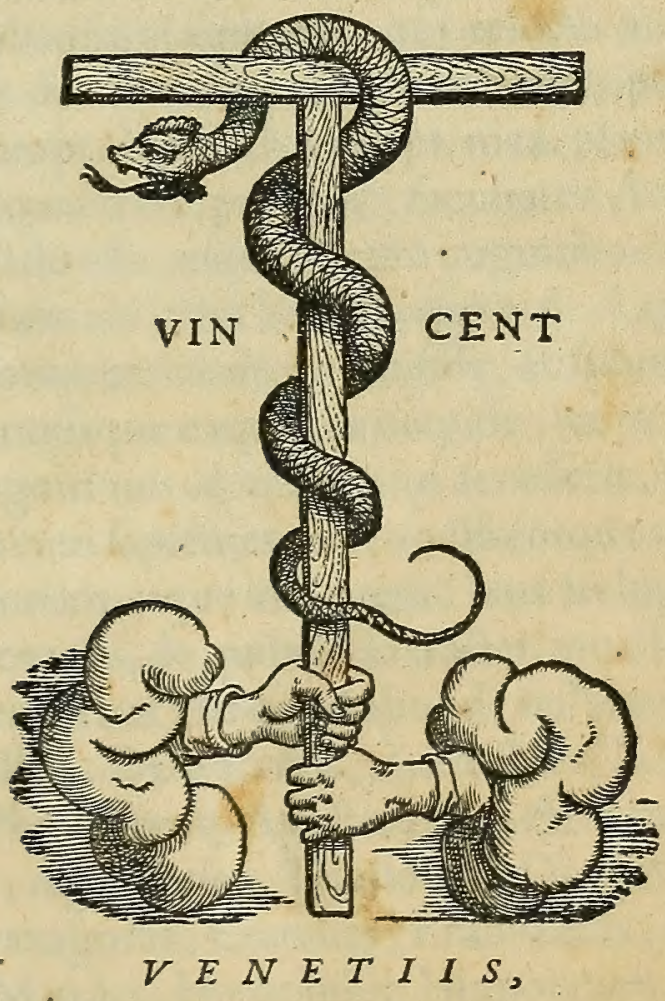

Ex Officina Erafmiana, Vincentij V.algrifij.

M D L VIII. 


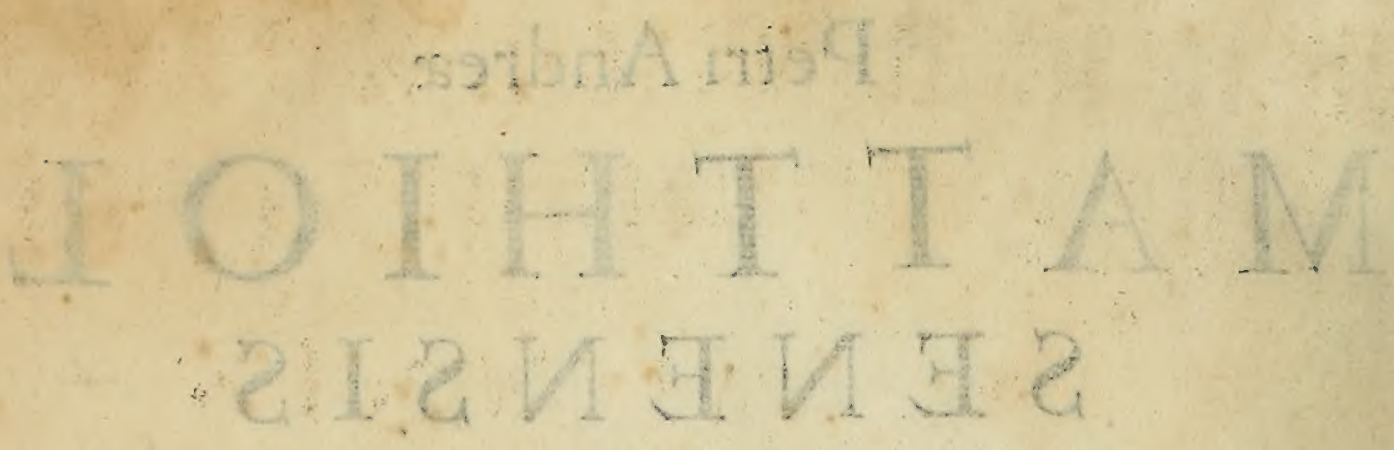

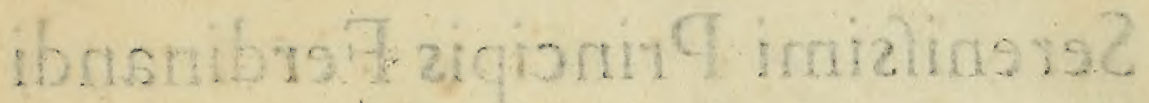
28 snfunAzoubidorA

$$
\text { isiboM }
$$

ITOVA OQИVOZZ IIAATИAMMOD

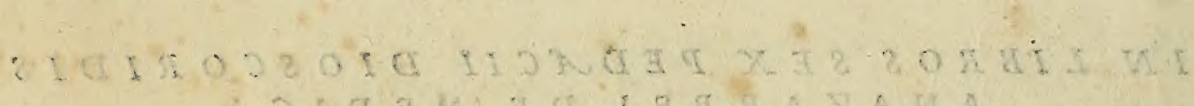

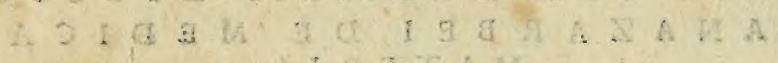
A I A $A+A$ I

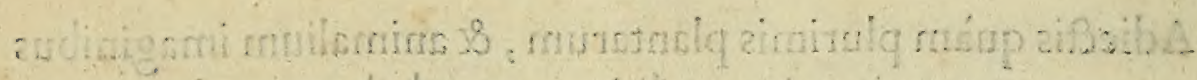

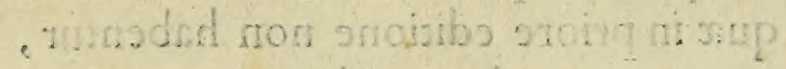
. stositus rapbos

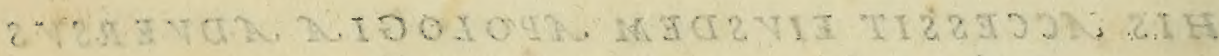

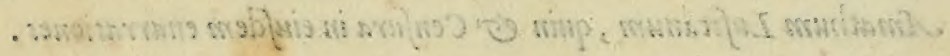

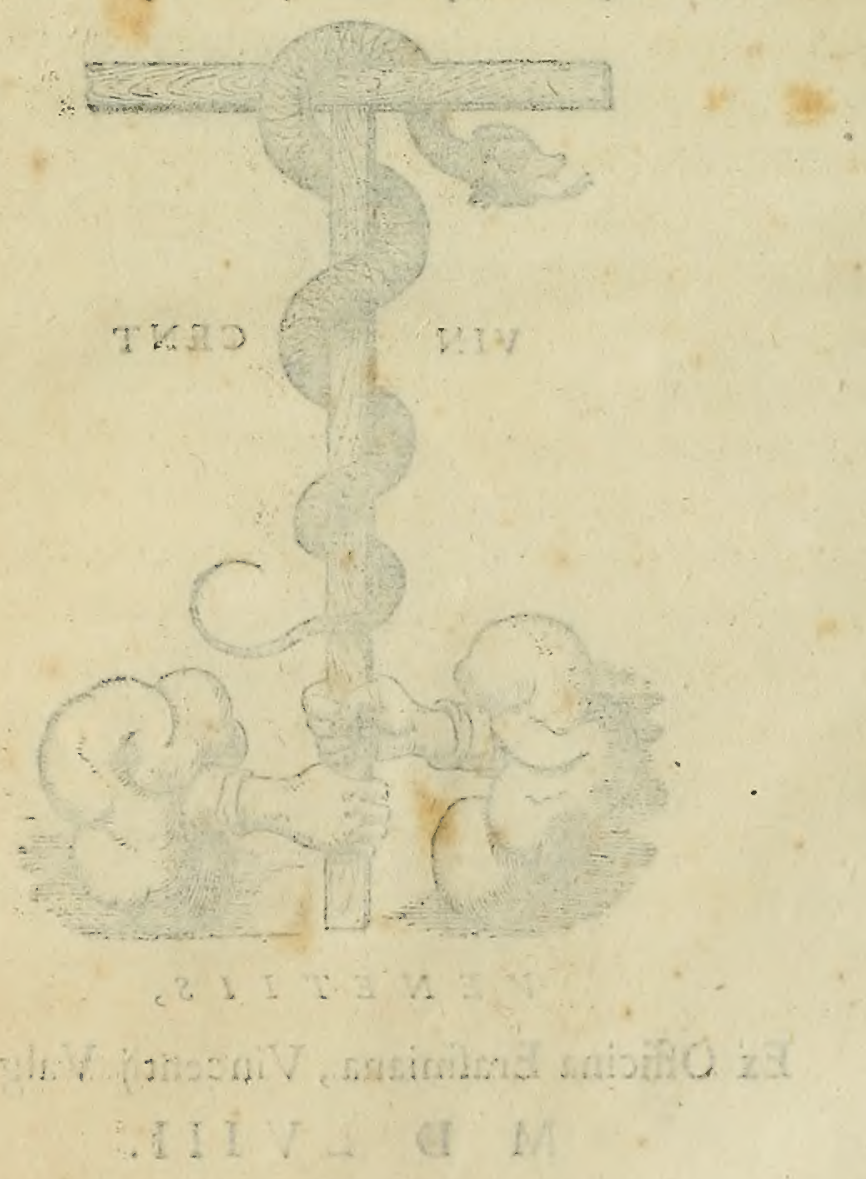




\section{S E R E N I S I M O \\ A C POTENTISSIMO}

PRINCIPI FERDINANDO

ROMANORVM, PAN NONIAE,

NT BOHEMIAE, ETC. REGI,

\section{INFANTI HISPANIARVM, ARCHIDVCI}

A V S T R I AE, D V C I B VR G V N D I AE, E T C.

Comiti Tyrolis \&c. Domino fuo clementifsimo.

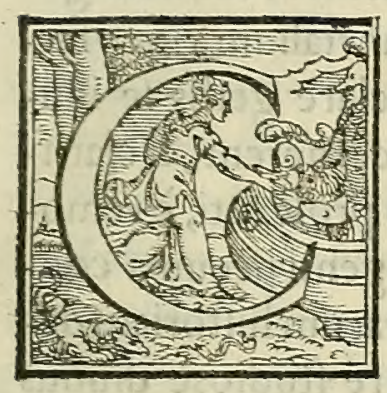

V M vniuerfam medicinam non modò vetuftifsimi quique fcriptores, Serenifsime Rex FER D IN A NDE, fed recentiorum quoque plerique Dijs immortalibus acceptam referant, eámque ob id non immerito fcien tiam antiquifsimam, celeberrimam, \& diuinam exiftment : tum eam praccipuè illius partem, qua medicame torum doctrinam pertractar, dignam elle cenfent, qua Dijs ipfis accepta referatur, \& planè diuina habeatur. Non enim fieri polfe putant, ut homo ipfe per fe abditas ftirpium, aut animalium, aut forfilium naturas facultatésque inueftiget, adipifcatur, \& perfpectas habeat, nifi eas primùm à maximo omnium rerum opifice fuerit edoctus. Quamobrem non defunt probatifsimi aurhores, qui reiectis nugis poettarum, \& aliorum, qui fabulosè de medicinx inuentoribus fcripferunt, certò credunt, ac rationibus comprobant, Deum opt max. plantarum \& reliquarum rerum omnium, quas terra procreat, facultates Ada primo humani generis propagatori indicalle, eique illarum cognitionem infudiffe, fimulátque illi è terra conformato, vitæ lumen infpirauit . A quo fubfecutam $x_{-}$ tatem uolunt, rerum omnium notitiam haufifle, ac fubinde, induftria adaucta, res altius diligentiúsque exquirere copiffe : ita vt hinc primùm rei medicx plurimum cognitionis ac ornamenti accefferit . Quod cùm poftea animaduertiffent innumeri fapientes uiri, nouifséntque maximam effe huiufce facultatis præftantiam atque vtilitatem, eius uoluptate capti, ipfi etiam rei herbarix, \& cxteris, de quibus illa tractat, inueftigandis ac cognofcendis ftudium impenderunt. Id quod abunde teftantur Pythagoras, Ariftoteles, Theophraftus, Democritus, Zoroaftres, Xenophon, Amphilochus, Athenæus, Philithenes, Apollodorus, Ariftander, Hipparchus, Ariftomachus, Bion, Agathocles, Diodorus, Diocles, Caryltius, Epigenes, Euagoras, Praxagoras, Crateuas, Erafiftratus, Merrodorus, Nicefius, Pamphilius, Mantias, Herophilus, Hippocrates, Diofcorides, Galenus, Plinius, \& alij anciquorum plurimi, quorum nomina, ne longior 


\section{Epiftola}

fim, quàm deceat, confultò prætereo. Ii fiquidem nobilitate ac iucunditate huius fcientix ducti, ftudio item pofteritatis iuuandx, \& perpetux fibi conciliand $x$ fam $x$, non dubitarunt varijs fefe uitæ periculis committere, dum permultas ignotas peragrarent regiones, vt ueram legitimámque fimplicium medicamentorum cognitionem confequerentur. Porrò quòd plantarum peritia, aut inuentio, prxter eam quam maximam fecum adfert voluptatem \& vtilitatem; gloriam quoque \& laudem pariat fempiternam, nouerunt non tantùm vniuerfi orbis fapientes, diligentifsimi rerum indagatores, fed fummi etiam ac potentifsimi reges. Quippe illorum claritatem, quæ hinc potifsimùm ortum habuerat, admirati, rati in hac antiquilsima facultate fummum fplendorem, fingularémque preftantiam effe, tantum otij ac ftudij ad eam percipiendam, \& illuftrandam contulerunt, vt eorum plerique de plantarum hiltoria \& viribus libros condiderint. Nonnulli generofa antidota compofuerunt, vt ita fux, \& aliorum mortalium vitx vfuique confulerent. Alij etfi ex rebus confilio \& armis preclarc geftis fe illuftres reddidiffent, cùm tamen illultriores effici fe poffe cernerent, fi clariffimam ftirpium facultatem ipfi quoque fuo effent ftudio profecuti, c̀ remotifsimis terrarum regionibus raras nobilésque plantas ingenti pecunia conquifitas, ad fe transferri curarunt, ut certam ac veram earum hiftoriam defcriberent . Neque illud certè hos latuit, quòd fi hac in re ftudiosc̀ diurius verfati, egregium quicquam inueniffent, aut fcriptis tradidiffent, fuum nomen effet nullis nó feculis celebre duraturum . quandoquidem herbx, qux fingulis annis reuiuifcunt, repullulant, \& reuirefcunt, eos perpetuò in ho. minum memoriam reuocant, quiillas inuenerunt, uel de ipfarum hiftoria \& viribus aliquid pofteritatis memorix prodiderunt. Qua in re eos minimè deceptos comperimus . nam fatis perfuafum eft omnibus, Gentianam herbam à Gentio Illyriorum rege inuentam, ab eo quidem appellationem mutuatarn effe, illi uerò claritatem, \& immortalitatem retribuiffe. Similiter $L y$ fimachia (vt Plinius eft author) Lyfimachum Macedonix regem, qui eam inuenit \& nominauit, perperuis laudibus celebrat. Scordium item, Mithridatem magnum illum Ponti regem, à quo Mithridatiæ herbæ nomen accepit : quin \& Eupatorium, eundem Eupatorem cognominatum, à quo herbam hanc inuentam \& dictam effe volunt, nominis æter nitati commendãt: Clymenos præterea herba Clymeno regi inuétori fuo, Euphorbium Iubx Mauritanorum, Telephium Telepho Myfix regibus, Echium \& Anchufa Alcibiadi Athenienfium duci, famam largiuntur aternam. Hinc etiam clarent, Attalus Pergami, \& Euax Arabum reges . fiquidem hic de fimpliciū medicamentorum viribus ad Neronem Imperatorem mulca confcripfit : 1 le verò,dum plura (vt Galenus perhibet) aduerfus venena, \& animalium virus eiaculantium iatus conficeret antidora, plurimum laboris infumplit, vt legitimas plantas nãcifceretur. His accedunt Archelaus Cappadocia, Mafinifla Numidix, Agamemnon Argiuorum reges, quorum nomina nulla vetuftate extingui poterunt, ob eam quam in cognofcendis prodendisque 


\section{Nuncupatoria}

firpibus curam ac diligentiam adhibuerunt. Omittam Philometora, Hieronem, \& alios plurimos magni nominis reges, ne verbofius, quàm oporteat, rem hanc profequi videar, qui uel ipfi ex hoc immortalem gloriam retulerunt, quòd rei plantarix ftudiofi exticerint,in eáque de pofteris præclarè fint meriti. Sunt etiámnum poëtæ quàm plurimi, in quorum poëmatibus Sole clarius lucet, rem herbariam \& antiquam fuiffe, \& femper laudibus decantatam. qua in re \& ipfin nedum infigne, fed etiam perpetuum nomen fíbi côciliarunt . Ex Græcis quidem produntur Orpheus, Mufxus, Hefiodus, Homerus, Alcaus, Rufus Ephefius, quem teftatur Galenus, libros quinque de herbis, verfibus feripfiffe . ex Latinis autem funt Vergilius, Ouidius, \& Aemilius Macer, qui plura de plantis notatu digna, \& nunquam interitura,carminibus cecinerunt. Herbarum gloriam mulieres quoque affectafle, \& affecutas efle, vt qux multum curæ ac ftudij earum viribus inueftigandis impéderint, non modò poetæ, fed etiam hiftorici tradunt. Etenim ob id Circen, à qua Circæa herba dicta eft, poetx Solis filiam fuiffe fabulantur. Sed hrc re vera eam demum exquifitam herbarum notitiam adepta ef, vt non temerè $\mathrm{b}$ eius admirabilia facta illis feculis diuina potius, quàm humana fit habita. Talis quoque Medea fuit, qux tantam herbarum notitiam habuit, vt cùm compofitis ex ijs medicamentis, pluribus fenectutem retardaffet, Aefonem poetæ finxerunt vltimo affectum fenio, ab hac iuuentuti fuiffe reftitutum. Helena ad hre Helenio herbx, quam primùm, ut quidam uolunt, feuit, fuú nomen impertita eft : atque ideo in ea nunc etiam nominatifsima viuit. Artemifia uerò Maufoli Cariæ regis vxor, alioquin præclari nominis mulier, vel ex hoc memorabilis \& immortalis reddita eft, quòd fuum nomen herbxe inditum reliquerit. Illud infuper fatis effe poffer, vt quenque ad plantarum cognitionem capeffendam inuitaret, quòd hxc tảtum in fe vtilitatis habeat, vt etiam animalia ip fa, natura docta plurimarum herbarum vires cognofeãt, eásque mortalibus indicarint. Quandoquidem cerui dictamnum herbam, quòd vulnerati, eius paftu telum eiecilfent, fagittarum vulneribus mederi oftenderunt. Item cerux fefeli herbam demonftrarunt : teftudines cunilam, muftelæ rutam, accipitres hicracium, columbx verbenacam, hirundines chelidonium, ciconix origanum, \& alia denique animalia alias innumeras herbas inuenere ac móftrauere. Quocirca fi ad prædicta mentem animúmque homines conuerterent, fi medicx materix primordia fpectarent, vtpote cùm plantæ fuis diuinis praditæ viribus, ftatim ab elementis conditis, è terra emerferint, nullum mihi dubium eft, quin omnes faterentur, hanc facultatem aritiquitate, nobilitate, \& diuinitate cxteras antecellere. Neque ob id folùm illi tantum laudis, admirationis, ac glorix debetur, quòd eius cognitio iucunda \&delectabilis fit, fed etiam quia vilis ac neceffaria exiftit. Ea nanque fanitatem (qua nihil homini exoptatius effe poteft) tuetur, varia innumeráque morborum genera fugat, ferarum virus euincit, \& venenorum vim demolitur . quinetiam homines in vita diutius feruat, \& fxpe deploratos, quorum fcilicet falutis nulla fpes reliqua eft, ad vitam reuocat. Quod 


\section{Epiftola}

cúm rectè quidem æftimaffent. Romanorum imperatorum nonnulli ( $v t$ libro primo de antidotis teftis eft Galenus) etfi in republica adminiftranda, $\&$ prouincijs gubernandis ac tutandis plurimùm effent occupati, costamen non mediocre ftudium tenuit colend $x$ atque illultrãda rei herbarix. Quippe vt legitimas plantas confequerentur, vtqúe veris aromatibus potirentur, in multis ac longinquis regionibus herbarios magnis fumptibus alebant, $m u$ neribúsque donabant : hac præterea animi inductione, ve inde non minus glorix quàm vtilitatis referrent, quòd ita quoque ftuderent mortalitatem beneficio demereri. Sanè memorabili fuorum maiorum exemplo ducebantur, qui non folùm exuuias regum, quos in bello vicerant, trophais dicatas, in triumphis portare, ipsósque reges victos ante fe ducere folebant, fed etiam peregrinas plātas, \& generofa aromata, quibus raræ præclaræqúc dotes inerant, in eifdem magno cum honore ferebant . Nec putabant ij, fe minorem laudem ac gloriam adepros effe ex plantis illis, quas poftea diligenter fuis in hortis ferebant, itémque ex aromatibus, qua inter fua alia pretiofa reponebant, in fuum \& aliorum commodum, quàm ex trophxis, fimulacris, \& arcubus, qux omnia erigi curabat fenatus populúsque Romanus in perpetuam rerum geftarum memoriam, \& eorum gratiam, qui fe tali laude dignos exhibuerãt. Magno etiam apud Romanos honore habiti funt ij, qui de plantarum hiftoria \& viribus fcriplerunt, inquée hac facultate claruerunt. Argumento fatis manifefto, quòd expugnata Carthagine, omnes bibliothecas, quas inuenerant, varijs regibus ac principibus donauerint, præter duo \& triginta volumina de re herbaria \& agricultura tantùm, à Magone Pœno fcripta, qux Romam attulerunt, \& vt in Latinam linguam verterentur, mandarunt : tantam nimirum folus cum Romanis inift gratiam Mago ille rei herbarix, \& agriculturx peritus. Vcrùm enimuero effr medica ma $\rightarrow$ teria nullis olim non feculis celebris, nec folùm tractata, fed eriam exculra fuerit, accidit tamen vel regnorum euerfionibus, vel feditionibus, \& bellis tum ciuilibus, tum externis, vel graffantis peltilentix facuitia, vel medicorum qui nos præcefferunt incuria, vt tam praclara diuináque facultas fuperiori noftro feculo obfoleta, intentata, \& inculta iacuerit, adeò vt perpauci reperirentur medici, qui alias ferè plantas, quàm olera, quorum frequens eft in cibis vfus, cognofcerent. Qua quidem re animàduerfa, complures $x-$ tatis noftra clarifsimi viri, \& rei medic diligentifsimi indagatores, Latini \& Græci fermonis peritifsimi, Hermolaus Barbarus, Nicolaus Leonicenus, Ioannes Mànardus, Ioannes Ruellius, Marcetlus Vergilius, Leonhartus Fuchfius apud Germanos claræ eruditionis medicus, Antonius Mufa in academia Ferrarienfi doctrina celebris, Otho Brunfelfius, Iacobus Syluius, Aloyfius Mundella, \& alij, ftrenuam nauarunt operam, ve difcuffa fuperioris feculi caligine, medicam materiam è tenebris eriperent, \& fux luci reftituerent. Quos equidem eo quo potui maiori ftudio atque induftria fecutus, cùm mulcis iam annis animaduertiffem in vniuerfis Italix pharmacopolijs cùm à feplafiarijs ipfis, tum maximè à medicis huius facultatis ignaris, quàm 


\section{Nuncupatoria}

plurimos errores, eósque graues \& deteltandos, commieti in humanæ vitæ difcrimen, ac fxpe in eiuldem perniciem, vt illorum errores tollerentur, habita noltrorum pharmacopœorum ratione, quorum pauci fatis Latinc fciunt, Diofcoridem Anazarbeum \& Gracum, \& antiquifsimum fcriptorem, ac in fimplacium medicamentorum hiltoria \& virıbus reddendis facilè principem, in Italicam linguam vertendum, \& Italicis item commentarijs , ve poffem, illuftrandum fufcepi . In quos vitique, quantum ingenio, quantum labore ac cura, quantum denique iudicio confequi potui, contuli, ve legirimas quas puto plantas proderem, meămque fimiliter de cæreris fimplicibus medicamentis proferrem lententiam. Qua in re coacti fuimus non modò feplafiariorum, \& medicorum fuperioris xtatis, qui hanc medicina partem neglexiffe videntur, errata pafsim explodere, fed recentiorum quoque, qui tamen materiam hanc diligentifsimè tractarunt, opiniones fapenumero refellere. Nec certè mirum, quòd viri alioqui doctîsimi, \& fumma laude digni impegerint, lapsíque fuerint, vel in tanto rerum difcrimine vacillantes, vel interdum humana caligine cocurientes . quod quidem \& nobis aliquando accidiffe hoc opere non dubitamus. Potrò plantarum \& animalium hiftoriam laté, quantum res poftulare vifa ef, complexus fum. In viribus autem recentendis, eas cuique plantre ex Gleno in fine reddidi, cóque ferè femper contentus fus, nifi quando quid ipfe pratermifit. Prxterea cum plura fint plantarum, aromatum, \& aliorum fimplicium medicamentorum genera, qux frequentem in medicina vfum obtinent, partim a Mauritanis, partim ab alijs qui per fingulas ætates claruerunt, inuenta, de quibus nusquam, quod extet, meminerunt Diofcorides, Galenus, alíque veterum Græcorum authores, ea omnia noftris commentarijs inferuimus, ipforúmque hiftoriam \& vires, ea qua poruimus diligentia, defcripimus. Hoc opus vbi ad vmbilicum perduxiffem, vel amicorum hortatu edidi, eo in primis animo, vt aliqua ex parte induftria mea hominum vitæ prodeffem, déque ea bene meritus exiftimarer. Affecutus hoc fim nécne, noftrum non eft ferre iudicium. Nifi temerè fortaffe à nobis dictum videretur, illud certè teftari poffem , me ex eo conieciffe non ingratum opus Italis , neque inurile fuiffe, quòd paucis pòft annis tertiò , \& quartò \& quintò (ni fallor) fuerit excufum \& vènditum. Adderémque non vulgare de eo doctorum virorum iudicium, ex quo etiam cognoui, me non oleum nec operam planè lufiffe. Id profecto me mouere debebat, vt fi quid de exteris quoque gentibus promereri poffem, tentarem, ne viderer in hoc Italis folis natus. Sed illud praterea huc accefsit, quòd ex illis etiam aliquos noftris commentarijs, quanuis Italicè confcriptis, delectatos effe, ex ísque fructum aliquem cepiffe intellexerim . Cuius rei illud mihi fatis manifefto indicio fuit, quòd ex recentioribus tam Germanis, quàm Gallis fcriptoribus inuenerim, quibus placuit noftras qualefcunque fententias interpretari, fuisque fcriptis interferere, neque eas tantùm nobis ingenuè acceptas referre, fed de nobis etiam (qux eorum fuit humanitas) admodum honorificè loqui. Quorum erga nos vo- 


\section{Epiftola}

luntatem vt augerem, \& ftudium omnium externorum fi poffem adiuuare vtque illis gratiam aliquam rependerem, \& cum alijs omnibus inirem, nulla mihi commodior ratio vifa elt, quàm ve Italicos noltros cómentarios in Latinam linguam trâsferrem. Hos itaque ut primùm potui, Latinos feci, in quibus tamen plura mutaui (quod maxima rei difficultas tulit) plura auxi, \& omnia quodammodo illuftraui. Adiecimus infuper quàm plurimas plantarum \& animalium imagines, quãtò fieri potuit diligentius, ad naturx imitationem expreffas, magnis cùm laboribus, tum fumptibus : non alia mehercle ratione, quàm vt ijs, qui terras peragrare non poffunt, nec præceptores habent, quafi hortulum exhiberemus, in quo omni tempore, nullo cultu adhibito, viuas ferè ftirpium effigies fpectarent. Quinetiam huic fecundre editioni quàm plurimas adiecimus imagines, qux partim plantas, partim verò animalia non nulla referunt: de quibus præter ea, qux Diofcoridi tradita funt in hifce commentarijs peculiariter diferuimus. Aucta funt vel iṕa cómentaria innumeris ferè locis, vt facilè conijcent ij, qui diligenter priorem editionem perlegerunt . Enimuero, Serenifsime Rex F E R D I N A N D E tanto femper cognofcend $x$ materix medicx, \& iuuand $x$ pofteritatis defiderio exarfi, vt facilè impulfus fim per varias ire folitudines, loca tum anı $\varrho_{-}^{-}$ na, tum horrida perluftrare, \& abditas terræ fibras fcrutari, ve res ipfas oculata fide cognofcerem . quas modò vel cum vita mex periculo in præruptis montium locis quxfiui, modò in denfis \& alperis fyluis, modò in conuallibus opacis, modò in collibus apricis, nunc in paludibus \& lacubus, nunc in fontium \& fluminum ripis, nunc in litoribus maris, aliâs in campeltribus; aruis, pratis, \& vinetis, aliâs in clarifsimarum vrbium viridarijs, aliâs in ruderibus \& collapfis ædificijs, aliàs in fpeluncis \& longis terr $x$ meatibus, aliâs in fubterraneis metallorum fodinis, \& eorum fornacibus. Ex quibus fanè locis plura mecum detuli fimplicia medicamenta, quæ ab adulterinis, quorum eft in officinis vfus, maximè diftant . Nec me certè labores aut pericula deterruiffent à magnis longísque itineribus, quòd Galeni exemplo mare traieciffem, \& Cyprum, Cretam, Lemnum, Syriam, Aegyptum, aliàsque regiones peràgraffem, vt multa præclara fimplicia, qux hodie defiderantur, effem confecutus, ad mortalium cognitionem \& vfum transferéda, nifi mea animi propenfioni obltitiffent negotia domeftica, xgros curandi pietas , \& corporis imbecilla fatis conftitutio, qux me quidem maris \& longæ peragra tionis incommoda ferre non diu permififfet. His tamen noftris fecundis conatibus magnam opem tulerunt (nec enim me pudet verum apertì fateri) nonnulli huius atatis medici clarifsimı, \& rei herbarix peritifsimi, quorü alij plantarum mifsione, alij confilio, alij rerum inuentarum communicatione, mihi multùm profuerunt. Inter quos potifsimùm non grauarer hoc loco commemorare, fi poffem illis ex beneficij accepti commemoratione aliquam referre gratiam, Lucam Ghinum Forocornelienfem medicum ingenij \& doctrinæ fingularis, Pifis magna cum omnium laudè rem herbariam profitentem : item Gabrielem Faloppium Mutinenfem, medicum eruditio- 


\section{Nuncupatoria}

ne \& experientia clarum, qui Patauij honoratifsimc humani corporis fabricam pariter \& materiam medicam profitetur : necnon Andream à Lacuna Secobienfem medicum praltantilsimum : prexterea Bartholomxum à Maranta Apulum medicum apprimc̀ eruditum : Vlyllem quoque Aldrouandum Bononienfem honeftilsimi generis, probatx doctrinx, \& magnx expectationis medicum. Quibus omnibus è magis me deuinctum efféntelligo, quò dij pro fua tantum hunanirate ac liberalitate, me, quem non no ununt nec viderunt vnquam, amore $\&$ officio profequantur : nifi fortè eorum in nos beneuolentia ex eo orta fit, quòd iam aliquam de nobis concepe rint opinionem ex noltris Italicis commentarijs. Non defuerunt etiam amicitia \& affinitate nobis coniuncti, quorum fudio ac diligentia, mibi licuit hoc tempore non aliter peragranti, ex diuerfis locis plures plantas confequi, earúmque pi\&uras edere. Sed prafertim in hoc pro nobis afsidaam nauauit opcram Io. Odoricus Melchiorius Tridentinus medicus fpectatx eruditionis, \& magnx fpei iuuenis, qui me in patris loco femper habuit. Et qui ob fuam praclaram eruditionem à Serenifsima Bohemix Regina in fui, \& aulx fure commodum in medicum honorificè afcitus eft. Sanc is tum Patauio, tï Venerijs complures ftirpes non vulgares ad nos perferri curauit. Adiuuit nos quoque mirum in modum Georgius Liberalis iuuenis artis pingendi pe ricifsimus, qui dum afsidue plantarum \& animalium imagines deliniaret, nul li quidem labori ac diligentix pepercit . Eft praterea fumma probitate, \& vi tx integritate vir Francifçus Parthinus Roboretanus, cuius egregix doctrina, fingularisque in re medica experientix tanta eft apud multos huius atatis Principes opinio, vt corum nonnulli, pracipuè verò Cardinales Tridentinus, \& Auguftanus, cuius aliquot annis Phificum egit, magnæ fibi laudi duxerins, quod talem hunc uirum amplilsimis muneribus, variísque ornamen tis decorauerint. Quo poftea factum eft, vt nunc in Serenifsimı Regis Bohemix Medicum meritó euectus fuerit. Elt etiam Hieronimus Donzelinus Brixianus, vtraq; lingua, eruditione, \& iudicio fummo clarifsimus medicus: qui quidé modis quàm plurimis labores hofce noltros adiuuãtes, maximo no bis fuerunt ornamento , Potuiffem equidem hæc omnia difsimulare, \& mihi foli vniuerfam laudem vendicare . fed abfit omnis inanis glorix cupiditas . Erenim benignum eft ( $v t$ Plinius in epiftola ad Vefpafianum fcite inquit) \& plenum ingenui pudoris, fateri per quos proficimus. Cxterùm quandoquidem Diofcorides nó modò quinque libris tradidit vniuerfam medicam materiam, qux plantis, animalibus, \& metallicis comprehenditur, fed his etiam fextum attexuit, in quo ad mortalis generis vfum de antidotis diferuit, quibus venenz omnia arcentur, ac omnium venenoforum animalium morfus ictúsque curantur, ideo nos ipfum fecuti in hunc quoque commentarios fcripfimus, in quos plura regetsimus, qux vitx hominum profutura fperamus. Nam praterquàm quòd improborum veneficorum infidi;s pateane cùm vniuerfum genus humanum, tum maximè reges ac principes, non de- 


\section{Epiftola}

funt etiam innumera animalium genera, qux morfu vel ictu homines ex tem pore interimunt. Quippe fcorpiones, ftelliones, phalangia noftris in domibus viuunt oberrántque, qux animalia cùm nullam habeant perfonarum aut locorum rationem, vbique fefe recipiunt, \& latebras nidósque parant . quo fit , vt interdum ab hominibus infcientibus moleltata, ictu venenum'inferant, \& ictos in perniciem agant. Latent præterea modò in hortis \& viridarijs, modò in vinetis, modò in pratis, aliísque in locis inter flores \& herbas, afpides, viper,$\&$ alia venenofa reptilia , qux vel fi tantillum quidem pede premantur, aut excitentur, illicò exitiofum vulnus infligunt : ex quo ftatim,vel paulò pònt icti commoriuntur, nifí eis quàm primùm antidotis fuc curratur. Eft \& canis, qui etfi homini familiarifsimus fit, tamen cum in rabiem agitur, quos momorderit, in horrendum mortis genus plerunque deducit. Quod cùm diligenter examinaffent rectéque expendiffent complures veterum fapientum, quorum fuperius meminimus, plantarum, aromatum, \& aliorum quoruncunque fimplicium medicamentorum vires al. tiùs perfcrutati, varia aduerfus venena \& virulentorum animalium morfus antidota compofuerunt. Quorum veftigia fecutus Mithridates magnus ille Ponti \& diuerfarum gentium rex, cuius etiam antc mentionem fecimus, cùm non magnam fatis fibi gloriam ex eo comparaffe iudicaffet, quòd mortalium folus (vt tradit Plinius) duabus \& viginti linguis loqueretur, adeò vt de fubiectis gentibus nullum hominem per interpretem compellaret; nec quòd plurimis potitus effet victorijs, ad maiorem adhuc immortalémque fuam gloriam medicinæ peculiariter curiofus fuit, \& rei herbariæ percipiendx maximum ftudium impendit. Quorum vtrunque planc̀ affecutus videtur : nam ex herbarum cognitione antidoti genera inuenit, ex quibus vnum compofuit, quod nomen etiam eius retinet, \& fuum authorem famæ immortalitati confacrat. Huius antidoti vfu adeò corpus fuum rex ille firmauerat, tutúmque à venenis reddiderat, vt cùm ipfe vitam finire mallet, quàm Romanorum feruitutem pati, id fxpius fertur fruftrà veneno tentaffe. Mithridatem imitatus eft Andromachus doctifsimus pariter \& elegantifsimus Neronis imperatoris medicus. Is fiquidem theriaces compofitionem inuenit, qux, Galenị teftimonio, à venenis feruauit non folùm plurimos Romanorum imperatores, ac innumeros principes, fed \& alios quosque, qui eam opportunè fumpferunt . quapropter Galeni tempore, ab ipfo magnificè ac fplendidè, ita iubentibus imperatoribus, hæc parabatur antidotus. Prxteribo Attalum Pergami regem, de quo etiam à nobis antè dictum eft, quem quoniam idem ftudium tenuit antidota conficiendi, ideo is ab ipfo Galeno maximis laudibus celebratur. Veruntamen noftra hæc xtas ex horum antidotorum vfunon eum fructum neque vilitatem capit fentítque, quam fenfit antiquitas. Nam etfi eorum nomina monumentis tradita habeamus, atque etiam antidota ipfa in feplafiariorum officinis parata reperiantur, non eos tamen effectus virćsque hæc præltant, quas fuis no- 


\section{Nuncupatoria}

minibus pollicentur, quásque illa præltare veteres memorix prodiderunt . Cuius difcriminis illud nimirum in caufa elt, quòd plura à nobis defiderenrur generofa \& pretiofa aromata, qux legitima ac omnium praftantilsima fuis antidotis inmifcebant Mithridates, Attalus, Andronachus, Galenus, $\&$ alij complures vercrum: quxqúe ingenti pecunia, fummo ftudio ac labore , ab Arabum, Aethiopum, Troglodytarum, aliarúmque diuerfarum gen tium regionibus, illius florentifsina atatis imperatores Romam adferricurabant. Vbi tamen nemini, prxterquàm medicis imperatorijs (quod fatetur Galenus) licebat veram ac legitimam theriacen conficere : nifi quis fortè potentiorum fauore, ab Imperatoribus elfet ijs præclaris donatus aromatibus. Id quod maximè facit, ne miremur, fi theriace noltri vlus, itémque antidotus Mithridatica non perinde pollent viribus, atque earum nomina promittunt, \& veterum fcripta teftantur. At certè in hoc fatis infoliciter actum efle conftat cum vita hominis, vtpote qux iacturam fecerit maximorum remediorum aduerfus venena, aliáque grauifsima incommoda, quibus obnoxia eft, ac fxpe affligitur. Quamobrem bac noftra $x$ tate, in qua quidem reliqua ferè omnia in priftinun candorem reduci, \& lux integritati reftitui videntur, gloriolü \& verè fortunatifsimus dici pollet fummus ille Pon tifex, inuictifsimus ille Imperator, ferenifsimus ille Rex, magnanimus ille Princeps, fapientifsimusille cuiufcunque reipub. Senatus, qui proprijs animi dotibus Romanos illos imperatores, $\&$ alios potentifsimos reges imitatus, nullis fineret fe vel fumptibus; vel Haboribus grauari, fed omne ftudium omnem operam,omnem denique fuam facultatem adhiberet, vt iamdudum deperdita aromata , qux omnino nobis defunt ad antidota conficienda, in lucem reuocarentur. Enimuero fi horum aliquis id faceret, vel fi omnes idem facere contenderent, non fux tantùm \& aliorum mortalium vitx confulerent, déque pofteris prxclarè mererentur, fed præterea hinc famam affequcrentur xternam. fiquidem bencficium id pofteri fumma cum laude proprijs authoribus perpetuò acceptum referrent. Equidem fi id mihi non licuit, id faltem quod potui, omni ltudio induftriáque mea praftare conatus fum. nam cùm viderem huius noftrx $x$ tatis homines in ijsdem qux prifcx, atque eriam in maioribus vitæ periculis verfari, nobis tamen deeffe vera illa ac generofa veterum antidota, ob ea qux hodie in ijfce defiderantur legitlma ac praclara fimplicia medicamenta, tentare volui, pofféntne ex legiti-. mis qux habemus, compofita fieri incdicamenta, quxillorum vicem penfarent. Feci id quidem magno meo labore, longóque rerum vfu \& experientia : fed affecutus fim nécne quod contenderam, ignoro. Illud certè fateri poffem, ea femper mihi uifa effe longè felicius theriacæ \& Mithridatica antidoti vires praftare, quàm qux pafsim hac tempeftate, earundem nomine conficiuntur. Verùm non omifi, quin in hoc, ficut in reliquis aliorum potius effet iudicium, quàm meum - quandoquidem eo promerendi animo, quem femper habui, in noltris commentarijs in fextum Diofcoridis li-

$$
\text { B } 2 \text { brum, }
$$




\section{Epiftola}

brum, non folum Diofcoridem ipfum, quantum potui, illuftraui, fed quxdam etiam antidota nobis inuenta defcripfi. Cxterùm cùn veterem \& viltatum fcriptorum morem fecutus, patronum quarerem, qui hofce noftros commentarios ab inuidis, maleuolis, \& vitilitigatoribus protegeret ac tueretur, cuius item amplitudine, authoritate, \& fplendore majores illi quodammodo, grauiores, \& illuftriores redderentur, prima omnium mihi occurrit Serenifsima maieftas tua, Potentifsime Rex F E R D I N A N D E, vt qux pro fua fumma virtute atque immenfa clementia, neminem vnquam inique depreffum non extulerit, aut iniuria aliqua affectum non defenderit. Prxterea mihi admodum condecens vifum eft, vt opus, in quo ea tractatur materia, cuius ftudio olim reges fummopere delectati (quod fuprà retulimus)perpetaum nomen fibi conciliarunt, non alij quàm Regi dicetur, eique præfertim, quem mira naturalis philofophix \& rei medicx voluptas tenet. Quarum facultatum dignitatem \& excellentiam quia Serenifsima maieftas tua fummo ftudio \& amore profequitur, ideo iure aliquo hos noltros commentarios illi dedicandos effe putaui. Illud quoque me adduxit, ve potifsimùm tuæ Serenifsimæ maieftati eos nuncuparem, quòd certò fciucrim,eam hilari admodum vultu, fummáque humanitate cuiufque conditionis hominum munera fufcipere : id quod chriltianæ charitatis, ac religionis maxımú prabet indicium. Huc etiam accedit immenfa erga fudiofos quofque Serenifsimæ maieftatis tux benignitas, qux eos perpetuò promouet, fouet, ac tuetur : fed maximè in medicos, quos ea præ cæteris præcipua benignitate complectitur, vtpote qui diuinam potius, quàm humanam profiteantur $\mathrm{fa}_{2}$ cultatem. Quod etiam apud Hebrxos teftatum reliquit Iefus Syrach diuino fpiritu afflatus, dum fic inquit. Ab altifsimo orta eft medicina, \& à rege accipiet munera . medicamenta de terra creauit dominus, \& vir prudens non contemnir illa . difciplina medici exaltabir caput eius, \& in confpectu magnatum collaudabitur . hæcille: Porrò illud omnibus mirum videri poffet, quòd Serenifsima maieltas tua, etfi in grauifsimis negotijs, fui imperij funċionibus, \& curis dies ferè noctésque verfetur, præfertim cùm ea fola in vniuerfa repub. chriftiana àduerfus immanifsimas Turcarum gentes iugiter firmifsimum fe fe offerat propugnaculum; nunquam tamen prætermittere foleat, quin fuccifiuis quibufdam horis, varijs fcientiarum ftudijs vacet. Sed quid plura referam de tanto Rege? caius nimirum religionem, iuftitiam, prudentiam, pietatem, generofitatem, liberalitatem, beneficentiam, humanitatem, ac probitatem admirantur non modò vniuerf reip.chriftianx prin cipes ac populi, fed alix quoque gentes, quando nutlis hominum præconijs præclarifsim $x$ animi illius dores fatis explicari pofsint . Reliquum igitur eft, vt Serenifsimam maieftatem ruam humillime rogem, vt hoc fui mancipif munufculum, qualecunque fit, in feruitutis mex teftimonium lata fronte accipiat, foueàt, \& tueatur. Id quod eam maximc facturam fpero . nam fi munus hoc quafi chartaceum perpendet; exiguum quidem, nec tanto regc di- 


\section{Nuncupatoria}

gnum uidebitur : at fi animum donantis refpiciet, maximum dicet, atque hoc nomine me (qua illius erit imméfa benigniras) fuo fauore complectetur. Quod fi ipla, ve f́pero, fecerit, prxterquàm quòd quàm plurimos ftudiofos doctósque viros excitabir, me quidẹm è inuitabit atque alliciet, quòd maiora fortafie atque exoptationa, qux noftra in officina concinuc cuduntur, diutius latere non finam. Qux fi in lucem quandogue prodibunt,

ea vniuería pofteritas Serenifsimx maieftari ruxaccepta feret.

Cui non folum hac, fed \& meipfum, \& feruitutem meam dedico, dono, ac voueo. Goritix, Calen.

$$
\text { Ianuarij, M. D. LIIII. }
$$

Serenifs, Maieltatis tux

Mancipium

Petrus Andreas Matthiolus medicus. 


\section{PET. ANDREAE MATTHIOLI ad medica materix ftudiofos,}

Prafatio.

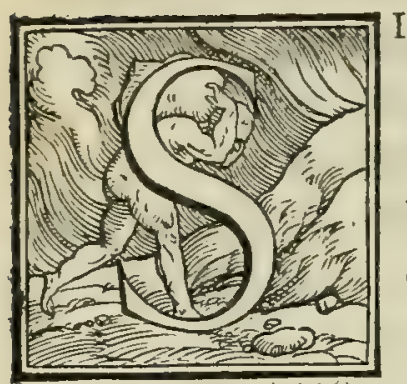

I VEL L E M corum morem fequi, qui antequàm opus fuum aggrediantur, illud in primis profitentur, nihil fibimaiori curæ ac ftudio effe, quàm ve vitæ vfuique mortalium confulant, hoc ipfe quoque ingenuè facere poffem. Nam ea animi propenfione ab ipfa iuuentute, quantum mihi otij ab artis medicx exercitatione, \& cura familiari impetrare licuit, id totum ad bonorŭ authorú libros cuoluendos, ad fimplicium medicamentorum cognitionem affequendam, ac demum ad fcribendum contuli. Qua in re, vt certè apud omnes teftatum relinquerem, me hac mente animoq́; elaboraffe, vt quantum ftudio, labore, atque induftria conlequi pollem, húmanæ vitæ prodeffem, deq́; ea optimè meritus exiftimarer, Diofcoridi ómnem meam operam ac diligentiă ądhibui, vt quantum in me effet, illuftrior redderetur, atque omnium manibus tereretur. Ad quod ea mihi vifa eft ratio commodifsima, vt ipfum Diofcoridem in noftram Italicam linguam transferrem, in eumq́; commentarios à nobis Italicè item cófcriptos adijcerem. quòd tunc nos priuatum ftudium maiorq́; cura fubiret Italos adiuuandi, quàm cæteros. Etenim pauci admodum funt jn Italia pharmacopolx, ad quos tamen potifsimum hrec de medica materia tractatio fpectat, qui Latinam linguam norint. Hoc opus, quod fumma animi alacritate fufceperam, vbi abfoluiffem, emifi vel hortantibus amicis, vt quem fructum antea ex meis labaribus mihi propofueram, eum poftea mortalibus percipiendum, $2 \mathrm{c}$ omnibus æeftimandum exhiberem. Vcrùm an is talis fuerit, qualis vt effet, contenderam, malim aliorum effe iudicium, quàm meum. Illud certò fcio ( fi tamen id abfque vitio nobis teftari lịcet) à multis in Italia, quorum judicium cæteris omnibus antepono, eo animi candore fcripta noftra æltimata ac commendata fuiffe, quo ipfi illa fcripfimus, atque ețiam Italis non inutilia, neque iniucunda fuiffe. Q'iorum fanè exemplo, deq́; noftris commentarijs iudicio non potui non mihi ipfi gratulari, ac omnibus, quibus illos legendos tradidimus. Accefsit interea mihi non minor inde cupiditas externos quoque demerendi. eamq́; cupiditatem illud auxit, quòd intellexerim ijs pergratum fore, fi noftri com mentarij Latini fierent. Hac igitur ratione adductus, vt etiam ab externis gratiam aliquam inirem, vtć; omnibus in vniuerfum ftudio, cura, induftriaq́; mea prodeffem (quod ego quidem antiquum femper habui, \& præcipuum ) noftros commentarios ex paruo, quod nobis fupereft otio, Latinos reddendos atque illuftrandos fufcepi. Quo in opere quid prættiterim, planè ignoro . vos, in quorum gratiam, tantum in eo laboris infumpfi, quòd iam abfolutum quidem ipfum, fed mihi non decoctum emitto, legendo iudicabitıs . Neque aliud ab omnibus petitum velim, quàm vt hos noftros commentarios ea animi fynceritate, \& xquitate $æ$ ftiment, qua fuos ab alijs æftimari \& per pendi vellent: vel qua ipfi aggrefsi fumus illos confcribere. Nam etfi multorum eruditorum fententias refellere aufus fum, atque non pauca fortaffe nimis acriter infequi, corrupta fcilicet, quæ indoctorum pertinacia nunquam fatis explodi poffunt ; id tamen eo confilio feci, vt quantum ingenio perficere, quantum mente elaborare, quantum denique iudicij in re medica ex ftudijs, laboribus, ac vigilijs mihi comparare potui, liberè in publiçum ad mortalitatis fructum \& vtilitatem proferrem. Sed certè in hoc longius, quạm ftatueram, digreffa eft oratio noftra : eò enim (nefcio quo modo) irrepfit, vt partem aliquam aperirem noftri fcribendi inftituti. Quod tamen non prorfus alienum fuiffet, nifr eius confilij ratio cùm alibi, tum præcipuè fuperius in epiftola nuncupatoria à nobis latius expofita effet, atque à pluribus, opinor, comprobata, quàm vt hoc loco paucis attingi debuiffet. Quare iam ad id nobis accedendum eft, quod in prim is medicx materix ftudiofos admonendos effe putamus, vtpote quod nonnihil priuatim ad rem prefentis operis facere videatur. Cùm enim ab eo tria potifsimùm comprehendantur, Diofcoridis contextus, noftri in eımfcommentarij, \& plantarum imagines, de fingulis aliqua nobis reddenda ratio eft, vt qualem me in vnoquoque gefferim, quod confitendum fit, non difsimulem. De contextu itaque Diofcoridis, quem nequaquam prætermittendum cenfuimus, ab plures caufas, quas hîc referre nimis lon gum effet, quæret aliquis, cur Ioannis Ruellij Galli medici eruditifsimi interpretationem prætulerim, dignamq́; exiftimauerim, quæ præ cæteris in noftris commentarijs legatur ; cùm tamen duo alij viri fummi pariter \& doetifsimi, Hermolaus Barbarus, \& Marcellus Virgilius Florentinus in idem ftudiuın nauiter incubuerint. Fateor ingenuè me Ruellij verfionem fecutum effe, fed non propterea aliorum præclaros conatus contempfiffe vnquam : quin potius vtriufque ftudium femper admiratum, quippe quòd vterque in eo maximam laudem promeruerit. Illud autem me magis mouit, vt Ruellium admiferim, quòd eius conuerfio omnibus facta fit vulgatior, ac frequen- 
tior in ftudioforum manibus verfetur. Adde ctiam, quòd hæe communi omnium ferè, medicorum præfertim, iudicio præf fratur; cui nimirum nobis quoque libuit fubfcribere. Non tamen illud me certè latuit, Ruellium nimis fortè in ea religiofum fuiffe. quippe qui intcrdum maluerir ipfum Diofcoridem deferere, quàm Plinium, modồ Latini fermonis nitore captus, modò etiă rei cognitione incertus. Qua re à nobis perfpeeta, Ruellij quidem interpretationem recepi, ita tamenvt nonnufquam aufus fim ab eo defcifcere, vel vetuftifsimorum probatifsimorumq́; exemplarium, \& vnius Oribasij codicis fidem fecutus, vel certa rei experientia fretus. Eorum autem quæ immutaui, nonnulla obelifco adnotata reliqui, nonnullis etiam fignum fupprefsimus. Sanè plura eiufmodi, pluresq́; infuper varias lectiones exhibuiffem, fi maius otium \& tempus nobis fup petijlfct. quæ tamen, Deo concedente, aliquando ad communem vtilitatem, \& ampliorem medicx materix dıfquirendx campum, dabuntur. Hinc factum eft, vt Ruellij nomen contextui præfrribendum non duxerim, ne viderer cum eo nomine conuenire, re autem fre ab eo diffentire. Satis enim forc putaui, fi hîc ftudiofos certiores facerem, me Ruellio Diofcoridis conuerfionem. accepiam referre: fi praterea rationem reddidiffem, cur illi non femper addictus effe voluerim. Quod quia abunde, vt arbitror, præftitimus, iam ad alterum nobis propofitum, quod de noftris commentarijs erat, progrediamur. De quibus profectò mihi melius effet tacere, quàm pauca diccre, fiv vellem nafutulis \& vitilitigatoribus occurrere. Frequens nanque hodic eft, indiesq́; magis pullulat huiufmodi genus hominum in Italia (nefcio quid fiat in alijs regionibus) qui nullum. in toto uit $x$ fux curfu fructum feménue proferunt, alienos tamen auidè carpunt, mox lacerant, \& pedibus obterunt. Sed hos nunc miffos faciam : alius enim locus, aliud ftudiorum noftrorum. otium poftulabit, vt cum ijs fermonem conferamus, vel eos ab hac mala mente deterrendi, vel ad fua quoque proferenda excitandi caufa. Verùm ad candidos, \& æquos, quibus hæc fcribimns, noftra fefe conuertat oratio. Neminem velim moueat, lectores optimi, nec id à nobis factum quifquam admiretur, fi nobis noftris fecundò auct is commentarijs, velut \& in prioribus, me inueniat plantas aliquas non incognitas prodidiffe, tam quarum meminir Diofcorides, quàm qux à nobis adiecta funt, neque tamen earum imagines pictura exprefsiffe. Hoc (mehercule) factum eft, non fol ùm quòd plantæ nobis cognitx, dum eas depingi curarem, non omnes nobis in promptu effent, fed quòd etiam deeffent fculptores, qui pietas iam in tabulis plantas inciderent. His accefsit magna negotiorum moles, qux ftudia noftra adeò impedierunt, vt nullus ferè fuerit reliquus lucubrandi locus. Siquidem pofteaquàm à Serenifsimo Romanorum Rege Ferdinando in eius Serenifsimi filij Ferdinandi Archiducis Auftrix Medicum afcitus fum, quum non folùm quotidiè præter opinionem multa emergant negotia, vt medicis quibufcunque aulicis plurimùm euenire folet, \& longa quandoque itinera fefe offerant, \& bella quò Medicos fuos op.orteat fequi Principes; fattum fanè eft, quum hæc omnia exequi me oportuerit, ut hifce negotijs impeditus, non potuerim per omnia, \& vobis, \& mihi fatisfacere. Atqui non nobis parum feciffe videmur, fi inter tot aulica, \& bellica incommoda, ingrauefcente admodum etiam ætate, commentarios noftros vobis nunc damus, non folùm fexcentis ferè locis auctos, fed quàm plurim is plantarum, \& animalium imaginibus infignitos, de quibus nos in ijfdem commentarijs fpeciatim diferuimus, quinetiam: -quibufdam, de quibus egit Diofcorides, qux in priori editione non habentur. Quxx uerò nunc o- mifimus cogentibus caufis præf́criptis, ea fortafsè aliquandò prodemus, nifí quid nobis humanitus accidat. Nec pigebit vnquam, fi fortè fortuna fuccefsiuas aliquas horas nakius ero, quin totum id temporis in ueftrum, \& totius reipublicæ impendam commodum. Cæterùm, vt de imaginibus quoque feorfum aliquid dicam, equidem aliàs abhorrui ab hoc dicendi genere, ratus neminem vnquam poffe ex iconibus tam ueram, \& exactam fimplicium medicamentorum peritiam affequi, vt eorum uarietas porsit vnica pictura comprehendi. Siquidcm non ea eft pullulanti herb $x$ facies, qux adultx, neque adultx, qux iam fenefcenti . Quòd fí eiufmodi herbarum mutationes omnes fingulis picturis deberent reprefentari, quis dubitet id opus futurum infiniti laboris, ac immen fi fumptus: Verum enimuerò quum vidiffem tales aliorum conatus ab omnibus propemodum cómendari, atque in dies crefcere ftudium virorum rerum effigies in publicum edentium, ne folus' viderer in diuerfam ire fententiam, re ipfa tandem melius perpenfa, \& aliter comperta, ac aliud docente ipfa experientia, nolui huic optimo, \& minimè infrugifero deeffe ftudio. Huc accedebat, quod non mediocriter ad hoc me incitaret, Typographi cuiufdam Mantuani vanitas, qui noft is operibus Italicè prius editis furtim quafdam inferuerat imagines minimè à nobis adiunstas, quæ quoduis potius, quàm rem ipfam referrent. Gaudebam id adhuc me fuperßtite contigiffe, vt turpem notam falsò mihi inuftam ipfe delerem. Ideò vt \& aliorum conatus, adiuuarem, \& malitiofi huiufce calcographi temeritati occurrerem, ip fe quoque experiri volui, fi quid hac in re præftare poffem, non tantùm, vt mea in medium proferrem, fed $\&$ vt de vobis ftudiofis, fi poffem, benemerer. Sed quàm res hæc nobis difficilis fuerit, non eft, quòd pluribus explicem. omnes enim fciunt, quàm difficilè inueniantur homines, qui res ipfas, ita ut funt, ad viuum depingant, \& qui dspictas diligenter infculpant. Quorum maior adhuc inopia eft, id quod etiam facilè dijudicabitis ftudiofi, qui in hoc opere nonnullas effigies affạbrè fatis, tonnullas uerò non fatis folcrter fculptas offen-

detis, 
detis. Sanè quod in rem communem nauare potui, licet illud exiguum effe intelligasm, in eo non commifi, ut meum ftudium, opera, aut diligentia à uobis defideretur. Quid autem proficerim Cornarij o- nefcio, veftrum erit iudicium. Sed longè aliter quàm nos uidetur feciffe Cornarius, vir alioqui in pinio explo- utraque lingua doctifsimus, \& qui inter omnes alios fortè fingularis haberi velit. Is enim fuo in ra. Diofcoride, quem nunc primùm uertir, \& emblematibus quibufdam auxit, non folùm nullas ap. pinxit imagines, fed eos etiam acriter damnat, qui eas fuis inferuerunt commentarijs. Sed an liuore potius, uel ratione ductus, uos iudices effe uelim, fi quandoque illius boni uiri legeritis prafationem, \& eius animum diligenter explorabitis. Nam etfi Galeno diłum fic (id quod \& nos an te Cornarium fcripfimus ) plantarum imagines parum conferre ad earum indagandan cognitionem, non tamen ob hoc accufandi funt, qui plantarum, \& animalium icones in fuos conferunt libros. Quippè quoniam nufquàm inuenerim damnaffe Galenum plătarum imagines, quẹ in libris appingi folent, fed eos, qui exiftimant fe rei plantariæ peritifsimos euadere poffe, non folim imaginum infpettione, fed \& librorum quorŭcunque lectione, licet fuerint ij à fumm is, grauifsimisq́; authoribus confcripti. Quamobrem non parum mirari fubit, Cornarium alioqui virum apprimè doctum Galeni verba non modò non intellexiffe, fed in reprobum quoque diftraxiffe fenfum. Q 110 fit, ut hinc facilè fufpicari quis pofsit, quòd quum viderit Cornarius omnium ultimus Diofcoridis inecrpres, nullum fibi reliquum iam effe locum, quò noui aliquid de plantarum imaginibus afferre potuerit, id fibi confilij afciuiffe, ut eos acriter deteftaretur, qui plantarum picturas in fuis libris habent, racus fortafsè hoc deteftandi genere, non folùm plurimum fibi laudis comparare, fed etiam fuum obtegere infortunium, fuamq́; ( quod eius pace dicam) in plantarum hiftoria imperitiam. Quæenim fit alia ratio, cur aliorum damnat indultriam? quafi pofteris non fit id licitum, vt \& ipfi aliquid fuo ingenio, \& ftudio excogite̋t, quod ab antiquis arte nó fit animaduerfum.At nô damnafe Galenum plantarú imagines, nec libros de plantarum hiftoria confcriptos, fed eos, qui horum tantùm infpectione poffe quenquam rei plantaria fieri peritum crediderant, id manifelto fucrit argumento, quòd ip femet Galenus lıbro primo de alimétorum facultatibus pofteritatis memorix prodidit, cum inquit, Comparatos nobis effe hofce libros, ut nobis fint eorum, quæ antè didicimus monumenta, non vt rudes \& ignari per illos doctrinam perfectam affequantur. Quòd fi qui fint qui præceptoribus careant, velintq́ue ijs, quæ luculentè ac copiosè funt fcripta diligenter incumbere, magnum indè fructum eos accepturos teftatur idem Galenus, præfertim fi ea relegere non grauentur. Quibus palàm eft longè magis deteftandos effe eos, qui clarifsimorum hominum laboribus inuidentes, nil aliud, quàm blaterare, ac carpere fciunt, quàm eos, qui reipublicx commodis femper prodeffe cupientes, nil aliud agunt, quàm ut boni femper aliquid, \& noui in publi-

Cornarius cum ufum promant. At qua re imagines, 2 non libros damnauerit Cornarius, cùm non minus notatur. ex Galeni fententia corum lectione, quàm imaginum infpectione, quis neutiquam proficere ualeat, non fatis animaduerto. Cur tantum laboris, fi nihil profuerit, in uertendo Diofcoride a dieEtis etiam emblematibus inçafum fufcepit? Hócne ei erat ftudium, hụncne capiebat anim um, ut in uanum laboraret? Porrò nil aliud uobis dandum, dicendumq́; fupereft. Spero tamen ab ijs, qui grati funt (ingratos, maleuolos, ac inuidos nihil fanè moror) me gratiam initurum, quandoqui$\mathrm{d} \in \mathrm{m}$ mihi communis utilitatis cupidifsimo hoc opus non aggrediendi uoluntas defuerit, fed perficiendi facultas, quam tamen omni ftudio confequi afsiduẹ conamur. Bene ualete, \& noftra boni confulite.

\section{Vincentius Valgrifius} Candido Lectori S.

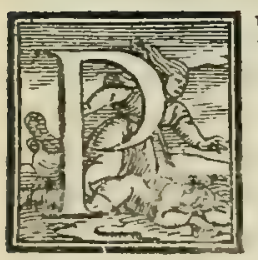

R AE S A G I T mihi animus, candide Lector, multos fore, qui vno ore infitutum hoc meum damnent', $\&$ iam odiofas eorum voces audire mihi videor, qui coniuratis animis aduerfum me nouum querele genus inftituát, Perperam enim $\&$ ineptè me facere, qui hofce Matthioli Commentarios toties excuffos, toties interpollatos mutatıs non folùm plantarum imaginibus, uerùm etiam additis plerifque rurfus in publicum emittam, meq́; in caufa effe, vt ftudiofi bonarum ałtumi iot hsancs, \& fuperuacaneos fumptus faciant. Porrò longè fatius fuiffe, $f i$ in aliquot annos editionem diftuliffem. Quis enim ambigat authorem ipfum hoc temporis fpacio plenis (quod aiunt ) viribus ad eam rem fuiffe acceffurum, \& fummam manum tanquam Colophonem femel abfoluto operi impofiturum. Nunc verò nihil aliud à nobis agi, quam quòd nouis fubindè editionibus cos obruimus, ut cò fpeciofius ab ipfis pecunias extorqueamus. Hxc \& fimilia de me fortafsè aliqui. Quibus quid eft quod interim refpondeam, nifi quòd conatus hic nofter eorum gratia non fufcipitur, quos auaritia ftudium tranfuerfos agit? Ab his enim tantum abeft, ut lu- 
ccllum aliquod expectem; vt fim potius illis vltrò etiam magnas gratias habiturus, fi tabernam noftram nunquam falutarint. Alijs uerò, quos infignis animi liberalitas, exccllentesq́; virtutes prax cæteris exornatos reddunt, nofter umnis labor, $\&$ induftria dicata eft, neque vlla cft res tanta, quam horum caufa non $\&$ libenter, \& ftudiosè fin facturus. Hxc samcn nequaquam eò dixerim, quafi fordidum lucrum communi hominum veilitati praferre uidear velle, id quod à me tantùm abeft, ut nihil abefle longius pofsit. Scd vt intelligas ftudiofe Lector, nullam cfie tam modeftam falicitatem, qua malignitatis aculeos eftugere pofsit; quanquam nolim totius defenfionis mex cardincm, ac vim in hoc folo ucrfari, cùm longè alix \& juftifsım $x$ quidem lint caufx, qux me ad cdendos rurfum hofec commentarios induxere. Etenim quis ët, qni nefciat, fi editionem hanc in aliud tcmpus reieciffcm, eucnturtum omninò fuiffe, ut quàm plurimi ftudiofi huius artis, '́me authore) iacturam in ftudijs facerent, præfertim cùm ab hinc annum nulla exemplaria Venetijs reliqua fucrint; quo tempore confluebant turmatim ad me undique ftudioli homines, qui quotidianis propè conuicijs à me coldem Commentarios effagitabant. Id quod cùm multis alijs exploratifsimum eft, tum uerò uel maximèmihi ipfi fatis fuperq́; cognitum : qui fingulis horarum momentis adeò ab ift is exagirabar, ut penè oblurduerim ad corum querelas. Itaque operæprecium me facturum exiftimaui, fi rurfus hofce commentarios excuderem : alıoqui videbam mihi eodem têpore duplex crimen fuftinendum. Nam \& multorum ftudioforum animos hac de caufa à me alienaflem, \& rationem nullam habuiffem eorum, qui Matthioli commentarios vel non viderunt, vel non legerunt. Quorum alterum priuatis meis rationibus plurimùm obfuiffet, alterum etiam inhumanum videri poterat, eos fcilicet huius lectionis fructu diutius priuari, qui minimè omnium dabebant. Quamobrem nullum iam cx ftudiofis futurum arbitror, qui mihi vitio uertat, quòd hole commentarios ita auctos, \& locupletatos adiectis quàm plurimis plantarum \& animalium jmagin ibus, qux in alijs editionibus defiderabantur, rurfus imprimendos fufceperim. Nam cùm huius artis cognitio longè, lateq́; pateat, neque vllis cancellis fit conclufa; non video, cur ei qui in hoc argumenti gencre aliquid feripferit, aut lucubrarit,non liceat fuo quafi iure quotidiè aliquid addere, im mutare, inducere, breuiter fcripta fua facere meliora ; id quod authorem ipfum in hifce com mentarijs feciffe mánifeftum eft. Quinimò aufim hoc planè affirmare, olim permoleftú ftudiofis omnibus futirum, vbi viderint illum alijs ftudijs impeditum ftationem hanc, quam diu tueri cepit, aliquando defercre, neque quicquam amplius in hoc genere meditari, quod in hos cómentarios conferat, cùm nerifimsle fit ipfum \& multa \& præclara adhuc habere, qux ad hanc pi $x$ ftantifsimam fimplicium cognitionem fpectent, in qua ille (uti ego abomnibus doctis palsim circumferri audio) non poftremum inter alios fibi locum ucndicat. Illud fatis conftat multos acer rimi iudicii homines pleraque ex illius commentariis mutaffe, \& fcriptis fuis inferuiffe, nonnullos etiam ex illius laboribus quofdam ueluti centones confarcinaffe : ut uel hinc coniectari liceat a qua eruditione, qua doctrina uir ille polleat. His igitur de caufis hunc librum denuo in manus affumpli, eumq́ue ( uti antea dixi) tot fimplicium \& animalium imaginibus auctum, multoǵ; magis quàm antea locupletatum, typis excudendum cenfui . Adiecimus praterea tabulam comprehendentem uim \& naturam omnium fimplicium ad on nes corporis morbos applicatam, ex qua uix dici poteft quantum utilitatis \& fructus firt ftudiofi percepturi. An igitur quisquam me reprehendat, quòd hanc prouinciam imprimendi præclari huius operis toties fufcipiam? Quòd fi iu ftos iudices fortiri mihi contingat, quiq́; ratione potius quàm liuore \& odio moueantur, nihil ad dubito quin omnibus calculis pro me fententiam ferant. Porrò quoniam fuperioribus annis receperam, me in lucem daturum Apologiam Matthioli contra Amatum Lufitanum; unà \& Cenfuras in illus enarrationes, ne fortè quis fidem meam hac in re defideraret, uifum eft eam hifce commantarijs adnętere. Quamquàm verò author femper eo animo fuerit, ut libellus non diuulgaretur, quòd exiftimaret non effe magnoperè gloriofum (ut ipfe ait ) uincere eum hominem, qui fe iam pafsim omnibus, ut uerbis ipfus utar,deridendum propinarit, palamq́; omnibus fecerit impudentiam fuam; tamen, ne quis me læf fidei reum in iudicio fifteret, nihil non feci, ut author precibus 'meis locum daret. Et iam omni prorfus fpe cadere cxperam, nifi acerrimi iudicij homines quotidiano propè conuicio id à Matthiolo effagitaffent. Aiebant illi plurimùm referre, ut ea fripta ede- rentur; fore enim ut hinc omnis pofteritas apertè intelligat, non folùm quàm ille omni culpa in - eo uacet, in quo falsò accufatur, 'uerùm etiam ut Lufitani ( uti jpli addebant) arrogantiam \& inuidentiam jerfpe\&tam \& exploratam habeat, cuius exemplo cæteri admonitiab hac prouincia pofthac abftincăt, neque in probos $\&$ doctos uiros tam contumeliosè debacchentur. Huc accedit quòd non parum emolumenti, \& frugis hinc ad fudiofos omnes fit peruenturum, ob uariam \& multiplicem doetrinam, qux in hilce friptis comprehenfa eft. Quid multis? Annuit Matthiolus, paftusqu, eft A pologiam unà cum Cêfuris in Iucem edi. Exılui meherculè pre nimio gaudio, quòd tandem id effem aliorum opera confequutus, quod tantoperê femper optaueram: Sed mirum cft quàm difficilê fefe hac in re author præftiterit. Reliquum eft, ftudiosè lector, ut ad hanc præclariffimam fimplicium cognitionem te horter; non enim dubito, quin uberiores \& fuaniorcs fructus in dies ex ea percipias. Vale, ac labore noftro fiuere. 


\section{EXEMPLVM PRIVILEGII PONTIFICII.}

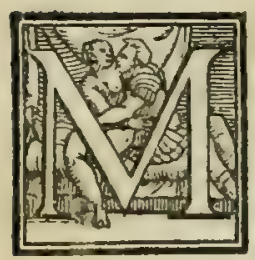

O т v P R O P R I o \&c. Cùm, ficut dilęus filius Vincentius Valgrifius bibliopola, \& typographus Venetus nobis nuper exponi fecie, ad communem omnium itudioforum veilitatem, fua propria impenfa, Commentaria dulecti filij Petri Andrex Matchioli medici Senenfis in fex Pedacij Diofcoridis Anazarbei libros de medica materia, nunc primum ab ipfo in Latinum conuerfa \& aucta, cum innumeris plantarun, \& animaliun figuris, qux ad idem opus fpeśtant: item Alinanachum fue Ephemerıdas fuppuzaras per dilectum filiun Nicolaum Simum Bononiêfen mathenaticum : neecnon Dialogos feu Colloguia dilecti filij Marci Mautui Bonautu Patauiui Iurifconfulti : adhæc Secundam partem philolophix naturalis per dilectum filiun Alexandrum Picolomineum Senenfem Herrufco fermone confcriptam: item Carminz dilectorum filio rum Io. Baptiltz Pig nx, \& Reuereń Calij Calcagnini, \& Ludouici Areofti Ferrarienlium : præteres Centurian confliliorum Io. Baptiftx Montani Verouentis : infuper libros Ioannis Schoneri mathematicı de iudicijs natiuitatum, in Italicum fermonem per Io. Baptrittam Carellum conuerfos, hacterus non in prefla, imprimi facere intendat, dubiterq́; ne huiulmodı opera po modum ab alijs abfque eius licentia imprimantur, quod in naximum fuum præiudicium tenderet. Nos pro prerea ejus indemnitati confulere volentes, Motu funili, \& ex certa feientia cidem Viacentio, ne fupradicta opera per ipfum imprimenda, per decen annos, polt dictorum operum imprefsionem à quocunque fine ipfius licentia imprimi, aut vendi, feut venalia teneri polsint, concedinus, \& indulgenus, inhibentes omnibus, \& fingulis tam in Italia, etiam in Fulginateń, \& Raccanateń ciuitatibus, quàm cxtra Italiam exiftentibus, bibliopolis, \& librorum imprefloribus lub excommunicationis latx fententix. In terris verò S. R. E. mediatè uel immediarè fubıectis, fub ducentorum ducatorum auri, pro vna, fifco camere A poftolic $x$, \& pro alia medietaribus, eidem Vincentio eo ipfo applicandis ponis: \& infuper amifsionis omnium librorum, quoties contrauentum fuerit ipfo facto, \& ablque alia declaratione incurrendis, ne intra decennium ab imprefsione dictorum operum relpectiuè computandun, dreta opera fine eitfdem Vincentij expreffa licentia imprimere, uendere, feu venalia habere, aut proponere quomodoliber audeant. Mandantes vniuetfis venerabilabus fratribus minoris, Archiepifcopis, Epifcopis, eorumq́; Vicarijs in Spiritualibus generalibus, \& in ftatu C.S. R. E. etiam Legatıs, \& Vicelegatis fedis Apoltolicx, ac ipfius ftarus gubernatoribus, vt quotiens pro ipfius Vincentij parte fuerint requifiti, vel eorum aliquis fuerit requifitus, eidem Vincen tio efficacis defenfion is præfidio afsiftentes, præmifla ad omnem ipfus requifitionem contra inobedientes, \& rcbelles per cenfuras Ecclefialticas etiam fxpius aggrauandos, \& per alia juris remedia, auctoritate A poltolica exequantur. Inuocato etıan ad hoc fi opus fuerit auxilıo brachij fecularis, non obftantibus conftitutionsbus, \& ordinationibus A po ftolicıs, priuilegi,s quoque, indultis, \& literis Apoltolicis quibuscunque, \& prafertim dictis Fulginater̆, \& Raccanstén ciurtatibus, fuper libertatibus, \& exemptionibus mercatorum quorumlibet, tempore nundinarum earundem ciuitari, ac aliâs quomodolibet edıtis, concefsis, confirmatis, \& innouatis etiam iteratis vicibus. Qubus omnibus slioı un veriores tenores pro fufficienter exprefsis habentes, hac vice duntaxat, fpecialiter $\&$ exprefsè pari motu derogamus, cærterisá; contrarijs quibufcunque. Et infuper quia difficile admodum eflet præfentem motum p:o priun ad qualibet loca deferri, volumus \& A poftolica auctoritate decernimus, ipfius tranfumptis, vel exemplis plenam, \& eandem prorfus fiden vbique tam in judicio, quàm extra haberi, quæ prefenti originali habeatur : \& quòd prxlentis motus proprij, absque eo quòd publicetur, aut in eo data apponatur, fola fignatura fufficiat, \& vbique fidem faciat in iudicio, \& extra, regula contraria non obftante.

\section{EXEMPLVM PRIVILEGII CAESAREI.}

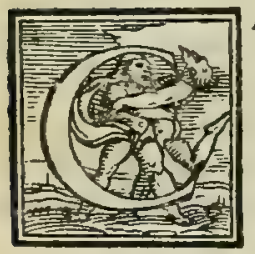

A 8 o I v s Quintus, Diuina fauente clementia, Romanorum Imperator Auguftus,ac Rex Germanix, Hifpaniarum, veriufque Sicilix, Hierufalem, Hungarix, Dalmatix, Croatix Scc. Archi dux Auftrix, Dux Burgundix, Brabantix \&c. Comes Habfpurgi, Flandrix, Tyrolis \&c. Notum facimus tenore præfentium uniuerfis. Q $\mathrm{v} v \mathrm{M}$ fyucerè nobis dileftus Vincentius Valgri fus bibliopola, \& chalcograghus venetus, nobis reterenter exponi fecerit, fe conftituiffe in communem omnium, \& prxcipuè rei imedicæ ftudioforum vcilitarem, fuis proprijs impenfis imprimere, \& imprimi,facere Commentaria hactenus nun imprefta in fex libros Diofcoridis Ana zarbei, de fimplicium hiftoria \& viribus latinitati reddita per honorabilem, doctum, noftrum \& Imperij facri fidelem dilectum Petrum Andream Matthiolum Senenfcm, artium \& medicinæ Doctorem, cum figuris omnium plantarum, animalium, aliarumá; rerum eidem operi fpectantium. Vereri aucem ne eiufmodi Commentaria \& figuræ, poftquàm ab ipfo magno labore ac fumptu imprefla fuerint, ab alijs claalcographis aut bibliopolis temerè imprimantur \& diftrahantur, in non modicum ipfius damnum \& derrimentum . A nobis proinde humiliter petendo, vt ipfun Priuilegio ac Edicto noftro aduerfus eam iniuriam munire uellemus. Nos igitur cupientes in primis illorum indemnitati conlultum, qui magnis fu is impenfis \& labortbus vtilitati publicx prodeffe ftudent. Iccirco tenore prxfentium, ex certs aoftra fcientıa, \& pro ea autoritate, qua tan racione Imperialis dignitatis, quàm alın̂s fungimur, "edicimus, ftatuimus, \& dittrictè inhibemus, ne quis typographus 〔eu impreflor, aut quíuis alius cujufcunque ltatus \& conditionis exiftat, per tozum Romanum Imperium, \& ciutates, terras, ac loca nobis \& eidem Romano Imperio, mediatc̀ vel immediaté fubıecta, tam in Italıa, quàı in Germania, \& vniuerfa Ditione noftra, predita Commentaria in Diofcoridem, per prefatum Vincentium Valgrifum imprimenda, infra decennium ab jllarum prima editione, abfque ipfius Vincentij expreffa licentia", imitari vel imprimere, feu alibi imprefla feu excufa, intra fines facri Romaıi Imperij, \& Dicion is noltrx importare, adducere, ac vendere audeat \& prefumat.Quátenus præter noftram, \& Imperif facri grauem indignationem, \& amifsionem librorum, fic per æmulationem impreflorum ( quos eidem Vincentio, vbicunque nactos, per fè vel agentes fuos ad fe recipiendi, \& in vfum fuum ucr-

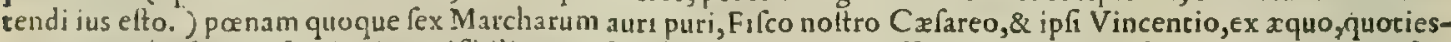
cunque contrafactum fuerie, irremifibiliter applicañ, cupiant cuitare. Harum teftimonio literarum, manu noftra fubfcriptarum, \& figilli noltri imprefsione munitarum. Datx in cinitate noltra Imperiali Augufta Vindelica, die vigefima prima mcifis Februarij. Anno Domini millefimo quingentefimo quinquagefimo primo, Imperij noitri trigefimo primo, \& Regnorum noftrorum trigefimo fexto. 


\section{EXEMPLVM PRIVILEGII GALLIARVM REGIS.}

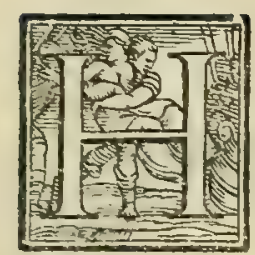

E N R Y parla grace de dieu Roy de France Aux Preuoftz de Paris Bailliz de Rouen Senechaulz de Lyon Tholole \& Bordeaux \& a cous noz aultres Lufticiers officicrs ou leurs lieuteń quil app.urtendra falue Noltre cher St bien a tne Vincent Vaugrys libraire \& imprumeur deñ a Venize Nous a faict entendre par lées que nous a elcripres noltre ame \& feal confeiller mailte des requeltes de noftre holtel \& noftre embafladcur deuers la feigneurie de Venize Que auec grandz fraiz peine foinz \& labcur Il a traduict le liente de Diofcoride auecles figures au nacurel \& les commentz latins du docteur philofophe \& medecin Maifte Pierre Andre Mathiol Senoys \& pareillement les figures de tous les fimplex qu'il a faia portraire $\&$ defigner au naturel Pour le benctice commung de tour le monde \& pour L ayde \& lupport des corps humains lefquelz il a faict imprimer audiâ Venize \& pour aultant qu'il craint que aulcuns libraires \& Imprimeurs de noftre Royauline ne fingerrent \& entremêิtn de faire Imprimer \& portraire ledict liure \& par ce moyen le fruftrer de ce qu'sl pretend du fruict de fon labeur Nous luppliant \& requerant a cefte caufe luy vouloir furce pourueoir Pource eft il que nous inclinans a la requcfte qui noftredift ambaffadeur nous a faikte pour ledict Vincent Vaugrys Et voulans luy fubuemir en ceft endroict amons de noz certaine fcience plaine puiffance \& auctorite Royal prohibe \& deffendu prohibons \& deffendons a tous libraires imprimeurs de noltre Royaulme \& aultres perfonnes quelz quilz foient Que durant le temps \& terme de dix ans enfuyuans \& confecutifz Commenceans au iour \& dacte de ces pñtes ilz n’ayent a imprimer ne faire extemper mectre ne expofer en vente lefdictes oeuures \& traduction dudict liure de Diofcoride ne aufil les portraictz \& figures de tous les fimples Sinon celluy ou ceulx qui auront charge d'en vendre S expofer en vente de la part du diet Vaugrys fur peine damende arbirraire a nous a applicquer \& de confifcation de tous les difts liures \& oeutres qui ainfi fe trouueront Imprimez fans charge ne commiffion dudiat Vincent Vausrys Si no us mandons commeftons \& a vnz chün de vous endroict foy \& fi comme a luy appartiendra Que fẹlon \& enluy uani ce que deflus vous faiftes ou faites faire expreffes Inhibitions \& deffences de par nous furles peines que deffus indictes \& aultres que verrez eftie a impofer a tous les dicts imprimeurs libraires demourans en voz iurifdictions \& e'eftroicz Que parcy apres ilz ne aulcun d'eulx aultres que celluy ou ceulx qui auront charge expreffe de ce faire dudict Vincent Vaugrys Ayent a imprimer ne faire extemper mectre ne expofer en vente lèdict liure traduQtió \& figures deffufdiftes \& fiapres lefdidz commandemens faicz yous trounez aulcuns contreuenans a iceulx yous pro cedez a lencontre d'eulx par condemnation defdictes peines \& aultres ainfi que verrez eltre a faire felon lexigence des cas Nö obltant oppóns ou appellaỏns quelcócques \& Ians preindice dicelles Pour lefquelles ne voulons eftrẹ differe Cartel eft noftre plaifir De ce faire vous auons donne \& donnons plain pouvoir puillance aucten \& mandement efpecial Mandons \& commandons a tous noz Tufticiers officiers \& fubgectz a vous en ce faifant eftre obey.

Donue a Sainat Germain en Leez le x x $_{\text {I }}$ x Iour de mars Lan de grace mil cinq cens cinquante deux auant pafque \& de noft:e Regnele Sixiefme.

$$
\text { Parle Roy Duthies }
$$

\section{EXEMPLVM PRIVILEGII ILLVSTRISS. SENATVS VENETI.}

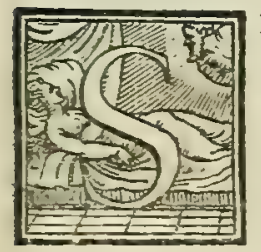

E R E N is S I M 'o Principe \& Illuftrifs. Signoria. Supolica il fedelifimo Sertitore di V.Sublimità Vincenzo Valgrifio libraro \& infieme ftampator de libri, che harendo deliberato di -far ftampar à honore, \& vtile di quefta inclita città, i commentari Latini dell Eccellentiffimo medico meffer P. Andrea Matchioli fopra Diofcoride, libro non men vtile, che defiderato da mol ti. Et hauendo per maggior intelligentia della materia, che in eflo libro fi triatta, fatto diffegoar \& intagliar infuice piante. Per il che lia făto vna grandifima fpefa, ne quella folamente è ftata in far ritrarre, \& intagliare le dette piante da valentifim'huomini, ma in farfi trouar, \& portar quelle piante (che fono molte) che qui non nafcono, da diuerfi paefi , tutto con fperamza di mandarle infieme co'l libro in luce, mercè però del fauore, che afpetta dalla bontà di V. Sublimità, fi per honore \& gloria di quefta Clarifinna cirtà, come per vrilità, \& beneficio del corpo humano. Et perche dubita il detto fupplicante ftampando il fopradetto libro con le dette figure fenza?l prinilegio di voftre Sublimità , che altro Libraro, ouer Sramparore non glí toglia la fatica, \& le ipefe infieme, cauando'l difegno dalle fue figure, facendole poi intagliare, \& vitimamente ftampandole, prendendo nel refto il fuo libro per effemplar, il che gli faria non folamente perdita delle faciche, \& fpefe fatte intorno à quefta opera, ma cagion grande di fua ruina. Per quefto egli hora ricorre alli piedi di V. Sublimità, \& à quelle con l'Eccellentifsimo Confeglio di Pregadi humilmente fupplica d'effergli conceflo in fpecial gratia, che altri, che egli, ouer chi da lui hauerà auttorità, non poffa ftampar, ò fare ftampar, pisliando quefto fuo Diofcoride per effemplare, \& da eflo cauando le figure delle piante, ne da altri in alcun modo ftampato vendere il detto libro per fpatio di anni quindici, fotto pena à chi contrafarà, di ducati feicento, \& di perder tutri i libri, \& i diflegni che fuffeto ftati fatti, \& di pagar ducati dui per ciafcuna opera, che fuffe ftata contrafatta. Et fe farà alcun'habitante in quefta inclita città, che lo facele ftampare, ouero fuffe caufa, che fi ftampafte, in terre aliene, che faria danno di V. Sublimità, \& di elfo fupplicante, trouandofi quefti tali s'intendano incorrer nelle fopradette pene . delle quali vn terzo vada all'hofpital dell'incurabili, l'altro all'accufator, \& l'vltimo all'officio, il qual farà l’ellecutione, \& che ogni officio, ouer magiftrato pofla far la detta eifecutione, doute farà fatta la confcientia.

Supplica ancora il medefimo per le fortoferitte opere nella forma iftefla, che quella di fopra, \& quefto tutto domanda in gratia à voftre Sublimità, allequali humilı fsimamente fi raccomanda .

Almanach, ouero Ephemeride per x v. anni, calculato per l’Eccellentifsimo M. Nicolò Simo Bolognefe.

Colloquia, feu Dialogi iuris \&c. dell'Eccellentifsimo M. Marco Mantoa Patauino.

La Seconda parte della Philofofia naturale di M. Aleffandro Piccolomini, volgare.

L- Poefia Latina di M. Giuma Bartifta Pigua, di Moufiguor Celio Calcagnino, \& di M. Lodouico Ariofto Ferrarefi.

I553. Die. 29. Septembris in Rogatis.

Che al foprafcritto fupplicante fia conceflo qquanto'l do manda, effendo obligato di offeruar tutto quello, che è difpolto in usaceria di ftampe.

Raphael Cornelius Ducalis Notar.\&c. 


\title{
Errata corrigenda.
}

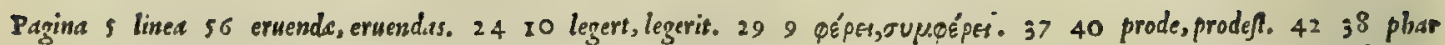

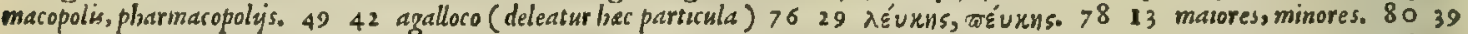
fiwores, fuorcs. 80 so lignis, ligni. 13237 uttex, falix. 13756 fubalteq́, Jubaite. 15756 germinatos, geminatos, 16816 Italis Moro, Italis More. 168 52 fcalpata, fcalpta. 18931 Adhic, At huc, 20249 Smaridi, Girols. 2065 millepedi (adde) Porcelletti. 22527 quem aquatiles, quàm aquatiles. $226 \quad 32$ expirarare, expirare. 22826 breuem, villofam. 23226 Mau-

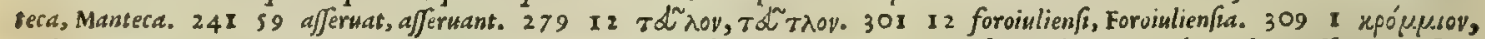

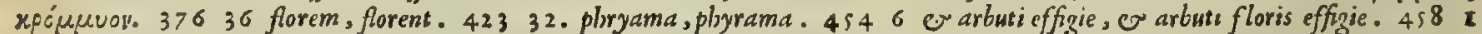
mlig;, maliq $q_{;}$. 46 I 58 fcribere, fubfcribere. 476 54 cuictiam Fuchfus fubfcribere videtur, cui etiam Cordus fubfribere videtur. 48448 cisis, conciuis. 5324 SOLATRVM SOMNIFERVM (adde) ALTERVM. 57045 dictat, difla 54547 grati $\beta_{8-}$ mo, gratißumi, 56821 tractis, tractus. 598 s8 ipfi modo, pifi modo. 60213 frripto, frripta. 60235 proßimus, pofsimus. 60242 glanx, glans. 60718 nostri, noftris. 615 51 intritus, illitus. 63931 quantum, quartum. 665 7 tertio, terito. 667 I6 affimare, affirmare. 5844 ceraginofis, ceraginofi. 7187 noua parua, non parua. 74216 infeclu, infectus. 749 s8 20mutionis, vomutiombus. 76754 ordilum, tordilum. 77028 quam fepa, quam Jepam.

Ex his erroribus nonnullos hoc loco neceffario annotauimus, quippè quòd authoris fententiam peruerterent;nónullos verò, qui verbum immutabant, lacinitaten'q́; offendebant unius vel alterius literzæadditione, aut defectu, aut mutatione, ea tantum ratione appofuimus, vt eorum exemplo alios fimiles inter excudcndum commiffos, benignus lector emendet. quinetiam prius quàm hæc commentaria legere incipiat omnia laxc deprauata loca reftituat, ne inter legendum fubfiftat.

\author{
Petri Bellony erratum 83.22 \\ Encely lapsus 200. 3 \\ Fuchsy errores 216.48 .242 .4 . \\ Gefineri lapfus $475.40,541.10$. 566.58. 568. 3:. \\ Melchworis Grilandini Bornßji explofa temeritas 541.40 .
}




\section{IN DEX EOR VM, QVAE IN HOC}

OPERE CONTINENTVR.

\section{Cuius primus numerus paginam, fequens verò}

pagina lineam denotat.

A

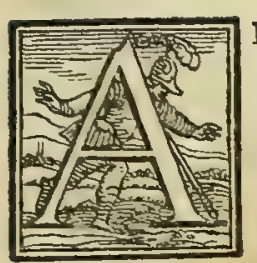

B I E I I biftoria 80.40 Abietis lacryma

80.56

Abietislacryme uires. $\quad 81.27$

Abrotonum Diofroridi $\$ 69.56$ abrotoni confiderstio 370.9 abrotoni maris genera diko ibid.

abrotoni foentme confideratio abrotoni nires ex Galeno

370.12

Abfinthium Diofcoridi

abfintbium marinum Diofcoridi

abfintbium Jantonicum Diofcoridi

dófinthij confideratio

abfintbium Ponticum

$a b /$ intbij marini confideratio

abfintbij feriphij confideratio

abfinthij uires ex Galeno

670.32

$367 \cdot 9$

$367 \cdot 44$

367.56

368.2

368.2

368.42

ibidem

369.10

Ab que fimplicium medicamentorum notitia recté me= deri nemo poteft

Acacalis Diofcoridi

acdcalis confideratio

Acacia Diofcoridi

acdcia altera Diofcoridi

acacie confideratio, or biforia

acdcis officinarum factitia

acacis alterum genus

acacie uires ex Galeno

Acanthium Diofcoridi

acantbij con/ideratio

Acantbus fatiuus Diofcoridi

acantbi fativi confider atio

acanthi uires ex Galeno

acanthus fylueftris Diofcoridi

acantbifylueftris confideratio

Acarne hiftorid ex Theophrasto

Acetum Diofcoridi

acetum ébetonica Diofcoridi

acetum mulfum Diofcoridi

acetum Jcillinum Diofcoridi

acetum ex foechade Diofcoridi

aceticonfideratio

acetum contrarijs conftat facultatibus

acetifcillini uires mirabiles ex Galeno

Acbate lapidis hytoria, or uires

Acbillea Diofcorididefcripta

achillee confideratio

achillex uires ex Galeno

Acbras Diofcoridi

Acida muria Diofcoridi

acide muris ufus exoleuit

Acinos Diofcoridi

acini confideratio

Aconitum Diofcoridi

aconitum alterum Diofcoridi

aconitigenera, $\sigma$ conjideratio

109.42

209.46

129.7

229.30

29.38

29.55

130.30

130.35

360.4

360.8

360.24

360.40

$362,21:$

360.34

361.20

428.35

645.52

652.56

646.35

647.23

652.50

646.7

646.8

647.39

700.6

506.33

506.45

$507 \cdot 14$ aconiti hiftorid ex Theophrafto

aconiti uires ex Galeno

538.52

540.59

730.29

730.39

770.40

770.48

x. 40

19.54

20.50

21.5

$1 \times 3.30$

113.39

316.38

$\times 24.8$ acutam pinam non effe berberim uulgi

Adami Loniceri errata, of fententi.e improbate 90.

50. et $1 x x .6 x$. E 129.37 .00343 .8 .et $30 x .22$

Adami poma

Adarces Diof coridi

adarce confideratio

adarce uires ex Galeno

153.62

Adeps omnis Diofcoridi

694.21

$694 \cdot 7$

694.32

adipis, of pinguedinis uires ex Galeno

234.12

adipis in cibis facultas

235.59

Adiantum Diofcoridi

adianti confideratio

adianti hiftoria ex Theophrafto

237.27

581.50

582.40

adianti uires ex Galeno

adianti uires ex Mefue

Aegilops Diof coridi

agilopis con/ideratio

egilops bordei uitium

agilopis uires ex Gäleno

582.40

583.5

583.22

584.4

Aeris flos Diofcoridi

aris floris biftoria

aris floris uires ex Galeno

$584: 20$

584.40

584.49

657.54

658.5

Acris fquama Diofcoridi

658.13

658.41

aris fquame lethifera uis, లూ eius remedia $\mathbf{7 4 4 . 3 4}$

Aerugo rafa Diofcoridi

arugo fcolecia Diofcoridi

aruginum confideratio

660.28

aruginum uires ex Galeno

660.40

$66 x .2$

661.6

eruginis uenenum, er eius remedia

Aes uftum Diofcoridi

srisufticonfideratio

cris ufti uires ex Galeno

Aethiopis Diofcoridi

athiopidis confideratio

athiopidis uires

A'étites lapis Diofcoridi

dêtite lapidis biftorid, or uires

Agallochum Diofcoridi

agallochiconfideratio

agallocbifabulofa uulgiopinio

agallochibiftoria ex serapione

agallocbifacultates ex Auicenind

745.52

657.30

$657 \cdot 43$

657.46

$563 \cdot 4$

563.17

563.22

705.16

705.23

48.18

48.25

48.36

48.45

40.30

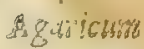


Agaricum Diofcoridi agariciconfideratio dgarici uires ex Galeno

agaricifacultates ex Mefue agaricinigrinoxa, or ciusremedia Diofc. agaricinigrinoxa, $\widetilde{J}$ eius curatio

Ageraton Diofcoridi ageraticonfideratio agerati uires ex Galeno Agnus Diof coridi Agria arbor Agrifolij confideratio

Aiuga Diofcoridi aiug confideratio ainge uires ex Galeno Alabaftrites lapis Diofcoridi alabaftrite lapidis confideratio alabaftrite uires ex Galeno Alberti Magnilapfis Alcea Diof coridi alcee confideratio alcex uires ex $\mathrm{P}$ aulo Alcibiadion Diofcoridi Alcyonium Diofcoridi alcyonij biftoria, er confideratio alcyonij uires ex Galeno Alge confideratio Alhaffer quid cx serapione Alifma Diofcoridi alifmatis confideratio alifmatis uires ex Galeno Alliaria berbe confideratio, tor uires Allium Diofcoridi allium Jylueftre Diofcoridi allij confideratio allij $\int y$ lueftris confideratio

Alni confideratio, er biftorid ex Theophr. alni ufus, or uires Aloë Diofcoridi aloés confideratio aloès uires ex Galeno aloës uires ex Mefile Alphafafat A phris quid Aljine Diofcoridi alfines confideratio alfines uires ex Galeno Althea Diof coridi althex confideratio althed Theophrasto duplex altbea uires ex Galeno Alumen Diofcoridi aluminum omnium confideratio aluminis rupei faciendi ratio alumina cognita 0 iam in lucem réddita aluminum uires ex Galeno

alunimum facultas calida, non frigida, ut quidam con=
tendunt $686.2 x$ Alypon Diofcoridi alypi confideratio alypi uires ex Paulo Alyfon Diofcoridi

308.6
$34.26 \quad$ alyßiconfideratio

341.60

342.12

342.24

$747 \cdot 57$

748.32

522.54

522.59

523.1

230.59

122. 51

12.33

479.50

480.34

480.40

702.15

702.18

702.25

$212.36, \cos ^{2} 23.60$

473.30

473.32

$473.5 \mathrm{x}$

500.20

693.24

693.39

693.54

558.25

245.20

476.42

476.55

477.12 .

$443 \cdot 52$.

309.12

309.37

$309.5 \mathrm{z}$

202.50

103.2

365.25

365.54

366.22

366.54

$305.3 \mathrm{z}$

$\therefore \quad 549.19$

549.29

549.36

472.47

$473 \cdot 9$

$473 \cdot 13$

473.18

684.22

684.48

685.6

685.54

686.15

618.25

618.34

$6 \times 8.54$

426,58

aly Jum Aétij

dlyfum Plinij

aly Jum Gdeni

amaracum quid

Ambaribiftoria

Ammi Diofcoridi

amomum fpurium

771.5

amurce ufus

amygdalini wires

amyli confideratio alyßi uires ex Galeno

Amaracum Diofcoridi

anaracini confideratio

Amaranti purpurei biftoria

Amati Lufitani errata

ambarigenera, $\mathcal{O}$ uires

Ambrofía Diofcoridi

ambrofie confideratio

ambrofie uires ex Galeno

Amellimentio Vergilio

Amiantus lapis Diofcoridi

amiantilapidis confideratio

amianto lapide fraus impoftorum

anmios confideratio

ammios uires ex Galeno

Ammodite hiftoria, or ueneficd uis

ammodite morfus figna, or eius curatio

Ammoniacum Diof coridi

ammoniaci confideratio

ammoniaci biftoria ex Plinio

ammoniaci lacryma duplex

ammoniaci uires ex Galeno

Amomis Diofcoridi

Amomum Diofcoridi

amomi confideratio

amomi uires ex Galeno

Ampelitis terra Diofcoridi

ampelitidis terre confideratio

Ampelopraffon Diofcoridi

ampelopraßi confideratio

ampelopraßi ufus ex Galeno

Amphisbiene ictus note, Er curatio Diofcoridi

amphisbene confideratio

amphisbenam bicipitem efe, falfum

amphisbene morfus figna, or curatio

Amurca Diofcoridi

Amygdale amare Diofcoridi

amygdale dulces Diofcoridi

amygdalarum confideratio

amygdalarum uires ex Galeno

Amygdalini parandiratio

amygdalorum gummi Diofcoridi

Amylum Diofcoridi

amyli uires ex Galeno

Andcardiorum mentio, tores

andcardiorum utneni fignd, $\sigma$ curdtio

Anagallis Diof coridi

anagallidis confideratio
427.6

ibidem

427.23

427.9

$4.27 \cdot 32$

$427 \cdot 4 x$

385.22

385.35

63.58

521.2

77.23 .028 .54

47.56

48.4

447.3

$447 \cdot 23$

$447 \cdot 34$

573.13

703.20

703.24

703.32

329.33

329.45

400.8

769.57

770.8

423.12

423.24

423.22

423.30

423.36

$38.4^{6}$

38.34

38.52

32.2

$39.5 \mathrm{z}$

$708.4^{8}$

708.54

307.29

307.24

307.32

771.10

771.26

772.38

133.52

134. 32

262.26

162.47

162.52

162:59

55.50

56.5

162.42

258.24

258.26

258.29

266.23

$729.4 \mathrm{E}$

333.50

333.59 anagallidum 


\section{Index}

andgatlidum uires ex Galcno

Anagyris Diofcoridi

andgyris confideratio, et gencra

andgyris uires ex Galeno

Anchufa Diofcoridi

anchularum confider atio

anchufarum uires ex Galeno

Andacochd Maturitanis quid

Andrex Lacune litere

Androfaces Diofcoridi

androfacis confideratio

androfacis uires ex Galcno

Androfemon Diofcoridi

androfemi confideratio

androfemi uires ex Galeno

Anemone Diofcoridi

anemones confideratio

anemones uires ex Galeno

Anethum Diofcoridi

anethi con/ideratio, et uires ex Galeno

Angelice hiforia, et uires

Anguium fenctia Diofcoridi

anguium fenecte confideratio

Anmalia ex ovis nafycentia

animali, alia preter canem rabie tentantur

Anefun Diofcoridi

anificonfideratio, or uires ex Galeno

Anonis Diofcoridi

anonidis confideratio

anonidis uires ex Gáleno

anonidis hiftoria ex Theophrafto

Anthemis Diofcoridi

anthemidis confideratio

anthemidis uires ex Galeno

Anthyllis Diofcoridi

antbyllidis confideratio

antbyllidis uires ex Galeno

Antidota contra uenend, er corum defcriptio 58. E deilude

Antidoti é Janguinibus de fcriptio

antidoti é fcinco de criptio

antidoti é terra Lemnia de fcriptio

antidotorum actio

Antipathes Diofcoridi

antipathes ubi uifum

Antirrbinon Diofcoridi

antirybini confideratio

antirrhini uires ex Galeno

Antifpoda Diofcoridi

Aparine Diofcoridi

aparines confideratio

aparines uires ex Galeno

Aphaca Diofcoridi

aphace con/ideratio

aphaca intybigenus

aphace er vicie uires ex Galeno

- Aptaftruin Diofcoridi

apiaftriconfideratio

apiaftri uires

apiaftrifacultates ex Galeno

Apios Diojcoridi
$334 \cdot 34$

474.50

474.58

476.3

500.14

$50 x \cdot 2$

501.10

448.2

387.54

462.36

463.2

$46 ; .6$

478.32

478.58

479.25

332.57

332.46

333.14

397.42

397.52

571.7

293.22

193.37

210.44

754.53

396.49

397.

362.20

362.35

362.3

361.48

466.4

466.30

466.37

465.24

465.35

465.52

722 .

$724 \cdot 38$

$724 \cdot 46$

725.23

725.20

695.43

696.10

580.20

580.17

580.28

$\therefore \quad 656.2$

426.33

426.43

426.49

305.38

305.42

305.55

305.48

435.49

435.58

436.9

436.26

614.3 .5 中ij confsderatio

A pium hartenfe Diofcoridi

apij hortenfis confideratio

apij omnis generis usires $\mathrm{ex}$ Galeno

apiumsaluftre

apiun montanum

apium rifus

Apocynon Diofcoridi

apocyni confideratio

apocyni wires ex Galeno

Apollinaris berba Diofcoridi

apollinaris herbe confideratio

apollinaris herba uires ex Galeno

A priliecur Diofcoridi

apri urina

Apun confideratio

apum rex or reginen

apes quibus gaudeant

apum mira prudentia

apum mira in opere induftria

apum reparatio ex Virgilio

apun ictus curatio Diofcoridi

apum il us, or eius remedia

Aqua Diofcoridi

aquarum differentia, e facultates

aquarum non potabilium facultates

aque frigida noxa, or curdtio Diofc.

$6 \times 4 \cdot 47$

403.33

404.9

405.5

404.25

404.32

$33 x \cdot 34$

543.33

$543 \cdot 44$

$544 \cdot 3$

529.12

529.54

530.7

207.10

241.59

246.57

247.2

247.16

247.24

247.26

$247 \cdot 47$

763.55

763.60

644.9

$644 \cdot 14$

644.50

750.7

745.44

240.35

aque aurificum noxd, er curdtio

aqud ex bumano fercore

Aque pauor quousque exorittur in demorfis à cane
rabiojo
759.22

aque paror quando, or quibus curetur $\quad 759.25$

Aqud marina Diofcoridi

645.30

aqua mulfa Diofcoridi

643.22

aque mulfs parande ratio uaria

aque ftillatitis que ceteris preftantiores 127.2

Aquifolium

A quilina, fiue aquileia

Aquofa que ament loca

Arabicum gummi non effe acacie

Arabicus lapis Diofcoridi

$643 \cdot 35$

Arabis Diofcoridi

arabidis confideratio

Árabum lapfus

Araneuspifcis

araneus Diofcoridi

aranei confideratio

dranei muris confideratio

Arbores qua plante fcandant

arboribus que inna cantur

Arbutus Diof coridi

arbuticonfideratio

arbuti defcriptio

arbuti ufus er uires

Arction Diofcoridi

arctij con/ideratio

22.44

337.20

9.25

$129.6 \mathrm{z}$

$70 \mathrm{x.22}$

313.52

313.59

309.55

$\therefore \quad 29.36$

222.26

222.40

227.2

20.4

20.2

262.4 .5

162.52

262.2

262.28

arctij uires ex Galeno

Arena Diofcoridi

Argemone Diofcoridi

argemones confideratio
563.37

563.42

563.48

706.35

333.26

333.33

argemo= 
argemones edput adulterinum argemones uires cx Guleno

Argentinaberbat

Argentirccrementum Diofcoridi

argenti fcorie conlideratio

A:gentiffuma Diofcoridi

argentipunte confideratio

argenti fr:me uires ex Galeno

argcntipume noxa, er curatio Diofcor.

argentipume mala

drgenti foume fumpte curatio

Argchtum viunur Diofcoridi

argenti uini confideratio

argenti fublimsti parandiratio.

argcnti mixi noxa, er duxilia Diofcoridi

argenti niui pernicislis natura

argenti uiui funpticuratio

Aria arbor

Aridaloca que plante ament.

Arifartur Diofcoridi

a)ifaribiftoria

arifari uires ex Galeno.

Ariftolochia clematitis Diofcoridi

ariftolochia longa Diofcoridi

aristolochia rotunda Diofcoridi

arisolochie con/ideratio

aristolochie clematitis examen

ariftolochiam longam unlgarem à Plinij piŝolochia nö differre

arifolochic uires ex Galeno.

Ariftotelis lapfus.

Armeniaca mala Diofcoridi

armeniacorum malorum confideratio

Armenius lapis.

armenii lapidis confideratio

armenij lapidis uires ex Alexandro.

armenij lapidis uires ex Aétio

armenij lapidis uires ex Galeno

Armenie terre uires ex Galeno.

Armoracia Diofcoride

Aron Diofcoridi

ari confideratio

ariuires ex Galcno

Arfenici fublimati uenenum, er curatio

Artenifia Diofcoridi

artemifia tenuifolia Diofcoridi

ariemific confideratio

artemifte uires ex Galeno

Arundo Diofcoridi

Arundinum confideratio, uide Harundinum:

A a arum. Diofcoridi

afari confideratio

dari uires ex Mefue

afarifacultates ex Galeno

Afclepias Diofcoridi

afclepiadis confideratio

afclepiadis uires ex Gdleno

Afcyron Diofcoridi

afcyri confideratio

afcyri uires ex Galeno
349.58

333.36

333.44

$323 \cdot 43$

666.3

666.7

666.19

667.1

667.13

743.53

743.60

744.8

673.52

674.2

674.42

744.45

744.48

$745 \cdot 14$

222.52

$0.4^{\circ}$

$325 \cdot 4$

325.8

325.14

$348 . x$

347.57

347.55

348.11

348.29

218.54. ct 222.56
630.35

149.32

2.5.2.47

669.46

669.8

669.35

669.57

670.5

678.20

267.55

323.54

324.2

324.12

$745: 42$

445.4

$445 \cdot 3 \mathrm{~K}$

446.52

106.3

29.19

29.33

29.56

30.5

427.52

427.56

428.14

477.53

478.58

479.2 .5
445.23
Afininum iecur Diofcoridi

207.7

afini ungula Diofcoridi

208.16

Afius lapis Diofcoridi

asij lapidis confideratio

696.48

696.60

asij lapidis biftoria, er wires ex Galeno

697.22

Afpalatbus Diofcoridi

appalathi confideratio

45.23

$45 \cdot 32$

apalatbi uires ex Galeno

A paragus Diofcoridi

45.50

279.62

aparagorum uires

280.22

Aphodeli confideratio, et bistoria

325.47

apphodeli uires ex Galeno

A pidis ictus not:e, or curatio Diof coridi

325.58

774.54

afpidis perniciofus ictus, et generd $\quad 775.2$

apidum biftoria, ittus figna, et cura

775.20

Aplenum Diofcoridi

appleni confideratio

463.18

463.32

463.56

apleni uires ex Galeno

Affa foetida

After Atticus Diofcoridi

419.58

572.49

afteris Attici confideratio

afteris Attici uires

573.2

Aftragalus Diofcoridi

573.26

524.22

524.22

$524 \cdot 30$

253.3

253.6

428.20

$4,28.26$

709.16

679.4

679.20

Atramentum futorium Diofcoridi

atramenti futorij confideratio

atramenti futorij biftoria, or uires ex Galeno

679. 52

Atriplex Diofcoridi

atriplicis confideratio

273.56

atriplicis vires ex Galeno

$274 \cdot 34$

atriplicis alia genera

Auellana nux Diofcoridi

auellanarum nucum confideratio

275.32

auellanarum uires ex Galeno

274.47

Auena Diofcoridi

auene confideratio

auene facultates

Auerrois uana calumnia contra Galenum

266.56

167.4

167.10

253.27

253.34

253.39

343 . 22

Auerrois locus reftitutus

Auicenne lapfus

390.42

Auicenna contra Galenum

73.2 .et 253.56 . et 735.9 539.58

Aucenne de generatione lapidum opinio comprobata $63 x .4$

Aurantia poind

Auribiftoria, et preftantia

153.61

auri uires ex Auicenna

Auricula muris Diof coridi

auricule muris confideratio

auricula muris facultates

$674 \cdot 58$

675.30

338.49 .

338.56

339.5

Auripigmentum Diofcoridi

683.28

auripigmenticonfideratio 


\section{Index}

vuripigmenti uires ex Galeno

auripigmenti noxa, et remedia Diofcoridi

auripigmenti uencfica uis, ct curatio

Azudaracht arbor is uencrium, cr remedia

Azaroli arboris deforiptio

\section{B}

B A C C AE lauri Diofcoridi

Baccharis Diofcoridi

baccharis confidcratio

baccharis uires ex Paulo

Balanimum olcum Diofcoridi

Baldniniolei confideratio

balaniniolei uires

Balaufium Diofcoridi

Balaufij confideratio

Ballote Diofcoridi .

bullotesconfideratio

Balfamina berba que

Galfamine biftoria

Balfamun Diofcoridi

balfanum cur in Syria non reperiatur

balfami confideratio, er biftoria

ballami uiridarium in Mempli

Galfamibiftoria ex Theopbrafto

balfanifrutum non legitimum officinis

balfami uires ex Galeno

balfami loco quid fupponendum

balfami factitij confectio

Barbula birci Diofcoridi

barbule birci confideratio, er uires

Bafilifcititus note, er curatio Diofc.

bafilici uariabiforia 775.47. er in eaplurafabu lo厅 776.12

Bdellium Diofcoridi

bdellium plant. genus

97.9

387.28

387.48

388.25

56.15

56.29

56.22

244.43

44.44

435.15

435.27

622.52

$622.5-5$

$43 \cdot 17$

$44 \cdot 4$

$43 \cdot 48$

$44 \cdot 7$

$44 \cdot 23$

44.33

$44 \cdot 40$

44.45

$45 \cdot 3$

302.2

312.78

775.42

bdellij confideratia

bdellij unlgaris generd

bdellij biftoria ex Plinio

bdellij uires ex Galeno

Beben album 0 rubrum

Bellis, or eius hiftorid, er uires

Belzoinum quid

Beta Diof coridi

bete confideratio

bete facultates ex Galeno

beta: Jylueftris

Betonica Diofcoridi

betonice confideratio

betonica uires ex Antonio Mu

betonice uires ex Galeno

Betule aiboris confideratio

betul e cortex bitumino $u s$

betule uires

Bezahar lapidis historia, er uires

Bislinguaberba

Bistorta berba que

biftorte uires

Bttumen Diofcoridi

bituminis confideratio

278.58

279.6

481.24

$\therefore \quad 481.56$

481.58 bitumints biftoria, uires ex Galcno

20.2

Blatta piftrinaria Diofcoridi

blattarun confideratio

blattaria herb.e biftorid, o vires

blatte bifantis

Bliton Diof coridi

bliti confideratio

blitiuires ex Galeno

206.9

206.12

562.32

82.55

272.20

272.23

272.34

68.25

Bacatica myrrba

Boli Armenij uires

$\therefore$

ifacia

Borraginis confideratio

678.20

579.48

577.42

$447 \cdot 42$

447.50

448.2

360.42

botryos uires ex $\mathbf{P}$ aulo

Branca urfina

Brafanalilapfius, er ciusdern opiniones non accepte

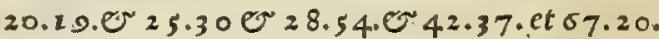

హ $73.37 .0 \% 84.59 .0 \% 88.46 .0 \% 102.29 .0$

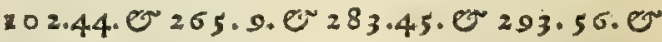

$300.29 .0 \% 309.58 .0 \% 317.20 .0 \% 332.49 .0$

$351.42 .0 \% 357.58 .00362 .55 .02374 .55 .0$

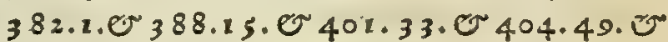

$421.18 .0 \% 418.1$. 445.55 . 449.32 .

$479.13 .0564 .25 .0 \% 518.30 .02606 .54 . \mathrm{Fr}^{\circ}$

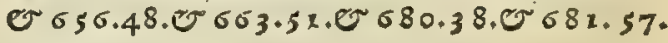

テr 684.58

Braßica Diofcoridi

braßice uires ex Galeno $\quad 277.35$

brajicam que oderunt $\quad x 5.34$

braßica fyluefris Diofcoridi $\quad 276.54$

braßice fylueftris confideratio : $\quad 277.32$

bral'sica marina Diofcoridi $\quad \because \quad 276.58$

braßic marine confideratio $\quad 277.58$

Britannica Diofcoridi

britannice confideratio

britannice biftoria ex Plinio

482.42

482.46

482.49

$483 \cdot 47$

584.57

Bromus Diofcoridi

bromi confideratio

Brunfelsij lapfis

Bryon Diof coridi

Bryonia Diofcoridi

s.

$327 \cdot 60$, et $557 \cdot 4 \cdot$ et 579.32

bryonic con/ideratio

46.7

620.20

620.42

bryonis noxd, et curatio $\quad 748.56$

Bubuliftercoris uires

Buccina Diofcoridi

240.42

buccini confideratio

$\therefore$

Bugloffum Diof coridi

777.55

178.29

577.37

482.32

103.7

$203 \cdot 17$

203.29

678.32

579.48

482.55

$483 \cdot 38$

87.28

87.52

bugloßicoinfideratio

577.42

bugloßide friptio ex Auicenth

577.52

bugloßi uires ex Galeno

578.9

Bulbus efculentus Diofcoridi

326.8

bulbus nomitorius Diof coridi

bulborum confideratio

326.23

$\therefore \quad 326.26$

326.38

Bunium Diofcoridi

575.50

bunij confideratio

576.2

bunif uires ex Galeno

576.12

Buphthalmum Diofcoridi 
buphthalmi confideratio

buplthalmi uires ex Galeno

Bupreftes Diofcoridi

bupreftium confideratio

bupreft is fumpte note, er auxilia Diofcor.

bupreftium uenenum eiusq;; curatio

Burfa paftoris, or eius uires

Butyrum Diofcoridi

butyri fuligo Diofcoridi

butyri confideratio

Buxi arboris confideratio

buxiufus

C

C A C A I I A Diofcorididefcripta

Cacalie confideratio

cacalix uircs ex Galeno

Cacbrys Diofcoridi

cacbrys quid

Cactus carduigenus

Cadmia Diofcoridi

cadmiz confideratio

cadmie hiftoria ex Galeno

cadmia biftoria ex Plinio

cadinis facultates ex Galeno

Cacilia iftus note , o curatio Diof coridi

cecilia morfus figna, er remedia

Caruleus, uide Coruleus

Calamus odoratus Diofcoridi

calami odorati biftoria ex Theophrafto

calami odorati uires ex Galeno

calamus odoratus of ficinarim $\$$ purius

Caliminthe Diof coridi

calaminthe confideratio

calaminthe uires ex Galeno

Calcifraga Diofcoridi

Callorunt equi uires

Calthe confideratio, er uircs

Calx uiua Diofcoridi

calcis uiure confideratio

calcis uires ex Galeno

calcis noxa, or remedia Diofcoridi

calcis malefica wis, er curatio

Canabel Apbris quid

Cancanum Diofcoridi

cancami confideratio

Cancellorum confideratio

Cancri Diofcoridi

cancrorum confideratio

cancrorum uires ex Galeno

cancrifluuiatiles in Hetruria frequentißimi

Canis rubus Diofcoridi

canis rubi confider atio

canis rubi uires ex Galeno

Canis rabidi iecur Diofcoridi

canis rabiofi figna Diofcoridi

canis rabiofi uenefica natura, or figna

canes quibus caufis rabie exagitentur

canis mor Jus neglecti difcrimina

canis rabidi morfus indicia falutifera

canis rabiofi morfus curatio Diofcoridi
467.51

468. 18

220.12

220.39

727.37

$727 \cdot 45$

313.30

229.46

229.55

230.59

228.45

128.50

575.30

575.35

575.42

$4 \times 3 \cdot 4^{8}$

414.25

359.7

653.50

654.23

654.27

654.49

654.38

771.5

771.38

$42 \cdot 3$

42.14

42.59

42.50

3.82 .33

381.56

382.32

619.10

209.2

628.46

692.4

692.13

692.20

745.29

745.35

368.40

49.45

49.52

$\times 85.43$

184.3

I $84 \cdot 27$

184.53

185.24

116.46

126.53

127.25

207.21

754.5

754.23

754.41

755.13

755.40

756.5 canis rabiofí morfus curatio

756.27

canis rabiofi mor fus remedia fuppecta

757.10

canis rabiofi mor fus auxilium religio fum

757.26

caninum ftercus, 0 eius uires

Cannabis Diofcoridi defcripta

242.4

$474 \cdot 3$

cannabis confideratio

cannabis uires ex Galeno

474.16

474.35

34.44

220.3

Cantharides Diofcoridi

cantharidum confideratio

cantharidum uires ex Galeno

cantharidum noxa, or remedia Diofcoridi

cantharidum malefica uis

221.3

725.35

725.59

726.22

cantharidum ueneni curatio

82.50

Capbure hiftoria, or genera

83.26

caphure probatio or conferuatio

$83 \cdot 23$

caphure temperamentum, or uires

Capnos Diofcoridi

capni confideratio, uide Fumarie confider.

Capparis Diofcoridi

565.22

capparum confideratio

capparum Satio

capparis uires ex Galeno

Capre ungula Diofcoridi

caprinum iecur Diofcoridi

capriniftercoris uires

Caput lactis

Carciofi

Cardamomum Diofcoridi

cardamomi confideratio

cardamomi officinis generd plurd

cardamomi Mauritanis genera duo

cardamomigenera ex Plinio

cardanomi uires ex Galeno

Cardiace confideratio, $\mathbb{\sigma}$ uires

Carduus Diofcoridi

carduorum con/ideratio, or genera

cardui uires ex Galeno

327.57

328.13

328.27

328.33

carduus pinea

carduus benedictus, or eius uires

Carlina

Carnes quo modo diutins afferuentur

208.16

207.8

240.47

231.8

359.12

23.23

23.22

23.24

$23 \cdot 30$

24.12

$24 \cdot 17$

554.45

358.55

358.59

359.52

359.25

429.25

354.17

15.55

750.18

Carpafi fucci noxa, or remedia Diofcoridi

734.4

$734 \cdot 7$

32.18

$3 \pi .26$

44.32

44.50

625.38

397.28

397.23

ibidem

397.32

497.26

Caryopbyllate uires

Caryophyllorum confideratio,e hiftoria

caryopbyllifloris mentio

Caryota Diofcoridi

caryotarum uires ex Galeno

Cafcus Diof coridi

cafei confideratio, er uires
$325 \cdot 52$

316.22

142.22

143.28

229.35

$23 x .21$

Cajia 
Caßid Diofcoridi

caßjie odorate confideratio

caßiam odoratam non effe caßiam corondriam

caßiam in cinnamoomum mutari

caßia fiftula Grecis quid

caßise odorate defcriptio ex Plinio

cafise odorate hiftoria ex Theophrafto

casia lignea

caßix wires ex Galeno

Cafsie folutiue confideratio

cafie folutine vires

Cafjutbe fine cufcute biftoria, or uires

Caftanea Diofcoridi

caftanearum confideratio

caftanedrumuires

caftanearum uires ex Gal.

Caftorium Diofcoridi

cafforij confideratio

caftorij uires ex Galeno

caf́torei uires ex Plinio

caftorci uirulenta uis, o curatio

Catanance Diofcoridi

catanances confideratio

Cataputia

Catoblepas

Caucalis Diofcoridi

caucalidis confideratio

caucalidis utres ex Galeno

Cauda cerui uenenum, or eius curatio

caulium in plantis differentic:

caufa metallorum efficiens

Cauterijutilitas

Cedria Diofcoridi

cedrides Diofcoridi

cedribiftoria

cedri er cedris uires ex Galeno

cedromela Diofcoridi

cedrus Diofcoridi

Celticum nardum Diofcoridi

celticinardiconfideratio

celtici nardi uires ex Galeno

Cenchri itus note, o remedia Diofcoridi

cenchricon/ideratio

Centatrium magnum Diofcoridi

centaurij magni confideratio

centaurij magni uires ex Galeno

Centaurium mitus Diofcoridi

centaurij minoris confideratio

centaurij minoris uires ex Galeno

Cepa Diofcoridi

ceparum confideratio, o biftoria

ceparum uires ex Galeno

Ceped Diofcoridi

cepere confideratio

ceper uires ex Paulo

Cera Diofcoridi

cere uires ex Galeno

Cerafia Diofcoridi

feraforum confideratio

cerdforum fatiuorum generd

ceraforum acidorum genera plurs
32.60

33.45

33.57

34.54

34.57

35.8

35.28

35.23

37.30

37.50

38.2

617.52

137.33

737.39

137.54

238.2

197.46

x 98.21

298.52

299.29

742.45

$580.4^{2}$

580.49

609.22

$77^{6.3}$

298.16

298.22

298.30

742.32

22.33

632.33

757.57

$24 \cdot 4$

24. 29

24.55

96.47

2.50 .2

24.4

27.24

27.40

28.25

$774: 17$

774: 24

352.24

$35 x+38$

352.2

3.52 .20

352.52

352.58

307.58

308.18

308.54

476.15

476.21

476.32

246.10

.246 .28

146.59

147.2

247.20

247.29 ceraforum uires ex Galeno

147.49

Cerafte ittus note, o ceius curatio Diofcoridi tradita 774. 32

cerafte morfus exitialis auxilia

Cerettaberba

Ceruinum cornu Diofcoridi

774.39

ceruigenitale Diofcoridi

$484 \cdot 43$

217.27

208.6

ceruorum biftoria

cervis uita longa

inerba inuentores

$217 \cdot 5 \mathrm{x}$

228.20

218.57

218.59

cerui uenenum atrocißimum in cauda babent 219.3 cius remedia

Ceruifia

742.32

Ceruffa Diofcoridi

ceruffe confideratio

251.25

667.3

ceruffe uires ex Galeno

667.55

ceruffe noxa, or curatio Diofcoridi

739.48

ceruffe lethalis natura

ceruffac ueneniremedia

739.57

740.9

Ceftron Diofcoridi

Chalcanthigenerd, or hiftoria

481.24

Chalcitis Diofcoridi

chalcitis confideratio

679.52

681.4

682.52

682.25

$\begin{array}{ll}\text { Chame Diofcoridi } & 180.26\end{array}$

chamarum confideratio . $\quad \ldots \ldots \ldots .35$

Chamedrte Diofcoridi $6 \times 3.42$

Chameciffos Diof coridi $\quad 576.28$

chamecißi confideratio . ........ $\quad 576.24$

chamecißi uires ex Galeno $\quad 576.37$

Chamedaphne Diof coridi $\quad 589.60$

chamedaphnes confideratio ....... 590.35

chamedaphnes uires ex Galeno $\quad 590.40$

Chamedrys Diof coridi .... . $\quad 432.50$

chamedryos confideratio

432.2

chamedryos hiftoria, or vires ex Theophr. 432.12

chamedryos uires ex Galeno ㄴ $\quad 432.25$

Chamaleo albus Diofcoridi $\quad 353.50$

chameleo niger Diofcoridi

354.4

chameleonis utriusque confideratio $\ldots .354 .27$

chameleonis utriusque biftoria, or uires ex Theophra= fto

chamaleonis nigri nenenum, or remedia

chameleontis hiftoria

chameleontis uires

Chameleuce Diofcoridi

355.28

739.35

225.62

226.9

$376.4,2$

576.45

576.55

466.30

ibidem

466.38

479.50

480.34

480.40

610.17

620.26

620.29

$62 \pi \cdot 45$

612.38

chamelate 


\section{Index}

chamelex uires ex Galeno

chamclec noxa, or curatio

Characias tithymalus Dio/coridi

Chelidonis herba ab hirundine inuente

chclidonium rnaius Diofcoridi

chelidonij maioris ccnfideratio

chelidonij maioris uires

Chelidonium minus Diofcoridi

chelidonij minoris confideratio

chclidonij minoris uires

Cher $\int y$ drinutura, mor $\int u s, o r$ curatio

Cheruc oleum

Chia terra Diof coridi

Chine radicis confideratio, or uires

Chondrilld Diofcoridi

chondrille utrius q; confideratio

chondrille wires ex Galeno

Chry anthemon Diofcoridi

chryfantbemi confideratio

cbrifanthemi lectio reftituta

Chryfobalanus

Chryfocolla Diofcoridi

chrifocoll s factitia

cbryfocolle confideratio, er hiftoria

chryfocolle uires ex Galeno

Chryfocome Diofcoridi

chryfocomes confideratio

chryfocomes uires ex Galeno

Chryfogonon Diofcoridi

chryfogoni confideratio

Clymiftarum de chelidonio uanitas

Cicade Diofcoridi

cicaddrum confideratio

cicadarum uires ex Galeno

Cicer. Satiuum Diofcoridi

ciceris confider atio, or uires ex Galeno

ciceris uires ex Aétio

cicer arietinum Diofcoridi

cicer Sylueftre Diof coridi

Cichorion Diofc.

cichorij uires ex Galeno

Cici Diofcoridi

Ciciniolei confideratio

cicini olei uires ex Mefue

Ciconie ftercus.

Cicuta Dio coridi

cicut ce confideratio

cicute uires ex Galeno

cicute pote noxa, or curatio Diofcor.

cicute uenefica uis

cicute fumpte remedia

Cimices Diofcoridi

cimicum confideratio

cimices fylucftres

Cimolia terra Diofcoridi

Cinis farmentitius Diofcoridi

cineris omnis uires ex Galeno

Cinnabaris Diofcoridi

cinnabaris confideratio

Cinnamomum Diofcoridi

cinnamomi confideratio
612.59

748.57

606.7

215.18

336.42

336.60

337.17

337.33

337.46

338.20

774.3

55.27

707.57

125.4

291.4

291.15

291.20

522.33

521.42

522.5

602.25

663.18

$242 \cdot 9$

668.28

668.48

519.60

520.4

520.8

520.25

520.20

337.3

212.3

212.22

$212.4 \mathrm{z}$

259.59

260.10

260.30

$260.5 \mathrm{z}$

261.7

287.20

290.8

$\therefore \quad 603.52$

55.27

55.32

242.25

542.23

542.32

542.43

732.19

732.28

732.47

205.12

205.28

205.35

708.9

692.54

693.1

671.46

671.57

33.28

$35 \cdot 30$ cimamomi biftoria ex Galeno

cimnamomi penuria unde

cinnamomi optimi note

35.37

36.9

35.56

cinnamomi uulgaris aqua ftillatitia

37.35

36.49

37.27

cinnamomi uires ex Galeno

Cionia Diofcoridi

Circea Diofcoridi

circee confideratio

circae uires ex Galeno

177.53

451.22

452.28

451.26

Circunforaneus floris uenenatiolfaftu interemptus

714.20

Circunfor aneorum uenena innoxié fumere profitenti= um fraudes $72 x \cdot 49.0$ deinde

Circunforaneorum diui $\mathrm{P}$ auliftirpem inêtientium fraus $762.53 .0 r$ deinde

Cirfium Diofcoridi

cirsij confideratio

572.20

Ciftus Diofcoridi

572.30

cifticonfideratio

20.48

cifti uires ex Galeno

Cirriamala Diofcoridi

citriorun mira facultas

19.60

20.57

citriorum uires

citrif mali uires ex Galeno

Clematis Diof coridi

clematis altera Diof coridi

clematidum confideratio

clematidum uires ex Galeno

250.2

Clinopodium Diofcoridi -

53.29

153.30

153.43

486.53

$487 \cdot 35$

487.39

488.9

430.37

430.43

430.46

493.25

$493.2 x$

clinopodij uires ex Galeno

Clymenon Diofcoridi

Cneori confideratio, or defcriptio ex Theophrafto

34. 27

Cnicus Diofcoridi

cniciconfideratio

cnici uires ex Gdleno

cnicifylueftris historia ex Theophrafto

Codgulum Diofcoridi

coaguli confideratio

coaguli facultates ex Galeno

Coccum Gnidium Diofcoridi

coccum infectorium Diofcoridi

cocci infectorï con/ideratio

cocci infettorij uires ex Galeno

625.12

625.36

625.48

428.30

233.36

233.50

233.56

612.53 .05622 .4

525.28

525.38

526.5

Cocblex Diofcoridi

cochlearum confideratio

cocblearum uires ex Galeno

cocblex pomatie que

cocblex marine

cochlex fine tefta

cocblearum lapis, or cius uires

282.52

283.6

183.23

18317

. 83.48

283.49

183.52

670.19

670.23

$67 x .2$

547.3

547.19

548.28

261.59 colocafine 
colocafia confideratio

Colocyntis Diof coridi

rolocyntbidis confideratio

colocyntbidis lefiones

colocynthidis nox.t, or curatio

colocynthidis uires ex Mefuc

colocynthidis uires ex Galeno

Colophonia refin. confideratio

Columelle lapfius

Colute colytes confideratio

Colymbades oliute Diofcoridi

Communis curatio in omnes iftus uirulentos Diof coridi 759.52

Confiligo berba

Confolida regalis

Conyza Diofcoridi

conyze con/ideratio

conyze uires ex Galeno

Corallium Diofcoridi

corallij confideratio

coralli facultates

Corallina, er eius uires

$39.17 .0517 .55 .0 \mathrm{O}$

Cordi errate

coriandrum Diofcoridi

Coriandrifeminis ufus

coriandri uires ex Auicenna

coriandri cpoti noxa, or curatio Diofcoridi

coriandri uenefica natura

coriandri ueneniremedia

Coria uetcramentaria Diofcoridi

coriorum ueteramentariorum uires

Coris Diofcoride

coris confideratio 51.0545 .56 .00694 .37

Cornu cerui Diofcoridi

cornucerui uires

Cornus Diofcoridi

corni confideratio

cornorum ufus in cibis

cornorum uires ex Galeno

Coronopus Diofcoridi

coronopi confideratio

coronopifyluestris uires

coronopiborten/is uires ex Galeno

Corpord itt fulmine non putre cunt

Corrago Apulcio quid

Corruda Diofccridi

Cortices quando ficcandi, ev reponendi

Corydalis herba

Cos Naxia Diofcoridi

Coftus Diofcoridi

cofticonfideratio

coftum que fuppleant

cofti uires ex Galeno

Cot Aphris quid

Cotonea mala Diofcoridi

cotoneorum malorum confideratio

cotoneorum malorum gettera
262.24

$6 \times 5.10$

625.29

615.32

748.55

615.39

615.48

85.8

$17 x .52$

410.54

232.62

33.50

399.5

452.33

452.53

$453 \cdot 7$

695.35

695.47

6.96 .22

557.32

520.26

400.17

400.30

$40 x .5$

402.25

731.46

$73 x .53$

732.60

209.10

209.23

478.47

478.58

36.44.

$217 \cdot 27$

219.8

157.48

257.53

158.22

$\therefore \quad 158.17$

285.12

$=8.5 .17$

236.19

286.25

$25 \cdot 56$

578.7

279.62

$7 \cdot 47$

566.14

706.49

39.57

40.8

40.30

40.44

305.33

149.2

752.3

251.4
Cotyledon Diofcoridi

cotyledonis utriusq; confideratio

$552.43+0.552 .52$

Crateogonum Diofcoridi

cratagoniconfideratio

Crepiniforma, er sires

552.57

$455 \cdot 33$

455.38

125.23

Crimnon Diofcoridi

crimni conjideratio

Critbmum, feu crithamon Diofcoridi

crithmi confideratio

critbmi uires ex Galcno

Crocodili aninalis biftoria

crocodili animalis genera, o uires

Crocodilion Diofcoridi

crocodilijconfideratio

crocodilij uires ex Galeno

Crocomagma Diofcoridi

252.22

252.22

284.43

284.52

285.5

225.39

225.49

355.39

355.44

355.56

51.58

51.25

52.3

52.7

52.20

625.36

603.51

$347 \cdot 1$

347.8

704.23

cryltallibiltoria

cryftalli uires

Cubebarum confideratio

704.42

32.60

32.2

cubebarum uires

Cucumis Jatiuus Dio fcoridi

cucumeris confideratio

cucumeris uires ex Galeno

Cucumis fylueftris Diofcoridi

cucumeris fylueftris confideratio

cucumeris fylueftris uires ex Galeno

Cucurbita Diof coridi

cucurbite con/ideratio

cucurbitarum uaria genera

cucurbite facultates ex Galeno

cucurbita Jylueftris

Culta que plante ament

Cuminum fatiuum Diofcoridi

cumini fatiui confideratio

cuminum fylueftre Diofcoridi

cuminum fylueftre alterum Diof coridi

cumini glueftris examinatio

cumini uires ex Galeno

Cunila Diofcoridi

Cupreßus Diofcoridi

cupreßibiftoria, $\widetilde{O}$ confideratio

cupreffus liquidam refinam fundit

222.54

293.36

294.34

595.18

596.8

596.43

291.30

291.42

291.3

292.8

620.42

9.47

398.42

399.2

398.52

398.57

399.2

399.24

373.15

20.26

20.38

90.59

$9 x \cdot 2$

$3 x .8$

cupreßi uires ex Galeno

633.7

cur pauci, cur multi lapides fiant

Curdtio uirulentorum ictum fecundum quendam eres
mitam $7 \sigma_{3.38} 8$

Curmi Diofcoridi

251.20

curmitis con/ideratio

251.24

29.2

320.12

320.47

320.54

cyclamini 


\section{Index}

cyclamini uires ex. Me fue

cyclamini wires ex Galeno

cyclamini noxs, or curatio

Cynocrambe Diofcoridi

cynocrambes confideratio

Cynogloffon Diofcoridi

cynogloßi confideratio

Cynoforchis Diofcoridi

Cyparifias tithymalus Diofcoridi

Cyperus Diofcoridi

cypericonfideratio, e genera

cypirus arbor

cyperi uires ex Galcno

Cyphi compofitio Diofcoridi

cyphi caput in Diofcoride adf cititium

Gytinus Diofcoridi

cytini confideratio

Cytifus Diofcoridi

cytifi confideratio

cytifus frutex cft, non berbd

cytifi biftoria ex Columella

cytifi bifturis ex Plinio

cytifh hires ex Galeno

\section{D}

DA MAS CEN A pruna DiofC.

Damafonium Diofcoridi

Daphnoides Diofcoridi

daphnoidis confideratio

daphnoidis uires ex Galeno

Daucum Diofcoridi

dauci confideratio

daucum à fylueftripaftinaca differre

dauci uires ex Galeno

Delpbinium Diofcoridi

delphinif confideratio

Dendroides tithymalus Diofcoridi

Deuteria Diofcoridi

Diapenfia

Dictamnum Diofcoridi

ditamnum Cretense

diftamni confideratio

dittamnum caulem, florem, or fructum ferre

diftamni uires ex Galeno

dittamni albi con/ideratio

29.44 .0377 .40

dictamni albi uires

Difficilé unum uniueneno proprium inuenire fignum

Diofcoridi

722.4

Diofcorides in fimpliciü medicamentorum materia pri mas tenet

5.33

5.24

8.14

Diofcorides à calumnia defenditur

Diof coridi uaria fimplicium nomina adulterind 8.34

Diofcoridislectio in ag allocho reftituta

48.28

Diofcoridis lectio in lentifcino oleo deprauata 58.27

Diofcoridis lectio in thure tribus in locis caftigata 75.4 or deinde

Diofcoridis lectio in pice reftituta

$87 \cdot 23$

Diofcoridis lectio quibufdam codicibus in me pilo depra uata

Diofcoridislocus in tblapfireftitutus

156.3

313.23
Diofcorid is lectio in moly reftituta

Diofcoridis lectio in oreofelino reftituta

Diofcoridis locus in afclepiade reftitutus

Diofcoridis codex in leucade diminutus

Diofcorid is locus in leucoio fuppectus.

Diofcoridis locus in aconito fupectus 659.51

Diofcoridis locus in alcyonio fuppectus

391.30

$404 \cdot 3=$

428.5

432.45

455.6

538.32

Diofcoridis locus in Braßica Juffectus

693.52

Diofcoridis lectio caftigata in lacte intus coagulato 743.33

Diphryges Diofcoridi

diphrygis confideratio

dipbrygis biftoria, er uires ex Galeno

682.52

$683 \cdot 5$

Dipfacun Diof coridi

683.10

356.2

dipfaciconfideratio

dipfaci uermiculus.

dipfaci uires cx Galeno

356.18 .

356.28 .

356.54

Dipfadis morfus notx, or rëmedia Diofc. $\quad 772.24$

dipfadis hiftoria, morfus figna, or curatio $\mathbf{7 7 3 . 1 2}$

Domeftica nobis noxia Diofcoridi

750.7

domefticarum rerum noxd.

domefticarnm rerum noxe remedia

750.14

750.25

Dorellaquid

Doroniciconfideratio

Dorycnion Diofcoridi

dorycnij confideratio

571.47

303.19

$534 \cdot 29$

534.38

dorycnij uires ex Galeno

534.42

730.4

$730: 12$

323.52

$3 \times 3.59$

188.48

189.27

dorycnij ueneni confideratio

Draba Diofcoridi

Draco marinus Diofcoridi

draconis marini ictus note, er remedia Diof coridi

draconis marini confideratio

767.22

Dracunculus maior Diofcoridi

dracunculus minor Diofcoridi

dracunculorum confideratio

321.49

dracunculifpecies plures

322.7

322.36

322.54

322.56

dracunculiuires ex Galeno

$323 \cdot 4$

732.27

dracunculi feminis nox , or duxilia

Dryini ictus note, er remedia Diofc.

dryini biftoria, or cius ictus figna

771.59

771.55

dryini morjus curatio

Dryopteris Diofcoridi

dryopteridis confideratio

dryopteridis uires ex Galeno

772.23

624.57

$625+2$

625.9

Dulcis radix Diofcoridi.

dulcis radicis confideratio

350.128

dulcis radicis uires ex Gal.

3.50 .34

3.50 .60

E

E B EN V S Diofcoridi

Ebeniconfideratio

ebenigenera duo

ebeni uires ex Galeno

Ebulum Diofcoridi

ebuli, \& fambucigenerd, or uires
1.22.1*

122.28

122.29

222.49

$6 \times 3 \cdot 42$

$6 \times 3 \cdot 5.5$ cbuli 


\section{Index}

cbuli uires ex Galeno

Ebur Diofcoridi

eboris confideratio

eboris wires

Echinus marinus Diofcoridi

echini marini con/ideratio, e biftoria

echinometra

echinorum uires ex Galeno

Ecbinus terreftris Diofcoridi

echini terreftris confideratio

echini terrcstris facultus

Echion Diofcoridi

echij confideratio

echii uires cx Paulo

Elaphobofcon Diofcoridi

elapbobofciconfideratio

elaplobofci uires ex Galeno

Elaterion Diofcoridi

elaterij uires ex Mcfue

claterij noxa, o renzedia Diofcoridi

elaterij noxa o curatio

Elatine Diofcoridi

elatines confideratio

Elcctarij in cur a cantharidum descriptio

Electrum Diofcoridi

Elecmeli Diofcoridi

eleomelitis confideratio

Elelipbacos Diofcoridi

Eleofelinum Diofcoridi

eleofelini conjideratio

Elephantorum hiftoria

Elichryfon Diofcoridi

elichry/i confideratio

elichryfi uires ex Galeno

Elleborine Diofcoridi

elleborines confideratio

Elleborum album Diofcoridi

elleborum nigrum Diofcoridi

ellebori utriusque confideratio

ellebori utriufque uires ex Mefue

ellebori utriufque uires ex Galena

ellebori albinoxa, or remedia Diofcoridi

ellebori albi noxa, er curatio

ellebori nigri noxa, or cura

Empetron Diofcoridi

empetri con/ideratio

empetri uires ex Galena

Encelij opinio uand

Ephemeron Diofcoridi

ephemeri, or colchici confideratio

ephemeri, 0 colchici uires ex Galeno

ephemeri colchici noxa, er remedium Diofcoridi

722.15

epbemeri colchici uenenum, et curatio

Epimedion Diofcoridi

epimedij confideratio

epimedij uires ex Galeno

Epipactis Diofcoridi

epipattidis confideratio

Epithymum Diofcoridi

epithymi con/iderdtio
614.22

215.32

$225 \cdot 52$

226.51

$74 \cdot 26$

$\times 74.44$

174.52

275.12

275.40

275.43

275.52

502.3

502.16

502.45

407.18

407.30

407.50

595.35

596.26

747.57

748.32

508.53

508.58

$727 \cdot 18$

100.42

54.60

55.6

378.35

403.45

404.26

225.52

520.27

520.42

520.59

565.33

565.6

590.58

591.52

502.14

594.10

594.28

747.57

$748.3=$

748.45

619.10

619.14

$6 \times 20.20$

242.24

$547 \cdot 14$

547.19

548.28

729.27

498.10

498.16

498.30

565.3

365.56

615.57

616.1 epitbymi diputatio

616.22

cpitbymum ubi plurimum

617.10

cpithymi uires cx Mcfue, Gr Galeno $\quad 617.44$

Equifetun maius Diofcoridi

equifetum minus Diofcoridi

524.52

equifeti utriufque confideratio

524.57

$5 \times 5.2$

equifetiutrinfque uires ex Galeno 525.15

Equorum lichenes Diofcoridi $\quad 208.43$

Eretria terra Diofcoridi

Erica Diofcoridi

erica confideratio

erice facultas ex Galeno

Erigeron Diofcoridi

707.12

109.4

109. 7

209.30

556.47

557.2

557.6

503.20

503.28

erini confideratio

erimi uires ex Galeno

Eruca Diofcoridi

$\therefore \quad 503.47$

298.47

229.22

219.23

219.39

ibidem

220.12

$220.4^{\circ}$

eruedrum pinorum confideratio

erucarum pinorum dolores, $\mathbb{E}$ remedia Diofcoridi

727.29

erucdrum pinorum uenenum, $\mathbb{O}^{\circ}$ curatio $\quad 727 \cdot 45$

Eruum Diofcoridi

erui confideratio

erui uires ex Galeno

264.44

265.5

265.22

364.39

$364 \cdot 57$

$364 \cdot 54$

364.58

365.8

324.20

324.24

471.35

$471 \cdot 47$

471.53

509.27

Eupatorium Diofcoridi

eupatorij confideratio

eupatorij uires ex Galeno

cupdtorium Auicenne quid

eupatorium $\mathrm{Me}$ fui quid

Euphorbium Diofcoridi

euphorbij con/ideratio

cuphorbium quis primum inuenerit

euphorbij uires ex Aëtio, et Actario

cuphorbij uires ex Mefue

euphorbij uires ex Galeno

cuphorbij potio noxid, et eius curatio

Euphragie defcriptio, et uires

509.30

520.32

509.48

520.2

422.45

421.60

422.8

422.20

422.26

422.32

748.53

512.32

F

FAB A Diofcoridi

Fabarum confid. et uires ex Gal.

260.46

262.8

262.49

262.5

Fex 
Fex Diofcoridi

fecis, of tartariditaticonfid. or uires

Fagus Diofcoridi

fagiconfteratio

Farris confideratio

furris, or halice differentia

Fel Dicfcoridi

fillis uires cx Galeno

frllis b:buli lapis, e eius uires

folls prortiucnenum, ciusq; remedix

fellis mincre wenefica uis, $O$ auxilia

fellis ch nis pifcis uenenum, or curd

Fclis, cins'; cercbri maleficium, or renedia

Ferri rr:bigo Diofcoridi

ferri rubiginis confideratio

Ferriftercus Diofcoridi

ferriftercoris confideratio

frrrifcobis noxd, er curatio

frrrifquame noxd, er cura

frrirecrementi noxa, er curd

Ferule Diofcoridi

fruls, in brutorum cibis uarius effectus

frrul $x$ confidcratio

ferule or ferulaginis hiftoria ex Tbcophra.

frule ules ex Galeno

ferule ubinaxime

frula tatd murend confeftim moritur

Fiber Diofcoridi

fibrini teftes Diofcoridi

fibriconfideratio

fibros fibi teftes amputare, udnum

fibri teftium adulteratio

fibritefrium uires ex Galeno

Ficus Cyprid

Fici Diofcoridi

ficorum confideratio

ficorum facultates ex Galeno

ficus agreftis

ficiprecoces

ficus cinis Diofcoridi

Fidicula Theodoro

Filicula Diofcoridi

filicula confideratio

Filipendula, or eirs uires

Filix ma Diofcoridi

filix forminu Diof coridi

filic is utriufque biftoria

filicis utriufque uires ex Galeno

Finum Diofcoridi

fimi uires, uide stercoris uires

Flarmula hiftoria, o uires

flammule noxa, or curatio

flammula noxa, or curatio 732.4

flores ficci quandiu durent

florum in plantis uarietas

Flos aris Diofcoridi

floris eris hiftoria

floris aris uires ex Galeno

Flos falis Diofcoridi

Flos punice Diofcoridi

flos Jylueftris punice Diofcoridi
691.40

691.54

134.54

136.16

254.55

ibidem

238.12

238.35

238.45

$741 \cdot 49$

742.57

742.5

742.8

661.23

661.34

661.31

661.34

744. I 5

ibidem

ibidem

415.25

15.40

415.27

415.33

425.55

425.53

425.53

197.46

197.47

193.22

298.32

298.35

108.52

169.2

$\therefore \quad 169.20$

170.13

270.19

17x. 2

271.4

170.

582.55

623.53

$\therefore \quad 623.60$

451.54

$623 \cdot 4$

623.15

623.23

623.40

239.35

$4.87 \cdot 55$

7.16
7.24

23.33

657.54

658.5

658.13

688.48

43.58

2446
Fluminibus que plante adnafcigaudeant

9. 18

Faniculum Diofcoridi

feniculum erraticum Diofcoridi

foniculi utriufque confideratio

$f$ eniculi uires ex Gal.

Fonum grecum Diofcoridi

fanigraci confid. Or uires ex Gdeno

Foliorum in plantis uarietas

407.57

408.13

408.25

408.38

258.52

259.4

4.32 foliorum in plantis comparatio, or fimilitudo inter $\int e$

11.13

foliorum in coloribus difcrimen

Fomes ignis ex tußildgine

22.5

Fontium in riguis qua plante proueniant

Fo Silium facultates

Fragarix, or fiagorum confid. er uires

Fraxinus Diofcoridi

fraxinipecies

fraxini confideratio, or hiftoria

fraxini uires ex Plinio

$444 \cdot 46$

2. 38

636.10

512.19

99.3

99.38

29.10

$99.4^{\circ}$

Fruttus quando decerpendi, 0 quomodo conferuandi $7 \cdot 36$

Frutices

8. 47

Fuchsij errores, eiusq́; fententix reprobate 20.34 . $\mathcal{O} 23.55 . \mathcal{O} 28.29 . \mathcal{O}_{3} 2.42 . \mathrm{O}_{3} 37.7 . \mathrm{O}^{\circ}$ 39.22 . O $42.52 .042 .55 .0 \% 44.54 .0 \% 48$. s.et 49.3 .et 50.41. et 69.14 .et 73.25 .et 74 . 36. et 83.3. et 88.33. et 96.18 . et 120.43 . et 127.24. et 140.19 . et 160.12 . et $166.19 . \mathrm{et}$ 181.49 . et $225 \cdot 21$. et $244 \cdot 6$. et $245 \cdot 34$. et $257 \cdot 47$. et $265 \cdot 9$. et $267 \cdot 3$. et 268.33 . et 294.32 .et 327.56 .et 320.4 . et 332.53 . et 338.16 .et 342 - 5.et 349.43. et 357.3 5.et 368 . 44 . et 390.27 . et 404.60 . et $415.4 . e t 428 . x$.

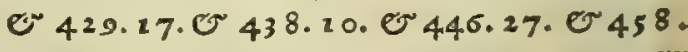
29.00459 .53 . O 461.46 . లr 465.37 . O $487 \cdot 52$.et 488.52 .et 506.8 et $5 \times 0.24$. et 515.22 . et 522.14 . et 533.13 .et 539.28 . et 539.33 .et $547.6 \mathrm{z} \cdot$ et $548 \cdot 10$. et $553.4 \mathrm{et}$ 555.42 . et 562.23. et 564.22. et 564.51 . et 579.2 . et $5 \$ 2.33$. et $60 \$ .43$.et 622.42 .et 684.58 . et 689.54. et $697 \cdot 29$. et $699 \cdot 34$. et 702,35

Fucus marinus Diofcoridi

558.3

fucimarini confideratio

558.10

fucimarini uires ex Galeno

558.28

Fuligo é myrrba, refina, ftyrace Diofcoridi 72.3

fuligo liquide picis Diofcoridi

86.24

fuligo pictoria Diofcoridi

709.12

fuligo thuris Diof coridi

71.55

87.8

fuliginum omnium uires

565.22

fumerie confderatio

fumaric alterum genus

fumarie gener a ex Plinio

566.2

549.52

566.4

fumaria uires ex $\mathrm{Me}$ fue

566.20

566.35

544.56

$545 .: 23$

$545 \cdot 4^{x}$

$545 \cdot 53$

546.21

fungorwio 


\section{Index}

fungorum uires cx Galeno

fungorum/trangulatus, or remedia Diofc.

fungorun uencica natura

fungorsm propuratio

fungorum wenentremedix

\section{G}

GAGates lapis Diofcoridi

G.rgura lupidis confidenatio

g.x.xte liputis hiftorit, o uires ex Galeno

Gilluttites lapis Diofcoridi

Galinitia lipidis hyltoris

Gilluge confidcratio, or generd

g.tlunger wires

Gallaxzes lupis Diofcoridi

Galbanmm Diofcoridi

g.libunconfid. 422.58 cius uires ex Gal.

Grlcgrn quid, o cius sures

Githm numigariones

Galenilectio in thure reftituta

Galen in prunis de fenfio contra Brafanolum 159.26

Galcule piftaciorum uiribus opinio ab Aucennare= probat.t

$254 . x$

Galeni, o Diofcoridis in Seripho, or Santonico abfin= thio fententis ustitis

369.18

Galenus in coriandro dे Diofcoride diffentit 400.31

Galem locus jupectus de apleno

Galcins notatur margento wimo

$464 \cdot 2$

$674 \cdot 42$

Galeni jententia de trifolio af haltite damnata 441.16

Galeniliber de theriaca ad Pijonem Jupectus. 44'.46

Galerita Diofcoridi

galerite confideratio

214.16

214.35

556.22

Galion Diofcoridi

galij corfid. : 555.31 . eius wires ex Gal.

Gallopfis Diofcoridi

galiop feos confideratio.

556.37

555.13

555.22

Galla Diof coridi

138.14

gallarum confid. 138.33 . O uires ex Gal. 334.12

galla omphacitis

138.39

Gallarum pre Jagium

Galli, $\sim$ gallinx Diofcoridi

139.5

209.33

gallorum, e gallinarum consid. ON uires 210.26

Gallitricum quid

Gammarorum lapilli

Garum Diofcoridi

gariconfideratio

378.46

785.52

$204 \cdot 53$

255.2

382.3

599.45

599.50

208.6

208.8

Genitale cervi Diofcoridi

genitalis cerui confideratio

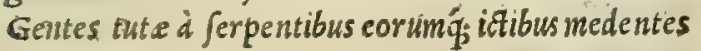

$$
762.36
$$

Gentiand Diofcoridi

346.37

gentiane confi. 346.52.eius uires ex Gal. 346.56

Gentianaminor

$347 \cdot 3$

Geodes lapis Diofcoridi

geodx lapidis confideratio

706.55

706.58

$228 . x$

$44^{3} \cdot 4^{2}$

$44^{8.46}$

Geranium Diofcoridi

geranij confideiatio

Gefnerilaphs
Gingiber Diofcoridi

gingiberis conlideratio, e biftoria

316.59

$3 \times 7.7$

gingiberis uires ex Galeno

Gingidion Diofcoridi

317.24

296.52

gingidij confid. $296.57 .0 \mathrm{~N}$ uires ex Galeno 297. 3

Gith Diofcoridi

gith confideratio

$417 \cdot 42$

$4.7 \cdot 54$

Gladiolus Diofcoridi

gladioliconfid. 498. is 5.eius uires ex Gal. 499.12

Glandes Diofcoridi

234.54

glandiferarum arborun confideratio

235.38

glandiferarum arborum uires ex Galeno $\quad 137.12$

Glans unguentaria Diofcoridi 600 , i g.eius confid.

$$
600.29
$$

glandis unguentaric uires ex Mefue

601.4

glandis unguentaria uires ex Galeno . $\quad 602.19$

Glaftun fatiuum Diofcoridi

339.13

glaftum fylueftre Diofcoridi

3.39 .20

glafti utriusq; cö/id. 339.27 .0 uires ex Gal.340.4

Glaucium Diofcoridi

424.25

glaucij confid. 4.2 .20 . eius uires ex Gal. $\quad 424.31$

Glaux Diofcoridi

glaucis con/id. 585.10 con 585.14

Gleucinum Diofcoridi

gleuciniconfideratio

585.40

63.25

63.32

227.48

424.46

$424 \cdot 39$

Gluten pifcium Diofcoridi

424.50

glutinis confideratio, or uires

448.54

Gnaphalion Diofcoridi

gnaphalij confid. 448.57. O. uires ex Gal. 450.37

Gnidium granum Di. f coridi

611.53

Gnidium oleum

Gobius Diof coridi

$56.60^{\circ}$

gobiorum confideratio

202.59

gobij facultas ex Galeno

203.29

Gobijftuniatiles

203.32

$2,03.36$

Goßipij con/ideratio

450.19

Gramen Dıofcoridi

503.56

$504 \cdot 2$

$504 \cdot 3$

graminis confid. O biftoria ex Plinio @ $\$ 04.17$

graminis uires ex Galeno

504.46

Grandinis impetum que arceant

Gratiole biftior.e uires

$x \cdot 5 \cdot 5 x$

Großi Diofcoridi

372.14

169.55

122.53

122.58

guaiacigenera tria

guaiacicortices

2.23 .42

guaiaci planta 123.50 . eius facultates 123.53

Guaiacium lignum preftantius

Gummi amygdale Diofcoridi

123.12

Gummi cerafi Diofcoridi

162.42

Gummi elemi facult. o confideratio

Gypsum Diofcoridi

146.59

134.35

692.32

3yp/i confid.69 2.34. U uires ex $\mathrm{G} d$ l.

gypfiftrangulatus remedia Diofcoridi

gyp/i ueneficium, eius'́; curatio

692.40

$740.50^{\circ}$

742.2

HAe m a t I t e s lapis Di- coride

hematite lapidis confideratio

$69 \div 4$

6.38. 0

B bumatiles 
bemulite lapidis uiresex Guleno

T.sinntiex lavidis ures ex Alex andro

Husmorrboi if́us note, ct curatio Diofc.

benur hoi pernic:sus ifus, o hrforia

b.emorrboi mor us note, er remedia

Halica Diofcoridi

balice con/id. 254.24 . et uires ex Gud.

ballee, of farris differentia

H.alicacabun jolanum Diofcoridi

Halinzus Diofcoridi

balliniconfideratio

b.llunus Niauritanis molochid.

balini utres ex Galeno

Handachocha A rabicis quid.

Harundo Diofcoridi

barundinum con/iderstio

barundumum genera plur.t

bartudinis, e filicis odium

Garundines uires ex Galeno

Haftula regia Diofcoridi

baftule regic confideratio, uide in Appodelo

Hedera Diofcoridi

bedere confideratio, er genera

bedere faciltas

Hedyclroon Diofcoridi

bedycbroi compofitio ex Galeno

Hedyfaron, uide Securidaca

Helcyfma Diofcoridi

Helenium Diofcoridi

beleniy con/ideratio

belenium alterun Diofcoridi

belenii Acgyptij confideratio

belcnii uires ex Galeno

Helichryfon, uide Suprà in Elichryfo

Heliofcopius titlyymalus Diofcoridi

Heliotropium magnum Diofcoridi

beliotropium parum Diofcoridi

beliotropij utriusq; con $\sqrt{1} d .628 .23 .0 \mathrm{v}$ uires $\sigma 28.25$

Helleborine uide Elleborine

Helleborum, uide Elleborum

Helxine ciffampelos Diofcoridi

belxines confideratio

belxines uires ex Galeno

Helxines altera Diofcoridi

belxines confid. 549.z. Wires ex Galeno

Hemerocallis Diofcoridi

hemerocallis confideratio

bemcrocallis uires ex Galeno

Hemionitis Diofcoridi

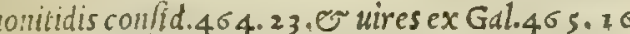

Herba mirabilis ad excitandam uenerem $\quad 458.48$

Herbarum forme defcripte parum conferunt ad co= gnofcenda fimplicia

berbie qu o pacto legendes, ficcandég; ;int

3.59

6.50

berbas colligere certis temporibus non eft abre 6.35

berbieque

8.52

I 0.6

berbe que in alias profiliunt plant as

$539.2 \mathrm{z}$

Herba $\mathrm{P}$ aris, or cius biftorla, er uircs

547.49

Hermodactyli conictura

Hermolai lapfus, er opiniones improbata $\mathrm{ON}^{2} 5.57$.
$12.0302 .16 .0 \% 314.47 .0 .329 .52 .0$

$428.26 .0 \% 449.23$.

Hermolaus à calumnia uindicatur $\quad \$ 36.49$

Hieracium magnum Diofcoridi $\quad \therefore \quad 401.57$

bieraciumparum Diofcoridi $\quad 401.6 \mathrm{x}$

bicracij utriusq; confid. e uires ex Plinio 402.35

Hieropili lapfus

Hiericuntam non effe Amomum

522.32

biericunte uires

32.13

33.19

76.6

Hippocampus Diofcoridi

176.45

hippocampi confideratio

177.25

177.29

bippocampi uires ex Aeliano

579.41

Hippogloffon Diofcoridi

hippogloßi confid. $\$ 79.49$. eius uires

579.55

271.9

Hippolapathon Diof coridi

bippolapatbiconfideratio

272.23

bippolapatbi facultates

272.29

Hippomaratbron Diof coridi

408.14

bippomaratbridefcriptio, er uires $\quad 408.34$

Hippophaes Diof coridi

603.22

hippophais con/ideratio

603.39

Hippophaston Dio coridi

603.33

bippophefti convideratio

Hippopotami teftes Diof coridi

603.39

$\times 97.26$

bippopotamibiftoria 197.28 . ciusuires 197.38

Hippofelinon Diofcoridi

bippofelini confideratio

bippofelint uires ex Galeno

403.59

$404 \cdot 47$

405.7

Hircibarbula Diofcoridi

bircibarbule confideratio

302.3

302.7

27.23

Hirculus Diofcoridi

$\begin{array}{ll}\text { Hirudinum deuoratarum remedia Diof co. } & \mathbf{7 4 7 . 2 8} \\ \text { birudinum deuoratarum noxa } & \mathbf{7 4 7 . 3 4}\end{array}$

birudinum deuoratarum curatio $\quad \quad \mathbf{7 4 7 . 4 0}$

Hirundines Diof coridi

$2 \times 5.4$

birundinum bift. 215.13 .edrü uires êx Gal. 215.11 Hiftoria ruftici à ferpẽte bafta trăsfixo infectiv 13.53 biftoria rustici fuctu mor Jus ferce perempti $\quad 724.24$ biftoria fraudis circunforanei ue nenum innoxie sume= reprofitentis

hiftoria cafus ex cicuta fumpta.

721.36

Holoftium Diofcoridi

732.32

2. eius uires ex Gal. 492.29

Hordeum Diofcoridi

249.55

hordei confideratio

250.15

hordeifacultas

Horminum Diofcoridi

250.34

hormini confideratio

452.14

borminum cereale

459.53

Humaniftercoris uires

460.7

Hyacinthus Diof coridi

240.15

$524 \cdot 4^{2}$

byacinthi confid. 524.520 eius uires ex Gal. 525.2

Hydri hiftoria, mor fus, er curatio

773.53

Hydromeli Diofcoridi

$643.3 x$

hydromelon Diofcoridi

648.59

Hydropiper Diojcoridi

318.14 .

bidropiperis confideratio

bydropiperis uires ex Galeno

328.25

319.6

56.38

byofcyamini olci uires 
byofcyamini parandi rat io

Hyofcy:mus Dio/coridi

byofcyamiconfid. 529.55 . cius uires ex Gal. 530.7

byof cy ami noxa, or auxiliat

734.50

hyofcyminoxis uis

byofcyami utriusq; noxe curatio

734.58

$735.2 \mathrm{t}$

528.54

528.57

529.2

hypecoi confideratio

bypecoi uires ex Galeno

Hypericon Diof coridi

$477 \cdot 38$

byperici confid. 478.58 . eius uires ex Gal.479.25

Hypocistis Diof coridi

hypociftidis confideratio

bypocifidis uires ex Galeno

Hy) Jopum Diofcoridi

by fopi uires ex Mefue

$\mathrm{H} y$ ftricis mentio

120.32

219.60

120.57

370.50

371.59

371.69

75.57

\section{I}

I A C E A berbd

Iacobi syluij in ac acia opinio improbata

I d minum Diofcoridi

iafmini unguenti confideratio

Iapis Diofcoridi

ispidum generd plurd, er uires

Iapidum natura

I appidis uires ex Gal.

Iberis Diofc. 172.4. eius confid.

iberis, e lepidiun idem

iberis à Danoocrate carmine de eriptt

iberis alterd

Ibicus, wide Althed

Icbthyocolla Diofcoridi

574.60

130.23

65.36

$65 \cdot 4^{2}$

$704 \cdot 5.1$

704.57

705.2

705.6

$172.1 \pm$

172.32

272.34

273.5

ICtuun uirulentorum comranis curatio Diofcoridi 759.52

Idea radix Diof coridi

ides radicis confideratio

523.28

idee radicis uires ex Galento

523.33

513.39

Iecur apri Diofcoridi

207.20

207.7

iecur afininum Diof coridi

$207.2 i$

207.8

iecur caprinum Diofcoridi

iecur mergi Diofcoridi

207.24

jecinorum diuer forum confideratio

$207 \cdot 33$

66.2

66.8

iefemini uires ex Serapione

34.54

Ilex Diafcoridi

ilic is confideratio

136.26

Imperatorie confideratio, biftoria, er uires 406.50

Impia berba Plinij

450.3

Impoftores quandoque etiam peritos decipiunt . 4-x.x

Indica barundo

Indicum Diofcoridi

indici confideratio

207.27

671.22

671.28

287.28

288.40

290.8

66.28

$137 \cdot 34$

63.17

$3 \times 4.20$ irionis confideratio

Iris Diofcorididefcripta

$324 \cdot 24$

27.34

iridis confid.0ं genera 7.54 , eiusuires 18.52

iris cognomine aftragalitis

iridis mentio d Galeno

18.57

79.9

Ifopyron Diofcoridi

ifopyri confideratio

574.4

574.9

Ind mufcata $\quad \mathbf{4 4 2 . 3 8}$

Iudaicus lapis Diofcoridi

$703 \cdot 4$

iudacilapidis uires ex Galeno

703.9

Iuglandes nuces

iuglandium confideratio

iuglandium uires ex Galeno

264.23

64.43

764.52

265.8

Iuglandes condite

Iuncus Diofcoridi

iunci confíderatio, er uires

Iuncus odoratus Diof coridi

iunciodoraticon/ideratio

iunci odorati uires ex Galeno

517.54

o dein.

40.57

42.9

$4 x \cdot 52$

92.22

22.39

iunipericonfideratio

iuniperi caput in Diofcoride deprauatum

iuniperidomeftice

iuniperigummi $9 \mathbf{1 . 5 7}$

iuniperi uires ex Galeno

Ius galli ueteris Diofcoridi

I us pifcium Diofcoridi

Ixia Diofcoridi

ixiam nigri chamaleonis radicibus innafci

ibidem

$2 x .52$

cius $u$ Jus 92.3

22.20

209.37

204.59

353.50

354.52

355.29

ixid uenenum mortiferum

739.4

ixia uenenum, er remedia Diofcoridi

739.20

K

K A L I Mduritanorum mentio

274.53

Karabe Mauritanorum

202.29

Keiriquid

Kepris quid

$455 \cdot 3$

Keruaquid

604.9

I

L A \& R V M Veneris Diofcoridi

356.2

Labri Veneris confideratio

356.28

labriVeneris uires ex Galeno

3.56 .56

637.8

Labrufa Diofcoridi

Lac.Diofcoridi

lactis confideratio

lactis probatio 230.32

228.56

230.22

lactis bibendi ratio

lattis facultates ex Galeno

lactis coagulati uires

lac humanum Diofcoridi

lac fchifton Diofcoridi

lactis ferum Diofcoridi

cius facult.

230.40

230.46

232.3

$230.5 x$

229.25

229.23

229.10

Lattis intus codgulati noxd, E duxilia Diofc. 742.58

lactis coagulati confideratio

$743 \cdot 4$

lactis in uentriculo codgulati noxa $\cdots, 2.43 .14$

lattis in uentriculo coagulati curatio

$743 \cdot 30$

$\mathrm{L} d c c d, \mathrm{C}$ de ed Arabun of inio uaria

50.2

lacca infectorum eft Aratum lacca

50.2

lacce factitie generd

50.34

$B=$ Iacerta 
I acerta Diofcoridi

lacertaruin confideratio

lecertarum Chalcidicarum confideratio

I acryme, refine, ev gummi

I aituca Dicfroridi

lactuca fylueftris Diofcoridi

lactucre confideratio

lsauca fylucftris confideratio

Lattuc $x$ uires ex Galeno

Ladamum Diofcoridi

ladani confideratio

ladariuires ex Galeno

Lagopus Diofcoridi

lagopi confideratio

ligopi uires ex Galeno

Lagrino uulgó quid

Lamium berbs

L ampjana Diofcoridi

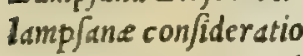

lamp $\int a n e$ uires ex Galeno

I ana Diofcoridi

I anaria berba. Diofcoridi

lanarie berbe confideratio

lanarix berbe uires ex Galeno

Lapatbum Diofcoridi

lapsthi confideratio

laputbi uires ex Galeno

Lapides cur pauci, cur multifiant

lapidun colores urde uarij

lapidum diuer fa difcrimina

Iapis.plumbarius

lapidis plumbarij.confideratio

I apis bezahar A rabum

lapidis bezabar hiftoria, or uires

lapis in fille bubulo repertus, or sius uires 238.45

lapis in oculo ceruorum natus

Larix arbor, e eius biftoria

larix agaricum profert

larigna refina

$\mathbf{L}$ afer Diofcoridi

laferis confideratio

laferis uires ex Galeno

Laferpitium Diofcoridi

laserpitij confideratio

laferpitij biftoria ex Theophrafto

Iaferpitì uires ex Galeno

Luffulata

Lathyris Diofcoridi

lathyris confideratio

lathyris uires ex Actudrio

lathyris uires ex Galeno

lathyris noxa, or curatio

Lauanda uulgó que

Lauer Diofcoridi

Iaueris confideratio

laueris uires ex Galeno

I aurus Diofcoridi

lauribacce Diofcoridi

lauribiftoria

Lurrini olei confideratio
223.42 Iauriniolei uires

58.4

$224.22 \quad$ laurus lapided

97.58

98.2

224.26 lauri uires ex Galeno

97.53

8.5

295.40

295.49

295.58

296.2

296.18

121.29

221.44

222.53

$497 \cdot 17$

497.20

$\therefore \quad 497.47$

80.58

555.60

272.49

271.53

272.1

232.52

319.42

312.49

320.2

269.56

271.22

271.26

633.7

633.20

634.18

662.30

662.48

678.32

ibidem

laurus ex fe ignem producit

588.47

laurus Alexandrina Diofcoridi

589.55

lauri Alexandrine uires ex Galeno

589.45

Ledon Diofcoridi

221.18

676.21

676.28

ibidem

lemnie terre confideratio

lemnia terra biftoria

lemnix terre uires

677.28

$677 \cdot 45$

677.59

lemnia terra adulter ande fraus detects

262.37

$263 \cdot 5$

lentium uires ex Galeno

550.5

550.9

lentis paluftris confideratio

lentis paluftris uires ex Galeno

550.22

58.14

Lentifcus Diofcoridi $\quad 82.52$

lentifcina refina Diofcoridi $\quad 82.5$

lentifciconfideratio $\quad \ldots . \cdots, 82.13$

lentifci uires ex Galeno

82.32

Leoniceni errata, ac eius opiniones dilute 295.46 . $\mathrm{O}_{348.25 .0} 388.15 . \mathrm{O}_{438} 30 . \mathrm{O}_{464}$. 24. 0773.39

Ieontopetalon Diofcoridi

430.52

leontopetaliconfideratio

leontopetali uires ex:Galeno

430.58

Leontopodion Diofcoridi

432.1

leontopodij confideratio

570.23

Lepidium Diofcoridi

579.29

lepidij confideratio

339.38

lepidium Plinij

339.43

339.46

166.56

Leptocarya Diofcoridi

Lepus marinus Diofcoridi

leporis marini confideratio

193.52

79.38

80.4

80.28

418.55

$\therefore \quad 410.23$

420.46

41.8 .50

415.23

420.22

420.46

380.35

609.3

609.22

609.27

$\therefore \quad 609.32$

748.56

26.54

281.58

282.2

282.23

97.2

97.10

97.20

58.1
Ieporis marini hauftinote, of curatio Diofcoridi

746.4

leporis marini fumpti indicia

eius noxa remedia

Lepus terreftris Diofcoridi

leporis terreftris confideritio

lepores ubi candidi

lepores ubi bina habent iecinora

leporis facultates

Leporinum coagulum Diofcoridi

Leucacantha Diofcoridi

leucacanthe confideratio

leucacanthe uires ex Galeno

Lencas Diofcoridi

leucadis confideratio

Leucoion Diofcoridi

leucoij con/ideratio

leucoijutres ex Galeno

Libri explodendi

Libyfticum Galeno ligufticum

Lichenes equorum Diofcoridi

lichenum equorum uires

Lichen Diofcoridi
746.24

746.26

294.2

294. 28

29433

224.50

194. 56

233.36

362.23

362.20

$363 \cdot 4$

432.38

$\therefore \quad 432.42$

454.50

451.2

$451: 14$

5.43

393.46

208.43

209.1

528.30

lichenis 


\section{Index}

lichenis confideratio

lichenis genera ex Plinio

lichenis uires ex Galeno

Lignuma aloës

I ignorum marcor Diofcoridi

lignorum marcoris uires

Iigufticum Diofcoridi

liguftici confideratio

Tiguftici, feu libyftici uires ex Galeno

Iiguftrum Diofcoridi

liguftriconfideratio

liguftri uires ex Galeno

Iilium Diofcoridi

Iilij confideratio

Tilijbiftoria ex Plinio

I ilia quonodo in totuna annum uiridia feruentur

$434 \cdot 24$

Tilia quomodo dinerfis temporibus floreant

lilis alba quomodo purpurea fiant

Tiliorum uires ex Galeno

Iilium conuallium non eft bemerocallis

lilij conualij biftoria, et uires

Iimonizm Diofcoridi

limonii con/ideratio

Iimonii uires ex Galeno

I imonis poma

limoniorum pomorum aquaftilatitia quibus confer dt $254 \cdot 9$

Linariaberba

Iingua ceruindeft phyllitis

lingud ceruind non eft hemionitis

Iingua ferpentina

lingue Jerpentine de friptio, et uires

Linozoftis Diofcoridi

linozoftis confideratio

Linum Diofcoridi

liniconfideratio

434.27

434.20

434.49

454.2

$454 \cdot 12$

496.54

496.59

$497 \cdot 10$

253.61

Tini uires ex Galeno

Tini feminis oleum, et eius uires

Litbargyros Diofcoridi

Iithargyri confideratio

Iithargyri uires ex Galeno

Iithocolla Diofcoridi

Iithopermon Diofcoridi

lithopermi confideratio

lithopermi hiftoria ex Plinio

Iixiuiy faponis noxd, et curatia

Locufte Diofcoridi

Tocuftarum confideratio

locuft arum ingens numerus quando It alidm inuafit

$$
213.20
$$

locufte in cibis

5.86 .9

437.54

43.8 .22

323.42

ibidem

625.60

620.38

259.23

259.29

259.49

259.33

666.19

667.2

667.18

$706.1=$

469.51

470.32

$470.4^{8}$

745.43

$223 \cdot 3$

213,8

Iolium Diofcoridi

lolij confideratio

lolij uires ex Galeno

Ionchitis Diofcoridi

Zonchitis altera Diof coridi

223.23

257.30

257.40

258.5

472.3

472.16

472.22

472.36

Toncbitis uires ex Galeno

Ioniceri lapsus, uide Adami Loniceri errata

Iora Diofcoridi lor $x$ parand $x$ ratio ex $\mathrm{G}$ dleno

Lotus arbor Diofcoridi

loti arboris confideratio

642.37

56.49

lotus Italica

156.53

loti arboris uires ex Galeno

257.23

$257 \cdot 37$

Lotus Aegyptia Diofcoridi $\quad 5,69.27$

loti Acgyptia hiftoria ex Thcophrafto $\quad 559.33$

loti Aegyptia mentio ex Galeno $569.5 \mathrm{~L}$

Lotusfyluestris Diofcoridi $\quad 566.52$

lotus urband Diofcoridi $\quad 566.47$

lotifylueftris, or urbane confideratio 566.58

lotiherbe utriusq; uires ex Galeno $\quad 567.49$

Lunariaminor

465.3

lunarie minoris uires

I upinus Diof coridi

Iupinorum confideratio

464.50

265.39

266.1

266.4

241.9

L upinorum fimum

Iupus falictarius

lupulibiftoria, or tires ex Mefues. $\quad 587.53$

Iychnis coronaria Diofcoridi $\quad 432.57$

lychnis fylueftris Diof coridi . $\quad 432.58$

7ychnidis utriusque confideratio $\quad 433.2$

Iychnidis facultas ex Galeno $\quad 433 \cdot 34$

Iycium Diofcoridi $\quad 127.47$

lycij confideratio $\quad \quad \geq 28.23$

lycij uires ex Galeno $\quad \therefore \quad 432.57$

Lycopfis Diofcoridi $\quad 50 \mathrm{z} .42$

Iycop/is confideratio $\quad . .5 \quad 50 x: 48$

Iycopfis uires ex Galeno $\quad 50 x .32$

Iygos Diofcoridi $\quad 30.47$

Iyncurium ex urinalyncis coale $\int c e r \bar{e}$, udnum putatur 242.14

Iyfimachia Diofcoridi

Zy/imachie confideratio

byfimachis uires ex Galeno

483.59

484.37

484.54

II

MACE R Diofcoridi

203.60

Maceris confideratio

204.2

macerem non effe officindrum macim

maceris facultates ex Galeno

Macis Arabum con/ideratio

Mene Diofcoridi

menarum, $\mathcal{\sim}$ fmaridum confídēratio

Magnes lapis Diofcoridi

magnetis lapidis hiftoria

magnetis lapidis uires ex Galeno

magnetis uenefica uis, or remedia

Magudaris Diofcoridi

Mald infand

malorum infanorum uires

104.20

104.14

55.34

202.22

202.47

700.44

700.48

701.25

744.30

428.60

536.52

537.5

Mala aurea Italis que $\quad \therefore \quad 537.9$

Malabathrum Diofcoridi $\quad 32.9$

malabathri confideratio

malabatbri uice quid fupponendum $\quad \therefore$ : $\quad 32.40$

malabatbri uires ex Auicennd $\quad 32.54$

Malicorium Diofcoridi

Malua Diofcoridi

malua mire magnitudinis

$244 \cdot 47$

272.55

273.24

malue uires ex Galeno 


\section{Index}

Alslum Diofcoridi

malorina confideratio

mslor unz generaplura

Nisla Grmeniaco Diofcoridi

malun cotoncun Diofroridi

mulun dulce Diofcoridi

mil:min NI dicum Diofcoridi

milorkn Mzdicorum confideratio

malum orbiculatun, fiue Epiroticum Diofcoridi

$$
48.60
$$

m.l'!n? Perficum Diofcoridi

malkin Funicum Diofcoridi

muli Puniciconfideratio

mali Punici generatria

mala Punica acria quomodo dulcia fiant

mald Punica quomodo diutius incorrupta feruentur

144.35

Mali punici uires ex Gal.

144.53

Menaidi Ferrarienfis erratd, ac eius opiniones confu= tate $25 \cdot 6.0 \cdot 69.8$. et $244 \cdot 6$. et $245 \cdot 8$. Or 264.33 .03304 .45 . et 329.51 .05387 .16 . C 433.10. et 511.40 .00600 .48 .et 656 . 27.0675 .61$. et $737 \cdot 34$

Mandragoras Diofcoridi

$534 \cdot 50$

mandragore utriusque conflderatio

535.52

mandragor bumanam formam referentes factutia

$$
536 . x
$$

mandragora uires ex Galeno

537.22

mandragore fumpte figna, er curatio Diofcoridi

735.22

mandragore noxid uis

inandragore noxe curatio

Manna thuris Diofcoridi

manne thuris confideratio

Manne coeleftis hiftoria, or generd

735.28

735.36

72.40

$73 \cdot 4$

$73 \cdot 18$

manna caeleftis Mauritanis duplex

$73 \cdot 31$

manne hiftoria ex Theopbrafto, Galeno, et Plinio

$73.43 .0 \%$ deinde

manua in comitatu Goritienfif, et Foro Iulij quo tem=

pore abundantißinta reperta fit

$74 \cdot x$

mannd fecto fraxini cortice manans $\quad 74.16$

manne caleftis temperamentum, et uires $\quad 74.30$

Marcelli Secretarij Florentini lap Jus, et opiniones re=

iect.e 65.48. et $x 17 \cdot 10$. et $1 \times$ 8.6.et $145.5 x$,

et 152.39 . et 125.37 , et 252.36 , et 264.24 i

et 371.23. ct 404.50. et $639.30^{\circ}$

Marcor lignorum Diofcoridi

Margaritarum biftoria

105.39

margaritarum uires

78.54

$179 . x 2$

Marium, et fluminum litora, que plante ament 9.32

Marrubium Diofcoridi

marr ubij confideratio

446.44

marrubij biftoria ex Theophrafto

marrubij uires ex Galeno

Marrubium nigrum Diofcoridi

marrubij nigri confideratio

Martagon, lilijgenus

Marum Diofcoridi...

mariconfideratio

marimentio ex Galeno

marum Italie peregrinum

$437 \cdot 2$

437.6

435.14

435.25

434.30

386.27

386.32

386.32

386.5 .8
Maftiche Diofcoridi

82.5

maftiches confideratio

82.27

mastiches uires ex Galeno

82.40

maftichini parandi ratio, or uires

58.39

Matricariain non effe artemifia genus $\quad$ 445.46

Matrifylua

493.53

Matthei syluatici errata 278.7 .0356 .49 .0 492.42 . ON $497 \cdot 22.499 .38$

Mauritanorum 0 fequacium error

$547 \cdot 2 i$

Mauritanorum tutela in Coruleo lapide

$670.4 i$

Meconium Diofcoridi

meconij mentio

526.25

527.12

meconij fumptinoxa er remedia Diofcoridi 736.28 meconij uenefica natura

meconij noxe curatio

736.33

736.48

Medica berba Diofcoridi

medice berbe confideratio

Medica mala Diofcoridi

medicorum malorum confideratio

305.28

305.24

150.2 Medicamenta adulteratabantur etiam Galeni tempore 2.55

medicamenta fimplicis uenenis aduerfantia 722.10 medicamenta compofita uenenis aduer antia $7=2.39$ Medicorum error

ITedium Diofcoridi

medij confideratio

638.33

medij uires ex Galeno

$497 \cdot 53$

497.60

498.2

Medulla Diofcoridi

237.37
$\quad 237.47$

medulle uires ex Galeno

medulle in cibis facultas

238.2

Mel Diofcoridi

242.55

mellis confideratio

243.35

243.49

Mel Heracloticum uenènofum

mellis Heraclix uenenum, or eius remedia Diofcoridi

731.35

mellis Heracleoticinoxa, er curatio $\quad 732.39$

mellis genera non rof cida

Mel frugum

Melanteria Diofcoridi

$243 \cdot 52$

melanterie confideratio

569.14

$68 x \cdot 3 x$

582.52

Melanthium Diofcoridi.

melantbij confideratio

melanthium jyluestre

melantbijuires ex Galeno

$417 \cdot 42$

$417 \cdot 54$

418.12

melanthinum olcum

428.27

57.5

Melia terra Diofcoridi

meliz confideratio

Melice confideratio, erujus

Melilotus Diofcoridi

meliloti confideratio

meliloti uulgaris ujus illegitimus

meliloti uires ex Galeno

Melimela Diof coridi

Melini confideratia

Meliffophyllon Diofcoridi

meliffophyllic confideratio

Melutites lapis Diofcoridi

701.37

melitite lapidis hiftoria

701.40

suclomeli Diofcoridi 


\section{Index}

Melopeponum confideratio $294 \cdot 13$. corum uires ex Galeno 294.57

Memphites lapis Diof coridi

memphite lapidis con:jideratio

704.6

Mentba Diof coridi

$704 \cdot 20$

379.45

379.56

380.2

menthe wires ex Gaieno

380.20

menthafylueftris Galcno caldmintha dicitur

Mentha Grace

380.33

menthe Grece uires

Menthafrum Diofcoridi

380.54

379.53

Meon Diofcoridi

mei confideratio

22.30

stei uires ex Galeno

$\therefore \quad 21.45$

$22 . i$

Mercurialis Dio/coridi

mer curialis confideratio

625.60

626.38

mercurialis biftoria, $\sigma$ uires ex Plinio $\quad \sigma 26.42$

mercurialis uires ex Galeno . $\quad .626 .57$

Mergiiecur Diofcoridi

Mefuis errydta

Mefpilus Diof coridi

392.47 .00421 .25

207.14
412.15
255.48

255.48

nuefpilorum confideratio

156.20

mepilus alters

mepilorum uires ex Galeno

156.28

633.36

$64 \cdot 34$

255.18

Ietopizm unguentum Diofcorid

Milium Diof coridi

milij uires ex Gdleno

255.23

milium Indicum $\mathrm{Plinio}$ quid

256.20

$470.3 x$

569.57

570.32

570.43

555.29

205.42

20.5 .60

673.12

682.23

682.52

682.15

179.34

179. 59

392.8

mitulorum confideratio

Moly Diof coridi

moly confideratio, o biftorid ex Theophrafto, er Pli=
nio
322.13 nio

392.25

665.25

665.33

665.53

662.3

662.33

molybdoidis confideratio

Momordica 449.38 . ON 622.53 .00622 .24

Monachorum, qui Mefuem commentati funt, lapfus, atque opiniones explofe 22.3 .et 23.46 .0 42.34 . et 56.52 . et 74.8 . et 204.27 . et 112 . 10 et $117 \cdot 20$ et 140.15 .et $173 \cdot x$. et 300 . 22 et $354 \cdot 30$. et 363.42 . et 368.52 . et 382 . 30 . et 389.20 . et 397.17 . Or 392. 10. et 400 . 6 . et 446.24 . et 458.36 .et 479.22 . et 525 . 52.et 548.22 .et 617.27 . et $69 x .18$

Montes que plante ament

2.25 .58
Morochthus Lapis Diof coridi

701.53

morochthi lapidis confideratio, wixes ex Galeno

708.60

Morfus diaboli defcriptio, en uires

Morus arbor Diofcoridi

334.42

167.20

mori aboris confideratio

mori arboris, er fruitus sires ex Gdleno

$167 \cdot 4^{2}$

Mofchiodorati hiftoria

mofchi odorati uives

Mullus pifcis Diofcoridi

mulli pifc is Diofcorid.

mullipifcis falcultas ex Galeno

Mulfum Diofcoridi

Mumia Sepulcrorum

mumise confideratio

167.50

47.3

47.29

196.42

$197 \cdot 1$

197.5

643.13

89.27

mumie uires

Muria Diolcoridi

Mures Diofcoridi

nurium confideratio

88.52

89.45

688.43

$227 \cdot 14$

227.34

$227 \cdot 39$

228.4

228.39

226.44

227.2 muris aranei confideratio

muris aranei morfus note, or remedia Diofc.767.59 muris aranei morfus figna

muris aranei morfus curatio

768.14

Muris auricula Diof coridi

768.19

muris auricule confideratio

338.49

Mufa arboris, er fructus confid.er bistorid 142.15

Mufcus Diofcoridi

mufci arborei confideratio

46.7

mufciarborci uires ex Galeno, or alijs

46.16

Mufcus marinus Diofcoridi

46.45

mufcimarini confideratio

$557 \cdot 25$

mufcimarini uires

Muftela Diofcoridi

557.30

muftele confideratio

557.53

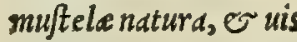

199.40

Myagron Diofcoridi

mydgriconfideratio

myagri uires ex Galeno

199.57

Myle, moly Galeno

Myrica Diof coridi.

myric confideratio

myric uires ex Galeno

200.27

572.37

571.42

571.49

$322: 25$

107.48

208.4

208.22

Myrobalanorum Arabicorum generd

myrobalanorum omnium uires ex Mefue

601.34

601.61

Myrrha Diofcoridi

66.27

66,54

66.57

66.58

67.32

67.47

myrrhe biftoria ex Theophrafto

67.35 .50

myrrbe arboris bistorid

myrrbe uires ex Galeno

68.21

myrrbe uice quid fupponendum 68.28

myrrhe Bocotic mentio

68.25

Myrrbis Diofcoridi

570.52

myrrhidis confideratio

570.60

574.28

Myrtcum 


\section{Index}

Nyrteum oleum, o eius uires myrtei oleiparandiratio Myrtidantun Diofcoridi myrtidani confideratio Myrtus fatiua Diofcoridi myrticonfideratio myrtus exotica, o T Tarentind myrtiufus

myrti uires cx Galcno Myrtus: [ylueftris Diofcoridi myrtifylueftris confideratio Myxa, o myxaria quid myxorum confideratio

NA P н т A Diofcoridi Naphthe confideratio

Napelli confideratio, o biftoria napelli wis le thalis

napelli wenenum, eiusq́q; remedia Napus Diofcoridi napi confideratio Narcaphthon Diofcoridi narcaphticonfideratio Narciffus Diofcoridi narcißibiftoria ex Theophrafto narcißi uires ex Galeno Nardum Indicum Diofcoridi nardum Syriacum Diofcoridi nardi Indica confideratio nardi Syriace confideratio nardi Indice uires ex Galeno nardum Celticum Diofcoridi nardi Celtici confideratio nardi Celtici uires ex Galeno Nardus Italica nardi Italice uires

Nardum montanum Diofcoridi nardi montani con/ideratio nardi montani lectio in Diofcoride deprauat at nardimontani uires ex Galeno

Nardinum unguentum Diofcoridi

Nafturtium Diofcoridi

nafturtij confideratio nafturtij uires ex Galeno

Natrix; $\mathrm{O}$ cius ictus curatio Diof coridi natric is hiftoria, morfus figna, Er remedia Naxiuslapis Diofcoridi naxij lapidis confideratio Nepeta Dofcoridi nepetie mentio

Nerion Diofcoridi nerij confideratio neriy uires ex Galeno nerij malefica natura nerij Jumpti noxe curatio

Nitrum Diofcoridi nitripuma Diafcoridi nitri, e cius pume confideratio nitri, er apbronitri uires ex Galeno Numulariaberba
57.12

$57 \cdot 38$

46.2

46.41

$245 \cdot 3$

145.42

1. 46.6

146.37

$\therefore \quad 246.47$

588.15

588.30

260.2

ibidem

$$
\therefore \quad \begin{aligned}
87.4^{\circ} & \text { Nux pined Diofcoridi } \\
88.4^{1} & \text { nucleorum pincorum uires } \\
539.4^{2} & \text { Nux uomica, or eilus biftoria } \\
539.4^{6} & \text { Nymphed Diofcoridi } \\
738.22 & \text { nymphea alterd } \\
267.23 & \text { nymphrea confideratio } \\
267.27 & \text { nymphes uires ex Galeno }
\end{aligned}
$$$$
49.27
$$$$
49.30
$$$$
602.46
$$$$
603.2
$$$$
603.23
$$$$
24.25
$$$$
\text { ibidem }
$$$$
24.54
$$$$
\therefore \quad \text { ibidem }
$$$$
27.3
$$

$27: 14$

27.40

28.25

$26.2 \mathrm{~L}$

26.54

28.33

28.38

28.40 28.59 65.22 322.7 322.16 312.20 773.46 773.53 706.49 705.58 381.37 381.59 544.12 $\therefore \quad 544.26$ 544.41 733.30 733.44 690.28 690.30 690.44 691.22 465.10 numularie uires ibidem Nux auellana Diof coridi

266.56 nucis auellane confideratio

$x 67.4$ nucis auellane uires ex Galeno

267.10

$\mathbb{N} u x$ Indicd, or cius hiftoria, er confideratio 165.13 nucis Indice uires

265.22

nucis Indice oleum, er cius uires $\quad 165.23$

Nux Iuglans Diofcoridi $\quad 164.23$

nucum Iuglandium confideratio $\quad 164.43$

sucum Iuglandium vires ex Galeno $\quad 64.52$

Nuxmetella, er ciushiftoria 266.2. Ordeinde nucis metelle fumpte noxd, er cius curatio $\mathbf{7 3 6 . 2 .}$ or deinde

INux myriftica, er eius hiftoria $\quad 165.28$ nuc is myriftice uires

265.46 76.3

2.4. 21

66.2 462.10 461.23 $4^{\sigma} 2.44$ 462.24

OCH R A Diofroridi

671.29

Ochre confideratio

$67 x \cdot 34$

Ocloros legumen

254.30

Ocimaftrum Diofcoridi

ocimaftri confideratio

502.53

502.58

- cimaftri uires ex Galeno

Ocimum Diofcoridi

503.2

ocimi confideratio

300.3

300.21

300.43

300.50

300.56

451.38

451.43

339.10

339.22

233.2

233.27

exypimentio

Officinarum lapfus, or abufus

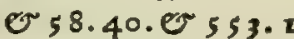

Olea fylueftris Diofcoridi

olex fylueftris confideratio

$3 \cdot 2.43$

olex, er quercus odium

134.2

Olece Aethiopica lacryma Diofcoridi

olex-Aethiopica lacrymx confideratio

34.23

233.43

34.2

53.28

oleiconfideratio

olei ufus apud ueteres qualis

oleifacultates ex Galeno

olei omnis generis parandi ratio

Oleum amygdalinum Diofcoridi

54.9

$54 \cdot 14$

$54 \cdot 30$

$57 \cdot 32$

olei amygdalini parandiratio

554.36

55.50

56.5

56.25

56.19

$56.2,2$

56.18

56.32

oleum 


\section{Index}

oleun cicinum Diofcoridi olei cicini confideratio oleum cnicinum Diofcoridi oleicnicini confideratio olcum ex bumano ftercore olcum Gnidinum Diofcoridi olei Gmidini con/ideratio Olcumbyofcyzminum Diofcoridi oleibyofcytmini uires oleibyofoy amint parandiratio Olcum laurinum Dıofcoridi olei lurini confideratio, o uires oieum lenticinum Diofcoridi. olci lentrfcini parandiratio, or uires Olcum muftichinum Diofcoridi olei maftichiniparandiratio oleummelanthinum Diofcoridi oleimelanthini confideratio oleunz unclinum Diofcoridi olcum myrteun Diofcoridi olci myrtei confideratio olcinyrtciparandiratio olcum ex ourum luteis oleun ex lnni femine, or eius uires Olemm altanthenum Diofcoridi oleum oline fylueftris Diofcoridi oleioliue Jylueftris facultas ex Galeno oleun omphacinum Digfconidi. olenn omphactmun quonodo arte parari poßsit 543.7 oleum picinum Diofcoridi Olewmiraplaninum Diafcoridi oleiraphanini confideratio Olcusa fe faninum Diofcoridi olei eesulnini con/ideratio, er uires olewn Sicyonium Diofcoridi oleun finapinum Diofcoridi olei/inhapini confideratio olcumftyruxinum Diofcoridi oleum fuffinum Diofcoridi olei fulini ntrentio Oleumi tercbinthinum Diofeoridi olet terebintibini confideratio, o uires olei noftri de fcorpionibus de fcriptio, er eius uires

$$
723.60
$$

Oluarum generaplura olcuarun uires ex Galeno

Olera quo pato ab erucarü iniuria uindicétur 219.46 olojchanos Diofcordi Otufarrumiof coridi Olyra Evofcoride. olyre confideratio Ompiscium Diofcoridi omplascij confideratio ompbacij uires ex Galeno Omibscomcle Diofcoridi Onagr stofeoride onagre confideratio onagre uires ex Galeno Onobrychis Disf corldi onobrychis confideratio onobrycbis uires ex Galeno
234.22

134.43 527.59 $403 \cdot 5.9$ 252:31

$55.16 \quad$ Ononis Diofcoridi

55.28 ononidis con/ideratio

56.42

57.2

240.40

50.42

56.66

56.38

56.50

56.58

57.53

58.1

58.9

58.24

58.34

58.49

56.45

57.5

$\times 48.54$

57.12

57.22

57.38

221.40

259.33

60.25

$53 \cdot 42$

5.4. 46

53.27

86.26

56.43

$57 \cdot 4$

56.26

56.29

53.5 .5

56.46

57.6

68.53

62.42

62.10

58.12

58.23

\section{es}

252.3 .4

639.52

640.2

640.8

649.4

572.55

571.60

572.13

477.20

477.24

477.29

Onofma Diofcoridi

Ophiogloffon

ophite lapidis biftoria

ophites marmor

Opium Diofcoridi

opijfacultas

opij ueneficandtura

opij ueneni curatio

Opuntia Plinij

Oryza Diofcoridi

oryze confideratio

Oßjif agus Diofcoridi

o ßifragi confideratio

O[yris Diofcoridi

ofyridis confideratio

Othonna Diofcoridi

othonne confideratio ononidis uires ex Galeno

362.20

onofmatis confideratio

onofmatis uires ex Galeno

Opacis locis que plante latentur

Ophiofcorodon Diofcoridi

ophiofcorodiconfideratio

Ophites-lapis Diofcoridi

368.35

362.3

460.48

460.55

462.3

9. 44

323.46

309.22

$309.5 \mathrm{E}$

705.38

705.43

opium, quo utimur, adulterinum

594.35

526.5

527.2

527.10

736.33

736.48

43.21

Opoballamum Diofcoridi

opobalfami uis ex Galeno

opobalfamum factitium

$44 \cdot 42$

Opocalpafum Galeni quid

45.3

opocarpafi confideratio

734.16

734.7

365.58

403.45

404. 33

oreofelini confideratio

oreofelini uires ex Galeno

405.5

Origanum Hracleoticum Diofcoridi

373.15

origanum onitis Diof coridi

37.3 .2 .5

373.26

origanum fylueftre Diofcoridi

origani hiftoria uaria 374.45

origani Heracleotici, onitidis confideratio 375.4

origani fylueftris confideratio.

375.1

origant uires ex Galeno

375.9

Ornithogalum Diofcoridi

302.26

orinithogali confideratio

303.2

Orobanche Diofcoridi

orobanches confideratio

301.23

oryze facultas ex Galeno

301.55

253.59

2.54. $\mathrm{x}$

254.5

213.37

223.40

706,16

Oftracites lapis Diofcoridi

706.22

oftracite lapidis confideratio, $\sigma^{\circ}$ uires

ofyridis uires ex Galeno

586.4

586.9

586.35

338.39

338.42

210.27

220.30

220.56

211.22

212.35

211.40

221.53

269.62

271.20

Oxaline 
Oxalme Diofcoridi

Oxycedri confideratio

Oxylapatbum Diofcoridi

oxylapathi confideratio

Oxymel Diofcoridi

oxymelitis confictio triplex Galeno

oxymclitis confectio ex Me fue

Oxys Plinio

\section{p}

PAEDEROTA, acantbus Diofcoridi

Paionia Diofcoridi defcripta

peonia confideratio

peonice uires ex Galeno

Paliurus Diofcoridi

paliuriconfideratio

paliurus diuerfi generis apud authores

paliuri uires ex Galcno

Palma Diofcoridi

palme confideratio

palmarum uires ex Galeno

palmularuin facultas ex Galeno

Palma elate Diofcoridi

palma elate que pars in palma

palma elate Galeno duplex

palme Indicx uinum fundentes

palme Thebaica

Palme Chrificonfideratio

palma Cbriftigenera dua

palme Cbrifti uires

Panaces A fclepij Diofcoridi

panaces Chironium Diofcoridi

panaces Heracleum Diofcoridi

panacis omnis generis confideratio

panacis cuiufque uires ex Galeno

panacis lacryme facultas ex Mefue

Pancration Diofcoridi

pancratiy confideratio

Panicum Diofcoridi

panici uires ex Galeno

Panis optimi conficiendiratio

panis bordeaceus

panis filigineus omnium jync erißimus

Pannum in larice nafcens

Papauer corniculatum Diofcoridi

papaneris corniculati confideratio

papaueris corniculari uires ex Galeno

papalıris corniculati noxa, $\mho^{\sim}$ auxilia Diofcoridi

736.30

Papauer erraticum siofcoridi

papaueris erratici confideratio

papauer fatiuum Diof coridi

papaueris fatiui confideratio

papaneris lacrymx facultas

papa:terum uires ex Galeno

Papuler Prumeum Diofcoridi

papaneris $\beta$ umei confideratio

Papyrus Diofcoridi

papyriconfideratio

pupyriconficiendiratio

pałyrinciulngenus
$647 \cdot 4$

95.38

259.62

272.24

646.35

646.42

$646.5 \mathrm{e}$

440.9

360.24

468.54

469.28

469.44

12.10

12.2.16

ibidem

23.22

142.12

141.53

243.25

143.25

341.42

243.1

143.5

242.39

142.22

458.5

458.8

458.17

322.18

392.32

321.45

392.38

322.58

393.8

327.28

327.35

255.50

255.53

249.43

250.57

252.49

80.34

527.52

528.12

527.40

525.43

526.32

52.5 .54

526.41

527.2

527.22

528.3

528.29

106.58

107.4

107.15

107.20 papyri uires éx Galeno

Paralios titbymalus Diofcoridi

107.30

Parietaria berba

$605.3 x$

Paronychia Diofcoridi

519.34

paronychie confideratio

519.39

paronychie uires ex Galeno

529.45

466.55

467.2

parthenij confideratio

Paffum Diofcoridi

640.28

323.59

$394.4^{\circ}$

395.3

195.6

paftinace uires ex Galeno

Paftinaca marina Diofcoridi

pastinace pifcis confideratio

. 95.28

paftinace pifcis, ev cius radï uires

195.42

paftinace marinc utus note, et eius caratio Diofcoridi 767.22

paftinace marine ittus figna

$767 \cdot 32$

pastinace marina ictus remedia

767.40

Pauli Iouij erratd,ac eius opiniones refutate 174.55 .

0279.60 .0202 .39

Pecten Veneris

298.5

Pedicularis herba Diofcoridi

596.59

Pelecinon Diofcoridi

460.29

pelecini confideratio

460.27

Peplis Diofcoridi

609.58

peplos Diofcoridi

609.44

pepli, er peplidis confideratio 610.4

pepli, ex peplidis uires ex Galeno $\quad 6: 0.7$

Pepo Diofcoridi $\quad 1,292.57$

peponum, er melopeponum confideratio 293.1

peponum uires ex Galeno

Periclymenon Diofcoridi

2.93 .49

493.32

periclymeni con/ideratio

493.50

periclymeni uires ex Galeno $\quad 494.4$

Periftereon, uerbenaca Diof coridi $\quad 523.19$

Perfea arbor Diofcoridi

perfee arboris confideratio

27.13

272.20

perfea arboris mentio, or uires ex Galeno $71.4=$

Perficamala Diofcoridi $\quad 149.52$

perficorum malorum confideratio .... ? $\quad$. $5 \times 49$

Perfonata Diofcoridi $\quad 563.57$

perjonate confideratio 564 .

perfonate uires ex Galeno

perfonatd, $\mathrm{P}$ linio perfolata

564.29

564.14

Petafites Diofcoridi

564.44

504.49

564.56

petafitis uires ex Galeno

Petribellonij errate $76.20 .0 \% 78.29 .0 \% 81.20$.

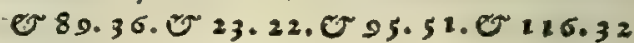

Petricriniti errata

Retrofelinum Diofcoridi

74.26 .0140 .29

Petrofelini confideratio

petrofelini uires ex Galeno

403.53

Pettimbor $f a$

Peucedanum Diofcoridi

peucedani confideratio

peucedanum officinarum fuppofititium

$404 \cdot 44$

405.5

$347 \cdot 24$

426.4

426.37

416.52

416.57

438.32

438.38

phalangi] 


\section{Index}

phalangij herbe uires ex Galeno

438.48

Phalangiorum animalium confideratio, on genera

222.40 .48 .223 .2

phalangiorum morfus not $x$, curatio Diofc.764.16

phalangiorum genera ex Aëtio 223.2. . 764 . 30.

pholangrorun gencra, e morfus note cx Nicandro

764.44

phalangiorunt morfus fignd, or curatio $\quad 765.10$

Phalaris Diofcoridi

phataridis confideratio

469.58

470.35

470.57

phaldridis uires ex Guleno

Fharicon, or eius ueneni note, or curatio Diojcoridi 737.4

phariciucneni confideratio

Plafioli Diojcoridi

platifolorum con/ideratio

phellodrys arbor que

phillyrex Diofcoridi

pliflyre confideratio

Phonix Diofcoridi

plicenicis confider atio

Pliryzius lapis Diofcoridi

phrygilapidis con/ideratio

phrygylapidis uires ex Galeno

737.10

263.53

263.56

137.8

128.25

2.29.2

523.33

$5 \times 3.12$

696.36

696.34

696.36

30.51

32.13

558.3

ph: con/id. $\quad 30.60 .0 \sim$ uires ex Galeno

Plycus morinus Diofcoridi

Pbyllitus Diofcoridi

phyllitidis confideratio

437.46

437.54

438.22

455.47

455.54

456.8

579.10

$579 \cdot \times 4$

Fhyllon Diofcoridi

phylliconfideratio

plyllimentio ex Theophrafto

Phytcuma Diojcuridi

platematis con/ideratio

Ficca arbor Diofcoridi $\because 75.50$

$80.4^{\circ}$

86.14

86.22

86.44

$491.5 \mathrm{x}$

516.43

76.3

$164.2 \mathrm{E}$

220.22

220.40

Pinorun eruce Diofcoride

pinorum erucarum biftoria

pinor um erucar um hausarum note, er remedia Diofc.

727.29

pinorum crucarum uenenum, er curatio

Pinus Diofcoridi

pini biftoria, or gener

$727 \cdot 45$

75.50

76.10

Piper Diofcoridi

piperis confideratio

piperis planta in Italia

piperifer plante uarie

piperis uires ex Galeno

324.55

315.17

$325 \cdot 42$

piper Indicum

$\mathbf{P}$ ifcium ius Diof coridi

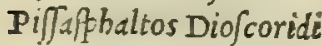

pifaphalti confideratio

Piffeleon Diojcoridi

23.57

204.59

87.36

88.27

86.26
Piftacia Diofcoridi

piftaciorum confideratio

piftaciorum uires ex Galen

63.22

Piftacia fylueftria quid

Piltolocbia

Pityufa Diofcoridi

pityufe confideratio

pityufe uires ex Galeno

63.55

263.59

164.7

348.54

608.22

608.24

608.55

Pix liquida Diofcoridi

86.

86.33

76.42

86.60

280.44

$28 x .35$

$28 x .40$

6.57

8.55

plantas meliorefcere caliclementia, or loci amicitia 9. 10

plantarum fitis naturales $\quad 9.25$

plantarim in radicibus uarietas $\quad 20.3$

plante pro locorum ac climatum differentia, faculta= tes variant

Platanus Diofcoridi

354.54

plataniconfi

ciusuires ex Gdl. 28.47

Platedrij in caphurd error $\quad 83.9$

Plinij lap Jus, e fententixnon probate 18.6 .0225 . 53. $63.38 .063 .28 .0 \% 78.53 . \sigma^{2} 79.12$. er 79.26 .679 .57$. et $99.20 .0100 .57 . e t$ $105.11 .0 \% 129.30 .02120 .55 .02121 .51$. Or $143.8 .0252 .37 .0 \% 179.14 .0 \% 291.27$.

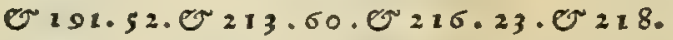

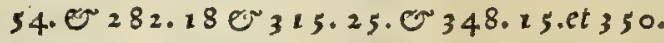
43.051 .61 .0574 .50$. et 378.58 . 3537 .

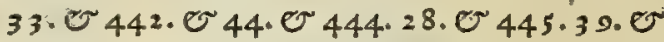
$451.27 \cdot 0460.3 \cdot \sigma^{2} 460.31$. 479.8 . $502.25 .0528 .33 \cdot 0.578 .57 \cdot O_{5} 581.41$. et $592.50 .02586 .30 .02617 .24 \cdot 0052$.

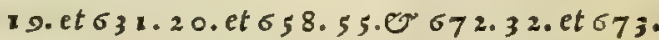
2. et 696.3. et 699.58 . et 704.25

plinius d Brafauoli impugnationie uindicatur 29.42 Plinius à Diofcoride in Gladiolo diffentit . 409.8 Plinius à Diofcoride in malabathro diffentit 32.32 Plinius in colligendo balfamo d̀ Theopbrafto, et Dio= fcoride difcordat

plinius in perfontat defenditno

plumbago Diof coridi

plumbaginis confideratio

$564 \cdot 20$

Plumbum elotum Diofcorid

665.25

plumbum uftum Diof coridi

665.33

plumbirecrementum Diofcoridi $\quad 662.2 \mathrm{~L}$

plumbi fcoria confideratio 662.33

plumbifacultates ex Galeno $\quad 66-2.55$

plumbifcobis noxa, et curatio $\quad 744.13$

Pnigitis terra Diofcoridi $\quad 707.17$

Polemonia Diofcoridi $\quad 488.37$

polemoniz confid. 488.45 . eius uires ex Galeno 489.55

Polente confideratio

Polion Diofcoridi

polij confideratio
250.59

441.57

$442 \cdot 34$

polij 
polijuirçs ex Galeno

Polycnemon Diofcoridi

polycnemi confideratio

polycnemi uires ex Galeno

polygala Diofcoridi

polygale confideratio

polygonaton Diojcoridi

polygonaticonfideratio

polygonati uires ex Galeno

Polyganon Diofcoridi

polygoni utrinfiue confideratio

polygoni utriufque uires ex Galeno

Polypi piscis mira magnitudo

Polypodium Diofcoridi

polypodij con/ideratio

polypodijuires ex Galcno, et Actuario

Pomate conficiend a ratio

Pompholyx Diofcoridi

pompbolygis confideratio

pompholygis, et ßpodijhiftoris ex Galeno

pompholygis uires ex Galeno

Populus alba Diofcoridi

populus nigra Diofcoridi

populi utriufque confideratio

populi lacrymam non effe fuccinum

populnei unguenti examinatio

Porrum capitatum Diofcoridi

porriconfideratio

porri facultates ex Galeno

porrun quo mangonio capitatum fiat

porri agreftis confideratio

Portulaca Diofcoridi

portulace confideratio

portulace uires ex Galeno

Potamogeton Diofcoridi

potamogetonis confideratio

potamogetonis uires ex Galeno

Potentilla

Poterion Diofcoridi

poteriy confideratio

poterij uires ex Galeno

Pratis qua plante latentur

Precipitati uocati facultus

Propolis Diofcoridi

propolis confideratio

propolis uires ex Galeno

Pruna, et prunus Diofcoridi

prunorum confideratio

prunorum uires ex Galeno

prunorum ufus

PSeudobunion Diofcoridi

pecudobunij confideratio

P feudodictamnum Diofcoridi

peeudodia ami confideratio

P. eudomelanthium

P foricon Diofcoridi

Pfyllion Diofcoridi

pfyllij confideratio

pyylii uires ex Galeno

pyyllij facultates ex Mefue

pjyllij cpotifigna, et remedia
442.48

429.49

429.54

429.53

585.50

585.56

486.12

486.22

486.42

485.35

485.48

485.52

196.12

623.53

623.60

624.43

237.23

655.15

656.12

$657 \cdot 3$

657.12

200.34

700.39

100.46

201.27

$20 x \cdot 5$

306.33

306,57

307.5

307.3

307.23

279.16

279.34

279.37

558.34

558.55

558.58

510.37

259.42

259.48

359.54

9. 50

758.12

246.39

246.44

246.50

159.3

159.25

759.22

759.55

575.59

576.8

376.49

377.37

418.22

681.12

530.24

530.44

532.7

530.50

732.7 psyllijueneninoxd, et curatio

732.20

Ptarmica Diofcoridi

ptarmice confideratio

312.14

329.23

ptarmica uires ex Galeno

$31.3 \mathrm{k}$

Ptifane confideratio

Puiegium Diofcoridi

250.50

375.20

375.39

$375 \cdot 44$

375.54

206.26

206.28

206.36

206.55

518.59

$5 \times 9.2$

332.54

687.40

$687.4^{\circ}$

687.52

777.54

278.19

614.20

$61.4 \cdot 27$

154.31

54.32

$254 \cdot 43$

pyrorumgenera

pyrorum facultates

pyrorum uires ex Galeno

$154.61 .0 \sim$ inde

$x 55.3$

164.34

412.20

412.30

$4: 2.50$

$697 \cdot 30$

697.39

$627 \cdot 49$

pyrite lapidis uires ex Gal.

$134 \cdot 54$

QVERCVS Diofcoridi

Quercus confideratio

235.38

quercus plura alia fert preter fructum

quercus uires ex Galeno

guercus, ev olea inimicitia

135.55

$37.2 \mathrm{c}$

15.30

510.57

512.24

512.10

quinquefolij confideratio, er genera

quinquefolij uires ex Galeno

Quirici Auguftilapsus

320,17

R A I CES quando effodiende

5.56

Radicum optimarum note .... $\quad . . .6 .7$

rddices quomodo mundande, ficcande ac conferuande 6.13

radices quibus in locis réponende

6.24

radicum differentic in coloribus, 6 faporibus, 20.41

Radicula Diofcoridi

radicule confideratio

319.42

Radix Diofcoridt

radicis confideratio

329.49

267.40

267.59

Radix dulcis Diof coridi

350.28

radicis dulcis confid. $350,34.0$ uires ex Galcno 350.60

Rddix fylueftris Diofcoridi

$267 \cdot 55$

Rana 


\section{Index}

Rana Diofcoridi

ranarum confideratio

200.40

201.2

201.8

ranarum partus

rane paluftris fumpta noxa, en renedia Diofcoridi 746.36

sane paluftris uenemum

rane malifice figna, or curatio

746.58

747.10

331.4

331.22

332.44

267.40

267.55

268.39

raphani T heophrafto plur a genere

raphaniconfid. 267.59 . Cr uires ex Gal. 268.44

Raphaninum oleum

Rapum Diofcoridi

gapi confideratio

rapi uircs ex Galcno

Ratio commentariorum in librum fextum

Recoct.x quid, or uires

Recrementum argenti Diofcoridi

266.37

266.48

267.5

712.50

231.45

666.3

Remedia ad uaria medicamentorum noxiorum fympto mit.

Remcdia ad conuulfiones

749.12

749.45

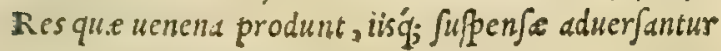
718.45

Refina lentifcina Diofcoridi

refins liquida é pinu, er picea Diofcoridi

refine alie Diofcoridi

refind terebinthina Diofcoridi

refine terebintbine confider atio

refinarum omnium confideratio

refinarum omnium uires ex Galeno

82.5

84.6

ibidem

83.54

84.49

84.56

85.26

Reftabouis

Rha Diofcoridi

361.42

342.42

345.60

210.36

Rbammes Diofcoridi

Ibamniconfideratio

120.49

$2 \times 2.23$

$342.4^{2}$

342.55

343.30

344.10

342.41

344.46

rhei Barbarici nomenclatura undé

rhei Barbarici, feu rbabarbari uires ex Me fue 345.27

rhei Indicinominatio

344.31

rbei Turcicinomenclatio

$344 \cdot 14$

Rhodia radix Diofcoridi

513.49

rbodie shadicis confideratio

523.53

513.12

544.22

Rhododendron Diofcoridi

rhododendri confideratio. uide Nerij confideratio

Rbus Diofcoridi

rbois confideratio

239.35

rhois uires ex Galeno

Ribes Mauritanis quid

ribis officinarum confideratio

Ricinus. Diofcoridi

ricini confideratio

gicini uires ex Me Jue

40.58

16.4

$7 \times 6.6$

603.52

604.2

604.15 ricini uires ex Galeno

ricini fumpti noxa, or curatio

604.82

748.56

55.27

$55.3 \mathrm{x}$

745.56

ricini olei uires ex Mefue

225.22

Rofa Diofcoridi

125.57

ibidem

rofarum genera plura

rofarum fuccus, or dilutum $\quad 226.8$

rofarum dilutum abfque noxa aluum deijcere $226.2 \mathrm{z}$

rofe fylueftres

126.26

rofe dureo colore

126.30

rofarum differentia, or generd ex Plinio $\quad 126.32$

rofarum partes, er earum uires $\quad 126.4 .5$

rofarum aqua fillatitia qua preftantior $\quad 127.2$

rofarum facultates ex Galeno $\quad 127.38$

Rofaceum Diofcoridi

58.54

rofacei confideratio

59.38

rofaceum num conueniat in noxa mădragore 735.43

Rofaceum omphacinum

rofacei omphacini uires

59.42

59.46

Rofcipaftilli Diofcoridi

25.45

Rofmarmum Diofcoridi

412.59

rofmarinum coronarium Diofcoridi

$4 \times 3.53$

sofinarini confideratio

$4 \times 4 \cdot 2$

rofmarinibiftorid ex Theoplorafto

$4 \times 4.9$

rofinarini uires ex Galeto

$4 \times 4.20$

Rubetu, e eius noxe remedia Diofcoridi $\quad 746.36$ rubete uenenifigna 746.58 . cius curatio. 747.10 Rubia Diof coridi 471.35

rubia confid. 477.48. Or uires ex Gal. 471.53

Rubigoferri Diofcoridi

662.23

661.34

rubiginis ferri con/ideratio

676.7

mubrice fabrilis confideratio

676.12

$675 \cdot 4^{2}$

675.49

507.23

507.49

508.1

$26.4^{6}$

E 26.53

27.25

$507.4^{\circ}$

507.55

Ruellij errata, ac eius opiniones reprobat.e $23.55 . \mathrm{Or}$

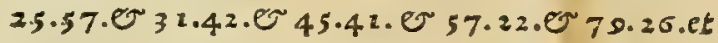
82.22 .0101 .5 .0110 .60 .et $157.32 . e t 173.12$. O $255.55 . \sigma^{2} 278.4$. O 324.41. C 318.28 . 320.55 . O 329.51 . O 333 3.9.0 $343.56 .0 \% 358$.

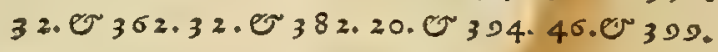
56.00404 .29 .00406 .30 . ON 407.41 .et 420.36 . \% 427.42 . C 428.26 . $429.10 .0438 .10 .0 \%$ 446.12 .et 449.3 . O 459.53 . O 484.40 .00484 . 50.E 495.15 . ON 506.11 . O 562.13 .et 564.49 Or $579.2 \% 580.53 .0 \% 585.29 .0 \% 52.7 .21$.

Rumex Diojcoridi

rumicis con/ideratio

rumic is facultas ex Galeno

Rufcum Diof coridi

rufciconfideratio
269.56

272.12.

272.26

588.15

588.30 
Ruta Diofcoridi

rutamontana Diofcoridi

ruta fylueftris Diofcoridi

rute fatiue, $O$ Jylueftris confideratio

rut $x$ utriufque uires ex Galeno

Rutafylucftris altera Diofcoridi

rute fylueftris alterius confideratio

rutie fylucstris alterius uircs i $x$ Galeno

Ruta capraria, or cius uires

\section{$s$}

SA B I N A Diofcorididefcripta

Sabinie confideratio

fabine vires ex Galeno

Saccharum Diofcoridi

facchariconfideratio

faccharum antiquorü d noftrate non differre 244.17

faccburi factitii inuentio

fuccharum candidun.

Sacraberba Diofcoridi

Sagapenon Diofcoridi

fagapeniconfideratio

Jagapeni uires ex Mefue

Jagapenifacultates ex Galeno

sal Diofcoridi dc fcriptus

falis onnis generis confideratio

Salisfacultates ex Galeno

Sal Ammoniacus Dio coridi

Salis Ammoniaciconfideratio

Sal Armeniacus officinis

Sal Indus quid Paulo, er Auicenne

falis Indi confideratio

Salisflos Diof coridi.

falis floris confideratio

Salis Apuma Diofcoridi

falis pume confideratio

Salnitri uJus

Salamandra Diofcoridi de fcripta

falamandre confideratio

falamandram igni non abfumi, falfum

falamandra aquatica

falamandra baufte figna, or remedia Dio $\int c, 727.55$

falamandre uenefica natura

Galamandre ueneni curatio

Saliua bumana, or cius facultates

Saliuaris berba,Pyrethrum Diof coridi

Saliunca $a_{2}$ eius confideratio

Salix Diofcoridi

Jalicis confid. 232.2. cius uires ēx Gdl.

Salja parilla quid,er uires

Saluia Diofcoridi

Saluie confideratio

faluia uires ex Gdeno

faluie fylueftris confideratio

Saluix Thcophrafto dux ppecics

faline uiresex Actio

Saluid Romand

Galuex Roinsne uires

Sambucis Diof coridi

fambuct, or ebuligener

fumbuci, or ebuli uires
388.33

389.4

$389 . x 2$

389.15

389.40

389.53

390.1

390.52

390.58

92.29

22.40

93.40

243.13

243.59

244.39

245.61

523.19

422.4

421.14

421.29

$421 \cdot 33$

688.9

688.58

689.61

688.20

689.24

689.28

$245 \cdot 48$

689.33

688.48

689.44

688.38

$689.4 x$

689.39 .0090 .5

221.22

221.42

221.56

222.8

728.2

728.17

242.34

412.20

28.15

172.53

132.21

225.24

378.34

278.43

378.59

378.44

378.51

378.62

380.34

380.54

613.38

613.55

614.1
Sambuciutriufque facultates éx Galeno

614.22

Samia terra Diofcoridi

famie terreconfideratio

707.23

Samius lapis Diofcoridi

707.37

707.33

707.50

385.20

famij lapidis confideratio

Sampfuchum Diofcoridi

Jampsuchi confid. 385.36 . cius uires ex Gdl.3 85.49

Sampfuchinum Diofcoridi

60.40

60.50

fampfuchini eonfideratio

683.39

Sandaracha Diofcoridi

683.47

fandarache confideratio

684.20

fandarache uires ex Galeno

Sandarache pote noxa, et eius remedia Diof. 745.29
fandarache malefica uis, or curatio 745.35

Sandarachagummi

$3 x .57 .02682 .55$

fandaracba ceraginofi mellis genus $22.15 . \mathrm{CN}^{\circ} 684.4$

Sandarax Arabum quid

Sandyx Diofcoridi

fandycis confideratio

$22,1.0683 .57$

657.50

667.55

fandycis facultas ex Galeno

668.2

Sanguinaria mas Diofcoridi

485.35

Janguinaria fomina Diofcoridi

Sanguinarix confid. er uires, uide in Polygono

Sanguis Diofcoridi

anguinis confideratio

485.43

38.53

fanguinis quorundam animalium uires peculiares à $G a$ leno improbata

239.12

Sanguis taurinus, eius q́; epoti note, er curatio Dio co ridi

732.24

Sanguinis tauri uenendta potio

731.24

fanguinis menstrui uenenum, cius remedia $741.4^{2}$

Sanicule generd, er uires.

Sanicula,quinquefolijpecies

$490 \cdot 47$

Santalorum confideratio, or genera

522.7

fantalorum uires

Sapa Diofcoridi

Sapphirus lapis Diofcoridi

fappbiriconfideratio

45.54

45.56

640.29

703.40

703.43

fapphirus nostri uJus fupectus

703.40

Sarcocolla Diojcoridi

423.45

423.48

423.58

farcocolle uires ex Arabibus

$\begin{array}{lr}\text { Sarcocolle facultates ex Galeno } & 424.7 \\ \text { Sardiane glandes Diofcoridi } & 37.3\end{array}$

Sardonia berbe noxa, or remedia Dio"c. 734.26

fardoni. berba uenenum,eiusq́; curatio

734.33

692.54

383.58

Satureia Diofcoridi

Jatureie confideratio

384.5

fatureia uires ex Paulo

$38.4 \cdot 26$

Satyrium Diof coridi

457.44

fatyrium eritbronium Diofcoridi $\quad 457.58$

fatyrij confid. 457.57 . cius uires ex Gal. 459.2

Saxifraga Diof coridi

faxifrage confideratio, uires

495.42

495.49

faxifrage nomen pluribus plantis communē 496.6

faxifragadba

496.20

9.42

Saxo/is locis qua plant gaudeant

492.45

492.50

fabiofe uires

Scammonia Diofcoridi

6.10 .37

fcammonic 
frammonis, er eius fucci confid.

frammonium of ficiarum uitiatum

fc.mmonij lefioncs cx Mcjue

fcammonil ures ex codem

fcammonij nox.i, o cius curatio

Scaldix Diofcoridi

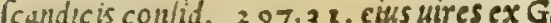

fcundicisconfid. 297.92. cius uires ex Gal.297.57.

Scuriols que pecies unizbi

Schiftum lac Diofcoride

Schiftos lapis Drojcoridi

fchiftrlapidis confidcratio

fot, ittlapudes uires ex Gileno

Scill. Doojcorid

foll e conlid. 327.35 . eius uircs ex Gsl. 327.54

falle prepursio

fall.r uenenofe noxa, or cur.stio

327.48

730.52

647.23

Scillinum acetum Diofcoridi

fcillini aceti uircs admirabiles ex Galeno

Scincus Diofcoridi

fcinciconfideratio

fcinci Vicentini

fcincimentio, wires ex Plinio

Scolopendrs Diofcoridi

fcolopendre marme confideratio

folopendre ittus nocter, or curatio Diofc.

frolopendre ucnenole con/ideratio

fcolopendre mor fus remedia

Scolopendrion Dıofcoridi

fcolopendrij confideratio

Scolymes Diofcoridi

Scordion Diofcoridi

fcordij con/ideratio

fcordium ubi optimum

fcordij uires ex Galeno

Scorkaferri Diofcoride

fcorie ferri confideratio

Galeno

Scoria plumbi Diofcoridi

fcorle plunbi confideratio

fcoris omnis uires ex Galeno

Scorodoprafum Diofcoridi

fcorodoprafi confideratio

Scorpente pifcis confideratio

Scorpioides Diofcoridi

fcorpoidis confid. 629 . 8.eius uires ex Gal. 629.20

Scorpiurus berba Diofcoridi

Scorpius marinus Diofcoridi

forpij marini con/ideratio

661.34 . eius uires $e x$

224.48

224.54

224.59

225.32

189.46

289.49

765.45

765.52

766.2

463.17

463.38

358.55

442.57

443.10

443.33

443.42

661.32

661.40

662.21

662.33

661.40

310.13

320.19

28.28

636.4

416.47

188.9

188.28

fcorplonis marini itlus note, G curatio Diof. 767.26

Scorpius terreftris Diofcoridi

fcorpionis terreftris confideratio

$187 \cdot 3$

187.23

187.23

I. 87.44

87.54

fcorpiones altgeri.

forpionum fxultates

fcorpionü oleum mir e facultatis 187.560723 .54
fcorpones aliqubus adinotis ttupidi redduntur. 25.62

fcorpiones qutbus adinotis reutuifcant

- Scorpionis it m probibentis

fcorpionis ifus note, er curstio Diof.

fcorplonum gonera ex Nicandro

16.2

16.4

766.12

766.30

766.90 fcrophuldria \$\$ \$.29. eiusuires

556.20

Secale firmentigenus

Secucu! Arsbum

Securidaca Diolcoridi

252.35

364.59

460.19

fecurdiace confideratio

fecurdixce uircs ex Gilleno

460.27

460.37

550.50

551.34

552.60

92.47

704.22

$704 \cdot 28$

708.4

550.50

552.4

551.12

552.33

368.34

7.26

feminum, o fructum in plantis diferimina 14.25

senaberba, $\mathcal{O}$ eius hiftoria $\quad 420.29$

fen $x, \mathcal{O}$ eius diluti uires $\quad 411.53$

fene dilutipropuratio $\quad 412.02$

fene uinum $\quad 412.5$

fenefolliculorum uires $\quad 422.23$

senecta anguium Diofcoridi $\quad 193.22$

fenect anguium confideratio $\quad \mathbf{9 3 . 3 7}$

Senecio Diofcoridi $\$ 56.49$

fenecionis confid. 557.1. eius uires ex Gd. 557.5

Sepia Diofcoridi $\quad 295.52$

Sepiarum confideratio $\quad 295.58$

Sepiarum facultates $\quad 206.22$

Seplafiariorumlapfus $\quad 27.61 .0 \% 50.49 .0 \mathrm{~s} 5$. 57.058 .40 .0280 .21 . Or 320.24 .

Seps Diofcoridi

fepis fere confideratio

224.3

fepis morfus figna, et remedid

$224.29 . \hat{e t} 770.27$

770.32

Serapionis errata $22.56 .0232 .57 .0 \% 39.7 .074$. $28.0 \%$ es $5.25 .0 \% 507.8 .0 \% 547.35 .0 \% 573.5$

Serica Galeno quid

fericiconfideratio, er uires

160.38 .00161 .1 ;

Seris Diofcoridi

168.2

feridis confideratio

287.28

Serpensmarina Ariftoteliquid . $\quad$ I 89.24

serpyllum Diofcoridi

ferpylli confideratio

384.32

Serpylli uires ex Galeno

384.52

Sertula Campana Diofcoridi

fertule Campane confid. uide Meliloti con/ist.

Seruij Grammatici error

Serumlatis Diofcoridi

Seriuires ex Galeno

Seriuires ex Mefue

Sefanum Diofcoridi

385.23

385.59

fefami confideratio

$\int e \int a m i$ uires ex Galeno

Sefamoides magnum Diof coridi

sefamoides paruum

120.22

229.10

231.50

232.55

256.20

257.2

257.26

594.55

595.4

505.9

395.49

325.58

Jejeli 
Sefelinuspitienfe Diofcoridi

feclil Pelopoincure Diofcoridi

fejelis omnis con/ideratto

fefelis uires cx Galeno

Sicyoniun olcum Diofcoridi

Sidcritis prima Dofcoridi

fidcritis fecunda Diofcoridi

fidcritis tertia Diofcoridi

fidertis ommis confideratio

fidcritis uires ex Galeno

Stgna in commune ueneni fumpti.

Siliqus Diofcoridi

filiquarum confid. 248.8. or uires ex Gal. 148.30 silurus Diofcoridi

filuri pifcis confideratio

silybum Diofcoridi

filybe confideratio

simplicium peritia dequirinon potef ex librorm tum lectione

simplicium peritia d preceptoribus, non ex libris com paratur

$4 \cdot 4$

Simplicium nomina uaria Diof coridi adulterina 8.34

Sinapi Diofcoridi

finapi confideratio

finapi uires ex Galeno

310.39

320.55

310.62

sion Diofcoridi

sij confideratio

sij uires ex Galeno

Sifer Diofcoridi

fîeris confideratio

fiferis uires ex Galeno

$28 x .58$

$282 . x$

382.23

269.34

269.37

269.42

fiferis forma

sifon Diofcoridi

fifonis confideratio.

sifymbrium Diofcoridi

fifymbrij confideratio.

fifymbrij in mentbam mutatio

fifymbrium aquaticum

fifymbrij utriufque uires ex Galeno

smarides pifces Diofcoridi

finaridum confideratio

Smilax hortenfis Diofcoridi

fimilacis borten/is confideratio

smilax apera Diof coridi

fmilacis apere bistoria ex Theophrafto

fmilax leuis Diofcoridi

fmilacis leuis biftorid

fimilacis utriufque uires ex Galeno

smilaç glandifere confideratio

Sinyris lapis Diofcoridi

fmyridis confid. uires ex Galeno

Smyrnion Diafcoridi

f myrnij con/id. 406.4 . cius uires ex $G l_{4}^{40} .44$

sodomeus lacus

406.4 . eilsuiresex Gal.406.33
$87.57 .0 \% 88.22$

Solanum halicacabum Diofcoridi

Solanum bortenfe Diofcoridi

folanum manicum, feu furiofum Diofe.

folanum fomniferum Diofcoridi

folani omnis generis confideratio

folani hiftoria ex Theoplorafto

folani uires ex Galeno

531.58

531.14

532.52

532.39

533.2

533.32

533.49 folani manici noxa, er curatio

730.16

solbaltrella,er cius uires

586.56

soldanella qua

277.60

Solidaginis minoris, er media uires

490.37

solidago regalis

420.54

Sonchus Diofcoridi

287.4

fonchiconfid. 287.12 , eius uires ex Gal. 287.27

Sorba Diof coridi

58.33

forborum confideratio

158.39

forborum uires ex Gdeno $\quad 258.51$

Sory Diofcoridi

foreos confideratio

foreos biftoria, er uires ex Galeno

$68 \mathrm{x} .38$

$68 \mathrm{x} .52$

Sparganion Diofcoride

682.25

499.22

Pearganii confi. 499.28. ciusuires ex Gal. 499.46

Spartion Diofcoridi

partij confideratio

508.41

568.48

Partij ufus ex Plinio

598.60

600.2

Spatha Diofcoridi

142.42

sphacelus

378.52

Sphondilium Diofcoridi

414.40

Phondilij confid. 414.57, cius uires ex Gal 425.7

Splragis agos Diofcoridi

676.23

Spinacia

spina acuta Diofcoridi

274.42

Bine acute con/ideratio

123.29

pine acute uires ex Galeno

223.38

Pind acuta legitima que

Bina alba Diofcoridi

126.39

224.35

pine alba confideratio

357.4

357.19

358.24

358.22

358.26

358.47

655.25

656.22

657.3

694.43 .

694.56

695.17

705.60

Pongiarum lapides Diof coridi

Spuma nitri, uide Nitri puma.

spuma falis,uide Salls ßpuma.

spuma argenti,uide Argenti puma

squdma aris, uide Aeris fquama

squama ftomomatis Diofcoridi

fquame ftomomatis confideratio

653.20

658.42

fquama fomomatis que legitima

659.23

squillarum confideratio

185.32

squinanthum

42.9

Stachys Diofcoridi

437.18

ftachyos confid. 437.27, eius uires ex Gal.437.39

Statte Diofcoridi

stactes confideratio

Stapbis agria Diofcoridi

64.50

64.55

596.58

597.24

597.19

729.52

164.8

573.32

Stellionum 


\section{Index}

Stellionum confideratio

felliontum morfus remedia

Stercoris uires

Stcreusfirri,uide Ferri stercus

Stióium Diofcoridi

ftibij confideratio

ftibii uires ex Galeno

ftibij uis deic ctoria

Stimmi,legge fuprà Stibiuns

Stoebe Diofcoridi

Slocbe Diofcoridi 492.29

sloechds Diofcoridi

Poechadis confideratio

fachadis uires ex Galeno

ftechadis uires cx MIcfue

Stomoma Diofcoridi

Stramonia lacrbat

Stratiotes Diofcoridi

fratiotic confideratio

Stratiotes millefolium Diofcoridi

ftratione millefolij con/ideratio

frratiote mille,folij uires ex Galeno

strigment: b.:Incurtum

struthium Diofcoridi

Struthij confid. 3 × 9.49. Or uires ex Gdl.

styrax Diofcoridi

fyrecis confideratio

fistax calanita unde difa

ftyracis uires ex Galeno

suberis confideratio, e biftorix

fuberis uires

succedanea quando admittenda

succi quomodo exprimendi,feruandiq́; ;int

Succinum Diofcoridi

fuccinibiforia uaria

sudoris animalium wirus, e remedia

suffrutices qui dicantur

Surilus pulmo Diofcoridi

fuilus talus Diofcoridi

Sulphur Diofcoridi

fulphuris confideratio

fulphuris faciendi ratio

fulphuris uires ex Galeno

sycomorus Diofcoridi

fycomoribiftorid

fycomori confideratio, er uires ex Galeno

fycomorus Italie adulterina

fycomoro ficus Cypria fimilis

syluas que plante addment

sympathid, e antipathid rerum

Symphyton petreon Diofcoridi

fymphyti petrei confider atio

Jymphytum alterum Diofcoridi

fymplysbi alterius confideratio

fymphyti utriufque uires ex Galeno

symphoriani Campegij lapjus

syrupus uiolaceus

$T$

IAL v s Juis Diofcoridi

Talli fuilli confideratio
728.29

729.3

$240 \times 0.0$ inde

663.33

$663 \cdot 44$

664.5

660.8

372.36

372.45

372.56

373.3

658.38

533.49

559.4

559.9

559.16

559.54

560.4

54.2

319.41

320.1

68.32

69.1

69.3

69.30

136.52

137.4

725.2

7.50

100.41

101.44

742.38

8.48

206.36

226.58

686.45

686.58

687.20

687.23

268.22

268.46

168.56

269.8

269.2

10.1

29.25

489.35

489.51

480.41

489.57

491.1

252.39

575.18

216.58

216.20
Tamedrix Diofcoridi

107.48

tamaricis confidcratio 208.4 . cils uires 108.22

Tamarindorum confideratio

242.46

tamarindorum uires

Taltacetum

Tarantule confideratio

tarantula iftus mirabiles cffectus

tarantula iftus mufica remedium

tardntule uenenum, or cius auxilia

42.55

467.23

223.26

ibidem

223.28

765.39

Taurifanguis, uide Sanguis taurinus

Taxus Diofcoridi

taxiconfideratio

taxi biftoria ex Theoplyrafto

542.55

543.4

543.10

taxibiforia ex Plinio

543.20

taxinires ex Galeno $\quad 543.20$

taxinoxa, er cius remedia Diofcoridi $\quad 732.55$

taxi uenefica natura

tuxus utrum calida, uel frigida

Tede confideratio

Teleplium siof coridi

telcoliij confid 340.20 .

Telline Diofcoridi

tellinarum confideratio

Tembulum Arabun

Terebintus Diofcoridi

terebinthi confideratio, o biftoria

terebintbi uires ex Galeno

Terebinthina Dio coridi

terebentlina refina confideratio

Terra omitis Diof coridi

732.58

733.22

78.55

340.14

terrarum brevis enarratio

terra fornacum Diof coridi

terras alias quare in fuis propris nominibus

Terrantula Italis quid

Tefta fornace D Diof coridi

Tefticulus Diof coridi

tefticulus alter Diofcoridi

tefliculor un confideratio

tefticulorum uires ex Galeno

279.40

179.59

32.36

83.44

84.25

85.2

$84 \cdot 5$

84.48

707.6

635.33

708.28

Teucrium, Teucris Diofcoridi

teucrij confideratio

teucrij uires, o hiftoria ex Plinio

teucrij facultates ex Galeno

Thalaffomeli Diofcoridi

$224 \cdot 38$

708.23

456.22

457.35

457.58

558.54

431.22

431.20

432.28

431.40

645.44

557.12

557.15

557.28

597.33

$598.2 \mathrm{~L}$

$\begin{array}{ll}\text { Thapfia Diofcoridi } & 597.33 \\ \text { thapfia confideratio } & 598.2\end{array}$

thapfía radices turpeti uicě illegitimé explět $598.2 \mathrm{z}$

thapfie uires ex Galeno $\quad 598.25$

thapfie noxa, or remedia Diofcoridi $\quad 747.57$

thapfie potionis figna, or curatio $\quad 748.32$

Thedmedes lapis, 0 eius mir a natura $\quad 701.12$

Theodorilapfus $\quad 153.4$

Theophrastifententix non probate 105.11 . O $20 \mathrm{~L}$

$54.0 \% 426.3$

Theophrafti locus in cornibiforia fupectus $\quad \times 58.6$

Theophraftide generatione lapidum opinio 636.53

Theriace componenderatio deprauda $\quad 64.28$

theriacalaudibus disleno celebrata

762.12

Thlapi 
Thlapi Diof coridi

thlapiconjederatio

thispl uires ex Galcno

312.31

322.45

322.56

766.27

700.30

204.7

$204 \cdot 14$

204.32

204.42

71.22

72.6

72.31

71.40

71.54

$7 \times \cdot 49$

$\therefore \quad 73.4$

702.32

$6 x 2.53$

612.38

748.57

$647 . \times 5$

$383 \cdot 4$

383.20

383.34

383.37

383.58

Thymbra Diolcoridi

tbymbra confid. 3 8.1. eius uires ex Paulo Tigname officinis quid

Tilla confid. 219.2 . eiusuires

Tithymali omnes Diofcoridi

tithymalorum omnium confideratio

titbymali cogniti

titbymali Theoplorafto tria tantum genera

tithymalorum uires ex Mcfue

titbymalorum uires ex Galeno

titbymalorum noxa, or remedia

Tordilium Diof coridi

- Tormentille defcriplio, er uires

Torpedo pifcis Diofcoridi

torpedinis confideratio

torpedinis mira facultas

torpedinis uires ex Galeno

Toxicum, e eius ueneni curatio Diofcoridi

toxici confideratio

roxicifumptinote ex Nicandro

toxici,e napclli difcrimen

Tragacantha Diofcoridi

tragacanthe confid.363.38. Cuires ex Gal. 364.2

Tragium Diofcoridi

tragium alterum Diofcoridi

tragijconfid. 516.27. er uires ex Gal.

Tragoriganum Diof coridi

tragorigani confideratio

Tragos Diofcoriali

tragi cerealis confidcratio

Tragum Diofcorti

tragi herbe confideratio

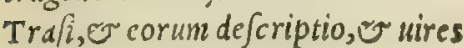

Tribulus Diofcoridi

tribulu utriufque confideratio

tribuli utriu/que wires ex Galeno

49.34

119.42

606.4

606.49

607.13

607.31

607.42

607.50

748.56

325.58

483.34

289.57

789.60

120.20

120.36

737.22

$737.3 \circ$

737.56

738.5

363.12

516.25

516.23

517.9

374.35

375.9

253.25

253.18

517.22

517.33

303.21

494.57

495.8

495.25
Trichomanes Diofcoridi

trichomanis confideratio

trichomanis hiftoria ex Theoplar afto

582.36

582.40

582.52

trichomanis uires ex Galeno

583.5

Trifolium Diofcoridi

trifolij omnis generis confideratio

trifolijacutibiftoria ex scribonio

438.58

439.49

440.2

trifolium pratenfe tempeftates prenunciat 440.52

triflium odoratum

trifolium acetofum

trifolij uires ex Galeno

Trinitas herba, o eius biftoria, et uires

440.43

440.8

442.8

440.55

581.4

Tripolion Diofcoridi

tripolij confid. 581.10 . et uires ex Gal. 581.44

Triffago Diofcoridi

triffaginis confideratio

431.50

$4,2.2$

triffaginis biftoria, et uires ex Theophrafto $\quad 432.22$

trifjaginis uires ex Galeno

Triticum Diofcoridi

tritici genera ex Treophrasto

triticum it alicum optimum

tritici oleum

249.18.

et uires ex Gal. $24,9.43$

$249 \cdot 41$

Tubera Diofcoridi

303.28

tuberun confideratio

tuberum uires ex Galeno

303.47

$304 \cdot 5$

Turbit Arabum

482.25

Turpetum, et eius confideratio, et biftoria ibidem, et 618.35

turpeti noxa, et curatio

748.55

Tußilago Diofcoridi

444.9

tußilaginis confid. 444.21 . et uires ex Gal. 444.49

Typha Diofcoridi

typhe confideratio

450.45

typhe ujus, et uires

450.52

450.56

V

VA L ER I A A maior

32.2

Valeriana minor

$3 x .9$

Varia de generatione lapidum fententia

uaria de metallorum ortu fententia

630.32

Veneficorum doli Diofcorid

$63 \times .58$

uenena quot modis mortem adferant

uenena petunt diuerfa membra $\quad 715.40$

uenena calida non pofjunt in nutrimentü uerti $\mathbf{7 1 7 . 3}$

uenena precauendi modus

717.52

Venena curandi ratio generalis Diofcoridi $72 x .3$

uenena curandi ratio uniuerfalis $\quad 719.27$

uenend incognita uomitu deprehenduntur Diofcoridi

721.24

Venenata animalia Diofcoridi

Veneni operatio qualis

uenenibumidi exemplum

750.36

713.13

uenenifumpti in commune indicid

724.46

729.5

uenenis, quorum nulld cognitio, que opitulentur Dio=

fcoridi

Venenorum generd unde

$72 x \cdot 13$

uenenorum effectus à diuerfis caufis

713.26

uenenorum pracautio quadam explofa

714.28

uenenorum pracautio ex medicamentis

$717: 54$

789.12

uenenorum 
zenenorum ressedia in genèr ali

wenenor um ahimalium diuerfi gradus, et affectus

760.56

Venennm quandoque morbis, or alteri ueneno remes diusn $\mathrm{c} f \mathrm{t}$

727.34

uencmum ferpentium figidum cfle, falfum 761.10

Veneris pecten

Vencris unblicus Diofcoridi

ueneris unibilicus alter Diofcoridi

298.5

552.43

552.52

weneris unbiliciutriufque confideratio $\quad 552.57$

uenvis umblici wtrinfque uires $\mathrm{ex}$ Galeno 553.17

Verutrum album, legr juprà in Elleboro albo.

ucratrwn wivmngice triginta perdurat annos $\quad 6.30$

Verb.ricum Dicicoridi

60.16

ucrbafriconfideratio, or gentera $\quad 562.9$

werb. 2 ci uires quid.um $\quad 562.23$

werb.efigenerd, 0 uires ex Guleno : $\quad 562.47$

ueringibjolucftris mentio

Verbinuca Diofcoridi

ucrbintace utriufane confideratio

ucrinsere uires cx Geleno

Vermestcreni Dicleosidi

werminn tcrenoium uires

wcrmiun terrenorun oleun

ucraiun in lignis chafcentium ufus

veronic elorbelififoria, wires

Veficaria folanigenus

weficarialters

Vceparumiqus curatio Diofcoridi

ueparumictus, $\odot$ rentedia

Vgonis Solerij de nigro ueratro opin. explo/a 593.2

Viburnum quid, er cius defcriptio $\quad \quad 140.46$

Vicie uires ex Galeno

vifus ratio in mor $\int u$ rabiofi canis Diofc.

witus ratio demor for ${ }^{2}$ à cane rabiofo

uictus ratio eorun, qui uenena fump ferunt

Vincetoxicum, o cius de criptio

Vina marina Diofcoridi

uina picata Diof coridi

uina re finata Diofcoridi

Vinet is qux plants leté nacantur

Vini natura, er genera Diofcoridi

uini facultates uarie pro modo ufus

uini ufus cui atati conueniat

uini ufus moderatus quantum profit

uini ufus immoderatus qudntum obfit

uinorum factitiorum confideratio

Vinum abiegnum Diofcoridi

uinum abrotonites Diofcoridi

uinum abfinthites Diofcoridi

uinum acorites Diof coridi

uinum adynamon D io coridi

uinum anethinum $\mathrm{D}$ to fcoridi

uinum apijtes Diofcoridi

vinum aromatites Diofcoridi

uinum afarites Diofcoridi

Vinum bunites Diofcoridi

Vinum calaminthites Diofcoridi

uinum catorchites Diof coride

uinun cedrinum Diofcoridi

unum cedrices Dicfecridl
305.48

562.9

523.5

523.36

523.56

226.18

226.22

226.26

105.46

370.22

533.3

533.43

763.55

763.60

758.24

758.56

720.24

428.2

648.35

640.37

ibidem

0.52

640.25

641.28

$64^{1.40}$

$64 x .25$

641.30

653.30

652.8

651.29

052.52

642.32

652.56

649.1x

652.14

652.37

651.59

652.8

650.23

250.55

652.2
650.55 uinume eCeltica nardo Diofcoridi

65232

winun ceftrites Diofcoridi

651.52

uinum ch smadryitcs Diofcoridi

uinum é camelex $a$ Diofcoridi

651.46

653.3

$6 \$ 3.6$

列

652.10

uinum e conyza Diofcoridi

650.55

648.48

$652.4 \%$

anum cydonites Dio/corid

uinum daucites Diofcoridi

uinum dict amnites Diofcoridi

652.62

652.52

uinum é dulci radice Diofcoridi

652.57

Vinum éflore follis Diofcoridi

diq́; ratio

224.25

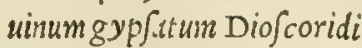

Vinum belleborites Diofcoridi

640.36

uinum by fJopites Diof coridi

652.59

Vinum ex iride Diofcoridi

652.37

uinun iuniperinum Diofcoridi

652.28

6.50 .55

Vinum é labrufca Diofcoridi

642.54

uini è labrufca uires

642.57

uinum laurinum Diofcoridi

uinum lentifcinun Diofcoridi

650.55

650.5

Vinum malabatbrinum Diofcoridi

652.32

uinum mandragorites Diofcoridi

653.7

uinum maratbrites Diofcoridi

uinum é marrubio Diofcoridi

652.56

652.2

uinum melites Diofcoridi

uinum melitites Diofcoridi

uinum melomeli Diofcoridi

uinum é myrrha Diofcoridi

648.48

643.4

648.53

652.27

649.57

649.49

652.39

652.30

640.27

649.17

649.4

642.19

652.7

650.12

6.52 .59

640.28

652.56

252.59

651.10

6.50 .55

641.57

$652: 8$

649.28

650.38

6.49 .42

679.23

652.47

652.6

Vinum Saluiatum Diofcoridi

uinum e fatureia Dic Ccoridi

uinum fcammonites Diofcoridi $652.59 .0 \% 6.53 .26$

uinum fallinum Diofcoridi

uinifcillini uires ex Galeno

uinum frechadites Diofcoridi

uinum Jtrobilites Diofcoridi

uinume $\dot{e}$ ycomoris Diofcoridi
648.7

248.20

651.49

650.48

65033 uinum 
2uinun e sy:isex intrdo Diofcoridi

Vinum terebinthinum Diofcoridi

uinum thy:nites Diofcoridi

uinum éthynelex Dof coridi

uinum tragorig smices Dio,coridi

Vinum uetus Diofcoridi

uinum vipacum, $\sigma$ cius uires

Viols allax Diofcoridi

Viola purpurea Diofcoridi

ziole purparce confideratio

molarum uires ex IIe fue

zioldrum uircs cx Galeno

Viperd ex bominis uentre fugata

uipere Aegyptijs cibus

wiper a wino delect antur

zipere iffus note, o curatio Diofcoridi

niperarun confideratio

uiperarum facies fexusq;; difcrimen

zuperarum morfus indicia

uipcrarum morfus remedia

siperarum uen atio, or carum paffitti

viperine carnes Diofcoridi

wiperine carnis uires ex Galeno

virga aurca, o cius biftoria, o wires

uirga pastoris, or cius confideratio

virulcntoruns iftum, uel norfumm curatio

vifcum Diofcoriti

mifcicon/ideratto

wifci utilttas in Hetrurid

wifci uires ex Galcno

vitex Diofcoridi

miticis confideratio

uiticis uires cx Galeno

Viticelle herbet biftoria

vitices alba Diofcoridi

witis albee confideratio

witis uires cx Galeno

Vitis nigra Diofcoridi

sitis nigre confideratio

uitis nigra uires ex Galena

vitis fylucftris Diofcoridi

zitisfylueftris confideratio

uitis fylueftris uires ex Galeno.

Vitisuirifera Diofcoridi

witis uinifere con/ideratio

uitis, E brafice odium

vitrmiti in larice error

Vlmus Dicfcoridi

ulni confideratio, e haftoria

ulmi facultates

ulmi tircs cx Galcno

vlua que

Vmbilicus Veneris, uide fuprà Veneris unbilicus

Vucdo, Arbutus,idco quare in Arbuto.

Vinguentorum ratio Diofcoridi

unguentorun conjideratio

Vngucntum abrotoniun Diofcoridi

anguentums amaracinum Defcoridi

unguentuas encthinum Diofcoriäi

viguentum butyrinum Diof coridi

Vuguenum cimmanomizim Diofcoridi
652.32

650.5

652.35

653.2

652.57

640.15

641.58

454.50

574.16

574.52

575.3

575.20

209.22

$\times 23.12$

202.21

768.35

121.11

201.40

768.57

769.17

192.28

120.60

191.57

506.24

356.33

761.20

425.4

$425 \cdot 31$

425.35

426.27

230.47

I $31 . x$

132.22

622.4

620.10

620.42

620.56

621.8

622.20

$62 \pi \cdot 48$

619.33

6. 9.43

620.3

$636.5 \mathrm{x}$

637.25

25.32

79.57

.04 .44

204.57

105.19

105.30

558.21

58.46

59.29

61.28

63.47

61.34

62.40

65.9 unguentum crocinum Diofcoridi

62.28

unguentum Cyprinum Diofcoridi

62.42

Vnguentum clatinum Diofcoridi

59.52

Vnguentum gleucinum, uide Gleucinum .

Vinguentum bedycbroon, uide Hedychroon.

Vngnentum iafminum, uide Iafminum .

unguentum irinum Diofcoridi

Vngueukum lilinum Diofcoridi

unguenti lilini co/ideratto

Vinguentum malabatbrinum Diofcoridi

unguentum megalinum Diofcoridi

unguentum melinum Diofcoridi

unguenti melini conficiendi ratio

unguentum Mendefium Diofcoridi

unguentum metopion Diofcoridi

Vuguentum narcißinum Diofcoridi

unguentum nardinum Diofcoridi

unguentum nicandri

Vnguentum ociminum Diofcoridi

unguentum œenanthinum Diofcoridi

unguentum onychinum Diofcoridi

62.58

61.42

62.10

65.32

64.5

59.59

60.10

64.44

$64 \cdot 34$

62.15

65.24

$763 \cdot 2$

61.18

60.55

62.38

Viguentrofaceum, lege Rofaceum.

Vnguentum Samp Juchinum Diofcoridi

unguenti famp fucbini confideratio

60.40

unguentum fry racinum Diofcoridi

unguentum fufinum Diofcoridi.

- Vnguentum telinum Diofcoridi

Vngula afini, er capre Diof coridi

ungularum animalium uires

Vnguis odoratus Diofcoridi

60.50

62.38

$6 x \cdot 42$

60.14

208.16

208.36

I 80.44

unguim odor ator um confideratio $\quad 280.52$

Vniones quipraftantißimi

unionum uires

Vrina Diof coridi

urinarum facultates

279.12

279.25

$242 \cdot 37$

Vrtica Diofcoridi

urtice.confideratio

241.55

553.59

554.16

5.54 .24

urica uires ex Galeno

555.50

urtice feminis nox $d_{2} \mathrm{O}$ curatio

731.17

vftio auxilium contra uirulentos iCtus Diofc. 757.42

uftionis utilitas

Vtrum uenena in ftatum diem interinere poßint

757.57

715.60

Vtrum quis affuefieripoßit, ut uenend innocué fumat $7 \times 6.43$

Vtrum animedia, qua cibis uenenofis uictitant, exitio=

fam uim rctineant

Vua Diofcoridi

uue confideratio

$7 \times 7.10$

$6,37 \cdot 14$

637.25

uuarum uires ex Galeno

$637 \cdot 44$

Vuapuffa Diofcoridi

638.4

une pajfe confideratio

638.12

638.47

115.56

621.22

$\checkmark$ ua pina, or eius ufus

206.37

$x$

XANTH I ON Diofcoride

Xantbij con/ideratio 
x antbij uires ex Galeno

Xiphion Diofcoridi

Xiphiapifcis

Xylon, $\mathrm{C}$ eius confideratio

xyli uires

Xyloballamum Diofcoridi

xylob.l[smun of ficinarum purium

xylob.15.sni siccm quid explest

Xylocinnamomum Diofcoridi

Xyris Diofcoridi

xyridis confideratio

xyridıs uires cx Galeno
583.58

498.38

204.28

25945.00450 .19

450.32

43.32

44.38

44.45

33.36

499.53

500.4

500.6
Z E A Diofcoridi

g

Zex confideratio

zea uires ex Galeno

Zedoarie confideratio, o uires

Zibettibiftoria, o facultas

Zizypha, $v$ corum confideratio

Zopiffa Diofcoridi

Zuccharum alhufar

Zurübet Arabibus, idě quod Grecis Arnabo $3 \times 7.49$

zurumbet quid

Zythum Diofcoridi

zythiconfideratio
258.54

252.58

252.22

317.42

47.35

260.35

86.40

$3: 7.52$

352.25

252.24

\section{SIMPLICIVM MEDICAMENTO- rum facultates fecundum locos ex Diofcoride.}

\section{ADCAPITIS DOLOREM EX FRI= GIDITATE GENITVM.}

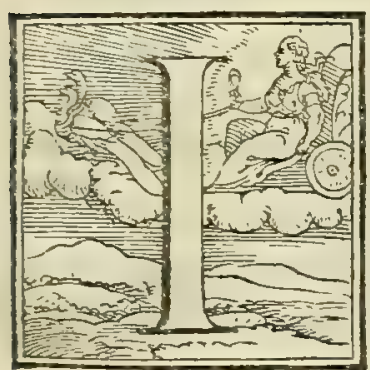

R I s Illyrica cumaces to, o rofaceo illita.

oleüfylueftres oliue in = unctum.

Oleum amygdalinum illi= tum perfe.

viticis femen emplaftri modo adhibitum.

Amygdale amare cum ace to uel rofaceo fronti uel temporibus illite .

Torpedo marina uiua per fe tantum admota.

I ana fuccida cum aceto, or rofaceo impofita.

Sijymbrium fronti,e tensporibus illitum.

Hedere corymborum, uel foliorum fuccus cum aceto, o' rofaceo perfufus.

Aloë temporibus, o fronti ex aceto, $\sigma$ rofaceo illita. Mentha fronti per fe illita.

Sexpyllum coctum, adiecto rofaceo, acetoq; madefactü, $\widetilde{r}$ appofitum.

Melilotus rofaceo, aut aceto madefacta, er impofita. Paccharis folis illita per fe.

Ruta cum rofaceo, er aceto illita.

Ansum potum per fe.

Sphondylium cum ruta illitum.

Peucedanum ex aceto or rofaceo illitum.

Melanthium fronti per Jefe illitum.

Conyza minor per fe illita.

Anagyris tener a folia drachme pondere ex uino pota. Rhodia radix recens cum rofacei momento impofita. Hippogloßsum pro.ferto capiti impofitum.

Chamedaphnes folia trita, o impofita.

Elaterium ex lacte naribus infufum.

Rufcifolia, er bacex in utno pota.
Scammonia ex aceto, or rofaceo perfufa.

Aque marine uapor operto capite receptus.

\section{ADCAPITIS DOLORES A CALI DA CAVSA EXORTOS.}

Oleum fylueftris oliux inunctum.

Vnguentum rofaceum linimentimodo impofitum.

Iiguftriflores fronti ex aceto illiti.

Rofarum aridarum ex uino mactratarum expreffus liquor appofitus.

Viticis fèmen appofitum.

Portulaca per fe impofita.

Melilotbus cum aceto, aut rofaceo apperfa.

Nymphea radix pota, o per fe naribus indita.

Rhodia radix cum ro faceo fronti, tëporibusq́; adhibita.

Papaueris liquor fronti cum rofaceo illitus.

Pfyllium ex rofaceo, aceto ó, aut aqua impofitum.

Hippogloßi Sertum appofitum.

sedum maius cum rofaceo illitum.

solanibortulanifolia adhibita.

vinifere uitis folia, or capreoli impofita.

Ophites lapis adalligatus.

Braßica Juccus

$$
\text { Ad expurgandum caput. }
$$

Anemonis Juccus

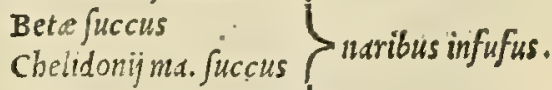

cyclaninima.juccus

Ceperuccus.

Pyrethrum 2 taphis dgri.t $\}$ diumanja.

Colccynthis in catapotijs denorata.

Vua pafa cum pipere commanducata .

Atranentum futorium lanis naribus inditum. 
C A PI TIS.

\section{Capitis dolores cxcitant.}

Styracinum olcum olf factuin.

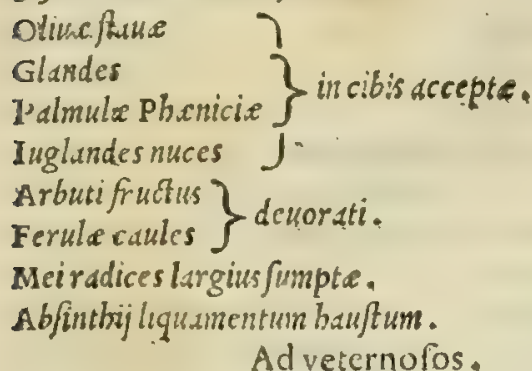

Viticis fenten cum rofaceo, $\mathbb{O}$ aceto perfufum.

Caftoresum ex ace to, or rofaceo naribus infufum.

Capadecosta, o in cibum fummetta.

sinapl derafo capiti appofitum.

sphondyliun fuffitum, er ex oleo capiti illitum.

Pencedanum cum aceto, or rofaceo inunctum.

Iris Illyrica pota.

Ad fomnum conciliandum,

Amomum fronti illitum.

Amygdale amare deuorate.

viticis femen potum.

I atuca in cibum fumpta.

Aloë illita per fefe, uel ex rofaceo.

Baccharis odorata.

Iunci Aetiopici femen potwm.

Papaucris crratici quinque, fexue capita in uini cyathis tribus ad dimidium decolta, et potui data.

Papaucris foliorum, et uafculorum decoctum, tum bi= bitum tum perfufum.

Hyofcyami femen potum, ac appifitum.

solani fomnifici radicum cortex drachine pondere in uino potus.

Mandragore redicis ex uino decotum cyathi unius $\therefore$ menfura potum.

Maridragore poma olf acta naribus.

Mandragora liquor fedi pro balano fubditus.

Somnia terribilia tumultuofaq́ue reprefentant.

Fabe $\}$ in cibum accepte.

Picnocomi femen drachme pondere potum.

Smilacis leuis femen cum dorycnio potum ternis fing lorum obolis.

Ad fternutamenta cienda.

sinapi femen tritum, et naribus admotum.

Pitarmice flores admoti.

Struthij radix trita, or admota.

Ranunculi radix ficca, 0 in puluerem trita, naribus indita.

Dxphnoides naribus indita.

Veratri albi radix trita o impofita. Aduertiginofos.

Ballami femen per fe potum.

Peucedanum ex aceto, or rofacco illitum.

Galbanum olfallusn.

Brionixe radix pota per continuum almum quotidic drachme pondere.

Vitis nigre uiticule prime recentes decodte, et in ci= bis accepte.

\section{A P I T I S.}

Acetum $\}$ scillinum potum.

Ad apoplexiam.

Vitis albe radix contmuo anno quotidie drachme pon derebaufta,

\section{Ad comitiales.}

Cardanomum ex aqua potum.

Cancamumper fe potum.

Balfami femen hauftum.

Eitumen Naptha fuffitum comitiales deprehendit.

Populi nigra femen ex aceto.

Ficus ficce in cibum decepte.

Concula Indice fuffite excitant.

Coagulum leporinum potum.

Muftel.e ventriculus coriandro infarctus, inueterd= tusq́; devoratus.

Mustelix eiusdem fanguis pottus.

Afininum iecur toftum in iciuno fumptum.

Vngula afini combufta cpota.

Equor um lichenes triti, or ex aceto baufti.

I apis in byrundinum pullorum prime foeture uentricu lo inuentus pro amuleto in ceruialuta fupenfus.

serum lact is potum quoufqué aluum citet .

Phoca coagulum bibitum.

Vrfinum fel ad lingendum datum.

Teftudinis fel naribusinditum.

Teftudinis terreftris fanguis potus.

Ciconix fimum ex aqua potum.

Plantago cum lenticula decocta, in cibis fumpta.

sinapi tritum naribus inditum.

Piper diu manjum.

scillabaufta.

Agaricus drachme pondere cum oxymelite hauftus.

Eryngï radix ex dulci aqua ebibita.

R ute jylueftris femen potum.

Sefolis Maßilienfis radix, or femen potum.

Peucedanum ex aceto, er rofaceo capiti inunctum.

Sagapenum potum.

I a erpitij liquor cum aceto muljo bibitus.

I adanum olf actum.

Ammoniacum in eclegmate cum melle datum.

Trifolij Semen, o folia pota.

Conyza cum ace to bibita.

Anthyllis altera ex oxymelite pota.

Betonice folia haufta.

Quinquefolium triginta dicbus hauftum.

Papaueris spumei semen cum mulfa.aqua potum.

Veratrum nigrum potum.

Hippophafti fuccus trium obolorum pondere hauftus.

Vitis alba draclima pödere anno toto quotidié hausta.

Vitis nigre uiticule prime wirentes cocte, e in cibis Jumpte.

Acetum mulfum potum.

Vinum, or acetum Scillinum potum.

Selenites lapis tritus ebibitus.

Aëtites lapis cum cyprino unguento, aut gleucino, uel alio excalfaciente illitus.

Cotes naxis pota.

Ad phrenefim.

Vnguentum crocinum perfufum, aut naribus admotü. uel illitum.

vitex cum aceto, or olco inftillatus. 


\section{A P I I I.}

Apardgus in uino albo potus.

Serpillum cum aceto or ro faceo impofitum.

Sphondylium fuffitum impolitum, er capiti ex oleo in=

- unitum.

Pencedanum ex aceto, er refaceo inunctum.

Ad cerebri inflammationes, quas fyriafin vocant.

Cucurbite ramenta fincipiti appofita.

Peporis rament. fincipiti adlibita.

Heliotropij folla fromi adhibita.

Acctum fronti illitum.

Ad mclancholiam.

Ocimifemen poium.

Vcrutru:u nigr:ma potume

Betonicic folia pota.

Epithymum potum.

Ad crapulam Sicbrietatem arcendam.

Crocum ex paffo prefumpum.

Pinicorum mulorwne fuccus $\}$ baufus.

Braßica fummo cibo fumpta.

Ab/inthiun presumptum.

Ad capitis defuxiones.

Vnguentum irimum nuribus illitum.

styraxillite, fuffitá; .

Bitunten naphtha fufitum.

Cinnuromun potusn.

Isci radices trit.e cunmelle in eclegmate deuordte, ubifluxio pequs afficiat.

Nuces aueline tofte, er cum exiguo piperis pote.

Drackisculi maioris radix tofta, uel elixa detorata.

Tragacantha in eclegmate cum melle fumpta.

Hy fopum cum fico, ruta, melleq́; ex aqua decoctum potum.

Helichry ij coma trium obolorum pondere in uino di= luto pota.

Hyofcyami fennen obolipondere, addito papaueris $\int e=$ mine husteane.

Ad cerebrum roborandum.

Agallochum potum.

Ad capitis manantia vlcera.

Thus cum Nitro confricatum.

Fici o caprificilacteus fuccus cum polentd appofitus.

Vrina inueteratd appofitd.

Fcenum grecum appofitum.

cicer adbibitum.

Malua ex urina bumand emplaftrata .

Alli cinis ex melle inuntus.

cyclamini decoctum fomenti modo adhibitum.

Bulbi cum cremato Nitro adbibiti.

Melilotus ex aqua cuin creta chid, uino gr $_{j}$, aut galla inuncta.

Rubifolia impofita.

Iilij cremata radix ex melle adbibita.

A diantum in lixiuio decoctum.

Acida muria in perfa.

\section{N E R V O R V M.}

\section{Ad conuulfionem.}

Irisillyrica ex aceto pota.

Acori decoctum bibituin:

Cardamoinum ex aqua potume.
NER VOR V M.

Iunciodorati radicis drachma una cum pari pondere piperis per dies aliquot data.

Coftus ex uino, or abfintbio exhibitus.

Balfamum ex aqua baufum.

Helenium ex melle in ecleginate exlibitum.

Vnguentum Sanpfuchinum more cataplafmatis apa pofitum.

Vnguentum Metopium illitum.

Bdellium illitum.

Iuniperibacce bibite.

Cedrides deuorate.

Halimi radix draclme pondere in aqua mulfa baufta.

Ficulneus cinis ex oleo illitus.

Erinacei terreftris caro in cipum fumpta.

Caftoreum ininctum, or potum.

Serpillum potum.

Fimun caprinum cum aceto bibitum.

Dracunculiradix tofta, ev elixa deuordta cum melle. A $\beta$ hodeli radix drachma pondere pota.

Capparis femen potum.

Capparis cortex pariter bauftus.

Argemone emplaftrata.

Agaricus fumptus trium obolorum pödere cum mulfo.

Rbaponticum potum.

Galbanum deglutitum.

Gentiane radix drachme pondere pota.

Ariftoloclizia rotunda bibita .

Centaurii maioris radix ex uino pota.

Spine alba femen potum.

Acanthij radices pote.

Abrotanifemen cum aqua potum.

Leucacantha radicis ex uino decoctum exbauftum.

Origanum eftum cum fico.

Eryngij radix pota cum aqua mul $f a$.

Pulegium cum pofca potum.

Calaminthe decoctum baufum.

Baccharis radix in aqua decocta, o pota.

Panaces berculeuin Finitum.

Libanotis radices cum loliaced farina emplaftrate.

Peucedanum cx aceto, or rofaceo inunctum.

Clinopodium bióitum.

Chamedryi íecoctum potum.

I afer obolipondere datum er deuoratum.

Sagapenum potum .

Galbanum deuoratum.

Betonice folia denarij pondere cum bydromelite data

Xyridis radix ex paffo bibita.

symphytum ex aceto mulfo bibitum.

pyyllium illitum.

Serpytlum potum, aut illitum.

verbafci decoctum bibitum.

Bryonia eclegma ex melle.

vinum fcillinum hauftum.

Vinum chamedryites bibitum.

vinum tragoriganites bibitum.

Satyrij radix ex uino nigro auftero bibita.

Coris ex uino potd.

Ad refolutionem neruorum.

Peucedanum ex aceto, o rofaceo inunctum.

Capparis Semen, or cortex potus.

Sagapenum potum.

Rubie radix haufta. 
volocynthis cliftere perŕfu.

Cttis nugre uittc thic preme recentes, cocte, comefteq Vinum Scillinum hauftum.

Ad tremorem.

Cerebrum leporinum toftuin comeftum.

Caftoreum potum, or inuntum.

BraßSica in cabo fumpta.

Althex decoctum potum. Ad Aluxiones.

Farina tritici cŭ Apollinaris berbe fucco dppofita.

Farina hordci ex ace to adbibita .

Ad $x$ gritudines \& dolores.

oleum sicyonium inunctum.

Oleum laurinum illitum.

Elacomelisllitum.

Vnguentum cyprinum

Vnguentum Gleusinum

Vinguensum Metopium

Vingentum Amaracinum J

Bdellium malagmati infertum.

Lixiuium ex cincre ficus ex oleo illitum.

Caftoreum potum, er illitum.

Erinacciterreftris caro denorata in cibis.

Viperine carnes decocte, o efui date.

Poterij radicis decostum potum.

Pcucedanum ex ace to, or rofaceo inunctums

I a er oboli pondere deuoratum.

Centauritum ininus ebibitum.

Iilij radix maffata, melleq́; excepta impofita.

Satyrif radix ex uino nigro auftero pota.

Althex radix per $\int e$, uel decocta in uino, aut aqua mul= fa emplaftri modo impofita.

Coccum infectorium cum aceto illitum precifos iuude neruos.

Senecijfolia ad eadem preftant illita.

Narcißiradix illita, ad eadem utiliter imponitur.

Hippophaftifuccus trium obolorum pondere potus.

A qua marina perfufa.

Acetum Scyllinum potum.

vinum de ftorchade hauftum.

vinum de thymo potusn.

Se Samum illitum craßitiem iunat.

Ad Neruorum vulnera.

Cocblex terreftres tufe, e impofite.

Terreni uermes tufi,, illiti.

Butyrum illitum .

Senecionis folia emplaftri modo impofita cum thuris mannd.

Dracunculi minoris folia illita.

Poterij radix $t u \sqrt{a}$, o impofita.

Lilij radix ex melle fubadta, er illita.

Coccum infectorium cum aceto illitum.

Narcißiradix illita.

Ad Neruorum crafsitiem.

Sefamum emplaftrimodo impofitum.

Sarmentitius cinis cum axungia, uel oleo ithitus:

\section{O C V L O R V M.}

Ad Palpebrarum pilorum defluuium:

Nardi Indica decoctum fotu adhibitum.

Cochlece terreftres acu traijciuntur ut effluat bumor, quo poftea palpebra illiniuntur.
Oefipusillitus.

Condrille gummi, ac pariter lac impofitum.

I apis armenius illitus.

Ad Palpcbrarum oculorumq́ue fcabritiem:

Thuris cortex toftus, $\sigma$ appofitus.

Picisfuligo illita.

Licium appofitum.

Sepic os leugatum or illitum.

EL

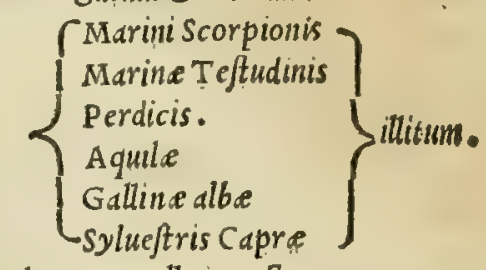

sinapi tritum ex melle inunctum.

$\therefore$ Omphacium impofitum.

squamd eris illita.

Rubigo ferri illita.

Chalcitis inunctd.

Hematites lapis melle exceptus adhibitus:

Ad Palpebrarum inflammationes .

Amaraci folia cum polenta illita.

Alfine cum polenta impofita.

Ricini folia cum polenta trita er emplaftri modo ads bibita.

Ad Minuendam palpebrarum crafsitiem.

Mitulorum cinis plumbi modo lotus o illitus.

Conchula Indice cinis inunctus.

Ad Palpebrarum fabiem.

Capa fuccus cum paris spodio impofitus.

Aloé illita.

Ficilac inunctun.

Ad Oculorum albugines :

Opobalfamum illitum, inftillatumí;.

Cancamum uino maceratum, or impofitum.

Myrrbaillita.

Bitumen naphtha impofitum.

Mitulorum cinis plumbi modo lotus er illitus?

Conchule Indice cinis oculis inditus.

Cocblearum putaminum cinis melle exceptus linitua.

Marini Scorpionis fel inftillatum.

Idemó; preftat fol testudinis, perdicis, aquile.

gallina alber, or sylueftris caprat.

Vrind bumana areo uafe decocta illita.

I actuca fylueftris lacteus fuccus inftillatus.

Dracunculifuccus immifus.

Caparum fuccus perfufus.

Gingiber illitus.

Cbamasyces fuccus cum melle inunctus.

Argemones follia impofita .

Ammoniacum impofitum.

Horminum ex melle impofitum.

Lotidomeftici fuccus ex melle illitus.

Sal impofitum.

Sal is flos eodem modo adbibitus.

Sapphyrus lapis appofitus.

Aeris Squama impofita .

Ad Oculorum cicatrices delendas.

Cancamum uino maceratum e infufum.

Myrrbaillita.

Bitumen naphtba infillatum.

Cedria illita. 
O C V L O R V M.

Cochlearun terreftrium cinis cum melle impofitus.

Vrina bumana ereo uaje decocta, infufa.

Frenigreci oleum cum myrteo impofitum.

Sagapenum inditum.

Chanefyces fuecus cum melle illitus.

Aerugo immiffa.

vinifiex adufta istpofita.

Corallium tritum inditum.

Hamatites lapis immiffus.

Sapplyrus lapis adbibitus.

Cocblex terreftres cum fuo putamine uste, or ex mel le impofite.

Ad oculorum nubeculas.

Acori fuccus inftillatus.

Cafía alijs medicamét is ocularibus excepta, o iniedta.

Cinnamomum impofitum.

Cerafi gummi inditum.

Acacalis dilutum ad collyria aditur, que oculis clari tatem faciunt.

Acacie fuccus elotus, $\sigma$ infufus.

Punicorum malorum cytini tres quătumuis minimide= uorati integro anno, ab omni lippitudine preferuăt.

Thus immißum.

Crocomagma illitum.

Ebeni tenuißima ramenta uino optimo macerata, 0 in collyria addita.

Iycium inditum.

Cedriainuncta.

Pruni arboris gummi illitum.

Vipere caro decocta, er in cibis de fumpta.

Hirundines ficedularum modo in cibis deuorate.

Cinis hirundinum collyrijs adbibitus.

Adeps pifcium inumitis.

Faniculi fuccus infufus.

E $1 \quad\left\{\begin{array}{l}\text { Marini Scorpionis } \\ \text { Marine Teftudinis } \\ \text { Perdicis. } \\ \text { Aquile } \\ \text { Galline albe } \\ \text { Sylueftris Capre }\end{array}\right\}$

Vrina bumana ereo uafe decolta infillata.

I actuce fyluefris lacteus fuecus illitus.

Dracunculima. rad. fuccus inunctus.

Ceparum fuccus inditus.

Ioti domeftici fuccus infufus.

Hirundinarie ma. fuccus areo uafe cum melle deco. Eus inunctus.

Othonne fuccus infillatus.

Centaurij minoris Juccus impofitus.

Ruta in cibis fumpta.

Omphacium inftillatum.

Panaces Herac. inunctum.

Iibanotis foliorum, radicis fuccus infufus cü mello.

Idfer ex melle inunctus.

A piaftri fuccus cum melle inditus.

Marrabij fuccus ex melle illitus.

Pumex indita.

salis flos inmiffus.

vini fex cremata impofita.

Pyrites lapis inditus :

Thyites lapis impo/itus.

Geodes lapis impofitus.

\section{O C V L O R V}

sapplyrus lapis impofitus.

Ad oculorum vngulas.

- Sepix pifcis os tritum er impofitum .

Glycyrrbize radicis puluis inperfus.

Ad oc ulorum ictus, \& recentia vulnera.

Iac bumanum cum thure iniectum.

sAN $=\left\{\begin{array}{l}\text { Palumbi } \\ \text { Columb } \\ \text { Turturis } \\ \text { Perdicis }\end{array}\right\}$ illitus.

Stcebis folia emplaftrimodo impofita.

Hematites lapis cum lacte iniectus.

Ad oculorum vlcerz.

Fuligo $\left\{\begin{array}{l}\text { Thuri } \\ \text { Terebinthine } \\ \text { Butyri }\end{array}\right\}$ illita.

Thuris cortex impofitus.

Myrrha iniecta.

Cornu ceruinum uftum impofitum lotum.

Amxlum linitum, o peculiariter cauis ulecribus.

Stimmi iniectum.

Lapis $\left\{\begin{array}{l}\text { Galactites } \\ \text { sapphyrus } \\ \text { samius. }\end{array}\right\}$ cum lacte infufus.

Ad e rofos oculorum angulos,

Oefypum inunctum.

Omphaciumillitum.

Adoculorum finus \& agilopas .

Iuglandium ueterum nuclei triti, or illiti.

Myrti decoctum infufum.

Malua cruda commanducata cum exiguo fale adhibita.

Plantago emplaftri modo impofita,

A uricula muris altera illita.

Baccharis folia emplaftrimodo in principio indita.

Anthemisillita.

Solanihortulani concifa folia impofita.

Eiufdem fuccus cum rubentigallinarum fimo illitus.

Aegilops adbibita.

Oenanthes. v.labrufca flos impofitus.

Cadmia illita.

Aeris fquama indita.

Stimmi inditum,

Ad procidentes oculos, \& vuas.

Fabarum farind cum rofis, ouorum albo, Er thure em plaftrimodo impofita.

Rubi folia trita, er impofita.

Sapphyrus lapis adbibitus.

Ad oculorum inflammationes.

Amomum ex und paffaillitum.

Fuligo $\left\{\begin{array}{l}\text { Thuris } \\ \text { Picis }\end{array}\right\}$ illita.

Cupreßi pilule cum polenta illite.

Myrtibacce cum polline polente impofite,

Cotoneorum malorum flores emplaftrimodo.

Cafeusillitus.

saccharum infufum.

Sefama herba ex uino decocta, er impofitd.

Portulaca cum polentaillita.

Intybus per $\int e$, or cum polenta adhibita.

Cucurbite ramenta impolita.

Anemones radix illita.

Auricula muris cum polents emplaftrimodo adbibita. 
O C V L O R V M.

Ge ntiane fuccus inunctus.

Abrotanum cum cydonio malo decoctum, aut panc, or emplaftri modo adbibitum.

Melilotus cataplafmatis addita.

Baccharis folid illita.

Sedi maioris folia impofita.

A piun cum pane, aut polenta impofitum.

Rubi Idei flos ex melle inunctus.

Elatine folia cum polenta impofita.

Papaueris liquor cum tofto oui uitello, or croco in= pofitus.

Hyof cyami femen, of folid cum farind, polentaue impofita.

Mandragore folia recentia ctom polenta adhibita.

Verbafci aureum florem ferentis folia impofita.

After Atticusillitus.

Viole purpuree folia illita.

Ricini folia cum polenta impo/ita.

Ad oculorum dolores.

Oui uitellus toftus addito rofaceo, or croco illitus.

Sefame berba in uino decocta illita.

Ocimi fuccus infufus.

Abfinthium ex paffo decoctum adh ibitum.

$\mathrm{R}$ uta cum polenta emplaftri modo impofita.

Aconiti pardalianches radix permifcetur oculariis mes dicamentis, que doloribus oculorum auxiliantur.

Ad lufciofos.

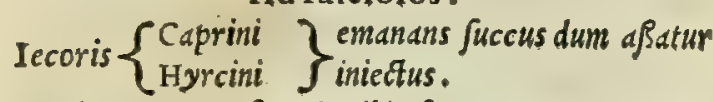

Caprinum iecur toftum in cibis Jumptum.

Syluef trium caprarum fel inunctum.

sanguis $\left\{\begin{array}{l}\text { Palumbi } \\ \text { Columbe } \\ \text { Turturis } \\ \text { Perdicis }\end{array}\right\}$ illitus.

Ad oculorum fuffufiones.

Fel inarini Scorpinis inditum .

Vipere adeps admixto cedrino liquore, Attico me lle, o uetere oleo. Gal. ueró non probat.

FEI $\left\{\begin{array}{l}\text { Teftudinis marina } \\ \text { Perdicis } \\ \text { Aquile } \\ \text { Galline albe } \\ \text { Capre fylueftris }\end{array}\right\}$ illitum.

Fabarum farina uino macerata, $\odot$ illitd.

Ceparum fuccus infillatus.

Cyclamini fuccus infufus.

Sagapenum umpofitum.

Eupborbium impofitum, cum cautela tamen.

Ad oculorum hebetudinem.

Cancamum ex uino maceratum infufum.

Populialbe pilule, que primo foliorum exortu exiliǔt ex melle illitio.

Marini Scorpionis fel inunctwon.

Braßica in cibo fumpta.

Sinapi cusn melle inunctum.

Anagallidis Juccus nutribus exceptus:

Abfintbium cum melle impofitum.

Thymus in cibo fumptus.

Thymbra obfonijs addita.

Rute fuccus in malicorio fcruefactus, addito foeniculi fucco ov melle infufus.
Rute fylueftris fuccus cum uino melle, gallindceorums felle, o freniculi fucco iniectus.

Solani fomnifici fuccus inunctus.

Flos falis inditus.

Ad oculorum fluxiones cohibendas.

Crocum illitum cum bumano lacte.

Thus ex oui uitello impofitum, uel eiufdem albo.

Thuris fuligo impofita.

Picis fuligo illita.

Platani tenerrima folia in uino decocta er illita.

Ebeni ramenta tenuißime trita indita .

Olex fylueftris foliorum fuccus iniectus.

Cornu ceruinum uftum, lotum, of iniectum.

Butyri fuligo illita.

Amylum impofitum.

Pompholis elota iniecta.

Fabe fine cortice commanducate, or fronti impofite.

Ocimi aquatici femen duarum drachmarum pondere ex quatuor mellis cyathis temperatum, inunetum.

Elatine folia cum polenta impojita.

Squama eris elota iniecta.

Plumbum elotum iniectum.

Galactites

Morochthus $\}$ Lapis cum lacte iniectus.

Samius

Hyofcyami fem. cremor exprefJus infufus.

sarcocolla infufa.

Alumen impofitum.

Corallium iniectum.

Pumex impofitus.

Hematites lapis iniectus.

Ad oculorum lippitudines.

Portuldcd, o eius fuccus impojitus .

Plantaginis fuccus infufus.

sedi maioris folia illita.

Chalcitis inditus, cun cautela tamen.

spongiarum crematarum cinis illitus, er prefertim in arida lippitudine.

Hamatites lapis tritus, cum lacte iniectus. Ad oculorum caligines.

Chamedrys trita infper $\int a$, aut ex oleo inuncta.

Loti domeftici fuccus cum melle impofitus.

Ver atrum nigrum in ocularibus collurijs additum.

Elos aris inditus.

A V R I V M.

Ad aurium dolores.

Iduribaccarum fuccus uino uetere, or rofaceo exce ptus inftillatus.

Populneorum foliorum fuccus infufus.

Iadanum ex uino illitum.

Rofarum aridarum decoctum ex uino infufum.

Salicis foliorum, $\sigma$ corticis fuccus cum rofdceo in $\mathrm{ma}$ licorio feruefactus illitus.

- Malorum acidorum punicorum fuccus cum melle cos ctus infufus.

Opium cum amygdalino oleo, croco myrrha qq iniectum. Anguium fenecta in uino decocta inftillata.

Millepede, fiue onifci concifi, or cum rofaceo in malis corio calefacti infufi.

Vulpini pulmonis adeps infillatus. 


\section{A V R I V M.}

Vermes terreni cum anferino ddipe elixi inditi。

Anserinus

Gallinacens $\}$ adeps inftillatus.

Vrins $\left\{\begin{array}{l}\text { Tauri } \\ \text { Apri }\end{array}\right\}$ cum myrrba cocta inftillata:

arel cum trito foßsili fale infufum.

sefami femen ex rofaceo iniectum.

Beta fuccus inditus.

Plantaginis fuccus immiffus in calida materid .

Cucurbite ramentorum fuccus cum rofaceo infufus.

Dracunculi utriufque fuccus inftillatus.

Porri fuccus cum accto, thure, e lacte iniectus.

sinapis fuccus, uel cius decoctum inftillatum.

Hedere, $\sigma$ eius corymbor um fuccus cum oleo inditus

Abfinthium fufitum, o cum inelle impofitum.

Origani uirentis fuccus cum lacte infufus.

Mente fuccusinditus.

Meliloti fuccus cun paffo iniectus.

Rute fuccus in malicorio feruefactus infufus.

Pcucedani fuccus cum rofaceo inditus.

Aparine fuccus iniectus.

Marrubii fuccus in rofaceo inftillatus.

Cannabis domeftice fuecus impofitus.

Polygoni maris fuccus infufus.

Helxine fuccus inditus.

Ocimi aquatici fuccus cum fulphure, or nitro iniecใus. Hyof cyami fominis cremor infillatus.

Soldni borten/is fuccus impofitus.

Alfine fuccus infufus.

Cucumeris afininif fliorum fuccus inditus.

Sal cum aceto iniectum.

Ad aurium internas inflammationes.

Crocum iniectum.

Sefamum cum rofaceo impofitum.

Oefypum impofitum.

Ad aurium parotidas.

Caprarum montanarum fimus, uino uel aceto decoctus ithitus.

I ini femen tritum, or emplaftri modo impofitum.

Fabarum farina cum melle, e formo greco illita.

Rumex decoctus adbibitus.

Plantago emplaftri modo illita.

Irionis Senren tu fum decoctumó; appofitum .

Hy]fopum fuffitu incen[um, $\sigma$ impofitum.

Vifcum cum pari refine, dc cere cömiftum adbibitum.

Althea decotaillita.

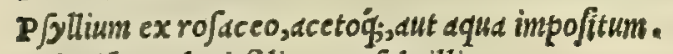

solani bortulani folia cum fale illita.

Galiop/is ex aceto adhibita.

Cimolia terra impofita .

Ad purulentas aures.

Myrrba cum meconio, caftoreo o glaucio iniecta.

Thus ex uino dulci infufum .

Refina $\left\{\begin{array}{l}\text { Terebinthina } \\ \text { Larigna } \\ \text { Abiegna } \\ \text { Piced }\end{array}\right\}$ exmelle, or oleo indita.

Iycium infusum .

Rhois decoctum iniectum.

Myrti baccarum fuccus infillatus.

olee jolueftris foliorum fuccus ex uino infusus.
A V R I V M.

Taurinum fel cum caprillo, bumanoúc lacte infilllatu.

Vrind infufa.

Vimbilicus Veneris cum medulla ceruina iniectus.

A phodeli radicum fuccus per $\int e, \sigma r a d d i t i s ~ t h u r e, m e l$

le, uino, or myrrha inftillatus.

Cepe fuccus impofitus.

Abfintbium cum melle inditum.

Anifum cum rofaceo inftillatum.

sphondilij florum fuccus inftillatus:

Polygoni fuccus infufus.

Strebis decoctum iniectum.

$\mathbf{p} \int y$ llij fuccus inditus.

Omphacium cum melle impofitum.

Alumen fanguinalis berbe fucco exceptum infufusm.

Flos Salisiniectus.

Ad contufas aures.

Bulbi cum polenta impofiti.

sulphur cum uino er melle illitum .

oefypum impofitum. Ad exulceratas aures,

suillum fel infillatum.

Ad aurium furditatem.

Haftule regie radicum ex oleo decoftum iniectum.

Crpe fuccus inftillatus.

Veratrum nigrum immiffum, $\sigma$ relictum ufque in diem tertium.

Bryonie fuccus cum melle inftillatus.

Flos aris candidus per fiftulam flatu impulfus.

sulphur raptim per fiftulam fuffitum.

Ad aurium tinnitum, \& incertos fonos,

Cedria infufa.

Lauri baccarum fuccus cum uino vetere, or rofaceo inftillatus.

Ficus ficce trite cum finapi, o liquore aliquo exces pte iniecter.

Taurinum fel infufum.

Mel cum trito fopili fale inditum.

Porri fuccus cum thure, aceto, lacte q; inftillatis .

Cepe fuccus impofitus .

sinapi tritum, of cum fico iniectum.

Acetü calidü $\int u f f i t u ̈$ per traiectorium inftrumentum. Ad vermiculofas aures.

Cedria cum aceto inftillata.

Vrina bumana in malicorio decocta instillata.

Capparis radicis fuccus iniectus.

Caldminthe fuccus inftillatus,

Pfyllijfuccus inditus.

Acetum infufum.

\section{N A R I V M.}

Ad fanguinis narium fluxiones.

Thus in puluerem tritum iniettum.

Cochlex terreftres cü furo putamine trite, et impofite.

Porrifeminis fuccus cum thuris polline infillatus.

Ruta trita indita.

Vrtice utriufque folia cum fucco impofita .

Cuminum ex aceto impofitum.

Ferula medulla intromiffa.

Lyfimacbia impofita.

Clymeni fuccus inditus .

Galiopfis flos impofitus.

Equifeti Juccus infusus. 
ORIS ET LINGVAE.

Acetum tum pcium, tum iniectum.

Stratiotes adlibita.

Chalcitis Jucco porri inftillata.

Ad linguinem è Naribus eliciendum :

Crocodilly radicis decottum bibitum.

A S Narium Polypum.

Cuprefípilule cun fico tuf.e, o impofite.

Dracuncule macoris radix impofita.

La erpirij liquor cun chalcantho, aut rafili arugine il

litus, forcipe pruus excifo polypo.

Flos aris inditus.

Sandaracha cum rofaceo immiffa.

Ad Nirium vlcera \& carcinomata.

Dracunculi matoris radix impofita.

Hedere fuccus infufus.

Sandaracha cun ro faceo iniecta.

Hedere fuccus infufus.

Ad Narium tedia.

Ad narium deftillationes .

Melantbij femen tritum, o in linteolo colligatum, fec pé ac Sepius olfactum.

Ad trahendum per nares.

Copas fuccus infufus.

Origani utriufque fuccus iniectus cum Irino unguéto.

Cyclamini maioris fuccus inftillatus.

Ad cienda fternutamenta.

Fibrorum tefticuli iniecti.

Ocymi femen, aut fuccus naribus infufa.

sinapi tritum inditum.

Ranunculi radix ficca, tritaớ; iniecta .

Ptarmica flores olfacti.

Strutbij radix impofita.

Veratrum album tritum iniectum.

\section{ORIS ET LINGVAE.}

Ad erodentia vlcera .

Cyperiradick farina in os indita, etiam fíulcera depe fcantur, uorentó;.

A filathi ex uino decoctum ore collutum,ad tetra oris ulcera.

Acacia indita.

Plantaginis fuccus in ore detentus.

Capparis in ace to decocta in collutione.

Glycyrrhize fuccus in ore detentus.

Origani fuccus in ore contentus.

I eucoij flores ex melle impo/iti.

Tefticulus ferapias impofitus.

Anthemis manja.

Britanice fuccus infufus.

Tribuli fuccus ex melle delinctus.

Rubidecottum in ore detentum.

Quinque folij rddcis decoctum ore collutum.

Verbenaca alterd ex uino dffufa.

Staphis agria cum melle indita.

I abrufce flos ori inper fus.

Alumen cum melle impofitum.

Sal cum polenta toftum, $\sigma$ iniectum.

Ad oris halitum commendandum .

Refina lentifcina manducata.

Myrrba mansa.

Mala medica manducata.
Anifuit matrfum.

D E N I V M.

Bromus cum ficcis ro/is decoct $d$, in ore retenta.

Menta confricata.

Ad linguæ fcabritiem.

Rbois femen cum melle fricatum.

D E N T I V M.

Ad dentes purgandos.

Cinis $\left\{\begin{array}{l}\text { Purpure } \\ \text { Buccine } \\ \text { Mitulorum } \\ \text { Conchule Indice } \\ \text { Cocblearun terreftriü } \\ \text { Sepie pifcis } \\ \text { Ceruini cornu }\end{array}\right\}$ dentibus affrica

Plantaginis radicis"decoctum in collutionibus.

Ariftolocbia rotunda confricata.

Alcyonium quintum

Pumex

Arabicus lapis

Samius lapis.

Ad dentium dolorem.

Pices', er pini folia trita ex aceto decota frequenti collutioue.

Cedria dentium cauis indita .

Platani corticis ex aceto decoctum ore collutum.'

Tamaricis foliorum ex uino decoctum in ore detentü.

Olei aminurca in cupreo uafe ad mellis craßitiem deco Ifa ex ace to, aut uino, aut mulfo colluta.

Mori corticis decoctum, aut pariter foliorum in collu= tionibus adhibitum.

Ficulneum lac land excep tum, et cauis dentib.inditum.

Anguium fenecta ex aceto decocta an collutionibus.

Paftindce pifcis aculeus in eius cauda prominens, dent bus adbibitus.

Ranarum ex aqua, et aceto decoctum in collutionibus.

Lacerte iecur cauis dentium impofitum.

Vermes terreni oleoelixi,et in cötrariă aurě inftillatio.

Rumicis decoctum in collutionibus.

Aparagi radicum decoctum in ore contentum.

Appodeliradicum fuccus in contrariam auré infufus.

Allij,tede, thurisó; fimul decoctum in ore contentum.

Ononis radicis ex pofcadecoctum in collutionibus.

Capparis feminis decoctum in collutionibus.

Idem preftat Capparis cortex. Quin o radix coms manducata.

Icpidij ( ut aiunt) radix collo Jupenfa.

Ranunculi radix impofita.

Anagallidis fuccus in contrariam nariŭ partě infufus.

Hedere corymborım acini quinque cum rofaceo in ma licorio ferue facti in contrariam aurem inftillatio

Chamaleonis nigri decoctumi in ore contentum.

spine albe decoctum it collutionibus.

Ieucacanthe radix commanducata.

Abfintbii decoctum fuffitum.

Hy ffopi ex aceto decoctum in ore retentum.

$P$ anaces Heracleum dentium cauis inditum.

Pyretbri decoctum ex ace to in ore acceptum.

Peucedani fuccus cauis dentium inditus.

Nigelle decoctü, und cü teda ex ace to in ore detentü. Laferpitij liquor catis dentium impofitus.

Galbanum ulitum, e corum cauis inditum. 


\section{E N T IV M.}

Apiaftri decoctum in collutionibus.

Altbex decoinm ex aceto in ore detentum.

Betorice decoćtum ex uino, uel aceto.

Clematis prima commanducata.

Polemonij radix commsnducata .

Quinguejolij radicis decoctum in ore retentum:

Hyofcyami radicis ex aceto decactum in collutionibus.

Solani fomnifici ex uino decoctum in ore retentum.

Ephemeriradicis decoctum in collutionibus.

Verbafcidecoctum collutum.

Arction ex uino decocta, e in ore detenta.

Cucumeris fylucftris diccoitum un os fumptum.

Colocynthidis de coctum in collutionibus.

Stuphis agria decoetum ex accto in ore contentum.

Tithy:nali caracia lac dentium cauernis inditum, dene te prius cera munito, ne luc in fauccs incidat.

Acetun calefactum in collutionibus.

Sory dentiunt cauis indituns.

Ad dentes cariofos frangendos.

Cedria eorum cauitatibus indita.

A murca olci cum omphacio reconta ad mellis crafitu= dinem, o impofita.

Paftinac p pif is aculcus impofitus.

Ranunculiradix iniect $x$ corum cauitatibus.

Chameleonis nigri radix cauernis dentium indite. Ad firmandos commotos dentes.

Ientifci decoctuns in ore retentum.

Colymbadum muria in collutionbus adhibita.

sylueftris olex olcum in ore contentusp.

Sory in collutionibus.

Alumen cum aceto, er melle folutum, o adhibitum. $\Lambda \mathrm{d}$ dentium torporem.

Portulded manducata. Ad fuidas gingiuas .

Cyperi farinaimpofita.

Rofarum aridarum ex uino decoctarum expreffus lit. quor, in collutionibus impofitus.

Colymbadum muria in ore contenta.

Oleum fylueftris olex in ore detentum.

Galle quoquo modo adhibite.

Mali puniciflorentes cytini in decoctis macer ati, $O$ in collutionibus additi.

Prunorum foliorum decoctum in ore retentum.

I ac afininum in collutionibus.

Pulegium fiecatum, crematumó; $\odot$ in puluerem tris tum appo/itum.

Rubi decoctum in ore detentum.

Staphis agris decoctum in collutionibus.

Omphacium cum melle impo/itum.

Acetum in collutionibus adhibitum.

Rubigo ferri illita.

Alumen quocunque modo adbibitum.

Sal toft um cum polenta impofitum.

$\left.\begin{array}{l}\text { Alabaftrites } \\ \text { Smyris }\end{array}\right\}$ Lapis tritus impofizus.

Ad Erofas putridasq́; gingiuas .

Cancamum impofitum, nibil'́; eo efficacius.

Iycium attritum impo/itum.

Plantaginis fuccus in ore detentus.

Aloë ex uino, o melle illtita.

Tribuli utriufque fructus ex melle inpofitus.

Iabrufce florum combuftorun cinis cum metle itlitus.
GVTTVRIS ET GVLAE.

Acetum in collutionibus.

$\begin{aligned} & \text { Chalcitis } \\ & \text { Alumen } \\ & \text { Pumex } \\ & \text { Acrugo }\end{aligned}$
\}

GVTTVRIS ET GVLAE.

Pix liquida peruncta.

Ad Anginam.

Morifructus fuccus in areo uafe decoctus, infolatus ${ }^{\circ}$. cun mellis exigua itlitus.

Multipeda fiue Orofcij ex melle inuncti.

Cinis crematarum byrundinum ex melle more empla ftriadhibitus.

H yrundines fale inueterate drach.i. pondere cum ax qua pote.

Fel taurinum cum melle inunctum.

Fel teftudinis illitum.

Acetum gargarizatum.

Mel gargarizatum.

cape fuccus inunctus.

Piper cum melle inunctum.

Abfinthium cum inelle, or nitroillitum.

Raphani fenzen ex aceto mulfo gargarizatune.

Hyßopi cun fico decoctum gargarizatum.

I a erpitii liquor cum mulfa aqua gargarizatus.

Viole purpuree ex aqua cotte, o pote.

Elaterium efficacißimé illinitur cü melle, uetere oleo, aut felle lawrino.

Sal ex melle, oleo, er aceto illitum.

Spartij fuccus é ramis in aqua maceratis, et mox tufis, extractus, er illitus.

Ad Gutturis inflammationes .

Cinis crematarum hyrundinum ex melle more enple= fri applicitus.

Ide gargarizatum.

Rane oleo elixe ceruicis er colli abjceßibusillite.

Melilltum.

Origani uirentis fuccus gargdrizdtus.

Helxine fuccus gargarizatus, forisq́; inunctus.

Vrtice utriufque fuccus gargarizatus.

Chalcitis impofita.

Alumenillitum.

Sal toftum cum melle inunctum.

Acetum gargarizatum.

Aloë cum uino aut melle appofita.

Britannice fuccus illitus.

Tribulifructus ex melle impofitus.

Rubi mororum fuccus gargarizatus.

Ficuum ficarum decoctum gargarizatunt.

. Ad columellam reprimendam.

I ajerpitii liquor cum melle inunctus.

Pruni foliorum ex uino decoctum gargarizatum.

Omphacium impofitum.

Acetum gargarizatum.

Flos aris in puluerem fubtilißimum impofitus.

Ad Gulæ deftillationes.

Papazeris uafculorï decoctum ex melle in eclegmatis forma redactum, Sepiusq́; linctum.

Acetunt gargarizatum.

Bdellium cum iciuna faliud dilutum, er illitum.

\& 3 Verbenaca


Verbenaca altera ex uino gargarizata.

Omphaciun impofitum.

Flos eris pulucrizatus, or inpofitus.

Alumen impofitum.

Acetum gargarizatum .

Ad Faucium \& Trachex arterix afperitates. Myrrbatingue fubdita, ibique liquata.

Pifanaliordeacca gargarizata.

Amylun dclinctum.

sinapis fuccus zargarizatus.

Glycyrrbize fuccus lingue fubditus.

Traj.rantbx in ccleginate cum melle fumpta.

I aferpitijliquor aquadilutus in delinctu.

symphytun petraum commanducatum.

Quinquefoij radicis decoctum gargarizatum .

Aethiopis cum melle in eclegmate.

Lac gargarizatum.

Licium attritum, et delinthum.

\section{PECTORIS ET PVLMONIS.}

Ad cruenta fputa \& fanguinis reiectiones. Ouum tepedum bibitum.

Cornu ceruini cinis lotus, er ebibitus cum tragacanthdo Climenumi potum.

serpilli fuccus drachmarum duarum pondere cum dce= to potus.

Fimum caprinum tritum, in uino, aqquaie potum.

Triticed farina glutinis modo elixa, in delinctu data. Amylum potum.

Ferule uirldis inedulla pota.

Portulaca ad fummum cocta deuorata.

Plantago quoquo modo exbibita, prefertim fuccus.

Eiufdem Jemen potum.

Porri femen drachmarum duarum pondere cum paris bus myrtibacis,

Agarıcus trium obolorŭ pödere cum aqua mulla potus. Rhaponticumbaufum .

Iyfimacbie fuccus bauftus, er perfufus.

Centauriy maioris radix pota.

Spine albe radix baufta.

Arabice Bine radix pota.

Aloë cochlearium duorum pondere cum frigida aqua uel fero potd.

Polygonimaris fuccus potus.

Saluse fuccus in orbiculos coneretus cü melle fumptus.

Symphytum petre un cum aqua potum.

Menthe fuccus cum ace to potus.

Althex decoctum potum.

Eetonice folia trium obolorum pödere in diluta uini po tione baufta.

Symployti alterius radix pota.

Achillea baufta.

Tragi cacumina decem in uino bibita.

Perfonate radix cum pineis nucibus pota.

ISopyri femen potum.

Adiancum potum.

Tricom.nes pota.

Vitis uinifer tollorum, or capreolorï fuccus hauftus.

Labrufieflores poti.

Omphacum parcé potum.

Corallium bauftum.
Hematites lapis

$\left.\begin{array}{l}\text { Morochthus lapis } \\ \text { Samia terra }\end{array}\right\}$ cum mali punici fucco pota.

Ad Phrifim, feu Tabem .

$\left.\begin{array}{l}\text { Piftacia } \\ \text { Pinea nuces }\end{array}\right\}$ per fe, aut ex melle fumpta

Terebintbina, refind per $\int e$, uel ex melle more eclege matis deuorata.

Pix liquida in eclegmate ex inelle cyatbimen fura dem uorata.

Iuniperibacce baufe.

Iauribacce trite cum melle uel pajjo,denorate.

Ficus ficce cum byffopo feruefacte, et pote.

Cancri fluniatiles elixi cum fuo iure fumpti.

Iac bumanum ex ubere fuctum.

Ius ef culentum omnium adipum datum.

Plantago in potu cxbibita.

Porrum cum mclle decoctum .

Agaricus draclome pondere fumptus cum paßo.

Acantbiradices pote.

Marrubij folia, fiue expreffus Juccus potus.

Betonice folia cum mclle data.

Myrrbis in forbitione pota.

Afil lapidis flos ex melle delinctus.

Ad pulmonis abiceffus.

semen cyclaminis fecunde pecici quadraginta diebus potum.

Tragoriganum cum melle in eclegmate exbibitum.

Tußilaginis ficce, incen $\int_{x}$ q́ $_{\text {; }}$ fumus ore bauftus, apofte matainterna pectoris rumpit.

$$
\text { Ad fufpiriofos . }
$$

Iduribacce trit cum melle, uel pafjo, et exhibite.

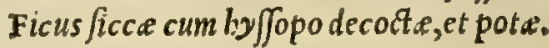

vulpinus pulmo exiccatus bibitus.

Ius Jenum gallorum potum.

vinum by fopites bibitum.

Plantago cum lenticula decocta comefta.

Rhaponticum bibitum.

Aqua mulfa pats.

Ariftolochia rotunda bibita.

Centaurij maioris radix pota.

Hyffopum decoctum cum fico, aqud,melle, rutaq́; potü.

Strcbis ex aqua decocta pota.

Pulegium cum melle, et aloë potum.

Sicylla ex melle trium obolorum pondere delincta.

Thymi cum melle decoctum potum.

Satureia eodem modo pota.

Baccharis radicis decoltum potum.

Ruta pota.

Peucedani fuccus in ouo fumptus.

Nigella in uino pota.

Galbanum deglutitum.

Marrubï decoctum, fiuc expreffus fuecus potus.

Parthenium ex oxymelite fumptum.

Anagyris folia cum pafjo bibita.

Periclymenifemen potum cum uino.

Adianti decoctum potum.

Fidicula fiue Tricbomanes baufta.

Elaterium optima fupiriofis eft purgatio.

Thapfie fuccus exhibitus.

Bryonia cum melle in eclegmate fumpta.

Sandaracha non refina in catat otiis data. 


\section{PECTORIS ET PVLMONIS.}

sulphur in ono funptum, uel fuffitum.

Agtricun drachmex unius pondere datwm.

C.nncamum bauftun ex aqqua uel mulo. Ad Tulsim.

Iris Illyrica affumptit.

Cardumomuin ex aqua potum.

Cinnamomum denorstum, uel potum.

Calsmus odoratus. fuffitus per fe, uel ex refina terebinthins.

Helenij celegina ex melle deglutitum.

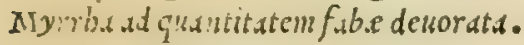

$\left.\begin{array}{l}\text { Sty:ux } \\ \text { Bdilium }\end{array}\right\}$ datain ecleginate.

Terebinthus refinte exfe, ucl ex metle eclegma des linctum.

M.iffix pot.s.

Itwipere b.tcce bibite.

Cedrifructus ásuorati.

Paliurifemen potum.

L ad.num in medicanentis, en malagmatibus infertum.

Cerafi grmmi cum uino diluto exbauftum .

Amygdule umurxe cümelle, o lacte in illinctu date.

Gummi anyygdulsram amurarü cun uino diluto potü.

Nuccs auellane cum aquit mulfa potes.

Ficus ficce denordte.

Camedryi decoltum potum.

Scordium potum.

Tußilago ficca fumpta, fine incenfa, accepto fumo. peros.

Propolisfuffita.

Mel deglutitum.

Favina tritici glutinis modo elixa, $\sigma$ ad lingendum c $\tilde{u}$ mentha, o butyro data.

Farine auene cremor in forbitione receptus.

semen lini cum melle, or pipere fumptum.

Fabs in cibis accepte.

Raphanus elixus manducatus, prefertim in uetere tußi.

Dracunculimaioris radix tofta, or elixa deuorata.

Af hodeli radix trium drachmarum pondere pota.

A Dium crudum, or coctum afjumptum in uetere tußsi.

Irionis femen cum melle linctum.

Piper delintu acceptum.

Scilla cum melle in eclegmate in diutinis tußibus.

Centaurij maioris radix baufta, in antiqua.

Tragacantha in eclegmate cum melle.

Hyffopum cam inelle, fico, ruta'g, ex aquad decoctum.

Stoechas eodem modo parata.

Origanum in eclegmate cum melle linctum.

Tragoriganum eodem modo paratum.

Baccharis radicum decoctum potum, in diutine.

- Panaces ctm uino dulci potum.

Sefelis maßilienfis radix, o femen hauflum:

Smyrnii radix comefta.

Dauci femen potum, in diutina .

Peucedani fuccus in oro fumptus.

I a expitiy liquor in forbili ouo datus.

Marubij decoctum, fine expreffus fuccus bibitus:

Galbanum deglutitum, in netere:

Sxgapenum deuoratum, in diutina.

Hei/ine fuccus cyathi pondere bibitus, in diutine.

Equifetiradix, ev herbapota.

\section{PECTORIS ET PVLMONIS.}

Iunci decoctum bibitum .

Papaueris uafcula in aquad dimidium decocta, decos

ctó́; addito melle, ut eclegma fiat ad lingendum.

Hyofciami femen potum.

Veróafci decoctum potum, iu antiqud.

Cacalix radix uino made facta comefta.

Bryonia cnm melle in eclegmate delincta.

Vue paffe albee caro exiccata deuorata.

Aqua mulsa pota.

Taphfiaillita.

Vinum bylfopites bibitum

Sandaracha fuffita cum refind, accepto uanore per fis ftulam uel traiectorium.

sulfur in ouo fumptum, uel fuffitum.

Ad pectoris alpcritates.

Glycirrbize fuccus in ore retentus quoufque colliques fcat.

Radix cacalic in uino madefacta, or delincta.

Ad vocem expediendam.

Myrrba lingue fubdita, quoufque tota lique fcat.

Tragacantha ex melle in delinctu adbibita.

Lafer aqua dilutum, o in forbitione fumptum.

Styrax delinctus.

Braßica commanducata.

Vinumbyfopites.

Ad Pleuretim.

Suillus adeps ex uino lotus, o cum cinere, or calce coactus impolitus.

Paftinace erratice femen potum.

Sagapenum emplaftrimodo illitum:

Ad Lateris dolores vbi febris abfit.

Fimum caprillum cum cera, et oleo fubactum, impofitü.

Hordeace a farina una cum meliloto, or papaucrum ud fculis ex mulfo elixd, illita.

Braßice caules uirides cremati, et fuillo adipe excepti, o impofiti.

Leucacanth. radicis ex uino decoctum bauftum.

Afphodeli radix drachme pondere ex uino pota.

Gentiane radicum fuccus dracbme pondere fumptus.

Ariftolocbia rotunda ex aqua bibita.

Centaurij maioris radix pota.

Lafer in forbitionibus datum.

Galbanumillitum.

Marrubijfolia ex melle adbibita.

Trifoliy bituminofi folia, femenue potum.

Aethiopis pota.

Acoridecoctum potum.

Costus cum abfintbio, or uino potus.

Agallochum ex aqua potum.

Myrrha fabse pondere deuarata.

Bdellium bauftum.

Refina terebinthina illita, appofitaie.

Bryonia ex melleo eclemate delincta.

Ad Pulmonis inflammationes.

Ocimum cumpolenta illitum.

Vrtice utriufque femen cum melle delinttum.

Tragoriganum ex melle in eclegmate fumptum.

Chryfocome pota.

Aqua mulfa baufta.

Ad purulentas excreationes.

Irionis.jemen cum melle delen Itum.

Betonica folia drachinarum duarum pondere in aque 


\section{PECTORIS ET PVLMONIS.}

mulle cytthis quatuor pota.

Perfonste radix cum pineis nucibus frumpta.

Aethiopis baufta.

vinum by fopites.

Sandaracha $\mathrm{ex}$ mulfo dita. (Hoc medicamentum ego nunquidm probauerim.)

sulfur th onv potum, uel fuffitum.

vinumby IJopites bibitum.

\section{Ad afthmaticos.}

I auri bacce ex melle, uel paffo accepte.

Ficus ficce cum by ffopo feruefacte, or pote.

Vrina impubis pota.

Ruta epota.

Cyclamini alterius femen potum.

Dracunculi maioris radix tofta, or elixa cü melle in ec legmate fumpta.

Aqua mulfa pota.

sphondilifemen, o herba ipja in forbitione.

Equifetiradix, o folia haufta.

Abrotani utriufque femen tritum, er con aqua potum. Hyffopum cum fico, melle, ruta q; 'ex aqua decoctum. potum.

Calamynthe decoctum potum.

vinum byffopites hauftum.

Thymi cum melle decoctum potum.

Saturcia cum melle baufta.

sefeli Maßsilienfe potum.

Fidicule fune Trichomanis decoctum bibitum:

Cuminum cum po fca fumptum.

Smyrnij radix comefta.

Tapfitillits.

Ammoniacum bibitum.

Melifopbyllifolia in eclegmate delinitd.

Tußilago ficca or fuffita, adcó ut fumus in os ingres diatur.

Hippophes sti fuccus trium obolorum pondere hafusus. Botrys pota, tel in ecleginate data.

Periclymeni femen potum.

Adianti decoctumbibitum.

\section{Ad renitentes excreationes .}

Irisillyrica pota.

Coagulum fré ontre potum.

Raphanus elixus deuoratus.

Porrum cum ptifana coctum, efui datum.

Nafturtium coctum, in forbitione datum .

Bulbi breui coctura elixi, et in cibum fumpti.

Ammoniacum in cclegmate datum.

Scordium potum.

Thap/ia linita.

Lini femen in eclegmate delinctum.

Scille ficce obolitres ex melle in eclegmate exbibiti.

Marrubium ficeum potum cum iritis farina.

Vinum byflopites bauftum .

Ad pectoris deftillationes.

Irionis femen cum melle delinctum.

Ad omnia peetoris incommoda .

Porrum cum mellc decoctum comeftun .

Glycyrrbize fuccus bibitus.

Thymus melli miftus in delinctu fumptus.

Thambrà codem modo parata.

Tordelij radix in eclegmate cum melle fumpta.

Libanotis radices pote.
C O R D I S.

symphytum petroum in mulfo decoctum bibitum.

Quinquefolij radicis fuccus potus.

\section{COR D I S.}

Cucumis olfactus.

Ad Defectum animi.

Pulegium ex ace to naribis admotum.

Bugloßum potum.

Ad Cardiacam,

Intybus per fe er cum polentaillita.

Abfintbium in paffo decoctum, er appofitum.

Rubifolia illita.

Ad Præcordiorum duritiem.

Rhaponticum potum.

Vinum abfintlites potum.

Ad Vetultas præcordiorum In-

flammationes.

Scordium cum cera coactum impofitum.

\section{A M M A R V M.}

Ad Mammarum inflammationes:

Thus cum cimolia, er rofaceo inunctum.

Cydonia mala cataplafmatis adiecta, $\sigma$ illita.

Nuces inglandes cum ruta, or exiguo melle impofitte.

Fabarum lomentum per fe, or cum polenta illitum,

Apphodeli radices, er folia ex vino adlibita.

Irionis femen illitum.

Hemerocallis radix emplaftri modo impolita.

Althed decocta, o fuperpofita.

Vuarum uinacei cum fale illiti.

Oftracites lapis cum melle impofitus.

Geodes lapis cum aqua illitus.

Terra Samid ex rofaceo, $v$ aqua impofita.

Ad Rigentes à partu mammas.

Triticei furfures ex ruta decocto elixi, or appofiti.

Baccharis folia emplaftri modo adbibita.

Eptmediy folia concifa ex oleo catapla fmatis addita.

Hyofcyami femen tritum ex uno illitum.

IRicini folia impofita.

Vuarum uinacei cum fale illiti.

Ad Mammarum duritiam.

Erui farina emplaftri modo impofita.

Chamapitys prima ex melle illita.

Vuarum uinacei cum fale triti o impofiti.

Ad Mammas exulceratas.

Conchule Indice cinis illitus.

Afclepiadis berbe radices impofite.

Ad Lac in mammis concretum.

Cera grumi decĕ granorum milì magnitudine fumpti.

Fabarum lomentum per $e_{2}$ er cum polents impofitum.

Ientium farina illita.

A pium, or eius fuccusillitus.

Ad Extinguendum Lac.

Cicuta impofita mammis.

Ad Lactis Vbertatem praftandam:

Halimi folia in cibis fumpta.

viticis femen potum .

Ptifana bordedced cum freniculisemine cocta, or in ci

bum fumpta.

salux decoctum potum. 


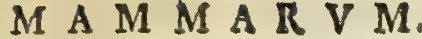

sonchi fuccus biuftus.

Lactuca in cibis recepta.

Ocimum deuordtum.

Erucd comefta.

Anemone or eitus caules cumptifand bordedeed dez uorati.

Anifum potums.

Aneti aridifeminis, or come decoctumbaftum.

Foniculum in cibo fumptum.

Nigells pluribus diebus pota.

circe ef femen in forbitione potum.

Clemstis prima in cibis accepta.

Echij radix in forbitione, uel cum uino baufta.

Glaux cum bordeacea farina, $\sqrt{a}$ ale, $e_{2}$ oleo coct $A_{2}$ or de uorata in forbitione.

Polygula pota.

Bryonix fuccus cum tritico coltus, in cibum fumptus ( ed bic prudentid opus eft.)

Ne Lac in mammis concrefcat.

Menta cum polenta impofita.

Fex uini cum ace to peruncta.

Ad Mammas cohibendas, ne nimis augeantur.

Cicuta contrita, or impojita.

Cotes naxisillita.

\section{VE N T R I C V L I.}

Ad Vomitiones \& naufeam.

Cotoneorum malorum maceratorum liquor hauftus.

Nardus Indica

Nardus Celtica $\}$ ex aqua pota.

Palmule in cibo fumpte.

Palmularum inuolucrum eataplafmatis conferentibus adiectum.

Gallinaccorum uentriculinterior folliculus ficeus, tri tusí; cum uino potus.

succinum baufunt.

Faba in pofca decoctd,

I entis $x x$ grana fine cortice deuorata.

Phafelus in cibo acceptus.

sifymbrium hauftum.

Rubifolix exteriusillita.

Idefued illota deuorata.

Iens Jylueftris efui data.

Scillaficca epota.

Agarceus trium drachmarum pondere per fe abfque li quore fumptus.

Gentiane radicis fuecus cum aqua potus.

Albe pine radix hausta.

Mente duo, tresice rami cum acids punice fucco potio

Peonie Jemien ex uino nigro potum.

Betonica commanducata ${ }_{2}$ mosq́; uino aqua mifto fus perbibito.

vitis uinifre foliorum, capreolorumiq́; fuccus potus.

Myrtites uinum potum.

vinifex illita.

scillinum uinum potum .

Ad cœliacos.

Iycium potum, 0 inditum.

Cotonea mala cruda comefta.

Mora immatura ficcata, tufáf, obfonijs immiftd.
VEN T R I V V L I.

Ficulnei cineris lixinium pondere cyathi exhibitum.

Myrica in potu data.

Galle cum aqua dut uino trite, or illite.

Rhois femen obfonijs infperfum.

Myrtifolia trita, or ex aqua illita.

Olex fylueftris folia cum polenta illita.

Coagulum leporinum, of equinum trium obolorum pö. dere ex uino potum.

Faba in pofca decocta, er deuorata.

Aegyptix fabe farina, 0 corticis ipfius decoctum, ex mulfo datum.

Oxylapathi,aut oxalidis femen in aqua, dut uino potü

Plantago elixa in aceto, er cum fale fumpta.

Hyacintbifemen potum.

Coronopus decoctus in cibo fumptus.

Rhaponticum potum.

Spine dlb.e radix pota.

Ferule uiridis medulla bibita.

I aferpitij liquor in uus acino fumptus.

Nymphae radix ficcata, of in uino bibite.

Clymeni fuccus potus.

I imonì berba femẽ acetabuli pödere ex uino fumptŭ.

Tragiberbe acini decem ex uno bibiti.

Papaueris uafculorun decoctum ex melle in eclegma te redactum in delinctu. Si ueró efficacius reddere uelis, adiungito bypocistidis, or acacia fuccum.

Vuarum uindceorum decoctum potum.

Vinaceorum nuclei in farinam polente modo inferfi.

Aqua uel uinum, in quibus ferrü extinctum fuerit pota.

Morochthus lapis potus.

vinum myrtites potum.

Adiantum ex uino bibitum.

Trichomanes ex uino pota. Ad vomitiones ciendas.

Iaurifolia pota.

Cocblea uepribus inherentes deuordte.

Peponis radix ficca drachme pondere ex hydromelite pota.

Bulbus uomitorius deuoratus.

Origanum cuin Rhois femine, or cepis in cupreo udfe diebus quadraginta, dum canicule fydus flagrat in folatuin potum.

Lemnia terra pota.

Iuncus odoratus potus. Ad ventriculi dolores.

Bulbi comefti.

Rhaponticum bibitum.

Abfinthium in paffo decoctum potum.

Melilotum ex uino decoctum hauftum.

Artemifia tenuia folia ex oleo contufa emplaftrimodo impofita.

Nymphere radix illita.

Senecionis caulis in paffo dccotus, denoratusuel potus.

Alabaftrites lapis cum cerato impofitus. Ad ventriculi erotiones.

$\left.\begin{array}{l}\text { Nardus Indica } \\ \text { Nardus Celtica }\end{array}\right\}$ ex aqua pota.

Iuncus odoratus potus.

sycomiorifuccus potus.

Pine nuces deuorate.

Iac bumanum potum. 
VE N T R.I C V L I:

sondifuecus bibitus.

Pulegum cum pofca fumptum.

Hecrscij utrieg gre furcus bouftus.

scordium dusrum drachmarum pondere com mulfa potum.

Penis Semen ex uino nigro poturn.

Ad ventriculi ardores,

Portulaca cum polenta illita.

Soncbus emplaftri modo impofitus.

Vmbilici veneris fuccus illttus.

Intybus utr aque ex ace to denorata .

Glycyrrbize fuccus potus.

A pitum ebibituns.

Freniculum cum frigida aqua potum,

Polygonum illitum:

Solani hortulanifolia appofita .

Chamedaphnes folia baufta.

vitis uinifer folia, 0 capreoli empl.ytri modo adbi bita.

Labrufce flos illitus.

Ad ventriculi Alatus.

inei radices ex aqua feruefactae, uel citra cotionen trite pote.

- Nardi Indice, or Celtice ex aqua pote.

Caftoreum bibitum.

Gallinaceorum fenefcentium ius potum.

Abfinthium cum fe feli, aut gillica nardo potum.

Liguftici femen, or radix pota.

smyrniy femen baufum.

Ad fingultum.

sifimbrij femen in uino potum ,

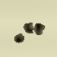

Rhaponticum ha!ftum.

Ariftolochia rotunda bibita.

Menthe duo, tresue rami cum acide punice fucco poti.

Anethicome, o feminis decottum potum.

Cuminum erraticum cum aceto potum.

A ly forl potum, fiue manibus geftatum, uel naribus ins fusum.

Aplenidecoctum potum.

Periclimenifemen potum.

Saxifraga bibita.

Ad acidos ructus.

Agaricus drachme pondere fumptus.

Tragoriganum potum:

Betonic s folia fabe pondere ex depumato melle Sumpta.

Ad fanguinem \& lac in ventriculo concreta.

Ficulnci cineris lixiuium potum.

g*

Codgulum $\left\{\begin{array}{l}\text { Equinum } \\ \text { Leporinum } \\ \text { Agninum } \\ \text { Hrdinum } \\ \text { Hinnulinum } \\ \text { vitulinum } \\ \text { Bubalinum }\end{array}\right\}$ re ex utno potum.

Helicbryfi coma cum mulfo pota.

I afer potum.

Ad inflammationes ventriculi.

Hier acium maius or minus emplaftri modo impofitii.

vitis uisif cre folid or capreoli cum polenta impofiti.

Viola purpurea ex polenta illita.

\section{IECI NORIS:}

Ad cıbi appetentiam ciendam.

Piper comeftum .

Acetum in obfonijs additum.

Abfinthium potum.

Ad concoctionem adiuuandam.

Eruca in cibo comefta.

Riper omne comeftum.

Gingiberis ufus,

Scylla cum melle cocta, er deuorata.

Abfinthium hauftum, uel uentriculo adbibituns,

Tragoriganum potum.

Pulegiun potum.

Iigufticifemen er radix pota.

Scfelis maß̦ıllienfis femen çum uino potum.

Carum potum.

Betonice folia poft coenam fumpta addito melle de= pumato fabe magnitudine.

vinum ab/inthites.

Ad ftomachi fluxiones.

Adiantum potum cum uino.

Perfici mali ficci decoctum, o bibitum .

Cotoneimali macerati liquor potus.

\section{E C I NOR I S.}

Ad iecinoris obftructiones.

Nardus Indica $\}$ ex aqua frigida baufta.

Lauri cortex tribus obolis in uino odorato potus.

Picee folia dracbme pondere in aqua, aut mulfa pota.

Amygdale amare cum melle, of lacte in illinctu date nucis auellane magnitudine.

Gentiane radicis fuccus cum dqua potus.

Agaricum potum .

Rhaponticuum exhauftum.

Eryngium ex uino affumptum.

Anthemidis decoctum potum.

Cbanapityos folia feprem diebus in uino pota.

Betonica in aceto mulfo drachme pondere bibita.

Eupatory berba aut femen in uino potum.

Papaueris corniculatiradix pota.

Rubrica sinopica baufta.

Glycyrrkize fuccus delinctus.

\section{Ad regium morbum?}

Nardus $\left\{\begin{array}{l}\text { Indica } \\ \text { Celtica }\end{array}\right\}$ haufta.

Ceruinum cornu uftum, ac lotum, potumq.;

Millepede fiue ouifci ex uino poti.

Cicer cum ror emareno decoctum comefum.

$\mathbf{R}$ umicis radices in uino decocte $v$ 'bibite.

Atriplicis femen bibitum cum mulfa aqua.

A paragi radicum decoftum potum, cum ficis, er ci ceribus.

Crithmi, or cius radicum feminü decoctum potum.

Irio cum melle lincta.

scilla cum melle in eclegmate pondere trium aboloa rumpota.

Hyrundinarie radix cum anifo, or uino pota.

sphondylij femen potum.

Agaricus drachone pondere fumptus.

Rhaponticum hauftum. 
I ECI NOR IS.

$A b / i n t b i j$ decoctum, dilutumie triun ciathorum ponde re quotidie biuftum.

Aloë drachme poidere pota.

Origani decoctum corpori perfusum.

Calamintha cum uino pota.

Foniculum erraticum potum.

Libanotis radices pote cum uino, or pipere.

Rorifmarini decoctum potum.

Nigells trita cum Irino unguento, naribus appofita.

Chelidonij radix cum anifo, er uino albo pota.

I afer ekm caricis datum.

Marrebij Juccus naribus infufius.

Polijwtriufgue decoitum bibitum.

Conyzefolis, or flores poti.

Afplenidecoctum potum.

Iicben ex melle inunctus.

Adisutidccoctun potum.

Trichomathes decoftum buftum.

Anthemides decoctum potum.

Bupbthalmam potumftatim à balneo.

Pronise radix bibita.

Hyacinthi fenten cum uino potum.

Rubie radix cum mulfa aqua bibita.

Chamepityos folia septem diebus in uino pota.

Betonice folis cum dulci dqua pota.

Elaterium potum.

Anchuse radicis decoctum potum.

Quinquefolij fuccus trium cyathorum pondere aliquos diebus potus.

ofyris decoctum potum.

Chryfanthemi decoctum balnei more adhibitum.

vinum Scillinum potum.

Verbenace fupine folia dracbma pondere cum thuris obolis tribus, o uini ueteris bemina una ieiunis 40. diebus pota.

Iycijberba in aceto decocta, or bibita.

Myrice decoctum potum.

Halycacabi fructus poti.

Chamecifi folia trium obolorum ponderé Senis diebus in aquapota.

Rufcifolia, o bacce in uino pota.

vinum Scillinum haustum.

Ceruini cornu cinis potus binis ligulis.

sulfur forbili ouo fumptum .

Afarum potum.

Adbydropem.

cinnamomum ebibitum.

Calami odorati decottum cum femine apij potum.

Erinacei terreftris caro.

Cochlearum terreftrium operimentum, o caro fimul contrita tumoribus hydropicorum impofita.

Amured in villo fa pelle peruncta, or impofita.

Vrina bumana fui ipfius bibita.

Vrina capre quotidie cum fpica pota.

Cicer cum rore marino decoctum.

Raphanus emplaftri modo impofitus.

Plantago cum lenticula decocta.

Ebuliradix in uino decocta, er pota.

Allium decottum manducatum.

Bulbi cum melle, o trito pipere emplaftri modo ins pofisti.

Scilla preparata Jumpta.
I E C I N O R I S.

Anagallidis fuccus uino potus.

Cbameleonis alba radix cum uino pota.

Ab/intbium bibitum cum ficubus, nitro, or loliaced farind.

Adianti decoctumpotum .

Trichomanes decoctum potum.

Hy]fopum cum fico, nitro q́; emplaftri modo impofitum.

Fidicule decoctum potam.

Origainum cum fico decoctum.

Sampfuchi decoctum potum.

Ruta cum fico emplaftrata, or eius decoctum ex uino tum potum, tum corpori perfuf fum.

$P$ aftinace erratice femen potum.

Anifum potum.

Smyrnij femen potum.

L a erpitij liquor cun cdric is datus .

Chamedrid decoctum potum.

Polij utriufque decoctam bibitum.

Androfaces in uino pota duarum drachmarum pödere.

Betonica folia cum aqua dulci pota .

Cucumeris afinini radicis fuccus fe fquioboli pondere, or cortex eius acetabuli quarta parte.

Aque marine balneum.

Vitis fylueftris radix in aqua feruefacta,er in uini cydo this duobus marina aqua diluti pota.

vinum Scillinum potum.

viticis femen potum.

Ficus ficcet in uino cum polenta, 0 ab/inthio decocte, or illite.

sal.

Alcyonium tertium.

Arena é littoribus fole feruefacta capite tenus bydropi cis obruta.

Ad refrigeratum iecur.

$\left.\begin{array}{l}\text { Nardus Indica } \\ \text { Nardus Celtica }\end{array}\right\}$ ebibita.

Amomi decoctum potum.

Pinorum, $v$ picea folia ex aqua, uel mulfo pota.

Ad iecinoris dolores.

Acori decoctum poturn.

Abfinthij decoctum expaffo appofitum .

Periclymeni femen potum cum uino .

Ad iecinoris duritiem.

Ammoniacumillitum, er ebibitum.

\section{I E N IS.}

Ad induratos lienes.

Cotonea mala cruda catapla fmatis addita er impofite.

sycomori liquor bauftus, evillitus.

Raphantus emplaftri modo impoftus.

Braßic e folia cum dceto deuorata.

Chamedrij decoctum potum.

Lupinorum farina illita,

Ad lienis obftructiones.

Nardus celtica ex uino pota.

Adiantum bibitum .

Trichomaneshaufta.

Ad lienis inflammationes.

Irisillyrica ex aceto pota .

Acorum potum.

Nardus celtica ex uino potd. 


\section{I E N IS.}

Nardus montana ex uino haufta.

Sarmenticius cinis ex aceto, rofacco, er ruta illitus.

anyrié. ex uino decoctum potum.

Vittcis femen potum.

Ad lienis dolores,

Ditamnum potum, er illitum.

Ad minuendos lienes.

Iris Illyricd ex aceto pota.

Acorum potum.

Nardus $\left\{\begin{array}{l}\text { Celtica } \\ \text { Monitan }\end{array}\right\}$ ex uino bibita.

Myrice ex uino deco.tum bauftum.

viticis emen potum.

cyclamini fecund e femĕ quadraginta diebus hauftum.

Sagapenum ebibitum.

Ammoniacum draclome pondere ex aceto fumptum.

Chamedrys ex aceto pota.

Nafurtium bauftum.

Piperis radixillita.

Polij utriufque decoctum cum deeto potum.

cyclamini fuccus inunt fus.

Capparis femen draclomar ü duarum pondere quadra ginta diebus ex uino bibitum.

Einfdem radix ex uino bibitd codem pondere.

Lepidium cum belenij radice impo/itum.

Hedere tenella folia ex uino decocta, uel arida ex pas ne coact impofita.

Ifatis sylueftris tum poto, tum illita .

Agaricŭ drachme pondere cum aceto mulfo datum.

Rhaponticum potum.

smyrnij radix comefta.

Gentiane radix duarum dracbmarum pondere pota.

Ariftolocbia rotunda pota.

Crocodilij radicis decoctum potum preesentaneo rea medio prodeft.

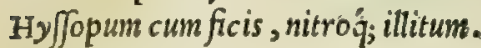

Tragoriganum cum aceto potum.

Pulegium ćùn fale illitum.

Sifon potum.

Pelucedanifuccus bauftus.

Vifcum cum calce, gagatèue lapide decoctum illiturn.

Tcucrium cum pofca potum, uel cum ficis appofitum.

Leucoij radices cum ace to illite.

-Nymphex radix ex uino bibita.

A pleni follia pota, uel eius decoctum cum aceto quadra ginta diebus baftum, uel folia ipfa ex aceto illita.

Bunij femen potum.

Hamionitis cum aceto pota.

Rubic femen ex aceto mulfo potum.

Ionchitis alterius folia cum aceto baufta.

Betonice folia ex oxymelite cbibita.

Polemonij radix ex aqua fumpta.

Periclymenifenen quadraginta diebus in uino potum:

Xyridis femen ex accto fumptum.

Anchufe radix cum mulfa aqua pota.

Vrtica utraque cuin cerato impofita .

Trichomanes pota.

vini fcillini ufus.

Glans unguëtaria cum erui farina pota $\mathrm{ex}$ mul $\int a$ aqud.

Bryonia trium obolorĩ ponderc triginta diebusex ace to baufta, aut cum ficis illita.

vitis nigre uiticula prime recentes cocte, ac comese.
IN T.ESTINOR.VM.

Pilicismaris radix baufts.

Aqua, uel uinum, in quibus chalybs, dut ferrum reftina

ctum fuerit in potu.

Alcyonium tertium bibikum.

Corallium ex aqua blbitum.

A fius lapis ex aceto, er uiud calce illitus.

Cotis naxie delimatd à ferro fcobes ex aceto bibita.

\section{N T EST I N O R V M,}

Ad colicos affectus .

Amygdale dmare illinitu adbibite.

Cocblea terreftres cum fuo putamine tufa, addita pau= ca myrrba, ex uino bibite.

Alauda auis tofta in cibo fumpta,

suillus talus crematus ad albedinẽ ufque potus, ubiflatus excruciet.

Butyrum infufum, ubicolon exulceratum fuerit,

Galline fimum cum ace to uel uino bauftum.

Ruta decoctuin ex oleo infufum.

Petrofelinum potum.

Colocynthis infufa clifmatibus.

Gnici decoctum infufum .

Ad inteltinorum dolores.

Iris illyrica pota.

Acori decoctum bibitum .

Meiradices trite cum melle in eclegmate fumpte.

Cardanomim ex aqua potum.

Àgallocbum ex aqua baustum.

Nuces inglandes cum fuo putamine perufte, er unbia lico admota.

Ficuum cum ruta decoctum cly fmate infufunt.

Halimi folia drachme pondere in aqua mul fa poka.

Crocum in potionibus bibitum.

Daucifemen potum.

Libanotidis radices haufte.

Ferule femen in potu fumptum.

Peucedani fuccus in ouo bauftus.

Meliffopbylli decoctum clyftere infufum.

Caftoreum potum.

Butyrum cly fmatibus infufum.

Serpyllum ebibitum.

Calaminthe decoctum hauftum.

Eryngium ad potandum datum .

Cera in forbitionibus data.

Ammi ex uino fumptum.

Triticei fur fures ex decocto rute elixi, or illiti.

Milium calefactum, in facculis adbibitum.

Orobifarina aceto macerata impofita.

sifymbrif femen in uino potum.

Piper cum lauri tenellis folijs bauftum.

scilla in eclegmate cum melle.

Rhaponticum potum.

sampfuchi decoctum ebibitum.

Centaurij maioris radix pota.

Ruta und com ficcato anetho elixa in potu fumpta.

Panaces cum uino bauftum.

Anethi come, or feminis decoctum potum.

Ligufticifemen o radix pota.

Cumini decoctum cum oleo clyfterc infufum.

Fbalangìfolia, flores, ac femen bauftum.

Centunculum auftero uino potum. 
I N T E S I I NOR VM.

Conyze folid, o florespoti.

peonie radix in uino pota.

P feudobunium ébibitum.

Aqua marina fotu adhibits.

Chamapitys haxuft.

Graminis decoctum ebibi tuitt.

Chamedaphucs folia in potudatd.

Sal calcfictum in Sacculis adbibitum.

Nitrun cuin cumino ex bydromelite bauftum.

Sefelis Maßilienfis femen ex uino potum.

Afclepiadis.radices ex uino potie.

Alifma per $\int e$, dut chm pari pondere feminis dauce baufum.

Suillus talus combuftus ad albedinem ufque ebibitus.

I ini feminis decoctump por fedcis infufum.

Agaricum dworum obolorum pondere fumptum.

Ad dy fentericos.

Afpaldthi decortun clyfterc infufunt.

Nigrrlat fabe magnitudine deuorate.

I enkif cus cbibits.

Pices cortex potas.

Maceris cortcx in potu fumptus.

Paliuri folid, eradix baufta.

Acrte fine frutus devoratizul epoti.

Rubicanini. fruettus deuoratus.

Cijfi foilis, or cytini in potibduts.

iypocift is laufta.

$\because 4$

I ad sinun cum uino uetere potum .

Rofurutit fructus in potu sumptus.

Iycium potui dat win.

Acacie. Juecushauftus.

Glandium interion tenuior

Caftancarum interior pariter tunica ebibita.

Galla on:phacitis ex uino, dut aqua tritaillita, aut banfs.

Rhois foliorum decoctum clyftere infufum, uel in potu acceptum.

Eiufdem" Semina pro fale cibis, obfonijsǿ; apperfa.

Palme inuolucri decođtum, tum infuJum, tum bibitum.

Punicorum acidorum nuclei ficcati, ev ebibiti, uel in defeßionibus additi.

IIyrthi femen, or folla pota.

Cotonea mala comefa crudd, uel coctd,'uel corum fuc= cus potus.

Pyra tam domestied, quàn fylueftria deuorata.

Mepila in cibum accepta.

Ioti arboris bacce comefte, uel baufte.

Corni arboris bacce fiue in eduliys, fiue in defruto af: fumpte.

Sorba ficca quoquo modo jumpta.

Prunorum fyluestrium bacce deuorate.

silique ficcate denorate.

Cocblex terreftres fuis cum putaminibus ufte (ut Gal. inquit) efui date.

siluri pifc is falfamentum fomento adhibitum.

Ieporinus fanguis frixus deuoratus.

Garum pifcium cly fmate infusum.

Ceruinü cornu potum duorum cocbledrium menfura.

Cerain forbitionibus data.

I ac ignitis iniectis calculis decoctĭ clyftere infufum. Ieporinum coagulum trium obolorum pondere ex Equinum \}uino potum.
I N T ES T I N R V M.

Afparagus altilis clixus, uel affus in cibo fumptus mis tigat.

Idea radix bibita.

Althee decocte fuccus ex uino bauftus.

Alcee radices cum uino, aut dqua pote.

Phyllitis pota.

Portulaca ad fummum cocta in cibis fumpts.

Plantago per Sedem infufa.

Equiferi fuccus potus.

Caprillus adeps cumpolenta, e Rboe datus, vel clya Atere infufus.

Melifophyllum bibitum.

Tragium fcolopendre /imilis elixü,

Faba in pofca decoeta, $\sigma$ come $\int a$.

Alifmatis radix cum paripondere feminis fylueftris paftinace bibita.

Oxylapathi aut oxalidis Semĕ, in aqua aut uino bibitü.

Iyfimachia potui data.

Tragi cacumina $x$ in uino pota.

Clematis folid cum uino baufta.

Stabis decoctum clyftere infufum。

Limonij femen in uino potum.

Elstine clixa pota.

Polemonij radix ex uino fumpta:

Eupatorij femen, or folia in uino haufte.

Nymphae ficcata radix ex uino ebibita.

Sedum maius cum uino potum.

Sanguis hyrci, capre, leporis, ceruig; in fartagine fri xus, in cibo fumptus.

vitis unifere foliorum er capreolorum fuccus potus.

Vinaceorum decoctum ebibitun.

Vinaccorum nuclei in farinam polente modo illiti.

Vua paffa alba come fa per fe cum fuis nucleis.

Omphacium clyftere infufum.

Vinum cenantinum

vinum Cydonites $\}$ potum.

vinum rhoites $\}$

Terra lemnia ebibita.

Muria clysmatibus infufa, ubi diutina dy fenteria inteffi na exulcerata extiterint.

scordiü duarü drachmarü pödere cü aqua dulci potü.

Hedere flores trium digitorum carpte bis in die ex ui no haufi.

Ad cohibendum aluum.

Codgulum leporinum potum.

Lac oé, in quo igniti calculi marini extincti fuerint .

Cafeus elixus, e ab elixatione ftatim $\int \mathrm{epofitus,moxós}$ ina Jatus in cibo fumptus.

Fimus caninus ardètesyrio acceptus, et in aqua bibitus.

Panis triticeus ficcus inueteratus comestus.

Hordeaced farina cum myrtibaccis, aut fylueftribus pyris, aut malicorio ex uino illita.

Puls ex zed

Puls ex Auena $\}$ in cibum fumpta.

Pulsexmilio

Oryzd in cibum dcceptd.

Létes cum fuo cortice decocte deuorate, prefertinn fi decoquantur ex aceto cum adftringentibus alijs. Oxylapatbi,aut oxalidis femen in uino, aut aqua potü. Braßica percocte cibus.

Beta nigra cum fua radice, or lente decocta efui data. Plantago ex aceto elixa, cum fale come $\int \alpha$, quin $\sigma$ eius 


\section{INTESTINOR V M.}

Femen ex uino potum. Preterea clyfteribus infufa: Intybus tam bortenfis, quă erratica in cibum accepta . Condrylle fuccus coctus potus.

Lens fylueftris quoquio modo Jumpta.

Acinos pota.

Anifum ebibitum .

Anethum,quin etiam eius comd, o femen haufum.

Apium in cibo fumptum.

Phyllitis potui data.

Acantbi radices bibite.

Foniculum erraticum potum.

Ruta in cibo uel potu fumpta.

Orclis serapias ex uino potus.

Pronie radix ex uino decocta baufta.

Althee decoctum bibitum.

Alifinatis radix pota.

Polygoni fuccus potus.

Clematis prima in uino bibita .

Lagopus ex uino, uel ex aqua fumpta ubi febrisfit.

Xyrid is radix in mulfo pota.

Anchufe folia ex uino fumpta.

Rubiramorun decottum potui datum.

Quinquefolij radic is decoctum bibitum.

phanix in uino duftero haufta.

Idea radix blbita.

Iunci,prefertim marini femen frixum, ov in diluto ui= no potum.

Aftragaliradix ex uino hauft.

Hyacinthi radix ebibita.

Papaneris nigri femen ex uino bauftum.

Verbafci radix, or flores potui dati .

Labrufce flores poti.

Punicorum acidorum uinum potui datum.

Rubrica sinopica in ouo'bauft d, dut clyftere infufa.

vini fexillita.

Sedum maius ex uino hauftum.

Adianti decoctum potum.

Trichomanes decoctum bibitum.

Acetum cibis incoctum.

Ad diuturnas alui fluxiones .

SaN $=\left\{\begin{array}{l}\text { Hyrcinus } \\ \text { Caprillus } \\ \text { Leporinus } \\ \text { Ceruinus }\end{array}\right\}$ in fartaginc frixus et comefus.

Ad ciendam, \& emoliendam aluum .

Cerufía comefa.

Melimela efui data.

Perfica in cibum fumpta.

Mora matura comefta.

Ficus mature denorate.

Marinus echinus in cibis.

Tcllinarum, chamarumíg ius cum fale bauftum.

Sepia in cibo fumpta.

silurus pifcis in cibis.

Gobii ius bibitum.

pifcium in uniuer fum ius per $\int e$, aut ex uino bibitum.

Gallinaceorum ueterum ius epotum.

I ac baustum.

serum lactis potum.

Cafeus recens in cibo fumptus.

Butyrum concftum uel bibitum.

Medulla ofitwin denorata.
I NTESTINOR V M.

Cicer in cibo Jumptum.

Rumex

Blitum

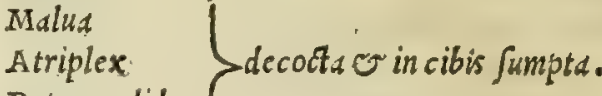

Beta candida

Aparagus

Lactuca

Braßica leuiter feruefacta, efui data.

Tragorinum potum.

Ad inteftinorum inflationes.

Farina tritici cum by of cyami fucco illita.

Farina bordei cum lini, et freni graci femine impofita.

Ocimi femen potum.

Rbsponticum bibitum.

Anetbicome, of feminis decoctum potum.

Cunini decoctum cum olco clyftere infusum, thel eius se men cum polenta $\mathrm{O}$ bydreleo maceratum et illitü.

Peucedani liquor in ouo ebibitus.

Anthemidis decoctum potum.

Ad latas inteftinorum tineas.

Cardamomum potum.

Mali punica radicum decoctum bibitum.

Nuces inglandes largius efitate.

Mori radicis corticum decoctum bauftum.

Allium potuidatum, vel comeftum.

Chameleonis albi radix acetabulipondere, ex caftorei, o origani decocto potd.

Filicis fomina radix trium drachmarum pondere ex melle baufta.

Melantbij femen potum, uel ex aqua umbilico illitum.

Atramentum futorium drachme pondere fumptum, uel cum melle delinctum.

Heliotropij ma.tum folid, tum semina cum hy fopo, ni= tro, er nafturtio pota.

Ad teretes inteftinorum tineas.

I upinorum farina cum melle lincta, uel cum aceto,pi pere, or ruta pota.

Brdsfice femen potum.

Portulace fuccus potui datus. Prestat idem o femen. Nafturtium bibitum.

Abfintbium marinum per fe, uel cum oriza decoctum, cum melle fumptum.

Abfintbium fantonic um, ut marinum, bauftum.

Hy]sopum cum melle linctum.

Mienta bibita.

Calamintbe decotum cum fale, o melle fumptum.

Thymum hauftum.

Thymbra potui data.

Ruta decoctum ex olco bibitum.

Coriandrum cum paffo fumptum.

Anclus a tertia cum by fopo, er nasturtio pota.

Vinum abfintbites potui datum.

Sedum maius ex uino baustum.

Filicis foemine radix drachmarum trium pondere cum uino pota. Sed qui fumunt preguftare allia debent. Ad aluum fluentem ab expurgante medicamento.

Gallorum gallinaceorum fenum uentriculus fale inue: teratus, o in umbra ficcatus potus.

Ad inteftinorum vulnera.

Equifetiradix, or folia cum aqua, pota. 


\section{E D I S.}

Ad intctinorum vlcera .

Lac omre igntis calculis calefactum, infufum?

Sapphyrus lupis bibutus.

\section{SE DIS.}

\section{Ad fedis rimas.}

Pix liquidaillita.

Amurca un cupreo uxe ad mellis pisitudinem decos Et.tillita.

vitic is fomen cum aquaillitum.

Cancriflunistiles combufti cum melle cotto illiti.

I abriveneris radix in uino decocta, o fubinde tufa impo/ita.

Iewcoij flores cera excepti,et emplaftrimodo adhibiti. $\mathrm{L}$ abrufce flores illiti.

Plumbina clotum impofitum.

Ad ledis vlecra.

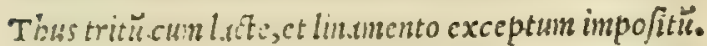
Punicorü acidorun fuccus cum melle decoctus illitus. Ociypus into irus explet o cmollit.

Plumbura clotun illitum.

\section{Ad codvlomata.}

Cotones malu cruda catiplafmatis adiecta.

Out utcllus aßsutus, e exrofaceo, er croco illitus.

Aloc cun parlyo adbibita.

Anctincremut foninis cinis illitus.

I tbunotis emplaftri modo impofita.

B. lloves folm in fermeiti cinere cocta impofita.

$\mathrm{R} u$ bl fols adlabita.

Helfine impofita .

Qumquefolij radix illita.

Sarmöttius cinis, quin 20 uindceorum ex dceto illitus ,

Rubıgo Ferrullita.

Plunbum elotun inpo/itun.

Sandarachacum rofucco inuncts.

suillus adeps illitus.

Crocunn cataplafmatis inditum.

Ad ledis in flammationes.

I ens cum fertula campand, ficcis rofis, cydonio malo, malicorio er rofaceo illita.

Soncbi fuccus illitus.

Mchlotus cun freni greci farina, o lini femine ex paf So impolitus.

Libsinotis adhibita.

Althes radix decotal illita.

Symphy i maioris radix, cum folijs senecionis cataplaf matis modo.

Senectonis flores, or folid, ex modico uino illita.

Ad induratos fcdis tumores.

Pix liquidaillita.

$$
\text { Ad procidentem fedem. }
$$

Ientifri fuecus, o folta illuta.

Malorum cydoniorun decoctum in de $\int e$ ßionibus.

Torpedo marina appofita .

Cyclamini fuccus ad mellis ßißitudinè decoctus, illitus.

Cerulei anagallidis flores appofiti.

After Atticus illitus.

Acetum illitum, or fotu adbibitume.

Acida muria in de ejeßionibus.

Ad tenalmos.

Isc ouithm, caprillım, bubulumág; ignitis calculis cale fatum, clyftere infufum.

\section{$R E N \vee M$.}

Penigreci feminis decoctum infufum.

Limi femen quoquo modo appofitum.

Erui farina uino maceratd illita. Ad penfiles fedis thymos.

Capre fylucftris fel illitum.

Fimum ouillum ex aceto imunctum.

I afer in malic orio cum aceto feruefactum:

Acetumillitum.

Cepaconfricata.

Ad hæmorrhoidas ciendas.

Ad hæmorrhoidum defluxiones:

Aloë cumpaßoillita.

Libanotis emplaftri modo impofita.

Rubi folia adhibtta.

Palmule illite.

Ad hæmorrhoidas fanandas.

Rhois Semen illitum.

Palmule illite.

Ononis decoctum (ut quidam aiunt) potum.

Plumbum elotum impo/itum.

Arabicus lapis illitus.

Portulaca ad fummum cocta impofita.

R E N V M.

Ad renum dolorem.

Cardamomum ex uino potum.

Nardum Celticum potum ac linitum.

Amoni decoctum bibitum.

Harundinis radix lumborum doloribus proficit cum d= ceto illita.

Tragacantha dracbme pondere in paffo dißoluta cune adufto, elatoó; cerui cornu, $\odot$ f cißilis aluminis tan tillo potum.

Pcucedani fuccus potus.

Vua paffa alba in cibun fumpta.

Alcyonium tertium potunn.

Foniculi come decoctun fubditum.

Anagallis pota.

Agarici drachma pota.

Glyccyrrbize fuccus cum paßo potus.

Tordilium bibitum.

Antbyllis pota.

Peonic radix ex uino pota.

symphytum petreum ex aqua potum.

Ancbufe decoctum ex aqua bauftum.

Vinum melitites ebibitum.

Ad renum calculos $\&$ arenulas.

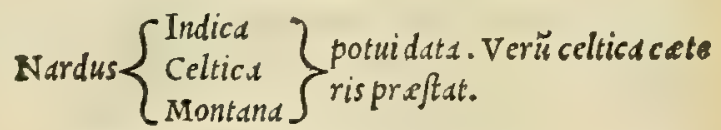

Laturi folia pota, quin 0 radicis cortex quilonge pos zentior eft,potus.

Cerafi gummi ex uino hauftum.

Amygdale amare gummi ex pafjo fumptum.

Ononis radicis cortex cum uino potui datus.

Anifum potum.

Cumini alterius fylueseris femen potum.

Artemifie decoctum in de e prombus adbibitum.

Chamemeli decoctum potum, uel forn adhibituin.

Parthenij folia baufta.

Althex decoctum bibitum.

Alifmatis decociuni putuidatum. 


\section{VES I C AE.}

Tribuli utriufque fructum fuccus baufus.

Rubi radix poid.

Papsueris corniculati radic is decoctum bauftum.

$\checkmark$ mbilici ueneris folia cum radice pota.

Vinum ab/intbites bibitum.

Adiantum potuidatus.

Trichomanes poini data.

Vua paffa albic come $\int a$.

Melitites uinum aßidué potum.

Alcyonium tertium potum.

Adrenum vlcers.

Idc omne potum .

Plantaginis radices, er folid ex paffo fumpta.

Vua paffa alba come $\int a$.

Melitites uinum aßidue potum.

Ad renum obftructiones.

Rhaponticum bauftum.

vinum abfinthites $\}$ potum.

\section{E S I C AE.}

Ad ciendam remorantem vrinam.

Acoridecoctum potum.

Mei radices ex aqua decocte , uel trite citra coction nem, o pote.

Nardus $\left\{\begin{array}{l}\text { Indica } \\ \text { Celtica } \\ \text { Montana }\end{array}\right\}$ potui date.

Cardamomum ex uino bauftum.

A farum bubitum.

Phuficca pota.

Malabatbrum potum.

Cafia in potu bausta.

Cinnamomum potum.

Coftus ebibitus.

Iuncus odoratus in potu fumptus.

Calamus odoratus cum graminis, aut apij femine fum: ptus.

Apalatbi decoctum hauftum.

Crocum ebibitum .

Helenij radicum decoctum potui datum .

Crocomagma potum.

Pinee nuces repurgate come $\int e$, aut cum pad $\int$ o uel cu cumeris femine pote.

Ientifci decoctum bauftum.

Terebintbi fructus comeftus.

Rejind omnis, preserting; terebinthina baufta.

Cupreßi folia ex paffo, $\mathcal{O}^{2}$ exiguo myrrhe pota.

Cedrides deuorat $x$, inel pote.

Iauri foliorum decoctum in defeßionibus.

Albe populi cortex uncia pondere bauftus.

Paliurifoliorum,"et radicü decoctum in potu fumptum.

Phillyrea folia pota.

I adanum ex uctere uino bauftum .

Olex Aethiopice, ac noftratis lachryma potui data.

Glandes in potu fumpte.

Falme inuolucridecoctum bibitum.

Punice acide fuccus potus.

Cerafi gummi baufum.

Amygdale amare lacbryma bibita .

Erinaceus marinus in cibum fumptus.

\section{VISICAE.}

Erindeci terreftris caro inueterata ex ace.mulfo pota.

Vermes terreni triti, or cum pafjo poti.

Mel haultum.

Ptifana bordeacea deuorata.

Zythum ex bordeo paratum potum .

Cicerum decoctum potui datum.

Erui decoctumn baustum.

I upinorum radicum decoctum bibitum.

Raporum cauliculus elixus, $\sigma$ in cibum fumptus.

Raphanus comeftus, quin e eiufdem $\int e m e n$ potum.

Siferis radix in cibum accepta.

Afparagibrenicoctura elixi, e in cibum propinati.

sion quoquo modo fumptum.

Cucumeris femen potum.

Eruce utriufque femen bibitum.

Dracunculus minor bauftus.

Horten/is fmilacis filique cum femine elixe, or in cis bum date.

A/phodeli radix potd.

Bulbus uomitorius in cibum sumptus, uel eius deco. tum potum.

Porrum domefticum, er filueftre comeftum.

Capa decocta in cibum fumpta.

Allium in cibum fumptum.

Capparis fructus quadraginta diebus potus.

Anagallidis fuccus bibitus.

Calaminthe decostum potum.

Saluie decoctum hauftum .

Crocodilij femen bibirum.

Thymi decoctum potui datum.

Thymbre decoctum bibitum.

serpyllum in potu fumptum.

Ruta quoquo modo fumpta.

Spine alberadix pota.

Acanthi radices pota.

Ononis radicis cortex ex uino hauftus.

Eryngij radix pota.

Abfinthiü potuidatum, uel eiufdem decoctum bibitum.

Hy fopi decoctum in potu affumptum.

Origanum bauftum.

Tragorigani decoctum ebibitum.

Ruta fyluestris pubi illita.

Iiguftici femen, o radix pota.

Paftinace erratica femen bauftum.

Cari femen potum.

Anethi come, or feminis decoctum bibitum.

A pium crudum, coctumue in cibum fumptum.

Petrofelinum in potu hauftum.

Feniculi decoctum potum.

Nigella pluribus diebus bibita.

Polij montani decoctum potui datum.

Artemifie decoctum in defe Sionibus ddhibitum.

Anthemidis decoctü bauftü, uel in de eßeßionibus additü.

Lithopermi femen ex uino albo fumptum.

$\mathrm{R}$ ubie radix pota.

Ionchitis radix ex uino fumpta.

Hypericum bibitum .

Betonica folia pota.

Periclymeni femen hastum, Eft enim ualentiSinum medicamentum.

Saxifraga potui data.

Xyridis radix trium obolorum pondere bibita. sed fee 
VES I C AE.

mini uis longé maior.

Innci m.urini fimen frixum, or ex diluto uino haftum. Ageratum Juffitum.

Veficarise fiuc baticacabi rubentes acini folliculis in= clufi deworati.

Solani fomnifici femen potum.

Rufci folix, bacce apparagi, radicesie in uino pote. spartij femen deuoratum.

vitis albe culiculi teneri decocti, or deworati .

cytifi decoftumpotum.

Danci femen bauftum.

Coris femen in potu fumptum.

Equifeti fuccus potus.

Vmbilici ueneris folta cum radicibus menducata.

Bunij, o peudobunij femen potui datum.

A.ftug alis adix ex uno fumpta.

Hyscinthi radiex bibita .

Vitis nigre uiticule prime cocte, concfteq́ó.

Chamedaplones foliorum fuccus ex uino Jumpitusa.

vinus $\left\{\begin{array}{l}\text { Cydonites } \\ \text { Hyßopites } \\ \text { Scilinum } \\ \text { Abfinthites }\end{array}\right\}$ potum.

Aqus mulfa in potum accepid. Advrinzanguftias .

Cimices leitularij triti, o urinaria fiftule impofiti

Millepede ex uino pote.

cicade inaffate manfit.

Locufte funfite, prefertim in fominis.

Ceruini cornu cinis clotus binis ligulis epotus.

Malue decoctum in Seß3ione adbibitum.

Portulaca in ciburin fumpta:

Afparagi radicun decoctum bauftum.

Crithami radix, femen, e folia ex uino decoctapots.

Sandycis decoitum potui datum.

Caucalis olerum modo in cibum fumpta.

Amaraci decoctum potum.

Baccharis radicum decoftum hauftuit.

Ocimi femen bibitum.

Simyrriÿradix pota.

Agaricum drachme pondere datum.

Peucedani fuccus potus.

Rhaponticum potam.

Phalaridis furcus ex aqua, aut uino bauftus.

Iotus fylueftris trita per $\int e_{2}$ aut cum malue femine ex uino, aut ex paffo pota.

Chamepitys potuidata.

Chameleonis albiradicis decotam bibitum.

Abrotani femen tritum, $\sigma$ ex aqua calef actum potum.

Pastinace fylueftris femen potum, uel pubi illitum.

Tordilij: emen in potu fumptum.

Polemonij radix ex aqua pota.

sifonis femen bauftum.

Ammi cum uino fumptum.

Petrofelini emen potum.

Galbanum bibitum.

Chamedryos decoctum potui ddtum .

Trifolij bituminofi femen, er folia in aqua baufta.

scordij decoctum ex uino, uel ex aqua paratü potum.

Anthyllis altera drachmarum duarum pondere bibita.

Peonia potui datd.

Alttex decolte fuccus ex uino potus.

\section{E S I AE.}

Graminis radicumi decoctum potui datum.

Arctij radix cum femine decocta, in potu sumpta.

Adiantum potum.

Trichomanes baufta.

Alcyonium tertium potum.

Iapis $\left\{\begin{array}{l}\text { Hematites cx uino } \\ \text { Morochthus ex aqua }\end{array}\right\}$ bibitus.

Iapis $\left\{\begin{array}{l}\text { Iudaicus ciceris magnitudine ex aqua calida } \\ \text { potus. }\end{array}\right.$ Lspongie ex uino bauftus.

Ad vrina ftillicidium.

Acori decoctum potum .

sifymbrij femen in uino bibitum.

Panaces beraclium ex uino hauftum.

sefelimaßilienfe potui datum .

Cumini jylueftris alterius femen in potu fumptum.

Olufatriradix cum femine ex mulfo pota.

Polycnemum ex uino bibitum.

Clinopodium baftum.

Oenanthes radix cum uino epota.

Conyze folia, or flores in potu.

Apleni decoctum potui datum.

Cape cum aparagi radicibus decoctü, in potu fumptï. Onobrychis bibita.

Polygoni fuccus baustus.

Saxifraga in uino decocta potuidata.

Xyridis radix ex mulfo pota.

Tragij liquor, femen, or folid in potu fumpta.

$\mathrm{R} u f$ ci folia, radices, bacce, bibite.

Lauri Alexandrine radix fex drachmarum pondere potui data.

Elichryfi coma ex uino bauft.

Ad vefice vicera.

Myrti folia, or remen pota.

Iac omne bibitum.

Cucumeris femen ex lacte, er paffo baustum.

Glycyrrbize fuccus expaßo fumptus.

Vua pafja alba come $\int a$.

Ad veficæ vulnera.

Butyrum infufum.

Equifeti folia ex aqua pota.

Ad eiiciendos veficæ calculos .

Oßifragi auis uentriculus paulatim in potu bauftus.

Muris qui muferta dicitur, fimuscum mulfo, $\mathrm{O}$ thus re potus.

Vrina apri potui data.

Rumicis radicum ex uino decoctun bibitum.

sion crudum, coctumúe hauftum, uel comeftum.

sifymbrij femen potum.

Baccharis decoctum bauftum.

Apij Jemen, uel radix uino bibita.

Foniculum erraticum potum.

sagapenum potui datum.

Adianti decoctum bibitum .

Trichomanes decoctum in potu fumptum.

Vitis uinifere lacbryma in caudice concreta ex ui= no pota.

Ad veficx calculos frangendos.

Cardamomum, cü corticis radicis lauri drachma,potü.

Bdellium potum.

Cerafi arboris gummibibitum .

Apleni decoctum bauftum.

E 3 Lithopermuin 
Iithopermum ex uino albo potuidatum.

Saxifraga ebibita.

Graminis decoltum bauftum.

Tragij femina pold.

Rufciradices, ac buccs in potu fumptre.

Iudacus lapis coti dclimatus, ex aqua calida potus.

I apis pongire potui datus.

Ad vrina incontinentiam .

Rute fylueftris femen frixum, $\odot$ in cibis fumptum. Phoentx in uino auftero bibita.

\section{Ad vefica fabiem.}

Panaces berculeum cusn mul $\int a$ aqua aut uino potum.

Cepraberbablbita.

Ad mitum grumorum fanguinis,

Cumini fylueftris alterius femen potum.

Elichryfic coma in mullo pota.

Adcruentos mictus, ex fractis calculis prouenientes.

Acida muria itlico cly fmate infufa per urine fiftulam.

\section{VIRILIVMET PVDENDORVM.}

Ad Venerem ciendam, ftimulandamq̣́; .

Coftus ex mulfo bibitus.

crocum potum.

Semen lini cum melle, er pipere deuoratum.

Rapum decoctum in cibum fumptum.

Eruca largius in cibis come $\int a$.

Eruca femen baftum.

Dracunculimaioris radix tofta, uel elixa ex uino bia bita.

Aphodeli radix affumpta.

Nafturtium potum, uel co mestum.

Porri femen potui datum.

Bulbus decoctus manducatus.

Allium cum coriandro tritum in cibis .

Vrtice Semen ex paffo potum.

Galij radix affumpta.

Mente fuccus potus.

Paftinace erratice radix comefta.

Anerum potum.

Tefticuli canis radix que uegetion eft bibita, uel co= mesa.

Satyrï radix efitata.

Horminum in uino potum.

Gladioli fuperior radix ex uino fumpte.

scincor um renes drachme pondere ex uino baufti.

Lac omne bauftum.

Ad a'ugendam genituram.

Coriandrum bibitum.

Omnia medicamenta qus uenerem excităt, prater ed, que in calore o ficcitate excellunt.

Ad Vencrem inhibendam.

viticis femen potum, $\odot$ folia teftibus illita.

Portulaca manducata, pudendisó; imuncta .

Lactuca femen potum nocturnas ueneris imaginatio= nes arcet.

Anethifeminis, en come decoctum a ßidue potum.

Ruta in cibo, potúq; fumpta.

Canini tefticuli berbe languida, flaccidaq̧; radix pos tui data.

Cannabis fatiue fencn in cibum largius fumptum.
Gladioli inferior radix potd.

Cicuta cum fua coma trita, or genitalibus illita, or eft potentißimum medicamentum.

Ad Ceminis profluuium .

Nymphea radix bibita.

Iridis illyrice radix ex aceto pota.

Ad pudendorum vlcera.

Oefypusillitus.

Aloë illit.x, or in puluerem impofitd.

Polygoni fuccus in uino decoctus cummelle adbibitus.

Alumen quocunque modo adhibitum.

Flos Salis inperfus.

Ad teftium inflammationes.

Cicer cum eruo decoct um appofitum.

Faba in uino decocta catapla fmatis adbibitd.

senecion is folia cum floribus emplaftrimodo impofita.

Afthodeliradix, of folia illita.

Cimolia illita.

Melilorum emplaftri modo adhibitum.

Geodes lapis illitus.

Ruta illita cum laurifolijs.

Sal cum origano or fermento illitum .

Cuminum cum paffa uua, fabsóg; lomento, aut cera impofitum.

Coriandrum cum paffa una, er melle illitum.

Lilij concifa radix cum apollinari herba, 0 triticed $f a$ rina catapla Jnatis modo.

Samia terra ex rofacco or aqua illita.

Hyof cyami femen tritum ex uino impofitum. Ad genitalium pruritum.

Saluia decoctum ex uino illitum.

Refince omnes, prefertimiq; terebinthina illita:

Irionis femen impofitum.

$$
\text { Ad induratos teltes. }
$$

Ad eos qui natura preputio carent.

Thapfie fuccus circumlinitus. Tumorem enim excis tat, qui deinde pinguium fotu emollitus, praputij is cturam refarcit.

Mel triginta diebus à balneo illitum.

Ad genitalium phagedenas exulcerationes.

Taurinum fel ex melle illitum.

Labrufce flos tritus cum melle, croco, myrrba, er ro faceo impofitus.

Ad gen italium thymos.

smaridis falfa crematum caputillitum.

Fel jylueftris capre inunctum.

Fimum ouillum ex aceto impofitum.

Thymus emplaftrimodo adhibitus.

Thymbra appofita.

Ruta cum pipere, nitroq́; confricata .

Titbymali characia lac inunctum.

Chamofices rami triti, er impofitio

Mercurialis fuccus illitus.

Heliotropiy femen illitum.

\section{T E R I.}

Ad vteri ftrangulatus:

Meiradices trite, or cü melle in ecleginate deuorate.

Inniperibacce pote.

Vngues odorati fuffiti.

Cimices lectularij naribus illiti. 


\section{T E R I.}

Bitumen olf sctum, fufjitum, or admotum.

Phoce cosgulum potume.

Vrina cun ligultrino oleo feruefacta infufa.

Plantaginis fuccus potus.

Sinapi tritum nar ibus illitum.

Agdricum drachme pondere fumptum.

Rutatrita excepta melle, pudendis o Sedi illits.

Pandcis herculei femen cum uino bibitum.

sefelis Masilien/is radix, o femen potum.

Peucedanum olfactum.

Sagspenum naribus ad olf scicndum illitum.

Trifolij bituminofifemen, o folia pota.

P.com.e nigre fomunis grant xv.bibita.

Alifmatis radix pots.

Betonic folla drachme pondere in aqua dulci baufta. Gagateslapis fufitus.

\section{Ad menfes ducendos.}

Iris Itlyric a ex uino fumpa, er fotu adbibita.

NIci radicimm dicoctun defeßionbus adhibitum .

Acori decottum in fe Bionibus.

Cyperi radicum decoct un fotu adbibition.

Afari radices fenis drachmis ex aqua bibite.

Phu decotum potuidatum.

Cafid odorata in potu fumptd.

Cinnumonum bauftum, uel ex myrrha fuppofitum.

A momum peßis, aut fcßionibus additum.

Coftus ebibittls.

Odoratus iuncus potui datus.

Calamus odoratus hauftus, er fuppofitus fotu.

Cancamum ex aqua mulfa potum.

Helenij radicum decoctum potum.

Isyrrba cum ab inthio, lupinorum cremore, wel rute Jucco admota.

Siyrax pota, er appofita.

Bitumen ex uino, er caftoreo bibituin.

Cedrides ex polline piperis baufte.

I aurifoliorum decoctum fotu admotum.

Phillyrex folis potui data.

viticis $\int e m e n$ dracbme pondere ex uino baufum,

Olea ethiopice, ac noftratis lacbryma pota.

Amygdale amare admote.

Ficulneum lac cum detrita nuce Greca sbibitum.

Cochles terreftres cum fuo operimento $t u f_{x}, \quad \mathcal{\sigma} f_{x}=$ mineis locis admote.

Caftoreun drachmarum duarum pondere hauftum.

Cope fuccus pudendis itlitus.

Oefypum in lana fuppofitum.

Anferinus, o gallinaceus adeps illitus.

Caprarum montanarum fimum ex odoramento aliquo potum.

scandulaceum bibitum.

Seminis lini decortum fotu admotum.

I upinorum decoctum cum myrrba, o melle fup= politum.

Raphanus in cibum fumptus, uel eius fuccus hauftus.

Aphodeli radix petui data".

Eryngij decoctum baufun.

Braßsce fuccus ex loliacea farina fuppofitus, uel eiufz den decoctum bibiiun.

sium pro olere fumptum.

Critbmum, uel eius decoctum in potu fumptum.

Centaurij maioris radix bibitas uel eiufdem fuccus $\int u p=$
V T E R I.

politus.

Condrylla gummi ex myrrba fubditus.

I attuce fylucftris lacteus fuccus bibttus.

Porrum domefticum, ov jylueftre comeftum.

Alli comarum decoctum in defeßionibus additum.

Cyclaminus tum pord, tum fuppofits.

Abrotanifemen ex aqua bauftum.

Capparis cortex, o Jemen potui datum.

Anemones radix ex uellere appofita.

Hedere Corymbi tritifubditi.

Pulegum bibitum.

Agaricum cum oxymelite drachme pondere haufum.

Origanum potum.

Abfintbium hauftum, uel exmelle fubditum.

Tragoriganuin potuidatum.

Saluisedecottum potum.

Ammi ex uino bauftum.

Thymi, thymbra'g; decoctum in potu fumptum.

Serpyllum potui datum.

smyrnij femen ebibitum .

Amaraci decoctum baftum, uel pudendis illitum.

Baccharis radicis decoctum potum.

Ruta utraque tum pota, tum fubdita.

Panaces Herculeum ex uino baufum.

Iiguftici radix, er femen potum; or illitum.

Paftinace erratice femen potum.

Sefelis Maßilienfis radix, or femen hauftum.

Tordilium potui datum.

Frniculum ex uino fumptum .

sifon bibitum.

Libanotis radices pote.

Peticedani fuccus potus.

Petrofelinum potui datum.

Daucumbauftum.

Hammoniacum in potu fumptum.

Nigella pluribus diebus baufta.

Sagapenum potum.

I aferpitij liquor cum pipere, er myrrha bibitus.

Galbanum fuppofitum, er Juffitum.

Clinopodium bauftum.

Chamedryos decoctum potui datum.

Lilij cremata radix ex rofaceo fubdita.

Meliffophylli decoctum in de eeßionibus.

Trifolijfemen, o folia pota.

Polij utriufque decoctum bauftum.

scordij fuccus bibitus, uel berba ip $\int a$ fubdita.

Artemijise decoctum $\int e$ ßionibus additum.

Myrrbis bibita .

Conyze folia, o flores poti.

Hemerocallis radix cum uellere fubdita.

$\mathrm{R} u$ ccifolia, e bacce ex uino fumpta.

I eucoij decoctum fotum, e feßionibus admotum.

Eiufdem femen duarum drachmarum pondere ex uino fumptum.

Anthemidis decoctum tum potum, tum fotu adhibitum.

peonie radix amygdale quantitate haufta.

$\mathrm{R}$ ubia radix fuppofita.

Adianti decoctum bibitum.

Trichomanes potui data.

Anagyris tria folia ex paffo fumpto.

Hypericum tam bibitum, quam Juppofifure.

Coris Semen potuidatum. 


\section{T E R I.}

Vrlice uiriufque folia trita, or cum myrrha fubdita, Betontice folia drachme pondere cum uino fumpta. Iredij /emen karifum.

Chamedaphes foliorum fuecus ex nino bibitus.

Gladioli fuperior radix fispofita.

Iragij liguor bibitus, quin ctiam femen, or folia pota drachme pondere.

chryfocome ex mellicrato fumpta.

Elaterium in peffo fubditum.

Helichryfi coma ex mulfo potui data.

Mandragore liquor femioboli ponderé fubditus.

Eiuftem Semen bibitum.

Daphnoideshaufta.

vcratrum $\left\{\begin{array}{l}\text { Nigrum } \\ \text { Album }\end{array}\right\}$ Juppofitum.

vitis nigre tenelle uiticula in cibum fumpte, decolte olerum, ucl apsagarum more.

Heliotropij folia fuppo fita .

vinum fcillinum bibitum.

vinum abfintbites baufum.

Vinum hy $\iint 0$ pites potum. Ad menfes cohibendos .

Nardus Indica.

Mufcus arboribus innafcens in fe ßionibus additum.

Thuris cortex in peffo fubditus.

Oxyscanthe bacce in potu, uel in cibo fumpte.

Hypocift is tum potd, tum indita .

olex fylueftris fuccus pudendis admotus.

Rhois femen potum. alba proflunia fiftit .

Palmula immature manducata.

Palmularum inuolucrum potui datum.

P unicorum acinorum nucleificcati in fole, ov obfonijs inperfi, concoctiue fumpti.

Galle in decoctis addite ad infeßiones paratis.

Glandium tenuior cortex tum bibitus, tum in paffo fup pofitus.

Myrti femen fotu fubditum, uel de $\int e$ Sionibus additum . Cotoneorum malorum decoitum fotu adhibitum.

Acacia tum pota, tum indita.

I ycium fubditum.

Loti ligni decoctum haustum, aut fotu admotunt.

Lentifeifolia tam pota, quàm fubdita.

Coagulum $\left\{\begin{array}{l}\text { Leporinum } \\ \text { Hedinum } \\ \text { Agninum } \\ \text { Cerrinum } \\ \text { Hinnulinum } \\ \text { vitulinum. }\end{array}\right\}$ potü, ac ctiä Jubditü.

Ceruinum cornu uftum, lotum ex adftringentiliquore aliquo bauftum.

Caprarum montandrun fimumficatum tritumie cum thure in lana fuppofituin.

$\mathrm{R}$ umicis radices fubdite.

Plantago tum bibita, tum fotu adbibita .

Barbe byrcine fuccus ex uino fumptus, uel fuppofitus.

Porri come decoctum ex aqua marina, vo aceto in de= Seßionibus.

Rubiramorum decoctum potum.

Arabicse pine radix manducata.

Phanix ex uino auftero bibita .

Papaueris nigrifemen potum.

Acbilleafubdita.
V T E R I.

Idearddix bulfta.

Rubi decoctum potuidatum.

Equifetifolia bibita,

Menta fotu fubdita.

Iuncimarini femen frixum, er ex uino diluto potum.

Ocimaftrum potum ex wino.

Anifuir hauftum, prefertim ad alba profluuid.

Cuminum ex ace to impofitum.

Nymphe e, flore luteo, radix, o femen ex uino nigro pota.

Peonix feminis grana xij. ex uino duftero fumpta.

Iyfimachie fuccus fubditus.

Moly berba cum loliscea farina inditd .

Polygoni fuccus fuppofitus.

symphyti petrai ex uino decoctum bauftum.

clymenifuccus bibitus.

Iimonij femen acetabuli pondere ex uino bibitum.

Medij radix elixa, of ex melle in eclegmate fumpta.

Tragi acini nunnero $x$. ex uino bausti.

Hyof cyami femen oboli pondere in mulfa aqua potum.

Solani bortenfis fuccus in lana inditus.

Mandragore fenè cum fulphure, or uino fuppofitum. semperuium maius in uellere fubditum.

vuarum uinaccorum decoctum baustum, or fotu aps pofitum.

Iabrufce flos pefjulo inditus.

Omphacium inditum.

Rubigo ferri fubdita.

Chalcitis cum fucco porri indita.

vinifex imo uentris, ac pudendis itlita :

Hematites lapis ex uino haufus.

Morochthus lapis in uellere inditus .

Oftracites lapis drachme pondere ex uino fumptus.

Samia terra cum Jyueftris punice floribus baufta.

Ad fecundas pellendas.

Catoreum drachmarum duarum pondere cum pule= gio bibitun.

Cyclaminis alterius femen hauftum.

Alli coma decoctum fotu impofitum.

Ariftolocbia longd cum myrrha, $\sigma$ pipere fumpta, uel peffulo indita.

Pulegium bibitum .

Thymi decoctum potui datum.

Thymbre decoctum bauftum.

Apij femen in potu fumptum.

Marrubij decoctum bibitum.

Stacbyos decoctum potuidatum?

Artemifie decoctum in defeßionibus ddhibitum:

Circee radix quatuor librarum pondere contu $\int_{a}, \sigma$ in fepten dulcis uini heminis macerata per noctem,dia emí; tribus diebus pota.

Denanthes femen, caulis; of folia ex mulfo bibita.

Leucoij femen drachmarum duarum pondere ex uino bauftum.

Rubia radix fuppofita .

Anagyris tritafolia ex pajJo bibita.

Cham. pityos ex melle fubdita.

Chryfocome ex aqua mulls pota.

Thrychomanes baufta .

Bryonia fuppofita.

KMyrrha pota.

Peucedanifuccus potus. 


\section{T E R I.}

Bunij femen potum:

smyrnij femers potui datum.

Adtantı decoctum bibitum.

Ad expellendum foetum .

Caftorcum dustum dracbmarum pondere cumpulegio fumptum.

Canicule lac prims fature heuftun mortuum pellit. Oefypus, in lana fuppofitus.

Caprarum montanar um fimum cum aliquo odoramens to potum.

viluris finum fuffitum .

Ciceris dccołum bibitum.

I upinorum decoctum cum myrrbd, er melle fotu ads bubitum.

sium pro olere in cibo fumptum.

Dracunculi maioris decoctum infufum .

Piper banfum.

Cyclaminis radix famori adalligata.

Heder foliorum pediculi melle illitifubditi.

Gentiane radix fubdita.

Centaurij maioris radixindita.

Centaurij minoris fuccus infufus.

Pulegum potum.

Dıq smmumb bibitum, inditum, incen $\int_{u n t} q_{\text {. }}$.

Thymi decoctum bauftum.

Thymbre decoftum potui datum.

Baccharis recentißima radix fuppofita.

Panacis Herculei acuminata radix indita.

Paftinace erratice radix fubdita.

Sefelis Maßilienfis radix pota, quin etiam on femen.

Galbanum cum myrrba, er uino potum, fuffituniq; -

Clinopodum potum.

Chamedryos decotum bauftum.

scordy fuccus drachme pondere fumptus.

Artemifie decofum in feßsionibus adbibitum.

Conyze folia, or flores bibita.

Ieucoij femen duarum drachmarum pondere ex uino potum.

Ono matis folid ex uino baufta.

Rubie radix Juppofita.

Anagyris trita, folia cum paffo pota,quin et adalligata, fed ftatim poft partum auferantur.

Anchufe radix appojita.

Mandragor a liquor infujus.

Myrrbis pota.

Heliotropijfolia indita.

sulplouris fumus in uterum permeans.

Daucifemen bibitum .

Ammoniscum hauftum.

Periclymeni femen drachme pondere in uino potum.

I auri A lexandrine radix fex dracbmarum pödere ex dulci uino fumpts.

Alumen fubdtum.

Iafpis lapis femori adalligatus.

Aétites lapis pro amuleto femorifupenfus.

Samius lapis adalligatus.

Ad conceptionem inhibendam.

Salicis folia per fe, or cum aqua fumpta.

Leporinum codgulum poft triduum à purgatione men frua fumptum.

sanguis menftruus illitus.

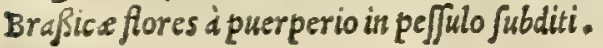

\section{$V T$ E R I.}

Aparagiradix fupensa.

Piper à coitu illico fubditum.

Hedere corymbi drachme pondere a purgatione baufti.

Hedy farum ante coitum freminis fubditum.

Cedria uirilimembro illita.

Oftracites lapis ficilici pondere quatuor diebus a pure gatione potus:

Aplenum (ut quidam credunt) filente luna nocturno tempore decerptum cü muli liene uĕtri ad alligatü.

Periclymeni femen, o folia diebus 36 , pota.

Epimedij folia trita illico à purgatione quinque diebus continuis bibita.

Gladioli inferior radix baufta.

Filicis fomine radix potui data.

Heliotropium adalligatum.

Rubigo ferri pota.

Menta ante cottum unlus admota.

Ad conceptionem iuuandam .

Leporinum coagulum cum butyro fubditum ftatim a menfium purgatione.

Ioliace a farina cum myrrha, thure, bitumine, er cros co fuffita.

Paftinace erratic e femen potun.

Ad fortum mortuum educendum.

Dictamnum tum potum, tum fubditum.

Saluie decoctum bibitum .

Galbanum cum myrrba ex uino potum.

Marrubij decoç̃um bauftum .

Tußilaginis decoctum potuidatum.

Ad prohibendum abortum .

Aétites lapis finiftro brachio adalligatus.

Samius lapis pro amuleto fupenfus.

Ad puerperia iuuanda.

Dictamni radix bibita.

Baccharis radicis decoctum fotu adhibitum.

Freniculum erratic um potum .

Peucedani fuccus bauftus.

Peonix ficcata radix potui data.

Althear decactum infurum.

Ad prægnantium malacias.

vitis uinifere foliorun capreolorum'́; fuccus potus. Ad vteri inflammationes.

Nardi Indice decoctum fotu adbibitum.

Iunci odorati decoctum in de e $\int$ Sionibus adbibitum .

viticis folior um or feminis decoctum fotu appofitum.

Butyrum recens illitum.

Sonchi fuccus inunctus.

Agaricum drachme pondere cum oxymelite potum.

Pulegij decoctum fotu fubditum.

Melilotus cum paffo emplastrimodo impofitus.

Panacis Herculei lacbryma ex melle indita.

Artemifix decoctum in defe Pionibus adbibitum.

Le ucoij decoctum fotu appofitum.

Antbyllidis rudix ex rofaceo, lacté ; indita.

Parthenij decoctum in de e $e$ șionibus ddditum.

Althea decocta, ac fubinde an ferino, suillóne adipe, aut refina tercbinthina fubacta, fubdita.

Act exulceratos locos.

Apalathi ex uino decoctum infufum.

I ac in quo igniticalculi extinct fuerit infusum.

Oefyoum inditum. Explet crim or cmollit. 
Fanigrecifolia ex accto illita.

Afolepiadisfolia adbibita.

Adinduratos locos.

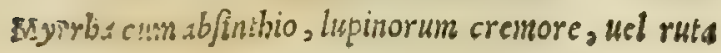
adimota.

Styraxillita.

Anferinus or Gillinaceus adepsillitus.

Bde!linir inenitune.

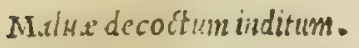

Laddnun peßis inm $\beta$ ßum.

P.naces Herculeumex malle inditum.

Ebuli, fantuctá; decoetum fotu admotum.

Paribenij decodtun iri defeßsionibus.

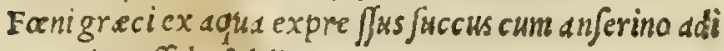
pe in peffulo fubditus.

Iiliy radix admota.

Ageratum fuffitum.

Ad vteri inflammationes.

Rute ex oleo decoitum clyftere perfufum.

Geranium, o cius radix drachme pondere pota.

Ad procidentem vterum.

Cafia for uel fuffitu adhibita.

Nyrtibaccarum fuccus in de ereßionibus.

Cotoneorum inalorum decoitum fotu adbibitum.

Gallarum decoctum in feßionibus additum.

Acacia fubdita:

Hypociftis fubdita.

vretce utriugque folix impofita.

Acetumforu adhibitum.

Ad vteri dolores \& erofiones.

Adeps $\left\{\begin{array}{l}\text { Anfcrinus } \\ \text { Gallinaceus }\end{array}\right\}$ illitus.

Vrind cun liguftrino oleo feruefacta impo]ita:

Iini feminis decoctum infufum.

Malue decoctum fotu adbibitum, uel infufum.

Portulace decoctum cly fmate inditum, proprie facio ad erofiones.

Rhaponticum potsm.

Centaurij maioris radix bibita.

Anethi decostum in defeßionibus.

Verbenace rect. folia ex recéti fuillo adipe, wel ex ros Sacco fubdita.

Hyofcyami feminis cremor inditus.

Nandragore liquor pe fJulis impofitus.

\section{E X T R E M O R V M M E M-} $B R \circ R$.

Amomusn illitum.

$$
\text { Ad podagram . }
$$

Mei radiccs impofite.

Populi nigrefolia ex aceto illita.

Amurca crudd, ac recens fotu adbibita:

Salicis foliorum, or corticis decoctum fotu impofitum.

Ficulneum lac cum farina fonigreci, o aceto catas plafinat is additum.

Cocblce terreftres, fuo cuin operinento tufe, ime pofite.

Muflele crenate cinis ex accto inunctus.

Marinus recens pulino concifus impofitus.

Lac humbunu cum opio, er cera illitum.
Adeps onillus, caprillu, bircinusue cx eiufdem enimds lis fino coactus inunctus.

Sanguis menftruus inunctus.

Caprarum montanarum finum ex carum adipc illituin.

Hordeifarina cum cotoneis malis impolita.

I ens cum poléta decocta, er emplaftri modo adbibita.

Raporum decottun fomentis additum.

Braßsica cum feeno greco, or aceto in cataplajmate.

Intybus per $f e$, o cum polenta illitus.

Cucurbite ramenta impofita.

Ariradix fimo bubulo emplaftrimodo excepta.

Affbodeliradix draclsmx pondere ex uino pota.

Cyclaminis decoctun fotu adlibitum.

Bulbi per $\int e$, o cun melle impofiti.

Panaces Herculeum cum paffa uua illitum.

Libanotis cum loliace a farina, $\mathrm{O}$ ace to cataplafmatis addita.

Scordium ex aceto, aut dqua impofitum.

Leucoium ex aceto illitum.

Androfacesimpofita.

Helxines fuccus cera, et bircino adipe exceptus illitus.

Hyo $\int$ cyamifemen, e folia oum polenta cataplafmatis adbibita.

Semperuiuum inundum, ubi calor exuperat.

Vrtica emplaftri modo illita.

Mufcus marinus impofitus.

cucumeris afininiradix ex aceto inunthd.

Thapfie fuccus illitus.

Glans unguentaria illita.

Sambucio Ebuli folia cum feno taurino, dut bircino impofita.

Bryonia cum caprino stercore cataplafmatis addita.

Heliotropij folia illita.

Vua paffa d nucleis repurgata, or cum panacis fucce inuntas.

Acetum calido fotu cum fulphure adhibitum.

Rubigo ferri illita .

Sulphur cum aqua, er nitro inunefum.

Sal cum aceto impojitum.

A fius lapis cum fabarum lomento illitus :

Gagates lapis inunctus.

Fornaces tefte exufte impofite .

\section{Meiradices impofite.}

Ad coxendicos affectus :

Helenii folia ex uino cocta impofita.

Iridis illyrica decoctum cly frmate inf us um:

Cardamomam ex aqua potum.

A farum potum, uel clyftere infufum.

Populi albe cortex uncie pondere haustus.'

Iberis contufa, or emplaftri modo impofita.

siluri piscis falfam cntum clyfteribus infufum .

Pifcium Garum clyfteribus iniectum.

smyrnij femen potum.

Bubulum fimum ex bubus in pafcuis degèntibus ittitum:

Iolij farina ex aqua mul fa decocta impofita.

I upinorum farina ex aceto illita.

Ammoniacum bibitumt .

Afcyri femen ex aqua potum:

Afparagi radicum decoctum bibitum.

Althe decoctum potui datum.

sinapi tritum cum fico impofitum donec ruborem ex. citct. 


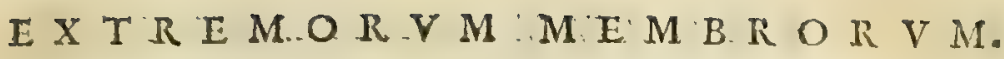

$\mathbf{N}$ dfurcium cly inate infusum.

Irionis ferren clyftere iniectum.

Bulbi per fe, o cum melle impofiti.

Capparis femen potum.

Iepidiy folid, or radices, cum belenij radice trita, e impolita.

Agaricum trium obolorü pondere in aceto mulfo potü. Rhaponticum potum.

Androfemi femen bibitum. Sed da purgatione aquamex orbere oportet.

Centaurij maioris decoctum clyftere infufum.

I eucacanthe radicis $c x$ uino decoctum bibitum.

Abrotanifemen cum aqua potum.

Rubic radix pota.

Pulcgium illitum,quonfque rube fcat cutis.

Calumintha impolina recens tritaǵ; donec exuratur lo cus.

Thymus cx fimo cum polent: impofitus. Idem preft at đTlynnbra.

Rute fy! ueftris femen quadraginta diebus potum.

Pandees Herculeum ex melle inundum.

I afer cera, ligufitino, o Irino olco fubuttum, illitum :

Euphorbium in odor at d potione fumptum.

Leontopetalum clyfteribus infurum.

Hyperici ennen q!udr aginta diebus totum.

Chan epityos folis quadraginta diebus $\mathrm{cx}$ dulci aqua bibitis.

Betonic $\boldsymbol{x}$ folita ex aqua bibita.

Polemonise radix ex aqua fumpta.

Xyridis radix ex mulfo pota:

Ocinuftri femen cum uino, mysrba, o pipere fumptü.

Quin.ucfelij radic is decoctum potum.

Hellochryfi coma ex uino baufta.

Papaueris corniçulatiradicis decoctum potum.

Actbiopis decoctum bibitum.

Arction cx uino hatufum, or illitum .

Chanecififolia trium obolorum pondere in aqua cyd= this tribus tricenis quadragenisue diebus pota.

Colocynthis clyftere infu $a, 0$, recens loco confricata.

Cucumeris Jyueftris radix clysinate infufa.

spartij ranoram ex aqua marina dilutum infufum.

Scammonia ex aceto decoita, or cumbordeaces fari= naimpofita.

Acetum mul win bauftum.

sory ex uino clyftere infufum.

Muria clyftere indita.

Adarcesillitus.

Ad articulorum dolores.

Gallorum fene centium ius potum.

Braßsca cum foeno graco, er aceto illita.

Ruta tum haufta, tum cataplafmatis adbibita.

A gariçum drachme pondere ex aceto mulfo fumptuin.

Meliffophyllum ex fale impofitum.

Quinquefolij radicis decoctum bibitum.

P $\int y$ thium ex ro $\int a c c o, v$ aceto, aut dqua illitum.

Mandrugore radix cum polenta impojita.

Vrtica cataplafmatis modo adbibita.

Veratruin nigrum potum .

Fuc:s snatinus recens inpofitus.

Thap?: e fircens inmetus.

Narcisivadix trita, or exmelle impofits.

Acetum malsum potum :
Vinum melitites frequentius potuns.

Ad articulorum collifiones.

Sarmentitius cinis cum axungia uel oleo illitus.

$\therefore \quad$ Adarticulorm tophos.

Cannabis fylueftris radix decocta, or illita.

Oclora inundx.

Ad perniones .

Thus cum fuillo adipe aut anferino impofitum.

Pix liquida inuncta.

Acacia illita.

Myrti feminis decoctum fotu adbibitum.

Ficus cremata cum cerato impofite.

Cancrorum fluuiatilium cinis cum decocto melle ithitus:

Pulmo marinus recens concijus, o impofitus .

Afinine ungule cinis oleo maceratus illitus.

Vrfinus adeps inunctus.

Vmbiliciueneris.fuccusimpofitus.

Ientes cum meliloto, ficcis rofis, malicorio, cydonio malo, or rofaceo adbibita.

Orobi decoctum fotu impofitum.

Rapor um decoctum formenti modo.

Beta decoctum impofitum.

Dracunculi maioris folia ex uino decoctd, e impofita.

oleum in excauata afphodeli radice decoctumitlitunn.

Cyclainini decoctum fo tu adlibibun, quinetiam oleum cun paucd cera in eius excaudta radice feruefactü, illitur.

Scills cremata impofita.

Ranunculideco.tum inunctum.

Arction ex uno illteim.

Alumen aqua aperfuin.

Ad pedum inflammationes ex calceo-

rum ateritu.

Pulmo $\left\{\begin{array}{l}\text { Agninus } \\ \text { Vrfinus } \\ \text { sullus }\end{array}\right\}$ impofitus.

Calceamentorum ueterum fole combufta, or illite.

Cape fuccuscum adipe gallinaceo impofitus.

Ad pedum rimas.

Căcrorum fluniatilium cints cum dec octo mellc illitus.

Scilla oleo feruefacta, or cum refind impofita.

Ad digitorum reduuias.

Punicorum malorum fuccus illitus.

Myrti folia trita, e in $\beta$ er $\int \alpha$.

Olex fylueftris folia trita, e impofitd .

Eboris ramenta in puluerem adbibita.

Aloé cum paffo impofita.

Paronychid concifa er illita.

Bryonia oleo decoita, quou fque lique feat, inunita.

I abrufce crematiflores ex melle impofiti .

Rubigo ferri illita.

Acacia illita.

Rhois folia ex aceto, dut melle illita.

Marrubij folia ex melle impofita.

Quinquefolij radix illita.

Titbymali characix lac intitum.

- Acctum illitum.

Alumen aqua infperfume.

Sal impofitum.

Ad Paronychia .

Thus cum melle illitum.

Eboris fcobes inperfus. 


\section{EXTR $\mathrm{E} M O R \vee M . M E B R O R V M$.}

Paronychiefolia tllita.

Ad fabros vngues suferendos,

Pix liquida illita.

Iini emen cum pari nafturtio or melle.

Cupreßi pilule impofite.

Lapatbi cuiurque radix in aceto decocta illita.

Ranunculifolla, er radices admote.

Chelidonium minus illitum.

vifcum cum trito auripigmento appofitum.

Alumen cum aqua aperfum.

sulpbur cum re/ina terebintbina inunatum.

Sandaracha cum pice impofila.

Fex uini cremata ex refind.

Ad mobiles vngues extrahendos.

Vua paffa illita.

Ad contufos vngues.

Bulbi cum polenta impofiti.
Ad clauos \& callos.

Fermentum triticeum illitum.

Ad varices.

" Cirfij radix dolenti loco adalligatd.

Echij radix pota.

Ad lumborum dolores.

Chameleuce illita.

Ad inguinum inflammationes.

Ieporinus pes berba impofita,

After atticus recens illitus.

Ad entcrocelas.

- Cupreßipilula illte.

Punicorum cytini cataplafmatis additi.

Sympbytum petraum emplaftri modo impofltum .

Quinquefolium bauftum.

Equifeti radix er folia pota.

Aloë emplaftri modo illita.

Ad farcocelas.

Cinis farmentitius itlitus.

\section{SIMPLICIVM MEDICAMENTO- rum facultates fecundum genera ex Diofcoride.}

F E B R I V M.

Ad tertianas .

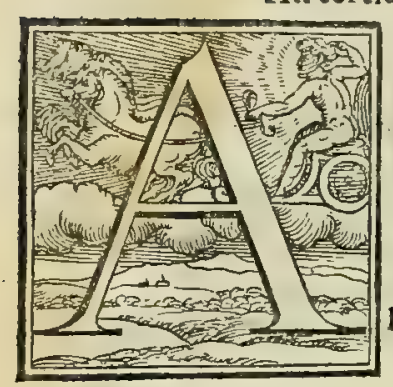

RANEVS plagelle corta fricatus, linteolóue illi= tus, mox fronti,aut tem= poribus impofitus.

Verines terre ni cum ant ferino adipe decocti or illiti.

$\mathrm{Plantaginis}$ radices intetribus, er pari aqua pote.

Trifoly bituminofi tria folia tritd, totidem $q_{5}$ emind epota.

Hypericum ex uino bibitum .

Verbenaces Juine tertius à terra geniculus cum adid centibus folijs bibitus.

Heliotropij feminis grana quatuor pota ante febris ace ceßionem.

Portulace fuccus hauftus.

Ad quartanas.

cimices lectularij Jeptem cauis fabdrum inclufi, 0 poti.

Plantaginis radices integre quatuor, cum uinicyathis quatuor, o pari aqua bibite.

Vermiculi, qui in Dip faci ecbino internis partibus con= clufi reperiütur, in aluta collo, bracbioue adalligati.

Rutd fylueftris cum uino pota.

Hypericum ex uino hauftum.

Quinquefolij rami quatuor fumpti.

Verbenace Supine quartus à terra geniculus unà cиm adiacentibusfolijs baufus.
F E B R I V M.

Heliotropiy feminis grana quatuor hord und ante dca ceßionem pota.
Ad diuturnas febres.

Galli fenis ius Diofcoridis modo paratum potum:

Agaric unt haustum.

Vinum melitites bauftum, ubi uentriculus magnd im. becillitate laboret.

Ad hepielas.

Hyofciami tria, uel quatuor folia pota. Ad febrium circuitus.

sinapicibis inperfum.

Smyrnij femen potum.

Piper bibitum.

Ruta pota.

Sagapenum bauftum.

Antbemis cly/mate infufa .

Polygoni fuccus hora ante acceßionem fumptus:

Quinquefolij folia ex dulci aqua, aut diluto uino cum exiguo pipere bibita.

$$
\text { Ad eticam. }
$$

Fortulacd tum uentriculi ofculo, tü bypocundrijs illite. Piper bauftum. Ad febrium algores.

Agdricum drachme pondere fumptum.

Ariftolocbia rotunda ante acceßionem bibita.

Abrotanum ex oleo inunctum,

Calamintbe decoctum potum.

Panaces Herculcum illitum .

Smyrnij femen, or radix ex mulfo pote.

Syrethrum inunctum.

I afer cum pipere, or thure ex vino bauftum. 
Conyzd ex olco inuncta.

Coris fenten cum pipere haufum.

Buglo ßi radix cum femine bibita.

Periclymeni femen ex oleo inuntum.

Ad peftilentes febres.

Marrbis bis, uel ter qualibet dic ex uino pota.

\section{T V M O R V M P R AE T E R} N A $T$ V R A M.

Ad inflammationes.

Harundinum uirentia folia tufallita.

Glandes intrite, o illitu appofite.

Rbois Jemen ex aqua illitum .

Lupinorum farina, cum polenta, or aqua impofita.

Vmbilici Veneris fuccus circumlitus.

Plantago emplaftri modo impofita.

Aphodcli radix cum polenta adhibita.

Acetum in Juccidis lanis, aut pongijs impofitum.

Rhaponticun cum acetoillitum, ubi diutius perfeuerd uerit inflammatio.

Pulegium cum polenta ilitum.

Tußslaginis folia contrita, $\sigma$ cx melle impofita.

$\mathbf{P}$ arthenium cmplafinimodo impofitum.

Lonchitis altera impofita.

Cannubis fylueftris radix emplaftrimodo adbibita.

Polygonon illitum.

Tribuli fructus cataplafmatis additus.

Xyridis radix ex ace to impofita.

Achillea illita.

Helxine cataplafmatis addito.

Iichen berba adbibita.

Verbenace fupine folia illita, ubi inflammatio dits tius perfeuerat.

Papaueris folia, unà cum calycibusillita, wel calyces tantum cum polenta adbibiti.

Hyofcyami femen, e folia impofita.

Mandragore recentia folia cum polentaillita.

Bryonis radix ex uino decocta adbibita.

Sambuci, ebaliq; pretenera folia cum polenta illita.

Indicum illitum rumpit.

Triticei furfures acerrimo dceto elixi impofiti.

Tritici pollen ex bydreleo, uel aqua mulfaillitus.

Triticeus panis ex aqua mulfa decoctus, $\sim$ herbis dd idem conferentibus additus, $\sigma$ impofitus.

se amum illitum.

\section{Ad carbunculos.}

Iiguftri folid impofita.

Pix liquida ex melle, or una paßa illita emarginat, difrumpit q;

Cupreßi folia trita, o impofita.

sabine folia ex uino illita carbunculos circüfcribunt.

Oline mature arefacte illite emarginant.

Nucum iugiandium ueterum nuclei peruncti.

Columbinum fimum cum melle, $\sigma$ lini femine fubaitü.

Erui farina emplaftrimodo impofita.

Lupinorum farind ex aceto adbibita.

Braßica cum Sale illita rumpit.

Nafturtium impofitum.

Porrum cum fale appofitun.

Panaces Herculeum illitum.

Coriandrum cum paßa uua exinelle impofitum.
Lajerpitij liquor inunctus.

Titbymalicaracia lac illitum.

Vua paja à nucleis repurgata, er cum ruta impofita.

Ad furunculos \& tubercula.

Fermentum triticeum impofitum .

Helxine illita.

Sal cum uua pafa, aut fuillo adipe, aut melle impo/itü.

Haftule regie radix in fece nini decocta, illita.

Ephemeri folia ex uino cocta, or impofita.

Vtriufque urtice folia illitd.

Leontopodij radix fupen $\sqrt{a}$.

Cucumeris $\int$ lueftris radix cum refind terebinthina impofita.

Scammonie fuccus cum melle, aut oleo illitus.

Mori radicis liquor illitus.

Thapfie fuccus ex melle illitus.

Pycnocomi folia inuncta.

Sandaracha cum adipe impofita.

A fius lapis liquida pice, aut refind terebinthind exce. ptus, illitus.

Cimolia terra exaceto illita.

Ad gangrænas.

Rhois folia ex aceto, 0 melle illita.

Punicorum succus inunctus.

Nucum iuglandium ueterum nuclei peruncti.

Ficulnei cineris lixiuiü ppongis exceptü et impofitum.

Loliace farina cum fale, er raphano cataplafmatis addita.

Cicerum farina cum hordeo, or melle adbibita.

Lentes cum fertula campand, rofaceo, ficcis rofis, ma licorio, er fal $\int a$ aqua illite.

Erui farinaillita.

Braßica elixa cum melle, cataplajmatis addita.

Bulbi per $f e, 0 r$ cum melle impofiti.

Ia erpitijliquor illitus, loco prius falpello excifo.

Galiop/is folia, femen, Juccus, $\mathcal{O}$ caulis, ex aceto impofita.

verbafci florem aureum ferentis folia adhibita.

Tithymali caracie lac impofitum.

Bryonic radix, fructus, or folia cum fale illita.

Vuapaßa à nucleis repurgata, er cum fale impojita. Ad eryfipelas, \& facros ignes.

Crocum illitum cum refrigerantibus.

Cupreßi foliaper $\int e$, or cum polenta impofita.

Rbamni folia illita.

Iiguftri folia adbibita.

Rofe illite.

Acacia fuccus inunctus.

Olex fylueftris folia contrita, et impofita.

Myrti folia cum omphacino oleo, aut exiguo ro acèo, et uino illita.

Menftrus mulierum fanguis circumlitus.

Caprarum montanarum fimum ex uino, wel aceto deco ctum impofitum.

Vrina bumane fedimen inunctum.

Ientes cum meliloto, ficcis rofis, rofaceo, et malis corio adbibite.

Malua ex oleo decocta, et illita.

Braßica utraque incifa, et cum polenta emplaftrimo= do impolita.

Portulaca cum polenta cataplajmatis addita.

Rlantago illita cum cimolia, $\mathrm{E}$ cerußa. 
Intybiradix, er folia cumpolenta impofita.

Ifacidis folia illita.

Acinos cataplafmatis addita.

Rute fuccus cum aceto, cerufa, er rofacco inunctus.

Coriandrun cum pane, polcntaú illitum.

Liliy follia ex aceto illita.

Tußilaginis folia trita, ex melle impofita.

$\mathbf{P}$ ar thenium cum floribus emplaftri modo impofitum.

Polygonum illitum.

Anchuse radix cum polentad adbibita.

Iycopfis radix cum polenta impofita.

Rubi Idaiflos illitus.

Helxine impofita.

Quinquefoliy radix decoca a cataplafmatis indita.

Verbenaca recta ex aceto inuncta.

Papaueris ud fcula concifa cum polenta impofita.

Solanibortěfis folia cum polline polente illita. Quin et

ciufdem fuccus inunctus.

Mandragora radix ex aceto illita.

Cicute fuccus inunatus.

$\checkmark m b i l i c i$ Veneris fuccus circumlitus .

Pyyllium, or eius piffamentum inunctum.

Iens paluftrisillita.

Ricini folia ex aceto illita.

Semperuizum maius inunctum.

Stratiotes impofita.

Acetum circumlitum .

Rubigo ferrilllita.

Chalcitis inuncta.

Sal cum aceto, dut byßopó illitum.

Ad herpetas.

Acdcie fuccus inunctus.

Myrti folia cum omphacino oleo, aut exiguo rofacco ex uino impofita.

olee fylueftris folia contrita, er impofita.

Caprarum montanarum fimum ex uino, uel aceto de= coctumillitum.

I entes cum fertula campand, rofaceo, ficcis rofis, er malicorio cataplafmatis indita.

Helxines fuccus cum cerußa inunctus.

Plantago impofita.

Chelidonium maius ex uino illitum.

Rubi foliaillita.

Solani bortulani fuccus cum ceruffa, rofaceo, $\mathbb{C r}^{2} \mathrm{rr}=$ genti pumaillitus.

Ad epinikydas.

Ouillum, caprillumie fimum ex aceto illitum .

Braßica concifa cum polenta impofita.

plantago quaquo modo adbibita.

Cucumeris folia cum melle inuncta.

Porri folia cum Rhoe obfoniorum cataplafmatis ins dita.

Ab/inthium cum aqua illitum.

Coriandrum cum paffa uud,er melle impofitum.

viscum in plenio adhibitum .

Heliotropij fenen ullitum.

Vua paffa a nucleis repurgate, cum ruta impofita. Ad ftrumas.

Iridis Illyrice radix cotta, $\odot$ illita.

Pix liquida cum farina bordeacea, or pueri impubis urina decocta, illita.

Fi.us ficce colte, er impolite.
Großicotte er illite.

viperine carnes cocte, ov in cibum fumpte: Muftelle Sanguis inunctus.

Afinini unguis cinis ex oleo maceratus illitus."

Bubulum finum é bubus herbas pafccrtibus fumptum illitum.

Hordei farina cum pice, et impubis pueri urind exce= pta impolita.

Loliacea farina cum fino columbino ex uino decoctd, adbibita.

Fabarum farind cum melle, et fono greco illita.

Lens in aceto cum meliloto decocta, illita.

I upinorum farina ex aceto inuncta .

Rumex decoctus circumlitus.

Plantago cum fale impofita, uel radix collo oufenfa.

sinapi cum fulphure illitum.

Nafturtium ex muria inunctum .

Piper cum pice impofitum.

Coriandrum cum fabse lomento adhibitum.

Galbanum illitum.

Aparine cum axungia inuncta.

Meliffopbylli folia cum fale catdplafmatis addita.

Althea ex uino, uel aqua mulfa decoct, impofita.

Quinque folij radix decocta, ac concifa adhibita.

I ajerpitì liquor ex ceraillitus.

Vmbilici uenenis juccus circumlitus.

Mandragor re recentia folia cum polenta impofita.

Semperuiuum tertium impofitum.

Galiop/is folia, caulis, femen, et fuccus cataplafind. tis indita.

P Seudobunij rami quaterni ex aqua poti illitiog;s.

Adiantum impofitum.

Fornacee tefte tofte ex cerato illite.

Capparis radix, et folia trita et impojita.

$$
\text { Ad panos. }
$$

olea fyluestris folia cum melle inuncta.

Ficus ficcer cotte, et illite.

Bubulum fimum ex pafcuis fumptum impofitum.

I upinorum farina ex aceto adbibita.

A triplex tam crudum, qudm coctum illitum.

Plantago cum fale impofita .

Bulbi elixi cum polenta, et fuillo adipe illiti.

Ifatidis folia impofita.

Eryngium adalligatum.

Abrotanum cum farina bordedced, er bydrelaco fuba acta illitum.

Acinos berba impoftita.

Panacis Afclepüflores, er femě cataplafmatis indita.

Coriandrum cum faba lomento appofitum.

Ammoniacum inunctum .

Onobrychis concifa, or emplaftri modo impofita.

Gladioli fuperior radix, cum loliace farina, et dul= ci aqua illits.

P yyllium ex rofaceo, dcetoie, dut aqua impofitum.

Mandragor fo folia recentia adhibita.

Galiopfis folia,caulis, fuccus, et femen illita.

Perfonate radix cum axügia fuo fuper folio impofite.

Pycnocomum adbibitum.

Conyza emplaftri modo impofita.

vini fexillita.

Ad tumores difcutiendos.

Cancri fluniariles impofiti. 
I ini fencritlituin.

Fonigreci farina cataplasmatis addita.

Capparis radix, er contufa folia impofita.

Sniyrnij radixillita.

Ammoniacum inunctum.

Buphthalmi folia, o flores cera excepta, $\sigma$ impofita.

Mandragor e recentis folia cum polentaillita.

Galiop/is folis, caulis, fuccus, or fenten adbibita

Acgilops impofita.

Diphryges cum refinaterebinthima, atut cerato.

Pyrites lapis illitus.

Alabsftrites lapis crematus, refuta, aut pice exceptu.

Cimoliaterraillita.

\section{Ad fcirrhum.}

Taurinus fanguis cum polenta illitus.

Bubulum finum cx pafcuis affumptum ex aceto ithis $\ddot{u}$.

I oliace farina cum fimo columbino in uino decocts.

I ini emen cum nitro, o liximio ficulnei cineris dow cortum.

Hydropiper illitum.

Cannabis fylueftris radix impofita.

Ad carcinomata.

Cancrorum fuuiatilium cinis cum melle decoltu, $\sigma$ illitus.

Irionis femen tritum, Orimpoftrum .

Vtraque urtica adbibita.

Galiop/is folia, caulis, Juccus, o femen impofita.

Ad tumores in uniuerfum.

suitus adeps illitus.

Braßica utraque concifa, cum polenta impofita.

Cucurbita impofita.

Xantbij Semen illitum.

Bulbi elixi cum polenta, er adipe fuillo illiti.

Iini femen catapla fmatis inditum.

Fonigreci femenilltum.

Cepa decocta, $\sigma$ cun paßa uud, $\odot$ ficu adhibita.

Narcißiradixillita.

Bryonie radix ex nino decocta, $\sigma$ impofits

Ifatidis folis applicata.

Simyrnij radixillita.

Iragoriganum cum polenta impofitums.

Mentha cum polentu eataplafmatis addita.

Amaraci folis cum cera coatta, er illita.

Dsucumillitum.

I ibanotis radices emplaftri modo inpolit te.

Nigella ex aceto inunita.

Horminum ex aqua illitum.

Buphthalmi fiores cera fubatii.

Althea decota impofita.

Cannabis fyluestris radix emplaftrimodo adhibits

Anagyris folla illita.

Polygonon cataplafmatis inditum.

Xyridis radix ex ace to inunta.

Helxine impofita.

Quinquefoly radix decoct 2 emplaftrimodo.

Verbenace jupine folia impofita.

PSyllium ex rofaceo, acetoine, aut aqua illitum.

Epbemeri folla ex uino decocta, illita.

cytifi folia cum pane inter initia impolita.

Cucumeris agreftis radix cum polenta impofita.

Chamefyces ramitriti, er impofiti.

Pycnocomi femen cum polenta illitum.
Indicum inunctunt.

Vini fex crudaper fe, uel cum myrto illita: Ad fteatomata.

Chryfanthemi flores cum cerato triti, er impofiti. Ad meliceridas.

Rumex cum rofacea, or croco illitus.

Melilotus ex aqua inuncta.

Vua paßsa à nuclels expurgata trita, cum rutaime pofita.

Ad tumores ex ictu.

Braßjica concifa cum polenta impofita.

Cucurbi ta emplaftrimodoillita.

Hydropiper impo/itum.

Tbymus, Tbymbrág; illita.

Cajeus recens illitus. Ad fugillaca.

succida lana oleo, ace toúc per fufa.

Fabarum farina ex melle, or fanogreco.

Lupinorum farina impofita.

Raphanus ex melle.

Allij cinis ex melle.

sinspi illitum.

Hydropiper impofitum.

Ptarmica cum floribus illita.

Bulbi per fe, aut ex oui uitello.

Rhaponticum ex aceto.

Alöex exelle.

Laferpitij liquor illitus.

Abfinthium ex melle.

Aqua insris calida fotu adbibits.

Hyßopum ex feruenti aqud.

Calamintba ex uino.

Amaraci ficcata folis ex melle.

Cuminum erraticum commanfum ex melle, or pafa una illitum.

Ammiex melle.

Acetum exinelle.

Thapfia fuccus, or radix cum thuris, er cere aquas li portione duabus tantum horis impofita, or fubin de marina aqua fotu adhibita.

Bryonid ex oleo decoita quoufque lique $\int \mathrm{c}$ t.

sal ex melle inunctum.

\section{V L N E R V M.}

Ad vulnera conglutinanda :

Cupreßi folia trita.

Vlmi folia, fed multó magis corticis tilia, fifafcie lo co intorqueatur.

sycomoriliquor illitus.

Amurcain cupreo uase decoctaitlita.

Palmulx immature illite.

Viticis folis, o femen impolita.

$\therefore \quad$ Punicorum cytini impofiti.

Thus infperfum .

Lane cinis impofitus.

syluestris braßice folid impofita.

Argemone illits.

Glycyrrbize fuucus illitus.

Centaurij maioris recens radix impofits.

Centaurijminoris folia tu $\sqrt{a}$, er illita.

Achillea impojita.

$\zeta$ Poterit 


\section{VL N E R V M.}

Poterij radix concifa illita.

smy:ny radix impofita.

Aloë in puluerem infperfa.

Surcocolla impofita.

P ycrimon ex aqua impofitum.

Puimun emplaferi modo imporitum.

Scord:um impofitum.

Equeret folia inpersa.

Ionchut is folia impofita.

Althe a in uino, aut mul 5 a qua decocts impofita.

Siderit is folla impofita.

Chame pitys, ex melle adbibita.

sideritis altera impofita.

Polygonum emplaftri modo adbibitum.

Polygonatum emplaftri modo admotum.

symplyytum petre aum inditum .

symphytum emplaftrimodoinpojitum.

Clymeni fuccus impofitus.

sideritis quelibet illita.

I ycop/is radix cataplafimatis indita.

Ocini Semenillitum.

Graninis radix concif $a, \sigma$ adbibits.

Conyza iilita.

Quinquefoliun adbrbitum.

Coccum infectorium tritum, or inperfum.

Verbenaca illita.

Erigerifolia, o flores cum thuris mannd adhibita.

Verbafci folia ex aceto.

spongie recentes fine pinguedine ex aqua uel pofcd.

succidalana uino, aceto, oleouce infusa.

Dracunculi folia ex uino decocta.

Ifatides folia illita.

stratiotes mille folium impofitum.

Morochtbus lapis infperfus.

Ad fluxum fanguinis vulnerum.

syluestris olex foliorum fuccus admotus.

Galle cremata uino, aceto, aut muria extincte, ins Bperre.

$\mathbf{P}$ unicorum cytini impofiti .

Perfece arida folia illita.

Cupreffus pilulde cum arboris coma trite $\mathrm{O}$ admote.

Thus inperfum.

Ranarum crematarum cinis illitus.

Araneorum tela adbibita .

Capráram montanarum fimum ex aceto .

A îninum fimum tum crudum, tum crematum ex as ceto,

strebis folia impofita.

Portulacaillita.

Plantago adinota.

Idea radix admota.

I atidis folid inuncta.

$\therefore$

Saluia adbibita.

Galij flos inditus.

Androfemi folia illita.

Quinquefolium adnotum.

Phenix berba cum punicea land corpori alligata.

Lichen berba adbibita.

Aftragali radix indita.

Hyofcyami femen oboli pondere in mulsa aqua pos tum.

stratotes millefolium admotum.
V VL NER V M.

Cinmabaris, o sanguis draconis inditus.

Alumen admotum.

Sulpbur impofitun.

Gypjum infperfun.

Spongtr freca recentes, or udeuc impofite.

spongiarum crematarum cinis ex pice.

Eretria terra inperfa.

stibium iniperfin.

Ad fanguinem ex cerebro erumpentem.

Gallinaceorum cerebrum ex uino potum.

Stibum tritum inperfum.

Thymus impofitus.

Ad languinis grumos.

Thymbraillita .

Ad vulnera telis venenatis illata .

Dictamni fuccus tum potus, tum inftillatus.

Iris Illyricaillita. Ad ofla carne veftienda.

Panacis Herculei radix impofita.

Myrrha cum cocblex carnibus peruntid .

Ad vulnera membranarum cerebri.

Butyrum admotum.

Ad vulnerum inflammationes.

Bubulum recens fimum ex pafcuis fimptum, dc fubs inde folijs inuolutum, $\sigma$ in feruenti cinere cale $f_{a}$ ctum impofitusn.

Pinorum, e picearum folia trita, or illtta.

Fabarum farina cataplafmatis indita.

I upinorum farina admota.

Strutiotes impofita.

Millefolium ex aceto illitum.

I abrufce flores cataplafmatis inditi.

Acrugoillita.

Ad infixa vulneribus extrahenda.

Cochlex terreftres cum fuo operimento tufe, $\sigma \mathrm{dp}$ pofite.

siluri falfi caro admota.

Lacerte concifum caput impofitum.

Bulbi cataplasmatis inditi.

Horminum ex aqua illitum.

Anagallis adhibita .

Narcißiradix cum lolij farina impofita.

Ariftolochia rotunda impofita.

Ditamnum admotum.

Gladioli radix fuperior ex uino, er thure illit to

Xyridis radix admota.

Tragij folia, femen, or liquor illita.

Pycnocomi femen cum polenta impofitum.

Acute pine radix illita.

Harundinis radix admota.

sirapi impofitum.

Ad carnis excrefcentias.

Galle trite, or inperfa.

Palmarum nuclei exifti, lotiq́; itliti.

Erinaccimarini operimenti cinis admotus.

Cremate purpurce cinis inditus.

Conchula Indica cinis illitus.

smaridis pifcis exuftum caput impofitum.

I ane creinate cinis inunctus.

Scordiun ficcatum infperfum.

Acs uftum inpofitum. Quin etiam eris flos admotus. 
V L C E R V M:

Plumbum clotum

Stibum

Argenti foumit

Ceruffar

Chryfocolld

ocbia

Diphryges

Auripigmentum

Pumex

Corallium

Afijlapidisflos/iccatus

Pyritcs lapis cum refina impofitus.

Ad vulnera cicatrice obducenda .

Cadmin elota inferera, uel illita.

Plumbum elotum impofitunn.

Trita, infperfa, iltitd, uel quoquo modo admota.

\section{L C E R V M.}

\section{Ad depafentia vlcera, quæ Græcis}

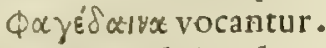

Pisi,pice. é ; cortex cun chalcantbo tritus illitus.

I entif cidccoctum fotu adbibitum.

cupreßi folla trita inunda.

Sabine utriufque folia trita, or admots.

Rh.anni cuiugque folia impofita.

cifti flores per fe illiti.

olec jyluejtris folla trita, o adhibita.

Lignorum marcor illitus.

Oluse mature exufte, trite, er infperfe.

Palme cortex fise inuolucrumadmotum.

Myrtifolia trita, cum omphacino oleo, aat exiguo ros faceo ex uino impofita.

A rnygdile dinare ex uino inuncte. .

Smaridis pifcis crematum caput, tritum, or illitum.

Garum pifcium admotum:

Teftudinis fel inanctum.

Ioliace a farina cum fale, or raphano ithita.

Iini femen ex uino decoctum.

Eru farina admota.

Raplanus tritus inunctus.

Bet.e folia impofita.

Plantago quoquo modo indita.

Dracunculimatoris radix concifa, ex melle, bryonit addita.

Aphodeliradix, or folid ex uino.

Anagallis trita adbibita .

Hedere decocta folia ex uino.

Chelidonij maioris radix ex uino.

1 satidis folia fuperpofita.

Ariftolochis rotunda adbibita.

Cbameleonis nigri radix cataplafmatis addita.

Pulegium uirens appofitum.

Marum adinotum.

Panacis A fclepii flores, or Jemen illitum.

Paftinace erratica folia contufa ex melle.

Coriandrum cum pane polentáce illitum.

Marrubif folia ex melle.

Tithymali characia lac illitum.

Omphacium ex aceto inunctum.

cicuie fuccus illitus.

Sedum maius impofitum.

Sphondylum cum ruta admotum.
VLCER V M.

Polygonun fuperpofitum.

Verbenaca ex aceto .

Solani bortulani folid cum polente polline illita.

Acetum fotu adhibitum .

Acida muria fotu impofita.

Petafites admota.

A eris fquamma infperfa.

Aerugo illita.

Sal tofium cum polenta adhibitum.

Salis flos inperfus.

Chalcitisillita.

Diphryges inunctum.

Afius lapis tritus ex aceto .

Alumen cü galle cremate paripondere ex acetifece. Ad vlcera diuturna.

Ciffi flores per fe illiti.

Centaurium minus admotum.

Panacis Herculei acuminata radix impofitt.

Vifcum cum thure inunctum.

Chamedrys ex melle.

I ill, foliorum fuccus in areo uafe decostus ex aceto, or melle.

scordium tritum ex melle.

Anchufa radix oleo incocta ex cera.

Verbellaca trita ex melle.

Aftragali radixillita.

Thalictri radix inuncta.

Perfonate folia impofita.

Omphacium ex aceto.

Spongix recentes ficce, or udcue impofite.

Afij lapidis flos ficcatus illitus.

Ad malefica dolofaq́; vlcera.

Plantago quoquo modo impofita.

Dracunculi concifa radix cum bryonia ex melle.

Petafitesillita.

P fylliem tritum ex melle.

Bryonis folia, fructus, radix cum fale impofita.

Filic is foemine radix trita, or illita.

Cadmix puluis infperfus.

Salis flositlitus.

Afï lapidis flos ex melle.

oftracites lapis ex melle.

Ad finus \& fiftulas .

Iridis Illyrice radicum decoctuminfufum.

suillus adeps infufus.

Mel infurum.

Plantaginis fuccus inditus.

Dracunculi maioris radicis fuccus ex melle .

Aristolochia rotunda cum iride ex melle.

sphondilij ramenta circüligata inuum callos erodunt.

Quinquefolium cum fale ex melle.

Stratiotes mille folium infufum.

Tithymali characie lacteus fuccus inditus.

Omphacium cum aceto.

Chalcitis collyrij modo infusa.

Cadmiaillita.

Spongia recens fine pinguitudine ex decocto melle ims pofita.

Gentiana quoquo modo adbibita.

Ad vicera in callum indurata .

Capparis radix exiccata impofita.

Aerugo cu m ammoniaco collyrii modo impofita.

$\zeta 3$ spongie 


\section{V.L C E R V M.}

spongie aride linoligate, o in panicilli nodo ins polite.

\section{Ad vlcera ab erodentibus} prouenientia.

Iac omne, o prefertim bubulum illitum. Ad phthirialim.

siaphis agria trita, or ex oleo illita. Ad fordida vlcera.

Olex fyluestris folia tufa ex melle.

Iris Illyrica ex mell.t.

Colymbades trite or impofite.

Refind terebintbina illita.

Pix liquida cum melle indita.

Erinacei marini operimentum exuftum impofitum.

Purpure cremste cinis illitus.

Concluble Indica cinis inperfus.

Orobi farina adinota.

Braßica cum freno graco, or aceto illita:

Aphodeli folia, or radices impofita.

Capparis cortex ficcatus, or adbibitus.

Anemones radix illita.

Hedere decocta folix ex uino.

Chelidonium maius cum axungia admotum.

Arifolochia rotunda impofita.

Libanotidis radices ficcate ex melle.

Ballote ex melle.

Marrubij folia ex melle.

Verbenace Jupine foliaillita.

Narcißiradix cum erui farina ex melle.

Bryonie radix, fructusq; cum fale admoka.

Aerugo ex melle cocta, o impofita.

Aes uftum infperfum.

Vrtica utraque trita, e illita.

Peucedani radix trita in perfa.

Cadmia indita .

Mel illitum.

Pompbolyx admota.

Muria indita.

Alunen quoquo modo adhibitum.

Afij lapidis flos exiccatus, ov illitus.

Ad ambufta .

Platani pilula adipe excepte illite.

Iigufri foliorum decoctum fotu adhibitum.

Cifti flores cum cerato impofiti.

Acacie gummi ex ouo illitum puftulas probibet.

Myrti folia cruda feu cremata cerato excepta.

Mori folia trita ex aceto illita.

Thus ex fuillo uel anferino adipe exceptum.

Buccina cinis illitus.

Mitulorum combuftorum cinis admotus.

Conchule Indic e cinis inunctas.

Calciamentorum ueterum cinis impofitus.

suillus adcps inunctus.

Fimum $\left\{\begin{array}{l}\text { Ouillum cera er rofaceo fubactum. } \\ \text { Columbinum } \\ \text { Gallinaceum }\end{array}\right\}$ cum lini femine ex oleo.

Sefamun ex rofaceo.

Malua deco ta ex oleo.

$\therefore$

Bete uirentia folia illitd.

Braficre cinis ex oui albo.

I actuce fyiueftris lacteus fuccus ex bumano lacte.

Hedere flores ex cera. Quin er decocta folia ex uino.
V L C E R M

Acdnthiradixillita .

Rute fylueftris femen, er folid admota.

Glutinum calida aqua maceratum illitum puftulas pro bibet.

Typhe flos uetexe fuillo adipe eloto exceptus.

Hemerocallis radix illita.

Althere folid ex exiguo oleo admota.

Hyperici femen, o folia impofita.

Afcyri femen, or folia adbibita.

Androfemi folia impofita.

Anchufe radix in oleo decocta ex cera.

Helxine admota.

Papsueris corniculati folia ex oleo.

Verbafci fyimeftris folia catapla fmatis addita.

Stimmi ex recenti adipe illitum poftulas prohibet.

Alumen ex aqua.

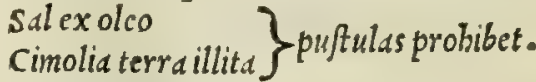

Phrygius lapis cerato exceptus.

Atramentum fcriptorium ex aqua.

Cinnabaris, or fanguis draconis illitus.

Galij flos inunctus.

Lilij radix crematd ex rofaceo.Quin or folia illita.

Cynogloße folia ex ueteri fuillo adipe.

Sambuci pretenera folia inuncta.

Narcißi radix cx exiguo melle.

Oleum ex cauatis aphodeli radicibus decoctum illis tum.

Ad fauos.

Peponis radix ex melle.

Nafturtium illitum.

\section{Ad ficos.}

Bulbi in cinere tosti, o cum capitum menarim cine re impofiti.

Ad intertrigines.

Calciamentorum crematorum folex illite.

Ad vlcerum inflammationem.

Arancitela impofita.

Thus inditum.

Ad vlcera caua explenda.

Pix liquida cum melle.

Pix arida impofita.

Medulla oßium quadrupedum quelibet inuncta.

Mel infufum.

Cadmia inperfa.

Corallium inditum.

A $3 i j$ lapis flos ex nelle.

Eretria terraillita.

Pumex injperfus,

\section{Ad vlcera cicatrice obducenda.}

Purpurarum crematarum cinis illitus.

Mitulorum $\left.{ }_{\text {Conchuls Indica }}\right\}$ cinisillitus.

Aloë inuncta.

Eupatorij folia concifa ex fuillo adipe.

Filicis feemine radix ficca in puluerem apperfa.

Cadmia admota.

Aes uftum impofitum.

squamma eris inperfa.

Aerugo ex olco o cera. 


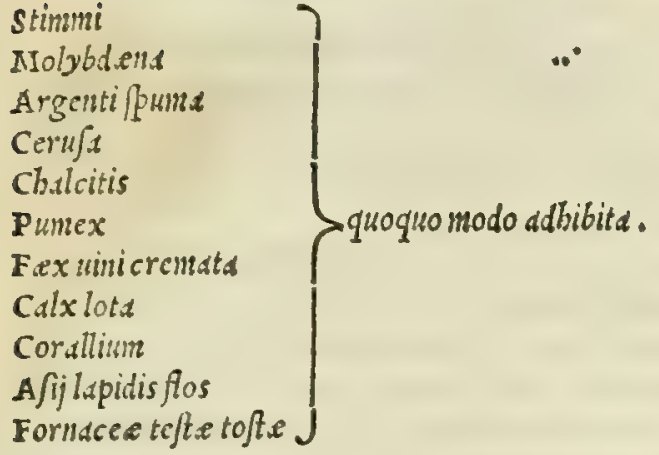

L $V X A T I O N V M$ E T FRACTVRARVM.

Ad artuum luxationes. H.trundinis ridix cum ace to adbibiti.

Perfonat r radix trita illita dolores artuum ḋ contors fionibus fed.t.

Acacie decoctum fotu adbibitum.

Viticis femen cum folijs cataplafinatis additum.

Stercus capritlun cum cerd, er rofaceo inunctum.

A paragiradix ex aceto, uel uino adhibita.

Cyclamini decoctun fomenti modo.

Bulbicataplafmatis more adhibiti.

Acantbi radices impofite.

Sumpofuchifolia cum cera coacta impofitd.

Anchase folia cum nelle, e farina adhibita.

Vretica utraque impofita.

Narcißi radix cun inelle trita.

vitis niogre folit cum uno impofita .

Filicula impolits.

Heliotropiy folia linita.

surmentorum uitis, or uindccorum cinis ex aceto li = nitus.

Sal cum farina, or melle.

Ad offa fracta.

Myrthi foliorum decoctum fotu adbibitum.

succida lana oleo, uino, aceto ó; perfufa.

Verbafcidecoctum potum.

Fulgo pittoria cum rofaceo cer ato impofita.

Vlmi foliorum, aut corticis radicum decoctum pers fufum.

\section{Ad offa fracta euellenda.}

Ariftolochia rotunda catapla fmatis more impofite.

Peucedani radix in puluerem impofits.

Euphorbium impofitum.

Xyridis radix addito flore aris.

Bryonia trita, er impofita.

vitis nigre radix.

Ad eos qui ab alto deuoluuntur.

Gentians radicis fuccus dracbme pondere hauftus.

Baccliaris radicis decoctum potum.

Mille foluum cum aqua, o fale potum .

Iixiuium ex cinere Sarmentitto factum cum aceto, fas le, or melle.

\section{Ad ruptos.}

Acori decoctum potum.

Cardanomum ex aqua potum.

Calami odorati decoctum cum graminis, aut apij fea mine potum.

Helenij radices in eclegmate cum melle deuordte.
Bdellium baufum.

I uniperibacce bibite.

Cedrides deuorate. .

Halimi radix drachme pondere in aqud mul $\int a$ pota.

Dracunculi maioris radix tofta, er elixa cum melle fumpta.

A phodeli radix drachme pondere in uino pota.

Bulbi elixi in aceto, or in cibo fumpti.

Agaricum trium obolorum pŏdere deuoratŭ că mulfo.

Gentiane radicis fuccus drachme pondere hauftus.

Ariftolochia rotunda bibita.

serpyllum potum.

Centaurij maioris radix haufta cum uino .

Acanthiradices pote.

Smyrniy radix comefta, uel pota.

Leucacanthe radicis ex uino decoctum potum.

Abrotani femen ex aqua potum.

Origanum cum ficu deuoratum.

Equifeti radix er folia pota.

Calaminthe decoctum hauftum.

Baccharis radicis decotaum bibitum.

Libanotis radices pota.

Sagapenum bibitun.

Laserpitij liquor cum lixiuio potus.

Galbanum deglutitum.

Polycnemon bibitum cun uino.

Scordiun additisnafturtio, melle, refinaq́; deworatü.

Althex decoctum potum.

Alcea radix in uino uel aqua, pota.

Betonic e folia dracbme pondere in dulci aqua bibita .

symphytum petraum cum aceto mulfo potum.

Symphyti radix pota.

$\mathrm{X}$ yridis radix ex mulfo pota.

Helichryfi coma in uino pota.

Verb.x ci decoctum potum.

Bryonia cum melle in eclegmate deuorata.

schiftus lapis potus,

\section{VEN E NOR V M.}

Ad omnium venenoforum morfum. ictumq́ue.

Iridisillyrice radix ex aceto pota.

Cardamomum ex uino potum.

Nardus Celtcca cum abfintbij decocto baufta.

Phu antidotis inferitur, qua uenenatis refiftunt more fibus.

Cinnamomum bibitum.

Cafia potuidata.

Helenij radicis decoctum potum.

Edellium potui datum.

Platani pilule ex uino haufte.

Erice flores poti. Luin etiam coma.

viticis Semen in potu Sumptum.

Glandes efitate.

Nuces comese.

sycomori lachrymaillita.

Ficulneum lac plagis inditum.

Pix liquida cum trito fale illita.

Paliurifoliorum, or radicis decoctum potum.

Gallinaccorum cerebrun cum uino potui datum.

Eruce, que in olexibus reperiuntur ex oleo illite. 
$V \cdot E \cdot N E \cdot N O R V M$.

Coagulum $\left\{\begin{array}{l}\text { Leporinum } \\ \text { Aguinum } \\ \text { Humulinum } \\ \text { Aprinum } \\ \text { Ccrsumum } \\ \text { Vitulinum } \\ \text { Bubalimun } \\ \text { Hedinum } \\ \text { Capres } \\ \text { Laticornis }\end{array}\right\}$ obolorumpondere.

Marinx teftudinis fanguis cumleporino cödgulo, on cumino potus.

Mel ex calidorofaceo bibitum.

Tritice a farind ex ace to or uino impofitd.

Porrifuccus ex melle fumptus. Quin or comaillita .

Porrum fylueftre efitatum.

Piper quoquo modo fumptum.

Eryngium ex uino baufum.

Teucrium ex aceto inunctum.

Argemone ex uino epota.

Agaricum trium obolorum pondere ex uino bauftum.

Rbaponticum potuid.tum.

Chamedrys ex uino bibita.

Gentiane radix drachme pondere cumpipere, or ruta ex uino pota.

Ariftolocbia longadrachme pondere potui data, de

- etiam plage adinota.

Origanidccoctum bauftum .

Leucas cx uino fumpta, uel catapla matis addita.

Pulegium ex uino potui datum.

Difamnifuccus ex uino potus.

Baccharis radix ex uino bibita.

Panacis Herculci femen cum aristolochia fumptum.

Iiguftici tum radix, tum femen bauftum.

Paftinace erratic e emen potui datum.

Anifum potum.

A clepiadis radices ex uino fumpte.

Cuminum ex uinobauftum.

Amml cum uino potui datum.

Delphiniun mor jui admotum.

Ia erpitij liquor tum inunctus, tum b́ibitus.

Galbanum inunctum homines tutos reddit.

Clinopodium bauftum.

Trifolij bitumino/ if flia ex oxymelite fumpta.

Polij decotium potum.

Betonice folia trium drachmarum ponderc ex uini fex=: tarijs duobus haufta, uel admota.

Polygonifuccus bibitus.

Clematis prima illita.

Sparganij radix ex uino pota.

Acida muria plage indita.

Terra Lemmia baufa.

sal cum origano, melle, er by/fopo illitum.

Ad viperarum morfum.

Coftus, femiuncie pondere potus.

Caßia potuidata.

Pix liquidaillita.

Iuniperifolid, or foliorum fuccus potui datus.

Fraxini folid, uel eorum fuccus bauftus.

Laurifolia admota.

Abrotanumillitum.

Galbanum splcnij loco fupcriectum.
VENENOR VM.

Origanum uirens inditun .

Pulli gallinarum difcerpti, e confeftim adusoti.

Anthemis detrita cum bordeaced farina, o mulfo dce to cataplafinatis modo admota. Sed locus antea ace to mulfo calido foueatur.

Rubifolia ex uino illita.

Porrifuccus ex meri bemina bauftus.

Apiaftri fuccus ex vino potus.

I eporis coagulum potui datum.

Omotarichi pif cis falite carnes in cibum fumpte, haus fto deinde copiofiore uino. Quin etiam admota.

Ceruigenitale tritum, e ex uino fumptum.

Vrind ip/iussize demor/í bibita.

Furfures triticei in decocto rute elixi,admoti.

Erui farina ex uino macerata illita.

Raphanus inuntus.

Braßice fuccus cum nitro o iride potus.

Chondrylla manducata.

Allium ex uino fumptum, er illitum.

Scilla decocta in aceto, $\mathcal{O}$ impofita .

Anagallidis fuccus ex uino fumptus.

Ferula medulla in uini potione.

Aparine fuccus ex uino potui datus.

Rubie radic is fuccus cum folijs potus.

Tribuli terreftris fuccus drachme pondere potus, plda geq́; admotus.

Anchufe Alcibiadis nomine foliu, radices q́, tum comes fta, tun bibitd, tum adalligatd.

Ocimaftri feinen ex uino bauftum.

Sambuci, ebuliq;; radix ex uino coctd, potui datd.

Bryonia radix duarum drachmarum pondere haufta.

Vitium farmentorum cinis ex aceto illitus.

Ad ferpentum \& afpidum morfum.

Cancri fluniatiles crudi, tritique cum afinino late poz tui dati.

Equi fluniatilis testiculus potus.

Caftorium bibitum.

Muftele falite, $\mathrm{O}$ in umbra exicate puluis drachma rum duarum pondere ex uine fumptus.

Rana cum fale in oleo decocte comesa.

Gobius pifcis deuoratus.

Cimices lectularij feptem quoquo modo baufti .

Aprinum iecur, o recens, or ficcum ex uino fumptü.

Gallinaceorum carnes dißecte, ita ut tepebunt appos fite, crebroó; mutate.

Butyrum illitum.

Caprarum montanarum fimum in uino, uel aceto deco: ctumillitum.

Mel ex calido rofaceo bibitum.

A phodeli radix trium drachmarum pondere fumpta: Quin e folia, flores, o radices in cataplajimatis. Nafturtium hauftum.

Spine albe femen potum.

Abrotanum ex uiro fumptum.

Hyffopum tritum cum melle, fale, or cumino impo/itü.

Nepeta pota, uel cataplafmatis indita.

Pandcis Afclepijfemen cum floribus bauftum, er ina unctum.

Panaces clyronium bibitum, o illitun.

Hieracij fuccus ex uino potus.

Elaphobofci femen in uini potione fumptum.

Euphorbium incifa capitis cute ad os, ufque in uulnus 
VE NENOR V M.

impofitum, ftatinq; confutum .

Leontopetalum bibitum illico dolorem aufert.

Iilig folixillita.

Neliffophyllum ex uino haustum, or plage admotum.

Marrubif folia haufta.

Serpyllwan tum potum, tum impofitum.

Ruta cumn nucibus inglandibus, o curicis fumpla.

Plyyllitis ex uino b.ult.t.

Smyraig rodix illite.

Faniculum ex uino fumptum .

Sag.tpenun cx uino potui datum. ..

I ibanatis rudices cum uino bibite.

scordium ficcatum ex uino funtetum.

Conyzlillita.

Clematis in accto bibita.

Ecbij radix ex uino'pota. Prepota uerò demorderipro biber, ud quod preftant feinen, er folia.

Ocimaftrifeinen potun.

Eupstorijfemen, o folia in uino fumpts.

Helicbry/i coma ex uino bibita.

Verbersece fupine radix, of folid cx uino haufta, tum ctism admota.

MIandragor re radix ex melle, att oleo illitx.

Nerij rdix ex uino fumpta.

Aceture calidun fotu adbibitun, ubi illatum uenenuir frigidisks fit: frigidun ucro ublculidum.

Adiantidecactum bibitum.

Aqui maris fotu adlubita.

Sal cum origna, melle, or byfopo inunctum.

Sarmentitius cinis ex aceto illitus.

Simia terrex aqua pota.

Ophites lapis pro amuleto geftatus.

Ad hæmorrhoi morfum.

Allium bibitam; o illitum.

Merum copio/ius baufum.

Vitiun uinferarim folla decocta, of ex melle fubatcs inpofitx.

Ad cerafte morfum.

Sefmum cum rofsceo inuntum.

Raphani emen ex uino bibtum.

Sal cun cedrid, aut pice, aut melle illitum.

Ad fcolopendræ morfum.

A phodeliradix, o femen ex uino potd.

sal ex melle, er aceto.

Ruta Jylueftris admota. Quir, er bibita ex uino.

Muris scida foru adbibita.

Ariftolochis ex uino pots.

serpyllum potui datum ex uino.

Calamintsa ex mero fumpta.

Ad drvini morfum.

Ariftolochia cum uino baufta.

Trifolij bitumino/i folix in potu fumpte.

A pphodeli radix potui data.

Glandes quecunque bibite.

Ilicis radices tufe, or ifto loco illite.

Ad natricis morfum.

Origanum tritum, e aqua fubactum ex lixiuio, $\sigma$ olco inditum.

Ariftolocbie cortex minutim contritus cum querna ra dice, o bordei farina ex melle illitus.

Ariftolochle bine dracbme in potione pofce pote.

Marrubij Juecus ex uino hauftus.
$V E N E N O R V M$.

Fauus recens ex aceto fumptus.

Ad cenchri morfum.

Latuce femen cum lini femine illitum.

Satureia cum fylueftri ruta, o ferpyllo, et apphodelira dice ex uino funzta.

Gentiana potui data.

Cardamomum denoratum.

Ad muris aranei morfum .

Mus araneus ipfe difcerptus, o impofitus.

Allium cum ficulneis folijs, o cumino illitum.

Abfintbium uino bibitum.

Chryfogoniradix conci]a, $\sigma^{\circ}$ ex deeto impolits.

Galbanum in Splenio admotum.

Hordedcea farina ex aceto mulfo illita.

Punicx dulcis acini decocti, er inuncti.

Porrum contritum impolitum.

Abrotani decoctum ex uino hauftum.

Serpyllum ex uino potum.

Eruca ex uino fumpta.

Cupreßi recentes pilule ex aceto potui date.

Cyclaminus ex aceto mulfo sumpta.

Pyrethrum ex uino potum.

Chamaleonis radix bibita.

Ad paftinacx marin $x$, fcorpionis \& draconis marini morfum .

Saluic decodtum potum.

simplicid omnia, qux uiperinis morfíbus conueniunt. Ab/intbij, aut Sulphuris ex aceto decocti potio.

Animalia ipfa diffecta fuo cuiufque ictui admota.

Mulus pifcis diffectus, o impofitus.

Ocimum cum polenta, er aceto impofitum.

Plumbum confricatum.

Sulphur admotusa .

Ad morfum muftelæ.

Eruca comefta, o poft eam bibitum uinum odoriferŭ. Ad morfum bafilifci.

Caftoreum drachme pondere ex uino potum.

Papalueris fuccusbauftus.

Portulaca percocta.

Ad calcidicæ lacertx morfum .

Ad rabidi canis morfum.

Iycium in catapotio datum, aut ex aqua bibitum.

Cancrorum flurialium cinis cocbleariun duorum ports. dere ex gentiane radicis wino, per triduum in uino potus.

Smaridis pifcis falfa caro.

Omotarichi pifcis falite carnes illite.

Garum omnium pifcium fomento adhibitum.

Canis ratidi epar toftum, $\mathrm{C}$ in sibo fumptum di mets aque preferuat.

Camuns fanguis bibitus.

Canina urina bibita.

Mel bibitum cusn rofaceo calido.

Triticuni conmanducatum, er appofitum.

Cape cum ruta, fale, $\sigma$ melle mixte.

Allium cum uino potum, er cataplafmatis inditum.

Panaccs Herculcum picimifum, en cataplafmatis ado ditusn.

Faniculi radices concife, or ex melle impofite.

I afer impolitum.

EAllote cutaplafmatis modo cum salcillita.

Mcliffophyllum 
$V E N E N O R V \cdot M$.

IS liffophyllum cum uino bibitum., er cataplajmatis inditum.

Alyfum in edulio contufum.

Aluum fyluc ere in cibo fumptum or ithitum.

salfamentum inditum.

Succus Cyrenalcus.

Ad canis non rabidi morfum.

Amygdale amare ex melle excepte.

Mitulorum caro impofita.

Gobius pifcis impofitus.

Orobifarina uino macerata indita.

Plantago cataplafinatis modo adhibita.

Cucumeris folia impofita .

Bulbi cum melle, e trito pipere cataplafmatis more impofiti.

Nienta impofita.

Vrtica utraque cum fale adbibita.

Cynogloßiradix, o folia cum fuillo adipe ueteri ins pofita.

sambuci, er ebuli folia ithita.

Sarmentitius cinis ex ace to illitus .

Ad phalangiorum morfum.

Nyrice frustus poti.

Myrtus ex mero haufta.

Morifoliorum fuccus cyathi men fura pottes.

I ixiuium ficulnei cineris potum, adiecto fale trito, $\mathbb{C}^{+}$ uino.

Cancrifluxiatiles crudi, tritiq; cum afinino lacte poti.

Mulus picis diffectus, or impofitus.

Malue decoctum impofitum.

Myrrhis ex uino pota.

Aparagi radicum decoctum baustum ex uino.

I actuca fylueftris bibita.

Coris $\int e m e n$ potum in uino.

Hedere fuctus cum aceto potus.

Abrotanum cum uino bibitum .

Dauci femen ex uino df Jumptum.

Nigella draclsme pondere cum aqua pota.

A parine ex uino pota.

MelifJophyllum cum uino bibitum, or cataplafmatis more additum.

Phalangij folla, flores, femenq́; potum.

Iunci marini tenella folia propé radicem erumpentia inpofita.

Hyacinthi radix pota.

Scmpcruiuum maius in potudatum.

A qua maris fotu applicata.

Punica fylueftris radix, quàm tenuißmé trita, aut dris ftolochid cum bordei farina, er ace to fubacta .

A piaftridecoctum fortu adbibitum,ant cius folia.

Abrotani

Anif

Cumini sthiopici

Ciceris [ylueftris J

Cedrides trite admote, nel bibite

platani cortex potus.

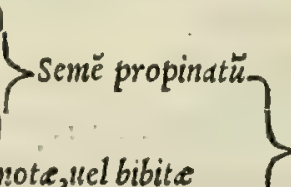

binarü drds clomarü pon Jere cumbe mina uini.

Cupreßi airidium pilularum admisto uino decoctum.

Chams pityos decoctum bibitum.

Trifoliifemen propinatum.

Ad ftcllionis morfum.

sefamum cum rofaceo.
VENINOR VM.

Ad crocodilorum morfum. Sal impojitum.

Ad quadrupsdum morfum .

A prinsum cpar tum recens, tum ficcum bibitum.

Cyperusimpo/itus.

Ad fcorpionum ictus .

Cardamomum ex uino potum.

Amonum ex ocimo llitum.

Lauribacce ex uino bibite.

Myrtifuccus ex mero bauflus.

Ficus fatiue lacteus fuccus plige inftilldtus.

Cancrifluuiatiles crudi, tritíq; cun a/inino lacte poti.

Scorpiusipfe tritus, er impofitus, uel toftus deuoratus.

Delphinium appofitum.

Mulus piscis dißectus, or impofitus.

Smaridis pifcis falita caro appofita.

Lacerta diffecta, or appofita dolorem feddt.

Mures domeftici diffecti, o impafiti.

Fimum $\left\{\begin{array}{l}\text { A/uni } \\ \text { Equi }\end{array}\right\}$ berbas pafcentis uino dilutum

Vrind humana pota.

Farina triticed ex aceto, o uino pofita.

Lychnidis femen cum uino potusn.

Oxylapathi, or oxalid is femen uino, alt aqua potum.

Soncbi fuccus cameftus, or cataplafmatis more impo= fitus.

Intybus more cataplafmatis.

Phalangium berba pota.

I actuca fylueftris bibita.

Ocimum cum polenta impofitum.

A phodelifemen, o flores in uino poti.

Abrotanum in uino potum.

Sampfuchum ex aceto, o falc impofitum.

Hieracium maius, o minus catapla $\int$ matis more appos fitum.

I afer oleo dilutum impoftum.

Colus ruftica cum uino pipereq́; bibita, er manibus ge ftata dolorem puncture ommino fugat.

Melißopbyllifolia adhibita.

Polemonij radix alligata.

Rubiflos, er mora.

Verbafci aureum florem frentis folid impo/itd.'

Chamefyces fuccusillitus.

Scorpioides illita.

Heliotropium potum cum uino, o illitum.

Aqua maris fotu impofita.

Sulfur ignem non expertum cum refina terebinthina exceptum admotum.

Calamintha trita illita, uel cum pofca, fota.

Galbanum splenij more ductum impoficum.

Hordei farina cum uino parata .

Rute decoctum fotu adbibitum.

Trifolium tritum iniectum.

Cuprefjus cum uino, or ruta.

Peucedanifuccus bauftus.

$\left.\begin{array}{l}\text { Pulegij } \\ \text { Gentiane }\end{array}\right\}$ decoctum potum.

Ariftolochic prafertim cortex drachmarum duarum pondere.

sal cum lini fomine.

Sapplirus lapisillitus. 


\section{VENENORVM.}

Ad vefparum \& apum ictum.

Idurifolia trita, er illita.

Malua concifa ex olco impofita.

sifymbrij follia impofita.

Althe e decoitum ex pofca bibitum.

Sal cum fepo titulino.

Ad fugandum animalia venenofa .

Iuniperi acceilse funus.

Cedrides peruncto corpore adipe uel medulla ceruina excepte.

viticis follia fuffita, uel fubftrata.

Cancri flusiatiles crudi cum ocimo triti fc orpionibus admoti.

Ceruinum cornu crudum incenfum, fuffitumíg; .

Cerui, o Elcplantus adeps inunctus.

Coruina medulla.

$\mathrm{N}$ afturtium fuffumigatum.

Abrotanum frictum, fuffituq; incenfum .

Origanifolia ftratis fubiecta.

Dit.snnum olfattum omnix, qux idtu, aut morfu uene: minn relinquunt, enceat.

Calaminthe fufitus.

Peucedani fuffitus.

I y/imaschia incenja fugat ferpentes, or murcas.

Nigelle fuffiums.

Galbanifuffirus.

Polium utrumí; incenfum, ftratumi; .

Conyze fuffitus.

Gagateslapis fuffitus.

Ad venena omnia .

Phu antidotis infertum.

Ciinnamomum potum.

Pix liqquida cyathi méfura in ecleginate ex melle data.

Cedrides antidotis impo/ite.

Nuces iuglandes cum ruta, or ficis pres fumpte.

Qzinquefolij radicis fuccus bibitus.

Coagulum leporinum potum.

Epipaltis haufta.

Caftoreum bibitum.

Calamintha prepota.

Muftele falite, o in umbra exiced te puluis cŭ uino.

Muftele uentriculus coriädro farctus, o inwețeratus.

Canicule lac primi partus potum.

Eryngium cum uino potum.

Butyrum deficiente oleo, hauftum.

Sanguis $\left\{\begin{array}{l}\text { Anferis } \\ \text { Anatis } \\ \text { Hadi }\end{array}\right\}$ antidotis commiftus.

Vrina ipfiufmet infirmipota.

Semen raparum hauftum.

Rute femen acetabuli pondere cum uino potum.

Napi emen potum.

Malux decoctum cum fuis radicibus frequenter potum, crebroó; enomitum.

Brafice femen antidotis impofitum.

Irionis emen baufum.

Iaserpitium potum.

Agaricum drachne pondere cum diluto vino fumptü.

Chameleonis alba radix cum uino pota.

Spinz alba in amalecum congefta, collog fuppenfa.

Abrotani Sentencum uino potum.

Ruta cum iu glandibus nucibus, or caricis fumpta.
VENENOR V M.

Apii decoctum potum.

Marrubij folia bibita.

Betonice folia drachme pondere in uino bibita .

Polemonia radix in uino bibita.

Tribuli terreftris fuccus hauftus cum uino.

Smilacis aperi acini prius, poftue fumpti .

Acetum tepidum bibitum.

Terra $\left\{\begin{array}{l}\text { Lemnia } \\ \text { Samia }\end{array}\right\}$ ex aqua baufta.

Ad leporem marinum ebibitum.

Cedrid contrita cum uino baufta.

Cancrifluniatiles cum fuo iure elixi, or comefti.

Ide afininum ?

$\mathbf{P}$ affum $\}$ continué datum.

Malue radicum decoctum hauftum.

Cyclamini radix cum uino bibita.

Veratrum nigrü $\}$ dracbme pondere data cü mulfa,

scămonijfuccus $\}$ er malipunicidcinis .

Anferinus fanguis tepidus bauftus.

Alifmatis drachma una, uel altera bibita.

Ad rubetam ranam ebibitam.

Teftudinis marina fanguis cum leporis coagulo, et cy= mino bibitus.

Alifmatis radix unius, uel duarum drachmarum ponde re in uino pota.

Merum largius potum, or enomitum.

Arundinis ?

Cyperi $\}$ radicis bine drachme pote.

Ad bupreftes \& pinorum erucas ebibitas.

oleum $\left\{\begin{array}{l}\text { Irinum } \\ \text { Melinum }\end{array}\right\}$ potum.

Carica come $\int e, 0$ earum decoctum ex uino.

Palmula thebaice in cibo fumpte, uel trite ex mulfo, aut lacte pote.

Pyra omne genus in cibum fumpta.

Humanum lac bibitum copiosé.

simplicid omnid, que epotis cantharidibus profunt. Ad epotas hirudines.

Muria in forbitionibus data .

Cyrenaicus fuccus potus.

I a ferpitî folia ex aceto baufta. Quin er fuccus" ex ace to gargarizatus.

Beta folia cum aceto bibita.

Niuis glebuld cum po fca fumpta.

Cimices uino ace toúe poti.

Acetum cum fale potum.

Nitrum ex aqua gargarizatum.

Atramentum futorium dceto dilutum er gargarizatü.

Haltece

oryze

Tragij

Malue

Sem. lini

Semëforni graci

Althex

otas cantharidas.

INitrum ex bydromelité potum.

Nuclei pinei ex uino fumpti.

Cucumeris Semẽ contritum, ex mulJo aut lațe hauflü.

Anferinus adeps ex pafjo potus.

Iac potum. 


\section{E N E NOR V M}

Vinum du lce liberalius bibitum.

Thuris cortex ex pafo fumptus.

Samia terra, que After appellatur ex defruto haufta.

Pulegium tritum ex aqua potui datum.

Rofaceum cum trino ex rute decocto fumptum.

vitis recentes ramuli detriti, er ex paffo hausti.

Ius efculentum omnium adipum.

Ad hauftam falamandram.

Refina pinea in delinttu.

Gatbanum ex melle deglutitun.

Nuclei ptnei contriti, ex ainge decocto poti.

$\checkmark r$ tica cum lilijs ex oleo decolta, e pota.

Teftudinis marine, o terreftris oua coct denordta.

Ranarum ius, in quo eryngij radix fuerit cocta,potum, Ad fanguinem \& lac in ventriculo concretum.

Coagulum leporinum epotum.

Acetum tepidum potum, \& uomitu redditum.

Großil lacteofucco turgentes ex pofca fumpti.

Nitrum per $\int e \int e$ potum.

Coagulum omne ex aceto, o laferpitij radice, aut lan fere bauftum.

Braßice femen ex lixiuio ficulnei cineris potum.

Conyze femen cum pipere ex aceto hauftum.

Rubi fuccus ex aceto potui datus.

Hordeacea farina uentriculo, or aluo ex aqua mulf inuncta.

Thymum ex uino bauftum .

Calaminthe folia arida potd.

Ad colchicum.

origanum cum paffo, aus oxymelite potunt.

Bubulum lac bauftum, quin or afininum largius potü.

Quercus foliorum, aut glandium decoitum potum.

Malicorium hauftum.

Serpyllum ex lacte decoctumbibitum.

sanguinalis berba fuccus potui datus.

vitis recentium uiticularum fuccus bibitus.

Rubifuccus in potu fumptus.

Ferula recentis medulla ex uino fumpta.

Myrti bacce tufe, or aqua macerate,, 0 in liquorem folute, pota.

Caftanedram media tunica.trita, or cum fanguinaric fucco epota.

Origanum cum lixiuio bibitumt.

Simplicid omnia, que fungis aduer fantur.

Ad folanum fomniferum.

A qua mul sa copiosé fumpta.

I ac caprillum?

Lac afininum $\}$ potum.

Vinum dulce tepidum cum anifo bibitum.

Amygdale amare deuorate.

Conchylia omnia tam cruda quam tofta deuorata.

Locuste marine, quin et $\mathrm{Gammari}$ in cibum fumpti, et corum iufcula pota.

$$
\text { Ad hyofcyamum. }
$$

Moricortex potus.

A qua mulfa largius ebibita.

Lac omne prefertim afininum potum.

Ficuum aridarum decoctum bibitum .

$\mathbf{N}$ ucleipinei denorati .

Cucumis femen ex paffo potui datum.

vinum fallum cum fuillo recentiadipe, et paffo potum.
VENENOR VM

Vrtice femen ex aqua fumptum.

Nitrum ex aqua bauftum.

Cichorium deuoratum.

sinapis quoquo modo fumpta,

Nafturtium?

Raphanus

Capa

Allium

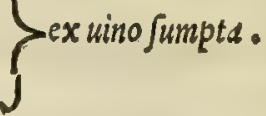

Ad aconitum .

Leporinum

Hadinum $\}$ coagulum ex uino potum,

Vitulinum $\}$

Chame pityos decoctum bauftum.

Scoria ferri ex aceto mulfo fumpta.

Origani ?

Rute

Marrubij

Abfintbij J

sedum maius

Abrotanum

Chamelea

Ainga.

decoatum cum uino abfinthite potum.

Opobalfamum drachme pondere ex melle, uel lacte cü caftoreo, pipere, er ruta equis ponderibus ex wi= no potum.

vinum, in quo aurum, argentum, ferrumúe candenste ftinctum fuerit, potum.

Galline ius ex lixiuio er uino paratum potume.

Bubuldrum carnium propinguid iura cŭ uino fumpta. Ad taxum.

Acetum calidun potum, or nomitu redditum. simplicid omnia, que cicute refiftunt.

$$
\text { Ad toxicum. }
$$

Sanguis $\left\{\begin{array}{l}\text { Hircinus } \\ \text { Caprillus } \\ \text { Leporinus } \\ \text { Ceruinus } \\ \text { Caninus }\end{array}\right\}$ frixus, or in cibis fumptus.

Galbanum cum myrrba ex uino bauftum.

Quinquefolij radix pota.

\section{Roboris}

Fagi 子cortex tritus ex lacte bauftus:

Ilicis $\}$

Cotoned mala deuoratd, aut cum pulegio, た" agqu bibita.

$\therefore \quad$ Amomum $\{$ expobalfamum $\}$ exaftum.

Ad opium et corniculatum papauer.

Mel ex rofaceo calido bibitum.

Origanum cum paßo aut oxymelite hauftum.

Alifmatis radix duarum dracbmarum pondere ex uino pota.

Acetum bibitum, er vomitu redditum .

Sal cum oxymelite fumptum.

Meracum uinum cum abfinthio, or cinnamomo bauftü.

Nitrum ex aqua potni datum.

$\therefore \quad$ Origanum cum lixiuio, aut pafjo potum.

Rute fylueftris femen cum pipere, or panace ex uino fumptum.

Piper cum caftoreo ex aceto mulfo, uel cum faturcie. aut origani decocto ex uino bibitum.

Pinguid iura in potum fumpta cum uino aut paffo . 


\section{VEN E N O R V M.}

o Bium medulla ex oleo pota. Ad cicutam.

Abfinthium ex uino bibitum.

Origanum cum pafo, aut oxymelite potum.

Acetum bibitum, or uomitu redditum.

IIeracun uinun largius epotum, et per interualla res petitum.

I ac tum bubulum, tum afininum potum.

Caftoriun cum rutd, et menta ex uino Jumptum.

Amomi

$\left.\begin{array}{l}\text { Cardamomi } \\ \text { styracis }\end{array}\right\}$ uncia cpota.

Piper cum urtice femine ex uiro buffum.

I auri folia potui data.

I afer ex oleo uel paffo potum.

Paßum per fe largins cbibitum.

Ad Ixiam.

Abfintlium cum ex uino bibitum.

Origanmm ex" uino funiptuin.

Acetum potum, uomituq́; rciectum.

Rute fylueftris femen

Laferpitij radix

\}ota.

Tragorigani decoctum baustum.

Refina lerebinthina deworats.

Nardus Indica potui data.

Caftoriun $\}$ obolipondere fumpta.

Nucesiuglandes cumrefind, castorio, et ruta trite, ita ut fingula dracbme pondus aquent ex uino baufte.

Chamelex
Thapfis. Juccus follici pondere ex aqua mulfs Thapfintbii. $\}$ hauftus.

Ad coriandrum .

Merim per fese, wel ex abfinthio pottm.

Oleum potum.

Oua in oleo exinanita, et ex muria liquefacta denos rista.

Murla epota.

Gallinarum, et anferum ius copiosé fal fum bauftum.

Paßum ex lixiuio afjumptum.

$$
\text { Ad pfyllium. }
$$

Simplicis omnia que coriandro aduer fantur.

Ad herbam fardoniam.

Aqua mulfa liberalius pota.

I ac affatin bibitum.

A qua calida fotu adbibita. Quin etiam et oleums.

Ad mandragoram.

A qua mulfa copiosé pota, et uomitu reiecta.

Nitrum cum abfinthio ex dulci uino, aut paffo fumptü.

Rofaceum cum aceto capiti perfufum.

Eupatorium?

Piper

Sinspi

Caftorizun

Ruta

Iueernarum extinctarum fumus olfactus. Ad fungos malos.

Fimus galline cum aceto bibitus.

Mel exirofacec calddo potum.

\section{VENENOR V M}

Raphanus deuoratus, uel potui datus.

Abfinthium cum ace to fumptum.

Meliffophylli folia cum nitro bibita.

I ixiuium farmentitij cineris ex acida muria potum.

Satureia feruefacta, bauftáq;

Origani iufculum potui datum.

Acetum calidum potum, e uomitu reiectum.

Atramentum futorium ex aqua potum.

Sal cum oxymelite bibitum.

pyraftrifolia pota, deuorat aq́; .

Oua gallinacea cum ariftolochic drachme ex pofca denorata.

Panacis radix, er femen ex uino pota.

Fex uini crematta ex aqua pota.

Sinapis bibita.

Nafturtium comeftum.

Ad gypfum.

Origanum cum paffo aut oxymelice potum.

Malue decoctum potum. Quin e toto corpori inpers fin.

Oleum ebibitum.

Aquid mulfa bibita.

Caricarum decoctum potum.

Lixiuiun é ficulneo, aut farmentitio cinere pardtü, chus uino copiofiore baufum.

Origanum cumt lixiuio, aut dceto, dut pusfo fumptum.

Quin etiame thymum.

simplicic omnia que fung is refistunt. Ad ceruffam.

Irinum $\}$ oleum potum.

Vlmi liquer potus.

Perficorum nuclei ex peifana poti.

Maricarum $\}$ decoctumbauffum:

Iac calidum bibitum.

Sefamun tritum ex uino fumptum.

Lixiuium ex farmentitio cinere hauftum.

Columbind ous cum thure pota. Ad argenti fpumam.

Hormini fylueftris femen potum.

Myrrba bibita

Ab/inthium

Hyfopum

Apijfemen

Piper

Liguftri flores.

Palumborum aridum fimun cum Nardo ex uino potü. Ad argentum viuum .

Iac copiosé potum, er uomitu reiectum.

simplicia omnia, que faciunt ad argenti spuman.

Ad calcem, fandaracham, \& auri-

pigmentum.

Edc ex aqua mulf a potune, or uomitum.

Carnium iura pinguid haufta.

$\left.\begin{array}{l}\text { Althex } \\ \text { Malua }\end{array}\right\}$ decoctum ad Jpißitudinem redaqum potu.

Tragi berbe Semen bibitum.

Seminis lini decoctum potui datum.

Oryze decoctum potum. 


\section{SIMPLICIVM MEDICAMENT
rum facultates, qux corpori decorem proftant, ex Diofcoride.}

\author{
DECORIS.
}

Ad alopeciam.

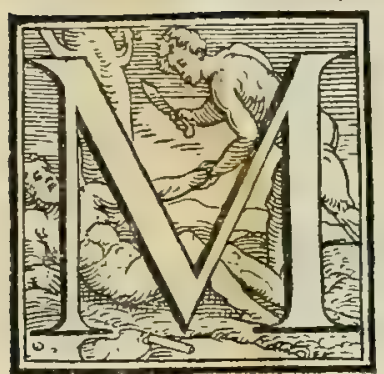

Y R R H A cum lada: no, er uino myrteo illi= tafirmat.

Harundinum corticum ci nis ex ace to inunctus.

Ladanum cuin uino, myr rha,et myrteo oleo ad motum.

illitus.

Myrti baccarum fuccus

Nucum iuglandium putamen combuftum, tritum $q$, impofitum.

Nucum auellanarum crematarum cinis ex urfino adis pe perunctus.

Erinacei terreftris corij cinis ex liquidd pice illitus.

Ieporinum caputcrematum ex ur/inno adipe.

Ranarum crematarum cinis ex liquida pice.

Murium ftercus combuftum ex aceto.

Vrfirus adeps illitus.

Caprarum fimus ex aceto.

Raphanus tritus ex loliaced farina admotus.

Braßjica cum fale confricata.

Beta recentia folia cruda illita.

A phodeli radicum cinis impofitus.

cepa confricata.

Allij cinis ex melle.

sinapi illitum.

Nafturtium confricatum.

Cyclamini fuccus inunctus.

Ranũculi folia, o radices illite paruo tĕporis ßatio.

Aloë ex uino.

Abrotoni cinis ex raphani fucco, aut cicino oleo.

I a erpitij liquor cum pipere ex aceto.

Nymphe radix ex pice.

Cynogloffe folia ex uetere fuillo adipe.

Adiantum illitum cum fufino, aut myrtino oleo,dut bys fopo, aut uino.

Thapfic fuccus inunctus.

Rubigo ferrillita .

Sandaracha ex refina.

Alcyonium tertiwn exuftum inunctum.

Cotex naxia illita.

Hippocampi cremati cinis ex liquida pice, aut axun gia, aut amaracino unguento.

Caprillarum ungularum cinis ex dceto inunctus. Ad pilos auellendos.

oleum in quo decota fuexit fcolopendra inunctum.

Lepus marinus per fe, er cum marina urtica tritus, or appofitus.

salamandre cinis ex oleo.

Heder lachrina illita.
DECORIS.

Dryopteris radix trita, or poft fudorem inuncts:" Aqua è uiridibus uitum farmentis igne incenfis emase nans admota.

Auripigmentum illitum.

Cyperus babilonicus illitus. Ad capitis furfures.

Salicis foliorum, $\sigma$ corticis decoctum in lotionibus. Myrti baccarum fuccus illitus.

Fel taurinum cum nitro, er cimolia inunctum.

Humana urina inueterata admota.

Adiantum in lixiuio decoctum.

Frenum grecumin lotionibus.

Malua ex urina bumana .

Beta decoctum admotum. $\therefore$

Allij cinis ex melle.

Bulbi cum cremato nitro illiti.

Lilï crematiradix ex melle.

Alumen cum eruo ex pice.

Ad ruffandum capillum.

Iiguftri folia trita, or in radicule fucco macerat a illita.

Iycium illitum.

Iotiligni decoctum in lotionibus admotum.

Vini fex cremata ex lentifcino oleo tota nocte illita. Ad denigrandos capillos.

Cupreßi folia trita ex aceto.

Rbois decoctum admotum.

Mori folia trita ex aceto.

Galle aceto, aut aqua macerate illite.

Palme corticis decoctum admotum, or subinde dee terfum.

Myrti foliorum decoctum in lotionibus.

Acacix fuccus illitus.

Iligne radicis cortex ex aqua coctus, donec mollitu intabe cat $_{\text {, tota nocte illitus. }}$

Hedere corymbi illiti.

saluia decoctum sepius inperfum.

Rubi folia admota.

Sory illitum.

Ad pediculos \& lendes necandos.

Cedria illita.

Myrice decoctum perfusum.

Mel inunctum capiti.

Bete decoctum perfufum.

Allium cum origani decocto potum.

Hedere lachryma illita.

Staphis agria admota.

Sandaracha ex oleo.

Alumen ex aqua.

Ad prohibendum folis aduftionem.

Albumen oui inunctum.

cyclamini fuccus inunetus. 


\section{DECORIS.}

Ad faciei nitorem.

vimi liquor in folliculis contentus illitus.

Mastiche illita.

I upinorum farina illita.

Raparum fylueftrium femen admotum.

Peponis fuccus cum eius femine, or farins in fole fic. catus, o inunctus.

Polygonatum illitum.

Glans unguentaria ex urina.

Ricini femen impofitum.

vitis fylueftris aciniilliti.

Argenti fpums clotainuncta.

Alcyonium primum, $\sigma$ fecundum admotum.

Chia terra impofita.

Crocodiliterrestris fimumillitum.

Ad colorem conciliandum.

Cicer in cibis fumptum.

Agaricum draclme pondere potum.

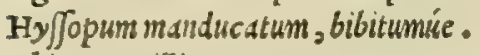

Chia terraillita.

Cerafig gummi illitum.

Carica in cibis fumpte.

Ad faciem derugandam.

Cacalis grana poft excußum florem prodeuntia tris $t a, G$ cum cerato illita.

Bryonie radix cum cruo, creta chia, or fano gres co illita.

Chia terra admota.

Ad cutis vitia in facie.

sabine decoctum perfufum.

Conchule Indic e cinis admotus.

Glans unguentaria trita ex urind .

Cancrorum fluuiatlium cinis illitus.

Narcißi radix cum femine urtice ex aceto.

Ricini femen admotum:

Vitis fylueftris acini illiti.

Cinnamomum ex melle.

Cofti radix cum aqua uel melle illitd.

Bryonie radix per fe, or cum cruo, cretd chid, fano graco adinota.

Alcyonium primum, of jecundum intpofitum. Ad ionthos \& varos.

wirroballita cum melle, er cafia.

Porri folia cum Rhoë obfoniorum loco admota.

Cepe fuccus cum fale appofitus.

Bulbiper fe, or ex oui uitello.

Pulegium ex cera.

Soriex aqua .

Alcyonium primum, or fecundum admotum.

Ad cutis faciei vitia à fole contracta.

Irid is Illyrice radix cum belleboro admota.

Cinnamomum ex melle.

Coft radix cum aqua uel melle itlita.

Amygdale amar e radicum tritarum decoctü admotü.

Ficilac inunctun.

Cochlearum tum caro, tum tefta fimul cremate ex melle.

Ieporinus anguis inuntus.

sepie cremate cinis admotus.

I ini remen illitum.

Orobi farins impofits.

sifymbrium inunctum.
DECORIS.

Bulbicremati cum Alcyonio impointi.

Hedere decocta folia ex uino.

Chameleonis nigriradix.

Alyffum concifum ex melle.

Melia terra inuncta.

Cyclamini fuccus illitus.

Ad lentigines delendas.

1ridis Illyrice radix cun albo ueratro admota.

Cafia ex melle illita.

Coftus ex aqua, er melle.

Sanguis leporinus calens inurctus.

$\therefore \quad$ Tritici furina ex aceto mulfo.

Raphanus cum loliaced farina admotus.

Brafice femen inßerfum.

sifymbrium tritum, er impofitum .

Allij cinis ex melle.

Dracunculi maioris radix ex melle.

Bulbi ex melle, or aceto.

Nigella confricata.

Galbanum cum nitro ex aceto.

Alyffum concifum ex melle.

Narcißi radix cum urtice femine ex decto.

Ricini femenillitum.

Vitis fylueftris acini liniti.

Bryonie radix cum eruo, freno greco, et creta chia.

Adarcesimpofita.

Alcyoniumillitum.

Ad nauos.

Majtiche inperfa.

vlmi liquor in folliculis conclufus illitus.

Butyrum inunctum.

Crocodiliterreftris fimum illitum .

Peponis fuccus cum eius femine, et farind in fole fic= catus ex aqua.

Bryonise radix inuncta.

Cyclamini fuccus inunctus.

Ad cicatrices delendas .

Afininus adeps inunctus.

Fabarum farina cataplajmatis indita.

Ranunculi folia, et radices illita.

Calamintha ex uino decocta admota.

Cucumeris fylueftris radix tritd, et infperfa.

Glans unguentaria cocta in aceto cum nitro adhibita.

Bryonix radix cum Eruo, creta chia, et fano greco admota.

Chryfocolld illite.

Alcyonium primum, et fecundum inunctum.

Ad vitiligines.

Cochlearum terreftrium testa cremate, et illite.

Leporinus Janguis inunctus.

Sepia cremate cinis admotus.

Fabarum farina inßperfa.

I upinorum farina impojita.

Bete cruda folid illita.

Chondrille radix, et folia ex melle, et nitro trita ex aqua.

Dracunculimaioris radix ex melle.

Aphodeliradicis fuccus inunetus, conficicata prius sub fole cute.

Cape fuccus in fole inunetus.

Alliy cinis ex melle. 


\section{E C R I S.}

Piper cum nitro impofitum.

Cappar.s radix trita ex aceto.

Argemone ficcata, tufáğ chms nitro, e uino fulphu= re admota.

Telepbii folia cum hordeacea farina ex bydreleo fex. boris admota.

Gentiane radicis fuccus inunclus.

Chamaleonis nigriradix cum fulphure illita.

Ruta cum uino, pipere, nitroq; confricata.

Libanot is femen ex acerrimo aceto.

Iilij cremata radix ex.melle.

Nymphea radix ex aqua:

Rubie radix ex aceto.

Althe femen tum recens, tum ficcum tritum ex ace to, in fole inunctum:

Ancluses radix ex aceto.

Narcißi radix cum urtica femine ex doeto.

Bryonia cum Eruo, creta chia, o foeno graco itlita.

Glans unguentaria in aceto decocta cü nitro impofita.

Cucumeris fyluestris radix trita, or inperfa.

Ricini femen illitum.

Veratrunz nigrum ex aceto.

Sulphur quoquo modo admotum.

Alcyonium prinum, of fecundun inunetume.

Ad lychenas, \& impetigines.

Pini, er picee cortex illitus.

Ientif ci foliorum decoctum fotu adhibitum.

Cupreßi folia cum polenta illita.

Rhamni folid admota.

Iignorum marcor inperfus.

Nafturtii femen admotum.

Rhaponticum ex aceto itlitum.

Veratrum nigrum ex aceto illitum.

Glanisunguentaria cum lotio impofita .

vitis uinifere gummi cum nitro illitum, loco tamen prius perfricato.

sulphur ex terebinthina refina.

Sal exoleo, es dceto perfrictum.

Alcyonium primum, er fecundum impofitums.

Adarcesillita.

Pix liquida inuncta.

Thus inperfum.

Acthyopice olea lachryma inunded.

Pruni arboris gummi illitum.

Ficulneum lac cum polenta illitum.

Mel cum alumme decoctumillitum .

Propolis inuncta.

Triticeus recens panis ex muria.

Ioliaced farina cum fulphure ex uino .

Cicer cuim bordeo ex melle.

Iapathi cuiufque radices in aceto decocte, loco prius fcarificato, o nitre confricato appofita.

Nafturtium ex melle appofitum.

Allij cinis ex melle illitus.

Sinapi ex ace to linitum.

Chameleonis nigre radix ex aceto coctd, or inunctd.

Ruta cum alumine $\mathrm{ex}$ melle.

I aferpiiij liquor ex aceto.

Glutinum in aceto folutum inunctum.

Cucumeris fylueftris radix trita, o inperfa.

Tuthymalicharacie lac illitum.

Bryonix radix cum Eruo, creta cbia, o fano gres co illita.

Aqua maris fotu adbibitd.

Ad papulas.

I ac omne potum cum crudo melte, admixta dqua,, 0 exiguo fale.

sẹrumlactis potum.

Acetum applicatum.

Butyrumillitum.

Vrinabumana inueterata:

L upinorum farina admota.

Cyclamini fuccus adlibitus.

$\mathbf{P}$ ulegij decoctum corpori perfufum.

Ruta cun cera; $\mathcal{E}$ myrteo oleo cataplafmati indita .

Staphis agria illita.

Glans unguentaria cum lotio linita.

Rubigo ferritilita.

Alumen cum melle.

Cinnabaris, Ideft fanguis draconis adbibitus.

Fornacee tefta tosta admote.

Ad alphos, \& cutis maculas.

Thapfise fuccus cum melle illitus.

Glans unguentaria cum lotio linita.

Narcifi radix cum femine urtica ex dceto.

Iotus fylueftris cum melle perunctus.

Cucumeris fylueftris puluerizata radix impofita.

Ricini feinen illitum.

Vitis fylueftris acini liniti.

Bryonia cum eruo, creta chia, o fano greco illita. Ad proram.

Staphis agria trita ex oleo illita.

Bryonice femen inunctum.

Aqua marina fotu adhibita.

Glans unguentaria in aceto cond.

Sal illitum.

\section{Ad fabiem.}

Cardamomum ex accto illitum.

Olex uirentis, o accenfe fudor manans illitus.

Ficulneum lac inunctum.

Erindcci marini tefta cruda, teft aúe cum alijs miffa, o illita.

Hippocampi marini cremati cinis liquida pice, dxun= gialie, aut amaracino unguento coactus, or capi= ti inunctus.

Vrina bumand inueteratd.

Serum lactis potum.

Cicer cum bordeo, er melle.

I supinorum farina.

Argemone ficcata, tufa $\alpha_{;}$cum nitro in balneo cons fricata.

Hirundinaria minor confricata.

Chameleonis nigri radix addito exiguo atramento form torio, cedrinoó; liquore, er axungia pauco linita. Quin etiam fulphure, or alumine miftis.

Glans unguentaria cum lotio linita.

Origani decoctum corpori perfufum .

Quinquefolij radix decocta, linitaq́.

Potamogeton ualet pruritui impofita.

Iotus fylueftris cum melle peruncta.

Veratrum nigrum linitum cum cerd, pice, or cedrie no oleo.

Stimmi cum cera, o exigua cerufJa.

Alumen sum aqua aperfum aduer fus pruritum. 
DECOR I S.

Adlepram grxcorum.

Fel taurinum cum nitro, o cimolia.

Vrind bumand addito nitro fota.

Inniperi cortex crematus $\mathrm{ex}$ aquu.

Fraxini cortex crematus ex aqua.

vlmi folia concifa ex aceto.

Aethyopice olea lacbryma illita.

$\operatorname{Refind}\left\{\begin{array}{l}\text { Tcrebinthind } \\ \text { Larign } \\ \text { Abicgin }\end{array}\right\}$ cun arugine, chalcans

Ficulne um lac cum polenta.

Triticei furfures ex accrrimo aceto elixi.

Hordci farind ex dceto acerrimo, of bydreleo.

Ioliif frind cum fulphure ex uino, o aceto.

Iapathicuinfque radices, loco prius facrificato, wr ni tro confricuto admota.

Braßica concifa cum polenta adibibitdo

Veratrumb nitrume ex aceto.

Allij cinis ex melle.

Simapi ex aceto.

Bryonie femen illitun.

Nafturtium ex melle.

Anchure r.dix ex aceto.

Ranunculifolia, or radices appofita.

Melanthij femen admotun.

Cucumeris agrefis rudix in "puluerem aperfa .

Glans unguentaria coita in accto cum nitro.

Thap/ise fuccus inunctus.

Scammonis in aceto decocta illita.

Vitis uinifere gummi admotum, loco tamen prius nitzo perfricto.

Aerugo cum nitro ex terebinthina refina.

Alumen cum braßica, or melle coctum.

Șulfur exrefina terebinthind, or aceto. . $\quad \therefore$

Sal ex oleo, or aceto feruefactum.

Alcyonium primum er fecundum illitum.

Adarcesimpo/ita.

Melia terra illits.

Ad pruritum .

Ficulneum lac ddmotum cum polentd.

sulphur ex nitro.

Sal exoleo, et aceto perfrittim.

Alumen cum aqua aperfum. Ad elephantiafim.

Erinacei terreftris exiccatü corpus in cibis fumptum:"

Cedria inuncta.

Cochlearum terreftrium cinisillitus.

Salamädra alijs conferétibus medicamétibus admixta. Serum lactis potum.

Fel $\left\{\begin{array}{l}\text { Caprasflueftris } \\ \text { Hircinum. }\end{array}\right\}$ inunctum.

Calamintha in cibis fero lattis fuperpofito.

Ad clauos, callos \& verrucas.

salicis corticis cinis admifto aceto maceratus illitus. smaridis pifcis faliti crematum caput.

Iacerte concifum caput.

Ouillum fimum ex aceto.

Mel cum alumine deco tum.
DECORIS.

Cicerung grana tot accipe, quot funt porri, et fingulis granis fingulas tange uerrucds, deinde liga girana. cicerum in linteolo, o poft tergum proijce, o boc non fiat nifinoud lusa.

Heliotropiif fenen linitum.

scilla cremata peruncta.

Ranunculifolia, et radices.

Dipfaci radix in uino decocta, tufa, et impo/ita.

Nigella ex uetere urina impojita, loco prius fearificato.

I aferpitij liquor cera pr.emollitus impofitus, fcarifia catione prius facta.

Clinopodium diebus aliquot potum.

Chamefices ramitriti, et impofiti.

Vitis farmentorum uiridium incenforum emanăs aqqua.

Acrugo impofita.

$$
\text { Ad acrochordonas, \& thymos \& }
$$
myrmecias .

Mali punici uinum adbibitum.

Iac ficulneum cum adipe circa adiacentem carnem illitum.

Thus ex aceto, et pice ittitum.

Ruta cum pipere, uino, et nitro affrict.

Cicer cum hordeo, et melle.

Ranuinculifolia, etradeces.

Dipfaciradix trita in uino decocta.

Tithymali chardcie fuccus, et lac illitum.

Chamejyces rami triti, et impofiti.

Heliotropij Semen linitum. Quin et heliotropiu minus.

vitium uiniferarum farmètorum wiridium incenforum emanans aqua illita .

Sal cum Seno uitulino illitum. Ad alarum tædia.

Myrrba cum liquido alwmine illita.

inyrtif folionum arentium farina inperfa.

Cardui radix cataplafmatis more adbibita.

Alumen Tinitum.

Ad labiorum rimas.

Adeps $\left\{\begin{array}{l}\text { Anferinus } \\ \text { Gallinaceus }\end{array}\right\}$ illitus.

Iycium adinotum. Ad fudorem ciendum.

Ferule femen ex oleo inunctim.

Onobrychis ex oleo inuncta.

Mel Heraclium quodam anni tempore deworatum.

Fici mature comefe.

Sinapi in cibum fumptum.

Bulbicomefti.

Ad fudorem compefcendum.

sulphiur confricatum.

Gypfum

Morochthus lapis $\}$ admota.

Samia terra.

Ad exterendam cutim.

Cyclaminiradix inuncta.

Ad extrahendum exalto.

$\left.\begin{array}{l}\text { Mel } \\ \text { Sinapi }\end{array}\right\}$ appojitum. 


\title{
SIMPLICIVM MEDICAMENTORVM VIRES. Quibus exuberantes in corpore humores vomitu \& alui deie- ctione excernuntur, ex Diofcoride .
}

\author{
EX P E L L E N T V M MEDICA M E N.
}

Ad bilem educendam .

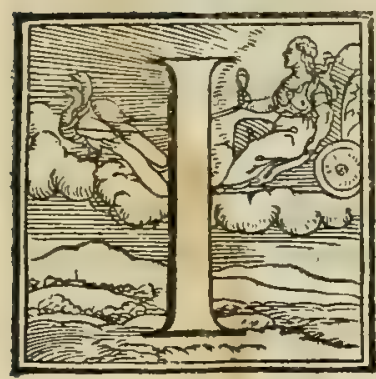

R I I Ilyricadrachmas rum feptem pondere ex bydromelite pota. Thlapifemen potum. Aloè bausta. Ab/inthiü potui datum. Tragoriganidecoctü bi= bitum:

Iychnidis fylueftris fee men drachmarum duarum pondere potum.

Androfemi femen duarum dracbmarum pondere batu ftum.

Veratrum nigrum per fe datum, aut ex Scămonia cum Salis dracbma.

Pycnocomi radix duarum drachmaram pondere ex $d=$ qua mulja.

Centaurium minus decoctum deuoratum.

Parthenium ficcatum cum aceto mulfo, aut fale.

Thapfe lacteus fuccus in aqua mulfa potus.

clematidis alterius femen tritum potum.

se famoides tritum datum.

Cucumeris fylueftris radicis fuccus, er cortex fexqui= oboli pondere bibitus.

Hippophe fuccus oboli pondere potus.

Ricini triginta grana purgata trita baufta.

Titbymalorü omniü succus binis obolis in pofca potus.

Mercurialis ius potum.

I atbyris grand $\int e x$ at $\int e p t e m$ cum fic is aut palmulis in catapotio deuorata.

Peplus in bydromelitis cyatho potus.

scämonij Juccus drachme unius, aut quaternum obolo rum pondere hauftus ex aqua mul $\sqrt{a}$, uel pura.

Chamelex folia in catapotijs deuorata cum duabus $a b=$ finthijpartibus adiecta chamelea und cum bydro= melite.

Thymelex uigintigranorum pars interna bibita.

Folia $\left\{\begin{array}{l}\text { sambuci } \\ \text { Ebuli }\end{array}\right\}$ olerum more cocta.

A pios, fclicet inferior pars denorata.

Empetrum in iure aliquo aut bydromelite potum.

Filicule aride farina aqua mulfa inper fa bibita.

cynocambe decoctum hauftum.

Hcliotropij decoctum ex aqua potum.

Agarici drachma una uel altera cum mulfa bibita.

Pityufe radix drachmarum duarum pondere cum mul fa baufta, feminis ueró drachma, or fucci cum fari= na fubacti cochlearium in catapotio.

Ad pituitam eijciendam.

Iris Illyrica drachmarum feptem ponderè ex bydros melite.

Mandragora fuccus duorum obolorum pödere potus.

Veratrum nigrum per fe datum, uel cum fcammonia cum falis drachind.

Iycij Indicifenen cyatbi dinidij menfura potum.
Vlmi craßior cortex in uino, aut aqud frigida unciatim potus.

Gallinaceorum fenefcentium ius Diofcoridis modo pan ratum, bauftum.

Cyclamini radix ex bydromelite pots.

scilla curin melle cocta pots.

Hy) Jopi decoctum ex aqua, melle, or ruta potum.

Thyinum cum fale, or aceto hauftum.

sphondilijfemess potum.

Amnoniacun drachme pondere bibitum.

Daphnoides folium recens, uel aridum potum.

Hippopheftifuccus trium obolorum pondere ebibitus. Epithymum potum cum melle.

Bryonix fuccus cum aqua mulfa.

Cnici feminis fuccus cum mulfo, tuel iure gallinaceo.

Magnes trium obolorum pondere cum mul $\int a$.

Centaurij minoris decotum deuoratum.

Parthenium ficcatum cum aceto mulfo, aut fale potum.

Clematidis alterius femen tritum, potum.

Sefamoides tritum datum.

Cucumeris fylueftris radic is fuccus, er cortex $\int e$ qquioa bolipondere bibitus.

Hippophdis fuccus oboli pondere potus.

Ricinigrana triginta trita epota.

Tithymalorum omnium fuccus binis obolis in pofca potus.

Iathyris grana fex, aut feptem in catapotio cum ficis. aut palmulis deuordta.

Peplus in bydromelitis cyatho potus.

Scaimmonij fuccus drachme unius, aut quaternum obo lorum pondere bauftus ex aqua pura uel mulfa.

Chamelex folia in catapotijs deuorata cum duabus $a b=$ fintbij partibus, adiecta chamelea unà cum bydrox melite.

Thymelex uigintigranorum pars interior bibita.

Folia $\left\{\begin{array}{l}\text { Sambuci } \\ \text { Ebuli }\end{array}\right\}$ olerum more cocta.

Apij inferior pars deuorata .

Empetrum in iure aliquo, aut bydromelite.

Filicule aride farina aqua mulfa infper fa haufta.

Cynocrambx decoctum bibitum.

Heliotropij decoctum ex aqua potum.

Agarici drachma una, aut altera cum mulfa bibita .

Pityufe radix drachmarum duarum pondere cum mul fa, e feminis drachma, fucci uero cum farina fubaEti cochlearium in catapotio exbibita.

Ad atram bilem pellendam .

Mandragore fuscus potus duorum obolorum pondea re ex mulfo.

Gallinaceorum fene fcentium ius Diofcoridis modo pan ratum bauftum.

Epithymum ex melle hauftum.

Serum lactis potum.

Origanum ficcum acetabuli menfura potume ex mulfa.

Pulegium bibitum.

Helleborum 


\section{EX P E L E N T IV M MEDICA M E N.}

Helleborum nigrum haustum.

spartium epotum.

Alypum menfura epitbymo paricum fale, 0 aceto fumptum.

Ad vomitum ciendum.

Thlapi potum bilem rubeam educit.

Mandragora pota atram bilem.

Thapfie lateus fuccus in mulfa bibitus.

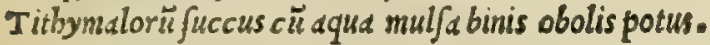

Apij fuperior pars deuorata.

spartijfores, or femina in mulfa pota.

Anagyris femen commanducatum.

Betonice radices ex bydromelite pote, pituitam eije ciunt.

$\boldsymbol{P}$ spaueris pumei femen in mulfa acetabuli menfurs potum.

Stapbidis agrie grana quindecim in mulfa data.

silybiradicis drachma pota.

Glans unguentarid cum bydromelice.

Narcifir adix cocta, efta, feu bubita.

Ricini grana triginta baufta.

Rapbani cortex ex aceto mulfo potus.

Titbymalorum omnium fuccus potus.

Aes ufum cum bydromelite bibitum.

Adaquam intercutem pellendam.

Cyclamini radix ex bydromelite haufta.

Polijdecoctum bibitum.

Hippopheftifuccus trium obolorum pendere potus.

Hippophais fuccus oboli pondere potus.

Ricinigrand triginta pota.

Latbyris cuiusó; grana $\int e x$, aut feptein in catapotio cum ficis, aut palmulis deuorata.

$\left.\begin{array}{l}\text { Sambuci } \\ \text { Ebuli }\end{array}\right\}$ folid olerum more cocta.

Empetrum in iure aliquo, dut bydromelite bauftum.

Cynocrambe decoctum potum.

A Jarum bibitum.

Iactuce fjlueftris fuccus in aceto mulfo potus.
Trifolij radix drachmarum duarum pondere in uino bibita.

Titbymalorum fuccus bibitus.

Thymelex uiginti granorum pondere pars interna bibita.

Vitis fylueftris radix feruefacta in aqua in cyathis duo bus uini aqua marina diluti, pota.

squamma eris ex aqua mulla haufta.

Mercurialis decocte ius potum.

Ad aluum emolliendam.

Cerafia recentia manducata.

Pruna in cibis fumpta.

silique devorate.

Ficimature deglutite.

Lac ficulneum potum.

Chamarum pifcium ius potum.

Vnguis odoratus ebibitus.

Raphanus comeftus.

Beta alba devorata.

$\therefore \quad$ Blitum comeftun.

Rumicis cuius q́; decoctum potum. Quin er ip $\int$ berba decocta deuorata.

Malua in cibo Jumpta.

Atriplex manducatum.

Braßica leuiter ferue fact d comefta.

Lentis decorticate decoctum primum haftum.

Aßparagorum cauliculi in cibum accepti.

Cucurbite integre feruefacte expreffus fuccus potus.

Gingiber quoquo modo fumptum.

Peucedanum potum.

Scillum ficce cocblear unum, aut alterum ieiunis datü. Androfemi femen tritum potum.

Helxines foliorum fuccus baftus.

Papaueris erratici femina acetabuli pondere ex mulfa aqua pota.

Cynogloßidecoctum bauftum.

Chamafices rami decocti,er in cibum fumpti.

Bryonix cduliculi recĕtes cocti, $\sigma$ in cibum devorati.

\section{Menfurarum \& Ponderum Typi ad Diofcoridis mentem. Ex Galeno.}

\begin{tabular}{|c|c|c|}
\hline & & \\
\hline & siliqua & Chalcum unum \\
\hline & Aegyptiafabe & $\begin{array}{l}\text { Chalcum unum er } \\
\text { Chalcos duos }\end{array}$ \\
\hline & obolus & Chalcostres \\
\hline & scrupulus & Obolos duos \\
\hline & Drachma & Scrupulos tres \\
\hline & Vncia & Drachmas octo \\
\hline & Acetabulum & Drachmas quindecin \\
\hline & Nux $\{$ Regia & Vncias Septem \\
\hline & Lonticat & $\begin{array}{l}\text { Vnciam unam } \\
\text { Vnciss duodecim }\end{array}$ \\
\hline & rMedicorum & Vncias.fexdecim \\
\hline & a $\left\{\begin{array}{l}\text { Italica } \\
\text { Alexandrind }\end{array}\right.$ & $\begin{array}{l}\text { Vncias decemer octo } \\
\text { Vncias uiginti. }\end{array}$ \\
\hline
\end{tabular}




\section{DE ARIDORVM MENSVRIS.}

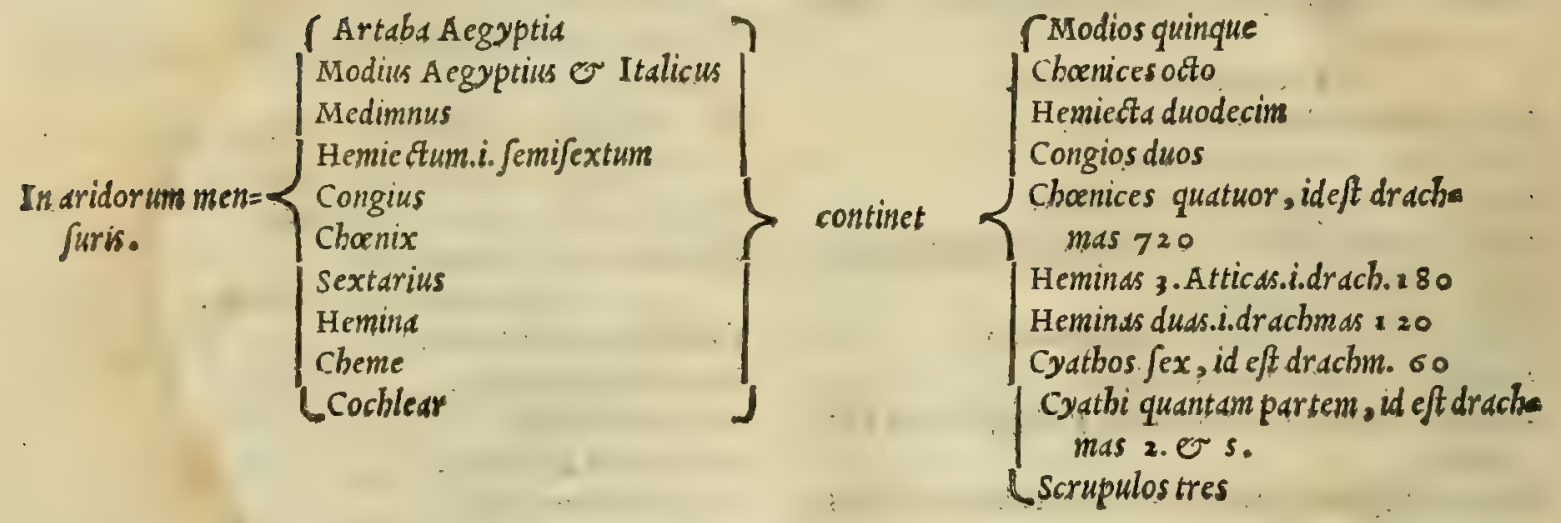

\section{Ponderum \& Menfurarum Liquidorum ratio.}

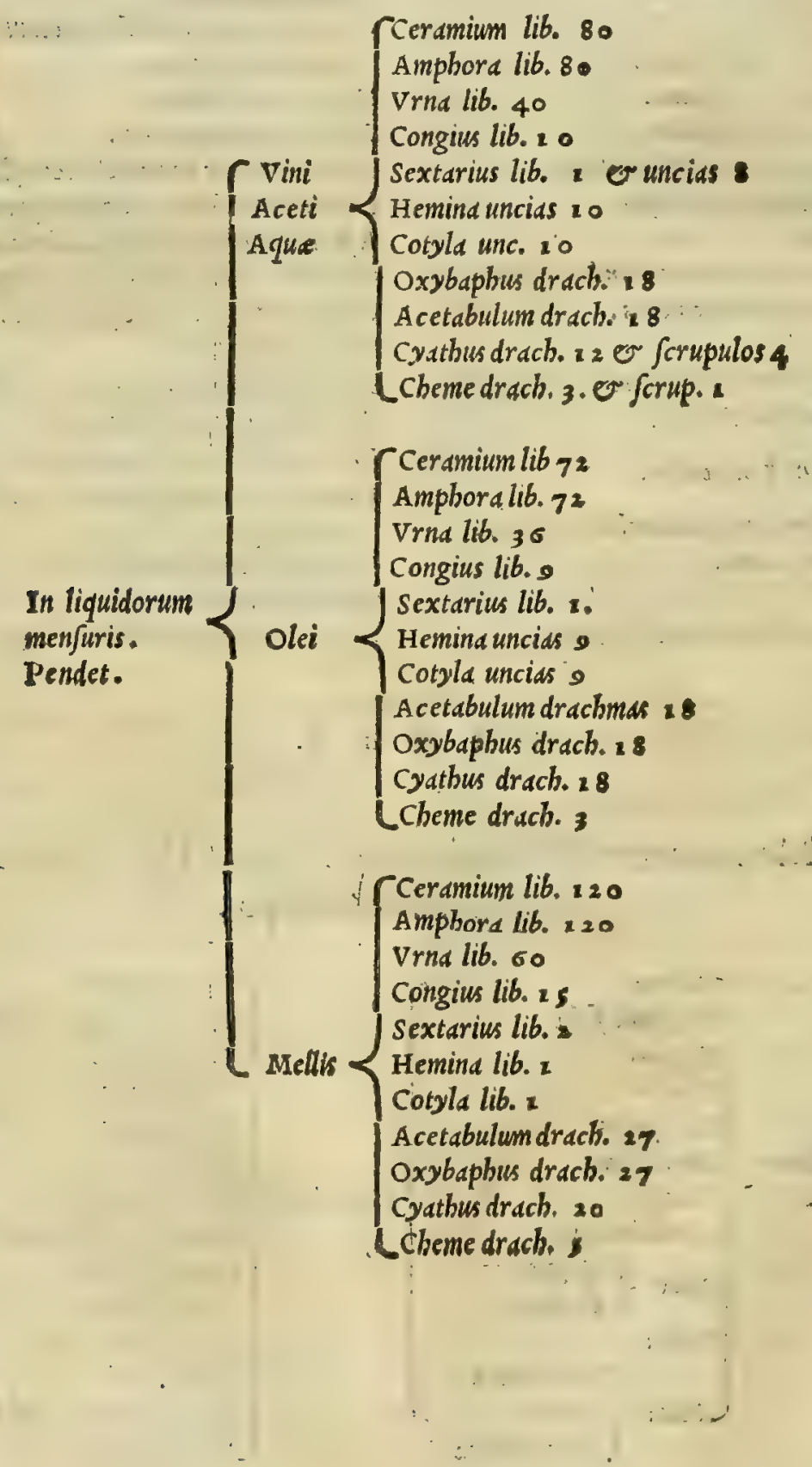


 \\ PETR I A NDREAE MATTHIOLI MEDICI Senenfis Commentarii,
}

\author{
IN LIB. PRIMVM PEDACII DIOSCORIDIS
}

A NAZARBEI, DE MEDICA MATERIA.

\section{Prxfatio Diofcoridis.}

20

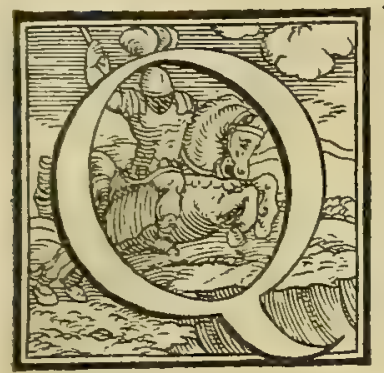

V A N QV A M, amicifsime Aree, complures non veterum modo, fed recentiorum quoque, de medicamentorum compofitione, uiribus, atq; probatione fcripferunt; nobis tamen nec uanum, nec à ratione abhorrentem impetum animi ad hoc opus incefsiffe, tibi oftendere tentabimus . propterea quòd eorum nonnulli abfolutum nihil ediderunt, alij plurima, vt ex narratione acceperant, fcriptis tradiderunt. Siquidem Bithynus. Iolas, \& Heraclides Tarentinus, omiffa prorfus herbarum tractatione, rem ipfam paucis perftrinxerunt , neque verò omnes illi de metallicis quicquam rebus, aut odoramentis memorix prodidcrunt. Crateuas autem herbarius, $\&$ Andreas medicus, qui cæteris diligentius hac in parte verfati videntur, radices multas apprimè vit30 les, herbasq́ue aliquas haud quaquam adnotatas reliquerunt. Veruntamen prifcorum fubfcribere oportet fententijs : quos, etfi pauca ipfis referantur accepta, magnam tamen impendiffe diligentram conftat. Iunoribus minus affentiendum : è quibus eft Iulius Baffus, \& Niceratus, \& Pctronius Niger, \& Diodotus, Afclepiadæ omnes, qui medicinalem materiam vernaculam, cognitamq́ue vulgò, dignam cenfuerunt, quæ ab ipfis literis exactè mandaretur: \& vt medicamentorum uires, probationesq́ue curfim complexi, fic nullo experimento eorum effectus colligentes, inani uerò reddendarum caufarum ftudio uerba fundentes, alia interdum pro alijs fcriptitando, $t$ rem in aceruum, congerıemq́ue controuerfiarum extulerunt. Siquidem qui inter eos cgregius habetur Niger, euphorbium nafcentis in Italia chamelæx fuccum effe contendit: androfxmonq́ue eandem herbam cum hy perico effe: quinetiam aloën in Iudæa fofsilem nafci : \& pleraque his fimilıa falsò exponit, qux prorfus ueritati refragantur. Quibus coniectura colligi poteft, ea non ołculata fide, fed narratione potius ab alijs accepiffe. In ordine preterea ijdem ipfi aberrarunt, partim eorum difcrepantes, nullaque cognatione coniunctas uires collidentes : partim per elementa literarum fcripta in ordinem digerentes, quò facilius memoriæ mandarentur, genera \& eoram effcetus à fua cognatione difiungentes. Nos uerò ab ineunte, ut ita dicam, iuuenta, iugi defiderio cognofcendx materiæ allecti, multis regionibus peragratis ( nec enim nefcis nos militarem uitam exegiffe) tuo hortatu commentationem in fex libros contulimus. Quod opus tibi dicamus, Aree, animi gratitudine obfequentes, ob eum quo nos - profequeris affe ¿̂u . Etenim natura cùm in omnes eruditione excultos, tum uerò in eos, quibus cum tibi eiufdem artis necefsitudo intercedit, pronus ad amicitiam effe foles, in nos etiam aliquantò peculiarius. Enimuero non paruum prębet tuæ probitatis argumentum, optimi uiri Licinij Bafsi fingularis erga te amicitia : quam unà nobifcum degentes nouimus, cùm mutuam inter uos beneuolentiam æmulatione dignam intueremur. Admonitum autem te uelim, eosćue qui in hofce commentarios incident, ne in uerbis facultatem noftram xttimetis, fed potius adhibitam rebus cum peritia curam. Etenim plurima uifu ipfi exactifsimè cognouimus : quædam etiam ex ea, de qua inter omnes conuenit, hiftoria, percunctationeq́ue rerum apud fingulos vernacularum, diligenter accepimus. Dabimus igitur operam, ut differenti ab alijs ordine tradito, genera fingularum medicinarum, uiresq́ue defcribantur. Quòd autem neceffaria fit medicamentorum doctrina, nemo eft ferme qui ignoret: quòd ea \& toti arti coniuncta fit, vniuerfisq́ue eius partibus efficax adminiftret auxilium. Quare per medicamentorum compofitiones, atque mifturas, \& facta in morbis pericula exten$\mathrm{di}, \&$ incrementum capeffere poteft, plurimùm conferente fingulorum medicaminum cognitione. Quinetiam uernaculam, familiaremq́ue materiam complectemur, ut perfecta fit, qux a nobis relinquetur, doctrina. Verùm in primis curam impendere oportet, ut fuis temporibus fingula \& de- 
metantur, \& recondantur . certè pro horum ratione, medicamenta aut ualent uiribus, aut euanido nulloq́ue munere funguntur. Serena igitur cxli conftitutione demetenda funt . magni fiquidem refert inter colligendum, fi ucl fqualores, uel imbres infefti fint: quemadmodum fi loca, in quibus prodeunt, cliuora, $\&$ uentis expofita fint, \& perfata, frigidaque, \& aquis carentia : in his enim locis uires eorum longè ualidiores intelliguntur. Contrà, qux in campeltribus, riguis, \& opacis, creterisq́ue locis à ueino filentibus enafcuntur, plerunque degenerant, \& minus uiribus ualent : multoq́ue magis, fi non fuo tempore, nec opportunè colligantu:, aut fi per imbecillitatem intabuerint. Neque ignorandum, hæc fæpe pro peculiari loci natura,aut anni clementia, maturius, aut ferius adolefcere nonnulla propria ui hyeme forent, $\&$ folia pariunt: quædam bis anno florifera. Quare cui in animo eft horum peritiam alfequi, neceffe eft eum prima germinatione folo emergentibus, adultis, \& fenefcentibus adeffe. Nam qui pullulanti herbæ duntaxat adftiterit, adultam cognofcere non poteft : neque qui adulcam tantìm infpexerit, nuper erumpentem nofcet. Quo fit, ut propter mutatam foliorum faciem, caulium proceritates, florum feminisqúc magnitudinem, \& id genus alias peculiares notas, nonnulli, qui olim has rerum uarietates non perfpexerunt, magno in errore uerfentur. Qure caufa etiam nonnullis fcriptoribus impofuit, qui herbas quafdam, uerbi gratia, gramen, quinquefolium, \& tufsilaginem emittere forem, fructum, \& caulem negant . Ergo qui frpius ad uifendas herbas, \& carum natales fe contulerit, earum cognnitionem maximè confequetur. Scire etiámnum conuenit, fola ex herbaceis medicaminibus veratri genera, nig:um, inquam, \& candidum, multis edurare anris : reliqua à trimatu inutilia . Quæ verò fruticofa funt, ficut ftœchas, triffago, polium, abrotonum, feriphum, abfinthium, hyffopum, \& alia id genus femine prægnantia demetantur. Flo- $=0$ res quoque antea, quàm fponte fua decidant. Fruetus autem, ut maturi deccrpantur, neceffe eft : \& femina, vbi ficcari cœperint, priufquàm defluant. Herbarum ftccus, \& foliorum elici debet, germinantibus tum primum cauliculis . Lac, \& lacrymæexcipiantur, incifo per fummum adolefcentix uigorem caule. Radices, \& liquamenta, corticésve ut recondantur, eximere conuenit, cùm herbæ fuis folijs exuuntur. ficcantur etiam expurgatæ inibi, locis afperginem non redolentibus : fed qux luto, aut puluere funt obfitx, aqua elui debent. Flores, \& omnia, quæ iucundum odorem efflant, arculis tiliaceis, nullo fitu obductis, reponantur. Nonnunquam charta, aut folijs femina, ut perennent, aptè inuoluuntur . Liquidis medicaminibus denfior materia, argentea, uitrea, aut cornea contenit . Fietilis etiam, fi modò rara non fit, accommodatur : \& lignea, præfertim è buxo: fed ænea uala ocularijs medicamentis, liquidisq́ue, 8 omnibus ijs, quæ aceto, pice liquida, aut cedria componuntur . Adi- 30 pem autem, \& medullas ftagneis tafis recondi conuenit.

\section{O M M E T A R I V S M A T T H I O I I.}

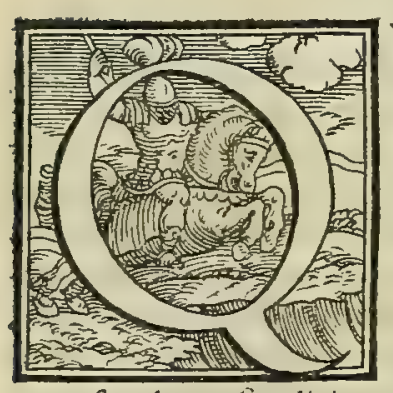

V A N T V M oporteat Medicosomnes, qui legitimum in arte nomen fibicompard= reftudent, smplicium quorumcunq; medicamentorum, que medicine ufui competunt, cognitionem, ac facultatem fenfibus exacté confequi, non modó hac pref fatione decla= rat Diofcorites Andzarbeus in bac materia cateris facile princeps; fed id quoq; poft Diofcoridě adnnirabili doctrina pluribus in locis memoris prodidit grakißinns auctor Galenus:qqui hac in re pre cateris Diof coridë fecutus(ut eius luculentißima monumen= ta paßim atteftantur) in fimplicium medicamentorum uiribus, ac facultatib.indagand is, relifta (boc etiam ipse fatetur) Diofcoridi hiftoriarü palma, omnes, qui in bac materia fcripferunt, longé admodum fuperauit. Quippe tanta animi propenfione oblectationeq́; cognofcendorun /implicium captus fuit ( fciebat enim non poffe rité fe dici medicum fine eorum fcientia) ut nullo ma= Galeni naui - gni laboris metu, null is periculis deterritus, in Lemnum, Cyprum, Syriam nauigauerit, atq; alias plurimas peragraue= gationes, ut le ritregiones, ea demum caufa, ut que legittina et fyncer a, quéq; fpurid o adulter ata effent medicamenti, certò digno gitima cogno fere pofet. Quapropter lib. I I I.de medic.contp.per genera ita fcriptum reliquit. Hinc enim puto bona indolis iuue= Iceret fimpli- nes incitatum iri, ut medicamentorum materiä cognofcant, ip fimet inpicientes, non femel aut bis, fed frequenter: quo=
cia. niam fenfibilium rerum cognitio fedula inppectione perficitur. cuius rei euidentißinum eft indicium, quód gemini per omnia fimiles effe nobis uideantur, differentes autem $i{ }^{5}$, qui ipjos infficere confuewerunt. Itaq; berbarum, fruticum, e arborum materiam, priufquim è terra eximantur, contemplari pulcherrimü eft, dum fructus videlicet futuri funt, dum eduntur, dum ange fcunt, er dum uigent. Hee fíquidem continua corum peculatio docebit te, quando potisimùm ipfos commodé decerpas, ac in ficc is domunculis repofitos cuftodius. Vos ergo admoneo, amic $i$, st in boc quoq; me $\int e=$ quamini, fi artis opera pulchre obire uolueritis. Nouiftis enim, quomodo ex omni natione praftantißima quot:annis mi

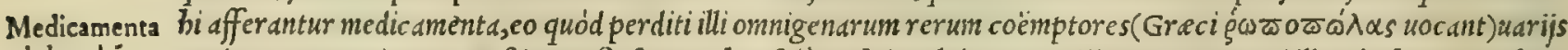
adulterabärur modis ea contaminant. Praftiterat forfan non hos folium, fed multo magis etiä mercatores, qui illa aduelıunt, incufare, etiam Galeni atq; bis multó magis ipfos berbarios.item nibil minus eos, qui radicü liquores, fuccos, fiuctus, flores, o germina ex tempore.

montibus in urbes conferunt : hi fiquidem onnium primi in eis dolum exercent. Quifquis igitur duxiliorum undiq; $c 0=$ piam babere uolet, omnis materie ftirpium, avimaliu, o metallorum, tum aliorum terreftrum corporum, qua ad nie= dicine ufum ducimus, expertus efto, ut ex eis ct cxact a, et notha cognof cat. Nific crim hoc modo inftructus ad pref entis operis prefidia ueniat, uerbótenus quidem medendi methodum fciet, opus ueró nüllum ipfa dignum perficiet. Et prumo 


\section{In Lib. primum Diofcoridis.}

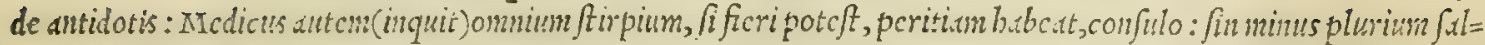
tem, qubus frequenter itimur. Earungenera quifquis toto etatis illarum decirfu noucrit, multis in partilus or= bis terarun reperet, ut cgo in Iralix multis in locis inueni: que ncc quando pullulant, nec quando crefcunt, no=

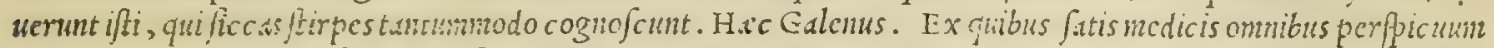

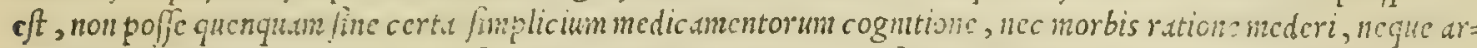

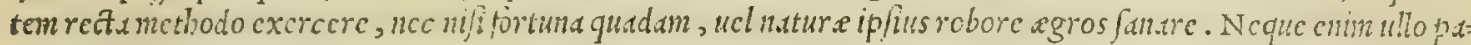

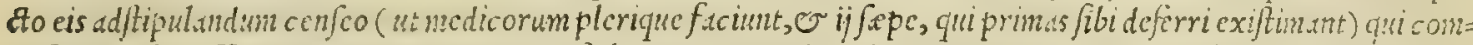

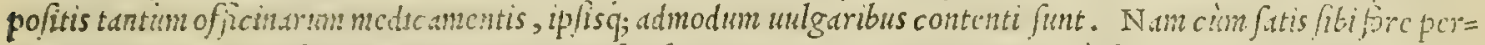

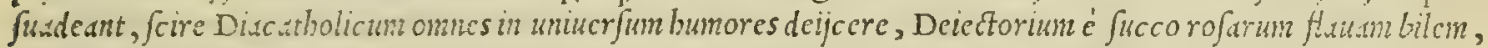

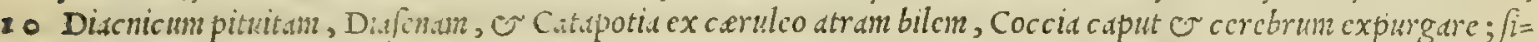
cuti, qux Lucidsmuncupan, oculis, of qux cx bcrmodactylis dicuntur, ac qux Fetida uocantur, ditbriticis cf fe peridonca, mbilultru requirunt: quin potius fcire negligunt, é quibus ca funplicibus componsmtur medicamen= ta, or an ijs cen inlint uircs, quet fuis nominibus pollicentur. an fimplicia, quibus confantur, lcgitinu fint an fou=

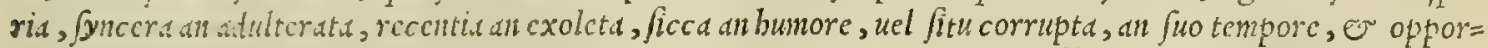
tunc deccspta, folc ficcats an mibrs, anigne, ut fepius in temporis angufis officinis fieri folct. Ncquc un= quam animaduertunt, quod dcicizorijs medicanentis, que noftro suo parantur ad bilem deijciendan, fenzper Scsmmonium late tithymalor:m, ac pityuf adulteratum, magno agrorum detrimento immifccut. Iis ueró, que pituiranducint, fepelcgirmi Turperiloco, modo pityufe, modó thapfice, modó peonia radicum cortices inipo= munt, qux intpojtorinu ungonis ita Tuspetum referunt, ut non feplafiariorun modó, fed etiam medicorum quo=

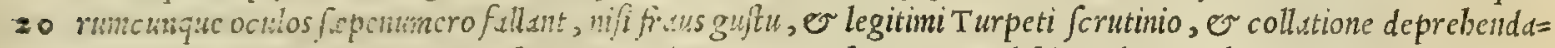

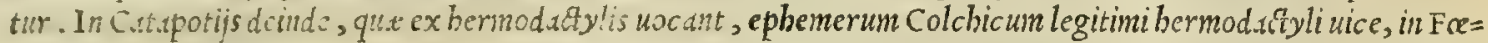

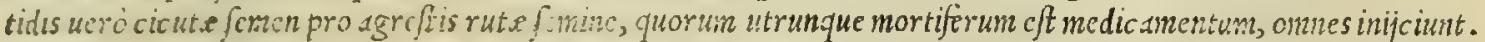

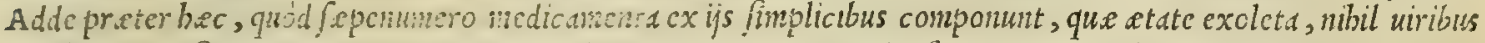

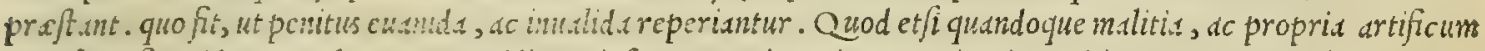

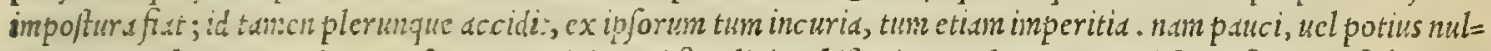

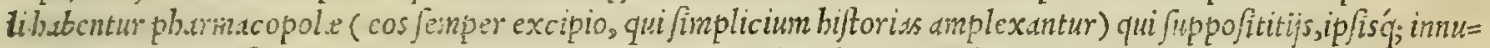
meris non utantur finnlicibus. Nanguc afouro utuntur pro bacchare, cytifo pro trifolio, fyluefri loto pro fertula Campana, coluteapro fan, acoro odorati calaniaice, cypero pro galanga, bieracio pro foncho, Bbondylio pro as cantho, chondrilla pro cichorio, agreflilactaca pro intubo, opbiofcorodo pro fcordio, quibufdan arborum lacry= 30 misprofuccino, thapfia pro turpeto, pice pio pifaphalto, refina larigna pro abiegna, co leginm.1 terebintbina, phyllitide pro afbleno, objcuris quibujdam ráicibus pro meo, peucedano, $\mathrm{O}$ cofto. Ad bec calixin pro cinnumomo ufurpant, fantala pro afpalabo, laccam ex brafilio er cocco infectorio confectam pro cancano, $\mathrm{R}$ bodium olesfrum pro agallocbo, of a caricm bumanam pro mumia, macim pro macere, chartan pro pepyro, crcpinum (fic enin uulgó uocant aculeatam quandan plantam ) pro oxyacantba, conuoluulum, fiue leuem fmilacem pro liguftro, agre= fium prunorun juccum pro acacia, fuccun ueró baccarum ligufri, e periclymeni pro lycio, nuces, quas A rabes uo= micas appellant, prometells ita :ocatis, cancros proganmaris, ranunculum pro coronopo, faponarian unlgo di=

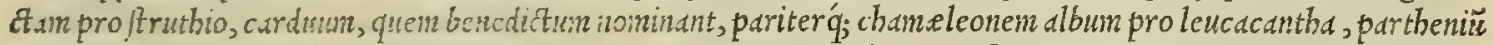
pro artcmlia, cotul.m fretidum spollstam pro parthenio, canis tefticulos (fic enim radices quxdan nominantur) pro fatyrio, polium pro chamzpity, patony chiam, er trichomanem pro adianto. Cadmia preterea officinis feré o= mnibus pompholygen refort, erugo eris forem, eris fquana ftomomatis (quod chalybem dictum puramus) fqua=

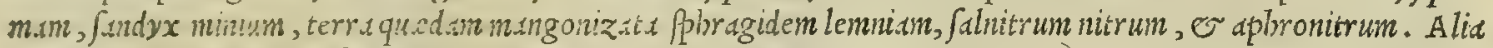
denique plur, ac diner fa fimplicia snedicancnta funt, qux ubique locorum apud uarias nationes, butus, uel illius uice nulli penitus ratione indifferenter fubijciuntur, ubi tum praum, tum purium fibi iandiu uendicant ufum. qua, ne uer bojus rem hanc profequluideanur, filcntio preternitenda cenfemus. Hec dutem pluribus in locis non euenirent, fi mediciomnes ueram, o exquyitam /impliciun rerum doctrinan confequerentur, quam maximé, er iure confequi deberent. Quippc materix buius teritism affecuti, er errorum cognitionem nacti, ne fepla fiarij in eiufmodi uer $\int a=$ rentur fcandalis, obfarcnt: neque cis ulld unquan nedicanenta confici permitterent, nifi fibi prius perpertis, co= gnitis, ac probutis fimplicibus, qux in ip/is componendis expetuntur. Dent itaque iam operdn imperiti, ut buiufce matcrie cognitioncm exaté confequdntur. quantoquidem artifici nibil quidem execrabilius, ac turpiuseffe poteft,

so quim fue arris fubicf:m, or inftrurients ignorare. Quod fane unicuique me dico ufu euenire comperimus, qui non modó alienis untuir mafturis, fed nec fimplicia quidem, nec corum facultates nouit. Proinde fcité à Galeno dictum eft lib.V I I.e V I I I. de compofit. saedic. Jecundum locos, quod non poterit is, ex quo ordine eiufdem generis me= dic amentorwn compolitum lit, cogro fcere, num ex mollißimo, an uebementißimo, aut medio, aut alio aliquo inter Junc, or alios intermedio, qui linsulorum fimplicium potefatem exacté antea non perceperit. Veruntamen nerno in

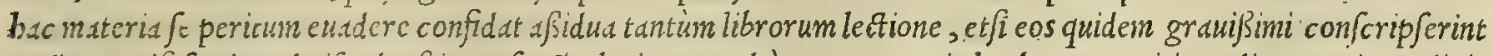

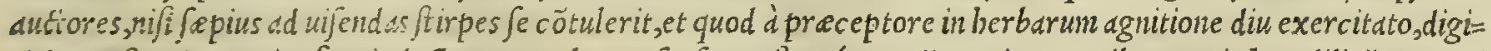

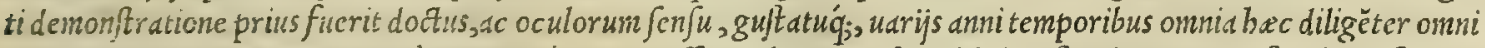
exparte perpendant. Id cnim, c um nn.sximé perpendiffet Galenus (ut fexti libri de fimplictum med. facul.praf fatione

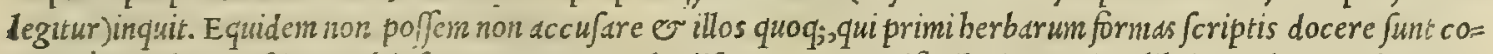
nati, cum melius exifinem ab ip fo traceptore oculis difcere, ac non adfimilari ijs, qui ex libris prodeunt gubernato=

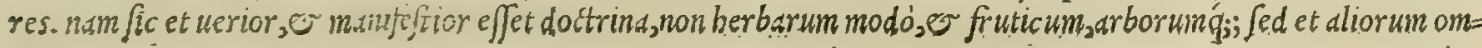

Sine fimpliciú cognitiós má ca elt medendi ratio.

Officinarum

lapfus.

\section{Officinarú a *} bufus \& jgno rantia.

Simpliciū peritiam nemo poteft adipíci ex librorü leEtione.

Herbarú formæ defcriptx paruai conferunt. 
Scripta quorü nium medicaminum. Verim enimuero fi omnino libris eft opus, quis adco mifer eft, ut preteritis fcriptis Diofcoridis; comendet $\mathrm{G}_{2}$ Nigri,Heraclidis, Crateue, et aliorum innumerorum, qui in arte ip a confenuerunt, libros grammaticos fcribentis in= lenus.

Simplicı̈ peritia à præceptoribus, non exlibris com paratur. cantationes, transformationes, or decanorum, denoniorumí; berbas sacrus perfer at? Et libro primo de alimentorum facultatibus: Optina (inquit) illa doctrma eft, que uiud uoce traditur. neq; enim quifquam ex libro nauclerus, aut al= tcrius artis artifex cuadit. In boc nang; comparati funt libri, ut nobis fint corum, que anté didicimus, monumenta, nŏ ut rudes cr ignariper illos doctrinam perfectam affequanur. Quod fi qui fint, qui preceptorıbus careant, uelint q́; ijs, qu. luculenté, ac copiosé funt fcripta (qui nobis fcribendi mos eft) diligenter incumbere, maxgnum ij fructum $c d=$ pient, prefcrtim fí cadem relcgerc identidem non graucentur. Et prino de antidotis: Quód fin nullo (ait) monftrante cx libri alicuius lectione, quales funt commentarij Heraclidis, Crateux, Diofcoridis, aliorumq́; quorundam in fim= plicium medicaminum cognitionem peruenire aliquis uelit, lóngé maiore ipfi opus eft infpectione, ut exacté finguld= 0 Importores rummedicinarum uirtutes, ac utïa dijudicare fciat. Nam qui fimplices medicinas diuendunt, tam callidé illarü quaf= quädoque èt dam concinnant adulterantóf, ut etiam excrcitatißimos in eis decipiant. Quare idem Galenus lib. I X. de fimpl. peritos deci- medic. Facultatibus in diphrygis mentione ita feriptum reliquit. Adijcidm buic, qui de illo babetur, fermoni, rem non piunt.

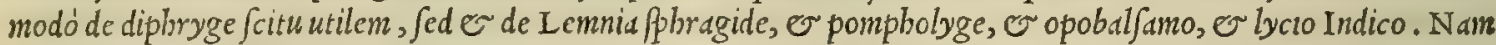
etiamnum adole fcens didici hec ita preparare, ut à ueris natiuis $\dot{q}_{\text {; }}$ mibil differre uiderentur. Erat autem quu me do= cebat ingentimercede, homo curiofisimus, non in bis tantim, fed or alijs fimilibus. Itag; in Lemnum, in Ciprum, in $\mathbf{P}$ al aftindm Syriam co ftudio nauigaui, ut medicamentorum iftorum cuiuf $q$; multam copiam, que in omnem uitam meam fatis foret, reponerem. Sed $\widetilde{L}$ I cium Indicum cum aloè Indica id temporis commodum accipere contigit, cum à $\mathbf{P}$ dlefina iter reflectercm: cùm perfuafumbaberem, eo quòd à cantelis cum tota farcina aduectum effet, pro= culdubio id effe Indicum: quód'́; adulteratum haud no $f c i$ ab ijs, qui portafent, pofet, propterea quód materia, ex 20 qua id preparatur, illis in locis haud nafceretur. Porró fatius ufum efl mibi illegitimorum compofitiones baudqud= quam adfcribere, utpote ckin homines fceler ati in lucro ponant talia poffe difcere. Nec enim neceffarium eft cum ue= rorum ac germanorum notis ac indicijs,adulterandorum noffe compofitiones, cim nibil ad ea difcernendì conferant: imó optem, fi queam, qua à maioribus me perperam conficiendorum atq; adulterandorum medicaminum prodite funt compofittones, oinnes prorfum delere atque extirpare. bactenus Galenus. Ex cuius uerbis inanifefté percipi po= teft, ex libris duntaxat non poffe in fimplicium agnitione peritum fieri quenquam, etiam /i in ip/is firpium imagines uirentibus perfimiles omni exquifito artificio fuerint adiecte. Siquidem (ut bac in prefatione fcribit Diofcorides, er locis iam citatis afferit Galenus) qui in ftirpium hiftoria peritifimus euadere cupit, illum quidem uiuds omnium plan= tas non femel tantum, fed diuerfis anni temporibus infpicere oportet. Quandoquidem plante ipfer folia alias exbi= bent, cuim prima germinatione emergunt, alids cùn adole $c$ cunt, o caulë edunt, aliàs ubiflores erumpunt, $\mathrm{O}$ aliàs ubi $3 \circ$ Stirpes folia ficcefcentes maturum geftant femen. Videmus enim aperté populum nigram, ficuti ricinum, per initia folia explicare immutantes. rotunda, que tamen poft temp us buic platani, illi uerò triangulari fectione laciniata uifuntur. Sed contrà bedere eue nit. quippe buic prima ftatim inuenta triquetra folid infunt, qux uetuftiora iam facta quadantenus rotundantur. Sisymbrij aquatici folium cùm primùm erumpit, rotundum eft, cùm uerò adoleuit, in erucà modum laciniatur. Lepidio, et nafturtio folia primo exortu circinata, ac circunquaq; apij feré modo laciniata emergunt: at cim pubefcunt, pre= long a oledceis fimilia elladunt. Qu etiam modo bortenfe noftrum uulgò petrof clinum nocatum cum fuis ludere cer= nimus. Latbyris amygdalinis folijs caulem ueftit, que in cacumine ita prioris forma obliuifcuntur, ut in ariftolochie, aut bedere folia degenerent. Nouellus acantbus folio lactuca lögiore uiref cit erucx incifuris diuifo:at fenior effectus quaddm circa totum caulem folia pronit tam crebra, acuta, implicita, den $\int a, a c$ minuta, it nucamenti peciem quan= dam referant. Sunt $v$ alie nonmulle, que has foliorum mutationes per tempora offendunt, quarum nomina breui=

Stirpiumimagines parum, uel nihil profunt ad fimpli cia dignofcen da. tati confulentes nunc pretereund cenfemus. At ficriquidem nequit, ut buiufcemodiftirpium uarlationes ex libris, in quibus figure expreffe, atq; etiam coloribus exornate habentur, omnes obferuari poßint . quandoquidem plante ip= Se appicte ex tot uarijsq́; unain nobis duntaxat inaginem reprafentant. Huc etiam illud accedit, quód ed, qua pietu= re artificio funt, etfí ex optimi artificis penicillo emergant, nunquam tamen naturalium rerum line amenta ad unguë referre, ac exprimere queunt, quanuis etiam naturam exactißime intentur. Eadem ratione putauerim ex cuiuslibet grauißimi auctoris commétarijs, qui ftirpium biftoriam continent, neminem abfolutam earum notionem unquam ade= pturum effe, que maximé medicis requiritur.quippc quòd ij fuis fimplicium monument is, ac foliorum, caulium, or re= liquarum partium biftorijs, non nifi unam lineamentorum, ac fimilitudinum enarrationem tradiderint. Qua tametfit . uera fint, nullum tamen prabent mutationis exemplum, ut fape ac fapius plantis compluribus uarijs totius anni cur= riculis tum in folijs, tum in caulibus, reliquis'; particulis euenire comperimus. Quo fit, ut hec uariandi ferics nullo as lio pacto addifci poßit, qualm long o culorum exercitatione, dum atate tota plante ip se folo educate uire fcunt. Cat= serim ubi fcriptores in fuis hiftorijs ftirpium not ds explicant, illi quidem feré femper fimilitudinibus utuntur, acorum exempli gratia, xyridem, gladiolum '; iridi fimilem reddentes: Meon pretered ane tho, cyperum porro, afarum bede= re, phu fmyrnio, o hoc illi, o illud buic Sepißsmé comparantes. Vnde fieri non potelt, quin aliquis, non prius per $\beta e=$ et is und cum doctißimis ac exercitatißmis preceptoribus plantis quibuslibet, cum quibus alia inijffe tum fimilitudi= nem, tum etiam cognationem narrant auctores; $\tilde{e}$ non babita hoc modo edrum ratione, poßit unquan ex folis libris cum ftirpium imaginibus, uel fine eis editis, in fummum o perfectum berbarium euddere. Quanobrem etfi ftirpium imagines, qua magno tum piftorum, tum typographorum ftudio libris excuduntur, inpicientium oculos blande admo= dum detineant, atq; ill ds prius à nobis cognitas in memoriam reuocent; magni tamen eds effe emolumenti ijs non cre = diderim, qui uifu $\mathrm{O}^{\circ}$ preceptoris auxilio numerofain earundem partem non acceperint prius: quanquam fortaffe fes cus unlgus exiftimet. Adhabeant igitur curam ij, quibus in animo eft reiberbariat peritiam adipif chut in primis uiros 


\section{In Lib. primum Diofcoridis.}

Buins rei non imperitos fibi preceptores afcifcant: deinde ut affuc fcant per diuerfa temporis interftitia, montes adi= re, ualles, fylus, ac catera terrs loca, wbi oculis, reliquisiq; fenfibus fimplicia medicamenta inpicere, er cognofccre ualeant. Quos nec pigeat fe conferre ad fodin.ts, ubi metallica er foßilia medicamenta tam diligenter contemplen= tur, ut legitima quac; deinde ab adultcrinis difcernere fci.mt. Nequc folim in fodinis ipfis uerfari debent, fed etiam in fornacibus, wbi metslla funduntur . nam ibi $\mathcal{O}$ dipbrygcm, o pomplolygcm, o podium, eo cadmiam, or argenti

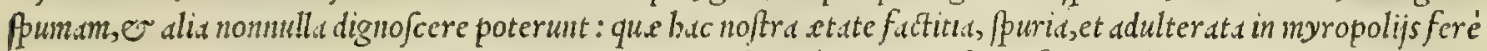
omnibus babentur. Quin or ad mignix emporia, luculcntisimas ; ciuit ates fe confer ant, ubi peregrin.t undiq; impor= tata ucneunt. At certé ridiculi funt, qui inter legendum tum berb.ws, tum etian radices, uana ducti religione, quibuf= dam uerborum, carminum, os fuffimcntorum fuperftitionibus uti pracipiunt, quafi uires, os fuctltates medicamento= so rum uerba, o carminuminc antstiones infunderc, augcre, o dininuere ualeant, ut ftulti, o f fuperftitiofif falsó crede= re, $\odot$ affirmare non erubc $\int$ cunt. Quos tamen lib.v I.de fimp.med. facul. Juperius citato accrrimé damunit Galenus, fic inquiens. Et Pamplilus cum in modum tractatum de herbis compo fuit, uerim is ad fabulas ucr fus aniles cft, fimul'q; preftigiaturas quadan, iunct is nonnullis incantationibus, quss, cum berbus colligunt, admurmurant. Et fane utitur ijs

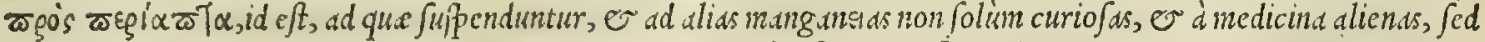
etiam fal $\int a s$ uniucr fas. Ex bac Galeni fententis omnibus palian fit, quód fi nodó commentarios altquos admittamus, omi|3is omni ex parte fuperftitio/is, cos tantum legere debedmus, atq; in ijs nauare operam, in quibus uera, er excul= ta fimplicium doctrina nitet. Quos prefertim pofteritati donarunt ij, qui exactam corum pertian indefe $\beta$ is labori= bus funt confecuti : inter quos ommium primus eft Diofcorides. Ideo \%; iure quidem eodem loco ceteris à Galeno pre= fertur, cum inquit. At Pimphilus, is fcilicet, qui libros de herbis compofuit, plane ex ijs, que uel ip $\int e$ fcrtbit, pra fe

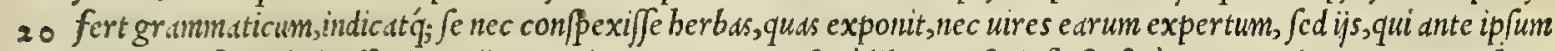
fcripfere, fidem babuilfc citra ullam explorationem. Hic fané libros exfcripfit fruftrì annexo ad unamquanque ber= ban nomium aceruo: deinde etiam exponens, fi qua ex homine ferebatur iransformatio: tum incantamenta, er libationes,atq; thymiamata, que in colligendis illis adbibebantur, adfcribens : necnon or alias eiufmodi preftigiaturas nugaces. At Diofcordes Anazarbenfis quinq; libris materiam omnem utilem abfoluit, non berbarum tantum, fed or arborum, o fruticum, o fuccorum, ov liquorum: memorans infuper er metallica omnia, ov partes aninalium. Et mihi utiq; uidetur omnium perfectißimé tract atum de materia medicamentorum confeciffe. Nasn licet à maioribus mul ta de illis bené fcripta extent, tamen à nemine omnium aqué de onnibus. Caterün que fcripta reliquit Heraclides Tarentinus, Crateuas, et Mantesas, nonin ordinem digefta, nec in unum omnia collecta uifuntur; 'quemadmodum il= 1d,que frrip/it Diofcorides. Et primo de antidotis uolumine: Ac de omsi quidem (inquit) medica inateria fufficien= 30 ter d Diofcoride quinq; libris traditum eft, d' quo tibi difcere licet cum alias omnes notas, tum guftu, olfactuq́; perce= ptus, quibus maxime probatiora medicamenta d deterioribus cognof cuntur os difcernuntur. Hinc ergo auctoritate

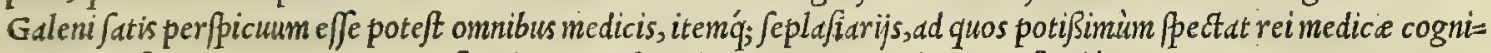
tio, in ea fimpl medicamentorum facultate Diofcoridem ceteros excellere, or facilé primas tenere. Quapropter ab ijs preclarißimé ageretur, fi eius fcripta tantiper legerent ac perlegerent, perpetwo $q_{;}$in finu geltarent, donec eü plané fibi familiarem redderent. e boc quidem eo prefertim tempore facerent, quo à peritifimis praceptoribus ue= ra, ac le gitima fimplicia tum oculorum, tum guftus, tum olfactus. fenjibus offerütur. Quod eó citius ducet illos ad opta= tum finem, quó magis Diofcoridis preclara fcripta caftigatißima, or à mendis quàm plurimis expurgata reperient. Quinetiam noftris commentarijs, qui preterea Galeno referunt, acceptum feré quicquid ip $\int e$ fcripfit de fimplicium medicamentorum materia, ita dilucidata o illuftrata, ut maximam (ni fallor) fecum adferant claritatem. Huic igitur foli fe dedant, bunc folum fequantur ob iam dictas rationes omnes $\ddot{y}$, qui non modó ftirpium, fed or reliquorum fim= plicium medicamentorum doctrinam or facultatem confequi uolunt. Ac contrà tum uulgo femper ignaro, tum ijs e= tian, qui coaxantium ranarum inftar, 'é fordido paluftrium aquarum limo caput exerére nequeunt, nugaces, ac peni= tus deprauatas $\mathrm{P}$ andect as relinquant, und cum tenebrofis officinarum $\mathrm{L}$ uminaribus, et reliquis mendactbus uolumini= bus, ubi fimplicium, ci compofitorum materia ab ijs tractatur, qui vix lactucam nouiffent, nifí eorum cœnis frequen= tißlima extitifet: pariter'́; urticam, nifí acerrime tangentes pupugiffet. Q uorum infcitiam animaduerfus Galenus, contra cos locutus effe uidetur lib. v 1.de fimpl.med. facul. prefatione breuiter es fcité, fic inquiens. Verum abftine dum eft a imultis mendacibus, multo ; ctiun magis fugiendus eft Pamplilus, qui ne per fomnium quidem berbas uidit, quarum aggreditur figuras perfcribcre.nam id genus hominum(quomodo a ßimilauit cos Heraclides-Tarétinus)/imil = limum eft preconibus, qui formam ac notas fugitiui mancipij, licet ipfi non uiderint unquam, praconio tamen publi= cant.notas enim ab alijs, qui norunt, accipiunt, er ceu cantilenam eds proferunt, ut fi forté is, quem preconio indicant,

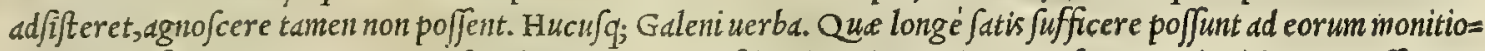
nem, qui ad fimplicium materiam nofcendam per rectum oftium introire cupiunt, 0 securo totius itineris gre]fu pro= gredi. Verum in primis, ut opportuné fingula demetantur, noffe oportet tempord, quibus maximé plante uiribus ualeant. Quapropter à radicibus initium fumentes, dicimus harum uires, ficut etiam aliarum ftirpium partium, non codem anni tempore equé in omnibus reperivi. quandoquidem alia boc tempore, alic ueró illo bumore pragnantes deprehenduntur. Tamet $f$ non defint, qui baud quaquam infirmis rationibus innixi, radices é terra eruenda affer ant femper autumno, cum fcilicet folia decidunt, or caules contabe fcunt alij uero ineunte uere; priufquam folia concre= $\int c a n t$ : fiquidem bifce temporibus radicibus maior uis ineft, quàm cateris partibus: Sed ut ingēenué in lsac re fatedr, quid fentian, crediderim ego omnino maiorem fucci ubertatem inueniri in bis, que uere effodiuntur.quippe quód plă= te nondum caules, folia, neque flores emiferint, à quibus omnis radicum fuccus exbaurttur. Sed er rationi conjo= num mibi uidetur, autumnales radices omnes tum paucioris, tum imbecillioris effe fucci, quàm uernales, quód fci=

Vanú \& fup. fititiosũ incan tationib" vt, dú plátix eftodiuntur.

Diofcorides à Galeno maxi mè commendatur.

Diofcorides : fimpliciŭ medica. materia primas tenet. Libri explodendi. legenda funt. Radices quan do effodiédx. 
licet paco anté tempore $\mathcal{O}$ caules, or folia, o fructus ediderint. Non tamen inficiari uelin, quòd que uere les guntur, copiofiore, quim par fit, lsumore redundantes, illóq; longc minus concocto eo, qui in autumnalibus babe= tur, putrcdeni o corruptioni non fint m.gis obnoxiz, prefertimq; fi longo dferuentur tempore. Qua re à Diofco= ride aninaduer $\int a$, is fanc iufst ftirpium radices effodicndas effe, cim firpes ip fe folijs exuintur. Quod cum uarijs anni temporibus eucniat pro natura diucr farum plantarum, curam impendcre oportet, ut fuo tempore unaqueq; ra= dix integré, fi ficri poteft, cum omnibus fuis adnatis cucllatur, $\sigma$ ijs in loc is, atq; fub ea creli conftitutione, quam maxi Radicü opti- mé famtiarem babcnt. Porró radices atunde nutrite fint oportet, ac omni putredine, et imbecillitate uacantes : non marum notx. ita tamen, ut pre nimio alimento ex pingui folo, ubi nafcuntur, accepto, debitan er bumoris copiam, or corpulentie metam excedant, ne ; ut ciufdem alimenti inopia inanes, er rugofe reddantur. Quod cim maximé perffexiffet Gale= nus de iridis radicibus diffcrens libro prino de antidotis: In uniuer fun (inquit) ex omni medicinarum genere ille ra $=$ 2o dices inutiles babcntur, qua inancs funt, or rugofe. At $q_{\text {; }}$ ille quidem deteriores funt mediocriter nutritis, or medio= crem magnitudinem nact is, qua crißitudinis modum excedunt, e plus bumoris in fe continent, quàm illis ufu ueniat.

Radices quo- Hac Galenus. Ceterim ubiradices é terra fuerint exempte, primim quidem tandiu aqua clara elui debent, donec modo mundä omni undiq; lerg', uel limo penitus abftergantur:mox deradi tum à fibris, tum capillamëtis omnibus, quibus uniuer.im $\mathrm{dx}$, ficcand $x$, fré omnes comantur:poftremó ficcuri cas conuenit omni adbibita cura. Qúd fi fuerint quales foniculi, apij, apard= ac conferuan- gi, rufci,polipudij, rubie, intubi, er confinilium, in umbra, ubiorientales uentirepirent, diligenter ficcentur. At om= nino cauendum $c f t$, ne folc firiantur : quippe quoniam potior earum pars ab eis prorfus ellane fceret, utpote raris $\sigma^{-}$ tenuibus. Veriun enimucro /i ex eis fucrint, qua natura craffe funt, uelutigentiane, belenij, mandragore, bryoniz,

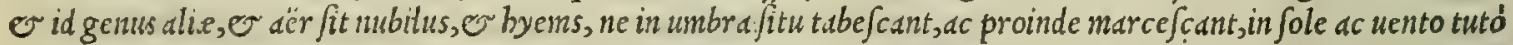
ficcari poffunt. Quod comodius fieri potcjt, fi fiuftatun diffecte ita tenuifuntculo traijciantur, ut partes non fe con= 20 tangant, aut cratibus impofite quotidie fe pius manibus reuoluantur. Atqui curandum eft, ante quà ficcentur, ut li= gnea natrix, que omibus feré radicibus includitur, ipfis in longum fcißis, integra eximatur : quippe omnino inutilis. eft,nullam $\dot{;}$; uim obtinet . etfi gentıand,cyclaminus, ariftolochia rotunda, iris, bryonia,centaurium maius, nymphad, Radices quib. aliéq; complures $a b \int q$; matrice funs pre fe ferantradices. Siccatis radicibus, quód plané conftet eas fine tabe, er te= in locis exic- redine per tempora adferuari poffe, ijs.reponantur in locis, ad qux folares radij non penetrent, neq; funo pateat adi=

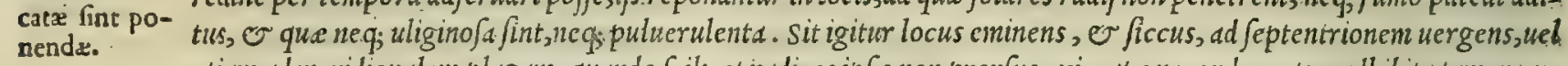
etian ad meridionalcm plagain, quando fcilicet radices ip $\int e$ non prorfus exiccata reconderentur:aúbibita tamen cu= ra,ne co tempore auftri bumidißime flatus admittantur. Ita deniq; recondi, ac feruari poffunt tot annis, quot ab inani=

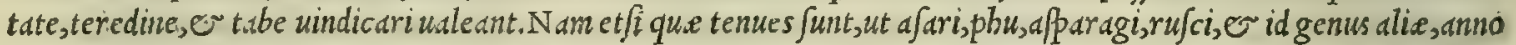
Veratrü vtrü- duntaxat perennent; ueratrun tanen utrun $q$; q qüuis radicibus conftet tenuibus, ad trigefimum annum ufque perdu=

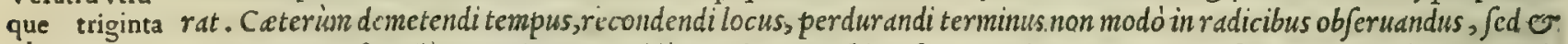
edurat anns. in cateris tumftirpiü, tum etiam animaliü partibus, ut in birci fanguine, lupi iocinore, inteftino; ac etiam flercore, $u$ ul $=$ pis pulmone, apri uefica, anguium fenect, alijs $\dot{q}_{\text {; }}$ confimilibus. A fjumantur igitur hac omitia co demum anni tempore, quo magis fuis uiribus funt predite, nullo plane modo neglecta temporum ratione, quibus fing ula decerpi poftulant.

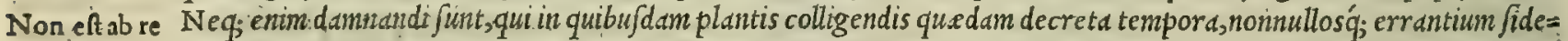
certis tempo- rum appectus abferuant: quippe quod apud graues auctores fcriptum inuenerint, pronix radices contra comitiales ribus herbas non effecuelleiddas;nifi decref.cente luna. Que quidem opinio non prorfus reprobanda uidetur, nec ad ineptias incan colligere. tationum, liarum,; usnitatum, quas. fulté (ut Galenus inquit) prodidit Pamphilus, comparanda. Nam cum inferiora terreftriaid Juperioribus caleftibus gubcrnentur, or regantur, fieri maximé potelt, ut lund, ut qua ceteris erranti= bus fideribus cf nobis magis proxima, motuq; uelocißima,naximan cum plantis onnibus, ac rebus quibufuis alijs ha= beat rationem; tum cum angotur, tum etian cum minuitur fingulis menfibus. Quxmobrem non temeré d' Galeno pro= ditum eft, aly fum herbam tantiun firio ardente ad canum rabioforum morfus effe euellendam, ficutictiam flutatiles cancros ad idem peridoneos. Quo etiam tempore captasnus fcorpiones, atque anchufa radice cöftat fanguineo fucco madente. Quemadmodum or ftirpes, quibus facultas excalfaciens infit, perpetuó in locis calidis, ac ficcis demetere conuenit. Zuocirca Hippocrates ad Crateuam fcribens: Adnitere (inquit) quantum potes, ut nobis montanas maxi= $m e \dot{,} \sigma$ in altis collibus nafcentes herbas à radicibus refeces: quandoquidem be firmiores, atque acriores funt ijs, que aquofioribus naf cuntur locis : id';; quód in montibus terra fit denfior, o cïr tenuior . nam quod attrabunt, fri= gidius eft. Quinetiam dabis operdm, ut flores ex bis herbis etiámnum decerpas, que circa ftagnantes aquas, palu= des, flutios, er fontes prodeunt, quas fané debiles, erexolutas, ac dulcis fucci effe fcio. H\&c Hippocrates.

Herbx quo Herbx fimiliter, at q; radices, legende funt, ficcandie, ac afferuanda, hts tamen demptis, que tum in medicine ufu, so pacto legédx, tum in cibis, tum etiam in obfoniorum condimentis quotidie wirentes ufurpantur, ueluti lactuca, intubus tam domeftica, ficcädxq; fint. quàm agreftis(cichorium appellant)portulaca, bugloffum, beta, atriplex, blitum, braßica, uiola nigra, malua, helxine, linozoftis, ocimum, apium, byofcyamus, fedum, plantigo, ap aragus, acanthus, or all.e complurcs. At tque no folim re= frigeranibus berbis, uerim etiam excalfacientibus recentibus utimur : plerunq; enin ex calida poteftate preditis, ui rides ficcis preponimus, prefertim ubi minus calefacere fit opus : fiquidem bumor in uirentibus exuber ans earum ca lorificam facultatem baud parum demulcet. Cuius quidem claßis babentur amaracus, eruca, nafturtiun, mentha, abfin

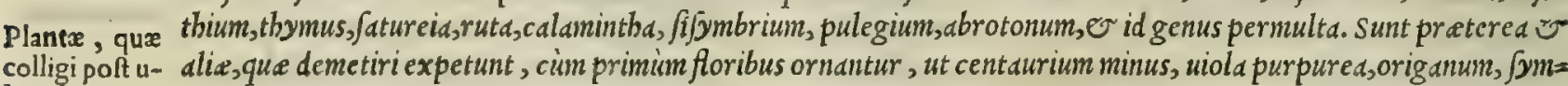
lant fiorib or phytum petreum, pulegium, ferpyllum, amaracus, polium, thymus, clamadrys, chamapitys, anthemis, chry fanthe= natx.

mum, ftechas, by fopum, funaria, aliáq; cöfimiles plante, quas ne longior, quàm par fit, effe uidear, ex induftria pre= terco. Hac igitur omnia ferena celi conftitutione, non nubibus, non imbribus infeftis in primis collegantur oportet. 


\section{In Lib. primum Diofcoridis.}

Deinde terra expurgats, ato; alijs aducttitijs excrementis amotis diligenter in umbra ficcentur. Nifi ex eo genere babeantur, quxt callis crafsitudinc, ut in acaitho, wel foliorum lentore, craßtie, or bumoris exuberatia, ut in portu= laca, e crithamo, onnimo infolari expctant . quandoquidem fi eiufmodi berbx in unb bra ficcandx reponantur, dubio procul fitu obducentur, or putrefcent. Cxetcrim cimn rectéficcate fuerint, decuffo pulucre, in facculis cx corio, ucl ligneis capfulis recondantur, ac diligenter cladduntur, ne earum uires enanefount. Qua in re errant feplafia=

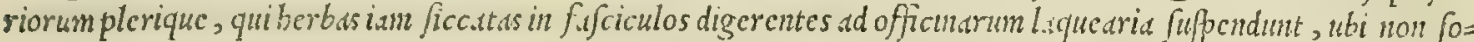
lim breu uiribus deftitumur, icris anbientis exutione, ac uentorum perjatu, fed etian in mille fortium fenti= nam defcifcunt: quandoquidem $\mathrm{C}^{2}$ puluere, ON aranedrum telis obfiduntur, ac inde mufcarum ftercore, quie illis die, noctúf; infident, l.ibcfactatx nigricant. Neque ueró plané landibus efferende funt ij, qui in lintc is facculis,

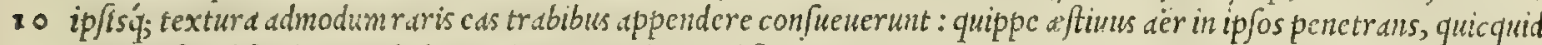
boni ineft, abfumit, of abolet. quinctiam puluere obfite comrumpuntur, of contabejcunt. Idcirco ut tam bcrbe, quain radices fuas integras afferuent facultates, nibil quidem pr.eftantius, quain eas capfulis tiliaceis, uel piceis, uel fictilibus diligenter claufis reponere, ut docet Hippocrates ad Crateuan bis uerbis fcribens. Omnia medicamenta, que fucci, E liquores fluidi funt, in uitreis uafis ferantur. que ueró folia, aut flores, aut radices funt in fittilibus no= uis probé obturatis, ut ne ucntis perflata, medicanenti uigoren, uclut in animi deliquium collap $\sqrt{a}$, amittant. Quod fi Hippocrates in reccntibus offcruandum precipit, id naxinte in ficcis ficri operepretium erit. Flores infuper non fecus, dtque reliqu.e plantasum partes, eo tcmpore colligendi funt, quo mag is fuo in uigore confiftunt, non au= teri cum ian flaccefcentes decidui euane fcunt. At cappurum flores muria aferuandi, antea quàm fe explicent, de= ccrpuntur : rofarum ueró cum non plané explicati uifuntur: ceterideinde cum omnino expanfis folijs patent. Ve=

so riun cum maiori cx parte oinnes fere flores fint berbis fragiliores, molliores, o tenuiores; idcirco tantum abeft, ut in fole ficcandi fint, ut ue quidem in unbra, ficalids, ucl cminentia fuerint loca: quippe, ut folis feruore, fic er dë= ris calore nimio exoluuntur. Siccntur igitur in locis temperat is, quo tempore fe pius reuoludntur, ne fitum contrd= bant, adbibita etian cura, ne ficci natiumm colorcna deperdant . quandoquidem certum cft flores, qui inter ficcandum à proprio colore degencrant, mullius effe in medicina ufus. Flores itac; in uniuer fum ficci ad ammun duntaxat, edu=

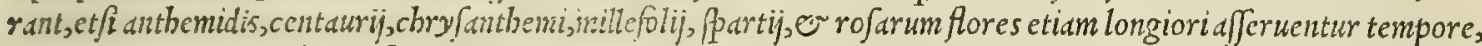
fi ligne is arculis optimé inclufi diligenter reconduntu.. Non minori ctian ftudio funt colligenda femina caned, qux fuis in firpibus nuda inna cuntur, ut lithofpermi, phalaridis, foniculi, anethi, or cari: uel uafculis, aut capitulis inclufa, ut papaueris, nimphea, melantbij, byo fyami, or ocimoidis : aut filiquis tecta, ut fabe, ciceris, pbafioli, doli= chi, o lupini : aut corniculis recondita, ut fenigraci, fertule Compane, finapis, er eruce : aut uarijs inuolucris

30 contenta; quimea, que circa medullam quorundam fructum intus conduntur, quale eft nalimedici femen; aur an= tii, limonis, pyrorun, cydoniorum malorum, peponum, or melopeponum, cucurbit e, er cucumeris. Veruntdmen bee affuncre oportet, cum fructus, à quibus exinuntur, fuam maturitatem plané fenferint: illa ueró, ubi berba iam ficca, non amplius uirent. Et quamuis multa reperiantur femina, qua ad annum ultrà fuds afferuent uires, ed tamen quo= tannis renouare fatius, ac tutius ertt : fiquidem pauca funt, que inueter ata rancorem non redoleant. quo fit, ut calorĕ nancif cantur extrancum, or fibi non congenitum. Vbi igitur ficca fuerint femin., arculis ligneis reponantur in locis

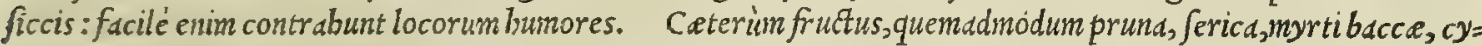
donia mald, cerafa (que uulgó marafcas uocant) corna, forba, ficus, punica mald, or dia id genus, qua in medicine ufum reponuntur, oper epretium eft, ut maturi ex arboribus decerpantur: quanquam forba, ut ficcentur, immatu= radecerpere conueniat. At aninaduertendumeft, quód ubi adftrictione, or reprefsione fit opus, fruatus adftrin=

40 gentes ut palulum potius immsituri, qudin fecus, demetantur oportet. Porró iuglandes, amygdale, piftacia, nu= clci pinei, er auellane non prius ex arboribus excutiantur, quam plané ultimum maturitatis gradum fenferint. Id autem recté cognofcitur, cum extima inuolucra ponte fua debifcunt, er arbore concuffa und cum fructibus decidunt, alioquin infolatu contrabuntur, er fiderantur. Exhis igitur, qui ficcati afferuantur, capfulis ligneis po= tius, quaim faccis recondantur, ne extraneos bumores concipiant. Qui ueró per annum recentes reponuntur, aut maiori ex anni parte perdurant, in locis ficcis minimé apperginem redolentibus appendantur, ut affolet de unis, pyris, malis cydonijs, of punicis: aut fuper paleas expandantur, ut fit cum malis, forbis, ac mepilis: aut bordeo, uel milio fepeliantur, quemadmodum medica, er aurantia mala. Cortices preterea, qui fructibus auferuntur, ut citrijs, punicis, E cucurbitis: quíq; arboribus decerpuntur, ueluti thuri, ligno guaiaco, fambuco, dc fraxino: qui item berbarum radicibus detrabuntur, ut capparum, mandragore, thapfie, alypie, pityufe, ac aliarum, non

so fecus funt ficcandi, atque radices: quinetiam fimiliter reponendi. Succiquoq; , utpote in medicina admodum ne= cefJarij, omni pror fis diligentia, ac ratione funt conficiendi, atque ita afferuandi, ut toto anni curriculo putredinem non fentiant. Ii igitur non folim ab berbis eliciantur oportet, fed etiam à radicibus, de fruttibus. Qui è radicibus exprimuntur, ut Cyrenaicus, or glycyrsbize, uere quidem parandi funt, cum primum folia emergunt. Ex folijs ueró, ante quam firpes flores edant, er carum caules lignofi fiant. Ex fructibus denique, quidam cum ipfi ulti= mam maturitatem fen ferint, cuiugmodi effe debet malorum punicorum, citriorum, limonum, er ex myrti baccis: quidam ueró antequam ad plenum naturuerint, ut ex iuglandibus, moris,pyxacantha,ligufribaccis, er acacia: qui= don ex immaturis adbuc uuis, ut omphacium. Horum omnium nonnull diu infoldti, dut lento igne ficcati reponunt tur, ut aloès, fyluefris cucumeris, abfintbij, eupatorij, bypociftidis, glycyrrbize, er buiufmodi generis : aliqui uerò bumidi, fluxibiles'́; reconduntur. Atqui non omnibus eadem cft conferuandiratio : quippe alij paululum primüm ad ignem feruefacti, moxq́; diligenter defacati, ut fieri folet de fucco ro farum, intubi, bugloßi, oxalidis, lupulor $\tilde{y}_{\text {, }}$ apij, o foniculi. Alij uerỏ ignem non experti tantum fubfidere permittuntur, ac deinde uafis tandiu transferuntur, do=

Officinarum laplus in herbis ficcis repo nendis.

Flores quo té pore fint de cerpendi, ficcandi, ac recödendi.

Flores quan diu durent. Semina quo modo deme. tenda.

Fruetus quan do decerpédi, \& quomodo conferuandi.

Cortices qũo ficcandi, \& reponendi.

Succi qüo exprimendi, cóferuädiç; fint. 
nec defecati pellucednt. Quod fit de fucco malorum punicornm, citriorum, linonum, cydoniorun, er mororum. Ve= runtamen diligenti admodum anunaduerfione opus eft ( $u$ t Galentus inquit lib. $\mathrm{v}$. de medicamentorum compofitione fecundum locos) in fucc is liquidis conferuandis : quandoquidem facile corrumpuntur, nifi feruefact is prus, or mox.

Gưmi, licrymx, \& refinx.

Diofeorides defenditur à calumniz.

Simplicium nomina varia Diofcoridi adulterina.

Arbores.

Frutices : Suffrutuces.

Herbx.

Plätarum degeneracio. a fecibus ommibus percolatis, olei parum fuperponatur, ut optime norunt folertißimi pharmacopolx. Adbac habentur uaria liquorun genera, qua quàm plurinis ex plantis difill.nt, ac defluunt, quorum alij gummi, alij re= fine, alij lacrymx uocantur. In gummigenere funt opopanax, lafer, ammoniacum, fagapenum, euphorbium, gal= banum, bdelliun, myrrba, thus, opocalpafum, farcocolla, ftyrax, o id genus alia. In refindrum ueró cenfu funt te= rebinthina, lentif cina, frobilina, pined, picea, larign $a_{,} \mathcal{O}$ abiegna. In lacrymatrum deniq; numero funt lac, quod ex pa pauerum uafculis excipitur, proprié opium appellatum, fcammonium, quod'q; ex thapfia fuit, tithymalorum omnium lac, cancamum, tragscanthe lacryma, quiq́; defluit é uitibus liquor, ex pruno, anygdalo, or cerafo. Quin or illud, 10 quod uulgus Arabicum uocat gummi. quanquam non de funt, qui tam boc, quàm prunorum, ceraforum, ov amygdalo= rum lacryme malint in gummi potius referre, quàn in lacrymas. Sed quoquo modo res babedt, có tantùm fumma ba= rum rerum pectat, ut exact a filicet earum notitia babeatur. quippe non defunt mangones, er impoftores, qui eas adulterent, quemadmodum or inedicamenta metallica. Po/tremó fi forfitan cuipiam nafuto uideretur Diofco= rides non parua erroris culpa fupectus effe, quod in hac prefatione abfoluté pronunciauerit, ex omni herbarum genere folum ueratrum multis edurare annis, reliqua ueró à trimatu inutilia effe, cum tamen in pluribus locis cius fententis reclamet Theopraftus antiquißimus plantarum fcriptor; dicimus, ut bos ab huiufcemodi opinione diftra= bamus, quód cùm Diof corides extiterit in bac facultate perittßimus, confummatißimus, or omnium facilé princeps, grauißinno quoque Galeni teftimonio, non modó non credendum uidetur, $\int e d$ ne cogitandum quidem, quód non callue= rit is omnes ftirpium proprietates, quodq; baud ftudiosé legerit ea, qux antc ip fum trecentis, aut pluribus annis 20 pofteritatis incmoric inald iuerat Theophraftus, OF aliorum ueterum plerique: prafertin cim nobis peripicuum

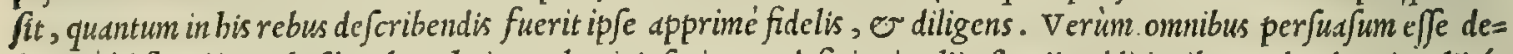
bet, quód ficuti in quibufdam locis huius uoluminis fcriptura deficit, in alijs purijs additionibus redundat, in alijsó; quandoque fcatet mendis, fcriptorum culpa, atque etiam eorum, qui in frribendis, uel excudendis auctorum uolus minibus plus, minujue cura impenderunt, quàm fua intereffet; ita etian in bac prafatione eueniffe facil'é potuit. Quare pro certo crediderim, longe plura hic defiderari, quamea, que bac in re tradiderit Theophraftus, qui ue= ratrum ait triginta perdurare annis, ariftolochiain quinque, uel fex, chameleonta nigrum quadraginta, centaurium maius decem, uel duodecim, peucedanum quinque, aut fex, uitem fylueftrem unico duntaxat anno, elaterium centenis annis, ita ut repertum effe atteftetur elaterium ducentorum annorum, quod optimum erat, of pretiofum. Harum ita= que rerum biftorias omnes tantum abfit, ut credamus non legiffe, notaffe, ac monument is tradidiffe Diof coridem, ut ne 30 inaginemur quidem, etfi fcriptis fuis non extent : quin potius locus ifte nobis fupectus er deprauatus babeatur. Id= circo non Diofcoridi, fed fcriptorum, er librariorum incurix id uitij adfcribendum eft: quemadmodum additio= num redundantia accufantur ij, qui, ut earum auctores effent, ab re hoc opus augere, ato; illuftrare exiftimarüt, quales

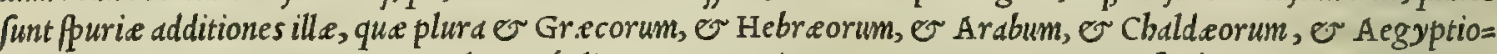

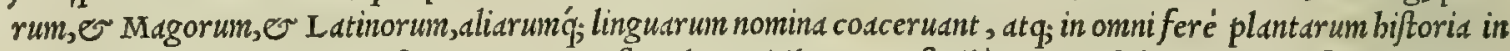
pluribus uoluminibus Grecis ftatim occurrunt fingulis capitibus. Qux facilé ex Pamphilo deprompta fuerunt: argu= mento quód (ut fuperius dictum elt) eirem hanc uitio uertat Galenus, at q; fine ulla ratione Iint in hoc Diofcoridis uo= lumen importata. Cuius rei nobis poftea prebuit teflimonium, quod in quibufdam antiquis bibliothecis legitima Dio= fcoridis uolunina reperta fint Grecé pluribus centenis annis fcriptd, in quibus nullum pror $\int u s$ ex bis purijs nomini= bus legebatur. Quorum uetuft.m auctoritatem fimul cum doctißino Ruellio fecutus, in meis uerfionibus Italica lin= 40 gua confcriptis omnia illa nomina adulterina ab opere abdicaui, quemadmodum facturus fum in boc Latino Diofcori= de : et $f$ i Hermolaus, er Marcellus uulgatis exemplaribus decepti,nomina illa fuis interpretationibus reliquerint, tan= quam Diofcoridi legitima. Sed quoniam non minus utile, quàm necefarium duximus, ut omnes $\ddot{j}$, quibus in animo eft plantarum peritiam affequi, fciant ad unguem, quo arbores à fruticibus dißidcant, frutices ipfi à fuffruticibus, $e^{\circ}$ fuffrutices ab berbis, dixerim ego Theoplrafti auctoritate, omnes illas firpes arbores appellari debere, que ab radi= ce ftatim fimplici caudice furculofo, diffolutúq; contumaci affurgunt, à quo per interualla tăquam brachia, cxorti ra= mi latius diffunduntur, uti oled, ficus, malus, pyrus, quercus, ilex, et id genus ali.e. Frutices ueró, qux ab radice caudi= ce multiplici,ramo $\int_{0} o_{;} \int e \int e$ attollunt, in quorun cla $\int e$ funt rubus, ro $\int a, p a l i u r u s . ~ S u f f r u t i c e s, q u i$ inter berbarum ge= nera annumerantur, ab radice caulem emittunt, lignofis adna centibus ramulis, folijsó; minutis, que nö uclut aliarum berbarum folia quotannis are $\int$ cunt, et decidunt, $\int e d$ perpetuis folijs toto anno uire $\int c u t, u t$, tachas, ladanum, ruta, by $\int=$ fopum, faluia, $\mathcal{O}^{\prime}$ eiufdem generis alia. Herbarum deniq; generi fub cribunt rclique plante, qux inter initia folia tä =

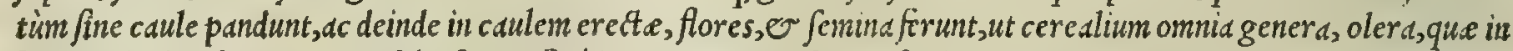
hortis ad cibos feruntur, o fylueftrium fere innumer , que fponte fua in pratis, campis, ac alijs compluribus locis

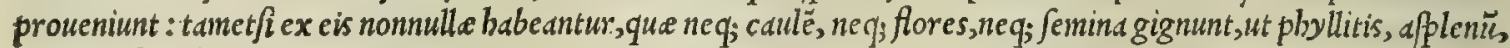
cynoglo/fum, bemionitis, onofma. His ita determinatis, fciendum pretered clt, herbas aßiduo quodan cultu, ac dili= gentia nonnunquam arbore fcere, quod maximé malux accidit. Hanc enim pluries uidi fenis, feptenisue menfibus cul= tam, tanta caudicis longitudine, craßitudine, et duritie proficere, ut baft inftar grande fcerct. Frutices quoq; aut tem poris diuturnitate, aut cultorum mangonio in arbores nö pumilas exeunt, ut uitex, bederd, myrica, paliurus. Contr.

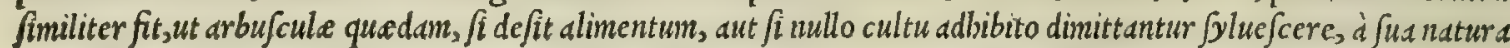
ita recedant, ut in frutices degenerent. Quandoquidem bi tum per adultam atatem, tum per cultus rationem, uendicat= to fibi robore, craffos preduros q, fundunt caudices, ac ramos. Ille ueró tanquam indomita furculis, folonibus ac ger= minibus, 


\section{In Lib. primum Diofcorldis.}

minibus, qui circa caudicem or radices adnafcuntur, luxuriantes, folidos ita ramos debilitant, er infirmant, fubrepto ill is bumore, ut in frutices fenfin el.nngue fant, ut myrto, lentifco, e corylo quandoq; eueniffe comperinus. Tantum Stirpium muenim in plantis nature germanias potcft, ut non folum fepe predictos preftet effectus; fed etian ut alteram in alte = tatio.

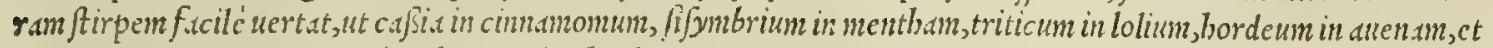

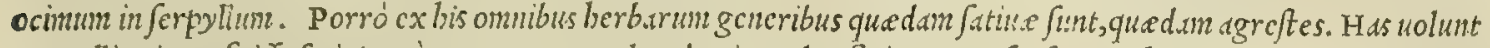

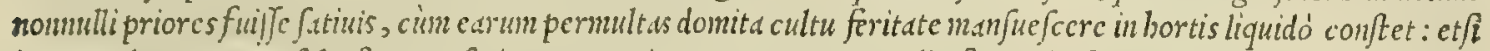

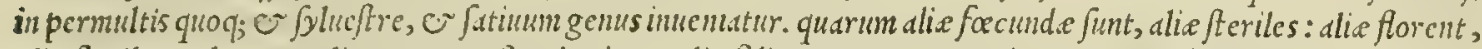
alie floribus orbantur: alle perpctut fronde uircnt, alie folia amittunt. Quod non aliunde proucnire fcribit Theo= phraftus, quim à loco ipfo, ubinafcuntur, ficuti ab aëre cas ambicnte : tametfi id accidat intcrdum particulariradicu 10 aitio. Mrgni qutpe refort, ut faccunde, floride, er perpetuó uirentes plante conferuentur, fí clemens creli confti= tutio, fitusç; germanitus adjit. Outure nil mirum, fic circa Nemplim, o in Elephantio agro ficubus, ac etiam uitibus

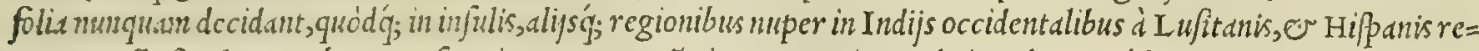
pertis, null xpectetur arbor, qux cempiterna coma nõ uircat. Neq; item admirandum, quód reperiantur arbores pro= ceriores, , zirentiores, apectu pulchriores, o magis frondibu, or fructibus cxornate in boc loco, quàm in illo : nanq, alie hoc fitu let tantur, alix illo pro fue queq; nature ratione. Proinde uidemus, quod qua montes amant, ut cedrus, lat= rix, abics, pinus, pices, tercbintbus, buxus, iuniperus, fagus, carpinus, ibi procere admodum, formáq; infigni profiliüt. Quemadmodsm in plantierum e collium nemoribus quercus, cerrus, fuber, ilex, lotus, ulmus, acer, fraxinus, cory= lus maximic proficiunt. Iuxtaftumina, $\mathcal{O}$ in aquofis letiores proueniunt platanus, alnus, populus utraq;, myrica, $\sqrt{a}=$ lix, harundo: ct ti harum permulte non equé lete in montibus, uallibus, planis, or fyluis exultent. Id quoc; difcriminis 20 in berbis, e fruticitus wilitur. quedam enim paludibus enafcuntur : alix in lacubus, of ftagnantibus aquis exiliunt:

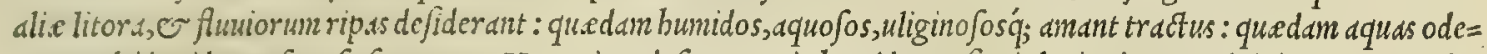
re, $\odot$ ob id arid $x$, $\odot$ faxofa fequuntur. Nec etiann de funt qux in bumidis $\mathcal{O} \sim$ ficcis locis uitam ancipitè ag ant. Sunt de= inde que in campeftribus degere cuplät, que uinet is letentur, que pratis gaudeant: preterea qux ualles, qux colles, que deniq; editos qquerant fitus. A he quoq; urbanioribus locis allecte iuxta urbium, or oppidorum menia in mace= rijs, o ruderibus prodcunt. In palluftribus, e buncntibus locis, ac fecus magnarum fcrobium aggeres feliciter end= fcuntur plantago, coronopus, poterium, fcordium, ranunculum, cleofelinum, phondylium, ly fimacbia, alifma, chelido= suum minus, epinedium, pentaplyyllum, erinus, cquifetum, linonium, beliotropium parum, uerbenaca, tußildago, bydro= piper, onobrychis, conyza tertij gcneris. Et magis paluftribus gaudent cyperus, typha, ßarganium, iuncus. At tam la= cunofis, quim admodum paluftribus innatant nymphsed, potamogetum, lotus Aegyptia, colocafia, folijs or in aquis 30 conditis, o extra eminentibus. Malabatbrum fimiliter in India paludibus nafcitur, atg; nobis in I talia oryza, hippo lapathon, ac millefolium ftratiotes. Tribulus eque in lacubus, paludibus, fuminibus nafcitur, atof; in mari: quorum litoribus, ac ripis faniliare pectatur nerium. Adianthum, itemq́; trichonunes uliginofis pecubus gaudent, prefer= tim fi fecundum amnes exiftant: aut appergino as fequuntur ripas, qua preruptis locis inberent. vitex deinde, elichry fon, bubonium, botry s, rha fluminus ripas accolunt. Crithamum ueró, braßica marina, chameleo niger, androfaces, corniculatum papauer, dorycnium, folanum fomniferum, glaux, hippophaès, byppophaftum, tragium, tithymalus para= lius, peplis, alypon, abfinthium jeriphum in maritimis tum litoribus, tum fcopulis, tü etiam collibus emergunt. Tripo= lium ctlam in maritimis exurgit, ubi fcilicet allidit unda, iterum '́; recedit, modó in mari, modó in ficco degens. Non nif açwis proueniunt bryon thala ajion, cor allium, $\sigma$ alga. At in riguis fontium, prefertim que byeme tepefcunt, fion, at q; aquaticunz fijymbrium und innatant, ut quafi inuicem fraternam uideantur inij]fe amicitiam. Caterum ex bis, que in 40 continentinafcuntur, arida, $\sim$ fiticulo fa loca petunt eryngium, fatureia, lythopermon, lycium, faluid, ftachys, onof= ma, lonchitis, cynoglofum, echium, bugiofum, chamepttys, ueratrum nigrum. Aridißimis, ov faxofis exurgunt cap= paris, lib.notis, fymplytum petreum, faxifragum, helxine, hemionitis, fedi utrung; genus, cotyledon, cymbalion, po= lytrichon, paronychia, applenum, clinopodum, circea, lichen, ita ut harum plereq; $\int x p i u s$ in edificiorum ruinis, ac faxofis adinodum locis uire cant. In opacis autem fimul $\sigma$ aridis nafcuntur belenium, chryfocome, afarum, wiola pur= purea, aftragalus, o cyclamiinus. In humidis clematis prima, que $\sim$ fecus aggeres inuenitur : item phyllitis. Col = lium anaoritate capiuntur partum, nepeta, fylueftre cuminum, chamedrys, et/i non oderit etiam aperd, o faxofa: - itern phalangium, thymum, quod etiam petrofo folo nafci uidemus: quin er boloftium. Culta deinde uirent lagopode, elatine, ornithog alo, coriandro, hy acintho, hypecoo, apio alio ab horten $i$, chamaciffo, e gilopé, ofyride, aphaca, oroban che, melant tio, buphthalmo, anthemide, fylueftripaparere, xyphio, leontopetalo, phenice, byperico, cyano. Inculta so ueró uirent pfyllio, hueracio. Pratıslet tantur trifolium, lotus fylueftris, anonis, daucts, carum, tragopogon, oxylapd= tbum, centsurium ininus, bemerocallis, colchicum, betonica: quanquam bac o colles, e montes abunde fcateant. In winet is aluntur telephium, portulaca (ylucftris, peplus, helxine bederaced, ampeloprafum, capnos. Tam intra, quam extrd oppida, er uróes in plateis, monumentis, parietinis, ruderibus, propter muros, o hortorum fepimenta uifun=

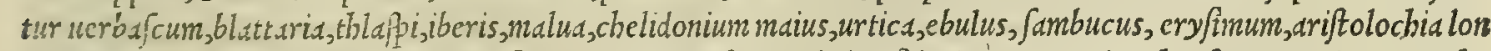
ga, marrubium, chryfanthemum, galiopfis, ,enecio, terreftris tribulus, fideritis, eupatorium, byo fcyamus, cicuta, perfo= nata, xanthium, fylucftris cucurnis. Campeftria cardui omni genere horrent, atractyli, ferulis, fylueftri foeniculo, gramine, thalictro, bunio. Agroruin, e pratorum $f_{\mathrm{ep}}$ ibus berent rufcum, apparagus, rubus, rbamnus, liguftrum; ru= bia. Ephemero autem, hippogloffo, filice, planitierum fylus uire fcunt. Montes adamant nardum tam Indicum, or syriacum, quadn Celticum, er montanum, centaurium maius, mandragoras, baftula regia, fatyrium, gentiand, ligufti= cum, aly fon, fmyrnium, ueratrum album, ruta fylueftris, polemonia, polygonatum, tithymalus characias, polium, ptarmica, thymeled, chamelea, glycyrrhiza, afclepids, narciffus, thapfid,peonid, ethiopis, clymenum, onagrd, cacd= 
lia,aconitum, daphnoides, by fopum agrefte, peucedanum, chamedaphne. In fyluis montanis emicat leucacantha, atq, inibi in premptis locis petrofelinum, o Rbodia radix. Sunt preterea, qux arboribus inna fi uelint, in quibus refident, atq; ab ij]dem fufcipiunt alimentum, ut agaricum, uifcum, phagnos, polypodium, dryoptcris, lichen. Alixe qui= dem in arboribus conpiciuntur, diae ueró prius é terra cxorte, per arborcs repunt, quemadmodum labrufea, uitis megra, bryonia, bedera, clematis altera, fmilax tam lewis, quàn apera, lupus falicarius, conuoluulus, periclyme= num. Non de funt ctiam berbx, que fine radicibus in alijs berbis profiliant, nco; alibi, qudin in illis reperiantur, ut caf= futha, epithymun, cpitbymbrum, o epificebe. Veruntamen illud fcire conuenit, quod et fi harum omnium quaque

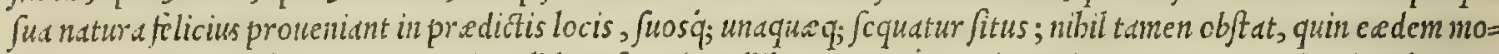
dó in moutibus, nodó in planis, nunc in collibus, fepe in uallibus, noinuniqum in agris, e pratis, ac etiam in alijs ud= rijs locis mullo difcrimine inucuiri poß3int. Et hec fatis fint quantü ad natalcm plantarum fitum. Catcrum ut, quan= tum per nue fieri potefi, harum rerum non minus utilis, quàm ncce faria doctrina excitetur, augeaturq́;, iam ad fingu= las berbarü partes nofer fe conuertet fermo, o de radicibus, folijs, caulibus, floribus, ac feminibus differemus, primo Plantarum in àrdicibus, ueluti a bafi aliarum partiun, rem ipfan exordientes. Frumentacea igitur cmmia snultis nituntur radi= radicibus us- cibus, ijsi; tenuibus. Legumina ucrofingulas babent radices prater fabam, edsq́; furculofas, o duras. Sic er olera rietas. fire onnia fingulariradice colscrent, ut lactucd,apium, teta, bugloffum, intubus, cichoriwn. Quinetiam radice fin= gularifuftinentur fylucftis ruta, quam harmalam uocant, peplos, crateogonum, cpbemerum, o fepius uerbenaca. Contrà numerofis radicibus donantur a arum, plu, baccaris, ueratrl genus utrung; , capparis, crithamum, baftula regia,cbclidonium mimus, afclcpids, circea, alcca, xthiopis, gramĕ, flix formina, muris auricula altera, plätago, chry= focome, afparagus, rufcus, bippogloffum, panaces Heracleum, bemionitis, peonia fermina, alifma. At nardi Indici, or Celtici radix in pica modum capillatur. Pregrandi, frrmá; radice exurgunt belcnium, bryonia, mandragoras, fcammonium, fylucftris cucumis, uitis mgra, rapum, nimphe a, colocafia, radix R bodia, e China nuper cx Indijs oc= cidentalibus importata, dracunculus, doè, centaurium maius, libanotis, phondylium, nenanthe, fymplitum fecundum, papauer corniculatum, raphanus, carduus, periclymenum, folanum fomniferum, fmilax appera, thap ha, bippophaĕs, bippophe, tum, tithymalus cbaracis, pityuja. Contrà exiguam, tenuem'q; radicen gignunt bydropiper, catanances genus fecundum, rununculum, panaces A fclepium, er Cbironium, phalangium, trifolium, antbyllis, beclium, onobry= chis, boleftium, britailica, epinedium, onagra, tragium fecundum, leontopodium, uerbenaca fupina, plbyteuma, păcrat = tium, aconiti tertium genus, chameciffos, a darum, utrunq; ueratrum, plantago minor, coronopus, fe famoides, origa= num fylueftre, alypon,atractylis, heliotropiun maius, ono fma, rubia,cepea, alifma, betonica, chame fyce, meon, gingi= dium, centaurium minus. Radices in lignum durefcunt ethropidi, fmlaciapere, poterio, leucacanthe, aftragalo, tithymalo characie, cypero, rbododendro. At molli, lenta; ; radice conftant althea, acantbus,alcea,malua. Genicula $=3$ tie ueluti arüdinibus, funt iridi, acoro, polygonato, rufco,nymphea, xyridi,bippogloffo, gramini, lauro Alexädrine, co locafie, galange, gingiberi,radici Chine nuper inuente, $\mathcal{O}$ R bodix. Radicem digiti craßitudinc fundunt orobanche, eryngium, polygondtum, pxonia mas, pyrethrum,daucus, paftinaca fyluefris, fymphytum petreum, dorycnium, ebu= Ium,echium, crithamum, elaphobofcum. Bulbofe autem infunt ceparum modo, lilio, bemerocalli, capis, bulbis, baftule regia, allio, porro, croco, narciffo, xiphio, tefticulorum omni generi, fatyrio, ornithog alo, utrifquc cphemeris, arifaro, byacinto, dracunculo, ampeloprafo, fcorodoprafo, moly. In globum extuber ant radices ariftolochie rotunde, cycla = mini, apij umitorij, leontopetali, chanthes, peonise fomine stapi, cbryfogoni, periclymeni, cyperi, argemiones, catd= nances fecunde, pycnocomi. Infuper radices inter fe difident, tum colore, tum odore, tum fapore: qua äifcrimina fi rette cognof cantur ab bis, qui breui hanc facultatem affequi defiderant, non parmm inde baurient utlitatis. Sicutic maxime confert fcire, que fint radices migne uel parue, qua dure uel molles, qua numerofe uel pauce, qua cepd=

Radicum dif- rum uel tuberculorum effigie, que denique geniculate, de quibus bucusq́; abunde differuimus. Sed iam de coloribus ferentix in co agamus. Nigricat foris chry fogoni radix, etfi candicet intus : item papaucris cornuti, nardi montani, helcnij fecundi, loribus \& [a- cyclamini, chameleonis, cardui, haftul.e regie, libanotidis, rbapontici, quan quam buius iniserna rube cant, peucedani,
poribus. leontopetali, epimedij, nympbex, eryngij, fympliti fecundi, fmirnij, echij, ueratri nigri, aftragali, ancmones, man= dragore, aconiti tertij generis, thapfie, perfonate, filicis marts, uitis nigra, arifolochie utriufque, quarum tamen un=

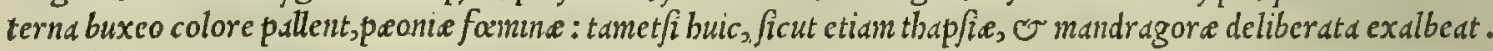
Contrà é candida proueniunt radice plantago, polygonatum, dracunculus, arum, arifarum, ranunculum, ucratrum al bum, anonis, ligufticum, aparagus, rufcus, bippogloffum, elaphobo fcum, libanotis, pbondylium, rapum, radix, circea, alcea, boleftum, tragum, trifolium, narciffus, allium, porrum, gingidium, ibcris, bippofelinum, tripolium, iris, panaces Heracle um, tragium, fomnifrum folanum, arction, onagra, chaneciffos, famnonium, althad, pityufa. At non pror= fus alba, fed fubalbide radices tribute funt aro, polemonia, belcnio prino. R ubcnt rubia, centaureo magno, rlad= pontico, rhabarbaro, tametfi tria hec exterius nonnibil nigricent : item pentaphyllo, hcptaphyllo, beta tertijgene=

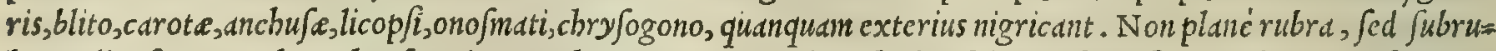
bra radice funt acanthus, phu, fatyrium crytbronium, xyris, rad $x$ R bodia, folanum fomniferum, alypum, cofus. Ex atro rubefcunt filicifomine, cypero, pycnocomo, ephemero Colchico. R ubro colorc purpurafcunt radices $\int y m p h y=$ ti petrai, ceparü, f cille,pancratij. Flaud intus radice funt arifolocbia rotunda, glycyrrbiza, lap.thum, bippolapa= thum, cyperus Babylonicus, argemone, cbelidonium maius, gentianx. At berbaceo colore in int polypodio, philigio, fmyrnio, et imperatorix. Odorata radice fragrant iris, acorus, meon, cyperus, galanga,zedoaria,nardum tan Galli=

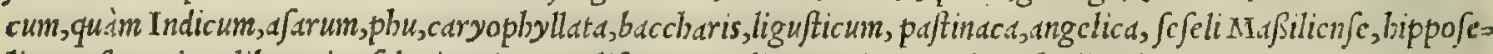
limum, fmyrnium, libanotis, afclepias, circed, alifna, tripoliun . quin er radix R bodis odorem expirat non iniucundum. Dulcediné guftui prebent glycyrrhiza, tragopogonis radix, rentaurij maioris, chamalconis albi, elapjobofci, ge= 


\section{In Lib. primum Diofcoridiș.}

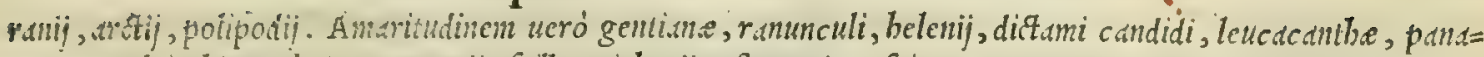
cis Heracici, hippophis, puncrutij, fcills, cichorij, apparagi, rufci, centaurij minoris, chelidonij m.tionis, $a=$ phodeli, cyclanimi. Acri autcm radice deprebcuduntur gingiber, acorus, galanga, zcdodria, imper.storia, crocodiliun, angelica, panices Cbironium, fimyrnium, pyrctbrum, dlfind, tripolium, raphanus tum fatiuus, tum fyluefris, utraque iberis, niafturtim, thlaffi, argemone, bydropiper, arum, dracunculus, cryfumum, $0=$ phiofcorodon, ampeloprufum, fcorodoprafum, caps, alliwn, porrum, fcandix. 2uo fit, $u t, \sqrt{i}$ cxact a nottia dif $=$ frentiarum habeatur, qus in radicibus forma, muncro, colore, odore, ac fapore notantur, inaximum indc pcr= cipiunt cmolumentum ij, qui magna animi delectatione in bac fimplicium medicancntorun facultate operam impendcrint. Ac prastered fulumim ijfdem contulerit, fi omncs firpium delineationes, fimilitudineś́; (dc

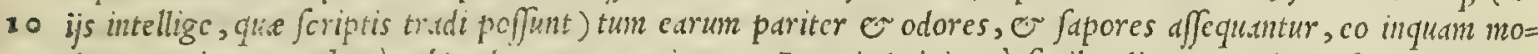
do, ac ratione, quo hic à nobis adiotata seperiuntur. In primis igitur a finilutudine, quam inter fe ineunt plan= ta, exorfus, pro uiribus cnitar, ut que plurimis ignota funt, ijs, que ommibus fané unlgarcs apparcht, recte comparcntur. quapropter ab bedera primum, ut qua neminem lateat, rem ip am auficabor. Hederam igitur fo:lijs cmulcntur, ct/i quedan matora, quedam ueróminora cernantur, fcammonium, darum, uterq; cyclaninus,

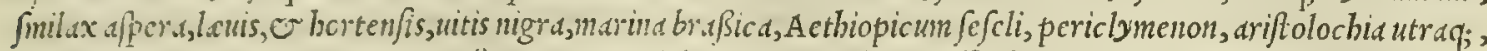

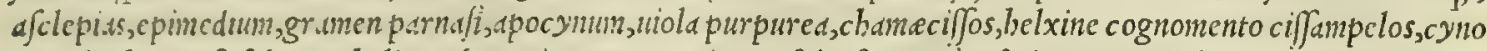
crambs, trortenfe folanum, halicacabum, circes, cucumis tam fylueftris, quam fatiuus, utraq; clematis. vitigineum fo= lium reprefent.unt platanus, accr, lupinus, ricinus, bryonia, uer atrum nigrum, balfamina, colocynthis, cucknis, quem Venctiangurim uocant. Alba pura, $\mathcal{O}$ ac antbium fimili uirent folio: ficuti abrotonum formina, or abfinthium Seri= so phum nocatinn folijs fo inilicen imitantur. Vitex, OU andgyris e folijs, or ramis conueniunt. Apij folia refrunt call= calis, fecundum daucigcnus, la ferpitiun, finyrnium, bunium: Amygdale fronde ueftiuntur perficus, rhododendrum, cbulus, fambucus. faipliylodendron, latbyris, quàn: officine cataputiam nominant. Anifum deinde ifopyno folijs adfit pulatur, an. allis antyrrbino, atriplex xanthio. Vtriufo; rubie folia imitatur aparine, ac galium : quanquam illis ma= ior., Isuic ucró minorafpectentur. Porri, bubió; folia pre fe ferunt byacinthus, narciffus, alliwn, colcbictum, cyperus, baltula regi.t, ampcloprafon, fcorodopiafon, canini tefticuli, lonchitis. Buxus, or lyciun confinili comantur fronde. vitus alba anomo jolijs corre Pondet, pyrethrum fylueftri dauco, hemionitis drac unculo, coris erice. Freniculi folia emittme altilis apparagus, painces Afclepium, fefeli, ducuin Creticum, anthemis, libanotis, buphthalmos, anetbum, thap fir. Anethifolijs aliurgtt meon. Plantagini no dißimilis funt folia candidi ueratri, gentiant, alifmatis, $\mathcal{O}$ clymeni. Phanij foliun gerdnium exprinit. Fllicem folio emulantur fideritis fecundwn genus, polypodium, dryopteris. Ferula 30 cicutam foliorum inagine refert, hec ueró myrrbidem. Buglofum,uerbuf cum, er cirfium confimili modo foliantur. Graminis folium proferuit moly, holoftium, granen arundinaceum, coronopus. Huius ueró folia habent catanance, pyllizun Cachorium, chondrylle utrund; genus, et quod quibufdä dens caninus dicitur, cófinili funt folio. Cnico atra= atylis fotio afimilatur, clsameleoni nigro crocodilium, chanelconi albo filybum. Glafto tripolium fimile eft. Corian= drifolijs connantur partbenium, adiantbum, fideritis tertid, omnia ranunculigenera (quorum tanen quadam propius, quedan longius cius peciem fequnntur)uterq; daucus, thalictrum, capnos. Helxines folia produnt anagallis, alfine, muris auricula : cannabis, aut quinquefolij eupatorium, fed qua quadripertitó diuidantur. Cotonei mali frondem ex= bubentrapp.ris, foldatm fommiferum. Smyrnij folikn preftant phu, lauer. Cupreßi effigiem promit fabina: iuniperi cedrus. Hypericum, andro femum, a f cyrum, folio non difcrepant. Ciftus, or ladanus ficutiin pecie, ita er in folijs conucnunt. Cyclaminifoliumpandii acontum primum: ciceris teucrium, fecuridaca: cumini fylucfris fratiotes 40 millefolum: cucurbite perfonata: lolij phenix: iuglandis centaurium maius, peonia mas, gentiana; etfi buic ma= gis cum plantagine conueniat. Iridis folia reddunt acorum, medion, fylueftris iris:item gladiolus, nifi bic breuiora, dne guftror a $\dot{q}$; folia fibi uendicaffet. In iunci pecie collocandum effet utrunq; equifetum, fed inani canle affurgit. Lenticu le follum find ant aphac , onobrychis, chame jyce, belenium alterum, anonis, tricbomanes, polygala, glaux. Laurea fronde uirent polygonatum, clematis pruna, daphnoides, nerium, chamedaphne. Lilij folia fpargunt hemerocallis, pan cratium, fatyrium, martagon ( fic enm appellant lilium quoddan agrefte) epbemerum, onagra. Lentifcum referunt glycyrrbza, tragus. Nec lepidium arabis dijimulat. I atuce effigie folia ferunt dip facus, fylueftris lactuca, lycopfis, ancbufa, fyluefre glaftum, mandragoras famina. Lingua bubula finilia funt fymplyyti alterius folia. Myrti folia ru= fcus babet, tithymalus fomina, er canirubus. Mentham fatiuam folio exprimint fifymbrium, bydropiper, pentapbyl= lon. Marrubii effigic affurgit apiaftrum, ballote, horminum, fideritis prima. Mercurialts folio uirent belxine, elatine,

so cynocrambc. Najtur iij folijs iberis nö refragdtur. Oleam emula foliorum facie reprafentăt balimus, ptarmica, phil= lyrea, liguftrum, uitex, conyza, thelygonum, caninus tefticulus, lithopermum, dorycnium, byppophaës. Platanum folio imitantur ricinus, nigrum ueratrum, febondylium, aconitum cynoctonum. Verbafcifolia fundunt belenium, ethiopis, artium, bugloffum, $\sigma$ tithymaligenus latifolium. Paftinaca, $\sigma$ gingidium folijs inter fe non dißident. Portulace fo= lto a) simulantur telephium,ceped, crithamum, terreftris tribulus, tithymalus beliofcopius. Trifolio correpondent lo= tus fylueltris, medica, cytifus, fertula Campana. Thymum,ftachadem, fatureiam finile comat follium. Acuta pina,er mepili primum genus fimili utrent folio. Nec dißimli pulegio, dictamum o caldmintba comantur. Myric e fabina, 0 cupreffus: ferpylli clinopodium: faluie fideritis prina, horminum, ucrbafcum fylueftre, folijs ueftiuntur. Pice foliu

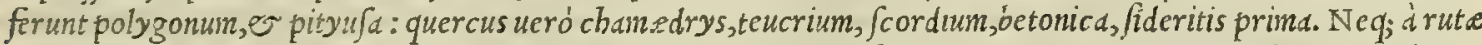
folijs disident acacia, centaurium minus, ferpyllum fylueftre, ambrofid, polygonum primum, andro femum, polemo= nix, peplus, parony chia, bypericum, apios. Alox, er fcill e fimilia tribura funt folia. Samp fucbifolium oftendunt ma= rum, et panaces cbironium. Solanifolio germinant circea, halicacabus. Rumicis folia amulantur arum, pbyllitis, bri= 


\section{And. Matthioli Comm.}

tanicd, er que uulgóbiftorta dicitur. Foliorum fimilitudine inter fe certant rufcus, bippogloffum, laurus Alexandris na. Apleni inaginem prebent muris auricula altera, $\mathbb{0}$ altera lonchitis : ficuti femperuiui minoris tertia ainge $\beta e=$ cies, ariftolochia clematitis. Salicis fronde prouenit ly/imacbid, fertule Campane ligufticum. Silybus, chamaleo albus, carduus, alba pind, fe fe foliys imitantur. Ex bis igitur facile quifq; herbarum germanitatem, cognationem, fimilitudi= Folionü in co nemq́; perdıccre poterit. que omnia in dignof cendis ftirpibus non paruant adferunt utilitatem. Caterim planta= loribus defcr rum omniun folia non modicam in coloribus differentiam babent, tamet fi folia ip fa coloribus adeó perpicuis, utiflo= mea. resbaud quaquam plendeant. Niger fane color in null is reperitur berbis, neque arboribus. quanuis nonnull $x$ atro quodam uirore fint fuffufe, ita ut paululum nigricent, ficut phillyrcd, buxus, liguftrum, hortenfe folanum, nigra uio= la, ofyris, byo fcianus, utraque clematis. Contrà nec folia babentur, què niueum candorem exprimant. uerüm ple= raque, que incana funt, fubalbicant, ut crithamo, echio, ranunculo, abrotono, abfinthio, faluix, calamintbe, maro, periclymeno, corniculato papaneri, ftachy, menthaftro, althex, polio, uerbafco, utriq; lychnidi, or mandragore. mari: que omnibus fuperne candicant, quemadmodun infirné rofmarino coronario, bechio, olex, populo, artemi= fie, o d alijs multis. Rubent punice malo, amygdalo, lentifco, terebintho, rhoi, cyclamino, botry, cori, androfemo, afcyro, lonchiti, ofyri, blito, amaranto, phyco marino, ee fame, irioni, atriplici, alypo, Celtico nardo, or cuidam beta generi. Folia, que lanugine pubent, infunt dictamno, uerbafco, lychnidi, gnaphalio, acantbio, althree, men= thaftro. Afpera funt fymphyto alteri, marrubio, fico, faluis, ballote, e bormino. Aculeis horrent folia bugloßi, cchij, urtice, eryngij, rufci, lycij, atractylis, fonchi, chamalconis utriufque, dip $\int a c i$ : quinetiam cdrdui onne genus. Humi iacent panacis folia, coronopi, anchufa, mandragore, utriufque andagllidis, cynogloßi, glauci, catanance fecundigeneris. Reptant ettam bumi lithopermi, graninis, onofinatis, canis tefticuli, albig; chamalconis. In uni= uerfum plante omnes, que caule o floribus orbantur, folia per terram pargunt. Acuta folia, ut quse olfactu na= resferiant, data funt allio, cepis, nafturtio utrique tam aquatico, quain terrcftri, finapi, eruce, lepidio, gingidio, bydropiperi, eryfino, clematidi fecunde, thlapi, ferpyllo, thymo, thymbre, fifymbrio, pulegio, calamintha, di= ctamno, dracunculo, aro, flammule, origano o que omnia non modó olf $a c t u$, fed mag is etiam guftu acrimonam pres= bent. At amaritudinem poßident chondrylla, cichorium, gentiand, rutd, abfinthium, aphaca, abrotonum, fcandix, aloë, fantonicum, fcripbum, chamedrys, marrubium, fcordium, glaucium, chamelea, empetrum, or que uulgá gratia Dei deiectorie facultatis herba dicitur. Odorata folla funt afaro, fio, fifymbrio, menthe, menthaftro, $c \cdot=$ laminthe, pulegio, faluia, ladano, byffopo, fampfucbo, origano, thymo, ferpyllo, fatureie, fymphyto petreo, rofmarino, liguftico, ftachy, malabathro. Nec infuauem efflant odorem chamedrys, baccaris, artemifia minor, o berba illa, quam aliquif flaream, nonnulli herbam fancti Ioannis, o plerique matrifaluiam nuncupant. Nec de funt ftirpium folia, que ab alijs tum plantis, tum liquoribus odorem emendicaffe uidentur, ut fcordium ab allio, trifo $=30$ lium ir ruta, $\mathcal{O}$ bitumine, cytifus ab eruca, apiaftrum à citreo malo, chame pytss à pino, xantbium à nafturtio : ita denique hydropiper à pipere mutuatur odorem. Grauiter olent abfintbium, abrotonum, feriphum, ballote, po= lium, ebulus, botrys, ariftolochia, cannabis, anagiris, galiopfis, cicuta, mandragoras, apocynum, glaucium.

Cauliư in plä

Non parum quoque difcriminis in plantarum tum caulibus, tum ftolonibus reperitur. quandoquidem ex eis quas= tis differétix damfingularem, fimplicenǵ; canlem proferunt: alie numerofos cauliculos edunt . quibufdam craßßi caules infunt: alijs tenues affurgunt : alijs inanes, E uacui eriguntur, fifularum, or arundinum inftar: alijs pleni conpiciuntur: quibufdam item longus profilit caulis, quibufdam ueró breuior : ibnnulli caules geniculis $f$ catent, dij enodes exeunt, alij leuore, alij fcabritiu, alij duritia, alij lentore notantur. Nec defunt, quilanugine ueftiantur, er qui pinis, $e^{\circ}$ acule is rigeant. Quibufdam plant is teretes funt, nonnullis quadranguli, $\mathfrak{V}$ aliquibus ftriati. Alij denique fur $\int u m$ eriguntur, alij per terram ferpunt, ac repunt. Dißident pratered inter fe ftirpium caules colore, rectitudine, ov curuitate : tanta fuit nature in plantis formandis uarietas, atque folertia. Plures igitur caules ab una tantim ra= dice exiliunt glafto fylueftri, ptarmica, plantagini, muris auricule, telephio, ariftolochie utrique, ruta fylueftri, byperico, elatine, pbenici, trago, folano fomnifero, or manico, minori fedo, chamaciffo, glauci, ofyrit, titbyma= lo.paralio, $\sigma$ heliofcopio, thymelex, heliotropio magno. Ramofo, ac pariter furculofo caule fruticant faluid, fatureia, thymum maius, origanum, hy fopum, ab/inthium, abrotonuin, ruta, ftech as, ocimum, amar acum, fym= phytum petreum: or ut fuminatim rem complectar, omnes denig; plante, que fuffrutices appellantur. Craffum cau= lem mittunt dracunculus, chamelco niger, enanthe, belenium, fymphytum alterum, byof cyamus, perfonata, fed ĭ ma= ius. Contrà proditur tenuis ornithogalo, thlafpi,polemonie, ranunculo, limonio, anemone, liguftico, panaci Afclepio, peucedano, artemifie, phyllo, cynocrambe, buphthalmo, alifmati, betonice, echio, eupatorio, plantagini, chelidonio m: $1=$ iori, muris auricule, ariftolochie utriq;, feripho, tragorigano, mentha, fifymbrio, ly fimachie, rute fylueftri, delphi= nio, melanthio, agrefti cumino, aparina, chamedry, fcordio, teucrio, trifolio, byperico, fideriti fecunde, eldtine, pen= taphyllo, ueneris umbilico, chamedaphne, tithymalo beliof copio, thymelea, alypo. Inanes in uniuerfum, ac fiftulofos caules babent frumenta, legumina, o olera. Particulatim ueró cauis emic ant colliculis plut, apium montanum, fon= chus, ueratrum album, gentiana, equifetum, narciffus, ricinus, cicuta, latbyris, bieracium maius, fymphitum fecundum, Bina alba, cape, porrum, bippofelinum, thapfia, ferula omne genus, onnes '; plante firulacea, qual is cicuta, pana= ces, laferpitium, fefell Pelopönenfe, e que guttatim ftillant fagapenum, galbanum, o ammoniacum. Geniculatum culmum gerunt cerealia omnia : quin $\sigma^{2}$ ebulus, fambucus, phu, cyclaminus fecundus, gentiana, panaces A fclepium, polycnemon, crateogonum, polygonum, equifetum, ferula, cicuta, meon, odoratus incus, pityufa, arundinum omne genus, bydropiper, ligufticum, xyphium, e omnes deniq; plante, qux freniculaceo caule affurgunt, ut el aphobo fcum, anethum, fe feli Maßilienfe, pyretbrum, phondylium, peucedanum. Laui conftant caule dracunculus, bafula regia, typha,nymphec, fideritis tertium genus, cbry fanthemum, aconitum lycoctonum, gentiana, ac antlius, alö̈, iberis, liy 


\section{In Lib. primum Diofcoridis.}

cinthus, millefolium, chamedaplne. Dodrantali caule excunt chameleo niger, tripolium, byacinthus, arum, fe amoi= des, daucum Creticum, caucalis, cunimus tefticulus, cpimedium, byperic um, fideritis tertium gcmus, centaurium minus, anonis, jlucftre cuminum, tußilago, antuthe, inthyllis, anthemis, coris, ocinoides, achillea, elatinc, pentaphyllu, tra

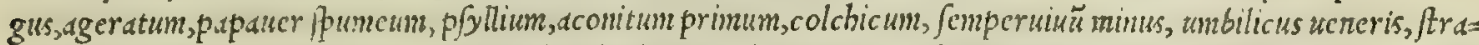
tiotes millefolium, chomeciffos, glaux, polygala, laurus Alcxandrina, tithymalusmyrfintes, puralius, heliofcopius,

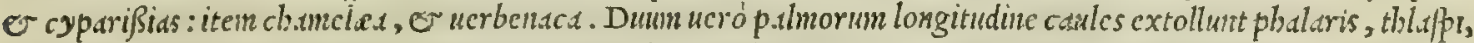
melantbium, peonis, ueratrun albim, cynocrambe. Caulis cubiti altitudine adole foit peta/itse, plantaginiminori,

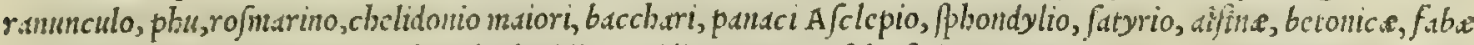

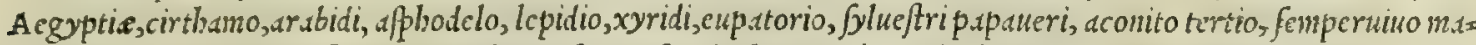

to iori, fenecioni, uerbafco femine, cytifo, xanthio, ru fco, diphnoidi, chamedaphna, lathyri, primo filic is generi, crico, gladiolo, afcyro, ly/imachis. Interdum cubiti longitudinem caule excedunt alifma, cyperis, titbymalis sharacias, pi=

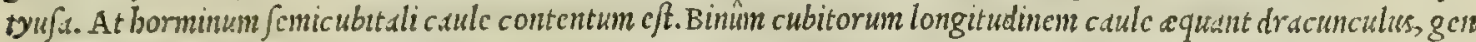
tiana, fina alba,acantbus, conyza maior, althea, fymphytum fecundum, belenium, glafum, glycyrrbiza, centauriun maius, dip facum, carduus, fe fcli A ethiopicum, lycop/is, fidericis fecunda, thanicum folanum, fylucftris lotus, cirfium. Quxternun cubitornn caulis cxit noly : tricubitalis ueró Medio. Duris ligno/is cं; nituntur cauliculis bypericum, cha medrys, teucrium, fymplbytum petreum, dindro femum, afcyrum, fatureia, thymum, origanum, millcfolium, cupato= riun, after Atticus, byfopum, frechas. Lentore o mollitia caules langue cunt irioni, poterio, malua, fmilacibus o= mnibus, cucsurbitis, peponibus, er mclopeponibus, cucumcribus; lupino, periclymeno, bryonia, uiti nigr $x$, uicie, belxi= ne, qusm ciffampelon cognomin.mt, fcrmmonio, iunco, typha, althax, alcea, folano fomnifero, ofyrigrufco, daphnoi=

2o di. Spinis borridum gcrunt caulcm dipfacum, poterium, agriacantha, fcolymos, p.liurus, rubus, canirubus, bieracium

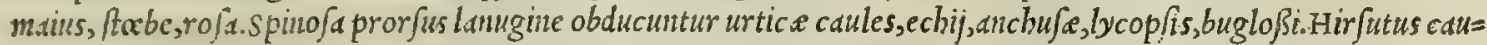
lis wifitur menthuftro, orobancha, helenio, ocinoidi, cup.torio, herbe quan pilofellam uocant, fecundo fymphytige= neri. Lanugineun calcm nutriunt acantbium, gnaphalium, uerbafcum, lychnis utrag;, tußilago, althed, ancmone, pa= naces Heraclium. Scabritia or aperitate caulium funt paftinaca, rubia utraque, lipus falictarius, aparine, baccharis, fylueftris cnicus, ethiopis, equifctum, ucratrum nigrum, papauer fylueftre, er corniculatum. Hunicauliculis repunt polygonum, lithopermum, andgallis, clemat is prima, holofium; tribulus terreftris, peplos. Canles cdunt quadrangulos

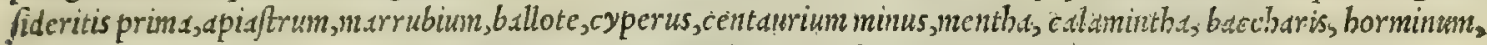
aparine, rubia, chamedrys, ftachys, fordium, teucrium, betonica, fymphytum fecaidin, clymentin, uevbenaca, urti= ca, galiop $/ i s, x$ thiopis, lotus Acgypti, bunium, xanthiun; cbulus, pycnocomum. Triangulares infunt cirfio, or quan: 30 doq; ctism cypero. Cetcrim caule albicant moly, utrig; iberidi, nafturtio, cnico, edicalia, cynocrambs: Rubefcunt mi= nori hieracio, foncho, artemifie, byperico, afcyro, phu, uirga aurea, bel wine, fenccioni, myriobly llo, orobanche: Caule dcftitumsur chaneleo albus, phyllitis, filix,cynogloffum, dryopteris, polypodium, ono ind, trichañanes, afples

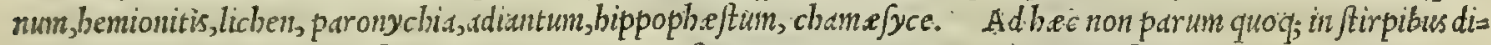
gnofcendis utilitatis praftat flor um tum coloris, tum forme cognitio quippe cuini rulla fit edrun pars, qux prius no= ftris fefe offerat oculis ucre, $\sigma$ aftate, quam flores, uaria colorum pictur, quie ineis ref ulget. Quapropter non ab re fucrut, hor um diferentias cdocere, que in coloribus ita fe babent. Plant te igitut, qua flore candido decor ätur, sunt ut oxyacantha, ligufrum, orneogloffum, fir axinus, rofe, quibus tum ruber, twm etian purpurcus erumpit. Item oled, myrtus, cerafus, malus, pyrus, me pilus, prunus, arbutus, iberis, raphanus, $\sqrt{i}$ fer, cucurbita, caucalis, eruca, ocimum, or s nithogalum, cyclanini fecunda fpecies, haftula regix, capparis, poterium, thymus,inoly, aparine, phalangium, trifoliü,

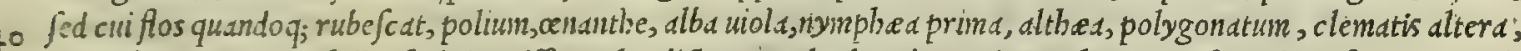
ocmafrum, erinus, achulled, belxine ciffanpelos dicta, conwoluulus, doryonium, ephcincrum fecundum, ftratiotes mile

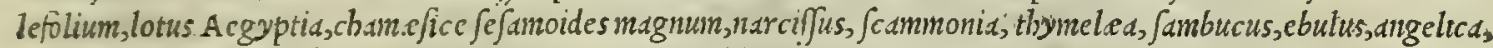
filipendula, viburnum, flammula, fragaria, imperatoria, lilium conuallium dictum, es uincetoxicum. Rubriflores emis cant rofis, in quibus tamen uariant, nam alij candidi, alij purpurei, alij lutei reperiuntur : item malis punic is, fabe $A c=$ gyptie, rumici, oxylapatho, oxalidi, blito, apbace, ophiofcorodo, anemone prino genteri, argemone, antgallidimax fcule, papaueri fylueftri, folano fomnifero, onigre, e caryophyllis uocatis, quem flor em recentiores quidam, ne cio qua auctoritate ducti,uetonic un appellant. quanquam $\sigma$ bi purpurei emergant, $\sigma^{\circ}$ quandoque uaria colorum miftu= ra inficiantur. Flores menthe, fifymbrij, o bydropiperis colore fubrubro apparent. In purpura albicantes infunt phu,rofis, perfico, amygdalo, eruo, bacchari, trifolio, alcex, periclymeno, rbododendro, pronix. Purpurei exeunt tbymo fatureix fimili, thymbr $x$, ferpyllo, fed qui in album quandoq; uarient, peudomelanthio, chanadry, lichnidi, fcordio, wiolse purpurca, canis teficulo, onobrychi, betonica, fymphyto utric;; : etfi fec undum modó candido, modó iuteo flore letetur. Item medio, gladiolo, ancbufe, lycop/i, echio, fiderititertia, tterbenac a, aftragalo, byacintbo, cir fio, capno, bubonio, fed cuius interna flaue $\int a n t$, antirrhino, acanthio, glauci, ueratro nigro : támet fi quando o, buic pa nicei, herbacei, candidi, o in purpuram albicantes flores reperiantur. Item fe famoidi maiori, rictino, amaranto, gale: ge, perfonate, xantbio, bormino, martago (fic uocant recentiores lilium quoddam ) fcrofuldrie maiori, geranio : A $t$ in purpura nigricantes in funt uiolis, leontopodio, delphinio, napello, pulfatilla. Aure is floribus coronantur be: Ienium, cornus, rapum, napus, lamp ana, braßica,crithamum, fonchus, dphaca cichorij genus, tragopogon, cucumis tă crraticus, quàm fatiuus, pepo, lactuca, irio, ranunculus, anemone fecunda, aconitam lycoctonon, cbelidoniwn utrin= que, fertula Campand, ruta, bieracium, atractylis, tußilago, conyza, ,emerocallis, wiold aure d, nympboe fec unda, and

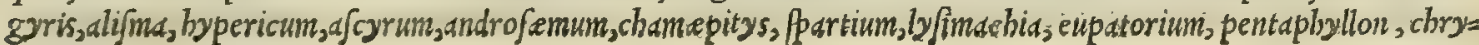

b. Socome, 


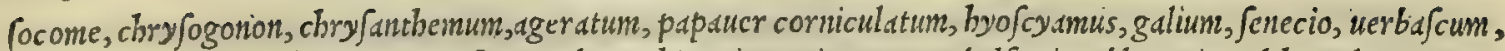

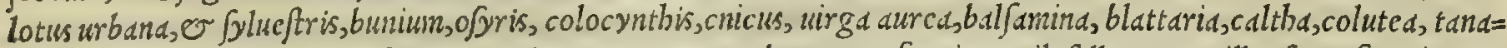
cetum, er quăfalsó oxy acantham recentiores nuncupant, abrotonum formina, pilofella, potentilla, fend, finapi. An= themidiflores exoriuntur in medio lutei, circinato orbe candidi, ficuti e parthenio, buphthalmo, bellidi, et cotula fre thd. . Ceruleum floren edunt limm, intubus, cichorium, chondrilla, anagallis formind, mur is auricula, clematis prima, bugloffun, melantbiun, eryngium, fcabiofa, o quà à uulgaribus mor Jus diaboli appellatur : item cyanus, or que trinitas recentioribus dicitur. Hyacintbino colore placent flores centaurij mxioris, chameleonis nigri, cinara : quin o uaria carduigenera. Vario colore inficiuntur iridi, tripolio, malus, cupbrafiz. Spicati infident blito, plantagini,

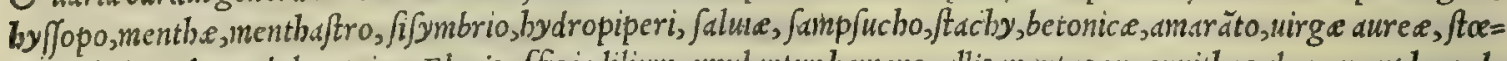
chadi,ladano, lauendula utri 6., belxine cognomento ciffampelos, lotus Aegyptia, narcifjus, crocus, conuoluulus, ephemerum primum. Flores, qui

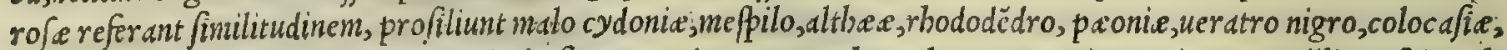
cornic ulato papaueri. Echinat is capitulis flores condunt uter $q$; chameleo, centaurium maius, crocodilium, fpind al = ba, dip $\int a c u s$, piina Arabic , poterium, acanthium, cinara, lencacantha, atractylis, cnicus, et reliqua carduorum genera. Mufcofos geftant flores laurus, labrufca, myrica, erica, liguftrum, olea, quercus, caftanea, cornus, galium. Flores in umbell ds radiantes, ucl mufcarijs emic antes in $\mathrm{unt}_{\mathrm{NeO}}$ fifaro, crithamo, caucalidi, origano, panaci, liguftico, pafti= nace, fefeli omni, fifoni, anifo, caro, idnetho, cumino, ammi, coriandro, apio, finyrnio, elaphobofco, freniculo, dauco, py= retbro, lib nnotidi, fibondylio, frularum omnigeneri, peucedano, laferpitio, fagapeno, galbano, panaci, ammonia= co, acbillc.e, clryy ocome, agerato, cicilta, fratiote millefolio, myrridi, thapfix, fambuco, ebulo, angelice, filipendu= $\boldsymbol{l}_{a}$, uiburno, imperatorie, cig; pimpinelle generi, que nonnuli bircinum faxifragum uocatur, quód hircum maxime 20 oleat. Cytini inaginem repr.efentant flores a fari, byofcyami, cifti, arbuti. Corymbis finiles racemation .coherent botry, ambrofie, andgyri, urtice, lunarie minori, hippophai. Lanugine quadam obducuntur, atque in pappos etuane= fcunt flores omnium carduorum, fonchi, tragopogoni, centaurij maioris, utriusq; chameleonis, utriusq; bieracij, fe= necionis, cirsij. Stellarum, folisq; flore imaginem referunt eryngium, after. Attic us, anthemis, parthenium, buphthal= Seminú, \& fiu mus, bellis, bypericum, pentaphyllum,intubus utraq; , cydllus. Preterea exquifitam prorfus plantarum cognitioné

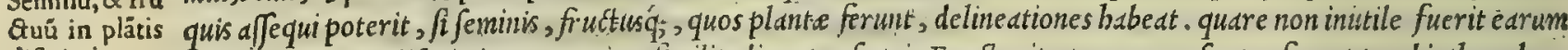
difcrimins.

tum figuras, tum difcrimina, tum etiam fimilitudines profequi.. Fructus itaque racemo os proferunt terebinthus, len= tifcus, populus utraq;, oxy acantha, uitis nigra, uitis alba, cyclaminus fecunda. Corymbaceos veró hedera, periclyme= nus, folanum hortenfe, or manicum, fmilax appera, polycnemon, hippophä́s. Semina autem racematim cobserent artemifie, ambrofie, botry, urtic a noftrati, mercurali famine, bydropiperi, ricino. A cino fa funt afaro, taxo, 30 ueficarix, apparago, rufco, lauro-Alexandrina: Semen folliculari pecie ineft fraxino, rbamno, fed quod uërticilli refe= rat imaginem, nafturtio, thlapi,androface. At in fquamofis folliculis occluditur gentiana, cumino fylueftri, atripli=

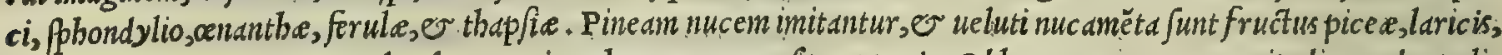

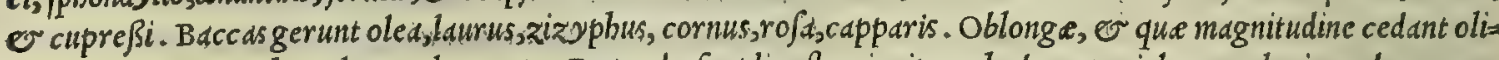
uis, uifuntur myrto, thymelae, polygonato. Rotuindx funt liguftro, iunipero, bedere, periclymeno, lycio, cedro, oxyd $=$ canthe, fabine. Ceterum fructum femen'́; filiquis includunt deacia, anagyris, genifta, filiqua arbor, cafia nigra,do= rycnium, apocynum, ftaphis agria, delphinium, cicer, faba, lens, phafiolus, lupinus, pifum, eruum, fena, fmilax hor = tenfs, medica, aphaca, uicia, peonia, leontopetalon,xyris, folanum fonniferum, o tertium aconitigenus. In follicus lis ueró abditur balicacabo, colucea, colchico, ev ft apbylodédro: fuumq́; in carniculis modó adunc is,modó rect is fer= uant delphinium, foenum grec um, lotus fylueftris, rapa, napus; rapbanus, lampfana, bra/3ica, eruca, finapi, erg/imum, 40 circea, letucoium, hedy farum, papauer corniculatum. Cipitibus femtnd condunt colocafid, anemone, argemone, melan thium, ocimoides, papauer tam fatiuum, quàm erraticum, byo fcyamus, lotus Aegyptia, xyris. At capitulis paruis con= cipiuntur lino, ptarmice, cumino fylueftri, fparganio, pfyllio, uerbafco, fcrofularie, ifopyro, ricino, tithymalo pa= $r a l i o$, e beliof copio . Semina in flocci modum conclufa afferunt porrum, ampeloprafum, fcorodoprafum, cepa; al $=$ lium, $\sigma$ fi prius folliculo quodam claudantur. Vmbellis nuda refídent femina omnibus panacis generibus: item $q$; $\int e f e=$ li,liguftico, apij omni generi, anifo, caro, anetho, cumino fatiuo, ammi, elaphobofco,dauco, phondylio, peucedano, elichryfo, cicute, mirrbidi, angelice, imperatorie, thapfie, coriandro, fmyrnio, foeniculo, pyrethro, ferulis omnibus, achillex, agerato, fratiote millefolio, fambuco, ebulo. Semen uelutipicis cötinetur origano tam fatiuo, quàm fylue=

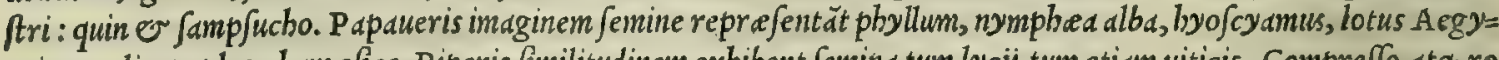
ptia, peplis, peplos, chamefice. Piperis fimilitudinem exhibent femina tum lycij, tum etiam uiticis. Compreffo, atq; ro tundo femine babentur malud, altbea, alced; fmilax lauts. Neque feminis effigie ab eputbymo dißidet alypon: à lolio phanix : d uiola alba chamaciffos: à faluia horminum. Hirfuto femine, ac appero, adeo ut id tactum uejtibus adbe= reat, funt perfondta, eupatorium, aparine, belxine, xanthium, or uulgare cynogloffum. Capiti uiperarum fimile fert cchium, er uituli non dißimile antirrbinum. Mucronatum oftendunt tragos, fpinachium fic uulgó uocatum, tribulus tam aquaticus, quadm terreftris. A foenigrecifemine non def cifcit femen my agri, item or loti fylueftris. Semen fani= culi modo ferunt ligufticum, fifon, cicuta, cuminum, carum. Anifi ueró femina, apì, or ammi confimilem nacta funt. formam. Cnici femen fuam impartitur imaginem minori centaurio, utriq; chamäleoni, pine albs, o Arabica, atra= ayl, cinare, Medio, nigro ueratro, er omnibus feré carduigeneribus. Milij femine conftant circad, crateoganum, panicum, $\int e$ amum, lithopermum, lotus Aegyptia, fe famoides : Erui femen poßsident catanance, tithymalus paralius, apbaca.Semine marrubium amulantur ballote, clinopodium, fideritis prina, pycnocomum. Confinilinafcuntur fe= mine libanotis, or crithamum: ut etiam femine conueniunt linum, fatyrium erythronium, e quoddan urtice genus. 


\section{In Lib. primum Diofcoridis.}

semine calude fcorpionis effigie cernitur fcorpioides : er uerruc arum modo pendet ninori heliotropio. Semind, que fructibus carno/is tam arborum, quàm herbarum dclite fcunt, geftant aluo mala, cotoned, pyra, citria, limones, aur ans tia, punic a,meßpila, cucurbit.t, pepones, melopepones, cucumcres, colocynthis : item balfamine unlgó uocata fi uctus, mandragora, ariftolochic, balicacabi. quin or mala infana confinili modo fuum recondunt: fencen. Minutum habent femen rut., iberis, cupreffu, circ.e $x$, pyllum, mandragoras, apios, cynocrambe, papaucr, byo fcyanus, ocimum. Diffe=

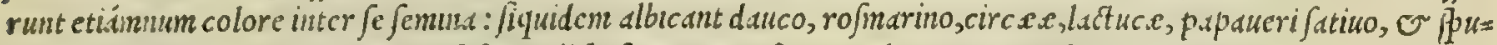
meo, cucurbite, peponi,cucuneri, fc fame, lithoppermo. Vt fructu rubent oxy acantha, tercbuthus, ccdrus, cornus, zi=

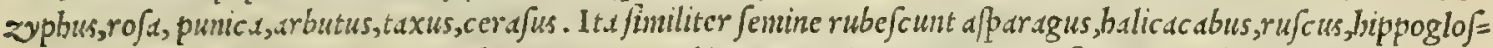
fum,rumex, dracunculics, arum,acanthium, peonia, rubia, tragus, iuncus, coccum infectoriun, appera finil.ix, chasnc=

so daphne, fefanoides. Succo fanguineo manant afcyri, androf emi, e bypercigrana. Nigrum ineft liguftro, lycio, myrto,olex. Quin er femina nigrant ocimo, hirci barbuls, porro, allio, cepis, ampeloprafo, byacintho, fcorodo= prafo, opbiofcorodo, faluie, rutx, bornino, liguftico, fefeli Acthiopico, fifoni, hippofelino, finyrnio, melanthio, phas ingio, rubis, fiteriti prime, uerbafco, laureole, narciffo, fylueftri cucuneri. In longum ueró protenfun proferunt fenten fe feli Mixfillenfe, ligufticum, fifon, bippofclinum, cuminum, narciffus, feniculum. Quadratumpectatur $\int e f c l i$ Maßilienfi, or libinotidi : triquetrum uerà ftaphidi agria, e latbyri. Geminatun femen ferunt tordylium, alyffon, athiopis, mercurialis alter d. Dijsident etian fapore femina : nanq; acre id proferunt porrum; cap $x$, allium,ampelo= prafum, fcorodopr 1 Jum, fisspis, nafturtim, eryfimum, frutbium, cyclaminus alter a, dracuncilus, origanum, panax Herculesm, fi feli Naßilicnje, tordylium, anifum, bippofelinum, faniculum, pyrethrum, peucedanum, cardamomum, clematis fecunda, fimlux a/perd, tblappi,bydropiper, ptarmica, arum, lepidium, ligufticum, er filiquaftrum, quod In= - dicum appellunc piper. Odorato fermine pollent omnia cardamomi Arabici genera, panaces Herculeum, meon, ca $=$ rum, panaces A fclepium, elapisobofcum, ligufticum, bippofelinum, finyrnium, forniculum, daucus, paftinaca fylue= ftris, melanthium, ifopyrum, bunium, origanum, ammi, libanotts. Amxrun femen ineft Acthiopico fe feli, omni abfin= thioruin generi, abrotono, ch.meciffo, gentiane, fe famoidi. In magnam denique duritiem femen coale fcit apparago, periclymeno, or rufco. Harum itaque rerum, qui exaitam cognitionem fuerit adeptus, is in hac preftantilsima facul = tate abfque ullo impedimento potcrit peritißimus euadere. Verùn enimuèro ne quid intactum relinquatur, quod in bac facultate tum ictile, tum neceffarium cxiftimari poßit, ob id fcire conuenit, quod permulta creauit natura rerum omnium parens, que inter fe uel maxime confentiunt, uel admodum diffentiant. Qus fit, ut nibil bac re admirabilius

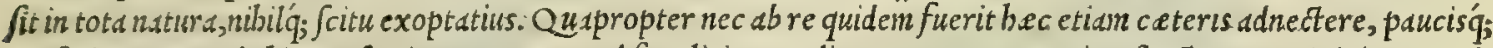
perftringere, e de bis prefertim agere ; que ad fimplicium medicamentortm materiam pectant. Tam igitur perti=

30 naci odio $\int e \int e$ profequuntur quercus; er olea, ut non folimn non uiuant, neque germinent, $\vec{j}$ altera effo $\iint_{a}$, in eius $\int c r o=$ be altera implantetur; fed etiam alter alteram interficiat, fi forté propé oriantur. Nec minor inter braßicam, uitem antip thbia cernitur: quandoquidem obferuatum fit, uitem, ad cuius radices aßsita fuerit braßica, non paruo in= teruallo ponte. fua rcfugere. Ideo nil mirum, fi tantum braßicam contra temulentiam pollere credant, "quód q;: Ger" mani quotidianis menfis id olus feimper apponat, ut uini noxam effugiant. Nec fecus braßicam oderunt origanum, ru= $t a$, o cyclaminus, atque illa uites: quippe perpectum eft, quód fi feratur braßica iuxta quavilibet explicatarum, confiftim cadit, totáf; contabe fcit. Scilla adeć ueneficijs, or admurmurantium incantationibus aduerfatur, ut in li= minc inuse domus integra fupenfa ab omni corusn noxa cos, qui inbabitant, uindicet. Quocirca non temere à doctif= fimis rerum naturalium inueltigatoribus memorie proditum eft, omnes in uniuerfum ftirpes, quibus fcilld adfita pro= filiat, non modó a feruari ab omni dëris intemperie, animalium $\tilde{\sigma}_{;}$noxa; fed etiam latiores, feracioresq́; euadere .

40 Ferula in pabulo ajinis gratißima eft, cosq́; mirifice alit: qux tanen, fi ab equis, uel bobus edatur, ueneni prefenta nei modo cos interficut: $t a m e t / i$ null a pror fus noxa e quoq; ab hominibus edatur prina foliorum germinatione. $\mathrm{R} b o=$ dodendriflores, $\sigma$ folia mulis, canibus, afinis, er quadrupedum plurimis uenena $\int u n t:$ bominibus ueró contra ferpë= tium morfus pr.efidia: Cicuta efitata bomines enecat :item or quadrupedes . nibilominus fturni innocue eius femine ue fcuntur. Cucumeres aquam ita diligunt, ut fi uas aque plenum, dum plantis inharent, illis. fubijciatur, admodum longiores effecti, miré in illan de fcendunt. Contrà oleum fuppofitum fic refugiunt, ut in hamos recuruentur . quan= doquidem in uniuer fmon ole um osnuibus, qux feruntur plantis, inimicum eft. 2uo fit, ut planta qualibet, qux. fuerit co peruncta, facile perare $f c a t$, or moriatur. $O b$ id enim admirandum non $\mathrm{e} f, f$ arbores, que oleum ferunt, ac re= finam mutunt, ceterarum infitiones appernantur : quemadmodum eas non reßpunt aliar um nonnillac, quae nec oleum nec refinam fundunt. (iquidem se pe conppecta eft quercus pyra ferre, platanus poma, myrtus puinica mala, oxyacan=

so tha mepila. At nunquam uife funt pinus, larix, piced, abies, oled, infitionis adminiculo, alios ferre fructus, qudm pro= prios. Grandinis impetum, item o fulminis ictum arcet pellis byene, crocodili, bippopotami, er uituli marini: neque fulmine iciuntur ficus, or laurus. Caprificorum großi domefticis ficis appenfi, non folum corü. fructus decidere pro=

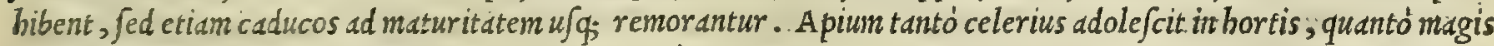
atterttur, e calcatur : cum tamen fecus, e contrà eueniat de reliquis plantis. Tenere fcunt galli, e fuiq; aptiores redduntur, qui iugulatiprius in arbore fici pependerint. Carnes putredine diutius illiefe afferuantur, quibus erreus claus fuerit infixus : Corpora if a fulmine, etfi exiccentur, nunquam tamen putrefcunt. Quare non immeritó poët ille damnatur, qui pliaéthontem cecinit de calo tąum quibufdam in uallibus computruiffe. Sed maiore miraculo no= bis illud fe fe offert, quod fcilicet fulminis itu é loculis dur um adimatur illis illafis, ac ne confufo quidem cera figno: pariter q́; ex dolio uinum euane fat, dolio nullibi fracto. Quid enim boc mirabilius? Martia princeps Rcomanarum grauida ita fulmine, partu exanimato, ip $\int$ citra ullum allud incommodum uxit. Mentba lacti impo/ita denjari ip= fum in cafeim non finit. Murene pifces ferula tata ftatim moriuntur. Scorpiones item admota delphinio berba, aut 
lyclinide fylueftri; atut aconiti radice, quod pardalianches nocsnt, adco torpe fcunt, or ftupidiredduntur, ut potias mortui, qudin uiui exiftimentur: ueruntamen albi ueratri contactu mirifice cxcitanitur, uiresq́; deperditas recupe $=$ vant. Succo cotule manus illite apun, ueparumig; aculco non infeftantur. Quod itcm inalua praftat oleo contufa,

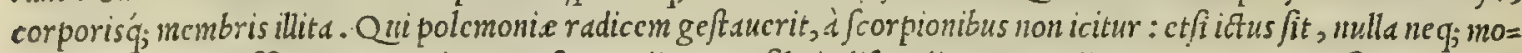
lefti, neq; noxa afficitur. Porrò tanta eft arundinis, o filtcis difcordid, ut arundine uomere annexa, filices in agro enats penitus deperdantur. At contrà magnam inter fe ineunt amicition arundines, e afparagi: quippe in arun=

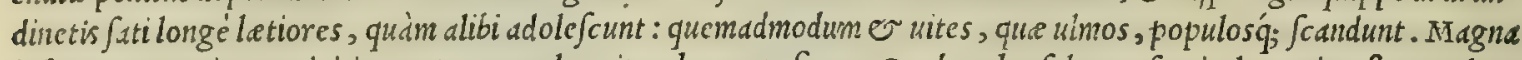
infuper conucniunt amicitia myrtus, o olca: itcm hac, or ficus. Orobanclse fola prafentia legumina ftrangulat. Metcllarum nucum efu peculiarius enecantur canes, quaim catera aninalia. Cimices lectularijfi uiui deuorentur, non folum quartanis febribus remedio funt, fed ctiam percußis ab apide profunt. Martyres, feles, or muftelz galli= 0 nas uon attingunt, que rute fucco fuerint peruncte: neque uulpes cas inuadunt, que pulmonem uulpinum comede= rint. vipcra fagiramulo obuiam facta gre fJum fiftit, or ueluti attonita manet . quod iten facit arundine etiam leui= ter percuffa. Furens elephas ariete tantim confpecto manfuefcit: nec cft taurus tam ferox, qui fico arbori adalliga= tus non mite $\int_{c a t}$. Magnes lapis mire ferrun ad $\int e$ trahit: at fí allio confricetur, id neutiquam agit, nifi fanguine hir= cino lotus uin $a b$ allio obfeffam redinat. Succinumpaleas, o feftucas ad fe trabit: nibilominus oleo illitum eas re $=$ perit. Equi, quos lupus momorderit, o pernici cur $f u$, o prolifica probitate pollebunt: at fi luporum ucftigia cal= caucrint, cruribus obftupe fcunt, ac conuelluntur. Carnes ouille a luporun morfibus dilaniate, cxteris teneriores, o guftatu fuaiores exiltunt: at carum lana ueftibus contexia, pediculos creat . Leo animal ferocißimum prefen= tem gallum mirum in modum ueretur, ac magis terrore concutitur audito eits cantu. Gallinacei pulli elephantem, bouen, of equum mininé metuunt : atqui fi umbrant tantum milui in aere uol sntis conpexerint, ad matrem maximé perterriti confugiunt. Nec fecus agint oues, o agni lupo conpecto. Idem lupus frille bulbo contacto quim pri= mum ideratur. Hyene umbra contecti canes obmutefcunt. itenh hyene ipfius lingud d latratu, ac morfu canum etiam. mordacißimorum ferentem uindicat. Polypodium herba cancro aninali admota efficit, ut is paruo temporis tractu tum integentes cruft as, tum ungues é pedibus abijciat. Ciconie platanifolijs nidos implent, ut inde uepertiliones abi= gant, quibus cumingens odium gerunt: Hirundines apiun comportant, ut tune as, \& blattas nidis ininicas arceant: item 0 chelidonium maius, quó obcacatis pullis uifun reftituant. Caeterum laurifolia nidulisimportant palumbes, accipitres bieraciuin, carui arum, upupe adiantum, cornices fupinam uerbendcam, turdus myritum, perdix arundi= nem, ardeola carum, aquila callitrichum, galerita gramen, cygni uiticem, ut di diuerfis animalium iniurijs fe uindi=. cent, aut ab alio quocunq;, quod noxam adferre poßit: tam admirabilis in wolatilbus, o quadrupedibus habetur ip= fius nature inftinctus, circa rerum uires abfconditas. Catus quadam berba adé gadudet, ut illi cataria nomen recen= tiores indiderint. Ranx iuncum, ranunculum, o ftcebem diligunt. Teftudines, O ciconic origanum adamant. Ser= pentes foeniculi affricatu uifum recuperant. Leo deuorata fimia fibrem efficacisiné difcutit. Cerue, o fere capre non modó dict ami pabulo illatd uulnerd in Creta infula fanant, fed o infixa tela uenatoribus reijciunt. Vrfi formicas deuorant, ubi mandragoram deguftauerint, quibus mirifice fanantur. Eleplantes devorato chameleonte animall o= leaftri froindes depafcuntur, quibus incolumes euddunt. Anferes, anates, ac relique aquatice aucs fiderite tantim berba fuis incommodis medentur: ficuti galline belxinem deuorant, grues iuncos, panthere bumanum ftercus, apri hederam, or cinaram cerua. Preterea rhabarbaro flaua bilis é corpore deijcitur, item'́; manna, or. fcammonio : pi= tuita colocynthide, or turpeto : bilis ueró a tra belleboro, o A rmenio lapide: ficuti o uenent theriacd fuperantur. Oculorum agritudines curant folo contactu fapphiri $\odot$ anthraces. Ebrietas ametbyfto lapide arcetur. Sanguinis de= fluxus iapide fiftitur. Topatio appenfo uenus infirma redditur : item er uitice le cto cubbantibus ftrata. Formic a alis 49 uepertilionis, er upupa corde fugantur. Quin e ferpentes ueterum calciamentorum fuffitu abiguntur: ut blatte, $\mathcal{O}$ papiliones bircino iocinore incen fo. Torpedo pifcis non modó manu, fed $\mathcal{\sim}$ longioribafta contadta tangentis bra cbium ftupidum reddit, quanuis ualidisinis musculis conftet. Catablepha quemcunq; oculo confpexerit, enecat, $\odot$ /f per mille paffus diftet. Nec inter homines de funt, qui laudibus, er oculorum intuitu conpectos effafcinent. Caterim fi.ceterarum uolatilium penne aquilinis permifceantur; breui caric contabe fcunt: quemadmodum teftudinum chor= da contact e difrumpuntur, fi una tantime ex lupi inteftino parata inter ess refonet. Eodem pariter modo tympana ouina pelle confructa franguntur, /i tympanum lupina membrana cötectun inter alia pul fatur. Tanta muficis, tibijs, caterisq́; id genus inftrumentis facultas aduerfus tar antule uenenum ineft, ut languentes etiam inuitos non modó ad

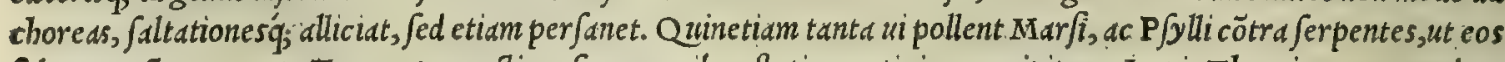
folo contactu enecent. Taurus perunctis rofaceo naribus ftatim uertigine corripitur. Lapis Thracius aqua madens so
igni admotus preter rerum naturam flammam ftatim concipit, nec re!tinguitur, nifi affufo oleo. Sed de his battenus: quandoquidem breuitatiftudentes plura adbuc filentio pretereunda duximus.

+ Hic locus (ut mibiretulit excellentiß. medicus Auguftinus Gadaldinus) in antiquo codice ita legebatur: eis

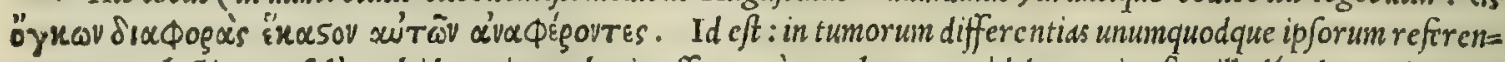
tes. Que lectio non folum ob id magis probaripoffet, quàm uulgata, quód dogmatica fit, illud'́; dogma innuat; quod facultatum medicamentorum caufam in tumores, $\odot$ meatus reftrebat; fed quòd etiam eius dogmatis memineris

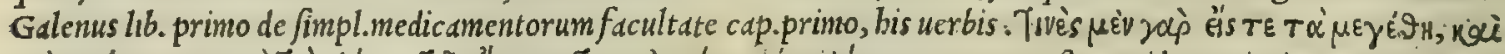

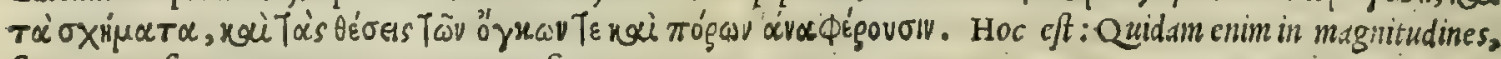
figurds, or fitus tumorum o meatuum referunt. 


\section{In Lib. primum Diofcoridis.}

IRIS DOMESTICA.

20

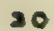

30

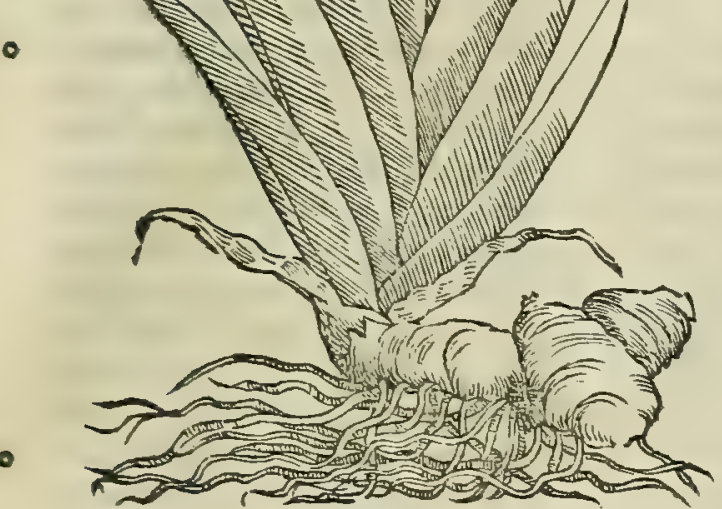

İers. I R I s.
IRIS SYLVESTRIS.

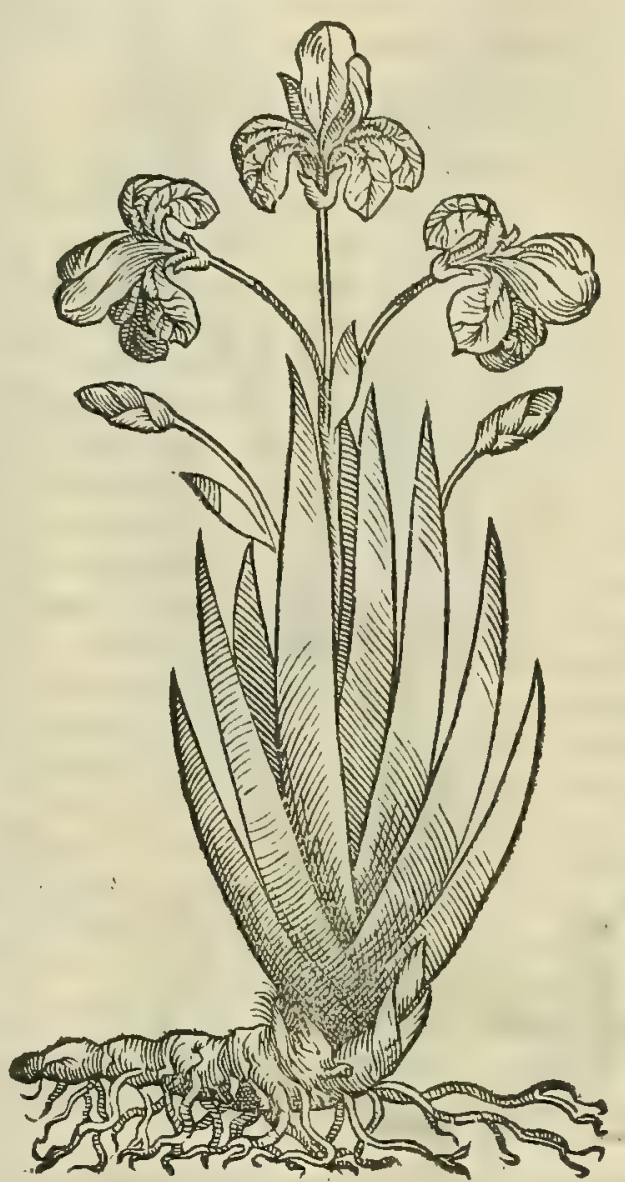

C A P. I.

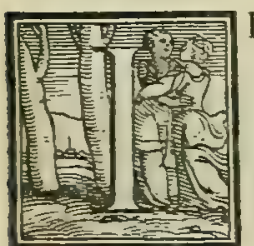

$R$ I s à cœleftis arcus fimilitudine nomen accepit. Folia fert gladioli, fed maiora, latiora, \& pinguiora. Flores $t$ in fummitate cuiufque caulis, $x$ qualibus inter $\mathrm{fe}$ fpatijs diftant, incurui, varij: fiquidem candidi, pallentes, lutei, purpurei, aut cxrulei confpiciuntur: qua diuerfi coloris fpecie, quædam cœleftis arcus imago repræfentari uidetur . Radices fubiacent geniculatæ, folidx, odoratæ: quæ fruftatim diffectx, in vmbra ficcantur, \& traiectæ lino reconduntur. Melior eft Illyrica, \& Mucedoncica: $\ddot{x}$ inter has laudatifsima, qux mutila fere, \& denfa conftat radice, frangenti contumax, fubrufo colore, guftu amaro, odore perquàm grato, \& fyncero, ita ut nullum prorfus fitum redoleat: quæ dum tunditur, fternutamenta mouet. Secundum locum habet Africana, candicans, guftuqque amara. Teredines in vetuftate fentiunt; tunc tamen odoratiores reddi folent. Vis omnibus excalfactoria, extenuans, contra tufsim efficax : humorum, qui xgrè reijciuntur, crafsitiem digerunt: bilem, craffamq́ue pituitam ex hydromelite drachmis feptem epotx purgant : fomnum conciliant, lacrymas ciunt, torminibus medentur. Exdem potæ ex aceto auxiliantur ferpentium ictibus, lienofis, conuulfis, perfrictionibus, horroribus, \& quibus genitura effluit : menfes ex uino potæ pellunt. Decoctum earum, føminarum fotibus vtiliter imponitur, ad emolliendos locos, laxandaque in eis uenarum fpiracula: ifchiadicis infunditur: fiftulas, ac finus carne explet. Radices ex melle glandis 50 modo fubditæ, partus extrahunt: quinetiam coctæ \& illitx, ftrumas, veteresq́ue duritias emolliunt. Siccæ quoque vlcera replent, \& cum melle purgant: nudata offa corpore operiunt: doloribus capitis cum aceto, \& rofaceo magna vtilitate illinuntur . Admotx cum albo veratro, $\&$ duabus mellis partibus, lentigines \& vitia cutis in facie à fole contracta emaculat. Pefsis, malagmatis, \& acopis inferuntur. In vniuerfum magni ad omnia vfus.

I R Is in uniuer $\int u m$ fatiua eft, o fylueftris. Hac duorum eft generum: alter d fatiue, 0 uulgarifinilis,folijstd= Iridis genero, men, flore, caule, radicég; pauló minoribus. A L T E R a folijs gladioli longioribus:radice tenui, lignof a, geniculd= ta, fubrufa, inodor a $\dot{q}_{;}$: caule breui : flore cateris longé minori, odore Armeniaci mali. Conftat bic folijs nouem pur= eiusque con: pureis, quorum extina, fuperiore tantum parte, aureis pinguntur lineis. Sunt qui banc legitimam Illyricam putent, I IIyricam ab Italica differre exiftimantes. In quorumfententiam etfi iampridem deuenerim; tamen longé aliter rem Se babere poftmodum cóperi. Quandoquidem preferri Illyricam nouerim, non quód genere, uel pecie à noftrate dif= 
Opinio repro bata.

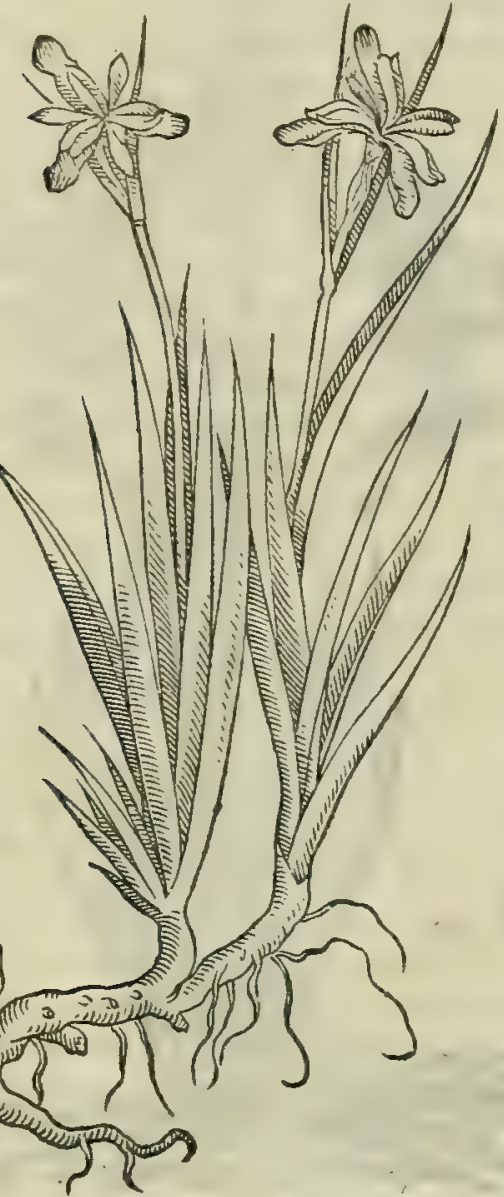

IRIS SYLV.ALTERA.

freat, fed qucd cxli, foliq; illius conucnicntia, preflantioribus pollcat facultatibus: ut abjinthium, ql!od in Ponto nafculur: aco= run, quod in Colcbide, $\leftarrow$ Galatix: cypcrus, qui in Syris, $\mathcal{C} C y=$ cladibus inflilis: coltus, qui in Arabix: crocks, qui in Coryco mon= te : myrrbt, que apud Troglodytas, o Ixincoos legitur: 0 alia quim plurina pr.efruntur à locis, quorum dote felectißima, pra:

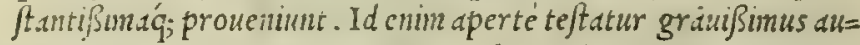
ctor Galcuus lib. prino de antidotis, bis uerbis. Omnes itaq; ber = barij unanimes fripferunt Irin in Illyrio natam optimam effe: pe= trofelimum ueró, quod in Macedonia proucnit: bitunten é Iudad 20 aducctum, itcm $\mathcal{O}^{\circ}$ opobal amum. Idcm $\sigma$ in reliquis fecerunt, quorum dotes à regicnibus acceptas, cum priuatin de unoquoque loquemur, ne omittcmus. Hac Galenus. Docuit id etium ante $G d=$ lenum Theoplaraftus lib. I X; cap. V I I. de hiftoria plantarum, fic inquiens. In Europa nibil prater Irim inueneris, que optima apud 1 llyrios exit, non tamen parte maritima, fed mediterranea, ma $=$ gisq; ad feptentrionem fita. Verim loci à locis differunt, ita ut producere meliorem poßint. Quibus paldmeft, Illyricam' Irim nongenere, or facie, fed uiribus tantum à noftrate difiungi. Sa= tiua (ut arbitror) ex agreftioriginem duxit, quemadmodum plan $=20$ tarum aliarum plereque, cultu tamen uegetior grandior $\dot{q}_{;}$effe $=$ cta. Seritur iam or altera, quan flore or folijs minorem effe dixi= mus, qux etiam in bortis fiequens cft, tumipfius floris amenitd= te, tum odoris preftantia, tum etian quód nouisfloribus delecten= tur bomines adeó ut iam to fatiua, quot fylueftris babeantur ge= nerd. Sunt tamen, qui putent nullam Irim domefticam reperi= ri, quod feripjerit Theophraftus loco anté citato, nullum Iridi cultum accommodari. Sed ij, neo quidem iudicio, decipiuntur. quandoquidem Theoplsaftus co in loco non de omni un unixèr fun Iride differit, fed de Illyrica tantum: que cum loci ac coeli cle $=30$ mentia in Illyrico tractu optima ponte proueniat, non eft necef= fe, ut coldtur. Pretered cim bodie Iris domeftica paßim in Italix hortis lxts, uirens, pulcbrá, fectetur: fylue= fris autem in plurimis montibus ponte na catur, floribus of folijs fatiue longé minoribus, radice tenuiore, breuio= re, $\sigma^{\circ}$ aridiore; nulli quidem $a b \int u r d u n$ videri debet, fi nos utranque depingi curauimus. Quinetian compertum ba= beo, ueteres quoque Iridis fylueftris mentionem ficife, non folum Marcellimedici austoritate cap. X X I I I I. qui preterea Irim domeftic am cultam q́; illis fuife oftendit; fed Galeni quidem teftimonio . is enim Iridis fyluefris memi= nit lib. $\mathrm{x}$. de comp. medic. fecundum locos, dum nepbritic as compolitiones ab a fclepisde confcriptas recenfet. Syl ueftris utriufque generis plurima oritur in Goritienfi agro Saluatino monte, or Iapidic collibus inter faxd, odore non ingrato: quanuis etian asmbas uiderim in campefribus non longé à Sontij ripis. Eft praterea in fatiuarum gene= re, que flores niuei candoris proftrat ( banc in pluribus Hetrurie locis uidinus) cuius radix odoris fragrantia, or uirium robore Illyricam feré a quat. Iridis meminit Plinius lib. $\mathrm{x} \times \mathrm{I}$. cap. V I I. fic inquiens. Iris radice tantim commendatur, unguentis, or medicine nafcens. Laudatißima in Illyrico: er ibi quoque non in maritimis, fed in fylueftribus Drilonis, er Narone. Proxima in Macedonid: longißimabec, er candicans, er exilis. Tcrtium lo= cum babet Africana, amplißima inter omnes, guftú; amarißina. Illyrica quoque duorum generun eft: raphanitis

Plinij contra à fimilitudine, qua o melior : rhizotomos fubrufa. Et cap. x x. eiufdem libri: Iris.rufa (inquit) melior eft, quàn dicto. candida. Quibus in locis fibl manifefté repugnare uidetur Plinius: quc d fuperius raphanitem, qua candicat, rhizoto= mo, qu.e rufe fcit, antepofucrit, bic uero contrà. Diof coridi praflat, qux fubrufo conftat colore, qualis plinio rbi= zotomos. Ceterum ( $f i$ Theopbrafto, or Plinio credamus) non omis Illyrica praftat, fed que tantum in fyluefri= bus nafcitur. fiquidem qua in maritimis foditur, bumore pregnans improbatur, quód fubinde flacce cens contraba= tur in rugas. Succus bydropicis propinandus, quonan recenti Illyrica deftithimur, é nofir ate elicitur, ducitq; abut=

Iridis vires p̈- de aquss. Excalfacit Iris ordine fecundo completo, uel tertio inchodnte, e pariter ficcat. Atque prater uires, - ter tradıas à quas illi adfcribit Diofcorides, alijs pluribus pollet. quandoquidcm compcrtum ef, manfam oris halitum commenda=
Diofc. re: dentium dolores mulccre, fi radicis decoeto ijdem foucantur . coquit item, abftcrgit, digert, , refolut, lenit, re= ferat, expurgat, or deijcit: unlnerarijs medicamentis inmifta farcotica eft. Radicis cxpreffus fuccus bilent fawam, pituitam, er aquas cutem fubeuntes pcllit: hemorrboidas fotu elicit. Radix ip a contrita, er ex accto bióta, onni= bus aduerfatur uenenis. Succus naribus infufus cercbrum di pituita mirifice purgat: uentrichlo tamen nocet, cim per fe tantum bibitur . ideóf; à peritis medicis exhibcri non folet, nifi admift. mulf, er Indic nardo. Reperio quod= dam effe Iridis genus, qux Aftragalitis cognomine dicliur. Id enim oftendit Galemus lib. I. de compofirione medi= camentorum fecundum locos cap. primo ex Sorano tranfcribens: item A cims lib. x I I r. cap. I I. qu quibufdam in emplaftris Irin aftragaletidem imponunt. Veruntamen clim antiquorum, ucl recentiorum repererin neminem, qui

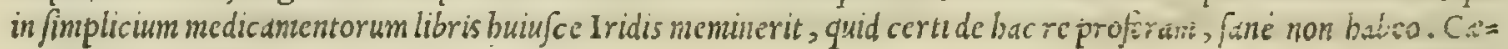




\section{In Lib. primumDiofcoridis.}

terim Cornatrius, ayi in predictos Galenil libros commentarios edidit, I rin aftragalitem, er aftragalum idem effe exiftinat : hoc argumento ductus, quod Plinius Iridenn duplicem cffe tradiderit; alteram, qux ruphanitis à fimilitu= dine; alteram, quxe shtzotomos dicitur. At cim aftragalus radicem raphani modo ferat, inde Iridem aftragalitem

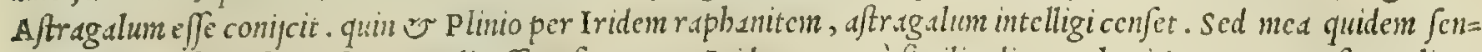

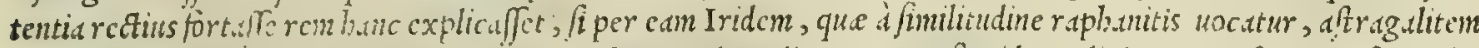
ideo defignari dixiffet, quod ut aftrag al us, ruphani modo radicen gerat: fiquidem Plinio Iris raphanitis afr ragalus non eft, fed altera Iridis Iilyricit pecies. Quamobrem ita Iridem aftragditim a Galeno cognominatan cffe puta=

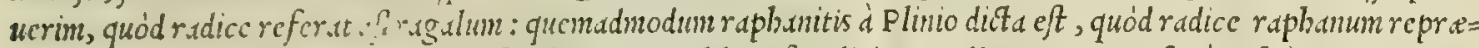
fentet. Iridem memorie prodit.m f:ilf]c Galeno in libris fimplicium medicamentorum fané me fquam repert: $t a=$ 10 metfi libro primo de antidotis cius poftmodum meminerit bis uerbis. Andromachus ro fis Iridem Illyricam adiungit. Iridis mentio

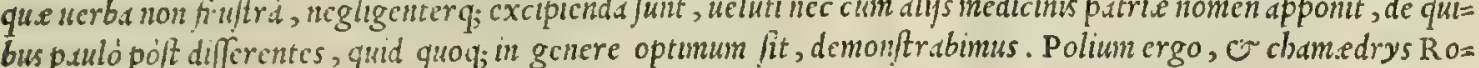
mam afferuntur, natis in Itali. paulo meliora in aliquot fiquidem I talia locis haud inultó deteriora prouenimut il= lis annis, qubus uer totum luunidum non fucrit, fed ficuti fxpe conting it, aftiuo temporifimile. Quódfi ueris cont= fitutio ficcior obuencrit, multa, ques in Italia nafcuntur, pluribus Creta allatis paria crunt, aut non multo infrio= $r a$, ueluti cham.edrys, cham.epitys, bypericum, gentiana, thlafpi, ueratrum nigrum, or td genus alia. At ueró, quod ad Irim pertinet, fecus fe reshabet: fi enim Iris I ybica, qua plurma ex Africa Romam affertur, Illyrice comparctur, tantum ip/ícedet, quantum cadauer wiuo corpori : non tamen alijs in gentibus orta tam multum ab Il= lyrica degener.are Iris uidetur. Irim igitur, uelut or reliquas medicinas, odoratiorem cligito: nam unumquodque 20 optimum eft, quod propriwn fil generis odorem uchementißimum babet, qui quidem ex multorum inpectione mani= fiftus unicuiq; /it. Ac de guftu quidem perceptis qualltatibus codcm modo cenfendum eft : id cnim optimum medicd= mentum efe conftat, in quo id, quod fro generi proprium cft, exuperat: pe ßimum ueró quod fuigeneris alijs o te= muius, o exilius eft. IIeliora narque funt omni in pecie, quecung; nec rugofa, nec exilia fuerint: ficut que con= uenientem fibi magnitudinem exceffere, peiora fint ijs, que bene nutritam, o adftriftam babent fubftantiam.

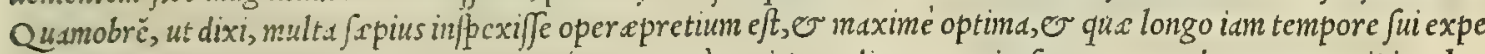
rientism ip fis nafcendi initris prebuere, que q́; uno ore à peritis medice indterixe funt commendatd. Omnes igitur ber barij unanimes fcripfcrunt Irin in Illyrio natam optinam effe. bee Galenus. Planta, qua Grecis íg1s, Iatinis item Iris nominatur: A rabibus, A fmeni inn, fiue Aierfa:Italis, Irtde, Giglio azurro, aut Giglio ccelefte: Ger= manis, Blaun gilgen, Blaut fchuuertel; Veiel uurtz, Huncl fclbuertel: Hipanis, Lirio cardeno: Gallis, Glaieul, aut Flambe.

A C O R V M.

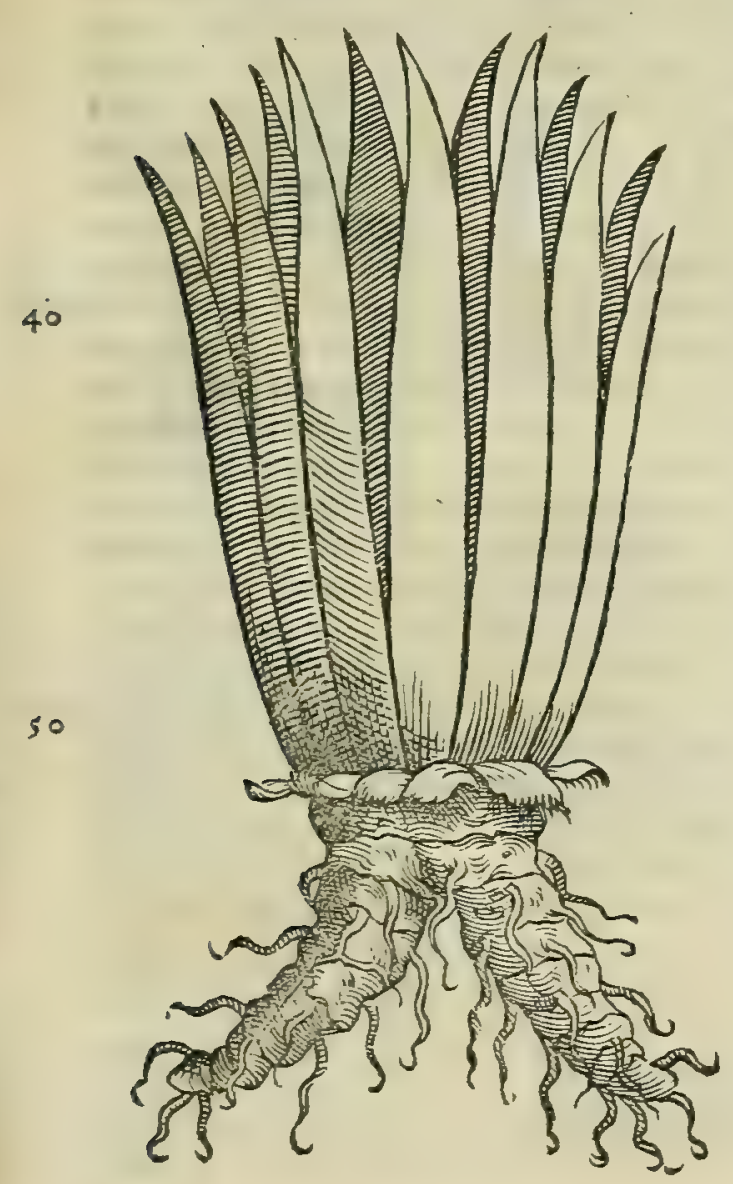

+ Maluiboc in loco Marcelli interpretationem fequi, quem= admodum alibi quandoq; facturus sum, qudm Ruelli, cui non $\int e m s$ per addictus ero: quod in aliquot Gracis codicibus legatur Ė $\pi i=$ $x$ w $\lambda \alpha$; qux uox in fummitate cunusq; caulis fignificare uidetur:

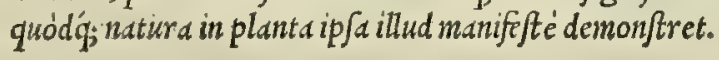

\section{Alno:v. ACORVM. CAP. II.}

A C. R v M folia iridis habet, anguftiora tamen: radices non difsimiles, complicatas, non in rectum, fed obliquum actas, \& fummo cefpite fparfas, geniculis interceptas, albicantes, guftu acres, odore non ingratas. Optimum eft denfum, candidum, plenum, $\mathrm{Ca}-$ rie non exefum, odoratum : cuiufmodi Colchidicum, \& Galaticum, quod afpletion dicunt. Radici uis calfactoria. Decoetum potu urinam cit : prodeft lateris doloribus, \& iocineris, atque thoracis : item torminibus, vulfis, ruptis . lienem abfumit : urinæ ftillicidio, \& ferpentum ictibus auxiliatur : infidentibus ad muliebres affectus, iridis modo, vtiliter imponitur. oculorum caligines fucco difcutit. Antidotis radix magno vfu commifcetur.

F E C I T diuturna reiberbarix ignorantia, ut hactenus non Acori confiin Italia folium, fed in quocunque terrarum loco, ubr feplafiarij, deratio. o medicibabeantur, in legitimi. Acori locum rufa quedam $r a=$ dix fucceßerit, qus paßim in paluftribus, or uliginofis locis inu= tilis, er inodor a plurima nafcitur . eo fané argumento, quód folia, or radices iridis profer at ; quanuis he colore rufe, illa ueró iri dis longiora fpectentur. Hac itaq; radix apud omines, quiplan= tarum biftorids neglexerunt, in boc ufque auum legitimi A cori 
ACORVM FALSVM.

Brafauoli error.

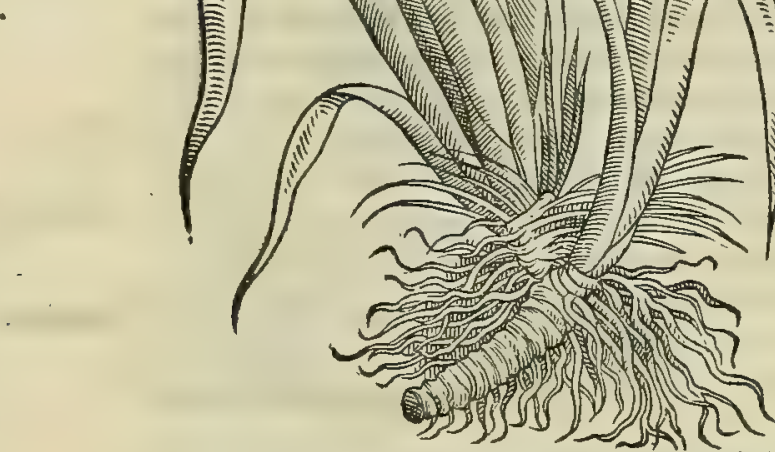

muncre functa cft: à qua quantum tum qualitatibus, tum facultas= tibus recedat, ex Diofcoride patet. quandoquidem paluftris bac nec candicans, nec gufu fit acris, nec ullo prorfus commendetur odore. At quanuis bac tempeftate à peritis rei berbarix medicis non parum improbentur ï, qui non in bac tantìm ftirpe, fed etian in alijs quim plurimis deficere, chim tamen ipfi probatißinos au= Etores nufquam legerint, potius excufandi funt, quàn quidam for: taffe etatis noftre fcriptores, tam Grece, quam Latine lingue peritißimi ; quibus res fole clariores propofite funt, quiqu, in fim=. plicium medicamentorum cognitione cateris preftantiores babe= ri uolunt, er ij longius nibilominus (ut arbitror) aberrant, quim ceteri. E' quorum numero eft Brafauolus Ferrarien/is, uir fane doctrina, e fama clarißimus: : qui dum innumera fimplicia medi= camenta declarare, explicare, er pal àm facere in fuo fimplicium examine ftudium impendit, etfi id in plurimis affecutus fuerit; in. boc tamen, alijs'; nonnull is (ut fuis locis in bis noftris commentd= rijs oftendemus) in tanto illugtrium auctorum lumine mibi magis cacutire videtur, quim qui ante ipfum in tenebris errauerunt. Is enim conftanter afferit, Acorum à Diofcoride defcriptum aliud non effe; quìm eam acerrimam, o odoratam radicem, quam of ficine Mauritanos fecute Galangam uocant .adeó ut malueritcü Leoniceno errare, tantum fuit precéptori fuo didditus,quàm cum Manaxdo bené fentire. Sed quantun eius opinio ì ueritate, quan= tumó; ab Acori biftoria recefferit, perquaim facilé probari poteft. Quippe galangaim folid iridis proferre apid syrios nullo nobis te= ftimonio conftat : verim quia cum cypero adeo contenit, ut is $\sqrt{y} \mathrm{~L}=$ ueftris Galang a nonnull is dicatur; ideo non ab re credendum fue rit, galangam potius cyperi, quàm iridis folio prouenire. Pre= terea quod galanga radices habeat iridis, nec mibi quidem ui= detur, nec ullum id affirmare exiffimo. neque illud etiam ui= dere polfum, quód exdem aliqua ex parte fubalbicent, ut de Accri radicibus fcribit Diofcorides: quin potius tam intus, quàm extra non obfcurérufe fcunt. Quód autem guftu fint acri, atq; morddici, qui neget, nullus eft. Sed non ta= men ob id dicendum erit, galangain effe Acorum, alijs non concurrentibus notis : prefertim cim Diofcoridis teftimo=

Fuch fj error. nio A corum effe debeat acre, non autem acerrimum, nec galange modo linguam adurens. Brafauolum fecutus eft Fucbjitus medicus clarifimus. is, cùm fibi nimis pumila uiderentur prioris gatlang radices, quìm ut Acori radices referrent, atque propterea Brafauoli fententiam non probandam duceret, in fuis de ftirpibus commentarijs, alteram craßiorem galangam, que iampridem in It aliam fertur, Acorum effe contendit. Verüm fi animaduertatur, quód ea

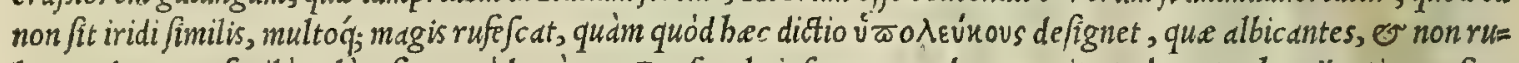
bentes denotat, facilé pal àm fiet, quód unà cum Brafauolo ipfe quoque aberrauerit. Sed prater bac ïj etiam refra= gatur Galenus lib.v x.de fimp. med. facult. quód afferat Acori radicein guftui non modó acrem effe, fed etiam fuba= maram : que tamen modica amaritudo neque in bac, neque in illa reperitur galanga: etfi inualidis quibufdam argu= mentis $\int u o$ ultimo examine contendat Brafauolus, quód galanga preter acerrinam facultatem etiam fit amara. Sed uereor, ne is tunc bile perfufus fuam deguftauerit galangam. Comprobatiur preterea aliud efe Acorum, or aliud ef= fe galangam Serapionis teftimonio: qui, cum fciret non parum difcriminis inter bas radices effe, de ijs feorfun egit per propria capita, utpote de rebus genere o facultate diuer/is. Hoc idem probatur ex Actuarij etiam monumen=

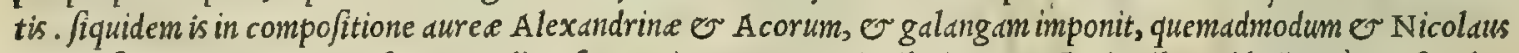
Myrepficus, tanquam inter $\int e$ genere diuer $\int_{a}$. His itaque tum rationibus, tum auctoritatibus adductus, à Brafauolo, o Fuchfio diuer fus effe cogor. Nec equidem intellexerim unquam, quomodo factum fit, quód galanga maior, que à minore non genere, e facultate, fed tantüm pecie differt, cum primum buc és syria aduecta eft, in Acorum fe com= Acorum le- mutauerit. Sed qui bec intelligunt, dijudicent. Caterim, ut dicam quid bac in re fentio, crediderim ego und cum

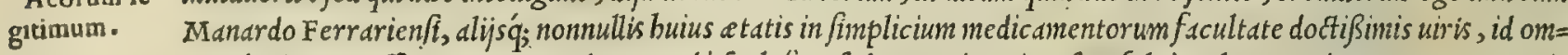
nino legitimum effe Acorum, quod non modó feplafie, fed omnes in uniuerfum falsó Calamum odoratum uocant. Si= quidem radices primum iridi perfimiles funt, geniculis diftintte, reflexe, fubalbide, dcres, odore preftantes, er (ut inquit Galenus) etiam fubamare. infuper o folia, que integra ad nos unà cum radicibus ( $u$ t bec pictura de= monftrat) é Conftantinopoli allat a funt, id apertius affirmant: funt enim ferme iridis. Ad hec ut Aeniponti (Germa= ni I Pruch dicunt) retulit mibiclarißimus medicus Ioannes Merula, qui pluribus annis degit apud Lituanos, quod paßim calamum aromaticum uocant, frequentißimum in Lituanid, $\sigma$ circa Tartarorum fones, nafcitur : folijs iridi amulis : flore etiam fimili, colore rofco purpurafcente, nulla ex parte uario : caule iridis longiore gracilioréq, à quto tamen nullus exoritur calamus : uocatur' ; ab incolis fuo idionate Tattarfchi zelij, id eft, berba Tartarica, quod for $=$ tafe à uicinis Tartaris in Lituaniam primum fuerit allata. Ideo ; Plinio menoria redtc proditum eft lib. X X V. cap. $x$ I I I.optimum id effe Acorum, quod ex Ponto aduchitur. Pontus enim his Tartaris feré iungitur, qui ultra I ituania inbabitant, 


\section{In Lib. primum Diofcoridis.}

inbabitant, ubiapud probatißimos auctores nufquan legitur, odoratum calamum oriri. Quamobrcm non poini non maximé Brafaulum admirari, quód fibi ram facilé perfuaferit, unlgaren calanum legitimun, or odoratum calds= mum cffe, d Diofcoride, Thcopr.sfto, Galcno, o Plinio non in radicum, fcd in arundinum generc defcriptum. num (ut fwo loco de calamo odor.to agentes latius explicabimus) is arundinea cft fitul.t, non autcm radix. Sed de bis batenus. Acori meminit Galcmus lib. v I. de fimplicium medicanentorum facul. fic inquicns. Acori utinur radi=

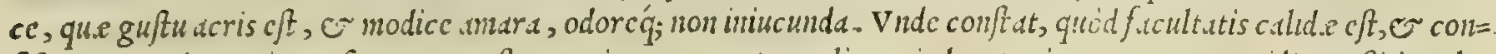
fiftentie tenuis. Huic confentaleum cft, ut urinam moneat, or lienes induratos iunet, tun ceratoidis craßsticm de= tergeat, fimuli, cxtenuet. Sed ad boc melior eft ipfius fuccus. Ommino ueró ficcificum cffe clurum cft. Et fané or= dinis efto tertij in utroque, in calfaciendo frilicet, or deficcando. Häc Galeius. Sed quando bic aligitid dicere de

10 Galanga occurrerit, cuin i Diofcoride, alijsí; antiquioribus Grecis nibil de ca memori.e proditunt fit, differam ego dc bac, que à Mauritanis, or sijs fum confecutus. Eft itaque G A L A N A duplex:maior altcra, al= Galangęconter minor. Minor tenuis eft ridix, interius or exterius in purpura rufefcens, geniculata, internodijs quibufdam fideratio.

reflexa, odor.uta, fapore udmodun acri, adcó ut manda piperis, er gingibcris modo lingudm, er fauces cxurdt, odore formá; cypero finilis quapropter quibufdan cyperus Babylonicus dicitur. In Italian nanq; tam cx Mem= phi, quim ex syria transfertur. Optima qux fuerit grauis, dcnfa, faturaté rufa, odorata, er guftu acerrima: Non defint tamen intpoftures, qui cyperi radices contorquentes, accto, o pipcre macerent, Ð pro Galanga uen= ditent. werim fraus facilé deprehenditur : quippe abrafo exteriori cortice, mulla in radic is fubftantia acredinis no=

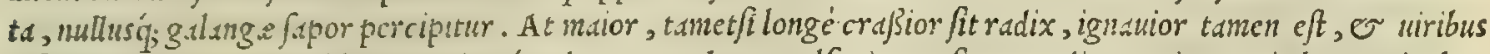
infirmior, colore ctiand dilutior, minus,ǵ; odorata. Galanga calfacit, er ficcat ordine tertio. Proinde uentriculum 2o roborat, $C^{2}$ cius dolores tollit; fi tuncn a frigore, uel flatu proucniant. Naribus admota frigefacto cerebro utilis eft: ore retenta andelitum comnendat. Facit $\sigma$ ad cordis palpitationcm, fie plantaginis fucco bibatur: caliacos fanut, or coliálores mulcet, qui i flatu oriuntur. Prodeft flatuofis uteri affectibus: uenerem roborat: renes re= frigeratos calefacit in fumma figidis ntorbis omibus fuccurrit. Ceterim omnino explodenda cft Monachorum in Mefue cribcutun opinio, qui conira Brafaulum $\sim$ Fuchfum quafi uelle uidcntur, Galangam potius odoratum iuncum effe, quim A cosum. quod tamen plané falfum omnibus iam compertum effe non dubitanus. Quod Grace äropoy, Latiné etian Acorum appellatur: Arabicé, Vage, feu Vgi: Italicé, Ácoro: Vulgo medicorum or fe= plafiariorum Calamus aromaticus.

MH̃oy. IIEON.

30

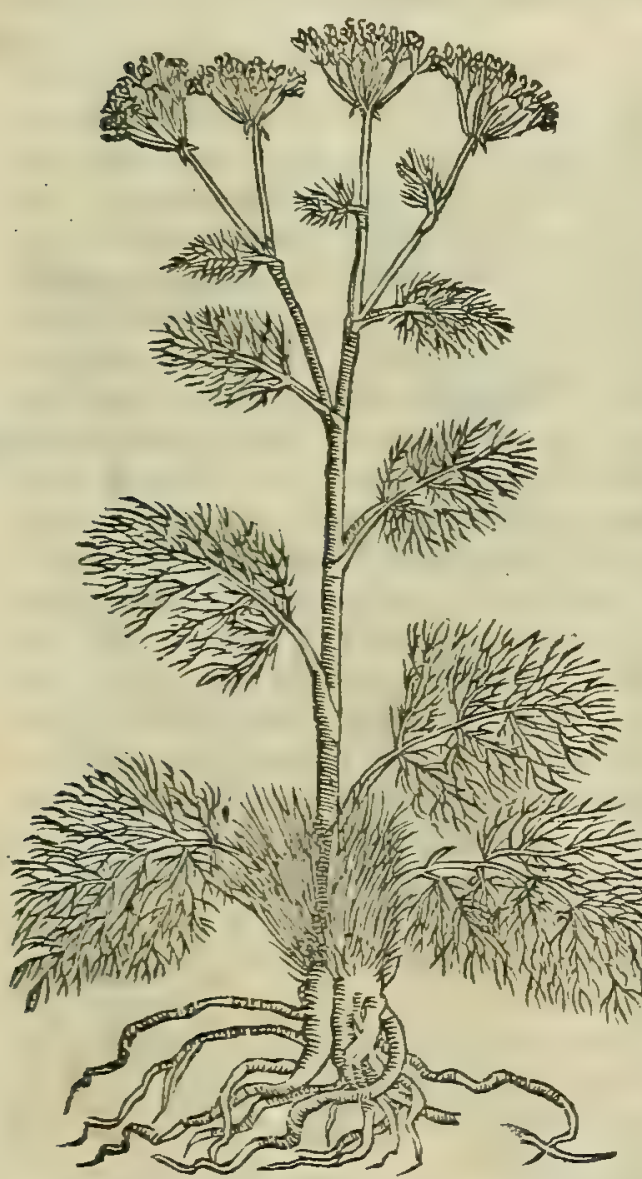

C A P. I I I.

ME ON, quod Athamanticum uocant, in Macedonia, \& Hifpania plurimum gignitur, anetho folijs \& caule fimile, fed eo crafsius : binûm ferme cubitorum altitudine attollitur : fparfis in oblıquum, rectumq́ue radicibus, longis, tenuibus, odoratis, linguam excalfacientibus. Qux feruefactx ex aqua, uel tritx citra coctionem, prxcluforum renum, ueficxáue farctæ uitia potu leniunt: vrine difficultati medentur : Atomachi inflationes difcutiunt. Torminibus, affectx vulux, articulorum doloribus, atque fluxionibus pectoris, tritæ cuin melle in eclegmate auxiliantur. Sanguinem per méftrua pellunt, defefsionibus feruefactx: infantibus autể illitx imo uentri,vrinas mouent. Quòd fi plus quàm deceat, ex his bibatur, caput dolore afficiunt.

C R.E D I D. I MVS fuperioribus annis, legitimum Meon Mei confidenon oriri in Italia, nec có aliunde duehi: primù quód Mei ui= ratio. ce uterentur feplaffarij quibufdam albicantibus radicibus, fapo= re paftinace fimili: deinde quod etiam Plinij tempore rarum effet. in Italia. quippe qui fcripferit non feri in I talia Meon, nifi à me= dicis, ijsq́; admodum paucis. Quod proculdubio indicare uide= tur, ufque ad Plinij auum peregrinum in Italia fuiffe Meon. Sed cum berbariorum quorundam diligentia, quedam nuper reperta fit planta que folijs conftat anethi, caule bicubitali, radicibus nigricantibus, longis, $\odot$ in obliquum, rectum $\dot{q}_{;}$parfis, graui= ter odoratis, acribusq́;, quam legitimum effe Meum, omnes feré reiberbari.e periti unanimes affirmant, ne uidear mordicus tene= re opinionem, facere equidem non poffum, quin in corum fenten= tiam deueniam : tamet $f$ in contrarium aliqua $\int e$ e offerat ratio, quód fcilicet buiufce plante radices odorem non ufque adeo gratum pirent, fed quaddantenus grauiter oleant, nee tenues cernantur, ut Diofcorides inquit. Plinius Meo folia anifo fimilia reddidit, uocum fortaffe fimilitudine dece= ptus. Fiquidem Diofcorides anethifolijs Meum oriri tradidit. Nobilius quod Athamanticum uocant, ita diftum, quód
Acori uires ex Galeno.

Monachorü opinio falla. Nomina. (n) 
Meivires ex ab Athamante Acolifilio inuentun fit, uel quod preftantifimum in Athamante Phthiotidis proueniat. Meminit Galeno.

Mei Galenus lib. V I I. fimplictum medicamentorum, his uerbis. Meiradices perutiles funt, calide tertio ordine, fic $\Rightarrow$ ca fecundo: proinde urinam, menfeśq; cicre uolentes boc utuntur pharmaco. Sed fi plufculum fumatur, capiti dolorem mouet, utpote cimp plufculumfit calidum, quàm ficcum . quippe quód eius calldit.s bumiditatem crudiorem

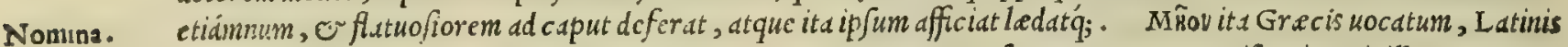
Mcun dicitur: Arabibus, Mu:Italis, Meo: Germanis, Baer uurtz, feu Hertz uurtz: Hifpanis, Pinillo.

\section{Kúøescos.}

C Y P E R V S.

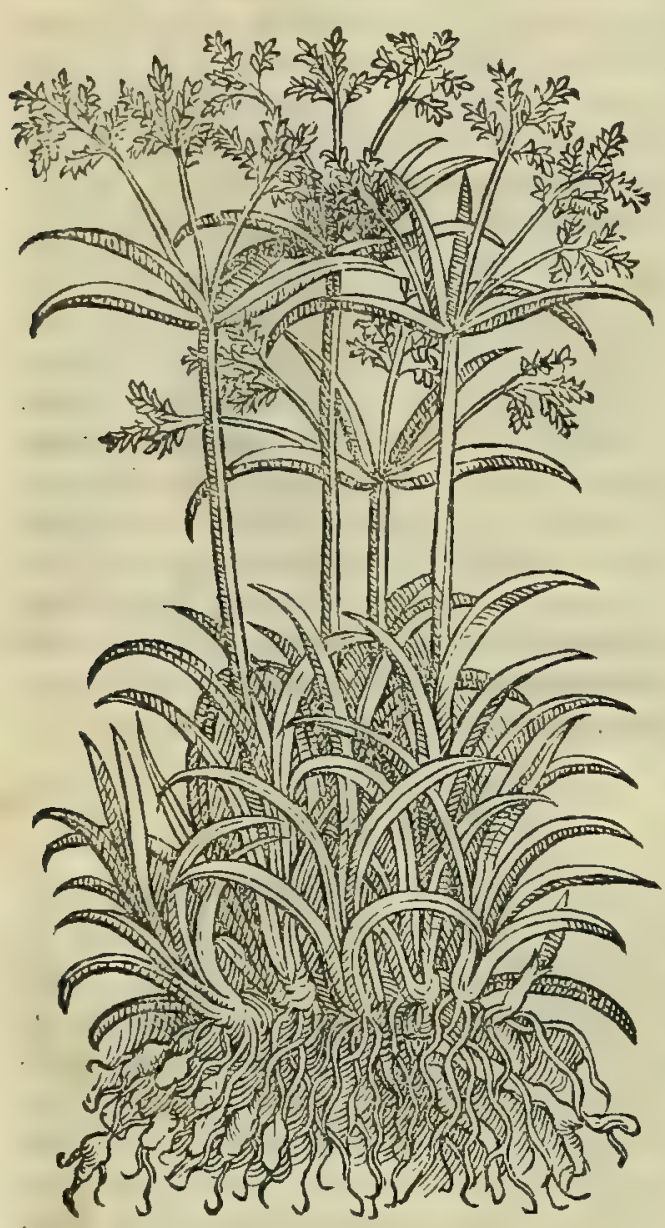

C Y P E R S , quem aliqui eryfifceptrum, ut afpalathum appellant, folia fert porraceis proxima, fed lon- 10 gior, \& exiliora: caulem odorati iunci, cubitalem, aut maiorem, angulofum : in cuius cacumine minuta folia cum femine exoriuntur : radices, quarum in medicina eft ufus, cohærentes inter fe, oleis oblongis fimiles, aur rotund $x$, nigro colore, fuaui odore, amaro guftu. In lacunofis, paluftribus, \& cultis enafcitur. Optima eft grauifsima, denfa, fractu contumax, plena, \& afpera, odoris cum quadam acrimonia iucundi : qualis eft Cilicia, $\mathrm{Sy}$ riaca, \& qux à Cycladibus infulis petitur. Huic calida uis ineft. Venarum fpiracula laxat : urinam ciet: ad calculos, aquamque fubtcr cutem utilifsimè bibitur: aduerfus fcorpionum ictus remedio eft : perfrictionibus vulux, is praclufionibus fotu prodeft: pellit menfes: Contra ulcera oris, etiam fi depafcant, uorentq́;, farina eius efficax eft. Malagmatis calfacientibus, \& unguentorum fpiffamentis benè adijci folet. Aliud Cyperi genus tradunt in India nafci, gingiberis effigie: quod manducatum croci uim reddit, guftu amaro fentitur, \& illitum prafentem pfilothri uim exhibet.

T A M E T S I unum tantum Cyperi genus memorix prodiderit Diofcorides, cuius radices inter fe coherentes oblong as re= frunt oleds, aut omnino rotunda funt; uifitur tamen Cyperus in pluribus I talic locis, qui radic ibus conftat longis,geniculatis fum= mo cepite uagantibus, colore in purpuram nigricante. Nafcitur boc Cypcrigenus laudatißimum prope Timauifontes circumftă= tibus palufribus locis in Iapidie finibus, gdlang $x$ uocdte (ut paux ló ante diximus) perfinile, non tantiun facie, fed etiam odore. Commendatur etiannum odore is, qui in Hetruria prouenit, radicibus feré filipendule emulis. Sed non ob id illi fue= rit preferendus, quem syria mittit: quandoquidem bic longc odoratior eft, $\sigma$ Jubamarus. Cyperi meminit Plinius lib. $\mathrm{x}$ x r.cap. $\mathrm{x}$ V I I I. ubi de iuncis egit, fic inquiens. Quidain etiamnum unum genus faciunt iunci trianguli, cype= ron uocant. Et pauló inferius: Cyperos, cit, iuncus $\mathrm{e} f$, ut diximus, angulofus, iuxta terrain candidus, cacumine niger, pinguisq́; : folia ima porraceis exiliora, in cacumine miuuta, inter que cft femen : radix oliue nigre fimilis, quam, cum oblonga eft, cyperida uocant, magni in medicind ufus. Reperitur cypcrus quandoque etiam quadran= gulari caule . unde non mirum, fi quadratum iuncum eum uocauerit Cornelius Celfus lib. I I I. cap. X X I. At Dio= fcorides in bac facultate preclarißimus, utranque differentian colligens, nec triangulum, nec quadrungulun $C y=$ perum dixit, fed angulo fum. Optimus defertur ad nos ex syria, er Alexandria A egypti, in cuius defectu Italicum Jupponunt officine. Non defunt, qui differentiam ponant inter Cyperum, or Cypirun Plinium fecuti, qui libro, o capite citatis, Cypirumgladiolum effe affirmat, Cyperum ueró angulofum odoratum iuncum. Sunt tarnc $n$ Dio= fcoridis interpretes, qui utroque uocabulo pro codem indifferenter utantur, eo quòd (ut recté Hermolaus adnota= uit) penultimam Cyperi quandoque diphthongo longam, quandoque uocalibreuem Graci foribant. Eft apud Pli=

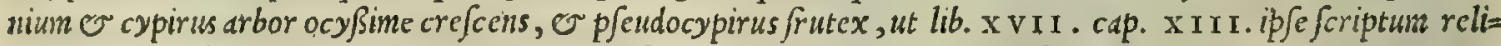

Cureuma cy- quit. Catérim id Cyperigenus, gingiberis cffigie, quod India mittit, ean cffe radicem peritiores medici putant, quam officine Mauritanos fecute Curcumam uocant. Nempe pre fe fert bac notus fanc omnes, quas Indico cype= ro rcddidit Diofcorides, quandoquidem gingiberi finilis eft, eius odorem ferme redolet, guftu fubanurcicit, facroci modo inficit. Quibus illud ctiam accedit, quod depilatorijs medicamentis quibufdaniminifcetur. Verunta= men fciendum cft, hane non effe curcumain à seraptonis interprete pro chclidonio defcriptum : ipfe critm ritl aliud pro curcuma intelligit, quàm Diofcoridis cbelidonium. quo fit; ut non defit jupicio erroris uel interpretis, uel fcri= ptoris, cim curcuma neque Mauritanum, neque Grecum fit uocabulum: Aplbrienis chelidonium Kauroch aps pellant. unde paldin eft, Curcuma pro Kauroch in Serapione depraudte legi. Quo fattun cft, ut priores tum medici, tum feplafiarij, qui nunquam bec perpenderunt, fwerint hallucinati. quippe cum cos lateret, cuiufnam plan= uata.
Lectio Serapionis depra 


\section{In Lib. primum Diofcoridis.}

te radicem Indica cyperus referret, chelidonij matoris radiccm cffe crediderunt ob crocei fucci fimilitudinem. It ta; serapionis deprauatum lectionem fecuti, Indicum Cyperum curcuman uocauere. Indicicyperi meminit Serapio Diofcoridem fecutus, proprio capite de Cypero. Ex quo aperte con/tat, curcumam Serapioni deprauate infcri= ptam, feplafiarum curcumam, que procul dubio Indicus eft Cyperus, effe nequaquam. Cyperum receifuit Gal. lib. vir. fimplicimm med. "bific inquit. Cyperiradices maxime ufuifunt, excalfacicntes pariter er exiccan= tes abfque mordscitate. Itag; ulccribus, que pre nimia bumiditate cicatricem difficulter admittunt, mirefice pro= funt: babcht cnin quiddan ctiam adfringens: quapropter ulceribusitcm oris conueniunt. Quin $\sigma$ incidendi uim

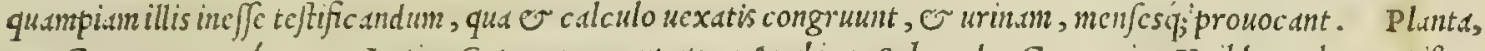
que Greca Hoce xúbejos, Latima Cyperus nuncupatur: Arabica, Sabcrade : Germanica, Vuilder galgan: Hipd= 20 nica, Iuncia de olor, o Iuncia aucllanda: Gallica, Soucbet.

$$
\text { Kao } \delta \alpha \mu q \mu o v . \quad C A R D A M O M V M \text {. }
$$

CAP. V.

C A R D A M M V is optimum eft, quodex Comagene, Armenia, Bofphoroq́ue deuehitur. in India quoque, \& Arabia prouenit. Eligi deber plenum, frangenti contumax, occlufum, farctumq́ue ( quod enim huiufmodi non eft, exoletum iudicatur) \& guftu acre, fubamarum, \& odore caput tentans. Excalfactoriam uim habet: potumqque ex aqua facit ad comitiales, ifchiadicos, tuffes, neruorum refolutionem : item ad rupta, vulfa,tormina: latas uentris tineas excutit. Ex uino autem potü, renibus, difficultati vrinx, à fcorpione ict is, neque non omnibus venenum vibrantibus, auxilio eft . Cum cortice radicis lauri epota drachma, calculos comminuit : partus fuffitu enccat : fcabiem ex ace20 to illitum adimit. Et ad unguentorum fpiflamenta additur.

L E G I T I M V M Cardamomum noftra tempeftate nec cognofci, nec minus à mercatoribus, qui ex syria, uel Acgypto arcmsis ad nos conucbunt, deforricompertum babeo. Quo fit, ut medici, ac pharmacopri in componen= dis medicanentis aque errent in Cardanomo, atque in alijs compluribus, quod Cardanomi loco uarijs quibufdam fentinibus, odoratis tamen, indifferenter utantur. Quorum primum Cardanomum maius: fecundum Nigellam, quod melanthij eft genus : tertium ucró Meleghettas, uel grana paradifi nuncupant; cim tamen eorum nullum nec Gre= cum, nec Nauritanum fit Cardanomum . quandoquidem aliud Graci, dliud ueró A fri pro Cardámomo intelligunt, ut apertifimé teftatur Serapio, quiquim plurina fimplicia medicamenta ex Diofcoride, or Galeno tranfcripfit. Is chim ( ut fua declarant monumenta) Diofcoridis Cardamomum Cordunenum appellat deinde auctore Ifach Ara= 30 bo fui Cardamomi peculiare caput inftituit, id ; $_{\text {; }}$ Saccolan fua lingua nominat: quin er duîm effe generum tradit, al=

PIPER INDICVM. terum maius, alterum ueró minus. quorum nulltum non modó Dio= feoridis Cardamomo reppondet, fed nec etiam ulli corum, quibus officine indifferenter vituntur. Probatur itaque primum, quód $0=$ mne officinarum Cardamomum Diof coridis Cardamomum effe nö poßit, pluribus tum notis, tum etiam qualitatibus quippe quod bee in uniuerfum parum, uel feré tantilluin den a fint, frangenti non contumacis, or guftui nibil amaroris relinquant. Quod pre= terea ab Arabicis diftent, fic cum illis comparentur, facile dipaz ritas deprebenditur . Fiquidem Serapionimaius Cardamomum $\int e=$ men eft plante, quod oblongis quibufdam concluditur capitibus, iis fane fimilibus, que è rofis prodeunt, granis obnigris, rotundis; pipere longe inaroribus; in quibus minuta femina concluduntur, angulofa, farcta, or adoratd : minus uerd nullo contegitur capi= tulo maioris modo, quanquan colore conueniant. Quod plané in= dicat, omne officinarum Cardamomum nec Arabum effe, nec pa: riter Gracorum, fed potius ab utrifque maximé differre. Qure' Monachorü putauerim, illudfalso fibi perfuafiffe Monachos, qui in Meficem; error. fcripere, quod Arabum Cardamomum minusillud femen fit, quod feplafia Meleghettus uocant, Andrex Bellunenfis, qui Auicennă mendis expurgatuit;auctoritate freti. sed cum Bellunenfis id affe= rat unlgari tantùm opinione ductus; cimiq; note mininé eorü fen= tentie adftipulentur, errafe Monachifacilé deprehenduntur, se= mina enim, que Meleghettas appellant (ut omnibus plané confat) capitulis exceptä fuboriütur, quod minori serapionis Cardamomo nö euenit. Crediderunt, Ruellius in fuis denatura ftirpium libris; Ruellij \& FuFuchfius in fua methodo, id omnino Mauritanorum effe Cardas chlijlaplus. momum, quod nos PI P E R I ND I CV M; alij filiquaftrum appel E. Piperis Indici lant . uerum cum planta hec fol ijs exeat horten/i folano fimilibus, mentio. floribus luteolis, fructu longo corniculorum inftar, qui prino exor tu uire $\int c a t$, maturus ueró adeó rufe $\int c a t$, ac leuore quodà ita pel $=$ Iuceat, ut corallium referat, er in quo concludatur pumiliu femen, 
lentium modo compreffum, ufqueddeo acre, ut ori tantim admotum maximé linguam, of palatum exurat, ex่ulce= ret'́; , anbo hac in re lapfi dcprebenduntur. Nam etfi Indicum piper in bifce corniculis rofarum ferć nodo fuum in= cludat femen, reliqua tamen Serapronis Cardamomo nullis notis correfpondent: boc eirim fuis in uafculis globulos quofdan concludit, non lenticuls fimiles, fed rotundos, of ptpere craßiores, qui intra fe minutum quoddsin femen continent. Huc ctian accedit, quód cum hoc piper corniculatum; tum fomine, tum corniculis ip is tanta fit acrino= nia praditum, ut non modj manfum, fed ori tantiom admotum ftatin quafi ignis cxurat, abjurdum utique fucrit cre= dere Scrapionis Cardanomum efe, ciun dixerit ipfe mxgis adftrictoria facultate pollere, quàn acri. Caterim feri= bit Auicenna maius Cardanomum grana ciceribus atris, minus ucró lentibus minora proferre. Quod cum fortaffe Ruellius lsaud rect ć percepiffet, ei errandi anfam prebuit. quippe minori Cardamomo, non autem maiori femina . lentium modo nafci ait Auicema: quançuan R ucllius, ut fuam tueatur fententian, fecus forté legertt Auicennam. Cardamomi Plinius lib. X I I. cap. X I I . quadruplex cffc Cardanomigenus fcribit, fic inquicns. Simile eft amomo Cardamo= genera ex Pli mum or nonine, or fiutice, fcmine obiongo. Metitur eodem modo o in Arabia. Quatior eius genera. uiridißi= no. mum ac pingue, acutis angulis, contumax ficianti, quod maxiné laudatur : proximum é rufo candicans : tertitum breuius, atque nigrius : peries tamen uarusn, of facile tritu, odorisi; praui, quod uerius colto uicinius effe debet: Hoc or apud Medos nafcitur. bactcnus Plinius. Sed nefcio quos auctores fit fecutus quandoquidem tam Diofcori= di, quàm ceteris Grecis, unum tantim extet Cardamomigenus. In cuius defectu fupponit Galenus aut myrtum, aut Cardamomi cyperum. Quipreterca Cardamomi meminit lib. V I I. fimplicium medic. his uerbis. Cardamomum cft fané facul=

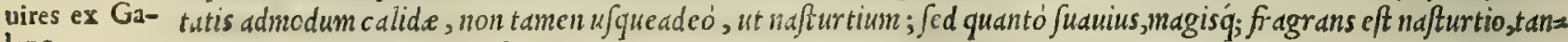
leno.

Nomina. tó or imbecillior cicalida facultas incft: nce crim ulccrare idoncum eft uel ipfum per fe illitum. Porró adiunctum habct quiddam ctiam anaritudinis, qua lumbricosinterficit, of cum accto ualenter poras detergit. Cardamo:

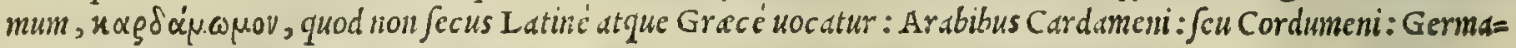
nis, Cardanomelin.

\section{NARDVS INDICA.}

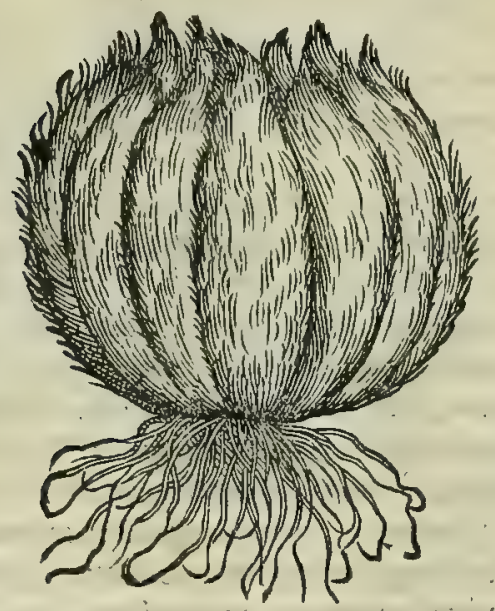

\section{NógSos. NARDVM. CAP. VI.}

D v o Nardi genera : unum Indicum, alterum Syriacum appellatur, non quòd in Syria proueniat, fed quòd montis, in quo oritur, pars vna ad Syrios, pars altera ad Indos fectitur: Ex hoc Syriaci genere, pracipuum eft recens, \& leue, largam gerens comam, flauum colore, perquàm odoratum, ac cyperum redolens, breui fpica, amaro fapore, linguam ficcante, quod diu in fua odoris gratia permaneat. Ex Indico autem Nardo quoddam Gangitis wocatur, à fluuio Gange, apud quem enafcitur, monté præterfluente : quod genus ob multan loci, in quo prodit,uliginem, uiribus infirmius eft,atque procerıus adolefcit; plures ferens fpicas, ab unica radice comofas, vnàque conuolutas, ac graujter olentes. Montanum autemodoratius, fpica bieurac mutila, odore cypero uicino, creteras habens Syriaci dotes. Eft \& genus quoddam, cui Sampharitico nomen locus indidit, fruti- $4 \circ$ ce breui, in magnas fe fpargens fpicas, candidiore interim medio caule, hircorum uirus fupra modum redolente-: quod improbatur. Madefactum uendi folet . quod uitium ex eo deprehenditur, quòd candida fut fpica, \& fqualida, fuaque careat lanugine. Adulteratur ftibio cum aqua, aut palmeouino, infpiffationis ponderisque caufa infpirato. Intueri autem oportet, fi lutum radicibus infideat, $\&$ incerniculo puluerem excutere, eluendis manibus utilem. Vim habent excalfactoriam, sc exiccantem. Vrinam mouent:aluum potu fiftunt: vulua profluuia, faniemque appofita fupprimunt. Naufex ex aqua frigida auxiliantur, \& ftomachi rofionibus, inflationi, iecinori, regio morbo, renum nitijs. Aquæ autem incoctz fotu ad inferfum, vulux inflammationibus medentur ad glabras oculorum genas ualent: fiquidein eas ad denfiorem pilum reducunt . perfufis humore corporibus infparguntur. Mifcenturantidotis, \&c in fi- $s 0$ ctili nouo non picato ad ocularia medicamenta reconduntur, trita in farinam, \& cum uine in paItillos coanta.

Nardi Indica \& Syriacécó fideratio.
- N A R.D V M officine Nardi ficam appellant. Sed non defunt, quicredant Indicam nardum in Italiam non aduchi ob regionis diftantiam, syriac am opinantes effe, qua noftro auo. feplafiarij utuntur : tamet/i (ut inquit Dio= fcorides) in Syria non oriatur, uerum ideo syriacam dici, quód ea montis partc proueniat, que flectitur ad syrios. At cum inter Indos, or Syrios amplißime interponantur regiones, nempe de ferta A rabia, Pcr/is, Carmania, Ge= drofia, Darangia, aliéq; non nulle, que ultra quatuor millia milliariorum continent, ne ciuerim profectó, quónam pacto ficri poßit, ut mons ille ad Gangem pofitus, altera parte syriam tam facilé repiciat, ut Nardus ca paite pro= ueniens syriaca dicimereatur. Quo fit, ut quandoque inec um dif quirere licuerit, ecm potius à syraftene regione, qua ad Indicum fluuium eft, syrij nomen fibi afciuiffe, quàm à syria. quandoquidesn, $f i$ P tolcmeus uerdinefert, mons 


\section{In Lib. primum Diofcoridis.}

in Indis uiftur, qui ḋangc fluuio ad Syraftenem extcnditur. Abfurdum cnin efet credere, Nardum ad nos non deferriex India, cisn in Syris mu/quan proueniat, chmiq; multa India aronata, mulla diftantia babita rationc, per curouanas ( ut wocant) in Alcx.udrian Acgypticonfrantur : cum quibus nec temeré credendum cft, quin Nardum etian conuebant mercatorcs; prefortim cum certó friam, Nardun Venctias cx Alcxandria afferri : nec eam alibi; quim in India nafri, Diofcoridis teftimonio futis apcrte monftretur; etfi Plimius contrà foribat nafci in syria Nar= dum, preter cam quam Indiamittit Syriucam Diofcoridiappellatam. Caterim Manardus Forraricnfis, officina= rum nardum nec Indicam, nec syriac an effe ccufet. In cuius fententiam non equidem pedibus co, etfi medica mate=rie is clarysismus fuerit indagator. quippe quomam Venctijs pluribus in locis $\mathrm{N}$ ardi ingentem copian uidi,lcuis, $c 0=$ Manardiopinio zeprobamofe, perquin odorate, cyperum redolcitis, thate, fubumare, or manfe non modó linguam exiccantis, fed odo=

to rem eriam non iniucundum per os apergentis, mullisif; deficientibus notis, quibus optima nardus ex Dtofcorides fen= tentia exploraripotc/t. Sed plerunq; accidit, dun per Indicum, or Arabicum mare in Alcxandrian defrrtur, or inde Venetiss, ut afcito fibi maris bumorc ( $t$ d nanq; fucile fit, quod Nardus fit ficcißina) ucl fitum contrabat, ucl fubputrcfat : unde poftea amiffa fuacolentia, grauiter oleat. Quo fit, ut hac in re Manardum longé hallucinatum crediderun : qui fi recté perpendiffet, que Nardi pars fit fpisa, atq; in emporijs, ubi numerofa, praftantißima'́, ui= fitur, accuratius ipfan expendiffet, non equiden uereor, quin aliter de ca fcripfiffet. Verum enimuero cum plané ignoraffet, qua nardi pars ppica cffet, felectamó, o incorruptan Nardum minime nouiffet, lib. v I. cpift. I I I. feribit, Galenum de nardiffic.t, que antidotss admifectur, loquentem, radicem quidem, non picam intelligere. Et. utinam, inqut, que nobis affertur, legitima effet: fed quod ea ip fa nonfit, cognofcitur, quod nulla odoris fuauitate commendetur. Et lib. VI I I. cpilt. 1. inquit. Galenus lib. I. de antidotis in theriac compofitione Nardiradicem

so tantununodo admi $c c t$, co quód uiribus ipfa praftantior fit: fpicam ueró paruipendit, or pro nibilo babet. Quod fané declarat, Manardum banc Galeni fententian perperan accepiffe, atque etian Nardibiftoriam ignoraffe . quando= quidem nx.li radix nil aliud eft, quimm ffica, it ipfemet teftatur Galenus codem de antidotis libro, fic inquiens. I $u=$ bet Andromschus adijcere nurdum Indicam : ca ucró cf, quam fpicam uocant, non quód pica fit, radix etenim eft; fed quod fpicx formun referat. Quibus pal in eft, idim cffe nardifpicam, er nardi radicem, ut etiámnum declarat iden Galcnus lib. Ix. de compofitione medicamentorum fecundum locos in philon is antidolum fcribens, dum inquit. Quin e nardi ipfus draclsnsin unam conijciendam cenfet, quam falfi nominis radicen dixit, quandoquidem pica nardinominstur. Quapropter idem lib. V I I I. fimp. medic. de Nardo caput facturus, illud infcripfit Nardi pica,

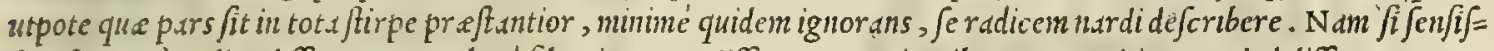
fet, picam à radice differre, edm plané filculio preterijfet tanquam inutilem; er capiti nomen indidiffet aut gene=

30 raliter ab ipf.t Nardo, aut à radice tuntim, uti uiribus preftantionc. In boc, ac longé maiori uerfatur errore Brafauoli erBrafuolus. fiquidesn fiso de fimplicium examine Nardi fpicam non modó non effe radicem cenfet, fed nullius ufus eă ror. exiftinat, fic inquicns. Venctijs fpican, caulem, or radicem emes, quanuis er ipfi adulterent. Iubco autem radi= cem, or caulem emere, quoniwn hec apud antiquos auctores, ut Diofcoridem, $\sigma$ Galenum magis in ufu medico funt, quàm fpica: quippe follu abijcit Diofcorides; ad nos tamen fica non defirtur, fed radix. Hac ille. Sed me= berculc quantunt ex Diofcortdis friptis percipere jotui, nunquam hactenus fum confecutus, quód ipfe ex omnibus nardi partibus aliam preferat, quam pica. Quod autem crediderit ipfe picam in Nardo uiribus magis praftare, quinn ceter e cius purtes; quód'q; cum de Nardo fcribit, tantum de pica intelligat, aperté oftendit, cum inquit. Ex

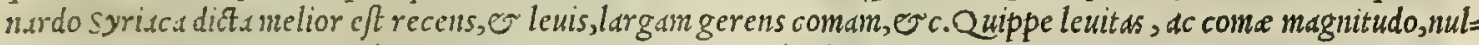

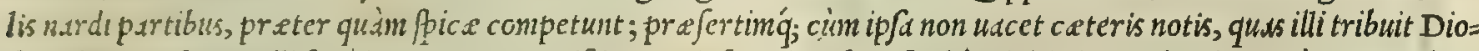

40 fcorides. Ad liac nulli fane incompertum exiftimo, Diofcoriden buiufce libri initio in probandis tantum radicibus, que odore commendantur, operan impendere, nempe iridis, acori, mei, nardi, phu, afari, o buiufmodiftirpium ge= nerum, non autem in effcrendis caulbus, floribus, fölijs, ac picis, qux caulium Jummitatibus innafcantur. Quo fit, ut etiam fateri liceat, Brafauolum ignoraffe fpicam ip fam effe nardiradicem: quin potius pro certo credidiffe in plan= te ip fius nardi cacumine, non in radice oriri pic am, que tamen $G$ aleno tefte radix cft, er cateris nardi partibus pra $=$ fantior . quandoquidem fi aliter res fe haberet, commoda longe plura radicibus ex more redderet Diof corides, qudam Pica: Quod praterea Galenus plus laudauerit Nardi caules, quain picam (ut afferit Brafauolus) nufquam comper= tum habeo. Caterim quanta Sententix incon/tantia Nardibiftoriam idem defcripferit, ex fuo pofteriori fimplicium examine, in quo ultimam manum impofuiffe fatetur, facilé conijcitur, dum fenem fecum colloquentem inftruit, bis uer

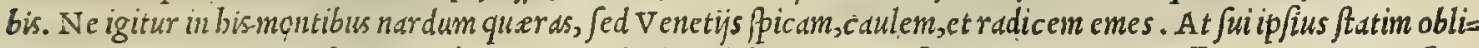

so tus uidetur non multis poft line is, cuin inquit. Aliud ueró funt pica, er flos, qua ad nos non afferuntur. Ex quo faci=

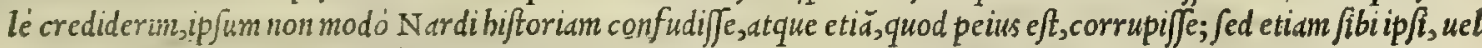
potius feni uerba dediffe primim nanque ait Venetijs fpicam, caulem, er radicem reperiri: mox picam ad nos ad= wehi negat. Sed ante bos bac in re Plinium quoque grauiter hallucinatum inuenio: quippe qui libro or capite

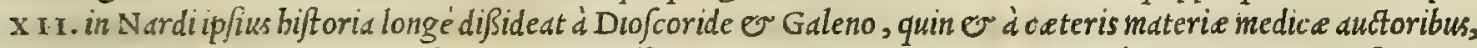
dum ite fcribit. Nardum frutex eft graui, or craffa radice, fed breui, ac nigra, fragiliq,; , quanuis pingui, fitum re= dolente, cyperi odore, appro fapore: folio paruo, denfóq. Cacumina in Ariftas fe pargunt: ideo gemina dote Nardifficas, acfolia celebrant. bec Plinius. Cuiusdoctrinam fecuti, non modó Ferrarienfes illi, fed Hermo= Ruel. \& Herlaus, eテ Ruellius, ipfi quoque pariter aberrarunt. fiquidem Ruellius ( $u$ t puto) nulla alia de caufa afferit, fe in of $=$ molai error. ficinis $\mathrm{Nardum}$ uidiffe, cui inerant dotes omnes illi à Plinio reddite, quàm ut $\mathrm{Plintanam}$ tueretur lectionem. Quod tamen fal fum effe arbitramur. Ego enim tamet fi Nardi quàm plurimum in Venetis officinis diligenter examinaue= rim, ac felegerim; aliud tamen, quàm picam uidere mihi non licuit. Quapropter nullum inueniri Nardum exiftimo, 
quod in edulium eacumine ßpicas profer at, quemadmodum tradidit Plinius, afferit $\mathrm{R}$ uellits, $\mathrm{or}$ contendit Brafauolus, contra Galeni , $\sigma$ Diofcoridis fententiam. Qui Nardum de fcribit plures ferre fpic as, non quidem à caulibus, fed ab una tantim radice prouenientes: non tamen quod alia radix urribus praftans picis ipfis fubfit, fed quoniam, cim plu= res in radice fint pica, neceffe eft, ut bafi, uel firmamento aliquo confift ant, à quo origincm trabant, ut in allio er lilii radicibus con/picitur. Quod pro explor ato confiteripofjum, cium fapenumero Venetijs Nardi /pica cepites ui= derim, tum figura, tum etiam picarum connexu allium referentes, ut unufquifque pro arbitrio experiri poterit.

Dilutiocuiuf Verùm enimuero ut probé reßponfum fit omnibus feré obiectionibus, dicimus, qucd fi forté reperirentur, qui affere= dam obiectio- rent illas effe proprias Nardiradices, que capillace is fibris i fpicarum bafi oriuntur, ut in allio, ca pis, ac bulbace is nis. omnibus uifitur, er ea propter ßpicas ijs adnexas non effe Nardiradices, fed per fe partes ab his admodum differen= tes, poteft eorum obiectio facile dilui Theophrafti teftimonio . Siquidem is lib. primo cap. $\mathrm{x}$. de plantarum hiftoria :o aperté declarat, in allio, capis, bulbis, lilijs, ac alijs eitus generis, e per confequens in ficicanon folim dici radices ea capillamenta, que bulbaceis illarum plantarum capitibus fubijciuntur, Fed etiam id bulbaceun totum, quod verra reconditur. Et ut res ipfa clarior omnibus fit, generali regula expreffum uoluit, quód totum id in quacis planta, quod fub terra obruitur, radix commodißimé dicatur. Proinde uidetur Nardum ipfam inter radices iden memor affe

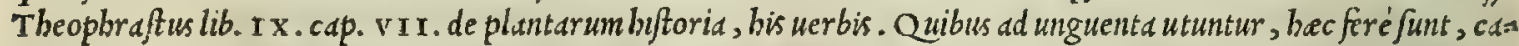
fia, cinnamomum, cardamomum, nardus, nerum, balfamum, appalathus, ftyrax, iris, narta, coltus, panaces, crocuun, myrrha, cyperus, iuncus, calamus, fampfucbum, lotus, anethum. Horum alia radices, alia cortices, alia rami, alia ligna, alia femind, alia lacryme, alia flores. Quibus paldim eft, non poffe Nardum nifi inter radices recenferi, cimm nec corticis, nec ligni, nec rami,nec flork, nec feminis, nec tandem lacryme peciem pra fe ferat. Quod cum recte fciuifet Galenus tum lib. I. de antidotis, tum I X. de comp. medic. Secundum locos, Nardi fpicam radicem effe des clarauit. Verum longé ab omni Nardo diftat N A R D V S I T A L I C A, que noftris unlgó uocatur spigo.

NARDVS ITALICA.

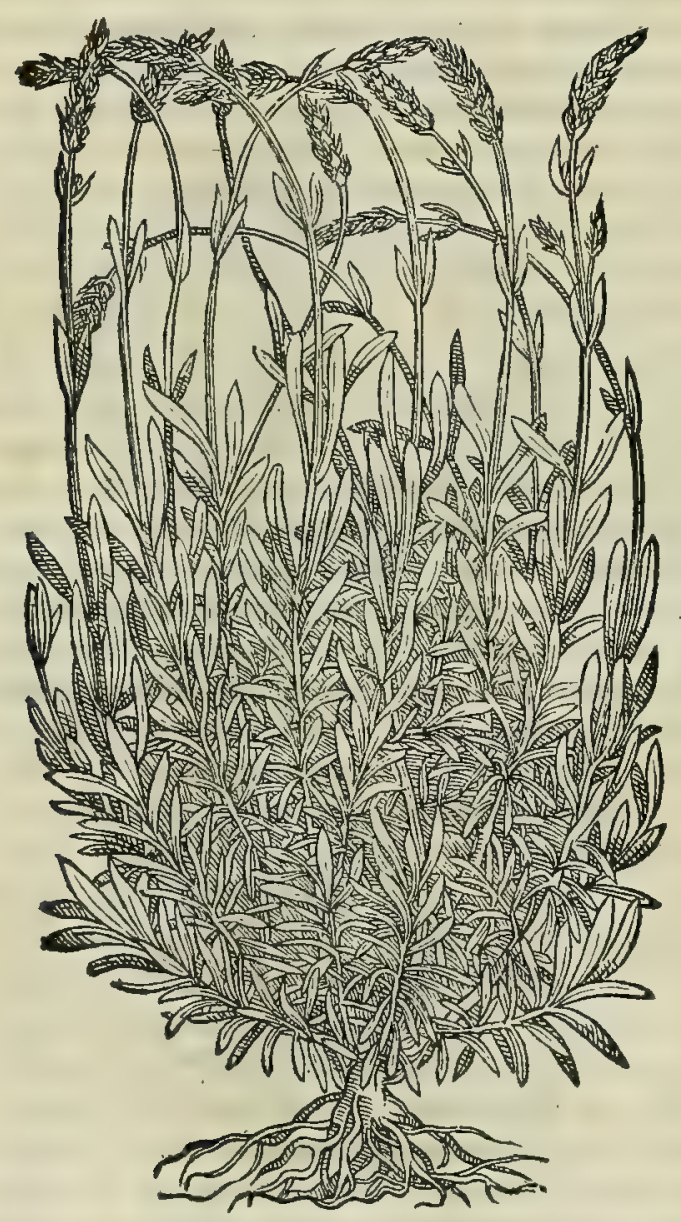

LAVENDVLA.

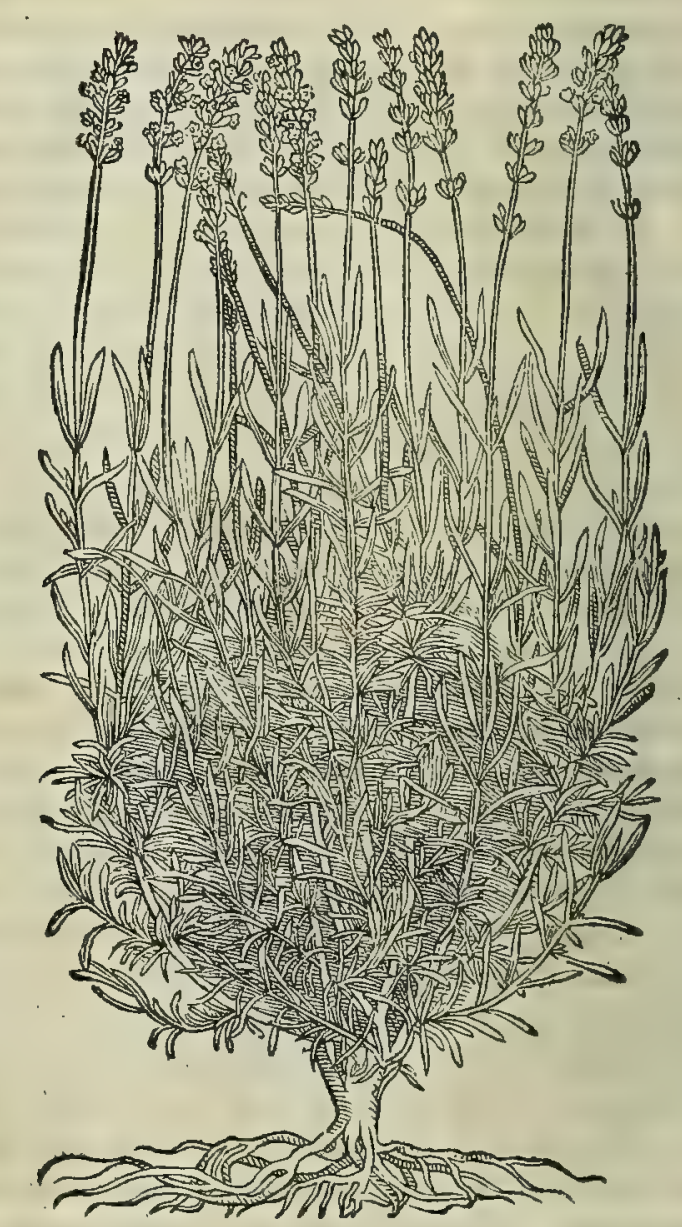

$3 \%$

40

Nardi Italica Cuius etiam generis ea eft planta, quam aliqui uulgò appellant Lauanda, alij ueró Lauendula adeò ut hac fremind. genera, \& ui- illt uerò mas in eo genere à quàm plurimis uocitentur. Mas folio conftat latiore, longiore, craßtore, robuftiore, aix res. bidioréq;, quàm famina. Sed utraque planta frutico fa, or rofmarini modo, innumeris referta cft fotijs : é quorun m: dio iuncei exeunt cauliculi, quadranguli, tenues, dodrantalem longitudinem cxcedentes: in quorum cacumine fi: res exeunt picati, colore purpureo, quanuis in fomina dilutiores, patentioresci;, odore fragrantes, uerinn ufqu:adeo acuto, ut nares feriat. Exralfaciunt, or exiccant ambo ordine fecundo completo, uel tertio inclioante, airib: ¿ $\mathrm{N}$ ardis omnibus nö longè recedentibus. Conferunt omnibus cerebri agritudinibus à frigido proueniètibus: conu:

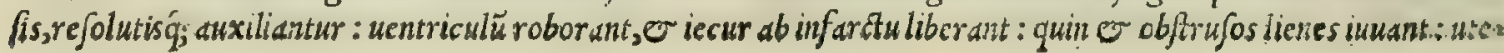




\section{In Lib. primum Diofcoridss.}

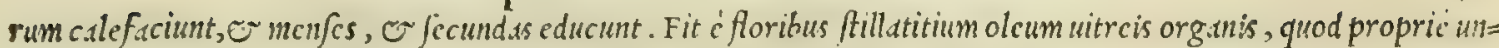
gucntary unlg' nocant olio di spigo, odoris adco accrrini, ut ceter odoramenta fuperet. quo fit, ut cxtra offici= nas illud afferuent, ne mofchi, ambari, zibetti, aliorumí; ungucntorum, $\mathcal{O}$ aromatü funitatem intercipiat. Nar= di Indice uires fcrip fit G.lenus lib. V I I I de fimplicium medicancntorum facultate, fic inquiens. Iv ardi fpica ex=

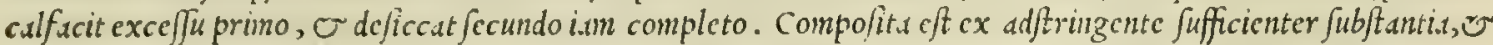
acricalida non inults, o quadum lcuiter amara. Ex bis conftuns facultatibus radix o ad iecur, or ad ftomachum rationsbiliter conuenit tum pota', tum extrinfecus impofita. Vrinan ciet, morfus ftom.thi fanat: in uentre, ac inte = ftinis confiftentes fluxiones deficcat, ad bec e ex, qux in capite, er thorace. Valentior of uocata Indica, ni=

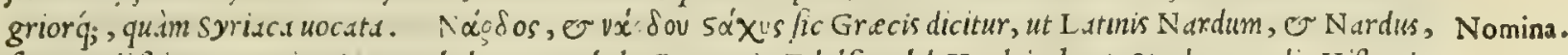

10 feu Nardiffica: Maturitanis, stumbel, aut Seubel: Germanis, Edelfrembd, Vuolriechent, Spicken nardi: Hipanis, Azumbar, aut Epiga fil: Gallis, Afic do ultremer.

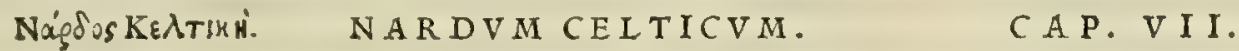

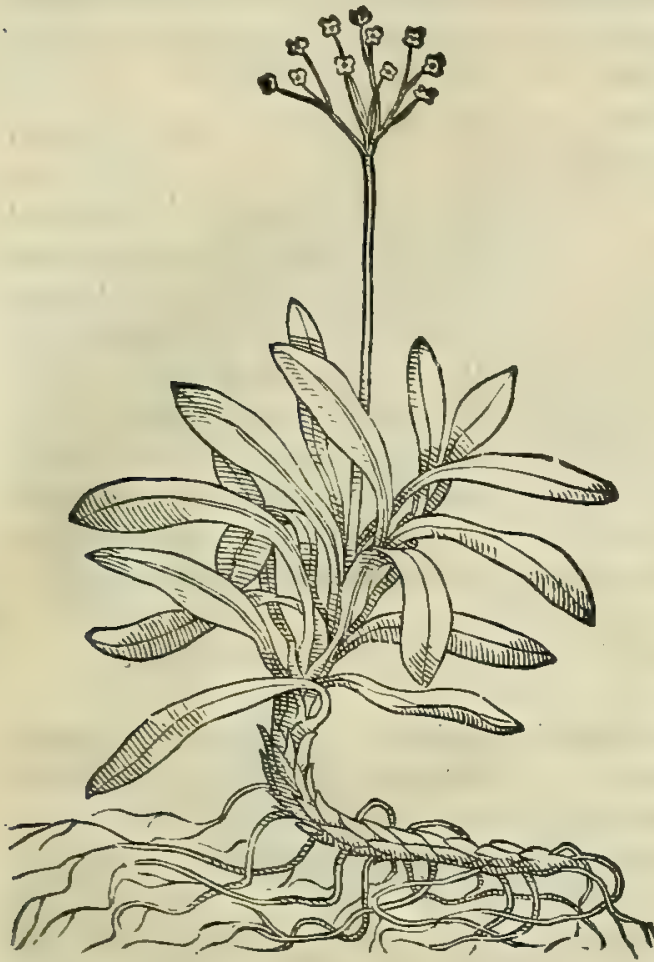

CE L T I C V M Nardum nafcitur in Ligurix alpibus, aliungia patrio nomine appellatum : prouenitque in Iftria . Exiguè fruticat, \& cum radicibus in manuales fafciculos componitur. Folia habet oblonga, colore in flauum languido: florem luteum . Caulium, \& radicum duntaxat ufus eft, \& odoris fuauitas . vnde pridie fifciculos aqua abluere expedit, \& exempta terra,pauito falo atque humenti, fubiecta charta reponere: poftridie repurgare. fiquidem utile, cum acerofo alienoque propter humoris uim, non excutitur. Adulteraturimpofta herba fimili, qux hirculus vocatur, ab odoris grauitate. Sed facilis coguitio: nanque herba candidior eft, fine caule, minus oblongis folijs, radice neque amara, neque odorata, uri ucrum Nardum eft. Itaque radices, atque cauliculi, abiectis folijs, triti fecernuntur, uino excipiuntur, digerunturq́ue in paftillos, \& ita fictili no uo diligenter operto, afferuari dcbent. Laudatur maximè, recens, iucundi odoris, radice numerofa cohærés, plenum, nec fragile. Ad eudem, quæ Syriacum, pollet: fed uehementius urinam cit.\& ftomacho utilius eft. Inflammationibus iecinoris, \& felle fuffufis auxiliatur. Contra ftomachi inflationes, cum abfinthij decoeto bibitur: item aduerfus licnem, renum $\&$ uefic $x$ uitia, $\&$ ue nenatosictus, ex uino. Additur in malagmata, potiones, \& calfacientia unguenta.

TANT A fuir ueterum, quinos preceferunt, negligentia, ne dic.tm ignorantia, ut non modó in ueram fimpli= Nardi Celti cium medic amentorum cognitionem, qux peregrind ex longinquis terrarum partibus aduebuntur, probatißimorum auftorum ope, uenire non elaborduerint; fed ne miniman quidem curam adhibuerint, communi reipublica benefi= cio, ut de bis faltem, que in quim plurimis Italix locis, ac alijs non longé dift.ntibus inueniuntur, quicquim lucis affequerentur, ac pofteris relinquerent. quin potius in fuis multó uidentur negligentiores, quim in alienis. Nafci= tur Celtica nardus in Ligurix alpibus, nafcitur $\approx$ in lftria, pariter'; in montibusnon longé a villaco Carinthie oppido, e I Idemburgio Stiris: attamen non ob id legttima in multis uifitur officinis: nec fortaffe in ijs uideretur, nifi bis noftris lucubrationibus annis fuperioribus It alico fcrmone editis, pharmacopole plures diligentiores redditi, medic am materiam accuratius expendere capiffent. Sed id magis deteftandum uidetur, quod ijs in regionibus, ubi

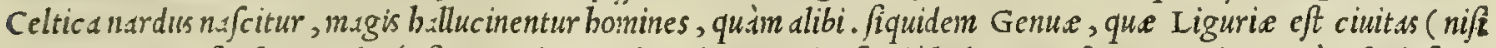
iam admonitirefipif cant ) alijs f́; finitimis locis, ubi Celtica nardus facilé baberi poteft, tam medici, quàm feplafiarij aliorum ignor antian fecuti, illus loco, Lauanda fic uocata, uel noftrate $\mathrm{N}$ ardo paßim utuntur. Quxe quantum in biftoria omnibus notis, non dic am uiribus, ¿̇ Celtica nardo difcrepent, quicunque primim rem optimé perpenderit, ac deinde notas, er qualitates illi a Diofcoride redditas, cum Lauandx, noftratis ; Nardi notis comparauerit, ma= nifftum eorum lap fun facilé incusare potcrit quippe Celtica nardus in breuem, exiguamý; plantam confurgit: La= uanda uero', e fccia nardus magno exoriuntur cepite, ramufculis proceris, denfißimisq;, comantibus foliijs. Illa folia fert fubrubca, es flores flauo colore: be autein folijs confurgunt incanis, floribuspicatis, er colore purpura= fcentibus. Illius caule, o radicibus utimur, quód bifce partibus maximé polled : harum ueró tantum flores commen dantur. Quod fatis claré demonftrat, quàm facilé decipiantur, qui tam leuibus er falfis feruntur opinionibus. Ve= rim quanquan ( ut in fuperioris Nardi mentione diximus) communi omnium fententia compertum fit, Lauanda, picé ; noftratis facultas ad omnix Nardigenera propius accedere; boc tamen eos ab errore non uindicat, qui $\mathrm{L}_{a}=$ uandam Celtic am nardum effe contendunt. Praterea non defunt pharmacopole rei herbarix penitus ignari, qui cæconfidera110.

Nardi Indicx urres ex Gil.

rand 
pro Celtica nardo plantam quandam incognitsm emant arbores $\int$ candentem, caulc longo reflexóf; , cuius folia, quse colore fubflauo conftant, adeó den fa ac minuta funt, ut potius nuf co fain arborum, e lapidum materiam, quàn aliud reprefentent. At quód in ueftiendis cauls ipfius ramujculis, cos tam densé circundat, ut feré pice effigicm pre fe ferant, pro Celtica nardo ab impoftoribus uenditur: fed bec baud amarc $f c i t$, nec ulla odoris praftantia commenda= tur. Ceterim ingens legitime nardi Celtic x prouentus babctur in Stivia Auftric, o Carintbia contermina, ubi Iu= demburgenfia rura fuis è montibus quotannis innumeros comportant fafciculos, quibus magnos admodum replent faccos, o mercatoribusuendunt, qui in Syriam, of Acgyptum morcinonis conucbunt. Siquidem (ut firunt) Sy= rijs, or Aegyptijs Celtica nardus maximé expctitur, ut balne is cam impon ant, quibus frequenter utuntur. Celti= cam nardum ad me primum mifit Petrus Salicetus clarißimus medicus ex Grazio Stirix oppido: in cuius plantis o Pice in radicibus, o folia, $\sigma$ flores in caule (ut appicta figura demonftrat) nullo impedimento cernebantur, adeo ut ¿ Diofcoridis biftoria nulla ex parte recederent: nec ullatamen foica in eius cactumine uidebatur, uti Ruellius 0 Brafauolus in Indica nafci fcripferunt. Qunmobrem nobis quoque iam liceat litcris memorié, mandare, Celticam nardum non modó in Liguria, e Iftria prouenire; fed ctian in Stiria, Carinthia, ac etiam alijs fortaffe locis. quip= pe Juperiore anno ego buius nardi nonnull as inucni plantas in quodan vipaci monte, qui tantüm uiginti millia paffüu à Goritia diftat. Verim fí eo deftituantur medici, commodé Indicam fupponere poterunt. An ueró Celtica nardus fit Saliunca, aut non, de qua Virgilius, ev Plinius fcripfere, etfi bec inter fe nullaim babere cognationem pluribus comprobare poffem; cum tamen ea parum, uel nibul reimedice conferant, filentio inuolucnda duximus. quanquam

Leoniceni, \& eruditißimus Lëonicenus non animaáuertens Diofcoridem Aliungiam, non Saliuncam Celticam nardum appellafe,

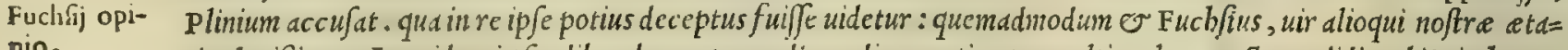
nio. $\quad$ tis clarißimus. Is quidem inf $[110$ libro de componendis medicamentis, quem ultimo loco auctum edidit, ubi Diathama= ron expendit, Celtican nardum à Saliunca nibil differre exiftimat. Plinius tamen locis feparatis de utraque, tan= quam berbis inter $\int e$ differentibus tractauit. Neque ex notis tantum dißident apud antiquos auctores, fed etiam na= talifolo. Diofcoridi enim Celtica nardus in Ligurie alpibus, atque in Iftria prouenit. Plinio ueró saliunca in Pan= nonia, o Noricis nafcitur. Itaque Fuchfius ut Ruellif fententiam fecutus, qui Celticam nardun Diofcoridi saliun= cam appellari affirmat, ita mili or à ueritate defeciffe, o unà cum illo erraffe creditur . quandoquidem Celtica

Nardi Celtica: uires éx Gateno.

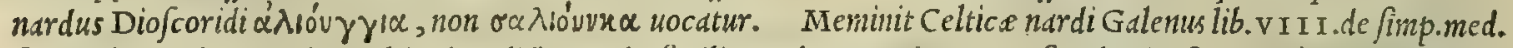
facult. his uerbis. Nardus Celtica ian dictis nardis fimilis quadantenus in genere facultatis eft. Ceterim ad omnia im= becillior, preter quàm ad prouocandam urman. fiquidem calidior llis eft, fed minus adfringut. Que pläta Gre

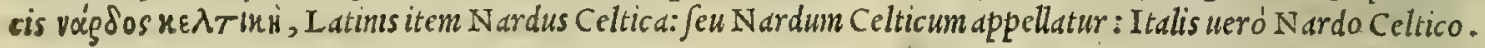

$$
\text { NágosógEvห'. NARDVM MONTANVM. CAP. VIII. }
$$

Montanym Nardum, quod ab aliquibus thylacitis, \& niris appellatur, in Cilicia, \& Syrianafcitur : caule \& folijs eryngio fimilibus, minoribus, minimè tamen fpinolis, afperisçue. Radicibus binis nititur, aut pluribus, nigris, odoratis, ceu haft ula regix, fed longè gracilioribus, $\&$ longè minoribus. $t$ Neque caulem, neque frufum, neque florem profert. Ad eadem, ad qux Celticum cfficax.

Nardi monta

VIDETVR in boc capite Diofcorides non parum à fe ipfo diffentire, quòd fcripferit primuim montanam Nar=

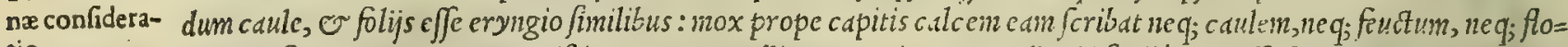
tio. rem proferre. Quapropter exiftinant tum Ruellius, tum etiam IIarcellus id facile accidiffe friptorum incuria, qui 40

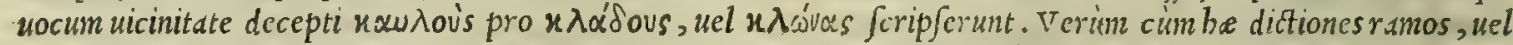
furculos defignent, que nomma potius arboribus conueniunt, quam berbis, fintó; idem rami in arboribus, quod cau= les in berbis; idcirco non uidetur bic locus, ut illifortaffe putdnt, d incndis uindicatus. Caterunn non crediderim ego, Diofcoridem, qui eft hac in facultate facile princeps, $\sigma$ quem antiqua, e fecuta atas tantopere commendat, in tam

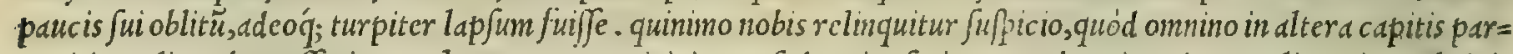
te uitium aliquod accefferit, non harum uocum uicinitate, fed potius fcripiorum dormitantium negligentia, uel uigi= lantium temeritate. Qulo factum eft, ut bactenus inccrtus dubussó; fucrin, cul bac planta in lialia proueniat, uel aliunde eó afferatur. Quidam tamen ex his, qui rei herbarie dant operam, ad nos hoc anno firpem mifit, cui bine inherebant radices aphodelifigura, fed longé minores, phu, uel nardum redolentes: adeo ut bac parte montanam $\mathrm{Nardum}$ pulcbré pre fe ferre uiderentur. Sed quonian folia, or caulis phu potius referebant, quàm eryngium, so quemadinodum er umbelld, cur eam montanam Nardum fuiffe comprobem, fané non babco: cum plané fciri non poßit, an in priori, an in poftcriori, an in alia buius capitis parte lateant menda. Itaque fi,forté aliquod ad manus cfect medicamentun, quod Montanum nardum excipcret, Jupponant audacter pharmacopol.e Indicam, ucl Celticam. Ta= Bral, opinio metfi in fuo de fimplicium examine affeucret Brafauolus Ferrarienfis Indic e nardi uice montane plurimum ad nos af = non accepta. ferri é Cilicia; edmq́; proprié montanam exiftimat, cuius paßsin in officinis eft ufis. Sed qua rationc ductus nouam banc protulerit opinionem, ip fe certé ne fcio: Nardus enim montana radiccs babet apphodelo fimiles, non utique pi= catas, leues, como $\int a$, quemadmodum ea, qua utimur ex India uducta. Nifi fortaffe Brafauolus uoluerit Indicam nardum idco montanam appellare, quód in montibus oriatur. Ita quidcm cius $\int \mathrm{cntentiam} \mathrm{ueram} \mathrm{c} \int \mathrm{c}$ putarem, non ta= Nardi mont. men à reiberbarie peritis acceptam iri. Nardimontana uires forip/it Galenus lib. v I I. fimp. med. fic inquicns. urres ex Gal. Nardus Montana, que o thylacitis, o pyritis nuncupatur, plurima in Cilicia nafcitur : fed preditis debilior cft. Nomina. Nágdos ógevis Grecis, Nardus montana, fiue Nardum montanum Latinis, Nardo montano Italis noninatur. 


\section{In Lib. primum Diofcoridis.}

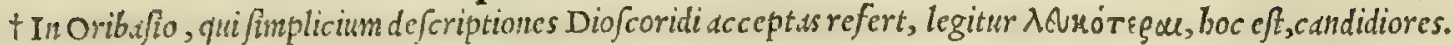
quòd Nardus montun conftet radicibus a phodelo non folimn minorib. Or gracilioribus, fed ctian candidioribus.

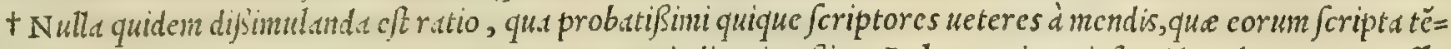

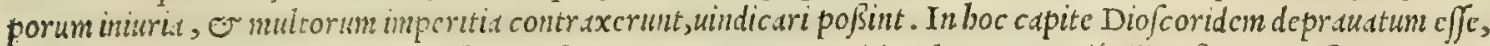
ita ut etian à feipfo difideat, in.nififtum cf: : in quat autem parte uitium lateat, quod'́; illud fit, dubix firuntur opi= mioncs. Vcrim ctfinos quoque cilis rci incertos effe anted fcrip/imus; nunc tamen inclinat antinus, ut in boc loco mĕ=

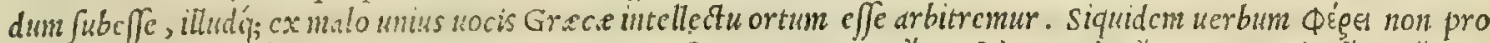

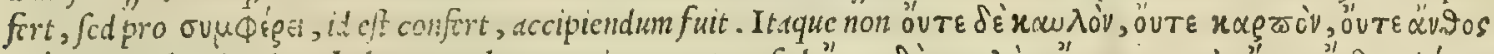

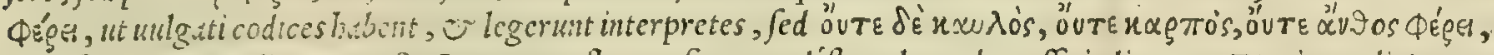

10 boc cft, Neque cuulis, neque frufurs, neque flos confert, prodéftue, legendum effe iudicamus. Etenim radicis, ut= pote odorute, usus precipué comnendatur, non aliarum partium, que ut odore carent, itd etiam inutilcs babenda funt. Et certe fucilis potuit c/fe crror hbrarij Graeci imperiti, uel potius temerarij, cafus nominum mutantis ad ine ptam ac incongruam buc loco ucrbi illius fignificationem. Subfcribunt buic noftre caftigationi cum alïrci ber= baric ftudiofi, tum Gubricl Falloppius Mutinenfis uir er ingenio o doctrina celcbris, tum etian Iodmes Odoricus Melchiorius Tridentinus, medicus non unlgaris eruditionis.

$$
\text { A" } \sigma \alpha_{5} \circ \% \text {. AS A R V M. }
$$

C A P. I X.

20

3o

40

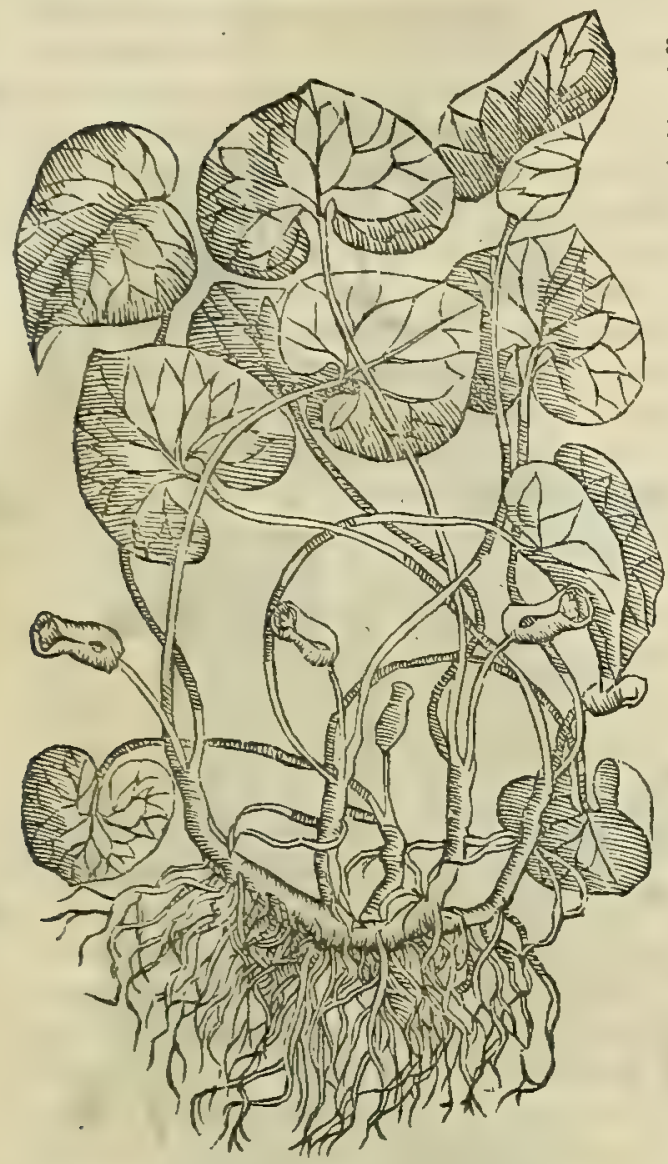

A s A R V M, quod \& ipfum aliqui fylueftre nardum appellant, hederæ folijs, minoribus multò, rotundioribusq́ue: floribus cytino hyofcyami fimilibus, purpureis, inter folia proximè radicem emicantibus, odoratis : in quibus femen acinofum. † Cauliculos habetangulofos, arperos, ic molles : radices numerofas, geniculatas, tenues, obliquas, gramini non dif́similes, longè tamen graciliores, odoratas, excalfacientes, $\&$ qux linguam uehementer mordent. Excalfactoriam uim habet: vrinam cit : hydropicis, \& uetufto coxendicum dolori prodeft. Radices fenis drachmis ex aqua mulfa pota, menfes trahunt: \& ueratri albi modo purgant. In unguenta addi tur. Vmbrofis montibus prouenit: fed plurimú in Ponto, Phrygia,Illyrico, \& Italiz Iuftinienfiagro .

NVel am noftris temporibus officine ponunt differentiam inter $\mathrm{A} \int \mathrm{arum}, \mathbb{e} b$ accharem: quinimo uno ore fere omnes $A \int d=$ rum Baccharam appellant, adeò ut o nomina bec corrumpant, er resipfas confundant. At quantum notis, er viribus inter fe differant, his reste iudicet, qui harum ftirpium buftorias accurd= tius perpenderit: differunt enim inter fe-ddmodum A farum, o baccharis, ut diffufius libro tertio differemus. A arum itaque procul dubio ill a fuerit planta, que uulgó Bacchara falsó appel = latur, cim nullis ab biftoria dißideat notis. Caterim Brafanolus immeritó in $\mathrm{Plinium}$ piculum contorfit, cùm dicat ipfum eo etiã in errore uerfari, ut Afarum baccharem effe exiftimauerit. sed profictó nefciuerim ego, qua ratione illud Brafauolus in Plinium fcripferit. quippe quilibro $\mathrm{x}$ x I.cap. v $\mathrm{I}$. eos acerrimé $d r=$ guat, qui baccharem, er fylueftrem nardum idem effe conten= dunt, his uerbis. Sed corum quoque èrror corrigendus eft, qui bacchar ruiticun nardum appellauere : eft enim alia berba fic cognominata, quam Greci A faron uocant, cuius peciem, figuram '́; diximus in nardigeneribus. hec Pli= nius. Quibus palàm eft, Plinium feipfum à Brafatolo defendiffe. Porrófi etiam Plinij atate non deerant, qui $A \int_{d=}$

50 rum baccharem wocitarent, non mirum fuerit, fi in bunc ufque diem protracta bec fit appellatio. In qua fortaffe perfeuerantes ueterum nonnulli Diofcoridis A faro eas feré onnes facultates reddidere prater auctoris mentem, quas ip $\int e$ libro tertio bacchari adfcripfit . quod facilius ad credendum uulgus allexit, A arum, or baccharem nomine tantum differre. Verim cùm recentiorum quorundam diligentia ac doctrina id totum Diofcoridi additum deprehen= fumfit, eo quòd diuerfis tum libris, tum capitibus ipfe de bis differuerit; cuimt $q_{\text {; }}$ Serapionem uiderint de Afaro ex Diofcoride fcribentem, adulterinam banc lectionem non admittere, id totum, quod eó accefferat preter auctoris fententiam, tanquam illegitimum abdicarunt. Afari uires fcripfit Me fues inter deieftoria medicamenta, ubi fic habet. Excalfacit A farum ordine fecundo, o ficcat tertio. Attenuat, referat, refoluit, o provocat; adffrictio= ne tamen non uacat. Bibitum non modó uomitiones ciet, fed e per aluum ducit, o per urinam. Pituitam, o bi= lem deijcit. Roboratur tamen admifto caprino fero, atut nardo, aut bydromelite. At manifftus pituitam, quim bi= lem educit. quo fit, ut coxendicum caterarum q́; compaginum dolore uexatis non obfcuré opituletur : pra fertin fi fero maceretur, uel decoquatur. Facit mirum in modum ad iocinoris er lienis infarctus, fcirrbofosóq; tumores.

A fariconfide ratio.

Plinij tutela aduertus Brafauolum. 
Afrivireser

Galeno.

Nomina.

Quamobrem fubeuntibus cutem aquis, fellisö; fuffufionibus datur maximo iunamento uino maceratum. Confert item diuturnis febribus, $\ddot{y} s q$; prefertim, que ex contumaci infar Etu proveniunt. Oleum macerationis ipfius admifto las dano, dorfi pondylis inunctum fudorem commouet : leviter tumen coqui debet, nam fi diu frrueat, uim feré onncm deperdit . neque etiam diuturna indiget contritione: diutius cnim contritum facilus uomitiones, quaim aluun ciet.

A farimeminit Galenus lib. V I. fimplicium medicamentorum, fic inquiens. A fari radices utiles funt, facultate fi= miles radicibus acori, intenfiores tamen. Itaque ex ijs, que de illis prodita funt lic facienda conicctura. Hactenus Galenus. A' cuius fententia ( fit tamen cum uenia dictum) maximé diffentio. fiquidem cism nulla in acoro deiectoria fit facultas, $\mathcal{O}$ A farum, ut Diofcorides inquit, Mefues fatetur, ov nobis experimento compcrtum eft, ueratri mo= do expurget, or bilem, pituitamǵ; $\mathcal{E}$ Juperné, $\mathcal{O}$ inferné propellat, non uideo fané, cur acoro in omnibus fuis fa=

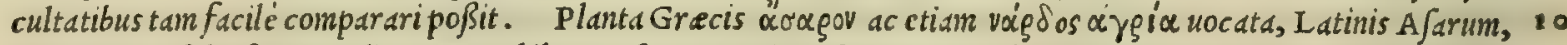
o Nardum fylueftre appellatur : Arabibus, A faron: Italis A faro, e Bacchard: Germanis, Hafel uurtz: Hifpas nis, A Jara baccara: Gallis, Cabaret.

† Hec uerba ut in Ruellio inuenimus, ita reliquimus. Sed admonendum effe lectorem duximus, ea non legi in Gre= cis noftris codicibus, neque a serapione referri. quod argumento cftilla Diofcoridi accreuiffe. Sufpicionem auge= re, uel potius ita effe confirmare poteft Oribafius, qui Diofcoridem tranfcripfit, or bac uerba non babet. Sunt ta=

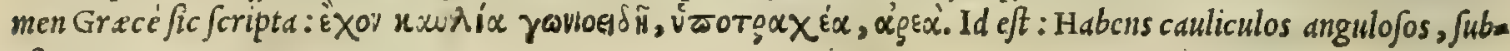
apperos, raros.

PHV MAGNVM.

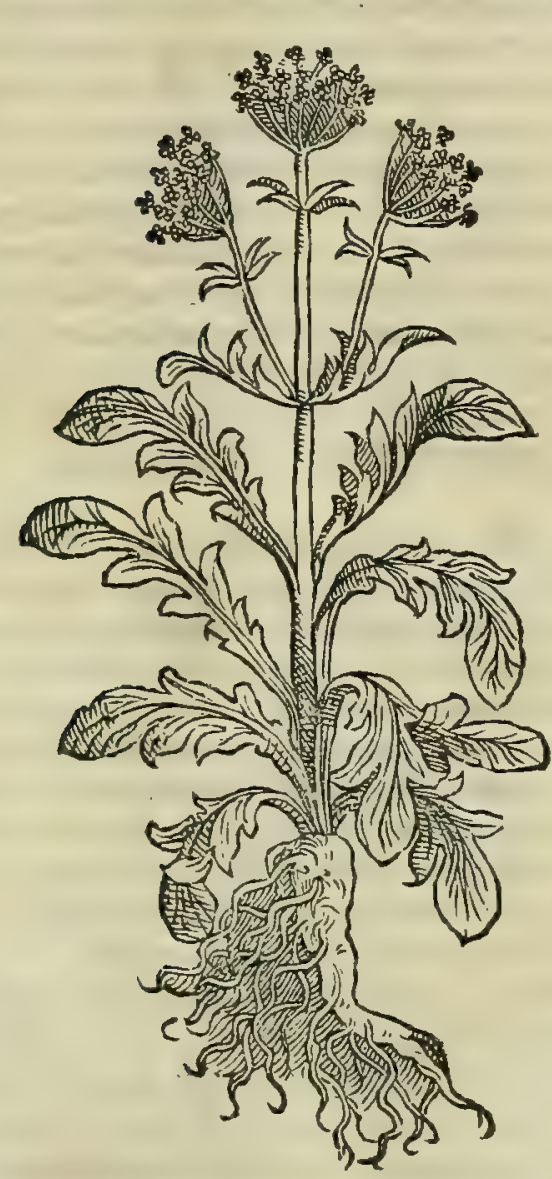

$\Phi \circ \tilde{\text {. }}$

P H V.
PHV PAR V VM.

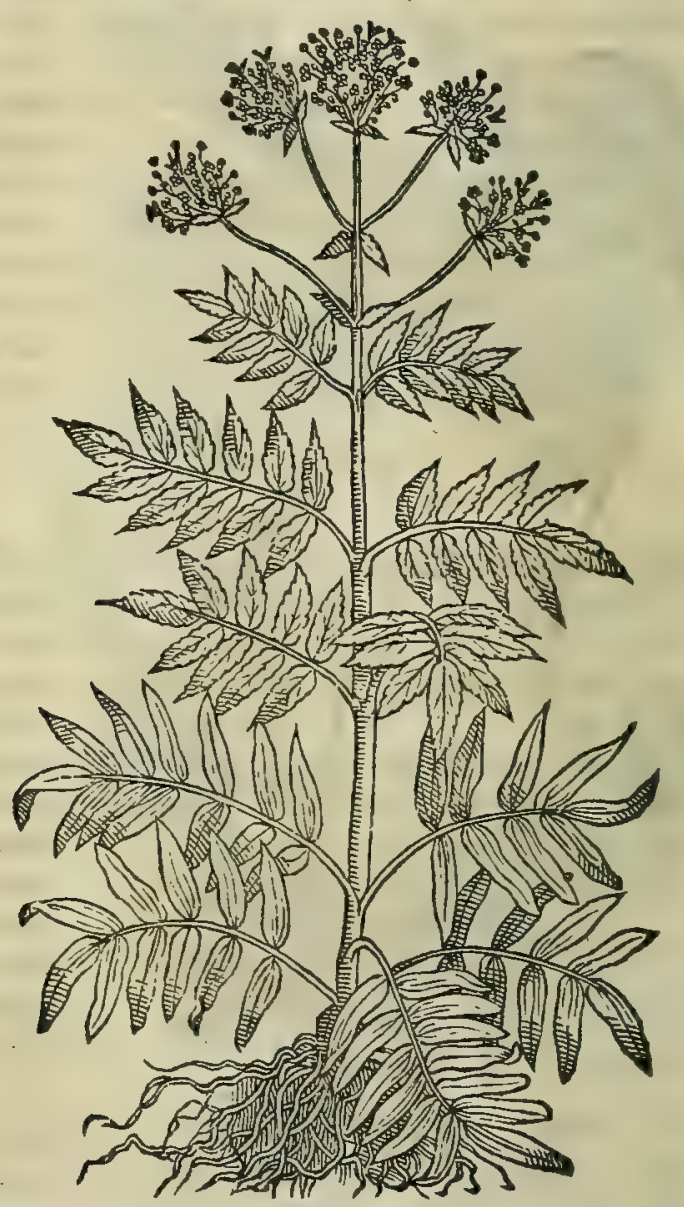

C A P. X.

P H v, quod \& aliqui fylueftrem nardum appellant, nafcitur in Ponto: folio olufatri,aut elaphobofci : caule cubitali, aut altiore, læui, cauo, molli, in purpuram uergente, geniculis intercepto: floribus narciffo proximis, maioribus, tenerioribus, $\&$ ex albicante purpureis : radice fuperius ad digiti minoris crafsitudinem, ex obliquo uillofa in nigri ueratri, aut iunci odorati modum : capillamétis inuicem contextis, flauefcentibus, odoratis, cum quadam odoris grauitate nardum xmulantibus. Excalfacit:vrinam mouet, fi ficca potui detur. Decoctum eadem praftare poteft. ad lateris etiam dolorem efficax : menfes cit . antidotis inferitur. Adulteratur radice rufci admifta. Sed ma leficium deprehenditur : quoniam hæc dura eft, \& frangenti contumax, fine ulla odoris gratia.

Thu confide- NoN poffum non fateri, eos omnes bene fentirc, qui maiorem Valerianam fic uocatam, qua pafsim in Italia na* ratio. fcitur, legitumum effe Pbu alferunt. Quippe radices primum forma, odore, colore, ac ceteris in uniuer fum notis ab 


\section{In Lib. primum Diolcoridis.}

ijs, que fibi phu ipfum adfcif it, haud quaquam recedunt. Indicani idem or folic, o caules : illa entun olufatro non Valeriama funt difimilia : Ji ueró adolefcunt cubitali menfura proceriorcs, lcues,inanes, mollcs, geniculati, o in purpur am uer= maior. gentes. Flores tamen ob,tare uidentur, qui in Plu lilij, ucl narcißi effigiem pre fe frrunt, non sutem unbelle, ucl inu= fearijpeciem, ut in matori valcriana uifuntur : quanquan flofculi per fe onnes, qui umbell an conficiunt, forma nar:=

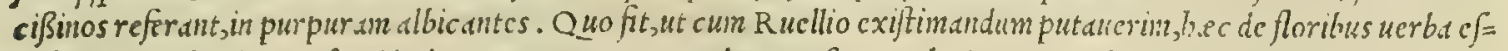
fe à fcriptoribus in Diofcoride deprauata. Nanque udetur noftras Valcriana, onamibus tum not is, tum qualitatibus adeo cum Plu conuenire, ut re vera dici polit, non aliud, qudmipfuin Phuad ungucn referre. Etfinon defint (ut

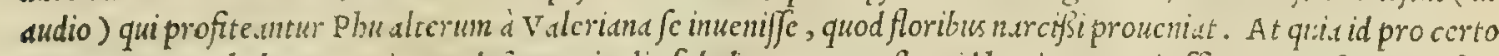
compertum non habco, $\sim$ quia non dejunt, qui tallia fabulentur, non eft, quid bac in re certi affirmatre pofsin. Ffof $\mathrm{ct}$

1. Valeriane dlerum genus, quod minus appellant, cuius caulis iuxta folit, que quadantcnus maioris finnititudincmi re= ferunt, molli linugine pubet, reliqua ucró parte maiori non abfimile affurgit, floribus fubpurpurcis, in umbellam is= mul cö̈untibus. Radices mittit bac tenues, qua in multifidas conglomerantur fibras, odore mifto inter irden, $\mathrm{Cr}$ nardum. Vtrag; odore comnendatur: proinde es ueftibus quidain interponunt. Plu (ut feriptunz relqquit Gale= sus lib.v I I I. fimplicium med.) odoratum quodammodo eft. Huius berba radix nardo uiribus fimilis, fed tamen ad pleraq; infirmior. Vrinam plus nouet, quàm aut Indica, aut Syriaca naddus: fimiliter auté ut Celtica. Simile Pbu afferit ipfe Galenus effe Carpcfium, cuius cum nullibi meminerit Diofcorides, ut recté fciri poßit quidnam fenioribus Grecis fuerit Carpc/ium, in primis Galeni reftinonio eius uires e formam defcribam: is enim lib. v I I. fimpl. med. fic babet. CAR PES I V M fimile eft uocato Phu, non guftu tantum, fed $\sim$ facultate. Sed plus habet tenuitatis: pro= inde mag is eo etiam uifcerum obftruftiones extergit, et urinam mout, renesq́; calculis degrauatos expurgat. Non ta. men eatenus tcnuium eft partium, ut lice st loco cimn.momi, fi non ad manum fit, uJurpare, ficutifaciebat Quintus. Preftantius eft Carpefium ponticum lärtio : non tamen uel ipfum cinnamomi uiribus uicinum eft, imó non paruo de= terius optima caßsia. Nuncupatur utrung; ḋ nnontibus quibufdam Pantphilix, in quibus nafcitur. Ingensq́; cius pro= uentus eft in Syria. Et primo libro de antidotis inquit. Quintus (ut aiunt) quoties cinnamomum decrat, Carpefium, ut quod uiribus nibil ab optina caßsia differret, in theriace compofitione imponebat. Ego idcirco cius plurimum mecü attuli ex ea peregrinatione, qux orientis pronincias adï, diligenter q; repofitum nunc ufq; multum feruo: quod odo= remétiamnum er Saporcm, fí non qualem prius babebat, certé nondum exoletum retinet. Eft auten Carpefium ber= ba phu appellato gencre fimilis, ualentior tamen, atg; odoratum quiddam fpirans. Plurimum boc in sidd $\mathbf{P}$ amphilie nafcitur, emiturq́; propterea illic uilißimo pretio. Quocirca fi quis urftrim ill uc acceffcrit, Carpesij plurinum emat, cism id fibi longo tempore duraturum nouerit. Tenuia autem funt farmenta, cimnanomi uirgultis finilia. Eius duo reperiuntur genera; unum quod laërtium; altcrun, quod ponticum cognominatur, à monte, in quo na cuntur, utraq; nomen adepta, fed ponticum melius eft. Quód cim eius non parum baberem, permultis medicamentis admifcui, in qui bus phu uocats imponi debuerat. Eft enim Carpefium phu fimile, ualentius tamen, $\sim$ in quo (ut dixi) nomibil odo= rate qualitatis guftu odoratúq; fentitur. hactenus Galenus. Verim quid hac tempeftate fit Carpefium, arduum fané fuerit explicare e milhi, costeris materie medice fcriptoribus. Tamet/î Hermoldus, Ruellius, Fuchfius, ac etiă Monachi Me fuem exponentes pro certo exploratum babeant, Auicenne, Serapionis, ec Adtuari auctoritatibus in= nixi, fructus piperi fimiles, qui unlgó Cubebe wocdntur, le gitimum effe carpefium. Siquidem Serapio quod Galeno car pefium nocatur, fub cubebs nomine ip/ïus Galcni teftimonio /ic defcribit. Cubebe eft medicina facultate, o fapore Phu non ab/imilis, quanuis longé teruior . quare obftructiones totius corporis aperit, urinam ciet, er calculos renum pellit. In hac fre é fententia uerfatur o Auicenna cubebas carpefiun appellans: quemadmodum $\sigma$ Actudrius, qui Mauritanorum nomina fecutus, in quibujdam medicamentis Carpefium imponit, quod àbarbaris noußtbas uocari ait. Cuibus auctoritatibus luce clarius patet, quód Galeni carpefium, o Arabum cubebse nulla ex parte differunt .

veruntamen illud animaduertendum eft, quod cos in errore uerfari exiftimem, qui credunt (ut Hermolaus, Ruel lius, E Fuclsfius) uulgares (eplafiariorum cubebas illas referre, de quibus fcripfere Serapio, Auicenna, o Actud= rius - quandoquidem qui dixerit cubebas plante fructum, uel femen effe, corum reperio neminem : nec minus probari

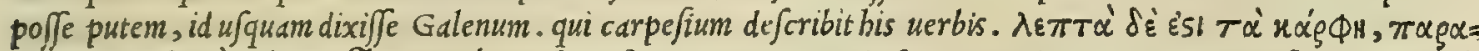

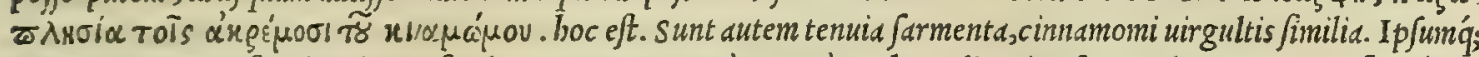
Phu er odore, o facultatibus adfimilat. Quapropter cum tantüm Phu radices in ufum inedicum ueniant, facilé dici poteft, carpe fium Galeno potius radicum effe farmenta, quàm caulium; o precipué cùm afferat diu afferuari poffe. quandoquidem folidiores funt radices, quam caules, qui facile in omni berbarun genere flaccefcunt, or pereunt.

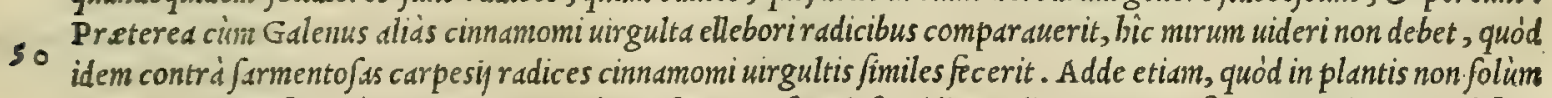
caules $\int a r m e n t o f i$, ucrum etiam radices plures $\int a r m e n t o \int e$ Diofcoridi appellantur. Quo fit, ut crediderim $F$ ucbfium in fuis Paradoxis immerito impugnaffe Leonicenum. Ad hec guftantibus nobis unlgares officinarum cubebas, nullum prorfus $\mathrm{Phu}$ Japorein deprebendimus. Quod manifefte indic at uulgares cubebas, nec A rabum cubebas effe, nec $\mathrm{G} d=$ leni carpefium. Obid igitur, ubr apud Grecoscarpefium medicamentis admifum reperitur, e cubebe apud Maus ritanos, phu eorun uice, cium fit carpefio in omnibus perfinile, uel caßia, potius qudm cubebe uulgaris ufus.,crunt fubijcienda. Iacobus syluius inter recentiores apprimé doctus, duanquam nouit cubebas noftrates carpefium non ef $\int e$; non tamen animaduertit, nec etiam serapionis, aliorum'; A rabum effe cubcbas. Aberrauit in cubebarum hi= ftoria etiam Serapio . quippe quicquid Diofcorides de rufco f criptum reliquit, is cubebis perperam reddidit. Cuius autemftirpis fructus unlgares CV B E B E fint, quid affirmare poßim non babeo, cium ex orientaliplaga nobis pe= regrine afferantur. Et fi eas dixerim odoratas effe baccas, raccmatim coberentes, corymborum bedere modo: qui

Quorundam opinio.

Valeriana mi nor.

Pluu vires ex Galeno.

Carpefij confideratio.

Hermo.Ruel lij \& Fuchfij error.

Serapionis laprus.

Cubebarum vulgarium có gufui 


\section{And. Matthioli Comm.}

guftui preter odoris gratiam, acrimonian o amaroris tantillum relinquunt. Quibus conftat, quód cxealfacere ut= leant tertij ordinis initio, $\mathcal{O}$ ficcent in fine eius. Quamobrem languentem ex pituita uentriculum, uel ctiam ex fatu roborant : pectus à lentis craßis q; bumoribus expurgant. Lienem iunant, flatus difcutiunt, o frigidis uteri affecti=

Nonina. bus auxilinntur. Diu cum maftiche manfe, pituitam à capite trabunt, e cerebrum roborant. 2uod థõv Grecis

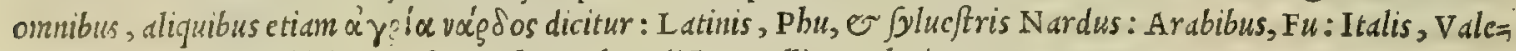
gixn: :ermanis, Baldrian: Hifp anis, herua benedicta: Gallis, Valeriane.

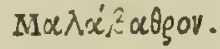
MA L A B A T H R V M.
CAP. XI.

MAI A B ATHRYM arbitrantur aliqui effe Indici nardi folium, falfi :quadam odoris cognatione: permulta enim nardum olent, quemadmodum phu, a farum, niris. Secus autem res fe habet: nanque Malabathrum folium fui generis eft, quod Indicæ gignunt paludes, Ientis paluftris modo innatans aquis, fine radice. Id collectum ftatim lino tranfuitur, \& ficcatum reconditur. Tradunt ficcatis $\mathfrak{x}$ ftiuo feruore aquis, humum aridis fruticibus uri : quod ubi non euenerit, ne amplius quidem renafci. Laudatur recens, ex candido nigricans, integrum, nec fragile, odore caput feriens, quod diu in fua vi odore permaneat, \& nardum fapore imitetur, nullo falis guftu. Infirmum uerò, \& minutim contufum, præfertim fi cariofum uirus olet, vitiofum eft. Eafdem nardo fortitur uires : fed efficacius oinnia præftat. Vrinam vehementius ciet, ac ftomacho magis prodeft Malabathri uis. Lippitudinibus, inflammationibusq́uc tritum, \& in uino ferucfactum commodè illinitur. Subditum linguæ, oris halitum, \& fuauitatem commendat. Veftium quoque odorem interpofitum feruat, \& ab erofione tuetur.

Malabathri

M A L A B A T H RVM, quod pleriq; folium Indicum uocant, qui hac atate uiderit, habeo neminem. Nafcitur (ut confideratio. Diofcorides inquit) in India paluftribus tantìm locis, aquis abfq; radice innatans, lenticule aquatica modo. Sed nec inde amplius ad nos aduehitur, quód fortafe indigenarum culpa perierit in India, quemadmodum 0 bals amum in $S y=$ ria. Etenim Diofcorides re fert, Malabatbrum non renafci, nifif ficcatis aftiuo feruore aquis, bumus aridis fruticibus peruratur. Quod cum iandiu forte non fit à natura factum, uel potius fit ab indigenis omiffum ob corum negligentiä, facilé poftea euenire potuit, ut Malabatbrigenus omnino deperditum fit . Plinius lib. $\mathrm{x}$ I I. cap. $\mathrm{x} \times \mathrm{v}$ I. duorum me $=$ minit generum, quorum alterum arboris cuiufdam syriace folium effe ait, bis uerbis. Dat e Malabatbrum Syria, ar. borem folio conioluto, arido colore, ex quo exprimitur oleum ad unguenta. Fertilior eft eiufdem Aegyptus: lauda= tius tamen ex India uenit. In paludibus ibi gigni tradunt lentis modo, odoratius croco, nigric ans, fcabrum q́, quodam falis guftu. Minus probatur candidum. Celerrimé fitum in uetuftate fentit . Sapor eius nardo fimilis effe debet fub lin gua. Odor uerò in uino fubferuefacti antecedit alios. hactenus Plinius. Quitamen pr.eter Diofcoridis fententiam preftantius Malabathruin duxit, quod fal fum eft, non quod infulfum. Ceterum non defunt, qui Indici folij loco,caßice odorate, uel cinnamomi folia fuppeditent, que effe caryophylli exiftimat Brafauolus. Nonnulli preterea, quedam

Hermolai, arborum folid, ex Alexandria aduecta, qua lauri, uel arbuti frondes referunt, in Malabatbri ufum uendicant. Hac Ruel. \& Braf. Hermolaus, Ruellius, pariter q́; Brafauolus eos fecutus, nulla (quod equidem fciam) auctoritate, Nigritarum Tem= opinio. bulum effe arbitrantur. Verum cum adbuc corum, qui Tembulibiftoriam, o notas foribant, inuenerin profectóne= minem, quanuis de co A uicenna breuiter fcripferit; idcirco illa potius afferam arborum folia effe nobis penitus inco= gnita, quàm horum fequar opinionem. Nullo itaq; modo bec ad ufum ueniunt admittenda. Fiquidem cüm eorum $f_{l=}=$ cultates nos lateant, non eft cur ea comprobare ualeamus. Sed ubi Malabatbro opus fit, caßiam odoratam, uel Indi= cam nardum fupponendam putamus, Galenum fecuti. qui ita decreuit tum in fuccidaneis, tum etiă lib.v I I. E V VI I. Fuchfij opi- fimplicium medicamentorum. Quanquam Fuchfius in libro, quem de compofitione medicamentorum nouifimé edi nio explofa. dit, dum ea perpendit, que Auream Alexandrinam conficiunt, Malabatbri loco Atractylim ftatuit fubijciendam, $\mathrm{G}_{a}$ lenum (ut inquit) in libello de fubftitutis medicamentis fecutus. Sed certé non fatis poffum mir ari Fucb fium, uirum dx lioqui doctrina er iudicio clarum, in hac re (ut mibi quidem uidetur) maniffeta, minus recté fenfirfe. Nam ut omittă, in libro illo de medicamentis, qux inter fe commutari polfunt, qui tamen liber Galeno adfcriptus cenfetur; me nuf= quam legiffe, quód atractylis Malabathri uicem fuppleat, fed caßia odorata, er nardi pica; eft Diofcorides boc lo= $c 0$, eft $\mathrm{G}$ alenus locis anté citatis in fimplicium cenfu: qui uno quafi ore fatentur, eandem uim babere malabathrum, quam nardum. Quorum equidem auctoritati grauißime longé fatius adbserendum exiftimo, quàm ut temere fortaffe fit atractylis in malabatbri locum fubftituenda. prafertim cim nobis non defit copia nardi, O caßiz odorata : atra Etylis autem uera bactenus, med opinione, dcfideretur, ut libro tertio fuo loco latius oftendemus. Quód etfí conce= damus, banc aliquibus compertame effe, tamen quis audebit ea uti pro malabatbro? etenim nullus, quod fciam, atra=

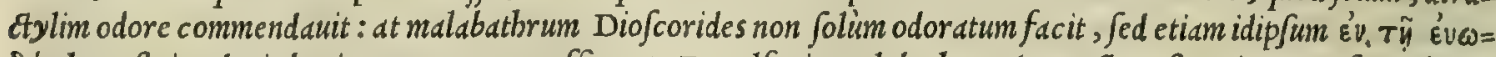
Sía hoc eft, in odoris bonitate permanere affirmat. Excalfacit Malabathrum (ut auctor eft A uicenna) ficcat' q $_{\text {; }}$ or $=$

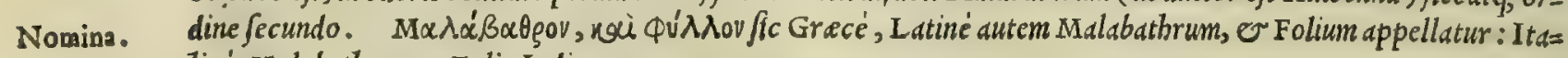
Ticé, Malabathro, e Folio Indiano.
Kasia.
C A S I A.
CA P. XII.

CA 5 S I A, cuius complura funt genera, itxta odoriferam Arabiam gignitur, crafsi corticis farmento: folijs piperis. Eligenda eft fuluefcens, pulchri coloris, corallij æmula,perquàm angufta,lon- 


\section{In Lib. primum Diofcoridis.}

- ga, craffa, \& fiftulo a, guftu mordens, \& cum aliquanto feruore adtringens, aromatica, vinofo odore:cuiufmodieft, qux ab incolis achy appellatur, ab Alexandriæ negotiatoribus daphnicis. Huic prxfertur crafia, purpurea, \& nigricans, zigil cognomine, qux rofam odore imitarur, pracipui in me dicina ufus. Secundum locum tenet antedicta. Tertia, cui Mofylitico blato, id eft, germinicognomen eft. Reliqux uiles, vt qux afyphemun dicitur, nigra, infuaurs, cortice tenui, ac rimofo: \& qua datca, \& cite uocitarur barbaro nomine. Similior huic eft preudocafsia, quàn ve explicari poŕst . qux guftu coarguicur, cùm nec acris, nec odorata lit, harencemq́ue medullec corticcm habeat. Inuenitur etiam hata quxdam filtula, mollis, leuis, furculofa, quxancedicx prefertur. Damnatur candicans, fabra, hircinum uirus redolcns, \& qux tenui fifula, \& fabra cute lit. Vim obtinet calfsto ciendi, urınam ciendi, ficiandi, \& leniter adfringendi. Conuenit ad medicamenta oculorum, que praftandx claritatis gratia concinnantur, $\&$ ad malagmata: Ientigines tollit cum melle illita : menles trahit: contra vipcratum ictus pota auxiliatur: aduerlus inteftinas infmmationes omnes, \& renum uitia, pota próicit: fueminis in folio defidentibus, aut fufímentis, prodeft ad dilatationcm vuluæ. Et duplo pondere medicamentis mifta, cinnamomi uicem fupplet, fi ipfum defit : nam eofdem effectus prabet. Ad plurima perquàm utilis eft.

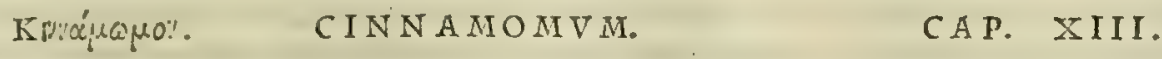

C I N N A M O I genera plura, patrium fibi nomen vendicantia. Præfertur tamen Mofyliticum, quòd cilsix, cui moly liti nomen eft, aliquam referat efligiem : fed in eo genere recens, nigrum, ex ui20 nofo in cinereum uergens, lxue, tenuibus ramulis, ac frequentibus nodis cinitum, perquàm iucundè olens. Optimi ferè indicium, iucundi odoris proprietate conftat: inuenitur enim cum optimo, coque quod peculiare ct, odor rute, aut cardamomo proximus. Infuper acre, mordens, \& cum calfactione quadántenus falfum, quod non citò confricanti afperum, aut frianci lanuginofum, lxuibus tamen internodjjs appareat. Si certior feri uoles, vellito ab radice furculim . facilis eft huiufcemodi probatio: nanque fragmenta mileellanea quxdam efle uidentur. Quę autem melius fpirant, fuo halitu, cùm nares primùn confuluntur, olfactum explentia, deterioris dignotionem impediunt. ERt etiam montanum, craffum, pumilum, fuluefcens admodum. Tertium à Mofylitico, perquàm fuauiter olet, nigrum, fitticofum, paucis intercedentibus geniculis. Quartum fungofum, candicans, afpectu tuberofum, vil, ac friabile, magnam habens radicem, quæ cafsiam planè reprefentat. Quin30 tum genus odore nares feriens, fubrufum, \& cortice fulux cafsix fimile, tangenti firmum, minus neruofum, denfa radice firmatum. Iis, quæ thuris, cafsir, myrti, aut amomi odorem fpirant, minus fuauitatis ineit. Deligito fcabrum, album, rugofum : at Lxue, \& lignofum circa radicem, ut inutile, reijcito. Eft etiámnum fimile aliud, cui pfeudocinnamomo cognomen eft, ulle, inualidiodoris, foJutarumque uirium. Vocatur etiam zingiber, cùm tamen fit xylocinnamomum, præbens quandam cinnamomi faciem. Eftautem lignofum cinnamomum, farmenta longa robultaq́ue ferens, odore longè cinnamomo inferiore. Sunt qui xylocinnamo mum à cinnamo mo genere differre dicant, quòd à narura eius abhorreat. Cinnamomum omncexcalfacit, emollit, \& concoquit : vrinam cict: tam menfes, quàm partus potum, aut ex myrrha impolitum pellit: contra beftias, quæ uirus eiaculantur, venenaq́ue conuenit: caliginem pupillis oculo:um obuerfantem difcutit:crafsitiem extenuat: lentigines, \& uitia cutis in facie ex melle illitum detergit: contra tuffes, defluxiones, aquam fubter cutem fufam, renum uitia, \& vrina difficultatem efficax eft. Vnguentis pretiofis inferi folet. Et in fumma, magni adomnia ufus. Tritum uino excipitur, umbraque ficcatum, quò diụtius eduret, reconditur.

N A T V R A omniun rerum parens in hoc terrarum orbe qusdam firpium genera adeo inexorabilia procred= uit, ut ne quim plurinis quidem delicijs, blanditijs, officijs, ob fequijsiq; ea apud nos quifpiam retinere potuerit. Si= quidem fturpesipfa uiuere coacta in bortis, uiridarijs, mitioribuśq. Italie locis, ceu Tempe, onni amonitate refer = tis, quemadnodun alpinibomines deticias urbium, of maieftatem afpernantes soliticis moribus omnino neglectis,

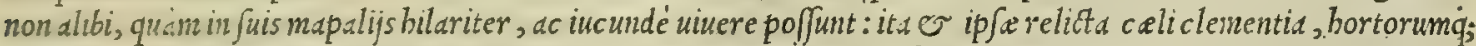
ancenitste, fpreto itcin fontium oble ctamento, onnium '́; urbanarum ac familiariun ftirpium confortio in de ferta, fo= Lindines ć, fus, i qubus primam duxerunt originem, fe tandem receperc . tantum patrie, natalis q́; foli amor in rerü nacura poti?. In quarum genere Caßia connumeranda uenit: que tametfin maiore illa Romanx gentis fortuna mul tis ac uaris iortorun locis confita babebatur; nullibi tamen bac atate (quod nouerim) in Italia, ne in tota dican Eu= ropa inuemur. Sed hec de Cajsa dixiffe uolumus fimplicium medicamentorum peritißinos fecuti, qui (ut corum te=

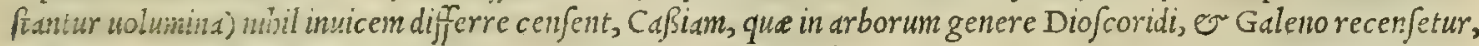

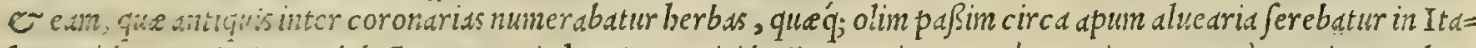

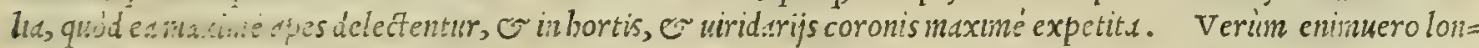

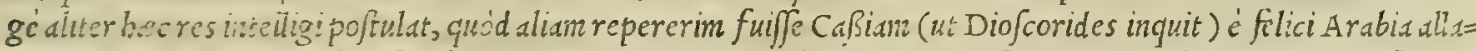
tam ex abore (alitore Theophrafto) viticis magnitudine, abbaclonge diuerfam, quam apibus, cr coronis fercbit

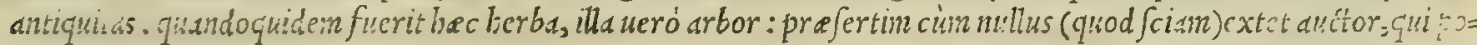

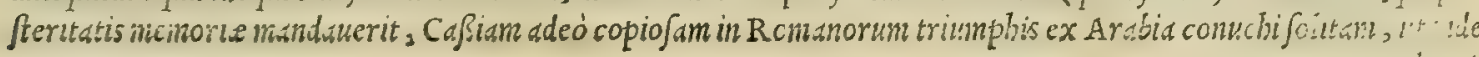

Cafsix confideratio.

Cafsix odora tir, ix ccrordriędılcrimen. 
uu!garis facta, ubic; paßim e reperirctur, e fereretur ab omnibus. Quod fi forté cueniffet, nunquam tanen mibi . perfuserim, quod Galenus bac in fcientia, of facultate omminn diligents!inus, or qui Rome diu uitam duxit, Itali=

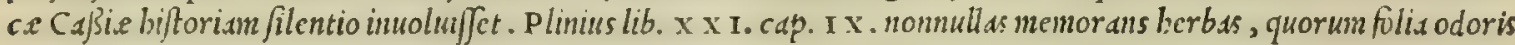
gratia in ufun coronarun uenerant, inquit. Ergo in coronamenta folio uevêre malctbron, feireon, trigonon, che= reon, quod cafiam Higinus uocat. Id quod ante ip fun palam ficcrat virgilius Cafiam inter coronarias berbas reco: lens in Bucolicis ecloga ij. bis uerfibus.

Tum cafia, atg; alijs intexens funibus berbis,

Mollia lutcola pingit uacinia caltba.

Et in Georgicis lib. I r.

Vix bumiles apibus cafias, roresn'; miniftrat. Item Georgicorum lib. I I I I.

Nec circum cafie uirides, er olentia laté

serpylla, $\sigma$ graniter pirant is copia thymbre

Floreat, irrigumm; bibat uiolaria fontem.

Hac Maro. Quibus paliun eft, Cafiam coronariam, qua tantopere delectantur apes, herbam, non arborem fuife. Quod etiam teftatur Plinius libro fupcrius citato cap. $\mathrm{x}$ I . bis uerbis. Verim bortis coronamentis q; maximé aluea=

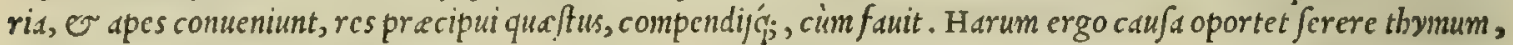
apiaftrum, rofan, uiola, liliun, cytifum, fab.sm, erwilium, cunilam, papauer, conyzam, cafiam, melilotum, meliffo= phyilum (lcgo myriophyllun) cerinthen. Hactenus Plinius. His itaq; rationibus, auctorumi; ueterum teftinonijs in= nixus Theodorus cneoron Theoplorafoc afiam appellat. Quamobrem potius fuerit credendum, cneoron Grecis uo= catum antiquis coronariam fuiffe Cafiam apibus gratißinam, quan eam, que in India Co filici Arabia prouenit, cin= nanomo perfimilis, odoramentis $\mathcal{F}^{-}$antidotis expetita, $\sigma$ qua per longus atates cinnamomi uice ufi funt medici. Neque tamen proptere a opinioni incfir a refiagari putamus Columellam lib. I I I. cap. v I I I de re rustica, ubi ita fcri ptum reliquit. Iudeam $\mathcal{O}$ A rabiam pretiofis odcribus illuftrem baberi, fed nec noftram ciuitatem pradictis egere firpibus : quippe chim pluribus loc is übis ian cafiam frondentem conficinus, iam tliuream plantam, florentesá; hor tos myrrba or croco. Nam quanuis concedi poßit Colwmelle, cafiam ex A rabia allatam urbis illiftrande gratia Ro= me fuo tempore conpicuan fuiffe in bortis proccrum er imperatorum; boc tamen non prohibct, quin cafia, quam prope apum aluearia paßin feuit antiquitas, dlia fuerit planta: prefertin cuin hec inter herbas coronarias, illa ue= Cneoridefcri ró inter arbores odoratas recenfeatur. CNE ORON autem defcribit Theopbraftus lib.VI. cap. I I. de plantarum ptio. bistoria, his uerbis. Cneoriduogenera, aliud enim candidum, aliud nigrum. Candido folium cutaneun, oblongum, figura quafi oleagineum : nigro quale tanarici, carnofum. Candidum magis fe bumi pargit, odoratumq́; cft : nigrum odore caret. Radix ambobus, qua alte defcendit, grandis: ramiq́; permulti, craßi, furculofíq; ab ip 「a protinus tel= lure, aut paulo fuperius parfi, lenti admodum conftant. Quamobrem bifce ad colligandum iuncimodo utuntur. Ger=minant, florentó; poft aquinoctium autumni, or multum deniq; tcmporis florcnt. Ha'c Theoplorastus. Scd quixnam plante oriantur in Italia, uel aliunde eć afferantur, que Cneoron refirant, quid ucri referam fané non babeo. Sed iam ad Caßiam odoratam redeamus. ob cuius cognitionem poftmodum factum eft, ut recentioribus medicis, in ea re: Medicorü, \& cuperanda, inueftigandáq; multum negocy accefferit. Nanq; hadtenus tum medict, tum feplafiarij (etfi plures iamt feplafiariolü refipifcant) odorate caßse loco quadam incognita arboris fegmenta, nec odore, nec uiribus predita femper capef error. ferunt. Veruntainen poftquàm nonnulli atatis noftre doctiß3mi uiri, firpium biftorias diligenter examinarunt, dete= i. fraude, mercatores ex Alexandria mercinonia Venetias comportantes, cum fuam impo, turam deprebenfam cer= nerent, inegocio defcifcentes in aliud noum Caßi.e genus fegmenta illa commutarunt. Que fané preter odorem; pariterq́; faporem, quibus feré penitus exoleta fentıtur, caßia à Diofcoride de fcripte admodum babctur confimilis. 4 Quapropter nec eos erraffe crediderim, qui dicerent, hanc Diofcoridis p feudoc ajiam effe. quippe er craffo cortice conftat, er in eius cauitate lignofa ctiam uifitur materies, paululum q; eft odorata, miniméq; acris. Nonnullibac non contenti, quedam uocati cimamomi fragmina $\mathrm{C}$ aßsic uice ufurpant: que cum nullo odore faporéf; commendentür;

Carsia legiti- potius quercum, uel fagum, quim Caßiam referunt. Caterim, ut dic am quid ego fentio, fi quis fiftulam, quam Cin= ma. namomum perperam appellamus, o unlgó Cannella, Caßix generibus rect ć comparauerit, facilé nouerit unlgaris ufus cinnamomum legitimam Caßiam procul dubio referre . quinimo diligenter inquifituris, iudic ij q $_{\text {; }}$ trutina exami= naturis huiufmodi cinnamomi ingentem copiam, qua magnis faccis Venetils in mercatorum refolitorijs afferuatur, nimirum omnia illa Caßix gener, qua d Diofcoride de fcribuntur, facile $\int c \int e$ offerent . quandoquidcm mercatores ( ut femper alfolent) ad expediendas deteriores merces bonarum lenocinio, quas illis admifcent, pro uirili utuntur. Galenus itaq; libro primo de antidotis multa Caßie genera recenfuit, ubi fané Diofcoridem fccutus, cam ceteris pre so ftare fatetur, qua zigi cognomine dicitur, bancó; a ferit cinnamomum ufque ddeo x'mulari, ut ef ent, qui fuo xuo cam cinnamomi loco uenderent. Quo fit, ut admirari non liceat, fi bodie quog; tot annis bac deducta, protractá;; con= fuetudine, ubique cajsia pro cinnamomo uenundetur. Nec quidem longé abcrrarent, fi modó optimam feligerent: quandoquidem Galenus eodem loco palim prodit, Caßiam fepenumero in cinnamomum tranfmutari, fatetur'q; $\int e$ iam uidiffe eximix Caßia ramulos omni ex parte cinnamomum referentes. Contrà pariter inpexiffe cinnamomi fur= culos Cafix prorfus perfimiles : adco ut aferat pro qualibet cinnamomi parte in componendis medicamentis duas ele et.e caßie adbibcripolfe. Defcribit item Galcnus quodd.m aliud deterioris Caßia genus, quod tradit iuniorem Ans dromachum Caßiam fiftulam nominaffe cum fftularum modo, inanis cauaǵ; fit, or craßi corticis: cruiufmodi in uuls gari cinnamomo frequcntißima conpicitur. Huius fané $e$ u uidetur cffe generis, quam in fuo conficicndorum pharma= corum libcllo prafert Cordus, quod uelit caßsiam, prater Diofcoridis o Galeni fententiam, lubrici cfe g'ffus. Porró Caßia odorate fruftulum cun cortice e ligno fuo interiore nuper dono mibi dedit Serenijimus Princeps 


\section{In Lib. primum Diofcoridis.}

Ferdinandus Archidux Auftrix dominus mibiclementißimus, ab integro ramulo abfcifun, quem ille inter plures alias res non minus pretiof us quàn raras, recondinum babet. Huius cortex colore quidem cincreo a noftro uulguri cimamomo dißidet, non tamels odore ac guftu: quandoquidem manfus idipfum, quod uulgus Cannellam nocat, ori plané reprefentut. At lignum, quod cortice contcgitur, fragiliconftut materie, ney; ullo prosfus odoré, faporcó; commendatur. Quare binc facile colligi potrft, corticis tantum eius ufum efe : ato; ctian Theophraftum non ab re

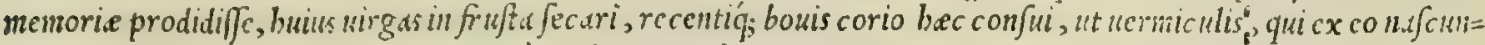
tur, lignüillud inutile erodatur. Ceterum odorate caßjie meminit ctism Virgilius prater coronaria lib. I 1. Georg. ubi cecinit boc carminc. Neccafia liquidi corrumpiturufus oliti. Quine plinius Capsie meninit lib.x I I.cap.

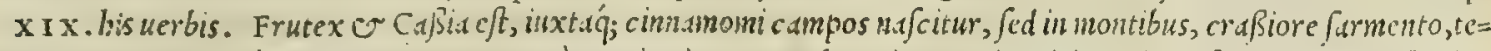

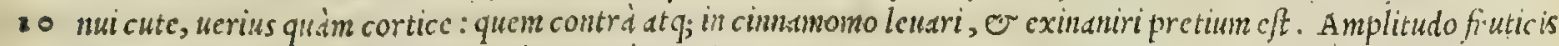
trium cubitorum. Colos triplex: cim primum cmicat, candiduspedali menfura: dcinde rubefcit addito femipede: ul= tra nigricans. Hec pars muximé landatur, ac deinde proxina: damuatur ueró candida. Confecant furculos longitu= dine binum cubitorum: mox prat funt recentibus corijs quadrupedum ob id interemptarum, ut ijs putre fcentibus, ucr miculi lignum crodant, o excanent corticen tutum acrimonia, or anaritudine. Probatur recens maximé, or qua fit odoris mollißini, guftuue quim maxiné feruens, potius quàm lento tepore leviter mordens, colore purpureo, quxég; plurima minimum pondcris faciat, breui tunicarum fiftula, o non fragili. Hac Plinius, quorum plura i Theo=

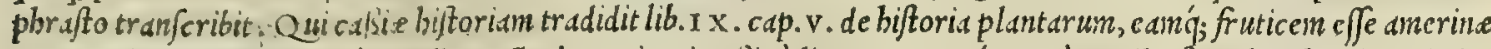
mugnitudine feribit: que cimm nullo pacto decorticari poßsit à ligno, cortcx'́; tantum utilis fit, ob id bominum indu= fria inuentum effe ait, ut corijs quadrupedum confuta, interius lignım uermiculis deuoretur. Caterum plané ballu

2o cinantur ij, qui Caßie filtule boro, filiquan Acgyptian, fiue Caßiam folutiuam unlgó dictam, atra medulla, femine duro, lignolisq; membranis confarctam, medicamentis admif cent Mauritanos fecuti. fiquidem Serapio, Auicenna,pa riter; Nefues, fiue fit ip forum, fiue interpretum lapfus, pari confenfu Caßiam nigran Caßiun fiftulam uocauêre: legitun sm ueró Caßiam, de quabic differit Diofcorides, Caßiam ligneam. Quamobrem certó crediderim, qućd ci tra omnem cenfu'an dici poßst, in onmibus ijs medicamentis à Mauritanis inuentis, que Caßian filtulam expetunt, folutiuam illam cffe inferendant. Si uerò in Graccorum monument is (excipio Actuarium, or . vicolaum Myrep/icum,

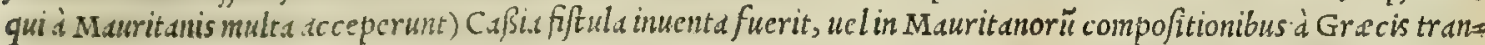
foriptis, Caßiam odoratam, à Diofcoride $\odot$ Galeno defcriptam, femper adbibendam exiftino. Nifi medici fecus inz telligentes in eum erroren Lbi uelint, in quem Leonicenus quofdam at tat is noftre medicos (que profectó imperitia multorum eff) temeré incurriffecteltatur, qui ad commouendos menfes, difficiles partus, remorantes q́; fecundas,

30 Caßix deieforie corticibus, odqrat loco:ufuequad; utebantur. CI N AMO MVM ueró, quod legitimum fit. quanquam dix smultwn;; tum Venetigs, tun INcapoli, co apud mercatores, quiferé quotannis in Alexandriam natiz Gant, diligenter conquifuerin, an quanid tamen mibinidere licuit, neq; etian percipere potui, num boc tempore apud magnos negociatores, qui é Lufitania Indiam, or felicem A rabiam claffe paratipima petunt; uel apud quen: pian principem, regen, uel imperatorem legitimum reperiri poßit. Quade re mininzé demiror, cum 6 Galeni tempore buius magna in Italia fuerit penuria, adeó ut Cinnamomum nullibi reperiretur, nifí apud Imperatores, qui admu sbili cuftodia inter alı pretiofa illwd afferuari curabant. Cuius reibiftoriam in medium affert Galenus libro pri mo de antedo:tis, fic inquiens. De Cimamomo contraria ijs, que de opobalfano narrauimus, compertun babeo: perjuafum nanq; mihi eft, ipfum omiun cognitu facillimum effe illis, qui fepe optinum cinnanomum uiderint . Opti= munz ueró confequi nemo poteft, nifî repofitum ab imperatoribus intue atur, fex generibus quodammodo diftributum.

40 fiquidem $\odot$ in boc ipjo, velut e in caßia, optimi ad deterrimum tan magna differentia eft, ut optima caßia d peßsiz mo cinnamomo parum diftet. Necj; ueró Cinnamomi uirtus ad ufim apta longo tempore durat: ad triginta fiquiden annos, quam à principio uim habuit, integran non conferuat. nugantur autem, qui Cinnamomum ex bifce medicinis ef e dicunt, que fenectutem non fentiant. Atqui ego non centun, neq; ducentüm annorum interuentu, fed pauciorum, fi quis ad tantum numerum conferat, iam aliquam mutaionem uetuftiori cinnamomo factam obferuaui. Quo tempo= re fiquiden Antonmo inperatori theriacam paraui, uaja ligned, in quibus eiufdem generis Cinnamomum inerat, mul= ta compexi, alia Traiani, quedam Adriani, nonnulla Antonini, qui poft Adrianum imperator fuit, atate repofita: omnia'; hec fe $\int e$ o faporis, or odoris imbecillitate, uebementidq; tantum plané fuperabant, quantum er tempore differebant. Olim é barbarorum terris arca cubitos quatuor or medium longi, Romam perlata cum fuifet, in quit Cinnamomi primi generis integra arbor erat, ex cóq; Marco Antonino imperatori antidotü quandam compo $u i \int f e m$.

so ip fam cateris multum preftare, deprebendi, adeo ut Imperator quog; ca deguftata medicine concoctionem, uelut in alijsfieri folet, expectare nolucrit, fed ftatm ed ufus fit nondum integré duobus menfibus elapfis. Antonino fubfecu= tus cft Commodus, qui nec theriace, nec cinnamomi cur am ullam babuit, fub quo non folim arboris illius, quod fuper= fuerat, omne dißipatum eft, uerim etian quodcunq; poft Adriani tempora comportatum fucrat. Quo factum eft, ut nune imperator nofter seuerus, cum me fibi antidotum eo modo conficere iußiffet, quo Antonino confeceram, ex Cins namomo Traiani, or Adriani tëpore repofito fumere codctus fim, imbecillior áf, plané mibi uifa funt, or tamen non dum anni triginta intercefferant. Hic nos optimi cinnamomi notas quafdam neceffarias fubijcere uolumus, ipfum fcilicet fummopere bene olere, inexplicabilem'; pre exteris bonum quendam odorem fpirare, dc calidum gujtattibus fe multum exhibere, non ita tamen ut mordicando trifitiam palato inferat: colorem deniq; talem babere, qualem $f_{2}$ quis lafti nigrum colorem admifceat, ato; cerulei, quem uocant, aliquantulum addat. Ex boc igitur quantum uoles bam, ut mos mihi fuit, cim accepifem, ramufculos paucos apud me repof ui in ed apotheca, in qua res meas omnes pre

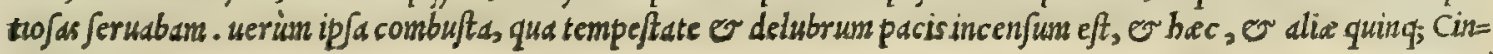

Cinnamomi confideratio.

Cinnam. hif. \& Galeno. 
namomi pecies, quas mibi conquifieram, periere. Nunc itaq; cum imperatori noftro scuero theriac am componerem, ex Cinnamomo Adriani temport repofito, quod optimum uifum eft elcgi, de quo etiam utile quiddam lecturis jubdere, cumpoßim, id facere non grauabor. Superfunt adbuc ibi multa uafa ligned, quse omnia babent plurium ras dicun, uel plurian ramiorum, uel ut quipiam dicere uclit, Cimanomorum differentias: anillum tamen ueliti truncus, in ramos plures diuifus at rollitur, fed ueratri utrius q; figuram pre fe fert, at q; etiam mag is damafonij uocati, qüod $e^{\circ}$ Creta ad nos adfertur. Quenis autem cinnamomipecies ab una radice, ceu frutex quidam paruus confurgit, cmit=

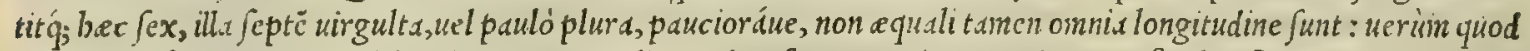
maximum eft, pedis Romani dinidium non excedit. Vniuerfa autcm Cinnamomi natura fimilis eft quodamnodo opti= Cinnamomi me caßse. Hactenus de Cinntumomo Galenus. Cuius uerbabic recenfere libuit, ut omnibus palam fit, quód cum fub penuris unde ijs tam magnis Imperatoribus, qui totifré orbi imperabant, tanta effet Cinnamoimi penuria, admirari non debeamus, fit.

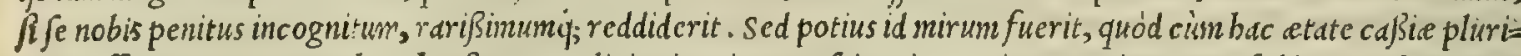
mum afferatur, que, ut Theophraftus, $\mathcal{O}$ Plinius inquiunt, nafcitur iuxta cinnamomi campos, fed in montibus, Cin= namomi tamen nibil importetur. Quare non deft fupicio, quin omne feré Cinnamomi genus deperierit in Arabia, quemadinodum e balfamum in I udax. Quandoquidem fcripferit Plinius lib. x I I.cap. x I x.combuftas iam effe plu= rimas Cinnamomi fyluds, his uerbis. Cimamomi pretia fuere quondam in libras denariorum mille. Sed poftea auctum id parte dimidis eft, inc enfis ( ut frrunt) fyluis ira barbarorum. Id acciderit ne ob iniquitatem prapotentium, an for = te, non fatis conftat. Auftros ibi tam ardenter flare, ut aftatibus fyluas accendant, inuenimus apud auctores. Qua fit, ut facilé credi poßit à Plinij a uo id, quod Cinnamomi reliqum erat, pariter uel barbarorum bello, uel igneis fld= tibus deperifffe. Nain fi aliter res fe baberer, qui caßiam ad nos deferunt, cum multó plus lucri.ex cinnamomo, quám ex caßia fe confecuturos fciant, Cinnamomum etiam unà cum caßia ueberent. Hac autem dixiffe uolut, non ut bac in re certi aliquid, exploratig; habcam, cim tantim coiecturis agam, fed ut alijs ulterius explorandi latius pateat iter. Ceterìm Strabo non modó cum Theophrafto, Diofcoride, Galeno, Plinió; cimnamomum in Arabia nafcifcribit, fed etiam in Indu, ea feilicet parte, que ad auftrum uergit . quippe cum bec Arabia, or Aethiopie fole perfimilisfit, ea omnia ( ut ip $\int \mathrm{c}$ ait) gignit aromata, nempe cinnamomum, caßiam, of alia, perinde ac ills. Vernitamen cur nec inde ad nos afferantur, an quod ctian ibi perierit, an aliam ob caufam, ij manifeftius refer ant, qui hoc tempore libur= nicis eó ad aromata conquirenda quotidie nauigant. Sed uidetur Galenus fatis perplexé de Cinnamomo fcriptitaffe : quippe primim arcain Romam delatam prodidit é barbarorum regione longitudine cubitorum quatuor, cum dimidio, in qua integra cinnamomi arbor erat. quibus omnino denotat Cinnamomum effe arborem. Deinde ueró unanquanq; Cinnamomi peciem fcribit, ab una radice, ceu frutex quidam paruus confurgere, adeo ut naiora eius uirgulta dimi= dium Romanum pedem noll excedant . quibus procul dubio fatetur, Cinnamomum effe in paruorum fruticum genere. 30 Vnde certé ne fciuerim ego explic are, quid fibi hac in biftoria noluerit Galenus; prefertimó ; cüm tam tenui ipfum far mento effe tradiderit, ut ueratri, uel damafonij radicibus comparauerit. Sed illud etiam mirum mibi uidetur, quod ex caßia ( ut ip $\int e$ ait) Cinnamomum oriatur, ßpectentur $\dot{q}$; nonnunquam caßia arbores integra, in quibus aliqua cinna= momi uirgulta é caßixe ramis prodeant, cuin tamen cinnamomum, or caßia diuerfe inter fe fint plante. . Nifi fortaffe inter utranque tanta fit generis cognatio, ut aliquando inuenta fint caßix uirgulta tanta odoris faporisq́; fragrantia, Opinio qua- ut omni ex parte cinnamomum referrent, ctfi legitima fuerit caßia. Praterea nondefunt, qui putauerint bac Gale= rundam falfa - ni audtoritate freti, caßiam or cinnamomum ex una, of eadem arbore prouen ire, qux dum pumila fit, cinnamomum edat, dum ueró adoleuerit, caßiam. Sed cün dic at Galenus, caßiam mutari in cinnamomum, non autem cinnamomum in caßiam, cadit corum fententia. Quibus ctiam refragatur Theoplraftus lib. I X. de plantarum biftoria cap.v. ubi caßiam, or cinnamcmum oftendit diucrfas effe plantas: licet de earum forma; or proceritate nibil certi exploratió. affirmet. Qu undoquidem initio capitis non ex $\int u \alpha_{3}$ fed aliorum fententia fcribit, cinnamomum er caßiam frutices effe magnitudine amerina: deinde ueró alios etiam fecutus auctores, cinnamomum fruticofum facit. Caterum cum fcri= bat Strabo Arabas cinnamomo, or caßia uti ad ignem parandum, caterorum lignorum loco, uidentur be plante non effe adeo pumile, ut quidam fcribunt. Quod de caßia facilé dicipoteft. Fiquidem Venetijs caßice Cannelle uocate fi= fule uifuntur tante craßitudinis, longitudinisó,; ut facilé quifq; iudicare poßit eds é ramis, feu uirgultis non fané bre subus fuiffe decerptas. Cinnamomi deniq; fex genera effe produntur à Diofcoride, $\sigma$ Galeno: fed is nullibi (quód fciuerim ) praterquam in libro de theriaca ad pifonem, quem tanen librumppurium putamus, ed per genera defcri= p/it, fortaffe ( ut folet) Diofcoridife remittens, qui etiam tantim à locis, ubi nafcuntur, plus minusue preitantia

Cinnamomi huic, quam illi reddidit. At Theophraftus citato nuper loco longé aliter cinnamomi differentias baberi ait, bis
differentix ex uerbis. Cinnamomum decerptum in quinas partes difcerm narrant, of effe precipue bonitatis, quod germinibus differentix ex uerbis. Cinnamomum decerptum in quinds partes difcerm narrant, of effe precipue bonitatis, quod germinibus
Theophr. proximum fuerit, id $\dot{q}$; ad palmi longitudinem cedi, aut pauló maius. Sccundum, quod fequitur, quod ctiam munus cefurd eft. Tertium deinde, es quartum notatur. Vltimum ueró, quod deterrimum, proximúnque radici: boc e= nim minimum corticis habet, in quo fumma gratia eft, non in ligno . qua de caufa preferri cacumina folent, quód corticis plurimum habeant. Quidam fic aiunt. Alij ueró cimnamomum fruticofum cnarrant, eiusq; genera duo, alterum nigrum, alterum candidum. Hac Theophraftus. Veruntamen cum nec is hac in biftoria aliquid conftanter, affirmanter'q; fcribat, Imperatorem, Regémuc quempiam defiderarem, qui bumanam rempublicam miferatus, $c x=$ plorand Cinnamomi gratia in Arabiam, E Indiam mitteret, magnanimos'; illos initarectur Imperatores, qui ip/ius Galeni euo ex ijfdem regionibus fibi Cinnamomum comparabant. Id enim Cafar nofter Carolus quintus, fi illt Deus opt. max. Chriftianam remp. pacatam redderet, commodé confequi poffet . uel fortaffe commodius $\mathrm{Re} x \mathrm{~L}$ ufitanus, - qui in orientalem Indiam $\int e p e$ ad aromata conquirenda fuas liburnic as mittit, quo in itinere uniuer fas frlicis Ara $=$ bie oras explorare poffet : qucmadmodum $\mathcal{O}$ uniuerfam Indie partem, qua ad auftrum ppectat, ubi inquit strabo 


\section{InLib. primum Diofcoridis.}

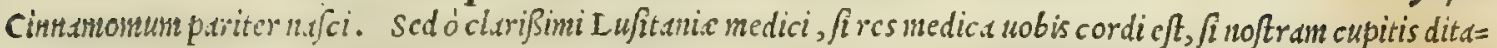

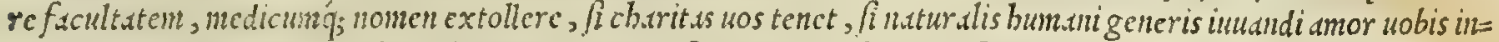
fitus oft, iamiam prouinciand anc fufcipite. Quippe fi princeps ucfter binc fibi inmortale nomen, uniuer fe ucró rei=

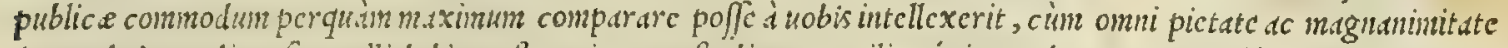
( ut audı) praditus fit, wi!li dubium c/t, quin omne fudiwin, duxiliumig; impendat, ut non modó chunamomum ip= fun renocetur in lucesn, fed or slia fortafe pleraq; medic amenta, quibus antiqua inc dicorum fanilia fuss illuftrauit antidotos. Porrótunctfin hatenusillud mibi abunde probatum effe nideatur, quod caßsian ueran habeamus, de= fidercmus autent optimum or legitimun cimamomum; funt tumenhac attate feriptores, qui non caßsie folim, fed etism cinnunomi gencrs inuciniri tradunt inter quos extat Fucb/ius uir clarißimus, qui libro illo de compofitione

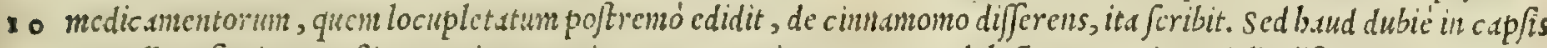

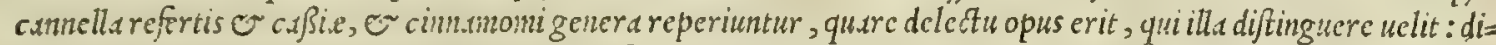
finguet autem notis utriufque diligenter expenfis. His nimirum uerbis Fucb/ius cinnamomun nobis uerun non deeff Se afeucrat. Sed quibus it rationibus, aut auctoritatibus comprobet, non uideo: nifi boc acceptum referat Amato I ufitano, qui có anentie deucriffe uide tur in fuis enarrationibus, quas in Diofcoridem foripfit, ut apud nos cimna= momigcnerainucniri, atquc etian illud aroma notißimum effe contendat. Verium buius incptias ac uanitates pluri= mus alibi per fequinur, ubi nos «b cius calumnijs defendimus. bic enin quod de materia medica fentimus, or ingenue profiteripofjunus, libenter frribinus. Quire ea fit noftra de cimnanoms fententia, quse a nobis antea fufius pro= bats eft, quin mo to oporte.t pluribus Fuch/ium refellere quem tamen doleo maiorem fidem preftitife Lufitani ils lius incptijs er mendacijs, quan nirum peritum deceat. Ceterim illud tantum addam, quód nobis, qui cinnamomun so lignum noncorticen effe oftcndinus, mirdri quidem fubit Fucb/ium, quilibro fuprà citato eodem loco pauló póft contrariun foripfit, ut cius urrbx, qux fubijciam, aperté teft intur. Cinnamomum, inquit, quod nobis Zeilam infu= Is mirtit, cortex eft arboris quatuor feré cubitorum alte, craßitudinis brachialis, fex uel feptem é trunco mittentis ramulos, qui ingulis annis amputantur, atque iterum pullulant: quorum cortex, qui cinnamomum eft, fit tenuis,

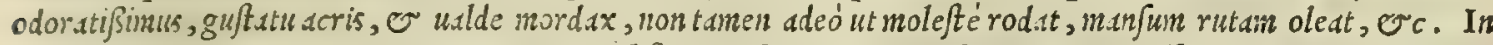
batc, neco qridem iudicio, tunxm opinionem Fuchfus non fecus atque in fuperiorem ueniffe deprehenditur fecutus Anstum Lufitanum : qui candem feré prius, quam ille póft cinnamomo effigiem reddidit, quanquam edm à quodam accepiffe fatetnr. Cinnamoni uires fcribit Galenus lib. v I 1 . fimplicium medicamentorum, fic inquiens. Cinna= mom:im fummé tenuium eft partium, non funné tanen calidum, fed ex tertio ordine. Nibil autem aqué deficcat eo= rum, que pari funt excalfaciendifacultate propter tenuitatem fcilicet effentie. At Cinnamomis eft uelut imbecillum 30 cinnmomum: nonnulli ip an peudocinnamomum nuncupant. Nemuit es Caßix codem libro citato, ubific babet. Caßia exiccst, ऽ excalf acit tertio quodammodo ordine, fed or tenuium admodum cft partium, gufu ueró pluri= mum in fe acris deprchenditur, leuiter quoque nonnibil adftringens. Quamobrem ob hac omnia incidit, finul $\dot{q}_{;}$di= gerit, que in corpore funt recrementa, $\sigma$ ad hec robur etiam inf trumentis addut. Idoneum ueró etiam fuppreßs menfibrs, cim uidelicet à copia fimul or craßitudine excrementorum, quod fuficiat, cuacuari nequit. bactenus Galenus. Ceterime ex uulgari cinnsmomo fit aquaftillatitia, que er odore er fapore idip fum pulchré reprafen= tat. esm autem extrdisendiratio hec eft. Sumito dicti cinnumomiquantun licet optimi libram, id'f; leuiter contu= Sum in us uitreum uel sneum, quod natule forman referat, conijcito: dein aque rofarum, fillatitie libras quatuor, or uin albiodorati felibram infundito. uss illud in balneum aque tepentis o non feruentis imponito, atque inibi ore uafis prius obturato, uiginti quatuor horis macerari inito . poft id tempus uitreo organo roftrato, quod ab effe= 40 Atu galerum uocant, uas antedianun cooperito, ev igne fornaci fuccenfo, per balneum aqu.e feruentis aquan ftillati= tiam elicito. Verum cannsfagned, uel uitrea, qux duorum circiter cubitorum longitudinem expleat, organi uitrei roftro admouends infcrend ág; eft. illi poftremó uas uitreun fubijcito, quod manantem aquam excipiat . infuper pros uidendum eft, ut omnia uaforum orificia diligenter obftruantur, ne quid expirare poßit. Hac aqua contra omnes agritudines, qus frigus excitauerit, effie ax eft : utpote qua pituitum bumorum '́, lentitiam digerat, incidat, $\sigma^{\circ}$ ab= fumst, flatusq́; difcutiat. Priuatim ueró uentriculum, iecur, Lienen, cerebrum, neruosq́; iuuat or roborat: animi deliquio, cardiacis $q_{;}$affectibus prefentano remedio fuccurrit : uenenis uenenoforumí; animalium mor $\sqrt{1}$ ibus aduer

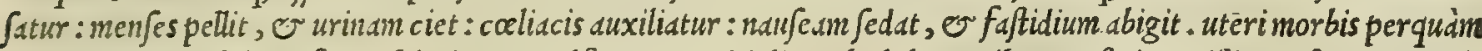
utilis eft: prode fupiriofis, re folutis, conullits, or comitiali morbo laborantibus : guftuigrati/3ina eft, atque oris balitum commendat. In funma ubi excalfacere, aperire, incidere, digerere, er roborare fit opus, buius aque ufus maximampreftat utilitatem. Veruntamen quoniam nec Diofcorides, nec ueterum Gracorum quifquam meminit C AS S I A SOIVI IVAE dite, qua boc tempore ad citandam aluum frequentißimé utuntur medici, quàn'; Acgyptiam filiquam recentiorum quidam appellant, ne he noftre lucubrationes tam nobili, tam prastanti, tam ' ; bumane falutineceffario medicamento deftituantur, differam bic de eo, quicquid ex Mauritanis compertum habeo. Aegyptic itaq; filiqux arbor inter ulde proceras annumeraripotest. Huius materies folida, compactáq, ui= fitur, cortice tenus buxeo colore, medullitus ueró nigra, non fecus ac ebenum, fue guaiacum. Recens gratriter o= let, ficca tamen minimé. Folto conftat filique, fed magis in acutun tendente, cortice cineritio, radicibus magnis iuglandis modó. A ramis filique pendent prelonge, teretes, den $\sqrt{x}$, o cum maturitatem fenferint, colore in rus brum nigricante. He nigra, dulciq; replentur medulla, leni ac lento cremorifimili, non tamen ut in oßibus continua, fed crebris lignofiś; membranis diftincta. Inheret unicuique membranæ femen durum, filiquarum femini adeo finile, ut alterum ab altero difcerni non poßit. ex quo eum non erraffe putauerim, qui crediderit, bas plantas effe congeneres. Eligenda eft, que ex Memphi, er Alexandria Aegypticonuehitur, non admodun craffa, pellucens,

Fuchfij, \& Amati opiniones reproba. tx.

Cinnamomi vires ex Gzleno.

Cafsia uires ex eodem.

Cinnamomi vulgaris aqua Aillaticia.

Cafsix folutiux confideratio. 
CASSIA SOLVTIVA.

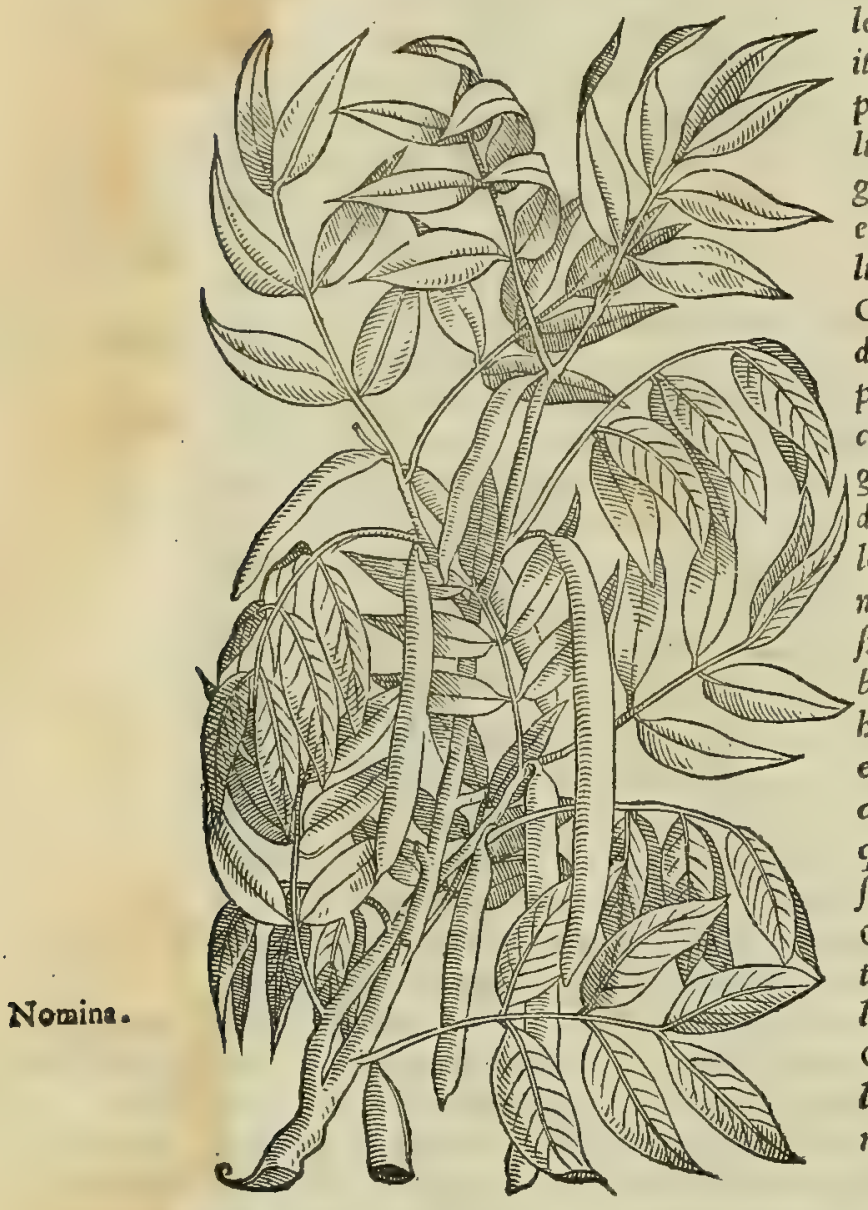

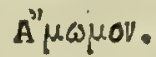

A MOMVM. recens, grauis, furfta, or qux concufd, inciufis feminibus minime conitrefit. Pulpa excalfacit, o bumectat ordine primo. Eadem lenit, refoluit, fanguinem mundat, bilisǵ,; feruorem extinguit: aluü item cômodißimé citat, cius'; wis uentriculum non pertranfit. qua propter fecuribimè datur à medic is inchoätibus febribus, alijsoù ca lidis morbis ante uene fectioncm, quód tantimn uentriculum repur get,et aluü emolliat. Nocet tamé inteftinorü imbecillitate affectis, et his, qui admodü lubrici funt: alids onnino babetur innoxid. Tol litur id noxe admiftis myrobalanis, rhabarbaro, nardo, et naftiche. Conftipatisfi detur, angenda cfor eius facultas ijs, que magis. $e d=10$ dem ui pollent: proinde funt, qui addant amygdalinunt oleum, Er pyyllijßiffamentum. Vrine difficultatibus mirificc auxiliatur,, $\mathbb{i}$ cum urinam cientibus medicamentis hauriatur, ucl deuoretur. Ae= gré aluum excernit: eaq́; propter nonnulli roborant eius uires, ad= dito byffopo, uel caprino fero. Bilem, or pituitam excernit, nul= lo fane incommodo: pectus, o fauces mulcet, o corum inflams mationes refoluit: renes à calculis, $\mathcal{O}$ fabulo expedit; prefertim fi cum glycyrrhize decocto, alijsue medic amentis urinam cienti= bus bibatur. quinetiam frequenter deuorata calculcs rena $\int c i$ pro= bibet. Admodum prater hec calidis confert febribus. Caterim $=0$ exterius illita eryfipel ds extinguit, cater ds q́; inflammationes, que cutétenus emergunt. Sunt é recentioribus medicis, qui eam nun= quam fuis agrotantibus exbibeant, nifi picre puluerem admi= fceant: quod conjulté factum exiftimo: presertim ubi uentriculi, c intcftinorum imbecillitas adfit. Qua Gracis $x \alpha \operatorname{ar}^{\prime} \alpha, I_{d}=$ tints item Caßia nominatur: Arabibus, selicha, Selche, aut Se= libacha: Italis, Caßia, atque etiam Italorum. unlgo Cannella: Germanis,Zimmet, feu Zimmetroerlin: Hipanis, Canela: $\mathrm{Gal}=$ lis, Canclle. Quod ueró Greci usvónuwuov, Latin quoq; Cin namomum dicunt: Arabes, Darfeni: Itali, Cinnamomo.

A M O M V M exiguè fruticat, ex ligno fe conuoluens in racemi modum : fore, ceu candid r nio$1 x$, paruo : folijs bryoniæ fimilibus. Laudatur quàm maximè Armeniacum, colore ad aurum uergens: ligno fubrufo, abunde odorato. Medicum, quoniam in campeftribus, \& aquolis enafcitur, infirmius effe conftat : eft autem magnum, fubuiride, tactu tenerum, frutice uenofo, odore origani . Ponticum uerò fubrufum, parưum, fragile, racemofum, fructu turgens, \& odore nares feriens . Deligito recens, candidum, uel fubrubrum, quod nec adftrictum cohreat, nec conuoluatur, fed folutum diffundatur: femine plenum, vuis paruis fimile, graue, ualde odoratum; modò cariem non contraxerit, acre, guftu mordens, fimplici colore non euariante. Vim habet calfaciendi, adftringendi, exiccandi. Somnum allicit : \& illitum fronti, doloris fenfum aufert : inflammationes, is meliceridas concoquit, difcutitq́ue: iuuat quos fcorpius percufsit, ex ocimo illitum:\& podagricis confert : inflammationes oculorum, uilcerumq́ue lenit ex vua paffa : ad vuluarum uitia in pefsis, att infefsionibus utile eft. Decoctum iocineri, renibus, podagræ, potu conuenit. Antidotis immifcetur, \& pretiofifsimis unguentis. Adulteratur Amomum herba fimili, qux Amomis uocatur, fed fine odore, fine fructu. Nafcitur in Armenia, flore origani. Quare in huinfcemodi rerum probationibus fragmenta fugienda funt : eligenda autem, quæ $a b$ una radice fuos integros furculos emittunt.

Amomicon- T A N T medicorum, qui nos precefferunt, in fimplicium medicamentorum biftoria, or facultatibus igno= fideratio. rantia, fegnitia'́; extitit, ut nifí Deus opt. max. acerrimi, ev feré diuini ingenij uiros, hac a ate nobis produxijfet in lucem, qui preter id, quod uniuer fam medicam facultatem ab erroribus fanc innumcris expurgauerint, edndentó; illuftrauerint, uera quidem fimplicia medicamenta inueftigarunt; minimé profectó uerendum fuerat, quin paruo të $\Rightarrow$ poris traftu ars medica penitus fubuer $\int_{a}$, extinita'; remanfiffet. Et certé fi longiori tempore res ita fe bubuiffet, nulli dubium eft, quin buiufce facultatis cognitio in auram evolaffet. quandoquidem bac peftis radices tam in altum fixerat, ac tam laté fe diffuderat, ut tamet fi nonnulli ingenio, o doctrina preftantes plurimim infudauerint, om= ne $\dot{q}_{j}$ ftudium, or operam qudm diligentißimé impenderint, quo errores, qui ignauia er negligentis emerferant, is re medicd excluderentur, cos tamen hactenus radicitus euellere nequiuerunt. Siquidem non de funt, qui (quanuis bas fee percipiant rationes) malint juos profequi abufus, omni ex parte deteflandos, quam candidißima inbserere ueri= tati. Quo fit, ut unà cun alijs imnumeris implicibus medicamentis etiam legitimo Amomo carednus. Cuius uice quis= 
dannfirpimm impoftores cx Gurguro Apulie monte profecti, pumilum quoddam fesnen fupponunt, colore nigro, $0=$ dore inclantini. Cuod cum tantillwa aromatis rcfipiat, $\mathcal{O}$ guftu acri deprebendatur, cxcogitarunt, ut facilius ip=

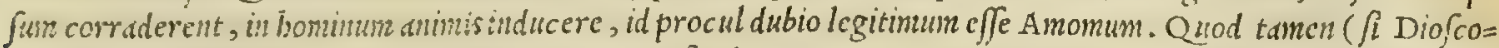

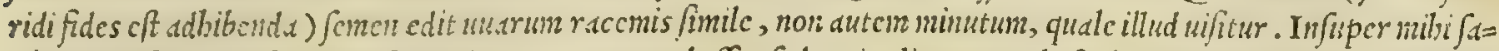
né nou conftat, Diojcoridem fertu in Amomo approbalfe, fed potius ligncan arbufcula matericm, ut in cinnamomo or caßsia uidere cft. quo fit, ut lcgitimum Amomum lignum potius, quim fenen exiftinatucrim. Sed o turpiter abcrrant, qui Sertpionis intcreprecedecepti, herbam Pedem columbinum quibufam wocat.m, que geranij pre fe fertpecien, A momum cffe contcndunt, $\mathcal{O}$ in Amomi locum fubftitum, nullam de bis biftcriam inquirentes. Cae= terim Amonum, quod iurc probaripoßsit, nullibi (quód fciuerim) in Italia proucnit, ncc có aliunde translatum bat=

20 etenus wa'ere potui. Nec; proptcrea urigare pro co upponendun effe cenfeo: quippe de incognitis pericultun face=. re nec decens ef, nec tituin. Scd petius Galcno mos gerendus fuerit, qui acoro, $\sim$ Amono uircs confiniles tribuit. Acorumata, locun Amoni fipplere potcrit. Porró or bi omnino explodendi funt, qui pro certo affercre non

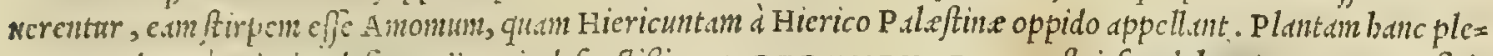
runque adnos é Hicricodefcrunt ij, qui ad functifsimum REDEMPTORIS noftri fepulcbrumperegre profici=

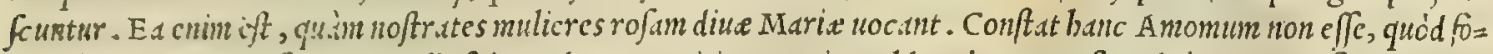
ha albe witis non proftrat, nec ullo fpiret odore. Legitinum enim ualde odoratum eft, adeo ut nares feriat primo fatum occurfu, origamun'q; refipiat. Cordus libello de conficiendis pharmacis fatis inconftanter de Amomo diffe= ruit. quippe in comiofitione curc.x Alexandrme procerto afferit Amomum uerum effe rofan Hicricuntis: in com= pofitione ucró theriace, fui infius oblitus babere nos Amomum negat. Vtuntur Hicricunta noftrates mulicres tem= 20 pore partus ad inucfigzindan fariendi horas . quondoquidem (ut ip fe fatentur) in aquam demifa non prius fati= fcit, quim fectus raki incipiat: tanta inter chrifticolas irrepfit fupcrfitio. Fuchfius medicus bac nostra etate celcbris in libro de componchdis medicamentis, quem nuper locupletatum edidit, dum ea fimplicid examinat, que Theriacun ingredimun, ej productus, ubi Anomi racemofi carmine meminit Andronacbus fonior, omnes Galeni interpretes in/inulut Tis ucrbis. Botryos) Gracé eft Eórgvos. In bac wocc interpretanda omucs Galcni, qui banc compofitioncin tradit, interpretes hallucinat funt. Siquidem Andernacus libro prino de antidotis, une conuertit:

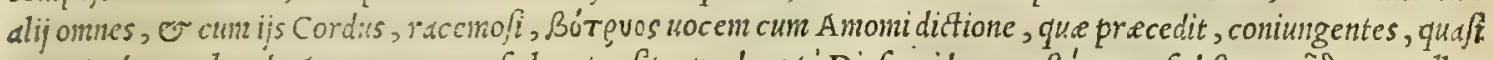

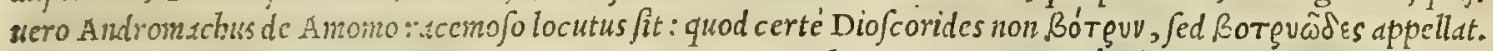

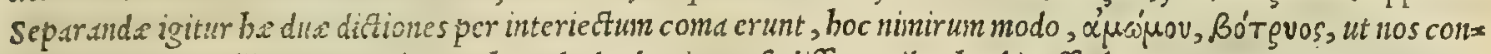
uertimus: ut intellig:tmu!s Andromachum de duabus inter fe differentibus berbis effe locutun, nempe Amomo, $\sigma^{\circ}$

30 botry. hec ille. Ex qiibus utique abunde liquet Fuch/ium fenfiffe, botryn quoq; berbam, de qua Diofcorides agit li= brotertio, lit therisc.sn addendanefe. Veruntamen in hoc nos à Fuchfio, uiro alioqui doctißino, plane diffenti= mus: quandoquiden Andromachum non botryn, fed amomum racemofum intellexife putamus, id'q; non fine rationi= bus, e conięuris. Et ne longé progrediamur, in primis Andromachus ip fe fenior Fuchjio aperté refragatur : il= lum enin non inucnio in sis camminibus, que libro primo de antidotis in Galeno leguntur, aliter de amomo ceciniffe,

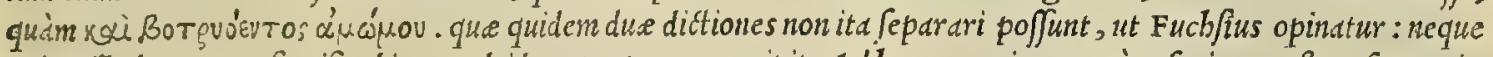
prior illud unquasn fignificabit, quod idesn perperam accipit. Adbec non minus, quàm fenior, noftre fententie adftipularideprobcnditur iunior Andromachus: utpote qui in tradenda theriace compoftione, quam foluta oratio= ne defcripfit, nufquan (quod equidem legerim) botryn commemoret, fed amomun tantim. Quodetfi Damocrates in eadem antidoto de cribenda carminibus, que loco citato à Galcno re feruntur, cecinerit Bór guós T' áuápov; be

40 tamen due dictiones non funt temere, meo iudicio, feparande: :uam eas auctor confultó coniunxiffe uidetur. Quid preterea de Galeno diccinus? ctenim is quanquam libro anté dicto figillatim enumerat, ac diligenter expendit fime plicis medicamenta, que in theriacan adduntur; tamen mufquam (quantum inuenerin) botryos mentionem facit: neq; ctiam cius meminit de theriac ad Pamphilianum foribens. quid, fî eädem plantam apud Galenumin fimplicium medicamentorun cen $u$ defiderari omnibus notum eft. Addam illud poftremó quód inter recentiores Grecos $\mathrm{P}$ dus lus, $\mathrm{e}$ inter Arabas A uicenna botryn berbam theriacis non inferunt fuis. Que fane omnia noftram augent, er con: firmant opinionem. Cuifillud obijciat Fuchfius quod Nicoldus Myrepficus in fua theriaca botryn Gallicam habeat; repondebo ego, quód Nicolai codex Grecus deprauatus eft, e innumeris f catet mendis: id quod ip $\int e$ Fucb/ius nö negabit, quód idem de Nicolai codice expenumero polliceatur. Ex bis itaq; fatis manifeftum fieri arbitror, quód ut

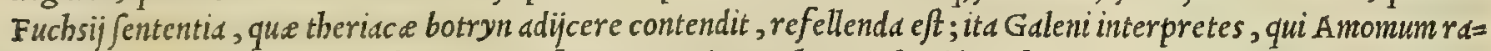

so cemofum uertunt, probandi funt, ut qui fint cum Andromacho Diofcoridem fecuti. is enim Amomi Pontici notas perftringens, ip fum racemofun fecit, ut fuprà in eius mentione legitur. Amomi meminit Galenus lib. vi. fimpl. med. fic inquiens. A momum acoro fimilem facultatem obtinet: nifí quód acorum ficcius fit, maiore autem concoquen

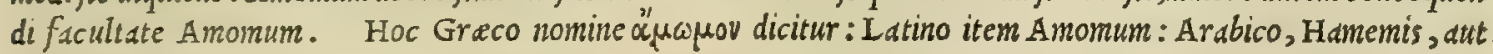
Hamama: Italico, Amomo.
Kósos.
$\cos T V S$.
C A P. X V.

PRAE C E I I I A Arabicus, candidus, leuis, eximia odoris fuauitate. Secundum locum fibi vendicat Indicus, leuis, vber, vt ferula niger. Tertius eft Syriacus, grauis, colore buxeus, \& odore feriens. Optimus eft recens, albus, abunde plenus, denfus, aridus, à teredinibus non erofus, fine graueolentia, guftu calidus ac mordens. Vis ei excalfactoria: vrinam ciet : menfes pellit: vitijs, qux vuluam malè habent, tam impofitu, quàm fotu, \& fuffitu axiliatur: Contra uiperarum morfus 
fextantem bibere prodeft: item aduerfus pectoris dolores, conuulfa, inflationesq́ue ex uino \& abfinthio: uenerem ex mulfo ftimulat : latas uentris tineas ex aqua pellit : horroribus ex oleo ante febrium accefsiones, \& neruorum refolutionibus oblinitur : uitia cutis in facie,cum aqua, uel melle illitus, emendat. Additur in antidota, \& malagmata. Sunt qui, admiftis helenij Comageni præduris radicibus, adulterent. Quod deprehenfu facile eft: fiquidem neque guftu feruct helenium, neque validum odorem uibrat, ut caput tentare polsit .

Colticonfide ratio.

Coltiqux uicem fuppleãt.

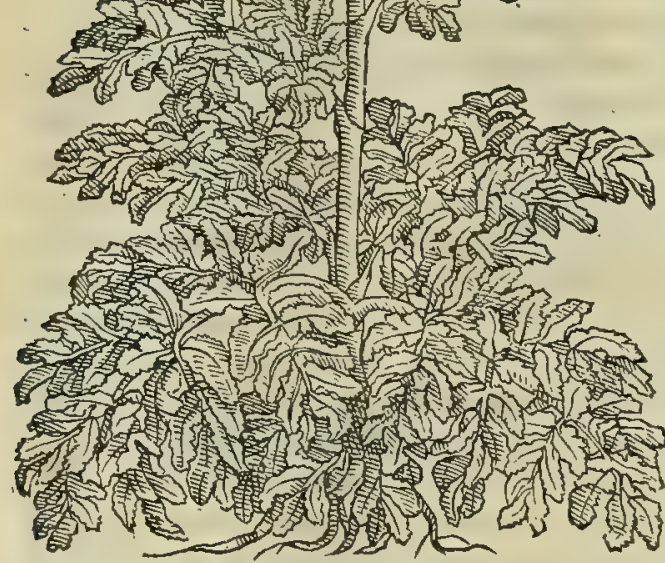

\section{PSEVDOCOSTVS.}

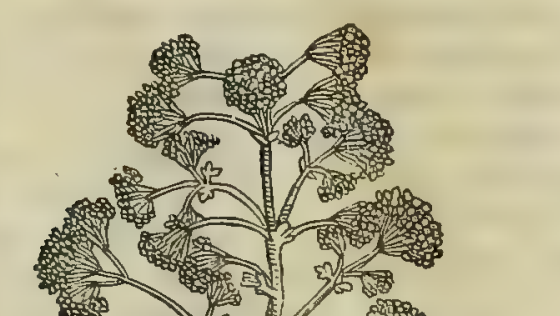

Cos rvs, quo ufe funt officine per longas atates, in andrum, o dulccm diuidifolet: tametfi tum Diofcori= des, tum etiam Plinius nec dulcis, ncc amari meminerint, fed nigri duntaxat, o albi. Galenus quidem fcribtt lcui= culam Cofto ine fe amaritudinem: féd qui inver Gracos fcripferit Coftum inueniri dulcent, bactenus compertum non babco: quanuis Mauritani, eo cos fecuti, dulcis, of amari quan= dog; mentionem frcerint. Qui in vinyropolijs paßim babetur,adul= terinus eft . quippe nec ulld odoris fuauitate commendatur; nec guftu adé acri deprebenditur, ut ddmotus exulceret, ut Galenus inquit. Proinde medicamentis, que Coftum excipiunt, non erit, meo iudicio, imponendus, cùm praterea nos plané lateat, cuius nam plante fit radix. Porrónon defunt bodic impoftores, qui ex Gargano Apulia monte quotannis ad nos conuebunt $\mathrm{P}$ feudocofti cuinfdam radices, amari faporis, qux facie quadäntenus $\mathrm{R}$ bodiam radicem reprefentant. Eas autem pro legitimo cofto uendunt no= ftratibus plormacopceis, is prefertim, qui in reiberbarie cogni= tionem negligentius incumbunt. Plantam nos babere , atq; etiam depingicurauinus ( ea enim aliogui non eft uulgaris iudicanda) ut exeius imatgine, quam bic damus, difcant imperiti cuius plans te fint radices illa. Hinc fortaffe fict, ut filli impofturain hanc ommibus cognitam effe intelligent, cam definant pofthac facere. Inuenitur Coftus (ut audio) apud quofdam Venerijs, fed adnodum rarus; quem legitimi not as habere aiunt. Vcrim cum hadenus ta= lcm non uiderim, non eft, cur eun probem, uel improbem. Ces= terùm feplafiarij, fi legitimum confequi nequeunt, d peudocoftis 30 abftineant. $\mathcal{O}$ Galenum, uel auforem illum fequantur : qui, $\sqrt{\mathrm{L}}$ Costus defecerit, dmmonidcum, uel helenium fupponi iubet. erit enim eis boc fatius, quim uri adulterino. Sed quidam adeo fuis pandectis, o luninaribus addicti funt (qua eft corum tum infci= tia, tum pertinaci.t) ut nullis unquam auctoritatibus, atg; ratio= nibus fuaderi poßint, ut ucterem femitam penitus deteftandam lin = quere uelint, que plerung; eft segris detrimento, of fibi, o me= dicis dedecori. Sunt infuper, qui Coftiloco Angelicam recen= tioribus uocatam fuppontendam exiftiment. quorum fententiam ma gis probandan ccnfercm, qudm corwm, qui peeudocoftis utun= 40 tur. Coftum enim bac radix non obfcure. refert : quandoqui= dem exinia illa odoris fuaritate tam iucundé pirat, ut angeli= ce nomen fibimeritó uendicaffe uideatur. Acris preterea elt, nec amaroris onnino expers. Quapropter eos

Cofti vires baudquaquam dannandos putauerim, qui Angclicam Cofti genus effe crediderint. Cofti uires fcribit Galenus ex Galeno. lib. VII. de fimplicium medicamentorum facultatibus, fic inquiens. Coftus leviculam plané amaram, plurimam autem acrem, $v$ calidam in fe qualitatem fimul o facultaltein continet, adeo ut etiam cxulceret. Vnde ipfo cum oleo perfricant corpus ante acceßionem in rigoribus per circuitus redeuntibus. Sic ueró etiam in refolutis, Oo ifchis dicis, atque in fumma in quibus excalfacere partem quamuis, aut ex alto in fuperficiem extrabere aliquem bumorcm eft opus, ad coftum confugitur. Eadem de caufa urinas, menfesí;; pronocat: O ad ruptd, conuulfa, ac lateruin do= lores conuenit. Porró ob amaritatem, que illi ineft, lumbricos latos enecat. ob candemer ad contrad as uclut ex

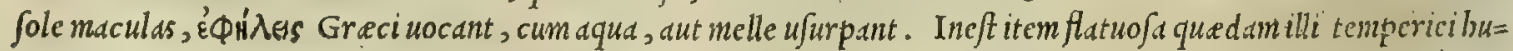
Nomina. miditas, per quam er uenerem excitat cum uino mullo. Kósosita Gracé nominatur, quemadmodum Latiné $\mathrm{C} 0=$ ftus, A rabicé Koftos, fiue Chaft, e Italice' Cofto.

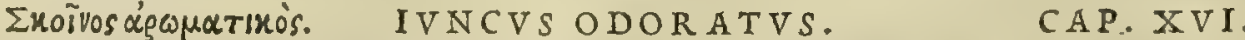

O D o R A T v S Iuncus in Africa, \& Arabia nafcitur. Laudatifsimus ex Nabathæa: proximus Arabicus, quem aliqui Babylonium cognominant, alij teuchitin: pefsimus ex Africa. Eligendus eft rufus, recens, floribus refertus, tenuis, rubentibus fragmentis, qui manibus confricando rof $x$ otorem emittit, ignex mordacitatis ad linguam. Floris, culmorum, radicisq́ue eft ufus . Vim urine ciund $x$ habet: menfes pellit, difcutit inflationes, caput aggra uat, modicè adfringit, comminuit, excoquit, 


\section{In Lib. primum Diofcoridis.}

IVNCVS ODORATVS.

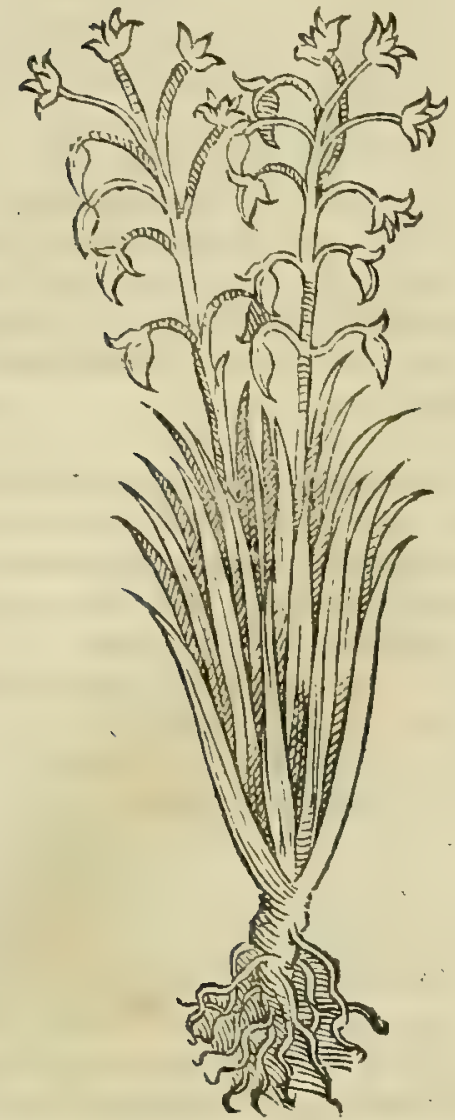

excoquit, ac uenarum fpiracula laxat. Flos eius in potu utilis fanguinem reijcientibus : doloribus ftomachi,pulmonis, iocineris, \& renum. mifcetur antidotis. Radix adltringentior eft: ideo faftidijs ftomachi, hydropicis, conuulfis, drachma una cum pari pondere piperis, per dies aliquot datur. Decoctum uulux inflammarionibus, ad defidentium fotus, utile eft.

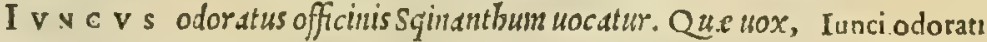
quanuis deprauate, ex plante, o goris nomine componttur, in confideratio. un am utrifque iunctis difionibus. Na'qque fquinantbum $/ 2$ ad rectan etymologium referatur, non aliud inferet, quàm duas basce Grecas

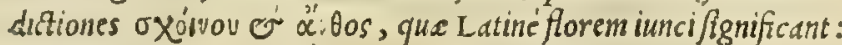
ox iwos cinin iuncum, «ँvos ueró florem Gracis defignat. Veruntamen flos ad nos non importatur. quod tamen mirum non est, cùm etian Galeni tempore non baberetur. Proinde inquit libro primo de antidotis. His praterca Iuncim odor atum ex Arabia allatum immite tiprecipit, quem ne cio quomodo fchani anthos, id est, iunci odos ratsflorem multi uocent, cum nobis floris copia non adeo fuppedis cet. Name etfi tota aduchatur berba, funt tanzen eius fuperioris pars tes à camelis fape depafte: ue fcuntur enim ed, $\sigma$ delectantur ma= xime . bec Galenus. Que (filicet nobis dicere quodfentimus) po= tius ridenda, quim probanda uidentur. Arduum quippe fuerit cre= dere, tam ingentenz effe cameloruin numerum, quil locuftarum mos do in uniuerfum fchreniflores depa $\int$ cantur, wi nulla penitus fuper fit planta, cuiflos non deuoretur. Referunt quidam nafci odoratum Iuncum etiam in A pulia . quin o in Campania prouenit, ut Brafa= uolus inquit pltnij aultoritate.'Sed uercor', ne ballucinentur, quodd nec inde flores afferantur, nec palex: neque etiam it Plinius affir: manter afferat. Is, quo Seplafiarii pasim utuntur, non affertur ds liunde, quim ex Alexandria. Ceterim non parus quidem diligen= tia, dum emitur, ef adbibenda . quandog̨uidem non defunt impoftores, qui ad merces augendas, fchenum palearumion berbarum quibufdam fijtucis adulterent. Fraterea uidendum $\mathrm{e}$ t, ne uetustate exoleuerit: facile enim (ut in libro de ans tidotis docust Galenus) ab hoc uis omnis euanefcit. Scribunt Monachi illi, qui in Mefuem commentarios ediderunt, odoratum Iuncum, quo paßim officine utuntur, ßpuriun er illegitimum effe, cùm be palea (ut eorum uerbis utar) Diofcoridis fchcenum minimé refer ant. Siquifem radices primum medicthe ufui congruas ill non ineffe contendunt, fed capillorum modo tenues: deinde paleas ipfas nullain guftanubus acrimoniam relinquere, nullóg; rofarum odore fragra= re, $\sqrt{i}$ manious confricentur : nec postremó iuncum aliquens proferre, fed calamos geniculis interceptos tritici, uel bor= dei inodo. Qua in re (pace corun dixerim) duplici errore notantur, primüm quód Diofcoridem ofcitanter legerint: des inde quód illud affirment, quod experimento procul dubio falfum effe deprehenditur . Quód autem Diofcoridem of citan= ter legerint, cüm dicunt f chonum iuncum proferre, non calamum, fucile patet . quandoquidem contrarium fcribit Dio=

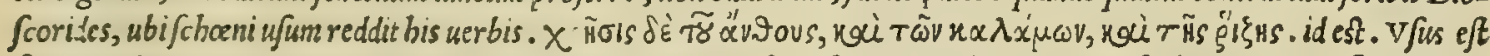
floris, calamorum, or radicis. Praterea quod communis ufus fchoenos acrimoniam non babeat, pariter fallum eft. quippe, ut experimento quotidie comprobari potest, qui non longo ternpore confenuerit, linguam manfu uellicat. Qui= bus palam est, Monacbos uil nunquan fchoenum deguskafe, uel fi deguftarunt, illum adeó uetuftate exoletum fuife, ut (quemadmodum Galenus inquit) omnein acrimoniam, odoreniq; amiferit. Quód autem nostri chceni radices tenues fint, nubil ad biftoriam refert: fiue enim tenues fint, fiue craffe, eas non defcripfit Diofcorides. Schceni flores ex Alexandria und cum integra planta allatos ego in manibus babui, qui digitis attriti rofarum odorem enittebant. Quamobrem non temeré contra Monachorum fententiam affirmandum putauerim, cominunis ufus fchrenum legitimum, ev probatifimum so efe. Sed ij quidem adhuc magis reprehendendi uidentur (non tamen ut eorum dignitati aliquid derogetur) quòd in Did= galange compofitione feripferint, radicem galangam uocatam legitimum efe fchonum, ipfamí; galangam ad nos afferri.

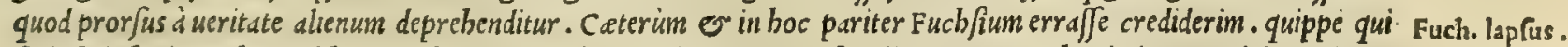
fcripferit fus in methodo, fchoeni anthiftipites nullam acrimoniam manfurelinquere, Scheni uires prodidit Galenus Iunci odorati Lb. VIII. fimp. med.ubific babet. Schoeni anthos modicé calfacit, modicéq; etiant adscringit, nec plané à tenuitatis na= uires ex Gal. tura alienus est. Quocirca his de caufis urin.m moutet, menfesó; ciet adbibitum fiue in fomentationem, fiue in potionem. prodeft o iecoris, e fomachi, ac uentris inflammationibus. Magis eo astringit radix. Quod ueró florem uocant, cd= Zudius est . Porró in omnibus fui partibus, in alijs magis, alijs minus, guftantibus apparet adstrictio: proinde medicinis,

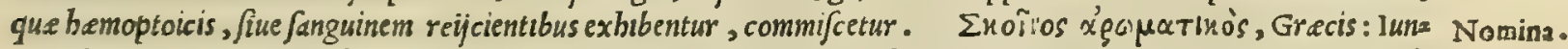
cus odoratus, Latinis: Adcher, Arabibus: Giunco odorato, or Squinantho, Italis: Ramelstro, Germanis: Paya de la Mequa, fiue Paya de chamellios, Hifpanis: Paifture di chameaulx, Gallis nominatur.
Monachorũ opinio explo fa. 


\section{And. Matthioli Comm.}

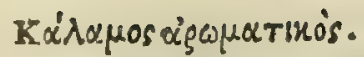

\section{CALAMVS ODORATVS.} rati hiftoria
Calami odoex Theo.

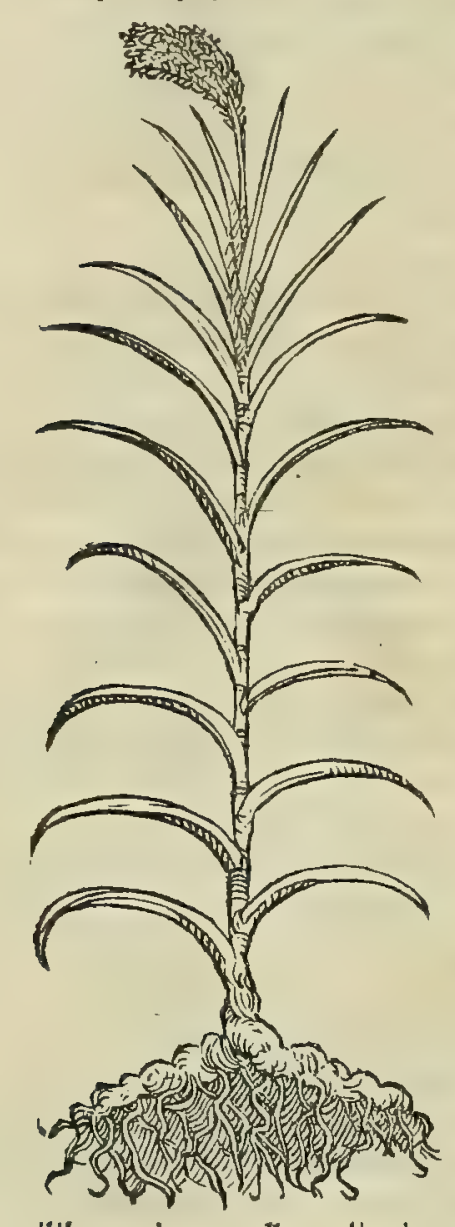

C A L A M V S odoratus in India nafcitur. Melior eft fuluus, densè geniculatus, \& qui aflulosè frangitur, plena arancorum fiftula,albicăs, lentus in mandendo, \& adfringens, cum aliquanta acrimonia. Vrinam potu cict: quare cum graminis, aut apij femine coctus, in aqua fubter cutem fufx morbo, renum uitijs, 1tillicidio urinæ, ruptisq́; commodè bibitur : menfes \& potu,\& appofitu pellit:tuffi fuffitu medetur per fe, aut ex refina terebinthina, haufto $\mathbf{z}_{0}, 0$ per arundinem fumo: ad muliebres infeffus decoquitur, \& clyfteribus imponitur. Malagmatis, \& fuffitionibus odoris gratia commifcetur.

CA L A M V s, er Iuncus odoratus(ut Theophraftus eft auctor lib. I X. cap.v I I. de biftoria plantarum) trans Libanum montem, inter ip fum Libanum, $\mathrm{r}$ alium quendam montem paruum ualle mi= nima exeunt: non, ut quidam dixere, inter Libanum atq; Antiliba $=$ nam. Inter quos campus amplißimus, o pulcherrimu eft, quem Aulonem appellant. Qừ ueró caldanus, er iuncus proueniunt, $l=2,0$ cus in amplumpatiatur, iuxta'; cum paluftribus ficcatis ifti afjur gunt. Occupant locum plus quàm triginta ftadia. Virides nequaquam effe uidentur, fed ficci: forma ueró nibil ab alijs differunt. Locum ingredienti protinus odor afpir at, no tamen longius pirat, ut quidam referunt. Hic enim locus à mari plus eft, quidim ftadia cen tum quinquaginta. Sed in Arabia apirationem agri odoratißimam effe inter omnes conftat. bae de Caldamo Theophraftus. Cui etiam fubfcribit Plinius libro $\mathrm{x}$ I I. cap. $\mathrm{x} \times \mathrm{I}$ I. ubi fic babet. Calamus quog; odoratus in Arabia nafcens communis Indis; atq; syrize eft: in qua uincit omnis a noftro mari centum quinquaginta ftadijs. In= ter Libanum montem alium'; ignobilcm, non (ut quidam exiftima= uere) Antilibanum in conualle modica iuxta lacum, cuius paluftria eftate ficcantur, tricenis ab co fradijs calamis is juncus odorati gignuntur. Nibil erga dे ceteris fuigeneris differunt appectu. Sed Calamus preftantior odore ftation

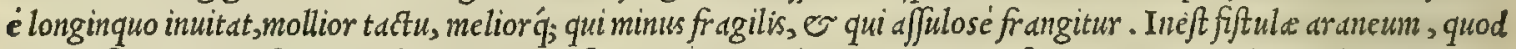
uocant florem. Preftantior eft, cui numerofius : reliqua probatio, ut integer fit. Damnatur alibi. Melior quo bre= uior, E craßior, lentus q; in frangendo . hactenus Plinius. Sed certé fatis paldme effe arbitror (ut in acori commen=

Brafuoli er- tarijs diximus) quàm magno ducatur errore Brafauolus Ferrarienfis, quod tam facile fibi perfudferit, legitimum ror. $\quad$ odoratum Calamum illam effe radicem, que temeré omnibus in pharmacopolis illius uicem explet, quamó; uerum effe acorum Juperius pluribus rationibus comprobatumus. Quandoquidem primùm ex ip $\int_{a}$ Calami appellatione, deinde ex eo, quod dixerint Theophraftus, $\mathcal{O}$ Plinius non differre bunc forma i reliquis fuigeneris, id eft, ab omni arun= dinum genere, utique conftat odoratum Calamum genere, $\mathcal{O}$ forma arundinem pree fe ferre, odoratam tamen, non au= tem effe radicem. Quocirca Plinius Diofcoridem fortaffe fecutus, dixit. Fiftule (boc eft cauitati) ineft arane ü, quod uocant florem: non autem radici, ut falsò contendit Brafauolus, a ancum illud inueniri in uulgari illo officinarum. Ad

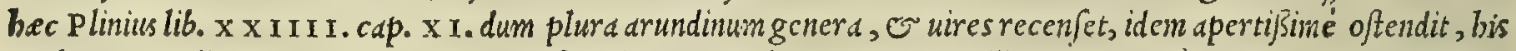
uerbis. Arundinis genera $\mathrm{x} x \mathrm{I} \mathrm{x}$. demonftraumus, non aliter evidentiore illa natura; quàm continuis iys uolumini: bus tractauimus. Et quoniam plura genera fecimus, illa, que in India Syria q̛; nafcitur, odorum unguentorumóg cau= $\int a$, urinam mouet cum gramine, aut apij femine decocta : cit en menftrua admotu : medetur conuulfis duobus obolis pota, iocinori, renibus, bydropi, tußi etiam fuffitu, magisq́; cum refind. bec Plinius. Sed preterea unlgares calamira = dices, quas acori effe cenfemus, affulose nequaquain frangi poffunt, fed tranfuerfim, quemadmodum o iridis. Quo fit,ut corum innotefcat lapfus, qui Calamum odoratum radicem effe contendunt, qui tamen (ut aperté oftendimus) nil so aliud eft $t$ quadm arundo. Ceterum fi quifpiam dixerit, has radices, quarum cft ufus, effe calami odorati proprias, non acori, illud fané argumentum deftruit, quod intuentibus euidenter apparet. quandoquidem etfi complures illius acori radices habeantur, que ficca gerunt in cacumine folid, iridi omni ex parte fimilia; nulla tamen ufquam inuenta eft, que fecum arundinis trunculum cacumini annexum deferat. nempe acori proprium, non odorati calami cft, iridis for Fuch. opinio liaferre. His itaq; rationibus Fucbsij quoq; fententia improbanda mibi uidetur . quippe qui putaucrit in fua metho= improbats. do, uulgarem officinarum calamum ueri odoratic calami effe radicem. Porró minimé quidem comapertum babeo, Dio= fcoridem, nedum Galenum, qui ex odoribus, ac faporibus uires aque, ac qualitates omnium fimplicium medic esnentorü accuratißimé inueftigauit, dixiffe aliquid odorato Calamo ineffe amaritudinis, quă tamé in acoro baberi Galenus pros Calami odo- didit. Qui Calami odorati uires pluribus de fcripfit lib. y I I . fimpl. medicamentorum, fic inquiens. Calamus odo= Caleno. o aërea, in caliditatis frigiditatisóf; coniugatione temperata. Quamobrem moderatc urinsm mouet, $O$ facultati= 


\section{In Lib. primum Diofcoridis.}

bus, qua iecori,e ftomacho imponuntur, mifceri poteft. tum in foment quoque utcri,qua phlegmones gratia, aut ir= ritand is menfibus affumuntur, utiliter admifcetur. Ponatur itaq; , habeatur'; fecmidi orainis corum, que excalfat ciunt, o deficcant: ualentius tamen deficcent, quim cxcalfaciant. Ineft quoc; ci quedam partium tcruitus, velut alijs omnibus odoratis. C.eterim illorum compluribus tenuium p.stium plurimum, caldino ueró non snultum adeft. bec Galenus. Quibus fucile patet, Calamum officinis uocatum, legitimum effe nequaqusm : mation enin illi inct acri= monia, quim fuo reforat Galcnus. Eać; propter legitino caldamo odorato nos cffe boc a'uo defitutos fatcri non du=

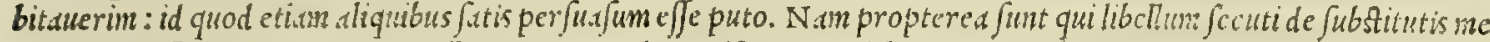

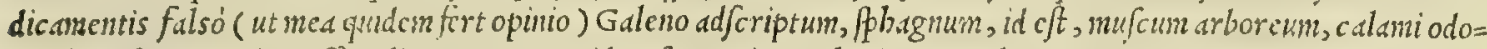
ratiloco fupponendum cfé uclint. Quum equidem fententiam ut battenus probaueram, ita ctian literis mandaucră. 30 Nunc autent quoniam illid mibi sbfurdum uidetur, quod ca medic ancnta inter fe commutari debcant, quae contra= rian facultutrem fortita funt, chiufnodi effe deprehenduntur calamus odoratus o phbagros; ideo non teneré cogor mutare fententiam, atg; abilitis defcifcere. Sed quid pro calamo odorato recté fubftitui poffe credamus, alibi, Deo

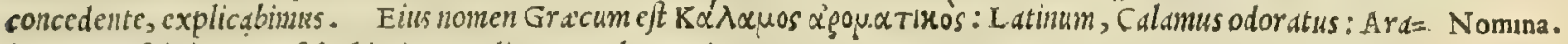
bicum, Hajabel, aut Cafab aldatira: Italicum, Calamo odorato.

\section{Bál $\sigma \alpha \mu: y . \quad$ BALSAMVM. CAP: XVIII.}

B A I S A M V M arbor albr violæ, lycij, fiue pyracanthæ magnitudine confpicitur. Folium rutæ proximum, longè candidius, perpetuò uirens. In Iudæa folùm quadam valle, \& Aegypto nafcitur: his differens modis, fcabritia, proceritate, gracilitate. Quod igitur tenui, \& capillacea coma eft,

so theriftum uocant, quali demefsile: fortafsis quoniam ob gracilitatem facile demetatur. Acftiuis fub ortu canis ardoribus, arbos vnguibus ferreis inciditur, manatq́ue è plaga fuccus, quem Opobalfamum uocant : fed tam exiguo ftillacu, vt annis fingulis, ne plures quidem, quàm feni fepteníve congij cogantur : inibiqque pondus duplo rependitur argento . Succi probatio eft, ut fit recens, ualidi odoris, fyncerus, non ad acorcm ucrgens, dilui facilis, læuis, adltringens, ac modicè mordens guftu. Sed uariè uitiatur, mifto ab aliquibus terebinthi, cypri, lentifci, balani unguento: item fufino, metopio, melle, aut Cypria cera liquida . Quod maleficium facilè deprehenditur : nanque merus in 12neam ueftem fufus, neque maculam facit, neque fi eluatur, notam relinquit : vitiatus autem inheret, \& lac inftillatus coagular, quod adultcratus non efficit. Quinetiam fyncerus in aqua, aut lacte celer= rimè liquatur, coloreg̨ue laetefcit: vitiatus uerò olei modo innatat, fe conuolucns, aut in ftellæ mo-

30 dum diffundens. Syncerus fenefcens craffefcit, deteriorq́ue redditur. Hallucinantur, qui aqua concretum peffum ire, \& ad ima fidere arbitrătur: poftea difsipatum fupernatare. E' ligni genere, quod Xylobalfamum uocant, probatur recens, farmento tenui, fuluum, odoratum, quadantenus opobalfamum fpirans. Neceffarius etiam feminis erumpit ufus: quare eligatur flauum, plenum, grande, ponderofum, mordens guftu, feruens in ore, modicè opobalfamum olens. Adulteratur femine hyperico fimili, quod à Petra oppido defertur . Sed coarguitur magnitudine, inanitate, virium ignauia, fapore piperis. Efficacifsima uis incft fucco, \& quàm maximè calfaciens : abftergit quæ tenebras oculorum pupillis offundunt: medetur perfrictionibus vuluę cum rofaceo cerato appofitus : menfes quoque, fecundas, \& partus extrahit : horrores illıtu difcutit : vlcęra fordida expurgat, \& cruda concoquit: vrinam potu ciet : ægrè fpirantibus prodeft: datur in lacte contra aconitum hauftum, aut fere

40 pentium ictus. Mifcetur acopis, malagmatis, \& antidotis. In fumma præcipua authoritas fucco, $\mathrm{fe}-$ cunda femini, minima ligno. Semen commodè potui datur doloribus lateris,pulmonum uitijs,tufsi, ifchiadicis, comitialibus, uertiginofis, orthopnoiçis, vrinæ difficultati, torminibus, ac ferpentium. morlibus: ad muliebres fuffitus perquàm utile eft : vuluam aperit in defefsionibus balnearum deco¿tum, \& humorem euocat. Lignum eafdem habet uires, aliquantò minores. Ex aqua potum cruditatibus, torminofis, vulfss, venenatorum ictibus opitulatur: vrinam cit : ad capitis vulnera cum ficca Iri conuenit : fquamas ofsium extrạhit . \& ad vnguentorum fpiffamenta additur ,

A N T I QV I I v S Balfamum (ut Plinius libro XII.cap. x X v. eft auctor) in duobus tantim hortis, utrog; regio, altero iugerum uiginti inon amplius, altero pauciorum uni terrarum Iuda a conceffum erat. Sed poftea prox

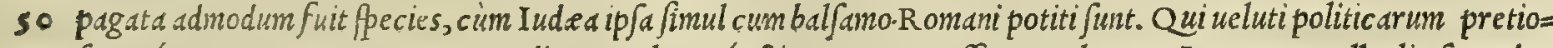
farum q́; rerum propagatores, tam dignam, claramq́; stirpem raram effe non tulerunt. Itaq; eam malleolis ferendo, atq; iterando non fecus ac uites in collibus propagantur, latius accreuerunt. Quocirca I fftinus quoq; hac de Balfa= mo memorie prodidit. Opes genti Iudaicx ex uectigalibus opobal Jami creuere, quad in bis tantüm regionibus gigni= tur. Eft uanc; vallis, que continuis montibus, uelut mura quodan cincta ad inftar caftrorum clauditur. Spatium lo=

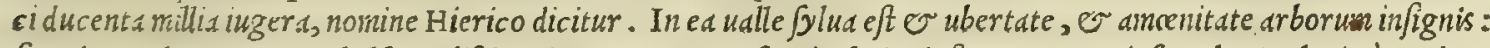
fiquidem palmeto, e opobalfamo difinguitur . quanquam pecies buius infignis, ac pretiofa arboris plurimum adau= Ata fit, hec I uftinus. Scripfit Ball sami hifforiam etiam Strabo hb. x v I. Jue geographie, ubific habet. Hiericus eft campus a montand quadam circundatus, qua in theatri peciem ad ip sum declinat. Hoc in loco ef palmetum palmis abundans fatio ftadiorum centum, o totum irrtguum, o babitationibus plenum, ubi o regia eff, o Balfami uiri= darium. Qus aibor odorata eft, or frutico $\int a$, cytifa, or terebintho perfimilis. Eius corticem unlnerantes, fuccum in uafis fufcipiunt tenaci lacti perfimilem. Sed glibi ettam, quàm in Iudaa nafci Balfamum eodem libro idem teftatur, 
preter Plinij, er solini fententiam, cim inquit. Et apud Sabeos thus; er myrrba, en cinmamomum naf citur : in ori etian Balfanum, or quedan alia planta ualde odorata. bac ille. Oririctian Balfamum in Arabia teftis eft $\mathbf{P}$ anda

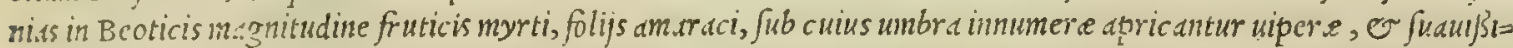
mo cius liquore aluntur. Sed quónam modo fit fatum ( ut in Syriam peregrinantes uno ore fateniur) quod loc tem $\Rightarrow$ pore omibus fore Balfami plantis I udea fit penitus deftituta, cum olvin fola Baljam ferax à compluribus credere=

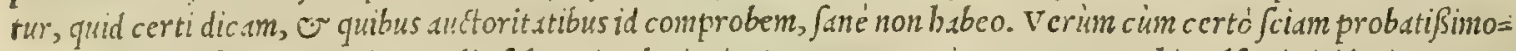
rum !irorum teftinonio, qui ex Italia foluentes pluries in Aegyptun naugarnut, Memphi Balfami uiridarium exta= re, illud fortaffe cucniffe putandun clt, quód é I udex ab Acgyptiregibus, quitus uniuerfa fubijcicbatur Syria, omne in uniuer $\int u m$ Balfanum é fucrit translatum, quó decoris inde plurmmm regi.e accederet. Quanquan Balfamum in Acgypto quog; proucnire antiquorum monumentis mandatum cft, ut exipfo Diofcoride conftat, atq; ctian ex Gale= $\bar{c}$ o no libro primo de antidotis, c.p. I I I . ubide melle agit componend is antidot is idonco. Veruntamen diu cft, quod in Italiam, ne in totam dicam Europam, neq; lacryma, neq; femen, neq; lignum, neq; cortex importantur, nifi adulte:

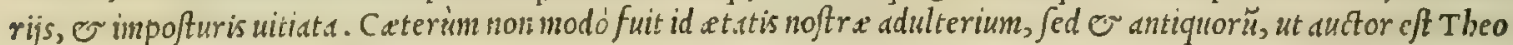
phraftus: qui hxc de Ealfamo lib. I X.cap. V I. de biftoria plantarum pofteritatis memorix mandauit. Balfamum in ualle Syri.e prouenit. Eius hortos duos tantim affirmant, alterum uiginti iugcrum, alterum multó minorem. Arbo= ris magnitudo, que malo punic $x$ m.gne : rami multi: folium rut xi fimile, candidum tamen, perpetuó uirens : fructus fimilis tercbintio tum magnitudine, of figurd, quain colore. Is qucq; admodum odoratus eft, er magis quam lacry= ma. Colligi lacryman in caudice, o parte fupcrna tradunt, facta incifura unguibus ferre is fub fydere, cum aftus ma ximé angit. Collectum ueró aft ate fieri tota. Sed quod manat, multum non effe : uix cnim to to die concham poffe im= pleri: odorem tancn inferri eximium, or copiofum, ad é ut ex paruo patiun per longum odor ualeat permeare. Vex is rion fyncerum ad nos nullum aduchi, fcd quod miftum colligitur : plurimis cnim niflionibus uitiari, quod'́; Gracise uenditur. Ideó;; Galenus lib. prino de antidotis narrabat, cum non ignoraret, opobal famum diuerfis modis adulte= rari polfe, ita ut difficulter ementi difcerni queat, fe proprio oculorum intuitu cernere uoluiffe or quomodo crefce= ret Balfamum, or quomodo lacryman nitteret : uoluit,; J s ncera eius lacryme partcm babere, uelutiregulan ad di gnofcendum alios Balfami liquores, qui per orbem ab impoftorilus uitiati circ unfrebantur. Modus dutem incidendi corticis, ut inde liquor cffluat, apud auctores fané udrius eft. quandoquidem Theophraftus, $\sigma$ Diofcorides arborem dixerunt unguibus frreis $\int$ calpi, ut inde uulnerato cortice fluat lacryma. Plinius ueró contri, fi ferro incidatur, fta= tim ficcari, ato; emori cribit: ob id'q; qui opoballamum colligunt, inquit, uitro, lapide, of eis q́; cultellis ad corticcm uulnerandum utuntur, deinde fuccum! land excipientes in corniculis colligunt. Caterim cum mecum fapius coguta= uerim à tot impof uris, qua indies funt, nos cauere non poffe, non alienum fore duximus illud in bominum memoriam reuocare, quód fi unquam opoballamum uenale inueniatur ( $t a m c t f i$ in I talia per longas atates non amplius ipfum uen turum putem ) non ematur, nifi prius de co omne fiat periculum, quo claré cognof catur omnibus ijs preftare tum no= Carpobalsa- tis, tum facultatibus, que illi ab auctoribus tribuntur. Ad bxc Balfamifructus, fiue fcmcn, quod Carpobal amum mum non le-" uocant, ab eo quidem longé differt, quod bis temporibus ex Alexandria comporiatur. Siquidenz optimum lcgitimum'́; giximum. flaum fit oportet, farctum, ponderofum, guftumordens, e firuens in ore: non autcm nigrum, lcue, inane, nö acre, or nullum fpirans odorem, quale, quod circunfertur, deprchenditur. Quo fit, ut non aliud fufpicandum fit, quàm quód hoc idem fit femen byperico fimile, quod etiam Dıofcoridis a uo à Petra Palxfina oppido defercbatur. Hoc idé ligno euenit, quod Xylobal famum uocant officine Grxecos fecute. quippe quod paßim in ijs babctur, potius myrtun, quàm Balfamum refert. Corticis non meminit Diofcorides; quanuis dixerit Plinius libro er cap. Juperius citatis, ip=

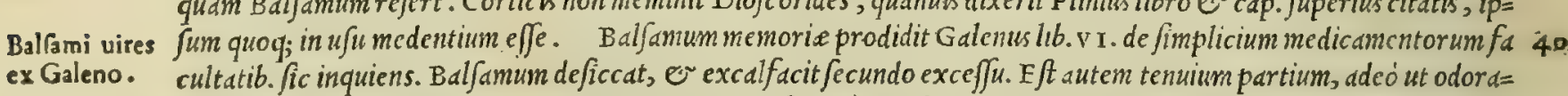
tum fit . Sed licuor eius fubtiliorum etiam partium cf, quam ip fa planta, non tamen adeó calidus, ut quidam exifti= mant tenuitate partium falfi. Porró fructus cius perfimilis genere facultatis of, catcrim longé in fubtilitate partiü inferior. Placet eidem Galeno ( ut in libello de fuppolititis medicamentis illi adfcripto lcgitur) ut Balfami uicc ftacte myrrhe, aut olcum irinum, in compofitis medicamentis commodé inféri po/3it:xylobal fami ueró loco lcucoij radix: Porró quid carpoballami uice fupponendum fit, nullibi apud eundem reperi. tametfi in quodam incerti auctoris libel = lo, quem feplafiarij Quid pro quo nuncupant, pro opobalfamo oleum terebintbinum, uel laurinum, uel gummi bede= re, Jubiyciatur; pro carpobal lamo hedere corymbus; or proxylobalfamo hedera ipfius lignum: tantamille hedera tribuit auctoritatem. Sed alia eft opinio noftra: nam ip fe libentius pro opobalfamo ole um myriftica nucis, uclftyra: cinum fuppofuerim, quàm terebinthinum, uel laurinum; pro xylobalfamo agallocbum; or pro carpobalfamo uulga= rescubebas. Quód autem Carpoba'l fami locum cubeb e recté Jupplere poßint, pleriq; rei medica ftudiofi id mecum. fentiunt. Sed addam pratered, quod $j i$ ca mandantur, dentibusue conficiantur, mordent guftum, feruentes in ore per cipiuntur, or aromatis non modicum refipiunt. quas nimirum qualitates Balfami fructui ine ffe Diofcorides teftatur.

Fuchfij opi- - Hinc igitur fit, ut in hoc d Fuchfio, uiro alioqui doctißsino, plane diffentiamus. nanq; is in libro, qucm de compo/i= nio improba- tione medicamentorum nuper auctum edidit, Carpobal fami loco leucoij radiccm fupponcndam cenfct: co quidcm ar= ta.

gumento (ut inquit) quód ita fcriptum repererit in co Galeni libro, cuititulus eft de fubftitutis medicamentis. Ve= rum cum ipe nufquam ( quod cquidem lcgerim) in legitimis Galcni libris imuenerim, lounc auctorcm, fi defit Carpo= balfamum, fubftituere, uel uiribus proximam facere lcucoij radicem, cui nulla prorfus incf qualitas, necy; facuitus, que Carpobalsamo repondedt, non eft, cur in boe Fuchsij probem fententiam. Catcrim affertur iam (ut audio) ex occidentalibus Indijs liquor odoratijimus liquido ftyraci admodum fimilis, quem qui deforunt, appellant Balfa. mum, quód notws nomullas Bal fami pre fe firat. Veruntamen cim tefte Strabone Balfami lacrama last co çolorc fit. crediderim 


\section{In Lib. primum Diofcoridis.}

crediderim potius noumm liquorem hunc, weram effe ftactem, uel ftyracis liquorem, quàm Ballauni : ob idq̆; non cffe penitus ab re, fi quipiam eo Balf ami loco uteretur. Quidam recentiores cum fe Opobalf smo deftitutos conpicerét, illud artificio quodun non fane damm:ndo componunt. Faciendi modum fic babeto : ego cnim bac ratione pluries

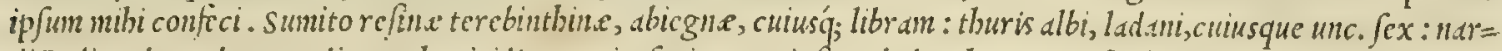
di Indice drac. duas : radicum plu, iridis, acori, afari, cypcri, fingul. drachmam: maftiches, galanga', caryophyllo= rum, cafix odordte, zedouri.e, cuiufq; drach. fex: nucum myriftic arum unc. quatuor : matcis unc. untm : ag allochi

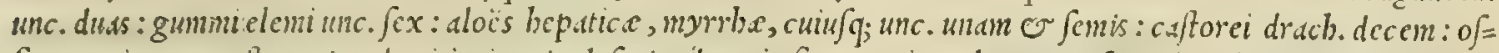

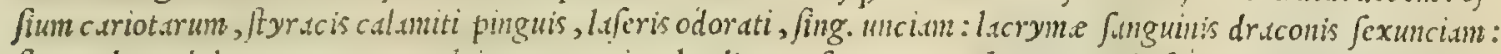
florum laucendule unc. quatwor : olciuigienturie glandis unc. Sex. Que ex bis atterend. f fint, in pulucrent contcri=

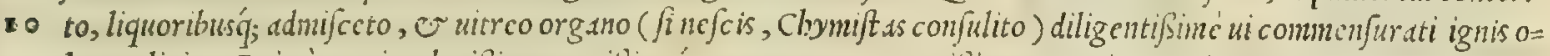

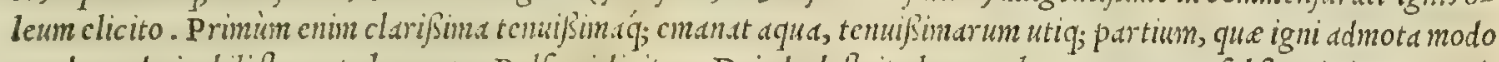

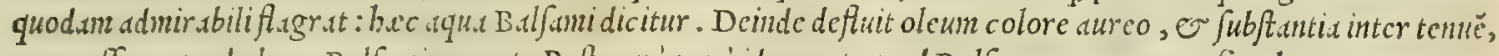

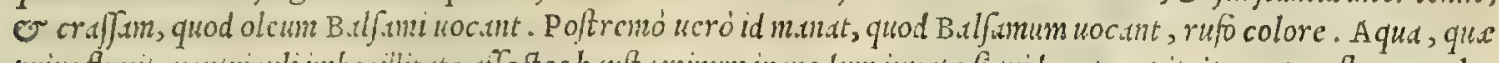

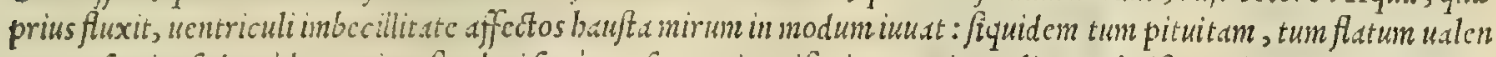
ter confunit. Sed quód accrime lit, duri fané per fe nequit, nifî uino, aut iure aliqno admifta. Liquor deinde, qui fes cundo ftillicid of fuxit, qucn quidam ce teris prefer runt, mirifice neruorum uulneribus, compaginum cruciatibus, con

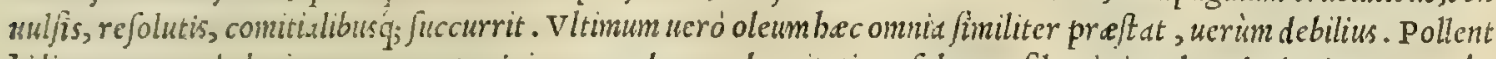

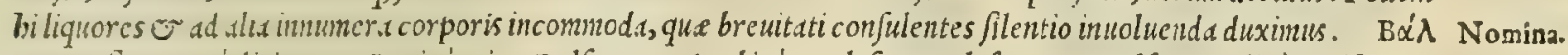
oxpov fic Grecé dicitur, ut Latinc etiam Balfamum: Arabicé, Balefem, Bolefma, aut Belfan: Italicé, Balfamo.

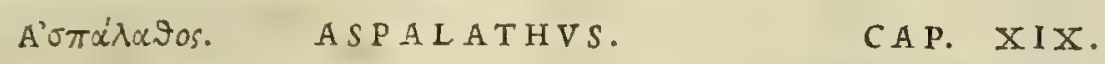

A S P A I A V S, alijs eryfifceptron, frutex eft furculofus, multis fpinis horrens. Nafcitur in Iftro, Nifyro, Syria, \& R hodiorum infula: quo ad vnguentorum fpiffamenta pigmentarij utuntur. Optimus elt grauis, detraito cortice rubefcens, aut in purpuram uergens, denfus, odoratus, guftatu amarus. Eft $\&$ alterum eius gcnus candidum, lignofum, fine odore: quod deterius habetur. Vim calfaciendi cum adfrictione obtinet. Vnde decoetum cum uino ad tetra oris ulcera colluenda conuenit: ad nomas genitalium, \& fordida ulcera infunditur: fubiectum in peffo, partum extrahic. Aluum fiftit eius decoctum: \& fanguinis reictionem potu cohibet: vrinæ difficultatem, inflatio30 nesq́ue difcutit.

A S P A L A T H V S quidcmex Crcta, Rhodo, ucl syria ad nos (quod cgo fci.m) non aduchitur : etfi exifti= mauerint nomulli fantalum rubrum uocatum effe Afpalatbum. Quorum errorem Serapio manifété prodidt: quan= doquidem de fantalo agens, nullum (ut affolet) affert Diofcoridis teftinonium, fed tantün fux gentis nititur audto= ritatibus. Quod maximo argunento cft, Jantalum rubrum nibil cun Appalatho babere cognationis. Meminit tamen Serapio Afe alathi fub Arabico nomine Darfifahan, ubileguntur omnia, que de ipfo tradidit Diofcorides. Huic alia ualidior accedit ratio . fiquidem Aloifius Cadamuftus, Columbus, o Pinzonus in fuis nauigationibus ad orientales Indus, aliss q́; ignotus terras, continuss fantalor um recia proceritate fyluas unanimiter nidiffe narrant. Quod longé abeft $a b \mathrm{~A} / \mathrm{pal}$ atho, qui frutex humilis cf? fuawitcr odoratus, ainarulento guftu, qua in rubro fantalo non depreben= duntur, rubrune citim fant alum odoratum non cft. Quód fi quandoque odoratum fentitur, id (ut optimé norunt pe=

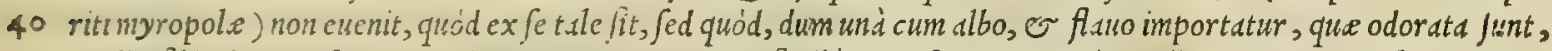
exillisfibiodorcm asciuerit, qui tanent traftu temporis facilé euznefcit. Porró Ruellius mediocricenfura non udx

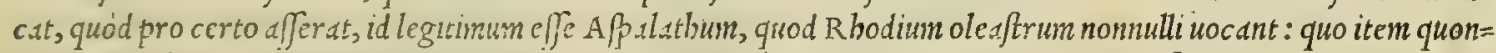
dain agallochi uice utebantur myropolia. Cuits naxtcricne cume in feplasijs, or apud artifices, qui precatorias (ut ita dicam ) coronus ad Deiparx uirginis falutationes torno conficunt, diligentifuné fim perfcrutatus, ea fané nigra partim, partim ucró cx nigro, flauoq; ucnofa mibi fe $\int c$ obtulit. Rubram autem, e fubrubram (ut Ruellius inquit) mufquam me uidifje ingenue fateri polfum. Adde etiamnum, qućd fit (quemadmodum R hodij narrant) bec planta ex olearumgenere Rhod:o tractu abunde proueniens, qux olluas ctim proferat, $f \mathrm{~cd}$ nec multis pinis borrens, nec de= trato cortice rubejcens. Quamobrcm ( ut mea fert opinio ) Afpalathus non erit R bodium oleaftrum, neq; fantalum

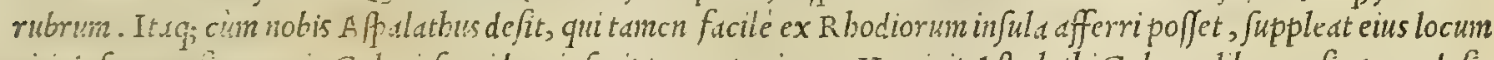

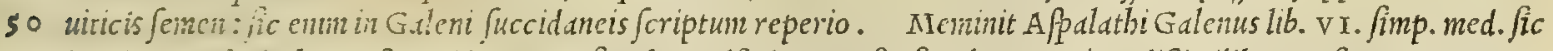

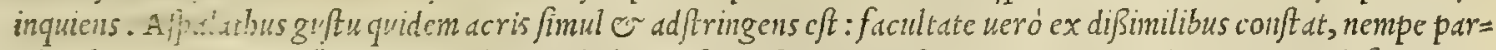
tibus fuis aribus excuifacicns, partibus ueró alis, anferis follicet, rcfigerans. Itaq; utriusq; ratione deficcat, or

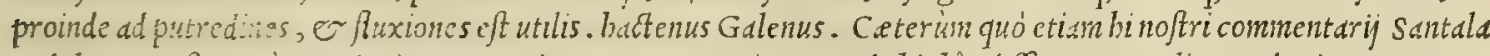
redole ant, peitex.qutin an tiquiores Greci cortun non meminerunt, de bis hic differere iton alicnum duximus. SAN=

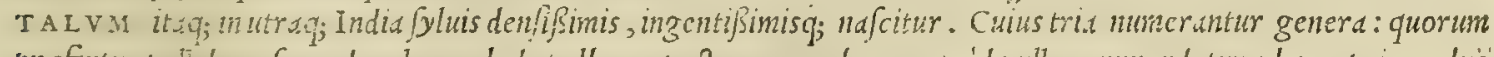
prefertur palidum, fecundum locum babet albun, postremum rubrim, quód nullo commendetur odore priora duo fuauter firant. Quapropter II auritan orum Sententian minime troband cm puiaulerim, qui santalum tertio ordine frigefacere, ficcare ucró fecundo memoris prodiderunt. Rubrum ( ur ipfi afferunt) priuatim defluxiones probibet: incande fcentibus infaminationibus, podagrisć; ex fucco folani, aut fedi, uel portulace utiliter illinitur. Candidum, ac pallidum, ex rofarum aqua fronti inpolita, capitis dolores milcent. Aduerfaitur omnid calidis febribus: epota eftuanti uentriculo mirifice auxiliantur. Fiunt ex ijs, or aqua rofsrume pithemata, que uentriculo illita eius feruo=

Afpalathi cöfideratio.

Ruellius erro re notatur.

Afpalathi เires ex Gal.

Santalorú cīfideratio, \& uires. 
renin ardcntißimis febribus extinguunt. Ad bec(ut auctor eft Auiccnua libro de uiribus cordis) Santalum non modó cordiefficacißimé letitiam affert, fed er robur non paruum addit. Quare bis inmijcetur medicamentis, quxe cordi,

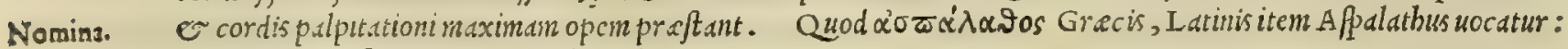
Arabibus, Darfifalan: Italis, Apdatho.

Bंvioi. $\quad I I V S \subset V S$.

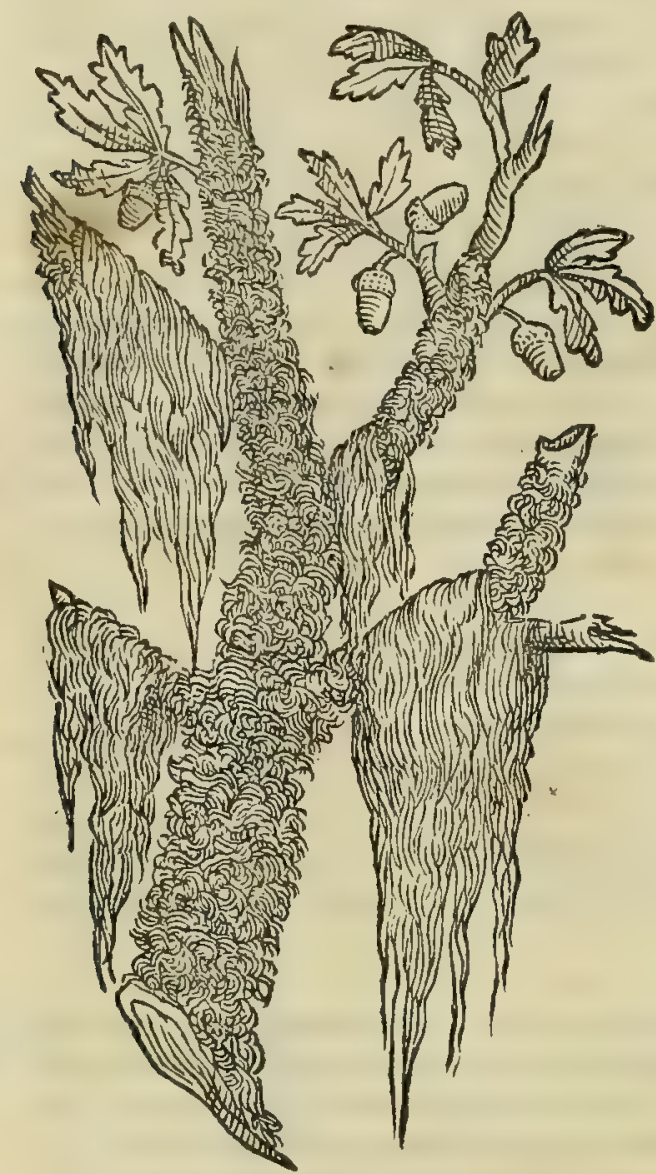

CAP. XX.

BRYon, id eft, Mufcus, à quibufdam fplachnon appellatur. In cedro arbore, populo alba, \& quercu inuenitur. Optimum eft cedrinum, proximum populneum: in quo genere candidum, \& odoratius præftat : nigricăs improbatur . Adftringendi vim habet. Decoctum infidentium vuluis vtile. Vnguento balanino, olcisq́ue infpiffandi gratia inferitur : thymiamatum, acoporumq́ue compolitionibus conueniens.

G A I E N v s lib.v r. de fimplicium med. facultate, er poft ip fun $\mathrm{P}$ aulus, noin nodó Mufcum, qui cedris innafcitur, intactum non retiquere; fed preterquàn quód populnei; o querni memi= nerint, de co etiámnum, qui in picea arbore abieti cognata oritur, tradiderunt. A' qua ipfe quidem in uallis Ananix montibus fupra 20 Tridentum mufcum admodum villofum proprijs manibus quàm= pluries decerpfi, multó fané odoratiorcin, pulchrioremíg; , quàm. qui in populo, or quercu prouenit. Nec minus picco fuaviter olet abiegnus, quo in eorundem mötiun fyluis, abietes innumeras adeó uillofas, incanas'́; mihi uidere Sepius contigit, ut prima ftatim $f_{a}=$ cle crediderin uillos frondium loco ijs in arboribus genitos effe. Sortitur drboreus Mufcus uaria, ac diuerfa nomina : quippe E mufcus, e bryon, o fphagnos, o placlinon, o bypnon appel: latur. Meminit huius Plinius lib. X I I. cap. X X I I I. fic inquiens. Sphagnos in Cyrenaica prouincia maxime probatur : alij bryon 30 uocant. Secundum locum obtinet Cyprius, tertium Phenicius. Fertur er in Aegypro nafci: quine in Gallia non dubitauerim. sunt enim hoc nomine cani arborum villi, quales in quercu maxi= mé uidemus, fed odore preftantes. Laus prina candidisimis, at q; altifsimis: fecunda rutilis: nulla nigris. Et in infulis, petrisóg, nas ti improbantur, omnesq;; quibus palmasum, atq; non fuus odor ineft. bactenus Plinius. Catcrum in eo genere, quod in Italia prouenit, is $\odot$ nobilior, o odoratior apparet, qui in larice nafcitur: quapropter $\odot$ uiribus fortaffe preftantior erit. Nimirum recordor me non parum eo quandoq; fuife oblectatum, dunn noeturno tempore quibuf= dam in montibus fuper foeno recumberem; ex conquifitis plantis dcfatigatus, ubi larices innumera crant omni ex par= tc uillofo mufco incane. Quandoquidem paftores, ut nos ueluti re noud, o uoluptuofa reficerent, quodam paruo ignis lumine bos uillos incendebant, qui tanto flagrabant impetu, er crepitu, ut nobis quidem uiderentur tormento= rum puluerem facile fuperare. Quippe flamme unà cumingenti fauillarum copid, in obfcure noct is filentio ad aftra tolli uidebantur, relicto fui odoris oblectamento. Vnde illud exiftimauerim, quodd Galenus, cum bryon in quercubus, o piceis inueniri tradiderit, non folim de piced intellexerit, fed etian de congeneribus plantis, nempe abicte, lari=

Mufci arbo- ce, er pinu. Is autem lib.v I. fimpl. med. citato, ita de eo fcriptunn rcliquit. Bryon, quidam ueró $\beta l a n c b n o n$. In= rei uires ex Galeno, \& Arabibus. uenitur autem in quercubus, o piceis, o populis albis. Vim habet adstringentem, inualidam. Nec enim multum eft frigidum, fed propinquum ferme mediys; quia uidelicet $\sigma$ digerendi, $\sigma$ emolliendi facultatis eft particeps, maximè quod in cedrinis lignis reperitur. Mufcum officine Arabas fecute V fneam uocant. Inter quos Serapio epotum ui= num retulit, in quo diebus aliquot ufnea maducrit, altum fomnum inducere, uentriculum roborare, uomitiones com= pefcere, o aluum fiftere. Ad bac Mufcus ( $u t$ Auicenna inquit) utiliter inter cordis medicamenta inferitur, quód so odoris fragrantia animi defectus iuuet. Sed quoniam arboreus mufcus odoratißimum Mofchon mibi in memorian re = degit, qui ab oriente, $\sigma$ occidente, quibufdam pilofis utriculis conclufus defertur, etfi Diofcoridis Galeniq;; aum bunc filentio preterierit; nos tamen baud quaquam dißimulanda putauimus, que ad banc rem pertinere arbitramur. siquidem bi noftricommentarij meritó de me conqueri potuiffent, fi eos tanta odoris fuauitate deffitutos reliquiffem; prefertim cùm omnibus palam fit ubiq; terrarum Mofchum inter pretiofa odoramenta primain fibi comparaffe $\int_{e}=$ dem. Quippe non modó collo, auribuśq; Jupenfus, ueftimentis interpofitus, chtrothecis illitus, crumenis conclufus, ore retentus, or barbe e fupercilijs inunctus defertur Mofchus, quó alarum, nariumi; tedid, fudoris graucolentia, O infuaues corporis balitus occulantur, la cciuix oblect amenta augeantur, nzolliorq́; politia fiat; fed etiam ut odoris fuauitate Deiparam uirginem concilient, ne dic an, ut hac fucata bypocrifi lafciuiam dißimulent ( có cnim uanitatis peruentum eft) Mofchum ipfum in orbiculos componunt, quibus funiculo traicitis angelicas falutationes in celum eructant. Omnia deniq; , quibus mifcetur Mofchus, fua odoris iucunditate commendat. Quod fi be lucubrationes co 


\section{In Lib. primum Diolcoridis .}

forté carkiffent, uerendum quidem erat, ne cun illis gratiam inijfent, qui mira undique odoramentorum fragrantia

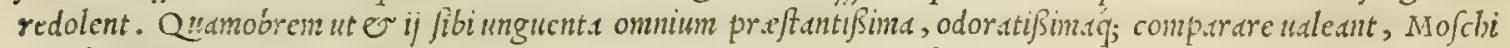
primum, deinde ucróliquoris zibetti nocati, o Amburi denique biftoriam, or ficultates defcribam. Mo= Mofchiodo-

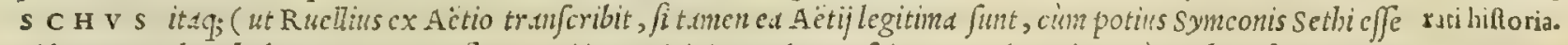

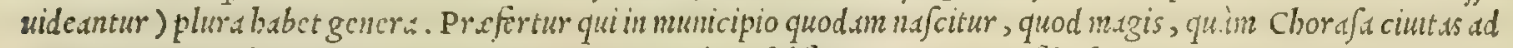
orientem ucrgit: boc barb.1ro nominc Pat dicitur, colore fubflawo. Secundan fibi fedcm arrogat, qui ab Indud de= frrtur, prioribonitate cedens, colore fubnigro. Eo infirmior cenfetur, qui à sinarum ag:o mittitur. At Mofchus omnis in unbilico cuiufdur anin. lis gignitur, quod caprex fimile eft, unico armatum cornu, pregrandi corpore.

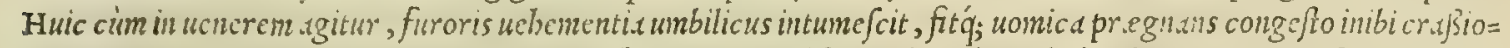

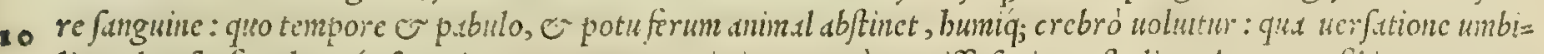

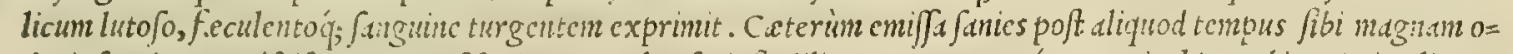

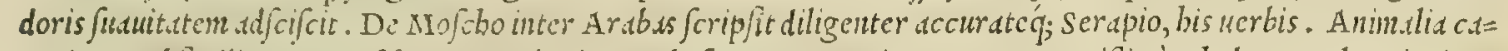
prcis non ab/imilix, que mo fohus: gignunt, in Tumbafcorum, o sinarum agro potisimim babentur, loca inuiccin

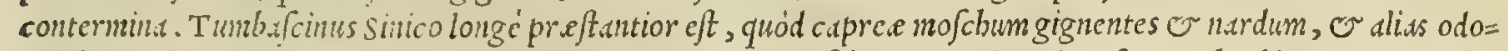

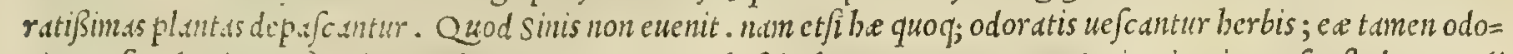
ris, o facultatis preftunti., nurdum, o catera Tumbafci plantas non a quant. Quinetiam in caufa eft demetendi

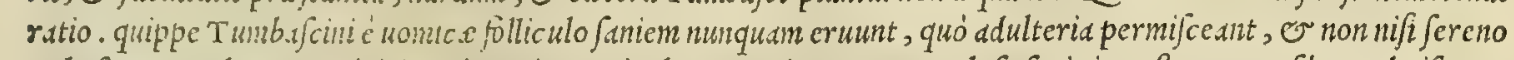
cxlo fyncerum legunt. Sinici ueró uonice utriculum exprinunt, o exclufa fanie impofturas quofdam admifcent, mubilo parumí; arridente calo, ¿r alabaftris recondunt. Is ceteris praftat, qui maiore odoris fragrantia redolet, 20 O qui è uonic. maximé matura cruitur. Sunt o inier bec animalia, que ab alijs mof chun frentibus nullo dif crimi= ne differunt, preterquim caninis uocstis dentibus. quippe bec uerrium modo exertos palmi longitudine dentes ba bent, e pariter mofchun preft.ntisinum gignunt. Mofchus precox tetro, er infualui odore difflicet . uerum uend= tores immaturif folliculos cxcuticntes, tantiper cum libero aëre fupendunt, dum abacto prorfus foxtore maturucrit. Is enim sèr is coetione perfect, miram fibi conciliat odoris fuanitatem. Veruntamen precipuns habetur, quifuapte natura in animalis utriculo fibimaturitatem cöparauerit. Hunc incole per faxa metunt, o arborun truncos. nanq; animal cium uonicam maturame efe prefentit, faxis er truncis fefe magno oblectamento affricat, donec facto uo= mice emiffario tota saniei uis effundatur. Hic ceteros fané antecellit, tanquam folis coctione, er cali benignitate ma turitatem ultiman confecutus. Hunc itaq; mofchum inde uenatores colligentes corum animalium utriculi afferuant, que allis uenatione captauerant. Iśf; ille mofchus eft, quo reges ev donantur, ov utuntur. Mofchus excalfacit 30 ordine fecundo, ficcat ueró tertio. Cor frigidum, ac tremulum roborat, or ominibus ip/ius affectibus opem preftat potus, atg; illtus. Detergit tenues oculorum albugines, o bumidas defluxiones exiccat: cerebrum roborat, o diti= turnum capitis dolorem mulcet, fi tamen pituite redundantia proveniat. Coles ex co cicino oleo macerato perun= ctus, promptius in ucnereme excitatur. Probant nonnuli an Mofchus legitimus fit, boc modo. Pondus libra exami= natun in labellun buntore perfufum immittunt, tum pauló poft iterum aqua lance ponderant. Quód fi superferatur, fyncerum 0 legitimum exiftimant: In cedat, purium, $\sigma$ ddulteratum putant. Huic fimile aliud quodpian babe= mus, sed preterquadin quód mirum in modum oleat, primoftatim occurfu odoris uehementia nares admodum ferit.

Molchi odorati uires.

\section{A N I M I I: ZIBET TI.}

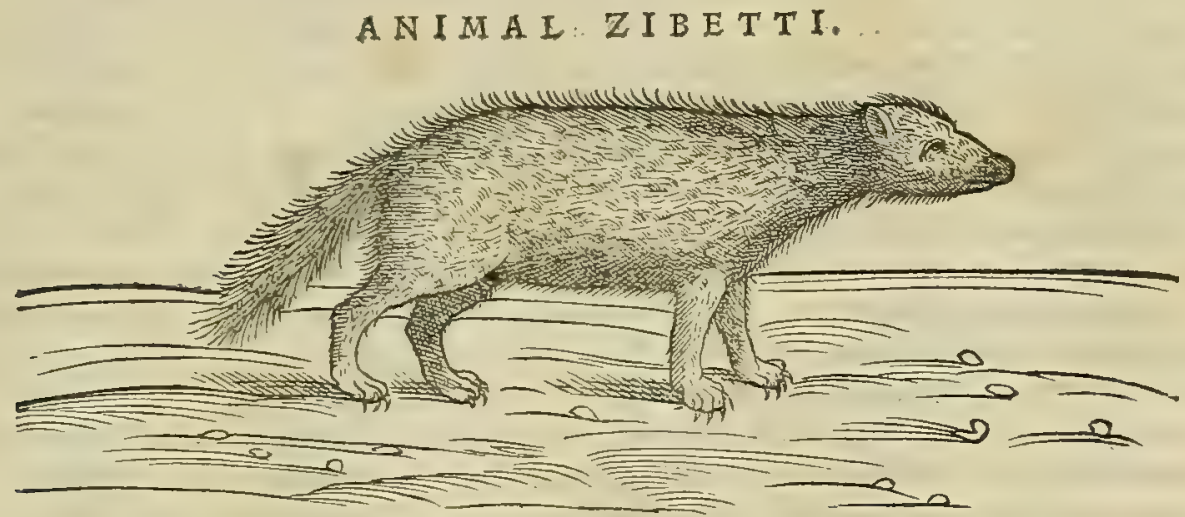

50

Hoc unlgarifermone uocainus Z I в Е T T o, unguentarijs maximé expetitum ad ed odoramenta componenda, que proprie suifturas appellant. Gignitur id in exteriori tefticulorum utriculo cuiufdam animalis, feli, qui ueteribus

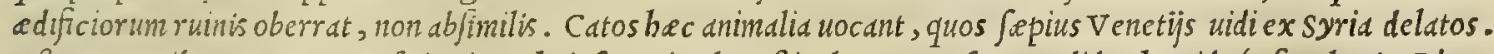
Eft alktem Zibetium tanduam fud or inter buiufce aninalis tefticulos concre fcens, calide, humidég, facultatis. Id cas uernule umbilici impofitum uulu.e. Erangulationibus mirifice prodeft: proinde nec mirum eft, fi eo uiri peni circum= lito magnum mulicribus in coitu afferant folatium. Porró ex quo AM B A RVM aliud odoramenti genusgigna= tur, quod nos uulgó uocamus Ambracane, uarij uarié opinantur. Alij nanq; tradunt ip fum in maris alueo non fecus, atq; in terra fungos oriri, ac deinde Senientibus procellis, é profundo elici, ev in litus expui. Nonnulli ueró refir rüt pifcem A zelum nomine Ambarum boc auidifimé profequi, cuius e fu necem fibiftatim confcifcere. Quod cùn fciant picatores huius rei peritipifcem bunc martuum, undis'; fluctuantem coniectis uncis o funibus extrabunt: 0 An= barun cuffo anumalis uentre crunnt. Quod ueró (ut perbibent) proximé dorfị pinan inuenitur, id maximé prafer =

Zibetti hiftoria, \& facul.

\section{Ambari hifto} ria uaria. 
tur alio. Quidam preterea in fontibus quibufdam Ambarum natare frribunt, quibituminis modo illud eruatant. Hus ius fententix é recentioribus Grec is inuenio Symeonem sethi, qui Ambarum defcribit lis uerbis. Ampar, quod er Ambar appellatur, in diuerfis locis fcaturit. Sunt enim eius fontes ut bituminis, or fulpluris, or rerum fimilium. Ambari gene Tria Anbarifaciunt genera. Prefirtur colore fulumm é Selaclito Indix petitum. Aliud fubalbidum, quod é Sinchrio ra, \& uires. felicis A rabix oppido aduebitur. Tertium atrum, o cateris uiribus imbecillius. Excalfacit Ambarum, $\sigma$ ficcat: ce rebrum, or cor olfactu roborat. Scnibus, or natura frigidis opem mirificé preftat. Quarc iffdem potius, quim iuue nibus chirotheca Ambaro imbute concedideberent. Vino infufum tcmulentos efficit. Caterim ex antedict is que fit Ambari hiftoria ut uerior accipienda, non equidem aufin decernere, qućd nibil adbue certi atq; explorati habeam.

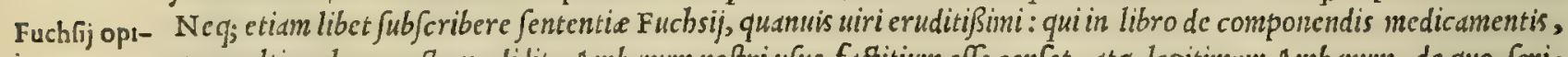
nio. quem ultimo loco auctum edidit, Ambarum noftri ufus factitium effe cenfet, at q; legitimum Ambarun, de quo fcri-

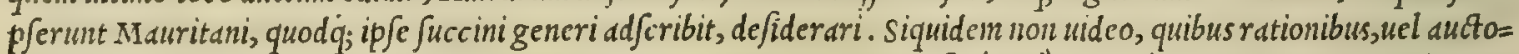
10 rum teftimonijs hanc fuam comprobet fententiam. Mufcus arboreus Ggúov, "̈ $\sigma \varpi \lambda \dot{\gamma} \gamma \times$ vov Gracis appellatur: Nomina. . Mufcus, Latinis: Axnech, aut vfnee, Arabibus: Mofco, Italis: Mcofz, Germanis. At Mofchus odoratus uóoxos Grecisrecentioribus nominatur: Mofchus, Latinis: Mifch, feu Mefch, Arabibus : Mufchio, Italis.

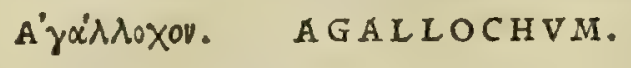

A G A L L о с н v м lignum eft, quod ex India, atque Arabia deportatur, thuix ligno fimile, maculatum, odoratum, guftu adfringens cum quadam amaritudine : cute uerius quàm cortice ueftitur, aliquantulum uerficolore. Manditur, aut decoeto os colluitur, commendandi halitus gratia: fudores arcet toto corpori infparfum: pro thure ad fuffimenta fubftituitur. Radix epota drachma unius pondere, humida ftomachi utria, \& imbecillitatem, feruoremó; mulcet: fi lateris, iocinerisúe dolor excruciat, fi dy fenterix, aut tormina infeltant, ex aqua bibere prodeft.

Agallochi có A G A L L C H V M ¿̇ Grecis, Latinisrecentioribus, ficuti ab Aphris Lignum aloës appellatur. Optimum Gideratio. à Lufitanis é Calecut Indix emporio ad nos contuebitur. Etfí etiam Venetias bac etate ex Alexandria A geypti pres= ftantißimum afferatur : fiquidem igni accenfum fuauißimum, ac periucundum Ppirdt odorem. Nec ob id putand $u$ boc

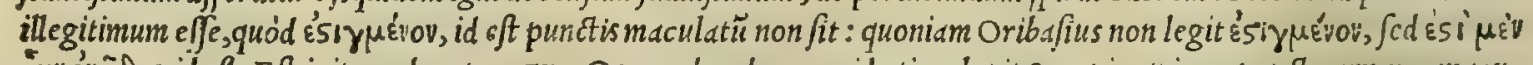
ovv Éväfes, id eft. Eft igitur odoratum orc. Quemadmodum nec id etiam legit scrapio, qui nec punctorum, $n$ tec mack= larum meminit: ficuti nec $\mathbf{P}$ aulus. Caterùm non diu $\mathrm{ef}$, quod legitimum importaricapit : nam licet anted, quibudan non deè fet Agallocbum uerum; nibilominus, quód rarißimum effet, officinc' feré omnes eius loco, ut fuperius diximus, oleaftrum Rhodium fuppeditatant : quem falsó exiftimauit Ruellius apalatbum cffe. Nafcitur Agallocbum (ut Iu= fitani per meridiem in orientem nauigantes teftantur) in infula Taprobana, alijśq; confinibus locis, cuius integros trun cos in I uftaniam, $\sigma$ H ifpaniam ijdem fecum attulere, qui non modó incenfi, fed manuum tantüm attritu fuauter (ut aiunt) redolent. Porró ubiq; pretiofum Agallochum eft: nam or in locis, ubinafcitur, plurimi penditur. Verum Agalloc. fabu Agallocbum, quod tantopere preftet, bactenus mibi uidere non licuit. Sunt, qui fomniantes dixerint, Agallochi arz lola opınio. borem uidiffe neminem, cum terreftri tantum paradifo proueniat: illud'q́ firri fabulantur fluminibus, que (ut facra teftantur monumenta)ex co manant. Arqui pro comperto habetur(ut paucis innuit Serapio) Gangem India amplißi= mum fluuium quàm plurima fecum Agallochi fragmina uebere, qux tamen in ip fum ducuntur aliorim fluminum curfu, qui in eum confluunt. Quippe cum fluuij transluant loca, ubi Agallochum proucnit, aquarum inundationibus turgen= tes, huius truncos, fragmina, ac ramenta rapiunt und cum alijs uarij generis lignis, $\mathcal{O}$ in Gangen transferunt: quem= admodum in noftris etiam fluminibus fepe ac fepius uifitur. Cuius rei indicium affert illud, quod venetijs uenditur, utpote quod longo aquarum difcurfu omni ex parte laceratum, exe fum, comminutum q́; pectetur. Quamobrem mi= rum non eft, fi dum manibus tractatur, id odoris non preftet, quo illud fragrare predicant ex natali folo in Lufitania Agallochi hi- aduectum. Eius plura numerantur genera, fi serapioni fides cjt adbibenda, qui ex Abobanifa A rabo ita tran $\int_{c r i b i t}$. forra ex Se- Dicunt Agallochum in Arabia nunquam oriri; tametfi quadam ibi crefcat planta neuig wocata, que quadántenus rap. \& Sym.
Agallochum refert. Verim preftantißimum India mittit : $\mathcal{~ q u a n u i s ~ b o c ~ g e n e r e ~ d i f f e r a t ~ ( ~} p l u r a$ enim Indis Agal= lochifunt genera) id tamen quod uiribus cetera precellit per excellentiam Indum peculiariter uocant, quemadmo= dum nigra myrobalana, quód cateris preftent, Inda pariter appellant. Indun in quadam Indie infula inuenitur, que Fimua nominatur. Selectißimum eft nigrum, quod uarium oftendat colorem, Jucci plenum, ponderofum, duritie com= pactum, craffum,non albicans, er quod accenfum egerrinéflagret. Secunde bonitatis eft Mondunum ḋ Mondel In= die urbe denominatum. Tertium eft seificum, quod non ob fur a bonitatis prefumitur, quód fux preftanti ui, ac gratue dine in aqua coniectum, non innatet, fed ftatim fubfidat . porró ex hoc genere id inag is preftat, quod craffumeft, er plurimo humore pregnans. Poftremam Sedem habet Alcumeric ŭ Seifico bonitate cedens: tametfi Alcumeri inon lon gius à Seifi diftet, quàm itinere triduano. Preftat in Alcumericigenere nigrum nulla albedinc uarium, graue, ignium flammis diu refiftens, ueruntamen uiribus Seifico infirmius eft. Item ex auctoritate Che df fetebeniidem ita.fribit.Fe= runt preterea, quod incole Agallochum ftatim ab arbore diffectum integro anno fepeliunt, ut ita terra obrutum mar= cefcat cortex, lignumí; tantium purum remanedt, adeo ut é ligno nibil erodatur. Ferunt infuper illis in regionibus col= labentes ex Agallochi arboribus ranos, raptos à fluminum inundationibus per circumftantes regiones deferri. bec serapio. Cuifubfcribit é recenticribus Grecis symeon Sethi, caufam etiam reddens, cur annua cpultura diffectum Agallochum recondatur, cum inquit. Non alias odoratius futurum existimant, nifi prius marcorem aliquem coredinem 


\section{In Lib. primum Diofcoridis.}

نे teredinem fenferit : proinde burun regionum incole diffectum fub terra condunt, fuo ; tempore eximunt, er negotiatoribus uendunt. Nicolaus Myrep/icus $\int x$ pius in fuis componendis medicanentis Agallochicrudi meminit, ubi Fuch/ius prima de artidotis fectione, fic adnotauit. Sape Agallochi crudementionem facit Nicolaus, ideoq; boc Fuchfij fentëloco, qux noftrid de illo fit fententix, exponemus. Per crudum itaf; lignum intelligo, quod non putruit: nan (ut te= tia improba-

ftis eft Symeon Sethi) cius regionis, in qua pronenit, incola idipfun concidunt, or fub terra multo pulucre obruunt, o poft aliquod temporis fpariun, quantum fcilicet fufficere uidetur, ligni partes educunt, or mercatoribus uen= dunt . crudum itag; exit, quod terra non obruitur, fed/tatin ab arbore cxcifum ad u wun rapitur. bac Fucbsij fen= tentia. A'quo tumen nos pace fua diffentimus. nam fi in componendis medicamentis preftuntiora fimplicia femper

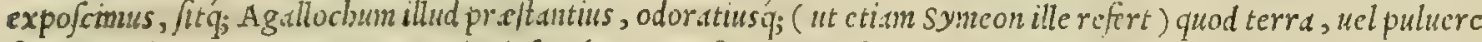

10 fuerit fepultum, non uideo, cur porius in fepultum, of fatinn ab ipsa arbore excifun (id cinin ob locorum dift antian recens habere nequinus ) crudum uocauerit Nicolaus, prift.untus q́; cxiftimauerit. Puluere enim uel terra condi= tum coqui non potc/t, quod mullus ibifit ignis, neq; calor, fed potius recrementitia bumiditate cxui, que fortaffe o= dorem eius obsundit. Verum crediderim potius, per crudum Agallocbum Nicolso illud defigutri, quod non fucrit antea elixum: quódinde fortaßis odoratißima lauacra ex Agallochi decocto fibi conficiunt Indi, aliá; odoramenta in regales preparent ufis, wt ctiam cum rhabarbaro fierinarrant. Vel forté per crudumillud intelligit Nicolaus, quod impetu fuminum, longo ;; eorum duct u per regiones non defertur. In bis nanque calorific is regionibus aqux a folbus non ob curcicalefactx non modo illud omni ex parte diluunt, fedetiam elixant. Illud pratered addiderim, quód cün non modó crudum, fcol etian bonum addiderit Nicolaus, nullum aliud expetere uidetur, quàm quod fe= pultun priftuntisimum ciafcrit.: Ceterim A gallocbi onne genus excalfacit, or exiccat ordine fecundo. Facit,

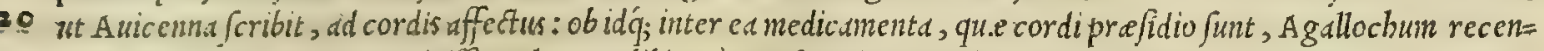
fuit. Huius non reperia neminifje Galcnum alibi, quaim in fuccidaneis, ubi centaurium fupplet pro Agallocho. Li=

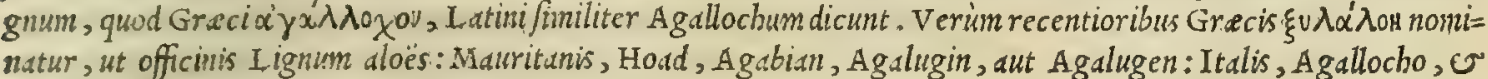
Legno aloe: Germanis, Aloes boltż feu Kreuzboltz: Hipanis, Lin aloe.

$$
\text { Nágrapion: NARCAPHTHVM. CAP. XXII. }
$$

NarCapHTHVM ex India defertur,corticofum, fimile fycomorilibro: quod iucundi odoris gra tia fuffitur. Mifcetur thy miamatis compofitis . Conftrictionibus vulua fufitu prodeft.

T A M breuiter, tam $\tilde{q}_{\text {; }}$ parce de Narcaphtho fcripfit Diofcorides, ut nimirum mibi perdifficile fit explicare; quidnam bac etate ad nos ex India afferatur, quod legitimum Narcaphthum referat. Eo ó; magis quód nibil de hoc ( quod equidem fcimn) Theophraftus, er Plinius fuis monumentis pofteritatis memoria prodiderunt. Attamen non de funt indicia, quse prefe ferant ( $f i$ modo ad nos deferatur) id omnino effe Narcaphtbum, quod uulgó officine uo= cant Tigname. nam tigname non aliud integrat, qudm thymiama apud Grecos, quod apud Latinos fuffimentum $f=$ Tigname. gnificat. Proinde cim buius in fuffimentis frequentißimus fit ufus, nil mirum fi nouum ex ufu fibi uendicauerit no= men, quod eft thymiama. Id quod corrumpentes pofteritigname protbymiamate dixere. Ad bec (ut Diofcorides inquit ) iucundi odoris gratia per fe luffitur, ac etian alijs fuffimentis inferitur. Quod in Tigname facile probatur. quippe id tantim uf uenit in cöpo/itis odoramentis, qux ad fuffiendum parantur, ita ut preterquàm quód per fe id mu neris preftet, rar $x$ quoq; fiant fuffinentor $\ddot{1}$ compofitiones, qux ip fum non recipiant. Quare admirarifindmus, fi reli

40. Ato proprio fue arboris nomine, /ibi a fititiam nomenclatură ex fuffimentis ufurpauerit. Serdpio Narcaphthü $\mathrm{L} a \int a=$ Nomina.

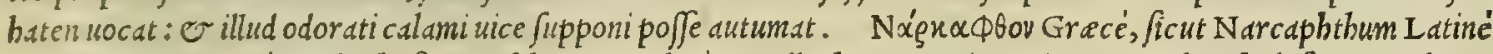
appellatur: Arabicé, Nabach, fiue Lafabaten : Italicé, Agallocho, atq; etiam Tigname, ueluti feplafiarum unlgo.

$$
\text { Kx́rxxuov. CANCAMVM. }
$$

CAP. XXIII.

CANCAMvM Arabicilignilacrymaeft, myrrhx quodammodo fimilis, uirof guftus, quam ad fuffimenta ufurpant. Veftes co, additis ftyrace, \& myrrha, fuffiuntur. Vim proditur obtinere extenuandi obcfos, fi ternúm obolorum pondere ex aqua,aut mulfo aceto plufculos dies ebibatur: lienolis datur; comitialıbus, \& fufpiriofis: menfes cum aqua mulfa pellit : oculorum cicatrices confeftim emendst : uino madefactum medetur eorundem hebetudinibus . aduerfus gingiuas humore prx so gnantes, doloresq́ue dentium, non aliud efficacius.

CAN CAMVM, quod notis omnibus Diofcoridis hiftorian referat (ut recentionum feré omnium medic materis fudioforum fert opinio ) nec ex Arabia, nec aliunde ad nos aduehitur. Quidam tamen pro Cancamo gummi quoddă rufum, ac pellucens oftendunt, quod furculos incogntte arboris undique circumuefit, myrrbse quadántenus fimile. Veruntamen quod nulla ( ut Diofcorides inquit) in eo manfo faporis uirofitus deprebendatur, alij id potius mentiri, quàm effe legitimum Cancamun uolunt. Expetitur hoc gummi genus hoc tempore maximé infectoribus rá inficiendx ferica ftanina, $\mathrm{d}$ 'q; uulgari fermone quid.m in I talia appellant Lacca, quidam diminuté Lacchetta. Cuius duo haben= tur genera, que tantum (ut opinor) bonitate differuat. Praftantius uulgó appellant I acca fumetri: quod ueró de= terius eft, Lacca comberti, cognomentısfortafje à locis Arabum, à quibus deferuntur, acceptis. Primum furculis perpetuó obuolutum uifitur : alterum abfque. furculis in glebas concretum myrrbx modo, quod etian uiliori pretio uendunt. Hinc itag; factum $\mathrm{eft}$, ut crediderint illi serapionis auctoritate freti, boc legitimume ffe Cancamum: inempe 


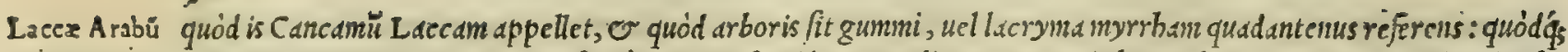
opino uaria. etian eius meminerit Serapio, poftquim de Diofcoridis et Pauli Cancano egit, bis uerbis. I A C C A (ut inquit I fac amran)res qu,edam eft rubea, que tenuibus lignorü furculis inberet, faporc non ingrato. Coquitur bec, ét inficiuntur ind pani rubeo colore, quam infecturam chermes appellant. Quod ueró poft infecturam fubfidet, er infectoribus re= manet, pariter Laccam uocant. Caterim Lacca ex Armenia defertur exiccans, $\sigma$ excalfaciens ordine fecundo. Ventriculum; er iccur roborat, eorumiq; infaretus cxpedit, ictericos iuuat, $\approx$ aquas pellit. Elititur ad medic amenta bac ratione. Ramuli, qui hoc f catent gummi, diligenter franguntur, ac fubinde aqua per fundutur, in qua odoratus iun cus ariftolochiág; inferbuerint, deinde piftillo agitantur, cum autem ab agitatione re federint, aqua lcuiter abijcitur: quód fi una tantum lotione non pelluceat, fecundó item repurgetur, demum ficcctur in umbra, er recondatur in uaje uitreo. hee Serapio. Quibus palim eft, gümi, quod infectoribus uulgó Lacca dicitur, Laccam effe Arabum, $\sigma$ ḋ Gra $x$ corum Cancamo differre : quód Diofcoridi Cancamum lacryma fit Arabica arboris, uirofi gufus:Serapioni ueró res quedam rubed, ex Armenia, non ex Arabia allata, tenuibus lignorum Jurculis inharens, fapore non ingrato. Item Diofcoridi Cancanum obefos extcnuat, licnofos iuuat, fupiriofis, er comitialibus prodeft, menfes pellit, oculorum ci= catrices delet, $\widetilde{\sigma}$ bebetudinem curat, tumentes gingiuas cobibet, o dentiun dolores tollit. Ser dpioni autem tantim obftructiones aperit, uifcera imbecilla roborat, iecoris dolores mulcet, o regium morbum, er bydropem fanat . que omnia medicamentorum diuer fitatem pre fe firunt. Quo fit, ut non ab re exiftimauerint peritiores medici,nos omniz

Cäcamum \& no Diofcoridis Cancamo effe deftitutos. Veruntamen non defunt rationes, nec probatifimorum auctorum teftimo= lacca quòdidē nia, quibus etiam probari poßit, Grecorun Cancamum, e A rabum Laccă idem effe. Nam etfi bec, qux allata funt, fint, proba - omni ex parte ucra uideantur; $f i$ quis tamen Diofcoridis codicem boc capite fcatere mendis animaduerterit, er rem
tur. omnem accuratius, diligentius q; perpenderit, certior fortaffe fiet, nos Cancamo non omnino deftitui. Ego enim cùm $=0$ $\mathbf{P}$ aulum,qui in omni fimplicium cenfu omnia ex Diofcoride tranfcripfit, accuratius perlegerem; imuenifjemq́; illi Cant: camum lacrymam effe Arabic arboris, myrrhe fimilem, odore grato, of quod nullius uiroli guftus meminerit, illico oxta eft fupicio, quód ea particula Diofcoridi illegitimé accefferit. Auxit deinde fupiciorem baric Serapio : quippe qui capite de Lacca de Canoamo agens, dum (ut affolet) ex Dio fcoride tranfcribit, nufquam buius particulse mentio.

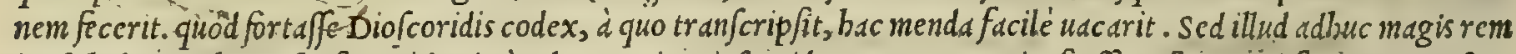
ita fe babere mibi perfuafit, quod primum legatur in Diofcoride, Cancamum uirofi effe guftus, quod foctoris, non fuas= meolentix indicium eft: mox cumftyrace, et myrrba ad fuffiendas ueftes expeti, ut grato cömendenfur odore . quie ut inter fe maximé-repugnant, ita etiam deprauate lectionis prabent fupicionem. His itaq; rationibus, or auctoritati= bus non ab re adductus c fe uideor, ut quafi crediderim Diofcoridis codicem hoc in loco uitiatum fuiffe. Vnde pofted

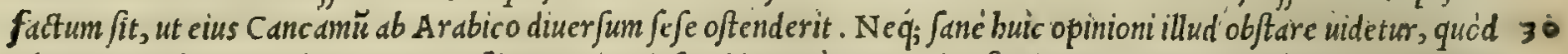
plura in morbis curandis Cancamo a ßignauerit Diofcorides, quìn serapio. fiquidem nulli dubium e,t, quin ea medica menta, que obe fos extenuant, lienofos iuuant, er menfes cient, poßsint pariter uentriculum et iecur roborare, eorum $\dot{q}_{5}$ infarctus expedire, $\sigma$ cutem fubeuntes aqus, o felle fuffufos fanare. Hac autem filentio inuoluenda non duximus,

Iace facticię non ut noftra hae probetur, uel improbetur opinio, fed ut alijs ueritatis inueftiganda pateat aditus. Sunt etian fas genera. Atitie Lacce plura generd: que ex diuerfarum infectionum fedimento pictoribus tantum parantur. Alia nanque con= ficitur ex pimpinelle bacca, quam uulgó uocant Cremefe, O Cremefino : ex infetorio cocco alia: alia ex natiua Se= rapionis lacca : alia denique ex ligno, quod brafilium uocant, omnium deterrima. quarum nulla ad medicamenta ad= mittitur. Non tamen de funt, qui credant, cbermefinum infectoribus uocatum effe arboris gummi : imó illud idem, quod Serapio, auctore I fac, rem rubcam (ut pauló anté diximus) effe dit, qu.e tenuibus lignorum furculis inbareat, $\mathcal{O}$ quód ea inficiantur panni rubeo colore, quem chermes appellant. quandoquiden buius fententie reperio fuiffe Fuchfium. 40

Fuchlij opi- sed meo iudicio non exacte rem explor alfe uidetur - quippe cherme finum, quo punceo, o purpureo colore ferica fta no improba- mina inficiuntur, eft (ut Itali optime norunt) piluld, uel bacca exigua pimpinelle radicibus in orientalibus regionibus ta. adnafcens, non autem gummi, uel ro cidum, uel aliud per fe manans, ab co perquàn longé diuer fum. Siquidem hoc nil aliud eft, quàm natiua Serapionis lacca, quam propriè I tali uocant uulgó lacca er lacchetta, infectoribus tantum ex: petita ìs inficiendis fericis, que uiliori ueneunt pretio. Nec obftat, quód dixerit serapio, que bî fecutus eft Fucbfius, buiufce lacce infectură nocari chermes: quippe proprio capite de chermes, nil fané aliud per chermes intelligut, quàm coccum infectorium Diofcoridis. quo fit, ut cxiftinauerim in eo capite de lacca omnino fubeffe mendam, uel auctoris, uel interpretis: of forté melior bec effet lectio. Coquitur bec, or inficiuntur inde panni rubeo colore, adeo ut cocci= Pharmacopo nei uideantur : uel adeo ut ijs fimiles fint, quor mm infecturis inijcitur chermes. A berrant preterea pharmacopolar larum error. quim plurimi Dialaccam antidotü componentes, quód legitime Armeniace lacca loco, quam Arabes prodidere, fas. ctitids, $\sigma$ pictoribus tantium dicatas immifceant. Sed caucant, qux $\int$, ne bunc errorem corrigentes in alterum non mi= Monachorü: nus deteftandum incidant : id nanq; is facilé continget, fi Monachis, qui in Me fuem fcrip ferunt, morë gerent. Hi enim lapfus. Lam reimedice profeffores afferere non dubitarunt, immifcendam effe loco cancami, feu lacce in magna dialacca an=. tidotum cam A pbrice arboris lacrymam, quam feplafie fanguinem draconis appcllant, quá '́; Diofcoridis cinnabaris ab omnibus effe cenfetur. Sed certé ij magis hallucinantur, quàm ut reflli debeant, quód ca lacryma in compluribus facultatibiis cancamo aduer fetur. Quippe Arabicum Cancamum, quod potisimé antidotusilla cxpo fcit, tanquam à

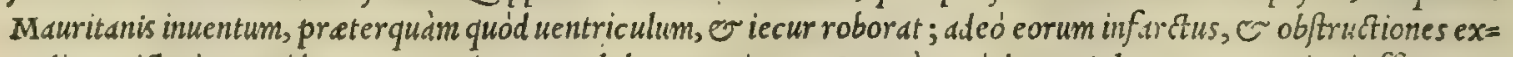
pedit, ut iatericos quidem, er aqua intercute labor antes iuuet. Contrà ueró draconis lacryma propria ui cfficactter. adftringit, ita ut feriptum reliquerit Diofcorides, cam lacrymam iffdem pollere uiribus, quibus ha matitcs lupis: cuius tamen uis eft, ut menfium proflunia fiflat, non autem ut eliciat, Cancami modo, prefertim ubi uiforun infarctu remo

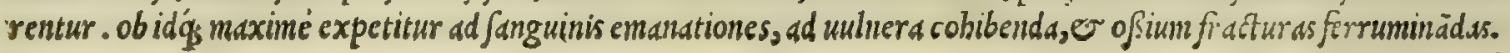




\section{In Lib. primum Diofcoridis.}

Sed monachos miffos faciamus: o feplafiarios admoneanus, ut fi noftro confilio uti uelint, non aliud pro lacca in cam antidotun imponant, quàm lacean ip fan Serapionis. que natiua ex Armenia ad fericorun uellerum infectum copiofipima ad nos de fertur. I iquidem de bac intellexerunt Mauritani : quos fecutus Nicolaus Myrcpficus in fua Did $=$

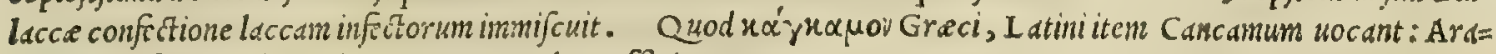
bes, Sach, fine I ach: Itali, Cancamo : uulgus officinarum, Lacca.
Küł!。
C Y P H I.
C A P. XXIIII.

C Ү P I odorati fufimenti compolitio eft, dicata dijs : qua abunde Aegyptij facerdotes utuntur. In antidota mifceri folet: fufpiriofis datur in potu. Permultæcomponendi rationes, quarum

2. una hæc eft. Sumito cyperi dimidium fextarium, cum paribaccarum iuniperi adultx modo: vux paffe pinguis, exemptis uinaceis, minas duodecim: rclinæ purgatæ minas quinque : calami, \& iunci odoratorum, \& afpalathi, fugulorum minam : myrrhæ duodecim : uini ueteris fextarios nouem, cum duabus mellis minis. Vuam paflam, derractis uinaceis, tufam cum uino, \& myrrha fubigito: cxtera tufa, \& cribrata adijcito: dic uno humorem combibere finito. dein mel coquito, dum fibi glucinis adfcifcat crafsitudinem : eliquatam refinam accuratè permifceto cum reliquis diligenter con tritis, \& in fictile uas recondito.

N o N onnes fane Diofcoridis codices, preeertimí; uetuftiores hoc Cyphi caput recipiunt. Quo fit, ut credi= Cyphi caput derim cum plevi fque rei medic peritis, id illegitimé huc acceßiffe. fiquidem non rationi confentaneum effe uidetur, adfcititium .

20 Diofcoridem bic de fimplicium nateria fcribentem, compofita medicanenta tam inconfulté, ac prater rem fimplici= bus inferuiffe : prafertin cum id nulli fuperiorum comnodé adnecti poßsit, quesnadmodum eft de multis alijs compofi= tionibus. Vtxũđl Gracis, ita etian Latimis, Er Italis, Cyphi appellatur.

Nomina.
Ķókos.
C R O V M.
C A P. $\mathrm{XXV}$.

C R o C. M optimum in medendivfu Coryceum,recens , \& boni coloris, paulum candidi gerens in capreolo, oblongum, omnibus fuis partibus conftans, non fragile; plenum, à quo detractum eft nihil, quod madefactum manus inficit, nec fitum redolet, aut cariem fentit, fubacre: fin huius generis non eft, aut uetus, aut humore perfufum creditur. Secundus locus datur Coryceo, è tractu Lyciæ contermino. 'Tertius Lycio, è monte $\mathrm{O}$ lympo. Dein ex Aegibus Aetoliæ . Cyrenaicum \& Centuripinum inter Sicilica omnia uiribus infirmius eft.

Omnium natura oleracea. Itali tamen ob fucci copiam, \& coloris uenuftatem, tingendis mortarijs dicauerunt: quibus de caufis magno uenditur. Vtilifsimum in medicina quod antè defcripfimus. Adulteratur immitto crocomagmate tufo, atque etiam fapre fublitu : contrita, quò pondus adijciatur, fimulargenti fpuma, aut plumbagine. Sed maleficium declarat infidens puluis, præfertim fi defrutum in odorando fubolet. Theffalus ipfum tantùm odoratum effe uoluic. Alij exitiofum, trubus drachmis ex aqua potis. Procul dubio uim coquendi, emolliendi, atque fubftringendi habet: vrinam cir: elegantem colorem præftat:qui ex paffo biberint, crapulam non fentient: oculorum fluxiones illitum cum humano lacte cohibet: additur in potiones, qux interaneorum caufa temperantur: ad vuluæe etiam, fedisq́ue cataplafmata, utiliter inditur: venerem ftimulat: vergentes ad ignem facrum inflammationes mulcet: auricularijs collectionibus utile. Quò facilius conteratur, in calido fictili fole ficcari oportet, celeriterq́ue uerfari. Vrinam mouet radix ex paffo pota.

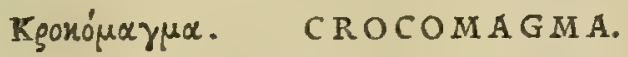

CAP. XXVP.

CR O C O M A M A fit exprefsis unguenticrocini odoramentis, \& in formas digeftis. Optimum eft odoratum, modicè my rrham olens, graue, nigrum, ligni expers, laue, fubamarum, quod madefactum croci colorem reddit, guftatumque uehementer dentes ac linguam inficit, multis durans annis: quale eft quod à Syria defertur. Habet fuas uires ad delenda, qua caliginem oculis obuerfant:

c 2 urinam 
vrinam cit, calfacit, concoquit, \& emollit: Vires croci proportione quadántenus repræfentat: quădoquidem plurimam croci partem fibi Crocomagma uendicat .

C R O C V M quiden ubique terrarum cognofcitur. In Italix, o prefertim in Hetruria, Mauritanorum mos Croei confi- do uulgó uocatur Zaffar ano : quainquam non de funt rura in agro noftro Senenfi, que corrupto a Croco uocabulo ip. deratio.

fum appcllant Gruogo. Ceterum crocum Coryceum, er Lycium in Olympo monte decerptum (quod fciam) ad nos non aduebitur. Quapropter quod ab. A quila Vcftinorum urbe affertur, primune fibi locum uendicat in Italia. Con= ftat optimum effe, o A quilano longe preftantius, quod in Germania oritur, $\dot{e}$ Viennt A ufrix metropoli deuectum. Sed buiufcemodi fané perexigutum eft, id'q; difficulter tranfit ad Italos, ob cius frequentißimum in cibis ufum apud Pannonios, o Germanos. Floret Crocum ( ut Theophraftus auctor eft) uergiliarum occafu, paucisq́; diebus : con=feftin ucró cum folio florem quoque expellit. Gaudet calcari, o melius ita euadit. Croci meminit Galenus libro Croei uires VII. fimplicium medicanentorum, fic inquiens. Crocus paululum etiam adftringens quid obtinet, quod terreum,

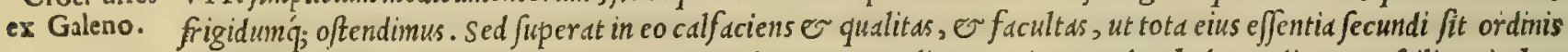
excalfacientium, o priml exiccantium, proinde concoquendi quog; uim quandam babet, adiuuante fcilicet in boc o pauca adftrictione. Quippe quibus medic amentis, cim non admodum excalfaciant, pacula adeft adftrictio, ea parem facultatem babent effentijs emplafticis uocatis, quas cum iunctas effe caliditati non uelementi contigerit, con= coquentes effe oftendimus. Et lib. I I. de comp. med. fecundum loccs: Crocum, dit, fuo odore caput ferit, o mene tem tentat, peucedani, e fructuum lentifci modo. Kóros, Gracé: Crocus, I atiné nominatur: Zabafaran, Nomina. aut Zafaran, Arabicé: Zaffarano, Italice: Saffran, Germanicé: Azafian, Hifpanicé: Saffram, Gallicé. Kgo= xüua $\gamma$ ux idem nomen retinet apud Grecos, Latinos, o Italos.

$$
\text { É } \lambda e ́ \text { iloy. HELENIVM. }
$$

\section{CAP. XXVII.}

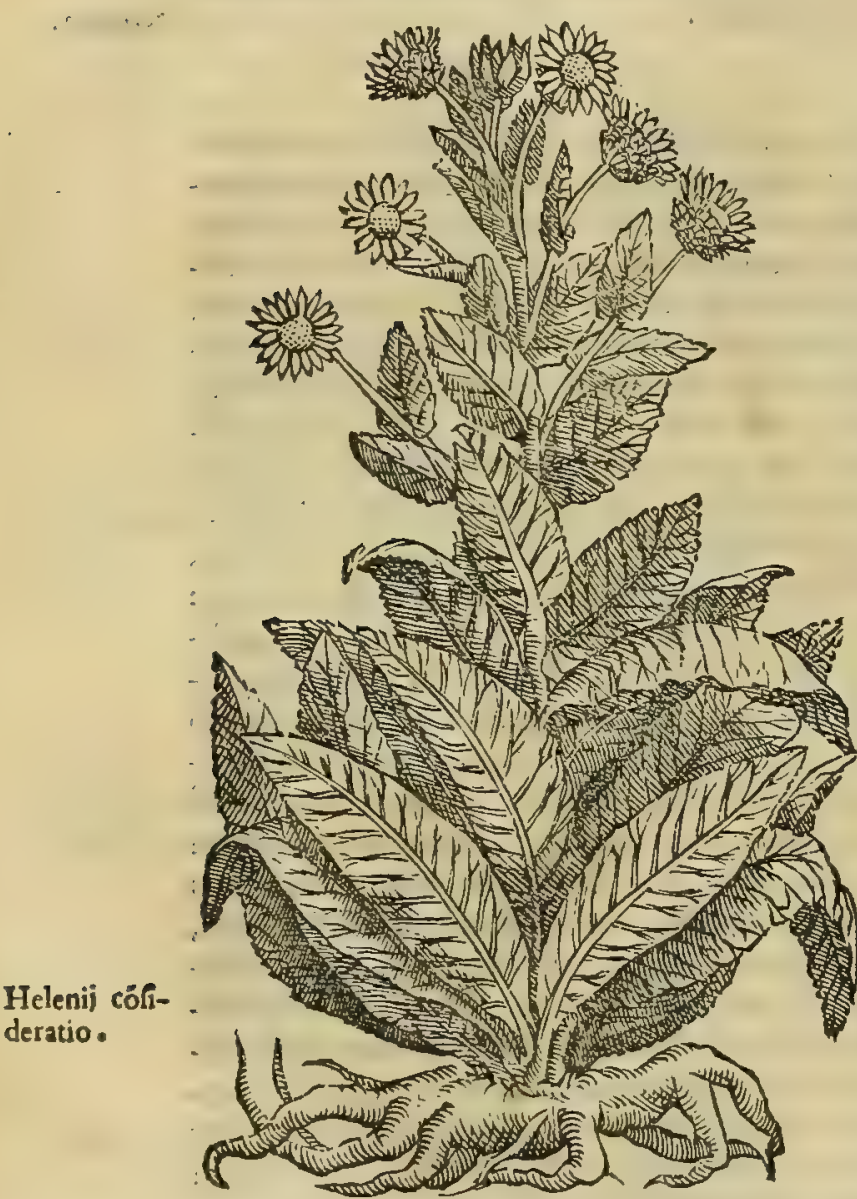

HE LE N I Y M folia habet uerbafci anguftioris folij, afperiora, oblonga : caulem quibufdam in locis non emittit : radicem fubalbidam, interdum fubrufan, odoratam, fubacrem, uegetam, magnam : ex qua agnatæ propagines liljorum, aut ari modo feruntur. Montanis, umbrofis, \& ficcis locis prouenit. Foditur æftate radix, particulatimque diffecta ficcatur. Putum radicis dečoctum menfes, \& urinas ciet. Ip faque in eclegmate ex mel le prodeft tufsi, orthopncex, ruptis, conuulfis, inflatio- 30 nibus, \& ferpentuum morfibus. In fumma excalfaciens eft. Folia eius ex uino cocta utiliter ifchiadicis illinuntur. Helenii radix \& ftomacho utilis elt in paffo condita: fiquidem falgamarii paululum ficcatá eam, mox deco ctam, \& frigida aqua madefactam, in fapam coniiciunt, $\&$ ad ufus recondunt. Trita, potaq́ue ad cruentas excrea tiones efficax eft. Alterum Helenii genus in Aegypto gigni.Crateuas tradit. Herba eft cubitalibus ramulis, fer pylli modo per humú repentibus.folijs léticula circa ra mos, fed longioribus crebrisq́ue: radice pallida, digiti mi $4^{\circ}$ noris crafsitudire, per ima tenui, fupernè crafsiore, cortice nigro. Nafcitur in maritimis, collibusq́ue. Radix una in uino epota, contra ferpentium ictus auxiliatur.

H E LEN I V M, quod Latinis etiam Inula dicitur, planta est unlgaris notitie. Quod autem in Italia prouenit, folio eft longé maiore, quàm tradiderit Diofcorides. Quippe non folum uer= bafco anguftifolio Inule Italice maiora infunt folia; uerum etiă ea magnitudine longé fuperant, qua latifflio exoriuntur. Quod tametfi prolocorum uarietate euenire facile poßit: crediderim so

tamen boc in loco Diofcoridis codicem pluribus fcatere mendis. siquidem teftatur Marcellus Florentinus tir quidem apprimé doctus, fe babuiffe Diofcoridis uetuftifimum, ac probatißimum codicem, in quo longe plura legebantur, quàm in cateris feré cunctis Gracis exemplaribus. Sed prafertim in boc capite bàc de caule, floribus, o femine ba bebantur. Caule ex fe mittit Helenium crafjum, birfutum, cubitalem, $v$ aliquando maiorem, angulofun q́; : flores lu teos: $\sigma^{-1}$ in his femen uerbafco fimile, tactu pruritum faciens. Quare mirum non eft, fi etiam alia bic defiderari poßint, cum non facilé adducar, ut credam, Diofcoridem Helenij radicis, cuius tantìm eft in medicanentis ufus, tum amaritudinem, tum formam fubticuiffe. Meminit Inuld Plinius lib. x I x. cap.v. ubific babet. sifer bis feritur men= fibus, fibruario, martio, aprili, augufto, feptembri, octobri. Breuior his eft, fed torofior amariori, Inula, per $\int_{e}$ ftomacho inimicilima. Eadem dulcibus miftis faluberrima. Illuftrata maximé Iulia Augufta quotidiano cibo. Su= peruacuum eius femen, quoniam oculis ex radice excifis, ut arundo feritur. Item lib. $\mathrm{x}$ x.cap. v. Inula quoq; in = quit, d̀ ieiunis commanducata dentes confrmat, fi ut eruta eft, terram non attingat. Condita tußsim cmendat . Radi= 


\section{In Lib. primum Diofcoridis.}

cis ueró decoct a fuccus tineas pellit. Siccatc autem in umbra farina, tußi, e conuulfis, er inflationibus, et arte= rijs medetur. Venenatorum morfus abigit. Folia ex uino lumborum dolori illinuntur. bactenus Plinius. Caterim Aegyptium belenium, quod Cratcua auctoritate memorix prodidit Diofcorides, ad nos (quod ego friam) non defer tur, nec in Italix proucnit. Hoc a noftrate ron distinxit Auicenna, fed utrunque fimul confudit. Meminit buius $e=$ tiam $\mathrm{Plinius} \mathrm{libro} \mathrm{x} \times \mathrm{x}$. cap. $\mathrm{x}$. bis uerbis. Helenium é lacrymis Helenx decitur natum: Oo ideo in Helend infula lau datißimun. Eft autem frutex bumi fe pargerss, dodrantalibus ramulis, folio finili forpyllo. Item lib. codem cap. $\mathrm{x} \times \mathrm{I}$. Helenium, inquit, ab Helene lacrymis (ut diximus) natum, fuuere creditur forme: cutem mulierum in $f_{a}=$ cie, reliquóque corpore nutrire incorruptam. Preterea putant ufu cius quandam gratiam ijs, uenerémque conci= liari. Attribunt e bilavitatis effectum eidem pote in uino, eimque quem babuerit nepenthes illud predicattum ab

- Homero. quod triftitia omnis aboleatur. Eft autem fucci predulcis. Prodeft or orthopnoicis radix eius in aqua iciu= nis pota. Eft auten candida intus, er dulcis. Bibitur e contra ferpentium ittus ex uino. Mures quog; contrita di= citur necare. bec Plinius. Quibus fatis conftat, non modo in Aegypto boc Helenij genus prouenire, fed etiam in Helena Aegei infula proyltantifimum haberi. Helenij uires fcripfit Gdlenus libro v r. fimpl. medic. fic inquiens. Helenij herbo radix maximé utilis eft, non primo ftatim occurfu excalfaciens : ac proinde non dicenda cft calida, or ficca exacté, ceupiper tum atrum, tun candidum, fed cum recrementitio bumore. Quapropter ecligmatis, qua fa= ciunt ad educendos ex thorace, er pulmone craffos, lentosí; bumores idoné commifcetur. Rubrificant quoque ea partes frigidis, ac duturnis uexatds affectibus, cuiugmodi funt nomulla coxarum paßiones, ifchiadas uocant, er. exigue aßiduæq́; articulorum quorundam pre bumiditate procidentix, ac luxationes. bac ille. Caterum funt, Fabulofum. qui dicunt (ut etian teftatur Galenus libro de theriaca ad Pifonen, fi tamen liber ille Galeni legitimus eft) quod $f$. ex Galeno.

20 Helenij fucco tela uenatoria inficiantur, uenenata efficiuntur, id $\dot{q}_{;}$in Dalmatia fieri narrant, ut fer as omnino per= dant. Quod tamen potius fabulofum, quàm hiftoricum crediderim. Planta, quæ Greco nomine É $\lambda$ Évıv, Latino Helenium er Inula dicitur: Arabico, Iafin, fiue Rafen: Italico, Lella, Enod, dut Enola: Germanico, Alant: Hiffanico, Raiz de alla: Gallico, Aulnee.

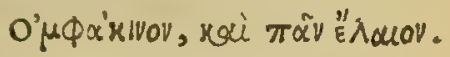 OLEVM. \\ OMPHACINVM, ET OMNE \\ CAP. XXVIII.}

O I E V M, quod ex immaturis oliuis exprimitur, ad multos ufus rectè ualentibus accommodatifsimum eft . omphacinum id appellatur . Praftat recens, odoratum, quod non mordeat. Tale vnguentorum compofitionibus idoneum intelligitur. Stomacho utile eft, quòd aftringat : gingiuas cótrahit, dentes firmat, fi contineatur in ore : fudores cohibet . quò autem uetuftius, ac pinguius, eò ad medicamenta aptius eft. Et (ut reliqua in commune dicantur) omne oleum calfacit, emollit uentrem, à perfrictionibus corpus tuetur, ipfumq́ue promptius ad obeunda munera reddit . aluum emollit, ulcerantium medicamentorum uires permiftum hebetat : contra uenena datur, afsiduè potü; redditumq́ue uomitionibus : foluit aluum hemınæ menfura cum pari ptifanæ fucco, aut aqua potum : ad tormina calidum fimul decocta ruta tribus fextarijs in potu datur : uentris animalia pellit: idem maximè ılei inteftini morbo laborantibus infunditur. Vetus magis calfacit, \& uehementius difcutit: oculorum claritati fublitum confert. Si uetufti non fit occafio, in uafe decoquitur ad mellis crafsitudinem, ut uetuftatem repræfentet.

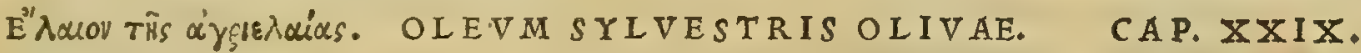

O I E V M, quod fylueftres oliuæ fundunt, uehementer aftringit, \& ad fanorum ufus fecundum fibi locum uendicat. In doloribus capitis utiliter pro rofaceo fubitituitur: fudores arcet, defluentes capillos inhibet: furfures, ulcera capitis manantia, fcabiem, leprasq́ue abftergit : tardius canitié fentiunt, qui eo quotidie perunguntnr. Candidum oleum fit hoc modo. Album colore, nec anniculo uetuftius, in nou um fictile oris patuli funditur, centum heminarum menfura, \& fub folem media quaque die concha refunditur, ex altoq́ue demittitur, ut afsidua deuolutione, ictuque agitatum refpumet: octaua die fonum græcum mundum quin quaginta denariorum pondere, calida aqua made factum, donec emollefcat, in fupradictum oleum deijcitur, ita ne extillet aqua : poltea tedx præpinguis piceæ, affulatim cæfæ æquale pondus adijcitur, \& tranfactis ofto diebus, oleum concha moue-

so tur. Vbi candorem contraxerit, in uas nou um uetere uino affufum recondi debet, fubfratis fertula Campanæ corollis drachmas undecim pendentibus, cum pari iridis pondere. fin minus, rurfus foli. mandandum, \& idem munus obeundum, ufque dum inalbefcat.

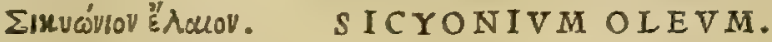

\section{CAP. XXX.}

SI CYONI I componendi ratio hæc eft. In lebetem oris lati,ftanno induftum,funditur noui olei albi,quod crudæ oliuæ reddiderunt, congius unus: aquæ femicongius. Leui id igne coquitur, leniter mouendo : at ubi bis efferbuit, \& fubtracto igne refrixit, innatans oleum concha decapulatur, $k$ adieEta noua aqua conferuefcit, \& leliquis, ut diximus, peractis reponitur. In Sicyonia maximè fieri confueuit,Sicyonij inde accepto cognomine. Calfactoriam ad quendam ufque modum uirn habet. Febri, ac neruorum uitijs prodeft. fominx ad commendandum faciei nitorem eo utuntur. 


\section{Pǘos. STRIGMENTVM.}

CAP. XXXI.

STRIGMENTA à balneis calfaciunt,molliunt, difcutiunt: ad fedis rimas, \& condylomata illinuntur. Illa ucrò, quæ ex palæftris puluerem fibi adfciuerunt, in fordis fpeciem redacta, articulorum nodos impolita adiuuant: ifchiadicis in fotus, aut malagmatis locum, calida commodè fufficiuntur . Derafæ gymnafiorum parietibus, fimulacrisque fordes, calfaciunt : tubercula, qux ægrc̀ ad costionem producuntur, difsipant: defquamatis, \& ulceribus antiquis profunt .

Olei confide- M V I T O quidem artificio veteres utebantur ad componendum multifarium olcum, ut ex Diofcoride fatis fus ratio. perq́; conftat. Quzod tamen bac tempeftate à nobis fieri non folet: quanuis fortaffe apud Grecos ciufmodi parandi olei confuetudo minimé exoleuerit. Quippe id tantum in communi omnium ufu apud nos habetur, quod é maturis oli= wis exprimitur : tametfi quidam, quód $\sigma$ guftatu iucundius, o fanitati conducibilius fibi oleum comparare uelint, id ab imnaturis oliuis exprimant, quas eo tempore legunt, cim ip $\int a$ iam plenéflaue tantillum fubrube cere cappe=

Olei ufus a- rint. Ceterim non mirum $\mathrm{e} f \mathrm{t}$, fi ueteres or illud candidum reddere, o multis parare modis cur abant : fiquidem pud veseres. non modó in ciborum condimentis oleo fiequenter utebantur; fed etiam ut agiliores, promptiores, ac expeditiorcs euderent ad obeunda corporis munerd, frequentius fibi totum corpus oleo perungebant. Quade caufa $\sigma^{\circ}$ balneds frequentabant, o thermas . nang; olei contracta fordes, ut corpora sepius perluerentur, maximé cxpetebat. Obi= bant autem id muneris ferui in balne is, qui non modó corpus totum intrantibus abluebant; fed or ipfum quibufdam ftri gilibus abradebant ad hoc opus aptißimis, quas alij ex auro, nonnulli ex argento; quidain ex ferro; aliqui ex ebeno, ac etiam ex preclaris lapidibus fibi combarabant, deniq; pro nobilitate, of facultatc corum, qui ad balneas conflue $=20$ bant. Quapropter dum fe in ip fis balne is abradere, fudorem'; emanantem detergere cur abant, oleiftrigmenta, quo Se prius perunxer ant, in balnei aquam decidebant : quorumbic meminit Dtofcorides. Fuit preterea in magno, ac pre $=$ cipuo ufu apud ueteres oleum ad perungendos atbletas, qui in theatris pale ftre nudi luct abantur, non fol ium ut corum corpora agiliora, expeditior dóf; in certamine redderentur, fed ut etiam ij difficilius $\int e$ e manibus comprebenderent. Cüm autem ibi puluis ob pedum frequentiorem motum concitaretur; athlete ip $\left\{\right.$ oleo affatim peruncti, illum in $\int e$ faci= lé contrabebant; ac multó magis cum in terram alter alterum confternebat. Qüare balneum ingre $\beta i$, frigilibusq́; abrafi conofa ftrigmenta relinquebant, quibus artuum affectibus Diofcorides mederi tradidit. Sed cim plurinti atble= te oleo copiosé peruncti inter luctandum paleftre parietibus, ac ftatuis lapideis $\int e \int e$ eepius affricarent, contacta lo= ca olei pinguedinem contrahebant. quo facile fiebat, ut adueniente puluere ccenofum qnoddam unguem parietibus in= Olei faculta- herefceret: de quo etiam Diof corides differuit. Oleif acultates fufius profecutus eft Galenus lib.v r.de fimplicium tes ex Gal.

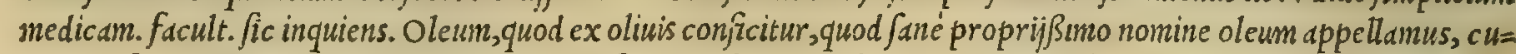
iufmodifit temperature, fuperioribus libris de finitum eft. quippe bumectatorium effe, or moderaté calidum oftendi=

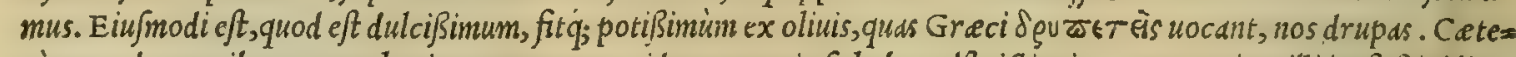
rùm quod omotribes, er omphacinum nuncupant, id quantum in se habet adfrictionis, tantun etian illi ine ft firigidita= tis. Porró oleum uetus, quod quidem ex dulci inueterato efficitur, e calidius cft, o mygis difcufforium. Quod ueró ex immaturo, id dum reliquum quippiam feruauerit adftrictionis, mifte permanet facultatis: ubi ueró ill am prorfum abiecerit, reliquo fit fimile. Quinetiam quicunq; in prepardndo germnina inijciunt, ij $\sigma$ ipfis omphacino finile ole ü effi ciunt. Caterum rogandum non eft, quo pacto fit praparatum, fed guftandum eft potius : ac fi preferat adstriftionis quippiam, eatenus etiam frigidum effe exiftinanaium, ccu illud, quod ab I beria portatur, quod spanum, id eft Hipanic nominant. Quod fi nequaquan guftantibus adferingere appareat, fed addmußim uideatur dulce, id modicé effe calidit putandum. Porró fi tenue quoq; cernatur( tale efl, quod purum est, quod q́; intucnti translucidun uidetur) ac modicum eius latißimé per cuten extenfum fibimaneat continuum, celeriteró;; à cute combibatur, id utiq; pro optino ducendü, ac olei uirtute qudim maximé pollere, quale eft sabinum. Porró quód oleum lotum maximć expers fit mordacitatis, $f_{\text {w }}$ \& prà pofitum eft. Caterim quo potißimùm modo id probißimé laues, in fequenti tradam opere, quod infcribetur de me dicaminum compofitione, ubi e de sicyonio, e fi quod eius generis pretered oleum eft, agetur . nunc fimplicia pro= Oleum fylue fequor, adijcianó; or de alijs oleipeciebus fermonem. I Im quod ex agresti oliua oleum exprimitur, non fimplicé ftre. $\quad$ temperaturam obtinet; fed extergit, fimul 'q; adftringit. Squalidijimum id est ex omni olei genere, e poft Iftricum

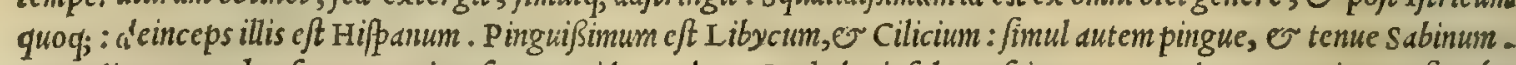
In medio comprehenforum omnium funt tum id, quod per Cyclades infulas nafcitur, tum quod per Greciam, Afiam q́;. Porró oleum pingue aftimatur, iudicaturq̧; uifcofitate : tenue ueró fi perluceat, fi purum fit, fi plurimum à minima so eius portione inungatur, fi facilé à cute combibatur. Ex dict is cognofcere iam liceat $v$ de aliys olei generibus, que aquiuocé ip/is dicuntur unguentis, puta rofaceo, melino liliaceo, 0 quecunq; id genus floribus, fructibus, germinibus, folijs in oleo maceratis conficiuntur. Horum quodq; ubi und cum aromatibus praparantur, unguentum efficitur. Pro cuiusq; iniectorum natur a oleum uariari contingit. Ex ijs ergo, qux in toto boc opere de quoque inijciendorum

Nomina. generatim difces, figillatim quoq; confectum ex ijfdem oleum cognofcere dabitur. Quod Graci Ë $\lambda$ wov, Latini $\mathrm{O}=$ leum dicunt. id Arabibus Cait, feu Zait nominatur : Italis, Olio: Germanis, Oel : Hifpanis, Azeyte : Gallis, Huyle.

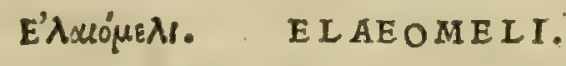
CAP. XXXII.

IN P A L M Y R IS Syrix, quod elæomeli uocant, ex quodam caudice manat, oleum melle craffius, fapore dulci . Bilem, cruditatesq́ue detrahit, fextario cum una aquæ hemina dato. Sed qui fumprere, 


\section{In Lib. primum Diofcoridis.}

pfere,torpefcunt, $\&$ uiribus deficiuntur . quod minimè uereri oportet : uerùm crebro excitare, ne veterno prefsi fomnos captent. Fit \& oleum è pinguitudine furculorum. Optimum uetus, craffum, pingue, non turbidum. Calfacit: priuatim caliginibus oculor um illinitur: lepras, neruorumq́ue dolores illitum emendat,

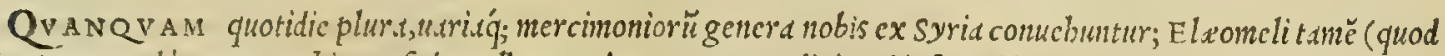
fcians) non modó non conuchitur, fed ne uthum qudem unquam audiui, qui ipfum uiderit, wel nonerit. Caterum Her=

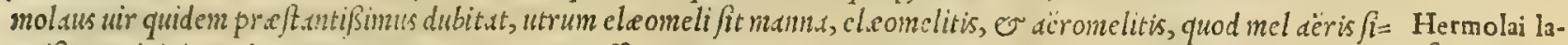
gnificat, uicinitate deccptus. Qun.propter non poffum non admir ari, doctißimum urrum bac in re dubitalfe, cirm tum pfus.

- D Diofcorides, tum ctiun Plinius, quitus cum longam contraxer st confuetudincm, communi fentcntia fcribant, elco= melioleun effe i quodam arboris cuudec manxus in syri. Palmyris, non mel déreum, neque rorem, qui ab ethere cadat. Eooj; mugis, cim addiderit Diofcorides, non nodó eleomeli per fe ex arbore muare, fed o factitiun ba= beri cufis, expreßisf; arboris furculis.

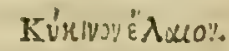
CICINVII OLEVM.
CAP. XXXIII.

CICINvM oleum hoc modo temperatur. Maturi ricini, qua uoles quantitate, torrido fole flaccefcunt, \& aliorum morecratibus inftrati tantifper infolantur, dum ueftiens cortex fractus decidat. Caro colligitur, \& coniça in pilam diligenter tunditur : poftea in Icbetem ftanno illitum, qui aquá habeat, demittitur, fubiectoq́; igni feruefcunt : \& ubi infitum prorfus humorem reddiderunt, fublato

so ab igni uafe, innatans oleum concha tollitur, \& reconditur. Sed in Aegypto, ubi largior increbuit ufus, longè fecus fieri folet. Nam repurgatos ricinus molæx mandant, \& accuratè mollitos per fportulă torculo exprimunt. Tum quidem ematurucrunt ricini, cùm continentibus orbiculis exuuntur. Cicinum oleum ad p foras; \& ulcera capitis manantia ualet : prodeft fedis inflammationibus, uuluis conuertis, atque præclufis : item indecoris cicatricibus, \& aurium doloribus : cmplaftra efficaciora reddit additum : potu aquam altio extrahit: uentris animalia pellit.

Ric I I NvM, fiuc Cicinum oleum, Cherue oleum officinis dicitur; quanuis rarioris fit ufus. Nanque femen plante, quam Diof corides rivinum appcllat, Arabume effe cbcruan nemo eft, qui igncret : quod ctiam Serapio pen= tadactylum uocat, ut diffufius fuo laco libro quasto cxplic abitur. Caterinn vicinus aninalculum eft fredum, liuidum,

30 O fanguine plenum, quod Itulis zeccs Hocatur, Juibus, canibus, capellis, o id genus animalibus infeftißimum. Cui

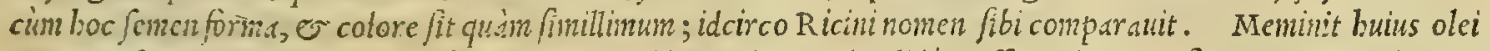
etiam Mefues, qui preter uires ei à Diofcoride redditas, addidit, id ualidé crafjar coërcere inflationes. Proinde uen= triculi, laterum, colig;; doloribus prodeffe illitum, potum, er infufum.

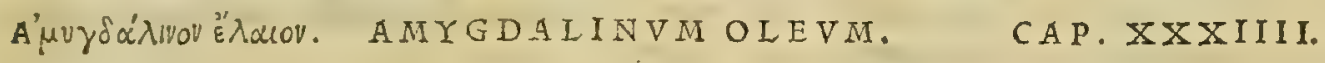

AMYGDALINVM oleum, quod aliqui metopium uocant, hoc fit modo. Semodius ex amaris nucibus repurgatis, ficcatisque, in pila ligneo piftillo leniter tunditur in offas, aq̨ux, quæ ferbuerit,fextarius adijcitur, ơ ubi dimidia hora hum orem hauferit, uehementius quàm antea tunditur : mox tabcllis promitur, $k$ quod digitis hæeft, concha excipitur. Prefsis nucibus rurfum hemina aquæ infper gitur, 3 poftquàm ebiberint, idem opus profequendum. fingulas heminas reddunt finguli modij. Contra uuluarum dolores, ftrangulatus, conuerfiones, \& corundem locorum inflammationes efficax eft : uitijs renum, calculofis, difficili urinx, fufpiriofis, lienofisq́ue proficit : dolores capitis, grauitatem auditus, fonos incertos, tinnitusq́ue difcutit . maculas, \& uitia cutis tollit è facie : \& eam erugat cum melle, radice lilij, \& Cypria cera, aut rofacco cerato : $\&$ oculorum hebetudines emendat. ulcera capitis manantia, \& furfures cum uino abftergit.

Cv'M amarum omnino dulcifit temperandum, delinquere fané exiftimarem, fi oleuni ex dulcibus anygdal is ex= preffun (cifiz allud Diofcorides filentio inuoluerit)ex amaris conféto non adijcerem, retumóg; conficiendi modum non explicarem : profertim cim nofir xatatis medicis maxino fit u.

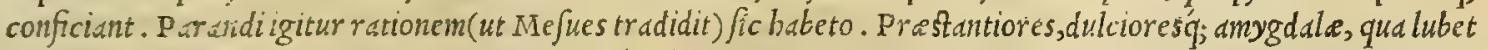
quätitate, ab uirifg; corticiEus repurgate, optimé in lapideo mortario tunduntur, et in locó calido reponuntur, quinq; borarum patio . dein parun tterum coniunduntuh mox prelo tandiu premuntur, quou fque omne, quod continent, effluat oleum. Elicitur etiam boc modo. Collocantur delibrate, conturég; amygdale in uitreo, uel ftameo uafe,

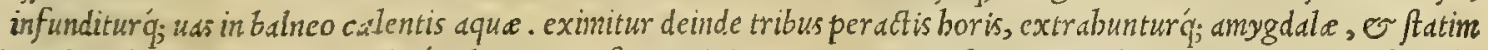
prelo calentes fubiiciuntur : itsq́; oleun copiofius excipitur. Trita rurfum amygdale, or repurgate in facculis panno duplicato iniolutis fub aren a, cineréue calido reconduntur, or poftqudin efferbuerint, prelo oleum elicitur.

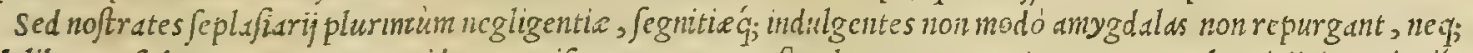

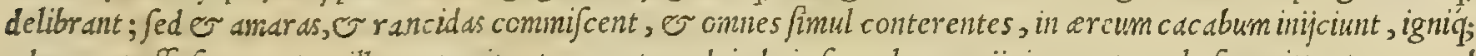
admouent affuso aque tantillo, ne penitus torreantur : deinde in facculun conijcimut, et preslo funmittunt, o quod inde fluit oleu excipunt. quod ples ung; exuftionis nidorem tantun obolet, ut baurienibus illico euomendi pariat nau

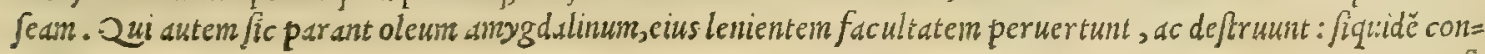

Ricini olei cö fideratio.

Ricinus unde dičtus.

Amygdalini parandi ratio. Myropolarü ignauia, \& laplus. 
iufis amygdalis non delibratis, oleum inde confectum corticum uires afferuat. Proinde or conftipat, ơ exafperat, er fabritiem inducit . id quod etiam adauget ignis uiolentia, dum in lebetibus amygdale torrentur. Hoc itaq; diligenter animaducrtens optimus Mefues Amygdalini faciundi rationem prodidit, ut uidelicet, cium purgat $x$, contufá $;$; cfent amygdale, calore quodam fuau, ac lcnto leniter calefierent, fic ut diximus, non autem carbonibus ardentibus, quem=

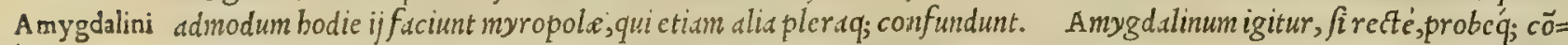
uires. $\quad$ ficiatur,mirifice lenit. quare potum ad libre dimidium aluum leniter deijcit: appere arterie, pulmonis, ac pectoris fcabritias tollit: duritias omncs emollit : or compaginum, or membrorum omnium ficcitates bumedat . quocirca be= Eticis plurimum conducit. Contra uuluarum dolores illitum or potum facilé praft at: ficuti uefica cruciatibus eft ef $=$ ficax, $\sqrt{i}$ argente a fifula coniectum impulforio inftruncento inijciatur. Quod autem ex amaris amygdalis exprimitur, dulci in omn ibus efficacius babetur. Idcirco in prouocandis lapillis, conciliandis $q$; uifcerum cruciatibus à flatu craf= fiore genitis, dulci longe' preftantius reperitur. Nimirum $\sigma$ obftructiones aperit, $\sigma$ interaneorum tineas enecat.

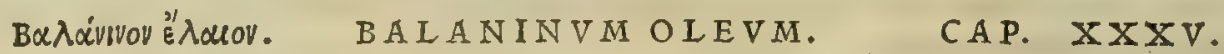

S I M I I I modo fit Balaninum oleum. Quod repurgat maculas, lentigines, varos, \& cicatrices nigras : aluum foluit, ftomacho aduerfatur : contra aurium dolorem, fonos, \& tinnitus auxilio eft, cur anferino adipe inftillatum. Similis fefaminum exfefamo conficiendi ratio. Fitetiam è nuce iuglande oleum, quod caryinum uocant. Eandem uim habet, quam balaninum.

Balanini con- OL E V unguentaric glandis, quod Balaninum uocant, àpharmacopolis, or unguentarijs oleum de Ben ap= fideratio. pellatur: quoniam myrobalanum, quod Latini unguentariam nuccm dicunt, ex qua hoc conficitur oleum, Mauritani Balanini facul Ben appellant, ut latius libro quarto differemus. Confimilimodo id Mefues fieri tradit. Et (ut idem etiam eft auctor) tates. abftergit, mundat, o obftructiones aperit. Illitum frumas diffoluit, duros'́, tumores. Frigidis tum iocineris, tum lienis affectibus opem mirificé praftat : facit or ad frigidas neruorum conuulfiones, er compaginum cruciatus. Sed illud fibi peculiariter adfciuit, quód ctiam fi diu ueterafcat, baud quaquam rancidum euadit. Ideóq; unguentarijs ex= petitur ad Juauißima odoramenta excipienda; prefertim cim mofcho, er ambaro clirothecas illinunt. quo fit, ut nul= lo temporis tracturancorem unquam refipiant, ut facilé eueniret, fi alio quóuis oleo eo in opere uterentur. Quam= obrem mirarinon licet, fi ueteres fructum, à quo elicitur boc oleum, glandem unguentariam nominaterint. Se $\int_{a}=$ Sefaminú, \& minum ueró ( ut Mefues inquit) amygdalini modo exprimitur. Quippe fe fami repurgatum femen primó cötunditur, eius uires. deinde codem artificio calefactum prelo fupponitur, tandiúq; premitur, quoufq; olcum reddat. Id (ut idem teftatur) pingue miniftrat alimentum: femen adauget, apperitates quafcunq, lenit, fed precipué gule : uocem expedit, er du= ra apoftemata mollit. Adijcitur sefaminum plerisq; unguentorum compofitionibus, quorum in officinis eft ufus. Ve= Oleum è nuci rüm quod é iuglandibus nucibus clicitur, nullius in medicina $u f u s$ effe reperio, et $f i$ lucernis, e lampadibus, qui par $f=$ bus iuglandi- monix ftudent, id maximopere expetant. quippe ignis funiculo non tam citó confumitur, quàm id, quod ex oliuis pa=
bus. ratur. Prefertur etiam pictoribus eo, quod é lini femine exprimitur. fiquidem hoc ceruffe admiftum tractu tempos ris colorem immutat, illud ueró incorruptum perpetuó afferuat.

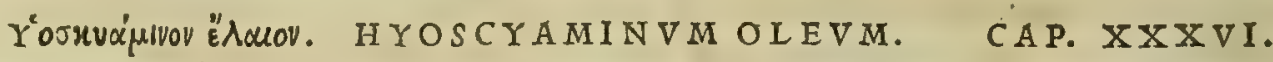

H y o S C Y A M I N V M fic fit. Semen candidum, recens, ac ficcum tunditur, \& calida afpergitur aqua, ut in amygdalino diximus : dumq́ue infolatur, ficcatæ, quæ fub manu funt, partes cum reliqua maffa permifceantur : hoc autem fieri oportet, dum nigrefcat, \& grauiter oleat: mox preffum, atque excolatum reconditur. Ad aurium dolores efficax eft: pefsis mifcetur, ad emolliendum utile.

Fit \& è grano gnidio purgato, \& tufo. Vis ei aluum foluere potu. Non fecus cnicinum oleum temperatur. cui facultas eadem eft, quæ facto è gnidio grano, verùm inualidior. Rhaphaninum è rhaphani femine fieri folet, caterorum more. Phthiriafes mala ualetudinc contractas tollit: fcabritias cutis in facie emendat. Ad obfonia utuntur Aegyptij. Melanthirum idem, quod rhaphaninum poteft, eodemq́ue modo paratur. Tritum finapis femen, \& calida aqua madefactum, adiecto poftea oleo exprimitur. Id ad diuturnos dolores efficax eft : transfert humores, qui in aliqua parte concreuerunt.

Hyofcyami - T A M E T I perpaucireperiantur medici, qui Hyofcyaminum oleum nouerint, ne dum in ufum receperint un= 50 ni uires. quam; ego tamen idipfum pluries confeci. siquidem ad tollendos omne genus dolores, ubi catera prafidia non iuue= rint, efficacißinum eft medicamentum, prefertimq́; inflammationibus pudendorum utriusque fexis. Item acutißimis aurium doloribus medetur cum caftoreo, uel croco infillatum. Prohibet preterea gonorrheam, renibus er teftibus illitum. Menfium exuberantiam cohibet, or albicantia uteri profluuia, tum pubi $\sigma^{\circ}$ lumbis perunctum, tum peßis in= fufum. Mammis à partu inflammatis utiliter illinitur. Dentium dolores wirifice mulcet, fi tepedum in ore contineas= tur. Pilorum exortum admodum retardat, alijs quibusdam additis, ita ut euulfi pili integro anno non renafcantur, $f$

Hyofcyam. codem dcpilata loca fapius perungantur. At ip $\int e$ in eo faciundo Diofcoridem minimé fecutus fum, fed aliam parandi parandi ratio. rationem adinueni, qua bec eft. Sumito noum, ficcum q́; byof cydmi femen, tundito deinde, ponitóg; in ftanneo, uel ui treo ua $\mathcal{e}_{\mathrm{e}}$ ardenti aqua, que é uino fit, parumper prius affufum. His factis ponito uds in calentis aque balneo die, ac Gnidinum. nocte, demum adhuc feruens facculis imponito, ơ prelo fubijcito, fić; oleum babeto. Quod autem é grano Gni= dio, quod ruftici Ananienfes montanum piper appellant, paratur, receßit boc auo à medicorü uJu,eo quod in deijcien= da aluo 


\section{In Lib. primum Diofcoridis.}

da alwo violentißintum fit medicamentum, rufticis tamen aptißimum, cim fapius, ne medicos confulant, coccum Gni= dium deuorent: quo ctian fepius morte occumbunt. Porró Cnicinum (ut Mefues inquit) potum aqua intercute la= borantibus, uifcerum ob/tructionibus, uentriculi, or coli cruciatibus à flatwofitate genitis, effic ax cft. sufpiriofis mi= rificé prodeft, er nocen clarificat. Epotuin pituitan tum nomitionibus clicit, tum per inferna ducit. R haphaninum pretered, Or Mclutbinum abolcuerunt, ficuti tiam sinapinum : ctfi ubi ad fummum excalfaccre opus fucrit, maxi= main opem praftare ualeant. Sinapinun ucró non nifi collacrynantibus oculis exprimi potcft: tanta cnisn cft uapo= ris acrinonia, ut concepto utpore, illico prode ant lacryme. Mifcetur quandoq; cum eo, quod é piftaceis nucibus cli= citur : perungunturó; co genitalia in frigidis, ut felicius coếant, addito la fere, or mofcho.

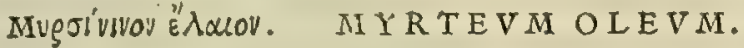 \\ CAP. XXXVII}

M Y R I.E I faciundi ratio hxc eft. E'myrto nigra fylueftri, aut fatiua, foliorum mollifsima quæquetufa premuntur: fucco parcs omphacini olei portiones adijciuntur, fubicctisque carbonibus inferuefcunt, donec concoquantur : innatans oleum deraditur. Sed longè facilior hæc compoftio. Tenera folia contufa coquuntur in oleo \& aqua, \& quod innatat, eximitur. Priuatim alij deieAta in oleum folia in fole maccrant: alij prius oleum infpiffant malicorio, cupreffo, cypero, \& iunco odorato. Efficacius eft amarum guftu, \& oleofum, uiride, translucens, \& olens myrtum. Aftringit, \& indurat: ideo nedicamentis mifcetur, quæ cicatricem obducunt: prodeft ulceribus in capite manantibus, ambuftis igni, \& papularum cruptionibus. Facit ad attrita, \& furfures, fedis rimas, condylomats, articulos laxatos; corporis fudores compcfit: \& ad omnia ualet, qux aftrictionem, inzo spiflationcmqque defiderant.

M Y R T E V M myropole feréonnes non quidem ex tenellis myrtifrondibus, Diofcoridis more, conficiunt, fed efructibus tantum, nulla feruata parandi ratione. Quandoquidem myrti baccas contundentes, oleo, nigroq́; uino im= mifcent, $\odot$ in eneum cacabum transferm, fubduntó; (ut citius opus expediant) ignitos carbones, ibiq; tandiu inferue fere finunt, donec uinum totum ab fumatur : mox ab igne tollunt, percolant, or afferuant. Neq; animaducrtunt conficiendi regulam à Me fue explicatam. Ifguidem is in calentis aqua balneo, non quidem uiolento carbonum igne Myr=

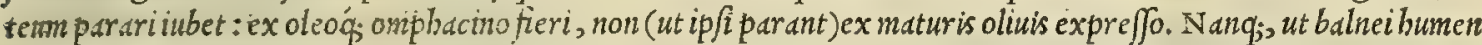
ti, ac leni calore olci compofitio mirlfice digeritur, ac eius omnes conferuantur partes: fic contrà uiolento igne fub= dito peruertitur, of deftruitur tota rei compofitio. Sed quoniam reipublic.e beneficio ( ut etiam ab ip fo exordio pol=

30 licitus fum ) decreui non preternittere quicquam, quó errores, qui indies contingunt, é médio tollantur, dico, oleum omne, quod officine ad medic amentd ufurpant illud excipio, quod ab arborum refinis, ftirpiumí; aliarum gummi, ui= treis organis per fublimationem, ut chymifte wocant, elicitur) uafe uitreo, uel faltem ftanneo in balneo calentis aquae fieri debere : $\sigma$ inibi primum impofitis imponendis tribus diebus macerari : poft tertium iero diem expreßis cunctis prius impofitis, er recentibus infufis pari temporis $\beta$ atio, eodem in balneo, eadem macerari. Itaq; tandiu opus profe quendum, donec fibi oleun amplißinas exceptor um medicaminum comparatuerit uires. Verum ingens hominun lucri auiditas, duriq; ingluuies, ut adinodum fuperlucrentur, arcam q; auro ad fummum ufq; impleant, non patitur myro pol.1s neceffarium tempus impendere ad medic amenta exacté paranda: cos, inquam, qui continué magis crumenis in tendunt, ơ inbiant, quim ut uita agrotantium fatagant. Probitanen, er diligentes bec mea uerba boni confulant, bis ieró mali errores emendent $\int u o s$. Idcirco Myrteum oleum, quod myrti preftantiam ad plenum referat, boc mo=

40 do temperatur. Sumito frutumm myrti libram, foliorum eius recentium uncias decem, uini nigri adftringentis libras dust, olei omphacini libras quinque : deinde contufis baccis, ac folijs omnia oleo excipito, or uafe uitreo, uel ftanneo reponito, tettoó; uafis ore in balneo calcntis aque inmergito, or poft tres dies extrabito, ac percoldto. Rurfis af= fumptis recenter baccis, folijs, er uino, ut antea oleo exceptis, in eodem balneo omnia recondito ad tertium ufq; dië. At poftremó uxis ore detecto, tandiu id apertum finito, donec balnei ferware uinum totum exiliat, ov oleum tantum remane at. Nec audiendi funt ij, qui Dio fcoridis teftimonio, eneo cacabo ( ut fuprà dictum eft) fubftratis carbonibus Myrtinum conficiunt. Quippe Diofcoridis tempore ars medica non adeó exculta erat, quin nec feplafíarid, ut noftra bac etate effe uifitur. Quamobrem putandum, quod fi buius balnei artificium Diofcoridi innotuifet, ip fum haudqua: quam filentio preterijfet, ueluti nec illud Mefues, nec alij complures preterierunt, qui fummo ftudio, er. diligentia medicasin facultatem excoluerunt, $v$ in ordinem redegerunt.

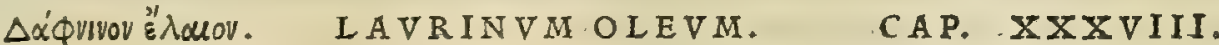

L A V R I N V M fithocmodo. Lauribaccæ cum maturæ funt, in aqua coquuntur:fiquidem ex. obducto cortice quandam pinguitudinem reddunt, quæ manibus fubacta, concha excipitur. Alij omphacinum prius oleum cypero, iunco odorato, \& calamo infpiffant, deinde tenera lauri folia concoquunt. alij etiam baccas, donec oleum odorem contraxerit . alij ftyracem, \& myrtum addunt. Optima laurus ad id latifolia, \& montana. Oleum laurinum utilius, quò recentius, quoque uiridius colore, amarifsimum, \& acre. Vis ei excalfactoria, emolliens : venarum f́piracula aperit, lafsitudines difcutit: omnibus neruorum uitijs, algoribus, deftillationibus, aurium doloribus, malis renum frigore contractis, illitum non aliudiuuantius : attamen potum naufeam parit. 


\section{And.Matthioli Comm.}

Laurini con- LA V R I I conficiendi rationem aliter à Mefue inftitutam legimus, fed tamen abliac parum recedentem. lideratio. Ideóq; quód ià psurum, wel nibil referat, rem ip fam filentio pretcreundam duximus: pr.e fertinq́; quód non me latct, I aurinum, cuius cf u us in officinis, à feplafiarijs nequaquam fieri, fed ab alijs confectum emi, qui lecta magna lauri Laurini uires baccarun quantitate ipjum eliciende artem excrcent. Mefues preter facultates ì Diofcoride traditas, id fummé lau= ex Mefue. dauit $\sigma$ dd iocineris dolores, or ad bcmicranian, qux frigidis contrabitur fuccis. Qun $\sigma^{\circ}$ ad uentriculi dolores, $c 0=$ li, uulue, or lienis effic ax elfe tradidit.

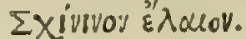 \\ LENTISCINVM OLEVM. \\ CAP. XXXIX.}

S I M I L I S Lentifcini ratio. Nam è maturo fruftu temperatur, factis prius fpiffamentis, ut in Lurino diximus. Hoc fabiem iumentorum, canumq́ue fanat: utilifsimum pefsis, acopis, \& leprarum medicamentis: fudores cohibet. Nec fecus Terebinthinum fieri folet: quod trefrigerat, \& aftringit.

Lentifcini pa sandi ratio, \& uires.

L E DN T I S C I N V M pluribus in locis Hetruria conficitur, fed prefertim in agronoftro senenfi; Itua, er Gilio Tyrrheni infulis, non longé à contincntinoftra diftantibus. Fit autem ab incolis boc modo. Racemofas lenti= fcibaccas affumunt, $\circlearrowleft$ a putaminibus cuntis expurgant, permittunt '́; aliquot diebus fimul flaccefcere: deinde ma= gnum in abenum collocant, affu a aq:a: or igni tandiu feruent, donec bacce debifcant: demum eds extrabunt, er faccis includunt, preló;; fubijciunt, expreffun'́; aferuant oleum. Quod er quibufdam Adriatici infulis hac fimili: ter rutione conficiaudio, abfque alterius cuiusuis olciadniniculo: fiquidem fructus is per fe olei fatis emittit. Incole (ut experincnto comprobatum affirmant) dd acuendam oculorum aciem, caliginesóg; delendas, illud cibis commi=

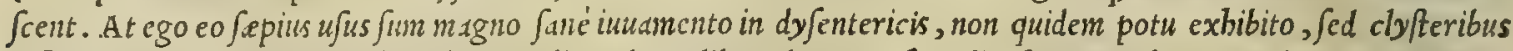
infufo. Lentif cinum fummis laudibus extulit Galenus lib. $v$. de compof. medic. Secundum locos, ad gingiuarum, er lin Terebinthini gux inflammationes, fios eo colluatur. Quod autem fit é fructibus terebinthi, quos Mauritani grand uirida nun= confideratio, cupant, non fit in Italia, neq; ad nos (quod equidem fciam) diunde conuebitur : proinde non uenit in ufum. Hoc tamen \& uires. (ut Mefues inquit) uulner a confolidat. Medetur item conuulfis, opiflsotonicis, neruorumiq; duritijs, er creberrimé cataplafmatis admifcetur:

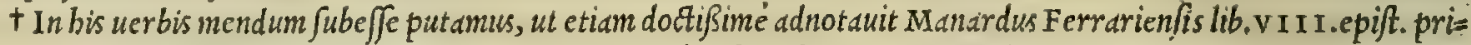
ma. Ali.is fiquidem fibi ipfirepugnafet Diofcorides, cum fcripferit in Terebinthimentione cius fructus excalface= re; hic ueró dicatur, oleo ex cifdem parato ine/fe refrigerandifacultatem. Huic deprauate lectioni illud quoq; re= fragatur, quòd fint nobis Graci Diofcoridis codices, in quibus uerbailla de Terebinthini olei facultatibus non legun= tur, $\int e d$ de eius tantum conficiendi ratione mentio babetur.

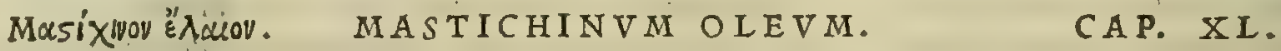

M A S T I C H I N v M è trita fit maftiche. Quod contra omnia uuluæ mala efficax eft: mediocriter calfacit, aftringit, \& emollit. Aduerfus prominentes ftomachi duritias, coliacorum, dyfentericorumq́ue cruciatus utile : faciem emaculat, \& colorem nitidum facit, optimum in Chio infula componitur.

Mas T I CH I I parandi rationem, fané quim paucis Diofcorides perftrinxit. quippe é trita tantum Maftiche Seplaliarionú fieritradidit, nulla alia explicata confictendiratione. Seplafiarij autem nonnulli prorfius obliti, frip/iffe Me fuem 40 lapfus. in balneo calentis aqua Maftichinum confici debere, communi oleo, albo uino permifto: maftichen admifcent, 0 r areo uafe carbonum igni admouent, ibiq,; tanto tempore efferue fcere finunt, quoad uimum prorfus exiliat, ac inde ufui afo feruant. At ipfe uitreis organis é purißimo tantum maftiche illud fepius confeci.

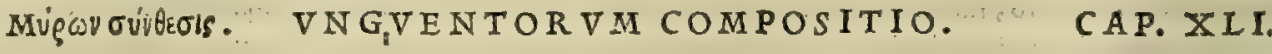

DE RATIONE vnguentorum confequéter tractandum exiftimauimus: quandoquidem ea in nónullis corporum uitijs,aut medicamentis mifta,aut corporis perfu氏a, aut naribus obiecta, plurimùm profunt . in quorum probationibus confulere nares oportet, an ea oleant, ex quibus temperantur. Optimum huiufcemodi iudicium. quod tamen in quibufdam planè obferuari non poteft, propter ea, qua admifcentur, odore cxteris præualentia : ut in amaracino, \& crocino, telino, \& plerifq; aljis, so quæ crebra circa hæc meditatione experiri conuenict.

$$
\text { pósivov. ROSACEVM. }
$$

\section{CAP. XLII.}

R o s A C E V M ficfit, Iunci odorati quinque libras \& beffem tundito, \& fubactas aqua in viginti olei libris, \& quincunce fubinde mouendo, coquito: dumq́ue percolaueris, in olei libras uiginti, \& quincuncem, adijcito rofas non madefactas numero mille, \& manibus melle perunctis identidem moueto, interdiu premens, finito nofte tota macerari, poftea exprimito: \& ubi recrementum peffum ierit, mutato uafe, in craterem melle illitum recondito. Cæterùm rofas, qux antea preffr fuerunt, in labellum demittito, \& affufis octo libris \& quadrante fpiffati olei, iterum premito, eritque fecundarium oleum. Quòd fi tertias ufque, quartásue perfufiones infundens exprimere uoles, fe- 


\section{In Lib.primum Diofcoridis.}

R O S A E V M

10
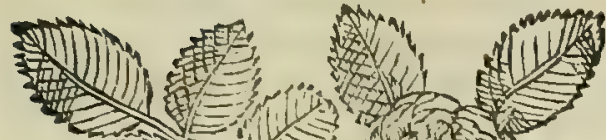

26
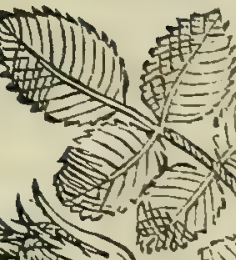
fecundam infulionem inftituere libet, in expreffum oleum, numero pari recentes rofas, nullo humore imbutas inijcito: manibus melle premadefactis agitans premito : \& iterum tertiò, aut quartò fimili modo exprimẹ̆s facito, totiesq́ue recentes rofas detraetis vnguibus immit tito : fiet enim ita oleum multò validius : nam fepties oleum rofarum infufionem admittit, nec amplius. Pralum mélle perungatur, oleum a fucco diligenter fecerni oportet: nam fi minimum quid relinquatur,vnguentum corrumpet, Alij autem detractis vnguibus, rofas tantùm oleo macerant in fole hoc modo. Rof x, qux felibrä pondere $æ q u a n t$, in fextario olei diebus octo madefcunt, \& ufque tertiam perfufionem quadraginta diebus infolantur, \& fic oleum reconditur. Alij calamo, aut afpalatho prius olei fpiffamenta faciunt. Alij coloris caufa anchufam admifcent, \& falem, quò minus oleat. Vimaftringendi, \& refrigerandi obtinet : fomentis, \& cataplafmatibus vtile. Potum foluit aluum: ftomachi ardorem reftinguit: vlcera caua replet, \& mulcet, quæ cacoëthe uo cantur : vlceribus in capire manantibus, atq; feruidis eru ptionibus illinitur : caput dolens co perfunditur: dentes inter initia doloris collui prodeft: ad genarum duritias illitum efficax cft : ad lacefsita interanea, \& concitatas vuluas utilifsimè fubijcitur.

H o c fub olei nomine comprebendit Diofcorides oleum of Vnguétorum mne, quod per fe tantum, nulld alterius olci admiftione, aut ex ar: confider.

borum fructibus, aut bevbarum diuer forum generum feminibus; aut ftirpium refinis elictitur: sed unghenti appetlatione intelligit oleum omne genus, cui or odoramenta, or alia fimplicia medicamenta-admifcentur, ut in pra' fentia de Rofaceo agés, $\checkmark$ deinde in fequentibus maniffété oftendit. Quo fit, ut apud Diofcoridem oleumuocetur, quod fimpliciter expref= Jum fit : unguentum ueró oleun quodlibet, cuius componendi ratio pluribus conftet medicamentis. Quapropter $\mathrm{G} a$ Lenus lib. I. finepl.medicamentorum de olco agens, fic inquit. Ex dictis cogñof fere iam liceat, o de alïs oleigene= ribus, qux aquinocé ipfis dicuntur unguentis, puta ro $\int a c e 0$, melino, tiliaceo, , 0 quacunque id genus floribus, frum Atibus, germinibus, folijs in oleo maceratis confictuntur. Horum quodque ubi und cum aromatibus praparantur, un= guentum efficitur. Ceterim oleum rofaceum, quod boc teinfore officine cöpletum appellant, ḋ Diofcoridis rofaceo longé difidet, quod ctiam co preftantius exiftimandum eft, fummum ob artificium, quod in ipfa parandi ratione di= ligentiores adhibent myropole. Quod corum tamen perpauci (ita ut ingenium eft mul orum à labore procliue ad ignauiam ) illud fecundum Me fuem temperant; tamet fi plures ab eo optimi rofacei conficiendi modum fint confecuti.

Fit etiaimnum rofaceum rofis non affatim debifcentibus in omphacinum" demißis, modo calentis balnei uiribus (ut in quibufdam alijs superius adnotauimus ) modó infolatu perquàm longo. Sunt $\mathfrak{o}$ qui, ut magis uiribus preftet, oleum prius ex aqua rofacea lauent, deinde plufculo temporis patio ter, aut quater rofas infundant, qua baud penitus fati= fcant: demum expreßione peracta, immaturarum rofarum fuccum adijciunt, ac inde din infolant. Poftremó ole um d fucco fecernunt, 0 diligenter afferuant. Hoc inflammationes dif cutit, roborat, adftringit, fluxiones'; cohibet, ne ad gras defluant partes. Potum torminibus dy fentericis medetur. Capitis uulneribus aptifimum eft, quód roboret, fic= cet, refoluat, inflammationesq́; non modo probibeat, fed etiam extinguat. Quocirca bac in re maximé probatur $\mathrm{G}_{d=}=$ leno lib. I I.de comp.medic. Secundum locos, ubi de dolore capitis fcribit, qui uel ex unlnere, uel cafu excitatur. Cuius etiam meminit lib. $\dot{x}$. fimp. medic. de fanguine agens.

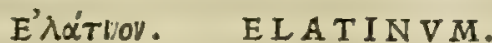

\section{CAP.XIII.}

F R A C I A elate, tura, \& farificata, in labellum deijcitur : omphacinum oleum triduo infunditur, mox per fportulam exprimitur : verùm pares efle debent utriufque portiones . dein mundo uafe ad ufus reconditur. Viribus rofaceo proportione refpondet: aluum tamen non mollit.

E I A I I N v M, quod ex Dactylorum inuolucris antiquitus parabatur, bac noftra tempeftate abfolcuit.

$$
\text { MÁA Lwov. MELINVM. CAP.XIIII. }
$$

M E I I N V M hoc modo temperatur. Olei congius decem aquæe fextarijs admifcetur. Adijcitur elatx palmarum fractx quadrans, \& iunci odorati uncia: quæ die uno macerata coquuntur, 
mox in vas oris patuli oleum excolatur, \& indita arundinacea crate, aut rara tegcte, cotonea mala fuperponuntur, \& veftimentis operta tantiffer inibi refident, dum malorum vires ad fe oleum alliciat. Aliqus cotonea decem dierum fpatio uperimentis inuoluunt, ve concineacur odoris fuauitas, nec euanefcat: poftea biduo macerata oleo cxpramuncur, oleumque reconditur. Id vim refrigeratoriam, \& aftringentem habet. Contra fcabiola vlcera, \& qua fupunt, ac furfures, perniunculosq́ue effe ctum præbet : exulceratis vuluis infunditur: citatam vrinam fiftit infufum : fudores cohibct: contra cantharidas, bupreftim, pinorum erucas, bibitur . Laudatur maximè quod cotonea mâla olet.

Melini confideratio.

M E I I N M oleumad hodiernum officinarum ufum hoc modo conficitur. Cotonea nondum plané matura in taleolis diffect a omphacino olco macerantur, or uino ex eis expreffo fuperaddito infolantur. Deinde in calentis aque balneo iterum, atque iterum perfunduntur, or extrabuntur, ut in aligs fuperius of cndimus .

\section{Sivx́villol. OEN ANTHINVM.}

CAP. XIV.

OE N A T H E è labruf́ca, oprimè olens poftquàm emarcuit, deiecta in omphacinum oleum mouetur, voluiturq́ue: \& cum biduo nanferit, exprimitur, \& reconditur. Aftringit, proximum rofaceo effectum præbens : fed aluum non refoluit aut mollit. Probatifsimum eft, quod odore œnan then refort.

OE N A N T H I N M nullam à nobisrequirit explanationem: quoniam à Diofcoride tam aperté proditur cius parandi ratio; ut non fit opus, illud pluribus explicare.

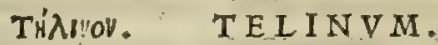

CAP. XLVI。

F OE N I græci librx quinque, calamilibra una, cyperi libræ duæ, olei libris nouem feptenis diebus inacerantur, quotidie ter móuentur, poftea premunrur, \& reponuntur. Aliqui pro calamo cardamomum fubftitumnt, \& cyperi toco xylobalfamum macerant. Alijoleo antea his odoribus fpiffato fonum gracum macerantes exprimunt. Hoc telinum abfeffus emollit, \& concoquit: omnibus vuluarum duritijs magnopere conuenit, freminis diflicilè parientibus fubijcitur, vbi præexcretis humoribus loci ficcitatem contraxerunt: fedis inflammationes lenit, tenefmo flibditum prodeft: vlcera capitis manantia, furfuresque expurgat:ambuftis, \& pernionibus addita cera proficit: vitia cutis in facic emendat: pigmentis ad conciliandum faciei nitorem inferitur. Eligioportet recens, quod non vehementer foeni græci odorem pra fe ferat; \& manus abttergat, fapore ex dulci in amarú inclinato : tale enim optimumiudicatur.

O F F I.C I.N A R V M Luminaria ex Rafis auctoritate aliam, quanuis exoletam, Telini componendirationem tradunt, in quo calamo odorato, o cypero elaterij beffem adijciunt.

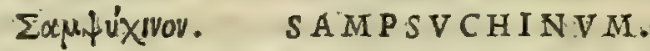

\section{CAP. XLVII.}

S E R P Y L L I, cafsiz, abrotoni, florum fifymbrij; frondium myrti, fampfuchi fungulæ portiories, quadam pro uiribus ipforum coniectatione, unà tunduntur, atque is omphacini olei modus adij citur, qui madencium uires non euincat : hac poft quatriduum e' primuntur. denuo noua alia fimili menfura, \& xquali tempore macerata premuntur : ita enim ualidius reddi folet . Eligi oportet fampfuchum colore exatro uiridi, plurimùm redolens, mediocriter acre. Vim habet acrem, calfactoriam, extenuantcm : aduerfus vuluæ preclufiones, conuerfionesque efficax eft : menfes, \& fecundas, \& partus extrahit : vulux ftrangulatus recreat : lumborum, inguinumá; dolores lenit: fed cum melle uti eo præftat; quandoquidem vehementi aftrictione locos indurat . Lafsitudines illitum difcutit: in opifthotonicorum, vulforumq́ue cataplafmata utilifsimè additur .

Sampluchini confid.

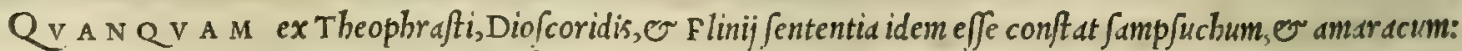

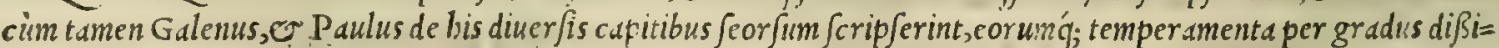
dere tradiderint; noin ab re credidere inonnulli aliud effe famp uchum, aliud ucró amaracum. Quorum opinionem au xit etiam Diofcorides, quód in bis unguentorum compofitionibus Sampfuchinum, $\mathcal{\sigma}$ Amaracinum diuerfis capitibus digefferit. Quod facilé plerof $q$; ad credendum induxit, bas firpes tum facie, tum uiribus differre, hac ratione freti, quod $/ i$ alterum $a b$ altero non diftaret, omnino prater rationem de his uarijs in locis fcripfiffet Diofcorides, alter $\ddot{u}$ un guentum Amaracinum, alterum ueró Sampfucbinum appellans. Porró ut buiufmodicontrouerfia tcllatur, fcien=

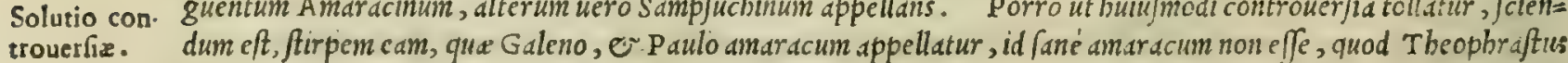

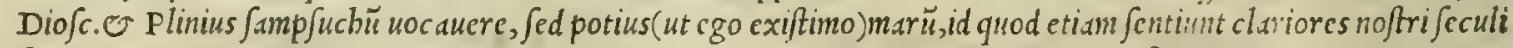
fimplicum indagatores. Nanq; marinec Galenus, nec item $\mathrm{P}$ aulus quicquam prorfus in fimpliciun m:dic.nnentorum libris meminerunt. Quare non decf fupicio, quin librariorum culpa, in Galeno Mari titulus in ant.r.tcim abierit: quandoquidem in cius tum gradibus, tum facultatibus aßignandis Galenus à Diofcoridis maro non longe recefferit: 


\section{In Lib. primum Diofcoridis.}

Sunt er qui uelint apud $\mathbf{P}$ atum, or Galcumn id amaracum dici,quod Diofcorides parthenium uocat: quippe or hoc quibufdum amar.cum uocatur. Cuius rei indicium effe exiftimant, quód tam Galems, quàn $\mathrm{P}$ aulus nullibi in finp. medic. libris aliquid de partherio pofteritatis memorix prodiderunt. quorum opinio non onnino reprobanda uidetur. Caterum licet Diofcorides Samb fuchini, o Amaracini dikerfis per fe capitibus meminerit; non obfat propterea, quó minus idem effe poßsint fang fucbum, ON Ams racum. Siquidem duabus de caufis ut alterun ab altero diftingue= ret, Dio corides facilc impulfus fuit . quarun altera eft, quod fi diligenter animaduertantur utrorunq; compofitio= nes, utiq; A moracinum tum multó odoratius, tum Sampfucbino pretio/ius iudicabitur. Ideó́; auctor, eo quód nole=

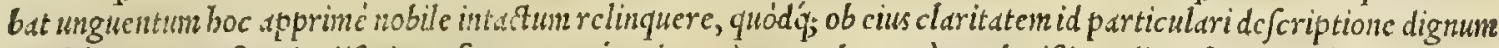
cenfebat, ut preftantix difcrimen faceret, ut $\dot{\sigma}_{\text {; }}$ etiam minus probatum à probatißino dignof ceretur, bomonymiam

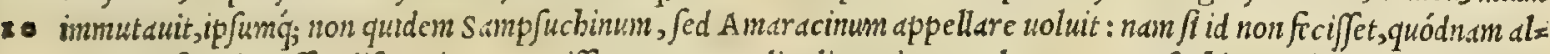
tero preft antius effet, difcerni non potuiffet. Huc accedit alia ratio, qua alterum Samp fuchinum, alterum uero Amas racinum Diofcorides appellancrit: quod (ut libro tertio proprio capite legitur) in Cyzıco fampfucum amaracum ap= pellabatur, unde boc unguentum infigne petitur. Et quoniam i cyzicenis claris illius compofitoribus ex eorum more Amar.cinum uocabatur, talcm nomenclaturam Diofcorides haud quaquam permutandam cenfuit. Quare ip fum in cadcm reliquit appellatione, quam fecum ex Cyzico tulerat.

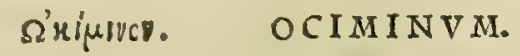

\section{CAP. XLVIII.}

Ocrminvm oleum fit ut cyprinum. Ocimi folia decerpta librarum undecim, \& befsis pondo, die nofuque viginti olei libris macerato, premito,colato: cùmq́ue exhauferis quallum, rurfus parế * olei modum fundito, \& exprimito. Vocatur autem id fecundarium : nam tertix perfufronis non eft capax. Deinde recens ocimum xquali pondere, ut in rofaceo diximus, rurfus maceratur, \& cùm tanto temporis fpatio madueric, exprimitur, \& oleum reconditur , quòd fi in animo fuerit ter, aut quater madefacere, femper ocimum recens addes. Poteft ex omphacino confici : fed illo modo melius . Idem guad fampluchinum potef, fed inefficacius :
A'Rpotónisov.
ABROTONINVM.
CAP. XIIX.

O I I cyprini odoribus imbuti libris nouem \& quincunce, foliorum abrotoni libras octo die noctuque madefactas, premito. Quòd fi in longum tempus oleum uelis afferuari, eiectis prioribus fo s. lijs, noua appones, \& macerata exprimes. Calfacit: ad vulux duritias, præclufionesq́ue efficax eft: mentruz, \& fecundas pellit.
A viótuov.
ANETHINVM.
CA P. I.

O I I libris ofto \& dodrante, florum anethi libras undecim \& beftem, maceratas in oleo die una, manibus premito, \& recondito. Quòd fi iterum perfundere uelis, recentes anethi flores confimiliter madefacito. Vuluarum duritias emollit, uenarum fpiracula laxat, contra horrores febrium circuitu redeuntes auxiliatur : calfacit enim, \& lassitudines difcutit : prodeft articulorum doloribus.

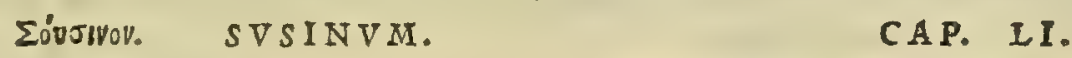

S v S I N v M, quod alij lilinum appellant, fic temperatur. Oleilibræ nouem cum quincunce, calami libræ quinque \& quadrans, myrrhæ uncix quinque, permifto odorifero uino decoquuntur, \& colato oleo, cardamomi tufi \& colefti aqua madefacti libræ tres \& femis macerantur, premunturq́ue, tres libræ cum femiffe fpiffatiolei affumuntur. mille lilia decerptis folijs, in latum, non tamen profundum, labellum demittuntur: iniectum oleum manibus melle perunctis agitatur: die noetuq́ue conquiefcunt, \& in pyxidem matutinis exprimuntur quod defluet oleum, protinus abaqua, qux fimul expreffa fuerat, colo incerni oportet : non enim, ut rofaceum moram tolerat; nam concalfactum feruet, \& computrefcit : quare fapius decapulandum. Vafa melle illinenda, tenuis fal infpargendus, \& fi qua fordes uafis faucibus hxfit, eximenda. Odoramentis iam exso prefsis ex quafillo in labellum transfufis, rurfum olei prius odoribus imbuendi, quod primum pondus æquet, \& cardamomi tufi drachmæ decem conijciuntur. Hæc manibus fcitè prefla, interięta breui mora exprimuntur : quod profluit, repurgatur. Tertiò eadem infunduntur, adiecto cardamomo, \& fale, \& manibus melle madefactis. Longè optimum erit, quod prius exprimitur : fecundum, quod fequitur : tertium locum fibi uendicat, quod nouifsimum prodit . Dento in mille lilia euulfis folijs expreffum primò oleum infunditur: tum eadem ratione profequendum, idemq́ue faciendum, ut prius : addito cardamomo, dein expreffo, fac eadem in fecundo, \& tertio, ut dictum eft : \& quò frequentius recentia lilia maceraueris, eò ualidius unguentum efficies. Deniquecum factum abunde uidebitur, fingulis compofitionibus mifcere conuenit myrrhæ quàm optimæ duas $\&$ feptuaginta drachmas, \& croci decem, cardamomi quinque \& feptuaginta . Croci uerò, \& cinnamomi pares portiones tunduntur, 8 cribratæ in lutram cum aqua demittuntur, expreffumq́ue primò vnguentum infunditur, \& paulò poft excipiuntur uafculis ficcis, myrrha, aut gummi antea per- 
fu fis, \&eroco, \& melle, \& aqua madefa $A$ is. Eadem fiunt in altera, aut tertia exprefsione. Aliqui fin:plex ex balanino, alióve oleo, \& lilijs componunt. Optimum effe conftat in Phænice, mox Aegypto factum. fed cum primis laudatur, quod lilia redolet. Excalfacit, emollit: uuluæ præclufiones, \& collectiones aperit : utilifsimum ad muliebria mala. ulcera in capite manantia, feruidas eruptiones, uaros, furfuresq́ue emendat: uibices, cicatricesq́ue celerrimè ad colorem reducit, ita ut fæpe fallant. In fumma extcnuat: potum bilem per aluum extrahit', urinam ciet : fed ftomacho alienum eft, \& naufeam parit.

Ho c, qrod ex liliijs temperatur : illud item, quod ex ocimo, abrotono, anetho ó; conficitur oleum, cim uniufcuiufs que parandiratio per fe clara fit, ideo nofiris explanationibus non indigent. Caterim Sufini compofitio milhi quidem 20 pluribus in locis librariorum potius, quàm auctoris incurea deprata uidetur.

Noguiorrioy. NARCISSINVM.

CAP. LII.

Narcissini fpiffamenta ita fiunt. Sex libræafpalathi cum fextante tunduntur : olei eloti libre feptuaginta cum uncijs quinque affumuntur. Afpalathus aqua madefactus in tertia olei parte coquitur: quo exempto, calamus quinque libris \& belle adijcitur, cum myrrhæ gleba contunditur, cribrataq́ue ac uino uetcri odorato immifta, decoquitur : fimulsc autem cum ijs efferbuerit, eximitur. refrigeratum oleum excolatur, cuius portio in labellum mittitur, flores narcifsi quàmplurimi conijciuntur, qui bidui (patio (ut in fufino dictum eft) permoti exprimuntur. Oleum fubinde decapulan 20 dum : fiquidem celerrimè putredinem fentit. Valct hoc ad emolliendas vulux duritias, preclufionesquue : fed capitis dolores facit:

NARC I S I N V M, quod ego fciam, non paratur noftratibus myropolis . quod mirum non ęt, cim id etiam Plinif etate pararidesijfet, ut ipfe libro X III. cap. primo memoria prodidit .
Kórivoy.
CROCINVM.
CAP. LIII.

Cv m Crocinum componere uoles, prius olei, ut in fufino diximus, fpiffamenta facies, eifdé ponderibus, \& menfuris : cuius olei libras tres \& femiffem, croci unciam unam affumes : identidem quoti die moueto, \& feřta die, quàm hoc afsiduo peregeris, oleum à croco colis incernito, eidem croco pa- $\$$ rem olei modum adijcito : moue triduo, dein contuf $x$ my rrh $x$, atque cribratæ drachmas quadraginta permifceto, \& in pila agitatum recondito . Aliqui oleo aromatibus ad cy prinum imbuto in crocini compofitione utuhtur. Optimum eft, quod abunde crocum fpirat, in medendi ufu expetitum. Proximum quod myrham refert. Calfacit, fom num allicit: quare perfepe phreniticis fubuenit perfufum,aut naribus admotum, aut illitum : pus mouet, ulcera purgat : contra nuluæ duritias; atque præclufiones, \& ulcera, qux cacoéthe uocantur, prodeft cum croco,cera, medulla, duplicato olei pondere : concoquit enim, emollit, humedtat, \& permulcet. ad oculorum glaucitates ex aqua illinitur. huic autem proportione refpondent butyrinum, onychinum, \& fyracinum : qux etfi nominibus diftant, uiribus, \& compofitione cognata funt .

$$
\text { Kúøg̨ivav. CYPRINVM. CA P. IIIII. }
$$

O I E I omphacini eloti pars una, aquæ cœleftis tantundem cum femiffe, cuius una parte oleum diluitur, altera adijciendis odoramentis admifcetur. Dein affumptis afpalathi libris quinque \& $\mathrm{fe}$ miffe, calamilibris fex \& femiffx, murrh $x$ libra una, cardamomi libris tribus \& dodrante, olci libris nouem $\&$ uncijs quinque, a fpalathus tufus, \& aqua affufus decoquitur in olco, donec conferuefcat: myrrha autem uino uetere odorifero fubacta, contufusq́ue fimul calamus, digeruntur in offulas, quæ exempto afpalatho immittuntur, \& ubi efferbuerint, fublato aheno oleum percolatur. Cardamomum tufum reliqua aqua afperfum infunditur, fpatha agitatur, nulla, dum refrixerit, interpellatione. Poft hæc colato oleo in uiginti octo libras olei, floris liguftri, quod cy prum uocant, lex \& qua draginta libræ cum bcffe inftillantur, qux fufficienter madefact $x$ per fportulam exprimuntur. Quòd so fi copiofius defidcretur. idem recentium florum pondus inicetum fimili modo prematur : \& iterum aut tertiò, fi quis uclit, madefacere poterit, \& ita reddetur efficacius. Eligi oportet bonum, quod cum odoris fuauitate nares feriat. Aliqui cinnamomum addunt. Calfacit, emollit: ora uenarum adaperit: uulux, neruorumq́ue uitijs conuenit, pleuriticis, fractisq́ue, per fe, uel cerato immiftum . malagmatis imponi folet, quæ opifthotonicis, angina laborantibus, inflammationique inguinum opi tulantur: item in acopa adijcitur .

$$
\text { İeIV0\%. IR I NVM. C A P. I V. }
$$

SPATHAE quàm minutifsimè côtufe fex libras cumbeffe, in tribus \& feptuaginta libris \& quincunce olei, æreo uafe,additis decem aqux heminis incoquito, quoad odorem acceperit : poftea in capulam melle oblitam colato : ex to atomatibus i mbuto olco, irinum primò temperatur, iride ex olco 


\section{In Lib. primum Diolcoridis.}

infpiffato macerata, ut feripfimus. Sed alia eft componendi ratio. In olei feptuaginta libris \& quincunce, xylubalfami (ut dictum eft) contufi libras qusnque \& fextantem excoquito: poftea detracto xylobalfamo, tufi odorati calami nouert libras \& dextantem adijcito, \& my rrhx glebam uetere uino odorato perfufam, \& in olei ita odoribus imbuti quatuordecim libris, totidcm tufx iridis, binis diebus ac noetibus madeficito, ftrenuè, $\&$ uchementer diftringito. Quòd fi uis ualidius fieri, par pondus iserum ac tertiò fimiliter maccratum exprimito . Longè optimum eft, quod folam irin olct, quale illud ct, quod in Pcrga Pamphilix, \& Elide Achaix componirur. Vim habet calfactoriam, atque emollientcm : cruftas adimit, fordida ulcera \& putrida purgat confert fominis vuluæ caufarijs : item inflam mationibus eiufdem, atque prxclufionibus : partus eijcit, hrmorhoidas recludit:

- contra aurium fonitus ex accto, ruta, \& amaris amygdalis, prodeft diuturnis deftillationibus, naribus illitum, \& contra graucolentia carum ulcera, quas ozæenas uocant, auxiliatur : aluum purgat cyathus epotus: facit ad ilei cruciatus, urinam mouet : difficiles uomitiones adiuuat, perunctis eo digitis \& immiśsis, uel ijs, quæ ad uomitum ciendum induntur : anginæ etiam illinitur, aut ex aqua mulfa gargarizarur: item contra arterix fcabritiam o datur etiam ijs, qui cicutam, coriandrum, aut uenenafungorum hauferunt.

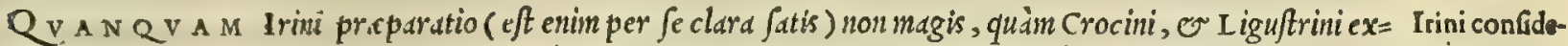
planari expoftulat : illud tamen filentio minimé pretereundum uidetur, quod non Iridisflores, fed radices, cum be ratio. odore fragrent, illi werószalé oleant, in boc olei ßiffamento imponi debent. Quod etfi Diofcorides non explis 2:0 cauerit; cim tamen unguents odorum iucunditate conmendentur, de Iridis radice, non de floribus intellexiffe Diofcoridem exiftimandzm. Quippe qua o fuauter oleant, er ad unguentorum fpiffanenta floribus praftans siores habedotur.

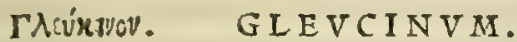

CAP. LVI.

GLEVCINVM abfolutè conftat omphacino oleo, iunco odorato, calamo, Celtica nardo, fpatha,afpa latho, fertula Campana, cofto, \& multo : circundatis interim uinaceis uafi, quod aromata, uinum, \& oleum conceperat. Tricenis diebus, bis in die mouetur, poftea expreffum olcum reconditur. Calfacit, emollit, remıttit : horroribus, \& neruorum, vuluæq́ue uitijs auxiliatur . omni acopo iuuantius, quippe quòd cmolliat :

M I N I M E quidem mirarilicet, quòd Gleucini parandirationem fimplicem appellanerit Diofcorides . siqui= Gleucini con dcm alie babentur unguentorum compofitiones, que multó pluribusfimplicibus conftant odoramentis, ficuti Colu= fideratio. mella lib. X I I I. capite 1 . aperté indicat. Célerum non poteft Gleucinum (firecté admifta fimplicia confideren= tur) non uebementer excalf acere : tametfi Plinius lib. x x I I I. cap. I I I . id tum adftringere, tum refrigerare foris perit. Quod euidenti argumento eft, aut Plinij gleucinum, fiue mufteum, ab hoc Diofcoridis, or Columelle diuer : fum effe, awt Plinivm non exacte illius temperamentum perpendiffe. Verüm cum is lib. X v.cap.v I I. frribat, gleuci= no muftum incoqui in uapore lento, non ut alia admoto igne, Jed cireundatis. uinaceis per fe calentibus; uidetur non parum сии Diofcoride conuenire. Quamobrem crediderim potius Plinium, cum dixit gleucinum refrigerare, lap= Plinij lap(us: fum fuiffe, quìm fecus. Nain etfi oleum oinphacinum, cum quo mufteum conficitur, tantum (ut Galenus inquit) frigi=

40 ditatis, quantum adftrictionis babeat: cium tamen fit aliarum qualitatum fusceptiuum, fieri quidem non poteft, quin admiftis calidis odoramentis, puta cypero, calamo odorato, Celtica nardo, dactylorum operimento, appalatho, melilo to, E cofto, ualdé calidum euadat. Quippe eadem ratione aqua, cium frigida admodum fit, temperamentum permu= tat (ut Galenus afferuit, o experimento comprobatur) cim calida in ea macerantur medicamenta : quandoquidem o ipfa facilé alias recipit qualitates.

$$
\text { A'uxpásuvov. AMARACINVM. }
$$

CAP. IVII.

Amaracinvm longè optimum in Cyzico fieri folet ex omphacino oleo, \& balanino: fpiffamen tis è xylobal famo, iunco odorato, \& calamo factis : conditisque amaraci, cofti, amoni, nardi,cafsia, carpobalfami, \& my rrhæ odoribus . aliqui, quò pretiofís fiat, cinnamomum addunt. Mel autem, \& uinum affumuntur: hoc in uaforum illitionem, illudad cogendas tuforum aromatum offas. Amaracinum calfacit, foporem mouet, venarum fpiracula aperit, emollit, feruorem excitat, vrinam cit: putrilaginibus, ac fiftulis perquàm utile: necnon humentibus hernijs, poftquàm medica manus operam fuam impenderit: cruftas, \& tetra ulcera, qux theriomata uocant, rumpit: difficili vrinæ illita fede, \& eius inflammationibus auxiliatur : hæmorrhoidas illitu foluit : vuluæ fubditum menftruos cur fus euocat: duritias, ac vuluæ tumores difcutit : uulneratis neruis, \& mufculis confert, laneo centunculo modicè madefactum, \& impofitum.

S V P E R I V S in fampfuchini commentario abunde de Amaracino d nobis ditum eft, Quo fit, ut hic de co plu= ga Scribere non fit opus. Huius meminit Galenus libro primo de antidotis, dum bedycroum explicat, quod theriace confideratio. Amaracini admifcetur, ubi diffufius de co agens fcribit, quod fui temporis unguentarij amaraci loco, ex quo in Cyzico antiquitus parabatur, marum imponebant, ut maiorem expiraret odorem. Caterùm fe iufiffe ait, ut legitimum experiretur ama= 
racinum, id fibiex folo amaraco praparari, quod etfí odoris fragrantia uideretur infrrius, non tamen uiribus imbes cillius fuiffe teftatur.

$$
\text { MEyxגẽov. MEGALINVM. CAP. IVIII. }
$$

Factit a e A T V r olim Mcgalınum, fed nunc compofitio exoleuit, \& prorfus obliterata eft. Cuius ad hiftorix complementum meminiffe non fuit alienum. Miftura cum amaracino eadem erat, fed refina evuperabat, hac tantùm ratione diffcrens. Qiare leuiter emollit. Refina unguentis, neq; tute$1 x$, neque uoluptatis gratia adijcitur, fed coloris, craffamentiq́ue caufa. Ea tantifper coquitur, dum definat olere: cuitus coquend $x$ ratio declarabitur, cùm de refina differcmus .

$$
\text { H'díx covv. HEDYCHROVM. CAP. IIX. }
$$

Qvod Hedychroon uocant, in Co fieri folet: eifdem preditum uiribus, \& mifturis; quibus ama racinum, fed fuauius fpirat.

HE D Y CH R I compofirionis meminit Galenus libro prino de antidotis, cim omnid, que continet, odoramen= ta uino fabacta Andromachi theriaca recipiat. Caterim etfi hedychroi parandirationes plures dicat reperiri, unam Hedychroi tamen clegit, quain boc modo de cripfit. Hedychroum babet mari dracbmas duas: afari, amaraci, affalatbi, fchoeni, cöpofitio ex calami odorati, phu pontici totidem : xylobalfami ueró, o opobalfani, cinnamomi, cofti, fingulorum dracbimas tres: Galeno. myrrhe drachmas fex, totiden, foli inalabatbrini, nardi Indicx, croci, caßix : duplo autem plus amomi, xduect s uero ex Chio abund ante plurimis fontibus infula maftiches drachmain uuam: uino falerno omnia excipe. Cüm igitur hec mifcueris, fac trochifcos fimiles theriacis, et foillinis, quos exiccabis eo modo, quo diximus. Productus fuit Galenus, ut bunc parandi modum de criberct, tum quod Andromaclus bedychroum (ut inquit) nullibiliteris mandanerit: tum etiam ut rei medicx imperitos doceret, quidnam effet bedychraum in theriace preparatione, ne in eum errorem $c a=$ derent, in quem fua etate inedicum quindam Rome lap fum fuiffe commemorat: qui compofiturus antidotum, quee= rebat apud myropolas Hedychroum; exiftimans effe herbain, aut radicem, aut quodpiam fimplex medicamentuin . id quod etiam liac noftra tempeftate quim plurinis eueniffe comperimus. Auticenna, o ceteri Arabic a familie fori= ptores in fua theriace compofittone hedychroum trochifcos Alindaracaron appellauere:tradentes uarias corum cö=

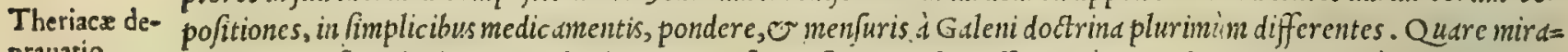

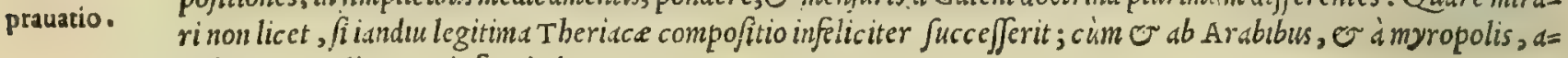
dullerinis medicamentis fuerit deprauata.

\section{METผ́ळ10\%. METOPIVM. CAP. IX.}

FIT in Aegypto unguentum, quod Mctopion patrio nomine appellatur, propter galbani miftionem : nam lignum, in quo galbanum ena fcitur, metopion uocant. Conftar amygdalis amaris, ompha cino oleo,cardamomo, odorato iunco,calamo, melle, uino, my rrba, balfami femine, galbano, \& refina. Probatur pingue, graui odore, quod magis cardamomum, \& my rrham, quàm galbanú refipiat. Calfacit uehementer, \& adurit, atque extrahit : ora uenarum aperit : vlcera purgat, extrahitq́ue : ad præci fos neruos, \& mufculos, ad hernias humore contractas, cum erodentibus medicamentis cficax eft. ceratis,\& malagmatis inferitur : horroribus, conuulfisque, præfertim quibus ceruix in fcapulas deiecta, \& rerrorfum contracta eft, vtile habetur : fudores ciet, vulua fpiracula recludit, \& eiufdem duritias laxat. In fumma molliendi naturam habet.

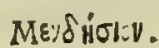
MENDESIVM.
CA P. IXI.

MENDESIV m conftat balanino oleo, myrrha, cafsia,\& refina. Aliqui tamen poft fingulorú pondera,cinnamomi exiguum addunt, nullo compendio: nam qua fimul excocta non fuere, vim nullam exhibent. : Similem metopio uim obtinet, fed inferiorem multò.

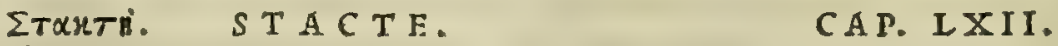

ST ACTE vocatur pinguitudo recentis my rrhx cum exigua aqua tuf $x$, \& organo expreffe. Ea perquàm odorata, ac pretiofa eft, atque vnguentum per fe facit, quot Stacte nominatur. Maximè probatur,qux nullam olei miftionem admifit,cujus minima portio compos eft uirium plurimarum. Vim calfactoriam, myrrh $x$, \& calidis vnguentis refpondentem habet.

Stactes confideratio.

Styrax liquidus.

Medicam.peregrinacuradulterentur.
ST A C T E Serapioni, quemadmodum $\odot \sim$ reliquis Mauritanis, pariter $\dot{q}$; fficinis styrax liquidus appellatur, cuius copia non folim $\mathrm{Venetijs} u b i q$; uenalis babctur, fed o in omnibus frre officinis reperitur, que medicamentorum com ponendorum artem exercent. Quid autcin stacte myrrbe fit liquidus uocatus styrax, fucile probat Scrapio . quip= pe qui captte de styrace calamita, liquidum ftyraccm ex inyrrba primum aqua conferfa, ac dcinde expreffe, fieri tradidit:qua in re Diofcoridem ad unguem imitatur. Cui quidem fententix illud adftipulatur, quód liquidus fyrax (de legitimo fané loquor) fit perquim odoratus, o guftui non obfcuré amarus. Porró anmaducrtendune eft, quód boc auo Jyncerum baud facilé inuenids, ut fermé euenit ciun ceteris medicamentis, que ex Alexdidria Acgypti, uel 


\section{In Lib. primum Diofcoridis.}

syria ad nos conuebuntur. Siquiden ciim omnia hec per Mauritanorum, Turcarum, Iudcorumí; manus tranfeant, qui nobis Chrifticolis femper dolos, fraudesq́; moliuntur, Diis facrificium facere fibi perfusdent, cim nos aliqua in re fallere poffunt. Ca'terim, ut redeam, unde diuerteram, mea quidem fert opinio, fi fynceram ftacten nancifci polfemus, non alienum fore, ipfan in myrrbx locum fubftituere. Sed certé perquam difficile erit legitimam mueniri. niff forté wera flacte fit liquor ille, de quo fuperius in balfami commentatione dixamus.

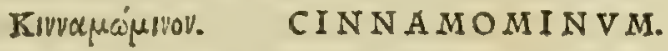 \\ C A P. LXIII.}

Cinnamominvm confit è balanino oleo: \& xylobalfami,calami,iunciodoratifpiffamétis:atq; 2. cinnamomi, \& feminis balfamini fuauitate condicur, quadruplaq́ue myrrhæad cinnamomum portione: mel ad cogenda omnia adijcicur. Laudacur non acre, molli odore, planè myrrham redolens, craffum,odoratum, guftu perquàm amaro. Id non à refina, fed myrrha crafsitudinem obtinuit: refina enim neque amaricudinem prabet, neque ullam odoris gratiam adijcit. Vim habet admodum acrem,amaram, \& calfacientem. Itaque ora uenarum aperit,calfacir,difcutit, diffundit: humores \& $f_{p}$ ritus attrahit,caput aggrauat : contra vulux uitia cum duplo oleo, cera, \& medulla efficax eft. Ita enim ferè multu m acrimoniæ exolefcit, \& quædam emollıendi uis contrahitur • alıoqui adurit, \& præ omnibus crafsis unguentis indurat. Facit mirum in modum ad fifulas, \& ulcera, qux putredinis uitium fenferunt : item ad hernias humidiores, carbuncılos, gangrænasque cum cardamomo: quin \& ad febrium harrores, \& tremorcs: aduerfus ferpentium morfus illinirur: fcorpionum, \& phalangiorum 20. ictibus, cum tritis grofsis imponitur.

Niǵfivov. NARDINVM.

CAP. LXIIII.

Ratro Nardini faciundi euariat. Nam aut malabathrino folio, aut fine eo fit: plerunque autem balanino oleo,aut omphacino. Iuncus odoratus fpillaméti gratia adijcitur : ficuti propter odoris fuauitatem, coltus, amomum, nardum, myrrha, balíamum. Laudatur ten ue, non acre, nardi aridx, aut amomi odorem referens. Vis ei extenuans, acris : expurgat, calfacit, abfterget humores, rarefacit : Hoc liquidum elt, nec haber ftrigmenti crafsitudinem, nifi refinam recipiat. Fit etiam fimplex ex omphacino oleo, iunco, calamo, colto, \& nardo.

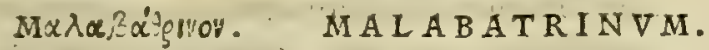

CAP. LXV.

Ma I a A THRINVM fpiffamenta nardini habet : infuper mýrhæ plufculum additur. Qua de cau facaltacit, crocino, aut amaracino uribus refpondens :
I'ási. เvo\%.
IASMINVM.
CAP. LVI.

APvD Perfas fit,quod Iafminum cognominatur, ex albis foribus uiole : quorum fextans in Italicam fexrarium fefamini olei demittitur, uinlis, ut in lilino diximus, vicifsim permutatis. Apud Perfas inter epulandum ufurpatur odoris eaufa. Quinetiam toti corpori conuenit ; prefertim cum in balneas defcenfum eft.Sed his opitulatur corporibus, qux calfactionem, laxationemq́ue defiderant . grauius tamen lpirat, quàm ut libenter à plerifque recıpıstur.

I A M I NVM unguentum non eo quidem filentio pretereundum duximus, quo aliqua in pracedentibus inobis os Iarmini confi

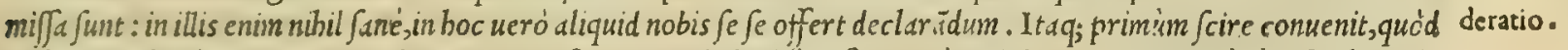
Iajine uocabulü apud Grecos, aliorum etiă teftimonio, nil aliud /ignificat, quàm uiolaceum. Et certé cum fribat Dio

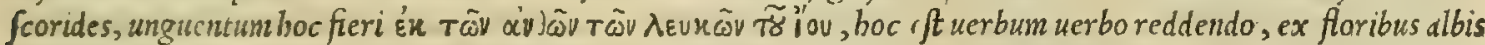
uiole, id violaceum meritó appellari debet. Sunt tamen é recentioribus, qui pro certo fibi per fuadeant, nocabulo= rum fortaffe uicinitate decepti, illud ex floribus ijs perquàm odoratis fieri,quos in Italia Gelfomini uulgó appellamus.

Quorum opinioni non parum fuffragantur tum Hermolaus Barbarts, tun Marcellus Florentinus Cui pracipué,

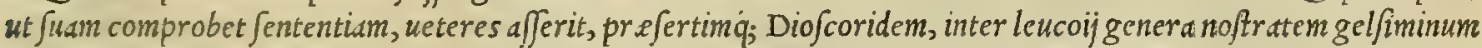
comprebendij]e, illud'q; fpeciating gelfiminumintellexife, quod floribus caruleis prouenire nonmulli pro certo affe= runt. Cuius fententiain non modó non probandam cenfeo, fed omnino refellendarn exiftimo. fiquidem nullo pacto co= gitandum eft,ncáum credendum, quid Diofcorides, qui in fimplicium biftoris, er in eorum declarandis feparandisq́; gcneribus, cmnium diligentijimus fui, adco imprudenter nullo difcrimine exiftimauert caruleum leucoium gelfiminum effe: cum id jijlis, uiticulo fo cuule, radicıbus, ramis, floribus, ceterisq́; notis ab omni leucoio dißideat. Sed boe uerum effe . Marccllc concedamus, etfi minus concedendum fit, quánam ratione dicet unquam, Ixfminum unguentü fieriexflo ibus grlimmi, cuod caruicum Diofcoridis leucoium effe afferit, fi Diofcorides ipfe paldm prodit, Iafmi= num ex albis uiolis temperari? Ad hec differre gel immum à leucoio abunde ofendit Serapio, qui non modó fuit Dio fcoridis intiutor, fed etiam interpres, cum alt erum ab altero diuerfis capitibus diftnxerit, o de utrifq; tanquam de rebus diuer is differuerit. Quimino de gelfinino agens capite centefino feptuagefimo fexto nullam Diofcoridis, nec Galeni auctoritatem affert, fed tantim fue gentis monumentis inberet, aferit'́; gelfiminum floribus tum albis, tum Iuteis, tum cerulèis reperiri, quale etian etate noftra uifitur. Q⿺辶od nobis maximo argunento effe potcft, utcre= 


\section{6 \\ And. Matthioli Comm.}

Ielemin rnde diâum.

Iefémini uiresex Serap.

Ioänis de Vi. golapfus.

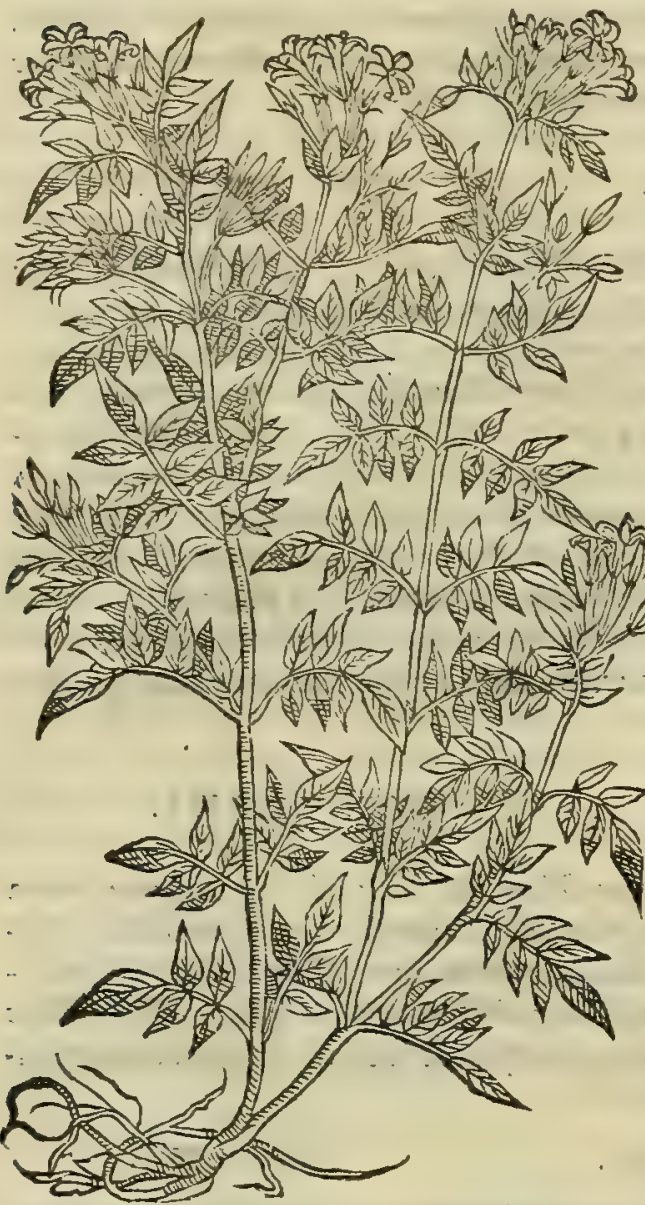

damus,gelfiminum Diofcoridi cxterisó; ueteribusincognitum fuif fe. Cetcrumeu Arabes ftirpem hane I ESEMIN appello verint, caufa facilé aßignari poteft : quód cùm gelfiminiflores $0=$ doratos, albicantesi;; alba uiole modo confpicerent, Gracos bar= baricé imitari uolentes, ipfi uiole nomen indidere, quod eft I e fea min: tamet fi uernacula corum lingua Zambach, fiue Sambacb uox citetur. Id autem ficut odore fragrat, ita $O$ uiribus pollet: fis quidem Serapionis teftimonio, excalfacit ordine fecundo, Jumo= res difcutit, pituite lentitiam fenibus frigidis digerit; cxuciatibas'́; ex pituite lentore prouenientibus mirificé prodeft. Flores tam res centes, quim ficci, lentigines, $\sigma$ impetigines in facie abftergunt. Paratur ex ijs etiam oleum Zambachinum appellatum, quod frigia dis affectibus non obfcurum affert auxilium. Hoc unguentarif cit. anygdalino oleo parant, bcminum barbis odoris gratia perfune dendum: quod tamen temperie calidis caput aded excalfacit, ut quandoque é naribus fangumemeliciat. Hallucinantur, quifalff uocabulifinilitudine Sambacinum, Sa Sambucinum idem cffe exi= ftimant. Inter quos errore implicatur Ioannes de vigo chirur= gicus noftri temporis non obfcurus capite de Sambuco in fwo par= uo de fimplicium libello. Nou diu eft, quod Ie feminum, fine (ut zo nos) Gelfiminum in Italiam allatum eft: quanuis nunc ubiq; horti opere topiario tum albis, tum luteis, tum etiam caruleis gclfiminis ornentur.

¿uvegua. MYRRHA.

CAP. LXVII.

MYRRAA lacryma eft arboris, qux in Arabia gignitur,Aegyptiæ fpinæ nó difsimilis: è cuius vulnere deÂuit lacryma in fubiectas tegetes : alia circum caudicé concre fcit. Dicitur ex his aliqua pediafn mos præpinguis, qua ex- 39 preffa, ftacte emittitur. Alia gabirea pinguifsima,lato \& pingui folo nafcens : ea copiofam fudat ftacten. Omnium prima eft, qua Troglody rica appellatur, accepto cognomine à loco, in quo prouenit, fplendens, fubuiridis, ac mordens. Quinetiam legitur tenuis quxdam, qux à Troglodytica fecunda eft, bdellij modo mollis,verùm odore grauiufcula,apricis nafcens. Alia caucalis cognominatur preter modum exoleta, nigra, \& retorrida. Omnium deterrima, qux ergafima dicitur, pingui carens, cáno fitu obducta, acris, ad gummi imaginem uergens, \& uiribus cius proxima. Improbatul aminnea cognomine. Ex ijs paftilli fiunt, fed è pinguibus pingues, \& odorati : è ficcioribus haudquaquam pingues, \& inodorati. Minus odore pollet, quæ oleum non admifit, cum in paftillos digerebatur. Adulteratur macerato gummi aqua, in qua my rrha.maduerit. Eligenda eft recens, fragilis, leuis, undique concolor, quæ confracta uenas vnguium modo candidas \& læues oftendat, minutis glebis,amara,acris,odorata, calfaciens . fuperuacua, \& inutilis eft ponderofa, coloris picei. Calfacit, cohibet, foporem gignit, glutinat, ficcat, aftringit, vuluam emollit, \& præclufam aperit: menfes \& partus celeriter extrahit curn ablinthio, lupinorum cremore, uel fucco ruta admota : tuberculo fabx deuoratur in uetere tu $\mathrm{si}_{\mathrm{i}}$, orthopnœa, in laterum pectorisq́ue doloribus, in alui profluuio, \& dy fenteria : horrores difcutit duabus horis ante febrium accelsiones fabæ magnitudine pota cum pipere, $\&$ aqua : fubdita lingur liquataq́ue, fcabritiem arteriæ expolit : obtufam vocé expedit, uentris tineas enecat, contra grauem oris halitum manditur, \& aduerfus alarum tadia cum liquido alumine illinitur : gingiuas, $\&$ dentes ftabilit colluto cum uino, $\&$ oleo ore : uulnera capitis illitu glutinat: medetur fractis auribus, ac ofsibus nudatis, peruncta cum cochlex carnibus : item purulentis auribus,inflammatisque cum meconio,caftorio, \& glaucio : ad uaros autem cum cafsia, \& melle illinitur: impetigines ex aceto purgat: defluentes capillos cum ladano, \& vino myrteo illita, fir mat : diuturnas deftillationes lenit, $f$ illitis penna naribus : oculorum ulcera complet, albugines tollit, caliginem difcutit, fcabritiem læuigat. Fit è myrrha, perinde atque thure, fuligo: \& ut poltea oftendemus, ad eadem conueniens. Bæotica myrrha diffecta radix eft arboris cuiufdam in Bcotia nafcentis. Melior eft, qux myrrham odoris fuauitate repræfentat. Vis ci calfactoria ineft, emollit, difcutitque : fuffimentis commodífsimè inferitur.

Myrrhe con M ₹ R H A, que ex Alexandria Aegypti hac etate ad nos affertur, admodum fané ab ea differt, quaminter. fideratio. preftantijimas Myrrbe pecies recenfuit Diofcorides. Quippe uniuerfa fer é myrrha, que in officinarum ufu babe: tur, ijs omnibus qualitatibus, ac notis deftituitur, quibus optima commendatur. Nanque ca (ut uidere cft)minime uires fcit, pinguis non eft, non odorata, non undiq; concolor, nec confracta uends unguium figura lcues intus oftendit, nec 


\section{InLib. primum Diofcoridis.}

fapore acrideprebenditur; tanet fi guftui anuritudincm relinquat. Verim fi fortalfe cnipism videretur et hec inter Myrrhe fpecies effe recipienda( $q u o d$ tamen non fat is cöpertum habco) aut caucalin, aut crgafiman, effecrediderim,

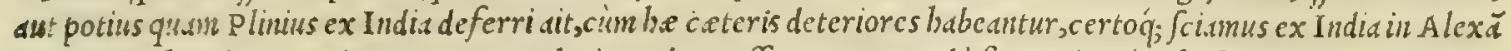

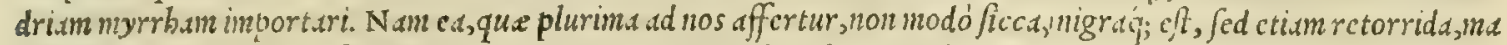

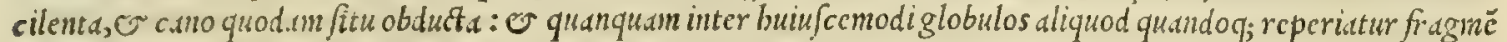
tum,q!od co clarum/it, o pellucens; confractum tancen diuer/icolor apparet. Ecquid inagis? nec guftui infigniter andriun, nec myrrbe odore preditum fentitur. Quo fit, ut credere liceat, ciufinodi Nyrrbam aut ć deterioribus clfc,

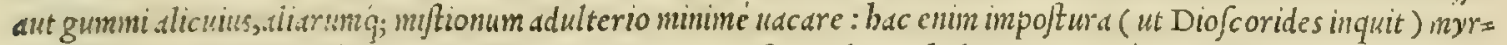

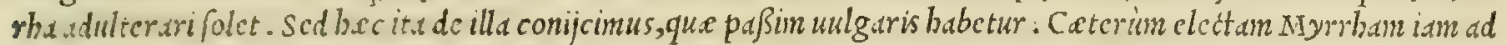
to nos aduchi fcimis, que o legitina, or probatißina effe cenfetur. Verim ea hactenus tam rara eft, ut non mifi ad often tationem affeructur, es al alisum dignofcendarum regulam. Adulterabatur myrrba Galeni temporc opocalpafo, que calpafi lethalis, uenenofig; oft lacryma. Idcirco libro primo de antidotis. Opocalpafum(inquit) exitialc cft, mul tosq́; nos forte quadum nidinus noftre xtatis dccurfu mori, quod inf cij myrrham, cui opocalpafum admiftum erat, af= funp/iffent. De indufris n.sng; nonnulli corum, qui ipfam preparant, ut laudatißimam imponebant, co quód uidcrent collyrijs inditum optimun cfe medic.tmentum. Quippe qux pus citra mordic ationem dif cutiat, er interdum incipien= tem oculorum fuffufionem fub: tuntia tenuem: fiuc autem in emplaftrum, fiue in ceratum, fiue in aliquod digereins ine dicamentum, quod extrinfecus imponitur, buiufnodi myrrbam iniyciss, uim ip fius augebis: at intra corpus affumptum lethale cft medicamentum. Hec igirur fufius dicta funt, tum quod orationis feric sita expoftularet, tum etiam quia hec peculari non cft inutile. Isactems Galenus. Adbibenda itaq; diligentia eft, ne er nos Myrrbam quandoq; opocal= so pafo adulteratan cmsmus. Ad hec Brafulolo Ferrarienfinamus inclinare uide tur, ut cxiftinet Myrrban officinis wulgarem bdellium cffe. Cui baud quaquam affentiendun putauerim: fiquidem myrrba bac pellucens adeo non eft, nec taurino glutino fimilis, ut 6 dellium cffe tradidit Diofcorides. Et licet quedam noftratis myrrbe fruftra quando q; translucids reperixntur; funt tancn potius bec(ut dictum $\mathrm{ff}$ ) gummi adulterid, qudin myrrhd, uel bdellium : nempe guftu malcficium detegitur. Preterea bdellum incenfum (Diofcoridis teftimonio) odorem unguibus odoratis fimilem firat, quod in noftrat: myrrba munquan, facto pertculo, fum confecutus. Huic etiam alia accedit ratio, qua magis ac mag is Brafacoli aninum inmutare potcrit: quod jcilicet bdelium diu digitis ductum, tractatum'́; facilé lente fcat, or confractum pingue pectetur : myrrba uero, qux officinis ueviditur, digitorum attritu conteritur, or fi frang tiur perquin arid a fe fe offert. Caterim improbuit Diof corides, omnium'; Myrrh e pecierum deterrimä iudicauit, que aliqubus minsea, slips aninne s uocatur, qudin cum Galenus probauerit libro primo de antidotis, omnibusq́; 'Troglody=

30 tic is pratulcrit, fuctum eft, ut exiftinauerint quidam, in boc loco Diofcoridis codicinendam fubeffe. Sed cum in Dio fcoride Graco leg stur aninned, 0 in Galeno minxa, ego potius crediderim, cos non idem myrrbe genus intellexiffe. Pliniแs lib. X I I. cap. X v. myrrbe arboris faciem diligenter expreßit, bis uerbis. Myrrham in ijfdem Jyluis, ubie thus, permif an arborem nafci tradidere aliqui : plures feparatim. Quippe mult is in loc is Arabix gignitur. Conue= bitur e ex fyluis laudata, petuntq́; cam etiam à Troglodytis Sabei tranfitu maris. Satiua quoque prouenit multum folueftriprelata. Gaudet raftris, or ablaqueationibus: melior radice refrigerata. Arbori altitudo ad quinq; cubi=

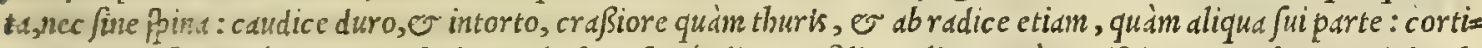

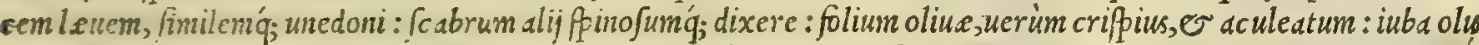
fatri. Aliqui fimlcn iunipero, fcabriorcin tantuin, fpinisq́; borridam, folio rotundiore, fed fapore iuniperi. Necnon fuerc qui e thuris arbore, utrunq; nafci nentirentur. Inciduntur bis er ip fe tburis modo, ijsdemó, temporibus, fed à io radk: $u \int \phi_{p}$ ad ramos, qui ualent. Sudant dutem fponte priufquam incidaritur, ftacten dictam, cui nulla prafertur. A $b$ bac fatiua, or in fy! ueftri quoq; melior aftua. Non dant ex myrrba portiones Deo, quoniam er apud alios nafcitur. Et fequenti capite inquit . Adultcratur myrrha lentifci glebis, er gummi : item cucumeris fucco amaritudinis caufa, ficut ponderis argentifpuna. Reliqua utti deprebenduntur fapore gumm dente lentc feentis. Facilliné autem adul= teratur Indica myrrha, que ibi de quadam pina colligitur. Hoc folum peius India affert, facili diftinctione, tantò de= terior eft. bec Plinius. 2uo fit, ut facilé crediderim noftri ufus myrrbam Indicam effe. nanque per mare rubrum, or inde per carouanas (ut dicunt) Alexandriam importatur. Myrrbe quo $q_{\text {; }}$ biftoriam non iniucundé fcrip/it Theo= pbraftus lib. I x.cap. I I I I. de plantarum biftoria, fic inquiens. Gignitur thus er myrrba regione Arabum media cir=

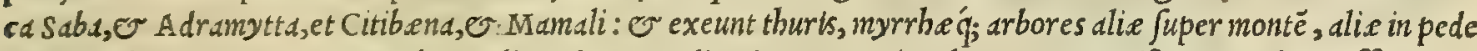
montis culturis proprijs : quamobrem alix coluntur, alix uitam agunt inculte. Montem if um prealtum affirmant, so or ningifolitum: amnes quoq; de co in plana fuere. Myrrhe arborem thure altitudine minorem, fruticofioremí; narrant : caudice duro, contortó; iuxta terram, craßioriq́; fura hominis, cortice laui adrachna finili. Alij ueró, qui fe uidiffe affirmant, de magnitudine feré confentiunt. Neutram earum arborum magnam referunt, or minorent myrrbe bumiliorem q;. Sed thuris folium laurinum, leuéq ; : nyrrhe aculeatum, non leue, ulmco fimile: crifpum tamen, extremó pina borridulum, ilignei modo. Iidem ea nauigatione, qua cx finu beroum uebementer egreffos $\int e j e$ aquam in monte qux fifje dixere, atq; ita uidıffe bas arbores, er lectionem notaffe boc modo ambarum: or caudices, et ramos incifos quidem, fed alios ueluti fecuri percufjos uideri, alios tenviores incifuras babere: $\sigma$ lacrymam aliams decidere, aliam arbori inharere: nonnufquam etian fubiectas tegetes ex palmis contextas, alibi folum tantummodo circumpaumentatum. Montem autem uniuer fum $S a b x$ is diuifum dixere : hos enin loci illius dominos effe, iuftitiäque mutua degere, quamobrem nullum fuss arbores cuftodire: unde o thus, myrrbam'́; fe fe largé ad naues folitudine de= portaffe narr arunt. Illud quoq; fe audiuiffe dixere, nivrrhă, thuśq; collectum undiq; ad folis delubrum conuebi: quod sabzorum effe fanctißimum inter omnia regionis illius, cuftodes 'q; Arabes armatos habere, quibus fingulos foum thus

Mytrhx hiAtoria ex Plis

Myrrha adul terats opocal palo.

Brafauoli opi nio improbata. Myrhe hi-
Atorex Theo phrafto. 
aceruatum, or mysh am codcm modo relinquere, pofita fuper acerumm tabella, literis fignificantc numerum menfu= rarum, e pretium, quod pro fingul is inenfuris poncndum fit. mercatores ueró, qui uenerm, tabellas aduerterc, elusq, quod placuerit, acta incn fur a pretium in eodem ponere loco, unde merces acceperint: facerdotem deinde uenire, par $=$

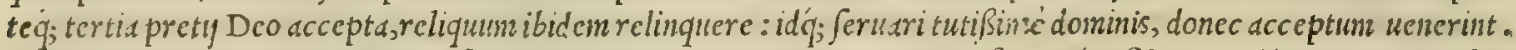

Alij myrrbe arborem terebintlo fimilem reddidere, fed fcabrioren, pinofioremiq; folium paulo rotundius, gufta tu proximum terebintho : earuni quoy; ucteres preftantiorcs baberi. Nafci ucró bane, er tbus in eodem loco terra fubargilia, o fabulofa: o aquas fonte fluentes raras admodum comperiri. Hec ergo illis repugnant, uidelecet nin= gi, o inbribus perlui, o annibus loc un illum exbilarari. Sed hi quidem altera gizoq; longe maiore ignorantia labo=

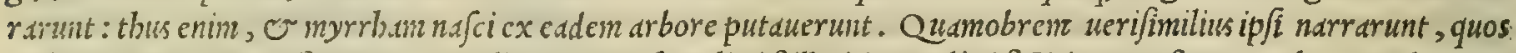
cx beroum oppido profectos nau retulimus. Myrrhe aliud fillatitium, aliud fititiun conftat. Probatur meliorgu= $\mathbf{0}$

Myrrhæ ui- stu, ciusá; norma concolorcm accipiunt. hactenus Thcoplbraftus. Myrrha meminit Galenus lib.v I I I. fimplicium res ex Gal. medic, ubitia foriptum reliquit. Myrrha fecundi ordinis elt tum excalfacientium, tun deficcantium. I taq; capitum uulncribus illita glutinarc ca poteft. Ineft or amaritas non pauca, per quam fotum, or lumbricos tum enecat, tum cijcit: adcft binc ci a sbfergendi potentia. sic igitur ocularibus mifcetur facultatibus, utiq; que ad ulcera, or craf= fas cicatrices proparantur. Eadcride caufa inditur or medicamentis, que ad tußim ueterem, or afthma, fiue anbelas. tionem exbibcntur: non tamen aricriam exafperat, ficut abitergentium nonmulla. Verün adeómoderatam obtinet abftcrfioncm, ut nonnulli eam arteriacis que $110 \mathrm{cant}$ medicament is commifce ant, tan quam fufficienter excalfaciens,

Myrrhx fuc- or deficcansmedicanen : cilicet abftcrfioncm proficifcentem ab anaritudine nibil uerentes. baec Galenus. Porrod cidanea. ubi myrrba de fit, Galenus in Juccidancis ( $\int \mathrm{i}$ tanzen liber is Galeni eft, nobis enim purius cenfetur) odoratun calamü fupplet: Conftantinus ueró amaras amygdalas codem pondere. Sed equidem bic myropolas admonitos uelim, ut nul= 20 lo pacto corum fequantur doctrinam, qui iubent, Auicenne auctoritate malé intellecta, myrribe loco piper nigrum. fupponere. Nanq; Auicenna bane fententiam omnino refillit, cim utatur bis uerbis. Pro myrrha fubftituendum pi=: peris nigri dimidium aliqui perbibent: fed boc falfum eft. Foftremó illud ctian notandum eft, quód (ut Galenus in = quit lib. I I. de comp.medic. per gencra) myrrba femper medicamentis eft commifcenda, cim ab igne tolluntur: quip. Boetica myr pe que coqui minime patiatur, ueluti etiam tbus, er aloé. De Bacotica autem myrrba, quid dicam non babeo, quód. rha. Nomina. atate noftra fit (ut arbitror) onmibus incognita. Euvgux fic Gräcis dicta, Myrrba Latinis appellatur: Ler; Mur, feu Mor, Arabibus: Mirrba, Italis: Mirrben, Germanis: Mird, Hifpanis: Myrrbc, Gallis.

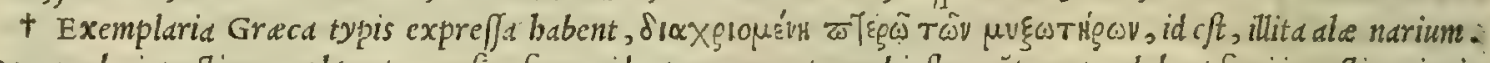
Que uerba inunctionem ad partenn ina fi referre uidentur, non autem ad infrumétun, quo debeat fieri inunctio. siqui $=$

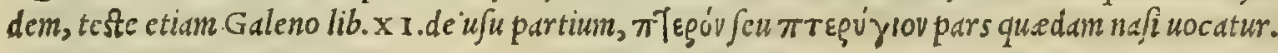

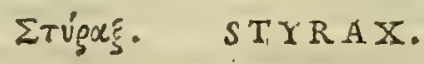

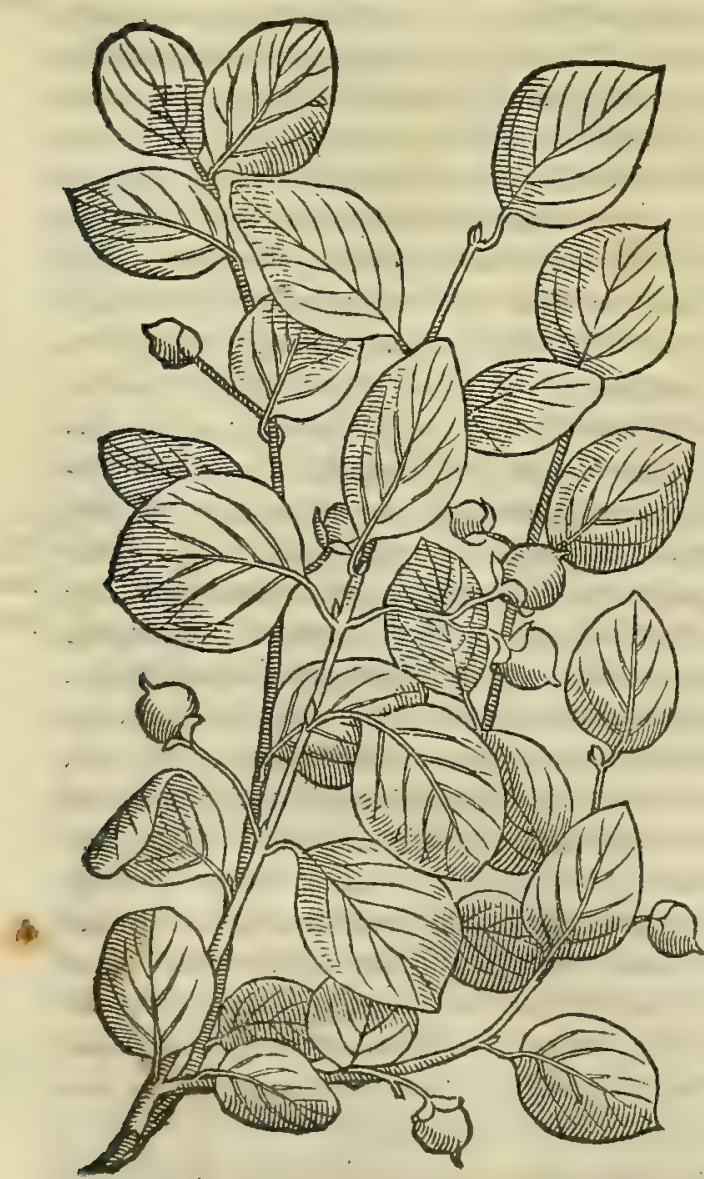

CAP. LXVIII.

S T Y R A X lacryma eft arboris malo cotonex fimilis . Prafertur pinguis, Alauus, refinofus, albicantibus gru mis, quàm plurimùm in fua odoris gratia permanés, quï dum mollicur, melleum liquoren reddit: qualis è Catabalis; Pissidia, \& Cilicia deuehitur. Deterior niger, furfurofus, friabilis, canoq́; futu obductus . Cæterùm lacryma inuenitur gummium fimilitudine, perlucida, \& myr rha æmula : verùm perpauca manat. Adulteratue ligni 40 fcobe, quam uermiculi erodentes excufferunt, melle, \&c iridis fedimento, \& quibufdam alijs . Alij ceram, aut adipem odoribus imbutum, flagrantifsimis folibus cum fty: race fubigunt, \& per laxa cribri foramina in frigida aqua ueluti uermiculos exprimunt,uænundantq́ue. Sryracem hunc, † quoniam in uermiculorum fpeciem cốtrahatur, fcoleciten cognominant, quem tanquam fyncerum imperiti approbant, non animaduertentes ad præcipuam odoris fragrantiam : fiquidem acer admodum elt,qui adul terationis uitio caret. Styrax calfacit, emollit, \& conco- 59 quit: medetur tufsi, deftillationibus, raucedini, grauedini, \& interceptæ voci : vuluxe præclufx, duritiáue laboranti conuenit : cit menfes potu, appofituq́ue : aluum le* uiter mollit, fi exiguum cum relina terebinthina catapotij modo deuoretur. Mifcetur utiliter difcutientibus ma lagmatis, acopisque. Adoletur autem, \& igni torretur, ut fiat ex co, veluti ex thure, fuligo: ad cadem conueniens, ad quæ thuris fuligo. Ex eo etiam in Syria Atyra. cinum oleum componitur, quod calefacit vehementer; \& emollit: verùm caput dolore afficit, aggrauatque, \& foporem adfert. 


\section{In Lib.primum Diofcoridis.}

S T Y R A X p.1Fim uil Italia Storax callamita officinis appellatur, quod cognomen ex Galeno libro primo de an=

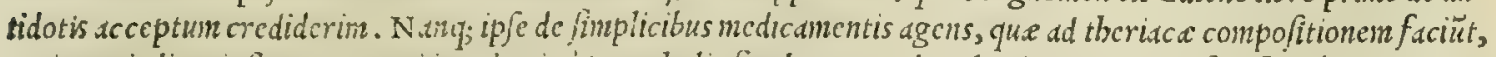
optimun iudicani:/tyracem, qui in cal smis é Fomplylia ferebatur: unde cal amite cognomen fibi facilé ucndicauit. It aq; cium non alius habcatur jïyrax, qui jit hoc generc preftantior, in ufu medentium eft, ut dime pharmucopolis in= perant fierimedic anents, que ftyracent excipiunt, cald amitx cognomen adiclant, quo indicent, fe primun dotibus in= relligere. Nec illud quiden atb re: quandoquiden Galenus eoden loco memorix prodiderit, boc styrucis genus tantü prest.are catcris, qu.minum uinum fal ermun llud bonitate excellit, quod à cauponibus uenditur. Quo argumento fice=

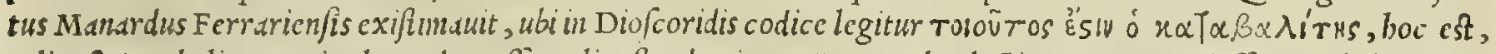

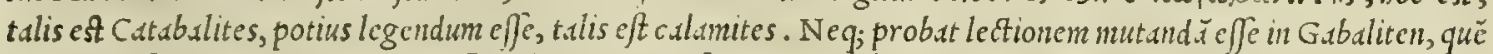
io admodun fecit MIarcellus. Scd profecto bac in re ( $\mathrm{et} / \mathrm{i}$ Manardus fuerit uir fumma doctrina praditus) mibi magis Marcelli fententis probanda uidetur. Quippe que Plinij testimonio comprobatur lib. X I I.cap. X x v. ubific inquit. Styracem Syria Iud.e e proxima fupra Phaniccm gignit circa Gabala, er Marathunta, e Caßium Seleucia montě .

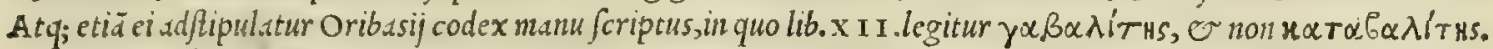

Porró Fuchlius medicus noftr a atatis clarißimus, in libro, quem de compofitione medicamentorum fecundó condi= dit, ftyracen calaniten liquidum fuife cenfet, non alia (quantum equidem uideo) ratione fretus, quàm quód in cald= mis adueheretur. Verim in boc Fucblius ( pace cius dixerim) i ueritate de fcifcit . quandoquidem Diofcoridi ftyrax lacryma eft arboris malo cotonce fimtlis : cuius ille praftat cateris, qui flauus eft, refinofus, grusnos babet albican= tes, e dum mollitur, melleum liquorem reddit. Ex quibus facile conftare arbitror, ftyracem non fuiffe liquidum, fed in grunos concretum. Neq; certé mili rationi confonum uidetur, ex eo quód Galeni tempore ftyrax in calamis ue= 2o bebatur, inferre ipfun fuiffe liquidum. Nain ( ut mea fert opinio) non alia de caufa quiftyracis lacrymam colligebăt, e.mftutim in calantis includebant, quim ut furuis cius odor conferuaretur. Id quod etiam cum dictamno faciebant if (ut memoris prodidit Thcophraftus lib. I X.cap. $\mathrm{x}$ I. de biftoria plantarum) qui ipfum in Creta legebant. Fiquidem ij difamni manipulos in forula, aut arundine intercludebant, ne vis eius expiraret. Praterea cum apud ueteres Gra = cos mula (quod legerim) extet liquidiftyracis mentio, baudquaquam poffum buic Fuchsij fententi.e adherere : quini= mo cogor can pror fus refillere, quod rectus fentire uidear cum A rabibus, or recentioribus, qui per liquidum ftyra. cem non aliud intelligunt, quim ftaden myrrhe. Ceterim Plinio loco citato laudatur ftyrax poft fupradita ex $P i=$ fidia, sidone, Cypro: é Creta ueró minimié. Reddidit Plinius caufam, qu.tre eft, quód Styrax plerunq; puluerulent= tus exift.st, dicens, quód in eum circa canis ortum aduoldnt pennati uersniculi erodentes, ob id q; ipfum in fcobe fordes fecre. Adnlteratur etian ftyrax ( ut idem fcribit) cedri lacryma, uel gummi, melle, aut amaris amygdalis. quocirca 30 retincnte funt not:e, quibus Diofcoridis auctoritate praftantißimus cognofci poteft. Styracis arbor uiret Venctiijs pluribus in locis, prefertim o; in uiridario clarißimi medici Maffei à Maffeo. Huius meminit Galenus lib. vI I I. fimplicium medicamentorum, fic inquiens. Styrax excalfacit, emollit, concoquit: quamobrem tußibus, catarrbis, pi=

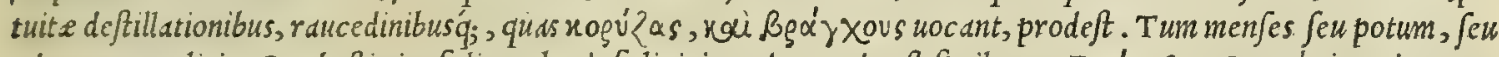

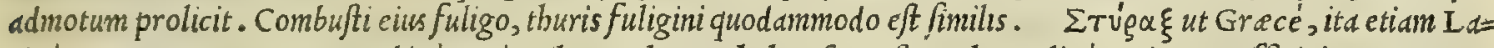
time Styrax nuncupatur: Aratice uerd Miba, Meha, Mebaba, Jeu Aftarach: Italicé, stirace: officinis, Storax ca= lamita: Hippanicé, Eftoraque.

+ quoniam in uermiculorum peciem contrabatur. Hac uerba non leguntur in Gracis codicibus. Sed ed(ut arbi= tror) i Rullio interprete adiecta funt ob:maiorem rei declarationem. Qule hanc ob caufam, lectore tamen admoni= to, nobis quoque relinquere placuit.

B D E I I I V M alij bolchon appellant, alij madelcon: lacryma eft + Saracenicæarboris. Probatur guftu amarum, translucidum, taurini glutinis in morem, intus pingue, liquefcens facilè, ligni ac fordis expers, + fufitu odoratum, vngui fimile. Eft etiámnum bdellijgenus fordidum, nigrum, vbe rioribus glebulis in ofras conuolutum, afpalathi odore, ex India aduectum. Defertur etiam à Petra oppido ficcum, refinofum, liuefcens, fed ficultate fecundum. Adulteratur gum mi, fed ita uitiatum non perinde guftui amaritudinem repræfentat, nec ufqueadeò fuffitionibus odoratum. Calfacit, $\&$ emollit: duritias, \& turgentia guttura, humidasque hernias difcutit cum ieiuna faliua dilutum: vulux fpiracula laxat appofitu, \& fuffitu : \& partus, humiditatesq́ue omnes extrahit: calculos potu comminuit, vrinam mouet: tufsientibus, ¿ à ferpente percufsis vtilifsimè datur : valet ad rupta, vulfa, laterum dolores, \& difcurfantes fpiritus. Malagmatis inferitur, quæ contra duritias, \& neruorum nodos profunt. Contufum refoluitur affufo uino, aut aqua calida.

PR AE S T A N T I S I M V M Bdellium Diofcoridi translucidum eft, tauriniglutinisin morem, amarum, tatu lique ccens facile, or quod incenfum odorem emittat ungui odorato fimilem. Quod fi modó neftro tempore in
Italixin importatur, adeo rarum eft, ut (quemadmodum de myrrha diximus) ad oftentationem tantüm afferuetur, uel Bdellii confiad adulterini, e reprcbati digno fcendi normam. Credidere quidam, boc uulgare Bdellium, cuius paßim in officinis eft ufus, conftare partim ex nigro, quod India mittit, partim ueró ex eo Arabici genere, quod ficcum, refinofum, li=

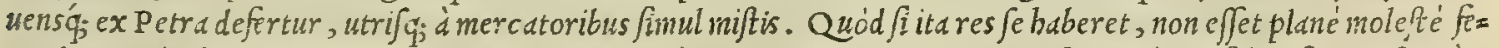

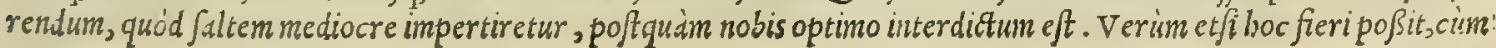

Fuchlij opino reproba ta.

Styracis uites ex Galeno.

\section{Nomins.}

Manardi letio non probata.

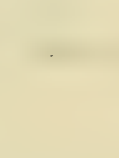

deratio.

tamer. 


\section{And. Matthioli Comm.}

tamen in eo parum, uel nihil amaroris fentiatur, ctemi, ceteris fré ommibus tum notis, tü qualitatibus fit cxpers, quas

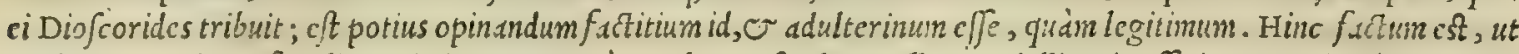
quidam recentiores finplicimm ind gatores, cum nobir perfyadere uellent, Edclliun in cfficinis reperiri, licet nö ad=

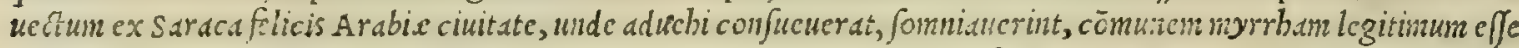

Ddellij uulga- bdclium, ut corum fententian refillentes, in precedenti commentario fcrip/inns. Huius, quo paßim utirur, plu= rus genera. ra quidem habentur genera. Siquidem aliquod quandoque uidi nigrum, rcfinofum, odore foxtido laferi quadántenus proximo: aliud translucidum, utpote taurinum glutinum, fed ficcum, amaroris expers, nulló, odore preditum: quoddán ueró adeó unlgarimyrrbe perfimile, ut ab ea uix dignofci poffet. Que omnis genēra tamet fíllegitina cée= Bdelli hifor. Seantur; officinis tamen ianquan legitima, or preftantisima in medicamentis paßim temeré ufurpantur. Bdel= ex Plınio, lium foriptis tradidit plinius lib. x 1 I.cap. 1 x. his ucrbis. Vicina eft Bastriand, in qua bdclium nominatißimum. Arbor nigra eft, magnitudine ole , folio roboris, fiuctu caprifici natura. Gimmi alij brochon appellant, alij mala= cloran, alij waldacon. Nigruin ueró, o in offas conuolutum hadrobolon. Effe autem debet translucidum, fimile ce= re, odoratum, os cum ficatur pingue, guftu amarum citra acorem. In facris uino perfufum odoratius. Nafcitur et in Arabia, Indis', $\sigma^{-}$Media, ac Babylone. Aliqui peraticum nocant ex Media aduectum: facilius boc, or crufto

Bdellijuires fius, amariusq́; . At Indicumbumidius, or gumnofum. Adulteratur amygdala nuce. hec Plinius. Bdellij facultas ex Galeno. tes prodidit Galcnus lib.v r. fimplicium inedicanentorum, fic inquiens. Bdellium quod Scythicum nominant, quod fas né $\mathrm{C}$ atrius eft, or refinofum magis, emollientis admodum, of efficacis uirtutis eft. At alterum, nempe Arabicum, quod dilucidius eft, magis deficcat, quàm emolliat. Igitur recens, e bumidum eft, er contufum facilé mollefcit, ad omnix, ad que Scythicum, idone um. At quod antiquius cft, of adinodum guftu amarum, of acre, er ficcum, ab co= rum, que indurata molliunt, mediocritate excidit. Vtuntur auten quidam illis, or potißimim Arabico, or ad guttu= ris ramices, of hernias aquofas, faliua matutina, ieiunaq; fubigentes, ut emplaftri confiftentiam accipiat. Porró $\mathrm{A}=$

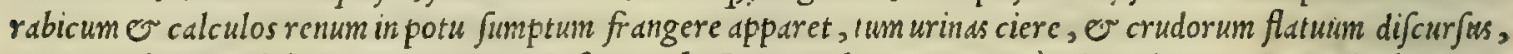
preterea laterhm dolores, o rupturas perfanare. hactenus Galenus. Caterim inuenio serapioncm duobus capi=

Bdellium al te tibus Bdellij meminife : quorum alterum appellauit I udaicum, quod nimirum eft if fum Diofcoridis bdellium : alterum rü Serapioni ueró cuiufdam plante palmx fimilis fructum effe tradidit. Hoc Neapoli frequentißimum uidimus, ijsó; in officinis ac= palmx genus. cepimus, ubi facchari arundines é sicilia petitas uenundantur. Nam cumillic effem cum Bernardo Cle fio Cardina= $l i, \mathcal{O}$ Principe Tridentino, qui apud Ca arem Carolum v. invictißimum Imperatorem agebat, multarum uidendar rerum, que ad medicam materiam pectant, fuit mibi facultas. Hcc igitur palma genus ( ut ab incolis accepi) ex si= cilia cum folijs palmeis, ac radice defertur cubitali, uel pauló ampliorilongitudine. Vecantur ba plante Neapoli

Cefilionis cö uulgó C E F A G L I O NI. quarum quoddam duntaxat germiculum comedunt, tenerrimum, fapidum, er ori gratijßi= 30 fjderatio. : mum. Includitur boc mille quibufdam inuolucris, tanquam totius plante corculum. Hoc quidem tuberibus, $\sigma$ car= duis, carduorumq́; echinatis capitibus (carioffi, o archichiochi Itali uulgó uocant) preferunt. quandoquidcm $\mathrm{ed}$ fe= cundis menfis pro bellarijs cum pipere, or fale folenniter affumunt, tum qucd guftui is cibus admodum arrideat, tum ctiam quód uenerem conciliet. Porró illa uulgaris Cefaglioni appellatio (quantum conijcere pofjumus) d Mauritanis accepta eft: fiquidem serapio fic inquit. Cefilio eft cor iftius palma", or natura eius eft, ficut natura palmerij. Gale= nus infuper lib. V I I . fimplicium medic. de palma differens, eius medullam encephalos appellari tradidit. Ex quo ad=

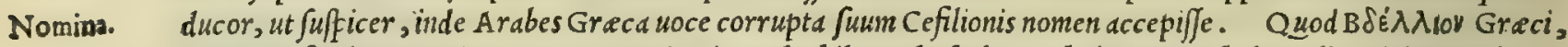
Bdelliun fimiliter Iatini uocant: Mauritani, Molochil, Molochal, Mochol, aut Mochel: Itali, Bdellio: Hifpani, Bedelio.

+ Licet Saracenica arboris lectio admittipoßit, quod Saraca, unde Saraceni dicti funt, urbs fit in Arabia; non 40 tamen improbanda uidetur lectio Arabicx arboris. Quód non folum Plinius frribat bdẹllium in Arabia nafci, $\sigma \mathrm{Ga}=$

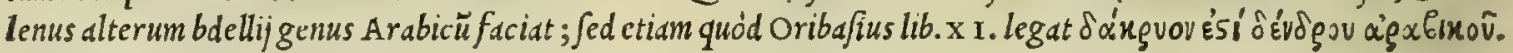
boc eft: lacryma eft arboris Arabica.

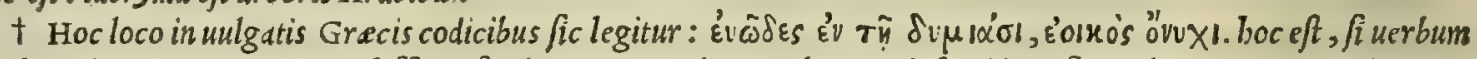
uerbo reddamus: odoratum in fuffitu, fimile ungui. Eadem uerba ex Diofcoride referunt inter Grecos Ac̈tius er Oribafius. Caterum in ijs uerbis illud dubiam fententiam facit, quód non facilé colligi poßßit, quid per övux intelli= gat Diofcorides. nam cum bec uox bomonyma fit, of plura fignificet, cui potißimim rei conueniat, auctor non ex= plic auit. ut hinc uel aliquid deeffe fuppicandun fit, uel hac uoce diuinandum de nota illa bdellij optimi magis fit, quàm aliquid certiftatuendü. Auget difficultatem, quod interpretes omnes, uiri doctißimi, uerba illa in diuer fum fenfum tra bant. Alij enim probatü bdellium uolunt bene odoratum effe femper, fed incenfum fieri ungui fimile, ut Manardus libro so fuarum epift .octauo: alij dum incenditur, odore malunt ungui aßimilari, ut Hermolaus. quorü tamen utrunq; confat de odorato ungue intellexiffe. His adftipulari uidetur Serapio inter Arabas, quibdellij defcriptionem Diofcoridi acce= ptam ferens, uerba illa interpretatur in bunc fen fum : cum incenditur, bonü pirat odorem, odori unguis odorati fimile.. sunt porró quibdellium fuffitu odoratum faciunt, ungui fimile, ut Ruellius. qui certé ed fimplici werborï illorum uer= fione non minus ambizuü reliquit illius note fenfum, quam in Greco reperiatur. Marcellus dutcm diuer fam ab antedi= ctis fententiă protulit, nam ita uertit illa uerba: cum incenditur, odoratum, et bumano ungni colore fimile. Hac utique Marcelli interpretatio plura babet, quàm in Grecis codicib. legantur, $c$ a fortaffe ratione $a b c o$ addita, ut nulla reliqua effet ambiguitas: quanquam in hoc à Manardo redarguitur. Mibi quidem hactenus placuit Serapionis interpretationi fubfcribere, ut patet in principio huius commentationis. Nunc ueró quid mili fenticndum fit, feré inccrtus sum. viden tur enim uerba illa Diofcoridis ita diftincta effe, ut duss bdellij optimi notas faciant: quarum altera eft, ut odoratil fit, cum fuffitur : altera, ut fit ungui finile. Sed relinquitur dubitatio, an unguis odoratus, aut hundius fit intelligen 


\section{In Lib. primum Diofcoridis.}

dus. Eó tamen inclinat aninus, ut putem bumanum unguem intelligi, quód Plinius lib. $\mathrm{x}$ I $\mathrm{x}$. cap. $\mathrm{x}$ x. de bdellio dif= ferèn, Bactriano ungues reddat candidos, ciun inquit. Bactriano nidor/iccus, multiq; candidi ung ues. Ex bis nimi= run uerbis liquet, bdellium illud albis niaculis ungu humano finilibus refertum effe. Id quod etiun uidetur bdellio af= fignaffe Damocrates in fuis carminibus, qubus cypheos compofitioncm cecinit, $\mathrm{O}$ qux a Galcno refiruntur lib. I I.

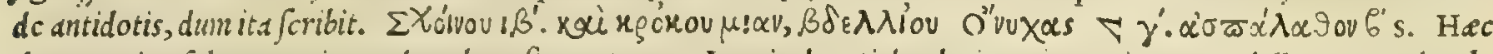
duo carmina folut.x or ttione ad uerhum fic uertemus. Iunci odorati duodecim, er croci unam, Bdellij ungues drach= mas tres, afpalaliid dus fomis. Sané quod Damocrates bdellij ungues in cypheos compofitionem addat, me magis mo= wet, ut credam bdcllium notam peculiaicm babere, qua unguiun effigiem reprefentat: aut quód illud bdclliti fit pres

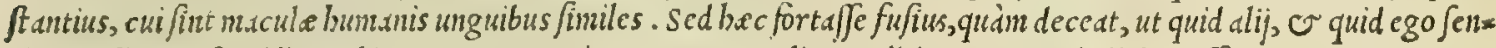
2. tiam in illis Diofcoridis ucrbis, exponerem, ita tamen, ut malim eruditiorum quoq; iudicium effe.

$$
\text { A!:Savs. THVS. CAP. LXX. }
$$

THVs in ea gignitur Arabia, quæ thurifera cognominatur. Primatum tenet in eo genere mafculum, Itagonias appellatum, fuapte natura rotundum : tale autem indiuiduum ef, candidum, cùm fran gitur, intus pingue, in fufitu ftatim ardens. Indicum uerò fuluefcit, \& colore liuet, fed rotundum induftria factitant : nam in quadrangulares formas diffectum fictilibus uerfant, donec rotunditatem contrahat : uerum huiufmodi thus tempore flacfcit, quod atomum, aut fyagrum appellant.Secundum locum habet $t$ Arabicum, \& in Smilo nafcens, quod aliqui copifcum uocant, minus multò, \& fuluius. Eft \& genus aliud, cui amo mite cognomen eft, alioqui candidum : quod dum mollitur, ma20 fiches more digitis cedir. Adulteratur omne thus t in itinere pini refina, \& gummi . quod facilè deprehendi po:elt: liquidem fufitum gummi flammam non eiaculatur, \& refina in fumum euanefcit, thus uerò ftatim ardet: idem maleficium odor prodic. Ad calfaciendum, \& aftringendum pollet: oculorum caliginem difcutit, caua ulcera complet, \& ad cicatricem perducit:cruenta uulnera glutinat, infrenatq́ue cunctas fanguinis eruptiones, etiamfi cerebri membranis effuat: ulcera,qux ca coethe uocantur, \& fedis, \& reliqüarum partium permulcet tritum cum eo \& lacte linamentum : for micantes uerrucas inter initia, impetiginesq́ue ex aceto, \& pice illitum tollit : ambufta igni, pernionesque cum fuillo adipe, aut anferino, \& ulcera in capite manantia cum nitro, fi infricetur, fanat: paronychijs cum melle, auribus fractis cum pice, medetur: ad reliquos aurium dolores cum dulci vino infunditur: inflammatæ à partu mammæ cum cimolia, \& rofaceo magna utilitate perunguntur: additur ad arteria, vifcertumq́ue medicamenta : prodeft fanguinis excreationi potum . Sed in fecunda valetudine haufum infaniam mouet, \& largius cum vino potum interficit. In fictili mundo thus crematur, flagrante glebula fuccenfum à lucerna, donec exuratur: poft perfectam vftionem operire oportet, ufquedum rẹtinguatur: ficenim incineres non redigitur. Aliqui ollulam æne vafẹ cauo circa medium perforato cingunt ad excipiendam fuliginem, vt in eius mentione mox oftendemus . Alij crudo fitili luto oblito, \& in fornacem indito, cremant. Fictili etiam nouo viuacibus prunis torretur, dưm non amplius bullet, aut pinguitudinem, vaporémve emittat : facilè enim comminuitur, quodperuftum non eft.

\section{ФAolós $\lambda_{1}$ Rávou. CORTEXTHVRIS. CAP. LXXI.}

PR A E E E T V R thuris cortex craffus, pinguis; odoratus, recens, læuis, minimè fcaber, fine mébranis. Adulteratur admifto pini, aut nucis eius cortice. fed horum index ignis eft : fiquidem reliquicortices fuffiti nequaquam incenduntur, fed fine odore fumum eructant : thuris uerò cortex ardet, \& cum odoris fragrantia vaporem eiaculatur. Thuris modo vritur: \& vis eadem, quæ thuri, fed validior, adfringentiorque. Quare potu cruentis excreationibus, vuluis fuxione laborantibus in peffo confert: ad cicatrices oculorum, \& caua, fordesq́ue efficax eft. tofus fcabris lippitudinibus auxiliatur.

\section{Mx́v\&ABX́vou. MANNA THVRIS. CAP. IXXII:}

$M \wedge N$ A thuris probatur candore, micarum frequentia, \& puritate. Vim habet eandem, quam so \& thus, fed inualidiufculam. Sunt qui cribrata pini refina, ac polline, aut cortice thuris contufi adul terant. Sed hxc igne deprehenduntur: neque enim æquè fuffitu aërium vaporem, fed fuliginofum, \& impurum expuit, \& permiftum fuaueolentiz halitus virus habet.

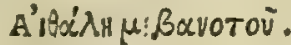
FVIIGO THVRIS.
CAP. LXXIIT.

F V I I G I N E M thuris fic facito. Forcipicula lucernis accenfas fingulatim thuris glebas in nouam fictilem ollam concauam imponito: \& areo uafe in medio perforato, deterfa diligenter forde, obtegito : alteram admoueto, ex altera eius parte, aut utraque fubiętis quaternûm digitorum altitudine lapillis, quò facilius perfpici queat, fi vrantur : \& quà locus capax fuerit, glebulas alias fupponito, \& anteaquàm prorfus prior gleba reftinguatur, aliam imponito, donec fufficientem fuliginem ui dearis coègiffe. Continuò tamen externæ æramenti partes fpongia, aqua frigida madefacta, abltelgantut : ita enim temperato æris feruore, fuligo omnis inhærebit, quæ alioqui per leuitatem decidua 
thuris cineribus admifcetur. Derafa itaque fuligine, cinis cremati thu ris feorfum fubftrahendus eft. Idem opus, quoad fatisfuetum tibi uidebitur, obeundum. Oculorum inflam mationes mitigat, fluxiones furpendit, vlcera purgat, caua explet, carcinomata liftit. Simili modo è myrrha, refina, ftyrace, reliquisque lacrymis fuligo excipitur, ad eadem conueniens .

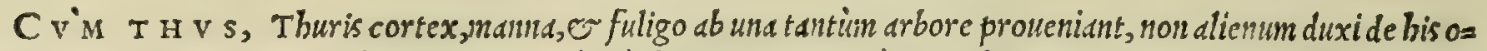
milibus unico comment.rio differere. Sed primum ḋ thure exordicns, cum Diofcorides in eius fribenda hiftorid, non late $\int e$ diffundat, ut eos uoti compotes facian, qui ean audire defidcrät, bic referam, que ex Theoplorafto lib. I X.cap. Thuris hitc. II I I.que q́; cx Plinio libro x I I. cap. X I I I I. diligenter exccrp/i. Gignitur itaq; thus (ut illi prodiderunt) preter ex Theophr. Arabiam nullis, ac ne Arabie quidem uniuer $\int e$, fed priuatime cuidam loco in medio feré rcgionis polt Atramitas pago 20

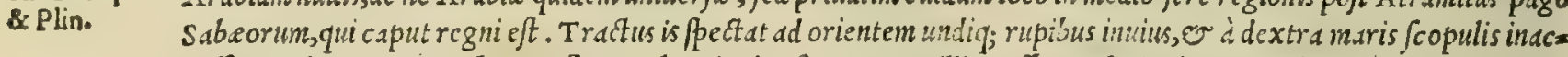
cefjus. Syluarum, que thus proferunt, longitudo cft centum milli.t paffun, latitudo auten dinidium eius : quas or Ninei attingunt aliun pagum colentes, per quos thus cuchitur uno tranite angufo, d quibus etian thus Mineñ olin dictum eft. siquidem hi primi fuere thuris repertores, eiusq;; cominercium primi fecere, insxime q́, exercent. Cateris interdictum eft, bis exccptis, uidere thuris arbores:ac ne Mineorum quidem omnes (ut perbibent) ipfas arbores uis dere po/funt. Ius enim in thus, ip sumq; legendi poteftss, tricentuin tantummodo effe familiarum dicunt, qux per fuc= ceßiones id fibi uendic ant; qux etiámnum ob id à propinquis popul is facre uoc dntur, quód cum uulnerant arborem, guó liquor défluat, aut cùm imetunt, nec freminarumn, nec funerum congreflu pothutuntur : att; ita religione merces au= gentur. Quidam promifcuum ius Minxis omnibus effe tradunt, of unoquog; anno inter ipfos diuidi. Caterùm quan= quam prifci Romani in Arabia bella geffere; thuris tamen arboris facies à nullo (quod equidem legerim) Latinorum 20 tradita eft: neque Grec is etiámurn auctoribus (et/i plures de ed confcrip/erint) de eius cffigie fatis inter fe conuenit, licet dixerit $\mathrm{T}$ beophraftus, quód arbos thuris, qua fuper sardes apud delubrum quoddam furrexit, fronde lauri conz ftet. Thus duntaxat metifolebat incifo arboris cortice, canis ortu, flagrantißimis aftibus, quód tune effet humoribus maximé pregnans, quod poftea legebatur fequenti autumno. verim dulcedo quxftus aliam uiam attulit, qua etiam primo uere ip fum legeretur, incifis per hycmen arboribus. Excipitur quod ex arbore profilit, atque diftildat pal mea tegete, ubi loci natura pofcit, aliubi area circumpanita. Purius, or perlucidius illo modo, Jed bec ponderofius; minus pellucet, minus'; uiribus pollet. Vindemia uerna thus rufum emittit, nec comparandum priori : uires enim im= becitliores fibifortitur. Creditur nouelle arboris candidus effe, quim ueteris. Quod befit in arbore, firro depectis tur, ideo ó; corticofum. Tradidit Diof corides prexter Arabicum inueniri e Indicum, id tamen flauej fcere . quod ins dicat, thus er in alijs regionibus nafci preter illud, quod ex Arabiadeuebitur. Quod cim Theophraftus, or Plinius fatis compertum haberent, quanuis prius fcripfiffent, thus preter Arabiam nullis gigni; dixere tamen pofted, quód Thuris facul. ex relatu acceperant, id etiam nafci in quibufdam infulis. Thus (ut fcribit Galenus lib.v I r. fimpl.medicamentorum) tates ex Gal. excalfacit ordine fecundo, deficcat ueró primo, paululum q́; adftringit. Sed caindido mininuim adftrictio manifeta. Cortex eius euidenter adftringit : proinde fanéftrenué quoq; deficcat, adeo ut ex fecundo fit ordine completo defic= cantium. Eft autem craßsiorum partium, quam ip $\int u m$ T bus, o minime particeps acrimonis. Ob has igitur tum $f_{a \neq}$ cultates, tum qualitates multus eft eius ufus apud medicos in hamoptoicis, ,tomachicis, creliacis, or dyfentericis, nont tantìm ijs, qua extrinfecus applicantur, ip fum admifcentes; fed or ijs, que intró in corpus fumuntur. Ramus eius (lego fuligo eius, er infra rationem reddam) tum ficcioris, tun calidioris eft facultatis, qudin ipfun thus, adeó ut ad tertium uf g; $_{\text {; }}$ exceffum perueniat . Habet ueró ctiam abfterforium quiddan : itaq; co nomine expurgare, o implere, Galeni locus qua in oculis confiftunt ulcera, uidetur, uelut or myrrhe, e ftyracis. bec Galenus. Verim, ne quipsiam for= refitutus. taffe me perperam Galeni lectionem immutaffe exiftimet, illud fciendum eft, quód in Galeni loco citato non folum Gerardi Gaudani werfio reprebendenda (quod tamen interpreti uitio minime dandum eft) fed etiam in Gracis tum ipfius Galeni, tum Pauli Aegineta codicibus communis lectio deprauata uidetur . quippe ubi in thuris capite legitur

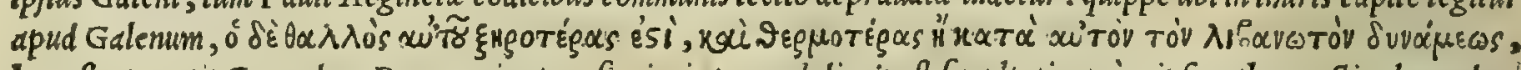
boc eft, ut uertit Gerardus, Ramus eius tum ficcioris, tum calddioris eft facultatis, quàm ip. rum thus, rectius legendum

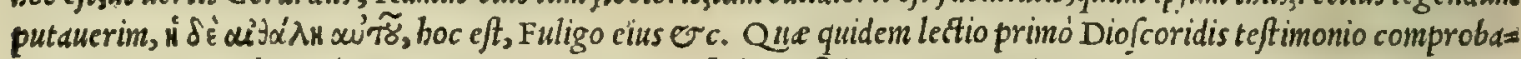
tur : qui preterquàm quòd ramorum non meminit, ipfi thur is fuligini, non ramis, tum expurgandi, tum implendi,que in oculis confiftunt ulcera, facultatem inc ffe testatur. Deinde id manifefte innuiffe uidetur Galenus in predicti capi= tis calce illa comparatione, cum inquit, ueliti ex myrrha, or ftyrace. Nam libro v I I I. fimpl. medic. de fyrace agens: ftyracis combufti fuligo, inquit, thuris fuligini quodammodo eft fimilis. Et libro v I I. de fuligine fcribens: Frimim enim, ait, thuris fuligine utuntur, in ocularias mediciras mista, cas uidelicet, que ad oc ulos etiämnum phleg=

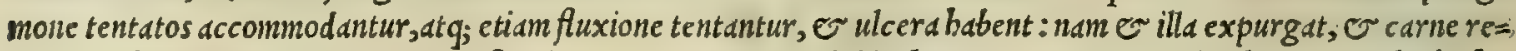
plet. Ad bec ufurpant quo o; cam ad facultates, quas wocant calliblepharas. Preterea terebinthine, myrrbeq $q_{\text {; }}$ fu= ligo moleftia caret, non aliter, quam thuris: Sed ftyracis his quodammodo ulentior eft. His igitur rationibus affere= re non dubitauerim, boc in loco unlgatos Gre cos codices fortaffe librariorum incuria uocum fimilitudine deceptorum

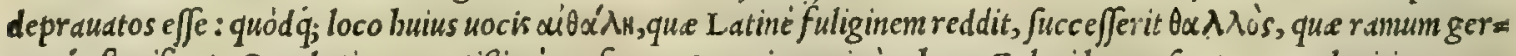
menue fignificat. Quod etiam apertißimé confirmat Serapio : qui cùm bunc Galeni locum fuo tempore legitimum, ons ineorruptum baberet, qua hoc Galeniloco noftra a tate de thuris ramo leguntur, ea ipfe Galeno accepta referens, de. thuris fumo, feu fuligine legit. Quod item apud Ac̈tium uidere licet : tamet $f$ Paulus hac menda non uacet, uel fui ip= fiusfortaffe, ucl potius librariorum culpa. Nam alitis non poffein nou admirari, quód in Galeno lectionem banc dea praustam effe non animaduertiffet, quemadimodum hac in re noftre etatis interpretes mibi quidem admiratione dis: 


\section{In Lib. primum Diofcoridis.}

gmi-uidentur. Catcrim thus (ut Galemus foribit lib. I I I. de comp. medicament.per genera) concoquit, or pus mo= uet in temperatis corporibus, nam in bumidis farcoticumeft. Preterea cum dixerit Diofcorides, thus in fecunda ualctudinc hauftun, infanian facere, o largius cum uino fumptum interficere, hinc Aucennum erraffecrediderim,

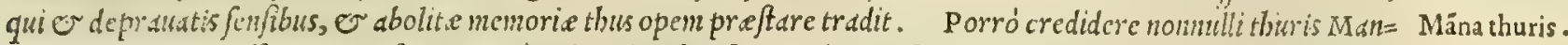

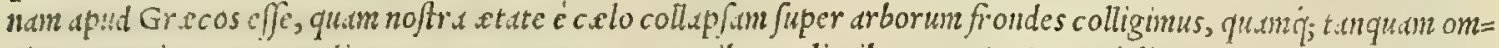
ni ex pate imocumm medic anentum, ơ utero gerentibus mulieribus, er pheris, or delicatis dcifciende aluigratia propinanus. Vertintres quidem aliter fe babet: nanq; Plinius, or alij complures produnt, Namum thuris cffe mi= cas eitus concuffu clif w, quod dum conuebitur, exienit. Quod ctian teftatus cft Galenus lib. I I I I de compofitione me= dic. fecundum locos. Sed quonian thuris Manna mibi redegit in mentem Mannam banc purgatoriam celitus demif=

so fam, ut plenius lcgentibus fatisfat, cim buius nufyuam meminerit Diofcorides, de ea tradam, que ex Arabum monu= mentis deprompfi, quxép; ipfe etian in Calabria uidi, ubilatudatißima colligitur. Eft igitur M A N A quidamros, fiuc liquor fuanis, qui ex aere ueniens fublucanis temporibus, arborum ramis, ev frondibus, berbis, lapidibus, e folo interdum inucitur harere : quibreui temporis curriculo coale fcens, grumofus in gummi morem efficitur. Huius duo tantim gencra ip se in Italia nidi, quorum alterum ab orientali plaga, alterum ueród Calabris defertur. Eius, quod ex oricnte petitur, duplex babetur pecies; preftantißima altera, quam Maftichinam appellant, nomine dे granorum naftiches /imilitudine fumpto : infirma uerò, or uilis alter a, qua Böbycina nuncupatur. quippe que nil aliud cf, quă aut cuandda, $\odot$ fenio exhaufta Naftichina, aut faccaro, alijs q́; impofturis adulterata. Calabrienfis plurimi penditur, que frip pum fiondibus infidens colligttur, proinde foliorum Manna cognominata, minutis granulis conftans, translu= cida, gramis, maftiches granulis fimilis, candida, guftudulcis at ; fuauis. Secundas partes fibi adfcifcit, qua ramis 20 infidst: tcrtiss ueró, que lapidibus, o folo inbaret: wimirum ba granulis conftant craßsioribus, or colore longè mi= mus fyncero. Exed,qux nocte peracta é calo ceciderat, Coffentix, qua eft Calabria ciuitas, mibifacta fuit copia fu= per fraxincis frondibus, que iulapij perfecté coctiguttas prorfus referebat. Accepi inibi ab incolis, quód bec mane lcgitur, priufüuin fol cxortus admodum cxcalfaciat: nanq; poftea fole liquefacta, abfortáf; facilé euancfcit. Quda propter plerig; , ubi in snagna deciderit copia, fummo mane arborum ramos prefcindunt, or in opacis collocant, ubi concretan matori commodo legunt. Hinc ueró fit, ut ne fciuerin ego, qua ratione ductus Fuchfius uir eruditißi= mus fcripferit libro de componendis medicamentis, quem nuper auctum edidit, Nannam (ut fuis uerbis utar) Cald= brinam grano conftare grandiori, floccorum lane or bombycis referente effigiem, candidiori, or obid alio nomine Bombycinam uocari : quin or banc uiliori pretirs uendi. Atqui cum is à nobis plané difentiat in Manna, qua ex $C d=$ labria aduebitur, biftorix, ratus gnarus,; banc, quam paulo anté reddidi, ueram effe, non plura adijciam: fed relin= 30 quam in boc fore iudicium eorum (fin uel medici, uel pharmacoprei, uel mercatores) qui Manne illius naturam re= ctus norunt, atg; ean fatis exploratan babe nt. Duo Manne genera etiämnum à Mauritanis diuerfis capitibus pro dita repcrio: quorum alterum Mannam, al terum ueró Tereniabin appellant. Tamen non aliam inter ea pecierum differentiam efje conftat, qudim quod alia liquefcens, mellifimilis, alia in grumos concreta uideatur : qua profecto illa eft, que ad nos aduebitur. Duam ueró ij Tereniabin uocant, Serapionis teftimonio or ip fam effe Manndm mani= Fefte oftenditur. Nanque Abic is auctoritate, Tereniabin, inquit, febrium ardentium inflammationes mulcet, fitim extinguit, alummediocriter e:mollit, pettori, er tußi opem preftat, nec alivd eft, qudin Manna. Teftatur Brafd= uolus Ferrarien/is, Nicolaum quendan Ferrarie (ut arbitror) pharmacopolam eniffe à quodam Mauritano uds ple $=$ num cuiufdam Manne melli fin ulis, que in medicamentis non fatis laudari potuit. Hanc equidem ex co genere fuiffe exiftimauerim, quod Mauritani Tereniabin nominant: etfi Brafauolus ip fe contrarium fenferit, cum uelit, Terenia=

40 bin Mauritanorum eam effe Ma'snă, qua communiter utimur : eorundem ueró Mannam effe buiufce liquida peciem. Que tamen fententia Arabum fcriptis prorfus refragatur. quandoquidem ip fe inuenerim apud serapionem, quód Tereniabut quidam ros eft é calo cadens melligrunofo fimilis, er quód aliter mel rofcidum appellatur. Auicenna ue ró de Manns agens, inquit, eam gu mmi modo concrefcere: à quo Me fuem nibil diffentire comperio. Credidit Auer= roes, $\sigma$ poft eum alij quam plurimi, Mannam ueteribus, prefertim Galeno, incognitam fuiffe. Quibus illud recla= mat, quod ip fe Galenus friptis tradidit libro 11 I. de alimentorum facultatibus, capite de melle, fic dicens. Memini aliquando cim af ate fuper arborum, ac frutic um, berbarumí; folia mel quàm plurimum fuiffet repertum, agrico= las welut ludentes ceciniffe, I upiter inelle pluit. Precefferat autem nox, ut per aftatem, fatis frigida (ndin tum tempus aniz eftium erat) pridieq ; cả̉dd, or ficca fuerat déris temperies. Atqui peritis natura interpretibus, balitus é terra, $\mathcal{O}$ aquis prodeuntes, folis calore exacté attenuati ac cocti, à frigore fecute noctis in unum

so coati, ac denfati fuife uidebantur: fed apud nos rará id accidit: in monte autem Libano quotannis perfepe. Ita= que coria fuper terram extendentes, $\sigma^{-}$arbores excutientes, quod ab eis defluit, excipiunt, $\sigma$ ollas, ac fictilia melle inplent, uocantó; id rofcidum mel, O-dérium. Hæc Galenus de Manna memorix prodidit. Ex quibus co= rum error deprebenditur, qui putant banc ei fuiffe incognitam. Exiftimandum igitur eft, quódbinc Arabes fuume deduxerint Tereniabin; preeertimó; cum feribat Serapio, boc ab eis mel dërium appellari. Huius etiam meminit Plinius libro undecimo capite duodccino bis uerbis. Venit mel hoc ex ä̈re, er maximé fiderum exortu, praci= puéque ip 50 firio explendente fit, nec omnino prius uergiliarum exortu fublucanis temporibus. Itaque cum pris ma aurora, folis arborum melle rofcida inueniuntur. At fi qui matutino fub dio fuere, unitas liquore ueftes, ca= pilluinque concretum fentiunt. Siue ille eft celi fudor, fiue quedam fiderum faliud, fiue purgantis fe dëris fuc= cus, utinam effet $e$ purus, ac liquidus, or fuse nature, qualis deflut primó. bactenus plinius. Sed tam antiqua Nianares eft, ut dnte Galenum, of Plinium, eius etiam meminerit Theopbraftus Hefiodi auctoritate, libro II I. capite nono de plantarum hiftoria, bis uerbis. sin autem auctore Hefiodo, melld, apesq́; quercus ferat, magis

Fuchfij opinio.

\section{Brafauoli la-} pfus.

Mannx Arabum.

Manne hilto ria ex Galen. Pli.\&Theop. 
Manna in co- quog; illud confirmatur. Ergo nafcitur uel hic melleus humor é calo cadens, in bac maximé infidens. Mannam u=

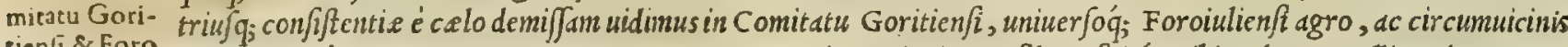
tienti, \& Foro Iuly.

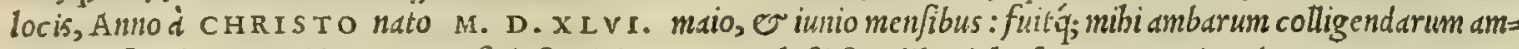
plißima facultas. Siquidem ca, que fici, fraxinib or orneogloßi frondibus inhxe ferst, gumni modo concreverat, co $=$ lore candida. At qux fuper amygdile, perfic e, ac quercus folia deciderat, mellis modo lique fcens ab arbore deflue= bat, flau colore. Quo factum eft, ut facile crediderim, quod non fui ip/ius facultate gummi modo Manna concre $\int c a t ; \int e d$ foliorum, in quibus delap $\int a$ recumbit. Qua re ab Arabibus diligentiJimé perpecta, utriusq; Manna bifto $=$ Monachorú riam diuerfis per $\int c$ capitibus fuis monumentis prodidere. Sed profectó non admittenda, quin potius explodenda opinio explo f. uidetur fententia Mondchorum, qui in Mefuem commentarios fcripfere, cim pro certo affer ant, firio ardente $M$ an= nam non folum ror is modo fuper arborum, or herbarum folia reperiri aěris, or cali clementia; fed etiam ab arbori= bus, fraxino $\int$ cilicct, 0 orneoglo $\iint_{0} a b \int_{q ;}$ aliquo cal i rore, gunmium modo incifo earum cortice in lacrymas concre fcere. Quod tamenut à rei natura, ita etiam à ratione, o à ueritate abhorrere putauerim. Siquidem ca Manna, que incifo harum arborum cortice in A pulia, of Calabrienfi agro bac atate canicularibus diebus collacrymare cae=

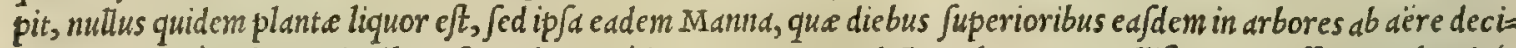
derat. Nam cum illis regionibus ufu ueniat, quod pra ceteris predicta arbores eo mellifluo rore affatim, abundeq;

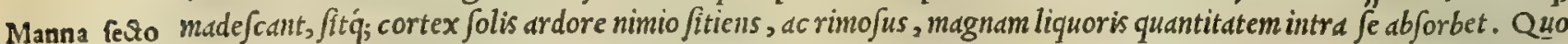
arborum cor fit, ut poftmodum exurente canicula incifo eoden cortice idem liquor exiliat, $\mathcal{O}$ in grumos concrefcat: qui tamen tice manans. cumleues, fungofíg; fint ob arbor is fucci niftionem, infeliciter operantur, nec alterius Manne uiribus correfpon= dent. Qu'd autem id tantim fraxino, orneogloffó ; eueniat, cim melleus ille ros in uniuerfum omnes occupet plans tas, in caufa eft harum arborum nobis occulta poteftas, ut magnetis ad ferrum, or fuccini ad paleas . quippe omnibus clarum eft, apud Calabros, er A pulos folam fraxinum, eí; congenerem orneoglofjum Mannam in fe contrabere, re= tinere, denfare, ac coblbere: ex alijs ueró arboribus eandem ftatin defluere, er in fubiect as berbas, petras, folumq́; diffundi. Quare ab his duntaxat arboribus incifo cortice non fané primó, e fecundum naturam, fed ex accidentide= fluit Manna. Verum optimi illi patres contenti ( nifallor) cortice, internas illarum arborum partes penetrare negle xerunt. At incole, qui ex maiori buius liquoris prouentu, plus auri referunt, rei naturam diligentius inueftigarunt.

Petri Criniti Caterum exbis, qui thuris Mamam celeftem banc effe crediderunt, unum Crinitum Florentinum fuiffe comperio. error.

Serap. lapfus. In cuius cenfuran Mandrdus Ferrarienfis libro primo fudrum cpifoldrum peculiarem epiftolam confcrip/it. Verun Mannæ tem- thuris Mannam cum celefti inepté confundat. Meminit Manne inter alios Grecos etiam Actuarius libro de medica= peramentü, \& mentorum compofitione, ibiq́; de eius uiribus ac facultatibus differuit. Manna tam Auicenna , quàm Me fuis testi= uires. monio, equaliferé temperamento confistit, licet ad calidum paululum inclinet: at Auèroi calida, humidáq; babetur. Aluum deuorata, aut bafta ciet, per fe tamen imbecilliter. Ideóf tum faminis utero gerentibus, tum pueris ipfis tutó femper exbiberipoteft. Alịs medicamentis addita uires corum auget. Bilem facilé educit: fitim extinguit, apé rit, emollit, leuigató; gule, pétorisq́; partes. Que ex Alexandria Aegypti adfretur Maftichina uocata, uno dun= taxat anno in fuis uiribus perfiftit : fed que in Italia prouenit, prefertiní; Calabrienfi agro, pluribus annis incor= Fuchfij opi- ruptaperdurat. Enimuero Fuchfius medicus noftra atate er doctrind, er rerum cognitione clarus, in libro de nio reproba- compofitione medicamentorum, quem fecundo auctum excudit, Mannam à nedicorum ufu explodere conatur his ta. uerbis. Manna leuem certé, aut feré nullam foluendi, aluumq́; fubducendi uin habet. Quod iss compertum eft, qui iuxta Libanium fuerunt. Nam referunt, indigends eius montis, cum abunde ea fatientur, nibil tamen ladi, aut al uum fibi quoquo pacto fubduci fentire, fed e a tanquam obfonio nutriri. Q uapropter cum mellt quodammodo fimilem facultatem babere conftet, facilé ea carere liceret, modó peregrinorum admiratione non ita duceremur : ne $\$$ f tul= $t i$, contemptis nof r ratibus, é longinquis regionibas allatis uti potius, quàm ijs, qua noftris in bortis proueniunt, mal= lemus. Sed ftultitia noftre, temerc fumptus immodicos facientes, condignds damus pands. hac Fucb/ius. Quibus ni= mirum uerbis liquct cum uelle ufum Manne prorfus adimi, atque ipfum ad medicamenta deferri, quae noftris in rex gionibus proucniunt. utinam equé commodé es tutó fieri poffer ifta commutatio, ut faltem, quod ipfe uebcmenter cu pit, immodicis fumptibus parcercmus. Sed quoniam rationes, quas affert, non funt ea, quibus id perfuaderi poßi= mus, idcirco cogor in boc eius fententic refragari. Nam quod Manna aluum fubducat, e e em quidem innocue, non foium conucnit inter auctores, qui hactenus de illa fcrip ferunt, fed id etiam quotidiana experientia docet. fiquidem duarum $\sigma$ femis unciarum pondere data aluun perbellé deijcit, or priuatim bilem educit. Quód autem Libani mon tis indigene Manna non ut medicamento quod purget, fed ut obfonio, quod nutriat, utantur, quis tam facilé ut Fu= chfius, referentibus credet: cium nos quotidie contrarium experiamur : aut fi credat, non aliquam facti illius ratio nem adenueniet, qua, ut decet, experimentum tueatur. certé nullus, fi recté iudico. Vt autem medicamenta pere= grina abole fcant, qux mitißtman foluendi uim habent, inter qux iandudum Manna principem fré locum obtinet, utemur noftratibus, er fortaffe latbyri, pityufa, titbymalis, bryonia, or alys buiufmodi, que paßsin nafcuntur in hor= tis er campeftribus, atque um lethiferain ac perniciofam fortita funts' abfit, meo quidcm iudicio. Malin ergo in boc fequi exemplum Diofcoridis, Galeni, or aliorum tum Grecorum, tum Arabum probatißimorum auctorum, quàm alterius quicuuq; fit . illi enim non contenti fimplicibus medic amentis, qux fuis in locis nafcebantur, peregrinis etiam uti uoluerunt. quos tamen tantum abeft, ut ftultos dicamus, wt etiam fapientes iudicemus. 2utre non potui fatis mi= rari Fuchfiun ita malé de Manna fenfiffe, quam omnibus, co excepto, perfficuum eft fine molcftia uentrem purga* re. Equidem opturem, ut ij, qui alicui medicanento ufun abrogare ftudent, uel id aquius or modeftius agerent, aut e noftratibus e proferrent, qua eandem uim praftare poßsent. neque enum ego is Jum, qui percgrina noltratibus pra: 


\section{In Lib. primum Diofcoridis.}

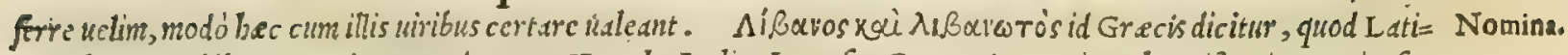
nis Thus: Arsbibus, Ronder, Conder, aut Kateth: Italis, Incenfo: Germanis, Vucirauch: Hipanis, Encicnfo, Gallicis, Encens.

täTou os. Hac dicto hic er pullo pift Ic gitur in unlgaribus Gracis codicibus: qua in primo loco thus natura ro tundum infignitur, in fecundo ucrò arte tule factum cognominatur. Scd quia abfurdum uidebatur Niarccllo, Diofro=

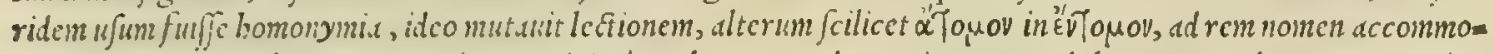
dans. Quum tancn lcctionis mutstionem minime probut Manardus: qui preterca dubitat quo modo atomos I atinis

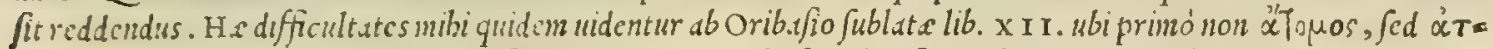

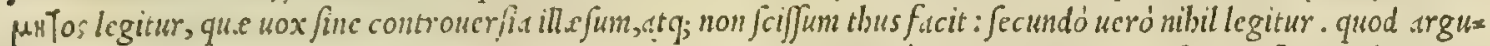

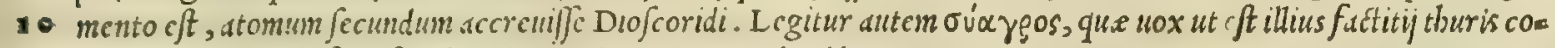
gnomicntum, Oribafíte tefe, Icgitimum, ita non mutanda uidetur.

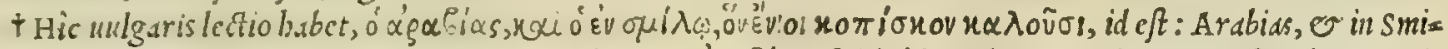

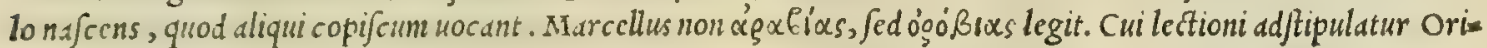
bafius libro x I I. ubi ó ópójibs tantium, reliqua ueró ut addititia non leguntur.

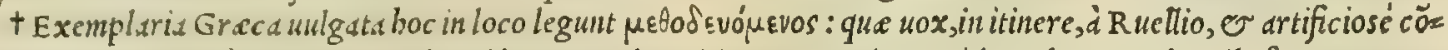
formatum, uertitur id Narcello. Sed cquidem eam aduentitiam putauerim, quod non legatur ab oribafio.

P I $N$ V S.

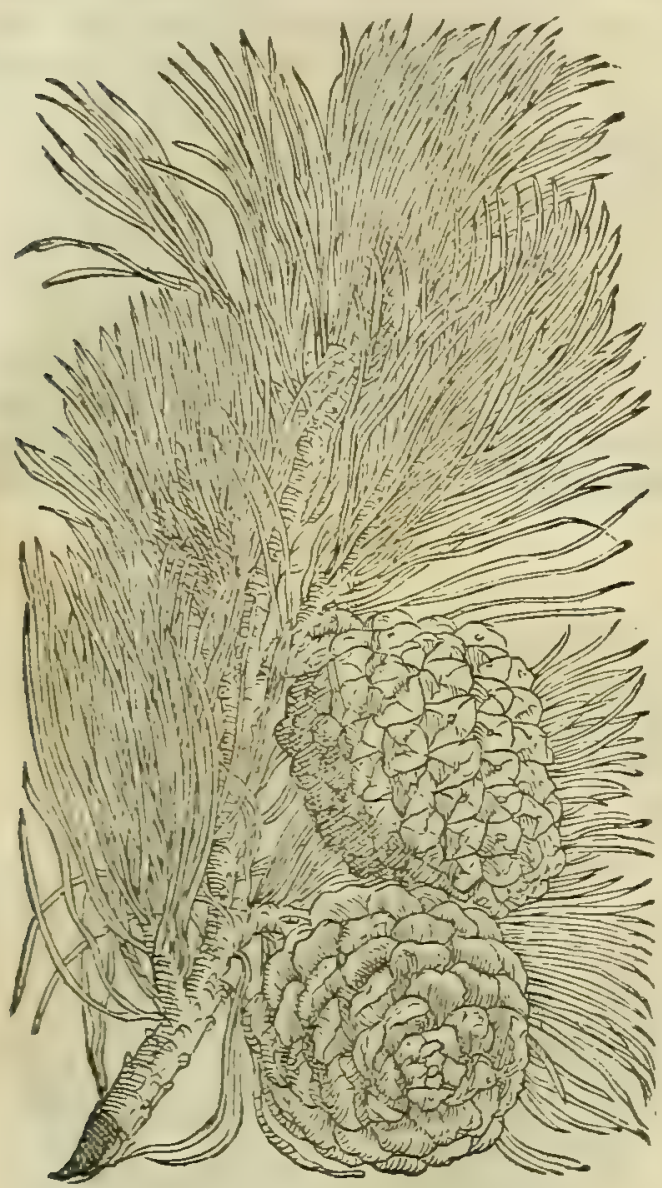

P I C E A.

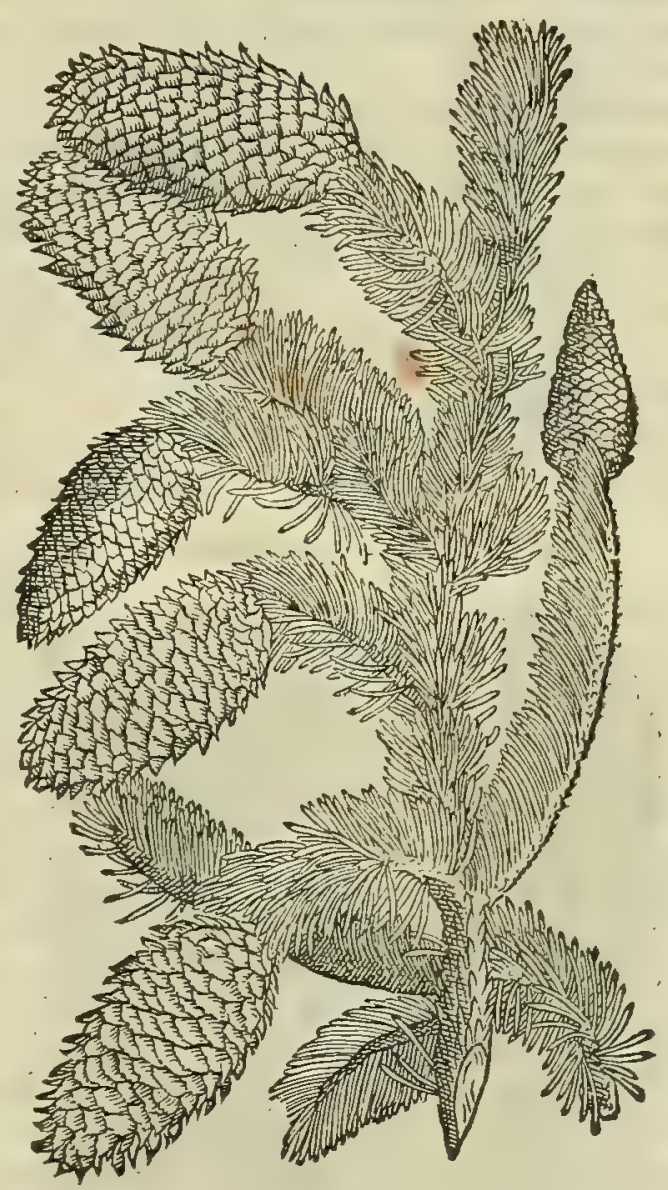

CAP. LXXIIII.

ГÉuxR, xqi nitus.

PINVS, ET PICEA.

50 PINVS, ET PICEA generi eidem afcribuntur, fed quandam flagitant fpecierum diftinationem.
arbores uulgò cognitæ. Quarum cortex aftringit: prodeft tritus, \& illitus intertrigini, ulceribus fummum corpus occupantibus, ambuftisque cum fpuma argenti, \& manna : ulcera delicatulorum acrimoniam recufantium cerato myrtino exceptus ad cicatricem perducit : tritus cum futorio atramento ferpentia cohibet: fuffitu partus, \& fecundas eijcit: potus aluum fiftit, urinam mouet. Folia eorum trita, \& illita inflammationes leniunt, ulnera ab inflammatione uindicant : trita autem, $\&$ decocta in aceto feruenti collutione dentium dolores mulcent: hepaticis utilia funt drachmæ pondere in aqua, aut mulfa pota. Pinex nucis cortex, \& folia potu idem præftant. Teda earum particulatim fecta, $f$ in aceto coquatur, $\&$ decocto dens colluatur,dolores leuat. Ex his etiam fit fpatha acoporim, pefforumq́ue compofitionibns idonea. Quinetiam earum crematarum fuligo ad librarij atramenti confectionem excipitur : ca circumlitionibus efficacifsimè imponitur, quibus palpebras ornant,coloremq́ue mentiuntur, calliblephara Græci uocant : arrofis oculorum_angulis, callofis, glabrisq́ue 
genis , \& collacrymationibus opitulatur . Pityides appellantur pinorum, picexq́ue fructus, qui in conis inueniuntur. Vim aftrictoriam habent, \& aliquantulum excalfacientem : tufsi, \& pećtoris uitijs auxiliantur, perfe, aut ex melle fumpti. Nuces pinex cùm repurgatæ manduntur, aut cum paffo, aut cucumeris femine bibuntur, vrinam cient : acrimonias in renibus, \& uefica hebetant : ftomachi roliones leniunt. datæ cum portulacx fucco, uirium infirmitatem roborant, corruptorum quoque humorum labem obtundunt. Pinex nuces integre recenter arboribus decerptx in paffo franguntur, \& decoct $x$, uctultx tufsi, ac tabitudini conferunt, fi quotidie ex eo liquore terni cyathi bibantur.

Pinihiftoria, NOSTRAE nimirum negligentia adfcribendum foret, cimmos aßiduébabeant pinorum, abietum, picearum, er

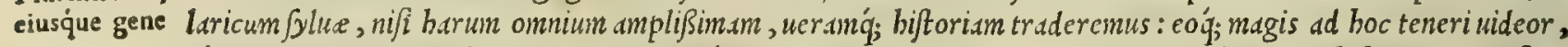
ra. cim animaduerterin Plinium, recentiorumiq; nonnullos euin fecutos, in buiufcemodi plantarum biftoria, qui refinas fundunt, longé ab co diffentire, quod in Tridentinis montibus noftris oculis perpectum, apud allos etiam teftatum relinquere pofjumus. Rem itaque à Pinu exordiens, inuenio Theophraftum libro I x $\mathrm{x}$. cap. $\mathrm{x}$. de plantarum hifto= ria, duas Pini pecies adnotafe, domefticam altcram, alteram ueró fylueftrem: huiusiq; in maritimam, o montanam

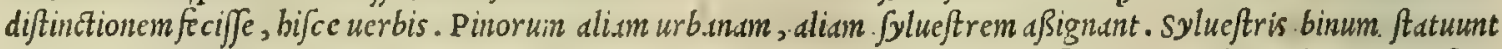
genus, quorum alterum Ideam, alterum naritinam uocant. Harum rectior, celfior, materiéq; craßsior Idad: folio imbeclliori, tenuioriq́; maritima: or cortice la'uiori, utiliq́; ad corid. quod alteri minus. Nux maritime rotunda, breviq́; debifcens: Idaa oblongior, uiridis, minusq́; hifcens, tanquam fylueftrior. buctenus Theophraftus. Ve= Petri Bellonij rim non defunt, qui contendant Theophrafum bec de picea f cripfiffe, non autem de pinu : ea nimirum ratione freti, 20 opinio explo qućd ఐ'́vหн, de qua bic differit Theophraftus, Grecis piceam, non pinum fignificet. Quamobrem Petrus Bellonius fa. Cenom anus communĕ Grecorum fententiă fecutus libro, quem arboribus coniferis dicauit, id totum picea arbori red=

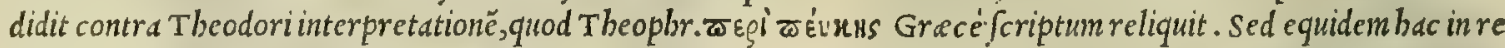
Bellonium ( pace uiri boni dixerim ) ballucinatum arbitror, non quód propterea eum Gracifermonis imperitum iudi= cem, fed quod mibi videatur non diu uerfatus in Tbeophraffi er Galcni lectione, aut de plantis ijs fcripfiffe, quarum non certam habuit cognitionem. nam plura funt, que eius opinioni re fraguntur. In prinis mihi quidcm non dubium

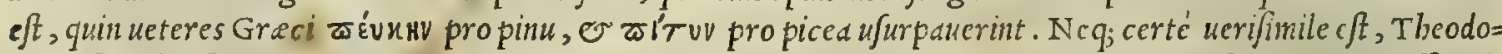
rum Theophrafti interpretem natione Grecum, of lingux tum Graca, thm Latine peritiß3imum, ignorafe quid

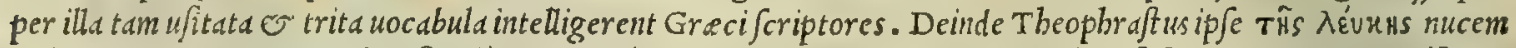

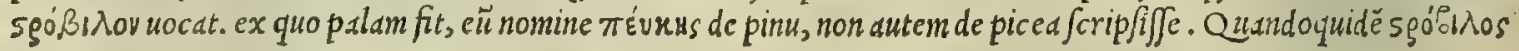

\section{PINVS SYLVESTRIS.}

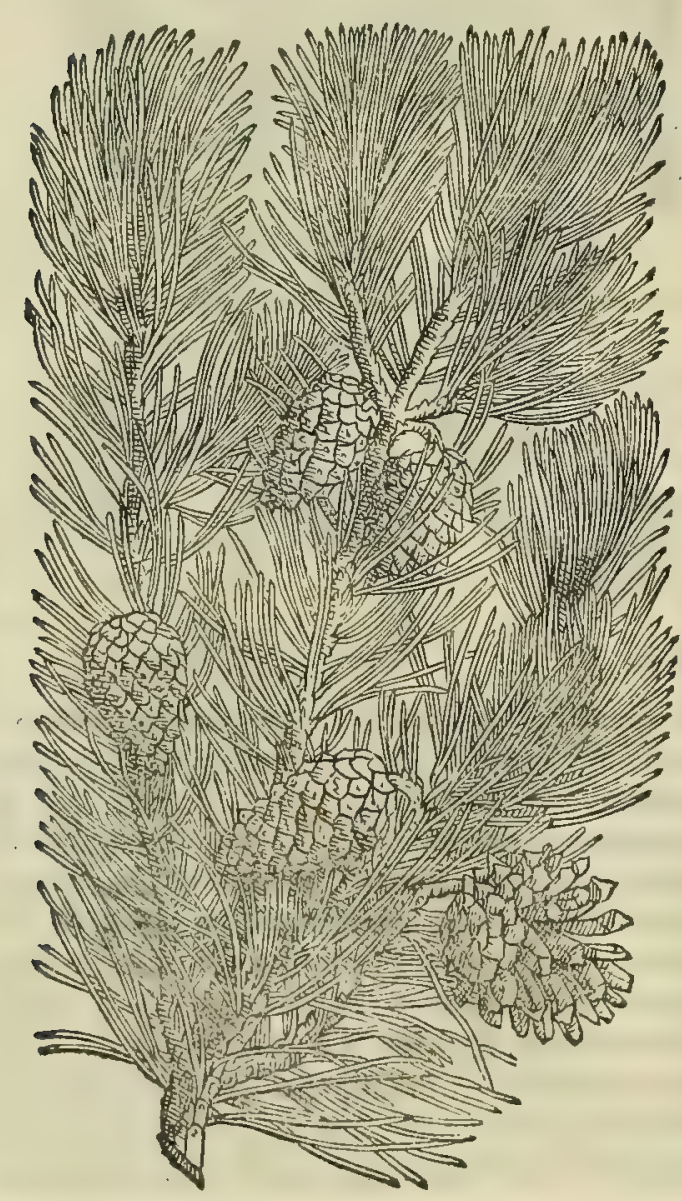

\section{PINVS MARITIMA.}

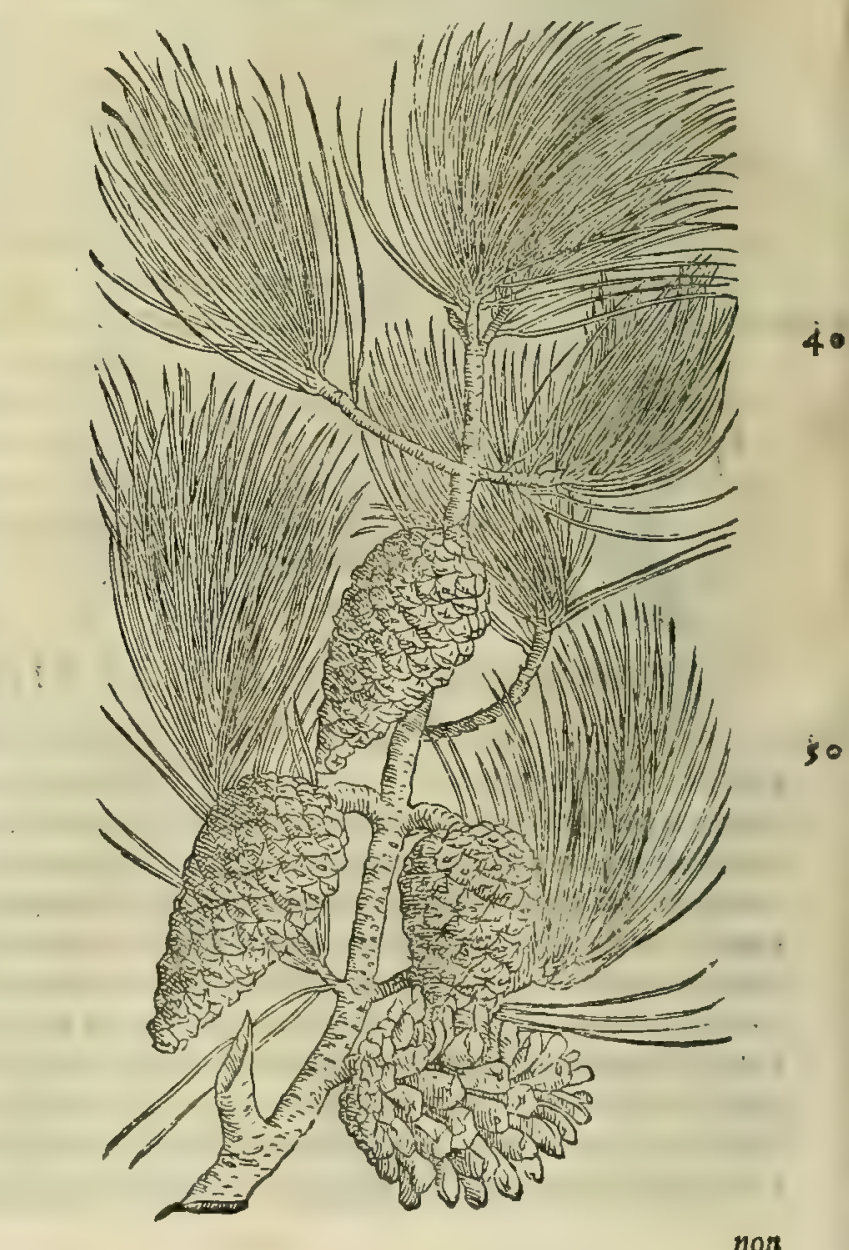




\section{In Lib. primum Diofcoridis.}

PINVS MARITINA ALTERA.
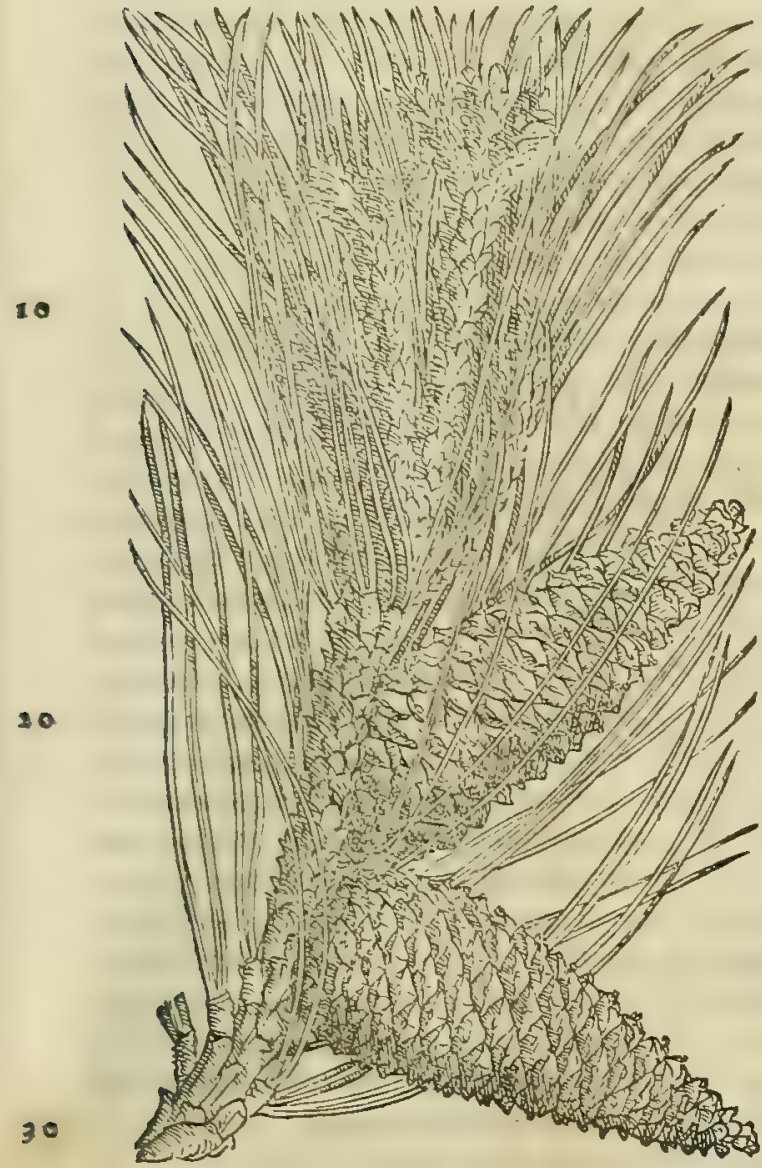

PINVS SYIV, MVGO.

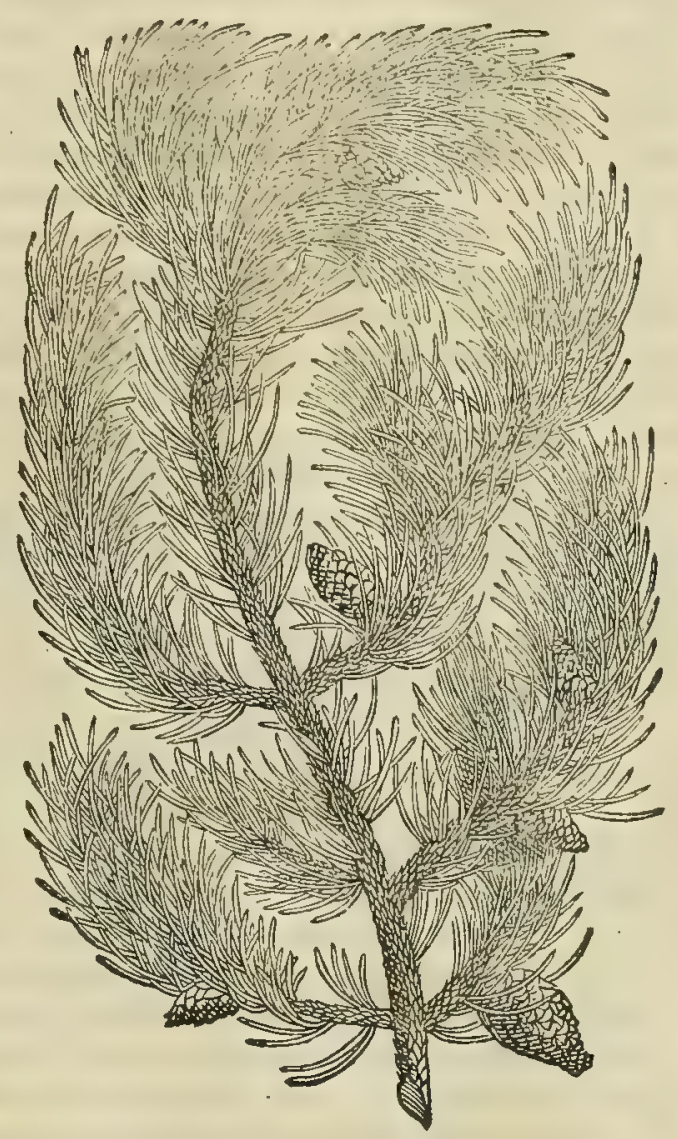

PINVSSYIV. CEMBRO.

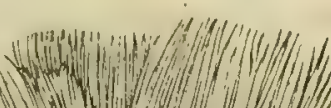

non aliud defignat, quàn nucem pineam, ut aperté declarat $G$ ds lenus lib. I I. de alimentorum facultatibus bis uerbis. Nux pined boni ac craßi eft fucci, multumó; nutrit, non tamen facile coqui=

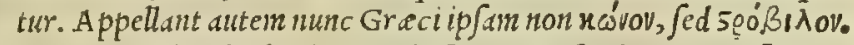
Idem libro de cibis boni or mali fucci, ita fcribit. His ip/is plus craßi, non auten mali, fucci habet nucleus pineks, qui xâvos uo=

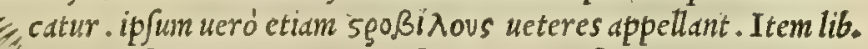
$1 /, \mathrm{V} I$ I. de fimplicium medicam. facultatibus, fic inquit. Coni fru= Aus, quem quidem er coccalon nominant, e ftrobilon erc. Ad= bec commentario quarto de uictus ratione in morbis acutis apud eundem bec fripta leguntur. Nempe róru $\alpha \lambda$ os ab Hippocrds te ditus, nonita, fed üwos magis ab antiquis Grecis appellac tur, ueluti à recentioribus medic is propemodum omnibus só́, 入os. Galeno deniq; adfipulatur symeon setbi, utpote qui nu=

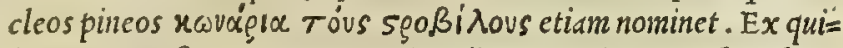
bus utiq; conftare puto contra Bellonij opinionem, Theoplra=

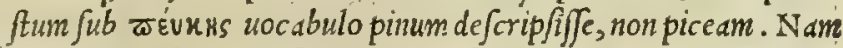
fi Theophrafto peuce frobilum profert, quem Galenus inter ci= bos connumerat, non uideo, quo modo is pice e fructus effe poßit, cuius nucleinon funt edendo, Bellonij etiam teftimonio. Quód in= fuper hoc loco per бย́ux pinum intelligat Theophraftus, illud maxino e $\int e$ poteft argumento, quód nu quam piced uifa fit urbas na, nififorté é fylueftrium femine ad pectaculum in bortis fatd. cuius tamen contrarium deprebenditur in pinu, qua domeftica atq; urband frequentifima conpicitur. Hinc porró factum eft, ut Bellonius fua ductus opinione, ex boc in alium quoque erroren inciderit. Quippe illud falfum eft, quod ex teda pice fiat pix, ut Bellonius afferit, perperam, meo iudicio, Theophr. hoc loco inter pretatus. Siquidem rara admodum eft picea, que ted am babeat: 


\section{8 \\ And. Matthioli Comm.}

Pinorum fyl fimia frequentifime funt pinorum fylux. Caterim bis, que de fylue trium pinorum generibus fcribit Thco= ueftrium ipe- phraftus, in noftro climate refragatur, que fen/ibus clarißimé patet experientia. fiquiden agreftes, que plurine in cies. maritimis noftris senenfibus proucniunt, fructum ferunt pithama oblongum, pyramidalcm, firmum, ac folidum, nee

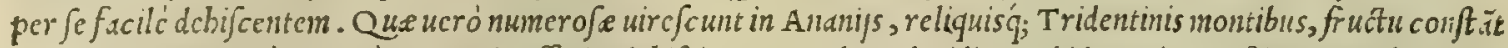
paruo, breu, qui quàm primum aruerit, affatim debifcit, $\sim$ ex arbore decidit . Sed id eucnire exiftimamus, climatum, e regionum karietate, uel etian quod märitima plura fint getrera. quandoquidem in maritimis Pifarum orts fyluc= fres proueniunt pini, quibreues nuces edunt, chpreßt modo, non tamen rotundds, $\int$ ed acuminatis, ut pictura, quam lic cxhibemus, oftendit. Quinetian in eodem Trudentino agro ijfdem Ananijs, er uallis Flemarum montibus alix due fylueftriun uifuntur fpecies à predictis longc figura dißidentes: quar um unam unlgó Mughi incole wocant. qux fi= 1 ne ftipite medio, ranos circunquaq; a radice fundentes, bumi repunt fpatio cubitorum decem, quindecing $;$; :quales etiam apud Ananios Roucnamonte, o in alijs plerif $q_{5}$ harum uallium locis aperté conpici poffunt. Proferunt be fructus fauló maiores cateris fylucftribus, fed qui magis refinam fundant. Harum ramis utuntur incole ad uafa uis naria cingenda: Junt enim tenaces admodum, of flexiles. Alterius ueró peciei funt, quas Ccmbri, or Cirnoli uul=

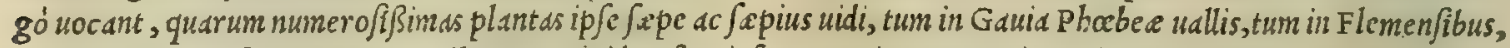
Vulturenz, $\odot$ Rbetinorum montibus. He quidem peciofa proueniunt proceritate, ita ut ad tabulas parandas mate= riem non modó pulcherrima am prabeant, fcd ctiam fuauiter odoratam : attamen non tanta affurgunt altitudine, quan= ta ceter $\int y$ lueftres. Ramos é caudice promunt, ceu o picea, qui pinifrondibus uirent. Caudicis cortex non ut pi= no fubrubet, fed abietis modo fubalbet. Fructus tam longitudine, quàm craßjitudine picco aqué fimilis eft, breuior ta= men, refinofus, colorc in nigrum purpur a cente : inter cuius nuc anenta nuces recluduntur domefticis fimiles, mino= res tamen, triangulares, breues, fractu faciles, ut qu.e dentibus facilé cedant: fapore quadántenus donrcftic as refis runt, nifi quód guftui quandam pené infenfibilen relinqusnt apperitatem : quód omnium fyluestrium proprium eft. Ex quofucilé adducor, ut credan boc nucum pinedrum gcinus illud effe, quod Plinius libro x v. cap. X. . Tarentinum nocat, digitis fragili putamine, auium'; expofitum furto in arbore. Eterim ille ita fragiles funt, ut non difficul= ter $a b$ auibus rostro foangantur. Ab ijsdem pinis refina tum alba, tum odorata, ueluti $a b$ alijs fui generis manat. Tabule ex bis parate ad extruenda adificia Germanis plurini funt, non modó quód pulchra uenu= rum ferie placeant, fed quöd etiam odoris fragrantia preftent: id cnin ad corum bypocaufa paranda, qui= bus maxime ob frigidißimam regionis tcmpcriem $\odot$ indigent, $\odot$ utuntur, plurimum affert ornsmenti .

Bellonii alia Bellonius, cuius pauló anté meminimus, libro de arboribus refiniferis hoc pini genus (quantum ex cius uerbis col= opını explo ligere potui) pinaftrum effe cenfet. Sed non recté, mea quidem fententia . nanque pinafter, Plinio lib. $\mathrm{x} v \mathrm{I}$. cap. $\mathrm{x}$. fa. auctore, nibil aliud eft, quàm pinus fylueftris, mira altitudine : gignitur q́q, non modó in montibus, fed etiam in planis, Bellonio ucró contr i, pinafter pino humilior eft: ev pland, er montivin fupercilia pror fus repuit, ncc alibi eroucs nit, praterquaim in excelfifinis montium iugis. Huic profictó ut quis adftipularctur, fortaffex eo adduci poffet, quód peregrinationi, quam ille in Afiam, Graciom, syrism, Acgyptum, alias'́; regiones fe feciffe fatetur, plura tribuere uellet, quain probutifimorum authorum fcriptis, quious fapc Bellonius perperàm ref-agatur, ita ut fu.m putet auftoritatem illis preferendan cffe. Sed ego miror, quod mihi rclatuin fit uirum bunc effe unlgaris peritie, neq; tot loca peragraffe, quot eius fcriptapcrbibent. Quód autem ad rem noftram attinct, Bellonius ubi pinaftri bifioriam exorditur, hanc pinaftri uocem $\mathrm{ex} \mathrm{ucr}$ fione L atina fiequenter legiffe ait apud Theophraftum, fed non pro pterea Theophraftum eam agnouiffe plant.sm, quod non nafcatur in Grecie, aut A/ie montibus : atque ideo nullum effe ex Gracis autboribus, qui de pinaftro, aut pinu fylueftri memiierit. Sed quanta fit buius boni uiri arrogantia, 40 o in Grecorun authorum lectione negligcntia, anted explicatimus, ubi ex Theopbrafto forip/imus duo effe pinige nera, unum urbanum, alterum fylueftre. Veruntanen fi is mordicus fün tenuerit opinionem, quod fcilicet Theo= pirafto беи'ин picean fignificet, non pinum, er quód ex con: fequenti dem bic de picca fylueftrifit locutus, dcmus

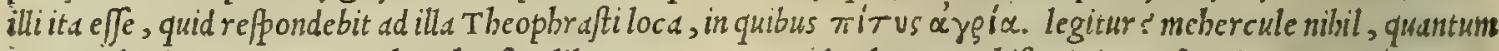
reor. Subijciamus ergo que Theophraftus lib. I I I. cap. I I I I. de plantarum hiforia in cenfu arborum qua in montis

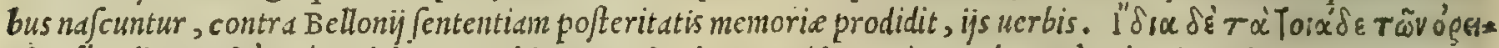

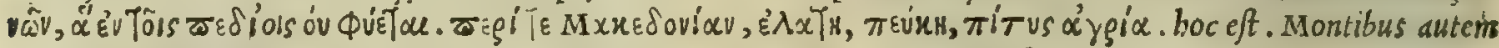
propria funt illa, qu.c in planis non proueniunt. Macedonia, abies, piced, pinafter. Addamus preterea qux eodem

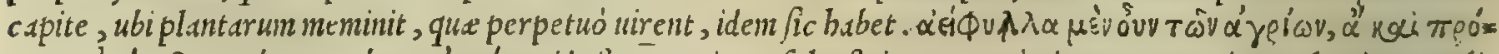

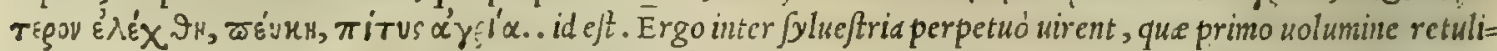
mus, abies, picea, pinafter. Ex bis itag; manifflum ficri arbitror, Bellonium multa in Theophrafto of citanter legif= fe, plura etiam temere o falso fcriptis tradid!fe : ut binc ipfum inanis glorix, ucl alicuius dignitatis cupidem pos

Plinij laplus. tius, quisn ueritatis fudiofun fuiffe fucile iudicem. Caterim non potuinon admirari dixiffe Plinium, fc.n= dulas e pino ad contegendas domos; ex omnibus, que re(inam fundunt, arboribus aptißinas cffc, cim larie Tedx confi- cem non ignoraret materici praftantia, duritie, or firmitate, nulli equiparandam effe. Pretered fcribit deratio. Theophrastus (nos id quotidie uidemus) quod pini interitus eft, ut teda fiat. Cuius ucrba funt bac loco fus pra citato. Morbun pinis accidere talcm Idxi incole narrant, cüm non folim cor, fed ctiam pars cxtcrns caudicis in tedam tranfiucrit, tunc frangulari quodanmodo. quod ponte accidit ubertate arboris largisima, quo= ad quis conictare poßit: teda enin totun cfficitur. Ergo bec pini propria affectio eft. Quare autem pinus te = dafiat, feribut idem Theophraftus libro v I. cap. x v.de caufis plantarum, fic inquicns. Pinus cnim radicen agii teds tot:m refertam, ut anté dictum eft. Ratio cadem, que in aninalibus e?t, quód pars alinenti, quat ferbuerit, excost áq; 


\section{In Lib. primum Diofcoridis.}

fit, quonism purgatißima eft, aßidet : er collerta, denfatáq; pinguedinem reddit. R eliquum ueró fur fun tranfmiffum, partes, qux fupraterran emincnt, nutrit: non per illam punguedinem fubiens, fed per alios quofdam meatus. Nam qua in tedam onni cx parte mutatx hint, obcfitate moriuntur, ut dictum eft : cim enim nullum tranfitum babeant, $p_{i}$ ritus frangulantur, ficut anims:libus accidit, que ultra modun pinguerint bec ille. Ce terum quod teda opus. fit ad picem conficiendum, non de fut func ratio, qua ctum arte ficripoßut, ita ut pinus non fua utiq; Pponte, fed artificio tes da fiat. Id enim iden docuit Theophralius libro $1 \mathrm{x}$.cap. I I de hiforia plantarum, his uerbis. Id ci ubi arboris casdi=

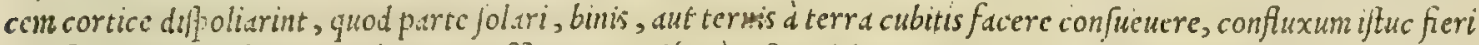

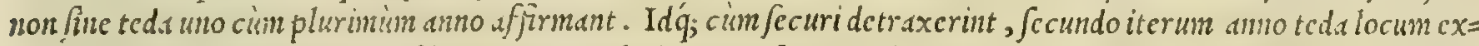
pleri: O tertio parimodo. Pofthsc ob eam paulatinam incifuram arborem extenuatam, putrefictanó; bumi faci=

20 le a flatu profterni, tun cius cor extrabi (boc cuin tedam maxime pref crt) necnon es radicem cffodi. hiec ctiam ille.

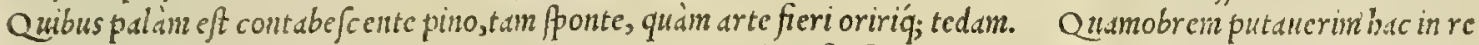
non p.run cecutiffe Plinium: quippe quilib. $\mathrm{x}$ v I.cap.x. ubi refiniferas enumerat arbores, tedam propriam, o per \& quorundä. fe clfe arborcm cenfet, cim inquit. Sextum genus cft teda proprié dicta, abund untior fucco, quin reliqua: parcior, li= quidiorq́, quìm picea : flammis, ac lumini facrorum ctian grata. E t lib.eodem cap. $\mathrm{x}$ V I I I. Nunc, ait, celeberrimis arborum dictis qued a in uniuer fum de cunctis indicanda funt. Montes amant cedrus, larix, ted $a, \leftarrow$ catcrex, é quibus refina gignitur . hac Flinius. Verum fi quis Plinij definfor diceret, per tedam ip fum boc in loco nö aliud intelligere, quim pimum,itáq; etun tueri uellet, hanc tutelamillid(ut puto)udnain effe oftendit, quod cum co capite plinius refini= ferssurbores omnes per genera de cribat, et primum omnium genus pinum faciat, nullo pacto pinü pro teda decepiffe uidetur, cum fexto refinurum generi tedam poftea ad fcripfcrit. Hinc fortaffc $\mathcal{O}$. Murcelli error defluxit, qui in boc

20 Diofcoridis cupite, pinum tedum interpretatur. In hoc etiam uer fatur errore Adamus Lonicerus Ruellium fecutus in fuo de plant.trum biftoria uolumine, ubi fictam potius, qusim ucram arborem pro tedapinxiffe uidetur. 'Sed ani= maducrendum eft, nori ć pinu tuntim fieri tedam, fed ex alijs ctiam plantis refinam fundentibus, nempe larice, or pi= cea : à quibus nos in Ananicnibus fyluis pinguifiman excr/imus. Quapropter dicebat Theoplraftus lib. I I I I. cap.

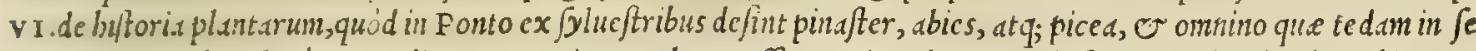
fe gerunt. Quibus clarepatet, alias preter pinum arhores effe, qux in tedam contabefcunt. Sed quid id morbi magis pino cueniat, quint cxteris, propria pini affectio effe creditur. Quo fit, ut $\mho^{\circ}$ in boc Pliniun crraffe crediderim, Plinii \& Ruel qui non pini, fed laricis mor'um effe ait, ut teda fiat: ac eidemomnes attribuit tum uires, tum notas, tum qualitates, lij error. quas Theoplra, tus pino reddidit. Quare cum $\mathrm{R}$ uellius eum fibi familiarißsmum ab buiufcemode lapfu uindicare uel= let, non mirun, inquit, quod in boc Plunius equiuocatione fit ufus, quando er perpetua fronde perindc ac pinus, fit 30 larix, $\odot$ fitus idem in montibus, eadem q́, fasies, minime animaduertens, quàm magno ip $\int e$ quoq; fuerit errore implici

L A R I X:

40

so

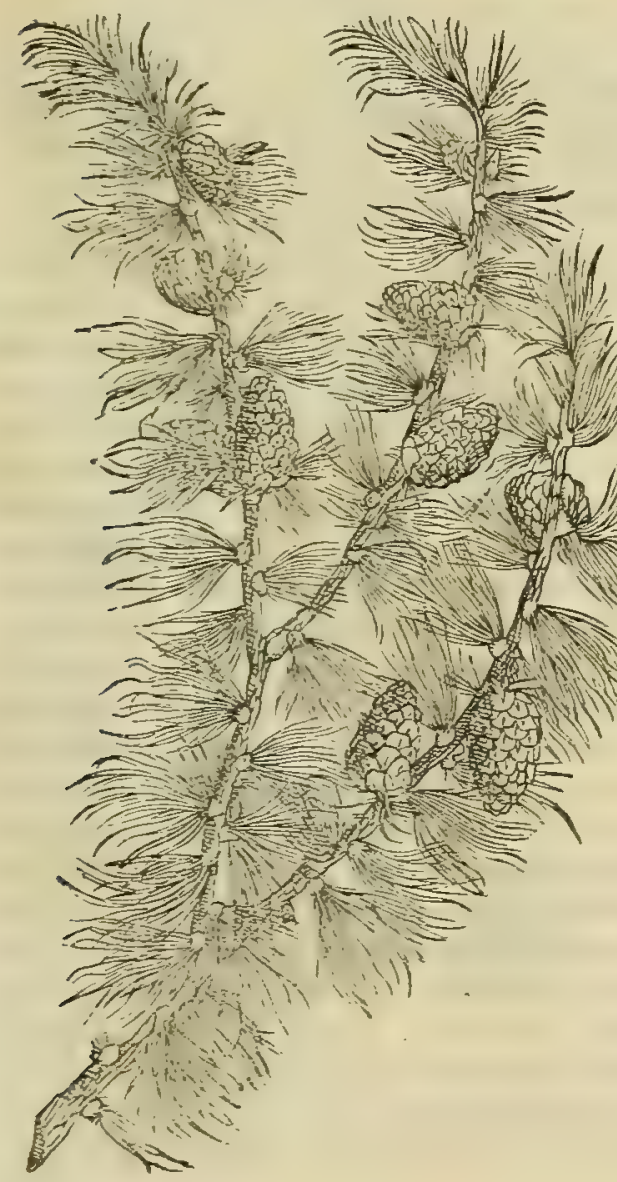

tus : quemadmodum er recentiorum alij. Quandoquidem procer to atteftari polfum, laricem me uidiffe nunquant (etfi centenas la= ricum fyluss uiderin) cuiper byemem, folia non deciderent, $\mathrm{O}^{\circ}$ que tuntam contraberet cum pino cognationem, quantam Ruel= litus tradidit. Itaq; ut uera eius quoq; promulgetur biftoria, bic cade larice dijJeremus, que e uidimus; es experteintia compro= batmus. LARIX igitur arbor eft eximix proceritatis, cor=: Laricis hifotice perquám craffo (non autem leiviori, quim piced, ut Adamus sı. Lonicerus fcribit ) in rimss undique dehifcenté, intus q; ribente: ramos gradatim circa fipitem totum emitteris, didnatis coinpluri= bus Jalic is more lentis, colore luteo, odore non iniucundo: folijs. circum ramulos prodeuntibus, denfis, oblongis, mollibus, comofis, pineis anguftioribus, minimé aculeatis, qux aduentante byeme, pallida effecta ad caudicis radices decidunt, ibiq; marce fcunt : ita ut fold larix inter caterds refinam fundentes arbores, fpreta om= nialgoris immanitate, nuda per byemem uitem tranfigat. Nouel= la cupreffum prorfum emulatur, non attem picedm, ut Ruellio placet. Eius coni( quanquam credidit plinius laricem fterlem ef= $f_{e}$ ) cupreßinis admodum fimiles funt, neq; ingrattim efflant odo= rem. Veruntamen flores longé odoratiores funt, qui uere emer= gentes é ramufculorum cacuminibus drborem uniuer fam mirum in modum condecorant - quippe cum in purpura ardenter rube= feant, comantibusq; foliolis, miro quodam nature artificio anne= A.tntur, non parum uiatorum oculos remorantur. Ligni miateries durißima, prafertimí; rubefcens, er in caudicts meditullio fita: edg; propter in adificijs omnibus éxtrueridis, caterds longé prez cellit. Vanum profectó eft credere ( $u$ Plinius, vitruaius, o Plinij, \& Virecentiorum plerio; perbibent) quód nec flagret $\mathrm{L}$ arix, nec in truuij error. earbones uertatur, fed ueluti calcarium faxim in fornace exura= tur. Quandoquidem baud recté cum fortiacibus ageretur, in qui= bus fit ferrum in Tridentinis montibus, er in ea profertim ualle 
Ananijs contermina, ¿quam solis nuncupant, ac alijs multis Camonice, $\sigma$ Eliotropie uallis fornacibus, in Brixienli agro, $\sqrt{1}$ larigno carbone carcrent, cuius inibi maxima conflagratur copia. Nanq; (ut referant in bac artc periii) nul lo alio carbone in fornacem indito, rudc firrimetallum tam celeriter colliquc foit, quàm lariceo. qun er ligntm nius ficcum, cisn abunde fit refinefum, impctuflagrat perquàm uchementi. Qkianobrem in Tridentinis montibus larici= A garicum la- nis tantim lignis furnos incendunt, t.m eos, quibus panis coquitur, quain quibus lsypocaufa calefunt. Caterim

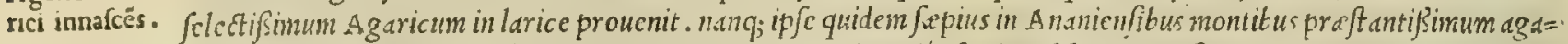
ricum parua quadam fecuri ḋ laricibus compluribus deicci, emiq ; fe pius ab his, qui refinas colligunt. Nafcitur etiam. agaricum (ut prodit Plinius) in Gallix, non in larice duntaxat, fed in alijs arboribus, prefertim glandiferis. Diofco=. rides, ficuti o Galenus, non fatis compertum babct, an Agaricum fungus fit, aut radix, licet afferat in cedro gigni. Brafalolics agaricum Comachiy in ilicibus inueniffe fatetur, necnon per Gallium equitans, id uidiffe ait quercuum cau dicibus inberere. Enimuero ipfe in tota Hetruriu, in alijs q́; quàm plurimis Italic locis, deniq; in multis Germanie,

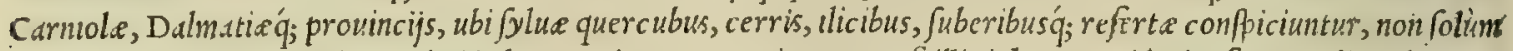
nunquam uidi, fed ne quidem audiui in bis agaricum prouenire : tamet fillis inbercre uidcrim fungos alios plurimos ligned materie concretos, duros, ac nigros: quibus ubiq; $p$ asim fomites fiunt ad fufcipiendum igncm, cum é filice ca=. lybe excutitur : quinctiam ïs ignitis ad maclinulas exonerandas uenatores frequentijimé utuntur. Ad hec quanuis in Tridentinis montibus, pree ertim q; Ananienfibus prater abictes, pinos, larices, $\mathcal{C}$ piceas, innumerabiles adfint

Refina lari- quercus; in nulla tamen agaricum, preterquím in larice, nafcitum. Porró cx larice etiámmum preftantißima illa re gns. find manat, qua falsó officinis tercbinthina uocatur, cim tercbuthina ex terebintho proueniat. Verim cum merca= tores preterito iam eno terebinthinam ad nos minime afferrent, ob idć; larigna cius loco uterentur tum medici, tum myropole, facilé factume eft, ut larigna ex ufu fibi terebinthine nonen uendic auerit. Et quod larigna terebinthine nomen o locum antea paßim cccupaucrit, ut etiam hodie in officinis eiufdem, fi defit, uicem fuppleat, omnibus no=. tißimum arbitror. Attamen Fuchfius uir dioqui doct ßsimus, in libro, qucm fecundó edidit de compofitione medica=. mentorum, fribit pharmacopaos legitine terebinthine uice abietinam Jupponere. Qua in re aperté fallitur, quód. omnes (ut dixi) pro terebinthina larignam ufurpent. Atqui Galeni tempore liquida picea terebinthins loco uendeba tur, ut ipse libro tertio de comp. medic. per genera memorte prodidit, fic inquiens. Ex harum genere eft or larigna uocata, predictis plané bumidior: fubftantia ueró fimilis liquide pice $x$, quam loco terebintbinx inftitores uendunt ignorantibus eas difcernere eft autem talis refina odore guftu, o facultate, quain terebintbina acrior. Cum hac igi= tur, er terebintbina, larigna uocata perfimulem potentiam obtinet, fed tenuiori fubfrantia, maioréq; difcutiendi uir=: tute predita eft. Hanc Tridentini, ac etiam qui ijs conterminifunt, uernaculo fermone I argd appellant, deflexa $\dot{d}$ larice, à qua emanat, appellatione. Hac tamen ffonte fua non defluit: fed qui ip fam colligunt, magno, of longo te= 30

A B I E $S$.

Pannum inla rice nafeens.

Picex, \& Abietis hiftor.

Abietis lacry ma. rebrolaricis caudicem ad medullam $u$ gune per aftatem perforant; $\sigma$ inde manantem refinam uafculis quibufdam é piceo cortice $p a=$ ratis excipiunt: Splendidiorem mittunt iunencule arbores, ficuti de thure diximus: turbidiorem ueró annofe. Reperitur prete= rea in annofis laricum caudicibus prope medullam ip am panim quoddam albicans quando q;, cubiti amplitudine, corio, ex quo chi= rothece conficiuntur, adeo perfimile, ut uix alterum ab altero di= fcerni poßit. Vtuntur boc incole ad uulneraglutinanda, $O$ ad fanguinis fuores compefcendos. Caterim admodum inter $\int e f=$ miles ex bis, qua refinam fundunt, arbores funt P I C F A, O $4^{\circ}$ A B I E S, ita ut fepe etiam lignarios fabros fallant. siquidemea dem utriq; proceritas : ambe iy fdem funt folijs oblongis, duris, ac den/is: utriufq; ramufculi produntur crucis in morem, d duorum duntaxat ramorum lateribus exemntes: quod o folijs enenit. Ve= runtamen boc tantim difcriminis inter $\int_{e}$ babent, quod pice a folia colore fint abiegnis longé nigrior a, quin e paululum latiora, mol liord, leuiord, minusós, pungentia. Preterea pice cortex nigre= fcit, tenax eft, lentus, of lori modo flexilis : abieti ueró albicat, et fiflectatur, facilé per fringitur. Pice rami plerunq; ad terram fle ctuntur: quod in abiegnis non uifitur. Lignis deniq; materies pi= so cea mul tó peciofior, ac étiam utilior : babet cnim uenas rectiores, minusq́; nodofas. In piccarum genere fola formina fructus adfrrt, fed in Ananienfibus, cateris $q_{\text {; }}$ Tridentinis montibus abics omnis infructifera eft, etfi Plinius abietem fructifer am fecerit. Pice a fert refinam inter corticem, or lignum gummi modo concretam, licet nonnunquam ex ea defluat liquida, larigne fimilis. Abiesueró inter corticen corticem praftatipimum liquorcmillum con= cludit, quem unlgó I A GRI MO, quafíabictis lacrymam,appel= lant: de quo ueteres nibil (quod equidem fciam) pofteritatis m :mo rixe prodidere: Nifi quipian dixerit, per abietis lacrym tm ittel= lexiffe Galenum lib. III. de compofitione ancdicamentorum per

\section{0}




\section{In Lib. primum Diofcoridis.}

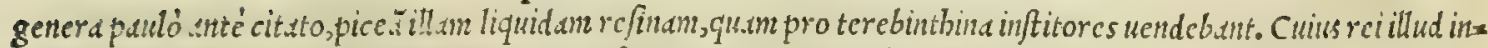

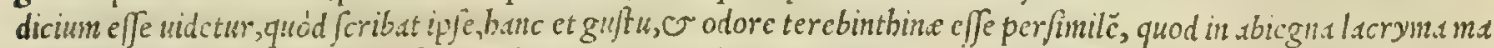

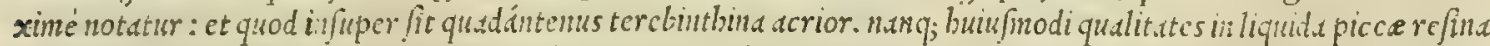

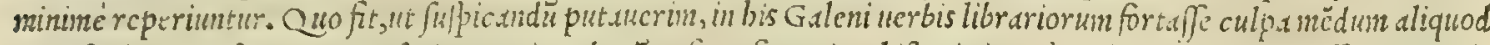

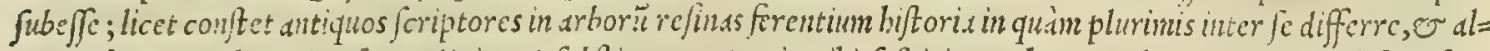

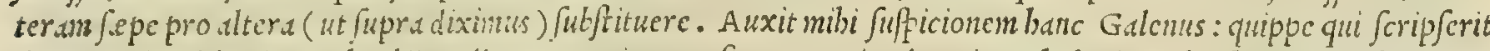
dcinde codem libro in Euphorbij medic amento, inter refinas cateris odoratiores babcri tercbinthin.m, or abiegnam, bancó; illa calidiorcm cffe. Falluntur autem, qui put.mt abicgnam lacryman, clarißimam efe larignam: quando=

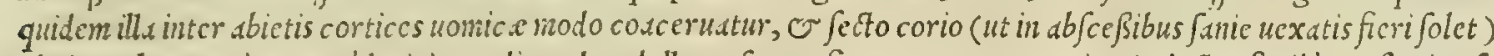

Error quori dam.

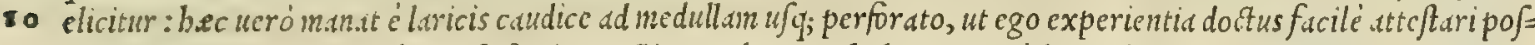
fun. Nam, nt rem omnem bs in biltoria cxactius exploratam baberem, 0 il larice larignam, of ab abietc abiegnam per ménet elicere libuit. Sunt qui buic ill.tm admifcent, ut bac impoftura mag is lucrentur, co quód onncs abicgnan plurifaciunt, quisin larignam. Nec defunt qui percolatan larignam, or ad ultiman claritatein redact am pro abiegna sendeteni, cimn sarißini repcriantur niyropolx, qui rectius alteran ab altera dignof cant. Sed fraus cognofci poteft, quód abictis lacryina lubftantia minus confiftat, odore prestantißsimo fragret, or gufui larigna fit amarior, ad an= nung; afferuata quadantenus flue fat. Ea uulneribus recentibus maximum affert prefidium, quòd non folim glu=

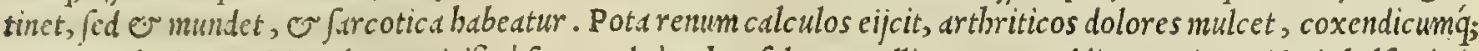
cruciatus lenit. Capitis uulncra mirifice é fanat, adcó ut bac fold nonnulli utantur. Additur er in antidotis balf.uni ui= ce. Affimat Rucllius abieti croceun florem imafci: uerim in Tridentinis montibus, ubi undiq; ea montes fylue=

20 funt, Abies omnis eft $\mathcal{O}$ floribus, or frutibus infacunda. Sed ut ad piceam noftra redeat oratio, non ratis com= pertum habco, quam arborem pro Picea intelligat Petrus Bellonius : quanquam ex inagine, quan exhibuit, atq; etiä ex notis, quas fue pice.e aßignauit, aliquod pinaftrigenus intelligere uidetur. Caterum arbor, quan idem fua tätum auctoritate, ne dic.sm temeritate, ductus perper im Sapinum uocat, ac abtetifimilem facit, non est (quantum cgo conij= cere potui) nifi legitima picea. Quippe bec abieti adeo fimilis elt, ut fepe fyluanos homines, or lignarios fabros fal= lat, ut fupriditum eft. Idcirco Plinims lib.x v I.cap. X X I I I I. eadem folia reddidit piceder abieti, fic inquiens. Infecta pectinum nodo (intellige, folia funt) pices, abieti. I is etiam idem Taxum fimilem fecit eodem lib.cap.x.quẽz admodum e Diofcorides lib. I I I. Taxum autem (ut obferuauimus) maxiné folijs amulatur picea, quam magno.er pudendo errore Bellonus Sapinum appellat. nain Sapinus, tcfte $\mathrm{Plinio}$, pars tantum eft in abiete, ut eius uerba decla rant lib. X V I.cap. X X X I X. ubitiaf fribit. Abetis quse pars à terra fuit, enodis ef. Hac, qua diximus, ratione flu=

30 uiata decorticatur, atg; ite Sapinus wocatur, fuperior pars nodofa durior $q$; fubterna. Quibus utiq; Plinij uerbis pa= lam eft Sapinum non effe per fe arborem, fed tantün abietis partem, ficuti etiä vitruuius teftatur. Verism Bellonius, I. E N T ISCVS.
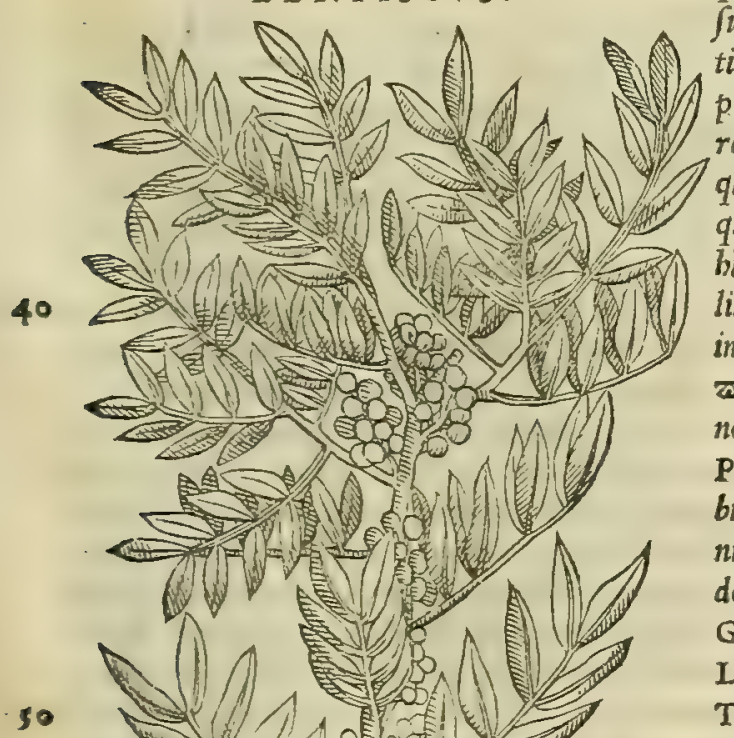
quód audiuerit tam piceam, quàm abietem indifferenter du sapin fuis Gallis nominari, hanc forté uulgarem er confufam nomencla= tioncm fecutus, ut eam ueram putanit, ita etiam Piceam sapinu ap= pellauit. Sed is mibi quidem non uidetur in Plinio recté cöfideraffe refiniferarum plätarum biftoriam, neq; in Theophraflo cognouife

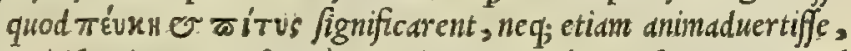
quód be due uoces fepe d̀ Grecis una pro altera ufurpantur. Sed hic fufius; quàn deceat, aliquot Bellonij errata perfecuti fumus. d= lius enim loc us erit, nifi quid mibi humanitus accidat, ubi alia plura in boc genere confulto tratabimus. Arbor, qua plerisq; Gracis Nomina. कiTus, Latinis Pinus appellatur: Arabibus, Sonobar: Italis, $\mathrm{P} i=$ no: Germanis, Hartzbaum, Kr Kynboltz: Hipanis, Pino: Gallis, Pin. Qux autem Grecé ๘ย่́ur, Latiné Piced nominatur; Ard= bicé, Arz: Italicé, Pezzo:-Germanicé, Rot dannenbaum: Hifpa nicé, Pino negro: Gallice, Vng abre dugenre du pin. Que dein= de Graco nomine $\lambda \alpha \rho \xi \xi$, Latino item Larix, Italico Larice, $\sigma$ Germanico Lerchenbaum uocatur. Que deniq; Gracis غं $\lambda x^{\prime} H_{\text {, }}$ Iatinis Abies dicitur:Italis; Abete: Germanis, Thannen, fiue Thannenbaum.

\section{EXĩos. LENTISCVS. CAP. LXXV.}

LEN T I S.CV S nota arbor eft. Cui toti uis ineftafringendi : femini enim, folio, ramo, cortici, radicibusć; cognatæ infunt uires: Liquamentum autem ita fieri: [olet.Folia, cortex, \& radix in aqua coquuntur, \& ubiabunde cocta, refrigerataq́ue funt, folia abijciuntur: aqua denuo coquitur, donec mellis habeat crafsitudinem.

Lentifcus fua aftringendi dote, ualet aduerfus fanguinis reiectiones, alui profluuia, \& dyfenterias in pott : item contra eruptionem fanguinis è vulua, \& ciufdem, aut fe- 
dis procidentia. In totum acacix, \& hypociltidis uicem repræfentat. Idem facit fuccus è tritis folijs. Decoctum fotu caua explet, \& fracta offa ferruminat, vulux fluxiones fiftit, nomas arcet, vrinam pellit, motus dentium collutione ftabilit. Virentes furculi calamulorum uice dentibus repurgandis affricantur. Fit è femine oleum aftrictoriam uim habens : quod prodeft, cùm quid aftringi opus eft. Lentifcus refinam gignit, qux lentifcina cognominatur, \& ab aliquibus maftiche. Pota vtilis eft fanguinem rejjcientibus, \& tulsi veteri : ftomacho auxiliatur, fed ructum mouct.addirur in dentifricia, \& illitiones faciei, ad nitorem cuti conciliandum: palpebras oculis incommodas replicat: manducata halitum oris commendat, gingiuas contrahit. Optima, \& copiofifsima in infula Chio prouenit. Præfertur, nitedulæ modo, refplendefcens, \& candore Tyrrhenicæ ceræ fimilis, adulta, retorrida, friabilis, odorata, fridorem edens. Viridis autem inferior eft. Adulteratur thuris, refinæáue pi- a nex nucis miltura.

Lentifcicon- LE N I 5 c v s in Italia frequentißina nafcitur, prefertin'́; in Hetruria maritimis noftris Senen/ibus. Gi fideratio. gnitur in collapfis Romanorum sedificijs, ac ruderibus. 2uinetiam in tractu Tyrrbeniubiq; copiofa oritur, in Cams pania maximé. Ceterim Lentifci nonnulle funt plante, que in arborem media proceritatis affurgunt: nonnulle ueró bumiles, que nullo grandiore caudice à radicibus fublato, fed uirgultis, Ptolonibusq́; innumeris corylorum folue= strium modo dißiliunt . ueruntamen Lentifcus tum ramis, tum folijs denfior constat, inagis $\dot{q} ;$ uirgultorum cacumini= bus ad terram deflectitur. Folijs utraq; eft piftacijgraueolentibus, pinguibus, friabilibus, of in obfcurum tirentibus, in ambitu tamen rubent, ficutier quibujdam uenulis. Perpetua fronde uiret. Cortice eft fubrufo, lento, tenaci, fle= xibiliq, . Profert terebintbi modo, prater racemofos fructus, folliculos corniculi modo intortos, in quibus includi= tur liquor limpidus: qui tandem ueterafcens uertitur in beftiolas ijs perfimiles, qus ex ulmi, er terebinthi folliculis Ruel.\& Her- euolant. Tota planta grauiter olet: quapropter nonnulli, quod olfactu caput aggrauet,ip $\int_{a m}$ deuitant. Sed Len= molai lapfus. tifcum, que roboris magnitudine proueniat, folio forbi, acinis fylueftris punice rubentibus, ut Ruellus fcribit, bactenus non uidi, nec id unquam me legiffe memini apud probatos auctores. Idcirco Ruellium bac in re ballucinatum. crediderim. quemadmodum $\sigma$ Hermolaum, qui ea effe lentifci folia exiftimat, quibus coriarij ventetijs pelles confi=. ciunt, uulgó proprié appellata foglia. siquidem planta, à qua bec folia decerpuntur, maximé à lentifco differt; etfi Maftiches có- cum terebintbo aliquam babcat fimilitudinem. Fert etiam Lentifcus Italica maftichen, ut ip $\int e$ atteftari poffum: fideratio. quanquam non ea copia, qua in Chio, er Creta Aegai infulis. Itaq; immeritó à nonnullis notatur Auicenna, quód maftichen Italican memorie prodiderit. Quippe quod ij, qui maiori in errore uerfantur, exiftimauerint non ali= bifortaffe, quàm in Chio nafci. Indicam maftichen é pinofa quadam planta manare, non folium Theoplraftus, fed $e=30$ tiam alij tradidere, quemadmodum or Plinius. quilib. X I I. cap. x v I r. non modó cbia maftiches meminit, fed a=

Lentifci uires liarum quoq; que in Arabia, Afia, Gracia, Pontoq; proueniunt. Lentifcimeminit Galenus lib. v I I I. de fimp. ex Galeno. medicam. facultatibus, fic inquiens. Lentifcus facultate ex aquea effentia leuiter calida, er terrena frigida nö pau= ca compofitus eft, ob quam er moderaté adftringit. Deficcat igitur fecundo ordine completo, aut tertio incipiente: in caliditatis, o frigiditatis differentia quodammodo eft medius, or fymmetrus. similem omnibus fui partibus ad= frictionem obtinet in radicibus, ramis, extremis turionibus, germinibus, ac folijs, preterea fructu, er cortice : ac fi fuccum ex folijs eius uiridibus exprimas, fimilis bic ordinis eft, moderaté adftringens. Itag; bibitur $\sigma^{\circ}$ per fe, $\odot$

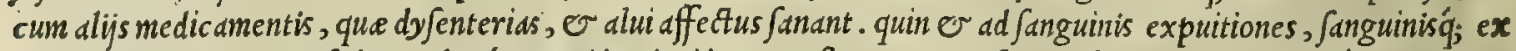
utero eruptiones, tum fedis, uuluéq procidentidsidoneus eft, utpote ad bypociftida nonnibil propé accedens.

Maftiches ui- Meminit idem 0 maftiches libro v I I. fimpl. medic. his uerbis. Maftiche candida quidem, $\mathcal{O}$ Chia confueto mo= 40 res ex.Gal: : re cognominat, quodammodo ex contrarijs compofita facultatibus eft, adftringente uidelicet, er emolliente. Pro= inde ftomachi, uentris, inteftinorum, iecorisó; inflammationibus competit, utputa fecundo ordine excalfaciens, er deficcans. Nigra ueró, qua Aegyptia cognominatur, tum magis deficcat, tum minus adfrictoria facultatis eft par= ticeps: quamobrem aptior eft ad ea, qua ualidiorem digeftionem per halitum expofcunt. bac igitur ratione $\mathcal{\sigma}$ fu= runculis bonum eft remedium. Porró oleum, ünguentumí; maftichinum ex Chia conficitur, non admodum fané ex Ae syptia. caterim fimilis eft $\mathrm{O}$ ipfum maftiche facultatis. Hec de lentifco, 0 maftiche Galenus pofteritatis memo= ria prodidit. Sed cummaftiche mihi Caphuram in memoriam redegerit, quód certó fciam, eam mafticbe, ardenti aqua, zedoariá;; ab impostoribus adulterari, cimq́; Diofcorides, Galenus, ש cateri illius feculi fcriptores ip[sm non folum non adnotauerint, fed ne nouerint quidem, filentio minime dißimulandum fore putauinus, quo magis le= gentibus fatisfiat, quantum tum à Serapione, tum etiam ab bis, qui meridionalem plagam, or Indie ora hoc aua nd= 50

Caphura hi- uigationibus perluftrarunt, memoria proditum eft. C A P H V R A igitur est gummi arboris cuiufdam in India ftoria, \& ge- nafcentis tanta magnitudine, ac proceritate, ut fub eius umbrà bominum centurie recondi poßsint. Nafcitur bec ar= bor in montibus mari propinquis, materie leui, firulaced, qua prodit Caphurd. Huius largioris prouentus augurium eft, cim frequentibus calum fulgetris corrufcat, aut crebro tonitru conftrepit, uel cumm terra motu concutttur. Hu= ius multa traduntur genera. Vna in interuenijs ligni, lamellarum modo impacta figitur. Alia foras emergit cortice abrupto, ueluti refine, illis q́; gummi modo inb.eret, maculis inter initia rubentibus, poftmodum uel calore folis extox fta, uel ignium ui cande fcit. hanc fumpto à rege quodam Riachillius loci nomine, indigene Riachinam appellant: quandoquidem is primus dealbande Caphure rationem adinuenit. Hec cateris $\mathrm{C}$ bonitate, er tenuitate prestat, Zongioriq; perdurat tempore. Alia craßior, nec pellucens, atro colore: proinde bonitate cedens. Tertia uilior re $\rightarrow$ peritur, fufco colore. Succedit huic impurior alia, qua arboris fcobe, ramentis, or affulis implicita, gummi more agglutinata lente fcit, tuberculo amar a nucis, aut fabe, aut ciceris. Hanc pontificum, er facerdotum fuffimentis, 


\section{In Lib. primum Diofcoridis.}

ficut thus, or myrrham, costumo, , in templis dicant. Sed he omnes in duo tantim faftigia rediguntur, in rudcm, $\mathrm{O}^{\circ}$ clabor utam. Fiquident rudis êt Caplura omis ignem nton experta : elaborata ueró, que folis, ucl ignis ardore exco= cta, atq; purgata album contraxit colorem, utpote $\odot$ cera. Fucblius lib. primo de componendis nedicamentis, putat Cuphur.am effe bituminis Indici genus, quod fcripferit Serapio auctoritate Alinazodi, Largioris Caphur.e pro= uentus augurium effe, cimn cellum crcbris fulgetris corrufcat, aut plusimis strepit tonitruis, uel ciun regio, in qua prouenit, terrsmotuconcutitur: argumento, quód fimiliter exterre concufu inagna tum fulphuris, tum bituni= nis copia profund foleat. Scd diffentit ab co opinio nostra: quandoquidem nec serapionis, nec aliorum quoruncun banc fuiffe fententian exiftiment ciun tam ipfe, quàn ceteri, qui de Capbura fcripfere, arboris cuiufdam uaftijinn proccritatis gummi, uel refinam Cxphur:sn effe fcribant. Nimirum of citanter de bac fcripfiffe uidetur Platedrius

20 Salernitanus: quippe qui Caphur an gummi arboris effe inficiatur, Diofcoridis, or complurium teftimonio, ex fucco cuiufdam berbx fieri tradcus. Quod profecto falfum eft, cim nullibi Caploure meminerit Diofcorides. Eam autem effe gummi non foliun Auccnne, er Scrapionis testimonio probatur, fed or Lufitanorum, qui noscro exo per meri= diem ad Calicut orientalis Indice emporium nauigant. Credidere Serapio, er Auicenna, Capburan tertio abfcef= fu o ficcare, or refrigerare : qux tanten cum uehementer etiam in aquam proiecta conflagret, $f_{i t}$ perquim odords

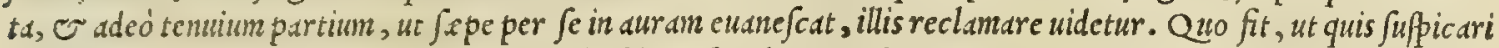
poßit, aut legitimain Caphurann ad nos non aduebi, aut boc loco Arabum monumenta (ut in alijs quim plurimis) effe uitiata. Capitis dolores ( $/$ it tuncn in bac parte credendum eft Mauritanis) ex calore prouenientes Caphura illita mulcct, incande fcentes influmuationcs reftinguit, prefertimq́; iocineris. Renes, o feminaria uafa refrigerat, fan= guinem '́; cogit. Circumlutionibus imponitur ad cutis nitorem conciliandum, $\sigma$ ad arcendas tam uulnerum, quàm ul= 20 cerum inflummationes. Eryfipel as extinguit, $\sigma$ aduerfus gonorrbeam, $\sigma$ albas unlue fluxiones efficax eft cum fuc $=$ cino, e aqua nymphrea haufta. Idem preftat pubi, fewimo uentri, teftibus, renibusí; illita : qua tamen anted pjyllij feminis fpiffamento, aut omphacio, aut folani fucco probé fit macerata. Sanguinem e naribus profluentem fiftit, aut cun urtic femine inmifs, aut ex maioris fedi, o plantaginis fucco fronti circumlita. Collyrijs ad calidas oculorum lippitudines utiliter imponitur. Renibus, ac teftibus illita uenerem extinguit. Corpora a putredine praferuat: proz inde commodé antidotis adnifcetur, que contra uenend, uenenoforum animalium ictum, or peftilentes affectus confis ciuntur. In uniuer fum uribus innumeris pollet, quas brenitati confulentes pretermittimus. Legitime probatio talis eft. In calido pane ć furno recentißimé fublato, bipartitoớ; manibus fcifo, Caphura ponatur. quód fi bumore madeat, fyncere eft argumentums: In contrà perarefcat, \#puria ac factitia fignum. Caterùm nifí diligenter affer=

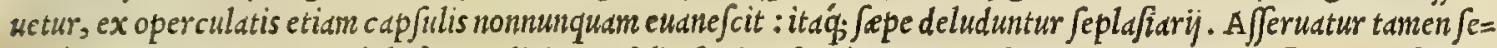
30 curé uafe marnoreo, aut alabaftrino, lini or pfyllij femine fepulta. Nec defunt, qui eam pipere felicius afferuari

TEREBINTHVS,

40

so

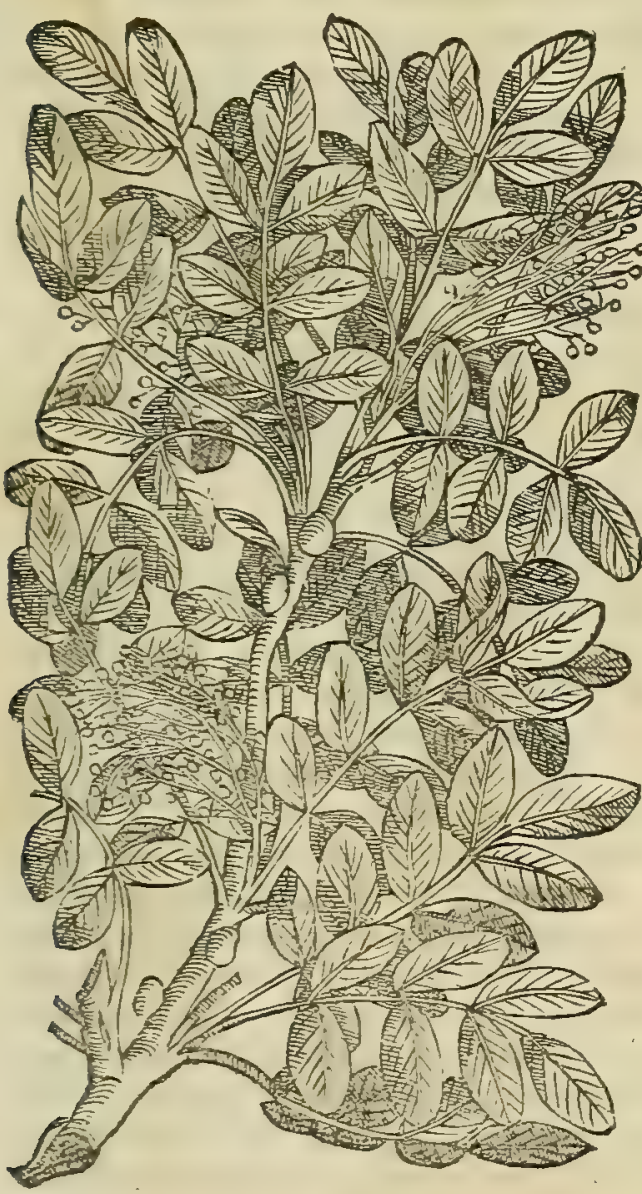

putent. quod nec plané comprobandum uidetur. Venetias Caphu= ram omnem rudem important, ibiğ; igne, $\mathbb{O}$ arte witreis organis elaboratur, fic ut cande $\int c a t$, atq; pelluceat. Exivos Grecis, Nomina. Lentifcus Latinis appellatur: Daru, Arabibus: Lentifco, Italis: Mata, aut Arueira, Hifpanis: Lentifque, Gallis. Huius refina

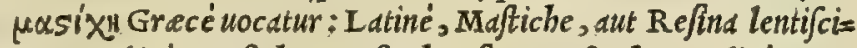
nd: Arabicé, Maftehc, Mafteche, fiue Mastoche: Italicé, Md= ftice : Germanicé ac Gallicé, Mastic: Hipanice, Almaftiga. Quod Arabibus Kaphor, Seu Chafur, recentioribus Gracis uxis Qovga ; ut etiam Latinis Caphura nominatur: Italis, Camphora: Germanis, Campher: Gallis, Camphre.

\section{TÉgusvOOS. TEREBINTHVS. CAP. IXXVI.}

TEREBINTHVS cognita arboreft. Cuius folia, $\&$ femen, \& cortex aftringunt, \& ad eadem, ad quæ lentilcus, conueniunt, fimili parata modo, fumptaq́ue. Fructus efui aptus eft, fed ftomacho aduerfatur: excalfacit, vrinam mouet, uenerem excitat: contra phalangiorum morfus conuenienter in vina bibitur . Refina eius ex Ara bia petræa defertur . Prouenit etiam in Iudæa, Syria, Cypro,Aphrica, \& Cycladibus infulis. Sed præualet candida, perlucida, uitreo colore, $\&$ in cæruleum uergente, terebinthum olens. Terebinthina refinas omnes antecedit : proxima lentifcina, \& è pinu, \& abiete: has fequitur è picea, \& pineis nucibus refina. Natura omnibus calfacere, mollire, difcutere, expurgare. Tufsi, ac tabi conueniunt perfe, aut in eclegmate ex melle:vitia pectoris expurgant, vrinam cient, cruda concoquunt, uen trem emolliunt, palpebras commodifsimè replicant : lepras tollunt, cŭ ærugine, ac futorio atramento, nitroq́ue;
Fuch.opinio improbata.

Platearij error.

Caphurx téperamentum, \& uires.

Caphurz pro batio, 8 conferuatio. 
auribus faniem emanantibus cum melle \& oleo, item in pruritu genitalium utiles . malagmatis, acopisq́ue adimifcentur. Laterum doloribus per fe, illitu \& appofitu auxilio funt.

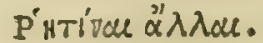
RESINAE A IIAE.
CAP.
IXXVII.

L I Qv I n a refina è pinu, \& picea, à Gallia, \$ Hetruria conuehi folet, atque olim à Colophone petebatur : hinc Colophoniæ fibi cognomentum uendicauit. A' Gallia quoque fubalpina : quam uer naculo nomine larica, hoc eft, larignam, appellant incol $x$. Ea in linetu, \& $\mathrm{x}$ per fe magnopere prodeft tufsi ueteri. Colore inter fe diftant: fiquidem alia candida eft, alia olcofa, alia mellei liquoris finilitudine, vt larigna. Cupreffus etiam liquidam fundit refinam, qux ad eadem pollet . Quæ uerò aridarum gencri afcribuntur, quædam ex pineis nucibus, a'iæ abiete, aliæ picca, \& pinu exierunt. Eligi debet longè omnium odoratifsima, translucens, non retorrida, neque diluta, quandam ceræ faciem præbens, \& friabilis. E' picea, \& abiete refinx cxteras antecedunt: odoratæ enim funt, atque thus odore imitantur. Præftantiores à Pity ufa infula deferuntur, qux fecundum Hifpaniam fita eft. Sed quæè picea, nucibus pineis', \& cupreffo manarunt, nihil ad illas, nec tantis uiribus potiuntur. veruntamen eorundem gratia, quorum $\&$ illæ, fumi folent. Lentifcina tcrcbinthinæ refpondet. Vritur refina omnis liquida in uafe quadruplæ capacitatis ad humorem, qui infunditur. itaque refinæ congius in duobus aqux pluviæ coquitur, fubiectis leuibus prunis, refina afsiduè movetur, donec omnis odor aboleatur, \& friabilis, \& retorrida reddatur, ac digitis cedat. Caterùm ubi refrixit, in fitile non picatum, quod aconitum uocant, id eft, non illitum, reconditur. Fiet etiam eximij can- $z 0$ doris, fi refina omnis eliquata præcoletur, quò freculenta fordes excernatur. Vruntur quoque fine aqua, primùm lento igne, \& ubi coire coperunt, maior carbonum ftrues fupponitur, \& triduo citra intermifsionem difcoquuntur, ufque dum antedictas naturæ fuæ notas exuerint: mox, vt dietum eft, reponuntur. Aridas vnius diei fpatio decoxiffe fatis eft. Vftx odoratis malagmatibus, \& acopis, \& vnguentor um colorationibus magnopere utiles funt. E' refina perinde atque thure, fuligo excipitur, ad circumlitiones idonea : quibus palpebras fucant, \& colorem mentiuntur. prodeft glabris genis, collacrymationibus, erofisq́; oculorum angulis. Ex ea fit atramcntum fcriptorium.

Terebinthihi Ator.ex Theo pliralto.

Refinaterebinthina.

Bral.opinio reprobata.
T E R E B I N T H O R V M (ut Theophrastus memoria prodidit lib. I I $\mathrm{T}$. capite $\mathrm{x}$ v. de biftoria plantarum)

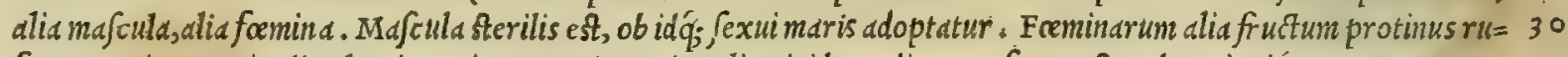
fun promit ${ }_{2}$ nagnitudine lentis, qui concoqui nequit : alia uiridem editum, rufum postmodum tingit, or cum uua ma = turefcentem, nigrum nouißimé facit, magnitudine fabe, refinofum, ev fulphurofum. Circa Idam, e Macedo=

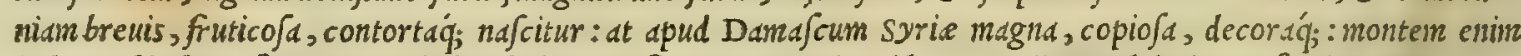
inibi terebinthis refertum, ut nil aliud habeat, referunt. Materies eilenta, radices ualidx in profundo, atque in to = tum incorrupta hec arbos babetur. Flos oles, uerium colore rufo. Folix circa unum pediculum, pleraq; pecie lau= rinorum, coniugatim, quemadmodum forbo, quód'; parte poftrema acuminet, impar exit : uerüm minus angulata, quaim forbo, ambituq; laurino fimiliora, o pinguia cum uniuerfo fructu. Fert e ad nucis fimilitudinem qusdam concaud, ut ulmus : quibus beftiole tanquam culices innafcuntur. Fit in bis refinofum quid, lentum $q_{\text {; }}$ : fed refina ta= men non hinc legitur, fed à ligno. Fructus refine copiam non mittit, fed manibus tantim adheret: : et fi non latuetur, poftquàm collectus eft, inter fe coherefcit: cum ueró lalatur, candidus, probe q; non maturus fupernatat, niger 40 fubfidit. Idem refert deinde lib. I I I I. cap.v. historia plantarum, Indicam etiamnum Terebintbum haberi : cui fo= lia, or rami, of reliqua omnia terebintho fimilia : fructus autem diuerfus, fimilis enim amygdalis. Nam $\odot$ in $\mathrm{B} a=$ Aris terebinthum hanc effe, frrréğ; nuces amygdalarum magnitudine: quoniam non magnas, fed uifu fimiles, or fuavitate amygdalis preftantiores: er ideo loci illus incol ss his potius uti. bec Theophraftus. Terebinthum uidi ego primim in colle uulgo cognomine Caftel Trento, non procul à ciuitate Tridenti prope Athefim, ḋ Theophraftihi= ftoria baud quaquam áißimilem, facta buius uidendi mibi copia à clarißino medico I ulio Alexandrino Tridentino: reperiq́; ipsam deinde in alijs compluribus Hetruriz locis, uidelicet in collap/is Romanoruin adificijs, ac ruderibus: fed frequenten admodum in I apidix collibus prope Pucinum caftrun, Adriatico finu non longé ḋ Tergefto. Ab bac fepe, dum illaciter baberem, o frultus, of folliculos caprarum cornibus non abfimiles, quibufdam intus be= ftiolis culicis figuram pra fe ferentibus, o refinam decerpfi : que etfi omnium praftantißima fit; non tamen diu eft, so quód Venetias defertur ex Cypro. Antea coctam affercbant, uel quód efet aduectu aptior, uel quód impoftoribus ad adulterationem aditus boc modo facilior fieret. Verume liquida ut per fe ex arbore manat, ian frequents facta est. Caterim quia terebintbina iandiu in I taliam non aduebebatur ( ut fuprà in laricis mentione diximus) larigna non mo dó terebinthine locum fibi uendicauerat, fed etixm cognomentum. At cùm eodem loco à nobis de pinea, piced, la= rigna, abiegnáq; refina, $\mathcal{O}$ earum à quibus colliguntur arboribus, abunde fcriptum fit, oper apretium quidem non eft, ut bic iterum ea repctamus. Scire tamen conuenit, rarißimas effe abictes in montibus Tridentinis, que preter fluentem lacrymam, aridam fundant refinam: fed fi quadam inueniuntur, bec eft (ut Plinius inquit) arboris morbus. Cuius rei manifcftum argumentume $c f t$, quod omnis abies, que re/inam fundit, tabida fit, putris, o c crrio= $\int a$. Brafauolus de rcfinis differens, Plinium in carumbiftoria ì Diofcoride diffentire autumat, qućd fcilicet Plis nius libro X $\mathrm{x}$ I I I I. capite v I. tradidèrit fummas refinx fpecics dus, ficcam o liquidam : ficcam in pinu, o picca fieri : liquidam é terebintho, larice, lentifco, cupreffo. Diofcorides ueró ex pinu, o picea, e liquidam prater ficcam 


\section{In Lib. primum Diofcoridis.}

haberi foripiun seliquerit. Qubos tancu melius crat fic conciliafe, quód quanuis alferat plinius, ficcas refinas é pinu, er piccs colligi; non propteres obstat, quominus ferant pariter buiujcenzodi arbores o liquidas, C ficc.1s refin.ts. Quandoquidem in Tridentino tractu pluribus uarijs ğ; locis, é pinu, piccá; antealongo tempore cefis, folis $\dot{q}$; ardore sftumtibus liquidas refinas exudare comperimus larigne non abfimiles. Quod etiam lape cucnit in afferibus ex bifec aboribus paratis, or in tignis, kel trabibus, que edificijs coaptantur. Verima cnunucro malin di= cere Plinium erraffe, quid liquidarum generi lentifcinam adfcribat, que eft nostra inaftiche, cx teris profictó durtor.

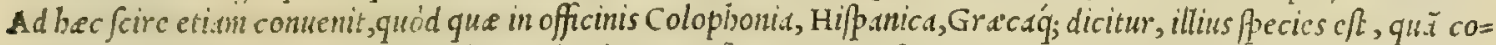
quere Diofcorides edocuit. Confat bec coloribus diuerfis, utpote cryftallina, ly acinthina, faturato ; colore, pro re= Colophonis finarun ex quibus conficitur, uarie tate . quippe (ut Diofcorides ait) alia candida cft, alia olei, alia mellis colore, qua= so lis cft larigna. Que ucró i Colophone Ionic urbe fibi cognomentum comparauit, eft (ut refert Plinius lib. X I I I I. cap. $\mathrm{x} \times$.) preter cateras fulua: neq; idia de caufa uocatur o Hipanica, or Gr.eca, nifi quod cx iifdem etian re= gionibus aduehatur. Att.men animaduertendum eft alian ab bac, que neq; fiicta, neq; excocta eft, babcri Colopbo= niam : fiquidem forbit Diofcorides quod pinea, piceá; liquida, ac pinguis refina ex Colophone affercbatur : ob id $\dot{q}_{;}$ Colophonia per excellentian uocabatur. Quod item teftatur Galenus lib. v I I de compof.med. per genera, cim in $=$ quit. Quonian ucró piecam refinam o fria an, er colophoniam appellare confueuerunt, fcicndun uenit, aliă quan= dam effc colophonism Chix maftiche perfimilem, molliens aliquid habens, quemadmodum illa, er thus. Et libro I I. eiufdem. Eft, inquit, inter liquids etiam colophonia tburis redolens, que nonnullis fola uocatur colophonia, odoratn fuatitatcm quandam refiens, ut abictina, or calore ficut illa mediocri predita. nafcitur admodum modica, atc; ob id pretiofa eft. Porró fi quifhian diceret, non cognouifse Plinium, neque Diofcoridem, liquidam abiegnam, quan ali=

20 qui lscrymam, nonnulli ueró abictis olcumnuncupant, eum ne tantillum quidem à ueritate de fcifcere putauerim: fis quidem la de liquida abiegna (quad Legerim) mbil memorix prodiderunt. Terebintbi, er refinarum meminit Ga= lenus lib. v I I I.áe limplic: medicani. facultate, ubi ita fcriptum reliquit. Terebintbi tum cortex, tum folia, tum fru= Etus adfrictorum quividum obtinent: fed $\odot$ fecundo ordine excalfaciunt. Itaq; quód etian deficcent, manifftum eft: recentes quidem etiámnum, bumidió; modice; ficci ueró, ordine fecundo. Caterim fructus aridus propinquus eft clisn tertio ordini dcficcantiun : cft enim adeó calddus, ut mandentibus protinus eius caliditas percipiatur. Itaq; etiam urinam prowocat, o lientibus prodeft. Paulc Juperius de refinis differens, fic inquit. Refinse omnes defics cant, oredifaciunt. Ceterim inter fe difcrepant, quod plus, ac minus habeant in guftu quidem acrimonis, in $f_{d}=$ cultate ueró caliditatis: tum quod alis plus, alic minus fortits funt partium tenuitatis: preterea quód nonmulle ad= frictionis funt participes, alice nequaquan. Primas meruit omnium non iniuria lentıfcina: eam uocant maftichen.

30 Nam preterquàm quòd paucula ei adeft adfrictio, adeo ut ftomachi uentrisq́; er iecoris imbecillitatibus, or pbleg= monis conuenist, infuper tlli ineft mordacitate uacans de ficcatio : mininim enim acris eft, o maxime tenuium par= tium. Inter alias prafertur terébinthind, manifeftan quidem, non tamen fimiliter at o; maftiche, adfrictionem pof= fidens. Caterim adiuncton habet amaritudinem quandam, per quam magis etiam, quam maftiche digerit. $O b$ eans den qualitatem incft $\mathbb{E}$ abfterfio, tanta quidem, ut $\mathfrak{O}$ p foras fanet. quinetiam qua in profundo refident, cateris refinis magis attrabit, nimirum cim illis malorem habeat partium tenuitatem. Attamen piced, or hac etiam magis frobilina acriores quidem ea funt, fed non magis tamen digerunt, neq; attrabunt. Mediat inter bas funt pinea, E abictina, acriores quidem quàn terebinthina, minus tamen, quàm aut piced, aut frobilina. Habet porró etiam e= molliens quiddam terebinthina: Secundum locum babet in emolliendo lentifcina, ficut er cyparißina acrimonix. Et lib. I I I. de compofitione medicamentorum per gentera inquit. Etenin cera ad liquiditatem multo pingui indiget : at 40 refine, qux quidem aride prorfus Junt, modico: liquide o ficcam quandam fubftantiam ad emplaftri craßitudinem a) Jumere pcftulant. In cer is igitur non magna bumidutatis, ac ficcitat is differentia elt : in refinis, ficut etian in picis genere contrd, aride ab humidis permultum differunt. Omnium ergo refinarum ficci] alij colophoniam appellant. Huic fuccedit, qux ex fictilibus impurd, nec fixa fumitur, quam ii purges, in frictam mutabitur. His ambabus ficcior eft, que dicitur pityinon phy fema, ac fi dic as pinea germinatio. Hanc fané, ceu fqud=

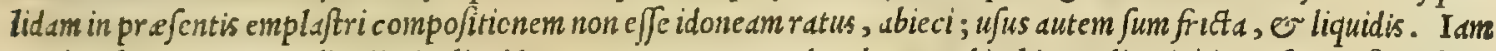
ueró ex bis quoq; nonnulle diutius liquide permanent, quemadmodum terebinthina, alie citó indre fcunt, /icut fro= bilina: media utriusf; eft abictina. Quinetiam facultate calidior eft quidem frobilina, mox ueró abietina, deinde te= rebinthind: cuprebi refinam mifcere non aufus fum, ut que nonnibil adftringeret. $\mathbf{P}$ utabit forfan aliquis nobifcum diffentire Diofcoridem Anazarbeum in fermone de refini hee uerba cribentem, primo de medica materia commen=

so tario. Ex omnibus refinis principatum terebinthine datur, polt eam lentifcine, tum ei, que de pinu raditur, or d* biete, poft quss piced, frobilina $\dot{q}_{;}$numeratur. In bis enin Diofcorides tanqualn de infina frobilina, optima uerä terebinthina fentire uidetur. Verum ego ex his trabus refinis frobilina, abietina, terebinthina, principem certéftrose bilinam calore, Jeeundam abietinam, poftremam tercbintbinam effe dixi. bactenus de refinis Galenus. Sed hac in re animaduertendum eft, quód boc in loco cater is frobilinam non aliter prafert Galenus, nif quód omnes caliditate tantum antecellat : fiquidem in uniuer fun in medicamentis componendis a Diofcoride nequaquam diffentit, uidelicet quód inter omnes terebinthina primas occupet Jedes, ut paulo poft declarauit, dicens. Inter refinas optimam, tans quam medic amentum in multiplices ufus accommodatum, meritó terebintbinam affirmaueris, non tamen caliditate primas obtinere. Arbor, que Grecé $\tau \dot{\rho} \rho\lrcorner \iota 00 s$, Latiné Terebinthus appellatur: Arabici, Baton, Boton, Bo= Nomina. tin, fiuc Albotin : Italicé, Terebintho. Refina ueró ita Latinis uocata, Grecis g̈Hт ív nuncupatur: Arabibus, Ratin, fiue Natig: Italis, Ragia: Germanis, Hartz.

Terebinthi ui resex Gal.

Refinarú uires ex Gal. 


\section{And. Matthioli Comm.}

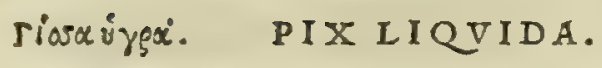

CAP. IXXVIII.

PIx liquida,quam alij conum uocant, è pinguifsimis pini, piceæáue lignis congregatur. Optima eft fplendens, fyncera, Lxuis. Contra uenena, phthifim, purulentam excreationem, tuffes, fufpiria, \& pectoris humores, qui difficilè extufsiuntur, efficax eft, eclegmate cyathi menfura cum melle da to : tonfillarum \& uux inflammationes, anginæqque utiliter perunguntur : purulentis auribus infunditur cum rofaceo, \& illinitur cum trito fale ferpentium morfibus : adiecta uerò pari cera, fcabros ungues extricat,impetiginesq́ue emendat : vuluæ duritias, ac fedis tubercula difcutit: cum farinaq́; hordeacea, \& pueri impubis urina decocta,ftrumas rumpit: cohiber ulcera, qua ferpunt,cum pineo corti ce,aut fulphure,aut furfuribus illita. Cæterùm cum thuris manna, \& cerato profundos ulcerum finus conglutinat: rimis fedis, \& pedum magno auxilio illinitur : ulcera replet, \& cum melle purgat : quin \& cum uua paffa, \& melle carbunculos, \& putrida ulcera emarginat, difrumpitq́ue. Erodentibus medicamentis, quas feptas uocant, probè immifcetur.
rior'́nduov.
PICINVM OLEVM.
CAP . LXXIX.

E' P I CE fit quod piffelæon appeliant, feparato liquore aquofo, qui fupernatat pici,ficut ferum 12 cti . Nam expanfa, quandiu pix coquitur, fupra cortinam uellera pura madefcunt, acceptoq́ue halitu eius exprimuntur in uas, idque tandiu fiat, donec pix coquatur. Quas pix liquida, prabet utilitates: alopecias capillo replet cum farina hordeacea illitum : quibus \& liquida pix medetur : iumentorum ulcera, fcabiemq́ue emendat.

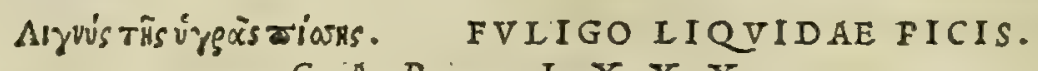

$$
\begin{aligned}
& \text { C A P. I } \times \text { X } \mathrm{X} \text {. }
\end{aligned}
$$

F I T н O C M O D o èliquida pice fuligo. In lucerna noua, qux ellychnium habeat, nonnihil picis incendito, lucernamq́ue fictili uafe in clibani fpeciem conformato, fuperius in anguftum fornicato, inferius perforato, ut clibani cffe folent, operito, $\&$ adoleri finito: confumptoq̣ue liquore nouum infundito, quoad fuficientem ufui fuliginem collegeris. Vis ei aftringens, acrisque. Vfui eft ad pigmenta, quibus palpebras linunt, \& uenuftant, \& ad circumlitiones. Item ubi glabris genis pilos reftitui oportet, ad imbecilles, lacrymofosq́ue oculos, infuper ad eorundem ulcera non inutilis eft.

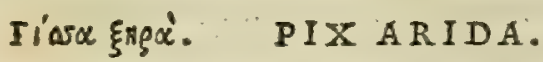

CAP. IXXXI.

Irevi D A pix decocta in fpiffam coit, quam uocant aliqui palimpiffam . quo in genere quædam uifci modo lentefcit, bofcas cognominata : altera ficca eft. Probatur pura, pinguis, todorata, fubrufa, refinofa. Talis Brutia, \& Lycia picis, refinæćue fimul naturam habentes. Calfactoriam uim habet : dura emollit, pus mouet, tubercula panosq́ue difcutit, ulcera replet : uulnerarijs medicaminibus commodè permifcetur.

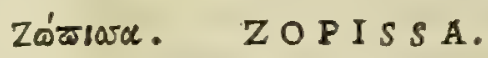

\section{CAP. IXXXII.}

Zopiss A a aliqui aiunt derafam nauibus refinam cum cera, quam alij apochyma appellant. Ea 40 difsipandi naturam habet: quoniam marino fale macerata fit. Alij pineam refinam hoc nomine uocauerunt.

TAME TS I de pluribus Picis generibus, de oleo, edrumiq; fuligine diuerfis, ac proprijs capitibus differat Dio: fcorides; cum tamen horum omnium biftoria notior fit, quàm ut à nobis explicari debcat, opere pretium non eft, ut de bis pluribus ag amus. Sed quoniam fortafe nonnullos deleçabit audire, quónam modo pix ipfa conficiatur, ut illis er mibi fit fatisfactum, hic rem paucis aperiam, omniáq; de ea referam, que Tridentino tractu in Flemarum monti bus coràm claré perpexi . sic ergo picem, qux paßim nauslis dicitur, co quód picandis nauigijs fit aptißind, artifi= Picis conficie ces conficiunt. Veteres pinos, qua prorfus teda confecte fint, in particulds fecuribus concidunt, ut ex aliarum dx ratio. arborum truncis ad carbonis opus ficrifolet. Deinde ueró area ex creta pauitur in medio paululum elata, extremita= tibus equaliter dependentibus, ut liquor è teda refudans in canalem totam aream anbicntem facilius defluere poßit. Itag; concifam tedam in area fruis congcric locant, uelut in carbonis artificio : mox bac primiım abictun, picea

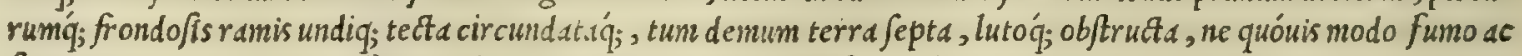
flammis pateat exitus, per foramen in cacumine paratum ignem fuccendunt eadem quoq; ratione, qua er carbones coquntur. Quare cum defit locus, per quem flamma erumpere poßit, fentiató; ob id congefta moles maximum ignis ardorem, pix liquitur, o per area pauimentum confuens in canalem circumpofitum defluit, qui per alios canales inibi artificiosé paratos picem fluentem corriust in frobes ligneis afferibus circundatas, ne terra defluxam picem cŏs bibat: unde pofted e dolia, o cadi, o utres implentur. Operis perfectifignum, $/ 2$ rogus decumbat, fubfidat ; $_{\text {, }}$ et liquor defluere definat. Sic enim picen ficri uiüimus à fyluicolis eam parantibus, qui quodamnodo fecuti uidentur Picis Gaculta. Theophraftun lib. I X. cap. I II. de byftroria plantarum, ubi eademz feré ratione Macedones picem urere latius tra* tes ez Gal. didit. Picisfacultatem inemorix prodedit Galesur lib. VI I I. fimplicium medicameritorum, fic inquiens. Pix fic. 
ed quiden deficcut, or cxcalfacit fecundo d mediocribus, fiue fymmetris cxccfll: ac plus deficctre poteft, quim

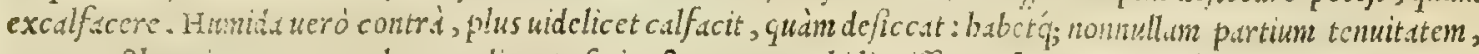

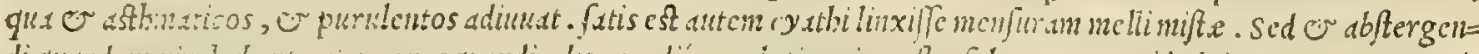

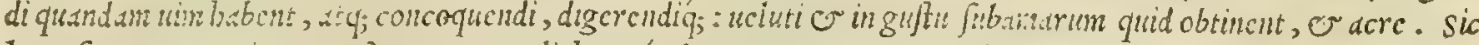

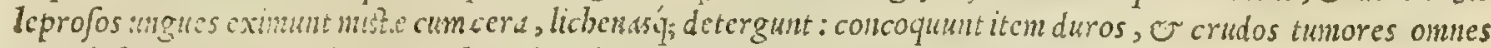

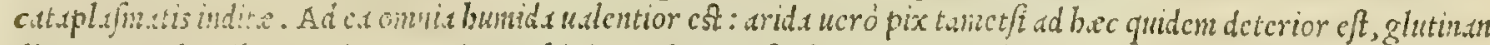

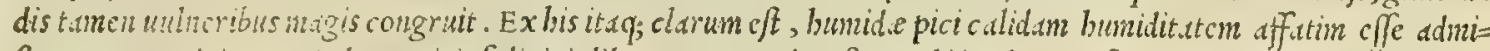
ftun. Icminit : ligo omnis cxiccutoriz cft, ac proinde tersestris ef effentix, babcns quafdan ctiam ignis, qui matcrian conbußit,

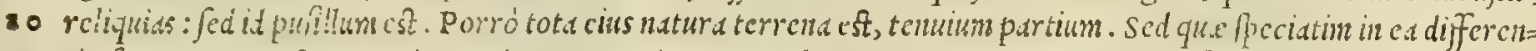

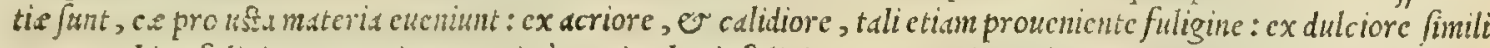
quoq; or biric fuligine proteniente. Primum cnin thuris fuligine utuniur, in ocularias medicinas mifta, eas uidelicet, qux ad oculos etiunmum phlcgnone tentatos accommodantur, atq; etianmum fluxionc uexantur, er ulccra babent: nam o illu expu"gat, o carnc inplet. Ad hac ufurpant quoc; cam ad facultates, qua uocant calliblepharas. Pre=

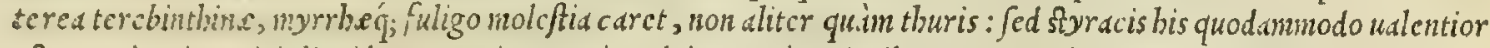
cst: magis eti.m picis liquid.c, qua eti.m magis cedri. Porró dcrioribus utuntur ad uit ia palpebrarum uocdta ptila, c crofesoculorwm angulos, humidosá; citra pblegmonem. At nollioribus, mitioribusiq; tum ad bec, tum ad ea,

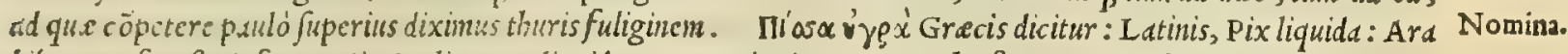
bibus, Ecrf, Ccf, Zcfr,aut Kir: Iralis, Pece liquida: Germanis pix omnis, Eech : ficut etiam Hipanis, Pex negra: Gal

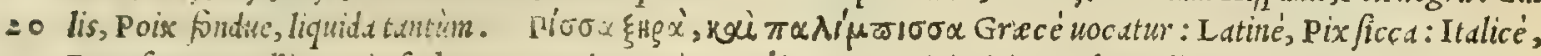

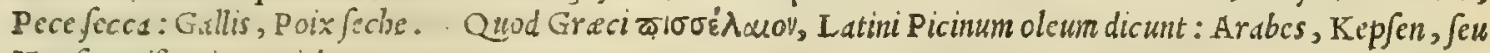
Kapfe: Hipsiti, Azcidipez.

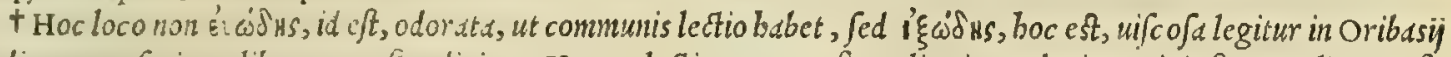
codice insmu feripto, libro $\mathrm{x}$ I. fonplicium. Harum lectionum qux fit melior in probatione pic is ficce, aliorum fit indiciunt .

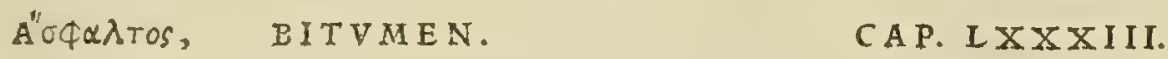

BI IV MIEN Iudaicum cxteris anteponitur. Cuius probatio eft,ut purpuræ modo fplendeat, fi tq́; ponderofum,ac ualidum odorem uibret . nigrum autem \& fordidum, uitiofum eft. Adulteratur pice. 30 Gignitur in Phœnice, Babylone, Zacyntho, \& Sydone. Liquidum inuenitur in Agragantino Siciliæ, fontibus innatans : quo utuntur ad lucernarum lumina,olei uice. Hallucinantur, qui id Sicilicum oleum nominant : nanque liquidi bituminis genus effe conłtat.

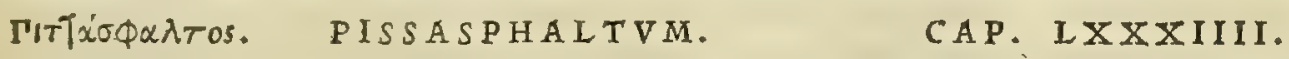

NAS CI TVR in Apollonianarum agro circa Epidaurum, qux piffarphaltos appellatur. Ea Ceraunijs montibus deuoluta impetu fuminis rapitur, xfuq́ue in litus expuitur,illic coacta in glebas. miftam bitumıi picem redolet.

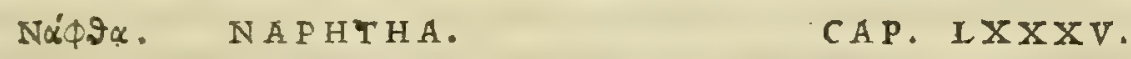

40 NapHTHA uocant Babylonij bituminis colamen, colore candidum : inuenitur etiam nigrum. Vis ei ignium rapax, ita ut ex fpatio protinus in eam tranfliant. Ad fuffufioncs oculorum, \& albugines utilis. Bitumen omne difcutit, glutinat,emollit,ab inflammatione tuetur : vuluarum proci dentia, frangulationesq́ue olfactu,fuffitu, impofitu,emendat : comitiales morbos fuffitum deprehendit, gagatæ lapidis more: purgationes mulierum cum uino, \& caftorio potum elicit : tufsim ueterem, $\&$ anhelitum adiuuat: ferpentium morfibus, coxendicum, laterumq́ue doloribus auxiliatur : datur coliacis in catapotio deuorandum : cum aceto potum difcutit fanguinem concretum : dy fentericis cum ptifana liquatum infunditur: deftillationibus fuffitione medetur: mitigat dentium dolores oblitum. Cxterum pilos incommodos ficcum replicat, fpecillo impofitum : concalfactum autem, \& cum farina hordeacea,nitro, \& cera illitum, podagris,articulorum doloribus, lethargicisq́ue prodeft .

so Pifaliphaltos eadem, qux pix, \& bitumen, fi mifceantur, potelt.

LEG I I I V M qridem I udaicum Bitumen boe euo (quod fciam) in Italiam non aduebitur : id nanq; quo offici= ne utuntur, impostura quedam eft, pice, petroleo, or alijs nonnullis parata. I gitur mirari non licet, fi id Diofco= ridis hiftorie mininé repondere uideatur. Optimum in Iuda a prouenit in quodam Iacu, quḋ Iordanis amnis influit, qui ab urbe Hierico quindecin taitim millia poffum diftat, I B Brocardo fideshabenda eft; qui Paleftine topogra= phian edidit. Nul ueró aliud bitumen eft, quàm pingue quoddam lacus illius aquis fupernatans, quod undis uentoó. agitatum in littore concre cit, den fatur, coit, tenacißimum q́; redditur. Nullum in boc lacu (ut Galenus teftatur lib. I I I . cap. X x. fimpl. medicamentorum) animal, nulla $\dot{;}$ ftirpis innafcitur, neq; uiftur ob aqua ingentern falfedi= nem. Imó cùn duo ingentia flumina in eum confluant, in quibus pifces innumeri, prafertim in eo, quod prope Ierichontem fluit, quod Iordanem appellnt, nullus omnino pifcium fluminum oftia excedit. Quinimo, codem auctore, de bis, que in eum proijciuntur, nibil mergitur, fed inftar nauis, fuper aquam fertur. Quippe bac effe uerum probari

Bitueainis cófideratio.

Fuliginum vires ex $\mathrm{G}_{2}$ leno. tona. 


\section{And. MatthioliComm.}

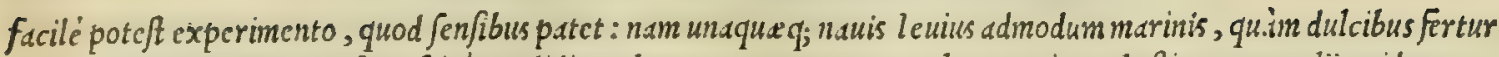
aquis. Proinde loco citato bec fcite prodidit Galenus. At aqua, que ex lacu syrix Palefinin, quem alij quidem ma $=$ re uocant mortuum, dij ftagnum bituminofiun, guftantibus non falfa nodó, $\int c d \in$ andra eft. Salem ueró etixin habet ex fe fe natum, perinde fubamarum, primoǵ; ftatin appecu unà cum uniuerfo mari tum candidior, tum craßsior appd= ret, fallugini nere fimilis : in quam fi falem inijcius, ne liquari quidem etian poßit : plurimum enim cius in fe habet:

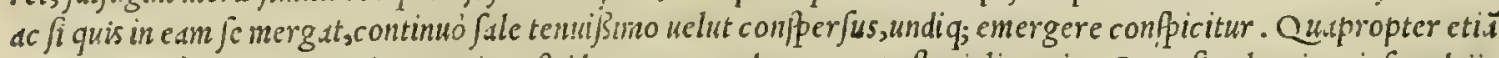
aqua illa, quàn cater a marina grauior ef, id fi; tanto pondere, quanto fluuiali marina. Itaq; fi uolueris te ipfum deij=

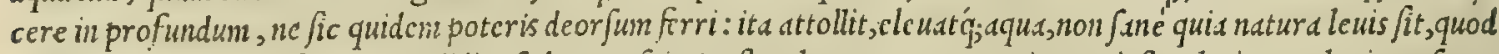
quid am ueterum fophiftaruin prodidit, fed ut cenfuit Arffotcles, propter grauitatcm inftar luti, quse leuiora funt, geftans. Proinde fi bominem ligatis manibus, pedibusq; inf fugnillius aquam conicceris, deorfum baud ferctur. quin 10 ueró ficut naucs in mari onera plura, quàm in flunils citra fubmerfionem portare ualent, eundem in modum in ft agno mortuo multó plura, quìm in mari. Tantó cnmm eft, que in illo eft aqua, marina grauior, quantó marina lacuftri, aut

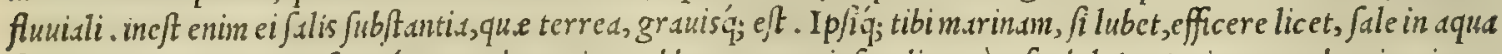
fluuiali colliquato, cognof ceréq; quantó grawior redd atur aqua ciufmodi, quim fit dulcis. Quin er modun iam inue=

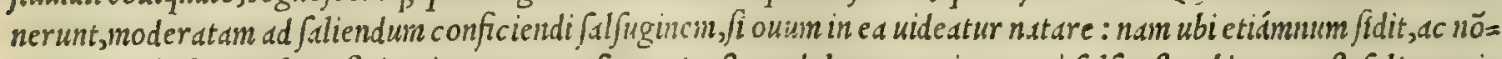
dum fuper falfuginis fuperficiem innatat, aquofa magis est, $\odot$ dulcts : grauiter ueró falfa eft, ubi tanta eft falis copis indita, ut amplius liquari, qui posted adijcitur, nequeat. quam aquan fi pendere non grauberis, omnium aquarun comperies gravißimam. I taq,; ego quandoq; inanein effe diuitis cuiufdam umbitionem oftendi, qui tantä in Italia maris mortui aquain deuexit, que cifternam implcre poffet. Nam id ip flim ego expedite praftiti, fale plurimo in aquam po tabilem coniecto . hac Galenus. Lacusife, quem aliqui mare moriuum uocant, ille quidem eft, qucm facra teftan= 2 tur monumenta exortum effe, ubi Sodoma, Gomorrha, alieif; funitine ciuitutes ca'lefti igne abfortie, fubuer féq; fuez rc. Quod etiam Galeni aufroritate comprobatur, qui codem loco citato lacum bunc sodomeum appellarifcribit.

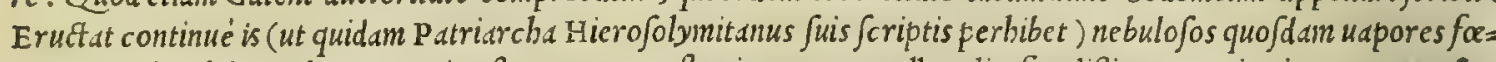
torem intoler abilem uibrantes, qui poftea uentorum flamine per conualles olim fertuli Simas exagitati, perpetuam ste= rilitatem relinquunt, ita ut longo tcrrarum patio nec herba, nec arbos, nec ullum deniq; germen proueniat, neq; nire. fcat, nifi iuxta Hiericum, ubl ab Elifei fonte irrigantur horti. Tradit Plmius bunc lacum longitudine centum millis Piffar, halti paffum excedere, latitudine maxima uiginti quinque millia paffurm inaplere. Idcm Piffaft halti inter picis genera confiderato. meminit libro X X I I I I. capite v I I. fic inquiens. Est O Piffaphaltos mifta bitumini pice náturaliter ex A pollo= niatarum agro: quidam autem ipfi mifcent. Affertur ex eodem agro etiúmnum boc a $u$ : fiquidem ex Apollonia Epiri,quam unlgó Valonam nuncupant, Venetius piffaphaltum pro picandis nauigijs copiofum importatur: quppe 30 quód pinea pici commiftum, ualentißiné id muneris praftet. Nuper ex Dalmatia afferricapit, ubi prope Lefinam non longé à Narenta foditur: cuius anicus quidam mibi copiam frcit. Foditur o in Pannonia, ubi id incole foßi=

Fuch. \& quo- tiam ceram effe exiftimant. Scribit Fuchfius libro primo de componendis medicamentis, piffaphaltum nunc $e=$ rundälaplus. tiam tribus fere milliaribus ab I/prucb reperiri, uocariģ; Germanico fermone Trifchemblut, cuius portionem ali= quam adbuc fe babere fatetur, , ibi dे Georgio Collimitio tranfmiffam, quas fuccenfa bitumen ac picem uerißimé re= dolet. Sed equidem uereor, ne ipfe quoque decipiatur, unà cum Gcorgio illo. Is cnin lapidem gagatem, qui feré tribus ab ea ciuitate Germanicis milliaribus ( $u t \mathrm{Fuch}$ (ins inquit) in litore cuiufdam torrentis frequentilsimus re= peritur, pro piffaphalto oftendebat. Sed illius error, dum ego in 1 pruch cfffem, à clarißimo Ioanne Petro $\mathrm{Me}=$ rendio medico Regio, o àme pariter deprehenfus eft: quod lapis Germanica lingua Trifchcmblut uocatus, etfis lapidis gagate modo conflagret, o bitumen redoleat accenfus; nunqquam tamen ut pix, $\odot$ apphaltus igne lique fit, Naphthę mé- Sed ligni, uel ted modo comburitur. Preterca ultimum bituminis gcnus, quod Naplththam uocant, plinius libro tio. $\quad$ I I. capite C I I I. in Auftagenis Parthix inucniri prodidit, tantam q́; effe buic ignium cognationem, ut tranfiliant protinus in ipfum undecung; uifum. Qunod etfi in Italiam aliunde (quod fciam) non inferatur; inibi tamen pluribus in locis id generis erumpit, quod eofdem cum igne praftat effectus: quale eft, quod in agro Mutinenfi fcaturit, pe= troleum, fiue faxeum appellatum. Sed ut redeamus, unde digreßi fumus, bitumen Sodomeum non nififictitium, uel Brafa. opinio impoftorum malitia adulteratum aduchitur. Proinde Brafauolus in fynceri defectu Mumiam à Mauritanis wocatam improbata. fubftituit, quód certó crediderit, mumiam effe legitimum Pal.eftinum afphaltum. Quandoquidem exiftimauit, ficca tum Arabum, tum aliarum gentium corpord, qua pro mumia ex syria, $\sigma$ Aegypto Venetias defertnntur, cum fint ex infima illius regionis plebecula, uice aloës, myrrha , croci, e balfami ex more Iudacco, duntaxat applalto im= plcri: quodd eorum pauperies aromatum fumptus non toleret. Hoc fundamentum binc icciffe uidetur, qucid Straboli= Mumix con- teris mandauerit bitumen Sodomcilacus in ufu effe ad tutanda bominum cadauera. Sed quantun iffe ex A rabun frideratio. fcriptisdeprompfi, apud cos M V M I A potius eft pilfaphaltrum, quim apphaltum: fiquidem foribit Auiccmu, mumiam eadem preftare, que afthaltus pice commiftus. Ex quo facilé conijcere poffumus, cadaucrailla piffa= Pphalto tantim impleri. Cui etiam fubfcribit Serapio, qui de Mumia differens, ex Diofcoridis auctoritate, eadem, que Diofcorides de piffaphalto tradidit, ipfe uerbótenus ad mumiam retulit, fic inquiens. Numid eft in terris A pollonix: defcendit nang; ex montibus, qui ductint flumina cun aqua, $\sigma$ cijcit eam aqua fiuminis in ripis, er eft coagulata, of fit ficut cera, o habet odorcm picis mifre cum afthalto cum aliquo fectore: $\sigma$ uirtus cius eft, ficut picis, o afphalti miftorum. Vnde potius affrcendtim putauerim, noftram IIumiam cffe piffafphaltum, quime aphaltum. Et quanuis dicat Strabo bituminis I uduici ujun fulfe ad conferuanda cadauerd; non tamen negat, quin bitumini picem admifceant, fiató; piffafh haltum fact ltium. Verim serapio, $\mathcal{O}$ A uicenna bas mifturas cptic mé nouerant, utpote quibus non modó Syri, fed e fux zentis Mauritani utercntur. Quo fit, ut Brafanolifens 


\section{In Lib. primum Diofcoridis.}

M V M I A.

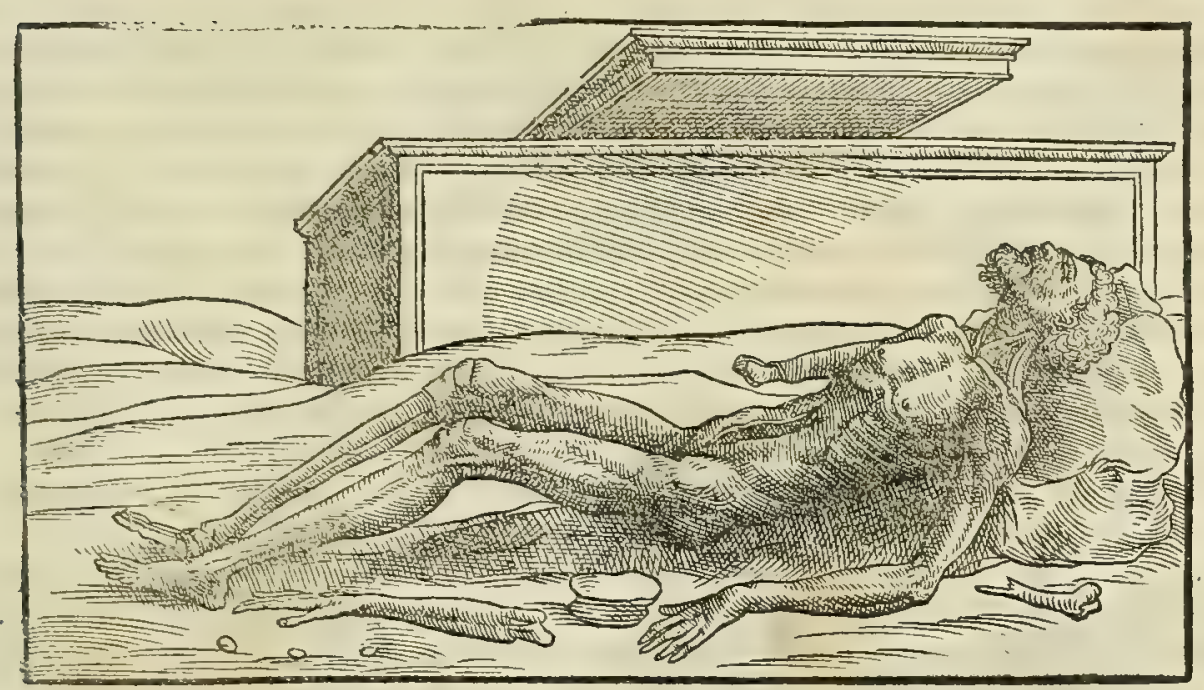

20 tention non prob.ndam exiftimem, quod foilicet unlgaris Mumia bituminis loco in componendis medicantentis fubs ftituatur. Nanque Munix praterquam quod eft (ut puto) Syncerum piffaphaltum, uel apphaltum pice miftum, concepsit deflucinetr hunorem, qui continuo é cadaueribus in Sepulcris liquatur. Ex quo credendum eft, eam non parum frum immutaffe naturam. Porró fatius ducerem Galenum, oc Paulum confulere, qui in fuccidancis, $f i$ de= fit apbillus, picen liquidam fubdunt. Caterimn notare conuenit, serapionem Mumiam Diofcoridis pifaphalto d= diecife, ut qus aliquam inter fe cognationem baberent, abinuicem non difinngeret: non enim erat ne fcius, buiufces modi cadauera piffaphal to impleri, quenadmodum myrrba, croco, alö̈, ac etiam balfamo fimul admiftis impleban= tur: que uer am trafulu temporis conficicbant munzian, cuius meminit einfdem capitis initio, his uerbis. Mumia sepul crorum fit émyrrha, aloë, alijs g; rebushis additis, o bumiditate, quam exudant humana corpora. Veruntamen bac nof tra tempeftate in Italiam haudquaquan aduehitur : quippe quod hac miftione nulla carü regionum cadauera prea 30 ter nobilium, ac diuitum condiantur: 0 bi quidem fepulcra babent fibi conftituta, diligenteróf; occlufa. Idcirco non it a facile iftornin corpora furripi poffunt à neercatoribus illuc profectis, ut minori tum difficultate, tum fuppicione alu

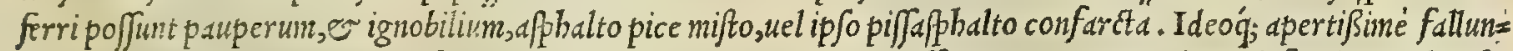
tur, qui pro legitind Mumia are factam iftiufmodicadduerum carnem affumunt, non auteme corum infarctum, uelutifere plafiariorusn quam pltmimi, qui carnes o offa contundunt, eáq; medicamentis admifcent, qua mumiam expofcunt. Neceflun igicur effet lcgitimam muniam expetentibus, ut in bopitalibus noftris cadaue a obcuntium aloé, myrrba, et croco repleri curarent, eamó; deinde fuo tempore eximi. Hanc tamen noftram sententiä pluribus refillere contendit Petrus Bcllonus Cenomanus, uir ex eo fortaffe peritus iudicandus, quód profiteatur fe Afiam, Greciam, Syriam, Ae=

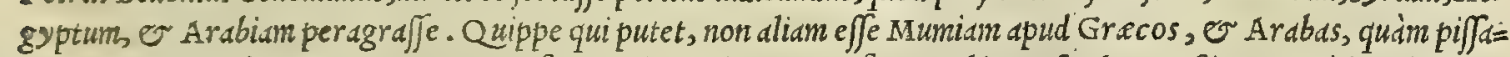
Pphaltum. Sed quód eiws argumenta non fint tanti momĕti, ut oppofitum nobis perfuadere poßint, o quód potius idens 40 hallucinetur, in epiftolis, quas confcribere inftitui, adiundnte Deo, latius oftendam. vbi etids plurind eius errata attexemus, que in libellis, quos tum de medicamentis cadauera feruantibus, tum de refinifris arboribus, tum etiam de pifcibus condidit, legendo adnotauimus. Quandoquidem noftrum in primis inftitutum non eft in bis contmentarijs noftras ad unguem tueri fententias, atq; ab erroribus, quibus notati erimus, nos uindicare; fed quantum poffumus ma teriam medicam dे mendis expurgare, eam 'q; ithuftriorem reddere, o in piftrinum candorem reftituere conamur. - Porró Mumia, de cuius uiribus iam nobis differendum eft, (ut Arabes tradunt) quàm plurimis pollet facultati- Mumix uire. bus: fiquidem fecundo ordine tun ficcat, tum excalfacit : capitis dolores frigiditate obortos ab $q_{q}$; humorum prafen= tia mulcet. Niedetur bemicranea, paralyfi, oris diftractionibus, comitialibus, uertiginofisq;; , fi ex amaraci aqua naribus inzmittatur. L eucoij oleo, fiue byof cy amino grani pondere fubacta, ad aurium dolores frogidos utiliter in eario concauitatem infunditur. Prodeft quatuor granorum pondere ex thymbra decocto refoluta, gula cruciatibus. Epo=

so ta ex zizypharum, hordei, et myxorum decocto tribus diebus continuis, tußientibus opem non modicam praftat. Grd= norum item quatuor pondere fumpta ex aqua ment he cordis affectus remouet: cum decocto ueró cumini, ammi, er cari, tum uentriculi, tum inteftinorum flatus difcutit . Bibitur utiliter ab alto deuolutis ex filique A egyptia medulla, additis L emnia fpbragide, e rubia radice. Haufta trium, uel quatuor granorum pondere fingultum inhibet, fi tamen ex cumini, er apij decocto affumatur. Erinis impofitd, additis mofcho, caftoreo, caphura, Or oleo balanino, naribus commodé inditur ad diuturnos capitis dolores; prefertim'́; cum, adhibitis alijs, contumax morbus non foluitur. Gar= garizalur. cun oxymelite aduerfus anginam: $\odot$ ad lienis affectus ex cari decocto utiliter bibitur : $v$ contra lethalia uenend ex decocto tribuli marini, o fretidi laferpitij gümi iuuamento non modico fumitur. item ex mero contra fcor= pionum itus bibitur, ittisq; locis cum recenti bubulo butyro utilißime imponitur. Adftringit mumia illita externa fan= guinis proftumis, pota uerò interna : proinde perutilis ad cruentas excreationes. Ex caprillo lacte pota opitulatur exulcerate uefice, internis penis de fquamationibus, er urinam agré continentibus. Non de funt qui credant, bumde norum cadduerum offa in puluerem redacta, ov in potu exbibita uarijs corporis languoribus prodeffe, os fuum uni= 
Bituminis hifor. \& uires ex Galeno.

Nomins.

CuprefsihiAtoria.

Adami Lonicerilapfus. cuiq; sembro tribuentes. Quod penitus refellendum non eft : il quidem ipfe pluries uidi in comitiali morbo cranium bumanum in puluerem redactum maximé profeciffe, ficuti etian calculo/is renibus, o corum doloribus. Sed ad $\mathrm{B} i=$ tunen rede amus, à quo nos pené difiunxerat mumia, ne a noftro inftituto recedamus. Huius meminit Galenus lib. $\mathrm{x}$.

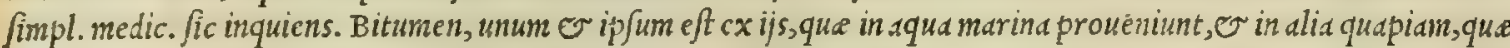
non eft marina difimilis, ut in A pollonio E piri, e per alia id genus loca, multis aquis ponte na centibus, ceu ß $u=$ ma quedam innatans boc medicamen reperitur, of molle quidem eft, duminnatat, poftca ueró reficcatum picc ficca durius cfjicitur. Optimum ueró bitwnen in mari, quod mortuum uocant, prouenit. Eft autem id ftagnum falfum in ccele, hoc eft caud, syria. Ceterim medicaminis ip/ius uis eft tum reficcatoria, tum excalfactoria in fecundo ordi= ne. Neritó itaq; co utunitur $\widetilde{\sigma}$ ad glutinationes uulnerum crucntorum, $\sigma$ ad alia omnia, que exiccari debent cum modica excalfacione. Nomen eius Grecum ef $\alpha^{\prime \prime} \phi \alpha \lambda \tau o s:$ Latinum, Bitumen: Arabicum, Hafral ieudi, fiue

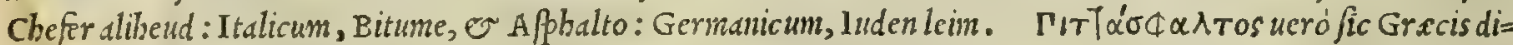
citur, ut Latinis Piffaphaltum: Arabibus, Mumie, Mumiay, feu Mumia: Italis, Piffalf halto: Hiffanis, Cera de minerd.

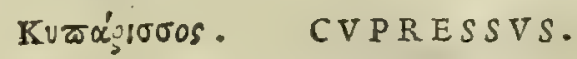

\section{CAP. LXXXVI.}

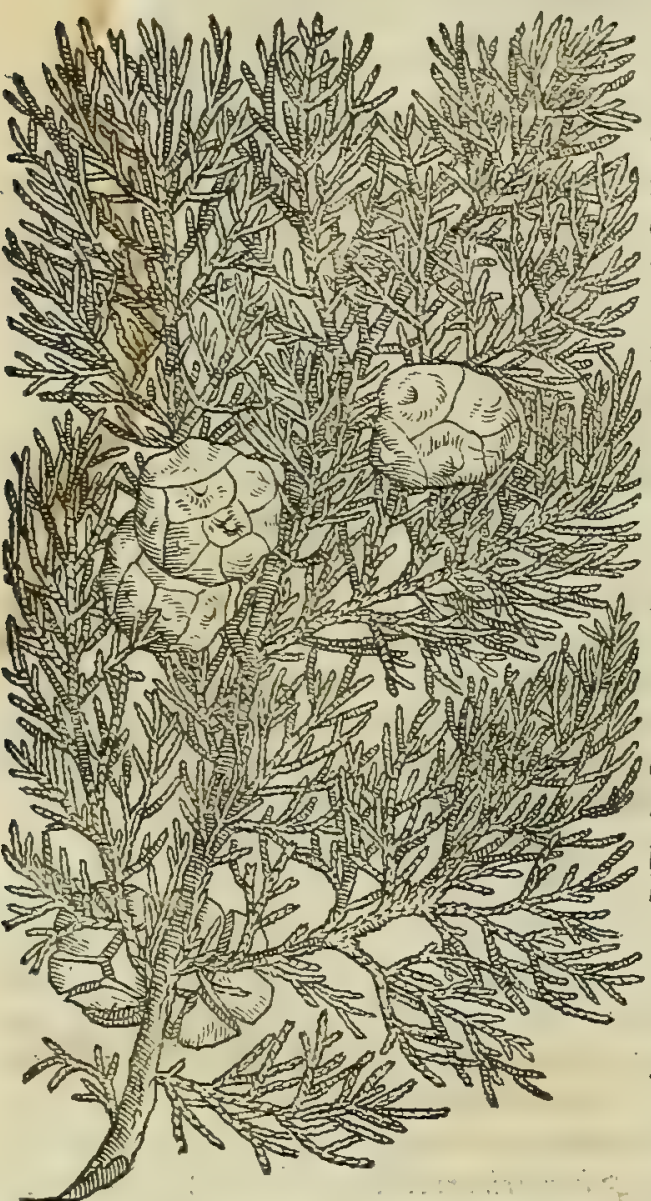

CV P RES S v refrigerat, \& altringit. Cuius folis expaflo, \& exiguo myrrhx pota, ueficx rheumatifmis, \& urine difficultati auxiliantur. Pilulx autem ex uino tufe in dy fenteria, alui fluxione, tufsi, \& orthopnœa,aut fireijciatur fanguis, conuenientifsimè bibuntur: earum 20 decoztum eofdem prabet effectus : tufx cum fico duritias emolliunt,nariumq́ue poly po medentur : in aceto co cta, \& cum lupinis detrit $x$ fcabros ungues eijciunt : hernias inteftinorum prolapfu erumpentes illitu reprimunt: Folia eadem praftant. Pilulx cum arboris coma fuffita, culices abigere exiftimantur. Folia trita, $\$$ impolita uulnera conglutinant, fanguinem fupprimunt: irita ex aceto capillum tingunt: illinuntur per fe, aut cum polenta ignibus facris, ulceribus qux ferpunt, carbunculis, $\&$ oculorum inflammationibus : admota cum cerato ftomachü corroborant.

T A M E T S I Cuprefius arbor notißinafit in Italia: quin etfi uulgaris fint notitix cius frutius, quos tain Greci, quim $\mathrm{L} d=$ tini conos appellant; attamen cum nibil de eius biftoria memorie prodiderit Diofcorides, ut lectoribus undequaq; fit fatisfactum, bic nobis differendum eft, quantum bac in biftoria à Plinio, alijs đ́f; nonnullis edocti, cognofcere quiuimus. Aduena igitur quon= dam fuit Italie Cupreffus, er difficillimé nafcentium, natuq; mo= rofa, ut que in educatione plurimum diligentix expetat, $\mathcal{\sigma}$ pre $=40$ fertim in locis, ubifuaptenatura non prouenit. Tradiderunt ue= teres cupreffun Diti facran: Or ideo funebri figno eius ramos ante domos ponere. folebant, ubi aliquis de functus iaceret. Ex quo more creditur cius umbra infausta, nec quidem gratio $\int a$. Duo babentur Cupreßigenerd, mas filicet, of fomina: bac meta in faftigiun conuoluta : ille ueró ramos in latus par $=$ gens. Harum patria, ac proprium natale folum Creta infula efl. nang; inibi quocunque loco terra moucatur, fuba= ¿ta'g; fit, nifi ferantur alia, bec fua pponte gignitur, atque protinus emigrat. In Ideis etıam montibus, qui ad Troas dem fpectant, non appellato folo, Cupreffus numerof a fonte profilit. Quod admiratione non uacat, alibi non nifi tempore, or perquàm diligeitti cultura proueniens, of cultorem magnopere faftidicns. Odere Cupre/3iflumina, la= cus, omneś́; aquofos tractus, quo fit, ut in eiufmodi locis fata confeftim inarefcant. Quod firecté fciuiffet Adamus so Lonicerus, non tan fucilè (ut puto) fcrip/iffet, cupreffum bumidis gaudere locis. Appernantur $\sigma$ finum, quo e tiam, fi circumfoffura impleatur, non multo póft tempore pereunt. Nira eft cupreßı facunditas: etenim trifres eft. colliguntur eius coni men/ibus ianuario, maio, $\mathcal{O}$ feptembri. Scmen ijs innafcitur, granis adeo pufillis, ac mi= nimis, ut atomis compararipoßit: ob id enim egré perpicitur. Non omittendum natura miraculum, ex tam par= uo emine gigni tam proceras arbores. Semen mire forsnicis expetitur, ampliato etiam miraculo, tantuli animalis cibo abfuminatalem tantarum arborum. quo fit, ut fructifere Cupreßinunquan formicis fint defitut:. Cuprefs. fus perpetua coma uiret, eius'́; materies nec cariem, nec uetuftatem fentit, ut etian cedri, cberi, loti, taxi, buxi, er olea. Proinde ueteres non aliam ob caufam ex cupreßina materie fimulacra fculpebant, nifi qućd ad aternam diu= turnitatem permanfura putarent, ueluti Rome illud Iouis in arce. Fert $\sigma$ Cupreffus liquidam refinam larigne fis. milem, fapore ueró acerriman. Reliqua fomina tradunt, folijs cupreßi tufis fi mifccantur, à uernic ulis quibufcung; non tangi, neque crodi. Lignum autem (ut aiunt) nulla temporis diuturnitate fuaucolentiam exuit. Sunt qui priz fillam 


\section{In Lib. primum Diofcoridis.}

fill.m cupreffum, nonmullis etiam Cipreffo uulgó dictam, abrotonum fominam uocent, a fimilitudine, quambac cum Cupreflus pus arbore in millis habet. Idctrco nec fortaffe aberyaret, qui certó crederet, Plinium libro X X II I I. capite X V. de filla. cbamecypariffo berba differentem, de bac intellexiffe: prefertim cim tradat, ipfam ex uino potan contra ferpen= tium omium ucnen, f corpionumí; ictus pollere: fiquiden oo noftra bac atate pleriq; abrotonum faminan ad idem uJurpant. Quoditem ad alui lincas necand ss bellarijs immifcent, ut arte pueros ad comedendum alliciant. Hetru= fi hanc Santolina uulgó nominant, de gua cum libro tertio in abrotont mentione nobislatius fit differcndum, bic pluradicere fuperuacancum effet. Cupreßi meminit Galenus libro vi I. Fimplicium medicimentorum, fic in= quiens. Cuprefiffilia, germina, piluls recentes, o molles magna uulnera conglutinant in duris corporibus: ex quo clarum eft, quód reficcandi uniz babcat abfque infigni acrimonia, aut caliditate, ficut certé $\sim$ guftus teftificd=

1. tur. Apparet enim in ca leuis quidem acrinonia, fed plurima amaritudo, multó́; ctiam plus acerbitatis in tota plan= ta. Tanta ci incet acrimonia caliditasq́;, quanta fatis fit deducenda in altum acerbitati, ac nullam tamen mordica= tionem, aut caliditatem in corporibus efficiat. Proinde in alto latentes in flaccidis, putre centibusq́; affectibus bu= miditates innoxié, tutóq; depafcitur, atque abfumit : cim que excalfaciunt fimul, deficcantó;, cas quidern que con= tcnte funt, abfunant : cxtcrim acrimonia, or caliditate alias attrabant. Sic enterocelicos iuuat: fiquidem exiccat, robur $\dot{q}$; addit corporis partibus pre buniditate laxis, utpote cum adftrictio in altum fubeat, deducente ip $\int_{\text {a }}$ calidi= tate, que admifta eft, eum feruante modum, ut deducere quidem ualeat, non tamen mordicare queat. Quidam ea utuntur ad carbunculos, or berpetes polente mifcentes, tanquam ab fumat citra excalfactionem eos morbos facien= tem humiditstem. Sunt qui ad eryfipclata utantur, admista nimirum polenta cum aqua, aut oxycrato aquofo. Ku= Nomina.

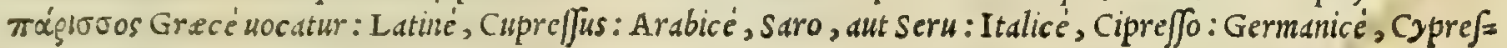
20 fen: Hippanice, Cipres: Gallice, Cyprez.

Áprevtis. IVNIPERVS.

\section{CAP. LXXXVII.}

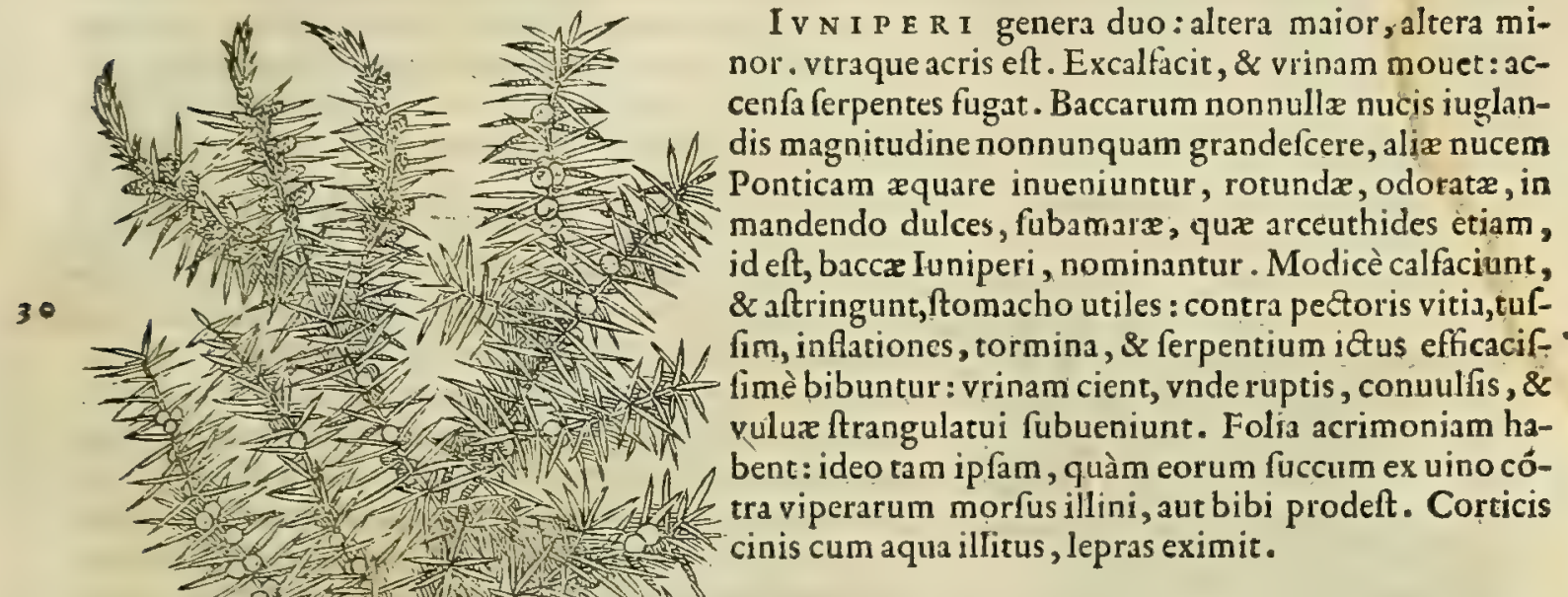

Cuprefsi ui res ex Gal.

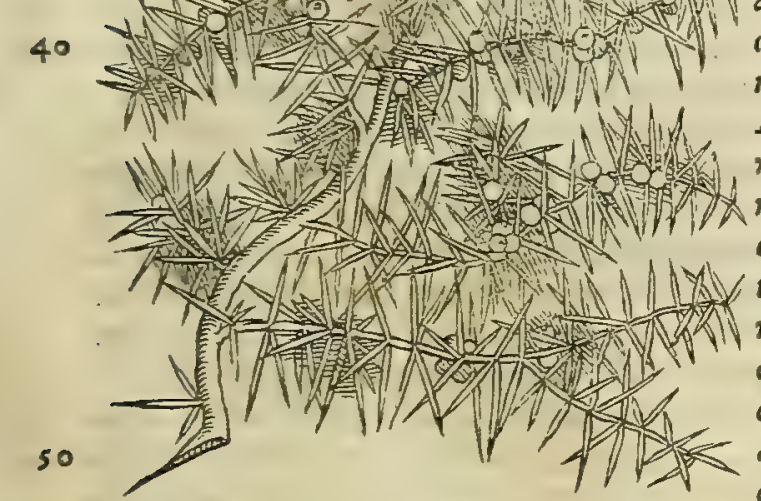

R E P E R I V N T V R Greci Diofcoridis codices (ut etiä Iuniperi conadnotatum reliquit Marcellus) in quibus I Iniperi caput prorfus fideratio. deprauatum legitur, quibufdam additis, que Diofcoridis doctri= nam minimé fapiunt. Siquidem nec Galenum, nec item $\mathbf{P}$ aulum Aeginetam, minus'; serapionem, qui tamen uèrbótenus Dio $c 0=$ ridis fripta per capita fingula refert, illud $u$ fquam pofteritatis memoria prodidiffe conftat, quod fcilicet ramenta ligni I uniperi epota bomines perdant; prefertim cim eius bacce contra ferpen tium ictus efficacißimé deuorentur : bibatur $\dot{q}_{;}$, ac illinatur folio. rum expreffus fuccus ad uiperarum mor fus. Addé etiam quód fax cto periculo id omnino falfun effe deprehendatur. Quare non mo dó ron credendum, fed ne cogitandum quidem, eiufinodi ineptias ¿ Diofcoride fcriptas: quin potius illi adfcriptas effe existiman dum. His ergo rationibis adductu, non temeré partem illam, ut= pote addititim, ex hoc capite re fecandam duxi. Mator, er minor I uniperi pecies in pluribus Italia locis reperis tur. Tufcia urbanas alit, que in proceram arborem affurgunt, uifuntur $q_{;}$ba frequentes in agro noftro senen/i: qud $\Rightarrow$ rum fructus $\sqrt{y}$ lucftribus of craßior, $\sigma$ dulcior habetur. I uniperimateries ad centenarios annos incorrupta perdu= rat: proinde iußit Hannibal (ut Plinius tradidit libro Xv I. cap. X I.) templum Diane Ephefia Iuniperinis trabi= bus extrui, quód per multas xtates effet dur aturum. Igitur mirari non licet, fi chymifte affeuerant, carbonem Iu= niperinum accenfum, ef fuo cinere obrutum ignem integro anno fouere. Profert ex fe I uniperus gummi maltiche fimile, quod $\sigma$ sandaracham, $\sigma$ Vernicem appellant. Hoc primum cum metitur, candido plende fcit colore: $\int e n e=$ fcens ueró in rufum abit. Porrç haud ignorandum ef, $h$ ăc Arabum fandaracham à Diof coridis fandaracha perquam longé dißider,e. Nanq; Grecis fandaracha eft fojßilis ad arfenici, fiue auripigmentigenera referenda, erodens, or exitiale medicamentu, ut amplius in quinto libro, Deo duce, dicemus. Verum hec Jandaracha nomenclatio in gum= 


\section{And. Matthioli Comm.}

mi Iuniperi inuect d fuit à medccis, qui Mauritanos fecuti fandarax Arabicum nomen (fic enin Arabes Iuniperi guin= mi uocant) in fandaracham conuerterunt. Quamobremillud adnotandum effe uidetur, quód ubi Arabes, fandards. cham medecamentis inferendam effe pracipiunt, gummi Iuniperi immifccndum intelligunt : ubi uerò à Grecis de fan darachafir mentio, fo Bilis illa rufa, e auriptgmento fimilis, ef intelligenda. Non defunt tamen qui uelint Maurita= noruin Sundar acham non effe gunmi Iuniperi, fed Oxycedri. Quorum equiden iudicio all im facilé fubfcriberc. ete= nim pauci admodum funt, qui non putent oxycedrum effe Iuniperum maiorem : adco ut pleriqg; uulgarium illam ab hac. ne fcisnt diftinguere. Tradit Plinius libro X I I I.cap. X I. plura gummi genera, ubigummi I uniperinum ad nibil ef= Gummi Iuni fe utile fcribit. Cuius tamen frequens ufus in medicamentis contrariun indicat. 2aippe hoc fyncero, er oleo ex lix. peri ufus. ni fenine preffo, fit ucrnix liquidus : cuius eft ufus ad illuftrandas pifturds, $\sigma$ ad nitorein firri conciliandum: utilis etiamnum ad ambuft t, o precipuus ad dolores, o tumores hewiorrboidum. Siccus uernix, hoc eft gummi Iuniperi $x$ (ut autbor eft serapio ) deftillationes fupendit, menfium profiunia fiffit, finus cxiccat immiftus, bauftus ueró pitui= tam, qux uentriculo, o inteftinis be ferit: tineas e catera uentris animalia necat. Neruorum refolutionibus, quas bumores frigidicontraxerint, opitulatur. Capitis defulldationes fuffitudifcutit. Idem exceptus fanguinis excreatiox. nes fupprimit, e bemorrhoidas fluentes illitus. Addito tum rofaceo, tum myrtino fedis rimas coërcet, e biantibus.

Sandaracha frigore manuum, pedum'́; fciffuris illitu fuccurrit. In fumma calfactt, $\sigma$ ficcat prino receffu. Eft $\sigma$ Sandard= alis Phnij. cha ceraginofi mellis genus apud Plinium, qui de ea libro X I. cap. v I I. ita fcribit. Prater bec conuchitur Eritha= ce, quam alij fandaracham, alij carinthum uocant. Hic erit apum, dum operantur, cibus, qui fape inuenitur in fauo=. ruin inanitatibus fepofitus, ev ip $\int e$ amari faporis : gignitur rore uerno. hactenus Plinius. Caterum oleum, quod $\mathrm{ex}$. Iuniperi materie (ut chymifte dicunt) per de cenforium duobus aduerfis fictilibus, tum pariter uitreis inftrumentis elicitur, calidum ore contentum dentiun dolores mirifice mulcet, fi tamen frigida defluxione afficiantur. Fit ex bac $=2.0$

Iuniperi uires cishoc longé praftantius, odore perquàm iucundo. I uniperimeminit Gal.lib.V I. Fimplicium medicamentorum, ex Galeno. fic inquiens. Iuniperus, calida, or ficca utring; tertij ordinis. At fruCtus fimiliter quidem callidus eft, fed non fimili=

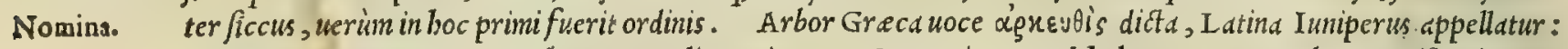
Mauritana, Arconds, aut Archencas: Italica, Ginepro: Germanica, Vuel.bolter, o Krametbaum: Hipanica, E=

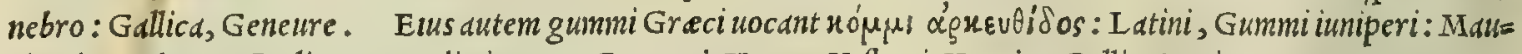
ritani, Sandarax: Itali, Gomma diginepro: Germani, Verns: Hzpani, Verniz: Galli, Vernix.

Bgóóus. $\quad$ SABINA.

\section{CAP. IXXXVIII.}

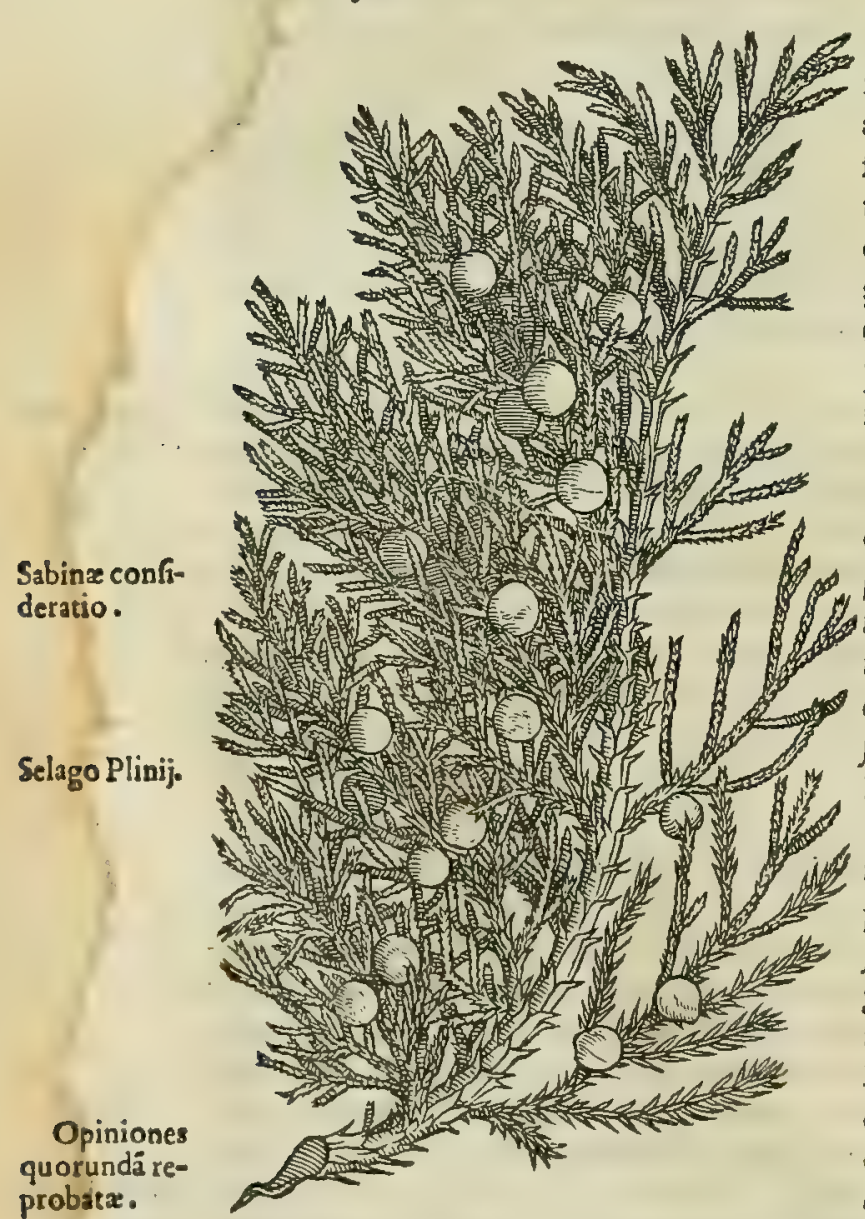

S A B I N A duorum generum eft. Vna folijs cupreflo fimilis, fpinis horridior, grauiter olens, acris, \& feruens. 30 arbor eft coact $x$ breuitatis, qux fefe magis in latitudinem fundit . huius folijs nonnulli pro fuffitu vtuntur. Altera tamarici folio fimilis eft. Vtriufque folia nomas fiftunt, collectiones illitu mitigant: quin \& cum melle illita nigritias, lordesq́ue repurgant, \& carbunculos rumpunt : cum vino pota fanguinem per urinam eliciunt : partus ap pofita extrahunt, \& fuffitu idem præftant. Vnguentis cal facientibus immifcentur, \& priuatim gleucino.

S A B I N A planta eft in Italia uulgaris notitix, illd fcilicet, 40 qua à Diofcoride primo generi aßignatur, folijs cupreffo fimilis, Binofior. Nerim eius folia non adeó plené uirent, ut Cupreßi, ¿ in cacumine aculeata conpiciuntur. Quod tamen fepe imperitis negotium exhibet: :iquidem aliquando uidi pro Sabina afjumi quan dam herbam dodrantalen, quae quibufdam in montibus plurima na fcitur, folio tamaricis, licet nec odore, nec fapore fabinam refer at.

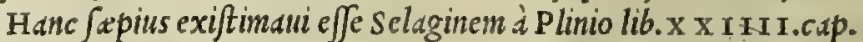
$\mathrm{x} \mathrm{r}$. commemoratam. Nanq; inibi felaginem effe affirmauit, fabi= ne fimilem. Olim felaginem contra omnem perniciem habendam prodidere Druida Gallorum, er contra omnia oculorum uitia $\int u f=50$ fitam prodeffe. At tanta extitit tunc temporis fuperftitionum ma= gorumg; uanitas, uelutio hoc ano apud plerasq; gentium turbas uifitur, ut ï nunquam ad felaginem legědam accederent, nifi prius Dijs facra feciffent. Quin er eam inualidam omnino cenfebant, nifî dextra manu, or nudis pedibus legeretur. Ceterim non defunt, qui plantam hanc, cuius hic inaginem damus, negent legitimam sa binam effe, hoc, nif allor, argumento, quod bac bacc as proferat. quarum in fud Diofcorides non meminit. Vnde factum eft, ut quidam putauerint, eam matorem iunperume effe, dlij ue rò thuiam, quam Theophraftus memoria prodidit lib. $\sigma$ cap.v. de hiftoria plantarum. Verium utriq;, meo iudicio, in errore uerfantur : illi quidem, quod bac planta nec folio, nec flore, neq; fructu, non materie, non odore, neq; fapo= re, non cateris deniq; notis imniperum referat : hi wero., quod thuia, ut eft autor Theoplraftus, nafcatur apud Am= 


\section{In Lib. primum Diofcoridis.}

monis delubrum, at i; in Cyrencnfi agro, forma cupreflo finilis cimm ramis, tun folijs, caudice, fructuó; uel potius ceu cupreffus fylueftris. preterea ghod, ut idem feribit, thuis materies omnino incorrupta perduret, nihil cius radice cripius fit, atq; fimulacra ex ea antiqui fculpere fint foliti, quemodmodun cxcedro, cupreffo, loto, 0 buxo. Hxec autem arbor conos jeu galbulos non firt cupreßimodo, fcd b.tccas : candice non attollitur longo, fed co breni conten ta eft : materie non conftat incorrupta folidiq; , fed caduca o fungofa: non ut thuis pect:liaribus locis gatedet, fed ubiq; feré locormm nestur. ut binc maius atq; euidentus difcrincn in ijs plantis appareat, quim ut illorume error, qui eas unam facunt thui.um, pluribus cxplodemereatur. Sed ccrté relinquitur, ut miremur cos, quiftirpens bunc, quam de pictan exbibimus, ueran Sabinam effe inficiantui", cum mullis careat notis ex ifs, quas illi Diofcorides reddi= dit. Ea enin arbor conpicitur cosct e breuitatis, que in latitudinem magis effunditur, folijs cupreffo fimulis, pino=

1. fior tanen: quin or graums olet, or acris feruensá; fentitur. A tqui illud nobis obijciunt, quód Diofcorides in de fcri benda s sbinx mullum baccarum mentionem ficerit. id mebercule, quod legatur, nonfecit. Sed quid diccnt ij, fi ir quàm plurimis plantis ex ijs ctian, que ab omnibus legitime babentur, plures note, or ex quidem precipue, non= nunquam defiderenturs quas nimirum Diofcoridem omiliffe credendum e/t, uel quód plant.e cee effent alioqui uulgo cogitite, uel qujd onnes carmm p.tries non fatis explorutas haberet, uel alits ob caufas, quas profcqui non eft bic lo= cus. quarum onmium dliyna fucile potuit c fe, cur S.abine baccas non adnotatas reliquerit. Addame id fortaffc ex co eueniffe, quod s. abin tr frequention fteril is occurrat, quim fructifera. Nam (ut equidem fateri poffum) inter innu= mer as Sabine plantas, quis un rijs in locis mibi uiderc contigit, tres duntaxat memini me obferuaffe, qux baccas fer $=$ rent, o cas quiden rubcutes sc innipcrinis maiorcs. Id quod me quandog; adduxit, ut putanerin in boc sabine ge= nere maren or famin an repermi : at o; alteran raran effe in Italis, quemadmodum eam quoq; raró uidimus, quam

20 Diofcorides fecindo loco reprefent.uit, tamaricifolijs fimilem, non autem acule atam. Ex ijs igitur meritó colligen= dum elfi arbitror, b.inc noftr.sn Sabinsm effe legitinatin, ut qu.e non folim notis Diofcoridis delineationi pulcbré re= ppondeut, jed etim facultuibus. Porró Petrus Bellonius de arboribus coniferis differens, ijs inepté fatis, meo qui demiudicio, Sabinum atimifeet: at, in ea defcribend, quam fecundo loco ponit Diofcorides, mibi non parum balluci

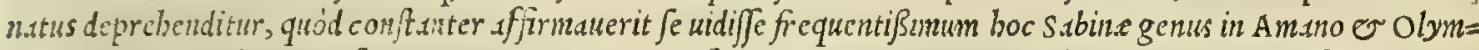
po Pbrygis montibus, tota ficic inniperum maiorem referens, magnitudine anygdale arboris maioris, folijs cupref= fo per onnia /imilibus, baccis per maturitatem in caruleo nigric antibus, e caudice refinam ferente. Etenin Dio= fcorides non tr.ddit qux fit buius plante facies, or que magnitudo, fed e.mn in folijs tantum à priori uariare foriptum reliquit. Quod non alia de caufa auctorem bunc feciffe reor, quàm quod fciret nullum utriufq; effe in reliquis notis di. ferimen. Quare quod alterum Sabine genus tota facie iuniperum maiorem referat, magnitudine amygdalum arbo= 30 rem equet, cupreffun folijs pror fus emule tur, of ex caudice refinam fundat, ut Bellonius fuum depingit, mibi qui= dem plané ab furdum uidetur. Sed quód rem hanc turpiter confuderit Bellonius, uel ex eo manifeftum effe puto, quód quam plantum nunc Diofcoridis alteram Sabinam afferit, eandem pauló póft arborem illam conftituit, quam Plinius lib. X I I.cap. x v I I. Brutam appellat, quafi Plinius non meminerit utriufque fabine lib. x X I I I I.cap. X I. Tantum quidam fuis peragrationibus tribuendun effe putant, ut cos non pudeat fepe abfurds, or fabulofa, or qux cum fum= mis or probstißimis authoribus pugnent, narrare ac fcriptis tradere. Neq; certé id propterea dico, quod peregrina tiones dumnem, quas femper, Galeni exemplo, utilißimas duxi ad legitima fimplicia medic amenta cognofcenda. Sed opt.trem, $u t i j$, qui multss regiones peragrarunt, illa tantum in medium proferrent, que effent rationi o ueritati con fond, er ueterum fortptorum auctoritste comprobata. Quod $f i$ i Bellonio, qui tot terras fe peragraffe profitetur, factum effet, nimirum eas laudes iure fibi compar afet, que rei medice inquifitoribus maxima debentur. Atque bec 40 obiter diata fint. Quód autem idcm Bellonius primum Sabine genus eam arborem fupicetur, quam Theoplraftus thuiam nominat, non miror: nam $\sigma$ alij idem fentiunt. Verim quandoquidem hanc opinionem fuperius abunde ( $m i$

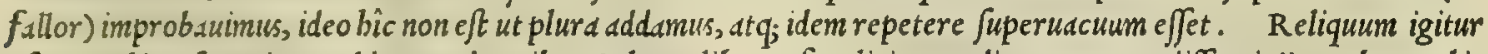
eft, ut Sabiux fus uires reddamus: de quibus Galenus lib. v r. fimplicium medicamentorum differuit ijs uerbis. Sabi= ns ex numero oft fortiter exiccantium, id' ; fecundun tres qualitates, quds in guftu pre fe fert, fimiliter cupreffo, nifई quód ea $\mathrm{E}$ acrior eft, $\mathrm{O}$ ut fic dixerim, magis aromatica, feu odoratior. I gitur buius, quam modo dixi qualitatis eft particeps, nempe acrimonia confiftentis in temperamento calido, preterea amaritudinis, or adftrictionis obfcurio= ris, quim in cupreffo. Siquidem quantó magis acrimonia uperat, tantó etiam potentius digerit. Itaq; glutinare ne= quit ob ficcitatis, $O$ caliditatis robur . nam utriufq; illi tantum ineft, ut etiam tendat, $\sigma^{2}$ inflammationem afferat. At putredinibus /imiliter cupreffo accommodari poteft, maxime ubirebelliores fuerint, or diuturniores . nam he citra 50 noxam uim medic amenti perferunt. Quin er qux atra funt reddita, or admodum fordida, ea cum melle expurgat: carbunculos item foluit. Porró effentia tenuitate menfes quoque prouocat, ut $f i$ quid aliud, $\mathcal{O}$ fanguinem per uri= nas mouet. Fatum etiam uiuentem interficit, of mortuum eijcit. Efto autem hoc medic amen tertij ordinis, tum ex= calfacientium, tum deficc antium ex numero corum, que uel maximé tenuium funt partium. Et boc utiq; nomine un. guentis inditur, er maximé gleucino, $\sigma$ in multas antidotos inijcitur. Quidam ueró ctiam cinnamomi uice duplum cius fubijciunt. Eft enim extenuandi, or digerendi facultatis, fi epotum fuerit. Bpóivus Gracé, Sabina Latiné nocatur: Arabicé, Abel, Abbel, feu Alharar:Italicé, Sabina: Germanicé, Seuenbaum: Hifpanicé, Sabina: Gals Nomina. licé, Sauiniera, aut Suinier. 


\section{Ké̊̊gos. CEDRVS.}

CAP. IXXXIX́.

CEDRVs arbor magna eft, ex qua picem colligunt, quax cedria nocatul. Iuniperi modo baccas parit, baccarum myrti magnitudine, rotundas. Cedria oprima eft crafia, perlucida, glauis odoris:: quæ dum effunditur, guttatim non difsipata coit. Cui ea uis inelt, ut defuncta corpora conferuet; \& uiuentia corrumpat: qua ex caufa mortuorum uitam aliqui eam appellaucre. Veftimenta quoque, \& pelles cximia calfaciendi, \& ficcandi dote, corrumpit magni ad ocularia medicamenta ufus : quip pe illita ocul is claritatem affert, albugines cicatricesq́ue detergit: inftillata autem cum aceto, uermes. aurium necat: cùm hyffopi decocto infura fonitus, libilosq́ue fedat: çuis dentium indita eos frangit , \& dolores leuat : idem facit cum ex aceto colluitur : peruncto ante coitum genitali, concipiendi uim adimit: anginæe perunguntur, tonfillarum inflam mationibus auxilio eft: lendes, pediculosq́; illitu enecat : ceraftx morfibus cum fale impofita fubuenit : contra haufta leporis marini uenena, in paffo fumpta, auxiliatur : in elephantia aut lintu, aut perunctione proficit: pulmonum ulcera purgat, \& fi cyathus eius abforbeatur, perfanat: vermes, \& tineas fubter indita necat, \& partus extrahit.

Fit $\&$ oleum à cedria feparatum dum coq'uitur, uelleribus fupra halitum eius expanfis, ut in pice. Eiufdem ad omnia ufus : priuatim uehementer perunctum, fcabiem quadrupedum, canum, boumq́ue perfanat : ijsq́ue inhærentes ricinos enecat, \& ulcera, quæ cx tonfura acceperunt, ad cicatrices perducit. Cedrides cedri fructus uocantur. Caifactoriam vim habent: ftomacho aduerfantur: auxilio funt tulsi, conuulfis, ruptis, ftrangurix : menfes ciunt ex polline piperis poti : contra haultum lepo- 20 rem marinum in uino fumuntur : ferpentes fugantur, perunto ex adipe ceruino, aut medulla, corpore. In antidota adduntur. + Fuliginem, quomodo ex pice, congeri oportet: qux eandem, quam picea fuligo, uim præbet.

\section{CEDRVS PHOENICIA.}

\section{CEDRVS LYCIA.}
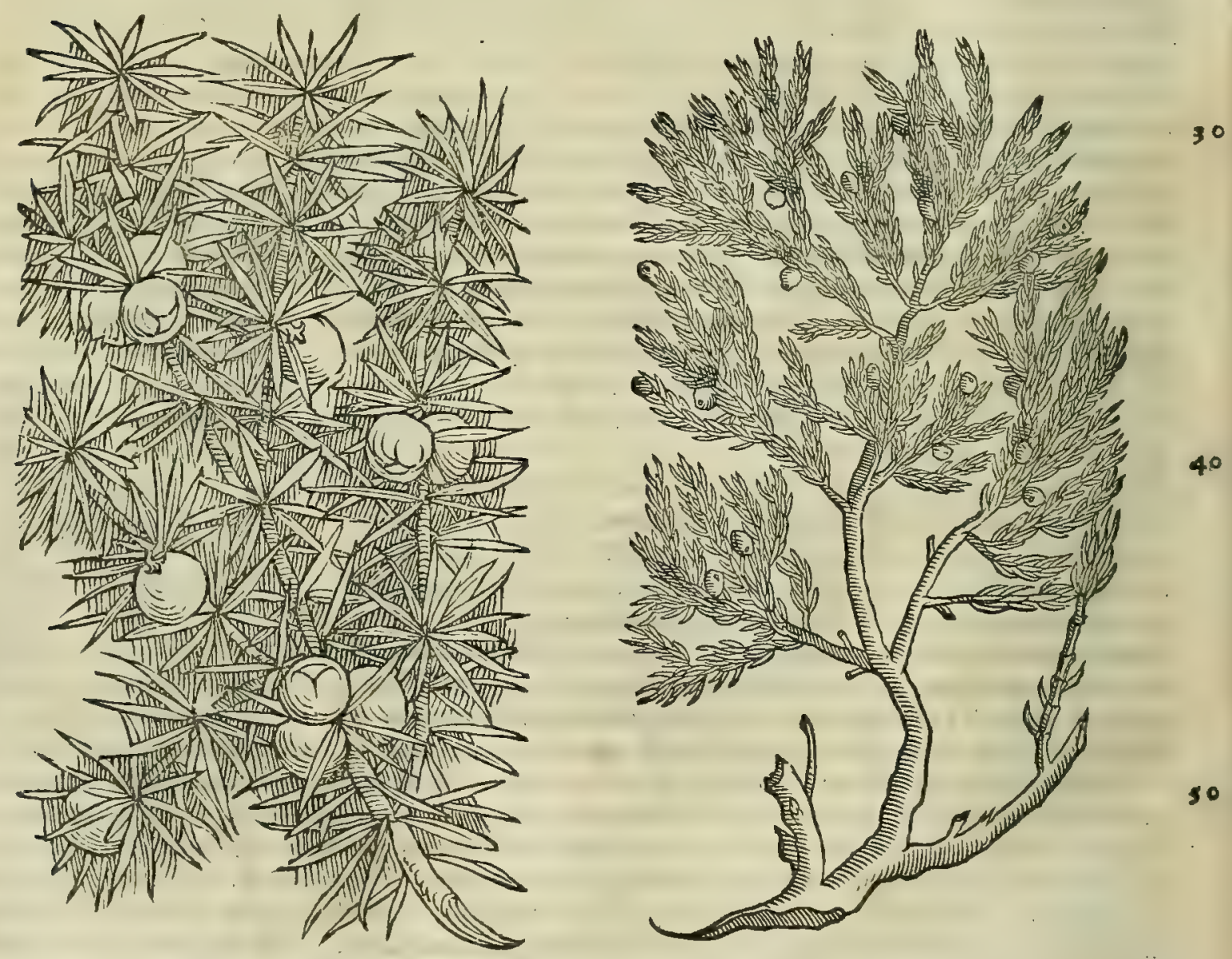

Cedri arboris

C E D R I arboris Theophrasto, Plinio, o Galeno duplex est genus, nempe maius er minus. Maius omnibus confid. arbor eft eximia magnitudinis, o proceritatis, atque à minori plane differens materie, cortice, folits, o f uctu. Plinius maioris cedri dwo genera facit lib. x I I I. cap.v. ubiita fcribit. Et maioris cedri duo gencra. qu.e floret, fru Aum non fert : fructifera non floret, o in ea antecedentem fructum occupat nouus. Semen cius cupreffo fimile. Quiz: dam cedrelaten uocant. Ex hac refina laudatifima. materie ueró ipfi aternitas. itag; o fimulacra dcoruin ex ca factitauerunt. Et libro X X I I I . cap.v. idem inquit. Cedrusmagna, quam cedrelaten uocant, dat picem, qua ce= 


\section{In Lib. primum Diolcoridis.}

dria tocatir. Baftenus Plinius. Quifortaffe non iteptémagnam cedrun cedrelatch appellauit, quonidm ecdriarbo= res, qux in monte L ib.no protsnumi ( ui mibi retulerunt amici, qui uniuerfam firé Syriam peragranunt) tota facic

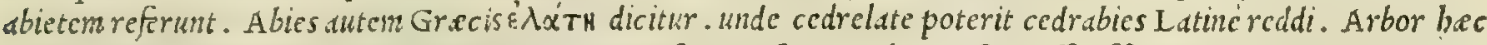

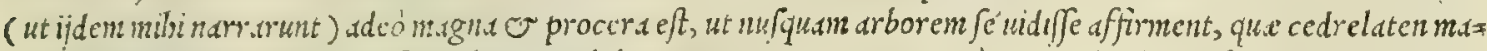
gnitudine cxccllat. Cortice ucfitur leu o glabro, ed partc excepta, qua d terra ad primos ufq; ranos attollitur: b.ec enin apera cernitur. corticis color cft ccu loti arboris. Rami ab imo ufq; ad cacumen fere is rot.e nodum per.

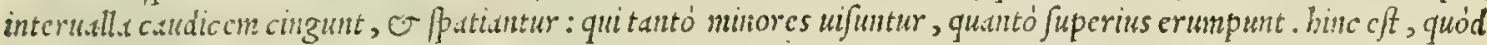
cminus conperta arbor pyramidis facien reprefentat. Folia lli capllata aßignant, ucluti larici, wel pho, breniora tancn, or minimé aculeata. id quod etian teftatur Plinius lib. X V I.cap. X X I I I I. Conos profert piccis amulos, 10 uerum longiores, duriores, or uegetiores, pediculo pertinuctter inherentes. in quibus femen includitur cupreffo fimile, ut pliniss tradit. Culdex refinam fundit albam, or liquidam: jed tractu tcmporis, fol is feruore in grumos con crefcit. Sunt qui aferant, banc ccárum duplicem refilunfirre : atque alteram intra corticen nomice modo codcer=

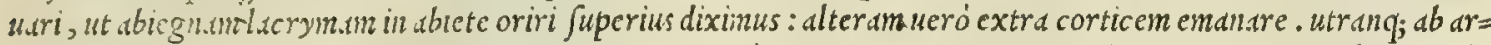
bore ccdrimm nonnunt. Hec funt, que de magna cedro d̀ peregrinis accepi. In quibus utiq; admirarifubit, quód

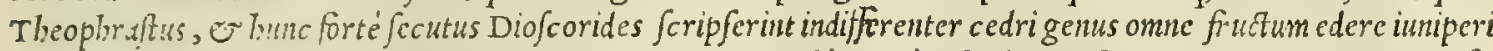
bxccis fimilem, crapiorcm. nun reuera Cedrus magna, de qua bic tantum fcribit Diofcorides, conos parit pice is fis miles. Porró Ccdius cor babct durißimum, ac odoratum, cuiore perinde rubens atque larignum. Toka cedri mate ries durifsima. quan ob caulam credidere maiores, eam rieq; cariem, neque uetuftatem fontire, fed aternam effe. Qus etionnum rutione ductus Salonon Hcbreorum rex Dei optimi maximi templum Hierofolynis ex cedri materie 20 extruendum curauit. Ex ex quog; prifci imulacra factitarunt, exiftinantes tantam illis ine ffe diuturnitatcm, quan t.am murmorcis, ant met.llicis. Cedrimateries optina naugijs non modó extruendis, fed $\mathcal{O}$ palatiorum, or arcium fubricis counenicns: quippe quoniam incorrupta quafi in perpetuum perdurat. Cedrus faxofis er frigidis locis gau= det, er montes amat prex cetcris tradibis. Perpetua coma uiret, qua fi caftretur, decacuminata demoritur, nec unqu.un ind regcrminat, utpote $\sim$ cupreffus, pints, Larix, or aluarum plures. In Aegypto ac Syria (ut Theopbra ftus $\mathrm{C}$ P linius surrant) reges inopia abietis cedro ad claffes feruntur ufi. Maxina ea in Cypro traditur ad undecire men Demetrij Juccifa, centun trigintd pedum longitudnis, craßitudinis ueró ad trium bominum complexum.

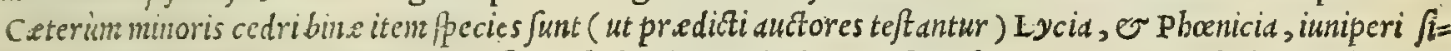
militudine. differunt folio: nam Phenicia folium babet itniperi, durum, fpinofum, acutum, or ob id oxycedros ap= pellatur. Lyci.t veró folio conjtat minore, frequentiore, longé minus aculeato, ut ita iuniperum paruan quadánte= ris genera.

30 nus referat: cortice obducitur fubrubro, er ramos emittit lentos, uitilium inftar. Vtraque omni tempore fructum gerit : ueriun in oxycedro maior o pulchrior ßpectatur. Phonicia cedrus frequentifina nafcitur in Iftria, atque etiam in nonnullis I pidic loc is, iunipero ddmodum fimilis, nec nifi fructu differens, maiore, rubente, ac dulci: quo tamen eam incolde ḋ iunipero ne ciunt fccernere. At cim ipfe oxycedri ramufculo effem donatus dे Georgio Reffin= gero primario pronincie Camole medico, qui illum ex Pefino Iftrix oppido fecum attulerat, rubentibus baccis un. dique refertum, edq; in memoria haberem, qua apud Theophraftum, Galenum, ac ueteres alios legeram, mibi quis dem fructum intuentiftatin inclinauit animus, hanc plantam minorem effe cedrum. Etenim (ut memorant ftirpium fcreptores tum ueteres, tum recentiores) difficlle admodum effet dignofcere oxycedrum à iunipero, nifi huic ceru= leus, pumilusq́; ; illi ueró flauus rsbénsue, ac grandior fructus ineffer. Eam igitur plantam, quam in Iftria nafci di= ximus, er cuius bic effigiem dumus, non muoris cedri genus ullum, fed minoris peciem effe cenfemus, nimirum 40 Phoniciam, que ov oxyccdros nocatu*. De Lycia autem cedro quid fentirem, uel quam plantam pro ed in me dium proferrem, batenus non habui, ut qux mibi plané incomperta effet. Sed hoc anno, dum Prage Bohemorum ago, plantam mibi oftendit Addmus Leonorus pectatx doctrine, e magne pei iuuenis, ex quibufdam Morauie montibus à quodan uulgariberbario pro sabina allatam. Vt autem ille hanc ueram cedrum Lyciam adinuenit, er proea mubi denonltrauit; ita mibi eius cognitionem illi acceptam referre iucundum est: atque ideo ipfam pictura, quam bic damus, exprinere curaui. Huius plante folia fi digitis atterantur, fuauißimum pirant odorem, illi quds dántenus fimlem, qui in pinorun frobilis percipitur. Ea baccss profert, longé tamen minores quàm altera, qux in ramuculorum tantum cacuminibus prodeunt. He non fecus ac ille primo exortu uirent, mox flaue $\int \mathrm{cunt}$, denique rubent ubi plené maturuerint. Saporembabent fubamarum, atque non obfcuré odorate fentiuntur. Mandt ab ar. bore cedri ( ut fuprà dictum cft) etian refind, qus proprie Cedria dicitur, utilis ad multos in medicindufus. Sed

50 hanc ad nos non adferunt ( ypriy, neque mercatores, qui ex Syria mercimonta conuebunt: tametfi regiones ille plu= rinis ( ut aiunt) cedris maioribus fcateant. Petrus Bellonius lib. I I. de medicato funere, item libro de coniferis arboribus putat non modó cedrun Cedriam fundere, fed er piceam, tedam, laricem, cupreffum, iuniperam er be= tulam. Quinetiam idem Juis malé excogitatis cedrijs eas omnes facultates aßignauit, quds Diofcorides, Galenus, o alij quàm plurimi auctores cedris duntaxat reddiderunt : adeo ut magno ac ridendo errore dixerit fuas hafce ce. drias defunita corpora conferuare, quemadmodum ea conseruat legitima cedria. quafi idem quoque uelit, quod pi: cea, pinus, larix, cupreffus, iuniperus, o betula nullis prorfus inter fe facultatibus differant. Neque certe alia widetur mili autoritate uel ratione ductus, ut in banc iuerit fententiam, quàm bac, quód fcripferit plinius lib.x v 1 . cap. $\mathrm{x}$. picem in Syria cedrium uocari. Sed quód Bellonius maximé ballucinetur, utpote qui Plinium non recté in= tcllexerit, exuerbis Plinij, que modó fubijciam, fatis, ut puto, manifeftum fiet. pix, inquit, liquida in Europa ć teda coquitur nauslibus muniendis, multósque ad alios ufus. Lignum eius concifum furnis undique igni extra cir= cuadato fruet. Frimus Judor aque modo fluit in candli. Hoc in Syria cedrium uocdtur cuitanta uis ineft, ut in 
Acgypto corpora hominum defuntorum ca perfufa feruentur. Ex ijs Plinij uerbis non aliad (meo quidem iudicio) intelligi poteft, quim quod syri liquarcmillum cedrium uocaucrint, quoniam olim ij ex cedro tantum picem fuam conficicbsitt, ut cs in Europa é teda fit. Qujd autem pix ex cedro paretur, authores effc poffunt Diofcorides, Gas lenus, or Plinius: nontancn contri, quod cedris ab alijs refiniteris plutitis defut. Addc quód i uctcribus, nem= pe Theophrasto, Diofcoride, $\mathcal{O}$ Galeno, nufquam (quod equidem fciam) memorie proditun e,t, refine aut picis genus uliun defuncta corpora conferuare, er uiuentia corrumpere, preter cedrian, de qua onnes illi id feriptis tradiderunt. Ex quo abunde conftare arbitror, Plinium quiden loco citato de pice tantiun cedri fcripfiffe; Bellox nium ueró in boc finiliter ballucinatum fuiffe, atque in alijs pluribus rebus, ut aliquando, Dco iuuante, latius often=

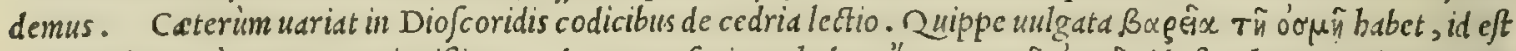

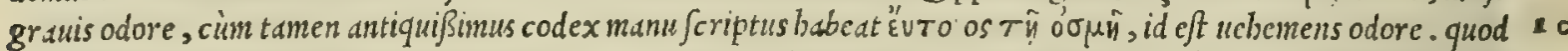
indic at cedriam effe uebementer odoratam, non autem grauitcr olere. Quod cliam maxiné teftatur Virgilius libro vrI. Aeneidos bis uerfibus de Circe canens.

Proxima Circex raduntur litor terre,

Diues inacceffos ubi fol is filia lucos

A ßiduo refonat cantu, tect is q; fuperbis

Vrit odoratam nocturna in lumina cedrum,

Arguto tenues percurrens peçtine telas.

Fuchfij opi- Gummi ccdrimeminit Fuch/ius uir eruditißimus libro illo de componendis medicament is, quem poltremó locupletd= nio. tum excudit, in compofitione antidoti Mitbridatis: pró,; eo, quando non poßsit inueniri, lacrymä abiet is fubftituen= dam pracipit, ratus utiq; candem utriq; facultatem ineffe. At ego quidem Galenum fecutus malim ladanum fubfti= 20 tui, donec $a b$ alijs aptior a profirantur, quorum meliori iudicio fubfcribendum fit. Neq; inepté fortaffe iuniperinum

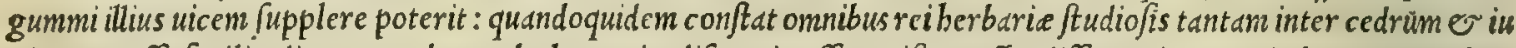
nipcrum effe fimilitudinem, ut altera ab altera uix difcerni poffet, nifi ea effet differentia, que in baccis utriufque maniffta deprebenditur. De Citris autem, quibus aurea totius fere 1 talix uiridaria exornantur, tam in Tyrrbeni, quaim Benaci litoribus in fequentibus, capite de malis, ubi ipforum mentionem facit Diofcorides, adiuudnte Deo,

Cedri \& $\mathrm{Ce}$ : drezuires ex Gạleno.

Nomina. plura dabuntur. fiquidem arbor illa ab hac, de qua nunc agitur, piurimùm differt. Cedrimeminit Galcnus libro VII. Fimplicium medicamentorum bis uerbis. Cedrus pecie duplex eft, altera fruticofa iuniperis adfinilis, altera arbor non exigua. Vtraque eft calida, ficcé;; temperature tertij quodammodo ordinis fecundum utrunque. Cate= rim Cedred ( uocatur ita cedri oleum) quartum etiam ordinem uidetur attingere, abunde calida fimul, ơ tenuium partium. Molles itaq; carnes prompté citráq; dolorem putrefacit; ficut alia omnia, que cim ciufdem fint in calfa= 30 ciendo ordinis, adiunctam etiam habent fubftantie tenuitatem. At in duris plufculo tenipore, e uix operatur. Por= ró talia omnia medicamenta feptica uocantur, o fepta: fed inter fe fe maioris, minoris'; ratione difident. Eft au= tem in boc genere medicamentorum ex primo, E infirmißimo ordine cedrea : pleraque enim eorum admodum funt efficacia. Talia itaque e mortuorum corporum carnes corrumpunt : at ccdred cxiccat, fimul'; a d corruptione tue= tur corpora demortila, utpote humiditates corum fuperfiuas depafcens, cxterium folida corpora baud attingens. At in uiuentibus calor ipfe, qui in corporibus eft, cedrea uires adaugens, caufa cfficitur, ut tenera ab ea carnes deuran= tur. Nec mirum uideri debet, fi cum tanta polleat potentia lendes, pediculos, o tineas, o in auribus natos uermes interficere ualeat, tum foetum appofita uiuentem quidem interimat, mortuum autem eijciat, ficut fané etiam in coi= t $u$ femen, pudendo circumlita . proinde conceptum impediens eft medicamentum, fific utaris, nulli fecundum : alia q ; multa eiufmodi particulatim efficit. I taque argumentum eft, ipfum ualenter excalfacere, ficut ubi dentium for ami=

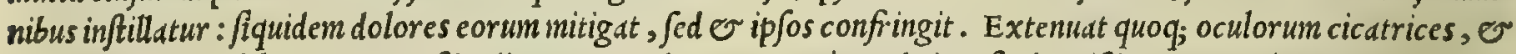
uifus be betudini ab humorum craßitudine orte medetur. Porró quod eius eft pinguißinnum, $\sigma$ ad unguem oleofum, quod fupenfis fupra eam dum coquitur, lanis excipitur, ac colligitur, tota cedrea tenuius quidem eft, fed minus d= cre; quanquam non minus excalfaciens. Eandem quippe rationem babet ad id quod reliquum eft cedrea, craßsius ils lud uidelicet, quàm oleum ad amurcam. Proinde illud utpote craßius, mordaxe eft, o maiore aperiendi facultate preditum. Itaq; ulcera irritat, pblegmonenq́q; illis excitat. Porró oleofa illa cedrea adeó clementibus eft uiribus, ut ctiam plebeij experientia docti uulnera ouibus occafione tundendi a forfice facta, illa illt a fanent, ficut etiam pice bu= mida. Vtuntur autem ea $\sigma$ ad ouium fcabiem, o ricinos, Græci ró́t wivas uocant. Porró cedrides (nam ita fru= Etum cedri nuneupant) moderatiores uires obtinent, adeo ut comedi quoq; poßint. Attamen fi liberalius ijs utare,

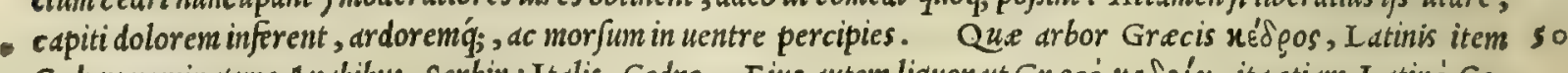

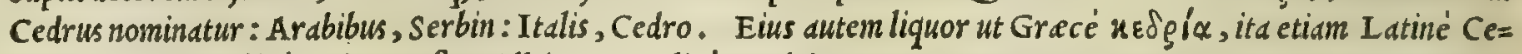
dria dicitur: Arabicé, Kitran, fiue Alkitran: Italice, Cedria.

$\dagger$ Hic lectorem admonitum uolumus, illa de fuligine Cedri uerba non legi in Gracis tum uulgatis, tum etian anti= quis quibufdam codicibus. Quare cumm neq; à Marcello uertantur, qui plura exemplaria Greca babuiffe fatetur, ea potius addititia, quàm legitima cenfenda uidentur. 


\section{In Lib. primum Diofcoridis.}

$\triangle \alpha \dot{\phi V H .} \quad$ LAVRVS.

C A P: X C:

io

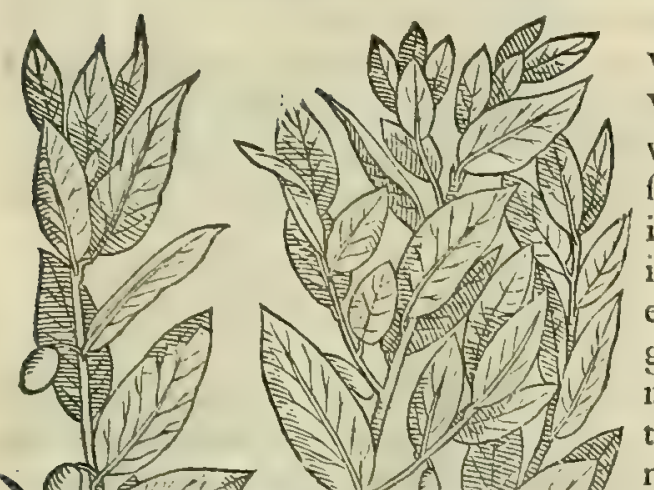

30
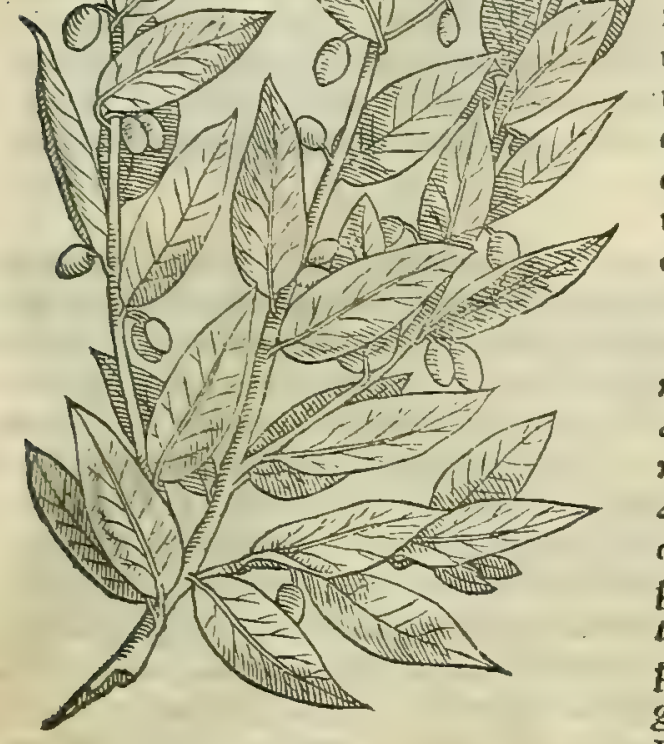

LAVRVs quxdam tenui folio conftat, altcra latiore. Vtraquc excalfactoriam naturam habet, \& emollientem. Vnde decoctum earum in muliebres infeftus addieum, vulux, \& ucficx uitijs conuenit. Virentia folia fentrm fubftringunt: illita quoque, ac trita uefparum apumó; i̊tibus opitulantur: eadem cum polenta, \& pane illita inflammationem omnem mitigant: fed pota ftomachü effundunt, \& uomitiones mouent - Lauri baccx magis, quàm folia calfaciunt . ergo in eclegmate tritx cum melle, tiel paffo profunt tabi, orthopuœx, \& omnibus thoracis rheumatifm is : contra fcorpionum ićtus ex vino bibuntur : uitiligines emaculant. Succus baccarum utilifsimè aurium dolori, \& grauitati inftillatur cum uino uetere, \& rofaceo. In medicamenta autem adijciuntur, quæ neruorum lafsitudines reficiunt, acopa uocant: $\&$ ad unguenta, qux cal faciunt, $\&$ difcutiunt. Cortex radicis calculos rumpit, partus necat, hepaticis prodeft, tribus obolis in uino odorato potus.

L A V R V S tam tenuifolia, quam latifolia arbor odoratißi= ma, o fi antiquis credimus, A pollini lucidißimo facrd: quinetiam Lauri hiftoà Ioue colitur. Vina quoque laurus Rome antiquitus imperato= rum pontificum q́; domos exornare folcbat. Quod fimiliter, at q; alij complures gentilium mores, in bunc uf q; diem apud nos per= durat. Nang; ubi dies feftus; aduenerit, laurus non modó tem plorum ualuas deccor at, fed er ubi dies geniales adfuerint, ingen= tium palatiorum eftianitrix: Q uo fit, ut magnis aduentantibus principibus, laurifrondibus $\mathrm{E}$ columne, $\mathcal{O}$ arcus in pacis $f t=$ gnum extruantur: fiquidem pacifra laurus eft, non fecus ac olea.

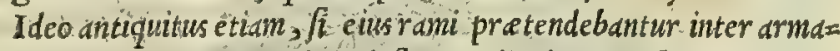
tos boftes, firmum quiet is er at indicium. Qud obferudtione duetus Beruardus clefîu Cardinalis amplißimus Triden= tinus, turs pacis, tum quictis fectator maximus, lauri, 0 palme florida ramum adnectebat, ut nitida marmora, preclara metalla, peciofe picture, aurea, or argentea uafa, ac reliqua admirarlda demonftrant, quibus magna eius palatia fulgent. Romanis laurus fercbatur la titic uictoriarung ǵ; fogno. Idcirco laurum in templis in Iouis gremio re= ponebunt, quoties Rome letitiam uitoria noua attulerat. Quinetiam giatd Apollini dona unoquoq; anno mittere folebant in Parnafo monte, quód ibil lurus pectatißima crefceret. Caterüm quód laurus Rome à Ioue éccelo miffa fuerit, ut ea imperatores corondrentur, facile perbiberipoteft: nang;: I iule: Drufille, que pofted Augufta matri= 40 monij nomen accepit, cum pacta effet illa Cefari, gallinan confpicui candoris fedenti in hortis aquila ex alto abiecit

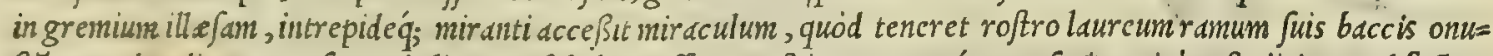
ftü. Quod audientes conferuari alitem, et fobolem iufere arupices, ramum'́;: eum feri, ac.rité cuftodiri. Quod factum eft in uilla Cefarum flutio Tyberi impofita, iuxta nonum lapidem flamminia uia, que ob id uocatur ad gatlinas. Por=

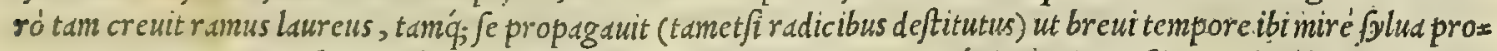

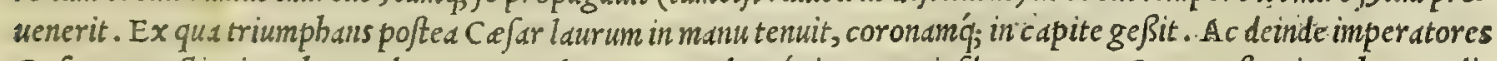
Cafares cuncti triumphantes lauro coronabantur, tenebant'́g; in manu eiufdem ramos. Quos poft triumphos traditus eft mos ferendi in eminentioribus locis in celebratis Roma collibus. Quo factim est, ut plures laurorum fyluce Rome uirefcerent, que ob id laureta nocabantur : qualis er at, que in monte Auentino multo ante alios tempore ui= guit. Nimirum indicat laurum dijs gratı ßimasn effe arborem, que fui habetur ab impetu fulminum ratio: Iiquidem so nulla habita, cim é celo ruunt, nec diuinitatis, nec principum amplitudinis ratione, plerunque templorum turres iciunt, Juperbx mundi palatia dilacerant, ac Sepius homines iminaniter interimunt. bec tamen fold arbor fulmine non percutitur, nifi in futurac calamitatis prodigium: ac ne quidem domus, in quibus adfint eius rami, de calo tan= gantur, pro certo creditur. Proinde Tyberius C e ar fulminibus perterritus, tonante calo lauro coronabatur. Lau= rus ex fe fe uim habet ignem producendi: quippe fi exicc ate ramus ramo frequentius confricetur, fuper apperfo ful= phuris puluere, ignisftatin exiliet. Eadem perpetua fronde uiret, tantá; pollet ui, ut eius ramis in arwo defixis, rubigo, maxima fegetum peftis, abigatur, tranjeat $\dot{q}_{\text {; }}$ in earum folia ex aruis. Poét a perfectionis figno lauro coronä= tur, id í; premium eft A pollineorum mufas colentium. Coruus occifo chaineleonte, fronde lauri deuorata infeftum

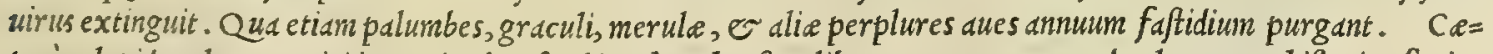
terim lapideas lauros oriri in mari rubro fcribit Theophraftus lib. I I I I. cap. V I I I. de plantarum biftoria, fic in= Laurus lapiquiens. In finu autem Heroo cognominato, ad quem defcendunt Aegyptij, laurus eft, o olea, o thymum: uerum non uiridia, fed lapidis pecie parte à mari eminente, fimilia tamen uiridibus tam folijs, quàm germinibus. Colos quog; 


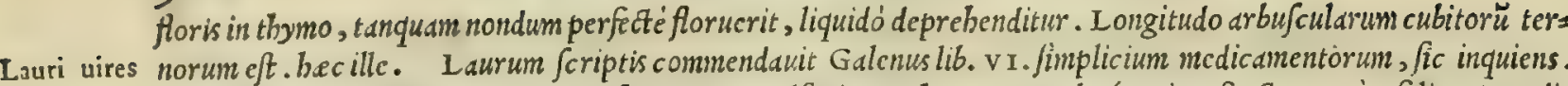
Lauri arboris o folia, er fructus deficcant, or calfaciunt uebcmenter, plusq́; etiam fructus, quam folia. Atradi= cis cortex minus quidem acris eft, or calidus, plus tanen amarus, babet f $_{\text {; }}$ ctian adfrictionis nonnihil. $2 u a m o b=$ rem er calculos confringit, er iccori prodeft. Bibitur ex uino fragrante triun obolorum pondere. Arbor $\delta \alpha=$

Nomina. QVH fic Grecis uocata, Latinis Laurus dicitur: Mauritanis, Gaur, feu Gar: Italis, Lauro: Germanis, Lorbeer=

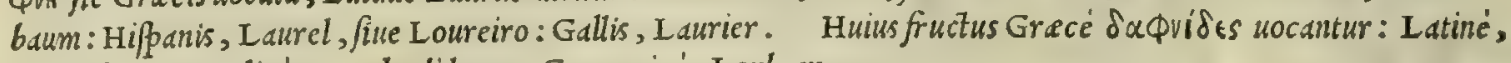
Lauri bacce: Italicé, Bacche di lauro: Gernanicé, Lorbeer.

IXótTayos. PLATANVS.

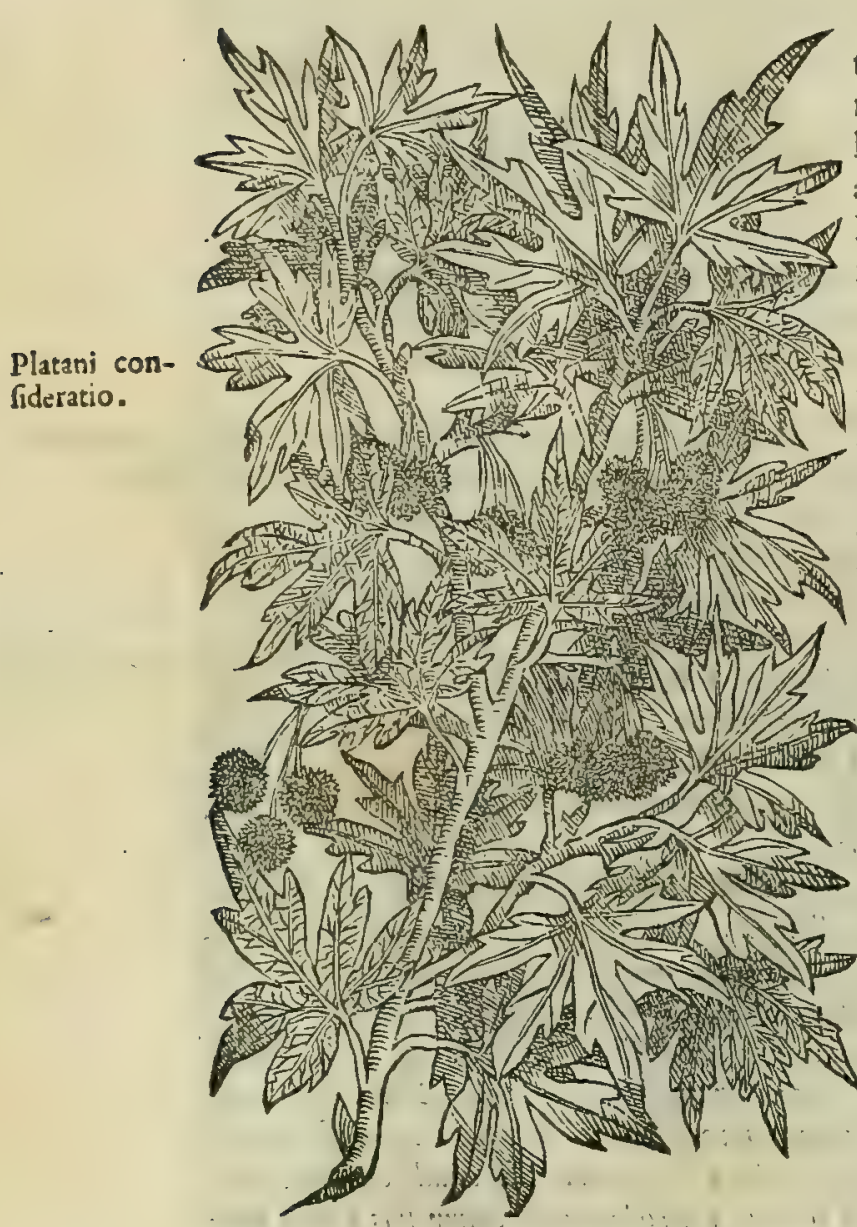

TENERRIMA Platani folia in uino decocta, moxillita, oculorum fluxiones fiftunt : tumores, \& inflammatio nes leuant. Decoetus cortex in aceto, dentes in dolore col luit. Virides pilulæ in uino potæ, ferpentium morfibus auxiliantur: exceptæ autem adipe, igni ambufta fanant . Inlidens foliorum, pilularumq́ue lanugo, oculos, \& aures offendit.

P I A T A N V S Italice aduena, peregrina $q_{;}$eft; quanquam 20 regionem dilunnt (ut $\mathrm{T} b e o p h r a f t u s$ eft auctor) multi, magniq́; $f$ lu= uij. Verim enimuero fi ibi nonnulle uirefcunt Platani plante, ut quas ipfe Neapoli, e Patalij uidi, funt quident ex longinquis re= gionibus allate, ut etiam antiquitus à Romanis per mare Ionium inuecte fuere, torum duntax at umbre gratia Rome expetite, ubi platanis tantum bonoris increbuit, ut diu nutrite fint mero radi= cibus infufo. Nanque bec arbor plurimim uini irrigatione gau= det : tametfindiorem in modum fontes, o fluuios amet: Plata= nus ad amplistinam ramorum amplitudinem adfurgit, adeó ut $\mathrm{L} i=$ cinius Mutianus ciuis Romanus, $\mathrm{Plinio}$ tefte, boc proderdum $e=30$ tiam pofter is putdrit : qui prouincie L icie legatus affirmat, in ed fuiffe platanum fociam gelidifontis amonitate itineri appofitam, octoginta atq; unius pedum pecu, numerofo nertice, fe uaftis pro= tegentem ramis arborum inftar, or agros longis obtinentem um= bris: ac ne quir de fit pelunce imagini, faxed intus crepidinis co= rona, mufcofos complex a pumices: intra quain fe epulatum cum duodevigefimo comite, largé ip fa toros prebente fronde, $a b$ ont $=$ ni afflatu fecurum, optantem imbrium per folia crepitus, latio= rem, qudme inarmorum nitore, piffure uarietate, laquedrium all= ro, cubuiffe in eadem. In Creta infula ad Cortyniam platanus $f e=40$ tiffe fertur apud fontem quendain; que folid byeme non amitre= ret. J fab qua Ioui compreffam Europam indigene fabulantur. Que in Italian inuecte fuerunt, climatis inclemen= tia in magnam proceritdtem non adolefcunt: attamen funt cortice craffo, fronde nitigined, latd, longo rubró, pe=

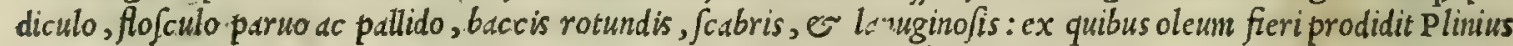
libro X v.capite VII. Platuni umbraufque eó delectatum Xerxem in terra Lydia fcribit Aelianus, ut dicm inte= grum fub ea cum maximo exercitu confumpferit, floccipendens tam breui uoluptate tot copias remorari. Platani aduerfantur uepertilionibus. Earum pilula addito melle, 0 illite, lentigines, ueteres'́; nigritias cmendant. De

Platani uires platano differuit Galenus lib. v I I. fimplicium snedic amentorum, fic inquiens. Platanus humidioris, frigidiorisóg. ex Galeno. effentie eft, non ita multó quàmfymmetra. Proinde follia uiridia trita, é illita, non obfcuré pbleginonas nafcen= tes adiunant. Cortex autem, or pilule magis deficcantem uim obtinent, ut ille quidem in aceto coctus ad dentium so adbibeatur dolores : pilule ueró cum adipe ad ulcerd ambufta. Sunt autem qui cortice combufto medicamen defic= catorium, er abfterforium efficiunt, ut cum aqua lepras fanet, per fefe autem illitum, ob bumorem nimium, ucte= $r a$, of fordida. Vitandus eft puluis folijs arboris infidens: alioqui fi piritu attrabatur, arteriam offendit, ualenter deficcans, er exaperans, nocem'́; ledit, ficut fane etiam uifum, $\sigma$ auditum, fi in oculos, aut aures inciderit.

Nomina.

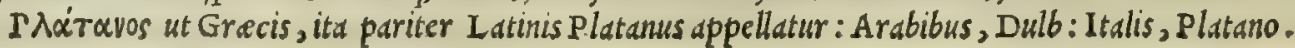




\section{In Lib. primum Diofcoridis.}

ME $\lambda$ ix. FRAXIVS.
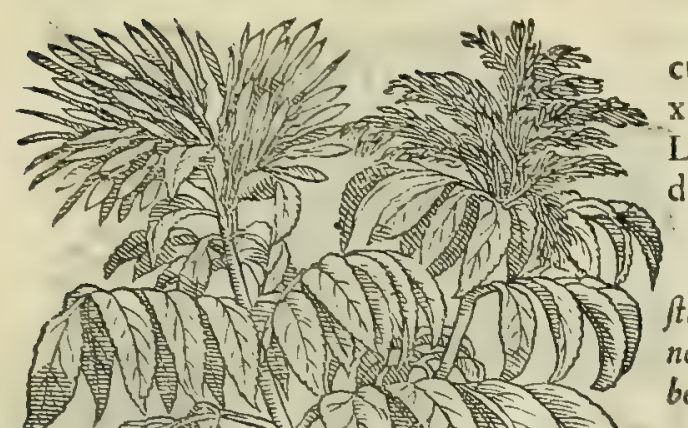

FRA X I N V S arboreft notißima. Eius (ut Theophrd= Fraxini hifto. ftus menoria prodidit lib. I I I.cap. $\mathrm{X}_{0}$ ) duo reperiuntur $\mathrm{g} e=\mathrm{ex}$ Theophr. nera: quorum alterum excelfum, proccrum q́; c/t, lignum ba $=$ bens candidum, craßsiuenium, neruatum, mollius, enodius, ac cripius: alterum bumilius, minus auctile; fcabrius, durius, o flauius. Folia laurinis, lauri latifolix fimilia, in acutius $t a=$ men coatta, $\mathcal{O}^{\circ}$ ambitu leuiter ferrata. Ramulus totus, quem folium unum putaueris, quód fimul cuncta folia ferat, fingulari pediculo, o fingulis folijs coningatim, ueluti per genicula, pen= dentibus constat: amplo interuallo coningationibus diftinctis,pe= rinde atque in forbo. Fert fructum in filiquis minutum, nuco= fum, qualem amygdale, guftu fubamarum. Tradidit Plinius Plinij lapfus. fraxinifolia iumentis mortiferd, cateris ruminantium innocua. Th, sentibe ex pin. If Que de $t a x o$, non de fraxino Theophraftus prodidit, inquiens. si iunenta (ut frunt) taxifolia comederint, emoriuntur: / r ru= minantia, nibil incommodi patiuntur. Sed nominum uicinitate Plinium deceptum effe crediderim: nam Gracis fraxinus $\mu \varepsilon=$ $\lambda i \alpha, t a x u s$ ueró $\sigma \mu(\lambda x \xi$, o $\mu i \lambda$ os appcllatur. Vnde unum pro altero fumens $P$ linius, facile ( $u$ tiximus.) in errorem inci= dit . Reifides fuerit in boc Plinium lapsun fuiffe, clard in It alia experientia: fiquidem taxifolijs, non fraximi iwnetita non rumi= nantia necantur. Quininó hac falutare preft ant remedium le= tbalibus ferpentium uenenis: quibus ddeó inimica eft fraxinus, ut ne matutinas quidem occidentésue umbras quàm libet ßpatio= Sas $\int e r p e n s$ arboris buius attingat. Quapropter expertum pro= ditur, fi fronde ea gyro claudatur ignis or ferpens, in ignem potius, quim in fraxinuin fugere erpenten: Mira nature benis gnitas, priusquà be prodeant, florere fraxinum, nec ante con= ditas folia dimittere. Fraxini pecies funt Ornus, itemq́; Or= neogloffum dictum, quód ferat femen illud, quod auis linguam appellant, ut ipfum quog; fraxinus fert. De quo differens Pli= nius libro x X I I I r. cap. V I I I. mederi id iocineris, o lateris doloribus in uino tradidit: aquam, qux fubdit cutem, extrabe= re: corpus obe fum leware onere, et ipfum fenfim ad maciem re= ducere. Id quoq; in recentiorum medicorum ufu eft ad ftimulan= dam uenerem. Folia fraxineis fimilia fert ftirpsilla apprime celebris, quam uulgó D I C T A M V M A L В V M nuncu= pant, ob idq'; à recentiorum nonnullis pumila fraxinus cogno $=$ minatur. Hac nullis tam Grecorum, qudm Arabum auctox ribus (quod equidem legerim) ufquam defcripta eft. Quare non po fum non admirari, quónam pacto fibi dictami nomen

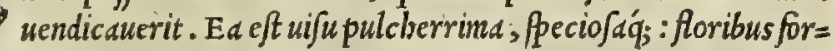
mofis, impense redolentibus; in purpura albicantibus, citrei arboris modo. Radix ei candida, odore bircl, amaro fapore: proinde mirum non eft, $f i$ uentris tineas perimat. Tradunt etiam fuapte vi pollere aduerfus letbalia uenend, dc omnium ueneno= forum animalium mor ${ }^{u} u m$, ictum $\dot{q}_{\text {; }}$, nec minus aduerfus peftilen tiam. Prodeft ftomachicis, or fupiriofis . Elicitur é floribus dz qua, que naribus infusa capitis morbos frigiditate obortos mis rifice propellit. Que arbor Grece $M \in \lambda i \alpha$, Latiné Fra= Nomina. xinus appellatur: Italice', Fraßino: Germanice', Efchern, $\mathrm{E}=$ febebaum, Steynefchern: Hippanice, Frefno, or Frexo:Gale licé, Fraifne.

Fraxini fpe cies ornus.

DiQami albi confideratio.

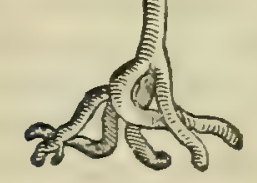

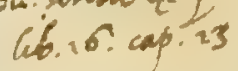


POPVLVS ALBA.

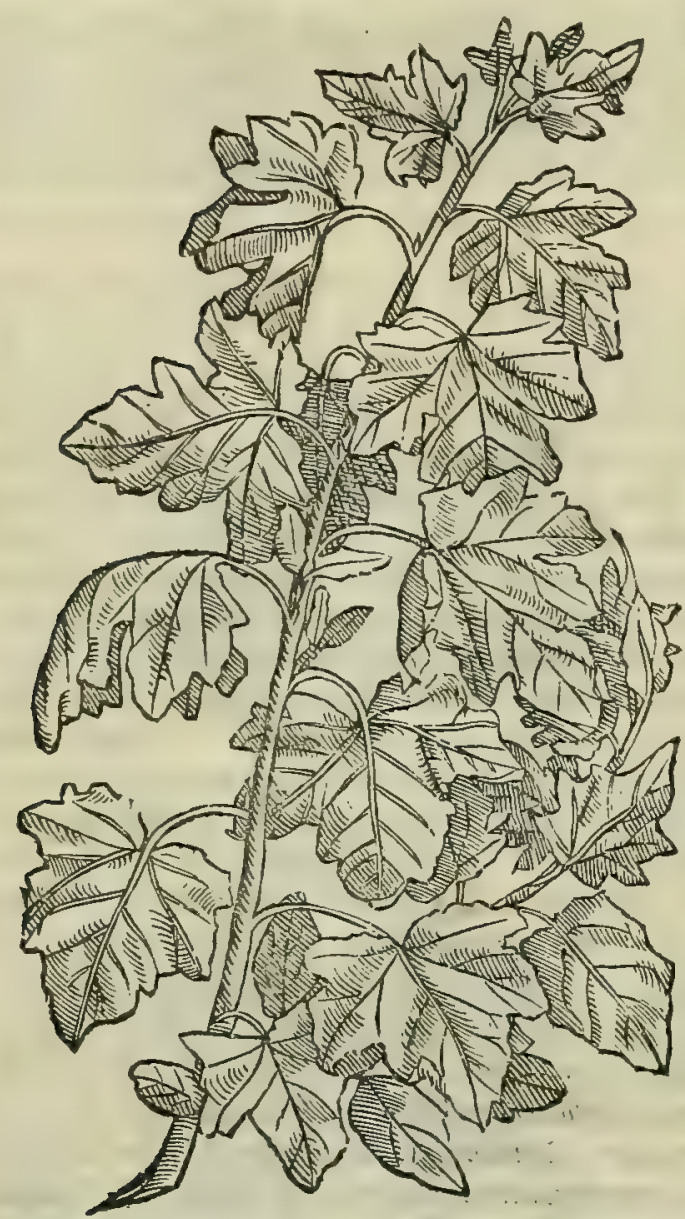

POPVLVS NIGRA.

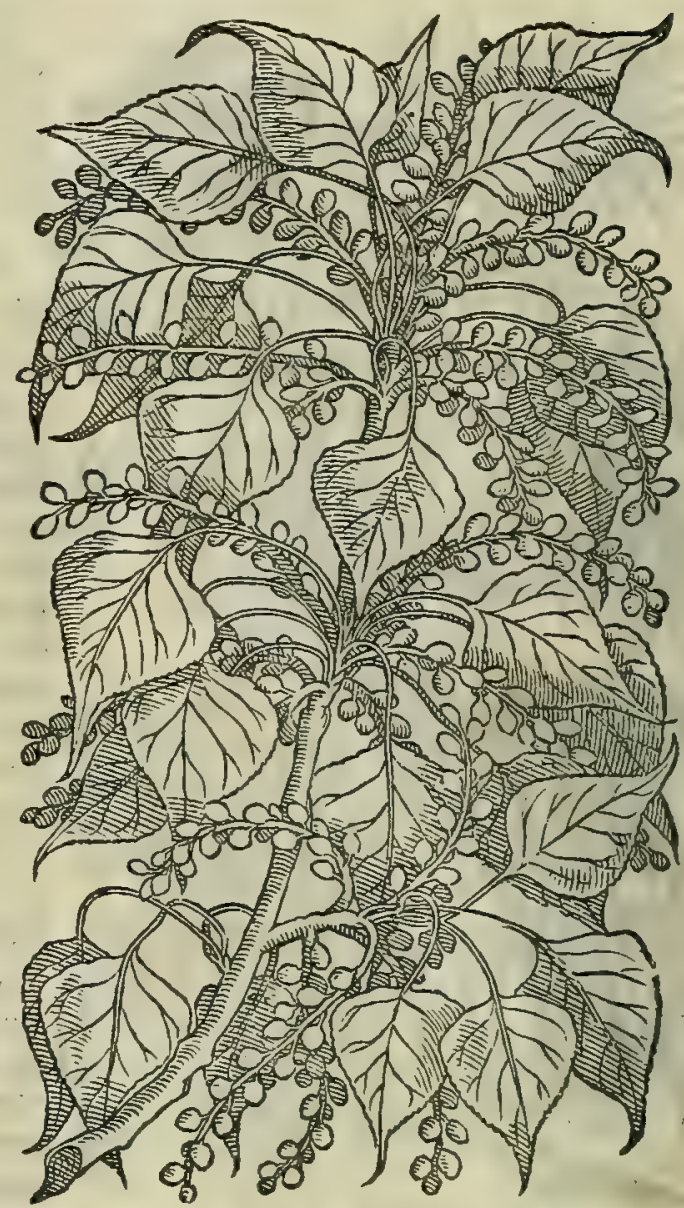

10

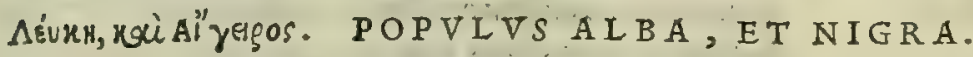

CAP. XCIII.

Po I v $s$ albæ populi cortex uncix unius pondere, ifchiadicis, ac urinæ ftillicidio prodeft . fterilitatem inducere tradunt, fi cum mulino rene bibatur. Folia quoque cum uino poft purgationes pota idem præeltare produntur. Tepens foliorum fuccus utiliter aurium dolori inftillatur. Pilulæ, qux primo foliorum partu exiliunt, tivtæ \& cum melle illitæ, oculorum hebetudini medentur. Memoriæ prodiderunt, corticem albæ p.opuli, \& nigræ particulatim cæfum, \& fulcis ftercoratis mandatum, omni tempore anni edules fungos proferre. Populi nigræ folia cum aceto illita, magna utilitate podagricis doloribus illinuntur. Refinam populus fundit, qux in malagmata additur. Semen potum ex aceto comitialibus utile eft. Lacrymam populorum commemorant, quæ in $\mathrm{Pa}-$ dum amnem defluat, durari, ac coire in fuccinum, quod electrum uocant, alij chrifophorum. Id attritu iucundum odorem fpirat, \& aurum colore imitatur : tritum, potumq́ue ftomachi , uentrisq́ue fluxiones fiftit.

Populorum

P o P V I v S Theophrafto triplici recenfetur genere lib. I I I. cap. X I I I I. de historia plantarum, ubific ha= confideratio

bet. Populus alba, nigra'; uniformes habentur : amber nattwa eretta, sed excelfior, leuior'; nigra: figur a foliorum adfimilis, o ligni materies albedine fimilis uifitur: utrang; ne florem quidem babere exiftimant. Kegris (quam quidam Alpinam, quidam Lybicam uertunt) populo albe non abfimilis, cùm magnitudine, tum ueró quód ramis al= bicantibus $\beta$ argitur : folio bedere, fed parte altera fine angulo, altera ucró oblongo, mó; angulum cxeunte acu= tum: colore parte refupina, prona óf, ferme fimili: pediculo prolixo, tenuiq; dimexo quamobrem non erecto, fed inflexo. Cortice apperiori, quàm populus alba, fcabrioriq́; ut pyrus fylucftris. bae Theopbraftus. Priora $0=$ mnibus paßim nota funt. Sed quirenam arbos nobis fit xepxis, non fatis compertum babeo. quanquam in fylud, quàm Goritienfes uulgó appellant il Panauizzo, arbor hac, cuius hic imaginem damus, crefcit betule amu= la : que mibi quidem I ybicam populum reprefentare uidetur. Plinio bec libro X v I. capite X X I I 1 . minima fo= lio eft, ac nigerrima, fungisó; enafcentibus laudatißima. Alba folio bicolor, fuperné candicans, infertore parte ui=

Plinij plures ridi. Sed hic Plinius aperté errore notatur, quód hec contrà fuperné uireat, infrné uero albicet, candida efflo= lapfus. $\quad$ refcente lanugine, que tamen in nigra non uifitur, ut Plinius exiftinat, cimm indifferenter inquit. Populorum folijs grandißima lanugo. Sed o terito idem erraffe deprebenditur : quippe qui fcripferit eodem libro capite $\mathrm{x} x \mathrm{x}$ I. po $=$ pulumnec fructum, nec femen ferre, cum tamen utraque fructum ferat, uuarum peciem pre fe ferentein, intus alba lanugine refertum : atq; etiam fcribat Diofcorides, femen ex accto potum comitialibus prodeffe. Sed quid opus efl 


\section{InLib. primum Diofcoridis.}

POPVLVS LYBICA.

20

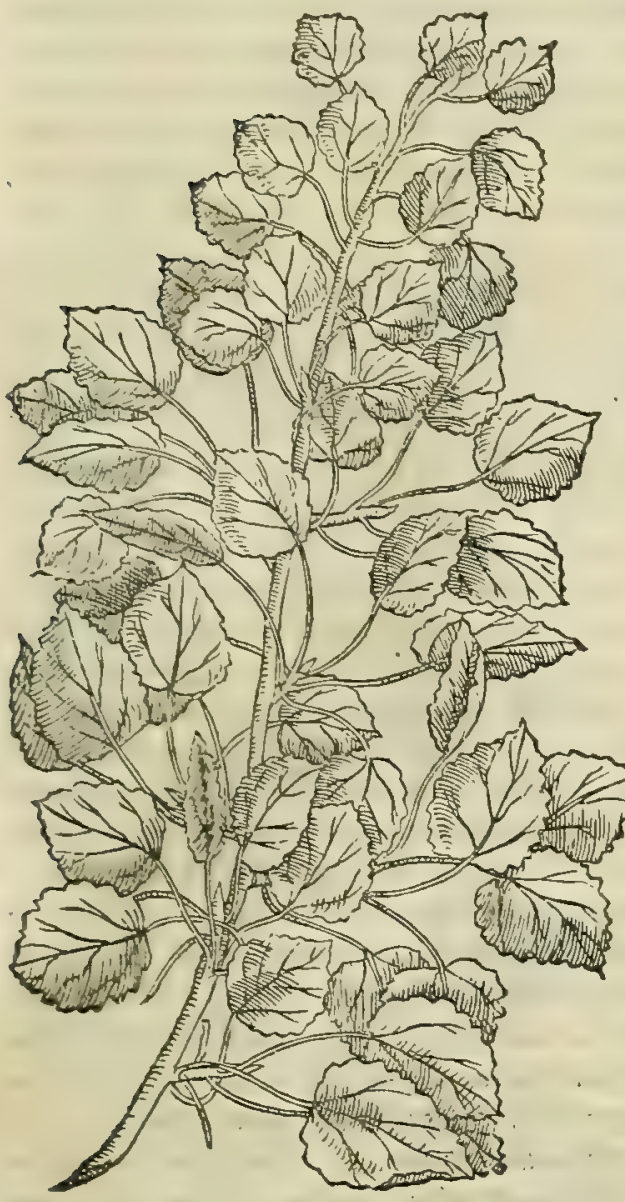

pluribus, fi Plinius feipfum accufat? fiquidem libro $x \times 1$ I I I . cap. VI I I. populum o unas, o femen ferre fatetur, illds utiq; unguentis, boc veró comitialibus preferens. Sed caucant myros pole, ne ob id communis ufus unguentum populncun nocatum, ex populi unis conficiant, ut Ruellius credidit ì Plinio deccptris, Ruellij erra$\odot \sim$ quód iis ad unguenta odorata uteretur antiquitos. Quandoqui tum. dem Nicolaus Myrepficus non unds, fed germina, were prino pro deuntia admifcet: odorata enim funt, er ceraginofa, cim tamen nullus prorfus unis fit odor. Veriun enimuero an antiquitas popu= li unas odoratis unguentis admifcuerit, dubitandum fanc eft. Nann. plinio libro v I I. cap. ultimo, ubi de unguentorum materia cgit, nil aliud cft populi uua, qudm bryon, Latinis mufcus uocatus.

Quem etiam preter cedrinum, or quernum pretulere ad unguen $t a$ Diofcorides, or Galenus, e inter alia odorata recenfuerunt. Quo fit, ut facilé credi poßit ; Plinium errore ductum existinaf fe, mufcum in populo nafcentem nibil ab eiufdem unis differre, cim inquit. Eódem es bryon pertinet una populi alba. Optima circa Gridum, er Cariam, in fitientibus, aut ficcis, aperisq́; locis. secunda in Lycia cedro. hec ille. Sed cim cedrus nullas ferat u= uas, fed mufcum perquàm odoratum, binc Plinij error manifefté deprebenditur. Populus utraque frequentißina naf citur in agro Mantuano, ac Ferrarienfi, non snodó in $\mathbf{P}$ ddi ampliesimi Auminis litoribus; fed o per agros, o prata in foffarum aggeribus.Ideó= que fabulantur poëte, icti Phaëtontis fulmine forores fletu mutd tas in populos arbores iuxta Eridanum amnem, quem $\mathrm{P}$ adum uo= bula. cant, ex corticis meatibus inftur atrate lacryma, , electrum, fiue fuccinum fundere, ut adhuc, iluentes lacrystiss effundebant: quas noftro tempore in orbiculos; quibus Deipare virgini fresnine $\int a x$ lutationes enumerant, effinguntur, o unlgaribus er infimis muन lierculis monilium uice, collo geftantur decoris gratia. Quare Diofcorides, qui poëtarum fabellis adhibere fidem haud quaquam cenfebat, noluit pro comperto fabulofam fuccini biftoriam affe= rere, fed dubiam, o fupen fam tenere. Ideóf; inquit. Lacrymam populorum commemorant, qux in Padum amnem defikat, durari, ac coire in fuccinum, quod electrum uocant, alij chryfophorum. Ex quo facilé percipi poteft, quód cim Diofcorides aliquid de fuccino fuis monumentis mandare decreuifet, nullam eius certam tenens biftoriam; ip= fum populi generi utrique adiunxit: ea tamen ratione id dijudicalls, quód non alio in huiufce operis loca aptius fucci: inun accomodaripcffet. Quandoquidem in fabulis nat tus effet poëtas cecinife carminibus, fuccinum populos funs: dere: tametfi non ignoraret, fuccinum populorum gummi effe nequaquam. Fiquidem buic fabule datus eft locus ob fuccini innumeros globulos, qui olim filo traiecti ab Eridani accolis collo fupendebantur. Quippe cùm plerique ip= 40 forum, prefertim uerò facmine, ob nimis humidum regionis aërem in gula morbos, ac It trumas incurrerent, bis exi= ftimabant fuccinum aduer fari. Quod fortaffe non er at ab omni ratione alienum: nanq; cim facultatem babeat fucci= wun fiftendifluxiones, collo etiam geftatum, facile inlibere poterat, ne capitis deftillationes in guttur defluerent. Quo fit, ut non demirer, fi etiámnum Germani in oculorum defluxionibus magno fucceffu fuccineos globulos occis pitio adnectant. Reperio in enarranda Succini biftorid, auctores complures, fed re uera admodum uarios : qui etfí Succini uaria grauius ( ut biftoricos decet) bac de re loquantur; tamen cùm ipfi fuccini originem nufquam tuiderint, or quicquid hiftoria. de eo fcripferunt, alijs deceptum referant, his nulla, aut fane pauca adhibetur fides. Philemon fuccinum fößlle effe dixit, $\mathcal{O}$ in Scythia erui duobus in locis, uno candidum, altero uero croceum. Sudines, $\mathcal{O}$ Metrodorus fuccinum prodiderunt in Liguria arboribus effluere. quod Sotacus credidit in Britannia euenire. Pytbias tradidit effe locum in Britannis prope Gutones, ubi a fluctibus maris non procul ab Abalo infula fuccinum aduehitur : quo incole ad ignem

so pro ligno utuntur, ip fum'; Teutonis uendunt. Nicias biftoricus fuccinum folis radiorum fuccum effe uoluit : hic enimcredit radios uebementius actos in terram pinguem fudorem in ea parte relinquere, deinde eftate ficcari, ev a flucti= bus maris in Germanorum litora ejjci. Idem $\mho^{\sim}$ Aegypto nafci fimili modo dixit. Item in India, gratius'́, thure effe. Indis. Non de fuerunt etrainnuni , qui fuccinum nafci tradiderint iuxta mare Atlanticum in lacu Cephifide dicto, qui: fole excalf actus é limo fundat electrum. Non de funt prater hos plures, qui de fuccino differentes in diuer fas iuerint. fententias, quas nunc, utpote non probandas, filentio inuoluam. Vnde iure dici poteft, fuccinum apud cos uel ce= reum, uel figulino luso fimile baberi, cum ipfun in tot uarias formas, ac imagines trafmutauerint. Sed ut tandem rea: feram, quod pro comperto babetur, gignitur fuccinum in infulis feptentrionalis oceani. Id olim à Germanis Gle fum appellabatur: unde à nonnullis, qui erant cum Germanico Ca Sare, ibiclaßibus rem gerente, una infularum ob fuccini copiam, Gle aria fuit appellata, quse prius Auftrauid à barbaris dicebatur. Hic nimirum (ut Flinius inquit) nafcitur fuccinum arboribus pineigeneri défluens in terram, ubi poftea den fatur. Cùm uerò intumefcens aftus fertur in proxi:

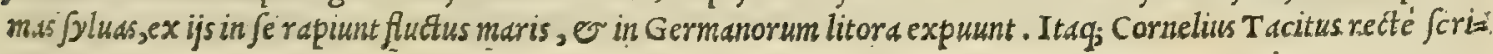


ptum reliquit. Germantos huius maris accolas folos omnium fuccinum babere, or legere. Quod fuccinum fit arboris ex pinorum genere lacryma, olim Romanis teftimonium perhibuit quidam corum eques illuc miffus ad id comparan= dum à Iuliano curante gladiatorium munus Neronis principis, qui ed litora peragrauit, ip fum uidit, ucram eius origi= nem didicit, or fecum ingentem copiam Romam inucxit. Pretere a fuccinum effe pincse arboris gummi indicio eft pineus in attritu odor, ơ quód accenfum ted e e refinarum modo deflagret. Liquorem effe copioséftillantem, tex nacem, ac lentum, argumento funt quadam intus implicita, ut formica, culices, ac etiam laccrta, fefices, ac pa= lex, que tranparentia inpiciuntur. Cum enim hec dnimalia, ov alia ftramenta bumoris lentore facile implicentur, durefcente dcinde materia, ucluti carcere includuntur. Hac partim ex Plinio, partin ueró ex aliorum fcriptis de= cerp/imus. Tametfi rationibus non Ppernendis probare nitatur Georgius Agricold, fuccinum non aliud effe, quàn bituminis genus, quod à quibufdam fcopulorum crepidinibus crumpens in mare defluit, ubi aquarum falfedine dure= fcit. Nam fuccinum, quod nigerrimum eft, ex quo ctiánnum globuli ad ang clicas numerandas falutationes conficiun tur, aliquid cognationis cum piffaphalto babere uidetur. Adde etian quód i pinu, neq; ab arboribus alyjs refinam per fe fundentibus tam pullo colore nulla defluit lacryma. Succinum incoctum adipe lactentis fuis expolitur, or redditur translucidum, quemadmodum tradit Archelaus, qui rubcum corticibus arboris, ex quadefiuit, inberens, fe uidiffe affirmat contra Agricole fententiam. Quo fit, ut de fuccini biftoria adhuc lis fub iudice pendeat. Ceterim comper= tum eft, quod ficutimagnes ferrum repuit, $f i$ adfit adamas, uel fi allio affricetur; ita nec fuccinum ad fe palle as alli= cit, qua fint oleo perfuse. Verim corum opinio uana eft, qui fuccinum tradiderunt peculiari dote ocimum repue=

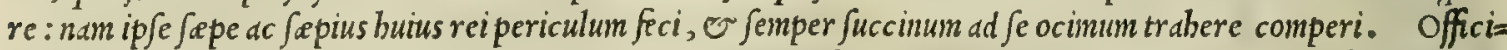
Brafauoli opi ne communi nomine fuccinum uocant Karabe Mauritanos fecute. Licet Brafanolus Ferraricnfis in fuo de nio reproba- fimplicium examine deceptus exiftinauerit, Arabum Karabe fuccinum effe nequaquam, fed uerum populi albe ta. gummi, Serapionis, er Auicenne teftimonio : etfi eorum neuter, ficut nec Diofcorides, quem illi fequntur, id quidem pro comperto affeuerauerit. Nanq; Serapio ( ut in omnibus adfolet) quicquid de Karabe adnotauit, uerbótenus ex Diof coride deprompfit, fic inquiens. Et dicitur, quód gummi Haur romi, quod nafcitur iuxta fluuium, qui dici $=$ tur Eridanus, quando diftillat in flumine illo, coagulatur ibi, of eft illud, quod dicitur Alipton, id cft electrum, efunt, qui nominant ip fum Arfopodon, or eft Karabe. Eadem fententia elicitur ex Auicenna: quippe quicapite de Haur, itemó; capite de Karabe, non afferat eam effe populorum gummi, fed quód ita perhibetur. Nec alia ratione duobus capitibus de Karabe differuit, nifi ut oftenderet, $\mathrm{K}$ arabe per fe à populorum gumni differre. Preterea com= probat id effe Karabe apud Mauritanos, quod elctrum apud Gracos, nominis fignificatum: quandoquidem Kara* be lingua Perfica, A uicenna auctore, non aliud defignat, quàm rapiens paleds. Quod fenfu comprehenditur pro= prium effe fuccini, aut electri, non autem populorum gummi. In Juper aftringentes paftillos, quos Galenus lib. v I I. de compofitione medicamentorum fecundum locos, Pautus fui uoluminis etiam feptimo, or Actuarius in fuo de coin= pofitione medicamentorum, electri trochifcos uocant, Arabes de Karabe appellant, cofdem à Galeno, $\sigma$ Paulo affumentes. Quo fit, ut hac in re manifefté aberraffe Brafauolus deprebendatur. It dque dicendum effe putduerim, electrum idem effe apud Grecos, quod fuccinimn apud Latmos, ev Karabe apud Arabes. Neq; etiam illud ideo pos pulorum gummi effe crediderim, ut Brafauolus affeuerat, quod Paulus quoque dixerit : Electrum populi alba lacry= mam dicunt, que iuxta Eridanum amnem deftillat, $\sigma$ in fpißitudinem ccit, aurco colore . Nam bis uerbis non pro= bat electrum e fe albe populi gummi, fed id tantum refert ex aliorum opinione, quemadmodum fecit Diofcorides, qué fecutus eft Paulus. Ex bis igitur fatis patere arbitror, falfum effe, quód idem fint electrum, gummi populi, $\mathrm{O}_{\mathrm{K}}^{\mathrm{K} a \mathrm{r}} \mathrm{a}=$ be : quin potius clarum, fuccinum, er gummi populneum effe inter $\int e$ diuer $\sqrt{a}$. Credidit Demoftratus fieri fuccinum ex lyncis urina (quemadmodum credidere pharmacopole, ev uulgus medicorum ex eadem fieri lapillos, quos lyn= 40 cis appellant) fuccinum afferens, quod flauefcit, fieri ex urina maris, album ueró ex urind fremina. Quibus refraga= tur Plinius: quandoquidem ipfe manifefté dicat, hoc effe falfum. Quod cum or Diocles, o Theophrastus credidif= fent ( non autem Diofcorides, ut eifalso Brafauolus imponit de lapidibus lyncis agens) cos eiufdem criminis Plinius Brafauoli la- accufat. Quód autem Diocles, or nö Diofcorides (ut Brafauolus putat) buius erroris accufetur, oftendit ip $e$ Diox plus. $\quad$ fcorides libro fecundo capite de urina, ubi in eandem Plinij Sententiam ueniens, hac uerba protulit: Lyncis urinam, quam lyncurium appellant, fimul ac excernitur, glaciari, coireue in calculi duritiam,ulgo creditum eft.quare quod de ea peoditum eft, uanum effe conuincitur. Eft enim quod à nonnullis uocatur fuccinum pterygophoron, ideo dictum, quód pennas ad fe alliciat. At cùm Brafauolus minus fortaffe accuraté Diofcoridis uerba legendo percurrifet, dixit de Karabe agens, fenfiffe Diofcoridem electrum effe lapillum, in quem lyncis urina concrefcit : Quod tamen falfum

Alni hiftoria, effe facilé conftat ex predictis Diofcoridis uerbis. Caterùm cüm non defintetiam poët a qui Phaèthontiadas nö in \& uires. populos, $f e d$ in alnos mutatas fabulentur, Alniquoq; biftoriam, or uires, precedentibus adnettere non ab re fore exi= ftimauimus. Ef itaque a L V s s ( ut Theophraltus eft auctor lib. I I I. cap. x I I I . de plantarum hiftoria) fterilis er unigend, natura caudice recto : ligno, medulla q́; molli, adeó ut graciliores uirga tota concauentur : folio pyri, fed am pliore, neruofíorég; : cortice fcabro, rufóf; intus, qua de caufa coria tingit: radice fumma, nec maiore, quìm laurus. nafcitur in aquofis, alio nullo pacto. bactenus Thcophraftus. Qui tamen eodem lib. cap.x v. non utiq; pyrifolio al= num uire fcere tradidit, fed pontice nucis. Nec eandem prodidit effe fterilem libro eodem cap. v1. cum inquit. Te=

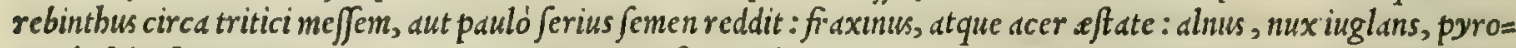
rum'́; fylueftrium genus quoddam autumno. Quo fit, ut alterum omnino fuppicandum uideatur, aut fibi ip/i $\sqrt{1}$ beo $=$ phrastum repugnare, aut eius codicem bis locis mendis fatere. Alnus in Italianafcens, folio eft coryli craßiore, neruofiore q́; , materie molli, rubente, in aquofis feré femper proueniens. Hetrufci uulgó appellant onio : alij ueró in Italia auno. Italica fructum fert uiridem, oblongum, moris forma fimilem, squamis quaim plurimis in fe compactis. 


\section{In Lib. primum Diofcoridis.}

Maturefcit autumno, minuto intus fensine, colore in nigrun fuluo. Prefertur lignum ad adificiorun fund amenta. que in fluminibus, lacubus, paludibusig, funt, quód in aqua nunquam putrefcat. Ob id cnime expctitur maxime' $\mathrm{V} e=$ netis ad iaciend «palatiorum, edium q; fundanenta, quód crebró fixa non modó ad atcrnitatem perm aneat intmorta= lis, fed quid ingentes adinodum ferat moles. Recentia folia tunores impofita diffolunnt, er inflammationes reftin=

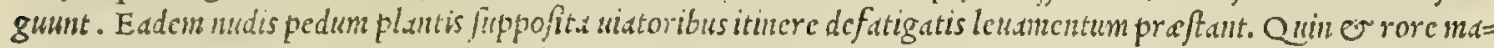
tutino madentix cubiculis ad necandos pulices per aftatcm utiliter parguntur. Preftat cortex tingendis corijs atro

B E T V L A.

10

20

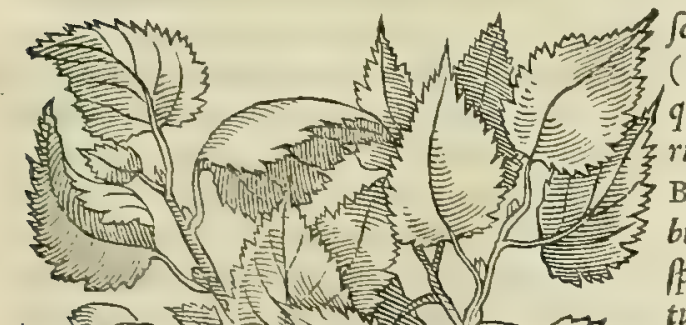

30

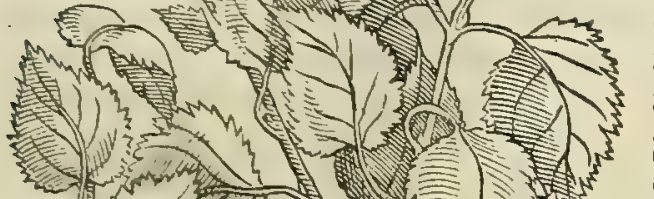
: que cuine Betulx conficortice albo fir alba populo ad/imilis, nunc nobis $\int e f c$ offert de $=$ deratio.

fcribenda. Hec Theoplrafto follo cft caryx fic Grec is uocate (quid autem fit caryd compertum badtcius non babco) practcy= quàm quod paulo anguftiori, cortice autem uerficolore, er mate= rie laui, non nif̌ ad baculos utili. Plinio lib. X V r. cap. X V I I I. Betula arbor eft Gankica mirabili candore, atq; tenuitate: terri= bilis magiftratum uirgis: eadem circulis flexilis: item corbum portis. Bitumen ex ea Gallia excoquunt. badtenus Plinius. Bc= tula in Tridentino agro frequentilima prouenit, materic adeo te= naci, lentaq́;, ut ad uafa uinaria cingenda circuli ex ea parati ont= nium praftantißimi babeantur. Ananij é fuis Betulis non modó o= ptimos conficiunt carbones, ad coquenda liquandáq; metalli, Sed é delibrato, contortoó; cortice, faces ad nocturia lumina parant, que quód bitumino a pinguitudine redundent, tede modo confld = grant, or refinofum quoddam picis colore reddunt. Nec fortaffe alia de caufa Betula dicitur, nifí quodd bitumine feateat . Hanc Tri dentini corrupta uoce unlgó appellant Bedollo. Gaudet frigido tractu ac nimojo: folio cft nigre populi, fed parte prona apperio= ri, uiridioriq; , per ambitum ferrato, o minutisimis quibufdam punctis, ipfisq; albicantibus in uniuerfum reßperfo. Sterilis bac, nec fructum ferens. Huius caudex terebro perforatus ingentem Betule uires. aque copiam reddit, cui uim maximam ineffe quidam afferunt ad cosnminuendos tam renum, quain ue fice calculos, fi diutius biba $=$ tur. Eadem maculas in cute delet, nitorem q́; conciliat : oris ulce= ra fanat collutione ex ed facta: Foliorum fuccus coagulo admi= ftus, cafcos à carie, ov uermibus uindicat. Sed iam ad Populos, or ad succinum noftra reuertatur or atio, in quibus medicine nos bis reddenda ratio eft, ut in omnibus feré facere confueuimus.

Primim igitur de uiribus Populi nigre differuit Galenus libro Populorú uiVr. fimplicium inedicamentorum, ubific inquit. Populi nigre flo res ex Gal. res calidi facultate quidem sunt in prino receffu d temperatis: fed in differentid, que babetur in ficcando o bume= ctando, paxlium à temperatis e medijs ad ficcius deflexerunt: uerim ש fubtiliorum potius, qudim craßiorum funt 40 partium. Et folia quidem ipfius quodammodo floribus fimilia funt, nifi quód ad omnia imbecilliord, minusóq; efficacia. Sed o refina eius floribus finilem facultatem obtinet, atque etiam calidiorem. Porró femen tum refind, tum floribus o fubtiliorum eft partium, o cxiccantius : non tamen eft admodum calidum. Deinde libro v I r. corundem fimpliz cium idem Galenus Populi alba uires de fcripfit bis uerbis. Populus alba arbor mifte quodammodo temperature eft, ex aquea tepida, o terrena extenuata effentia. quamobrem e abftergentis facultatis eft particeps. bactenus $\mathrm{G} d=$ lenus de utriuf q; $_{\text {; }}$ Populifacultatibus. Caterim non inuenio Galenum succini meminiffe in fimplicium medicamen= torum cenfu. qui tamen lib. I I .cap. I I $\mathrm{x}$. de compofitione medicamentorum fecundum locos paftillum ex fuccino confectum ab Afclepiade tran fcripfit: quem quidem is hamoptoicis, longo tempore tußientibus, 0 recenter phthi= ficis, purulenta e pectore difficulter eijcientibus, fuppuratis, cceliacis, dyfentericis, er inflatis conferre tradidit . Atqui referunt Prutheni, in quorum litor a fluctus maris fuccini plurimum expunt, eius genus quoddam reperiri,

so quod plane cryftallum reprefentat. Huic uim mirabilem ine ffe teftantur, quó fcilicet famma deprebendatur an uir= go fit e incorruptá, nécne. Nam fi ex uino iciune exbibeatur, efficere diunt, ut corrupta $\sigma$ vitiata protinus urină reddere cogatur. id quod utrgmi euenire negant. Arbor $\lambda$ fikx Grecis dicta, Latinis Populus alba uocatur: $A=$ rabibus, Haur: Italis, Popolo blanco : Germanis, Bellen, Poppelbaum, or Sarbaum: Hipanis, Alamo blanco: Gal lis, Peuplier. Que ueró Al' yecos Greco nomine, Latino Populus nigra uocatur: Mauritano, Haur romi: Itali= co, Popolo nero: Germanico, A ßpen, aut Poppel uueiden: Hi panico, Alamo nigrilho: Gallico, Tremble, or Peu=

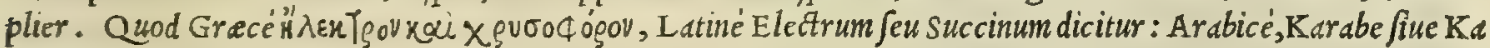
kabre: Italicé, succino, e Ambra gialla : Germanice', Agftein, aut Boernftein: Hipanice, Efcldrimente, aut Am= bar: Gallicé, Ambra.

Márep. MACER.

CAP. XCIIII.

M A C E R ex Barbaria aduehitur, cortex flauefcens, craffus, guftu perquàm aftringens. Quicontra cruentas excreationes, dyfenterias, \& alui fluxiones bibitur . 
Maceris, \&. N v N Q v I officinarum Macis, quo myriftice nuces pretextus inftar conteguntur, Diofcoridis fit Macer, Macis difcri - non modó dubitandum eft, fed etiam credendum (ut cgo arbitror)magnam inter utrunq; effe differcntiam. Cum enim men.

Maceris facul Diofcorides dicat: Macer, qui ex Barbaria aduebitur, eft cortex craffus, flaucfeens, of guftu perqudim aftringens; maniffté declarat, Maccrem nö effe officinarum macin, quàd hoc tenue fit, gufu fruens, acre, perquàm odoratum, amariucculum'́; . Adde quód dixerit Plinius lib. X I I. cap. V I I I. Macir ex India aduebitur, cortex rubens, radicis magne, nomine arboris $\int u x:$ qualis fit ea, incompertum babeo. Hanc etiámnun differentiam non ignorauit serapio : nam poftquim tradidiffet ex auctoritate Ifach, Macim effe nucis odorate operimentum, dixit fecus effe, de quo lo= quebatur Diofcorides: quippe quód fcriptum reliqucrit, Macerem effe ligni corticem, fiue corium. Quod cum com= pertum haberet Auicenna, de utroq; feor fum tractatit, $\sim$ Macin odorate nucis inuolucrum ad caput 456. relega= uit: Macerem ueró radicis corticem capite 694 . Jub titulo Thalisfar dcfcripfit. Preterea maximo eft argumento; qŭod Macis er Macer utiq; inter fe differant, quod Diofcorides", Galenus, $\mathcal{O}$ Paulus de odoratis nucibus, quorum Macis eft tegunentum, nibil frriptis memorie reliquerint. Quippe fi Macer, qui eis conuebebatur, Macis nobis uul= gare cxtitiffet, credendam fané eft, quód ct:an illo quoq; aduecte effent myriftice nuces: quarum illi hiftoriam, o $f_{a}$ tates ex Gal. Lenus lib.v I I. fimplicium mcdicamentorum, hac fcriptis tradidit. Macer cortex cf, qui ex India conuebitur, guftu multim acerbo, cum lcuicula quadam acrimonia odorat, iucundum fané redolens, ut pleraq; aromata, fiue odorata, que ex India conuebuntur. videtur itaq; $\odot$ ip $\int e x$ mifta conftare effentia, pleraq; terrena frigida, paucula ueró ca

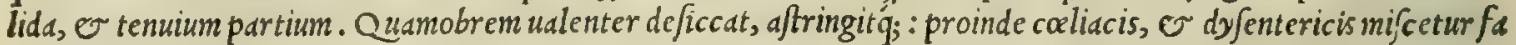
cultatibus: in tertio exiccantium confiftens ordine, in caloris, frigorisq́; differentia ne utrum infigniter efficiens. hec Galenus. Ex quibus baud ob curé colligi potelt, quod Macer longé differat à Maci. nang; ipfe guftu non reperio boc 20 effe adeo acerbum, nec tam leuiufcule acrinonie : quin potius fi deguftetur, linguam, o fauces admodum uellicdt: odorem iucundum perfundit, o leuiufculum amarcrem quadam cum ficcitate relinquit. Quod facilé oftendit, quód Macis tantum calidi, quantum ficci conceperit, uel fortaffe plus calidi: er quód pleraq; ipfius effentia fit tenuiü par= tium. Idcirco errare non crediderim, qui dixerint Macim odoratum excalfacere, $\sigma$ pariter ficcare in fine fecüdi, uel in principio tertij. Quamobrem id Macer effe non poteft, cum dicat Galcnus conftare macerem effentia plcraq; fris gida terreftri, paucula ueró calida. Quibus facilé concludi poteft, quòd macer à Diofcoride, $\sigma$ Galeno defcriptus

Monachorú opinio falfa. hoc auo ad nos non aduehatur : fiquidem nullus in officinis reperitur cortex, qui poßit maceris hiftoriam explere. Et quanuis Monacbi illi,qui in Me fuem commentarios fcripfere, nullam inter macim, $\sigma$ macerem ponendam effe differen tiam pro certo affirment; nulla tamen auctoritate (quod equidem fciam) aut ratione nituntur. Ceterum haud igno= randum eft nec Galeno, nec Plinio, quód dixerint ex India aduehimacerem, Diofcoridem repugnare, cum ex Earba $=30$
V L M V $S$.

Nomina. ris.
Vlmi hiftoria ipfe afferri dixerit: quoniam (ut $\mathrm{P}$ tolomeus eft auctor) quad a in Indo fluuio infula, uel urbs fita eft, que Barbaria dicitur; ex qua facilé comportabatur macer. Vel quód afferretur ex A rabia co maris finu,qui à Barbaria infuld Barbaricus appellatur. Qüa= doquidem (ut, inquit Strabo) omnid, que in India proueniunt, ea fcilicet parte, quxe ad auftrum uergit, fimiliter in Arabia nd cun tur. Máxep ut Grecis, ita Latinis Macer, atq; etiam Machir appellatur: Arabibus, Thalisfar: Italis, Macero. Quod Ara

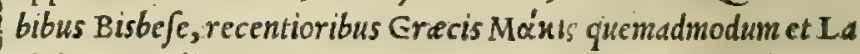
tinis, or Italis Macis nominatur : Germanis, Mufcaten blumen: $4^{\circ}$ Hipanis, Macids, er Macas.

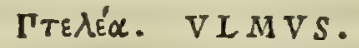

CAP. XCV.

V I M I \& folia, \& cortex, \& rami vim habent fpiffandi. Folia trita ex aceto ad lepras efficaciter illinuntur: vulnera glutinant, fed multo magis corticis tilia, fi fafcie loco intorqueatur: nam in lori moré flccti poteft. Craffior cortex in uino, aut aqua frigida unciatim potus, pituitas trahit . fracta offa celerius folidefcunt, fi decocto foliorum, corticis, aut radicis foueantur. Humor in fol- sa liculis enafcens prima germinis eruptione, cuti illitus ni corem inducit, faciemq́ue fplendidiorem praftat: qui dum ficcatur, in animalia abit, qux culicum formam ge runt. Folia ctim tenerefcunt cocta, olerum more ad obfonia ufurpantur.

T A M E T 5 I Vlmus notißima omnibus feré fit arbor; non tamen ob boc filentio inuoluenda putauimus; que de ea pofteriz tatis memorie prodidit antiquitas. Vlmus itaq; (ut Theophraftus eft auctor lib. I I I .eap. X I I I I de plantarum biftoria) duobus di= ftınguitur generibus : cuius altera montana, quam Graci ópenTी 


\section{In Lib. primum Diofcoridis.}

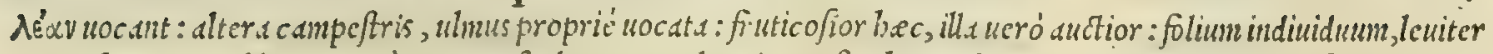
circunferratum, oblongius quam pyro, fexbrum, non leue. Praftat bec arbor or amplitudine, o celfitudine, non crebra circa Idan, fed ratra, irriguis amica: matcries fluta, robufta, nerwofa, deformis, ut que tota cor fit. Vtunta

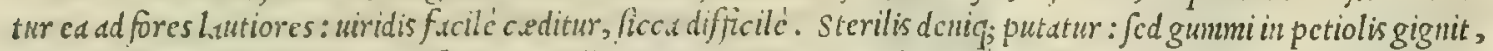
$\mathcal{O}$ animalia quatdan culicea : cachnycs peculiurcs gerit, autumo mult as, minutas, nigras: cater is uerò tempoributs quid for at, minus animaduerjum elt . bactenus Theoplouftus. Plinius ucró quatuor ilmi generaftatuit lib. x v I. cap.

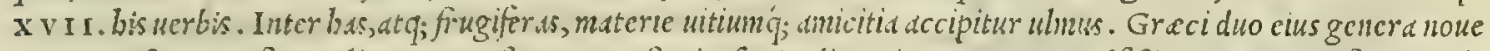

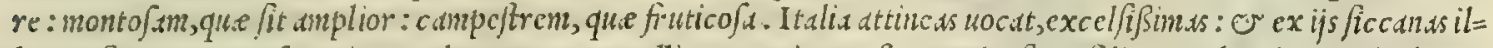
lis prefert, qua non funt rigue. alterum genus Gallicas. tertiun noftrates, denfiore folio, or ab coden pediculo nu= 20 merofiore . quartum fylueftre. Attine e non frunt famaram, ita uocatur ulmifemen : onncs q́; é radicum plantis pro ueniunt, relique ucró Femine. Irec Plinius. Qui tamen unì cum Theopbrafto err.afe deprebendetur, quód bic ulnum cmiufuis generisfterilen effe foripferit : ille autem, qujd attineam fic Italis appellatam, femen nullu ferre prodiderit. Qumdoquidem Theophruffo precer id; quod experiětia nobis compertum eft, repugnat Plinij authoritas : quippe qui

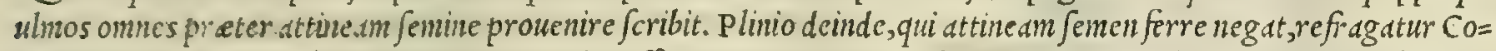

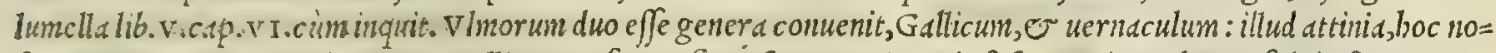
for as dicitur. Atrinsan ulmum Tremellus scrof a non ferrè famaram (quod eft femen eius arboris) falsó cft opinatus. N.un ruriorcm fine dubio credt, er idcirco plerisq; e fterilis uidetur, feninibus inter frondem, quam prina germina tione cdit, lutentibus. It dqg; nemo ium ferit ex famara, fed ex fobolibus. Eft autem ulmus longé latior, o procerior,

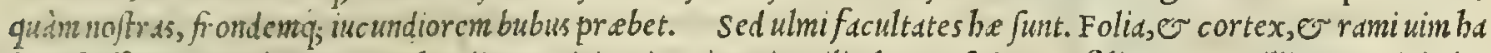

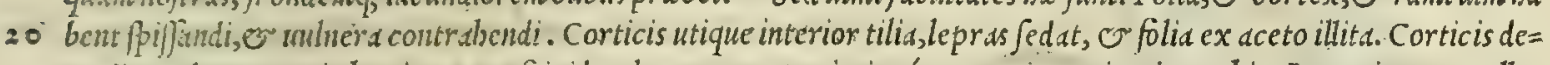

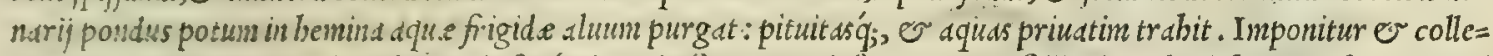

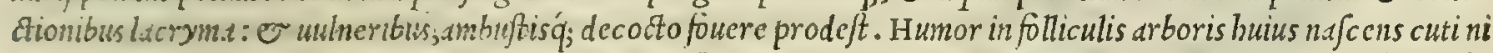

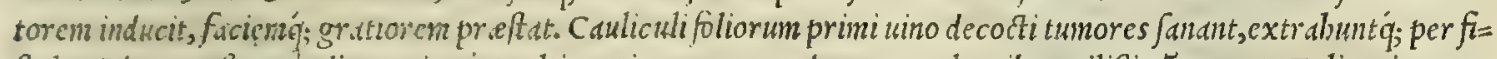
fulas. Idem preftant e talia cortices. Aultic corticem commanducatum uulneribus utilifinü putant. Folia trita, dqua

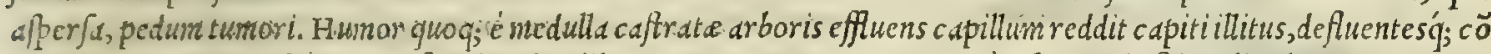
tinet. Hac Plinij werbai de ulmi facultatibus lib. x $x$ I I I I.cap. v I I I. Ceterum bumor in folliculis ulmi contentus (ut ego experientia compcrtum habco) sne detur puerorĭ enterocelis, fi plenia fiue linteola in eo madcfacta fepe inguini partis rupte fuper imponantur, atq; inibi fubfemorali, quòd I talis uulgó brachiere appellatur, fubligentur, er con= ftring antur. Quin e corticis rudicum decoctum articulorun duritias emollit, ov nernorum conuil fiones refoluit, /i 30 in fotus, uel ballncimodum adlibeatur: item tunores difcutit, qquos iugi attritus in collo boum excitauit. vlmu memi= nit Galemus lib. I I I. Fimpl.medic. Fic inquiens. Vlmifolijs quandoq; recens ïulnus glutinauimus, confidentes adftrin gentem pariter o abftergentem ineffe illis facultatem. Cortex amplius etiam fubamarus eft, o adftriftorius : itaque cum aceto o lepram fanat. Porró uiridıs etiámnum àc recens, fi wulneribus uinculi uice circumligetur, ea glutinare poteft. Radices eandem uim obtinent : nam er decocto earwom quidam perf undunt fracturas, que toplo, fiue callo in = ducto opus habent. Huius arboris noinen Grecum eft $\pi T \in \lambda \varepsilon \dot{\alpha} \alpha$ : L atinum, vlmus: Arabicum, Didar, Dirdar, feu Nomina. Iuzach: Italicum, Olmo: Germanicum, Ylmen, Ritholtz, Lindbaft, Yffenholtz: Hipanicü, Vlmo: Gallicum,Orme.

Theophr.\& Plinij error.

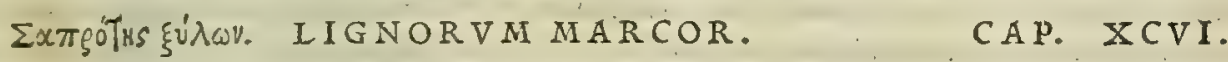

Ex caudicibus, lignisq́; veteribus caries congeritur - quæ farinæ modo illita ulcera purgat, \& ad 40 cicatricem perducit : Ierpétia cohibet, fi cum pari anifo \& uino fubacta, linteisq́; impofita illinarur.

$\mathrm{N}$ o $\mathrm{N}$ fané prorfus negligenda eft lignorum ueterum, $\mathrm{er}$ contabefactorum caries, cum tanta facultate polleat,

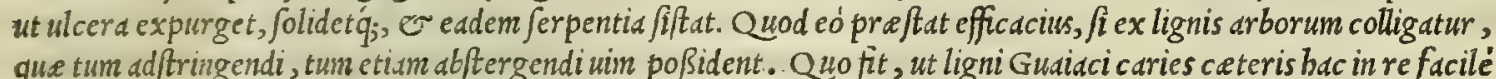
preftet : quippe que rzon modó ulcera, que contumacia non funt, fanat; fed Ð qux cacoëthe dicütur, quéó; Gallica pefte contraid funt. Quare pudendorum exedentibus ulceribus infperfa mirificé medetur. Caterum non modó lgnorum marcor, fiue caries in medicum ufun uenit, fed $\sigma$ VERMES in cariofis lignorum caudicibus ndfcentes, fi Plinio credinus, qui libro x x x. cap. x I I I. de his fic fcriptum reliquit. Coßi, qui in ligno nafcuntur, fanant ul= cera ommis: nomas uero combufti, cum pari pondere anifi, $\sigma$ ex oleo illiti. Delicatiores fuiffe hos olim $\sigma$ in cibis

so idem pofteritatis menorie tradidit lib. x v I r. cap. X X I I I . cùm inquit. Vermiculantur magis, minúsue quadam, omnes tanen fré, id q́; aues caul corticis fono experiuntur. I am quideme in hoc luxuria elfe coepit, pregrandesóg, roborum delicatiore funt in cibo, coffos nocant: atq; etiam farina faginati, hi quoq; altiles fiunt. Quapropter mirum non fuerit, fi etiam antiquitas cicadas, qua nondum al as deprompferint, in cibis deuorauerit, Ariftotelis testimonio, qui ctiam addidit guftantibus effe fuauilimas. Sed cur illud adinirandum fuerit, fi noftris etiam temporibus uermes, qui cariofis cafeis innafcuntur, magna admodum cum uoluptate i compluribus deuorentur? Galenus cùm er ipfe ad arborem, ex qua caries decidit, particularem fcopum babuiffet, lib. v I I I. fimp, medic. fic de illa fcripfit. Caries li= gnorum, e maximé, qua particeps eft adftrictionis fimul, e abfterfionis, uelut ulmus, expurgat, implet $\dot{q}_{\text {; }}$ ulcer $a$ bu=

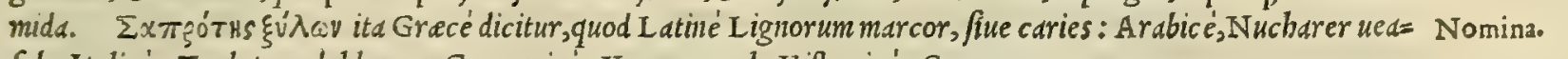
fab: Italice', Tarlatura del legno: Germanicé, Vuurm meel : Hipanicé, Carcoma.

Cariei ligno. rum confid.

Vermium lignorum vfus.

(1)

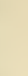

\section{Cariei uires}

ex Galeno. 


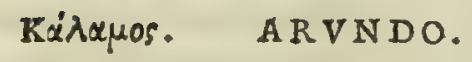

CAP. XCVII.

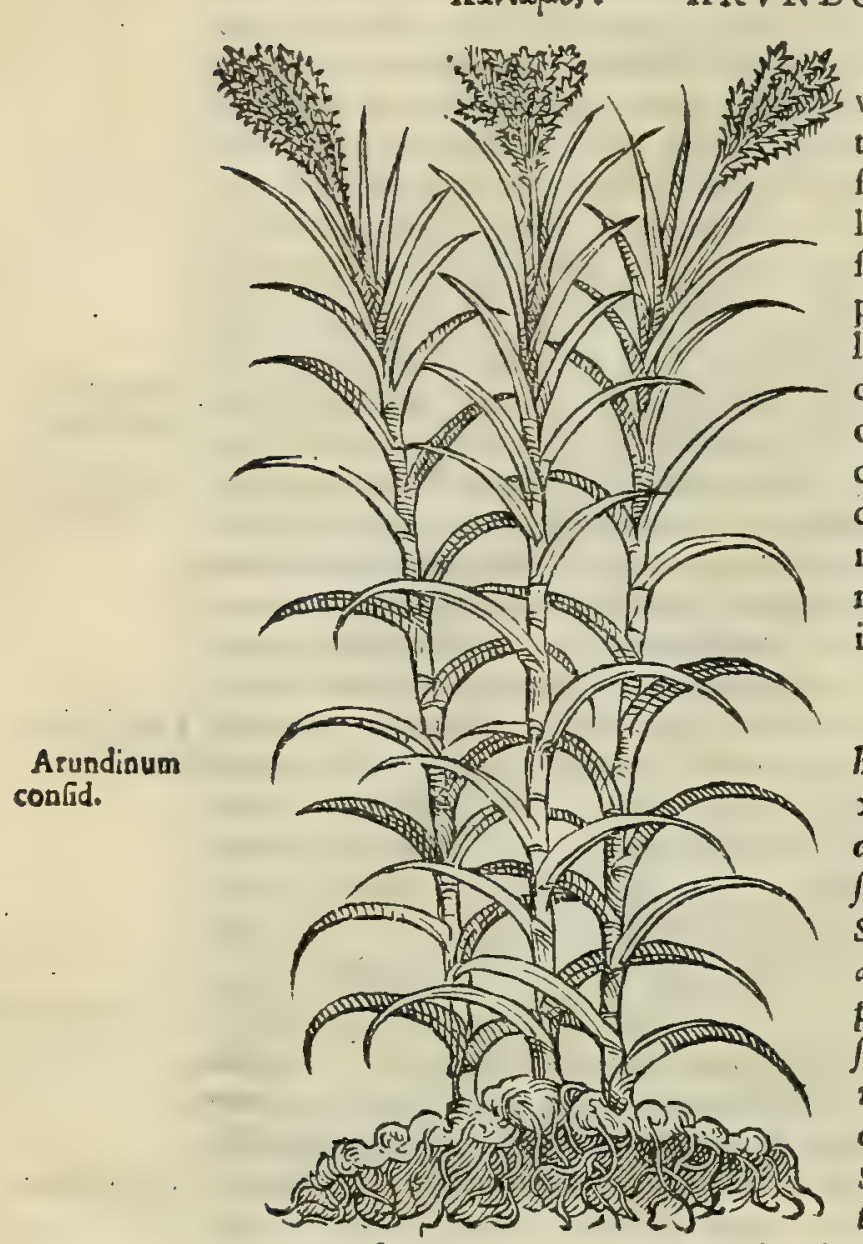

IN Arundinum genere quxdam naftos, id eft fartior vocatur, ex qua fagittx factitari folent. Alia formina, qua tibiarum ligulas efficiunt. Alia, quòd fiftulis addicta fit, fyringias : cui multum ineft carnis, crebris cincta genicu lis, ad librorum confriptionem accommodata. Alia craf $f a$, concaux, apud amues nafcens : qux à quibufdam cypria, ab alijs donax appellatur. Alia phragmites, feu uallatoria, gracilis, candicans, vulgò cognita : cuius trita radix per fe, aut cum bulbis fuis illita, fpicula aculeosq́ue corpore extrahit : luxata, limborumq́ue dolores cum aceto mulcet. Virentia folia tufa, \& impofita ignibus facris medentur, \& cateris inflammationibus. Corticis cinere perunctx cum aceto alopecix fanantur. Paniculx lanugo, fi aures intrauerit, exurdat. Eundem effectum implet arundo, qua cypria dicitur.

A R V N D I N V M quinque generd tantim, ueluti notiord boc in loco id Diofcoride produntur: licet Plinius lib. X VI. cap. 20 $\mathrm{x} \times \mathrm{x}$ v I. ev lib. $\mathrm{x}$ x I I I I.cap. x x .uiginti nouem arundinum pe. cies defcripferit : inter quas ( ut fuperius diximus) odoratam recé

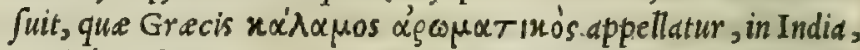
syriaq'; nafcens, odoris iucunditate unguentis accömodata. Quod aperte indicat calamum odoratum effe inter arundinum genera re ponendum, non autem inter radices, ut uulgus medicorum, $\mathrm{Cr}$ - Bra fauolus Ferrärienfis contendunt; acori radices pro legitima odo $=$ rats arundine affurientes, Illa, que naftos dicitior, folida, far= Elaq́; quanuis gracilis $\mathbb{e}$ le $u$ is, in communem fagittarum ufum d Syris accepta, non oritur, quod fciam, in Italid; nifi inafcatur (ut 30 tradidit Plinius.) in R heno Bononienfi amne. Illa etiam, que the = bs, boc eft, foemina appellatur, cuius tantim eft ufus ad tibiarum ligulds, hactenus mibi incognita eft. Naniq; noftra. tempestate funt eiufmodi ligule ex communibus arundinibus, ex ea fcilicet pecie, quam Diofcorides uallatoriä nun= cupat, qua noftri in uiridarijs, ac bortis in topiarijs extruend is utuntur, ac palos uitibus aptißimos efficiunt. Quid an tem uallatoria fit hac noftra communis, mibi aliquando dubitandi prabuit anfam Diofcorides : quippe qui dicat, eam effe gracilem, er candidam, cum tamen communis noftra fit craßior. Verium cum poftea inucnerim Theophraftum fcribentem lib. I I I I.cap. X I I. de plantarum bifloria, craßiorem, firmiorem'́ ; ill am arundinem effe, qua uallatoria nominatur; facilé fum ad credendum inductus, hunc Diof coridis locum effe depraudtum : coó; mag is, quód feptis, pa=

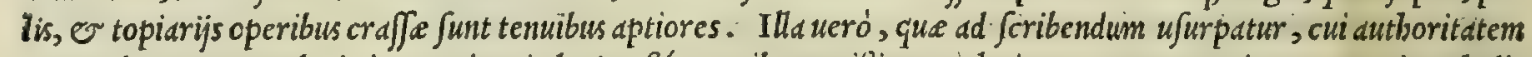
penne derog arunt, plurimis reperitur in locis, eft 'q omnibus notisima : ueluti o ea, que cypria nocatur, in paludi= 40

Arundinis, \& bus nafcens, o apud amnes. Traditur à pluribus rei agraria anctoribus, tum etiam à Plinio, inter arundinem, $\sigma$ filicis odium. filicem berbam inteftinum effe odium : proinde arundinem uomeri alligatam filicem in agro deftruere, ac enecare pro= diderunt. At eó maior arundini cum aparagis intercedt amicitia: nam fi ferantur in arundinetis, inibi mirificé pro= weniunt. Quidam preterea prodiderunt, arundines in India ad tantam affurgere molem, ut fingula internodia naui=giorum uicem praftent per fluuios, o lacus, ternos bomines capiente alueo. At $f i$ plura de arundinü generibus quis Arundinis vi audire cupiat, Theophraftum legat, quilongiori fermone earum hiftoriam literis memoria q́; mandauit. De arun= res ex GaL. dine Galenus lib.v I I. Fimpl. medic. hec f cripta reliquit. Caldmi phragmitis radicem cum bulbis aculeos, O ftipites ex alto extrabere quidam fcripfere, ceu trabendi quadam uis ci ineffet. Nos tamen eius rei periculum non fecimus: uerum quantum guftu liceat conijcere, abftergentem facultatem poßidet non paucam, minimeq́; acrem. Catterim fo= lix ipfa abftergentis funt facultatis. Cortex ueró cius combuftus admodum tenuium partium', o digerentis facultatis efficitur, adiunctum habens abfterforium quiddam, ut exiccet, or excalfaciat tertio quodammodo ordine, plus tamen defficcet, quàm excalfaciat. Vitandum autem eft eitus id, quod antbelen uocant : nam fi in aurcs incidat, adeó tenaci=

Nomina. ter adherens affigitur, ut auelli non poßit, auditumí; uitiat: quamobrem Sapißimé exurdat. Arundo fic Latina

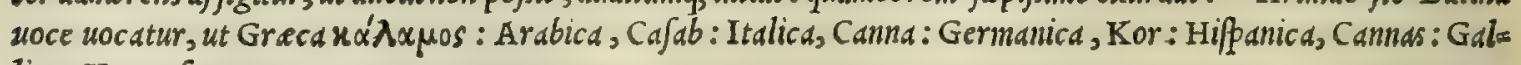
lica, Ving rofealu.

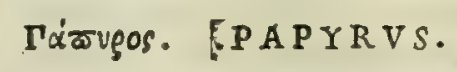

CAP. XCVIII.

P A P Y R V S, qua chartæ funt, nullis non cognita, præcipuæ in medicina utilitatis ad laxandas fiftulas : madefacta lino inuoluitur, ufque dum inaruerit : conftricta enim, atque immiffa in hiatum humore completur, \& intumefcendo fiftulas aperit. Habet nefcio quid alimenti radix : itaque Aegyptij eam mandunt, fuccum tantùm deuorantes, \& manfam expuunt. Ipfis radicibus pro ligno utun- 


\section{In Lib. primum Diofcoridis.}

tur. Crematx papyri cinis depafcentia ulcera cùm omnium partium, tum oris maximè, cohibet : verùm melius id combulta charta praftat.

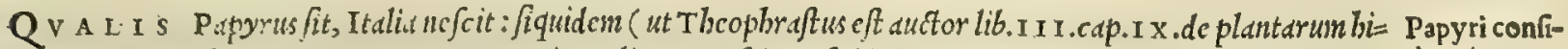
ftoria, e P linius lib.x I I I.cap. X I.) Papyrus in Italia non nafcitur, fed in Aegypto quibufdain in locis tantim pro= deratio. pe Nilum fluuium, quicfertitibus Nili aquis, ubi ha chagataftagnant, duo cubita non excedcnte altitudine gurgitum: bracbiali oblique radicis craßitudine, tritugulis lateribus, decem non amplius cubitorum longitudine, ing racilita= tem faftigiatum, thyrfi modo cacumen includens: femine nullo, aut ufu cius alio quàm floris ad deos coronandos. Ra dicibus incole pro ligno utuntur, nec ignis tantion gratia, fed ad alia quoq; utenfilla uaforum. Exipfo quidem papy= 20 ro nauigia texunt: o ć libro ucla, tegetesq́;, necnon o ueftem, etiam ftragulam, ac funem. Mandunt quoq; crudum, decoctum'; , fuccum tantum deuorantes. Nafcitur e in syria, circa quem odoratus ille calamus lacun. Nuper or in E uphrate nafcens circa Babylonem. Papyrum intellectum cst eundem ufunt babere, quem charte: : o tamen adbuc malunt $\mathrm{P}$ arthi literas ueftibus intexere. Preparantur ex eo charte diuifa acu in pretenues, fed quam latißimas phi= luras . bec Plinius. Quideinde fequenti capite fufus dockit Papyri conficiendi rationem, his uerbis. Poft banc pa= pyrum eft, cxtremumí; éius forrpo fimile, ac ne funibus quidem nifí in bumore utile. Texunturq"; omnes tabule madé= tes Nili aqua. Turbidus liquor uin glutini prebet, cum primó fupina tabula fcheda adlinitur longitudine papyri, qu.e potuit effe, refegminibus utring; amputtatis. Tranfuerfa poftea crates peragitur : premitur deinde pralis, or ficcan tur fole plagule, atg; inter fe iunguntur. proximarum femper bonitatis diminutione ad deterrimas. Nunquam plu= res fcapo, quaim uicen es magina in latitudine earum differentia $\mathrm{x} 1 \mathrm{I}$. digitorü.optimis. Hactenus de papyro Plinius.

20 videntur $\sigma$ Papyri quoddan effe genus, tenuia, leuidig; illa folia é iuncea quadam planta prodeuntia, que ab infulis diui Tbome, Brafilin, $\mathcal{O}$ Meder $\mathfrak{x}$, ad nos comuchuntur, facchareis ut nocant panibus inde delatis circüuoluta . Quan= doquitem fragmentum retinemus à clarißimo medico Luca Gbino Pifis ad nos miffum, nigris rubriś́; Arabicis cha= racteribus imanu friptum. Quod clarißimum prabet indicium, earum infularum incolds tenuißimis his folijs, pro pa= pyro pasion uti. Veruntamen boc non effe papyrum, é quo antiquitas fuas confecit chartas, certó fcimus, quód boc ar= te (ut Plinius eft audfor) ficret, illud uerò tale à natura producatur, er proprium fue ftirpis fit folium. Antiqui itag; ex Papyro chartam factitabant; qquemadmodum nos ip $\int a m$ ex contritis linteis conficimus : unde battenus antiquum re tinens nomen, etiämnum Papyrus apud plerof q; dicitur. Credidere nonnulli, ueram effe Papyrum arundines illas, Indicaarunquas Indicas uocant, quibus inbecilles principes, at $q$; hierarcho, prelati unlgò dicti, ad rgram fenectutem fulciendam do. pro fcipione utuntur, materiem auro, wel argento fuccingentes. Quod tamen affercre non aufim, nec utiq; reproba= 30 re, cum huiufce rci certam cognitionem adhuc affequi non potuerim. Papyrimeminit Galenus lib.v I I I. fimp.me= Papyri uires

M Y R I C A.

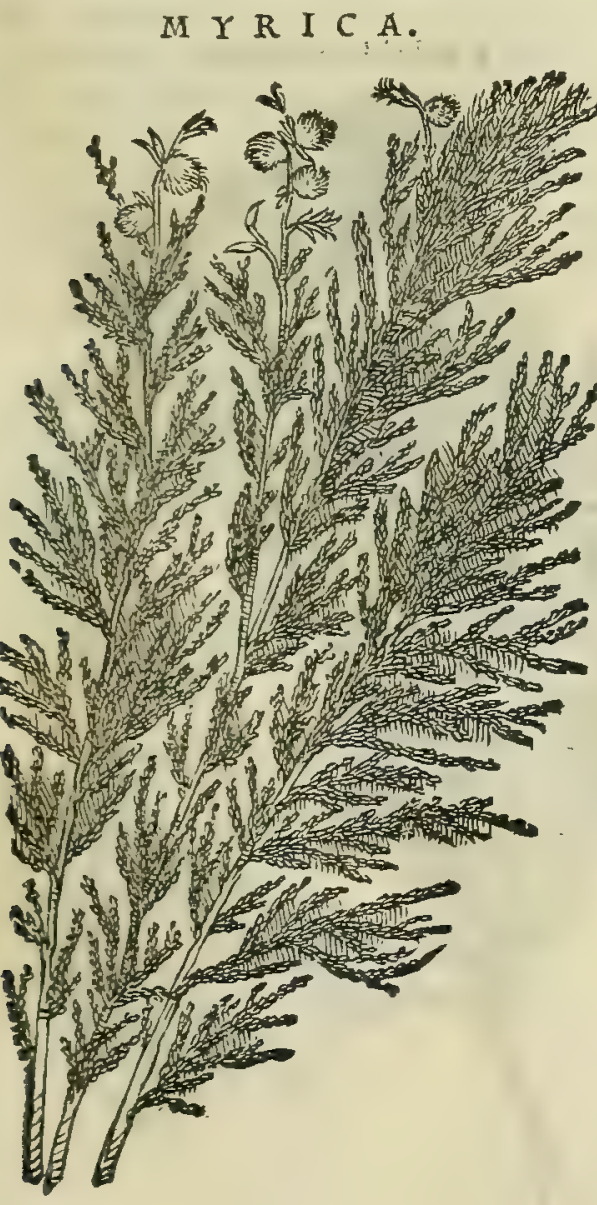
dic am. fic inquiens. Papyrus ip $\int$ quidem per fe in ufum medicind= ex Galeno. lem non uenit: at maceratd, aut ulta utilis efficitur. I gitur oxy= crato, uinóue macerata, recentia ulcera glutinat, maximé in cir= culum circumpofita. Verim bic quidem eft, ceu materia, que me dicamina fanantia accipidt: at ubi ufta fuerit, medicamen eft exic= catorium, uelut o charte combufte cinis, nifi quatenus infirmior eft, quim papyri . hec Galenus. Ceterim anim.dduertendum eft, quodd nof tri ufus charta, que ex ueteribus conficitur linteis, ijfdem non pollet facultatibus, quibus ed commendatur, quam ueteres $\mathrm{ex}$ papyro arbore parabant. Quo fit, ut dubium mibi fit, quónam mo do parari poßsit illud Galeni medicamentum, quod de charta com= bufta dicitur, ulceribus fordidis, ơ finuofis utilißimum: item $q_{\text {; }}$

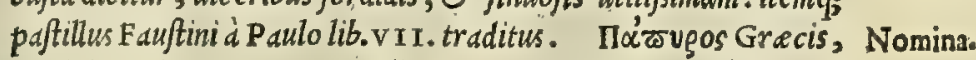
Iatinis pariter Papyrus appellatur: Arabibus, Burdi, feu Eerdi: Italis, Papiro.

\section{Mugín, MYRICA. CA.P. XCIX.}

M Y R I CA, feu tamarix, arbor vulgo cognita eft, cùm apud pigras, \& ftagnantes aquas enafcatur, fructum quafi florcm ferens, compage mufcofum. Aegyptus, Syriaq́ue alteram gignunt mitiorem, fylueftri cæetera fimilem. Fruetum parit gallæ proximum, inæqualiter aftringentem guftu: quo conuenienter utimur uice galle in medicaminibus oculorum, orisq́ue. Datur cruentæexcreationi in potu, \& cceliacis , \& contra profluuia fominarum, regium morbum, \& phalangiorum morfus: illitus tumores inhibet. Cortex in cofdem ufus adhibetur. Decotum foliorum cum uino potum, lienem abfumit: ad dolorem dentium in collutionibus falutare, \& mulieribus fluxione vuluæ opportunis in defefsionibus : phthi riafi, lendibusque circumfurum prodeft. Abundantiam 
fœminarum fítit impofitus arboris cinis. Potorios calices è caudice licnofis moliuntur; quồ datus in his potus proficiat.

Myricæ con-" V R B A N A Myrica, quódd ciam, non nafcitur in Italia; quanquam in Aegypto, or syria gignitur. Qua uerò fideratio. alicubireperitur in hortis, e in quibufdam uriddrijs mitior credita, non alia eft, quadm fylueftris, in locos mitiores. translatd. Cuius rcicerto funt indicio fructus, e flores, quos omnino fylueftribus fimiles profert, non autem galle modo, ut doneftica. Vmbra arboris infigni proceritare fape per aftatem Rome me oblectatum fuiffe recordor ad $\mathrm{Ty}$ beris rip.ts, in hortulo quodain bopitalis sanctipiritus. que etfi donreftica baberetur ab omnibus; florem tamen; fructum ferebat fylueftri fimilem. Hac in fluminum ripis frequentilsima nafcitur in Italid. Quare non potui non ad= mirarl Diof coridem: quippe qui dicat tantimn nafci Myricam apud paludes, ac refides aquas, cum oppofitum fané eue niat in Italia. Quod me fepius adduxit, ut crediderim, aut Diofcoridis codicem boc loco deprawatun effe, aut in Gre

Myricx medi cia fecus, quadm in Italia myricam proxime ftagna, ac paludes oriri. E' myrice trunco aluei excauantur ( ut Colu= cinz. mella fcribit) aquaq; replentur, ut fubinde poftea bibant fues : nam boc potufplenis incremento fanantur, quo morbo aftate maxime torquentur, dum, que corum eft pabuli infatiabilis auiditas, arborum fruqus confectantur, qui plurimi eo tempore propter ariditatem in terram decidunt. Porró myric x cinerem omnid ulcerd ignis exuftione contracta, efficaciter cxiccare author eft serapio . Folia fimul cum tota planta fot frigid as collectiones inbibent, ac reprimunt. Elephantiafim ex lienis uitio obortam myrica radicum decoctum, o cim paßßis unis epötum fanare tradidit Alcan= zius Arabs : id quod fe uidiffe ait in duiabus mulieribus, qu.e bac labe laborarunit. Ex quo mibi perfuafum eft, id nö in= congrumm in Gallica pefte fore medic amentum, Guaiaco forfitan ligno non abfimile. Myrica radices pro odoratd cat fia uenditabant impoftores. Sed poftqudim fraus à peritis medica materia uiris deprebenfa eft, eius in officinis ufus io

Myricx uires penitus exoleuit. Meminit myrice Galenus lib.v I r. fimplicium medicamentorum, ubific inquit : Myrica abfter= ex Galeno. gentis cft, ac incidentis facultatis, abf $q_{;}$perpetcua deficcatione: babet ueró etiam adffrictionem nonnullam. Has ob qualitates, facultatesóf; admodum prodeft lieni indurato decocta cum aceto, aut uino, fine radice, fitue folijs, fiue $e x=$ tremis ramulis: Sanat porró dentium dolores. Caterim fructus, or cortex non pauc an fortita funt adfritionem, adeó ut galle omphacitidi proxima fint, nifi quód acerbitas euidens eft in galla, fed myrica fructui temperatura ineft inequalis : immifta eft cnim nature eius multa partium tenuitas, atq; uis abftergédi: quod fané galle non accidit. At= tamen ubi galla forté ad manum non erit, co uti liceat ad omnia, ad que illa utimur : in eifdem $\mathbb{E}$ cortice . Porró my= rica combuft a cinis admodum deficcatorie facultatis eft, plurimain habens abfergendi facultatem, pauxillam ad=

Nomina. fringendi. Mveixh arbor ita Grecé uocatd, Latiné Myrica, o Tamarix nuncupatur: Arabice, Tarfa, feu Car= fa: Italicé, Tamarigio: Germanice, Tamarifcken, aut Porft: Hipanice, Tamargueira, e Tamariz: Gallice, 30 Tamarife.

E R I C A.

\section{ERICA ALIA,}
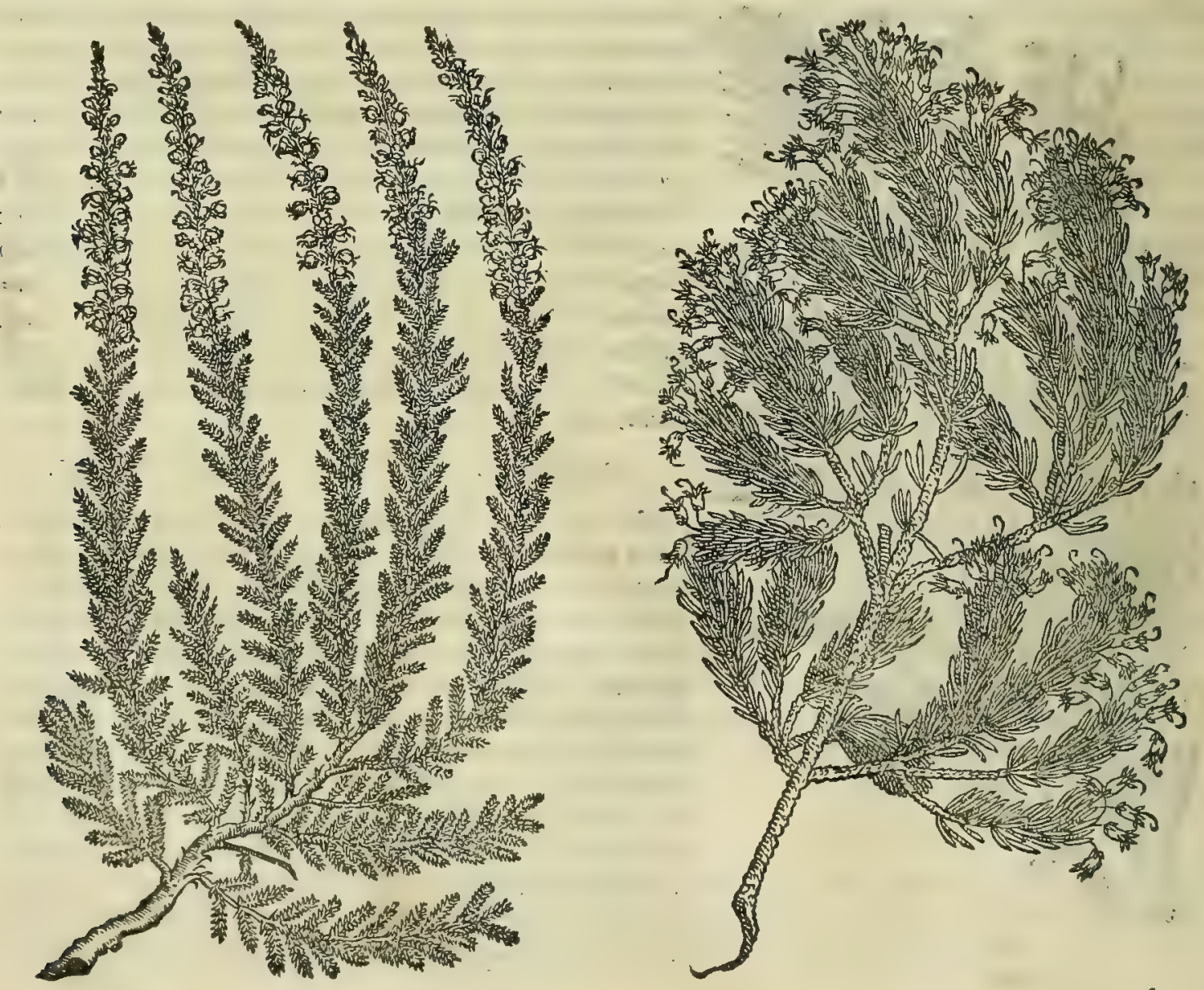


\section{In Lib primum Diolcoridis.}
E'g̣ix.
ERICA.
C A P
c.

ERICa fruticofa arbor, myricæ fimilis, longè minor cuius forespes reprobum mel efficiunt. Tam tos, quàm coma ferpentium ictibus illitu medetur.

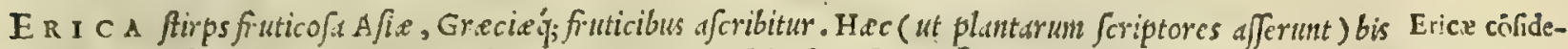
anno floret . quo fit, wt prima, or ultima habeatur, qua inter fylueftres ftirpesflorcat. Plinius lib. x x I I I I cap. ratio.

$\mathrm{IX}$. erican defcribens inquit. Ericen Greci uocant fikticcm non multum à myrice differentem, colore roris marj=

2o ni, o pené fólio. Hanc aduerfarif crpentibus tradunt hace Plinij uerba. Verum non ob id facile fuerit affirmare, quenum planta nobis legitiman Erican pre fe ferat, cuint tan paucis not is de fcribatur ab omnibus : tametfi hac, ch= ius hic figuram appinximus, nil aliud, quàm cricam defignare uideatur. Siquidem fruticofa eft planta, femicubitalis, colore roris marini, folijs fire myrice, cui eam Diofcorides a Bimilat: uere primo os autumuo flore fcens, quod hu= ius fruticis propriwn eft, fi reiberbutrie fcriptoribus eft adhibenda fides. Adde, quód buiufce flores auturnto maxi= mé depafcantur apes, ca fortaffe de callfa, quód non modó Erica prima fit, or uftina fylucftrium, que floreat; fed quód ctim diutius floribus quam plurinis ornetur, nempe autumno toto, o ad hyemem ufque. Vnde mel, quod ex ijs apes faciunt, ericcum (ut Plinius cft anthor) antiquis appellatur, qued conuebi tradidit poft primos autumni in= bres, cimm cricat fol. floret in fyluis. Pretered cim lib. I I I. Ccribat Diofcorides, corim, bypericum dliquibus uocd= tum, fruticem \&ffe folto crice, minore tamen, fit ơ bae cori folio admodum fimilis, magis adbuc inclinauit ani= 20 mus ad credendum, banc cffe Diofcoridis ericam. His ergo rationibus adductus non temeré factum putau, pro legirima crica huius cffigien cxpreffan dare. Oritur hec frequentijima in Goritienfi agro co prefcrtim tractu, qui i Dino Andrea (ita appellitur uicus) ad vipacun flunium itur , incole uernaculo fermone eam nominant

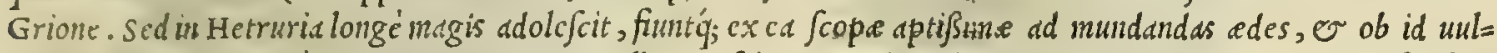
go bec plants proprié nocatur Scopa. Marccllus, nefcio qua ratione ductus, ericam magno crrore genifte $\beta e=$ ciem putst. Erican alium, cuius etiam lic inaginem exhibemus, ut que fortaffe non minus, quam antedicta, ucram refiat, nilit ad me Gabriel Falloppius Mutinenfis medicus fingularis ingenij o cruditionis, dum Patd= wij honorifice humani corporis diffectionem o materiam medicam profitetur. Eam autem libenter depingi curd= uinus, atque in medium profirre libuit, ut rei berbarie peritos in bis, quemadmodum o in cateris plantis, iudices conftituamus: quorum fané iudicio fubfcribcnt ftudiofi, quibus nos quidem, quantum labore atque indu=

30 ftria confequi poffumus, non grauamur prodeffe. Ericam paucis perftrinxit Galenus libro v $\mathrm{I}$. fimplicium medicamentorum, fic inquiens. Erica digerendi per halitum facultatem obtinet. Flore eims potißimum, ac fo= lijs utendum. hac Galenus. Ceterim aqua, in qua Erica decocid fit, fumpta tepida tam mane quàm ueperi tri= ginta dies quinque unciarum pondere tribus horis ante cibum, ualet ad uefice calculos comminuendos or expel lendos. Verim poft id tempus male affecti in balneum decostionis eiufdem plante ingredi, atque inibi dum mo= rantur, fuper Ericain decoctam Sedcre debent: id $\dot{q}_{\text {; }}$ pluries repetendum eft. Equidem noui aliquos, qui ferud= ta recta wiftus ratione, boc tantim potu uefice calctlum in minimas partes comminutum eiecerunt. Plan= Nomina. ta hec, que Grecis épeixk, Latinis item Erica nominatur, pariter $\sim$ Italis: Heyden, Germanis: Queiro, Hi= ffanis: Druycre, Gallis.

$$
\text { A'roradis. ACACAIIS. }
$$$$
\text { CAP. CI. }
$$

Mel ericeum.

Ericæ faeultas ex Gal.

A CACALIs fruetus eft nafcentis in Aegypto fruticis, feminis myricx quadantenus fimilis. Cuius aqua, in qua maduerit, ad collyria additur, quæad excitandam oculorum aciem conueniunt.

A C A C I I M Aegyptix arbufcule femen ad nos bac atate conuehi non equidem arbitror. quippe quód inter fec mins, qu: peregrina nobis importantur, nullum adbuc repererim, quod Acacalim legitimé referat. 


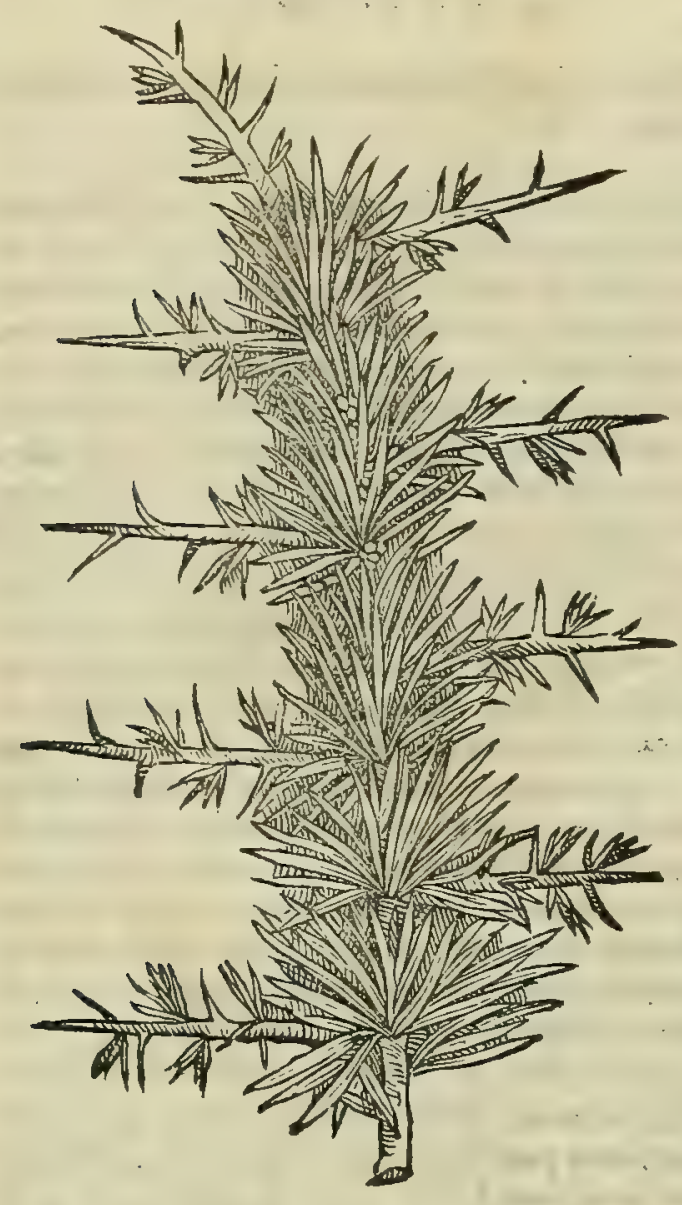

RHAMNVS TERTIVS.

Rhamnorum confideratio.

Ruellij error.

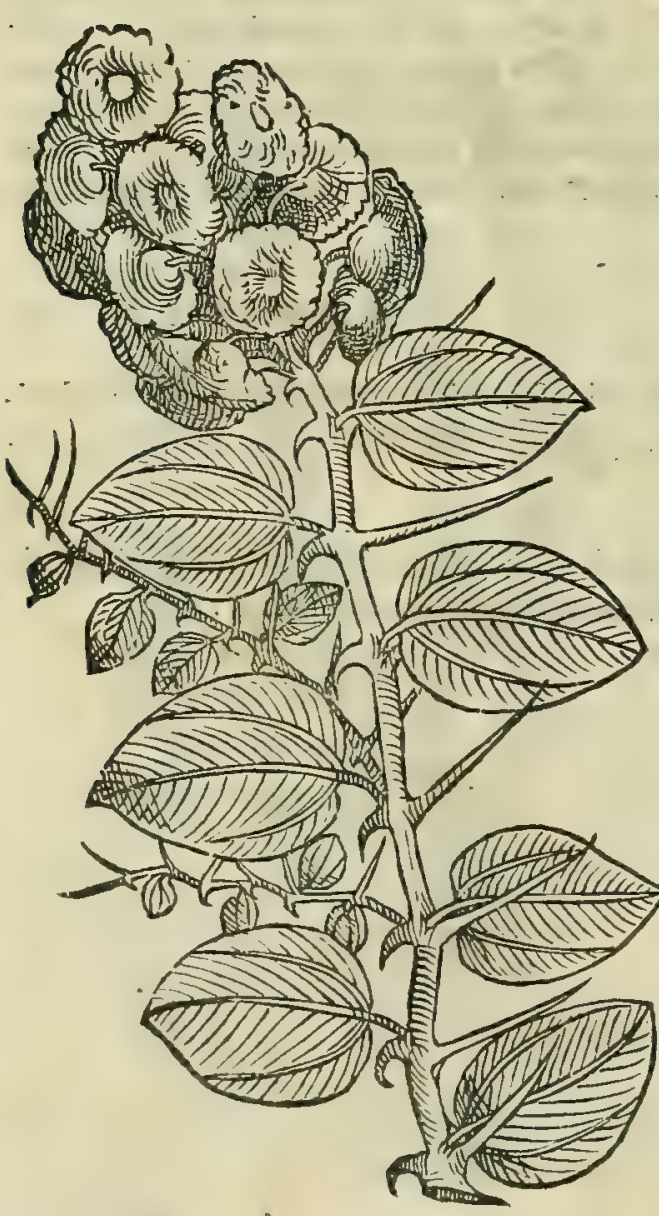

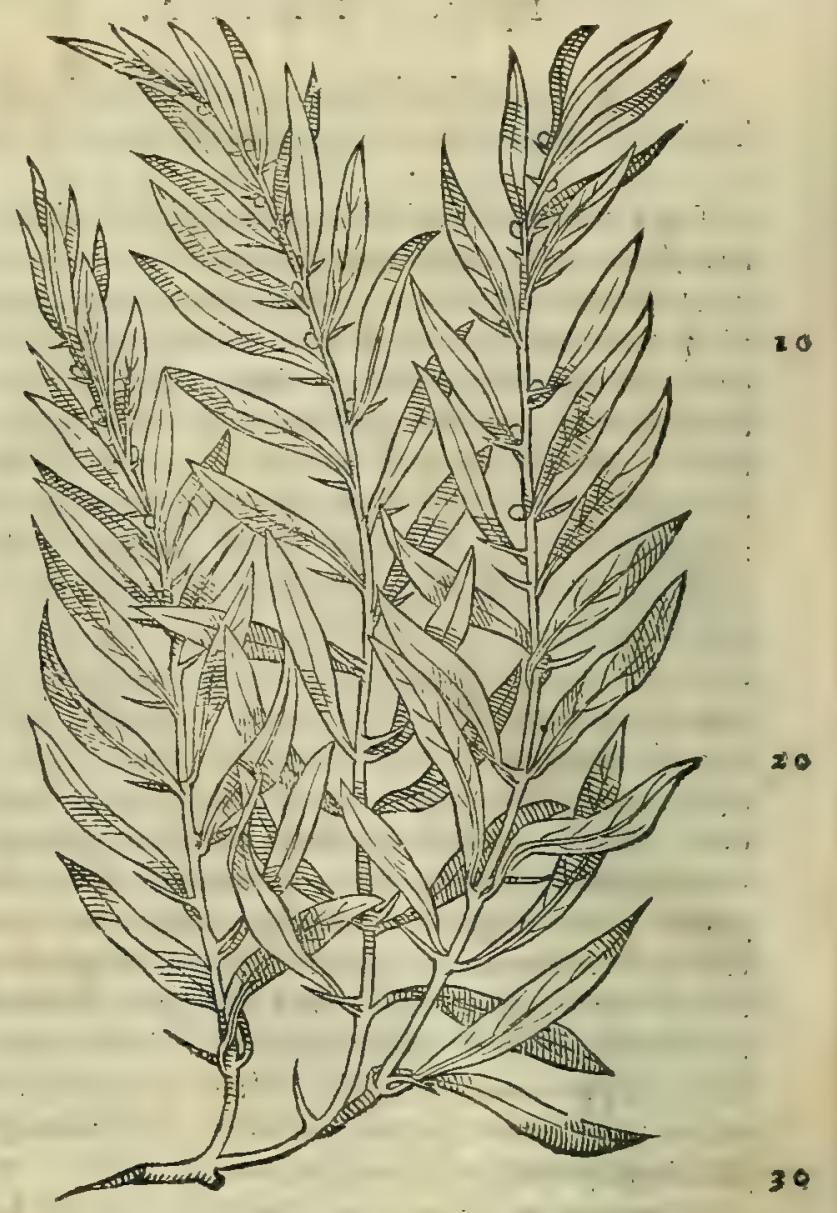

páuvos.

R H A M N V s.

C A P. C I I.

R.H A M.N v s fruticat in fepibus, ramos ferens reEtos, \& aculeos in acutæ fpinæ modum : folijs paruis; oblongis, fubpinguibus, teneris. Alterum ei genus can didius. 'Tertium nigrioribus, latioribusqúue folijs conftat, \& quadántenus rubentibus : cuius rami quinûm 40 ferè cubitorum longitudinem implent, fpinofiores quidem, fed infirmioribus, minusq́ue rigentibus aculeis. Fruetum edit latum, candidum, tenuem, follicularifpecie, uerticillo fimilem. Omnium folia igni facro, \& ferpentibus ulceribus, efficaciter illinuntur. Fama eft ramos huius ualuis, feneftrísue impofitos, ueneficia depellere.

R H A M N I tria genera facit Diofcorides. Primum, er tertium ubiq; in Hetruria fruticant. Illud priuatin in fepibus so nafcitur, quo noftrates mulieres utuntur ad infolandas ficus: fiquidem eas adbuc recentes longis buiufce fruticis acule is per= forant, or ad folem appcndunt. Fert aculcos in acute pine mo= dum : folia oblonga, mollia, fubpinguia: corticem babet admo= dum album. Hoc, quod nigrius eft (ut etiam Diofcorides inquit) quinûm ferme cubitorum altitudine attollitur, infirmioribus acu= leis: fructu tenui, folliculari pecie, rotundo, uerticillo non $a b=$ fimili. Secundum ueró gerus, quod cateris candidius e/t, ad nos inifit clarißimus medicus I ucas Ghinus, cuius etism hic cffigicm damus. Caterim Ruellium deceptum eße crediderim. quippe qui Rhamnigemus eam effe firpem arbitretur, quam nos uulgari fermonie 


\section{In Lib. primumDiofcoridis.}

SPINO MERIO ITALICE'.

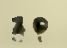

20
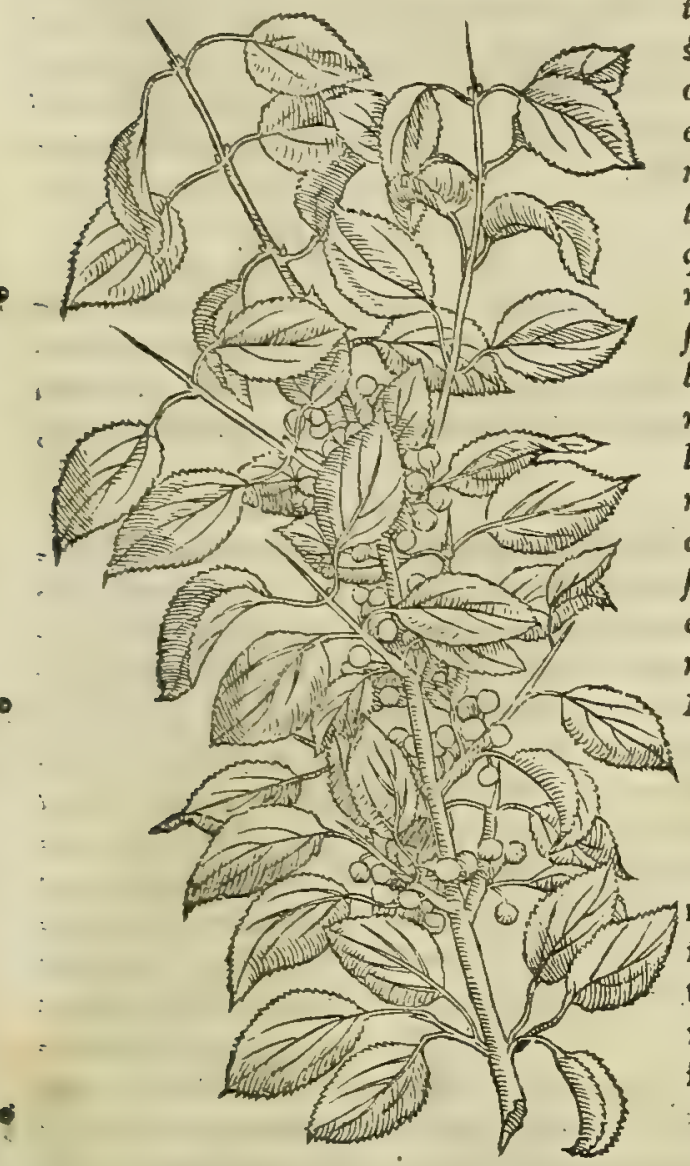

HALIMVS VVIGARIS.

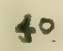

10

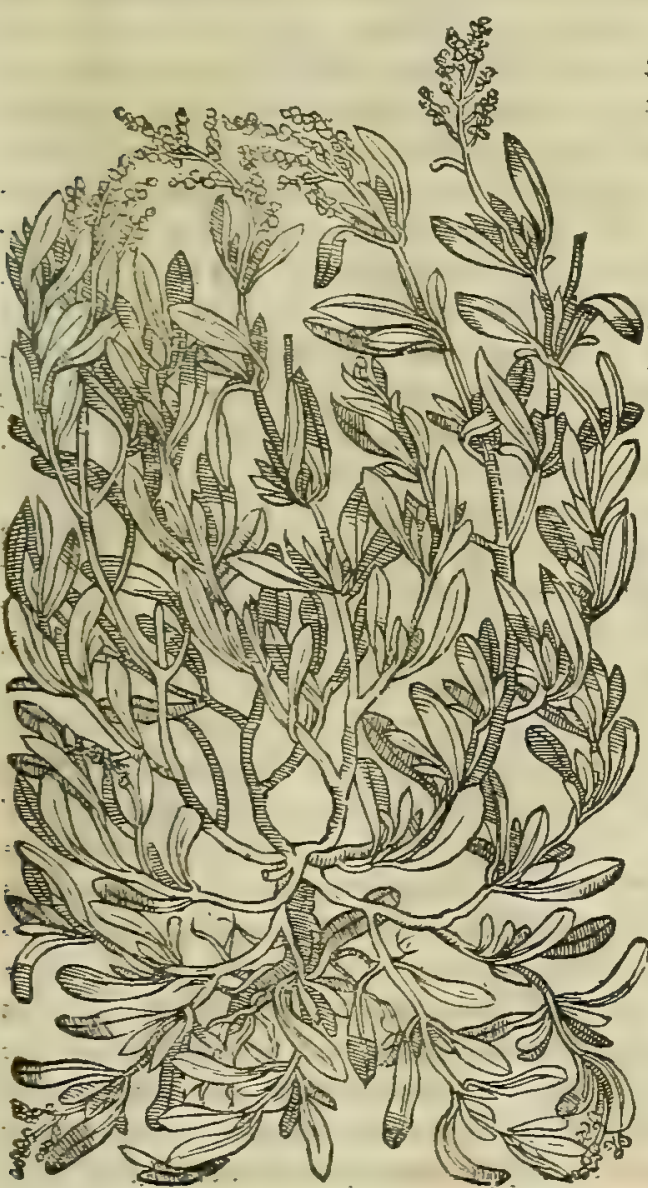

fermone SPINo merlo, Longobardi Ventetif̆; Spin ceruino, Foroiulicnes ueró Spin guerzo appellant. Hac enin folijs eft $l a=$ tis, pyri quadántenus modo: fruftu ligufric effigic, baccarum in= star, cuius fucco utuntur pictores, ubi colore wiridi inficere fit opus: alij ueró ad refoluendam aluun cum faccharo decoquunt: eigcit enim atram bilem, o pituitan .qux fané nota $\mathrm{R}$ hamnis mi= nimé correßpondent. Aberraffe pratered Rucllus deprebendi= tur, quod Theophrafti teftimonio ca de Rbanni fructu tradiderit, qua ftatim Tbeoplrastus abfoluta rhamni historia de paliuro diffe ruit. Sed in errore longé maiore uerfantur. Monacli, qui in Me= fuem commentarios edidere, cùm Rhamnum exiftimauerint ru= bum quendam, quibumirepens, incultis $\dot{\text {; }}$ proueniens, mard ca $=$ ruleo potius, quàm nigro colore profert . Rbamni meminit $\mathrm{Ga}=$ lenus lib.v I I I. fimpliciun medicamentorum, fic inquiens. Rha= mnus deficcat, e digerit excefu fecundo, refrigerat in primo completo, aut fecundo incipiente - proinde berpetes fandt, ev ery= fipelata non magnopere calida. Caterum ad hac teneris utendam

eft folijs. : Huic plante nomen Grecum gápuvos: L atinum; Rbd= Nomina. mnus: Matritanum, Naufig, fiue Naufegi: Italicum, Rbammo, et Marruca: Hipanicum, Scambrones.

\section{Ádiuos. HALIMVS. CAP. CIII.}

Hal imvs frutex eft fepimentis idoneus; fimilis rhamno, fine fpinis, folijs olex, fed latioribus. Nafcitur in fepibus, \& maritimis. Folia decoquuntur ciborum gra tia. Radix conuulfa, rupta, torminaq́ue mitigat, drach$m x$ pondere in aqua mulfa pota : eadem lact is ubertatem facit.

Es T profictó er Halimus planta, cuius uaria funt inter au= Halimi confi ctores fententia. Alij enim (ut Plinius auffor eft lib. 0 cap. deratio. $\mathrm{x} \times \mathrm{I}$. ) balinum fruticem effe dicunt, Diofcoridem fecuti . Alij ........... maritimum otus, falfo fapore. Tertium quoq; genus addidit $\mathrm{Cr} d=$ tewas fub beder a tantüm nafci, longioribus folïs, biřfutioribusq̆; odore cupreßi. Que autem dे Diofcoride boc loco defcribitur, et / alicubi fortaßis proneniat in Italia; tamen qui itlam mibioften deret, adbue reperi neminem. Verim, $f i$ Ruellio credimus, fre $=$ quens in Gallia nafcitur in Sepibus. Solinus plurimam in cretande fci tradit, suirabili, fi credamus, effectu, quód ea tantum admor: fa fames arceatur. unde fi nomen adinueniffet, ea procul dubio fine afpiratione fcribenda effet. Halinus Mauritanis molochid, O atriplex marinus appellatur. Cuius biforiam referens serd= pio, narrat, quód eam uenalem circumferentes in manuales $f_{a-}$ fciculos componunt, $\sigma$ per Babyloniam clamitant, molochia, molochia. Quod maniffé indicat, Halimum apud Mauritanos berbam potius effe, quàm fruticem, uel arborem, eamó; fortaffe, quam Plinius maritimam, ac falfam prodidit. Quo fit, ut falfam quandam berbam (incole Bidone uulgó appellant) que frequents tißjima in litoribus Venetis prouenit, banc effe putauerim: quip= pe quod ea inftar oleris in ciborum ufum recipiatur. Hec nimi= rum (ut eius pictura, quam bic damus, aperte demonittrat) folia fert oliuce fimilia, craßiora tamen, ac perinde feré pinguid, ut portulace, fubalbida, louia, fapore falfo. Caules emittit albiz cantes, tenues, o lentos, in quorum fummitate femen profert minutum, racematim cobarens. Nafcitur frequens prope Ter= geftimoenia circa falinas, ubi, etiam feparatim, nec minus copio= fa vifitur atriplex marina, qué fylueftrem maximé amulatur. quanquam apud Mauritanos atriplex marina idem effe uidetur cü balimo. Sed quód inter fe differant, manifeftum fie libro fecun= do in atriplicis commentatione. Ceterim putat Addamus Loni=
Monachorí error.

Rhamni uires ex Gal. 
cerus, Halimumeam effe plantam uuas ferentem, quàm uulgó Ribcm uocant. Sed cùm buius folia non repondeant Halimi uires olcaginis, fed potius uitigineis, eum plané ballucinatum effe constat. Halimimeminit Galenus lib. v r. fimplicium ex Gleno. medicamentorum, fic inquiens. Halimum, hec planta frutex est plurimo in Cilicia pracipué prouentu, ubier ger= mina eius recentia efitant, or reponunt quoq; in pofterum futura ufui. Semen pariter, or lac planta ip $\int a$ generat,

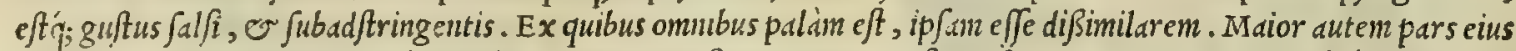

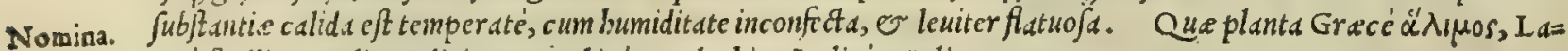
tiné fimiliter Halimus dicitur: Arabicé, Molochia: Italicé, Halimo.

\section{raxíovos. PALIVRVS.}

\section{CAP. CIIII.}

P A I I V R v frutex cognofcitur, aculeatus, durus : cuius fcmen, pingue, \& fuliginofum inue- io nitur. Quod potum tufsi opitulatur, ueficæ calculos comminuit, ferpentium itibus aduerfatur. Folia \& radix aftrictoriam uim habent: quorum decoctum potualuum fiftit, urinam trahit, contra ucnena, \& fcrpentium morfus auxiliatur. Radix recentia tubercula, tumoresq́ue omnes difcutit, trita, 8 impofita.

Paliuriconf- . A D E O' inter fe in quibufdam plantarum biftorifs difcrepant fcriptores, ut per fape eorum mentes maximé per= deratio. turbent, qui rerum ueritatcm indagare ftudent. Id autem difcriminis nimirum euenit de $\mathbf{P}$ aliuro. Nam qua buiufce firpis à Diofcoride-traditur historia, omnino differt ab ed, quam diuerfis generibus protulit Theopbraftus. Hec au= tem non conuenit cum ea, quain memorix prodidit Agatbocles: neque buic illa correpondet, cuius Plutarchus eft auctor: ov bac i pradict is omnibus prorfus diffentire uidetur. Paliurus Diofcoridis (ut ab eo primum exordiar) cft 20 frutex pino fus, durus, omnibus notus : cui femen pingue, of fuliginofum. Paucis eius biftoriam perfrinxit Diofco= rides, mulla babita de folijs mentione, quód Juperuacaneum exiftimauerit pluribus agere de Paliuro, utpote planta apud fuas regiones notißima. quod nobis eft impedimento, quó minus ueram $P$ aliurum, de qua ip $\sqrt{e}$ intellexit, co= gnofcere ualeatnus. Theophrafto deinde lib. I I I. cap.x v I I. de plantarum biftoria plura funt Paliurigenera,qu.e omnia in filiquis femina terna, aut quaterna proferunt, lentorem pra fe ferentia, ut lini femen. Amat nafci locis ari= dis, quemadmodum o rubus, nec minus qucque dilutis. Catcrum ab hac non parum differre uidetur or illa, cuius idem meminit infrius libro, $\sigma$ capite quarto: fiquidem banc plurimam nafci teftatur in A phrica folijs ei, qua in Gracia nafcitur, non abfimilem. Que quanuis folio Gracam a mulctur; fr vatu tamen diuer fo prouenit, ut quinon la= tus, neq; folliculari ppecie; fed rotundus, ruber $\dot{q}_{\text {; }}^{\text {fit }}$, eedri fructibus magnitudine fimilis : cui or nucleus ineft acino= rum punici modo, qui non manditur. Fructus uero per fe iucundus babetur, at $q_{;}$f $i$ quis uimum infundat, tum ip fum fua=

A GRIFOLIVM.

Agrifolium.

Aquifolium.

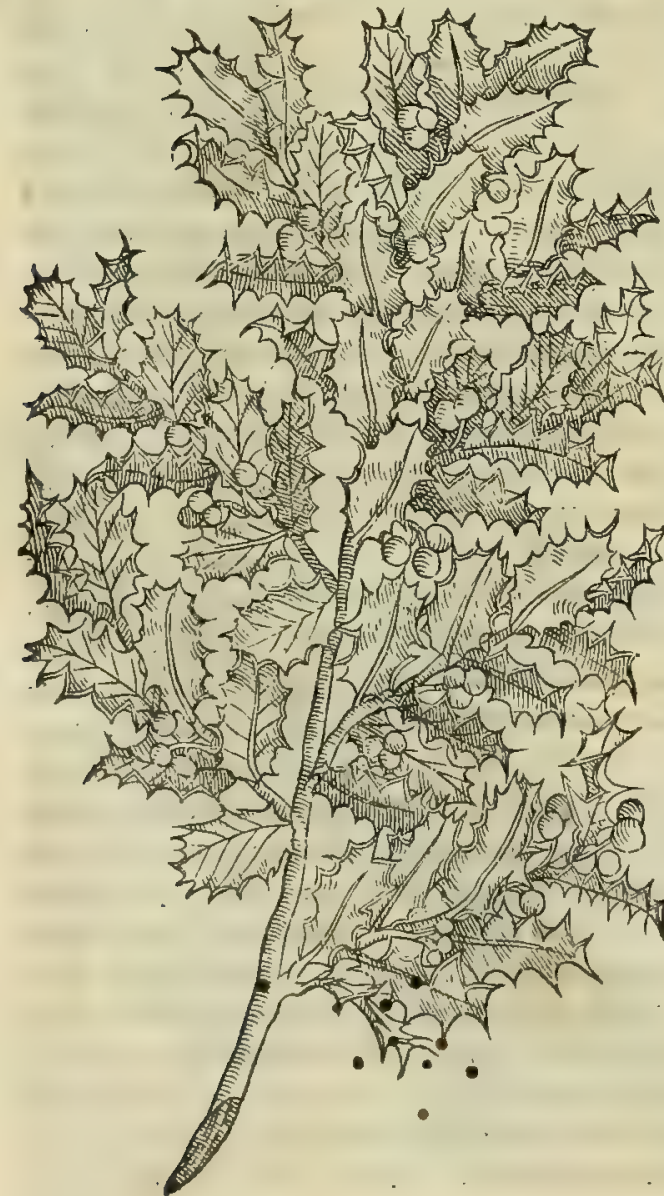
uiorem, tum uinum fuauius reddi aiunt. Ex quo aliquädo mibi per= fuafi, eum non longé aberrare, qui dixerit, hanc illam effe ftirpem, quam nos AGRIFOLIVM dicimus, quod folijs fit undig; acu= leatis loto maioribus, fructu cedri, rotundo, rubro, nucleum intus babente, iucundo, $\sigma$ guftui non ingrato: non tamen, quod pro certo boc afferere uelim, quód hac propria fit Aphrica planta; fed quòd aliquando bis notis perfin fus putauerim, $\mathrm{P}$ aliurum bane aut Agrifolium effe, aut omnino arborem/ibi fimilem. Plinius ex Theoplrafto hanc ip fam literis mandauit lib. X I I I.cap. x x v I 1 . sed cùm de uiribus cius differeret lib. $\mathrm{x}$ X 1 I I I. ean recĕ er Diofcorides. Nullam ego arborem bactenus reperi, qua $\mathrm{P}_{d}=$ liuro Apbric ans fimilitudine repondeat, preter. Agrifolium, ut dixi. Nondico Aquifolium: nam ( ut Plinius refert lib. X X VIr. cap. v I.I.) A quifolium ed eft in Italia arbor, quam Theophraftus Cratcogona vocat, omnibus fere not is meppilo fimilis. Illa uérd, quam Agrifolium appellamus, confat folijs perpetuis, lauri, latio= ribus tamen, fubpinguibus, oj per ambitum aculeatis : cortice ui= ridi : ramis lentis, ac flexilibus. Fructus ci rotundus, lucidus, ruber, rufcum er cedrum baccis amulans. Huius radicum cortice incole uifcum parant, quo etiam modo ex uiburno conficiunt. Hanc non so defunt, qui uelint eam effe ftirpen, quain Theophrastus Agriam, fiue Ariam appellat, fempiterne frondis arborem, inter robur; $e^{\circ}$ ilicem mediam. Verùm ut aú noftrum inftitutum redeamus, Agat= thocles Paliurum omnino ab illis differentem tradit: quippe quos (niam affurgat in Alexandria (ut ipfe inquit) ad pinus, ulmiq'; pro ceritatem, ramis frequentibus, or acule atis : folio uiridi, rotuls do, tenui. Hac bifera est, nam tam uere, quàm autumno fructum profert; oliue phaulic uocate magnitudine. Crudus mäditur is ac uirens: ubi ueró exaruit, in farinam molitur, atq; ea ita ftur nul lo liquore fubacta. Aliud Paliuri genus in monte Coccygio najci prodit Plutarclius ex Ctefiphontis authoritate libro arboribus di= 


\section{In Lib. primum Diofcoridis.}

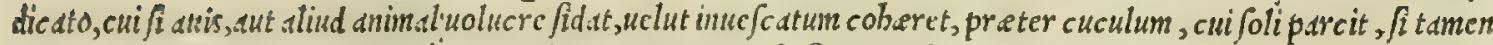
bisfides $\mathrm{eft}$ adhibenda. Quare cium de P.liuro, tot ac diuer fe ferantur fententix, o babeantur biforix, facile cre = diderim, a aliurum effe nomen ad nationum placita uarijs, ac diuerfis acule at is ftirpibus impofitum . et $f \mathbf{l}$ Iofephus $S d=$ landius inedicus apprime doctus, e- in ftirpium hiftoria non imperitus, dum Vencta claffc in Greciam traicciffet, Dio= fcoridis $\mathrm{P}$ alurume fe uidiffe mili pro certo afjirmucucrit, femine fuliginofo, ac pingui : atq; inibi proprium adbuc no= men retinere. Sunt tumen érccutioribus, qui putent Palurrun Diofcoridis eame effe arborem, quan nos fequenti

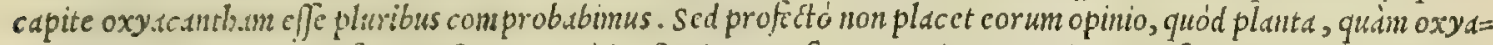
cunth.,m cenficmus, arbor fit, non frutex: quodd; fructum proferat myrti magnitudine, confertum, fragilem, rub rü,

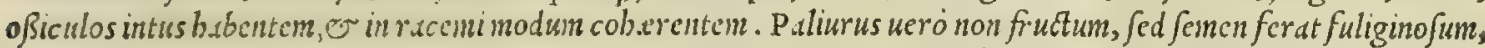
20 pingue, o (ut Theoph.inquit lib. I I I.cap. X V I I de biftoria plantarun) in fliquis conclufum, lentun, pingue qu, line

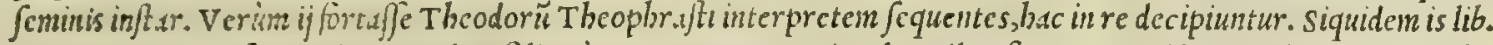
primo cap. x V 1 . fic ucrtit: Q Queddan folia cim extremo, tum etiam lateribus finuata concidunt, ut ilicis, roboris, fmi Lacis (glundifcre fcilicet, or ilici finulis) rubi, paliuri, e aliorum. Vbi animaducrtendum eft, eum perperain nertiffe

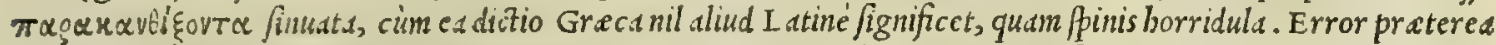
ex co munififte deprehenditur, quod omnibus fenfu pateat, ilicem, fimilacem, rubum folia non proferre aliqua parte fis nuatusuti ca efe cerruntur, qua plante illi excunt, quam nos acutam /pinam arbitramur; fedlonga, o per ambitum ubiक tenuilinis, accrebris aculcis circumfepta, in eiufdem capitis progreffu idem oftendit Theophraftus, cum in= quit. Sinili modo nonulda ex his caulem primo mitem, póft borridulum pinis gerunt, ut lactucd, $\sigma$ cuncta folia $\beta i=$ nofa radduntur, atg; etiam magis in fruticum genere, ut rubus, paliurus. Quibus paldin fit, plantam, quam nos uulgó

20 uoc anmus Bagai,a, alij ucró Amperlo, non effe $\mathrm{P}$ aliurum, fed potius acutam pinam ijs tum rattonibus, tum auctoritatio bus, que fequenti capite nobis adducentur. Galenus Paliuri ḋ Diofcoride defcripti meminit lib. v I I I. fimp. med. bis uerbis. Faliurifolia, or radix adcó non obfcuram habent adftringendi facultatem, ut $\sigma$ uentrem fluentem cobiz

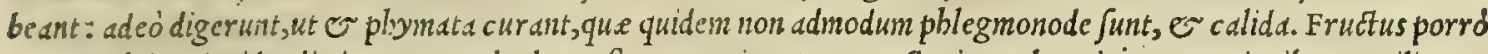
tuntam obtinet incidendi uin, ut $\sigma$ calculos uefic comminuat : $\odot$ pectoris, pulmonisq; excretionibus auxilietur.

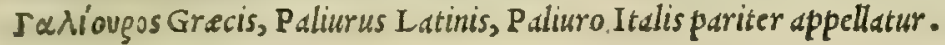

Recentiorū opinio repro bata.

\section{o'gुứxupgx. ACVTA SPINA.}

\section{A P. C V.}

30

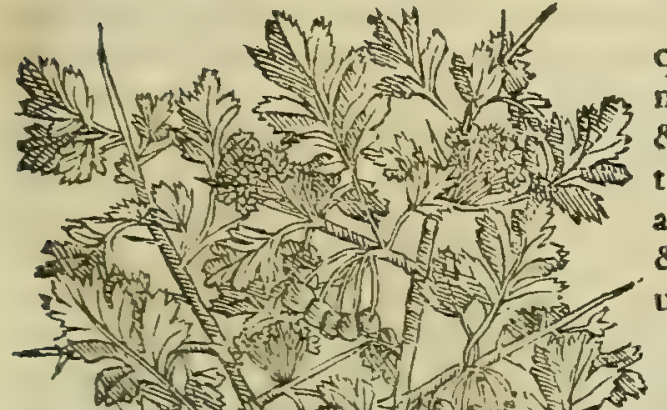

40

so

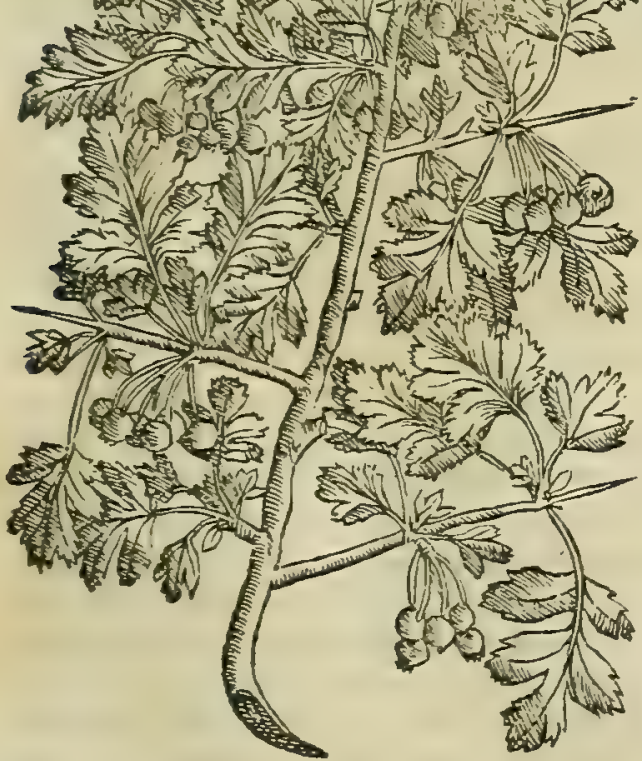

A C V T A fpina, quam pyrinam, aut pityanthem aliqui uocant, arbor eft pyraftro fimilis, fpinofa ualde, \& minor : baccas profert myrti, plenas, rubras, fragiles, $R$ intus nucleum : radicem multifidam, altè defcendentem. Huius baccx potu, aut cibo, alui profluium, \& abundantiam fominarum fiftunt. Radix illita aculeos, \& fpicula extrahit:abortum fieri tradunt, fi ter radice uenter aut fenfim feriatur, aut perungatur .

H А в E T procomperto tota recentiorum medicorum $f d=$ Acuex f pinse

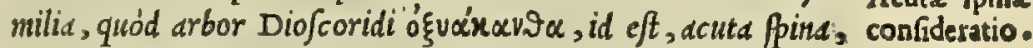
uocatd, quam Mauritani Berberim dixere, ed fit nimirum arbu= feula pinis horrens, quam rura Tridentind, ubi in Sepibus, jyluis, e conuallibus frequentisima nafcitur, Creßpino uulgó nomi= nant: medicorum ueró unlgus, ac officine Arabes fecute Bers berim appellant, ita effe certó credentes, ut opinione ducuntur . Veruntamen fi recté delineationes, notæó; perpendantur, quas oxyacanthe reddidit Diofcorides, crepini notis prorfus deuta Bina reclamare conftabit. Qua potißimim ratione adductus, quò magis ueritas cluceat, erroris $\dot{q}_{3}$ nebula tollatur, non dubitaui corum opiniones refellere, qui inter recentiores medicos de Atir. pibus commentaria confcribentes, Crepinum uocatum legiti= mam oxyacantham effe affeuerant. Neque me fugit, non parum fufcepiffe negotij, ut eos à concepta iandiu opinione in fententiame noftram, quam ueram putamus, uenire compellam, cum magne admodum fit tum medicorum, tum feplafiariorum turba, quxe bac in biftoria longo ufu aberrat. Verum cùm compertum habeam,

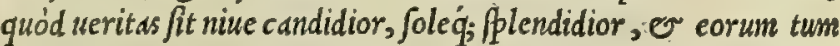
uera, tum fida comes, qui uirtutibus, $₫ c$ probitate preftant, duxi meas rátiones multorum auctoritate comprobatas, nullam horum doctißimorum uirorum auribus moleftiam allatus ras, qui nolentes aberrarunt: quinimo ijs, utpote weri defenforibus, fore iucundißimas, atq; gratißimas. Nam qui, ut fibi placeant, malunt errare quàin ueritati, o. equo cedentes, errores cognofcere, cosq́; corrigere, non funt in philofophorum, ac rationabilium hominum numero recipiendi. Sed ne apologeticis uerbis tempus conte= 
Acuta fpina ratur, rem inftitutam aggredior. Diofcorides acutam pinam arborem effe pyraftro fimilein fcribit, ininorein tamen, non eft offic. magis ; aculeatam, fiuctumí; gerere myrti fimilitudine, plenum, fragilem, rubentem, or intus nucleum, cui radi= Berberis, five ces Jubfint multifide, altéq; defcendentes. Ex quo palain eft, ipfum non aliss acute ppine notas expreßiffe, quàm Crefpinus. proceritatis, craßitudinis'́; , fipitis, ramorum, radicum, ac fructum, omiffa foliorwn, florum, $\mathcal{O}^{\circ}$ corticis biftos ria. Que omnia ip e accurate perpendens, in promis Crepinum omnibus notis pyraftro reclamantem comperio, cui tanen prorfus adfipulari acutam pinam Diofcorides cf auctor. Siquidem fylueftris pyrus, quemadmodum $\sigma$ oxyd= cantha, fimplex é folo profilit, atque unico duntax at caudice attollitur, ac inde tam in longum latumí; crefcit, ut ad communem arborum proceritatem affurgat. Crepinus ueró, cuius fané inmumere mibi pre oculis quotidie fefe offerunt plante, nullum ab radicibus mittit caudicem, fed pluribus, ac diuerfis aculcat is ftolonibus fruticat, qui uir= garum modo in altum fe attollunt, nee unquam arborefcunt, nifi raró, e longo temporis tractu: quippe qui omitiu maiores babentur, pollicarem craßitudinem rarißimé excedunt, nifi etate longa incrementum fufceperint . quin er rara inueniuntur eius uirgulta, que bominis longitudinem equent. Ad bec pyrafter cortice conft at afpero, fquas= mofo, inequali, craffo, colore in nigro rufefcente. Creffinus ueró cortice ucftitur albo, leui, er adinodun tenui: quo fit ut non adco leuiter ferro, ucl lapide tangi poßit, quin, tatim cortex frangatur, or crocea ligni materics de=: tegatur. Preterea pyrafter prunorum modo aculeata conpicitur, aculeis fingulis ex eodem loco crumpentibus,

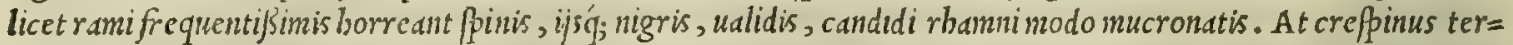
nis per interualla armatur aculc is, fimul ex uno, codem '́; puncto prodeuntibus, adeó ut trifurcato ordine prodeăt, duobus falicct utrinque fe pandentibus, tertio ueró medium occupante, albis, planis, non quidem rotundis, fragili= bus, or admodum pungentibus. Illudinfuper difcriminis addam, acutam pinam fructum afferre myrti magnitudi= ne. Crepinun ucró racenatim in una modun, cuius oblongi acini tritico pauló maiores, uiuidi, ac rubentes, ele= ganter'́; ruccnis adncxi, puniccos acinos quadántenus reprefentant : quanquam minores, oblongiores, dcidiores, Or colore etiam multó uiuaciores babeantur. Crepini dcinde folia mimmé pyraftrum reforunt, fed potius punicam nalum, quanuis latiora, nec adeó in mucronem de inentia, perambitum ppinis tenuißimis, frequentißimis $q_{;}$borri= da. Radices etian, qux profectó aqué flauxe funt, acficroco effent inficte, etfi piures fint, atq; 'exilcs; nibilo= minus alté non defcendunt, ueluti dcute ffine, fed in latus fummo cepite uagantur. Flos denique pyraftro admodum refragatur : nanque mclimus cx racemo ume fimili erumpit, fui frutic is interno colore, à quo dun explicatur, atq;

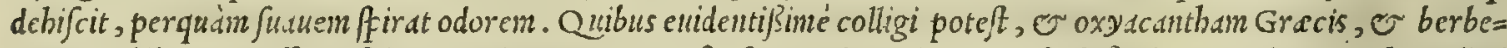
rim Arabibus non clfe crepinum, cuius ccmmunis eft ufus apud medicos, e feplafiarios. Sed praterbec illud eitiam certó credcidum eft, quódfi Diofcorides per acutam fpinsm creffinum intcllexiffet, nunquam filentio dißi= mulaffet folia mirabiliopere per ambitum aculeata: neque fructum, quen ramis pendulum gerit, acinis inter $\sqrt{e} 30$ racematim coherentibus, myrti baccis a Similafet : nec fcriptun reliquifet, radices in profundum agi : nec denique flauum earun colorem unquam reticuiffet, quo infigniter natura infict a funt. Non pretermififet etiam finarum blforiam, utpote que terne fuis uirgis inna feantur, à pede ad uerticcin: non corticis candorem, non tenuitatem: non itesn, quod fepius fine caudice, udrijs ueluti ftolonibus fruticet: non denique ipfnn pyraftro prorfus. fimilcm Legitima o. reddidifet, a qua profectó non minus dißidet, quàm quercus ab clea. Caterum fi modo dicendum eft, Oxyacan= xyacantha. tham nafci in Italia, cam equidem aculeatam arborem effe'credidcrim, ftipitc, cortice, ramis, floribus, proccritate, ac lignimaterie plané pyraftrum referentem, quam in Hetruriarura nofra Senenjia Bagaia uulgó nominant, Ana= nienfes, or cateri Tridentinarum uallium incole quidam Aimpcrlo, quidan ueró Pan d'or fo uernaculis nontinibus uocant, er Goritienfes Barazzo bianco uu! garifermone appellant : quippe que omnibus notis, ac lineis acutam pi= nam referat. Primim enim bac manfefto indicio effe poffunt, arboris filicet fipes, rami in qualibet parte acu= tißimis, firmisq́; aculeis armati, ligni materies, fubfcaber fquamoluśq; cortcx, ueluti pyraftro. Tum ita cffe com= probant radices in profundum defcendentes, \& fructus, quem fert myrticraßitudine, uifu iucundus, rubc $\int c c n s, p l e=$ mu, fractu facilis, ori fubaufterus, in quo modò unus, modò plures concluduntur nuclei. Flos ctiam, quen album edit, pyraftro admodum adftipulatur: quippe quod fit illibaud quaquam abfimilis. Porró folia duntaxat à pyraftrodif= fidere uidentur : nam diffecta funt apij modo, paululumq́; longiora. Verün milsi quiden illud non widctur ob multas rationes aliqux ex parte noftre repugnare fententix: conuenientias enim pluribus ex partibus peticertum cft, non autem ex paucioribus. Quali ergo ac uta pina uireat fronde, hic non explicauit Diofcorides; fed tantum dixit, edm cffe arborem pyraftro fimilem: quod magis ad fipitis, ramorun, corticis, florum delineationcm, or ligni materiem repiceret, quàm ad folia, que mhilominus lacintata conftant apij modo: tanet fi boc in loco id adnotare pratermife= rit Diofcorides. Hoc autem prebatur maniffto ipfius Diofcoridis, ac etiam Theophrafti teftimonio. Nam Diofcori= des, cum de mepilo ageret, duo mepilorum genera conftituit, or relicta in capitis calce uulgata, que frequens, $\sigma^{\circ}$ communis uifitur in Italia, illam in prinis defcripfit, que Neapoli noftra tempeftate unlg $\dot{o}$ A zinolo wocatur, er

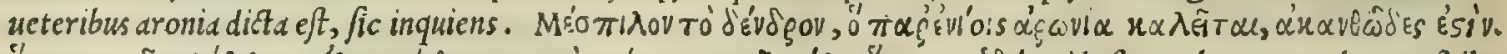

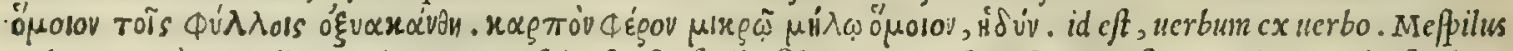
arbor, que à nonnullis aronia uocatur, pino $\int \mathrm{c} f \mathrm{t}$, fimilis folijs oxy.1cantha : frilt um frens exiguo malo fimilem,

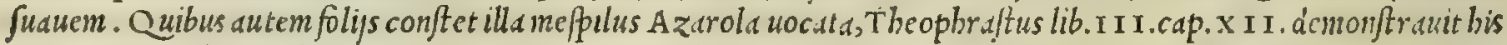
uerbis. Huius folia diffecta funt, extremutate ó; apio fimilia. It a fit, ut concludanus oporteat, $\sqrt{i}$ inepilus arcnia folio oxyacanthe prouent, cóg; faffo (ut Theoplirs/tus prodidit) apij inftar, banc frinofam arborem Bagaia uulgo di= ctam, effe procul dubio acutam fFinam. quandoquidem cius folia in modum apii diffecta funt, mc pili aronie modo. Theopbraftus lib.v I .cap.ultimo de hiftoria plantarum fcribit, oxy.cantha fruftum fuiffe antiquis in coronarum ufu. Quod etiam non paruo eft argumento, illan legitmam $\mathrm{c} \int \mathrm{c}$ oxyacantham, qualn in medium attulimus. Quandoquidcm 


\section{In Lib. primum Diofcoridis. \\ fructus cius, qui autumo toto, er ad nedism byemen $u \int q$; perdu=}

C.RESPINVS.

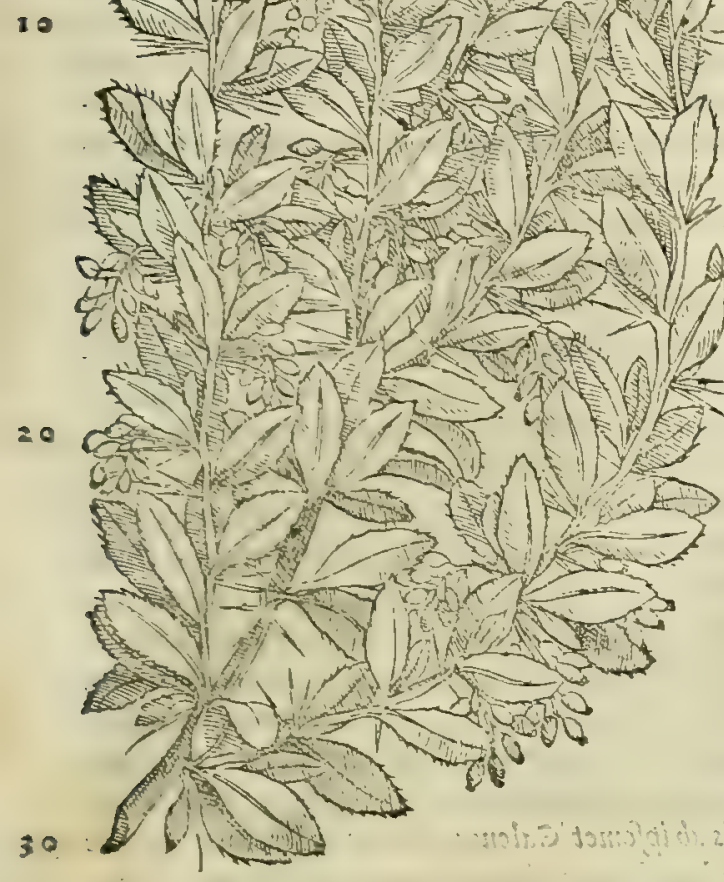

VVA SPINA.

40

so

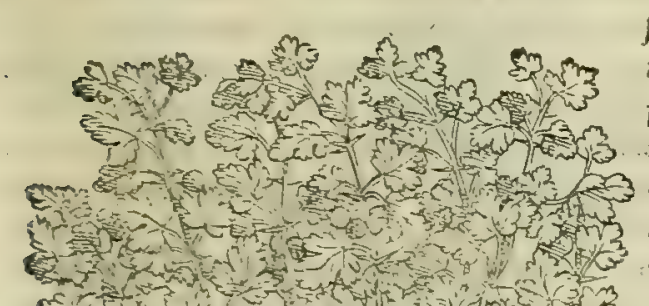

rat, adcó leuore quodam pellucet, ruborcó;; decoratur, ut globu= los e preftantioricor allio paratos referat: id quod in coronis ma= xime preftaffe crediderim. Hacc cf noftradc oxyacantha fentě= tia, in nobis fatis, ut arbitror, tum rationibus", thm anctoritatibus comprobata. Quan tamen quód infirmare uidcatur Thcophrafti auctoritus lib. I.cap. x v.e lib. I I I.cap. I I I .dc hiftoria planta = runs, ubioxy.teantha connuncratur inter exs arborcs, qux perpe= a tua fronde uirent, cium noftre folia decidant, non efi qui non faci= lé intelligat. Sed ego quidem non poffum buic anctoritati alioqui grauißtma affentiri, quin potius adducor, ut fupicer codicem ijs in locis deprauatum effe. supicion em nobis facit illud,'quod ibitie lia, myrica, quercus, er terebintbus fempitcrna coma prodantur. quod ut falfum deprebendetur ab omnibus, qui hifce plantis folia decidua effe obferuabunt, ita quo q; oxyacanthe contigife cogno=

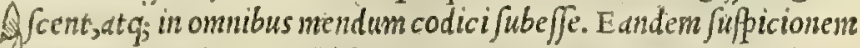

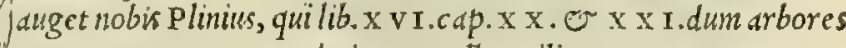
enumerat, qua perpetuó uirent, nullam tilite, nec quercus, neque oxyacantbe mentionem facit: attame is reliqua Theopbrafto acs ccpta referre poteft. Reliquuin igitur eft, ut dicamus, Creßpinum aliud effe ab oxyacantha, plantamq; ideo fuiffe ueteribus incogni= tam, quód corum nullussqui de plantarwin biftoria fcripferunt, bu= ius aculeate firpis (quod ego fciam) mcminerit. porró CRE= SPINV' frutex potius, quàm arbor eft, é terra uirgultis pluri= mis afjurgens, veluti corylus: é quibus non de funt, que quandoq; longo temporis tracting egré tamen, arborefcant. Heec ab imo ad

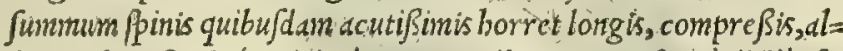
bic antibus, fractuq; minimé contumacibus, que (ut fuprd dictü eft) pex interualla terna $\mathrm{ex}$ eodem prodeunt puncta. Cortex toti plante candidus, la uis, ac teniuis : ciil fubcft ligini materies flaud, frugilis, at $q_{;}$fungo $\int_{a}$. Numerofis tota uirgultorum congeries ni= ticur radicibus impensé flawis, qua per funima ferr e diudgantur: folijs feré punice, tenuioribus tamen, latioribus, minus ó in mucro nem extcnfis, per extremum ambitum minutisinis pinis circumfe ptis. Flores emittit ineunte maio luteos, racematin coharentes in une fré moduss, odore non ingrato. Quibus.poftea fuccedit fras atus acinis oblong is, racemo pendulis, qui maturitate maximé rue bent, punice mali achinis baid quaquam abfimiles, quanquam figu= ralongiores, guftu acido, o fubauftero, paruis reconditis intus nu cleis. E' fructu polt uindemi is incole uinumexprimüt, quod falsó de Berberi uocant officine xui aufteritatis aciditatisó; longé plus ${ }^{3}$ ineft, quàm mali punice fucco. Quod fi in acutis, perniciofisóg; fer bribus, uti caufus, er qua peftilens ef, iulapio violaceo commiftu, ac.aqua egrotantibus exhibeatur, non modó fitim reftinguit, fed bilio as, peftilentesq́; exhalationes fupprinit.:Datur.utiliter cre= liacis, cibum reijcientibus, o dyfentericis, o ubibilis di iocinere in uentriculum regurgitans cholericos excitauerit affectus. Non fecus tame fumptum, quam ind itum menfium profluxia cobibet. Ti neas uentris enecat, prefertimfi bibatur exaqua graminis, uel por tulace, uel abrotoni, addito facchari tantillo . Prodeft cruentis excreationibus: firmat commotos dentes, fi eo fepius foueantur: quinetiam gingiuas roborat, et gargarizatu faucium, unu 'q; inflam mationes difcutit, dtq; deftillationes é confluentes reprimit. Vul nera recentia in carnis fuperficie glutinat, - ulcera uetera defico cat. Nibilominus nocet his, qui ex flatu; ac frigiditate laborant uentriculi doloribus, atq; etiä agré pirantibus. Ceterum poft $=$ quám acute pina hiftoria eó me deduxit, ut de nonnullis alijs ucu= leatisftirpibus differucrim, non erit ab re, ut plantarum facultas augeatur, fi illam addiderim plantam, que falio etidm ap iy conftat $t_{\text {i }}$ o undiq; pinis riget, abaliquibus V VA SPINA, à nonnullis Vua marina, er à pluribus Vua crepina wocata. Plenta hae anti-

Crefpinifor$\mathrm{ma}, 8$ uires.

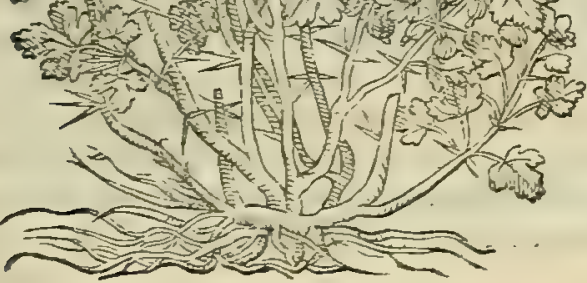

Vux fpine mentio. 


\section{6}

quis fortaffe incognita fuit, nune autem omnibus notior cft, quaim ut à me pluribus defcribi debcat. Huius bacce in ufu ciborum funt uux omphacis loco. Qux or fibricntibus iuf culis incocta non fine utilitate cxhibentur. In fumma mulieribus utero gerentibus magnopere expctuniur. Huic accedit 0 altcra planta ueteribus, quantum reor, in $=$

\section{RIBES VVIGARIS.}

Ribis officin. confid.

Errorquoiũdam.

Bellonij opinio improbat.

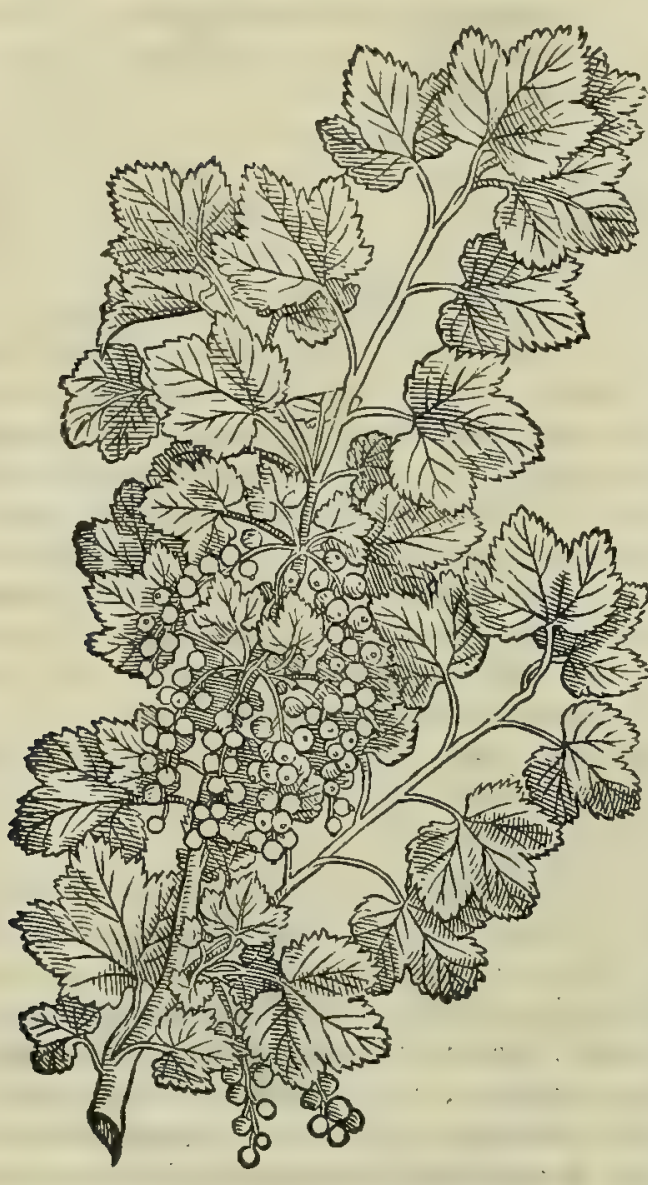
cognita o filentio inuoluta, quam aliqui falso Mauritanorum R I в E M effe contendunt. Ea fiutico $\int \mathrm{e} f \mathrm{t}$, folio paruo, zitugi= neo, perinde ac albe populo. Ramuli funt cilenti, acflexibiles: equibus fructus paruarum uuarum modo, ut in creßpino, racema tim dependent, rotundis, finul';; cohx rentubus acinis magnitudi= ne piperis, quimaturitatcin adepti, maximé rubent, fapore fuba= cido, adinifto etiă dulci. Vulgaris cft planta, in bortis ǵ frequens: 20 quippe quoniam ad f cpiendos hor torum puluinos eleganter fera= tur. Verim cosballucinari abunde conftat, qui putant, haine arbufculan effe Arabum Ribcm. Siquidem, ut pofteritatis memo rie prodidit Serapio, Ribes eft arbor proferens capreolos colore uiridi rubefcente, or folia lata, magna, er rotunda. Quas fanc notus buic non reppondere Satis notum eft: neq; enim fert beec ca= preolos, neq; eiufinodifolijs uiret . tamet fi fructu Ribem admodü referat, qucd is guftuifit acidus fimul $\sigma$ dulcis, qualem effe Ri= bis baccam alstor oft Scrapio. Quamobrem is ad ea, que ille iu= re poterit ufurpari, utpote quod febribus acutis opituletur, aftuā 20 tem uentriculum refigeret, , fitim reftinguat, naufeam or nomi= tiones ffftat, cibi appetentiam incitet, coliacos, $\sigma$ lientericos iu= $u$ et, e biliofis defluxionibus uexatos: fangninis feruorem demul ceat, bilis acrimoniam retundat, impetum $\dot{q}_{;}$domet. Quare non damnandi, quin potius laudandi uidentur cplafiarij, qui ex buiu= fce arbufcule fructu uinum exprimunt, e per annum afferuant. ut illud Ribis loco medic amentis immifceant. Non de funt, qui id effe banc plantam arbitrentur, quod Galenus lib. v I I. de compo fitione incdicament. fecundum locos Vrfi uuam appellat. Quo= rum error fatis ab ip fomet Galeno refillitur eodem loco: quando 30 quidem afferit buiufce uua plantam memacyli folio uirefcere.

Bellonio veró in libro de arboribus coniferis Ribes serapionis planta queddin cenfetur, quam fe inuenife fcribit in monte Liba= no ad fupremum cacumen, folijs oxylapathi, grandioribus retufio ribusq́; : é quorum medio racematim exeunt bacce rubistes, ut in hippogloffo, rufco, Oo lauro Alexandrina. At cer té cgo non audeo, nec polfum Bellonij iudicio fubfcribere, quod planta illa non reflondeat notis, quas Ribi tribuit Se= rapio. Ea enim folia non fert rotunda, fed oxylapathi, non babet capreolos, er baccas é medijs folijs exerit. Vnde fa= Oxyacanthx cilé adducor, ut putem eius Ribem falfam er adulterinam effe potius, quàm ueram o legitimam. Oxydcanthe me uires ex Gal. minit Galenus lib.v I I 1 . fimplicium medic amentorum, fic inquiens. Oxyacanthus, arbor ut pyro fylueftrifimilem ba

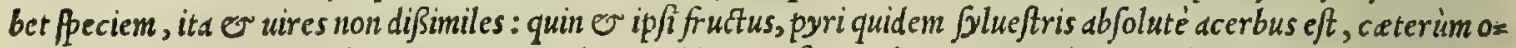
$x y$ acanthe, or renuium eft partium, or paulum quiddam incifium obtinet. Porró arboris buius fructus pyri fylue= fris fructui fimilis non eft, uerum myrtis, fcilicet rubens $\sigma$ rarus. Habet ueró $\sigma$ nucleos. Porró non efus tantuin,

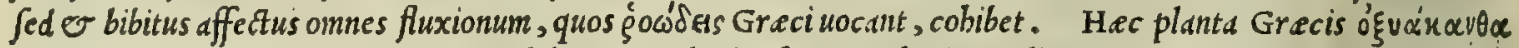
nominatur : Latinis, Acuta fpina: Arabibus, Amirberis, feu Amyrbaris: Italis, Bagaia, er Amperlo: Hipanis, Pirlitero, $\mathcal{O}$ Piliriteros.

\section{Kunóoßatos. RVBVSCANIS. CAP. CVI.}

F $\mathrm{R} \mathrm{V} \mathrm{T} \mathrm{E} \mathrm{x}$ eft arboris inftar; rubolongè maior. Folia fert multò latiora myrto, robuftis circa ramos fpinis, flore candido : fructu oblongo, nucleo oliuæ fimili, qui per maturitatem fulucfcit, $\& c$ flocculos intus continet. Fructus exemptis interioribus floccis arefactus, aluum fiftit: feruefacti 50 enim $i j$ in vino, mox puti, arteriam infeftant.

Rubi canis NON E QV I D E putauerim effe Rubum canis illud rofarum fyluefrium genus, que rofas edunt ijs quas confid. dántenus fimiles, quas Mofchette uulgó uocamus; quáq; rubentes baccar rofarum fructibus non abfimilcs, licet mino= res, proferunt: nec etiam quóduis aliud $\int y l u e f t r c$ rofarum genus, quemadmodum nonnulli exiftimant. Nam fi itares fe baberet, fat erat Diofcoridi dicere, quod canis Rubus rofe fimilis effet, non autem quód arboris inftar affurgeret, rubo longè maior, quód'́; folia ferret myrto latior a, a quibus fylueftris rofa profectó plurimum dißidere uidetur, fru= ¿tumq́; mittere non modó oliuarum nucleis, fed oliuis ip/is multó craßiorem. In eam autem fententiam non modó me pluries deduxit, fed etiam confirmauit Plinius : quandoquidem ip fe lib. v I I 1.cap. X I I. peculiari nosnine rofam fyle ueftrem cynorrbodon appellat, id eft, caninam ro $\int a m$, non cynosbaton, id eft, caninum rubum, cuius radicem ad cas= nis rabidi mor fum miris laudibus extulit . Quod iterum afferuit lib. x x v,cap. I I. ubi illud ctiam addidit, quód apud 


\section{In Lib. primum Diofcoridis.}

wetercs nil alind cyntorrlodon erat, quim ppongiola ills, que medijs fylueftrium rofarum ramis oboritur. Certerim cim de cynosbsto, hoc oft, caniruto idem differeret, eum à rofa fylueftri longè diuerfum fecit, ut uidere eft libro x X I I I I.cap. X I I I I. ubi ،it, cynasbston folio effe ucfligio bominis fimilesn. Huc illud etiam accedit, quod pofteris

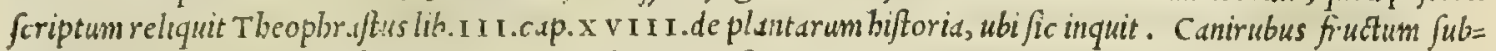
rubrum p.rit malo punico inilem: cst inter arboren o fiuticem medius, er punice proximus, folio uticis. Ex qui= bus palam cft, non parum inter fe habcre difcriminis canirubum, e fyluestrem rofam, de qua poftea libro o cap.v I. particularem tradidit biftorizm. vabicim primiun fatiuas rof as long a profecutus fuiffet or atione, de fylucftri ita pau cis differuit. sylusttres rof c domesticis apperiores tum uirgis, tum follijs conftant, o florem minus odoratum, minuif= que color atum, nec t.ant.، m.tgnitudinc frrunt. Qulare pro comperto habetur, aliud genus effe rofam fylucftrem à cd=

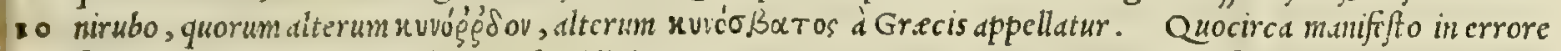
fuiffe deprehenditur Marcellus Diof coridis interpres, o commentator : quippe qui idem effe crediderit cynosbaton, ov cynorrhodon, non animaduertens, quìm illa inter $\int_{c}$ dißimulia ficerit Plinius fibi familiarißimus. Hunc for fitan fe cuti Monachi in Mefucm foribentes, infi quog; in cundem lapfun inciderunt, credentes fylueftrem rofam legitimun effe canizubum. Quibus prestcrea animo exciderat, Diofcoridem fcripfiffe rubicanis fructum oliuarum nucleis cffe fimilem: quandoquidem ipfi illun pyris compararunt. Ex quo aliquis facile iudicabit, bos nullam canis rubi cognitio nem babuife. Ad bee non reperio, quód dixerit Diofcorides, canis rubi fructum femen aliquod includere, quo tamen rofarum fylueftrium finctus refertus inuenitur : (cd lanofum quoddam continere dixit. Accedit bis serapionis aule thoritas, qui de canino rubo inter alia rubigenera egit, non autem inter rof as : quod omnino compertum baberet, büc à rofis quim plurimuin differre. Illud infuper addiderim, quód cim rofe fylueftres feré onnes non leuiter ex albo so purpurefcant, cynosbato ueró flos perpetuó fit candidus, non eft legitumé afferendum, fylueftrem rofam effe cynosba ton. Ex ijs igitur omibus fatis (ut arbitror) liquet, canirubun a fylue/tri rofa longé abcffe: tantó́; magis, quòd me morie prodiderit Theoph. lib. $v$ cap. I x. de plantarum hiftorix, canina fentis fructum auerfo flatu colligendum ef = fe, alioqui periculum oculis imminere. Quod aperté demonftrat, fuper eo uel tenuem quandam lanuginem, uel quid pulucrulenti infidere, quod fi a uento expellatur in colligentium oculos, facilé ijs cacitatem inducat . quod tamen in jylueftriun rofarum fructibus nunquam uifitur. Meminit Rubi canis Galenuslib. VII. fimpl: medic. fic inquiens. Rubi canis ui Huius fruticis fructus, non fegniter adftringit, folid ueró mediocriter. Itaq; particularis eius ufus baud ignotus est. res ex Gal. Cauendum ab eo, quod in fructu eius lane peciem babet, ceu arteria infestum. Frutex is Gracé nvvóo $\beta \alpha$ tos uo catur : Latiné, Rubus caninus : Arabicé, Sent: Italicé, Rouo canino.

Nomina.

Marcelli, \& Monachorü lapfiss.

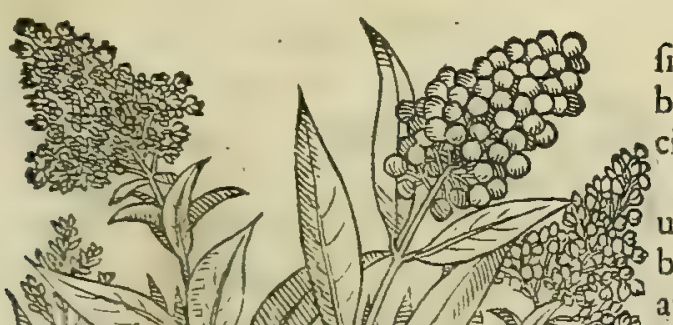

L I G V S T R V M arbor eft olex folijs circum ramos fimilibus, latioribus, mollioribus, \& colore uiridioribus : Alore candido, mulcofo, odorato: femine fambuci, nigro. Optimum nafcitúr in Canope, \& Afcalone. Folia aftrictoriam uim habent : quare commanducata ulceribus oris medentur: illita feruidis inflammationi-) bus, carbunculisq́ue profunt: decocto eorundem igni ambufta fouentur : capillum rufant trita folia, qux in ra diculx fucco maduerint. Flos ex aceto fronti illitus, capitis dolorem fedat. Cyprinum oleum, quod ex eo fit, odoratum, excalfacit,emollitq́ue neruos; fi quxe feruen; ti natura prædita fint; affumat .

L I G V S T R V M in Hetruria Guistrico corrupta uoce Liguftriconuulgus nof trum appellare confuevit. Quod inibi.etiam aliqui Oli $=$ fideratio.

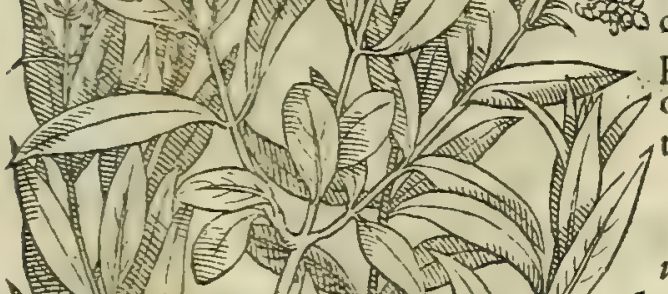
uetta, nonnulli oliuella, quidam Chambroffene uulgo uocant. Mauritanis ueró A canna nominatur. Nafcitur frequens in Sepi bus Secus uids pa Sim in Italia. Floret abeunte vere, e ineunte eftate, flore mufcofo, uel (quandoquidě Oribafiuslegit Botgu $\omega^{\prime}=$

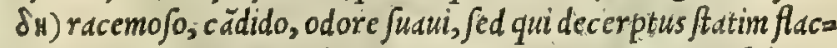
cefcat. Oriuntur ex eobaccae in cacumine racematim coberen= tes pyramidis modo, heder e baccis minores, leuiores, ac nigrio= res, quarum in medicamentis eft ufus. Sunt qui bas baccas di Virgilio, uacinia uocari putent. Sed meo quidem iudicio non re= Aè plané fentiunt. Quemidmodum nec Fuchfius, qui rubi mora, quoniam Grecis bár two, iacinia effe putat: : Iqquidem udcinium florem, non fructum effe pluribus conftat. Ceterum in nothis Diofcoridis ftirpium nomenclaturis legitur, byacintbum uaciniü Romanis fuiffe uocatum. Ex quo facilé crediderim, uacinium Virgilio nil aliud defignare, quàm hyacinthum. Neq; mirum eft, quód virgilius bydcinthum uacinij nomine nigrum appallauerit: nam byacinthus facile cum uiolis colore purpureo certat, purpureus autem color à compluribus ni= 
ger intelligitur. Hane noftram fententiam comprobat Virgilius: quippe qui femper uacinid floribus admifcet, ijf demá; cöparat, non autě fructibus. Quod manifefté declarauit in Bucolicis, ubi de uacinio fic cecinit,promió Eclog. II. Alba liguftra cadunt, uacinia nigra leguntur. Deinde in eadem.

Mollia luteola pingit uacinia caltha. Itemin ultind.

Et nigre uiole funt, er uacinia nigra.

Marcelli opi- Nec placet prsterea Marcelli opinio, qui pluribus comprobare nititur, uaciniü effe Irim. siquidem praterquàm nio seprob. quód nunquam legerim Irim in coronis uenIfe, color non aqué prompté correßpondet, quód uarius adeo fit, utinon aliunde fibi nomen comparaucrit, quàm à celeftis arcus colorum uarietate. Adde etiam, quód cùm Irid is flos omnium fragilißimus caducißinusó,; fit, poëta nullo pacto bunc liguftro pratuliffet. Quidam Liguftrum cam conuoluuli pecciem effe auiumant, que fepibus, fruticibus, ev arbuftis fe circumuoluit, ac etiam fapius uttium palis in uinetis, flore candido, lilij, feu calathi effigie, quam ego lenem effe fmilacem nunquam dubitaui. E' quorum numero fuit Seruij Gram. Seruius Grammaticus Virgilij commentator Ecloga fecunda Bucolicorum. Nempe falfus (ut arbitror) quód negle= laplus. $\quad x$ erit in hac biftoria Plinium confulere, Diofcoridem, or alios de ftirpium natura differentes. Non defuerunt etiam qui exiftimaucrint liguftrum effe Mauritanorum caprifoliuin, quod fané nil aliud cft, quim Diofcoridis pyxacantha,

Liguftri uires feulycium, non autempericlymenon, ut Rucllio placet. Sed sffi quoque di ueritate defcifcunt. Liguftri meminit ex Galeno. Galenus libro v I I. fimplicium medic amentorum, fic inquiens. Cypri feu liguftri folid, fumnà; germina in ufum ueniunt, o facultatis, $\odot$ temperamenti maximé mifti: babent enim quiddan digerens cum aquea fubftantia modi cé calida, habentó; etiam adftrictorium quiddam ex terrena fubftantia frigida. Itaque eorum decocto quidam am:bufta fouent. Vtuntur ucró etiam aduerfus igneas phleginonas, er carbunculos. Nam abfq; moleftia er mor fu deficF cant. 2uinetiam ponté prouenientibus in ore ulceribus aphthodefi, er ipfis pucrorum aphthis commanfa accom=

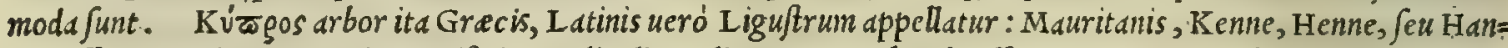
ne: officinis, Alcanna: Italis, Guiftrico, Oliuella, Oliuetta, o Chambroffene: Germanis, Rbeinuuciden, Beyne boeltzlin, 0 Mundholtz: Hipanis, Alfena, fiue Alhena: Gallis, Dutroefne.

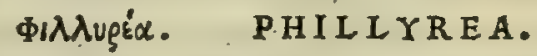

CAP. CVIII.

PH I L Y Y R A arbor eft liguftri magnitudine, folijs olex nigrioribus, \& latioribus : fruetu lentifci, nigro, fubdulci, racematim cohærente . afperis nafcitur. Huius folia aftringunt:ad eadem utilia, ad quæ oleafter, cùm aftrittione eft opus : maximè ad oris ulcera commanducata, aut fi decoAo colluantur : pota vrinam, ac menfes cient.

PHILIYREA.

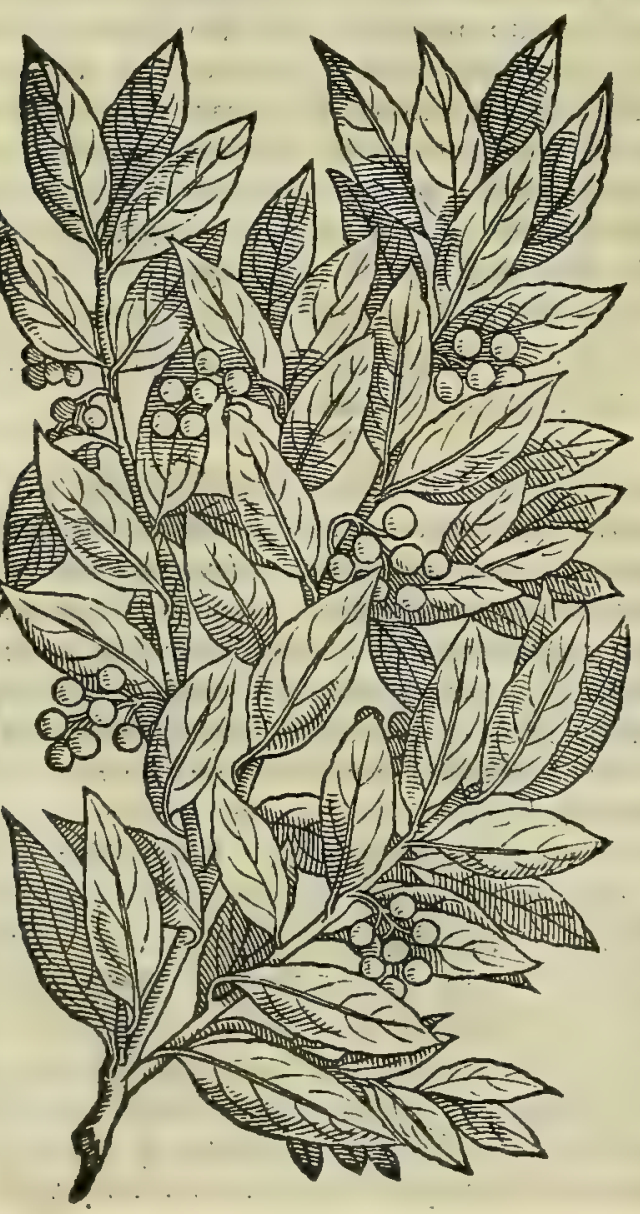

T I I I A.

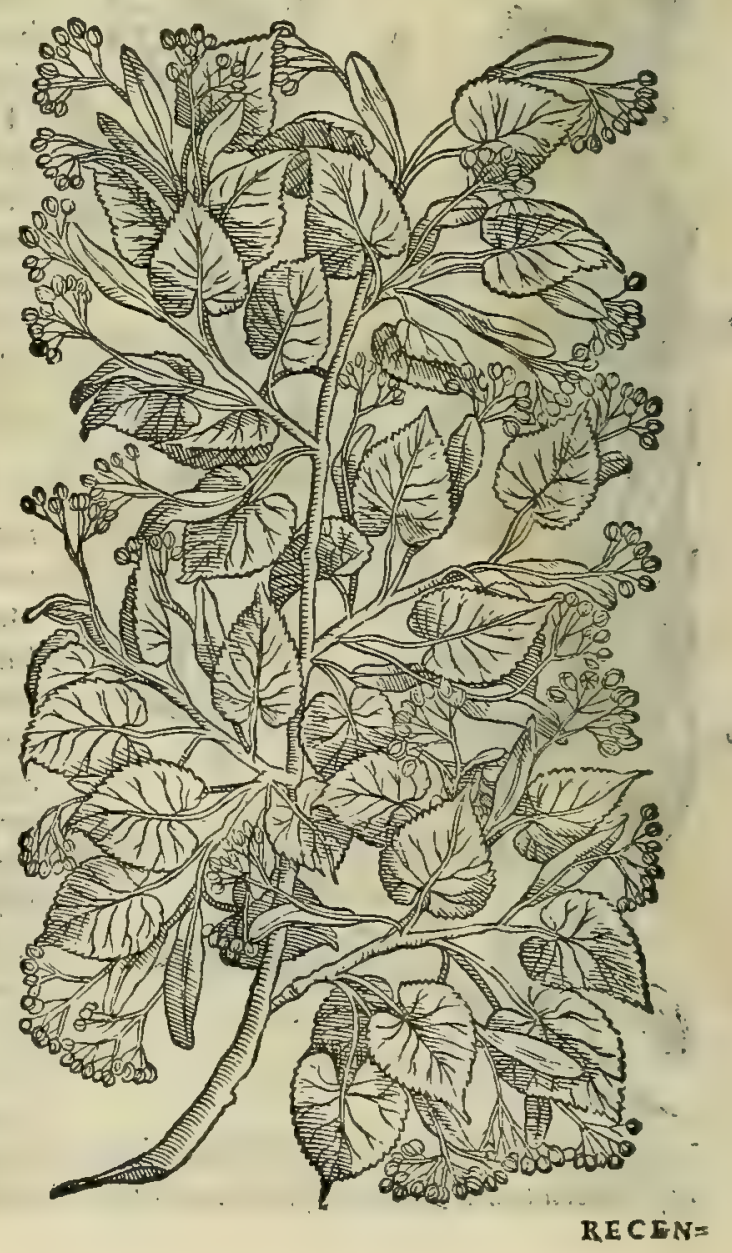

40 


\section{I20 And. Matthioli Comm.}

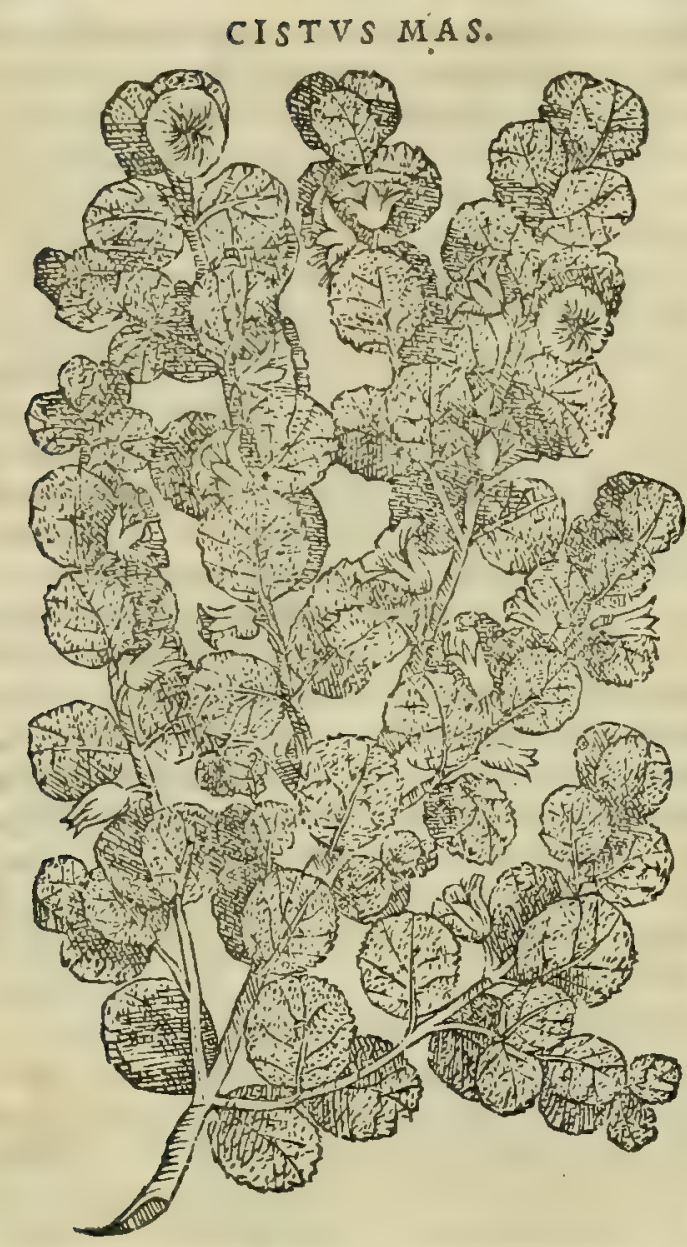

CISTVS FOEMINA.

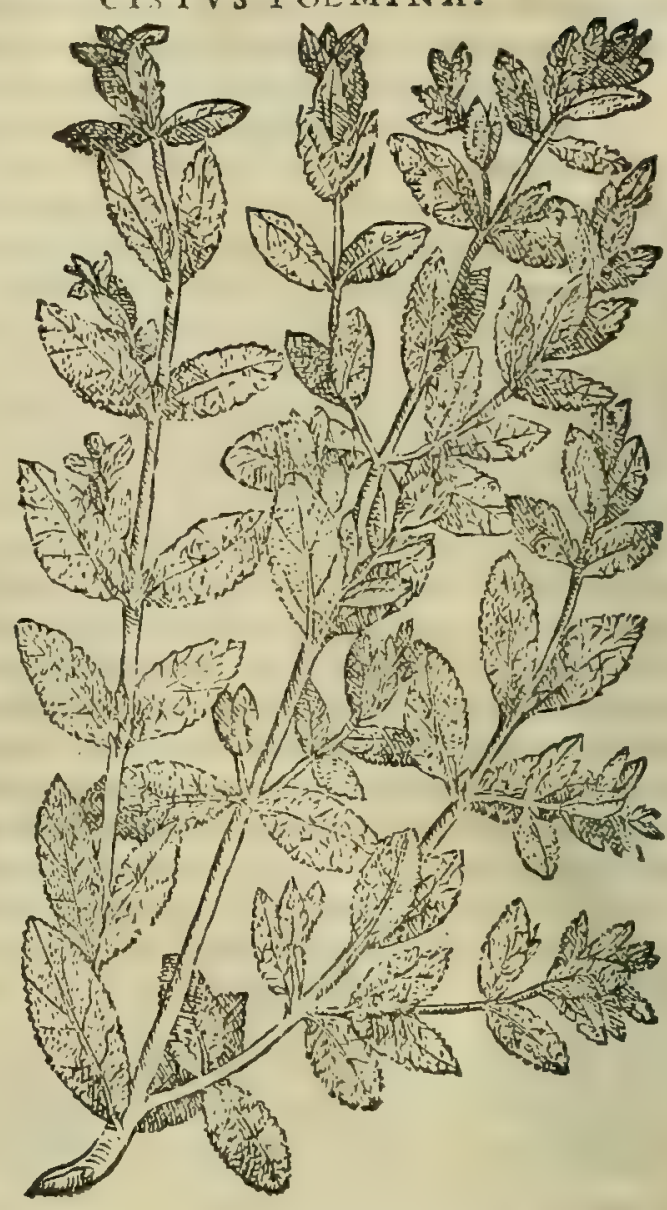

HYPOCISTIS.

Fuchfijerror.
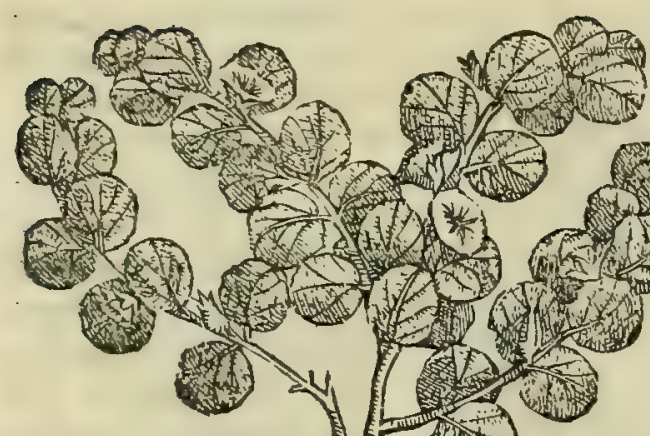

sim (1) $x^{2}$ *
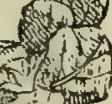

\section{is}

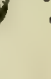

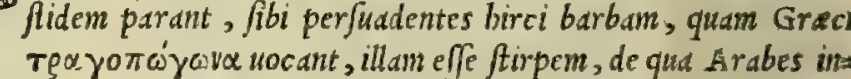
wo wocant, tllant effe ftirpem, de qua Arabes in teligunt. Quo errore ducti non modó feip fos decipiunt, fed eti. alios, qui paßim adulterina by pociftide utuntur. Atqui Fucb= fius in libro de componendis medic amenti s,quem fecundó edidit, ubi paftillos ex fuccino perpendit, non fine magno errorè (pace uiri eruditi dixerim) putat by pociftim fungum effe. Q Landoquz* dem by pociftis non fungus eft, fed uelutigermen, quod è ciftiras dicibus pullulat, effigie fre punicorum cytinos reprefentans, ut optimé fciunt ij, apud quos cifti flantes copiofe proueniunt.

Hypociftidis locum fupplere acaciam tradidit Diofcorides, ut so etiam babetur in Galenic is fuccidane is : qua illius uice uti poffent officine, /i modo e $\sigma$ eacareret adulterio. Poteft etiámum, $\beta$ defit bypociftis, afjumi cius loco floris agreftis punica fuccus: quippe qui cadem preftet, qua bypocift is, auctore Diofcoride.

Plinius deceptus uocabulorum germanitate inepré fritis, meo iu dicio, commifret cifti, or cifi hiftoriam: quamobrem non imme= ritó eum damnauit doct Rimus Leonicenus: Ciftimeminit $\mathrm{Ga}=$ lenus lib. v I I. fimp.medic. fic inquiens. Ciftus, aut Cift arus frum tex cft guftu adftringens, omnibus q; particulatim operibus. At

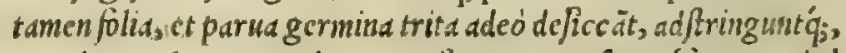
ut uulnera glutmare ualeant. At fiores magis funt efficaces,adeo 
ut culn uino poridy enterias, ucntris imbecillitates, fuxusif, ac bumiditates fanent: cataplafmatis rituillita ulce:

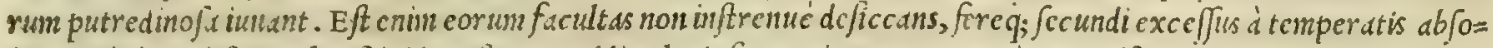
Iuti. Adeó ucró frutex buc frigidus eft, ut tepidicaloris fit purticeps. Porró Hypociftis, quam nocant, multó eft. magis adfrictoria, quim folli, admedun cfficax remediun ad onnes fluxionum affectus, puta anguinis rciectiones,

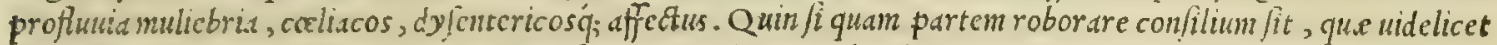
plufculo humore exoluts fucrit, robur, ac firmitatem illi non imbecilliter addit. Sic fane ftomachic is cpithematis, bepaticisq́; commif cctur, or ex uiperis confecto antidoto inditur, nimirum quó corpora confirmet, ac roboret.

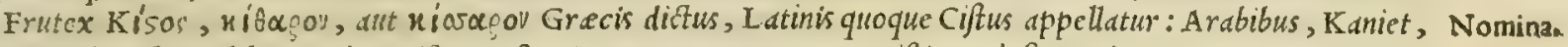
Althets, feu Lhate althis: It dis, Ciflo: Hefpanis, Cerguacos. Hypociftis ucró fic L atina noce, quemadmodum. - vंwousis Gracé dicitur: Arabicé, Taratith: Italicé, Hipocifto: Hipanicé, Pultegras.

t Hec diftio non ligitur in Grecis codicibus. Sed eam huc ad clariorem(ut puto) fenfun ex Plinio tranftulit Ruel lius : quód uerbun illud à Diofcoride ftudio fortaffe brenitatis omifum, fatius addendun effe duxerit, quaim fubintel= ligendun . quod etiam Hermolaus fecit.

+ Nil mirum effe debet, quód Plinio duo tantum bypociftidis genera prodintur, coloribus rufo, or candido diftin=

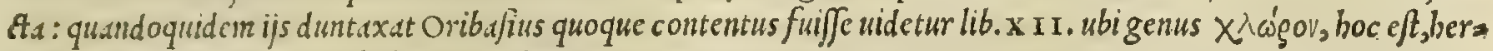
baceum, ut uulgaticodices habent, non legutur.

$\Lambda \tilde{u} \delta$ V. LEDVM.

30
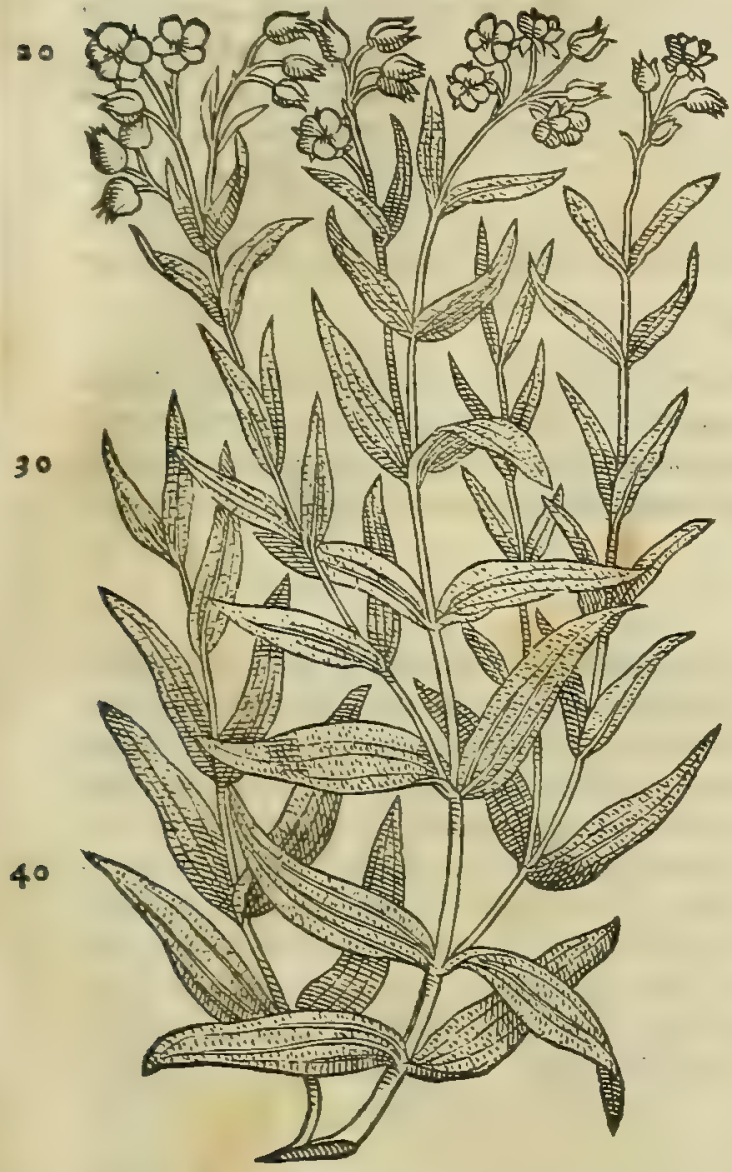

\section{$\triangle \alpha ́ \delta$ avov. LADANVM.}

CAP. CX.

E S T E T alterum cifti genus, Ledon à nonnullis appellatum, frutex fimili modo nafcens, longiorbus folijs, \& nigrioribus : quæ verno tempore quiddam cótrahunt pingue: Foliorum uis aftringens, ac eofdom, quos ciftus, effectus præbens. Fit ex eo quod Ladanum dicitur . frquidem cùm cifti frondes pafcuntur caprx, hircique, pinguitudinem confpicuè barba carpüt, \& fuo lentore uillofis cruribus adhxrefcentem reportant: quam depećtentes incolæ, colantesque cogunt in offas, \& ita recondunt - Alij uerò attractis funculis, infidentem fruticibus lentarem abftergunt;conglomerătquéin ladanum . Maximè probatur odoratumin, fubuiride,facilèmollefcens,quod arenas nô collegit, nec fqua lore obfitum eft, refinofum, quale in Cypro gignitur. Arabicum uerò, Libicumque ùilius v Natura ei fpiffan di, calfaciendi, molliendi:ora uenarum patefacit: capillum tuentem continet, addito uino, myrrha, \& mvrteo oleo: cicatricibus decorem reddit, cum uino illitum : medetur aurium doloribus, cum hydromelite, aut rofaceo infufum: fuffitu fecundas eijcit: pefsis immiftum uulus duritiem fanat. In medicamenta, quæ aurium dolorem, tuifsimq́ue finiunt, \& malagmata utiliter inferitur:aluom filtit cum uino uetere potum, \& urinam ciet.

L A D A N v M, quód uulgó alij appellant Laudano, alij ueró Odano, tametfí plerung; impoftorum malitia adeó fabulo, $\mathcal{O}^{\circ}$ alijs adulterijs fit uitiatum, ut nibil ualoris preftet; ego ta= men preftantißimum fepius Venetijs emi ab unguentarijs, qui odoramenta conjzciunt. Verim apud pharmacopolds, quimedicamenta nobis parant, Ladanum, quod fyncerum, purum q; fit, rarijisné reperitur : cum corum plurimı potius curent, ut rem minoris emant, qudm ut feligant legitima 50 abadulterinis. quod tamen inıqum est, inhumanum, ac deteftabile crinen. Arbufculd, é qua Ladanum colligitur, Ledum appellatur, ev inter cift genera recenfetur. Ceterim Plinius uocabulorum uicinitate deceptus (ut etiam Plinij laplus. in fiperiori commentatione dictum eft) ex ciffo, id eft, hedera, non autem ex cifo ladanum colligi dixit. Ex quo item multis falsó perfuafum eft, quíd non à cifto, fed ab hedera Ladanum legeretur. De Ladano plura memoria pro= didit Galenus libro v I I. Jimplicium medicamentorun, fic inquiens. Ciftus, dut Ladanum. In calidioribus regionibus bic Ciftus proucniens, tamet/i haud alius fit genere, quim qui apud nos nafcitur; eximium tamen à regione; ac peculiarem, digerentem 'q; caliditatem nactus eft: atq; utroq; à noftrate differt, tum quia frigiditatem depofuit, tum quia calorem alfimp/it. Itaq; cetera quidem buius cifti, illis que in noftrate uifuntur, fimilia funt. Verim Iadanü; quod uocant, ex eo prouenit, medicamentum primo exceffu iam quodammodo completec calidum, ut uidelicet $\boldsymbol{\sigma}_{\mathrm{r}} \mathrm{fe}=$ cundum attingat, babens etiam adfrictionis paululum. Ad bac fubftantia tenui, ac proinde emolliens, fiue maldcti=

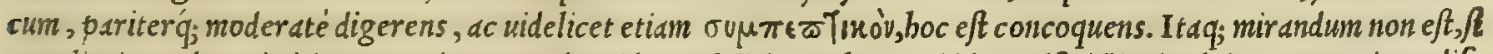
peculiariter ad uteri vitia conueniat: quandoquidem ad dita paulum quiddam adftrictionis obtinet. Quocirca dif:

Ladani contideratio.

Ladani uirés ex Galeno. 
fuentes capillos retinet. Nam quicquid ad radices cor ü praui humoris federit, id omne abfumit: tuin meatus, quibus infixi funt, contrabit, o constringit adstrictione. Caterum alopecias, O ophthalmias fiue lippitudines, fanare non poteft, utpote magis difcufforias uires, quàm qua Ladano infunt, pofcentes. quippe proueniunt be ex prauis fuccis,

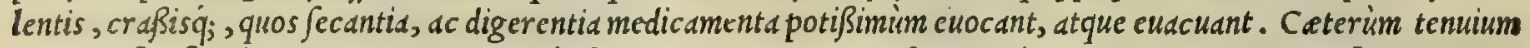
partiun fint facultatis oportet, $\mathrm{er}$ minimé aftringentis : non tamen ufque adeo tenuium partium, or deficcatorix, ut nimio plus deficcent, unaq́; cum collect is inibi fuccis preter naturam, naturalem quóg, bumiditatem incrementa pilis Juppeditantem abfumant . nam fic non tantim alopecialiberabunt, fed caluiciem afferent. Sed bae ad curandi

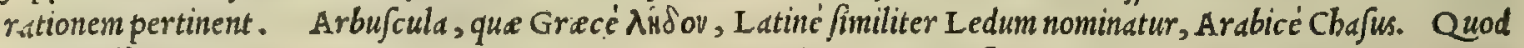
ueró $\lambda \alpha \dot{\delta}$ avov Graci, Latini item Ladanum uocant: Mauritani, Ieden, fiue Laden: Itali, Laudano, er Odano: Hipani, Xara.
E'BEVOS.
E B E N V S
CA P. C XI.

E B $\mathrm{E}$ v s optima babetur Ethiopica, \& nig'a, nullos habens uenarum difcurfus, factitij cornus dxucre:cùm frangitur, denfa apparet, mordens guftu, atque aftringens. Suffituriucundo odore fupra carbones, fine fumitxdio. Recens autem ad ignem prolata, ob pinguitudinem accenditur, \& trita ad cotem rufefcit. Altera eft Indica, internatis fegmentis candicantibus, \& modicè fuluis, item frequentibus maculis . cæterùm prior bonitate antecedit. Apudquofdam fefamina, aut fpinea ligna conlimilia pro ebeno uæneunt. Quod difcernituri cxeo, quòd fungofa funt, \& in purpurcas affulas refoluuntur, nihil mordacitatis in guftu, nec redolentia in fuffitu præferentia. Caliginem oculorum abfterget: ad ueteres deftillationes, puftutasq́ue mirum in modum pollet: fi quifpiam facta ex eo coticula collyrijs utatur, melius proficiet. Ad oculorum medicamenta efficax eft , fi fcobes, ramentáue uino Chio die, noctuque macerata, in colly ria digerantur. Nonnulli præterita ipfa excolant. reliquaq́ue eundem in modum peragunt. Alij pro uino aqua utuntur. Vritur in fictili nouo, donec in carbones redigatur. Lauatur plumbi ufti modo, \& ita ficcis, fcabrisq́ue lippitudinibus conducit.

Ebeni confi- CREDIDIT Theopbraftus in India tantim nafci Ebenum libro I I I.cap. v. de biftoria plantarum, ubi fic deratio. babet. Ebenus quoque eius regionis uernacula eft. Huius duo genera conftant : alterü materie laudatum, pulchrum $q_{j}$ : alterum uile, e uitiatum. Rarum, quod praftantius : reliquum permultum babetur. Colorem commendatum, non 30 recondita, fed ftatim fua natura cape fcit, hec Theophrastus. Quodetiam fenfiffe uidetur Virgilius in Georgicis li bro Ix, itacanens.

\section{Sola India nigrum}

Fert ebenum, folis eft thurea uirga sabeis.

Plinius etiam lib. X I I. cap. I I I 1 . Ebenum nufquam alibi, qualm in İndia nafci fcriptum reliquit: nec eam tamen In= diă uniuer fam mittere, fed exigua fui parte gigni, prater quodda fruticofi genus cytifi modo, in tota India difper fum. Herodotus ueró (eodem auctore) Ebenum Aethiopiam folam frrre intellexiffe uidetur: quippe qui de Indica nullam fecerit mentionem. Veruntamen ex boc Diofcoridis capite paldm eft, nafci Ebenum in ambabus his regionibus. Indi quidem non nifi ex ebeno Deorum fimulacra fingunt, regesó; ex co tantum fceptrum fumunt. Item poculd, craterasq;

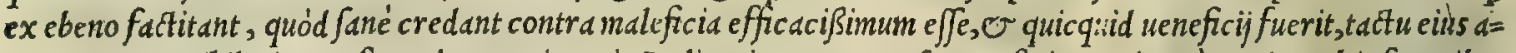
uerti. Itaque nibil mirum, fi quod peregrinum in Italiam importatur, fummo fit in pretio, cuin etiam ab ipfis, quibus prouent, maximo honore habeatur. Ebenum ex India Rome prinum magnus Pompeius Mithridatico triumpho $0=$ ftendit, cuius materies denfifßima omnium constat. Quo fit, ut quanuis multis annis exare $f$ cat, non fluitet in aguis, fed tota mergatur. Ebenificcatos truncos maximé bac atate nouit Italia: nanque imumeri uifuntur in eorum offici= nis, qui pectines conficiunt ad explicandos, aptandosój; capillos: item q́; apud illos, qui globulos funiculo traijcien= dos ad mulierum preces numerandas torno in orbiculos expoliunt. Ebeni uires fcripfit plinius lib. X X I I I I. cap. $\mathbf{x}$ I .bis uerbis. Non omittam propter miraculum ebenum. Scobem eius oculis unicé mederi dicunt : lignóg; ad cotem trito cum paffo caliginem difcutit, ex aqua ueró or radice albugines oculorum. Item tujsim pari modo cum melle,

Ebeni uircs acdracunculi adiecta radice. Ebenum medici $\sigma$ inter erodentia affumunt. Ebenimeminit Galenus lib.v I. fimp. ex Galeno. med. fic inquiens. Ebenus ex ijs lignis eft, que trita cum aqua in fuccum foluuntur, ut lapidum nonnulli. $v$ is ci ineft ex= calfaciendi, extergendi, e tenuium partium. Quamobré qua pupillas offufcant, extergere.creditur : mifcetur alijs re medijs ocularibus, qua ad ulcera ueter a, fluxiones, er bullas, fiue puftulds accommoda funt. bactenus Galenus. Sunt

Guaiaci con- qui lignum ex Indijs petitum, quod quidam G VA I A CVM,nonnulli Guaiacanum, pleriq; ueró Lignum fanctum ap= Gderatio:: $\therefore$ pellant, cuius aduerfus Gallicam luem praciptus cft ufus, ebenigenus effe crediderint. Quod quidem nec afferere, nec negare aufim : quandoquidem nufquam inuenerim apud quenquam tum ueterum, tumrecentiorum friptorum, quas frondes, quos flores, quosq́; fructus profer at ebenus : Illud tamen omnibus perpicuum eft; Guaiacum nibil, nifi funma nigritia, ab ebeno dißidere, que in boc fummo fplendore nigric at, in illo albefcit: cateris uero qualitatibus id maximé cum ebeno certat. Tria ad nos Guaiaci generd afferuntur, ut in fuis Epiftolis doctißimé annotanit Manar= das Ferrarienfis : quod or nobis iandiu plané compertum eft, cum hec omnia dà pius nobis pre manibus fuerint. Pri $=$ mum itaque genus craßiori, uegetioriq; mole conftat, quo refecto materies apparet interiore parte nigra, exteriore ueró Jubpallida, or ueluti perplexis line is quibufdam ad fufcum tendentibus per. longum interfecta. Alterum caudice 


\section{In Lib. primum Diofcoridis.}

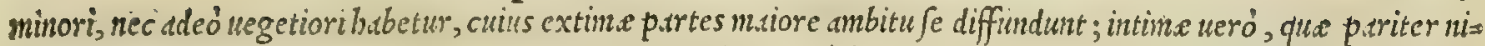
gric ant, minore fatis orbe concluduntur. Tertium, quod propric fanctum appell ant, caudice cateris exiliore uifitur, intrinfecusq; O extrinfecus albicants, cuius materies lincis admodum cxilibus in longum actis perplexé diftinguitur: eft'́; boc longé catcris o acrius, or odoratius. Catcrim credcndum non eft ciufmodiligna, et $f \hat{i}$ colore, magnitu=

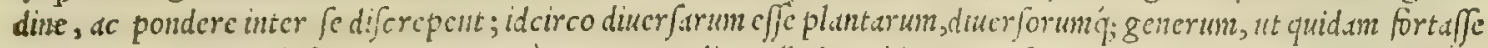
existinant. Nan quód boc tam intus, quam extra candicet, llud ucró interiore fui parte nigricet, nit, quàm quod hoc magis, illud ucro minus adoleucrit, uel confenterit. (2uipe co fané nigrius cernitur lignum Gusixcum, quó ad m.turiorem atatcm peruenerit arbor, a qua decifun fuerit: Oo per confequens tantó magis al= bum apparet, quantó minus adolcuerit illa, quemadmodum conpicitur in nofrris nonmullis I tallid arboribus, Or pres=

20 fertim in moro, nuce, or an.gyri. Veruntamen illud cuique perfuafun fit, etatem uni plus, quain alreri uirium ad= dere, ac demere. Quade re uerba facturi, dicamus, cimnillud, quod plane omni ex parte albicat, odoratius, $a=$

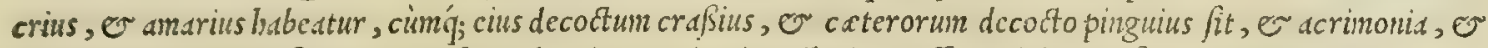
amarore adnodum refertum, ut ipfane docuit cxpcricntia, nil minum effe crediderin, fi ineo, utpote iuniore, uis

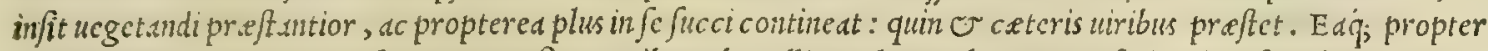
putauerim cgo, boc illis in ufu perpetuo fore, quibus ob Gallicam lucin ulcera emerfcrint dep. afcntia, contuma

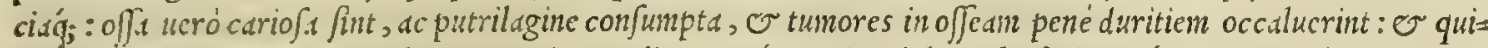
bus denique perpetuus articulorum cruciatus, diuturnusq́; capitis dolor inbe ferit, coó; magis, quò paticns in= nior cxttterit, fortior, or ntura robuftior. Huic illud fuccedere exiftimamus, quod medium obtinet locum: fi= quidem hoc $\circlearrowleft$ odoratius eff, or acrius eo, quod nigrius, ac craßius inuenitur: neq; illud quidem ab re, quandoqui=

20 dem idminus cf atate confectum, e maiore bumoris copia redundat. Quocirca commodißimé boc utipoterunt, quinaturadelicatiores funt, or temperamento inbecilliores, atque ctiam ij, in quorum artus buiufce luis furor nondum graffiri capcrit. Poftremo illud nunus cateris praftat, uiribusque infirmius babetur, quod nigrius, craßius, or ammolius reperitur. Nanq; quelibet confene fcens planta (quemadnodum ctian cunctis animalibus $e=$ uenit ) continuó cxare cit, bumidóg; priuatur. Cuius rei certißinum cft argumentum, quód in annofarum arborum trunc is inior appareat nigredo, quim in alijs ucl iunioribus, ucl atate tenellis: nigrcdo enim ficcitatis indicium eft, quinetian depcrditi caloris innati, o bunidinaturalis: id quod tam in plantis, quàm in animalibus locum babet. Ni= bilo tamen fecius illud diligenter animsducrtendum eft, quód Guaiacum albicanti prorfus colore preditum, recens, incorruptumq; it: quippe cum ceteris exilius fit, citius ac facilius exarefcit, or ob bunoris redundantian uelocius

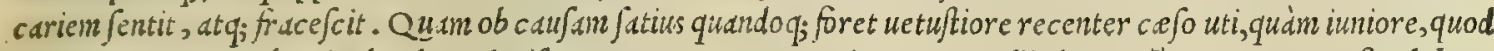
30 multo ante tempore fuerit ab arbore decifin. Sunt quoq; recentiorum nonmulli, de quorü nunero unus eft Alphon= jus Ferreus, qui de ligni gualaci decocto elegans admodum opu culum edidit, qui tantim Guaidcum illud preferunt, quod é plantarum ramis etatis medie de fumptum fuerit. Quorum opinio non plané refellenda uidetur : nam quicun= que rem naturalibus expenderit rationibus, ramos antiquioris à caudice mediocris atatis parun differre cognofcet: item ramos buius à calidice iunioris. quippe plus bumoris ad fe trabit ramorum auctrix facultas, quam caudicis. Id circo non alia de caufa plante reiunene f cunt, cim earum rami implantantur, feruntur, er propagantur, nifi quódil= lud idem bunidum innatum intra $\int e$ continĕt, or eodem uigent temperamento, quo qui adole $\int$ cunt : etenim furculi, at ${ }_{;}$ rami funt caudici, perinde atq; fili, or propterea animalibus atate tenellis non abjimiles. Atqui mibi longé magis iunior 15 caudicis placeret ufus: /iquiden in bunc tmmediaté à terra bumor, er alinentum defertur, ac preterea quo= niam is fortaffe nullum adhuc fructum protulerit: quandoquidem fotus à plantis, ut etiam ab animalibus, multum ui=

40 riun aufert. Preftantißimum itag; lignum Guaiacun illud erit, quod exinniori caudice recenter cafum fuerit, tam exterius, quìn interius albicans, rimis carens, denfun, pondero fum, minimé cariofun, odoratum, guftui er acre, o fubamarum. Ceterim quoniam noftra atate equé cortices, at y; lignum in ufun ueniunt; eandem in ijs ratione feruandam cen $\left[e 0\right.$, ut quinam meliores, preftantiores $q_{3}$ /int, digno fai poßint, quan nos in eligendo optimo ligno in medium attulimus, ut filicet illi eligantur, o probatifimi babeantur, qui à praftantiori caudice detracti fuerint. Importatur Guaiacum tam ex occidentalibus, quim orientalibus Indijs: nam e Hipani é Juis regionibus nouiter repertis, of Lufitani ex Calicuí, Taprobana, of Iaua infulis, on Mauritani, Aegyptij, Arabes, ac Perfe ḋma= ri rubro per camelorum carouaras ( ut aiunt) Guaiacum ad nos conuebunt: qun er ex Aethiopia, ut quidan nar= rant. At cum omnibus compertum fit, ea in medicamentorum genere longé inagis catera pracellere, que ex orien tali plag. comportantur, ob id omnino cen fendum fuerit, Hipanicum uiribus effe imbecillius, qudm quod ex Lufita=

so nia, uel Alcxandria in Italiam importatur. Guaiaci planta (ut ij referunt, qui.ean in fyluis fe uidiffe teftantur.) ad fraxini proceritatem, os ad hominis mediocris babitus craßitudinem plerunq; affurgit. Folia fert quadántenus plantaginis amula, dura, ac breuia. Flores eius produntur lutei: fructus ueró iuglandis magnitudine, qut efu aluum fubducit: cortex anno/is niger, iuuenibus ueró fubrutilus. Porró $f i$ Gualaci uires, ac qualitates recte perpendan= tur, procul dubı liquidó confabit, ea praftare poffe, que in arcenda Gallica lue requiruntur : nam cum id ex par= tibus admodum calidis, ac tenubus confiftat, iten'q; ficcis, habeat $q_{;}$fibi refine plurimum admifum, nimirum etiane poteft fuis uiribus ea eficaciter exiccare, attenuare, liquefacere, atq; expurgare, qua bumores infecerint: quine= tiam fudorem ciere. Huc accedit etiam, quód parte refinofa, quam poßidet, contagioni, atq; putredini mirificé refi= ftit: que quidem incommoda banc peftem comitarifolent. Ceterum eo tempore, quo primum in Iţaliam Guaiacum inferricapit, necnon etiam multis poft annis, non fine fummo timore dabatur potandum. Etenim ferebaturilli manifeftum necis periculum imminere, quirectam exquifit uiltus rationem per panis, or uux paffe modic um non feruafjet, quique non perfitifjet in curatione ad quadragefimum diem ufque in tenebris inclufus, ita ut ne dëris qui=

Guaiaci corticis electio.

Guaiaci planta.

Guaiaci facul tates. 
dcm claritatem inpiceret, nedum peden é cubiculo efferret: ijs infuper carniun c $\int u$, or uini potu interdicturi erdt; non fccus atque ueneno. Veriun cnimuerocim fa pius cueniffet, ut antc conftitutum tempus quidam ob tenuißimam sictus rationem ita imbccilles, ac uiribus destituti confpicerentur, ut penć /biritus, cr uita deficercnt, ij nc in tam ma= nififto uite difcrinine uerfarcntur, di confanguineis, er aßidentibus perfuafi, caporum, gallinarum'́; iura, ac con= tufas carncs in cibu: fumere, tantum inde percipicbant iuuamentum, ut uitam cuafi depcrditam recupcrarent. Quo poftea medici cxperimento edocti, uanam illorum doctrinam ridentes, qui tam graucm agris $l$ cgem inpontebant, pau= ló plcniori uictu uti iufferunt, nempc iuncnun gallinaccorum carnibus, ac maiore panis portionc. At nullus tamen

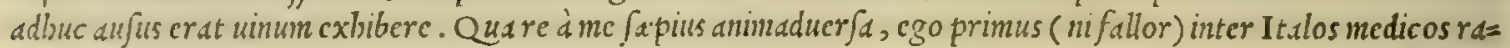
tionibus non obfcuris adductus tentarc uolui, poffet ne uinun daricx Guaiaci maceratione ijs maiori cum iuuamen= to, qui Gallicilue correpticfent. Quod cim mibi in frigidis morbis felicius ceßsifet, quim ex aqua tantim li= gnusn decoqucre, id potisimum me adduxit, ut banc uini potandirationem ad commune omnium commodum literis, pofteritatiś; memorix mandarcm. id quod fici pluribus iam annis clap/is, quo fcilicet tempore Dialogus nofter de norbo Gallico Bononia excufus prodijt in lucé, ubi codem anno Carolus v. inuictißimus Impcrator à Clemente v I I. Pontificc maximo imperialidiademate feliciter cft coronatus. Ex quo poftea factum effe audiui, ut plerique medici $c x$ illis noftris lucubrationibus, breui tcmporis trat $u$ plarimum laudis, ac gloria fibi comparauerint, utpo= te qui uinum Guaiaci ad Juam praxin ucrtiffent, propero admodum fucceffu. Licet fuerint, qui alijs perfuadere conatifint, fuum illud efe inucntum: qui ut rem fucilius practcxerent, omnibus buiufmodi uini preparationem dißi:

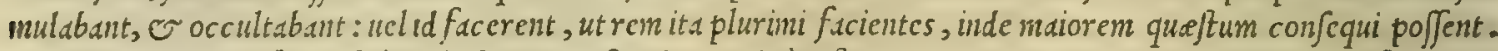
Sed caucndum profectó cft à quibufdam impoftoribus, qui cum fint earum rerum ignari, qua ad medice facultatis contemplationem Pectant, dum lignum, uel cius cortices ex uino dccoquunt, cyclaminum, bryoniam, pityufam, co= locyntbidem, or turpetum admif cent, atque alios mille cacod.emones, qui eos de medio tollant. Quippe nulla babita temperamenti, agritudinis, temporum anmi, fexus, nec atatis ratione, fingulis diebus huiufce decocti tepidi cyatbum omnibus indifferenter prabcnt potandun. Quo fit, ut fi forte quadam unum quandoquc per fanant, deccm poftea iu= gulent, tanquam improbi carnifices. Vcrim ut quifq; borum manus cuitare, atque cffugere poßsit, operepretium Vini Gusiaci uifun eft, uini Guaiaci conficiendirationem fubiungere, ac fubinde hauriendi modum addere. Sumito igitur ligni cófciendi, \& Guaisci praftantißini lima in froben tenuißumam attriti, aut tornatili in/rumento minutim concifi libras quatuor: exhbendi ra" corticum ciujdem libras duas: carduibcnedictilibram unam $\sim \sim$ cmis : adianti, appleni, florum utriufq; bugloßs, cu=

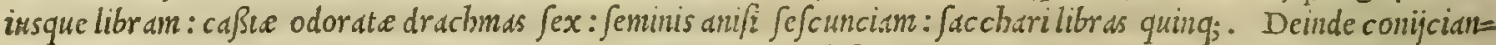
tur omnia in cado uinario mundo apte capacitatis, defiper affufis uinialbi qualm optimi e ferucntis, libris cen= tun, of quinquaginta, mox diligenter uas operculctur, omniá,; fic macerari triduo dimittantur. Poft triduum ueró linteo percolentur, afferuetur q; buiufce macerationis uinum in alio uafe ad agrotantium potum. Siquidem bibitur hoc tam in prandio, quam in cana fecundı Guaiaci decocti loco: non mane, neq; uefperi ferapij uice, quemadmodum temeré multi facere confucucrunt. Hoc idem uinum longé etiam melius, or maiore quantitate uindemid= rum tempore confici potef, admiftis lignto, cortice, cæteris'; alijs, reccntibus unis albis in mufum compreßis : ibió,

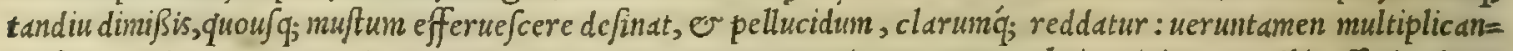
da funt omnia, qua conueniunt medicamenta, pro uuarun quantitate. Preter huius uini potum cibis affociandum, bis in die mane fcilicet, $\sigma^{-}$ueperi tribus, aut quatuor horis, anted quìn fumatur cibus, egrotantibus exhibeo deco= ftiligni ex aqua fecundun communem medicorum ufum fenas uncias, admift is uncijs duabus liquoris hoc modo pas randi. Sumito prinum adiantbi, lupi falizarij, funarie, apleni, fene, fingulorum manipulos tres : radicum centaurip magni, glycyrrbize, filicule, utriufq; bugloßi, fingularum uncias quatuor: feminis anifi, melantbij, florsm fatiui, or erratici bugloßi, omnium fantalorum, caßix, quam cinnamomum uocant, fingulorum dracbmas quinq; . Hec ex aqua libris uiginti quatuor decoquantur ad tertids, demum colentur. Sumito deinde praftantißsime fene lilsas durs, conijcitó; in uas fictile oris angufti, dcmum pcrcolatum decoctum ferucns fuperimponito, ac inde obturato fictilis ore puluinari anferinis plumis fareto, igniq́; prius calefacto fictile inuolutto, et loco calido collocato, itac; per dič, ac noctem reponito. Poftridic ueró manibus fend premitur, mox dilutum percolatur : cui adiiciuntur diluti rofarum ef=

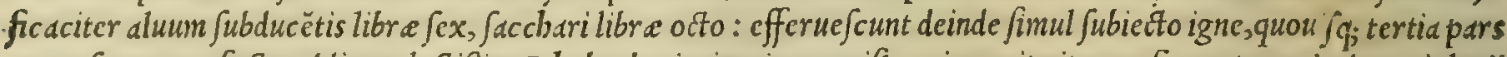
euane $\int a t$. quo facto additur clectißimt $\mathrm{R}$ habarbariminutin concifi uncid, ac ita iterum feruent omria donec iulapij modo confistat liquor. Poftremó percolatur lintcolo, $\odot$ uafe uitreo reconditur. At $\sqrt{i}$ agrotantes raulta pituita re= dundent, decocto prefcripto optimi turpeti uncia utiliter addi potcft. Supcrest uictus ratio, que a.gro talis prefori= benda eft, fcilicet ut tam in prandio, quam in cana cdat panis tcrnas tantum uncias, fit ; $_{\text {; }}$ is limi'saceus, ac probe in clibano coctus: item totidem carmis pullorum gallinaccorum, perdicum, attagenarum, turdor om, $\Delta c$ auiculdrum in Gyluis, uincis, ac montibus uictitantium, affata potius, quàm lixe : quin er uue paffe modicu m. Bibat autem opor= tet preferipti uini aquan cum cibo menfur am. Quojd fi quis purum id bibere non poffet, dil uatur aqua, que in phia lis uitreis addita Guaiaci unc cola breui tcmporis $\beta$ atio efferbuerit. Tempus autem buic curationi aptißimum pros fectó uer eft martio, aprili,er maio men/ibus. quód /i boc tempore ficri non poßit, fiat menfe feptembri in dutumno: nam ficuti estiuis ardoribus, Er exurentc iam firto non modó diuturna pharmaca, fed ne quidem brenia tolerant bos mines; ita nec brumali tempore, dum ingentifigore feuit bycms. Intered agris fine met unoxa indulgere licet, mo= dó cali ferenitas adfit, ut quandoq; iu proximis bortis, ac uiridarijs folatij caufa léto gradudcambulcnt: quippe quo= miam eiujmodi bortorum amenitate animus plurimum leuarifolct. In bac ettan curandi ratione quofdă magis, alios minus perfeuerare oportet, pro morbi necelsitate, of falutis menfura. Hac ergo ratione uinum Gualaci exhibitum nö modó medetur cuiq; acerrimo Gallice peftis incommodo ; fed etian diuturnis articulorum, capitis, neruorum, uen* 


\section{In Lib. primum Diofcoridis.}

triculi,iocineris, lienisq́; morbis pituita genitis mirifice fuccurrit. Nec minus etiam podagra labò rantibuis opem fert; modó diuturna admodun non fucrit agritudo. Porró in boc illnd ctiam obferuandum eft, quód ego Guaiaci uinum ijs tantim potandum exhbeo, qubus pituita redunder: uel laltem non exuperet bilis. Siquidem biliofis fecundum, ac ter $=$ tium ligni ex aqua decoct um, nini loco femper cum cibis prabendun cenfui, ut communiter ab alijs freri folet. . Non defunt preterca boc tempore, qui radicem illam, quam alij CINAM, aly Chinam wocant, Guaiaco praferant, et $f$ Ve falius admir. bilis bundni corporis fabrice profeffor oppofitum fenferit. Hutus radicis iandudum apud Hilpanos inualuit ufus contra podagras, in.axmég; apud inuictußimum Imperatorem Carolum v. cui meritó praclaram laux dem acceptam referre potcf. Aduchitur bec ( ut audio) tam à Lufitanis, quàm ab Hifpanis ex regionibus aquino= ctiali proximis, legiturí; in litoribus maris c terra cuulfa. nam in paludibus cxorta, ac inde maris fluctibus rapta,

10 in litus reijcitur. Radix $\mathrm{ft}$ fungofa, perinde ac arundinacea, leuis, colore ruffecente, $\mathrm{R}$ bodix radic is admodum semula. Prefertur recens, firma, o qux neque teredinem, neque cariem fenferit, or qux magis rubefcat. Da= mnat eam acriter Vefalius, ut dixi. Sed quibus ualidis rationibus id faciat, compertum fatis non habeo, prafer= tim cumillud certó fciam Cefarcm inuictißimum nunquamea toties ufum fuiffe, nifí ex ed plurimum adiumenti

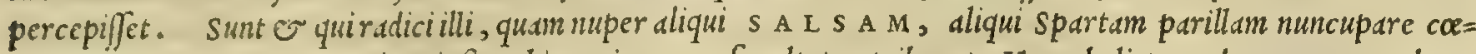
permit, tum guaisci, tum etian ipfius chine wires, er facultates tribuant. Hac ebuli tam ad unguem amulatur radices, ut quandoque crediderin Spartam parillam, ev ebulum effe idem: tamen id afferere non aufim, cuin bax Atenus cius folia non uiderim. Sed iam ad Ebenum redeamus, atque de nominibus agamus. Eius nomen Gree

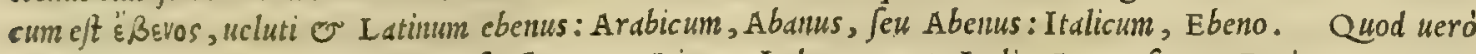
Latini Lignum Guaiacum, Lignum fantum, aut Lignum Indum uocant, Italis, Legno fanto, Guaiaco, er Gud=

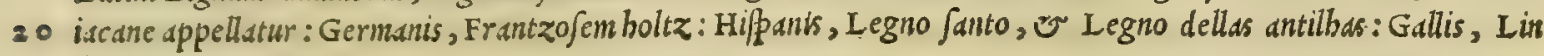
faint.

Pódor. ROSA.

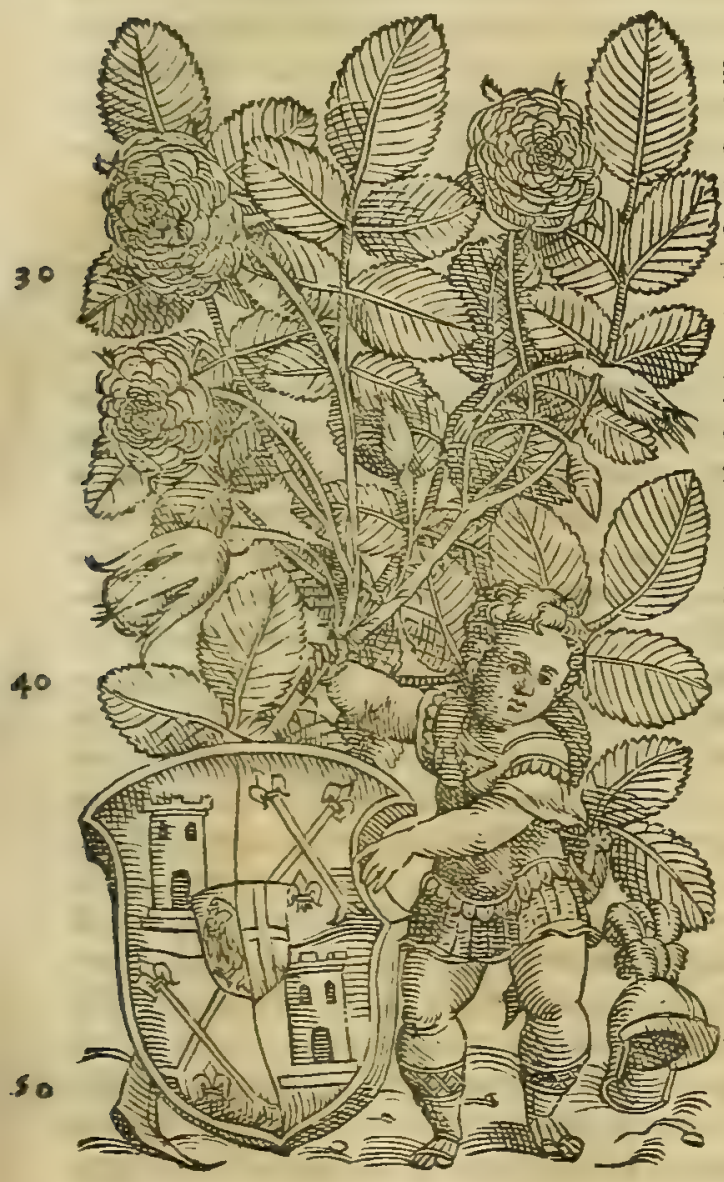

CAP, CXII.

Ros a refrigerat, \& aftringit, fed ficca magis aftringit. Succus recentibus folijs exprimitur, defectis forfice unguibus(fic appellantur candid foliorum partes) reliquum in pila premi, \& teri debet in umbra, donec cogatur, \& ita ad oculorum circumlitiones recondi. Siccantur etiámnum folia rofarum, continuo uerfata, ne muceant, néue fitus in ijs infideat: Aridis rofis, \& in uino decoetis expreffus liquor, facir ad dolores capitis, aurium; oculo= rum, gingiuarum, fedis recti inteftini,ac uulux penna illitus, aut infufus. Eadem line exprefsione tufa, pracordiórum inflammationibus, humidis. Ptomachi uitijs, igni facro illini prodeft: ficcis, ac tritis femina afperguntur. Mifceri folent uulnerarijs antidotis, atque compofitioni bus, quas antheras uocant. Folia uruntur in calliblephara. Flos,qui in medijs rofis inucnitur,ficcatus, gingiuarú fluxionibus efficaciter infpergitur. Capita pota citam aluum, \& cruentas reiectiones fiftunt.

\section{Módíss. ROSEI PASTILLI. C A P. C X I I I.}

P.A S I I I I, quos rhodides uocant, hac ratione conficiuntur. Rofarum uiridium, qux nullo àntea humo re madefact extabuerint, drachm $x$ quadraginta, Indicx nardidrachm $x$ decem, myrrhæ drachmæ fex, tritæ digeruntur in paftillos, qui trium obolorum pondus źquent: ficcatique in umbra in fictili non picato; atque obturato reconduntur. Alij adijciunt colti drachmas duas, iridis Illiricæ totidem, \& uinum Chium cum melle mifcent. Mulieribus monilium uice collo circundato ufui funt, ad retundendum graue fudoris uirus. Tritis etiam utıntur ad illitiones, \& diapafmata, qux fiunt ad fudores coërcendos, ita ut à balneis inareicant corpora, dein frigida aqua abluantur.

M V I T A quidem funt Rofarum generd, que in ufum medicum ueniunt. At unlgatißime in Italid funt, albi= Rofarum cól cantes, punicea, o que ex albo rufe fcunt, quas uulgó appellant incarnate. Preftantißime, que puniceo colore ru= deratio. bent : proxims laus ijs, que in rufum candicant: uilißime albicantes, in quarum tamen generie ex odoratißime exci= piuntur, que Hetrufcis Damafcene, o alijs Mof chette uulgó dicuntur. siquidem non modó ceterds excellunt, quòd odore admodun fuaui fragrent, fed quód etiam magis aluum. fubducant, id quod indicat earum iucundißimus odor. 
Rofe diucrfis partibius conftant . quo fit, ut pro diuer is tam internis, quàm externis particulis, diuer fum quo o; tem= peramentum fibi afcifcant. Primum itaq; terrescribus, er aque is partibus, qux tamen in ip/is mediocriter fe babent, Jubfantiam, ov adftrictoriam facultatcm acceptas referunt. Ab aéreis ueró o fubdulccm, O odoratum faporem affumunt. Ex bis demum, que ignis naturam fequuntur, amaroren concipiunt, ac etian coloris rubedinem, que fci= licct rubicunde pectantur. quo fit, ut plus infit caloris puniceis, quam Jubrubcnibus. In recentibus adftrictioni praftut amaritudo, in ficcis ueró minimé : cá, propter compertum eft, earum deijcicnd.e alui facultatem, quxin priores Greci non aninaduerterunt, tantim ex amaritudine prouenire, cim recentes aluum fubducant, ficce ueró

Rofarum fuc nequaquam. Succus medicamentis componendis expetitus, preftantior é puniccis clicitur, item ex fubrutilis, uex

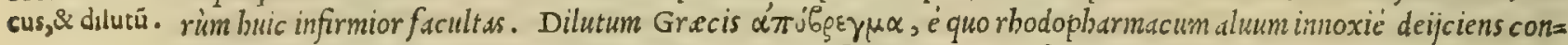
ficiunt, pleinuquc $\mathrm{x}$ fubrubcfcentium maceratis aqua folijs paratur : et fi bac in re ijs Danafcene Hetrufcis uocate longé prastent: quibpe ex earun uicenis detoratis folijs facilé quiden, or citra noxum fubducitu aluus. Rofarum fuccus referat, difcutit, abftergit, er deijcit: quapropter o bilem trabit, er finguincm biliojum cxpurgat. Idem felle fuffufis, er ucntriculi, iocincrisq́; obftructionibus opem mirificé preft st. Cor item corroborat, eius'́; palpi tationifaluture eft rentedium: nam illos deijcit bumores, qui cordi officiunt. Facit $\mathrm{C}$ ad bilic fas frbres, cuiufmodi funt cuiufuis generis tertianx. Ad hec rofarum dilutum, ex quo conficitur rhodopharmacum, quod pharmacopole Sirupum rofatum folutium appellant, in eorum medicamentorum genere recentiores medici recenf ent, qua quoniam

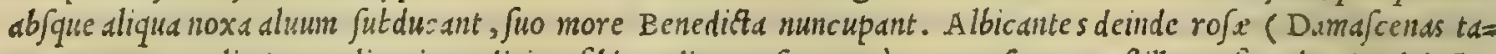
men exccptas uelin) non alium in medicina fibi uendicant ufum, quàm ut ex fe aquam ftillent: /iqutdcm ijs deiecto= ria uis, qua pollent punice , ac Jubrutile, multo infirmior incft. Quamobrcm uidetur Manardus Ferrarienfis, uir alioqui doctifimis, immeritó id Mefui vitio nertiffe. Nam albe, quas Damafccnds appellamus, et $f_{i}$ maiore deij= 20 ciendi ui cateris praftent; credendum tamen eft, de bis non intellexiffe Me fuem, quód eas illi facilé incognitas fuif= fe exiftimcm; ucrim dc ijs albis tantim, quibus paßim rofetaflorent. Cuiss reilllid naxino argimento cfje potcft, quód Damafcene Hetrufcis uocate nuper in Italia florere creperint, guid qj $_{\text {cas }}$ ueteritus cognitas flitjje (quod

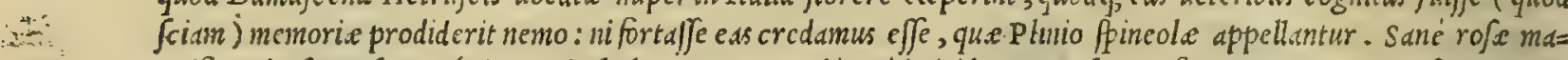
gnificande funt, fummóq; in pretio babende, non modó qucd uiridarijs, š bortis futt ornamento, ac appcitu per= quàn iucundo; fed ctiam quod in preclarißimis medicamentis conueniant, quibus buman.c nitxe fuccurritur. Syl= meftres maiore adftringendifacultate funt pradite, quaim fatiue, fed minori fragrantia redolent, atque deijciendx aluine tantulum quidem facultatis retinent. Idcirco Thecphraftus libro, O cap. v x. de hiftoria plantarum: syl= ueftres, inquit, rofe domefticis afpcriores tum uirgis, tum. folis conftunt: florem praterca frunt, quo ab illis odore, colore, atq; magnitudine fuperantur. hac Theophraftus. Caterim quedam etiam rofe nafcuntur in Italia, que aureo 30

Rofarum ge- colore fulgent, fed odore funt admodum ingrato, ato; infuaui. Rofarum differentias longa biftoria profequitur $\mathrm{Pli}$

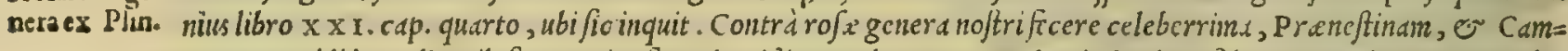
panam. Addidere dij Milefiam, cuius fit ardentilsimus colos, non cxcedentis duodena folia. Proximam ei Trachi= niam, minus rubentem. Mox Alabandicam uiliorem, albicantibus folijs. Vtilifimam ueró plurimis, jed minutißimis fpineolam. Differunt enim multitudine foliorum, apperitate, leuore, colore, odorc. P aucißima Ginina folia, ac deinde numerofiora. Cim fit genus cius, quam centifoliam uocant, que eft in Campania Italize, Gracia ueró circa Philip= pos, fed ibinon fuxe terra prouentu. Panga us nanq; mons in uicino fert, munerofis folijs, ac paruis: inde accole träs= ferentes conferunt, ip dáq; plantatione proficiunt, non autem talis odoratißind eft, ncc cui latißimuin, maximun'; fo= lium : breuiter'q; indicium eft odoris fcabritia corticis, Cyrenis odoratißima cft: ideo q́; ibi unguentum pulchcrrimü . Carthagine Hifpuni.t byeme tota precox. Refirt er celi temperies: quibufdam cnim annis minus odorata proue= nit. Preterea locis ficcis, quaim humidis, omnis cft odoratior. Seri nec pinguibus uult, nec argillofis locis, necriguis, contcritäraris, proprié,; ruderatum agrumamat. Pracox Campana, ferd Milefia, nouijsime tamen definit preneftina. Rofa ex pina nafcitur. Germinat primo inclufa granofo cortice, quo mox intume $\int c$ nte, $\sigma$ in uirides alabaftros faftigiato, paulatim rubefcens dehijcit, ac $\int \mathrm{e} \int \mathrm{e}$ pandit, in calyc is medio juiftantis complexa lutcos apices. Partes in ro- bactenus plinius. Partes in Rofa fex antiqui adnotarunt; que omnes funt or fcitu dignx, er in medicina utiles;

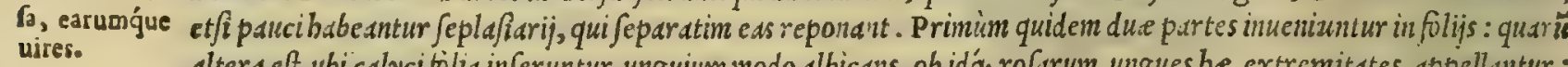
altera cft, ubicalycifolia inferuntur, unguium modo albicans, ob id'q; rofarum ungues be extrcmitates appellantur: altera ueró foliorum reliqum. His alia dux Juccedunt, in ijs flofculis, qui ucluti minuta fominc temipimis capill is annexi flaue fcunt in rofarum umbilico : borum enim partem faciunt granula, partem ucró capilli. Fo, trcmo quse reliqux funt, in ip $\int 0$ Rofarum alabaftro continentur, una fcilicet in cacumine, alterd in fundo. Folis cor, wentri= 50 culum, iecur, or retentricem infuper facultatem corroborant: dolores ex caliditate proucnientes leninnt, e inflama matcones auferunt. Vngues etfi propriam a fcriptoribus non receperint dotem; inferuntur tamcil uilitcr lotionibus, $\sigma$ clyfteribus ad inbibend ss fluxiones. Flofculi medij.cum fuis capillis gingiuarum defluxiones cobibent, quinetiam, auctore Plinio, alba freminarum proflunia mirific é inbibent. Calyx deniq;, qucm caput etiam aliqui dicunt, cum reli= qua parte bafis, aluifluores, er cruentas cxcreationcs fiftit. Caterim preter bas, qua in florentibus rofis conlifiut; tres etiämnum in fructu comperiuntur partes, ,birubcfcit is, or maturitatcm fenfit, uidclicet, $\int u t f$ tantia carnis, $\int e=$ men, o lanugo conclufa : quibus non obfcura inclt adftringendi uis. Idctrco or ip fe remculio funt contra alui fluo*

Quorundaw res, $\sigma$ freminarum abundantian qualencunque item contra gonorrba am, in qua pracipué pollcut. Sunt, qui flox

laplus. $\quad$ fcuios capillis appenfos, qui ucró alabaftros, antheram effe exiftuncnt. Sed re uera bac inre planc hailucinantur: etenum anthera Celfo, Galeno, or Paulo nufquan fimplex est medic amentum, fed quedam cx pluribus jobus compo=

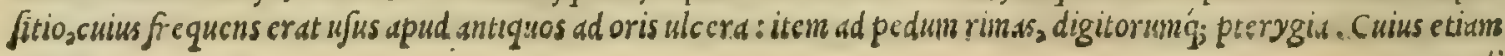




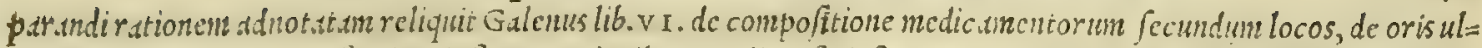
ceribus differens. Ex Ro/is ut ignisfit aqua pluribus, ac diverfis infl rumentis: ucruntamcn caceteris praftantior, ac odore fiagr.ntior bubctur, que per balncum calentis squ.t uitrcis organis clicitur, cuinfinodier alise funt, qu.e codem modo ad uniuerfunt medicine ufum confici folcnt. Ruandoqnidem inter has, or illas, que plumbeis in= frunentis lignorum, ucl carbonum ignc cxtrabuntur, tunta doprebcnditur differentia, quanta inter plumbum, er

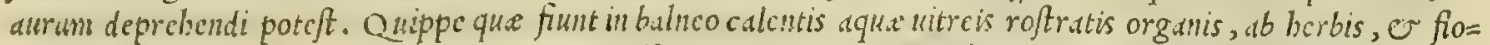
ribus, ¿ quibus m.an.ant; nec fapore, nec odore diffentuunt, adcó ut non folim proprias plantarunt qualitutes fecum referant, jed ne etism t.int!lum quidem tum fumi, tum rei adufte refipiant. Ouod quidem in ijs non inucnias, quac

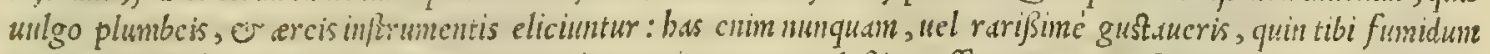

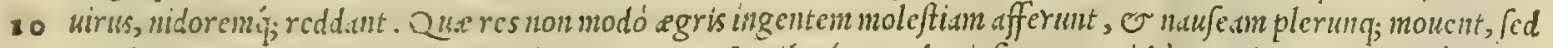
e plurinum noxa pectori, ucncruculo, iocineri, uifcribiśq; ommbus infrunt: quód à metallicis organis, à quibus diftullant, malam corum qualitutem fibiuendicent, ut libro tertio in abfinthij commcntationc, anmuente Deo, latius explicabinuss. Quat ic bac atutc perpecta, doctijimi, ac peritißin?imediciucteres fecuti, dccodis, ac dilutis tan=

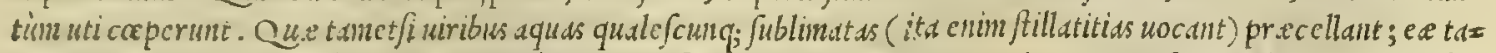
uzen, qux calentis aque feruorc ( wr fuprd diximus) funi, cum proprios tum odores, tum faporcs bcrbarum, acflo= rum, ¿qubus extrabuntur, fecum trabant, iure quidem decoctis non modó ipjas aquipollcre, fed ctism preftare cre difcrin: non tuncn, quód uiribus praccllere dixerin, fed quód gufui fusuiores, er uifui iucundiores habcantur: quod non parun folatij egrotuntibus affert. Nos quidem alijs tquis non utinur, quam bis, ad quas eliciendas nobis organum affabré pararificimus, cuius ope bafce ftillatitids, ac preftantisimas aquats fuo tcmpore conficimus. Qus=

so rum alix fapore conftant andro, alie ueró acri, dlix auftero, alie acido, dlix dentiq; infipido pro uarijs fimplicium nedic.mentorum qualitatbus, a quibus cliciuntur. Quapropter fcplafiarij, or medici, quos magis decet bumandn

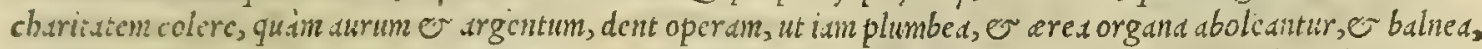
de quibus deximus, in eorum locum fuccedant. quippe in boc etian (quanuis plis laboris, minus ueró cnnolumenti fu=

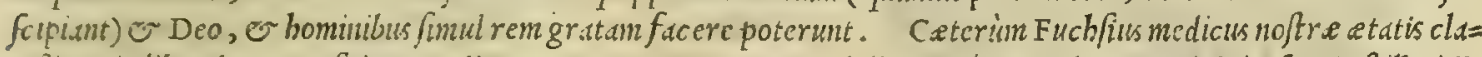
rijimus in libro de compofitione medicamentorum, quem nuper edidit, unice cauendum pracipit in Juccis ftillatitijs eliciendis, ne eius uafculifundum, in quo ftipes continentur, aquam in cacabo bullientem attingat, fed folo uapore ab ca elewato mcale fcat. Qu ain re fecutus potius uidetur fuife Mandrdum uirum de arte medica proctaré meritü, qui is fcriptum reliquit in fuis cpiftolis, qudin rei experimentum. Verin ip fe non poffum omnino corü fententie fub=

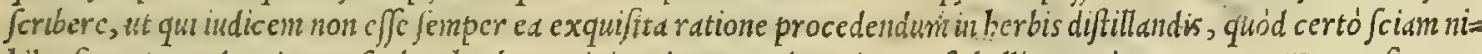
30 bil referre, quando citam ux culum berbas rccipiens in aquam in maiore uafe bullientcm immergatur. Nam etfi aqua, quas illi uolunc cx berbis uapore tantim ab aqua bulliente eleuato extrahi, cateris preftantiorcs habeantur; tamen que ex berbis eliciuntur uafculo impofitis, quod aqua bulliens circumlisat, parum certé, aut ferrè nibil illis bonitate

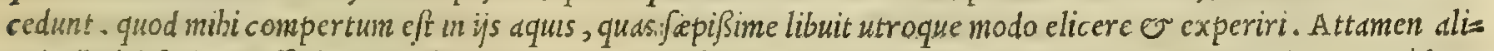
quis illud ail crimen elfe dicet, quod illo modo aqu.e ex herbis extrabantur, qux tenuiores partes retinent, quód uds poris illus caliditas imbccillior fit, quàm ut po/3it totam herbse fubjtantian conficere : boc autem modo aqua clicianz tur, que omnes herbarum partes fecum referunt. H.ec fané differentia, que factlé concedi poteft, nost eft, meo iu= dicio, tanti momenti, ut illa regul a perpetuó fit ob cruanda, haec ueró euitanda: quin potius facit, ut hec milbi uided= tur probanda, illa ueró reijcienda tanquan cautio nimis religio $\int a$. Rofarun uires collegit Galenus lib. $\mathrm{V}$ I I. fim= pliciun medicanentorum, fic inquiens. Rofarum uis, atque facultas fuperioribus libris pluribus ucrbis expofita eft,

40 nempe quód ex aquea fubftantis calida mifta duabus alijs qualitatibus; adjtringenti uidelicet; $\odot$ amara, compofita fit. Quinetian cuius fit nature utraque, amara fcilicet, 6 adftringens, in borum conmentariorum quarto decla= rauimus. Flos earum magis etiam ip/is rofis adfringit, ac proinde fane etian exiccatorius cft. Rofa, quam ita Latini wocant, Gracis god'ov dicitur : Arabibus, Nard, Naron, feu Vard: Italis, Rofa: Germanis, Rofen: Hi= Pranis, Rofas: Gallis, Vne rofe.

\section{Aúriov. IYCIVM.}

CAP. CXIIII.

LY C I v M, quodaliqui pyxacantham uocant, arbor eft fpinofa, ramis trium cubitorum, aut longioribus : folijs buxi, denfis : fructu piperis, nigro, læui, amaro, denfoǵue : cortice pallido, non difsimililycio madefacto : radicibus multis, obliquis, lignofis. Nafcitur plurimum in Cappadocia,

so Lycia, \& plerisque alijs locis . afpera loca amat. Succi extrahendi ratio hæc eft. Rami cum radiculis tufi, \& antè per multos dies macerati coquuntur, tum abiectis lignis, itidem liquor coquitur, donec mellis crafsitudo fiat. Adulteratur id lycium, adiecta decoetioni amurca, aut abfinthij fucco, aut felle bubulo. Innatans fpuma inter coquendum exempta, oculorum medicamentis additur: reliquo ad alia vtuntur. Simili modo fit lycium femine expreffo, 8 infolato. Optimum, quod uri poteft, reftinctumq́ue rubentem fpumam oftendit, glebis intrinfecus nigris, intus, cùm fregeris, rufis, odore minimè uirofo, cum amaritudine aftringens, crocino colore: cuiufmodi Indicum eft, cæteris præftans, Sc efficacius. Lycium adftringit, caliginem oculorum difcutit : genarum fcabiem, pruritus, veteresque fuxiones fanat: facit ad purulentas aures, exulceratas gingiuas, tonfillas, labiorum fiffuras, fedis rimas, attritusq́ue illitum : coliacis, dy fentericis, potum, inditumq́ue conuenit : datur fanguinem excreantibus, \& tulsi cx aqua : contra rabiofi canis morfus in catapotiodecoratur, aut in aqua bibitur: flauos facit pilos : reduujjs, ulceribus, quæ ferpunt, aut putrent, medetur : fominarum pro-:

Fuchfij opinio non pro: bat2. Rofarum fa-
cultas ex Gal. Rolarum fa-
cultas ex Gal. Nomins:

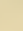

.45

Aqua rofarú praituntior. 
i $\dot{I} \dot{C} \dot{I V}$.

Iycij confideratio.

Lyciú in Iteliz azfcens.

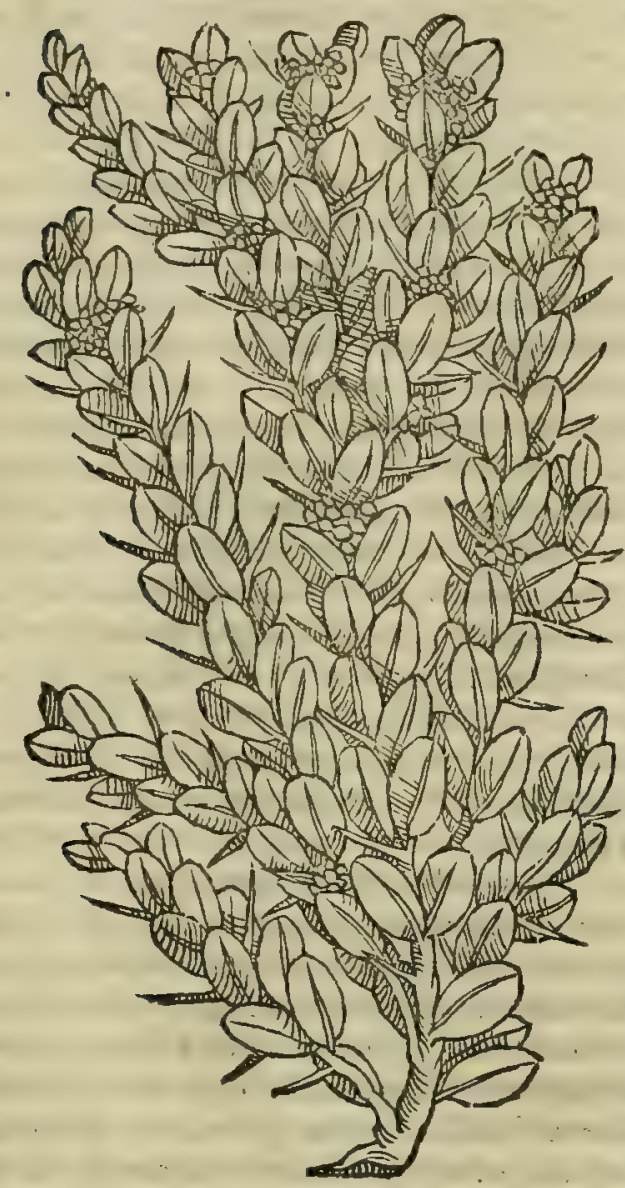

fluuia appofitum fiftit: rabioforum ictibus ex melle potum, aut uice catapotij deuoratum, auxiliatur. Tradunt Indicum fieri Lycium, ex frutice lonchitide appellato. Ea fpinarum generi afcribitur, ramos rectos habens, ternûm cubitorum longitudine, maiorésve, rubo crafsiores, à radice numerofos : fractus cortex rubefcit : folia olex fimilia. Herba in aceto decocta proditur lienis inflámationibus, \& regio morbo mederi, \& fominarum pur gationes elicere. Affeuerant etiam crudam in potu, eofdem effectus præftare: femen cyatho dimidio potum,pi- a tuitam expurgare, venenis quoque auxilio effe.

L. Y C I V M medicamentum, quo hodie officine paßim utun= tur, nimirum notis illi plurimim reclamat, quod nobis bic reddi= dit Diofcorides. Siquidem illud officinarum igni admotum non ace cenditur, nec intus rufe foit, nec ullam guftantibus affert amaritu=

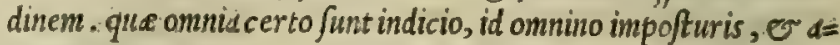
dulterijs non uacare. Tradidere, quidam hoc ab impoftoribus fie= viè ligufri fructu, alij id tribuunt periclymeni baccis, alij fanguinee uirge corymbis, alij porró ex his omnibus fimul contufis eli= 20 ci produnt; ac inde infolari. At legitimum, er quod fyncerum fit, quoquomodo fe res illa babeat, compertum eft, boc auo ex I ycia; unde illi nomen, ad nos non importari.s. Veruntamen er in Italia bycij arbor nafcitur: quandoquidem ( ut Brafauolus teftatur) in Liguria alpibus frequens illa uifitur. Eadem $\sigma$ in Dalnatia pro. uenit, unde nuper eius ramuli fuis baccis onuftimibi allati fuerü: quippe (ut mibiretulerunt) uis, qua ex Zara itur Nondm, ubiq; uire fcit. sed, que maxima tum feplafiariorum; tum etiam medico ruwincuria, ac negligentia eft in ijs exquirendis, qux ad arten medicam pectant, plerung; fit, ut ne illud quidem, quod nobis $\beta$ o $=30$ te natura tribuit, cognof calur, nedum recipiatur in ufum? Iycip üices Diofcoridi explet amurca in cupreo ude decocta, aut etiam rhus decoctus, quouf $q_{;}$eius liquamentü mellis craf Lyeij uires fitudinem acquirat. Lycï meminit Galenus lib.v.I I. fimplicium medicamentorun fic inquiens. Lycion, fiue pyxa ex Galeno. canthon, arbor ppinofa, ex qua lycium, quod uocant, conficitur : id uidclicet medicanentum liquidum, quo ad fugil=: lata ituntur, ơ jedis, orisó; pblegmonas, ulcerationesq́; ; tum berpetas, putredines, or ulcera contumacia, er au= res puire fluentes, of intertrigines, ac paronychias. Eft autem facultatis exiccatoria, compo/itun ex diuerfi gene=

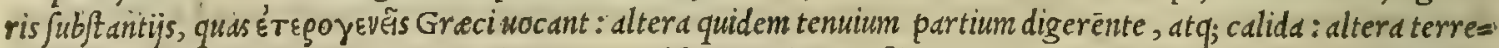
Ari, $\mathcal{O}$ frïgida, ex qua àdftriftionem obtinet. Porró bec qualitas pufilla medicamento ineft, digerit ueró, $v$ defic= cat non parum, nempe in fecundo receffu, in calore autem medijs, $\mathcal{O}^{-}$fymmetris proximum eft. Proinde ad diuerfos affectus boc utuntur medicamine, ut abftergente quidem ad ed, qux pupillas obtenebrant: ut contrabente uetó, cae 40 liac is, dy fentcricis; ac muliebri profluuio adbibentes. I ycium boc in Lycia, or Cappadocia plurimum prouenit: al= terum ueró Indic um ad onnia ualentius eft. Et primo de antidotis, non facilé adulterinum lycium à legitimo digno=

Buxi confide- Fciidem memorix prodidit. hac Galenus... Cxeterim quonidn Pyxacantba, quo nomine lycium ab aliquibus appels zatio.

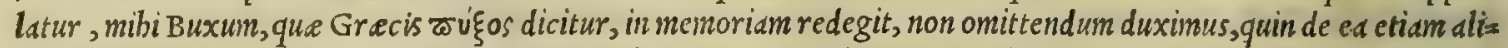
quid dicamus. Bvx vs itaq; nobis notißima eft planta, quód plurima in Italia proueniat, folio myrtiminore, craf= fiore, uiridiore; ac fubrotundiore : uirèt perpetua coma, ed'; propter topiario operi accommodatißima : flore herba ceo: femine rufe fcente, omnibus animantibus inufo. Crafsijsima in Corfica, flore non ferendo: qua caufa amaritudis nis incllis. Frigidis gaudet, or apricis. Materies buxo honorata, raró cripanti, nec nifiradice : ceteró lenis quies. materia, filentio quodaim, e duritie; ac pallore commendabilis. Eadem fpißißima, e denfißima, atq; ponderofißsi=

Quorundam $M 1$, adeó ut in aquis non fluitet, nec caricm fentiat. Hac et fi nullius fit in medicind ufus, ut ueteres prodidere; nö opinio repro defunt tamen é recentioribus, qut uelint non aliud effe I $t$ al is buxum, qudm Indis lignum, quod guaiacum appellant: bata. ea tantùm ratione dusti, quod pluries experimeñio compértum fit, eius decocto ctiam filicius cos fanatos effe, qui Gal

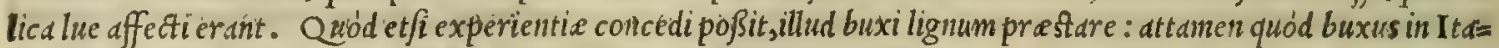
lia nafcens, ev gualacum áb Indis petituin una, er edem fint planta ( ut in fecunda centuria Amatus Lufitanus affe= rere uidetur) nunquain profecto crediderim. Siquidem guaiacum pingue, refinofumi; uifitur : materie intus nigra ébenifré modo : quin o fapor buic amarior, oc acris. quibus omnibus notis ficcan buximateriem carere conftat. Quinetiam guaiaco ( ut narrant ij, qui ab Indis ad nos redeunt) folia infunt plantaginis, brewiora, craßior a, durios rá;: : luteiflores, of fructus inglandis im.tgnitudine. Buxus ueró folia fert myrti, breniora : florès herbuceos, of fru ctum myrto nufquan grandiorem. Quo fit, ut onnino exiftimem cos hallucihari, qui putant, buxum qux in Italia nas fcitur, idem effe cum Indico guaiaco, ut uuper fenfife uidetur Lufitanus loco antedicto. Sed quàn db eo ieiune, nè dicam imprudenter actum fit de fimplicium medicamentorın cognitione, corum facilé iudicium futurum fpero, qui 


\section{In Lib. primum Diofcoridis.}

non mediocriter in re berbaria uer fat fucrint, $\mathcal{O}$ buius foripta legent: atq; ctiam legere non graluabuntur apologiă, quam nos aducr fus illun forip/imus, cui plurima errata attexuinus, que in eiufdcm in Diofcoridem enarrationes ad=

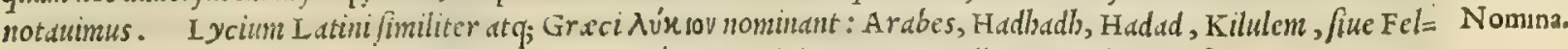
zalarag: Itali, Licio. Qux ueró planta Grecis mígos, Latinis Buxus appellatur: Italis, Boffo.

A'raxia. ACACIA.

20

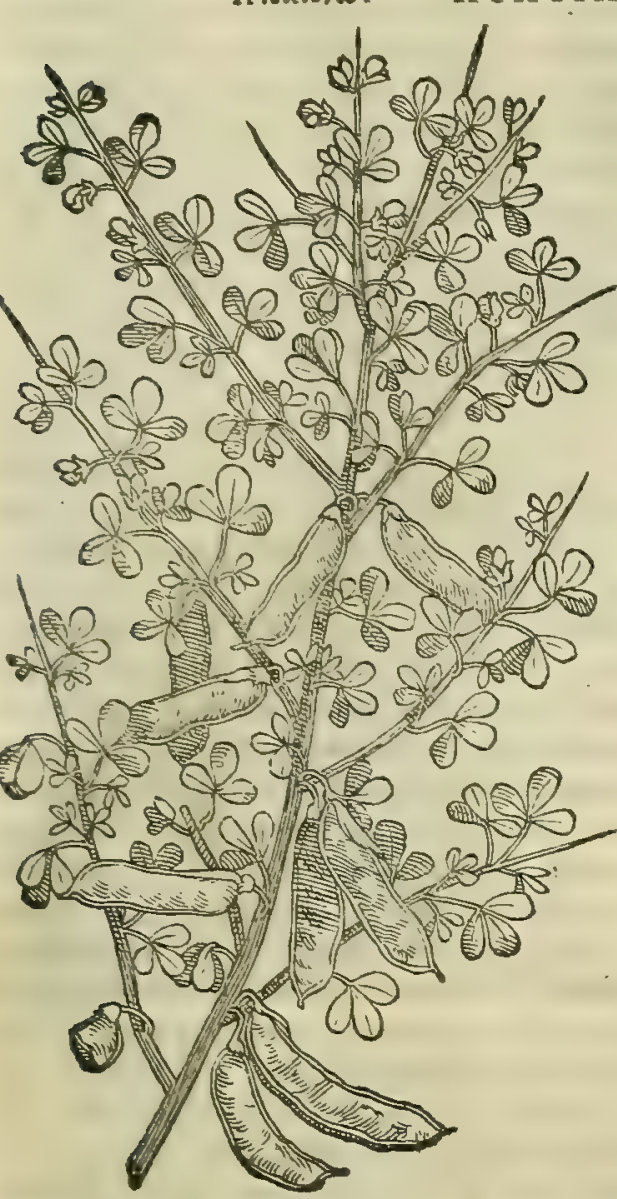

CAP. CXV.

A C A C I A in Acrypto nafcitur, fpina inftar arboris, fruricofa, non fe in rcctum attollens. Florem habet candidum, \& femen lupino fimile in folliculis : ex quo fuccus expreflus ficcatur in umbra, niger ex maturo femine, fubrufus ex uiridi . Eligatur modicè rufus, \& odoratus, vt in hac arbore effe poteft. Aliqui exprimunt ex folijs, \& femine fuccum. Manat \& gummi ex ea fpina. Vis ei ad fpiflandum, refrigerandumq́ue efficax. Succus oculorum medicamentis utilis: valet ad ignem facrum, vlcera qux ferpunt, perniones, pterygia, \& oris vlcera : procidentes oculos reprimic: menfum abundan tiam fiftit, prociduam vuluam cohibet: citam aluum fupprimic, aut potus, aut fubter inditus : capillos denigrat. Lawatur oculorum medicamentis, trito in aqua, mox effufo, quod concreuerat, donec pura extet aqua: \& ita cogitur in paftillos. Vritur etiam in cruda fidelia, donec fietile fornacibus percoquatur : torreturq́; in carbonum halitu perflata. Spinæ decoctum folutos artus fotu committic. Prefertur eius fpinæ gummi, quod in vermiculorum fpeciem contrahatur, \& uitri modo perluceat, ligni expers : proximum eft candidum: fordidú verò, ac refinofum inutile. Cutis meatus obftruit, $\&$ me dicamentorum, quibus admifcetur, acrimoniam hebetat:a mbuftis ex ouo illitum, puftulas non patitur erum pere. Alterum Acacia genus in Cappadocia, Pontoque prouenit, Aegy ptıx fpinæ fimilitudine, longè minus, tenerius, humile : aculeorum tallo munitur, folia habens rutæ: femen lenticula minus fert autumno, in lo culis connexis, ternûm, quaternûmúe capacibus . Succus eius aditringit, viribus inferior, \& ocularibus medicamentis inutilis:

A R B O R, qux Diofcoridi Acscia uocatur, Theophrafto Spina fimpliciter dicitur lib. I I I r. cap. I r.de plan= tarum hiftoris, ubi de ea ita fcriptum reliquit. Spina ex co nomen accepit, quód tota arbos aculeis borret, excepto 40 caldice: nam o fuper germina, foliá,; aculeos gerit. Magnitudine excellit, materies quippe duodenorum cubito= rum. tectis idonea ceditur. Eius duo generd funt: queddin enim candida, quadan nigra: er alterd imbecillis, fa= cilé; putrefcens: nigra autem robuftior, atq; incorrupta, ob id in nauiun fabrica ad coftas, Hentrisq́; compagines ea utuntur. Erect a non ualde affurgit. Fructum fert in filiqu, leguminum inodo, quo incole coria perficiunt uice gal le. Flos e puicber apectu, ut coronas ex eo facerent: er medicamentis perutilis, qua de caufa colligi à medicis fo let. Fit o gumma ex ed: manat hec tum arbore percufJa, tum fponte fine ulla plaga: cum anteln cee fuerit, anno tertio protinus refurgit. Copia huius arboris largébabetur, of fylua ingens circa agrum Thebanum eft, ubie ro= bur, er perfea, or olea quo q; eo loco emigrat, non aquis fluuij riguo (diftat enim plus, qudin trec èttis fadijs) fed fuis fontibus, qui circa eum trąqum permulti exiliunt. Materies arboris durd, or cxea colorem celtis utiq; reprefent= tat . bactcnss Theophraftus. A'quo Plinius non diffentiens,ipfe quoq; eius hiftoriä memorix prodidit lib. $\mathrm{x} \times \mathrm{x}$ I I I.

so cap. x I I. cuius fic ucrba fonant. Eft $\circlearrowleft$ acacie ßina. Fit in Aegypto alba, nigráq; arbore, item uiridi, fed longé melior é prioribus. Fit é in Galatia tenerrima, fpinofiore arbore. Semen omnium lenticula fimile, minore eft ta= men or grano, er follculo. Colligttur autumno, quoniam anté collectum nimio ualidius. Spifatur. fuccus ex folliculis aqua celefti perfu/is, mox in pila tufis : exprimitur organis, tum denfatur in fole mortarijs in paftillos acacia dicta, arboris uidelicet fue nomine. Fit ex ex folijs per fe minus efficax. Ad coria perficienda femine pro galla utuntur. Fo liorum fuccus, or Galatiace acscix nigerrimus improbatur : item qui ualde rufus eft. bec Plinius. Succus é recen = ti femine expreffus, ac polted long a in folatione concretus Grecis nomine fue arboris Acacia nuncupatur. In cuius

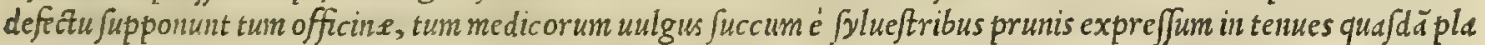
centulas in fole den fatum: fiquidem legitima acacia ad nos non affertur. Vbiacacia defecerit, licet ( $f$ Diofcoridi credimus ) eius uice tum rhois arbufcule folid, tum lentifci foliorum fuccum, tum etiam bby pocifidem medicamentis inmifcere. Quamobrem bis potius feplafidrijuti deberent, quàm fuppofititio fylueftrium prunorum fucco. Scire etiamnum conuenit, gummi, qlod ab arbore acacie manat, ideo serapioni Arabicum nuncupari, quód ab Arabia re= bicum.
Acacix hif. ex Theophr.
Acscia officinarum.

\section{Gummi Arz-} gione 
gione Aegypto contermina fuo tempore importaretur. Sed animaduertere oportet, quod Arabicum uulgaris ufus gumni longc quidem ab illo differt, quod ab acacia colligitur: nanq; illud non contratis uermiculis fimile, fed in grtl= mis uerficoloribus conpicitur, quorum alij fuccinum, alij topatium, alij cbryfopatium, alij beryllum colore, er nito= re referunt. 2 uod autem nobis zummi Acacia de fit, illud argunzento effe poteft, quod ip fa quoq; legitima acacia ba $=$ ctenus, quod fciam, non defrrtur. Nam fi boc, quo utimur, fyncerum, legitimumq́; acacie effet gummi, procul dubio ip $\int$ quoq; acacia ad nos conueherctur, cum longe m.gis in paranda theriaca, alys ;́ componendis medicamentis ex= petatur, quàngumni. Hinc itag; facilc quifq; conijcere poteft, gumni ex Aegyptia pina defluens ab co fané pluri= mim differre, quod A rabicigummi nomine offic narum uulgus babet. Hoc igitur unlgare gumni illud equidem effe exiftinaucrin, quod Grecis gummi fimpliciter uocatur. In quan fententiam ine adduxit Galcnus: fiquidem libro V I I. fimplicium medicamentorum, fic inquit. Gummi lacryma eft congelata, concrctág; in truncis arborum ip an $\mathbf{2}$ fundentium, uclut refina quoque in multis uifitur plantis, que refinam funderc po/funt. Ceterim quód exiccatoria, emplafic x'; fit facultatis, confat . bec Galenus. Ex cuius uerbis palim eft, gummific in uniter fum Grecis atpcl= latum, noftrum gummi effe uulgá Arabicum dictum. Quod quidem (quantum fenfuum iudicio confequi poflumus) ex pluribus arborum gummi mifcellaneum cft. Cuils rei manifefto indicio funt cium grumorum forme diuerfitas, tum colorum uarietas. Huc ctian accedit, quod Galenus unica nomenclatione omnia carum arborum gummi comprehen=

Quorundam dit, que refinam non proferunt. Cuamobrem omnino explodenda uide tur eorum fententia, qui ubi Graci gumni laplus. abfoluté fcriptum reliquerunt, illud gummi intelligendum effe contendunt, quod é pina Acgyptia manat. Non de funt preterea, qui gummi fpine Aegyptic illud effe opincntur, quod gummi Dragaganti, hoc eft, tragacathe officinis ap= pellatur, propterea quod effigic contractos uermiculos referat, quo nibil certé melius illi competere poffet. Sed td= men hoc etian illud non eft, ut fuo loco dicemus. Galenus lib.v I I. de compofitione medicamentorü per genera, $A=30$

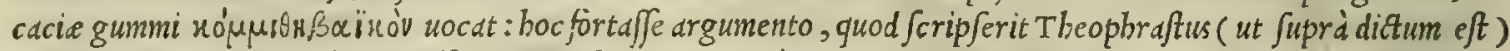
ingentem buiufce pina fyluam effe in agro Thebano. Sed cum ad nos non perferatur acacia ( $u t$ pauló anté frip/i= Iacobi Syluij mus) nec etian eius gunmi importaricredendum eft. Gummi Acacie meminit Iacobus syluius uir fane etatis no= opinio repro ftre ingenio or doctrina celebris, fuo de naturafimpliciun medic amentorum libello, bis uerbis. Gummi acacia non bata. meminit Galenus in Acacia libro fexto fomplicium, utinec acacie mentionem facit pauló polt in Acantha Acgyptia, feu Arabica, quo nomine folo Diof coridi uocatur. Vnde colligas licet, ,caciam, or acanthain Aegyptian, feu Arabi= cam, diuerfas effe in Aegypto pinas arbores. hice ille. Scd med quidem fententia, syluiusmanfesté aberraffe de= prehenditur : quandoquidem Galeno deantha A egyptia arbor utiq; non ef, fed licrba é carduorum genere, quem=

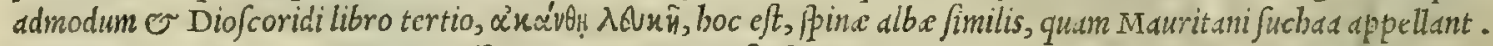

Acacix alterú Quocirca eo capite acacie meminiffe Galen um omnino fuißet abfurdum. Caterim alteram Acaciam, quam in 30 genus.

Cappadocia, Ponto q; prouenire tradit Diofcorides folijs rute, quam'́; bic depictam damus, accepimus boc anno a quodam ex ijs, qui nei herbarie dant operam. Et quoniam ca Diofcoridis bistorian perbellé reprefentaré uila eft, non potuit animus non inclinari ad credendum banc fecundasn effc Acaciam. Eft cnim acule is borrida, folio ruta, $\int e=$ mine lenticula minore, in filiquis ternûm quaternûmue capacibus, quod autumno profirt, guftu ctiam adfringente:co= Acaciz uires lor filiquis aureo quodam fulgore refperfus,adeo ut in fole atcri modo pellucedt. Acacie uires adnotatas reliquit ex Galeno. Galenus lib.v r. fimplicium medic amentorum, ubific inquit. Acacia er planta ip $\sqrt{a}$ acerba est, er fructus, 0 Juccus, qui lotus quidem er imbecillior, er minus mordax redditur, utpote acrimonian quandam per lotionem deponens. Porro fi parti alicui fane illinatur, protinus eam er ficciorem, er contractam efficiet, nuillum quidem caloris fenfum iumehens, fed nec frigoris admodum ualentem. Vnde conftat medicamin id effe frigidum, 0 terrofum, imnista qua= dam etiam effentia aqued. Et fane coniecturd est, non effe fimilare, uerin quafdamin fefe differ fas habere partes te= 40. nies; 0 calidas, que in ip fa ablutione egregentur. Eftóg; er boc tertij ordinis exiccantium, ov fecundirefrigeran-

Nomina. tium, ubi quidem elotum fuerit, illotum ueró primi. Nomen,quod a’saria babet apud Grecos,idem,quod $f t$ A cacid.s retinet apud I atinos or Italos. Ea autem Arabice Achachie appellatur.

$$
\text { A" yoos. VITEX. }
$$

CAP. CXVI.

V I T E X, fuelygos, frutex eft in arborem affurgens. Nafcitur in fluminum ripis,afperisquelocis, ac correntium alueis: ramos gerit longos, fractu peruicaces : folia oliux, fed molliora. Duo genera eius : una harum album florem mittitcum ptrpureo: altera tantùm purpureum, \& femen, ut p1per . Excalfactorias uires habet, \& aftrictorias. Semen eius potum uenenatis ictibus, aquæ quæcu so tem fubijt, lienofisq́ue auxiliatur : lac euocat: menfes ciet, drachmæ pondere in uino potum : genituram exoluit: capur tentat, \& foporem affert. Decoctum herbæ, \& feminis in defefsione, mulicribus uuluæ malo opportun opitulatul: item inflammationibus. Purgationes mouet femen cum pulegio potum, etiam fuffitu, uel appolitu: capitis dolorem diffoluit illitum : inftillatur cum aceto, \& oleo capiti in lethargo, \& phrenitide. Folia fuffitu, aut fubltratu fugant uenenata : illita cuoq; ferpentium morfibus auxiliantur : teftium duritias, cum butyro, \& folijs uitium emolliunt. Rimas fedis femen cum aqua illitum mitigat : \& cum folijs medetur luxatis, uulneribusque. Virgam qui manu teneat, dum iter facit, negatur intcrtiginem fentire. Agnum, quafi dicas caftum, uocant Græci, quoniam matronx in Thefmophorijs Athenienfium caftitatem cultodientes, folijs huius cubitus fibifternunt. \& Jygon, quafi uimen, propter inuistam ferè ramorum flexilitatem. 


\section{In Lib. primum Diofcoridis.}

V I T E X, fiue Salix Amerina, quam uulgusherbariorum Viticiscong-

VI T E X.

20

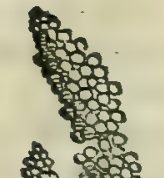

.
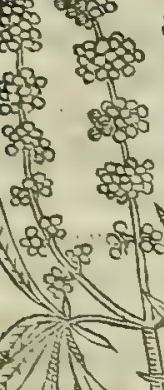

wis

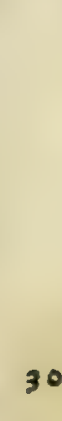

30

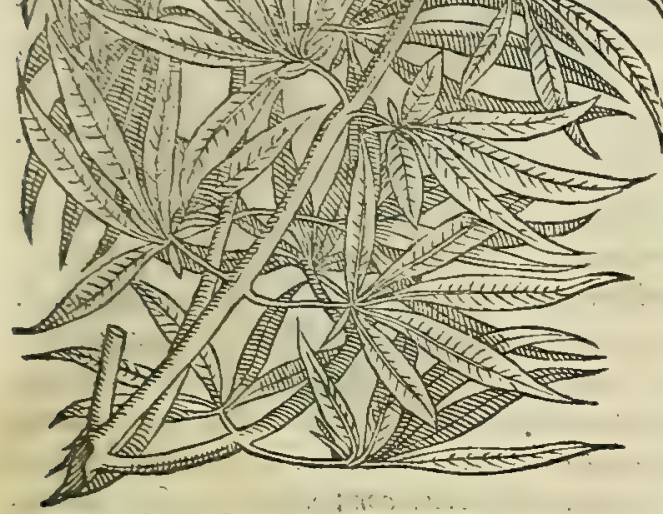

A gnum caftum appcllat, arbufcula eft in Italia uulgaris notitix. Duo eius genera reccnfet $\mathrm{Plinius}$ lib. X X I I I I . cap. I X. Maior in arborcm falicis modo affurgit: minor ramofa, folijs candidio= rifus, lanuginofis. Prina album florem mittit cü puspurco, quie or cundid uocatur: nigra, qua tantum purpuscum. Na cun= tur in paluftribus campis. Non multum a falice uitiliun ufudi= ftut uitex: foliorum quoq; apectu, nifi odore gratior cffet. Gr.t= cilygan uocant, alij agnon, quoniam matrone in The maphorijs Athenienfum caftitaten cuftodientes ijs folijs cubitus fibi fter= nunt. Vitex, ut foriptum reliquit Galenus lib. v I. fimplicium medicanentorum, caliditatis, e ficcitatis claffem tertian for tita eft, uerim ea cft nultum tenuis fubftantia, tum guftu acris fimul o adfringens : in fas tamĕ uitices ad medicinam habet inu tiles: creterum folia, fcmen'q; calida, ficcá, facultate funt, fubs ftantia ueró tenui. Nam $\mathcal{O}^{\circ}$ utentibus ita apparet, o guftantic bus acre fimul o fubadftringens percipitur tum fo lium, tum flos, tum femen. Edendo tamen etiam femen eft, uerim tam perpicuó calfacit, ut capiti boc nomine dolorem pariat. At fif frigatur ( nam e fic editur cum bellarijs) minus caput tentat. Porró fla tus uentris difcutit er cum non frictum, er multo mag is cim fri= ctum fuerit. Cobibet pretered femen impetus in uenerem tum frictionis expers, tum etiam ip am expertum. Eेolia item, floresúf; ipfins fruticis idipfum preftare poffunt. Itdq; non tantume efa, potá; ad caftitatem conforre creduntur, uerum etiam fubftrata. Hinc ef, quód Atbenis in The imophorijs,boc eft, facris Cereris, mulieres totum fibifruticem fubfternunt: binc illi quoq; nomen inditum agni, boc eft, cafti. Ex quibus omnibus manifeftum. ejt, f quidem memoria teneamus, que fuperioribus commentarijs funt dicta, agnum calfacere, fimul'q; exiccare, tum omnium maximé flatus difcutere. Porró quód exactè tenuium fit partium, facul= $t \leq 5$ clos undicio cft. Nam quéd caput tentat, non magis a multitudine uaporum ab eo prognatorum, quàm à caliditate cius, ac Jubtilitate partium fieri rationabile eft. Nam fiflatuofum piritum procreare poffet, fané er uentrem infla= ret, or uenerem fimularet, perinde ut eruca. Verum cim non tantion non excitare, imo etian reprinere queat, fuerit.profectó fecundum rute.maxime facultatem tum in excalfaciendo, tum in reficcando: non tamen illi par eft, nam utroq; palo eft infirior : fiquiden ruta tum magis eft excalfactoria, tum magis deficcatoria. Differt etiam quat litatis finul, ac facultatis miftione. Nam agni femen, ac germina modicam ferunt adfrictionem : at ruta ubi aruerit, exatté amara eft, o acris; ubi ueró bumida, fubamara. Non tamen aufteritas, aut acerbitas illi ineft: aut ficui ui= deatur ineffe, ea utiq; omnino obfcura, fcio, uidebitur, nec par ei, que eft in agno. Quocirca er ad iecur, o lienem indurata, $e$ obftruatd agni femen potiu, quan rute compctit. Sed bec ad curandi iam methodum pertinent, quam ut ommino non atting an de medic amentorum pronuncians facultatibus, fieri non poteft: uerìn celeriter ad rem pro pofitam reflectere, uiri ef utiq; temperati. Magis ; etiam idipfum in fequentibus medicamentis efficere conabor, boc eft, ubi ex quibusd am paucis euidentibus generalem facultatem collegero, particulares poftea actiones omittam. Nam in prefens id folim nouiffe fufficit, qucid agnus calidus eft $\widetilde{\sigma}$ ficcus facultate, id'́; non mediocriter, fed tertio

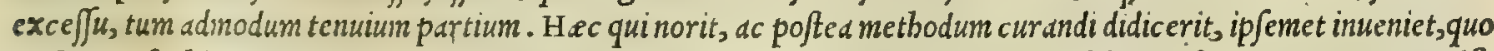
pacto men fes binc cieat, quo pacto partes induratas digerat, quo pacto laßitudinem foluens, $\int e u$ acopum, excalfa

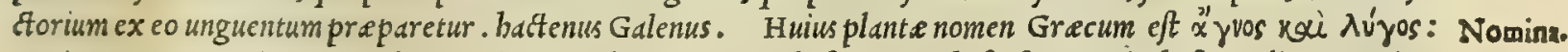
Latinum, Agnus, Vitex, or Salix amerina: Arabicum, Famancheft, Samancheft, feu Bengiecheft: Italicum, Vitice, $\leftarrow$ uulgare, Agno cafto: Germanicum, Schaffs mulle, $\odot$ Keufchlamp : Hipanicum, Gattillo cafto.

so

$$
\text { I'TÉQ. SALIX. }
$$

\section{CAP. CXVII.}

S A I I x vulgo nota eft. Cuius femen, folia, cortex, \& fuccus fpiffandi vim habent. Trita folia cum exiguo pipere, $\&$ vino pota, ileofis fubueniunt: fumpta per $\mathrm{fe}, \& \mathrm{cum}$ aqua praftant mulieribus, ne concipiant. Salignum femen in potu fanguinem expuentibus prodelt. Cortex coldem prabet effectus . corticis cinis admifto aceto maceratus, illitu clauos, \& callos tollit . Ex folijs, \& corticefuccus cum rofaceo in calyce punici calfactus, aurium doloribus auxiliatur. Decocto eorum podigras foueri vtilifsimum : furfures purgat in corpore. Excipitur fuccus, qui manat ex ea, cùm floret, excifo cortice: in plaga enim concretus humor inuenitur, qui ad purganda, qux obftant oculis, fuam uim prabet. ex Gal. deratio.

Viticis uires 
Salicis confideratio.

Salicis vires ex Gleno.

Nomina.
S A L I X.

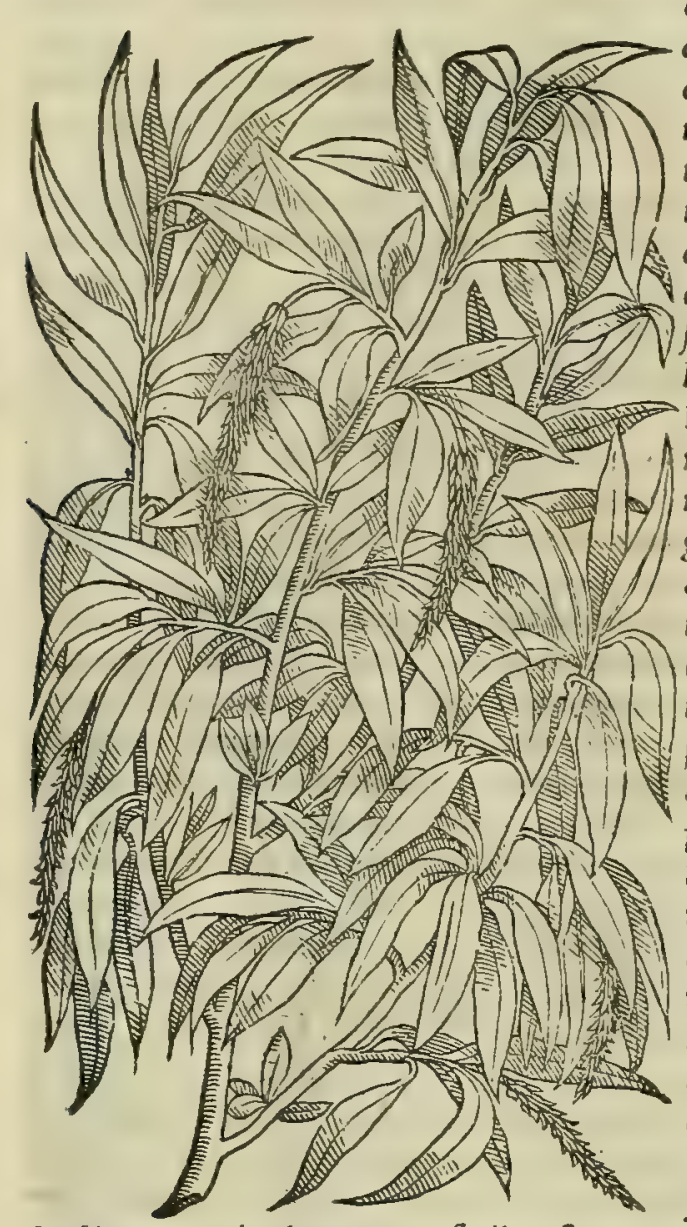

Q Y A V I s de Salice, ut anatantim agat Diofcorides; eius tamen plura traduntur genera tum a Theophrafto lib. III. cap. X I I I. de plantarum biftoria, tum etiam i Plinio lib.X V I. cap. X X VII. Nam quxedam in tantam proccritatem affurgunt, ut ex eis in Liguria fiant o pertice, or pali maximi iffus ad ui= tium pedamenta. Alia rion tam procera crefcunt, colore fufescen tes, fequacis lentitie, que ligandis cadorum unariórum circulis commodéfinduitur. Rurfus alie firmiores corbibus, or rufti= cane fuppellectili admodum expetitie. Alire denique funt minu= fcule, ac pectabili tenuitate, texendis canistris, ciftellis, ac $c d=$ lathis aptißime. Salycis lacryinam trium generum effe prodidit Plinius libro XX I I I. cap. I.X.tametfi unius tantum generis meminerit Diofcorides. Vnam arbor i $\int_{a}$ pponte exudat: altera manat in plaga, tum floret, excifo cortice trium digitorum ma= gnitudine : tertia esc detruncatione ramortum autumni tempore a falce diftillans. Caterum qui salicis albicantem pumam adno= tatam reliquerit, inuenio neminem: que delapfis ftatim floribus é ramufculis uue modo dependet, donec uentis arrepta buc, or illuc plume modo impellitur. Salix citó fenefcit, ac breui uite. Patio perdurat. Eius materies ideó fcutis faciundis apta, quòd lenta admodum fit, tendx, \& leuis... Salicis uires memorie prodidit Galenus lib. v I. fimplicium medicamentorum bis uerbis. Salicis foligs ad cruenti unlneris glutinationem quis uti poffet. Ve= rùm florıbus eius maximé propé omines utuntur medici ad exiccan tis emplaftri preparationem : eft enin uis corum ita deficcato= ria, ut morfu abftineat : babct uerò eticm quandain adftrictioné. sunt uerò etiam, qui fuccum ex ea expreffum, medicamen fer: uent mordacitatis expers, o exiccatorium, ad multds res uti= le. Haud enim inuenias quid ad plurés res usilius medicamiento citra mordacitatem exiccante, quod paulim etiam adftringat: ficut in opere de medicamentorum compofitione exactius demor:

Atrabitur. Porró arboris cortex fimilem facultatem obtinet tum floribus, tum folijs, nifíquöd temperature fit fic= cioris, uelut omnes cortices. Sed bunc quidam comburunt, eius;; cinere utuntur ad omilid, que ualenter deficca.

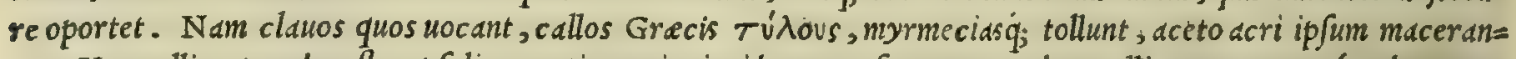
tes. Nonnulli autem dum floret falix, corticem eius incidunt, o fuccum quendam colligunt, utunturq; ad ea, quae pupillas offufcant, extergente uidelicet, fimul'g; tenuium partium medicamine. Vti ueró itto ad multa alia quis pof= fet, fiquidem talis fuerit. vitex ita Latinis dicta, Grecis itéd: Arabibus, Bulef, Bhulles, saffaf, aut Cha= lif nominatur: Italis, Salice, o Salcio: Germanis, Vueiden, $\mathbb{F}$ Felbinger : Hifpanis, salce, aut Salgueiro: Gallis, saulz.

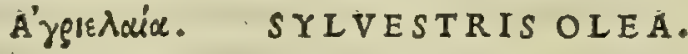

CAP. CXVIII.

S Y L V E S T R I olex, quam aliqui cotinon, id eft, oleaftrum appellant, alij Aethiopicam oliuam, folis aftringunt : trita autem \& impofita ignem facrum, ulcera qua ferpent, epiny etidas, carbunculos, reduuias, nomasq́ue cohibent : cruftas emarginant cum melle illita : quinetiam fordida ulcera repurgant: inflammationes, panosq́ue cum melle impofita difcutiunt: cutem à capite uulfam conglutinant:oris ulceribus, \& priuatim infantium commanducata medentur. Succus, \& decoetum eofdem habent eftectus : fanguinis eruptiones, ac muliebre profluuium, admotus fuccus inhi= bet: uuæ oculorum, puftulisq́ue prodeft: ulcera, \& ueteres defluxiones fiftit: quapropter in collyria additur, ad palpebrarum erofiones perquàm utilis. Exprimitur fuccus tufis folijs, affufo uino, aut aqua, ficcatusque fole in paftillos digeritur: fed longè ualidior ad recondendum fuccus haberur, qui cum uino, quàm cum aqua expreffus eft . auribus fubuenit, fiue ulcerentur, fiue pus effluat. Folia conuenienter coliacis cum farina hordeacea illinuntur. Vruntur cum floribus folia, ut fpodij uicem cinis præftet, in cruda olla, oblito ore luto, ufque dum figlinum percoquatur : reftinctaq́ue ui* no, \& rurfus fubacta; eodem modo uruntur: poftremò cerufx modo elota coguntur in paftillos. Huiufcerodi cinerem in medicamentis oculorum, conftat fpodio noncedere, fud eifdem uiribus præditum effe putandum eft. Foliorum fatiux olex eadem uis intelligitur, fed aliquantò inferior: unde ocularıbus medicamentis ob fuam mitiorem nim conuenientior eft . Sudor ligni uirenti accenfo manans, illitu fanat lichenas, furfures, \& fcabiem. Oleaginum femen illitum medetur furfuris bus, \& ulceribus, qux depafcunt, vorantq́ue: quod autem intra nucleum eft, ex adipc, \& farina fcabros ungues excutit. Coly mbades tritæ, \& ambuftis illitæ, puftulas gigni prohibent : fordida ulce- 


\section{In Lib. primum Diofcoridis.}

OLEA SYITESTRIS.

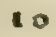
Etentur.

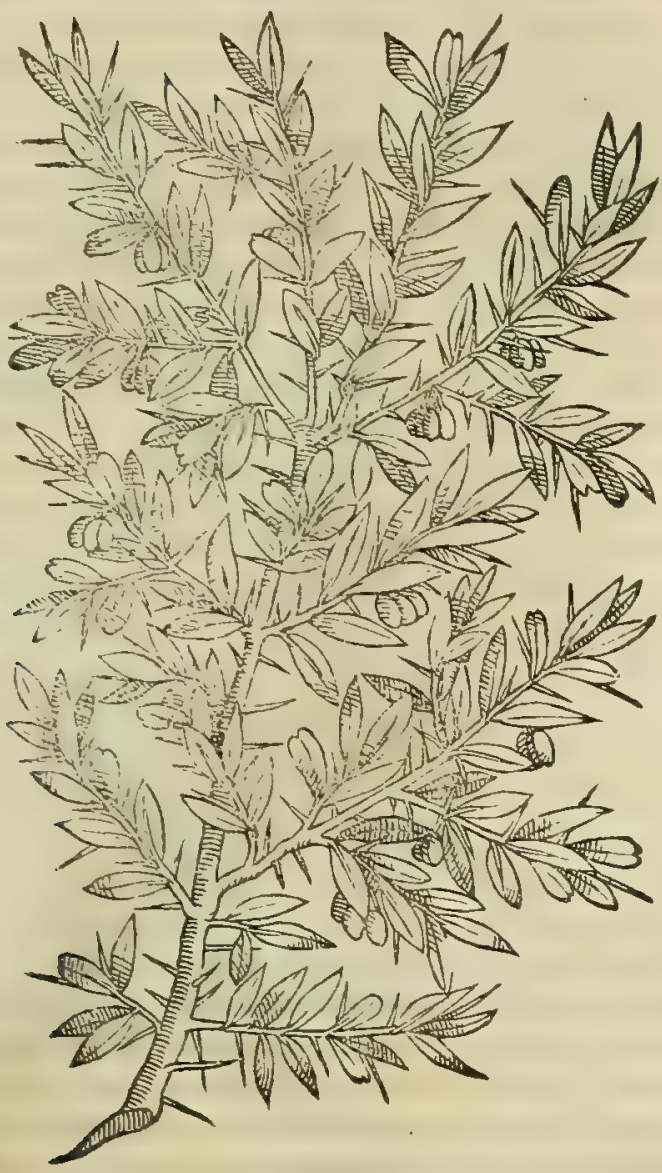

OLEA SATIVA.

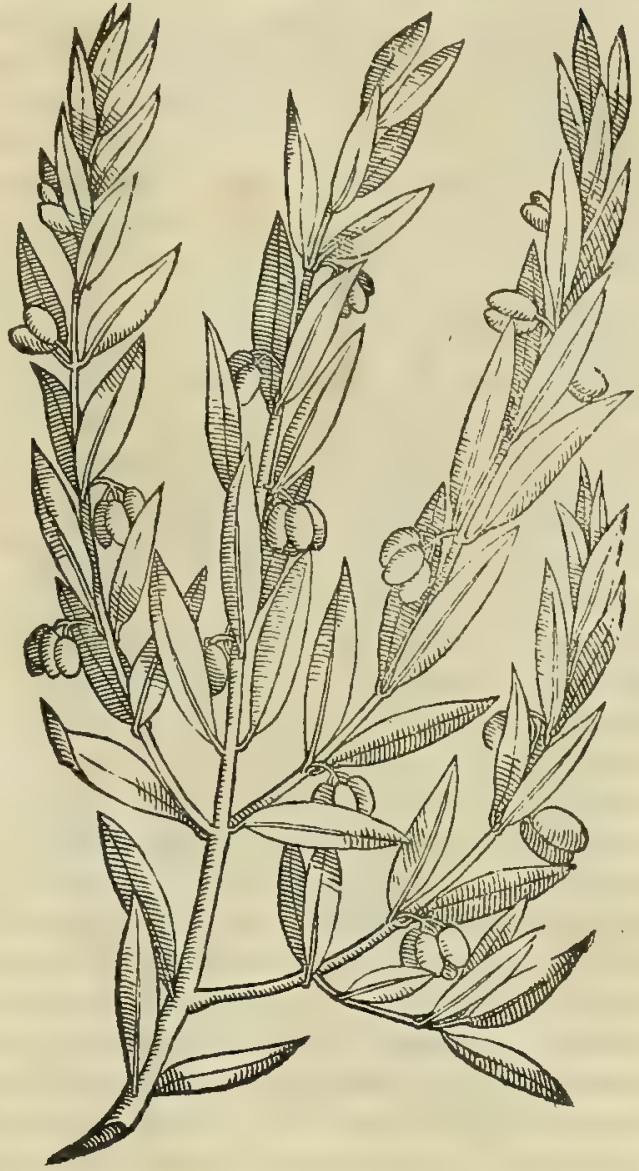

ra purgant. Muriæ fuccus collutas gingiuas contrahit, \& motus dentium firmat. Oliua flaua, \& recens ftomacho utilior $\mathrm{eft}$, nentri difficilis : nigra autem, \& matura corruptioni opportuna eft, ftomacho adueifatur, oculis non conucnir, capiris dolorem movet: arefaeta 1 llitu depafcentia ulcera fiftit, \& carbunculos emarginat. Olcum fylutftris oliuæ gingiuis putri uligine laborantibus collutitur, dentium mobilitates ftabilit: calfacti fotus gingiuis fluxione laborantibus utilis eft : lanam enim fpecillo circumigatım oleo madefacere oportet, \& gingiuis admouere, donec albæ fpe-

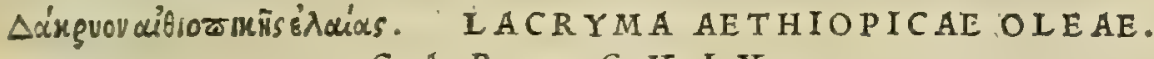 $C A$ P. C X I X.}

LACRYMA, quam Aethiopica olea ftillat,fcammonio fimilis quadántenus eft, fulua, ftillis, exilibus conftans, mordax. Quæ autem ammoniaci, aut gummi fimilitudinem refert, colore nigricans, nec guftu mordens, fuperuacua eft. Noftrates olex, oleaftrique fimilem lacry mam fudant, quæ commodè ad oculorum hebetudines illinitur : cicatrices, albuginesq́ue illitu emendat : urinam, \& menfes cict : cauis dentium impreffa ad dolores effic $3 x$ eft. Inter uenena fcribitur, partus pellit : lepras; $\&$ impetigines fanat. Appellatur autem Aethiopica, \& agreftis olea .

$$
\text { A'pógry. AMVRCA. }
$$

\section{CAP. CXX.}

A M V R C A exprefix oliuæ recrementum eft. Decocta in cupreo uafe ad crafsitudinem mellis adAtringit, cæteros præbens lycij effectus. Infuper dentium dolori, \& unlneribus cum aceto, uino, aut mulfo commodè illinitur: additur in medicamenta ocularia, \& meatus inductu fuo obftruentia. Vetuftate meliorem fieri conftat. Vtiliter infunditur fedis, genitalium, ac uulux exulcerationi. Si uerò cum omphacino recoquatur ad mellis crafsitudinem, cariofos dentes extrahit : iumentorum fcabiem cum decocto lupini, \& chamæleonte illitu fanat. Cruda, \& recenti amurca podagras, articulariosq́ue dolores foueri, utilifsimum : peruncta in uillofa pelle, \& hydropicis impofita, tumoris molem reprimit. 
C v m olius, olcum, olee Acthiopice lacryma, er amurca ex una tantim arbore proueniant; non ab re duximus de bis omnibus fimul pertractare, e ita fingulis partibus unica commentatione, quantum opus erit, fatisfacere, ON quicquid ad eds fpestat, fimul perftringere. N.xcuntur fylueftres olce copio $\int_{x}$ in agro noftro senenfi, alijs $\dot{q}_{;}, \mathrm{He}=$

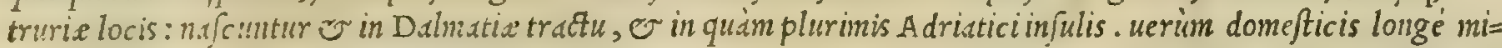
nores, forijs brctioribus, aculcatisó; ramis. Earumbacce et/i numero fa facunditate uinc ant; magnitudine tamen $\int a=$ tivis cedunt : quin or orifapidiores existunt. Cuius reicerto funt teftimonio turdi,nerula, ac furni: quippe quonia fylucftres oliu:1s liócntius deuorant, quim fatiuas. Incole, qui aucupijs delectantur, agreftes oless fumino ftudio, ac indufria ab aubus tucntur : nompe quód confecta fatiuarunt uindemia, auicul.e ad has aduolant, ubi menfe decem= bri, e ianuario uifco innuncre capiuntur, prefertim q; turdi. Pauci admodum funt in Hetruria, qui oleaftribacc as

Oliuarum ge legant, ut olcum inde cxprinant: nam ea demum magna fatiuarun copia eft, qux facit, ut inibi omnino paruipen= nera plura. danturfylueftres. Olinarum gencra decem in antiquorum notitiam peruenffe reperio, paufias uidclicet, algia= nas, liciniand, fergias, neuias, culminias, orcbites, regias, circites, murteas: et $/ \mathrm{i}$ virgilius trium generum tantum meminerit, quemadnodum etian plura non nouit hac noftra etate Hetruria, prefertim $\dot{q}$; nofter senenfis ager. Pri= mum harum genus eas nof rif aciunt, qua licet a minoribus ole arum plantis profirantur; funt tamen fpectata forma, er mgnitudine Boizonienfibus non quiden inferiores. His tantum muria a) feruat is utuntur in cibis: quandoquidem olco minus apte funt, quód multó plus anurcé,quàim oleifundät. Proximx tü colore, tü magnitudinc preftätes, quan= uis predittis longé minores fint; funt tanen onnium aptißsine ad olei conficiendi ufum. quippe quodoleum cx eis expreffum, fit nois modó flaum, dulce, pellucidum, ac ceteris preftans; fed eliam copiofum. Gigmuntur be à pro= cerißimis oleis, pregrandibus, iuglandium nucum inftar, ramos in altum, latum'́; amplißimé fundentibus. cas rura noftra Oliuaftre unlgó uocant. Tertij ueró, ac poftremigeneris ea deniq; funt, qua palßim in uniuer $\int_{a}$ Italia na= 20 fcuntur, er omnium unlgarißima babcitur. Laudatißims olex Eononienfibus, o noftratibus craßiores muria af=

Olex, \& quer feruatie Roman, Venetias, $\odot$ ad alias compluses Italia clarißimas urbes, ubinagnific $x$, opipará

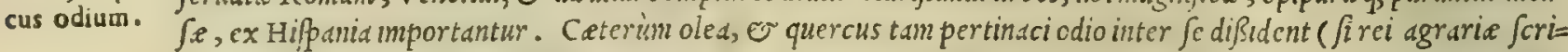
ptoribus fides eft adbibenda) ut altera prope alterasn depacta breui tempore percat. Oles item fi primo germinatu à capra depafcantur, adcóferile fcunt, ut millo remedio in pofterum prolific fiant. At fi alia de caufa raras admo=

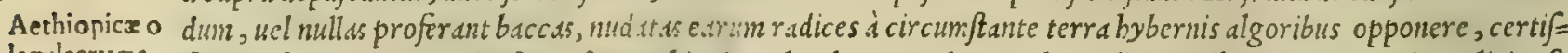
lez lacryma. fimum eft remedium. Sylucferis, Seu Acthiopic elex lacryma, licet multis polleat uiribu:s; cius tamen in Italicis of ficinis nullus cst ufus: $l 1 e$; quod ca ad nos afferatur, adliuc compertum babeo. Sunt, giul hanc putent illud effe gum= mi, quod medici receltiores, or officme gummiclcmi appellant. Verim illud certo argumento cft, olea Acthio= pice lacrymam gummi clcminon cfee, qućd gufatu mordax non fit, neq; linguam uellicet: tum ctiam, quód omni= 30 bus perfpicuun fit, cam lacrynam (etfi improprie gummi appelletur) non in gummi quidem; fed uerius in refind= rum genere cfe recipicndam : cim igni expofita statim collique fcat, o diffundatur, quemadmodume refine, que ¿́ pinu, piced, or alijs refinam fundentibus plantis colliguntur : licet nobis prorfus ignota fit plante, à qua in orien= te defluit . Siquidcm nullum gummi genus (quod ego fciam) igne colliquefcit, nifí addito ace to, uel uino: quin potius

Gümi elemi. ftatim comburitur. E $l$ e alia olea maris rubrilacryma,ex qua ( ut Theopbraftus inquit lib. I I I I. cap. v I I I.) medicififtendo fanguini medic amentum componunt. Ceterum quanuis atate noftra obfcura admodum fit gummi Elemi origo; eius tamen uires clarißine apud chirurgicos, or uulnerarios medicos reperiuntur: nam in caluarie

Amurca olei. fracturis, ac uulneribus mirifice unguentis, or emplaftris additur, adeo ut prxfrantißimum fit in bis fanandis medica mentum. De Anurca olei poftremó nil aliud dic endum est, nifi quód fit admodum utilis (ut memoria prodidit $C_{a}=$ to) apotecharum, or officinarum fabricis, ubi lanei, uel fericci pannireconduntur. Nanficalciadmifceatur, $\sigma^{\circ} 40$ ex ed inde parietes incruftentur, oblinantur $\dot{q}_{j}$, itcm laque aria, or pauimenta non modó parietes contractos, uel ad=

Oliux vires uentitios humores nunquam collacrymant, $\sim$ fitum minimé contrahunt; fed nec blatta, nec aranei, nec cuiufuis ge= ex Galeno. neris uermiculi ibidem gigni poffunt. Oliue uires prodidit Galenus lib. v r. fimplicium medicamentorum, fic inte Nomina. quiens. Oliua rami quantumbabent adfrictionis, tanta e frigiditatis participes funt. Fructus ueró, fi quidcm ad unguem maturuit, moderaté calidus est: fin immaturus cst, magis tum adfringit, tum refrigerdt. Oled fatiua,

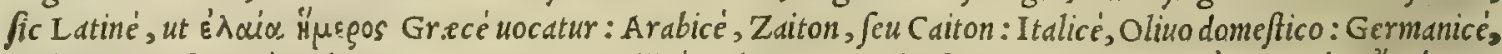

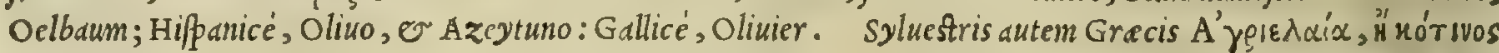
appellatur: Latinis, Oleaster, or Olca Jylucstris : Italis, Olino faluatico: Germanis, Vuilder oelbaum: Hipanis, Azebuche: Gallis, Oliuier Jaunage.

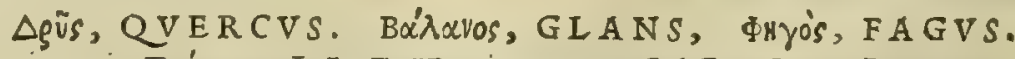
İgivos, I L EX. CAP. CXXI.

QVER C v omnis adfrictoriam uim habet, præfertim liber, quicortici, \& ligno intercedit : quinetiam tunica putamini glandiś fubiecta. Decoćtum ex ijs datur dyfentericis, coliacis, fanguinem excreantibus. 'Trita in peffo fominis fluxione vuluælaborantibus fubijcitur. Glandes eofdem effectus exhibent: urinam ciunt: capitis dolorem, \& flatus in cibum fumptx pariunt: refiftunt efitatæ uencnatorum ictibus. Decoctum earum, \& corticis cum lacte uaccino potum, prodeft contra toxica. Intritx crudx infammationes illitu leniunt: ad duritias, quas cacoethe uocant, \& malefica ulcera cum falfa axungia conueniunt. Iligneæ glandes uiribus quernas antecellunt . Fagus, \& Ilex quercus generi afsignantur, \& confimile munus obeunt. Ilignex radicis cortex cum 
QVERCVS.

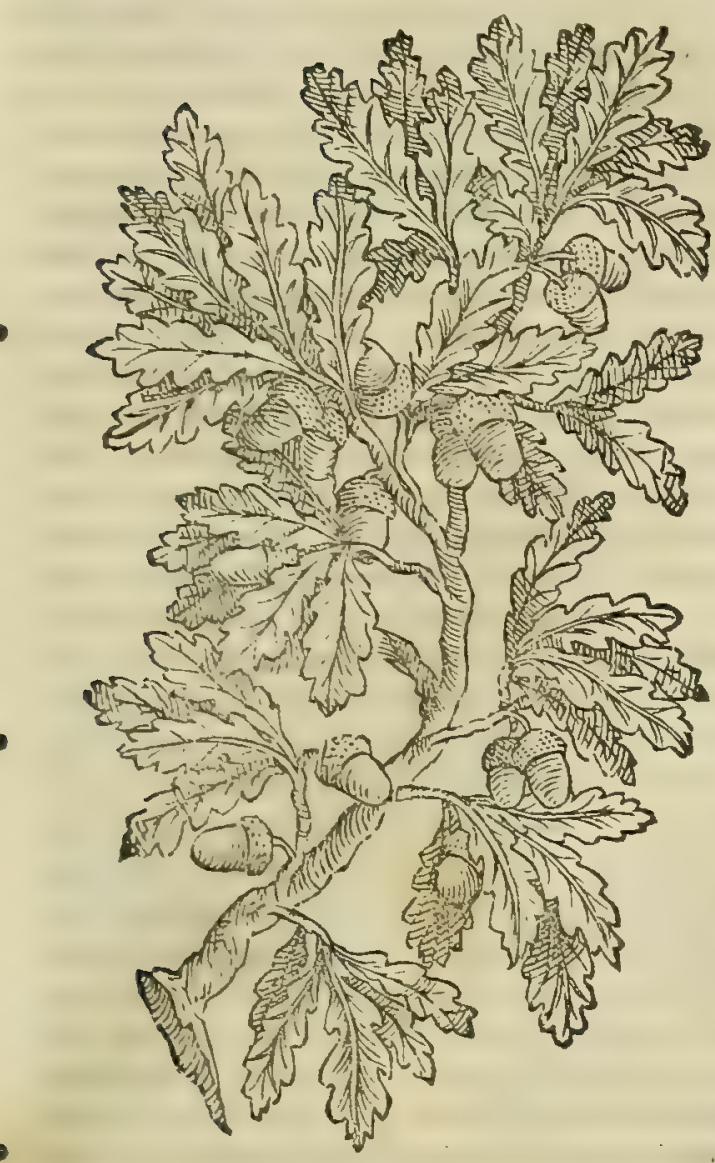

F A G V S .

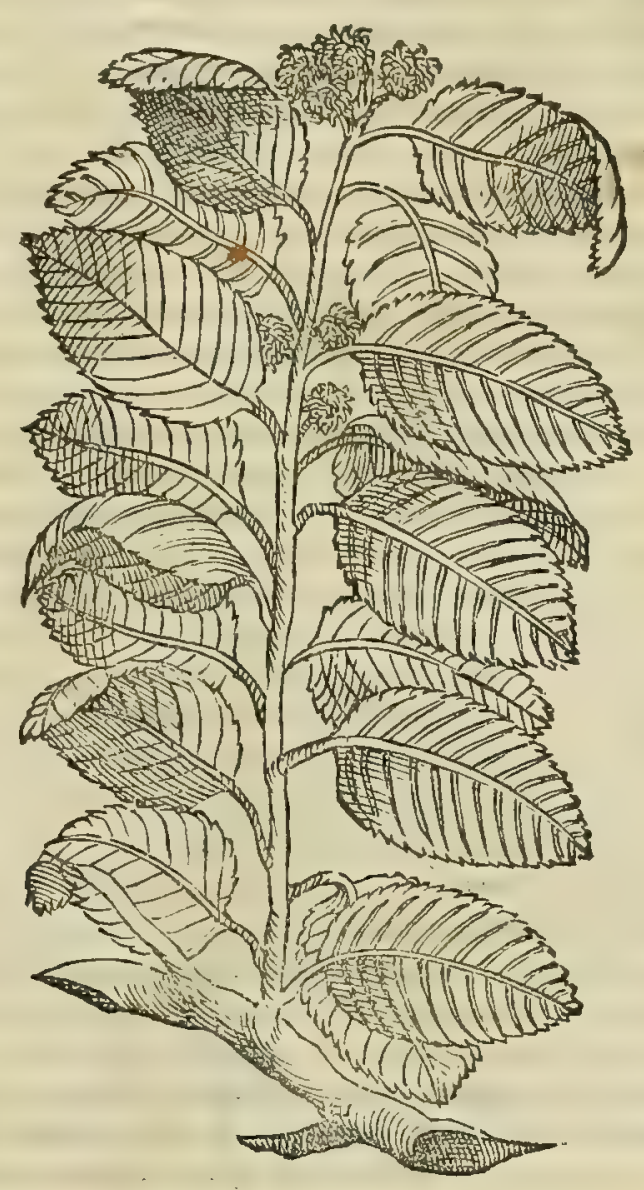

I L E X.

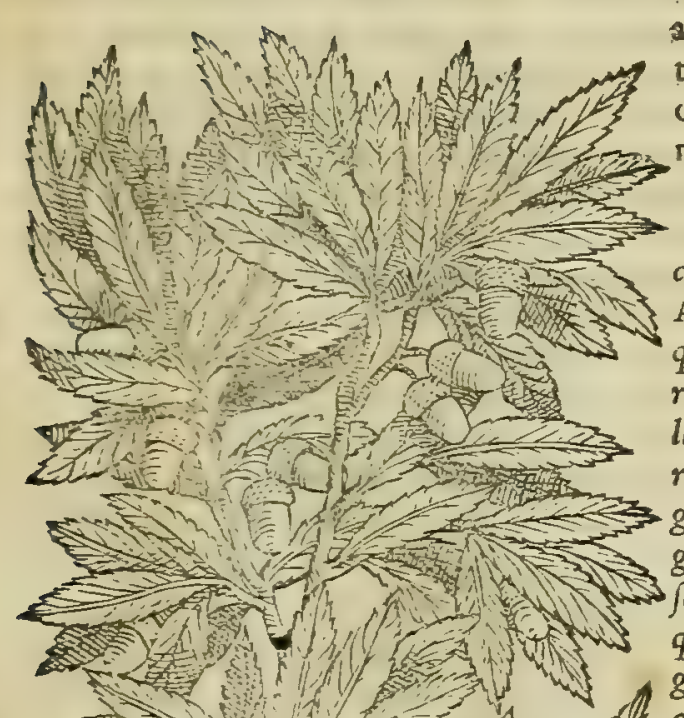

qua coctus, dum mollitus intabefcat, \& tota nocte illitus, denigrat capillos, priuścimolia terra purgatos, Folia omnium tufa, \& trita tumoribus profunt, \& imbecillas membrorum partes corroborant.

S V N T O alie glandiferigeneris arbores, preter Quer= Glädiferarum cum, Ilicem, o Fagum: inter quas numerantur Cerrus, suber, arborum cō." Aefculus, er alic nonnulles, qux fuo more rura nostra appellant, fideratio. quarum omnium exacte rationem reddere potest uniuer $\int a$ Hetru= ria. Quippe quodd or in maritimis nostris senenfibus, er Fa= lifcorum agro, ac etiam Romano tractu, omnia bec glandiffra $=$ rum genera adeo numerofa in uastißimis fyluis proueniant, ut glandibus innumerabiles porcorum greges incolx ibi quotannis $\int_{a}$ ginent. Verum ne aliquis existimet, harum non meminiffe Dioc fcoridem, quód fortaffe eas non cognouerit, fciendum est, eüu, meo quidem iudicio, ¿gvios nomine cöprehendife in uniuerfum omnes glandiferas arbores, non folum quod fairet, una voce omnia itla genera côtineri poffe, fed etiă ut breuitati confuleret : Sọve enim apud Gracos nō modó quercum particulation fignificat; fed uni= uerfim quancunque glandiferam arborem. Quo fie, ut dixerit ip=

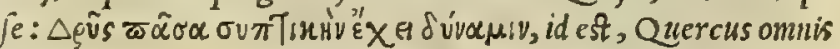
adftriftoriam uim habet, ac fi dixiffet, arbor omnis glandifera ad= stringit. Porró mirum est ( ut Theophrastus eft auctor lib. I I I. Quercus que cap.vIII. E IX. de plant. historia) quód alia plurima prater proferas. fructum ferat quercus. Nam gallam gignit paruuldm, atog; alteră refinofam, e nigrä: quin e aliud pecie ueluti morum, fed du= rum, $v$ fractu admodum difficile : id tamen rarum. Ad hec aliud effigiě colis reprefentans. Cüm ueró perficitur,durum quid par= te emicante, $\odot$ perforatum, $\sigma$ tauricaput quodammodo amulans 
profert, quod preruptum nuclei olex pecicm intus oftendit. Fert 0 quod quidam pilum appellant. Id pilule eft coe man gerens lanaccam, mollem, nucleo durior,qua in lucernarum luminibus utuntur. Flagrat etenim probé, ut galla nigra. Fert es alter an comigcrain pilulam, ceterim quidem inutilem, uerno autem tempore fucco melligeno inficiē= ten tum tactu, tun gultatu. Inq́; ranorum alis pilulam alian gignt fine pediculo, concauó ; $\int_{\text {e }}$ illem, peculiarem certé, uerficoloremá;. Nam esminentes quofdan umbilicos candicantes, uel paßim uariantes nigris maculis habet: partem mediam grani tin ftura infectam, plendidan'q́; oftendit, aperta, nigra, er putricans cernitur. Lapillum quo= quc puniceum magna ex parte gignit, quanquam raró. Item aliam có rarioren pilulan ć folijs conuolutam, cómpref= fam, atque oblongam. Super folijs weró tergo adharentem pilulam fert candidam, aquofan, dum tenera eft: bac etiam interdum mufcas intus continet, ueniens'́; ad incrementum iuftum in modum levis paruule galle indurcfcit. Fungos omitto, qui è radicibus, o inxta radices erumpunt: communes enim cos cum cateris babet arboribus. Quin= $\mathbf{0}$ etiam uifcum taceo, quippc cum in alijs quoq; proueniat. Sed nibilominus (ut dictum cf) ferax bac arbor babetur plurimarum. bactenus Theophraftus. Caterum non dubitandum eft, quin onnes ij partus fuos babeant ufus, fuis q́; polleant uiribus. Stillatitia aqua, que in balnei calentis aqua uitreo organo à tencllis qucrcus folijs primo ip arum exortu decerptis elicitur, iocineris defluxiones fiftit, renun calculos comminuit, o mulicrum alba profluuid cobibet. Ad hec cius echinate pilule ficce, ac trite uim apprimé adfrictoriam poßidcnt: eá,; propter efficacißimo funt re= Fagi confide- medio contra omnes aluifluxiontes. In fumma preftant, ubifupprimere fit opus. Fagusquog; glandiferis arborix ratio. bus adnumeratur, tamet $f$ f fructus cffigies glandibus pror $\int u$ reclamet. Hic enim extina parte calyculo includitur ro tundo, quadántenus echinato, bijpido, ac f cabro: interius ucró triangulari forma nuclei funt, qui tenui, er leui cute, caftanearum modo, in atrum rubefcente obteguntur. Horum fapor dulcis, o fubadftringens. Glires boc pabulo ma= ximé delectantur, ac pingue c cunt. Quamobrem cum eius aducnit maturitas, innuneri capiuntur glires in Carniole, sti 20 ris, er Carinthie fyluis: quippe ijs in locis incolas mane inpexeris, quifaccos gliritus plenos frr snt una tantum no= cte capis. Delectantur fagifructu etiam mures: fiquidem é longinquis regionibus natura ducti gregatim fyluas in= grediuntur. Item o f ciuris gratißimus eft cibus, ac etian turdis, merulis, dijs'́, compluribus uolatilibus. Quin or obfeffos boftibus bomines in oppido Chio ed tantum glande victitaffe, Conclius Alexander eft auctor, donec $\int e$ obfi=

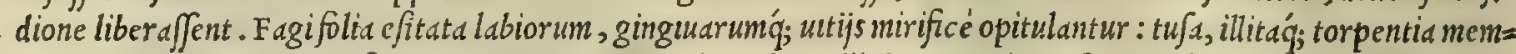
Ilicis confide bracorroborant. Glandis faginex cinis renum calculis utiliter illinitur. Ilex infuper arbor eft in Italia notifima, ratio. Bectaté; proceritatis, cortice in rufum nigricante. Materics eius denfa admodum cft, ac robufta, ill atrum rubez

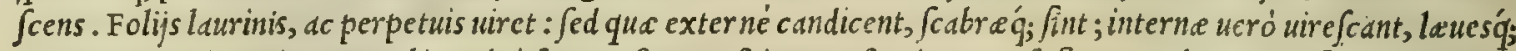
cernantur: quine in to to ambitu adeo ferrata funt, ut pinarum peciem pra fe ferant. Glandes profert quernis mi= nores, que e in reliquis minus praftant. Iligneus carbo Hetruf cis in pretio eft, non modó quód ignem diu fouedt, fed

$S$ V B E R.

Smilacis confideratio.

fus.

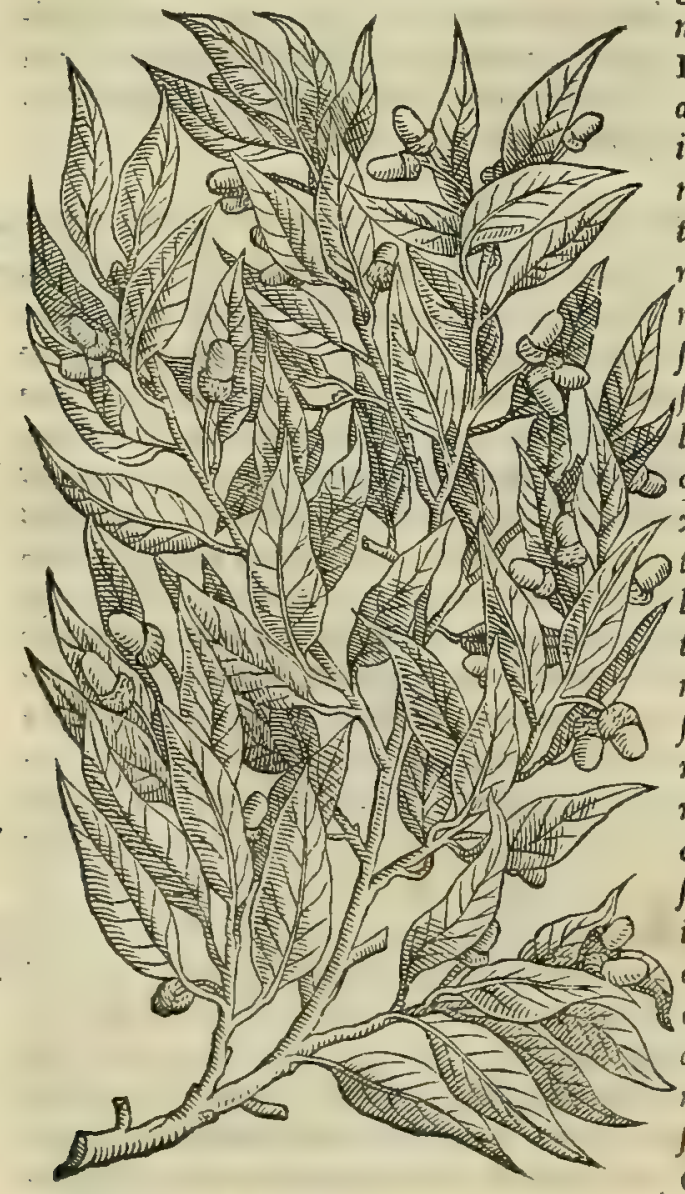
etiam quód (ut aiunt) uapore caput minimé tentet. Hac preter glandes, pilulas quafdam rubentes gignit, que trite cum accto uul neribus recentibus, $\sigma$ cruentis oculis utiliter imponuniur. In Ilic is genere (ut memoric prodidit Theophr. lib. I I I. cdp. x v I. de plant. hiftoria) eft arbor illd, quam Ârcades smilacem uocant, ilici fimilis (ed dutem non eft taxus,qua etiam fmilax dicitur, quo'= niam de taxo capite $x$. eiufdem libri differuit Theophraftus ) folio tamen nón aculeato, fed molliori, profundioriq, differentijsó; plu ribus diftinguendum: nec materie, ut illa, folida, $\beta i \iint_{a} q_{;}$, fed foluta, molliq, in opere. Meminit buius Gal. lib.v I.cap. I I I de cöp.med. 40 fecundum locos in columelle remedijs, fic inquiens. His fortior a fint myrti,ac baccarum eius decoctum, $\sigma$ ex acerbis cotoneis ma= lis, o uirgultorum tenerorum ilicis, arbuti, finilacis, ac fagi.super quo loco dubitat Cornarius, quomodo fieri poteft, quód fmilax ( $t a=$ xum, uel eius peciem intelligit)qux ab omnibus ueneno $\int$ de cribi= tur, ponatur ḋ Galeno inter gurgulionis remedia.In dubij verò $\int 0=$ lutione nil aliud determinat, nifi quód, cum non ubique (fic ip $\int e$ pu= tat) tdxus fit uenenofa, ex eo genere fumi debeat, que leth li c areat noxd. Séd fi Cornarius Theophraftum fibi alioquin faniliarem cŏ= fuluifet, qui milacem quandam(ut pauló anté oftendimus)in arbo= 50 rem ilici fimilem refert, re Gius, ,meo quidem iudicio, 0 p.tucioribus rem hanc explicaffet. s V В ER deniq; arbor ef fructu, et folio ili= cis, perpetua fimiliter coma uirens, quanquam id negat Theoplra= ftus, fed craßißimo cortice ueftitur, al y; ilici magnitudine cedit, ut ij quidem atteftari poffunt, qui Baccano Romam profecti funt : eo enim in itinere innumere Suberum plante uifuntur. Hac cortice exuta minimé are foit, quemadmodum reliqux arbores: quandoqui dem natura haud ignara, quod Sepißimé cortice expolianda cfeet, materiem duplici cortice muniuit. Inter plures, ac uarios cortic is fuberei ufus, qui in rebus doneftic is celebrantur, ille pracipuus eft, or unlgaris, quod futoribus maxiné fit expctita ad crepidas conji:

ciendas. 


\section{In Lib: primum Diofcoridis .}

ciendas. Quin orglobis ex ea fuct is utumtur pifcatorcs, quód ea nunquam aquis mergatur, fed fupernatet fuftinèdis retibus, plumbeis glandibus in altum ductis. Ideóf; Plinius lib. $x$ v I. cap.V I I I. Fcriptum fic reliquit. Suberi minima arbor, glans peßsina, raraq́; : cortex tantum precraffus, ac renafcens, aty; etiam in denos pedes undiq; explanatus. Vfus eius anchoralibus maxime nauiun, pifcantium '; tragulis, or cadorun obturament is : praterea in biberno farmi= narum calceatu. quamobrem non infacete Greci mulieres cortices arborum appellant. Sunt qui suberem freminam jlicem uocent, atq; ubi non nafcitur ilex, pro ea fubere utuntur, in carpentarijs precipué fabricis, ut circa Elin, o $\mathbf{I}$ acedemonem. Nec in I talia tota nafcitur, ncc in Gallia omnino. Et codem libro, cap. X L. inquit. Eius materies tar disimé uetuftatem fentit, ficut robur, larix, caftaned, iuglans. hec Plinius. Eft e alia arbor glandifera, quan, Phelladrys. quòd folis fir at fuberis, corticem ucró, o ligni matericm cerro non abfimilem, Hetruria uulgó appellat Cerrofu=

10 guaro, quasi Cerrifuberem dic as. Id quod ctiam feciffe uidetur antiquitas: quandoquidem Theophrafto loco fupe= rius citato ea Pbellodrys dicitur. Subcris cortex tritus ex aqua caldd a potus fanguenem fluentem ex utralibet par= te fiftit. Eiufdem cinis ex uino calido fanguinem excreantibus magnopere laudatur. Galenotam quercus, qudin

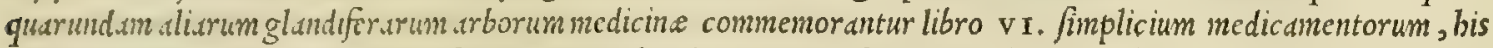
uerbis. Quercus partes onmes adferingentis qualitatis participes funt. Sed plus tamen babet, quec in trunci corti= ce membrana fubeft, tune que fub glandis ipfius calyculo, ed uidelicet, que fructus carnein conueftit. Quamobrem ad proflumium smuliebre, o fangunis expuitiones, tum dyfenterias, o diuturnos uentris fluxus commodam effe credunt. NIaximé ueró ea utuntur decocta. Valentius tamen adftringunt, fagus, o ilex, feu quis eas pecies effe roboris uelit, feu toto genere diuer $f_{a s}$. Quin er folia bar um plantarum tenella illita non inftrenué deficcare ualent, minus autem que funt alterius roboris, niminum quanto minus fortuta funt adftrictionis. Siquidem ego quandoque

20 glutinafe me uhinus meenini falce inflictum, ciun nullum adeffet ad manum medicamen preter ipfius quercus folid:

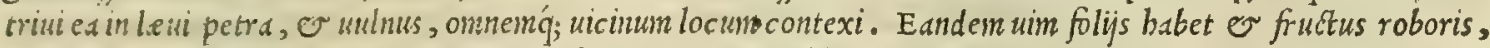
coó; medici nomull ad incipientes, or crefcentes utuntur. phlegmonas, nam que iam uebementes sunt, ad,trin= gentis repunt. Sed talia ad curandi potius rationem, quim prefentem tractatum attinent. Caterim in prat = fentis no:uffe, quod catenus adftringentem, quatcnus dicum est, facultatem quercus obtineat, fufficit: ac proin= de dejîccandi,atg; adffringendi : excalfaciendi autesn paulo infra media, in genere fcilicet eorum, que ( ut fic dicam)

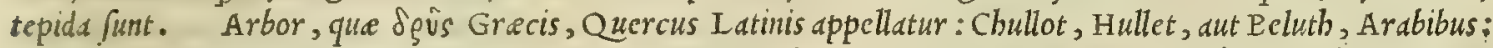

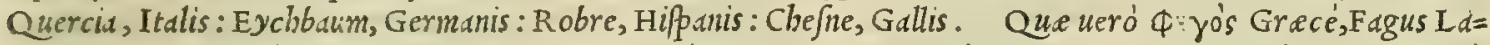
tiné dicitur: Arabicé, Chinaos, aut Chiachas: Italicé, Faggio : Germanicé, Buochbaum: Hipanicé,Haia : Gallicé, F.us. Qua deniq;; Graca noce wọivos, Latina Ilex nominatur: Arabica, Barbes, fiue Carmas: Italica, Elice: 30 Hipanica, Anzind, er Anzinheira.

$$
\text { K'́sove. CASTANEAE. }
$$

\section{CAP. CXXII.}

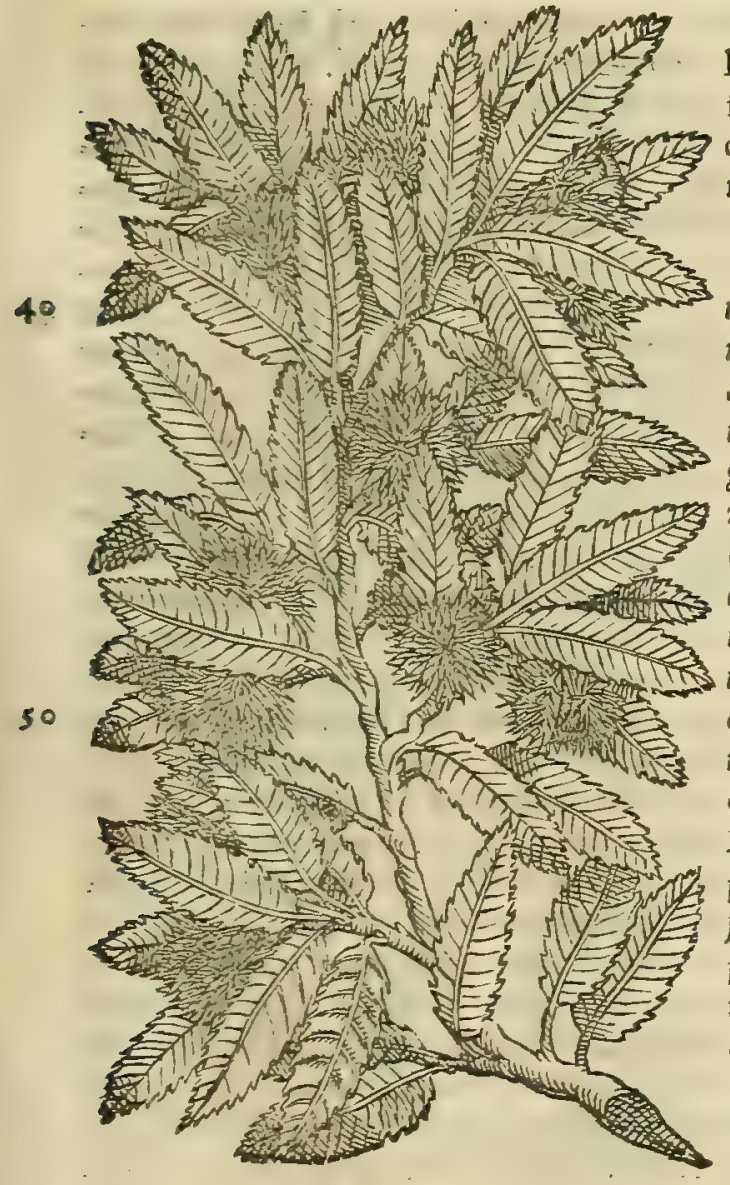

S A R D I A N AE glandes, quas aliqui Caftaneas, aut lopima; aut glandes Touis appellant, adfringunt \& ip$\mathfrak{r}$, fimilesque effectus præbent: præfertim tunica, quæ carnem, \&x corticé media intercurfat . Caro his, qui ephemerum biberunt, conueniens eft.

C A S T A N E AE nuces funt in tota Italia unlgó notifime: item or earum arbores haud quaquam incognite. Antiqui cafta= nearum complura fecerunt generd, nominibus plerunque inditis à locis, unde importabantur. Sed duo tantum in Hetruria baben= tur genera, fatiuum fcilicet, o fylueftre. Mitiores facile pura gantur, harumq́; illa principem locum tenent, quds uulgus Mar= roni appellat: quippe quod ceteris fint maiores, fapidiores, fpe: ciofioresí;. In montanis, ubi quotannis aliarum frugum annond deficit, incole caftaneis per byemem uictitant. Nanq; eds in cras= tibus fumo prius exicc at as ab utroque cortice repurgant, molunt $q$ 's in farinam, ac deinde cogunt in panem. Materies arboris adifi= cijs, atque alijs domefticis utenfilibus admodum apta eft: fiquidem non modó ex ea fiunt trabes, tigna, afferes, or pedamenta; fed T cadorum cofte, ש corum cinctus: uerum igniarijs inepta. Montibus, o o opacis gaudet magis, quàm campeftribus, or d= pricis. Caftanea uebementer fiftunt tum alui, tum uentriculi Coftanearum fluxionés, id'q́; maximé ficce: quin er fanguinem excreantibus uires. profunt. Trite cum fale, melleq́; jubact xóp rabidorum canum morfibus utiliter imponuntur : er cum bordeacea polenta, $\sigma a$ ceto illite manmarum duritias difcutiunt. Venerem excitant, eo quod flatum gignant. Largius in cibis fumpte capiti dolorem inferunt, inflant, aluum adfringunt, ac agre concoquuntur.

Attamen que cineribus obrute torrentur, uulnerdto prius in lat 
Cantearum De caftaneis differens Galenus libro fecundo de alinentorum facultatibus, fic inquit. Caftane amnium glane

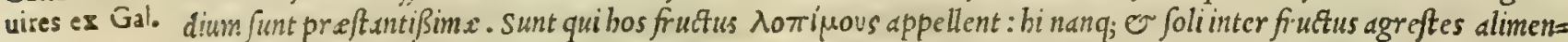
tum menorabile corpori prebent. bactenus Galenus. Illud porró in bis uerbis animaduertendum, quód Caftanea, quanuis cas Galenus plurimum nutrire prodiderit; non tamen in cibis commcndantur, $f i$ comedantur frequenter. Nanque, ut idem auctor eft libro de tenui uictus ratione, fint ills in aqui cocte, fint tofte, fint etiam frixe, fem= per efitantibus noxam inferunt, multó; magis, fi cruda edantur. Quod etiam libro de cibis boni, 0 malifucci me=

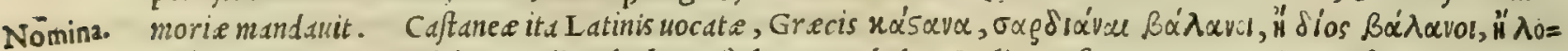
wiua dicuntur: Arabibus, Sadianalach, Caftal, $\sigma$ Stebulot:Italis, Caftagne: Germanis, Keften : Hipanis, Marones: Gallis, Caftaignes.

Kниis. GALLA.

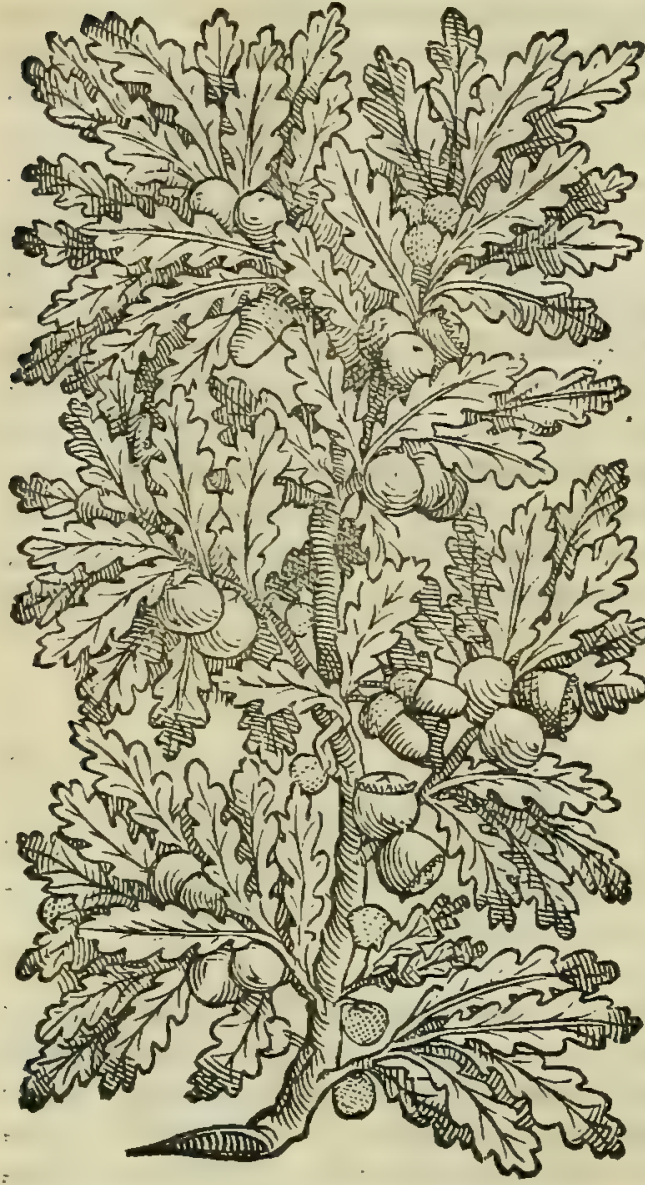

GA L I A fructus eft quercus. Aliqua omphacitis appellatur, parua quidem, fed + articulorum manus modo rugofa, folida, nullo foramine peruia. Altera plana, leuis, perforata. Eligi debet omphacitis, qua efficacior eft. Vtriufque uis uchementer adfringere, trit $x$ excrefcentia in carne, fluxiones gingiuarum \& vur, atque oris ulcerationem colibent. Nuclcus dentium cauernis inditus, dolorem fedat. Cremata carbonibus, donec igne flagrent, \& uino, aut aceto, aut acida muria extinExx, fanguinem fupprimunt. Decoftum quibus infidere expedit, efficax eft, \& contra uuluas pracidentes, fluxionesq́ue. Capillos denigrant, aceto, aut aqua maceratæ: dyfentericis, coliacisq́ue cum uino, aut aqua tritx conuenienter illinuntur, aut bibúntur : obfonijs addi debét, aut integræ in aqua præcoqui, in qua nonnihsl excoquen dum eft, quod his affectibus conferat. In fumma his uten dum ad adfringenda, aut fiftenda, aut ficcanda, qux o- 30 pus funt.

Gallarum cóGideratio.

Cornarij opi nio reprobata.

G A I I A E unlgó notißime funt, eds $\dot{q}^{;}$fertunt arbores $\alpha=$ mnes (ut Plinius auctor eft) que o glandem. Nafcuntur fole de geminis exeunte: o fi aftunimio excipiuntur, arefcunt proti= nus, nee amplius adolefcunt. Quercus in Italia prater glans des duo Gallarum genera ferunt. Minores que rugofa cute pe= Etantur, fullonibus, or coriarijs expetite, que Gracis omphaci= tides dicuntur. Maiores ueró, que lauiorcs babentur. . $C_{d}=$ terim neque in boc Cornario adfripulandum effe iudico, quód $4^{\circ}$ fuis in Galenum commentarijs tam primo, qudm fexto libro de compofitione medicamentorum fecundum locos, acriter cons tendat, nil aliud omphacitidem gallam effe Diofcoridi, $\sigma$ Gas Ieno; quam calycem illum, quo glandes in arboribus continen= tur. Hoc tantumargumento ductus, quòd Pallus capite de dyfenteria in quodam clyfteri fcribat: óuథaxí́os

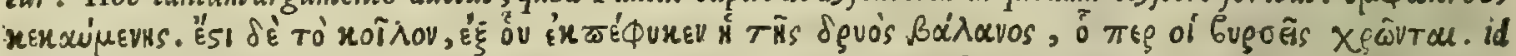
eft: omphacidis ufte. eft autem caunm illud, ex quo glans quercina enafcitur, quo coriarij utuntur. Vbt ipfe non omphacidos, fed omphacitidos putat legendum, unlgatam lectionem inmutans. Ex qua poftea non aliud om= phacitidem gallam (ut diximus) effe exiftimat, quàm cauum illud, in quo glandes inferuntur, quod recentiores $c u=$ pulam uocant . statuitớ; nunquam à fua opinione recedere, nifi quis plane corruptum apud $\mathrm{P}$ aulum locum docucrit,

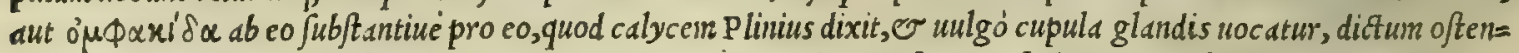
dat. Sed equidem non poffum non admirari, quód is, quem alioquin fuorum fcriptorum teftimonio, acutissmi in= genij, fanißimíq; iudicij uirum femper exiftimaui, in re tam, meo iudicio, clara, tam facilé aberrauerit. Nam fa Paulus non putaffet, quód oj 4 \axis Grecum uocabulum ob fui raritatem permultis fuiffet obfcurum, quemads modum e Corilario fuife uidetur, ei certé non fuifet opus per circumlocutionem illud declarare, ut fecit, cims inquit. Eft autem ou $\Phi$ axis cauum illud, ex quo glans querna eriafcitur, quo coriarij utuntur. Quod preteréa Paulus pro omphacitide galla glandium calycem non acceperit, illud manifefto argumento effe poteft, quicd ipfe libro feptimo de gallis, non autem de glandibus diferat, duo qu; gallarum genera conftituat, quarum alteram omphacitidem appellat; alteram ueró magnam, flauo colore, uiribusq; inferiorem effe fcribit. Quod etiam antea Diofcorides, o Galenus fecere .qui omphacitidem gallam glandıum calycem effe nufquam, quod fciam, tradidere : quod non ignora

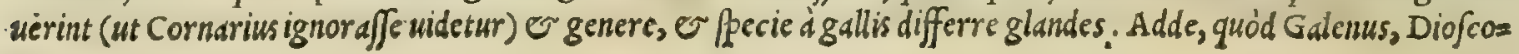




\section{In Lib. primum Diofcoridis.}

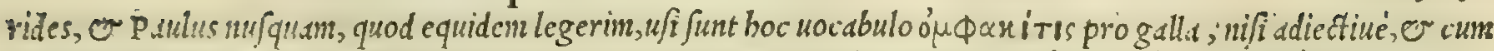

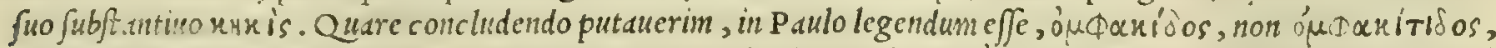

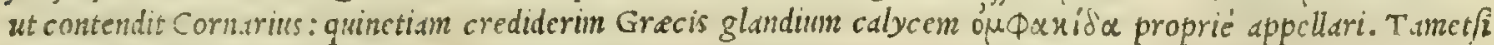
Cormarius, er Andcrnacus, qui in $\mathrm{P}$ aulo uocem illan accrbam unam interpretatur, Grece lingus peritißimi, bec nö cognouife, neq; animaduertilfe deprebendantur. Iltud peculiare fibi maiores galle uendicancre, ut quotanis aut Gallarí pre.

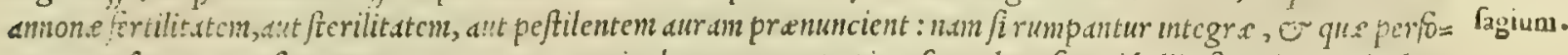
ratie non funt, aut inuf cam, aut arancum, aut ucrmiculum exponent. Si inufca nolat, futuri belli; fi repit ucrniculus, annone penuric: /i currit arancus, peftilentium morborum prafagitum eft. Neque cuiquan merum uidcatur, quèd

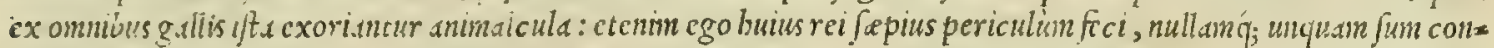

10 Secutus, pruts non perforaranz, qux ex tribus animalibus unum intra fe non contineret: nam foramuic conpecto faci= le indicium funmi poteft, ian aninal exiffe. Dicamus igitur licct, quercum of fructum, o animal gignerc. Cuius reibaud ignariucteres illi patres, non fine caufa quercum dixerunt Ioui fummo c/fe dicatam. Gallarum uires me= morie prodidit Galenus lib. v I I. fimpi. medicunentorum, fic inquiens. Galld, qux omphacitis nuncupatur, admo= dum acerbum eft medicamer, plerdq; fuiparte effentie terrene, ov figide : perquim deficcat, o repercutit fluxio= nes: ad bee conftringit, contrabit'; partes laxas, ac languidas: omnibus क́; fluxionum affectibus frenue refiftit. Efto ueró tertij in deficcando, fecundi sutem in refrigerando ordinis. Altera auten galla, flus illa, or magna, las $x \leq \dot{q}$, e ipfa deficcat quidem, fed tantó minus, quantó minus acerbe qualitat is eft particeps. Coct a it dq; ipfa per fe, ac dcinde trita, cat aplafm.x eft non mitrenuum fedis phlegmonarum, ac procidentiarum. Porró coquenda cft, fi mo= dica opus fit ad itritione, in aqua: /in uchementiore, in uino. Ac fi augere infuper adftrictionem fit opus, uino utare

so auferiore. Hanc ruftici noftrates o. 'o"suid'a, quafi uinigallam dicas, nominant. Deniq; galle combufte fangut= nis reprimendi facultatem aequirunt, ac ninurum etlam calorem; or acrimoniam ex uftione affumunt: funt q́; ijs, que igneme experta non fucrint, rum fubtiliorum partium, tum maiore deficcandipotcstate. Caterim cium ad fanguinis fupercfsonem preparare ess volcs, carbonibus impofitas, dum undequaq; candeant, açeto, aut uino extinguere opor:

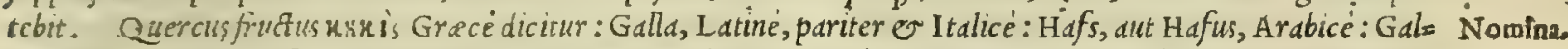
locpffel, $\odot$ Eychoepffel, Geimanice : Gall $\alpha_{\lambda} \odot \sim$ Bugalla, Hipanicé: Noix de galle, Gallicé.

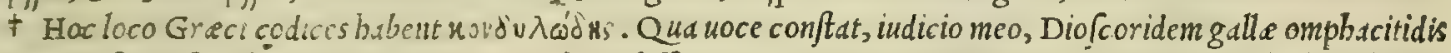
figur ande/ignaffe, cium prius magnitudinem expreßiffet. Attamen ex intcrpretibus Marcellus manifest c eame etiam ad magnitudinem retulit. Ructius autcm, cüm eam tubero fam interpretetur, ipfe quoq; magnitudinem innulfe ui=

90

detur. Quocircs nobis fatius uf um eft, omphacitin rugofa parti articulorum in digitis, cum cxtenduntur, fimilem reddere: quod non folimid innuat Grecum uocabulum; fed mul tó etiam magis omphacitides ipfe apertifimé demonftrent.

\section{Poốs. RHVS.}

\section{CAP. CXXIIII。}

R H v S, quæ obfonijs afpergitur, ab aliquibus erythros appellata, femen eft coriarij fruticis, fic uocati, quoniam coriorum infectores eo vtunturad infpiflandas pelles. Arbufcula eft in petris nafcens binûm ferè cu bitorum altitudine: folijs oblongis, fubrubentibus, in ambitu ferratis tilicis modo: acino vuarum gracilium, dento, magnıtudine terebinthi, quadántenus lato:cuius corticofa tunica perquàm utilis eft. Folia uim habent adftringendi, \& acaciæ effętus prabent. Decoetú capillos denigrat: dy fentericis infunditur, $\&$ in potus eorum, infeffusque adijcitur : inftillatur auribus purulentis . gangrænas, \& pterygia cohibent folia ex aceto, aut melle illita. Liquamentum fit ex aridis folijs,ad craffitudinem mellis in aqua dccoctis, ad cadem, vt lycium, conueniens. Semen eofdem effectus exhibet: cœliacorum, dyfentericorumq́ue obfonijs infpergitur : fracta, defquamata, liuidaq́ue illitum ex aqua, ab inflammatio ne vindicat: linguæ afperitatis cum melle abftergit : can dida fominarum profluuia fiftit: hæmorrhoidas fanat, cum querno carbone intrito admotum. Aqua, in qua fe men maduit, decocta cogitur, coirq́ue, efficacior quodammodo ipfo femine. Gummi defert, quod dentium cauis imprimitur, ad dolores finiendos.

R H v 5 Grecorum, cui (ut fcribit Plinius libro X X I I11. Rhois conficap $\times x_{\text {. }}$ ) Latinis uon eft inditum nomen, sumach officinis uul= deratio. gó hocatur, uocabulo nimirum à Mauritanis accepto, ut in alijs 
quim plurimis ab illis frerifolet. Hac in condimentis pro fale utebantur antiqui : idcirco Diofcoridi in ipfius capitis fronte, Rbus dicitur, que obfonijs appergitur. Cuius ufus, ut audio, or apud syros, o apud Aegyptios in bunc ufq; diem perdurat, ubi thus prouenit preftantior. Nafcitur er in Italia A pennino monte pluribus in locis, ijs omnibus plané notis, que illi à Diofcoride tribuuntur. Huius aridis folijs bircorum, caprarumiq; pellcs ille fpiffantur, crippan= tur, concinnantur'q; quas uulgó somachi nuncupant. Caterim illud non uidetur pratereundum, quód etfi Gale= nus tum alibi, tum precipue lib. $\mathrm{v}$. de compofitione medic amentorum fec undum locos, plura Rbois nomina, or ge= nera explicaffe uideatur, ut qui id modó syrixcum appellet, modó Ponticum, modó obfoniorum, modó coriarium, ino dó rubrim; non tamen propterea cen endum eft, Rbois arbores inter fe genere, uel pecie differre. Qundoquidem nobis conftat, unum tantuin genus Diofcoridiboc loco defcriptum effe, quemadmodum o Galena libro v 1 I 1 . fimpl. med. Atquilsac in re fcire conuenit, quod Rhus obfoniorum nil aliud eft, quàm fesmen: coriariorun ueró nil aliud, quàm folia, er fruticis ramufculi. Noftre enim fententie fubjcribit Diofcorides, qui fcriptum reliquit. R hus femen eft exigua plant $x$, qua cortarij ad infiffandas pelles utuntur. Quod etiam Galenus confirmat loco citato. Rbus ue= ró rubens nil aliud effe comperitur, quam cius femen immaturum, cui maior adftringendi uis ine $f$, qudm maturo, cu= ius acini quadántenus nigricant. Syriaca pratered, atq; Pontica rbus, etfi in alijs na fcatur regionibus, à quibus nomé Monachorú inuénit; mibil tamen genere distat ab Italica, atq; Iberica, nifi illa magis, bac ueró minus uiribus praftet. Ideoó; error. Monachos illos, qui in Me fuem commentarios edidere, longé ballucinari crediderin: nempe qui fibi perfuaferint, Rboëm Ponticam alterius effe generis ab ea, cuius extitit ufus apud antiquos in obfonijs. Qua in re or Plinius dece= ptus effe uidetur, cum de coriario particulariter fcripferit, ip fum ;́; diuiferit ab eo, quo in ciborum condimentis anti= Fuchfij opin. quitus utebantur. Fuchfius ueró medicus fingularis cruditionis, non contentus duobus $\mathrm{R}$ bois generibus $\mathrm{P}$ linij imi= damnata.

tatione, tertium adinuenit. Etenim is in libro de componendis nedicamentis, quem fecundo loco edidit, $R$ hoëm $S y=$ riacum non folum differre fcribit ab co, qui tun culinis, tum coriarijs expetitur; fed peculiarem quidem syriaca ar= bufcula fuccum effe cenfet, quod Galenus lib.v I. de compofitione medicamentor ü fecundum locos fuccum rhois Sy= riaci in quoddam medicamentum addat. Sed errat $\mathrm{F}$ uchfius in boc, mea quidem fententia. quandoquidem non uideo, quomodo ex mentione fuccirbois Syriaci ḋ Galeno facta, colligi poßit, rboèn Syriacum effe genus feparatum. nam ego potius adducar ut credam, ita eum cognominatum fuiße à Galeno, quód apud syros coli er foli illius temperie proueniat ceteris preftantior. Et quanuis Theophrafto lib. I I I.cap. X. V I I I. Rhus duplex reddatur, mas fcilicet, o faimina, quod alia fterilis, alia fructifera fit; non tamen ob hoc pofteritatis memorie prodidit, quód altera cibis, altera corijs nafceretur, fed ambus ad coria inficienda deftinauit : quód coriarij folia, er ramufculos tantum accipiait, Petri Criniti non autem femen. Rboëm, que in Cornelio Celfo ros Syriacus deprauaté lcgitur, Mannă, que ex syria nobis ad= laptus. uebitur, effe putanit Petrus Crinitus Florentinus capite feptimo libri ultimi de bonefta difciplin a, falfus uocun fimi=

VIBVRNVM.

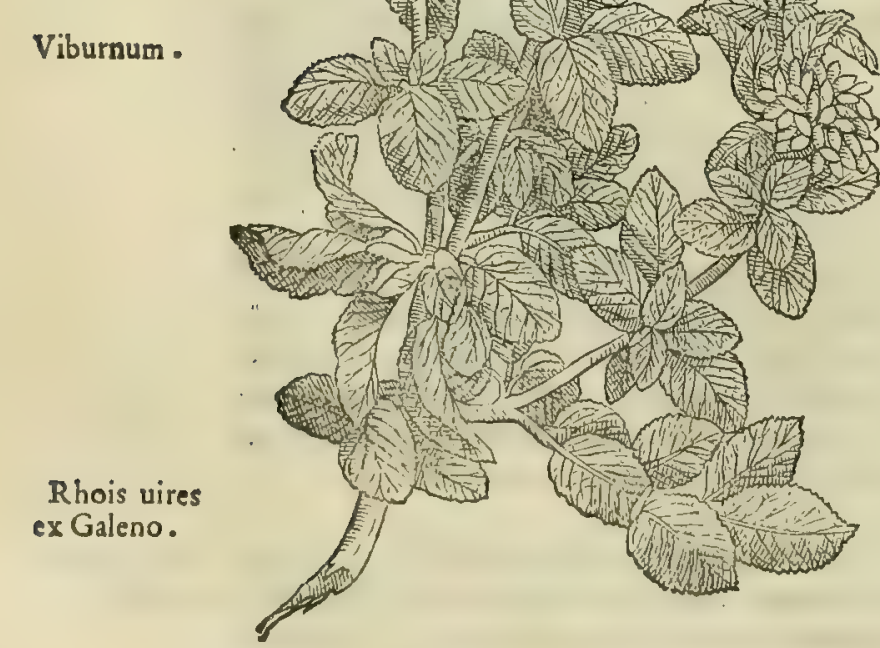

litudine, quód ros, qua dictio rhos Grecé legenda eft in Celfo, dé ris rorèn fignificare crediderit : etenim manna ros quidan eft. Veruntamen eius fententiam acriter explofit Manardus Ferra= rien/is libro epiftolarum fuarum primo. Theodorus in Theophra fto, Rbois yocabulum fluidam interpretatur, quod nomen Graci etymum fecutus fibi Latiné finxit : quippe (ut Plinius eft auctor) rbus Latinum nonen non babet. Id quod mibi errädi prabuit an= Sam, cum iandudum pro certo exiftimauerim, fluidam Theophra= fto eam arbufculam effe, que unlgo Lantand uocatur, é cuius ra= dicibus uifcum quid ain confrciunt. Verüm cüm accuratius Gracü Theopbrafticodicem perlegiffem, Theodoriq; noum uocabulum non fine bile examinafem, erroris mei caufam facilé deprebendi. Quo factume ef, ut ian faterilibeat, fluidam Theodorinil aliud Theophrafto defignare, quàm Rhoèm, er ob id Lantanam fic dे uulgaribus nocatam, ut prius credideram, non effe. Qu.e tamé (ut meafertopinio) potius VI BVRNVM imitatur, quod ma

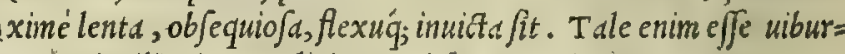
num Virgilius in $\mathrm{B}$ ucolicis cecinit hoc carmine.

Quantumlenta folent inter uiburna cupreßi.

Exit bec ramulis digitali craßitudine, bicubitalibus, folijs ulmeis, so inc anis, or pilofioribus, qux paribus internodijs aduerfis pedicu= lis coniugatim adherent, per ambitum tenuißime ferrata. Florem edit album, umbelle modo colserentem : a qua acini prodeunt lene tium modo preßs, qui primo ftatim exortu uirides, deinde rubsi, demum ueró nigri pectantur : radice per fumina cefpitum ungan te. Hanc Ruellius rhoëm exiftinat, cum tanen alia Diofcoridi, ec Galeno rhus fit plant., Hetrufcis notißima, quod flurima oria= tur eo Apennini tractu, qui Hetruriam repicit. De Rboèlbac, qux fequuntur, nobis fcripta reliquit Galenus lib. v I I I. fimpli= cium medicamentorum, fic inquiens. Rhus fruticofa planta ad= ftringit, deficcat . Nam e coriarij ad deficcandum, o adfrin= 


\section{In Lib. primum Diofcoridis.}

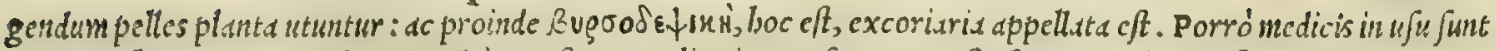

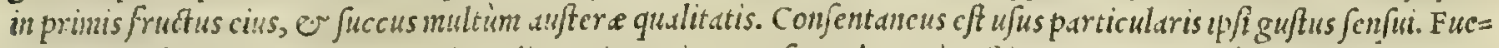

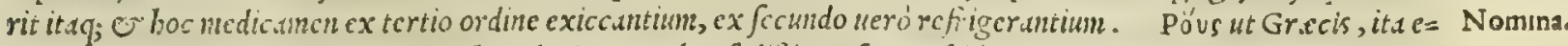

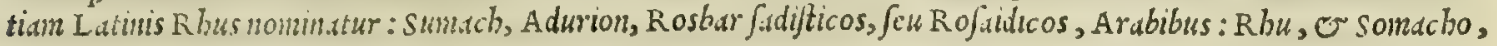
Italis: sumach, or sumagre, Hifpunis.

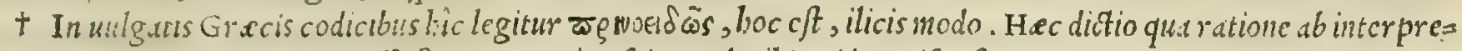

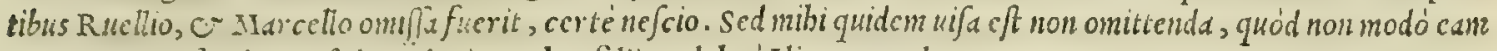
quoque Oribsius legut, fed quod etian Rhus folijs pulchré Ilicen emulctur. soivg. PALIIA.

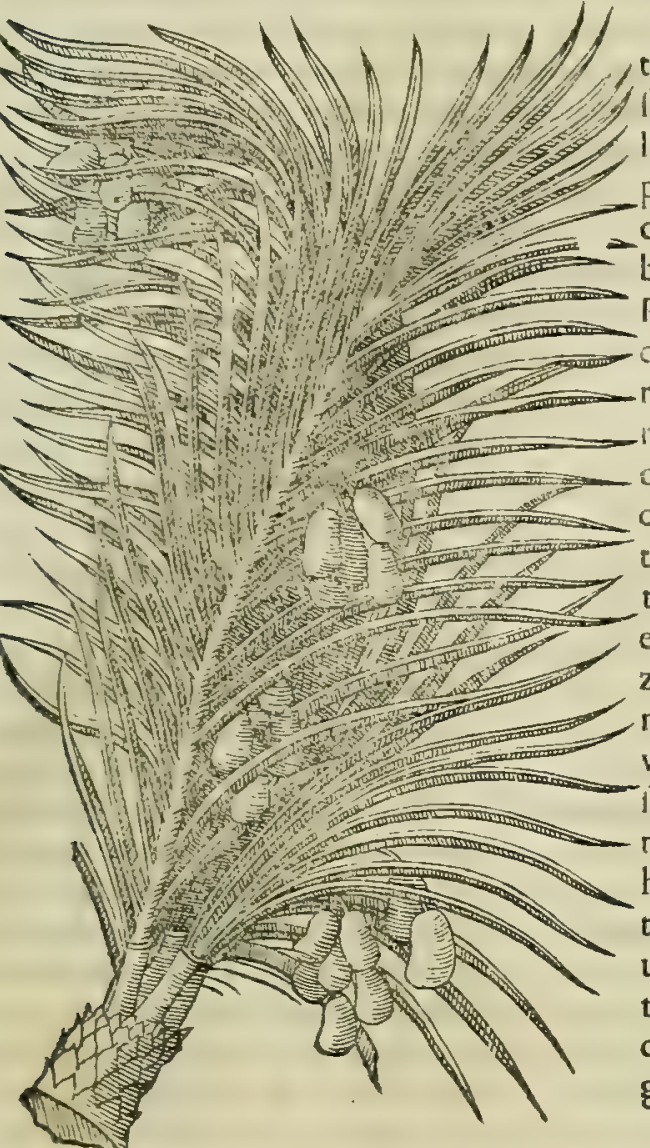

P A I M A in Aegyptogignitur. Ea medio maturitatis vigore, autumno decerpı folet, Arabici myrobalani limilis, pomatis cognomine, colore virudi, \& odore malicotonei : quòd. fi ad maturitatem peruenire finatur, phonicobulanus fiet. Palına acerba eft, Sradltingens: contra alui, fominarumque profluuia, in uino auftero bibitur: hamorhioidas fiftit: vulnera glutinat illitu. Phœnicobalani recentes plus ficcis adftringunt: capitis dolorem afferunt : copiofiores in cibo inebriant. Sicciores fanguinem excreantibus, ftomachicis, \& dyfenteicis utiles in cibo: illinuntur cum cotoneo, \& cerato œnanthino ueficx uitijs. Caryotx, præfertim efu, faucium afperitati medentur. Thebaicarum decoctum potu xfuationem fedat: vires recreat cum hydromelite ue teri fumptum : cibo idem faciunt. Fit ex eis vinum ad eadem conueniens. Decoetum per fe potu, \& gargarizatione magnopere adfringit, \& cohibet. Nuclei palmarum, caterorum more, cremati in crudo fictili, $\&$ vino reftincti, cinere loto, fpodij uicem efficiunt, miicenturq́ue in calliblephara. quòd fi non iuftam uftionem acceperint, denuo cremandi. : Vim adftringendi habent, \& f piracula cutis obductu fuo claudunt: contra oculorum uuam, \& puftulas, palpebrarum defluuia, cum nardo effectum prebent: corporis excrefcentias cum uino reprimunt: ulcera ad cicatricem perducunt. Sed inter primas utiles ex palmis humilibus Acgyptix.

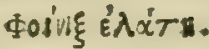

PALMA ELATE.

\section{CAP. CXXVI.}

P A I M A, quam aliqui elaten, aut fpathan appellant, fructus palmarum adhuc florentium inuolucrum eft, calyxqque : quo in fpiffamenta unguentarijutuntur. Optima habetur odorata, adftringens, ponderofa, præclufa, intus pinguis. Vis ei adfrictoria : fiftıt ulcera, qux depafcunt: laxatos artus committit: trita mifcetur cataplafmatis, \& malagmatis : prodeft præcordijs, imbecilli ftomacho, \& iocineri affecto, mifta conferentibus cataplafmatis. Eius decoctum fubinde deterfum, capillos denigrat: datur bibendum congruè renum, uefic , \& uifcerum uitijs : uuluæ, ac uentris fluxiones fiftit: fcabiem cum refina, \& cera fanat, fr uiginti diebus recens apponatur. Inuolutusque in ea elate fructus, quem fuo amplexu fouet, elate etiam uocarj folet, \& ab aliquibus borafus . Aditringit, \& fpathx cffectus praftat, non fic ungtentis expetitus. Alba medulla caudicis recens in cibo, aut decocta, eadem facit, qux borallus.

T A M E I S I in compluribus I talix ciuitatibus, nempe in bortis, uiridarïs, er monachor um clauftris diftis, Palme confreperiantur Palme infigni magnitudine, ac peciofa proceritate; chim tamen climatis noftri temperies earum natu= deratio. ris inclenentior fit, fructum notis non proferunt, fedfteriles confenefcunt. In Hipania tamen maritumis quibuf= dam locis frua ü edunt, uerum immitem, et qui nunquam mature fat. Qua in Creta proueniunt, fructum fane per= coquunt, $\int e d$ magis admodum Cyprix. Principem locun tenent, or palmulas omnium preft antißimas ferunt, qux in Iudea proueniunt, er inter has maximé (ut inquit Galenus) que in Hiericunte nafcuntur. Venetias palmarum fru= cus, qui nonmultis palmule, aliquibus cariote, quibufdam ueró dactyli dicuntur, ex Syria, er Alexandria Aegypti aduebuntur, ac etiam ex Neapoli illuc prius ex Numidia importati. Ex recentibus ab arbore ftatim decerptis, qui= bus I talia carct, uinum fieri auctor eft Plin. lib. X I I I I. cap. X V I. quo Partbi, er Indi utuntur, ac ceteri, qui oriens talem plagam incolunt. Et ut idem refert lib. $\mathrm{x}$ I 1 I. cap. 1 I I I. Palme famine fructum non proferunt, nifi prope 
marem conferantur : quo excifo, aut exiccato, uidus pofted fterilefcunt. Nec tamen ob id putandum, quód mares fructum non ferant. Quandoquidem fcribit Theophraftus lib. I I. cap. v I I I. de biftoria plantarum, quód ex fructi= fris (plures enim funt, qux fructum non ferunt) tam mares, quàm fremine fructus cdunt. Quorum plures funt dif= ferentie, quoniam alij fine offe, alij duro offe, alij molli proueniunt. Colore quog; inter fe difcrepant: alij cnim can= didi, alij nigri, alijflui : ad fummum non pauciores, quàm ficorum colores, neq; abfolute pauciora genera itatuunt. Ad bec differre magnitudine, figura'q; uolunt: quofdam cnim rotundos effe in modum malorun : magnitudine q́; tan= tos, ut quatuor tantim in picam teneantur, alios minutos cicerum magnitudine. Saporibus item plurimum differre inquiunt, fed optimum tam inter nigros, quàm inter candidos, genus, quod regium uocant, cum magnitudime, tü uir=

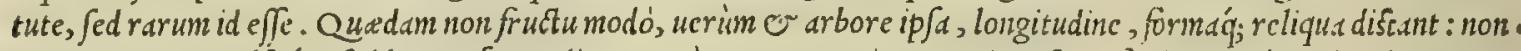

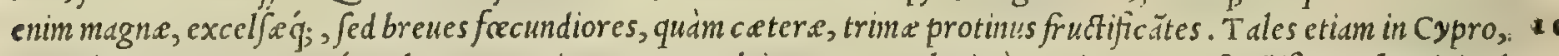
in syria quoq;, Aegy ptó'; palma proueniunt, que quadrina, dut ut plurinum quinquennes fructificant, boninis al titudine affurgentes. Genus aliud cft in Cypro, quod o folium amplius babet, ov fiuctum multó ampliorem, difcri= -mineó; peculiari difcretum, magnitudine mali punici, figura oblongum: non tamen fapidun, tanquam cetere; fed ra dicibus fimilem, ut non devorctur, fed fucco tantim exprcffo expuatur. bec de palmis biftoria ex Theopbrafto.

Mufe plante hiftoria, \&: viers. dcuntes proceritatem é folonibus alterius futa: folio cft arundmeo, quod tamen perquám longo, lató; ambitu fe diffundit, adeó ut in longun triun cubitorum menfuram quandoq; exccdat; in latum ueró fefquicubitum patietur, lata, craf= fáq; per medium excurrente cofta. Torrcfcunt folia aftate fui natura, ucl ctiam fortaffe folis ardore, adeó ut menfe Septembri corum cost.e pror $\int u$ nude ccrnantur, decidente folionum materia, quod admodum fit tenuis. Caulis fqua= rofo foliorum cortice ucftitur, palma, uel arundinis modo. Ramos babet nullos, fed caudice tantum confiftit. E' uer= tice germen emergit materie molli, longitudine frcé cubitali, à quo alia ab origine, ad fummum prodcüt germina ters num, quaternumue digitorum inuicem difrantia: é quibus circumcminent fructus, parui cucumeris magnitudine, qui per maturitatem quadántenus flauefrunt, cortice fici, qui codem modo digitis detrahitur. Subftantir pulpe confiftit melopeponum modo, nullo intus offe, neq; femine. Primim guftuntibus fructus infipiditatem quandam pra fe ferre ui= dentur, adeó ut primo ftatim guftu non placeant, ucrim qui cfui affuc fcunt, ijs indies magis delectantur : quippe qui quadam occulta faporis fusuitate alle cti, que nifi traf u temporis cum palato init gratian, nunquam faturi uideătur. Ita Mufam mibi defcripfere qui $\mathrm{ex}$ A geypto, o cypro ad nos rescrtuntur. Sed qúxilam antiquis Mu fa fuerit plan= $t d$, quid referam non babeo. Inclinat tamen aninus eam $\mathrm{c} f \mathfrak{c}$, qua T beoplsafto in pulmarum genere recen $\int \mathrm{ctur}: q u \tilde{a}$ idem in Cypro nafci tradidit, folio catcris ampliore, or fructu longé maiore, magnitudine mali punici, or figura ob 30 longo. Mufe ex Arabibus Serapionem inuenio mentionem ficiffe inter fimplicia, ubi de eims uiribus in bunc fen= fum differuit. Mufa excalfacit in medio primi abfceffus, bumectat autem in cius fine. paucum prabet alimentum. Pri= - uatim prodeft thoracis, pulsnonis, ac ucfice ardoritus. aluum emollit. Verim liberalior eius ufus stomacho aduer $\int d=$ tur, ac iecur obftruit. Cuamobrem i quis, cum frigidi fit temperamenti, ea copiofius ue fcatur, fubinde aquam mul = fam, oxymel, aut gingiber conditum fumat neceffe eft. Fatum in utero alit, renibus opitulatur, urinam ciet, or uene rem ftimulat . bactenus serapio. Palmas plurimas gignunt maritima noftra in uall is Alma campeftribus, fed pumi= 1ds, or qua cubitalem men uram nunquan excedant. Pailo lis maiores or tla babentur, qua ex sicilia Neapolim inuchuntur, quas unlgo', uocabulo ab A rabic is accepto, Cefaglioni appellant, de quibus fuprà in Edellij commenta= rio abundc diximus. Palme genus India profert ( 1 t Iofepli Indi naugationes perbibent) é cuius truncis, excifis confultó ramis men $\int e$ augufto, diftillat liquor, quem incole uafis cxcipiunt, cbibunt q́; fuauter uini uice : ueruntamẽ nifi excoquatur, poft triduum in acctum accrrimum dc cilcit. Edq́; propter illum decoquunt, ut nos defrutum, fit $\dot{q}_{\text {; }}$ boc nodo, uclut mel fuauißimum, quod poftsnodum ex aqua rc foluunt, or diebus uiginti artificio quodam percolant, donec optimé fit defacatum, atque pellucidum: quo artificio iucundisimus redditur potus, diúg; perennat. Porró palmuld, quas Diofcorides Thebaic ds tocat, quantum ex pluribus auctoribus comperi, adeo tractu temporis infola= teficcefcunt, ut molita cogantur in pancm. Eft or aliud ab his palmularum genus, quod officine Mauritanos $\int_{\varepsilon}=$ Tamarindo- cute TAMARINDOS appellant, Graciueró à faporis acrimonia oxypbonica: fiquidem Mauritani per Tamar rum confid. dactylos fignificant: quare Tamarindorum uocabulo idem intelligunt, quod noftri palmulas Indicas. Indici igitur da Etyli producuntur (ut inquit serapio) d̀ quibufdain plantis, qua folijs longis, acuminatiś, , falignis fimilibus uirent: licrt à nonnullis exiftimentur Tamarindi fructus agrcfium palmarum. Sed equidem malim adftipulari scrapioni, quàm illis; praeertim cim non conftet é ueteribus, qui de Tamarindis quicquam memorix prodiderit. Exijs, qui ad nos importantur, nulli, ucl pauci adnodum integri reperiuntur. Nam plerunq; contriti, o in mafjam quandam com pacti deferuntur, quam fi difieceris, flauos nucleos inuenies, uarias formas refrentes. Prastant, qui m obfcuro ru= befcunt, molles, recentesq́; , o qui neruofis quibufdan uillis farcti imueniuntur. Adulterantur ab impoftoribus pru= nis, fed deprebenditur fraus tum colore, tum etiam guftu: quippe nec admodum funt acidi, nec tam faturato colore Tamarindo- nigricant. Refrigerant, ac deficcant ( $u$ fcribut Mefues) ordine fecundo, tametfi Auerroi tertio adfcribantur. rum aires. Aluum cient, quapropter potibilcm facile foluunt: item e praffatos bunores leniunt, o infaniam, e furorem mulcent. Dantur obftructis, aqua intercute affectis, arquatis, o licnofis utiliter. Faciunt $\mathcal{O}$ ad fcabicm, lepras, uitiligines, o lichenus: quin $\mathcal{O}$ contra omne's cutancas exulcerationes, que à fanguine pratafato cmerfere. Offi= ciunt tämen frigidum ucntriculum babentibus: fed noxu tollitur, admiftis maci, maftiche, cafsia, aut Indica nardo. Acgré munus obcunt fum, fed roborantur, fiudnifto caprino fero, aut fumaria, aut lupifalicarif fucco bibantur. In fusma palmarum uaria, ac diuer fa funt genera. Quare curiofum remittcmus ad Theophraftum loco fuperius ci= 


\section{In Lib. primum Diofcoridis. $\quad 143$}

fato, os ad Plinium libro x I I r. cap. I I I r. ubi de his latißime forip/it. Caterim quid in palmaillud fit, quod ali= Pal ana elave. qui elaten, aliqui pathan wocant, manifiste declarat Diofcorides, cum inquit. Palma, quam aliqui claten, aliquipas= than appellant, frlictus p.lmarum adluc florentiun imolucrum cft. Cuidstipulatur Theophraftus loco iam citato,

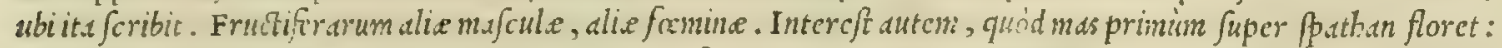

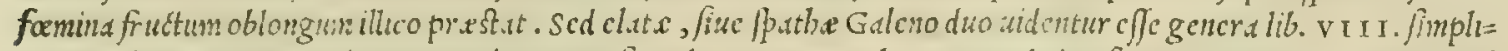
cium medicamentorum, alterum quod tencrum fit p.lme germen, altcrun quod cius fit tegunentum. Primun ueró genus fort.rfe illud crit, quod in interiore p.rte inuolucrigtgnitur, antequaim fores prodeant. Id, Diofcoridis testi=

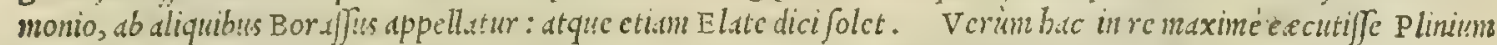
illud apertipinc oftendit, quod ip fe libro $x$ I 1 . cap. ultimo fcriptum rcliquit, fic inquicns. Eft pretcrea arbor ad ea=

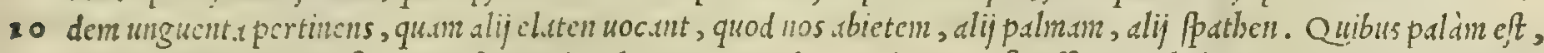
Plinium palme adhuc florentis fructus intolucrum cum abictc arbore confudifje, uocabulorum propinquitate dece=

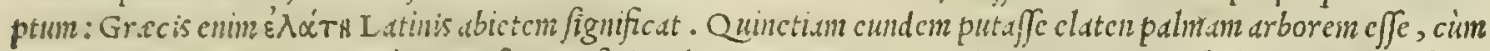

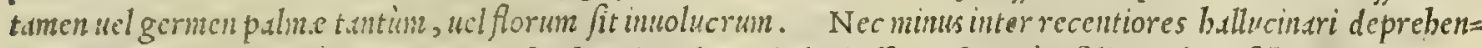
ditur Ad.mms Lonicerus Gemanus, qui patham in palma nil aliud effe cenfet, quim folia, quód cnfiformia uideantur.

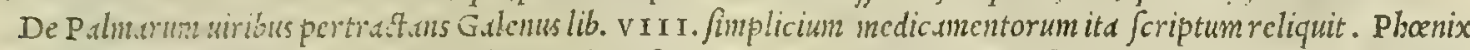
arbor diftriñorid. fucultatis omnibus fui partibus eft particeps. Igitur ramorum fuccus aufterus eft, ex aquea fub= ftantia tepit, o terrea figidit conft.uns. Similis natur.e cft cuccphalos, quem nocant, hoc eft cercbrum, fiue me=

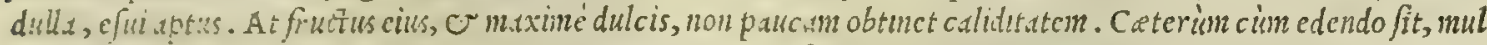

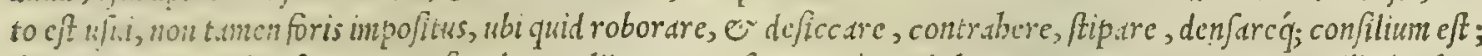

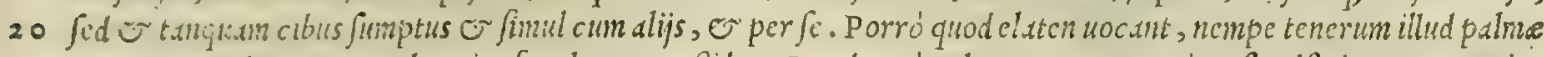
germen, exinem cum cerebrocius facultutem poßidet. Quod ueró uclut tegumentum cius cft, adfringentener ip=

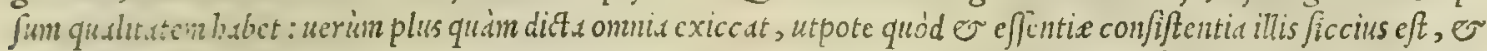
minime particeps clt buniditatis. Itag; iwre utuntur llo ad uicerum putrefcentia, mifcentq́; medicanentis articulos plus infto luxatos contrabcutibus: ad bec fucultatibus bepaticis, of fromachicis, feu intró fumantur, feu foris ad=

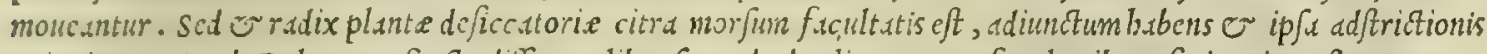
quippian. Et de Pulinurum fructu differens libro fecundo de alimentorum facultatibus, fic inquit. Eft autem non purux in Palmulis differentix: alse num; ficc.e funt, er adfringentes, ut Acgyptie: alie molles, or bumidz, er dulces, ut qux caryote appellantur. Hx autem preftantißine in Syria $\mathrm{P}$ alestina naj cuntur in Hierichunte : relique omnes p.lmule inter difta duo genera medie cenfentur. Verum concoctu difficiles funt, capitiq; doloren inferunt: 30 quarum alix quidcm m.gis, alix minus funt bunide ac dulces, ficc.e atq; adfringentes. Sed conftitutis extremis, iam omne quod in medio eft, facillimé deprehendes. Nulla ergo ex ipfis eft, qu.e non dulcedinem quandam, o adftri= ctionem babcat. Siquidem caryot leuiuf culé adftringunt, or Thebaicis ob fura quadam meft dulcedo. At fuccum quiden dulcem nutrire, aufterun autem gratum effe ftomacbo, or aluun fiftere oftendimus. Omnes autem palmula, fi largius fum mintur, concoctu funt dificiles, o capiti dolorem adferunt. Quadam etiam mor fus cuiufdam fenfum. ori uentriculi, quod mediciftomacbum uocant, inducunt. Succus autem ex ijs in corpus diftributus, craffus quidem omnino oft, cum quodam etian lentore, ubi pingues fuerint palmule, ut caryots. Cum autem buic fucco dulcedo $c=$ tiam mult $x$ fuerit, celcrrimé quidem bepar ab co obftrutur: leditur autem maximé ab ipforum efu, quód er inflam= metur, e fcirrbo ob/uteatur. Poft bepar autcm e-lien obftruitur, ac leditur. At multó fané maximé uirides pal= mule ad onum funt noxix, fi puio largius fundntur. Perficuum porró eft, dulces quidem calidiore; adfringentes 40 ueró frigidiorc jucco preditas $c / \int e$. Tirides preterea palmule inflationes pariunt, uelutie ficus : eadem nanq; pal= mularun uiridiun ad alis eft proportio; que ficuum ad caricas. Ceterum in regionibus non adinodum calidis, pal= mule non perfecté mature fcunt, adeo uireponi queant. Quo fit, ut bomines ip is uiridibus ue fci coacti, crudis fuccis

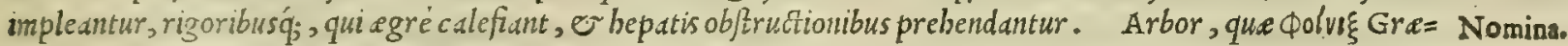
cis, Latinis P.ibna uocatur: Arabibus Machla, aut Nachal: Italis, Palma: Germanis, Dattelbaum: Hifpanis, Pal=

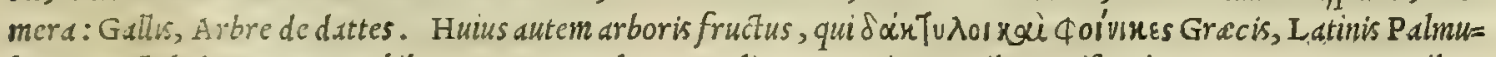
le E Datyit dicuntur: Arabibus, Tamar: Italis, Dattoli: Germanis, Dattilen: Hipanis, Tamardi, or Datiles: Gallis, Dattes.

\section{P'osx́. MALVM PVNICVM. CAP. CXXVII.}

so MA L V P V I C M omneboni fuccieft, ftomacho utile, perexiguum fufficiens alimentum. Dulcia ftomacho utiliora habentur, fed aliquantulum jn co calorem gignunt, inflationes pariunt, unde in tébri abdicantur. Acida adftringunt, aftuanti ftomacho auxiliantur, \& multò magis contrahunt, ac urinam cient: ora, gingiuasque lædunt. Vinofa uerò mediam fortiuntur naturam. Nuclei acinorum acidi punici in fole ficcati, \& obfonijs infparfi, concoftiúe, fluentem aluum, ftomachumq́ue fiftunt : ccelefti aqua madefcunt, bibunturq́ue commodè fanguinem excreantibus: ad $\mathrm{d}$ - eflus dy fentericorum, fominarumq́ue fluxione uulux laborantium utiles funt. Expreffus nucisor.m fuccus coquitur cum melle, ad oris, uirilitatis, \& fedis ulcera, nomas, reduuias, \& ea, qu in zirpore ex tuberant, aurium dolores, \& nariums uitia : præfertim acidorum. Huius flores cytini wo cantur: qui adfringunt, ficcant, cohibent: fanguinolenta glutinant: quas punicum, præftant utilicares . humida gingiuarum uitia, mobilesq́ue dentes decocto colluuntur : herniam prolapfu intefini erumpeniem, cataplafmate repellunt. Memorix tradunt, qui tres quàm minimos cytinos de- 
MALVM PVICVM.

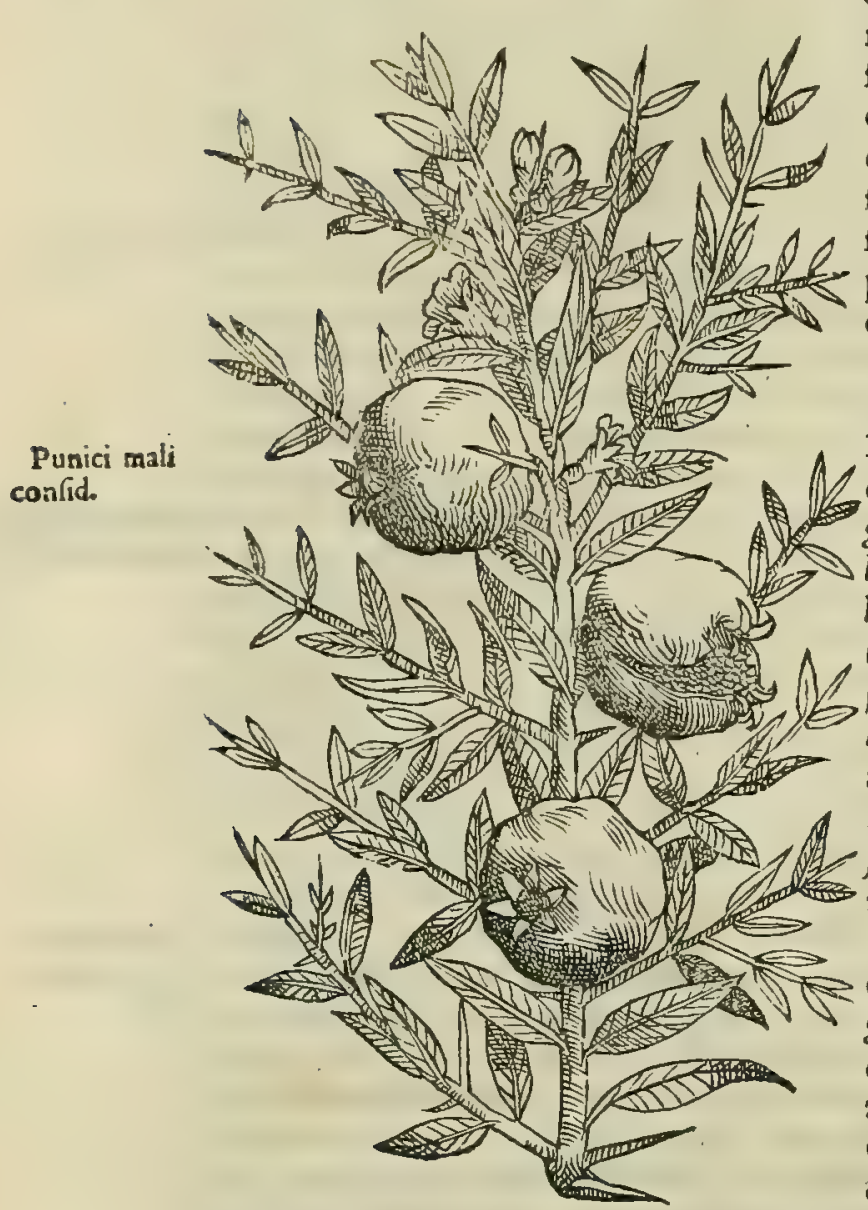

uorauerit, nullam eo anno lippitudinem paffurum. Eliquatur hypociftidis exemplo. Malicorium afperum eft mali punici putamen, quod aliqui fidion appellant. Id fpiffandi vim habet, \& quos cytini, prabet ufus. DecoCtum radicis, potu latas ventris tineas pellit, \& eafdem euocat. Balauftium fylueftris punicæ flos eft, cytino fimilis . Cuius complura genera reperiuntur, candidü, fuluum, colore rofacco. Succus ex eo exprimitur, hypociftidis modo: cui adftrictoria uis ineft, eadem faciês, quæ hypociftis, \& cy tinus.

PV N I C a mala in pluribus I talic locis uulgó, ficut ctiams Latine Granata dicuntur, à multis intus conclufis granis: quan= quam non de funt, qui ita appellari uelint d Granata Hipani.e re= gno, quód inili numerofa proueniant. Sed quomodocunq; feres habeat, nufquam non cognita funt in Italia: fiquidem inibi $\mathbb{N}$ in bortis, e in uinc is, $\mathcal{O}$ in uiridarijs, corum fi equentißima uifun tur arbores. Triplici (ut etiam fcribit Diofcorides) diftinguñtur pecie : quippe quód alia dulcia fint, alia acida, alia uinofa. Vino= lêta ea funt, que uulgò Vaiani nocat Hetruria, quáǵ; aliubi Schia 20 $u i, \mathfrak{W}$ alibi dimezo fapore Italico fermone appellantur. At Plinio lib. X I I x.cap. X v I I. quinq; enumerantur pecies, dulcis fcilicet, acria, mifta, acida, o uino fa. Verim bac omnia Diofco rides in tria redegit faftigia: utpote qui uni dulcia; alteri acria, $\mathcal{E}$ acida; tertio ueró generi mifta, $\mathcal{O}$ uinofa adfcripferit. Hac

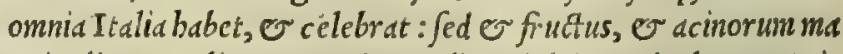
gnitudine, tum liquoris copid excellunt dulcid, et uinolenta. Aci= da inite fere, er dulcia fieri tradunt, fi fuillo, aut bumano fterco= re foueantur arboris radices, 0 uetere urina fepius irrigentur. Caterìm ne fructus in arbore debifcăt, remedio funt lapides tres, 30 cim feritur arbor, ad radices collocati : quin et fí iam confita fit, o fructum fer rat, eadem ratione emendatur. Sed er hoc item preftabitur, fi foilla fecundum radices conferatur. Si fiorem arbor non continet, urinam ueterem cum pari aque menfura temperare, $\sigma$ ter per antium radicibus infunde= re, efficacißimum eft remedium. Eundem praftabis effectum, fi arboris florentis truncum plumbeo concluferis, circu lo, uel anguis corio inuolueris. Seruantur punica mald incorrupta anno toto, $f i$ cùm fere matura fuerint, petioli, qui= bus pendent, intorqueantur in arbore : uel fi poft quàm decerpta fuerint, argilla ex aqua rejoluta undiq; oblinantur, ac deinde pluribus diebus infolentur. Sunt $e$ qui, ut diu integra perennent, ea in feruentem aquam immergant, fta= timiq; eximant, o fole ficcanda exponant, octo dierum Patio. Vini ex omnibus conficiendiratio bec est. Acinima= turi diligenter à corij5, 0 membranis purgati prelo committuntur, ac exprimuntur : mox uinum faccis ad id accom= modatis percolatur, $\mathcal{O}$ in uafculis reponitur, quoufque fex refidat: defecaturq, deinde, $\mathcal{\sigma}$ clar $u m$ reponitur, aff $u=40$

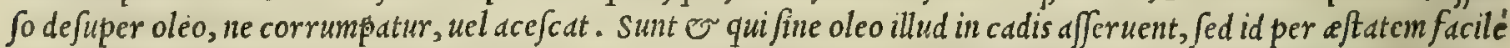
Cytinus, \& ace fcit. Deflofculi nomine inter $\int e$ difcrepant auctorum fententix. Dio $\int$ corides florem fatiuc punica cytinum ap= balaustium. pellat, balduftium ueró fylueftris. Plinio lib. X X I I I.cap.v I. primus tam fatiue, quàm fylueftris partus florere inci= pientis cytinus uocatur ; balauftium ueró flos utriufq; in ipfo erumpens cytino. Laudatißimi fatiuarum flores colore perquaim rubro ex Cretd, e Cypro boc atu Venetias importantur, afpectu quidem ppeciofo, o uiribus cateris pre

Malicorium. ftantiores. Sed er mangonio fiunt in Italia percgrinis nondißimiles, non tamen ufqueadeó praftantes. Immatu= rus punici cortex ideo Malicorium antiquis dicebst:str, quodd $\mathrm{eo}, u t \mathrm{R}$ bu ad perficienda coria uterentur. Dulcia puni= $c d, q u a$ apyrena alio nomine uocantur, uentriculo inutilia haberi, dentes gingiudś́; ledere, auctor eft Plinius; etfit rectus forte id Diofcorides acidis attribuat. Puluis mali punici in olla noud operculo indito in furno tofti, potus fluen tem aluum efficaciter fiftit. Sylueftris ueró acinorum ofsiculi utiliter bibuntur triti ad aquam, qua cutem fubierit, so ficcandam. Cortice punici ex uino decocto, er impofito perniones fanantur. P unica, o myrtus, (fi rei agrarie au= foribus credimus) mutua confuetudine mirum in modum oblectantur, ita ut etiam reddantur fertiliores, $f i$ altera in

Mali punici alteram inferatur. Malorum punicorum uires prodidit Galenus lib. I I I. fimp. med. fic inquiens. Malum grand= uires ex Gal. tum omne adfltringentem qualitatem obtinet; non tumen in ommibus ed exuperat. Sunt enim inter ed quedam acida, quedam plus dulcia, quàm auftera: e fané q̣ue ab unoquoq; eorum procedit utilitas, fecundum uincentem eueniat qualitatem neceffe eft. Dictum autem in quarto horum commentariorum eft fuper dulci fapore, auftero, or acido. Itaq; exillis de malorum punicorum differentia liceat colligere. Porró acini magis, quàm fuccus tum adftringunt, tum exiccant, his etiam magis putamina: wocantur autem fidia. Adfinilemillis uim babent cytini. Malum, quod Gracis éob', Latinis Malum punicum appellatur: Arabibus, Kuman, Ruman, feu Roman: Italis, Melagrano, of Poino granato: Germanis, Granatoepjif $f^{f}$ : Hipanis, Granadas, $\mathcal{O}$ Romanat: Gallis, Pomme de granade, et $M y=$ grenes. 


\section{In Lib primum Diofcoridis .}

Mugoír. MYRTVS.

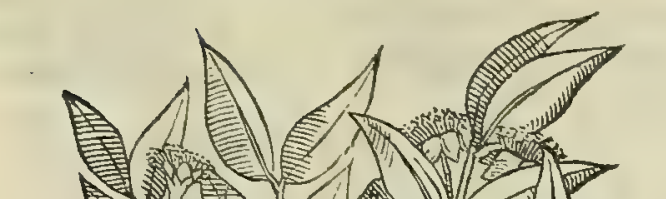

MYRTys fatiua nigra utilior eft medicinx, quàm can dida, \& in hor genere multò magis montana : femen tamen imbecillius parit. Vis \& myrti, \& feminis adftrin git. Semen uiride, aut aridum in cibo datur fanguinem excreantibus, \& ueficæ erofionibus. Succus uirentibus baccis expreffus, eofdem effectus exhibet: ftomacho urilis, urinam cit: prodeft contra phalangij morfum, \& Icorpionis ictus in mero. Seminis decoctum capillum tingit. Ius decocti in uino ulcera in extremis membris nata fanat : oculorum inflammationes illitum cum polline polentæ lenit : contra ægilopas illinitur: crapulam arcet prefumptum uinum, quod feruefacto aliquantùm eius femine exprimatur : aliàs enim acorem contraheret. Praftat idem feminis effectus : utile procidētix vultharum in defefsionibus, fedis uitijs, \& fominis fluxione uulux laborantibus : purgat furfures, ulcera capitis manantia, atque eruptiones papularum : fuentes capillos continet. Additur quoque in medicamenta, quas liparas uocant, uti oleum, quod ex folijs eius factum eft. Decoctum foliorum ad defefsiones balnearum conuenit, \& contra laxatos artus, \& malè folidefcentes: eo fracta ferruminationi repugnantia utilifsimè fouentur: uitiliginem emendat, purulentis auribus infunditur, \& capillos denigrat. Succus eorum eadem efficit. Trita folia, \& ex aqua illita humidis ulceribus, \& partibus.omnibus fluxione laborantibus, cœliacisq́ue profunt: \& admifto omphacino oleo, aut exiguo rofaceo cum uino, ad ulcera ferpentia, ignem facrum, teftium inflammationes, epinyctidas, \& condylomata. Arentium foliorum farina utiliter infpargitur paronychijs, ptery-

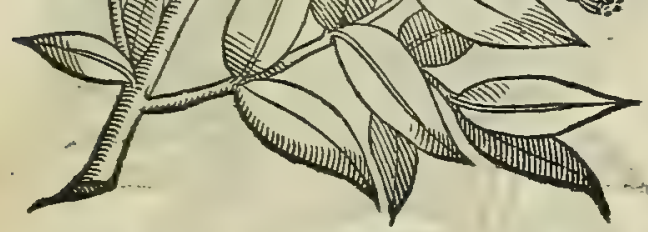
gijs, \& contra alarum, feminumq́ue perfufiones : cardiacorum fudores cohibet. Folia cruda, feı
cremata cum cerato, ambuftis, paronychijs, pterygijsq́ue medentur. Exprimitur folijs fuccus,adcremata cum cerato, ambultis, paronychijs, pterygijsque medentur. Exprimitur foljjs fuccus, ad-
fufo uetere uino, aut aqua cælefti, cuius recentis ufus eft : nam exiccatus planè cariem fentit, \& uires amittit. Myrtidanum dicitur, adnatum inæquabile, uerrucofım, intumefcensq́ue, \& concolor: quod perinde quafi manus, myrti caudicem amplectitur. Magis quàm myrtus adftringit. Tufum addito auftero uino reponitur, conctumq́ue in paftillos ficcatur in umbra : multò efficacius \& folio, \& femine, cerato, pefsis, infefsionibus, cataplafmatis admiftum : ubi adftringendum ali40 quid eft.

M Y R I V S arbor frequens in Italia nafcitur. Cuius duo produntur generd: fatinum, quod in candidum, er.

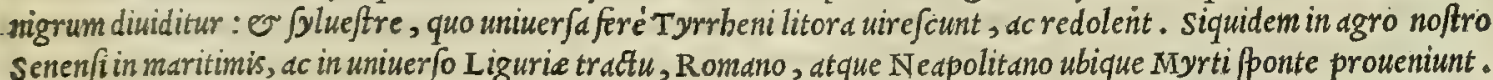
Satiue in arbores facilé adole $\int c u n t$, ramis flexilibus, ac lentis : rubro cortice: folijs longiufculis, perpetuoó; uiren= tibus, punice amulis; quanquam in nigris nigriora, in candidis candidior a ßpectantur. Flores omnibus infident can= didi, odorati: ideoǵ; aqua exijs confecta odoris fuaritate unguentarijs plurimum expetitur. At cùm noftras equé fit odorata, atque olfactu iucunda ; eam tamen odoratißimam exiftimauerim, qua ex Aegyptia myrto elicitur: $\beta=$ quidem er odoratißimam, or iucundißimam in Aegypto nafci Myrtum memorie prodidit Theophraftus. Satiud= rum utrunqque genus baccas fert oblongas, agreftes ole as quaddántenus referentes, multó fané fylueftribus maiores: et fi contrarium affeueret Marcellus. Quippe experientid compertum eft, quód ubicunque fatiud Myrtus colitur, Marcelli lapgrandiores, uegetioresó; baccas edit, quadm fyluestris: culturd enim Myrti manfue fcunt; er longé magis bumore fus . replentur, utpote o alix fatiux ftirpes omnes: quod quidem indomita tellus fylueftribus denégat. Ceterùm, he quis decipiatur, hic lectorem admonendum effe duxi, cium de fylueftri Myrto loquor, non me de rufco intelligere, qui o Diofcoridi, o Plinio fylueftris, o acuta myrtus appellatur; fed de verd fylueftrimyrto; qua fua.pponte in litoribus fine cultu oritur : que item in mediterraneis, in collibus, fyluis, ac campeftribus provienit. Hac tamet $\beta$ preter rufcum à Dio fcoride non fuerit expreffa c cum tamen dicat initio capitis, Myrtus fatiud, or reliq. his uerbis o jylueftrem eiufdem generis myrtum tacité dari fatetur. Forró inter fylueftres alba quoque, er nigra reperitur, quemadmodum $\approx$ inter urbanas: quandoquidem ipfe quàm plurimas fyluestres myrti plantas uidi in mille locis, qui= bus matura inerant bacca, non fane nigra, fed in purpuram albic antes. Myrti montes non amant, quin ov frigidos odêre tractus: tamen cum in mediterraneis, nempe in hortis, uiridarijs, uinetis, or campis naximé proueniunt; tum $\therefore$ : 
in maritimis precipué, at $q_{\text {; }}$ amenis ftagnorum, er lacuum ripis à natura nullo ftudio edite, mirifice proficiunt, $u i=$ Myrtidanum tami,; letam agunt. Quod Diofcoridi Myrtidanum nominatur, uulgó notißinum eft, ubi fcilicet myrtus frequens Myrtialia ge nafcitur. Sunt o alia uetcribus Myrtigenera, nobis quoq; non ignota, nempe Tarentinum, er exoticum: quo= nera.

rum Plinius meminit lib x v. cap. X X I X. his uerbis. Satiuarum genera topiarij faciunt. Tarentinam folio minuto,

MYRTVSTARENTINA.

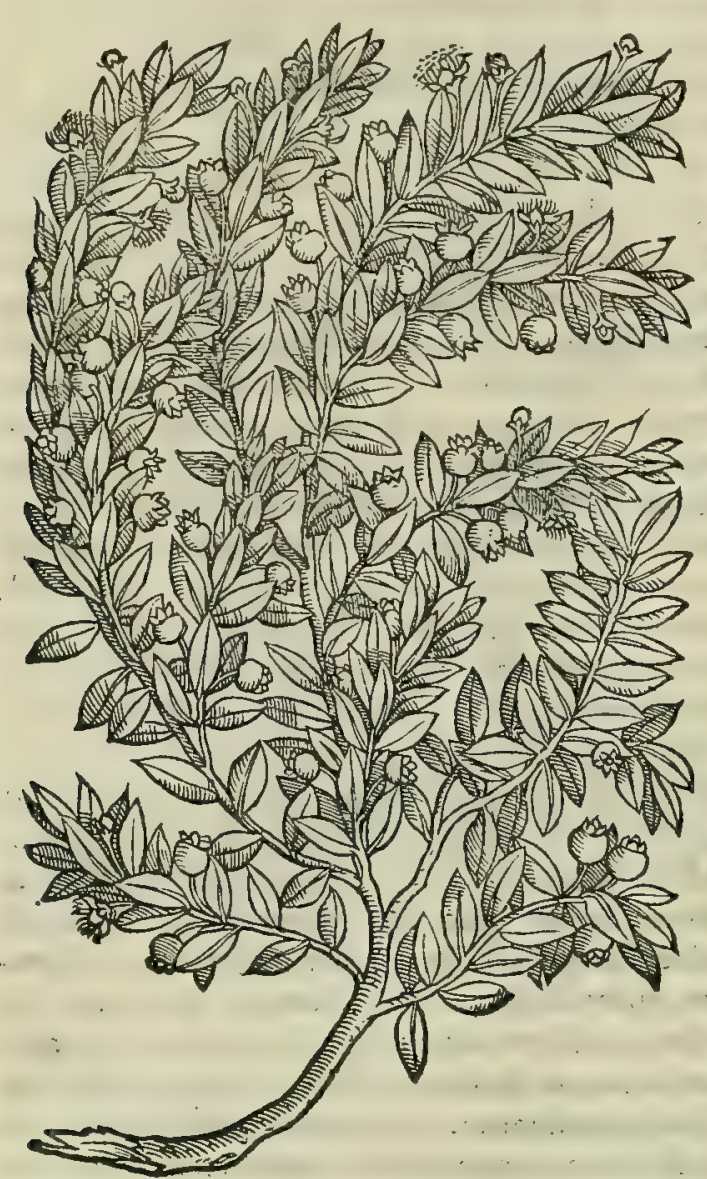

MYRTVSEXOTICA.

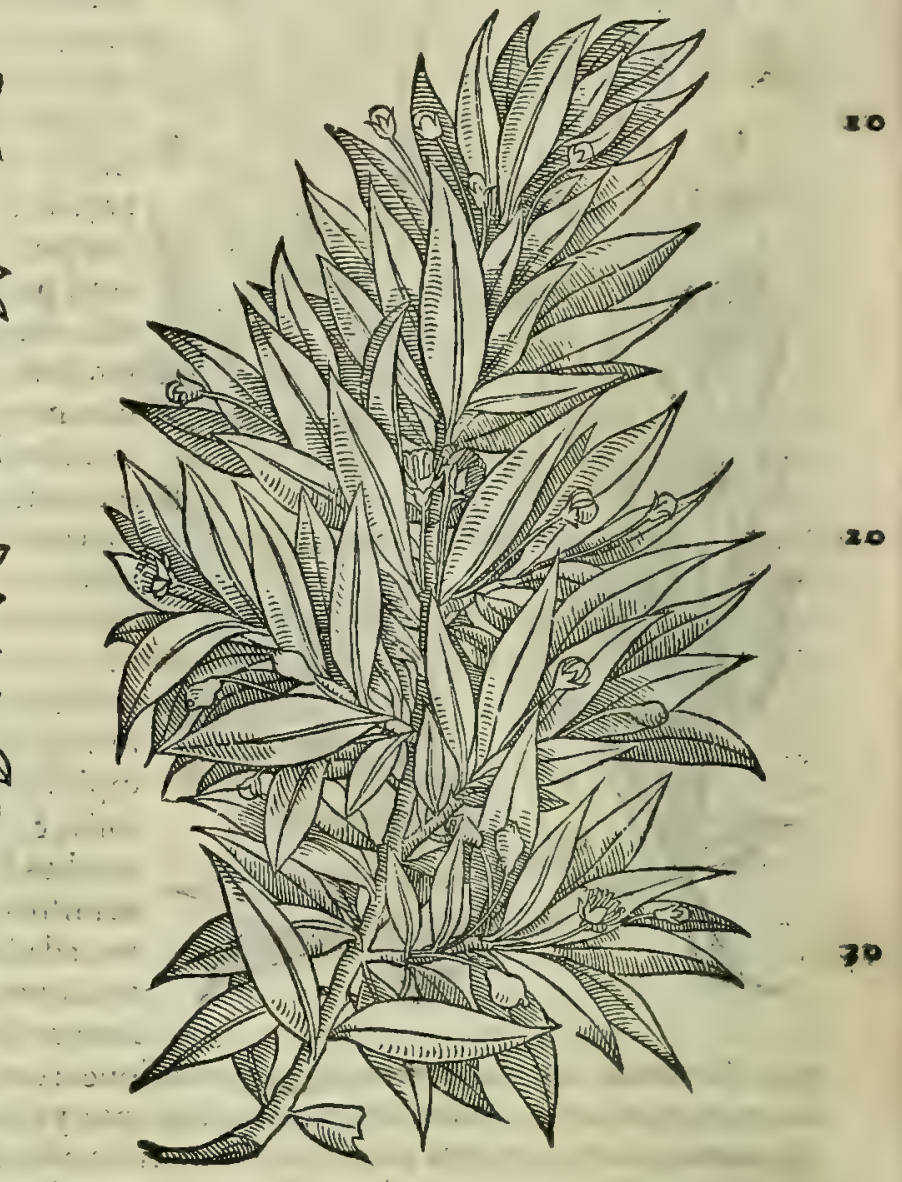

Myri ulus. nostratem patulo, exoticam denfîfimo, fenis foliorum uerfitus. Hac non eft in ufu : ramo $\int a$ utr aque alia. Mym tinoftratis in Hetruria coria ubique perficiuntur : quippe quidea pelles denfentur, crifpentur, atque craffefcant. Myrtibaccis ultimam maturitatem adcptis, noftrates mulieres utuntur ad ciborum intinct us, qui cum affatis carni= bus cfitati maximam cum palato incunt gratiam. Idec'́; Plinius loco fuprà citato ita fcriptum reliquit. Succorum 40 natura precipuam admirationem in myrto habet, quando ex und omnium olei, uiniq; bina genera fint . Item myrti= danum, ut diximus. Et alius ufus bacc.e fut apud antiquos, anteaqudm piper reperiretur, illius obtinens uicem. Qudam etiam generofi ob fonij nomine inde tracto, quod etiámnum myrtatum uocatur. Eadem;́; origine aprorun Sapor cosmmendatur, plerunque ad intinct us additis myrtis. hac Plinius. Myrteum condimentum languddos uentri= culos roborat : idcirco e cocliacis, $\mathcal{O}$ dyfentericis utile : quin $\mathcal{O}$ faminarum fuxiones, qualefcunque fint, ud: lenter inhibet. Myrti frondes, item q́; baccarum femen tritum contra fungorum ftrangulationes mirifice prez

Myrti uires ftant. Myrtus (ut memorie prodidit Galenus libro feptimo fimplicium medicamentorum) ex contrarijs fubs ex Galeno. Atantijs planta conftat: uincit tamen in ea frigidum terrenum. Habet ueró etiam ténue quiddam calidum: unde ua* lenter deficcat. Porró tum folia, tum germina, tum fructus, tum. fuccus, non parum inter fe in adfrictione difident. Ceste rùm quod ramis, ov trunco adna fcitur tuberofum, quam quidam myrtada nuncupant, quantò dictis ficcius eft, so tanto or deficcat, ov adfringit uebementius. Quidam id tundentes reponunt, poftea uino fubigentes in paftil = los formant. Folia item arida uiridibus plus deficcant: mifcetur enim uirentibus bumiditas quadam. Porró fucs cus non tantime ex uirentibus folijs exprimitur, fed $\mathcal{O}$ fructu. Reftringendi uim bac omnia babent tum foris im: pofita, tum intro. fumpta in corpus, quodd filicet nondum ullam deleteriam, aut purgatortam fubftantian habeant.

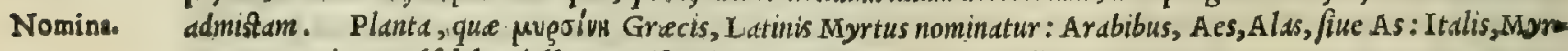
to : Germanis, Vueifch heydelbeer: Hipanis, Murta, aut Raiam: Gallis, Meurte.

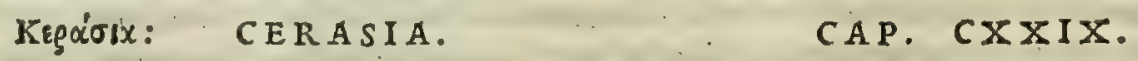

CERAS i a aluo vtilia funt, fi uiridia fumantur : eadem ficcata illam fiftunt. Gummi, quod ceraff refudarunt, cum uino diluto, tufsi uetuft $x$ medetur : colorem commendat; uifum exacuit, appetentiam inuitat : idem ex uino potum calculofis auxilio eft. 


\section{In Lib. primum Diofcoridis. I47}

CERASIA.

10

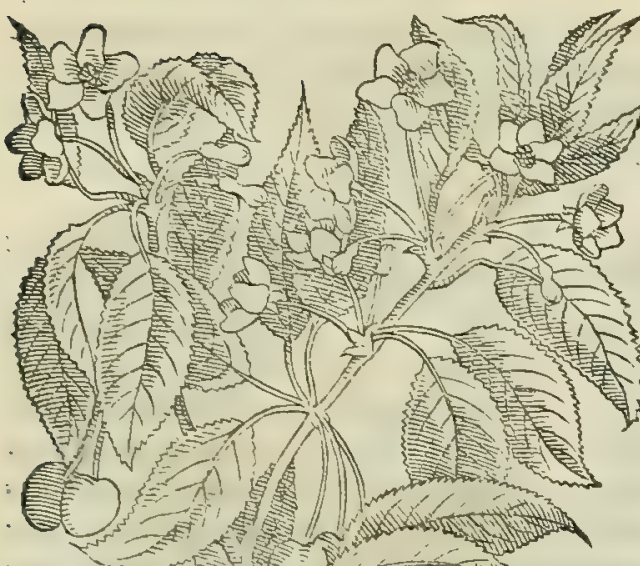

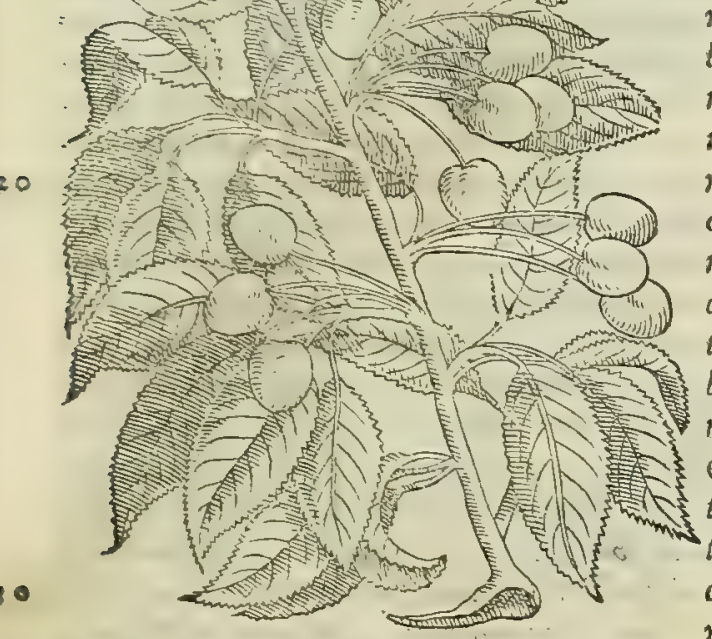

$\mathrm{N}$ V L I A bodic arbor eft in Italia, qua unlgo notior fit Cerafis. Has fcribit Plinius libro $\mathrm{x}$ v. cap. $\mathrm{x} \times \mathrm{x}$. nouds, e pe= regrinuś, nec antex uifus é Ponto fecum primim aduexife in Ita= liam Lucullum, poftquim debellato Mithridute is uitoria po= titus Romam uenti. Sed pofter tanta agro Irulo amanisino cum hac arborc interceßit affinitas, or confcrtikin, ut non folim ager is fatiuarum plantas feruauerit, propagaberit, or adauxerit; fed or uiluti ex ciusbumore (que funma fuit inter fe focictas) grauida terra facta, fine aliquo femine in campis, in montibus, or Jyluis numerofißimas plantas procreakerit, or edidcrit. Sd= Cerafiorú go tiuaruin peciofißimi fructus, quicerafa, e Cerafia I atinis $e=$ nera. tian appellantur, diuerforum funt gencrum: quo fit, ut diter $\sqrt{a}$ quoque fortiantur itonind. Inter bac illa principen fobi. locunt uendicant, que Hetrufcis unlgó Marchiune, e durdcine uocan tur : tamet fi horum alia maiord, alia minord, dlis faturato colore rubeant, alit ueró potius albicent. Que autem Plinio Iuliand, no= bis ueró unlgó Acquaiuole, boc eft, aquea dicuntur, in nullo $\int_{d=}$

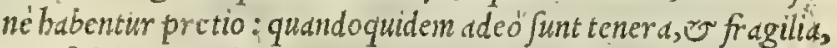
ut nifi fub arbore fua comedantur, facilé geftatu collidantur, $\mathrm{O}$ marce fcant: quin et ob aquea partis redundantiam infipida funt, oriğingrata. Que autem, quod admodum nigricent, Corbine nos uulgó uocamus, Plinius uerò actia, or cxeiliana, ckim fint duriufculd, or dulcia, guftatu babentur non iniucundd : uerun= tamen quiod manus, dentes, aclabra atro colore inficiant, difcü= bentes; ;eturpent, menfis raró apponuntur. In cerdfiorum ge= nere numerantur é illa, que Rome Vifciole, Senis Amarine, o in alijs compluribus Italia locis Marafche uulgó nuncupan= tur, à Japore (ut puto.) dicta, quod non iniucundi amaroris tdin= tillumrefipidat. Horumporró udria notantur generd, que et/f omrita fibi acidum afcifcant faporem; hac tamen eius plus, illa ue= ró minus habent. Rura Tridentina ea Marafche unlgó nominant,

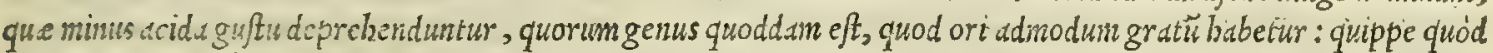
in ijs acido dulce fit adinifum, ob idq; illa palato maxime placeant. Ruedam preterea inibi Marine, e Marinelle cognominanutr, que e nunora; e rotundiors funt, e breuiori pediculo appenfa, guftu nibil frè predictis recla= mante. Eft o horun tertium zenus, qu.c uulgus ill ud Verule nominat, longiore pediculo, bacca etiámnum cateris

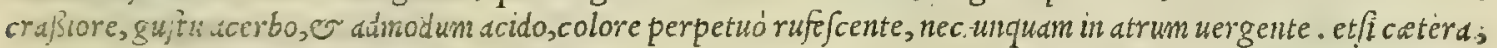
ubl plene maturterint, in atrun rubefcant. Omnia hac cerafiorum ( ut ita dicam) Amarinorum genera aptißima funt, ur infolentur, or ut faccharo condiantur. Quinetian fapore cömendantur ad intinctus conficiendos, quibus non mad janis edulix incundißimé condiuntur; fed etidin agrotantibus, prefertimq́; biliofis febribus uexatis. Siquidem

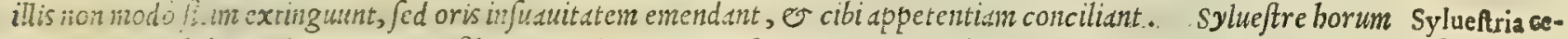
genus null. sdbibuta cultura Ananienfibus in Tridentino dgro Ponte prouenit, nihul pror fus tun colore, tum etiam $\int a=$ rafia.

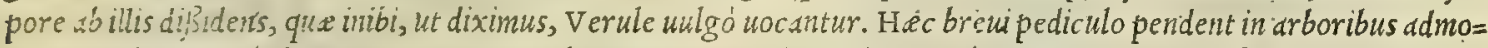
dum pusnlis, isuta q ; breuitutis, ut rare, uel potius nulle dodrantalcm aquent menfuram: Qu factumeft, ut credi= derin (eifi id pro comperto afferere non aufim) bec eadem effe, qu, Plinio Macedonica dicuntur. Sylueftrid, quibis plerung; ue cun:ur aues, raro in cibis admittuntur, praterquadm à rufticis, tum quód plus oßis, qudim carnus babeant. tum etim quid cun quad am acerbitate aimar a fentiantur. Degenerant cerafí quocunq; fino radicibus admoto, id $u \int_{z}$ que adej odcrunt, er borrent. Conträ proficiunt, fi fui ip fius putamina falce concifa circum radices fepeliantur, ibió, marcefcant. Precoces ille fructus ferunt, quibus ante florusn exortun call uiua radicibus circumponitur: vel quibus aqua callda sapius pedes irrigancur, etfi poftea paruo temporis trattu inarefcant. Galenus babita Cerafiorum om=

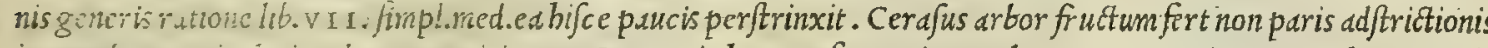
in omibus puticuiation plants participem. Name in horum, ficut etiam malorum granatorum, e malorum, qui=

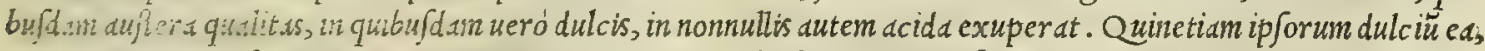

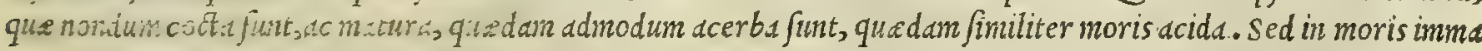
turis acida quelta as acerbs:n exup prat, in cerasijs non femper. Ergo qua dulciora funt, magis que in inteftinis funt,

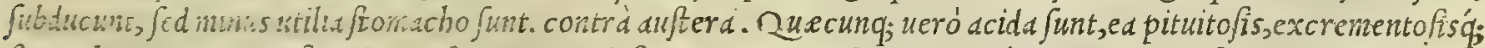

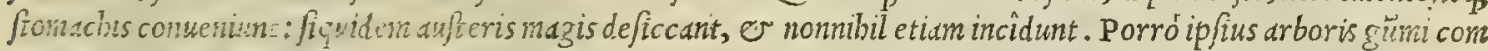
munem omnibus vejcolis, ev mord:cirate carentibus medic amentis facuitatem obtinet, qua o dd arterias exapera= tas acconmoda cif. Proprié auten ( hi quidem uerum eft quod quidam fcribunt) calculis uexatos cum uino potü ad=

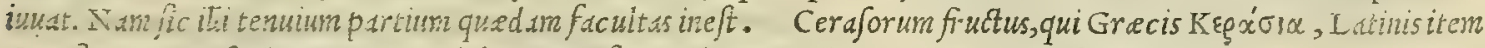
Ceralis, et Ceiafa decuntur: Arabiérs, Sarafie: Italls, Ciregie: Germanis, Kirfen: Hifpanis, Cerezus: Gallis, Cerife.

$$
\text { n } 2 \text { Kegitia. }
$$

Ceraforum confideratio.
(1)

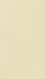

(1)

.

西

西

西


KepQiTIE. SILIQVAE.

Siliquarú con fideratio.

Siliquarum ui res cx Gal.

Nomina.

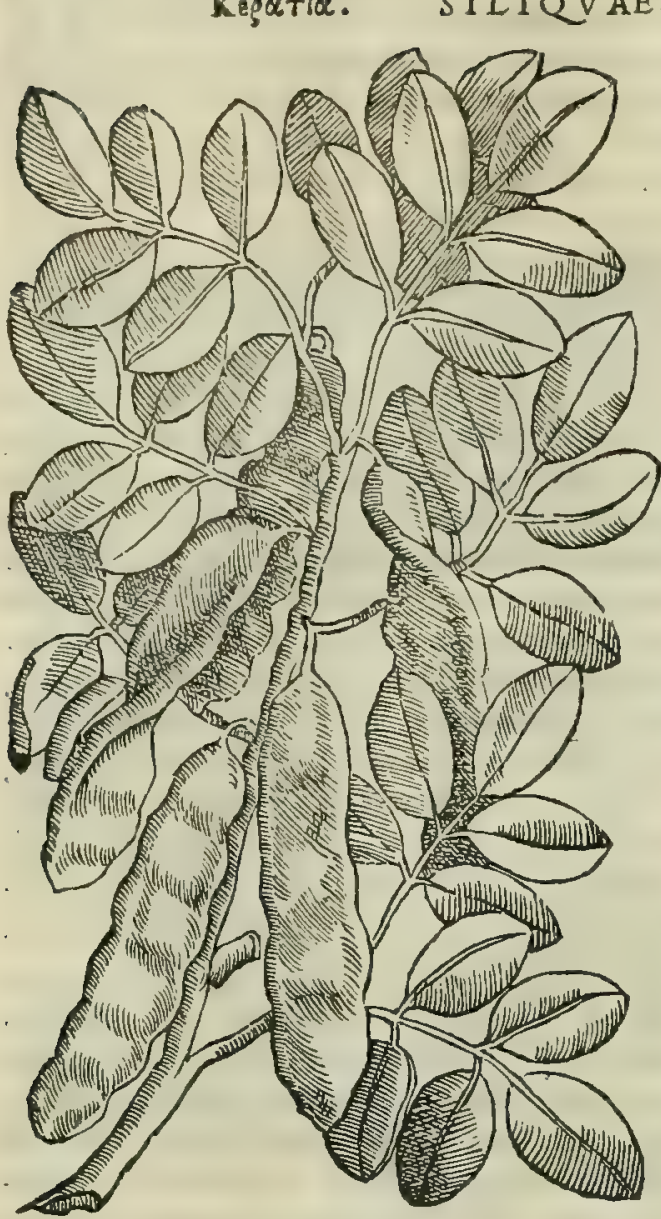

\section{CAP. CXXX.}

SI I I QV AE recentes ftomacho aduer fantur, a K $^{-}$ uum foluunt : exdem ficcatæ fiftunt, ftomachoque utiliores fiunt : urinam ciunt, fed præcipuè, quæ uinaceis condiuntur.

SI I I QV AE, que Grecis ue $x^{\prime} T 1 \alpha$ dicuntur , in Italia officinis uulgó Carobe, or Carobole appellantur. Nafcuntur arbores, que siliquas ferunt, in regno Neapolitano, prefertim in Apulia, ac etiam in Campania, ut optimé friunt $\ddot{\eta}$, qui Furi= do Itrum, o binc Molam iter faciunt: fíqudem in illa ob levix gatos lapides inibiftratos laboriofa admodum uia,quam Appiam uocant, frequentißine conpiciuntur. Incole bas plantas Sales qua unlgó nominant, uocabulo nimir um à siliqua detorto. Ar= bores in pectatam fatis proceritatem attolluntur', ramis in lati= tudinem potius, quàm in longitudinem protenfis: cortice cine= ritio ad caruleun inclinante, loti arboris inftar. Folio uirent fraxineo, latiore tamen, duriore, rariore, de magis circinna $=$ to. Florent difcedente byeme, aut uere ium appetente: fructifis 20 cant ueró aftate, or autumno. silique recenter ab arbore de= cerpte ing ato difplicent Sapore, fed trattu temporis in cratibus expanfe, o ficrate, adeó mite $\int_{c u n t}$, ut $v$ dulces eudant ad= moduin, es guftui fuaues fiant. Aliud filiquarum genus, quod ficum Aegyptiam cognominant, fcriptis tradider unt Theophra ftus, or Plinius: de quibus milhi differendum non propofui, tum quód I talis nufquam ( quantum equidem fciam ) nafcantur, neq; cognofcartur; tum etiam quód nillum babednt ufum in medict= na. Siliquas in cibis damnauit Galenus lib. I I. de alimentor $\tilde{u}$ facultatibus, his uerbis. Ceratia, quorum tertia fyllaba per, $t, 30$. literam o feribitur, or pronunciatur, nibil cuin cerasijs per, $f_{\text {, }}$ fcriptishabent fimilitudinis. Eft autem praui fucci edulium, ac lignofun : unde necelfario fequitur, ut concoctu fit difficile: nibil enim quod lignofum eft, facile coquitur. Fraterea inconmodum illud ip/isineft non paruum, quód non celeriter deijciantur. Proinde fatius effet, ea ad nos non importariä regionibus orientalibus, in quibus nafcun= tur. Sed de uiribus, quas o arbor, e ipfa babent in medicina, idem Galenus differens lib. v I I. de fimplicium medicamentorum facultate, fic inquit. Ceratonid exiccantis eft, or adftringentis facultatis, ficut o fructus eius, que ceratia uocant, nonnibil etidin dulcedinis continent. Accidit autem iftis quiddam fimile cerasijs. Nam fi humi= da fumas, magis uentrem fubducunt: ficca ucró mag is fiftunt: utpote cim buiniditatem expirent, or quod effentice eft craßioris, tantim reliquum babeant. Kęxं to Gracé, Latiné silique uocantur: Arabicé, Charnub: Ita= licé, Carobe er Carobole: Germanicé, S. Iohanes brot: Hilpanicé, Alfarobas: Gallicé, Carouge.
Mî̀ $\lambda \alpha$.
M A L A.
CAP. CXXXI.

F O L I A, flores, \& germina cùm omnis mali, tum maximè cotoneæe adftringunt. Pomis acerbis adftringendi uis ineft, maturis uerò longè fecus. Ex ijs uerna bilem gignunt, neruos omnes lxdunt, inflationes pariunt. Cotonea ftomacho utilia, urinam cient : uerùm tofta mitiora habentur, Profunt cœliacis, dy fentericis, purulenta extufsientibus, cholericis, præfertim cruda . Maceratorum liquor commodè in ftomachi, aut uentris fluxionibus, potui datur. Succus crudorum aflumptus orthopnoicis falutaris eft. 'Decocto fouentur uulux, \& fedes, fi procidant. Cotonea, qux melle condiuntur, urinam mouent: mel autem fibi conftringentem illorum uim, \& infpiffantem adfcifcit . Quæ cum melle coquuntur, ftomacho, atque ori gratiora funt, fed minus infpiffant. Cruda cataplalmatis adijciuntur, ad cohibendum aluum, aut fi ftomachus xftuet, aut in uomitiones effundatur, ad mammarum inflammationes, præduros lienes, \& condylomata. Fit uinum ex ipfis tufis, exprefsisq́ue: fed quò perduret, quindecim fextarijs fucci unus mellis adiungitur, alioquin in acorem degenerat. Prodeft ad omnia, qux dicta funt. Fit \& oleum ex ijs, quod melinum uocauimus : quo utimur, quoties adftringenti oleo eft opus. Eligi oportet uera, quæ fanè funt rotunda, parua, $\&$ odorata . quæ uerò ftruthia dicuntur, magna quidem funt, fed minus utilia. Flos \& uiridis, \& ficcus catapla fmatis imponitur: ijs conueniens, qux adftrictionem defiderant, inflammationibus oculorum, reiectionibusq́; fanguinis : contra citam aluum, \& menfium impetus, in uino bibitur. Melime. la uentrem molliunt, \& ab eo animalı expellunt: ftomacho negotium exhibent: $æ$ ftuationem faciunt. ea multis dulcia mala uocantur. Epirotica mala, quæ Latinè orbiculata dicuntur, ftomacho uti lia : fiftunt aluum, vrinas euocant: malis tamen cotoneis inualidiora. Sylueftria mala fimilia funt 


\section{In Lib. primum Diofcoridis.}

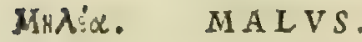
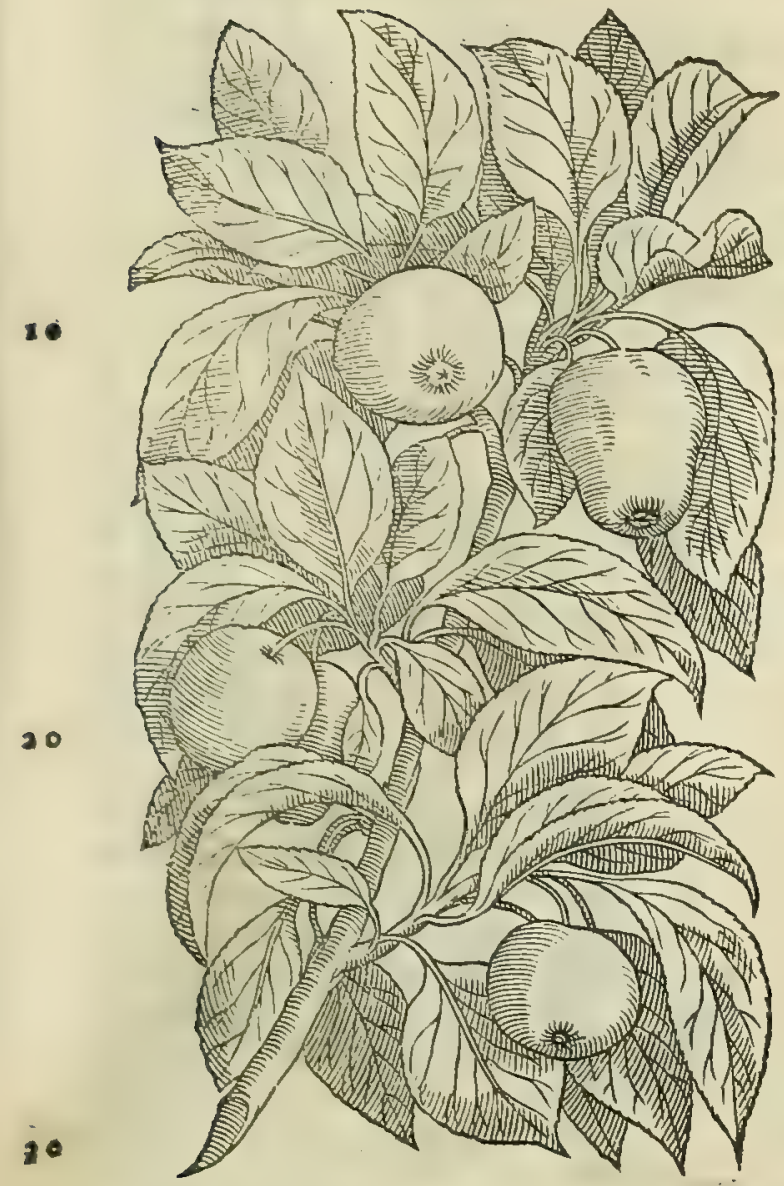

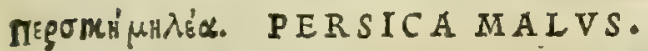

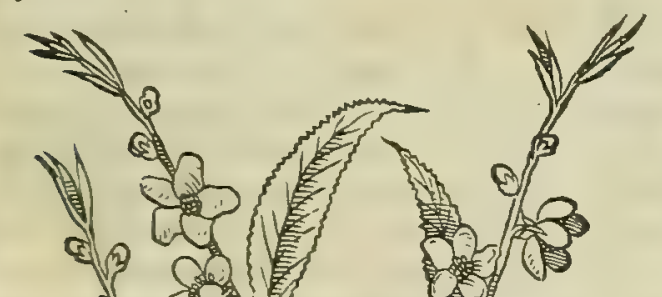

40
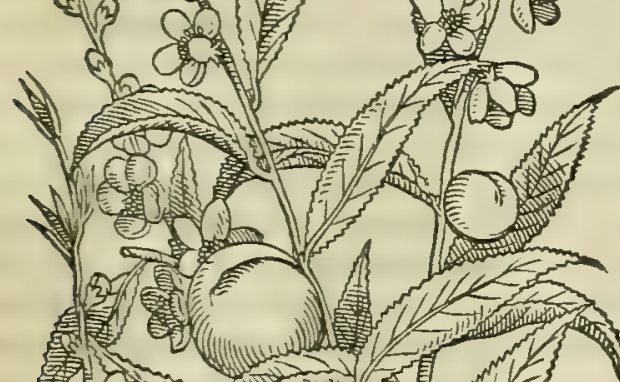

(r)

so

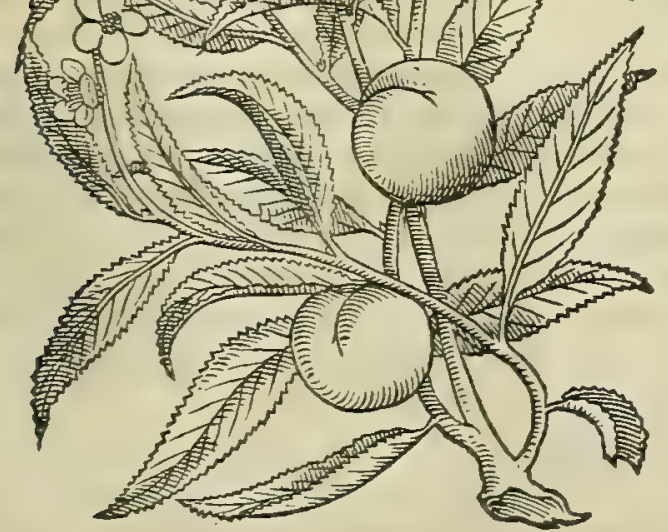

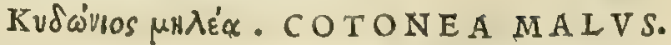

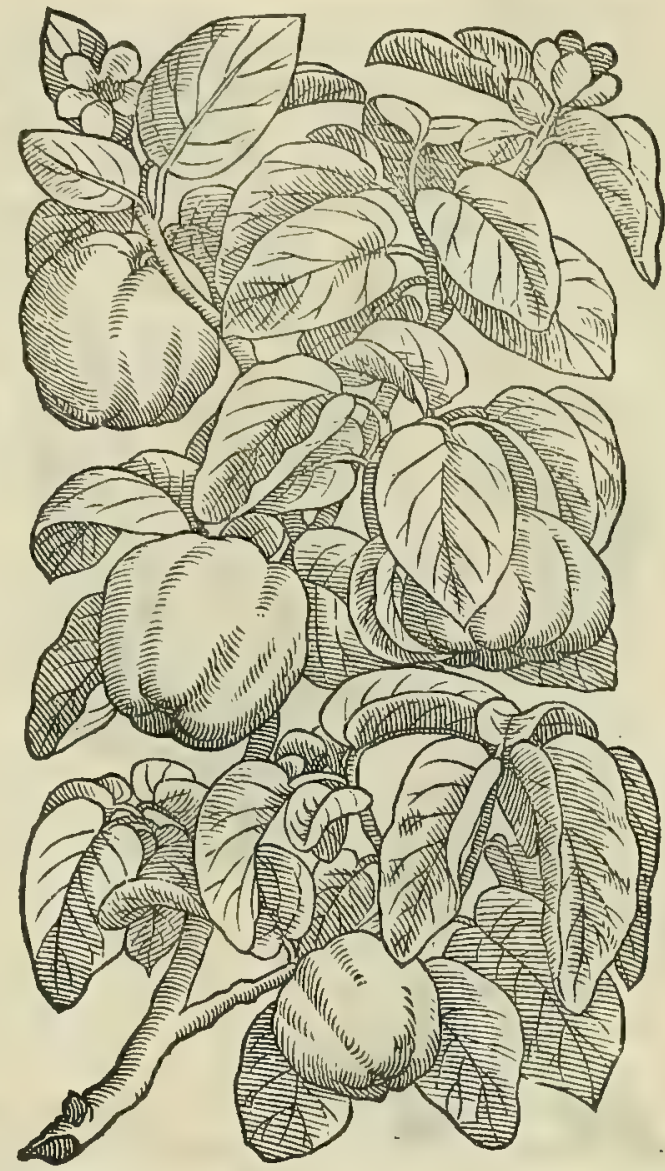

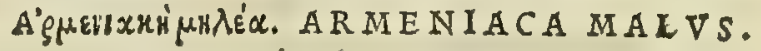

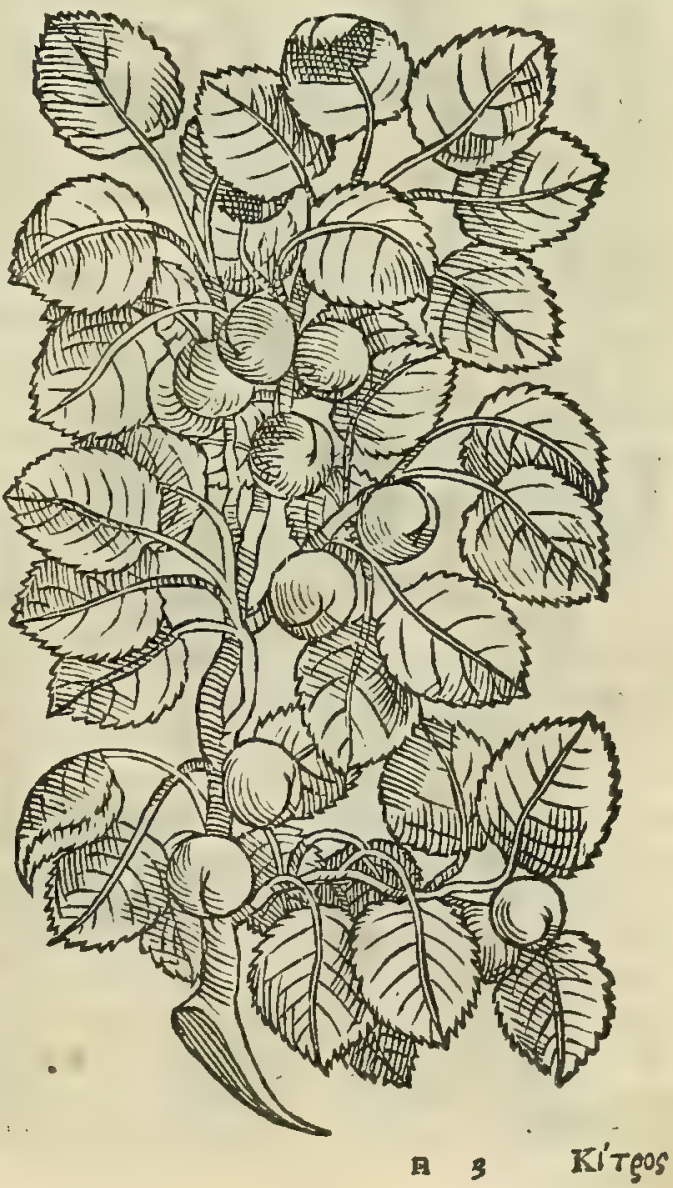




\section{And. Matthioli Comm.}

KITpos. MEDICA MALVS:

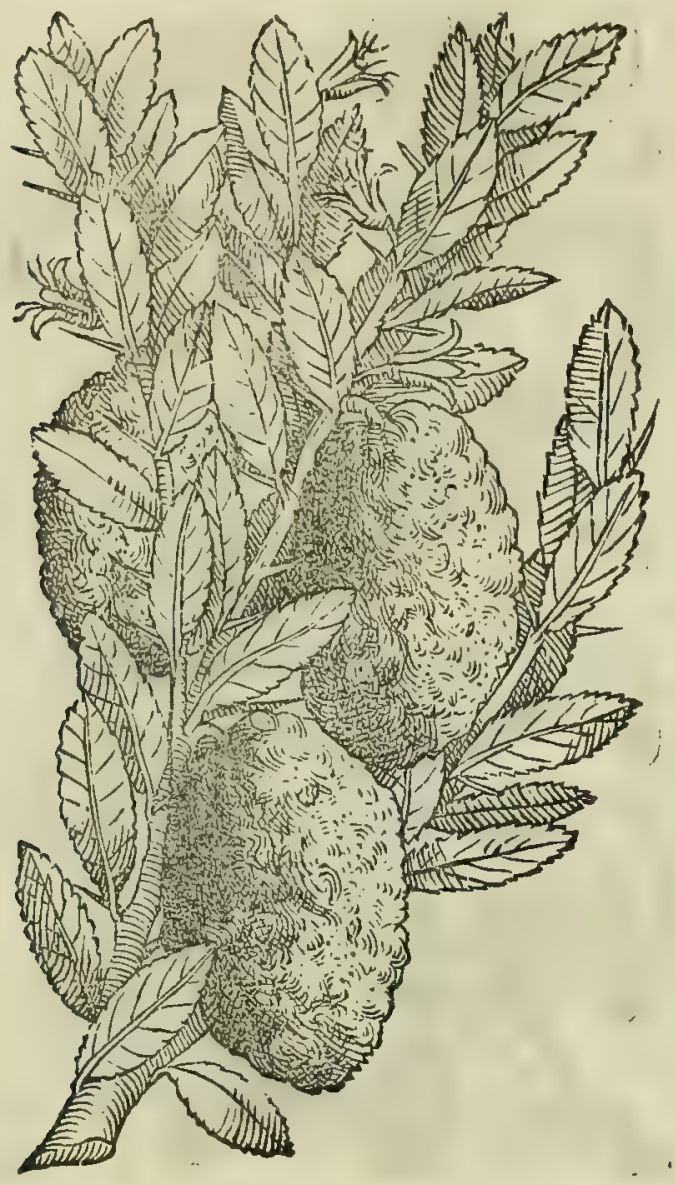

AVRANTIA MALA:

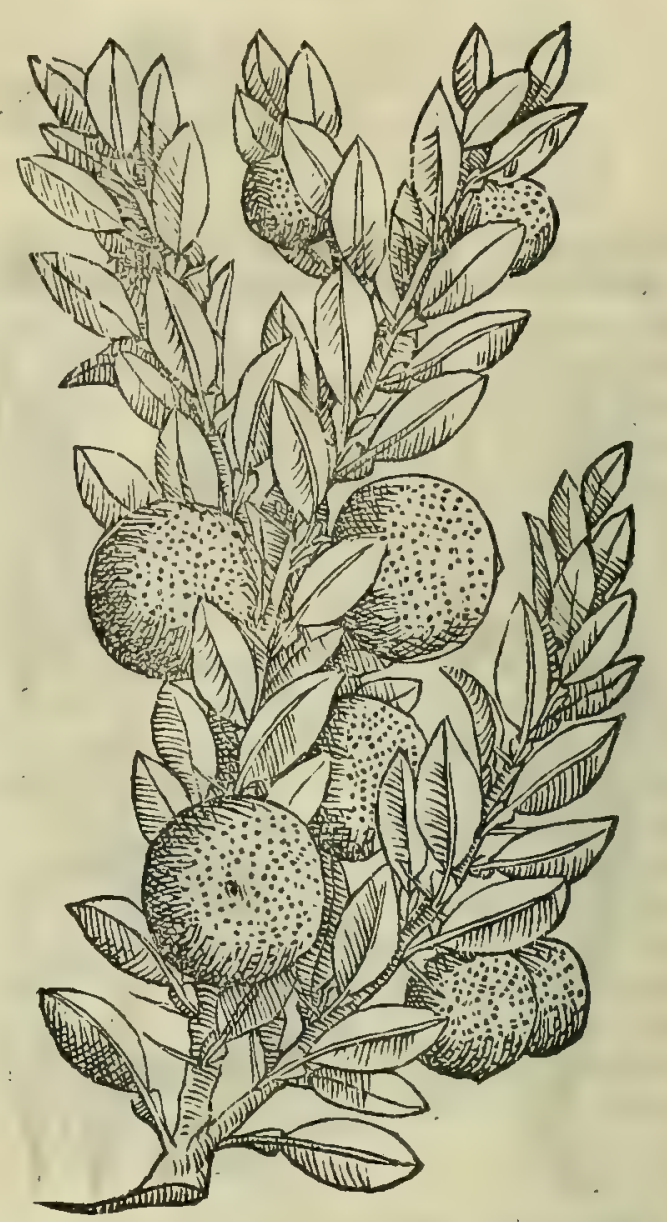

19

20

3.0
IIMONIA MALA.

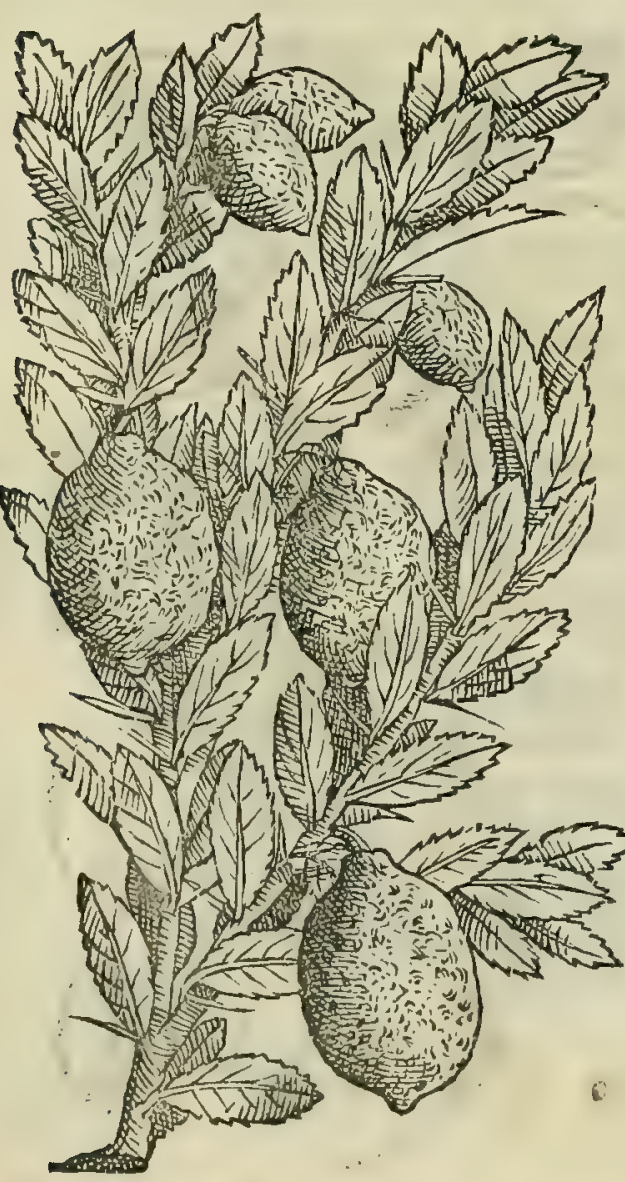

uernis, \& adfringunt. Sanè in hunc ufum immatura omnia opus funt: Perfica poma matura tam fomacho, quàm uentri utilia funt . acerba aluum cohibent, fed ficca uchemeritius : Decoctum è ficcis alui, ftomachique fluxiones fifti. Armcniaca; qux à Latinis præcocia dicuntur, minora funt fupradictis, \& fomacho utiliora. Medica mala, perficátie, aut cedromela, qux Latini citria uocant, nemini non cognita. Arbor ipfa 49 omnibus anni teroporibus pomifera, alijs deciduis, alijs fubnafcentibus. Malum oblongum eft, rugofum, colore aurum imitans, cum grauitate odoratum : femen habet pyri. Id in uino potum uenenis refiftit, aluum mouet : oris faruitatem commendat, decoeto eius colluto, aut fucco: $x$ fur in malacia mulieribus, Veftiarijs impofitum ab croflonis uitio ueftes uindicare exiftimatur.

I N M A L O R V M quoq; genere Diofcoridi recenfentur su Perfica, Pracocia, Cotonca, er Citria: quippe quód eandem effigiem, e forman reprafentare uideantur. Sed nos primùm de unlgaribus malis agemus, reliqua fubinde figillatim profeque= mur. Eorum itaque (ut Galenus libro fecundo de alinentorum facultatibus pofteritatis mcmoric prodidit) uarij, ac multipli= ces funt fapores, quos etiam uarix fequntur functiones. Alia nanque anfterum, alia acidin, dulcemie faporem gerunt : Sunt etisin que ex ijs mifum b, sbeant, ita ut appareant or dulcia $h_{1}=$ mul or auftera. Quxdan preterea cundulcediie maniffté $d=$ cida fentiuntur : ad bec alia cum acore acerba. Invenias autem ro:munquam o que tres fimul fapores plane refirant, dulcem 


\section{In Lib. primum Diofcoridis.}

fcilicet, or acidun, acerbiq; nonnibil. Catcrum mals quidem, que adfringunt, fuccum babent frigidun, ac terreum. Que ueró acida apparcu, frigidum gnidem fuccum babent, ueriun temium es partium. Medie autem temperature funt dulcix, que ad calidus uergunt. Cuemudnodun que onnis qualitat is fint expertia, infipidáne, ac ucluti aquo=.

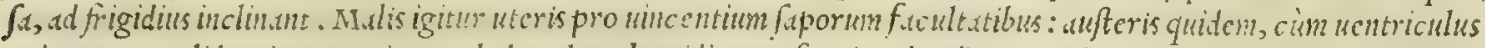

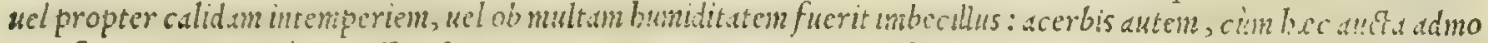

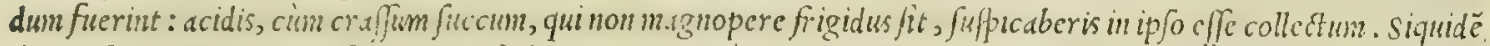

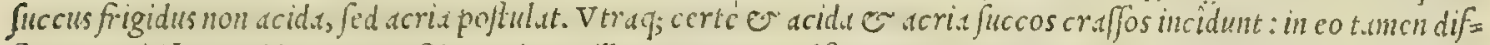
ferunt, quód hec quitem cum reffigeratione; illa aucen cum calfutione id prastent. Porró dulcis malorun fuccus,

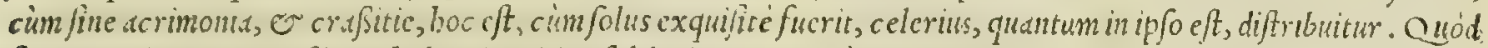

1e fi acrinoniam, aut crafsiticm babuerit, citius fubducitur. Cecertim optina etian gcnere mala uitanda funt, ante=

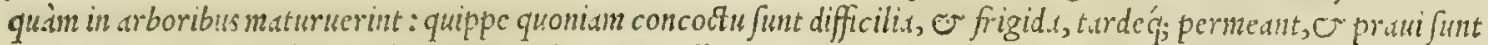
fucci: ad bec fuccumb.abcnt frigidum, or leuiter craffum. Qux ueró belle matur.t in byemem, er uer proxinu af = ferusut, ca noorbis fepcnumcro perquine utilis funt, aut farina aqua fubada circumlita, dut calidis cincribus nedio=

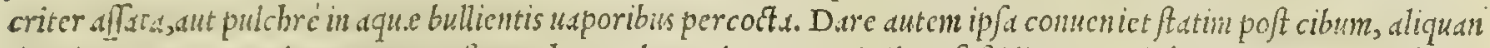
do etian cum pane, ad uentrem, o fromxchum roborandum, ijs qui cibum! fiftidiunt, tardég; concoqunt, quiqg; uo= mitu, diarbhes, ac dy fontcris infift.mtur. In bunc quo o; ufum apta funt acerba: nam parata, ut modó dixi, medio= crem retinent asfltifionem. In Hetruria principatum obtinent, que Appie, er Mele rofe uulgó noc antur: quan= doquidem h,se duo gentr, cim Juauiter olecnt, guftuig;; arrideant, cum nuribus, et palato maxim.m ineunt gratiam. Esq; propere non longé cum aberrare putauerim, qui dixerit A ppia effe Diofcoridi melimela: Rofca ueró, qux eidé

20 epirotica, O I anis orticulata dicuriur. Que ucró adeó rubent, ut cruore perfufa uidedntur, Cr acido guftu funt

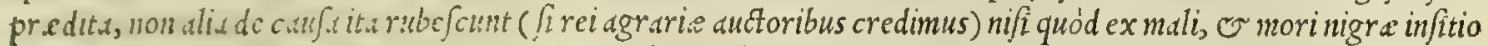
ne fusm traxerin origncm. Cornarius fua tantim, nifillor, opinione dudus, putat in fuis commentarijs in Gale= ni libros de compofitione medic sinentorum fecundum locos, Ceftiana pona effe arantia, fiue curantia mald, que in

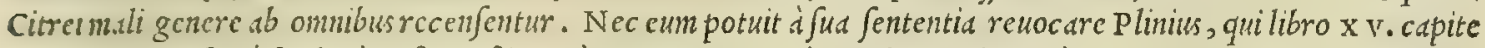
X I I I I. apertißiné fcribit à Ceftio cefiana, ¿̀ Matio matiana, ¿ Manlio manliana, à Claudio claudiana, er ab Appio appiana mala per inucntorum nomina, à quibus babuerunt originem, Romanis fuiffe cognominata. Quocirca eo loco feripsum reliquit Galenus ex auctoritate Apollonij, quód in capitis dolore ex ebrietate ccftiana male fic in urbe $\mathrm{R} O=$ mana appellata, in cibis cocta conferunt, quod auftera fint facultate: non ut fomnialfe uidetur Cornarius, aurantia, que preterquàn quód A pollonio, or Galeno incognita fuiffe cenfentur, nufquan gentium, quod equidem fciam, co=

30 a a exbbentur. Quo fit, pace omitun dixerim, ut qui fue ceruicis duritian confulunt, fuas fa pius reprobare fenten= tias audiant. Malos, qus frustus fuos tanquam feriles, dare recufant, focundas effeceris, fi plumbeo circulo earum caudicen altitudine pedis a terrafritim concluferis ante florum aduentum, or cum mala coperint adole ficere, folu to uinculo cas libertate donaueris. Mala Cotonea primùn in Italiam aduecta fuerunt é Cydone Crete oppido, un= de Grec is cydonia difa funt. Horum tra in Italia inueniuntur genera. Palmaillis, que peculiariter Mala cotonea.

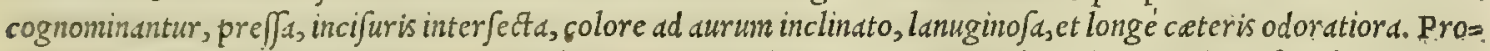
ximum locum fortuntur, qux maiore admodum corporis mole proueniunt, Diofcoridi, or Galeno ftrutbia uocata. Hetrufci bec pyra cotonea uocant: quippe quód forma mag is pyra, quam mala referant. Pulpa, ac fucco ceteris pre ualent, colore tamen, fuacolentia, ac uiribus cedunt. Poftremó plinio miluiand funt, qua nonnullis notha dicun= tur, quod tantim proucniant ex coconcis malis, que frutbe is infite fuerint, uel ex frutbeis, que cotonedrum furcus

40. los receperint. Hxc malis grandiora, pyris ueró, fiue ftrutbeis minoraifuntur: forma ueró, ac facultate inter us trunque media. Ceterim fané bec omnia, precipué mald, maximé officinis expetuntur in medicina ufum. Nempe quód ex omnibus prater uinum, miuam, oleum, o quod Dyacidonium uocant, conficiantur o intinctus, er cons. gelatiliquores: qux omnia non agris modó apta funt, fed etiam fanis utilia aqué or grata. Galeni auo (ut ipẹe te fatur in libris, quos de alinentorum facultatibus confcripfit) (ydonite placenta, quan officine Diacydonium nun= cupant, ex Iberí, er Syria Romam conuebebatur, ex melle tantion, $\mathcal{O}$ cotoneorum carne confecta, tam ad cibi, quàm medicamenti commodum. 2ue faccharo, uel melle condita reponuntur, perfecté matura legi debent, aliàs indure funt lignorun inftar, tta ut dentibus conficinequeant. Qua cruda per hyemem afferuantur., feorfum à pen= filibus unis reponenda funt, quod uuas fuo acerrimo fapore adeo uitient, ut ex ftatim marcore conficiantur. Per= ficorum quoque plurime reperiuntur pecies. nam quedam rubent, alia aureo colore fulgent, alia uirefcunt, alia so candida funt, ali. fanguinea, alia duracina, alia cotonea uocantur. Ad bec quadam babentur dulcia, quedam a= cida, quedam uino $\int a, q u x d a m$ anariufcula, or quedam etiam auftera. Primalaus in cibis duracinis, fic ex re di=. atis, quód caro tam pertinaciter bereat oßji, ut nullo pacto ab eo auelli queat. Precipud autem in boc genere illis laus, qux ab aurei coloris nitore, odoréq; perquàm iucundo Cotoned cognominant. Secundas fibi uendicant pare tes, qux cortice detratto fanguineum fuccum fundunt, non propterea modó quód fint guftu reliquis fuauiora; Sed etian quis magnitudine, 0 colore funt peciofa. Proxima funt, nec prodito generi fortaffe cedunt, qua $d$. nucis fimilitudine $\mathrm{Nuciperfica}$ cognominantur : hec enim cum colore, er fapore non refragentur perficis coto= neis, tum etiam non ingrata dentibus duritie, gufum mira afficiunt uoluptate. Est or genus alud Perficorum in Hetruria, ac in alijs Italie locis agricolarum mangonio factum, qua ideo Perfica amygdala appellant, quo= niam perficorum oßium uice dulces amygdalarum nucleos includunt. Caterum fané multis contendit Corna $=$ rius, in fuis commentarijs in fecundum Galenilibrum de compofitione medicanentorum fecundum locos, ubique

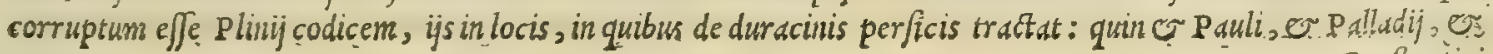

Malorum cotoneorum có fideratio.

Perficorum confid. 
Conftantini Cafaris libros corruptos effe, ubi in ijs de duracinis perficis aliquid fcriptum reperitur. Quandoz. quidem is, ubi in horum monumentis de duracinis perficis factam fuiffe incntionem legitur, ibi de rbodacenis, non autem de duracinis iegendum effe cenfet. Verim cum inibi nulla uel ratione, uel auctoritate nitatur, quibus id comprobet, fua tantim ductus opmione uidetur : atque ob id facilé pronunciaffe, borum onnium codicibus (quod. tamen abfurdun cffct credere) mendum fubeffe. Quamobrem in boc potius Cornarium ballucinatum, quam libros. duprantos effe crediderin. Quinimo uirum alioquin doctijimum admiror, quód rem per fe clar an obfcuram rede.

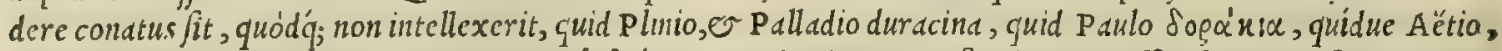

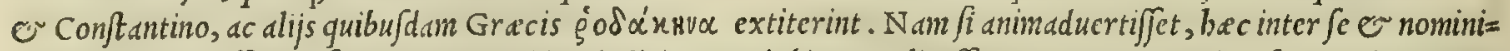
bus, or re ip a differre, facilius, meo quidem iudicio, rem dubian explicaffet, nec onnes in uniuerfum auctorum co= dices deprauatos pronunciaffet: cum, ut equidem arbitror, corum nullus his in locis fit uitiatus. Paulo enim $\delta 0 \rho \alpha=$

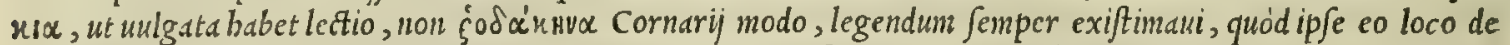
precocibus, of armeniacis tantum malis differat, non autem fimpliciter de perficis. Siquiden, ut Cornarius ipfe. fatetur, $\mathrm{R}$ bodacene non eft aiia, quàm malus perfica, quemadmodum R bodacena nil aliud funt, quim mala ipfa La. tinis perfica uocata. id quod $\sigma$ nos fine ulla controuerfia probamus. Sed $\mathrm{Paulo} \delta$ ogáx sa (ut diximus) genus eft.

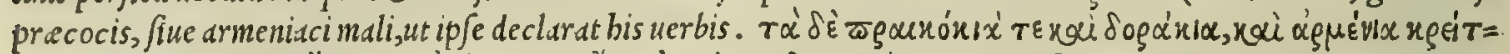

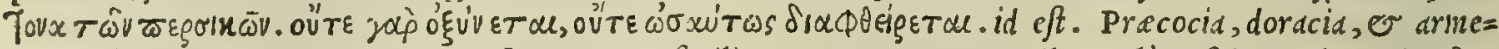
nia perfic is praftant: neque enim ace cunt, neque fimiliter corrumpuntur. Quibus paldim eft in $\mathbf{P}$ aulo potius $\delta 0=$

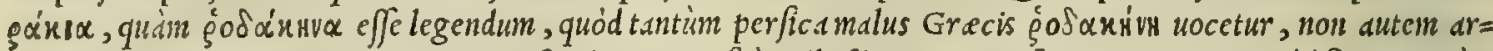
menica, doracia, er precox: quarum fructus, tametfi à quibufdam inter perfica numerentur, quód forma tantum

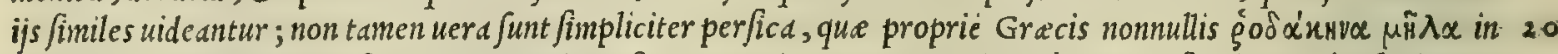
uniuer fum uocantur, ut if $\int e$ etiam Cornarius teftatur. Quippe nugaretur incpté $\mathrm{P}$ aulus, fi ucllet, quód rhodacena perficis preftarent, cim mil aliud fint rhodacend, quam perfica. His itaque rationibus liceat nobis dicere, foox'x $1 x$ $\mathbf{P}$ aulo nec éof áx nva, nec duracina defignare, fed precocis, fiue armeniaci maligenns fibi peculiare. Sed iam ad Plinium uenio, cui duracina perfica perficorum pecies funt, quibus palma inter omnes, non autem genus, quemad= modum er duracina cerafa, $\mathcal{O}$ unx etiam duracine inter uarius ceraforum, Ev uutrum pecies codem plinio, $\mathcal{O}^{\circ}$

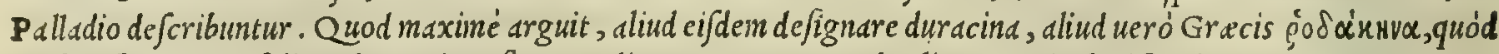
uerbum boc uniuer faliter de omni perfico predicetur, non autesn de aliqua particularipecie. Neque, ut ait Cor= narius, uocat noftra atas quedain perfica mala duracina, quod offe cateris duriora fint, fed antiquos fecuta, quód pulpe confiftentia guftuigratior a fe fe offerant, e longiori tempore perdurent. Quod quidem pal am facit Flinius lib. X I I I I. cap. I I I. cum ait. Duracina uua fine ullis uafis in uite feruabilis eft: tanta cft contra frigora, ,eftus, tempeftateś; firmitas. Hanc er Columella pratulit in cibis. Poftremó quót rbodacene arbor, perfic ann arborem in uniuerfumfignificet, cim Cornarius ip fe id firmiter afferat, opus fané non effet, boc pluribus comprobsre. Sed ne fortaßis putaret fibi ipfi non effe adbibendan fidem, Aëtium confulat, Conftantinum $C$ a $\int a r e m, ~ \mathfrak{O}$ Symeonem Sethi inter recentiores Grecos. Siquidem ij pluribus in locis manifefte demonftrant, nul aliud per $\mathrm{R}$ bodacenem fe intelle= xiffe, quìm ueram, legitimam '; perficiplantam. Perficorum onne genus damnauit Galenus libro $\mathrm{I}$. de alimen= torum facultatibus, ut praui fucci, er qua facile corrumpantur, ac nox sm uentriculo inferant : quapropter Perfica Plinij lapfus. primis menfis femper edenda pracipit. Quare ego certé nefcio, ex quortm fcriptis deprompferit plinius, quód inno cua expetantur agris. Nififortaffe đ ipse pro perfico perfeum deceptus acceperit, quemadmodum fecere recentio= Marcelli, \& rum nonnulli. Perficiflores efu aluum deijciunt, itcmó; uomitiones cient, fed non abfq; labore, ac detrinento. Non Simphoriani defuerunt, ut Marcellus Florentinus, of simphorianus Campegius in biftorialibus Galeni campis, qui exiftinauerint error. eandem plantam effe perficam, or perfeam, de qua agit Diofcorides in buiufce primi uoluminis calce. Que (ut tra= dunt) ea profectó eft, que in Perfide exitio a nafcitur, etfit translata in Aegyptum cali illius clementia mortiferam in falutarem uerterit naturam, adeo vitàn cibos recepta, tam fanis, quain morbofis pror fus habeatur tnnocua. Huius bi= ftoriam latius profequitur Theophrastus lib. I I I $\mathrm{r}$. de plantarum biltoria (ut infr.i fuo loco dicemus) qu $\mathrm{f} / \mathrm{i}$ quis per = legerit, hanc à noftris perficis plurimùn dißjidere comperiet. Manifesto etiámmum argumento funt Diof corides, or

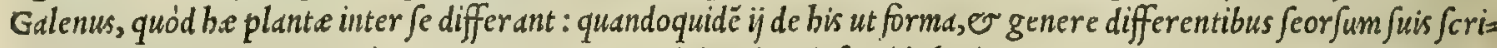

A rmeniaco- ptis tradiderunt. Armeniaca praterea, qua Latini, ut in Diofcoride legitur, pracocia nominant, er Graciberi= rum confide- cocia pronunciant, nos in Hetruria Grecos imitati uulgó Bacoche, er Moniache corruptis uccabulis appell.tmus, dc ratio. fi diceremus Bericocid, o Armeniaca. Plura corum uifuntur genera magnitudine potius, qudm genere differentid. Quod euenit non modó celiclementia, er terre admodum frugifere dotibus; fed er cultorum mangonio: nanq; ex so multiplicata infitione maximé proficiunt. Porró omnia, ubi maturitatem fenferint, aureo colore fplendent. Idcirco Romanis uulgó Grifomele, quafi chryfomela dicuntur, eáq; pracipué, qua eo tractu cum perficis magnitudine cer=. tant. Mature fcunt ineunte eftate men fe iunio ante alios fugaces fructus, unde meritó Pracocia dicta. Ea parum ge=

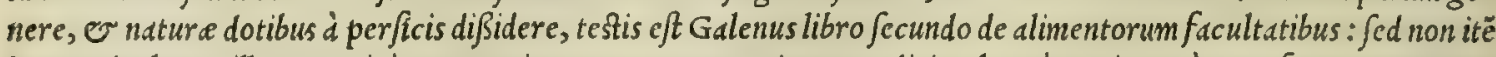
in uentriculo, ut illa, tam citó corrumpi. quanquam recentiores medici ea longé magis, quàm perfica, corruptioni

Medicorú ma obnoxid experientia contendunt. Infuper Medica mald, ut ex nomine cognofci poteft, ex Media primim aduect. Jorum confi- funt. hec Latinis Citria, uel Citromala uocantur. Eorumarbor aurantiorum, ac limoniorum plantas magnitudine deratio. $\quad$ equat. Folia, que perpetuó ci uirefcunt, aurantijs parum, ucl nibil refragantur, foraminibus uifum feré effugicntis bus ubiq; punctin traiecta. Quamobrem ne fciucrim ego, qua ratione Theophrastus ( $u$ t Theodorus interpretatur) ei folia aßignauerit portulac.e, que illi nullis notis confentiunt. Quo fit, ut admirarinon liceat, fi recentiorum pleriq;

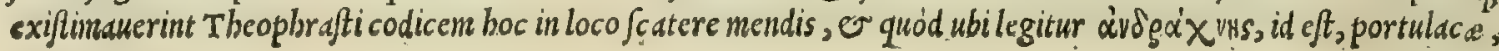




\section{InLib. primum Diofcoridis.}

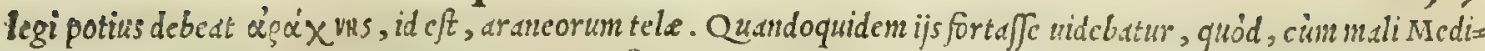

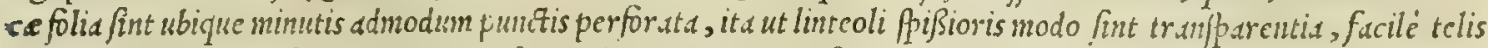
araneis comparari poßent. In quorum jententis ego quoque perftiti, quoufquc Plinius inde me reuocauit. Quippc

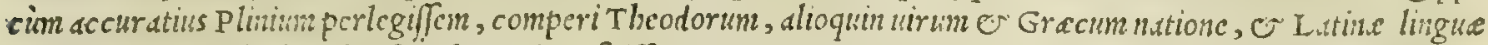

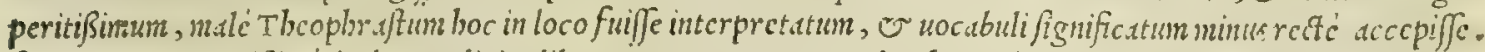
fiquidem, ut apertifimé declar.at Plinius lib. X I I I. cap. $\mathrm{x}$ X I I. Adrachne arbor cft arbuto adinodum finilis. In=

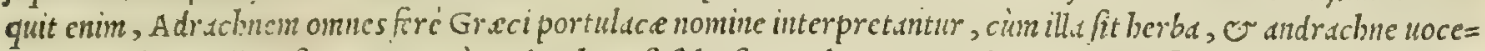
tur, wnius litere diwerfitate. Cxtcrim adrachne eft fylueftris arbor, neq; in planis nafe ens, fimilis uncdoni, folio tans. tum minore, $\sigma$ nunquan decidentè. Hine ergo facilé colligı poteft, buic plante, que arbuti frondibus perpetuó ui=

- refcit laurinis fimilibus, Medice malifolia compuraffe Theophraftum. Citrea arbor omnibus horis pomifrrd eft: alia. nanq; matura cadunt, alia maturcfcunt, alia ucró fubnafcuntur. He Plinij a uo non erant in Italia, ut ipfe testatur lib. X I I.cxp. I I r. wbi inquit, fepius tentaffe gentes, plantas é Media transferre ad fe, quxe tamen ibi diu uiuere ne= quiuerunt, licet magna cultorum folcrtia fuerint enutrite. Nunc ueró contrà translatitix facta funt, atq; cum Itd= Io folo tantan iniere gratiam, ut non modó in maritinis, fed in meditcrrane is quidem tum hortis, tum uiridarijs, tum etian nobilium lacuum ripis fi equentißima filicter germinent. Poftquàn cultu, o diligentia $\mathrm{P}$ alladij (is enim pro= ditur primus arten adinuenife ) factume eft, ut ex Media in Italiam translate profilierint, ac propagaucrint. Theo= plr afti is rate Citris mala nondum in ciborum ufum uenerant, corum teftimonio, qua ipfe lib. I I I I. de plantarum bi= foria memoric prodidit, fid tuntim odoris gratid ueftibus inferebantur. Quin er corum ufus crat antidoti loco con= tra uenend, ad que demolienda femen precipue cfficacißimum babent. Refert Atheneus, quod cum princeps qui=

20 dam Aegyptius maleficos quofdam damnafjer nebulones, quó fuorum facinorum luerent penas, apidibus fecundum Acgyptias leges in predan cxponendos, ij Citrian in itinere, dum ad beftiarum pabulum ducèrentur, comederunt?, quod caupona quedam uicem eorum dolens, ato; miferiam, illis dederat. Mox cum in theatrum de fcendiffent, er ab

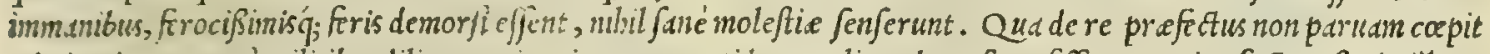
admirstionem, or i militibus diligenter inquirens, an antidotum aliquod prx funpfiffent, certior factus eft, citriü tain. tim ex integra fmplicitate donatum, eos comediffe. Poftridie uerò iufit uni praberi, alteri denezari, or denuo in thestrum trudi ad fupplicium. Quo farto, qui comedcrat, demorfus nibil incommodi paffus eft : alter ueró à fera iEtus undig; liuidus factius, confeftiminterijt. Narrat proterea Theopompus chius duodequadragefimo fuarum biftorida rum uolumine, Clearchum Hcraclcotan Ponti ty:ainum multos ueneno necaffe: fed ille, inquit, plures adbuc inters. feiffet, $\sqrt{i}$ populum praftantißima citrij uis latuiffet. Seruantur citrianala diutius incorrupta, fi bordei, uelmilij

30 aceruis obruantur." Sed babita medicine ratione, iam de corum uiribus plenibs differendum eft. Citria ita $q_{;}$uene=

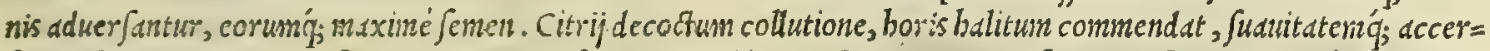
fit. Ip fa autem integra uefriarijs condita, ueftes non modó gratißimo odore perfundunt; fed eas ctiam ḋ tineis, er blattis uindicant. Sicruda tamen manduntur, nonfacilé coctioni obediunt : quin er craffum generant fuccum: ob hoc ue fci ijs melle, aut faccbaro conditis furius eft, quód uentriculum commodé cale faciant, ac roborent: quanuis bec no fra atas gule nimiun indulgens in cibis citria cruda preferat cum affatis carnibus efitata. Citria aduerfus atram bi= lem, o morbos moftos, quos ill s cxcitat, opitulantur. Semen priuatin foorpionum ittibus er potum, ¿ appofitum mirifice medciur. Acidus eorum fuccus flau.m reprinit bilem, arcetó; peftis contagia. Proinde recentiores medici ad fobres peftilentes ferapijs ex co confectis feliciter utuntur. Eaprincipem in cibis obtinent locum, qux in lacus Be: naci ripis proueniunt; qux etfi parum m.lla Linonia dita magnitudine fuperent; maiorem tamen cateris ab ore ins

40 eunt gratian. Qux ueró ex Ligurix uiridarijs, er Adriatici, er Acgęipelagi infulis, alijsq́; locis afferuntur, etf melopeponum modo crafe $\int c a n t$, pecio áq; magnitudine excellant; cim tamen infipido guftu non multum placeant, in cibis non equé ac illa, preftant: uerum quỏd pulpa copiofíore conftent, of ficinis expetütur faccharo, uel melle afs feruanda. Citrij mali meminit Galenus lib. vi I. fimplicium medic. fic inquiens. Malimedice fructus non am= plius malum medicum, fed ab omnibus Citrium nuncupari adfolet. In femine quidem uincentem babet qualitatem as= cidam, er ficcam; ut ip fum tertij fit ordinis reficcantium, refrigerantiumó;. In cortice ueró itidem deficcantem tem periem eft fortitus, non parum tamen habeniem acrimonix : proinde deficcat bic fecundo exceffu, non tamen frigic dus eft, fed aut temperatus, aut pauló infrà. Porró caro cius pariter craßi fucci eft, er pituito $a$, frigidáq; : nam o ip $\int a$ editur, ficut er cortex. Semen omne edi ineptum eft, tum humidum illud, er acidum, de quo primùm differ: ui: tum nucleus, qui in illo inuenitur, id quod re uera femen eft. Hic amarus eft, er digerendi uidelicet, ficcandiģ; $f_{a=}$ 5. cultatem obtinens, fecundo quodammodo ordine à temperatis recedens. Folia ueró deniq; exiccandi, ac digerendi uim obtinent. hactenus Galenus. Vbi animaduertendum eft, quód cum initio capitis inquit, In femine quidem uincen= tem habet qualitatem acidam, er ficcam; ut ip fum tertij fit ordinis reficcantiun, ac refrigerantium, Galenus non de

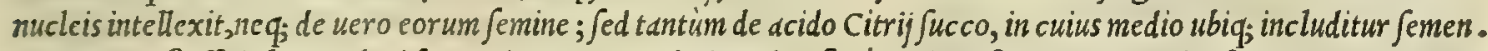
Eam autem fuife in boc Galenifententiam, eius uerba in calce feré capitis oftendunt, qua ita fonant. Semen omne

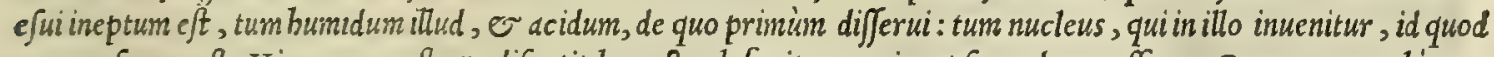
re uera femen eft. Hic amarus eft, o difcutit, hoc est calefacit, er exiccat fecundo receffu. Quam rem male, meo quidem iudicio, a fecutus Auicenna, utpote qut non recté diftinxerit, neque bac in re plané Galeni fententiam acce= perit, libro fuorum canonum fecundo femini citrï fecundam calidorum, or ficcorum fedem aßignauit : tractatu ue= ro, quem cordis uiribus dicauit, eidem tertiam frigidorum, or ficcorum claffem adfcripfit, nullum quidem uerbum $f_{a}$ ciens de acido Citrij fucco, quem ḋ Galeno fub feminis nomine compreben fum fuiffe demonftrauimus. Non longé nd.

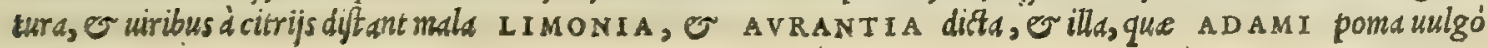

Theodorilaplus.

Citrionŭ mira facultas.

\section{Citriorum ui} res.

\section{Citrij mali ui res es Gal.}

Auicenna no tatur.

Limonia, $A u$ rantia, \& Ade mi poma. 
uocantur, nos ueró Lomie dicinus: tametfi Limonia, cim fint guftu omnibus ijs peciebus acidiora, ob id fucco er

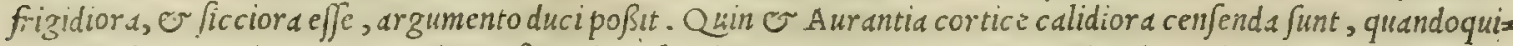
dem is reliquis scrior, atq; anarior guftatu deprebenditur. Aurantiorum (quemadmodusn etiam de punicis fuperius diximus) in It.lla tria obferuantur genera, dulcia, acida, o uinolenta, fic mifta. Dulcit in ommbus partibus ex= calfaciunt. Aliorun ucró fuccus refigigerai, prout maiore, feu minore refirta funt aciditate. Quocirca fubricitanti= bus ad reftinguendam fitim, acids quiden, or uno $\int$, non autent dulcia funt cxblberida. Fit é Limoniorum fucco, ficut $\sim$ citriorım, ferapium ad rcjtinguendum blis firuorcin non inutile. Item 0 ad peftilcntes febres, or eds, que contagione non uxant. Aqua, que e L imoniorum fucco calcntis aque bulneo, e uitreis organis extrabitur, pre= terquim quod mulieribus expettur profuco ad fuciem expolicndam, uittigines ubicunq; fint, er totius corporis ma culas emendat, uaros delet, or acaros interimit. Serapiys admifta febribus acutis, et contagio/is nire fuccurrit. Epo $\mathbf{2}$ o ra uentris inteas cnecat : id quod etian pres/tat fuccus reccuter expreffus, uncia pondere potus. Caterim non pa=

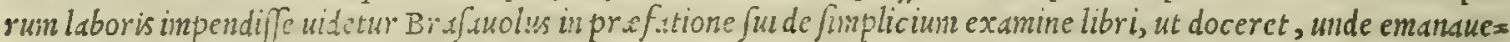
rit Arantiorum uocabulim. Scd licet ibi plura de cius orgine referat; ea tamen, meo quidem iudicio, non multum no

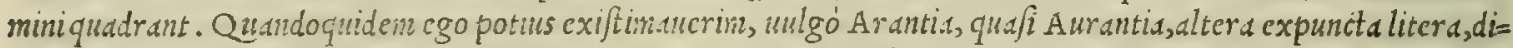
It a fuiffe. Nan cüm hec poma auri colore reluceant, ab auro meritó nomen accepiffe uidentur : unde, quantum equi

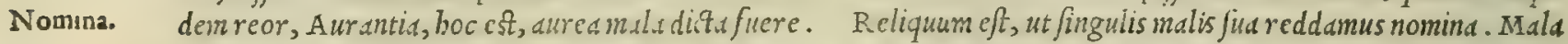
ita Latinis diđa, Grecis $\mu \tilde{\mathrm{H}} \lambda \alpha$ uoc.ntur : Arabibus, Tuffa, jeuTufaba: Italis, Mele : Germanis, Oepffel: Hipa $=$

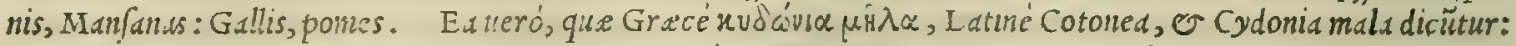
Arabice Saffargel: Italice, Ncle cotogne: Germanice, Quitten, aut Kutten: Hifpanicé, Membrilhos, O Marmel=

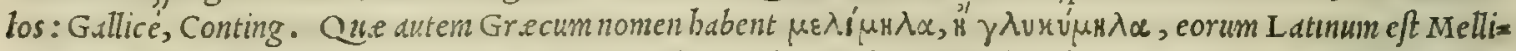

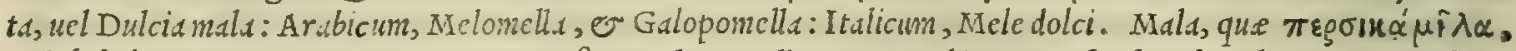
vei jof́árnva Greco nomine, Latino Perfics mala appellantur: Arabico, Sauch, feu Chauch: Italico, Pefche:

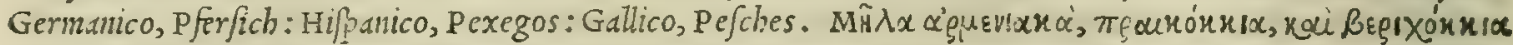
que Greci, Latini Armeniaca mala, et Pricocia nominant: Kauritani, Mermex feu Mirmix, Mex, Mefmes, fiue Mifinis: Itali, Armeniache, Eacoche, Moniache, et Grifonele: Germani, S. Iobans pfrrfich: Hipani, Albirico=

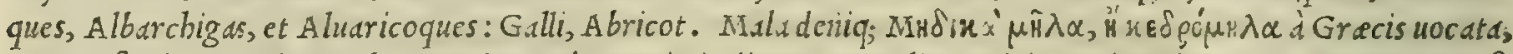
Latinis finiliter Medica mala, aut Citromald, et Cirria dicuntur: Italis, Cedri, et Citroni: Germanis, Citrin oepf fel, Iuden ocpffel, et Citronaten : Hifpanis, Cidras: Gallis, ung Citron.

Ä๘Ix. P Y R A.

Pyrorum cōfideratio.

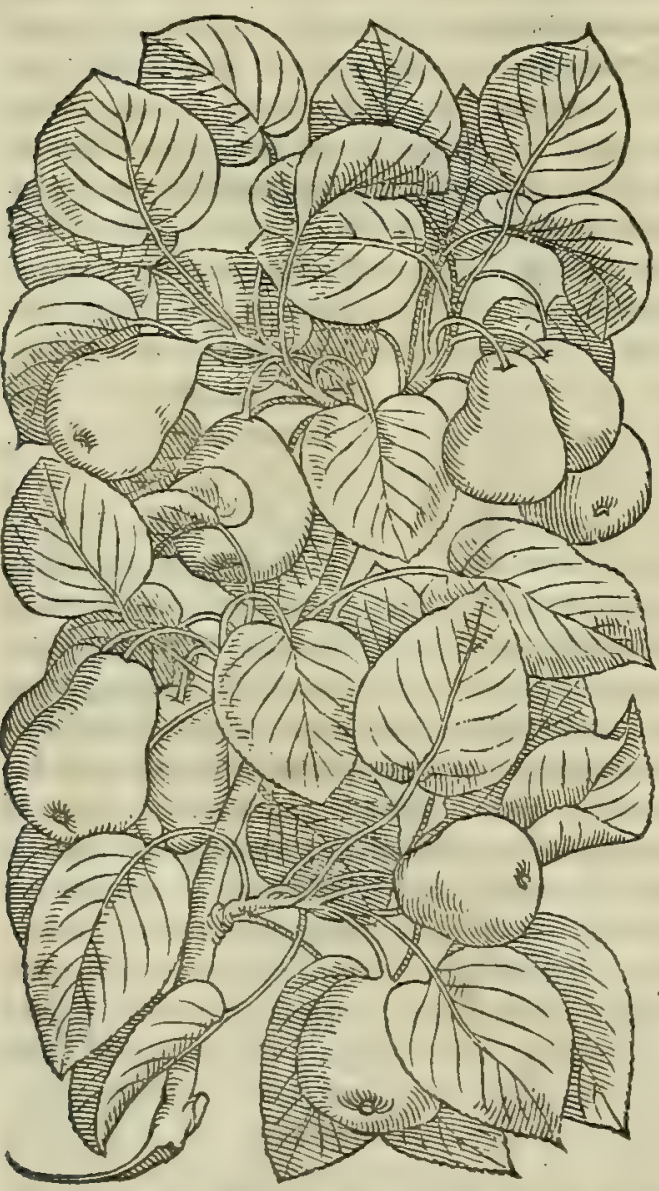

\section{CAP. CXXXII.}

P Y R O R V M multa genera. Quxtamen omnia adfringunt: proinde adduntur conuenienter in repellentia cataplafmata. Deca\&um è ficcis, \& cruda ıpfa aluum fiftunt: jeiunos efitata lædunt. Achras pyraftri genus eft, quod tardifsimè maturefcit: Vim pyro adfringentiorem habet, \& ad cadem conuenit. ftringunt etiam eius folia. Ligni pyrorum cinis efficaciter his auxiliatur, quos fungi ftrangulant. Aiunt fungos, fi fylueftria pyra cum eis coquantur, innoxios fieri.

Qv o N I A M Pyra uulgatißima funt non modo' in Italia, fed ubiq; in tota Europa; ideo fuperuacaneum duxi eorum arbo= res per biftoriam explicare. Multa; ac waria apud nos Pyrorum numerantur generd, quemadmodum or apud antiquos. Qui, ut Plinius refert libro, e capite $\mathrm{x}$ v.celebrauere fupcrbo, falerna, decumiana, dolobelliana, pompeiana, liceriana, feueriana, tyran=: niand, favoniand, lateriand, anitiand, tiberiand, fignina, purpu= rea, fementina, laurea, amphorina, corioland, cucurbitand, or alia, quarum enumeratio long a foret: Quas fané warias appella= tiones mutuata funt, uel ab bominbus, qui primum ea in cibarum u um reuocarunt; uel à locis, unde uener ant; aut à notis, quas ali quibus fructibus acceptas refercbant; aut à colore proprio; aut a tempore, in qua ab arboribus decerpebantur. In hoc itaq; no= fri quoq; Hetrufci antiquorum confuetudinem fecuti, uarijs no= minibus à diuerfis inditis caufis fua Pyra unlgó appellant mo fcha. telle, giugnole, ciampoline, roggie, ghiacciuole, fpinofe, quadrat ne, carouelle, papali, fan Nicolo, durelle, zuccaie, campane, uer nareccic, gentili, porcme, fementine, er plura alla babent alijs nomenclaturis appellata. Caterum fi quis uellet in nojtratibus ue „erum Pyra collatione affequi, oper pretium effet, ut unumquodq; corum genus peculiarem, per picuamq; batuiffet Pyrorum 5. defcriptionem: quandoquidem fieri non poteft, ut ex fola nomenclatura innotefcant. Porró in uniucr fum de corum cultas. 

uiribus differentes, dic amus, ficutietiant de malis diximus, quod pyrorum facultates, ex faporibus guftu dignofcun=
tur : cum dulcia natura diftent ab acerbis, acidis, aufteris, e ab bis, qua unum, uel plures pre fe firunt fapores: 0 contrà, bec deinceps ab illis fint ditur $\int_{a}$. Pyra (ut fcriptum reliquit Galenus lib.v. fimpliciun medic.) efu ftona= gis praftant contrafluxiontes. Et ibro I I. de alimentorum facultatibus ita fcribit. Qux de malis dixemus, fi onnila ad pyra, er punica transfer.mtur, mibil nou alio juper bis fermone opus erit. Nam in ijs quog; alia auftcra tantim, uel acerba apparent: ueluti quedan acida, quedain dulcix, quedam deniq; ex horum nuftione compolita: funt qua nullam penitus buinf cemodi qualitatem exuperantem habent: quo fit, ut cum aquea fint, ac bebetia, nulla roborandi uipolleant. Talis igitur onmino pyrorwm ufus, qualis malorum. At pyris, prefertimq; grandibus, que apud nos ine=

so nats Hocantur, aliqua alendi facultas donata eft. Proinde ea fecta in tenues orbiculos, ficcatág; reponunt. Quibus

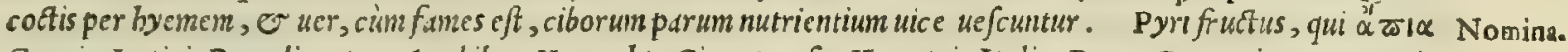
Gracis, Latinis Pyra dicuntur : Arabibus, Humecbte, Cirmetre, fell Kemetri: Italis, Pere : Germanis, Byren: Hi= Ppanis, Perws: Gallis, Poires.

MESPILVS PRIMA.

20

30

40

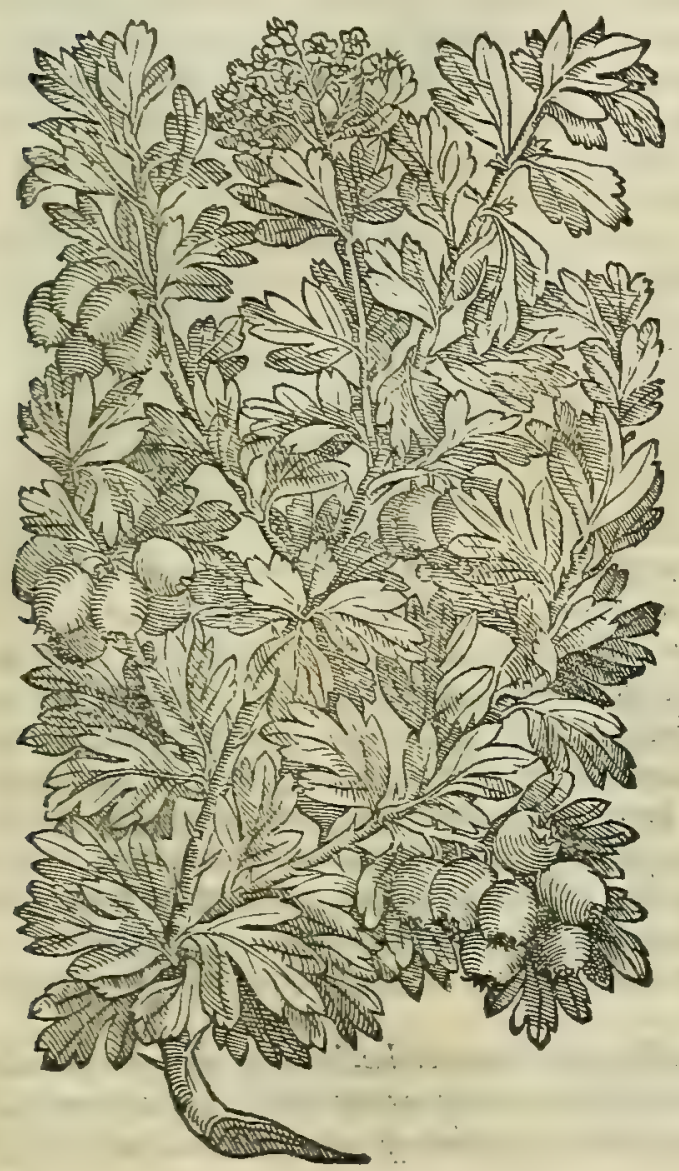

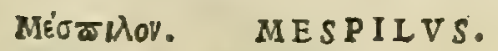

MESPILVS ALTERA.

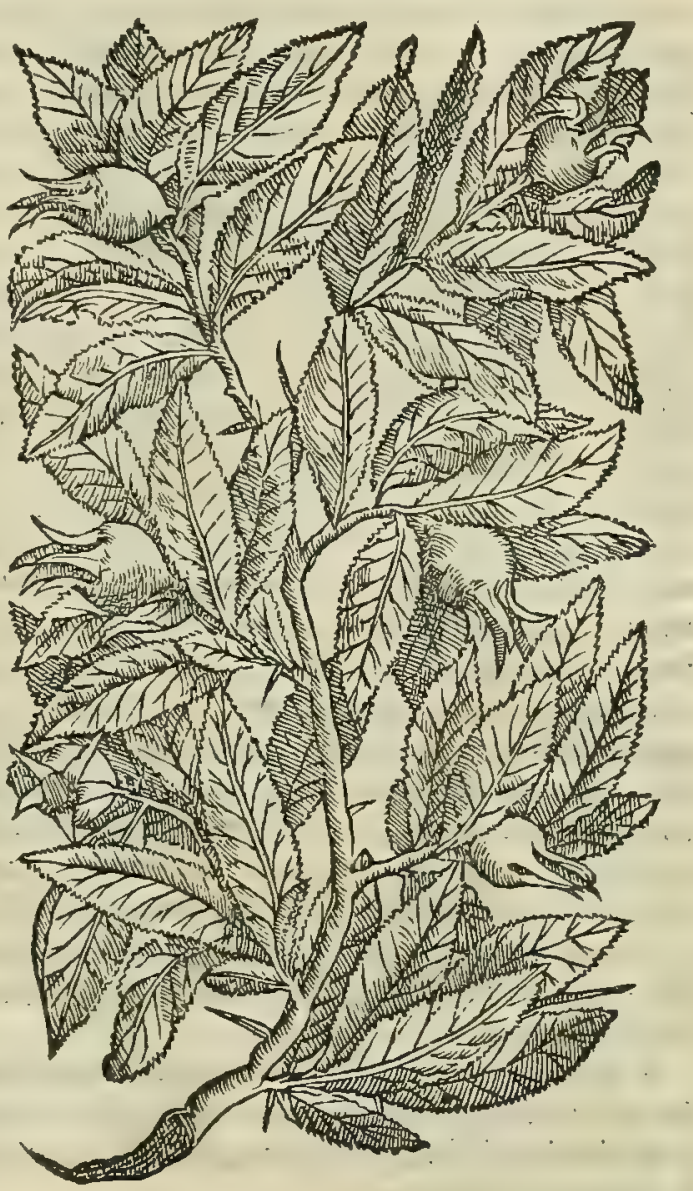

CAP. CXXXIII.

MES P I L V , qux à nonnullis aronia uocatur, fpinofa arbor eft, folio t pyracanthæ, fiue oxyacanthæ . Fert pomum fuate, exiguo malo non difsimile, tribus intus of siculis : qua ex caufa id so nonnulli tricoccon appellauere. Tardè maturefcit, efu adftringit, ftomacho gratum eft, aluumq́ue fupprimit. Alterum mefpiligenus in Italia nafcitur, quod aliqui fetanium, alij cpimelida uocant. Arbor folijs mali, fed minoribus. Pomum fert rotundum, efui aptum, vmbilico latiore : quod adftringit, feroqúe maturefcit.

M E S P I I O R V M bic d Diofcoride duo recenfentur generd: quorum illd; que folijs eft pyracanthe, fture oxyacantbe noftratibus haud quaquam adftipulari uidetur. Quippe ( ut $\int e n \int u$ patet) noftrates Meffili folijs oblon= Merpilorum gis, laurinis fr re fimilibus uirent, non autem apij modo per ambitum incifis, uelutioxyacantha. Fructum ferunt non quidem guftatu fraicen, fed potius iniucundum, quòd acerbus fit, $\mathcal{E}$ aufterus. Quine is quina includit oßicula, non fanè terna, ut primo Mefpilorum generi aßignat Diofcorides. Ceterium fi fructum profert Italia, qui priori Mepilo legitimé adfcribi poßit, eius nimirum arboris erit, qua Neapoli, ubi copiofa feritur in hortis, uiridarijs, ac uis neis, Azarolo unlgó nominatur. Huius plures plantas uidi ego primùm Neapoli in amplifimo uiridario Pompei Car= 


\section{6}

\section{And. MatthioliComm.}

Asaroli de- dinalis à Columna uid, qud itur ad poëte Maronis fepulcrum, uel ut uulgó dicunt à Pedigrotta. Arbor eft mediocris Icriptio. proceritatis, cortice, ac materia pruno.haud abfimilis: Ppinis horrida, non tamen admodum acutis: folijs laciniatis, apij emulis. Ex quo perpici potcft, cos Diofcoridis codices hoc loco fcatere mendis, in quibus deprauate legitur, hanc arborem folijs effe pyxacanthe, non autem, ut legitimé legi debet, oxyac anthe. Nam (ut fuperius fuo loco ex= plic auimus ) oxyacantha folijs germinat diffectis; pyxacantha ueró buxi modo oblongis. Cuius rei illed manifesto eft indicio, quod de boc Mefpilorun genere pofteritatis memoric prodidit Theoplyaftus lib. I I I. cap. x I I. cum inquit. Magnitudine arbor ifla excellit, gyróq; comatur. Foliummagna ex parte infifum, quod uel apium parte poltrema initatur, ampliore figura, quod q́; promiffum, neruofum, apio tenuius, oblongius, totumí; circuntufum eft, or pedi= culo tenui, ac longo dependet : antequam decidat, uehementer rubet. Radice numerofa, altág; arbor coberet: ob id diuturna, er inextirpabilis eft. bactenus Theopbraftus. Que fane uerba certo funt argumento, eam Diofcoridis lectionem plané deprauatam effe, qua buic Mepilorum generi pyxacanthe frondes reddit. Quinetiam folium expli= cant oxyacdnthe à Diofcoride eius in hiftoria filentio dißsimulatum, quod fcilicet apij modo per ambitum fit diffe= ctum. Sed illud etiam non ignorandum, tantan oxyacanthe cum hac Mepilo interceßiffe cognationem, ut fi Meßpi lus hec oxyacanthe inferatur, omnium fpeciofißima proueniat, or longe magis fructifera euadat. Sed ut rededmus $c o$, unde codicis mende, que librariorum incuria eft, nos diduxerant, dicimus, quód Azaroli wocdte fructus nullis pror fus notis reclamant Meppilis, que primo loco d Diofcoride de fcripta funt. Siquidem ij exigui funt, terna inclu= dunt oßicula alijs Mcpilis duriora; quanquam magnitudine, er forma dißimili, feram fentiunt maturitatem, ori grati babentur, ftomacho non iniucundi, or reliquis deniq; notis, ac qualitatibus illorum peciem adeó reprafen= tant; ut non aliud bac in re afferendum puţauerim, quàm quód idem int Azarola, or Diofcoridis Meppila à quibuf=

Mefpilus al- dam Aronia dicta. Que porró Mepili aliquibus setanie, E Epimelides appellantur, uulgaribus noftratibus col= 20 tere. late, nibil inter fe diffentire comperiuntur. Quapropter nil mirum fcriptis mandafe, Diofcoridem, alterum boc Me piligenus copiofum in Italia nafci. Veruntamen Galenum Epinelidis appellatione aliam arborem à noftratibus Me= pilis diuer fam fumpfi]fe, liquidò conftat. Quandoquidem libro v r. fimplicium medicamentorum fcribit, eius fru= ctum acerbum effe, ev uentriculo noxium. Epimelida autem à rufticis Itälice unedonem nominari. Hoc infuper illud

Serap. lapfus. confirmat, quod Galenus de utroque Mepilorum genere, feorfum diuerfis capitibus tradiderit. In Mefpilorum biftoria Serapio aperté ballucinari deprebenditur: quippe qui forbi titulo omnia referat, qua de utroque Mepilo= rum genere fripfit Diofcorides. Verum etfi bac in re is quidem abcrret; declarat tamen primum Mefpiligenus no=

Mefpilorum bis Italis Mauritanos fecutis Azarolum effe : nanque is Arabico idiomate Mepila Zaror appellat. Mefpilorum uires ex Gal. uires recenfuit Galenus libro v I I. fimplicium medicanentorum, fic inquiens. Mipilifructum, alij tricoccum nomi= nant, quód tria intus in uniuer fum gerat grand, quorum unumquodq; arboris eft femen, ceu ed, qua in malis inuc= 30

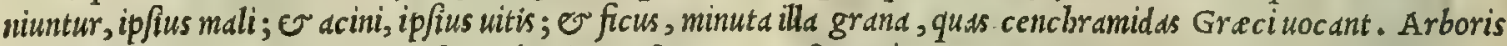
buius fructus admodum acerbus eft, uixó; edi poteft, uentrem frenué coèrcens. Quin er in germinibus, er folijs a= cerba hee qualitas non pauca reperitur. Et libro I I. de alimentorum facultatibus fic inquit. Horum eadem quo= que predictis eft ratio. Ambo enim adfringunt, fed multó fortius Mefpila, quàm forba. Quamobrem aluo fluenti in cibo dccommodatißime exbibentur: forba tamen ip/is funt fuatiora. Prorfus nanque nibil acerbi, uti Mefpila obti= nent, $\int e d$ fuccus eorum citra acerbitatem aufterus eft. Illud porró neminem puto latere, bec omnia parcé, non affa= tim, ut ficus, uuds q́; effe comedenda : nequaquam enim eis, ut cibis, fed ut medicamentis potius indigemus. Hac no=

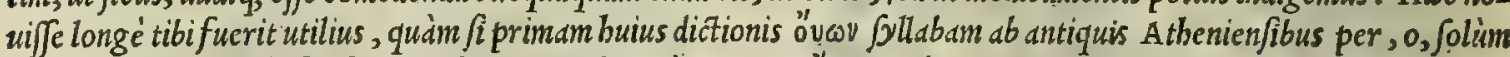

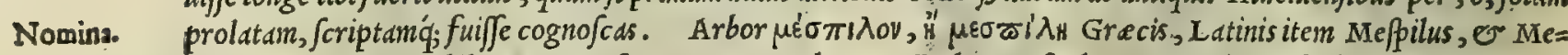
pila nominatur : Arabibus, Zaror, feu Zarur, er Alzarur : Italis, Neppolo: Germanis, Nepel: Hipanis, Neßpe= 40 ras: Gallis, Neplier.

+ Ne videamur bic temeré communem lctionem immutaffe, que eft pyxacanthe, lectorem admonere non'alienü duximus, uariam effe buius loci fcripturam in Grecis tum impreßis, tum uetuftis exemplaribus. Verim ea nobis ma= gis probanda uifa funt, qua babent pyracantham, uel oxyacantham (idem enim effe putamus) innixi rationibus, quds in commentario adduximus.

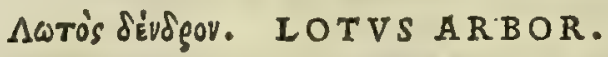

\section{CAP. CXXXIII.}

L o T v s arbor eft vafte magnitudinis, ferens baceam piperc maiorem, dulcem, cibis gratam, ftomacho facilem. Aluum fiftit baccis . Ramentorum ligni decoctum fiue potu, fiue infufione dyfente- 50 ricis, ac fominis fluxione vulux laborantibus, auxilıo eft : rufat capillos : citam aluum cohibet.

Loti arboris Lo T v arbor Latinis Celtis uocatur. Differentie generumplures (ut libro or capite I I I I. de plantarum hiltoria. biftoria prodidit Theophraftus) eaǵ; maximé fructuum uarietate inter fe difcreta produntur. Sed Loti proprium ge= nus confurgit pyrimagnitudine, aut pauló minore: folijs perjambitum ferratis, alioqui ilicis uiderentur. Fructum profert magnitudine faba, qui uuarum modo mature fcit, uarié colores immutans, guftatu predulcis, fuauis, at of etiā ftomacho falubris. Gignitur alter $a b \int q_{\text {; }}$ interiore nucleo, qui non modó ceteris prefertur, quód uentriculo fuauior fit; fed etiam quod uinum reddat. Numerofa hec arbor in Pharide infuld, ideo Lotophagia uocata, quod inibi Loti fructu uictitent incole. Ceterùm non minor Lotorü copia in continenti, fed longé largior : plurima enim bac in $\mathrm{A}=$ frica, ubitanta fructus $\mathcal{E}$ arbor is copia naryatur, ut diebus pluribus exercitum Ophelli Cartbaginem petentis in cö:

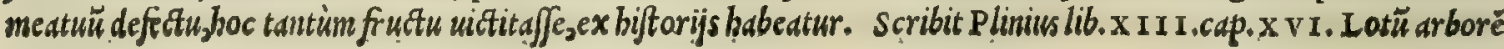




\section{In Lib. primum Diofcoridis.}

L $\circ T \vee S$.

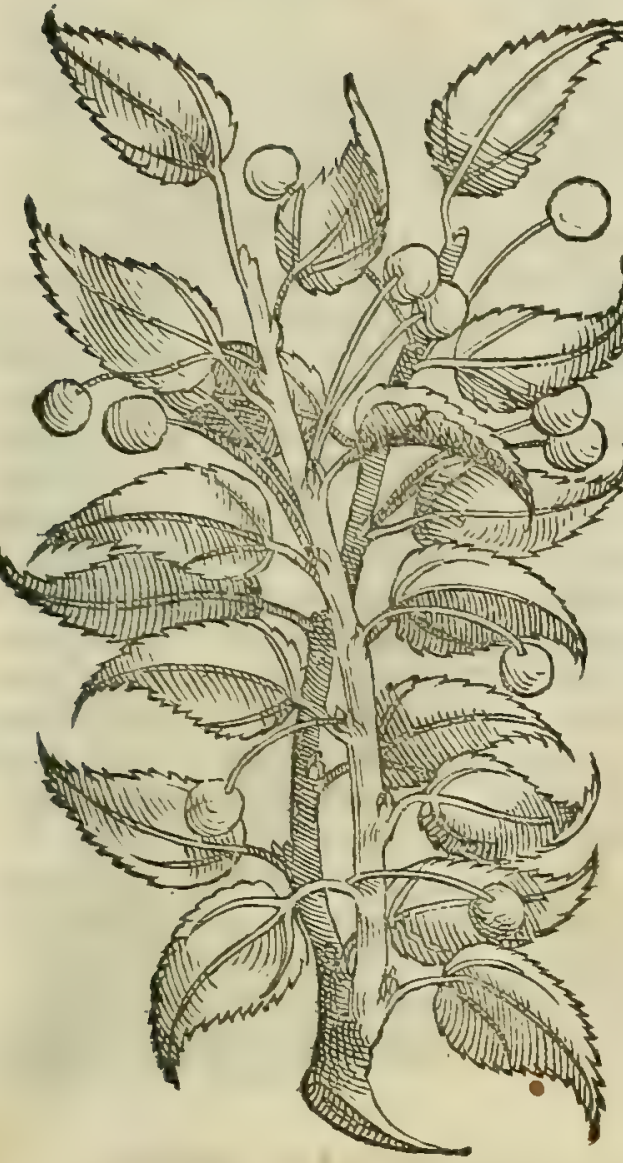

etate fua extitiffe I taliie familiarem, ac unlgó cognitam, licet mutato folo, caeliq; climate, unde nobis allata cft, ì grata illa fructuum dulcedine degeneraucrit. Diofcorides non alij not is reddidit Lotum, quain quod arbox effet uaiste proceritatis. Cui fubfcribens Plinius lib. $\mathrm{x}$ v I. cap. $\times 1 \times$. fic inguit. Lotus prez= cipué domibus expetitur, ramorum petulantia, latißina exp. tiantium umbra, $\mathcal{O}$ in uicinas domos fepe tranfilientium. Item codem loco ita fcribit. Loti fructus fylueftris quideme eft, fed ce= raforum pené natura. Nulli breuior opacitas, nec aufrert folent byeme decidentibus folijs. Nulli cortex iucundior, aut oculos excipiens blandius. Nullirami longiores, ualidiores q́; aut plu= res, ut dixiffe totidem arbores liceat. Cortice pelles tingunt, ra= dicelanas. Quamobrem putauerinz ego, $i$ modo bodie Loti nafcuntur in Italia, eum non aberrare, qui ueram lotum, pres fertim Diofcoridi, $O$ plinio, eam effe arborem dixerit, quxe in Tridentino, er Goritienfí agro unlgó Bagoldro uocatur : in Vex ronenfi ueró, $v$ in alijs quibufdam Italia locis Perlaro. Siqui= dem licet harum arborum multe pyri magnitudiuem eqquent; pler que tamen conficiuntur, que longé pyrum proceritate uin cunt. Hæ itaq; preterquàm quòd caudice conftant craßsißimo, ramis latißimis in altitudinem fe extollentibus; cortice ßectan= tur leui, colore in ceruleum nigrefcente. Quo fit, ut is grato coloris afpectu repicientium oculos mirum in modum ad fe allis ciat, ut tradidit Plinius. Foliys uirent ilici proximis, per ambi= tum ferratis, aßperisfós, que medio autumno flacce $\int$ cunt. Fructus eis ceraforum fimilitudine, qui ut illa, longiore pediculo pendet. Is primo uiret, mox in candidum flaue fcit, deinde per maturita tem rube fcit: dẹnique, poftqudin maturuerit, nigricat, guftu fuau, non ingrato. Q we omnes buiufce arboris delineationes, ac notes Theophrafti, Diofcoridis, o Plinij loto plané reßpons dere uidentur. Quare non equidem diffitebor, Lotum quog; boc eno Italie effe copiofam. Ceterimn nefciuerim ego, quorum teftimonio, or auctoritate frétus Ruellius lotum exifimaıcrït plantam exiguamillam, quisan Hetrufci uulgó Agrifolio dic unt : é cuius cortice (ut fuperius de paliuro difะ Serentes diximus) uti ex uiburno noftro, uulgó ueró lantana, quidam uif cum conficiunt, quo aues capiuntur. Que Jané opinio tantum abeft ab hiftoria loti, quam ex Theophrafto, Plinió,; retulimus, utetiam ei prorfus aduerfetur. Quippe quoniam Agrifolim arbor eft, perpetua uirens coma, folijs admodum per ambitum aculeatis, exigua pro= ceritate, e cortice uiridi : que note penitus loti defcriptioni repugnant. Lotum feriptis tradidit Galenus libro vi I. fimplicium medicamentorum, his uerbis. Lotus arbor non ita multe adftrictorie qualitatis eft particeps, fed O tenuium partium eft, Er exiccatorix. I taque lignorum ipforum ramenta muliebri accommodantur proflunio, er dy fenterijs, 0 caliacis affectibus. Decoquuntur ueró interim in aqua, interim in uino, nimirum prout ufus popo= fcerit, nec inf unduntur tantum, fed o bibuntur. Quinetiam quód pilos defluentes cohibeat, non paruum fignum eft ipfum adftringentis effe cuiufdam, finiliter mediocriter deficcantis facultatis. Dietum quippe eft 0 in fermone de ladano, eiufmodie ffe facultatis oportere, quod fuentes capillos effet cohibiturum. Planta, que Gracis $\lambda$ ato's

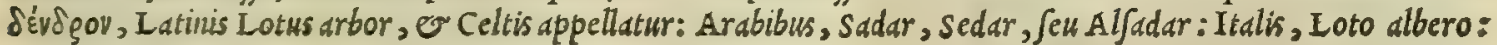
Hifpanis, Almez.

\section{Kęvix. CORNVS.}

\section{CAP. CXXXV.}

Cornvs dura arbor eft, baccas ferens oliuæ modo oblongas, quæ primùm uirent, dein per maturitatem rubefcunt, aut ceræ colorem reprafentant. In cibo adftringunt: profluuio alui,atque dy fenso terix falutares, fiue in edulio, fiue in defruto exhibeantur . Muria, ut oliuæ, condiuntur. Sanies, quam uirentia folia torrendo refudarunt, impetigini conuenienter illinuntur .

C O R N v s eft unlgaris notitie. Ceterim ( ut lib. I I I. de plantarum biftoria, cap. X I I. memoric prodidit Corni confTheophraftus) fexus in ea duplex inuenitur. Nanq; confurgit mas duodecim cubitorum altitudine : folio amygdale, deratio. nifi quód pinguius, craßiusó; : cortice neruo $\int 0$, E tenui : caudice non minus crafo. Fœmina uirgas paruds, ficut $\int a=$ lix amerina, fuo latere profert, o fruticofior eft. Nodos ambe, perinde ac uitex, tum germinatos, tuin inuicem congruos habent. Materies maris excors, totág; folida, carnibus denfitate, firmitateq́. fimilis, unde illi nomen. Fremine uerò medullam continet, o mollior eft, atque caudtur : ob id ad uenabulorum ufum inutilis. Qui Idam Troianam incolunt, marem fterilem dicunt; foeminam autem fructuofam. Nucleum fructus oliue fimilem babet, gus ftudulcis, odoratúf; gratus. Flos oles, o floret, fructificatóf; codem modo, ut fingulari pediculo plura profirat. In Macedonia ueró (ueluti etiam in I talia) ambe frutifiere funt: Sed mas per aftatem, faemina werò per autumnum 


\section{I58 And. Matthioli Comm.}

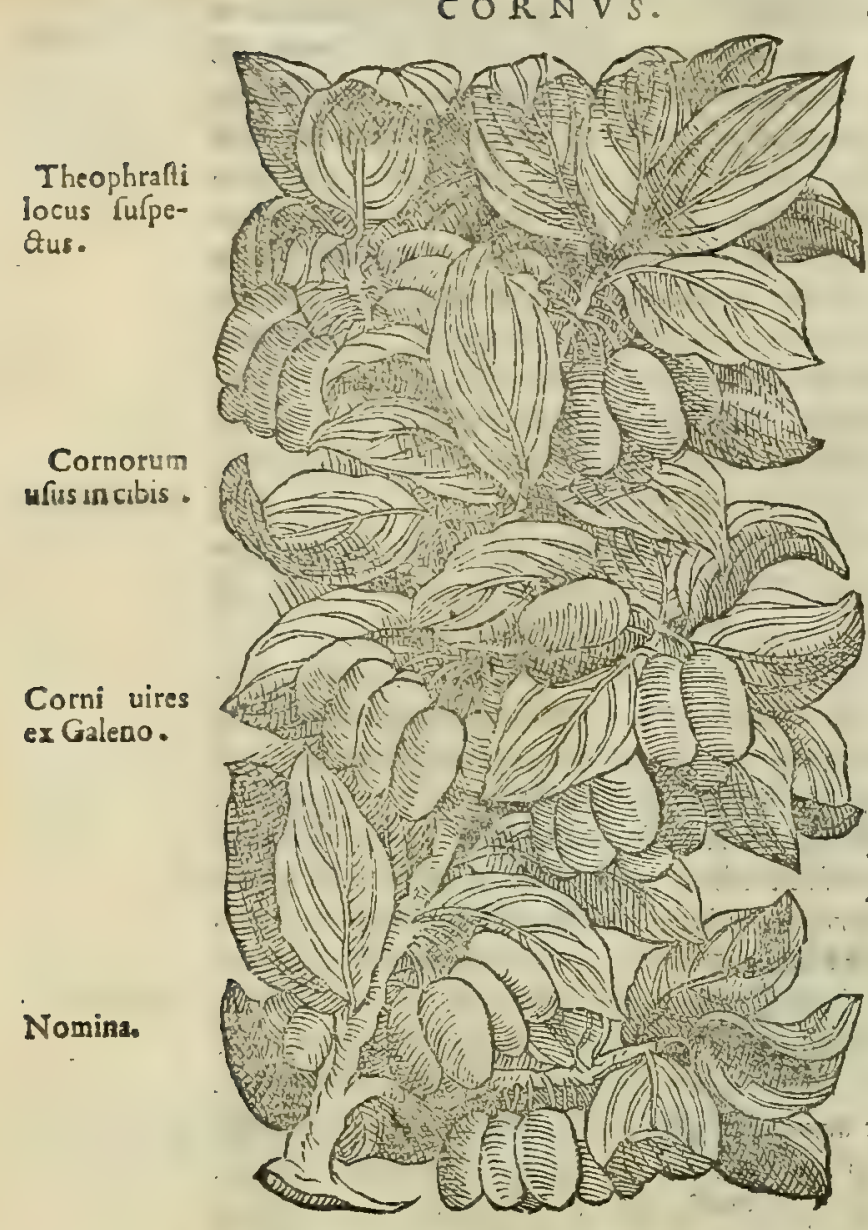

$S \circ R B V S$.

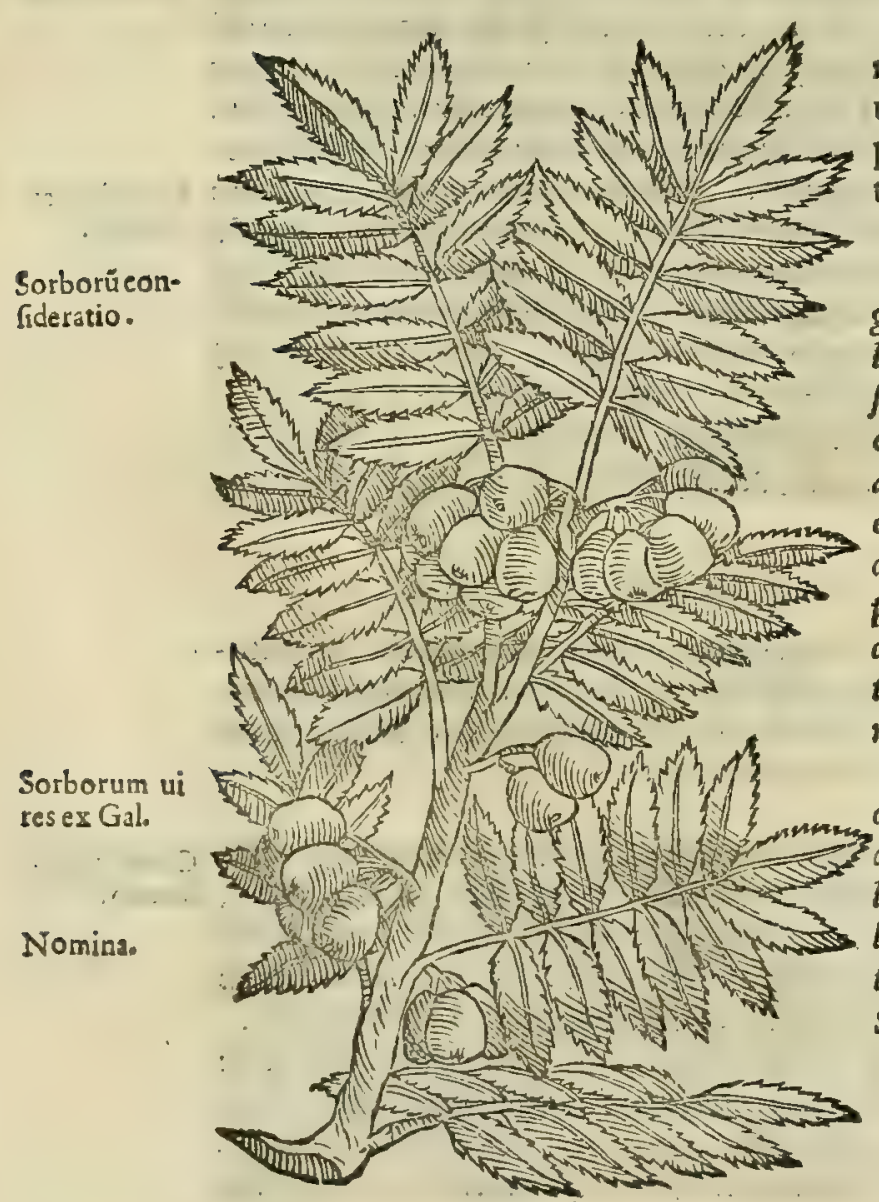

baccas maturat, buius tamen bacce tantum mafcule bonitdte ces dunt, ut mandi uix poßint. Porró cauendun eft, ne Corni arbo res prope aluearia coiferantur, uel à natura producta ibidem permittaritux: quandoquidem apes ilore eius deguftato aluo citd= ta commoriuntur. At certé mir andum eft, quod f criptis mans dauerit Theophraftus, Cornum arboré annygdala folio wirefcere, ckim longé diuerfo prorumpat. Ea s. propter dixerime ego, aut in Theopbrafti excemplaribus hoc loco mendum fubeffe, aut in Ida monte prope Troiam tum foli, tum etian cali magis aftuante na tura, corno folia aáeó refringi, tut amygdale quadántenus smu= la uideantur: ct fi, meo quidem iudicio, potius putandum fit, Theo phrastilectionem boc in loco deprauatam effe. Fit ex baccd= rtun pulpa quoddam obfonij genus cydonite non dißsinile. Quin e ex eorum decocto, e facclaro liquor ignis opere, e cotu= ra concrefcit, coagulaturǵ; , qui preterquàm quód gratißimo placeat gufu, datur utiliter dyfentericis, ac forminis menfium proflunio laborantibus. Corni uires memorie prodidit Gale= nus libro vi $\mathrm{I}$. de fimplicium medic amentorum facultate, fic in= quiens. Corni arboris fructus admodum acerbus eft, efui aptus. Itaque merum uiderinon debet, ip fum ualenter uentrem reftrin= gere, ficuter meffila. Folia quoque, or germina gustu acerbá funt, ualenterǵ; deficcant. Itaque maxima uulnera glutinare poffunt, potißimum durorum corporum: at paruis uulneribus, o mollioribus corporibus magis contraria funt. Nam nimium ex contendunt, acplus fatis deficcant. Arbor, que Grecis

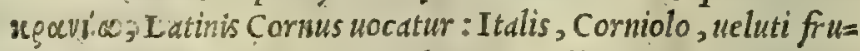
ctus cius Connole: Germanis arbor, Cornelbaum, Kurbeerbatum, o Dierlem: fructus ueró Vuelfch kir $\mathrm{cn}$ : Hipanis, Cornizolos: Gallis, Cornier.

\section{OV̌e. SORBA. CAP. CXXXVI.}

So R B A colorem luteum referentia, priusquàm maturefcant, diffecta, \& fole ficcata mandunttir , ut aluum fiftant. Eadem eft functio molitorum farinæ, fi polentæ loco fumatur. Quod \& decoctum eorum in potu præftat.

S O R B A fructus funt in Italia uulgatißimi, nullisq́; non co= gniti. Veruntamen illud non duxi pretereundum (ut hic nonnul= 4 . la perftring an ex his, que de sorbis latius tridit Theophra= ftus libro XII.cap. XII. de ftirpium hiftoria ) quod in forba etiam maris, ac formine differentia dignofcitur, certo quidem argumento, quód una ferilis fit ; dltera ueró fruttiferd: Qunit= etiam in posnis difcrimen, quód alia fint orbiculatd, er fucce os doratiore, dulcioréq; placeant: alia ueró ouata, tut que etiam pyri effigiem reprefentent, gustui acidiord, $e$ aperiora prea $=$ dictis, minusq́; olentia. Sunt er jyluatica Sorba 3 qra naturi= tatem adepta ori non infuaria habentur. Hec adf triftoria ui do= mefticis longé excellunt ; fi tamen immatura infolentur.

Sorba, teftimonio Galeni tun libro. VIII. frmpliciun me dicamentorum, tum libro I I. de alimentorum facultatibus, eans dem adftringendinaturam preftant, qudm me pila, fed imbecil = liore effectu. Vtraque tamen in medico ufu magis, qudm in cis bis expetuntur, probanturq; . Sorbi fructus Grect ovid, $\mathrm{L}_{\alpha}=$ tini Sorba :Itali, Sorbe : Germani, speierling, sporoepffel, sperbieren: Hipanis, Sorbas: Galli, Cormiera nominant. 


\section{In Lib. primum Diofcoridis.}

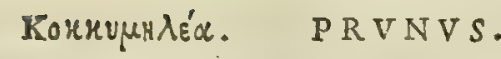

xo

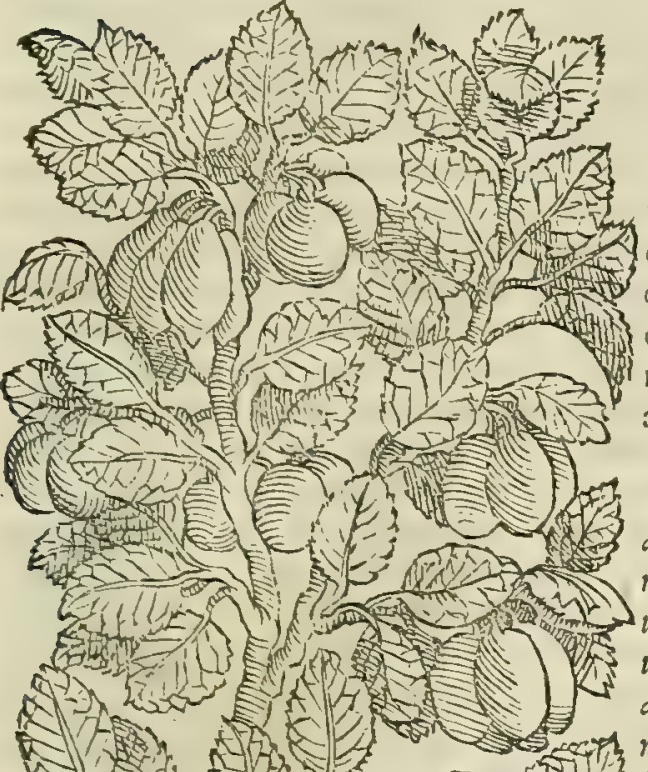

30

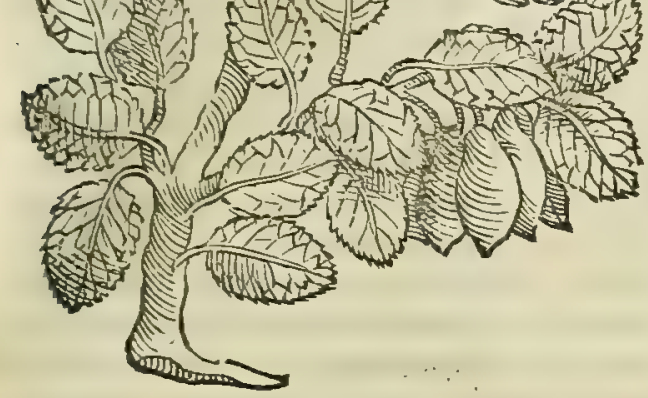

PRVNVS arboreft nota. Cuius pomumeftur, fed ftomachum malè habet, aluum mollit. Sy riaca pruna, \& pracipuè qux Damafci gignuntur, exiccata ftomacho utilia funt : aluum adftringunt . Fol ia pruni in uino decoeta collutione, \& gargarizatu, uuam, gingiuas, \& tonfillas fluxione laborantes reprimunt. Priftant idem fylueftrium Prunorum bacca, poft maturitatem cxiccatx : cum fapa vero decoctx ftomacho utiliores redduntur, aluumq́ue magis adfringunt. Gummi prunorum agglutinat : potum in uino calculos comminuit: ex aceto quoque illitum, lichenas infantium fanat.

P R V N O R V M differentix inexplicabiles feréfunt. Nam alia reperiuntur berbaceo colore perf $u f a$, alia rubco, alia ebur = neo, alia luteo, alia furpureo: quadan deinde inagns, quedam ueró parua, quedam mediocria: dulcia nonnull, alid acida, alia uino $\int a$, alia dura, alia mollia: alia denique rotunda, alia oblonga, alia ouata conpiciuntur. Caterum licet Diofcorides pruna Da= mafcena ficca aluum fiftere prodiderit: Galenus tamen aliter fen fiffe uidetur feptimo fimplicium cenfu, ubific inquit. Pruni fru= ctus uentrem fubducit; recensquidem plus, aridus ueró minus. Sed haud fcio, cur Diofcorides pruna Damafcena ficcata uentrem fiftere dicat, cum e ipfa perfpicuó foluant, minus tannen ijs, qux importantur ex Iberia . bactenus Galenus. Atqui in boc $\mathrm{Brd}=$ fauolus Ferrarienfis medicus noftre etatis clarißimus, aperté re = fragatur Galeno in fimplicium medicamentorum omnium peri= tißsimo equé atque docti isimo, fuo de fimplicium examine, $u b i G_{d}=$ lenum fcribit bac in re, non Diofcorldem fuiffe deceptum. Quip= pe quód Galenus non animaduerterit, Dof coridem de ficcis pru= nis Damafcenis loqui : qua praterquàm quód ficca funt, guftue $=$ tiam acida fentiuntur, or ddftringentis. Qua quidem in re Brafauolus potius ( pace fua dixerim) plané ballucind=

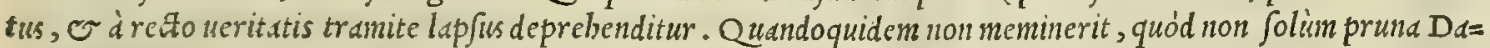
mafcena ficca; fed etiam alia quàm plurima fimplicia medicamenta deiectoriam fimul $\sigma^{\circ}$ adfringentem uim obti= nent, ut maniff to teftimonio funt tainarindi, o myrobalana omne genus: item rbabarbarum, $\mathbb{E}$ alia pleraq;, que prater id quód primum aluum deijciant, poftea illam adftrictam relinquunt. Qüam fane prunorum facultatem et fí Brafauolus non perpenderit; Galemus tamen optimé nouit, ov expertus $\mathrm{cft}$. Idcirco cum loco citato pruna Dama= fena ficca aluum ciere tradiderit, eadem etiam adstrictoria ui pollere, lib. II. de aliment. facultatibus bis uerbis 40 atteft atur, Prunis equé ac ficubus conceffun cft, ut uel exiccata utilia permaneant. Damafcenis à Damafco Syrie monte, in quo nafcuntur, appellatis, prima laus bonitatis magna hominum opinione defertur. Proxima ijs, qua in Iberia, \& Hipania proueniunt. Verium bae quidem nibil adftrictionis pre fe ferunt: nonnulla ueró Damafceno= rum uel plurimum. Probatifina in his funt, que cum mediocriadftrictione, magna, laxa'g; funt. At parud, durd,

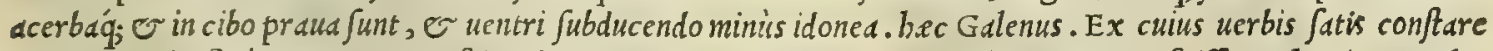
arbitror, nulla feré ratione, nec nifi inualidis admodum argumentis Brafauolum adductuni fuiffe, ut hac in re Gale= num ipfum accusaret, quafi Galenus omnino ignorauert, quam fapores, quam odores, quam cetere denique non fruitumm modo; fed e omnium feré implicium medicamentorum qualitates naturam, $\sigma$ facultatem fortite e ffent. De quibus omnibus adeó docté, o copiosé diputauit, ut parem unquam repererit neminem, ut omnibus perpicuum eft ex fuis primis quinque libris, quos de fimplicium medicamentorum facultatibus accuratißimé confcripfit. Huic 50 Sententic aque o rationibus accedit quoque comminis medicorum experientia: nempe quod compertum fit, pru= na Damafcena laudatißina, ijs fimilia, qua Galeno preferuntur, efu uentrem foluere non inefficaciter, adftritta aluo poftmodum relitta, tamarindorum, or myrobalanorum modo. Sic igitur Galenum à Brafauoli reprehenfione feruaffe uolumus. Sed fi Diofcoridem quoque tueri uelimus, nil aliud dicendum putauerim, quam quod pruna $\mathrm{D} x=$ mafcena ficcata aluum adftringere tradiderit, ut referuntur ad alia, qua minus adftringunt: non tamen, quòd uo= Tuerit, ea effe deiectorie facultatis expertia. Porró pruna bilem deijciunt: proinde ea uttliter ufurpant medici ad fíbres, aliosq́; biliofos affectus. Quin e Seplafiarijs expetuntur: quippe qui exijs quotannis electaria, intinctus, liquoresq́; uarios par.ıre confueuerint, qquibus non modó faniguftu non ingrato delectantur; fed etiam qui languent, refocillantur. Habetur e in Aegypto prunus (ut Theophraftus eft auctor lib. I I I I. cap. I I I. de plantarum bi= ftoria) infignis magnitudinis, fructum frens natura, or magnitudine meßpilis proximum; nifi quód rotundum nu= cleum habet. Florere incipit mene I ulio, fructum circa brumam perficit, nec folia dimittit. Qzil circa agrum The= banum babitant, propter arboris copiam fructum ficcant, or offe exempto tundunt, offaś. faciunt. Non dißiz

Prunorum ufus.

02 dent 


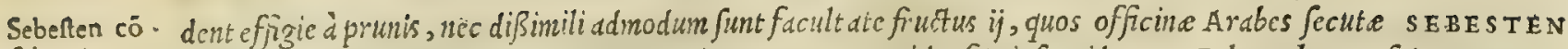
fideratio.

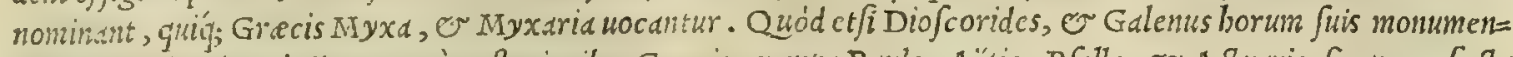
tis non memainesint; de ijs tancn à pofterioribus Gracis, nempe Paulo, Aëtio, P fello, or A ctucrio frequens facta fuit mentio. Arbores feri in Italia ceeperunt Plinij xtute: nunc ueró non ubique familiares, fed raris admodum bor= tis, ov tividariis uircnt. Arbor cft pruno ualde finilis, citumen magnitudine cedens. Cortex caudicicandicat, rd= mis uerò uiret. Folijs comatur rofundis, ac frrmis. Fruflus adole fcunt exiguipruni magnitudine, nucleo intus tri= angulariforma, quifatis bacce proportione refjcndet. Fruaus maturitatem adepti, in atrum uirc fcunt, gufu funt preduici, aclenta, tchaciä pripa. Ex qua Syri, O Acgyptij uifcum conficiunt, quod Venetijs Alexandrinum appcllant, atcupijs coimnodisimum: Argunento funt muclci, qui in co reperiuntur, color, o dulcedo, que guftatu deprebcnditur. Pollcut autcm deictoria facultate, non fecus atquc pruna, tan Gracorun, quàm Arabum tcfti= 10

Fuchsij opinio reprobata.

Zizyphorum confideratio.

A uicennæ de fenfio contra Fuchfium .

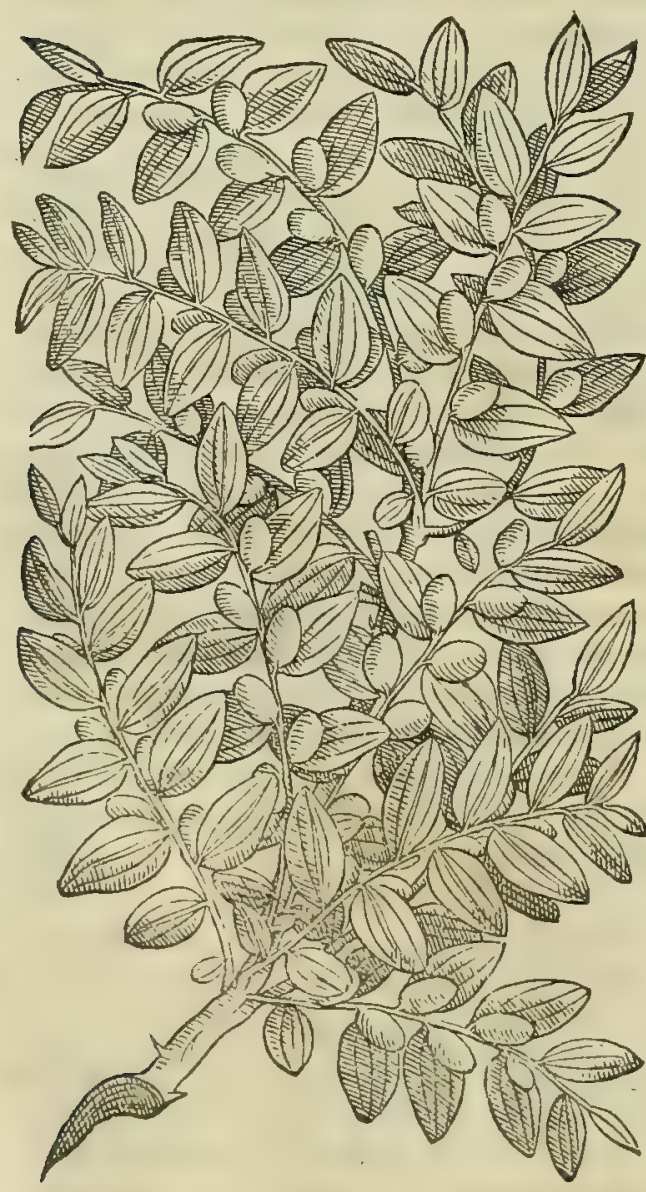

ZIZYPHA.

monio : id quod ctian comprobatur quotidiana medicorum experientid. Tametfi contrariun fen ferit Fuchfius me= dicus hac noftra a tate celcberrimus: quippe qui fuis in paradoxis cap. X X V I I. ut fortaffe in Arabes imueberetur, quos ubique firé odiffe uidetur, null an scbeftenis deicctorian effe facultatem contendit, quin potius ea adfrictoria ui pollere. Sed longé diffentit ab eo opinio noftra, * uulgat., comprobatá́; continud medicorum experientia. Quandoquiden quód sebeften affunpta in medicamentis aluum cieant, tcftis in primis eft $\mathrm{P}$ aulus Aegineta, quili= brovil. de ijs uerba faciens, fic inquit. Myxa arboris fructus eft, minor quidem prunis, facultate ueró confimis lis. Ex quibus pauli uerbis clicitur, qucd ita ucnircne nolliant sebfftena, quemadmodum pruna. de quibus idem dif= ferens eodem libro Galen um fccutus: Fruni fructus, inquit, uentrem fubducit, recens quidem mag is, aridus ueró mi= nus. Neq; buius rei ne fcius A Euarius bee pluribus commifcet medicamentis, que bilene eijciunt, ut uidere eft fuo de compofitione medicamentorum compendio. Eorum infuper deijcicnda alui facultatem maximé comprobat uul=20 garis experientia, clarißimum ommium lumen. Siquidem (ut iam millies expertus fum) eorum pulpa drachmarum decem pondere deuorata, aut ad fummum duodecim, cofdcm feré prabet effectus, quos Acgyptia filiqua caßia uocata. His ergo rationibus, Or auctoritatibus adducor", ut illan quog; Fucbsijopinionem minis probem, quae eft, quód ele= Etuarium de Sebeften officinis dictum uentren deijciat, non sebeftenorum facultate, fed aliorum fimplicium medica= mentorum deiectoria ui preditorum, que ijs adduntur. Nam fi id per fe preftant, ut oftendimus, idem etiam alijs admifta preftabunt. Quare, ut ingenté dicam quod fentio, non Fuchfius tantum, quem alioquin femper admiratus fum, ut uirım doctißimum, er de medicina amplijimé meritum; fed plerique alij, nunaudm adcó Gracis addiati ef= fe deberent, ut prorfus à Mauritana familia defcifcentes, nomnunquan or rationcs, ơ cxperintenta, firma noftra artis, $\sigma$ ueritatis prefidia, cogantur de erere. Sed ut eo noftra reuertatur oratio, unde diucrterat, dicimus aucto= ritatibus, er experientia freti, sebeftena deiectorian uim babere. Quocirca utiliter dantur ex bile febricitantibus, atque (ut auctores funt Paulus, Aëtius, P fellus, or Actuarius) lingue aperitatem mirificé leniunt: quin or pectori, atque tußi opitulantur : uentris tineas pellunt: urine ardoribus a bile, uel fal= fa pituita prouenientibus maximam opem preftant. . Caterum quoniam scbeftena nobis. $\mathbf{z}$ I Z Y P: $\mathbf{H}$ : $;$; que officinis Iuiube dicuntur, in mentem reuocarunt, cum eorum Diof corides nufquă, quod extet, meminerit, duximus non fore quidem ab re, hic id de corum uiribus differere, quod à Galeno, qui ea Serica nominat ( $f$ tamen serica effe Galeno I uiubas afferere liceat) libro I I. de ali= mentorum facultatibus proditur, ubi fic ait. Ne his quidem, quid 40 ad tuendam fanitatem, morbósue profligandos ualeant, teft is effe poffum. Nam ab infolentibus, ac effranatis pueris, or mulicribus cibo duntaxat expetuntur. Exiguum prabent alimentuin, difficilé concoquuntur : ideo ftomacho non funt utilia. Eandem fententiam ex ipfo Galeno fumptam reddidit Auicenna, cui tantim illud addi= dit, quod ea ad pectoris, atque pulmonis uitia conferant, en quód quidam ( $u$ t frunt) cum maxime renum, tum etiam ucfica affecti= bus prodeffe cenfeant. Verim quoniam ( ut diximus) fcribit $G d=$ lenus, null am fe adinueniffe in sericis facultatem ad corporum af = fectus curandos, hinc capta occa fione Fuchfius iterun digladiatur, bonefo quidem Itudio, non modò cum. Axicenna; fed etian cum ceteris Arabice familize anctoribus, afferens id omne, quod de zizyphis Arabes fuis monumentis commendarunt, omnino falfum effe, or a ueritate alienum. In quo tamen fi uitium aliquod Mau= ritanis adfcribendim eft, illud quoque Grecis pofterioribus ad= cribendum erit. Quandoquidem conftat, Actuarium or Grecü, $\sim$ medicum peritisimum $\int$ uo de compofitione medicamentor um uo lumine, zizypba ad pectoris uitia compofitis medicamentis com= pluribus admifcere, ubi fcilicet ex calidor um bumorü redundantia morbus emerferit: item eandem in bis ufurpare, qua bilcm deij= ciunt. Quod $\sigma$ Nicolaum Alexandrinum in fuis compofitis med $i=$

canentis: 


\section{In Lib. primum Diofcoridis.}

mettis, perfepe feciffe comperio. Idco\%; nil mirum, fi ad hec omnia preftare zizypha tradiderit Auicenna: nanq; fuo lentore, ac fut, qua a gré pcrmednt, craßitie ( ut rei ueritas adfruit) fanguincm craffun reddunt, qui flaue bilis redundantis temior, quim pur fit, redditur. Cim itaque tradat Auicema, zizypha er pectori, er pulmoni prodeffe, non tencré quidem cum locutun cffe crediderin ( ut fortalfe aliqui putant) fed illud ca ratione fcripfiffe,

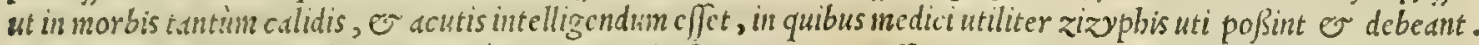
Id quod ciusuerbu aperté indicant, cum dicat, quód fanguinem incraffant. Neque enim erat Auicenna adeó ignd= rus, ut datis ism primißs ne foret fubinde conclufionem inferre. Sed certc pulchrum, atque tutum effe iudico, quód quandoque cum mortuis luctemur. Et quonism (ut fepe antea polliciti fumus) mulli medicorum fecte, nec buic magis, quain illinolter animus crit addictus, fed ueritati propagande, addan ex predictis rationibus cum Auicen=

so $n a, \cos$, mco quidem udicio, labi, ac falli, qui zizyphis fanguinesn expurgari, ac abftergi contendunt, quiq́; ea ijs commifcent medicamentis, qux peitoris affectibus frigiditate obortis parari folent, ut recentionum nonnulli: qui zizyplis nulla corm habita ratione ad quóduis pectoris uitium indifferenter utuntur, es plerunque cum maximo egrotantiun difcrinine. C.eterim an Galeno Serica zizypla fint, dubitandun fane fuerit, cim aliud Plinio fuif= fe reperintur lib. x v. c.up. X I I I I. ubi fic babct. Aequé peregrina funt zizypha e tuberes, que e ipfa non pri= dem uenere in Italism. Hec ex Africa, illa ex Syria Sextus Papinius, quem confulem uidimus, primus utique attu= lit, diui Auguftinouißimis tcmporibus in caftrorum aggeribus fata, baccis fimiliora, quam malis: fed aggeribus prex cipuć decora, quonium o tecta ium fylue fcandunt. Tuberun duo genera, candidum i colore Scricum dictum. Et libro $\mathrm{x} v \mathrm{r}$. cap. $\mathrm{x} \times \mathrm{v} . \mathrm{Ab}$ anygdald, inquit, proximéflorent armeniaca, dein tuberes, o pracoces: illa pere= grine, hx cosite. Item libro x v I I. cap. x. Et zizyphe ait, grano feruntur menfe aprili. Tuberes melius infes

so runtur in pruno fylucfri, e malo cotoneo, o in calabrice, ea ef pina fylueftris. bec plinius. Colunella ta= nen tubcrus nufquan, quod legerin, meninit, fed zlzyphorun libro i x. cap. I I I I. duo tradidit genera, quód barum floribus nisximé delectcntur apcs, nempe rutilum, o album. 2uo fit, ut fupicandum fit, Plinij codicem boc in loco deprsuatum effe. Illud fufpicionem auxit, quod inter Arabes Auicenns, ơ inter Gracos recentiores sy= mcon sethi, duas zizyphipecies feriptis mandauerint, es quod tamen in Plinio una tantum legatur zizyphus. Ve=

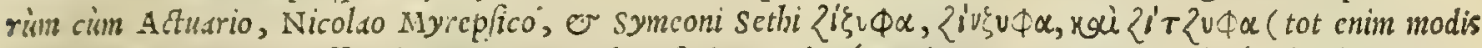
feripta inueniuntur) ed effe uideantur, que Galcno ferica, eadem q́; Auicenne, serapioni, alijś́; pluribus Mauri= tanis, mhi quidem ftatucndm uidetur, Galeno feriea non aliud defignare, quám zizypha. Ex bis praterea omni= bus nuximum effc argumentum crediderim, in plinio hic fubeffe mendam, er illi de zizyphis id adfcribcndum effe,

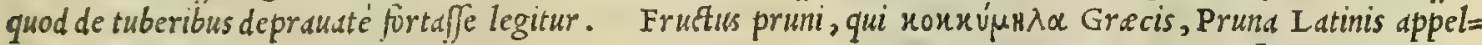
30 lantur: Arabibus, Anas, Auas, feu Agis: Italis, Prune, of succine : Gerinanis, Praumen, Pflaumen, of Kric=

Nomide.

A R B V T VS.

40

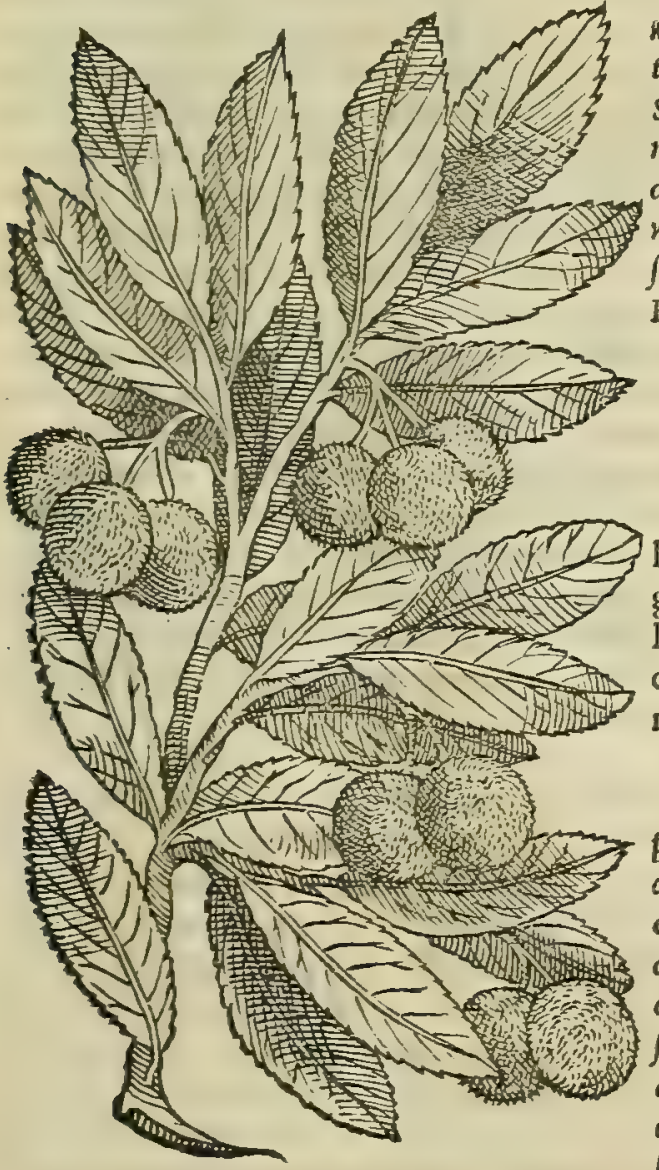
chen: Hipanis, Prunas, Andrinas, or Amexeas: Gallis, Pru= ne. Fructusueró, qui Grecis recentioribus, $\mu v \dot{\xi} x, \mu v \dot{\xi} \alpha$, squ $\mu \nu \xi \alpha \rho \alpha$, Latinis fimiliter Myxa, or Myxaria, atque $e=$ tiam Sebestena Mauritanorum imitatione dicuntur: Arabibus, Sebeften, Motheic.s, Mulceita, $\sim$ Mokaita. Vulgo $\mathcal{O}^{\circ}$ officinis, Sebeften: Gallis, Sebefte. . Fructus pretered, qui item re: centioribus Gracis $2 i 2 v \Phi \propto$ rai Zí $21 \Phi \propto$, e Galeno oxpi= na, Idrinis Zizypha uocantur: Arabibus, Hunen, Zufalzef, feu Hanab: Officinis, Iuiube: Italis, Giuggiole : Germanis, Rot burftbeerle: Hipanis, Azuficifa: Gallis, I uiubes.

\section{Kópapos. A R B V T V $S$. \\ CAP. CXXXVIII.}

A R B V T v's fiue vnedo; arbor ett cotonez maló non difsimilis, tenui folio: cuitus fructus pruni magnitudinem implet, nullo intus nucleo . huic memxcylo cognomen eft. Maturus aut flauet, aut rubefcit: in cfu acerofus, ftomacho aduerfatur, capitisque dolorem mouet.

A R E V T V S in Hetruria frequentißima prouenit, ubiuel Arbuti conper byemem perpetuis uirefcit frondibus. Hec et/f Diofcori= fideratio. direddatur malo cotonea adfimilis, magis tamen putauerim, $a b$ eo arboris proceritatem reprefentari cotone, quam folia, $\sigma^{\circ}$ caudicis corticem. Vel deprauatus fortaffe (ut magis fupicor) eft boc in loco Diofcoridis codex: quandoquidem Serapio, Dio= fcoridis ipfius teftimonio, Arbutum nondefcribit in uniuerfum cotone malo fimilem, fed eam tantum proferre folia malo cotonex minord. nec fcribit tenuid habere folia, ut unlgata ha= bet Diofcoridis lectio. siquidem, ut palim eft, Arbuto folid in 
funt laurinis, oriagneis cralsiord. Meminit Arbuti Theophraftus libro I I I. cap.x v I de plantarum biftorid, fic inqueizs. Arbutus, qux pomun cibo idoneum frat, magnitudine non nimium praftat: corticem tenuem, tamari= cifimilem habet, folium inter ilicem, e laurum : floret menfe iulio. Flores fingulari appendice parte poftrema ra= cenatin cobarent, pecie quifque myrto oblongo fimilis, $\sim$ magnitudine tantus: non foliatus, concauns, tanquam oum excalptum, ore aperto. chim autem defloruevit, retinaculum perforatur: quod'́; defloruerit, tenue, ficus ucrticillus circa fufun. Frutt!s anno integro maturc fcit, ut fimul bunc haberi, atque alterum flore fondericontin= gat. hactenus Theopbraftus. Qua in Hetruria nafcitur, folia profert laurinis, iligneisue fimilia, breuiora tamen paulo, crafiorá,; , colore potius pallido, quàm uridi, mambitu ubique ferrata, rubra per mediun excurrente co= fta. Caudex cortice uefitur fubrubro, afpero, 〔quamofó,; a quo rami prodeunt rubentiores, ac leuiores. Flo $=$ ret menfibus iulio, or augufto, floribus candidis, paruis, liij conuallij uocati figura, racematim dependentibus. E' 20 quibus fructus gignuntur rolundi, forborum fire magnitudine : qui primo exortu uirent, deinde flaue cunt, maturi ueró rubcut, appero tactu, nulio intus oßiculo, fragorum modo, quorum ctiam effigiem referunt. Sapor bis infipia dus, fimul $\odot$ alfterus: quinciiam dum eduntur, linguam, $\odot$ palatum ftimulant acerofa quadam fubftantia, qua $e x=$

Arbuti ufus, terius contcguntur, ita ut plané acerofi uideantur. His maximé delectantur turdi, er merulat. Quo fit, ut bye

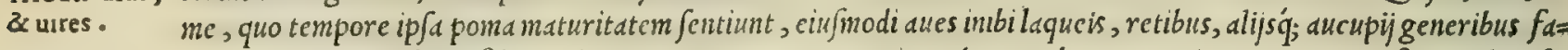
cile capiantur. Arboris folia coriaris cxpetuntur. Sunt qui credant, arbutum maximam opem praftare aduerfus peftem. Cuamobrem aquan, que cx folijs extracta fit, admifto offe in cerui corde reperto, ubi ftatim morbus ins uafit, magno ( ut ip/i aiunt) iuuamenio egrotantibus exbibent. Arbutimeminit Galenus libro v I I. fimpli= cium medicamentorum, ubi paucis inquit. Arbutus arbor ip $\int a$ qualitate acerba unà cum fructu eft. eum meme=

Nomina. cylum nuncupant. Eft autem bic, $\sigma$ infenfus fomacho, $\sigma$ caputi dolorem infrens. Huius arboris nomen Gre $=2$ cum eft rópagos: Latinum, Arbutus: Arabicum, Hatiladib:Italicum, Albatro: Hipanis, Madronho, aut Ma. dromeiro: Gallis, Arbouces.

A'uv $\delta \alpha \lambda \alpha i$. AMYGDALAE.

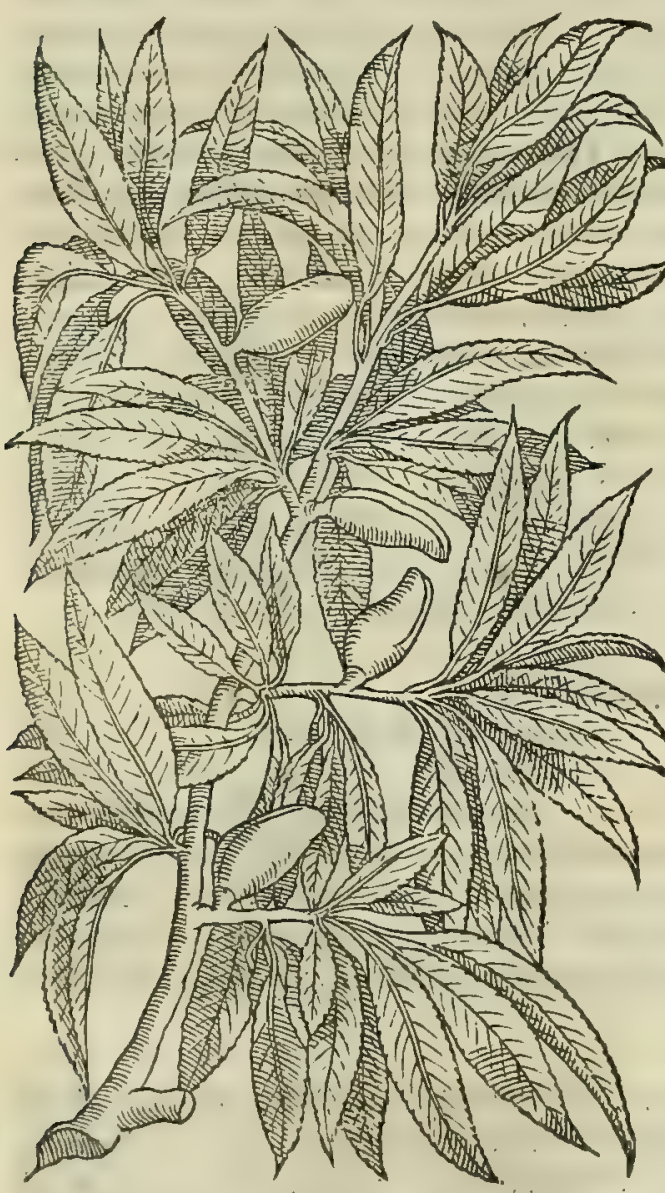

\section{CAP. CXXXIX.}

A M Y G D A L AE amaræ radicum tritarum decoetum uitia cutis in facie corrigit. Illitæ nuces idem munus præftant: menfes admotæ ciunt: capitis dolori auxiliantur, illitæ fronti, aut temporibus cum accto, uel rofaceo : epinyotidas fanăt ex uino: item putrelcentia 30 ulcera, \& qux ferpunt, \& morfus canum cum melle. Earum autem efu dolores finiuntur, aluiim emolliunt, fomnum faciunt, urinam cient: contra fanguinis reieEtiones cum amylo, $+\&$ mentha affumuntur : renum ui tijs, \&x pulmonum inflammationibus ex aqua in potu, aut eclegmate cum refina terebinthina dantur : calculofis, difficilique urinæ in paffo auxiliantur : \& illinetu cum melle, \& lacte hepaticis, tufsi, \& inflationsus coli, nucis auellmæ magnitudine. quinis, feptenísue profumptis, cbrietatem non fentiunt potores. Vul- 40 pes fi cum quadam efca eas uorauerint, emoriuntur. Gummi citis calfacit, \& adftringit : reijcientibus fanguinem, potum auxilio eft : impetigines, qux fummum corpus occuparunt, illitum cum aceto tollit: tufsi uetuftæ cum diluto uino potum medetur : calculofis cum paffo bibere prodeft. E' nucibus Græcis, dulcés cibo idonex, fed multò minus ualent in remedijs, quàm amaræ: attamen extenuant, urinam ciunt. Recentium feu cum fuo putamine, humida ftomachi uitia emendantur .

A M Y G D A L A E tam dulces, qudim amare fructils sunt ubiq; unlgó notiljimi. Differunt tamen inter fe: nam amar $m s=$ iore excalfaciendi, exiccandig; facultate predite funt, quìm dulces. quo fit, ut etiam dulcibus longe preférantur ad craffos, pituitofosó; bumores expectorandos. Galenus dul ces paucis perftringens libro II. de alimentorum facultatibus, fic inqutt. A mygdale nibil pror $\int u s$ adffrictorie $f_{a x}$ cultatıs fortite funt: fold cnim extenuandi, atque atftergendi ui pollent: qua tum uifcera purgant, trm bumorum ¿ pulmone, ac tborace excreatus moliuntur, ac promouent. Et de utroque Amygdalarum genere differens libro Amygdalorú V I. fimplicium medicamentorum, primo amaras, deinde dulces profequitur bis uerbis. Amygdala, qua qui= uires ex Gal. dem paläm amara Junt, omnino extenuandi uim pojsident: quod o qualitas ipfa indicat, o experientia comprobat. Ac de amara quidem qualitate in quarto horum commentariorum proditum eft. Caterìm duo experientiz exempla 


\section{InLib. primum Diofcoridis.}

proponi atis ef, unde uim corum poßjis difcere. siquidem eplsclin expurgant, o cxcreationibus ex pectore, pul= monéq; crafforum, lentorumiq; hunorum impendio conferunt. Porró hee often fa funt genere quiden incidentis, $p e=$ cie ueró extergentis clfe facultatis. Quin or quod per accidens facultatcin iten babe ant ab ob!tructione liberandi, o ipfun fuprid demonjtratum efl, fid e experientiu monftrat : nam in iecore crafforum, uifco forumó; bumorum in extremis uilis mmpatoruns obftructioncs abınde expurgant, expediunt'́;. Quin e laterum dolores ab buiufmodi caufa natos, o lienis, o coli, ơ renum fariant. Porró $\mathcal{C} \iota p$ fa arbor uniuer $\int_{a}$ finilem fortita uim $\mathrm{c} f \mathrm{t}$. Nam buius radices coste, atque illite epheles purgant. Quotquot ueró funt amygdaladulcia, or ip faleuiculum amaritudi= nem po/3ident, que tamen dulcedine fuperante occultatur : caterim id temporis patio clurum fit. Demonftratum autem: retró eft, qualiatem dulccm moderate effe calidam. bactcnus Galenus. Amygdale, ut Theophraftus, er

- Plimius prodiderc, ex anaris dulces fiunt, fi circumfoffo ftipite, o ab ima parte circumforato, dcflucns undique hux mor abftergatur. Et contri, dulces alnatec cunt, fi primo germinatu tenelle arbores a pecore decacuminentur. $A=$ mygdale (ut etiam tradidit Galenus) non multum Suppeditant alinenti : quanquam eis plerique utuntur 0 ad robo= randan uenercm, o ad reficiendas wires. Ha ut Gracis $\alpha u u \gamma \delta \alpha \dot{\lambda} \alpha$, ita etiam Latinis Amygdale uocitantur: Nomina. Arabibus, Iauz, Kauz, feu Lauzi: Italis, Mandorie: Germanis, Mandelliern: Hipanis, Almendra: Gallis, Amandes.

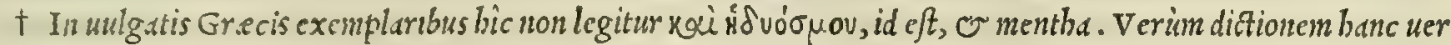
tit Marcellus ex antiquis codicibus, quos habuife tejtatur. eam quoq; er Oribafius, er Serapio ex Diofcoride trana fcribunt. Qux ut ueve Diofcoridis lectioniadftipulantur; ita hoc loco mentham addendan effe putauimus.

P I S T A C I A, quæ conftat in Syria gigni, pineis nucibus fimilia funt, \& ftomacho amica. Trita cum vimo contra ferpentium ictus profunt, fiue edantur, fiue bibantur.

\section{PISTACIA.}

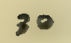

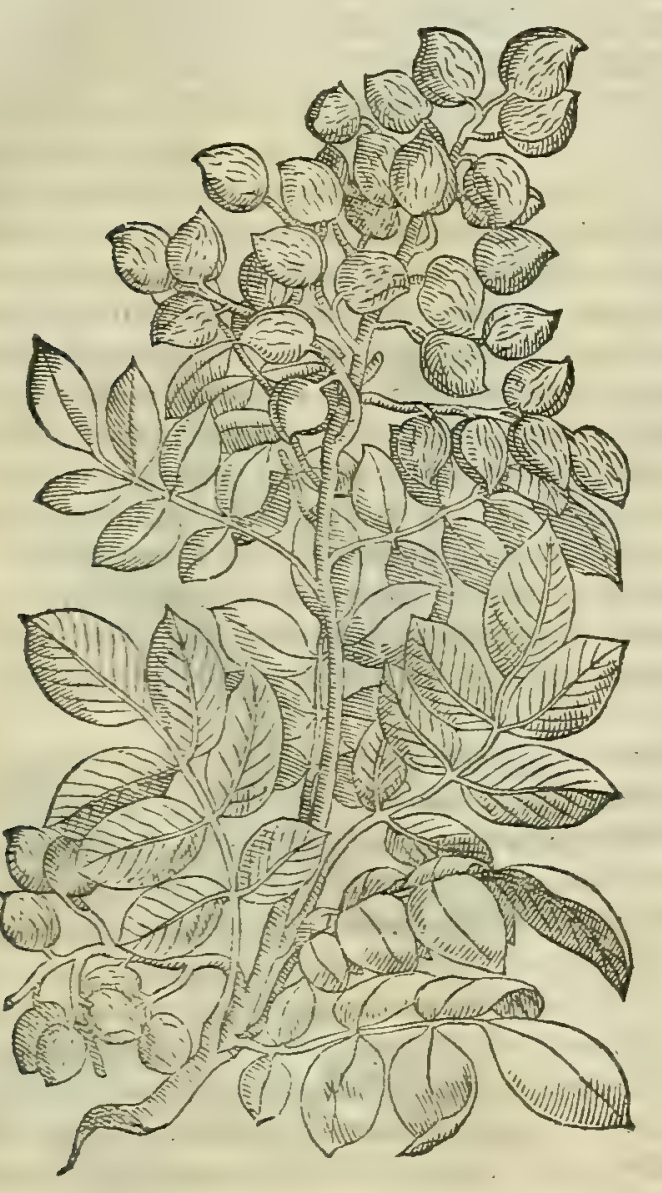

\section{$S T A P H Y L O D E N D R O N$.}

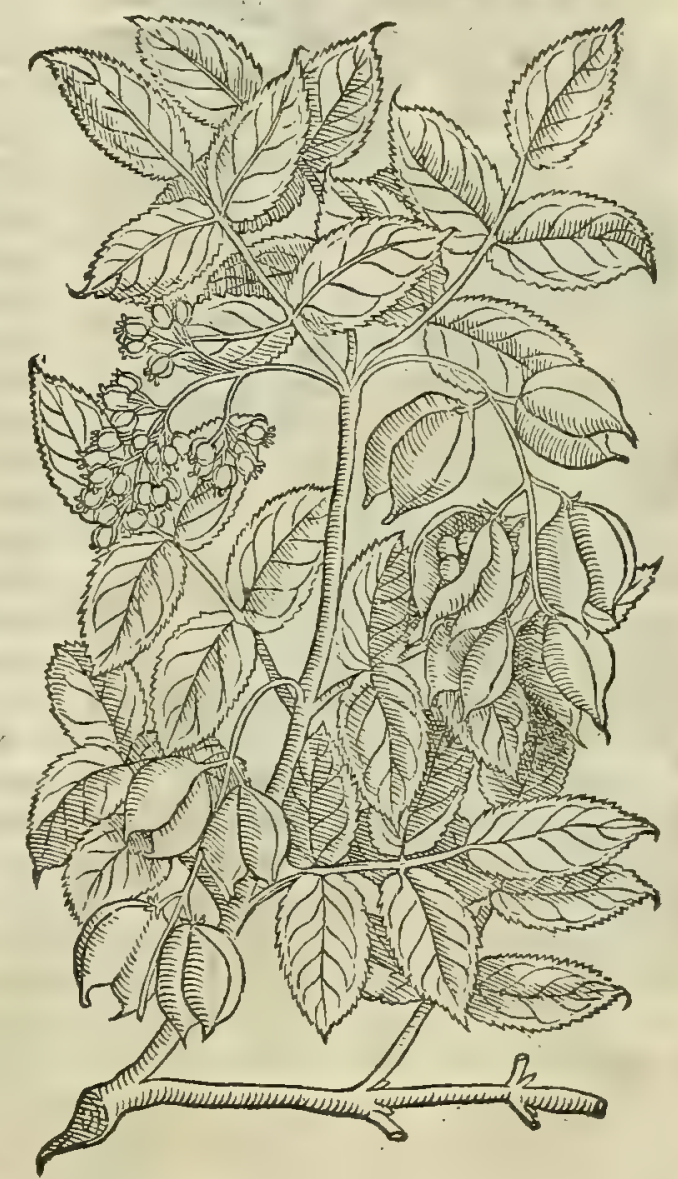

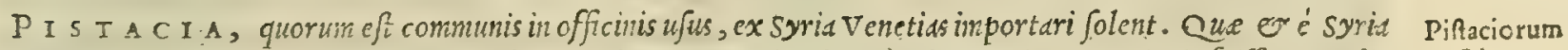

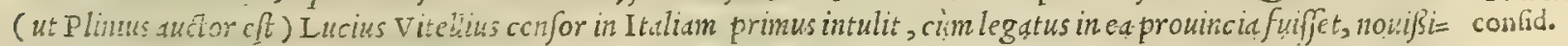

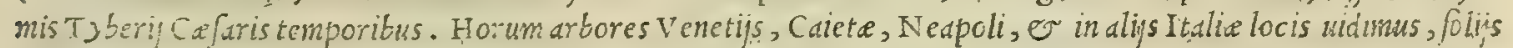

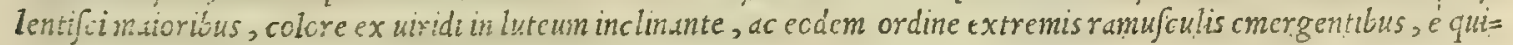

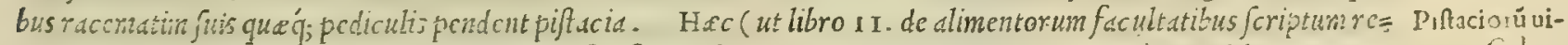

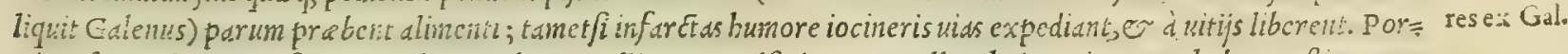

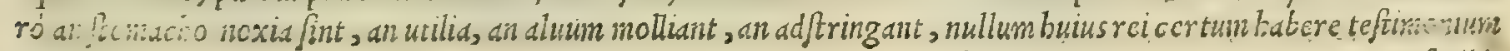


feribit Galenus. Cuius fententic refragatur Auicenna, quicim paldin, or nominatim Galenum refellere nollet, lio bro fecundo hac dicendi ratione utitur, his feré uerbis. Inquit quidam, non inuenio, quod Piliacia ftomacho pro= fint, aut fané officiant. Ego autem dico, quód naufcam difcutunt, o uentriculi os roborant. A rgumento cft fubde m.tra, Jubsuftcraf́, qualitas, que guftu in ijs deprehenditur. Hac igitur ratione freti medicorum nonnulli, non modd ad iocineris infarctus Galenum fecuti piftacia exbibent; fed ad iecur ip fum, uentriculumq́; rcborandun, ea tam ci= bis, quàm medicamentis inmifcent. quin er ad conciliandam uenerem, or ad pinguedincm inducendam macie, or marafmo affectis commendant. Quibufdam in loc is piftaciorum fylueftrium nomine appellantur cuiufdam arboris

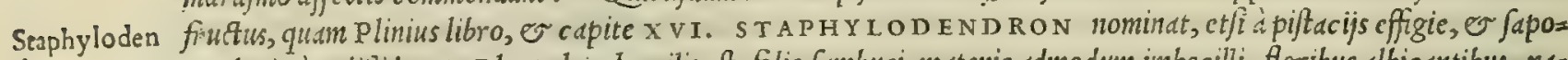
dron. re plurimum dibideant. Planta bae busnilis eft, folio fambuci, materie admodum inbecilli, floribus albicantibus, $r a=$ cematim dependentibus, quemadmodum o fructus : qui folliculis prouenit, rufo colore, ciceris effigic, maior tamen:

Nuclei pinei ir quo fubuirens nucleus includitur, fapore dulcis, fed naufcam commouens. Sapore piftacijs fimiles funt Pinei nu= uires. clei, qui in frobilis includuntur. Hi enim ( ut loco citato tradidit $\mathrm{G}$ alenus) corpus alunt, bonum procreant fuccum, fed craffum; tametfí egré concoquantur. Verìm, fi Auicenna etiam credimus, digerunt, leniunt, re foluunt, ac ims pinguant. Profunt pretcrea pulinonum uitijs, purulenta excreantibus, e tußi moleftatis : fed priufquìm edantur. aqua calida macerare cos oportet, alioquin uentriculum ledunt. Semen augent, or uenerem excitant. Renes, of ue ficam non modó expurgant; ;ed etidn robor ant, corumq́; ulcera probibent. Vrine fillicidio opem mirificé pra = |tant. Quam ob caufam ftrobilini nuclci apud recentiores medicos in frequentißimo habentur ufu ad buiufcemodi af =

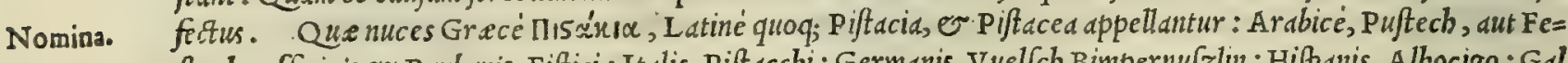
ftuch: officinis e Barbaris, Fiftici : Italis, Piftacchi: Germanis, Vuelfch Bimpernufzlin : Hipanis, Alhocigo: Gal lis, Piftaches.

\section{K⿺́丶龴}

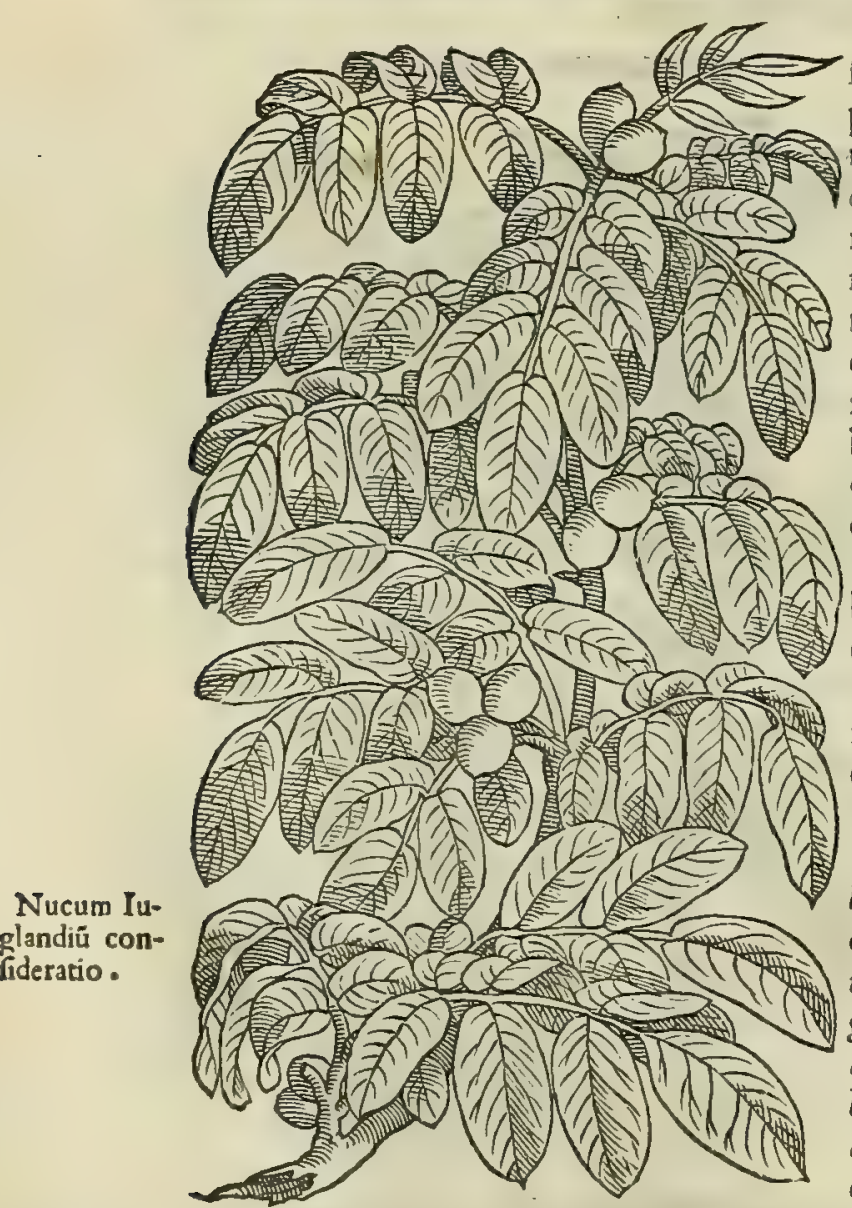

N v C E S Iuglandes, quas nonnulli Perficas uocant, funt difficiles concoctu, ftomacho inutiles, biliof $x, \mathrm{ca}-$ pitis dolorem inferentes, tufsientibus inimicx: tromituris tamen ieiunis in cibo aptæ. Cum ruta uerò, \& caricis præfumptx, \& à fummo cibo, uenenis refiftunt, nec minus fi à ueneni haufu comedantur : largius efitatæ, tineas latas pellunt: illinuntur mammarum inflammationi, abfcefsibus, luxatisq́ue, cum mellis exiguo, \& ruta: 30 cum cepa autem, fale, \& melle, canis, hominisq́ue morfui proficiunt : tormina, cum calyce fuo peruftæ, \& umbilico admotx, fedant. Putamen combuftum, tritumque in oleo, \& uino, infantium capite peruncto, nutrit capillum, alopecias replet. Siftunt menfes nuclei ufti, fi triti ex uino admoueantur : ijdem è ueteribus illiti carbunculis, 'gangranis, \& æailopijs medentur: alopecijs commanducati, \& impofiti præfenti funt remedio.

Nucibus tufis oleum exprimitur. Recentes ftomacho innocentiores funt, utpote fuauiores: itaque allio miftx $4^{\circ}$ eximunt acrimoniam. livores in corpore illitu tollunt.

N v C E S. I uglandes; que in communi funt ufu, itemó; dr= bores, à quibus eduntur, ommibus unlgo in Italia notiores funt, quadm ut à nobis reprefentari debeant, cum nulla arbor Nuce ubiq; frequentius occurrat. Hæ Latinis I uglandes, quafi Iouis glandes interlifis literis appellantur. Quo nomine primo mundi auo eas appellatas effe, plures tradidere auctores. Quippe cùm bomines primùm glandibus tantùm diu riçitaffent, inuenta tandë arbore, qua nuces ferebat, deguft ato nucleorum fapore, horun dulcedine mirum in modum allecti, nuces Iouis glandes ob excel=

Iuglandiü ui- lentiam appellauere. De ijs differcns Galenus libro v I I. fimplicium medicanentorum, ita fcriptum reliquit. Nu= res ex Gal. cis arbor tum in folijs, tum in germinibus ad/frictionem quandam poßtdct : caterim euidentcm, multamó; in nucis pu tamine recenti pariter o ficco . proinde co tinctores quoque utifolent. At nos eius expreßifucco fimiliter, ut mo= rorum, or ruborum in melle decocto, uice ftomaticimedicaminis utimur, or ad omnia reliqua adbibemus, ad que mo dò ditti fucci conuenire cenfentur. Porró nucis ipfius id, quod edendo eft, oleofum eft, $v$ r tenue : itaq; ob id etiam fa cile exprinitur, or quó diutius reconditum fueril, mag is tale efficitur. 2uamobrem oleum ex eo inueterato expri= mere liceat. Tunc fane admodum fit per halitum cuaporatorium. It aque quidam eo gangrands, or carbunc ulos, of agilopas fanant, ac nonnulli ad vevgót $\rho \omega T \alpha$, hoc eft, ncruorum uulnera utuntur. Et libro I1. de alimentorum $f_{\mathfrak{d}}=$ cultatibus fic inquit. Habet l uglans o adftringentls qualitatis non exiguum, que temporis proceffu marce $c$ cit, de= generante tota eius fubftantid in pinguem fuccum, adeo ut cibo pror fus fiat inidonea, qquód ueteri oleo, fus pinguitu= 


\section{In Lib. primum Diofcoridis.}

dine ad/imilis appareat. Viridis autem, atque ctiammum bumida, neq; adftringentis qualitatis, ne q, oleofe confpicue eft particeps; fed magis eft quodammodo $\alpha \pi 0 l \alpha$, id cft, qualitatis expers : quod faporis genus aqueum ( $u t$ dixi) uo=

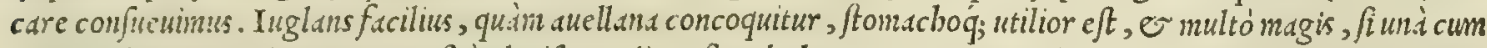
caricis edutur. Proditum autem cft a plerifg; medicis, fi anbo bac cum ruta ante alios cibos fumantur, boninem non magnopere dilchalibus phamacis le di poffe. Conftat preterea bunidas decectioni magis, aridas ueró minus conues nire. Non paci quoque cum garo inglundes pr.e Jumunt, ucntris fubducendigratia. Ad hoc autem uirides aptiores funt,utpote qux adfringentis qualitatis minus participes funt. Quin $\sigma$ aridarum quoq; ubi prius in aqua fucrint ma cerate (ut nonmllif faciunt) fintlis, ac uiridium facultas babetur. bec Galenus. Catcrion Iuglandesuirides de= cerptre menfe mio, uel iunio appetcnte, antequdin carum putamina obduruerint, faccharo, uel inclle afferuate fto=

20 macho wtiles cuadunt, or ori non ingrats". Sed quoniam fermo nobis eft de nucibus, cuim Diofcorides, Galenus, ac ceteri pofteriores Graci de Indic is, Miyriftic is, Mctellis, ac Vomicis nibil, quód constet, memoria prodiderint, bic ca non dißimulanda putaui, neq; aliemun duxirecenfere, que de ijs ex Mauritanor un monumentis, or recentiorum quor undan bificrijs fum confecutus. Sed primó de Indicis dicamus. Nuces igitur I N D I C A E myropolijs omnibus uulgatißin.t, fructus funt arboris cuiufdam (ut Mauritani auctores funt) palmx effigie, pregrandes, inagnorum me lonim inftar, ab arbore dependentes: nanq; magna inuolucrorum mole obteguntur. Cortex ijs extimus colore cöftat In atrum ruff cente, fubdurus, tenax, callofus q́; : intus ueró uillo fa materie compactus, que manibus extrita in capil= lament. faticit. Subtus eft putamen triquctrum, willofun, barbatumq;, cormu infar predurum, ciufdem fer é color is muclcun continens, oui anf crini magnitudine, intus concaumm: Jubftantia illi pinguis, crafsitudine femidigitali, du= riufculk, tenax, callo $\int_{a} \eta_{\text {; }}$, albicans, fapore dulci, butyrum referens, tenui fed appero obtecta cortice, putaminis co=

20 lore. Probintur recentes, ex' $q_{5}$ prefertim, in cuius concauitate liquor quidam dulcis includitur : fiquidem boc argu= mento recentiores fucilé cognofcuntur. Excalf aciunt fecundo abjcelfu, humectant ueró primó. In cibis fumpte, etfi noxium admodum fuccum non gignant; uentriculo tamen laborem inferunt: femen augent, er ueneresn cxcitant . Oleum, quod é nucibus Indicis exprimitur, utiliter bemorrboiditus inungitur, oleo prefertin admifto, quod é perft= cormm nucleis clicitur : per fe illitum lumborum, ov genuum dolores mulcet, er uentris aninalia pellit. Quod ueró recentes nuces preffe fillauerunt oleum, den fum eft, candidum, e pingue: in fumma fubftantia, qualitate, fapore, ac deniq; facultatibus butyro non dißimile, fed longé melius fubminiftrat alimentum. Nux Indica letiore fagina cor pora reficit. Idcirco frigofas mulieres mirum in modum impinguat, of ad craßitiem reducit. hactenus de Indicis.

NVX MYRISTICA.

30

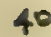

50

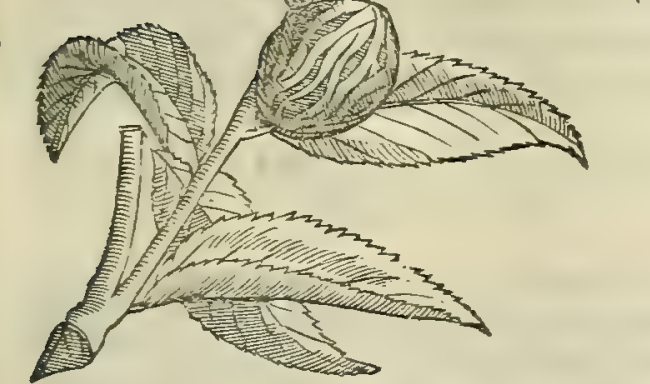

His fuccedunt M Y R I S. I I C A E, qux uulgó officinis ob odoris preftantiam Mufcate, quafi mofchate dicuntur. Ha ( ut referunt $i j$, qui Indica litora perluftrarunt) proueniunt copiofi $\beta i$ ma in infila quadam nomine. Badan : ibiq;; eas proferunt arbores quedam nof tratibus perficis haud abfimiles, anguftioribus tamen folijs, ac breuioribus. He poft foliorum germinationem, florem ftatim emittunt, quem Macim Arabes uocant. Pandtur is fylue= frium rofarum modó : é cuius medio nux erumpit, or proceffu temporis perficitur, or ubi maturitatem fen ferit, macis rofarum inftar, expanfus eam circumplectitur : quam poftea fuo tempore cultores legunt certatim, $\sigma$ qudin quifque poteft uberius, quoniä funt ibi omitia communia. Arbores $a b q_{q} ;$ cultu, fuppeditante tan= tum natura, fuos fructus edunt. Myriftic a nuces fuo maci, taniquă rete comprebenfe, Venetijs in officinis quàm plurimis uifuntur, duro putamine concluse, auellanarum modo, colore fubnigro: quo fracto compactilis fubeft globulus, nuclei uice, or is eft nux Myriftica, quam ufurpare folemus. Preferuntur recentes, que nullam prefenferint cariě : item pondero $\int e$, farcte, prapingués, bumore redundantes, ita ut adacta acu confeftini è uulnuf culo ex $=$ catbumor. Siccant ( $u$ t Mauritani foribunt) o excalfaciunt ordine fecundo completo. Adftringunt, oris fuauitatem commen= dant, $\odot$ fotentis anime uirus commanfe abolent: lentigines, in facie emendant, uifum acuunt, uentriculum 0 iecur roborant: lienem abfumunt, urinam ciunt, fluentem aluum fiftunt, flatus dis fcutiunt, er frigidis uteri affectibus mirifice profunt: $0 r$ ut in uni uerfun dicam, facultas eis eddem, que ov caryopbythis. E' recent= tibus prius contufis, $\mathcal{O}$ in cacabo cale factis prelo exprimitur li= quor, qui refrigeratus cere noue inftar concre $\int c i t$, fragrantißi= mum pirans odorem, neruorum $\sigma$ articulorum diuturnis dolo= ribus d frigore excitatis utilißimus: quin er ueneris inuntioni= bus maximé expetitur. Myrifticas nuces ueteribus Gracis ignos tas fuife itlud fidem facit, quód Theophraftus, Diofcorides, er Galenus edrum, quod in Juis monumentis legerin, nufquam meminerint. Quxpe e hic quoque a) Jerere non dubitauerim, macerem (ut in eius mentione diximus) Dio= fcoriä, $e^{-}$Galeno myriftic e nucis florem effe nequaquam. Nam fi ad eosfloris cognitio perueniffet, ueri quidem fi=
Iuglandes có ditx.

Nucis Indice confid.

Oleum ex nu cibus Indicis. Nucis Myriftice conlid.

Myrifticará uites. millimum 
millimum eft, quód etiam fructus notitiam habuifent : quos, certó fcio, ob fus admir abules facultates, or nature doe

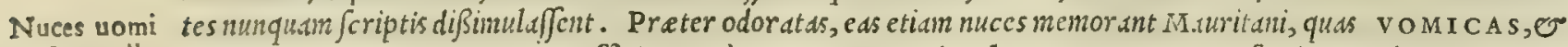
cæ, \& metelle. METEL L AS uocant. Sed tam officina, quäm medicorum uulgusbas magno errore confundunt, quód plerunq; le = gitimas uomic as metellarum loco uJurpent, or contrà metellas nonnunquam uonicarum uice. Nain Vonicas quidem eds appellant errore ducti, qua lupinorum inftar compreffa funt, ev tcnui quadam lanugine contecte, quarum efu canes necantur. Netellas ueró, que nonnibil extuberantes, quibufdam nodis, ueluti paruis oculis, per ambitum funt Mulcorumer referte. At corun lapfus facilé deprebendi poteft serapionis teftimonio, qui A braliami cuctoritate reddidit nucem ror. Vomic am colore inter glaucum, or album, allellana pauló natorem, nodofam $\dot{q}$; . Qubus notis eas cfe preditas con= ftat, quas feplafiariorum unlgus metellas appellat, que nullo modo refpondent legitinis metellis à Ser apione de fcri= ptis, bis uerbis. Nucis metelle arbor, uomice arbori non dißimilis, fitut!m gerit mandragora, oleofum, birfuto cor = tice, fapore non iniucundo. Que nota perfpicuó adftipulantur ijs, quas Vomicas nuncupant : ea fiquidem corticem

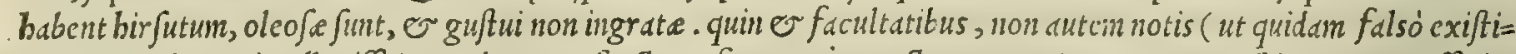
mant Serapionem intellexiffe ) mandragore fructus referunt, cuin auttore Serapione, quarto refirigerent exceffu, ita ut drachmarum duarusn pondere efitats interimant, minore ueró menfura temulentiam faciant. Quos quidem effe= Atus preftare uidemus non modó in canibus, fed etiam in bominibus, quibus ha date fuerint, quas uomic as cffe conten= dunt . Fiquidem Serapio de Vomicarum facultatibus differens, nullam lctbalem uim eis adfcribit, fed qućd tantün dud= run drachmarum pondere cum ane thi decocto, uel fale hauste, mirifice uomitum cliciant. Quamobrem dixerin ego, illas, quibus callo fa tubera fupercminent, nodiq;; uifuntur, oc ulorum firé inftar, legitimas effe uomicas: metcllas ueró,

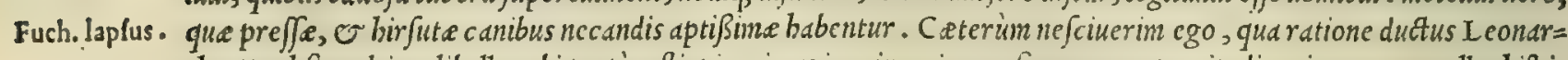
thus Fuch,fus ultimo libello, ubi tantùm ftirpium inagines in exiguam forman contraxit, dixerit nuccs metellas bipi= 20 dos effe fructus peregrinc illius plante, quam antea magno volumine Stramoniam uocalcrat. Quod prorfus reclama re uidetur Mauritanorum fententia, à quibus harum bijtorias accepimus. Sed quonian foribenti mili de Nucibus

Anacardij mẻ omnibus ANACARD I A fe e obtulere Grecis ueteribus ignotu, cum er ip da in officinarum ufu expetantur, de cis kio, \& uires. quoq; uerba facere ex Arabum teftimonio, non quidem ab refore duximus. Sunt igitur Anacardia (ut teftis eft sera= pio) fructus cuiufdam arboris auicularum corculis non dißiniles, unde er nomen, colore ctiannum cordis modo rufe= fcente, cim fcilicet ab arbore decerpuntur. Ineft ijs liquor mellis craßitie fub cortice refidens, fanguinis modo rubi= cundus, fub quo eft o nucleus paruse amygdale effigze. Nafcuntur in sicilie montibus, qui continue igneas eructant flammas. Excalfaciunt, or cxiccant tertio exceffu. Preftat in medicina liquor; ct fi myropole communi errore er cortice, or nucleo utantur. Anacardia (ut aiunt) labantes reuocant $\int \mathrm{en}$ fus, inemorix iacturam re a arciunt, er neruo= rum, er cerebri affectibus, quos frigida caufa attulerit, auxiliantur: nibilominus fanguincm cxurunt, or cutim ulce $=30$ rant. Quare Audacardia iunenibus noxia funt, cim er adurant, et deleteria facultate non uacent : cui tamen remedio

NVCES A VELLA NAE.

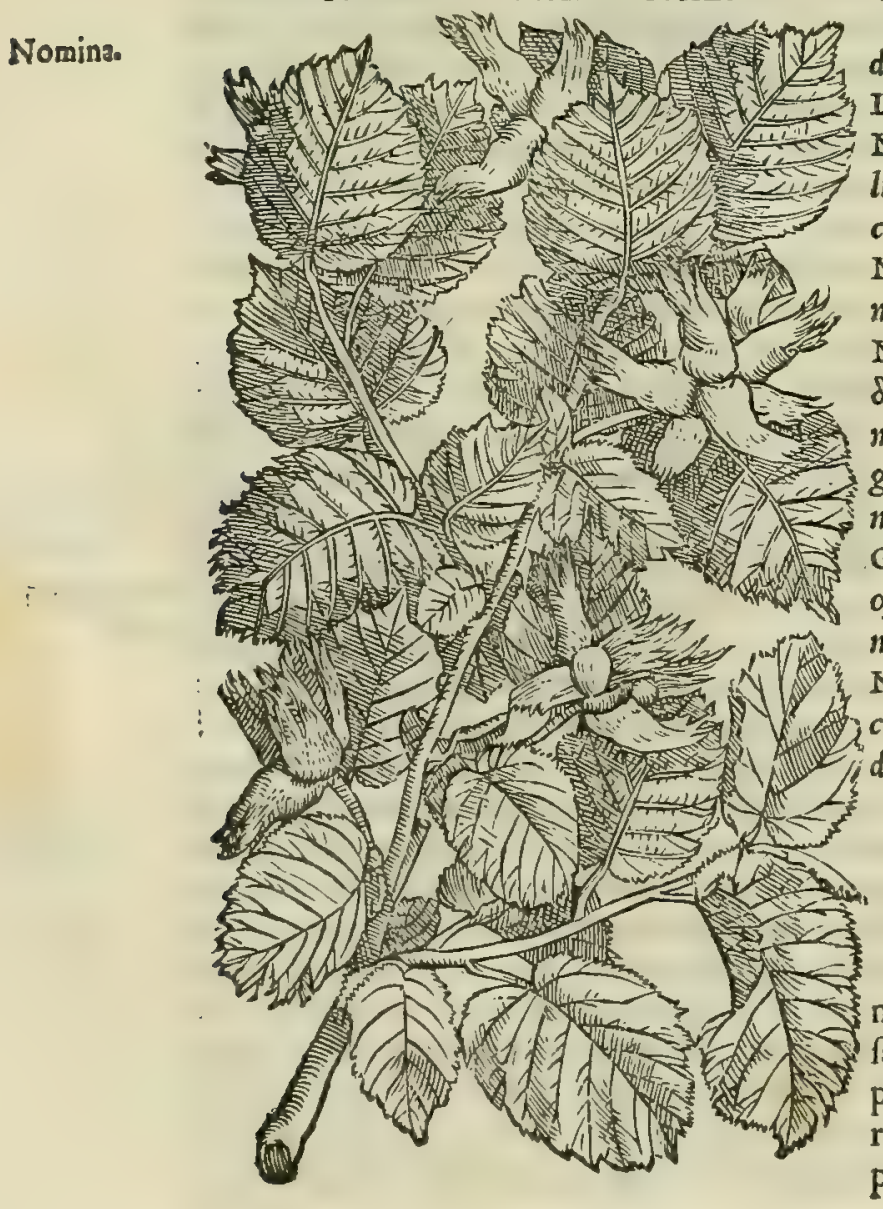
eft lac affatim potum, or oleum ex eorum nucleis expreflum.

Hactenvis de uarïs nucibus, nunc earum nomina funt nobis red

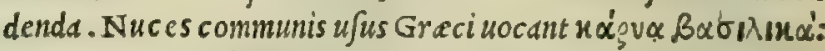
Iatini,nuces I uglandes: Arabes, Ieuz, Leuz,aut Giauzi : Itali,

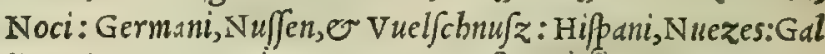
li, Noix. Nux ueró, qux ex India defertur, recentioribus Gre cis rágvovivó ixòv appellatur: Latinis, Nux Indica: Arabibus, Neregil; Dabig, feu Giauzi albend: Italis, Noce d'India: Ger= manis, Indianifch nufz: Hipanis, Nuezde las:Indias: Gallis, 40

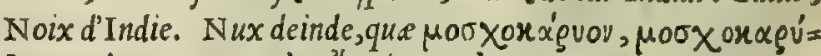
$\delta$ lov, $x \alpha$ '́ myriftica,dut Nux mofchata Latiné dicitur: leuzbaue, Iusba= gue, feu Giauzi ban, Arabice': Noce mofcada,Italice: Mufchat mujz, Germanice : Nuez de epecie, Hifpanice : Nois mufcades, Gallice. Nux praterea, qux Arabibus Leuzalkei, feu alke, officinis ac Barbaris Nux uomica, $\mathcal{O}$ Italis Noce uomica nomi= natur. Nux denig; Arabica noce Leuz alrachaha dicta, Latina Nux metella : Barbara, $\mathrm{N}$ ux methel: Italicd, Noce metella nun

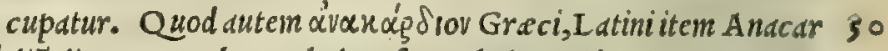
diü dicunt: Arabes, Baladar, feu Beladur:Hippani,Anacardo.

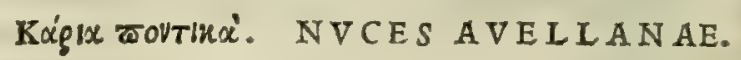
CAP. CXIII.

N v C E S auellanx, quas \& leptocarya uocant, ftomacho infeft $x^{\prime}$ funt: ip fre tamen tritx, $\&$ in aqua mulfa potæ, tufsi veteri medentur: toftr, \& cum exiguo piperis potæ, deftillationem concoquunt. Crematarum cinis cum axungia, aut adipe urfi perunctus, alopecijs capillum reddit. Aiunt nonnulli ufta earum pu- 


\section{InLib. primum Diofcoridis.}

tamina, \& in cineris f peciem redacta, cum oleo, cxfiorum oculorum pupillas infantibus denigrare, perfúfo fincipite.

A V E L I A N AE nucesidco Grecis Pontice dif.e funt, quód in Graciam (ut Plinius inquit) é Ponto primimn Auellanarum allate fucrunt. In I talia tamen $\mathcal{O}$ in urbanarum, $\mathcal{O}$ in fylucstriun genere numerofe reperiuntur. Caterim ex do= confid. mefticis alic oblong.e, alie rotunder funt: ucruntamen oblong as or preftantiores, of guftui gratiores cffe conftat; o ithe prefertim, qux putaminc uchementer rubent, o fratu mininé funt contumaces, quales funt vicentina. Ob= longa ferius maturitatem fentimnt, cclerius ucró rotunda . quapropter illa vegetiori funt nucleo, diứ; perdurant . Sylueftribus coryietis ferc iniumeris fcatent Tridentini montes, qua oblong as pariter, o rotundas largiuntur nuces,

xo tanta ubertatc, ut eds rura faccis legant, ubimaturitatem fenfermt. Aucllane (ut mentoria prodidit Galcnus tum libro v I I. (impliciun medic. tum fecundo de alimentorun facultatibus) plus habent effentia terreftris, ac frigidie, quim I uglandes . quin o plus prabent alimenti: fiquidem denfiores funt, 0 minus pingues. Diocles auctor eft, $A=$ uellun as muces minus amygdalis alere, cibis in uentriculo fupernatare, largius efitatas caput tentare; innocentiores

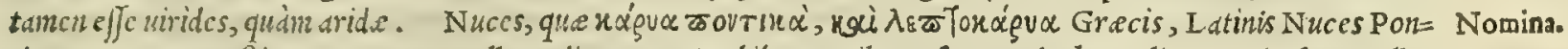
tice, nuces Preneftind, o nuccs Auellane dicuntur: A rabibus, Agileuz, feu Bunduch: Italis, Noccinole, Auelld=

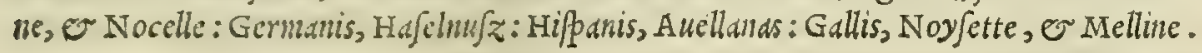

$$
\text { Mogéa. MORVS. }
$$

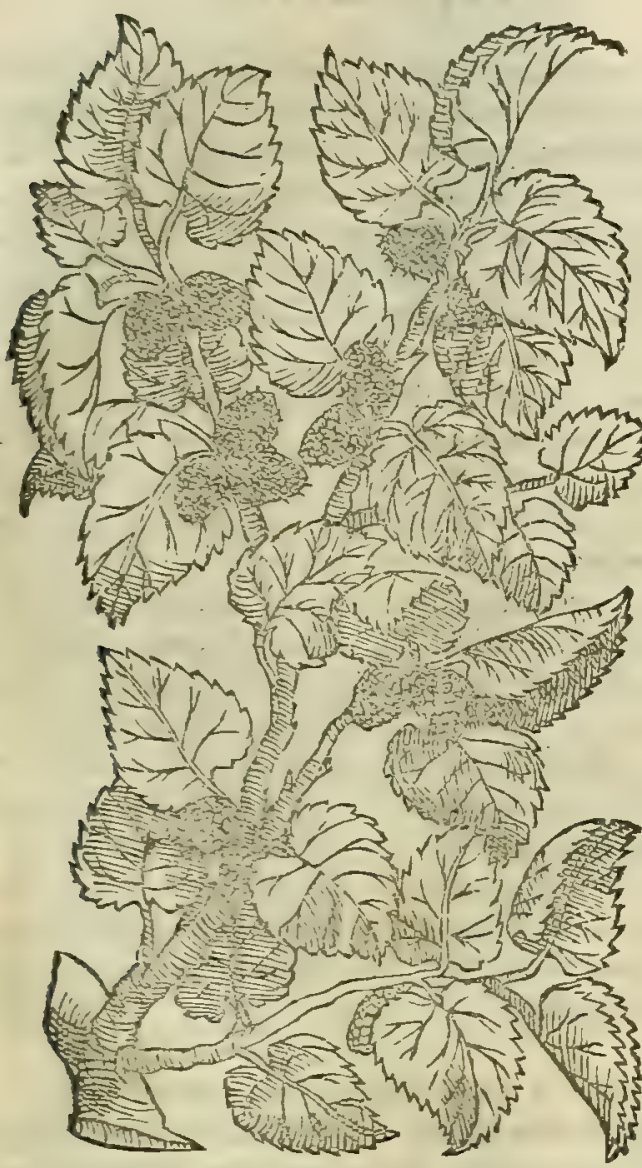

Morvs arbornota eft. Cuius fructus aluum foluia, ftomacho inutilis eft, \& facilè corruptionem fentit. Hoc idem præftat mori fuccus: decoctus autem $x-$ reo uafe, atque infolatus, adftringentior redditur. Facitad fluxiones, nomas, \& tonfillarum inflammationes, addito mellis exiguo. Sed inolefcit uis eius adjecto fciffiliahimine, galla, croco, \& myrrha :item myricæ femine, iri, \& thure. Im matura mori poma ficcantur, tufaquue acinorum ihois vice, obfonijs mifcentur, ut cœliacos iuuent. Radicis cortex decoetus in aqua, \& potus aluum refoluit: latas ventris tineas excutit : his quoque auxiliatur, qui aconitum hauferunt. Folia trita exaceto illita, ambuftis igni medentur: tinguntq́ue capillum, vitium, \& fici nigræ frondibus fimul coetis in aqua coelefti. Succus foliorum cyathi menfura potus, contra phalangiorum morfus auxilio eft. Feruefacti cor ticis, \& foliorum iure, dentes aptifsimè in dolore colluuntur. Radix circiter meffem incifa, facto in ambitu fcrobe, fuccum emittit, qui poftridie concretus inueniri folet. Is in dolore dentium efficax eft : tubercula difcutit, \& aluum purgat.

E S T E T Mori utrunque genus album, er nigrum paßim Mori confide unlgaris notitie in Italid; précipué his in locis, ubi bombyces $\int e=$ ratio. ricifici aluntur. Conftat alba mororum poma adf Iringentem $f_{d}=$ cultatem longé minorem, quàm nigra effe adepta (etfi Diofcori= des, o Galenus alborumi non meminerint) ex multd $\widetilde{D}$ perßi= cua, fed paululum infipidadulcedine, qua gujtatu deprebendi= tur: fiquidem inmaturis nulla adftringendi uis plané percipi po= teft. Morus nouißina urbanarum gerninat, foliáf; enittit : eáq; propter ueteribus dict a fuit arborum Sapientißina. so IIora ( ut prodidit Galenus libro v I I. Jimplicum medic amentorum, item Secundo de alimentorum facultakibus) matura quidcm uentrem fubducunt, imsiatura ueró ubi aruerint, admodum reftringunt. It tog; ad dyfenterias accom= moda funt, itcm ad cceliac ds, \& quafcunque alias fluentes affectiones. Porró quód maturorum fuccus ad oris medi= camenta fit utilis, propter cam uidelicet, que ineft illi, adfrictionem, iccminem latet. Pretered ad alia complura par ticularia, que mediocrem expof cunt adfrictionem, competit. At immatura mora prater acerbitatem, fortita funt e aciditatem, $\odot$ tcta adcó arbor in ommibus suis partibus mistam aliquam uim obtinere uidetur, ex reftringente, er purgante compofitam. Attamen in radicis cortice purgatoria cum quadam amaritudine exuperat; adeó ut $\odot$ latas interaneorum tineds perinat. In alijs autem partibus reftringens uincit; in folijs tamen, or germinibus quodammoz do media utrifque ternperies eft. Mora ubi primum nanja fuerint, ingefta citißumé tranfeunt, er alijs cibis fuo uclu= ti ductu uian ftruunt. Verim fecundo loco sumpts, celerrime alijs un à cum cibis corrumpuntur : id quod etiann $f_{\text {ta }}$ ciunt, ,i ciun eduntur, prauo in uentriculo bunori cccurrant. Quód fi corruptionem non fentiant, corpus quidem

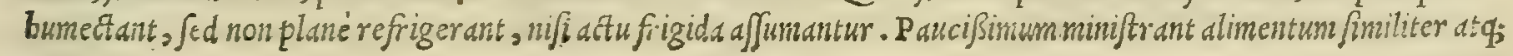




\section{8}

\section{And. Matthioli Comm.}

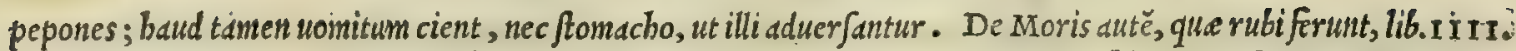
Serici métio, in Ruborum commentatione, Deo fauente, latius differemus. Sed quoniam mori folijs $\mathcal{O}$ uefcuntur, $\mathfrak{O}$ aluntur. \&uires. uermiculi, qui admirabili nature pectaculo nobis S E I C V:M ucllus conficiunt, quo recentiores medici in bis; qux cordi conueniunt, medicamentorum compofitionibus utuntur, ut, quantum per me fieri poteft, omnibus rei ime= dic a fudiofis fiat fat is, ea de Serici uiribus bic perftringam (quandoquidem non inuenio é ueteribus Gracis, qui de. boc quicquan prodiderit) que Auicenna pofteritatis memoria commendauit tractatu, quem de uiribus cordis infcri=. p fit. Sericumitaq; ( codem auctore) mirifice exhilarat. qua in re crudum co longé praftat, quod ignem fuerit ex= pertum; tametfl coctum quandoque in ufum ueniat, uerim antequam in infectorum cortinis immerfum inficiatur. Excalfacit fericum, reficcat q́; ordine primo: exiccat, of attenuat ea nature dote, ut cor recreet, letumí; efficiat: Quapropter laxat, firmat, purificat, er illuftrat piritus. neque eius facultas uni tantum aßignatur pirituum ge= neri in una tantim difpofitione; $\int e d$ ei proprium eft, onnibus aqué piritibus opem ferre, ita ut piritus tam uitales, or animales, quàn naturales reficere ualeat. Ceteró quanuis negauerit Auicenna decoctum fericum, or fullonum coloribus inbutum in medicos uenire ufus; Mefues tamen in eo ferapio, quod de pomis infcribitur, id fericum admita tit, quod cocco legitiné fit infectum. Id q́; fimiliter inferit in ea medicamenti compofitione, quam Alchermes, ipfe

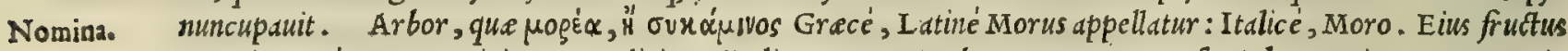

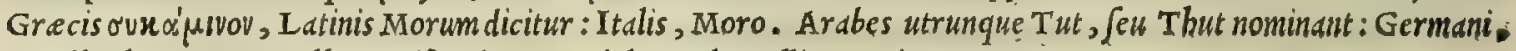
Maulberbaum, $O$ Maulber : Hipani, Moras del moral: Galli, Meurier or Meure.

Evrópogos. SYCOMORVS.

CAP. CXLIIII.

SY $\mathrm{COMORVM}$, aliqui etiam fycaminú,id eft, mo-

Sycomeri hiftor. ex Theo phrafto.

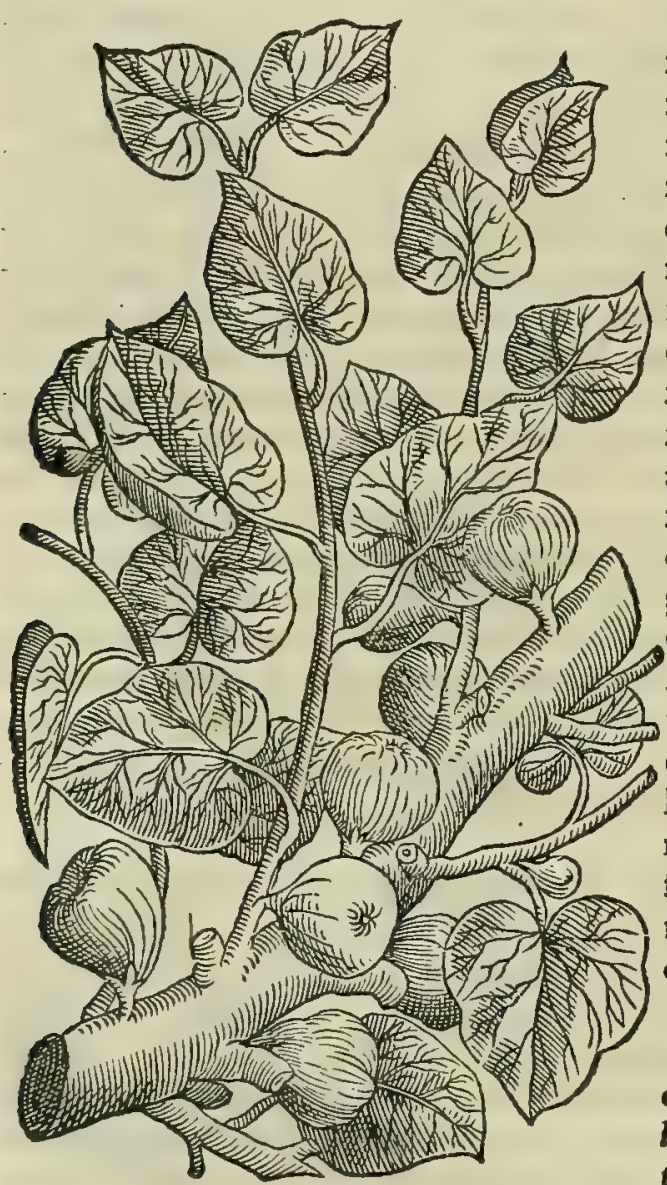

um, vocant, cuius fructus fycomorum etiam, propter inefficacem guftum, appellatur. Arbor eft magna, fico fimilis, frondofa, multo lacte abundans: folijs mori : pomum ter, aut quater anno fert, non ramis, vt fico, fed caudice.ipfo, caprifico non difsimile, dulcius grofsis, fine gra nis interioribus : quod non maturefcit,nifi vngue,aut fer ro fcalparur. Nafcitur plurimum in Caria, Rhodo,locisque non multi tritici feracibus : vbi prouentu fcecundo, reftibiliq́; iuuamentum adfert, cùm annonæ caritas pre- 30 mit. Pomum aluo vtile eft, fed perquàm exilem præbet alimoniam : ftomacho aduerfatur. Succus primo uere tenera arbore antequàm fructum ferat, eximitur, lapidis ictu fummo cortice defquamato: fr enim altiore plaga uioletur cortex, nihil effluet. Spongia, aut uellere lacryma excipitur, quæ ficcata, \& in paftillos coacta, fictili vafe reponitur. Vis fucci emollit, vulnera conglutinat, difcutit collectiones coctioni repugnantes : bibitur etiam, aut illinitur contra ferpentium morfus, duratos lienes, ftomachi dolores', \& perfrittiones . celerrimè te- 40 redinem fentit. Gignitur \& in Cypro arbor genere diftans, qua cùm fit vlmus, prædita tamen eft folijs fycomori, fructu pruni magnitudine, multò dulciore, fupradietis catera fimilis.

S Y COM OR V S (ut Theophraftus eft anctor libro IIII. capite I I. de plantarum biftoria) arbor eft moro noftrati finis lis, quippe folio, magnitudine, appectuq́; proxima. Fructum pres = ter cateras peculiariter gignit : non enim germinibus, non ramis extremis, fed caudice pomum parit inagnitudine ficus, or uifu proximum, fucco at $q_{5}$ fapore caprificis fané fimile, $u e=50$ rum longé dulcius, granisq́; internis omnino carens, multitudine numerofius mature fcere nequit, nifif fcalpatur. Scal pitur autem unguibus ferreis : $\sigma$ cum $\int c a l p a t a$ pond $\int u n t$, ad quartum diem mature $f$ cunt : bifce ablatis, alia, or alia ex codem loco fubnafcuntur, terno ita, o quaterno partu copiofa. L actuofa arbor admodum eft, o materies (quód fit folida, robufta, er nigra)ad multa commoda exiftit. Hac inter ceter as arbores id fibi propriü uendicauit, quód ce fa continuó uiret, neq; ficcatur unquam, nifi aqua obruatur. Ea q́; propter. o lacubus, e ftagnis demergitur, madefa Sycomori mé 'ctaq́; in profundo ficcatur, ckimqं; ficca omnino fuerit, Juperfluitat, at q; innatat. hactenus Theophraftus. De Syco= tio ex Gal.

moro differuit Galenus libro I I. de alimentorun facultatibus, ubi ita fcriptum reliquit. In Alexandria sycomori plă tam uidi und cum fructu, parue, candidéq; ficui adfimilem. Is fructus nullam babet acrimoniam, exigux dulcedinis eft particeps, eft $\dot{q}_{;}$facultate bumidior quodammodo, ac frigidior, ueluti mord. Quinimo inter mora, ac ficus mediums iure quis ip fum collocarit, atque binc nomen ipfi inditum effe mibi uidetur. Ridiculi nanq; funt, qui fructum bunc ob id aiunt Jycomora fuiffe nominatum, quòd paruis ficubus aßimiletur. Ipfius autem najcendi ratio ab alijs arborum 
cum cruo, \& uino illitæ, auxiliantur. Fit ex cjnere ficus tam fylueftris, quàm fatiux lixiuiú, crematis ramorum cauliculis, quod fubinde macerari opus eft, \& inueterafcere : fiquidem inter cauftica intelligitur. Gangrænis prodeft : nanque expurgat, \& confumit, quæ excrefcunt, eoque fic utendumeft: fpongia afsiduc hoc lixiuio imbuta fuperponitur. Interdum dyfentericis, \& in fluxiones uetußtas, \& finus cuniculatim cxedentes, magnosque, infillari conueniet. Etcnim purgat, conglutinat, carne replet, \& oras committit, non fecus atque cmplaftra, qux cruentis vulneribus inijciuntur, enxma uocant. Bibitur ad difcutiendum fanguinem concretum, \& contra pracipitationes, rupta, conuulfa, cum cyatho aqua recenter colatum, addito olei exiguo: coliacis, dyfentericis, per fecyathus datus prodeft : ncruorum uitıjs, conulfionibus, commodè illinitur cx oleo, utpote quod fudores moneat: aduerfus gypli potum, ix phalangiorum morfus bibitur. Hace eadem præftant reliqua lixiuia, prafertim quernum : omnia tamen adit ringunt .

Ficorum con F I c I fructus funt in Italia uulgó notißimi. Ozarum etfi plura notentur genera in candicantium, er nigre: fideratio. Scentium difcrimme; fint tamen ommibus notiores ob frequentißsimum in autumno carum in cibis ufum, quàn ut no= bis praftantiores reprefentare, ac defcribere fit opus. Stquidem omnes fatis guftus edocuit, cas effe laudatißimas, que plané mature pinguedine, o Japore ceteras antccellunt. Sed ut preter id, quod ḋ Diofcoride proditum eft, earum omnibus facultas innotefcat, o temperamcntum: quin $\sigma$ ut omnes cognof cant, quod prabeant alimentum, quamí; utilitatem, ac noxam inferre poßint, ea paucis cdifferam, que ex Galcno deprompfi, qui in primis lib. I I. Ficorü facul- de alimentorum facultalibus fic fcriptum reliquit. Ficus tumetfi minus praui fuccigignant, quàm cateri omnes non tasex Gal. modó fingaces, fed ctiam autumnales fructus, non tamen id uitium prorfus cffugere potuerunt. Caterum hee ip/is

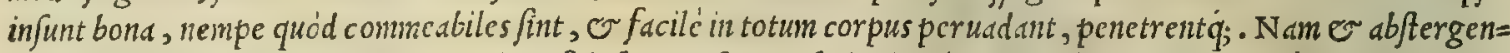

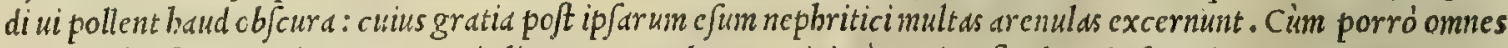
autumnales frubtus exiguum corpori alimentum prebcant, minimé omnium ficubus id ufunenit. Carnem tamen non compactam, neque firman generant, ceu panis, of fuilld caro, , cd turgidulam, or fubinanem, ueluti faba. Quin uentrem flatibus implent $\sim$ ip $s$, e non mediocrem binc profectó molcfiam intuliffent, ni etian celerem defcen= fum effent adcpte, cuius beneficio, cim ccleriter peruadant, flatus qucm cxcitant, non diu manct, atque ob id mi= nus catcris' autumnifructibus ledere confueucrunt. Ceterion mature ficus immatur as non mediocriter antecellunt, quod or in alijs quidem omnibus ccrnitur fructibus : quanquan non tantum in illis difcrimen cxitit. Siquidem ad ple $=$ num matur e ficus paulo minus omni prorfus noxa uacant. Et fcqucnticapite, wbi unarum facultates recenfet, fic inquit. Ficus, o uue qucinadmodun inter fructus autumnales principatum obtinent; ita fugacibus omnibus mag is nutriunt, minimum'́; praui fuccibabent, prefertim cüm cxact.m maturitatcm fuerint adepta. Porró quód ip fa nu= triant, maximo argumento funt ij, qui umearum fructum cuftodiunt: fiquidcm lic cum duos men $c s$ folis uuis, ac fi= cubus, quor un cuftodia prafunt, ue cantur (nififforté panis quidpiam cum illis addant) obefi tamen, ac pingues fiunt. At caro, que ex ipfis gignitur, haud quaquam eft firma, ac den $\int a$, qucmadmodumed, quxe ex carnibus fit; fed laxa eft, ac prebumida: ob id celeriter etiam, cum ue ciip/is defierint, contrabitur, ac confidet. Idem etiam de Ficubus ficcis differens loco prius citato, ita fcribit. Carica multiplicem quidem babent utilitatem; fi quis tamen largius efitaucrit, ab eis offendetur: non admodum cnin probum fanguincm gignunt, quapropter pediculorum quoque agmen eds comitatur. Incidendi, extenuandiq́; uim babent, qua or ucntrcm ad excretioncm irritant, er re= nes expurgant. Iecori autem, licnić; inflammatione obje $\beta$ is funt noxie, quemadmodum $\sigma$ ficus, non peculiari qua = dam eximia facultate, fed communi ratione dulcium omnimsn ciborum, ac potum . Obfructis autem illis, aut fcir $=$ rho tentatis, ip fe ex fe fe nibil profunt, uec obfunt: fed medicamentis incidentibus, ac extenuantibus, or abftergen= tibus mift.x, non mediocriter auxiliantur. Ideóf; nonnulli medicorum in dict is lienis, ac bepatis affectibus exhibent ip as longe ante cibun cuin thymo, aut pipere, aut vingibere, aut pulcgio, dut faturcid, aut calamintha, aut ori= gano, aut byffopo. Ad cunden etiam modum, fi caric $x$ cum alio quopiam corum, que facultatem babent acrem, aut omnino incidendi, ac extenuandi afjumantur, non folim fic affectis; fed fanis quoque utiles erunt. Siquidem iecoris meatus, per quos fertur alimentum, apertos effe non egrotantibus modó; fed bené ualentibus etiam tutißi= mum eft. Proindc hoc pacto ficus cum fale extenuante, aceto, or garo prapardtas uulgó comedunt, quód id utile effe experientia didicerint. Verifimile autem eft, ipforum nonnullos medici cuiufdam confilio adductos, ficus boc modó priminn comediffe; deinde cam notitiam ad uulgus dimanaffe. Qui ueró cum cibo dliquo incrafjante ficus, $\mathfrak{O}$ caricas edunt, non mediocriter offenduntur. Itcm libro vi II. de fimplicium medicamentorum facultate idcm Galenus ita feribit. Ficus aridx uim babent excalfaciendi ordine prino etian completo, aut fecundo incipien= te : babent ueró etian partiun tenuitatě quandam. Ex iftis duabus idone.e funt, qux tumores duros, concoquant: fta= tim ueró ctian cadifcutiunt. Atque ip $\int \mathbb{e}$ per feillite eiufmodi uin obtinent. Sed o decoltum earum ciufdem utique natura eft. Verim ubi magis concoquere confilium eft, mifcenda eft farina triticed: ubi uero plus di= fcutere, lordeaced. panis borum in medio eft. Scd hec magis funt propria tractatus de medicamentorum com: pofitione, e rationis cur andi. uerim in prafentia bec de caricis nouiffc fufficiat. Porro fcire oportet, quod que pinguiores funt, magis poffunt concoquere: qua uero' gufuacriores, magis tum extergere, tum difcutere. Cos terum quod $e x$ ijs plurimim in aqua coftis fficitur, fimile eft melli, non folim confiftentia, fed er facultate. porró ficus uirides come $\int e$, propter admiftan buniáitatem, faculiatis funt imbecillioris: fubducunt tamen aluum utraque tum bumidx, tum ficce. Ficus arbor calidse, tenuiung; partiun ternperature eft, ceu indicant tum li= quor cius, tum foliorum fuccus: ualenter cnin corun uterque calidus cit. I inque non mordicat tantùm, dut abs 


\section{In Lib. primum Diofcoridis.}

fterget webnenter; fed er ulcerdt, or ord udforum referdt, o formicas, quas myrmecias uocant, eijcit: quinetiam purgare potcft. Porró ficus agreftis, quam erineum Grecé (L.atiné caprificum) nominant, tum liquor, tum fuccus ad omnix quàm fatuce walentior cft. Sed $\sigma$ crade, boc eft, rami carum adé funt calide, tenuium'; parthin tcmpcramcuto, ut carncs bubulas duras, $f i$ coquendis adijciantur, friabiles, ac tencras effi= Fici pręcoces. ciant. Wae de ficubus Galenus. Democritus precoces ficos fieri pollicetur, $\sqrt{i}$ olco, or columbaceo fimo ar= bor illinatur. Et contrd, ferotinds; $/ i$ prime großji, cuin fabe magnitudincme exceffere, detrabsutur. Ficum arborem item atquc lumrun, écslo fulminbus non icicompertum eft. "Ficifructus $\sigma \dot{u} x x$ Grecis, Latinis Fi= $c i$, o Ficus appellantur : Arabibus, Sin, Fin, Jeu Tin: Italis, Fichi: Germanis, Feigben: Hipanis, Higos: Gal= lis, Figuier.

10
$\Gamma_{\ell} \sigma_{\varepsilon} \varepsilon^{\prime} \alpha$.
PERSEA.

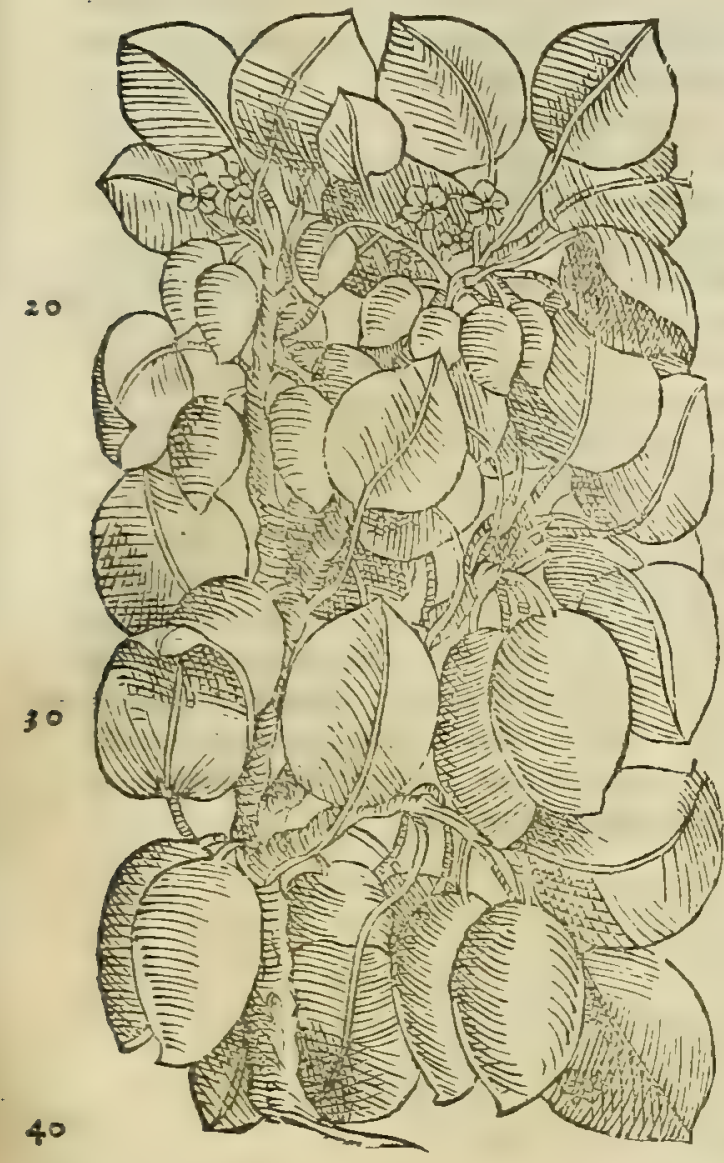

PE R S E A arbor elt in Aegypto, fructum ferens cibo idoneum, ftomacho vitilem . in quo phalạngia cranocolapta nomine inueniuntur, præfertim in Thebaide. Arida folia in farinam redacta, illitu fanguinis eruptiones fiftunt. Arborem hanc prodiderunt aliqui in Perfide exitiofam effe, translatamq́ue in Aegyptum, mutata natura in cibos receptam.

Q V E M A D M O D M fuperius in malorum commenta= tione prodidinus, Perfea arbor Aegyptia non eft ( ut putat Mar= cellus virgilius Florentinus) noftras Italica malus perfica, fed planta plurimùm dißidens af ed, ut or Diofcoridis, or Gale= ni teftinonio facile probari poteft: quandoquidem ij utranque, fed ut alteram ab altera diver $\int a m$, diverfis capitibus tradide $=$ runt. Hec (ut libro I I I I. de plantarum hiftoria cap. I I. fcribit Theophraftus) arbor eft Aegypti, afpectu magna, for= mofác;: folio, flore, ramo, totáq, figura potifirnim pyro ui= cina; nifí quodd altera folio perpetuo altera deciduo eft. Frus ctum abunde parit, omnif;; tempore perficit: quippe nouns an= niculuin femper occupat. Maturitas anniver fariorum afflatu con= ficitur : reliqum crudiorem auferent, atque recondunt . Eft mas gnitudine pyri, figura oblongus, amygdalie modo, colore ber= bidus. Nucein intis babet, ut prunum; uturin longè mitorem, mollioremó;. Caro eius fuauis, ac predulcis manditur, conco= Etúg; facilis, er innocud, etiam largiore cibo fumpta. Radice arbor exuperat, tum longitudine, tum etiam craßitudine, mul= titudine ó, . Materie conftat robufta, durd, uifú, decord, we= luti lotus. Quxpropter ex ed o fimulacrd, o lectulos, o ment= Tas, erètiqua fimiliaf fattitant. Exhis igitur Theophrafti ner= bis, fit Perfea note, ac delineationes cumn noftra perfica malo diligenter conferantur, liquidó patere arbitror, las plantas inter $\int e$ diuer $\int a s e \int f e$. De Ferfea uerba faciens Galenus lib. II. de alimentorum facultatibus, bec memo= gie commendauit. Hanc etiam plantam uidi in Alexandrid;que o ip $\int a$ magnis arboribus eft annumeranda. Tradunt autem fructus huius apud Perfas adeó noxium effe, ut edentes interimat: in Aegyptum ueró translatum, in efculen= tum mitefcere, o pyrorum, malorumí; modo, cum quibus o magnitudine conuenit, efitari. Eadem recenfuit $\mathrm{G} d=$ lenus libro I I. de compofitione medic dimentorum fecundum locos, ubi de cephalea curatione agens, fic inquit. In fola Alexandria perfex arborem uidi, at non in alia Romanis fubdita gente. Quidam perfion ipfam appellant, $d=$ iunto; in Perfis lethalem cius arboris fructum effe, cim tamen is in Aegyptiorum regione innocuus exiftat . bacte= so nus Galenus. Ex cuilus etiam uerbis palàm effe crediderim, perfeam d perfica malo prorfus dißidere, cum in to= ta ferè Europs perficamalus frequentißima proueniat. Quin o ex ijs facilé dixerim, Columellam erraffe, quód Columellals exiftimauerit, perfica ed effe poma, qua à Perfis ad Aegyptios allata perfed dicuntur, ut libro cultui hortorum di= pfus: cato his uerfibus teftatur.

Tunc precox bifera de cèndit ab arbore ficus,

Armenijs's; \& cereolis, prunisq; Damafci

stipantur calathi, of pomis quie Barbard Perfis

Miserat ( ut fand eft) patriys drmatd wenenis.

At nunc expofiti pariu difcrimine lethi

Ambrofios prebent fuccos, oblita nocendi.

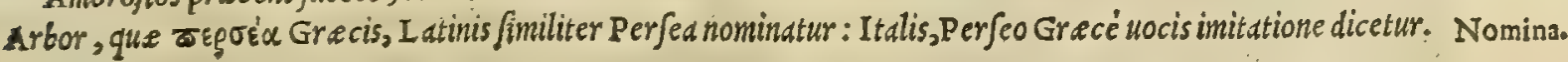

Perlex arbotio.

Perlex men. tio ex Gal. ris confidera-

$$
\mathrm{P}=\text { IBsgis }
$$


I'Eeçis. I B E R I S.

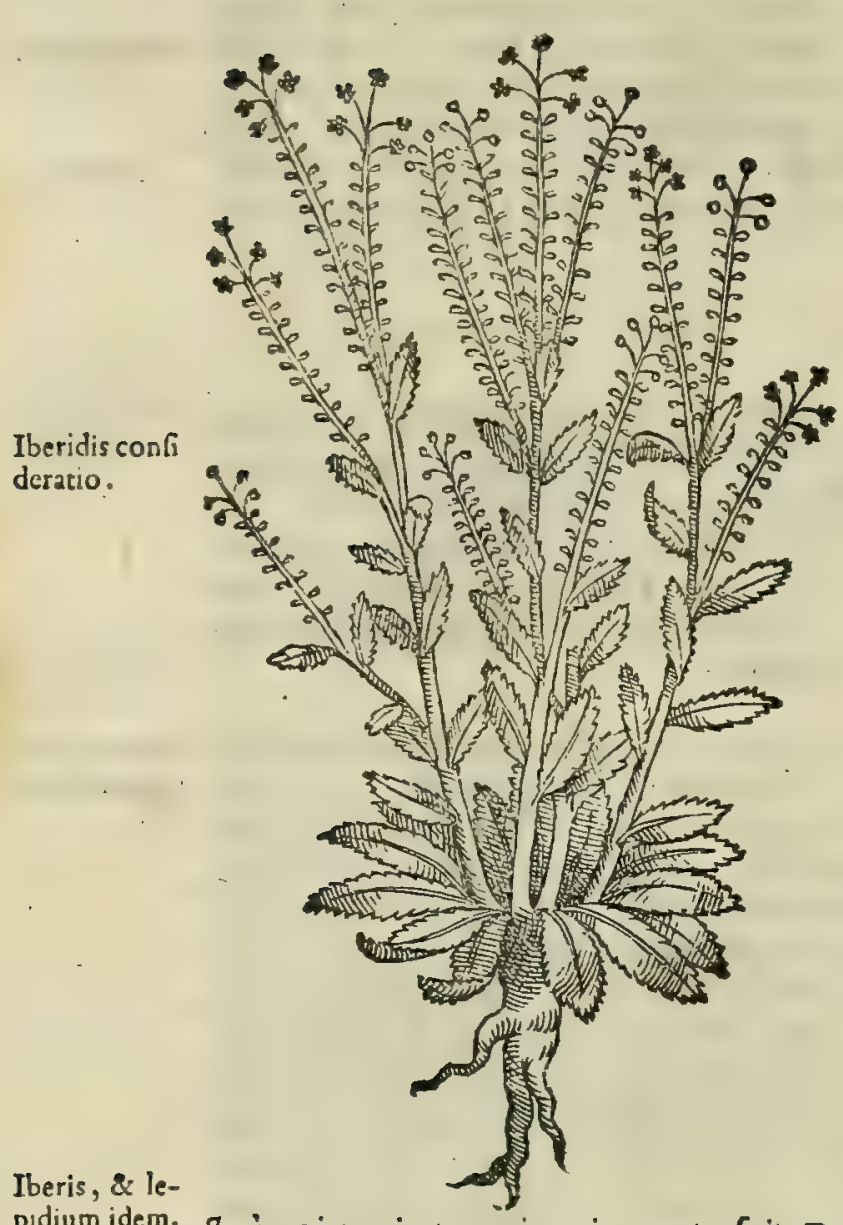

CAP. CXIVII.

† I B E I $s$, fiue cardamantica, folia habet nafturtij, uere uirentiora : caulem cubitalem, aut minorem, in incultis naficitur. Aeftate lacteum florem promit; quo tempore efficacior eft. Radices duas nafturtio fimiles ha bet, calfacientes, \& adurentes. Ip $æ$ enim ifchiadicis cum falfa axungia emplaftri modo vtiles, quaternis horis alligatæ, vt dein in balneas defcendatur, \& poftea oleo cú $\geq 0$ lana locus perungatur.

V I I I M V $s$ primiın Iberidem, quam nobis indicauerat Iulius Alexandrinus medicus Tridentinus, qui nunc ob praclara fui ingeniy, o $\sim$ doctrine dotes, apud Sercniß. Ferdinandum Re= gem Roman. artem medic am exercet, extra ciuitatem Tridenti, ubi uulgó dicitur alle Lafte, effigie nimirum, qua defcribitur ḋ Diofcoride, ac alijs pluribus Grecis auctoribus. Huius Galenus in fimp. cenfu nufquam feparatim meminit, fed hanc, or Lepidium non nifi nomine differre prodidit. Quod etiam idem teftatus eft 20 libro x. de compofitione medicamentorum fecundum locos circa finem de coxendicum curatione agens, ubi ex Damocrate fic in= quit. Damocratis extat libellus, qui Clinic us infcribitur, in quo uerfibusiambicis, quemadmodum folet, de tribus differit medica $=$ mentis. Ac primó quidem de co differit, quod ex herba conftat, quan ipfe Iberidem appellat, quod ad coxendicum dolores com= mend sut . In Iberide medicum quendam amicum fuum curatum fuiffe ait herba, quam (ut dixi) ipfe Dumocrates Iberidem nocdt, ut qui tantium uifu berbam cognouerit, nomen autem eius nullum audierit, cum etiam id ipfum ignorauerit is, à quo eius ufum didi $=30$ cerat. Porró ex notis, quibus eam reprefentat, uidetur iberidem appellare, que dे Grecis lepidium nominatur, appellatione du= pidium idem. at à regione, in qua amicus cius curatus fuit. Defcribit autem ipfius forman ijs carminibus.

Herba bec ubiq; multa'; frequens nafcitur,

Monumenta iuxtd antiqud, muros, o veteres.

Tritasó; quondam publicé pedibus uias,

Quas iuxta aratrun duxit haud quis agricold.

semper uirefcens, folijs nafturtii

Florentibus uere, attamen maioribus.

Caulcm cubitalis longitudinis gerit

aulo minorem, aut rurfus ampliorem : ab hoc

Aeftate pendent folia, donec multa byems

Sarmentitiam deducat bec ad imaginem, $O$

Deicta, o exiccata depereant gelu.

Adnata radici tamen cernes alia.

Acftate florem fert colore lacteo,

Multùm tenuem, uarium ; ualde, cauliculis.

Ad quem fequitur femen penitus fic exiguum;

Vifum feré ut fallens, oculos quoque effugiat.

Odorem habet radix at indé acerrimum,

Veró fimilem quìm maximénafturtio .

Huc illud etian accedit, quód Galenus item loco citato, Hygieni Hipparchi auctoritate, Iberidem, or Lcpidium idĕ effe tcft.tur his uerbis. Si coxcndicum dolores leuare eft animus, herb. .m I Iberidem, quam aliquil lcpidivim uocant, Iberidis caput aut nafturtium fylucftre colligito. Excuius rerté fententia afferere non dubitauerin, Ibcridcm apud Grecos addititium. eanden effe cum Lepidio. Vude perpicuum eft, hoc Iberidis caput buiufce primi uoluminis calct accreuife nimis uel librariorum, uel medicorum curiofitate. In quam fententiann cum antedictis caufis, ea ratio me potißimuin deducit, quodd conftet, huius primi woluninis calcem, non cffe legitimum locum, in quo Ibcridis hiftoria fuerit collocanda: quandoquidem eiufmodi herbas Diofcorides lib.r I ordinate difofuit, ac de cis differuit, ubi priustim lepidio, quod Damocrati Iberidem exift imamus, propriam aßignauit fedem. Idcirco recté $\mathbf{P}$ aulus Aegineta Lepidium Iberida etiă appellarifcribit, or cx tcrtio excalfacientium ordine effe, ac nafturtio uiribus proximum. Et lib. I. I. in ifchiadis curatione: In totum, inquit, ifchiadicos reftituit fantati iberidis berbe ufus, quam lepidium quoque appcllnit. 


\section{In Lib. primum Diofcoridis. $\quad 173$}

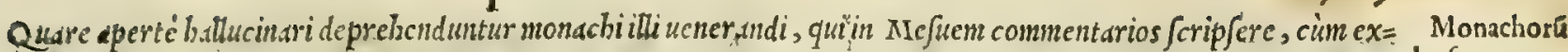
preßé contra Galeni, or Pâli auctoritatem, o contra rationcs, quas fuperius adduximus, aliud ḋ lepidio iberidem Iaplus.

effe contendant. Quos tamen excufatos babeo, utpote qui fortaffc maius ftudium rebus diuinis impenderint, quàm ut certam fimplicimn nedicantentorum cognitionem affequi potuerint. Cetcrimnonignorandum $\mathrm{f} f, \mathrm{P}$ aulum

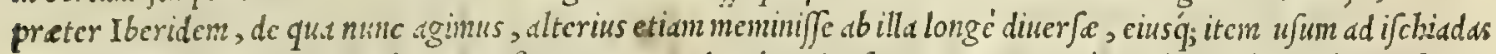
commend.tfe: Quod eius scrba demonftrant, quxe edem loco ita fonant: Qua ueró apud nos Iberis fiuticofa na= fcitur fimilibus laurifolijs, $\mathfrak{O}$ multó dmplioribus, reponderc multa experincuta tcftantur, non folim in coxarum, fed in alijs quoque diuturnis affectibus. Huic plané adftipulatur Lepidium, quod Plinio lib. x I X. cap. v I I I. his paucis de feribitur. Exit lepidium in cubitalem altitudinem, folijs laurinis. Quibus fane notis fatis apparet, boc fe= cundun Ibcridis gemus, ucllepidij dicamus, quod laurifolia mittit, eam effeftirpem, qua bodie paßim in hortis fre= quens nufcitur, à quibufdan Piperitis ob uebementem eius acrimonian dictd. Itaque maniffté aberrarunt uirialio= qui ch.rifini Barbarus, o Rucllius, cum lepidium illud effe putauerint, quod uulgus herbariorum Raphanum ru= fticamun appellant. Veruntamen folia, que buic raphano infunt, uerbafco maiora, er belenio aqualia, manifffé declarant, bis legitimum non innotuife lepidium. niff forfan leptdium Raphani nomine acceperint. Plante, que

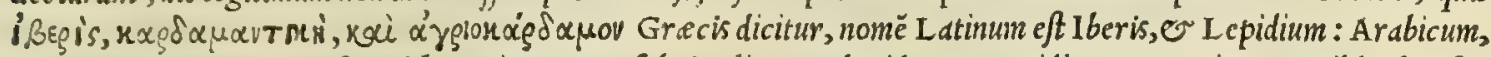
Seitar.gi, A fccituragi, feu sitharegi, o Haufab: Italicum, Iberide, o Lepidio: Germanicum, Vuilder lirefz: Hifpanicum, Nafturtio montefmo: Gallicum, Chaffe rage, Pafferaige, er Nafitort faunage.

+ Quod caput hoc de 1 beride dccreucrit in Diofcoride, eif; adfcriptum fit, illud maximé corroborat rationes in commeniario allatas, quod repertifint uetuftißimi Greci codices, in quibus hoc eaput non lcgebatur.

\section{I B R I P R I M I F I N I S.}




\title{
PETR I A NDR EAE MATTHIOLI MEDICI Senenfis Commentarii,
}

\section{IN LIB. SECVNDVM PEDACII DIOSCORIDIS}

\author{
A N A ARBEI, DE MEDICA MATERIA.
}

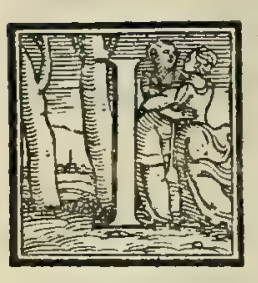

$N$ P R I M O, charißime Aree, libro, quem de medicinali materia condidimus, de aromatibus, oleis, vinguentis, arboribus, $\mathcal{G}$ nafcentibus ex eis fuccis, lacrymis, feminibusq́u differuimus. In hoc autem fecundo de animantibus, melle, lacte, adipe, frug $i_{\text {- }}$ bus, atque oleribus explicabimus, fubnexis herbaceis, que acri predita funt facultate, 20 vtpote que cum ip 2 s cognatione iuncta fint : qualia allium, cepa, finapi intelliguntur. Idque ideo, ne cognatorum vires difunxiffe videamur .
CAP. I.

MARINVS Echinus ftomacho, uentrique utilis eft : urinam cit. Huius tefta cruda inaffata commodè medicament is admifcetur, quæ pforas abftergunt. Crematæ uerò cinis fordida ulcera expurgat, luxuriantem carnem reprimit.

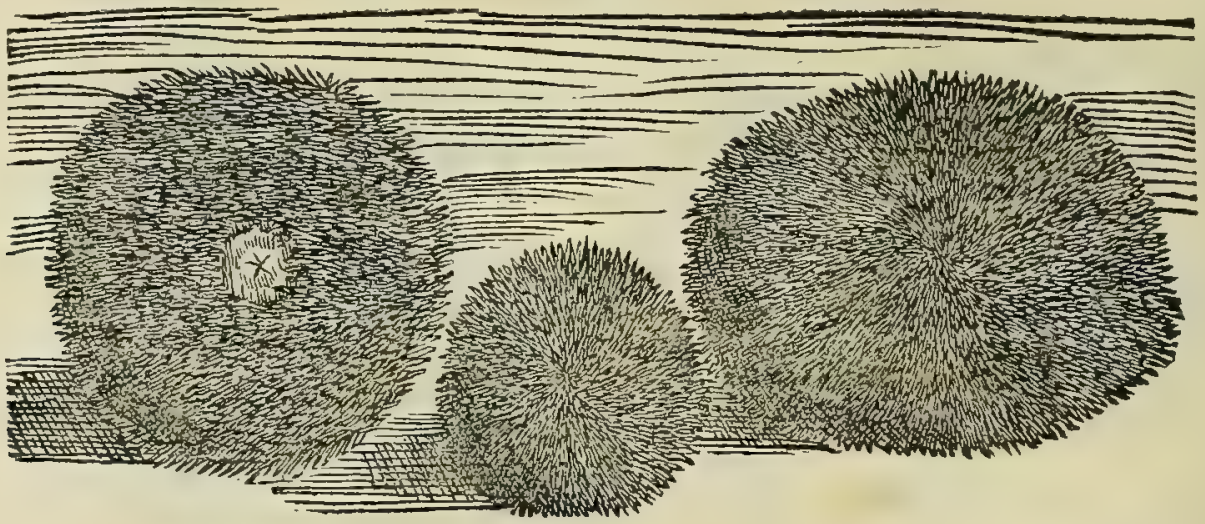

Echini marini confideratio.

E C H I N $s$ marinus notifimuseft, ijs prefertim, qui in Italia tam Tyrrbeni, quàm Adriaticilittora dcco= lunt. Ingentem Echinorum numerum uidimus nos, dum placidis mare ageretur undis, in alueo magni portus Ciuita= tis uetere in Romano litore, nigris borrentibus pinis. Alios ueró uidi ex Pirano Iftria oppido allatos, his longe maiores, purpurco colore $\int u f f u \int o s, q u o s$ Echinometras appellauerim, quód fcripferit Ariftoteles libro I I $1 x$. de bi= ftoria animaliun capite quinto, bos ceteros magnitudine excedere. Habentur circa Toronem Echini marini candidi tefta, pina, or ouo: augeri forma productiore, quàn cateri, foliti: pinis paruis, non rigidis, fed mollioribus. Ge= ner.t (ut idcm inquit) Echinorum plurima funt. Primum, quod cibo idoneum eft, in quo, qua oua appellantur, ma= gna, efculcntá;; confiftunt, pariter in maiore corpore, or minore: nam nouelli adbuc, paruiq́; pleniufculiillis cö=

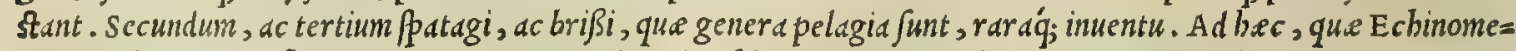
tra appellatur ( quafi inatrcin, aut matricem dixcris cchinorum) qua quidem omnes magnitudine excedit. Genus item aliud eft minutum, pinis longis, preduris $q_{;}$, gigni in al to gurgite folitum, quo nonnulli ad deftillationes urine nedicamento utuntur. Quo fit, ut Paulum Iouium plane abcrrafe crediderim : quippe qui fuo de Romanis pifci= bus libello, Echinometram Ariftoteli deftillationbus urine opitulari, non autem buiufce minutigenus, memorta pro= diderit. Corpus Echinis clibani forma uifitur, priore, atque nouißima parte ßpifum, er continens : catera ueró non continuum, fed finile laterne, cui non obducta membrana eft. Omnium maximé à natura muniti funt, utpote qui te fta undique penis circumuallata celentur, quibus utuntur perinde ac pedibus : ijs cnim nitibundi mouentur, fedeng. permutant, cuius reiargumentum eft, quód femper algam pinis implexam gerant. Euenit autem, ut quod caput appellant, $\mathcal{O}^{\circ}$ os, eclinis uerfum in terran fit : quod ueró ad excrementi exitum deputatum eft, id fupra babeatur. 


\section{In Lib. fecundum Diolcoridis.}

quod idem omibus turbinatis, patcllisif; eucnit: paftus enim de inis petatur neceffe eft. Vnde fit, ut os inuerfum ad paftum fit, excrementum ucró fuperius parte prona tefte continedtur. Dentes quini Echinis onmibus. funt, caui in= trinfecus: inter quos carunculy quxdam interiacens lingux officio fungttur, mox iungitur guld, deinde uenter in partes quinq; diftinctus, perinde ac fi plures numcro ucntres boc animal habeat: funt cnim onmes difincti, pleniq́, uacit is materi.e, er ex uno ftomacho dependent, in unumq́; oftum excrementifiniunt. Caro echinis circa uentrem nulla, ficuti in uniuer fo corpore. Sed que oux appellantur, nunerofiora tefta adherent, membranulis fingula obu noluta, es paribus diftinct. interuallis: nigra ctian quadan circum ab ore fufin parguntur, nomine adbuc nul= lo appellats. Sed cum non unum, fed plura genera Eclinorum fint, cmnium partes quidem cas onnes fortiuntur: fed ous appellats, nec omnes cibo idoned, or parua admodum continent, exceptis ijs, qui uada incolunt. Tradunt

10 Senitiam maris Echinos prefagire, correptisq́; operiri lapillis, mobilitatem pondere ftabilientes. Quod ubi uidere nautici, fatim pluribus ancboris nauigia infianant. hec ex Ariftotele. Meminit utriusq; Echin Galenus, mari= $n i$, fcilicet, or terrçtris unico tantiun capite libro x I. fimplicium medicamentorum, fic inquiens. Ertinacei utriufq; tum marini, tum tcrreftris corpus totum uftum cinerem efficit facultatis-tum extergentis, tum digerentis, tum detrd= bentis. Itaque eo quidam $\sigma$ ad cxcrefcentia, of ad fordida ufi funt ulcera. Animal, quod Ex ivos a $\alpha \lambda x$ arios Gracis, Iatinis Echinus marinus appellatur: Hipanis, Erizo de la mar: Italis, Riccio marino.

HYSTRIX.

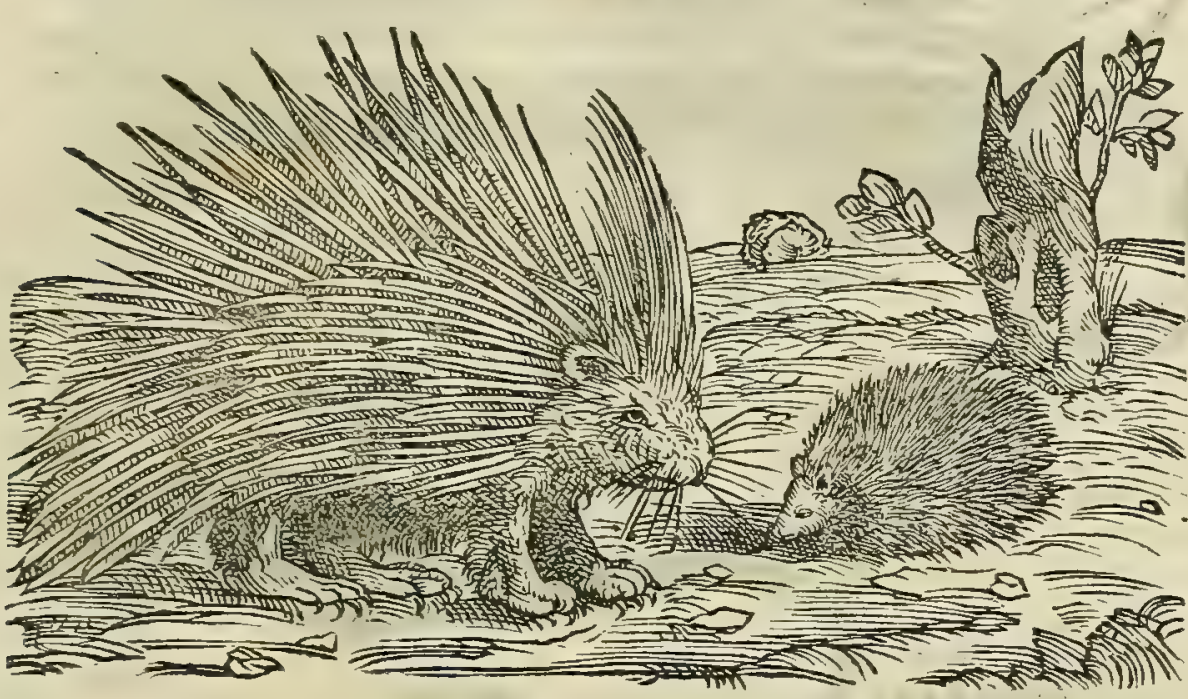

E'Xĩyos Xesoũós. ECHINVS TERRESTRIS.
Echinorū uires cx Galen. Nomina.

TER R S TR I \& erinacei corium combuftum alopecijs cum pice liquida aptifsimè illinitur. Afsicatum corpus, \& cum aceto mulfo potum renum uitijs auxilio eft: item aquæ, qux cutem fubijt, conuulfionibus, clephantia, \& malè habitis, quos cachectos uocant : uifcerum flu49 xiones exiccat. Eiufdem iecur fictili folibus excocto arefactum, ad eofdem ufus utilifsimè reconditur.

T E R R E S T R I S Erindecus uulgaris notitix animal in Italia eft. Dülici conftat genere, canino fcilicet, Echini terreac fuillo, quemadmodum e tafju.s. Differentia dignofcitur ex corum roftro. Id nanque alij fuillum, alij ueró $c d=$ ninum babent. Raró ex cauernis exeunt, nifi noctu. quo fit, ut nocturno tempore ḋ uenatoribus plerunque capian= tur. Mature fcentibus unis per aftatem, $\odot$ autumnum uineas petunt, ubi ad uuds, qua folum attingunt, acceden= tes, acinos pedibus áiducunt. His conftratis in terra, in orbem fe conglomerant, e fuper cos fe uolutant, itáf; pis. nis affixos portant in pecuin. Eodemó; actu fylueftrium arborum poma à uentis decuffa, aut maturitate decidua, in calus arbores gerunt. Inter quadrupedes folus Erinaceus uolatilium more teftes renibus berentes habet : eág; pro= so pter uelocißine coit, non quidem aliorum quadrupedum more fuperueniens; fed erectus coniungitur propter $p i=$ nas. Vbi prefenfit uenantem, ftatim in glotum fe contrabit, ne quid comprehendi poßit prater aculeos: itáque oblatrantes deludit canes. Affufa conglomerato aqua, illico foluitur is, $\mathrm{O}$ ingreditur. Frigidi temperamenti $a=$ nimal Echunus eft, excrementis compluribus redundans, quibus aculei nutriuntur. Idcirco eius carnes in medica = mentorum potius, quim in ciborum ufu funt expetenda : terreftres enim cum fint, agré concoquuntur, o $r$ miniz. mum fane prebent alimenti. Vires longè plures ijs Echino reddidit $\mathrm{R}$ afis libro de fexaginta animalibus. Veruntd= men quoniam itha, qua ibileguntur, potius apocrypha, quàm fide digna femper exiftimaui; ideo hic ea ddnotanda non duxi. Ceterüm qui funt harum rerum cupidi, eo fe conferre poterunt, ubi diffufius tractantur. Erinaceo Hyftricis m. rum generi adfcribitur HYS TRIX, quód forma fit illinon abfimilis, quanquam corpore longé maior: quin er tio. longioribus aculeis, firmis, tenuißiméue mucronatis undequaque riget : in pecubus moratur, ev noctu magis, quadin interdiu ad pafcua exit. Latet boc animal byeme in cauernis, ut urfus, totidemǵ; diebus fert utero fretum. Irata byftrix intendit cutem, o tunc fuos iaculatur aculeos. Quo fit, ut non modo canes, fed quandoçue uenatores fe=

Atris confideratio.

Echini terrefris facult.

riat." 
riat. Combufti cinis potus ( $u$ t plinius eft audtor) partus conceptos continet. Animal, quod Éx ivos Xégंǘs Graco fermone, Echinus terreftris Latino uocatur: Arabico, Ceufud, fue Caufed: Italico, Riccio terreftre: Ger= manico, Hechel, aut Ygel: Hipanico, Erizo : Gallico, Herifon.

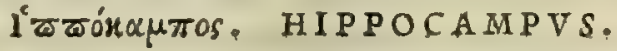
CA P. III.

H I P P o C A M P V S marinum animal eft exiguum. Cuius cremati cinis exceptus cum liquida: pice, aut axungia, feu amaracino vnguento illitus, alopecias replet.

HIPPOCAMPVS, LOCVSTAE GENVS.

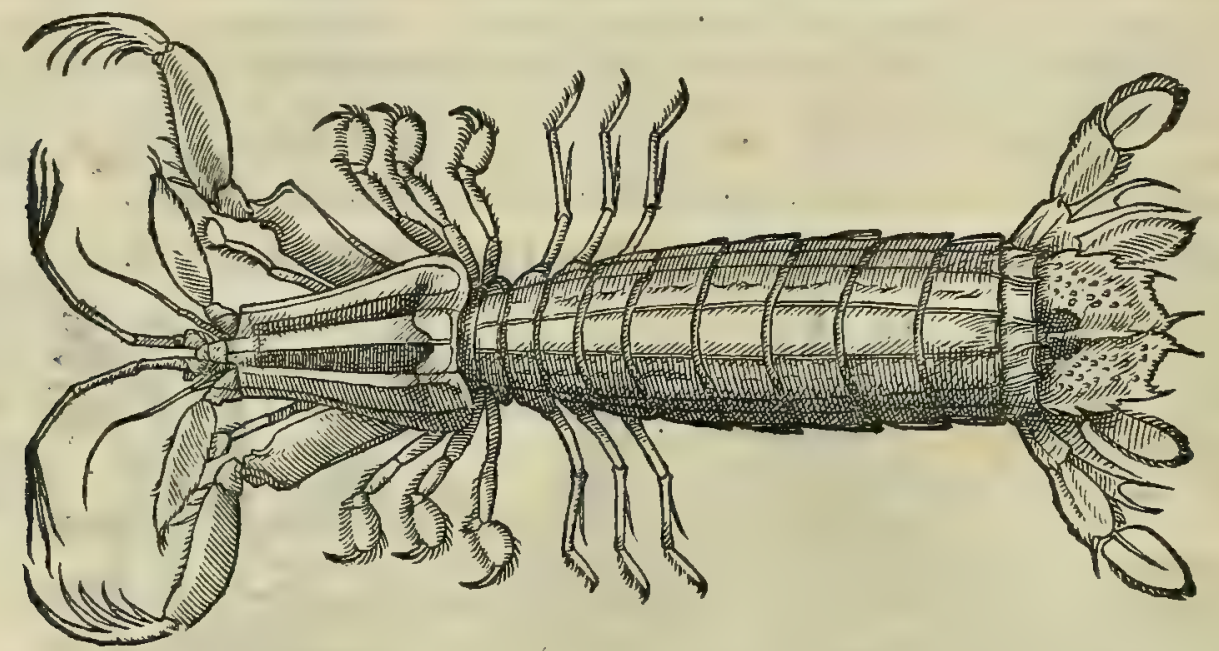

HIP POCAMPVS, EQVVLVS MARINVS.

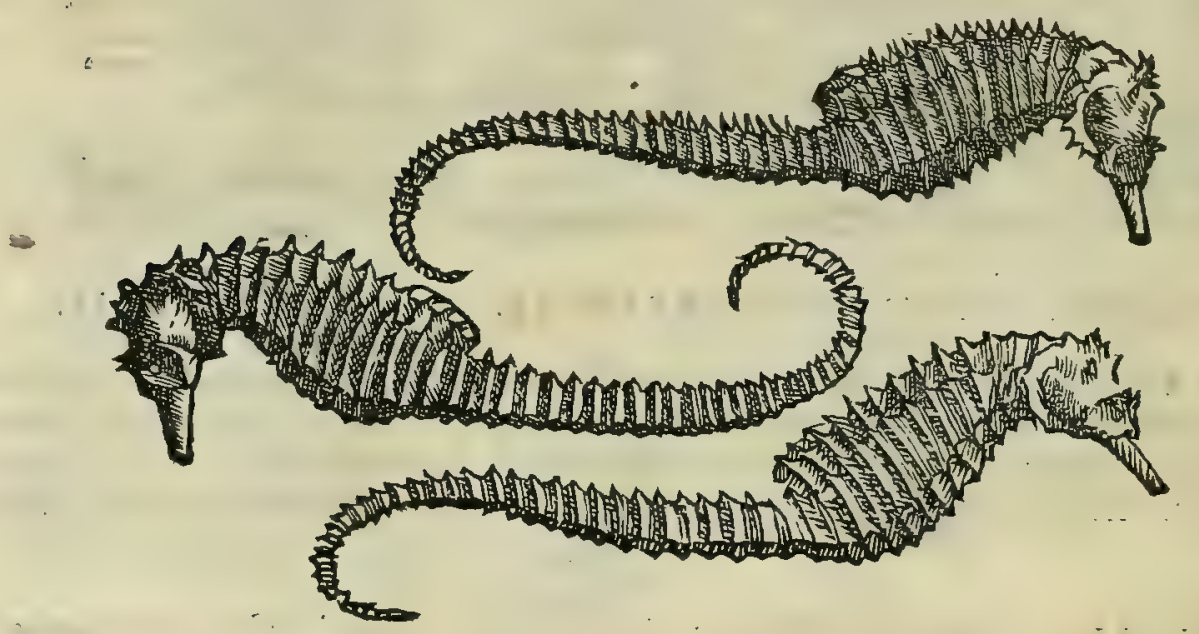

Hippocampi confideratio, 8 opiniones.

Qv A $\mathrm{N}$ v A M non defunt fcriptores, tam inter ueteres, quim recentiores, qui in locuftarum gencre Hippo= campun recenfeant, quiq; ad multos in medicinis $u$ us eum cominendent; corum tamen bactenus reperi neminem, qui peculiaribus notis eius biftoriam tradiderit, effigiem q; exprompferit. Ceterùm funt, qui credant, Hippocampum id nominis fibi afciuiffe ab erucis, que in bort is olera; in campis ueró berbss uniuer $\int a s, \mathcal{O}$ arborum frondes depafcun=

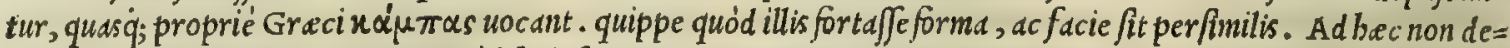
funt, qui Diofcoridem mirentur, quód fcripferit, Hippocampum exiguum animal efe, cum tamen nomen plerunque

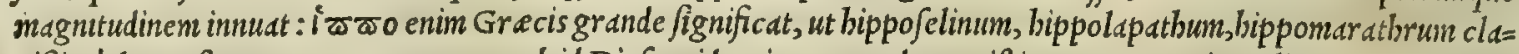
rißime demonftrant. Veruntamen non ob id Diofcoridem impugnandum exiftimant, nec pariter alios, qui de eo idem fcripfere. Quoniam licet comparatum boc animal marinis beluis, alijsó; in aquatilium genere grandioribus, paruum tideatur; fi tamen eo erucarum generi comparetur, quarum imaginem, formam q́; reddit, es à quibuis nomen accepit,

Prima opin. grande fanéfuerit. Vnde inclinauit quandoq; animus, eum effe Hippocampum, qui pifcatoribus A quileienfibus uul= go uocatur Faloppa. Corpus buic ineft locuft a modo in longitudinem protenfun : capite, er ceruice oblongis: chel is minimé bifidis, fed acutißimis folidisq́; aculeis rigentibus : pedibus fexdenis, quorum decem, qui circum os habentur; fcorpionum caudas extremitatibus referunt; cateri ueró ut in locuftis pectantur. Cormud capite gerit fex, quor um poftrema in latum funduntur. Dorfo eft flexuo fo erucarum modo, adeó ut in ficco earum feré modo perambulet. Can dam gerit latam, alis pluribus $\int e$ pandentem, rigentibus undiq; aculeis, maculis duabus purpureis natura artificio in fignitam : adeó ut bis notis qua dam uillofas erucas referat in nigro rufefcentes, qua part forma fub terra degunt in 


\section{In Lib. fecundum Diofcoridis.}

bortis, $\odot$ agris; olerum, co fegetun radices erodentes. Has Tridentina rura uocant unlgó Cagne; Ananicnfes ue=

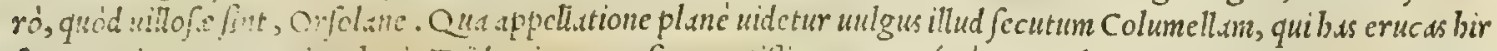

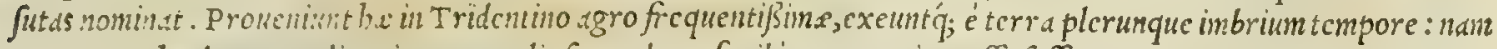
que prope berb.rum radices in cauc mulis fe condunt, fucile aquarun ingreffu fuffocantur. Quapropter olitores ijs

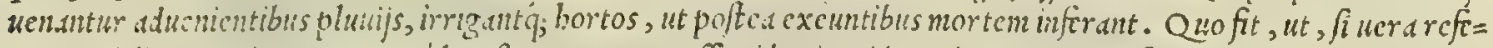

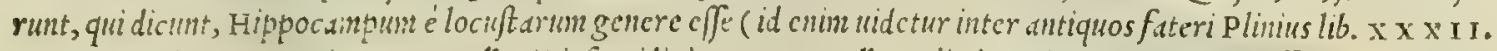
cap. $\mathrm{X}$ I. O inter recentiores Na arcellus Diofcoridis interpres) nullum aliud nurimum animal fefe offerat, quod illud magis refrre ualcat, quisrid, de quo dixumus. Sunt er alij, qui pro certo uelint, Hippocampum effe pifciculum illum, uel pothis nn.rinum nonftrum, qui quibufdan Dracunculus, alijs ueró Equiculus marinus uocatur, ckius nullus

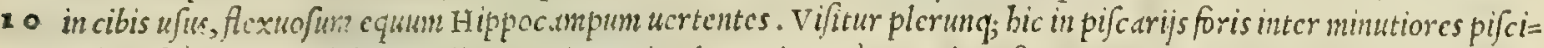
culos, feinidodrantdi longitudine : capite potius draconis, quim equi: roftro anteriori parte prominente, pectore

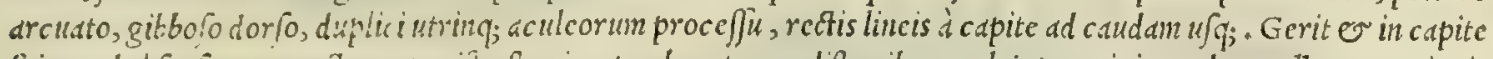

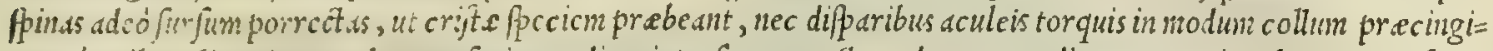
tur : é quibus ali. oritur acsilcorun feries medium interfec ans pectus, duorum inedia, qua utring; later a tranfcur=

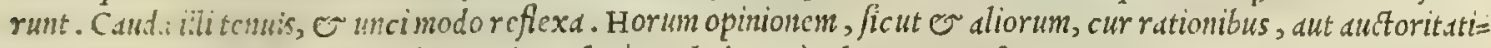
bus comprobem, cur iten contrì reprobem, fané non labeo, cum hactenus nufquam in probatißimorun auctorun mo

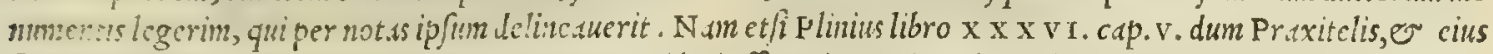
filij Conkifodori admiranda percurrit marmo:a, uideri aferat in maxima dignatione Cn. Domitij delubro in circo Fl.tmminio Neptumum, Thetim, atq; A chillem, Nereidasq; fupra delphinos, e bippocampos; cum t.men bec poëti=

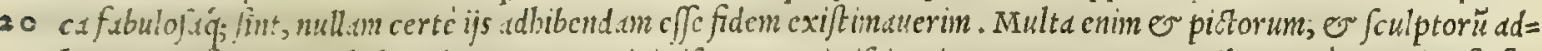
buc ext.nt figmenta, wbi locis immmeris in arini uifuntur equi pifcium in morcm natantes, quibus tantum equind fit $f_{d=}$

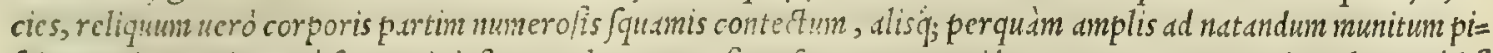
frium modo, partin ucró ferpentis inftar prelongum ac finuofm, inxgna quidem, non parua corporis inole. Quòd fi

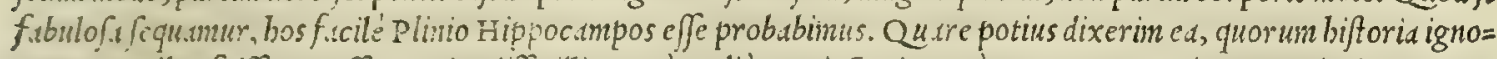
ratur, comnibus fuife, e effe cognitu difficillima, cim alias coniceturis tantum agatur. Hippocampi uires recen= fuit Gulcmus libro X I. finplicinm medicainentorum, fic inquicns. Et $t$ Hippocampum animal illud marinum fi totum ufferis, alopeciijs prodeffe proditum quibufdam eft, ipfunǵ; uidelicet de iccantis effe facultatis, o tenuium partium, dut certe' cius cincrem: quen quidam unguento amaracino commifcent, quidam piciliquida, alij ueteri adipi fuillo. bac Galenus. Ceterinn longé alias Hippocampi uires retulit Aclianus lib. X I. cap. L I I. de biftoria animalium:

3.0 cuius ucrba bic fubijcitm. Reipif diorie vite periti homines dicunt Hippocampi uentren in uino decoctum /i quis de= derit cuptin: bibcre, cum primó ex cx potione acerrino fingultu affici, deinde tußire, 0 ficcd ciuidem tußi uchemen ter torqueri. At cinn nibil excreare, fed o fuperiorem ei uentrem intume fccre, $\sigma$ calidos naporcs in caput furfum efferri, uc inde per nares minutation defuere, o pufculentum odorem reddere, finul e oculos eitis. fanguine fuffu= fos ignei coloris flagrantia labor are, or corundem oculornm gends inflari, oo uomendi quidem cupiditate ardere fe= runt, uerkinn nilil emittere . Quód fi nutura cuicerit, hunc tumen, periclitat. prius morte, in obliuionem, or demen= tium incurrere. fin in ucntrem inferioren del apfum fucrit, ipfum omnibus ian menbris captun ć uita excedere. Ex

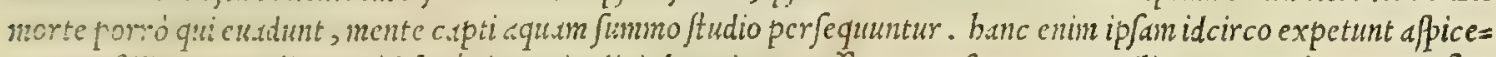

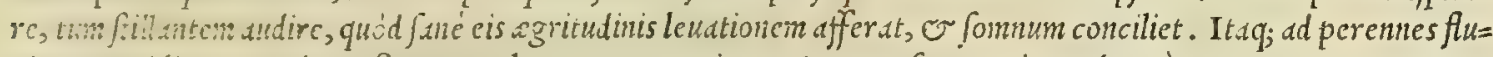
tivs, aut ad litor, aut inges fontes, aut lacus commorationes eis grate funt, o iucinda : cum tamen non magnopere 40. defiderent bibere, sed $\sim$ ipfun natare, o pedes aqua alluere eis plurinum iucunditatis adfert. Sunt qui non bec ina la dic unt huius beftix nentrem creare, fcd Hippocampum algam acerbißimam, ex qua ita afficitur, depafci. Verunta men folertia ueterani pifcatoris, of ad res maritimas benc prudentis, faluiaris etian repertus eft Hippocaimpus o is $\sim C$ Cretenfis erat, $\odot$ filios adinodum adolefcentes pifcatores etiam babebat. Accidit autem, ut hic pifcator Hippo= campos finul cum alijs pifcibus caperet, er peradolefcentes d̀ rabida canicula morderentur. Cün corum in Methy= $n$. Cretcn/i ad litus iacentiun uiccm dolentes pectatores interficiendam caniculam cenferent, o illius iecur medica mentum ad rabicm cdendumiurenibus dandum effe : alij confulerent à Diana falutem petendam c fe ; fenex pifcator cos de confilijs, quie afferrent, laudatos dimifit, e Hippocainporum exenteratorum alios affos eis comedendum de=

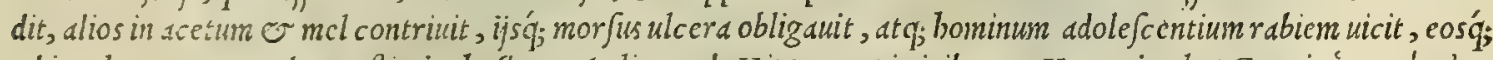

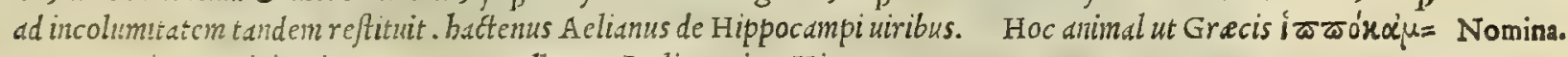

so $\pi 0 s$, ita etiam Latinis Hippocampus appellatur: Italis pariter Hippocampo.

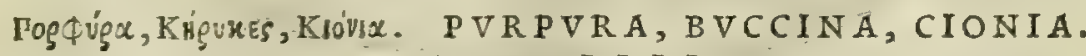 C A P. I I I I.}

PVRPVRA ufta exiccat, dentes abftergit, excrefcentias in carne cohibet, vlcera purgat, \& ad cicatri cem perducit. Eadem præftant concremata Buccina, fed vehementius vrunt. Siquis falis plena fictili crudo adurat, dentificio conueniunt: ambuftis utiliter illinuntur, quibus folui medicamentum non oportet: nam pofteaquàm vulnus cicatrıcem duxerit, ipfum in teftx modum induratum, fponte fua decidet. Fit etiam calx è buccinis, vt in eius mentione demonftrabimus . Cionia uocantur purpu rarum, buccinorumq́. medix partes, circa quas teftre volumen clauiculatim intorquetur. Cremata fimili modo, maioré purpuris, buccinisć; facultatem urendi confequuntur, quoniam apprimendi natu ram obtinent. Buccinorum carnes ori gratæ funt, \& Itomacho vtiles, fed aluum non molliunt. 


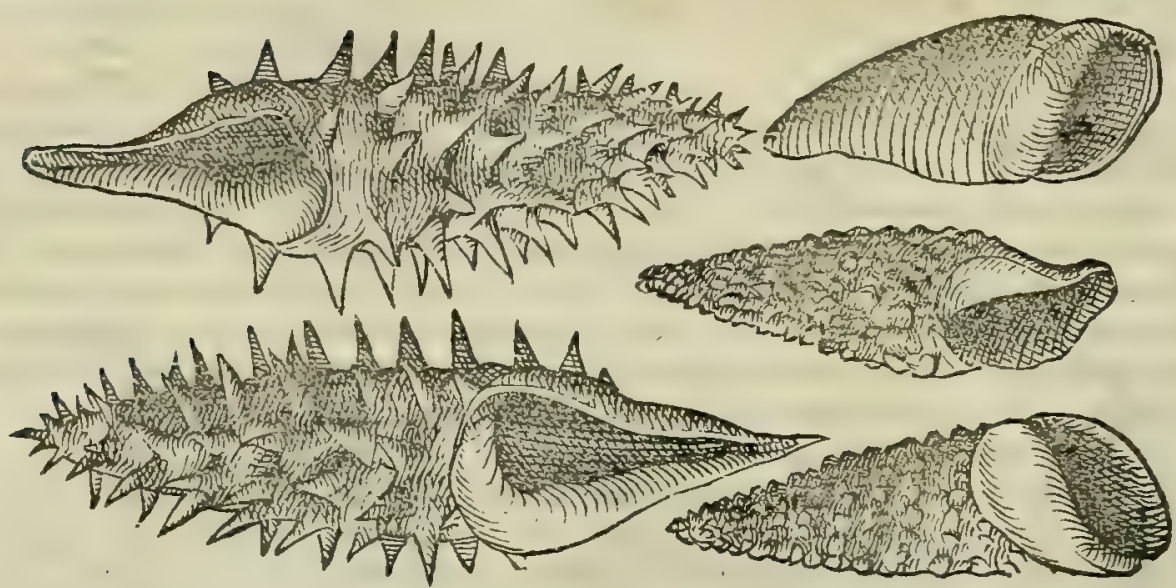

Purpurarum confid.

Buccinum.
S V N T O Purpure marini pifces, eius fané generis, que tefta integuntur. He (ut autor eft Plinius lib. I X capite $\mathrm{x} \times \mathrm{X}$ V I.) illum magni pretij florem retinent, purpureum proprie dictum, tingendis regum uestibus expeti= tum. Hunc in medijs faucibus gerunt, candida quadam uena conclufum, colore nigricantis rof e pellucidum. Viuas capere contendunt, quis cum uit a fua fuccann illum euomunt. L atent circa canis ortum tricenis dicbus. Congregan= tur uerno tempore, mutuoq́; attritulentorem cuiufdan cere faliuant. Lingua Purpura digitali longitudine, qua pafcitur perfor ando reliqua conchylia : tanta duritia aculeo eft. Capiuniur autem purpura paruulis, rarisq́; textu. ueluti naßis, in alto iatiis. Inest ìs efca, clufiles, mordacesq; conche, quales mitulos uidemus. has femineces, fed redditas mari anido biatu reuiuifcentes, appetunt purpure, porrettis q́; linguis infestant. At ille aculeo extimulate claudunt $\int e f e$, comprimuntó; , nordentia : ita pendentes auiditate fua purpura tolluntur. Aqua dulci necantur, o $f i=$ cubiflumini immerguntur : alioqui capte diebus quinquagenis uiunt faliua fua. Anno magnitudinem implent,celer= riméq; crefcunt, quemadmodun o conchylia omnia. Eft in purpurarum genere e Buccinum ad fimilitudinem cius buccini, quo fonus editur: unde $\sigma$ caufa nomini, o rotunditate oris in margine incifa. Sed inaior cft purpura, 30 cuniculatim procurrente roftro, or cuniculi latere introrfus tubulato, qua proferatur lingud. Cui circim orbes acu leati, qui buccino non infunt, ed utrifq; orbes totidem, quot babent annos. Buccinum non nifi petris adberet, circdí; fcopulos legitur . Purpure, buccind q; fimul, quemadmodum er reliqua conchylium genera longa fané narratione fcriptis celebrata funt $a b$ Atbeneo. Ad eius igitur uolumina accedant ij, qui plura fcire defidcrant. Sed quonian

\section{MARGARITARVM CONCHA.}

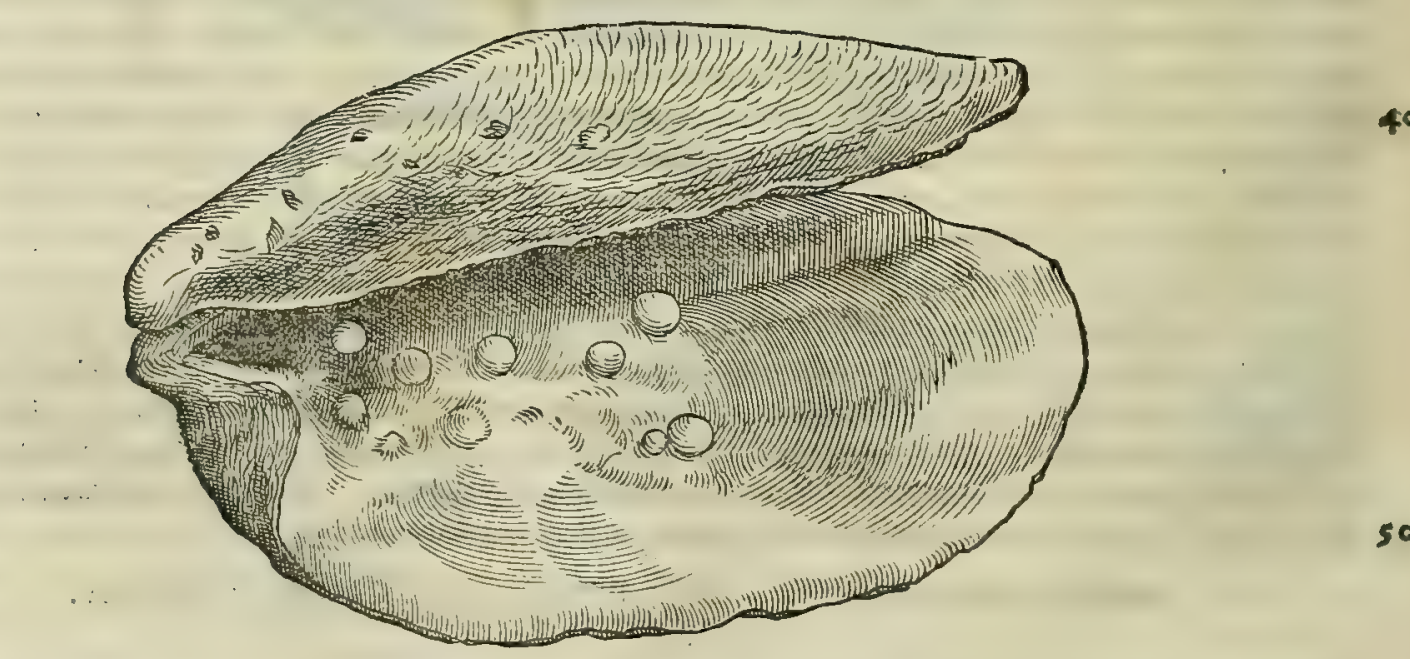

Margaritarŭ, M A R G A R I T A E, que non modó ad mulierum, bominumí; decorem, fed etiam ad medicamenta maximo luxu. \& earum con expetuntur, a marinis $\mathcal{O}$ ipfe gignuntur conchis, hic inter pretiofa conchylia eas recenfere non ab re fore duximus; che hiftoria.

prafertim quód neq; Diofcorides, neque Galenus de bis quicquam, quod legerim, pofteritatis memoria prodiderunt. Nafci itaque animalia, que margaritas gignunt, in oceano Indico refert Plinius lib. I X. cap. $\mathrm{x} \times \mathrm{x}$ v. Fertilis admo= dum earum eft Taprobane, of Torois, item Perimula promontorium Indie, circa A rabiam in Perfico finu maris ru= bri. origo, atque genitur a conche eft haud multim oftrearum conchis differens, ut liquidó conftat ex ijs, quas no= friuulgó Madriperle appellant, que ad nos deferuntur. Has ubigenitalis anni ftimulauerit bora, pandentes fefe quadam ofcitatione impleri rofcido conceptu tradunt, grauidas fattas poltea eniti, partum q́; concharum effe Margd= 


\section{In Lib.fecundum Diofcoridis. $\quad 179$}

ritas, pro qualit.tte roris sccepti. Nam fi purus infuxerit, candorem conpici: fi ucró turbidus, or fatum fordefce= re:cundem pallere celo nimante conceptum. Et cx co quippe conftare, calí; cis maiorem focictatem efle, quim maris. Inde mbilum trabi colorem, aut pro claritate matutina fcrenum: fi tempcftiue faticntur, grande fcere er par tus: fi fulguret, comprini conch.r, o pro iciunij modo minui. Si ueró o tonucrit, pauidas, ac repenté compreffas, que nocant Plyyfenata cfjecre peciem, werum inani inflatun fine corporc. Cateró in aqua molles funt Margarite, at cxempt.c protunus durcj cunt. Quid.m tradunt, ficut apibus, ita concharun cxaminibus fingul as magnitudinc, or uetufate pracipuas cfic, uciuli diccs, mire ad caucudum folertic. Quocirca bas fummo ftudio petunt urinantcs pi= fcatores: fiquidcm coper rege facilius cateras palantes retibus includunt. Concha ip a cum manum uidet captiofam,

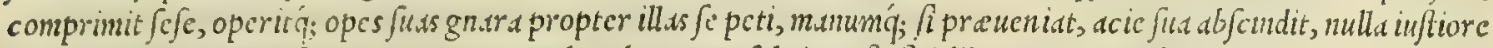

30 paend, er dijs munita lupplicijs. Capte multo obruntur fale in uafis fictlibus: nanq; crofa carne, uniones, fiue mar gurite pure, o expurgate decidunt in ina uxis. Dos omnis in candore, magnitudine, orbe, levore, pondere; tametfir ar. adnodum /int Margarite, que bis omnibus dotbus preftent. Tradit I uba A rabicis conchameffe fimi= leme pectivi infecto, hirfutan echinorum modo, ineflé,; illi Margaritan grandini fimilcm. In conchis quaternos, aut

ad fummum quinos unones repcriri Plinius foriptum reliquit. Verim Americus Veputius, qui noftro auo liburnicis Plınij error. omncin ferc auftralen occanum cxplorauit, talem ibi concham fe quandoque babuiffe teftatur, in qua uniones ultra ccntun, or trigintareperti funt. Qüod non modó confirmant ij, qui poft ipfum ad occidentales Indias natigarunt; fed ctian addunt numerofioses ibi unioncs in una tantim concha nafci: preterca alia plura de Margaritarum bifto= riarcfrunt, que à Plinij fententia plurimùn dißident. Porró certum eff e nafci, or capi margaritus in oceano oc= cidcut.ll Scoto, $c$ Anglico finu, $\int e d$ cas quidem paruds, nec adeó pellucidas, ut orientalibus comparari po/Sint, $\dot{e}$ 20 quibus contextum thoracen afferunt, quen Diana templo I ulius Caear dicauit. Ad bec non in maritantum, fed $e=$ tian in funinibus aque dulcis conch.e proueniunt, que margaritas geftant. Huius autem rei ego quidem teftimonium perbibere poffum, quód ium muli in Bolsania degenticompertum fit in Vuotauua flumine or reperiri or capi con= chas, qux pulcherrmos includunt uniones, magnitudine, forma, or candore preftantes. At $q_{;}$certé milsi fubijt quan= doque mirari, cinn carum nargatriarum copian widi tum apud Sercniß. Principem dominum nzcun, tum etiam apud primarios.Bohnmis lomincs. Murgarita in medicum etian ufun ueniunt: quandoquidem fcribunt serapio, er Auiccma, cas ad cordis affectus precipuam open ferre. Quinetian collyrijs admiftas oculorum nubeculas deterge=

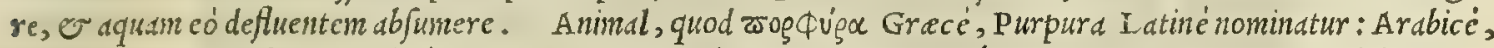
Naporam, G Porphyra: Italici, Porpora. Que ueró Latinis Buccina, uń cora, Cobros, feu Cobron : Italis, Buccine: Hipanis, Bozios: Gallis, Bioscornetos. Ceterum quod Greci $\mu \alpha \rho=$

30 yagitas, I atinitem Margaritas er Vuiones uocant: Arabes, Hageralbato: Itali, Perle: Germani, Perlin: Hi= Pani, Perlas.
Múares. MITVLI.
CAP. V.

M I T V L I laudatifsimi in Ponto. Cremati eundem buccinis effectum præbent. priuatim plumbimore eloti, oculorum medicamentis cum melle utiles habentur: palpebrarum crafsitudines abfumunt, albugines purgant, \& cætera, quæ oculis caliginem offundunt. Carnes corum ad canis morrus vtıliter imponuntur.

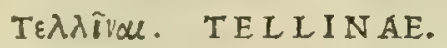

CAP. VI,

40. R E C E T E S Tellinæaluo utiles, fed maximè ius earum. Salitæ uruntur, tritæq́ue in cinerem, \& cum cedria inftillatæ, auulfos palpebrarum pilos renafci non patiuntur.

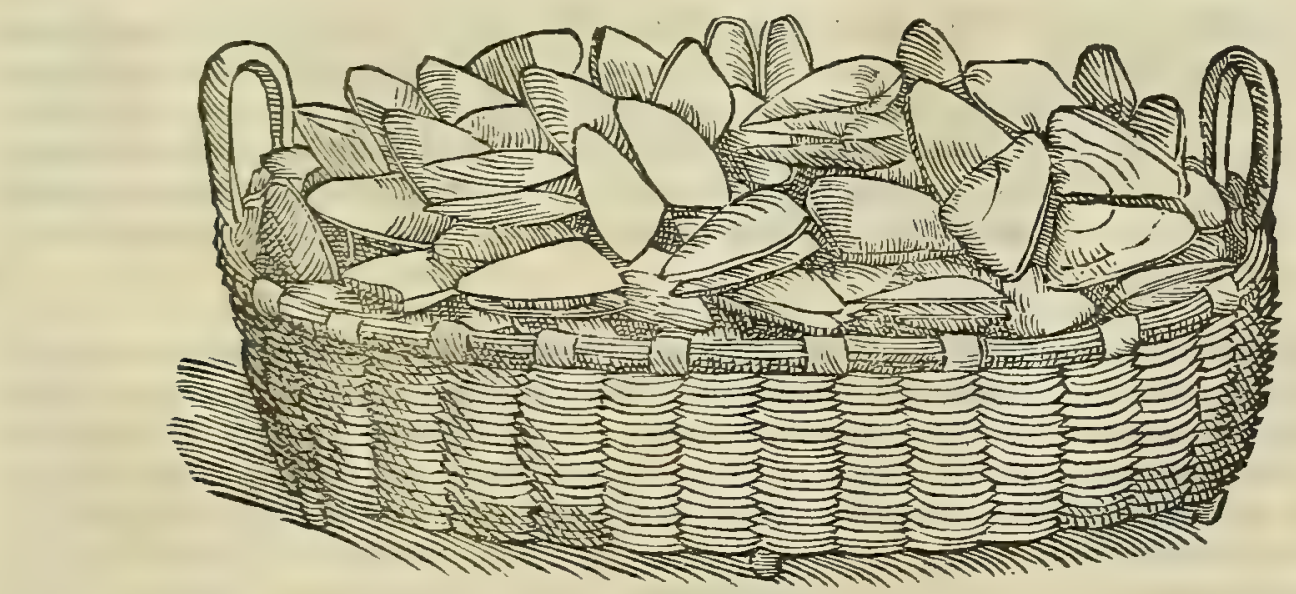

No $\mathrm{N}$ defunt, qui Mitulos, or Tellinas idem effe cenfeant. In quam fententiam potißimim ueniffe comperio Paulum Iovium uir un appriné eruditum : quippe qui libello, quem de Romanis pifcibus edidit, malit (et $\sqrt{2}$ medicus effet) cum A theneo errare, quàm cum Diof coride recte fentire. Ex cuius fcriptis fatis aperté conftat, aliud effe mi=

Vnionum uires.

Nomina.
Vniones prx Atantifsimi. 
tulos, aliud tellinas : Mam praterquam quód de bir duobus diuerfis capitibus ipfe differuerit, differentes etiam utrif= que redidit dotes, haud nefcius illis ineffe differentian. Iden fintiliter fenfit Galenus lib. $\mathbf{x} \mathbf{I}$. de finplicium medica mentorum facultatibus, ubi de uiperis differens, coden capite mitulorum etiam meminit ; tellinarum ueró peculiari capite, fingul is proprias, 0 diucr $\int a s$ reddens facultates. Non fecus ac illi, fenfit Paulus Acgincta, fidelis nempe $u=$

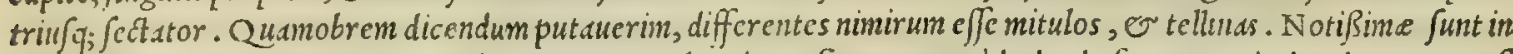
Itdli Tclline, prefertin Rome, ubi plurine uenales circumferuntur, quód edendo fint, $\sigma$ ori admodum grate, $f$ tamen ab arcna optime repurgentur. Ceterim quales Mituli fint in Italia, qui hac noftra tempefate explicauerit, bstenus inucni neminem. Preter unum Maffarium Venetum, qui cos mitulos putat, quos Adriatici accolà unlgó ap= pellant Mufcioli, quafi mufculos dixerint. Cuius opinio nobis maximé probatur : quippe qućd o forma, o nomine concbylis ita uocat legitimos refrant mitulos. Sunt enin tellinis panlo maiores, tefta cxterius lincis quibu $\int d d m \int c d=$

Nomna. bra: intus ueró pcllucida, $\odot$ tota pondcre leuis. Múxues ita Grac is, Mituli Latinis appellantur, pariter $\approx \sim$ Ita=

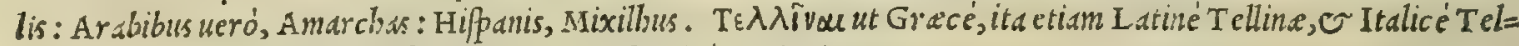
line dicuntur: Arabicé, Sedef, or Tallam : Hipanicé, Brignigois.

$$
\text { Xîuxi. C H A M AE. C A P. VII. }
$$

C н A M A R V M, aliarumq́ue conchularum in exigua aqua decoctarum ius, aluum ciet . id cum uino affumitur.

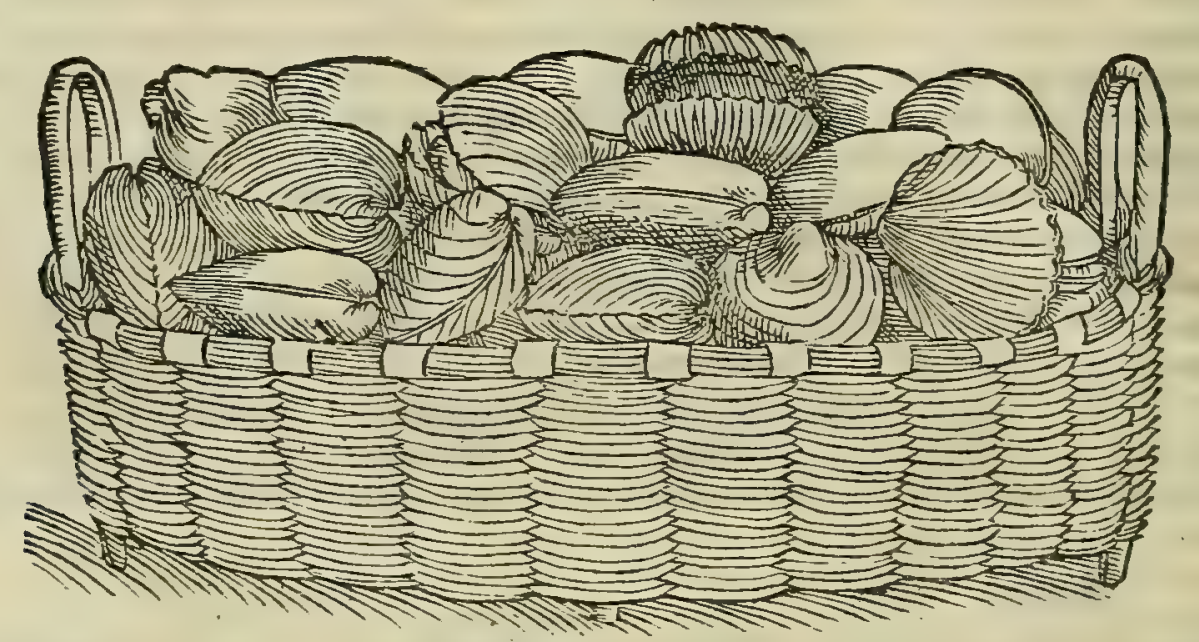

Chamarum QV A N QV A Cbame inter cetera concbyliorum genera longa defcriptione ab A theneo referuntur; nibilo confideratio. minus tamen tot buiufmodi teftaccorum habentur pecies, ut non facilé fit, eas inter fe diftinguere. Caterum prater ceteras conchas, id fibi peculiare afciucre Chanx., quod plerunque in litore biantes inueniuntur. Idcirco cas recte Chamas dici poffe putauerin, que in marinis oris, pandentes fefe leui tefta contccte reperiuntur. Harum quaim plu= rimas ip fe uidi in Adriatici litore. Verùm quoniam mulla alla facultate funt pr.editz, prater eds, quibus er reliqua concharum genera commendantur ; ideo non eft, ut plura de bis dicamus. Qux Gracis Xĩ Arabibus Hame, $\mathrm{O}^{\circ}$ Italis Chame nominantur.

\section{O"v६. VNGVIS ODORATVS.}

\section{CAP. VIII.}

V N G I s, fue onyx conchylij tegumentum eft, ei fimile, quo purpura integitur: quod in Indix nardiferis:paludibus inuenitur, fuauem ideo fpirans odorem, quòd conchylia inibi nardi pabulo uefcantur. Colligitur polteaquàm ftagnantes aquæ æłtuis fqualoribus inaruerunt. Laudatifsimus qui à rubro mari defertur, candicans, pinguis. Babylonicus nigrefcit, atque minor confpicitur. Ambo odoris gratia fuffiuntur, fed aliquátenus caftoreum olent. Iidem fuffitu excitant fominas vulux ftrangulatu oppreflas, comitialesq́ue : poti uentrem molliunt. Crematum conchylium eadem efficit, quæ purpura, \& buccinum.

Vnguium o- Qv I diligenter caput hoc de unguibus odoratis legunt, ex expendunt, non ab re fortafe mirantur Diofcori= doratorú con dem, quód fcrip ferit, onyches, id eft ungues odoratos in Indix nardiferis paludibus inueniri. quando nufquam ḋuete= fideratio. ribus er recentioribus memorix proditum fit, nardum in paludibus nafci, fed in montibus, arido er ficco folo. Adt= mirationi fux illud non obftare putant, quod memoret Diofcorides, Indicinardigenus effe, quod Gangitis uocatur, afluuio Gange, apud quem enafcitur, montem praterfluente. Neq; enim uolunt eam nardum in ftuuio illo, aut in pd= ludibus prouenire, fed in monte, aut infima cius parte, quam flumen ip fum allutt. Preterca cim fcribat Diofcorides, conchulas odoratas in Indie paludibus inueniri, ill is plane ab furdum uidetur, quód pre ceteris eas laudauerit, qux a rubromari defruntur: quód item Babylonici generis meminerit. Addunt infuper, quód cum ungues ij, quorum in officinis plarmacopocorum communis eft u[us, $\sqrt{i}$ uruntur, non fuauem fpirent odorem, fed potius caftoreum oleant; qui nimiruin odor ab omnibus er iniucundus, or ingratus babetur, fieri non poteft, quód odoris gratia fuffiantur: 


\title{
In Lib. fecundum Diofcoridis.
}

\author{
VNGVESODORA T I
}

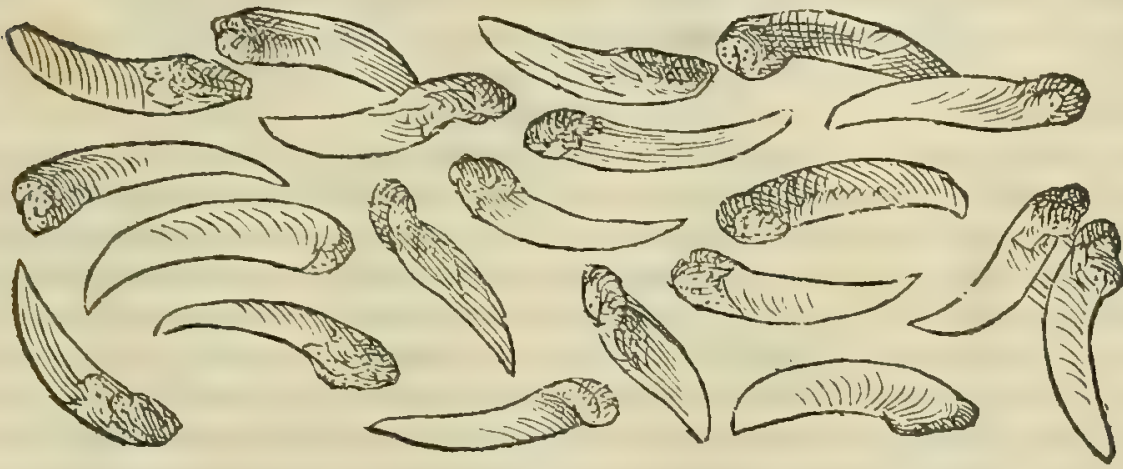

prefertim quód ijdan fuffitu (ut Diofcorides tratit) cxcitant ferminas unluxe ftrangulatu oppreffus, comitidlesq; .

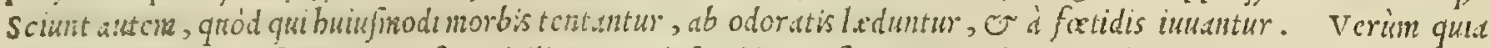

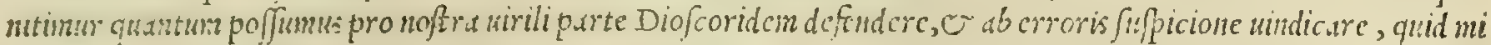

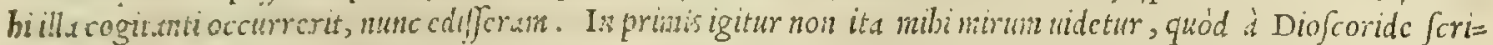
2o ptun fit, ungues odor.tos in xarditris Indix pubutibus inueniri. Nam fi, codcm audore, aliqui arbitrati funt, malsbabrum c/fe Indicinardi folum, fulfi quadan odoris cognatione, facle ficripotuit, wt ijacm rei berbaria int=

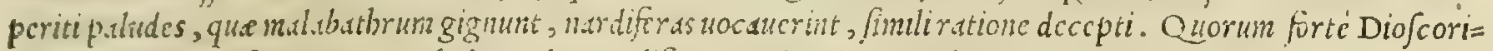

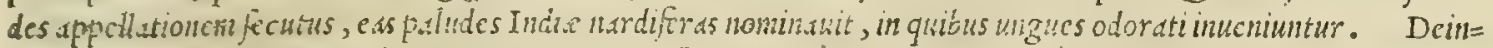
dc illud quoquc mirum non effe detet, giat ad nos adfrantur conchule Indice cx mari rubro, ac Babylone. Etcnim boc won cucut, quod inbi nijcultur, jed qudd Diofcoridis tempore non jecus ac noltro, mercinonia, que ex India

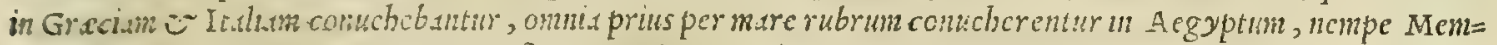
pbin, xut Alexindriam. Sed quonzodo fit, dicei aliquis, quod rare admodum reperiantur conchula Indica, qua fuasun fircntodoren, cog; nardun imicntur, atque odoris gratis fuffuntur? Corté won alian ob caufam fieri puto, nifi uel quod propicr maxinum loccr tmi difantian in longo itinere adfcititim illum malabatbriodorem amit= 10 tant, ut Indice nivido cucnire libro fupcriori in cius nentionc diximus: uel quod ca, que ad nos adfrumtur, in pa=

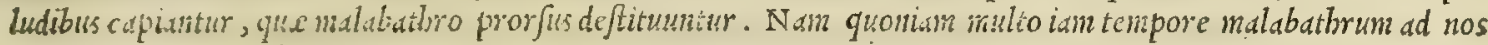

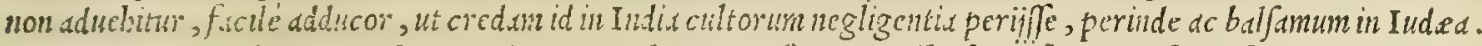

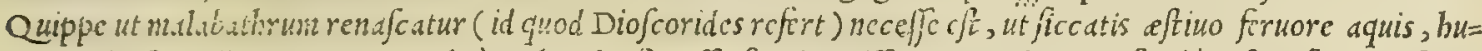
mus aridis finticious uratur. Quod cim ab Indis fortaffe fucrit oniffum er negictum, facilc poftea factum eft, ut

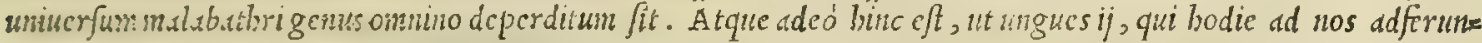
tur, mulio nardiodorc commendentur. Pofremó illud mibi baudquaqusn abjurdum cfic uidetur, quód conchule Indic $x$ uffit: preffis uterifuffocatione mulicres comitialcsq́; rewocent. Nanque, quódfieri potucrit, nos non nes ganus, ony lises olin fuiff: odoris grati atque iucundi, utpote qui nalabathrum redolcrent. Sed equidem existino

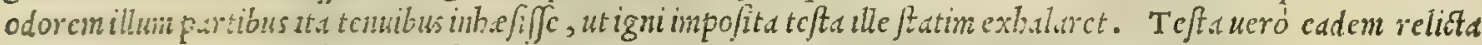

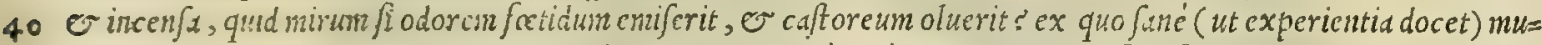
lieres unlux ftrangulatione laboianics fif citantur. Cetcrum cim onyx ungucm fignificet (unde conclula Indica

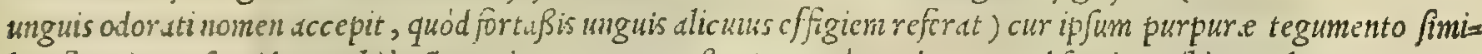
lem fecerit Dtofcorides, mibibactenus incompertum eft. At certe, ut dicam quod fentio, mibi non placet corum o= pinio, qui nou alis de caufa hoc concbylijgcnus onychem appellari nolunt, quam quod eius tegumentum fit rugarü, concauitatis, apcritatisq́; expers: laxore autem, sc c.ndore preditum, humanorim unguium modo. Siquidem purpure tefta, cui onycbem afsimilat Diofcorides, in unius fun aculeata conpicitur: quin or inequali, finuofóq. cortice obducitur. Porró quód uide an ungues odoratos, qui in myropolijs paßin babentur, brutorum quorundan ungues reprefcutare, atque fi urantur caftoreumolere, facit ut feré non dubitem affirmare eds legitinas effe.

Fuchfius in fuis tit siccolaum Nyrcpficum doctißimis annotationibus in compofitione aurex Alcxandrina, ubi ipfo Fuchsij opi-

so uertente legitur, oß is anterioris narium purpure, fribit id nil aliud Nicolao defignare, quám quod Actuario, 0 alijs pofterioribus B lattiun byz.utium, fiuc by antis dicitur, quod in quibufdam interpretationibus in Nicolaum le=

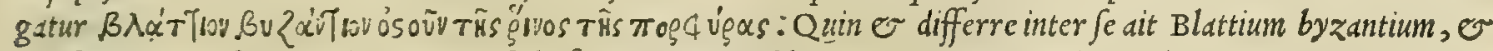
Diof cortdis onychem, quód ony x conchilifit tegumentum, blattium autem os anterius narium purpure. Quod etiă confirmauit libro primo de compofitione inedicamentorum, illud etiam addens, officinis bodie boc os, quod in ore, aut naribus purpure reperitur, Elattam bifantiam uocari. Sed longé quidem ab eo dißidet opinio noftra. Primum quód Serapioni, er Auicenne, quorum uocabula medic anentá; tam fimplicia, quim compofita (ut ip femet fatetur

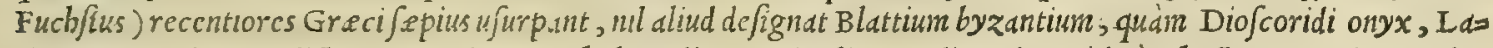
tinis ung uis odoratus ditius, ac pariter conchula indica. Huic alia accedit ratio, quód cum bactenus non inuenerim, qui purpurarum os tam oris, quam narium ( $u t$ Fuch/io placet) fiue tefta earum tegumentum odore aliquo commen= daucrit, quiq; inter odoramenta recenfuerit, atque antidotis inferuerit; fed qui tantün forip ferint, edrum crema tarum cinercm exiccare $e_{2}$ dentes abftergere, excrefcentias in carne cobibere, $u l c e r a$ purgare, et ad cicatricem perdu= 
cere: contrà uerò conftet omnibus odoratos ungues à Mauritanis preferri, quód aroma quoddam refipiant, $\sigma$ te $=$ nuium, atque adftringentium fint partium, ad uentricul, iocineris, cordis, uteriq́; affectus, non modó Fuchsij, fed Ni= colai quoque fententia (modó buius codex non fit deprauatus) inanis profectó, o plané refellenda uidetur. Quód autem ad hos affectus odoratos ungues pretulerint Arabes, quibus recentiores Graci longe plura accepta refe= runt, teftis eft Serapio authoritate Me ehas, cim inquit. Conchula Indica excalfacit, of ficcat ordine tertio : quin $\mathcal{O}$ adfrictionis, er tenuium partium eft particcps: uentriculo, cordisó ; palpitationi, iocineri, uulua q́; odoris fras= grantia conferens. Quo fit, ut etiam facile crediderim, Actuario nil aliud Blattium, fiue blattium by fantiun repre= fentare, quàm Indic am odoratam conchulam, non ut Fucb/ins arbitratur, os in ore, uel naribus purpure innentum.

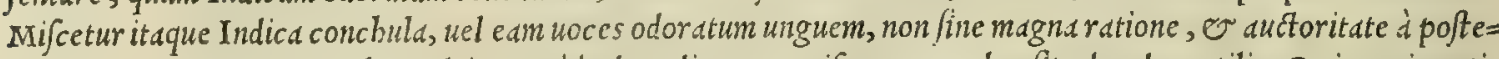
rioribus Gracis in aurea Alexandrinu, quód ad cardiacos, $\sigma$ uifcerum morbos fit admodum utilis. Quin $\odot$ in anti= doto é margaritis, quód omnem uirium imbecillitaten firmet, animi defectum fiue à corde, fiue ḋ uentriculo originem ducat, maximé iuuet: longo morbo dciectos, o imbecillitate languentes recrect, er uteriftrangulatus in mulieri= bus auertat, ut Actuarius, o Nicolaus Miyrepficus tcftantur. Que r'nnia odorata conchula per fe fré preftare poteft, fi primum eius qualitates, demum ueró facultates perpenderimus, quarum nulle (quod fciam) purpuris a $\beta i=$ gnantur. Quare non immeritó Nicoldun damnauerin ( $\sqrt{i}$ tamen error illi adfcribendus eft) qui narium purpurarum offa excogitauerit bis antidotis effe admifcenda, cum purpure in uniuer fum preter teftam, qua conteguntur, oßibus careant. Nififorté is in purpuris narium os appellauerit, quod in anteriori tefte parte prominet, or roftri potius, quàm narium peciem reprofentat. Illud preterea fallum effe deprebenditur, quód officinis hec excogitata pur= purarum offa Blatte bizantic uocentur, cum etiam qua legitima in officinis babentur, proprie fint odorati ungues. Poftremó queque fint ille in Nicolaum expofitiones, quibus maximé nititur Fucbfius, eas noftris rationibus, , au=, 2 Etoritatibus adductis haudquaquan obftare poffe putauerim, cim fortaffe incerti fint auctoris, uel $f i$ certi, minine probandi, quod is rationi, ac ueritati refragetur. Nifi quis dixerit, illum contrà quàm Fuchjius intellexerit, Nico=

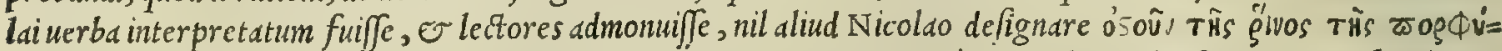

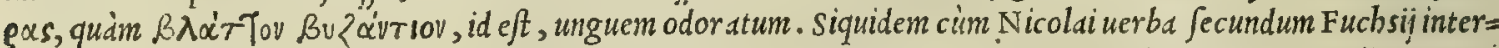
pretationem adeó per fe clara fint, ut nulla indigeant explanatione, non erat opus, ut ille interpres ed aliter expo= neret; fed potius, ut declararet, animaduer $\int a$ deprauata Nicolailectione, pro co purpurarum offe in Nicoldi anti= dotis Blattum byzantium, id eft, Indicam concbulam admifceri debere . quod facilé fciret, fabulo fum effe purpuras in nafo uel ore gerere offa. Quod etiam fenfife uidetur antiquus fragmentorum Nicolai interpres: quippe qui non purpurarum offa in aurea Alexandrina, or diamargarito fit interpretatus, fed byzantiam blattam, quam odoratum unguem effe, hactenus nos abunde demonftrafe exiftinamus. Huius nomen Gracum eft övv̧ : Latinum, Vnguis odoratus, es conchula Indica: Arabicum, Athfar ateb, aut Adfar althaib: Italicum, Vnghid odorata.

\section{O C H L E AE.}

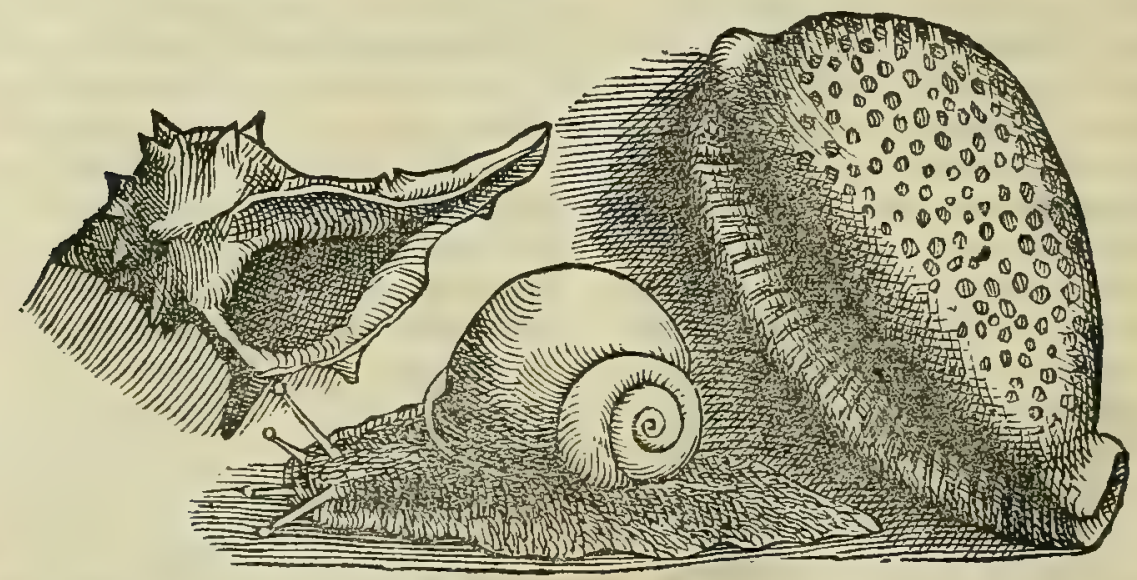

Koxגia. COCHLEAE.

C A P. IX.

TERRESTRES cochlex ftomacho utiles funt, \& non facilè corrumpuntur. Optimæ Sardonicæ, Aphricanæ, Aftypaleic,$\&$ quæ in Sicilia, ac Chio gignuntur, \& qux in Ligurix alpibus, pomatiæ, id eft, operculares, cognominatæ. Marina ftomacho jdonea, \& facilè aluo excernitur. fluuiatilis uirus olet. Quæ uerò uepribus, frutetisq́ue glutinata cohæret, quam uocant nonnulli fefilon, uentrem, \& ftomachum turbat, uomitiones excitat. Crematx omnium teftæexcalfaciendi, \& urendi naturam fortiuntur: purgant lepras, vitiligines, dentesque: cmendant oculorum cicatrices, \& uitia cutis in facie,albugines, ac uifus hebetudines, fi cum carne fua ufta, tritxq́ue ex melle illinantur. Crudx cum tegumentis impofitæ, aquæ inter cutem tumores exugunt: fed non antè foluantur, quàm om nis hauriatur humor podagricas inflammationes leniunt: impactos corpori aculcos illitæ euocant: menfes tritæ, \& admotæ ciunt . Carnes earum cum thure, \& myrrha illitæ, cum uulnera alia, tum maximè 


\section{In Lib. fecundum Diofcoridis.}

qua nerui acceperunt, conglutinant : tritx in aceto, fanguinem naribas erumpentem infranant. Viuæ corpus, \& prafertim Aphricanx,cum aceto deuoratum, ftomachi dolores mitigat . trita cum tcfta, uino, \& myrrha, li exiguum inde bibatur,coli, uelicæque cruciatus fanat. Terreftris pilos incommodos replicat, fi quis abrafo acu lentore eius, pilum attingat .

C O C H L E A E ulgó notißsimx funt. Ha licet albs, nigráq; reperiantur, tun magne, tum parua, tum nedio= cres; omnes tamen eand cm natur am in uniuerfum obtinent. Si ueró aliquo pacto inter fe differunt, id natalis folicau fe afcribitur: : nam que in apricis adnodum locis odoratis uictitant berbis, ijs fane preftant, qux in opacis dcgunt, ac in paluftribus. Id ening guftu facilé deprchenditur, quod ba uel infipide babcantur, ucl paluftrem refipiant linum;

- ille reró fapidiores, cfuic; gratiorcs exiftant. Quandoquidem abfinthium depafte amaritudinem rcddunt, ficuti que ferpyllum, pulcgium, calamintham, or iganum, alias q; odoratas herbas affumunt,odoris gratia commendantur. In qud= rum numerum aqué refersip ofjurit, qua pauló lupinis maiores in agro Romano leguntur, ubi autumno quorundam carduorum caulibus aceruatim cober cntes immunere uifuntur. Cocbleas ol im ufqueadeó canis expetitas memo= rat Plinius lib. IX. cap. L VI. ut ijs uiuaria à nonnullis fuerint inftituta, diftinctis quidem generibus earum, quó melius gula fieret fatis: feparatiut ut cffent albe, que in Reatino agro nafcuntur : eparatim Illyrica, quibus magni= tudo precipus: Aplorican.e, quibus fac und ttas: Solitane, quibus nobilitas. Sagindm quinetiam commentatifunt fapa, O farre, alijsq́; rebus. qua eas alcbant. Nonme fugit,quas Diofcorides pomatias uocat, plurinas reperiri in mon= tibus Tridentinis,uicinisq́; alijs locis; er eds quidé praftantißimas. Eruuntur enim é terra byeme in fepibus, e frute= tis, uncis quibufdam firreis, prope fruticum radices terra circunfojfu. Concluduntur he contra frigoris iniuriă, quo=

20 dam albo opcrimento, duro, gypfi pecien referente, fic q; contecta terra fe condunt. Fit enim ob hoc, ut in cibis ijs löz gí Juatiorcs, gratioresq́; habeantur, qux uere, e aftate imbribus excitate binc inde uagantur. Quód autem fic byeme recondantur, delite fcantó; fub terra circum fruticum radices, Hetruria plané ignorat; cum tamen o ibi cos dem modo ab bis eruantur, qui alibi artem didicerunt. Cocblex fi tote cum teftis urantur ( $u t$ Galenus memofixe prodidit libro $\mathrm{x}$ I. (implicium medic anentorum) admifta galla omphacitide, fimulq́; pipere albo, mirifice profunt dy= fenterijs, in quibus ulcera nondun putredino $\int$ funt. Conuenit autem ut piperis fit par suna, galle uero dua, quatuor cineris cocblearum. Hac ubi ad unguem lauigaris, cibis inpergito, bibendum q́;, aut ex aqua, aut ex uino albo, $\mathcal{O}^{\circ}$ au Rero prebeto. Caterim absigs galle miltione cimis cochledrum admodum reficcantis eft facultatis, obtinens item nö = nibil ex uftione caldum. Porró cocblea, qua uftionem non funt experte, fi trite und cum teft is imponaltitr, en to= ti uentri aqua inter cutem labor antiusn, er in arthriticis articulorum tumoribus, sgré quidem diuelli poterunt, cetes

30 rum impensé deficcant. Et omnino inherere ip $\int a s$ finere oportet, quoad pponte decidant. Idem '́, faciendum in tumo ribus ex iff natis difficile folubilibus, o ex contufione fact a in auribus. Deficcant enim illos magnopere univerfos, etian fi uifcofus, crajfusq; in al to hianor contineatur. Idem libro citato, cum de diuer is carnibus uerba faceret, fic de cocblearum quog; carne differuit. At cocblearum caro prius in mortario contufa,ac pofted ad letiorem redacta,

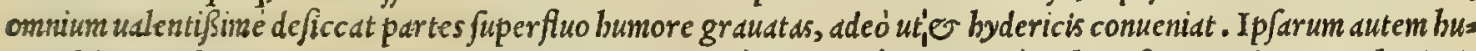
mor folus per fe citra carnem fumptus ( uocatur autem is ḋ multis $\mu v ่ \xi \alpha$ xox $\lambda$ iov, hoc eft, mucus limacis) thuri mi= ftus,aut alo 2 , aut myrrhe, aut horum quibufdam, aut omnibus, quoad babeat ceraticraßitiem, medicamentum fit glu= tinstorium, deficcat q́; pulchré purulentos inucos aurium : fed $\mathcal{\sigma}$ fronti impofitum inheret, oculorum fluxiones re. ficcans. Quidam etiam ad palos eximendos utuntur totis unà cum teft is ad lauorem tritis: fed $\sigma$ quidam ad fiften. dosmerfes. Et quidem ego dliquando in agro carnes ip as folds in uulnus cum nerui uulneratione, or contufione fam

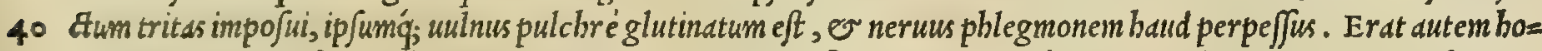
mo durus, or agreftis : mifcui tamen illis contritis pollinem farine acceptum a pariete mole proximo. Scrip fere aus tem maiores me nonnulli medici, ad ciufmodi ufum mifcendum ipfi thus, aut myrrbam. Verùm hor ü habebam tum neu. trum, ut qui tunc ab urbe abefem in uilla. Poßis autem o refine fricte contrite admifcere, fi adfit, quippiam . Pors ró ubi multi muci cochlearum accipere uoles feorfum, ftylo carnem edrum pungito. Sed non ante multos dies uena tas effe expedit : alioqui enim tempore deficc antur. Nam recentes plurimum babent uifcofe illius bumiditatis, quam fylo compuncte effundunt. Humidita hec pilorum in palpebris preter naturam gluten eft. bec Galenus. Cocbles tum crude, tum cocte cum teftis fuis, aut fine, contrite emplaftris concoquentibus, er faniem é uomic is fracta cute educ entibus utiliter immifcentur. Marine in Italie mediterrane is perquàm raró in cibis ueniunt: quanquam ijs, qui maris litora inhabitant, frequentiori fint ufui. Sunt $\sigma$ in cocblearum genere, que tegumento, uel tefta carent,

so que nobis peciatim Lumache uulgo appellantur, noctu potius, quam interdiu ad pafcua exeuntes. Degunt be non modó in campis, er hortis; fed in cellis uinarijs, $\sigma$ alijs Jubterraneis uliginofisq́; adium locis. Gerunt in capite lapi dem (non tamen omnes) quem febribus tertianis adalligatum uulgus prodefe exiftimat. At Plinius lib. $\mathrm{x} x \mathrm{x}$. cap. $\mathrm{x} v$. auctor eft, hunc lapidem adalligatum dentitionem facilem preftare. Expetuntur be mulieribus ad expoliendam faciem : nanq; ex ijs in ftillatorium uas coniectis, additis quibufdam alijs, aquam eliciunt, qua inde carum elota facies

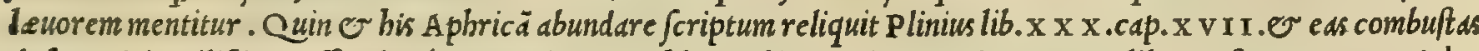

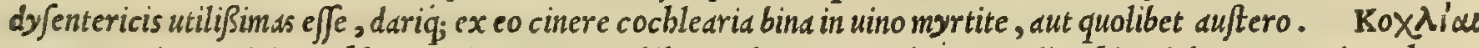
ut Grecis, ita L atinis Cochle nominantur : Arabibus, Balzum, $\sigma$ Halzum; Italis, Chiocciole : Germanis, Schnec. Len: Hifpanis, Caramuyos, Caracoles: Gallis, E fargotz.

Cochlearum confideratio.

\section{Cochlexpo-} matix.

Cochlearum uires ex Gal.

\section{Cochlex ma}

rin $x$.

Cochlex fine tefta.

Nomina. 


\section{And. Matthioli Comm.}

Kagrivor. E A C R I.

C A P. X.

C A N C R O R V M flutiatilium exuftorum cinis, qui duo cochlearia expleat, adiecto dimidio radicis gentianx modo, triduo potus cum uino, magnopere prodeft canis rabiofi morfibus : rimas pedum fedisqúue, perniunculos, \& carcinomata, cım decocto melle lenit. Triti crudi, potiq́ue ex afinino ląte, auxiliantur contra ferpentium phalangiorumq́ue morfus, atque fcorpionum ictus. Decocti autem, \& cum iure efitati, ijs profunt, qui tabe conficiuntur, aut leporem marinum hauferunt. Necant fcorpiones triti, \& cum ocimo admoti . Poffunt eadem marini, uerùm inefficacius omnia præetant .

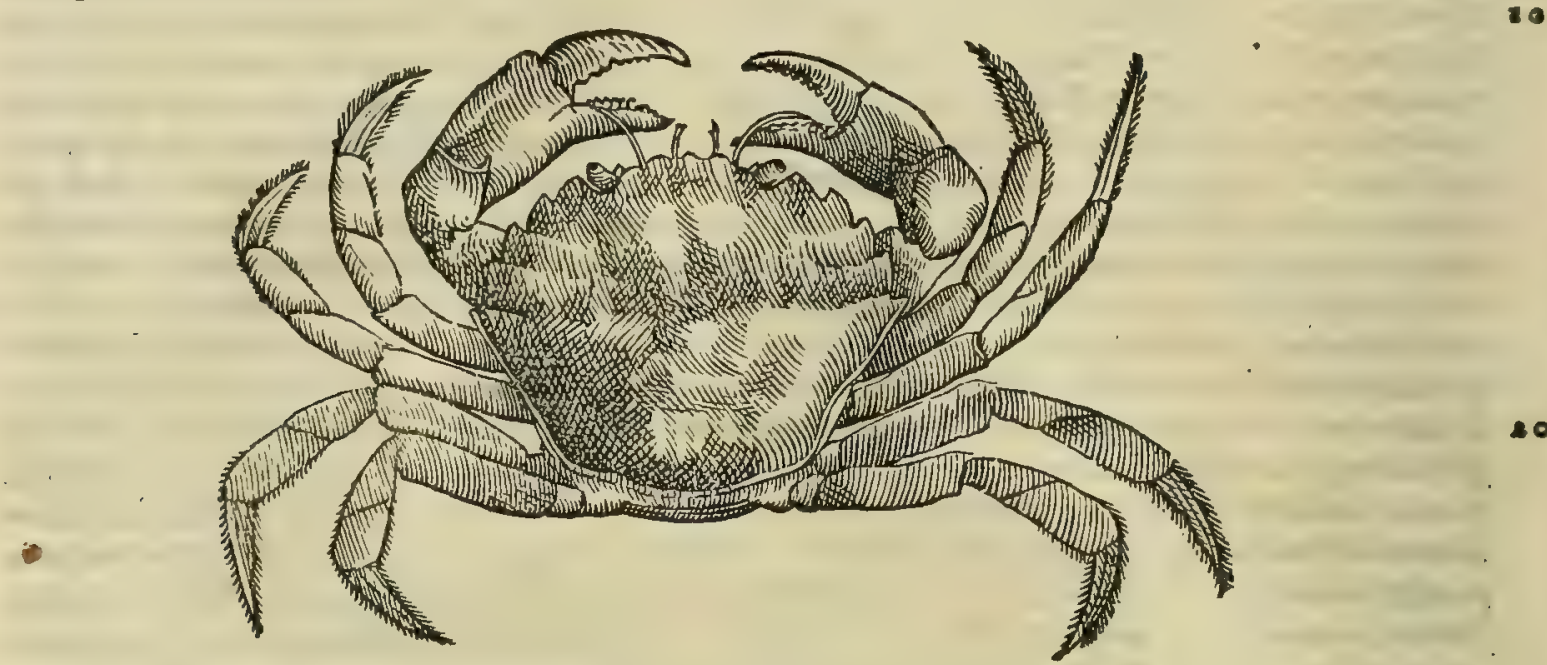

Cancrorum

Hal L v c I N ANT VR, quicredunt Cancros ḋ Diofcoride, er Galeno defcriptos illos efe, quos unlgus Italo*.

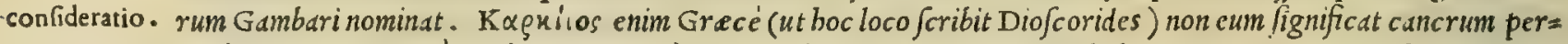
pcràm uocatum, qui a'saxiós appellatur à Gracis; fed qui rotundo corpore babetur, quem nos Hetrufci uulgari no

Multorum mine dicimus Granchio. Is Venetijs, ubi marinorum numerus propé infinitus babetur, ubi cruft am exuerit, à corporis error. mollitie uulgó uocatur Mollecca. E' quorü genere funt etiam qux appellantur Macinette: nam o ba fuo tempore cruff am exuunt. Hoc ita effe teftatum reliquit Ariftoteles libro I I I I.cap. I I.de biftoria dnimalium, ubi fic inquit.

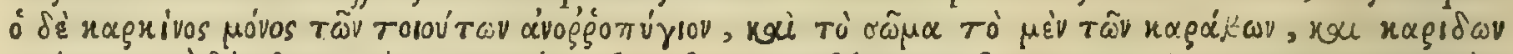

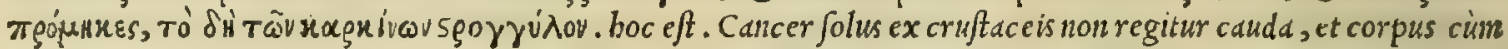
quidem locuftis, fquill iś, longum fit, cancris uerò rotundü $\mathrm{e} f$. Porró aftacos Oppiano peciatim dicitur gammarus magnus ille marinus, qué Romani, 0 Tyrrbeni litora mcolentes Leonem appellant. Veneti autem, quafi adbuc Gre=. cum nomen retineant, eum unlgo Aftafe nominare confueuerunt. Idem dictus eft gammarus à Tbeodoro Ariftote= lis interprete : quippe quod uulgaris gammari faciem repra fentent. Veruntamen (nifallor) Ariftoteli ásaxiós nil. aliv' effe crediderim, quàm quod Venetis aftafe, Romanis ucrò leo nuncupatur : quandoquidem is pauló inferius poft = quàm de marinis, qux crufta integuntur, animalibus differuiffet, uidetur fané uulgares fluniatiles gammaros defcribe $=40$

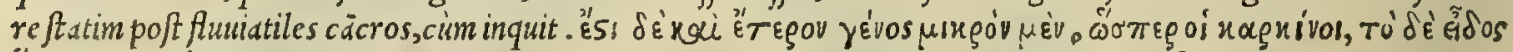
ónosov tố sa'sanoîs . boc cft. Genusitem aliud eft, quod quidě paruum eft ueluticancri, facie ueró aftacis fimile. Hac, neo quidem iudicio, declarant, Gracis fluniatilem gammarum proprio carere nomine, utpote o paruorü can* crorum aliqua generd, ut ipfe codem loco teftatur Ariftotcles, cim inquit. Cateri minutiores, er nullis penè nomini=

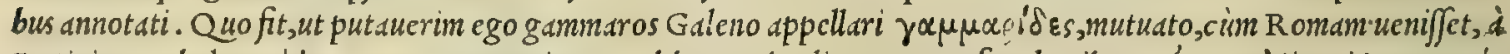
Iatinis uocabulo, quód eo carerent Graci. Nanq; lib. I I de alimentorum facultatibus: A's axoi' (inquit) nqu 'ø $\alpha$ '=

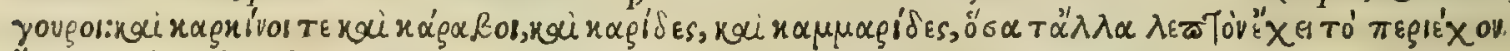
"s garov. boc eft. Aftaci, paguri, cancri, locufta, carides, gammarides, e id genus alia tenui tefta concludun= tur. Magisq; hoc affirmare non dubitauerim, quód nomen boc à Galeno Grecum factum,nec apud Ariftotelem,nec apud qucnquam repererin unquam. Quibus etiam ex uerbis paldam certé eft, inter gammaros, er cancros manif $=5$ ftam effe differentiam. Quamobrem cos medicos ballucinari cenfemus, qui pro Cancris ad canum rabidorum mor= fus, itemǵ; ad tabidos, \& marafmo laborantes Gammaris utuntur : quandoquidem cim Diofcoridem, tum Galenum Cancrorum non de gammaris quidem, fed de cancris intellexiffe nobis compertum fit. De cancris Galenus libro X $\mathbf{I}$. de fim= urres ex Gal. plicium medicamcntorum, hac fufius fcripta rcliquit. At fluuiatilium cancrorum cinis, quanquam fimiliter predictis exiccatorius eft; fubftantix tamen proprictate mirifice contra rabioforum morfum efficax eft, isq;; tum folus, tum cun gentiana, $\mathcal{E}$ thure multó preftantior. Thuris fené parten uname efe oportet, quinque autem gentiane, porró cancrorum decem. Et raró equidem aliter illis ufitis nos fumus ufi: catcrim ad eum modum plerunq; quo Aefcbrion empiricus ille utebatur, medic amentorum peritifinus fenex, conciuis, ac preceptor meus. Patella er at a ris rubri, in quam impofitos cancros uiucntes, haffenus urcbut, dum facilé ad lakorem redigi poffcht. Hic Aefchrion paratun promptum femper in adibus boc babcbat medic amen, thens cancros tempore aft tuo polt ortum canis, quando fol in leonem tranlifj]ct, luna decima octaua. Porró bibcudun boc medic amen ijs, qui à cane rabido fuiffent mor $f i$, pre bebat 


\section{In Lib. fecundum Diofcoridis.}

quotidie ufq; ad diem quadragefimum, menfura cocblearij fatis magni aqux infperfum. At fi non protinus ab initio, uerum aliquot poft dies curan copplfie! demorfi, tunc quotidic duo cochle wris aque infpergebat. Ad ipfum ueró uul= nus emplafticum applicabat medicamcutum, quod expice brutir, or opopanacc, acctóf; conficitur, babens pic is libră

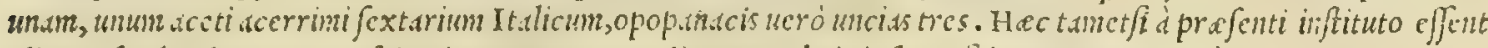

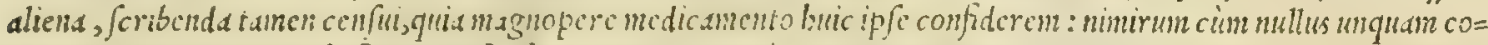

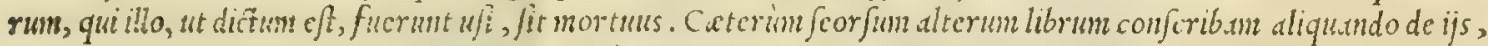

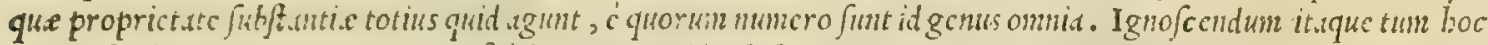

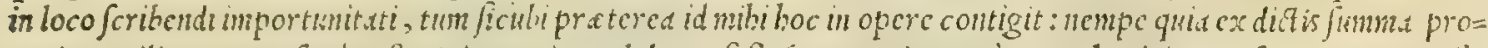
ueniret utilitas, quam fanc pefteris impertire uolebam, fi forfan me prius, quim qua bis dcuccps funt oper, , perfi=

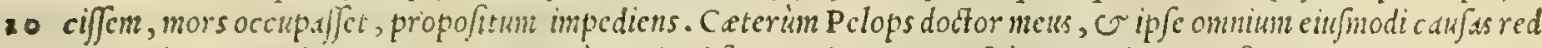
dere uolens, non abs re inquit. Cancer cum animal fit aquaticum, prodeft à cune rabido morfis, quibus nideliset me=

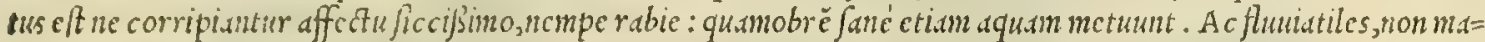
rinos conucnire cancros diatiabat, fcilicet quod aninalia marina ob admiftionem falis natma ficcifini baud aque exactam tucrentur cam, que cf aduer fus rabicm, contrarietatem. Ac cim quidam fubieciffet, cur non ommia, que in potsbili aqua degunt anim.lix, perinde ut cancri, iuuare a)Jolentr quis, inquit, fimilem cancris praparationem non admitunt. Nam borm uftorum cinerem, exiccatorius crim fit, canum mordcntium uenenum abfumere, fimulí;; di= gerere profeffus cft. Hace igitur Pelops dicebat ambitione magna udtitans, omnium fe talium nouiffe caufas. A 6 ego nifiplune me fetre quippiun prius perfuafum babeam, alijs perfuadere non tento. Itag; nec Pclopis rationcm, ut ne= ram accepi,ut qua crebr.s babcat contridictiones: ucrim cancros opinor ex proprietate totius fubftanti.e prodef= 20 $\int_{e}$. Quchiam autcm mullwn cormm mo: tuum fciucram, qui fucrant illis ufi, totis utiq; corporibus, hoc aperiendum, recenfendumíg; àme exiftinaui, tametfí non cffct buius inftituti proprium: nam id non erat propofitum. bactenus Galenus. Cxterim gammarorum facicm refrrunt locufte, o fquilla; quanquam be chelis c.reant. Gerunt gan:mari co tantiun tempore, quo crult an exuunt, duos in capite lapillos albos, rotundosq́; , quibus utuntur medici unliter ad expellevidos remun calculos: contcrunt enimbos in puluerem, or exuino potandos exhibent. Rotun= dis autem calcris matinis fimilbus, quos Adriaticiaccole, maris o fomine difcrimina unlgó Granci, or Maci= nette nuncup.unt, tbundat muxime ubiq; fuis un fuminibus, ac riuulis Hetruria. nam quemadmodum Infubria, Tran= Salpinarumg; regionum flunii, ac lacus ganmaros alunt; Ita Hetruria cancros, utpote e Gracia, ubi ab Aefcbrio= ne, or Galeno à cune rabido dcmorfis ex corum cinere faluberrina parabatur antidotus. Sed or illi non minori in errore uer faniur, qui putant marinos minutiores (ut ita dican) gaminarulos, quas uulgó Gambarelli, er Gambaru

30 foli appellamus, eos $c \int c$, quos tum Ariftoteles, tum Galenus, tum Aelianus, tum Plinius cancellos nominant . quippe

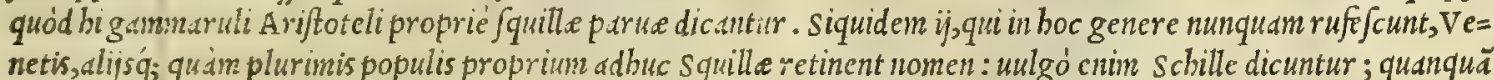
in Hipania, prefertin' ; in Cantabrix onnes bi gammaruli squille nulla differentia uocitentur. His, ut diximus, ddfi pulatur Ariftoteles $l b$. I I I .de partibus animainun cap.v I I I.cum inquit. Squillde à cancrario genere differunt,eo quód caudum babeant: à locuftarto ueró, quod forcipe careant. Quibus fané claret,cancris nullam ineße caudam. quapropter onne cruft.torun genus, cui cauda defit, in cancrario genere fuerit recen fendum. Cuiufmodi funt inaie iulgo Granceuole, paguri unlgó Granciporri, marini ac fluuiatiles canchri uulgó Granchi appellati, or id genus plu ra. Nec aliam ob caufam deximus, gammarulos parus dicifquillas, nifi ut omnibus notum fit, eds etian baberibis lon ge maiores, ut memoria prodidit Ariftoteles lib. I I I I. cap. I I. de biftoria animalium, fic inquiens. Squillarum e= 40 nim genere continentur gibba, crangones, or parus, qua maiores nunquan effici poffunt. Quibus liquidó conftat, uulgares gammarulos Ariftotcli paruas facilè effe squillas, chim ijmaiores nunquam euadant, quàm qut femper parui in pifcarijs babentur uenales. Quinetian id ipfum affirmare non dubitamus, quòd ïs cauda fit locuftarum, o gammarorun modo, chele ueró, feuforcipesdeficiant. Quiautem, qualésue C A N C E L I I fint, nomine

Gammarorú lapilli.

Cancri fluuia tiles.

\section{Quorundam}

error.

Squillarú con fideratio.

G R A C E V O L A.

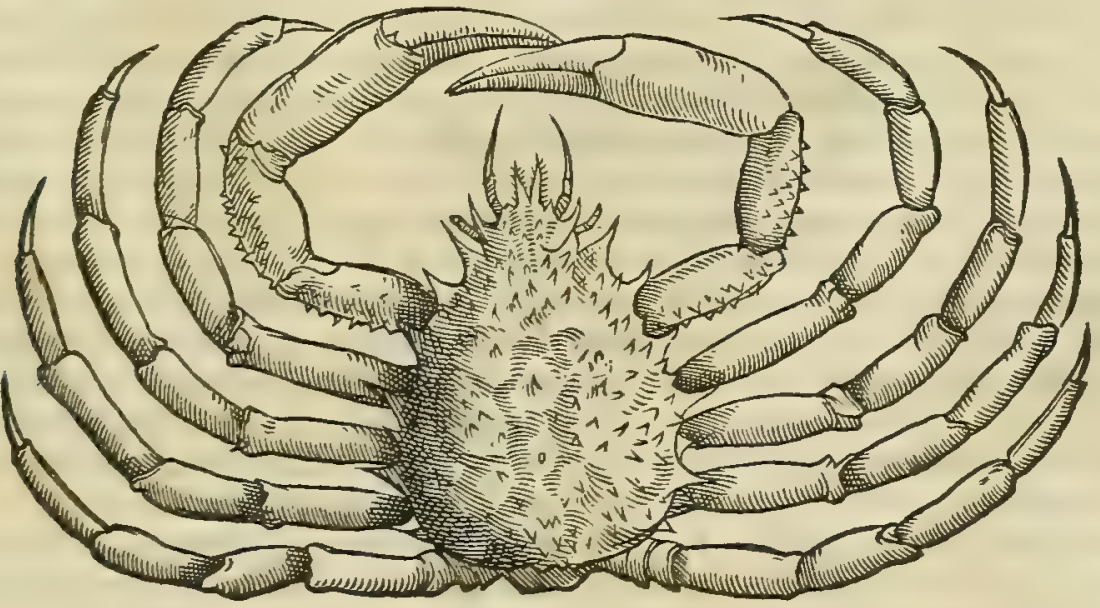


GRANCIPORRO.

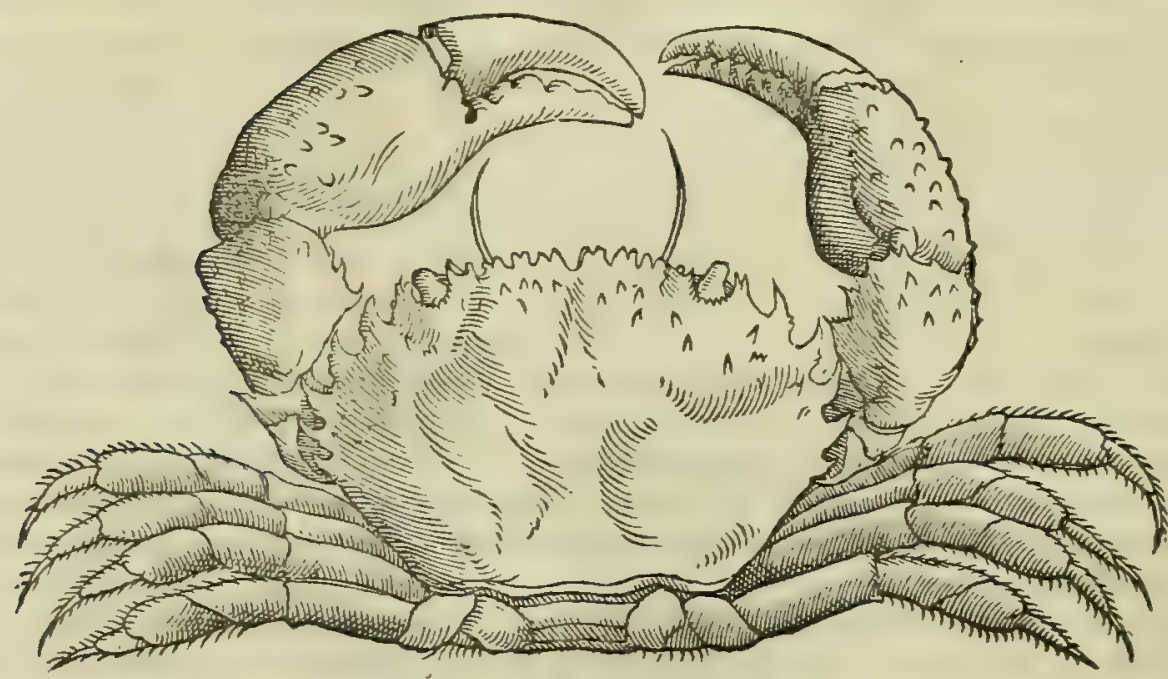

C A N C E I I I.

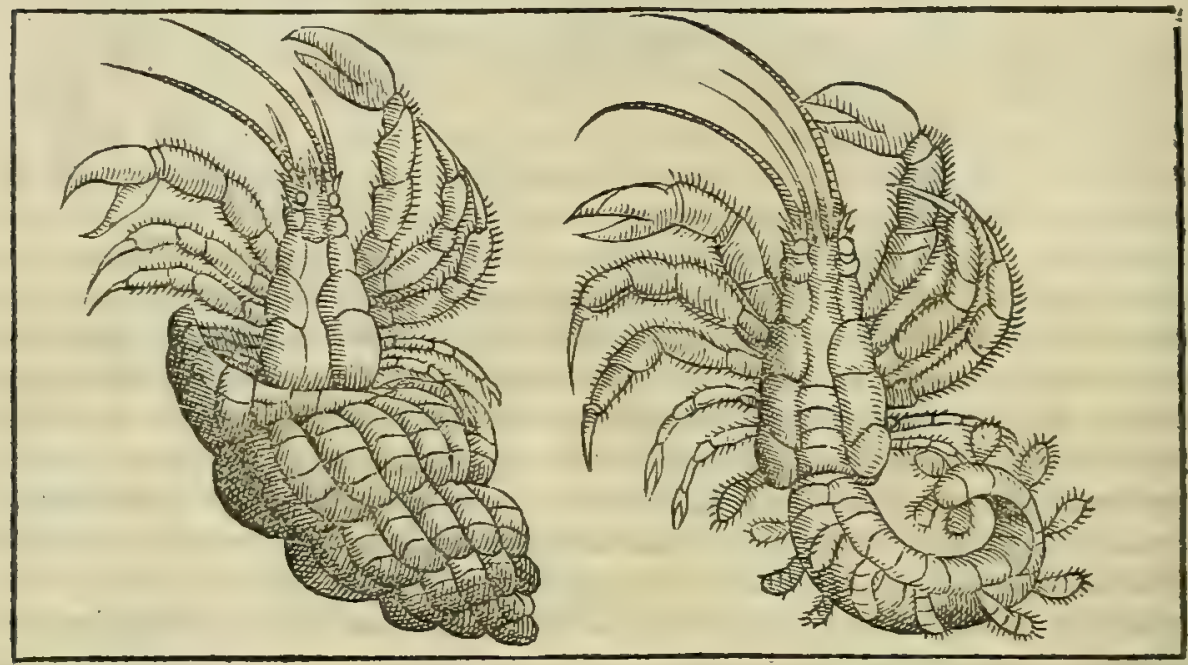

ip fo paruulos cancros defignantes, fcripfit Galenus libro tertio de alinzentorwm facultatibus: Cancelli, inquiens, ani= malcula funt perexiguis cancris fimilix, colore flano. Afferuntur enin cancelli inter minutulos pifciculos duplici Sane genere, ut quirto tum libro, tuin capite de animalium bifforia retulit A riftoteles bis uerbis. Quem autem cance! lum appcllant, communis feré focius cruftatorum, er teftatarun generum coft. quippé qui natura locuft is fimilis ppe= Actur, inafci'; feorfum per fe folitus fit. Verium quòd tef tam deinde pettt, quam ingreffus uitam traducat, binc fimilis tefta contectis animantibus eft. quapropter is in ancipiti effe, genusí; fibi uendic are utrung; uidetur. Forma tamen ( quod fimplicius dixerim ) fimilis araneis eft; nifi quòd partenz capitt, o pectori fubditam ampliorem, quàm aranei babcaut. Cornicula duo rufa, tenuia gerit, quibus oculi magni totidem fubiacent, qui nunquant intró recedant, ut că= crorum, fed Semper eminentes appareant. Os fubijs cft, quod uclut capillamentis quibufdam pluribus circundatur. I is pedes fubiunci duo tifurces, qubus cibun ori adinoncat: bini item utriq; adbarent lateri, e tertius paruus. Tbo= racis pars inferior mollis tota cft,difiectóg; finu pallidum initus cernitur. Meatus ab ore ad uentrem pergit. foramen cxcrcmenti perfeici nullum potcft. Pedes, ac thorax duriticin pre fe ferunt, fed minus, quam cancri. Nexu nullo te= fis adheret, purpurarum modo, o buccinarum, fed abfolutus liber $q_{\text {; }}$ uagatur. Oblongior eft, qui turbincm fubit, quàn qui neritem (quem naticcm interpretamur) genus enim diuerfum eft, quod in nattce degit, catera quidem non abfimile : $\int e d$ dextrum bifurculatum pedem paruum habens, cim laum grandiufculum habeat, er ingredi eodem ip= fo grandiore potißimim folet. hec A ristotcles. Aelianus ucró lib. x I I I.cap.x i x. de cancellis ita fcribit. A cõ= chis quidem inopes, $\mathbb{E}$ nudi primün cancclli na fcuntur, deinde eas tanquan domicilia ad habitandun deligunt. Cüm cnin uachas, o inanes offenderunt conclualus purpur.e, aut turbinis, primó intra eas ingrediütur : deind c cim in am= pliorem magnitudinem excreuerunt, quàm ijs ut capi queant, inteftam laxiorem tanquam domum alteram demigrät,

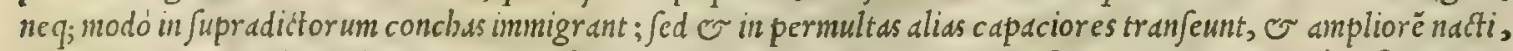
ca t.mquam imaiore domicilio gaudent: ac se pe de polijs multo certamine inter fe contendunt, pulfo, witor exunias affequitur . bactenus Aclianus. Crit in omnibus fubfcribit Plinius lib. I X.cap. X X x I.et X I I I. His igitur diligenter perpectis, ommbus, ut arbitror, palim fiet, $\mathcal{O}$ cuncros à gammaris, et cancellos à fquillis dif=

Nomina. Ferre. Aninal, quod xxou'vos Gracé, Cancer Latinc appellatur: Arabicé, Sartham, feu Sarthan: Italicé, Granchio: Iiliftanicé, Cangreio : Gallicé, Cancres. 


\section{InLib. fecundum Diofcoridis.}

Erogaios xepoũos. SCORPIO TERRESTRIS. CAP. XI.

TERRESTRIS Scorpio tritus crudus, \& impofitus, fux plugx remedium eft. Quin efturaffatus, ad eadcm.

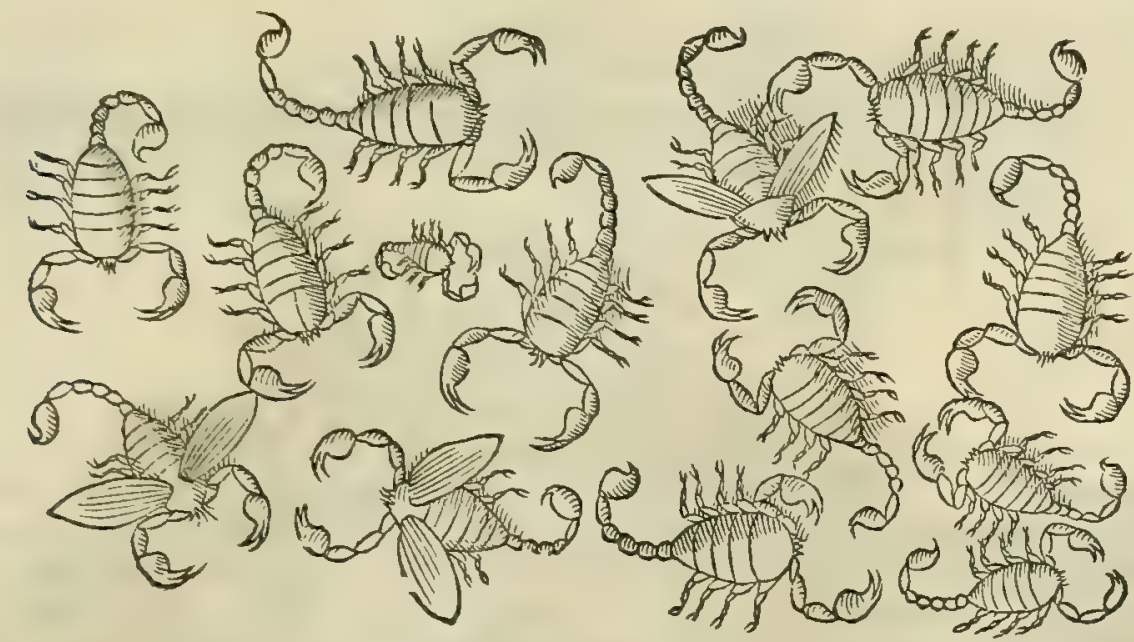

T E R R E S T R E S Scorpiones animalit funt uulgó nota, quód in quacunque domo, non modó in cubiculis, er

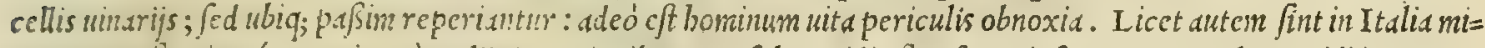
nus uenenofi, minusq; nocui, quaim alijs in rcgionibus, que fub meridie fite funt; ipfe tamen complures uidi in Hetru=

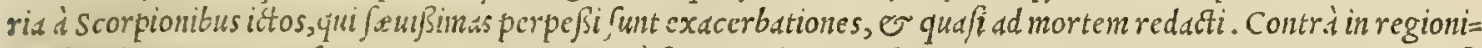
bus frigidis minus nocui funt. In agro Tridentino d fcorpionibus itti mibil noxe percipiunt. Qunod tamen euenire af $=$ firmant gratia peculiarl jibi d Dco impertita precibus diui vigilij epifsopi, quem er patronum precipuum babent, o aduocatum apud Deum. Hoc idcm afferit Ariftoteles lib. I I I.cap. X X I X. de animalium biftoria, ubific inquit.

30 Morfus beluarun ex locorum diuer fitate plurimun differunt, ut in $\mathrm{Pharo}$, locisq; alijs, fcorpiones non ladunt. At in alijs locis, e precipue in Scythia, multi $\odot$ magni nocui funt, ơ uel bominem, uel quámuis beftiam percuferint, interimunt : nec fues euadere pol]Junt, quanquan cateros uirulentos ictus minimé fentiunt. Plinius, Auicenna, $\mathrm{Al}=$ bertus, Aclimus, $\odot$ aliorum plerique nouem Scorpionibus genera asignant, diuerfis duntaxat coloribus diftinita: nimirü quód alij fint flaui, alij rufi, alij cinerei, alij ferruginei, uirides alij, alij lutei fubatraq́; cauda, alii uinofí, alij al= bi, alij deniq; fulliginis colore. Preter nigros, E ferrugineos, virides qudm plurimos me uidife, legifféq; recordor, in comitatu Arcinon longé is sarca flumine, quadam in fyluula nouellis quercubus confita apud facellum diui $\mathbf{P}$ auli, ubi paruo admodum tempore, firio ardente, ego, o erenita quidam, de bis qui fub faxis latebant, plus quàm mille, $v$ quingentos collegimus, craffos, er plurimum farctos. Plures inter eos freminas inuenimus, que fuos nuper editos foe tus albos, pediculi magnitudine, fub uentre fecum ubique gerebant, finguli fingulis cruribus adbarentes. Quapro=

40 pter non ab re prodidit Ariftoteles lib.v.cap. $\mathrm{x}$ x $\mathrm{v}$ I.de biftoria animalium, quód terreftres Scorpiones wermiculos ouorum fpecic pariant complures, o incubent: mox ut prolem perfecerunt, pellantur ab ea ipfa, er interimantur à fuis liberis magno numero: Sepius enim undenos pariunt. Plinius auctor eft, Scorpionumictum, multó mag is formi= nis pernicialein effe, quain uiris; prefertim uirginibus, quibus femper lethalem effe ait, Quibus fepteni in cauda in= ternodij numerancur, longé Seuiores habentur, quàm ij, quibus tantü feni infunt. Nonnull praterea literis man= darunt, quibus fub fribit strabo lib.x v, fue Geographie, Scorpiones quofdam babere alds, quibus per aéra uolitan tes de una in aliam regionem deferuntur. Hoc enim credere non uidetur abfurdum!, cum idem formicis fimiliter ene=

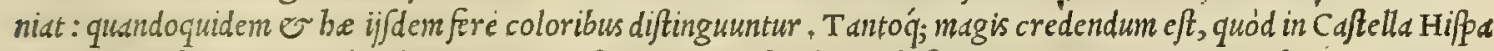
nie regione $\int_{x}$ pius agricole aliquos terre ceßpites ar atro fcindant, ubi formicarum more innumeri fcorpiones grega tim byeme delite cunt. Citra Cymamoluos Aethiopas late deferta regio eft, a fcorpionibus gente fublata, if Plinto cre

so dimus. Qui precierea tradit, quód, fi decen cancri cum ocimi manipulo adalligentur, omnes, qui ibi funt fcorpiones, ad eum locum coibunt. Quod tamen Diofcoridi manifefté refragari uidetur . nam fuperius in cancris ita fcriptum reliquit Diofcorides. Cancri fcorpiones necant, fi triti cum ocimo admoueantur. Ferunt d uepis, apibus, o crabro= nibus cos non ici,qui prius à corpione percußi fuerint. Quinetiam narrat $\mathrm{P}$ linius lib. $\mathrm{x} \times \mathrm{x}$ v.cap. $\mathrm{X}$.Scorpiones mor= tuos reuiuifcere, almo to aibo ueratro. Quidam medici utuntur Scorpionum cinere, qui uiui fint exuffi, ad urinam ciendam, ijs precipué, qui renum, aut uefice calculo obftruuntur. Quo fit, ut in hunc ufum commendäuerit Me fues oleum ex ijs paratum, quod officine babent, renibus o pubi illitum. Hoc idem commendauit Auicenna ad aurium do Tores. Ego tamen illud ufu exploratum babeo, quód oleum per me factum, in quod fané magnus fcorpionum ingre= ditur numerus, cordi duntaxat, $\odot$ pulfantibus temporum, manuum, $\odot$ pedum arterijs illitum, ab onnibus liberat ue= neris, dummodo erodent f facultate uacent. Cuin or eos fanat, qui tam à uiperis, quàn ceteris uenenofis animalibus uel icti, uel demorfif fuerint. Qua de re ij (abfit tamen uerbis iactantia)teftimonium perhibere poffunt, qui prius oleo fanto id acerdotibus illiti,noftro poftnodum peruncti euafere incolumes. Praftat item maxime hoc oleum, cum in bo

Scorpionum confideratio.

Scorpionum genera.

Scorpiones aligeri.

Scorpionum facultates.

Olei ex fcorpionib. uires. mines 
mines peftilentia fauit : quippe quód non modó pefte infectos iuuet, fed $\odot$ fanos pra feruet. Praftat deniq; ad omnes interaneorum uermes, omneś́; dolores mulcet ex flatu, ucl ex frigore genitos, prefertim uentriculi, coli, ac uteri. Eius parandi rationem trademus (Deo concedente) libro fexto, ubi de uenenorum remedijs, fiue antidotis latius dif=

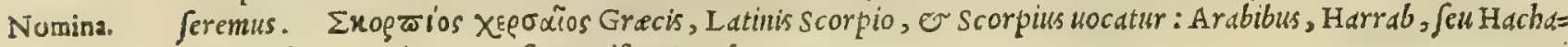
rab: Italis, scorpione terreftre: Hipanis, Alacran.

¿rogaios $\theta \alpha \lambda \alpha$ asios. SCORPIO MARINVS. CAP. XII.

M A I N I Scorpionis fel conuenitad fuffufiones oculorum, albugines, \& hebetudines .

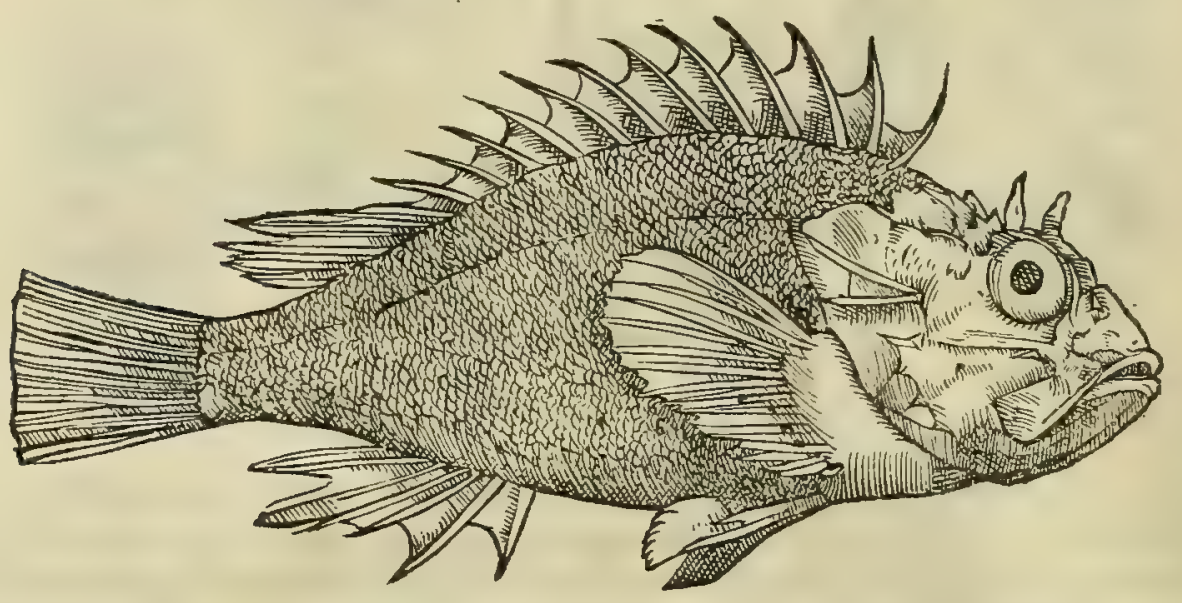

Scorp. mari ni, \& f corpzne confid.

Nomins.

C R E D I D E R E. quidam marinum Scorpionem, er Scorpanan uocatam, nibil inter fe differre. Veruntamé quod f corpana fit marinus fcorpio, nemo non ibit inficias, qui $\odot$ A riftotelis, et A thena i actoritate nitatur : uterque enim ad inuicem diftinxit illos. Porró Scorpena in dorfo pinam gerit uenendtam, qua imprudentes pifcatores $\int a$ pius 30 icit: $n e q_{;}$iam de fuerunt, qui cius ictu fint interempti. Proinde exiftimarunt nonnulli, ictuum fimilitudine falfi, inter fcorpenam, or marinum fcorpionem mullun prorfis intereffe difcrimen. Caterum Scorpio, or scorpana (ut equidem arbitror ) ciufdem feré generis funt, fed in pecie e forma, inter fe plur ibus differunt. Siquidem Scorpius $\dot{E}$ pelagijs pifcibus eft, fcorpana longé maior; adeó ut octonas, nouenaśq; quandog; ponderet libras. Scorpana ueró pifcis, eft litoralis, fcorpione multo minor. Scorpius item uniuerfo corpore rubet: cornua bina in capite gerit, fed mollia : or acutos in ore dentes, minutulos tamen : pinnis conftat aculeatis, tain bis, qua per medium excurrunt dor = fum; quàm bis, quas anteriore; ov pofteriore parte gerit, fed ijs tantum acule is icit, qui dor $\int 0$ annectuntur : quorum tamen uis bis, qui fcorpane infunt, imbecillior eft. Hunc funt, qui uulgó uocent Pefce cappone, fed in Hetrurie mat. ritimis quibufdam locis uocatur Cerna. Scorpena autem, que fuum apud omnes retinet nomen, nec cornua babet, nec dentes adeó acutos: gerit tamen in dor fo aculeos fcorpij modo, fed eminentiores, ac duriores, nec ufqueadeo pin natos : in ceteris ueró pinnis ijs omnino caret, preterquim circa branchids, ubiduos pralongos habet aculeos, $\mathcal{C}$ nonnullos circa caput : corpore eft in nigro uire fcente. Sunt tamen, qui indifferenter fcorpium fcorpanam uocent;

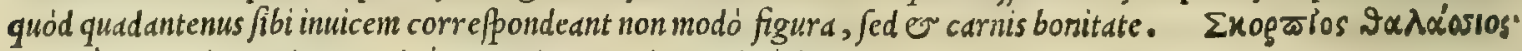
Grecé, scorpio marinus Latiné, scorpione marino I talice dicitur.

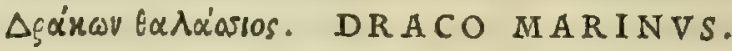

CA P. XIII.

D R A C o marinus diffectus, \& apertus, impofitusq́ue ictus fpinæ fux, qua ferit, medcla eft:

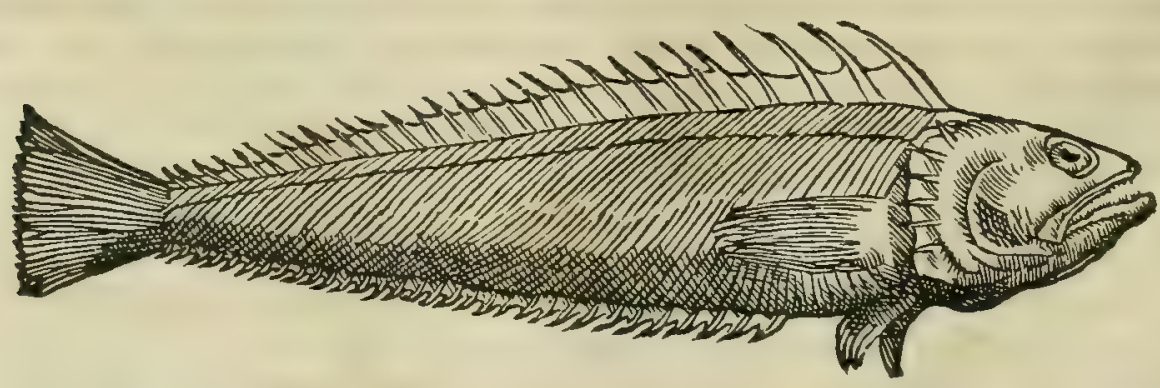




\section{In Lib. fecundum Diofcoridis.}

DRACO MARINVSALTER.

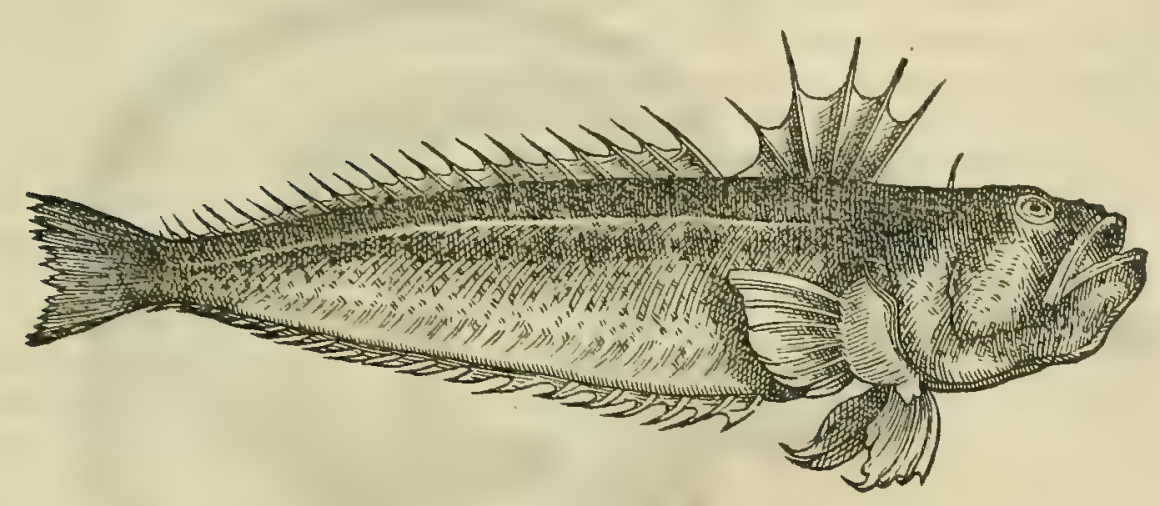

$V$ A R I A $\mathrm{T}$ auctorum fententis in marini Draconis biftoria. Quandoquidem Albertomarinus draco ingens eft befti., ferpentis facicm referens, dis non amplioribus, quaim que ad natandum fufficiant, fed ob uirium praft un= Draconis ma tism onnu!m aqustilium uclocisimus cenfetur. quspropter breui admodum tempore ingentia metitur maria. Quin 20 or uenenof um cft illi animal, adeo ut quof cumque pifes, uel alia quecunq; animalia dente uulneraucrit, interimat. Pifcatormmpreterea artificio captus, ftatim ut in arenam fe $\int \mathrm{c}$ protrabi cermit, mira celeritate fcrobem in litore fos dit, qua fe conderc poßsit. bee Albertus. Qui ctfi $e x$ Ariftotele, o Plinio (ut opinor) tranfcribat; plura tamen ad= dcre widctur, quibus an multa fit adbibendafides, quid ftatuam non b.beo. siquidem boc animal A rifoteli tanta ads miratione non preftat, nec draco appellatur, fed ferpens, ut is pofteritatis memorix commendauit libro I x. cap. $\mathrm{x}$ X x v I r. de bitorix anim.lium his ucrbis. Serpens marina colore, e corpore congro proxima eft, fed obfcurior,

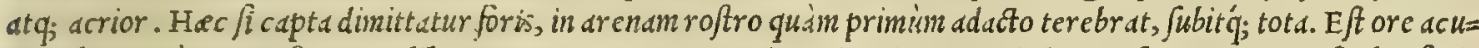
tiore bec, quaim terreftres. Et lib. I I. cap. x I I I I. Sunt etian (inquit) maris indigene ferpentes terreftribus fimi= les; nifi quód caput babeant congri. Et quidem generd earum plura funt, colore numerofo uarietatis. Nafci eas non in altißimis gurgitibus certum eft. Plinius hoc animal non ferpentem, fed draconem marinum pariter cum Alberto 30 uocat lib. I X. cap. X x V I I. fic inquiens. Rurfus draco marinus captus, at $q$; inmiffus in arenam, cauernam fibiro= fro mira celeritate cxcaudt. Ad bic, mea quidem fententia, Draco marinus baud quaquam fucrit, de quo fcribit Dio feorides, fed per fe maris ferpens. Quandoquidem Ariftoteli lib. v I I I. cap. X I I I. draco marinus piccis eft litord= lis, qucmadmodum dentex, fcarabeus, cernua, aurata, mugilis, mullus, turdus, pulcber, gobius, atq; alij complures, o omne faxatile genus. Proinde dicebat Plinius lib. $\mathrm{x}$ X X I I.cap. X I I I. Extra has funt rotundx in oleario ufu co= chlex, cucunis, cynopus, cammarus, cynosdexia, draco . quidam uolunt effe dracunculum. Eft autem graculo fimilis: aculeos in branchys habet ad caudan pectantes. Hxic fane non parum correpondere uidetur is, quem Vene= ti pifcatores, itcm; ; Aquileien $\int e s, \mathcal{O}$ Tergeftini Araneum uocant, $\mathcal{O}$ uulgó Pefce ragno. Quippe qui inter litora $=$ Pifcis arales aculeos circ um branchias habeat, caudan uer fus pectantes, er alios in dorfo adeó venenatos, ut ab eo itti, nifi cu ram adiniferint, facilé interimantur. Itaq; $\sigma$ is uidetur Plinio fuife draco, uel dracunculus, quem libro I x. cap.

40 X L VII. ip $\int e$ araneum quog; uocauit, cum inquit. A equé peftiferum animal araneus, fine in dor fo aculeo noxius. Prefertin cim litro x x X I I. capite ultino inter litorales, 0 maris mag is peculiares pifces non aliter araneum re=

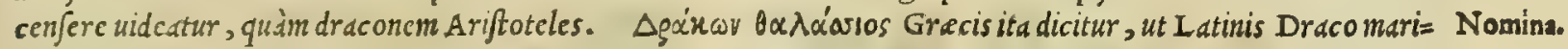
nus, or Italis Drago marino.

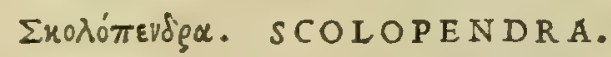

\section{CAP. XIIII.}

SCO I O P E N D R A marina in oleo decocta fi illinatur, auellit capillos : fed contactu pruritus facit.

S C O I O P E N D R A marind dnimal e? exigutum: atque, ut prodidit Plinius libro I X. capite X I I I I. ed eft - terreftrinon difimilis, quam ctiam Hetruria centipedam appellat. Dicunt banc ( $f$ tamen $i j s$ auctoribus eft adbiben= da fides) ftatim, dcuor ato bamo, omnia interaned innocue euomere, ac deinde, co ab inteftinis explicato, fua eadem reforbere uifcerd. 2 uocirca mecum fepius cogitaui, non iniucundum fore, eius uifcerum peculari anatomen. Sed

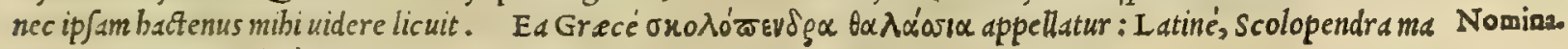
rina, pariter er Italicé.

\section{Názkr. TORPEDO.}

CAP. XV.

M A R I N A Torpedo diuturnis capitis doloribus admota, cruciatus uehementiam mulcet.eadem appofita euerfam fedem, prociduamq́ue coërcet.

T O R P E D O in chartilagineorum, planorumí; pifcium genēre ab auctoribus recenfetur, perinde ac raia, le= Torpedinis wiaia, rbombus, foled, paftinaca, or alia id genus plure. Hec dorfo rube fcit, maculis quinq; nigris (quod in adultis confideratio . 
TOR PE D O.

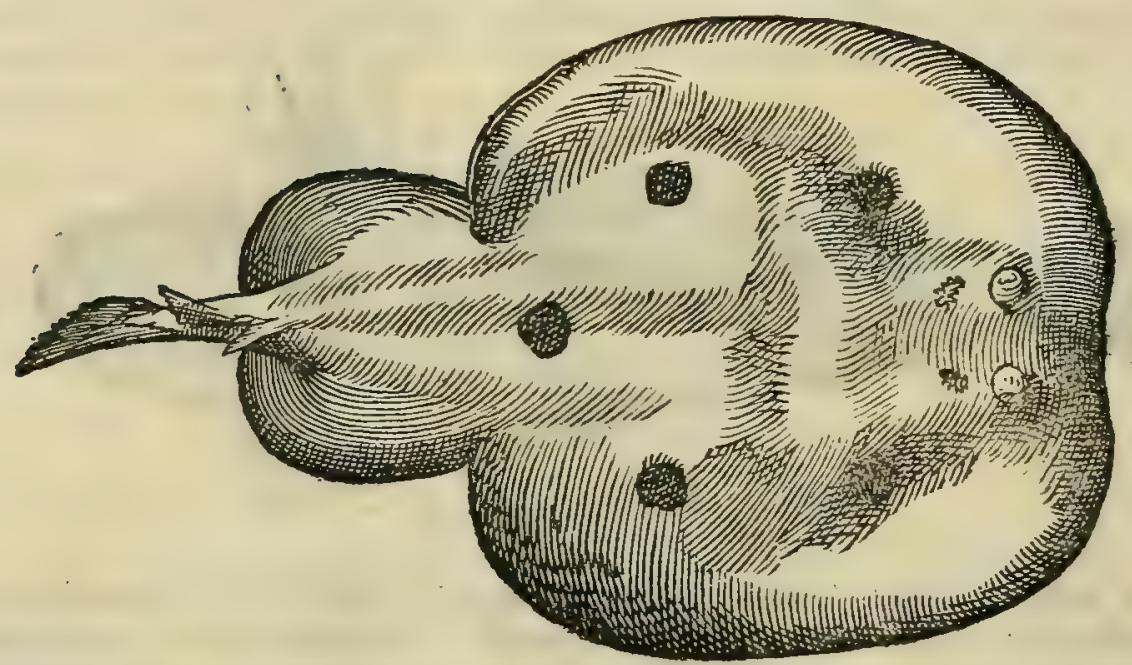

10

Torpedinis tantum uifitur) interiectis, oculis fimilibus : fupina uerò parté albicat. Tanta buic uis peculiaris ineft, utretibus mira facultas. capta, anteaquàm manu attingatur, $\mathcal{V}$ manus, $\mathcal{E}$ lacertos pifcatoris ftupore non modico afficiat : id quod etiam fit, fi capiatur hamo. Talis nanque buius facultas per fetas, $\odot$ haftam infenfibili quodam modo perineans, ad manum pi= fcatoris tandem tranfuecta, celeriter torporem inducit. Idcirco Galenus libro v I. de locis affectis: Ea (inquit) po= tentia torpedo preditta eft, ut fi fufcina attingatur à pifcatore, tranfmiffa qualitate per haftam ad manum, eam repen té obftupefacit. Idem poftea retulit Plinius libro x x x I I. cap.r. fic inquiens. Torpedoetiam procul, ev é longin= quo uel fi hafta, uirgáue attingatur, quàmuis praualidos lacertos torpe fcere facit, e̋ pedes quàm libet ad curfus ue toces alligat, er retinet. Et lib. I X. cap. X I I I. it a fribit. Nouit torpedo uim fuam:ipfa enim non torpens, mer= fağ; in limo fe occultat, pifces, qui fecuri adnatantes obtorputre, corripiens. Quod ante ipfum prodiderat Ariftote= les lib. I x. cap. X x x V I I. de biftoria animalitum. Caterum proprietas hac uiuis duntaxat ineft: nam fi eadem in Torpedinis exanimatis perfifteret, comefte (ueniunt enim frequenter in cibis) uniuerfum corpus ftupidum redderent. Q $u a m=$ uires ex Gal. obrem Galenus libro X I. fimplicium medic. de ed ita fcriptum reliquit. Sed $\sigma$ Torpedinem totam (dico autem. animal marinum ) capitis dolores fanare capiti admotam, fedemó;; euerfam coürcere, à quibufdam eft proditum. Ve= rüm ego cum utrunq; effem expertus, neutrum facere comperi. Eam igitur cum cogitaffem, adbuc uiudm effe appli= candam, cui caput doleret ( poffe enim fieri, ut boc medicamen anodynon fit, hoc eft, dolore liberet, fimiliter alijs, que fenfum obftupefaciunt) ita babere comperi. Putog; c'um, qui primus eft ufus, tali quapiam motum ratione uti ag $=$ greffum. bac Galenus. Venetijs pifcis hic ab effectu, uulgó Tremolo appellatur : fiquidem membro ftupefacto, fub= inde tremorem incutit. Romani ueró (me quidem latet, unde id nomen traxere) cundem uulgari nomine Batti potta,

Nomina. O Fotterigia dicere confueuerunt. Qux vхं Torpedine: Hifpanis, Hugia: Gallis, Turpilles.

VI P E R A.

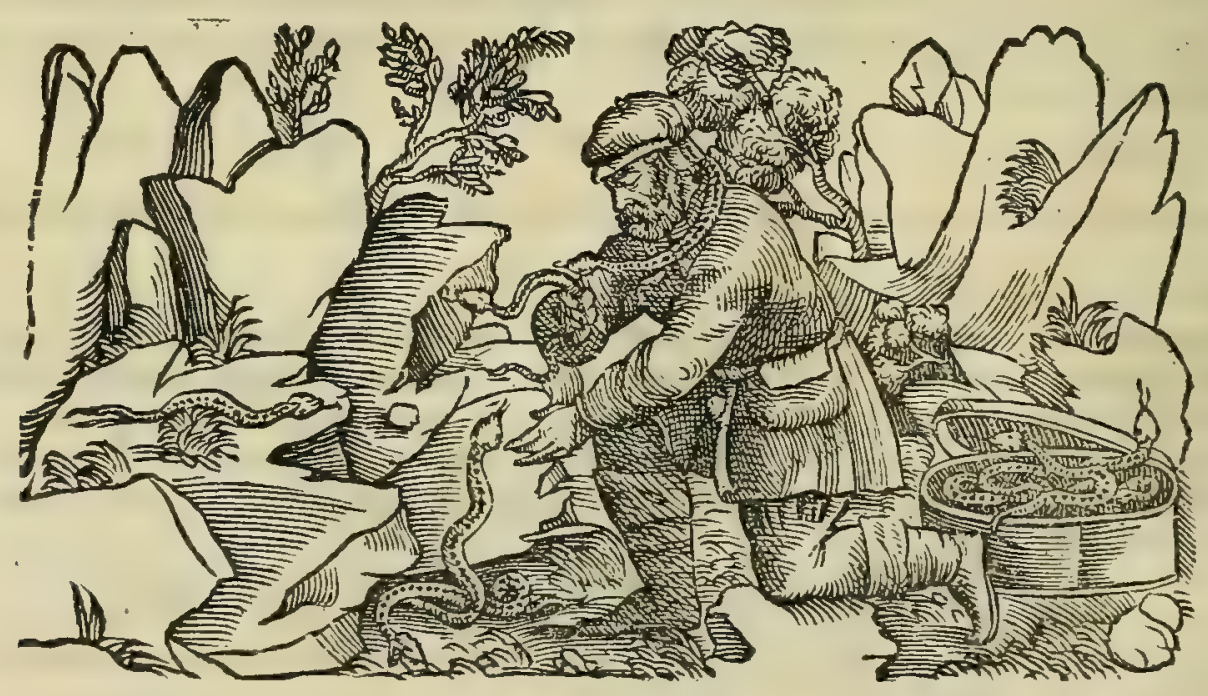

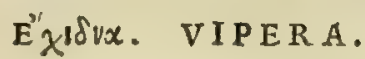

CA. XVI.

VI PER I NAE carnes fi coetredantur, claritatem oculis afferunt: neruorum uitijs auxiliantur : increfcentes ftrumas reprimunt. Detracta autem cute, caput caudaq́ue, quoniam carne uacant, 


\section{InLib. fecundum Diofcoridis.}

amputari dcbent. quippe commentitium eft quod precipitur, certam utrinque menfuram præcidi oportere. Reliquum verò corpus exemptis interaneis elotum, diffêtumq́ue difcoquitur cum oleo, vino, falis exiguo, \& anetho. Aiunt ijs, qui viperas efitent, pediculos procreari : quod planè à ueritate abhorret. Adijciunt aliqui longam fenectutem agere, qui eo cibo vefcuntur. Sal ex eis ad eadem conficitur, fel inefficacior eft. Viua autem uipera in fietile noutum demittitur: adjiciuntur falis, caricarumque tritarum, fingulatim quinque fextarij, mellis cyathi fex, mox fittilis operculum luto oblinitur, \& fornacibus inafiatur, donec fal in carbones redigatur, qui poftea tritus in pulueris faciem, reconditur. Plerunque, ut ori gratior fiat, immifcetur fpica, aut folium nardi, aut malabathri momentum.

I A M P R I D E M cxptume eft ueras Viperas nancifciin Italia. Earum crim partus exs indicarunt: quando= quidem recentiorum medicorum quidam viperas fummo ftudio indagantes, ut Galeni nore, boc etiam a uo legitimam poffent parare theriacam, inito confilio cum his circunfor aneis, qui ferpentibus alendis quaftum factitant, viperas ipfas pregnantes funt confecuti, que in capfulis conclufe catulos peperere, quod proprium viperarum fit animal edere, non quidem oux, c.eterorum ferpentiun more. Nec tamen proptered illud uerunn effe compertum eft, quód na fcentes vipere uifcerd abrodant, occifa parente, ut libro de theriaca ad Pifonem prodidit Galenus ( fi tamen is liber

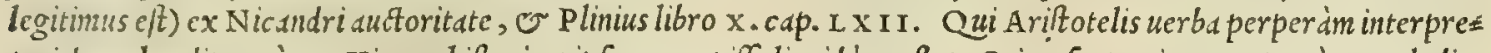
tari deprebenditur, à quo Vipere biftoriam ipfun accepiffe liquidó conftat. Cuius fententiam non tantim explodit, quod experimento compertum eft; fed o A riftoteles ip $\int e$ : quandoquidem nufquam dixerit, uiperinos fat tus parentis 20 uifcera, aut uterum abrodere, fed quód qui tardius eduntur catuli (tardius enim ideo illi excludütur, quód vipera fin * gulos fingulis dicbus parit) abrodunt membranam quandam, qua in matris utero obuoluuntur, ut citius prodeant in lucem. Qus in re, ut hoc omnibus paldin fit, fic lib.v.de biftoria aninaliume capite ultimo, fonant A riftotelis uerba.

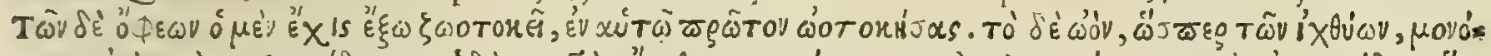

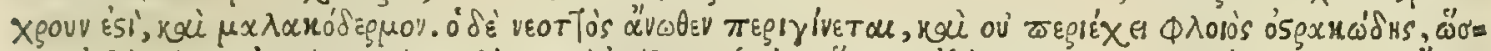

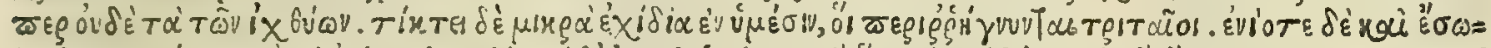

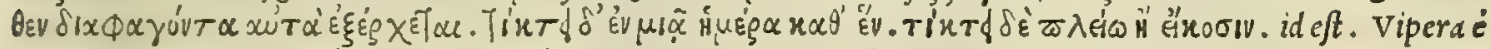
ferpentibus animal edit, cum intra $\int e$ primim oua pepererit. Oumm boc unius coloris, er molli cute contectum, ut pis fcium eft . Fotus fuperné gignitur, nec duro cortice continetur, ficut nec pifcium quidem. Parit paruas uiperulas nembranis obuolutas, que tertia die rumpuntur. Euenit interdum, ut qui in utero funt, abrofis membranis prorum:

30 pant. Singulos diebus /ingulis parit, pluresq́; parit, quàm uiginti. hec Ariftoteles. Cuius Sententiam (ut dictum eft) peruertens Plinius, ubi ei dicendum fuerat, quòd ultime uiperule adhuc in matris utero degentes, fud abrodunt inuo lucra, anteaguìm prorumpant, dixit ceteras tarditatis impatientes, perrumpere latera, occifa parente. Porró buic explofa fententix etiam Pbiloftratus refragatur, nam in uita Apollonif Tyanei narrat, A pollonium ip fum ui= uam, ac incolumen uidiffe viperam, qua fuos catulos nouißimé exclufos lingebat. Marfi protered, qui ferpentium domitores (e predicant, quïg; falso ex diui Pauli profapia fe originem duxiffe gloriantur, viperam Maraffo uulgo

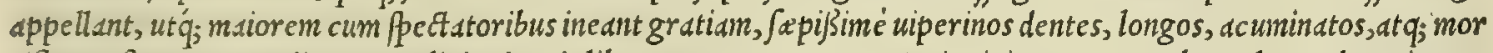
tiferos oftentant, conditos ( ut Plinius inquit libro X I. cap. X X X V I. ) ginginis, atque membranula quadam circunx. datos, lethali ueneno referta. Quin e uiperarum nuper editos feetus oftendunt, quos viper e fuis alunt in capfulis, quibus eas deferunt: nec tamen illi matris uifcera fcindunt. Caterün quód vipere primim intra fe oud pariant, mox

40 animalia gignant, Theophraftus quoque allitor eft libro v I r. cap. X I I I . contra eos, qui fecus fentiunt. 'vipe= re (ut fcribit Auicenna libro quarto, ubi de uenenis agit) caput babent prefsum, latumq́; , ubi ceruici annectitur, que peculiariter illis tenuis eft: nec corpore adinodum funt longo, utpose nec cauda. Ad hec Galenus, cim fcriptis trd= dere uellet, quibus notis mares viper a d forminis diftent, co libro, qui de theriaça ad Pifonem infcribitur, fic inquit. Viper e fomine fubrufe funt, o perqudm agiles, ceruice elata : oculis fubrubentibus, inuerecundis, atque intuitus feri : ijs caput latius, quam mari, quem etiam excedunt uniuerfa corporis mole, earumq́; excernens meatus fuum propius caudam obtinet fitum. Mari duo tantum infunt canini dentes; fremina uerò plures. Proinde igitur Nicanse der cecinit bis uerfibus.

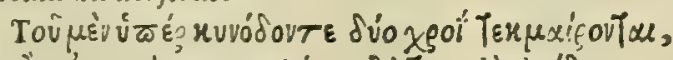

I"o) É

Hoc eft foluta oratione.

5o Mafculi quidem fuprà canini dentes duo colore notantur?, uenenum eructantes: at plures femper foemine infunt. Il lud infuper addiderim, A riftotelem memoris mand affe lib. v I I I. cap.x v. de hiftoria animalium, quód licet hyeme cateri ferpentes cauernas fubeant terre; uipere tamen fub faxis condantur. Ex quo pal ime eft, Plinium boc etiam loco non recté intellexiffe Arıfotelem: quippe quód tradiderit lib. I I I. cap. $\mathrm{x}$ x x I x. viperam folam terra con= di; ceteras arborum, aut faxorum cauis. Illud item reticuit Arifoteles, quod Plinius poëtds fecutus retulit, fremină fcilicet in coitu maricaput abrodere uoluptatis dulcedine. Sed ut iam viperis uires fuas, ac facultatés reddamus, bic ea nunc referam, que de ijs lib. $x$ I. fimplicium medicam. tum libris de antidotis pluribus pofteritatis memorix prodi= dit Galenus. Viperarum igitur carnes palam uidere eft excalfacientes, o deficcantes, ubi condiuntur ceu anguil= $l e$, nempe oleo, sạle, anetho, porro, o aqua, feruato nimirum modo. Quód autem totum corpus per cutim purgét, difcere tibiliceat uel exijs, qux ego iunenis etiámnum in Afia noftra fum expertus: que fingulatin deinceps nar= rabo. Homo quidam morbo, quein elephanta cognominant, laborans aliquoufq; cum fodalibus conuer $\int a b a t u r$, donec exipfius confuetudine conuerfationég quidam noftrûm morbi inficerentur contagione : ille iam graueolens crat, ac

Viperarum confid.

Plinij laplus. (n)

Viperarum fa cies, \& ferue difcrimen.

Plinij lapfus. deformis. 
deformis. Confructo igitur illi tugurio proxime uicum in ingo collis propter fontem, illic bominem collocant, tan= tum illi quotidic ciborum ferentes, quãtum uictui fuppeteret. Caterim ad canis cxortum, cùm fortć mefforibus haud procul inde metentibus uinum effet allatum in fictili fane quiin fragrans, is quidem, qui attulerat, depofito illo propé me ffores, abijt. Verim ubi eius bibendi adueniffet tempus, fublato fictili adole fccus, ut pro more implcto cratere, competente aqua uinum temperaret, in cratera uinum effudit, o uni excidit uipera mortua. Qua re attonitimef $=$ fores, weritine quod, fi ebibiffent, inde fibi malum eueniret, fuam quidem fitim aque potione fedare maluerunt. Caterim cumillinc difcederent, quafi pre bumanitate ac mifericordia, bomini illi elcphanti obnoxio uinum largiun: tur, rati expedire illi potius mori, quim uiuere in ea miferia. A tille, ubi ex boc bibiffet, admirabili quodam modo fa= nitati rcftit: tus cft. Nan tuberofun illud omne cutis totius non aliter, quam animaliun a teftis mollitic nuncupato= rum malacoftracon, tegmen decidtt. Quantum autem reliquun erat, molle admodum apparuit, inftar cutis cancro= rum, e locufarum (carabos Grsci uocant) ubi extma tefta exciderit. Altcrum quoq; ciufmodinon dißinili ca= fu in $\mathrm{M} y$ fia A fie, non procul ab urbe noftra accidit. Vir quidam clephanto laborans profictus eft ad aquarum cali= darum ponte nafcentium uJum, perans inde nomibil fe commodi adepturum. Frat illi fcortum ancilla, iunencu= la fane formo $a$, compluribus andtoribus ambita. Profect is igitur illis, cum aquis uterctur, in cditus, quibus uicinus erut locus $\int$ qualidus, or uiperarum plenus, forte fortuna ex illis und in urceum uiniincidit negligentius pofitum: ex= tinctdi; cf. Ac fcortun quidem in lucro id reputans, quod fors eueniffet, bero id uini propirat. Catcrim ille, ubi ebihiffet, ad eum nodum, quo ille, quidegebat in tugurio, perfanatus eft. hec Galenus. Quietfi alia é uiperis cxpe= rinenta ibiden fcripferit, unde fimiliter alij incolumes euafere, ut eius firmior redderetur ratio, quod filicet uipe= rarum $\mathrm{e}$ u clephantiaci fanentur; attamen breuitati confulentes, ea boc loco filcntio intoluenda duximus. Verum enimuero nil mirum alicuifuerit, viperas ambas, quarum meminit Galenus, fe tain facilé immerfiffe uino: fiquidem Vipere uino illis natura comparatum eft, ut uino fummopere delectentur. Quanobrem narrat Ariftotcles lib. V I I I. cap. I I I I. delectantur. de biftoria animulium, quód ideo uiperas aliqui uino cum ficilibus ad fepes difpofito uenantur, quia uini incontinentes funt: cbrie enin capiuntur. Id quodetiam dixit Diofcorides in fexti libri prefatione de uenenis, uenenatisq́; d= gens. Quinetiam uipere (ut ad Pifonem fribit Galenus) bupreftes, or cantharides decorant. Item Ariftotelis te= ftimonio lib: v I I I. cap. X x I x. de biftoria animalium, fcorpium deworari à uipera certum cft: ob id'q; ( ut idem eft auctor) corum uenenatorum morfus grauiores funt, qua alijs aninalibus ucnenatis ue $\int$ cuntur: quod profecto $f_{d=}$ ciunt uipera. Ha theriacen ingrediuntur: at non omncs, nec omni tempore capta probantur. Proinde Galenusli= Viperarü ue- broprimo de antidotis rem banc fcité er aperté declarauit, fic inquicns. Viperas non ut aliqut faciunt, aftate me=

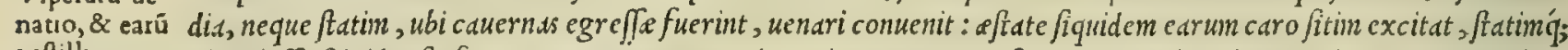
paftilli. $a b$ egreffu frigid 1 eft, ficca, $\sigma$ extenuata. Optimum itaque tempus eft, quod ijs medium intercedit, quod $\approx$ Andro= machus ip $\int e$ /ignificauit, quo tempore $\widetilde{\circlearrowleft} q u i$ Baccho facra faciunt, uiperas dilacerare folcnt, uere quidcm finiente, nondum tamen aftate inchoata. Vel fi uer ad magnam fui partem byemale fucrit, circa principium aftatis, non mul= to tempore poft pleiadum ortum. Viperas autem, qua pregnantes funt, reijcere oportet: aliarum veró caput, ac caudam abfcindere. nam praterquàm quód ba particule uirulentiores effe uideantur, eliam dure, or parum carnis babent. Sufficit autem in magnis uiperis, id, quod utrinque amputatur, quatuor digitos aquare. Totum ueró reli= quum corpus, inteftinis exemptis, pelle 'q; detracta, aquis primo abluenduin, at que in uas fitile conijciendum e,t : de= inde aqua pura Juperinfu $\int$, uiridiq;; anetho (tunc eninu uiget) olla prunds, ut coquatur fubijcere conuenit; uel ari=

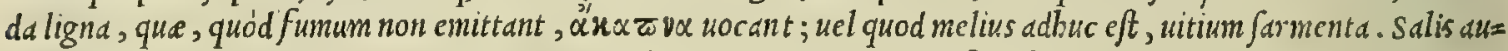
tem, fiquidem fuo tempore uiperas ceperis, tantillum immittere oportet: fin aftatc iam incipiente, nibil. Porró ob= feruandum eft,ne illa capiantur, qua in maritimis loc is, quice ue in aliqua falfa aquarum lacuna degunt: antidotus enim 40 que ex buiufinodi uiperis confect a fuerit, fitim excitabit. Cim igitur vipera probé cocte fuerint, ac fi quis comede= re uellet, eas ex aqua eximere oportet, deinde carnes ita aे pinis auellere, ut nibil ex ffinis fimul auferatur : ato; bis exquifité contritis, panis ex purißima farina optiméq; conficti, qui pracipué $\sigma$ bené fermentatus fit, er in furno, nö fub clibano coctus, modicum quiddam admifcere. Nonnullitamen in commifcendo panem viperis hanc menfuram fer* uandam precipiunt, ut panis pondus uiperinarum carnium dimidio minus fit: alij ne tertiam partem excedat malunt. Ego ueró quandoq; quartam, quandoq; o quintam panis impofui. Caterim nifí probé codtus fuerit, periculumeft, ne aliquid aciditatis medicanentum contrabat. At fatius eft, panem bunc ita coctum per aliquot dies loco aliquo fic= ciori prius exiccaffe. Verim cùm uiperas, o panem coniunxeris, diligenter $\dot{q}$; adeó fubegeris, ut nulla utperin.e car= nis particula non contufa remanferit, paftillos ex ea maffa conficito, qui tenues fint: nam craßicum difficulter ficce $=$ fecre foleant, or carnem putrere, er panem ace fcere finunt. Quanobrem panem quoq; antéficcatum ierere melius eft, or non, quemadmodum ante nos qui Ce fari theriacam faciebant, uiperarum iure macer atum: id quod ip $\int e$ quoq; diufeci, fed mibi poflea melius effe uifum eft, panem antea contritum uiperarum carnibus exacté iam fubactis admi= feere: citius nanque paftillificcantur, qui ficcum panem, non madidum acceperint. Sit antem cella, in qua paftillos ficcabis, in fuperioridomus parte, ad meridicm conuer $\int a$, uel faltem ad fcptentrionem non repiciat, ut folis radios to ta pené die admittat . tali enim in loco commodéficcefcent. Statim ubi fucrint conformati, ca parte collocentur, qua folares radij peruenire non poßint. Frequenter autem ipfos conuertere opus erit, ut adualiter utraque ex parte fic= cefcant . quod facere fi quis omiferit, fuperior quidem pars celeriter arefect; inferior autem bumids diutius perma= nebit, periculumó; erit ne marce $\int$ ant. Poftea ueró qud̀n exiccatifuerint, maneant adbuc aliquot dicbus cadent in cel la longius, quàm prius à folis radijs, fepcó; denuo conucrtantur. Sufficient autem ad hac omnia quindecim dies ad fummum: poft quod tempus donec theriacam conficere uolueris, recondidcbent in uafe fianneo, aut uitreo, aut etia aureo. Vitrum fiquidem, o aurum nullam fraudem admittit : ftannum autem plumbi miftura adulteratur . quod ui= 


\section{In Lib. fecundum Diof coridis.}

tare conkeniet, non folum in bac; fed $\odot$ in quibufcunquc alijs antidotis : qucmadnodum or algentum, fi purum nö

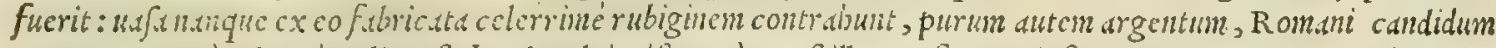

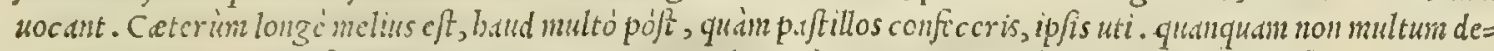

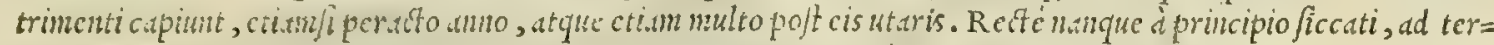

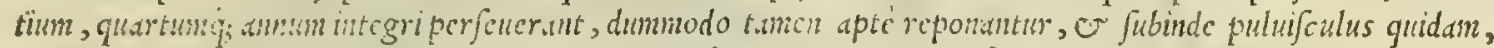

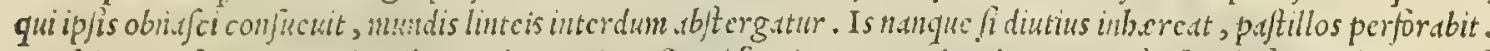

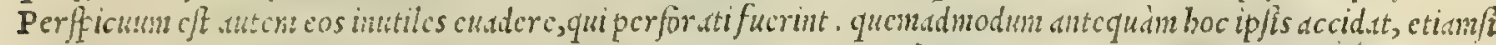
mulcun tempus interccif:rit, utiles permancut. Hee Galcnus de conficiendi paltillos vipercos ratione, quo opli=

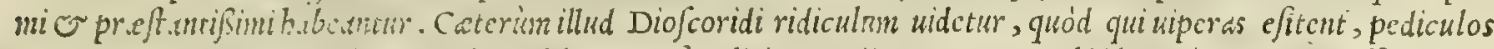

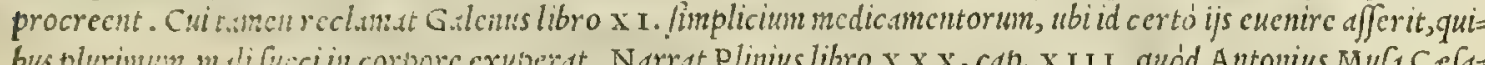

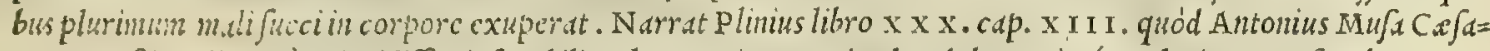
ris Auguftimedicus cimm incidiffet infanabilia ulcera, wiperas edcndas dabat, mirág; celeritate perfanabat. In Aegyptijs ui-

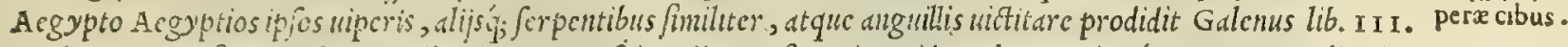
de alimentorma freulitiblis. Qubus iten cos uefcitraditun cft, qui occidentales, nouiterq́; repertas Indias in=

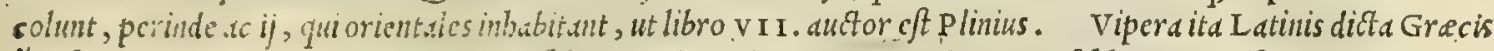

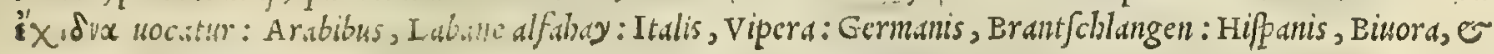
Bicha: Gallis, viperes.

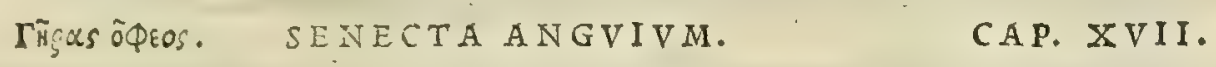

SE N E C T V s anguium in uino decocta doloriaurium, infufu : \& dentium, collutione auxilio eft. Addunt cam in medicamenta oculorum, fed prxcipuè uiperinam.

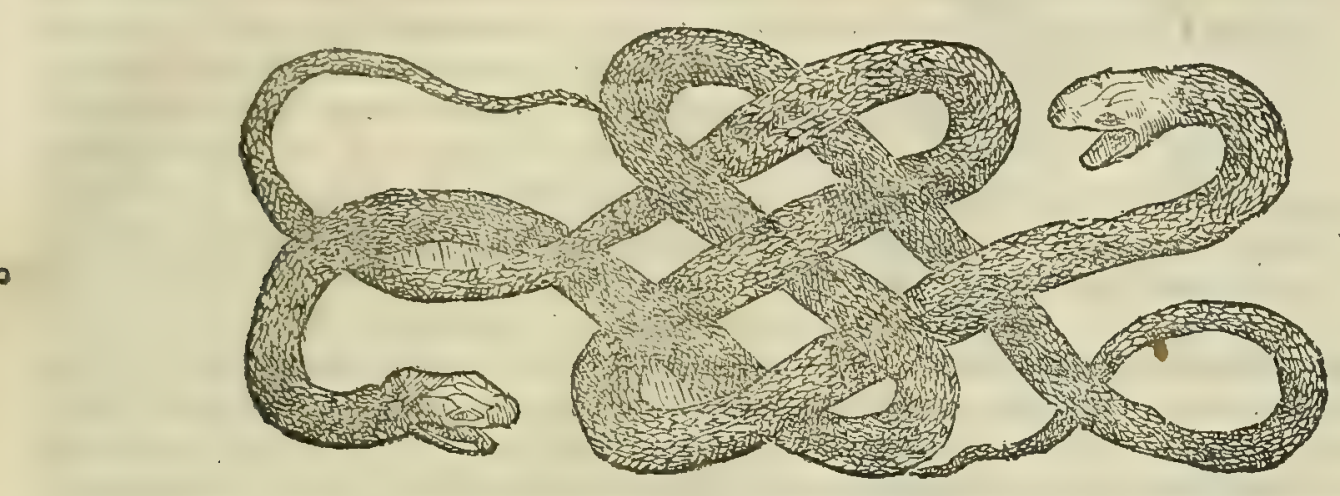

Nomina.

N v I I I s non cognita anguiun seneqd: quippe que fepe in campeftribus inter faxd, of firpes inueniatur. Seneax anDe hac cum differeret Ariftotcles lib. v I I I. de biftoria animal. cap. X v I I. fic inquit. Serpentes fenectain exuunt guium cólid. tum uere, cum egrediuntur, tun etian autumno. vipera etian exuit tam uere, quim autumno. Cim ferpens exue= 40 re incipit, ab oculis priminz detrabi aiunt, ita ut obcacari uideatur ijs, qui rem non intelligunt. Tum caput exui= tur : glabrum enim hoc omnium antequin reliqum corpus, apparet: atq; und fi ré nodte, or die fencetus totd exuitur à capite or $\int a$ ad caudam: $\sigma$ cute altera intus fubna fcente, ip fa remouetur. Vt enim foetus inuolucro fecüdarum, quo. contentus prodierit, exuitur; fic ifta fenectute detracta renouantur. Porró de ea nil aliud memoria prodidit Gale= nus libro $\mathrm{x}$ I. de fimplicium medicamentorum facultatibus, quàm quod in ace to decocta dentium dolorimedetur.

$\Gamma$ ügas ö $\$$ eos Gracé, senecta anguium Lativé nocatur: Alchalba, or Selach albaie, Arabicé: Spoglia delle serpi, Italice: Schlangen balck, Germanicé : Pelle de la culebra, Hipanicé.

Nomina.

L E P V s marinus loligini parux fimilis eft : qui per fefe tritus, aut cum urtica marina illitus capillos euellit. Terreftris leporis inaffatum cerebrum manditur, iuuandis tremoribus, qui ualetudine contra\&i funt: affrictu, aut cibo facilem infantibus dentitionem preftat: exuftum caput, \& cum adipe urfino, aut aceto illitum, alopeciarum inanitatibus medetur. Leporinum coagulum poft triduum à concubitu potum, conceptum adimere, partusq́uc fpem intercipere proditur: uuluæ, \& alui fluorem fiftit: comitiales iuuat: contra uenena ex aceto bibitur, præfertim aduerfus concretum lac, \& uiperarum morfus . Sanguis eius fi calidus illinatur, uitia cutis in facie, uitiliginem, lentiginesquue fanat. 


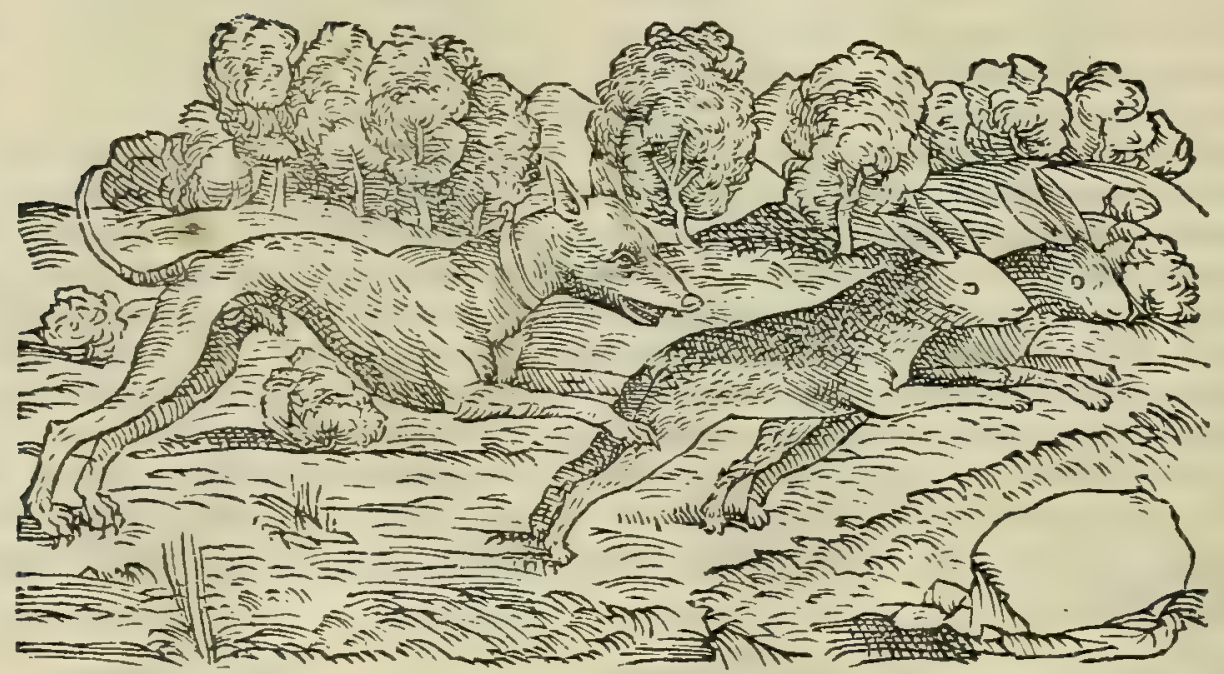

Leporis mari MA R I N S Lepus (ut nonnulli memorie prodidere) fic primum appellari crepit, quód terreftris leporis 20 ni confid.

faciem referat. Quapropter bec de eo d Plinio produntur libro I X. cap. X L V I I I. Lepus, inquit, qui Indico mas rinafcitur, etiam taltu peftilens, uomitum, diffolutionem'́; ftomachi protinus creat. In noftro offa informis, colo= re tantum leporifimilis: in Indis o magnitudine, o pilo duriore tantum. nec uiuusibi capitur. bac Plinius. Ex quibus facilé conijci poteft, Diofcoridem potius de noftrattun marium Lepore intellexiffe, quain de ijs, qui in In= dico innatant pelago, argumento quód parue loligini fimilem marinum leporem reddiderit. Albertus auctor eft, tertium Leporis marini genus reperiri, communi pifcium magnitudine, fed capite lepori non abfinili, dorfo rufe= fcente, efculentum: tametfi à nomullis explodatur, ut pote quodd o concoctu contumax fit, e elephantiafim gi= Leporis terre gnat. Ceterim terreftris Lepus notißimum animal eft, o curfu uelocißimun. Solum hoc inter catera terre Atris.confict animalia, qua utrinque dentata funt ( ut fcriptum reliquit Ariftoteles lib. I I I. de partibus animalium, cap. X v.)

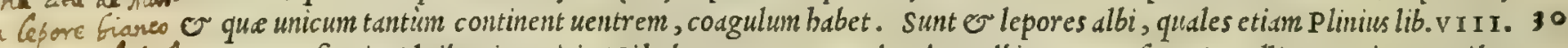
olal Vei.cap. I v. refert in Alpibus inueniri. Hibyberno tempore admodum albicantes in fummis uallis Ananie montibus \& Carhinffrequentes reperiuntur; co prefertim tempore, quo ij niuibus altifimis ueftiuntur : qui tamen adeó magni non funt, nec ita in cibum paraticum palato ineunt gratiain, ut qui in campeftribus capiuntur. Ceterimz candidi byeme tantum conpiciuntur: nam liquefcente niue fubrubefcunt, quemadmodun er cesteri. Cuius rei indicio funt illi, qui cum non perfecté priores pilos exuerint, partin candidi, partin fubrutili uifuntur. Lepores apertis oculis dorminnt, nec (qua fua maxima timiditas eft) alio quim fuga fe tutari fcunt. Huic foli pilos in bucca intus, o

Vana opinio. Jub pedibus effe adnotauit Ariftoteles libro I I I. de biftoria animaliun, cap. X I I. Archelaus auctor eft, cui $e=$ tiam fententia plerique fubfcribunt, Leporibus utrunque fexum, or utranque gignendi uim ineffe, or omnes $l e=$ pores aqué gignere, ac fi effent hermapbroditi. Quod ita facilé polfe pati naturam, nullo pacto crediderim: fed potius ridiculam hane opinionem in hominum mentibus infitam putauerim, quod uiderint, Lepores, quanquam $40^{\circ}$ plurimi quotidie capiantur, etiam quodammodo focundius procreare. Veruntamen id non euenit, quoniam ma= res ipfi pariant; fed quia ( tefte Ariftotele libro v I. de biftoria animalium, cap. $\mathrm{x}$ x $\mathrm{x}$ I $\mathrm{I}$ I.) fuper faetant,dum ad= huc utero gerunt, fimiliteróg; ftatim à partu concipiunt, ita quod fingulis menfibus generant. Sed fatus edunt non uniuer fos: interpofitis enim diebus, quot res tulerit, peragunt partionem. Vnde tam imnumera frecunditas: nam etfi foemina lac nuper natis prebeat; nil tamen probibet, quin eadem repetat coitum, o lactans, gerensq́; utero, denuo concipiat fretum. Mares (ut loco citato idem prodidit Ariftoteles) auerfi coëunt cum forminis : retro. cnim ijs genitale membrum a natura datume eft, ut apparet, dum urinam reddunt. Ex quo etiam multis perfuafum eft, ma: res foetum concipere: Jiquidem cognitu perquim difficilé eft, an mares, an fremine fint, ut etian cuniculis con= tingit: qui cum frecundius etiam prolificent, quam lepores; non ob id tamen mares unquam parere uifi funt, quan=

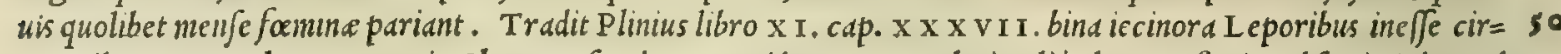
ca Briletum, e Thernem, or in Cherronefo ad Propontidem : at translatis alio alterum ftatim abfumi. Id quod ante ipfum memoria prodiderat Ariftoteles libro I I. de hiftoria animalium, capite X V I I. Item libro I I I de par= tibus animalium, cap. v I I. ubihoc leporum genus pluribus in locis reperiri teftatur, pecistim uero in sycino agro, circiter Bolkain lacum. In Ithaca infula (ut idem tradidit libro v I I I. de biftoria animalium, cap. X X V I I I.) Lepores fi aliunde illati dimittantur, uiuere nequeunt: $\int e d$ códcm reuer $/$, unde maris introierint infulan, moriun=

Leporis facul tur. Leporine carnes in cibis efitate preter id quód agré concoquuntur, craffum, atrabiliofumq; generant fuc= tates. cum. Veruntamen (ut inquit $\mathrm{R}$ afis libro de $\mathrm{Lx}$. animalbus) dyfentericis confirunt, fi afjate fumantur. Iecur ue= róarefactum, iecinorofis utiliter exbibetur potandum. Integer cum pelle Lepus, opcrculato fictili impofitus, in cli= banog;; igne fuccenfo tandiu dimiffus, ut penitus exuratur, urine uitijs mirifice opitulatur, adeó ut calculos eijcist, tam in renibus, quàm in uefica gentitos. L eporinum fel faccharo exceptum, oculorum argemas, nubcculasq́; delet. Leporinum ftercus (ut aiunt) mulieribus geftatum, conceptum impedit. Sed illud expertentia compertum eft, quód unluis 


\section{In Lib. fecundum Diofcoridis. I95}

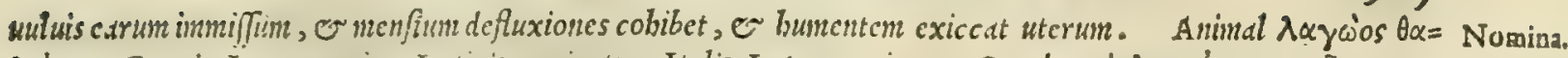

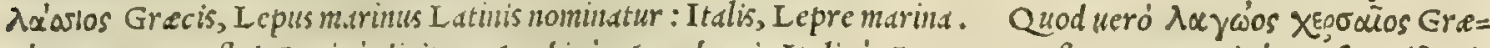
cé, Lepusterreftris I atine dicitur : Arabice, Arneberri: Italice, Lepre terrcftre: Germanice, Haje: Hipani= cé, Licure: Gallicé itcm Licure.

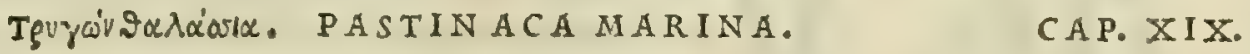

M A I N A E Paftinaca radius, qui cius cauda cnatus aduerfis fquamis reflectitur, dentium dolorem mitigat: nam eos frangit, \& euocat.

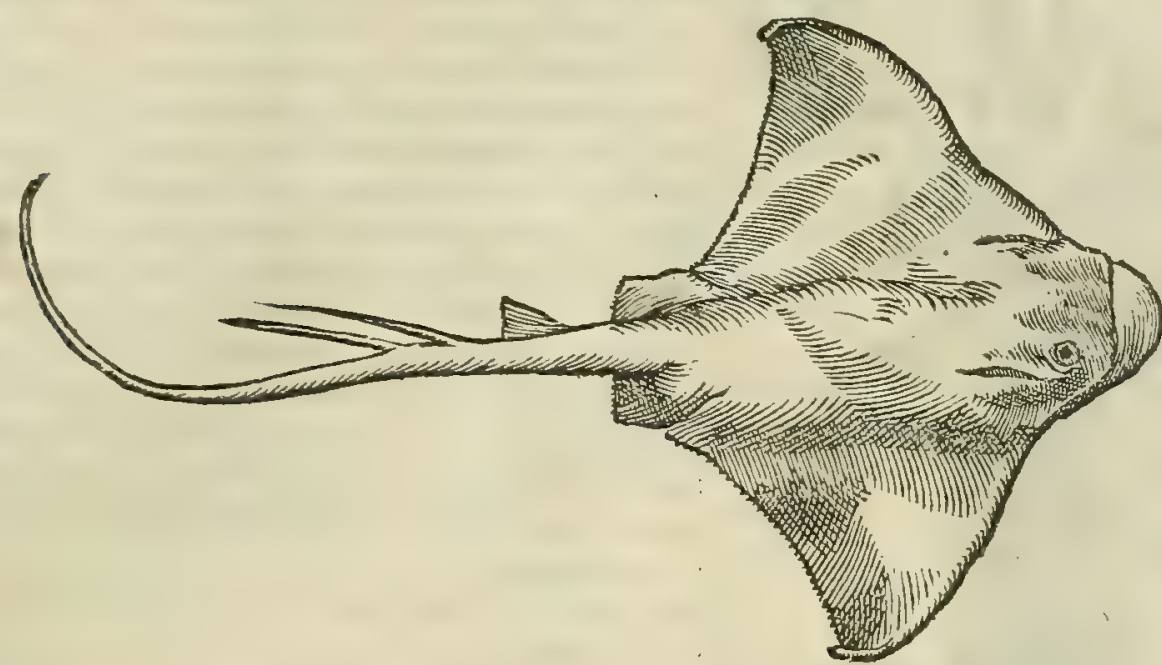

P A 3 I N A C A Marina fimiliter dtque raia, E dia id genus, in pifcium planorum, er chartilagineorun ge= Paftinaex pinere collocatur. Hanc quidam uulgó uocant Pefce colombo. Gerit hac in cada fuperné radios duos preduros, acu fcis confid.

10 tos, or utrinq; minutißimé dentatos, quorum uenenato itu pifcatores grauiter afficiuntur. Quam ob caufammemo rix prodidit Aëtius lib. I I I. quòd qui à marina paftinaca percußi funt, his uulneris locus manifefté apparet. Sequi= tur autem dolor pertinax, or totius corporisftupor acutum enim, or firmum babet aculeum, quo uehementißima ui in altum impulfo nerui fauciantur. Quapropter in aliquibus mor serepenté totum conuellens corpus comitatur.Id= circo non abfque fortiratione Plinius libro I x. cap. X L V I I I. ita fcriptum reliquit. Nullum .ufquam execrabilius. uenenun, quàm radius fuper caudam eminens trigonis, quam noftri $\mathrm{P}$ aftinac am appellant, quincunciali magnitudi=. ne, arbores infixus radici necat. Arma ut telum perfor at or ferri, er ueneni malo. Latet pifcis bic : er ut idem au= ctor eft libro citato, cap. x L I r. Latrocinatur ex occulto, tranfeuntes radio figens. Marcellus virgilius, nimirum Marcelligne cupidus ineundirationem, qua paftinace radio uti poffet, dentium doloribus fedandis, quippe quod id filentio inuol= ratio. uerit Diofcorides, fatetur, et fi diligenter, ut confentaneum eft, inquifiuerit, nunquam tamen apud antiquos foripto= res ean fe con $\int$ ccutü fuiße. Qua in re aperté declarat, fibi cum Plinio parum interceßiffe confuctudinis: quandoqui= dem Plinius lib. x x x I I. cap. V I I. nos abunde docuerit modum, quo eo radio in dentiuin doloribus uti ualeamis, fic inquiens. Paftinace quoq; radio f carificare gingiuas, or in dentium dolore utilißimum. Conteritur is, $O$ cumbelle $=$ Goro albo illitus, dentes fine uexatione extrabit. Quapropter mirari non licet, fi quando i; in plateis circulatores, dentiun extradtores cernimus, qui dentes abf $q_{\text {; }}$ frre is inftrumentis, nullo illato dolore extrabant. Idem radius equos

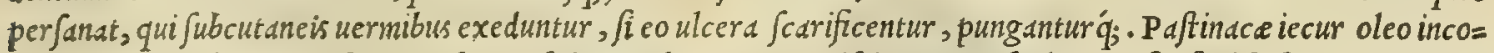

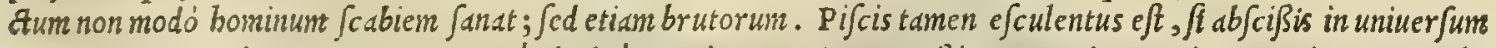

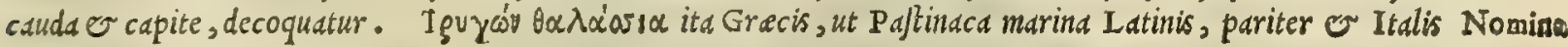
nuncupatur.

SE P I A coctx dum eftur atramentum, xgrè concoquitur: aluum mollit. Collyrijs c̀ tefta factis conuenienter genarum fcabritix perfricantur. Vftum in fua tefta, donec id, quod cruftofum eft, abfcedat, poftea tritum, expurgat uitiligines, furfures, dentes, \& uitia cutis in facie .clotum in medicamenta oculorum addi folet: contra albugines, oculis iumentorum efficaciter infpiratur: pterygia oculorum ablumit, cum fale tritum, \& iniectum.

SE P I AE in omnibus Italix pifcarijs, proprium retinent nomen, uenalesqí; babentur, in ïs inquam, in qui= Sepiarum cöbus marini ueneunt pifces. Hæ polypis fimiles funt, preterquan quód hi innumeris pedibus excellunt, ille ueró ma= fideratio. iore corporis mole. Eft sepijs in dorfo os candidum, fuperioriparte durum, ac laue : inferiori autem fungofa qua $=$ dam medulla repletum, que er leuiter apera, or ligni modo frequentibus uenis diftincta uiftur. Expetuntur se= $\therefore \ldots$ 


\section{And. Matthioli Comm.}

SEPIA.

Polypi mira magnitudo.

Sepiarum facultates.

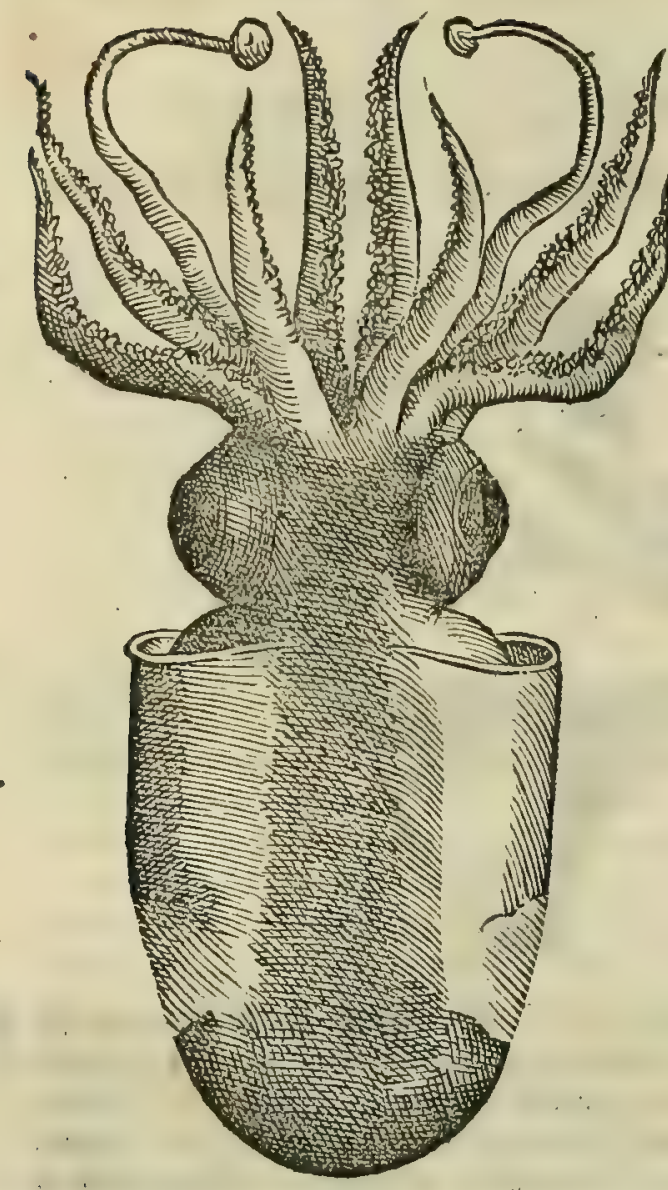

preffat: mifta preterea fo Bili fali, in oculis exiftentes ungues cliquat: $\sigma$ antequim uratur frictione dentibus plent= dorem affert, er illitione ulcera deficcat. Sepie oux in cibis fumpta urinam ciere Plinius conmmemorat, renuníg; lentorem disijcere. Sepijs nucibus, o allio paratis quidam ue fcuntur, ut falaciores in uenerem prorumpant. Que otrisia Grecis, Scpia item Latinis, o Italis appellatur: Arabibus, Sarathan, o Sarthan: Germanis, Blacfich: Hipanis, siba: Gallis, seche.

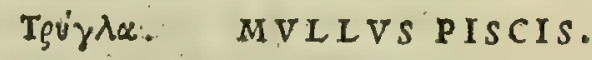

CAP. $\mathrm{XXI}$.

M V L I O R V.M afsiduo ćibo, aciem oculorum hebetariconftat. Is marini draconis, aranei, ac corpionis morfibus medetur: fi crudus, atque diffectus admoueatur.
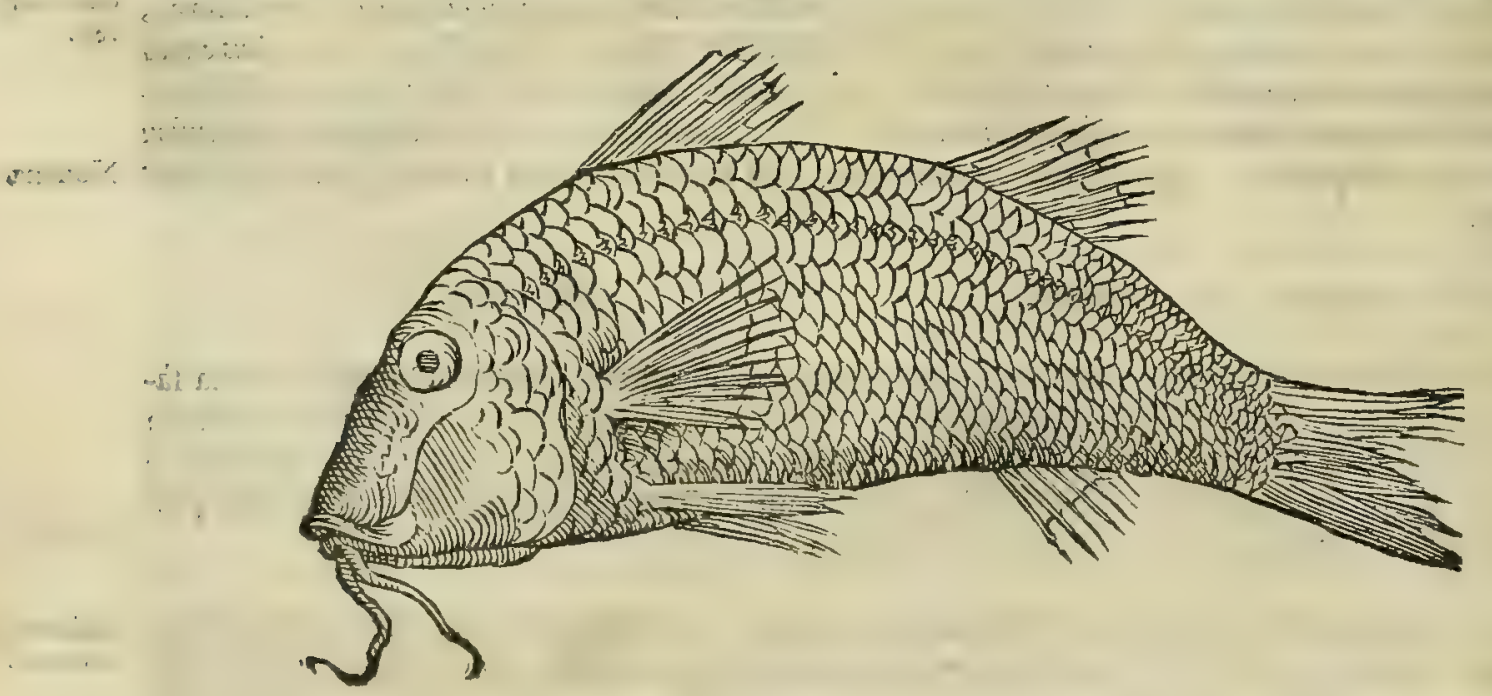


\section{In Lib. jecundum Diofcoridis.}

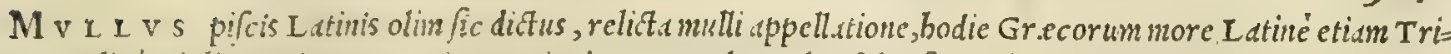
gla J It.lice triglis nominatur. Huc magnitudo non ampls, color fubrufus, ueluti purpureus. Antiquis is magno experebatur prctlo, precipué gunconiós : cum ex fide dignis conftct monumentis, Mullos fepcnumero à priuatis

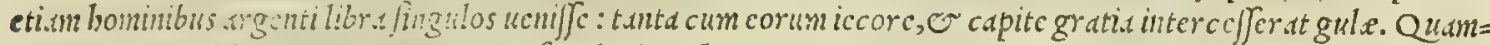
obrem G.lenus ló. I I I. de alimentorum facult. de co b.e memorix prodidit. Mulliceur à gulofismirabilem in modum noinptatis nominc commendutur. Cutdam ucrò ipfun ne per fe quidem folum cdendun cenfent, fed garelao,

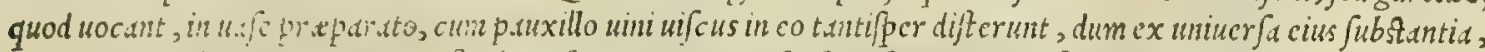
o pr.epur.uto liqumine unu, wc fimlaris fuccus, quantum fenfu poßis iudicare, factus effe uideatur, in quo intin=

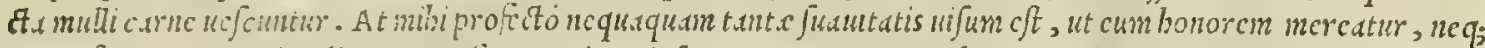

20 tam infigncm corpori utilitaten conline, uti nec ip fum caput: quanquan hoc quoq; ladant gancones, ac fecundas pofticcur firre pixdicant. Cecterum intelligere nequeo, cur permulti grandißinnos mullos emptitent, cum nec adeo fuatuifint carne, ut minores : nec concoitu fucili, ut qux dura adnodum cft. Itaque cusin aliquando quendam ingenti pecunia pregrandes mullos cnentem interrogarem, cuius reigratia illos tantopere expeteret, refpondit fe primím propter lacpar illos tanti emiffe : tum autem $\sigma$ propter caput. Idcm loco citato, circa capitis initimita fribit. Mul= lus onmium firé alionum durifsinam babet carnem, impendio $;$; friabilem: quod perinde, ac fi dicas, nibil in eo effe lentoris, neq; pinguedinis. Eaqj; ex parte cunctis alijs preftantius nutrit, dummodo probé concoquatur. bactenus Galenus. Numli, auctore Plmio, ter anno fretificant: tantaq́; ijs inglunics, ut etiam bominum cadaueribus ue can= tur. Iicxteris in cibis preftant, qui infcriorilabro, utrinq; barbati babentur. Romani Neapolitanis, er Venetis longe preff.nt. Vimum, inquit A theneus, in quo mullus uiuus immergitur, baufum, ucnerem uiris mirum in modum 20 inhibet: feminis ueró conceptum. Inulli, quod barbatifint, Venetis uulgó dicuntur Barboni, non autem Spari, ut

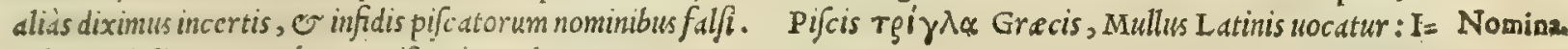
talis, Triglia, or Barbone: Hipanis, Salmoneta.

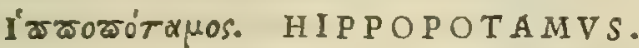

\section{CAP. XXII}

H I P P O O I A M I teftes exiccati, actriti, contra ferpentium morfus bibuntur.

H I P P O P O T A M v s eft (ut Plinius narrat lib.v I I I.cap. X x v.et $x$ x v I. belua,qux in Nilo editur cro

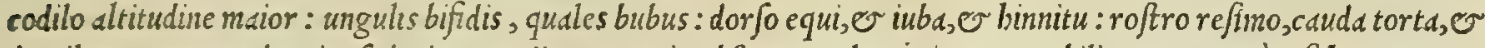
Hippopotae dentibus aprorum aduncis, fed minus noxijs : tergoris ad fcuta, gale ss $q_{;}$impenetrabilis, preterqudm fi bumore ma= deat. At Arıftoteles lib. I I. de hiftoria animalium, cap. v I I. buic belua dentes exertos reddidit, non apri: fed cau= dam quidem apri eam habere prodidit, magnitudincm afini,binnitum equi, $\sigma$ tergoris craßitudinem tantam, ut ex eo. uenabula fiant: quin 0 interior omnia equo, $\mathcal{O}$ afino imilia. Segetes boc animal aftu magno depafcitur definatio= ne ante determinat is in diem: nempe $c x$ agro ferentibus ueftigijs, ne qua reuertenti infidie comparentur. Primus. cum uiuum, es qunn; crocodilos, Rome edilitatis fue ludis $M$. Scaurus temporario euripo oftendit. Hippopotamus in quadam medend parte ctiant magifter exiftit. Aßidua nanq; fatictate obefus exit in litus, recentes harundinun ce Suras perfpeculatus, atq; ubi acutısimun uidet ftiptem, imprimens corpus uenain quandam in crure uulnerat: atq; ita profluuio anguinis morbidun aliàs corpus exonerat, er plagam limo rur fus obducit. Huius corï cinis cü aqua illitus panos sanat. Adeps frigidas febres: item finus fuffitu. Dentes é parte leua dolores dentium, fcarificatis gin= 40 giuis. Pellis eius é finiftra parte front is in inguina adalligata, uenerem inbibet. Eiufdem cinis alopecias explet. Te= fticuli draclma ex aqua contra ferpentes bibitur. Belua, que i tinis, er fluniatilis equus appellatur : Italis, Hippopotamo.

\section{Kx́sog, FIBER:- CAP. XXIII.}

F I B E R ancipitis vitæanimal, plerunque cum pifcibus, \& cancris ex aqua uictum capefsit. Huius teftes ferpentium uenenıs aduerfantur, fternutamenta mouent, \& in unjuerfum uarios obtinét ufus. Siquidem menfes, ac partus ciunt, duabus drachmis cum pulegio poti : partus, fecundásque eijciunt : contra inflationes, tormina, fingultus, uenena, ixiamq́ue ex aceto bibuntur : lethargi-

$50 \cos , \&$ utcunque ueterno obdormif centes excitant infu $6:$ cum aceto autem, \& rofaceo olfactu, \& odo ris fuffitu, idem faciüt: poti \& illiti profunt tremulis, conuulfis, \& omnibus neruorum uitijs . In fumma calfactoriam uim habent. Eligi debent teftes, qui ex uno ortu connexi funt (fieri enim non potett, ut gemini folliculi in una membrana coniuncti reperiantur) liquore intus ueluti cerofo, odore graui, \& uirus redolente, guftu acri, mordente,ac friabili, naturalibus tunicis circundato. Qué fraude aliqui corrumpunt, conijcientes in follem gummi, aut ammoniacum cum fanguine, \& caftorio fubactum,\&.ita exiccantes. Vanum eft, quod traditur,teftes ab ipfis euelli,\& à fefe abijci, cùm venatu urgentur : Gquidem tangi nequeunt,ita, ut in fue, fubltricti. Operæ autem pretium eft, diuifa pelle melleum liquorem cum eueftiente tunica affumere, \& ficcatum $\dagger$ potui dare. mi hiftoria.

Hippopotami uires.

Nomina 


\section{8

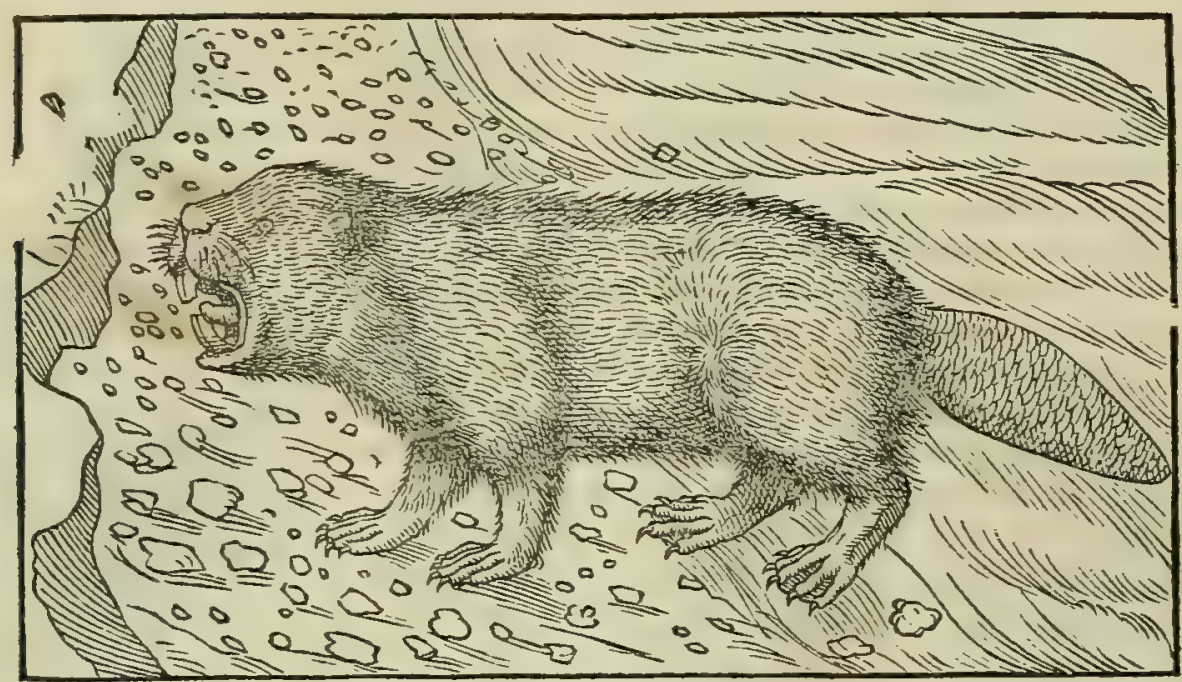

Fibri confide Q Q E M D D O D V M in fuperiore ßectatur Girmania, ubicunque Rhenus influit: quin e in Auftria, at= satio. que Pannonia, ubi Danubius, in alijsf; finitimis prouincijs, ubi Drauus, $\sigma$ Sauus difcurrunt, Fibcr fané, quem Graeci $x \times$ 'sog $\alpha$ appellant, animal eff ( $u t$ Diofcorides inquit) quod ex amphibio babetur genere: quippe quod o terris, or aquis uitann ducat : ibinang; uidetur modó in fluminibus natare, modó in litore uagari,modó in propinquis fyluis $\mathbb{p a}=$ tiari. Fiber lutra feré faciem refert, maior tamen. Pedes buic funt pofteriores anferinis fimiles; anteriores uerò ut

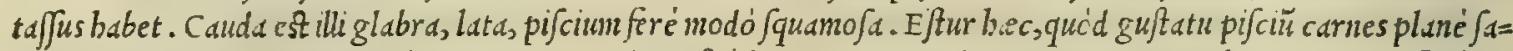
piat, ijs etiam diebus, quibus nobis carne interdidum eft à lege. In cateris deniq; corporis partibus parum, aut fe ré ni= bil à latra dißidet. Quo factun cft, ut crediderint medicorum nonnulli eafdem lutr.e teftitus ineffe uires, que fibro= rum tefticulis infunt. Dentes Fibris anteriores frocißimi, at f; acuts? smi funt, qubus arborum ramos, ut firro, cadit, quos poftea miro coaptat artificio, fibiq́; domum conftruit pluribus tabulatis in riparum cauis, ubi iuxia flumina de $=30$ git. Animal cft horrendi morfus: nam bominis parte compreben fa, non ante, quàm fracta concrepucrint offa, mor fu

Vana opinio. refoluit. Vanum profictó eft (ut etiam fcribit Diofcorides, itemǵ; seftius smedicine diligentißimus)credere Fibros fibi teftes dentibus amput.tre, cum uenatu urgentur, ob hoc fe peti gnari. Qutandoquidem id nunqusm in bis comper= tam fit, qui noftra atate capiuntur. Plinius huius facti anceps id affirmauit lib.v I I I.cap. $\mathrm{x} x$.. quod tamen poftea Fibri teftium negauit lib. $\mathrm{x}$ x $\mathrm{x}$ I I.cap. I I I. Caterùn diligenter animaduertere oportet, ne ab imeoftoribus adultcrati Fibrorum adulteratı. teftes emantur: nanq; pauci admodum habentur ex ijs, qui uenales venetius importantur, qui quidem adulterio $c d=$ reant. Cuius manifesto eft indicio nimia corum magnitudo, cim legitimi parui adnzodum fint. Quinetiam praftantice indicium prabet conclufus liquor in recentibus mellis inftar, in diutius uerò afferuatis, cere modo concretus. Adulte= rantur contritis eiufdem animalis renibus, farth is inde teftiun folliculis. At milbi quide fapius conting it o uidere, $\sigma$ babere ex Auftria, Stiria, $\odot$ Carniola Fibri teftes, qui omni prorfus adulterio uacant: quos magnitudine, colore, odo $=40$ re,guftu, dtq; etidm uiribus longé ab ijs dißjimiles effe comperimus, quibus offictnarum utitur uulgus. Plinüs libro X X X I I.cap. II I cos Caftoris teftes efficacisimos putat, qui é Ponto afferuntur. Cui tamen refragatur strabo lib. II I. fue Geographis his uerbis. Producit Capreas Hipanid, equosq́; fylueftres affatim. Quibufdam in locis lacus incrementa fufcipiunt. Cygni, $\sigma$ eius generis aues plurime: : immliter $\mathbb{E}$ otides aues. Flunijquidem fer runt $C$ aftoras: fed Caftoreum non eam, quain Ponticum, habet uim. Pontico enim proprium eft, ut uenenofun fit, ut in alijs permul= tis. hee Strabo. Ex quibus facilé conftat plurima in Ponto uenenofa nafci. Id quod etiam in Bucolicis teftatur vir= gilius hisuerfibus.

Has herbas, atq; bac Ponto mibilecta uenend

Ipfe dedit Mer is: nafcuntur plurima Fonto.

Hinc ueró fit, ut nefciam ego, cur iufferit Damocrates caftorium Ponticum addi in Mithridatis antidotum, cum tas men Andromacho in theriaces compofitione eligantur teftes illi, quos caftor Istrius, hoc eft, ad Danubium uiuens,

Caftorei ui- protulit. Horum meminit Galenus libro X I. fimplicium medicamentorum, fic inquiens. Tefticulos caftoris nun= resex Gal. capant Caftorium, medicamentum $\sigma$ celebre, e multi ufus, adeó ut Arcbigenes de Caftorị ufu totum confcripfe= rit librum. Atque ille fané particulares eius fucultates expofuit, nos ueró uclut in alijs medicanentis fecimus, ita $\sigma$ in boc quoque gener alem modo facultatem dicemus: ad quam fi quis repiciat, ip $\sqrt{e}$ per fe particulares inuenire poterit. It aque quod excalfaciat, maniff fum eft . nam fi noles ipfum ad ungucm leuigatum oleo maceratum parti cuipiam illinire, or infricare, cuidenter illan incalefcere percipies. Porró calfacicitia omnia, ubi contacte $\int u b=$ ftantie quippiam digerunt, continuó etiam illam deficcant; nifi fi quid natura fucrit bumidum, ceu oleum $\mathrm{E}$ aqua , atque aduentitiam qualitatem calidam, non facultatem a fjump ferit: ficut certe hec ipfa igni, o foli a'stiuo adno= ta. Itaque cimm Caftorij confiftentia quoque fit ficca, o calfaciendi potentiam habeat adiunctam, meritó deficcat. Atque boc illi cum multis alys inedicamcntis commune cxiftit. Porró quoniam impensé fubtilium cft partium; ob id 


\section{In Lib.fecundum Diolcoridis.}

plus uslet, quìn alia, que fimiliter ut ip fum or calfaciunt, o deficcant. Nam qux tenuium funt partium medica= thenta, ijs que funt craffarum, plus funt efficacia, ctiamfi parem fortita fucrint facultatem, nimirum quid pene= trent, o in altum fubcant admotorun corporum, potißinum fi ea den a fucrint, uelut neruacea. Paldim igitur ta= lia ob caufam pofitam mxgnifice iuusutur à caftorio. Ceterum falluntur medicorum plerique in ufu Caftorij, cuim id modó confiderant, partcm quampian sut trcmere, aut conuclli, aut fenfumotiue priudtan, aut egré fentire : haud feientes id genus fymptomata ad dißimiles fequi corporis affectus. At tuab Hippocrate doctus, ex plenitu= dine pariter, o intmitione conuulfionem ficri, ubi quidem qux in ncruis continentur pretger naturam, cuacuare cons filum $f$, ibie bibendum cxbibe, er foris cuticaftorium impone. Vbi ueró ex ficcitate nintis obuenerit conuulfio, feito boc medicsmen illic effe aducrfissimum. Ad eundem modum, ijs qui pra plenitudine trenunt, utilißinum : aduer - fissimum ueró ijs, quibus buufnodi affcctus accidit ab inanitione. Ad portionem modó dictorum affectuum, ubi fingul tus eisenerit ftonachi, perfcrutato prius, intento q; illius affectu, ac difcreto, fi quidé a plenitudine ip $\int u m$ agrotiper= petiantur, ad ca|torij ufun accedito. Sin autcm a ficcitate, or cuacuatione, aut acrium bumorum mor fu prouenerit, medicamen hoc fugito. Sane fi odori, guftuiq; aduertas animum, fuppic aberis bumano corpori aduerfißimam babere fubftantiam : tamet fi in natura nibil efficere comperiatur corm, que talia facere affolent. Siquidem alia ftomachü uitiant, alia ucntrem, alia caput, alia alian quámuis partem ladunt. A t boc medicamen fiue corpori bumido applices reficcationem pofenti, fiue frigido cxcalfactionem, fue bumido finul frigidóg; excalfactionem pariter er reficcd= tioncm requirenti, magnam utiq; oftendit utilitatem : nec ullam parti cuiquam noxam imprimit, potißimim fi fibri ua cet, alit non admodum calid.m perpctiutur bonno frbrem, fed ut fic dicam tepidam, qualis accidit in cataploris maxis mé, $\circlearrowleft$ lethargis. Ac multis fane Caftorium exhibuimus unà cum pipere albo, utrunq; menfura cochlearij cx meli=

20 crato bibendum prebentes: nec quifquam ullam fenfit noxam. Sed er menfibus retentis, ubi per uenam, qua in talo ef, modicé cuacuaffem, oblato caftorio unà cum pulegio, aut calamintba, femper medicamen boc expertus fum pur= gationem ciere, abjque ut feminam lederet. Praterea locos morantes cijcit . ea $\dot{q}$; omnia ex melicrato potum effi= cit. At quibus ita uenter flitu diftenditur, ut agré curationem admittat, aut torminibus uexatur, atq; fingultu, id $\dot{q}_{;}$ ob frigidos, uifcofosá; bunores, alt craffos, flatulentos q́; piritus, eos ex oxycrato potum adiuuat. Qux porró itu= uat in corpus intró fumptun, ijs prodeft quo ; cuti impolitum cum ficyonio, aut ucteriolco. Que ueró ampliori ca= Tiditate indigent, ijs etiam per $\int e f e$ inficicari debet. Iuuat etiam, fi quis fuffitü eius in prunis impofiti infpiratione bau riat, maxime humidos, e frigidos affectus in pulmone, aut cerebro confiftentes. A ttameii lethargicos, o catapho= ricos affectus, qui quidem adiunctam babent febrem, preftat non dictorum oleorum quopiam macerantes curare; fed potius ex rofaceo capiti, colló, imponere. hactenus de caftoreo Galenus. Caterim, it plinius eft auctor libro Caftorei ui -

$30 \mathrm{x} \times \mathrm{x}$ I I. cap. I I I. Caftoreum fumptum comitialibus auxillatur. Medetur er dentibus ex olco in aurem infufum, a res ex Plin. cuius parte doleant. Aurium doloribus nelius, $f \mathrm{i}$ cum meconio infundatur. Vrina quog; Fibri refiftit uenenis, or ob id in antidota additur. Afferuatur autem optiné in fua uefiea, ut aliqui exiftimant. Animal, quodxx́swg Grecé; Nomina. Fiber Latiné dicitur: Arabicé, Inchiam alginde bedufter, Giendedeftar, feu Giendibideftar: Italicé, Caftoreo: Germanicé, Byber: Hipanicé, Biuaro, $\mathcal{O}$ Biuerio: Gallicé, Bieure.

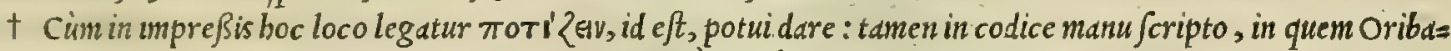

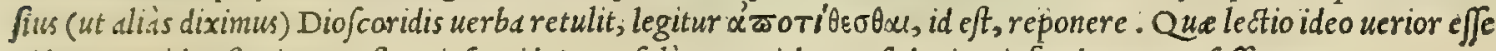
widetur, quidd caftorium ( $t$ ffte Diofcoride) non folum potuidetur; fed etiam infundatur, or fuffiatur.

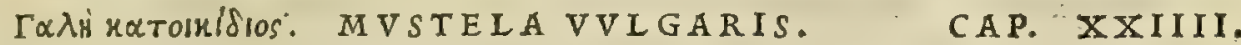

40 MV S E L A, quæ in domibus noftris oberrat, ambufta exenteratur, \& inucterata fale, in umbra ficcatur. Ea binis drachmis cum uino pota, aduerfus omnia ferpentium uenena præfentaneo eft remedio: toxico, fimili fumpta modo, refiftit. Eius ventriculus coriandro farctus, inueteratusq́ue, percufsis à ferpente, \& comitialibus potu auxiliatur. Cremata in fictili podagricis confert, cinere ex aceto illito. Sanguine perunctx ftrumx iuuantur : comitialibus etiam prodeft .

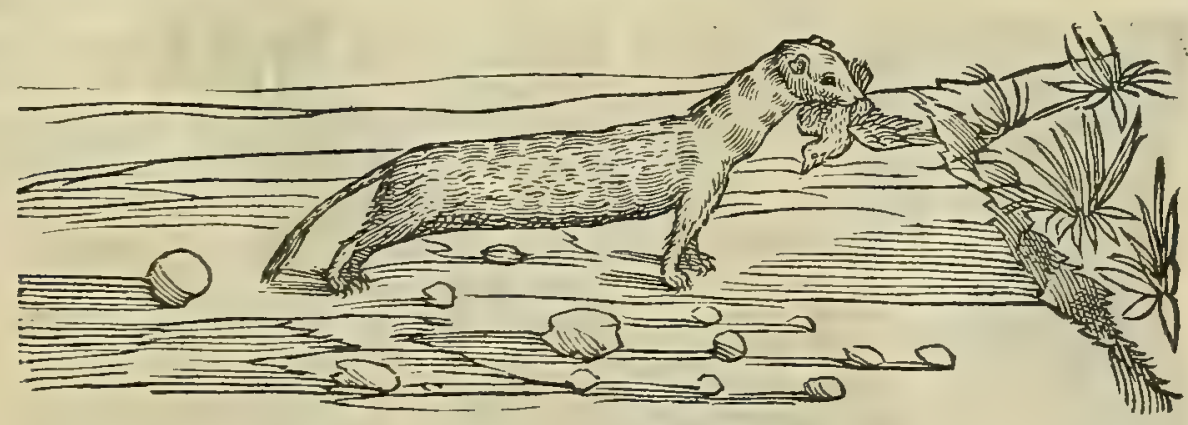

MVS I E I A unlgaris notitix in Italid, animal eft mire fagacitatis, $\sigma$ quanquam corpore paruum; dnimo Muftelæ con tamen inuicto conftat, atg; feroci. Muftelarum duo genera effe auctor eft Plinius lib. X X I X.cap. I I I I. Alterum fyl fideratio. ueftre, quod in agris, or uepribus uitam agit. Alterum domefticum, quod in domibus noftris oberrat. Vtreque adeo cupidé catulos fuos diligunt, ut cos binc alio transferant, uerentes ne fibi ï furripiantur. Quo fditum eft, quemad= Vana quorū.. modum memorie prodidit Ariftoteles lib. I I I.de generatione animalium, cap. v x. ut cuion uidifjent quidam, Muftelas dam opinio. 
catulos fuos, quos paruos admodum parit, ore fufceptos transferre, falsó opinatifunt, cas ore parere. Quorum opis nionibus adftipulatur Onidius : cuit tamen uenia danda $\mathrm{c} f \mathrm{t}$, cum poëtis quallibet audendi amplisinza fit poteftas. Non eft fimiliter in eo ardiendus Chriftophorus Encelius, uir alioquin cruditus, quód lib. I I I. cap. I I I I I.de foßBilium na= tura, uulgifortaffe fententie addictus magis, quàm A riftotelis or aliorum probatifimorum aultorum, fepias, loligi= nes, locuftas, E fquillas ore coire ac parere, ridenda biftorua fcriptum reliquerit. qui preterea cortos e fylueftres

Martes,\& easum hiltor. Storia.

Viuerra. locis etian, ubi capiuntur . quo fit, ut uenatores quandoq; ditißimi fiant. Forró $\sigma$ V IVERRA inter muftelas an= - numeratur. Ea autem animal eft fciuri magnitudine, pilo fubluteo, audax admodum, ON dninantibus feré cunctis ini= 20 micum, prefertim cuniculis, quos fape gregatim fuis ex antris pellit. Oblectatur fanguine mirum in modusn, adeo ut fanguine potius, quàm carnibus uictitet. Inueniuntur preterea (ut audio) in Germanid, Polonid, er vicinis locis alia Muftelarum genera: que quoniam battenus ipfe non uidi, neque expiorata funt mihi, ideo quid de ijs fcribam, non bd= beo. Verum quód nunc in Boboemid uitam ag am, equidem futurum pero fauore atq; auxilio Screniß. Ferdinandi Ar= chiducis Auftrix Principis, er domini mibicolendißimi, ut non folum mibiliceat tractu temporis bac o d alia anima= lia uidere $\sigma$ cognofcere, que in bac boreali plaga proueniunt; fcd E multa rara confequi, qua ad rem tum herba= Muftelæ natu riam, tum metallicam pectabunt. Muftele ferpentes acriter perfequnntur, dinic.nntó; devorata prius ruta. Bafi= ra, \& uis. Iifco muftele uirus exitio effe auctor eft Plinius libro v $\mathrm{I}$ I. cap. $\mathrm{x} \times \mathrm{I}$. adeó nature nibil placuit effe fine pari. Inij= ciunt enim eas cauernis facilé cognitis, fold tabe. Nec dnt illi fimul odore, moriuntur '; , o nature pugntum confi= ciunt. Muftele etiam oculis punctu erutis aiunt nifum reuerti, eademq́; , que in lacertis, er annulis faciunt. Mufte= la cuiuslibet fimus mo fchum nonnilil refipit. Is neelle exceptus, addita lupinorum aut foeni grecif farind, ftrunds, cae teros'́; pituitofos tumores difcutit. Muftelar um felle cum fucco freniculi utuntur quidam ad oculorum argemas er nu beculas. quinetian idem lentigines, or alia buiufmodi cutis uitia emaculare perbibent, fi cum melle, or uitis aiba ra= dicis, aut arifarina illinatur. Nec de funt, qui putent Multelarum pulmonem ad omnes pulmonis morbos efficacem effe. Muftelurum combuftarum cinis aqua fubactus llitu capitis dolores mulcet : oculis uerò iniectus fuffufiones emen dat. Hoc animal $\Gamma \propto \lambda$ i Grecis dicitur : Latinis, Muftela: Italis, Donnola.

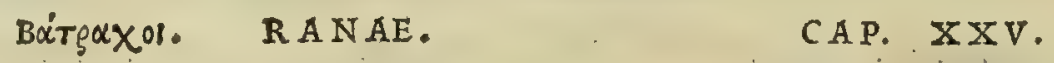

C q N T R A omnium ferpentium venena pro antidoto funt $R a n æ$, fi ex fale $\&$ oleo decoftx edan- 40 tur, iusq́ue earum itidem forbeatur : contra inueteratos tendinum rigores pollent. Illitus earum cinis, profluentis fanguinis impetus fiftit : explendis alopeciarum inanitatibus ex liquida pice illinitur: Viridium ranarum cruor auulfos genis pilos renafci prohibet, in ueftigia euulforum inftillatus . decoctx in aceto, \& aqua, dentium dolores collutione leniunt.

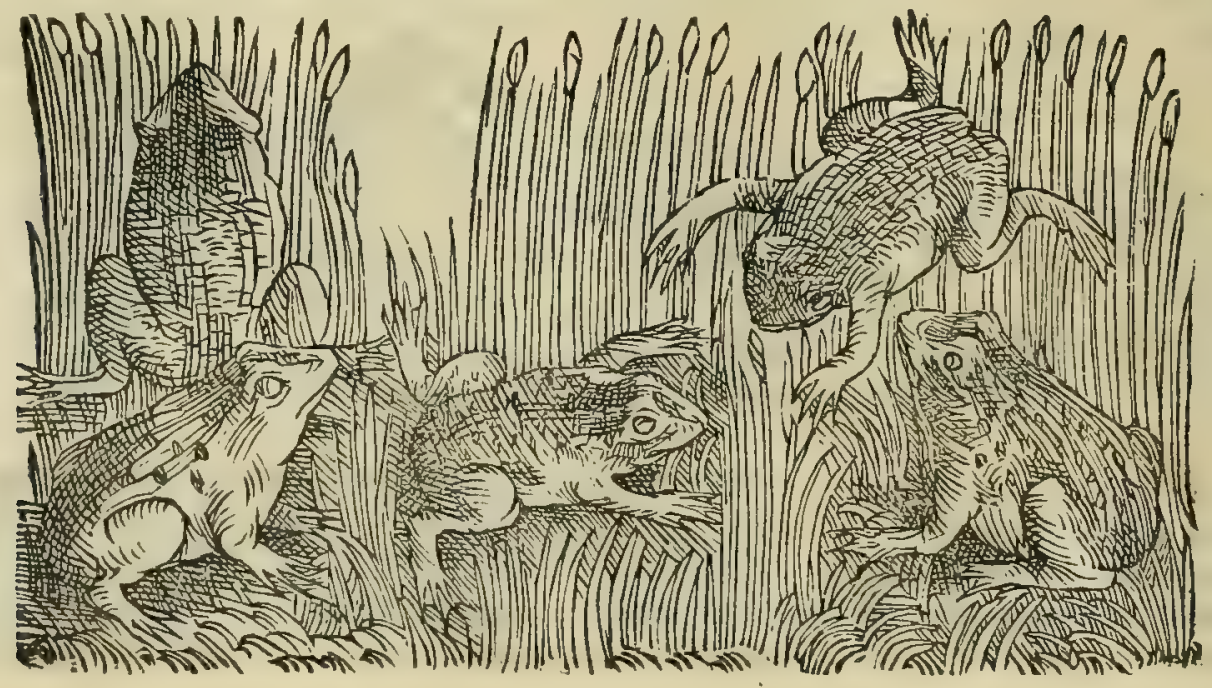




\section{InLib. fecundum Diofcoridis. $\quad 20 \mathrm{I}$}

R A N AE It.lis, prefertimq́; Inlubri.epopulis frequentißimx. Genere fané differunt, qucmadmodum magni= Ranaxŭ contudine, colore, $1 \mathrm{c}$ ntur.1. Alix nanq; exputredine gignuntur eftiuis imbribus puluere madc fucto, quibus fic ortis fideratio. breuis eft uita, nullusiq; carum wis. Alie ueró rité, er fecundum nature ordinem, proueniunt in mari, flumijs, pullu= dibus, ac lacubus. Sunt $\circlearrowleft$ terreftres, que in frutetis, or rubetis plerunque nictitant, ob id' $q$; Rubete Latinis dicun=

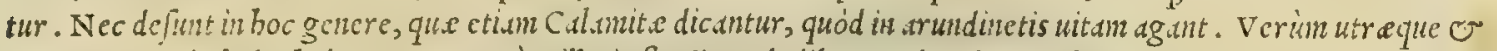
uenenate, o lethales babentur. Ceterim ille influnijs, paludibus, o lacubus uerantur, or degunt, quarun nobis in cibis inusluit ufu, colore uridi, aut fubrutilo, cinereóue. tametfier inibi quandoq; ex bis cernuntur, qua inon tu= tó cdi poffunt: utpote que à rubctis non multum pernicie diftent. P.ariunt Rane, ut Plinius tradit lib. I X.cap.L. I. Ranarum par

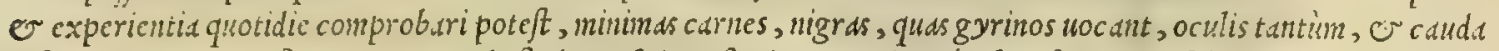

a infignes: mox pędes figurantur, cauda fundente fe in pofteriores. Mirumó; femeftri uita refolumtur un limum nullo cernente, or rur us uernis aquis renafcuntur, que fucre nate, perinde occulta ratione, cum ommibus annis id cuc= niat. bee Plinius. Cui tamen fententie prorfus refragatur experientia: quippe quod in paludibus maritimis, que glacicm nunquam byeme contrahunt, quocunque anmi tempore ranas conpicere liceat. Quapropter dicendum fuce rit, Plinium cas tantim quotanis in limun refolui exiftimaffe, qua cx ip/fus aqua, er terra putredine gignuntur.

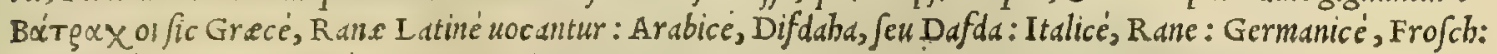
Hipsnice, Ranss: Gallice, Granoille; è Raine.
Ailiovgos. SILVRVS.
CAP, XXVI.

20 S I I VR V s recens in cibo nutrit, \& facilem præbet aluum : fale uerò conditus, minimum fuppeditat alimentum arteriam expurgat, $\mathbb{E}$ uocem expedit. Illita faliti caro, aculeos, \& infixa corpori fpi cula extrahit. Muria eius incipientibus dyfenterijs prodeft, fi in defidentium fotus adijciatur: fluxio res fiquidem ad fumma cutis elicit. ifchiadicis infufa medetur.

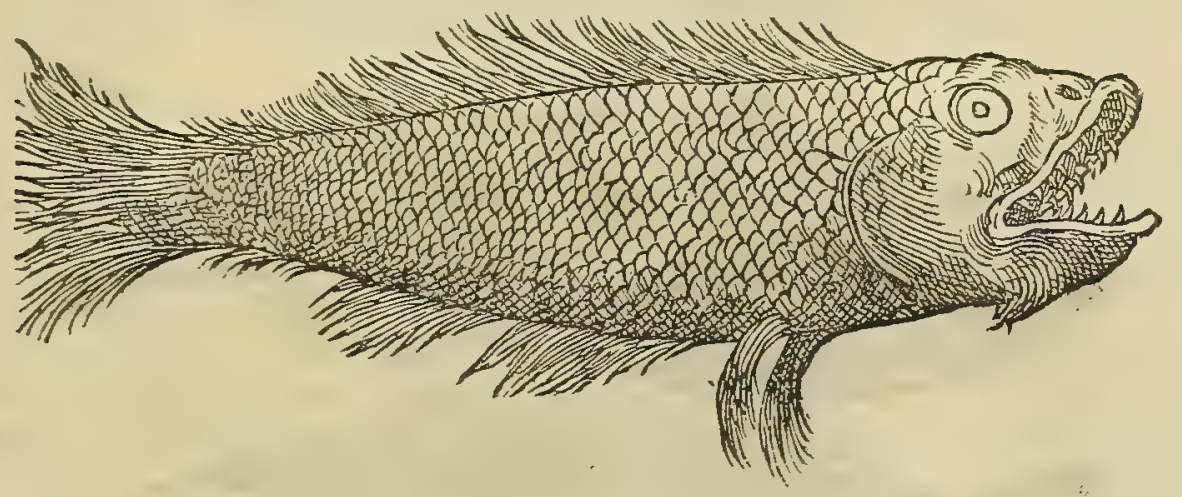

Ex I 5 I I A T Paulus Iouius in libello de Romanis pifcibus, silurum eum effe pifcem, quem unlgus sturios 40. nem appellat. Veruntamen $f i$ Artftotel, e Plinio eft adbibenda fides, liquidó conftabit, aliud pifcis genus effe silu= rum, aliud sturionem. Nanq; Ariftoteles siluro dentes aßignat adeo firmos, atq; acutos, ut ijs hamos etiam ferreos frangere ualeat. Plinius item lib. I x.cap. xv. tradidit, silurum ubicunq; fit, graffari, omnéq; animal appetere: id = circo innatantes equos fepe demergere, pracipué in R heno Germanise amne prope Lisboum, $O$ in $D a n u b i o$. At sturiones et fi pregrandes fint, edentuli penitus habentur. Ad bec silurus Arifoteli, or Plinio fluniatilis femper de fcribitur pifcis, cum tamen sturio frequentius in mari, quàm in fluminibus reperiatur. Quo factum eft, ut facilé de= ductus fim in fententian clarißimi Manardi Ferrarienfis : quippe quod pro certo crediderim, silur um I talis haudqua quam effe cognitum. Quandoquidem inibi in fluminibus, quanquam ingentibus, nunquam (quod fciam) silurus fue= rit repertus. Pannoni Danubij accole Silurum uulgarifermone wocant Acchia: R heni veró litora inbabitantes Ger manica lingua Bolich appellant: fiquidem is maximé graffatur, morfúq; petit omne animal, quod fibi obuiam fit. Is

so effigie gobium refert capite magno, ore amplo, or deatibus ferocißimis. Hac in fententia me quoque Plinius confir =

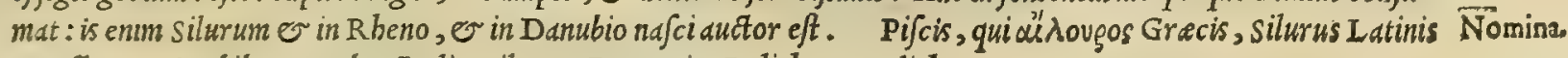
appellatur: Arabibus, Harbe : Italis, siluro: Germanis, Bolich, er Balich.

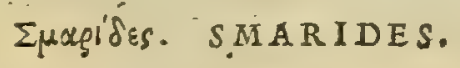

CAP. XXVII.

S M A I D I s pifcis faliti caput exuftum, excrefcentes ulcerum oras, puluillosq́ue reprimit: nomas cohibet: thymos, clauosque abfumit. Caro non fecus atque falfamentum prodeft à fcorpione percufsis, aut à cane demorfis.

Pauli Iouij opinioimpro bata. -

\section{Nomina.}


S M A R I DES.

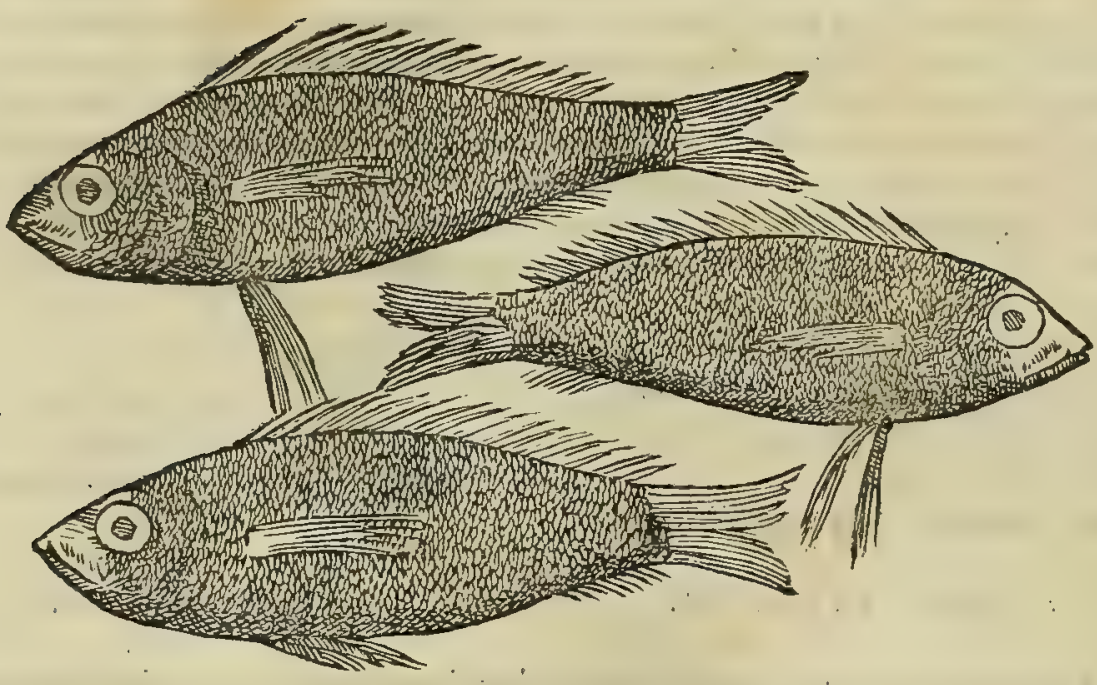

Mouvises. MAENAE.

CAP. XXVIII.

M A E N A R v M ex capitibus cinis, fi illinatur, callofas fedis rimas abolet. Eius etiam garum oris putrilagines collutione fedat.

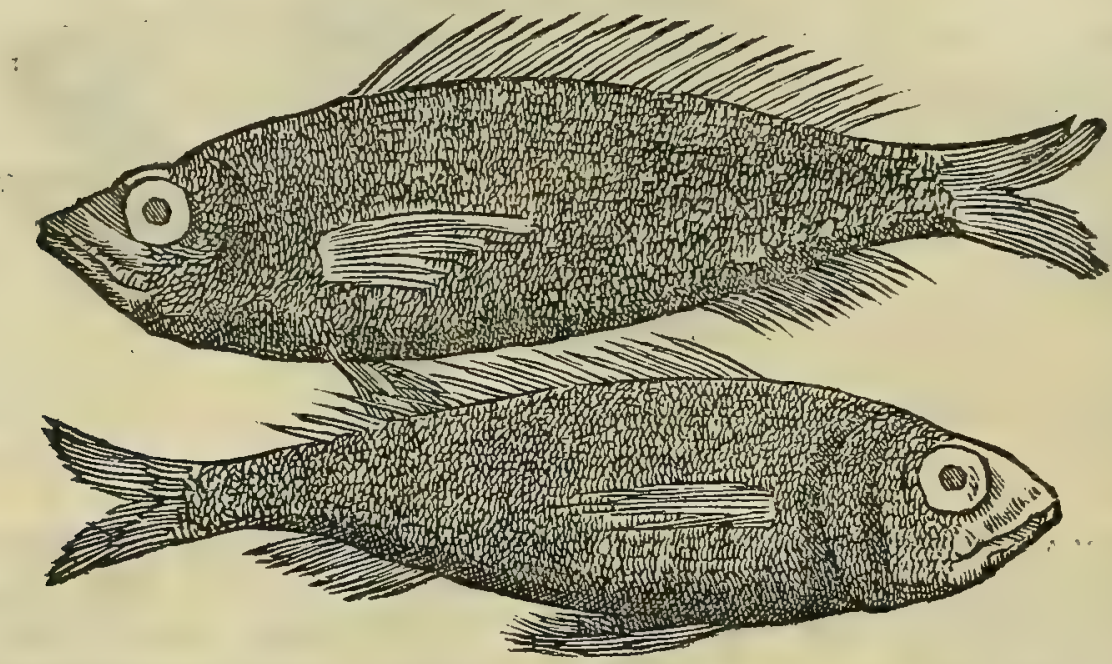

Smaridis con fideratio.

Mañ. Nomıs.
E I $~ I$ ftudij, de diligentie plurimum impenderim, ut quinam piscis fit smaris, certior fierem; nunquam tamen apud Ariftotelem, nec Plinium, nec deniq; ueterum quenquam aliquid certi nactus fum, ita ut plané Smaridem cogno fcere, ac defcribere poffem. Illud tantum inueni, ijs Smaridem effe pifciculun, menis facie fimilem. Ex quo facilé adductus fum, ut eos non longé aberrare putauerim, qui smarides eos pifciculos dixerit,quos unlgó Veneti appellant Giroli : nanque bi preter id quod corpore minores funt, mends notis omnibus reprafentant. Ceterim cum Ma=

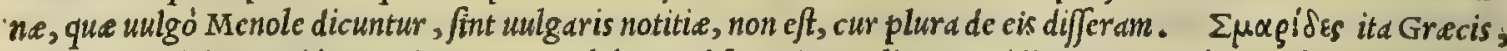
ut etiam Latinis Smarides nominantur : Arabibus, Abfamaris : Italis, smaridi. Qua ueró Graecé $\mu \alpha u v i \delta \varepsilon s, ~ L a=$ tine Mane dicuntur : Italicé, Menole: Hipanicé, Pandelhas.

\section{KoBios. GOBIVS.}

G O B I v $S$ recens in fuillum ventrem coniectus, fi confuta rima in duodecim aqux fextarijs, donec duo fuperfint, decoquatur, excolatus $\&$ fub diuo refrigeratus potui detur, aluus fine moleftia deijcitur. Illitus contra ferpentium, canumqquemorfus auxilio eft. 


\section{In Lib. fecundum Diolcoridis.}

G O B I V $s$.

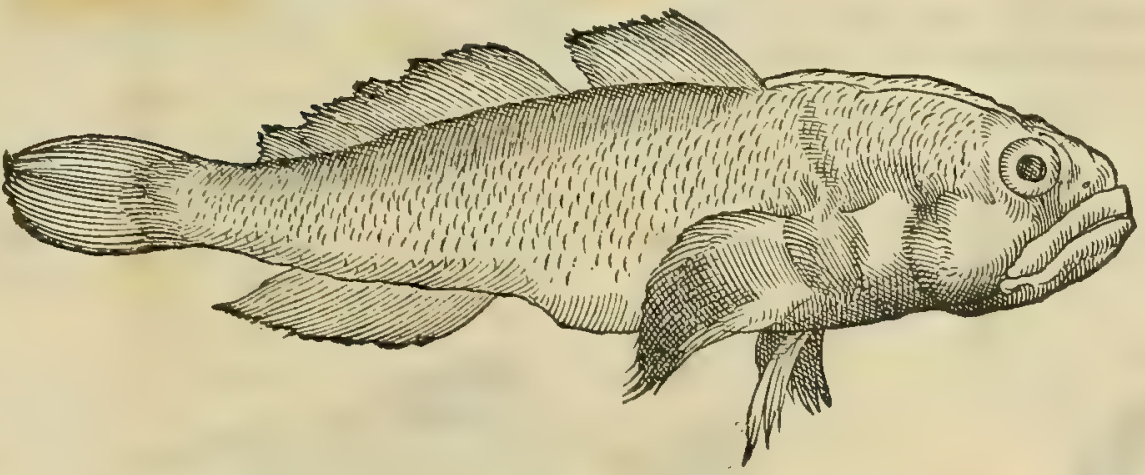

GOBII ALIVD GENVS, OVER PAGANELLO.

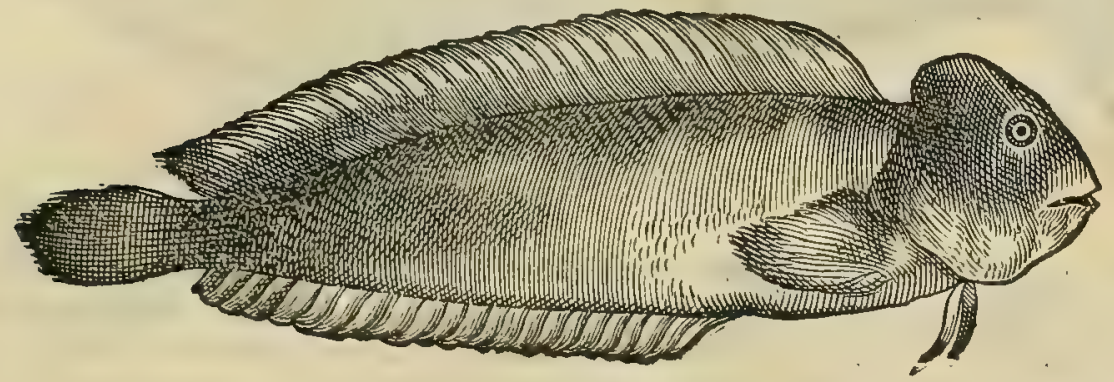

G 8 I I in Venetis ichthyopolïs frequentißimi conpiciuntur, quòd inibi in funitimis lacunis mirum in modum Gobiorü con 30 fatific ent, ac numero/i proueniant. Quare non inmeritò prodidit Ariftoteles in marinis litoribus, ubi in profundum fideratio. non labatur aqua, fuinma cum uoluptate morari Gobios. Hos Veneti detractis pofterioribus fyllabis Go uulgó uo= cant. Capite funt amplo, guftuq́; perfuaues, quód carnem babeant-tum pinguem, tum etiam friabilem. Proinde de bis differens Galenus libro I I I. de alinentorum facultatibus, fic inquit. Gobius litoralis eft pifcis, ex eorum nume= ro, qui parui perpetuo manent. Preftantißimus autem ad uoluptatem, coctionem, finul ac diftributionem, $\mathcal{\sigma}$ fucci bonttatem eft is, qui in arenofis litoribus, aut faxofis promontorijs uiuit. At qui in fluminum oftijs, dut ftagnis, dut ftagnis marinis uerfatur, non equé fuaris eft, neq; probifucci, neque concoctu facilis. Caterum fciendum eft (ut Gobij fluisetian annotauit Galenus) Gobios non in mari tantiun reperiri; uerum etiam in fluninibus, er lacubus, quemadmo= tiles. dum teftantur ij, qui in Lario lacu, item'́, Verbano capiuntur, laudatißimi quidem, propterea quód corum iecur ma

Gobij freules resex Gal.

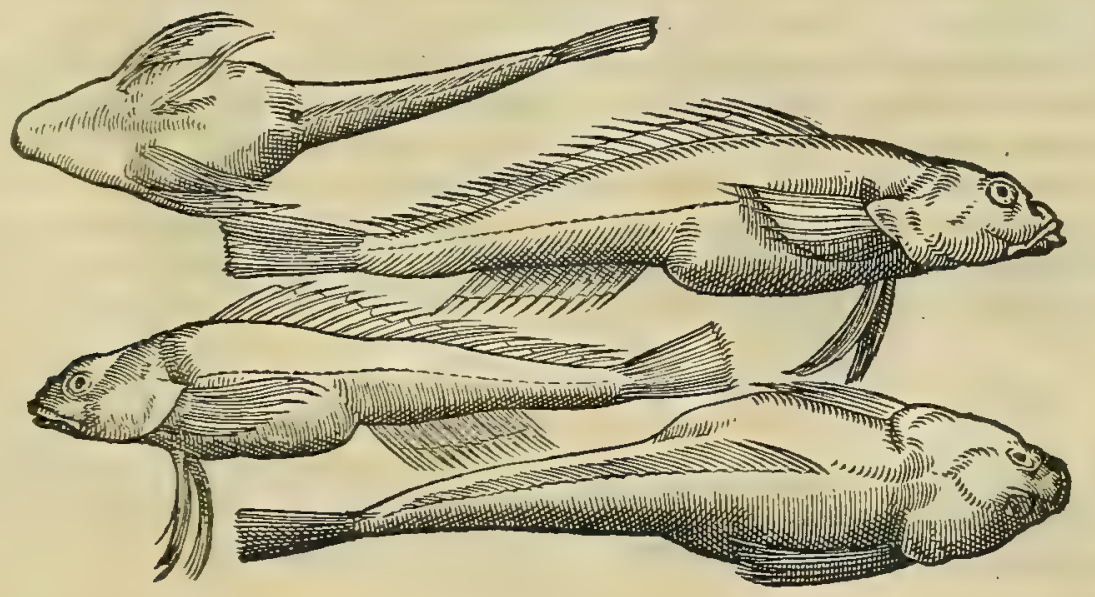

ximam cumpalato ineat gratiam. In fuuijs uniuerfim minores exiftunt, quanquam ex ijs etiam nonnullos inuenias, qui duas, aut tres uncias pendant. In agro Tridentino pauci admodum funt fluuij, qui Gobios non alant: nanque or Athefis $\odot \sim$ Nofius, $\mathbb{E}$ Lauifius, $\sim \sim$ sarca ijs refertifimi funt. Hos inibi quidam unlgo uocant Capitoni, quidam uerö AIarfoni : at in Hetruria, ubi tamen rarijimi habentur, corrupto d̀ Gobïs uocabulo, uulgó dicuntur Ghiozzi. Sunt 
bi pifciculi non modó concoctu facillimi; fed or orifuauißimi, atq; gratißinzi, prefertin cum ouis turgent: hac enin in bis or pinguia, or copiof a funt, guftui ueró fuauisima. Quo fit, ut folertißsimi pifcatores borum ferturas ob feruan Nomina. tes, non minus expifcandis ouis operam nauent, quam pifcibusiplis. Kwilos Gracis, Latinis finiliter Gobius appellatur: Arabibus, Kancn: Italis, Gobio : Germants, Goeb: Hipanis, Cadozes: Gallis, Gouiones.
Evívos.
THVNNVS.
CAP. XXX.

CONDITANEI thunni caro, quam omotarichon uocant, fumpta ijs auxiliatur, quos uipera nomine prefter momorderit: fed oportet vinum quàm plurimùm fubinde cogantur haurire, ita ve uomitione reddatur. Contra acrimonias ffitatorum maximè ualet: canum morlibus utilifsimèillinitur.

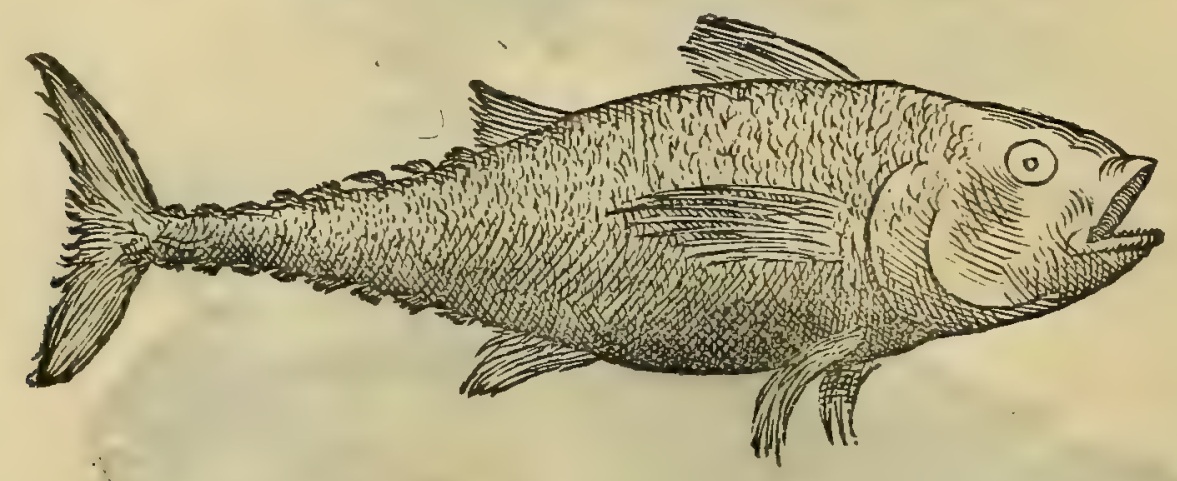

Thunnicon-

T H V N N I pifcesinter cetaceorum generarecenfentur. I imultitudine fud omnibus litoribus funt noti, prex Gideratio. fertimiq; Tyrrbeni accolis magis, quain ijs, qui Adriatici litora inbabitant. In Euripis maxima corum eft captura. Irrumpunt maio menfe, ac iunio in marc noftruin mediterraneum per Herculis columnas ab Atlantico oceano, co= gentibus xiphijs, boc eft, ßpathis pifcibus, qui enfe iroftris prominente inftructi, eos toto mari per equuntur: funt Xiphia pircis. enin xiphix immanes belux. Nam ( ut Plinius inquit libro x x x I. I.ck. I I mucronato roftro tam ualidé naues per= fodunt, ut in oceano mergantur, prefertinad Mauritante locum, qui Cotta uocatur, non procul ḋ Lixo flumine. Thumi igitur cim pifcium fimplicißimi, tunidißimi '; fint, non aliter in fugam à xiphijs gregatim aguntur, quàmo= uium greges à lupis. Quin ob caufan uel inanibus terriculamentis acti, facile uadis, atque litoribus intruduntur. Thunnorum Porró fumma pectantium uoluptate maio, er iunio menfibus Thunni ḋ Gaditanis non longé ab Herculeo fretu ca= captura,\& no piuntur, ad quam pifcationem uniuer fus concurrit populus, maximo clamore, tympanorum fonitu, ac bcllicis pulue=

re, ov igne concrepitantibus terriculamentis. Hec enim eorum capturam faciliorem rcddunt: quandoquidein foli= di cum fint, uocibus, of frepitu territi, concitantur ad uada: quo in loco poftea gregatim retibus capiuntur, maxi= mo \%; omnium plaufu trabuntur in litus. Thumi diuer fa fortiuntur nomina: nanque primus thunnorum fatus ab ip= fo ftatun ou Cordilla dicitur, qui mox in Limarias eudid: ex limarijs autem adole fcentibus Pelamides fiunt, fic a luto diate: crim ueró be pedalem exceffere menfuram, in Thunnos abeunt. Atheneus hos diu uiuere ait, er in pre= grandes cuadere pifces. Sed buic opinioni uidetur aduer fari Ariftoteles, cum affeueret, cos biennio uitam finire. A= nimal eft parum (ut fcribit Plinius) fcorpionis effigie. Hoc ardente firio fub pinna affigit aculeo, tanto' infeftat 40

Thunnorŭ in dolore, ut in naues exiliant: quo tempore, ut maxime noxij damnantur in cibis. Caterim thunnorum uentres, quó cibis facultas. in cibatu origratiores babentur, eó magis uentriculo nocent: contrà corum carnes, que omni prorfus pinguedine carent, etfi non tantam cum palato ineant gratiam; minorem tamen uentriculo infrunt noxam. Quanquam buiufce= modi pifces, qui in cetaceorum genere recen $\int e n t u r(u t$ Galenus eft author lib. I I I. de almentorum facultatibus) du= ra carne funt prediti : quam ob caufam o praui funt fucci, $\sigma$ excrementitium prabent alimentum. Quapropter fa= le macerata plerunque eduntur, quod inde alimonia tenuior facta ex ip/is in corpus diftribuatur : ob ıd'́; fit coctioni, o Sanguinifaciendo accommodatior. Nam recens borum caro ni admodum probé concoquatur, magnam crudorum

Nomina. fuccorum copiam in uenis congerit. Pifcis, qui Gracis 甘vivvos, Latinis item Thunnus uocatur: Arabibus, Ke $\int_{a m,}$ or Aliena: Italis, Tonno: Hipanis, Atuni: Gallis, Thun.

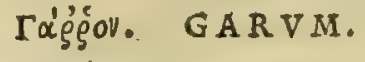

CAP. XXXI.

G A R v M omne, quod ex pifcibus, carnibusque fale maceratis liquamen eft, fi ex eo fotus fiat, depafcentia ulcera fiftit. Morfus à cane medetur . dyfentericis, atque if́chiadicis infunditur : nonnullis, vt exulcerata adurat : alijs autem ad laceffenda, qux ulcera non fenferunt.

\section{Zouos ixdī. IVS PISCIVM.}

CAP. XXXII.

R E C E N T I V M pifcium ius, modò perfe, modò ex uino potum, aluum fubducit. Priuatim ad hunc ufum conficitur è phycidibus, \& fcorpionibus, \& iulide, è percis, \& recentibus alijs faxatilibus, nec uirus refipientibus, fimpliciter cum aqua, oleo, \& anetho. 


\section{In Lib. lecundum Diofcoridis. $\quad 205$}

G A R v M dictum effe à uctéribus tradidit Plinius lib. $x \times x$ I. cap.v I I. quód olim conficeretur expifce, quem GariconfideGreci garon uocabant, intcftinis illius falc maceratis, ac eliquatis. Quoditem poftea é fcombri extis conficic $\alpha=$ ratio. ptum eft. Fuit olim Garum complurium ciborum condimentum, adcó ut mullus feré liquor, qui ad gule luxum ma= gis preftarct, ab antiquis fucrit cxcogitatus. Veruntanten de boc non intellexit Diofcorides; fed generatin de $0=$ mni pifcium, or carnium muria, qua bxe diutius afferuarifolcut. Caterim de pifcium iure non eft cur pluribus d=

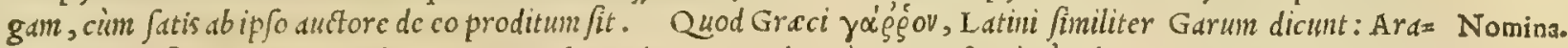
bes, Muri, fiuc Almumi : Itali, Garo, O Salumuoia. Quoducró Grecis Zouo's íx v'wv, I atinis Ius pifcium di= citur: Italis, Brodo de pefci.

C I M I C E S, qui in cubilibus enafcuntur, cauis fabarum inclufi, fi ante febrium fignificationes fepteni deuorentur, quartanis auxilio funt: \& citra fabas fumpti, percufsis ab afpide profunt: vuluarum exanimationes olfactu reuocant. Poti cum uino aut aceto, adharentes fanguifugas abigunt : triti, \& urinarix fiftulx impofiti, urinæ anguftias leuant.

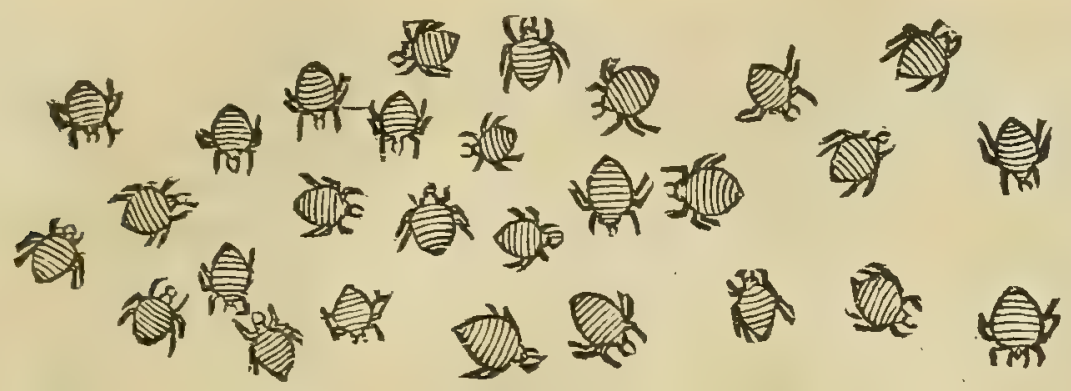

I T T E R ommes nocturnos hoftes, qui nobis dulcem fomni quietem intercipiunt, nulli quidem nocentiores, infe= Cimicum cäs fioresq́; habcntur, quàn Cimices: quippe qui inon folum morfudilacerent, quo or fommum interturbant, $\mathcal{O}$ fan= 30 guinem nobis adinumt; fed etian fatorem adeo deteftabilem, abominandum '́; nobis ex fe relinquunt, ut co longé

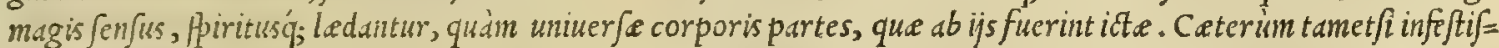
fint, foetidisima; ; int animalia; noluit tamen eos genuiffe natura omnium rerum parens, quin fuum baberent in medicina ufum. Vtuntur ijs recentiores quidam ad ciendain urinam, uiuis in penis organum immißis, non autem mor tuis, o tritis, Diofcoridis modo. Quod mibi mag is confentaneum effe uidetur: fiquidem in mectum urinarium indi= ti, ingreffutitillationem excitant, $\approx$ urine uim expultricem proritant. Sunt $\approx$ fylueftres Cimices, qui ex berbis nifum, $\mathcal{F}$ locumbabent, lectularijs maiores, colore uiridi, aquéac illifoetidi. Sed hi nullum, quod fciam, obtinent nmedicina ufun. Cimicesita Larinis, xópgs Gracis appellantur:Italis, Cimici: Germanis, Vuantzen: Hipa= $\boldsymbol{i}$ is, Chifmes, Chime das, E Farauelhos: Gallis, Pune $\int e s$.

$$
\text { O’vos. MILLEPEDAE. }
$$

\section{CAP. XXXIII.}

M I I L E P E D AE, quæ fub aquario uafe ftabulantur,animalia funt multis pedibus nitentia, qux contacta manu contrahuntur in orbem. Hæ ex uino potæ difficili urinæ, \& regio morbo auxiliantur. Millepedæ cum melle anginis utiliter illinuntur. tritæ, \& in cortice mali punici calfactæ, doloribus aurium, addito rofaceo, conuenienter inft illantur.

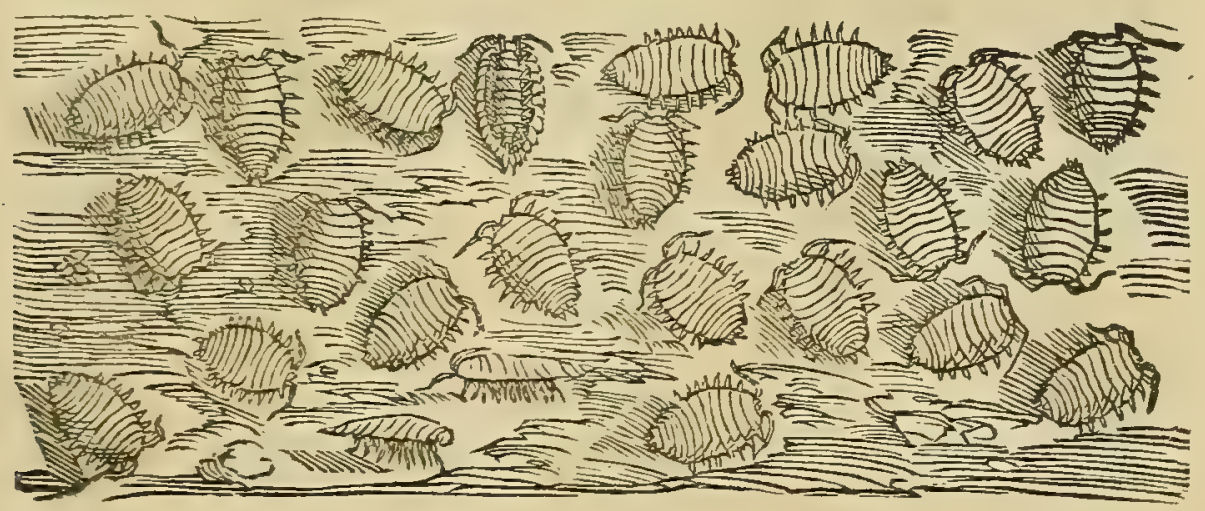

M I I L E P E D AE, quas uulgó appellamus Porceletti, animalia funt exigua, or omnibus uulgaria. Proin= de non oper epretium duxi, ut plura de eis in prefentia referam, quam tradiderit Diofcorides. Caterum animalcu= ufus.

Cimices fylueftres.

Nomina. deratio. 
la bee Galeno commendata funt libro II. de compofitione medicamentorum fecundum locos ad diuturnos capitis dolores, ubific inquit. Maximé etiam profunt fub aquario uafe nafcentes afelli, millepede appellati, fi oleo inco= quantur. Qu amobrem nefciucrim, cur dixerit Plinius lib. x x I x. cap. ultimo, Millepedam animal effe é uermibus terrapilofum, multis pedibus arcuatim repens. Animalia, qua Grecé övor, Latiné Millepede, Afelli, or Multipede uocantur : Arabicé, Harna:Italicé, Millepedi: Germanicé, Efel: Hipanicé, Gallmilha: Gallicé, Cloporte.

$$
\text { इіRфH. BLATTA. CAP. } \mathrm{XXXV} \text {. }
$$

B I A T T AE eius, qux in piftrinis inuenitur, interanea trita, aut cum oleo decoEta,aurium dolores inftillatu mitigant.

Blattarum có. B L A T T A R V M plura cfe generd, auctor eft Plinius lib. $\mathrm{x}$ x I x. cap. ultimo. Verim be, quarum in He= Gideratio. truria aliquibus locis ingens eft multitudo, e qua uulgó uocantur Piattole, noctu magis, quàm interdiu in cellis uinarijs apparentes circa latrinarum or a, in piftrinis, balneis, uliginofisq́; adium partibus, foedisima quidem, naus feofaq; funt animalia. Gryllos be, qui noctibus aftate ftridcnt, quaddntenus referunt: planiores tamen, cruribus $e=$ tiaimnum tenuioribus araneorum modo: proinde fuge citibina. Lux ift is aduer fi Bima, ita ut, fi nocte lumen repen= té inferatur bumentibus locis, in quilus degunt, celerrimo curfu refugiant. De bisigitur, utpote que multùm in pi= frinis uerfantur, intellexiffe Diofcoridem credendum eft: non autem de illis uermiculorum modo oblongis, que in apum aluearijs, o in carnibus diu fale inueteratis enafcuntur : quanquam o be Blatte nomen fibi uendicauerint. Nobis he uocantur uulgó Barbeggie, alijs ueró Carpe. Blattarum uires, 'quas pluribus Plinius confcripfit, filen $=20$ tio inuoluimus, rati gratioribus, falubrioribusq; remedijs morbos poffe fanari, quàm ijs, qui à tam foetid is, at q; exe=

Nomina. crandis fumuntur animalibus. Qua Gracis $\sigma i \lambda \phi_{H}, \mathrm{~L}$ atimis, pariter 0 Italis Blatta nominatur : Germanis, Gril= len, $\mathbb{O}$ Heymichen: Hipanis, Rapa coua.

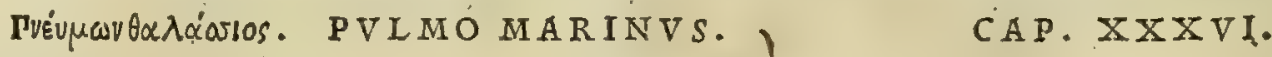

POD A G R-As, pernionesq́ue emendat pulmo marinus recens, tritus, \& illitus.

Pulmonisma PVLMON E marini animaliumpulmonibus non abfimiles habentur. His ( ut Plinius eft auctor libro IX. rini confid. cap. X LVI I.) eadem que frutici ineft naturd, perinde ac ßpongijs, urticis, ftellis, $\mathcal{O}$ olothyris. Confficiun= tur marini pulmones plerunque undis fupernatantes, futurain maris procellam prefagientes. Mirum, quód fi ijs 30

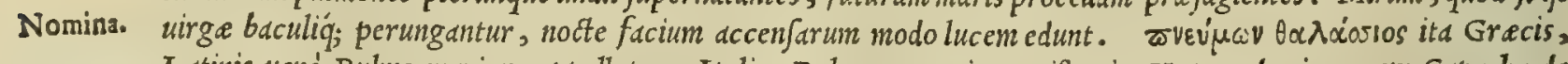
I atinis ueró Pulmo marinus appellatur : Italis, Polmone marino:Hifpanis, Natura de nieya, Oo Capacha de uelha.

IVEvinoves. PVLMONES.

CAP. XXXVII.

S v I l L v s, \& agninus, vrfinusq́ue pulmo impofitu, attritus à calceamentis contractos, ab inflammatione tuetur. Vulpinus uero fi arefactus bibatur, furpiriofos adiuuat. Adeps quoque liquefactus, infufusq́ue aurium dolores finit.

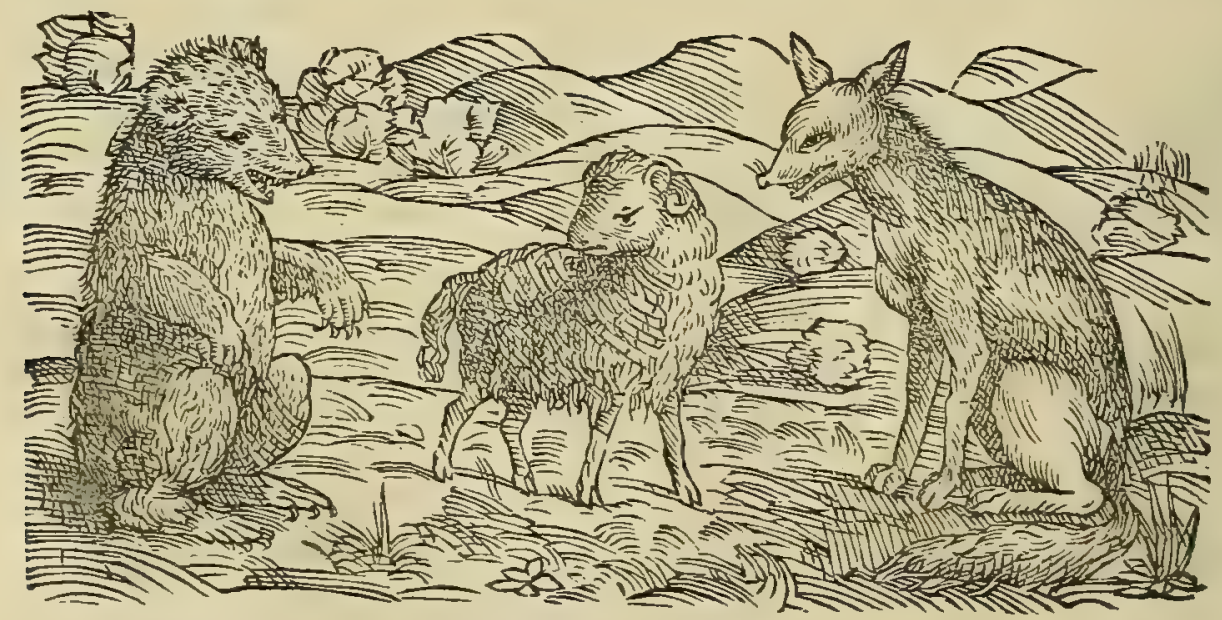

Vana de urfex partu opinio.

M V L T A pretered funt horum animalium membra, de pulmonibus quorum differit Diofcorides, que medica= menti uim poßident, de quibus poftea peciation fuis locis dicetur. Verium cum bec animalia nemini non int cognita, non opus c ffe exiftimo, ut de ijs plura dicamus. Quanquam illud filentio non dißsimulandun, quod fcilicet $\mathrm{Vr} \int \mathrm{a}=$ rum partus non fit plurimis membris indifcretus, cruribus prefertim, or undique rudis, ac informis: nec quód pa= rentis linctuformain tandem recipiat urfinam, ut nonnulli fcriptis commendarunt, $e^{-}$credit uulgus. Quandoqui= dem in ualle Anania fupra Tridentum uidimus nos pregrandem Vrfam pregnantem, ab ipfis uenatoribus exentera= tam, cuius catuli adbuc in utero exiftentes, omibus fuis membris diftinctis, ac formatis repertifunt, non autem in= 


\section{In Lib. fecundum Diofcoridis.}

formes, ut pleriquc exiftimant, mag is fortaffe Ariftotelis, ov plinij auctoritatibus freti, qui ita effe memoric prodi=

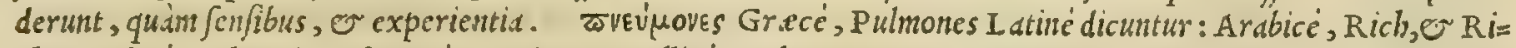
che : Italicé, Polmoni : Hißpanicé, Lenianos: Gallicé, Polmon.

\section{H"ซ}

A S I N I Y E C V R inaffatum efu comitialibus prodef : veruntamen iciunis edendum præcipitur. Caprx uerò inaffati decidua lanie, inungi lu fciofos prodeft: \& dum coquitur, apertos oculos halitu eius uaporari . prodeft in cibo toftum ad cadem. Tradunt hircini iocineris cibo co-

2. mitiales deprehendi. Aprinum recens fiarefactum teratur, ex uino potum, contra ferpentium, † uolucrumq́ue morfus auxilio eft. Iecur canis, qui rabie exagitatur, toftum, \& in cibo ab emorfis fumptum, ne tententur metu aqua tueri creditur. Vtuntur autem ad arcendos aqux pauores dente eo, qui caninus dicitur. hunc à cane, qui momordit, exemptum, \& folliculo indıtum, pro amuleto brachio adnettunt. Inueteratum autem fale mergi iecur, ex hydromelite binis ligulis potum, recundas pellir.

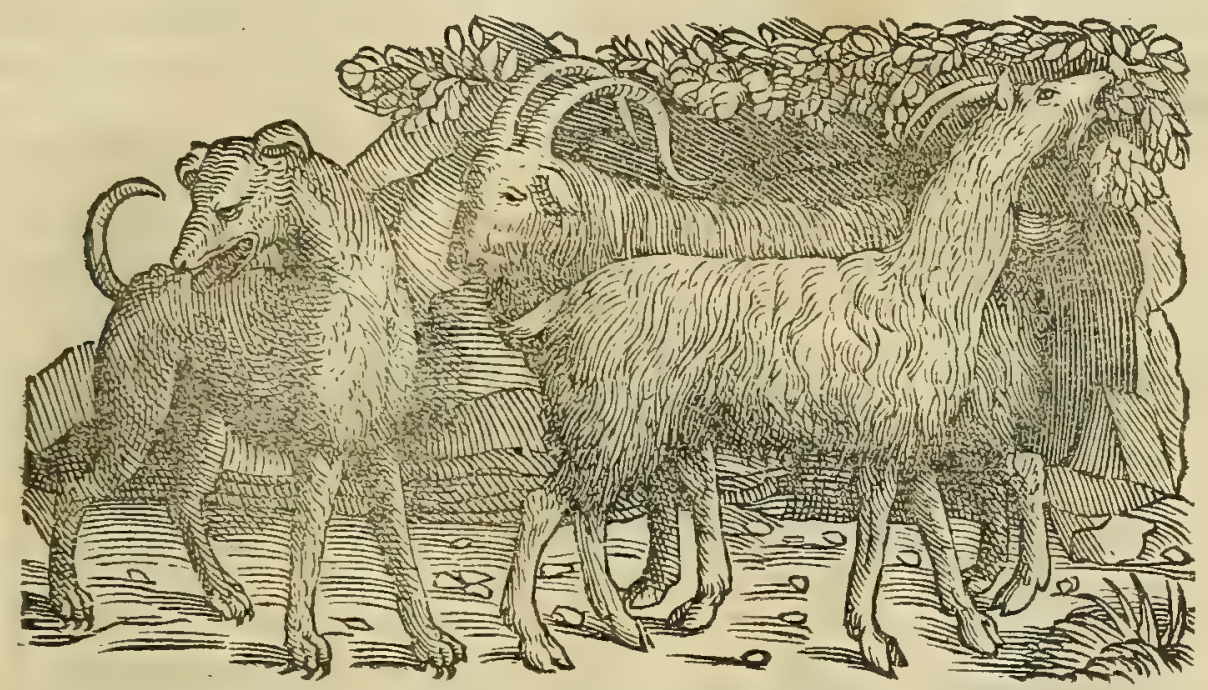

PR AE TE R Afini, Capre, Hirci, Apri, rabidi Canis, or Mergi iecur, eft Or I upinum, quo utuntur medicos rum nonnuli, qui primas tenent in uniuer $\int_{a}$ I tali. . Siccant enm lupinum iecur, mox in puluerem conterunt, or tan= quam precipum medicamentum ijs exhibcut, qui iocinerofis afficiuntur fluxionibus: ijsớ; finiliter, qui aqua inter cutem laborant. Quanquam id probarc non videatur Galenus lib. $\mathrm{x}$. Jimplicium medic ainentorum, fic inquiens. Iecur lupinum Sepeitumero in inedicamentum indidi bepaticum, quod ex eupatorio conjicitur; nec tamen quod me= moria dignum fit, amplius preftare comperi, ad illud uidelicet comparans, quod fine ipfo componitur. Secus au= tem Galenus de iecore lupino feripfit poftea lib. or cap. v I I r. de compofitione medicamentorum fecundum locos,

40 ubi iecinoris medicamenta recenfet, cum fic inquit. Cocblearum terreftrium carnem ualde probé terito, $\sigma$ affufis uini nigri cyatisis tribus calfacito, ac bibcndum dato. Videntur autem bec iuxta totam fubftantiam efficacia effe, nō Secundum unam aut alteram qualitatem. Quale eft er. Lupinumbepar, cuius abunde experimenitum habemus. vfus sutem ip fius confimilis cocbleis est. teritur enim exalté hepar lupinum, es datur dracbma una cum uino dliquo duls $c i$, qualia funt thereum Creticum, of fcybelites, ac dulce protropum. Benigna enim bec funt vifceri, ipfum nutris

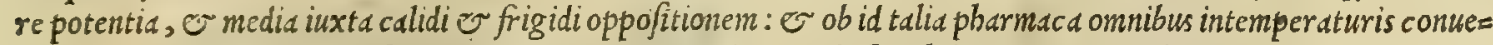
nire uidentur, ut que ex fubftantie proprietate commoditatem de $\int e$ exbibent, o neq; calidas, neq; frigidas intem = peries ledant. hađtenus Galenus. Catērùm idem in fimplicium medicamentorum cenfu, libro pauló anté citato, Canis rabidi iecur non ijs preftare uiribus, quibus aliquorum fert opinio, fcriptum reliquit his uerbis. Iecur rabien= tis canis,,$i$ a ffum edatur, remedium exiftere $i j s$, qui ab ip fo fuerint demor $f i$ quibufdam memoria eft proditum. Ac Canis rabidi.

so fcio certé quofdam, qui ipfum fumplere, manfiffe fuperftites, uerùm non illo folo. siquidem alijs praterea remedijs ufi funt, quorum fecimus periculum in rabioforum morfibus. Audiui ueró quofdam, cim illi foli fidem babuißent, poftea mortuos. De iecore Mergi in aqua degentis, tametfi Galenus nibil literis mandauerit; Paulus tamen id renum calculos eijcere tradidit. Diofcorides ueró fecundas, non autem calculos pellere protulit. Quo fit, ut Pau= li codicem deprauatum effe credidcrim. At uentris quidem Mergi meminit Galenus citato loco, eoruin opinionem ut uanam explodens, qui nentriculo robor ando ipfunt exhibent. Eosq;; item deridet medicos, qui ad iden ufurpant internas uentriculorum gallinarum tunic as : fiquidem ait, fe utrunque expertum fuiffe, nec inde quicquam confecu= tum emolumenti. Q 1 od tamen cum ignorent recentiorum quidam, cim feplafiarijs ad uentriculum roborandum ali= quid precipiunt, nihil frequentius habent in ore, quìm illud, Recipe ftomachigallinarum, longé magis unlgum, qudim Galeni dogmata fecuti : quanquam in hoc Galenus fua experientia fretus, aperté Diofcoridi refragetur.

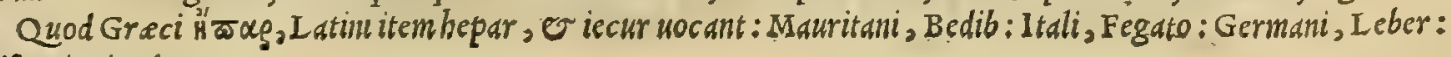
Hipani, Figado. 


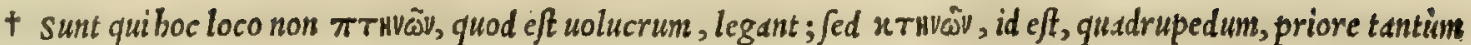
mutata litera. Certé facilis bic fuit librariorum lapfus : tamen que fit uera Diofcoridis fcriptura, non facile intela ligi poteft, cum Plinio aues etiam dentate prodantur.
Aỉooio é $\lambda$ x́đov.
GENIT ALE CER VI.
CAP. XXXIX.

GE N I T A L E cerui tritum, \& in uino potum, à uipera demorfis auxiliatur.

Genitalis cer R A S Is auctor eft, Genitalc cerui, preter uim, quam fibinaturd comparauit contra uiperarum morfus, ut etiä ui uires. $\quad$ cribit Diofcorides, aluxilio effe remorantibus urinis, ac coli cruciatibus affectis, is ubi aqua probé fuerit elotum, ip $\int_{a}$ ftatim ablutionis bibatur aqua. Aint in pulucrem tritum, $\odot$ ijs medicamentis inditum, qua uenerem excitant,ea ua= $\mathbf{2} 0$

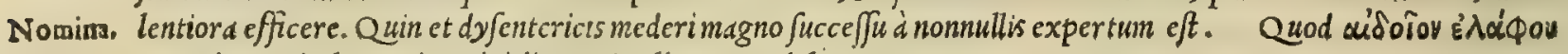
Greci, Genitale cerui Latini dicunt: Itali, Verga del ceruo.

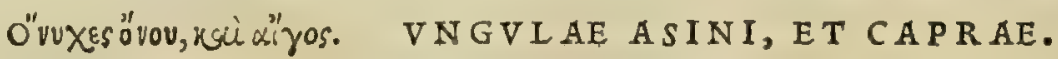

$$
\begin{aligned}
& C A \text { P. } X \quad L \text {. }
\end{aligned}
$$

VNG V L A R V M afini cinis per dies multos binis cochlearibus potus, proditur comitiales adiuuare . eædem oleo fubątæ ftrumas difcutiunt: \& illitæ pernionibus medentur. Caprinarum cinere perunctx ex aceto alopecix fanantur.

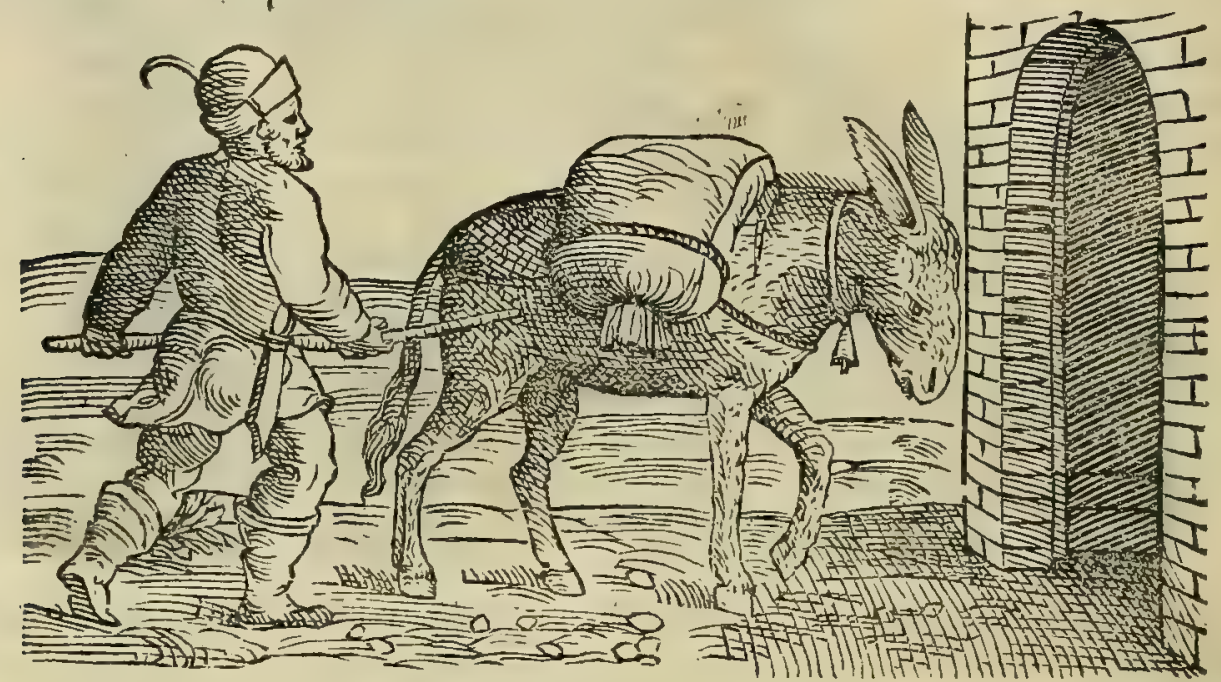

Vagularum No Nolim A fini, o Caprarum ungula in medicum ueniunt ufum; fed o Vaccarum ex prioribus tantim pe= uıres. dibus exute, ut auctor eft Rafis libello de I X. animalibus. siquidem barum combuftarum cinerem potum, nutricibus lactis copiam prabere exiftimat, Mularum ueró mulieres infoec cundas reddere. Quinetiam mures edrum fuffitu fu=

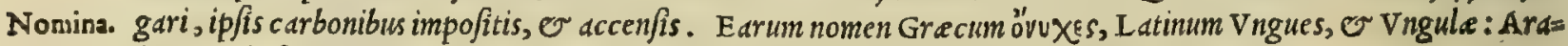
bicum, Chafit, stes, $\sigma$ Dalef: Italicum, Vinghie: Hippanicum, Vnhas de animal: Gallicum, Ongle.

SEX

CAP. XII.

L. I C H E N $S$ funt in equorum genibus, \& fuper ungulas indurati calli . qui triti, \& in aceto poti, comitialibus mederi traduntur.

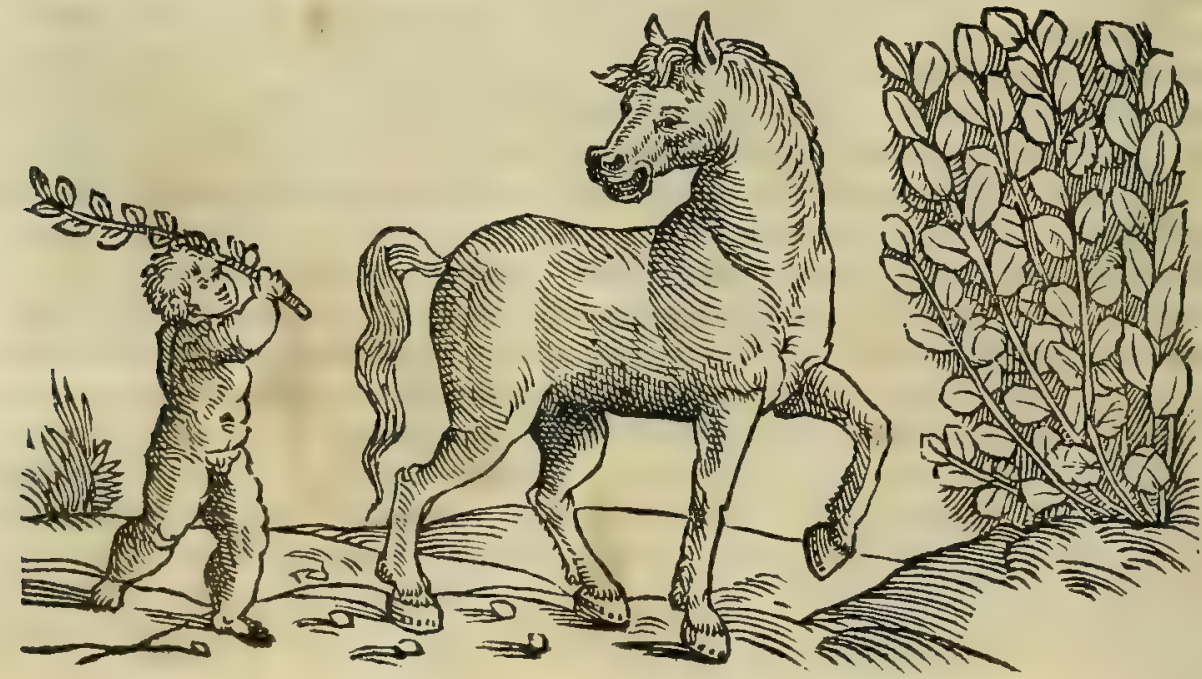




\section{In Lib. fecundum Diofcoridis. 209}

D E C A L I I s, qui equorum cruribus innafcuntur, meminit Plinius libro $\mathrm{x} \times \mathrm{v}$ I I I. capite $\mathrm{x}$. Callorŭ equi

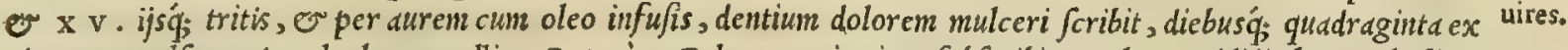
uino aut mulfo potis calculos expelli. Caterum Galenus. cui etiam fubfcribit Paulus, addidit hos quibufdam

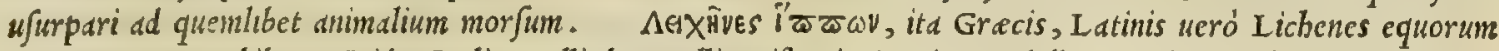
nominantur: Arabibus, Zeide: Italis, Calli de caualli: Hifpanis, Impigenes dellos cauallos: Gallis, Cal des iam= Nomina. bes des chenas.

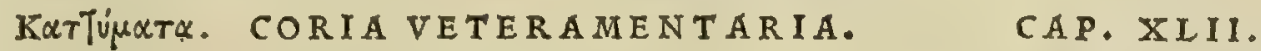

30 V T I R I S corij cremati illitus cinis ambufta igni, intertrigines, necnon calceamentorum attritus fanat.

C O $\mathrm{R}$ I A uetera, que tidclicet ueteramentorum funt, ufta ( $u t$ Galenus memorix prodidit libro $\mathrm{x} x$. de fim: plicium medicamentorum facultatibus) ad attritiones commodaricalceamentorum foriptum diquibufdam eft, tan= quam fcilicet boc faciant ex antipatbea quadam. Certe qu:e phlegmone obfidentur, baudquaquam iuuantur: ue= sim ubi fedala fucrit plslegmone, non iniuria iuuantur, nempe quia reficcantur. bac Galenus. Caterim ucterd= menta prunis accenf a fumo naribus accepto, efficacißimum conftat effe remedium ad uulua ftrangulatus, ut mibi quoque experientia comprobatum eft: quandoquidem boc tantum remedio ego deploratas in eo dffectu mulieres in= columes pluries reddidi. I is fimiliter accenfis ferpentes efficaciter fugari compertum eft, neque cos modo, qui in

20 domibus nof tris oberrant; fed eos etian, qui in bominum corporaingrediuntur, dum bomines per aftaten alto fo= mno oppre/si, ore apcrto in campc/fribus obdormiunt. Quod feriptis tradidit Marcus Gattinaria noftre etatis me= dicus non contcmicndis, accidiffe fuo tempore cuidam bomini; cui cùn fiuftrà adbibita effent innumera medicamen ta, ipfá, alioquin cfficacißima; illud tamen magnific é preftitit ueteramentorum fumus traiectorio in corpus bau= ftus. Siquiden cim primism immanis fera (erat enin uipera non parua) fumi nidorem prafenfit, uifa est dे circum=

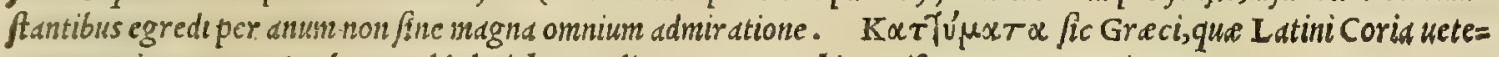
Veteramétorum uires ex Galeno. rautentaria nocant: Arabes, Geldalatiche: Itali, Scarpe uecchie: Hipant, Zepatos uiegos.

D I s S E C T AE gallinx, \& adhuc calentes appofitx, ferpentium morfibus auxiliantur: fed identidem alias fufficere oportet . Earum cerebellum in uino bibendum datur contra ferpentium morfus : fanguinem à cerebri membrana profluentem fiftit. Qua interiore uentriculi galli finu refidet membiana, feeti in laminas cornus fpecie fimilis (ea uerò inter coquendum abijci (olet) ficcatur, tritaque in uino conuenientifsimè ftomachicis datur in potu . † Ius è uetere gallinaceo aluum deijcit . Abiçtis itaque interaneis falem conijci oportet, \& confuto uentre decoqui in uiginti fextarijs aquæ, donec ad tres heminas redigantur: totum id refrigeratum fub diuo, da-

40 tur. Aliqui incoquunt olus marinum, mercurialem, cnicum, aut filiculam. Crudos humores, craffosque, atram bilem, \& ftrigmenta elicit: prodeft longis febribus, fufpirijs, articularijs morbis, \& inflationibus ftomachi.

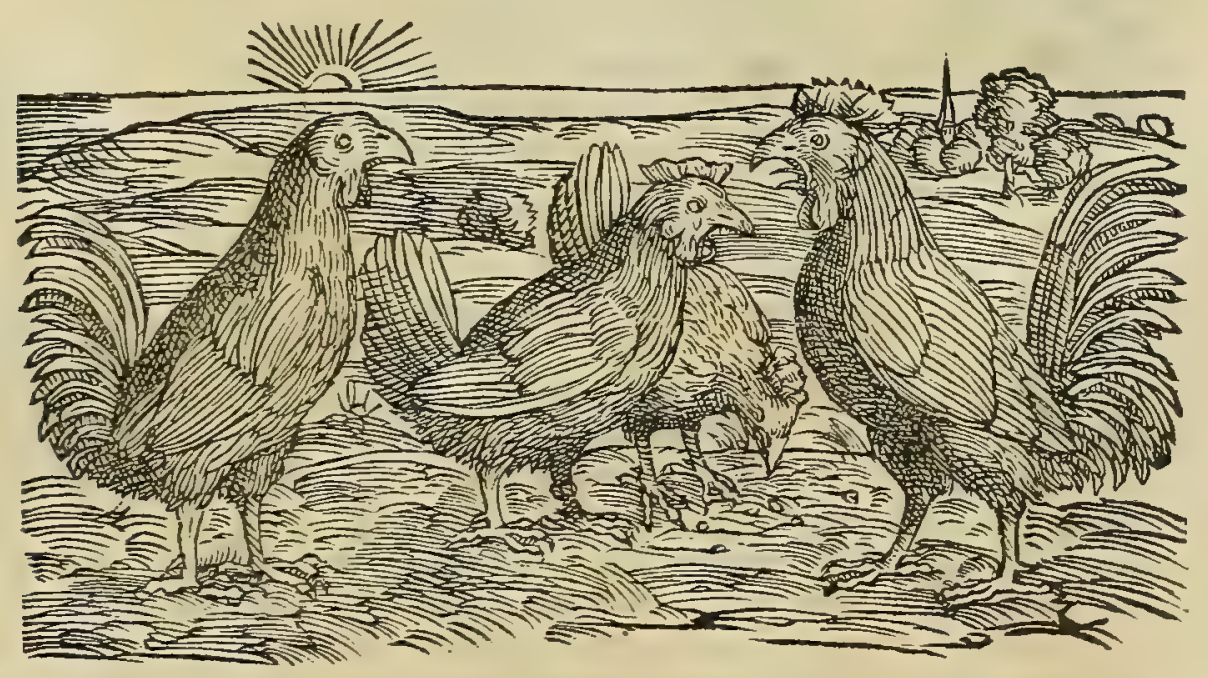


Gallorum, \& gallinarum ui res ex Gal. \& alijs.

T A M E T'S I Gallinarumius fimplex (ut Galeno proditum ef libro $x$ I. fimplicium medicamentorum) reti= nendi uim habeat; gallorum tamen ueterum cum fale diutius decoctorum, Jubducendi facultatem obtinet. Aduerfus ferpentium morfus tam gallinis, quadm gallinaceis utuntur medici, non tantum ipfis diffectis, er appofitis (ut docet Diofcorides ) fcd uiuentibus adbuc plumas detrabunt ab ano, eum q́; demorfis partibus apponunt: attrabunt enim bec animalia cuckrbitularum modo in fe uenenum, quo mox interficiuntur. Quanobrem allios gallinaceos uiuos cõ= tinuò apponere necefe eft, donec iniectum uirus penitus abfumatur. Vtuntur pretered gallinarum adolefcentium iure, ad a quandos corporis bumores, poft febrium difceffum, cum faccharo, ferapij modo. Ad bec gallorum cum gallinis nondum coëuntium teftes, deperdit as in morbis uires mirifice reftitunnt: quàm ob caufam betticis, er mar af= mo laborantibus, morborumq; diuturnitate macrefactis utiliter exhibentur. Infupergallinaceorum teftes femen prolificum fuppeditant, o nenere as roborant uires. Plinius cum de gallinis differeret lib. x x I X. cap. I I I I. hac inter cetera memorie prodidit. Non preteribo (inquit) miraculum, quanquam ad medicinam non pertinens : $\left\{\begin{array}{l}i \\ \text { auro }\end{array}\right.$ lique fcentigallinarum incmbra mifceantur, confumunt illud in $\int e$. Ita hoc uenenum auri eft. At gallinaceis ipfis cir= culo é farmentis addito collo non canunt. In quibus illud quoq; fibi à natura datum, non eft non fummopere admiran= dum, quod noctis horas diftinguant fuo cantu: qua in re nunquam adeo forno capiuntur, quin ftatis boris cantent;

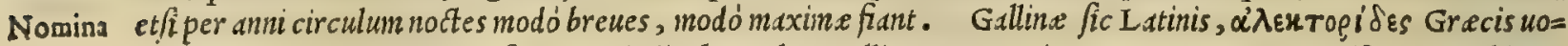
cantur : Arabibus, Degedi, fiue Giaziudiucb: Italis, Galline: Germanis, Han, o Hennen: Hipanis, Gallinas: Gallis, Gallines, er Coque.

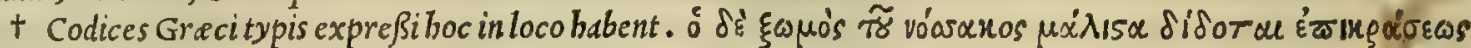

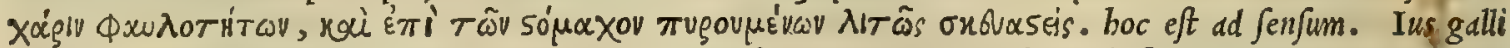
iunioris maximé datur ad contemperandos bumores uitiofos, $\mathcal{O}$ in ardoribus ftomachi fimpliciter paratum. Verba i: illa Ruellius, cuius interpretationem alioquin fequimur, uel neglexit, uel illegittma iudicauit. Nos ueró buc ea affe= renda duximus, non folum quód in uulgatis codicibus, ac antiquißimo (tefte Marcello) legantur; fed quia etiam à Se= rapione referuntur. Quibus etidm fubfcribere uidetur werborum feries, ev communis rei ufus .

$$
\text { s’òv. O V V M. }
$$

CAP. XLIIII.

O v v m molliculum plus alit forbili, \& durum plus molli. Luteum oui contra oculorum dolores utile eft : inaflatum fedis inflammationibus prodeft, cum croco, \& rofaceo: \& condylomatis, cum meliloto: cum vua autem fruticis eius, quem rhoa dicunt, aut galla in patinis frigitur, ut cibo al uos fiftat : per fe etiam offerri folet. Candidum oui crudum refrigerat: fpiramenta cutis occludit: inflammationes oculorum infufum lenit : ambufta, fi ftatims eo perungantur, puftulas non fentiunt: faciem à folis aduftione tuetur: fronti impofitum cum thure fluxioncs arcet, auertitçue : inflammariones oculorum lana exceptum, addito rofaceo, melle, \& vino mitigat : vtilitcr contra hæemorrhoidis ferpentis morfus crudum forbetur : fummè tepidum prodeft ueficæ rofionibus, renum exulcerationibus, gutturis fcabritiæ, reietionibus fanguinis, deftillationibus, \& thoracis rheumatifmis .

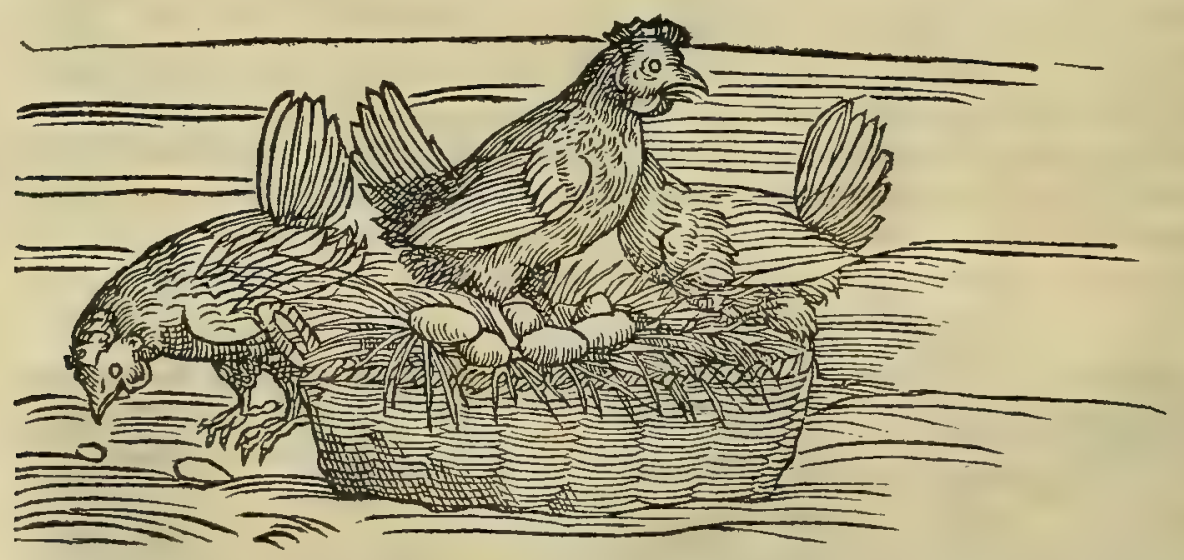

Ouorum con

DE G A I I I N A R. V M tantium ouis hic locutum fuiffe Diofcoridem, credendum eft: quippe qux fint cete= fideratio.

ris preftantiora, corumǵ; fit tum in cibis, cum in medicinis pracipuus ufus. Nam quemadmodum teftatur Galenus lib. I I. de facultatibus alimentorum, $\mathcal{N}$ Ifach Arabicus in fuis diatis, gallinarum oud gratioris funt faporis, ori iu= cundiord, plus б́; afferunt alimenti, qudint ceterd. Alunt hec, er breui reficiunt tesnpore, recreant, feinen prolifis

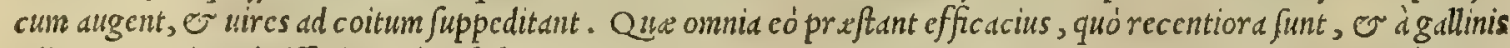
edita, que prius admiffarios gallos $\int u f c e p c r i n t: q u a n d o q u i d e n$ (ut Galenus inquit) recentia uetcribus plurimim pre ftant: quippe optima funt recentißima, peßima autem uetuftißima . Secundum loc un fibi uendicant à perdicibus, or phafianis edita, quanquam gallinacea uiribus non cxcellant. Deteriora ueró funt anatum, anferum, gruum, or reli quarum aquatiliusn: aggrauant cnim uentriculum, fuccum crafjum gignunt, o agré concoquuntur; tantet i pluri= mum prabeant alinenti, ubi dualidis, robuftiri,; ucntriculis optiné conficiantur. Columbartum oua admodum calids funt, potius in medicamentorwn, quàm ciborum ufum expctcrida. Pauonum autesn, acftrutbiocamelor ̈̈ peßima funt, 


\section{InLib. fecundum Diofcoridis.}

fapor is horrendi, concoctu contumacia, or bumane temperature inimica. In ouis luteum candido longe praftat: nempe quód illud temperatum conjt at, ori non ingratum, boni fucci, er concoctu mininté contumax : boc ucró frigi= dum eft, pituitan gignit, agreq́; concoquitur. Oua uarijs, o diuerfis modis decoquuntur . quo fit, ut etiam diuerfum afferant nutrimentum, $\sigma$ ob id diucr fos in corpore parlant fuccos. Probantur, qua cum putamine decoquuntur, er borum pre ceteris, que tremula uocant, quód lactis femicoagulati inftar tremant. Sorbilia, que ut nelocius bau riantur, breniorein coduram experiuntur, minus fane nutriunt. Quxe autem cum putamine longiore clixatione ins durefcunt, difficilliné concoquuntur, craffos generant fuccos, obftrunt, in uentriculo marcc font : arcnulas, er calculos gignunt : o coli, or uentriculi excitant cruciatus. Porró ex ijs, que extra putamina coquuntur, ca cateris preftant, que integra in feruentem immerguntur aquam. bac i noftris, quod quafi differgantur, wulgó spcrdute uo

o cantur. Veruntamen curandum, ne bec quoq; indurentur: / iquidem ubi duritiem contraxcrint, non fecus atque alia diutius cocta, redduntur noxia. Que deinde cx olco, aut butyro integra friguntur, uentriculum ledunt, ructus com= mouent, agré conficiuntur, confocium corrumpunt cibum, malum prabent alimentum, er putridas pariunt exhald= tiones. Que demum fuper prunis torrentur, aut ignitis figulinis tegulis inafantur, aluum cobibent, difficiléq; conco= quuntur. Et hec fufficiant ad ouorum in alimentis facultates. Ceterum quibus, quantis'q; oud in medic amentis pol leant uiribus, retulit Galenus libro x I. de fmp. medicam. facultatibus, fic inquiens. Onorum album er tenue illud, quo item ad ophithalmiss utimur, ex numero eft medicamentorum minimé mordicantium. Itaq; utendumeft oui albu= mine non tantùm ad oculos; uerim etiam ad alia omnia, qu.ecunque medicamenta requirunt maximé expertia mor = dacit:stis, ut funt omnia fedis, ac pudendorum ulcera maligna. Mifcetur quoq; utiliter medicamentis profluxium fan: guinis ex cerebrimembranis fupprinentibus, que nimirum citra mor fun illinuntur, atque adfringunt. Sed $\sigma$ ad ul=

20 cers rebellit mifcetur ijs, qux abfq; mor $\int u$ ea poffunt deficcare : cuiufmodi eft medicamen pompholyx elota, or. mee tallicorus quaddsm elota, de quibus priuatim fuprà diffcruinus. Porró or ip fe vitellus adfinilis eft natura, ac pro= inde mifcetur ceratis mor fus expertibus, onis uidelicet aut lixis, aut a ßis. Verum id tamen manifeftun eft inter bec leuiculam exiftere differentiau, quód pauló plus deficcent que funt affa: ac quantum buius accipiunt facultatis, tan: tum deperdant de mitigandi potentix. Mifcetur, on cataplafmatis phlegmonem arcentibus, ut ijs que ex meliloto conftan, fedi applicandis. Crudo ueró ouo to to utimur admifto rofaceo ad palpebrarü, aurium, mammarumó; phleg monas, qua fcilicet aut ifis illis, aut alio quóuis modo euenerint, aut extiterint in neruofis corporibus, puta cubito, or digitorum tendonibus, aut articulis, idq; in pedibus pariter, or manibus. Porró in aceto coctum ouum fi edatur, fluxiones uentris deficcat. At fi etiam quippiam corum, qua ad dy fenteriam, aut coliacum affectum conueniunt, illi

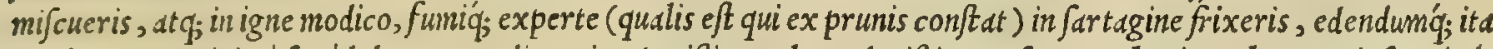

30 prebeas, non minine fané laborantes adiuneris. Aptißima talem ad miftionem funt omphacium, rhus, tum ipfe qui ci= bis adpergitur ery thros nunc upatus, tum fuccus ip/ius, galla, fidia, boc eft mali granati putamind, cinis cochledrum integrarum uftarum. Apta quog; o uuarum acini, or myrta, or mepila, er corna. Magis iftis medicamentofa funt

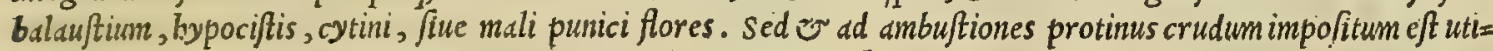
Ie, fiue quis feor fun albumen duntaxat ip fum molli land excipiat, fiue etiam cum uitello totum commifcens applicet. Etenim mediocriter refrigerat, $\mathrm{O}$ citra mor fum deficcat. Nam medicamentis, que bumiditates defic cant, dut lixum, aut affunt, aut in fartagine frictum mifcetur: ijs uero, que craffa in pectore, pulmonéq; incidunt, forbile quod uocăt: id quod in aqua co ufque lixari debet, dum incaluerit. Eiufdem ipfius natur a nomine $\mathcal{O}^{\circ}$ ad cos, quibus fauces aut ex wociferasione, aut ex bumorum acrimonia exapperate funt, affumitur : tum fcilicet quód affectis partibus illinitur,

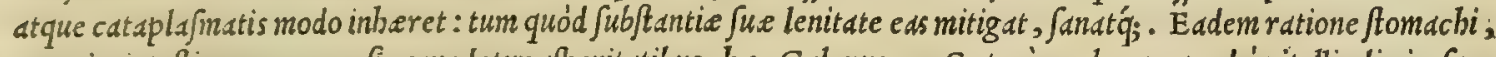
40 uentris, intefinorun, ac uefice medetur apperitatibus. bac Galenus. Ceterum olcum, quod é uitellis diu in far= tagine frixis elicitur, illitum apperitatibus cutane is mirifice prodeft: ferpigines, or uitiligines emendat : rimas labio= rum, manuum, $\int e d i s \dot{q}_{j}$ fanat. Quinetian ulcerum dolores, ev articulorum cruciatus mulcet. Prodeft $\sigma^{\circ}$ aurium do= loribus, atq; ulceribus: item ambuft is utiliter illinitur : cerebri contufas membranas putrilagine affectas mirum in modum à partibus fanis fegregat, ut nos compluries magno cum bonore periculum fecimus. Ex ouis pratered $0=$ mnibus uolucribus generatio euenit, quanquam $\mathrm{O}$ aquatilibus fer é omnibus, preterquàm phoce, delphino, $\mathrm{O}^{\circ}$ alijs nonnullis. Gignuntur item ex ijs o é terreftribus quadam, ut crocodili, lacerte, teftudines, ftelliones, $\mathcal{O}^{\circ}$ alia: $\mathcal{O}^{\circ}$ é reptilibus omnia, uiperd excepta. Verum, ut Hippocrates auctor eft libro de natura pueri, feu fotus (nifi fortaf $=$ (is librar iorum culpa co in loco codex fit deprauatus) pullus ex vitello nafcitur, informatur $q_{;}$; ex albumine ueró ali-

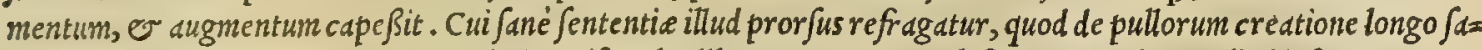
so tis ferntone pofteritatis memoria prodidit Ariftoteles lib. v I. cap. I I I de biftoria animalium. Illud infuper ean re= fellit fententiam, quod experientia fepe a mulierculis compertum eft, que fuis gallinis oua incubanda fubijciunt. Si= quidem exempto quando ; fotu, die uno, atque duobus ante tempus exclufionis, fractis pulli uifceribus magnam uitel= li partem inuenerunt in corpus aJJumptam. Teftudinum oua, quanquam diutius elixantur; nunquam tamen eorum

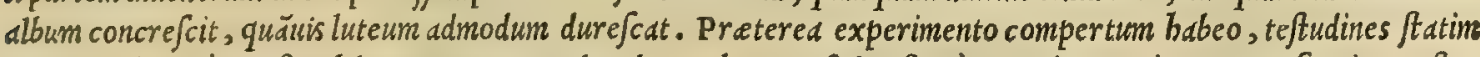
oux non edere cim tefta obducuntur, quemadmodum uolucres, fed poftqudm omnia, qua in corpore fuerint, teft d= ceum contraxerint putamen : nanq; mibi quandoque contigit diffecuiffe teftudinem, qua utero feptena gerebat oua,

fuo putamine obducta, quod e ferpentibus euenire quidam exiftinant. Ouum quod Latini, wòv, Greci uocant: Nomins. Arabes, Naid, Beid, Jeu Baid: Itali, Vouo: Germani, Ein, $\mathcal{O}$ Ey: Hipanis, Hueuo, or ouo : Gallis, Oeuf.

Ouorum par tes, \& cotura uaria.

Ouorum vires'ex Gal.

Oleum ex ouorum luteis. Animalia ex ouis orta. Ous teftudinum. 


\section{T'́Tilyes. CICADAE.}

CAP. XIV.

$C I C A D A E$, qux inaffatæ manduntur, ueficæ doloribus profint .

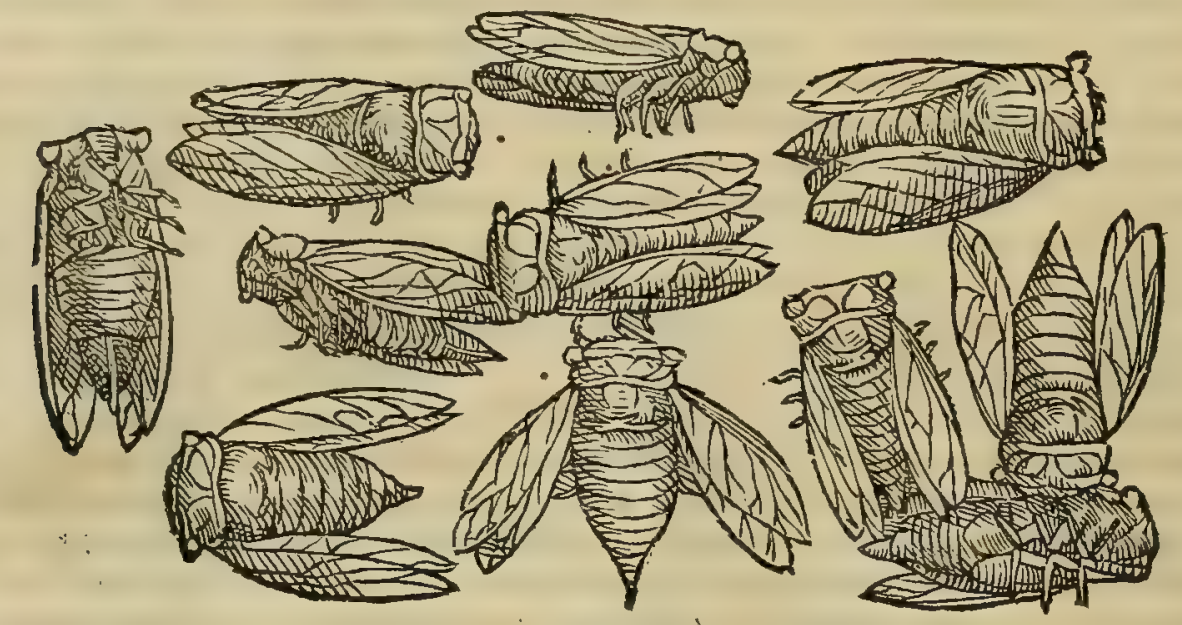

Cicadarícon fideratio.

fus.

Albertilape

CI C A D AE paßim in Italid cognofcuntur, at $\phi_{;}$adeo inibi unlgaris notitie funt, ut fape aftate aßiduo cantu meffores, agricolas, ac uiatores in campeftribus obtundant. Ceterum, quemadmodum tradidit Ariftoteles libro v.

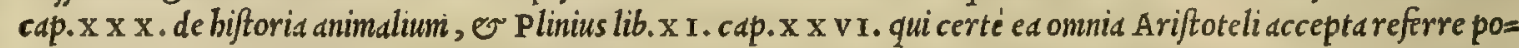
teft, Cicadarum duo funt genera: alia enim minores, que prime prodeunt, $\sigma$ nouißimx pereunt. Alie maiores, quee

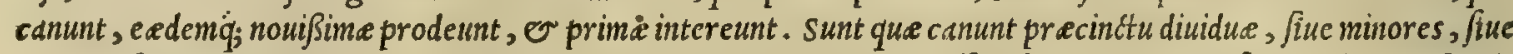
maiores funt: que autem non canunt, indiuidua funt. Pariunt in aruis cefantibus, excauantes freture locum apperis tate pracuta, quam parte babent pofteriore, quemadmodum 0 bruci. Quinetiam in arundinibus, quo adininiculo uites eriguntur, nidum foetur excaluant. Proueniunt largé copia imbrium. Cre fcit prinó in terra uermiculus, deine de fit ex eo, qux tettigometra uocatur parentis nomine, quo tempore guftu fuauißime funt, anteaquàm cortex rum= patur. Poftmodum circa folftitia noctu exeunt, ftatim '́; rupto cortice prodeunt cicada ex matrice illa cicada, quam modó tettigometram dixi. Mares canunt in utroq; genere, fremine ueró filent. Vnum boc animal cx ijs, que uiunt, fine ore eft. Pro co quiddam aculeatum linguis fimile babent, o boc in pectore, quo rorem lambunt. Pectus ipfum fiftulofum, unde illis redditur cantus. Oleas maximé amant, ut minus umbrofas, quanquadm er cetcras non appernan= tur arbores: proinde ubi arbores defint, nafci non polfunt. Loca praterea frigidiora oderunt : quamobrem in um= bro/is nemoribus effe nequeunt, nec in frigidis etiámnum regionibus. Quo factum eft, ut crediderit Albertus cogno= mento magnus, gryllos, qui noctu ftrident, cicadas effe : quippe quód in Germanid, qua fuit oriundus, frigidisima res gione ad articum ßpectante, tametff frequentes habeantur grythi aftate in campeftribus, byeme ueró ad hypocauftor fornaces plerunq; ftabulantes; cicada tamen de funt. Partbi Cicadis uefcuntur, quemadmodun o gentes ad orien= tem. Idcirco mirum non eft, quód dixerit Ariftoteles, eds effe guftu fuauißimas, antedqudim teitigometr a rumpatur Cicadnū ui- cortex. Cicadarum uires defcripfit Galenus libro x I. fimplicium medic amentorum, fic inquiens. Sed or cicadis res ex Gal. ficcis quiddm utuntur ad colicos affectus, cum paribus numero piperis granis, dant $q_{\text {; }}$ aut tres, aut quinque, aut $f e=$ ptem, per intermißionem uidelicet, o ipfos etiam paroxyfmos. Porró aliy affas edendas offerunt, quibus affecta ue= Nomina. fica eft. TéTTryes Grecis, Cicade Latinis dicuntur : Italis, Cicale: Hifpanis, Ciguattregas: Gallis, sigale.

L O C V S T AE.

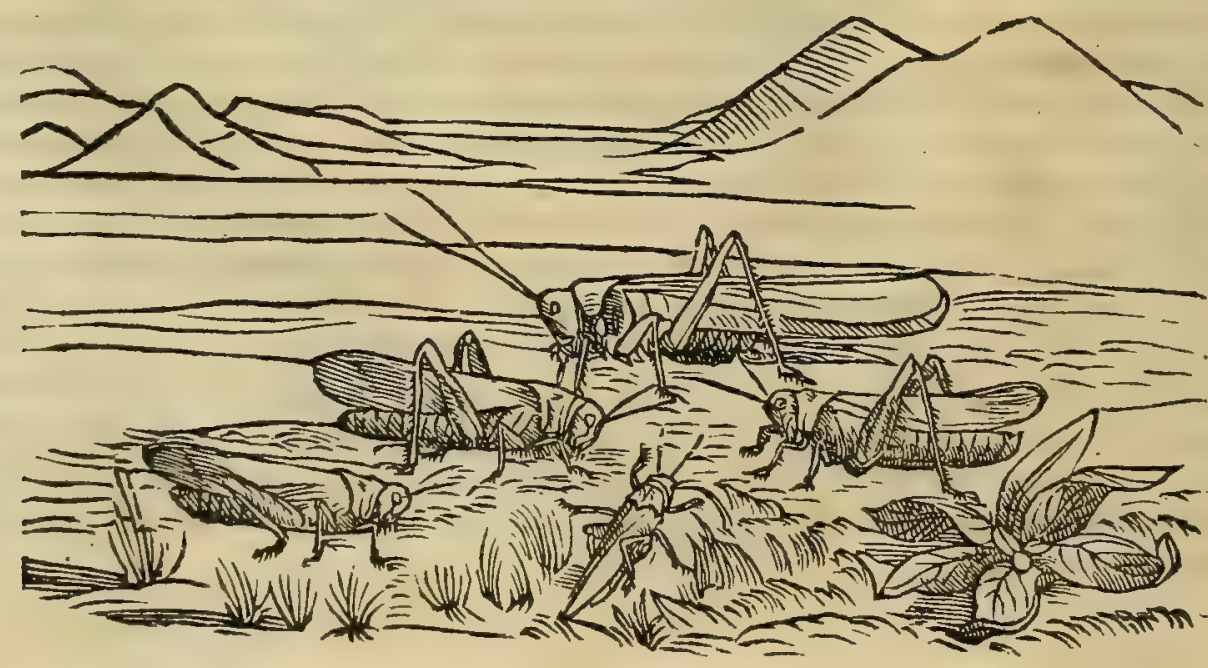

A'ridis. 


\title{
In Lib.fecundum Diofcoridis.
}

\section{A'ropíses. LOCVSTAE. CAP. XLVX.}

L O C V S I AE odoris fufitia srinæ difficultates adiuuant, prxfertim qux foeminas malè habent. earum carnes nullo funt in ufu. Eft \& quoddam genus locultx, qux aliracos, aut onos dicitur, fine pennis, pralongis cruribus. Exiccata autem fi ex uino bibatur, contra fcorpionis morfus magnopere proderit. Hac abunde uefcuntur Aphri, qui Leptin incolunt.

L O C V S T A E omnibus note, uaria pro morum, O locorum diuerfitate fortiuntur nomind. Verùm bērbis, et Locufarum

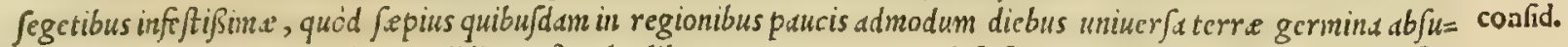

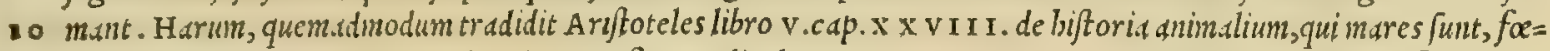
minis magnitudine cedunt. Pariunt in terra fixo cauliculo, quo mares uacant : ac uniuer $\int e^{2}$, o loco codern fretum de= ponunt, ita ut quaf f suus effe wideatur. Hinc wermiculi pecien oui gerentes oriuntur, qui terra quadam pretenui t.nquam membranula ambiuntur : qua difiect d emergunt locufte, ac euolant. Tam mollis fxeturabce eft, ut ad tas ctum leuißimum dilab.tutr, o pereat. Pariunt exitu ucris, o ftation i partu moriuntur, uermiculis circa collum in= uxfcentibus tempore partus, qui eas ftrangulent. Mares quoq; codem tempore obeunt. Locis montanis, aut tenuibus locufte non funt, fed planis, rinzolis ; ; p.riunt cuinz in rimis fud oud. Tranfeunt Locufte immenfa maria, inmens Sosq;; tractus permecunt (ut Plinius inquit) diraq́; meßibus contegunt nube, multa contactu adurentes, omnia ueró mor fu erodentes. It diam cx A plorica m.ximé coorte infeftant, tanta fané multitudine, ut folem obumbrent folicitc fu= Apcctanubus populis, ne fiftentes fus operiant terras . quód non modo uniuer as ciun fegetes, tum berbas deuorent ad 2o radicenz ufque; fed O radices ipfas regcrminare probibeant. Huius rei teftimonio fuere inaudita Locuftarum ag= minx, qque noftro tempore uoluente amo domini M. D. X I I I. ex paludibus Mrotidibus profecte, non folim uniuer=

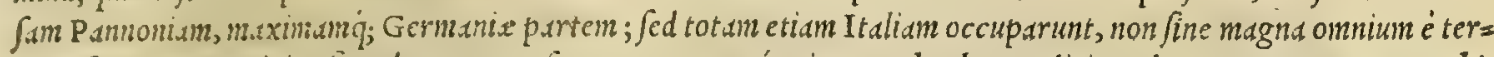
ra nafcentiun pernicic : fiqudem onmlem fegetem, onnemq́, uirentem berbam radicitus deuorarunt. He Parthis Locufte inci

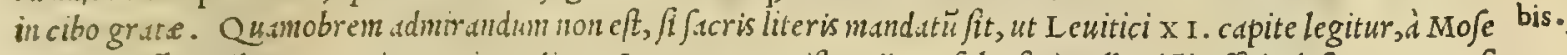
probat.as effe incibis. Nec mirum etiann, diuum Ioanmem Baptiftam ijs ex fylueftri melle uiftitaffe in de ferto; tametff non dejint interporcces, qui uel lit pro locuftis quafdan berbarum radices intelligi: alij ucró nomullas arborum fum= mitates. At mebercule in horun fententtam deuenire nunquam potui: quin potius certó crediderim, ipfum nempe le= gis NIofaice fectatorem acerrinum, hifce Locuftis animalibus uictitaffe, quemadmodum etiam fentit diuus Augufti= nus, exponens diui Paulicpift. ad Romanos. In Carenaica regione (ut Plinius eft auctór) lex eft ter anno debels

30 landi Locuftus, prinio ous obterendo, deinde fatums poitt remó adultas, de fertoris poend in eum, qui cefJauerit. Et in Lemno infula certa menfura pre finita eft, quam finguli enecatarum ad magiftratus re fer ant. Necare $\widetilde{\sigma}$ in syria mi litari inperio coguntur : tot orbis partibus uagatur id malum. In India ternum pedum longitudinis e fe traduntur,

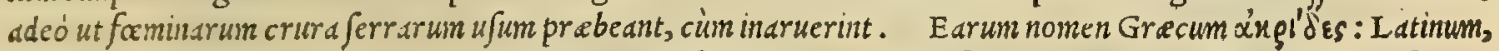
Iocufte: : Italicum item Locufte : Hifpanicum, Lagoftas de tierra, o Gafanhotes grandes: Gallicum, Locufte.

Фivis. OSS IFRAGVS.

CAP. XLVII.

VENTER eius auis, quam Latini ofsifragum ap-

40

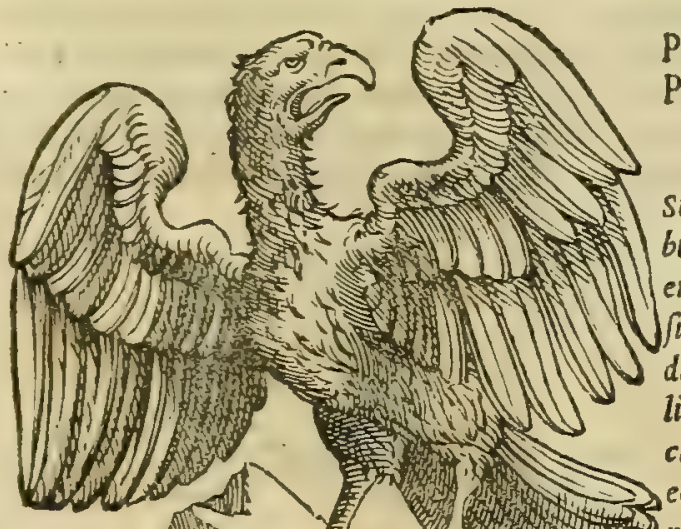

so

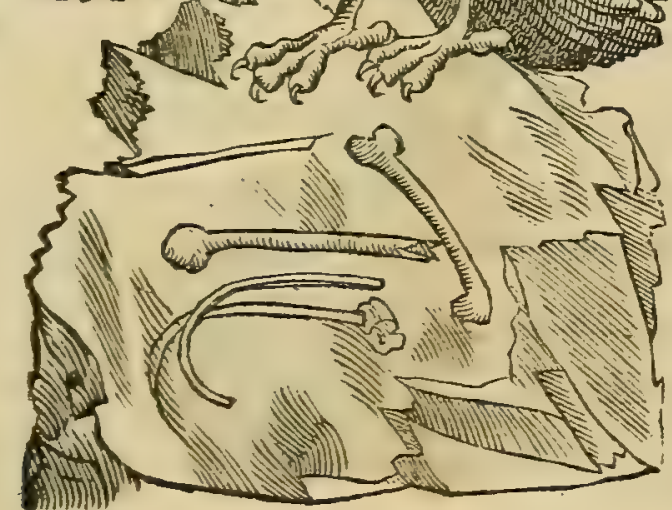
pellant, particulatim potus, calculos cum lotio pellere proditur.

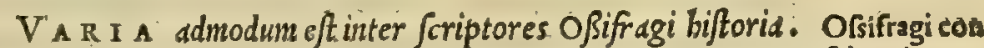
siquidem Ariftoteli uolucris eft aquila maior, colore cinereo, al $=$ fiderstio. bicante. Probé bec fretificat, or uiuit. Pia, er benignd eft : non enim fuos tantùm nutricat pullos; fed $\odot$ aquile. Cüm autem illa $\int$ suos é nido eiecerit, anteaquàm adole fcant, quód inter fe cibi aui= ditate dimicét, bac recipit eós, er educat. Parum Oßifragus ocu lis ualet: nubecula enim oculos habet la fos. At Plinio lib. $\mathbf{x}$. cap. I I 1 . Oßifragus in aquilarum genere annumeratur, is q́; ab eodem proditur ex baliaéto, boc eft, aquila marina natus. Mari= nam bane fuum genus non babere, fed ex diuerfo aquilarum cois tunafci, ideri auctor eft. Alberto praterea Oßifragus ea uide tur auis, quam idem lib. x x I I . Arabica uoce appellat Kirij, cìm fic inquit. Kirij auis eft preda uictitans bone pullificationis, or diligenter pullos nutriens non fol im fuos, fed et $a b a q u i l d a b=$ iectos tedio nutriendi. hec ille, Qui uel clarius meminit ofsifras gi inter aquilarum generd, ubi ita fcribit. Quintum autem aquis le genus eft paruulum ualde, o d̀ quibufdam uocatur frangens os, eo quód quando carnes comedit, offa in altum defert, or fus per lapidem cadere permittit, ut ex ijs confractis medullam $\int u=$ gat. bactenus Albertus. Verum is ab Arifotele diffentire ma= nifęté cognoscitur, quòd Ariftoteli oßjifragus nŏ fit genus aqui=

Nomina.

Nomina.

\author{
(n)
}


1. mininum, fed auis mator aquilis, dempta Germana. Quo fit, ut in bic biftoria Albertumballucinatunt cffecredä, qucmadmodum $\sim$ Plinium in cadem deceptum puto. Nanq; marina illa clarißina aquila uocata (ut Ariftoteles trd= dit) oculorum acie maximé pollet, ac pullos adbuc implumes cogit aduerfum intucrifolem: tum cuius oculi prius las = crymarint, bunc occidit, rcliquum educat. Id quod abunde oftendit bac in re Plinium erraffe, atq; of citanter fortaffe Ariftotelen lcgiffe . quippe cim marine aquile pulli acerrimi omnino fint uifus, nullam ij cum Oßifrago cognationent habere nidentur, quód bic potius quadantenus cacitate laboret. Caterim, quód nobis efet Alberti codex librarios rum culpa deprauatus, in quo oßifiaga pro of ina legebatur, iandudum credidimus oßifiagum apud Albertum eam auen effe, qux in maritimis noftris senenfibus circa Herculis portum, o orbetelliftagnum frequens uifitur, cygno maior, roftro longo, inferiori parte facculi inftar ample. Hec autem incolis uulgó uocatur A grotto. Sed cum poftea animaduertiffem Albertum in hac biftoria aperté Ariltoteli refragari, atq; allud Alberti exemplar nactus effem, in 20 quo ofind, non oßifraga, ut uitiosé in alio, fcriptum erat, capi cos acriter accu fare librarios, quorum negligentia in

Nomina. caufa fuit, ut in boc mibi ip/i hactenus imponerem, fecutus deprauatam Alberti lectionem. Auis, qua Grecis $\phi i=$ "Ls, Latinis Oßifiagus nominatur.

\section{Kogud $\alpha \lambda \lambda$ òs. GALERITA.}

CAP. XLVIII.

G A L E R I T A auicula eft parua, apicem in uertice, pauonis modo, geftans. Hæc affa, \& in cibo fumpta, coliacos adiuuat .

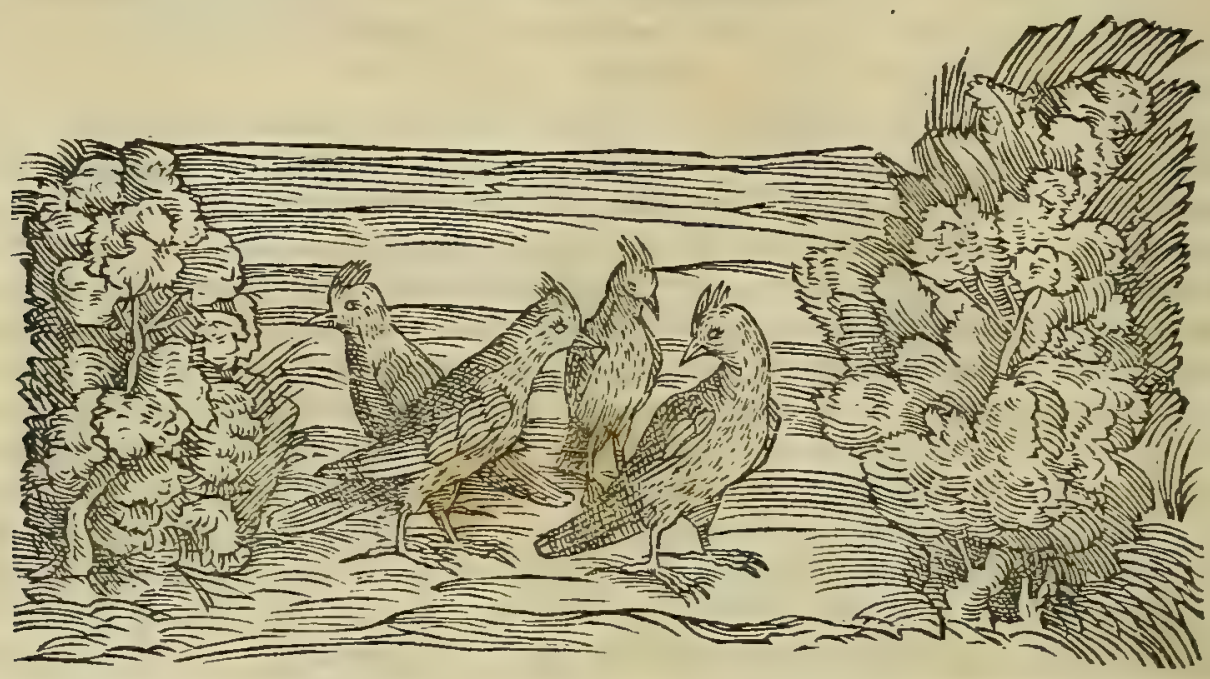

Alaudarum

A I A V D A R V M (ut memorie prodidit Arifoteles libro I x.cap. x x v. de biftoria animalium) duo funt gee hiftoria. nera. Alterum terrenum, criftatum, Galerita d̀ crifta appellatum. Alterum gregale, nec fingulare, more alterius, uerün colore fimile: quanquam magnitudinè minus, er galero carens. Campeftres amba funt aues, uermiculis ui= ctitantes, decidentibusq;; feminibus. Mares Juauiter canunt, primé q; funt aues, quae aftatem cantu pronunciët. Por=

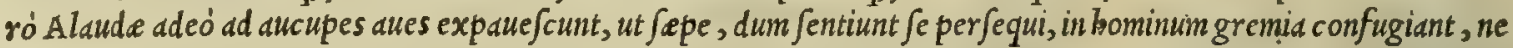

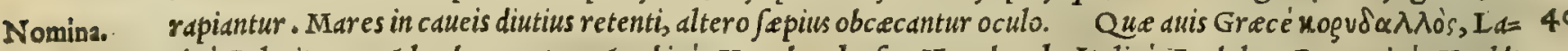
tiné Galerita, or Alauda uocatur: Arabicé, Hanabroch, feu Kanabroch: Italicé, Lodola : Germanicé, Vualdt lerch: Hipanicé, Cucuyada: Gallicé, Alouette.

I R V N D O.

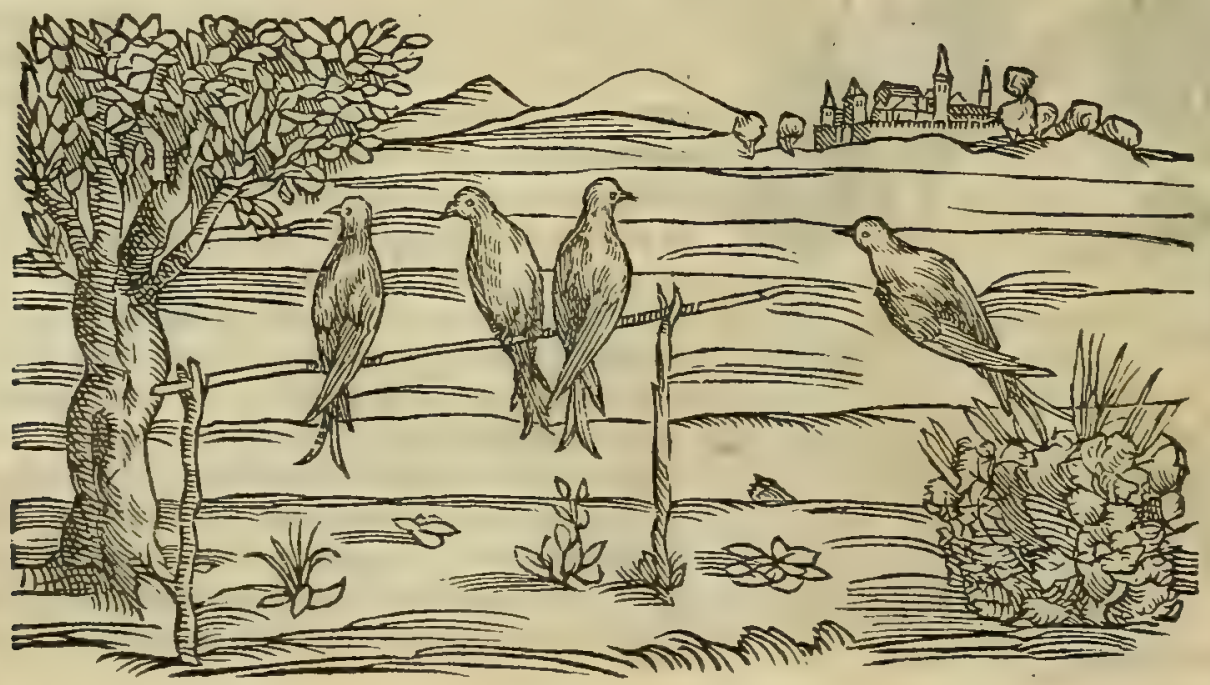




\section{InLib.fecundum Diofcoridis.}

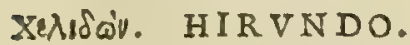

CAP. XIX.

D I S E C T I S crefcente luna pullis hirundinis, qui primo partu exclufi funt, in ucntre corum lapillos offendes : è quibus duos, unum colore uarium, alterum purum eximes: ij priufquàm terram attigerint, in iuuencx corio, aut ceruina pelle brachio, aut collo adalligati, comitialibus proderunt', \& frpe prorfus cos recreabunt. Hirundines, uti ficedulæ, in cibo, aciei uifus medicamentum præbent. Tam pullorum, quàm matrum in firtili olla crematarum cinis cum melle oblitus, oculis claritatem adfert: anginæ co commodè perunguntur : vuæ \& tonfillarum inflammationibus hoc cito nere fuccurritur. Et ip fe, \& pulli exiccati, fi drachmx pondere ex aqua bibantur, hos iuuant, qui anginæ morbo conflictantur.

I I R V N D I N V M tria habentur generd: unum nof tra tect a fubit: alterum uetuftorum a dificiorum muros, calkernulds, o montium fcopulos expetit : tertium ueró nidificat in altis fluminum ripis. Hé quotannis (ut Plinius au ctor eft ) ex A phrica maria tranfeuntes, appetente uere ad nos aduolant, er martio plerung; menfe noftras ingre= diuntur ades: ibiq;; é luto, er quibufdan ftramentis/ibi conftrumt nidos, in quibus bis oua pariunt, er bis pullos ex= cludunt, tantum hunane fidunt benignitati: atq; ubi ultinos educaucrint partus, equinoctij autunnalis tempore in fuas remigrant regiones. Cloclidonian herbam ab his inuentam tradunt, unde illi nomen eft inditum. Hanc fuis ob= cecatis pullis defrrunt in nidum, hoc tentim medicamento ijs uifun reddentes. Quinetiam cxpericntia compertum

20 eft, quód fi data opera pullorum hirundinum oculi acu perforentur, fanantur paucis diebus, allata di matre chelidonia berba. Hinc igitur edocti medici ad oculorum cldritatem chelidonium adbibent. Hirundinum ueró ftercus oppofitum preftat: excecat enim, fi calidum in oculos decidat. Quod ctiam facra teftantur monumenta, in quibus, Tobiam hoc ftercore excecatum fuiffe, legitur: Caterum uires Hirundinum recenfuit Galenus lib.x I. de /impl.medic. facul= tatibus, fic inquiens. Hirundinibus quog; ufi funt multi, comburentes uidelicet, o cineri mel admifcentes, ac deinde fynanchicos inungentes, 0 in totum omnes quicunque in faucibus atq; columella cum tumoribus confiftunt affectus. Vtuntur or ad ackendum uifun boc cinere nonnulli. Alij ueró eds arefactas dracbme pondere bibendas cxlibent.

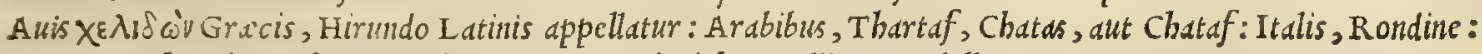
Germanis, Schualb: Hipanis, Golandrina, E Andorinha: Gallis, Arondelles.

E в о R I $s$ fcobeillito, paronychia fanantur. Vim adftringendi ebur obtinet.

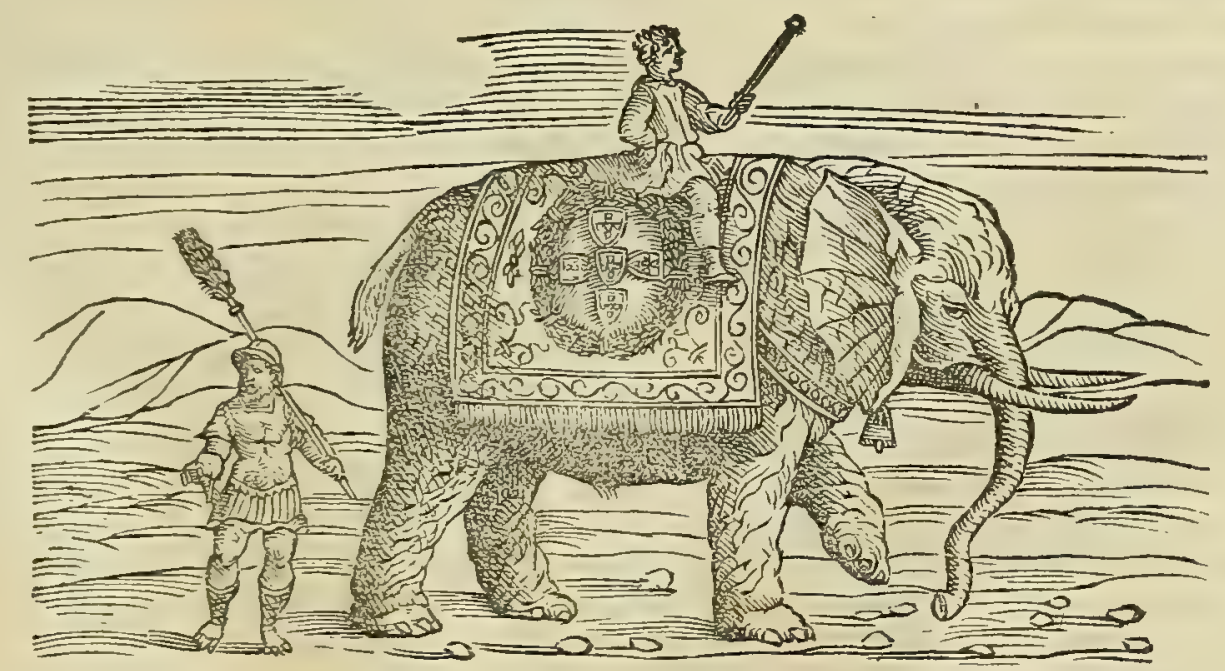

so

O M N I I V S fanéper/picum eft, nil aliud Ebur effe, quàm Elephantinorun dentium materies, multis apta operibus. Elephantorlm inemunit Plinius longa admodum hiftoria initio librioctaui pluribus capitibus : tamet fi non omnia, qua fcribit, proband a putaucrim. Elephantos fert Apbrica ultra Syrtic ds folitudines, item Mauritanid, or Aethiopia: Sed maximos India mittıt. I quanquam magnitudine catera excedant quadrupeda, Arifotelis tamen te= ftimonio adeo cicurantur, ut omniuin ferarum mitißsmi, e placidisimi euadant: quippe qui per multa officia er crudisntur, e intclligant. Corio Elcphanti integuntur bubalino finili, ut is uerum prabuit excmplum, quem $\mathrm{R} 0=$ ma uidit Lconis decini Pont. Max. ceno, etfí rarißimis horreat pilis. Caput eis magnum, collum breue, aures ueró undique duim palmorum amplivudine : nafum, quem peculiariter in Elephanto promuscidem appellant, longißimum habent; concauun, grandis tube inftar : bic infra anteriores dentes ad terram ferme promittitur, quo pro manibus utuntur. Os gerunt pectori proximum, ut quod cum fuillo ineat fimilitudinem : é cuius Juperna parte dentes duo pro= minent pracipue magnitudinis (quales plurimi uenales confticiuntur Venetijs in publico foro uulgó Merceria dįlo, Elephătorum

Hirundinum hiflotia.

Chelidonia.

Hirundinum uires ex Gal.

Nomina. hiftoria. ac in 


\section{And. Matthioli Comm.}

ac in alijs Italie esmporijs) qui proni cupide deorfum uergunt. Pedibus nituntur rotundis, difci inftar, latitudine duîm, triumú palinorum, quos callofa materia obducit: ungulis quinque circim, rotundis, mediocrium concharum Error quorú- magnitudine. Crura ijs magna, ac fortia, neque (ut quidam imperiti exiftinant) uno tantim offe conftant indiui= dam. $f_{a}$, fed genua flectunt, utpote er caterd quadrupeda. Quamobrem Elephanti (ut refert Aloifius Cadamufus, qui claffe in Acthiopiam, or ad Calicut nuigauit) ut eos, qui deferri uolunt, fufcipiant, genua fubmittunt, fe feq́; eri= gunt deinde. Elephantis cauda bubali, trium palmorum circiter longitudinc, rarisimis fetis referta. Quocirca baud

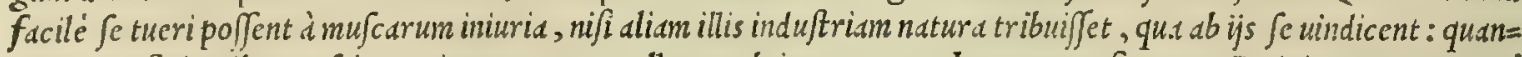
doquidem frientibus mufcis, cutin, quam cancellatam obtinent, contrabunt. Quo fit, ut arêatis in rugas repente cancellis, mufcas comprebenfas enecent. Hominibus non nifi lace ßiti nocent. Veruntamen irritatibomines promu= fcide comprebenfos, adeo in fublime iaciunt, ut priufquàm in terram decidant, fuffocentur, er percant. Ad bac nul to lus hominum tantac pernicitatis inuenitur, quem mox Elephas non comprchendat, etiam non currens, fed gradatim incedens. Id efficit uafta animalis moles: quandoquidem fui greffus longitudinc, bumanam omncm pernicitatem euin= cat. Vittitant arborum tam frondibus, quam fructibus : ne q; ulla tam ingens eft arbos, quam ij promufcide non pro= fternant, frangant, ac dilacerent. Adole fcunt ad fexdccim palmorum altitudinem. quapropter qui eos confcendere non affueuere, non Secus faftidio afficiuntur, ac illi, qui nauibus non affueti maria fulcant. Effrenes preterea adeó na tura Elephanti funt, ut nullis habenis cohiberi poßint . quo fit, ut liberi incedere dimittantur: uerìm cùm maximé gu bernantibus fuarum regionum bominibus pareant, e corum fermonem intelligant, idcirco uerbis facilé reguntur. Adeó conpectum ignem expauescunt, ut eo ierriti à fuga reuocari non queant. Quare ab ïs non cognita, qui eius Elephanti curam gerebant Rome, in cuius.dorfo oppidulum conftruxerant, eo die, quo Iulianus Medices Pontificis $M a x$. frater uxorem $\dot{e}$ Gallia duxit, in magno fane difcrimine uer fati. fuat: : nam ubibellica tormenta ignem eructan $=20$ tia conpexifet, magnumq́;, ac terrificum fonum fenfiffet, tante fe fuga dedit, ut nunquă cobiberi uoluerit, donec und̀ cum conclufis in oppidulo bominibus in Tyberim $\int \mathcal{e} \int \mathrm{e}$ commiferit. Elepbanti non coëunt, neque gignunt, nifi annum

Plinij lapfus. uigefimum agant, ut auttor eft Ariftoteles lib.v I. cap. X X V I I. de biftoria animalium. Qund in re Plinij error ma= nife/tus deprebenditur : quippe qui marem quinquennem, founinam decennem generare memorie prodiderit. Ele= phanti nulla nouere adulteria : nam unius tantìm formine coitu utuntur, eam q́; cùn uterum gerentem uiderint, non amplius tangunt. Quantum ueró temporis unaqueq; fremina utero gerat, baudquaquam fciri poteft: quód Elephan= ti pudore nunquam niff in abdito coëant. Idcirco alij eis annum or fex menfes ftatuerunt, alij biennium, aliy dcnique triennium. Pariunt fomine cum dolore, quemadmodum o mulieres. Pullum cditum ore lanbunt, quiftatim cum na tus eft, cernit, or dinbulat. Viuere Elephantos (ut inquit Ariftoteles) tradunt quiddm amnos duccntos: fed florere atate circa fexagefimum, uel feptuagefimum narrant. I idem byemis, ac frigoris impatientes funt. Gaudent amnibus 30 maximé, circáq; flutios uagantur, quos intrant libenter bubalorum more. Ceterim Elephanti ingenio, $\odot$ intel lectu bominibus proximi funt: fiquidem patrios fermones intelligunt, fummam proftant obedientiam, prudentiam fer uant, or religionem pra fe ferunt : folem nanq;, dc lunam uenerantur. Cuius rei auctores funt Mauritani, in quorum regionibus Elephanti innumeri confpiciuntur : qui gregatim noud nitefcente luna ad amnes defcendunt, ibic; lauan= tur: mox purificatigenibus flexis falutant fidus, \& in $\int y$ luas reuertuntur. Sunt, qui tradant tanta intellectus $\int a g a c i=$ tate Elephantos pollere, ut maria tranfituri ad alienas regiones, non antea naues confcendere uoluerint, quam ij, qui cos ducebant, iureiurando de reditu promiferint. In fyluas ituri gregatim feré femper ingrediuntur, quorum agmen ducit natumaximus: cogit ueró atate illi proximus. Produnt Elephantos à uenatoribus circumuentos, cùm fciant predam folum in dentibus fuis ab illis expeti,dentibus uebementer impingentes arboribus eos fibi euellere, prada $q_{;}$fe redimere. Quod facilé crediderim uanum, ac fabulo fum effe : queinadmodum effe fal fum fuperius oftendimus, quód 40 fiber uifo uenatore, fibi ipfi teftes amputet. Elephanti omnes natura indomiti, fylueftres $q_{;}$; funt: mite fount autem ar= te, ut pleraque alia fera animalia. Item fi parui, or atate tenelli educantur: quanquam Plinius fcribit, natu grardes domarifame, or uerberibus; prafertim fi alijs domitis, qui tumultuantem coërceant, admoueantur. Porró non de= funt in Elephantorum genere, qui nature feritate nunquam domari poßint, quales in Senega ( ut in fuis nauigationi= bus friptum reliquit Aloifius Caddmuftus) Aethiopia regno reperiuntur. Elephantorum dentes admir abills mad = gnitudinis uenales ppectari poffunt in. compluribus I talia urbibus, ueluti Rome, Venetijs, Mediolani, or Neapoli: é quibus non folìn innumeri pectines parantur ad explicandos capillos, fed etiam alia plura inftrumenta, que ad bu= manum ufum accommodantur. Hinc itaque fit, ut ne fciam ego, qua ratione ductus Fuchfius, uir alioqui rerum peri= tus, fcripferit in libro de compofitione medicamentorum, quem nuper auctum edidit, Ebur nullibi pené uerum repe= riri: atque illud, quod uulgó cius uice in officinis proftat, marinorum piscium dentes effe. quód in hoc erret euiden $=50$

Eboris uires. tius, quam ut à nobis oftendatur. Preftat Ebur ad albas mulicrum fluxiones; fi tamen in tenuißimum puluerem, $l_{d}=$ pide porphyreo redigatur, propineturó;; ex lactuca feminis cremore, aqua, in qua chalybs extinctus fuerit, prius ma cerato femine. Quod Grecis é $\lambda e^{\phi} \phi \alpha s$, Latmis Ebur nominatur: Italis, Auorio: Germanis, Helffantheyn: Hi= panis, Diente de elefante, aut Marfil: Gallis, l'Yuoire.

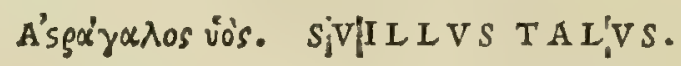

CAP. II.

S v i s talus comburitur, dum è nigro albefcat: qui tritus, \& potus inflationibus coli , longisque torminibus medetur: 


\section{InLib. fecundum Diofcoridis.}

$S V I L I V S T A L V S$.

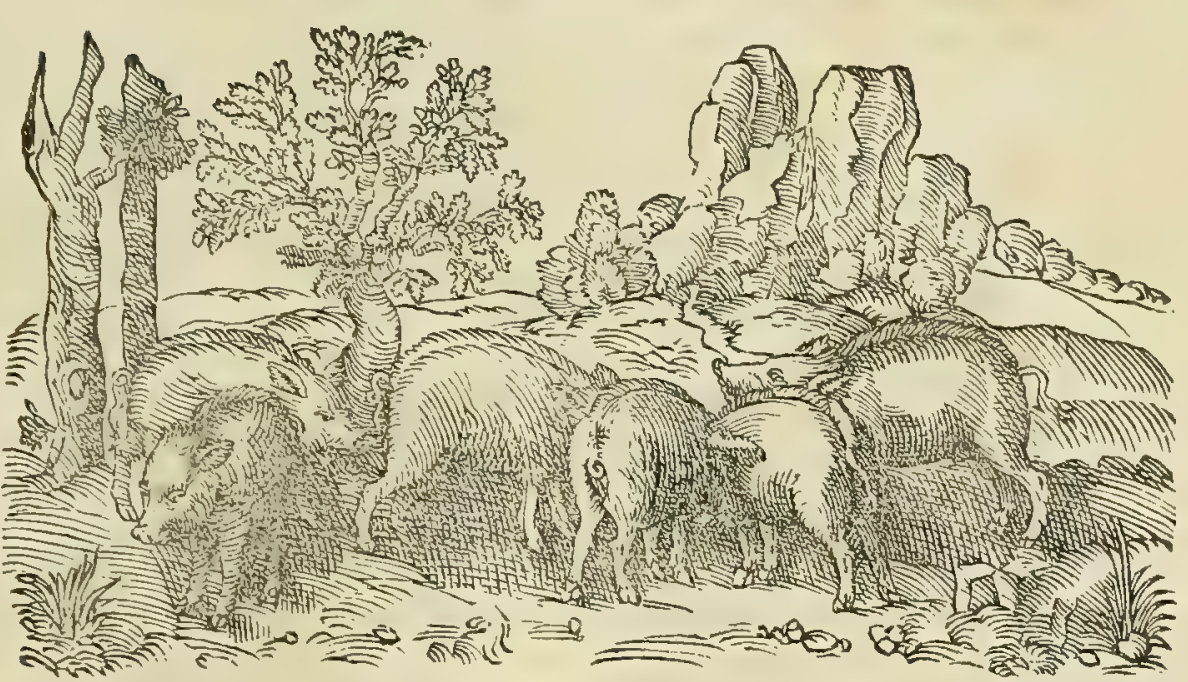

20 T A L V s in animalibus os illud ultimum pedis eft, quod tibia cruris annectitur. Id Gracis a's $\alpha^{\prime} \gamma \alpha \lambda$ os, uul= gó autem os claticule appellatur, de quo non opcrepretiun eft, ut plura dicamus. Nomina fubijciam. Grecum Nomina.

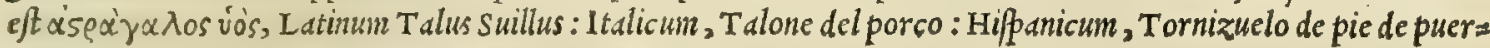
co: Gallicum, Talon de porceau.

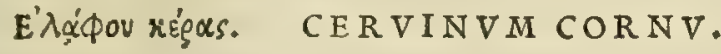

CAP. LII.

C E R V I N I cornu cinis elotus, binis ligulis epotus, prodeft dy fentericis, excreantibus fanguinem, cœliacis, regio morbo, \& ueficx doloribus cum tragacantha : fomin is fuxione vuluæ laborantibus, cum liquore huic rei accommodato . Cerui cornu contufum, crudo fictili, luto circumlito, \& 30 in furnum indito, uritur donec albefcat. Id cadmix modo elotum, ulceribus oculorum, \& defluxionibus falutare eft, infrictum dentes expurgat. Crudi cornu fuffiti nidore ferpentes fugantur, feruefactum in aceto, fi eo gingiuæ colluantur, maxillarum à dentitione dolorem adimit .

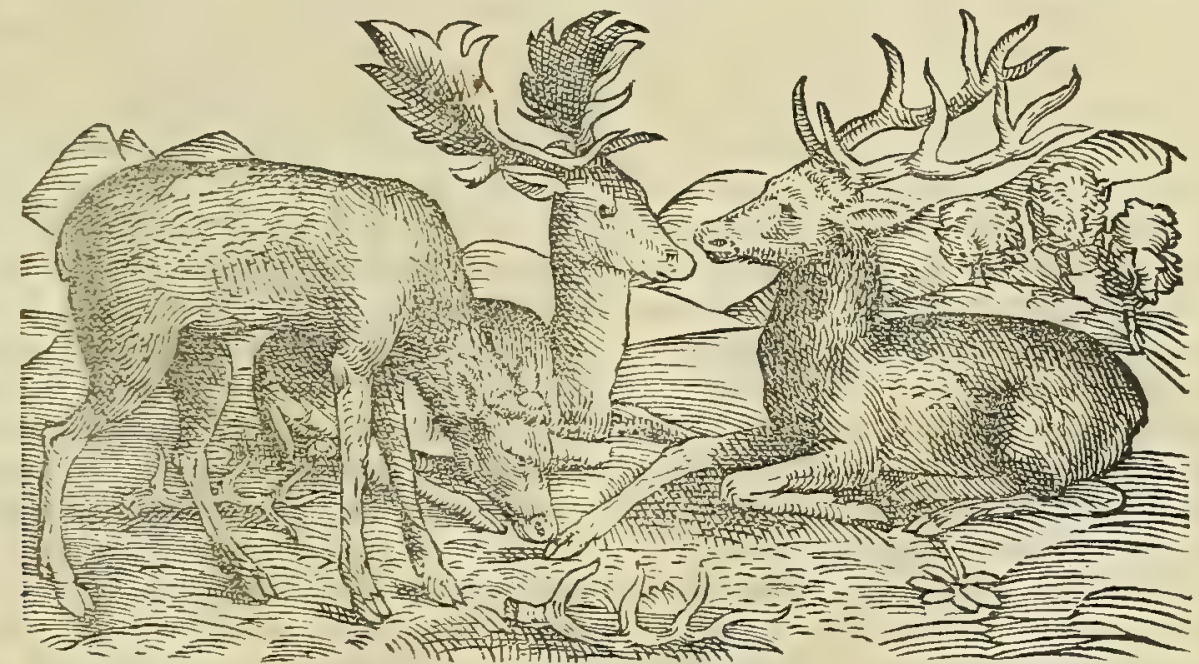

C E R V I animalia funt notißima. Sed quoniam eorum natura non omnibus cognita eft, ut candido cuiq; lectori fiat fatis, ea de Ceruis bic referam, que Ariftoteles tum V I. E I X. de biftoria animaliu libris, tum I I I. de parti= Ceruorum hi bus corundem pofteritatis menoria prodidit. Cerui itaque fylueftrium animalium genere conftant, magnitudine af inorum, curfu uelocißimi, e ingentibus armati cornibus. Ii cùm turgente iam uenere coitum appetunt, adeó $r a=$ bie libidinis $\int x u l u n t$, ut infaniant, or maximo cum ftrepitu, E clamore uagentur in fyluis. quo fit, ut conualles, et montium cauitates, corum boatu re fonent. Tanto impetu, tantág; rabie mares feruntur in coitum, ut $\int a p e$ inter coë́= unduin forminas declinent, atque profternant in terram. Cim autem maris genitale utpote durum, fuftinere non pof= fint, fermine euntes, or currentes coéunt, of concipiunt. Mares non in eadem immorantur, fed mutant, o bir= corum modo, breui interpofito tempore aliam, atc; aliam fupergrediuntur. Siforté fortuna in unam tantùm formină concurrant plures, imis cornum adminiculisftatim fupra frötem enatis, acriter inter fe pugnant ad mortem ufque. Cum mares inpleuerint foeminas, separantur per $\int e$ ipfi, er propter libidinis graueolentiam quifque folitarius fcro= 


\section{And. Matthioli Comm.}

bes fodit. Fretent ut hirci: facies quoq; eorum nigrefcit apergine, ut hircorum. Degunt ita quoufq; imber accedat, tum pafcuat repetunt. Hac ideo ceruo accidunt, quid $\int a l$ ax animal fuapte natura eft, atque etiam quia pingui abun=

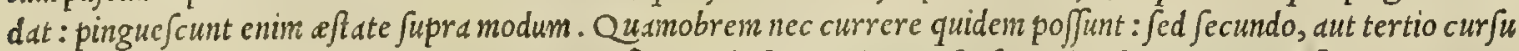
capiuntur ab.ijs, qui pedibus infectantur. Quo fit, ut ubi fe prepingues fenfere, latebras querant, fatentes incom= modum pondus. Coitus eft ab arcturo, menfe augufto, o eeptembri. Implentur cerux paucis diebus, ov ab eodem multe. V tero ferunt octo men fes. Pariunt magnd ex parte unum: fed nonnullis etitm geminos cerudm peperiffe per= pectum eft. Fcrarum quadrupedun Cerua maxiné prudentia pr aftare uidetur, tun quia circa femitas pariat, quó fcilicet belux rapaces propter bomines minus accedunt: tum etian quia cuim pcpcrit, inuolucrum primum exedit, quód ad multa ( ut nonnulli afferunt) in medicamentis expetatur. Redeunt mox ad prolĕ, deuorata à partu fefeli her $\overrightarrow{b a}$. Anniculis maribus nondum cornua nafcuntur, nifi quodd indicij g"atid fit initium quoddam pretuberans, quod 10 breue, birtumq́; eft. Bimis cornud primim oriuntur fimplicid, o recid ad fubularum fimilitudinem: qualnobrem subulones per id temporis cos nocant. Trimis bifida excunt. Quadrinis trifida, atque deinceps ad hunc modum (ut Ariftoteles inquit) procedit nunerus uf q; ad annum fextum. Ab boc fimilia feneper prodeunt, itd ne fit dignofcere atatem ramorum numero. Verim in Italia ( fit tanen cum Ariftotelis uenia dictum) ufque ad undenarium numerum ramificant. quod o Albertus teftatur fe uidiffe in Germania, quemadinodum, o nos uidiffe fatemur. Addam pra= terea, quod certó fcimus, Guglielmum Bauarix ducem inter res fuas pretiofas habuiffe bina cerui cornua, quorum fingulus unum $\mathrm{\sigma}$ uiginti ramos fundebat. Hac admiranda cornua pofted dono, utpote raro ac fingulari, data fue= runt Serenißime Pannoniorum Regina Marie, Caroli v. Imperatoris, or Ferdinandi Romanorun Regis forori.

Vulgaris opi Vanum eft credere Ceruorum atatis annos dignofci poffe ramorum numero, quód fingulis annis unum fuperaddant: nio uzna. quippe cùm longaui admodum fint, fi quotannis ramorum numerus augeretur, profectó ijs, qui ultra cétum annos ui 20 xiffe narrant auctores, cornud quercubus, ov pinis indiora fuiffent. Coterum (ut Ariftoteles fcribit) duplici indicio fenes cognofcimus, tum quod dentes aut nullos, aut paucos habeant : tum quod adminiculis careant, qui imis corni= bus prominent ante frontem. Nam ijs in pugna utuntur iuniores, fed in fenibus non renafcuntur, cum prelijs omni= no cefferint. Cerui (ut etiam Theophraftus inquit libro, o capite primo de biftoria plantarum) quotannis cornua amittunt: ideo fub ipfa die quàm maximé inuia petunt. Latent amißis uelut inermes, fed $\sigma$ ipfi bono fuo inuidentes. Fit boc menfe aprili, ftatuto tempore. Id q́; opacis faciunt locis, ut mu fcarum tadio uacent. Pdfcuntur per id tem= pus noctu quafi uerecundantes, donec recipiant cormua. Decidua amittunt difficilibus, e inacceß $\beta_{\text {is }}$ locis, ov qua inueniri nequeant. unde illud prouerbium ortum. Qua cerui amittunt cormud. Quafi enin fua amiferint arma, $c d=$ uent ne inermes reperiantur. Cornu finiftrum compertum effe (inquit Ariftoteles) à nemine adbuc fertur : occulunt enim id tanquam quodam medicamento preditum: et $/ i \mathrm{Plinius,} \mathrm{or} \mathrm{Albertus} \mathrm{occulidextrum} \mathrm{memorice} \mathrm{prodiderint.} 30$ A' phalangio demorfi, uel d quouis generis ciufdem, cancros edunt: quod idem bomini etidm prode $\iint e$ putatur: $\int e d$ nö carent faftidio. Ceruifibilo, or cantu uenantium, pastorum q́; fiftulis capiuntur : mulcentur cnim alliciuntürque ed: uoluptate, ita ut alter uenantium cantet palàm, aut fibilet, alter clam feriat à tergo, ubi focius iam tempus effe $f i=$ gnificarit. Nanque animal fimplex ceruus est, or omnium rerun miraculo shupens, intantum ut equo, aut bucula', accedente propius bominem iuxta uenantem non cernat, aut ficernat, arcum ipfum fagittasq́;; miretur. Si ceruus erectas auriculas tene at, acerrimé fentit, nec latere infidix poffunt" jin demiffas, facile interimitur. Maria tranant gregatim natantes porrecto ordine, er capita imponentes precedentium clunibus, uicibusq; ad tergaredeuntes. Hoc maximé notatur à Cilicia Cyprum traijcientibus. Nec uident terras, fed in odore edrusn natant. Ceruorum f $\alpha=$ mine cornua non babent: nec maribus nafcuntur, fi cim per atatem nondum cornua gerunt, caftrentur: fed fi cor= nigeris testes exciduntur, non decidunt cornua, 0 magnitudine eddem feruantur. Ceruds tamen cornigerds, non 40 fine nature miraculo, quandoq; inuentas effe compertum babeo. Huius autem siraculifidem facere poffunt illa cor= nud cerue, que funt Augufta Vindelicorum apud Antonium Fuggerum notili Sinzum diuitem, in quorum fingulo fex rami conpiciuntur. Atq; idipfun confirmari poteft non dißimilibus cerue cornibus, que argento laborato ornd= ta conferuat Dux ille Baurria, de quo a nobis pauló anté facta eft mentio. Vita Ceruis (ut Plinius memoria prodi= dit lib.V I I . cap. X X X I I.) in confeffo longa : quandoquidem post cétum annos quidam capti int cun torquibus au= reis, quos Alexander inagnus addiderat, adopertis ian cute in magna obefitate. Caterum quód uita tam longa fint ccrui, quantacos effe ferunt, non uidetur approbajfe Aristoteles libro v I . de biftoria animalium, ubi fic inquit. vita effe quam longa boc animal fertur. Sed nibil certi exijs, que narrantur, uidemus: nec gefatio, aut incre= mentum binuli ita euenit, quafi uita effet pralonga. hec Ariftoteles. Quire wera nibil certi nancifci potuit ex bis, qui centum annos post Alexandrum capti funt cum torquibus aureis. Nec etianmum ex Cefaris Augufti cerud, que so fimiliter innumeris elapfis annis poft eius imperium capta,nunquam iugulari potuit, probibente torque argenteo tem poris diuturnitate cute quafi contecto, in quo fcripta legebantur uerba hac. Noli me tangere, quid Caedaris fume.

Monte Afte Elapho nomine apud Arginufam, quo loco Alcibiades mortem obijt, ceruxe omnes fciffa aure funt, qua

Arifotelis, \& nota uel alibifi loca mutauerint, dignofcuntur. Mirum quippe eft dixiffe Ariftotelem lib.v 1 I I.cap. X x v I I I.de Plinij laptus. Biftoria animalium, Aphricam nec ceruos, nec apros gignere. Cui etiam fubfcribit Plinius lib.v I I r. cap. X x x II I. Cum tamen palàm omnibus fit, o aprorum, e ceruorum greges in A pbrica baberi. Nifi forfan polteriori auo a= liunde co fuerint illati. Ditamnum berbam extrabendis fagittis (ut Plinius auctor eft lib. v I I I. cap. x x v I I.) cerui monftrauere percußi co teio, paftúq; cius berbe eiecto . Quod tamen Diofcorides capris attribuit telo in Crez ta uulneratis. Cerui manifefto fel in iecore non babent, quemadmodum equi, afini, muli, cameli, dame: $\mho^{o}$ in natalitium genere delphinus, o phoca: fed id in ucnulis continent, qua per inteftina parguntur: quo fit, ut co= rum uifcera non modo in cibis minimé recipiantur; fed nec à canibus quidem edantur, nifi prepinguia fint : amas 


\title{
In Lib. fecundum Diolcoridis.
}

refcutt enin bill, qua Juffunduntur. At ceruis Acbainis cognomine, fel contincri in cauda creditur, auctore Arifto= tele. Eft quod ibi contineri aiunt, colore quident fimile flli, fed non ita ut fil bumidun, lieni fimile parte interiore. Hoc deguftantibus atrocißimum eft uenenum, adeó ut breui temporis patio boninem émedio tollat. Vermescer= Vermes in ca ui omine continc nt in capice uiwos, qui nafci folent fub lingua in conca circiter wertebram, qua ceruici imectitur pite cerui. caput, magnitudinc bud minores ijs, quos maximos carnes putres ediderint. Gigni unituer $/ \mathrm{i}$, dto;; contiguifolent nu= mero adeo circiter niginti. Ceruinus fangmis ( $u t$ Rafis inquit libro fex.tginta animalibus dic ato ) cly/teribus infu= fus inteftincrum ulccra fanat, or diucurnas aluifluxiones cobibet: cx uino ucró fumptus, uenenatis fagittis refiftit. Eius cerebrum ncriorum, o compaginum collectioncs mutdat. Cornu ad candoren $u f_{q ;}$ exustum, ex melle hau= fum, alui tineas pellit. Imucnum ceruorum tenerrina cornua, que adbuc lanuginofa cuticula operiuntur (anctore to Scribonio Largo) in tsicolis concifa, er nou fictiliindita, ac inde opercuio argilla circumlito, in clibanum impo $\int=$ ta, donec adeó arcfcant, ut in puluerem facilé conteri poßint, additis pipere, o myrtha, colicruciatibus mirifice medentur. Os preterca, qnod in ceruorum corde reperitur ( ametfi Ve falius uir alioqui clarißimus libro, quem de bumana fabrica edidit, nullum inibios reperirifalsó contendat) omnibus cordis affectibus confert. Quin Er contra omnia uenens mirificé preftut, antidotisq; admifcetur, que peftilentixe aduerfantur. Sed cauendum eft, ne buims lo= co fepla/iarij bubulam tsichedin arteriam acclpiant in compofitionibus, ut facere confuenerunt. Quod Greci

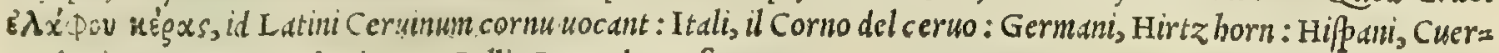
no de cieruo, e punta de cieruo: Galli, Corne de cerf.

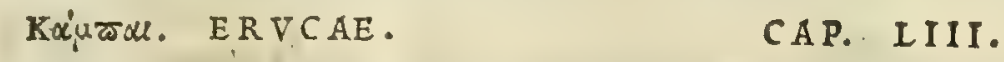

E R V C I s, qux in oleribus gignuntur, cum oleo peruncti, à uenenatis beftijs feriri negantur.

E R V C AE, quibss olitores maximé inimic antur, aninalcula funt uulgaris notitia, fed bortis admodum noxit, quòd quandoq; adeo numerof.e proncuinut, ut inuitis olitoribus olera cunct unt tantum deworent nocte. Gignuntur ( ut memoris prodidit A riflotcles libro v.cap. X I x. de biftoria animalium) ex uirentibus berbarum folijs, inaxime $\dot{q}_{;}$ ex braßsica. Primim minus quid milio confiftit in folio: mox uermiculi inde contrabuntur, or augentur : tum intra

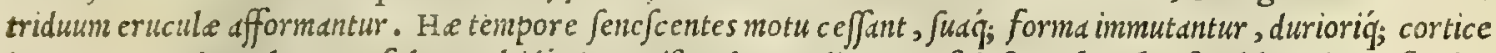
integuntur, cuius color auro fulget: ob id $\dot{q}$; (ut Ariftoteles prodit, o poft ipfun Theophraftus lib.v. de caufis plan tarum) appellantur tantiper chryfalides, quafi aurelias dixeris. Dum eo putamine integuntur, ad tactum tantim mo

30 biles funt, er palpitantes, meatibus araneo/is obducte: non os, non aliud ex membris, quod confpicuum fit, poßidĕt. Longo poft tempore putamitie obrupto, enolant inde animalia pennigera, quos papiliones uocamus. Itaque primùn dum Eruce funt, cibo aluntur, atog; excrementum emittunt : at ueró cum in aurelias tranfierint, nibil uel guftant, uel *excernunt. Harum, dum adbuc puer efsm, ingentem copiam quodam anno peperit Hetruria, adeó ut pueri omnes mir abili quad an of tent atione numerof as in plate is geftarent aurelids; ita aureo nitore fulgentes, ut ex puro auri mé= tallo fat as quifque credidifet, nifi deprehen $\int e$ fuiffent palpitantes. Fuit co anno tanta Erucarum multitudo, ut uni= wer fs croferint berbas. Quo poftmodun factum eft, ut ubiq; firpium folia, ac rami, adificiorum'́; parictes, ijs ue= Iuti uiuo ac palpitantifulgerent auro. Facies eis quafi buin.1na, capite bicorni, corpore infantulimodo fafcia obdu= At $i$ id quod filentio dißimulauit Ariftoteles. He querentibus quotannis fefe offerunt circa urbium manit, or adi= ficiorum muros, circa cos prefertin, quibus adiacent horti, ac uiridaria : plerunq; enin in edificiorum cauis capite

40 ad terram uerfo reperiuntur appen $\int x$. Ceterum etfi dixerit Ariftoteles, Erucas ex berbarum, olerumq́; prefertim folijs ex fe fe gigni, ab fque animalis femine; uifuntur tamen boc auo papiliones ex aurelijs exorti, auerfis olerum $f 0=$ lijs oua parere fubalbida, milio minora, ex quibus eruc.e tandem prodeunt, ut fericino Erucarum generi euenire com perimus. Vnde mibi quidem dubitandun uidetur, an rem banc diligenter perpenderit, uel exquifité tractaucrit Ari= ftoteles. Quanquam minimé negauerim, quin er exputri quodam bumore per fe Eruc.e nafci poßint, quemadmodum er mures, angues, uermes, aliáq; complura generantur. Plinius grand illa ex rore fieri putat, foleq́; addenfari. quod tamen naturepeculatores non ita facilé comprobant. Erucis olera non erodiauctor eft plinius, $f i$ palo im: ponantur in hortis offa capitis ex equino genere famine duntaxat. Aduerfus quas $\sigma$ cancrum fluuiatilem in medio borto fuppenfum auxiliari narrant. Sunt etiam qui fanguineis uirgis tang unt ed, qua nolunt bis obnoxia effe. hec Pli= nius. Columella preterea libro $\mathrm{x}$. de re rufica circa calcem, necandis probibendis $q$; erucis hec in medium protu= so lit. Vbi ueró apricis regionibus poft pluuids noxia incefferunt animalia, quxe à nobis appellantur Eruce, Grecé du=

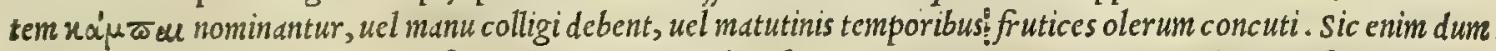
adbuc torpent noct urno frigore, fi deciderint, non amplius fuperiorem partem prorepunt. Id tamen fuperuacuum. eff facere, fi ante fationem femina fucco berbx fedi maceratd funt: nibil enim fic medicat is nocent eruca. Sed De=

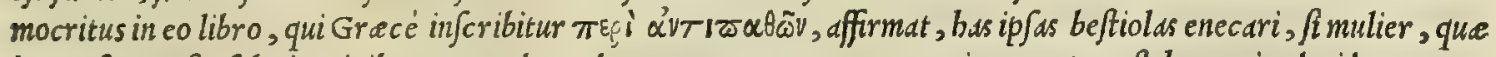
in menftruis eft, folutis crinibus, o nudo pede unamquanque aream ter circumeat: poft boc cnim decidere omnes. uermiculos, o ita emori. Sed poftrema hac, que à Colunella referuntur, fuperftitiofis funt relinquenda. Káj = Nomina. कu ita Grecé, Latiné Eruce uocantur : Arabicé, Riap $\int a$ : Italicé, Bruchi: Germanicé, Raup, feu Holtz uurm: Hipanice, Bruchi.

\section{Erucarŭ ge-} neratio.

Erucarum hiftoria.

Cerui ufus in medicina.

Nomina. .

\author{
.
}

Remediacon tracrucas. 


\section{KaviogldEs. CANTHARIDES.}

CAP. LIIII.

E' F R V M E N T I s congeft Cantharides ad recondendum idone $x$ funt, quæ fictili uafe non picato conduntur, \& raro mundoq́ue linteo obligato ore, \& deorfum conuerfo fufpenduntur fuper ace ti feruentis quàm acerrimi halitum, donec æftu exanimentur: poftea lino transfixæ reponuntur. Potentifsimæ omnes uariæ, luteis lineis, quas in pennis tranfuerfas habent, promiffoque corpore, craf$f \mathfrak{x}$, ac blattarum modo perpingues : fed inertes, ac imbecill $x$, quæ unius funt coloris .

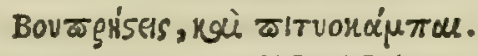 \\ BVPRESTES, ET PINORVM E R V CAE.

S I M I L I modo reconduntur bupreftes, genera quædam cantharidum, \& pinorum erucæ : quæ fupra cribrum fufpenfum feruenti cinere paulifper intoftæ, reponuntur. Vis omnium communis erodere, vlcerare,calorem elicere: qua de caufa admıfcentur medicamentis, quæ lepras, ferosq́ue lichenas, \& carcinomata fanant . menfes ciunt pefsis emollientibus additæ. Aliqui cantharidas antidotis impofitas, aqux fubter cutem auxiliari prodiderunt : argumento, quòd urinam moueant. Alij penaas, pedesq́ue contra potarum ueneficia, remedio effe tradiderunt.

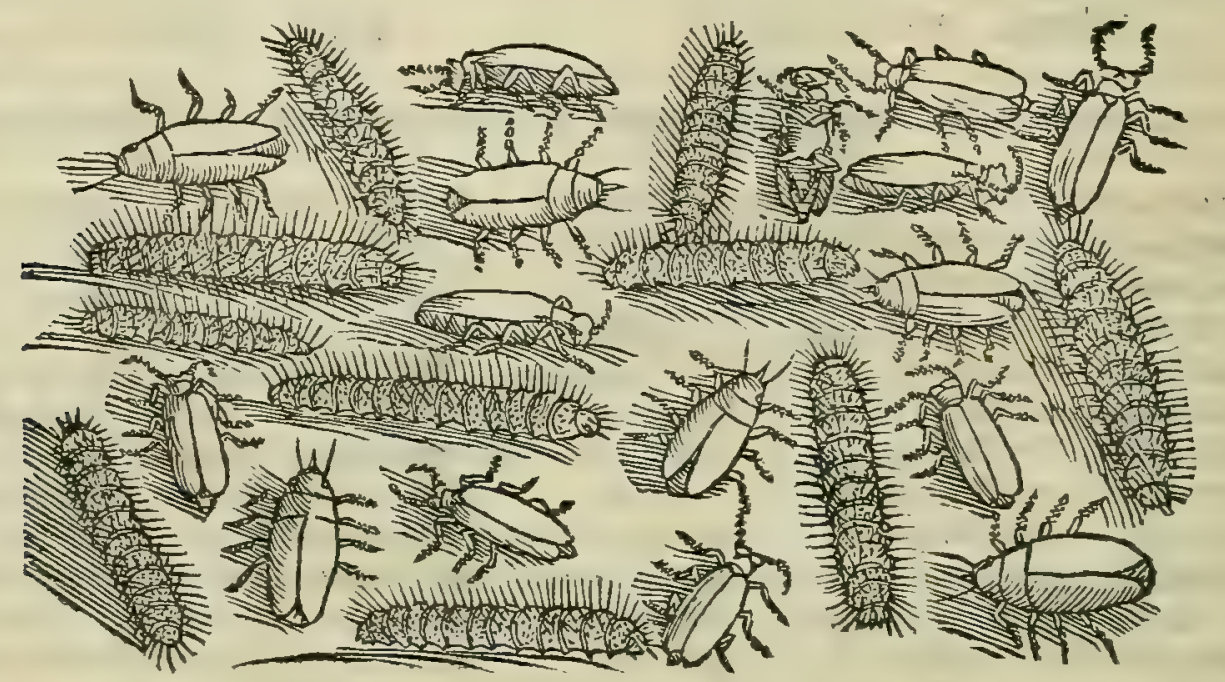

Cantharidum confideratio.

Bupreftes. Pinorum eru ce.

Error multosum.
C A N T H A R X D E S unlgata funt animalid, nomine dे cantharo, qui Latiné fcarabeus eft, dedutto, ac fir eas dixeris paruos fcar abeos. Sunt in Italia frequentißime, calidioribus prafertim regionibus, ubi non modó in frumen= tis inueniuntur; fed in fraxinis quoq; ftabulantur. Praft ant qua folida, recentes $q_{5}$ funt, nam ueter afcentes facilé ca riĕ fentiunt, unde inutiles funt in medicamentis. Bupreftes autem (ut Plinius inquit lib. $\mathrm{x}$ X X.cap. I I I I.)non per= inde in Italia funt uulgares, $\mathcal{O}$ frequentes; funt tamen fcarabe is fimiles, quanquam minores. At pinorï eruce nu= 40 mero $\int \mathbb{x}$ fané babentur in Tridentinis montibus, quód inibi pinorum perpetuó uireant fylue, Ananienfi prefertim trd= au, ac Flemarum conuallibus. In extremis arbor ü ramis, ev ijs plerunq;, qui in earum cacumine attolluntur, innume= rabiles Eruca rufe c centes, ac pilo fa miro artificio nidificant, quibufdă tenuißimis uelleribus innumeris inuolucris con= textis. Latent in his byeme, ita frigoris noxam euitantes. Nidi magnitudo adeó ampla eft, ut nonnunquam conclufe uermiculi millenarium numerum excedant. Inuolucrimateries, qua concluduntur, tenuißima ferici uelamina ma= ximé amulantur, tenuior tamen eft. Hac fanguinis manationbus aptißina eft: quare impofita confeftim fluorem $f i=$ ftit. Sed de bis hactenus. Caterum funt medicorum quìm plurimi Mauritanos precipue fequentes, qui quotiefcunq; Cantharidas medicamentis mifcent, precipunt capita, alds, er pedes abijci, tanqua partes cateris nocentiores. Quod tamen Galeni fententice omnino repugnat. Quippe qui lib. $\mathrm{x}$. Fimp.med. integras cantharidas medicamentis adden= das precipit,quemadmodum e ijs integris ipfe perpetuó fuerat ufus. Sed fi reponderintij, illud nec eorum effe in so ftitutum, nec Mauritanorum, fed Hippocratis lib. II II. de uitus ratione in morbis acutis, audiant que fo quibus uerbis eodem loco Hippocratis fententiam declaret Galenus, cum inquit. Quidam dictionis huius mentem baud qua= quam intelligens and ax medicus, prediftas partes à cantbaridibus abiecit, deditó; bydropi : cui cùm à primo die ab= fceffus in fura comparuiffet, poft tres alios dies fectus eft, effufá; copiofa aqua, curatus effe uifus eft : quód pars tu= moris prater naturam plurima ftatim ad moderationem redact a fit, ueruntamen non multis póft diebus obijt. Quam ob caufam medico quidam crimen ingeßit, perperàm data effe cantharidum corpora inquicns. Nempe propinanda, ablatis corporibus, tum caput, tum pedes, tum alas, id q'; effe quod in diftione enunciaretur. Quare non cunctatus au= daxille medicus, bydropi alteri ita propinauit : mox f; facto fimiliter in femore abfceffu, fecto ó;, multis póft diebus bominem mori contigit . quanquam urinarum prouocatorio medicamento ex cantharidibus confecto, quidam citra bibentium incommodum ufi fint. bec Galenus. Ex quibus facilé cognofcitur, Arabes non recté Hippocratem intellez xiffe. Quamobrem dicendum effe exiftmauerim, quod ablatis cantharidum extremitatibus, exuantur antidoto, quo 


\section{In Lib. fecundum Diofcoridis.}

Hatura funt predice in proprij ueneni remedium. Quod cum accuraté perpendiffet Galenus, cas integras fuis medi= camentis femper admifcuit; ut facile atteft dntur qua libro $\mathrm{x}$ I. de fimplicium medicamcntorum facultatibus memo= ria prodidit, fic inquicus. Veruntamen fufficicntem babemus de cantharidibus experientian, quod in ungucs pfo= rodes cum idoneis ccratis, aut cmpluftris impofitx, fic illos cducunt, ut toticadant. Mifcuunus eds ctiam faculta= tibus p foris, er lepris congrucntibus, necnon quibufdan feptis, atq; interin etian ijs qux clanos, quos uocant, eij= ciunt. Porró preceptorum meortun quidan carum paulü quiddan in medicamenta urinam cientia inijcicbat. At qui=

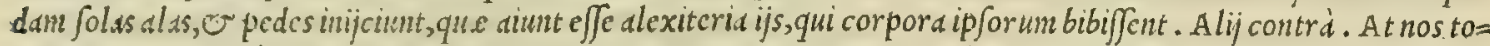
tas indimus. Ceterim sptiores funt ad $e x$, qua cxpertum me dixi,ex cantharidum, que inuenta in frumento, lutea thanfuerfim in alis cingula obtincnt, potißumim fin inijciantur in uas fictile noum, deinde ori uafis linteum obduct $\tilde{u}$

10 fit rarum, 0 uas ita teneas inuer fun, ur linteum, quod cantharidibus fubeft, uaporem ab accto furfun elatum excipiat, donec emoriantur ip $x$ cantharides. Et de bupreftibus agens, ita fubdit. Sic Bupreftes quoq; reponere expedit. Sunt. anten o ip fe amin.l is quoddan genus catharidibus tum pecie, tum uiribus adfimile. Mox de pinorum erucis: quin Or cruca (inquit) qux in pinis nafcuntur, meritó nuncupate pityocampae, buius funt facultatis. Kavbapides ut Nomina. Gr.ecis, itactism Latinis Cantharides appellantur: Arabibus, Dherarie, fiuc Carariba: Italis, Cantarelle: Ger=

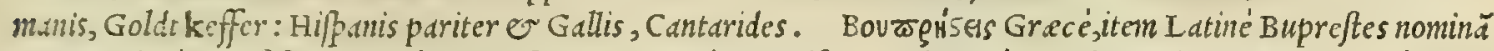

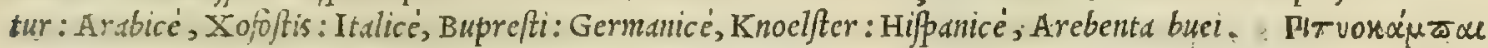

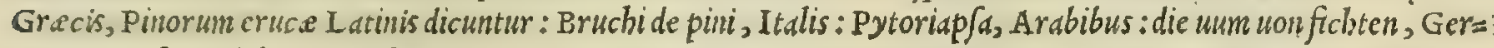
manis: Gufarios del pino, Hipanis.

$$
\sum x \lambda \propto \mu \alpha \dot{v} \delta \rho \alpha . \quad S A I A M A N D R A .
$$

CAP. LVI:

S A I A M A N D R A lacertæ genus eft, iners, varium, quod fruftrà creditum elt, ignibus non uri. Vim habct erodentem, calfactoriam, exulcerantem. Additur, vt cantharis, in medicamenta, quorum uis eft exelle,\& lepras abolere : limilique modo reconditur. Liquefacta in oleo pilos cuellit. Exenterata, detractis pedibus, \& capite, in melle feruatur ad eundem ufum:

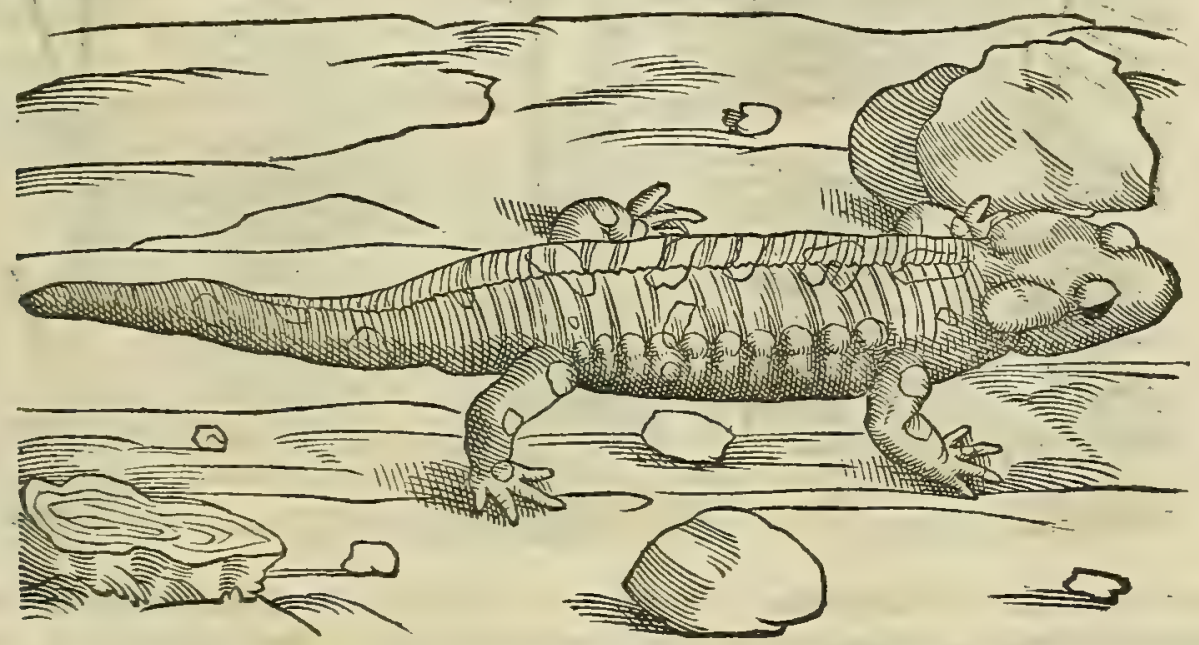

S A I A M A N D R AE in agro Tridentino copiofe inueniuntur, Ananienfiprefertim ualle, iuxta femitas, es. in opacis, uligino is q́; locis. Incipiunt cnim apparere uerno tempore, atq; etiam autumno, calo maximé pluuio. Sed. aftate ob folis frruores; item ; byeme ob urgentißima frigora, fuis é latebris non exeunt. Salamandra corporis ma= gnitudine, formá, lacerto fimilis eft; uerum capitis, ac uentris craßitudine excellit, breviore tamen conftat cauda. Il $=$ Ia etfi altioribus nitatur cruribus, ad greflum tamen ignauior eft, hic ueró contrà agilis, celerq́; conpicitur . Color: illi niger, lutcis non minimis infictus maculis, quadam leuitate pellucidus. Vifu Salamandre borribiles, atque abomi=: nands funt, ita ut facilé cor um appectus hominibus naufe am pariat. De hac differens Plinius lib. X. cap. I X v I I. fio inquit. Salamandra animal lacerti figura ftellatum, nunquam nifi magnis imbribus prouenit, et ferenitate deficit. Huic 50 tantus rigor, ut ignem taltu extinguat, non alio modo, quàn glacies. Quod quidem facit prunis fuperpofita, non $f_{e=}$ cus dique ceter animalium carnes, que prunis affande traduntur. Veruntamen in medium magni ignis, ubi flam= ma ualentius agit, uel in fornacem proiecta, fatim comburitur. Vanum eft ergocredere (ut etian Diofcorides confideratio.

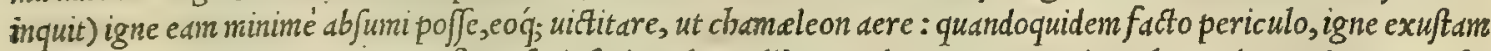
breuifalamandram uidimus. Quo fit, ut foripferit Galenus lib. I I I. de temperamentis, saldmandram ad certum ufi; temporis patium ab igne nibil pati: uri tamen, fi ea longius ignifit admota. Quod poftea effecit, ut. explicare ne=. fciam, quo argumento, quáue ratione prodiderit Ariftoteles lib.v. cap. x I x. de hiftoria animalium, Saldmandram. igne minimé comburi, fed per eum inambulantem flammas, et prunas extinguere: cùm contrarium experientia facilé Ariftot. vanx probari poßit. Illud preterea mihi dubium eft, an idem eodem capite uera retulerit, cum afferit in Cypro infula $a=$ rarijs fornacibus, ubi cbalcites lapis ingeftus compluribus diebus crematur, in medio igne exoriripennatds beftiolds, pauló mufcis grandibus maiores, que per ignem faliant, atque ambulent, anotóq;igneftatim emoriantur. Quippe. quod maxime id nature operibus repugnet. Adde etiam quod fi hec uera effent, ed nunquam reticuifet Galenus, qui

\section{政}


diligentißimé omnia Cypri metalla inueftigauit, ac nouit, pariterq́; metallorum fornaces, cum fuerit ip $\int$ bar um me= morabilium rerum accuratißimus indagator. Vidi ego in Germania ararias complures fornaces, ḋ quibus utranque cadmiam, poinpholygem, podium, aris florem, $\sigma$ alia mecum retuli; fed mufcas per ignem obambulantes mibi nun= quan uidere licuit. Qua in re ncfciucrim, quónam pacto Ariftoteles feruaripojsit. Nifi dixerimus, ip $\int_{m}$ boc in lo= co non fusm, fed aliorum biftoriain recenfere. Sed de bis batcenus. Caterim Sal amandre nibul gignunt (ut Plinius tradit) ncq; eft in eis genus majculinum, fomineumúc. Nafcuntur enim ex putri quodam bumore terra. Mor fu uene= num inferwnt, ferpentium modo. Quineian fiuctus, or berbas quadam oris faliua ueneno inficiunt, maxima degu=

Salamandra ftantium iactura. quandoquidem non paucirepertifunt, qui hoc ueneno interiere. Est er Salamandra aquaticum acquatsa. Genus v tinenfibus frequentiß3imum, capite terreftribus breuior e rotundiore $\dot{q}_{;}$, cauda anguillarum modo, nigro undiq;

Nomina. dorfo, uentre autem rufe fcnte, luteis maculis refperfo, borrendo appectu, equé atque terreftre. Animal, quod 10

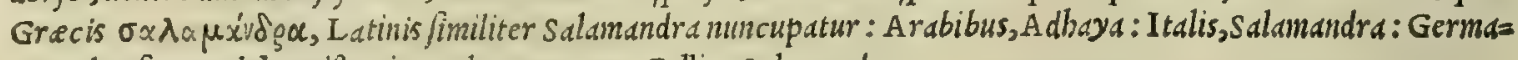
nis, Olm fiue Molch: Hipanis, Salamantegua: Gallis, Salamandre.

$$
\text { A' } \alpha^{\prime} X \text { VH. ARANEVS. }
$$

\section{CAP: IVII.}

A R A NEVs, quem holcum, alijlycon, id eft lupum vocant, fubactus cum fplenio, \& linteo illitus, prolatusq́ue utrifque temporibus, aut fronti, tertianos circuitus perfanat. Tela eius impofita fanguinem fiftit, vulnera, quæ fummam cutem occuparunt, ab inflammationis iniuria vindicat. Elt \& alterum aranei genus, qui candidam, tenuem, denfamq́ue telam orditur. quem in aluta ligatum, \& lacerto appenfum, quartanis circuitibus mederi narrant. Decoctus ex rofaceo, \& infufus, aurium doloribus auxiliatur.

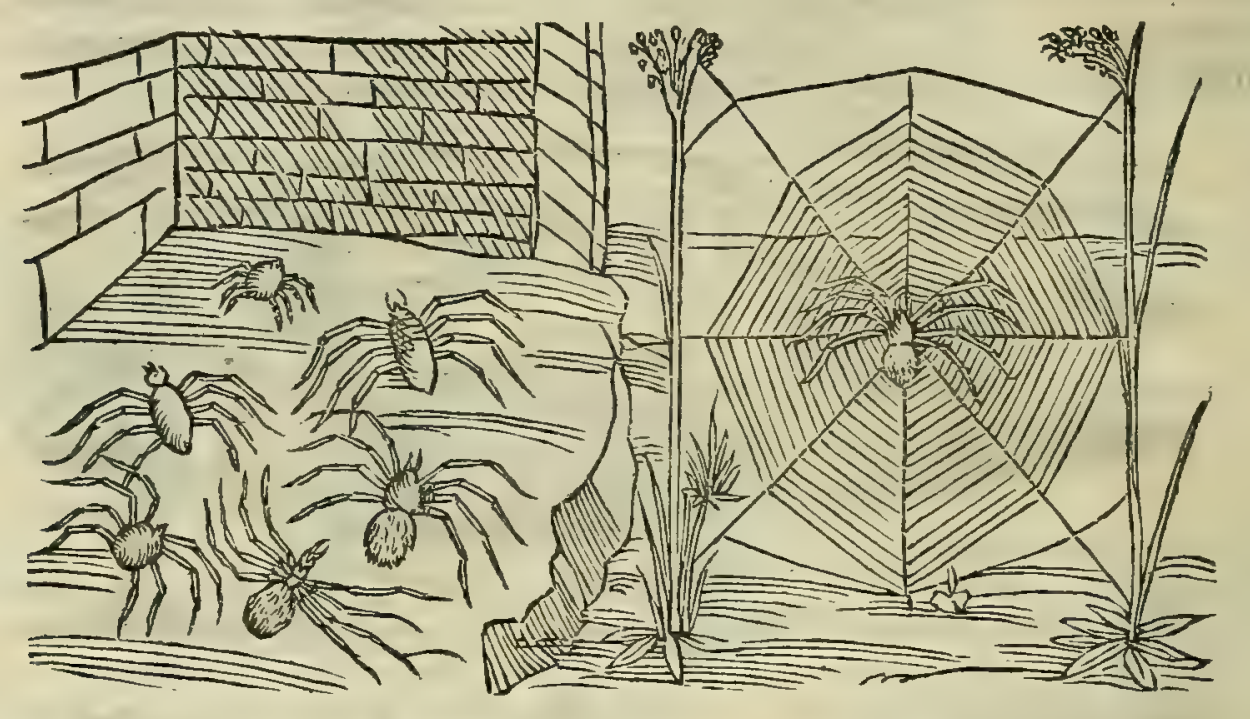

Araneorŭ, \& phalägiorum genera.

Phalágiorum genera ex Pli.
A R A N E O R v M, er phalangiorum (utlib. I x.cap. x x x I x.de biftoria animalium fcribit Arifoteles) 40 plura funt genera. Mordax, quod in duo diftinguitur, alterum fimile ijs, que lupos appellant, eft paruum, uax rium, procax, falax, pulex nuncupatum. Alterum maius, coloris nigri, cruribus prioribus nigris, tardum, $\sigma$ lenté ambulans, nec. uiribus valens, neque faliens. Catera, que medicamentarij proponunt, aut nullum, aut certé exilem inferunt morfum. Genus fecundum, quod lupinomen accepit, partim exiguum eft, quod non te xit : partim inaius, quod aperam, paruamq́; tclam apud terram, aut fepes orditur, bucculis intexere folitum pri= mordijs intus pofitis obferuatur, dum aliquid in tela offendens commouerit, mox accurrit, ut capiat: partim ua= rium eft, quod paucam uilemq; telam fub arboribus facit. Tertium genus, quod fapientißimum, lautißimumq; omnium elt, noftris edificijs latißimas contexit telas. Huius, ut equidem arbitror, bic meminit Diofcorides.

Plinius araneos, qui ictu, uel morfu uenenum inferunt, phalangia nominat, quorum biftoriam libro $\mathrm{x} \times \mathrm{x}$. cap. I I I . diffufius enarrauit bis uerbis. Phalangium eft Italia ignotum, or plurium generum. Vnum fimile so formica, fed multo maius, rufo capite, reliqua parte corporis nigra, albis intercurfantibus refperfum guttis. A= cerbior buius; quàm uepe ictus. Viuit maximé circa furnos, or molas. Aequé phalangion Grxeci uocant inter generd araneorum, fed diftinguunt lupi nomine. Tertium genus eft eodem phalangij nomine araneus, lanugino= fus, grandißimo capite. Quo diffecto inueniri dic untur intus uermiculi duo, qui ceruina pelle conclufi, $\sigma$ mulie= ribus adalligati ante folis ortum, praftant, ne concipiant. Vocatur $\mathcal{C}$ rbagio, acino nigro fimilis, ore minimo fub aluo, pedibus breuißimis, tanquam imperfectis. Dolor à morfu cius, qualis à fcorpione. Vrina fimilis araneis textis. Idem erat aftertion, nifi diftingueretur uirgulis albis. Huius morfu genua labefactantur. Pcior utroque eft ceruleus, lanugine nigra, caliginem concitans, or uomitus araneofos: etiannum deterior, d crabrone penna tantim differens. bic $\sigma^{\circ}$ ad maciem perducit. Myrmecion capite formica fimilis, aluo nigra, guttis albis difin guentibus. ueparum dolore torquet. Tetragantbij duo genera babent, peior medium caput diftinguente lined alba, Or tranfuerfum altera , bic oris tumor em facit. At cinereus pofteriori parte candic ans, lentior. Minimé autem no: 


\section{In Lib.fecundum Diofcoridis.}

xius, eodem colore, qui telas mufcis in parietibus latißimé pandit. Hactenus de araneis, et phalangijs Plinius. Cuifub= fcribens Aëtius lib. X I I I.cap.X VIII. Phalangiorü generd, inquit, plur a funt. Que.e ueró apud cos, qui de noxijs beftijs fcrip ferunt, referuntur, ut plurimum fex numero exiltunt. Vnum quidem ex eis rbagium, alterum lupum, ter= tium formicarium, quartum cranocolaptes, quintum fclerocephalon, fextum fcolecion appellatum. Ac primuin quice dem rhagium, id cft acineum, figura rotundum eft, colore ucró nigrum, acini uu.e nigra fimilitudine, unde ctiam appel lationem accepit: o os quidem iuxta medium uentrem babet, pedes ueró ex utraq; parte qudim breuißimos. Alteris uero lupus appellatŭ, mufcas perdit, eisớ; pafcitur : ac corpus quidem babet latum, ac uolubile, partes ueró circa cius ceruicem incife funt : amplius autem, o os eius cminentias tres habet. Tertium autem myrmecium, hoc eft, formica= gium dictü, quod formic is maximé a Bimiletur, colore eft fuligino fum : corpus ucró eius uelut aftris quibufdam infigni=

so tum, prefertin circa dorfum. 2uartum deinde cranocolaptes, oblongun eft, o uiride, ftimulumq; iuxta collum ba= bet, atq; fin in aliquem irruat, locos circa caput petit. Quintum fclerocephalum dictum, caput babet $\int a x c u m, \mathbb{E}$ obs duratum : lineamenta ueró per omne corpus fimilia aninalibus illis, qua lucernas noctu circumuolttant. Sextum po= fremó frolecium, fine uermicarium appellatum, fublongum eft, of fubmaculofum, maximé circa caput. At g $_{5}$ be qui dem ßpecics phal.nngiorume enumerantur. Hae de phalangijs Aëtius. Ego autem afferere non dubitauerim, omnia

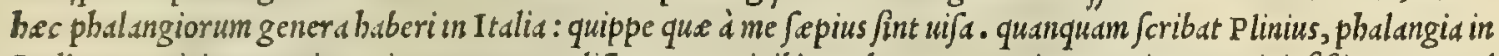
Italia non oriri. Quin potius preter predicta genera, inibi $\odot$ alterun reperitur omnium perniciofi ßimum, quod ¿̀ Taranto Apulite ciuitate, ubi iunumera aftate tota uagantur in campis, Tarantulam appellant. Itti ueró ab his ua rié, ac dinerse torquentur : fiquidem alij perpetuó canunt, alij rident, alij plorant, alij clamitant, alij dormiunt, alij uigilìs afficiuntur, pleriq; uomitionibus laborant, nonnulli faltant, funt qui fudant, alij tremebundifunt, quidam pa=

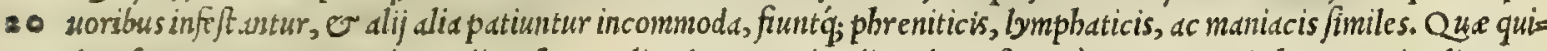
dem fynptomata tam uaria, ac diuerfa non aliunde proucnire dicendum eft, quadm aut ex uario borum animalium ue= neno, aut ex demorforuma bominun temperamentis. Nam atra bile tentatis, pro corum temperaturis omnia bec accis diffe confpeximus: tamet/i non defint, qui putent Tarantule uenenum dietim, uel bor atim immutari, fieriǵ; ob boc, ut tam uarijs fymptomatibus ucxentur, qui ab ea iciuntur. Habentur Tarantula etiámnum in maritimis noftris Senen fibus Tyrrheno litori adiacentibus, o Romano agro frequentes: ueruntamen non perinde ac in Apulia numerofe. Degunt he inter fegetes in quibusdain tcrre cauernulis, é quibus interdiu exeuntes, fepe cos meffores iciunt, qui bu= ius infidix igndri, crurd ocre is non munierunt. I Ctos uidi ego nonnunquam in plateis iacentes, 0 in xenodochijs, qui predict is affectibus torquebantur. Sed mirum certé, quàm facilé buiufce ueneni uis mufica mulceatur. Quandoz quidem (ut equidem atseftari poffum) auditis lyricis inftrumentis, uel tibiarum fono, primo ftatim occurfu itti a $\mathrm{T} d=$

30 rantula à languoribus ceffant, e in medium tripudiare, O faltare incipiunt, tam 'ó; diu rem profequuntur, ac fi fani effent, er nullo unquam tenerentur dolore. Qúd fi euenat, ut tibicines tantillum conquief cant, ac interponant, nö multo póft tempore in terram concidunt, $\mathrm{O}$ ad priflinos redeunt languores : nifít tandiu indeficiente fonitu faliant, atq; tripudient, donec ueneni uirus, partim infenfibiliter per cutis meatus, partim per fudorem exeat, or difcutiatur. Ob id igitur tibicines ftipendio conductntur, alternatimqं; mutantur, $u t a b \int q_{;}$ulld fonitus intermifione, tandiu tripu= dient demorfi, quoufque penitus curati quiefcant: cum tamen, dumbec aguntur, fint, qui antidotis eos corroborent,

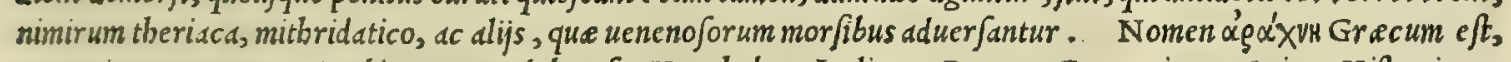
ut Latinum Arancus: Arabicum, Hamdebut, feu Hanchcbut : Italicum, Ragno: Germanicum, Spinil : Hipanicum, Arans: Gallicuum, Areine.

L A C E R T AE caput intritum, \& appofitum, aculeos, \& omnia corpori infixá extrahit: varos, formicantes verrucas, \& penfiles, quas acrochordonas uocant, tollit. Iecur exefis dentibus coniestum dolores finit. Si diuulfa admoueatur, ictis à fcorpione leuamentum praftat .

Tarantulę remedium. .

(1)



Exit.
SE P S.
CA P. I IX.

SE P s, quam aliqui lacertam chalcidicam uocarunt, in uino pota, morfus fuos fanat.

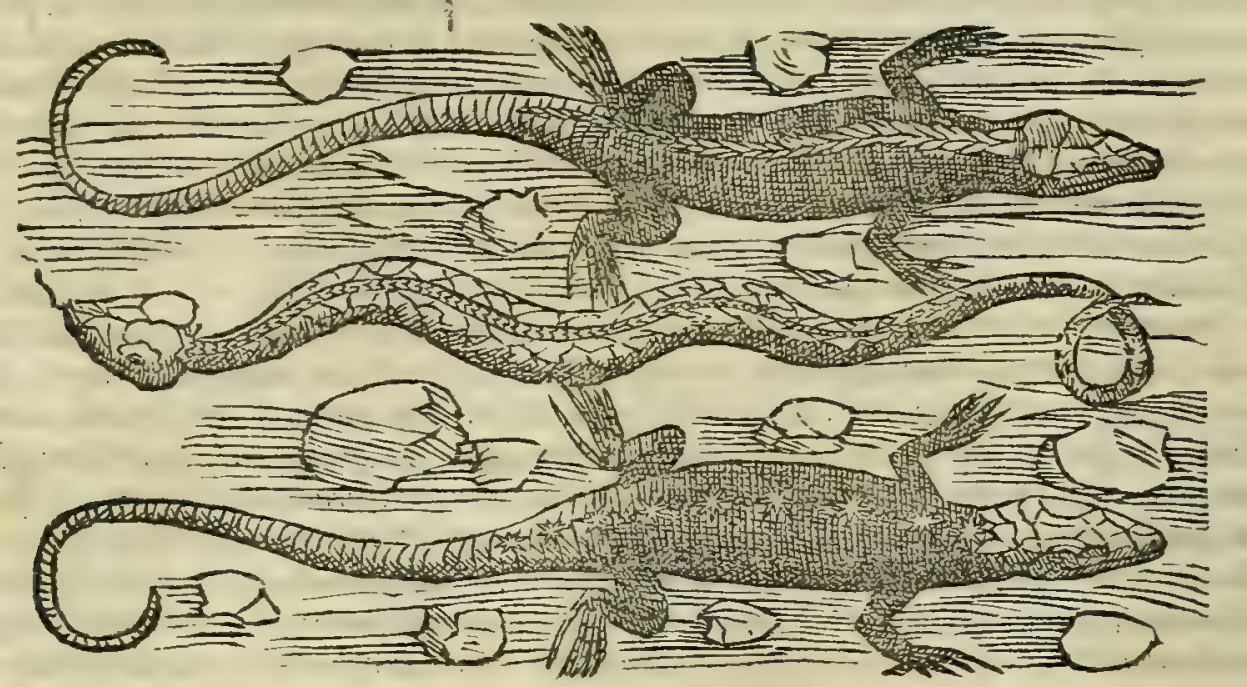

Lacertarum confideratio.

I A C E R T A E, que ubiqf; uulgares oberrant, oua quemadntodum erpentes pariunt, o cochleismaximé in: fidiantur. In Arabia (ut Plinius eft alctor) cubitalem aquant menfuram: 0 in Mauritania, autore Strabone, bis cubitales reperiuntur: in India ueró Nifa nonte, fi Plinio credimus, ad X XIIII pedum longitudinem lacerti. reperiuntur, colore fului, aut punicei, aut carulei. Eft $\mathbb{O}$ Infula Capraria lacertis maximis referta, ut referunt, Chạlcidicarŭ qui dd fortunatus nanigarunt infulas. Caterum, que Chalcidica uocantur, in Libya, er Cypro copiosé proue= confideratio. nientes, non babentur in Italia. Morantur be plerunque in locis aridis, o inter faxa. Varia eft barum hiftoria apud autores : nam quidam noftratibus lacertis fimiles ipfas fecere, quidam ucró inter ferpentium generd re= cenfent. Nicander Diofcoridi fubfcribit: quippe quit in theriacis fuis dicat. Vitabis or Sepem corpore bumils bus lacertis fimilem. Veruntamen Aëtius libro X II.I. Sepam inter mortifrros recolit angues, fic inquiens. serpens, qui seps appellatur, longitudine quidem duorum cubitorum rcperitur, ex crafso autem in tenucm $a=$ bit: recta ueró, ac tardé proferpit. Caput habet latum, os acutum, uniuerfun autem corpus multis albis notis res Perfum. Ceterim ij, qui abeo percußi funt, intra tres, aut quatuor dies pereunt. bec Aëtius. Paufanids porró aliter fentire uidetur : inquit enin. Aegyptum Arcadie quondam regem in uenatione occupatum, o im= prudentem sepsoppreßit. vipere fimilis eft minime, cineris colore, maculis ex interuallo uarius, lato capi= te, angufta ceruice, aluo maiori, canda breui, obliquo inceffu, quafi cancer, quod or cerafta serpenti pro= prium eft. Quamobrem credendun putauerin, aut fabulofam effe lacerte Chalcidica hiftoriam, aut pluribus

Terrantola boc nomen conuenire ferpentibus. Verùm minime reticendum duximus, reperiri in Hetruria, in Romano d= gro, ac etiam in Apulia quoddam lacertarum genus Terrantola uulgó dictum, quoniam fúb terra delite $\int a t$. Que cum homines.mor fu perimat, fecit, ut mecum quandoque cogitauerim, an ed fortaßis Nicandro, ac Diofco= 49 ridichalcidica effet lacerta: aut Stellio, quód ftellis maculata, infignita'́; cernatur. Sed bec libro fexto, duce Nomina. Deo, latius explicabimus, ubi de bis, que morfu, uel ictu uenenum emittunt, fermonem faciemus." Que Grecis: oxijg, Latinis L acerta nominatur: Italis, Lucertola: Germanis, Heidex: Hipanis, Gartixa. Que ueró ox́t Gracé, Latiné Seps, er Lacerta Chalcidica nocatur: Italicé, sepa.

\section{¿ríruos. . SCINCVS. $\quad$ CAP. LX.}

S C I N C v S aut Aegypti, aut Indix, aut rubri maris alumnus, quanuis inueniatur in Lydia Mau ritaniæ. Eft autem terreftris crocodilus, fui generis, fale inueteratus cum nafturtio. Aiunt carnes, qux renes amplectantur, id fibi virium vendicaffe, ut fi drachmæ pondere bibantur, uenerem accen- 50 dant. Verùm decocto lentis cum melle, aut femine lactucx cum aqua poto, veneris cupiditates inhibentur. additur in antidota.

Scinci contsderatio.

T A M I T I fcribat Diofcorides, scincum effe terreftrem crocodilum, fui generis; aquatile tamen animal eft. Quandoquidem qui Venetias importantur, in mari rubro, o in Aegypto Nilo flumine capiuntur. Hi quanuis forma crocodilos referant; magnitudinem tamen longé minorem babent : nanq; qui ad fummum adoleuerunt, noftra= tes lacertas magnitudine non excedunt. Squamis ucftiuntur fubluteis, c.efia à capite ad caudam difcurrente lined. At non eadem crocodilis tunica : quippe quinigro natura funt dorfo. Paufanias in I ibya bicubitales reperiri scin= Scinci Vicen- cos tradidit: ueruntamen ij ad nos non de fruntur. Sunt in agro vicentino lacus quidam, qui scincos etian gignunt. tini. fed minutulos,ac nigricantes, quibus sepius utuntur feplafiarij deficientibus marinis, non fine magno fortaffe honimis difcrimine. Reprobat hos Fucbjus quog; libro primo de compofitione medicamentorum, fic inquiens. Scincus ani- 


\section{In Lib. fecundum Diofcoridis.}

$s \subset I N \subset V s$.

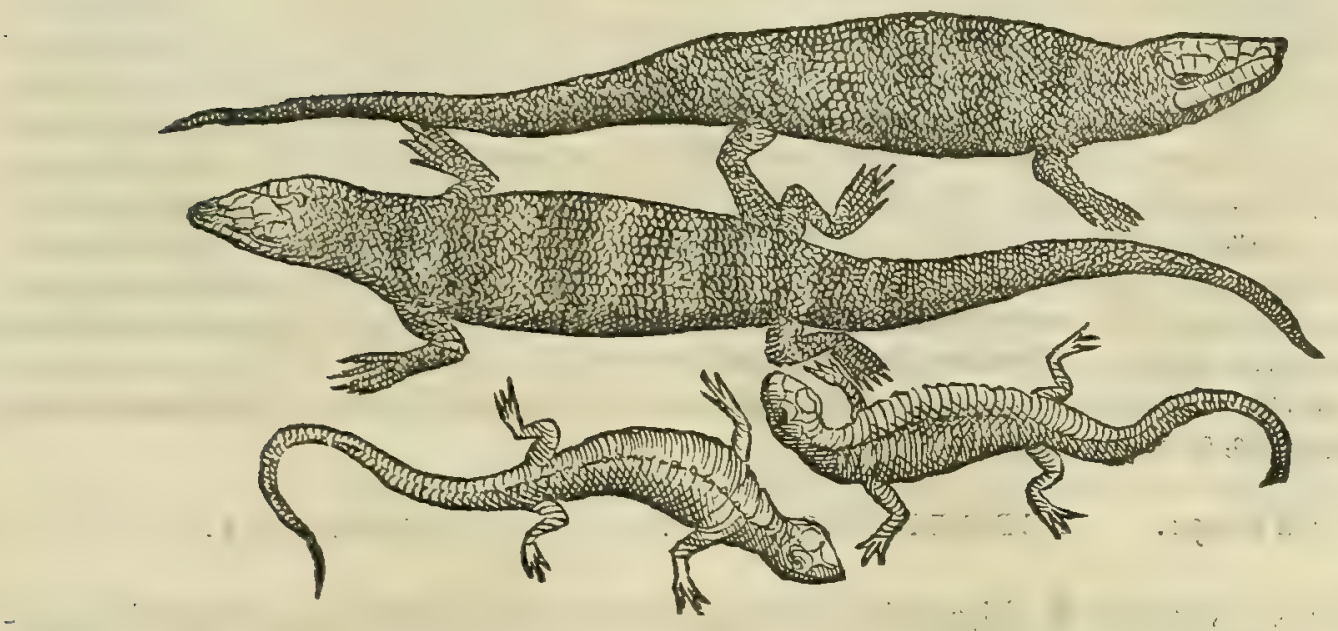

20 mal eft in aquis degens, lacerte magne fimile, fed ucntricofius : cauda lata, ut anguilla, ad natandum apta.: Quapro= pter quos officine fubijciunt, cum duabus caudis, ueri non funt, fed ex vicentino agro allati . bec ille. Qui tamen dü aliorun errorem merito damnat, ip $\int$ (pace uiri alioquin clarißsimi dixerim) in alterum non minorem mibi quidemi in= cidıfe uidetur, quód exiftinauerit, legitinum scincum, cuius effigiem damus, regilata cauda ad natändü, anguille mo=do. Quandoquidem Fuchsij Scincus, quo Foroiulienfis ager, e qux circum V tinum ciuitatem ftagnantes funt aqux, maximé fatent : o cuilacerta magne corpus, tumidus uenter, ac maculis udrius, rotundum quadantenus caput, an: guill c cauda, nigrumq; dor fum eft, scincus uerus non eft: fed potius animal falanandre generi adf cribendum, quòd terreftrem falamandrain non paucioribus refer at notis, quem aquatiles teftudines terreftres reprafentant. ob id itat que recté $v$ tinen es boc animal salamandram aquaticam uocant, abborrent q́; maximé, quód inter uenenatd omnino

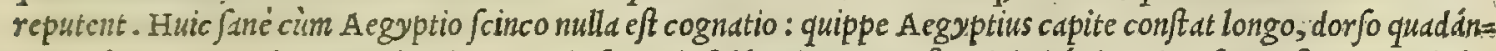

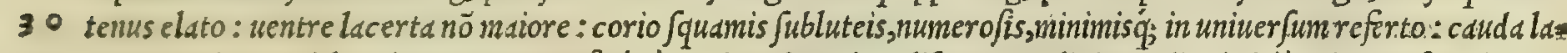
certe modo tereti, breuiore tamen: cafláq; ḋ capite ad caudam difcurrente linéa. Talis nimirü scincus eft, qui quat= annis ab Alexandria Aegypti Venetias numerofus conuebitur. Scincorum meminit Plinius libro x x v I I r. cdp. v I I . ubi ita fcribit. Ex chameleont is fimilitudine eft scincus, quem quidam terreftrem crocodilume effe dixerunt: candidiore autem, $\sigma$ tenuiore cute. Precipua tamen differentia dignof citur à crocodilo aquatico fquiamarum feta. $\dot{d}$ cauda ad caput uer $\int a$. Maximus Indicus, deinde Arabicus. Afferuntur falfi. Roftrum eius, er pedes in uino albo po= ti, cupiditates ueneris accendunt. Vtiq; cum fatyrio, $\mathcal{V}$ erucc femine fingulis dracbmis omnium, ac piperis duabus admiff is, ita ut paftilli fingularun drachmarum bibantur. Per fe laterum carnes obolis binis cum myrrha; o pipere pari modo pota efficaciores ad idem creduntur. Prodeft $\sigma$ contra fagittarum ueneria, anté pofted q́: fumptus. In an tidota quog; nobilis additur. hec Plinius. Porró CRO CO D I I V (ut refert Ariftoteles in libris de biftoria, o

40 partibus animalirm ) animal eft magnum, ad quindecim ufक cubita cre $\int c e n s$ : quanuis ad duodeuiginti fcripferit $\mathrm{Pli}$ nius. Hic animal non parit, fed oum anferini inagnitudinem non excedens: id q; in terra, non autem in aquis. Parit

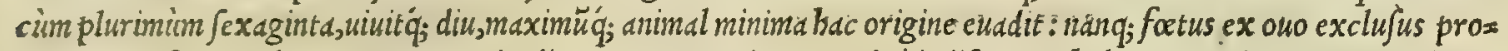
portione repondet, lacertorum magnitudinem equans. Linguam adeó indifcretam babet, ut omnino ea carere uided= tur. Cuius rei caufa eft, quód idem 0 terreftris, 0 a aquatilis quodammodo eft.: Ergout terreftris, locum obtinet lin gux, üt ueró aquaticus elinguis. Pi fces enim aut null am habere linguam uidentur, nifi ualde refupinentur, aut inexpla natam babent. Solus inter cater a fuperiorem mouet mandibulam, minimeq́;; inferiorem . caufa eft, quód pedes ad cas piendum, retinendumíg; inutiles habet. Oculi crocodilo fuilli,dentes exerti, er ungues in pedibus acutißimi, corium q́;

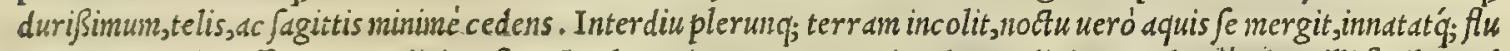
mine. Duo eius effe genera Plinius eft auctor loco citato. Vnum maius, de quo diximus: alter ru minusilli fimile, mul

so tum infrà magnitudinĕ, in terra tantüm, odoratißimisq́; floribus uiuit. Ob id inteftina cius diligentèr exquiruntur, iu= cundo nidore farcta. Crocodileam uocant, oculorum uitijs utili $i$ imam, cum porri $\int u c c o$ inunkiam, o contra $\int u f f u f i o=$ nes, uel caligines. Illita quoque ex oleo cyprino moleftias in facic enafcĕtes tollit. Exaqua ueró morbos omnes, quow rum natura erpit in facie, nitoremq; reddit. Lentigines tollit, ac uaros, omnes q́; maculas. Et contra comitiales mor= bos bibitur ex aceto mulfo binis obolis. Felle inunatis oculis contra fuffufiones nibil utilius predicant. Adaioris den= tes é dextra maxill adalligati dextro lacerto ( $f$ credimus) coitusftimulant. Corij utriufq; cinis, ex dceto illitus bis partibus, quas fecariopus fit, aut nidor cremati, fenfun omnem fcalpelli aufert.sanguis utriufg; claritatèm uifus inus Eis donat, ${ }^{\circ}$ cicatrices oculorum emendat. Cor annexum in land ouis nigre, cui nullus alius color incikx faucrit, or primo partu genite, quastands abigere dicitur. Corpus ipfum, excepto capite pedibusq́g, elixum manditur ifchiadicis. hec Plinius. Verintamen que is alterius inteftnis a Bignauit,ea Diofcoridem fimo tribuiffe conftat. Ceteriun cum Scincus Cbameleontem, ckius forman refert, mihi in mentem rewocauerit, ueniat $\tilde{f}_{j}$ O ipfe in medic um if um, non ab re fore duxi, eius tum hiftoriam, tum etiam facultates enarrare. C H A M A I I O N igitur(ut Ariftoteles memorise 


\section{And. Matthioli Comm.}

prodidit lib. II.cap, X 1 . de biftoria animalium) figura totius corporis lacertam plane reprefentat. Latera deopa fun ducta uentri iunguntur, ut pifcibus: E Pina modo piccium cminet. Roftrum fimize porcaria fimillimum : cauda prelonga in tenue de finens, o longis implicatd in fe orbibus. Elatior à terra eft, qudin lacerta. Pedes finguli bipar= tito fecantur, partesq́; talem inter fe habent fitum, qualem pollex ad manus, reliquam partem obiestain. Sed ipfe $e=$ tiam relique partes paulótenus in digitos quofdam finduntur, aduncis unguiculis. Corpus aperum totum, ut croco= dilo. Mutat fuun colorem inflatus. Omnium ouiperorum tenuißimus eft : quippe qui omnium maximé inopia fangui= nis rigeat. Caufa ad mores anima eius referenda eft : pre nimio nanq; metu multiformis efficitur. Motus ei piger ad= modum, ut teftudinis. palle cit cumm moritur, de functusó; colorem eundem feruat. Subit cauernas, e latitat more la=

Chamæleötis certarum. Caput eius, O guttur fi quernis accendatur lignis, imbrium, 0 tonitruum concurfus facere Democri= uires. $\quad$ tus narrat. Item iecur in tegulis uftum. Dextro oculo, fi uiuenti eruatur, albugines oculorum cum lacte caprino tol= li. Lingua adalligata, pericula puerperij adimi. Linguam, , fiumenti excmptafit, ad iudiciorum euentus pollere di= cunt. Item dextram maxillam ad formidines, pauoresqु; : corpore uero illito detrabi pilos : E felle glaucomata, o

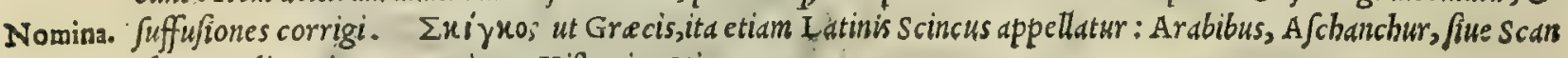
chur: Italis, stinco, er Scinco: Hipanis, stinco.

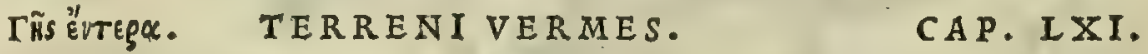

T E R R E I vermes impofiti, præcifos neruos glutinant: tertianas difcutiunt. Decocti cum anferino adipe, infufi, affectis auribus medentur : cum oleo autem decofti, fi in contrariam aurem inftillentur, dentium doloribus præftant auxilium. Triti in potu ex paffo urinam ciunt.

Terrenorum uermiü,\&eorũ olei uires.

T E R R E N I uermes etiam in medicum ufum ueniunt .quädoquidem oleo incoquntur ad articulorum,neruo: rumí; cruciatus. Veruntamen aberrant plerunq; myropole in olei conficiendiratione. Imponunt enim uermiculos in aneu cacabum, et affufo inde oleo igni feruefaciunt: quo fit, ut paruo momento ij non modo inaffentur; fed penitus co $=$ burantur, nullo in oleo bumore relicto. Fit autem rectius, cum uafe uitreo excipiuntur, o diutius calore balnei maces rantur, oleo innatantes: nang; boc modo corum fuccus elicitur, cöburiq́; nequeunt. Preftat hoc oleum ita paratum, prefertim fi uermes rofaceo macerentur, ad podagricorum dolores, a calidis defluxionibus prouenicntes, inunitis prius locis dolentibus oleo, ac mox fuperpofit is uermibus in eo elixis, tufis, admiftis is; cum a quali cerati pondere, quod triapbarmacum upcant, ex̀ argéti 1 puma, oleo, et aceto conflatum. Quibus etiam commendauit Plinius lib. X. X X.cap. $\mathbf{x}$. ipforum uermium cinerem cum melle triduo emplaftrimore impofitum. Quin er ipfos uermes in oleo ueteri eli= 3

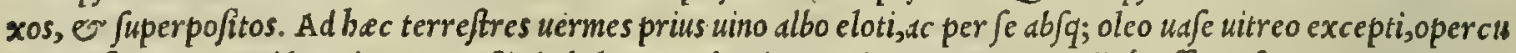
lato uafis ore, ne quid expirarare poßit, in balneum calentis aqua immerguntur, tandiug $_{\text {; }}$ efferue fcere permittuntur, donec in liquorem oleo fimilem uertantur. Praferunt quidam boc, quod maximé praftet neruorum, $\mathcal{O}$ inteftinorum. unlneribus glutinandis. Quod longé efficacius efficit, fi factitio bal famo, de quo libro primo diximus, fuerit admiftü: aut oleo, quod uitreis organis é larigna, fiue abiegna lacryma elicitur. Nanq; bis additis uniuer $\int a$ corporis recentia uulnera breui tempore glutinat, ijs exceptis, que capiti inferuntur. Dantur utiliter. terreni uermiculi igne cremati, et in puluerem contritifelle $\int u f f u f i s$, ex marrubij, uel abfintbij decocto : addunturq;; in electudrijs ad idem paratis, ut $\mathrm{G} a=$ lenus docuit libro de theriacd ad Pifonem. Triti, ac rofaceo fubacti (ut idem author eft) podagricorum inflammatio=

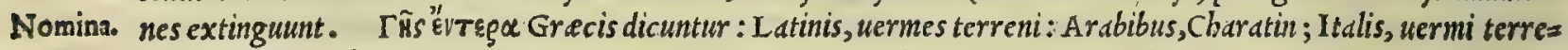
ftri, $\mathbb{O}$ Lombrichi: Germanis, Regen uurm: Hipanis, Lumbrizes de tierra: Gallis, Vers de terre.

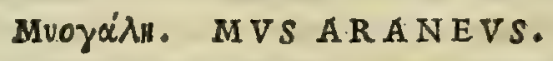

CAP. LXII.

M v s araneus diffectus, \& impofitus, fui morfus ueneficia luit.

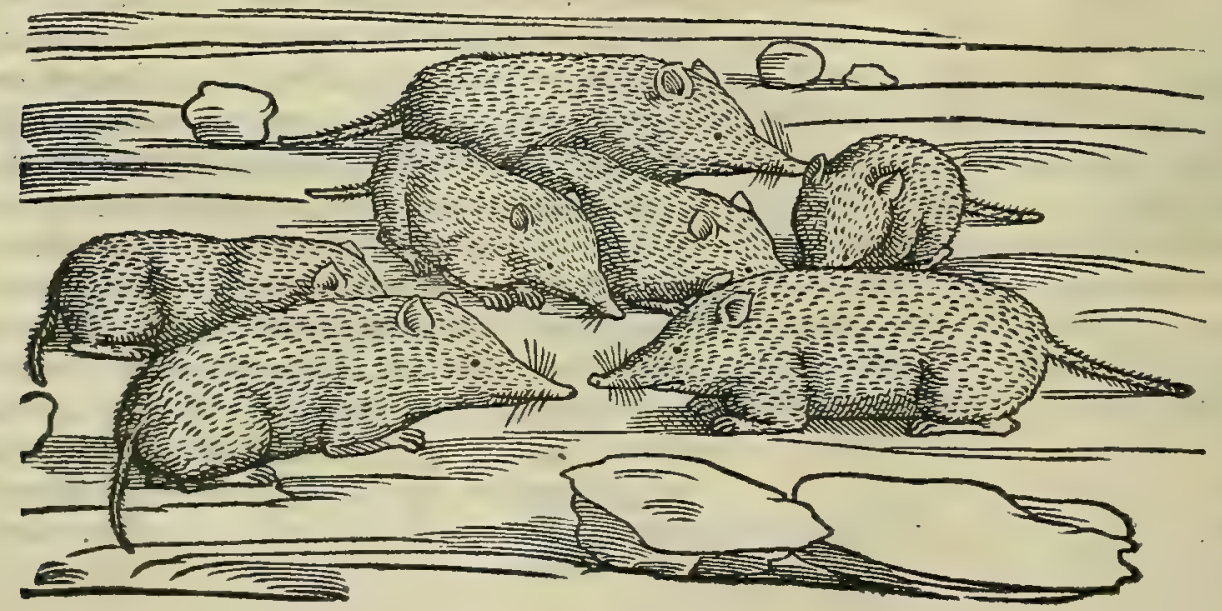




\section{In Lib. fecundum Diofcoridis.}

A R A N E S mus (ut Aëtiusinquit) colore quidem muflcle fimilis $\mathrm{c} f$, mantutudine autem muri. Os ueró fublongun habet, or cxiguan caldan. Dentes ci tcnucs, dupliciordine nati, in utraque maxilla: quo fit, ut qua= tuor dentium ordin's habcat. Quibus utiq; notis abunde reffondent ij, à quibus picturam, quam bic damus, mutuati

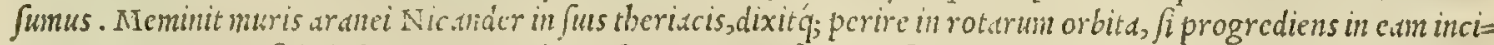
derit. Quod cancu fubulofwn, pocticumí;; ccnfemus: tancti non defint, qui terra è plauftrorum rotis excufda, $b u=$ iufce fuccurrant morfibus. Scribit Plinius lib. V I I I. cap. I v I I . mures ar ancos ultra A pciminum nö haberi, cün

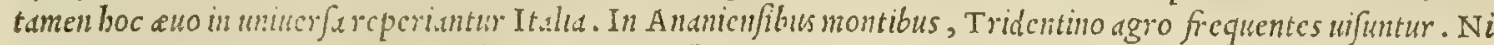

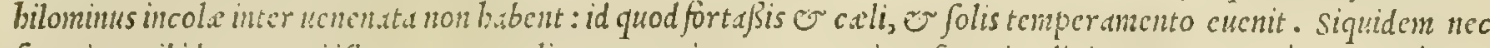

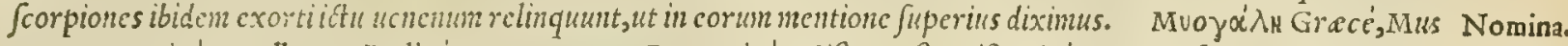

20 araneus Latinc appcllatur : Italicé, Topo ragno: Germanice, Ziß mauß: Hifpanice, Murganbo.

$$
\text { MŨss. } \quad M V R \text { E }
$$

CAP. LXIII.

M v $\mathrm{ES}$, qui in domibus oberrant, concifos fcorpionum plagis utilifsimè imponi, in confeffo eft. Si inaflatos infantes ederint, oris faliuam exiccari promittunt.

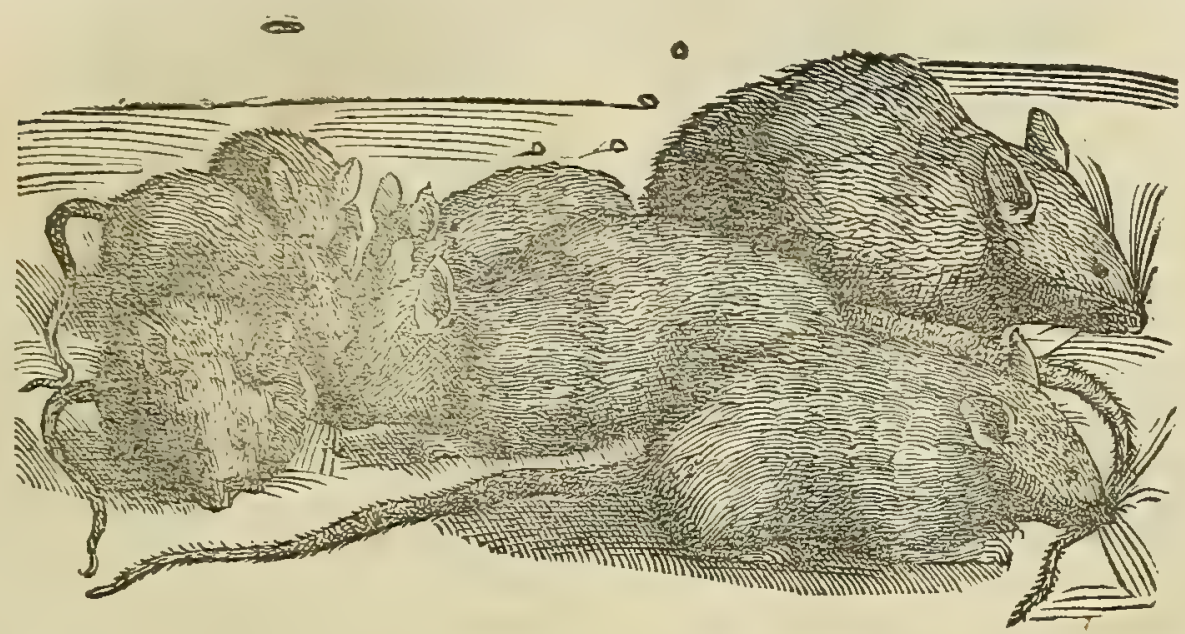

MV R E S diuer forum funt generum: fiquiden domeftici, fylueftres, ac montanireperiuntur : funt etiamnum aquatiles marini. Verim primimn de ijs differentes, qui noftris in domibus oberrant, quiq́; ctian in agris in magnam fegctum pernicięm mor dittur, Ariftotelis uerba referă, qui lib. v I. de biftoria animalium, cap.ultimo fic babet. Mu= rium generatio mirablis preter cxtera animalia,maioren in modum eft, tum numcro, tun celeritate. I an enim foe= mina pregnante in use miliario aliquando occupata, paulo póft referato uafe, mufculi numero uiginti er centum reperti funt. Iirum etiam percipimus ortum redundantis agreftis murium generis. Locis enim compluribus agri,

40 tam inaudito modo oriri folent, ut parun ex uniuer fo frumentirelinquatur : tam cito abfumitur, ut nonnulli me= diocres agricols, cum pridie metendum fatuerint, poftridie mane cum me foribus accedentes ad fegetem, abfum= ptam inueniant totam. Interitus autem minimé euenit ratione:paucis enim diebus omnino abolentur: quan= quan fuperiore tempore bomines uincere, uel fufficndo, uel fues, ut latibula effoderent, admittendo, non pof= fent. Quinetiam uulpes cosuendntur, $\mathfrak{O}$ cati fyluefres in primis: fed tamen fuperare copiam, $\sigma$ celerita $=$ tem prouentus nequeunt. Nec aliud quicquam omnium uincit, nifi imbres: ijs enim quàm primum intereunt. Terra Perfice parte quadam mure fomina refiffa, foctus fominini pregnantes comperiuntur. sunt qui uebe= menter confirment, Mures, fi falem lambant, impleri fine coitu. Aegyptijs muribus predurus, feréut erindceis, piluseft. Habentur in murimn genere G G I I R S. Idcirco (ut Plinius auctor eft libro XXXX V . cap. Glirium conprimo) apud Romanos cenforia extabant leges, Glires in canis apponi uetantes. Verum boc auo ganeonibus fideratio.

so maxime expctuntur in cibis, non modicam palato iniuriam fieri putantes, fi tam pingui prutuetur alimento. Sed ij mininé perpendunt, uel poitus negligunt, quòd glires pinguedinis exuberantid uentriculi appetentiam deftru= ant, lentum ac frigidum gignent fuccum, concoctǘ; contumaces exiftant. Notatum non congregari glires, nif populares eiufdem $\int y l u x$, or fi milcedutur alienigene, amne, uel monte difcreti, interire dimicando. Genitores fuos feffos fenecta alunt infigni pietate. Senium finitur byberna quiete. Conditi enim et bi cubant, rur fus aftate iune nefcunt. Montibus Goritien/L agro conterminis, er in Carniola, Carinthix, ac Stirie alpinis fyluis maxima eft borü quandoq; fotura. Quo fit, ut numerofi à uenatoribus capiantur, prefertin cum fagina glanda abundant fylue. Exeunt uenatum nocte, $\mathcal{O}^{\sim}$ arbores $\int u$ fjentes, in quibus ftabulantur, $\sqrt{i c}$ eos ftupefactos innumeros capiunt, adeó ut ijs repletis faccis domum plerunq; redeant, quos poftea excoriant, E impofitos pre nimia copia cadis fale, er muria afferuant, quemadmoduin pifces. Horum caro ijs utiliter cftur, qui canina laborant fame: nanq; exuberante pin= guedine obtunditur appetentia, or tollitur morbus. Difcoquitur Gliris caro detratta pelle, or inteftinis exemptis melle in fictili nouo, addito nardo ad tertias, ato; ita aferuatur, quód conftet deplorata auriü uitia co remedio fanari.

Murium con fideratio.

(1)


Agricole error.

Mlurium mötanorum cófideratio.
Georgius Agricold, uir alioqui doctißimus, ơ acerrimus rei metallica indagator, quod fortaffe theros glires non uiderit neque cognouerit, non fine magno errore putat in libello, quem fubterrane is animalibus dicauit, Sciuros $\dot{a}$ uillofa cauta, qua fe operiunt er inumbrant, ita uocatos, Glires elfe. Sed quod bac duo animalia inter fe maxime. differant, omnibus notius effe arbitror, quism ut pluribus cxponidebeat. Porró M O N T A I mures cunicus los magn tudine aquant, ac etiam nonnunquam fuperant, cruribus non ufqucadcó longis. Capite leporcm refe= runt : uerum tan brcuibus auribus funt, ut uix fupra pilos appareant. Pilo ucftiuntur uario tajsi modo, oblongo.

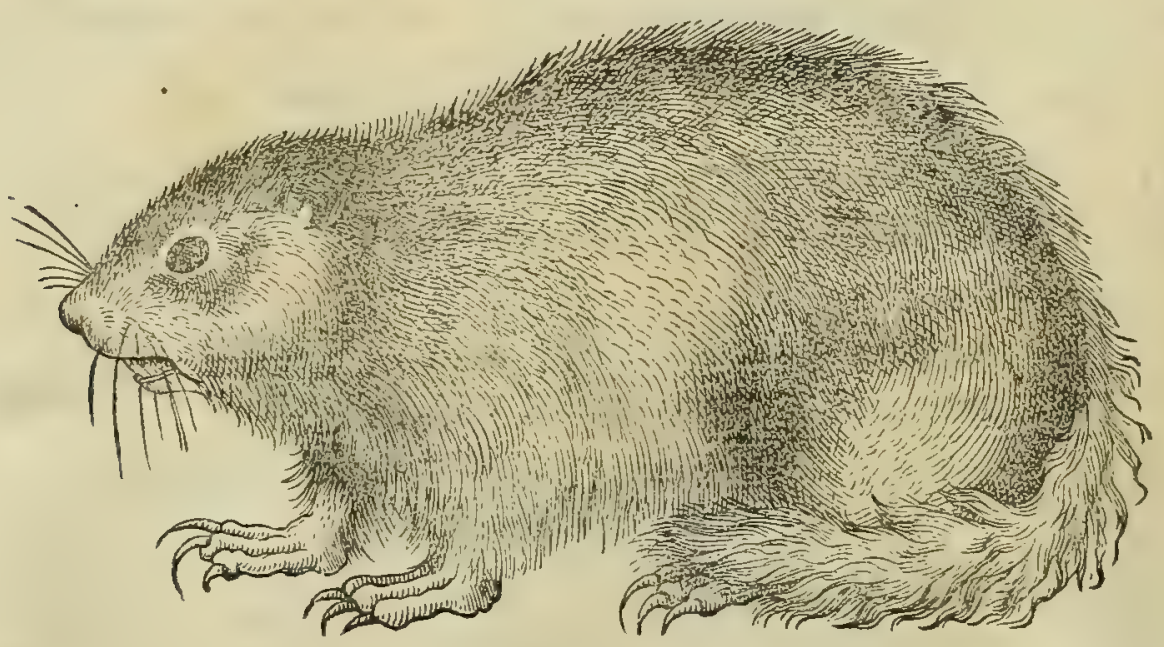

Breuem habent caudam, or pedes acutis unguibus armatos. Hyente admodum pingue fcunt, or obefifunt, ita ut ali= quando monfrosé intume fcant. Hi Ananicn/ibus, $\mathrm{Pbeb}$ eis ; $_{\text {; }}$ montibus, in Tridentino agro frequentes labentur, uo= canturq́; unlgo corrupto nocabulo Marmontane, quafi Mures montanos dixerint. Eriguntur fopius urfi modo, dn= terioribus pedibus ueluti nanibus, cibum ori miniftrantes. Dentes anteriores quatuor babent leporis inftar, fed lon= giores, atque acutiores, quibus feuißsime mordent. Sed mirum eft (ego enim quipericulum feci, id certó teftari 30 polfum ) quod fi acut is forcipibus fecentur, una tantim nocte renafcuntur. Domi retenti fi iunenes fint, exuta qua = dántenus feritate mite fcunt, fed utenfilibus damnum inferunt: quippc qui omnia, quibus obuiant, erodant, er deftruăt. Hyeme delite $\int c u n t$, fono ac paleis, in aceruwn congefis plerung; fe condentes. Dormiunt integris menfibus, quem= admodum o glires. In montibus uiuunt. Stramenta in cauernas comportant, quibus à frigore fe tue antur. Exter= refacti acutifimé uocifirantur, ac fibilant, o ad tumulos confugiunt. Horum carnes fylueftri, or graui quodam odore adeó pirant, ut quibufdam naufeam moneant. Quo fit, ut fale, er muria afferuati tum odoris grauitatem, tum etian exuperantem bumiditatem ob pinguedinis copiam exuant: cum tamen tam recentes, quam fale conditi concostu admodum contumaces exiftant, uentriculo latorem inferant, corpusq́; uniuer fum excalfaciant. Horum pin

Murium alis guedo medicıs expetitur, quód contractos molliat er reftituat neruos. Sunt ueró er alia quoque murium generd, genera. nempe Ponticum, I aßicum, Noricum, Pannonicum, Indicum, à regionibus prouincijsó, cognominata. Ponticus 40 pilo eft niucicandoris, fed Juperiore caude parte faturaté nigricat: ed enim digiti longitudinem non excedit. cor= poris magnitudo illi ut fciuro . infectatur aues er mures. Hunc fané id effe cenfemus, quod Armellinum uocamus. Laßicus pilis ueftitur in cinereo candidis, uentre tamen albicante : eft Pontico paulo maior. bunc Varium appella= mus. Noricus corporis mole domefticam muftelam à quat, pilis leporinis fré fimilibus. breui confat cauda. caret auribus, non tamen for aminibus, que babet auriun inftar. Pannonicus, cui color fubuiridis, muftele peciem re= fert, uerùm magnitudine domefticos mures non fuperat. Poftremó Indic us colorem babet feré murium mötanorum, albis tamen compluribus intercur fantibus pilis . capite eft $\mathcal{O}$ ore in longum porrectis, quin $\sigma$ auriculis breuiufcu= lis : cauda $a b \mathrm{t} p$ is clunibus cra/3iore in exilitatem ad imum prolixe defluente: cruribus dodrantalibus. Corpore fe= lem aquat, pedibus aliquantó breuioribus, ac pilo bipidiore, prafertim fi aduer 0 tractu mulceas. Atque bacte= nus de murium generibus. Ceterim murium ftercus (ut in libro de theriaca ad Pifonem legitur) aceto fubactum, so

Nomina. capillis defluentibus utiliter illinitur. Quinetiam per fe potum, uefica lapidem comminuit. Mṽes ita Gracis, La= tinis ueró Mures appellantur: Italis, Topi: Germants, Mauß: Hifpanis, Ratones: Gallis, sorizes.

$$
\Gamma \alpha \dot{\lambda} \alpha . \quad \text { I } A \text { C. }
$$$$
\text { C A P. L X I I I I. }
$$

L A C generatim omne boni fuccieft, corpus alit, aluum emollit: ftomachum, \& inteftina inflatione uexat. Vernum tamen dilutius aftıuo habetur, \& è uiridi pabulo aluum magis emollit. Probatur autem candidum, xqualicrafsitudine, quod ungui inftillatum cozitur. Aluum minus tentat caprinum: quoniam pecus hoc adtringentibus pabulis, robore, lentifico, \& oleaginis frondibus, \& terebintho magna exparte uefcitur: inde ftomacho accommodatissimum reddi folet. Ouillum autem dulce, craffum, \& præpingue : non autem ufqueadeò utile flomacho. Bubulum t3- 


\section{In Lib. fecundum Diofcoridis.}

men,afninum, \& cquinum, uentri magis idonea: fed ipfum turbant. Quibus in locis pecora, fcammoniam, ueratrum, clemaidem,aut mercurialem pafcuntur, lac omne uentrem, \& ftomachum fubuer tit: quale in Iuftinis montibus elle, à nobis proditum eft. Siquidem capræ, quibus candidum ueratrum pabulo fucic, primo foliorum partu euom unt : \& corum lac haultum naufeam creat, \& ftomachum in uomitiones efiundit. Ventrem adfringit lac omne decocerum, præcipueć: candentibus calculis marinis exuftum. Et in fumma, omnibus auxiliatur internis cxulcerationibus; profertim faucium, pulmonis, incrancorum, uelicæ, \& renum : foris uerò contra pruritum cutis, eruptioncs papularum, \& uitiatos corporıs fuccos, recens cum melle crudo, addito fale, datur exigua aqua dilutum .

Minus inflat quedcunque fomel feruefactum. Decoctum cum calculis marinis ad dimidias,ulccrofas

1. uentris thuxiones adiuuat. Lâc quodcunque ferum continet implicitum,quod ubi difcclsit à laEte, multò potentius ad purgationes redditur. Datur quibus fine acrimonia uolumus deicčionem moliri,ut melancholicis, comitislibus, lepris, elephantijs, ic erumpentibus toto corporc papulis . Ex omni lacte fit, quod fchifton, id eft fcifsile, appellant. Lac autcm ficili nouo feruct, ramoq́ue ficulneo recenti mouetur, infparfis, poftquàm bis, aut ter cfferbuerit, totidem aceti mulfi cyathis, quot funt he mina laftis: ita enim ferefens liquidum ab co diuiditur, quod in cafeum concreuit. Sed cùm feruet, ne fuperfundatur, conuenict fpongia ex frigida continuo fietilis labrum detergere, fextariumque argenteum frigidx aqux plenum demittere. Bibitur heminis per interualla lingulis, ufque ad quinas, ita ut intercedentibus fpatijs, potantes ambulent. Lac autem recens efficax eft contra rofiones, uftionesq́ue,ab exitialibus mcdicamentis.factas : vti à cantharidibus, aut falamandra, buprefte, autpi20 norum eruca, hyofcyamo, dorycnio,aconito, aut ephemero: præfertim bubulum ad id eximiè confert.gargarizatur autem exulceracis faucibus, tonlillisq́ue. Alininum peculiariter collutos dentes, gingiuasque ftabilit. Fluxiones alui, li vlcera fentiantur, tenefmosq́ue, ouillum, bubulum, aut caprinum, cum marinis lapillis decoctum, fiftit per fe autem, \& cum hordeacea ptifana, aut halicaceocremore infufum magnopere inteftinorum rofiones mitigat: exulceratæ uuluæ immittitur.

Humanum lac dulcifsimum eft, \& maximè alit: mammis autem exuctum, prodeft tabi, \& ftomachi rotionibus: contra haultum leporem marinum prafidio eft : oculis cruore ex ičtu fuffufis, cum. thuris polline inltillatur : podagricis utile eft, cum meconio, \& cerato illitum. Lac omne refpuendum fplenicis, hepaticis, comitialibus, vertiginofis, \& neruorum uitio laborantibus, febriculofis, $\&$. capite dolentibus : nifi fi quis interdum purgationis gratia, ut oftendimus, fchiftum præbeat. Pri-

30 miparæ canis lače perunctos narrant glabrefcere : potum contra uenena antidoti uicem obtinet: abortus mortuos expellit.

\section{Tugós. CASEVS.}

\section{CAP. IXV.}

C A E v s recens fine fale fumptus alit, ftomacho utilis eft, \& facilè in membra delegatur: carnem facit, aluum modicè emollic : alius tamen alio præftantior, pro natura lactis, à quo conficitur. Decoftus autem, \& expreffus, deinde inaffatus, aluum fiftit . illitus, oculorum inflammationibus, \& fugillatis prodêt. Qui ucrò recens falitus êt, minus alimenti prxbet . carnem aptè minuit, ftomacho aduerfatur, negotium uentri, interaneisq́ue exhibet. Vetuftiore fiftituraluus. Sero, quod a 40 cafeo manauit, quàm optimè canes aluntur. Quod hippacen uocant, cafeus eft equinus : ea uirus redolet, magnopere alit, bubuloq́ue proportione refpondet. Nec defunt, qui hippacen,equinum coagulum appellarint.

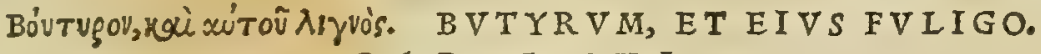 C A P. I X V I.}

E' I A C T E pinguifsimo probatum fit butyrum, quale ouillum eft. Fit \& ex caprino, agitato in uafis lacte, donec pingue feparetur. Butyrum natura oleofum eft, \& emolliens: unde largius epotum, uentrem refoluit: prodeft, ubioleum non adfuerit, contra uenena. Cum melle fi infricetur, dentitiones adiuuat : gingiuarum pruritus, \& oris ulcera infantibus emendat. Illitum foris ca30 paciora alimentorum facit corpora, $\&$ ab albidis puftulis per fumma fcatentibus afferit. Contra inflammationes, \& duritias uulux, quod nec uirus refipit, nec uetuftatem fentit butyrum efficax eft: dyfentericis, \& coli exulcerationibus infunditur. In mcdicamenta addi folet, qux pus mouent : utile prafertim cùm nerui, aut cerebri membranæ, ueficæ ceruix, uulnera acceperit. Id autem purgat, replet, carnem creat:ab afpide percufsis utilifsimè imponitur. Recens obfonijs additum olei uicem penfat, $\&$ adipis uice fungitur in bellarijs. Colligend ex eo fuliginis ratio hæc eft. Butyrum in lucernam nouam ingeftum accenditur, fictiliq́ue operculato, quod fupernè in fiphunculi fpeciem definat, \& infima parte cuniculos clibani modo habeat, crematur, \& fubinde aliud in abfumpti locum fufficitur, dum coaceruetur fuliginis modus, quem facere inftitueris : penna pòt deraditur ad ufus . Eius effectus eft in medicamentis oculorum, exiccare, $\&$ adfringere : fluxiones cohibet, $\& *^{\circ}$ ulcera celeriter ad cicatricem perducit. 


\section{And.Matthioli Comm.}

L A C.

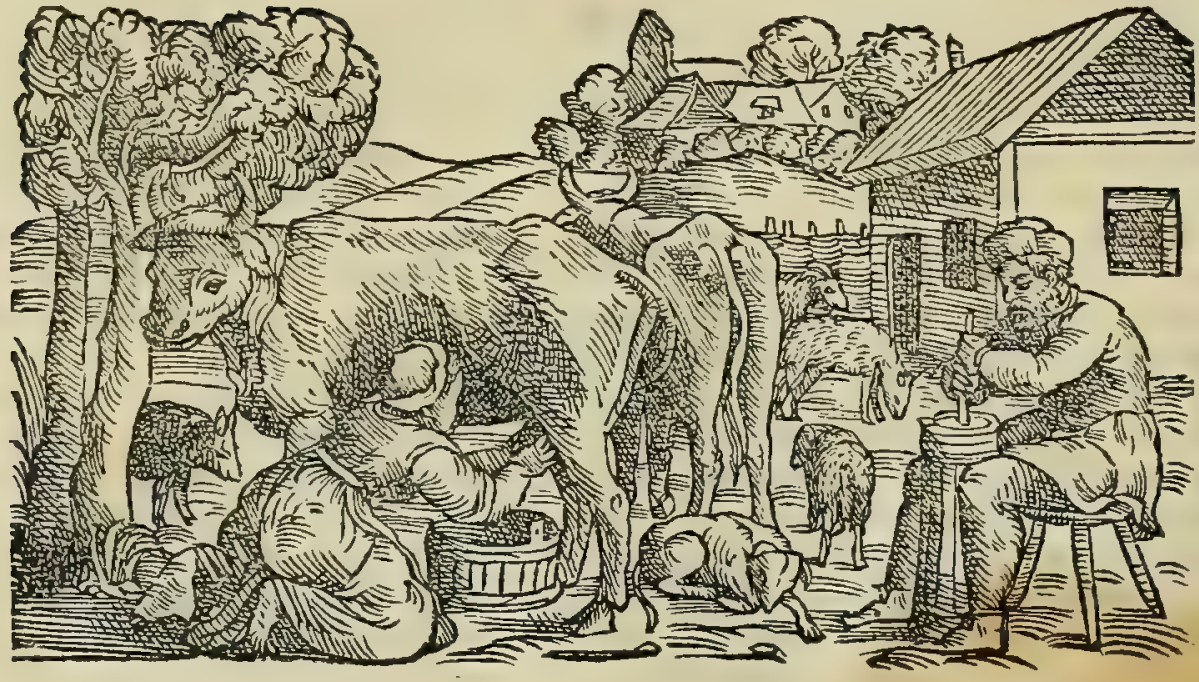

Laêis confi- I A C eft benigni alimenti fuperfluum in fceminarum mamillis ex bina fanguinis coctione progenitum. Conftat deratio.

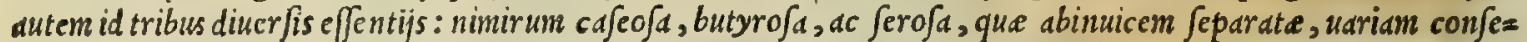
quuntur temperiem. Sed à lacte primùm rem exorfus, de co tantùm facultates differam, cuius hac tempeftate tã in ci bis, quàm in medicamentis eft ufus. Tale autem eft bumanum, caprinum, ouillum, bubulum, bubalinum, e a fininü. Et quanuis ueteres ufi fuerint tum camelino, tum etiam equino; cumn tamen in Italia,ac in alijs contermin is regionibus, quodd fciam, corum nullus fit ufus, bec tanquain fuperuacaned omnino reticenda cenfemus. Praccellit igitur buma= num, quod temperatum fit in omnibus fuis partibus. Hoc fequitur caprinum, et í aliquantó ficcius fit. His craßius eft ouillum, minusǵ;; ferofum. Bubulum deinde, dc bubalinum, prater id quód admodum fit craffum, catcris longé pinguius habetur. Quamobrem lib. x. Simplicium medicamentorum dicebat Galenus. Miror autem quo pacto Dio= fcorides ex ouillo, et caprino butyrum confici refr rat. Ego nang; ex bubulo fieri noui, ac proinde nuncupatŭ effe bu= 30 tyrum exiftimo. bac Galenus. Porrò afininum ficut lac omne fcri exuberantid fuperat, fic cateris pinguedine cedit.

Probatur in uniucr fum lac colore, odore, sapore, ac fubftantia. Ob id igitur prefcrtur quod colore perquàm albo Laxis proba- uifitur, pellucidum, ac clarum, non uiride, non lutcum, nö nigrü, nlec aliquo liuore fuffufum: odore fuani, fyncero, mi= nimé graui, aut uirofo: fapore quidé dulci, non amaro, acri,acido, aut falfo : fubftantia media inter craffum, ct tenue, ita ut eius gutta ungui infillata non defluat, fed in fua pherula permaneat. Quod autě tale fuerit, omniü fane pre= ftantißimum erit, o in cibis optimum. Contrà pe ßimum prabet alimentum, ucntriculum, ac totum corpus fubuertit, quod contrarias notas babuerit, quod'q, ex morbofis animalibus cmul fun fuerit, ucl etiámnum ab ijs, que reprobatas, uenenofasó; plant as depafcuntur. Quocirca memoria prodidit Galenus lib. I I r.de facult.alimentorwin, quód fi ca= pre, aut alterius cuiupiam animalis fcannzoniam, aut tthbymalum depafti,lac cibiloco quis fumpferit, omninó aluus

Lactis facul- illifluet. Optimum datur utiliter atate con/iftentibus, fenibus non naturaliter frigidis, biliofis, er mar afmo affe $=40$ tates. $\quad$ ctis, et deniq; ubi uentriculus excrementis uacct. Nocet lac potum contra frbriétibus, capitis dolore affectis, ophthal micis, re folutis, conuul is, fluxione tentatis, calculo oppreßis, pitutofis, adolefcentibus, ob, Iructis, er ijs prefertim, quil lacte, $\sigma$ edulijs lacte paratis, ccends et prandia claudunt : tantóq; maior inde fequitur noxa, quätó cra Bius lac af = fumptum cxtiterit. Eáq; propter citato loco inquit Galenus. Lac, quod feri plurimum habet, etiamfi f cmper co uta re,nullum prorfus periculum adfirt. Quod ucró buiufcemodi buniditatis exiguun babet, cafeo $\int a$ autcm cr a Situdinis Lactisbibendi multum, omnibus qui ipfo frequcntius utuntur, cft periculo fum. Caterum ut lac, quod bibendum eft, profit; beec di ratio. praterea adfint oportct, lac nimirum recenter fit mulfum : aliquid mellis, facchari, aut falis admiftum fit, ne in uentri= culo concre cat : tantum q́; ex eo fumatur, quantun concoqucre ualeat uentriculus. A cibis etiam omnibus, o uino, poftquim affumptum fuerit, abftinendum eft, quoufq; i uentriculo fecefferit, minime $\dot{q}_{\text {; }}$ cxercitio utend $u$ cft. At quo= niam lac détes inficit (etfi Diofcorides contrariü de afinino fcripferit) coftatim ebibito, uino, aut bydromelite os ab=

Iactis coagu- luere oportet. Quod autem immifto coagulo concreuit, quanquam uerno, ac aftiuo tempore, menfis frequentifimé lati uires. expetatur; tamen anguftiam parit, uentriculum opprimit, caput uaporibus replet, agré concoquitur, er crafjum gi= gnit fuccum. Qulamobrem fi quandoq; in cibum ueniat, primum omnium ingeratur : fiquidem ultimo loco fumptü (ut fieri adfolet) aut ftatin putrefcit, aut fubfidentem cibum fecun ad ima incoctum trabit. Lac omne, bumanum prafer. tim, cerebrü auget, corpus impinguat, ficcam et aperam tußin lenit, uenerem roborat, urine ardoribus fubuenit, dif foluta corpora reficit, probi multió; eft alimenti, bondm facit aluum, facile in fanguinem uertitur, carnem auget, pe: ctus dilatat, o catcris alimentis maius adfirt nutrimentum. Q Qüd autem lac primipare canis pcrunctos glabre $f c e$ re faciat, potum ucró emortuos educat fxetus, ut nonnullis proditume e $\beta e$ fcribit Diofcorides, reprobat Galcnus lib.x.

Butyri uires fimp.medic. Butyrum preterea (ut loco citato fcribit Galcnus) facultatis eft concoquentis, paulum habens etiam ex Galeno. digerendi potentia, in medijs nimirum corporibus fecundum duritiem, ac molliticn. Corporum ctenim plané duro. rum tumores preter naturam hoc nequit medicamen digerere: at que in mollibus funt phlegmone, eds o concoquit, 


\section{In Lib. fecundum Diofcoridis.}

o digerit perfacilé. Nam parotides, or bubones; oris phlegmonc, aliéq; partes contulures illo pror fus folo curantur, nimirum in pucris, ac mulieribus. Sed J denticntiun pucrorun gingiuis illitum, nibilo imbecillius melle gingiuas extenuat, per quas cxitus cft dentibus: $\mathrm{O}$ alios omnes in ore affectus phlegmonofos, pofteaquan fluxio reftiterit, digcrit paritcr $c$ concognit. Proind cataplafmatis inditur, qua extrinfccus imponuntur parotidibus, bypochondrijs, o bubonibus. Sid er in ucntrem deuoratum, o cx co diftribntum, magnificé confirt exputionibus expulinone, idq; im pleturiticis, coperipncumonicis affectibus, cumboc, quid cos ctiom concoquat. Atque fi fo= lum lingatur, magis quidsm concoquit, ucrum minus cducit: plus ueró ficum melle, or amaris anygdalis, fed mi= mus concoquit. Fit ex bubuli profertim latis pingucdine id, quod unlgó Roma, ac in uniuerfa ferc Italia Capo dilatte appclant, menfis plurmim cxpctitun, quod guftui, ac palato maximé armdeat. Verum cnimuero ob pin= 20 guedinis copium, pieterquim qued ucntriculum relaxat, er cuncto fupernatat cibo; nutrinentum cijcit, anted= quan concoguatur, wapores in caput mittit, o craflun generat fuccum. Cafeus autem fit cx crupiorc cuiuslibet latis fubftantia, admifto co.gulo, o cxpreffo ind fero. Prefertur in cibis recens, quód noxam ucntriculo non inferat, concoghuturq́; facilius, quìn qui diutius affcruatur. Nanque uetus, qui quód linguan parumper uellicet, quàn plurinis givior redditur, onmium pessimus eft : quippe qui cateris magis adurat, fitin cxcitet, en difficilius

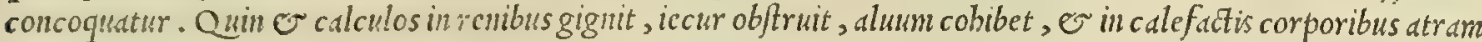
bilen gignit. Quo fit, ut plus damni ex cius fucci prauitate, or feruentiqualitate inferat, qudm quód bumores craf= fos attenusudo compenfare posit. Fugicndus igitur iftivemodicafeus eft, cum neque ad concoctionem, neque ad mo= 1cend.an: urin.sm, ncque ad cicndam denique alumm, quicquam boni conferat, quemadmodum neque ad fucci pro= buarcm. De hoc autem edifferens Galenus libro x. Fimplicium medicancntorum, fic inquit. Itaque cum mibi olim 20 crfeus allatus efet bubulus, quem ex odore acrem effe conijciebam, abieci, o iam à ainulis abfumptum putabam: ucrum illi talia feruare foliti, longo póft tempore ex promptuario profirentes, quidnan de illo fieri iubcrem, ro= g:unt. Cims igitur edendo non cffet propter acrimoniam, ludicrum nobis problema cxtitit, proponentibus, cui rei guis illum utiliter poffet accomnodare. Interca cum ad me artbriticus quipian in curru contectus effet, tophos, quos Greci कw ac probé in mortario fubigendo unitum, toplis imponere. Et fané artbriticus ab boc medicamine magnificé adiutus cft. nam ruptaffontc fuacute atfque incifione uidelicet, emergebant quotidic citradolorem tophonwn particu= 1c. Vbiautem totus, qui apud me erar cafcus, fuiffet abjumptus, talem fibi alium comparans arthriticus in pofte= rum feruanit; Oo poftea rurfun ujus eft imueter a to : atque ubi tunc quoque idem percepit commodum, fepius dein=

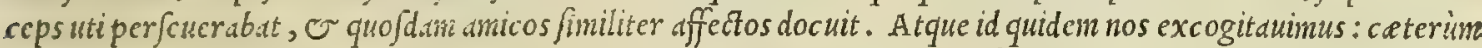

3o comprobauit, ac confirmanit experientia. bacienus Galenus. Ex quo palim fit, eiufmodicafeum effe omnino inci= bis reprobandum. Q Qui ucró necrecens, nce uetuftus fuert, cum er ipfe non fit expers lafionis; minore tamen conftat noxa. Preftat ceteris outhis. Terim ficuti Pergamenum cafeum Galenus in laudem fue patrie pre cate= ris commendauit libro I I I. de alinentorum facultatibus; ita nec mibi fané uitio uertendum exiftimauerim, fi He= trufcum ceteris Italicis praferan, eum prefertin, qui in noftro senenfi agro, ac etiámnum Florentino ex ouillo lacte conficitur, qui unlgo appellatur Cafcio marzolino, guftudulcis atque fuauis, quod lac, ex quo paratu",cod= gulo non fit concretum, fed cinar e floribus, qui paßstin uniuer fe feré Hetruria coaguli uicem preftant : quo fit; ut fene cens nunquam acris enadat. Cuinec alter ccdit, qui in noftro agro preftantißimus fit cx caprarum lacte, men=

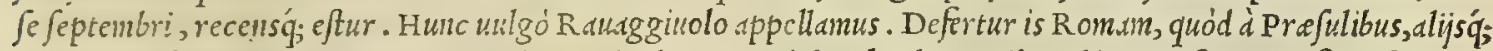
primatibus fummopere expetatur. Quippe qui odoratas redoleat berbas, quibus ubique noftrates referti funt col=

40 les, ijक; prefertim, qui non longédifant ab urbe noftra. Bubulus pretcred cafeus, etfi plus cèteris nutriat, pinguiorq́; exifat; ; eft tanen reliquis concolu difficilior. Caprinus ueró quanquam ex temperatiorilate fit con= fectus; inueteratus tamen reliquis cafeis eft deterior, cum ftatim exiccetur, or friabilis fiat. Bubalinus denique in globos illos iunceis uinculis conftrictus conformatur, qui noftris Mozze, Romanis autem Priuature 'uulgari fermone dicuntur. Is cafeus, quo paßim Hetrufci uefcuntur, ori quidem gratißimus eft, er dulcis, fed agré concoquitur, quód Jubftantian babeat admodum pinguem aclentan. His accedit, qus uulgó nobis Recotta dicitur. Fit hec ex ferofalactis parte ad ignem decocta. Recens ( $/$ i Auicenne, Rafi, or I fach credimus) mi= res. nus uentriculum uexat, quàm cafeus omnis recenter preffus. Confert calidis defluxionibus obnoxijs, fitim fe= $d a t$, fommun conciliat: ueruntamen obeft uentriculum frigidum babentibus, es neruorum morbis. Inueterata autern agré concoquitur, fitim excitat, parum nutrit, aluum cobibet, of flatus procreat. Reliquum eft serum,

so quod lactis aquofa eft jubftantix. Hoc (ut Galenus inquit lib. x. Fimplicium medic amentorum) extergendi poten= tiam poßidet, fumiturq́; fubducendiuentris gratia, ac per clyfteres inijcitur, extergens, or abluens fine morda= citate inteftinorum acrimoniam. Praterea fí quisulcera, qua fakie infeftantur acri, uice aqua fero colluat, opti= mé fane ficerit. Preterea quecunque medicamenta digerere folent ecchymomaţa, o atra, ed praftat fero, quàm aqua diluere. Sic etiam eo utimur ad fugillata, é bypoßpbagmats, peculiaribus ad bec medicamentis commifcen= tes. Pretulit Mefues ferum, quod ex nigrarun caprarum latte elicitur, deinde quod ex ouillo, fic inquiens. $\mathrm{A}=\mathrm{Ex}$ Mefue. qua lactis macer ationis materi.t eft, er per fe quidem innocuum medicamentum. Prefertur, que fit ex lacte nigra= rumeaprarum, in laudatis pafcuis uititantium, recenter'; fotarum. Excalfacit bee, atque ficcat ordine primo completo, o ufque ad fecundum. Quinetiam attenuat, abluit, abftergit, or nitrofa, qua referta eft facultate, al= uum abfque aliqua mordacitate leniter fubducit. Bilem tum flauam, tum atram ab cxuftis bumoribus genitam deij= cit: quo fit, ut mirificé conferat maniacis, or melancholicis. Praftat item ad uifcerum infarctus, er morbis inde prouenientibus opitulatur: nimirum aqua inter cute laborantibus, felle fuffufis, er lienofis. Datur utilitcr fibrien=

Recotix uires.

Cafei confide ratio, \& facul tates.

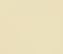




\section{And. Matthioli Comm.}

tibus ex bile, vr vifcerum, ac uaforum obftructionibus. Competit etiúmnum uitijs in cute àbile, er peruftis bumo=

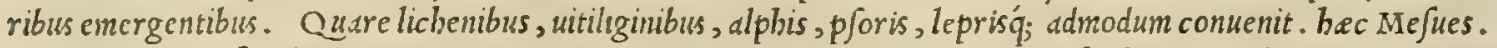

Lactis facul- Lactis autem facultates inemorie prodidit Galenus loco nupcr citato, ubl ita fcribit. Lac ubi aliam quampiam tates ex Gal. exiccantem facultatem babuerit adiuntam, optimum eft remediun dy fenterix, er omnium uentris acrium fluxio= num. Eam acciptt à lapidibus, qui pradecocto ipfi inijciuntur igniti. Porró cos effe oportet, quos uocant $x \alpha^{\prime} \times \lambda$ H= ras. Et lac coufque decoqui debet, dun pleraque ferofi in eo humoris abfumpta pars fuerit. At nos iniectis ferreis in ipfun cylindris candentibus eandem, aut etian meliorem facultatcm efficimns. Porró lac totum ad acres oculo= rumfluxiones tum per $\int e$, tun cum mollium collyriorum quopiam eft utile: preterea ad bypopia, e bypoßhag= mata. Quinetiam palpebris extrinfecus, ubi qui opbthalmia laborant, fomno fefe dabunt, impofitum fimul cum ro= faceo, e ouo, phlegmonss corum concoquet. Sed hoc efto lac mulieris recens ex mamilis expreffum. Infundimus ip fum $\mathbb{\sigma}$ utero ulcerato tum per $\int \mathcal{c} \int e$, tum ijs medic ament is commifcentes, quibus inifceri poteft, utique citra mor= fun curantibus, or ubi in fede ulcera mitigumus pre faniei acrimonia dolentia, aut phlegmonds, aut rugas perpe= tienda. Sic er ad ulcera pudendorum utinur, o omnia que leniri poftulant, fiue ob inflammationem, fiue mor fum fiue ob malignitatem. Edq; propter o cancrofis applicatur ulceribus, medicamentis anodynis comniniftum, qualia funt, que ex pompholyge conftat. Et quid attinet commemorare, quód ore contentum, collutum, gargariza= tumiq; uel maximé phlegmonas eius mitigat ?' Sed $\odot$ tonfillas, $\odot$ columellam, $\odot$ antiadas pblegmone affect ds admo= dum mitigat, o proinde anginam. Atg; ut femel dicam, medicamentum eft leniens, totam quidem fubft antiam habës mordacitatus expertem: Sed multo magis, ubi concoctione moderata poti]ima pars ferofi humoris abfumpita eft. Sic mubi uidentur etiam mediciad uenena, que crofione interimunt, lac darifuadere, uelut er lepus marinus interfi= cit, or cantharis. Sed $\sigma$ funt, qui exhibent ijs, qui aconitum, of thapfiam fumpferint. Sed bec ex ratione $f=20$

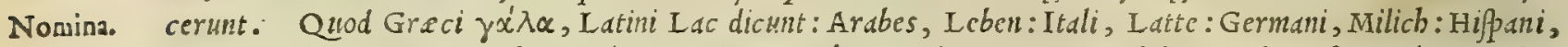
Leche: Galli, Laict. Cafeus ueró ita Latinis, Tugós Gracis uocatur: Arabibus, Lubon, feu Gieben: Italis,

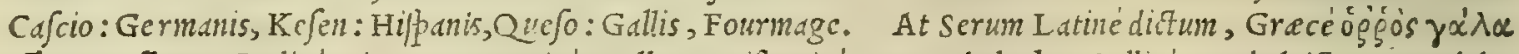

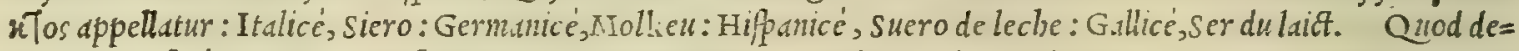
niy; Greci Gov'r vęar, Latini finiliter Eutyrum nominant: Arabcs, Zebd: Itali, Burro: Germani, Butter, $\sigma$ An= dren:Hipani, Matuteca: Galli, Beurre, o Buyre.

t Illud hoc loco non pretercundum duxi, quod in Greco codice manu fcripto non \$uasstixo'v, hoc eft inflatio=

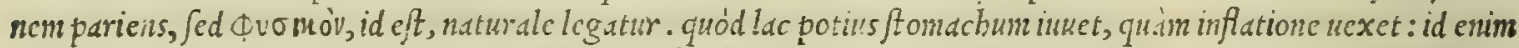
innuit ucrbum naturale. Hainc lectionem fecutus fuiffe uidetur serapio : quippe qui ex Diofcoride ita tranfcribat. Et lac confertftomacho. Quin es fucilis potuit effe librariorum lapfus ob uocum fimilitudinem.

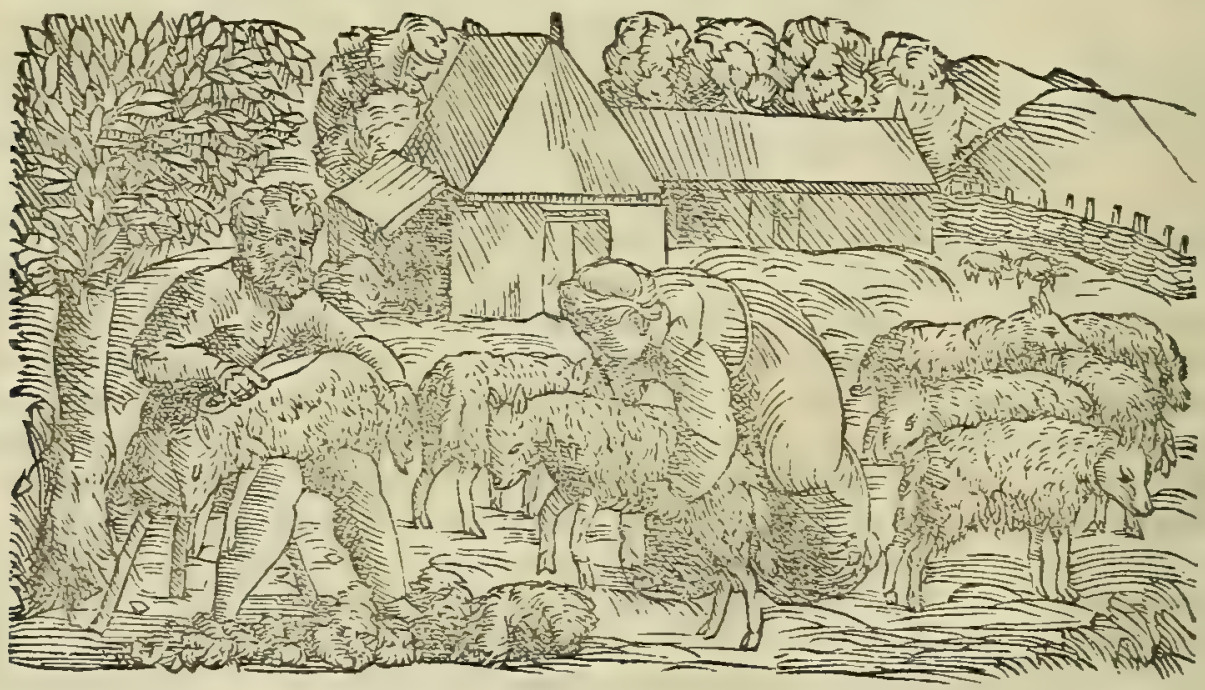

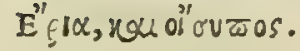

LANAE, ET OESYPVS.

CAP. LXVII.

S v C C I D A E lanæ molles è collo, feminibusqque laudatifsimæ habentur . Subueniunt inter initia vulneribus, percufsis, defquamatis, liuidis, olsibus fractis, aceto, oleo, aut vino imbutx: $\mathrm{fl}_{\mathrm{f}}$ quidem facilè fuccos combibunt, quibus immerguntur, \& ob pecudum fordem ( fic cnim âfypum uocant) emolliunt.capitis, Atomachi, aliarumque partium doloribus, cum aceto, \& rofaceo efficaciter imponuntur. Crematarum lanarum cinis cruftas obducit, excrefcentias in carne cohibet, \& ulcera ad cicatricem perducit. Mundx autem, \& carptæ, in fietili crudo, cæterorum more, uruntur. Nec fecus finibriati marinarum purpurarum flocculi cremari folent. Aliqui cum fordibus lanas carpunt, \& melle irrigant, codemçue modo urunt. Alij in fietili oris patuli, uerucula inter fe diftantia componunt, \& concerptas carminatasq́uelanas, oleo ita fuffułas, ut ne ftillare quidem polsint, affulis tedæ fubicetis, \& eifdem, lanisque permutatim interftratis, leuiter fuccendunt, \& uftas tollunt. Quòd li è teda pix, pinguitudóue ulla proHuit, collecta reconditur. La- 


\section{In Lib. fecundum Diof coridis.}

uaturad oculorum medicamenta . cinerem in labellis, aqua addita, manibus confricant, \& confiderepatiuntur : idq́uc fxpius, mutantes aquam, donec linguam adifringat, nec mordeat. Oefypum uocant Græci, fuccidarum lanarum pinguitudinem: cuius parandi ratio hæc cft. Succidx molles, radicula non curatæ, calida aqua lauantur, \& quibufcunque fordibus exprefsis, \& in labellum oris ampli coniectis, aqua infunditur, magnoq́ue impetu ligula, uti refpumct, agitatur, aut lignea rude ualidiufculè conturbatur, quo largıus fordida fpuma collıgi pofsit, deinde marina refpergitur: $8 c$ confidente pingui, quod fupernatabat, collectoq́ue in altero fictili uafe, denuo aqua in labcllum fufa agitatur : fpuma iterum mari perfunditur, \& demum cximitur . hoc tantifper ficri folet, dum confumpta pinguitudine, nihil. prorfus fpumæ extet. Collectum œfy pum manibus emollitur, \& fi

- 0 qua infedir fpurcicia, confeftim demitur: exclufaque fenfim omni aqua, recentiq́ue affufa, manibus mifceatur, donec admotum lingux œfypum adiftringat leuiter, nec mordeat, atque pingue, candidumq́ue fpectetur : tum in fictili uafe conditur o uerùm omnia feruido fole fiant. Nonnulli excolatum pingue frigida aqua eluunt, \& manibus, non fecus atque ceratum mulietes, confricant : ita enim candidius redditur. Alij elotis lanis, \& fordibus quibufcunque exemptis, ac lento igni in xneo uafe exaqua decoctis, pingue, quod fupernatat, collectum aqua, ut diximus, lauant: colatumq́ue in fitilem patellam, qux calidam aquam contineat, linteo operiunt, atque foli mandant, donec candidum fiat, \& fatis craffum. Alij bidui fpatio aquam effundunt, nouamq́ue adijciunt. Melius cft lieue, radicula non curatum, quod fuccidarum virus oleat, \& fi manu in concha fricetur cum aqua frigida, albefcat, nihil in fe duri, aut concreti habens: ueluti quod cerato, aut adipe adul-

so teratur. Oefypum excalfacit, explet ulcera, \& emollit; præfertim fedis, ac uulua, cum meliloto, \& butyro. In uellere appofitum monfes, \& partus euocat: ulcera non aurium modò fanat, fed \& genitalium cum anferino adipe : contra erofos angulos oculorum, fcabiofosq́ue, genas quæ occalluerunt, \& ciliorum defluuia, eficax cf. In tefta noua torretur, donec redactum in cinerem pinguitudinem amittat. Ex eo etiam fuligo colligitur, uti demonftrauimus : qux in oculorum medicamenta commodè addi folet.

C v's Lane fuccide, or edrum fordida pinguitudo, quam Graciocfypum appetlant, er.officinarum unlgus Ifopum bumidam uocat, plenifimé à Diofcoride defcripta fint, nibil nobis bic relictum eft, quod declarandum, uel

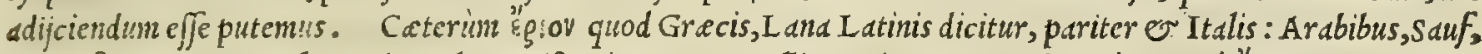

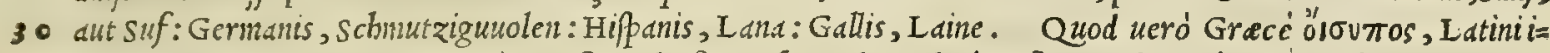
tem Ocfypus nominatur : Arabice', senferatab, fiue Iufaratab: Italice', E/ipo: Hipanicé, Ifopilho bumido; Gallic ci, Grefe de la laine forge.

\section{PiTÜ. COAGVLVM.}

CAP. LXVIII。

LE P O I $s$ coagulum tribus obolis ex uino, uenenatorum morfibus, cœliacis, dy fentericis, \& fominis fuxione uuluæ laborantibus, ac reicctionibus à pectore, auxiliatur. fanguinem in grumos concretum difcutit. Poft menftruas purgationes appofitum uulua cum butyro, spræftat mulieribus, ut concipiant: potum uerò partus enecat, \& à puerperio, pariendi fpem adimit. Equi coa40 gulum, quam hippacen aliqui uocant, priuatim cœeliacis, dy fentericisq́ue conuenit. Hœdi,agni, hinnuli, caprex laticornis, \& dorci, apri, cerui, uituli, bubaliq́ue coagula, fimiles naturas fortiuntur: contra aconiti potum in uino, \& concretum lac in aceto conuenienter affumuntur. Hinnuli priuatim triduo à purgationibus admotum, partus fpem intercipit. Vituli marini, caftorei uires repræfentat: comitialibus, ftrangulatis uuluis, potu conferre exiftimatur. Sed fi fituituli màrini, hoc experimentum eft : aqua infpergitur, qua paulifper cùm alterius animantis, tum præcipuè agni coagulum, maduerit: nam fi erit fyncerum, ftatim liquefcit in aquam: fin minus, confimile permanet. Excipitur autem catulis, qui nondum natare poffunt. In fumma, coagulum omne difsipata cogit, es coacta diffoluit.

A N I M A I I V M coagulum (ut Ariftoteles memorie prodidit lib. I I. cap. $\mathrm{X} \times \mathrm{X}$. de biftoria animalium) $l_{d=}$ Atis fubft antia eft: quippe quod in eorum uentriculo, que adbuc lactent, contineatur. Eft ergo codgulum lac ignem habens intra $\int e \int_{e}$, quod cum aninalis tepore concoqueretur, cafeum traxerit. Habent codgulum omnia ruminan= tia, e inter dentata utrinque lepus. Quó uetuftius codgulum eft, eó preftantius : tale enim profluuio alui mederi precipué poteft: atque etiam quod leporis est. Sed laudatißimum binnuli. bac Ariftoteles. Quód autem lepori= num coagulkm fanguinem reijcientibus conueniat, ut Diofcorides fcribit, minime quidem probare uidetur Galenus lib. $\mathrm{x}$. fimp.medicamentorum ubific inquit. Codgulum omne acris, ac digerentis potentix eft, ac nimirum etiam exiccatorie : nam necefJario id fuperiora comitatur. Ac leporis quidem coagulum comitidlem morbum, fi cum aceto ebibatur, preterea proflunium mulicbre fandre proditum eft : fed $\sigma$ lac in uentre coagulatum diffoluere: quod cer té e nos experti fumus, non folum in leporino; fed etiam in aliorun animalium codgulo. Attamen leporinü ontrium eft praftantifimum. Sed e fanguinem in uentre concretum fimili irodo epotum diffoluit, ac efficacius fortaffe cete= ris leporinuin : uerum non folum, quod quibufdam fcriptum legitur, fec' $e^{\prime}$ boc commune eft omni coagulo. Qui=

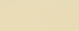


dam autem fanguinis ex thordce reiectiones leporinum coagulum cpotum fupprimere prodiderunt. caterim nec aliu quenquam eo ufum noui, nec ipfe fum aufus acri uti remedio ad affectum adfrictione m pofcentem. Porró coagulum equinum ad dy fentericos, et caliacos accommodari fcripferunt nonnulli. At phoc a coagulum eximié aptum effe qui= dam predicant, tanquam uires obtineat caftorij. Verim quacunq; proditum eft, quodque coagulum fecundum effen= tix totius praftare proprietatem, non eft nunc tempus exponere. Eius nomen Gracum $\pi ı$ it $v$ : Latinum, Cod= Nomına. gulum: Arabicum, Anfea, Anfhac, Jeu Anfhad: Italicum, Caglio: Germanicum, Iypp, Kymnlypp, $\mathcal{O}$ Kaeß lypp: Hipanicum, Coalho: Gallicum, Preßeure.

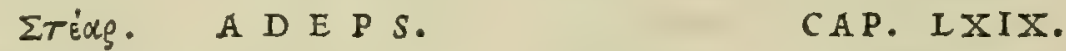

A D E P s anferinus, aut gallinaccus recens, \& fine falecondîtus, ad vuluæuitia proficit. Sale inueteratus, \& qui temporis fpatio acrimoniam concepit, uuluæ inimscus cft. Recens exemptis membranis in fietilem ollam demiffus, qua altero tantoperecapacior fit, quantus fit modus adipis, quem curare inftitueris, obftructo diligenter uafe, flagrantifsimo foli exponitur: eliqucfcens inde humor in fictile alterum excolatur, donec adeps omnis abfumatur: mox loco uehementer frigido reconditur, \& ad ufus digeritur. Alij ficfle fulciunt fuper aquam calidam, aut tenuem \& elanguidam prunam, qua folis uicem penfet. Eft $\&$ alia curandi ratio. Exemptis membranis reritur, conięusque in ollam eliquatur, adiecto minuti falis momento : mox lineo colo transfufus reponitur. Vtiliter in medicamenta additur, qux lafsitudines, \& fatigationes leuant. Suillus adeps, $\&$ urfinus hoc curantur modo. Recens, præpinguis, renibus potifsimùm detractus, 20 in largiore aqua cælefti, \& quàm frigidifsima, exemptisq́ue tunicis, diligentifsimè manibus confricatur, \& exprimendo ferme ficcatur, fubindeque noua aqua abluitur : cæterùm fictili capacitatis dupla inditus, in aquam demergitur, \& fubditis leuibus prunis fpatha mouetur: eliquatusque, colo transfunditur in aquam. Vbi verò refrixit, \& guttatim aquam omnem exclufit, in prxiotum fictile demittitur, \& infula aqua leniter eliquari debet, \& manu deprimi, quò facilius fxculentum uirus pêfum eat : poftea in pilam fpongia madefaftam transfunditur. ubi coire cœpit, refidens in imo fordes eximitur. Tertiò citra aquam eliquatur, repurgatusćue, fictili bene operculato, perquàm frigidjs locis reponitur. Hircinum feuum, ouillum, ceruinumq́ue ita curato. Elotum ex his quodcunque tunicis ( $u t$ in fuilli mentione diftum eft) exemptis, pilæ emolliendum tradico, ac manibus fricato, affufa paulatim aqua, donec ne amplius quidem cruentum uirus ex- 30 cernatur, aut pingue aliquod innatet, fed nitida fpectetur. Deinde in ollam fictilem conijcito, $\mathbb{3}$ adiceta aqua, ut fuperemineat, leui pruna liquefacito, \& moueto, atque in aquam colato: cùmq́ue refrixerit, iterum in loto fictili eliquato, \& quæantè diximus, facito. Tertiò fine aqua liquefaEtum, in perfufam liquore pilam colato, refrigeratumque, ut in fuilli ratione diximus, recondito.

Bubulum autem feuum, renibus maximè detractum, exemptis membranis, aqua marina ex alto petita eluendum eft: mox in pila tundendum diligenter, affufa maris aqua. Cùm uerò diffolutum fuerit, in fictilem ollam conijciendum, \& marina aqua, quæ non minus dodrante fuperemineat, proluendum . decoquendum, donec omnis aboleatur odor, additis ad fingulas feui Atticas minas, quaternis Tyrrhenicæ ceræ drachmis : cxcolatumq́ue, detractis quæ peffum ierant fordibus, in nouo fictili reponendum, opertumq́ue foli interdiu credendum, ut ad candorem reducatur, \& odoris uirus euanefcat. Priuatim taurorum pingue fic curaridebet. Renibus cuulfum pingue profluente amnis aqua abluito, detractisq̨ue tunicis, fictili nouo, poftquàm exiguum falem infperferis, liquefacito: dein in nicentem aquam excolato: \& vbi concrefcere cœpit, manibus iterum confricando vehementer lauato, aqua fxpius infura, refußáque, donec quàm optimè elotum uideatur. Rurfus in olla cum pari modo uini odorati decoquito, \& cùm iterum efferbuerit, dempto ab igni uafe, ibidem finito pernoctare: poltridie fi grauiter adhuc oleat, noua olla repetıtum, uino odorato perfundatur . eadem qux prius, fiant, dum omne uirus euanefcat. Colliquatur \& fine fale, præfertim affectionum earum caufa, quibus fal aduerfari folet: fedita paratum non magnopere albefcit. Eodem modo pardorum, ac leonum pinguia curari oportet. Taurinum autem, \& uitulinum pingue, necnon ceruinum, atque etiam huius animalis medulla, odoramentis imbuitur, hac racione. Pingue, quod odoratum reddi debet, demptis, quo diximus modo, membranis, elotum, \& uino quàm odoratifsimo, nulla maris aqua diluto, feruefactum, pernoctare finitur:alterum id genus uinum eadem menfura infunditur, colliquatur, \& exquifitè colatur : nouemáuc cius heminis, iunci Arabıci feptem drachmx adijciuntur. Quòd fi ipfum odoris fragrantioris fieri uoles, quadraginta floris eiufdem drachmæ, cum paribus palmæ, calami, \& cafsiæ modis adduntur: \& xylobalfami, afpalathi fingulæ drachmæ: cinnamoini, cardamomi, \& nardi, fingula vncire omnia exactius tunduntur, $\&$ affufo vino odorato, in vafe operto, quod fupra carbones firmiter collocatum fit, ter efferuefcunt, \& femoto ab igni vafe inibi pernottant: poftridic vinum effunditur, aliudque generis eiufdem adijcitur. Ter fimili modo bene conferuefcat : deinde matutinis exempto adipe vinumeffundatur, \& abluto vafe, fi quid imo fublidens hxfit, detergatur . poftremò eliquatum pingue, \& excolatum, ad ufus reconditur. Hoc autem modo odoramentis imbuitur, quod antea curatum elt. Verùm 


\section{InLib. fecundum Diofcoridis.}

antè dicta prius infpiffari folent, quò facilius fibi odoramentorum uires adfcifcant. Itaque affumens quodcunque horum uoles, cum uino ferucfacito, impolitis unà myrti ramulis, ferpyllo, cypero, item afpalatho plenius tufo. Aliqui tamen ad hunc ufum, uno duntaxat horum contenti funt. Cùm autem ter efferbuit, exemptum leniter, \& linteo colatum, aromatis, vti expofitum eft, imbuitur.

Adipibus fpiffamenta fic fiunt ( quemcunque acceperis, oportet, ut recens tundatur .) Syncerus, \& fanguinis expers adeps, rcliquas habens notas, quas fxpc retulimus, in ollam nouam demirtitur, infufo vino albo, vetere, odorato, quod femipedis altitudinem fuperet: lento igni ferucfat, dum uernaculus odor aboleatur, planeq́ue uinum rcdoleat. At ubi depofjto uale refrixit, duæ adipis minæ in ollam mittuntur, \& duo uini eiufdem fextarij, \& feminis loti, cius inquam, cuius è ligno ludi20 cræ tibiæ factitantur, tuli minæ quatuor adijciuntur: lento igni fubinde mifcendo decoquuntur: cùmq́ue odoris uirus euanuerit, excolatusq́ue adeps refrixerit, una contufi afpalathi mina, cum amaracini floris minis quatuor, \& uetere unno fubigitur. Nocte una hæc odorem rapiunt, combibúntue: poftridie in fietilem ollam tricongialem ea omnia cum adipe iniecta, additis fextarijs tribus uini, unà feruefcunt, quoufque \& uim, \& odorem fpiffamentorum adeps ipfe contraxerit: qui eliquefcens colatur, \& reponitur. Quòd fi maiorem odoris fragrantiam efflagites, drachmas octo quàm pinguifsimæ myrrhæ uino maceratæ, quod multos in annos afferuatum eft, mifceto. Gallinaceus, anferinusque fic odoribus imbui folent. Cuiufuis eorum percurati fextarij duo fictili olJa excipiuntur: eryfifceptri, xylobalfami, palmæ elatæ, \& calani planè contufi, fingulorum fefcuncia admifcetur : uini Lesbij ueteris cyathus vnus adijcitur: ea ter efferuefcunt prunis, mox ua20 fe fublato ab igne, die, noctuq́ue refrigerantur: poftridieliquata per linteum craffum mundum in uas excolantur. ubi uerò adeps coierit, concha excipitur, fictiliq́úe nouo denfius operto perfrigidis locis reponitur. Hyberno tempore id inftituere oportet: æftate fiquidem pinguia non coguntur. Nec defunt, qui Tyrrhenicæ ceræ momentum adijiciant, quò facilius in unum corpus omnia coalefcant. Eadem ratione fuillus adeps, \& urfinus, cxteriq́ue id genus, odoramentis imbuuntur. Verùm fampfuchi odorem adeps ipfe reprefentabit hoc modo. Curati quàm optimè adipis, præfertim taurini, mina una, tempeftiuique fampfuchi exquifitè confracti fefquimina mifcentur, $\&$ infperfo largiore uino digeruntur in oftas, quæ in uafe cooperto nocte quiefcunt. Matutinis in fictili olla leuiufcuio igni, affufa aqua leuiter coquuntur: dumq́ue fuum adcps odorem exuerit, defrecatus, ac bene opcrtus, noßte tota permanet - poftcro die deterfa forde, qux peflum ierat, fam30 pruchi, ut dictum eft, contufi iterum fefquimina priori paftillo adjjcitur, eodem q́ue modo in offas cogitur : alijs qua diximus peractis, decoquitur, \& colatur, \& fiqua fundo hæfit fpurcitia, deraditur, \& frigido loco reconditur. Si quis tamen incuratum adipem anferinum, gallinaceum,aut uitulinum à putredine tueri uelit, ita faciundum eft . Quémuis adipem diligenter elotum, \& ficcatumi in umbra fuper cribrum, per lintea munda manibus uehementer exprimat, linoq́ue confutum umbrofo in loco fufpendat, \& polt multos dies noua charta inuolutum, frigido loco recoudat. Pinguia autem indito melle uindicantur à putredinis uitio. Vis omnium eft excalfacere, mollire, rarefacere. Taurinus adeps, bubulus, \& uitulinus aliquantum adftringunt . Earundem uirium compos leoninus: nam refiftere eum aiunt ijs, qui infidias moliuntur. Ceruino, elephantinoq́ue perunctos, ferpentes fugiunt. Adftringentior eft caprinus : qua ex caufa decoEtus cum polenta, rhoë, $40 \&$ cafeo dy fentericis datur, \& cum ptifanæ fucco infunditur. Ius decoeti ph thificis in forbitionibus prodeft, datur quoque uliliter ijs, qui cantharidum uenena hauferunt. Hircinus, ut qui ualidifsimè difcutiat, podagricis auxiliatur, cum fimo capr $x, \&$ croco impofitus . huic proportione refpondet ouillus. Suillus uerò contra uulux, \& fedis uitia idoneus eft: ambuftis igni medetur. E' fue uetuftifsimus quifque fale conditus excalfacit, $\&$ emollit : elotus uino pleuriticis prodeft : cinere,aut calce exceptus, inflammationibus, fiftulis, ac tumoribus fuccurrit. Afininum tradunt cicatrices corpori concolores reddere. Anferinus, gallinaceusque conueniunt muliebribus malis, \& ad labiorum rimas, ad mangonizandam faciem, \& contra aurium dolores. Vrfinum conftat raptos uitia alopeciæ capillos reftituere, pernionibus fubuenire. Vulpinus medetur aurium doloribus. Fluuiatilium pifcium pinguia perunetis oculis claritatem afferunt, fi in fole liquefcant, \& melli admifceantur .

so Viperæa adeps contra oculorum hebetudines, fuffufionesque efficax eft, addita cedria, melle Attico, \& pari oleo uetere: pilos alis euulfos perunctis radicibus recens, \& per fe illitus obliterat, atque renafinon patitur.

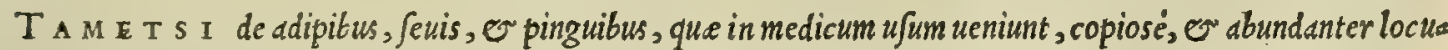
tus fit Diofcorides: utpote qui non corum modó facultates, ev uires tradiderit; fed etiam rationem docuerit, qua illa curentur, ßpiffa e odorata reddantur, ov à putredine uindicentur. tamen cum de corum natura, or faculta= te accuratius (meo quidem iudicio) copiofius etiam, ev particularius differuerit Gale nus, nec uanum, nec à noftro inftituto alienum duximus, bic ea omnia referre, quas abipfo memoris prodita funt libro $\mathrm{x} 1$. Jimplicium medicd= mentorum, ubi ita fcriptum reliquit. Pinguedo, $\sigma$ adeps $\mathbb{G}$ bec quoque communißima funt inter animalium partes. Nam omnia, qua bené nutriuntur, aut pinguedinem, aut adipem obtinent. Qu.e ueró macilenta funt, ma= uires ex GaL

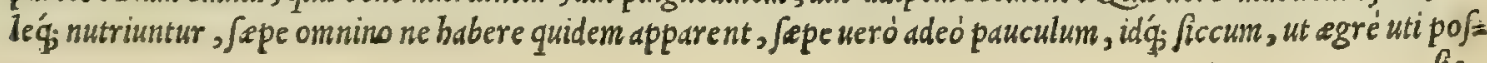


fis. Porró differt à pingucdine adeps craßitic: ac propterea aninantibus totam naturam terroftorem babentibus adeps proucnit, uclut burnidioribus pinguedo. Proinde pingucdo ccleriter ab igne lique cit, nec facilé, ubi liquata fue rit, rurfum concre fcit, cogituric. At adeps nec facilé funditur, lique fcituc, $\mathcal{O}$ fufus celerrimé coit, ac conglacia= tur, multó; apparct pinguedine durior. Sus enin bene nutritus, paftusue multan habet pinguedinem, ob naturalem tcinperamentibumiditatem. At boucs, or capre, of quecung; id genus cornigera, ob ficcitatem adipem plurimum generant. At $t$ if uoles, olcofam, or pinguem in animalibus fubftantiam omnem adipem appellato, ut plerig; medici. Sed o pingucdincm appellare totum boc genus tibilicet. Non tamenlicet tibi citra mendacium adipem caprinum bu= snidiorem cffe dicere, quàm fuum. Nam bic onnium ferme aliorum eft bumidißinus, ac proinde dctione fua tuicinam oleo uim poßidens, quanquam olco magis tum emolliat, tum concoquat : ac proinde cataplafmatis, quse ad phlegmo= nus accommodantur, commifcerifolet. Qu ueró mordicationes perpetiuntur aut in recto inteftino, aut in colo, ijs po tius caprinum adipcm, quaim fuillum inijcimus: non quód acrimonias plus obtundat (nam ex natura fua fuillus obtun= dit magis, ac proinde mifcetur medicanentis ulcera curantibus, cuiufmodi eft, quod uocant parygrum) fed quód ca=

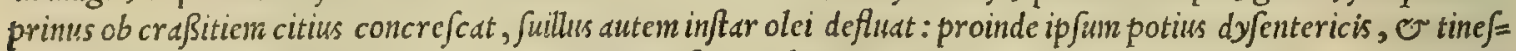
mofis inijcimus, quando morfum eorum mitigare confilium eft. Porró ob tenuitatem partium nonnulla acrimonias ma gis retundunt, ubi nimirum inalto mordicatorum corporum, quod moleftum eft, beferit. Nam quod craffarum eft partium, minus; magis autem quod fubtilium partium eft, tota corpora penetrat, o omnibus ipfum fanic bus mordi= cantibus permifcetur. Hac ratione adeps anferinus, qua in al to corporum mordicant, magis obtundit: fed $\sigma$ fuillo calldior eft. Horum tamen in medio eft gallinaceorum adcps, ac gallinarum. Porró calidior femper, ac ficcior eft mafculorum animalium, or borum ip forum exectorum minus tum calidus, tum ficcus. Quippe mas caftratus eiufdem Semper generis famine a Similatur. Hoc autem fermonis caput commune $\mathrm{eft}$, cuius mesniniffe oportet: Pro animaliu temperatura femper exiftere differentias eius, que in illis eft, pinguedinis, aut adipis, aut quocunque modo appellare libe bit totum boc genus corporis in animantibus oleofi, or pinguis. Igitur cum fus ommibus propé quadrupedibus ani= malibus in caliditate, ac ficcitate inferior fit ; proinde pinguedinem quoquc minus babet calidam, magis ó; humidam . Omnis igitur pinguedinis facultas eft bume fatoria, o excalfactoria bumanorum corporum. Huius enim meminiffe perpetuó oportet in principijs buius operis dicti. At differentia, qua funt cuiufq; fingulatim, in maioris, minorisq́; ra tione funt. Nam pinguedo fuis, ut ad nos quidem, largius bumectare poteft, fed non equé excalfacere, ut olcum: ue= rum pinguedinis fuum talis eft caliditus, qualis $\beta$ pectatur in nobis. Porró taurorum adeps fuillo multó calidior $c f t, o r$ ficcior. Rurfum id o bic memoria repetentibus nobis, marem fomina effe tum calidiorcm, tum ficciorem: marem autem caftratum asimilari fomine, uelut quicquid iuuenilis eft atatis. Et inter iunenilia fomina mare bumidior eft, or minus calida. Sic er adeps uitulinus, taurino minus tum calidus eft, tum ficcus: es bedorum, qudim caprarum: 30 fed $\sigma$ caprarum minus, qudm bircorum. Et rurfum taurorum minus, quàm leonum : nam horum adeps omnium pro= pé quadrupedum adipe potentius digerit. nam er ipforum calidi/simus eft, or maximé tenuium partium. Itaq; $/ \mathrm{i}$ ip= fum medicamentis ad ulcera, o phlegmonas conuenientibus commifceds, non modó nibil adiuturis; uerium etian le= feris, nimirum addita maiori, quam conueniat acrinonia. Inueteratis tamen tumoribus atque fcirrbi in morem indu=

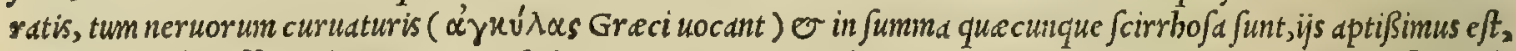

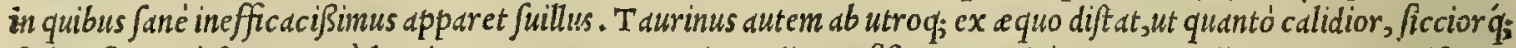
fuillo eft, tantó fuperetur à leonino. Itaque tanquam in medio confiftens, meritó utrique medic amentorum mifcetur generi, er ijs fcilicet, qua fcirrbo/is medentur, er ijs, qua phlegmonas concoquunt, cuiufinodi cft tetrapharmacum quod uocant, ex cera, refina, pice, es adipe conftans. Nam fiue in boc taurinum, fiue uitulinum, fiue bircinum, fiue caprinum, fiue fuillum indideris, femper purimouendo aptum, $\sim \sim$ concoctorium medicamen effeceris. Sed fuillus $f i 4^{\circ}$ addatur, in pueris, or foeminis, or ut breuter dicam, omnibus, quibus caro eft mollior, competit. Sin taurinum adie= ceris, fofforibus, or meforibus, or omnibus carnem duram babentibus, fiue ob natur alem temperiem, fiue ex ratio= $n e$, ac forma uite, conueniens effeceris. Caterum adeps omnis dum inueterafcit, fe ipfo or calidior, or tenuior effi= citur, ac proinde quoque mag is difcuforius. Verim id omnibus feré inueter a centibus accidit, qua quidem putre fce= ge non anticipent. Nam uinum, mel, acetum, frumentum, butyrum, lana fuccida, oleum omne, fiue lentifcinum, fiue cicinum, fiue raphaninum, fiue ipfum quod ex oliuis conficitur, uctuftate $\sigma$ calldiord, $\sigma$ tenuioris effentie efficiun= tur : ac proinde guftantibus apparent acriora, or ad induratos, egreq; folubiles affectus ommes adhibcntibus poten= tius digerentia. At ; $_{\text {ego }}$ ané guftantibns acriora uideri dixi. At quidam, quibus ftudium eft nominum fignificatus corrumpere, non acria, fed adftringentia uocant id genus omnia, adufque piper : tanquam interfit nibil, adftringens, an acre dixeris. Et/i denuo illos roges de galla, myrtis, mepilis, mali puniciputaminibus, que fidia uocant, rhöé, or omphacio, $\sigma^{\circ}$ bec dicunt adftringere: $t a m e t f i$ aduerfißimum ex illis fenfum percipiamus ci, qui in nobis fit à pipe= re, pyretbro, napy, cuphorbio, cepa, allio, 0 adarce. I gitur $f \mathfrak{i}$ quemadmodum adf trictionis uocabulum de utroque affect u, quem gustu percipimus, communiter efferunt, fic ip fos quo q; affectus unam habere naturam cxiftimant, quid= uis aliud potius habendifunt, qudim homines, ut qui foli proprios fen $\sqrt{u}$ obtine ant. At fi omphaca, rhoa, gallam, balau ftium, bypociftida contrabere, conftringeré,; noftrdin fateantur fubftantiam: Fecernere ueró, mordicare, ac pene= trare, piper, napy, pyrethrum, improprie adfringentia nuncupant, qua mordicant, er excalfaciunt: caterisn in cognofcendis ip/is medicamentis non peccant. Verium fioportet coniectantcm dicere, an in uocabulis, aut in rebus ballucinentur, equidem in uocabulis potius falfos uiros illos dixerim, $\sigma^{-}$maximé quibus Graca lingux infueta cft, qua= Tis eft Diofcorides Anazarbenfis. qui profectó multa bene dixit eorum, que de materia medic a memorix prodidit, $c$ a $=$ terum fignificata Grecanic arum uocum non fatis pernouit. Hic ergo cum ait mag is effe adftrictorium adipem cap: $i=$ num fuillo: fi quidem acriorem fignificare uelit, per magis adfrictorium, accipimus fermonem ceu ucrum. At fi il= 


\section{In Lib. fecundum Diofcoridis.}

Iud, talem babentem qualitatem, of fucultatcm, qualem rhus, rheon, bypociftis, balauftiun, haud ucrun effe fermo= nem dicemus. Porró quoniam uipcr.trun adipen, ubi radicitus pilos fub al is euulferis, probiberc illos recrefcere il= litum referunt, wifum eft mibi cius facerc pericul un effe fatius : at ubi prout iubent, ficifem, neentitos comperi, ficut

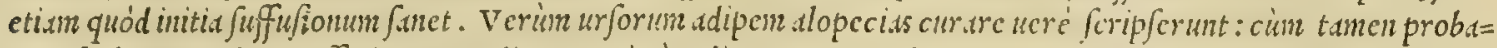
tior a babeanus ad cum affectum remedia. Porrò cim dicant tanten unlpinun adipen dolores auriun fandre, abfque ut explicent, quos auriuun dolores dicant, ceu non no fecntibus ipfis diftingucre, que dicunt, attendendun non eft. Alij pifcium adipem laudant, tanquasm ad fuffufioncs, aut quencunque alum affectum nominare uclint, congruat . Alij non fimpliciter pifcium, Sed addunt flumiatilium : alij ucró potius marinorum, quó uidelicet aliguid plus forre ui=

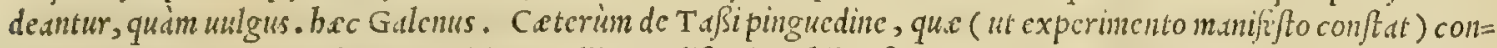

so tractos nerwos, o articulorum duritius emollit, o difcutit, nibil pofterit atis memoric prodiderunt Dicfcorides, $G d$ lenus, o Paulus. Nec preterca Galenus pinguedinis curande, ac parand.e rationch ull.un, quod fciam, tradidit: nee quibus odoramentis ucteres pinguedincm imbuerent, or in ungucnti morem conficcrent. qucmadmodum bac no= ftra etate unguentarij illun parant, quan uulgó POMA T A uocamus. Ea autem boc modo paratur. Sumunt cer= uini adipis, aut hedi binas libras: fuilli ueró recentis uncias $f(x$ : deinde exemptis membranis, nino albo lauxnt, expri= munt'́; tandiu, donce uinun omne exeat. Poft bec clotan pinguedinem in fictile noum, uitro, uel plumbo oblitun conijciunt, additis nurdi Indici granis tribus, caryopbyllorun femuncia, nucis myriftica dracbmis duabus, malis ap= pianis, kel fylueftribus femicontufis fenis, wel feptenis. Hec omnia in fufjicic nti aque rofacex quantitate macerant die un.t: dcinde lento igne tandiu decoqunt uas opcrculo contegentes, er rudicula fepius mifcentes, quoufque uni= uev fa feré squa cudnc fat. Percolant deinde linteolo pißiori fubdito uafe mundo, aqua rofarü madcnte, dimittuntó;: to concrefcere. Quro fafto in fictilc nowum iterun conijciunt, ddiectis olei dinygdalini dulcis uncijs fex, cere albx un= cijs qutruor, or ad ignem colliquant, ac poftmodum linteolo percolant in nitldijsintmn catinum aqua rofarum affufa: finuntó; concrefcere. Demun cadem aqua mooclbum cxperta, aut alijs reforagrantibus aquis, tandiu lauant rude mi=

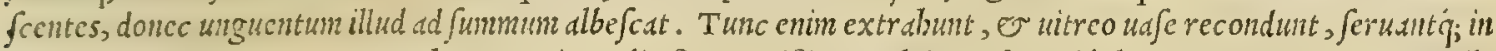

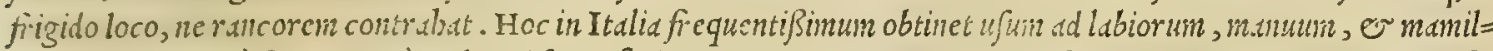
larum rinus, tam à frigore, qudin ab acrifucco fact as. Vtuntur eo pratered ad defquamatam cutem, or ad crustofas papulas, qux pueris in capite cind fcuntur. Sunt qui ei corallia porphyreo lapide leuigata admifceant, ut melius, ci= tiusic; rime occlud.ntur. Alij ucró cinnabarin addunt, ut flannmeum referat colorem. Porró ( ut libro tertio de ficulrate alimentorm foribit Galenus, o I fach Arabicus in diet is) Adeps omnis in cibis fumptus uentriculum effun dit, appetentian deijcit, pituitam anget, parum nutrit, fuccumillaudabilem gignit, aluifluxiones comnouet, reten=

30 triccm uentriculi facultatem imbecillem reddit: Senfus, $\sigma$ intellectum bebeiat, fomnolentiam inducit, or in uentri= culisfacile in bilem uertitur, er in uapores caput petentes. Quare adeps cft potius in ciborum condimentis, quam in altnentis expetendus. ETÉa Gracis, Latinis adeps, o pinguedo appellatur: Arabibus, Meñin, Vxabam, fiuc Nomina. Sahdm: Ifalis, Graffo: Germanis, Feyft, Fettigleit, er Schinaltz: Hifpanis, Gordira: Gallis, Greffe.

MVEXós. MEDVILA.

CAP. IXX.

L A V D A T I S S I M A eft ceruina, mox vitulina, poft hanc taurina, dein caprina, \& ouilla. Colliguntur æftatis exitu, cùm appetit autumnus : quippe cùm alijs anni temporibus concrementum fan guinis, \& veluti caro friabilis, in ofsibus inucnıtur : nec facilè cogno fci poteft, ni quis eam of sibus 40 extrahat, \& recondat. Omnes medullæ molliunt, calfaciunt, rarefaciunt, vlcera explent. Ceruina perunetos venenata fugiunt . Curantur recentes, adipis modo, aquxe refperfu fubactre, felectisçue offibus tantifper elotæ, \& in linteum expreffx, donec aqua fyncera emanet : \& deterfa forde pinna, fiqua innatet, liquatæ in duplicato vafe in pilam exprimuntur: \& ubi coiere, omni fæce, quæ ad ima fidit, derafa, fictili nouo reponuntur. Quòd fi libet incuratas reponere, facito omnia, quæ de anferum, \& gallinarum adipe demonftrauimus.

M E D V L L A, ut fcriptuin reliquit Galenus libro x I. Fimplicium medicamentorum, wim habet induratd, or fcirrbo fa corpord emolliendi, fiue mufculis, fiue tendonibus, fiue ligamentis id accidat, fiue etiam ur ceribus . Opti= Medullæuimam femper expertus fum ceruinam: deinde ipforum iuniorum boun, quos uitulos etiam nominant, ac proinde me= so dullarn corun uitulinam appellitant. At bircorum, es taurorum tum acrior eft, tum ficcior. Itaq; durities fcirrho= fas diffoluere nequit, fiqua etiam memorid inanet corum, que in quinto libro de bis funt prodita. Ex uitulina igitur, o ceruina medulla peßicomponuntur uteros emollientes. Et extrinfecus uteris medicamenta imponuntur, que ex medulla preparantur, uim habentia emolliendi. Accipitur autem non folum medulla ex oßsibus, que fané re uera eft medulla; fed er ex pina, quam er ip fam medullam nominant, pinalem uidelicet: que tum durior, tum ficcior eft, quàm alia. Illa enini mollior eft 0 pinguior : ac proinde ego pindem feorfum per fefe abfq; illa repono. Sed ea mibi utriufque medulle cura eft, ne aut puire f cant, aut fitum colligant. Itaq; in byeme primuin eas capio, uelut o adi= pem, deinde in edibus ficcis, atque cditis, plané bunoris expertibus, cum folijs laurificcis repono. Nam qua recen $=$ tia funt $\subset$ bumida, multum etian qualitatis fux illis impartiunt, ut acriores fiant medulla. At fi quando ambiente calido, e auftrino inedull ws, aut adipem uoles reponere, paratum fit in boc cubiculum neque calidun, qualia fie funt qua meridiem pectant (putrefcunt enin in talibus) nec bumo proximum, atque bumidum (ndm in talibus fitum

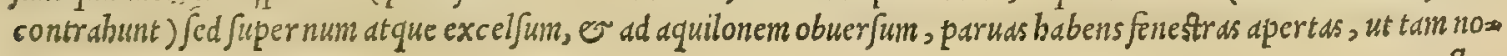

Adipis in cibis facultas.

Pomatre parädx racio, \& vfus. 


\section{And. Matthioli Comm.}

Au, quàm interdiu ab Arcto pirantès uentos accipiat. hactenus Galenus. In ufu ueró ciborum pinalis medulla id nutrimenti corporibus exbibet, quod cercbrum. Idcirco pituitofum, ac craffum gencrat fuccum, egré concoquitur; uentriculo nocet, nau eam concitat: robuftis tamen uentriculis concodta, bonum prabet alinentum. Porró qua ex oßibus elicitur medulla, quanquam largius fumpta uentriculi appetentiam deftruat, pituitan'q; gignat; fi tamé pro= bé conficitur, ualentißimé nutrit, magisq́; ori placet, qudim pinalis, quòd bac fapidior fit in omnibus fuis partibus.

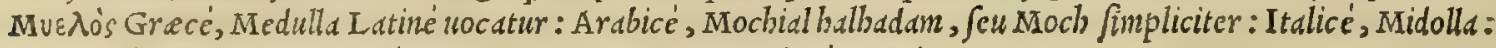
Germanicé, Marck: Hipanicé, Tuetanos, O Tutanos: Gallicé, Moelle.

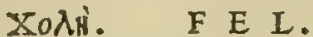

C A P. LXXI.

FE I omne reponitur hoc modo. Recens præligato ore folliculi lino tandiu demiffum in feruen tem aquam, duin quis fpatium trium ftadiorum percurfaret, mox exemptum ficcatur vmbrofo loco, afperginem non rcdolente. Sed quod ad oculorum medicamenta adijci folet, ligatum lino in vitreú vas, quod mel habeat, immittitur : circumuoluto ad os vafis lini principio, \& operto vafe reconditur. Eft autem omnis fellis uis acris, \& excalfaciens: intenfis tamen, \& remifsis viribus differunt .

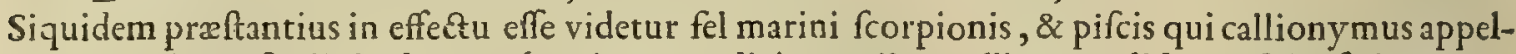
latur, marinæ teftudinis, hyænæq́ue: item perdicis, aquilæ, gallinæ candidæ, \& fylueftris capræ. quod priuatim prodeft contra fuffufiones incipientes, \& oculorum caligines, argemas, \& genarum fcabritias. Ouillo, fuillo, hircino, atque vrfino, taurinum multò efficacius. Felle omni perfacilem, præfertim infantibus, deiectionem quis molietur, fi intinctum eo tométum, aut fimbriam fedi fubijciat. Priuatim taurino anginæ cum melle perunguntur: fedis vlcera fanat, $\&$ ad cicatricem vfque perducit. Idem auribus fractis, \& purulentis cum muliebri lacte, aut caprino inftillatum, medetur : \& fibilo earundem ex porri fucco. Admifceri infueuit vulnerarijs emplaftris, \& circumlinitionibus, quæ contra venenata parantur: phagedænicis vlceribus, colis, \& fcroti doloribus ex melle prodeft: lepras, furfures cum nitro, \& terra cimolia quàm optimè purgat. Ouillum, \& vrfinum contra eadem pollent, verùm inefficacius hæc præftant. Vrfinum eclegmate comitiales adiuuat. Fel teftudinum anginis, $\&$ in ore infantium nomis, prodeft : naribus inditum comitiales erigit. Sylueftrium caprarum felle peculiariter peruncti lufciofi fanantur. Hircinum idem obit munus : thymia abolet, \& luxuriantes elephanticorum extuberationes illitu reprimit. Sullum autem contra aurium vlcera, reliquaq́ue omnia magno ufu affumitur.

Q Y A N V I s defellis reponendi ratione, ató; etiam de eius uiribus abunde fcripferit Diofcorides; non tamen ob hoc pratermittenda exiftimaui nonnulla, qua di Galeno libro x. Fimplicium medic amentorum de fill is facultatibus foité memorixe funt commendatd. Eft igitur fel (auctore Galeno) fuccorum, qui in quoque funt aninzalium, calidißli=

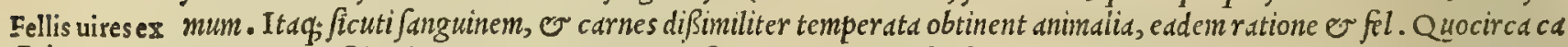
Galeno. lidißimorum fel, aliorum quog; animaliun fel excellere neceffe efl: ${ }^{\circ}$ qua illis minus funt calida, proportione er

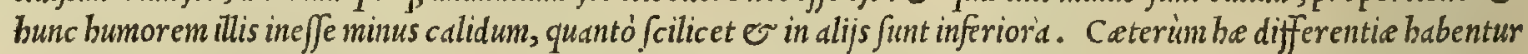
non inodó pro diuerfo animalium genere, quód hae magis, illa ueró minus calida fint; uerùm etiam pro diuerfo ciuf= dem generis animalium temperamento, ac etiam irritamento : Quandoquidem fel tauri interfecti, qui funibus adalli=

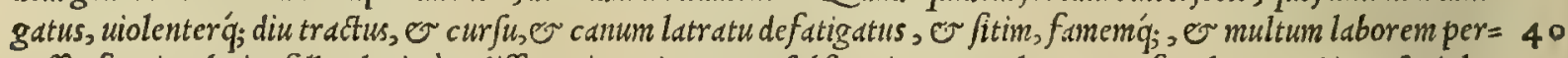
peffus fuerit, ab eius felle plurimim differre inuenietur tum fubfiantia, tum colore, tum facultate, qui in pafcuis lae $=$ tus, liberó, uitam defidem, ac quiet am duxerit. Nam defatigati, ac uexatl animalis fel fubftantia craßius erit, colo= re nigrius, aut uiridius, aut magis c.eruleum, magisq́; arugini fimile : ob idq; etiam longé calidius erit, quàm alterius, qui in pace, $\mathrm{O}$ otio degerit. Ideóq; fel animalium quantó tenuius eft, ac colore conftat dilutiore; tantó minus ßpißio= Fellis bubuli ribus e magis colore faturatis excalfacit. Gignitur in bubulo felle lapis quidam nonnunquam oui magnitudine, lapis, \& eius croceo colore, facile q, friabilis, cuius Diofcoridem, o Galenum meminiffe non reperio. Hic (ut plerique perbibent uires. auctores) potus, uefic ce calculos comminuit. Naribus inditus uifum mirificé acuit, $\mathbb{O}$ aquam in oculos fluentem in= bibet. Tritus lentis quantitate, $\mathcal{O}$ bete fucco commiftus, $\mathcal{O}$ in erinis naribus attractus, comitialibus fubucnit. Non defunt etiam qui idem magno fucceffu ex uino cxhibeant potandum fille fuffufis. Denique aurata, lupi pifcis, perdi=

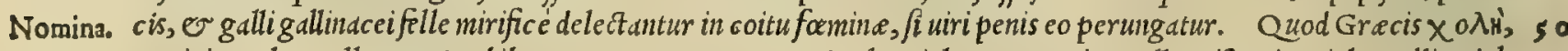
Latinis, Fel appellatur: Arabibus, saratac, aut Merara: Italis,Fiele: Germanis, Goll : Hipanis, Hiel: Gallis, Fiel.

\section{Aĩux. SANGVIS.}

\section{CAP. LXXII.}

S A N G V t $s$ anferis, anatis, \& hœdi, vtilifsimè in antidota mifcentur. Palumbi autem, turturis, \& columbx, necnon perdicis, oculis cruore fuffufis, \& recentibus eorum vulneribus, lufciofisq́ue illinuntur. Peculiariter columbæ fanguis, cruorem membranis cerebri erumpentem inh ibet. Hirci, capræ, cerui, \& leporis fanguis inaffatus fartagine, dyfenterias, \& cœliacorum profluuia fiftit: in vino potus contra toxica efficax eft. Lcporinus fanguis it a ut tepet illitus, nitia cutis in facie, lentiginesq́uc emaculat. Caninus commodè ab his bibitur, quos efferata in rabicm beftia momorderit: contra epotum toxicum auxilio eft. Teftudinis terreftris fanguinem epotum tradunt prom deffe 


\section{In Lib. lecundum Diofcoridis.}

deffe comitialibus. Marinx autem teftudinis cum vino, \& leporis coagulo, cuminoǵue contra ferpentium morfus, \& haufta rubetæ venena conuenienter bibitur. Taurinus cum polenta illitus, duritias difcutit, emollitq́ue. Sanguis equarum, quæ admiffuram expertæ funt, in medicamenta additur, qux erodunt, feptica vocant. Sanguine chamæleonis genarum palpebras euelli creditum eft. Hoc idem viridium ranarum fanguine præftatur. Menftuus fainguis fæeminarum, circumlitu conceptum inhibere exiftimatur : aut fi omnino mulier mentrua fupergrediatur . leuat podagr $x$ dolores,'\& ignem facrum illitus.

D I S S E R E N $S$ de fanguine Galenus, ftatim initio libri x. de fimplicium medicamentorum facultatibus, etfí Sanguinis có20 minimé eat inficias, quin animalium fanguini aliquid infit, quod medicamentorum ufuirecté competat, ut Diofcori= fideratio. des, o pleriq; alij, qui de eius uiribus f cripferunt, liquidó affirmarunt: declarat tamen, smulta de fanguinis uiribus a fcriptoribus cffe prodita, que facto periculo fabulofa potius, o wana reperiuntur, quàm uera. Siquidem, ut idem refert Galenus, falfum fanè effe omnibus in conf $f \iint_{0} c / t$, quòd epotus noctue fanguis difficulter pirantes fani= tati reftituat. Veppertilionum ucrò perüntis uirginum mammis, eas extuberare non inat: pilosq́; renafci inhibeat, ijs partibus illitus, unde recenter ip/i euulfi fuerint. Falfum fimiliter effe afferit, comitiales ebibito agnifanguine cu= rari : pilosq́; é palpebris euul Jos renafci prohiberi uiridium ranarum cruore. Quibus facilé conijcere poffumus, hoc in loco Diofcoridis codiccm libiariorum fortaffe culpa inendofum effe. Quippe quód ibi legatur, oculorum palpes bras rathrum uiridium fanguine depilari, cum potius Galeni testinonio (etfi fententiam banc non approbet) euulfi in palpebris pili harum fanguine rend fci prohibeantur. Quin o aliud buic capiti mendun fubeffe uidetur : quod bic ea, 20 que de adiniffariorum equorum fanguine prodidit Galenus, de equarum fanguine, que admiffuram experte funt, le= ganttur. Nifi forte interpretum uitum fit, qui fexum in Diofcoride perperam nutarint. Pretered inquit Galenus. Tamet $f t$ non de int, qui turturis, uel columba fanguine preferant in perfor ata caluaria, ubi rofaceo melius inuenire nibil poßjis: nonnull ueró laudibus extollant gallorum, gallinarum 'q; fanguinem ad Janguinis fuorem é cerebri mem branis: crocodili uerò terreftris ad roborandain oculorum aciem: admifariorum equor ü, quód fepticus fit, ad exul=

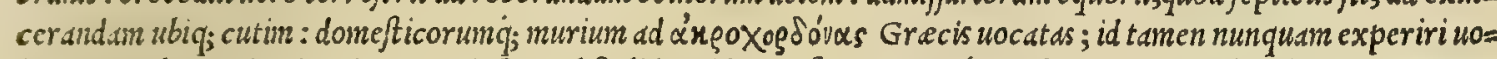
lui. Metucb. im enim (inquit) ne curiofus, uel folidus uiderer, fi tantis, tam'; probatis remedijs femel preteritis con fiderem, sanguinem borum animalium illis plus poffe preftare. Quód fi quis bec experiri wolet, certó fcio, damnd= bit non modo, qui talia fcripferunt, fed $\sigma$ fe delufum facto periculo reperiet. Taurinus autem fanguis epotus anted quàm concrefcat, inter deleteria recenfetur medicamenta, quód haurientem protinus ftrangulet, ut fexto uolumine 30 diffujius dicetur. Eius nomen Grecum $\alpha^{2} \mu \alpha$ : Latinum, Sanguis: Arabicum, Dem: Italicum, Sangue: Germas Nomina. nicum, Bluot: Hifpanicum, sangre : Gallicum, Sang.

\section{A'ซóTаTOS. FIMVM. CAP. LXXIII.}

A R M E N I R I AE bouis fimum, fi recens admoueatur, vulnerum inflammationes mitigat: folijs autem inuoluitur, \& calfactum cinere feruenti fuperponitur . coxendicis cruciatus fotu compefcit : illitum ex aceto duritias, panos, \& ftrumas difcutic. Priuatim fuffitu fimi, quod à mafculo bcue redditum eft, procidentes vulux reprimuntur : accenfi nidore culices abiguntur. Fimum caprarum, præfertim in montibus degentium, potum in uino, regium morbum emendat : menfes cit cum 40 odoramentis hauftum, \& partus euocat. Tritum in farinam, \& impofitum lanis cum thure, fominarum profluuia fiftit, cæterosq́ue fanguinis impetus ex aceto cohibet. Medetur alopecijs exuftum, \& cum aceto, aut oxymelite illitum : cum axungia verò impofitum his, qui podagra tentantur, auxilio eft. Caprillum in aceto decoctum imponitur ferpentium morfibus, vlceribus quæ ferpunt, igni facro, \& parotidibus. Vtilem ifchiadici vftionem hunc in modum accipiunt. In eo interftitio, vbi pollex brachiali committitur, caua veluti lacuna fubfidet, in qua lana oleo imbuta fubfternitur, deinde figillatim feruentes ftercoris caprini pilula imponuntur, dum vapor per brachium ad coxam fentiatur peruenire, \& coxendicis dolorem mitigare. aduftio id genus Arabica appellatur. Ouillum ex aceto illitum fanat epinyctidas, clauos, penfiles verrucas, thymos, \& ambufta igni, rofaceo cerato exceptum. Fimum fuis fylueftris aridum, in aqua, aut vino potum, reiectiones fanguinis $\mathrm{fi}-$

so ftit: vetultum lateris dolorem mulcet: ad rupta, \& conuulfa ex aceto bibitur : luxatis cum cerato rofaceo medetur. Tam afinorum, quàm equorum fimum, fiue crudum, fiue crematum, addito aceto, fanguinis eruptiones cohibet. Armentarij, qui herba pafcitur, ficcum fimum liquatum in vino, mox potum, contra fcorpionum i\&tus magnopere auxiliatur. Columbinum vehementius \& excalfacit, \& vrit: cum hordeacea farina miftum, ftrumas ex aceto difcutit : carbunculos emarginat, tritum cum melle, lini femine \& oleo : ambuftis igni medetur. Gallinaceum verò omnia eadem, fed inefficacius præftat: priuatim tamen contra venena fungorum, \& coli cruciatus ex aceto, aut vino bibitur. Ciconix fimum, fi ex aqua hauriatur, comitialibus prodeffe credunt. Vulturini fimi nidore partus excuti produntur. Murinum detritum cum aceto, \& illitum, alopecijs medetur : cum thure, \& mulfo calculos expellit: fubditæ infantibus mufcerdx, al ui deiectionem promouent. Caninum, quod flagrantifsimo canis fydere fuerit exceptum, cum vino, aut aqua potum, fiftit aluum. Humanum ftercus illitum, vulnera ab inflammatione vindicat, $\&$ obiter intumefcere non patitur:

Vana fanguinis experime ta. 
fed ea ftatim glutinat. ficco ex melle anginæ perungi commodifsimè traduntur. Terreftris crocodili fimum, crocodileam vocant, quæ mulieribus colorem nutrit in facie, nitoremq́ue feruat. Optima elt candidifsima, \& frubilis, amyli modo, minimè ponderofa, in humore ftatim eliquefcens: quxe cùm teritur, fermenti acorem quadántenus refert. Adulterant eam fturnorum fimo, quos captos oryza pafcunt, ipfumq́ue non difsimile vendunt. Alij amylum, aut cimoliam mifcent, \& adfcito anchufe colore per rarum cribrum paulatim exprimunt, vt fe contrahat in vermiculorum fpecicm : qui ficcati pro crocodilca vaneunt. Inter omncs conuenire inuenio, humanum ftercus, caninumqque gutturi impofitum, anginis auxiliari.

Stercoris ui- STERCV S, ut pofteritatis memorix prodidit Galenus librox. fimplicium medicamentorum, uim babet uel to xes ex Gal. maximé digerenten. Verum humanum ob fetorem abominandum cft. At bubulum, caprinum, crocodilorum terre= frium, o canum, ubi oßibus duntaxat ue fcuntur, neq; grauiter olct, e mult. experientia non tantium nobis; fed o alijs medicis me natu maioribus comprobatum eft. Siquidem Afclepiades, cuicognomentum erat Pharmacecon, or dlia omnia compofita imedicamenta collegit, ut multos impleret libros, o ficrcore ad multos fepe affectus utitur, non Humani ner modó medicamentis, que foris imponuntur commifcens; fed ijs quoque, que intró in os fumuntur. Caterün bu= coris experi- maniftercoris hoc habeo experimentum. Afidué quidam à pllegmonis adfauces exiftentibus ucxabatur, adeó uebe= mentum. menter, ut fuffocationis fubiret periculum, or fané ob hoc periculum uen am fecare cogebatur. In bunc cùm forté quis incidiffet, pollicitus eft fe prebiturum medicamenti experimentum, $\odot \int e$ ocari, $f i$ quando rur $f u s$ aliqua in par= te gutturis emicuiffet phlegmone, ante fanguinis mißionem pracepit. Itaq; uocatus, medicamento illito, ftatin bo= minem curauit. Vt autem iterum profecit, non in ipfo tantüm; fed $\sigma$ in alijs, qui fimiliter erant affecti, rogabat is, qui aßiduó fuffocari periclitabatur, data mercede, ut fe medicamentum illud doceret. Erat enim ille o locuples, o in pecunie fumptu liberalis. Porró ubi conuentum effet de p'retio, is qui uendebat fcripturam : Hoc medicamentum,

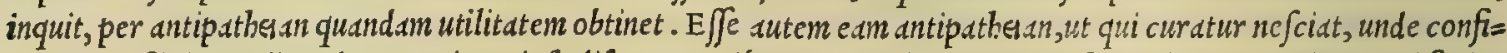

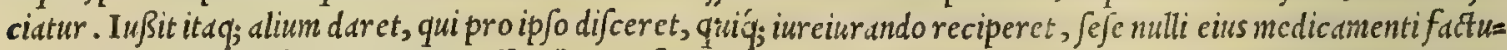
rum copiam, priufquaim ip $\int e$, qui dediffet, foret defunctus. I $t$ dque à morte eius, qui indicarat, nont tantim ille qui didi cerat, Juum bominem; fed er alios fanabat: er mibi ne petenti quidem medic amenti exemplum volens ac lubens ob= tulit. Erat autem ftercus puerificcuin, cum melle Atttco ad lexuorem tritum. vietitabat autem puter, cuius ftercus accepturus erat, ut ipfe qui medicamentwin dederat oftendit, lupinis, illis widelicet, qui ex morc edi folent cuin pane bene cocto in clibano, modicum Salem, o fermentum babente. Prabebat autem bibendum uinum uctus: atq; bec om= nia mediocri in quantitate, modò ut perfecté ea puer poffet concoquere. Itaq; cùm primo die eo uitu effet ufus, po= ftero tamen die nondum ftercus capiebat, fed in eo quoq; die rurfum eodem alebat uiltu, ac tertio demum excretum fumebat: ac pofted arefacto utebatur, fimiliter ut ftercore canino, ut ante dictum $\mathrm{c} f$. Dicebat autem illum, qui do= cuerat, fugitantem alios cibos ob foctorem, pretuliffe lupinos: fefc ueró experimenti gratix, carnes gallinaceas, aut perdicum ex aqua, aut tenui iure bene coct is perfape exbibuiffe, on medic amentum nibilo minus operatum. Atque

Aqqua, \& oleü ex humano ftercore.

Bubuli fter.ui tesex Gal. ego fané bac tibi de humano stercore narrare poffum . hec Galenus. Caterim fit ex bumano ftercore uitreis or= ganis aqua, prefertimó; ex eo, quod bomo rufus excreuerit, que cuniculofis, exedentibus, finuo/is, o contumaci= bus ulceribus mirifice opem praftat. Delet o oculortum argemas, ac nubeculas. Quinetiam carcinomat fanat exte rius adhibita. Intus ueró $\int$ umpta comitiales iunat : lapidem in renibus, o ue fica comminuit : aqua intercute laboran tibus prodeft : item o ijs auxiliatir, qui non modò à cane rabido demorfif funt; fed etiam ab omnibus alijs animalibus icti, que uenenum eiaculantur. Porró olcun, quod poft cius ftillatitiam aquam ab organo emanare folet, carcinoma ta, finus, aliaq́; ulcerd, que Grecis cacoëthe dicuntur, etiam ualentius fanat. Bubulum deinde fercus (ut idem Galenus citato loco fcriptum reliquit) exiccantis, attrabentis q; o ipfum eft facultatis, ut palam facit, dum apum ue ßparum q́; morjus inuat: Atq; bec ut à proprietate fubftantix totius iunentur, fieri poteft. Caterim bumidum illud uere collectum, cum boues berbas depaf cuntur, impofitum rufticorum phlegmonas difcutit, $\sigma$ aqua intercute labo= rantes iuuat. Scire tamen oportet, omnid id genus medicamenta duris agreftium bominum corporibus aptari, nempe fofforumb e mefforum, o qui opus obeunt adeó ualidum. Que $\mathbb{O}$ ad corum fcirrbofos tumores aceto in cataplaf= Caprini Rer. matis forman compofita illinuntur. Caprinum preterea digerentis, 6 acris eft facultatis, adeo ut induratis fcir=
uires ex Gal. rhorum in modum tumoribus congruat, nec tantum lienis, ad quos creberrine medici non pauct buiufmodi ftercora applicant; ;ed etiam aliarum partium. Siquidem ego (inquit Galenus) eo ufus fum ad genu tumorem habens inuete= ratum, or egré. folubilem, iuffo fiericataplafimate ex farina bordeacea per oxycratum, indito uidelicet hoc fterco $=50$ re, or mirifice homo ille fuit adiutus. Erat dutem rufticus, in quo id factum eft. Et iam etiam alius rufticus, cum fic $u$ us effet, non tantìm in genu; fed etiam alijs in partibus ad tumores fimiles, perinde adiutus eff. Nam acrius est me= dicamentum, quam ut mulieres urbands, aut pueros, aut omnino qui molli funt carne, fanare poßit. Quin er ad $a=$ quam intercutem, o ad plenicos uarie caprino ftercore utimur. Sed e uftun tenuiorum quidem partium, uerim haud manifestó redditur acrius. Quamobrem fané ad alopecias congruit, o omnia adeó que extergentia medicat= menta defiderant, ut lepras, pforas, lichenas, G boc genus alia. Mifcetur o digerentibus cataplafmatis, qualia funt

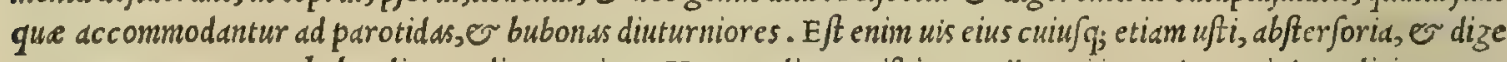
gens, nec eam paruam habet digerendi potentiain. Nam medicus quipian ex ijs, qui in agris, $\odot$ vicis medicinan ex= ercent, utebatur eo ex aceto ad uiperarum mor fus, or multo fané etiam mag is aliarum beftiarum, ac profectó ex ijs complures feruauit. Et bic ipfe quoq; medicus arquatis potandas ip as $\sigma \pi \mathrm{v} \rho \alpha$ bous, boc eft, pilulas caprinas ex uino prebuit, 0 ad proftunium muliebre cum thure appofuit. Que omnia fané optimus medicus ignorare non delet. caz 


\section{In Lib. fecundum Diofcoridis.}

terim potior áligere potißimim ad urbanos, er bonoratos, alicuiusq́; cxiftimationis uiros : in quibus equidem cgo tali nanquam fun ufus medicamine, cim multó melior um fuppcteret copia. Attamen cxiftit nonnunquam talium $u=$ fos, aut in itinere, aut in ucnatione, aut rufticatione, cum feilicet melio rum nibil adfucrit, aut bomo ruficus perinde fuerit carnis dur $x$, ac afinus. Nan eiufnodimultos in agris reperias dignos, qui bibant fpyrathos. Caterim éca nibus offa comedentibus ftercus, preterquain quod cetcris tum praftuntius, tum candidius babcatur, fifuld gutturi infufflatum anginan curat : ficutior dyfenterian ex lacte caprino buftü, in quo prius igniti calculi fucrint extincti,

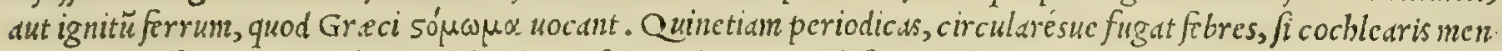
fura in acceffu ex nino prebeatur bibendum in cio patiente. Prodeft er malignis ulceribus in/perfum, ucl emplaftris ad id facientibus commiftum. Pollet etian fuis uiribus Lupinum: idcirco id magnis laudibus cxiulit Galenus citato

20 loco, fic inquic ns. Lupinum ftercus quidam colicis potandum dabat, non tantim in iofis paroxy fnis; fed etiam in interuallis, fi quidem phlcgmone uacarent. Quorum ego quofdam uidi non dmplius boc affectu correptos, or corre= ptos non amplius id grauiter paffos, fed nec poft paucum temporis. Accipicbat autesn ille albius potius luporü fter= cus, quale ubi offa cderint, folcnt cxcernere. Verum illud ctiam in eo mirabar, quod uel fupenfum euidenter fepe= numero iuniffet. Itaq; bic ftercus capiebat, quod non decidiffet in terram : id quod non erat inucntu difficile. Ea enim cft luporum natura, que canum, ut fupenfo altero pofteriorum crurum, er meiant, or cacent in cmine nti quopiä loco

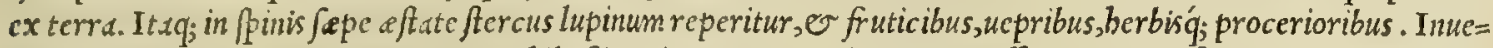
nitur porró infercore illorum $\odot$ nomibil oßium deworati animalis, quod ut effugit commanfionem, ita $\sigma$ concoctio nem : quod o ipfum contundens, ac conterens, bibcndum prabuit colic is : ac fi bomo effet puritatis amans, mifcebat o falis qrippiam, aut piperis, aut quippian eiufmodi. Vt plurimum autem ex uino albo confiftentio tenuis bibendum 20 prebebat: interin ueró ctian ex aqua. Hoc ergo ftercoris,quod patientibus ilibus applicandum effet, iubebat fupen= di uinculo confreto ex lana non cuiuslibet ouis, ucrum multo preft abat eam effe ouis a lupo laniate, unde quod ad büc. ufun accommodaretur, effct conficiendum. Quod fi talis non adcffet lana, ex pelle ccruina, $\sigma$ lor um quod cingeret $i=$ lis, $e^{2}$ in quo fercus contineretur, parari precipiebat. At nos ollulam ad magnitudinem maxima fabe confecinus, quan expcriundigratia indito fercore quibufdam fuppendinus, nec potuinus non murari, cum plurimos ip forum uide remus adiutos: ceteriun ad oliulan duas ceu aures affiximus, per quas lorum tranfmitti poffet. Qúd autem cico nixe fonum comitiales iwuet, planté refellit Galcnus, afferens eos effe redarguendos, qui talia fcripferunt. De ouillo, columbino, gallinaceo, murino, er crocodilino, cuin fat is fuper'́, differuerit Diof corides, nec plura d Galeno, $\sigma^{\circ}$ alijs de cripta repererim, que medicine magis compctere poßint, non eft quid amplius addendum exiftimem. Veruntame animaduertendum eft, quod, quemadmodum etiam de animalium fellibus diximus, ftercord ip $\int$ a inter $\int e$ plurimim dif $=$

30 frunt temperamenti, uigus aninalis ratione. Cuippe quod alterum fit altero plus, minusue calidum, pro anima. lium diuer forum generum temperie, aut pro alimentorum temperamento in eiufdem peciei animalibus. Quod Gre

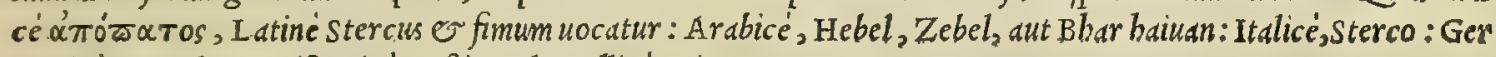
manicé, Drecken; Hifpanicé, Eftiercol: Gallicé, Fiante.

$$
\text { Oigol. } \quad \forall R I N A . \quad C A P, I X X I I I I
$$

HV M A A M vrinam fuam cuique bibere, contra uiperæ morfus, ac uenena, incipientemq́ue aquam inter cutem proderit: fcorpionis, viperæ marinorum, draconisqúue morfus, ea conuenientif́simè fouentur. Canina ad perfundendos canis morfus idonea eft: pruritus, \& lepras nitro addito 40 expurgat. Sed vetus ulccra capitis manantia, furfures, pforas, \& feruidas eruptiones, multò magis abftergit: nomas, \& præcipuè genitalium, cohibet : auribus infufa manans pus fupprimit: decostaq́ue in calyce mali punici, earum uermiculos abigit. Pueri impubis reforpta urina, orthopnoi-n cis auxiliatur : decocta in æreo uafe cum melle emendat cicatrices, argema, caliginesq́ue. ex ea, \&z cu pro idoneum auri ferrumen conficiunt. Quod in urina fubfidit, jllitu ignem facrum mitigat : feruefactum cum cyprino, inditumq́ue, vuluæ dolores mulcet, ftrangulatus leuat, genas deterget, oculorum cicatrices expurgat. Taurina fi cum myrra inftilletur, aurium dolores lenit. A prina uiribus eifdem pradita eft : priuatim comminuit ueficx calculos, \& potu expellit . Caprina ad aquam qux cutem fubijt, cum nardi fpica quotidie binis cyathis cum aqua bibitur, vrinamque per aluum extrahit:aurium doloribus inftillata medetur. Afnina traditur renum vitijs mederi. Lyncis uri30 nam, quam lyncurium appellant, fimulac excernitur, glaciari coiréue in calculi duritiam, uulgo creditum eft. quare quod de ea proditum eft,uanum effe conuincitur. Eft enim quod à nonnullis uocatur fuccinum pterygophoron, ideo dictum, quòd pennas ad fe alliciat. Id potum ex aqua ftomacho, aluoque fluxione laboranti conuenit.

VR I N A E omnes quidem, ut feriptis tradidit Galenus lib.x. fimplicium medicamentorum, facultate funt cali Vrinarú facul de: $\int e d$ plus tamen animalium calidorum, minus autem frigidorum. At urina bominis omnium propé alidrum urind= tates ex Gal. rum eft imbecillima, exceptis porcis domefticis, quibus exempti funt teftes. Namillorum fimilis eft totius corporis temperatura temperiei bominum, en urina fimiliter debilis. Verum montanorum aprorum ualida eft, ut etiam ex $0=$ dore apparet, qui utiq; acerrimus eft. Hac utuntur Hetrufci ad puerorum uermes, oleum fuo in utriculo urine Vrina apri. admifcentes, et in fumo tandiu fupendentes, donec craffe fcat ad mellis Pißitudinem: deinde illud diligenter afferuat,

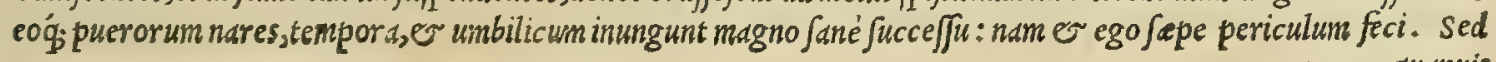


quanuis Diofcorides complurium urinarum uires defcripferit, ut quas uarijs, ac diuerfis morbis utiles effe exiftima= Vrinx medici uerit; Galenus tamen urmarum medicamenta paruipendiffe uidetur. Quippe qui crediderit (quemadmodum er de nas cötemplit fanguinibus differens inquit) cüm parata reperiantur ualentiora medicamenta, ac experimento comprobata, ijs pra $=$ Galenus. - cipue morbis congruentia, quibus urinam conferre nonnulli autumant, earum medicinas ad curio os fuperftitiofosó;;

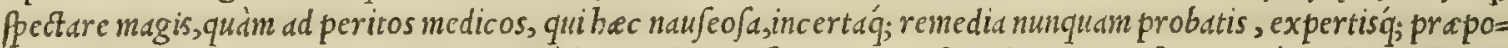
nunt. Quid autem puerorum urina agrépirantibus conferat ( $u t$ Diofcorides auctor eft) minimé probat Gdlenus, cim loco citato inquit. Vrinam pucri or thopnoe uocat gratid ebibere necelfarium non eft, cim fint or alia medi= camenta, qua buic medeantur affectui. Quin cum bibiffet quidam, affectu liberatus non cft, ut non eximium quid pre= Chrylocolla ter alia poßideat. Cbryfocolle conficiende rationem, quam fieriex puerorum urina prodidit Diofcorides, quam '́; factitia. feplafiarij, $\leftarrow$ aurifices uulgó Borrace nominant, duobus in locis friptan reliquit Galenus lib. Ix. fimplicium me $=\mathbf{x}$ dicamentorum, ubi de ea fpeciatim egit, e lib.x.corundem de urinis diffcrens. Et quanuis (ut libro quinto dicetur) legitima, probatad; chryfocolla foßitia babcatur; fit tamen artificio ex pueri urina in ardentißimis folis caloribus $a=$ "eo mortario, att; etiam piftillo areo tandiu circumacta, donec mellis fißißtudiné affequatur. Prefertur, qua boc mo=

Vans de lyn - do parata fit, ad contumacia ulcera fananda, cxedentiáq; coërccnda. Illud profectó uanum, ac fabulo fum effe mani curio opinio. fefté deprehenditur (ut hic Diofcorides fcribit, er nos eum fecuti fuperiori libro in fuccini mẹtrione oftendimus) quód urina lyncis, fimulac excernitur, duretur, cö̈́tue in lapidem illum, quem I yncurium uoc ant. Quippe quód is inter fuccinigenera ab omnibus fide dignis auctoribus recenfeatur, quod fux proprietate nature pennas ad fe trabat, qué= admodun or catera fuccini genera paleds, frftucas, ac leuißima queq; alliciunt. Quantum ueró à legitino lyncurio uulgaris ille lapillus differ at, qui officinis lapis lyncis appellatur, ov cuitus eft ufus apud feplafiarios, or medicos, qui fimplicium medic amentorum frientiam negligunt, ij dijudicent, qui fimplicium biftorias, or facultates optimé norunt. 20 Quandoquidem is, quem pro fabulofo lapide lyncis uenditant impoftores, lyncurium fuccini genus haudquaquam eft, nec alius quiuis lapis ei uiribus re pondens, nec fi quidem urinam cieat, or renum, ue fic é $q_{;}$calculos comminuat, ut $\int_{e}=$ plafiariorum, er medicorum uulgus opinatur : quiparum Diofcoridis, aliorum q́; in re medica bonorum auctorum fa=

Encelij opi- miliaritatem curant. Caterum binc fatis conftare arbitror, Chrifophorum Encelium (pace uiri alioquin docti di= nio uana. xerim) plané hallucinari, quod lib. I I I.cap. x x v I I. de re metallica, poëtarum fortaffe, or aliorum quorundam fabulis addictus magis, quadm ueris probatißimorum auctorum teftimonijs, probare contendat, I yncurium ex uri= na lyncis coale fcere, at ; ex maris urina fulum fieri, ex famine ueró urina album. Hanc autem opinionem fuam ex co comprobare uidetur, quód aliquando in uefica apri, item $q_{;}$fuis domeftici lapillos inuenerit. Ex quo poftea colli= git, mirum non effe, quód lyncis quoque urind in lapillos concre fcat. Sed qudim leuis e infirma fit hac ratiocinatio, ut comprobet quod contendit, quamq; uana fit opinio hec, corum fit iudicium, qui magnis laboribus, multis ftudijs, 30 fummaque diligentia rerum fimplicium peritiam funt affecuti. Atque bactenus de urinis, or byncurio. Reftat modó, ut etiam de Saliua aliquid in medium afferamus. Itaq; cum cius non meminerit bis libris Diofcorides, poßit '́;. nonnullis humani corporis morbis opitulari, ea de cius uiribus, ef facultatibus bic referam, que à Galeno libro x.

Saliue uires fimplic. medicam.memorix produntur bis uerbis. Sielon, fiue fialon, fiue ptyelon appellare libet, nibil intereft. ex Galeno. Verum id fciendum eft, uim eius effe differentem, tum in animalium fpeciebus, tum in eorum unoquoque fano, dut agroto, ieiuno dut fitibundo, aut cibo potique fumpto. Etenim ut urina, er bilis, or fudor; fic etiam faliua fum= pto quidem cibo imbecilla eft: ualida 0 acris eorum, qui ingenti aut inedia, aut fiti premuntur. In medio utriufque eft eorum, qui probé concoxere quidem, nondum tamen cibum potúmue ingefferunt. Hac ergo faliua nutrices pue= rorum lichenas curant, paruun uidelicet digitum rigantes, ac deinde cutem affectam confricantes. Id'q; faciunt fubinde, tanto fcilicet interuallo, dum faliue uires in lichene perdurent, ac nondum fint extincta. Sed ơ triticum 40 mandentes rufticinon pauci furunculis imponunt. Nam celeriter eos $\widetilde{\sigma}$ digerit, of concoquit: cum fi macerarent aqua, non aqué prodeffet. Ex quo liquet, Saliudm ipfam auxilij robur adferre. Atq; corporibus mollibus, er puero= rum, panem, non triticum imponunt ore commanfum. Porró omnia fic commanfa digerunt, er fugillata, ceteráque eccbymomata, maximé ubi panis fimul cum pauco radicule fuerit commanfus. Porró tota fubftantia uel maximé ad= uerfa eft faliua beftijs hominem interficientibus,ceu alicubi etidn Nicander poëta refert. Pollicitus autem mibi quidă incantationem fe fe oftenfurum, que fcorpios interficeret: ubi ill am femel dixifet, in fcorpium expuit : inde rurfum cam obmurmurans iterum fcorpium con/puit : ac ubi tertio dixiffet, atq; expulffet, mortuus eft fcorpius. At poftea ego abfq; incantatione à fold faliua morientem uidi fcorpium, idó; celeriter paffum à faliua efurientium, aut fitien=

Nomina. tium: tdrdé autem ab illis, qui cibo, potug; fuerant impleti: in alijs autem proportione. Quod óvov Gracis, Ld=

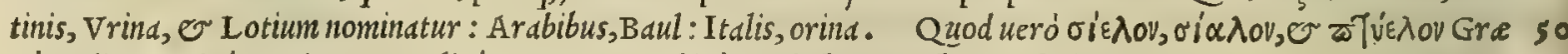
cr, saliua Latiné, pariter or Italicé tiocatur: Arabicé, Bufach, Bezach, or Lhab.

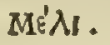
M E L。
C A P.
I X X V.

P R I N C I P E M locum obtinet mel, quod Atticæ regionis eft, præcipuè ex Hymetto, mox Cycladibus infulis, \& è Sicilia, cognomine hyblæum. Magis probatur dulcius \& acre, odoratius, fubfluum, nec humectum, graue, \& minimè fluxum, quod ob fequacem lentitiam non facilè abrumpitur, traćtumq́ue refilit in digitos. Melabftergendi uim habet:ora uenarum aperit, humores euocat . qua ratione in fordida ulcera, linusq́ue, commodifsimè infunditur. Decoctum, atque impofitum, abfcedentem carnem glutinat: medetu impetigini coctum cum liquido alumine, \& illitum : item aurium fonitui, \& dolori cum forsili fale trito, tepidum inftillatur : lendes, \& foeda capi- 


\section{In Lib. fecundum Diof coridis.}

tis animalia illitum recat: $n$ udam glandom recutitis operit, præfertim qux circuncifione aperta nó eft, fi melle præputium à balneo triginta dicbus cmolliatur: oculorum caliginem difcutit : faucibus, tonfillis,anginæ collutum, gargarizatúmue medecur : urinam cict : auxiliatur tufsi, \& à ferpente percufsis: contra hauftum meconium, cum rofaceo calidum affumitur : aduerfus venena fungortm, \& rabiofi canis morfus linetum, aut potum proficit. crudum tamen aluum inflat, tufsim lacefsit, is ca de re defpumati ufus aptior elt. Primatum tenct in mellis genere uernum, dejnde æft juum : hybernum uerò, utpote quod cralsius conftet, deterrimum reputatur, ceragini faciundx idoneum . Quod in Sardinia gignitur mel, amarum eft : quoniam apcs inibi abfinthio uefcantur. quo uitia cutis in facie, \& maculæ aptifsimè perunguntur. Heraclix in Ponto quibufdam anni téporibus, propria quo. 0 rundam florum dote, mel conflatur : quod qui edêre, mente abalienantur; ac fudore diffuunt. Rcme dio funt efrtata ruta, \& falfamenta, aut epotum mulfum, refumpta, quoties uomitione reijciuntur. Acre autem eft, \& olfactu fternutamenta mouet. Quod cum cofto illitum,fœminarum cutem emédat, \& cum fale fugillationes rapit. Eft \& aliud concreti mcllis genus, quod faccharon nominatur. In India verò, \& felici Arabia in arundinıbus inuenitur . falis modo coaetum eft, dentibus, ut fal, fragile : aluo idoneum, \& ftomacho utile, fi aqua dilutum bibatur: vexatæ uefic $x$, renibusq́ue auxiliatur. Illitum ea difcutit, qux tenebras oculorum pupillis offundunt.

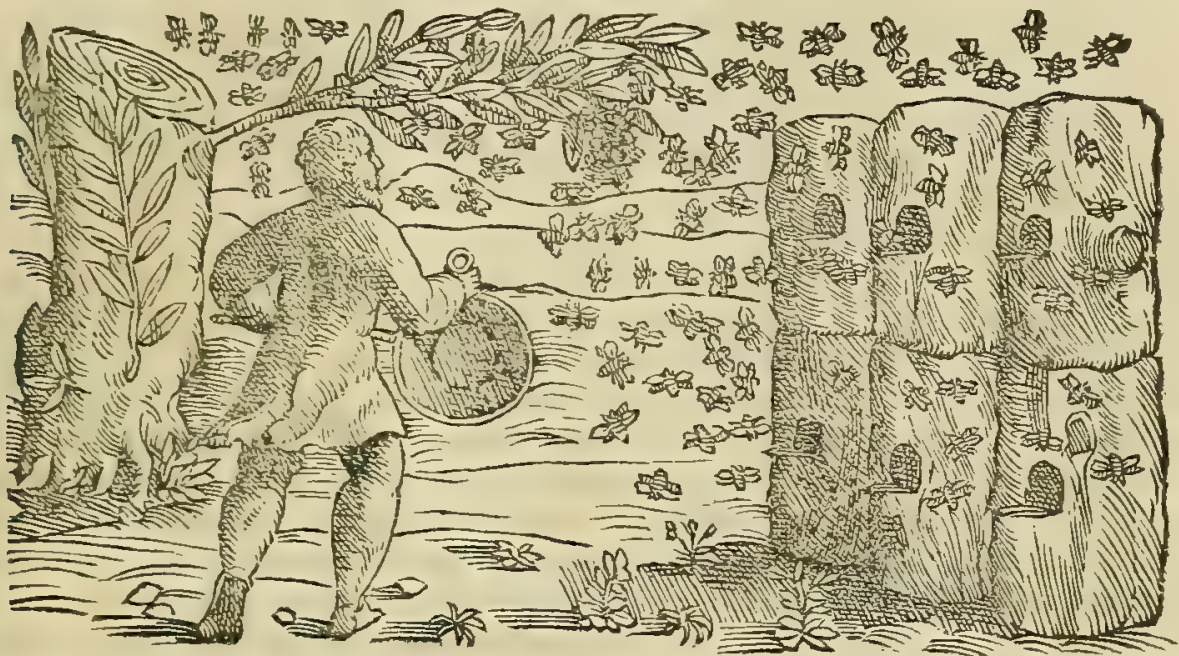

M E L, quod apes colligunt, ommibusq́; uulgarißimun cft (anctore Galeno lib. I I I de alimentorum facultati= bus)oritur in plantarum folijs: caruní, neq; fuccus,neq; fructus, neq; pars, ullo pacto dici poteft, fed eiufdem cum ro= re gencris cft: non tamen aßidué,nec copiosé, ut ille, provenit: repertunn'; eft aliquando aftate Juper arbor ü, ac fru ticum, herb́srum q́; folis mel quàm piurimum, adeó ut agricol.e uelut ludentes canerent, I upiter melle pluit. Cui

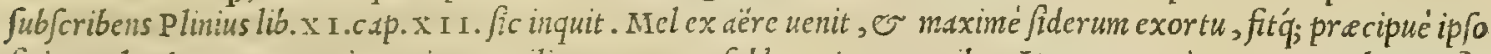
40 firio explendente, ntec omnino prius uergiliarum exortu fubluc anis temporibus. Ita\%, cum prina aurora arbor $u m$ fo= lia melle rofcida inueniuntur. At fi qui matutino fub dro fucre, unct as liquore ueftes, capillum'́, concretum fentiunt. siue ille eft coeli fudor, fiue quedan fiderum faliux, fiue purgantis fe aëris fuccus, utiname effet $\sigma$ purus, ac liquidus, $\checkmark$ fue nuture, qualis defluit primó. Nunc ueró é tanta cadens altitudine, multumq́; dum uenit fordefcens, ¿ obuio terre balitu infectus. Pratered de fronde, ac pabul is potus, e in uterculos congeftus apum: ore enim uomunt. Ad bec fucco florum corruptus, o alueis maceratus, totiesć; mutatus: magnam tamen caleftis nature uoluptatem af = firt. Ibi optimus feimper, ubi optimoruin doliolis florum conditur. Attice regionis hic, er sicula Hymetto, of $\mathrm{Hy}=$ bla ablocis, mox Calydna infula. Hactenus de melle Plmus citato loco. Verum enimuero (ut idem auctor eft libro $\mathrm{x}$ x.cap.x I I I r.)inel, quod in Creta Carina monte colligitur, mufce non attingunt, nec eo in monte eadem ufquam reperiuntur. Porróuenenatum mel, quod in Heraclia Ponti prouenit, cuius hic meminit Diofcorides, Plinius quo= so que recenfuit libro anté citato, cap. $x$ I I I. Subiunxitó; \& alterum eodem in Ponto gigni gente Sannorum, quod ab infania, quin gignit, Nienomenon uocant. Id exiftimatur contrabiflore rbododendri, quo fcatent fylue. Haben= tur praterea e alia neclls genera, qua ro fcida non funt, fed ex plantis nafcuntur, ut illud, quod ex anacardijs flue=. re Arabes fcribunt, $\sim$ inter Gracos strabo Geographicorum libro $\mathrm{x} v$. ex arborum filiquis, quas arbores profe=. runt, denorum digitorum longitudine, mellis plenas, quod qui ederint, non facilé euadant. Quinetiam refert Pom= ponius II llla tertio de fitu orbis, tam pinguis alicubi, $\mathcal{O}$ tam fer acis foli Indiam efe, ut in eo mella ex arborum fron= dibus defluät. Exprimitur etiámnum é uulgaribus filiquis, qua Grecis uęx́тı dic untur, quo tam Indi, quàm qui Troglodyiic an Arabiam incolunt, gingiberis radices recentes uiridesq́; affer uant, ac etiámumm myrobalana omne ge nus. Quod facilé conijcitur ex ijs, que ex Alexandria Aegypti Venetias quotannis comportantur. Caterim non defunt inter recentiores medicos, qui difputent, an Saccharun, quod fub inellis genere fcripferunt ueteres, prefertin Diofcorides, er Galenus in India, e felici Arabia nafci,idem cum noftrate Saccharo dicipoßit. Et quăuis plerique.

Mellis conf1deratio.

Mel Heracleoticum. Mellis generz non rofcida.

Sacchari cófideratio. reperiantur, qui dubio procul exiftiment, ac pro certo affirment, cormumis ufus $\int a c c h a r u m$, or quod ab antiquis de $=$ 
fcribitur, unum $\mathcal{O}^{-}$idem effe, quód ex eadem proueniant planta; tamen Manardus Ferrarien/is, $\mathcal{\sigma}^{\circ}$ Leonardus Fus chfius ip fum fecutus, maximam inter ea ponunt differentiam, omnino opinantes in alio arundinum genere cons creuiffe antiquorum faccharum, de quo inter mellis genera fcripfere Diofcorides, e Galenus: concrefcereq́; ad banc dicm $u \int q_{;}$ex calefti rore, quemadmodum $\sim \sim$ id, quod mannam uocamus: non autem in $i j s$ arundinibus, $\dot{e}$ quibus in aqua decoctis buiufce atatis faccharum in Medera, sicilia, Creta, R hodo, ev Cypro infulis, ac etiam in Ac=

Manardi, \& Fuch. opinio reprobata.

Antiquorum faccharum.

Facitij facch ri inuentio.

Aliquorum laplus. gypto exprimitur. Qua in re cos uiros alioqui doctißimos, plané ballucinatos crediderim, quód nullo, ut puto, au= ftorum probatorum teftimonio ducti fibi perfuaferint, manne in modum ex rore concre feere antiquorum faccharum folis ardore fuper bar undinum folia tan in India, quàm in felici Arabia. Quippe quód nufquam repererim fcripfif= fe Diofcoridem, Galcnum, nec ueterum, uel recentiorum quenquam, concrefere faccharum in arundinum folijs ex rore folis feruore concreto, fiue potius exiccato, quemadinodum in quibufdam arborum frondibus manna per fe con= crefcit. Quo fit, ut mibi refellenda uideatur eorum fententia. Nam fí uerum illud efet, ut ip/i inaginantur, non modó non eft credendum, fed ne cogitandum quidem, Diofcoridem, qui diligenti]3imé fimplicium medicamentorum hiftorids

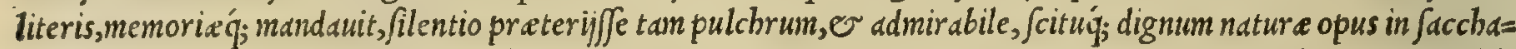
ro conficiendo. Nec minus id reticuiffet Galenus natur a operum maximus ind gator, quemadmodü nec retıcuit lib. I I I. de alimentorum facultatibus, dèrei mellis liftoriam, quod nos mannam uocamus, quod'́; fua aetate in monte Liba= no, alijsć; locis fuper arborum frondes repertum fcribit. Quanobrem mag is ueritati confonü uidetur, ut dic amus, nil aliud ueteribus faccharum extitife, quim noftratis facchari arundinum lacryma, feu liquor, qui nimia fucci co= pia aperto in latere calamo, perinde ac gummi, exterius concreuerit. Huic noftr e opinioni fub fribit Plinis lib. X I I. cap.v I I I. fic inquicns. Saccharon er Arabia fert, fed laudatius India. Eft autem mel in arundinibus collectü gum= mium modo, candidum, dentibus fragile, amplißimum nucis auellane magnitudine. bec Plinius . Ex quibus facilé co= so gnofci poteft, quód non ex rore, ut manne euenit, coale fceret antiquorum facchar um fuper arundinü folia, fed quòd fiactis calamis earum internodijs cohereret collacrymans, é quibus uulgare noftrum conficitur. Quandoquidem boc modo refine, gummx́ q; omnes fcifo fui arboris cortice emanant. Alla preterea buc accedit ratio, qua (ut equi=

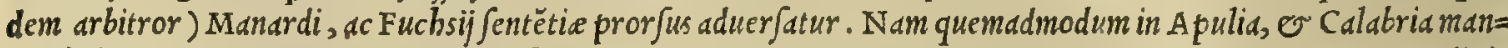
na d fole tald, dum arborum inharet folijs, paruo temporis intcruallo in auram euane cit ( ut libro primo dixi= mus in manne mentione) eadem fané ratione id faccharo eueniffet, fi ex rore ( ut ipfi contendunt) concrefceret. siquidem à fole tactum, rarefactumí; facilé difilijfet in auram, nec gummium modo concreuiffet. Eo q; magis, quód nufquam legerim in Diofcoride, nec Galeno faccharum é folijs arundinum colligi, fed in ipfis calamis concre= tum reperiri. Quod etiam teftatur Strabo libro x v. Geographiz, ubi aperté fcribit, in India arundinem mel fine apibus gignere: non autem quod ex rore in arundine fiat, ut quidam peruicax, ignaruisque medicus mecum conten= dere, atque etiam, ut fuam mordicus te neret opinionem, Strabonis codicem corrumpere non eft ucritus. praterea cummemoris prodiderint Diofcorides, Galenus, er plinius, antiquorum facchar um durum effe, falis modo cod= ctum, album, dentibus fragile, ex bis coniectare licet, é rore faccharum nequaquam fieri. Quippe quoniam manna, que eodem modo è rore concrefcit, fal minimé refirt, nec dentibus fragilis deprebenditur, fed potius mandentibustenax, o cere modo lente fcens. Quare crediderim antiquis faccharum fuife tenuiorem, dc pra= ftantiorem illius partem in arundinum facchariferarum medulla, que per internodiorum fiffurds exiens folis ca= lore concreuerat, ut er faccharum noftrum calore ignis arte concrefcit, er addenfatur. Quod cum accura= tißime perpendiffent bomines, liquorisq́; praftantiam agnouiffent, d natura edocti hoc arte fe facturos exiftimas runt. Neque id incaffum attentaffe uidentur . quandoquidem facchari integros calamos affumentes, minutimq́; in= cidentes, ignis calore tandiu decoxerunt, donec uniuerfus liquor, abfumptaigni aqua, diu efferue fcens in faccha= rum falis modo in uafis fundo concreuerit. Verim et/i facchariarte facti nibil meminerint Diofcorides, $O$ Gale= nus; non defunt tamen qui dicant, boc etiam ante cos factum effe, solini auctoritate freti, qui in Indix paluftri= bus arundinem ita craffam progigni ait, ut fißis internodijs lembi uice uectitet nauigantes, $\dot{e}$ cuius radicibus dul= cem etiam exprimunt bumorem ad mellis fuauitatem. At qui liquorem bunc, qui ex barum cannarum radicibus elicitur, faccharum noftri ufus fuiffe exiftimant, procul dubio falluntur. quód Indi non modó ex decoctis cannarum; fed aliarum quoque arborum radicibus fibi potus parent, cim illius coll o foliclementia frequentißima fint plan= tarum radices, que mellea dulcedine imbuuntur, ut strabo teftis eft loco nuper citato, ubi fic inquit. Nullus an= nus in India inuenitur utroque tempore fine pluuid. Qudpropter contingit annum feracem effe, cum femper terra fit facunda: fructus autem arboreos multos gigni, arborumque radices, prafertim magnarum arundi= num, er natura, er decoctione dulces effe, aqua à folibus tepefacta, tam calefti, quàm fluuiali. Adeó quód ea, que apud alios er fructuum, o fuccorum maturitas dicitur, apud illos concoctio eft: qua tantum ad dulcedi= nem operatur, quantum ea, que perignem fit. Sententie noftre Lucanus quoque fuffragatur, illud expli= cans boc carmine.

Quiq; bibunt tenera dulces ab arundine fuccos.

Quinetiam Marcus Varro, qui eodem feré tempore claruit, his tribus uerfibus atteftatur, dum inquit.

Indica non magna nimis arbore crefcit arundo,

Illius or lentis premitur radicibus bumor,

Dulcia cuinequeant fucco contendere mella.

Ex ijs paldm eft, hos omnes de factitijs Indorum potionibus, que ijs uini loco funt, fuiffe locutos: non autem quód ex illis cannarum radicibus faccharum aliquod pararetur. Quandoquidem or nós é glycyrrbiza radicibus, quin $e r$ decoctis, preßisq́; filiquis, ficut $\mathrm{O}^{\circ}$ alij é dactylis, dulces elicinus fuccos ad uarij ufus patationes . quemadmodum er 


\section{InLib. fecundum Diofcoridis.}

occidentales Indi épluribus dulcibus arbortm fructibus fuos fibi parant potus. Scd non ob id dicctidum bos liquores, quód mellis dulcedincm preftét, effe mel, neq; faccharum. Ncc mirum fané fi Indic a arundincs rudicibus duilcißimüe prebeant fuccum nö modó ille nagne; fed etiam que ibinafcuntur noftris fortafé non multó grandiores : cuin cti.un noftrates recentes manfe quadúntenus ori dulces fentiantur. Quód auté minores artundincs in India radicibus dul= ces prabeant potus, fuperioribus curminibus explicauit abunde Mircus Varro : cui nö mugna nimis cft arbor. In hoc tamen a solino diffentit: cui arundines, quar um meminit, uaftißimx funt proceritatis. Hinc crgo corii fententia ex= plodëda uidetur, gü credunt exillanum magnarum arundinum radic biss, facclurum noftro fimilius factitaffe Indos, quod non quidem facchurum, fed dulces inde potus uini loco fibi conficiant. Scd ut fum opinionem auctoritatibus

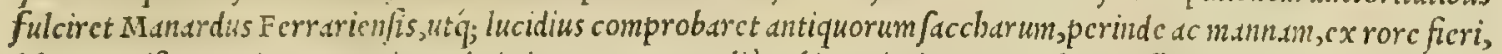

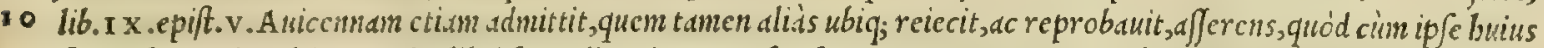
fuerit fententic, ultino capite libri fecundi antiquorum faccharum mannam uocauit, cum inquit. Zucch, wru alhufar eft manna cadens fupcr al hufar, o c ft ficut fiufta falis. At nos, qui buic opinioni minintc adftipulamur, dicimus Albufar, fine Albaffer (ut Bellunenfis caftigauit)nullo pacto Arabica lingua arundinem fignificare, fed alian Aegypti, er Arabie arborem, fic ab cius loci indigcnis appcllatam: quandoquidem Arabes ( $u$ tc ttatur Serapio) arundinem ca= fab dicunt. Quod maniffé declsrat zuccharum alhaffer apud Auicennam buiufce arboris effe mannam, ucl gummi, non autem Grecorum faccharm in calamis concretum. Illud infuper noftrain comprobat fententiam, quod codem laco addidit Anicemna, fic inquicns. Et in zuccharo quidesn albufar eft cum abfterfione pauca, fipticitas, er amari= tudo. Siquiden aufteritatis, $\sigma$ ansoritudinis, que in antiquorum faccharo fuerint, nufquam memincre Diof corides, Or Galcnk: nec iten quód conferret id pulnoni, o aque intercuti, ut pauló infrà uoluit Auicenna. Qui etfi dixe=

20 rit deinde zuccharum hoc oculorum morbis, paritcr'́; renum, or uefice uitijs auxiliari : non tamen ob hoc dici pos teft, zuccharum alhaffer effe antiquorum facchartm. Sed recte quidem contra Manardi ententiam, A uicenne tefti= monio (cim $\sim$ ip fe boc in loco Auccme autoritate nitatur) probari poteft, quód antiquorum faccharum gummi modo collacrymans in ar undinibus concrefccret, nö autem ex rore. Quippe quòd is de zuccharo agens loco nuper. citato, ibiq; antiquorum, faccharum recenfens, inquit. Afumptü ficut gummi ab barundine abltergit oculum. Qui= bus palim fit, antiquorum faccbarun, perinde ac gummi, ab interiorimedulla exterius emanaffe, ibiq; poftmodum fo= lis ardoribus concreuiffc. Verim enimucro quod albaffer apud Arabcs fuigeneris arbor fit, $\sigma$ ab arundine maxi= mé diffcrst, or quód cius zuccharum, quanuis ab Auicenna manna dic atur, quód fortaffe granulis concrefcat manna fimilibus, ex rore haudquaquam fiat, fed gummium modo ab arbore deftillet, manifefte oftendit serapio capite de fac= charo his uerbis. Alhafer baber lata folia, of babet zuccharum, quod egreditur ab oculis ramorum fuorum, or $d$

30 lacis foliorum eius, er colligunt de ẹ bomines ren conuenienten, o in zuccharo eius eft amaritudo, or cgrediuntur ab hac planta mala quedam, ficut teficuli camelorum, é quibus liquor quidam emanat adurens, ftipticáq; facultatis, ad cauteria peridoneus. Et lignum quidem Albaffer eft leue, crafjum, rcitum, pulcbrumiq;, or ideo aßimilauerunt cantilenarij in cantilenis fuis brachia, o crura dominarum ligno cius . hac serapio . Ex quibus facile et Manardum, - Fuch/ium, uiros alioquidofifimos, hac in re ballucinatos putauerim. Caterim Fuchfius, ut probaret antiquo=- Fuchfij opin: rum faccharum è rofcido cali fucco in calamis concrefcere, ut'́; illud ḋ noftrate diucrfum oftenderet, dicit, quód reprobata. cùm nofri ufus faccharum, perinde ac ncl, calidum reperiatur, fitiní, facilc concitet, antiquorum faccharum 'effe non poteft, co quod Galcnis fux statis faccharum id efficere non prodiderit. Cuius tamen fententia (pace fua di= xerim ) experimento minimé repondet : à quo non difcedens Galenus lib. v I I. fimpl.medic. de faccharo ita feribit . Sacchar, quod ex India, at q; felici Arabia conuebitur, in calamis, ut aiunt, concrefcit, et ip fum mellis eft pecies: mi=

40 nus certé noftrate dulce, fed adfimiles ei uires obtinens, quod ad abftergendum, deficcandum, or digerendum attinet. Porró quatenus nec inimicum ftomacho eft, ceu noftras, nec fitim affercns, eatenus ab illo fubftantia differt. Quibus Galeni uerbis clarum eft, quód cum faccbarum melle minus fit dulce, minus etiam calidum fit neceffe eft. Eaq́; pro= pter afferit Galenus, faccharum non perinde ac mel, fitim excitare: non tanen quód nulla ab eo fitis excitetur, uti Fucb/ius interpretari uidetur. Quinetiam idem Galenus lib.v I I I.cap. I I I I.methodi medendi, faccharü inter ea connumerat, que febrientibus exhiberi poffunt. His igitur rationibus, er auctoritatibus adductus fun, ut certó cre= diderim, antiquorum faccharum ab ijsdem arundinibus emandre, ḋ quibus uulgare noftrum exprimitur: fed banc tantum inter fe differentiam effe, quod à natura factum fit noftrate fuctitio longé tenuius. Ideo ó; Auicenna: Zuc= charum (inquit) tabarzed frigidius eft, e Jubtilius. Hoc laudibus extulit Paulus, e poft ip fum Auicenna Archigenis auctoritate Sal Induin ip Jum appellans, ad ling ua fcabritiem, ariditatem 'ं; in acutißimis febribus. Sed co nos bac a

so tate caremus, quód amplius non afferatur. quanquam ego non ita pridem à uiris fide dignis accepi, qui diui Thome infulam, item'; Mederam luftrarunt, adbuc ijs in locis faccharum inueniri in arundinibus facchariferis concre= tum (illinon dißsinile, quod arte fit, or candidun cognominatur) poftquàm ab illis ponte emanarit gummi modo. Quód autem adferri defierit, non aliud in caufa effe exiftimamus, quim quód bodie paucum admodum proueniat. siquidem Diofcoridis, et Galeni tempore, quo ad eos copiofum conuebebatur, cum adbuc non innotuiffet exprimendi ratio, neceffe quidem erat, ut arundines facchariliquore pragnantes, cum annis compluribus adoleuiffent, $\mathcal{O}^{\circ}$ fal= cem nunquam experte efent, per fe liquorem exudarent, ueluti innumeris arboribus gummi, or refine emanant.Pro= inde non mirum, fi eius à natura facti antiquis fuerit ubertas. sed post quàm lucridulcedo, fulgentis $\dot{q}_{;}$aurifitis do=

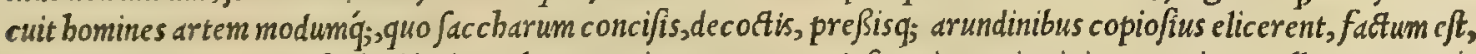
ut Indi quotannis uniuer fos inciderint calamos, ac iterum quotannis feverint. Hinc igitur euenit, ut nullis remanenti= bus, que faccbaro plurium annorü atate turgeant, natur $x$ impedita fit operatio, deperditǘ, bac de caufa fit antiquo rü faccharü. Cuius uice co recentiores utuntur, quod officine candidum cognominant, arte factum, pellucidum, falis

Manardiratio infirma.
Alhafter quid ex Serapio.

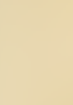


foßitij modo, dentibusq; fragile, ut antiquorum faccharum undequaq; referat. Competit perinde ac illud, fcabritiei" lingux, pectoris'; apperitatibus. Verium ad bac id praftantius eft, quod in fictilibus, ubi uiolaceum I ulapium:afjer= uatur, aftate concreuit : eo quód uiolarum diluti facultate bumectet, leniató; magis. Quod Grecis $\mu \dot{\varepsilon} \lambda \lambda_{1}$, Lati= nis Miel appellatur: Arabibus, Hdël, feu Haffel:Italis, Mele: Germanis, Honig: Hipanis, Miel: Gallis, Myel.

Nomina. Cuodauten Gracé cá $\gamma \chi \alpha \rho o v$, Latiné quoq; Saccharum dicitur: Arabicé, Zuchar: Italicé,Zucchero: Ger= manice, Zuclier; Hipanice, Azucar : Gallice', succre.

$$
\text { KHęós. CERA. }
$$

\section{CAP. LXXVI.}

C E R A optima eft fubfulua, fubpinguis, pura, odorata, \& halitum quadántenus melleum refe- 0 rens, natione Pontica, aut Cretica. Secundum locum obtinet candicans, \& fuapte natura pinguis.

Candida fit hoc modo. Ex ea radunt album, fyncerumq́ue, atque transfundunt in uas, quod fatis habeat marinæ ex alto petitæ, infperfoq́ue nitri momento, decoquunt : cùmq́ue iterum, tertióue inferbuit, feparatum uas refrigerant, ac ceræ paftillum eximunt, deterfa forde, fiqua fortè adhæfit : tü denuo indita noua maris aqua feruct, uti retulimus : $\&$ uafe dempto ex igne, fundum ollulæ nou $x$ aqua frigida madefactum, in ceram fummam fufpenfa manu intingunt, quò celerius concréfcat, \& quàm ninima portio extrahatur. Sufcepto primo ceræ orbiculo, iterum uafis imum aquia refrigeratum, tantifper in ceram immitti debet, dum tota excipiatur. Orbiculi lino confuti, interuacante fpatio fufpenduntur, \& interdiu continuò fub fole, noctu fub luna afperguntur, ufque dum perfectè albefcant. Verùm fi eximius ille candor defideretur, eadem factitari, \& identidem recoqui ope- 20 ræpretium eft. Nec defunt, qui pro marina, in muria quàm acerrima femel, aut iterum excoquant: dein laguncula tenui, rotunda, anfam habente extrahunt: poftea orbiculos fübftrato affatim cefpite herbofo, infolant, donec candorem fummum contraxerint. Præcipiunt hoc obeundum munus vere, cùm fol remiffa uehementia humorem pariat, ut non facilè liquetur. Cera omnis mollit, calfacit, modicè explet corpora: datur in forbitione dy fentericis. ac milij magnitudine decem grana ceræ haufta, lac in nutricibus non patiuntur coagulari.

Cerx uiresex C E R A, ut Galenus fcriptis mandauit libro vI I fimplicium medicamentorum, medio quodammodo tenèt Galeno. calfacientium, refrigerantium, humectantium, o deficcantium. Habet ueró quiddam etian craffarum partium, atque emplafticum. quamotrem non modó exiccare; fcd o per accidens humectare uideri fortaßis poterit, per $=30$ Birationes uidelicet probibens. Quapropter aliorum medic amentorum tum excalfacientium, tum refrigerantium materia eft. Ipfa autem per fe ex genere fuerit deboliter concoguentium: nec temen intró in corpus affumpta, fed fris impofita . siquidem paulum quiddam digerentis, calidég; facultatis retinet, qua plurima melli inerat.

Nomina. Eius nomen Gracum xноo's: Latinum, cera: Arabicum, Hamaha: Italicum, cera: Germanicum, Vuachs: Hi= fpanicum, Ciera: Gallicum, Ciere. •

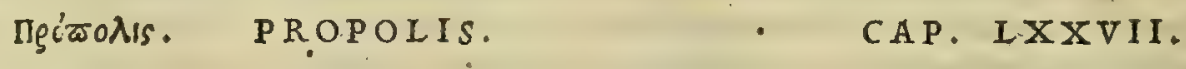

PR O POL I S eligi debet flaua, odorata, ftyracem referens, in vehementi ariditate mollis, \& maftiches more ductilis. Magnopere calfacit, \& euocat : aculeos, \& omnia infixa corpori extra- 40 hit: in uetere tufsi fuffita proficit, impetigines admota tollit. Ea in alueariorum foribus, cerofænaturæ inuenitur.

Propolis cófideratio.

Qv A N Q V A M, ut hic Diofcorides inquit, or Marcus Varro libro tertio de re rustica, Propolis ea eft cero fa materia, qua in aluearijs pre foribus reperitur, feu, ut apcrtius dicam, pre piraculis, ubi intrandi, exeundiq́; apibus patet aditus : tameh Plinius libro X I. cap. V I I. ita fcriptum reiiquit. Prima fundamenta comofin uocant periti, fecunda ptffoceron, tertia propolin. Inter coria', cerds'g; magni ad medicamina ufus. Comofis crufta eft pri ma, faporis amdri. Piffoceros fuper eam uenit picantium modo, ceu dilutior. Cere initium, plcrunque é mitiore gummi. Propolis craßioris iam materix, additis floribus, nondü tamen cera, fed fauorum ftabilinentum, qua onnes frigoris, aut iniuria aditus obftruuntur : odore $\mathrm{O}$ ip $\int a$ e tiămnum graui, ut qua plerique pro galbano utantur. $\mathrm{H} u=50$ Propolis ui- ius etiam meminit Galenus libro v I I I. fimplicium medic amentorum, fic inquiens. Propolis extergentis, non ita ud= resex Gal. lentis eft facultatis, ceterùm admodum ualenter attrabentis: eft enim effentia tenui. Porró excalfacit recefju fe= cundo completo, aut certé tertio incipiente. Et ut idem quoque fcribit libro I I I. de compofitione medicamento= rum fecundum genera, Propolis ualentius attrahit, qudim cuiúfuis generis refind. Quamobrem illis in neruorum uulneribus medendis propolin admifcet. Caterum cim propolis, cerd, or mel, de qubus hic differuit Diofcori= des, medicamenta fint omnia miro artificio ab apibus conflata, non ab re bis quoque addendam fore duximus A pum

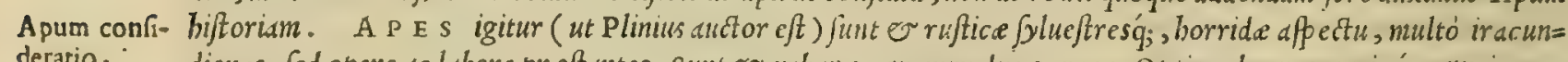
deratio." diores, fed opere ac labore preftantes. Sunt or urbane, quarum dio genera. Optime breues uarié $q_{;}, \sigma$ in ro=

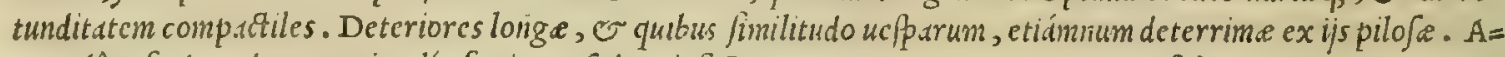
pes odêre foedos odores, procul'q; fugiunt, fed E infitos. Itaq; ungue nta redolentes infeftant. Icientes percunt: relicto enim aculco intertor difrumpunt. Quin o morbos fuapte natura fentiunt. Index eorum trifitia torpens; 
o cium ante fores in tcporem folis promotis alie cibos minifrant : cum defunct as progerunt, funerantium'; more comitantur exequivs. Regesbabcht, plureság; inchoantur, ne defint. Poftea exbis foboles cum adultacffe captt, Apum rex, \& concordifuffragio deterrimos necant, ne diftrabant agmina. Duo corü genera: inclior rufus, quàn niger, uariuś, regimen. Omnibus forma funper egregia, e duplo quin ceteris indior : penux brewiores, orura refi, ingreffus celfior: in frontc macula quodun diademate candicuits. Multum etiam nitore à unlgo differunt. Cim rexprocedit, unà cft to= - tum cx.ımen, circ.íf; cum conglob.itur, cingit, protegit, cerni non pututur. R cliquo tempore cum popuius in labore eft, ipfe opera intus circuit, funilis exhostanti, folus inmmunis. Circa cum fatellites quidan, lictoresio; ajsiduicufto= des auctoritatis. Procedic foras non nifímigratwro cxamine. Id multó intelligitur anté aliqusot dicbus murmure intus frepente, apparatus indice dicm tempeftium cligentium. Siquis alan ci detruncet, non fugiet exambn. Cümpro= 10 ceffere, fe qua q; proxim un illi cupit effe, or in officio conpici gaudet. Feffum bumeris fublcuant: ualidius futig.d= tum ex toto portant. Si qua lafjatus deficit, aut fortć aberrauit, odore profequintur. vbicuny; ille confedit, ibi chil= starum caftra funt. Duce prebcnfo totum tenetur agment: amiffo dilabitur, migrant'́; ad alios. Effe utique fine rege non polfunt. Inute auten intcrimunt cos, cum plures fuere, potiusq; nafcentium domos diruunt. Rege confumpio, meret plebs ignauo dolore: non cibos conuchunt, non procedunt, fed trift tantum murmure glomerantur circa cor pus eius. Subtrabitur utaq; deduct a multitudine : al his ppectantes exanimem luctum non ninuunt. Tunc quoq; ni $\int u b=$ ueniatur, fame morikntur. Gaudent Apes aris plaufu, ac tinnitu, amœnißimisq́; locis, e fragrantibus berbis. Ha= rum ergo caufaprope alucaria oportet ferere thymum, apiaftrum, rofam, uiolas, lilium, cytifum, fabam, eruilium, cunilam, papauer, conyzam, caftam, melilotum, meliffophyllum (malin legere myriophyllum) cerinthen. Eft autem ccrinthe folio candido, incuruo, cubitalis, capite concauo, mellis fuccum babente. Hor un florum auidißime funt, at=

20 que etiam fynapis. quod miremur, cim olius florem ab bis non attingi conftet. Idcóq; banc arbor em procul effe me= liuseft, cium sliquas quàm proximé feri conueniat : que or euolantiun exdmina inuitent, nec longius abire patiantur. Connum quoq; arborem caueri oportet: nasn flore eius deguftato ( $\mathrm{et} f \mathrm{i}$ is nobis profluuid fiftat) aluo concita moriun= tur. Remedium forba contufa è melle prebere ijs, uel urinam bominum, uel boum, aut grana punici mali amineo ui= no confper $\int a$. Amant e geniftas circunferi aluearijs, $\ddot{j}$ s $\dot{q}$; gratißimum. Mira apum prudentia, carum $q_{\text {; }}$ operis obferuatio, ut amotauit Ariftomacbus Solenfis, quem admirabiliadinodun diligentia duode $\int e x a g i n t a$ annis, apum $a=$ more captum, nibilaliud egiffe tradunt. Ratio autem operis ita fe habet. Interdiuftatio ad portas more caftro= rum: noctu quics in matutimu, donec una excitet omnes gemino, aut triplici bombo, ut buccino aliquo. Tunc uniuer Se prouolant, fi dies mitis futurus eft. Prediuinant enim uentos, imbresq;, or tunc fe continent tectis. It ta ; tempe= ric cali (hanc entm inter tse fcita babent) cim agmen ad opera proceßit, alixe flores aggerunt pedibus, alia aquann

30 ore, guttas ; lanugine totius corporï, quibus est. Quarum adole fcentiores ad operam exeunt, or fupradicta conuce= bunt: feniores intus operantur. Que flores comportant, prioribus pedibus femina onerant, propter id natura fca= bra, pedes priores roftro, toté $;$; onufte remeant farcind pandate. Excipiunt eds terne aut quaterns, at $q_{;}$exone= rant. Sunt enin intus quoq; officia diuifa: alie fruunt, alte poliunt, alia fuggerunt, alix cibum comparant ex co, quod allatum eft. Neq; enin feparatim ue cuntur, ne inequalitas operis, ér cibifiat, e temporis. Struunt orfa ea. concameratione aluei, textumíg; uel ufque dd fumna tecta deducunt, limitibus binis circa fingulos arcus, ut alijs in= trent, alijs exe.snt. Faui fuperiore parte affixi, er paululum etidm lateribus fimul barent, or pendent und. Alueum non contingunt, mnc obliqui, nunc rotundi, qualiter pofcit alueus, aliquando er duorum generum, cum duo exami:na concordibus populis difiniles babuere ritus. Ruentes ceras fulciunt, pilarum intergerinis à folo fornicatis, ne de= fit adisus ad farciendun. Priniferé très uerfus inanes ftruuntur, ne promptum fit quod inuitet furantem. Nouißi= 40 mi naxiné implentur melle: ideóq auer fo dlueo faui eximuntur. Gerula fecundos flatus captant . si cooriatur pro= cclla, appreben $/$ ipondufculo lapillife librant. Quidam in bumeros eum imponi tradunt. I uxta uero'terram uolant in aduerfo flatu uepribus bebetato. Mird ob feruatio operis. Ceffantium inertiam notant, caftigant, mox or puniunt morte. Mir a munditia. Amoliuntur omnia é medio, nulleq́;; inter opera purcitia iacent. Quin $\sigma^{\circ}$ excrementa ope: rantium intus, ne-longius recedant, unum congefta in locum, turbidis diebus, ov operis ocio egerunt. Cum aduepe= rafcit in alueo frepunt minus, ac minus, donec una circumuolet, eodem quo excitauit bombo, ceu quictem capere im= perans : $\sigma$ boc caftrorum more . tunc repenté omnes contice fcunt. Si forté fortuna apum uniuer fum deperderetur genus, facilè reparari poffet ex bienni uitulo, ut libro I I I I. Georgicorum claré docuit virgilius, ita canens. gaudeant.

Mirs apum in opere fuo induftria:.

Exiguus primism, atque ipfos contractus ad ufus

Eligitur locus : bunc anguftiq; imbrice tecti,

Parietibus $\dot{q}_{\text {p }}$ premunt arcits: $\sigma$ quatuor addunt

Quatuor à uentis obliqualuoe feneftras.

Tum uitulus bind curudns iam cornua fronte

Queritur : buic gemine nares, er piritus or is

Mulia reluctanti obftruitur : plagiś; perempto

Tunfa per integram foluuntur uifcera pellem.

sic pofitam in claufo linquunt: Oo ramed coftis

subijciunt fragnenta, thymum, cafias qu; uirentes.

Hoc geritur zeplorris primum impellentibus unds.

Anté nouis rubeant quàn prata coloribus, anté

Garrula quam tignis nidum fupendat birundo.

Interea teneris tepefactus in oßjibus bumor 
Aeftuat: er uifenda modis animalia miris,

Trunca pedum primó, mox or ftridentia pinnis

Mifcentur : tenuemó; magis, magis ä̈ra carpunt:

Donec, ut aftiuis effufus nubibus imber,

Erupêre: aut ut neruo pul Jante fagitte,

Primaleues ineunt $f i$ quando prelia $\mathrm{P}$ arthi.

De reparatione Apum bactenus Virgilius. Ceterim etiam apes in medicina $u$ fum babent: fiquidem ficce er in pul=

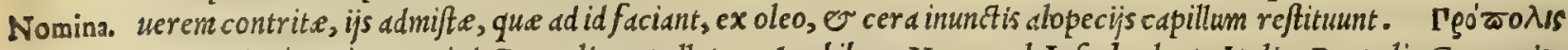
ut Grecis, ita etiam Latinis Propolis appellatur: Arabibus, Mum, kel, Iafach alcut: Italis, Propoli: Germanis, Vorftofz: Hippanis, Betum de colmena.

Iugós. T RITICVM.

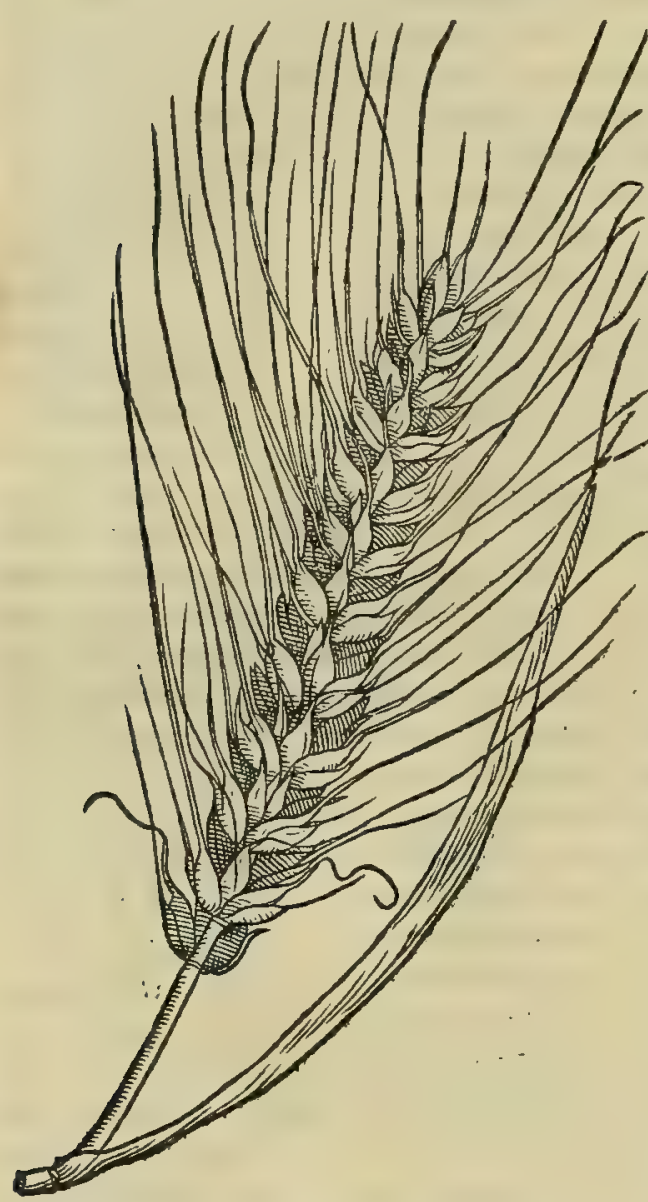

\section{CAP. IXXVIII.}

O P T I M A è tritici generibus ad fecundæ valetudinis ufus habentur, qux recentia, $\&$ iam perfeftè adulta; colorem luteum referunt . dein fequuntur trimettria, quæe nonnullis fitanja nominantur. Itaque cruda in cibis teretes tineas gignunt : canum morfibus profunt, manfa \& impofita. Confectus eorum fimilagine panis, plus alit, quàm cibarius. E' trimeftrium farina panis, le- 20 uiorern cibum præbet, \& qui facilè in membra demandetur. Farina eorum cum hyofcyami fucco illinitur aduerfus neruorum fluxiones, quas Græci rheumatifmos vocant : item contra interaneorum inflationes: lentigines ex aceto mulfo tollit. Furfures autem in acriaceto decocti,turgentes mammas fedant : viperarum iEtibus auxiliantur: \& torminofis profunt. Farinaceum fermentum calfaciendi, extrahendiq̣ue vim habet:priua tim callos pedum, clauosq́ue extenuat : $\&$ cætera tubercula furunculosq́ue ex fale concoquit, \& aperit. Si- 30 taniorum farina, contra venenatos ictus cum aceto, aut vino commodifsimè illinitur : eadem fi decocta in glutini modum delingatur, cruentis excreationibus proderit: contra tufsim, \& exafperatas arterias, cum mentha \& butyro decocta, efficax eft. Tritici pollen fi exaqua mulla,aut hydrelæo decoquatur, omnem difcutit inflam mationem. Panis \& crudus, \& coctus cum aqua mulfa inflammationes omnes illitu mulcet, cùm emolliat, \& quadántenus refrigeret: fed herbis, fuccísve huic rei accommodatis admifceatur. Vetus panis aridus, adiectis $4^{\circ}$ conuenientibus, citam aluum cohibet. Recens muria maceratus, illitu vetuftas impetigines fanat. Glutinum ex fimilagine, \& polline, quo chartæ glutinantur , fanguinem excreantibus prodeft, $f \mathrm{l}$ liquidius, ac tepidum cochlearis menfura detur forbendum .

Tritici genera ex Theophrafto.
T R I T I C I genera ( ut Theophraftus auctor eft lib. vi I I. cap. I I I I. de plantarum biftoria) plura notans tur, cognomina ex locis fortita, ut Aphricum, Ponticum, Thracium, Aßyrium, Aegyptium, siculum . que er colo= $r e, \&$ magnitudine, $\odot$ pecie, $\odot$ proprietate inter fe differunt. Quadam uel aliunde cognomina fortiuntur pro fuis uiribus tum alijs, tum uel maximé que ad cibum pertineant, ut cachrydias, ftlengys, alexandrinus. quorum omnium differentias in fupradict is colligere licet. Nec ueró ab re fuerit, fillla quoque pro differentijs capies: $\sigma$ aliud pre $=50$ cox, aliud ferum: $\sigma$ aliud auctu amplum multum q́; reddens, aliud ieiunum quoddam parum $q_{;}$ferens: $\sigma$ aliad $\beta i=$ cam grandiorem effundens, aliud paruam: o alıd diu in folliculo manens, aliud aptum breui abfolui, ut A ploricum: O aliud culmo tenui conftans, aliud craffo . quod etiam ip fum Aphrico datum eft : craffo tamen $\mathrm{O}$ cachrydias dictum confiftit. Item aliud tunicis paucis, aliud multis ueftitur, ut Thracium: $\mathrm{O}$ aliud unicalamum, aliud multicald= mum, or magis, minus $q_{;}$. Adde etiam fi quid aliud bis, aut predictis, ratione uirium proximum eft : eiufmodi nanque differentix naturaliores profectó appareant. Quibus e trimeftrium annumerarigenus par eft, $\mathcal{O}$ bimeftrium, $\mathcal{E}$ fi quid intra pauciores dies ualeat confummari, ut in Eubce a genus quoddam intra quadraginta dies craffari, perficiófs poffe affirmant : idem'; firmum effe, ac ponderofum, nec trimeftris modoleue. Quamobrem famulis id prebcri in= quiunt: etenim nec multum in boc furfuris effe uolunt. I gitur genus id celerrimum quidem ad confummationem, fed inuentu rarißinum eft. Et bineftria uerò qua dam babentur, que ex sicilia or in Achaiam aduecta funt: fed hac pau cum reddunt, parumq́i facunda babentur : quanquam cibo facilia, o iucunda funt. Nafcuntur o alia quadam ge= 


\section{In Lib. lecundum Diofcoridis.}

nerd in Euboed, or precipué apud Cariftum. Trimeftria ueró permulta, $\odot$ ubiq; babcntur : Icuia bac, or parum foe cunda, unicaldnut funt, atq; in totum infirma. Leuißimum igitur triticum, quodd finplici ratione agcre licet, Ponti= cum eft: poilderofius ex ijs, que in Greciam aduebifolent, siculum datur. Sed co pondero/ius, quod Breotiafert. Indiciun afferunt, quod athlete, qui Bceotix ternos femifextarios uix poßint confumere, cim A thenis fuerint, faci= lé quina confumunt. Leue fatis er quod in Laconico agro conficitur. Horum igitur caufa in terris cceló;; intelligi debet. Nam or Afie ultra Bditra quod am in loco adcó grande frumentum frevi tradunt, ut nucleis oliux fua aquipa rent m.gnitudine grana fingul.t. In Pifforis autem dictis adeó firmum nafci affirmant, ut fi quis plus comederit, dif= rumpatur neceffe fit. Hactcmus de triticigeneribus Theopbraftus. Ceteriun Plinius Italicum nofrum omnibus pretulit libro x V I I I. cap. V I I. his uerbis. Triticigenera plurd, qua fecere gentes. It alico nullun equidem com=

$\therefore$ parauerin candore, ac pondere, quo maximé decernitur. Montanis modó comparctur Italix agris cxternum. He fuere fententic Alexandro magno regnante, cum clarißima fuit Grecia, atq; in toto terrarim orbe potentißima: ita tamen, ut ante mortem eius ammi feré centum quadraginta quinque sophocles poëta un fabula Triprolemo frumen tum Italicum ante cuncta laudacrit, ad uerbum translata fententid.

Et fortmatan Italiam frumento canere candido.

Qux I.tus peculiaris bodic Italico cft. Quo magis admiror, pofteros Grecorum nullam mentionem buius feciffe fru= menti. hec Plinius. Nec fane mirum uideridebet, quod Grecus illc sophocles Italicum frumentü ceteris pratu= lerit. Quandoquidem natura Italos adeó pre ceteris adamanit, or moribus, ac legibus, omní́; ornatu ad politice (ut ita dicam) nuuendum inftituit, ut sucritó etian frumentum omnium preft antißimum in eorum alimentum procred= rit: quemadmodum or slia multa, quibus Italia plerasq; fuperat gentes. Triticum autem, ex quo omnium optinus

20 fit panis, cligi debet fratu contunax, denfum, graue, colore aureum, lucidum, laue, trium inenjium, maturum, mun= diont, pinguiq; terra ortun. Nam plerunque euenit ( tefte etiam Galeno libro primo de alimentorun facultatibus) ut quod foris flaum, denfunq;; apparet triticum, intus rarum, Laxum, albun'́; confpiciatur, quod utiq; plurinum fur = furis habet. Quofit, ut panes furfuracei inde confecti infirmum non modó prabeant alinentum; uer im etiam uen= triculum ip fun excrementis repleant. Farina porró ea ceteris praft at, que non ad fummum molita, non noud, non longitemporis, er craßifurfuris fuerit. Nam que fuperflué molitur, furfuraccos facit panes: er que recentior eft, adfititiam mole caliditatem rctinet: qua ueró iandiu molita fuit, puluere, fitu, carie, aut uirofo aliquo odore la= befactatur. Hec deinde, dum fit panis, optine eft affocianda aque, ed q́. Jubigenda, que fluxerit é laudatißimis fontis bus, pellucida fit, non paluftris, neq; canum, aut linum redoledt. Quinetiam fermentum admifcendum fuerit triti ceum, non antiquum, mediocris quantitatis, ne inde ipfius abundantia panis acorem contrabat. Inijciendum eft er fa

30 lis albi parum, ut panis fapidior efficiatur. Poft bec farina ita fubacta, optime manibus pinfitur : mox maffa illa in pa nes mediocris magnitudinis digeritur, qui poftquàn abunde creuerint, of fermentatifuerint, in clibanum prius sequa liter calefactum, dein à cineribus, e prunis expurgatum decoquendi immittuntur. Sed furnus iufte capacitatis fit oportet, ita ut quantitati panis proportione repondeat. Quippe quemadmodum modica panum quantitas in amplum clibanum mifa cxiccatur, ac comburitur : ita $\sigma$ magna in angufto fimul comprimitur, or decoqui nequit. Quamob= rem panes (dicebat Galenus citato loco) ad concoctionem probatißimi funt, qui plurimuim fermentati, or probé elas borati in clibano igne moderato percoquuntur. Nam profufior ignis primo ftatim occurfu adurens, exteriorem fu= perficiem in telte modum indurat, crudis incoctis' ; remanentibus interioribus partibus. Vnde accidit, panem bunc uifu iniucundum fieri, 0 duplici nomine praum. quod interné crudus fit, ato; illaboratus : externé ueró ficcus, $\sigma$ prealJatus. Qui autem longiore fpatio undiq; equabiliter preadfatur, bic er probé in uentriculo concoquitur, atque 40 ad actiones, que coctionem confequntur, accommodatißimus redditur. Triticum in agris facilé degenerat in lo= lium: prefertim cum annus pluuius, frigidusq́; aduenerit, ut in lolij mentione latius dicemus. Fit è triticigranis in= ter ferri laminas igne cale facti compreßis oleum, quod ad ulcerum finus commendant. Sunt etiámnum, qui eo utan= tur ad pedum, $\mathrm{C}^{\mathrm{r}}$ manuum rimas, quas frigus excitauerit : item ad aperam cutim le uigandam. Meminit tritici Gd= lenus libro v I I . Fimplicium medic amentorum, fic inquiens. Triticum ut medicamentum foris impofitum, primi eft ordinis excalfacientium; non tamen nec reficcare, nec refrigerare manifeftó poteft: babet ueró etiam quiddam ui= fco $u m$, ob obtruens. Porró quod ex co conficitur amylum, co tum frigidius eft, tum ficcius. Quod ueró ex pane fit cataplafma, uim habet magis digerentem, quàm quod ex tritico : nimirum ciun ev falem, o fermentum panis adiuncta habeat: quippe cum fermentum uim babeat attrabendi, digerendiq́; ed, que in alto refident. Et primode fa= cultate alimentorum: In cibum affumptum (inquit) egré concoquitur, flatus excitat, laborem uentriculo infert, er caput uaporibus tentat. Triticum fic Latiné dicitur :

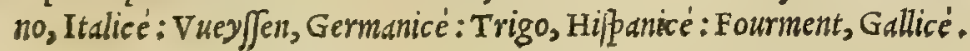

\section{K९७७่. HOR DEVM.}

\section{CAP. LXXIX.}

H O R D E V M eft candidum, purumq́ue. Id minus, quàm triticum alit. Ptifana tamen ob cremorem in decoctione redditum, plus alimenti prabet, quàm polents ex hordeo facta. contra acrimonias, atque gutturis fcabritias, exulcerationesq́ue pollet: quibus etiam triticea ptifana præfidio eft: fed plus alit, magisq́ue vrinam mouet. Lacabunde luppeditat, fi cum foeniculi femine decocta forbeatur. Hordeum abfterget, vrinam ciet, inflationem parit, ftomacho aduerfatur, tumores concoquit. Farina hordeacea decoquitur in mulfa aqua cum fico, vt inflammationes, collectionesq́ue difcutiat: duritias cum refina, \& fimo columbarum concoquit: cum meliloto autem, \& papaueris calyce 


\section{And. Matthioli Comm.}

HOR DEVNI.

Hordei conf deratio.

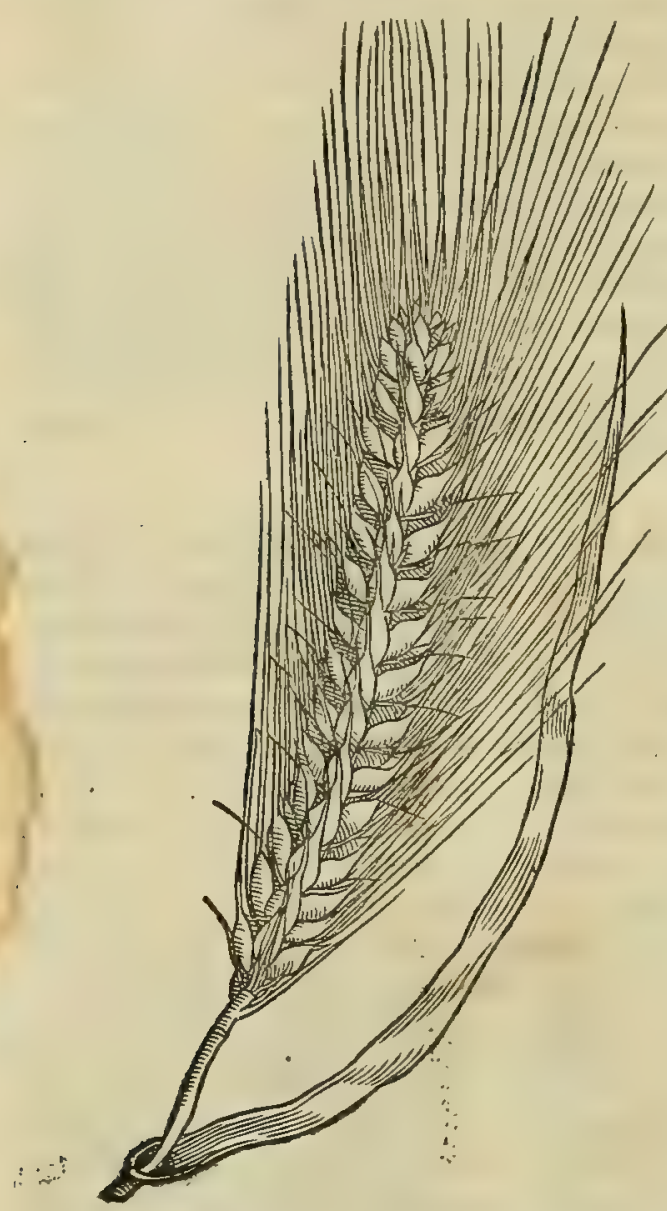

calyce dolores finit, qui latus excruciant: aduerfus inteftinorum inflationes cum lini femine, fonograco, \& ruta illini iuuat: ftrumas cum pice liquida, cera, oleo, \& impubis pueri vrina, ad concoctionem perducit': \& cum myrto, aut vino, aut malicorio, aut fylueftribus pyris, aut rubo, alui profluuia fiftit : podagricis inflammationibus cum cotoneis, aut aceto prodeft: decocta in acri aceto, modo quo hordeaceum cataplafma, \& calida impofita, lepris medetur. Cremor verò farinx ex aqua, atq; cum pice, \& oleo decoßtus, puri mouendo eft : cum 10 aceto fubactus, itidem $\&$ cum pice contra articulorum fluxiones prodeft. Farina ex his aluum cohibet, inflammarionesq́ue mitigat.

$\mathrm{N}$ o $\mathrm{N}$ minus Hordeum in Italia unlgaris notitix eft, quàm triticum. Eft autem (ut Theoploraftus libro v I I I. cap. I I II. de plantarum biftoria memoria prodidit) in hordei genere diffe= rentia. quippe quód aliud binis uerfibus, aliud ternis, quater= nisq́; , cumq́; plurimum fenis: eft enim uel eiufimodi quoddam ge= nus. Quod ueró pluribus conftruitur uerfibus, hoc.femper feré Bißius, pofitug; arctius constat. Magnam e Indicum differen= tiam facit: quandoquidem ramis natum fit brachiari, ut propo= fui . Et ßícé ueró alijs grandiores, rariores q́; conftant: alijs mi= nores, frequentioresó; : 0 alijs diftantiores à folijs, alijs proxi= miores, ut Achilleis cognomine. Et hordeorum ipforum aliud ro tundius, minusq́;; aliud oblongius, maiusq; , atq; in pica rarius. Item aliud candidum, aliud accedens ad purpuram, quod o fa= rinam reddere copiofius creditur : $\sigma$ contra byemem, $\odot$ flatus, et in totum contra cali mutationes candido ualidius effe uidetur. biacterias Theophraftus. Oritur e in Gallia bordeum, quod can $=30$ therinum dici pututuerim, quia folliculo caftratum end fcitur. Gal= Ii qui ferunt, mundum nocdnt bordeum, quod pponte granum gluma cosidat, in reliquo autem non nifi agré deglu= bitur. Hordeum magis, quàm triticum, rubiginem fentit, minus'q; tolerat imbrium impetus. Siquidem infrftis imbri= Hordei facul bus, aut uligino/is locis, aut longiore plunia dilutis fatum in lolium degencrare affirmant. Hordeimeminit Gale=
tates ex Gal. nus libro v I I. Fimplicium medicancutorum, ubi ita fcriptum rcliquit. Hordeum primi eft ordinis in exiccando, $\mathrm{O}$ refrigerando : babet etiam pauxillum abfterfionis. Pauló etiam plus defiçcat, quàm farina fabacea, cui nō infint cor= tices: cetera ueró fimilia funt foris utentibus. In cibo autem boc fabis preftat, quod flatuofam naturam exuat: $f_{d=}=$ bis, quantumcunq; coxerris, flatuofa natura remanet: funt enim craßioris effentia, quàm hordeum. quamobrem eo plus etiam alunt. Porró quoniam utrung; paulìm à medio receßit, multo funt ufui. Nam talia medicamenta multis alijs mifcentur, ceu materia quedam: itaque etian ccrd, ON olcum, non paucis medicamentis coniunguntur. Alphi= 40 ton ueró, boc eft polenta, multó plus hordeo deficcat. Et primo de facults alinentorum fic inquit. Hoc item fesnen in ufu frequenti apud bomines eft, quod non eandem cum tritico babet facultatcm. Siquidem illud paldin calf actt, hoc ueró non modó non calfacit (quo modo nonmull, qux in medio funt calcfacientium, or refrigerdntium, uti amylum, o elotus panis) Sed quoquo modo ipfo utare, fiue panes ex ipfo feccris, fiue ptifandan coxeris, fiue polentam pard= ueris, uim quandan refrigerandi babere cernitur. Dißidet praterea fucci pecie à tritici natura bordeum: nam ex fuccis, quos utrunque femen gignere natum eft, qui quidcm e tritico in nobis prouenit, craffus, o nifcofus eft: qui ab bordeo, tenuis, ac nonnibil deter forius. Nulla igitur apparandi ratione bordeun unquam calf acit: :ed uaric pro mo= do preparationis bumectat, ac deficcat. Etenim maniffté cernimus, polentan ex tofto lordco factam ficcare: pti= fanam contrà bumectare, fi quidem ut decet fuerit parata, hoc eft, cim in coctione quadm plurimim intumucrit, $p o=$ fted igne lento per multum otium in chylum fuerit redacta. bec Galenus. Caterün cium recentiorcs medici Gale= so

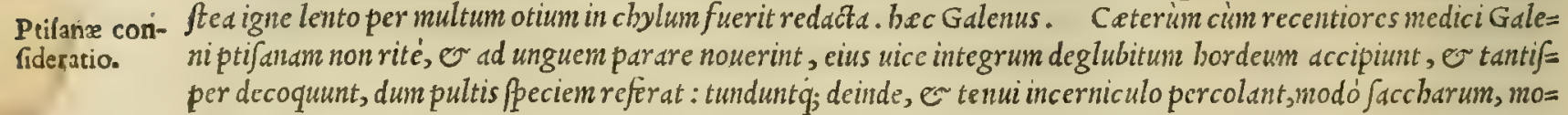
dó dulcium amygdalarum, modó mclopeponum, ac papauerum feminis cremorem, pro morborun ratione addentes.

Manardi opi- Manardus ueró Ferrarienfis atate noftra acutis morbis mininé competere antiquorum ptifanam, minusq́; recen= nio. tiorum exiftimat: quodd, ut ipfe afferit, Itali buic cibo à tcneris non affueuerint, quod q'; noftri ufus bordeum antiquos rum bordeo facultate fit longé infirmius. Cuius tamen fententie non uulgari ratione ducti medici Hippocratican,

Paris horde- Galenicamó; doctrinam fequentes, minimé adftipulantur. Porróbordcaceus panis prater id, quód uentriculo la=

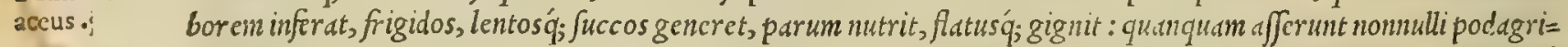

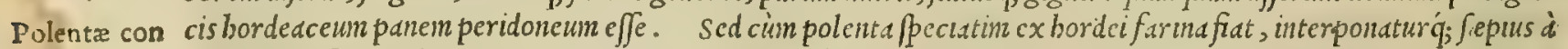
fidesatio. Diofcoride fimplicibus medicamentis, ut ommibus palam fit, quidinan cxtitcrit polcnta apud antiquos, non alienum duximus hic de ea differere. Polentam ucteres pluribus modis facicbailt, ut Plinius cft auctor lib.x v I I .cap.v I $x$. 


\section{In Lib. fecundum Diofcoridis .}

Graci enim perfusun aqua hordeun note una ficcabant, ac poftero die frigebant : deinde molis frangebant. Erant or qui uebementius toftun rurjus exigus aqua ofpergerent, ficcarentí; prius quàm molirent. Alij ueró uirentibus pic is decufjum bordeun recens purgabant, madidumí; tundcbant in pila,at $q_{\text {; }}$ in corbibus clucbant: ficcatumí; in $\Gamma_{0}=$ le rurfus tundeb.unt, or purgatum molebant. Quocunq; auten genere praparato uicenis bordel libris, ternas fent= nis limi, or coriandri felibr ss, falisq́; acctubulo, torrentes ante onnia mifccbant in mold. Itali ueró fine perfufione hordeum toftum in fubtilcm formam molebant, ijsdem additis, atg; ctianmilio. hec ex Plinio. Catcrim aliann ratio= nem parandi polentam prodidit Gale nus libro primo de alinentorum facultatibus. Vbi non cx alijs Seminibus admi= fis, ut Plinius tradit; fed ex lordeo tantim recenti, ac nouo mediocriter tofto laudatißinnan fieri polentam fcribit. Quare crediderin, ijs medicumentis, que in Diofcoridis, $\sim$ Galeni fcriptis polentam expetcre inucnimutur, ean le $=$

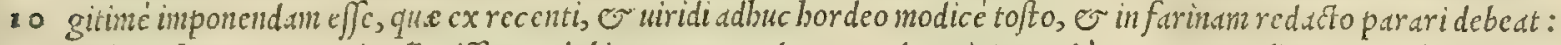

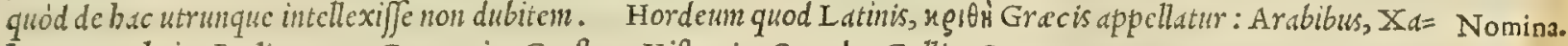
haer, aut shair: Italis, orzo: Germanis, Gerften: Hipanis, Ceuada: Gallis, Orge.

\section{Zùos. ZXTHVM. CAP. IXXX.}

$\mathrm{EX}$ H O R D E potus fit, cui Zytho nomen eft. Is vrinam cit. renes, \& neruos tentat: membranis, prafertim cerebrum veftientibus, officit. Inflationem parit, vitiofum fuccum creat, elephantiafin gignit. Perfufum zytho ebur, obfequiofun, \& operi tractabile redditur.
Koũgul. CVRMI.
CAP. LXXXI.

20 F I T E T ex hordeo potus; quem Curmi nominant , coq́ue frpe potupro uino vtuntur: verùm dolorem capitis monet, malum fuccum gignit, neruis nocet. Confimilia etiam potus genera ex tritico fieri folent, in Iberia, qux accidentem fpectat, \& Britannia .

Z Y T H V M, quantum ex Diofcoride colligi poteft, potus fane fuerit ex macerato hordeo, uel tritico paratus, Zythi, \& curilli maxine fmilis, qui aquilonaribus regionibus Ceruifia dppellatur. Siquidcm buius rei tefis eft $\mathrm{Plinius}$ lib. $\mathrm{x} \mathrm{x} \mathrm{I}$. mitis confide capite ultino, ubific inquit. Etfrugum quidem bec funt in ufu medico. Ex ijfdem funt or potus:zythum in Aegy= ratio.

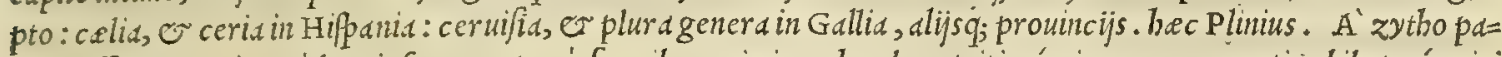
rum differt Curmi, quod é ip fum paretur é frugibus, nimirum bordeo, tritico'́; in aqua maceratis, bibaturó; uini loco. Ouamobrem credendum ef, nil aliud zythum, or curmi fuiffe antiquis, quan Ceruifid, quam loco uinibibit boc

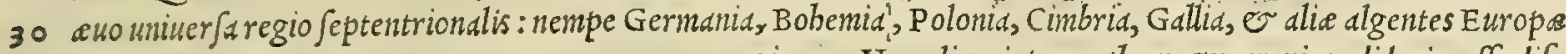

\section{Z $E A$.}

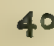

50

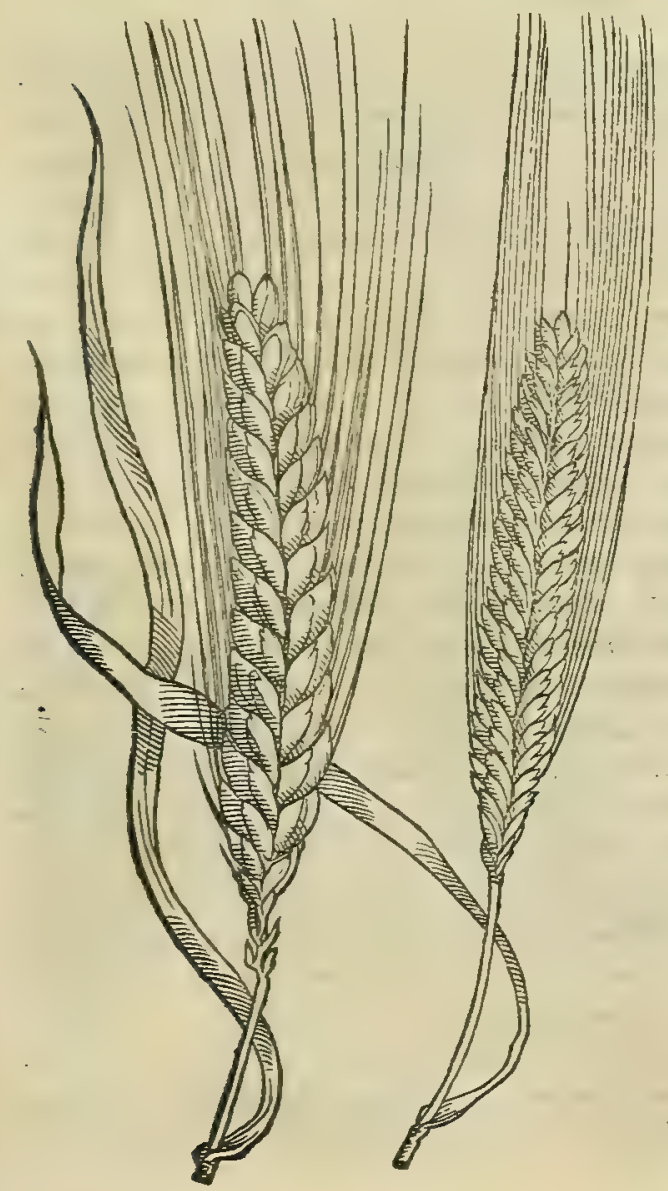
regiones. Nec aliam inter zythum, cr curmicrediderim effe dif= ferentiam, qudm in conficiendiratione, cum eorum utrunque fiat ex eadem fruge. Siquidem conficiendir atio uno, uel altero modo adbibita, rerum facultates or auget, or imminuit, cim plus, uel minus cocturie adlibent artifices, quemadmodum etiam bac tem= peftate in Germania euenit. Nam etfi omnes illi potus ex bordeo, uel tritico parentur; diuer $\int a$ tamen eft apparandi ratio, cum fapo ribus inter fe differant. Alia nanq; dulces, gratéq; guftui funt:

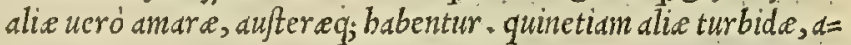
lie clare pellucidá, cernuntur. In Baudria antequdm potus fuos conficiant, hordeum, or triticum macerant lupulorum decocto. Quo fit, ut non leui plectatur pond, quilupulos fecuerit, uel de= perderit. Serunt enim Bauarilupulos, coluntó hanc ob caudan, ut nos uites, demetunt ; $_{\text {; }}$ corumflores, o fructus statutis tempo= ribus: quandoquidem eorum decocto macerate fruges, non modó fermentuntur; jed or uini peciem induunt. Qudpropter potus inde confectus guftatu gratior eudit. Inebriat is largius fumptus, quemadnodum o uinum, perdurató, eius temulentia longé diu=

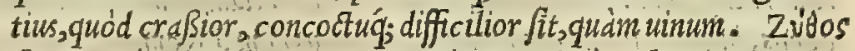
fic Grece, ut Zythum item Iatine, o Italicé Zitho uocatur

Nomina,
ZEX.. ZEA.
CAP. LXXXII.

$\mathrm{Z} E \mathrm{~A}$ duorum generum eft: vna fimplex : altera in ge minis putaminibus grana bina iuncta gerit, ob id dicoccos appellatur. Plus quàm hordeum alit, ori grata. digeritur in panificia, minus quàm triticum alens.

N I s I Zea, dequabic differit.Diofcorides, illudfuerit fru= gis genus, quod Itali partim spelta, partin Pirra uulgo dicint; aliam quidem frugis peciem prouenire in Italia non facile credi=

Zex confideratio. 
derim, que legitimam referat zeam. Verim enimuero quód zed, Italica fit $\beta$ clita, facilc ex Diofcoride coniectaripo teft, quod f cripferit duplicem effe zeam, quarum una implex, alter a dicoccos appellatur, eo quód in geminis puta= minibus grana bin.1 gerat. Nan or Spelta apud I talos duun eft generwin: una fpic as profirt fimplicibus granorum uerfibus: altera ucró ijs duplicibus confat, in quilus fingulus folliculus duo colicludit grana. Zeam banc quidam, $u t$ Foroiulienfes, pirra farra uulgó appellant, quód ex ipfius deglubitis granis farris modo halicam conficiant. Pli= nius preterea libro x v I I I. cap.V I I I. zeam effe Italia in Campania maxime, o femen uocari ait. Id quod nani= fifte ostendit, cim zea fuerit copiof a fruges in Italia, facilé in bunc ufque dien cius perdurarc prouentum. Quod cum ita effe certó credam, nil aliud antiquorum zea effe poteft, quàm pelta nobis uocata. Hanc Hetrufci antiquos quadántenus fccuti appellant uulgó biada. Nam quemadmodum boc nomen femcil, omnibus ferninibus eft commune:

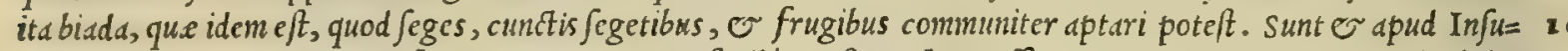
bres, qui speltam, algan quafi alicann uocent . quod facilé atteftatur banc effe zeam. siquidem o ueteres deglubi=

Zex uires ex tam zeam halicam appellauere. Zea memint Galenus lib.v I. fimpl. medicamentorum fic inquiens. Zea uniuerfa Galeno. fua facultate quodammodo in medio eft tritici, o hordei. Itaq; exillis cognofcatur. Eius nomen Grecum $2 \mathrm{e} \alpha^{\prime}$,

Nonina. Latinum, pariter O. Italicum zea: Arabicum, Hais: Germanicum, Speltz, S. Peters lorn, Kin : korn, O Din= ckelliorn: Hifpanicum, Spelta: Gallicum, Eppeltra, er Epeautre.

\section{Kęirvov. CRIMNON. CAP. LXXXIII.}

C R I M N o N cralsior eft ex zea, triticoq́ue farina, ex qua pultem faciunt. Abunde alit, + fed $x$ ğrè conficitur : al uum vehementius adftringit, fi zea, ex quáfit, prius torreatur.

Crimni confideratio.

C R' I M N V M craßior zea, aut tritici farina extitit apud antiquos, qua ad pultem conficiendam utebantur: Nomina. quaq́; loco panis diutius uictitarunt, ut Plinius eft auttor libro X V I I I. cap.v I I I. Kgịvov id Graci, quod ctiam Latini Crimnum, $\mathcal{O} \mathrm{Hippani}$ Farina atorcoldda, aut Rolam uocant.

† Neque Ruellium, neque communem, unlgatamíf; Gracam lectionem bic fecuti fumus: fed Marcellum,qui pro=

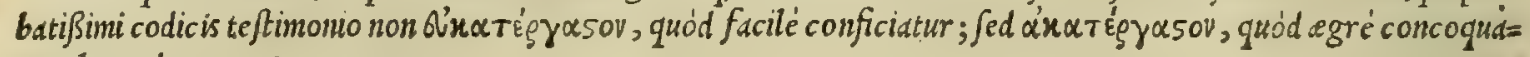
tur, legendum putat.

\section{O"Avęox. OI YRA.}

\section{CAP. LXXXIIII.}

E I D E M zex generi † olyra adfcribitur, fed minus aliquantò nutrit. In panes, vt zea, cogitur. Fit quoque ex olyra crafsior farina, quam Græci crimnon vocitant.

Olyreconfideratio:

O I Y R A M zee effe peciem, Diofcoridis teftimonio, ambigit nemo; tametfi bac atate non feratur in I talid. Marcelli, \& multori opi. Ideo\%; Galenus ijsdem Olyram pollere facultatibus ait, quibus o zea: is enim utrang; inter triticum, o bordeü me= reprobata. dium tenere temperamentum afferuit. Adducitur autem Marcellus, ut feré credat, olyran à Sccale unlgó nocd= to, é quo ruftici alpium cultores panem conficiunt, minimé differre. Qua in re Plinium fíbi alioqui familiarem of $i=$ tanter legife demonftrat, cum non animaduerterit feor fum, ac differenter fcripfiffe Plinium de olyra, et fecale, quod peciatim farraginem appellauit lib. $x$ V I I I. Nam cap.X. ex arinca, quam Graci olyram uocant, fieri dulcißimum panem fcribit. At X v I. ex fecale deterrimum, er tantime ad arcendam famem utilem. In eodem uerfatur errore Otho Brunfilfius eo compendio, in quo fibi omnia Diofcoridis fimplicia medicamenta declaraffe, nobis autem confu= diffe uidetur . siquidem is inter alias ineprias afferit olyram omnino effe fecale. Ad hac non poffum non admirari Hermolaum, Manardum, o R uellium alioqui dotisimos uiros: qquippe qui uno ore fateantur, olyram Plinio filigi= nem nuncupari, cùm is ppeciation de filigine, $\sigma$ olyra, tanquam de rebus inuicem difcrepätibus fcrip ferit lib. $\mathrm{X}$ V I I $\mathrm{I}$. capite octauo, nono, $\mathcal{O}$ decimo. Quandoquidem is pro siligine intelligit quoddam preftantißimi frumentigenus, $e x$ cuius farina ukteres panem candidißimum, Ie vißimumq́; conficiebant : pro Olyra dutem aliam frugis pecicm, ex qua

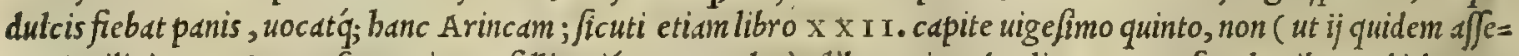
runt) siliginem. Horum fententiam refillit etiámnum Galenìs libro primo de alimentorum fucultatibus, ubide pane agens, inquit. $\mathbf{P}$ anis quidem fyncerißimus cùm ḋ Romanis, tum ab omnibus feré, qui illorum fubiacent imperio, filigi= neus uocitatur. Nam filignis, que I atina inflexione filigo dicitur, Greca nox non eft, nec apud illos alia babctur. Quod minimé dixiffet Galenus, fi olyra, o filigo idem fuifent: cùm olyra Greca plané fit uox. Ex quibus colligi poteft, quodd fi olyra, o filigo idem extitiffent, nequaquam affirmaffet Galenus, filiginem apud Gracos carere no= mine. Hallucinantur itaq; non folum qui putant ueterum filiginem, $\sigma$ olyram effe idem; fed E qui exifimant olyră efe fecalé, quam Plinius farraginem, nos ueró uulgò Ségala appellamus. Siquidem prater rationes, o auctoritates a nobis addact as, id etiam experimento falfum effe maniffté deprehenditur, quód panis filigineus Galeno purißimus, candidißimus, o omnium ad alendur aptißsimus reddatur. A pud nos ueró impurißimus fit, nigerrimus, or ad alen=

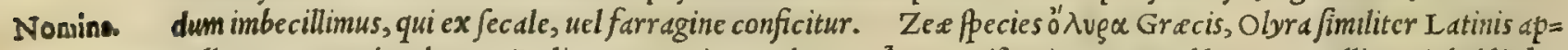
pellatur, quemadmodum O Italis : Germanis, Rocken, et korn: Hipanis, Centcno blanquo: Gallis, Sciglc bläche.

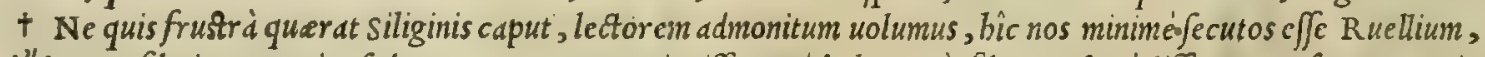
qui ö $\lambda$ vęu fillginem uertit: fed Grecam uocem retinuiffe, quod olyram à filigune plané differre ccufeamus, ut in commentario oftendimus. 


\section{In Lib. fecundum Diofcoridis.}

- Áḋégx. ATHERA.

CAP. L.XXXV.

A T H E R A exzea fit tenuifsimè molita. Eft autem forbitio, quafi liquida pulticula, infantibus conueniens, \&x cataplafmątis efficax.

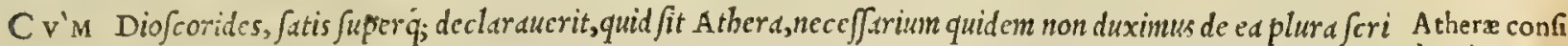
bere. Veruntamen illid ignor andun non cft, quod nonnulli auctores funt, qui Atheram etian fieri afferant ex triti= co,olyra, er amylo . H.ec Germanis unlgó MIofa nuncupatur : utunturó;; ea plurimìm non modó inf antulorunz lacten tium cibis, quemadmodum nos pane in aqqua decocto; fed o quotidianis men $/$ is, quam ex farina, lacte, o butyro pa=

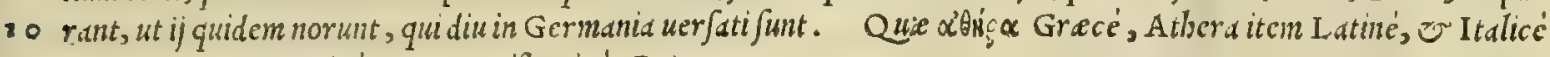
noninatur: Germanice, Muos: Hipanicé, Papas.

\section{Ţ́áyos. TRAGOS. CAP. LXXXVI.}

$T R A$ C O S quandam halicx frugis figuram gerit. Multò minus, quàm zea nutrit, quòd multum aceris habeat: quare $x$ grius conficitur, aluumque magis emollit .

T R A C O S, quein aliqui balicam, nonmulli ueró far notis referre afferunt, hac etate, quod ego fciam, non Tragi confiprouenit in Italix. At quonisum (ut Flinius inquit bib. $\mathrm{x}$ V I I I.cap.x.) ex oricnte peregrinus nobis inuectus erat, unde deratio.

20 noftro etian axwo inmuncre de frumtur plante; ; mirum quidem non eft, fi tam longo temporis tractu, relicto Italico cultu, in propriun redicrit folum, ex quo primim ad nos aduebi coepit, ut in alijs qudm plurinis euenife comperi= mus. Nomen eus Grecum Tgx́zos, Latinum quoq. Tragus: A rabicum, sult: Gernanicum, Hamelkorn: Gal= licum, Duble turguet.

$$
\text { Bgènos. A VENA. }
$$

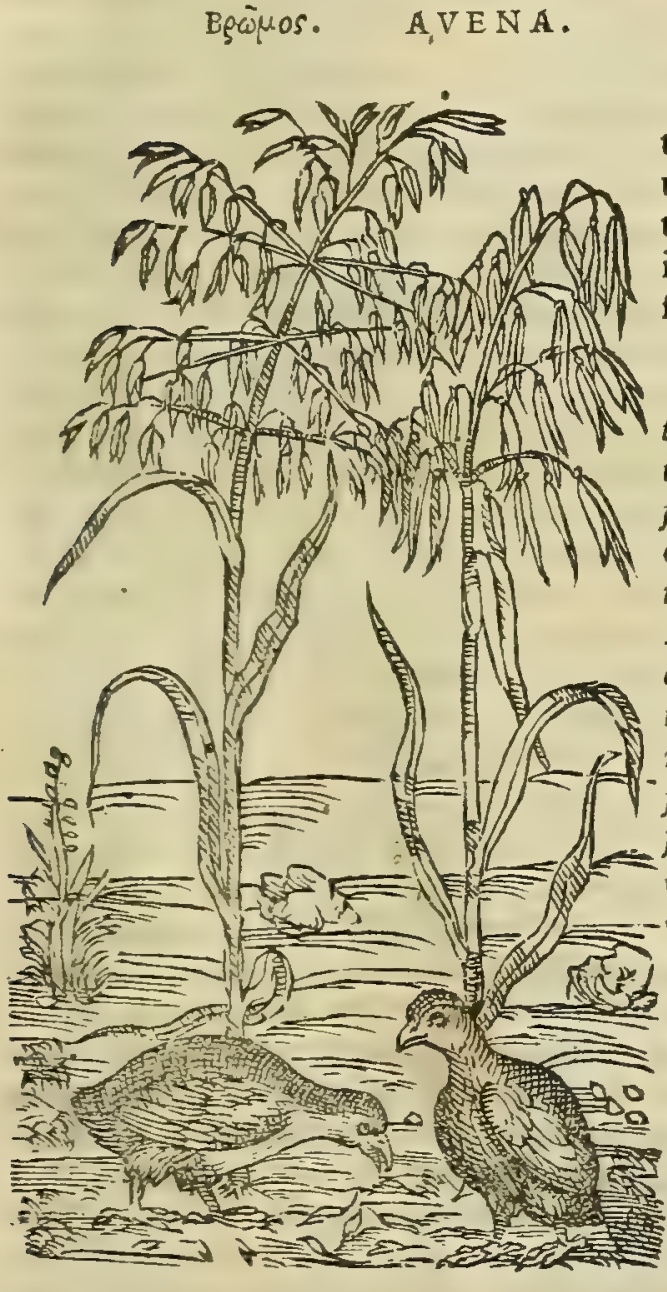

$$
\text { C"gr } 2 \alpha . \quad \text { ORYZA. }
$$

\section{CAP. IXXXVII.}

A v E N A genicula quadam habet: folio, \& ftipula triticum imitatur : \& in cacuminibus dependentes paruulas ueluti locuftas bipedes gerit, in quibus femen continecur, utile ad cataplafmata, uti hordeum. Pulte huius aluus fiftitur - prodeft tufsientibus in forbitione fuccus.

T А M E T S I Auena,unlgaris notitix feges, edita fit ḋ hd= Auenæ contura in equorum potius, quidm bominum alimentum; in Germania fideratio. tamen ab aceribus repurgatd, o iure pinguium carnium elixa, frequenter in cibis fumitur, quemadmodum in Hetruria far, $\sigma^{\circ}$ oryza. Quin or pulticulam Germani ex ea parant eadem ratio= $n e$, quam in Athera paulo fuperius retulimus. Bromos, id eft, AuenxfaculAuena ( ut Galenus memoria prodidit libro v. I. fimplicium me= tas ex Gal. dicamentorum ) unum eft ex leguminibus: uerùm ut medicamen= tum fimilem bordeo uim obtinet. Nam illitum deficcat, $\sigma$ dige rit mediocriter, o fine morfu. Temperiem autem babet paulo frigidiorem. Nonmhil etiam adftriffionis obtinet, ut uentris pros fluuia iuuet. Et primo de alimentorum facultatibus; Hoc femen (inquit) in A fia perfrequens eft, o potißimùm in $\mathrm{M} y$ fia, que eft Jupra Pergamum, ubi $\in$ typha, e olyra uberrimus eft proa uentus. I umentorum, autem efl alimentum, non hominum: nift utique aliquando extrema fame, ad panes ex eo quoque femine conficiendos compellantur. Citra famenn autem coctum, ex aqua eftur cum uino dulci, aut $\int a p a$, aut mulfo. Coterim Auenx fä rina (ut Plinius adnotauit lib. $\times$ X I I, cap. $\mathrm{x} \times \mathrm{V}$.) decocta in ace

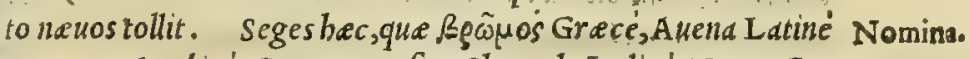
uocatur: Arabicé, Cartamum, fiue Churtal: Italicé, Vena: Ger manicé, Habern: Hipteanicé, Auena, or aued : Gallicé, A uogne.

\section{CAP. LXXXVIII,}

O R Y z \& frugum generis, eft, in paluftribus, riguisque nafcens. Mediocriter alit: fed aluum fupprimit: 
Orizx facultas ex Gal:

\section{ORYZA.}

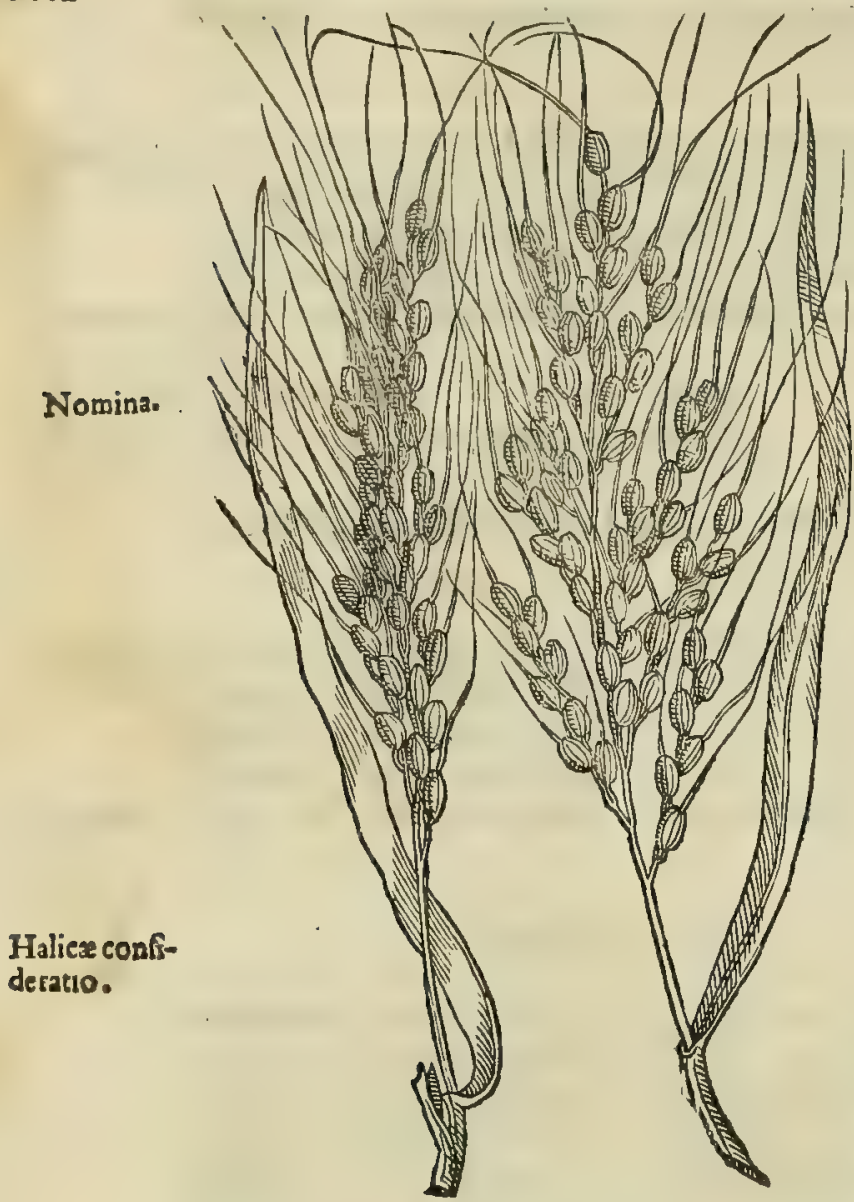

O R Y z A ddeo omnibus in cibis familiaris, frequensơ; eft, ut nulla prorfus explanatione in ed defcribenda fit opus. Quine= tiam de eius uiribus nil aliud explicandum relinquitur, quàm quod literis mandauit Galcnus . quil libro v I I I. de fimplicium medicde mentorum facultate, fic de ea paucis fcribit. Oryza liabet adfri= ctorium quippiam: quare mediocriter uentrem fiftit. Et lib. pri mo de alimentorum facultatibus: Semine hoc, inquit, omnes in $/ i=$ ftenda aluo utuntur, ipfum eodem modo, quo balicam decoquen= tes. Difficilius tamen quadm halica conficitur, er minus alit, ceu

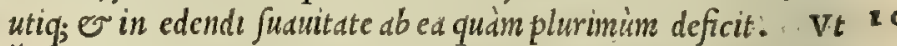
öv $\{\alpha$ Grecis, ita etiam Latinis oryza nominatur: Arabibus, Arzeu Arzi: Italis, Rifo : Germanis, Reifz: Hipanis,Atroz: Gallis, Ris.

\section{Xórb̧os. HALICA. CAP. LXXXIX.}

H A L I C A fit cx zea, quam dicoccon appellauimus. Plus alit, quàm oryza : aluum magis cohibet : ftomacho longè vtilior. Decocta in aceto, illitaque lepras tollit: vnguium fcabritias extricat: incipientibus ægy- 20 lopijs medetur. Decontum dy lentericis, quos excruciat dolor, infufum, idoneum eft.

H A L I C A M antiquitus parabant ex zed, cretam, or gy= pfum admifcentes. Huitur rei ductor cft Plinius lib. X v I I I. cap. $\mathrm{x} 1$. fic inquiens. Halica fit é zea, quam femen appellauimus. Tunditur grarum eius in pila lignea: sam-lapidis duritia conte= ritur. Nobilius, ut notum eft, pilo uinctorum poenali opera. Pri= mori ineft $p 2 x$ is ferred, excußis inde tunic is. Iterum ïfdem ar= mamentis nudata conciditur medulla. It fiunt halica tria gene $=30$ $r a$, minimum, ac fecundarium, grandifimum ueró apberema ap= pellant. Nondum babent candorem fuum, quo precellunt. Iam tamen Alexandrina prefiruntur. Pofted, mirum di= ctu, admifcetur creta, que tranfit in corpus, colorem $\dot{\text {; }}$, o teneritatem affert. Inuenitur bec inter Puteolos, of Neapolim in colle Leucogeo appellato. Halica adulterina fit maximé é zca, qua in Apbrica degenerat. Iatiores

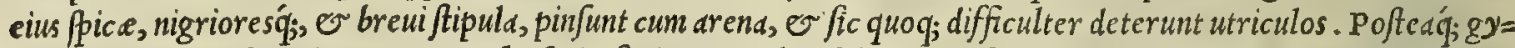
p/i pars quarta in pergitur, atq; ut coha ferit, farinario cribro fubcernunt. bactenus Plinius. Ex quo non fatis admis raripolfum, quod ueteres or cretam, or gyp fum in cibis fimul cum Hallca citra noxam efitaffent, cum procul dubio compertum fit, gyp fum in corpus affumptum adeo pirttibus meatus obftruere, ut facilé bomincs ftrangulet. Nifi for = tafe dixerimus, quòd quanquam aliqui cretam, alij ueró gyp fum balica commifcerent, ut candidior, e mollior eud= deret: ablutionibus tamen prius eam expurgabant, quam decoquendam traderent. $\mathrm{Nanq}$; $\sigma$ boc tempore gingiberis 40

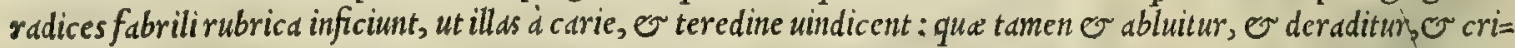
bro excutitur, cum in ciborum condimentis, uel medicamentorum mifturis exe expetuntur. Hoc enim mibi uifus eft in= nuiffe Galenus libro primo de alimentorum facultatibus, cùm ait. Caterùm diligentißimé, dum ex balica elota for= bitiones paranitur, animaduertere oportet. Quippe cim Halicam ad forbitiones parand as elui precipiat, id $\int_{\text {ane }} f_{a}=$ cere uidetur, ut repurgetur à creta, er gyp $\int o$, quibus inficiebatur. Quod autem in cibum non fumeretur Halica, qua ab omni mangonio non effet purgata, oftendit idem Galenus loco nuper citato, cùm inquit. Halica ex genere eft tri=

Halicx uires aboi, que ualenter nutrit, fuccum'́; I lentum babet, fiue in aqua duntaxat coctasn cun mulfo, aut dulci uino, aut etiam adftringente fumas, fiue ex oleo, falég; conditam. Qui autem per. Janitatem ob uebementem uentris mordicationem, fiue à biliofi bumorïs copia, fiue aliunde profectam, forbitione egent, ijs halicam affatim coctam, quoad teneram flaccitatem adepta colliquefcat, deinde conditam, $\mathcal{O}$ colatam, ut ptifane coldto cremoriperfimilis fit, forbendam 50 exhibeto. Hac Galenus. qui certé tot laudibus bac in re Halicain non commendaffet, fi creta, uel gyp $\int_{0}$ admiftam a)fump/iffent in cibum. Fiebat antiquitus Halica non modó ex zed, que dicoccos dicitur; ;ed etiam ex tritico, o

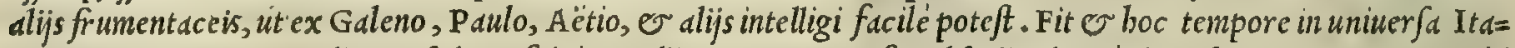

Farris, \& hali- Iia, quanuis eam nón Halicam, fed Far falsó appellitent. Nanque far ab balica longé diuer fum putamus. Quód

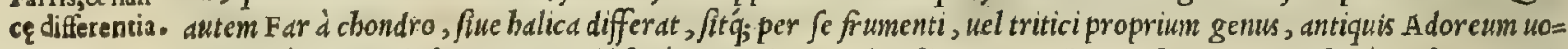
catum, é quo Far ipfum paratur, id fané ex plurium probatißimorum auctorum fcriptis apertißimé conftat. Siqui= dem id primum declarat Plinius lib. X V I I I.cap. I I I. fic inquiens. Frumentigenera non eadem ubiq; neque ubiea dem, funt ijfdem nominibus. Vulgarißimum far, quod Adoreum ueteres appellauere. Quin or eodem capite, ut for = taffe palam faceret, aliud effe zeam,é qua fit balica; aliud ueró far: Q zii zed utuntur, inquit, non babent far. Item cap.v I I. eiufdem libri: Populum Romanum, ait, farre tantùm é frumêto trecentis unnis u/um Verrius tradidit. Quo tempore Romanis nullus fuit balic ufus,ut ipfe teftatur Plinius lib. $\mathrm{X}$ X I I.cap. $\mathrm{X}$ X V.cim inquit. Halica res Romas na eft, 


\section{In Lib. fecundum Diofcoridis.}

ni èft, co non pridem excogitata,neq; arbitror Pompcimagni atate in ufu fuiffe. His accedit Afelcpiadis, er Galeni auctoritas lib.V I I. de compofitone medicanentorum fecundum locos in quodam eclegmate ad cruenta putasubific babet. Farris Clufini appcllati fextarij dinnidium, decocti marrubij uiridis fextarium unum. Hec in uas uitren̈ conie ats per dicm, er nodem n.icerari finto. Sequenti die pharmacum nollito, quemadmodum halican maceramus. bec Galenus. Quibus paldin cf a farre differre balican. Galcno deinde fubfrribit Aëtius lib. I x .c ap. x L v.ubiex Ar= cligene hec babct. Quoducró Latine in regionibus Rome uicinis far appellant, boc modo paratur. Frumcutum modico tempore aqua nudefucito : indéf; cxtractum, ar in pilan coniectum, ucluti ptifanan, à corticc repurgato. $\checkmark$ bi ucró corticem exucrit tollito, at $\mathrm{c}_{\text {; }}$ in folc ficcato: deinde manibus tritum, donec penitus à cortice fucrit mund $=$ tun, craßijsimé molito, ita ut granme unum in quatuor, aut quinq; partes redigatur, or ficcum afferuato. vfus au=

1o tem tempore ballice modo coquitur, et a fanis in cibo funitur. Pro egris uero uarix apparatur, Cr epithematis quoq;

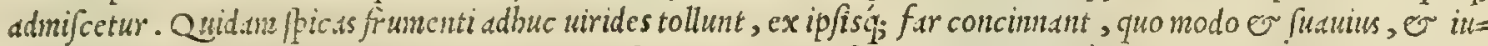
cundius redditur. battenus Aëtius. Ex cuius, et fupradictorun teftinonio, illud plané omnibus patere arbutror, quod far ab halica dißidcat. qua de re etiam plura, duce Deo, dicemus in epiftolis noftris. Quod Gre cis Xóvgos, La= Nomina. sinis pariter or Italis Halica nunctupatur: Arabibus, Chandaros.
K'́ryXos.
MI I I M.
CAP. XC.
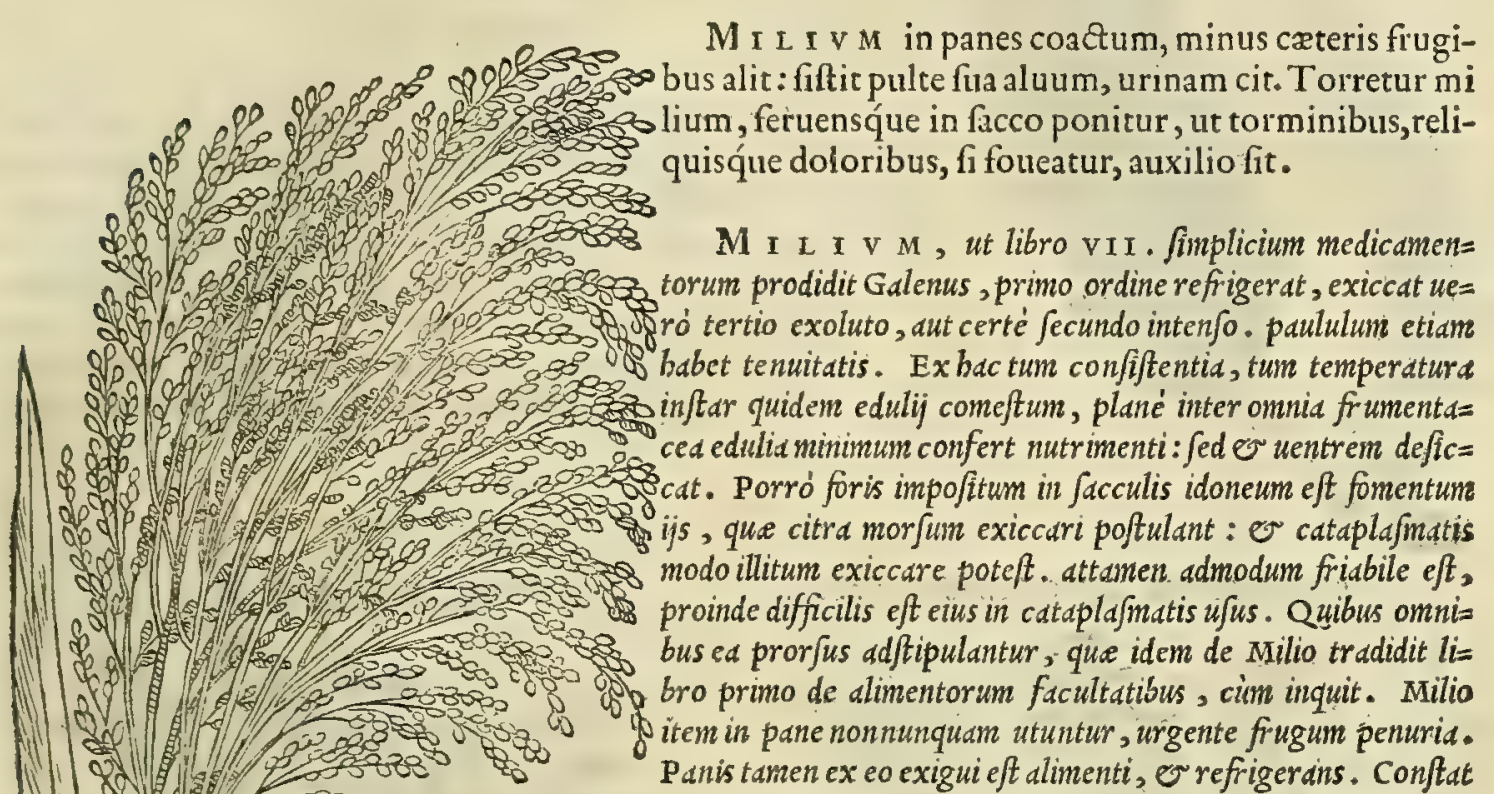

M I L I v M, ut libro v II. fimplicium medicamen= torum prodidit Galenus, primo ordine refriger at, exiccat ue= ró tertio exoluto, aut certé fecundo intenfo. paululum etiam habet tenuitatis. Ex hac tum confiftentia, tum temperatura inftar quidem edulij comeftum, plané inter omnia frumenta= ced edulid ninimum confert nutrimenti: fed or uentrem defic= cat. Porró foris impofitum in facculis idoneum eft fomentum ijs, qua citra morfum exiccari poftulant: or cataplafmatis modo illitum exiccare poteft. attamen admodum friabile eft. proinde difficilis eft eius in cataplafmatis ufus. Quibus omni= bus ea prorjus adftipulantur, que idem de Milio tradidit li= bro primo de alimentorum facultatibus, cim inquit. Milio item in pane nonnunquam utuntur, urgente frugum penuria. Panis tamen ex co exigui eft alimenti, o refrigerdins. Conftat infuper pradridum, o inftar arene, aut cineris friabilem ef= fe: nibil enim in fe babet pinguitudinis, or lentoris. Iure er= go aluum bumentem deficcat. Agricole buius farind coctd, ädinifto adipe fuillo, or oleo ue fcultur. KéyXgos Grecé, Milium Latiné dicitur: Arabicé, Ieuers, Geguers, fiue Giau= res: Italicé, Miglio: Germanicé, Hirrz: Hi ßanicé, Milho,er miyo: Gallicé, Millet.

P A x I C v M frumentaceis feminibus annumeratur, milio fimile, eodemq́ue modo in panes fubigitur . Eofdem habet ufus; minus tamen \& nutrit, \& Atringit.

P A N I C V M, ut fcriptun reliquit Galenus lib. vi. fimplicium medicamentorum, exleguminum genere eft, Panici uires milio ppecie fimile, facultate certé pauci nutrimenti, or exiccatoria: siftit quoq; nonnibil uentris fluxus, ceu ip fum ex Galono. etidin milium. Si ueró foris illinatur, exiccat, atq; refrigerat. bec Galenus. Ceterum fcribit Ruellius fecundo de Ruel. lapfus. natura ftirpium volumine, $\mathrm{P}$ anicum in Italia Melicam appellari. Qua in re aperté ballucinatur : nanq; melica, quae apud In wubres uulgo Melega nominatur, illud genus frugis eft, quam noftrum uulgus in Hetruria Saggina uocat. Alii ueró in It alia populi sorgo appellant. Nec ufquam, quod fciam, in Italia panicum melica uocatur. M E L I C A Melicx conautem (ut uitar boc nomine) frugis eft genus tam forma, quàm proceritate arundinem referens, adeó ut campi, in fideratio. quibus ad maturitatem ufque adoleuerit, a) undineta reprefentare uideantur. Eius tamen calamus non ut uulga= rium arundinum, inanis eft, fed facchariferarum arundinum modo, alba farctus medulla. Pánicule, quas ad Cybelis 


\section{And. Matthioli Comm.}

PANICVM.

Nomina.

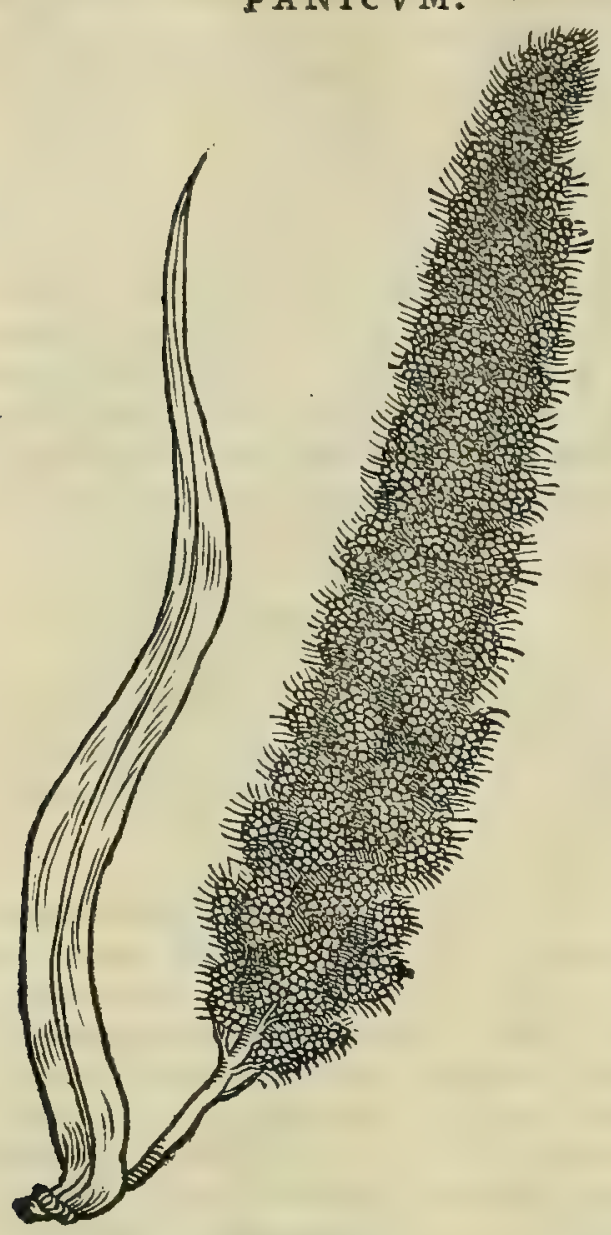

pomorum magnitudinem fummis proferunt culmis, quedam cùn maturitate in fenferint, in nigro rufe fcunt: quadam ueró nigredi= nem in uniuerfum contrabunt, granis compluribus onuftet . Depe= ctitur granum à ruficis, molituró; in farinam, $\mathcal{O}$ inde in agre= ftem cogitur panem: et fi in Hetruris potius ad columbarum, gal= linarumi; feratur faginam, quàm ad hominum alimentum. Hoc Plinio libro X v I I. cap. v I r. milium eft Indicum. quod tamen non animaduertit Ruellus alioqui maximus Plinij fectator. Pli= nius enim fic babet. Milium intra bos decem annos ex India in $\mathrm{I} t=$ liam inuectum eft, nigrum colore, amplum grano, arundineum 10 culno. Adole fcit ad pedes altitudine feptem, pregrandibus cul= mis, lobas uocant, omnium frugum fertilißimum. Quod '

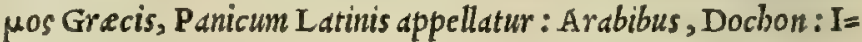
talis, Panico ; Germanis, Pfenich, Heydelpfenich pray, Fuchs= fchuuantz: Hipanis, Panizo, o Panifo: Gallis, Paniz.

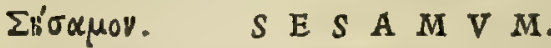 C A P. X C I I.}

S E S A M V M ftomacho inutilis cibus . halitus graui- 20 tatem facit, quoties inter mandendum, commiffuris dentium inhæfit : neruorum crafsitiem illitu difcutit : medetur auribus fractis, ambultis, inflammationibus, coli doloribus, \& ceraltx morfibus : capitis dolores, qui æftuatione concitantur, ex rofaceolenit. Eadem efficit herba decocta in uino: præfertim inflammationibus oculorum, doloribusq́ue prodeft. Ex ea fit oleum, quo Aegyptij utuntur.

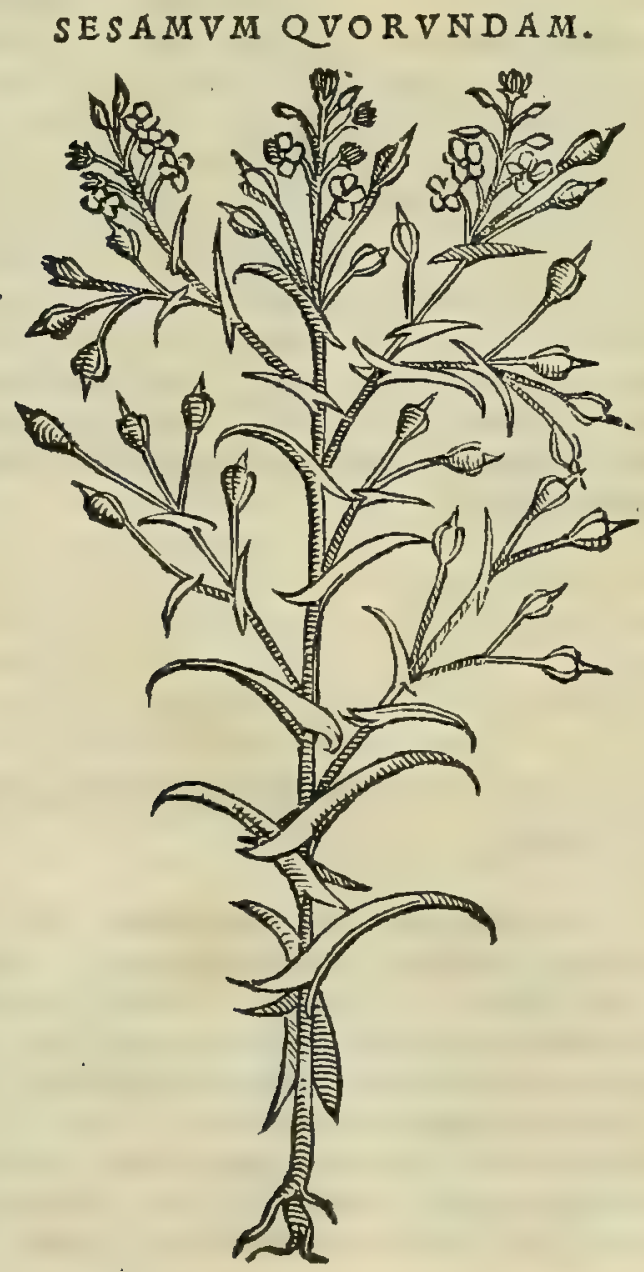

SESAMVM ALIORVM.

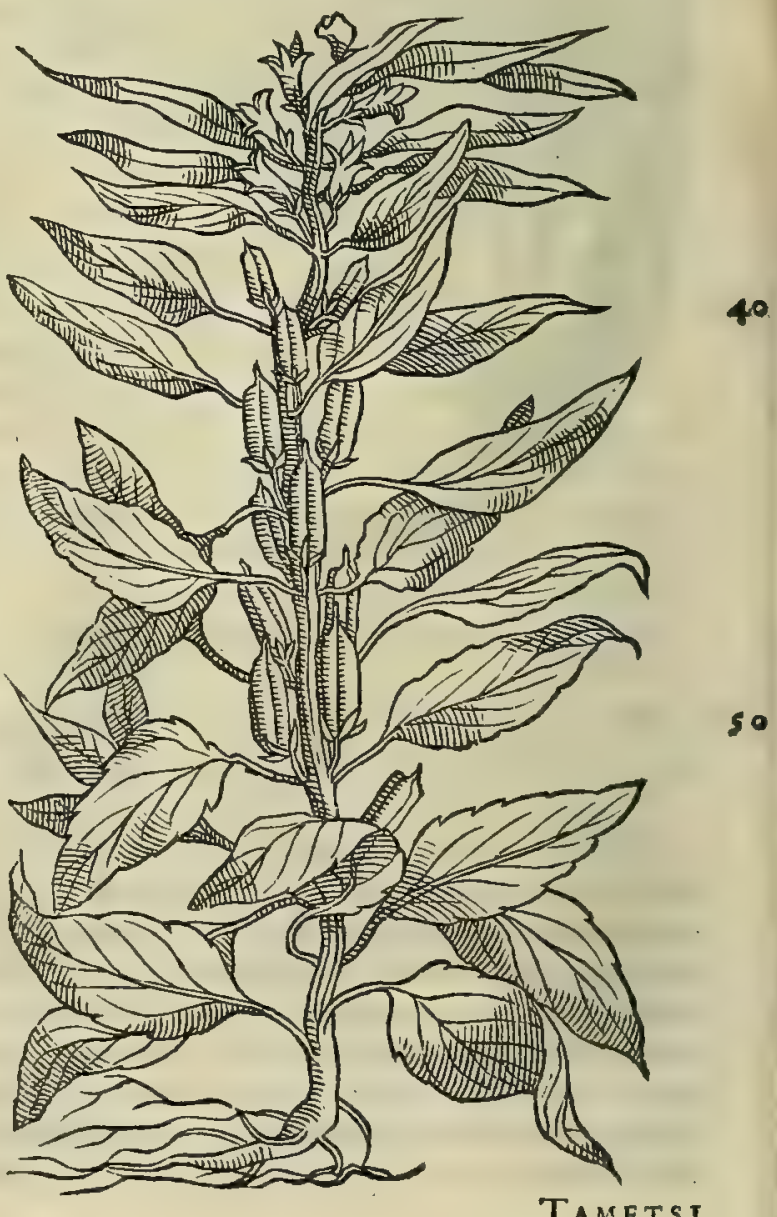

TAMETSI 


\section{In Lib. fecundum Diofcoridis.}

T A.M E T S I Sefamifemen, à quo copiofum exprimitur oleum, officinis notißimum fit : pauci tamen reperi=

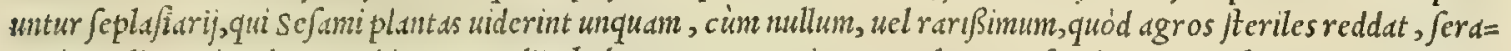
tur in Italia. Siquden quod in myropolijs habctur, ex Grecia, er Peloponnefo ad nos conuchitur. Prouenit (ut Theophraftus eft auctor) caule milio fimili, craßiore tamen, ac altiore : folijs rubentibus: flore uiridi, berbaceo: $\int e=$ mine uafculis inclufo, papaucris nodo. Sefamun, tefte Plinio, ab Indis primum aducctum cft. Ibi enim copiofißi= mum feritur, cimn olctum inde maximo prouentu conficiant, non modó ad luccrnarum ufum: $\int c d$ ad ciborun condi= mentun, qucmadmodum nos $\mathrm{ex}$ oliuis. Non temeré fcripfiffe uidetur Rucllius, nibil ita, ut Sefamum, emacrare folum, utpote cuicraßior, o multiplicior arundo fit, quam milio, o radix quoq; numerofior. Siquidem id legi= mus Theophrafto prodetum effe lib. I I I .cap. I X. de plantarum biftoria, ubi ficinquit. Omnium, qua effiuis femen=

o tibus ager rectpit, scfama terre moleftißima effe, plurimum craßioriq; calamo, or monerofiore conftet radice, quam milium. bactenus Theophraftus. Caterum duas diuer as imigines pro Sefano exbibuimus, qudd uaria quoq; fit hoc tempore berbariorum de co fententia : alij enim băc plan tam, illam alij pro lcgitimo sefamo demonftrant. Mihi quidem (ut ingenué fatear) neutra placet, quód utraq; hifto= rie refragetur, quxin de Sefaino Theopbraftus er Plinius tradiderunt. Has tamen plantas bic depingi curaumus,ea faltem ratione, ut illud lcatores adinoncrem, quód ea, meo iudicio, notis ueri sefami non reppondeant: quódq'; in ma: niff to crrore uerfentur, qui fecus opinantur. Sefami meminit Galenus lib. v I I I. fimplicium medicamentorum, ita fcribens. Scf,onon non parun in fe continet uif cofun, ov pingue : quare emplafticum eft, ov enolliens, ac mo= dice calidum. Eiufdem facultatis eft, quod ex eo conficitur oleum: or berbe quoque decoctum fimilem uim obtinet. Et libro prinzo de alimentorum facultakibus: Se fami femen, inquit, pingue eft, ideoǵ; repofitum celerris -o mé fit olcofum: quamobrem $\mathrm{O}$ cos, qui ipfo uefcuntur, celeriter implet, $\mathrm{O}$ fromacbum fubuertit, tardé conco= quicur, o pingue corpori prabet alimentum. Liquet ergo quód uentris partibus uigorem, ac robur addere ne=

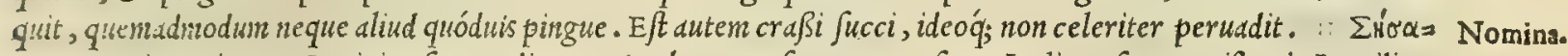

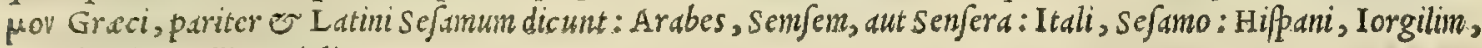
or Alegria: Galli, Iugioline.

A Igx. LOLIVM.

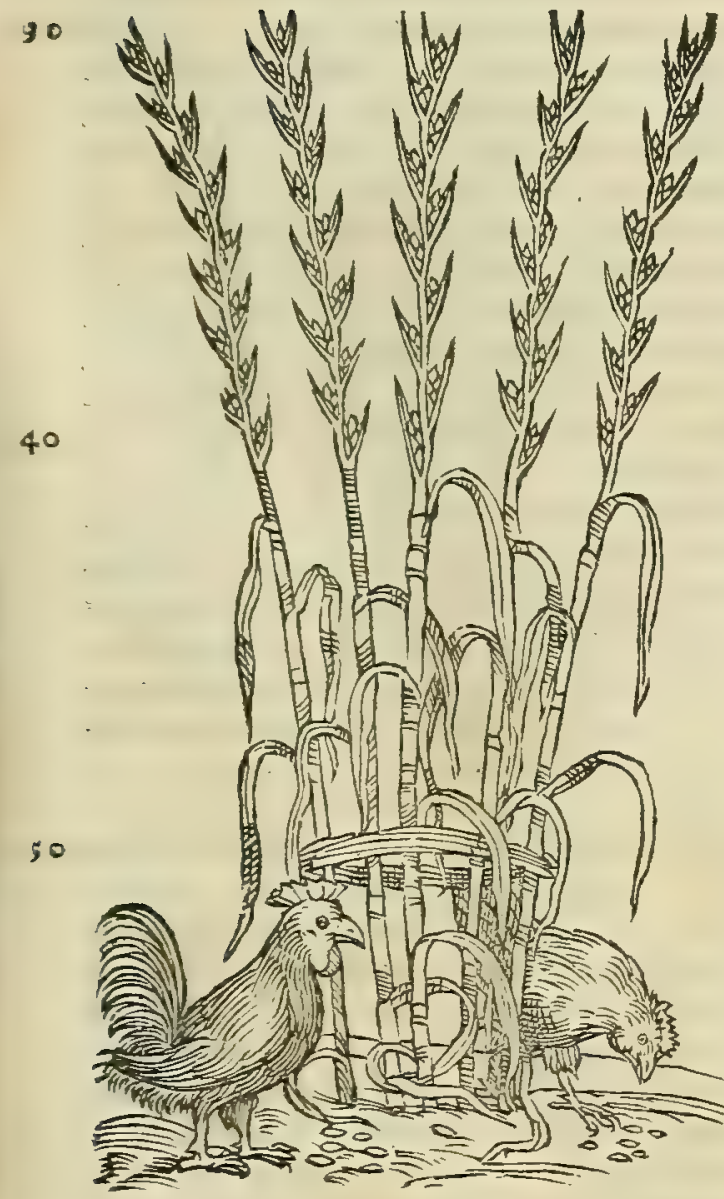

Sefami confideratio.

Sefami uires ex Galeno.
L O L I V M, quod inter fegetes nafcitur, molitum, nomas, putrefcentia ulcera, gạngrænasq́ue compefcit cum raphanis, \& fale illitum : \& ex aceto, \& fulphure uiuo feros lichenas, \& lepras fanat: frumas quoque difcu tit, cum fimo columbino, \& lini femine decoctum in uino: rumpit, qux égrius ad coctionê perducuntur. Decoetum ex aqua mulfa utilifsimè ifchiadicis illinitur : fi cum polenta, thure, myrrha, aut croco fuffiatur, conceptionem adiuuat.

L O L I V M omnibus notißimum eft. Nafritur in ar= wis é tritico, ơ bordeo corruptis uligine feminibus, aut per byenzem imbre nimio madidis, ut superius quoque in tritici, o bordei commentatione dictum eft. Verüm etfi non defint, qui Lolium uere tantim exoriri putent; prouenit tamen (ut Theophraftus memoria prodidit libro $\mathrm{V}$ I I I . capite V I I. de plantarum biftoria) byeme ineunte, folio angufto, pilofo, o pingui, eiusq́; peculitre pinguitudo notdtur. Credidit Fuchfijerror. Leonardus Fucb/ius (ut declarauit in fuis clarißimis de ftir= pium biftoria commentarijs ) P (eudomelanthium, quod inter fegetes frequens nascitur, legitimum effe Lolium. Id quod ( $p a=$ ce fua dixerim ) non-modó communi doctißimorum uirorum, qui inftirpium doctrind diu uerfati funt, fententie refragatur; fed or ueterum fcriptis, qui Lolium in pica, non calyce, non capitulis melanthij, uel papaueris modo inclufum, femen pro= ferre tradiderunt. Et quanuis Theophrafti auctoritate nitd= tur, ut fui Lolij effigiem reprefentet, plura tamen ex co reds didife uidetur, quam ipfe ufquam in Theophrafto legerim.

Qua in re mibi quandoque iocandi fuit occafio, ut dixerim. Fucbfium ideo in lolio tam maniffté lapfum fuife, quód forté co tembore, quo hec fribebat, contigerit ei lolium in pane comediffe. Quód autem id legitimum fit Lolium, quod rei herbari.e peritis, agricolis etiam, o omnibus feré uulgó cognitum eft, teftis eft Diofcorides lib. II I I. cap. de
Lolij confideratio. 
phonice, ubi phonicem fpicam lolio fimilem proferre prodidit. Ex quo paldim fit, lolium in pica, non autem in cd= pitulis peudomelantbij, er papauerismodo femen ferre. Ex uulgata quoq; Lolij facultate Fuchsij error depre= bendipoteft. siquidem panis, in quo lolium fucrit, ftupiditatem quandam, o ueluti temulentiam efitantibus parit cum inexpugnabili firé fonno. Quamobrem ubiq; locorum incerniculis à tritico, alijs q́; cerealibus ipfum scparant,

Lolij uires ex qui eius noxam fenfere. Lolium, ut fcriptun reliquit Galenus lib.v I. fimplicium medic amentorum, deficcat, e; Galeno. excalfacit efficaciter, ut propinquum fit acribus, magis quam iris. fed non eft perinde ut illa fubtilis effentia, uerim muitum in boc deficit. Secundum hoc ponat ip fun quipiam in principio tertij ordinis excalfacientium, fecundi ueró

Nomina. extremó exiccantium. Eiusnomen Grecum äios: Latinum, Lolium: Arabicum, Sccilem, feu Zeuen: Itali= cum, Loglio, or Gioglio: Germanicum, Tuualch treße, Rueuneyfen, er Lulch: Hifpanicum, Yoio: Gallicum, Inayra, $\mathcal{O}$ Yuroie.

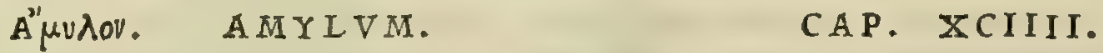

A M Y L V M ex eo appellatum eft, quòd fine mola fiat. Optimum ex trimeftri, natione Creticum, aut Aegyptium . Ratio faciundi amyli hac eft. Purgatum trimeftre triticum madefcit quinquies die, \&, fi fieri poteft, nocte: cùm emollitum fuerit, effunditur fenfim fine agitatione aqua, quò minus cremor utilis unà excludatur. ubi mollifsimum effe uidetur, mutata aqua ${ }_{2}$ pedibus calcari oportet: rurfus infufa, teri : tum demum enatantes ibi furfures incerniculo eximendi . reliquumq́ue quallo fportisq́ue ficcatum tegulis nouis confeftim torreatur flagrantifsimo in fole: nanque fi paulifper vdum naneat, acorem concipit. Contra fluxiones oculorum, puftulas, cauaque ulcera efficax eft: 20 languinis reiectiones potu cohibet, exafperatas fauces lenit. lacti, atque obfonijs admifcetur. Fit etiam amylum ex zea, qua maceratur, ac eluitur uno, aut altero die, \& fubactæ farinæ modo manibus fubigitur: preffaq́ue feruentifsimo in fole, ut antè retulimus, exiccatur. Null us in medicina ufus, ad alia tamen conueniens.

Amyli conf- A M Y I V M, quod uulgó Amidun officinis uocatur, omnibus quidem notum eft. Probatur autem, atctore plinio deratio. lib.x v I I r.cap.v I r. leuitate, ac leuore, atq; ut recens fit, o candidum. Caterimet/i pratulerit Diofcorides Amy lum, quod è Creta aduehitur; Plinius tamen longé magis Chium, cui infule (ut ipfe fcribit) Amyli inuentio debetur, Amyli uires preftare afferit. Amylum, ut memoria prodidit Galenus lib.I. de alimentorum facultatibus, ex tritico conficitur, ex Galeno. la uigandi exafperatas partes uim obtinens: qux communis eft omnibus fubftantijs confiftentia ficc is, qux neque ad=

FOENVM GRAECVM.

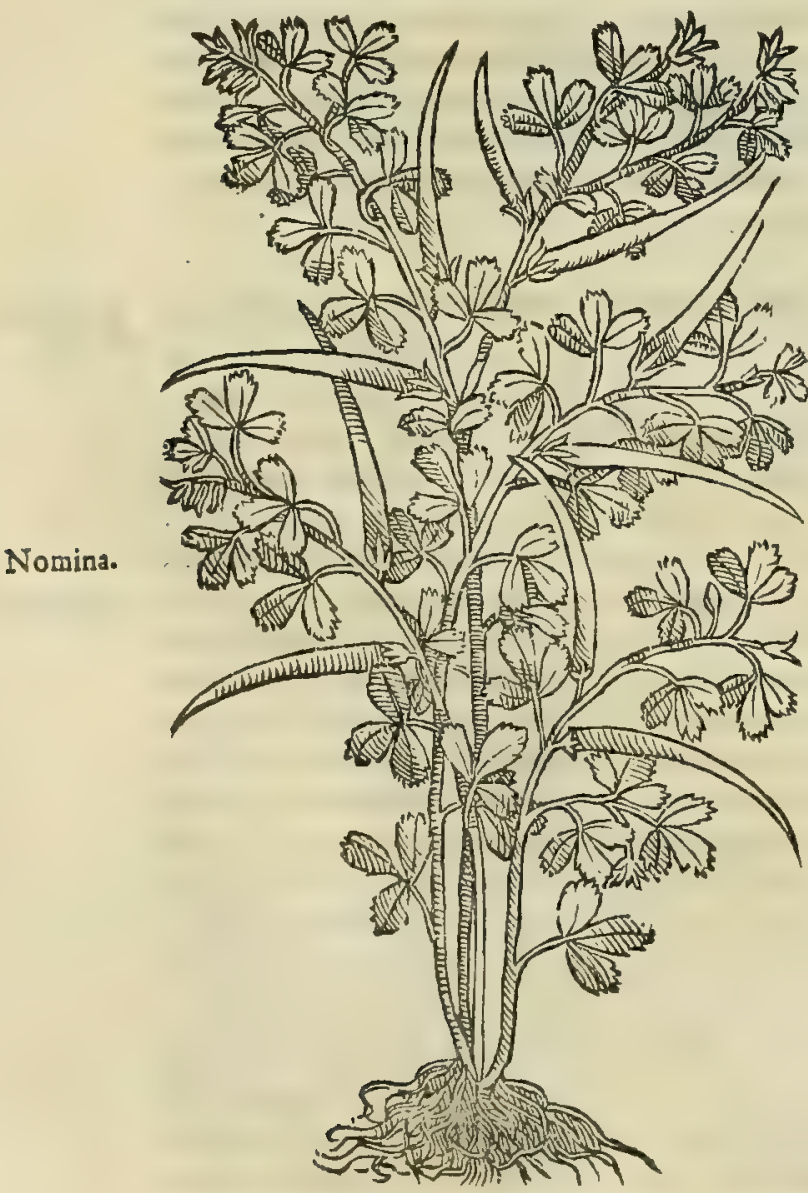
frictionem, neq; acrimoniam, neq; alian quámuis facultatem ha = bent infignem. quas fubftantias iure áwo'rovs, ideft, qualitat's, qux fenfu deprehendi queat, expertes appellant: qualis inter bu= midas fubftantias eft aqua. Caterim amylum fimilem lotis pani= bus babet facultatem: nam, ut illi, minus quam panes non loti, corpori prebet alimentum, er non calfacit, cùm cateri panes cal faciant. Quód ucró ad triticum in aqua elixum attinet, cum ea amylum ne confirendum quidem eft, cum palim id tum calfaciat, tum ualenter nutriat, fi coctum fuerit : id quod factu ( $u t$ di= ximus) eft difficilé. Porró A mylon (ut Plinius tradit lib. x x I I. 40 cap. $\mathrm{x} \times \mathrm{v}$.) bebetat oculos, or gule inutile, contrì quàn credi=

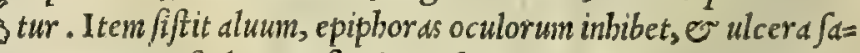
nat. Item puftulds, or fluxiones fanguinis . gends dur ds emollit. Datur cum ouo his, qui fanguinem reiecerint : in uefice ueró do= lore femuncia amylicum ono, er paßis tribus, Sufferuefact d

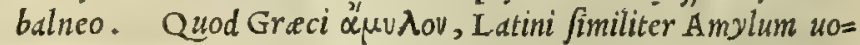
cant: Maritani, Nixe: Itali, Amido: Germani, Amlung: Hi= Pani, Amydon: Galli, Amydum.

THIAIS. FOENVM GRAECVM. CAP, XCV.

F OE N I Greci farina uim habet emolliendi, difcutiendiq́ue : in aqua mulfa deco\&a aduerfus tam interıas, quàm externas inflammationes, efficaciter illinitur: liené cum aceto, \& nitro trita extenuat. Succus decocti eius fee minarum malis fubuenit: \& fiue tumor, fine pręclufio fit vulux, foucntur, $\&$ infident. Foni graci in aqua decoeti cremor expreffus, capillos, furfures, \& manantia capitis ulcera purgat: locos dilatat, \& emollit, fi cum anferino adipe pefsi uice fubijciatur. Viride cum aceto ut lifsimú imbecillibus locis, \& ulcera fentientibus. Decoćtũ eius 


\section{In Lib. lecundum Diofcoridis.}

prodeft aduerfus tenefmos, fœtidamq́ue dy fentericorum proluuiem. Oleum, quod ex eo exprimitur, \& myrto, capillos, \& genitalium cicatrices abfterget.

F OE N I Greci femen profert planta trifolio fimilis, corniculis quibufdan inclufum : unde illi Buceras nomen Fani Graci impofuit Theophraftus. Huius memintit Galenus libro v I II. Fimpliciun medicamentorum, fic inquitens. Fonum Gre uires ex Ga'. cum calidum eft fecundi ordinis, deficcat prino : proinde ferucntes pblegmonas irritat, acerbat $q_{5}$. quse ueró minus

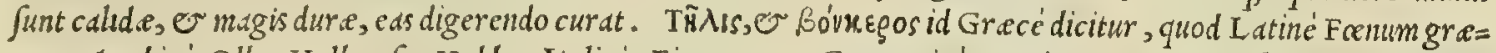
cum: Arabicé, Olba, Helbe, feu Hebbe: Italice, Fien graco : Germanicé, Fenigrec, ON Boclishorn: Hipanicé, Alfornas or Alboluas: Gallicé, Fenigrec, or senegreue.

10

Aivov. LINVM:

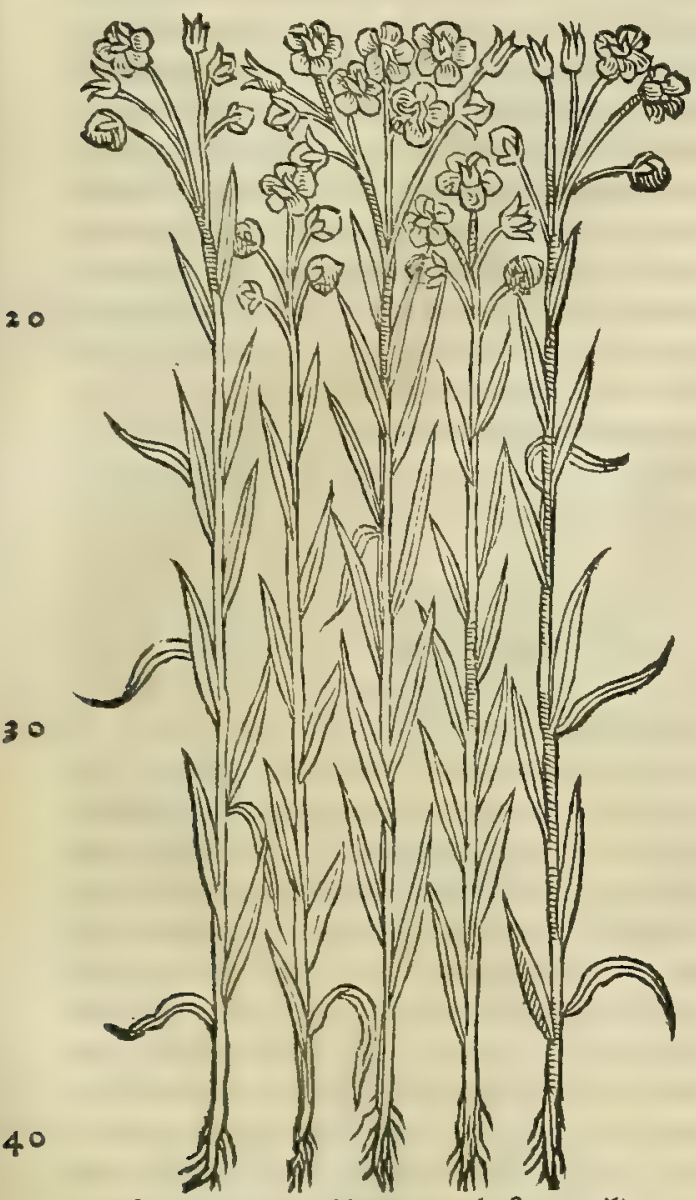

\section{CAP. XCVI.}

L I N V M úulgò notum eft. cuius femen eafdem, quas fonum græcum, uires habet. Difcutit, \& emcilit omnem intus, forisq́ue inflammationem, cum melle, oleo, exiguaq́ue aqua decoctum, aut melle cocto exceptum : uitia cutis in facie, varosq́ue crudum tollit: illitum cum nitro, \& ficulneo cinere, parotidas, duritiasq́ue difcutit : ulcera, quæ ferpunt, fauosq́ue cum uino decoctum expurgat: vngues fabros eximit, cum pari modo nafturtij, \& mellis : vitia pećtoris extrahit, fi ex mclle in eclegmatss vicem fubftituatur : tufsim lenit: venerem ftimulat, fi farina piperis, \& melle exceptum, pro placenta largius adfumatur. Huius decoctum interaneorum, vuluxq́ue erofionibus immittrtur, alui excrementa euocat, ad vuluæ inflammationes in defefsionibus perquàm vtile .

C V'M Linum, er cius femen fint non modó medic is omni= bus; fed etiam cateris, er prefertim agricolis, unlgó notißima, fuperuacaneum quidem foret, pluribus eorum hiftoriam perfe $=$ qui; etfi feminis ufus, o vires minimé filentio fint pretereun= de. Exprimitur ex femine oleum, quod non folum medicis, Seplafiarijs expetitur; fed etiam pittoribus, lapicidis, lignarijs, cementarijs, ac ferrarijs fabris. Praftat er ad lucernarü ufum, quód diutius igni refiftat, qudm quod ex oliuis exprimitur. In me dico autem ufu neruorun conuulfionibus peridoneum eft. Quin= etiam ad eorum emolliendas duritias, o ad oßsium compagines explicandas mirifice prodeft. Perutile eft omnibus fedis affecti= bus, nempe hemorrhoidibus, condylomatibus, rimis, ac dolori bus: foeminarum induratos locos mollit. Nymphee, aut ro $\int_{d}=$ rum filltattia aqua ablutum, ambuftis auxiliatur. Sunt 0 qui hoc bibendum magno fucceffu ijs exhibeant, qui late= rali dolore uex antur . uerùm recens fit oportet: quandoquidem inueter atum, contracto rancore non modó excalf $\alpha=$ cit, plus quàm par fit; fed o naufeam commouet. Caterim quoniam ( ut Plinius inquit libro x I X . capite primo) $\mathrm{X} Y \mathrm{~L}$ o N, fiue Goßipium, quod nos uulgari fermone Bambagid, alij Cotone appellant, inter lini genera nonnulli an= mumerant, cium eius, quod fciam, nufquam meminerint Diofcorides, o Galenus, non difimulandum duxi, quód Xyli femen, quod tamen rancorem non fen $\int e r i t, t u ß i$, o pector is uitijs opitulatur. quinetiam excalfacit, ov emollit, $\sigma^{\circ}$ femen auget . Candidißima ueró eius lanugo fanguinem é uulneribus manantě fiftit, prafertim fi prius paululum exu= ratur. Sed plura de xylo dicemus libro fequentiin gnaphalij mentione, ubi eius quoq; effigiem dabimus. Lini $f e=$ Lini uires ex

so minis facultates memorle prodidit Galenus lib. $\mathrm{I}$ I. Fimplicium medicamentorum, fic foribens. Lini femen efum fla= tuofum eft, etiam fí frigatur : adeó fané excrementitia bumiditate plenum eft. Eft ueró etiam in primo ordine quo= dammodo calidum, ac bumiditatis, $O$ ficcitatis quodammodo in medio eft fitum. Quod Greci Linum appellant: Arabes, Bazarichichen, fiue Bezerchetan: Itali, Lino: Germani, Lein, E Flachs: Hipani, Li= no: Galli, Lin.

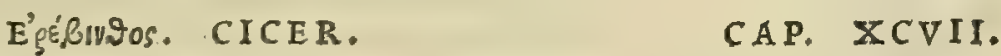

C I C E R fatiuum aluo idoneum eft, vrinam ciet, inflationem parit, colorem commendat, menfes ac partus expellit, lac auget. Cum eruo decoctum illinitur ad inflammationes teftium, verrucofas informicationes : ad fcabiem, vlcera capitis manantia, impetiginesq́ue, item contra carcinomata, \& vlcera, quæ cacoëthe vocantur, cum melle, \& hordeo prodeft. Alterum genus arietinum nomi-
Nomina.

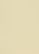


C I C E R.

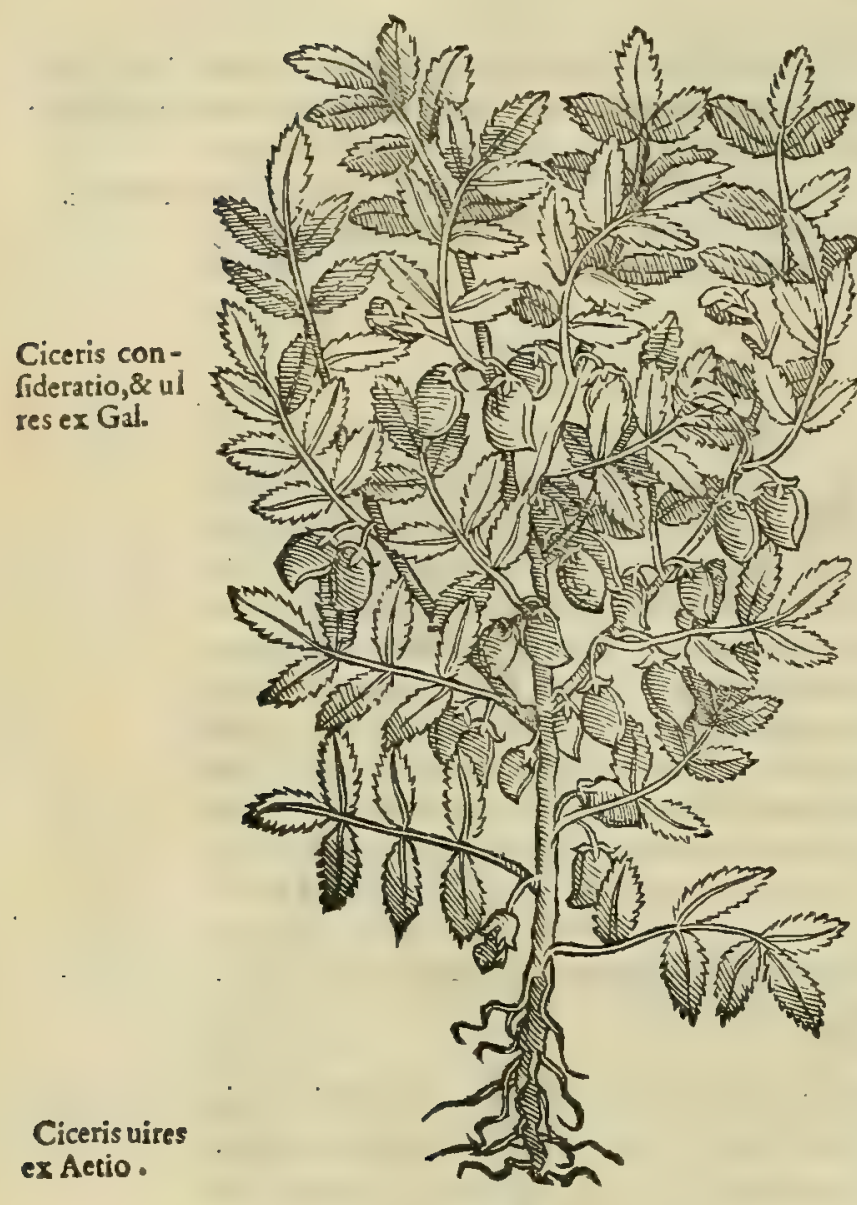

F A B A.

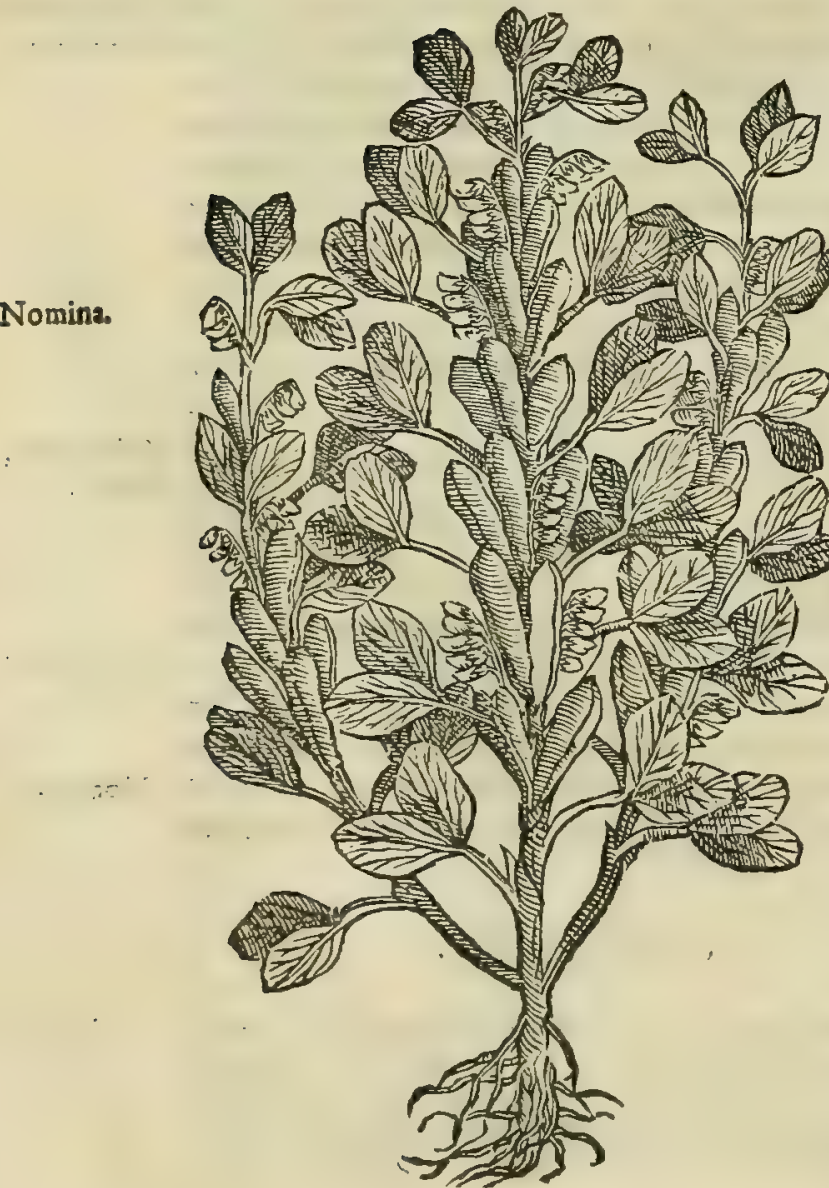

natur. Vtrunque cit vrinas; dato cum rore marino hy: dropicis, aut regio morbo laborantibus, eorum decom cto. Lædunt ea exulceratam ueficam, \& renes. In verrucarum formicantium, penfiliumq́ue genere, prima lína fingulis granis fingulas tangunt, eaque grana linteolo de ligata abjjci poft fe precipiunt, ita decidere eas arbitrantur. Sylueftre cicer, folijs fatiuo fimile eft, odore acri, fed femine difcrepat. Idem quod fatiuum præftat .

IN CI CE R V M gencre babctur candidum, quod $\mathrm{O} C \mathrm{C}=20$ lumbinum uocatur. Eft o rubeun Venereum diftum, quód ad excitandam uenerem mirifice praftet. Habetur item 0 nigrum ceteris minus, quod Arietinum appellant. Horum meminit Gale= nus primo de aliment. facultatibus, fic inquiens. Cicer non minus qudin faba inflationes excitat, fed ualentius nutrit. Venerem fti= mulat, creditum'́; eft etiam fimul femen generare: cuius gratia admiffarijs equis quidam ipfum exbibent. Ineft preterea Ciceri= bus facultas abfergendi maior, quàm fabis : adeó ut quadam ex ip fis contractos in renibus calculos enidenter frangant, atq; com= minuant. Nigra autem $\int u n t c d, 0$ exigua in Bithynia precipue 20 nafcentia, Arietina'; uocata. Huius ex aqua decoctum potare proftiterit. Vefcuntur et uirentibus adbuc ciceribus bomines an= te adeptam maturitatem, quemadmodum o fabis. hattenus $G d=$ lenus: Nigrum uocari Arietinum tradidit Plinius, quodd arie= tum capind jud inagine reprefentet. Theophrafto quoq; Cice= rum plures funt differentia lib.VI I I. cap.V. de hiftoria plantd= rum, ubific habet. Cicer er magnitudine, e fapore, o odore, or forma, pler as q; differentias oftendit, ut arietinum, o colum= binum. Candida inter omnia dulcedine preft ant. Ciceris facul = tates recenfuit etiámnum Aëtius, fic inquiens. Cicer flatuofün le 39 gumen, ac alimentofum, uentri accominodatum, urinam, ac men= fes euocat, E lac, E perma copiosé generat. Huius decoctum, prefertimq́; nigri, calculos renum frangit. Alterum ueró genus, quod Orobieum uocatur, attralsit, difcutit, incidit, or abftergit. Iecur, lienem, or renes expurgat: $\int c a b i e m$, 0 impetigines $e x=$ terit : parotidas, ac kefticulorum durities difcutit : affert $\dot{q}^{\prime}$ ad ul $=$ cera maligna prafídium non poenitendum. battenus Aètius. $C a=$ terum fylueftre omnibus feré notum eft. o fi Plinio fides eft $d d=$ bibenda, uentrem fubducit: fed flatus, er inteftinorum dolores gi gnit. Grecis égé, $\beta \omega \theta 0 s, \mathrm{~L}$ atinis Cicer nominatur: Arabibus, 40 Chemps, Hamos, feu Alhamos: Italis, Ceci: Germanis, Kichern, Kichererbs, O Zifer erbs: Hipanis, Grauancos: Gallis, Cices.

Kúapos. FABA.

CAP. XCVIII.

F A B A inflationem excitat, ægrè concoquitur, tumultuofa fomnia facit, tufsi confert, carnem gignit, media calidi, frigidiqúu natura. Decoeta in pofca, $\$ \mathrm{cum}$ fuo cortice efitata, dy fenterias, \& cœliacorum proffuuia fiftit : contra vomitiones conuenienter manditur. Infla- 50 tio leuior contrahitur, fi aqua prior inter coquendum abijciatur. Viridis plus negotij ftomacho exhibet, maioremq́ue flatum parit . Lomentum eius \& per fe, \& cum polenta illitum, inflammationes, quas vulnus excitauit, mitigat : cicatrices concolores facit : turgentes grumofo lacte mammas, etiam fi inflammatione tententur, adiuuat : lac reftinguit : furunculos, fugillata, parotidasq́ue cum focni græci farina, \& melle difcutit : cum rofa autem, thure, \& oui candido, procidentes oculos, tumores, vuasq́ue reprimit: fubactum uino, fuffufiones, \& ietus oculorum recreat. Manducata fine cortice faba, ad 


\section{In Lib. fecundum Diofcoridis.}

auertendas fuxiones, fronti illinitur: decocta in vino teftium collectiones fanat : quò tardius pubes erumpat, pueris imo ventri illinitur : vitiliginem purgat. Fabarum cortice illiti capilli, qui polt euulfionem renafcuntur, gracilefcunt, \& minus alimenti capeffunt: cum polenta, fciffo al umine, \& uetere oleo impofiti cortices, ftrumas difcutiunt. Decoeto carum lanx inficiuntur. Faba dempto cor tice in illas partes diuifa, in quas fuapte natura fcinditur, imponi folet fanguinis defluxionibus ab hirudine concitatis : nanque eas fupprimit, fi femifecta apprimatur.

F A B AE omnibus notifime funt. $\sigma$, ut memoric prodidit Galenus libro $\mathrm{V}$ I I. fintplicium medicanentorum, in Fabarum con exiccando, or refrigerando fecundun utrunque ad medium temperamentum propinquifinie accedunt. Caro Faba 20 paulum quid abftergentis facultatis continet, ficut cortex nonnibil adftringentis. Idcirco medicorum nonnulli totam fideretio, \& vi

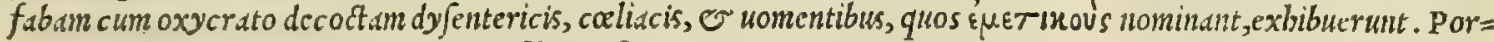
ró ut edulium, flatulenta eft, ac coctu difficilis, i quid aliud : excreationibus ex thordce, 0 pulmone idonea. Vt nile dicamentum ueró for is impo fitd, fine moleftia deficcat. In podagricis ea fepenumero ufi fumus ex aqua decocta, ow deinde adipi fuillo admifta. Ad ncruorum tum contufiones, tum uulnerationes, farinam cius cum oxymelite impofui= mus. Ad cos, quos ex ittu iam phlegmone occupauerat, cum polenta. Sed o teftium, o mammarum aptum eft ca= taplajna. Nam be partes cum phlegmone tenentur, moderaté refriger ari amant, maximé cim mamme ex lacte ip= fis concreto phlegmonem patiantur. Quin lac quoq; ab eo cataplafmate cxtinguitur, ficut puerorum pubes farina fabscca illita plurimo tempore glabra permanet. Et libro primo de aliment. facultatibus, fic inquit. Inflat is $c i=$ bus quocunq; modo apparetur : nec per quámuis longam decoctionem id uitij poteft amittere . quod ptifane minimé

20 negatum eft: deponit enim per illam quicquid habet flatulenti. Cui porró affectus fingulos cibos sequi natos, animad uertere, er nente confequi uolet, quandam totius corporis tenfionem, quafi a flatulento piritu perfentifcet, maxi= mcó; qui ad buiufmodi c c culentum non fuerit afjuefactus, aut ipfum minus recté coctum affumpferit. Habent autem

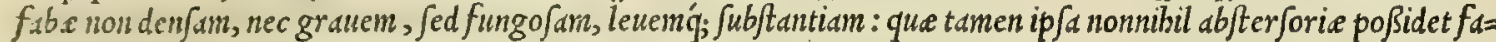
cultatis, fimiliter ptifarix. Etenim manifefté fabaced farina cutis fordes detergere conficitur. Quod intelligentes mangones, ac muliercule, in balneis quotidie hac utuntur, uelut alij nitro, atq; apbronitro, ev in uniuerfum ijs, qua ab.tcrgent. Illinunt praterea o faciem hac, quemadmodum ptifalla: nam qua in fumma cute eminent lentes, exte= rit, o maculas uelut ex fole contradtss. Huius ergo facultatis nomine ne in alui quidem tranfitu diu cunctatur, ficut que glutimofa, er craßsi fucci funt fine ulla abftergendifacultate, qualia halicam, tragum, fimilaginem, or amylum efe perhibuimus. Cüm porró ferculum ex fre $\int a$ faba paratum, quod ËTvos Greci nuncupant, fatibus non careat, mul 30 tó amplius integre fabe inflabit cibus . quanquam fricta (nam boc modo aliquando pro bellarijs fumunt) flatum depo= nit, fed tum concoctu perdifficilis, tardog; defcenfu incommodior redditur, or craßi fucci alimentum in corpus diffun dit. Quód fi tiridis, immatura, nondumq; arefacta edatur, commune omnium fructuum, quos ante perfectam matu= vitatem ingerimus, rationem obtinens, corpori humidiorem alimoniam exhibebit, ac proinde maiorem excremento= rum uim non tantum in uijs inte/tinorum; jed etiam per uniuerfum corporis habitum producet. Meritó igitur minus quoq; nutriet, $\int e d$ promptius deijcietur . Pleriq; autem bominum non crudds folds fabas comedentes, unà eds cü fuilla

FABA AEGYPTIA.

40

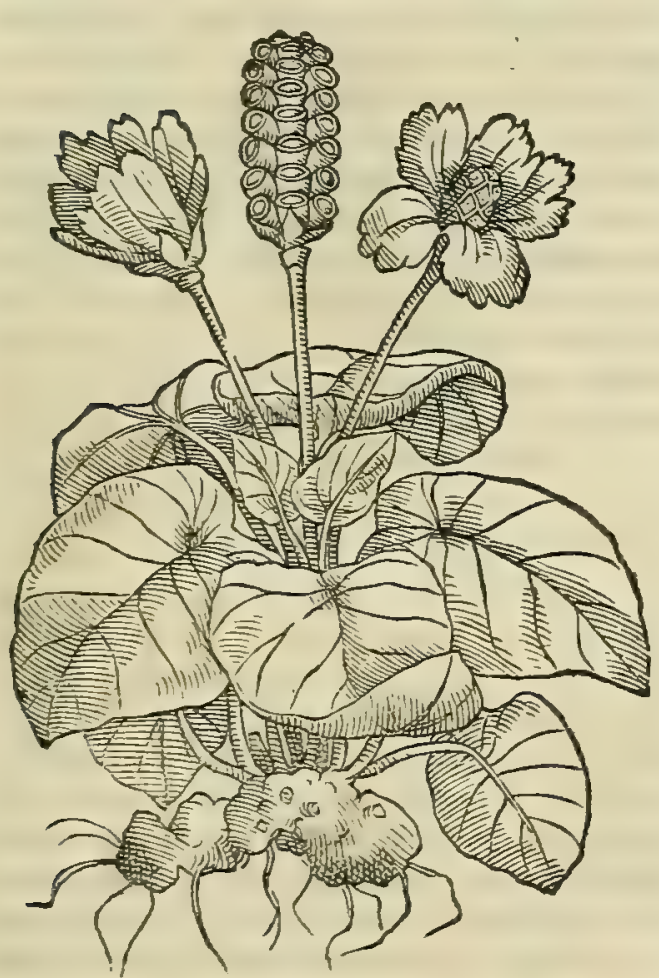
carne decoquunt, uelutio oler a confueuerunt : ruri ueró etiam cü caprina, E ouilla. Alij fabas inflare fentientes, cepas ad̦ifcĕt, cim in oll is pulmentum ex illis fruunt. Sunt qui non fimul elixd= $t$ tos, fed cum pulmento cepas ingerant crudas. In omnibus nanq; dapibus quicquid flatuofum continetur, per calfacientia, $\sigma$ ex= tenuantia corrigi comparatum eft. Kuं\&uos fic Grecis, $L d=$ tinis,uerò Faba uocatur: Arabibus, Hachille, Haballe, fiue Ba= chale: Italis, Faud: Germanis, Bonen: Gallis, Fabue.

\section{Kúaposaiyú-̄ios. FAB A AEGYPTIA. CA P. XCIX.}

AE G Y P T I A Faba, quam aliqui Ponticam vocant, in Aegypto plurima prouenit, in Afix etiam, Ciliciæque lacubus inuenitur. Folia habet ampla, †etiam fi ad arborum fiondes comparentur: caulem cubitalem, digiti crafsitudine: florem rofeum, dupla papaueris amplitudine: $\&$ vbi flore exuitur, fert folliculos vefparum fauis fimiles, in quibus faba fupra operculum, bullantis ampullæ modo, prominet . Ciborion, aut Cibotion, id eft arculam, ideo nominant, quoniam feratur ipfa, humenti glebæ mandata, \& ita in aquam demifra. Radice firmatur arundine crafsiore, quæ cruda coctáve eftur. ei Colocafiæ nomen eft. Faba virens manditur, \& exiccata nigrefcit : vulgarem magnitudine fuperat. Adfringendi facultatem obtinet, \& ftomacho vtilem : dyfen- 
tericis, cœliacisque prodeft, infparfo polentæuice, lomento : datur quoque in pulte . Cortices in vino mulfo decozti, fi terni inde cyathi bibantnr, magis proficient. Facit ad aurium dolorem, quod in earum medio viride fpectatur, guftu amarum, fi tritum, \& cum rofaceo coctum inftilletur.

Aegyptix fa- SV N T qui Acgyptian fabam fuc radicis appellatione Colocafiam nuncupent. Hanc primim Tridentianno

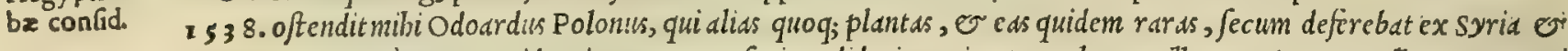
A ggypto. Caterim eos equidcm in errore uerfari crediderim, qui putant plantam illane ex Acgypto allatam, que ari peciem reprefentat, effe fabam Aegyptiam. fiquidem illa florem non edit dupla papasucris nagnitudine; non profert $f a b a s$, nec radicem babet, qux cruda mandi poßtt ob uebementem eius acrimoniam. Huius tàmen arifolia uidëtur effe faba Aegyptie. Et certé hanc adeó c’mulantur, ut aliquando exiftimawerim eas firpes nibil inter fe differre. Sed poftquàm rem banc diligentius examinaui, earum difcrimen cognoui, atq; illos plane falli iudicaui, qui arum Aegy= ptium non diftinguunt $a b$ Aegyptia faba. Meminit huius Theophraftus lib. I I I I. cap.x. de plantarum biftoria, ubi ita fribit . Faba Acgyptia in paludibus, ftagniş; exit. Caulis eius, qui longißimus, quaterna cubita perficit: craßi= tudo digitalis eft, fimilis caldamo molli, non geniculato. Rimas intrinfecus habet tendentes per totum, lilij modo. $C_{a}=$ put in cacumine orbiculatum, ueßarum fau non abfimile. Inq́;, fingulis cellis, fingule faba cötinentur, paulo fuper id eminentes, multitudine plurinum terdena. Flos papauere duplo maior, colore rofeus in plenum eaput. Super as quam folia ad ingulas fabas amplexa exeunt. Fabam quanq; conterenti amarum illud, ex quo pilula fit, inflexum pa= tefcit. Fructus ita fe babet. Radix illi craßißima, arundine plenior, rimas fimiliter atg; caulisbabens : manditur $\mathrm{O}^{-}$

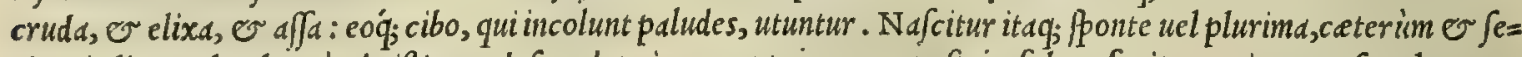
vitur in limo paleis large admiftis, ut de cendat, incorrupta $\dot{q}_{\text {; }}$ maneat: fic $q_{\text {; }}$ fabeta faciunt. Si autem femel appre= benderit, perpetuo manet. Radix enim ualida eft, nec procul arundinum ftirpibus, uerùm pinis fubhorrens. Qudm= obrem eam crocodilus refugit, ne occurrens oculo offendatur, quoniam acute non uidet. Nafcitur bac etiam in $S y=$

Colocafia ex ria, Ciliciaq́; . bactenus Theophraftus. Hanc amplißima emittere folia tradidit Plinius lib. x x I. cap. x v. ubific Plinio. inquit. In Aegypto nobilißima eft Colocafia , quam cyamon uocant aliqui. Hanc à Nilo metunt: caule, cùm coctus eft, araneofo in mandendo : thyrfo autem, qui inter folia emicat, ßpectabilis : folijs latißimis, ctiam fi ad arbores com= parentur, ad fimilitudinem eorum, qux perfonata in noftris amnibus uocamus. Adeoq́; Nili fui dotibus gaudent, ut implexis Colocafia folijs, in udriam peciem ud forum potare gratißimum babeant. Seritur iam bac in Italia . bac Pli nius. Aegyptia faba (ut Galenus auctor eft libro primo de alimentis) ficuti noftratem magnitudine longé preccellit,

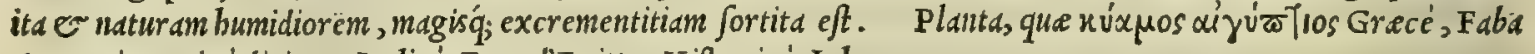
Aegyptia Latiné dicitur: I talicé, Faua d'Egitto: Hipanicé, Inbame.

I E N S.

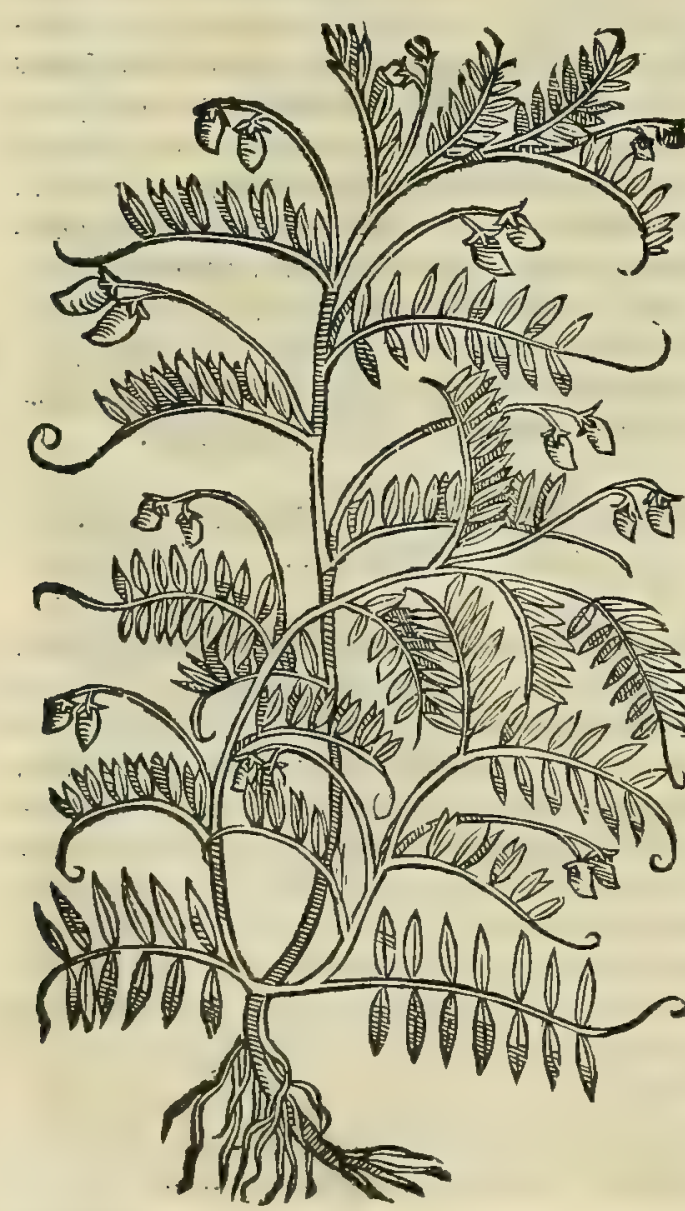

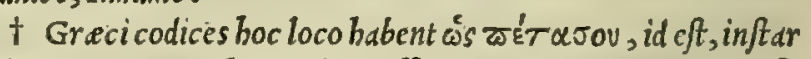
galeri: Que autem borum loco affert R uellius ex Plinio fumpfit loco citato. vbi verbis, que ill fequuntur, rectius forté hunc Dio foridis locum interpretari uidetur.

\section{¿axós. LENS. CAP. C.}

LEN S frequenti cibo aciem oculorum obtundit, xgrè concoquitur, ftomachum malè habet, eumq́ue $\&$ inteftina inflat: fed aluum cum cortice cocta fiftit. Præftat in cibo, qux facillimè coquitur, nihil atri in mace- $4^{\circ}$ ratione reddens. Vim habet adftringendi : qua ex caufa aluum cohibet, fi detracto antea cortice difcoquatur accuratè, primaq́ue aqua inter coquendum effundatur (quippe primum id decoctum ventrem refoluit.) Somnia tumultuofa excitat: capiti, neruis, ac pulmoni inutilis : melius fuo fungetur munere contra alui fluxiones, addito cum aceto intybo, aut portulaca, aut beta nigra, aut baccis myrti, aut putamine punici, aut aridis rofis, aut mefpilis, forbísve, pyris Thebanis, aut malis cotoneis, aut cichorio, aut plantagine,aut gallis integris, qux so poft decoctionem abijciuntur, vel rhoé, quæ obfonijs infpargitur: verùm acetum cum ea diligenter percoqui debet, aliàs aluum conturbat. Contra fubuerfionem fto machi, triginta grana lentis delibrata denorari proderit. Decocta cum polenta, \& illira, podagras lenit: finus cŭ melle glutinat, cruftas rumpit, vlcera purgat. Decoćta in aceto duritias, \& ftrumas difcutit : cum cotoneo, aut meliloto medetur inflammationibus oculorum, fedisq́ue, addito rofaceo: fed in amplo finu, aut infammationibus fedis, qur maius remedium exigunt, cum putąmine punici, ac ficcis rolis, adiecto melle, decoquitur: 


\section{In Lib. lecundum Diofcoridis.}

nomis qux in gangrænam cuafcrunt, adiuneta maris aqua : puftulis, \& his qux ferpunt, igni facro, pernionibusq́ue, vtantea dictum eft : contra mammas in quibus lac in grumos coijt, \& præ nimia fui copia profunditur, cocta in aqua maris, \& illita auxiliatur.

LE N T E S, quemadmodum libro v I I I. fimplicium medicanentorum fcriptum reliquit Galenus, ualentcr ad= fringunt: in caliditate ucró, er frigiditate medium tenent; deficcant tamen in fecundo ordine. Ip fum itaque edrum Létium uires corpus deficcat, $\circlearrowleft$ fiftit uentrem: catcrum decoctum prouocat : proinde ctian prior aqua abijcitur, ubi retentio= nis caufa adbibcntur. bactenus loco citato Galenus. Catcrim afferenti Diofcoridi Lentes aluum cobibere, fi detrd= cto antea cortice dif coquantur accuraté, prina $\hat{j}_{j}$ aqua inter coquendum effundatur, omnino rcfr.tgatur Galcnus, qui 10 libro primo de alimentorum facultatibus fic fcribit. Ne cxlente quidem pancm quis tentaucrit : prax arida enim fine pingui, friabilis cft. Cortex cius uebcmenter adftringit, carnea fubftantia temuiter, que er crafsifucci, er terre= fris eft. Succus porró lentis, ficut ante retultmus, adfringentieft contrarius. Quocirca fi clixe in aqua iufculum falc, garo, olcóq; conditum bibatur, aluum deijciet. At quod ex bis decocta lente ad eum modü, quem retulimus, fer $=$ culum apparatur, contrariam fucco nim obtinet. Nam que uentri obueniunt, fluxiones deficcur, os uentriculi, intefti= $n x_{3} \odot$ totum deniq; uentrem corroborans. Quamobrem caliacis, $\mathcal{O}$ dy entericis accommodatus eft cibus. Lens ue= ró decorticata, ut illum adftringendi uebementian, cum ö; bac alia uidelicet omnia, qua confequntur, amitrit : ita alim

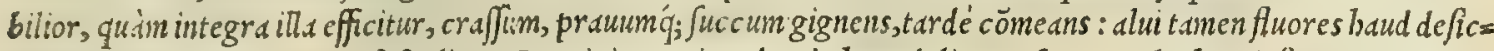
cat, uti ea que cortice non cft fpoliata. I ure igitur qui modum in boc edulio non feruant, elephantiafin quam uocant, $\mathcal{O}$ cancrum incurrunt. siquidem craffa, ficcá; cibaria facilé in melancholicos bumores uertuntur. Quare ijs duno

20 taxat, quibus uitio a eft babitudo ob aquam in carne diffu fam, lens cibo utiliter prebetur : ccu aridis, er fqualentibus admodum damnosé. Eandem ob caufam uifum integrum, ev inculpatum bebetat, immoderaté exiccans. Ei ueró, qui contrario modo fe habet, bumidiori uidelicet, opitulatur. Menftruis purgationibus inepta eft: craffum enim, Or tar= diflum fanguinem facit. At muliebri appellato profuuio conuenientißima. Cim porró lens, es ptifand contrarie in= ter $\int \mathrm{e}$ fint facuitatis, ex amborum commiftione preftantißimum edulium componitur, quod nos in A/ia pbacoptifas nam nuncspawus. Verim non equa utriufq; portio effe debet: minus enim ptifanx adijcicndun, ut que per deco Ctionem in cremorem laté difunditur, or in magnam attollitur molem : lens auten cocta exigunn quendam tumorem afcifcit. Sed cnin huius cduly eadem ac ptifanx eft confectio,preterquàm quod fatureid, ev pulegio adiectis, iucun= dius e paratrus concoctioni efficitur : cum ptifana illis minimé gaudeat, fed folo anetho, porroǵ; fit contenta. De= terrima eft lentis conditio, quam diuitum coci fapa infic iunt: mininé enim incraffantia fibi uult admifceri, fed liquida

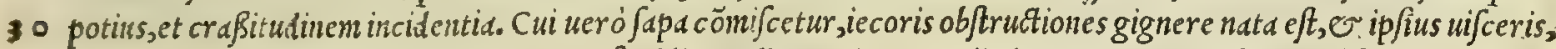
atq; und lienis inflammationes indugere, $m f i$ addito melle corrigatur. Illud preterea non arbitror obfcurun, durefcé tes mifceris utriusq; affectus, quos fcirrbos nocdnt, boc epulo exacerbari. Quód fi fuillam finul libeat incoquere, pti=

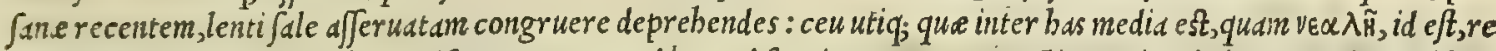
center falitan appellant,phacoptifane percommodé er ad fuautatem, ơ concoctionem immittitur. Magis tané lens cam falfis carnibus efitata, craffos humores augebit. Nam be quoq; fanguinem craßsiorem, or melancbolicum magis generant. Quapropter neq, iftis affatim, fepé,; uti expediet, prefertim cui corpus melancholico precraffo, or om= rino prano bumori obnoxium eft. Hec eddem e de regionibus, anni temporibus, $\sigma$ aéris conftitutionibus in unoquo que cdulio intelligere oportet. Ac autumno quidem melancholic is, ac ficcantibus cibis abfinendum : byeme ueró eis utendum : utifane in altate bumectantibus, or refrigerantibus : in uere medij temperamenti,media $q_{;}$facultatis epu=

40 las offerendum. Eft porró mediorum non una, nec fimplex pecies : quedam enim buin fnodi funt, quoniam cum extre mis nibil habent commune: quadam ex duorum contrariorum aquo interuallo à medio diftantium miftione funt me= diocritatem adepta: ut fi quis iuxta id, quod pauló anté dixi, ptifanan lenti commifcedt. sic er teutlophacen, que ex beta, er lente nomen apud Gracos inuenit, Heraclides Tarentinus non fanis modó, uerum etiam laborantibus ex= bibebat. Ef enim er boc ex pugnantibus compofitum edulium: quamobrem etian tardius, quim beta; citius ueró, quam lens per aluum defcendit. Eft o illud perpicuum, buius fuccum in corpus difpartitum, ex amborum uirtute, Ientis uidelicet, ac beta, effe permifum. hattenus Galenus. Ex cuius uerbis facilé colligi poteft, I entes in frequens ti ciborum ufu minimé effe recipiendas; praterquàm ab ijs, quibus morbi alicuius ratione, ut medicamenta potius,

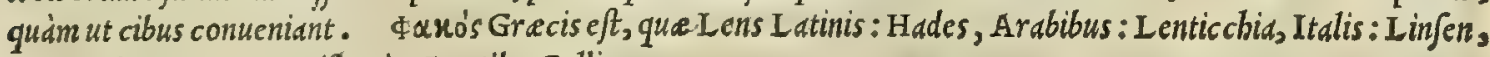
Germanis : Lenteyds, Hippanis : Lentile, Gallis:

so

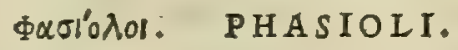

\section{CAP. CI.}

PHA I O I I inflant, fpiritus cient, agrè coquuntur. Virides cibo aluum emolliunt: ad vomitiones idonei.

P H A S I O I I funt in I talia unlgares, or in bortis, ac aruis frequentes. Diuerfa corum habentur generd, ud= Phafeolorum rijs coloribus diftincta: nam er candidi, er rube fcentes, or melini, ac diuerfis reperfi maculis reperiuntur. Quos confideratio. fuperiori quoq; tati cognitos fuiffe putauerim, et $f$ nonnulli cos muper in Italia ueniffe exiftiment. Candidi, quibus granum ceteris minus eft, ceterorum leguminum more, in aruis feruntur. At rube fcentes, melini, ac uarij feminan= tur in hortis alijsice locis, ubi umbra eftiua fuerit opus. Siquidem praterquàm quód fructum fuo tempore demeten= dum proferunt, fuis etiam inuolucris, ac fequacifoliorum, clauicularum ${ }_{i}$ reptatu, teftudines, attegias, mapalia,

\section{Nomins:}




\section{4

P H A S I O L I.

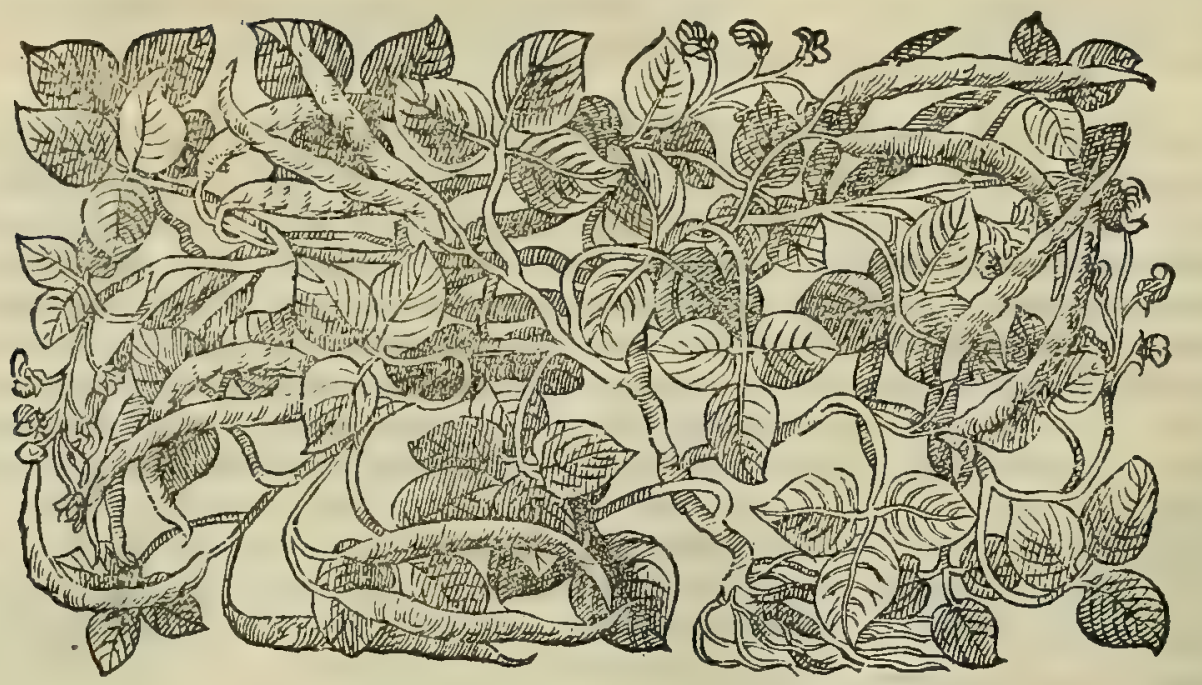

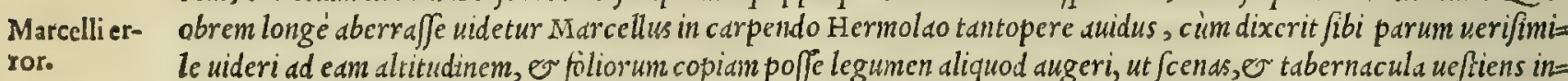
Marcelli er- obrem longé aberraffe videtur Marcellus in carpendo Hermolao tantopere auidus, cim dixcrit fibi parum verifimi=
ror.
le uideri ad eam altitudinem, or follorum copian poffe le gumen aliquod augeri, ut fends, or tabernacula uefiens in= umbret. Quandoquidem non modó buic refragatur Diofcorides; fed er ipfius fmilacis numerofus plantarum pros uentus, que in quam plurimis bortis, ac uiridarijs longißimos fcandunt palos, es cancellata tecta conueftiunt. C $C_{2}=$ terim nec eos quidem ballucinari putauerim, qui pro certo afferuerint, Phafiolos fupradictis coloribus infectos, quos equidem nibil ab hortenfi jmilace differre exiftimo, Dolichos effe, quorum meminit Theophraftus lib. I I I.cap. I I I. de plantarum biftoria: 0 Galenus libro primo de facultate alimentorum: 0 ipfum fecutus Paulus. Quippe quo= 30

tuguria, cameras, pergulas, fcenas, ac tabernactla é lignis cancellatim fabricata opacant, ac ucluti topidrio opere contexunt: foldres⿱千; ; radios inhibent, non fccus quàm uitis, lupus falictarius, bryonia, colocyntbis, clematis, peri $=20$ clynenum, o ftirpium id genus, qua arbores, \& fepes fcandunt, perreptant, implicant, ac conueftiunt. Quo fit, ut crediderime ego, illos à ueritate batidquaquam defifcere, qui dixerint, boc Phafeolorum genus hortenfem effe finild= cem, hoc etiam libro à Diofcoride de fcriptum: quippe quód illi indxiné repondeat, ut in fequentibus dicetur. Qu $\bar{a}=$

ERVVM.

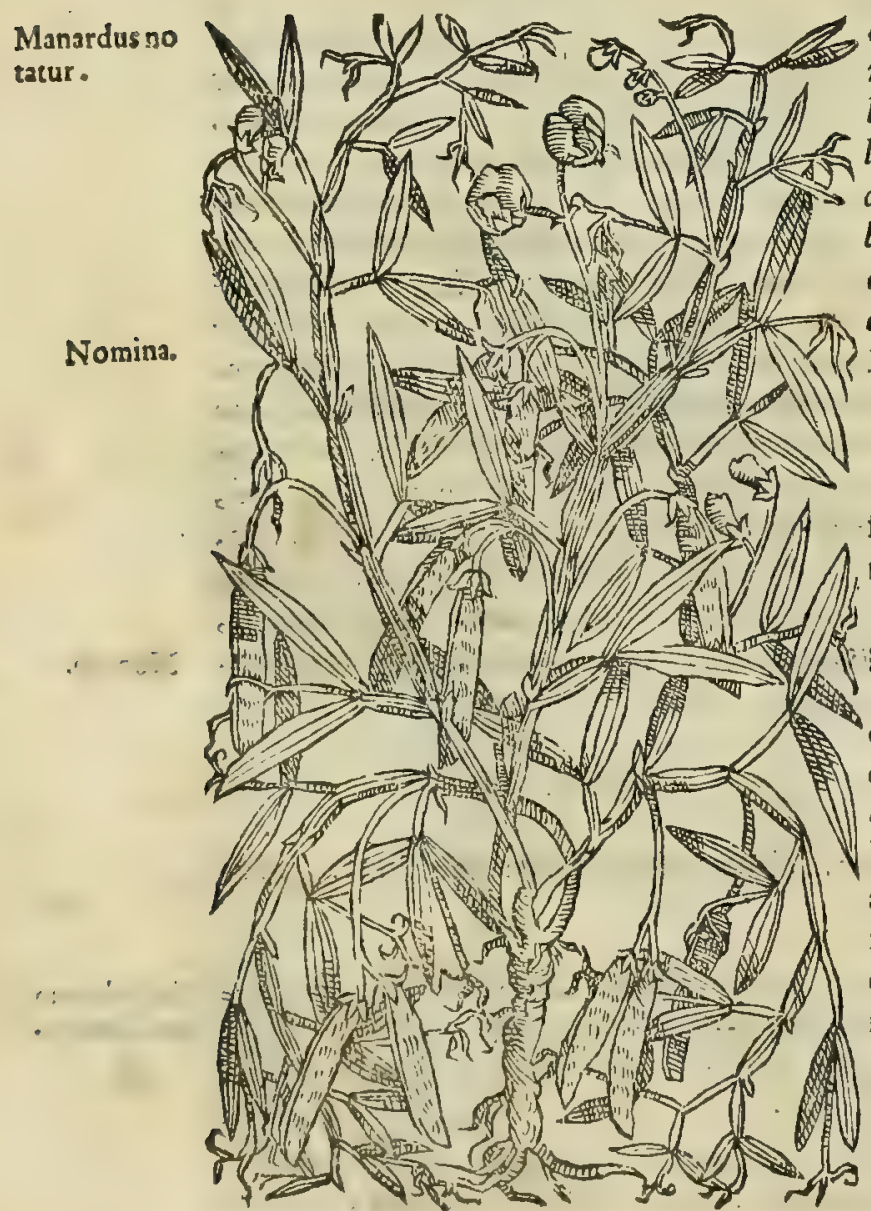
niam dolichi (ut adiunante Deo infrà in fmilacis hortenfis mentio ne dicemus) non funt illud piforum genus, quod Aiufoniys uulgó dicitur Rouiglione, Tridentinis ueró Arabeid, ut Manardo Fer a rarienfi placet. Quandoquidem hanc fub ocbri nomine, tam $\mathrm{Gd}=$ le nus, quim Paulus defcripferé, ut eo, quem modó cituuimus, loco patebit. Porró in boc prefenticapite Diofcorides de can= didis tantum, ac unlgaribus phafiolis differuit, non de eruilia Ard beia uulgo uocata: in fequentibus uero capite de bortenfi fmild= ce, corum mentionem fecit, qui uel rubentes, uel lutei, uel uerfi=

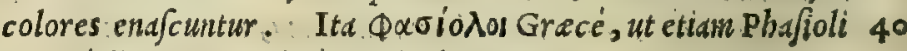
Latiné dicuntur : Italicé, Faginoli.

$$
\text { o’goßos. ERVVM, CA.P. CII. }
$$

E R V V M paruus frutex omnibus cognitus, angufto folio, tenuis, femina in valuulis habens : è quibus farina fit, nomine eruina, ad medendi ufus conueniens. Eruum capiti onerofum eft : aluum efu turbat: fanguinem per vrinam extrahit: elixo boues faginantur. Parandæ farinæ ratio hæc eft. Vberiora grana candidaq́ue deliguntur, permifcendoq́ue aqua refperguntur, so donec fufficienter combibant : poftea torrentur, vfque dum hians cortex difrumpatur: molitaq́ue, farinario cri bro incernuntur : poltremò farina reconditur. Hæc aluo veilis eft: vrinam ciet: meliorem colorem efficit: fanguinem per ueficam, aut aluum cum torminibus elicit, fi largius in cibo, aut potu affumàtur: vlcera cum melle purgat : lentigines, \& vitia cutis in facie , \& maculas, totumque corpus emendat : nomas, gangrenas, duritiasque, ferpere non patitur:mammarum duritias emollit : atra vlcera, qux theriomata uocant, fauosque emarginat : carbunculos rumpit : cum vino fubatta illitu morfibus 
morfibus uiperarum, canum, hominumq́ue medetur: urinx difficultates, rencimosq́uc ex acero mitigat. Eruum tabidis, qui alimentum non fentiunt, toftum, $K$ ad nucis magntudincm melle exceptú, fumptumq́ueconuenit. Eius cremor perniones, \& pruritus in tote corpore, fanat fouendo.

E R V V M officinx, Grecorum moré, Orobum appellant. 'Ceterün quod ex Alcxandrix, syriać; Venctias Eruiconlideconuebitur, aliud nimirum femen reprefentare cenfemus, quìn Erui, quod frequcntijimum in Hciruria nafcitur, ac ratio.

feritur. Folia mittit Erum, quod unlgò Mocho uocanus, lathyri, uel cicerculx uulgò uocate anula: florcm piforü modo, admodum rufe fecntcm: filiqus forma teretes, et oblong as, in quibus femen, colore in aliquibus pallido, in nönul= lis candido, in quibufdum ucró rufificente. Porró cimboc ignoraret Brafauolus, credidit Eruiliam, que Thcoplora= Brafauoli, \& 10 fto,Galeno, ac Palulo ochros appclixtur, legitimum effe Erum,nominis uicinitate fortaffe deceptus. Qua in re Fuch= Fuch. laplus. fius quoq; ballucinatus depseclsciditur, quòd fuo de plantarum biftoria wolumine Cicerculam unlgó nocatam, fatiuum Eruum effe cxiftinaucrit : ct/i cicerculan onnes reiberbarie periti Galeno latbyrum appellarinon dubitent. In ci= cercula cnim, ut periculum facicntibus clarißimum eft, badquaquan ex reperiuntur facultates, quibus pollere Erü̈ tradidit Diofcorides. Quxndoquidem prater id,quód ommi prorfus amaritudine uacat, largius efitata nunquam fant= guinem per ucfican, or aluum cum torminibus clicit, ut de orobo fatentur Diofcorides, or Galcnus. Ex quo planẻ

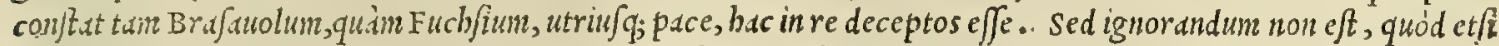
Eruum ab.agricolis feratur; habctur tamen er inter ponte nafcentia: nanque or per fe inter fegetes fiequens ori= tur. Terim cim a paucis cognofcatur, illud inter uicix Pecies annumerant. "Animaduertendum praterea eft, quód quanquam ad Eruinum farinan conficiendan eligit Diofcorides candidius Eruifemen: Galenus tamen lib. I.

2o de fácultate alincntorun, candidum pallido, ac rufefcente, longé minus preftare fcribit. Quapropter Brafauo= Ius Gale ni rationem mininé babuife uidctur, cim fibi ex Diofcoridis tantim fententia perfuaferit, album erui femen in medicanentorum ufu tam rufum, quim pallidum uiribus antecellere. Erui uires prodidit Galenus lib. VI I I. Erui uires ex fimplicium medic. it intquiens. Orobus deficcat quidem exce $\iint$ fecundo intenfo, calfacit ueró primo. Porró qua= Galeno. tenus amaritudinis eft particeps, eatcnus incidit, extergit, atque obftructiones expedit. Caterum fi fumatur copio= sé, f.riguinem per urinas euocat. Et libro I. de alimentorum facultatibus ait. Boues apud nos, ut apud alias pleraf= que gestes, Eruo in aqua edulcato pafcuntur. Hominum cibis prorfus boc femendamnatur eft enim er infuaif $i=$ mum, e prau fucci. Ceterum in magna fame nonnunquam, ficut Hippocrates quoq; foripfit, neceßitate coacti mincs ad id ctian confugiunt. Nos cruo inftar lupini preparato ex melle utinur, ut medicamento craffos pulmonis, thoracisó; bumores expurgante. Candidum minus eft inedic amento oum, quàn id, quod ad flauum, aut pallidü colorem 30 tendit. Eruum bis elixum, $\mathcal{O}$ in aqua identidem condulcefactum, infuauitatem certé deponit, fed und cum ea $\mathcal{O}$ ab=

\section{V P I N I.}

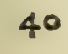
ftergendi, o incidendi uim, ut fola in eo relinquatur terreftris jubftantia. Itaque citra amaritudinis intellectum deficcans fit $e=$ fculentum. Id Gracis ögoßos, quod Latinis Eruum nomind= Nomina. tur: Arabibus, Herbum, Kcifene, fiue Kerfene: Italis, Eruo: Ger manis, Eruen: Hipanis, Ieruos: Gallis, Ers.

\section{Eégpol. LVPINI. CAP. CIII。}

S A T I v v s Lupinus notus eft. Cuius farina cum melle delinctu, aut potu, uentris animalia expellit . Ipfi quoque macerati, \& cum fua amaritudine efitati, eadem efficiunt. Decoctum eorum idem munus præftat, cú ruta,\& pipere potum : quare lienofis prodeft. eodem ulcera tetra, quæ theriomata uocant, gangrænas, incipientem fcabiem, eruptiones puftularum, vlcera in capite manantia,uitiligines, maculasq̣ue fouere utilifsimum: menfes, \& partus extrahit, cum myrrha, \& melle fubditũ in vellere. Eorum farina cutem, liquoresq́ue corrigit : inflammationes cum polenta,\& aqua mitigat: tubercula, \& coxendicum cruciatus, ex aceto lenit: ftrumas in aceto cóĖa,illitaq́ue difsipat: carbunculos rumpit. Decoeti coelefti aqua, donec in cremorem lentefcant, faciem abftergunt: medentur pecorum fcabiei, cum radice nigri chamæleontis, ita ut tepente decocto abluantur. Cir urinam radix cum aqua cocta. Lupini triti, vbi maceratu dulcefcere coperint, cum aceto poti, faftidium detrahunt, \& cibi auiditatem faciunt. Gignuntur \& fylueftrcs Lupini,fatiuis fimiles, fed omnino minores : qui eadem quę fatiui poflunt. 


\section{6}

Lupinorum confideratio.

S E R V N T V R in Hctruria Lupini non modó ad alimentorum ufum, fed adagros impinguandos. Ceterum preter fatiuos Lupinos, Jylueltriun in Hetruria innumere exoriuntur plante, qua maio menfe in campefribus ui= funtur, floribus rofeo colore rufe fcentibus. Satiui dulcorantur in Italia,ibiq́; frequenter eduntur cum fale. Lu= Lupinorum pinus (ut fcriptum reliquit Galcnus lib. I.de alımentorum facultatibus) multi ufus legumen cenfetur. Elixus enim, ac faculc.ex Gal. deinde in aqua dulci, donec omnem fibi ingenitan exuat infuauitatem, commadc faćtus, ita editur cum garo, ac oxy= garo, uel fine bis etian, fale modico conditus: non uelut bordeum, es alia multifariam inftructa. Lupini dura, ac terreftris fubftantia c/t. Quocirca neceffarió concoctioni repugnat, or craffun gignit fucc un : ex quo non probé in uenis confecto, crudus proprié appellatus fuccus aceruatur. Et libro v I. fimplicium medicamentorum, fic inquit. Iupinus editur coctus, inult is anté dicbus in maceratione in aqua amaritudinem deponens: fit q́; tunc mitrimentum fuccicraßi. Caterum ut medicanentum ita preparatus ex genere eft emplafticorum. At qui natiuan amaritudinem habet, is etiam extergendi, digercndiq́; uim obtinet. Interficit lumbricos tum illitus, tum addito melle linctus, tum ex pofca epotus. Quin o decoctum cius lumbricos eijcere poteft. Tum etian foris identidem perfufum, uitiligines, achoras, puftulas, exanthemata Greci uocant, p foras, gangrenas, ulcera maligna, qua cacoëthe uocant, iuuat, partim extergendo, partim citra mordacitatem digerendo, ficcando q;. Expurgat iccur, o licnem cum ruta, $\sigma$ pipere fud= uitatis gratia afjumptum. Elicit men $e s$, ac fatum cum myrrha, o melle impofitum. Porró Lupinorum farina fine mordicatione digerit: nec enin liuida tantum, $\int e d \odot$ charadds, $\sigma$ dura phymata curat: $\int e d$ tunc in aceto, aut oxy= melite, aut po fca coquatur oportet, id'́; pro laborantium temperamento, $\sigma$ affectus diuerfitate, quod ex ufu eft eli= gendo. Sed non eft prae entis inftituti talia diftinguere. Digerit item que liuida Junt. Et quacung; modó diximus pre= ftare poffe decoctum, eadem omnia efficit of farma. Sunt ueró etiam qui eam ifchiadicis catapla fmatis modo illinüt .

Nomina. Lupinus agreftis anarior eft, et ad omnia ualentior domeftico, eiufdem genere cum ip fo facultatis. Iupinus fatiuus 20

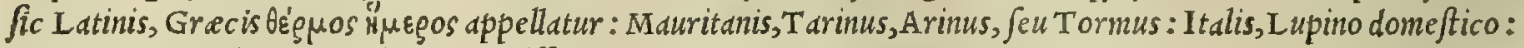
Germanis, Vuickbonen,Feigbonen,Vuolffafkbonen: Hipanis, Entramuces, er Entramocos: Gallis, Lupinis. Iu=

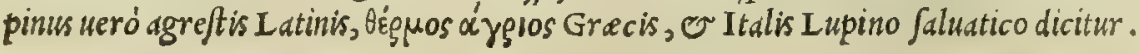

TorjúAN. RAPVM. CAP. CIIII.

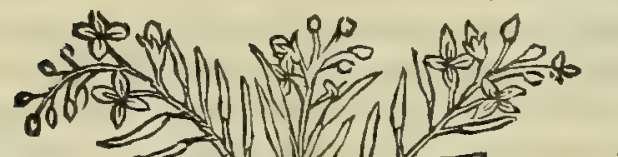

D E C O C T A Rapi radix halit, inflationem parit, humentem ac fluxam carnem creat, venerem ftimulat. Deco Eto podagræ, pernionesq́; fouentur : contritoq́ue rapo, atque impofito iuuantur. Si excauatæ radici rofaceum 30 ceratum adigatur, \& feruenti cinere eliquefcat, exulceratis pernionibus proficiet. Cymæ eius decoctæ manduntur, \& urinam ciunt. Semen antidotis, \& theriacis, prafertim quæ fenfum doloris auferunt, anodyna uocát,idoneum eft : potum contra uenena falutare eft : uenerế concitar. Rapum muria condîtum, minus alimenti fufficit: fed multò magis appetentiam recreat. Sylueftre rapum in aruis nafcitur. + Frutex eft in cubiti altitudinem affurgens, ramofus, læuis in cacumine. Folia fert læuia, digitali latitudine, aut maiora : \& fructum in filiquis calyculatis : cùmq́uc eorum inuolucra aperiuntur, alia intus filiqua fpeetatur, quæ quandam capitis fpeciem præbet . in qua femina paruula concipiuntur, for is nigra, intus alba. Additur in medicamenta, quibus ad detergendá cutem in facie, totoq́ue corpore, utimur : præfertim quæ ex lupini,aut erui, tritici, atit lolij farina, fieri folent.

R A P V M in Italia unlgó notißimum eff, prafertim apud Infubres, ubiftatim poft meffer xftate, innio, ac iulio menfibus, in aruis fecundo feritur: deinde menfe octobri, cum radix ad fum $=50$ mum extuberauerit, é terra eruitur. Satiuum in triplici recen $\sqrt{e}=$ tur genere, fe ßille, longum, er rotundum: tamet $f i$ literis manda $=$ uerit Plinius libro X V I I I. cap. X I I I. longum erraticum effe. Non omittendum nature miraculum, extam paruo femine tri= bus pené menfibus gignitur tam magna radix, ut ea aliquibus in lo= cis plus quàm centenas libr as pendat. At librarum triginta pondere nos $\int x p i u s$ imnumera rapa uidimus in A nanien/i agro, longa, or colore purpurea. Rapum, e radix (ut Theophraftus eft auctor lib. v I I.cap. I I I i. de planta= rum biftoria (gaudent frigoribus: \& fic ed dulce fcere putant, fimul'; incrementum in radicem, non in follia uerti. Auftrinis, atq; ferenis temporibus celeriter caule $\int c u n t$. Nurfinis Plinio palma, quód eo fortaffe folo magnitudine, or dulcedine ceteris preftent. Alpinis, quibus rara feges, rapa utilia admodum, ac neceffaria habentur, tam in ho= minum alimentum, quam iumentorum pabulum. Qux aftate feruntur, uindicantur ab erucarum iniuria, qua ple= 


\section{InLib. fecundum Diofcoridis.}

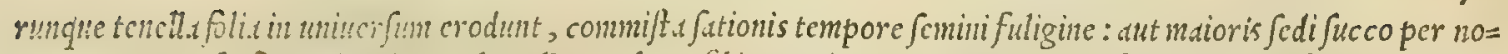

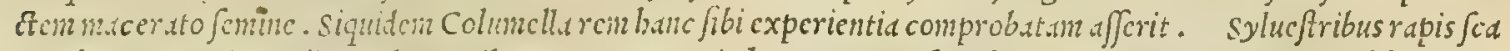

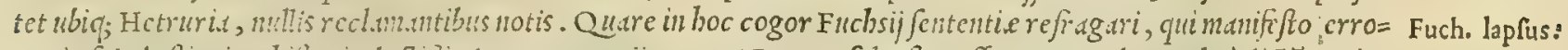

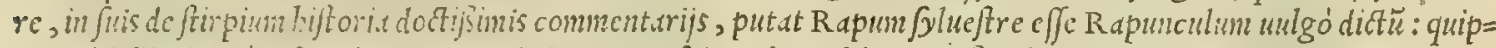

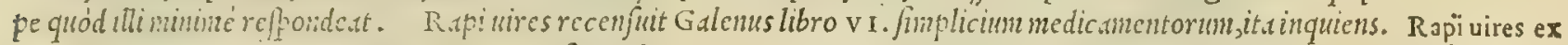

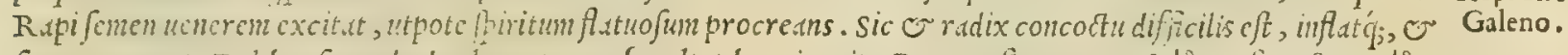

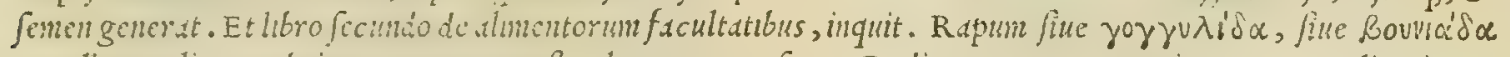
appellare uelis, quod cius cxtrater. ann eft, olcraceum cenfetur. Radix, quie terra continctur, ante elixationem o dura eft, e cibo alicna: in aqua auten decoct.t, mirum fi aliqua ex congeneribus plantis minus nutriat. Hanc

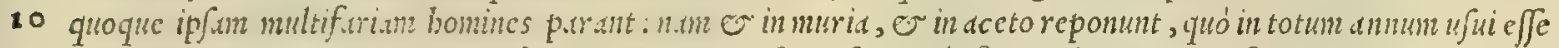

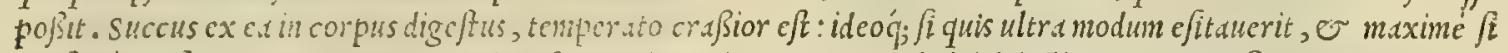

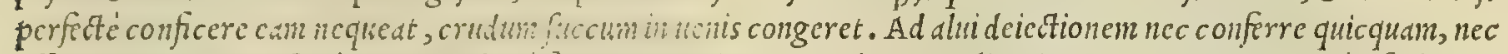

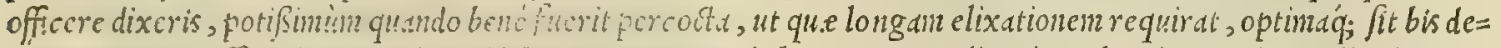

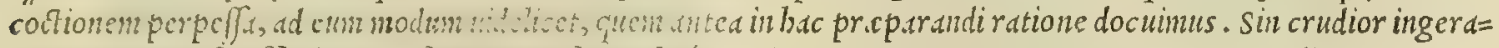

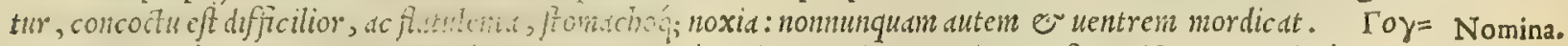

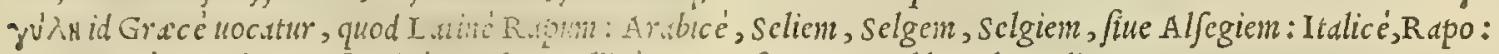
Germanicé, Rueben: Hifpanicé, Nabo: Gellicé, Raue, feu Naueau blanc de uardin.

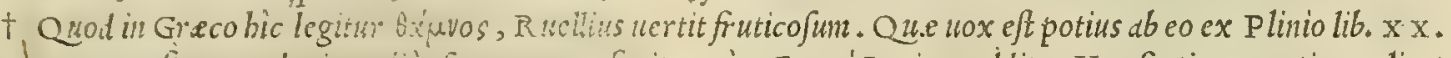

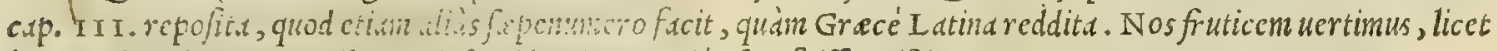
20 buc, ut alijs plerisque nocitus, Diof coridom improprié ufun fuiffe exiftimemus.

Bouviás. INAPVS.

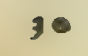

\section{A P. C V.}

Co C T A Napi radix inflat, modicum alit. Semen eius potum uenenorum uires hebetat : antidotis admifcetur. Conditurfale radix.

N A P I in raporuingenere recenfentur. Plura Theopbrd= Naporúconfto, er Plinio produntur generd: quanquam bac tempeftate duo fideratio. tantum repererim, nempe album, o flaum. Flaui tametfí albos craßitudine fuperent, magis f; colore placeant; funt tamen inf $=$ pidiores, or guftui ob id minus grati. In Aegypto frequentius feruntur, quod inibi ex corum femine copiofum exprimant $0=$ leum. Bovvosis, nomen Gracumeft: Napus, I atinum: Italli= cum, Napo: Germanicum, Steckrueben: Hifpanicum, Nabicas: Gallicum, Nauet.

$$
\begin{gathered}
\text { Pe } \text { cuvis. }_{\text {C A P. }} \text { CVI. }
\end{gathered}
$$

R A D I X, quæ Græcis raphanus dicitur, excalfacit, flatus gignit, ori fuauis eft: fed ftomacho aduerfatur, ruEtus ciet, urinam pellit, aluo aptior : fummo tamen cibo fumi debet, quò magis eius diftributionem adiuuet : cùm autem præfumitur, cibum fufpendit: quare uomituris commodifsimè datur ante cibum : fenfuum aciem excitat. Deco\&ta contra ueterem tufsim, \& pituitæ crafsitiem in pectore, efficax eft. Cortex ex aceto mulfo, celerius vomitiones mout: hydropicis commodifsimè illinitur: lienofis vtilis : fugillata cum melle rapit, \& nomas amolitur: contra uiperarum i\&us auxiliatur : alopecias ad pilum reducit : lentigines cum loliacea farina emendat: his quifungis ftrangulantur, tam cibo, quàm potu falutaris eft : menfes cit. Semen , uomitiones facit,vrinam mouet, lienem extenuat : cum aceto illitum gangrænas ualidifsimè emarginat : coctum cum aceto mulfo, anginis perquàm utiliter gargarizatur: contra ceraftis morfus, potum ex uino, auxilio eft. Sylueftris raphani, quam Romani armoraciam uocant, folia fatiuo fimilia, fed magis lamplanam imitantur: radix gracilis, tenera fubacris. Tam folium, quàm radix in olera recipitur: fed hæc excalfacit, urinam concitat, aftuofa eft.

$\mathrm{R}$ A P H A N V S Grecis ditus, Iatinis Radix appellatur. In Hetrurid, quód Latinum nomen imiten= tur, Radice uulgó uocant : quemadmodum $\mathrm{O}^{\circ}$ Romani fuam antiquam Raphani fylueftris appellationem reti=
nent, qui ipfum prime liter metathefí Ramoraciam appellant. Caterium cün fylueftris, fatiua longé du= Raphani confideratio. 
R A P H A N $\mathrm{V} S$.

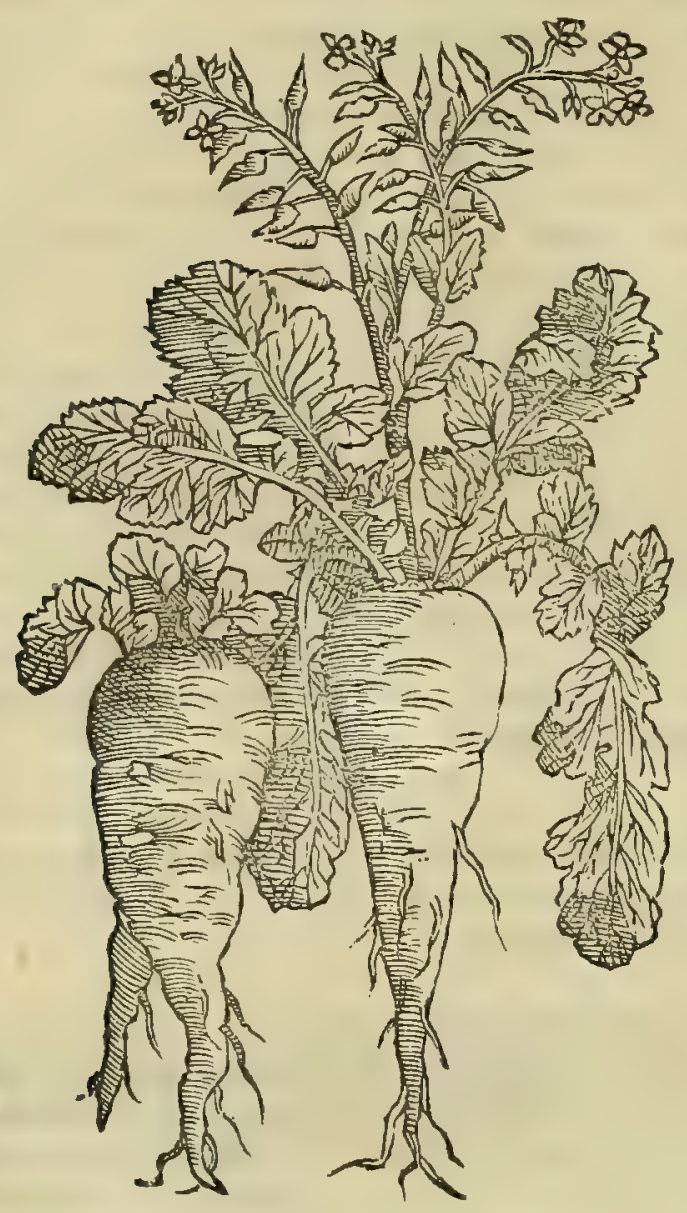

RAPHANVS VVLGARIS.

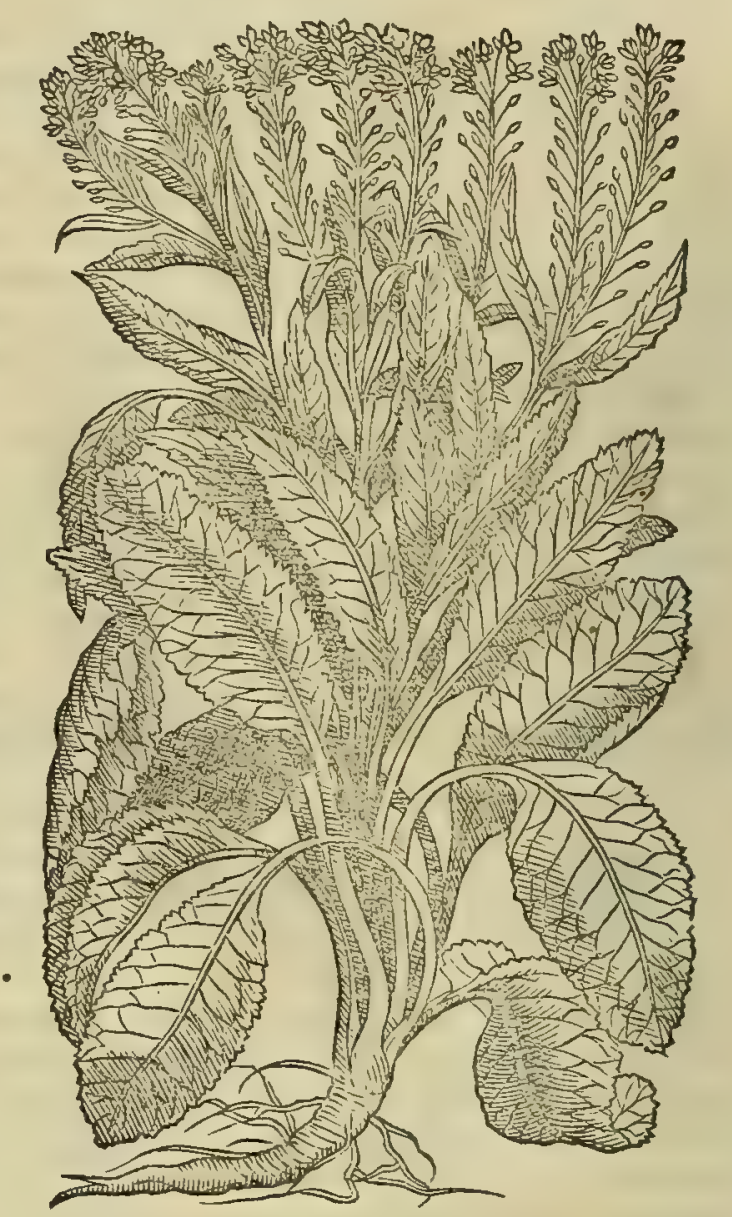

20

$\pm 0$

rior, acriorq; deprebendatur, Diofcoridis codex hic, ut in alijs pleris \%; locis, mendi fuptitione non uacat, utpote qui

FuchGj error. Armoracie radicem reddat tenerain mollemue, o fubacrem. Ieonardus Fuchfius, médicus a tatis noftre clarif= fimus, Armoraciam eam effe ftirpem putat, quam Raphanum rufticum nonnulli uocauere, folijs oxylapatho maio= ribus, radicibus acerrimis, quibus utitur uniuer $\int_{a}$ Germania, or Pannonia ad carnium intin $q$ tus. Qua in re cü, alio= qui peritum, facile ballucinatum crediderim, icerrimo fortaffe illius plante fapore fretum. Quod fi is uel Romam unquam profectus effet, uel cateras notas accuratius perpendiffet, nunquain (ut drbitror)in eum errorem incidiffet.

Rapliani Theophrafto lib. v I I.cap. I I I de biforia plaintarun, plura funt generd: nempe corinthium, cleo= neum, liothalaßium, bootium. Adolefcit amplißimé Corinthium, quod ucl radicc conftet detecta. Hoc enim fur fum 40 uerfus protruditur, non ut caterd in terram ampliari folitum eft. I iothal a ßium, quod Thracium uocant, ualidißiniu aduer $\int u s$ frigor a traditur. Bocotiwn dulcisinnm eft, e figwra roundun, nec ut Cleoneum pralongum. Quibus for lia lacuia, dulciord, fuauior a'́; funt: quibus autem, fcabra, acriora. Gentus praterea redditur, quod folijs eruce fini=

Raphani ui- le conftat. Raphanus (ut lib.v I I I. Fimplicium medic anzentorum foribit Galenus) excalfacit quidem exceffu tertio, res ex Gal. deficcat ueró fecundo : agreft is auten in utroque efficacior eft. Quin er femen ipfum planta efficacius eft. Facultas ci ineft digerendi. Itaq; ad fugillata, er alia id genus limida ob talem facultatcin acconmoda exiftunt. Meminit item Galenus Raphani libro I I. de alimentorun facultatibus, fic inquicns. Radiculan folam, crudamq́; urbani bomi= nes ut plurimum prima menfa ex garo fumunt, alui ducenda gratia : pauci autem acetum admifcent. Ruftici ucró frequenter cum pane efitant, non fecus ac alia, que nobis natura non ars parauit ob fonia : in quibus cft origanum ui= ride, nafturtium, thymum, fatureid, pulegium, ferpyllum, mentha, calaninthd, pyrethrum, cruca. Cuippe hec $0=50$ mnia uiridia, cduliorum funt obfonia, und cum ellis fumpta, Juntq; berbaccigencris plante. Radicula caulis quoq;, of folia nonnunquam eduntur, fed nece Ritate magis, qudin ponte. Radix in eorum nurnero cft, anibus obfonij po= tius, quàm nutrimenti nomine aßidué ue fcinur. vime extenuatorism gerit, cum qua confricuc unì calfacit: acris $\mathrm{c}=$ nim in ed qualitas exuperat. Verno temporc caulem in altum affurgentem producerc folet, ceu alia, que nata funt

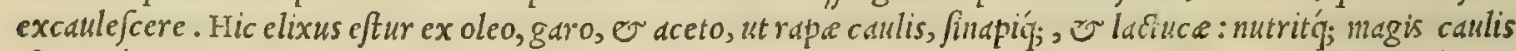
ifte, quàm cruda radiculd, ut qui acrimoniam in aquadeponat: quanquan minum sane e ipfe alendi poteftatem

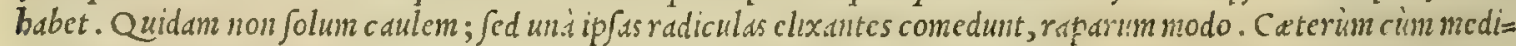
cos, tum idiotas illos mirarifubit, qui à crena crud as cas cdunt, concoctionis iunand.e gratia. Ip/i quidem id fe expe=

Nomina, rientia abunde compertum habere dicunt; nulins tamen eos citra dannum potuit inutari. Radix, que Gracis $5 \alpha=$ Qavis, Latinis item Raphanus o radix appellatur: Arabibus, Fugcl, fiue Fegiel: Italis, Raphatio, o Radice: Germanis, Rettich: Hipanis, Rauano, O Rauanilio: Gullis, Refort. 


\section{In Lib. fecundum Diofcoridis. $\quad 269$}

$S$ I S E R.

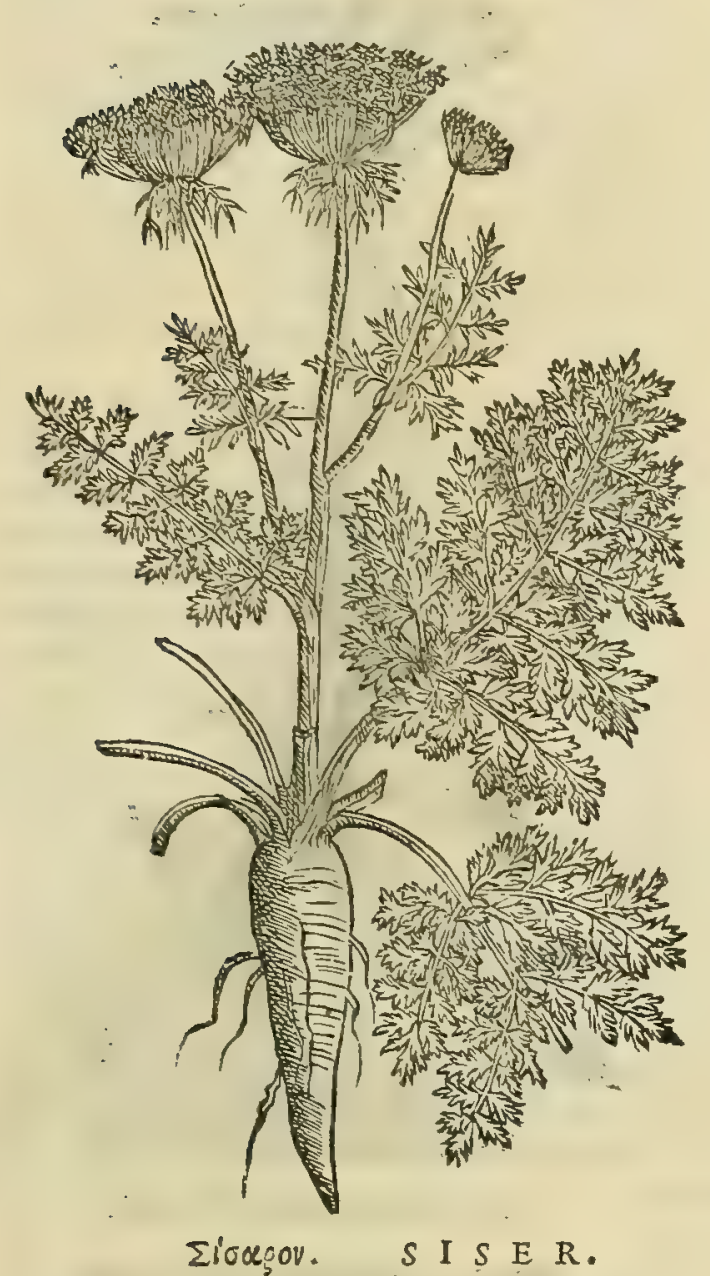

SISER ALTERVM.

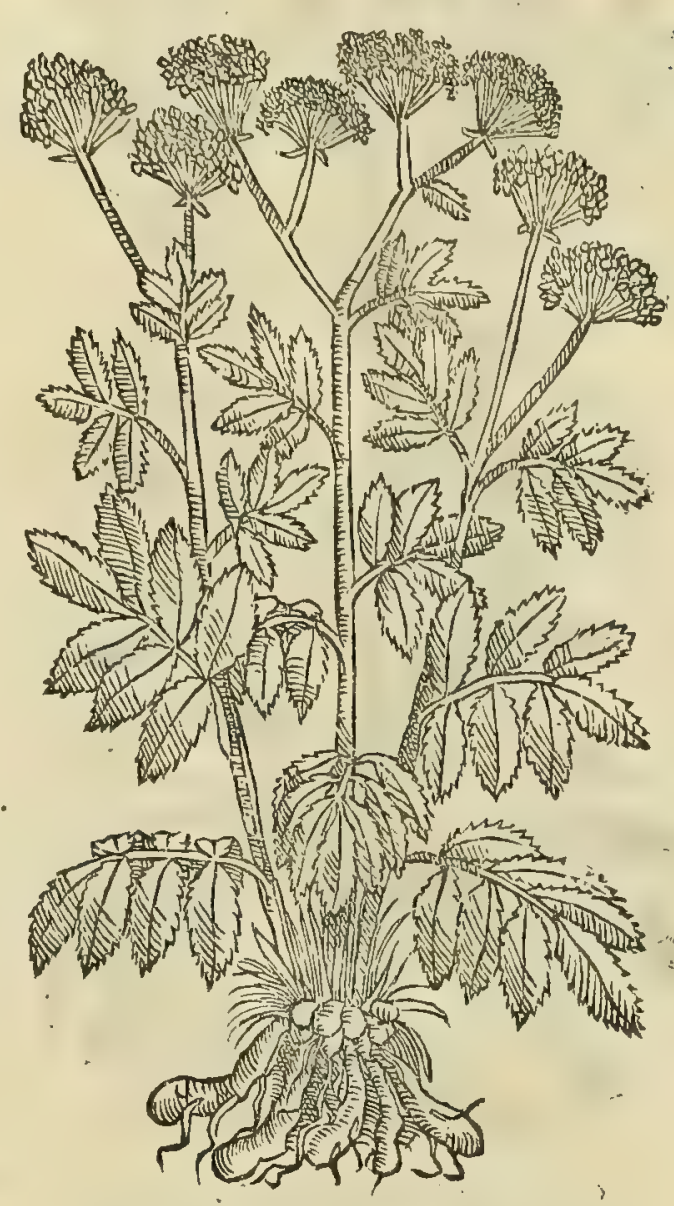

CAP. CVII。

S I S E R vulgò cognitum. Cuius radix decoeta ori grata eft, \& ftomacho utilis : urinam ciet, \& appetentiam inuitat.

N o N defunt, qui crediderint, albun quoddam Carotarum uocatarum genus, que naportum modo carnitum iu= ri inco quntur, legitimun cffe sifer. Ceterim cos hallucinari putauerim, Plinij tefimonio ductus; quilib. x I x. Sileris conscap.v.hec habet. Ineft sifcribus longitudme neruus, qui decoctis extrabitur, amaritudinis tamen magna parte reli= $40 \mathrm{cta}$. Id quod in bifce Carctarum radicibus haudquqquam reperire licet: quippe que nec neruum concludant; nec guftui amaritudinem relinquant; fed dulcedinem potius quand $m$ pre fe ferant. Quód preterea sifer fapore fit fub $=$ amaro, facilé ex Galeni fententia comprobari poteft lib. v I I r. Fimplicium medicamentorum, ubific fcribit. Sifari Sifari uires es radix cocta ftomacho gratd eft, o urinum nouet, fecundo ordine excalfaciens, adiectà babens amaritudinem quan= Galeno. dam, cum lewicula adftriftione. bac Galenus. Ex quibus facilé cölligi poteft, sifera ab bifce carotis plurimùm rece= dere. Sciendum igitur eft, quòd sifer in It dilia non feritur ; tametfi in Germania, Rbeni prefertim fluminis accolle,

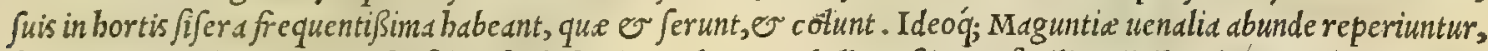
¿' Tincao agro itluc allata. Sifer folio eft olufatri, caule, er umbella paftinace fimili, radicibus dodrantalibus, neruo= fam intus matricem continentibus, fubamaris, o colore fubcroceo, $\sigma$ qua guftatu gratiam cum palato non modicam ineant. Quarum in cibis preftantia allectus Tiberius Cefar (ut citato loco tradit Plinius)omnibus, annis à Germania

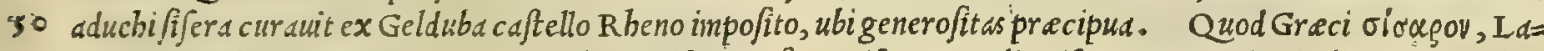
tiniquog; sifer uocant : Mauritani, Culcas, Fifarum, fiue Seifaron: Itali, sifaro: Germani, Gierlin, ev Girgelin: Hipani, Chiriuids: Galli, Cheruy, er Gyroles.

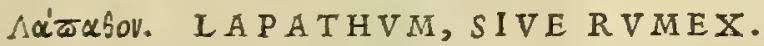

\section{CAP. CVIII.}

EX G E N E I BVS rumicis, oxylapathum uocant, quod in acutum tendit, dura habens extrema, in paluftribus nafcens. Alius eft fatiuus, tilli difsimilis. Tercium genus fylueftre, paruum, plan tagini proximum, humile, \& molle. Quartum eft, quod alij oxalida, alij anaxirida, aut lapathon uocant. Folia eius fylueftri, ac exiguo rumici fimilia: caule non magno: femine fubacuto, rubente, acri, in caule, \& agnatis appendicibus, emicante. Omnium decoeto olere aluus emollitur . Crudi illitu, melicerides, rofaceo,aut croco adiecto, difcutiuntur . Sylueftris, \&roxylapathi, \& eius, quaä oxa- 


\section{$270 \quad$ And. Matthioli Comm.}

OXY IA P A T H M.

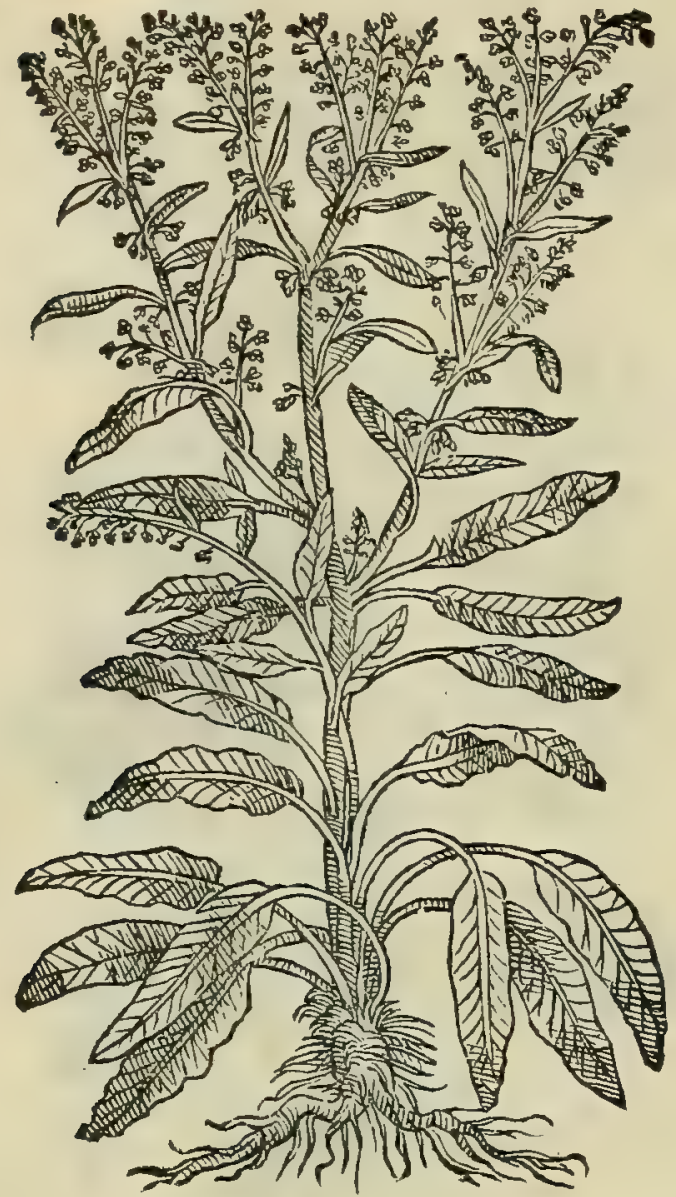

OXALISALTERA.

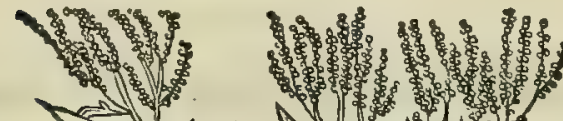
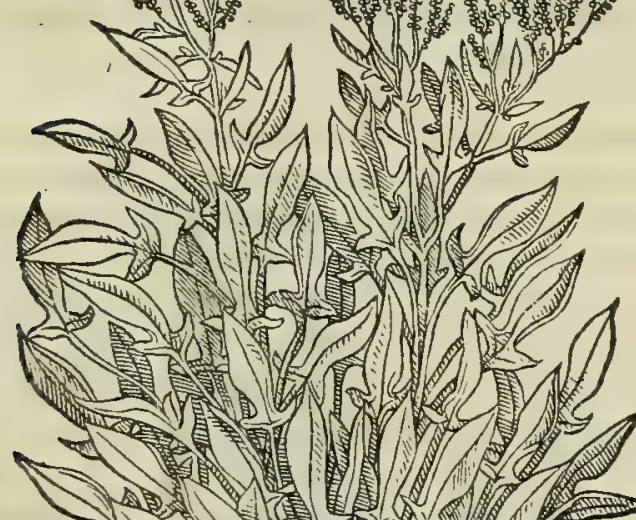

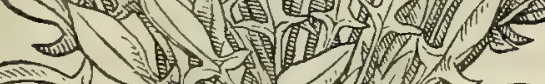

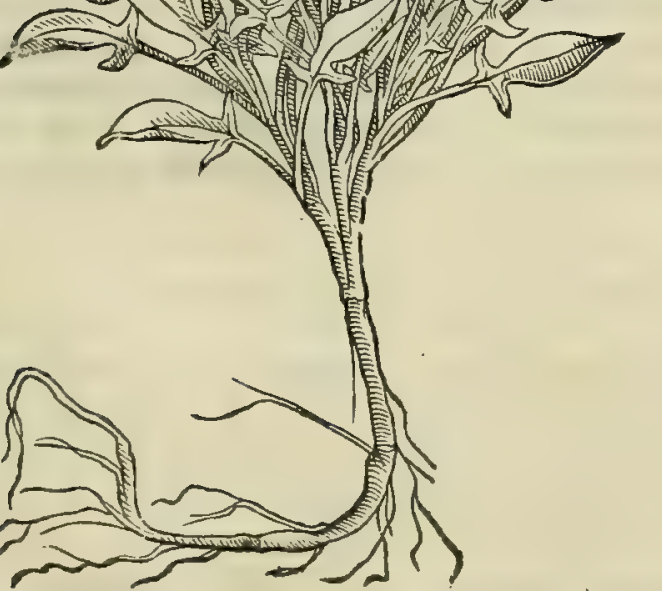

OXALIS.

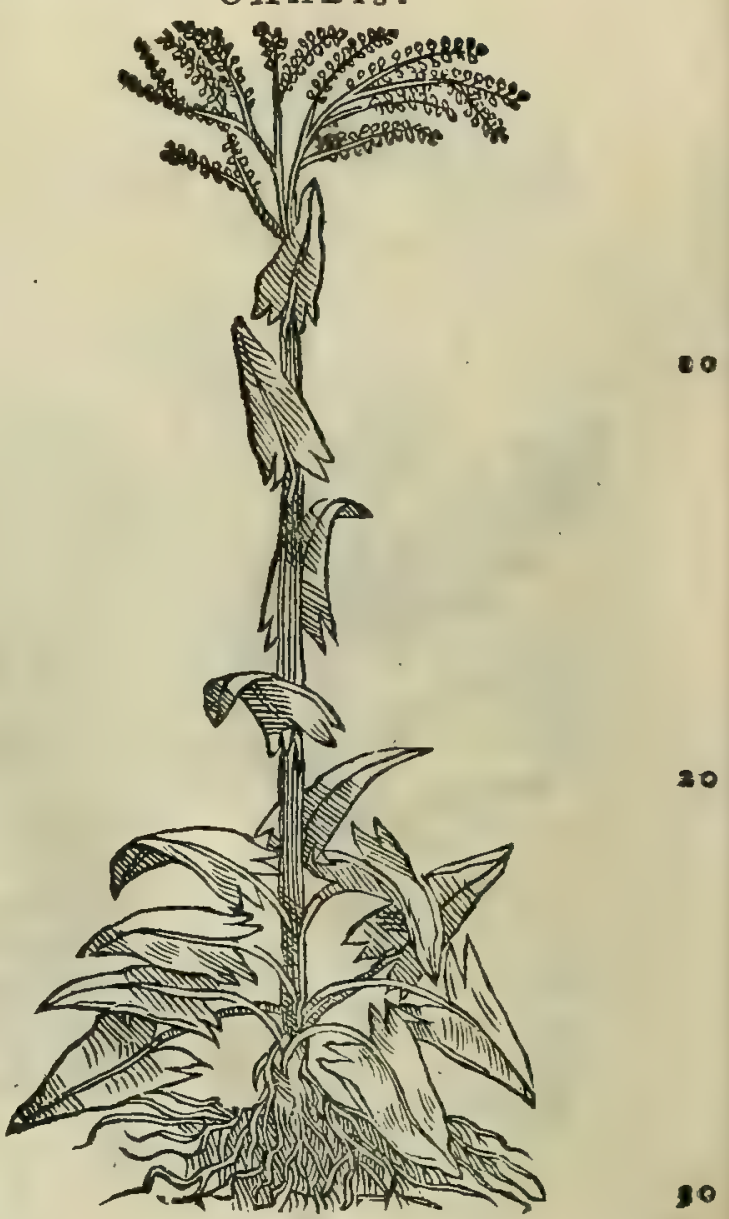

H IPPOLA P T H V M.

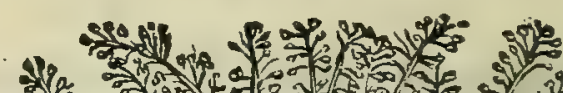

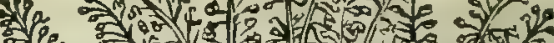

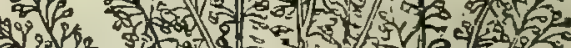

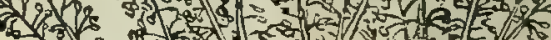
3. 근

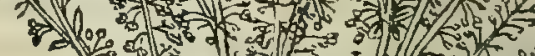
- 19 i

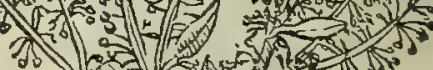
menco 5 .

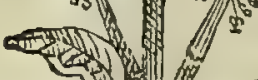

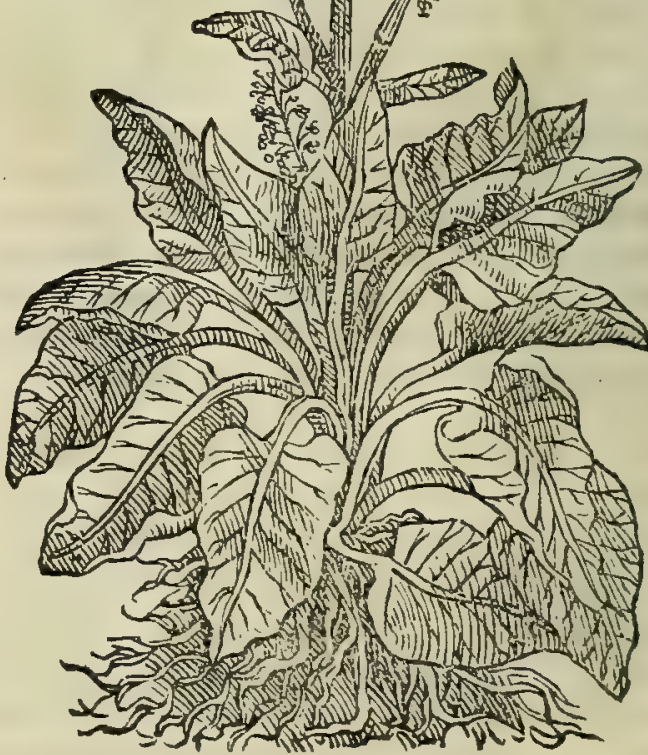




\section{In Lib.fecundum Diofcoridis.}

lida nom inant, femen ex aqua, aut uino vtiliter tibitur, contra dy fenterias, \& coliacorum affectus, ftomachi faftidia, fcorpionum ictus. Quòd fi quis in potu præfumat, nihil molefti ex ictu patietur. Radices ex aceto coct:x, aut illitæ crudx, lepras, impetigines, \& fcabrofos vngues perfanant: fed antea locus aceto, \& nitro in fole perfricandus eft. Pruritus corporis, decoctum earum fedat, fi foncatur, aut in folijs balnearum confricetur. Coctx in uino, \& inftillat $x$, aurium, dentiumq́ue dolorem mulccnt: ftrumas, parotidasqúue difcutiunt: liẹnem cum aceto extenuant. Aliqui amoliendis ftrumis radicum geftamine utuntur, eas collo appendentes. Tritæ, $\&$ admotæ freminarum profluuia $f_{1-}$ ftunt : curr vino autem potæ regio morbo medentur, calculos ueficx comminuunt, menfes cient, fcor pionum ictibus auxiliantur. Hippolapathon olus eft magnum, in paludibus nafcens. Eafdem habet to vires, quas fupradicta rumicis genera.

T A M E I S I Rumex, qui L Lapatlbum, nomine à Grecis mutuato, appellatur, bodie in bortis non feratur; in ijs tamen Bponte frequentilisinus nafcitur, null is deficientibus notis, quibus fatiuus delineatur. Lapatbun, quod in p.rludibus nafcitur, Diofcoridi oxylapatbuin uocatur, non quidem quód guftu acutum, feu acidum fentiatur, ut o= Rumicis con fideratio. x.lis, quam uulgus officinarum Acetojam appellat, fed quod folijs proueniat in deutum defanentibus. Siquidem ókvi Gracorun appellutione, modó fignificat acutum fapor is repectu, modó mucronatum reppectu forme. Ad quod non aducrtentes Auicemnd, pariterq; Serapio L apatbum omne nullo difcrimine Aceto $\int a m$ nominant, perperàm id ad $\int a=$ porcm referentes, quod ad foliorum figuram retulit Diojcorides in primo lapathigenere. Plinius lib. X X.cap.x x I. Oxylapathon non nifi in paluftribus nafcens, fatiuo fimilius efJe fcribit, cum tamen alterum alteri dißsinile faciat Dio

20 fcorides. Illud ueró, quod ab acido fucco ó $\xi x \lambda i s$ Grecis dicitur (etfí id filentio inuoluat Diofcorides) duorum eft generum, maius nimirum, er minus. Illi folia funt hortenfi fimilia : buic ueró fagittarum figura, mollia, lauia, qui= bufd am ucluti cxpill amentis fubrubentibus infper $\int a$, fucco $\int a$, folijsq́; maioris acidiora. Semen utrique idem, preter= quàm quód maiori maiks, minori ueró minus. Hippolapatbum porró non folum in paluftribus prouenire uidemus; fed etiam in montibus, ijs prefertim in locis, ubi pecudes diutius flabulari folent, or ubi corum fino pinguefcit folum, ill plante omnino repondens, qux fub R habarbari nomenclatura, paAim hodie in hortis, ac uiridarijs plantatur.

Lapathi meminit Galenus lib. V I I. fimpl. medic. fic inquiens. Lapathum moderaté digerentem fortitum faculta= Lapathi uires tem eft, at oxylapathum miftam : nam fimul cun eo quód digerit, nonnihil quoq; repercutit. Semen eorum manifeftam ex Galeno.

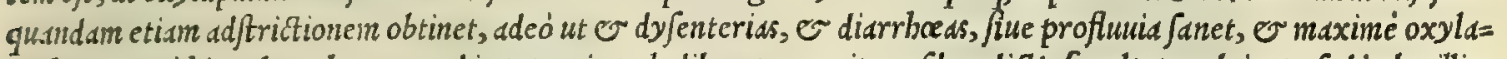
pathi. Porró hippolapathum, quod in totum in paludibus prouenit, eafdem dictis facultates obtinet, fed inbecillios 30 res. Et libro fecundo de alimentorum facultatibus: $\mathrm{R}$ umicem, ait, uti ante diximus, fyllueftrem betam poßit quis

\section{IAMPSANA.}

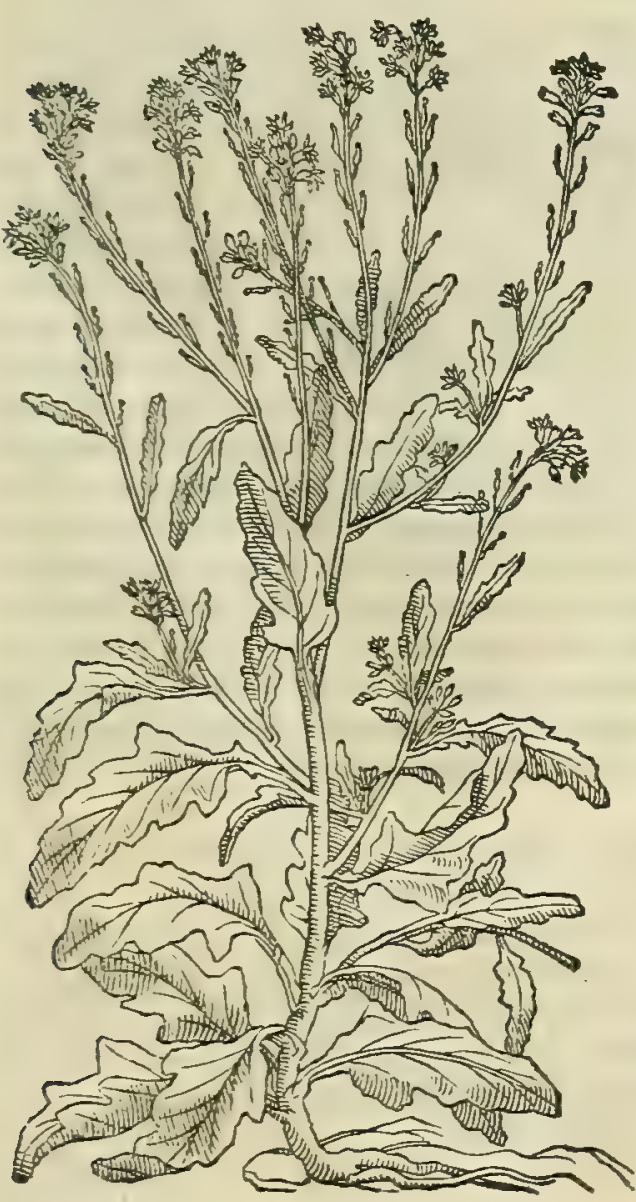

appellare, cim non guftu folum; uerim etiam facultate horten/E bete perfimilis fit. Quoniam autem beta iucundior eft rumice, id= circo ea magis bomines ue fcuntur. Quare nec nos quog; prolixius bic de rumice foribere oportet, cim in beta omnia ad rem facien= tia expofuerimus. Planta, que Grecis $\lambda \alpha^{\prime} \bar{\omega} \alpha$ Aov, Latinis etiä I apatbum $\mathrm{\sigma}$ R umex appellatur: Arabibus, Humadh, Hunadh, feu Hamad: Italis; Rombice, o Lapatio : Germanis, Ampffer:

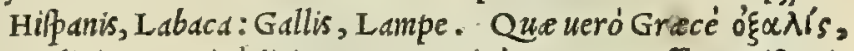
oxalis item Latiné dicitur: Germanicé, sauer ampffer : Hipani= cí, Azederilha: Gallice', Ozeille, vinette, or salette.

+ Nihil fortaffe Plinius à Diofcoride diffentiet, fi in hoc loco $\int e=$ quamur lectionem Oribasij 7ib. $\times 1$. Fimplicium: qui habet ơv $x \alpha=$

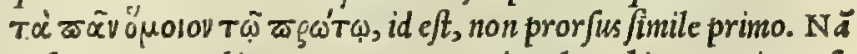
ex hac patere arbitror, non tantum priora lapathi genera inter $f e$ differre, quantum uulgata lectio innuere uidetur.

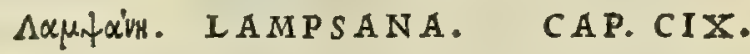

L A M P S A N A fylueftre olus eft. Plus alit, quàm rumex, \& ftomacho vtilius. Cuius folia, caulesq́; coquuntur in cibo.

QV A N v I s hic inter olera, qua in alimentorume ufum ue= Lampfanx co nere, Lamp fana recenfeatur d̀ Diofcoride; nullis tamen notis ab fideratio. ipfo defcribitur, quod fortaffe fuis in regionibus notißima habere=

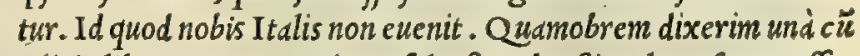
Plinio lib. X X . cap. I x. inter fylueftres braficas lamp fandm effe, pedalis altitudinis, bir futis folijs, napi fimillimis, nift candidior ef= fet flore. Nafcitur hec frequentißima in Hetrurid, A pulid, dc ple risq; Italia locis, ijs prafertim campis, qui aratrum eo anno mini= me ensere : tametfi nobis hac tempeftate non fuerit, nifif for fal ur= 
Iamprane ui res ex Gal.

Nomina.

Bliti confideratio.

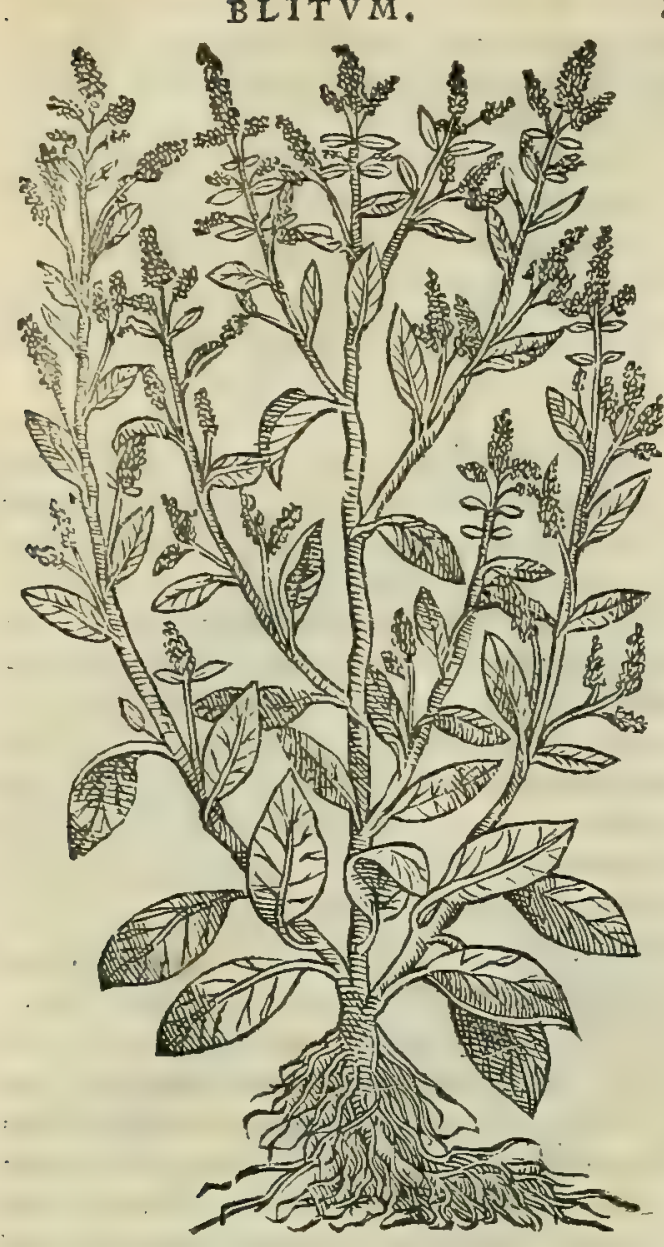

M A I V A.

Bliti uires ex

Galeno.

Nomina.

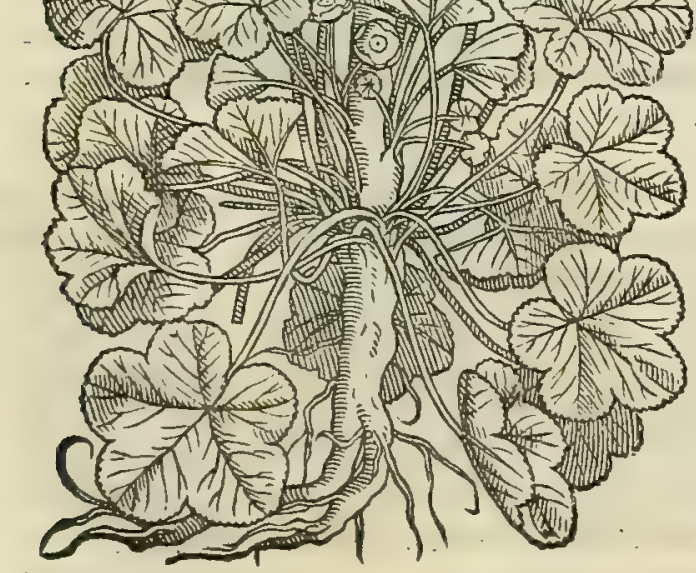

gente annone penurid, in alimentorum ufun recepta. Memi= nit buius Galenus libro VI I. fimplicium medicamentorum, bis paucis uerbis. I amp fana efa ficcos prauos procreat. Ceterim illita abftergendi nonnullam, áigerendiq̆; facultatem poßidet.

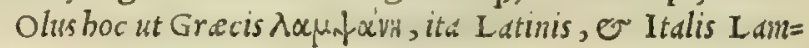
pana nominatur.

\section{в $\lambda$ HTT ToV. BIITVM. CAP. CX.}

B L I T V M eftur oleris modo. aluo vtile eft: nul- 10 lius in medicina ufus.

B I I T V M duorum eft generum, rubrum nimirum, er al= bum. Vtrunq; notum, in bortis, or campis nafcens. Rubro cau= lis, of folia adeó rubefcunt, ut coccineo colore infecta uidean= tur, et $\sqrt{i}$ temporis tractu tandem purpure $\int c a n t$. Folia amaran= tum referunt, ficut ctiam caulis. Quin or radix fanguineo fuc= co madet. Album prouenit ijsdem folijs, latioribus tanen, 0 co= lore fubalbidis. Flores 0 femenracematim coharentes, tenui= bus infident ramufulis, ex alarum cauis prodeuntibus, panicu= 20 larum effigie, fylueftris panici modo. Hoc olus Tridentina rura Biedone uulgo appellant, recipituriq; nonnullis in cibum. Id nan que aqua prius decoquunt, demum affufo oleo, uel butyro in $\int a r=$ tagine frigunt, additis allio, omphacio, tiel aceto. Verunta= mencibus is nonnunquam ( $u t$ ego ex uifu teftaripoffum) uomi= tiones monet, uentriculier inteftinorun tormina facit; 0 dui fluxiones ciet, excitata bile. Ed q; propter Plinius lib. x Xap.

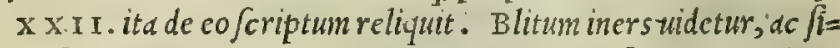
ne fapore, aut acrimonia ulla. Vnde conuitium forminis apud Me nandrum faciunt mariti. Stomacbo inutile eft. Ventrem adcó 30 turbat, ut choleram faciat aliquibus. Dicitur tamen aduerfus fcorpiones potum, é uino prodeffe, or clduis pedum illini. Item lienibus, er temporum dolori ex oleo. Hippocrates menfrud $\sqrt{i}=$ fti co cibo putat battenus plinius: Blitimeminit Galenusli= bro v I, fimplicium medic amentorum, bis uerbis. Blitum olus eft efculentum, bumide, frigidé; temperature, in fecundo maxi= mé éxceffu d̀ temperatis. Item fecundo de alimentorum facultd= tibus: Qui porró, inquit, atriplicis, blitiq; guftabilem qualitatem intelligit, braßic q́; faporis çommeminit, lactucam in braßice, ac borum olerum medio effe non diffite bitur: : iquidem illa egre $=40$ gié deficcat, bec contra plané bumida, aquo á funt. Quapro= pter non ex folo oleo, garóq; , fed addito aceto fapius, meliusq́q; affumuntur: alids nang; ftomacho infefta funt. Diximus autem iftiusmodiolera nonnibil ad leuigandam aluum momenti affer = re, maximé fi cum bumiditate glutino fam lubricitatě fortita fint . bec Galenus. Quo fit, ut mirariliceat, fi Pliniy, o Galeni fori= ptaperpendamus, quód dixerit Diofcorides, Blitum aluo utile effe, er nullius in medicina ufus. Eius nomen Gracum eft

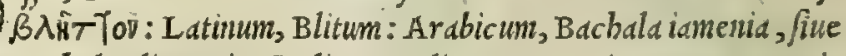
Bachale aliemanie: Italicum, Blito: Germanicum, Mayer: H $i=\$ 0$ panicum, Bredos: Gallicum, Poree rouge.

\section{M $\alpha \lambda \alpha^{\prime} X^{H . ~ M A L V A . ~ C A P . ~ C X I . ~}$}

M A L v: A fátiua efuilongè aptior fylueftri. ftomacho aduerfatur : aluum iuuat, fed multò magis caules: interaneis, \& veficæ vtilis. Cruda folia cum falis exiguo manducata, ægilopas ex melle fanant:verùm cùm cicatricem trahere cœperint, ea demum citra falem viếdum eft. Contra aculeatos apium, vefparumq́ue ietus, illita efficax eft : eadem cruda cum oleo trita peruneti 


\section{In Lib. fecundum Diofcoridis.}

MALVA AREOREA.
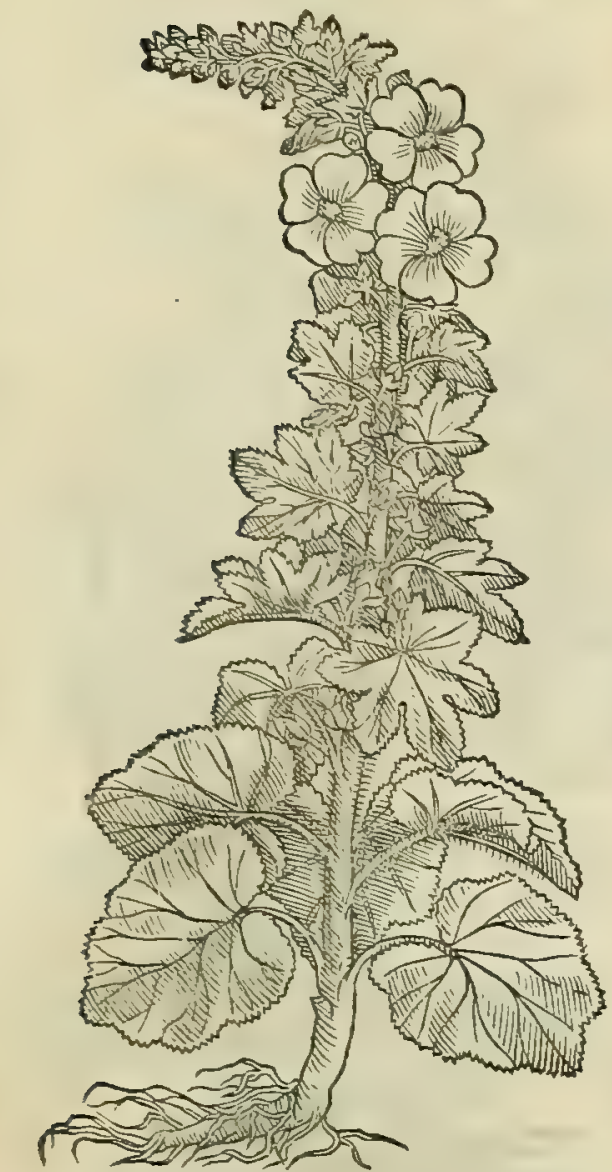

non feriuntur : vlcera manantia in capitc, furfuresć; cum vrina fanat. Sacris ignibus, \& ambuftis decocta folia, tritaq́ue, vtilifsimè ex oleo imponuntur. Eius decoctum vuluas infefsione mollit : prodeft erofionibus ueficæ, \& inteltinorum, uulur, fedisque, clyftere infufum. Ius decoctre cum radice fua conera omnia uenena auxilatur, fi continuò à bibentibus reuonatur. contra phalangiorum morfus remedio eft. lac etrocat. Semen in uino potum, addito loti fylueftris femine, ueficæ cruciatus lenit.

M A I V A unlgaris adcónotitia eft, ut nulli fercéreperian= Malux confitur, qui eam non nouerint. Plura eius generd: fed ea, qua ali= deratio. quibus loc is in I talia arbore fcit, nil aliud eft, quim fatiud culto= rum mangonio in tantam magnitudinem affurgens, ut libro pri= mo de plantarum hiftoria cap. v. prodidit Theopbraftus, cùm in= quit. Quedam etiam comperta funt ob culturam diuerfa effici, atq; d fua natura difcedere, ut Malua in altum $\int e$ attollens, dtque in arborem tranfiens. Quippe ita fit neque tempore longo, fed men/ibus fenis, aut feptenis, ita ut longitudine, craßitudine ơ; in= Star bafte poßit grandefcere: quapropter commodé ad ufum ba= culi uenit. Tempore ueró longiore exacto, pro ratione magis quo que incrementa capeßit . bactenus Theophraftus. Plinio libro $\mathrm{X} I \mathrm{X}$. cap. I I I. preter eam, que in Arabia feptimo mense ar = bore fcit, e baculorum ufum prabet extemplo, eft $0 \mathrm{M}$ Malud ar= bor in Mauritania Lixi oppidi aftuario, ubi Hefperidum borti fuife produntur. I $p \int a$ altitudinis pedum uiginti,craßitudinis quă circumplecti nemo poßit. In fimili genere babetur o canabis.

Maluam, qua in arborem degeneraluerat, uidi ego primim Gri= gnani ad Benaci ripas in quodam monachorum conobio, abi eo= rumotio, or cultu tantam fibiafciuerat amplitudinem. Eft $\sigma$ ea inter inaluarum genera recenfenda, qua in bor tis ac uiridarijs folio exit magno, rotundo : caule tricubitali: floris bus rofarum effigie rubentibus, candidis, uel fubrubeis, nullo tamen odore fragrantibus. Nam fi ut rofe nares cont= ciliarent, quemadmodum oculos bilariforma, ac coloris uiuacitate alliciunt, nulli dubium eft, quin de preftantia, ac pulchritudine cum ipfis rofis certare potuiffent. Malue meminit Galenus libro V I I. fimplicium medicamen= torun, fic inquiens. Malua agrestis quidem digerentis paululum, ov emollientis leuiter eff facultatis. Hortenfis ue= ró quantó plus babet aquex humiditatis, tantó facultate imbecillior eff. Fructus eius tantó ualidior eft, quantó $\mathrm{\sigma}$ ficcior. Porró buius generis eft $\approx \sim$ ea, que anadendromalache nuncupatur, fed efficacißima comprehenfarum in di= gerendo. Appellatur etiam althea. Et libro II. de alimentorum facultatibus: Est, inquit, ab hac hortenfi alia qua=

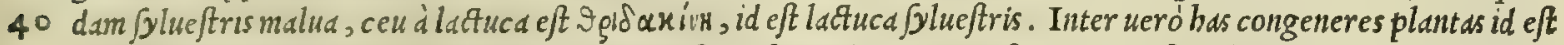
discriminis, nempe quód ficcior a fint fylueftrla, fatiua bumidiora. Permiftum quog; eft malue fucco aliquid glutinos fum, quo lactuca caret. A' refrigerandifacultate manifefté abeft, ut etiam ante fumptionem cernere licet, fit ex ams bobus uicifim oleribus cataplafma ad caliduin quempiam affectum, qualc eft ery/ipelas, componas : id quod factitare bomines confueuerunt, molliufcula folia perquàm diligenter tundentes, donec ad leuorem exactißimum redacta fint. Tum nanque cogno [ces lactucam manifeftò refrigerare : maluam ueró modicum, o quafi tepidum quendam calorem obtinere. Facilé boc olus deorfunn labitur, non tantùm quia bumidum eft; fed etiam quia glutinofum, pracipué cim oleum, garumǵ; affatin uni bauritur. Ad concoctionem mediocriter fe babet . si horum trium olerum, fuccos inter fe compares, tenuis o abfterforius bete, malue craßior glutinofior $\dot{q}_{\text {; }}$ lactuce in utriufque medio ftatuetur.

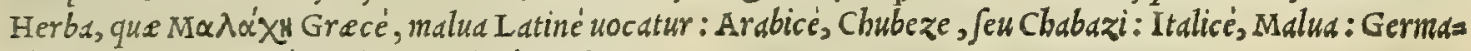
50 nicé, Pappel: Hifpanicé, Maluas: Gallicé, Malue.

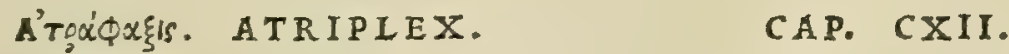

A T R I P I I CE M aliqui chryfolachanon vocant. cognitum olus eft. Duo eius genera, fylueftre, \& fatiuum. Coctum eftur, vt olus : aluum mollit . Panos difcutit, fiue crudum, frue coctum illinatur. Semen cum aqua mulfa potum, regium morbum fanat. 


\section{And. Matthioli Comm.}

ATRIPLEX SATIVA.

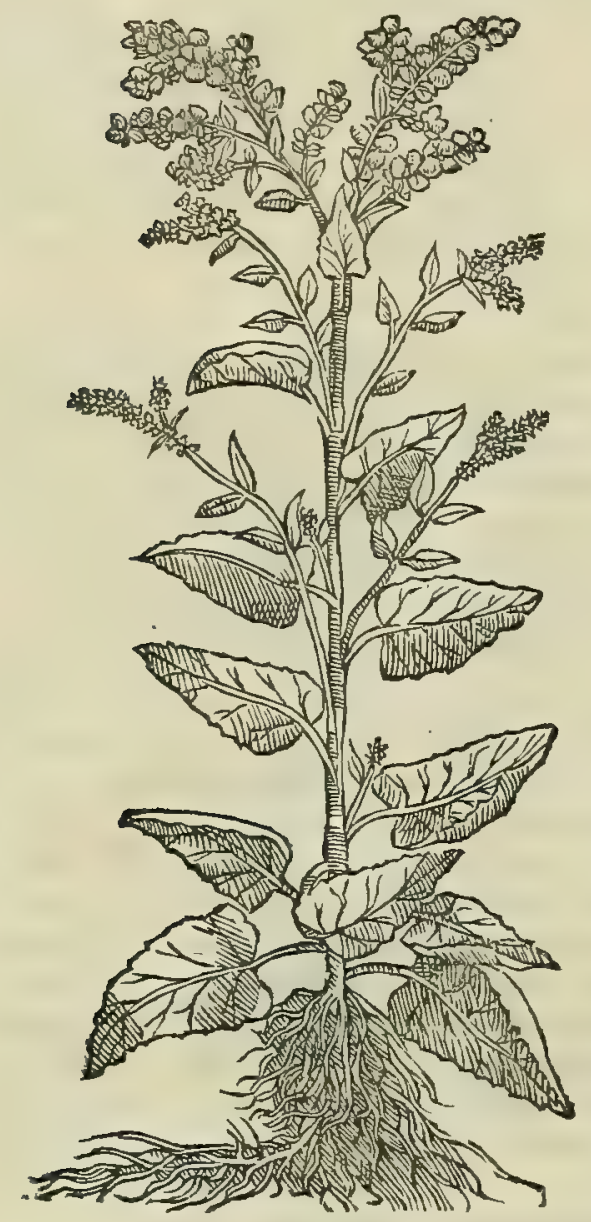

ATRIPLEX SYIVESTRIS.

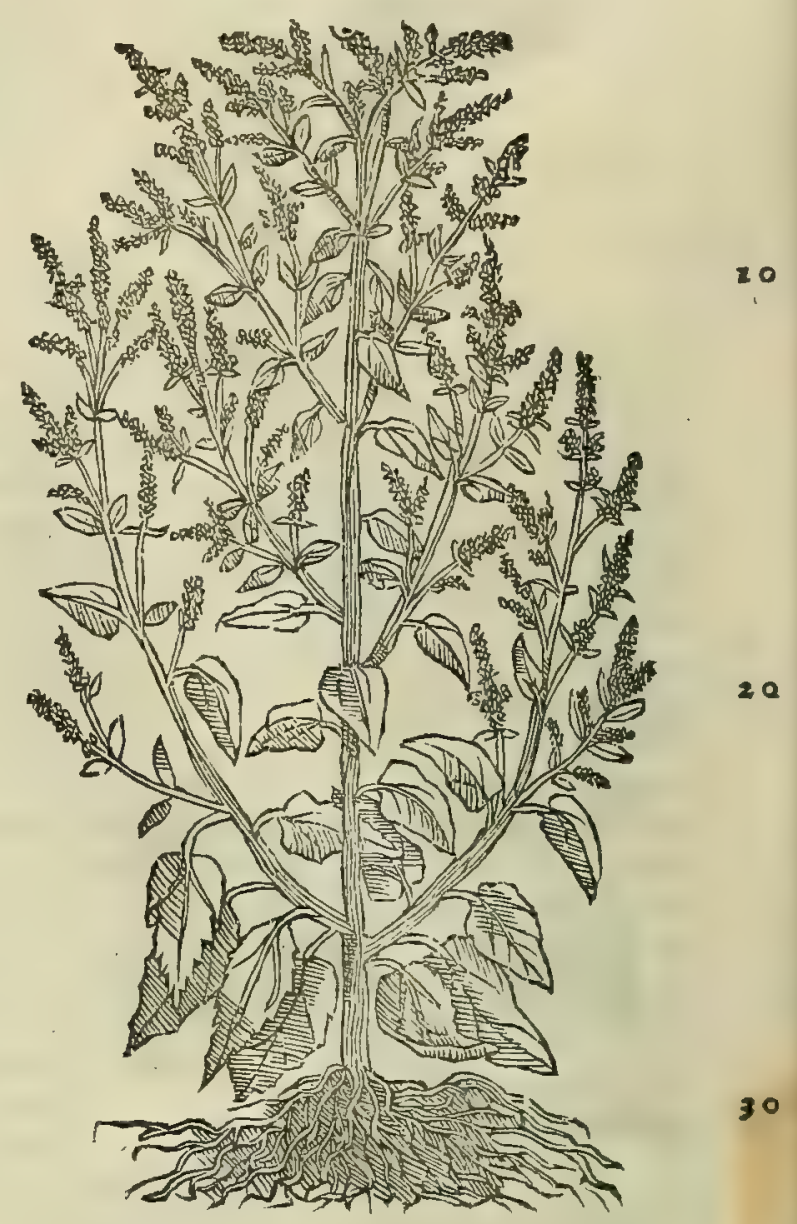

Atriplicis cófideratio.
Recentiorum quorüdä opinio reprob.

Atriplicis alia genera.

Kali Mauri tanorum men tio.
E $\mathrm{T}$ S I in Hetrurix bortis rara ddmodum fit Atriplex; frequentipind tamen apud Infubres feritur, quod ex ea prefertim rur a fibi quoddam placenta genus conficiant hoc modo. Incidunt enim acutißimo cultello Atriplicis folia, or cafeo in fcobem attrito, butyro, ac ouis commifcent, $\mathcal{O}$ in fartaginibus foliofa pafta fubftrata, decoquunt, come=

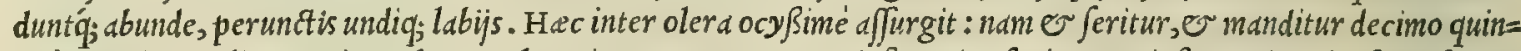

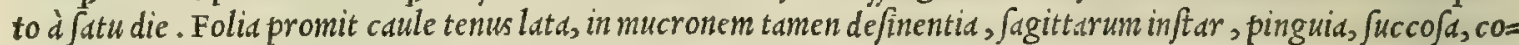
lore ex uiridi in luteum langue cente. Caulis, qui illirubet, multis undiq; adnatis, ad quatuor cubitorum menfur am adole fit : femine preßsis, tenuibusq́; folliculis conclufo. Preftat Atriplex in cibis uere tantim: fiquidem ut ocyßimé 40 crefcit, ita er uelocißine fene fcit, $\odot$ deperditur. Credidere recentiorum quidam Atriplicem, $\sigma$ spinaciam uul $=$ gó dittam, eiufdem effe generis. Verìm ij, meo quidem iudicio, falluntur apertisimé . quippe preter id, quód spina= cia nouum in Italia olus eft, o foliorum, o caulis, e feminis forma, atq; colore ab atriplice maximé differt, ficuti O fapore. Nanq; fupicatur Mandrdus Ferrarienfis, ne cio tamen qua ratione ductus, Atriplicem, $\sigma$ Spinaciam chryfolachani peciem effe. Sed eius fententiam minimé probandam,cenfeo : chryfolachanon enim $\mathrm{L}$ atinis aureum $0=$ lus fignificat. quod tametfi A triplici competere poßit; non tamen ob id Spinacia conuenire uidetur, que folijs, cau= $l e$, flore, ac femine perpetuó uire fait . Caterim duo alia A triplicis genera babentur, unum fylueftre, alterum ma= ritimum. Illud in campeftribus, atque etiam alibißponte prouenit. borten/i omnibus propé notis reßpondet, prater quàm folijs, qua albidiora fpectantur . herba uulgó cognita eft. Atriplex ueró in maritimis nafcens, cuius nulla (quod equidem fciam) facta eft mentio à Diofcoride er Galeno, ijs facile fe e e offeret, qui non grauabuntur, ut bane O alias maritimas berbas cognofcant, maris litora peragrare. Eam nos copiofam inuenimus Tergefti ad falinas in maris litore', nimirum diuerfam ab balino olere maritimo, ut eius inndgo, quam bic damus, aperté declarat. Inibi quoque plantam illam nobis contigit uidere, que KA I . Mauritanis appellatur, cuius cinere utuntur fabri uitrid= rij ad uitrum conficiendum: ex decocto autem eiufdem berba paratur fal illud, quod Alliali ijfdcm dicitur. Hac cùm primum terra emergit, follium eft teretif forma, minori fedo non abfimile : atque deinde crefcens, caule erecta genicu= lato, non multo póft tempore in digitalem fermé longitudinem attollitur. Cümi ueró amplius adoleuerit, é geniculis folia emittit pinguia ac craffa, in medio caud, er ex lata origine mucronata. Vbi deni $q_{;}$planta adulta fene foit, folia in caulium cacuminibus longe minora exilio ríg; confpiciuntur, colore rufo: ex quorum ortu pilule prodeunt rotun= de ac parue : quibus exile femen includitur. Caules babet pingues er rufos. Sapor mincerfe plante falfus, ueluti crithmo. Hanc quidam alteram Diofcoridis Anthyllidem effe cenfent. Sed errant, meo quidem iudicio, ut latius di= ctum eft in fequenti libro, tum ctiam in ea A pologia, quam in Amatum illum Lufitanum feripfimus. Atriplex, ut memorie 


\section{In Lib. fecundum Diofcoridis.}

$S$ PINACIA.

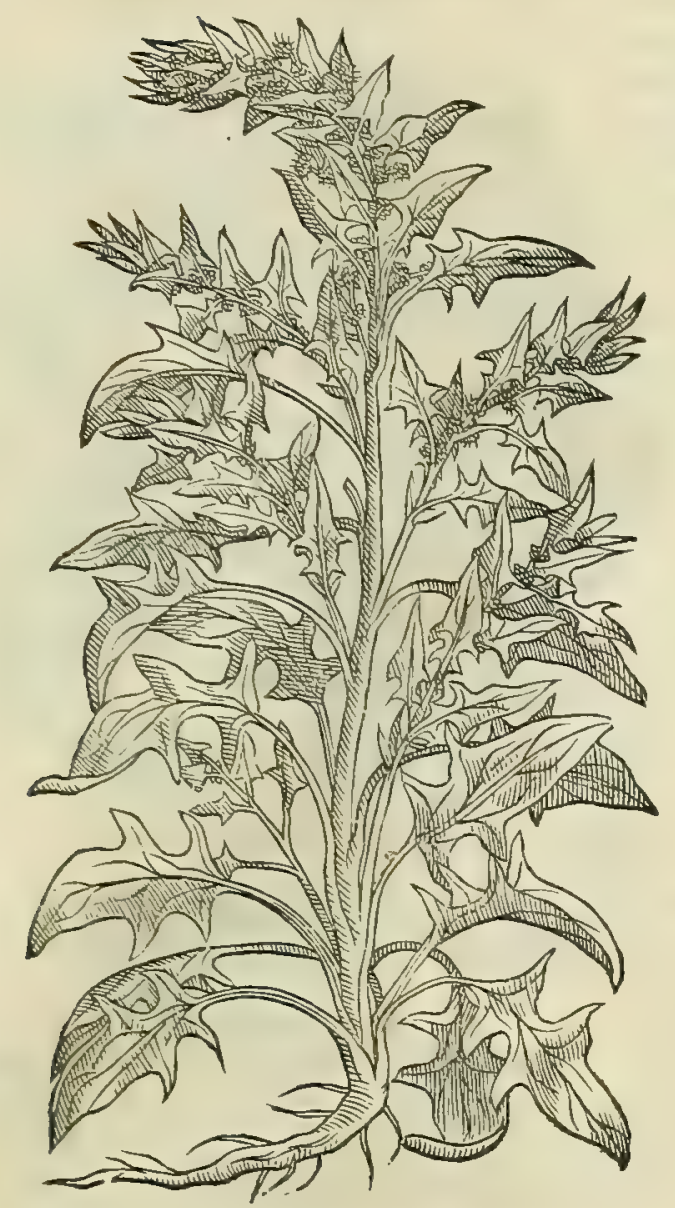

ATRIPLEX MARINA.

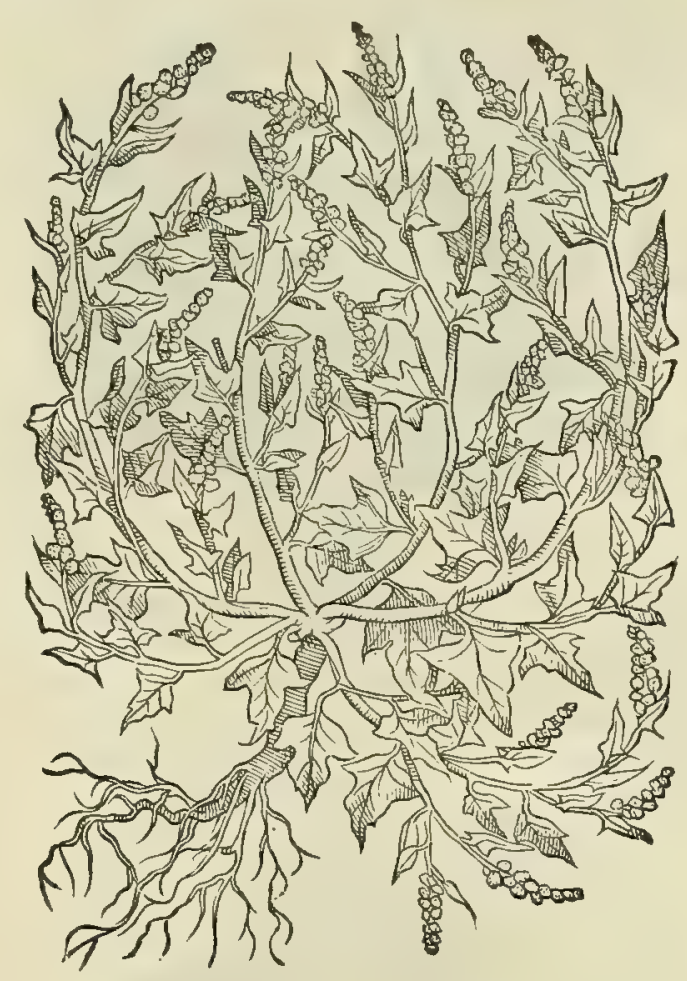

K A L I.

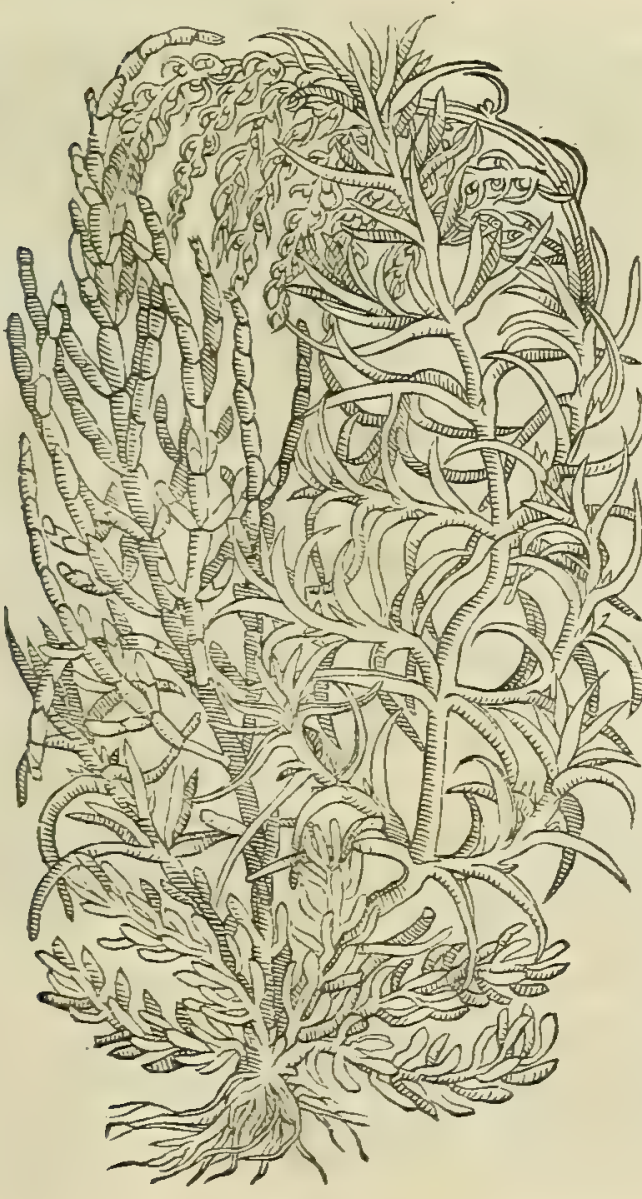

memorice prodidit Galenus libro VI. fimplicium medicamen- Atriplicis uitorum, bumida, $\sigma$ frigida temperic eft, bumida quidem $\int_{e}=$ res ex Gal. cundi ordinis à medijs, frigida ueró primi, quam utique tepi= dam effe caliditatem pofuimus, cuiufmodi rofis inef: non ta $=$ men adfriftionis eft particeps, fed aquea eft, or minimum ter. rena, fimiliter malue. Quin wentrem celeriter permed, ut illa, ob lubricitatem. Porró paululum omnino eius eft, quod digerendi obtinet potentiam. Hortenfes autem atriplex, malua, quàm agreftes tum bumidiores funt, tum frigidiores. Proinde pblegmonis, or phygetblis incipientibus, glifcentis bus $\dot{q}$, or mollibus etiảmnum, ac uelut feruentibus hortenfes: uigentibus autem, $\mathcal{O}$ declinantibus, ac indurefcentibus com= modiores funt agreftes. Semen eius abfergendi nim babet: itaque ad norbum regium ex pituite (rectius forté bepatis le= gendum ) infarctu prognatam utile eft. bec Galenus. Scribit Serapio Rafim uidiffe bominem quendam, qui ex Atriplicis $\int c=$ mine duarum draclbmarum pondere fumpto, crebris tum $u 0=$ mitionibus, tum alui deiectionibus uexatus fuit, adeó ut ad ex= tremam uirium imbecillitatem deuenerit. Quod mibi quidem mirum non eft : quandoquidem noui ego pharmacopolam quen dam, qui ad rufticos purgandos A triplicis tantim Jemen exbi= bebat: quod ijs non fine moleftia magna aluum abunde ciebat, atque etiam fimul crebros prouoc abat uomitus. Qua tamen $f a$ cultas paucis, ut puto, bactenus innotuit. Atriplex fic $\mathbf{L} d=$

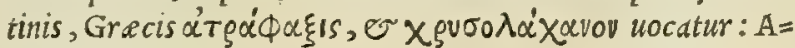
rabibus, Cataf, feu Caraf: Italis, Atriplice : Germanis, Mol= ten er Milten: Hipanis, Armoles: Gallis, Follete, $O \sim F e=$ mes. 


\section{And. Matthiol ${ }_{1}$ Comm.}

BRASSICA CRISPA.

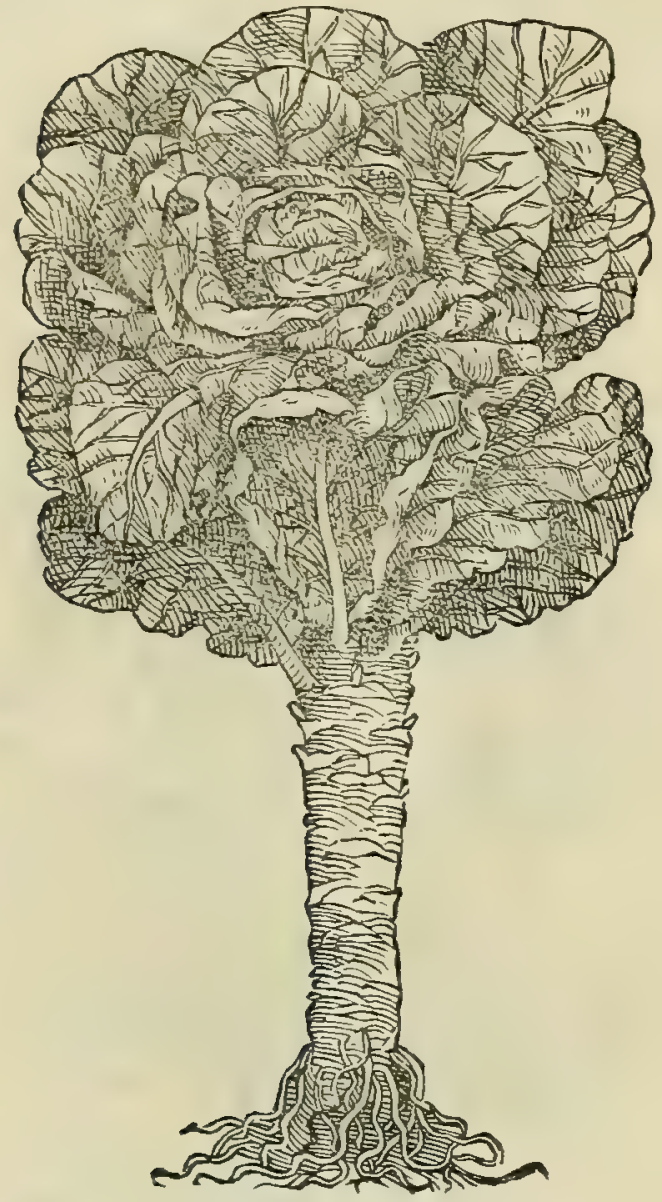

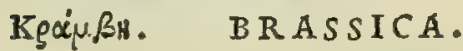

BRASSICA CAPITATA.

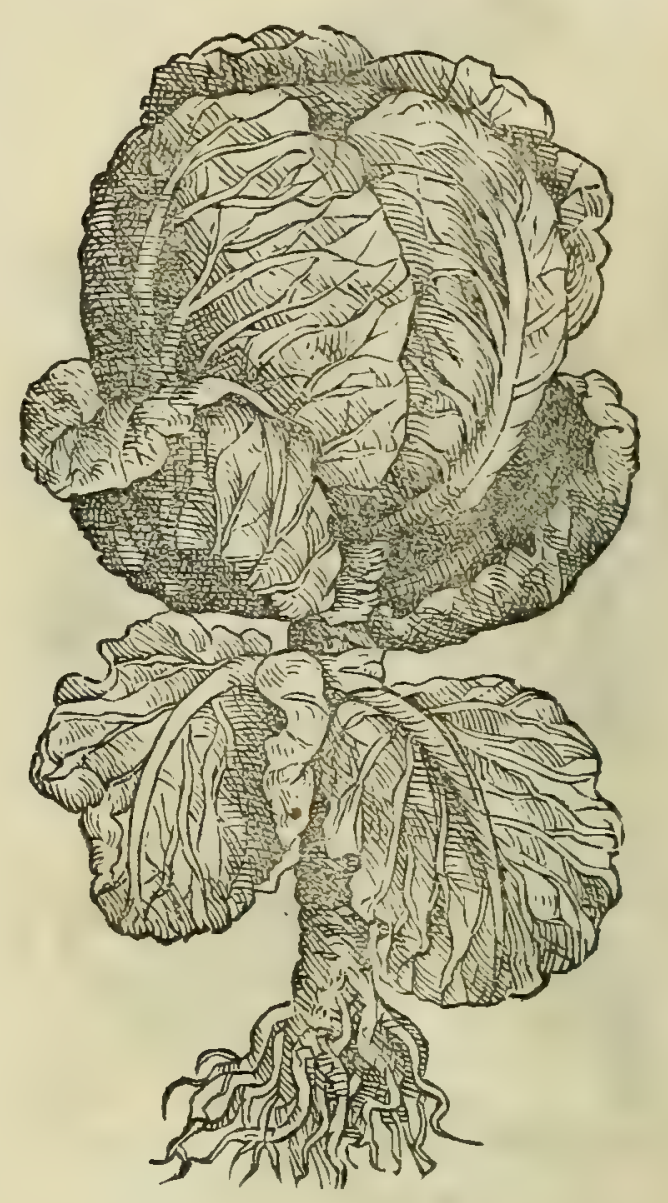

10

20

B R A S S I C A fatiua aluo idonea eft, fi modò leuiter feruefacta edatur. nam percocta aluum fiftit, fed multò magis bis cocta, aut qux in lixiuio coquitur: ftomachum autem malè habet. acrior eft æétiua. In Acgypto propter amaritudinem non eftur. Cæcutientibus, \& tremulis effe prodeft. Summo cibo fumpta crapulam difcutit, \& vini noxam reftinguit. Melior ftomacho cyma, fedacrior, \& ad ciendum vrinam validior . ea condîta ftomacho inimica eft : aluum conturbat. Crudus fuccus cum nitro, \& iri deuoratus, aluum emollit: cum vino quoque epotus, viperarum morfibus auxiliatur : cum fœeni greci farina, \& aceto, podagris, \& articulorum vitijs illinitur : prodeft $\&$ fordidis viceribus, \& vetuft is illitus : caput purgat naribus infufus: menfes extrahit, cum Joliacea farina inditus. Folia per fefe illita, aut cum polenta trita, conferunt inflammationibus, tumoribusq́ue: epinyatidas, ignem facrum, leprasq́ue fanant. carbunculos cx fale rumpunt: fluentes capillos retinent. Cocta addito melle aduerfus depafcentia vlcera, gangrænasq́ue valcnt. Lienofisq́ue ex aceto cruda prolunt. Manfa, deuorato fucco, retufam vocem inftaurant. Decoctum eius potu, aluum, \& menfes ciet. Flos poft conceptionem in peffo:fubditus, partum abortu vitiat. Semen eius, præfertim qua in Aegypto nafcitur, potum tineas repellit. In antidota theriaca additur : facici cutem, lentiginesq́ue expurgat. Virentes cauliculi cum radice cremati, \& adipe porci vetufto excepti, diuturnos laterum dolores mitigant .

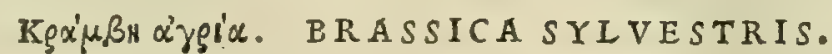

CAP. CXIIII.

S Y L V E S T R I S Brafsica, maritimis præruptisq́ue locis, magna ex parte gignitur: fatiux fimilis, fed candidior, hirfutiorq́ue, amara. Cuius cyma in lixiuio coita, ori non infuauis . Folia illitu vulnera conglutinant, \& inflammationes, tumoresq́ue difcutiunt .

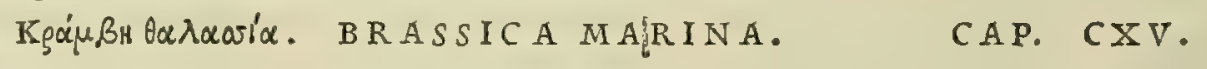

M A R I N A Brafsica à fatiua prorfus abhorrer, quòd folia ferat rotund $x$ ariftolochix, longa, tenuia: fingula à ramulis rubentibus exeunt, fingulari, vt hedera, pediculo. Albo fucco predita cf, fed pauco, falfo guftu, \& aliquantum amaro, pingui concretu. Herba in totum ftomacho inimica, acris: vehementilsimè aluum ciet in cibo coćta. Coquitur propter acrimoniam cum pingui carne. 


\section{In Lib. fecundum Diofcoridis.}

BRASSICA IIARINA.

10

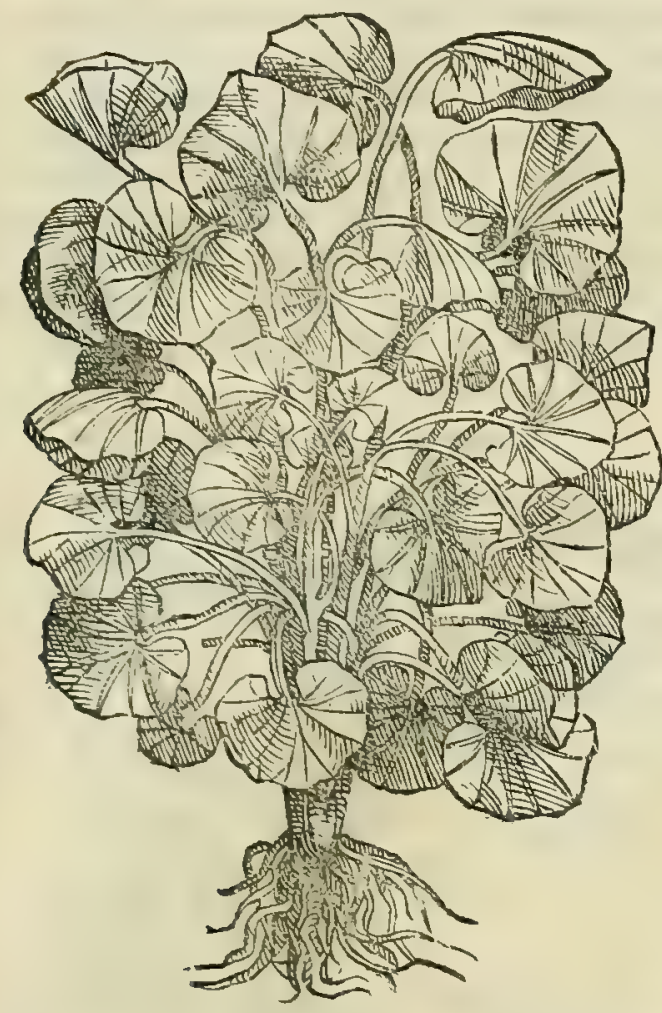

S A T I V A Braßica, Theoplorafto, er plinio audtoribus, in Brafsicx fatimultiplici recenfetur genere. Id quod $\odot$ borti in I talia atteftan= uæ genera. tur: nam in ijs multiplex, or uaria crefcit Braßica. Cato braßi= ce tria fecit faftigia. Vnamgrandibus, latiś, folijs, caule magno, tonfilli cymarum luxuria. Alteram cripo folio, quam ab apij fimi= litudine apianam uocant. Tertiam proprié nocatami crambem, minutis caulibus, tenerioribus folijs, leuem, teneram, tenui fuc= $c 0$, acerrimam quidem omnium, Or magis medicamentofam. Ve= rim Plinius libro x I X. cap.v I I I. Braßica (ut diximus) com= plures enumerauit pecies. Inter quas eam Sabellicam appellari tradidit, que cripis admodun folijs, lactuce modo in fe conclu= ditur, intus albicans, tenera, fubdulc is, $\widetilde{0}$ que bac etate omnium preftantißima babetur. Ait enim, sabellica ufque in admiratio= nem cripa funt folia, quorim crajsitudo caulem extenuat, fed dul cißina perbibetur ex omnibus. Eft or capitata congloneratis undique in orbem folijs, Plinio lacuturris appellata, quiloco ci= tato fic inquit. Nuper fubiere lacuturres exconualle Aricina, ubi quondam fuit lacus turris q; , que remanet, capite pregran= des, folio inmmeri. Alij in orbem porrecil, alij in latitudinem to= roft. Nec plus capitis ullis poft tritianum, cui pedale aliquando confpicitur : er cyma nullis ferior. Que omnia noftratibus braf= ficiscapitatis, que uulgó Capuccidicintur, pulcbré repondét. Eft infuper ex ijs, que noftris Italix hortis proweniunt, alia quxdam, cuius caulis rapiin ntorem extuberat, manditur'́; fubs inde medulla, pingui iure incodaraporum modo. Huius non re= perio meminiffe Flinium, nec eo uetuftiores alios, qui de bortos rum fationibus fcripfere: ficuti nec illius, que folijs admodum per ambitum lacinatis, ninutimúf; intercifis affurgit. Pcrnicialia porró Braßicis omnibus cum uitibusodia feruantur. Vicm'; uium oleris huius odore fugari Theophraftus, or Plinius affirmant: aßitamó; ad olus diffugere Varro tra 30 didit. Quo arg!nento uJus Androcides, Brafsican contra temulentum pollere credidit. Sed cur crapulam fedet, id caufe rcddidit in problematibus Ariftoteles, quod fcilicet dulcem nimirum fuccum, abftergentemq́; contineat.

Sylucfris ii maritinis noftris Senenfibus A rgentario promontorio, alijsó; tum Tyrrbeni, tum Adriatici litoribus Brafsicx fylfrequens nafcitur. Hane non longe a Terracina urbe, uia qua itur Neapolim, plurimă uidimus, folïs domeftica fimi= ueftris cófid. libus, fed hyofcy.mi modo birfutis, amaro ac infuauigufu. Ex femine Braßica ueteris (ut Plinius eft auctor lib. X I x.

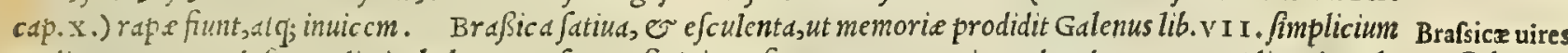

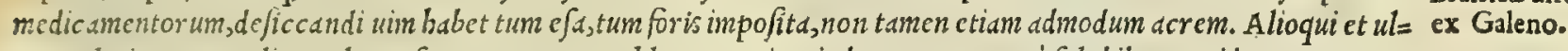
cera glutinat, o muligna ulcera fandt: pretered phlegmonas iam induratas, ac agré folubiles, er id genus quoque ery ipclata. Eadem facultate eping ctidas, ev berpetes fanat. Habet quiddam etian in fe abfter forium, quo lepras cu= rat. Porró fcmen eius potum lumbricos interficit,maximé braßic Aegyptia, quantó ed fcilicet temperatura ficcior $40 \mathrm{cft}$. Sané amare qualitatis particeps $\int e m e \check{e} e f t$, ficut uidelicet omnia alia medicamenta, quxe ad lumbricos idonea $\int u n t$. Secundum eandem facultatem ephclidas, e lentes, e quecunq; alia modicam abfterfionem poftulät, adiuuak. Caules brafsice combufti, cineres efficiunt admodum deficcantes, ut uidelicet iam adurentem uim participent. Hac ratione ei ueterem adipem commifcentes, ad inueteratos laterum dolores, o fi quid eius fuerit generis, adbibent. Nam ualenter digerens medic amentü cfficitur. Braßica ueró agreft is quodammodo calidior, ficcior'q; domeftica eft, ceu alia pro= pemodum omnis agreftia fui generis, domefticis fecundum utranq; banc facultatem ualentiora funt. Quamobrem nes que intra corpus citra noxam fumitur, ut que longius ab humana recefferit temperatura. Eadé de caufa er guftall= tibus amarior eft, quàm domeftica : quanquă domeftica quoq; fubamarum quiddam, er acre contineat : fed utranq; ba bet agreftis ualidam. quare etiam extergit, o digerit quàm domeftic a ulentius. Marina autem braßica fuprà qudm

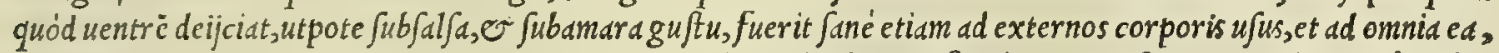
so ad que tales qualitates accommodantur, idoned. Et lib. I I. de aliment. facultate: Braßic $q u o q ;$, inquit, àmult is ut obfonium eftur: medici autem, ut deficcante medicamento, ed utuntur. Diximus de bac quadam cum de facultatim bus medicamentorum ageremus, tum etiam in libro fuperiore: que nunc fummatin perftringemus. Ergo braßice fuccus purgandi uim quandam obtinet : contra folidum eius corpus ficcitatis ratione cobibere mag is, qudm incitare deiettionem poteft. Proinde cim expellere alui excrementa propofitum erit, abeno, in quo elixa und cum aqua fuit, propius admoto, ip fam eximere confeftim, uafculog; in quo paratur, oleum cum garo inijcere oportebit: $f i$ falem pro garo fumat, nhil refrert. At bumentem aluum ficcare volentes, cum mediocriter bullijfe uidebitur, priore aqua effu= ja repenté, aliam calentem inijcimus : ac itarurfus in ea difcoquimus, $u \int q ;$ dum tenera flaccidáq; euafcrit . quod non Brafsicx mari facimus,cum uentris Jutducendi gratia Jumitur. bactenus Galenus. Caterum licet Diofcorides prodidevit marinam na confid. braßSicam folia firre rotunde ariftolochie, longd, ac tenuid; ea tamen non ab re ab omnibus effe cenfetur, quam uul= gus officinarum soldanellam appellat. Quippe que in maritimis nafcatur, folijs lacteo fucco madeat, ramulis cenftet subentibus, è quibus prodeunt ip fa folia, beder modo, qua gufu $\int_{a} l f_{2}$, or amard, or quadántenus acria fentiuntur. 


\section{8

Loeus Diofc. Quamobrem Diofcoridis codicem boc in loco, ficut et in alijs permultis, mendi fupicione non udedre putamus. Fd=

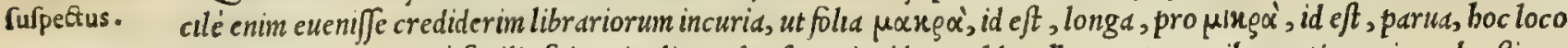
fuccefferint: $\mathcal{G}$ certé facilis fuit unius litere lapfus. siquidem soldanella nocata omnibus notis marinam braßicam

Ruellij error. reprefentat, exceptis folijs, que funt aristolochie rotunde minora. Ruellius uir doctißimus, etfi in boc nobifcum cateriśq; confentiat, quód marina braßica bec fit berba, que uulgó soldana, er soldanella dicitur, nulla etiam (ut inquit) reclamante nota; in co tamen manifefté aberrafe deprehenditur, quód soldanx folia ariftolocbia longa, at $q$;

Syluatici er- etiam pralongareddiderit. Errat preterca in bac pläta Mattheus syluaticus pandectarum auctor, quod crediderit ror. Arabum Chachile Soldanellam $\mathrm{c} \int \mathrm{e}$. Cuius error aperté conuincitur ipfius serapionis teftimonio: quippe qui Cachile fuum ufnea fimile fecerit, foliog; non ariftolocbiam, fed nafturtium imitari tradiderit . Marinam braßicam in litori=

Nomina. bus Venetis, A quileienfibus, ac Tergeftinis, ubi copiofa nafcitur, nos fapius uidimus, ac legimus. K $\alpha^{\alpha} \mu, B \mathrm{H}$ ita Gracis, Braßica Latinis appellatur: Mauritanis, Corumb, fiue Karumb: Italis, Cauolo, er Verza: Germanis, Koel: Hipanis, Colhes, or Counes: Gallir, Choils.

BETA NIGRA.

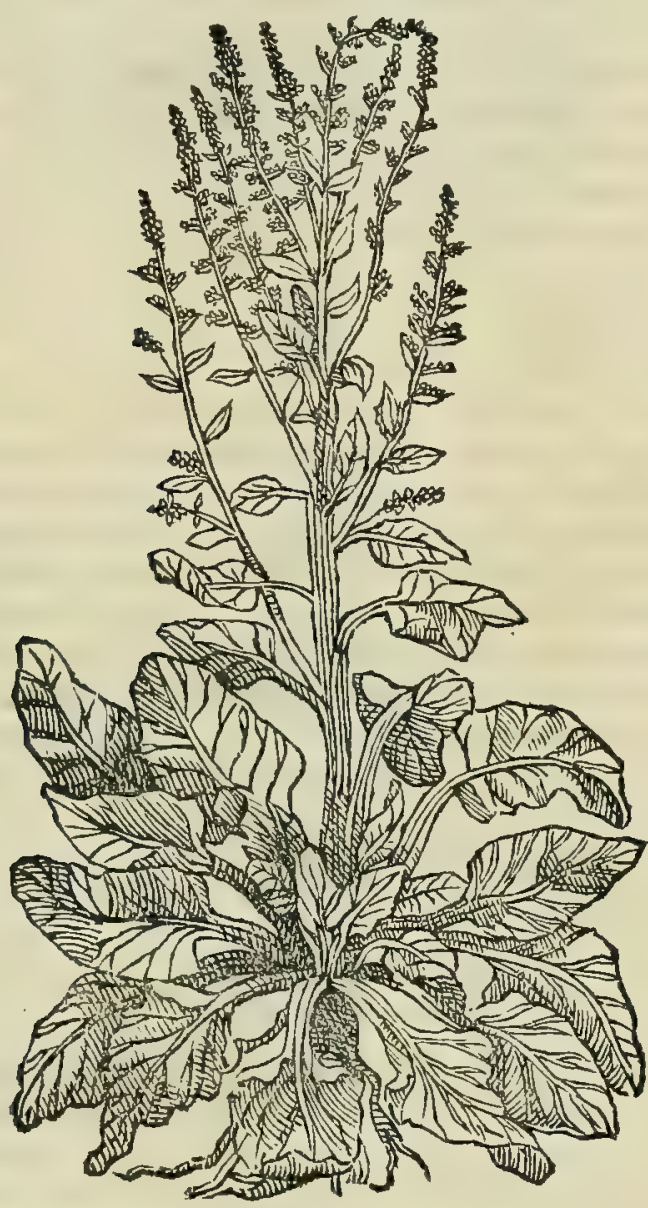

Tör iov.

E E T A.

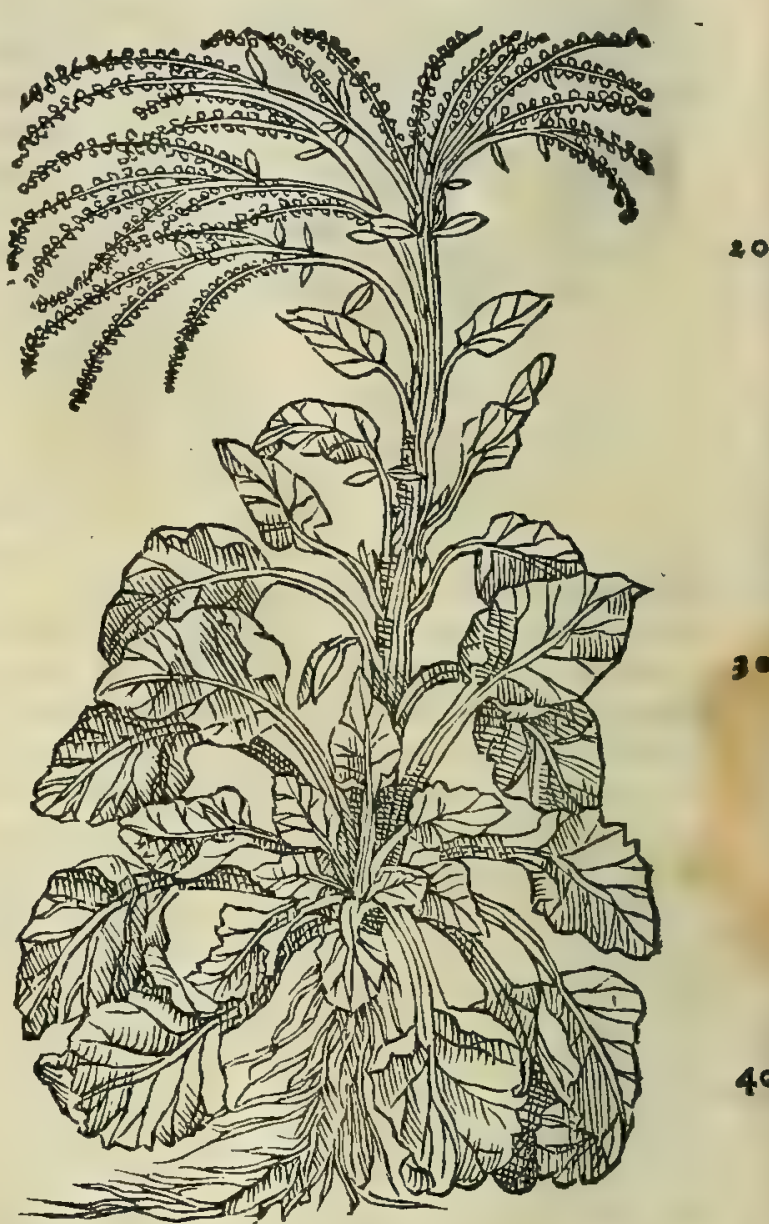

CA. P. CXVI.

B E T A duorum generum eft. E' quibus nigra coquitur cum lenticula, ut uentrem fiftat: quod magis radice eius præftatur. Candida aluo utilis eft. Vtraque tamen propter nitrofum humorem, quem habet in fe, noxij fucci eft. Vnde fuccus earum, cum melle naribus inditus, caput purgat: aurium doloribus auxiliatur. Decoctum radicis, \& foliorum, furfures, lendesq́ue deterget : perniones fotu mitigat. Crudis folijs uitiligines, nitro antea perfrictas : alopeciarum inanitates, icalpello prius so exafperatas : atque depafcentia ulcera, illini prodeft . Eruptionibus papularum, igni facro, ambuftisq́ue cocta medecur.

Betz confide.

B E T A tam candida, quàn nigra in Italia bortis frequentißima nafcitur. In Germania tamen habetur et rufa, ratio. non modó folijs; fed etiam radice, qux illi raporü oblongorum magnitudine extuberat: colore adeó rufe fcëte, ut eius fuccus uiuum fanguinem referat. Hanc Gcrmanibyeme cineribus calentibus obrutam coquunt, fubinde corticibus

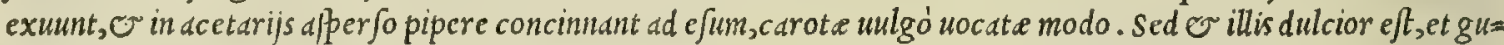
Betz faculta- Jtuigratior. Bet e facultates adnotauit Galenus lib. I I r. fimplicium medicamcntorum, fic inquiens. Beta nitrofa tes ex Gal. facultatis particeps cft, qua tum digerit, tum extcrgit, o per nares purgat. Cecterìm cocta nitrofitatem omnë exuit, fit $q_{;}$facultatis phlcgmonis aduer $\int e$, , leuiter digerentis. Porró ad detergendum, digerendumó; walidior cft beta alba. Nam nigra adiunctum babet adftrictionis quippiam, o mag is in radice, quim alijs partibus. Et libro I $\mathrm{r}$, de alimen= 


\section{InLib. fecundum Diofcoridis.}

torum facultatibus inquit. Bete abfterforius ineffe fuccus conpicitus, adeo ut aluun ad cxcretionem extimulet, er nonnunquan ftomachusn de mordeat, praefertim ijs, quibus natura fenfu cxaf́tiore preditus eft: ob idó; largius com= manfa, ftomachum inf ff at. Huius, ccu alionum olerum, exigua eft alimonia. Iecoris obfructionibus, quam malua, aptius accommodatur : magis autcm ubi cum finapi oftur, aut accto. Lienofos item fimiliter manducata mirificé iuuat. lure enim qus ipfan medicanc:tum potius, quan almentun dixerit, ubi hoc modo manditur. hactenus Galenus. Inue nirifylueftrem Bet.m tratidit Plinius libro x x. cap.v I I I. eamq́; uocari Limonium, quod defcribitur à Diofcoride libro quarto, d Galcno ucró Libro v I I. fimplicium medicamentorum. Cuius fententie refragatur Galenus libro I I. de alunentorum facultatibus, chim inquit. Equidem non fatiuam folim maluam; fed agreft'm quandan etiam effe per= bibuimus,qucnadmodun o lactucan. At agreftis Beta nulla eft, nifí utiq; quis lapatbum ita nominare uelit. Candida

20 beta, Plinio loco muper cirato auctorc, coct $\alpha_{2}$, c cum allio crudo Jumpta, alui tincas cnecat. Succus à facibus expur gatus (ut ip $\sqrt{e}$ feppius periculum feci) clyfteribus infufus, ad indurata alui euocanda cxcrementa mirum in modum

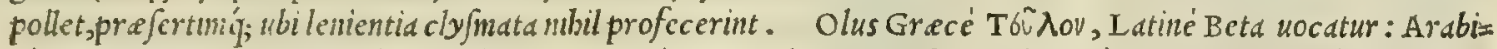
cé, Declia, o Celb: Italicé, Bietola: Germanicé, Mangolt, or Pieffen: Hifpanicé, Afelgas: Gallicé, Porree.

\section{A'S $\rho \alpha$ 'vr. PORTVLACA. CAP. CXVII.}

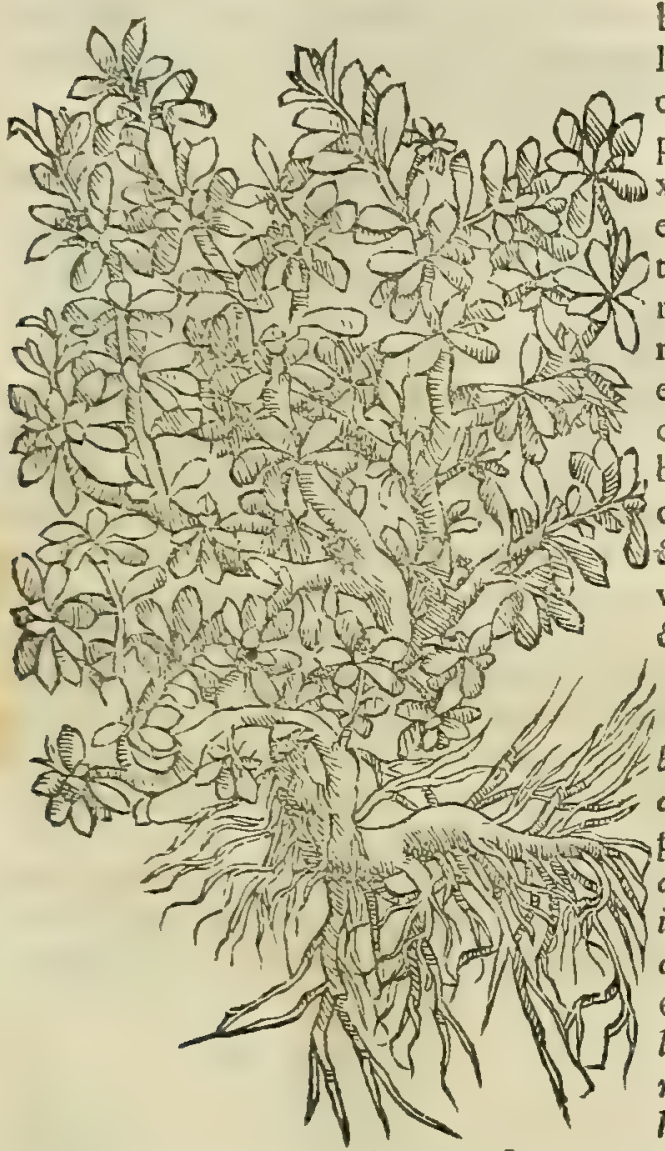

POR T V I A AE vis adltringit. Capitis doloribus, inflammationibus oculorum, cæterisq́ue, cum polenta imponitur : ardoribus ftomachi, facro igni, veficx doloribus, auxilio eft : commanducata dentium ftupores fedat : ftomachi, \& inteftinorum æftuationem, flu xionesq́ue mulcet : renes, \& ueficam adiuuat, etiam fi erofionem fentiant: veneris impetus exoluit. Succus epo tus fimili effectu prodeft, in febribus ualens. Contra teretes uentris tineas, cruentam excreationem, dyfenteriam, hamorrhoidas, \& profluuia fanguinis, percokta efficax eft : item contra fepis morfus. Ocularibus medicamentis utilifsimè commifcetur: interaneis fluxionela borantibus, atque vuluarum erofionibus, infunditur: contra dolores, quos æftus excitauit, caput ex rofaceo, \& oleo foutur:eruptiones popularum in capite, cum vino emendat : vulneribus, quæ ad fyderationem fpeetant, ex polenta illinitur.

POR T V L A C A omnibusuulgarißima eft. Duo eius had= bentur generd. Vnum fatium, cui folia infunt latiord, er callis ners. craßior in altum fe attollens. Alterum ueró fylueftre bumire= pens, minoribus, tenuioribus, dc crebrioribus folijs. : Portuld Portulace vi ce meminit Galenus libro v I. fimplicium medicamentorum, ubi res ex Gal. ita fribit. Portulaca frigidd; or aquea temperamento eft, pau ca cuiufdam particeps aufteritatis. Proinde fluxiones repellit, or maximé bilio $a s$, er calidas, cum co,quod eds mutet, et in qua= litate alteret, magnopere refrigerans. Et fuerit fane in refrige= randi quidcm facultate tertij exceffus à temperatis, ac medijs : in bumectandi ueró fecundi. Hac ratione er aftuantes, ut fi quid aliud, adiunat tum uentris of culo impofita, tum totis bypocondrijs, potißimum in febribus hecticis. Pratereaden= tium ftuporem fanat, nempe qua ab acidorum fuccorum contactu, dperé exiccata fuerant, leniens, atque replens, utpote cum uifcofan habeat humiditatem. Similiter ueró o fuccus eius. Itaq; non foris modó impofitus; fed epotus

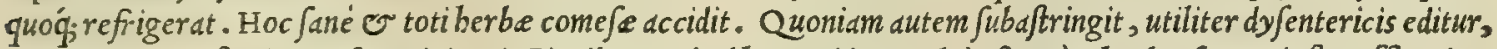
o mulicbri proftunio, $\mho$ fanguinis reiectionibus. Sed ad bec quidem multò eft, quàm berba, fuccus ipfius efficacior.

so Et lib. II. de alimentorum facultatibus: Portulaca (inquit) quidan ut cibo utuntur : fed imbecillem prabet alimo niam, eamá; humidam, frigidam, er glutino $\int_{a m}$. Vt medicamentum autem, dentium ftuporimedetur ob lentorem fuum morfus expertem. de ea diffufius in opere de facilé parabilibus fumus locuti. Hæe ip $\sqrt{a}$, ut tradidit Plinius lib.

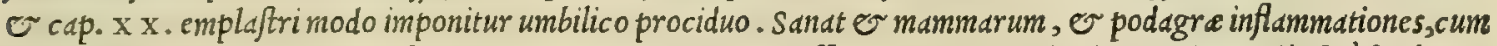

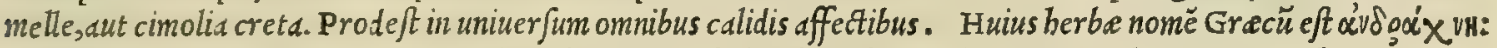
Iatinum, Portulaca: Arabicum, Balsleancba, feu Bacbele alhanicha: Italicum, Portulaca, Procacchid, é Por= Nomina celland: Germanicum, Burtzelkraut, $\mathcal{O}$ Portzelkraut : Hipanicum, Verdoldgas, $\mathcal{O}$ Baldroegas : Gallicum, Pourpier, or Pourchaille.

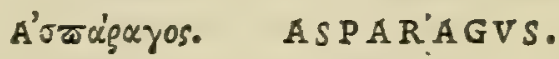

\section{A P. CXVIII}

C OR R V D A, fiue fyluefris afparagus, vulgaris eft notitiæ. Huius caliculi in cibo coeti,uentrem A 2 emolliunt, 


\section{And. Matthioli Comm.}

ASPARAGVS.

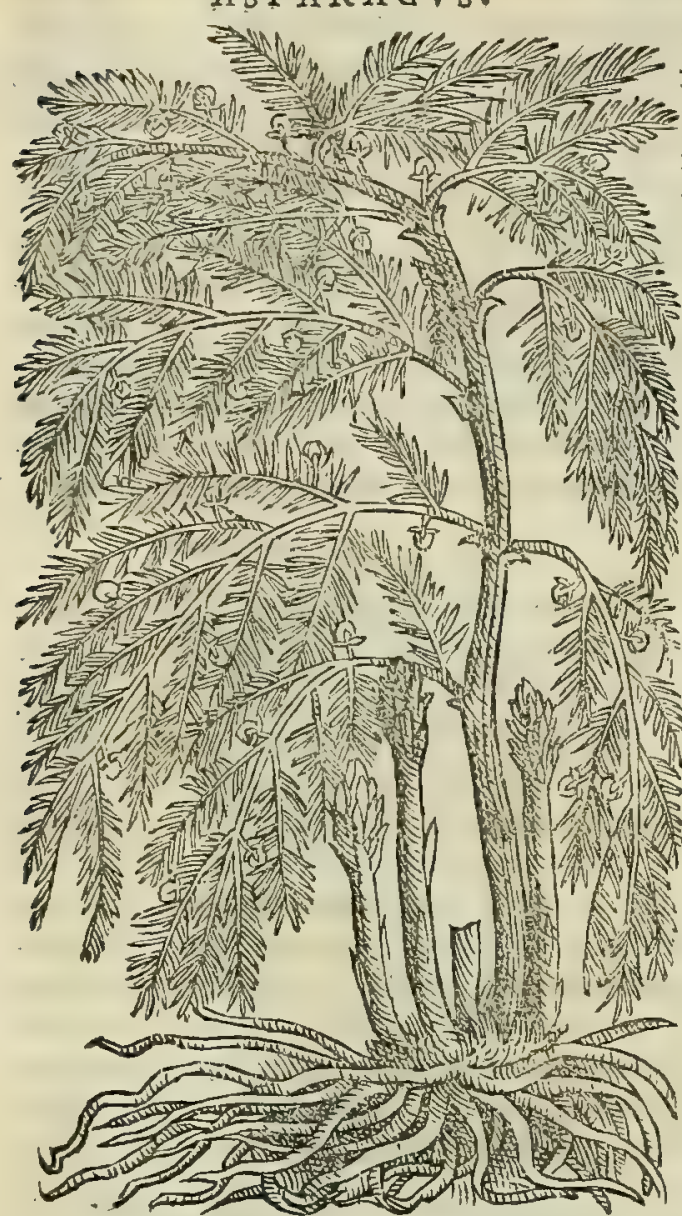

emolliunt, vrinam cient . Radicis decoctum contra vrinæ difficultatem, regium morbum, renum uitia, \& coxendicum cruciatus, in potu proficit: cum vino autem, phalangiorum morfibus auxiliatur. Si decoeti fuccus fuper dente contineatur, eius dolori medetur. Semen potum ad eadem ualet. Canes, vt aiunt, fi decoctum bibant, emoriuntur. Afparagum etiam nafci prodiderunt, arietis cornibus contufis, atque defofsis, quod, quantum equidem fentio, planè à ueritate abhorret. + t Altilis autem afparagus, multis ramis fruticat, folijs fonicu 1

Afparazorü vires ex Gal.

Ex Plinio, \& Auicenna.

Nomina.

ftomacho utiles funt, urinam cient, $\mathcal{O}$ parum prebent nutrimenti. Si tamen ij probé concoquantur, olerun afpara giam habente. Huius tenericauliculi triti in uino albo renum dolores fedant. Affus autem, coctúsue, urinæ ftil licidium, difícultatemq́ue, ac dy fenterias mitigat . Radix cum uino, aut aceto cocta, luxatos artus mulcet. Decoeta cum ficis, aut ciceribus, fumpta, regium morbum fanat : coxendicis cruciatus, ftranguriamq́ue leuat. Alli gata radix, aut hauftum eius decoctum, conceptum adimit, \& fterilitatem adfert.

A S P A R A G I tam fatiui, quàm pponte nafcentes, in I $t d=$ lia notißimi funt. Meminit horum Galenus libro v. I. fimpli=

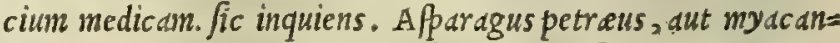
thinus abflergendi uim babet, id'; citra manifeftam aut calidita= tem, aut frigiditatem. Hinc renes, ac iecur infarctu liberat, or maximé berba ipfius radices, or femen. Quin er dentium do= lores fanat ficcitatis nomine, quam uel maximé dentes requirunt. Et lib. I r. de aliment. facultatibus: Infuper (inquit) afpara= gorum alius regius in bortis nafcens, aliusé $\lambda$ etos id eft, paluftris appetlatur, ceu alius ab iis, qui a bryonia oriur. Omnes autem 30 gis magis alunt, nimirum quantó illis funt ficciores. bee Galenus. Aparagiin cibo fumpti, ut fcribit Piinius lib. $\mathrm{x} x$. capite $\mathrm{x}$. oculis claritatem afferunt: pectoris, $\mathrm{O}$ Bine doloribus profunt. Veneresn fimulant, o ucntrenn leniter molliunt. Aparago trito cum olco perunctos, pungi ab apibus negant. hactenus Plinius. Caterim, tit ni:c= morie prodidit A uicenna Fen ultima libri quarti, Aparagi in cibis fuauiodore corpus totum comnendwnt: llerima urinam foetidam trabunt. Grecis $\alpha^{3} \sigma \varpi \alpha^{\prime} \alpha \alpha$ os, Latinis aparagus nominatur: Mauritanis, Halion, fiuc Heli= um: Italis, Aparago: Germanis, spargen: Hißpanis, Eßaragos: Gallis, Eßarge.

+ Licet in Grecis non plané conftet, hic altilis, uel fatiui aparagi inentionem fieri: tamen non uideo, quomodo bec ad fylueftrem quoq; referri poßint, ut aliquireferenda cenfent. Cüm enim bunc notum effe antea dixiffet Dio= Forides, non aliam, ut folet, eius fubieciffet defcriptionem. Quo fit , ut heec potius ad fatium refercnda putemus, 40 uel faltem mendum fubeffe fupicemur.

$$
\text { A'ẹvóy hwasov, PIANTAGO. }
$$

CAP. CXIX.

D v o Plantaginis genera. Minor folia habet anguftiora, minora, molliora, læuiora, \& tenuiora: cauliculo angulofo, in terram inclinato : floribus pallidis: femine fummis caulibus emicante.

Altera maior, lætior, uirentiorq́u, latis conftans folijs, oleracei generis : cuius caulis cubiti aititu dinem petit, angulofus, fubruber, à medio ad uerticem tenui femine circundatus : radicibus nititur teneris, hirfutis, candidis, digitum crafsitudine æquantibus. Nafcitur in lacunofis, fepibus, \& locis humidis. Multò utilior magna eft. Vim habent folia exiccatoriam, confringentem . quare omnibus malignis ulceribus, \& fluxioni opportunis, atque elephanticis, fcrdidisq́ue illita profunt: profuuia fanguinis, vlcera qux ferpunt, epinyctidas, carbunculos, nomasq́ue cohibent : vetera ulcera, \& in $x$ qualia cicatrice obducunt : chironia fanant : finus conglutinant : morfibus canis, ambuftis igni, inflammationibus, panis parotidibus, ftrumis, xgilopijs, illita cum fale profunt. Coctum cum aceto \& fale olus, dy fentericis, cœliacisque, fumptum fubuenit . Datur \& in locum betæcum lenticula coctum. \& ad aquam intercutem, cui leucophlegmatiæ nomen eft, datur $\&$ herba decoeta poft aridas cpulas, fic ut media antecedar . comitialibus, \& fufpiriofis data proficit. Foliorum fuccus, colluta fubinde oris ulcera, purgat: cum cimolia, aut cerufa igni facro medetur ; fiftulis infufus prodelt: lippi tudinibus, \& aurium doloribus idem fuccus inftillatur . additur quoque in oculorum colly ria . gingi uis cruore fuffufis, \& fanguinis reiectionibus, potu confert: clyftere dyfentericis infunditur; contra ta bem datur in potu: aduerfus ftrangulationes vulux, in uellere fubijcitur, ctiam fi vulua fluxione labo ret. Semen ex uino potum alui fluxiones, \& fanguinis excreationes fiftit. Decocta radix, ir măducacu, 


\section{In Lib. fecundum Diofcoridis. $\quad 28 \mathrm{I}$}

PLANTAGO MAIOR.

2.

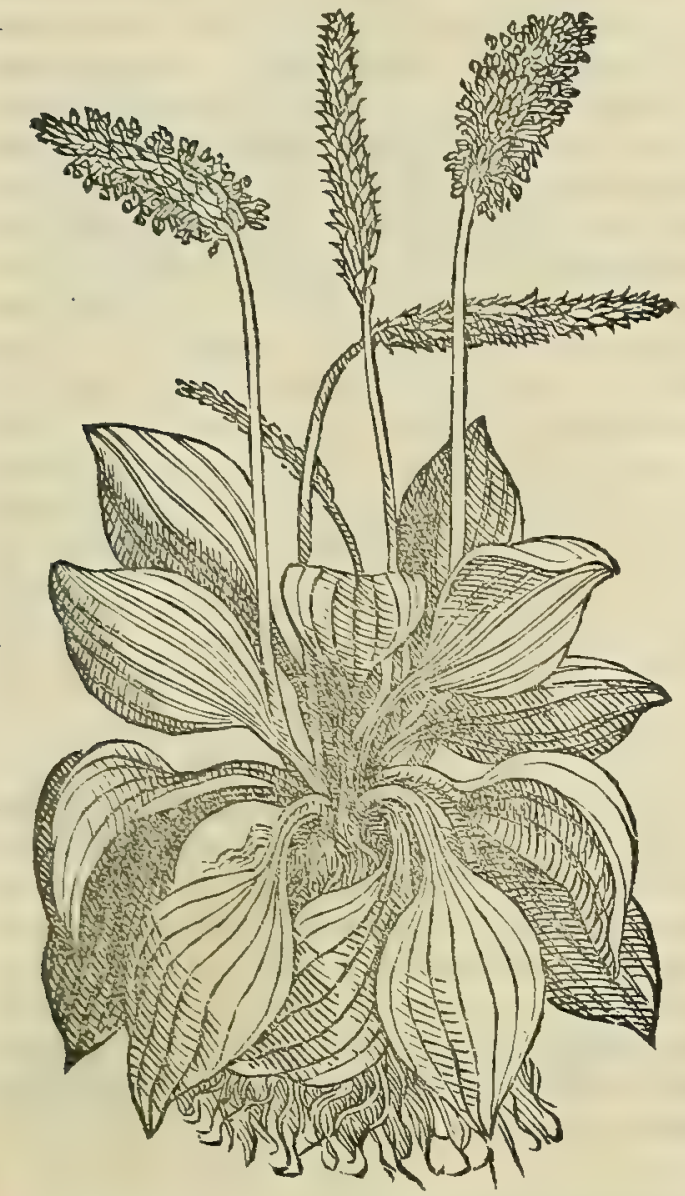

PLANTAGO MINOR.

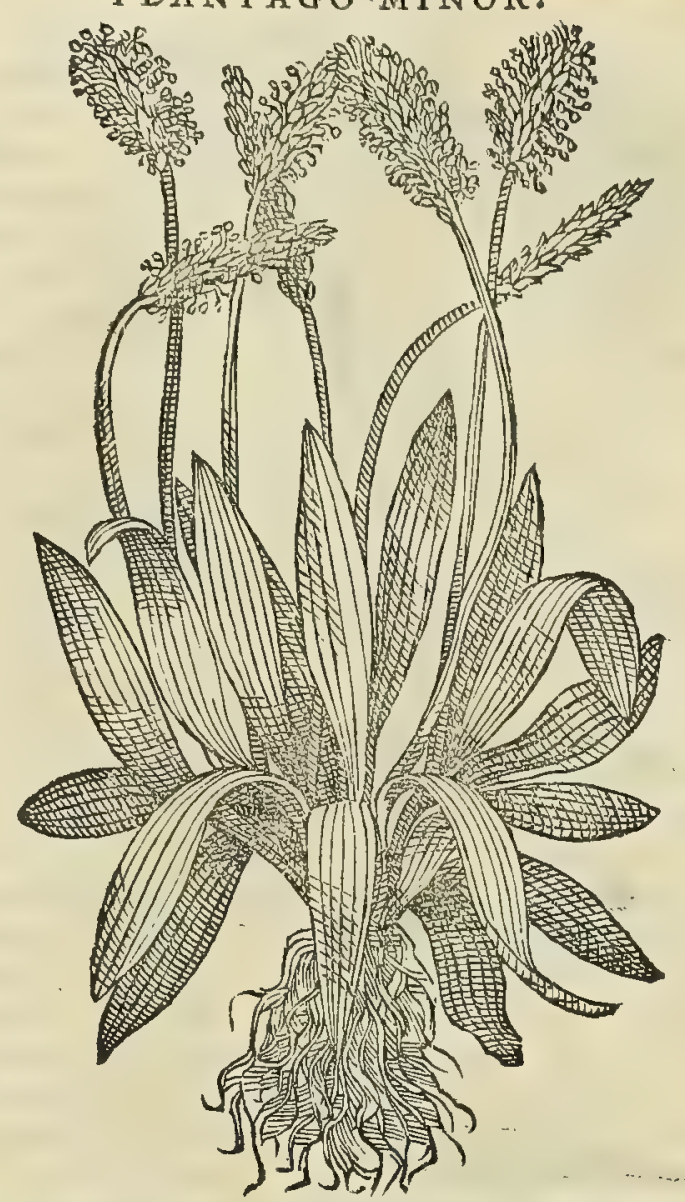

\& collutione, dentium dolores fedat : eadem cum folijs, vlceribus renum, \& ueficæ in paffo datur. Ferunt tres radices, cum tribus uini cyathis, \& pari aqux modo, tertianis auxiliari : \& quatuor, quartanis. Sunt qui radicis geftamine, difcutiendis ftrumis utantur.

Qvan Qvam à Diofcoride, Plinio, A puleio, alijsq́; omnibus antiquis autboribus, duo tantum Plantaginis gene=

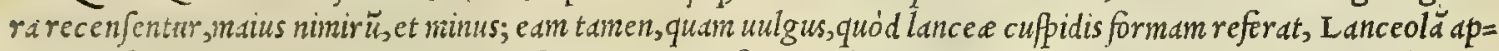
pellat, effe tertiam quandam $\mathrm{P}$ lantaginis peciem, nemo eft qui ambigat. Hetrufcis plantago Centinerbia uulgó uoca= tur, corrupto d Q uinqueneruir nocabulo. Mdior, eo quód eius folia, qua latiora funt, fibris feptem tanquam neruis diftinguintur, Septineruia appellatur. Media, quoniam in eius folijs quing; apparent cofte, Quinqueneruia dicitur.

40. Ininima ueró, quód eius folia, que leuiter birfuta funt, tres tantum ba beant neruos, Trineruia dici poteft. Plantago (ut Scriptum reliquit Galenus lib.v I. Jimp. medic.) mifte est temperature : habet enim quiddam aqueum frigidum: habet ueró 0 aufterum quidddm, id quod terreume eft, ficcum, frigidü. Itaq; refrigerat fimul, $\odot$ deficcat, et in utroq; fecundi exceffus à medijs eft. Porró medicamenta, que cum hoc quód refrigerant, und̀ etiam ficcd funt,ed er ad ulce=

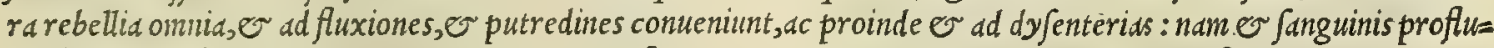
uid fiftunt, e f q quid aduratur, refrigerant: tum finus quoq; glutinant, er alia ulcera recentia fimul er uetera. In $0=$ snnibus feré id genus medicamentis primas tenet, aut certé nullifecunda eft plantago, id $q_{\text {; }}$ temperatura fymmetria,et convenientid. Nam ficcitatem obtint tmor fus expertem, o frigiditatem, qua nondum obflupefaciat. Semen eius, or radix fimilis funt facultatis, nifí quód ficcioris, o minus frigida. Sed femen etiam fubtilium eft partium: radices ue= rò craßiorum. Ip $\int_{a}$ autem herba folia exiccata tenuioris, o minus frigida facultatis fiunt: nempe diffldo ex eo,dc so digefto excremento aqueo. Hac ratione or radicibus utuntur ad dentium dolores itum mandentes, tum collutionibus ip forum incoquentes. Preterea ad iecinoris, er renum obftructiones, non bas tantùm adbibent; fed folia quoq;, et mul tó magis femina. Hac enim quandam in $\int e$ abftergendi facultatem obtinent: quame in herba uiridi ine fe fatis conij ci poteft, uerum ab humiditatis copia uinci. Herba, qua Grecis a'gvó $\gamma \lambda \omega$ asov, Latinis Plantago uocatur: Arabis bus, Lifen, aut I efan alhamel: Italis, Piantagine: Germanis, Vuegerich: Hipanis, Ihantem, Tamebagem: Gal= lis, Plantain .

$$
\text { siov. SIVM, SEV LAVER. }
$$

\section{CAP. CXX.}

Srov in aquis inuenitur, frutice pingui,recto, folijs latis, olufatro fimilibus, fed minoribus, \& odoracis. Qux cruda,co\&aq́; efu, calculos rumpunt, atque excernunt : vrinas cient : menfes, \& partus extrahunt: dyfentericis in cibo auxiliantur. De fio Crateuas tradit, herbam effe fruticis fpecie, pauca folia ferentem, rotunda, maiora quàm menth $x$, nigra, $\&$ ad erucam accedentia :
Plantaginis confideratio.

Plantaginis uires ex Gal.

Numina:

$$
\text { A } 3 \text { SIVM }
$$




\section{2}

Sij con.idera-

tio.

Plinij lapfus .

Sii uires ex Galeno.

Nomina.

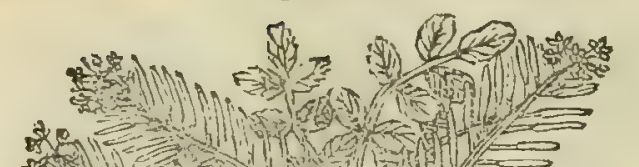

$S I V M$.

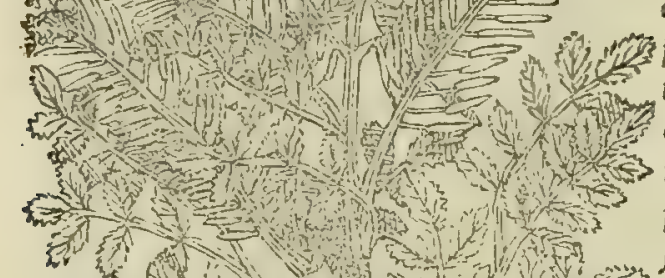

3.

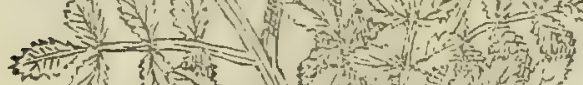

(1)

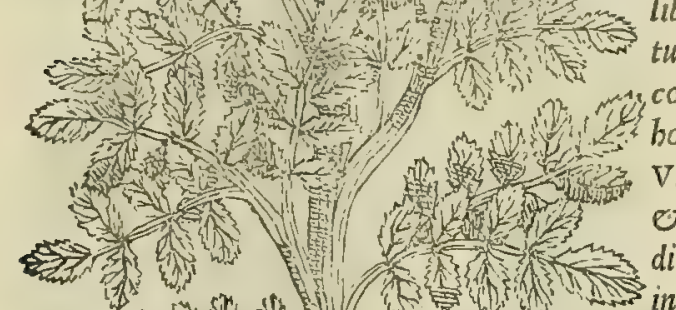

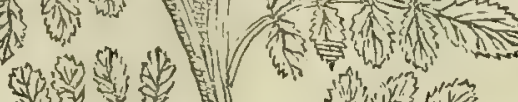
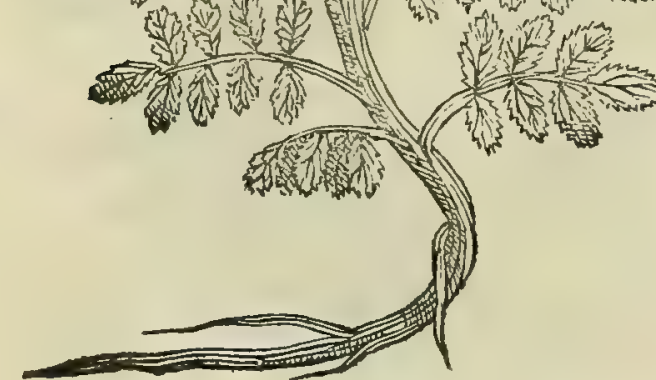

SISYMBRIVM HORTENSE.

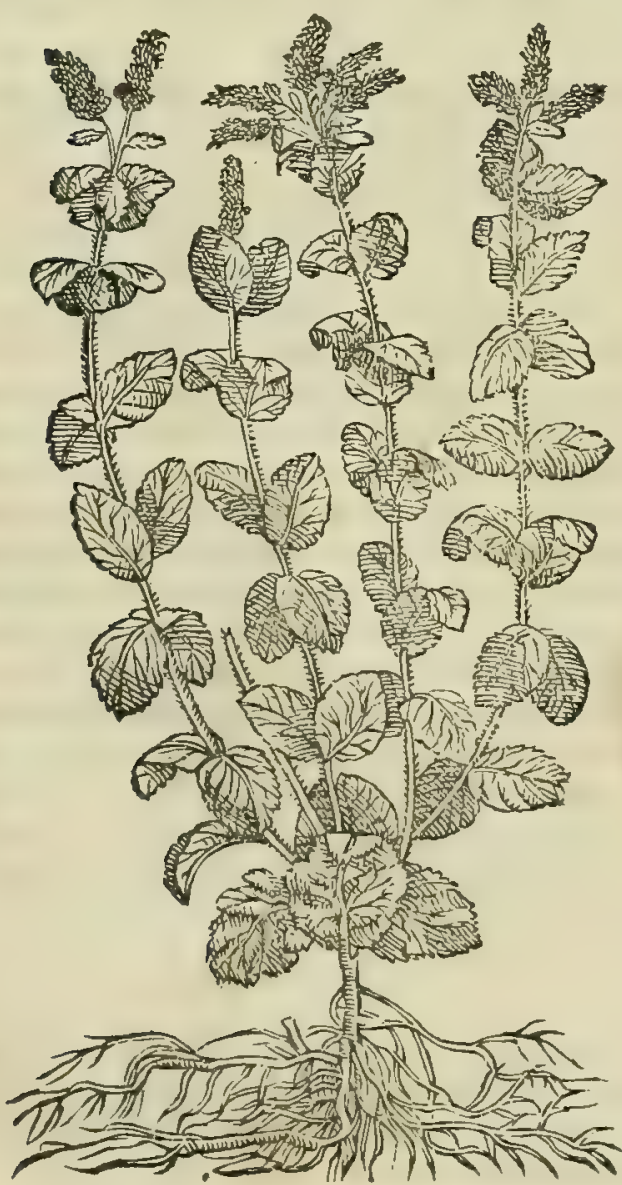

$S_{\text {I }} \mathrm{v}$ M in fcaturientiun fontium riuis, quorum dque hyeme calent, aflute ueró frige fcunt, plerunq; nafcitur. Caterum fal = luntur apertißiné, qui pro sio berbam Crefcione uulgó uocatam, tam fcilicet dulc en lactuce fimilen, quadm acrem, ac fubamaram, cui nafturtij fapor, or eruce folia infunt, in medicamentis ufur= pant. Quippe quód ea non alia fit planta, quàm fifymbrium aqua= ticum fequéti capite à Diofcoride de fcriptum, non legitimum siü, quod noft ratibuis Senenibus unlgó nocatur Gorgoleftro. Hoc e= uim à Diofcoridis sio nullis prorfus difidet notis: quandoquidem pinguis eft planta, caule recto : fol ijs latis, in ambitum ferratis, olu 20 Satro fimilibus, fed minoribus, ev odoratis: floribus candidis: $\int e=$ mine corniculis inclufo. Rari adnodum funt fontiü riuuli, quibus aquaticun fífynbriun imatet, qui siun etiă non babeant. Plinius lib. O cap. X X I I. Siun cun aquatico fifymbrio confudiffe uide= tur: quod sio fifymbrij aquatici uires a ßignauerit, nominis fortaffe cominuntate deceptus. Nam Diofcoridis teftimonio, fifymbrium boc, quod aliqui cardaminam uocant, nonnulli etiam fium appellăt. Vude quód forté exiftimauerit Flinius sium, o cardamină unam, o eandem plantam effe, uni tantim sio utriuf $\sigma_{;}$facultates reddi= dit: etfi prius lib. $\mathrm{x} x . c a p . \mathrm{x} \times \mathrm{x}$ I I. peciatin de fylueftrififymbrio 20 in riguis proucniente differuerit. Serapio siun senacion uocat: Verüm fenecio Diofcoridi alia eft planta, ut lib. I I I I , in eius men tione explicabitur. Sij meminit Galenus lib.v I I I. fimp.med. fic inquiens. sium quantum guftu odoratum eft, tantum etiam excal= facientis facultatis eft particeps. Digerit autem, é urinä mouet, or calculos renï frangit, er menfes enocat. Quod Grecioion, Latini quoq; siun uocant: Mauritani, Ror eathalmi, o Inhame $=$ banella, feu Hamehanella: Itali, sio, e Gorgoleftro: Germani, Vuaffermerck: Hifpani, Rabacas: Galli, Berle.

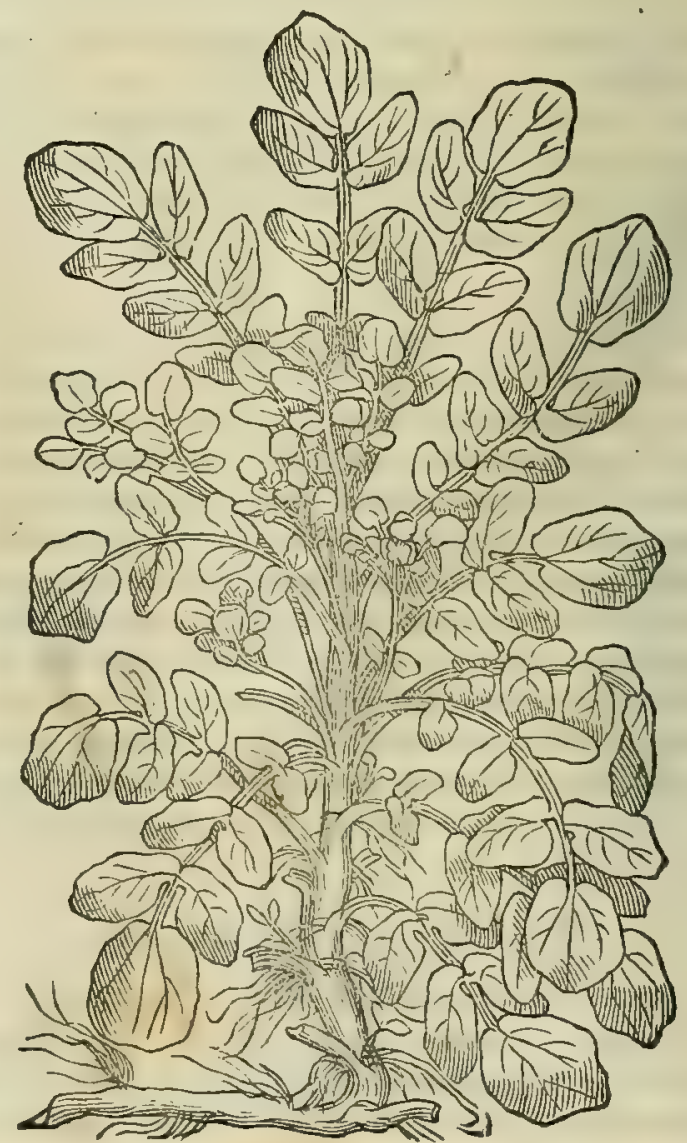

40 


\section{In Lib. fecundum Diofcoridis.}

IS XIB.AQV.ALTERVM.

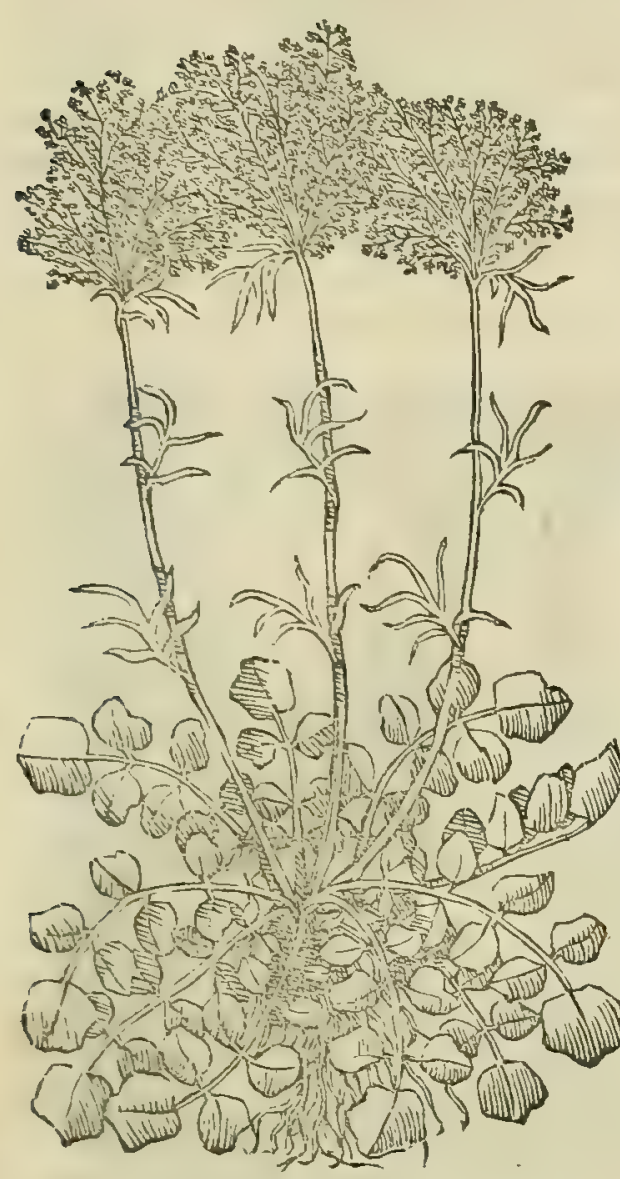

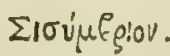
C A P.
$S I S Y M B R I V M$.

CXXI.

S I S Y M B R I V M (alij ferpyllum fyluefte uocant) in folo inculto nafcitur, menthæ hortenfis fimilitudine, odoratius, latiore folio. Inferitur coronis . Calfaciendi nim habet . contra ftillicidia urinx, calculosq́ue, femen ex uino bibitur : tormina, \& fingultus fedat . Folia in capitis dolore, fronti, aut temporibus illinuntur . item cótra uefparum, apumq́ue ictus. Vomitiones potu cohibet.

Alterum fifymbrij genus,aliqui cardamină, alij fion appellant . Ea herba riguis gaudet, \& eifdem in locis, quibus fion, prouenit: qua ideo nonnullis cardamina nominatur, quòd guftu cardamum, id eft nafturtium repræfentet. Folia primùm rotunda prodeunt,adulta erucx modo finduntur. Id excalfacit, urinas mouet . crudum eftur . Purgat lếtigines, cutisque uitia in facie,noctibus impofitum, matutinisq́ue detractum.

T A M E T S I prodiderit Diofcorides sifymbrium in folo itte Sifymbrij cöculto nafci, Theophraftus tainen lib. V I. cap. V I I de plantarum fideratio. hiftorid, e lib. v. cap. v I I I. de earun caufis, fatium etiámnü sifynbriwn in bortis reperiripofteritatis memoria commendauit . Quod fané eam herbann effe crediderim, qua bodie in omnibus feré hortis prouenit, quam noftrates officine Balfamitam, unlgus ueró mentham Romanam,uel crifpam appellat. Quippe quód bec pro= ferat folid circinata, o unlgaris inenthe latiora, cripa tamen:

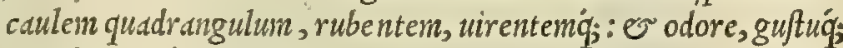
mentha longé acrior Sentiatur: Cuins rei illud etidm, prater afi= gnatas notas, maniffetum indicium facit, quòd Balfamita bec faci= lé in mentbam degeneret, nifí diligensadmodum adbibeatur cul= turs. Quod libro de plantarm caufis paulò dnté citato, aperté teftatur Theophraftushis uerbis. Sifymbrijmu= txtio in mentham, uelut predictis oppofita fcilicet eft, cün ex neglectueneniat. Fit enim cùm quis non excolit, ne= que curan folitam adbiót, ut radices amplius deducantur, quaim in partem ui tota connerfa, debilior pars fuperna confiltit, odorisq́; fui uebementiam amittit, quafi ex anbobus illis, germine, atque odore fimilitudo prouenut. Quippe acritudinc exolc fcente, reliquus odor, quia nollis quidam, remifus q́; eft, proximé ad mentham accedit. Qüanobrem tr.nsferre fepenumero iubent, ne ilud cueniat. Hec Sifymbrij caufa eft. bactenus Theophrastus. Sed equidenn non putauerim Diofcorides sifymbrium fponte in incultis nafcens, cum Theopbrafti sifymbrio conuenire: quin potius alterun ab altero longé dißidcre crediderim. Sylueftre enin in Ananienfi agro in incultis natum com= 40 pluribus locis uidinuus, ac legimus, nullis deficientibus notis illi à Diofcoride tributis. quod mibi quidem fatiuo effigie plané reclamare wijun eft. Huc alia accedit ratio, qua facilé probari poteft, fylueftre sifymbrium à fatiuo pluria minn differre. Quundoguidem fi idem effent, cün sifymbrium culture negligentia in mentham degeneret, fieri quidem non poffet, ut Jylueftre aliter ufquan inueniretur, quàm in menthan permutatum, cùn nulld hominum cultura nascatur. Quo poftnodum fieret, ut locus, in quo sifymbrium prinó cdoleuifet, breui temporis tractu ubique mentha fcaterct. quod tanen nufquam bactenus factum reperi. Caterün Brafauolus, cum bec fortaffe Brafauoli ernon perpendiffet, credidit Ballanitam, quain ipfe Florentindin menthani appellat, tam fatiuum, quain fylueftrē ror. sifynbriun indifferenter explere poffe. Qui praterea fatetur fe uidiffe (quód potius eun oculos fefellife putaue= rim ) Balfamitan defciuife in calanintham, Pliniun quidem, non Theopbraftum fecutus. Siquidem Theophraftus in menthan, non in calamintbam Sifymbriun descifcere prodidit. Plinij ueró codices nonnulli libro x I X.cap. X.

so fcriptum quidem habent, quòd sifymbriun in caldminthan degenerat, quan lectionem accepit Brafauolus: fed ea lectio deprausta cenfetur. Idcirco factun eft, ut ij, qui Plinium caftigarunt, edin reftituerint, quód compertum babuerint Pliniwn ex Theophrafto hiforian funtpfiffe. It aque idm eiuslociuera, er legitima lectio eft, ut in cd= ftigatis codicibus legitur, quód sifymbriun in menthan defcifcat, non in caldmintham. Sifymbrium ueró, quod (ut Diofcorides inquit) allqui Cardaminam, alij sium appellant, ea nimirum berba eft, quam uulgó noftri Crefcio= ne appellant, acri Japore predita, de qua etiam diximus in precedenti capite, de sio'diferentes. Siquidem ea in fontium riuis difcurrentibus comite sio nafcitur, folijs primo exortu rotundis: cumn ueró adoleuerint, eruca modo diffectis : otore, ac fapore fati!o nafturtio proximis. Meminit huius Plinius libro x x . cap. X XII . quanuis libro x I x. cap. v I I . aliud sifynbrij genus cominemoret his uerbis . sifymbrium fimili modo feritur . lati ijimun $n a f c i t u r$ in puteorum parietibus, o circa pifcinas, or ftagna. Hinc quidam exiftimarunt, Plinium de uulgari men= thuftro, quod in aquo/is paßim prouenit, differuiffe. Sifymbrij utriufque mentionem fecit Galenus libro vi I I. triufque uires de fimplicium medicamentorun facultate, fic inquiens. Sifybrium tenuium partium, digerentis, excalfacien= ex Galeno.

Sifymbrium aquaticum. 
tis, or cxiceantis facultatis eft, or temperature in tertio ordinc. Sed or femen eius tenuium partiun eft, or ca= lidun. Quocirca ipfum quidam cum uino exbibent fingultientibus, er tormtna paticntibus. Sifymbrium ueró, quod quidam Cardaminem uocant, quandoquidem cardamo, boc eft, nafturtio fimile quiddan guftu prafert, cim fic=

Nomina. cum eft, tertij eft ordinis excalfacientium, or deficcantium: cum bumidum, $\mathcal{O}$ uiride, fecundi. $\quad \nabla t$ Groci $\sigma t=$ oúphgrov, ita etian Latini sifymbrium dicunt: Arabes, sifnabarion, feu sifnasbar:Itall, sifembro, or Menta Romana: Germani, Vuafermuntz, or Eachmuntz: Hipani, Hierua buena de agua: Galli, Mcnthe aquatiche.

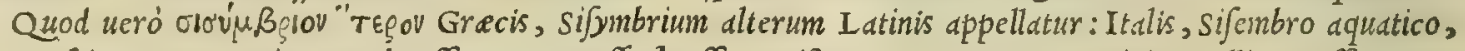
er Crefcione: Germanis, Brunkreffen, ev Vuafferkreffen: Hipanis, Berros, er Agriois, Gallis, Creffon .

\section{CRITH MVM.}

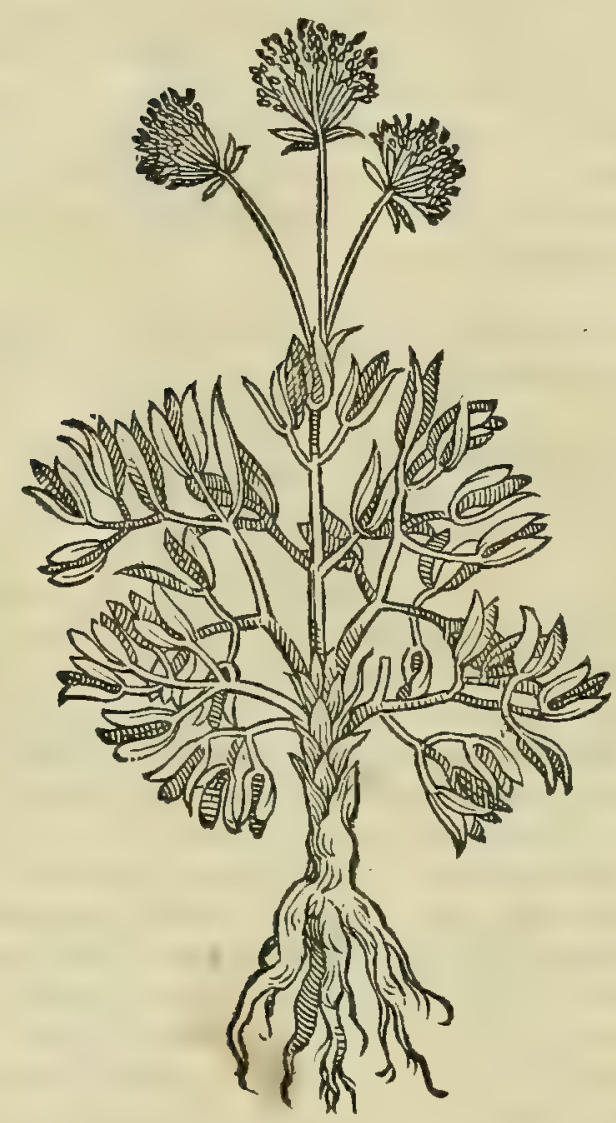

Keífuov.

CRITHMVM.
CRITHMI MAR. SPECIES.

10

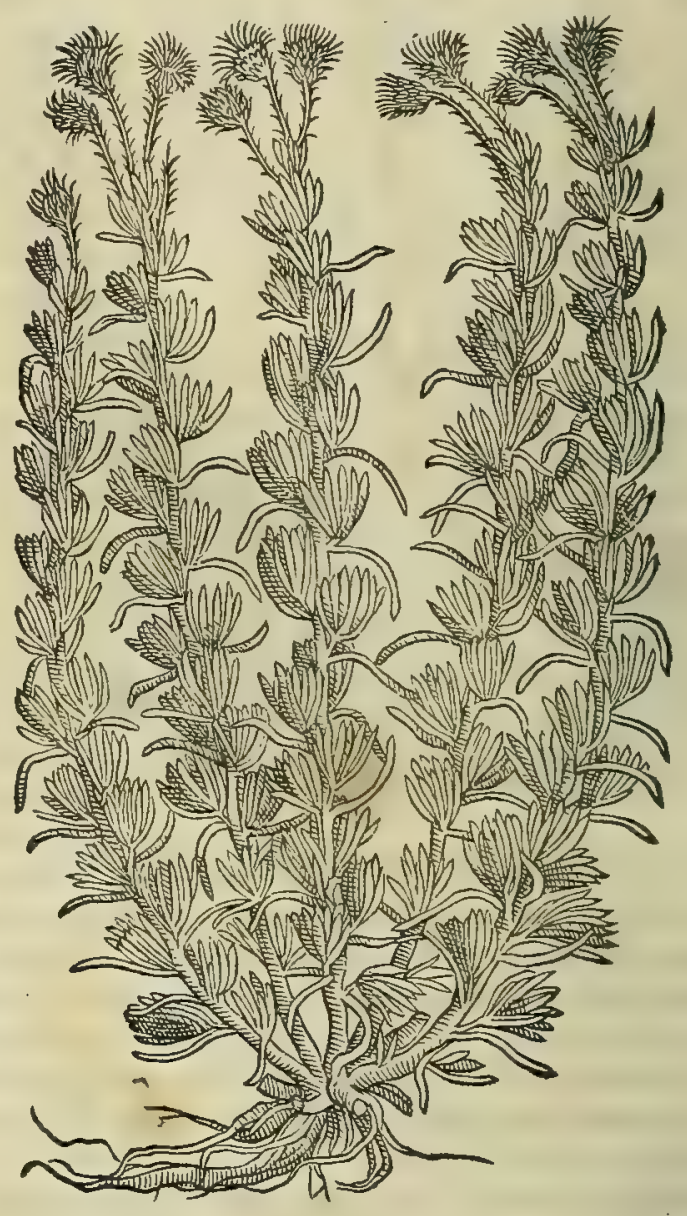

CAP. CXXII.

C R т т н v M, feu, vt aliqui, Crithamon, fruticofa, \& vndique foliofa herbula eft, cubiti altitudinem ferè petens . Nafcitur in maritimis, \& petrofis : folijs pinguibus, numerofis, albicantibus, veluti portulacæ, latioribus, \& longioribus, falfo guftu : Alores candidi funt : \& femen, ceu rofmarini, odoratum, molle, rotundum, quod ficcatum rumpitur : habet intus tritici modo nuclcum : radices digiti crafsitudine, tres, aut quatuor, grati odoris, \& iucundi. Radix, femen, \& folıa incocta uino, potu urinæ difficultati, \& regio morbo auxiliantur: menfes cient. Eftur crudum, coctúmue in olere. feruatur etiam in muria.

Crithmi con- N A S C I T V R Crithmum non modó in omnibus Tyrrheni promontorijs, fcopulis, ac rupibus, presertim fideratio. Argentario monte in maritimis noftris Scnenfibus, o uniucrjo circum Italiam litore; fed etian in Adriaticc finu, ubi fcopulofa, e prerupta fuperftant litora: quemadmodum nobis contigit uidere co tractu per quem à Tiriano fonte Tergeftum nauigatur : nanq; inibi illa fcopulofa litora critbmo referta funt. Critbmuin Rome, of in uniuer= fa feré Hetruria Foniculum marinum dicitur : etfí in diis quàm plurimis It alia locis, ubi à maritimis in hortis, ac uiridarijs translatum uire fcit, herbam fancti Petri appellitet uulgus. Quo nominis argumento non defunt, qui exi= Quorundam ftiment, plantam banc legitimum effe Empetron, libro I I I I. à Diofcoride de criptum inter fimplicia medicamen= lapfus. $\quad t a$, que deiectoria pollent facultate. Inter hos inuento $\mathrm{P}$ andulpbum Collinutiun in de fenfionibus Plinij contra Leonicenum. qui Empetron corrupto uocabulo Sanpetram berbam uocari put «t, nulla babita facultaris, notarumóg; ratione. Cuius fentcntia maximé refragatur experientia, quód Critbmum, quanquam abunde, copioféq; ingeftum, nec pituitam, nec bilem, nec aquam intercutcm trabit, qucmadmodum empetro reddidit Diofcorides. qui propte=. 


\section{In Lib.fecundum Diofcoridis.}

reaillud inter ea, qux alü̆ deijciunt, medicamenta locauit. Quomodo autč Empetron quis idem cum berba fancti Pe trirecté dixerit, fi empetron nullis alijs à Diofcoride reprefentatur notis, quìn quód nafcatur in montibus, or mari timis, falle, a amaro fapore? Verim enimucro non modó putandum; fed etiam pro certo, meo quidem iudicio, affir: mandü erit, herbam hanc Crithmum effe'. Quippe quód ea notis omnibus, que radicibus, folijs, caulibus, ac feminibus, ct uniuer fe denig; plante tribuit Diofcorides, Crithmum plané referat. Crithami uires recenfuit Galenus lib.v I. fim plicium medicamentorü, is uerbis. Crcthmum gustantibus falfun quodanmodo eft, cum paucula amaritate. quamobrẽ

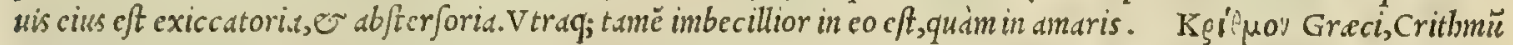
item ct Crithamun Latini uocant: Itali, Crithamo, Finocchio marino, e berba difan Pietro: Germani, Bacilen, er IIcerfenchel: Hifani, Perexil de la mar, o vnhas de agnula ycrua: Gallis, Bacille, er Fenoil marin.

$$
\text { Koçcuritious. CORONOPVS. }
$$

CAP. CXXIII.

Crithmi vires ex Gal.

C O R O N OPYS oblonga herbula eft, per terram ftrata, fifsis folijs . coquitur in olere. Radicem habet tenuem, adftringentem, quæ in cibo cœliacis facit. Proue nit in aggeribus, \& locis incultis, \& fecus vias.

V A R I A s, ac diuer as reperio corum fuife fententics, qui non parum laboris, ac studij impenderunt, ut plantarï biftoriam Coronopi cö a mendis omnibus expurgatam priftine, ac proprie redderent in =

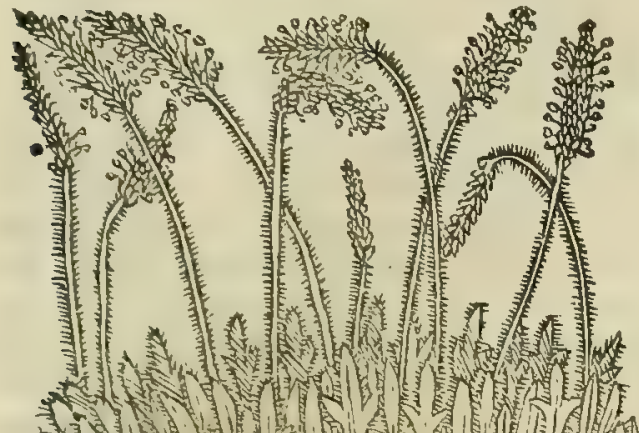
tegritati, in inueftigando, quienam inter tot plantas legitimé $\mathrm{Co}=$ ronopus dicipoßit. Quorum unus extitit Nicolaus Leonicenus, uir quidem ingenio, o doctrina praclarus, qui longa uerborum ferie bac de re fcripfit, conclufit ó; tandem, Coronopum eam ber bam effe, quam ipfe uernacula fua lingua Capriola, nos ueró no= ftra Sanguinella appellamus, quód ea pueri aftate naribus indant, ut inde fanguinem eliciant. Verùm cüm eius fententiă minime pro bandam exiftimauerit Manardus Ferrarienfis, hac in re magis Diofcoridi addictus, qudim Plinij,ac Theoploraftiplacitis, qui $\mathrm{Co}=$ ronopum inter aculeata recenfent, bis magis adftipulandum effe iudicauit, qui uolunt Coronopum Diofcoridi eame $\in \int e$ herbă, quise

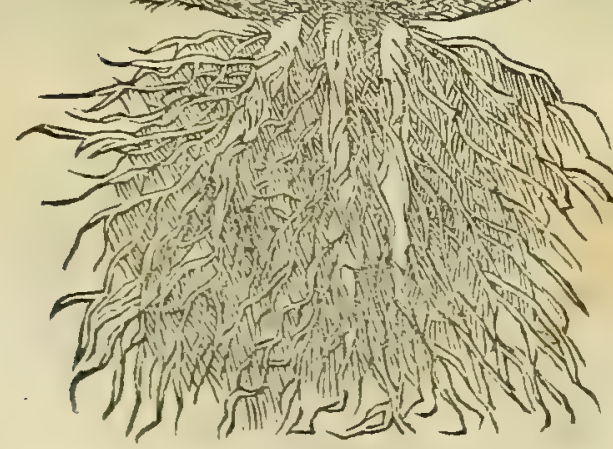
unlgó dicitur Herbaftelld, omnibus Italize bortis uulgaris, ac ad= modum frequens, quód in acetarijs paßim ufurpetur, quadm ijs, qui Capriolam, fiue Sanguinellan dittan Coronopum effe cenfent. Qus andoquidem bec nufquam, quod fciam, in cibis fumitur, fed in brutorum tantüm uenit pabulum. Nec defunt praterea, qui fir = miter affeuerent, quód que inter plantas unlgó nonnullis Pes cor uinus nocatur, aliquibus ueró Pes gallinaceus, qua utütur nonnun quam medici ad exulcerandas corporis particulas, ubi id expoftu let neceßitas, legitimus fit Coronopus. Inter quos non modó depre benfi funt commentatores Auicenne, quos nullam rei berbaric peritiam habuiffe conftat; fed er recentiorum quidam, prefertim ex corum numero, qui deftirpium biftoria, o fa= cultatibus fcripfere commentarios. Nanq; Otbo ille Germanus cognomine Brunfelfius, tametfi non ignoraret, cos d probatißinis uiris refelli, qui in hanc uenerunt fententiam: tamen (qua multorum eft pertinacia) maluit cum rei ber burix imperitis errare, qud̀m cum doctls, o peritis recté fentire. Quippe Pes coruinus uulgó uocatus (ut in fequen tibus fuo loco differemus) Coronopus non eft, fed proculdubio ranunculus, qui Gracis $\beta \alpha \tau \rho \alpha$ ' $\operatorname{llov}_{\text {appellatur, cuius }}$ uarix Diofcoridi produntur pecies: inter quas unlgaris Pescoruinus fuam retinet fedem. Quidd autem Leeonice ni Capriola Coronopus fit Dio coridis, ego quidem cum Manardo nunquam affirmauerim. Nam 0 figerat hec her ba in fui culmi faftigio quing; uelutigraciles $\beta$ ic as, qua cim manibus dilatantur, cornicis, uel alterius uolucris for mam pedis reprefentant; cum tamen (ut etiam Manardus inquit) in bominum cibum non expetatur, folio exeat nullis so incifuris diffe to, non fer atur in hortis, er arida tanquam fornum affurgat, nullo patto afferendum cenfeo Capriolam

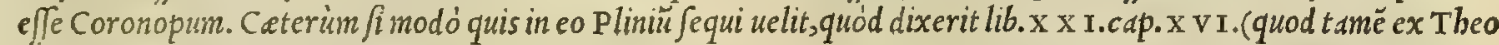
phrafto fump fit) aculeatarum caules aliquarum per terram ferpere, ut eius, quam Coronopum uocant; fruffr $\dot{d}_{\text {, meo }}$ quidem iudicio, probare contendet, sanguinellam, fiue Capriolam effe Coronopum. quód eius caulis culmi modo geni= culis inter fectus, bumi minimé repat, fed rectus in altum affurgat, et culmorum in morem picas ferat. Verümeos non aterrare putauerim, qui dixerint Capriolam hanc aculeatum effe gramen, cuius meminit $\mathrm{Plinius}$ lib. $\mathrm{x} \mathrm{x}$ I I I $\mathrm{I}$.
cap. $\mathrm{x}$ I $\mathrm{x}$. his uerbis. Sunt qui o aculeatum gramen uocant trium generum, cum in cacumine aculei funt plurimüm quini, dactylon uocant. Hos conuolutos naribus inferunt, extrabunt $q_{;}$;anguinis ciendigratia. Neq; ufquä, quod equi dem legerin, expreßit Plinius (ut Ruellius teftari uidetur) gramen boc aculeatum effe coronopum. Illud preterea animaduertere oportet, quód Diofcorides non fcribit Coronopum aculeatam plantam effe, neq; eum inter aculeatas Tibro tertio recenfuit, fed hic inter olerd, qua in ciborum ufum ueniunt. Quanuis contrarium fecerit Theoplraftus, quód fortaffe ad foliorun formam alluferit, qui laciniarü tenuitate coronopo aculeata uidentur; cum tamen pungere 
286 And. Matthioli Comm.

\section{SER PENTINA.}

Coronopi fylueltris mé tio, \& uires.

.
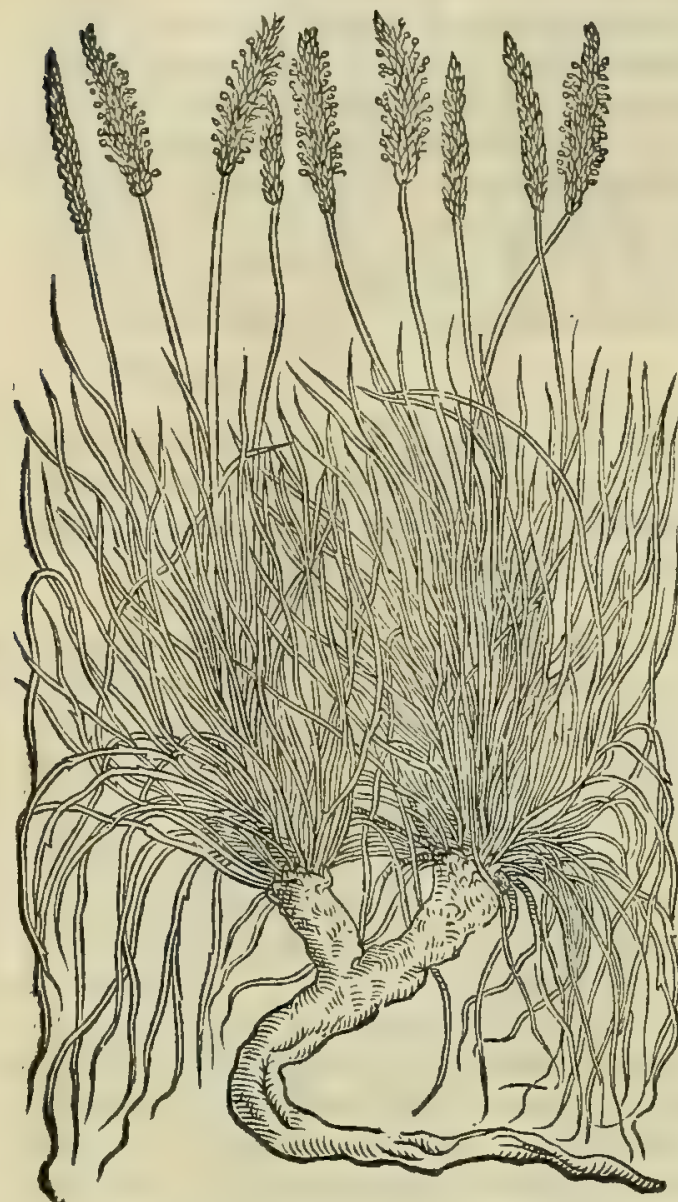

non ualeant, ut cun acanthinis pariter lufit Diofcorides , Quare facile adducor, ut creddin, Coronopum tam Theophrafo, quàm Diofcoridi idem effe. Idcoif; Plinius libro X X I. Throphraftum $\int e$ cutus, Coronopum aculcatum facit : libro ucró $\mathrm{x}$ x I I . Diofcori= dein fortaffe imitatus, aculeoruin baudquaquam meminit. Sed et illud filendun non duximus, quód cx illo graminis genere, quo pue riludentes fanguinem é naribus eliciunt, sclaui Carniole incole, item Goritienfes femen colligunt, deglubuntóp in pilis, $\mathbb{O}$ milij, uel panici modo carnitum iure decoquunt, granulis oblongiufculis panico minoribus, guftui non ingratis, adeo' ut Germani bimeldaul 20 uocent, hoc eft, calcftem mannam. Huius plantam Sclaui cornic is pedem appellant. Quo fit, ut quafí certó crediderim, quód L eoni cenus ab ijs fortaffe doctus, putaucrit hanc plantam effe Diofcori= dis Coronopum. Qui cùn Coronopum feribat pinis nullis rigere, feriq; in bortis in ciborusn ufum, eos nibil falli exiftimanerim, qui nobifcum fenferint eam plantam legitimum effe Coronopum, que uulgó nobis Herba fella uocatur. Nempe nullam hactenus plan= tam uidi, que perinde ac illa addmußin Coronopum referat. In= uenitur hec etiam pponte nafcens diluto extenuato ó; folo in comi tatu Goritienfi, non longè à Sontij fluminis ripis, er in loco, qui di 20 citur in collibus. Eam inibi uulgó serpentinä appellant, quòd eius radix in uino pots uiperarum, aliorum,; wenenoforum animalium morfibus maximé aduerfetur, fit $q_{\text {; }}$ precipuum remedium, ita ut ip $\int$ a fola (quod equidem experientia compcrtum babeo) liberct de norfos. Coronopi uires paucis perferinxit Galenus libro v I. fim plicium medicamentorum, fic inquiens. Coronopodis radix colia cis prodeffe creditur manducata. Eius nomen Grecum nof̧ $\omega=$ vóa ous, item e Latimum Coronopus: Italicum?, Coronopo, or berbaftella: Germanicum, Kraenfuoß: Hifpanicum, Guiabelha: Gallicum, Capriole.

SONCHVS ASPERVS.

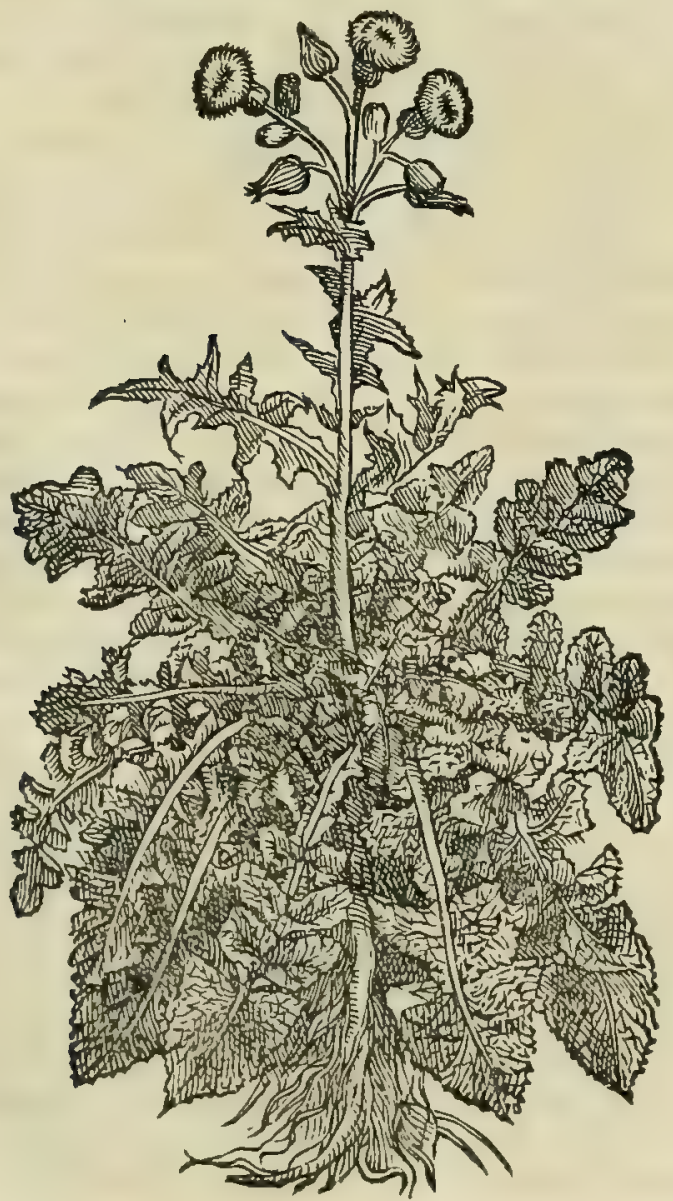

SONCHVS PIANVS.

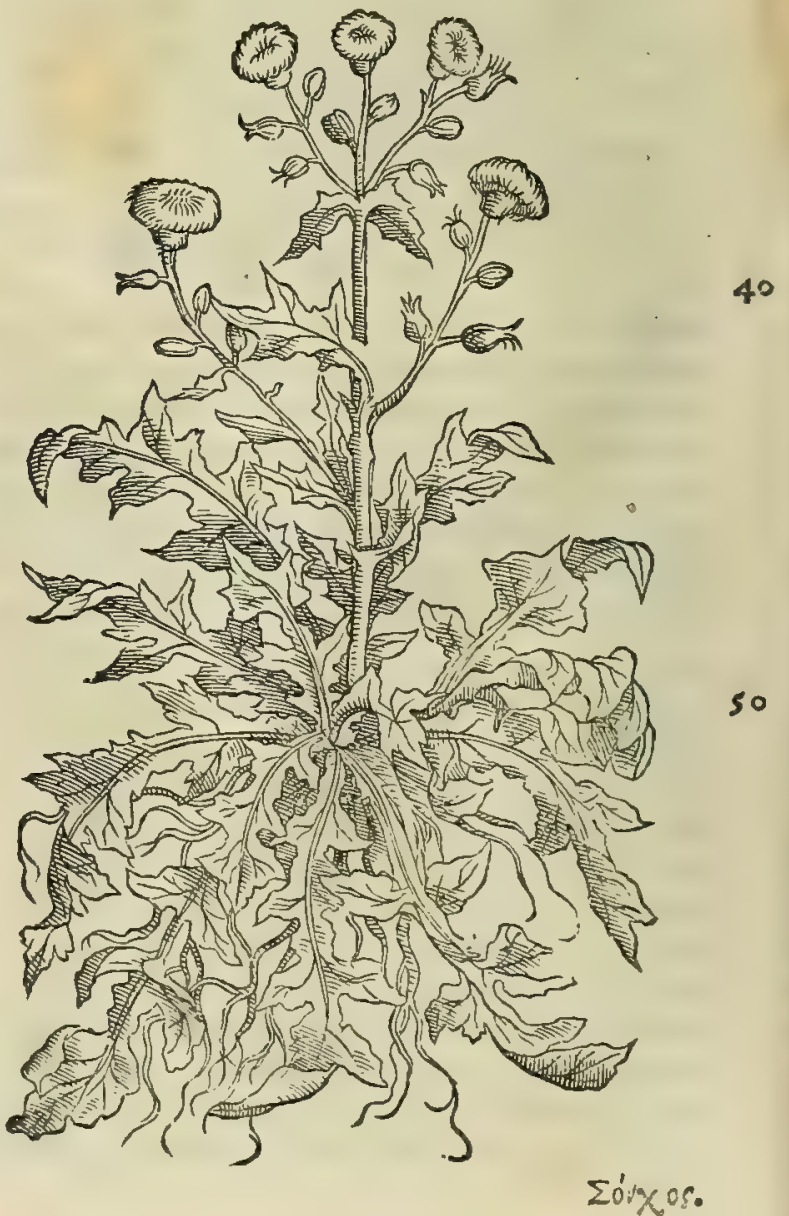




\section{In Lib. fecundum Diofcoridis.}

\section{SónXos. SONCHVS.}

CAP. CXXIIII.

S O N C H I duo genera. Sylueftrior quidam eft, \& magis fpinis horret. Alter teneritate quadam mollefcit, cibis expetitus. Caule conftat angulofo, $\dagger$ inani, interdum rubente: folijs in ambitu per interualla diffeetis. Vtriufque uis refrigerat, modicè adftringit. vnde xftuanti ftomacho, \& inflammationibus illıti profunt. Succus eorum ftomachi rofiones forbitione mitigat : lac elicit . inuellere appofitus, fedis, ac vulux collectionibus opitulatur. Tam herba, quàm radix illıta, uibratis à fcorpione iatibus fubuenit. Alter fonchus tenerior, arboris inftar eft, latis conftans folijs: caulem in ra20 mos exeuntem folia diftinguunt. fed ad eadem pollet.

S O N C H V S in Hctruria, ubi Latinumnomen adbuc perdurat, Cicerbita unlgo uocatur. vifuntur in bortis, campis, o uine is duo fonchigenera. Sed tertium illud genus, de quo in fine capitis differuit Diofcorides, non folum non inucnitur in Italia, ubi non recordor me bactenus uidife plantam, que Soncbum arborefcentem referat; fed ne q; etiam de co quic quam, quod equidem legerim, memorix prodiderunt Theophraftus, o Plinius. Soncho noftri utuntur byeme in acetarijs, prefertinǵ; eius radicibus, que cum tener, fint, manfuq́; dulces, frequenter menfis expetuntur. Soncbi nires nobis defcrip/it Galenus libro v I I . fimplicium medicamentorum, bis uerbis. Sonchus Sonchi uires ubi adoleucrit, cx pinofis plantis eft. Caterim uiridis etiänum, or tener cftur, perinde ut catera olera fylueftrid. ex Galeno.

Temperamentum eius quodammodo miftü eft: conftat enin ex aqued, terreaq; effentia, utraq; leuiter frigida. Nam $20 \mathrm{O}$ adftriftionis cuiufdam eft particeps: $O$ fiue cataplafinatis in morem illinatur, fiue edatur, manifeftó refrigerat: poftea uerò quàm plané reficcatus fuerit, terreftre eius temperamentum redditur, modicam babens caliditatem.

Eóvxos fic Grecé, ut etiam I atine sonchus appellatur: Italicé, Soncho, or Cicerbita: Germanicé, Vuilder

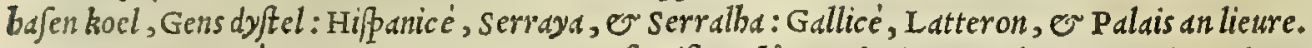

† Hac dictio xevo's, que uacuum, or inanem fignificat, hic non legitur in unlgatis Grecis. Sed tamen eam habent wetufticodices, quibus etiam adftipulatur Oribafius. Ergo non crit, ut aliqui putant, ex Plinio duntaxat repofita.

EE⿱ÖIS. SERIS, SIVE INTYBVS

CAP. CXXV.

SE R I s duûm generum eft. Altera fylueftris, qux picris, \& cichorion uocatur. Altera fatiua, 30. latioribus folijs conftat, ftomacho quàm hortenfis utilior. Qux iterum in duas fpecies digeritur.

INTYBVS HORTENSIS.

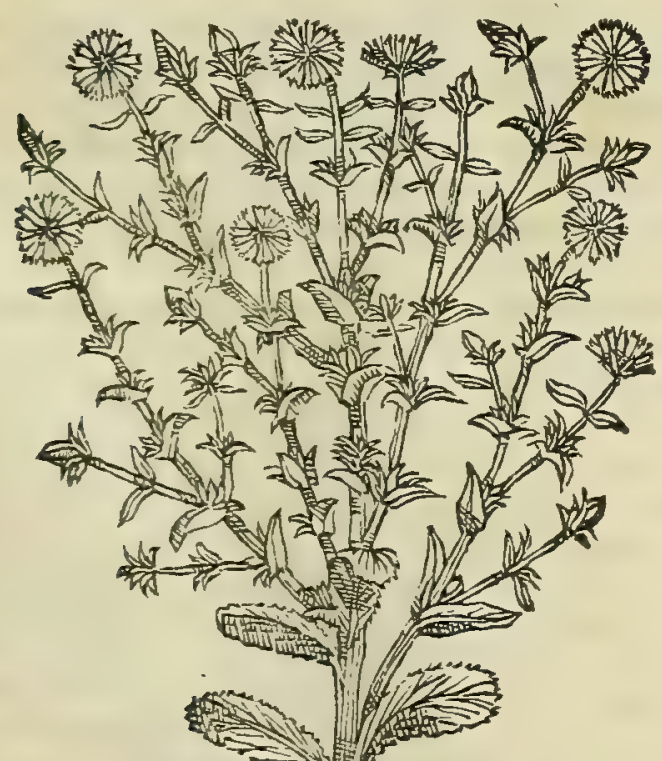

50
INTYBVS HORT.ALTER.

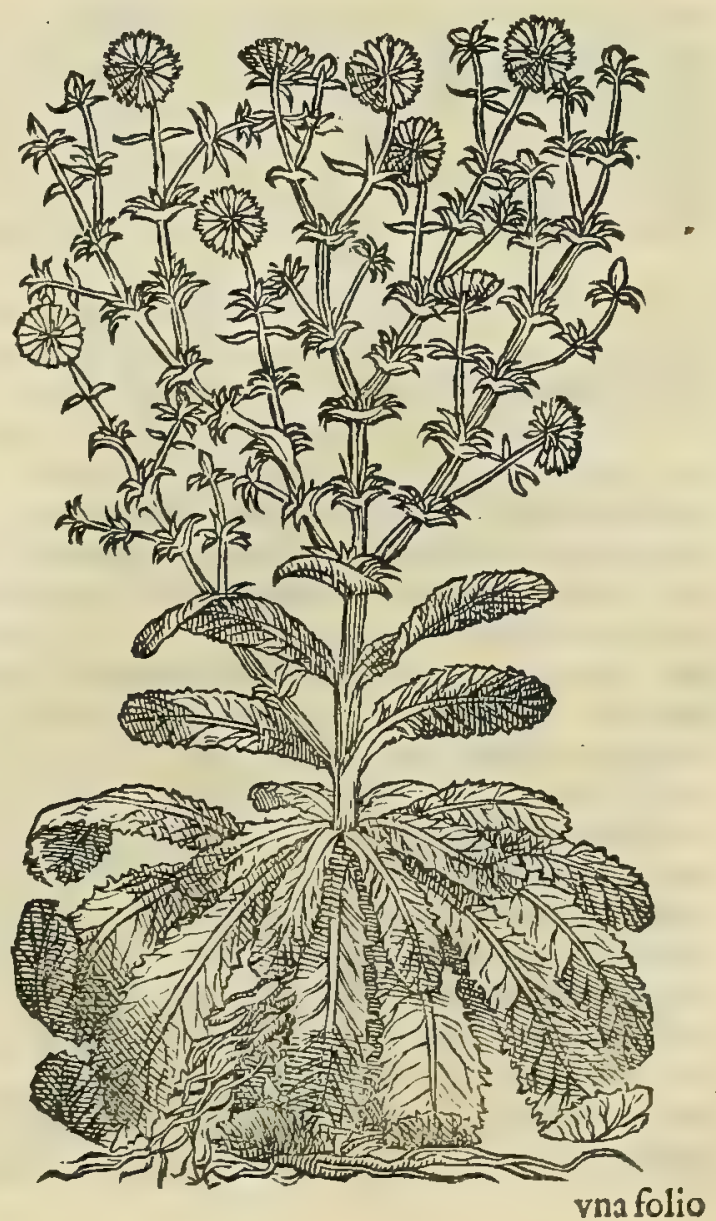

Sonchiconfideratio.

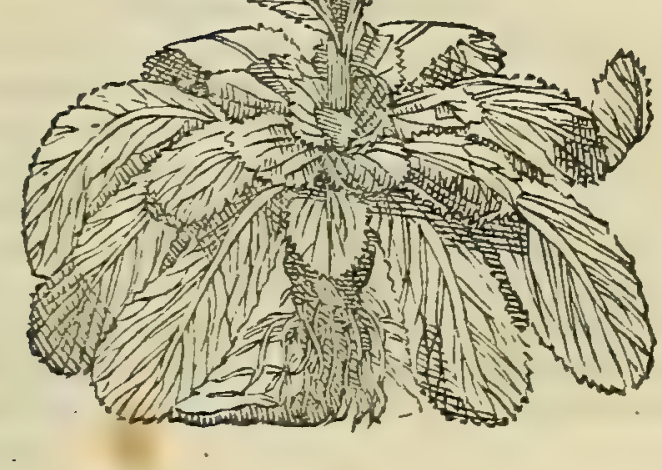


INT YBVS SYL. SIVE CICHORIVM,

CICHORIVM SATIVVM.
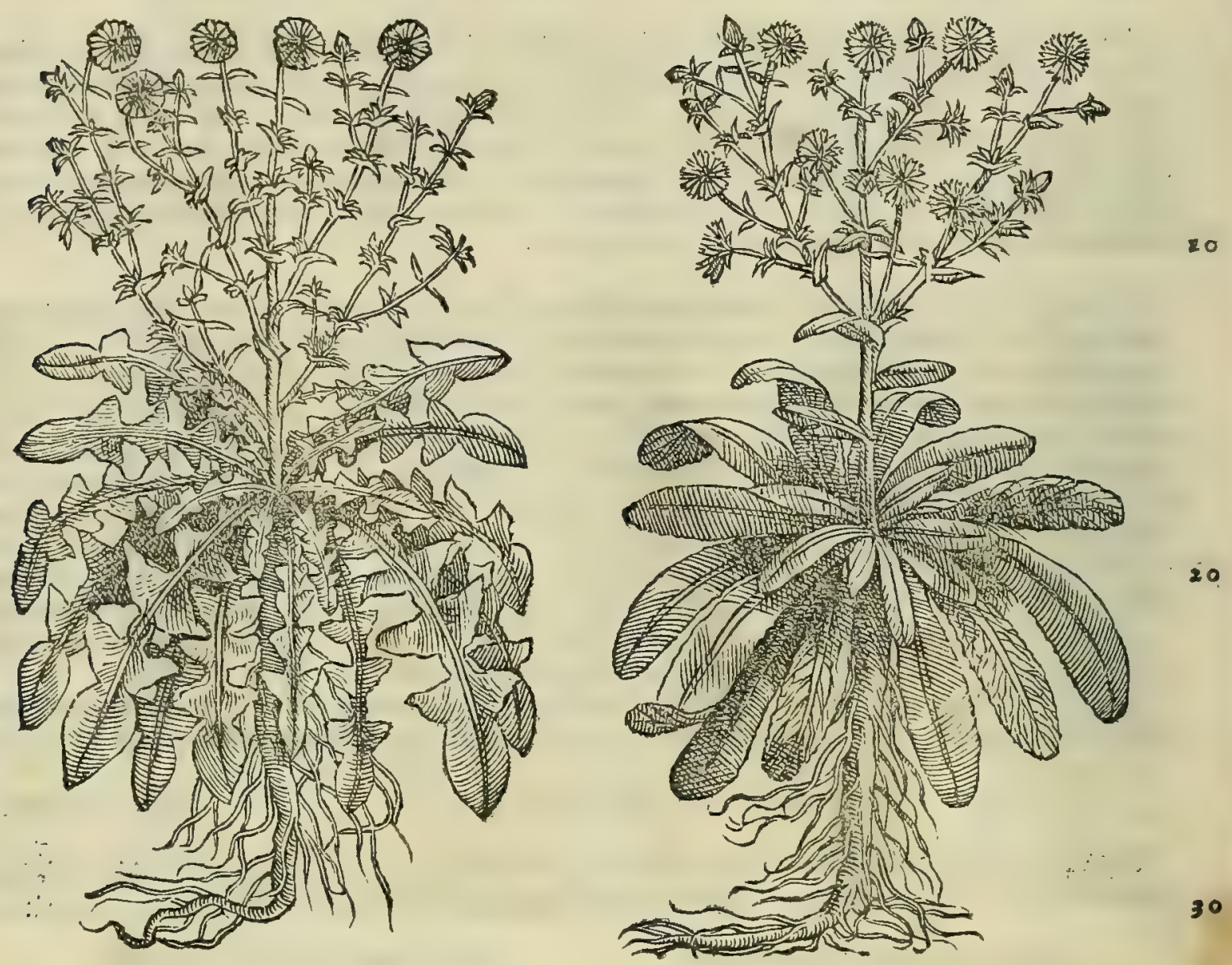

vna folio latiore prodit, lactucarum fimillima : altera anguftiore ett folıo, \& guftu amara. Vtraq; re frigerat, 8 adftringit, ftomacho utilifsima : aluum fiftic coeta, fi cum accto adfu matur. Sylueftrcs ftomacho meliores: quandoquidem xftuantem ipfum, \& quem imbecillitas uexet, cibo leniunt. Cardiacis per fe, aut cum polenta, utiliter illinuntur : padagris, \& oculorum inflammationibus auxilio funt . Herba cum radice illita, percufsis à fcorpione fubuenit : igni facro cum polenta medetur. Succus cum cerufa, \& aceto, ualet ad illitus corum, quæ refrigerationem defidcrant.

Seridis, fiue Intybi confideracio.

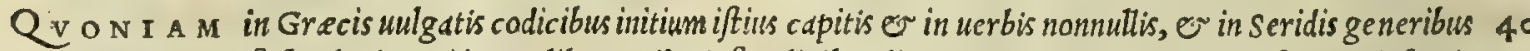
deprauatum, or confinfum legitur; ideo ex libro Oribasij fimplicibus dicato, atque etiam ex antiquißimis Diofcori=

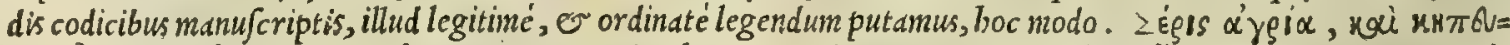

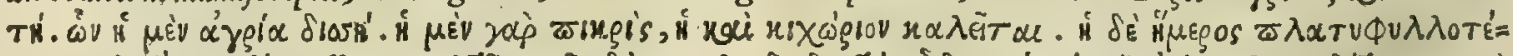

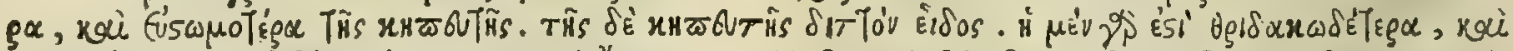

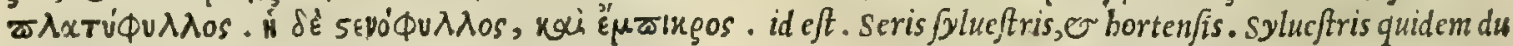
plex : altera picris, que or sichorion uocatur: altera fatiua latioribus folijs, o origratior, quam hortenfis. Hor tenfis uerò duplex genus : una folio latiore, lactuce fimilior : altera folio anguftiore, er guftu amara. Huic lectio= ni maximè adstipulatur Serapio . quippe qui ex Diofcoride tot habeat fylucftris seridispecies, quot domeftica. Id quod etiam ex ufu clarißime patet, cum tam fatiua, quàm fua ponte nafcens seris quotidie fit pre manibus, $\widetilde{c}$ fuma tur in cibis. Satiua quidem ubiq; feré in Italia in bortis colitur, folio erratice ampliore, lauiorc q; , ab hortenfî an= so guftifolia Seride non longé dißinilis : quin or ori erratica gratior. Ea ueró, qux ponte prouenit, paßin ferme uire fcit, folijs in ambitu longè magis laciniatis, anguftioribus, apperioribus, e amarioribus. Sunt quii pro certo babeãt, scariol am à domeftica latifolia seride nibil differre, quòd ita effe comprobet serapionis fcriptura. Alij scariolam uocant alterä domeftice ppeciem, que anguftiore eft folio, et guftu amarior. Scd animaduertendü cft, scariolam in se rapione, Serapionis non effe, $\int$ ed interpretis, cui nulld, mea quidem fententia, in hoc fuerit adbibenda fides. Quippe cum fciucrit is Scariolam, corrupta à barbaris uoce, nil aliud fignificare, quàm Seriolam, Scring; no aliud effe Gre cis, quàm Latinis Intybum, buius genuslatifolium (perperam tamen) Scarioldm appellauit. Cua in re corü equidem fententiam magis laudauerim, qui anguftifoliam Scrim, quod latifolia fit minor, Scariolam, feu potius Seriolam, ac fi paruä Serim dixeris, uocăt:tametfin in jylucftrium quoq; genere, ed etiam seriola dicippoßsit,qux paßim in hor tis coli= tur, quód domeftica Seriole nö longé fit abfimilis. Omnes itaq; in It alia uulgaris funt notitia, quòd noftratibus menfis frequentißime in acetarijs apponantur. Quamobrem olitores has byeme terra, $\odot$ fabulo in bortis obruunt, quoniams 


\section{InLib. lecundum Diofcoridis. $\quad 289$}

DENS LEONIS.

$\mathbf{c}$

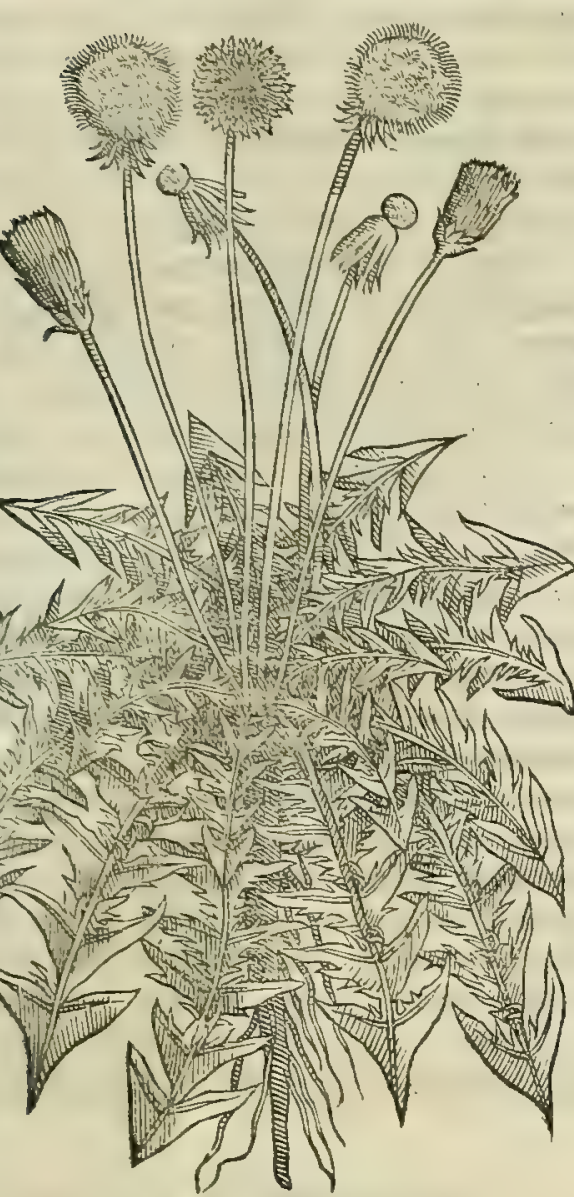

CYANVS MAIOR. boc artificio mirum in modum albefcunt, or tenterime eud= dunt, o in totan a feruantur byemcm, artem banc à natura docti, quodd uiderint fepius in campeftribus Cichorium aqua= rum inundationibus terra, uel arena obrutum, o tenerrimü; $\mathcal{O}$ candidißimum reddi, exuta omni ex parte andritudine.

Vcrim quanuis afferat Diofcorides fylucftrcn Intybü, quents admodum o fatiuun duorum tantum effe generum; Chondrit= lam tamen, cuius biftoriam ip fe fub duplici pecie fequenti cas pite defcribit, inter Cichorijgenerd effe reponendan, nemo cft qui ambigat. Quemadmodun ver tertiam illaniquse Theoplora fto lib. v I I. cap. x I. de plantarum biftoria A placa nocatur. Hec enim illi inguftabilis; et amara eft: frefinanter bec floret; fed celeriter flos fene fcit, atq; in pappos euane fcit. Tum álius iterum prouenit, at q; iterum alius, id q́; tota byeme, neré,; toto $u q_{;}$aftatem factitatur. Flos melini peciem gerit. bac ille. Huic per omnia in uniuer fum repondet, que nomullis D E.N S LEONIS, alijs Dens caninus, quibufdan Caput monacbi,ali quibus Roftrum porcinum, plerifq; uerò Ambubeia uocatur. Tametfi Plinio Cichorium ip $\int u m$ proprié Ambugia;uel Ambu= beia dicatur. Sed profectó maxima eft feplafiariorum multo= rum neligentia mum, praftantißimuin'; babeant Intybum, or in campeftri= bus Cichorium ubiq; fiequentißimum, barum plantarum loca modó bieracium, modó fylueftrem lactuc am fuo lacte refertam Jubijciunt, atq; exijs aquam, quam nomende Endiuia mentiri faciunt, fuis plumbeis eliciunt organis. Quod maximé dete= ftandum eft: nam etfi.hieracio, fylueftriq́; lafluce uis frigida infit: tamen praterquàm quód nullam cum iocinore babeant conuenientiam, lac, quo eo potißimim tempore turgent, qui= bufdam fuis partibus calorificum adco eft, ut linguam exurat,

CYANVS MINOR.

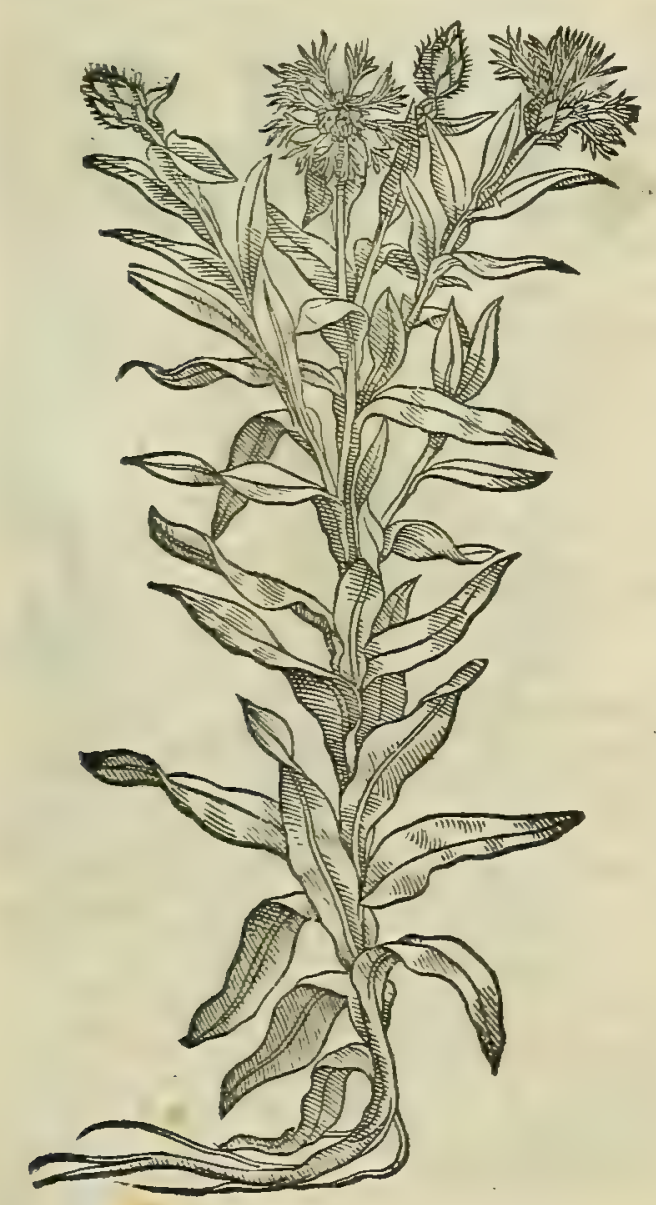

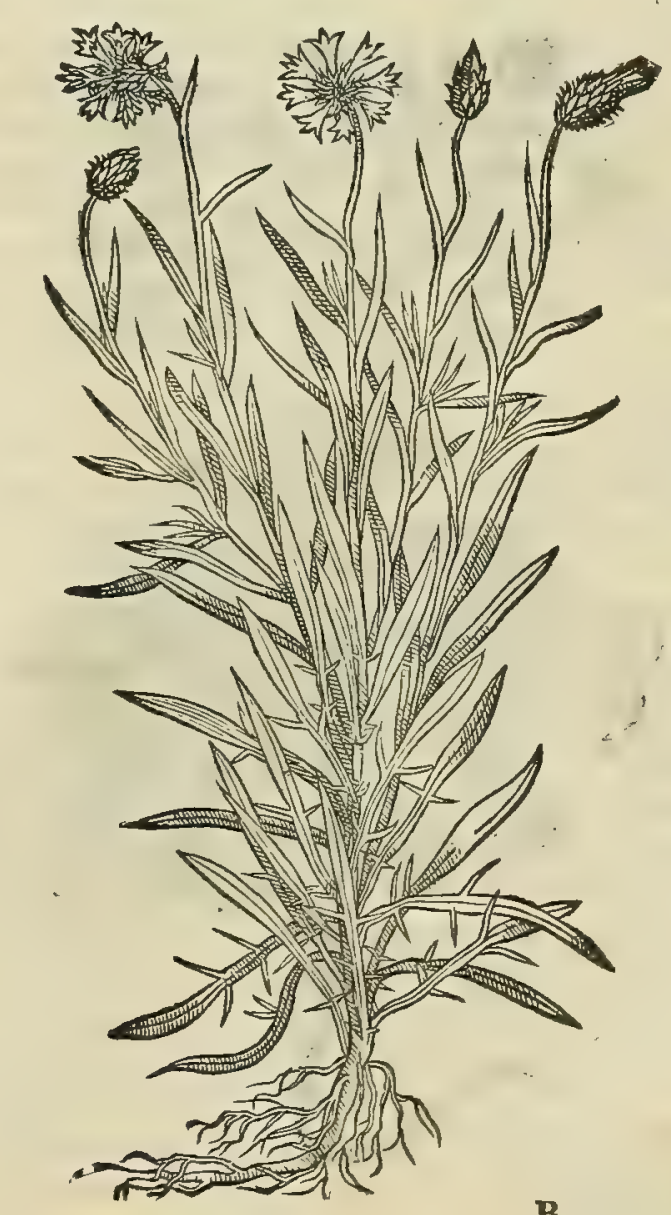

B negligentis. 


\section{0

(co fomnificum, ut non defint, tefte infra Diofcoride, qui illud meconio pent

Sunt preterea qui Intybaceo generiberbam adfcribant; que áflore cyaneo C Y A N V S Plinio dicitur, ali= quibus ueró uulgó Battifeculd, uel Battifuocere, nobis autem fior Campe $\int e$, quód in campis inter fegetes, maio, or iunio men/ibus numerofus proueniat. Expetitur hic maximé rufticanis puellis, fuis contexendis coronis, quibus per aftatem caput o tempora cingunt. Sed quibus notis, quibúsue rationibus inter Intybacea annumerari poßit, quid di= cam, non babco. Huiufce uires nullus antiquorum, quod fciuerim, fcriptis mandauit. quanquam Placentinus, quòd affirmauerint aliqui Cyanum peftilentibus morbis propria dote aduer fari, fuo de Cichorea ferapio, quod ad pefti= Intybi,\& Ci- lentes fébres maximé commendauit, Cyanum etiam inferuit. Intybi, e Cichorij uires recenfuit Galenus libro chorii uires VIII. fimplicium medicamentorum, fic inquiens. Intybus olus eft fubamarum, o magis quod agrefte eft, quod ob ex Galeno. id ipfum picrida, hoc eft amaram, quidam nuncupant, quidam ueró Cichorium appellant. Eft autem ed ficce, frie gideq́; temperature, utrunque fecundo exceffu. Porró domeftica mag is etian quàm agreftis refrigerat. Sed $\sigma$ bumiditatis multe admiftio ficcitatem extinguit : uerùm utraque adftringentis qualitatis eft particeps, uelut $\mathcal{F}^{\circ}$ chŏ= drilla: nam er ipfa eft feridis, Jeu intybifpecies. Et libro v I I I. de compofitione medicamentorun fecundum lo cos: Cichorium, inquit, o seris cibarij generis exiftunt: apud nos nanque rurales ambo bac edunt or cruda, o cocta. Facultas horum olerum fubfrigida eft, of fubamara, ac moderate adftringens: 0 propter has qualitates, optima pharmaca calidis intemperaturis ipfius bepatis exiftunt. vltra boc enim, quód moderate re frigerant, amplius o robur uifceri addunt per adftrittorian facultatem : infuperq; commiffur as ofculorum uenarum in fima uifceris parte ad eas, que in gibba funt, extergent. Neque ueró frigidas intemperies magnopere ledunt, quemadmodü que frigidam bumiditatem abfque adftrizitione, aut amaritudine poßident, facere folent. Iundre etiam uifcus talitim ole= rum fubftantia poteft, etiam fi citra feroforum, aut aliorum bumorum uitiationem intemperies fiat per fe, er cum to bumiditatis cuiufcunque complexu: ex mifurd enim mellis bumiditatem per urinam educunt. Quapropter etiam fit ficeatu tufa, quis potioni infpergat, itidcm iurant. Quin $\mathrm{V}$ decoctorum decoctum potatum multum commodi affert. si ueró non calida aliqua intemperies infeftet, aut fi obturatio quadam fit circa uifcus, magnopere auxiliantur ex uino albo tenui potata cum bis, qua urinam ciunt. Vtilis autem non folum fuccus ipforum eft tum recens, tum exic= catus; $\int e d$ er ipfa olera exiccata, tufaí;, ac trita potui inper $a_{,}$er corum decoctum in potu acceptum, auxiliantur.

Planta, que oégls Grecis, Intybus fatiuus Latinis dicitur: Mauritanis, Dumbebe, Hundebe, feu Endeba:Ita=

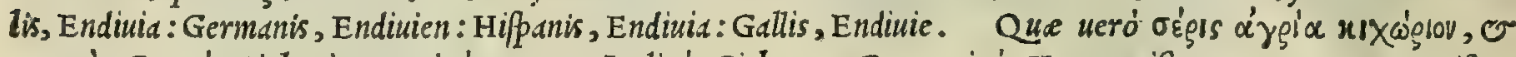

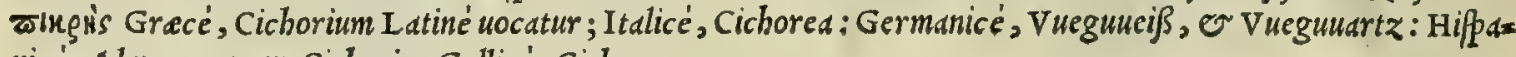
nicé, Almerones, $\sim$ Cichoria: Gallicé, Cichoree.
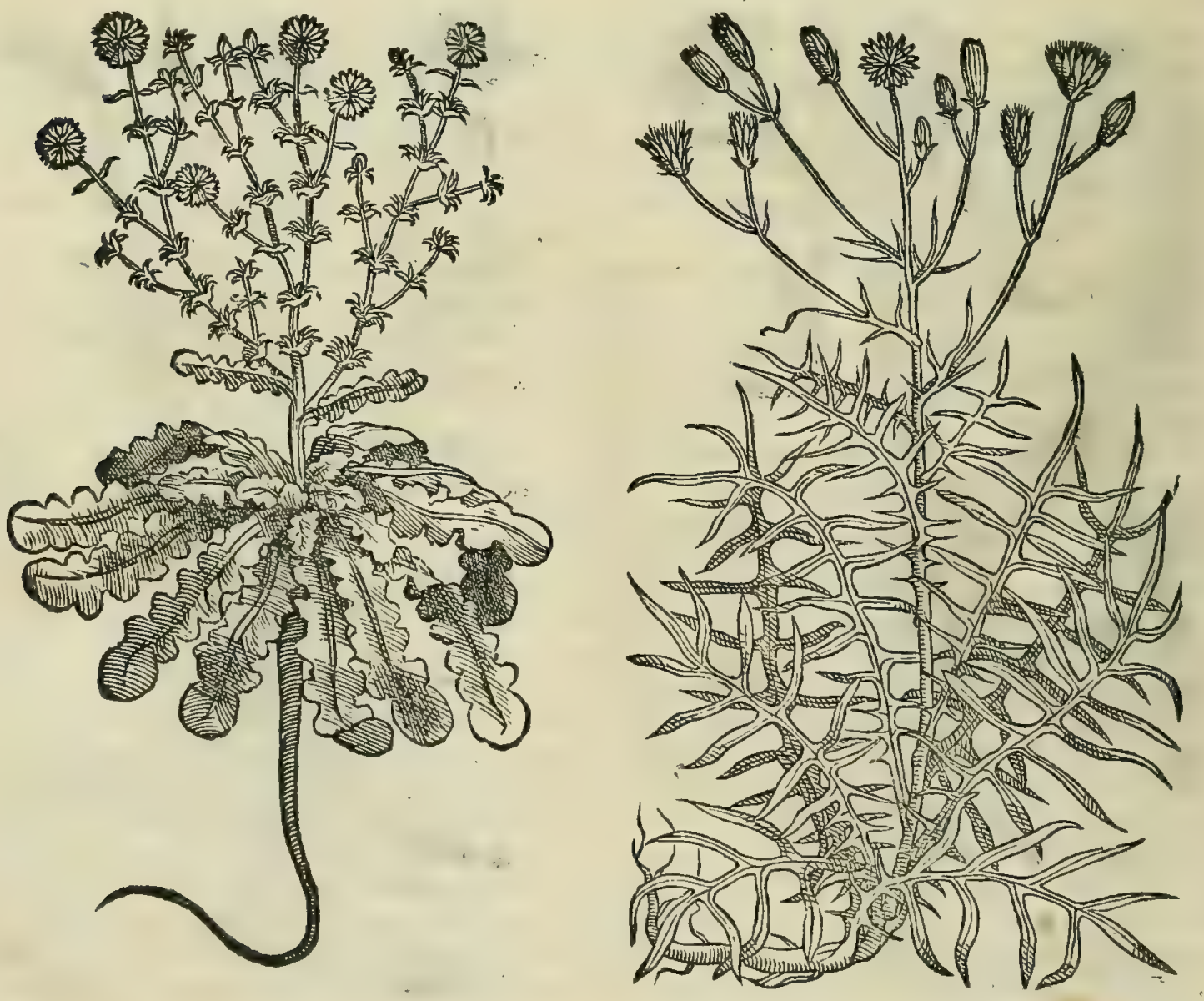


\section{InLib. lecundum Diofcoridis.}

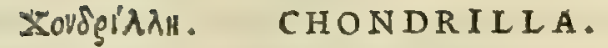

CAP. CXXVI.

CHON D R I L L A, quam aliqui cichorion, alij ferin appellant, caulem, flores, \& folia ha- $^{-}$ bet cichorio fimilia . qua ex caufa nonnulli fylueftris inty bi fpeciem effe pronunciarunt, verùm tenuior tota eft. In euius ramulis, gummi maftiches fimillimum, magnitudine faba inueniri folet: quod cum myrrha tritum, \& linteo appofitum, inftar oliux, focm inarum menfes trahit. Tufa cum radicibus herba, adiecto melle, diuiditur in paftillos : qui nitro admifti uitiligines emaculant. Gummi inordinatos pilos replicat. Quod item tenera radix efficit, fi intincta fucco acus, pilis admoueato tur: contra viperas in uno pota proficit. Succus decoctx, in uino, aut per fefe potus, aluum fiftit.

Aliud habetur chondrillæ genus, folium ferens oblongum, circumrofum, humi fparfum : caulis, $\&$ folia concoquendi uim habent. Succus incommodos palpebrarum pilos reflectit . Nafcitur in lætis, \& cultis .

N I M I R v M fylueftris cichorijßpecies Chondrilld eft: gracilioribus tamen folijs, caule, floribus, ac femine. Frequentißima hec non modó in Hetrurid; fed etiam in uniuer $\int \mathrm{d}$ Italia in cultis locis, fcrobium aggeribus, er fecus uiss uirefcere, „c fuo tempore flore fcere confpicttur : nec minus etiam, quàm cichorium, in acetarijs recipitur, quă= uis amarior fit. vifitur e alterum genus buic non longé dißunile, folijs tamen non ita in ambitum laciniatis, nec adcó in mucronem definentibus. Hec à lact is ubertate, quo in omni parte, prefertimq́; radice redundat, à noftris unlgó 20 Lattaiuola wocatur. Rura eam fuis acetarijs pro cichorio indifferenter admifcent. Chondrille uires fcripfit Gale= nus.lib. V I I I. fimplicium medicamentorum, ubi finul de intybo, o cichorio differuit, nibilq'; ei peculiare reddidit, preterquàm quod intybi fit pecies. Veruntamen libro I I. de facultatibus alimentorum non fané intybo, nec cicho=

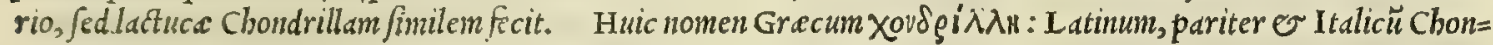
drilla: Arabicum, Candarel, Cadaron, feu Amiron: Hifpanicum, Leitugas, o Lechugas dentre los planos: Gal = Ticum, Lettron.

Chondrille utriufy; confideratio.

Nomina.

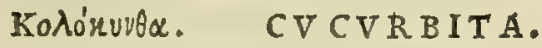

CAP. CXXVII.
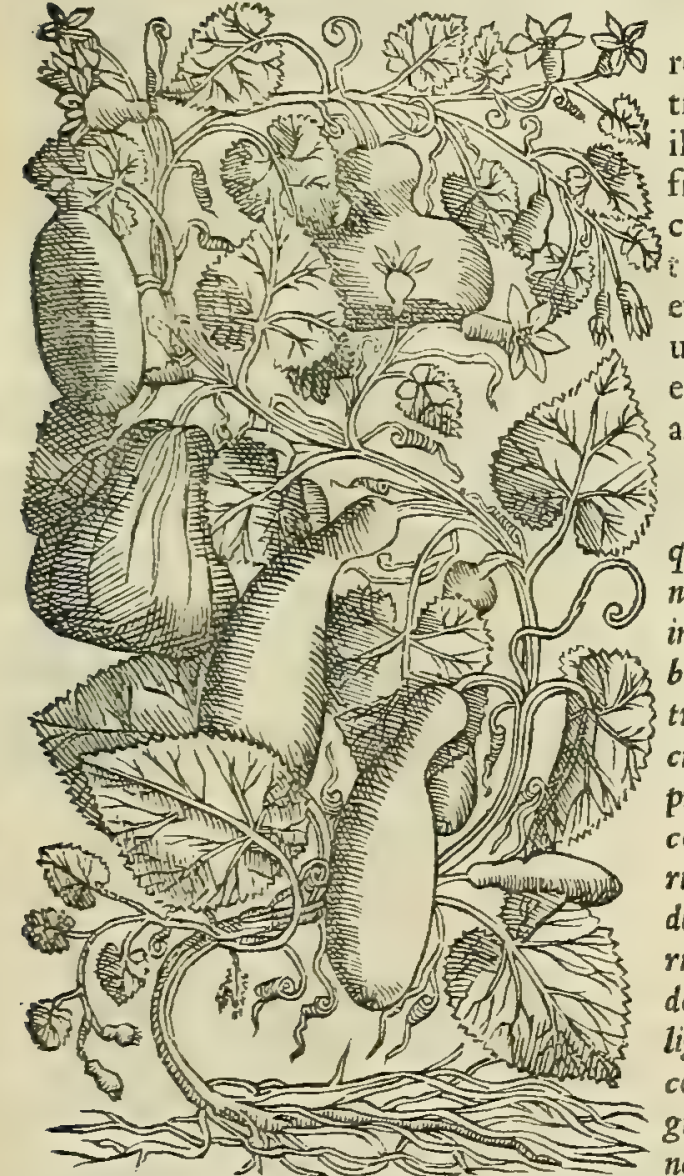

C v C V R B I T A efui apta. Cruda, trita illitu tumores, \& abfceffus mitigat. Ramenta eius infantibus contra capitis ardorem, quam fyriafin vocant, in fincipite illinuntur : oculorum inflammationes, podagrasque refrigerant. Succus è ramentis tufis per fe, aut cum rofaceo infufus aurium doloribus auxiliatur : aduftiones cu$t$ is in ardenti febre illitu adiuuat. Totius feruefactx, \& expreff $x$ fuccus, cum melle exiguo, \& nitro potus, aluum leniter refoluit. Vinum in cucurbitam recentem excauatam, infufum, fi miftum fub diuo teneatur, potum aluum læuigabit .

C V C V R B I T A fatiud, que per eftatem in cibum fres quentiSime uario fumitur apparatu, in triplici cenfetur genere, nempe longa, rotunda, o fesilis. Sed quanquam Cucurbite inter fe forma dißimiles babeantur; non tamen propterea uiri= bus, o natura fibi inuicem repuginant. Siquidem (ut Columella tradit, er Plinius refert libro x I X.cap. v.) forma uaria in cu= curbitis arte, or mangonio fierifacile poteft. Nam emina, que proxima collo fuerint, proceras pariunt: item ab imis, fed non comparandas fupradictis: qux in medio, rotundas: qux in late=

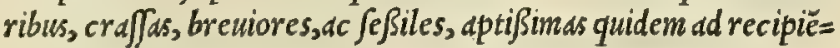
dum tum uinum, tum oleum, tum alios quioslibet liquores, urceo= rum, et cadorum uice. Si uero cordifit, ut fiant corpore uaftiores, de media cucurbite parte femen inuerfo feratur cacumine. Sed di ligenter cuftodiendum est, ne eó mulieres accedant : nanq; earum contactu facilé elangue fcunt incrementa uirentium . tanto $q_{;} m a=$ gis, fie eis fluxerint menfes: tunc enim folo oculorum intuitu te= nellos enecant foetus. Qua autem ad Semina Seruantur, è pri= mo feligantur prouentu, pendeant'; in fua uite ad byemem uf $q_{;}:$deinde fublate infolentur, aut pondntur in fumo,do= nec penitus ficce f cant: aliter facile earum femina, afcita putredine, depereunt. Amant Cucurbita mirum in modumb aquas: nam fi propé in patens uafculum aqua fubijciatur, à quinq, uel fex digitorum interuallo, ante pofterum diem B 2 adrepentes
Cucurbitx confíderatio. 
ZVCCHE INDIANE.

Cucurbitæ facultates ex Galeno.

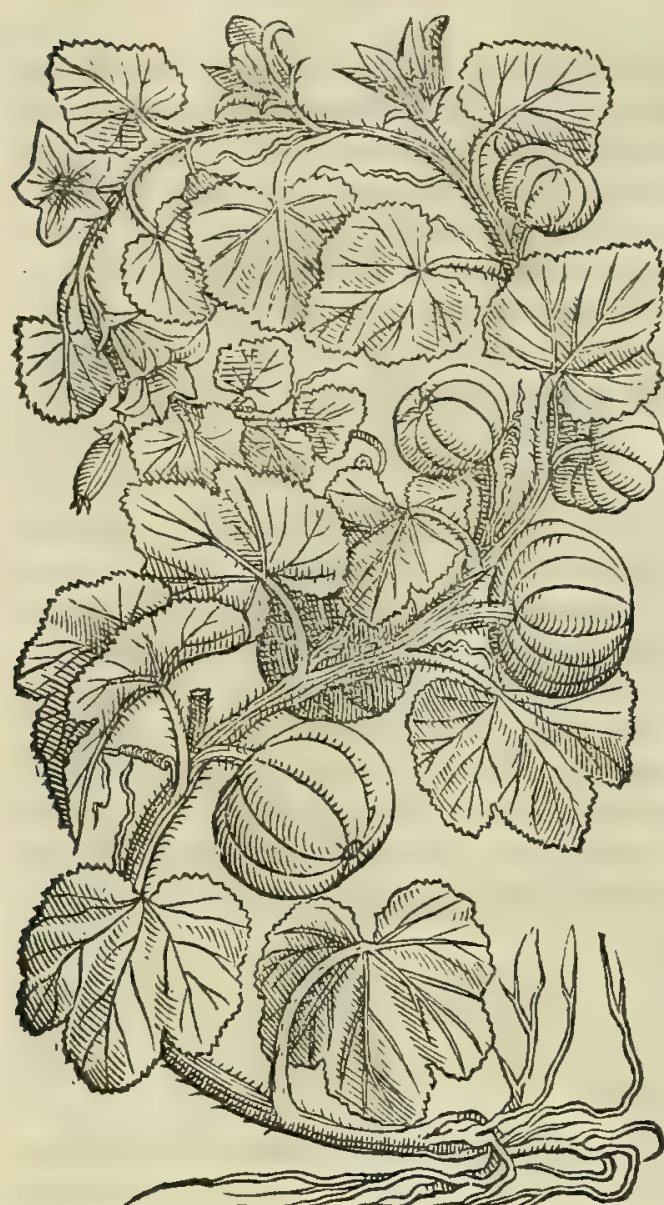

adrepentes cognofcentur defcendiffe. Sine femine nafcentur, $f \boldsymbol{i}$ per triduum antea, pargenda femina oleo fe $\int a m i n o$ macerentur.

Sunt ct alia Cucurbitarum uaria generd Italix peregrind, que diu per byemem recentes afferiadi polfunt. Ferunt bas ab occi= dentalibus Indys in Italiam uenife : unde Indic.e à pluribus uoci= tantur. Sapor ijs fubdulcis, non ut noftratibus ufqueadeó in/ipi= dus: uerim guftui infuasues funt. nifi precipuis condimentis $\int d=$ turentur. Cucurbite facultates fcriptas religuit Galenus libro vI11. Fimplicium medicamentortm bis uerbis. Cuiurbita bumi= de, frigidéf; temperature eft, utr.que qualitate fecundi ordi= nis. Quocirca ramentorum eius fuccus ad aurium dolores cum phlegmone iunctos, cunn rofaceo utentibus utilis eft. Sic tota quo= que illita calidas phlegmonas mediocriter refrigerat. Comefta au= tem bumida eft, er fitim propellens. Et libro I I. de alimentor facultatibus: Cucurbita, inquit, cruda cibo infuaris eft, Romacho pernicio $\sqrt{a}$, or concoctu plane inexpugnabilis : adeó ut $\int \hat{i} q u i s$ al $=$ terius cibi inopia ingerere eam compellatur, cen quidam idm aufus cft., pondus cum algore uentriculo incumbere fit fenfurus, ftomd = chumq;' euertet, $\sigma$ ad uomitum concitabit, quo folo ab urgenti= bus fymptomatibus'poterit uindicari. Hanc igitur, alia'; ex fu= gacibus complura, aut mox quim elixata cft, aut fritam in $\int a r=$ tagine, aut affam omnes bomines effe confueuerunt. Cucurbita ueró, de qua dicere capimus, elixa nullam euidentem $\int_{a p o r}$ is qua= litatem babet: nifi quis eum quoque faporem nominare uelit, qui neq; acris, neque fallus eft, nec acerbus, nec amarus, nec id ge= nus quippiam inanifefté reprefentat, ueluti nec ip $\int a$ aqua. At bu= iufmodi cuncta communi nomine omnes $\alpha^{\prime \prime} \pi 01 \alpha$, id e $f \hat{t}$, qualitatis expertia uocitare folent ( $\mathrm{L}$ atini fatud, aut infipida dicunt) quo quo modo nos quoque clarioris doctrine gratia appellabinus. $T d=$ lis ergo cùm fit cucurbita non immeritó uarios apparandi modos 30 admittit, utpote que in medio omnis exceffus confliturd eft, ob idq; ad quémuis exceffum ex aquo duci poteft. Proinde cucurbita, quantum in $\int e$ eft, humidum, frigidumí; cor = pori alimentum prabet, omnium bumidorum ciborum rationem; qui fcilicet citra adftriftionem tales funt. Nec fané infeliciter concoquitur, modó non anteuertat corruptio. Nam ea illifolet nonnunquam accidere, cùm aut uitiosé fuerit preparata, aut prauos bumore in uentriculo aceruatos offenderit. Eft aliquando cb nimiam in eo moram: quod alijs quoque omnibus fugacibus, qua bumido funt temperamento, evenire folet. Nam in uentri= culo corrumpuntur $\mathcal{O}$ ip $f i$, ni celeri defcenfu id mali effugiant. Quemadmodum ergo cucurbita pura, o ut in fe ipfa eft, fuccum in totum corpus alendi gratia digeftum, expertern qualitatis guftabilis obtinet: ita cum alicui uebementem babenti facultatem fuerit iuncta, facile illi adfinilatur; ut fi cum finapi fumatur, fuccus ex utro= que in nembra diffufus acris efficietur cum manifefta caliditate. Eadem ratione, $\sqrt{i}$ cum falfo quopiam efite= tur, ceu nonnulli in patinis cum falfamento inftruunt, fallum in corpore bumorem genterabit. Eft porró fic ap= parata cibus longé fuauißimus, fi falfamentum ex ponticis illis fucrit, que $\mu \dot{\nu} \lambda \lambda \alpha$ appellantur. Qưdd fi cum malis cotoneis elixa, decenterq́; condita fuerit, fuccum aufterum in diftributione babebit prapollentem. Affa autem, uel in Sartagine frithd, ut proprix permultum bumiditatis deponit; ita reliqua eius pars nullam fibi ualentem uim adfcifcit, uti nec cum in iure fimplicl paratur. Caterüm ob aqueam qualitatem fibi innatam non immeritó $0=$ rigano iungi gaudet. Quxecunque enim talia funt, acribus, aut acidis, aufterisue, aut falfis permifceri fapori=

Nomina. bus poftulant, fi quils o cum uoluptate ea fumere, o naufeam cupiat cuitare. Cucurbita Latinis dicta, Gra $=$

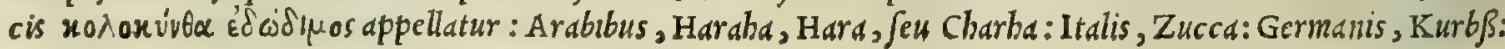
Hifpanis, Calabaca: Gallis, Vne courge.

\section{Eikos ïuegos. CVCVMER SATIVVS.}

CAP. CXXVIII.

S A T I v v S Cucumis aluo, \& ftomacho perquàm vtilis habetur : refrigerat, qui corruptionem non fentit: vcficæ prodeft: olfactu reuocat, quos animus liquerit. Semen modicè vrinam mout: cum lacte, aut paffo, veficæ exulcerationibus fubuenit. Illita cum vino folia, morfus canum fanant: \& epinyctidas, cum melle. Peponis caro in cibis, vrinam cit: inflammationes oculorum illita fedat. Ramenta eius contra aduftionem infantium, quam fyriafin uocant, fincipiti imponuntur: fronti admota oculorum fluxiones auertunt. Succus cum femine, adiefta farina, ficcatus in fole cogitur in fmegmata, qux faciem repurgant, \& nitorem afferunt. Radix ficca, \& ex hydromelite pota, drachmæ pondere, vomitıonem mouet. Si quifquam moderatè fccundum cœnam vomere 
quàm maximi, or citrini, aut nigri. Placent copio/îßimi Aphrice, grandißimi Mofie. viunnt haufi in ftomacho in pofterum dicm. Quod proprium eft citruli nobis uocati, non autem angurie uulgó Infubribus appellate. An= gurix cnim in Italia in magnam extubcrant molem, ov cim aquex fint fubfantix, ac pradulces, que maturita= tem fenfere, ing efte facilè à uentriculo labuntur. Quod noftratibus citrulis, e Infubrium cucuneribus non eue= nit. Nan cim glutino fo, frigidóg; fucco referti fint, ob id'q; concoctu perquàm contumaces habeantur, non nifi poft longum tempus à uentriculo defccndunt. Adbec (utctato loco fubdit Plinius) Cucumeres, in fifula flore demiffo, mira longitudine crefcunt. A tquue ijdem in tantum odêre oleum, ut fiè uite pendcntibus uxs olei fubij= ciatur, adcó refugiunt, ut in hamun curuentur quod angurijs, que phericam forman referunt, minime eue= nire poffe comperio. Videmus pretered Citrulos noftrates adbuc florentes in fiftulas coniectos mira longitu= dine creuiffe. E' quorum femine qui pofmodum orti funt, eandem retinuerunt formain, adeo ut in uite pendentes anguium modo contorti uiderentur. Scruantur Cucumeres ( $u t$ Plinius auctor eft) ufque ad alios pené prouentus: o id quidem non folim muria fit, fed $\sim$ fcrobe opaco in loco arena fubftrato, foeno $;$; ficco opertos, ac deinde terra obrutos: ita enim uirides feruaritradunt. Quid autem ueteribus fuerint, quidue nobis fint Pepones, dc Peponum, \& Melopepones, non equidem facilè aufin decernere: etfinon defint, qui dicant Melopepones Galeno libro $I x$. melopeponü de alinentorum facultatibus, communes noftros Melones effe: Pepones ueró, quos in eo genere Veneti corrupt confideratio. inde uoce uulgó pipone uocant. Verum enimuero cùm afferat Galenus, quód pars intina carni femen inclufum tangens, cum in Peponibus edendo non fit, in Melopeponibus paßim ab hominibus manditur, mihi animum adeo dubium reddit, ut aliquid in bac re certi ftatuere nequeam, neque inuenire poßim, quid Pepones, $\mathcal{O}$ Mclope= pones Galeno extiterint. Quippe quoniam utriufque generis, tam fcilicet Peponum, quàm Melopeponum carnea pars femen continens eftur, or non eftur, prout fiuctus $i j$, plus, minusue maturitatis fuerint adepti: nam utrif= 20 que, cim ultimam fenferint maturitatem, id fupreme carnis und̀ cum feminibus in medium fructus concidit . quod cusn euanidum, or infuaue reperiatur, nufquan comeditur. Quod tamen utrifque minus maturis, non euenit: eáq; propter extractis prius feminibus eftur tota eorun caro. Hac igitur tametfi me (ut dixi) dubium reddant; incli= nat tamen animus adcredendum, per Melopepones Galenum noftrates Melones intellexiffe, fi modó ipfe corum unquam babuit notitiam. Sed quid per Pepones intellexerit, nibil prorfus (ut ingenué fatear) quod proferam, ba= ctenus non babeo. Veruntamen cum illis mibi non facilé conuenit, qui Venetus Piponas dictas Galeno Pepones ef= fe exiftimant. Minus adluc illis affentior, qui Pepones Angurids cffe dicunt. Nanq; Serapio cum primum ex $G d=$ leni auctoritate de Peponibus, es Melopeponibus differmiffet, dein peculiare de Anguria caput fecit, quam Ara= bica lingua Dullaha nuncupauit. In cuius reddendis uiribus nullum affert Grecorum teftinonium, fed tantum fuxe gentis auttoritatibus innititur. Hinc facile adducor, ut credam angurids ueteribus Grecis penitus ignotas fuiffe.

Fuchfij error. Eds equidem nunquam uidiffe, uel non cognouilfe demonftrat Fuch/ius medicus clarißimus. quippe qui fuis de ftir= pium hiftoria commentarijs non fine mago errore putat cucumeres, quos citrulos Hetrufci nominant, angurids ef= $\int e$. Nam etfi Hetruria angurias nocitet cucumeres, non tanen contra cucumeres uulgares nocat angurias, ut per= Cucumeris perdm, meo quidem iudicio, Fuchfius or intellexiffe, er foriptis mandaffe uidetur. Cucumeris uiresmemorie uires ex Gal. prodidit Galenus libro v I I. fimplicium medicamentorum, his uerbis. Cucumis cfculentus maturus quidem te= nuioris eßentia eft, qui veró immaturus eft, craßioris. Sed or abftergendi, or incidendi facultate participant. quare o urinam mouent, o corpus plendidun reddunt: ac magis quoque fi quis semine arefacto, contufo ${ }^{\prime}$, at $=$ que cribrato, uice pulueris abfterforijutatur. Superat in eis bumida, frigidá; temperies, non tamen magnope $=$ re, $e d q u a f i$ in fecundo cenfetur ordine. Attamen fi quis aut femen, aut radicem arefaciat, baud etiam bumide fuerit natur e, fed iam deficcantis, id q; in prino quodammodo ordine, aut etian in fecundo incipiente. Est or in iftis maior abftergendi facultas, quam in fructus ipfius carne. Et libro I I. de alimentorum facultatibus idem de Cucumeribus ita fcribit. Vrinam quidem $\sim$ ipfi, quemadmodum pepones, cient, fed minus quàn illi, quód ip $\int 0=$ rum Jubftantia minus eft bumida: ideo q́; non facile, ut illi, in uentriculo corrumpuntur. Ergo quibus cucume= res bene concoquere datum eft, dum in boc fifi, intrepidé, affatinq; ijs fe explent, longi temporis tractu, geli= dum, er utcunque crafjum bumorem in uenis aceruari contingit, qui per ean, qua uene funguntur, concoctio= nem, haud facile in probum fanguinem poteft conuerti. Proinde omnibus praui fucci edulijs, quantumuis probé d nonnullis conficiantur, abfinere in totum confuluerim. Clan cnin fenfimq́; poft longum tempus praus in uenis fuccus ex ipfis (uggeritur, atque accumulatur: qui uel leuicula putredinis arrepta occafione, febres fauißimas, Peponum ui- E miré contumaces excitabit. Et pauló antea de Peponibus foribens: Vniuer $\int a$ (inquit) peponum natura fri ${ }^{\prime}$ ses ex Gal. gidior cum larga bumiditate exiftit: babent o quandam abfergendi uim: ideó́; urinam cient, or deorfunt ex= peditius, quàm cucurbita, or melopepones rapiuntur. Quód porró abftergeant, difcere licet fordidam cutem de= fricando. Quanobrem etiam maculas calore folis factas, or lentes faciem occupantes, atque in fuperficie alphos extergere poffunt. Sed femen, quod in corum ueluti carne continctur, ad boc efficacius, adeó ut renibus etiam calculo infeftatis fit accommodatum. Gignit pepo in corpore uitiofum humorem, potißimim quando non probe concoctum fuerit. Tum ueró morbum etiam, qui cbolera dicitur, inducere confueuit. Etenim priufquàm dd cor= ruptionem peruenit, uomitioni quoque idoneus eft: largiusq;; ingeftus, nif quis aliquid corum, qux probi funt fucs

Melopeponú ci, fupermandat, omnino uomitum concitabit. Et de Melopeponibus agens: Mclopepones (ait) minus hu= facultates ex midi quàm pepones funt, nec adeó praui fucci: minus itcm urinam prouocant, tardius $\dot{q}_{\text {; }}$ deorfum de fcendunt.

Galeno. Ad uomitum ueró excitandum non canden uim peponibus obtinent, ficut neccclcriter adco ut illi in uentriculo carrumpuntur, cum prauus bumor in co collectus fuerit, aut alia quapiam corruptionis cauja ip $\int u m$ prchende= rit. Ceterim tametfi in iuuando ftomacho autumnalibus fructibus longe funt inferiores, haudquaquam tamen ei, 


\section{In Lib.fecundum Diolcoridis.}

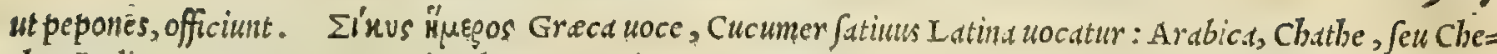
tha: Italica, Cocomero, o Cedruolo: Germanica, Cucumeru: Hipanica, Cogombro: Gallica, Cocombre. At

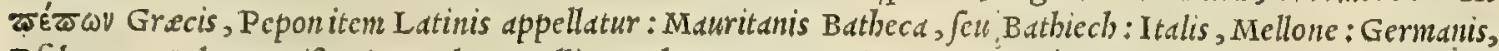
P feben, II Ildon: Hipanis, Melon: Gallis, Melons. Anguria ita o Latiné, e Italicé nominatur: Arabicé, Dullabd: Germanicé, Gurcben: Hifpanicé, Cogombro : Gallicé, Cogombre.

\section{IACTVCA CRISPA,}

10

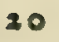

30

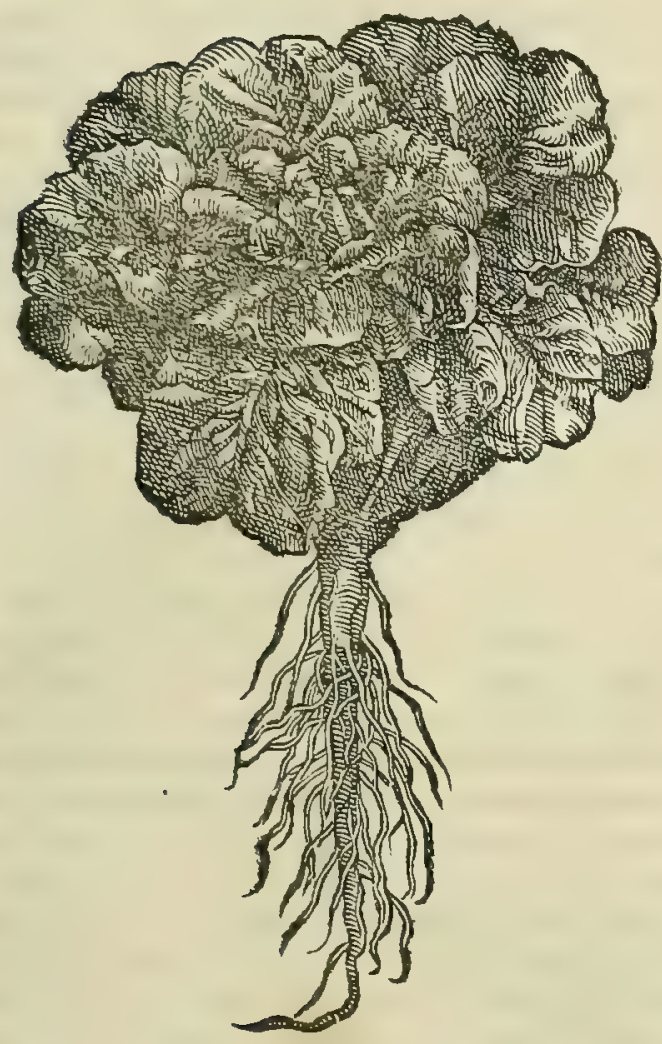

egída६. LACTVCA.
IACTVCA FLORIDA.

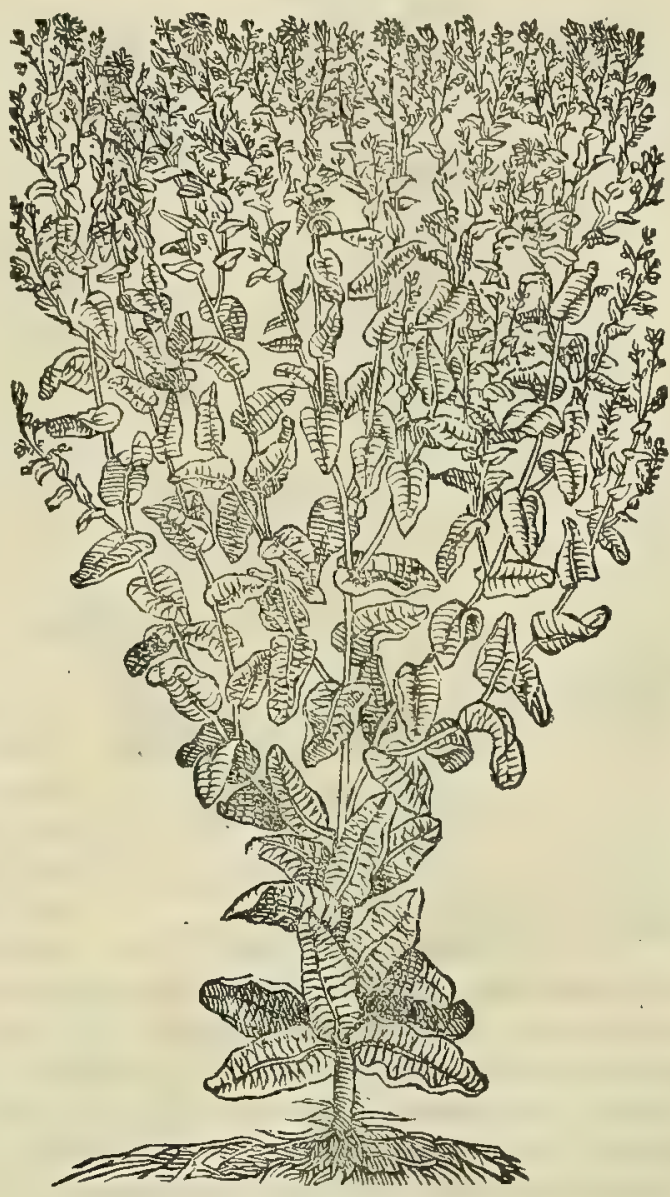

CAP. CXXIX.

40 L A C T V C AE fatiux, quibus natura refrigeratrix ineft, ftomacho gratæ habentur, fomnum cóciliant, aluum emolliunt, lac euocant : uerùm decoctx magis alunt. Stomachicis illotas effe prodeft. Epotum femen, afsiduas libidinum imaginationes in fomno compefcit, \& ueneri refragatur. Ipf $x$ verò frequentiores in cibo, claritati oculorum officiunt : inflammationibus, \& ignibus facris opitulantur. Muria condiuntur. Cùm in caulem exierunt, vim quandam nancifcuntur fucco, aut lacti fyl ueftris lactucæ fimilem.

CAP. $\mathrm{CXXX}$.

S Y L V E S T R I S Lactuca fatiuæ fimilis eft, fed longior caulis, \& candidiora folia, graciliora, \& so afperiora. Amaro guftu eft, \& viribus aliquantum papaueri fimilis : vnde lacteum eius fuccum aliqui meconio permifcuerunt. Aquam per aluum elicit, potus in aceto mulfo fuccus ad duos obolos:ar gema, caliginemq́ue repurgat: contra aduftiones efficaciter illinitur, cum lacte mulierum. In fumma fomnum allicit, doloris leuamentum præftat, menfes trahit : contra fcorpionum, \& phalangiorum iEtus bibitur. Semen non aliter quàm fatiux libidinum imaginationes in fomno amolitur, ac venerem arcet. Succus ad eadem valet, fed viribus infirmior . Reponitur in fictili nouo lac eius, antea, vt in alijs liquaminibus moris eft, infolatum.

L A C T V C A Satiua herbarum feré omnium unlgó notißima eft. Cuius etfi plurd, ac diuerfa in Italia reperian tur genera, ut in hortis, er olitorïs foris aftate tota con/pici poteft; non ob id tamen exiftimandum eft, quód ea ui= Lactucæ confideratio. ribus, e facultatibus inter fe differant: quanquam non negauerim ego, alteram alteri in cibis praftare . Eam iiqui= dem,qua conglobatis in orbem folijs cripa, , tenerd í, inuenitur, quis neget maiorem cum palato inire gratiam, quàm 


\section{And. Matthioli Comm.}

Latucafylue ftris.

Latuce vires ex Gal.

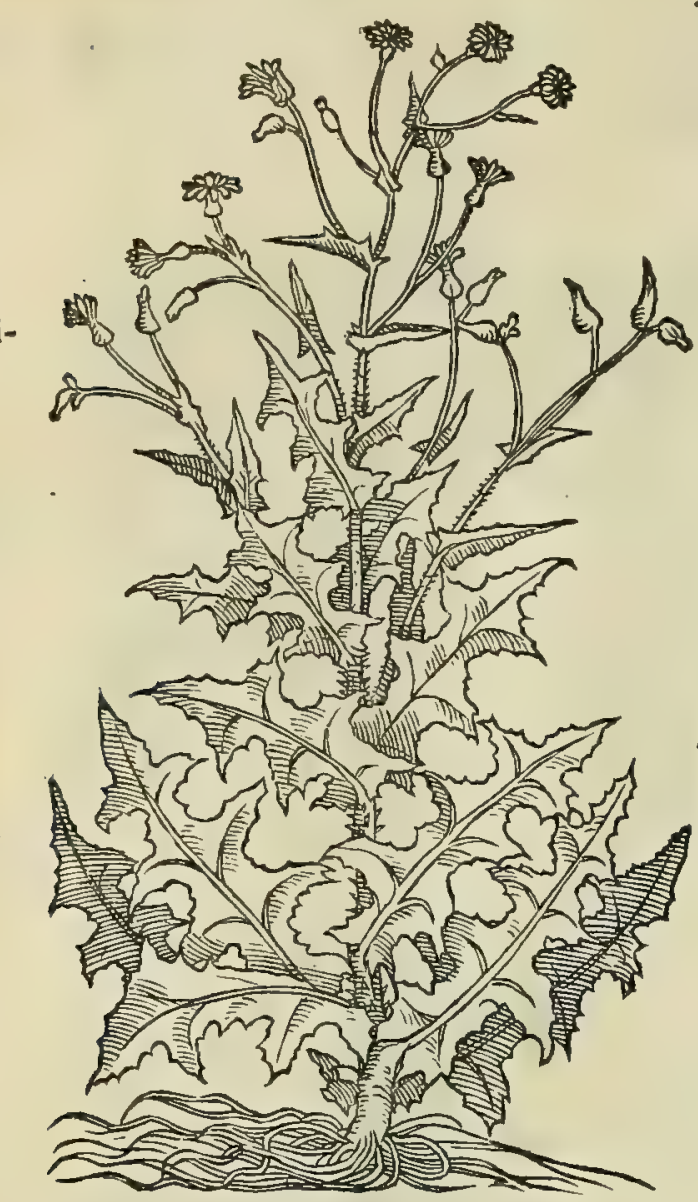

que dura, patula, ac lactefcens babetur? Sylueftris in campe fribus najcens, facile dignof citur, quód caule, floribus, femine, e folio fatiuam iam flores, e femina proferentem amuletur: uerum gufu amara eft, o lacte copio/tore referta. Meminit buius Theopbraftus libro v I I. cap.v I. de plantarum biftoria, fic inquiens. Sylueftris lactuca folio breuior, quàn fatiua eft, idq; confummatun dculeatur, er caule fimili modo brewiore perfici= tur: fuccum acrem, ac medicatum habet. Nafcitur in aruis. Lac eius extrabunt per meffem tritici, or purgare aquam intercutem dicunt, 0 caliginem arcere ab oculis, $\mathcal{O}$ argeman auferre, cum 20 lacte mulieris. Satiua (ut memorie fcriptum reliquit Galenus lib. v I. fimpliciun medicamentorum ) hunidum eft, frigidum' olus; non tamen extremé (fiquidem edendo non foret) uerium ma ximé fecundum aque, ut fic dicam, fontane frigiditatem: proin= de ad calidas phlegmonas accommodum eft, $\mathcal{O}$ ad parua, or leuia eryfipelata: non tamé maioribus fatisfacere idonea eft. Eft etiam edulium fitim arcens. At femen potu geniture profluuium cobit bet : quamobrem etiam ijs, qui libidinofis fomnijs uexantur, datur. sic er agreftis lactuce femen. Cuius quoq; colligitur fuccus, dr= gema, $\mathcal{O}$ caliginem expurgans: ad aduftionesetiam cum lacte mu 20. lierum inungitur. Et libro Ir.de alimentorum facultatibus: pleriq; medicorum (inquit) reliquis omnibus boc olus, ceu ficus autumnalibus fructibus, pratulerunt. Nam inter ip fa aliud melio= ris fucci non inuenias. Quod porró nonnulli uitio uerterunt, id in pracipuam ei laudem cedit: $\sigma$ fi ita fe re uera baberet, non mo dó nulli olerum; fed ne optimi quidem fucci, ac maximi nutrimcn= ti edulijs effet fecundun. nempe fanguinem aiunt lactucam genera re. Quidam non fimpliciter fanguinem dicunt, fed multum dádunt, multum fanguinem lattucam generare affirmantes. Verum ij ta= met $f$ p prudentius obijciant, longius tamen alijs à uero abfunt.quan 30 quam hoc ipfin, puta multum Sanguinem procredre, non eft quod meritó quis damnet. Conftat enim huiufmodi edulium laudatißimi fucci cenferdum effe, quód plurimum quidem fan= guinis, aliorum ueró fuccorum nullum producere fit comparatum. si ueró, quia permultum é lactuca fanguinis conge ratur, idcirco damnandam eam cenfeant, facillimé buic malo occurri poteft : quippe cùm uefcentibus, or liberalius exerceri, $\sigma^{-}$ea parcius uti integrum eft. Hec ergo aduerfus eos, qui olus boc non recté uituperant, dixiffe fufficiat. 1 llud porró nouife conuenit, omnibus alijs oleribus paucißimum fanguinem, or uitiofum generantibus, ex fold lactu ca non multum quidem, nèc uitio $u m$, haud tamen omni ex parte laudabilem gigni. Vt plurimuin quidem cruda ip $\int a$ ue fcuntur. Aeftate autem, cim in femen iam proruptura eft, in aqua dulci pracoquentes, cum oleo, garo, er ace to affu munt, aut cum aliquo ex condimentis, obfonijsue, prefertim ijs, que cajeo conftant. Pleriq; etiam antequam excau= lef $c$ at, in aqua elixa utuntur : uti ego iam facio, ex quo dentes mibi deteriores effe coperunt. Nam amicus quidam $4^{\circ}$ meus, cum olere boc à longo tempore me ut familiari cibo $u \int u m$ fulfe fciret, uideret $q_{\text {; }}$ poft mandi à me citra magnam moleftiam non poffe, coctura rationem indicauit. Etenim in iuuentute, quoniam aßiduo os uentriculi bile efferue fce bat, eftus moderandigratia lactucis utebar. Cim autem ad prouectam atatem perueniffem, olus boc contra quàm in iuuentute, fommumiam ftudio, er indufria accerfenti mihi, auxilio fuit. Quippe qui etiamnum iuuenis lucubrandi gratia uigilijs dedita opera me affuefeceram, declinante iam etate, ip $\sqrt{a}$ ex $\int e$ infomni, grauius hoc incommodo mo= leftabar. Aduerfus quod unicum mibi prafentißimum remedium laftuca uepere commanducata femper fuit. La=

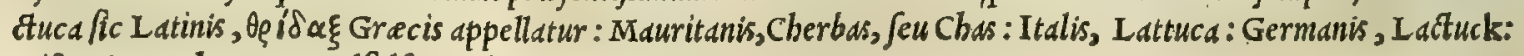
Hipanis, Lechuga, aut Alfalfa: Gallis, Laitue.

\section{rigyidiov. GINGIDIVM.}

C A P. CXXXI.

G I N G I D I V M, aliqui lepidion, in Syria, \& Cilicia plurimum nafcitur. Herbula eft fylueftri paftinacæ fimilis, tenuior, \& amarior: radice parua, candicante, fubamara. Olus hoc crudum, coctum, conditúmve eftur, magna ftomachi vtilitate: vrinam cit. Decoctum ex vino potum veficx prodeft.

Gingidij con

H v I v s C E fententix effe comperiuntur Ruellius, $\sigma$ Fuchfius uiri clarißimi (licet ille non plané adfipule= tur) necnon etiam recentiorum alij, qui ftirpium cognitionem profitentur, in boc confentiunt, quod Gingidiun ea fit herba, quam nos uulgó Cerofolio uocamus, illi ueró cherefolium. Veruntamen cum bac radice nitatur, que nibil ama ra fentitur, fed potius acris, $\sigma$ odorata, quemadmodum er folia; idcirco eorum opinionem non equidem ( $u$ t dicam quod fentio ) probandam putauerim. Quinimó crediderim uel Gingidium bagtenus in Italia non effe repertum, uel 


\section{In Lib. fecundum Diofcoridis.}

\section{CHAEROFOLIVM.}

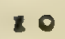

20
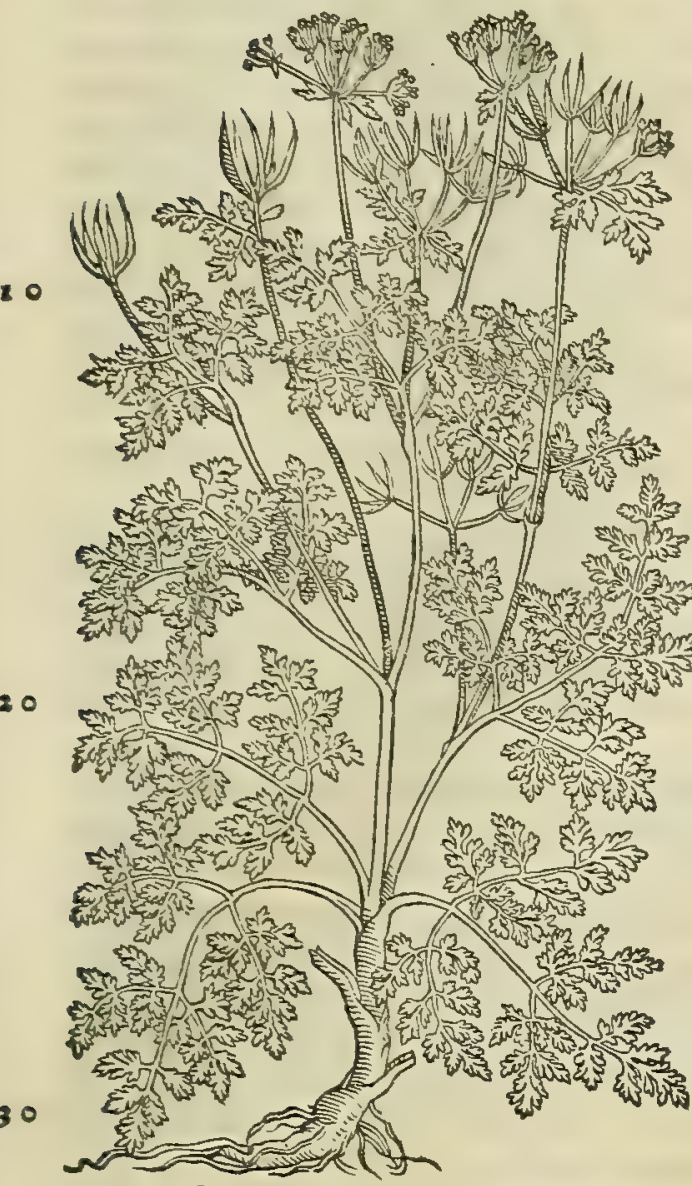

inibifacilé non oriri : prefertim cim Diofcorides, or Plinius affe rere sideantur, peculiare olus effe Gingidium tam Syria', qudm Gingidii uiCilici.e bortis. Meminit Gingidif Gale nus libro v r. fimplicium res ex Gal. medicamentorum bis uerbis. Gingidium ficut guftu amaritudinem, $o$ adf triftionem prefert, fic temperamento quog; $\iota$ fo calidita $=$ tein, $\odot$ frigiditatem. Seckidun ueró utraing; qualitutem dcficca torium eff. Sed enim ftomacho amicunz eft, utpote non paruam obtinens adftriftionem. Quamobrem non adinodum conpicuam caliditatem poßidet: : fecundo autem rece fJu deficcat. Et lib. II. de alimentorum facultatibus, fic inquit. "Plurimum in syria Gin= gidium nafcitur : efturqu; fimiliter ac fcandix apud nos. Stomacbo mirć utile fiue crudum, fiue elixum libeat funere: longioris alts tem decoctionis impatiens eft. Nonnulli ipfun cum oleo, or ga= ro inandunt. Alij uinum etian, aut acetum adijciunt, ac multó magis ita ftomachum iunat. Cum ace to fumptum faftidio fos ad $c i=$ bun inuitat. Perpicuum ueró eft, quód hac berba medicamen= tum potius eft, qudim alimentum. Quippe que adfriftionis, or amaritudinis non obfcure, nec exigue particeps eft . bec Galenus. Ex quibus facilé comprobari poteft, Cherefolium non effe Gingi= dium, quod in ip fo ea amaroris, o adftrictionis qualitates guftu

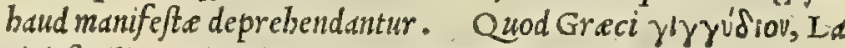
tini fimiliter Gingidium uocant: Itali, Gingidio : Germani, Ko= erffel, er Kerbelkraut: Galli, Cerfueil.

\section{$\sum x \alpha^{\prime} y \delta \xi . \quad S C A N D I X . \quad$ CAP. CXXXII.}

SCANDIX, fylueftrc olus eft, amarum, fubacre: quod crudum, coetûmve manditur : ftomacho, \& ventri vtile. Decoctú in potu, veficææ, renibus, \& iecinori côfert.

Nomina.

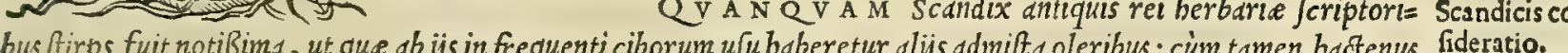
corum repererin neminem, cui fides fit adbibenda, qui scandicë notis aliquibus, uel lineamentis defcripferit, nefci=

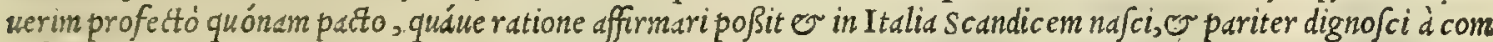
plinibus. Caterum feribit Hermolaus uir doctißimus, e in firpium biftoria omnium fua a'tatis facile primus, e ui= diffe Scandicem in exemplari Graco Diofcoridis appiatam folijs foniculo proximis, floribus luteis, fiue albis, cor=

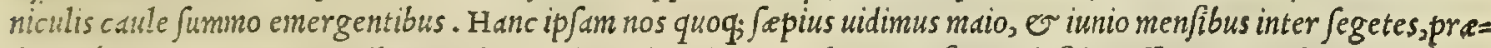
fertin'; in agrorum marginibus. Sed quanuis tradiderit Hermolaus eam freniculi folijs ef Jurgere; mihi tamen magis fumariam, er quadantenus anthemidem referre uidetur, quàn freniculum. Flores gerit hec cherefolio proximos,

40 albicantesq; , é quibus tandem prodeunt cornicula tenuia, longiufcula, recta, acuminata, acubus, que in geranio emicant, non difinilia, quemidmodum er in cherefolio uifuntur, licet buic longé tenuiord, of fragiliora inna çan= tur. Quo fit, ut recté intuéntibus pecie tantim, non autem genere differre he plante haud dubiè appareant; id quod etiam indicat corum fapor. Quamobrem qui cherefolium fcripferunt effe gingidium, id non fine ratione fecerunt. Cùm enim certó crederent, hanc, de qua in prefentia differimus, plantam legitimain effe Scandicem, facilè etiam binc perfuaderi potucrunt, ut affererent cherefolium effe gingidium. quoniam Diofcorides confueuit firpes per cos

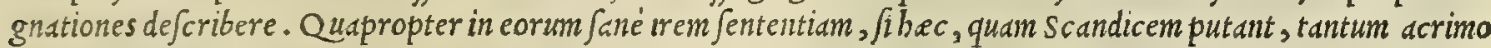
nix, ov amaroris guftantibus relinqueret, quantum in scandice ueteres inueniri prodiderunt. Veriun cum eas non obfcur as quidem qualitates, quas ueteres uere Scandici a ßignant, in hac, ut ita dicam, noud Scandice nunquam ego repererim, ficuti nec in cherefolio, que ueteribus gingidio tribuuntur, cogor omnino corum fententie refragari,

so abipfis diffentire. 2 uapropter nifi regionis, er climatis ratione, o locorum mutatione eueniat, ut he ftirpes omnem tum acrimoniam, tum amarorem exuerint, non facile quidem adduci potero, ut crédam barum alteran gingidium, alteram ueró fcandicem erfe. Neq; ab hac mea me deterret opinione Hermolaus, quód uiderit is scandicem hanc in Greco Diofcoridis codice appiqum: quippe cum inter omnes reiherbaria fcriptores nullus, quod equidem fciam, reperiatur, qui per notas aliquas Scandicem de cripferit, ne fçiuerim ego quánam biftoria, er ratione fretus aliquis

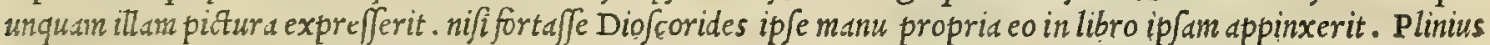
Scandicem anthrico fimilem reddidit. Sed cum ignotum per ignotius defcripferit, nibil nobis luminis his in tenebris affert. Scandicem commemor at Galenus lib. V I II. Fimp. medicamentorum his uerbis. Scandix ex agreftium ole rum genere eft, fubacre, er amarum, adeo ut in ficcando, or excalfaciendo fecundifit ordinis intenfi. Vrinam ualen ter ciet, ov uifcera obftruttione liberat, ex dittis qualitatibus conftans. hec Galenus. Ex quibus etiam manifefté col = ligi poteft, plintam, quam pro Scandice accepit Hermolaus, quain'; pro eddem pleriq; recentium berbariorum bodie oftendunt, nullo pato legitimam effe Scandicem. Quandoguidem ea non tantam acrimoniam, nec amaritudinem gu= fideratio. 
PECTEN VENERIS.

Caucaldis có fideratio.

Caucalidis ui res ex Gal.

Nomina.

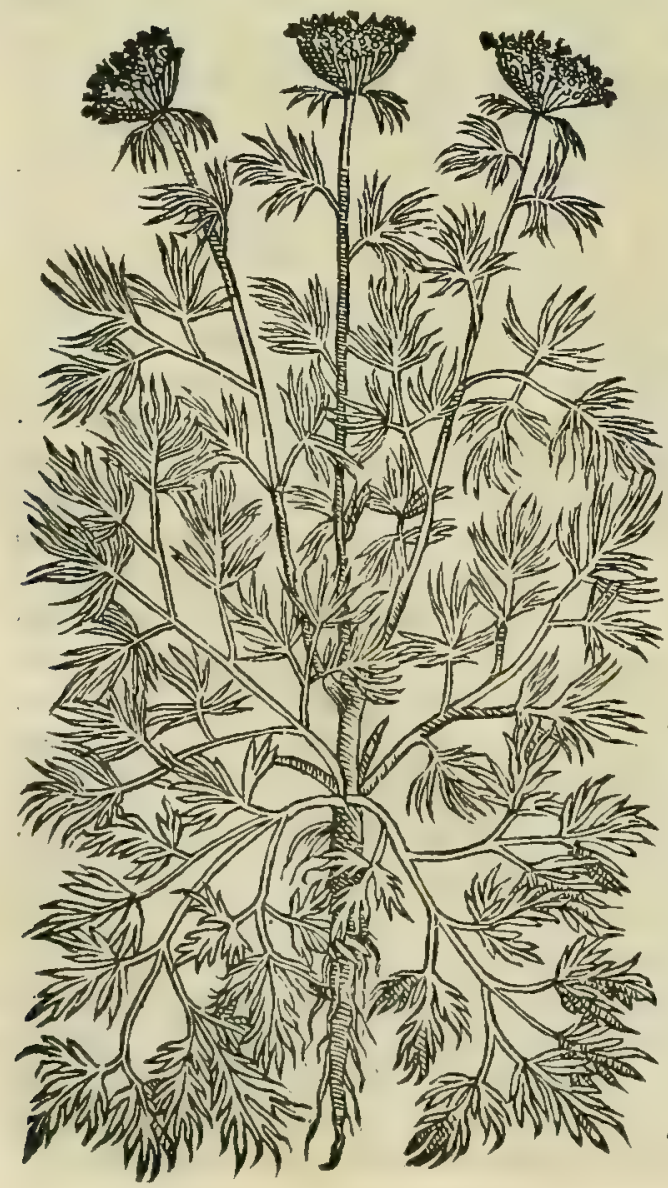

ftui reprefentat, ut dici poßit primum caliditatis, on ficcitatis, gradum excedere. Ceterim fi ulla eft planta, cui bec comparari poßit, eam ad.mußim mili quidem referre uidetur, quain $\mathrm{P}$ linius lib. $\mathrm{x}$ X I I I . csp. $\mathrm{x}$ I X . i pectinun fimilitudi= nc, VENER I S pecten appell.tt. Siquid:m bxc radice nitutur can dida, caliculis femipede maioribus: folijs fylue feros paftinace, uel fere anthemidis, exilibus: floribus albis, tenuibus, enicanti= bus fummatm ab eodem capitello compluribus acuminatis roftel= lis, inter fe difunctis, qua pectines plané re ferıni, quibus linum mulieres concinnant. Qux certé omnia reperiuntur in bac uul $=0$

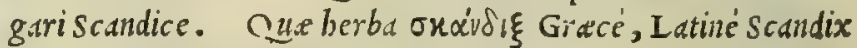
finiliter nominatur: Italicé, scandice.

\section{Kaurx入is, CAVCALIS, CAP, CXXXIII.}

C A v C A I I s, quam alij fylueftre daucum vocant, cauliculo eft dodrantali, aut maiore, fubhirfuto: folijs apio fimilibus, foniculi modo per extrema multifidis, hifpidisq́;: candida in cacum ine umbella, fuau iter olente. Crudum, coctúmve olerum modo eftur: vrinam mouet, " 20

V I S I T V R. Cancalis in Hetruria campeftribus, inculto prefertim folo, ut $0 \%$ Ananien/i tractu in Tridentino agro, nullis reclamantibus notis. Rura noftra banc Petrofello faluatico uuls gó appellant. Quippe quód folia, que per ina prope radicem exeunt, avium quadántenus effigie refirant, qu:od unlgó Petro= fello dicunt. Et $\sqrt{i}$ que fuperiore parte prodet:nt, per ambitun fint fenicui inodo capill amentis dinifa. Coulem mitit paftinace : in cuius cacumine umbellam gerit floribus candicantem, odoratam, dauco non abfimilem. Quapropter Galemis lib. v I I. finplicium 30 medicamentorum, ita de a fcriptum reliquit. Caucalidem quidam daucun fylueftrem nunc upant: eft enim ei ddfinilis guftu fimul ac uiribus. Nam excalfacit ut ille, $\mathcal{O}$ dcficcat, urinam ciet, er muria ad repofitionem conditur. VtGrecis $u \alpha \cup 4 \alpha \lambda$ is, ita etiam Latinis Caucalis appellatur: Italis, Caucalide.

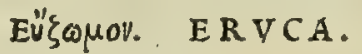

CAP. CXXXIII.

CRVDA ER V A venerem largiore' cibo conci= tat. Semen eius idem praftat, vrinam cit, Concoctioni prodeft, aluo perquàm accommodata. Semine ad condi $4^{\circ}$ menta vtuntur: quod, vti in longum tempus afferuetur, adiecto lacte, aut aceto, digerunt in paftillos. Gignitur etiámnum fylueftris eruca, maximè in Iberia, qux occidentem fpectar. Cuius femine pro finapi incolæ vtuntur. Vrinam vehementius pellit, \& multò fatiua acrior.

V V L G A R I s admodumplăta eft Eruca tam fatiua, quảm ponte nafcens, quód frequentißimé in conis acctarijs inferatur. Excalfacit olus boc (ut teftatur Galenus libro I I. de alimentor $\ddot{u}$ facultatibus) perquàm manifefté, adeò ut non facilé folun abfque so iunctis lactuca folijs edatur : nam ita immodico calori par frigus admiftum exceffum temperat. Quinetiangenitale femen augere creditur, er in uenerem ftimulos addere. Caput etiam magis dolo re affictet, fi folum edatur. Semen (ut fcribunt antiquorum non= nulli) muris araneimorfibus medetur. Ventris tineds enecat, lie= nem'́; extenuat. Tritum, er cum fille bubulo mifum,nigras ulce= rum cicatrices ad candorem reducit. Cum melle ueró perunctum, uitia cuits in facie emendat, or lentigines emaculat. Herba, que Grecis है" 2 wuov, Latinis Eruca uocatur: Mauritanis, Icre gir, Ergit,feu Giargir : Italis, R uchetta, o Rucola: Germanis, Vueifz Senff: Hipanis, oruga, or Arugud: Gallis, Roquette. 


\section{In Lib.fecundum Diofcoridis.}

ERVCA SATIVA.

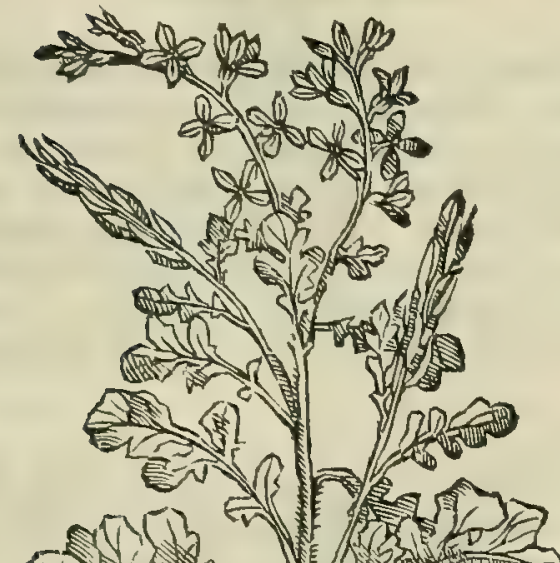

E. 10 . Q 7 . - $\rightarrow$ r 20 R 2 . and as -2 3 ? \& OCIMVM MAGNVM.
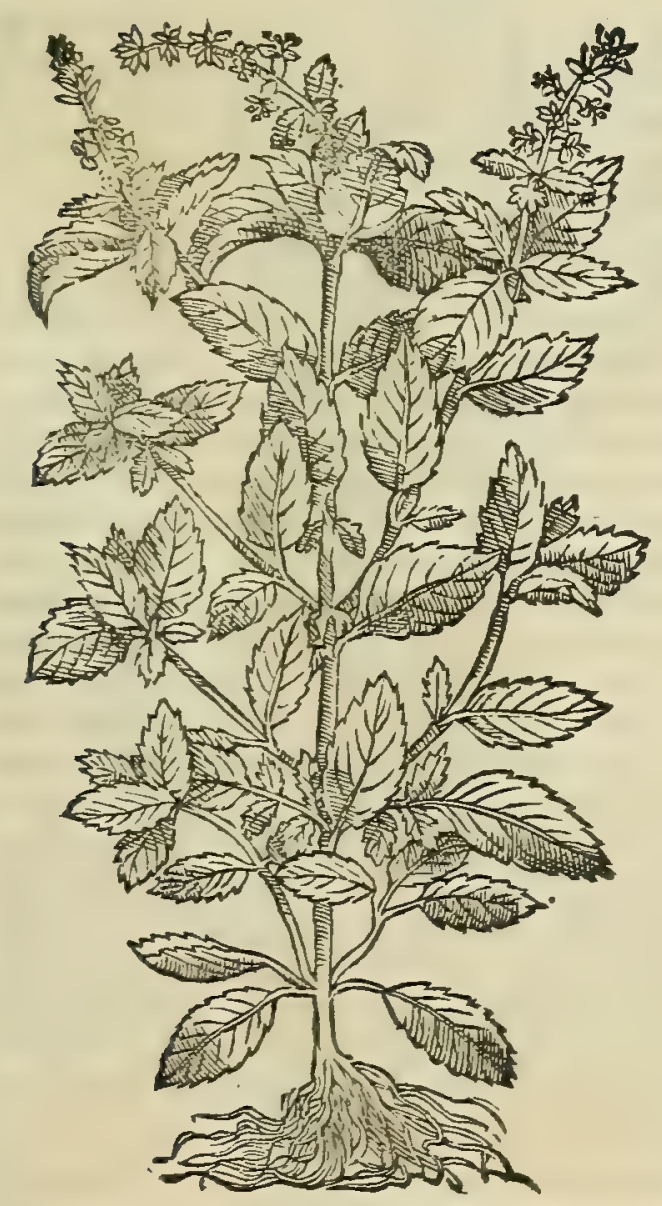

ERVCA SYLVESTRIS.

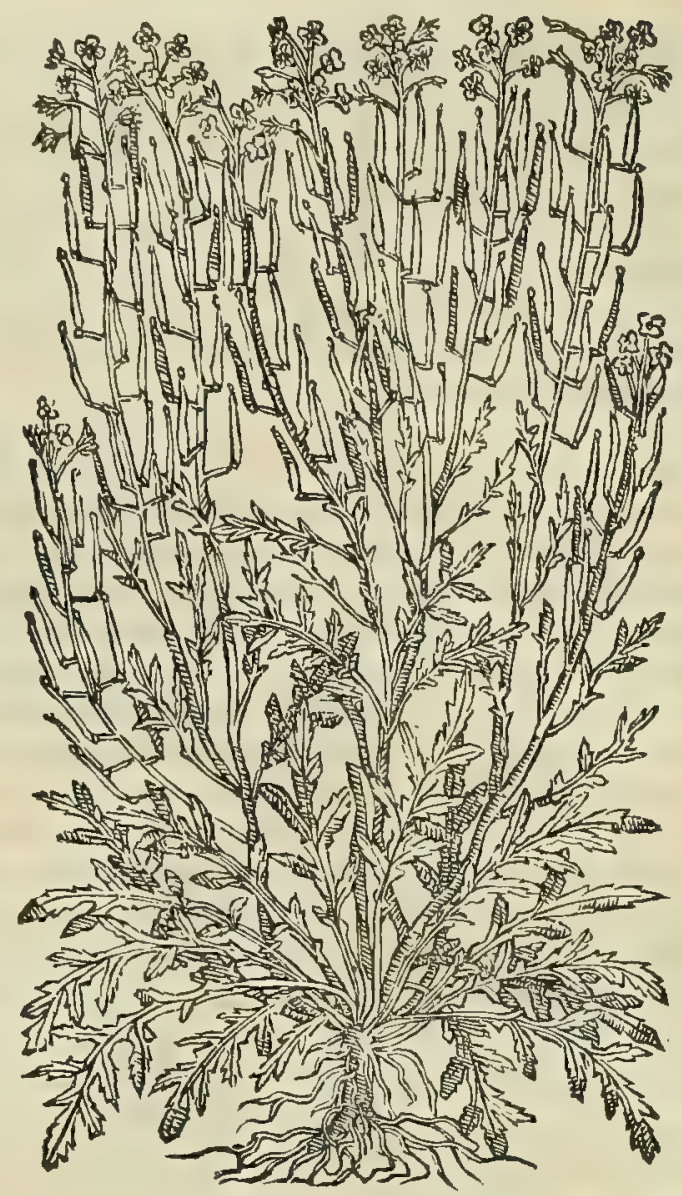

DCIMVM PARVVM.

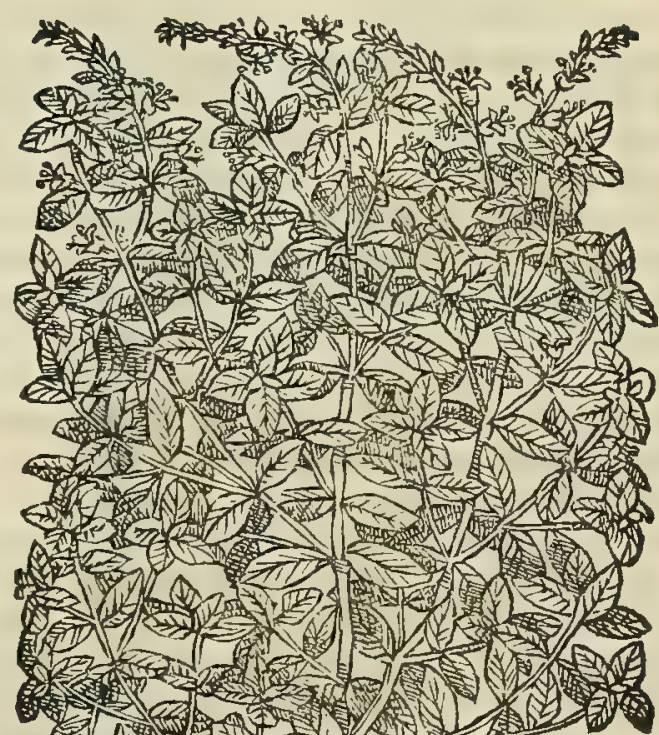

6. A . .

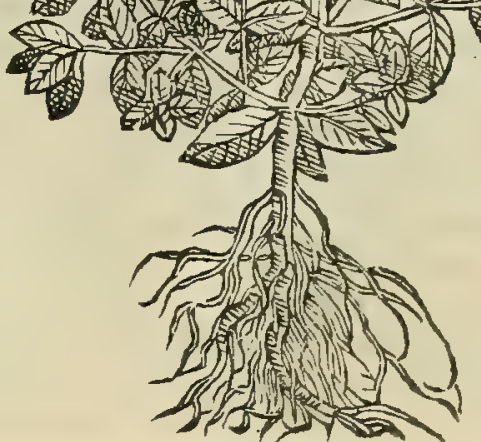




\section{And. Matthioli Comm.}

s"xurov. OCIMVM.

CAP. $\operatorname{CXXXV}$.

O C I M v M vulgò cognitum. Id copiofiore cibo oculorum aciem hebetat, aluum mollit, fpiri: tum monet, vrinam pellit, lac euocat : $\mathfrak{x g}$ rè tamen conficitur illitum cum polline polentæ, aceto, \& rofacen, pulmonum inflammationibus auxilio eft. Draconis marini, \& fcorpionis ictibus per.fe pro deft : \& cum vino Chio, oculorum doloribus. Succus vifus caliginem abftergit: deftillationes exiccat. Semen potum conuenit atram bilem gignentibus, diffcili vrinæ, infatisque: naribus haufum, fubinde mouet fternutamenta . quod idem herba efficit. Sed oculos premi neceffum eft, cùm fternu tamentum urget. Sunt qui in cibis abdicandum cenfeant : quandoquidem manducatum, $\&$ in fole pofitum vermiculos creat. Aphri autem adijciunt, fi feriantur à fcorpione, qui ocimum ederint, nul lo conflictaridolore.

Ocimi confideratio.

O C I M V M quemadmodum odoratißimum, ita er omnibus notißimum eft. Nang; perrare funt ubig; adium feneftre,perraráque coendcula, ac uiridaria, qu\& Ocimo non redoleant, utpote quod fic cuens fer atur, or foueatur in figulinis uafis. In Italia hoc auo Ocimi tria babentur genera. Quorum primum folijs affurgit amaranto longe maloribus, latis, longis, ac craßis, citrex malo fimilibus, ì quorum effigic ipfum facilé uocarunt Arabes Ocimum ci= tratum, quo modo ip $\int u m$ Me fues nominat. Secundum folijs exit, ac ramulis, ditto longe minoribus. Tertium, quód fo= lijs conftet minutis at $q$; anguftis, fit $t_{\text {; }}$ ceteris odore fragrantius, It alis uulgo appellatur Bafilico gentile. Horum om nium meminit Serapio, uocduitóg; medium hic à Diofcoride de fcriptum, Ocimum non garyophyllatum: garyophylla= tum ueró, quod cateris tum minutius, tum odoratius babetur. Demum illud Citratum à foliorum fimilitudine nuncu pauit, quod citri folijs amulum effe diximus, ut facilé omnilus perpicumm effe poteft, qui serapionis monumenta per

Monacorum legerint de Ocino differentis. Idcirco uidednt quafo patres illi reucrendi, qui in Mefucm commentarios feripfere, iactaritia . quo iure, quáue ratione in electuario de gensmis fe iactent Ocimum garyophyllatum bac tcmpeftate primos adinue= niffe, cum boc Serapioni folijs exeat paruis, et caule quadrangulari: monachis ueró folijs meliffophyllo maioribus, per ambitum ferratis, or caule minimé angulofo. Qua in re eos, pace fua, aperté hallucinatos putauerim. Nec equidem credendum arbitror, quód de alio ocimi generc intellexerit Me fues, quàn de tertio illo gencre in delicijs habito, de quo dixinus. Nam cum ceteris odoris fragrantia longé praftet, nulli dubium eft, quin in roborandis cordis ipfius ui= ribus cateris fit longé aptius, atq; etiam praftantius, ut quod in electurrium de gemmis addatur ad cordis effectus.

Scribit Brafauolus fuo de fimplicitme examine Rome primùm excufo libro, tantam de ocimi uiribus inter Pliniu,

Brafauoli lap

fus. o Diofcoridem cffe controuerfiam, ut altcrum ipforum erraffe dicendum fit. Quippe ex A Abris tradit Diofcori=
des, quòd fí à corpione feriantur, qui ocimum ederint, nullo dolore afficiuntur. Contrà ueró plinius, qui libro x I I. cap.x x. fl eo die, inquit, feriatur quipiann a fcorpione, quo ederit ocimum, feruari non poffe. Cua in re lectionis ins patiens deprebenditur Brafauolus: quandoquidem fi co loco Plinium de Ocimo differentein, patienter pcrlegiffet, cognouifet utiq; quàm recté Plinius ipfe banc dirimat controuerfiam, ïsś;; reffondcat, qui ocimum accufant, cum in= quit. Ocimum quoq; Chry/ippus acriter increpuit, inutile effe dicens ftomacho, trine, or oculorum claritati. Prete= rea infaniam fac ere, o lethargos, $\mathcal{O}$ iecinoris uitia. Ideog; capras id appernari, hominibus quog; fugiendun cen= fet. Adijciunt quidam tritum fi operiatur lapide, fcorpionem gignere. Commanducatum, e in fole pofitum uermes afferre. A phri ueró, fi eo die feriatur quippiam à fcorpione, quo ederit ocimum, feruari non poffe. Secutd et ds ald= criter ocimun defendit: nam id effe capras, nec minus, qudm mentham, ov rutam fcorpionum terreftrium ictibus, marinorun'́g; uenenis mederi ex uino, addito aceto exiguo. vfu quog; compertum deficientibus ex aceto odor atu $\int_{a}$ lutare effe. Item lethargicis, of inflammatis refrigerationi. Illitum capitis doloribus cum rofaceo, aut myrteo, aut aceto. Itcm oculorum epithoris, impofitum cx uino:ftomacho quoq; ejfe utile.bec Plinius. Ex quibus clarißimé pd= Ocimi dege- tct, $\mathrm{Plinium}$ corum placitis refragdri, qui tam acriter ocimum damnarunt. Degenerat quandoque Ocimum un fer=
peratlio. neratio. co foli expofito fitum eft, tranfit in ferpyllum, quia uehementer ficcatur. Folio nanq; minus, odorć; uebrmentius red ditur. Quippe cum alimenti quog; minus babeant, que ficca funt. Sed buiufmodi mutationes ita cuenire putandum, ut aliquid fimilitudinis faciant, non ut omnino ppeciem exprimant alienam. hactenus Theophraftus. Catcrim Aui= cenna libro de uiribus cordis à Diofcoride diffentire uidetur, Nam ocinum, fcribit, fanguinem turbidum, er melan

Ocimi uires cholicum generat, quoniam fuperflua bumiditas, que eft in ipfo, parit inflationem in uenis. Nec aliter uidetur fen
ex Gal. ex Gal. dine calfacientium : habet autem recrementitiam bumiditatem : proinde nec commodum eft, quod in corpus fumatur. Caterum foris illitum, ad digerendum, o concoquendum uttle cft . Item libro i I. de alinentorum facultatibus, cum inquit. Ocimo etiam plerique ut obfonio utuntur, ex oleo, or garoefitantes. Vitiofi autem cft fucci. Admentiuntur ob hoc quidam dicentes, , it tritum fictili nouo inditum operiatur, celerrimé intra paucos dies fcorpiones gigncre, pre fertim ubi quis quotidre ollam ad folem calfecerit. Sed hoc fanè à uero abeft. Id porró ueré de codixcris, olus effe Ocymi ab oci praui fucci, ftomacho noxiun, or concoctu difficile. Sed illud in Ocimo non ignorandum "puto, quód ocymum per mo differétia $y$ ab ocimo per i maximé differre deprebenditur probatißinorum auctorum teftinonio . siquidem apud antiquos Ocy mum erat pabuligenus dictum ucl quód citó proueniret: ucl primun inter caetera pabuligenerd è terra erumperet: uel quód iumentis citaret aluum, fic appellatum w’rv's ab Greca noce, qua Latinis ualet citó.Ocimum ueró berba eft

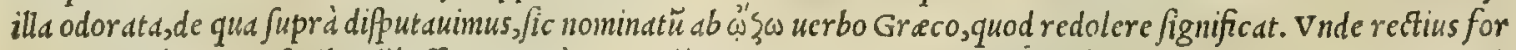
té per zoqudim per c fcribendü effet.Ce.terùm ocymü antiquis quibufdäboum päbulü erat ex fecta uiridi fegete,priufs 


\section{InLib. fecundum Diofcoridis.}

quàn indwre ferent culni : tecl cx fcminibus pluribis finul in agro fatis. Nempe é fabärum modijs decem, uicia duo=

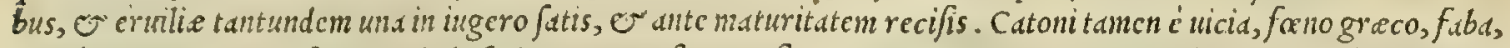
eruó, in unum, commiftis, ct exinde fatis ocymun eft. Qua fit, ut putauerin ocymum antiquis, non nodo berbaceam, uiridem í; fuij]e fegctent, $\dot{e}$ pluribus fcminibus und in agro fat is in primum iumentorum pabulü; fcd ctian ex uno tan= tùm cercalium genere, nempe hordco, auend, uicia, eruo, dijs ;́; bis cognatis, quód eiufmodi pabulo ucrno tempore, na modó alantur boues, ac etian equi : fid etiam repurgentur. Id quod noftra quoq; atate fit pluribus in locis in Italia, prefertin cum bordeo, crno, $\odot$ uicia. Nec placet corum fententia, qui fibi mulla, ut arbitror, ratione, nec anctorita $=$ te perfuadent, Ocymun plantame efe fui proprijgeneris. quód è ueteribus nullum bactenus inuencrim(quantü equi= dem uid, , legi) qui ocymi herb.e biftorian literis mentorix ; mandatuerit: fed comperi quidem, quód uocabulü boc 20 non magis uni, quàm alteri conueniat. quandoquidem unicuiq; pabuligeneri, quod primo fatim ucre citó prousniat, accommodari poteft. Quarc planc explodenda uiàctur Addmi Loniceriopinio, quód non fine errore ridendo fru= mentum Turcicum, fiue, ut alijs placet, Saracenicum, quod Tridentina rura uulgó appellant Formentone, $\sigma$ Foroiu= lienfi a pullo feminis colore Saracino, ocymum effe firmiter cxiftimct. Quinctiam is turputer abcrraffe deprchendi= tur, quód buic plante, que fuum ocymum eft, omnes odoruti ocimi facultates reddiderit. Nec alia ratione motus fru= mentum Saracenic um ocymum effe cenfet, quàm quod fatum tertia à fatu die erunzpat. Verim ocymü non éa de cau fa nomen boc (mea quidem fententia) fibi comparanit, fed quod citius ceteris pabulorum generibus uere primo adole fcat: nan innumera effent ocymigenerd, fi id omne, quod ftatim feré à fatu oritur, ocymum nocari debcat. Quod ผr'luo" ( $u$ anté ditum eft ) Greci, ocimum item Latini appellant: Mauritani,Berendaros, Bedarog: Itali, Bafl= lico: Germani, Bafilien, O Bafilgram: Hipani, Albahaca: Galli, Bafilich.

\section{O'gobáxxH. OROBANCHE.}

O R O в A N C H E cauliculus eft fefquipedalis, 2 interdum maior, fubruber, hirfutus, tener, fine folio, pinguis : flore fubalbido, aut in luteum vergente : radice digiti crafsitudine, \& cùm ariditate flaccefcit caulis, filtulofs. Hanc inter quædam legumina nafci conftat, \& ez ftrangulare: vnde orobanche fibi cognomentum ufurpauit . Eftur yt olus, cruda, \& in patinis, af paragi modo, decotta. Legumentis addita, concoetionem accelerare creditur.

O R O в A N C H E N, que omnibus notislegitime Diofco ridis repondet, "uidimus primum in Ananienfi agro Jupra Tri= dentum, ac deinde ubique feré in Italia nafci comperinus, in cam= pis non modó intcr oinnia leguminum genera, fed et inter fegetes, cainabim, linum, o in uijs fecus agrorum Jepes. Caterim et $\sqrt{\hat{\mathbf{t}}}$ fcriptis mandauerit Theophraftus lib.vi I I de hiftoria, ov v. de caufis plantarum, Orobanchem eruum necare amplexu, comple= $x u q_{;}$fuo; ed tamen, qua bic di Diofcoride reprefentatur, o d Plinio lib. x x I 1.cap.ultimo, nullo fané complexu, fed fua tătum prefentid,legumina, fegetes, cannabiin, or linum interimit, que prope ip $\int a m$ oriuntur. Quam ob caufam Ananienfes, quód uici= nas ftrangulet, ac deuoret plantas, Herba lupa uulgó orobancbě appellant. Profilit bec (ut inquit Diófcorides) nullis unquam foliys, fed uno tantùm a fjurgit cäuliculo, apparagi inftar, colore fubrubro, birfuto, molli, pinguiq́;, o qui fe fquipedalem non excedat longitudinem. Flos é quibufdam patefcit globulis in $c d=$ cumine congeftis, fubalbidus. Radix digitali uifitur craßitudi= ne, fungo $\int_{a}$, ac fragilis. Hec planta nonnillis etiam uulgó Coda di leone appellatur, alijs ueró Herba tora uocatur, quód uacce ed deguftata (ut paftores facto periculo teftantur) ftatim taurum adeant. Sunt $\mho^{2}$ qui (ut loco citato fcribit Plinius) uel Theophraftum (pace fua) hac in re deceptum effe, uel aliam à Diofcoride, O Plinio orobanchem concepiffe.

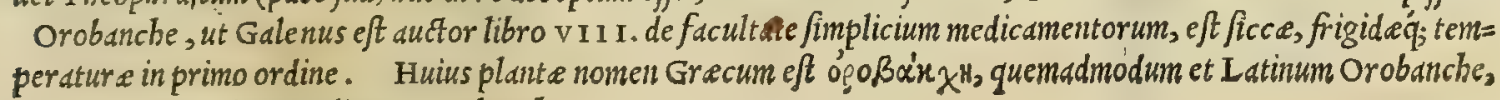
necnon Erui angina: Italicum, Orobanche.
Adami opinio vana.

Nomina:

Orobanches confideratio.

Orobanches facultas. Nomina. 
Barbulx hirci confideratio.

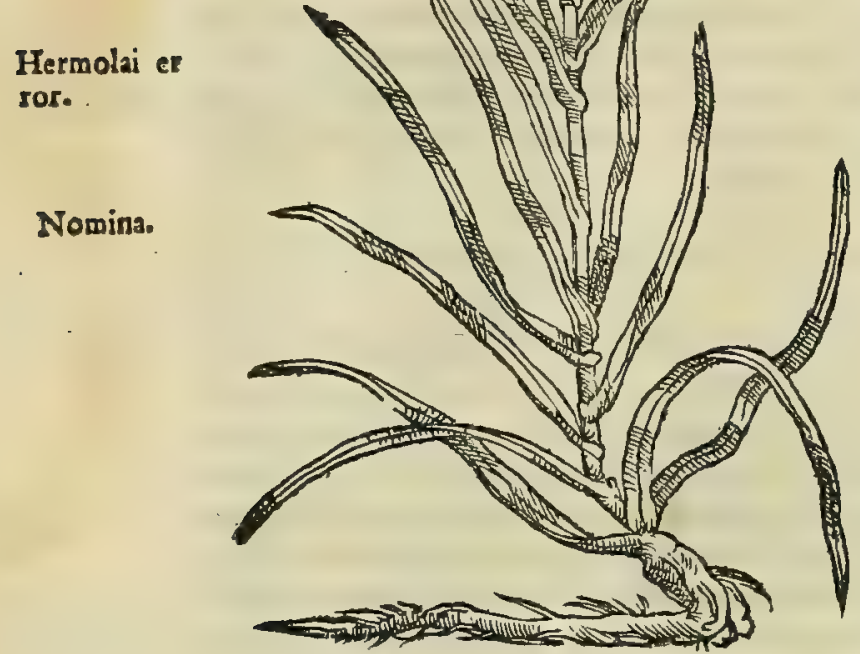

OR NITHOGAIVM.

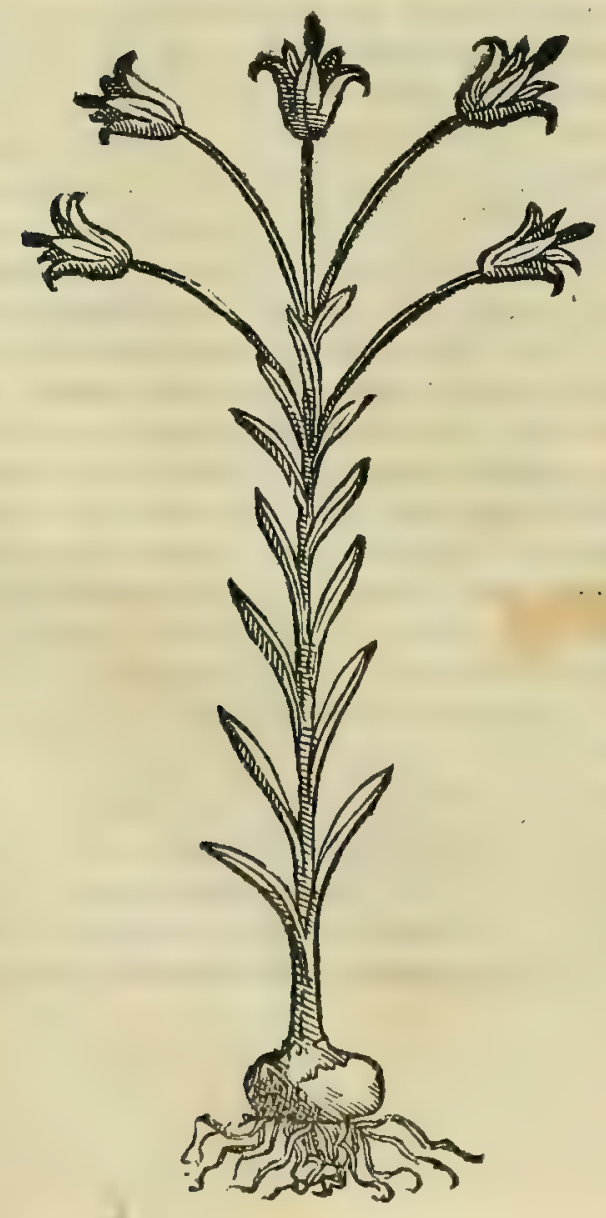

CAP. CXXXVII.

BA RBVLA hirci, qua ab alijs come vocatur, breui eft caule : folijs croci : radice longa,dulci : magno fuper caulem calyce : è cuius fummo femen nigrum dependet, vnde nomen inditum eft. Herba efui apta eft.

H I R C I barbula, quam Hetruria unlgó appellat saffefri= cd, unlgaris admodum eft notitia. Radix, quod gufu dulcis, iucun da q, fit, eftur byeme frequenter in acetarijs. Folijs exit hec croci, latioribus tamen, ac longioribus: flore aureo,roftro porcino uoca 20 to non abfimili, maiore tamen, qui calyce continetur. Is fereno ce lo fatifcit, nubilofo ueró contrabitur, occluditur'́; calyce, quem= admodum or chamelonis echinus. E' conclufo calycis uertice bar ba dependet incana, prolixaq;. Vnde nomé accepit, ut Theophra ftus prodidit lib. E cap.vi I.de plantarum bifloria. Sed certé nee fciuerim ego, qua ratione ductus negauerit Hermolaus, häc Theo phrafto,et Diofcoridi legitimam Hirci barbulam effe, cim illa pul chré buius notis repondeat. Glutinat bec recentia uulner $a, f$ if $0=$ liorum fuccus, uel eius ftillatitia aqua plenijs, or attritis linteolis

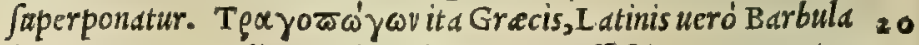
birci hocatur: 1talis, Barba di becco, O Saffefrica: Germanis, Bocks bart, or Galuch brott: Hipanis, Barba de cabron.

\section{O'evi $q$ ó $\gamma \alpha \lambda$ os. ORNITHOGALVM. \\ CAP. CXXXVIII.}

OrNITHOGALVM cauliculus eft tener, candicans, te nuis, fefquipedalis, tribus aut quatuor in cacumine molli bus agnatis : à quibus flores prodeunt foris herbacei, $\mathrm{Se}$ cùm hiătes fe pãdunt,lactei vifuntur:inter quos diffectú, cachryos modo, capitulú emicat. Coquitur cum pane, vt melanthium. Radix bulbofa,cruda, \& cocta manditur,

T R A S I.

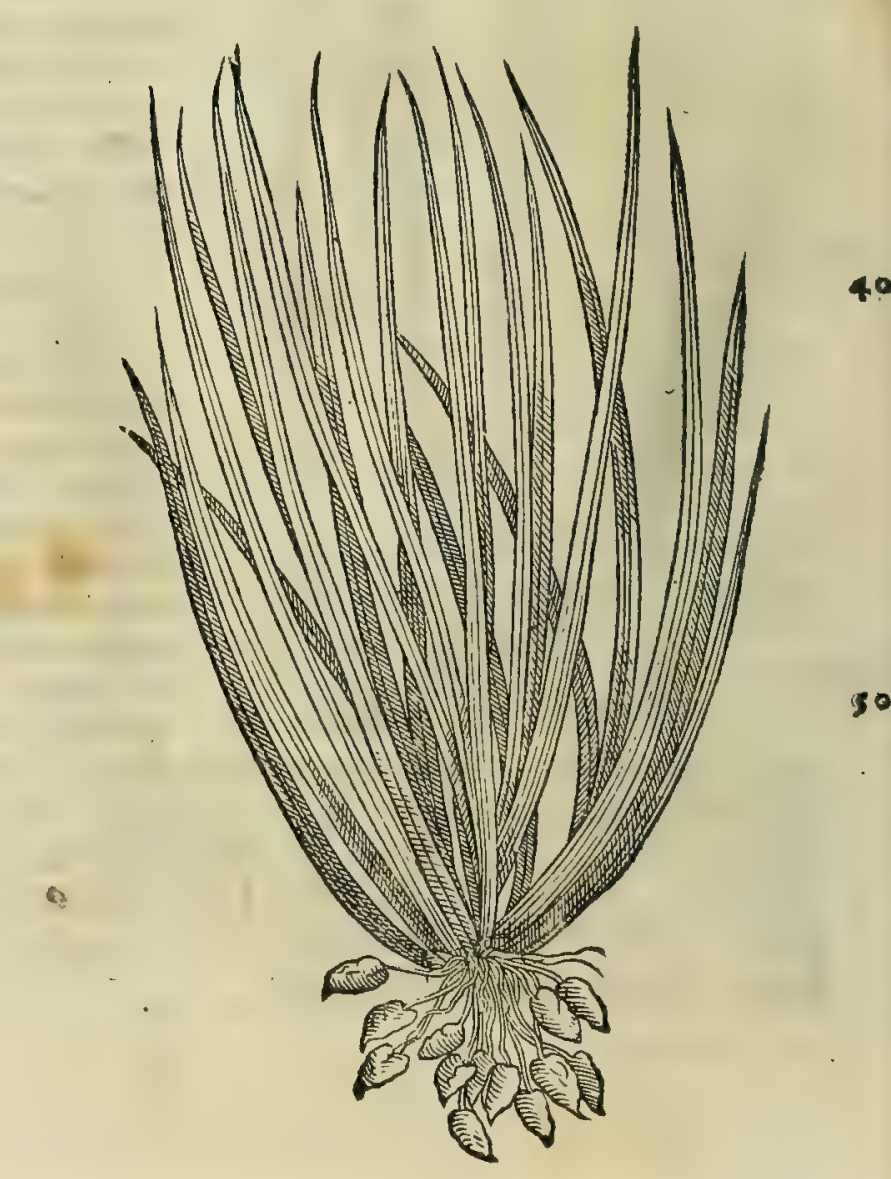

O R N I 


\section{In Lib.lecundum Diofcoridis.}

O R N I T H O G A L V M adco inter fegetes frequens oritur, wt fi maio menfe in aruis requiratur, perperis prius notis illi d Diof coride attributis, facilé abomnibus inucniatur. Rucllius in Gallia ornithogalun copiofum na fcifcribit, pueris non incog witum, qui propter aftantes, cim ab agricolis aratro terra profcinditur, aut in latiores por

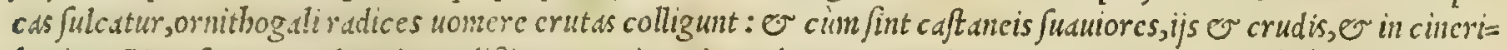
bus incoits ue cuntu', odore iucundißimo, os mirum in modum commendante. Radices in orbem fire' collecte funt: cortice pullo: candidißins intus came, perquam odorata: ucre, uel aftate cim fronde uirent, bycme uel autumno ciun exarastur agri, radicins uclluntur. Diu feruari poffunt, ơ ubi annone premit inopia, ple bis ruftic e famem, o ieiunia caftunearun more fatian. Niré fuibus expetuntur, qui roftro frobiculos cxcauant, o barum capti dul= cedine, gregatin ad bäs clicicndas, radicitusq́; uellendas aduolant. Coterün cum ornithogali radices. Juatuitatis

xo fue preftantia, in mentem mibircuocauerint illas, que in agro Veronenfi, ubitantum, neq; alibi, quod fciam, nd= fcuntur in Italia, wulgó uocantur T R A S I , faporis dulcedine caftaneis proximé accedentes, reccntioribuś. quibufdam in medicamentis eadem expetantur, eas hic recenfere non ab re fore duximus. Sunt igitur $T$ rafi radi= cule figura, ac forma per/iniles foricinis erucis, que feruentibalneo elixe contrabuntur, dum ferica ftanina inde muliercs conglonerant. Harun cremore pedoris, or laterum uitid expurgantur quo fit, ut tußientibus opem non modic sn preftent: tunduntur cnin, macerantur $;$; carnium iure, deinde per linteolum exprimitur cremor. qu!cin etian uenereis potionibus mifcent recentiorum nonulli. Sunt radices be, ut experientia compcrtum eft, or ex dulcedine conijci poteft, in calcfacientium, e bumectantium genere, fed flatus quodammodo gignunt. planta germinat ucre, $\mathrm{O}$ aftate folijs farragini fimilibus, cuius radicibus Traficoharent. Hds ueró fatis reprefen= tare tidentur radicesilla, quss $\mathrm{D} \circ \mathrm{R}$ O N I C O $\mathrm{Sulgus}$ officinarum nominat. Quus, quidem in primis com=

20 mendarunt Arabes, or prefertim A uicenna ad cordis affectus, contra uenena, e deleteria medicamenta. Plan= tam, curis be funt radiccs, hactenus non uidimus : quanquam afferit Ruellius folijs effe feré acuti rumicis. Alij ueró ca leucoio finilia cffe wolunt. Doronicus Actuario carnabadium dicitur. Affertur ex Alexandria Acgypti, ex ex

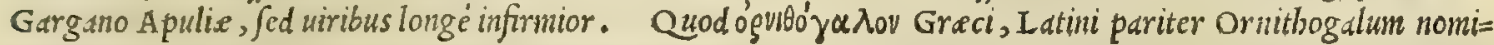
nant: Itali, Ornithogalo.

$$
\text { Y'SVx. TVBERA. }
$$

\section{CAP. CXXXIX.}

T V B E R A rotunda radices funt, fine caule, fine folijs, fauefcentes, vere fodiuntur. Cruda, ir cocta eduntur.

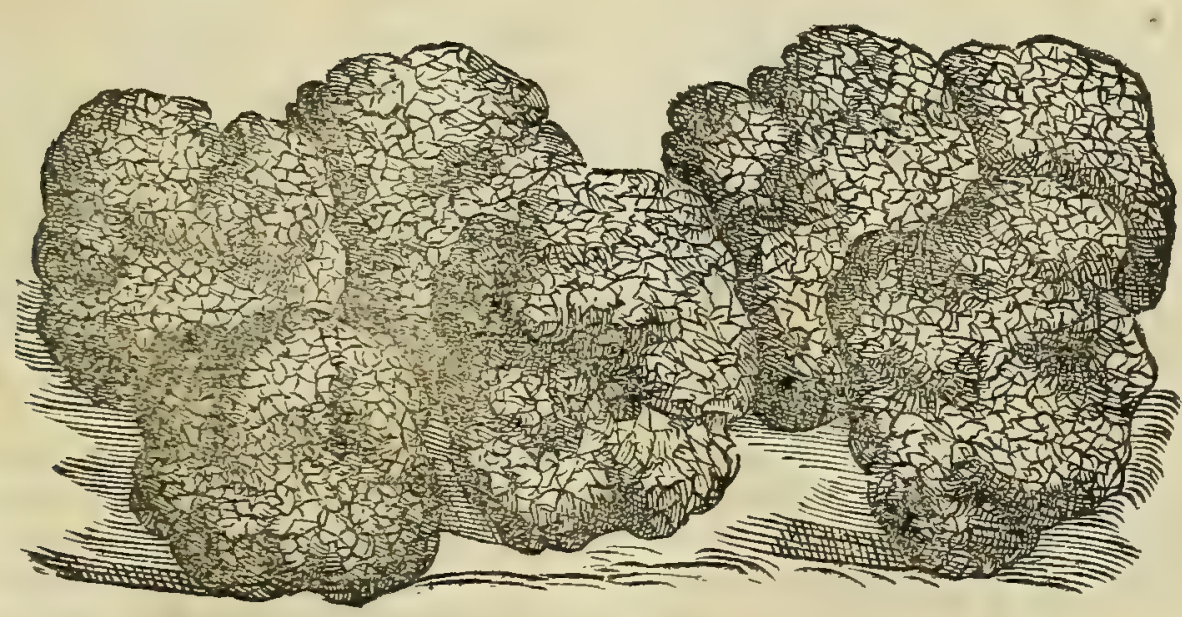

T V B E R A, que occulta quadam facultate terra in fe parit, os conglobat, numerofa in Hetruria d ruftic is effodiuntur, quód magnatibus maximé expetantur in conis. Duo corum in Romano agro habentur genera. Quo= rum alteri candida, pulld ueró alteri pulpa fubeft. Rimofus utrifque cortex, ac niger. Eft or tertium genus in And= so nienfi, e Tridentino tractu proueniens leui cortice, colore fubrufo, cateris longè minus, infipidum, $\widetilde{g}$ gufu iniu cundo. Tuberum meminit Plinius lib. $\mathrm{x}$ I x.cap. I I. fic inquiens. Et quoniam à miraculis rerum copimus, sequemur cor um ordinem, in quibus uel maximum eft diquid nafci,aut uiuere fine ulla radice. Tubera uocantur bec, $u n d i q_{;}$ter ra circundata, nullisq́; fibris nixa, aut faltem capillamentis, nec utiq; extuberante loco, in quo gignuntir, aut rimds urgente, nec; ip a terre cobarent. Cortice etidin includuntur, ut plané nec terram effe poßimus dicere, neq; aliud,

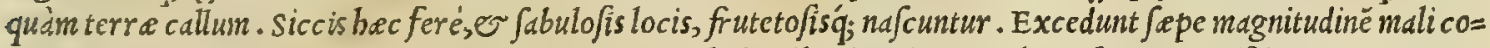
tonei, etiam librali pondere. Duo eorum genera areno $\int$ a, dentibus inimica, er altera fyncera. Diftinguuntur er co= lore rufo, nigróg;; intus candido. Laudatißima que A pbrice crefcunt. An ne uitium id terra?' neq; enim aliud in= telligi poteft: malum ne id ea protinus globetur magnitudine, qua futurum eft, $\sigma$ uiuat ne, aut non, haud facilé arbi= tror intelligi poffe. Putre feendi enim ratio communis eft ijs cü ligno. Lartio Licinio pretorio uiro iura reddéti in Hipania Carthagine paucis bis annis fcimus accidiffe, mordenti tuber, ut deprebenfus intus denarius primos dentes inflecteret. Quo maniffftum erit terre naturam in fe globari. Quod certum eft ex ijs, qua nafcumtur., en ferinon

Tuberum cófideratio: plinio. 
poffunt, Et libro codem capite tertio : De tuberibus (inquit) hec traduntur peculiariter, Cim fuerint imbres aus tuinnales, ac tonitrua crebra, tune nafci, er maximé é tonitribus, nec ultra annum durare, tenerrima autem uerno efs $\int e$, Quibufdam locis acceptantur riguis, o Seruntur, ficut Mitylenis. Negant nafci, nifi exundatione fluminum inuecto femine ab Tiaris. Eft autem is locus, in quo plurima na funtur. Sunt $\mathrm{O}$ in fungorum genere dे Grecis dicti Tuberum ui- pezice, qui fine radice, aut pediculo nafcuntur. Hattenus de tuberibus Plinius. Tubera (ut memorix prodidit res ex Gal, Galenus.libro I I. de alimentor um facultate) radicibus, aut bulbis funt annumeranda, ut que nullam euidentem babent qualitatem. Qui ergo his utuntur, ad excipienda condinenta tanguam materiam habent, ceu alia qualitatis exper= tix, e innoxia, guffuq; aquofa funt. Quibus omnibus conmune eft, ut alimentuin nulld infigni facultate conftans, corpori prebeant, Sed frigidiufculum duntaxat, craßitudine tale, quale id ipfum eft, quod ingeftum fuerit: ex tube=

Ex Auicẻna, ribus quidem craßsius, ex cucurbita liquidius o tenuius. In alijs eadem eft proportio. Sed longé aliter de bis fcri= p fit Auicenna, cum inquit. Tubera terrena magis, quàm aqquea funt,omniq; prorfus fapore expertia. Atrabiliares, e craffos gignunt humores, magis quim catera ciborum genera. Quo fit, ut frequenter deuorati apoplexiam, or paralyfim concitent. Ad bac concođu contumacia funt, e ventriculum aggrallant. Que Grecé v' v'va, Tubera

Nomina, Latine dicuntur : Arabicé, Ramech, Alchamech, Tamer, $\subset$ Kema: Italice, Tartuffi : Germanicé, Hirtzbrunst: Hipanicé, Turmas de tierra: Gallicé, Truffle.

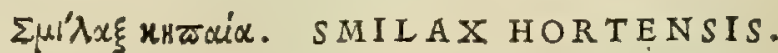

\section{CAP. CXL.}

HorT ENSIS Smilax frutex eft, cuius femen nonnullis lobia vocatur. Folia habet hederæ, molliora tamen : tenues caules, \& capreolos uicinis fruticibus cir- 20 cumuolutos : qui tantum adolefcunt, ut topiarias fcenas reprefentare videantur : filiquas foni græci profert, longiores, torofiores: in quibus femina renum fimilia, fed inæquali colore, recluduntur: quæ quadam ex parte fuluefcunt. Siliqua cocta, cum femine in oleribus afparagi modo eftur. Vrinam ciet, \$ tumultuofa fomnia facit.

Smilacis hortenfis confideratio.

Manardi error.

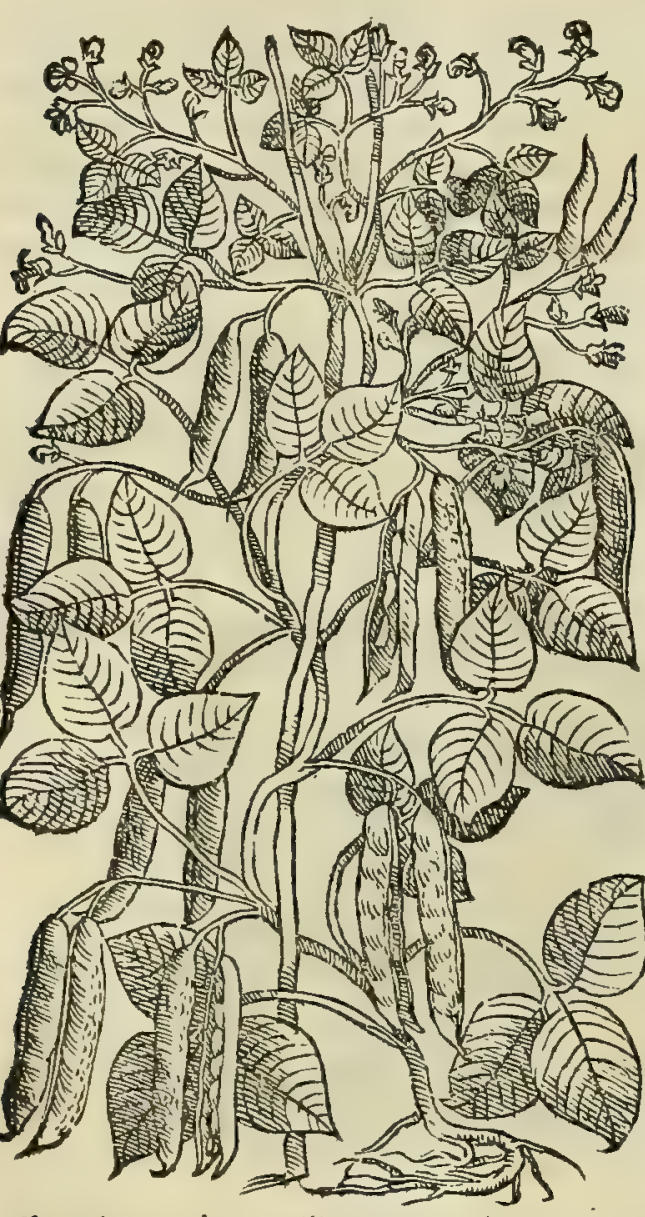

HOR TENS I s smilax (ut fuprì nobis ditumeft in Phus= feolis, fub quorum appellatione falsó credidit Manardus de eruilia fcripfiffe Diofcoridem ) nil aliud, med quidem fententia, effe po $=30$ teft, quadm ea Phafeolorum genera, uarijs coloribus depitta, que unlgó It alis dicuntur Faginoli Turcbefchi. Siquidem preter id, quod rubentes, uerficolores, $\sigma$ (ut Diofcorides inquit) renum fi= gura cernantur, folijs exeunt bederaceis, caule tenui, é quo capreo li prodeunt, quorum reptatu non modó palos, e arbores fcan= dunt, ac uinciunt; fed in bortis attegids, pergulds, teftudines, fce= nas, or tentoria inumbrant, or opacant. Hos Galenus lib. primo de alimentorum facultatibus, ex auctoritate Theophrafti dolichos appellat, fic inquiens. Dolichus adacto longo palo confurgit, $\sigma$ fructum gerit: fin boc adminiculo careat, uitiofus fit, or rubigine tentatur. Quod quotidie uifitur in boc phafiolorum genere. quip= pe quod nullo fuftentaculo in altum eue ${ }^{t} i$, bumi repunt, or con= tracto tractu temporis bunore, fitu, ac rubigine depereunt. At ubi longißimo inbe ferint pedamento, brevi temporis $\beta$ atio, ad cul men usque illife circumuoluunt. Quo fit, ut longé aberrafe Ma nardum exiftimem, quód aßerat lib. I.epift. I I I.Dolichos nil aliud effe Galeno, quàm Eruiliam, qua Italorum nonnullis uulgó appellatur R ouiglione, alijs ueró Arabeia, cum tanzen Galenus, item $\dot{q} ;$ Paulus Eruiliam appellitent Ocbrum. Nec nobis obftat, quod E ruilia (ut ipfe aferit) rubiginĕ con= trabat, cùm adminiculis caret, qubbus à terra fubleuetur, quod '̆́ buiufce tantùm leguminis filiqua unà cum femine comedantur, ut Galenus libri I I. de aliment. facult. prafatione, or Paulus Dolichos mandi teftantur. Nam etfiali= quando Eruilie feiti arborum rami apponantur, ut illos implicent; nunquam tamen longißimi adfiguntur pali, quód ea minimé illos fcandere ualeat, uerficolorum phafiolorum modo. Ad hec Eruilia, que bumi ferpat, rubigine mi= nimé deperit, ut Tridentinus ager ubiq; teftari poteft. Quippe quód ibi frequentißima fcratur, dimittatur'́; nullo prope fixo pedamento bumi accumbere. Nec obfat preterea ( ut ip $\int e$ Manardus fcribit) quód fola Eruilia inter le= gumina cum filiquis conedatur. Nam quantis decocta und cum filiquis menfis appanatur; nunquam tamen aliquem me uidiffe fateri poffum, qui filiquas fimul cum granis deuorauerit : eft enim eruilia inuolucrum fuibus potius, quam bominibus in cibum exbibendum. Vnde cquidcm omnes, quod uiderin, Eruilian mandentes, femina dentibus extra= bunt, e membranofas, exbauftasq;; filiquas dentium attritui pror fus repugnantes, in patinis fuibus relinqunnt . Se= cus autem cum huiufmodi phafiolor um corniculis euenit : quandoquidem cum tenella ddole fcunt, ante aquàm confe=

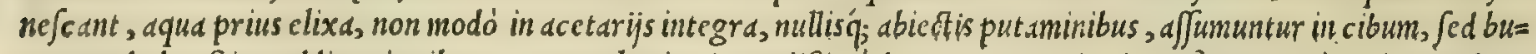
tyro, uel oleo frixa addito gingibere, or omphacio, iucundißimé deuorantur. Hinc itaq; fit, ut certó potius credam, 


\section{In Lib. fecundum Diofcoridis.}

hoc pli:f folorim genus dolichos cfe, quam eruilian Manardo uocat.m. Ithud infuper bac in re fentit Manardus, quỏd Dicfcoridcs phafiolorum appellatione, de quibus fuprà mentioncm ficit, non quidem communcs, ac triuiales, fod Eruilam fignificuucrit: Smilacis ucrỏ bortenfis nomine, de qua bic fermo, uulgarcs illos phafiolos reprefenta=

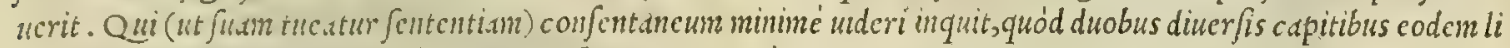
bro de phateolis fcripferit Diofcorides. Sed haudquaquam à ratione, o ucritate eum alienum exiftimaren, qui re= ponderit, primum tratafac Diofcoriden de unlgaribus, 0 candidis phatcolis, qui paßin in campis aliorum lcgumi= mun morc fcminanur, ubi de ommi fegcte, $\odot$ lcguminibus differuit. Deinde ucró de uerficoloribus, qui in bortis, or uiridarijs ad opera topiaris ixplenda formtur, inter ed, que in hortis, er uiridarijs coluntur. Quanobrem ut bor= tenfes à campe/tribus fecenteret, inquit: Hortenfis smilax frutex eft, erc. Qtad manifefté declarat, cum hic de hor=

xo tenfibus,illic ueró de ijs, qux in campis proncniunt, ixtellexiffe, atc; cos ita feiunxiffe. Qua in re non potui non quă= doq; admurari Manardum medicum alionuin ingens, o doctrina infignem, quod tan facilé adductus cfjet, ut affeuc= raret dolichos effe eruilium, cinn cum ic giffe exiftimandum fit, Galeno, $\mathcal{O}$ Paulo eruiliam ochrum uocari. Planta,

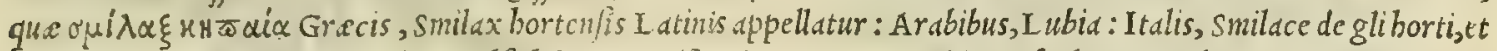
Fagiuolo Turchefco: Germanis, Vueljsch bonen: Hipanis, Feyones: Gallis, Fafeoles, or Fabes painctes.

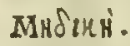
MEDICA.
CAP. CXLI.

MED I C A, cùm recentcr prodijt, fclijs., \& caule trifolio pratenfi fimilis eft : procedens uerò folia contrahit, caules edens trifolij, \& filiquas corniculorum modo intortas, in quibus femen len20. tis magnitudine dependet. Id ficcatum, iucundi faporis gratia, conditaneo fali admifcetur. Viride, quibus refrigeratione opus eft, illitu fuffragatul. Hcrba tota pro gramine vtuntur, qui pecoraalunt.

M E D I C A M inde nominationcm inucniffe certum ef, quód primum, Plinio lib. x v I I r.cap. x v I.auctore,ex

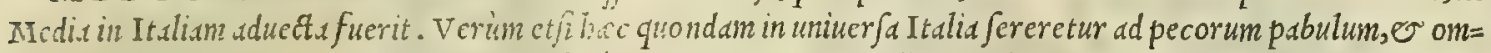
nibus fé cógnofceretur; nec tumen pauci fane reperiuntur, qui Medic am uiderint, ne dum ferant: quanquam non

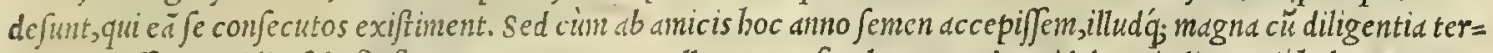
re mandaffem, accidit, folo forfitan repugnante, ut nulld exorta fit planta: unde quid de ea iudicem nö babeo. Hec(ut

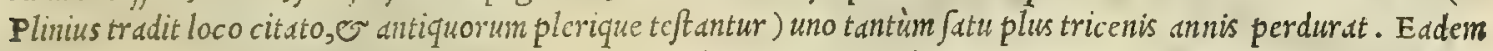
30 (ut quidam referunt) abundat Hipanid, ubinagna admodum cura colitur ad iumentorum, or pecudum pabulum: eamó; Alfalfa uocant, nomine ab Arabicis corrupté mutusto. Nam (ut lib. I r.capite de Cot inquit Auicennd) uoca= tur etiámnum Apbris Alfafafat. Nafcitur or $m$ Gallia, fi Ruellio credimus, ibí; maius trifolium appellatur. - Medi=

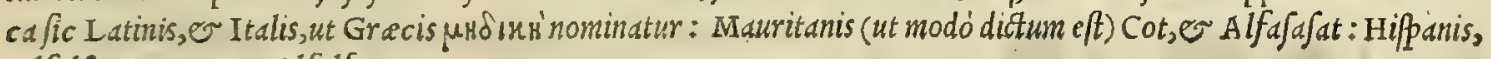
Alfalfe, Eruaye, er Alfalfa.

$$
\text { A’фаंи. APHACA. }
$$

\section{CAP. CXLII.}

A P A A C A in aruis nafcitur,altior lente,tenuibus folijs: filiquas lenticula maiores fert, in quibus terna, quaternáve femina nigra, lente minora, continentur. Quæ adfringendi vim habent . quare 40 torrefa ta, $_{\text {, }}$ tomachi, aluique fluxiones filtunt, fi frefa lentis more decoquantur.

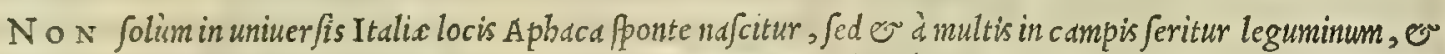
erui modo ad columbarum faginam. Folio germinat uicis maiore, craßiori j $_{2}$ quadrangulari caule, flore fubrubeo, $f=$ Tiquis inde dependentibus piforum instar, brevioribus tamen, fed lenticule maioribus, in quibus includitur femen, uicia quadäntenus maius. Goritienfi agro frequentisima nafcitur inter fegetes, o prope fepes. Quo fit, ut maxime aber=

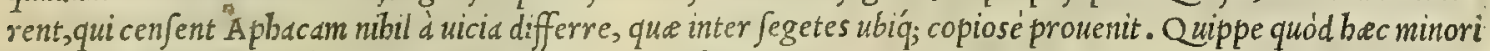
fit follo, tenuiori caule, flore in purpur am rubefcente, filiquis longioribus, gracilioribus, ac rotundioribus. Eáq; pro= pter de Aphaca, e vicia differens Galenus lib. I. de alimentorum facultatibus, ita fcribit. Apbace, er uicia feminü figura non rotunda eft, ueluti fabarum, fed aliquantó latiufcula, fimiliter lenti. Hec quoq; cum fua planta, et ualuu= so iis integra ruftici reponunt, ut brutis pecudibus pabulo int. Per famem tamen quofdam noui, qui hec quoq; comede= rint, potißsimim ucre, cùn etiämnum uirent, quemadmodum fabds, or cicerd efitare confueuerunt. Semina autě bec

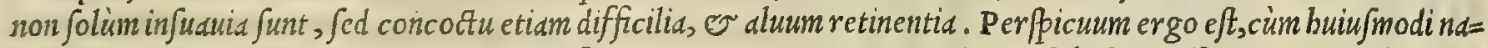
turam obtineant, alimoniam quo $;$; que ex ip is in corpus permanat, improbi, craßsiq; fucci effe, idoneam ad humoris melancbolicigenerationem. bactenus Galenus. Ceterum illud animaduertendum eft,quód Theopbraftus lib. v I I. cap.V I I. $\sigma \mathrm{x}$ I de plantarum biftoria Aphacam inter intybacea, uel cichorij genera connumerat. Quare mirandum non eft, fi etiam in alijs quibufdam à Diofcoride difcrepet, quemadmodum in coronopo, orobancbe, ac alijs nonnullis oftendimus. Nec mirum etiam Plinium hac in biftoria uariafe: nam lib. x x VII. cap. v. Diofcoridis Aphacam ad

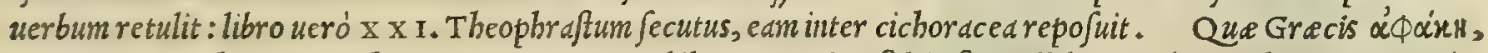
Latinis item Aphaca, er Aphace nuncupatur: Arabibus, Apaki, Afalii, fiue Albikia: Italis, Aphaca: Germanis, Vuilde uuicken, Ð Vogels unicken.

Aphacx confideratio.

Quorundam lapfus.

Aphaca intybi genus.

C . 


\section{And. Matthioli Comm.}

A P H A C A.

Galeno.

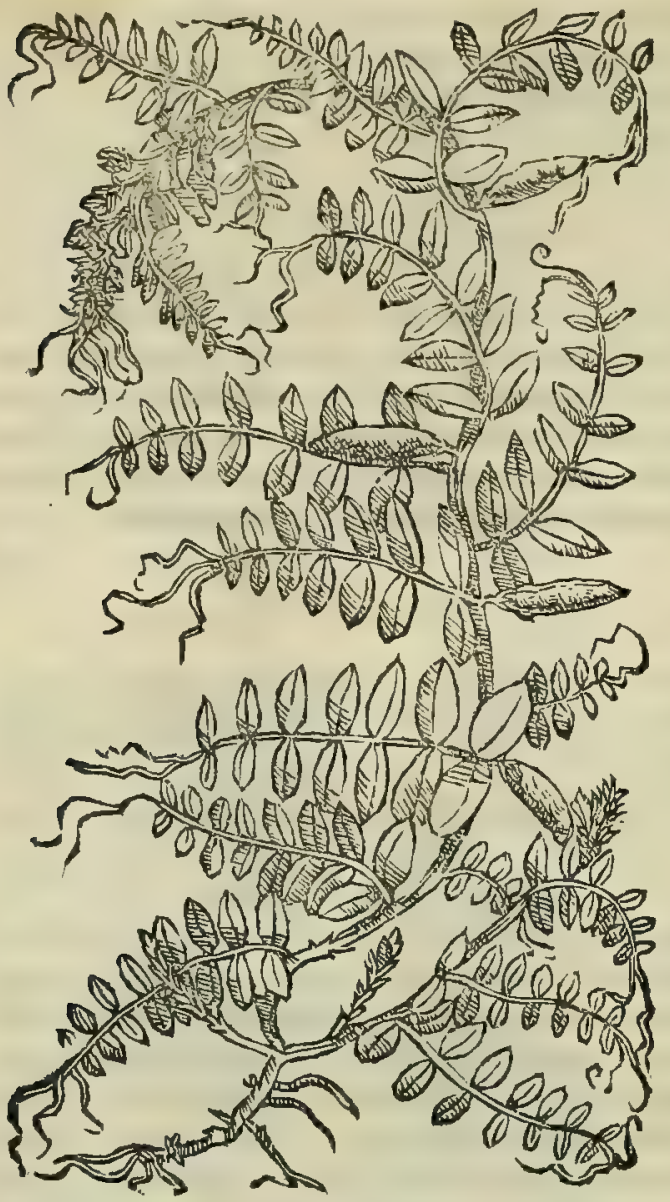

V I C I A.

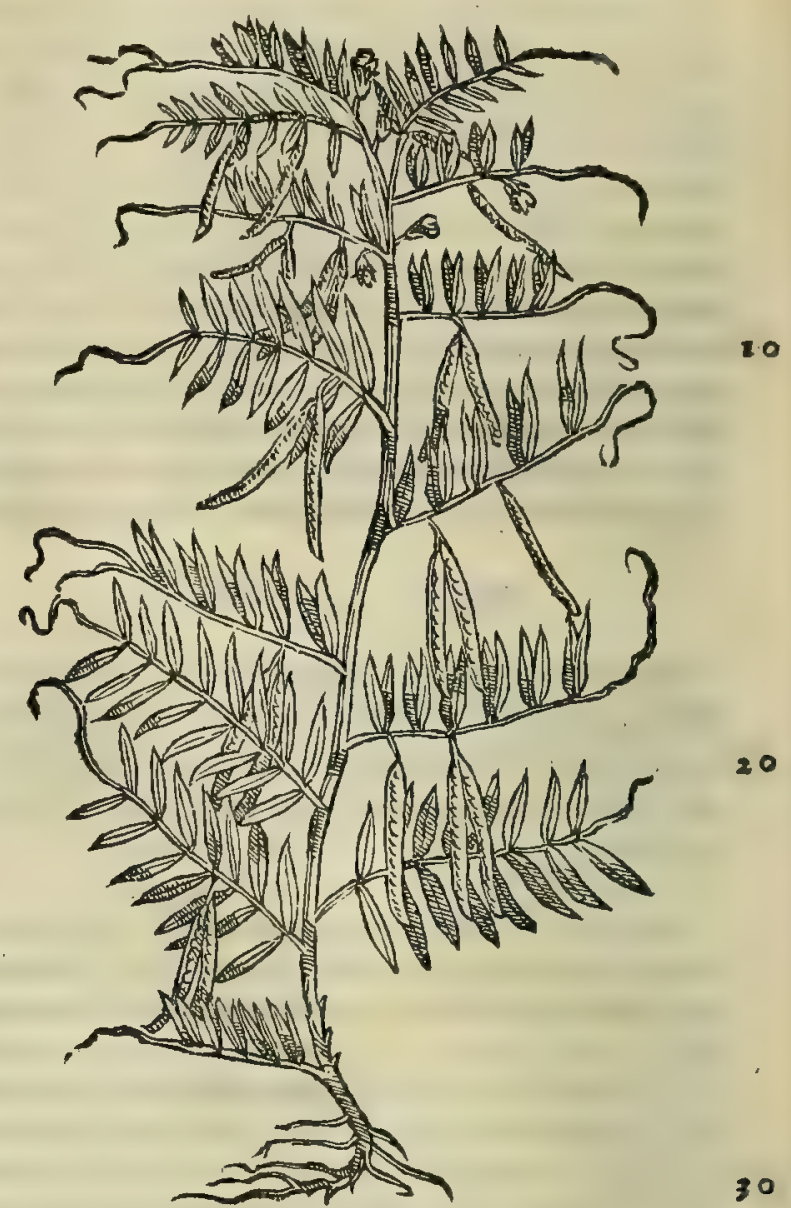

CAP. CXLIII.

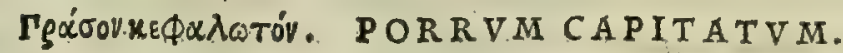

CA P I T A T V M porruminfationem facit,noxium

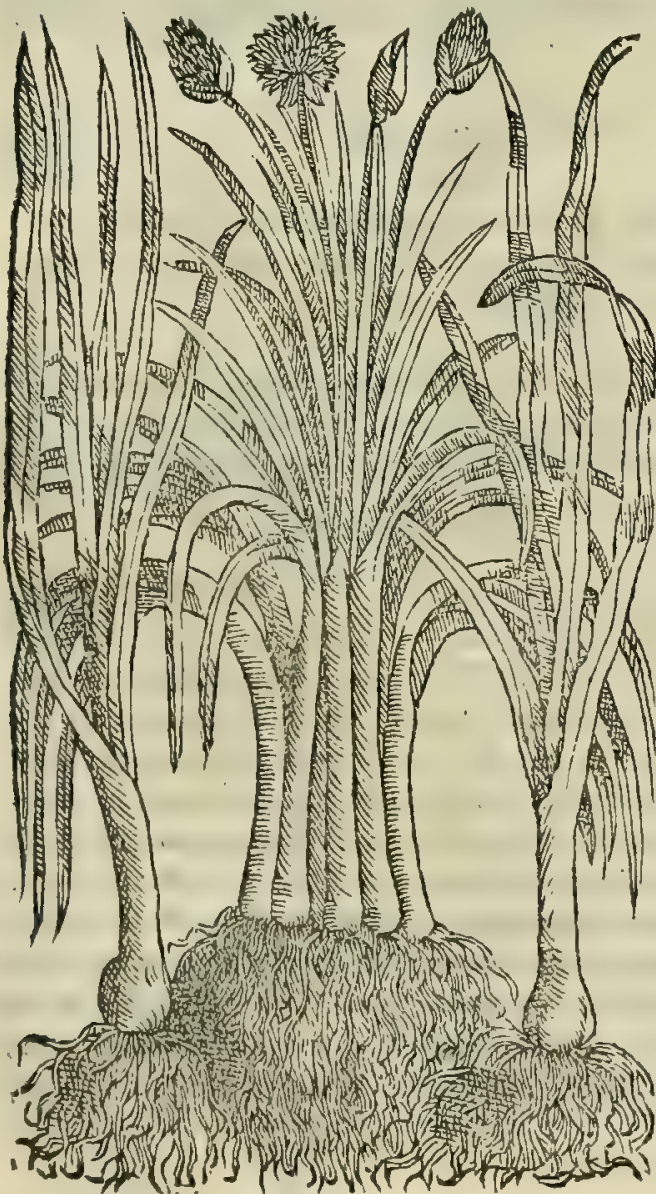

fuccum creat, tumultuofum fomnium parit, vrinam ciet, aluo accommodatur, extenuat, oculorum aciem hebetat,menfes pcllit: fed lædit exulceratam ueficam, renesque. cum ptifana uerò coctum, efu pectoris uitia extrahit. Coma eius in aqua maris, \& aceto cocta, in defeffionibus ad præclufiones vuluæ, \& duritias, vtilis habetur. Porrum bis aqua mutata coctum, tum frigida mace- 40 ratum, dulcefcit, \& multò minus inflat. Semen acrius eft, \& quandam adftrictoriam vim habet. quare fuccus cum aceto, addito thure, aut manna, fanguinis profluuia fiftit, maximè fi naribus enumpat. Venerem ftimulat : contra omnia thoracis vitia, tabemq́ue, pro delinEtu efficax eft : arteriam efu purgat: fed fi afsiduè cftur, uifus obfcuritatem inducit: ftomacho aduerfatur. Succus ex melle potus, aut illitus, conrta beftiarum morfus auxilio eft. Ipfum quoque cum aceto aut thuris polline, lacte ant rofaceo, vtiliter aurum doloribus, \& fonitui 50 inftillatur, Varos tollunt folia illita cum rhoé, qua ad obfonia vtuntur : epiny ctidi medentur : cruftas ex fale illita rumpunt. Veteres fanguinıs reiectiones cohibent, feminis drachmæibinæ, cum ęquali baccarum myrti pon dere potx.

P O R R V M, quod copiofun quadragefimalis noftri ieiunij tempore plerung; in foris olitorijs und cum oleribus uenale re=

Porriconfi. deratio. peritur; omnibus notijimun eft. C.etcrum etfi magnopere labo= rent bortorum cultores, ut cor um porri, longi, cra $\beta i$; candidi, ac tencri euadant; ne fiunt tamen eos capitatos efficerc, ceparum inftar: 


\section{In Lib. fecundum Diofcorids.}

inff.tu" : qu:thuis ij apud ueteres in frequentilimo ufu fuiffent, quód longis, qui proprié fectiui appellantur, fapidiores, guftuig; gratiores haberentur. De his igitur tanquan praftantioribus fcripfit Diofcorides, non tamen quód à fectiuis genere differrent, é quibus inägonio capitatifinin, tegula in tranflantatione juppofita, incifis prius ante medulläfö= lijs, ne adolendi facultas in fublime feratur, nec ad radices, fed in ipfo capite confideat: uel farculo conuelluntur $r a=$ dices, ut delumbate alant, neque diffrahant, ut fcriptum reliquit Plinius lib. $\mathrm{x}$ I X.cap. v I. Porrifacultatesre = Porri faculea cenfuit Galcnus lib. I I. de alimentorum facultatibus, ubi fimul etian de allio, e cepis agens, fic inquit. Harum tesex Gal.

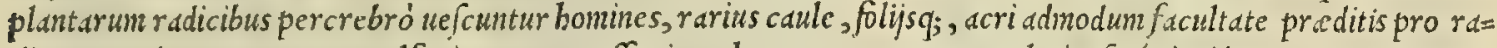
dicum portione. Corpus excalfaciunt, er craffos in eo bumores extenuant, glutinofosq́; incidunt. B is tamen, aut ter in aqua decocta, dcrimonia poliantur : quanquam ne fic quidem uim perdunt extenuandi. Verùm facultatems

- quandan obfcurißinam alendi corporis exinde acquirunt, cuius anted, quàm decoquerentur, nibil profus obsine= bant. Cecterum allium non modó ut obfonium, uerum ctiam ut medicamentun fanitati accommodum, quód obftru= cta foluere, or difcutere poßit, ufurpatur. Aliquantiper elixum, ufque dum acritudinem abijcid, uiribus qui= dem fuis imbecillius fit, fed fucci prauitatem non amplius feruat, quemadmodun nec porri, nec cepa, cim bis fue=

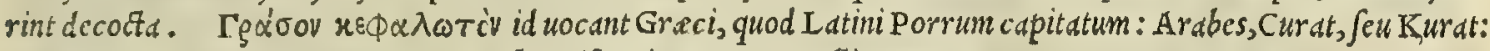
Itali, Porro capitato: Gcrmani, Lauch: Hifpani, Puerro: Galli, Poureau.

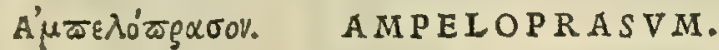

\section{CAP, CXIIII.}

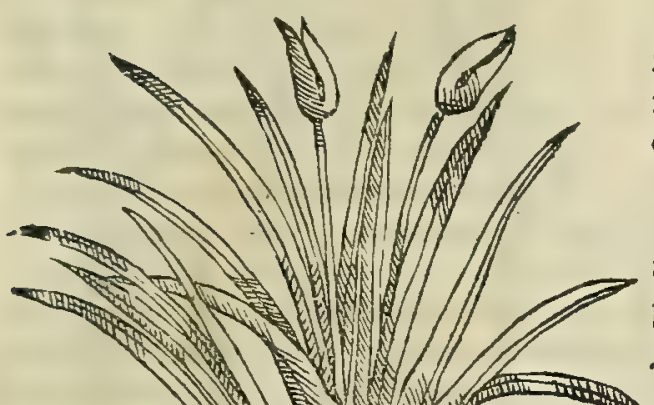

30
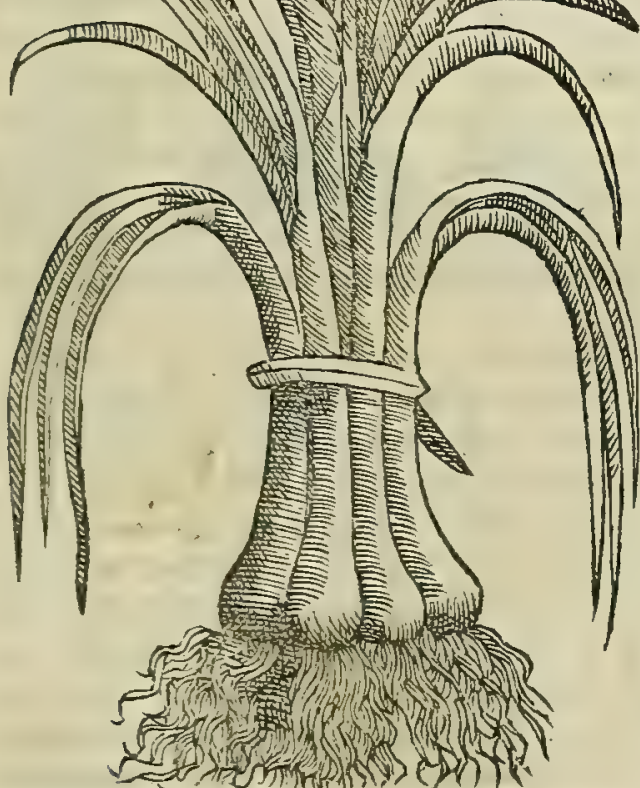

A M P E I O P R A S V M ftomacho magis, quàm por rum aduerfatur: plus autem excalfacit : vrinam, \& men fes vehementius ciet. Id contra ferpentium morfus effe conuenit.

P R O V E N I T agrefte porrum pleruing; in uineis, unde d

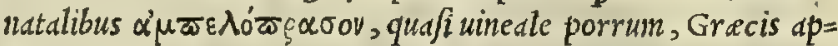
Agreftis porpellatur. Nafcitur boc in uniuer $\int a$ Hetriria non folim in uinetis; fed etiam frequens admodum in agrorum marginibus, $\odot$ in amoe= nis collium locis. Rura noftra ipsumulgari fermone appellant Porrandello. Eftur à rufticis, $\sigma$ agricolis in acetarijs crudum, recentis allij uice : quanqudm manfu durius fit, guftu acrius, or concoctu difficilius. Eft praterea Ampeloprafum (ut lib. v I. fimplicium medicamentorum prodidit Galenus) dcrius, \& ficcius domeftico, ficut agreftia onnia reliqua domefticis: dc proinde fto macho, qudm illud nocentius: fed o craffos; ac lentos bumores potentius incidit, ualentiusq́; infarcta organd obftructione libe=

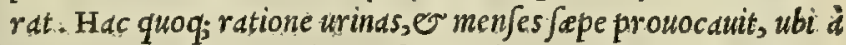
craßis, or lentis retinebantur bumoribus. A deó ueró eft calidum, ut illitum cataplafmatis modo exulceret. Dictum eft autem anté, quòd que eum in modum funt calida, extremi fint ordinis. batte = nus Galenus. Caterim illud filentio baud disimulandum puto, quòd Galenus minus fortaffe recté id tribuerit Ampeloprafo, quod nominis fignificationi reclamat, $\odot$ potius fcorodoprafo compete re uidetur, cum loco citato inquit. Si inter allium., os porrum medium quiddam concipias, facultatem amapeloprafie inueneris. Quandoquidem fcorodoprafum, tefte infrà Diofcoride, ut allij, et porri uires; ita er nomen. fibi uendicauit: ampeloprafum ueró dictum eft, quód in uinetis nafcatur. Id quod ipfemet Galenus con= firmat libro v I I I. fimp. medic amentorum bis uerbis. Scorodoprafon ficut guftu, ov odore mediam allij, or porri qua

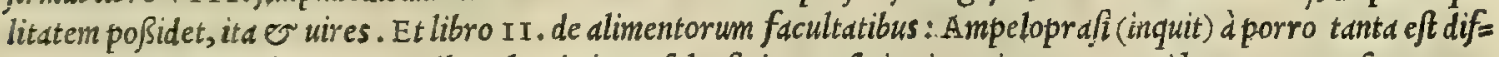
50 ferentia, quanta in alijs congeneribus plantis inter Jylueftria, of fatiua inuenitur. Sunt qui hoc in totum fequentem annum reponant, aceto condientes, baud aliter qudm cepas, ea óg, ex parte cibo commodius, er prauo minus fucco ob=

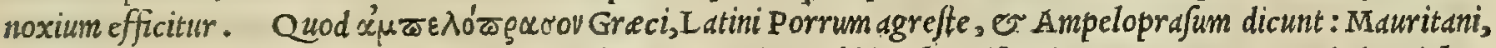

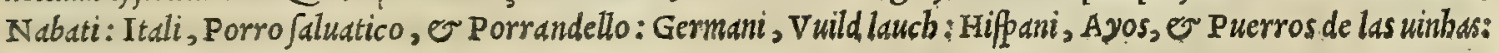
Galli, Pouree de chien.

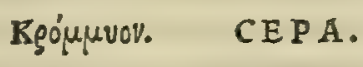

\section{A P. CXLV.}

C E P A longa acrior eft, quàm rotunda, item flaua quàm candida $;$ \& ficca quàm viridis, \&z cruda quàm cocta, aut fale condita. O mnes tamen mordent, flatus gignunt, appetentiam inuitant, fitim mouent, \& extenuant, faftidium pariunt, \& expurgant : aluo vtiles funt. Eæ detractis purgamentis in oleum coniętx, hæmorrhoidas, reliquosq́ue excretionum exitus referant, fubditæ pro balanis. 
C E P A.

Ceparum hiAtoria ex The ophrafto.

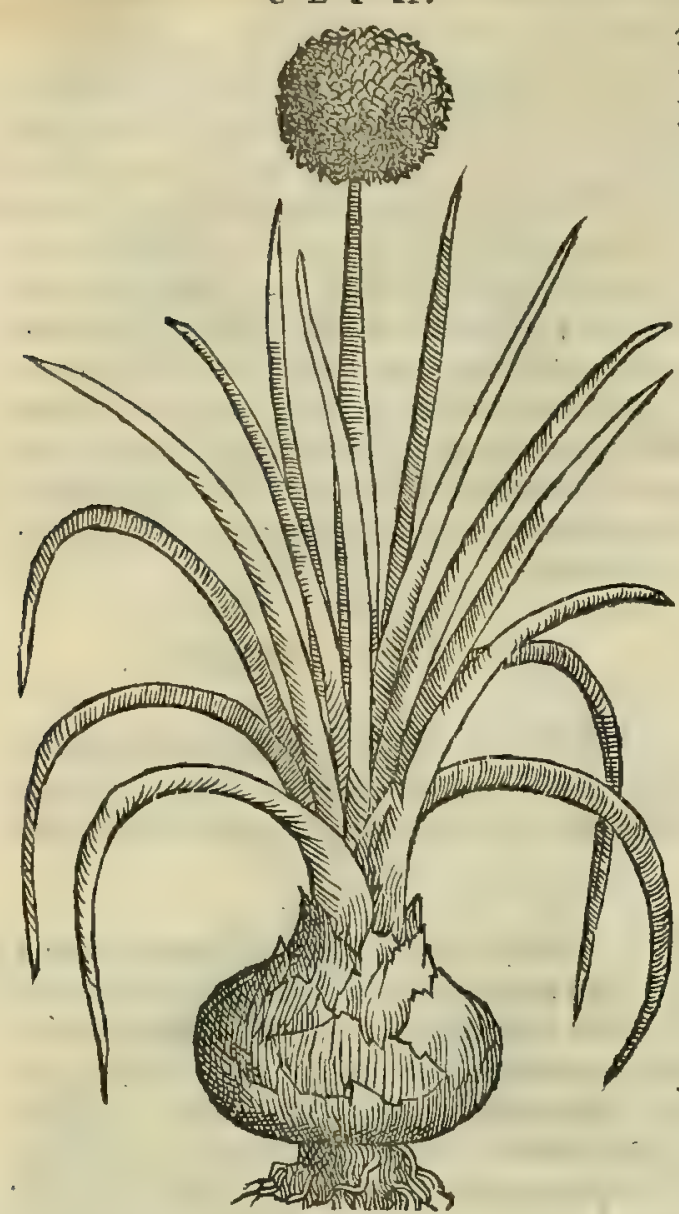

Succus cum melle illitus, oculorum hebetudinibus, argemis, nubeculis, \& incipientibus fuffufonibus auxilia tur: anginæe edem perunguntur: fuppreffos menfes pel lit: caput purgat, naribus infufus : canis morfibus cum aceto, ruta, \& melle illinitur : cum aceto autem perunEtas in fole vitiligines fanat: \& cum pari fpodio, fcabras lippitudines fedat: varos cum fale reprimit: contra calceamentorum attritus, cum gallinaceo adjpe vtilis eft : ci tæ aluo prodeft : in auribus fonitum, ac grauitatem emê dat: ad purulentas aures, \&z eliciendam earundem aquá, valet:alopeciæ earum fuccó perfricantur, qui celerius quàm alcyonium pilos euocat. Largiore cibo ccpa capitis dolores ciet, coctaćue vehementius vrinam pellit:cos lethargicos efficit, qui valetudinibus aduer $f$ s, ea etiam co Eta, plus æquo vefcantur. elixa, \& cum pafsis vuis, \& fico illita tubercula concoquit, $\&$ celerrimè rumpit.

C E P A R V M plura Theoplrafto notantur generd libro V I r.cap. I I I I. de plantarum hiftorid, ubi fic babet. Differunt or cepe, or allia genere. Sed Ceparum genera plura, ut que à lo cis nomind accepere : gardie, cnidie, famothracie : item fetanis, or fißiles, or afcalonie, Ex lis Setanie minime, sed largé dulces. Fißiles ueró, er afcalonix, tü cultu, tum natura inter fe differunt. Fisilem etenim byeme fua cum coma, inertem relinqunut, uere externa folia detrabunt, è reliqua colunt: detractis bis folijs, al tero germinant, fimulo; infrius finditur, unde fißiles appellate funt: Quidam uel omnibusdetrabenda folia cenfent, ut uim fuam imo contineant, neq; effufe fonine $c$ cant. A caloniarim peculia= ris quaddm natura notata eft: etenim fole fißiles, ơ quafi fteri les; ab radice confiftuni, nec ea parte crefcere, ac proficere pof=

funt. Qudmobresn non eds deponunt, fed femine ferunt:deinde circa uer, cim gcrminatü fit, transferwist. Perficiutur adeò celeriter, ut cum ceteris, aut etiă prius euelli poßint. Plus tęmporis diniffe in terra, putre fcint. Plantate caulĕ edunt, femenơ; tantummodo fundunt: tum exinaniuntur, atque inare fcunt. Harum igitur talis natura cft. Differunt e colore nonnulle : etenim apud l fum ceter a quidem candidis fimiles conftant, fed colore candide admodum pro= ueniunt, Sardianisq́; fimiliter ferre affirmant: Cretenfium peculiaris maximé natura notatur, sed A ccalonijs quodám modo proxima, ni forté uel eddem dici debeat. Eft enim in Creta genus quoddam, quod femine quidem fatum in radi= ce craffatur : depofitum ueró, in caulem, femenó; totum funditur : fine capite, Japorcí; dulce eft. Id enim quafi $\dot{e}$ contrario cateris habet: omnes nanque depofite melius,celerius; ; perficiuntur. Omnes poft arcturum proueniunt, tepido adhuc folo, ut depofitas imbres occupent. Seruntur e toto capite, er circuncifo, Jed germinationes baud $i=$ miles fierifolent. Parte nanque inferiore cepe nafcuntur, fuperiore herba tantum erumpit: fect e uerò in rectum, germinare omnino nequeunt. Getbyum dictum fine capite eft, or quafí longa ceruice confiftens : ob id germinatio to= ta in fronde; fepiusó;; retondetur, ut porrum . qua de caufa femine feritur, id nec deponitur. Cepas bifce feré diffe= rentijs difcernere licet. bactenus Theophraftus. Nafcuntur Cepa in uniuer $\int_{a}$ Italia frequentißina, que etiam inibi multiplicifignantur genere, ut refert Plinius lib. X I X.cap. vI. $\odot$ ut nos quotidie uidemus. Quandoquidem for = ma alia maiores, alia minores, quedam longre, queddm rotunda, quadam ueró feßiles proueniunt. sicut coloré rubentes, or fubrubentes alia, quedam uirides, e candidia tönnulle. Quin o faporc uel acerrime, uel medio= cri acrimonia preditx funt, aut nibil penitus acres inuéniuntur. Omnium maxime funt, que Caieta Romam impor tantur. He tametfiad funmum rubefcant, ac craßioribus tunicis compacte fint; leuiufcula tamen acrimonia pol= lent, manfǘ; tenerrime comperiuntur : ob id $\dot{q}_{\text {; }}$ in cibis cateras antecellunt. In Hetruria ee minus acres notantur, que magis rubent. Contrà uerò albe, quippe que omnium ibi acerrime proueniant. Quam ob caufam ad medicd= menta potius, quàm ad cibos feruantur : quanquam fecus fortaffe in Grecia eueniat, quód flauas candidis acriores effe memoret Diofcorides. Connumerantur etiámnum inter ceparum genera (ut locis fupra citatis. Theophraftus, $\checkmark$ Plinius teftantur) que Afcalonix ab Afcalone Iudex oppido appellantur; or qux bis fimiles funt Theopbrafto Ceparum ui- Sectiles nominate, nobis ueró in Hetruria uulgó Cipolle maligie. Cepa (ut memorie prodidit Galenus libro v I I. res ex Gal. fimplicium medicamentorum) ex quarto oft ordinc excalfacientium : cffentia autem eius potius cr.1farum eft partiü. Vnde etiam bemorrboidas aperit rum appofita, tum cum aceto inuncta. In fole alphos abftergit, tum alopecijs attri ta pilos alcyonio citius reftituit. Porró fi fuccum eius exprimas, quod reliquum eft, admodum terrex fubftantie eft, eiusq́; calida : at fuccus aquex, aerex'́; caliditatis. Hic igitur ijs, qui fuffufif funt, aut aciem oculorum obtufam pra craßitudine bumorum obtinent, inunctus prodeft. Ex builus temperatura tota cep a flatuofa eft manducata.Itaq; que temperatura funt ficciore, minus flatuum generant. hac Galenus. Quod autem Cepa corporibus prabeant ali mentum, fuprà in porri mentione retulimus ex ipfo Galcno, qui de ijs fimul differuit libro I 1. de alimentorum $f_{a=}$ cultatibus, 


\section{In Lib. fecundum Diofcoridis.}

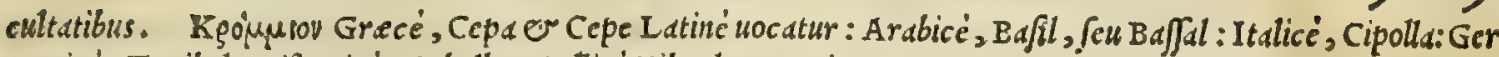
manicé, Zunibel: Hipanicé, Cebolba: Gallice, Fiboule, or Oignon.

Exógodov. ALLYVM.

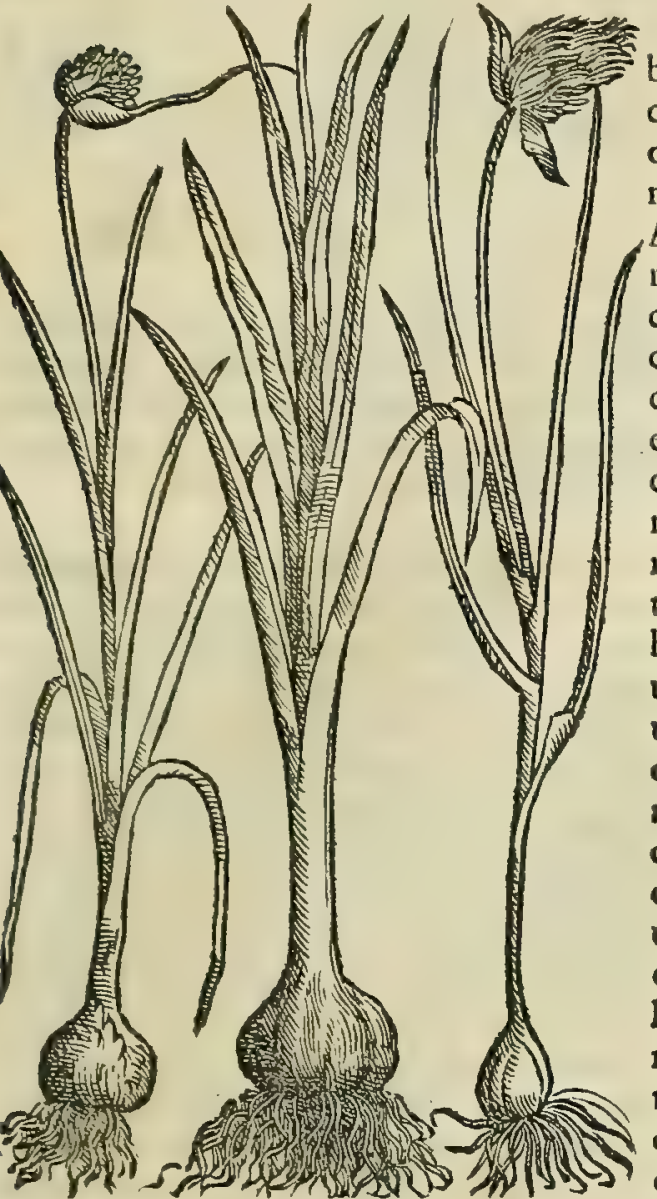

CAP. CXIVI.

A I I I V M quoddam fatiuum, atque hortenfe habetur. quod in Aegypto, fingulari ut porrum, capite conftat, dulce, in purpureum uergens, paruum: reliqua uerò magna \& candida, ex pluribus coagmentantur nucleis, quos aglithas, id eft fpicas, Grxci nominant. Aliud eft fylueftre, quod ophiofcorodon, id eft anguinum, uocant. Vis allij acris eft : excalfacit, mordet, excernit, aluum turbat, inflationes facit, ftomachum exic cat, fitim gignit, flatum permouet, fummam corporis cutem exulcerat : aciem oculorum efu hebetat . Eofdem effectus præbet anguinum, quod \& elaphofcorodon dicitur : latas uentris tineas in cibo fumptum abigit, urinas detrahit: contra uiperarú ictus, \& priuatim hæmorrhoi, prodeft, ita ut non aliud magis, fr cum uino iugiter affumatur, aut tritum in eodem cbibatur : contra rabioforum morfus, \& illitu, \& cibo ualer. Magn $\&$ allio utilitates contra aquarum mutationes : uocem clarificat: ueterem tufsim crudum, coßtúmve lenit : potum autem cum origani deco\&to, pediculos, \& lendes enecat: cremati cinis illitus fugillationibıs cum melle, \& alopecijs cum nardino unguine, medetur : eruptiones papularum cum oleo, \& fale fanat : uitiligines, lichenas, lentigines, ulcera capitis manantia, lepras, \& furfures, cum melle eximit: cum thure, \& teda decoctum, dentium dolorế leuat, fi in ore contineatur: contra uenenatos muris aranei morfus, cum ficulneis frondibus, \& cumino illinitur. Feruefact $x$ comæ ius, fominarum defefsionibus ad ditum, menfes, \& fecundos partus extrahit. Allium ciufdem gratia fuffitur. Factum ex eo, \& nigra oliua intritŭ, quod myttoton uocant, efu cit urinam, ora uenarum patefacit, hydropicis utile.

A I I I v M uulgaris eft notitie. Ceterium quanquan fcribit Diofcorides Allium, quod non coherentibus nu= Allij confidecleis, fiue picis, fed fingulari, o folido capite conftat, in Aegypto nafci ; eiufmodi tamen er in Hetruria, er in com ratio. pluribus alijs It alie locis prouenit, ibiq;; Allum mas appellatur. Allij meminit Theophraftus lib.v I I.cap. I I I. 40 de plantarumbiftoris/ic inquiens. Allium ante folftitia, aut paulo poft folftitia feritur nucleatim diuifum. Difcrimen corum, quód aliud precox, aliud ferotinun : eft enim genus quoddam eiufinodi, ut fexaginta diebus perfici poßit. Dif= ferunt preterea magnitudine fingulari. Cyprium uocatum maxiné tale eft, quod non decoquunt, fed in myttotis utun tur: $\sigma$ cim tunditur, mirum quàm feuma increfcat. Quin $\sigma$ illud differentiam facit, quód quadam non nucleis codgmentantur. Duldedo autem, E odor, or craßitudo, corumq́; caufa, tempore, cultuq; pené uidentur continge re, ut etiam aliorum. Perfici etiam femine poteft, fed tardé : primo etenim anno caput accipit porri, fequente difcere ni in nucleos incipit, tertio redditur perfetum, nec quicquain deterius, fed etidm quidam uel depofito melius id exis fimant. Radicis autem allij, aut cepe haud fimilis ortus fierifolet: allij nanque cum nucleus extumuerit, tota intor quetur: $\sigma$ binc autta in nucleos rurfus difcernitur, at q; ex uno plura efficiuntur, dum caput confummatur. At ce. pe continuó ab radice aliud, atque aliud obducit, ut $\mathbb{\sigma}$ bulbus, $\mathcal{F}_{2} \int c y l l a$, E eiufmodi omnia. Etenim allia, or cepa, so fi non euellantur, plura indies fiunt. Super fiftula quoq;, or allium capitari poffe, 0 cepe affirmant. bactenus Theo

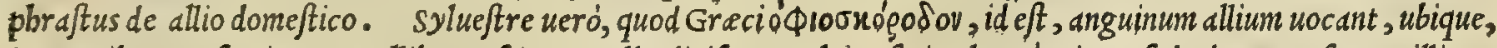
in montibus prefertim, o collibus nafcitur, null ts diuifum nucleis, fatiuo longè minus, fed odore, o fapore illiper fimile : folijs anguftioribus, gracilicaule : in cuius cacumine flos emicat, ex rubeo purpurafcens, a quo nigrum gi= gnitur femen. Hoc, cìm aliquando in montibus legerem unà cum alijs berbạrijs, nobis occafionem prabuit loquendi de errore deteftando, in quo turpiter uer fati funt Arabes, o cos fecuti : quód pro fcordio berba, que triffaginem fo = Arabülapfuso lijs amulatur, de qua Andromaclbus, e Galemus intellexerunt, allium fylueftre in paftillos theriacos addiderint, er in illius locum fuffecerint, non minus uocabulorum vicinitate, qudm imperitia decepti, ut fequenti libro in fcordij mentione (Deo fauente) latius explicabimus. Porró illud hic filentio non dißimulandum duxine forté feplafiarijs im ponat, quód Brafauolus apertẹ falli deprebhenditur libro fuo de fimplicium examine Romie prius excufo, ubi fylueftrè erros. alliuin ampeloprafon, fiue fcorodoprafon à rei medice auctoribus appellari fcribit. Qua in re non uno tantum, meo quidem iudicio, fed duplici, pace eius dixerim, notatur errore, Primum quód exiftimauerit, allium fylueftre froro 
doprafum, uel ampeloprafum effe. Deinde quód certó crediderit, ampcloprafum, er fcorodoprafum unam er eank dem plantan cffe. Hi Brafauolierrores manifeftéredarguuntur Diofcoridis auctoritate. Siquiden is non folum cas flantas nominibus, fed etian capitibus, or facultatibus diftinxit: quem etiam feculus eft Galenus, licet, ut in ampclobrafo diximus, buic.tribuerit, quod fcorodoprafo tribuendum erat. In bis igitur pald an fit, allium fylueftre ophiof corodum appellari : fylucftre porrum, quod in uineis proucniat, ampeloprafon: tertium ueró, quód promi= fcuas allij, e porri facultates obtineat, fcorodoprafum. Quare mirari fubit Brafauolum uirum alioqui doctißimum, quomodo is, qui fimplicium medicamentorum examen confcripfit, hac in Diofcoride, or Galeno non uiderit, uel non

Nomina. animaducrterit. Exópodov Greci, Latini Allium dicunt: Arabes, Chaum, Cairin, er Thum: Itali, Aglio: Ger mani, Knoblauch: Hipani, Ayos: Galli,Ail, E Aux.

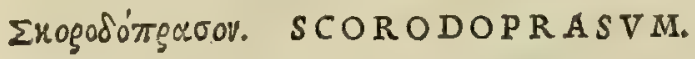

\section{CAP. CXLVII.}

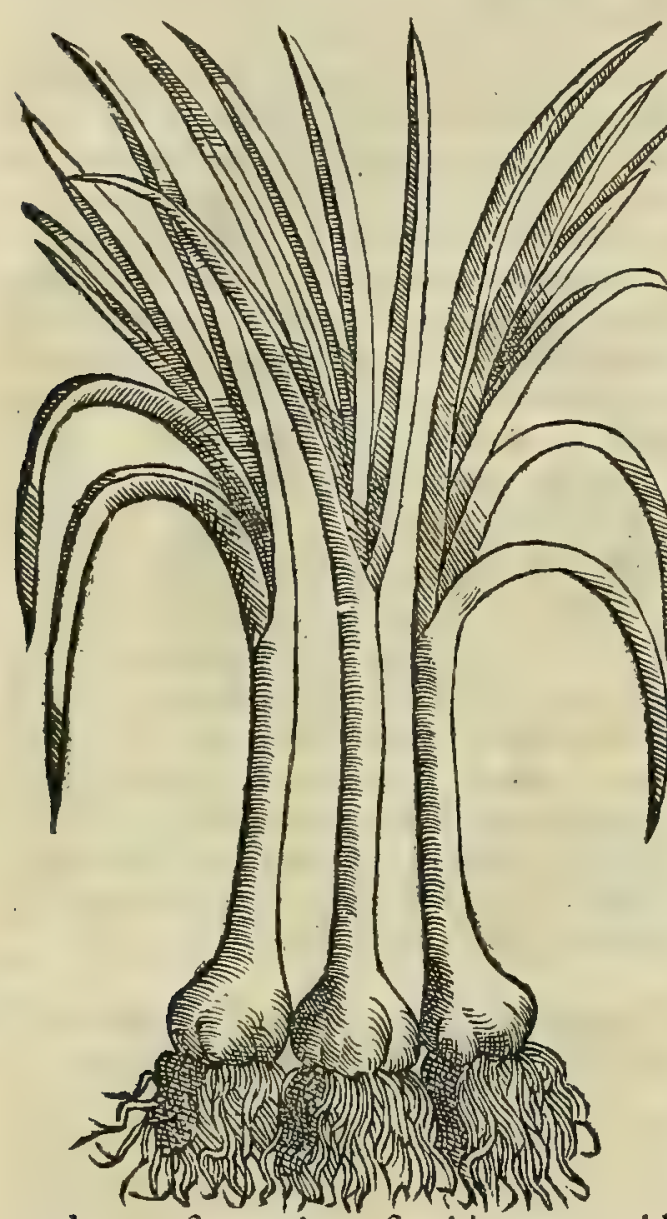

SCORODOPRAS V M magnitudine porrum $2-$ quat, qualitatum porri, \& allij particeps. Vnde promifcuas fibi uires ex utroque uendicauit, effectus allij, \& porri prabens : inefficacius tamen. Coctum, porri modo, dulcefcit, \& in olerum uicem tranfit .

QV o N I A M antiquorum nullus, preter Diof coridem, $G a$ lenum, er Paulum, scorodoprafi meminit, proptered exiftimat: 20 Marcellus arte, er cultorum mangonio ex altio, or porro in unum fub terra colligatis, non autem natura, fcorodoprafum prouenire. Sed bac in re Marcellum, pace fua dixerim, cecutiffe illud maniffeto indicio eft, quód compertum fit, legitimum scoro doprafum natura, non mangonio factum, in compluribus Italie locis ponte fua nafci : ac inde poftea translatum, in hortis, o ui ridarijs depofitum uire fecre, ita ut intuentibus legitimum fe often dat, $\sim$ Marcelli errorem prodat. Crefcit id porraceis folijs, qua digitis attrita itd allium, o porrum fimul refipiunt, ut illorum etiam effectus prebent, quemadmodum recte prodidit Diofcori $=30$ des, O Galenus atteftatur lib. v I I I. fimplimedicamentorum, his paucis. Scorodoprafum ficut guftu o odore mediam allij $\sigma$ por= riqualitatem poßidet, ita er uires. Id Grece ou opas ór gecoov, Latiné fimiliter Scorodoprafum appellatur: Italicé, Scorodopra fo: Germanicé, Aber lnoblauch: Gallicé, Ail porreau.

EIVHळ!. SINAPI.

CAP. CXLVIII.

S I N A P I hortenfe, aliqui napi uocant. Eligi debetadultum, ualde rufum, non magnopere ficcum, fed $4 \circ$ quod fractum internè uirefcat, \& ueluti quodam fucco madeat, cæfium colore: fiquidem recens id genus, tempeftiuum habetur. Ad calfaciendum, exte nuandum, extrahendum, efficax eft. Ad eliciendam capitis pituitam manditur: contra præduros ton fillarum tumores, ac ueterem, callofamque arterix fcabritiem, fuccus ex aqua, \& melle conuenienter gargarizatur : fternutamenta ciet, tritum, \& naribus admotum : comitialibus quoque auxiliatur: fo minas vulua ftrangulatu oppreffas excitat : lethargicis, derafo capite, illinitur. Cum ficis admiftum, donec rubefcat locus, $\&$ ad coxendicum cruciatus impolitum, ad lienes, \& omne genus dolores con fert,cum permutand $æ$ ualetudinis caufa ex alto uitia extrahenda funt : alopecijs illitum medetur : $\mathrm{fa}=$ ciem purgat: fugillata cum melle, adipe, aut cerato rapit: feræ impetigines, \& Icpræx, eo cum aceto perunguntur : contra febrium circuitus aridum bibitur,aut potui, polente modo infpargitur : extra- so hentibus emplaftris, fcabiemq́ue extenuantibus, utiliter admifceri folet : tritum grauitati aurium, \& fonitui cum fico impofitum prodeft. Succus ad hebetudines oculorum, \& genarum fcabritias magna utilitate cum melle illinitur. Expreffus recenti femine fuccus in fole ficcatur.

Sinapi confideratio.

S I N A P I, Plinio libro X I X. cap. VII I. auctore, trium eft generum. Quorum unum gracili affurgit folio: alterum rapitiam frondem exprimit: tertium eruca folio laciniatur. Hac omnia Sinapis genera obferuantur in Ita= Tia : illud fiquidem, quod tum folio, tum etiam femine tenui nafcitur, crraticum elt. Quod ueró rapifronde conftat, ceteris maius, hortenfe eft, ciusq́; in officinis ufus. Tertium deinde er ipfun fatiuum eft, femine albo, minus q́; acri. Tritum boc, muftó,; recenti commiftum, diutius eius dulcedinem tuetur, atq; caln dcficere probibet, quód cbullitio= Sinapi vi- nem reprimat. Eág; propter qui ex Tridentino agro in Germaniam muftum comportant, boc sinapis genere cadis
impo/ito, dulcedinem mufliconferuant. sinapis temperamentum tantummodo expreßit Galcnus libro $\mathrm{V}$ I I I. fim res ex Gal. 


\section{In Lib. fecundum Diofcoridis.}

SINAPI PRIMVM.

a oi

(12) 14 s

20.7.

数

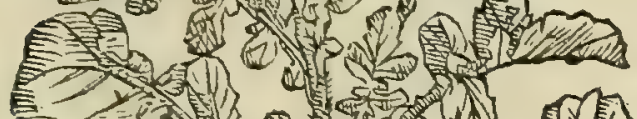

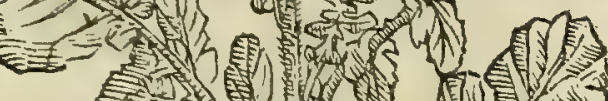

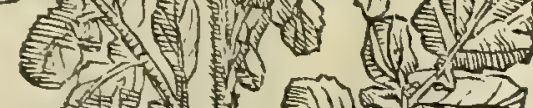
S n n

20

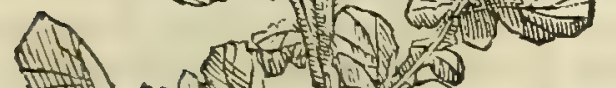

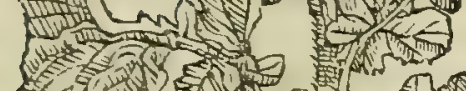

s. sin sin

-1) G.1.2 3.

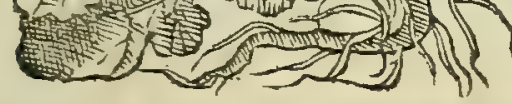

SINAPI TERTIVM.

40

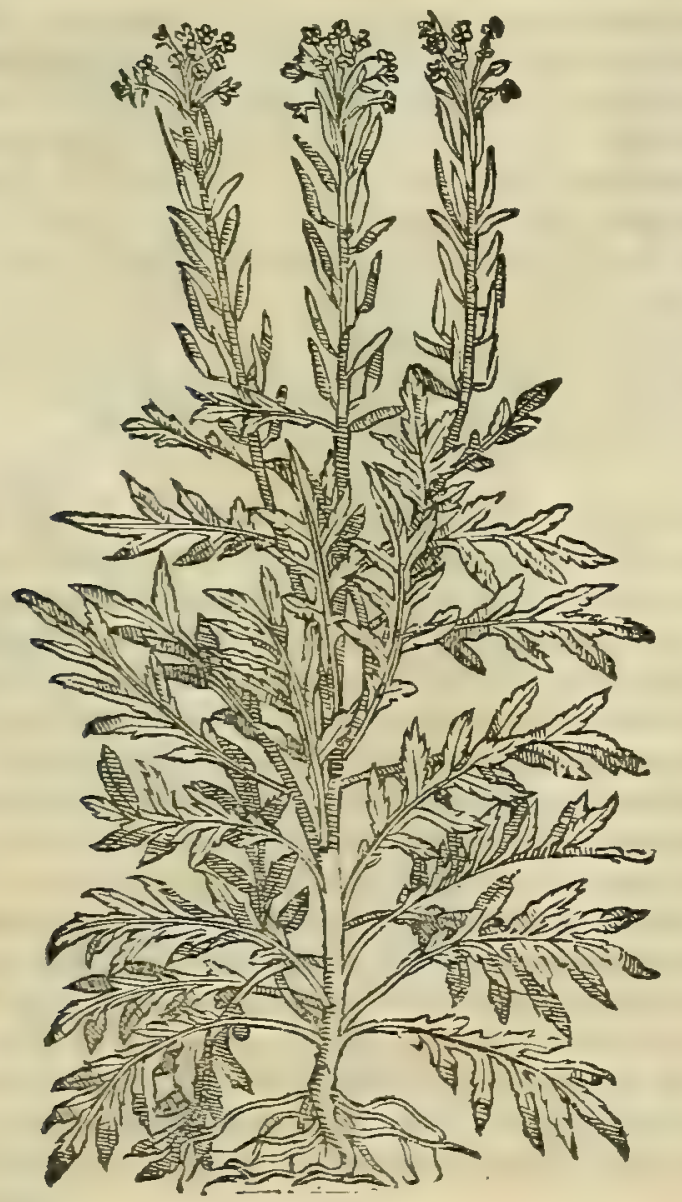

SINAPI SECVNDVM.

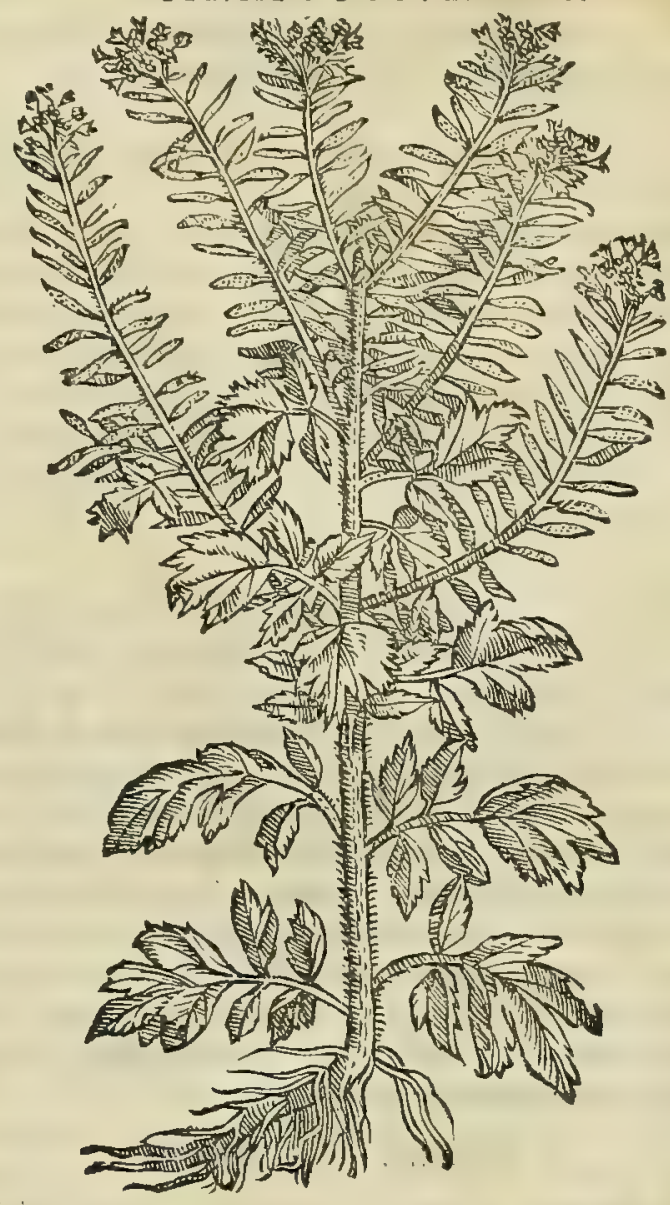

NASTVRTIVM.

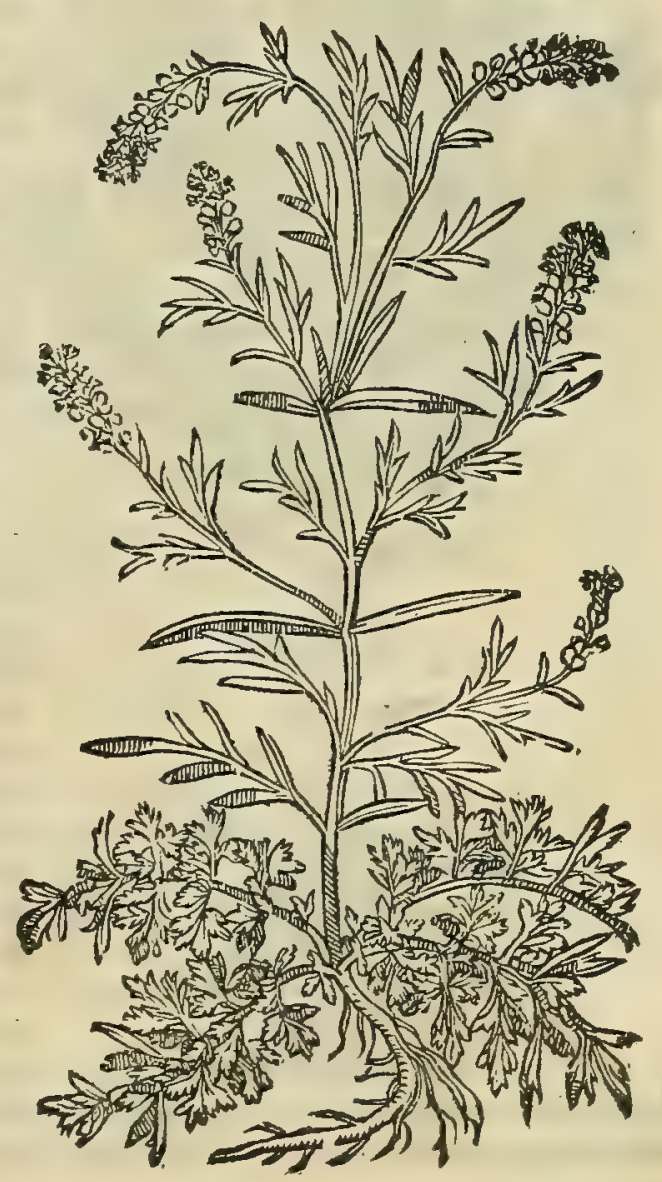




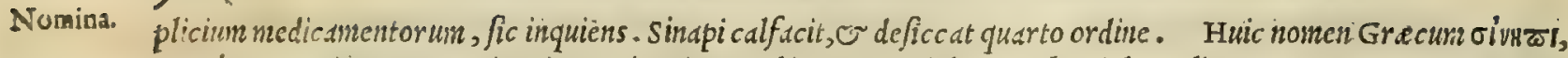
or vá s: I tinum quoq; sinapi, er sinapis: Arabicum, Cardel, wut Chardel: Italicum, Senape: Germanicum, Seneff: Helis ancum; Noftaza: Gallicum, Seneue.

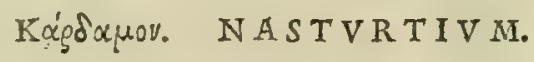

\section{CAP. CXIIX.}

NAS T V R T I V M optimum confat effe Babylonicum. Omnium femen eft acre : excalfacit, fto macho aduerfatur, aluum turbat, tineas excutit, lienem imminuit, partus exanimat, menfes cit, uenerem fimulat, finapis, \& erucx fimile intelligitur : lepras, \& impetigines abferget. Illitum cum melle lienem extenuat, fauos expurgat: pulmonum uitia extrahit, forbitionibus incoctum : ferpentium uenenis potum refiftit, atque cas fuffitu fugat: capillorum defuuia cohibet:carbunculos ad fuppurationem perducit, \& rumpit : coxendicibus cum polenta commodè ex aceto illinitur: tumo.. res, collectionesq́ue difcutit : emittit furunculos illitum cum muria. Herbæad omnia eadem effectus, licet minor.

Nafturtii cófideratio.

Nafturtii uires ex Gale.

Nomina.

Thlafpi confideratio.

Thlalpi uires ex Galeno.
N A s T V R T I V M hortis familiaris, e frequensherba eft, tenuis: folijs paruis, laciniatis: caule tenui, $e=$ Squipedali:flore albo: femine in rubeum nigricante, folliculis rotundis, ac preßsis contento, thlapi modo. Plmius au= thor eft lib. X x.cap. X I I $\mathrm{r}$. album, er nigrum reperiri. Verum cum $\mathrm{N}$ afturtiun ueneren inbibere fcribit, iuel co= dicem eo in loco deprauatum, uel Plinium ipfum Nafturtij naturam non recté nouife, et ideo in boc deceptum effe crediderim, quód experimento, 6 Diofcoridi repugnet. Nafturtij femen (ut libro VI I. de fimplicium medicam. facultate inemoria prodidit Galenus) adurentis facultatis particeps oft, ficut finapi. Proinde coxendicis, 6 capitis dolores atg; adeó quodcunq; aliud rubrificationem poftulat, eo perinde atq; finapi excalfaciunt. Mifcetur quog; re medijs, qux exbibentur afthmaticis, tanquam falicet id, quod craffos fuccos ualenter incidere ualeat, uelut $\sim f=$ napi. Nam omnia ci fimile eft. Porró o berba arefacta fimilem femini uim poßidet. Humida ueró adhuc, or uiridis propter aquea bumiditatis admiftionem, multö, femine inferior eft: adeóq; fic mordacitas eius moderata eft, ut cum pane ea utiliceat, ceu obfonio. Káģ $\alpha \mu o v$ Gracis, Nafturtium Latinis uocatur: Mauritanis, Norf alchef, feu Narf:Italis, Nafturtio, er Agretto: Germanis, Kreffen, e Gartenlsreß:Hipanis, Nafturcyo, er Malpica: Gallis, Creffon de iardin, $\sigma$ Nafitort.

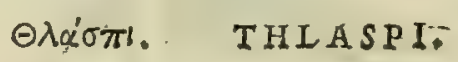

CAP. CL.

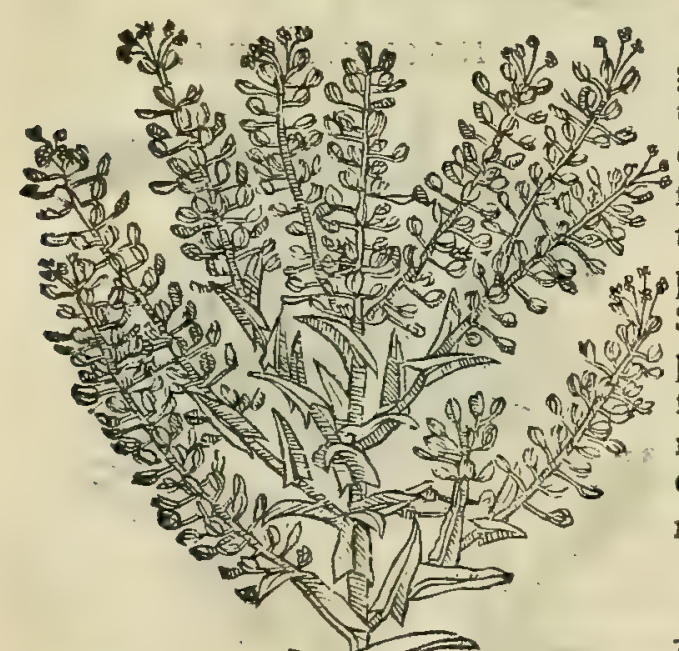

T if I A S P I herbula eft anguftis folijs, digitalilon gitudine, in terram uerfis, fubpinguibus : binûm dodrătum cauliculo, tenui, non fine adnafcentibus ramis : fru Ctu circa ipfum totum, ab extremo in latius fe pandente: femine nafturtij, inclufo uafis in cacuminc diuifrs, + lenticulæ effigie, nifi quòd infringitur : unde nomen accepit. flos albicat . Nafcitur in femitis, \& fepibus, fofsisq́; Semen afperi guftus, excalfaciens: bilem vtrinq; extrahit, potum acetabuli menfura : prodeft ifchiadicis infufum: fanguinem potu educit, internas fuppurationes rumpit: 40 menfes ciet, fed partus enecat : Alterum thlafpi tradit Crateuas, quod aliqui Perficon finapi uocant, latis folijs, radicibus magnis: utile ifchiadicorum infutioni.

T А M E T S I nondefint, qui exiftimaucrint, Thlafpi, Burfam paftoris unlgó dictam unam, o eandcm effe plantam; cum tamen buiufce Burfap paftoris folia, que per ambitum fonud= tim laciniata uifuntur, fenen'; bis, que de Thlapimemoris pro= didere Diofcorides, $\sigma$ Galenus, minimé conueniant, corum fen tentia prorfus explodenda uidetur. Ceterum legitimun reperiri 50 in Italia certum eft: fiquidem eo maximé abundant or Goritienfis ager, er Gradifce monid, ea parte qua Sontius alluit. Nafcitur frequentißinum, on acerrimum in $\mathrm{P}$ ago fancti Petrinon longé d Goritia, alijsog, circumftantibus locis, femine perquam acri, in fol Ticulis inclufo, in cacumine diuifis, lenticuls effigie, fuperna par te preßis, ut Diofcorides inquit. Meminit Thlapi Galenùs libro VI. fimplicium medicamentorum, fic inquiens. Thlapi femen ba bet er ipfum facultatem acrem, adeo ut internos abfcelfus potum difrumpat. Menfes ciet, er fxetus enecat. Per jedent infusum fanguinolenta euacuans, ifchiadibus prodeft. Eft enim aloqui tum fuperné, tum inferné bilioforum bumorum cua= cuatorium, acetabuli menfura potum. Et libro primo de antidotis: Vtuntur Thlapi (inquit) quód é Creta affertur, 


\section{In Lib.fecundum Diofcoridis.}

BVRSA PASTORIS.
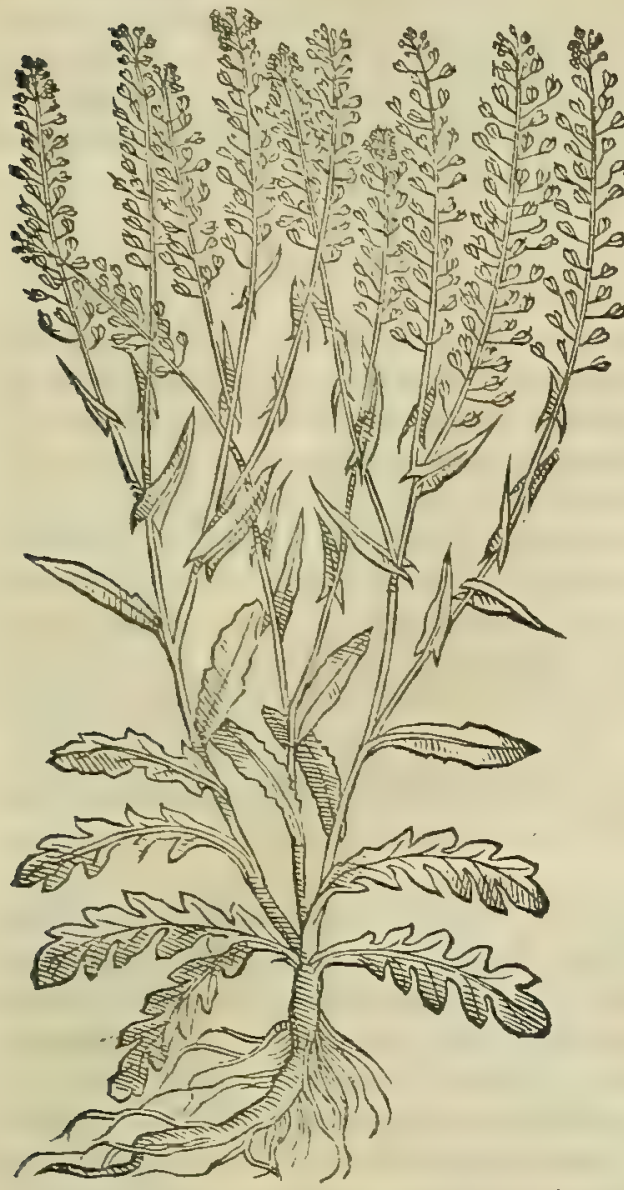

A R A B IS.

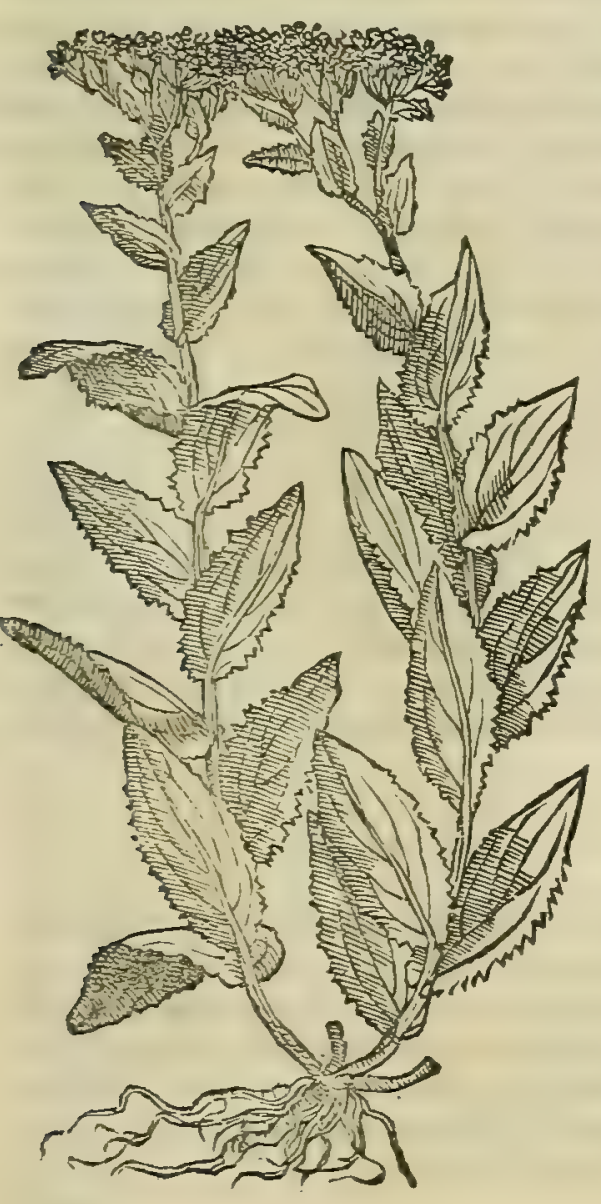

quod'q ubiq; nafcitur, colore inter lutcum, o flawum medium, fis gura rotundum, exiguum adcó, ut multoties grano milij cedat.

Melius eft auteme é Cappadocia comportatü thlapi imponamus. Hoc ad nigredinem inclinat: figur am nŏ exacfé rotundam babet, $\mathcal{O}$ antediatum magnitudinc permultim fupcrat, sto; ab uno late= 3reparkan quardam, ueluti compreßsionem pre fe fert, unde et no mell obtinuit. Proncnit autem ut hoc, ita eo illud in Cappodocia quimplurimim. Ideó, non abfoluté quod inde apportatur, opti= naum cenfendum eft, fed quod peculiariter in Sauro na fcitur, nec Cretico, nec pafsun nafcenti imile. Hac de thlapi Galcnus. Ex quibus fat is conftat, I talicü thlapi illi,quod Cappiadocia profert, non efe uiribus comparandum. Porró illud animaduertendü effé duximus, quod boc in loco legitur in Diofcoride : $€ \lambda \lambda^{\prime} \sigma \varpi 1 \beta 0=$

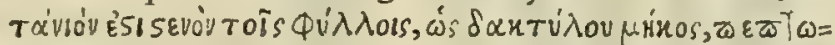

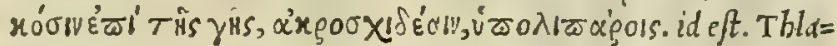
pi herbuld eft anguft is folijs, digitali iongitudine, in terrã uer fis, in cacumine diuifis, fubpinguibus. Atqui diuifure $c x$ in noftrati non uifuntur in folijs, fed in folliculorum cacumine. Quo fit, ut plané fupicer hoc loco Diofcoridis codici mendum ac uitiü fub $=$ effe, ut in alijs compluribus: or quod fortaffe nota bac, que pro= pria folliculorum efi, librariorum incuria in folia tranflerit, pres= fertim quód in cateris notis noftrü Diofcoridis, er Galeni defcri ptioni pror Jus adffipulatur. Hac igitur ratione is locus, nobis ui= fus eft, qui reftituatur, o legatur, quemadmodü nunc in textu le= gipoteft. Reliqum eft, utde B V R S A P A T T O R I S, cuius fuperius meminimus aliquid in medium afferamus. Sed cum ueteres nibil de hac pofteritatis memorie mandauerint, ea tan= tùmrecerfebo, que ì recentioribus de eius uiribus adnotatd in $=$ uenio, cim planta ip $\int a$ omnibus unlgó notißima fit. Eft igitur Burfa paftoris ex refrigerantium, exiccantium, er adfringettium genere. Quapropter prodeft attrita, o emplaftri more impofita inflammationibus, et facris ignibus. Decoquitur pluniali aqua cü plantagine, et Armienio luto, bibiturq́; cius decoctum ad inteftinos rum difficultatem, of dd cruentas excreationes. Herbe fuccus recentia uulnera glutitiat, et auribus purulentis infufus medetur. siftit menfium abundantiam, fi eius, or perficaria decocto infl= deart malieres. Eftur mis fluxiones efficax eft tenui pulticula circumlita, 0 in oleo fri $x d$. Additur in emplaftris, que id capitis uulinera componuntur, o in unguentis compluribus. Que berbd $\theta \lambda \alpha \dot{\sigma} \sigma \pi$ Grecis, Thlappi quoq; Latinis dicitur : Barbaris, $\mathbb{N}$ afturtium tectorum: Italis, Thlapi: Germanis, Bifemkraut: Hipanis, Panique fo de flor blanquo: Gallis, seneue Sauuage.

† Hoc loco Ruellius legiffe uidetur థaroes és, quód uerte= rit lenticula effigie : nec temeré, quód Thlapi femen illi pulchrè

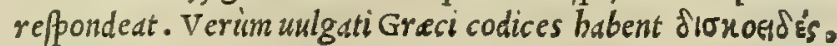
boc eft, difcifigura.

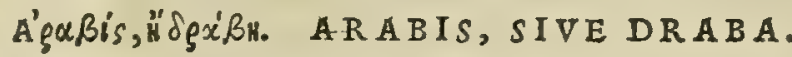 C A P. C I I.}

DRABA herbaad cubitialtitudinem affurgit, tenues fpargens ramos, \& ex utroque latere folia,ceu lepidij, fed molliora, \& candidiora. In cacumine uerò fambuci um. bellam gerit, candidos flores habentem. Herba haec cú ptifana coquitur, in Cappadocia maximè.Semen aridum propipere obfonijs admifcetur.

N A S C I T V R in Ananienfi agro,prefertim $\phi_{\text {; }}$ in campes Drabec conGfribus, o agrorum marginibus, cubitalis planta, folijs lepidio deratio. non dißimilibus, er umbella feré $\int a m b u c i$, Drabam adamußim re $=$
Diofcoridis locus reftitutus.

Burfe pattoris uires.

Nomipa. 
frens. quemadmodum et in Gallijs nafci Ruellius teftatur in noualibus, o fape cultis. Caterim quoniam Serapio in nafturtij mentionc, de Draba etiam differit, edinq́; Nafturtium oricntale nominat, quod infignis eius acrimonia indi= cium eft : o quoniam in noftrate leuiufcula fentitur acrimonia, idcirco an bec , que in I talia nafcitur, serapionis fal= tcm fit Draba, cgo profictó a fïrmare non aufin : nifi fortć id Draba accidat pro regionum dinter/itate, quemadmo=

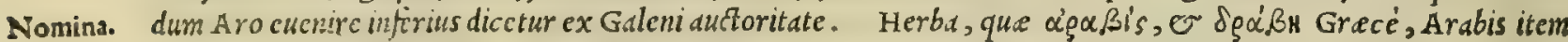
O D:"aba Latinc, pariter o Italicé appeliatur: Barbaricé, Nafturtiun oricntale: Gallicé, Draue.

$$
\text { E'gúsplu\%. IRIO. }
$$

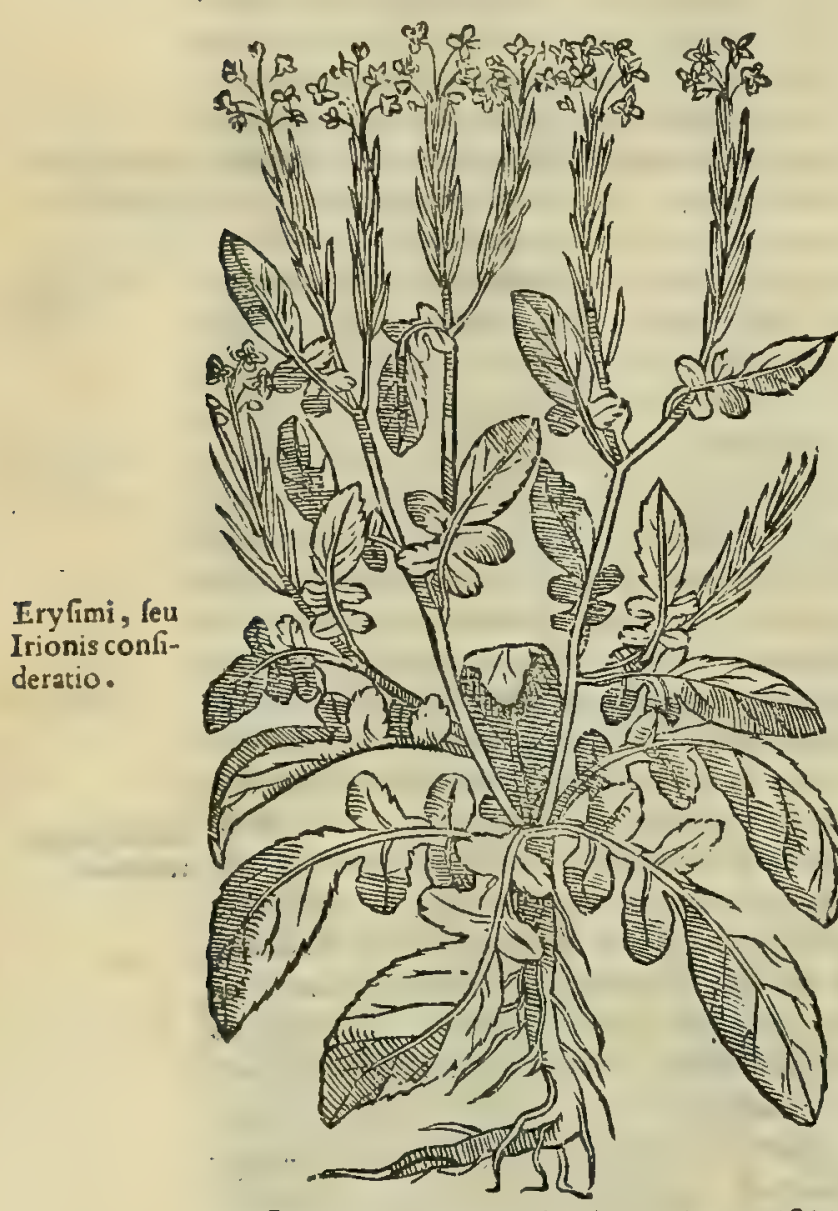

E R Y S I M o N, Latini Irionem vocant, iuxta vibes, 0 rudera, hortosq́ue nafcitur: folijs erucæ fylueftris : cauliculis in lori modum lentis, \& obfequiofis : floribus luteis: filiquis in cacumine gracilibus, ut fono grzeco, corniculatis : femine nafturtij, exiguo, urentis guftus . Contra thoracis fluxiones efficax eft, \& $\mathrm{ri}$ purulenta extufsiun tur: regio morbo, \& cox endicibus prodeft : contrá uene$\mathrm{na}$ in delinetu cum melle datur. Illinitur ex aqua,aut melle vtiliter cacis carcinom atis, parotidibus, duritijs mammarum, ix teftium inflammationibus. In totum extenuat, \& excalfacit. Mitius multò ad clyfteres fiet, fi aqua ma- 20 defcat, atque torreatur, vel linteo illigatum, pinfita farina oblitum peraffetur.

Qv A N QV A M Theophraftus, or antiquorum alij Ery/t= moninter cerealia commenorant: $O$ fe famo fintile faciunt: quod tamen à Diofcoride reprefentatur, folijs eruce amulis, tanquam ab illo admodum diSimile, bic inter acerrimas plantas, non inter frumentacea, ubi de fe fano differuit, ab eo rcpofitum eft. Eatq; propter facile dici poteft, Ery/imon aliud de fignare Theopbrafto, aliud ueró Diofcoridi. Ideoǵ; Plinius utríqque in Eryfimi hiftoria 30 adftipulari uidetur. Nanq; lib. X V I I I.cap.v I I.ac X. Theophra ftum fecutus, ip fum frugibus adfcribit, fefamo' ; fimile facit.Et lib. $\mathrm{X} \times$ I I.cap. X X v.Diofcoridem imitatus, folijs cruca paulò angu= ftioribus, o femine nafturtij Eryfimum effe prodidit. Hoc idem pas làm eft frciffe Galcnum: quippe quilib.v I. fimplicium medic amen torum, Eryfimum plantis comparanit, que acrimonia predite funt, uti nafturtium, o finapi. Et lib. I. de alimentorum facultas tibus ip $\int u m$ intcr frugcs retulit, que in cibum ueniunt, und cum $\int e \int_{d}$ mo, fic inquiens, vt porrò milio panicum adfinile eft quodammodo, fed ad omnit deterius, ita e fe famo Eryfimum corporis fubftantia nonrihil affine: fed manfum infuauus eft, e temioris alimenti, adco quod in omnibus illo dete $=40$

Ruellii, \& Hes rius cxiftit. Celerim Rucllius, quód dixerit plinius Ery/inum, o fe famum rubentibus prouenire folijs, itcm ipfis molai lapfus. uirentibus nullum animal ue fci, illud frugis genus autumat Eryfimmm effe, quod uulgó Tridentina rura appellant For mentone, Foroiulienfes uero, quod pullo fit colore, nominant Saracino. Verima hac in re Ruellius deceptus depre= henditur, quód nullis notis repondeat boc Eryfimo, quod Theoplirafto, or Plinio defcribitur : quand cquidé, quod uulgò appetlatur Formentone, caule tantiın rubet, non folijs, it nulloó; pecude reßpuitur, fcd ab omnibus anidißime depafcitur, nec ulla ex parte fe famum emuldtur. Porró fciendun eft, Diofcoridis Eryfinum non cffe fylucftrem erucam illam, quam nos nobilem appellamus, ut credit Hermolaus, item;; R uellius ipfum fccutus, fed ftirpen effe, que pafim in plateis, edificiorum arcis, o ruderibus, ש fecus uids oritur, folijs eruce, floribus luteis, paruis: $e$ quibus cornicula prodeunt, tenuid, acuminatáq; : femine nafturtij, minore tancn, e acri. Id Grecis ęươquv dicitur,

Nomina. quod Latinis fimiliter Ery/imum, $\odot$ Irio: Italis, Erifimo, o Irione: Germanis, Hederich, $\odot$ Vuilder fenff: Hi $i$ so Panis, Rinchan: Gallis, Velar, ou de la tortelle.

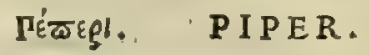

CAP. CLIII.

P I P E in India nafci, breui arbore traditur : qux inter initia, prælongum fructum, veluti filiquam, promit,quod longum piper eft : habet intus aliquid tenui milio fimile, quod tandem in perfectum piper euadit. Id autem fuis temporibus dehifcens, pandensq́ue fefe, racemos emittic, grana ferentes qualia uidemus. Ea acerba candidum piper faciunt, aptum ocularibus remedijs, antidotis , \& medicaminibus, qux contra uenenata parantur, theriaca vocant. Longum uerò uehementius mordet : \& quoniam priufquàm ematurefcat, decerptum eft, fubamarum relinquitur, antidotis, \& theriacis medicaminibus expctitum. Nigrum uerò, vtpote quod tempeltiua maturitate col- 


\section{In Lib.fecundum Diofcoridis.}

leturn fit, odoratum effe conftat, candido fuauius, acrius, \& ori gratius, necnon ad condimenta vtia lius. fed candidum, \& adhuc in acerbum vcrgens, antedietis infirmius eft. Eligi oportet grauifsimum, plenum, nigrum, line mulis rugis, recens, ac minimè furfurofum. Inueniuntur etiámnum in gevere nigrifemina nutrimento dcfeita, caffa, inania, minimiq́ue ponderis, quod uocant brafma. Vis omnium excalfacit, vrinam cict, concoquit, extrahit, difcutit, abfterget caliginem, qux oculis obuerfatur. Piper fébrium horroribus circuitu rcpetentibus, fuc potu, fuc illitu fubuenit : ferpentium morfibus auxiliatur: partus extrahit: conceptum adimere creditur, ftatin à concubitu fuppofitum : tufsi,omnibusque pe itoris vitijs, frue eclcogmate, fiuc potu fuccurrit : anginæe co, \& mclle connenienter pertng untur : potum cum recentibus lauri folijs, tormina difcutit: cum uua paffa mandu-

20 catum pituitam à capite elicit : ualetudinem tuetur, dolores finit, appetentiam monet, concoctionem adiutuat. ad intinctus efculentorum additum : ftrumas cum pice difcutit : tritiligines ex nitro cmaculat. Fiktilinouo, t vt aiunt, motum torretur. Non eft huius arboris radix gingiber, ut aliqui exiftimauere, ficuti paulò pòft oftendemus. Nanque piperis radix cofto fimilis eft, ora guftantium accendit, falıum ciet. Hxc lienem reprimit, cum aceto illita, aut pota: caput etiam purgat, manducatacum femine pedicularis herbx'; quam ftaphidem agriam uocant.

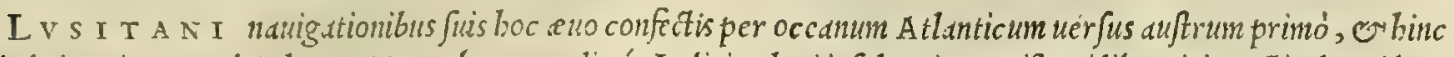
dcinde in orienten ad Calecut, Taprobantun, aliaśg; Indici pelagi infulas: item Hipani liburnicis uccti ad occideu= tales Indius, Pcru, atque alits complures regiones, que antiquos Geographos penitus latuerunt, non modó Pipe= $20 \mathrm{re}$, O huinfmodiodoratis fimplicibus uniuer fon replcucrunt Europam; fed o firpium biftorias, à quibus oriun= tur, poftcritatis memorix prodiderunt. Qrod poftea ficit, ut nobis plane ignoraffe uideantur Theoplraftus, Dio= fcorides, o Plinius, dut ob regionum diftantidn (indigcnam potius in boc fidem fecuti, quin quod forté ed uiderint, que de pipere foriptis tradidcrunt) aut ob alian quamuis caufam, plante illius formam, ac notas, que piper in In= dia gignit, ac guónum modo piperis plant.t furme edat fruthun, an fcilicet raccmatim, ant corymborun modo, an in filiquis inclufum, an bacciferanum arbormmore. Siquidem Plinius lib. X I I.eap. v I I. ita fcribit. Arboresque Plinijlapfus.

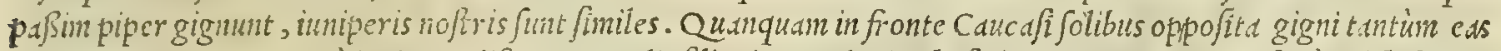
aliqui tradidere. Semina à iunipcro diftant paruulis filiquis, quales in phafolis uidemus. He priufquàn debifcant, deccrpte, toftéq; fole, facitmt, quod wocatur piper longun. paulatin ueró dehifcentes per maturitatem, oftendunt candidun piper, quod deinde tofun folibus colore, rugisq́; mutdtur. hac Plinius. Quibus à Diofcoride non longé

30 disidere uideretur, nifip piperis plantam finilem iunipero reddidiffet: nang; Diofcorides nullis eam notis reprefen= tauit, neq; alicui fimilem fecit. Theophraftus preterea quanquam fcriptum reliquit lib. I X.cap. X $\mathrm{x}$ I I de planta= rumi hiftorid, Piperis duo effe genera unun rotundum, alterum oblongum ; eius tamen arboris effigiem filentio pria= terijt. At bi, qui fuis liburnic is immen a traiecerunt maria, propridsóg; perluftrarunt regiones, ubipiperis utriuf=. que plante inmuncre uire fcunt, nigrum, ac rotundun gigni narrant a quibufdam infirmis titiculis uicinds arbores altiore complexa fcandentibus, acute clematidinon dißimilibus, folio tamen malum Affyrium amulantibus. Quin o racematim proferri unarum labrufce modo, confertius tamen, deinde menfe octobri per maturitatem decērpi, o fub fruenti fole tegetibus paline is expanfum torreri, quoufque nigrefcat, or rugofun cuadat: quod tridui $\beta \mathrm{p}=$ tio plerwique fit. Iongun autem, ut ijdem teftantur, alia ferunt arbores, eft ; $_{\text {; }}$ uelut nucamentum quoddam, exilibus granulis fquamatim compactum, quod uelut iulus in pontica nuce, cui pulcbrc adftipulatur, uermiculofa

40 facie dependet, piperato gufu: nunquan tumen in album, uel nigrum piper coale fcit. Galenus indigenam fidem, $\sim$ Diofcoridem fecutis, eandem plantam tain rotundun, quam longun piper edere credidit. Piperis fruticem uidimus nos Neapoli, qui Lufitanorun de criptioni naxisné repondere vifus c $f t$, quód uiticulofo càle effet, clema= tidis acute modo. Sed e alian arbufculam piper racematin profe rentem uidi venctijs, qua prorfus illius plante faciem exprimit, quasn unlgus Ribem appellat. Viret bec in horto clarißimi medici Maphei à Mapheo, in quo plu=: rima fimplicia notatu digna vifuntur. Quo fit, ut mirum non fit, fi in piperis biftoria udriant auctores. Ruando= quidem cün uarie in Italia piperiferé habedntur arbufcule, facile credendum eft, uarietatis longé maioris eds in In= dia reperivi. Piperismeminit Galenus lib. v I I. fimpliciun medicamentorum, fic inquiens. Piperis radix uires: Piperis uires cofto fimiles potißunùn obtinet. Porró fructus cius nuper quidem admodum germinantis, longum piper eft: qudre ex. Galeno.. ctiam nuaturo humidius eft. buniditatis eius indiciŭ eft, quód facilé repofitum perforetur, ac non protinus mordicet,

50 fed póft paulo incipiat, uerim plufculum duret. Porró fru itus, qui uelut omphax eft, piper album eft, nigro quidem. acrius. Nam illud ium quafi fuperafsatun eft, e fuperexiccatum. Verim utrunque ualenter tum excalfacit, tum, deficcat. Caterum quoniam Diofcorides inter fimplicia de C A R Y O P H Y I I I S, que mibipiper in men= tem redegit, nibil pofteritatis mentorix mandauit, cüm ed ex eifdem afferantur regionlbus, fint $\sigma^{\prime}$; in pracipuo medi= corum ufu, adeó preftantißimum, odoratißimum q́; medicamentum, filentio non dißsimulandum duxi. Prouenit igi= tur Caryophyllorum arbor in orientali plaga, quibufdam Indici pelagi infulis, non longé à Baddn. Huius caudex bu=:

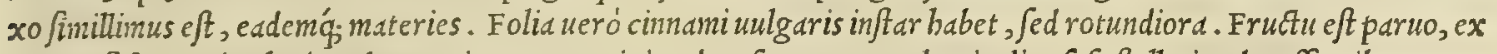
atro ruffecente, in clui modum capitato, exertis in aduerfum quatuor denticulis, fe fe ftellatim decuffantibus, pro= minulo apicé, quadrati alueoli finu medio unbilicatim prodeunte. Cultores arundinibus flagellant arborem, con= ftrato prius circunquaq; tegetibus palineis folo. Caryophylli meminit Plinius libro x Ix. cap. v I I. his uerbis. Eft etiámmum in India piperis grani fimile, quod uocant Caryophyllon, grandius, fragiliusq́;. Tradunt in Indico luco id: gigni. Aduehitur odoris gratia. Horum nufquam inuenio mentionem feciffe Galenum : tametfi sexapio ex Galeni au=

Piperis plătx in Italia.

\section{Caryophyl-}

lorum hift. 


\section{6

Caryo phylli que hattenus de bifzoria o uiribus Caryopbylli feminis aromatici. Caterìm quoniam in Caryophylli nomen inci= floris \& eius dimus, bîc non prorfus intactos reliquemusflores illos, qui abodore fimiliter C A R Y O P H Y L L I, O Garofoli mentio.

Etoritate plura de Caryophyllis tradiderit fuo de fimplicium medicamentorum uolumine. Quamobrem crediderim aut Galeni librum, in quo de Caryopbyllis differuit, perïfe, aut $\mathrm{P}$ auli potius, quam Galeni teftimonio de his fcri= p/iffe Serapionem. Nain de Caryopbyllis prius Paulus ijfdem, quibus poftea Serapio, uerbis tractauit, libro v I I. ubi bee babct. Caryophyllon, quafi dicas nucifolium, noll eam habet fubftantiam, que nomine pretenditur, fed ex India ueluti fores cuiufdam arboris feftucacei, o nigri funt, longitudine feré digitali, odorati, acres, fubamari, calid, e ficci in tertio propenodum ordine : qui multiplic is ufus funt, tum ad obfonia, tum ad alia multa medica= menta. Caryophylli, ut fcribit Serapio, iecinori, ftomacho, E cordi auxiliantur. Concoctionem adiuuant, er al= ui fuxiones cohibent. Quinetiam eor um puluis quatuor drachmarum pondere cum lacte fumptus, uenereas uires ad= auget. Exacuunt preterea, A uiccnna auctore, oculorum nifum, $\sigma$ eorum nubeculas, argemasó; exterunt. At $=$

GAROFOLI DOMESTICHI.

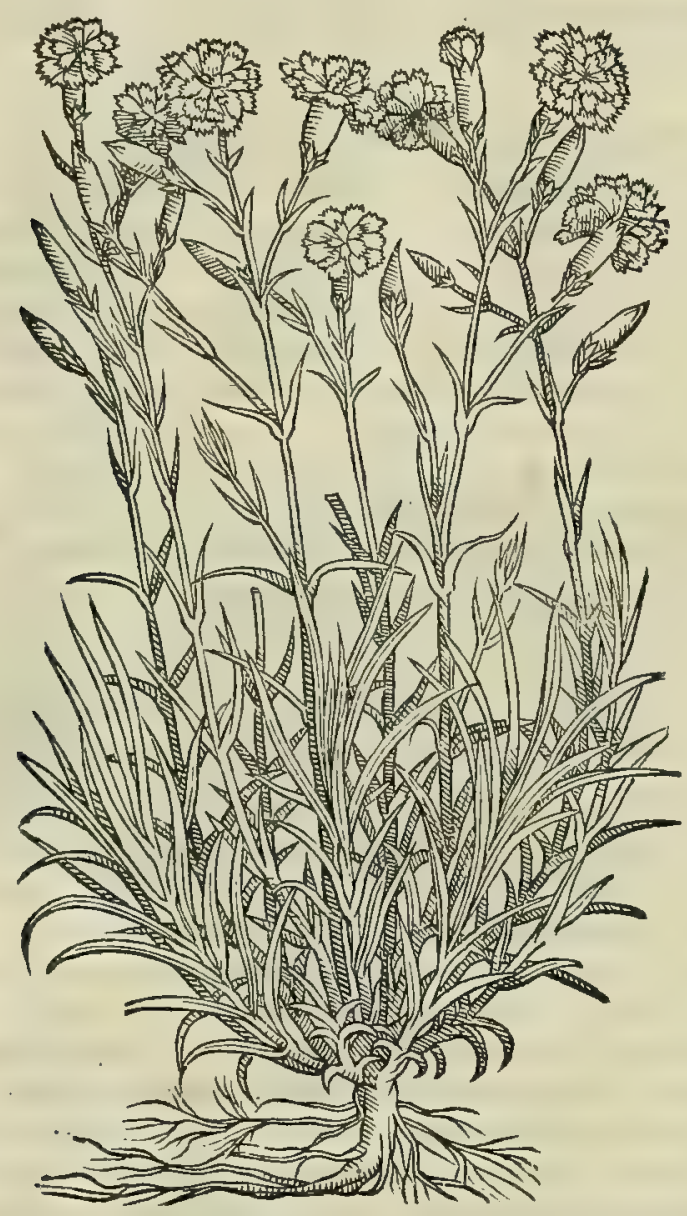

GAROFOLI SALVATICHI.

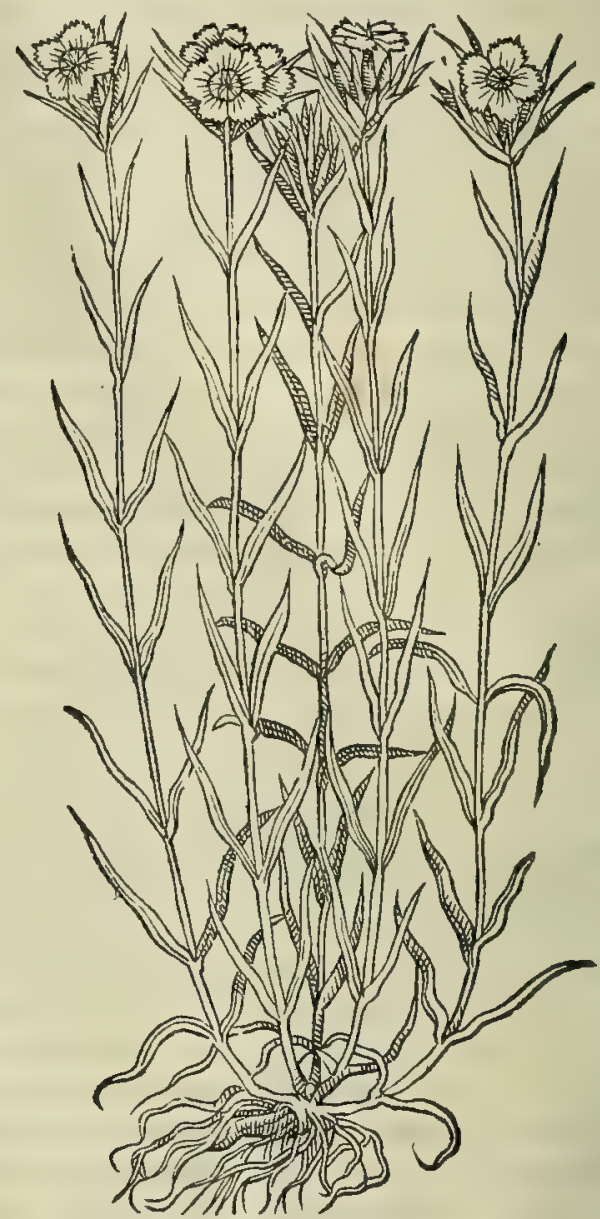

20

30

uulgo uocantur. Hi quidem non fuerunt, quod ego fciam, à ueteribus cogniti, etfi nobis bodie fint adeó celebres, uul gares a que ac iucundi, ut fuperuacaneum putem $\mathcal{O}$ plantam, $\mathcal{O}$ flores cos defcribere. Quare fatis fore duxi, $/ \mathrm{B}$ boc loco corum imagines duntaxat exbibuero. Cüm igitur duo fint corum fumma generd, nos primó Caryophyl= lum florem altileum feu fatiuum, deinde fylueftrem depingi curauimus, ut ex duplici effigie, quam damus, aperté

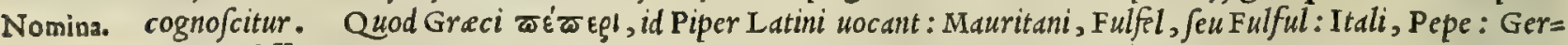

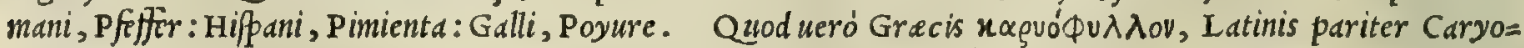
phyllum appellatur: Mauritanis, Carunfel, feu Charunful: Barbaris, Gariofilus: Italis, Garofano: Germanis, Nae= so gel: Hipanis, Clano de epecia, fiue Clauel: Gallis, Girophles.

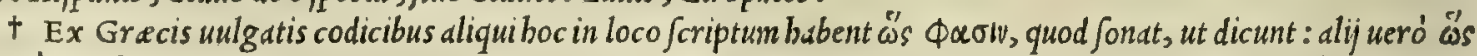

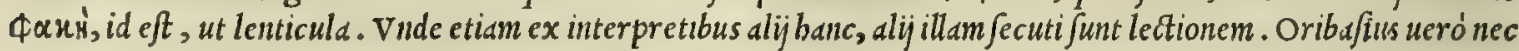
boc, nec illud legit: qui praterea alia multa o bic, or alibinon defcribit, qua fortafje non temeré quis illegitina iudicare poßit.

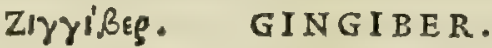

CA P. CLIIIII.

G I N G I B E R fui generis planta eft, in Troglodytica Arabia magna ex parte nafcens. Qua uirente ad multa, perinde atque nos ruta, vtuntur, \& primis potibus, \& edulijs admifcent. Huius radices, cyperi modo, parux funt, candicantes, \& odoratæ, atque piper faporc imitantur. Eligi debent, 


\section{In Lib. fecundum Diofcoridis.}

debent, qux teredines non nouerunt. A'multis tamen ob id condiuntur, quòd celeriter cariem fentiant: \& fictilibus in Italiam afportantur. Gingiber cibo conueniens eft, $\&$ cum condimento affumitur. Excalfactoriam vim, \& cxcoquentem habet:aluum leniter emollit: ftomacho utilis eft: efficax aduerfus ea, qux oculis caliginem offundunt. in antidota addi folet. In fumma, piperis uiribus refpondet.

G I N G I B E R (ut referunt L ufitani, qui plurimum fe uidiffe fatentur in India) radix eft, quse geniculat is Gingiberis hi repit internodijs, folijs arundinaccis, qua bis, terue in anno reuiuifcunt, ac reuirefcunt, fed qua in cacumine faftix ftorsa. giantur graminis amplitudinesn non excedere aiunt, nec quicquam in ea regione frequentius inueniri. Subdunt - nonnibil Jubeffe difcriminis in fapore cum precox eruitur. Opportunun demetendi tempus, cùm folia inaruerint,

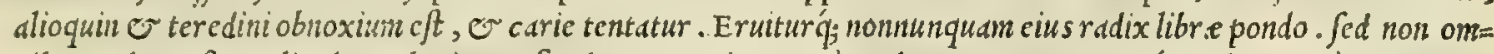
nibus exdem eft amplitudo. Plus in profundum non agitur, quam ad ternos, quaternosíe palmos. Cùm cruitur, radic is internodiun in fcrobe foffores relinqunnt, terrami; illi aggerunt, ceu eius radicis femen, proximo anno cru= wrri f uctum, id eft, regerminat as radices. Aduchitur gingiber in Italiam copiofun ex Calccut magno Indice em= porio, atque ex Troglodytica A rabia non folim tractu temporis exiccatum, fed or faccharo recentilimum affer = ustum, uel quodam mellis genere, quod quibufdam é filiquis exprimunt. Id fané longè magis veneto preftat: cuirn boc. officinarum mangonio ex aridis fiat radicibus, longo temporis tractu modó acerrimo, lixivio, calce, qucrnó= que cincre parato; modó muria ; modó dulci aqua maceratis, er edomitis, quibus non modó odor deperditur, ac cuanefcit; fed $\odot$ fapor, or acrmonia fubtrabitur. Illud ueró cùm ftatim è terra effoffum nulla feré maceratione

20 condiatur, uires $\sim$ facultates non exuit, fed eas feruat. Qunanquam Brafauolus non recté, meo quidem iudi= Brafauoli ercio, welle uideatur, quód venetijs inangonizatum Gingiber guftantibus plus acrimonia relinquat, qudin illud, ror. quod recentisimum in India filiquarum melle, aut faccharo conditum afferuatur, or cum alijs aromatum gene= ribus ad nos conuchitur. Quod quantum à ueritate, o ratione diffonet, ï iudicare poterunt, qui diu in myropo= lijs uer fati, remonmino exploratam babent. Gingiberis uires memorie prodidit Galenus libro v I. fimplicium medicamentorum, fic inquiens. Gingiberis radix utilis eft, quam utique $\varepsilon x$ Barbaria ad nos conuebunt : Excalfa= cit potenter, fed non primo ftatim occurfu, uelut piper : unde fané or minus effe fubtilium partium, quàm piper, exiftimandum. Fiquidem in tenues folueretur partes, 0 celerrimé actu ut illud fieret calidum. Apparet enim illa= borata, o craßior adluc quedaun ei ineffe fubftantia, nec ea ficca, or terreftris, fed bumida potius atque aqued. Quo fit, ut facile perforetur, cim fcilicet recrementitia infit bumiditas. Neque enin quicquam eorum, quxe aut 30 plane ficca fint, aut humida, fed elaboratam, o familiarem continentia buniditatem, buic uitio obnoxia funt. Idem usu uenit piperi longo. Atque binc eft, quód diutius perfeuerat, que proficifcitur à gingibere, aut pipere longo caliditas, quidn que ab albo, aut nigro. Nam ficut ab aridis calamis flamma fimul celerrimé accenditur, o undequaque dipergitur : eundcni in modum, qua dificcis poteftate medicamentis editur caliditas. At qua pros dit ab bumidioribus, ceu ligna funt utridia, o tardius accenditur, o durat diutius. Ex quo fit, ut utriufque mes dicanenti diuer $\int u s$ fit ufus. Siquidem ubi totum corpus celeriter excalfacere confilium eft, ea tunc exbibenda funt, que e celeriter à caloris noftri contactu incale cant, er celeriter quocunque ferantur. Verüm ubi partem quámuis refrigeratam recalfacere ftudemus, contrà agendum, nimirum que tardé calefcentia plurimo tempore perdurent, ea offeruntur. Caterim licet gingiber, o piper album bac ratione à nigro pipere differant; non magna tamen eff differentia. At nafturtium, napi, thapfia, ev agreftium columbarum ftercus maiori tempore

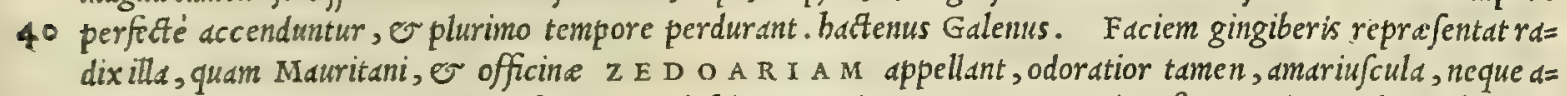
dixilla, quam Mauritani, 0 officine $\mathrm{Z}$ E D O A R I A M appellant, odoratior tamen, amariufcula, neque $d=$
deó ut gingiber acris. Huius nufquam, quod fciam, meminere ueteres Gr.eci, etfí recentiores ab Arabicis $e=$ docti, nempe Aëtius, or Attuarius edin fuis medicamentorum compofitionibus admifceant. Zedodria (ut cap. C I X X I I. teftis eft Serapio conuebitur é sinarum regione ultra extremas Indie or as. Excalfacit, o ficcat or= dine fecundo. Flatus difcutit, e pinguedinem auget propria quadam facultate, non quidem elementari. Póft fums pta graue uirus anime, quod allium, cepa, uel uinum excitauit, abigit . uenenoforum animalium mor fibus opitulas tur : alui fluxiones fiftit, uteri abfceffus refoluit, uomitiones reprimit, er coli cruciatus tollit, item $q_{\text {; }}$ uentriculi . A lui tineas quascunque enecat, $\odot$ in antidotis additur. Ideoóg; dixit Auicenna, nibil effe ea praftantius ad ebibitum napellum. Nondefunt, qui crediderint, quód A R N A B O, de quo fcribit Paulus, G Mauritanorum zedod=

50 ria unum, or idem referant medicamentum. Verim Serapionis teftimonio cap. CCI X X I. Arnabo apud Grecos nibil aliud defignat, quam Zurumbet apud Arabes:quippe quodd hoc loco de zurumbet eadem fcribat Serapio, que de arnabo ante ip fum adnotauit Paulus. Eft autem Arnabo, ut ex Serapionis authoritate memorie prodidit I $\int a c h$, arbor procera, in oriente proueniens: folijs longis, colore uiridi, in luteum languefcente, falicis modo, $f=$ cuti o ramorum cortex. Infrugifera eft, citreum odorem pirans. Quibus facilé patet, arnabo non modó ze= doariam non effe, fed nec in Europam ad nos aduehi. Quo fit, ut Cordus aberraffe deprehendatur : quippe qui zurumbet zedoaris genus exiftinet. Hunc fortafe fecutus Fuchfius medicus doctißimus, in libro de com= pofitione medicamentorum, quem locupletatum nuper edidit, non fine magno errore putat zurumbet or ze= doriam idem effe. Quinon minus in Arnabo quoque errajfe cognofcitur, quod uelit Doronicum orientale id ief $\int e, q u o d$ Paulo Arnabo. atqui reshec aliter fe habet, ut ex anté dittis fatis colligi poteft. Hallucinatur etiam bac in re Brunfellius: quod is fcripferit fuo de medicis uocabulis onomaftico, quodd arnabo unguentum eft odori= frum. Verum eius lapjus non aliam causam fuiffe arbitror, quàm quód ofcitanter Paulum legerit: nam Paulus

.

-




\section{And. Matthioli Comm.}

H Y D R OP I P E R.

Nomina.

Hydropiperis confid.

Ruel. lapfus.

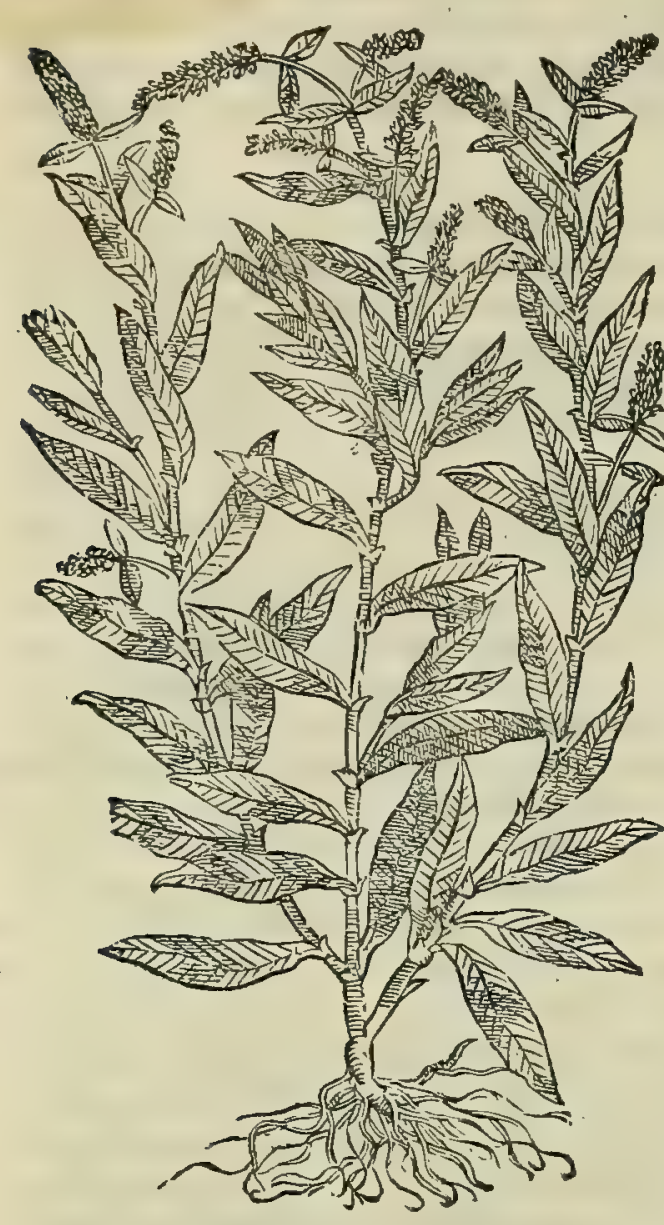

PERSICARIA.

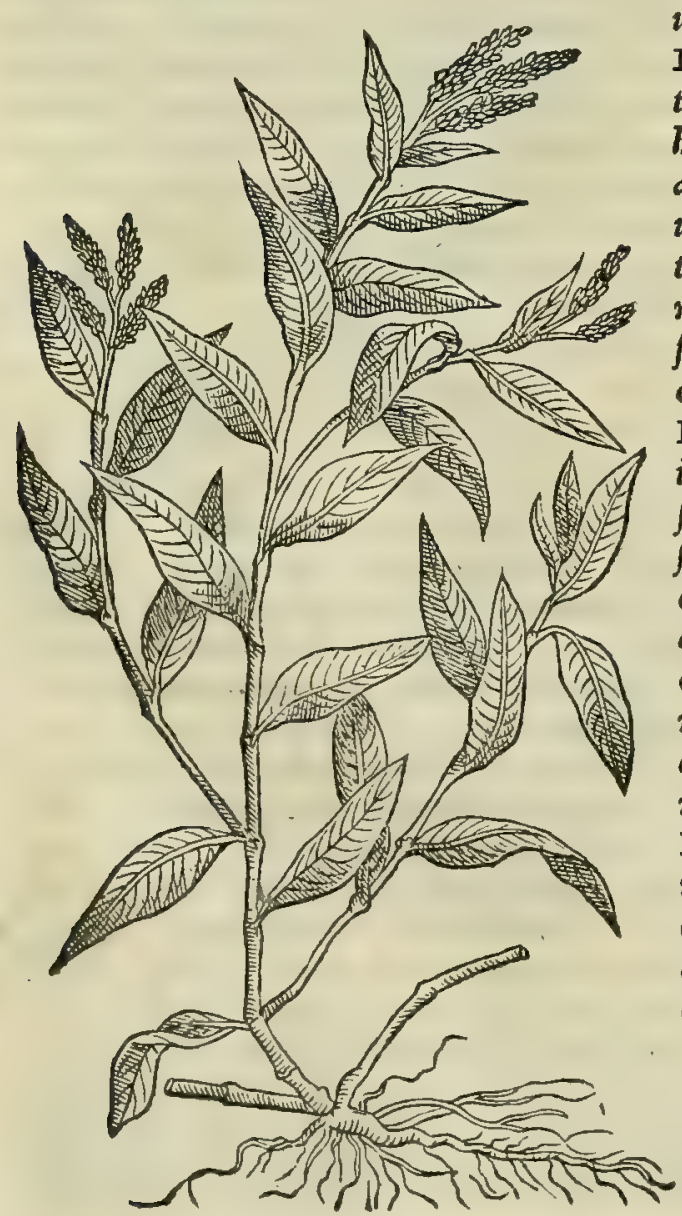

apertißimè aßerit, Arnabo unguentis expeti, quod fualuiter o= leat, non autem unguentum effe, ut Brunfelfius fomniafe uide=

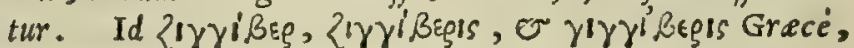
quod item Latine Zingiber, \& Gingiber nominatur: Arabicé, Lengibel, seu Zingibel: Italicé, Gengeuo : Germunicé, Ingber: Hipanice, Gengiure: Gallice, Gingimbre. Quod uero Zoũ =

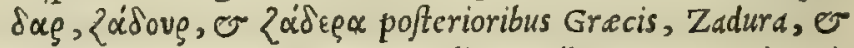
Zedodria L atinis: pariter e Italis appellatur: Germanis, $Z i=$ tunen: Gallis, Cretonart.

\section{Yं\$ C A P. C L V.}

HY D RO P I PER apud aquas nafcitur, qux ftagnant, aut pigro lapfu repunt. Caulem edit geniculatum, folidum, multis alis concauum : folia menthæ, maiora, molliora, candidioraq́ue, guftu piperis, acri , citra tamen ullam odoris gratiam : fruetum acrem, in furculis paruis, prope folia racematim cohærentem. Folia cú femine illita tumores, veteresq́ue duritias difcutiunt, fu- 20 gillata delent: quæ poftquàm inaruerunt, tufa pro pipere in obfonijs admifcentur. Radix parua, nullius in medicina ufus.

T A M E T S I proviriliparte contendat Ruellius, ut non minus doctis, quim elegantißimis uerbis comprobet, eam non Apernendam ftirpem, quam unlgus officinarum E upatorium ap= pellat, legitimun effe $\mathrm{H} y d r o p i p e r ;$ is tamen bac in re aperté bals lucinari deprebenditur, quanuis alioqui fuerit non modó in medi= ca materia peritus, fed $\mathrm{O}$ Latinis, $\mathrm{O}$ Gracis literis apprime 30 doctus. Siquidem Diofcoridi Hydropiper folia edit mentha $m a=$ iora, molliora, candidiora'́; , guftu piperis, deri, citra tamen ullam odoris gratiam: non autem amaro fapore, ut Ruellius ait, Dio, coridis uerba peruertens, quó facilius fudm aftruat fenten= tian. Vulgare ueró Eupatorium folijs crefcit cannabinis, duris, birfutis, dmaro guftu, non quidem acri, ut piperis : quinetiam adeo odoratis, utbac de caufd berbam effe uiribus infignem, quă= uis ab antiquis filentio pretermi Jam, femper exiftimauerin, cums tamen odoris fragrantiam in bydropipere reperivineget Diofec: rides. Preterea hydropiperi caulis ineft geniculatus, folidus, dे 40 foliorum, o adnatorum exortualis plurimis concaum: femine etiámnum acri, in ramufculis prope folia racematim coharente. $\mathbf{P}$ feudoeupatorio zeró caulis eft procerus, minimé geniculatus, in cuius ramis nullum apud frondes racematim cobaret femen: fed in cacumine flores gerit fubrubentes, qui dixifi muscarii facie, fylueftris origanimodo, permaturitatem in pappos euane $\int c a n t:$ é quibus femen prodit amarum totius plante fapore; quanquam effe boc acrinonia preditum non recte Ruellius affeueret. Qui quoniam unlgare Eupatorium plerunq; in aquofis oriri compexe rit, id omnino legitimum effe Hydropiper pro certo afferere non so dubitawit, nulla prorfus habita ratione, an alic inter fe reßponde= rent nota. Qutamobrem, ut ex dictis rationibus clarißime patet, Ruellius bac in re non ita maturé mibi uidetur fenfiffe, ut eius cla ra doctrind, ingenij q́; preftantia expofcere uidebatur. Quando= quidem cim unlgare boc Eupatorium primo ftatim occurfu guftui amarorem relinquat baudquaquam obfcurum, facilé binc indiciü confequi potuiffet, hoc non effe bydropiper, quo und cum fale in ciborum condimentis piperis uice prifca etas utebatur : nan que amara funt, preterqud̀m quód piperis uicem explere minimé ualent in eibis addita, ab omnibus repunntur tanquam nature inimica. Ceterim fi in Italia Hydropiper nafcitur, illa meo 


\section{In Lib.fecundumDiofcoridis.}

quidcm iudicio eft perficarie (ut uocant) pecies, que it alterius difcrinen, cui folid infunt pullo colore enaculata, nullis fimilibus inficitur not is, fed folio tantim uiridi adole fcit. Quippe qux folijs proueniat oblongis, menthe maio= ribus, mollioribus, ac candidioribus: caule admodum geniculato, duro q; alis concauo : é cuius adnatis rufum fenen racematim prodit, acri adinodum guftu, ita ut linguan uebementer uellicet. Illud infuper banc opinionem corrobo= rat, quod prope ftagnantes aquas hac planta plerunq; uirefcat, ubi eam Diofcorides nafci teftatur. Mcminit Hy= dropiperis Galenus libro v I I I. fimplicium medicamentorum, fic inquiens. Hydropiper à locis, in quibus nafcitur, C d fimilitudine, que illi cum pipere in guftu eft, nomen fortitum eft. Ceterim calidum eft, fed non tantum, ut peper. Attamen berba ip fa etiámum uiridis cum fenine, cataplafmatis in modum impofita, fugillata, o tumores induratos digerit. Herba, quz Grecis if 20 acquatico: Germanis, Vuaffer pfeffer, Or Mucken kraut: Hipanice, Hierua pexiguera fun manchas.

PT\&guाки́. PTARMICA.

20

30

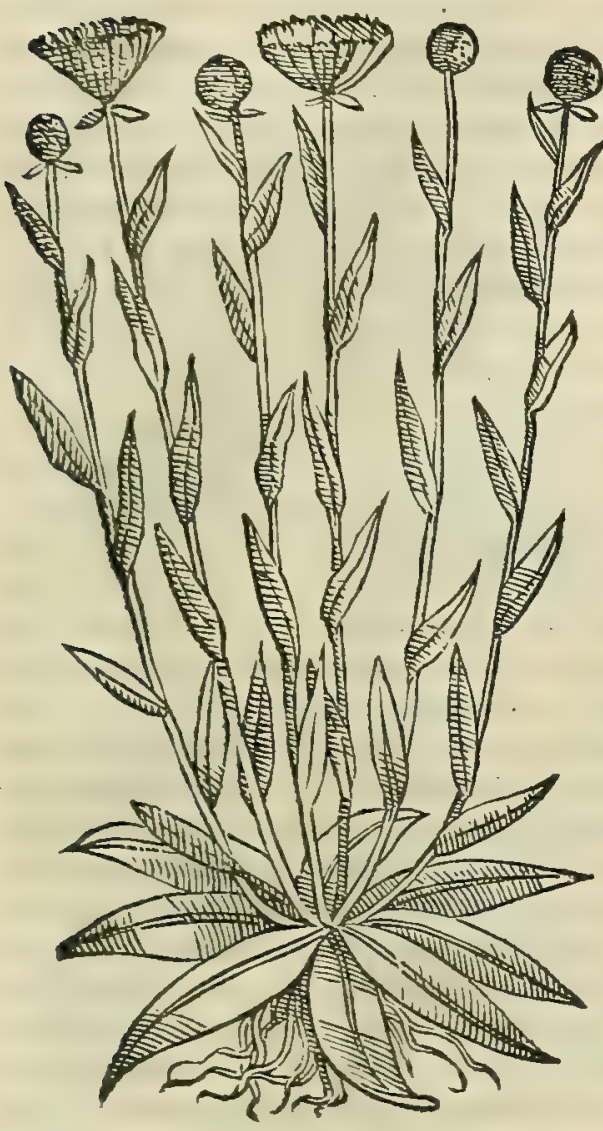

CAP. CLVI.

PTARMICA exiguus frutex eft, furculos habens paruos, multos, $\&$ rotundos, abrotono non difsimiles: \& circa eos folia oleæ, longa, multa: \& in cacumine capitulum, uti anthemidis, paruum, rotundum . quod fuo acri odore fternutamentum excitat: vnde nomen accepit. Folia cum floribus illita, fugillationes rapiunt. Flores fternutamenta efficacifsimè moutent. Nafcitur in mó tibus, \& petrofis.

P T A R M I C A in Hetruria frequentißima prouenit. Na= Ptarmicx hifcitur e in Tridentino agro, prefertim Ananienfi trad?u, furculis frequentibus,paruis, roturdis, abrotono non dißimulibus : é quibus plurima prodeunt folia incaind, olea modo oblonga : unde er Oli uelld à multis uulgó nominatur. Gerit in furculorum cacuminibus capitulum, chamemeli deflorentis modo: cui quemadmodum o berba, uis quedam adeó acris ineft, ut olfatu ftatim fternutd= menta excitet. Rura noftra ex P tarmica fcopas,quibus pauimen= taierruntur, conficiunt, nec in alium colligunt ufum. Huiufce meminit Galenus libro v I I I. fimplicium medicanentorum, bis uer bis. Ptarmicaflores ciende fternutationis uim obtinent: eft enim temperies eius calida, $\sigma$ ficca; uiridis etiámnum ordine fecundo,

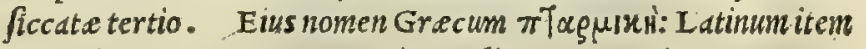
Ptarmica, o Sternutamentaria: Italicum, Ptarmica.

\section{ET ̧ớAlov. RADICVLA, SEV LANARIA. HERBA. CAP. CLVII.}

S T R V T H I V M herba vulgò nota : qua purgandis lanis vtuntur, qui eas eluunt. Huius radix eft acris, vrinam ciet : prodeft tufsi, iocinerofs, orthopncex ex melle fumpta, cochlearis menfura : aluum foluit. Eadem cum panace, \& capparis radice,calculos frangit, \& cum vrina exturbat : duritiam lienis abfumit: menfes impofita trahit: partus efficaciter enecat. Cum polenta autem, \& aceto illita,lepras tollit : tubercula difcutit, cum farina hordeacea , \& vino decoeta. Mifcetur \& malagmatis, \& ocularibus collyrijs,claritatis caufa. Sternutamenta mouet: per os purgat, trita cum melle, \& naribus infufa.

S I R V T H I O N, Jeu Radicula, adeó olim unlgaris notitis fuit, quód purgandis lanis ea uterentur, ut Dio= so fcorides eam notis ullis reprefentare fuperuacaneum duxerit. Sed cim tractu temporis huius exoleuerit ufus, eius quoq; notitia fimul abolita uidetur. Quo fit, ut arduum fit nobis nunc dijudicare, qüanam planta It dilis strutbion iu= re dici poßit. Mauritanis, o officinis Condifi ea nominatur, quam illi frequenter medicamentis admifcent, quibus naribus inditis fternutamenta cient. Nec proptered ufquam in officinis reperitur, quanuis medicorum compofitioni= bus fapius inferatur. Quamobrem afferere non aufim, an struthion nafcatur in I talia: quippe quód bactenus ip fum non modó non uiderim, fed neminem, qui illud cognofceret, e oftenderet, adinuenerim. Theophraftus inter folio acu leatas frutbium babet lib. v I. cap. I I I. de plantarum hiftoria.Plinius ueró libro X I X.cap. I I I. bis uerbis ftruthium defcribit. At que wocatur Radicula, lauandis demum lanis fuccum babet : mirum quantum conferens candori, molli=

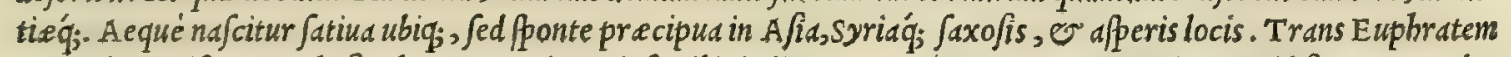
tamen laudatißina, caule ferulaceo, tenui, e ip fo cibis indigenarum expetito, $\mathbb{E}$ tingenti quicquid fit, cum quo de $=$ coquatur : folio oles, ftruthion Greci uocant. Floret aftate, grata apectu, uerim fine odore, $\beta$ inofa, or caule la nugino 0 . Semen ei nullum . radix magna, que çonciditur ad quem ditam eft ufum. Strutbij uires adnotauit Gale res ex Gal.

Nomina. Struthiconfideratio.
Quę Perficaria fit Hydro piper.

Hydropi peris uires ex Gal.

\section{Nomina.}


Seruthii uires nus libro v I I r. fimplicium medicamentorum,fic inquiens. Strutbij radice potißsimim utimur, utpote guftu deri, e ex Galeno. calida,ficcáq; temperamento, ex quarto quodámmodo ordine. Sed er abftergit, er irritat: proinde quoq; fternutatio nem prouocat, ceu cetera omnia, que calida funt temperie, er guftu acria. Ex bis omnibus paldm fit Fuchfium ui=

Fuch. lapfus . rum alioqui doctißimum, in hoc erraffe, quod in fuis de ftirpium biftoria clarißinis commentarijs, plantam uulgó sas ponariam uocat.m lcgitimum struthium effe cenfeat,eam q; pro struthı depingat. Hac enim folio plantaginis exit, non olex; laui, non aculeato: caule geniculato, non lanugino $\int 0:$ guftu potius infipido eft, quàm adeó acri, ut quar=

Nomina. tum excalfacientium ordinem attingat. Que berba 5 ̧óv Эiov Gracé, strutbium, Radicula, er Herba landria La tiné dicitur: Arabicé, Condes, Chundes, feu Kunder: Barbaré, Condifi: Italicé, Radicetta, $\sigma$ Herbalanaria.

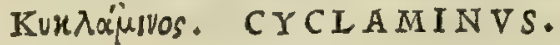

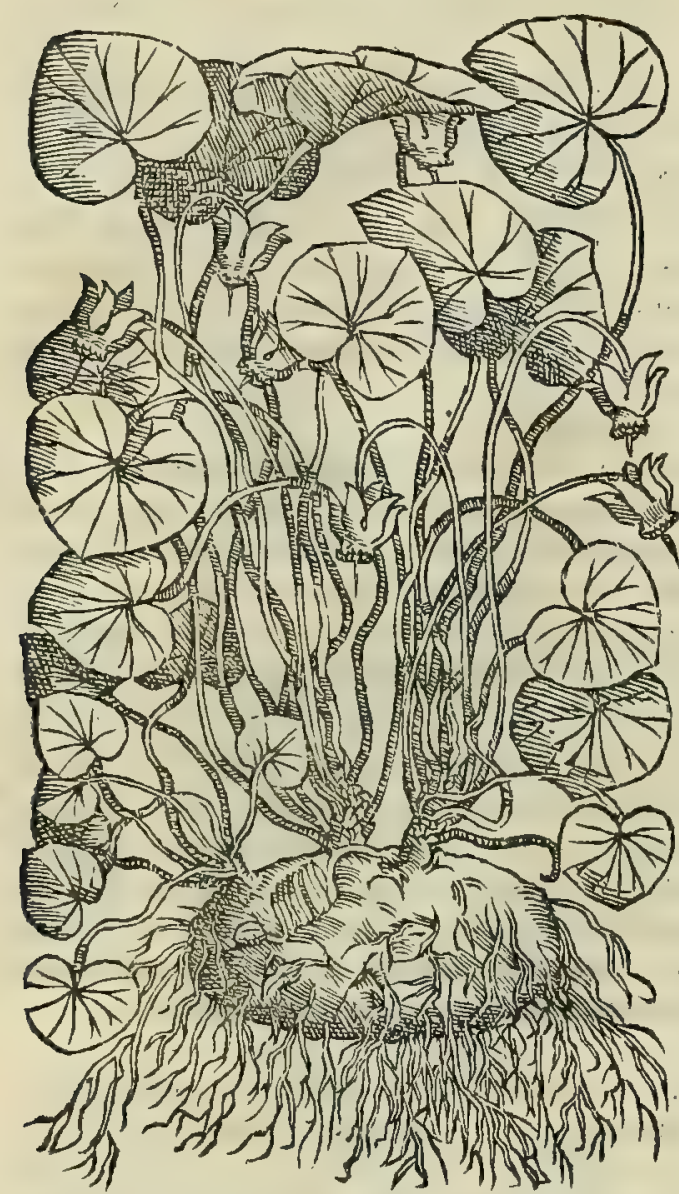

- CAP. CIVIII.

CY C L A M I v s folia habet hederæ, purpurea, varia, in quibus fuprà infraque albicant maculæ: caule nudo, quaternos digitos requante: floribus in eo purpureis, rofarum effigie: radice nigra, \& aliquantum la ta, vt rapum videri pofsit. Qux cum hydromelite pota, pituitam, aquamq́ue detrahic : menfes potu, appofitúve ciet. Tradunt, fi prægnans radicem tranfgrediatur,abortum fieri.partum appenfa accelerat: contra venena, prefertim leporis marini, ex vino bibitur : illita contra 20 ferpentium iftus remedio eft : immifta vino inebriat: re gium morbum difcutit, tribus drachmis pota, cum paffo, aut diluto mulfo. Sed oportet eum qui ebibit, multis veltibus contectum, loco calido, \& à perfrictionibus tuto, recumbere, quò facilius exudet : eiecti autem fudo res fcllei colore inueniuntur. Succus eius ad purgandum caput, naribus infunditur : ad dcijcienda quoque alui ex crementa, in vellere fedi fubijcitur : illito umbilico, \& imo ventre coxarum tenus, aluum emollit, \& abortum efficit: fuffufionibus, \& retufx oculorum aciei, oblitus $3: 0$ cum melle fuccus prodeft. medicamentis abortum inferentibus admifcetur. Succus cum accto illitus, prociduá fedem reftituit. Exprimitur tufa radice fuccus, \& ad mel lis crafsitudinem decoquitur. Radix cutem purgat, eruptiones papularum reprimit: vulneribus ex aceto per $f e$, aut cum melle medetur, lienem abfumit, vitia cutis in facie, \& alopecias emendat. Eius decocto luxata, podagras; \& capitis vlcufcula, pernionesq́ue foueri congruú eft: ipfaque in oleo vetere feruefacta, illito oleo vlcera cicatricem perducit . Cauata radix oleo expletur, \& cine re feruenti imponitur, adieeto interdum Tyrrhenicæ ceræ momento, vt ftrigmenti crafsitudinem vnguentum contrahat, cum primis vtile pernionibus . Radix, fcillæ modo, concifa reponitur . Narrant, ad a matoria affumi côtufam,\& in paftillos diuisă, Nafcitur in umbrofis, maximè fub arboribus:

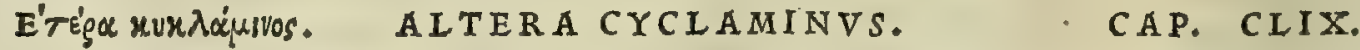

E S T E T altera cyclaminus, quam ciffanthemon, aut ciffophyllon vccant: folijs hederæ, fed minoribus: geniculatis caulibus, cralsisq́ue, circa vicinas arbores, capreolorum modo le voluentibus : flore candido, odorato : acinis hederæ mollibus, lenti guftus, alliquantulum acris : radice fuper uacua. Nafcitur in afperis. Huius acini, drachmæ vnius pondere poti, cum uini albi cyath is duo- so bus, quadraginta diebus, lienem per vrinam, \& aluum abfamunt : ad orthopncam bibitur: reliquias à partu purgat.

Cyclamini confideratio. Ruel. lapfus.

T A M E T I Cyclaminus prima,qua uulgó Panis porcinus dicitur, planta fit uulgaris notitix; fecundam ta= men bucufq; mibi uidere non licuit in It alia : quanquam afferit $\mathrm{R} u e l l i u s, b$ anc illam efe firpem, quam berbariorum, $\sim$ officinarum unlgus sigillum fancte Maria uocat. Et cum plures fint berbe, que ab imperitis eo nomine appellan tur, polygonatum fcilicet, serapionis fecacul, e tertia, que hydropiperifimilis eft; barumn Ruellius nullam effe $C y=$ claminum putat, fed aliam ab bis longé diuer $\int a m$, cuius facies, ut ip $\int e$ delineat, nil aliud reprefcntare uidetur, quadm zitem nigram à Diofcoride libro quarto defcriptam, quam nos in Hetruria unlgò uocamus Tamaro. Hanc fcribit ip= fe sigilli fancta Maria nomen fibi afciuife, quód eam Mauritani Botbomarien nominent. Qua in re Ruellius, eius pace dixerim a aperté fallitur : qquandoquidem tota. Mauritanorum familia primum tantim genus, non autem alte= 


\section{In Lib. fecundum Diofcoridis.}

ram Cyelaminum Bothomaricn nuncupat. Cyclamini primigeneris dus (ut Mefues auctor eft) reperiuntur pe= cies, maior, o minor. Hec radice prouenit parua, nucis auellane, cicerumíg; magnitudine. Illa ueró magna conftat radice, in rapi modum extuberdnte, pullo colore: que (ut diximus) unlgaris admodum eft, er paßim in fyluis, $\mathcal{O V}^{\mathrm{r}}$ um brofis nafeens. Ninorem widi cgo in agro foliun Tridentino in uallis Ananix montibus, ubi copiofanafcitur. Cycla= minus (ut idem IIclues memoric prodidit) tam haufta, quàm clyftere infufa pttuitam uifcofan mirifice detrabit. Coli cruciatus tollit a pituits progenitos, ant ab induratis excrementis. Succus in erinis additur ad expurgandum cere= brum, quod diuturnos fini.t cupitis dolores, fiigidisó; conueniat bemicranijs. Item refolutis opitulatur, ac omnibus cercbri, er neruorum affectibus a frigiditate prouenientibus. Cyclamini meminit Galenus lib. v I I. fimplicium

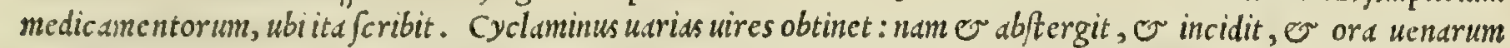
- aperit, $\mathcal{O}$ attrabit, $\mathcal{O}$ digerit. Clarum ueró id eft ex particularibus operibus. Adeó uchemens eius facultas eft, ut abdomine illito, uentrem fubducat, or fretum interimat. Kux入x'ulvos berba fic Grecis, Latinis quoq; Ciclami= nus, or Rapum terre nocatur: Mauritanis, Buchormarien, Butbermarien, feu Bothormarie : Barbaris, Cyclamen, Panis porcinus, O Arthamita: Italis, Ciclamino, o P an porcino: Germanis, Schucinbrot, Erdapffel: Hipa= mis, Pande puerco: Gallis, Pain de pourcedu.

DRACVNCVLVS MAIOR.

20

30

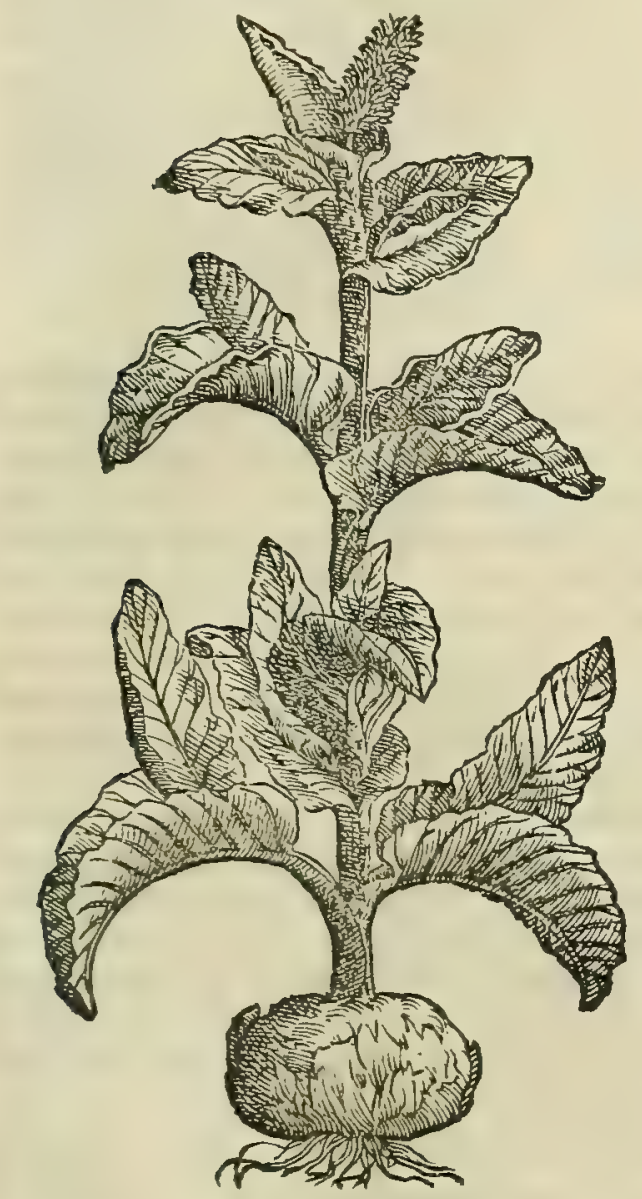

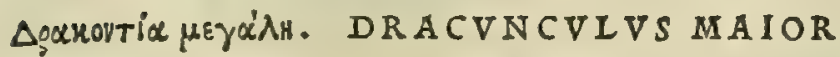

DRACVNCVLVS MINOR.

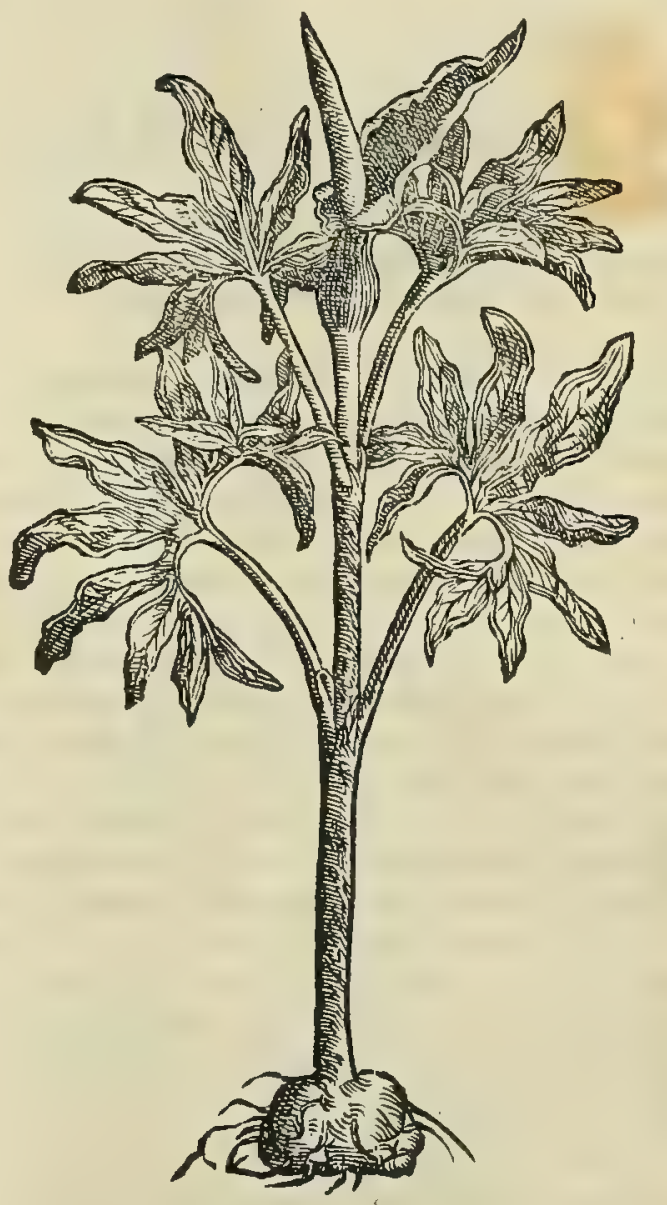

CAP. CIX.
Cyclamini genera, \& uires ex Mef.

\section{Cyclamini ui} res ex Gal.

Nomina.

D R A C V N C V L V S maior in vmbrofis circum fepta gignitur. Caulem habet rectum, Ixuem, . 50 duûm cubitorum, baculi crafsitudine, verficoloribus draconum maculis, purpureis tamen euincen tibus : folia rumicis, fibi inuicem implicita. Fructum fummo caule facit, racemofum, coloris pri mùm cineracei, mox per maturitatem in crocum, \& purpuram vergentis : radicem prægrandem, ro tundam, candidam, cortice tenui veftitam . Colligitur, dum maturefcit, \& fuccus exprimitur, ficca turq́; in umbra. Radix quoque mefsibus effoditur, elotaq́ue particulatim conciditur, \& funiculo transfixa ficcatur in vmbra. Vis ei calfaciendi cum diluta vini potione. Crudam, coktámve cum melle delingi prodeft contra orthopnœas, rupta, conuulfa, tufsim, \& deftillationes . pota cum vino venerem ftimulat: vlcera, quæ cacoethe vocantur, atque phagedænica expurgat, præfertim cum vite alba . ex ea , \& melle collyria ad fiftulas, \& partus euocandos componuntur . ad vitiligines cú melle,efficaciter illinitur: poly pos, \& carcinomata abfumit. Succus ad oculorum medicamenta, item contra nubeculas, caliginem, albuginesq́; effectum præbet . Herbæ, radicisq́ue odor teneros conceptus abortu vitiat. item fi triginta grana eius in pofca bibantur. Sunt, qui eius fuccum cum oleo,au- 
rium doloribus infudere: quinctiam folia, vtpote qux adftringant, vulneribus recentibus impofue re, $\$$ coßta in uino pernionibus. Qui folia manibus affricuerit, aut radicem exemerit, poffe à uipera feriri inficiantur.

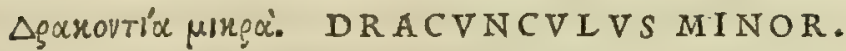

\section{CAP. CIXI.}

D R A C V N C.V L V S minor folio conftat hederaceo, magno, candidis notis infigni : caule reeto, bicubitali, verficolore, maculis refperfo purpurcis, ita ut anguem planè referat, baculi crafsitudine: fructus fummo caule recematim cohæret, colore primùm herbaceo, \& cùm ematuruit, croceo, guftu feruens, mordaxq́ue:radice aliquantulum rotunda,bulbofa, aro non abfimili, tenui obducta cor tice. Nafcitur in fepibus umbrofis. Seminis fuccus cum oleo inftillatus, aurium dolorem mitigat: naribus etiam ex lana impofitus, polypum abfumit : carcinomata illitu. fittit : triginta eius grana, $f i$ in pofca bibantur, abortus inferunt. Odorem aiunt, poftea quàm flaccidi flores emarcuerunt, conccptus adhuc teneros enecare. Radix excalfacit: orthopnœis, ruptis, vulfis, tufsi, deftillationibus auxiliatur : humores pectoris excreatu faciles reddit, fiue cocta, toftać; cum melle,aut per fefe edatur, fue farina eius ex melle delingatur . vrinarn pellit, venerem excitat,cum vino pota : phagedænas vlce rum, \& quæ cacoethe vocantur, trita cum melle, \& bryonia alba expurgat, \& ad cicatricem perducit: collyria ex ip fa ad fifulas, \& eijciendos partus fieri folent . qui radice fua manus perfricuerunt, à viperis feriri negantur: illita ex aceto vitiligines emaculat. Folia recentibus vulneribus linamentorum. vice,conuenienter imponuntur: decocta in vino pernionibus appofuiffe prodeft. Cafeus folijs inuo lutus, à putredine defenditur. Süccus radicis ad nubeculas, albugines, \& oculorum caligines conue nit. Radix cocta, crudáve, ad fanorum vfus, pro olere recipitur. In Gymnefjjs infulis, quæ Baleares vocantur,coctam radicem cum melle multo, in conuiuijs placentarum loco offerunt. Radix mefsibus effoditur, lotaq́ue fruftatim conciditur, \& lino traiceta, ficcatur in vmbra, \& ita reconditur.

Dracunculorum confideratio.
L I c e T in uetuftis quibufdam Diofcoridis codicibus maioris,minoris q́; Dracunculı hiftoria ßpeciatim diuifis ca pitibus adnotata reperiatur : attamen cüm altera ab alteraparum difidere uideatur, cum $q$; etiain $G$ alenus, $\mathbf{P}$ aulus, $\mathfrak{F}$ Serapio, qui in fimplicium snateria Diofcoridem ad unguem fecutifunt, eiusó; dict a bona fide rctulerunt, unius tantùm Dracunculi meminerint; non ab re credidere recentiorum nonnulli,horum alterum ex alterius auctoris officina pro= dijffe, ề alicuius curiofitate hic hiftoria Diofcoridis accreuiffe. Qu umobrem ego quoq; cogor eifdem adductus $r a=30$ tionibus, aliquatenus in eorum ire fententiam . quanquam ingenué fateri pofjum, me utrunq; Dracunculun Triden ti,ac Venetijs nidiffe. Alterum quidem, qui inaior eft, ari,fiue rumicis fo! culi craß̉itudine, ucrficolore, maculis in purpuram nïgricantibus repperfo, adeó ut angui fimilis uideatur. Altcrun ue ró, qui er minor, er omnibus unlgaris eft, folijs bederaceis, albis, quibufdam maculis confperfis : caule, ac fructu maio ri finilibus. Quippe quòd longam ex fe udginam emittat externa parte berbaceam, interna teró nigricanti purpura infectam, é cuiusmedio corniculum profilit purpurafcens, à quo demum racemofum oritur femen (ut Diofcorides in= quit) cinereo primim colore, per maturitatem ueró aureo rufe fcente. Quinetiam in cat teris totius plante notis, à ma ioris Dracunculi biftoria nibil feré differre confpicitur. Quapropter et fi predicta recentiorum fententie non aufim refragari,quòd rationibus fatis euidentibus nitatur, o doctißinorum confenfu confirmetur; cuim tamen fepius maio reme minorem Dracunculum uiderim, non prorfus alienum effe mecum quandog; cogitaui, fi quis fuppicetur duo ut funt dracunculi genera, $\dot{d}$ Diofcoride fuiffe duplici etiam biftoria reprafentata. Hanc quog; illi fupicionemi angere poterit Plinius, qui non tantüm duds, fed quatuor enumerat Dracunculifpecies lib. $\mathrm{x}$ X I I I I.cap. X.V I. fic inquiens. Id autem quod Greci Dracontion uocant, triplicieffigie mibi demonftratum eft, folijs bete, non finte thyr fo, flore pur nio. tia demonftratio fuit folio maiore, quim cornus, radice arundinacea, totidem (ut affirmabant) geniculaia nodis, quot baberet annos, totidem q́; effe folia. Quarti ueró generis meminit ip e in fequentibus lib. $\mathrm{x}$ x V.cap. I I cum inquit. Ed dem Lufitane prouincia cognoui in agro boßpitis nuper ibirepertum dracunculum appellatum, caule pollicaricraf= fitudine, uerficoloribus uiperarum snaculis, quem ferebant contra omnium morfus effe remedium. Alij funt, quos in priori iloluminc eiufdesn nominis diximus: fed buic alia figura. Aliudoǵ; miraculum excuntis è terra ad prinus ferpen tium uernationes bipedali feré altitudine, rurfusq́; cum ijfdem in terram $\int e$ condentis: nec onnino occultato co appa $=$ ret ferpens . bec Plinius. Huc etian accedat Theophrafti auctoritas, qu! libro V I I.cap. X I.de plantarum hiftoria fe cundum dracunculi genus.inter ari genera conflituit, bis uerbis. Dracuncult autein radix ( Junt enim qui genus quod dam aridracunculum appellent, quod eius caulis udriet dtem babeat quandan) cibo inepta penitus eft, o medicis tan= tim commoda. Ex bisigitur, o P linij uerbis perpicumm omnibus fieri puto,plura effe Dracontij,fiue Dracunculige nera, ut etiam Venetijs oculata fide comprobari poteft in horto clarißimi medici Miaphei a Mapheo, ubi preter Arum

Dracunculi duo uirent aftate Dracunculi genera: : Dracunculus, ut Galenus teftatum reliquit lib.v $\mathrm{r}$. fimplicium medicamen uires ex Gal. torum, quiddam Aro perfimile obtinet, tum folijs, tum radice.ceterüm illo tum acrius cft, tum amarius : ac proinde cal factorium magis, er tenuioribus partibus. Habet etian lcuem quandam adfrictionem, que quandoquidcm ctum predi= ctis duabus qualitatibus, acri fcilicet, er amara, coniuncta eft, medicamentuin factum oft utiq; maxine' efficax. Nam radix uifcera omnia expurgat, craffos potißimùm, e lentos fuccos extenuans:optinumí; remedium c ft contumacium ulcerum, que raroxisk nuncupant. hec Galenus. Cetcrim de Dracunculo differens Mefues inter catera fimplicia medicamentas 


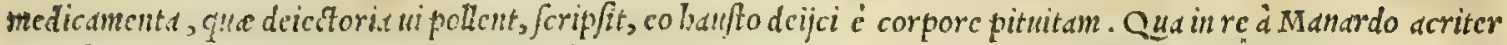
reprebenditur : quippe qwòd ubi dixcrit Galenus, ac etian Paulus ipfun fecutus, Dracunculum omnia corporis vifce ra expurgare, noit quid deijciut, id agerc intelligunt, fed quód obftructioncs aperiat, craj) am pituitum attenuet, o uafadetergat. Ab ommibus his forma maxmé differi H O R T E N S I S Dracunculus, quo in acctorijs uefcimur,

DRAGONCELIO.

20

3.

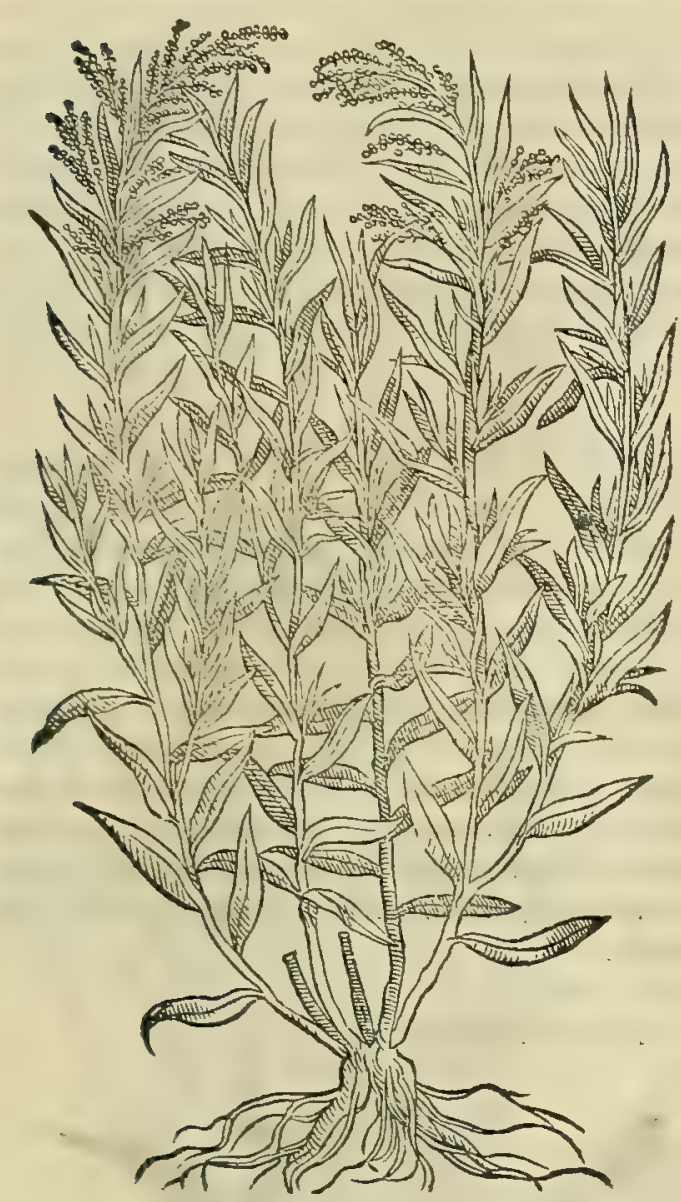

OPHIOGLOSSON.

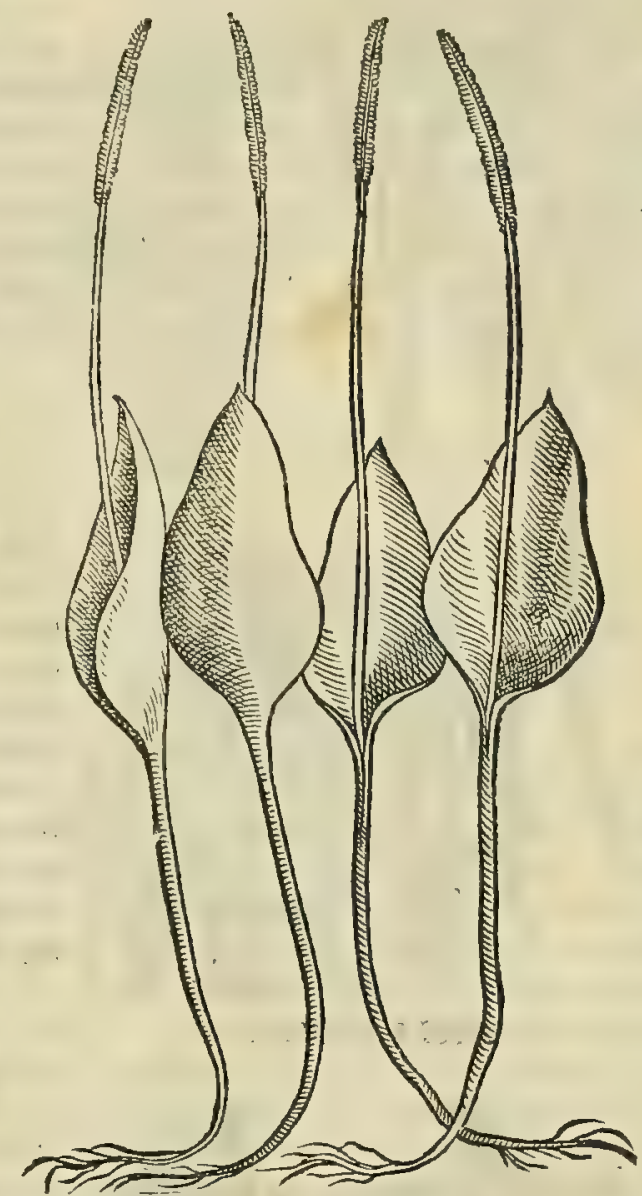

utimur'; ad intinctus acerrimo guftu, folio oblongo, radicibus humi repentibus, graminis modo. sunt qui afferant hane plantan cultorum mangonio factitiam effe, $\sigma$ non fui natura prouenire : edm fiquidem nafci putant lini femine excd= u.atis cepis impofito, ac deinde terra recondito. Sed bos falli crediderim, quód facto periculo, operam quidam perdi=

40. derint. Huius nec Greci, nec etiam Mauritani, quod fciam, meminere. Verimperpenfa eius acrimonia, qua maxi= mé linguam uellicat, corum effe medicamentoruin, qux ualentißiné excalfaciunt, facilé conijci poteft. Habetur preteres $\mathrm{O}$ alia herba, quam inter Dracunculifpecies, quidam recenfent, quod I I N G V A Serpentina nonnul lis dicatur, etfin non defint, qui Lucciolam, O Argentinam ipfam appellitent. Nafcitur hec in pratis, fed ocyßime deperditur. Profilit enim menfe maio, fed cim tenerrima fit, pauco póft tempore euanida flacce $\int c i t$, ac fubinde nuf= quam apparet. Mittit unum tantüm folium, pingue, plantagini aquatice uocate haud dißimile, $\dot{e}$ cuius inferiore fint cauliculus exit,patlidam ferpentis ligulam in cacumine gerens:unde Gracorum uoce Ophiogloßi nomen inuenit.Pre ftat hec maximé ad recentia uulnera glutinanda. Quo fit, ut eam quidam mirifice extollant ad enterocelas. Macerd=

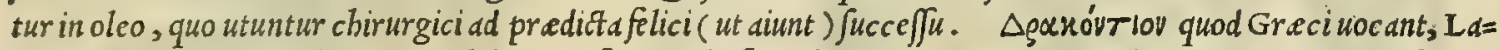
tinis Dracunculus appellatur : Arabibus, I uf, $\mathcal{O}$ Alluf: Itralis, Dragontea: Germanis, Natter uurtz: Hipanis,

Dracuncalus hortenfis. so Taragontid: Gallis, Serpentine.

$$
\text { Ä gov. AR V M. }
$$

\section{CAP. CL XII.}

A R o N, apud Syros lupha vocitatum, folia emittit dracunculi, fed lóngiora, \& paucioribus diftin Ata maculis : caulem fubpurpureum, dodrantalem, piftilli fpecie, à quo croceum femen exit: radice dracunculi alba . quæ decoeta eftur, vtpote cùm minus acris fit. Folia ad efum condiuntur, \& arida perfe, decocta manduntur. Radix, femen, \& folia dracunculi vires habent. Priuatim radix ex fimo bubulo podagris illinitur . \& dracunculi more reponitur.In totum,ob mitiorem eius acrimoniâ, in cibum expetitur. 
Ari confide.

ratio.

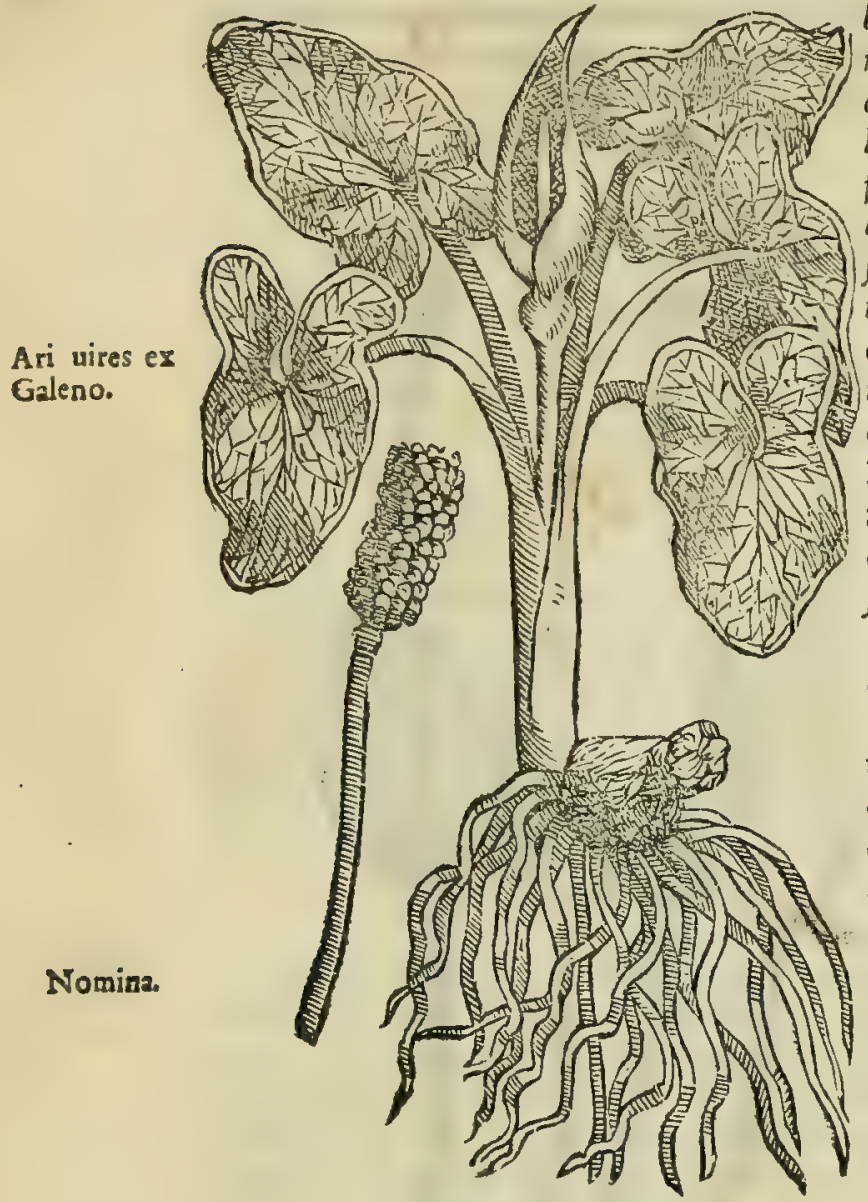

ARISARVM.

A R V M in Hetruria, item in agro Goriticn $\sqrt{\mathrm{l}}$, frequentißi mum proucnit, in campeftrbus, in uincis, in fcrobium margini= bus, Oo pasin in femitis propter fepes, prefertimé, in maritimis noftris Senenfibus, ubi uulgó ipfum uocant Gigaro ad Iarum allu dentes: quo modo officinis Arum corrupto uocabulo appellari fo let. Noftrates mulieres ex Ariradicibus fillatitias aquas ad fuc $\tilde{u}$ parant, quas ad faciem crugandam, illuftrandamó; magnis laudi= bus efferunt. Id quod etiam efficaciter praftat infolatus radicum succus, ceruffe peciem referens, quen Gerfa uulgó nominant: is fiquidem mirum in modum carni fplendorem, er candorem con 1 ciliat. Ariuires memoria prodidit Galenus lib. x $x$. fimp.med. ubi ita fribit. Arum terrend effentia conftat, fed calida:proinde extergendi uim poßidet, uerim non ualentem, ficut dracontium. $\mathrm{E} f \mathrm{t}$ itaq; in exiccando, $\sigma$ cale faciědo primi ordinis. Radices cius maxime funt utiles: fiquidem comefe craßitiem bumorum medio= criter incidunt, adcó ut $\mathcal{O}$ excreationibus ex pectore idone $\mathrm{fint}$ : fed magis tamen aptum eft dracontium. Et lib. I I.de aliment. $f_{d}=$ cult. fic inquit. Ariradix rapimodo manditur. In quibusdam au tem regionibus acrior quodámnodo nafcitur, ut dracontio feré $f=$ milis fit. Dum recté parare uoles, prioris decoctionis aqua effufa, repente in alteram calidam inijcere conuenit. Cyrenis contrà, quam in noftra regione, Arum fe habet: nam illic minimum medi casnentofi, minimumq; acrimonia poßidet, adeó ut uel rapis fit utilius. Idcirco radicem quoq; in I taliam comportät, $u t q u x a b \oint_{i}$ ut putre $\int a t$, aut regerminet, longo tempore perdurare pojiti. Herba, quam Greci ápov, $\sigma$ Latini fimiliter Arum dicunt, Mauritanis Iarus er Sara wocatur: Barbaris, Aron, Barba a= aron, Dragontea minor, o serpentaria minor: Italis, Aro, or Gigaro: Germanis, Clein natter uurtz: Hipanis, Yaro: Gal lis, vid de chien.

ARISARVM ALTERVM.
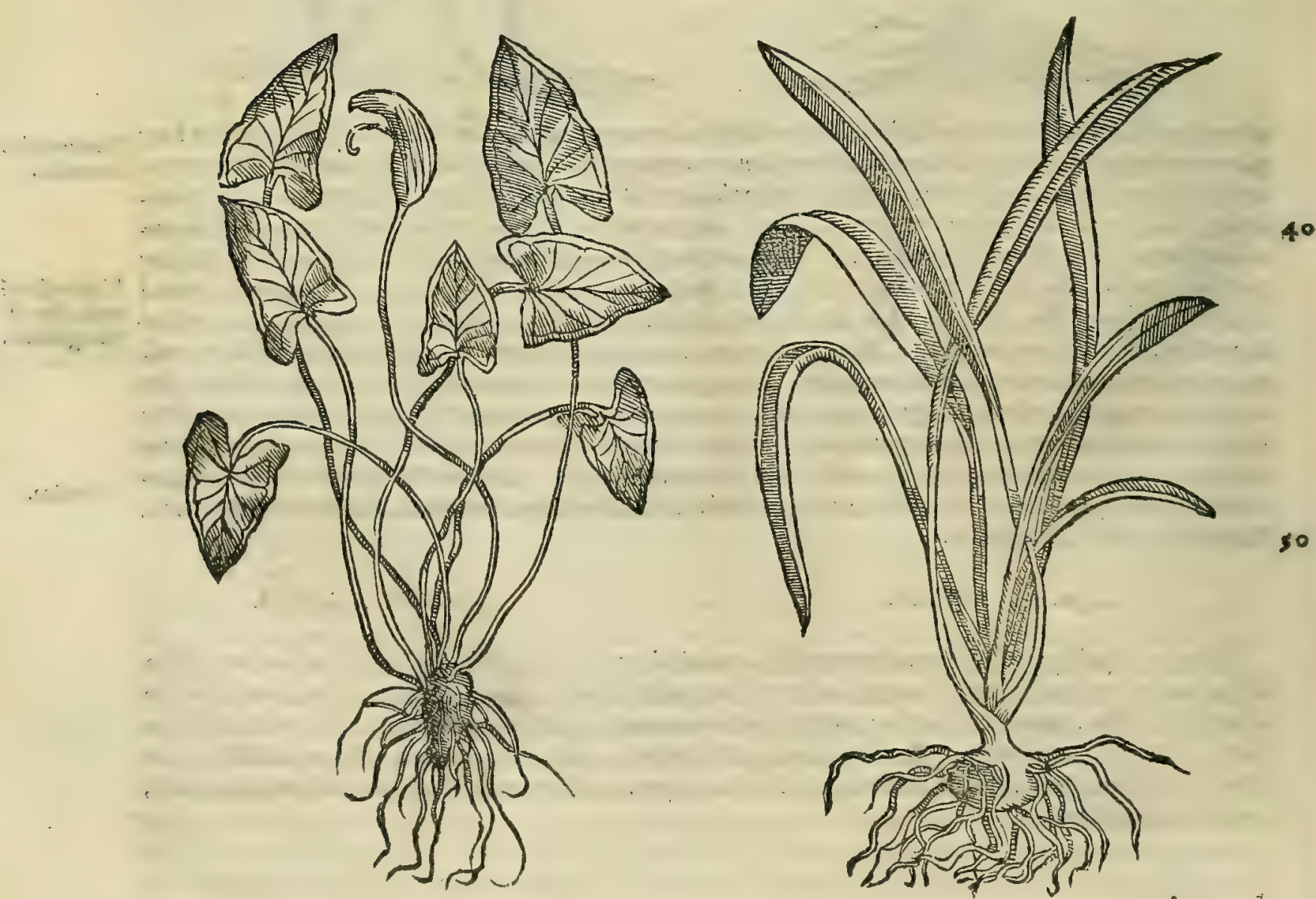

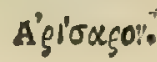




\section{In Lib.fecundum Diolcoridis.}

\section{A'gíogov. ARISARVM. CAP. CLXIII.}

$A R$ I S A R V M exigua herbula eft: cuins radix olex magnitudinem implet, longè maioris quàm aron acrimonix. Vnde illitu nomas fiftit. Fiunt colly ria ex ea, ad fiftulas efficacia. Illitu radicis,genitale animalis cuiufcunque in perniciem agitur.

A R I S A RON, Plinio lib. XX I I I I. cap. X V r. aultore, in Aegypto nafcitur, fimilis aro, minor tantim, Arifari hifominoribusóp folijs, o utique radice, que tamen oliue grandis magnitudinem implet. Huius duo hodie ab herbarijs ria.

20 oftenduntur genera : quorum utrunque ad me primum mifit Aloifius Anguillarius Romanus borti Patauini profic= cas, diligentißimus reiberbaria inquifitor . Qui preterea teftatus eft; Arifarum plurimum nafci in agro Romano, non longe ab urbe. Hec eddem Arifarigenera poftea ab alijs etiam accepimus. V triufque picturam exbibere libuit, non quód utrunque probemus (alterum enim non uerum putamus) fed ut de ijs aliorum etiam fit iudicium. Memi= nit Arifari Galenus lib. v I. fimplicium medicamentorum his paucis. Arifarum multó minus eft aro. Radicem babet ex Galeno.

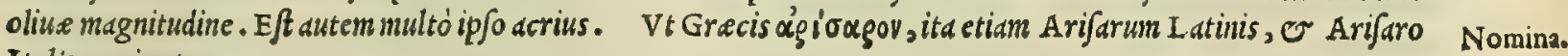
Italis nominatur.

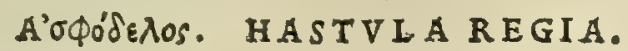

CAP. CLXIIII.

20

30

40

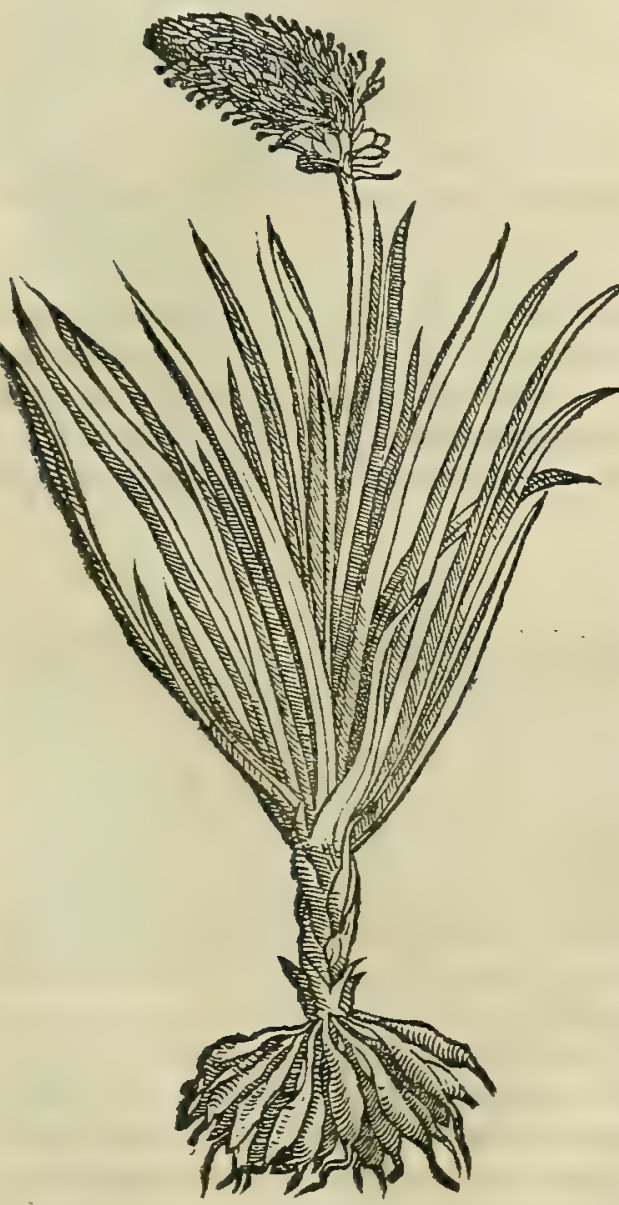

H A S T V L A RE G I vulgaris notitix eft: folijs maioris porri : caule lxui, ferente in cacumine florem, quem anthericon appellant : radices fubiacent oblongæx, rotund $x$, glandibus fimiles, guftu acres. Qux excalfaciunt : vrinas, \& menfes epotæciunt : lateris doloribus, ruptis, conuulfis, \& tufsibus, drachmæ pondere potæ ex vino medentur. Ea verò vomitiones adiuuat, ludicri tali magnitudine commanducata : à ferpente demorfis datur aptifsimè,trium drachmarum pondere, verùm folijs, floribus, \& radice ex vino morfus illinire oportet : item vlcera fordida, \& depafcentia : mammarú quoque, \& teftium inflammationes, tubercula,furunculosq́ue: decoctis in fxce uini bulbis, recentibus inflammationibus ex polenta auxiliatur . Radicis fuccus adiecto uetere vino dulci,myrrha,\& croco decoquitur, fitq́; perquàm utile oculis medicamentum : ad purulentas au res per $\mathrm{fe}, \&$ cŭ thure,mclle, vino, \& myrrha tritus, prodeft : in contrariam aurem infufus, dentium dolorem $\mathrm{mi}$ tigat. Cinis è radice illitus, alopecias ad pilum reducit . oleum in excauatis radicibus igni decoetum, illitu exuleeratis pernionibus, \& ambuftis igni, conducit : \& furditati inftillatum in aurem auxiliatur. Candidam uitiliginem, linteo antea perfictam in fole, illita radix emendat. Semen, floresq́ue in uino poti, fcolopendræ, \& fcorpionum venenis, mirum in modum refiftút : aluum purgant.

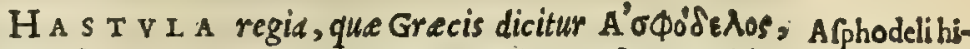
planta eft non ignota. Huius caulem (ut Plinius eft auctor libro Atoria. X XI.cap. X VI I 1.) Theophraftus, or feré Graci omnes cu=

s. bitalem, Or fepe duîm cubitorum, anthericum uocauere: radicem uerò, id eft, bulbos, aphodelon. Latini aus tem illud albucum, $\sigma$ apphodelum haftulam regiam dixere. Planta hac Apectatu mira, $v$ iucunda eft, cum integra effoditur, ob ingentem bulborum numerum,qui circunqudig; dependēt: :quippe quód aliquando eius aliquam uiderims bulbis ultra centum radicicoherentibus . quanquam loco citato tradit Plinius, A phodeli radicem alijs numero/io= rem efe, ut que octoginta fimul aceruatis $\int e p e$ bulbis reperiatur. Vermes Albucum creat ( $u t$ Theoploraftus ait) qui in wolucres beftiolas flo fculorum pecie degenerant: ij tandem cim flacce $\int c e n s$ inaruerit $f\left(a p u s_{2}\right.$ erofo concepta $=$ culo prouolant. Mandebatur antiquitus, Hefiodo tefte, huiufce plante tum caulis in cinere toftus, tum bulbus cum femine, oleo, $\odot$ fale addito: quinetiam cum ficis, mira uoluptate. Extulit magnis laudibus A phodeli radices Nican der in fuis theriacis, ad ferpentium mor fus, er fcorpionum ictus. Meminit edrum quoq; Galenus lib.v I. Fimplicium Afphodeli vimedicamentorum, fic inquiens. Aphodeli radix utilis eft, ficut ari, afari, or dracontij, nempe extergentis, of res ex Gal. difcutientis facultatis. Vfte autem cinis calidior, e exiccantior, fubtilior' $q_{j}$, ac digerere potentior efficitur, ac pro= inde $v$ alopecids fantat. hec Galenus. Ceterùm aphodeli radix mirifice commendatur Aĕtio libro primo ad cien= 
dos menes, his uerbis. Aphodeli radix in uino albo uetere decoeta, uino calido meraco cyathi menfura haufto;

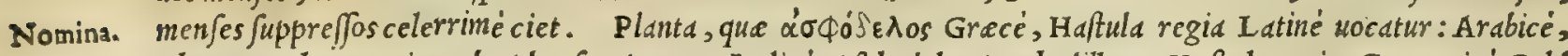
Cheunce, Bhunte, Biruacb, Abg, feu Axeras: Italice, Aphodelo, Amphodillo, er Hafula regia: Germanicé, Gold uurtz, $\mathcal{O}^{-}$Heidnifcls: Hifpanicé, Gamones, Gamonites: Gallice, Aplorodiles.

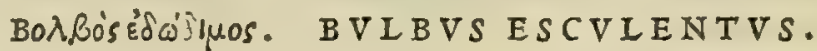

CA P. CLXV.

E S C V L E T v s bulbus vulgò cognitus, à nobis eftur. Stomacho, \& aluo ut ilis rufus, \& quí ex Aphrica defertur. Amarus uerò, \& f cillinus, ftomacho aptıor eft, \& concoctionem adiuuat. Bulbí omnes acrimoniam habent, excalfaciunt, venerem ftimulant, linguam, tonfillasq́ue exafperant, multú alimenti prabent, carnes creant, inflationem pariunt . luxat:s, fractis, articulorum doloribus efficaciter illinuntur : fpicula extrahunt : gangrænas, \& podagras ex melle, aut per fefe hydropicorum tumores, \& canum morfus cum melle, \& piperis polline illiti cohibent : fudores compefcunt : ftomachi dolores mitigant : furfu res, \& ulcera, qux in capite manant, cum tofto nitro abftergunt , fugillata , varosq́ue per fe, aut ex ouiluteo, \& lentigines cum melle, vel aceto, emendant: fractis auriculis, vnguibusque,ex polenta medentur. Ijdem calidis cineribus torrefacti, tollunt ficus : item cum cinere è mænarum capitibus, impofiti . Cremati uerò, \& cum alcyonio mifti, vitia cutis in facie,atrasq́; cicatrices, in fole illiti emaculant . faciunt ad rupta,fi cum aceto cocti edantur. Sed copiofiore corum cibo abftinendum, quoniam neruos tentant.

\section{BOA óséustikós. BVIBVS VOMITORIVS. CAP. CIXVI.}

B v L B V s, quem vomitorium uocant,folia habet lentiora multò, \& longiora, quàm bulbus efcu lentus : radicem fimilem, cortice nigro. Ea radix manfa, aut decoctum eius potum, ueficæ malis medetur: vomitiones mouet.

Bulborum có B v L B O R V M generd, efculentum, er uomitorium, antiquis uulgó notißima fuiffe ex eo maximé conftat, Gderatio. quód corum faciem non reprefentauerit Diofcorides. Nobis ucró Bulbi cam ob cau fam, uel quód iandiu exoleucrint, hodic omnibus tum medicis, tum herbarijs adeo incogniti funt, ut neminem hactenus inuenerim, qui cos legitimé demon fret. Veteribus autem fuerunt in frequentißimo ciborum $u f u$; bis prafertim admifti,que ueneris conciliande gra $=.30$ tia parabantur, utpote qui uenerem ftimulent. Qüंd autem ad id expetiti, or commendati fuerint, Martialls aperté teftatus eft in Xenijs Juis, dum cecinit.

Cùm fit anus coniunx, cum fint tibi mortua membra, Nil aliud bulbis quàm fatur effe potes.

Multorumer Ceterum non defueré, qui crediderint Bulbum efculentum effe Afcalonium cepe, aut fißile illud ceparum ge= ror. nus, quod Hetrufis uulgó uocatur Cipolla maligia. Sed horum error maniffé deprebenditur ex Theophrafto, qui A calonium, fißiléq; cepe inter ceparum genera libro v I I cap. I I I I de plantarum biftoria recenfuit, Bulborum ui non autem inter Bulbos, de quibus peciatim differuit libro v I I . cap. X I I I . Bulborum meminit Galenus li= res ex Gale. bro V I . fimplicium medicamentorum. fic fcribens. Bulbus efculentus frigidior, er craßior eft, lentumq́q; fuccum procreat. Nam or coctudifficilis eft, $\mathcal{\sigma}$ flatuofus, $\mathcal{\sigma}$ uenerem prouocans. Attamen illitus ob amari= 40 tatem, fimul or adfritionem, abftergit, fimul or glutindt, or nimirum etian exiccdt. Eft enim oftenfun, $d=$ maritudinem in extergentibus effe Jubftantijs, adftrictionem ueró in glutinantibus. At ficcitas utranque confequi= tur. Bulbus autem nomitorius multó eft calidioris temperature, quàn predictus bulbus. Et libro I I. de ali= mentorum facultatibus, fic de bulbis fcribit. Bulbi genere cum predictis conueniunt. Nam borum quoquc ra= dix direptis foligs manditur : in uere interdumipje etian coliculis. Amaram, aufteramq; uim cuidenter bulbi in fe babent : quamobrem elangue fentis ftomachi aliquatenus excitant auiditatem. At ueró neque ijs aduer fantur, quibus e thorace, atque pulmone pus conuenit expuere: quanquam craßiore, ac glutinofiore funt corporis fub= Atantia. Etenim amaritudo craßitudini reluctatur, lenta, crafjáf; nata incidere, quemadmodim in commenta= rijs de medicamentis prodidimus. Quapropter bis elixi uberius quidem alent, fed excreare uolentibus aduer= fabuntur, utpote omni amartudine exuti. Tum ueró $x$ aceto, oleo, garóque mulis, efitare fatius fuerit: nam so

Nomina. ita magis profectó oblectabunt, ac nutrient, minuśg; inflabunt, ac facilius concoquentur. BoגBos qui Gre= cis édódiuos, Latinis Bulbus efculentus cognominatur : Mauritanis, Bafar alzir: Italis, Bulbo che fi manx

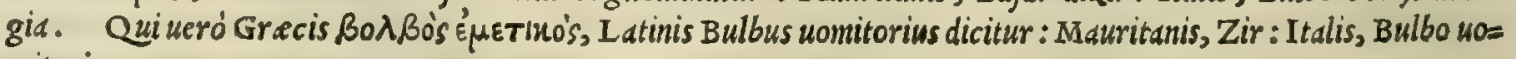
mitorio.

$$
\sum x i \lambda \alpha_{0} \quad \operatorname{SCILLA.~}
$$

\section{CAP. CLXVII.}

S C I L L A uim acrem, atque feruentem habet.affatam ad multa utiliorem effeconftat. Polli ne ad cruftam fubacto, aut luto oblita, in clibanum conjicitur, aut carbonibus obruitur, donec obducens crufta fufficienter intolta fuerit : qua exempta, fi non emollefcat, altero polline fimili, aut luto circumlinitur, \& eadem, qux prius, funt: nam quæ ita non affatur, interaneis maximè noxia eft. Torretur item in olla, indito operculo, qux in furnum demittatur. Sumi etiam folet 


\section{In Lib. fecundum Diofcoridis.}

SCILLA.

10

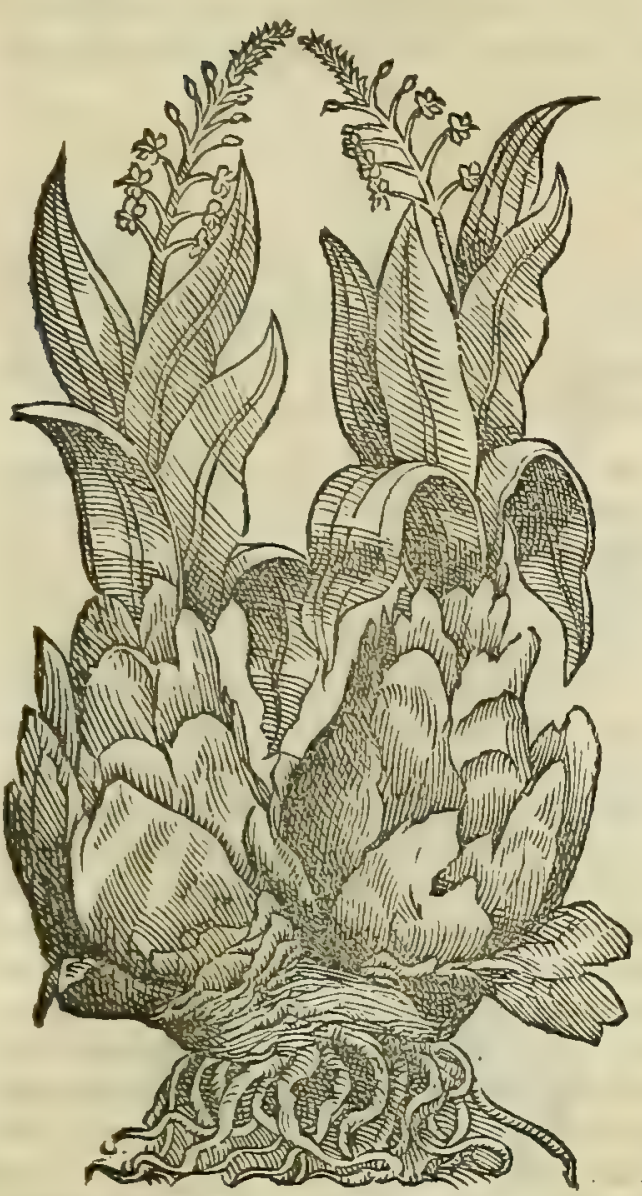

quod maximè eft medium, direptis viuótenus tunicis, quod fruftatim cófectum coquitur, mutata frepius aqua, donec ipfa nec amaritudinem, nec acrimoniam habeat: traiętaq́; lino frufta ficcantur in vmbra, ita ut ne ulla qui dem parte fe contingant. His fcillæ fegminibus ad oleŭ, vinum, aut acetum fcillinum utimur. Ad rimas pedum, interna pars crudx fcillæ in olco feruefaita, aut cum refina liquefacta, imponitur. decocta in aceto demorfis à vipera,cataplafma eft. Ad fingulas affr partes adiectis octonis tofti falis, cochlear vnum, aut alterum damus ieiunis, ad emolliendam aluum : in potu autem, \& odoratis medicaminibus, \& quibus vrinam ciere volumus, hydro picisque, \& ftomachicis, quibus innatat cibus, regio mor bo, torminibus, in tufsi vetere, fufpiriofis, \& ore reijcientibus, tres obolos in delinctu ex melle fumpfiffe fatis eft. Coquitur cum melle, \& eftur eorundem gratia, maximè vt concoctionem adiuuet: ftrigmenta per aluum extrahit. Cocta, \& fimili fumpta modo,eordem præbet effectus : fed cauendus fcillie ufus his, qui inteftinum fen tiunt ulcus . ad penfiles uerrucas, \& perniones, tolta efficaciter illinitui:. Tritum femen, \& in carica, aut melle deuoratum, aluum emollit. Scilla tota in limine ianua fulpenfa, mali medicamenti noxam arcet.

\section{Poyrex́tiov. PANCRATIVM. CAP. CLXVII.}

P A N C R A T I V M, quod aliqui fcillam appellant, radice eft magni búlbi, fubrufo colore, aut fubpurpureo, guftuamaro, ac feruente folijs lilij, fed longioribus. Scillæ uires, \& præparationem habet, eodemq́ue pondere in morbis efficaciter affumitur : cui tamen mitior, quàm fcillæ facultas ineft. Radicis fuccus cum eruif farina digeritur in paftillos, qui hydropicis, fplenicisq́ue cum hydromelite, commodifsimè dantar.

SV PER I OR I B V S annis credidimus, scillas, quarum in Italia omnibus tum medicis, tum feplafiarys communis ef ufus, legitimas Scillx, \& Pan efe: in hase autem opinionem veneram pluribus coniecluris ac rationibus fretus. In primis enim Plinium inueneram lib. XIX.cap. V. Scille cratij confide maiorem quàm cateris bulbaceis radicibus amplitudinem reddidife. quare cùm fape uidiffem ex yjs Scillis, quibus paßsim utinur, nonnullas ad ratio. cantam niagnitudinems crewij]e, vt ferè caput hominis equarent, non poteram non exiflimare. illas effe uerrs. Deinde legevam apud Theophrafum lib.V I I. cap.XI I. de plantarum hiforia, Scillam prius caulem floresǵ; giznere, quàm folia. Id quod in noftratibus cùm manifefie deprehendatur, mihi quidem non uidebatur efe difcedendum à vulgari opinione. A dde quod fapenumero quasdam Scillas uidi paruas, pyro paulo ma-

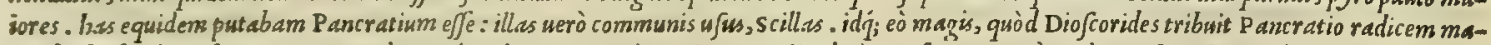

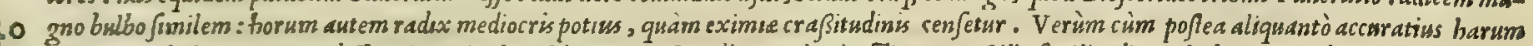
plantarum b:forians expendiffem, inseni Aloes folum, Diofcoridis or Pliny testimonio, fille fimilitudinem babcre. Quod nimirum refiagatur Scille commurais ufus, ut qua folia fer at non aloe, fed liho proxinsa : inter qua non parua quidem intercedit differentia. Quinetiam legi ins Theophrafo ; o Plinio, quod Scilla foret ter in anno. hoc item nous enenit noffris unlgaribus scillis. Hinc itaque iure quodam factum eft, ut de

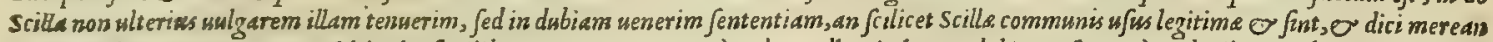
twr: aut alie reperiantur, quc folyjs aloe fimilibus proweniant. Calerùm dum adlssc in hac re dubia uerfarer, à quibufdam medicis Hifpanis acsepi in Hißanis maritimis Scillas innumer as oriri noftratibus duplo maiores, folys aloen amulantibus, fed minus craßsis : qua amaritudine, aGimonia, ac uirium preftätia communes noftras Scillas longe sincunt. I am ergo non dubitauerinz afjerere predict as Hifpanie Scillas, weras ef-

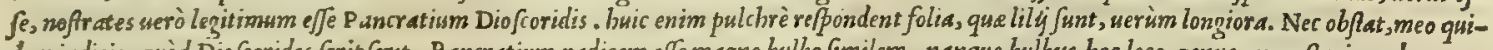
dem iudicio, quiod Diofcorides fcripfert, Pancratium radicem effe magno bulbo fimilem. nanque bulbus hoc loco genis, non ßpeciem denot at. Atque adeo lins fortaj]e fit, ut Scille, quarum est communis ufus, non ea prefent efficaciter, quelegitime pollicentur : quòd Pancratio (ut Diofcorides teflatur) mitior, quàm Scille facultas infit. Quidam atatis nofre medici in cerebri, or neruorum frigidis affectibus, scillam crudam ab inuolucris repurrat am ninutim fecant, or cum melle plurimo in uas uitreum conyjiunt, infolantí; per affatem, ardente prefertim firio. De-

50 mum percolato mellc utuntur ad comitiales, or alias cerebri egritudines, à firiditate excitatrs. Sed alia longè diuerfa fuit Galeni ad hos ufus frille pur ands rasio. Quippe qui concrfam Scillam nunguam melle commifam expofuit infolandam s jed ut ab ea fuccum fole colliguatum in diebes casicularibus eximeret, in ficile, uel vitreum urs, in quo primim mel fuiffet, difjectam frillam immittebat : deinde tantijper infolabat, donec Jolaribus radys ipfaliguefceret. Ex quso palam fut, quod plerique à Galeni infituto prorfus aberiant, ut qui fcillinum mel confuiant fcillde liguoris uice. Scilla ( Dt remoria fcriptum reliquit Galenus lib. VIII. Jimplicium medicamentorum) admodum incidentem facultatem obtinet, non tamen admodum calidam. Sed jecundum hoc eam quipiam fecunds ordinis cenfeat excalfacientium. Preffat autem aut afjam, aut e-

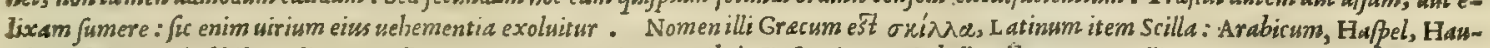
fel, Afchil, feu Alafchil: Italicum, Scilla: Germanicum, Mer Zunibel:Hijpanicum, Cebolla albatrana: Gallicum, Stipoulle, Charpersinire, Oignon maris.

$$
\text { Káareprs. CAPPARIS. }
$$

\section{CAP. CLXIX.}

CA P P A R I s aculeatus frutex eft, qui in terra ftratus magis in orbem enagatur. Spinas, vt rubus, habet in hami modum aduncas: folia mali cotonex, rotunda: fructum olex fimilem, qui cùm dehifcens panditut, florem candidum promit: quo excuflo, nonnihil glandis oblong $x$ figura inuenitur, quod apertum grana acinis punicorum fimilia oftendir, parua, rubicunda : radices lignofas fpargit, grandes, numerofasq́; . Tenui plerunq; folo, afperisq́; Locis, in infulis, \& iuxta rudera nafcitur. Caulis, \& fuctus, cibi gratia condiútur . aluum turbat, ftomacho aduerfatur, fitim gignit: co-

E : Q Q a tamen

Scillx uires ex Galeno. Nomina. 
CAPPARIS.

Capparú con fideratio.

Capparum fa tio.

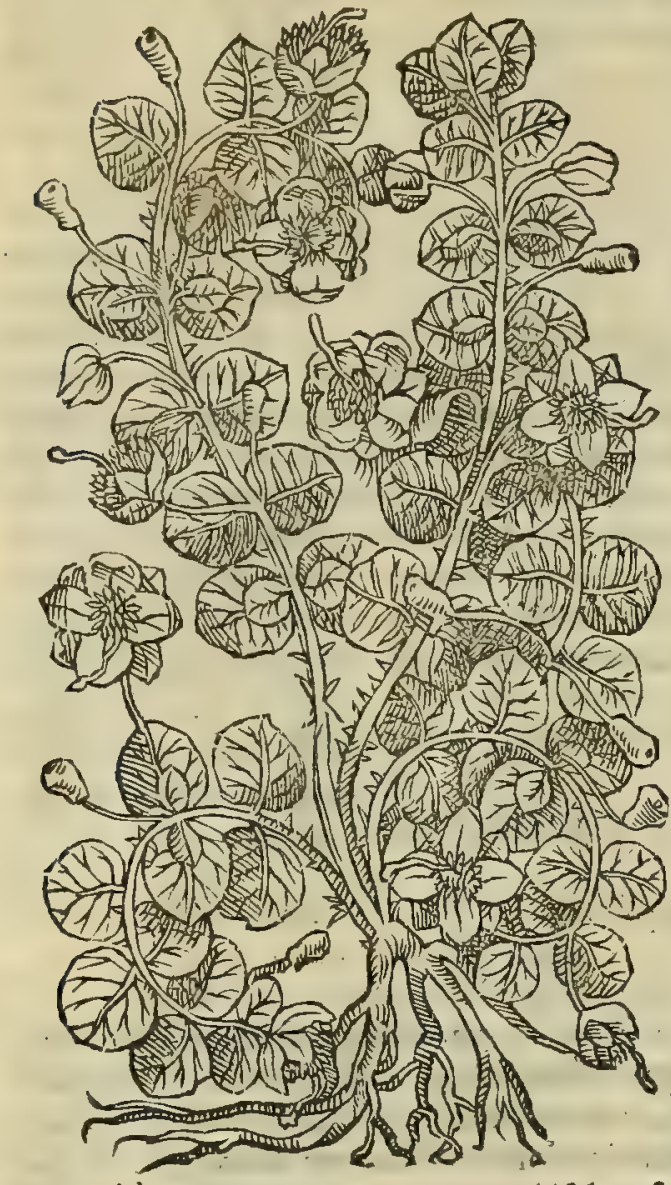

cta tamế ftomacho, quàm cruda vtilior eft . Fruktus drachmis duab" in vino potus, quadraginta dicbus, lienem abfumit, \&c vrinä, cruentumque excrenentum emıttit : bibitur vtilifsimè in coxarum doloribus, \& neruorum refolutione, "item ruptis, \& conuulfis : menfes ciet, caput purgat. Dentum dolorem fedat femen exaceto de cottum, colluto inde ore. Aridus radicis cortex ad eadem proficit: vlcera omnia vetera, \& fordida, \& qui occallucrunt, expurgat : lienofis cum farina hordei illinitur : dente demorfa, dolori eius auxiliatur : cum aceto trita, vitiligines albas abfterget . Radix, foliaǵue intrita, ftrumas, ac duritias difcutiunt. Aurium vermiculos infufus fuccus enecat. Aphrica, \& præfertim Marmarica capparis, vehe menter inflat. Apula vomitus facit . \& qux à Lybico, \& qux Rubro inari, defertul', mirum in modum acris eft : Yiquidem in ore puftulas excitat, gingiuasq́; offe tenus exeft . quare in cibis non ab re damnatur.

C A P P A R I s frutex eft in Italia unlgaris fatis notitie. Floribus enim, of fruatibus inuria afferuatis frequentißime in ci= bis utimur. Ex ijs fuauiores, or qui cum palato maiorem ineant gratiam, funt recentes acerrino afferuati aceto, quod pleriq; $f a=$ ciunt in Hetruria. Praftantißime cappares ex Alexandria Ae= gypti Venetias aduebuntur. Eft $\mathrm{o}$ in A pulia capparum prouen= tus, unde etiam plurime deferuntur, terim longé deteriores bis, que ex Aegypto importantur. Vomitiones cappares baudqua $=20$ quam cient, ut Diofcorides inquit: nififortaffe hac facultate fint praditai, dun recentes, ac utrides comeduntur, antedquam mu= riam experiantur, or inde elixentur. Proueniunt etiam Roine in collap/is edificiorum parietibus, ruderibusq́;, praertim cir= ca Pacis templum, item q́; Senis, que quidem Apulis faporis pra $=$ ftantiaminime cedunt. In cultis nafci cappares negat Tbeoplira= ftus lib. vi, cap.v. de plantarum biftoria. Seruntur tamen bac atate, coluntur'q; perinde ac fegetes, et legumina, quemadmodum o. Plinij tempore qui ferendi rationem lib. X r X.cdp.V I I I. bis uerbis explicauit. Quppe cum capparis quoque feratur, ficcis 3 maximé, area in defoffu cauata, ripisó, undiq; circumftructis $l d=$ pide, aliàs eudgatur per agros, or cogit folum fterilefcere. Floret aftate . uiret ufque ad vergiliarum occafum. Capparis ui- Sabulofis familarißimum. Capparis uires reddidit Galenus libro vi.r. fimplicium medicamentorum, fic inquiens. res ex Gal. Capparis radicis cortcx uincentem babet qualitatem amaram, proximam acrem, deinde acerbam. Ex quo liquet,

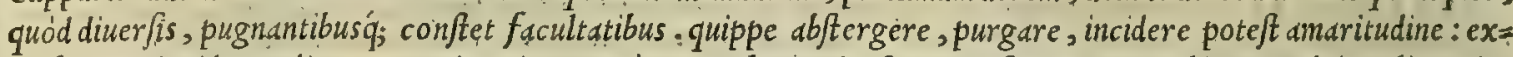
calfacere, incidere, digerere acrinonia : porró contrabere, denfare, confringere acerbitate. Idcirco lienes in= duratos, fi quid aliud, hoc medicanentuni iuuare ualet, tum foris idone is illinendis remedijs admiftum, tum intró in corpus affumptum; fune dècoltum in aceto, aut oxymelite, or id genus, frue aridum contufum, illisq́; permiftum. Quippe cum aperté craffos, lentosó; bumores boc pacto fumptum euacuet, nec cos tantium per urinas; fed $\mathcal{O}$ per uentrem: Sepe etian fanguinolentos defert, unde e lienes adiuti funt, er coxarum dolores. Quinetiam menfes. 40 promouet, or ex capite purgat, detrabit ó;, auxiliatur q́; ruptis, atq; conuullis. Ceterum cuinam ip fum 'potioni in quoque affectuum mifcericonueniat, non eft prefentis inftituti perfequi. Porró radicis eius cortex ulceribus mali= gnis cataplafmatis modo impofitus, non malum eft remedium, ut qui illa extergere ualeat, ne fegniter deficcare. Praterea dentium labores predictarum qualitatum ratione adiunat, interim cum accto coctus, interim cum uino, fepe etian folus dentibus man fus, ac morfus. Ex dictis ergo clarum eft, incidendi quandam eifacultatem ineffe, itém= que extergendi, digerendi, contrabendi. vitiligines fiquidem cum ace to detrabit, 0 chacrdda, $\sigma$ duros tumores di= gerit, idoneis ad ea medic amentis miftus. Radicis cortici, fructus proportione uirium reppondet, nifi quód ad omnia fit imbecillior. Imó et folia, or caules eius, fimilem uim obtinent . meminiq́; me folijs quandoq; paucis dicbus duritiem cheerad is naturam referentem difcußiffe. Sed admifcemus fcilicet illis quippiam, quod eorum uirium obtundat uelee mentiam. Nec mirum eft, quód durium uermes fuccus amaritate occidat fud. Porró capparis, que in admodum fer $=$ uentibus regionibus prouenit, ut quam fert Arabia, multó est noftrate acrior, adeó ut plurimum etiam babeat facul= tatis adurentis. Et lib.I I. de aliment. facultatibus, fic de Cappare fcribit. In Cypro Capparis plurima prouenit . Facultus eius tenuium admodum eft partium : proinde minimum alinenti in corpus eorum, qui ip $\int a$ ue cuntur, diftri= buit. quemadmodum er alia omnia, que tenuibus conftant partibus. Vtimur autem fructu huius planta imagis, ut medicamento, quàm ut alimento. Importatur ad nos etiam fale conperfus, quia folus afferuatus putrefcit. Clarum ergo eft, quód capparis adbuc uiridis, anteaquàm fale condiatur, plus babet nutrimenti : nam ex falitura permultum cius amittit, n'q́' fal abluatur, prorfus haud quicquam nutriet : aluum tamen fubducet. Verùn ablutus, er demacera tus, donec omnem falis naturam exuat, ut minimi fané alimenti cibus eft, ita obfonium, or medicamentum, cum ad ex= citandum proftratum appetitum, tum ad deradendam, dcijcie ndamí; pituitam uentri adhare fcentem accommadatum erit,ac deniq; ad lienis, iecorisq́; amoliendas obftructiones. Verium in hos ufus cum oxymelite, aut oxeleo ante alias om nes dapes fumi oportet. Tencllis porró capparis germinibus homines, ut tercbinthe turionibus, uc fcuntur : cum '́; ads 


\section{In Lib. fecundum Diofcoridis. $\quad 329$}

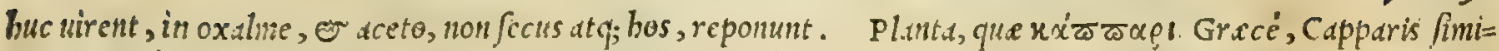
Titer Latimé dicitur: Arabicé, Cappar $\odot$ Kappar : Italicé, Capparo: Germanicé, Kappren : Hipanicé, Alca= parras: Gallicé, Capprez.

LEP I DIVM DIOSC.

id

$20^{\circ}$

30

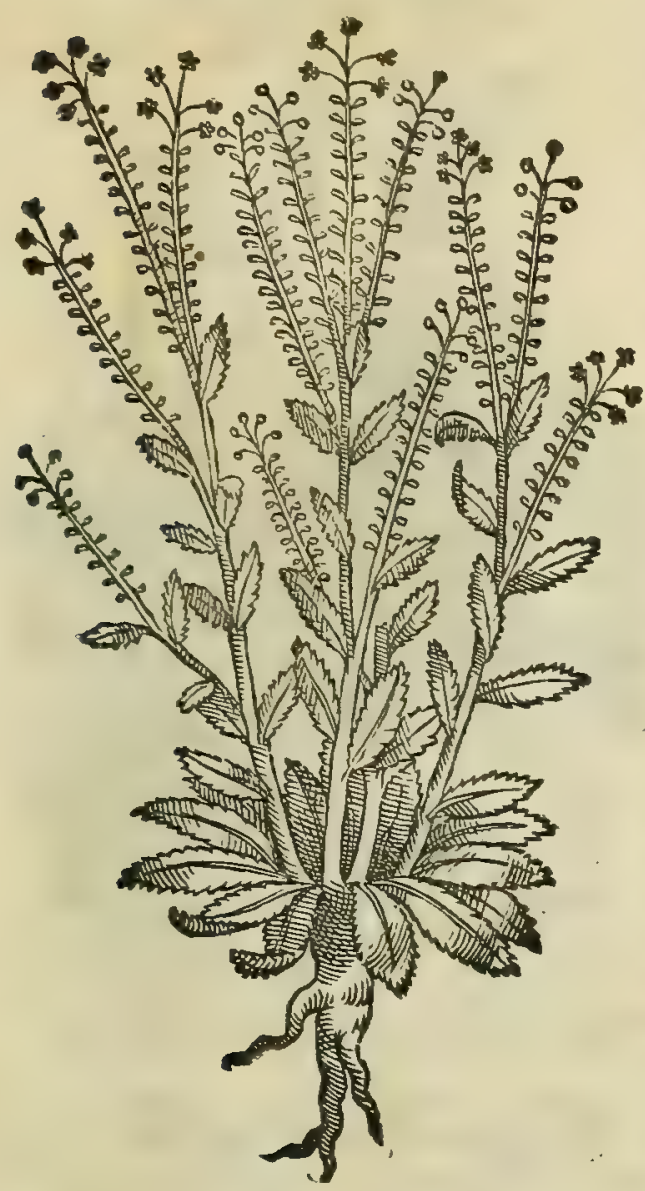

Aeळíio\%.

LE P I DIVM.
LEPIDIVM PAVLI, ET PLIN.

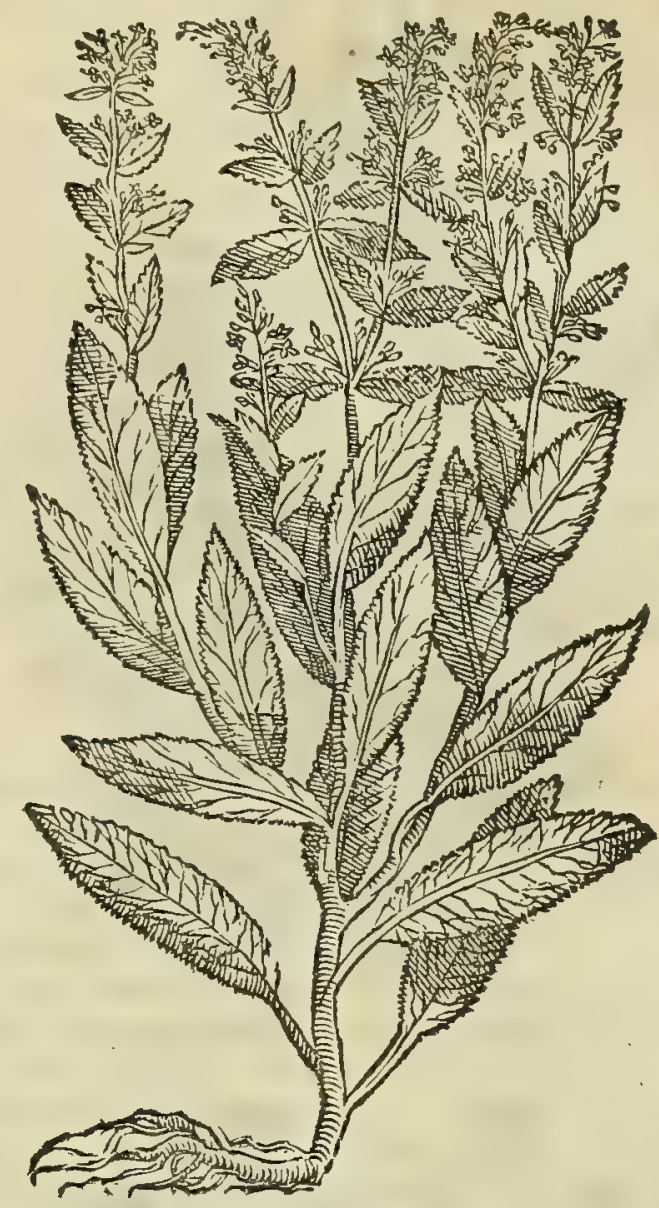

CA P. CLXX.

L E P I D I V M, aliqui gingidium vocant, herbula vulgò nota . muria cum lacte feruatur. Vis foliorum acris , \& exulcerans - quapropter ifchiadicis trita, præfentifsimum eft auxilium, fi cum hele40 nij radice, quarta parte horæ, illinatur : lienofis fimili modo prodeft: lepras eximit. Radix appenfa collo, dolore dentium liberare exiftimatur.

Cv'M fatis fuperó; ḋ nobis often fum fit, in primi libri calce, in Iberidis commentatione, Iberidem nibil à Lepi= dio differre, fuperuacaneum effet, hic ea repetere, qu.e ad Lepidij biftoriam explicandam loco citato diffufius addu= ximus. siquidem eó qui $q_{\text {; }}$ facilé accedere poteft, qui ed, que ibi diximus, fcire defiderat. Veruntamen illud filentio non inuoluendum duxi, quòd Plinius in Lepidij hiftoria prorfus à Diofcoride diffentire deprehenditur. Quippe qui fcripferit lib. X I X. cap. V I I I. Lepidium cubitali longitudine affurgere, folijs laurinis, non autem nafturtij, ut Dio= fcorides inquit. Quod fané nobis in finhare uidetur, Plinij Lepidium eam effe Iberidis ppeciem, quam fcribit Paulus lib. I I . de coxendicum dolore agens, folia lauri profrrre. Hac enim (ut libro fuperiore diximus) ed facilé fuerit,

so quam uulgus herbariorum ideo Piperitim nominat, quód acerrimo guftu linguam mirum in modum uellicet. Caterùm non poffum non admir ari, quód tam facilé crediderint Hermolaus, Manardus, ac R uellius illos fecutus, Le pidium eam plantam effe, que unlgó in Italia appellatur Raphano. Nam cumbac folijs fit belenio pauló minoribus', ơ uerbafco maioribus, nullo pacto Diofcoridis Lepidium referre potelt, ut quod tenuis admodum fit herba. Nec item Plinio ad= Lepidij confi deratio.

Lepidium Pli nij. ftipulari uidentur, qui Lepidium prodidit laurints folijs exire in cubitalem altitudinem : nifi fortaffe ij clarißimi uiri

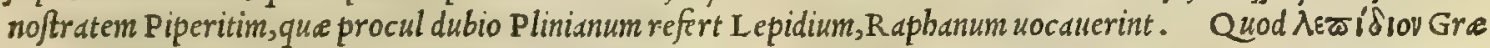
ci, Lepidium quoq; I atini uocant: Mauritani, Seitaragi, Hau $\int a b$, A fceitaragi, feu Sitharegi: Itali, Lepidio: Ger mani, Gauchbluon, E Vuilder Lrefz; Galli, Pafferaige, E Nafitort faunage. 
RANVNCVIVS PRIMVS.

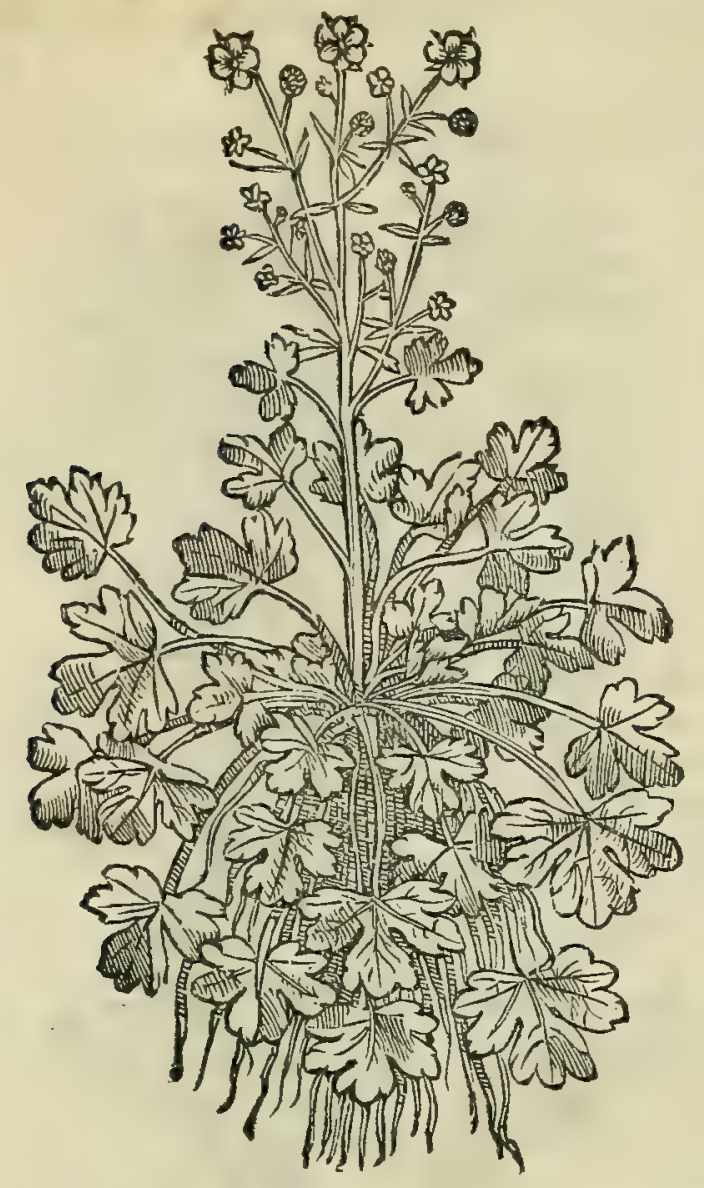

RANVNCVLVS TERTIVS.

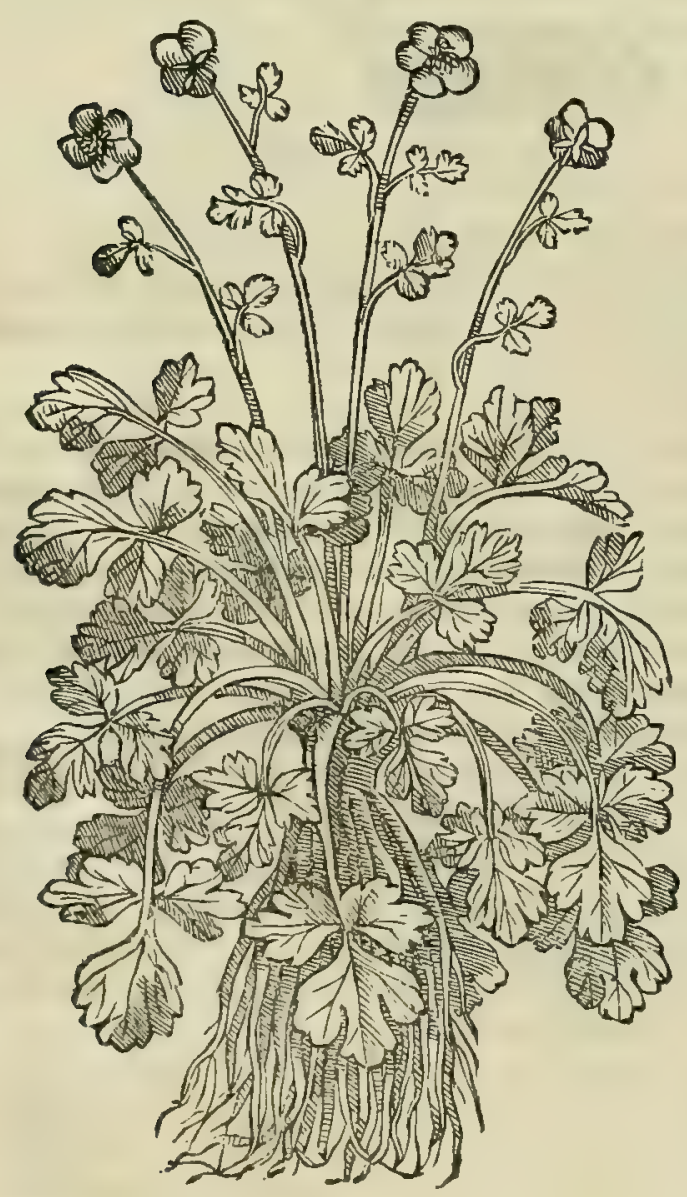

RANVNCVLVS SECVNDVS.

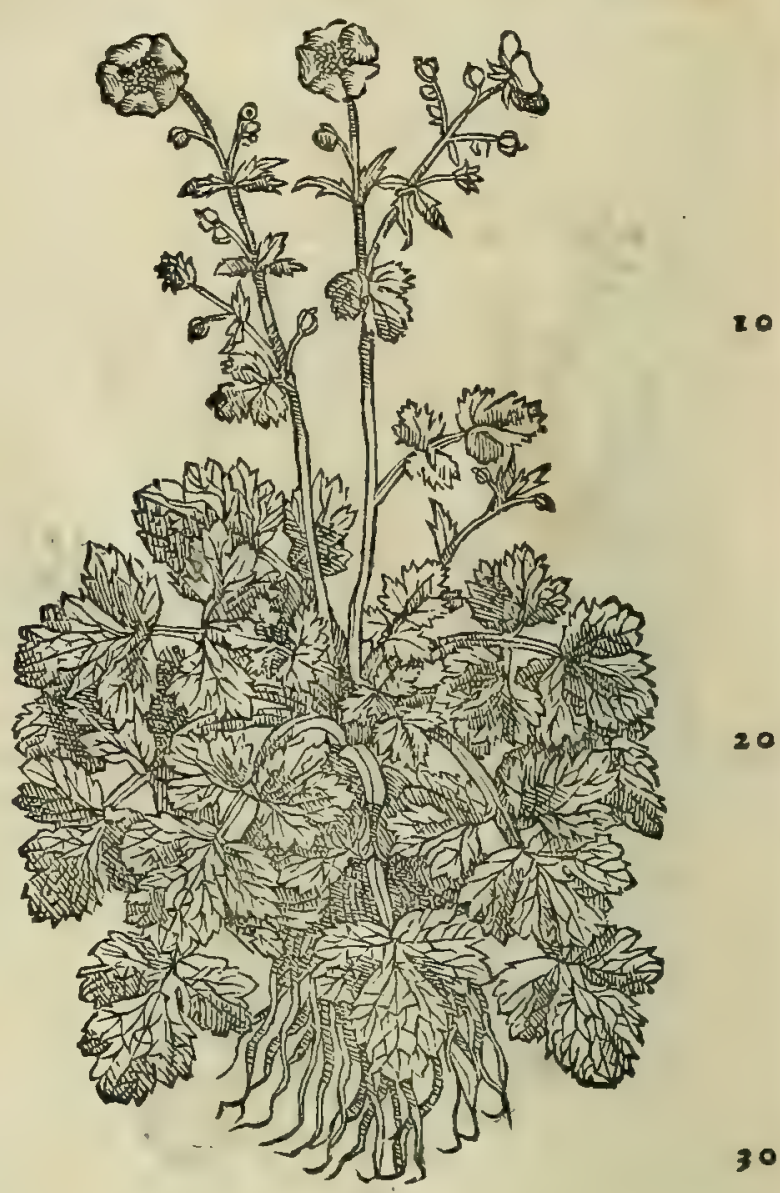

RANVNCVLVS QVARTVS.
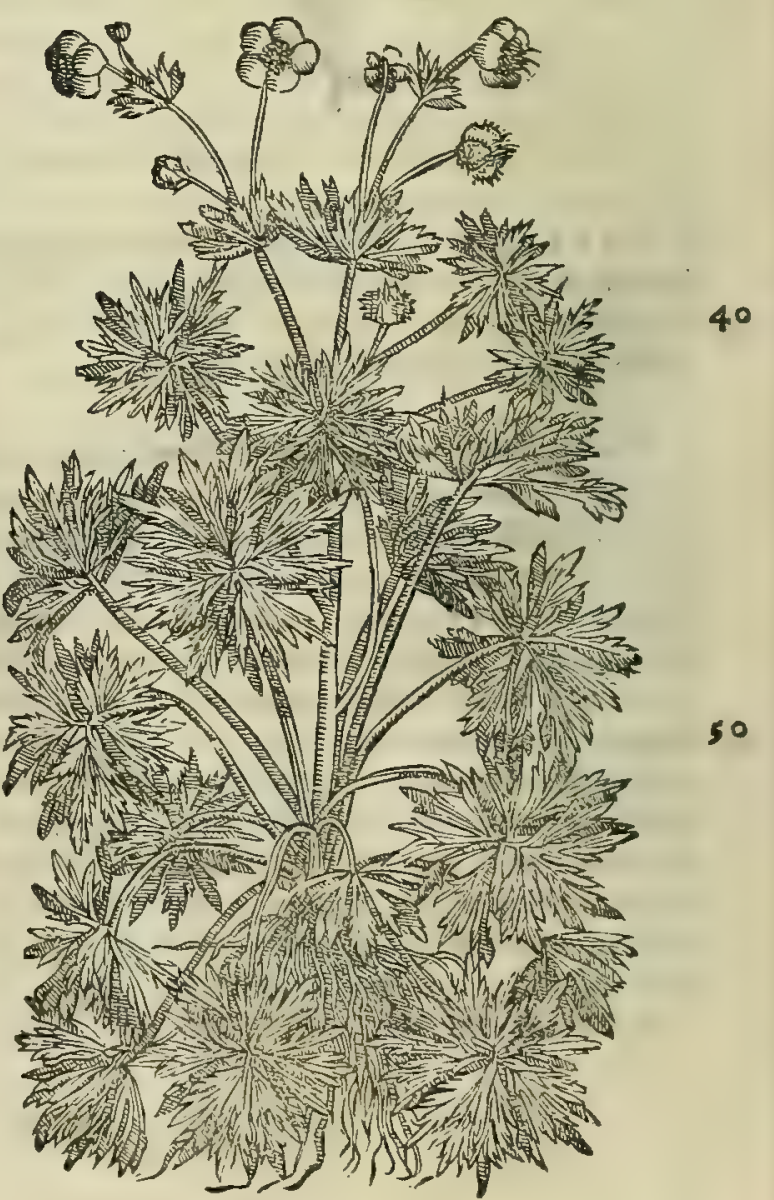


\section{In Lib. fecundum Diofcoridis.}

Tatpóx 10V. RANVNCVLVS.

\section{CAP. CIXXI.}

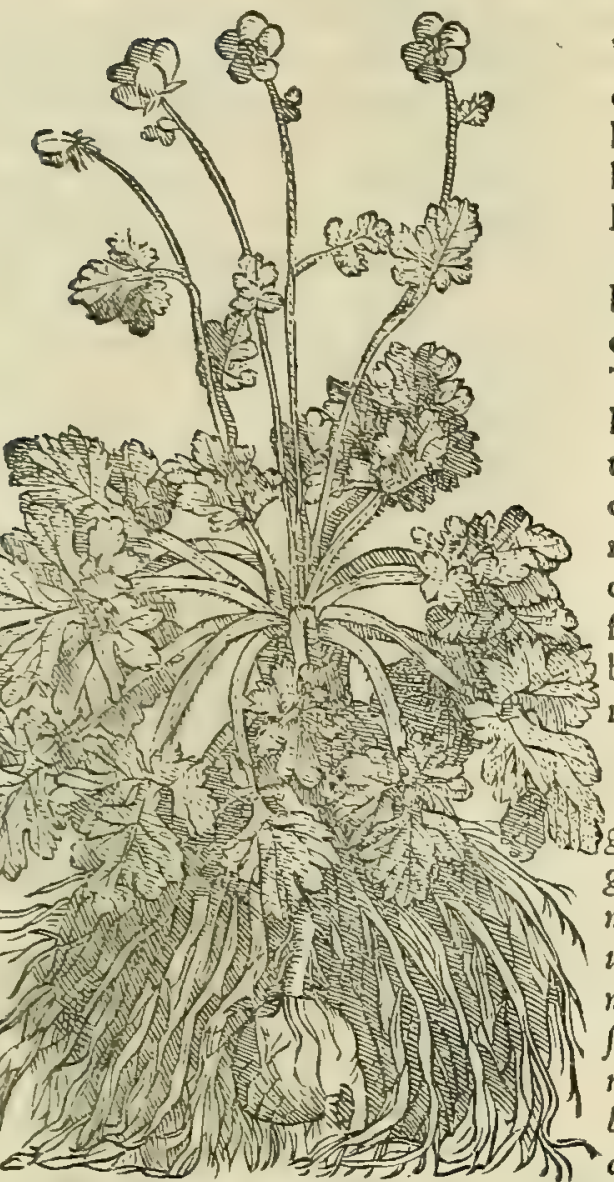

Cо м P L V R A Ranunculigenera. vis tamen omnibus vna, acris, \& vehementer exulcerans. Nam unum coriandri folijs conftat, latioribus, fubalbidis, pingribus: floreluteo, interdum purpureo: caule gracili, $\mathrm{cu}-$ bitum alto : radice alba, cxigua, amaraq́ue, multis capillamentis, hellebori modo, fibrata . nafcitur in limitibus humidis. Alterum lanuginofus, longiori caule, pluribus foliorum incifuris, plurimü in Sardinia prouenjens, quàm acerrimum, quod fylueftre apium appellant.

Tertium minimum, odore graui, Hore aureo. Quartum huic fimile, flore lacten. Folia, flores, \& cauliculi recen tes, illitu exulcerant, $\&$ cruttas non fine dolore gignunt. quare vngues fcabros extricant, fcabiem eximunt, ftigmata delent : formicantes verrucas, $\&$ penfiles, alopeciasq́ue paulifper illita tollunt. Tepente decocto perniones fouentur. Sicca radix, tritaq́ue fternutamenta ciet, naribus admota: dentium dolorem appenfa leuat, ipfos tamen frangit.

R A N V N C V L V M, qui Gracis $\beta \alpha \tau_{0} \alpha \alpha^{\prime}$ 'lov dicitur, uul= Ranunculicó gus herbariorum in Italid, Or dibi etiam Pedem corui, $\mathcal{O}$ Pedem fideratio. galli, quanuis perperdm', uocant, ut fuperius quoque in coronopi mentione diximus. Planta eft unlgó nota, pluribus tamen, er di= uer is generibus diftincts. Et quanuis quatuor tantum generum meminerii Diofcorides; nos tanen or quintum, o fextum genus Sapißimé uidinus. Ex his,quorum particulatim non fecit mentio= nem Diofcorides, unum genus eft, quod nobis quinto loco afignd= bitur, quod quidem folijs primo proximis prouenit, fed cut inter complures, quibus nititur, radices, tuberofa quadam pendeat ra= dix nucisiuglandis magnitudine, rapi modo albicans, acris tamen, er exulcerans, qua per byemem, arefcentibus iam folijs, utuntur quidam, ubi exulcerandifit opus. IIlud porró genus lanuginofíus, uel, ut plinius ait, foliofius copio= fijumum in Sardinia nafcens pluribus foliorum incifuris, altiore caule, acerrimo guftu, plerig; ideo A pium rifus no= minsnt, quòd quibufdam memoris proditum fit, cos täquam pre latitia ridentes interire, qui ipfun comederint. Sed rem fe aliter babere crediderin, o alijs potius adftipulandum effe. siquidem $\mathrm{P}$ aufanias auctor eft, berbam hanc, $f \mathrm{t}$ edulio fuerit, ue centibus neruos contrabere, rifu' ; $_{\text {; }}$ or a diducere, ita ut qui mortem oppetunt, uelut ridentium $f_{a=}$ cie intereant. Quad o saluftus confirmat, quibuius uenenate berbe meminit, fic inquiens. In Sardinia quedame

40 berbanajcitur, que Sardoa dicitur, agrefti apio fimilis. Hac or a bominum, ov riftus dolore contrabit, or quafi $r i=$ dentes interimit. Ideoǵ; Diofcorides libro v I. Sardoniam ranunculi genus effe teftatur, qux ue fcentibus mentem d= dinat, o quadam neruorum diftentione dehifcere in riftus ora cogat, ita ut imaginem ridentium prebeat. Ob id sar donius rifus in adgigim ceßit. Ceterim quàm magno in errore uerfentur, qui exiftimant Ranunculum effe Coro= nopum, fuperius in Coronopi commentatione latius explicaumus. Ranunculi meminit Galenus lib.v I. fimplicium medicanentorum, wbitita crip tum reliquit. Batrachium, id eft, Ranunc ulus, quatuor babet peciatim differentias. Oinnu ueró uehementer acrem facultatem poßident, adeó ut cum dolore exulcerent. Hac itag; ratione, $\sqrt{i}$ modera $=$ té utare, pforas, o lepr,as excoriant, o ungues leprofos diuellunt, o f tigmata difcutiunt, o acrochordonas, o myrmecius detrabunt. Quin $\sigma$ alopecius iuuant, pauce tempore admota. Nam fi diutius inh areant, non excoriatur folim ipfa cutis; fed e in cruftam uritur. Atq; igitur hac omnia caulis, e foliorum funt opera, fi imponas uiren= 50 tix. Porró radix arefact $x$ fernutatorium eft medicamentum fimiliter alijs omnibus, qua ualenter deficcant. Sed $\mathrm{C}_{\text {. }}$ dentium dolores iunat, ut $\odot$ frangat eos ualentifcilicet exiccatione. O ut femel dicam, calida, o ficca ualde eft tüc, radix, tum uniuerfa adeó berba. Baт $\rho \alpha$ x $10 v$ ite Gracis, Latinis ueró Ranunculus appellatur: Italis, Ranunco= lo, er Pie coruino: Germanis, Hanen fuosz: Hipanis, Hierua belida : Gallis, Bacins.

\section{A'vequivr. ANEMONE.}

\section{CAP. CLXXII.}

D v o Anemones genera, vnum fylueftre, alterum in cultis nafcens. Cuius multæ fpecies: vns phaniceum florem profert : altera candicantem, aut lacteum, aut purpureum. Harum folia coriandro fimilia, caterùm fciffa tenuius in terram inclinantur: caules lanuginofi, tenues, in quibus flores, vi papaueris, \& in medio capitula nigra, aut cærulea : radix olex magnitudine, aut amplius paulò grandefcit, ac veluti geniculis quibufdam cingitur. Sylueftri amplitudo prorfus maior, latioraque

Apium rifus.

Quorundam error.

Ranunculi ui res ex Gal.

Nomina. 
folia, \& duriora : oblongius caput : flore puniceo : tenuibus, \& multis radicum capillamétis . Acrior eft, quæ nigra habet folia. Vis vtriufq; acris , ta de caufa fuccus naribus infufus purgat caput. Commanducata radix pituitam trahit . decocta in paffo, \& illita, medetur oculorum inflammationibus: cicatrices eorundem, \& hebetudines emendat $:$ fordida vlcera abftergit. Folia , \& caules, fi cum ptifana decocti edantur, copiam laćtis prabent: menftrua ciunt, vellere appofita : illita quoque.lepras eximunt. Sunt qui errore ducti argemonem nominari eupatorium putent : quoniam à fylueftri Anemone, argemonem, \& papauer, quod rhcada appellant (de quo inter papaueris genera referemus) propter colorum cognationem in floribus diftinguere non poffunt. Verùm papauer, \& argemone colore minus faturato fpectantur, \& vtraque tardius floret. Quinetiam argemone croceum fuccum, guftu admodum acrem, reddit: rhœas verò candidiorem, \& acrem. Infuper ancmone, \& rhœadi capitula fylueftris papaueris fimilia infunt, fed in anemone fupernè crafsiufculum, in rhcade fubanguftius. Anemones genera fuccum remittunt, nec calyces habent, fed quafi afparagi cacumen. In aruis illa fapius enafcuntur.

A NEMONE.

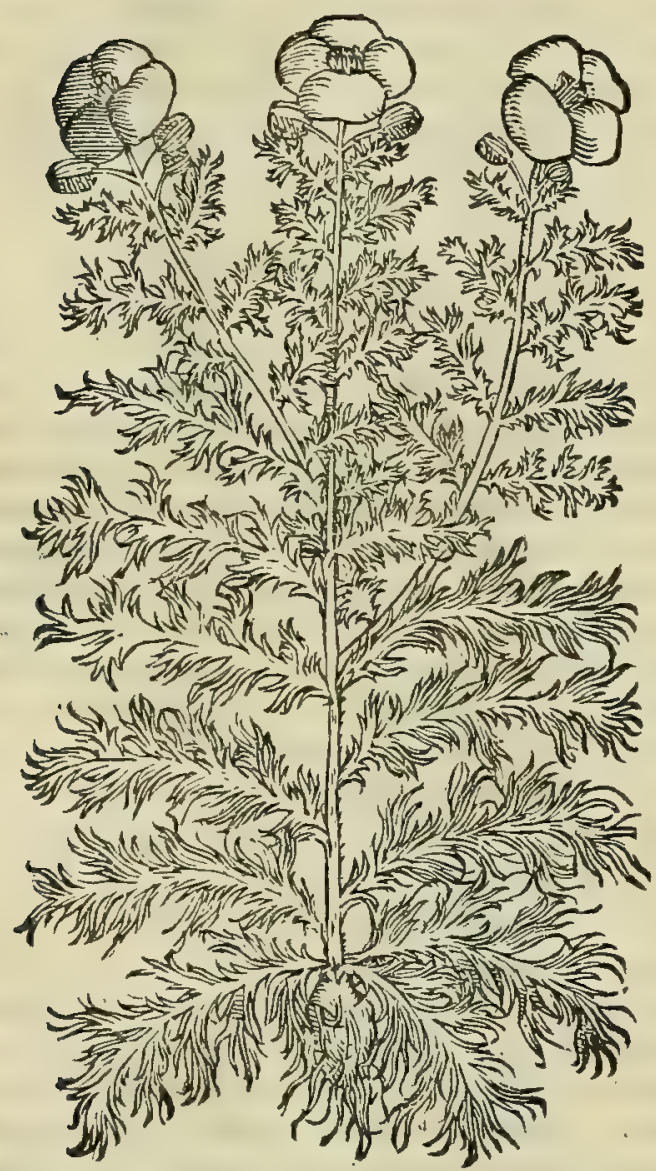

ANEMONE ALTERA.

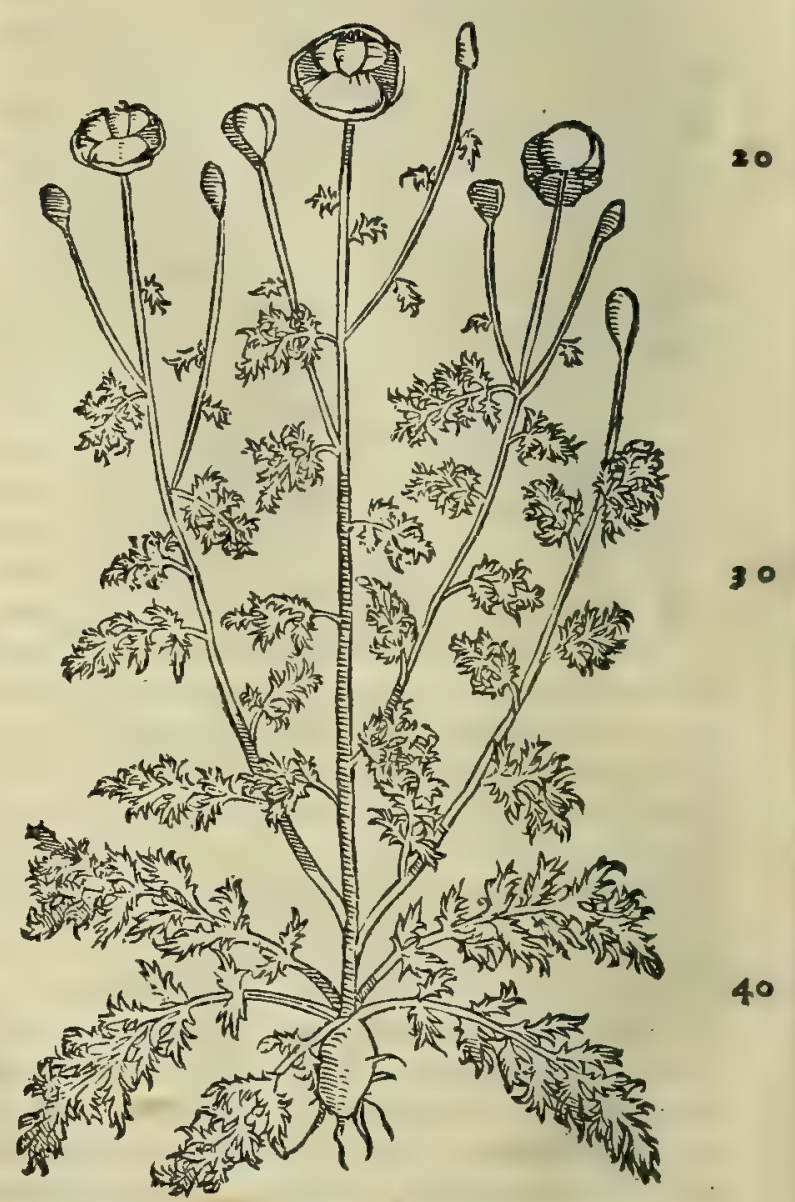

Anemones confid.

Brafauoli laplus.

Fuch.lapfus . Pulfatille hiftoria.
N O N DES V N T profectó, qui credant, Anemonem, o fylueftre papauer idem effe: fin minus, faltem ciufdem effe generis. Sed $i_{j}$, mea quidem fententia, falluntur, $\sigma$ prorfus aberrant d Diofcoridis propofito. Quan= doquidem fi boc idem fenfiffet Diofcorides, alterum ab altero diuerfis capitibus non diftinxiffet, neque, ut legitur in buius capitis calce, differre Anemonem à Jylueftri papauere tradidiffet. Tamet/zi exiftimet Brafauolus, Diofco= ridis Anemonem id omnino effe fylueftris papaneris genus, quod flore prodit cateris rubentiore: ninimé aninzaduer = so tens, qròd fi huius cauliculi frangantur, ftatim lac ipfum diffillant. Quin nec illud quidem animaduertiffe uidetur, quód boc longa conftet radice, non autem oliua modo rotunda: capitulum'q; ferat papaueris, non aparagorum cd= cuminibus fimile. Fuchfius pretered in eo libello, in quo tantim firpium imagines expreßit, Anemones purpu= rea loco, illam depingit herbam, qux plerifque P V I S A T I I I A cognominatur, et î nullam, quantum equi= dem Sentio, habeat cum Anemone cognationem. Illa nanq; cim primium erumpit, folia mittit admodum birfuta, mi= nutimq́; laciniata, que sapore funt perquim acri, adco ut non minus exulcerent, quim ranunculus, $\sigma$ flammula uul= gó dicta. Flos, qui inftelle modum, fimiliter birfutus, incunte vere debifcit, anteaquàn fölia erumpant, nigricanti Bplendet purpura : é cuius medio quidam aurei flo fculi enic ant cos admodŭ $x$ muldntes, qui rofis inna $f$ cuntur : in quos rum umbilico floccus quidam purpureus uifitur, fericinum referens opus. Exteriori ueró parte in ipfius caulis cacu= mine circa floris bafim uillofus alter circunquaq; $\int e$ panditfloccus, colore cinereo, fericino ftamini mollitia, ac leuo= re minimé cedens, Semen capillo fo, incanóg; capitulo, iuglandis feré inagnitudine, continetur. Radix illi fubeft pe= 


\section{In Lib. fecundum Diofcoridis.}

PVISATILIA.

10

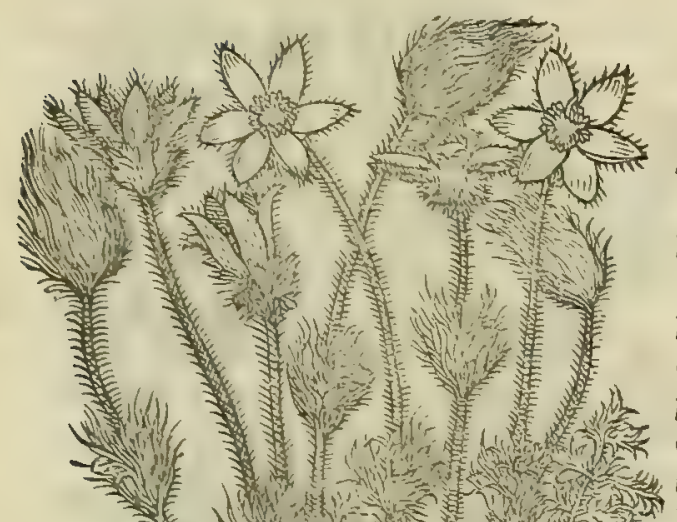

20

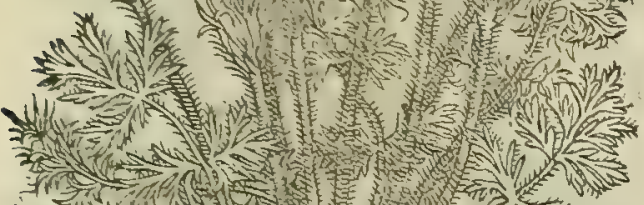

30

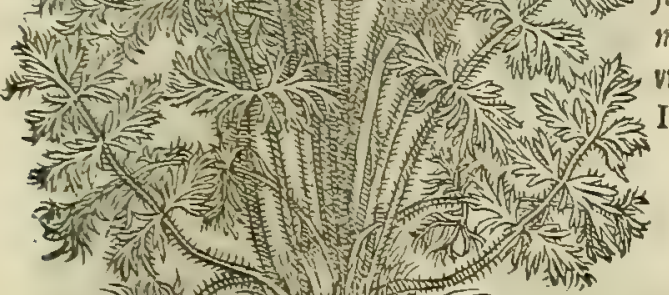

dali longitudine, exca, nigri chamelconis.modo: chi japor qui= dem fubdulcis, non autem acris, uelutifolijs, et caulibus. Sunt qui b. me miris laudibus efferant contra peftilentiun, $O$ ad hault a ue ncha, itcmó; contra omnium ucueno for $u m$ tum mor fus, tum iqus: quanobrem in antidotis adtitur. Coterinn Iegitimam utriufque generis Anemonem legimus nos in Ananienfig doro, qux, ut arbi= tror, Diofcoridis de fcriptioni nibl prorfus reclamint. Eas itcm poftea uidi Venetijs, in hor to clarißma medici Maphei di M.tpheo.

Scribit Ruellius Anemonem in Gallia copiofam na cci,camó; cffe Ruel. lapfus. plantan, quam berbarij Herbam uenti uocant. Verim fi berba ucnti helxine fuerit, uel folidago minor, ut simon Ianuenfis inter pretatur, aberraffe R uellius maniffté deprebenditur : fin aliter, quid dicam niefcio, cüm me omnino lateat, quid R uellius per ber= bam uenti intelligere uolterit. Meminit Anemones Galenus libro v I. fimplicium inedicamentorum, ubi ita fcribit. Anemone onnes acrem, extergendi, attrabendi, er ora uaforum referandi facultatem obtinent. Itaqq; radix commanfa pituitam enocat: $\mathcal{O}^{\circ}$ fuccus ex naribus purgat, o oculorun cicatrices extenuat. Int= Juper fordida ulcerum dnemone expurgant, et lepras detrabunt, menfesq́; appofite cliciunt, o lac trabunt. Vt Gracis áveuci'=

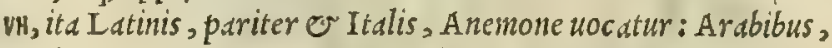
Iackaik alnabamen, feu Sakaik anbeamen.

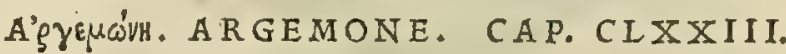

A R GEMONE in totum fylueftri papaueri fimilis eft. Folia habet anemones, diuifa: florem puniceum : ca put in cauliculo papaueris rhœadis, oblongius, \& fummis partibus latum : radicem rotundam: fuccum croci colore, acrem dimittit. Argema, \& nubeculas expurgat. Folia illitu inflammationes compefcunt.

E X T A N T nonmulli Diofcoridis codices, in quibus duo Argemonès genera diuerfis capitibus leguntur, non= nulli verò hoc tantùm babent, quod nos legitimum effe credimus, non diffentientes à compluribus doctißimis uiris, qui alterum buc illegitime acceßiffe cenfent : profertim cim Galenus, o Paulus iltius nufquam meminerint. Verunta= men, ut fatisfactum omnibus fit, alterius quo ; A rgemones hiftoriam bic adijciendam duximus, que fic habet. Arge= mone altera folijs fylueftri papaueri fimilis eft. Vis ci ineft, fi recens trita imponatur, intercifiones fandre, or oculo= rum inflammationes mitigare. Pota cum aqua dy fentericis auxiliatur, uulnera conglutinat, ${ }^{\circ}$ inflaminationibus uti= Tis eft. Conuul is', o uellicatibus impofita medetur: contra ferpentium morfus utiliter cum uino bibitur. Plinius li= 40 bro X X v.cap.v I I I. Argemones tria ficri genera memorat, id'; demum probari, cuius radix thus redoleat. Pro= uenit argemone frequentißina in Hetruria, prefertim in agro noftro Senenfi : ficut e in quibufdam locis uallis And nix Tridentini tractus, que nullis, quantum equidem iudico, notis Diofcoridis defcriptionirefragatur. Quamobrem in maximo errore fuiffe deprehenduntur ueteres noftri tum medici, tum Seplafiarij, quód Eupatorium Argemones uice acceperint, fuo Agrimonis nomine, de qua libro quarto fuo loco, Deo duce, lattus differemus. Argemones ui= res fané quàm paucis perftrinxit Galenus libro v I. fimplicium medicamentorum, fic inquiens. Et huius berbæ $f_{d}=$

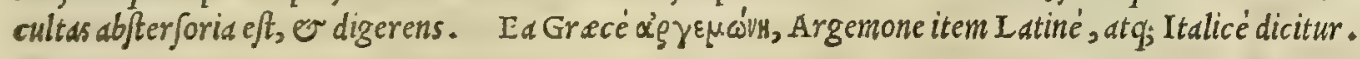

Argemones confideratio.

Caput Argemones adulterinum.

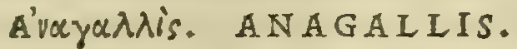

CAP. CIXXIIII.

so D vo funt Anagallidis genera, quæ tantùm flore diftant. nam quæ cærulco flore eft, fcemina dicitur : mas quæ phœniceo. Frutices funt parui, in terra iacentes : folijs in quadrangulo caule pufillis, fubrotundis, ad helxinæ folia accedentibus : femine rotundo. Vtraq; mitigandi vim habet, inflammationem arcet, adactos corpori aculeos extrahit, nomas cohibet. Succus earum gargarizatus, capitis pituitam purgat: $\&$ naribus infufus, dolorem dentium lenit, $f i$ in aduerfam narem inijciatur : argema cum melle Attico emendat : retufæ oculorum aciei auxiliatur : contra viperarum morfus, iecinoris, \& renum uitia, fi ex uino bibatur prodeft. Tradunt eam, qua cæruleum edit florem, prociduä fedem reprimere: quæ uerò phœniceum, illitu euocare.

A N A G A L I I S tammas, quàm farmina, que officinis uulgò Morfus galline dicitur, notißima est. Caterìm plané, meo quidem iudicio, ballucinantur, qui Anagallidem eame effe plantam putant, qua in Hetruria uernaculo no= Anagalldis mine Centone uocatur, Injubribus ueró Paudrina. Nam hac florem frrt candidum, o caulem rotundum; Anagalli= 
ANAGALLIS MAS.

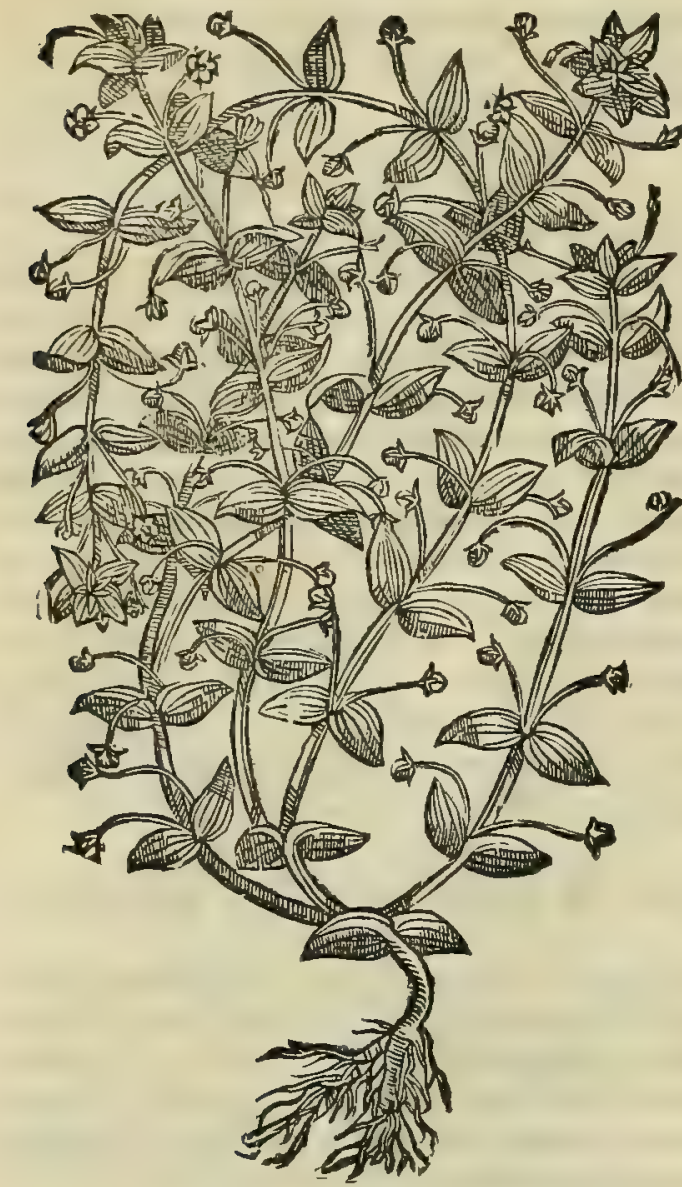

MORSVS DIABOLI.

Anagallidum uires er Gal.

Morfus diaboli hiltor. \& vires.

Opinio lupes fitiofa.

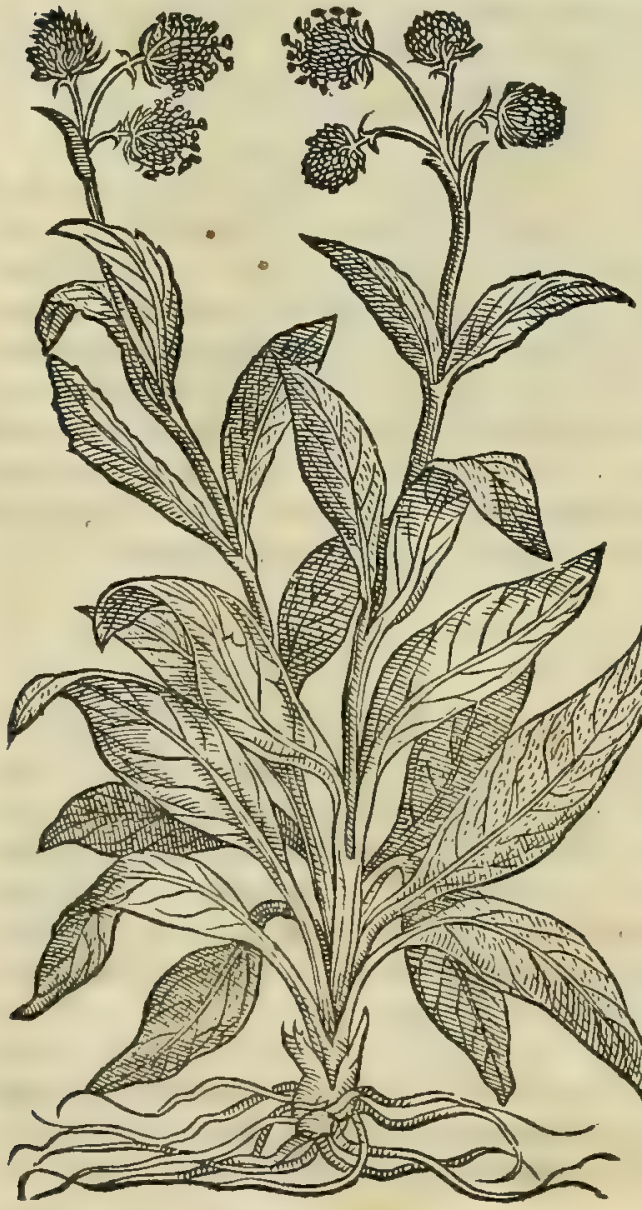

ANAGALIIS FOEMINA.

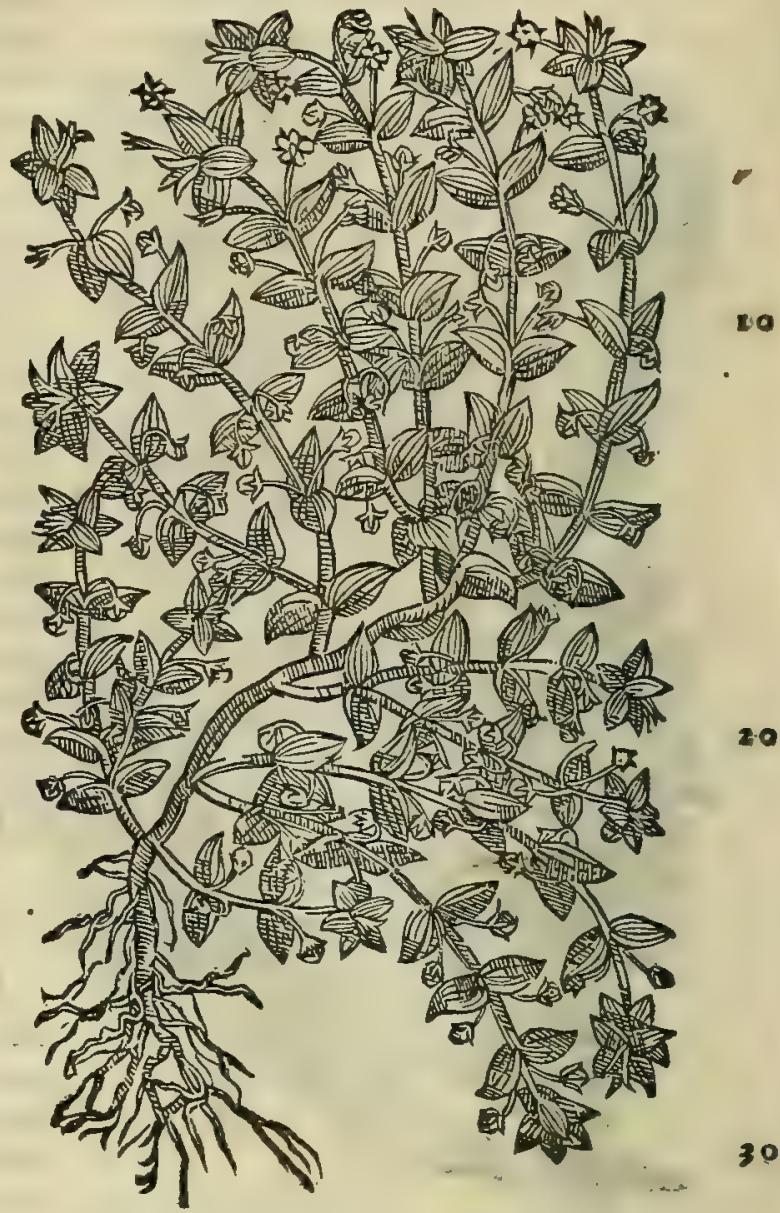

dum uerỏ alteri flos eft ceruleus, alteri puniceus, or quadrangu= lus utrisq; caulis. Anagallidum uires recenfuit Galenus lib, v I. fimplicium medicamentorum, fic imquiens. Anagallis utraq; tam $e a$, qua ceruleum habet florem, qudmea, qux purpureum, ad= modum extergentis funt facultatis. Habent uerò quendam etiam calorem attractorium, ita ut $\sigma$ infixos corpori aculeos extrabăt. succus earum ex naribus purgat eadem de caufa. In fumma au= tem deficcandi uim habent citra mordicationem: quamobrem er. uulnera glutinant, or putrida adiundnt. bec Galenus. Verùm $4{ }^{\circ}$ cùm Morfus gallina edm ftirpem in mẽtem mihi reuocauerit, quä uulgus berbariorum MO RS V M diaboli, alij Succifam appellant, cùmó; putem me, qud̀m plurimis fortafe rem gratam facturum, /t bis noftris commentarijs ip $\int a m$ quoq; inferam, hic locus uifus $\mathrm{eft}$, ubi commodé de ea aliquid dicam. Morfus igitur diaboli herba eft locis incultis proueniens, faltibus, ac etian interdum pratis, 0 dumetis. Folijs conftat plantagini,quam uulgó lanceolam uocät, fimilibus, leuioribus tamen, or que circa caules, qui ad binûn $c$ u bitorum longitudinem affurgunt, exeant breuiora, anguftiora, $l e=$ niteró; per ambitum laciniata. Floret aftate, fcabiofa nocate mo 50 do. Multifidas habet radices, nigricantes, fuccifas, o circumro= fas : unde fuperftitiofum nomen inkenit. Siquidé fcripferuit non= nulli fuperftitionibus dediti, quos credulum uulgus fequitur, caco= damona ob tante efficacie radiccm inuidere hominibus, at $q_{j}$ bac de caufa, ubi fuccreuerit, ftatim eam undiquaq; dentibus fuccide= re, o circumrodere: tanta eft bominum fuperftitio. Herba bac fi uiridis cruda, tritaq́; carbunculis peftiferis imponatur, prefen= taneo remedio (ut aiunt) cos fanat, aut fi uinum, in quo decoct a fuerit, bibatur. Radix per fe eftur, aut eius decocti uinum utiliter bibitur non modó ad uteridolores; fed etiam ad peftilentem aum ram arcendam. Guftu admodum amara cft : ex quo perpicuum

\section{0}

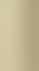




\section{In Lib. fecundum Diofcoridis.}

efe poteft, eam effe calide, $\sigma$ ficce facultatis. Siccate puluerem prabent pleriq; ad alui tine as necand is, ac ea=

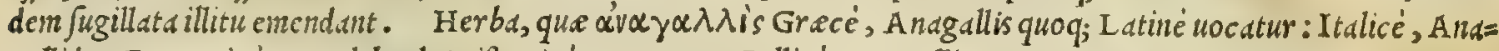
gatlide: Germanicé, Gauch heyl: Hipanicé, Muruges: Gallicé, Morgelline, or Mouron.

Nomina,

HEDERA HELIX.

10

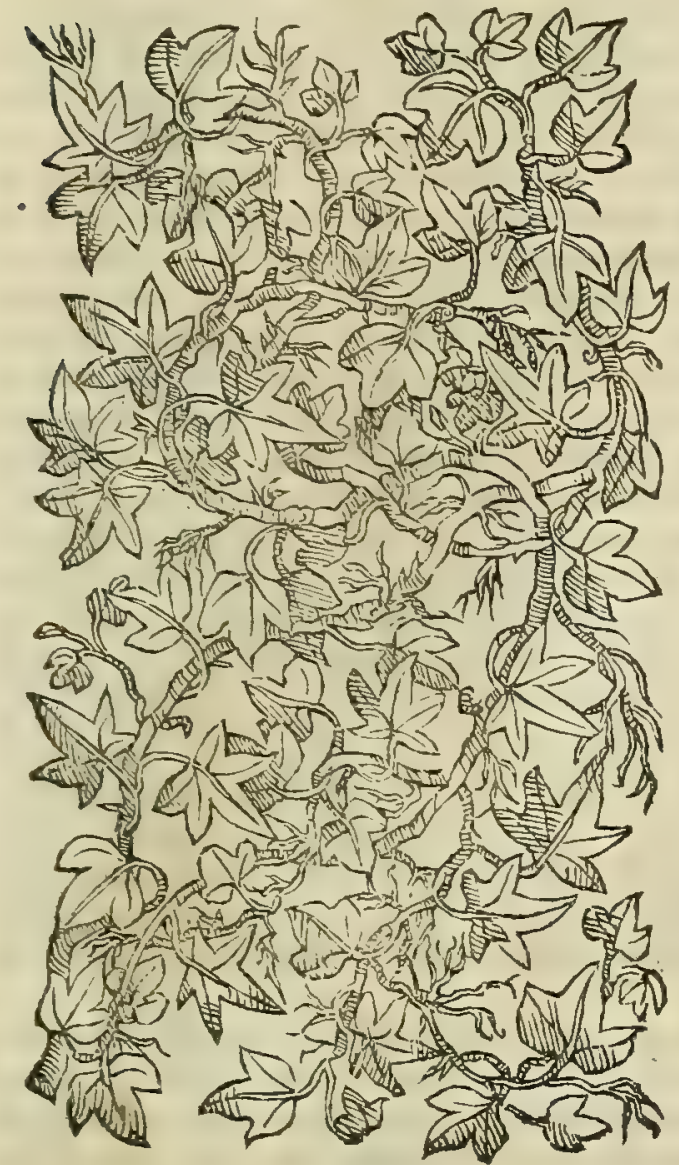

Kiaràs. HEDERA.
HEDERA ARBOREA.

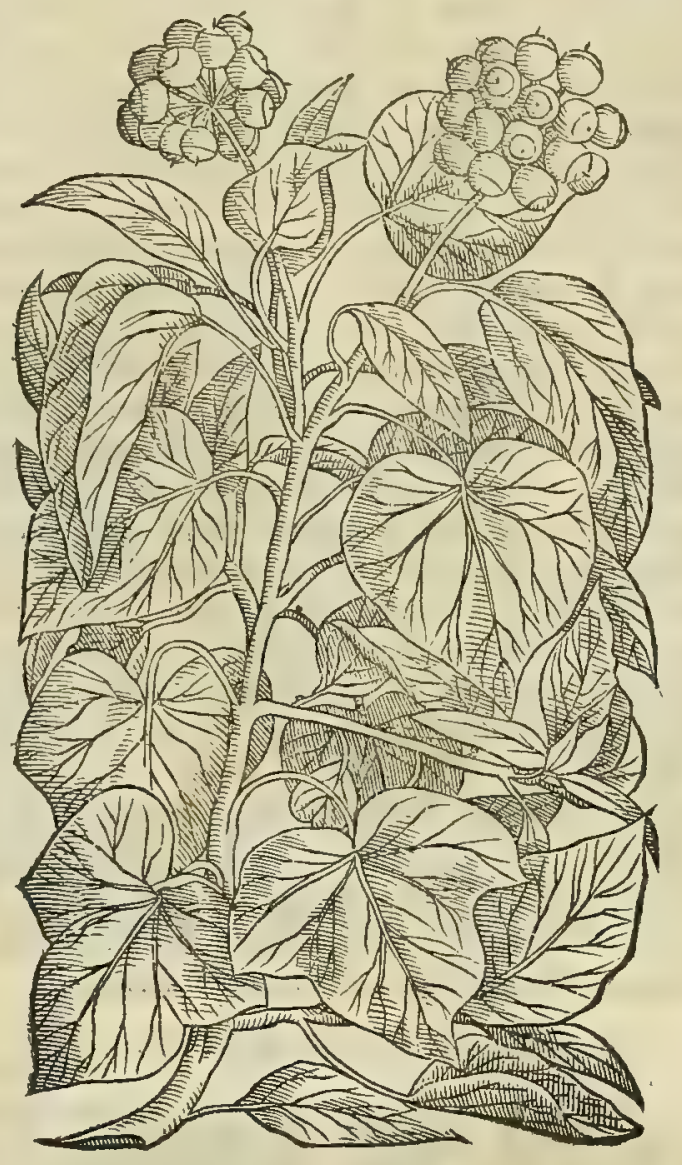

CAP. CLXXV.

H E D E R A differentias multas in fpecie fortitur, fummas autem genere tres. Nam quxdam candida eft, altera nigra, tertia helix. Candida fructum fert candidum : nigra nigrum, aut croci æmulü, quam vulgus Diony fram vocat. Helix fructum non gignit, fed tenues habet viticulas, \& folia par$40 \mathrm{ua}$, angulofa, \& + rubra. Hedera omnis acris eft, \& adftringens. neruos tentat. Flos trium digitorum carptu, facit ad dy fentericos, in vino bis die potus : ambuftis cum cerato tritus illinitur. Recentia folia ex aceto cocta, aut cruda cum pane detrita, lienes fanant. Foliorum, \& corymborum fuccus; cum irino vnguento, melle, aut nitro, naribus infunditur: \& contra veteres capitis dolores, caput eo cum aceto, \& rofaceo perfundi vtile eft : purulentis auribus, aut dolentibus, cum oleo medetur. Nigræ hederæ fuccus, aut epoti corymbi, corpus infirmant, mentemq́ue turbant largitis fumpti . Acini quinque triti, calfactiq́ue in punici mali cortice cum rofaceo, fi inftillentur à contraria aure, dolorem dentium mitigant. Denigrant capillum illiti corymbi . Folia in vino decocta illinuntur omnium vlcerum generi, etiam fi cacoëthe fint. vitia cutis in facie, \& a mbufta fanant, vti antea dix:mus, decocta. Mouent menfes triti, \& fubditi corymbi : ijdem poti, poft purgationes fominarum; so drachmæ pondere, concipiendi f pem adimunt. Pediculus foliorum melle irrigatus, ac vuluæ inditus, menftrua, \& partus extrahit. Inftillatus fuccus putrida tædia narium, graueolentiamq́ue emendat, \& fanitati reftituit. Lacryma hederæ pfilothrum eft : illitu pediculos enecat. Succus radicum in aceto potus, contra phalangia prodeft.

$H E D E R A$, cuius hic tria tantìm fumma generd fecit Diofcorides, etfi plures eius in Pecie differentids effe Hederx conteftetur, planta eft uulgar is notitix. Verium fi quis Heder e plura genera noffe defiderat, non fortaffe Plinio content tus, licet de ipfis abunde differuerit lib. X V I. cap. X X X I I I I.legat Theophraftum lib. I I . . cap. X V I I I de plantd= fideratio, 82 rum hiftoria, ubi hedere figillatim pecies diligentißiné perfequitur, e de ijs copiofifimé pertractat: wel potius ip= fum audiat, nam hac, que e equntur, ip $\int_{i}$ ad uerbum accepta referimus, qui loco citato fic babet. Hedera quo q; mul $=$ tigenta eft: quedam enim humi repens, quadam fe in excelfum attollens: ${ }^{0}$ excelfarum genera plura, fed trina fum=

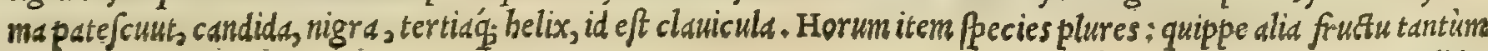


candida, alia etiam folijs : rurfus fructum tantum candidum ferentiun, dia maiufculum, denfum, or uelut in globum circumadum fructum profert, quam corymbian quidam uocarunt, Athenenfes acharnicam riguam eam appellant:

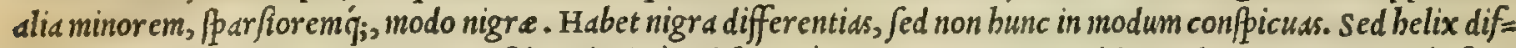
ferentijs maximis difcernitur : etenim folijs plurimium diftat, cum paruitate, tum quòd angulata, concinniorá;; fint: cum bedera rotundiora, fimplicior áf; babeat. Diftant etiam internodiorum longitudine, at $q_{;}$etiam fterilitate, quo= niam fructum quadam non ferant : quod non in bederam transfigtrentur, ut quidam uolunt: at ueró fi omnes bedere= $\int c a n t, u t$ alijs placet, etatis certé, difpofitionisq́;, non generis erit difcrimen, quemadmodum pyri ad pyraftrum. Ta= men cius quoq; folium multum ab bedera distat, uerum id rarum, $\sigma$ in paucis euenit, ut uetuftate permutetur, ceu in populo alba, $\mathcal{E}^{\sim}$ crotone. Ergo belicis plura genera, fed quie confpectiora, fummáq; occurrant, tria funt. Herbaced, quxe plurima eft : fecunda candida : tertia uerficolor, quam Thraciam quidam appellant. Et harum quéq; diftare ui= detur, quippe herbace quedam folio tenuiori, oblongiori,atq; etiam denfiori : quedam minus bec omnia babens. Et in uerficoloris genere, alia folio amplior, alia minori, macularum'́; babitu diuer $\int a$ : pari modo or magnitudine, co= loréq; diftant. Auctu perfacilis berbacea, in $\dot{q}_{\text {; }}$ plurimum uenit. Manifeftam effe qua bedere fcat, affirmant, non tan tum folijs, que maiora, latiora'; habet, uer üm etiam germinibus: protinus enim er ecta gerit, non inflexa gracilitate, e longitudine. Herbace a ueró craßsiora, breuior aq́;. Ac bedera, ut femé proferre incepit, germen fublime, rectum $\dot{q}_{;}$ edit. Eft quidem uniuer $\int a$ bedera radice numero $\int a$, den $\int a$, flexuo $\int a$, furculo $\int a$, craffa, nec nimis alta, fed precipue nigra, $\sigma$ inter candidas, qua apperrima, immitißima ; babetur . quamobrem eius amplexus arbores omnes infefat, $0=$ mnes enim necat, or exiccat, ablato alinento. Craffatur bec maiorem in modum, atq; arborefcit intantum, ut per fe ip $\int a$ bedere arbor fiat. Attamen ex maiore parte femper fuper aliud uitam degere folet,ato; (ut ita dixerim) ample= xicaulis eft, ita pro fua natura, uel quiddam eiufmodi illico gerit. Nam é germinibus radiculas aßidué inter folia mit= tit, quibus arboribus, murisq́; obrepit, quafí de induftria à natura exbibitis : atq; ita bumorem auferens, exhauriensq.

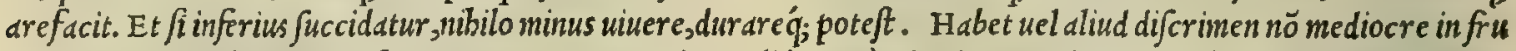
ctu: nam alius dulcis, alius uebementer amarus, tam in candida, quàm in nigra. Indicium, quód alium aues mandunt, Hedere facul alium minimé attingunt. Hedera ita fe habet. Hattenus Tbeopbraftus de bedera generibus. Hedera (ut auctor eft tates ex Gal. Galenus lib. vI I. fimpl.medic.) ex contrarijs compofita eft facultatibus: habet enim quiddam adftringentis fubftans tix, quam terrenam, e frigidam effe oftendimus : habet'̆; etiam nonnibil acris, quam calidam effe uel guftus compro= bat. Nec deeft tertia : aqueam nanq; fubftantiam quandam tepidam obtinet, certé fi uiridis fit. Siquidem dum arefcit,

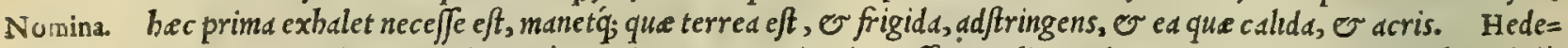
ra, que ita Latinis, Grecis rlaròs nominatur : Mauritanis, Cuffus: Italis, Hedera: Germanis, Mauer, Epheuu baü, Epheuu: Hißpanis, Edera, Era: Gallis, Lierre.

CHELIDONIVM MAIVS.

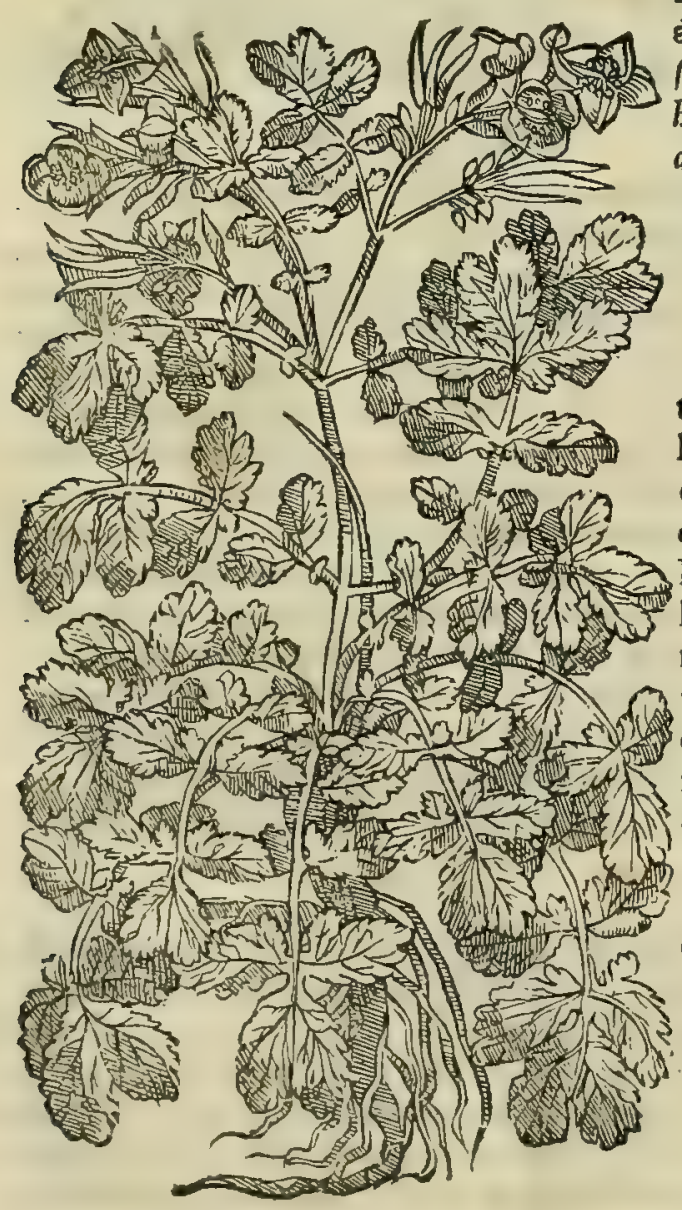

+ Non ab re quidem fupicandum eft ( ut doctißimé adnotauit Marcellus) buic loco in Diofcoride mendum fubeffe, er quòd non Egulga', boc eft, rubra, ut babent uulgati codices, legendum fit, fed éputunótęo, id eft, cöcinniora. Nam preter alias rationes, buic lectioni adftipulatur Theopliraftus, qui lib. I I I. cd. X V I I I. de plant arum hiftoria co nomine bedere helicis folia depingit.

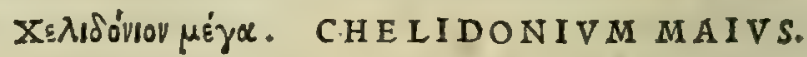 CAP. CLXXVI.}

CH E I D O N I M maius, caule eft gracili, cubitali, aut altiore, agnatis foliofis : folijs ranunculi, mollioribus tamen, \& colore cæfjjs : flore viol $x$ albx, fecundum fingula folia prodeunte. In eo fuccus croci, mordax, acris, \& aliquantulum fubamarus, grauiter olens. Radix fupernè fingularis, infernè in multa crocea capillamenta fibratur. Siliqua, ceu corniculati papaueris, tenuis, in meta figuram longa : in qua femen papauere maius recluditur. Succus in æreo vafe, cum melle prunis decoetus, oculis claritatem adfert. Folijs, caule, radice, so fuccus exprimitur ineunte $x$ tate, $\&$ ficcatus in vmbra digeritur in paftillos. Radix cum anifo, \& vino albo pota, medetur regio morbo, \& vlceribus qua ferpunt : impofita cum vino, aut manducata, dentium dolorem fedat. Hoc nomen fibi videtur vendicaffe, quòd aduentu hirundinum exoriatur, \& difceffu emarcefcat. Sunt qui narrant, hirundines matres excacatis pullis, admota her ba, vifum reftituere.

Chelidonij maioris confi deratio.
C H E L I D O N I V M, quod maius cognominatur, uulgó it Hetruria Celidonia dicitur. At imperiti, prefertim cbymifte,

10. 20 


\section{In Lib. fecundum Diofcoridis .}

$\triangle Q V I L I N A$.
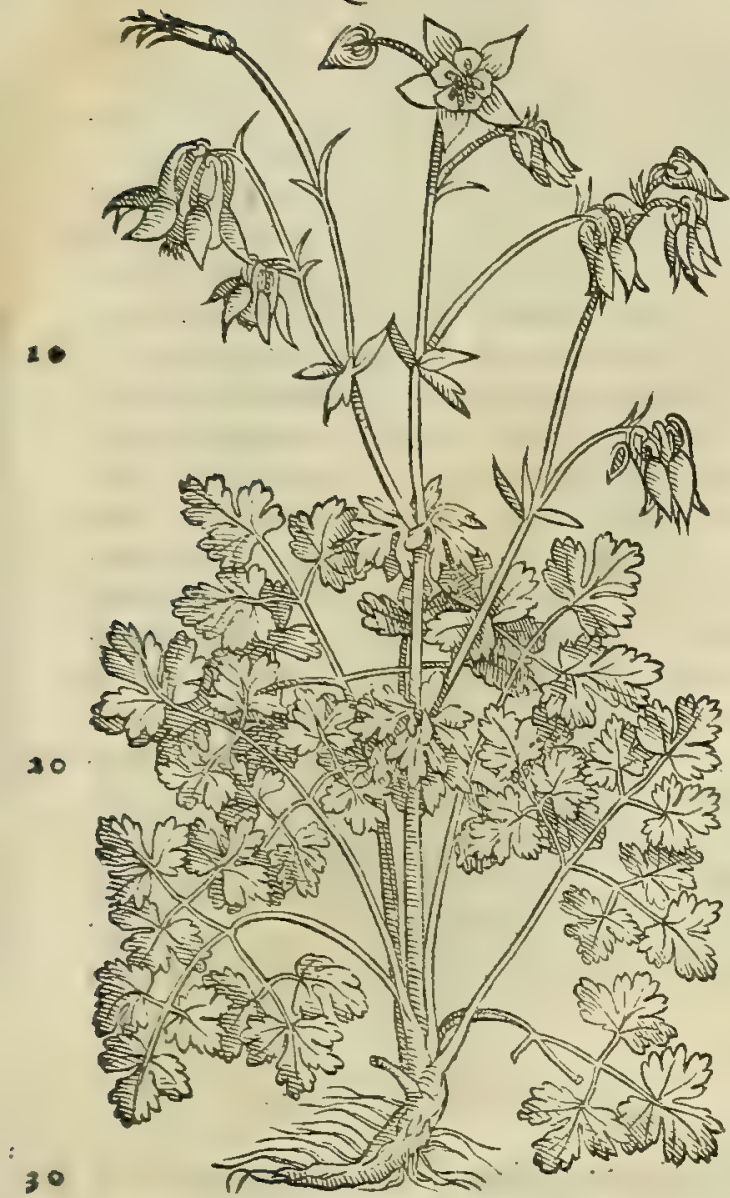

qux multorum fultitia eft, quod Graci nominis uim ignorent, non Cbelidonium, quod Latiné nil aliud, quam hirundinariam $f=$ gnificat, fed Cali donum appellitant. Cüa poftea falfa nominis preftantia freti, ex bac berba quandam quintam effentiam fieri predicant, non modó fuis uanis alchymicis imaginationibus ac= commodatißimain; fed ad tuendam etian hominum fanitatem, morbos'́; quàm plurimos profligandos utilem. Prouenit $\mathrm{Che}=$ lidoniun ubique in I talia propter fepes, in fcrobium ripis, $\int e=$ cus uias, inter ruderd, O in adificiorum ruinis, feu parietinus. sunt, qui Chelidonium maius uocent berbam quam aliqui $\mathrm{ACV}$ I = I I N A M, alij Aquilegiam nominant: folijs fre' chelidonì ma= ioris, pauló tamen rotundioribus, ac mollioribus : caule cubitali, recto, tenuique : in cuius cacumine flos emicat purpureus, ì quo quatuor exeunt cornicula, reflexa, ac intus undiq; concaud: $\int e=$ mine atro, in capitulis reclufo, melantbij modo. Sed quibus brec uiribus predita fit, hactenus neq; mea, neq; aliorum experientia compertum babeo. Chelidonij maioris meminit Galenus libro VI I I. Iimplicium medicamentorum, ubi hee fcribit. Chelidonium maius extergentis admodum, $\sigma$ calida facultatis eft. Sed $\odot-$ fuc $=$ cus eius ad acuendum uifum commodus eff, utiq; in quibus craffum quiddam in pupilla colligitur, digeftione, att; discußione indigens. Vfi funt quidam radice eius ad morbum regium d̀ lecoris obftru= ctione proficifcentem, in uino albo eam potui exhibentes cum ani= fo. Pari modo manfa dentium doloribus confert. Id $\chi \in \lambda \mid \delta_{0}^{\prime}=$ vov $\mu$ É $y \alpha$ Greci,quod Latini Chelidonium maius, uocant: Mau= ritani, Kaluroch, Chalidunium, Chilodomontoma, or Memiram: Itali, Celidonia : Germani, scheluurtz, or schelkraut: Hipani, Céliduenha, or yerua de las golundrinhas: Galli, Chelidonie, er Esclere.
$\mathrm{XE \lambda i \delta óvior} \mu$ ingio.

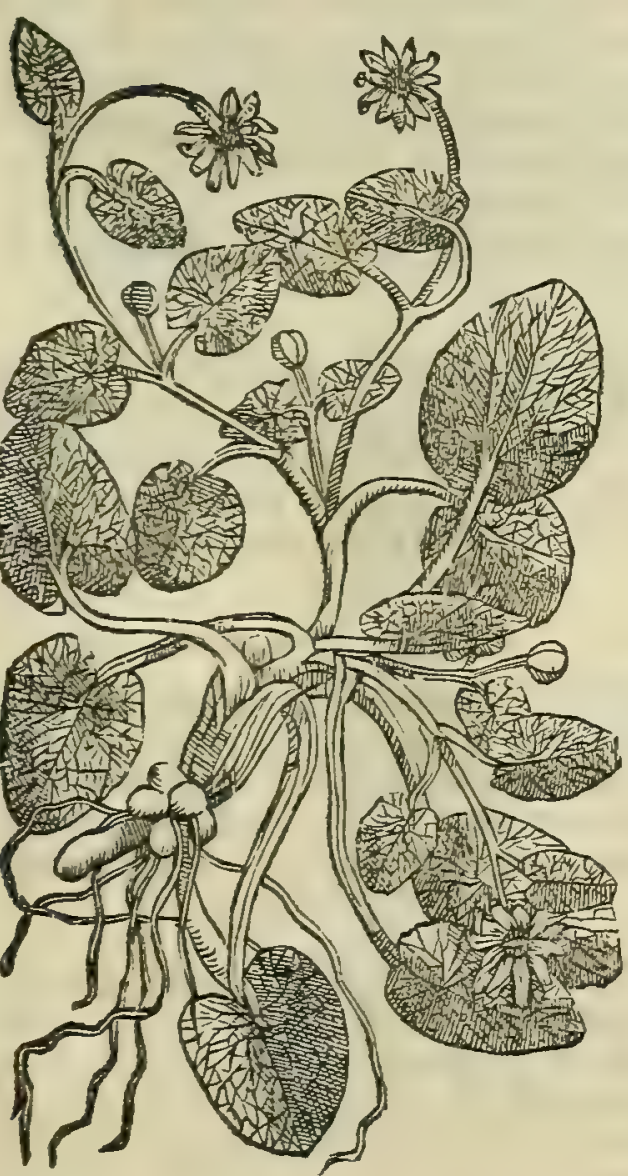

\section{CAP. CIXXVII.}

CHE L I D O N I Y M minus, quod triticum fylueftre aliqui nuncuparunt, herbula pediculis ab radice pendens, fine caule: folijs heder $x$, miltò rotundioribus, $\&$ minoribus, teneris, \& fubpinguibus. radices habet ex eodem callo complures, pufillas, in granorum tritici mo dum aceruatim congeftas: quarum tres, aut quatuor in longitudiné excunt. Iuxta aquas, \& lacus nafcitur. Vis ei acris, \& anemones modo fummam cutế exulcerat. pfo ras, \& fcabros ungues eximit. Succus radicibns expreffus ad purgandum caput, naribus infunditur. Decoetú eius ex melle gargarizatum, magnificè id præftat : $\&$ omnia pectoris uitia extrahit.

P L A N T A, quam omnes frè reiberbaria periti Chelido: nium minus appell ant, omnibus. I talie locis, uerno duntaxat tem= pore, frequens gignitur, uliginofo prefertim folo, 0 in fcrobiü, fof arumí; marginibus: folis bedere minoribus, rotundioribus, ac fubpinguibus, fine caule: flore luteo, etfi eius non meminerit Dios fcorides, tenui pediculo appen $\int 0$. Radicibus nititur compluribus, ex eodem callo prodeuntibus, pufitis, in granorum tritici modum aceruatim congeftis, quarum nonnulle tantum in longitudineme progrediuntur. Herba hac breui deperditur : quippe qua vere et nafcatur, or arefcat. Sunt qui banc Scropbulariam minorem ap= pellent, à radicum fimilitudine, ut que multis granorum tritici grumulis, uelutiftrumis, que Greca imitatione fcropbule uocan= tur, coaluiffe uideantur . quanquam alij ex boc potius fic dictam putant, quod ftrumis, fiue fcrophulis (ut quidam afferunt) impo of $=$ ta medeatur. Noftris ea in Hetruria uulgó uocari Fanofcello pus= taucrim, quod fabarum modo folia Jubpinguia proferat. Nec ea
Vanitas chymiltarum.

A cuilina.

Chelidonij maioris uires ex Galeno.

Nomina.

Chelidonil minorisconfideratio. 
aliunde fibi Chelidonij nomen uédic affe cxiftinutur, auctore Theophrafto lib.v I I.cap. X I I 1 I de plant.hiftor. quàm quód birundinum aduentu florem excitet, qucmadmodkm o chelidonium maius. Verum an bae fit Chelidonium mi= nus, cuius menimere Diofcorides, $\mathcal{\sigma}$ Galenus, non parua uidetur effe dubitatio : quód nullam pror fus nec folijs, nec radicibus pre fe ferat acrimoniam, cuin tamen accrrima, o mordax effe deberet, longeǵ; magis, quàm chelidonium maius : quandoquidem, Galeno tefte, Chelidonium minus cutem cxulcerat, ov excalfacit ordine quarto. Id quod $\mathrm{f}=$ tis manifefte oftendere poffet, hanc non effe Chelidonium minus: nifi quis in hoc illud dixcrit, quod de Aro fcriptum reliquit Galcnus libro I I. de alimentorum facultatibus. Nam facile contingere poteft, quód quemadmodum arum Cyrenis minimum medic smentofí, minimumóg; acrimonix poßidet, adeo ut in cibis uel rapis utilius babeatur ; in Ita= lia ueró, ac minori Afia contrà adeó acre, ut medicamentis duntaxat expetatur : itd $\widetilde{C}$ Cbelidonium minus, quod in I talia na fatur, minimum acrimonic fortiatur; quod ueró in Gracia prouenit, acre admodum fentiatur. Si= quidem exccpta acrimonis tantim, nof tratinibil preterea deefe nidetur, quin legitimum Chelidonium minus dici queat. Ex quo facilé adductus fum, ut credam, quòd quanuis in Italico defideretur acrinonia; non tamen id effe Chelidonium mimus diffitendum eft: tametfí inficias ire non liceat, noftrum Chelidonium minus, quód omnino acri= monis fit expers, ijs noorbis haudquaquam conuenire poffe, quibus itlud conferre, quod in Gracia gignitur, tra= diderunt Diofcorides, $\mathcal{O}$ Galenus. Nam hac deficiente qualitate, neceffe quidem eft, ut $\mathrm{V}$ uires, que illam con $\int e=$ Fuchsij opi- quuntur, deficiant, o pereant. Hinc igitur fit, ut non poßim ego fub cribere iudicio Fuchsij uiri alioquin eru= nlo reprob. ditißimi, qui in libro de compofitione medicamentorum, quem auctum fecundó excudit, Chelidonium minus cenfet alteran Malacocißi fpecien. Quinimo eius opinio mibi refellenda uidetur, quód planta illa nullis feré notis aliquam mollem bederam referat. Ea quidem folijs hederam quodánmodo amulatur, Sed quod magis attendendum erat uiti-

Chelidonij culas non profert, quibus bumi repat: id quod bedera cuiq; natura tributum e $\Omega$. Minoris chelidonij uires memorie minoris vires prodidit Galenus lib.v I I I. Jimpl. medic. fic inquiens. Chelidonium minus, cum acrius fit maiore, celeriter illitum cu ex Galeno. tem exulcerat, ungues'; ; cabros eijcit. Succus eius per nares purgat, utpote admodum acer. Itaq; hac herba quar=

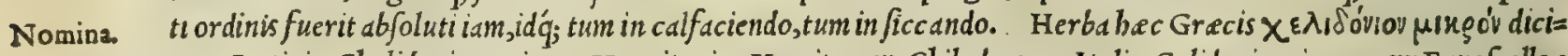
tur: Latinis, Chelidonium minus: Mauritanis, Ncmiten, o Chilodomon: Italis, Celidonia minore, or Fauofcello: Germanis, Feiguuartzen, Blanterliraut, Pfafenhoedlin, o MeienLraut: Hipanis, Scrofularia menor: Gallis, Caullons des preftes, or Eclere petite.

\section{o'tóvo. OTHONNA.}

\section{CAP. CIXXVIII.}

O T H O N N A M aliqui maioris chelidoniæ fuccum efle aiunt: quidam glaucij : alij fuccum flori- 30 bus corniculati papaueris expreffum. Alij permiftos cærulex anagallidis, hyofcyami, \& papaueris fuccos effe contendunt. Alij Troglody ticæ cuiufdam herbæ fuccum, quæ othonna uocatur: nafciq́; eam in eo Arabix tractu, qui ad Aegyptum fpectat. Othonna folijs erucx, perforatis cribri modo, \& veluti à tinea derofis, fqualore obfitis, paucis : fore croci, latifolio : quare quidam anemones fpeciem effe putauerunt. Extractus fuccus oculorum medicamentis adijcitur, ubi cxpurgare eft opus : mordet enim, \& abfterget omnem caliginem, quæ oculis offundıtur. Tradunt humorem quendă ex herba emanare, qui elotus, femotis calculis, in paftillos ad eadem digeritur. Aliqui tamen affirmant, lapidem effe Aegyptium, in 'Thebaide nafcentem, exigua magnitudine, xreo colore, guftu cum feruore quodam, \& aditrictione, mordaci.

Othonn O т н о N N A M Diofcoridi fuiffe incognitam, illud nobis maniffto argumento effe poteft, quód nibil ex confideratio. Se de ea certi fcribat, fed omnia alijs accepta referat, ex quorum tantün opinione famá, bac de Othonna me= moris prodidit. Quare mirari non licet, fi noftra quoque atate Othonna minimé cognofcatur. Hanc cim adis mifceat $\mathrm{P}$ aulus fuis medicamentis, afferit quibufdam in locis maioris chelidonij fuccum effe, eorum fortaffe opinio= Nomina nem fecutus, qui ita feripferunt, ut refert Diofcorides. Eius nomen Grecum ósóvvo, Latinum item, $\sigma$ Ita $=$ Ium Othonna.

\section{MVós $\operatorname{LT}^{2} \alpha$. AVRICVLA MVRIS.}

\section{CAP. CLXXIX.}

M v R I $s$ auricula, quam myofotida uocant, herba eft caulibus pluribus ab vna radice, aliquatenus ab imo rubentibus, \& concauis; folijs anguftis, oblongis, dorfo acuto, elato, nigricantibus, per interualla afsiduè geminatis, atque in mucronem definentibus, \& tenuibus cauliculis ex alarum finu prodeuntibus : flofculo, vt anagallidis, cæruleo: radix digitali crafsitudine, multis capillamentis fibrata. Radix illita xgilopia fanat. Sunt qui alfinem, muris auriculam vocitant.

Auriculx mu R E P E R I N T V R quidam Diofcoridis codices, qui boc loco Alfinem babent, que.e libro quarto poft tisconfid. belxinem defcribitur, quod $\sigma$ ipfa nonnullis Muris auricula appelletur. Kua forfitan nominis cognatione addu= $c t i$, pofteriorum quidam, ex quarto Diofcoridis uolunine in bunc locuin ipfam tranftulere, ubifvi generis, uel po= tius nominis alteram reprafcntauit Diofcorides. Sed quoniam ipfa Diofcoridis fcribendi ferics clarisime $d e=$ monftrat, Alfinem ftatim poft belxinem fequi debere, quod ei adeo finilis fit, ut tradat Diofcorides ean= dem fuiffe cum belxine, nifi bumilior effet; idcirco libro quarto de ea nobis dicendum erit, quód inibi cius legi= 


\section{In Lib. fecundum Diofcoridıs .}

AVRICVLA MVRIS.

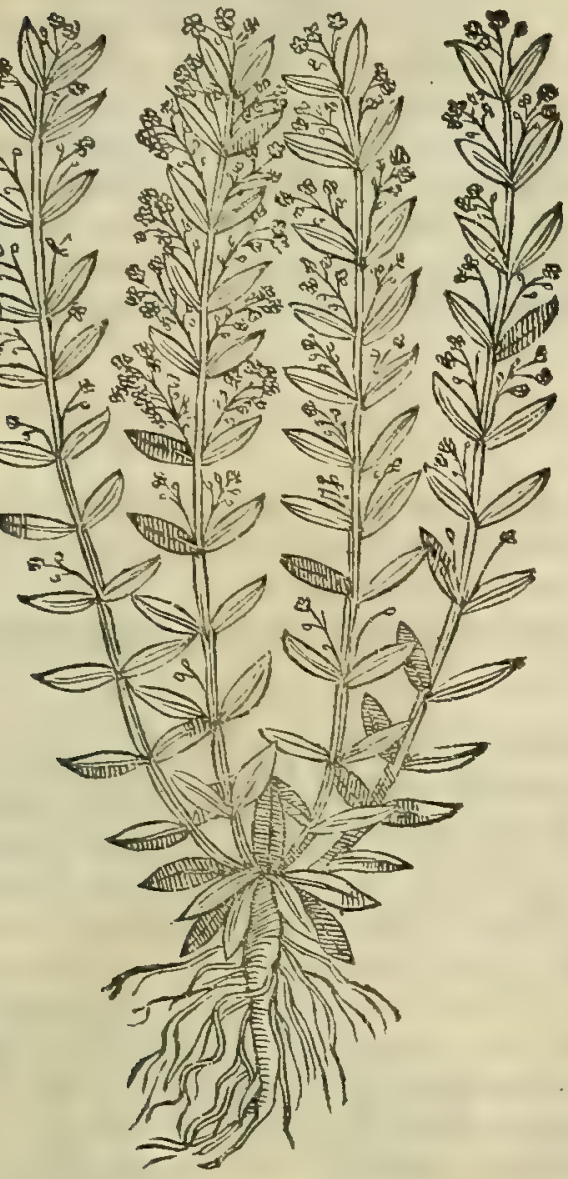

30

I S A T IS A T IVA.

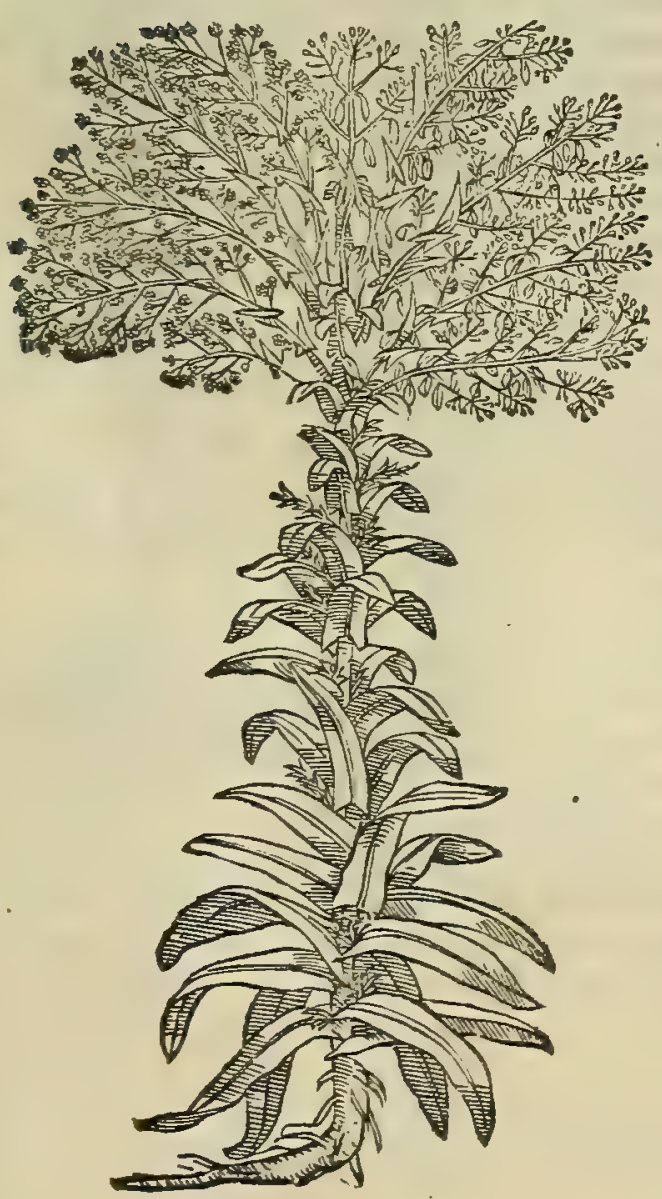

timan fedem eße exiftimemus. Ceterum bec, de qua líc inentio eft, paßim menfe maio floribus ornata uifitur, nimirum in pratis, in campis, in bortis, fecus uids, or ubique firé locormm. Huiufece uires paucis perftrinxit Galenus lib. V I I. fimp.med. fic inquiens. Auricula muris deficcat ordine fecundo: ceterum nullam euiden tem caliditatem poßidet. Ea Grecć $\mu$ vo's witiov uocatur: $\mathrm{Ld}=$ tiné, A uricula muris: Italicé, Orecchia di topo: Germanicé, V= ualdt mangolt mit blauuen bluomen: Hipanicé, Oreya de raton jerua: Gallicé, Orelge du ratte.

l'ớtIs. GLASTVM. CAP. CLXXX.

S A T. I v v M Glaftum, quo infectores lanarum vtun tur, folium habet plantagini fimile, uerùm pinguius, nigriusq́ue : cuius caulis dun̂m cubitorum altitudinem excedit. Illita folia tumores omnes difcuriunt, cruenta vulnera glutinant, fanguinis profluuia fiftunt : ignem facrum, phagedænas, putrefcentia ulcera, \& quæ ferpunt, fanant. Sylueftre glaftum fatiuo fimule eft. Folia fert maiora, lactucaceis proxima: caules tenuiores, multifidos, quadámtenus rubentes: in quorum cacumine folliculi multi dependent, quandam linguarum ef figiem referentes, in quibus femen : flore tenui, luteo. Eadem, qua \& fuprà dicta, praftat : potu, \& illitu lienofis auxiliatur.

I's A I Is fatila, quam in Hetruria uulgó Guado appelld= mus, tingendis lanis fullonibus, infectoribus maximé expeti= tur, quód Lanarum infectus, quibus cum admifcetur, firmet, or

Ifatidis, feu Glati coufinunquamdeperdi patiatur. Huiufce maximus babetur prouentus

ISATIS SYLVESTRIS.

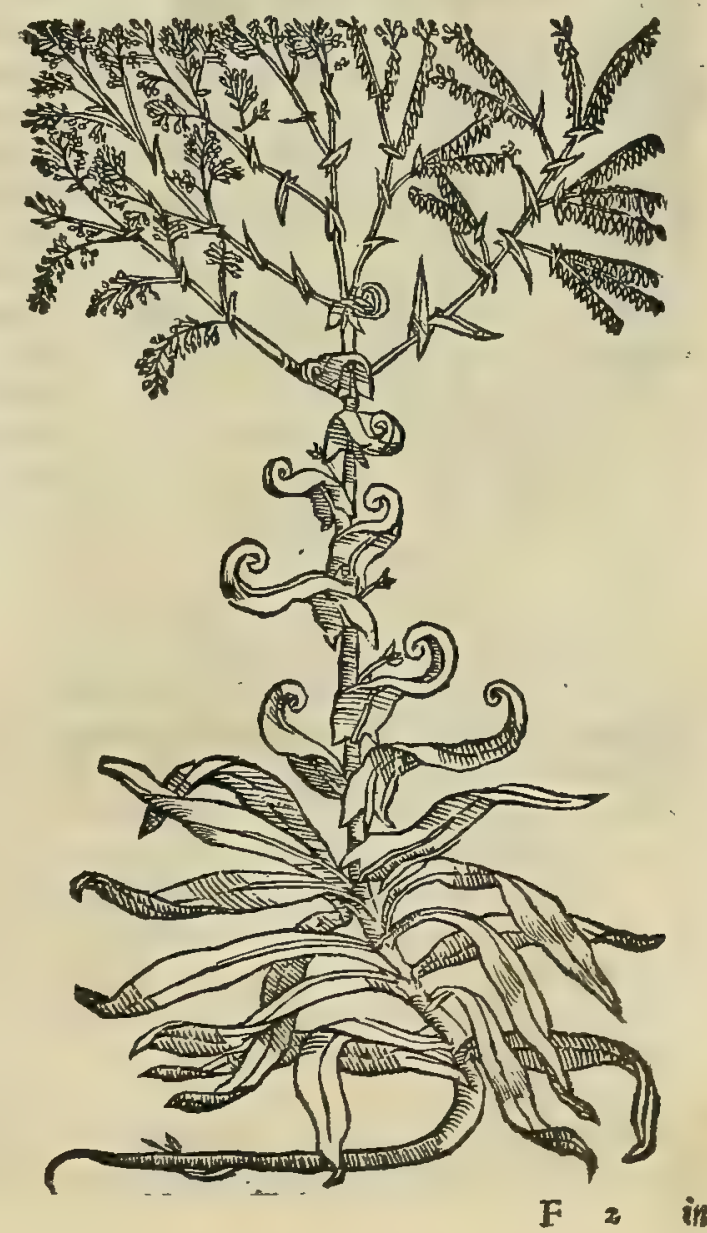


in Vmbria circa Noceram, ubi oppidum eft Guadum ideo appellatum, quod ibi Ifatis frequentißima feratur. Glaftum fylueftre Plinio inter fy lueftres lactucas recenfetur lib. x x.cap.v I I. quippe quód illi non fit abfimile. Fit ex Ifati= Iratidum vi- de ceruleus ille color pictoribus expetitus, quem Indicum uocant, de quo diffufius lib v. fuo loco differemus. Me= res ex Gal, minit utriufq; Ifatidis Galenus lib. VI. Iimpl. medic. Fic inquiens. Ifatis fatiua, qua utuntur tinctores, facultatis eft ualenter exiccantis, nondum tamen mordentis : eft enim fimul amara, atque adfringens. At Ifacis fylueftris mant= fifté iam acre quiddam tum guftu, tum aftione prefert. Proinde quàm fatiua ualentius deficcans, ualentius etiam

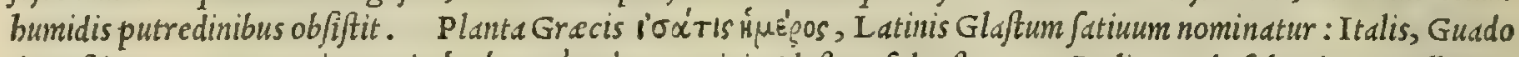

Nomina. domeftico. Que ueró Grecis icór is áypia, Latinis Glaftum fylueftre, or Italis Guado faluatico appellatur. Vtrunq; Glaftum uocant Maruritani Dili, Dileg, Vefine, Chate, Chatis, feu Alchat, Adlen,aut Adblen, er Nil: Ger= mani, Vueidt: Hifpani, Paftel: Galli, $\mathrm{P}$ aftel de languedoc.

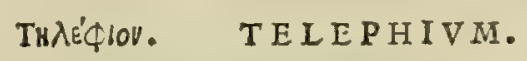

\section{CAP. CLXXXI.}

T E L E P H I V M herba portulac $x$ fimilis, \& caule, \& folijs : alas binas in fingulis foliorum geniculis anneetit : ramuli à radice feni, fepteníve prodeunt, folijs referti cæruleis,crafsis, lentis, carnofis: flore luteo, aut candido. Nafcitur in cultis, \& maximè inter uites tempore uerno. Folia fenị horis illita albam vitiliginem fanant: fed poftea hordeacea farina illini debet. perunctam ex aceto etiam in fole vitiliginem tollunt: fed ubi inaruerunt, abfterguntur.

Telephij con QV A N QV A M non defunt reiherbarie periti, qui exiftiment, Telephium cam effe ftirpem, quam quidam fideratio.

Fabarium, alij Fabam pinguem feu craffam, quidam ueró Fabam inuerfan appellant; cim tamen nulla reperiatur

FAB A R I .

Telephij uiresex Gal.

Nomina.

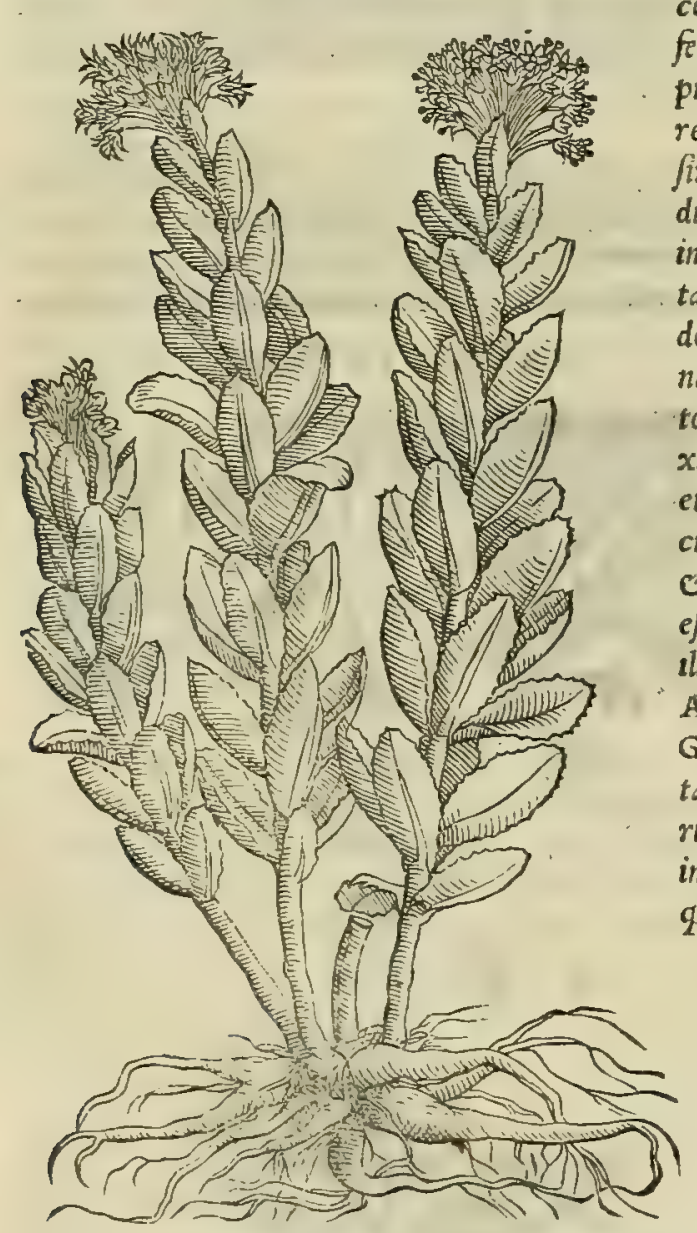
qualitate predita, qua abfterforic, ficcantisq; facultatis parti= ceps dici poßit, ut Galenus Tclepbium effe tejtatur, foliağ; pro=

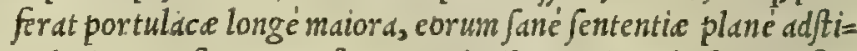
pulari non aufin: tametfi ea compluribus notis. Telephium refer= re uidedtur. Telephij uires memorix prodidit Galenus lib. v I I I. fimplicium medicdmentorum, ubi ita fcribit. Telepbiume exiccan= di, eo detergendi facultate eft, non tamé infigniter calida : werùum in hoc forfan quifiam ipfum primi effe ordinis cenfedt. Deficcat tainen fecundo ordine intenfo, aut certé principio tcrtij: proin $=30$ de ad putrida ulcerd conuenit, o leucas, e alphos cumn aceto $\int a=$ nat. battenus Galenus. Caterim illas quiden Tclephij qualita= tes haud reperies in Fabaria noftrate; etfi bec (ut paulo anté di= ximus) notis pluribus proximé ad Telepbij biftoriam accedat, ut eius piđtura, quam bîc damus, aperté fatis demonftrat. At $f \hat{\imath} f a=$ cultates tantum obftant, quó minus ca planta Telephium o effe, $\mathcal{O}$ dici mereatur, in boc illa ratio non parum ponder is babitura eft, qua fuperius oftendinus, uerum Chelidonium ininus herbam illam effe, quam in etus mentione depitam exbibuimus. Nam fi Arum, tefte Galeno, ijs carce facultatibus in Italia, quibus in 40 Grecia preditum eft, nil mirum uideri debet, quod o alis plan= ta cun folo uires mutanerint fuss, ut illi plante', o buic Faba= rie dicte facilé euemefe fupicandum eft. Velim tamen in bis, ut in alijs quog; dubijs plantis, fuum cuiq; effe iudicium. Herba,

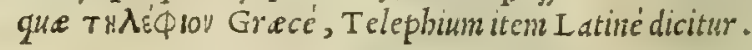

I I B R I SECV N D I FIN I $S$. 


\title{
PETRI A NDREAE MATTHIOLI MEDICI Senenfis Commentarii,
}

\section{IN LIB. TERTIVM PEDACII DIOSCORIDIS}

20

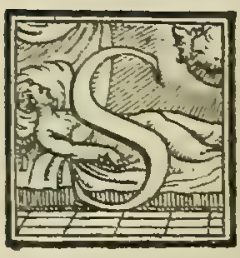

\author{
A NAZARBEI, DE MEDICA MATER IA.
}

V P E R I O R I B V S, charißime Aree, commentarÿs, tradidimus de aromatibus, Inguentis, oleis, arboribus, earum fructibus, of lacrymis: item de animalibus, cerealibus, oleraceis, ow herbis acrimonia preditis. In hoc autem tertio radices, fuccos, $\sqrt{e}$ mina, herbas, of qua vernacula, of inter fe cognata cenfentur, quxque pluribus $\int c a-$ tent remedïs, profequemur.

A'voginóv. AGARICVM.

C A P. I.

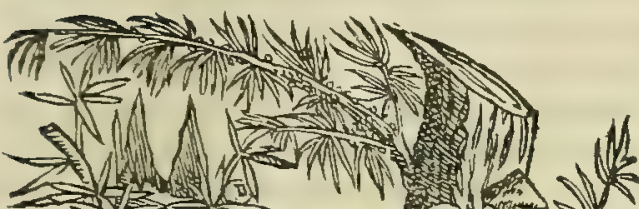

A G A R I C V M radix fertur laferpitij fimilis, fed facie fumma folutior, \& rariore, fungofoq́ue tota contextu. Duo eius genera : fomina, qux prafertur, rectis intus uenarum difcurfibus conftat: mas rotundus eft, $\&$

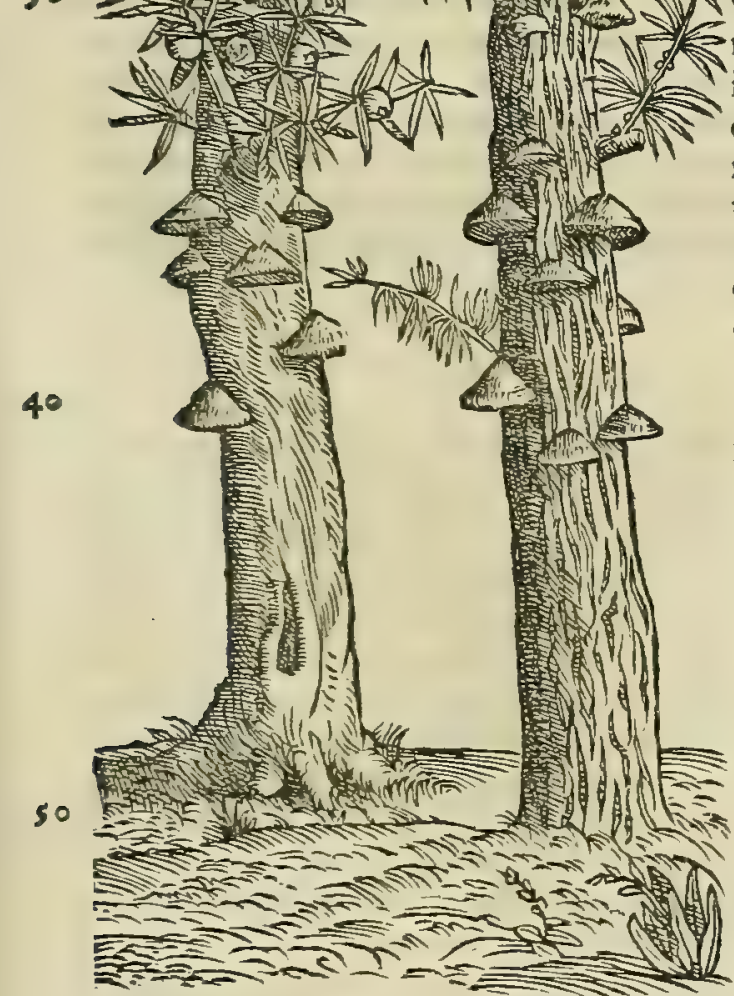
vndique compactior. Vtrique guftus in initio dulcis; mox ex diftributione in amaritudinem tranfit . Gignitur in Sarmatix regione, qux Agaria dicitur. Sunt qui radicem effe plantæaffirment : alij ut fungos nafci in arborum caudicibus, quadam putredine. Gignitur in Galatia Afix, \& Cilicia in cedris, fed friabile, \& infirmum,

Adftringendi, calfaciendiq́ue naturam habet. efficax eft contra tormina, cruditates, \& rupta: prodeft itidem contufis, \& ab alto deuolutis, Datur duobus obolis in uino mulfo febrim non fentientibus : febriculofis uerò in aqua mulfa : arquatis quoque, fufpiriofis, iocineris, renumq́ue vitio laborantibus, dyfentericis. Item fi ủrina ægrè reddatur, fi uulux ftrangulatus urgeat, fi pallor membra decoloret, drachma vna dari folet: fi tabes infeftat, ex paffo: fi lien negotium exhibet, ex aceto mulfo: fi diffolutio ftomachi eft, ita ut cibi tenax non fit, manditur, \& fine ulla humoris forbitione deuoratur: fit mili modo acida ructantibus propinatur , fanguinis reiectiones fittit, tribus obolis ex aqua fumptum. Facit ad coxendicum, \& articulorum dolores, \& comitiales morbos, fi cum aceto mulfo, pari pondere affumatur: menfes ciet : fominis, quas inflatio vuluæ uerat, utiliter æquali modo datur : horrores foluit, datum ante febrium accefsiones: aluum purgat, drachma vna, aut altcra, fi cum aqua mulfa bibatur : venenorum antidotum eft denarij inftar, cum diluta potione fumptum : fi ferpentes ictum uibrarunt, morfumq́ue fubfixerunt, tribus obolis ex uıno potum, mirè auxiliatur. In fumma, internis omnibus uitijs conuenit, pro uiribus, \& xtate datum, nunc ex aqua, nunc ex vino: ijs ex aceto mullo, alijs ex aqua mulfa.

A G A R I C V M fungus eft in arboribus nafcens. Plura de eo diximus libro primo in laricis arboris biforid. Agarici conPreftantißimum habetur in Tridentinis montibus, ubi Sxpißimé proprijs manibus illud diuulfimus, adacta fecuricu= fideratio. 
1a. Caterum tametfi. Plinius lib. X VI. cap.v I I r. omnes glandiferas arbores Agaricum ferre tradat; in Tridentinis. tamen fyluis, ac etiam in reliquis I talic locis, quod equidem uiderim, folitantim larici innafcitur. In cedro Agaris cum gigni, tum in Afie Galatia, tum it Cilicia fcribik-Diofcorides, nulla eius mentione facta, quod in larice ip= $\int a, d c$ glandiferis ( $u t$ Plinius inquit) arboribus prouenit. Fuchfius medicus atate noftra celebris in libro de com =

Fuch. laplus. pofitione medicamentorum, quem nuper autum excudit, Agaricum ex Sarmatia per Illyriam venetias afferri tras= dit, o ex Galatia e cilicia Alexandriam, er ab Alexandria Venetias. eo fortaffe argumento ductus, quód Dios fcorides auctor fit agaricum nafci in Sarmatia regione, in Galatia Afie, o cilicia. Verum iampridem desijt ex il= lis locis importari, ut teftantur mercatores $\mathcal{F}$ pharmacopoi. Equidem compertum babeo, omne fere agaricü,quod Venetijs uenditur, partim deferri ex Tridentinis montibus, in quibus funt fylue laricibus referte, partin ex Vultu= rene agro, er aliis finitimis locis, partim $\mathrm{ex}$ Norico traftu. Neque certé unquam, dum ego Venetijs agerem, in $=t$ telligere potui, quod agaricum aliunde conueberetur. Quare adducor, ut putem, Fuch/ium uirum alioquin erudi=

Agarici uires tißimum, in boc plané deceptum effe. Agaricimeminit Galenus fub quodam radicis genere lib. v I. de fimplicium ex Galeno. medicamentorum facultate, ubific inquit. Agariciradix, boc eft, que trunco innafcitur, primo quidem guftu dul cis, fed paulo póft fubamara apparet: er acrimonic quaridam peciem temporis patio inducit, leuiculé́ ; adftri= ctionis. eft $\mathrm{Jr}_{\mathrm{r}}$ confiftentia laxa. Ex quibus omnibus maniff fun eft, fi quidem que fuperioribus commentarijs dicta funt, meminerimus, quód medic amentum boc compofitum eft ex fubftantia dëred, o r terrea à caliditate extenuata:

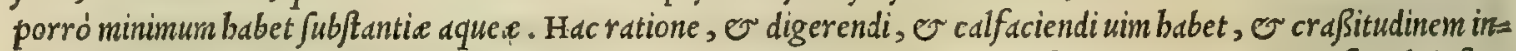
cidendi, tum infaritus uifcerum expurgandi. Proinde regio morbolaborantes fanat, eos utique, qui fic ab infar= ctu iecoris laborant. I uuat o morbo comitiali obnoxios eadem facultate, tum rigores per circuitum recurrentes ex craßis, aut uifcofis humoribus natos fandt. I uuat e morjos à beftijs frigore ledentibus, aut compunctos, tum for is so in affect a parte impofitum, tumintró in corpus fumptum pondere dracbine unius cum uino diluto. Eft or purgato= rium. Et lib. primo de antidotis idem Galenus inquit. Agaricum fraudem nullam admittit. optimum eft lauißimum: denfum ueró, or graue, ov lignofum deterrimum. Quod autem inter hec medium eft, quantum fignis, tantum vo uiribus ab utrifque diftabit. bactenus Galenus. De uiribus Agarici Mefues quoque feripfit, fic inquiens. Agd= ricum de igcit utranque bilem, ac etiam pituitam ip $\int a m$ : craffos, lentos, putre $\int c e n t e s q$; bumores expellit. Eius pro= pria facultas eft cerebrum, omniumí; fenfuum organd, ac mufculos expurgare : excrementa, qua fpinalimedulle pariter or neruis inbserint, educere : pulmonem, ac pectus à lentis, ac putrefcentibus bumoribus detergere: ac deinde uentriculum, iecur, lienem, renes, or in mulieribus uterum mundare. Preter hec foluit Agaricum compagi= num omnium contumacem materiam. Quapropter non mirum uidetur, uocafe Democritum agaricum familiarem medicinam, cim ad omnes corporis partes conformitatem babeat. Nam non imbecilles poßsidet uires ad plerofque jo. tum capitis, tum cerebri, tum eiufdem membranarum morbos: nempe diuturnum dolorem, comitialem morbum, $a=$ poplexiam, uertigines, maniam, atram bilem, er cerebri inflammationes. Eft etiam morborum omnium, quor $u$ caufa fuit obftructio, medicina admodum fingularis. quo fit, ut regio morbo affectis, aqua intercute labor antibus, ac liene uexat is leuamentum pr.ffet. Vrinam quoq; pellit, ac menfes commodé ciet. Coloris nitorem Agarici ufus toti cor= pori commendat. Ventris tineas tum necat, tum deijcit. Coxendicum doloribus conuenit, $\sigma$ diuturnas febres difcu= tit. Quod Graci á yoplkò, Latini quoq; Agaricum diant: Mauritani, Garichum, feu Garicum: Itali,Agari= co: Germani, Dannen fchuuam: Hipani, Agarico : Galli, Agaric.

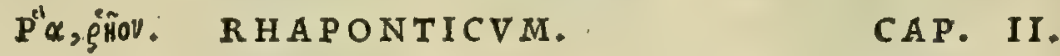

R $\mathrm{H}$ A, aliqui rheum, Latini rhaponticum uocant, prouenit in ijs, quæ fupra Bofphorum funt, regionibus, ex quibus affertur. Radix nigra, centaurio magno fimilis, fed minor, \& ru fior, fungo$\mathrm{fa}$, aliquantum læuis, fine odore. Optimum habetur, quod teredines non fenfit, fi guftatu cum remiffa adftrictione lentefcat, manducatumq́ue colorem reddat pallidum, aut ad crocum inclinantem. Id epotum facit ad inflationes, ftomachi imberillitatem, \& omne genus dolores, ad conuulfa, rupta, lienofos, hepaticos, tormina, \& renum, veficæ \& pectoris uitia, aduerfus intenta præcordia, \& - vuluæ mala, coxendicum dolores, fanguinis excreationes, fufpiria, fingultus, dy fenterias, \& cœliacorum affectus, contra febrium circuitus, \& venenatorum morfus. Datur in fingulis valetudinibus co$\mathrm{dem}$, quo agaricum pondere, \& cum cifdem liquoribus $:$ fi febri careant in mulfo: fin aliter ex aqu 3 mulfa : fi tabem experiuntur, ex paffo: fil lienis exercet, in aceto mulfo: fi diffolutio eft ftomachi, id eft, cum cibi tenax non elt, manditur, \& fine forbitione vlla deuoratur. Liuentia, lichenasq́; tollit, cum aceto illitum. Inflammationes om nes veteres ex aqua oblitum difsipat. Summa eius vis adftrin gens, cum aliquanto calore.

Rhapontici : R H A P ON T I C V M officine Rbeuponticum uocant. Quod nomen fibi afciuiffe uidettur à Rba flunio re= confideratio. gionem quandam Ponto conterminam preterluente, in cuius fluminis ripis numerofum nafcitur. Cuius rei teftis eft Ammianus Marcellinus lib. x I I. fuarum biftoriarum, ubl fic fcribit. Tandis, qui inter Caucafias oriens rupes per finuo os labitur circunflexus, Afiam'́; a Europa difterminans, in ftagnis Meoticis delitefcit. Huic Rba uicinus eft amnis, in cuius fupercilijs uegetabilis quadam eiufdem nominis gignitur radix, ad multiplices medelarum ufus proa ficiens. bec Ammianus. Legitimü paucis abhinc annis ad nos aduelis capit. Nă multo untea tempore R hapontici uice maioris centaurij radix in medicine ufum irrepferat. Qua etiam noftra atate non defunt, qui R hapontici loco utan= 


\section{In Lib. tertium Diofcoridis.}

wit, , recentiorum inuenta refpuentes, cim bactenus legitimum $\mathrm{R}$ baponticum ne ; nouerint, neque viderint: tanta cft : Quorundam quorundan pertinacia. Credidere ad bec peritißimorum medicorum quidam, preterito nuper auo, R habarbarum error. Q Rbapontico Diofcoridis nullo difcrimine differre. Quippe quoniam eorum temporis curriculo legitimum $\mathrm{R}$ bapon= ticum Italia non uiderat. Quod cim paucos poft annos ad nos effet allatum, non defuere qui priorum reuocauerint fententiam. Id quod maximé palam facit Manardus Ferrarienfis in fuis epiftolis. Quandoquidem is lib. v I. epiltola I I. firma hac, $\mathcal{O}$ ftabili ducebstur opinione, unlgare noftri ufus R habarbarum, $\mathcal{~}$ Diofcoridis R baponticum et idem effe, or nibil inter fe cognatione differre. Veruntamen cim pofted legitimun conpexiffet Rhaponticum é Mofcho= ria all wtum, quad Diofcorid is biftoriam notis omnibus referret, nouam ftatim induit opinionem, er priorem, quam babuit, rewocauit, ultina quinti libri epiftola ad Leonicenum fcribens. Rhaponticum primion uidi cgo Venetijs in

- offcina ad medici infigniume é Conftantinopoli allatum, ac deinde alijs pluribus in locis etiam ex Alexandria conue= ctum. quod mullis reclamantibus notis, uerum antiquorum R baponticum refert. Inuchitur Auerroes lib. V. fuarum collectane ar um tum in Galenum, tum in reliquos, qui dixerunt $R$ babarbarum facultate tantum adftringenti pollere, quòd purgatoriam, que illi ineft, facultatem minime compererint: cum tamen Auerroes ip $\int e$ fit maximopere carpen dus, quód neque Galemus, neque ceteri feniores R babarbari noftri ufus ufquam meminerint, nec quic quam de eo po= feritatis memoria prodiderint, tamet $\sqrt{i}$ de R hapontico a Diof coride defcripto plura tradiderint, inter cuius facul= tates iull.t penitus, qux purgando fit, inueniri potelt. Rhaponticimeminere, fub R habarbaritamen titulo, nifi in= terpretis ( ut frré fupicor) /it lapfus, chum Serapio, tum etiam Auicenna. quandoquidem non plures fuo Rbabarbaro aßignauere facultates, quàm qui cos praceferunt, Rhapontico aßignauerint. Quippe quód corum neuter fcri= perit, fuum Rhab.ubatrum deiectoria facultate pollere. Id quod uerum indicium prabet, fcripfiffe bos de $R$ ba= 2o pontico, non autem de $\mathrm{R}$ habarbaro. Quo fit, ut non ab re putandum fit, id eueniffe interpretum ignorantia $\mathrm{R} h a=$ ponticun in R babarbarum permutantium . Cognouit tamen legitimum ( ni fallor) etatis noftre R habarbarum $\mathrm{P}$ au= lus Acgincta, c cim ipfius meminerit libro v I I. cap. x I. in quibufdam medicamentis aduerfus podagras, quorum co= gnomina funt diacorallion, compofitio Agapeti, e compofitio atactos. Verim non propterea credidit ipfe, $\mathrm{R} b a=$ ponticum a Rlsabarbaro differre. Cuius rei auctor is fidem manififtam facit libro primo cap. X I I I I. ubi fcribit, quod denorata terebinthina refind oliue quantitate dormituris aluum leniter mollit, er quód id preftatur efficacius, fi Rheiponticimonentun admifceatur. Ex quibus palam fit, per Rbaponticum Paulo Rbabarbarum defignari,quód fortaffe inter hec exiftimauerit null im intercedere cognationis differentiam. quemadmodum credidere recentiorum quidan, de quibus pauló anté diximus. Paulo enim fi Rbeipontici, or R heibarbari aliqua interceßiffet differentia, ubi peculiariter de fimplicibus medicamentis agit, de utrorum $q_{;}$facultate peciatim fcrip/iffet. Sed cum ibitantüm

30. Ponticimeminerit, indicium haud dubium eft, illi Barbarn, or Pontici nullam fuiffe differentian. Caterim Ruel= lius cos acriter reprehendit, qui inter Rbaponticum, of Rhabarbarum noftrum difrimen faciunt, cum fua ferat opinio, alterum ab altero minimé dißidere: atque fi qua differentia reperiatur, eam non aliunde prouenire, quàm regionum, ubigignitur, diuerfitate, clementia, uel inclementia cali. Neque alia ratione afferit, Ponticum nullo odore commendiri, quim aquilonarium regionum, in quibus oritur, immani frigiditate : cum tamen Pontica regio non ufqueadeo fit frigida, ut Ruellij fententia admitti debeat, fed ut potius tanquam inanis reprobanda uideatur. Quandoquidem fequeretur, quód cetera ftirpium genera, que tam in oriente, quàm in meridie odoris fragrantia commendantur, in aquilonari plaga: $\sim$ in ip $f$ Ponti regione penitus inodore reperir entur. Quod tamen falfum effe femper crediderim: nam quanuis firpes omnes, que in aquilonaribus regionibus oriuntur (de bis, que natura odoratiores habentur, intelligo ) ex climatum, or aéris algore, fint odore, ac cateris qualitatibus imbecilliores; 40 non ob id tamen barum qualitatum adeo expertes deprebenduntur, ut difcerni nequeant: quin er in quemlibet ufum, ubifcilicet confer ant, non recipiantur fuis in regionibus. Quippe fi ob frigoris, ac regionum inclementiam fuds in= natas qualitates penitus exuerent, adeó ut fola tantuin forma remaneret, propriam omnino peruerterent peciem. Quod tamen nulla ratione, nec auftoritate probatur . Siquidem compertum iampridem apud nos eft, quód quanquam Celtica nardus, qux à quibufdam Carintbix, or stirix alpibus nobis affertur, à quibus pené quatuor, uel quinque totius anni menfibus, nix colliquata labitur; itemq; acori adix, qua noftro auo ex sarmatia Europa glacie, er ni= uibus maiore anni parte emper obducta, aduehitur in caldmi odorati ufum, odore tam ualido, naresq́; feriente fras grare non deprchenduntur, quemadmodum Celticailla nardus, quex ex Liguria, er Iftria defertur, or acorum, quod ex Ponto, Syria, o Aegypto petitur; non tamen ob boc euenit unquam, quin fuis proprijs ac naturalibus fras= grent odoribus. Quo fit, ut infirma admodum, quantum equidem conijcio, fit Ruellij fententia. Quare binc nobis so concludere liceat, Rbaponticum odoris expers non effe, dëris, foli, Õ regionis algore, fed quód alia à Rhabar= barico, uel Indico fit planta. Declarant preter bec, Rbabarbarum a R hapontico plurimium diftare purgatoric uis, quam natura ip $\int a$ R habarbaro largita eft, odor nares feriens, compacta fimul fubftantia, dureus color, aridi= tas, amaritudo, que guftu percipitur, o ponderis grauitas. Quandoquidem R baponticum nullo odore commenda= tur, minimé deiectionem molitur, cum potius adfringat; non eft amarum, fed fubacre; non aridum, fed lentum; non compactum, fed rarum; non pondero fun, fed admodum leue. Quibus rationibus fretus non temeré afferendum putas Ruellij, \& aliuerim, Ruellium hac in re magnopere ballucinatum fuife, prefertim $q_{;}$cum dicat, nullo alio difcrimine Rhabarbarum quorü error. ¿ Rbapontico differre, quàm odore tantum. Vanum quippe uidetur argumentari, Rhabarbarum, or Rhaponticum unam or eandem effe radicem, quód forma, colore, ac pecie nibil inter fe diftare oculorum fenfibus appareant, cum tam in facultatibus, quàm qualitatibus, maxime inter $\int e$ differant. In fimili errore uer fantur etiam $i$ ( funt enim qui ita fentiant) qui fibt falso perfuadent, abietis lacrymam à larigna nibil dißidere, ac unam er eandem lacryman efe, eo quód in colore, in Jubftantia, ac in ceterts notis, in quibus perpendendis oculi tantum iudices funt, adeo per=

Rhapontici, \& rhabarbari difcrimen.
Vana Auerrors calumnia contra Gal. 
fimiles uidedntur, ut uifibilifucultate altera ab alter difcerni non poßit . Verum fi quis rem cueteris fenfibus experi= ri aggrediatur, difcriminis certior fiet: $n$ anq; olf actu odoris fragrantian baud in fualem, guftu ueró amarorem in a= bietis lacryma comperiet, quibus larigna carct. Et quisnam iuniperi re inam à lentifcina fecerneret, nifi rei ipfius in= corruptus iudex fuerit guftus? Quis à trobolina refina, o d quibufdam gummi globulis thus ipfum agnofceret, niff adulterium tum igne, tum gufu deprebenderetur? T anta preterea intercedit fimilitudo inter piftacium, $\circlearrowleft$ unguen= tariam glandem, ut mf h hac amariiudincm guftui relinqueret; illud uerò dulcedinem, difficillimum fané fuerit alte= rum $a b$ altera diftingucre. Quid porró inter $\int$ e fimilius reperitur, qudm caßia, o cinnamomum, et $f i$ hec omnino pe cie non conueniant? Hinc facile adductus fum, ut nullius momenti eorum argumenta femper exiftimauerim, quires fecundum quafdam tantün qualitates dijudic ant, quibus etiam fepe decipiuntur, ut ij, qui bsc leui ratione ducti, $R$ ba= Rhapótici ui- barbarum, $\widetilde{C}$ Rhaponticum idem effe contendunt. Meminit Rbapontici Galenus lib.v I I I. fimplicium medica= res ex Gal. mentorum, ubi de eius uiribus ita fcriptum reliquit. Rbeum, quidam ipfum Rba nuncupant: miftam babet tun tem= peraturam, tum facultatem. Habet enim quiddam terreftre frigidum, ceu indicio eft adftrictio, o adiuncta eft qua = dam illi caliditas: fiquidem fi plufculum mandatur, fubacre confpicitur. Quinetiam aërex cuiufdam fubftantia fub= tilis eft particeps, quod indicat tum laxitas, tum leuitas: uerim non minimé er opera. Ob id enim licet adftringens, tamen non tantim conuul is, fed er ruptis, or orthopnce prodeft. Sic quog; liuentid, or lichenas fanat cum aceto illitum. Porró quód adftrictionis opera baud instrenua funt, binc difcere liceat, quód Janguinem expuentibus, cce= liacis, o dy fentericis conferat: nec enim reluctatur terreftri frigido tenue cëreum, imó eo quód deducat, et in altum perducat, ualentioris effectus caufa exiftit. Et in libro de antidotis primo: In Rbeo, inquit, quoque fraus commit= titur : nain quibus in locis nafcitur, fimul atq; euul Jum eft, ipfum elixant, quó fuccum remittant, ac tam fuccum, ut fyncerum, $\mathfrak{o}$ aqux impermiftum, quàm Rbeum exiccatum, ut non elixum ad nos poftea mittunt. Idcirco fcire opor $=20$ tet aduiter atum dignofcere . quod facillimé ab bis deprebenditur, qui $\mathrm{R}$ beum fua fponte nafcens uiderunt. hactenus Galenus. Ceterim adulterium, quod in Rbeo fieri prodidit Galenus, id ( ut paulo poft dicturifunus) de Rhabarba= ro tradidit Mefues. Cui tria R hei conftituuniur generd, nempe Turcicum, Barbarum, er Indicum, quod o sceniti= Rhei Turcici cum uocdt, onnia dे regionibus, dquibus conuebuntur, cognominata, uel in quibus proueniunt. Quippe Turcicum nomenclatio. nil aliud illi defignatur, quàm Ponticum, uel quód é Ponto ad Turcas uicinos deferatur, uel quód ab ijs faltuofis con= uallibus, in quibus ultra Tanain fluuium priores Turca, Pomponij Mels, o Plinij teftimonio, uenationibus feré ui= xere tantim, iampridem in Pontum fuerit delatum. siquidem ab bis non longé diftat R ba flumius, circa quem $\mathrm{R}$ ba, quod Ponticum pofteri uocauere, probatißimorum anctorum teftimonio, oriricertó fcimus, fluninis illius nomine pariter appellatum. Quo fit, ut bac in re non dubitauerim erraffe cticm Me fuem. quippe qui inter Rhei genera dluü ducentia Ponticum admifcuerit, à cateris tum fpecie, tum facultate diuer $\int u m$, quanuis fortaffe rectius id Turcicum 30

Rhei Indici appellauerit, quàm Ponticum. Porrò Indicum ab India dictum, ubi frequentijimum prouenit, nemo eft qui ambi= nominatio. gat. Sed quánam ratione Sceniticum, o Indicum idem effe dixerit Mefues, hactenus compcrtum non babeo : nifi for taffe sinicum rectius legendum fuerit, quód à sinis cxtreme Indie populis (ut arbitror) deferatur, cim plura quoq; dromatum genera ea regio mittat. Id quod manifefté idem declarat Mefues : quippe qui Scenicum, uel sceniticum

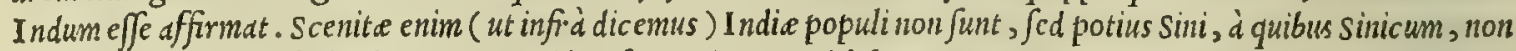
Scenicum, ut uulgatd babet lectio, mea quiden fententia, uocaridebet. Sunt tamen qui uelint Scenicum, neç Indicum effe, nec à sinarum regione oriundum, quod à Mauritanis non sinicum, Sed Scenicum dic atur. Quamobrem eorum quiddm, ut Adamus Lonicerus, in Arabia hoc nafci cenfet, or à Scenitis illius regionis populis Scenicum, fiue Sceni ticum uocari putat . Fuclffius ueró Me fuis opinionem fecutus, nullam inter Indicum, o scenicum facit differentiam. quippe qui fcripferit libro primo de compofitione inedicamentorum, Rheum Indicum effe nocatum, quód ex India, 40 aut loc is indix proximis, nempe ḋ Scenitis populis, ut auctor eft stephanus de urbibus Perfidis, deferatur. verum cim Scenite de ferte Arabix populi omni aromatum genere fint defrituti, cimg; afferat Mefues Sceniticum rbeum, o Indicum idem effe, cadit, perit q́, Loniceriopinio. Velim tamen fi poffem Fuchsij fententiă probare. Verün cium Scenita etidn Straboni populifint é Parthorum collegio Arle, o Martydne montes incolentes, diftentó; ab Indie finibus milliaribus plufquàm mille er quingentis, ne fcio profectó, quónam modo Indicum rbeum à Scenitis $\mathrm{P}$ artho= R hei Barbori- rum populis Sceniticun dici poßit. quo fit, ut etiam Fuchsij optnioncm longius fuftinere nequeam. Ad bec de Bar= ci nomencla- barici nomenclatura uaria admodum eft recentiorns: medicorum sententia. Quandoquidcm funt qui uelint fic dictum tura. à Barbaria Apbrica prouincia, fic unlgariter appellata, ubiolin Carthago clarißima habuit fedem. Horumopinio= nem fequitur Fucbfius, quodd fcripfertt libro primo de compofitione medicamentorum, id uerum fuiffe Rhabarbari= cum, quod fuperioribus annis fecum adduxere milites, qui cun Carolo Imperatore Tunetcm expugnauere. Alij Bar= so baricum nocaricredunt, quód à Barbari India ciuitate, que intra Indi flunij fuces eft fitto, deuebi cenfent, rati In= dicum, er Barbaricum idem effe. Alij autem à Barbaria Erythrsipelagi infuld, fic appellatum exiftimant, quòd In= die naues, ac liburnicic aromata de ferentes magnum fue mercis ibi iampridcm habuerint cmporium, à quo per Arda bicum Iinum, traiecto prius angufto mari de Mecha, aromatum omne genus in Aegyptum per aliss deferebatur natio= nes. Sed aliter fe habet opinio noftra: quippe quód Jemper exiftimaucrim, Rbabarbarum ex Troglodytica Aechio= pia regione ad nos de ferri, et ibi etiam oriri, quód ea regio Barbarica antiquis fuerit appellata. Siquidem inucnio Ga lenium fcripfiffe tum lib.v I. de fimplicium medicamentorum faculiate, tum lib. I I I 1. cap.v I. de tuenda fanitate, gin= giber ex Barbaria ad nos conueli: quod tamen Diofcorides fupcriore libro, $\mathcal{O}$ Plinius lib.x I I cap.v I I. à Troglo= dytis deferri, e in corum regione nafci tradunt. Quinetian reperio, glandem ungucntariam, quam Galenus cx $\mathrm{Bar}$ barica regione adferrifcribit, Diofcoridem libro fequentt in Aethiopia, ubieft Treglodytica regio, or Plinimm libro $\mathrm{x}$ I I. cap. $\mathrm{x}$ X I. Troglodytis nafcipofteritatis memoria prodidiffe . Ex qubus fané liquıdó conftare puto, Troglo= 


\section{In Lib. tertium Diolcoridis.}

dytican regionem, er Barbaricam antiquis unam er eandem fuiffe. Huc preterea accedit alia plinij auctoritas, qui Tibro iam bis citato, cap. $\mathrm{x}$ I X . ubi raritatis cimnumoni canfan reddit, id accidiffe foribit, incenfis fyluis Barbarorum ira. Nan cum, ip fo inibitc/te, oriatur cimanomum in Acthiopia Troglodytis conmubio permift at, non alias utiq; gen tes Barbaras appellafe credimus, quaim Troglodytas. Quamobrcm e myrbam Troglodyticam appcllauit Barbat= ram cap. X V I. ciufdem noluminis. Nce ab re quidem Galcno, or Flinio Troglodyte Barbaripeciatin dicütur, cim

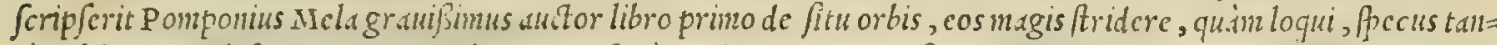

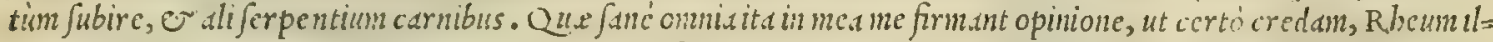
lud ueré effe Barb.sricum, quod $c x$ Troglodytica afferatur regione. Sententiam noftrain magis adbuc confinmare ui

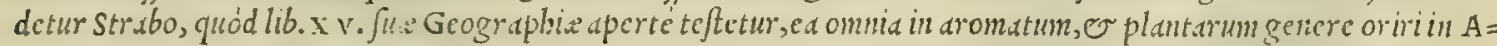

- rabid, $\sigma$ Actbiopix, que in India auftrali proueniunt, quod be regiones fole perfimiles fint. Non placet igitur, ut dic.un liberé quod fentio, Fucbsij obinio ob predict is tum rationes, tum auctoritatcs, tum ctiam quoni.sn apud nullum ufquan legerin ex ea Aplric $x$ purte, qux unlgó dicitur Barbaria, Rba aliquod afferri, quod ibi prouencrtt. Cuin

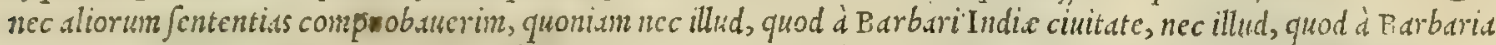
Erythrai pelagi infula adulbiur, recté Barbsrum dici poteft, chm ex India utrunq; petatur, er quid nullus extet

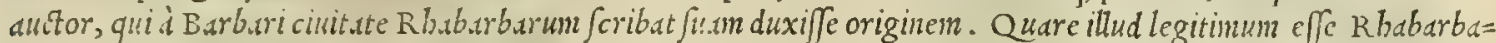
rum mex demum firma fententia eft, quod cx Troglodytica Aetbiopie regione fuerit aduectum. Qusod facilé fortaf= fe Venteti, qui quotamis in Alcxandriam uauigant, feligere poffent ab Indico: quod certó fcian, multa aromatum gener. preter Indica có ex Aetbiopia, e felici Arabia per caroudnds (ut uocant) comportari. Ceterinu, ante=

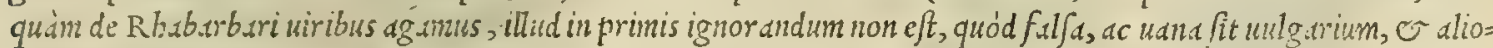
rum quorumlibct opinio, qui fibi firmiter perfudent, Rbabarbarum uiolentum admodun effe medicanentum, o quód propterea à nedicis non exibcatur, nifi in de ploratis feré morborum affectibus. Siquidem ( ut infrius clarif= lime patcbit) inud hud dubié tuio o pueris, o utero gerentibus mulieribus omni tempore, or atute cxbiberi po= tcft. Atqui in ciufmodibominum mentibus inualuit bec inanis opinio : quoniam elapfis temporibus tant. Barbaric e buius radic is cxtitit pcinuria (equli enim cum suro pondere uendcbatur) ut ad pretij magnitudinem cuitandam, edm tunc non dediffent medici, nifi ubi morbos uel mortis periculo, uel diuturnis languoribus non uacare, certis fignis conieciffent. Quo factum fuit, ut paßim bac reprobands opinione ducerentur bomines ad credendum, quód in mor= bis curand is ualentißimum, ino uiolentißimum omnium medicanentorum efet $\mathrm{R}$ habarbarum. Huius uiresceteris diligentius, latiusq́; de fcripfit IIefues, fic inquiens. Rbabarbarum innocens, clemens, or excellens eft medicamen= tum, multas dotes medic amento purgante nuximé expetitas complexum. Pracellit in omni genere Indicum, quod re 30 cens fit, colore fubnigro rufis cente, ponder of un, quanus fua fubftantia rarum, eo quód cim frangitur, ru, 0 , er glau co colore alternante fpeciatur : item quod manfum croceo inficit colore. Adulteratur autem, quod onnino te ani= maduertere cautius oportet, boc modo. Accipiunt impoftores Rbabarbari multum, totum $q$; aqua macerant quinq; diebus, exemptum deinde ficcant, fubtractaq,; ui, or quafí anima uendunt. Aquam ueró, qua maduit, igne, uel fole fimiliter ficcant, o in paftillos conformant ad regales ufus. Fraus cognofcitur, quod fyncerum non uchementer ad= Jtringat, $\int u b f$ fantia rarius fit, e colore croceo inficiat. Adulteratum ueró contrà fe babet, coloris interni narieta tem dinifit, $\sim$ fubnigricat. Calcfacit, ac ficcat fecundo ordine, etfinonnulli primo tantiun dicant. Conftat tum $a=$ queis, tum terreis qualitatibus, que adftringentem ei facultatem tribuunt, er eius fubftantiam conferuant. Eft $\odot$ acreis raritatem $\int u b f$ tanti.e conferentibus particeps. Nec igneis quidem expers eft, à quibus amaritudinem, concur= rentıbus etian terreis qualitatibus, acquirit. Ac ip fa terreftris qualitas in imo delitefcit: ignea ueró in fublime fer=

40 i:ur . quo fit, ut cius diuidantur qualitates cum aqua, aut uino perfunditur. Operatur autem in obftructionum affecti= lis igne is tantuin facultatibus: terreis ueró, ubi adfrictione fit opus. Omni penitus noxa uacat, daturq́; omni tem= pore, $\odot$ atate, adeó ut pueris atate tenellis, o pregnantibus facilé exbiberi poßit. Auget $\mathrm{R}$ babarbari uires caprinum ferum, uel fi maceretur intubi, uel apij, aut plantaginis decocto. Nullimemoria excidat, quin femper Indica nardi tantillum ip $\mathrm{f}$ commifceatur, cim maximopere conferat. Addendum etiam femper erit uini albi odorati modi=

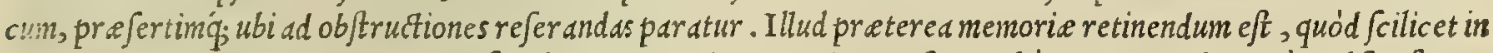
adulterato nulla deiectoria reperitur facultus. Synceri macerati expreßio probé conuenit, ubi tantim abfterfione,

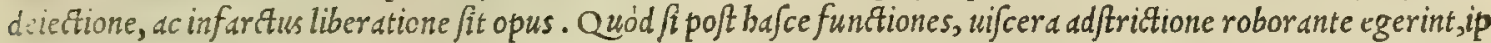
Juin quidem in puluerem contritum exhibendum fuerit. At illud, quod igne torrefcit, uebementer operatur, ac uebe= mentius quod comburitur. Purum, felectum, ac fubftantia compactum, ab $\int_{\text {; }}$ iactura in tenuem puluerem conteri po so tc, $\{$. Rarum ueró, ac laxum minimé, quoniam ex uebementi, ac longiori contritione facilé euane cit, ac deperditur. P.efoluitur item eius uis, cum aqua, uel uino decoquitur. Deijcit Rbabarbarum non modó bilem, fed etiam pituitam ib fun. Eiq; propria facultas ineft cum abfergendi, tum etiam roboranditam uentriculum, quàm iecur, er eorum compunctiones amouendi. Clarificat $R$ babarbarum fanguinem, obftructiones aperit, ac omnes pariter affectus fa= nat, dilos generant obftruationes: nempe aquam intercutem, regium morbum, lienis craßitiem, ac diuturnas febres. Sangiunem reijcientibus, ac eius à qualibet parte manationibus qualitate, ac facultate fubftantie prodeft. Datur $e=$ tiam ab alto denolutis, ruptis, e tan interné, quàm externé fract is maximo iuuamento, pra fertunǵ; fi uino auftero drachme pondere commifceatur, addito fyncer mumia momento, ac etian erythrodaniradicis tantundem. Singul= tientibus opiculatur, $d y$ fenteriam cobibet, prefertim quod igne fit torre factum, addito tamen adfringente uino, er plantaginis fucco. Vindicatur à carie, es teredine anis tribus, uel quatuor. Verum fi cera oblinatur, uel in mel=

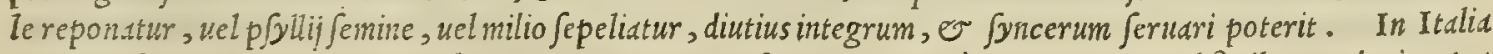
quogue $\mathrm{R}$ babarbarum quoddan in hortis, $\mathrm{E}^{\mathrm{N}}$ uiridarijs paßim reperitur, à peregrino non abfimile quod etiam ( $u t$ 


\section{And. Matthioli Comm.}

Nomina. à medicıs fide dignis mibi relatum eft) bilem deijcit, quanuis peregrino fit longé infirmius. Radix, que p̋o, er geñov Grecis, Rbaponticum Latinis appellatur : Arabibusz Raued, feu Rduend: Italis, Rbapontico.

\section{GENTIANA.}

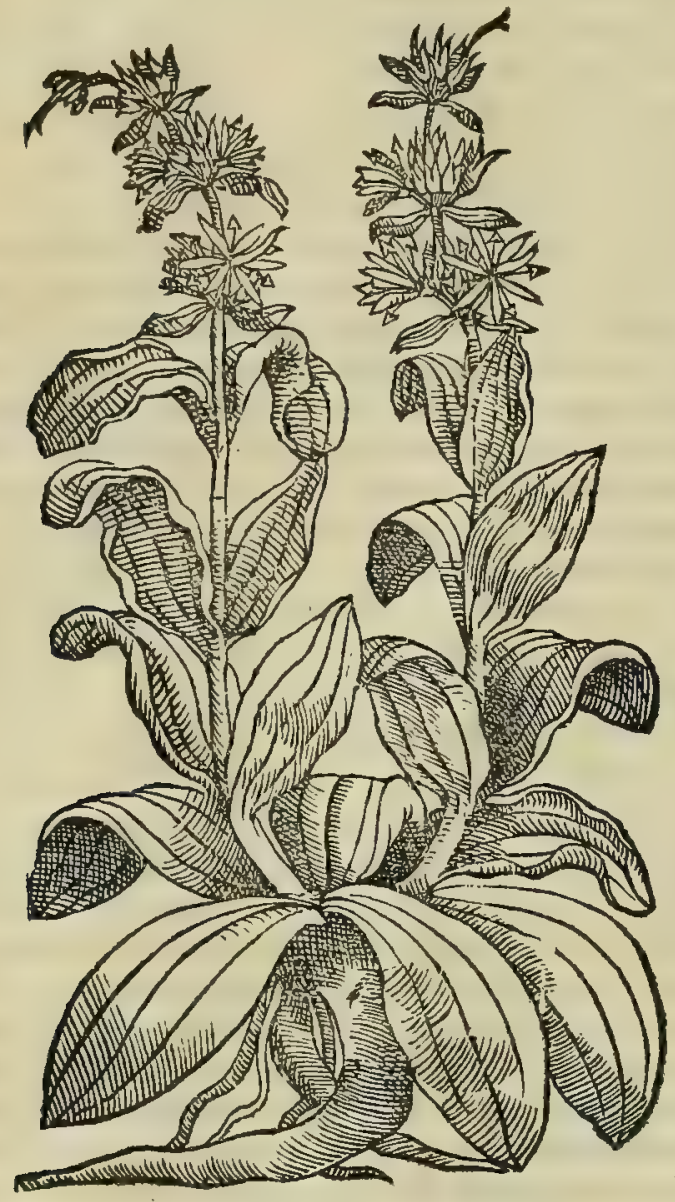

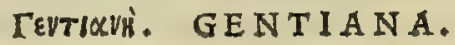

GENTIANA MINOR.

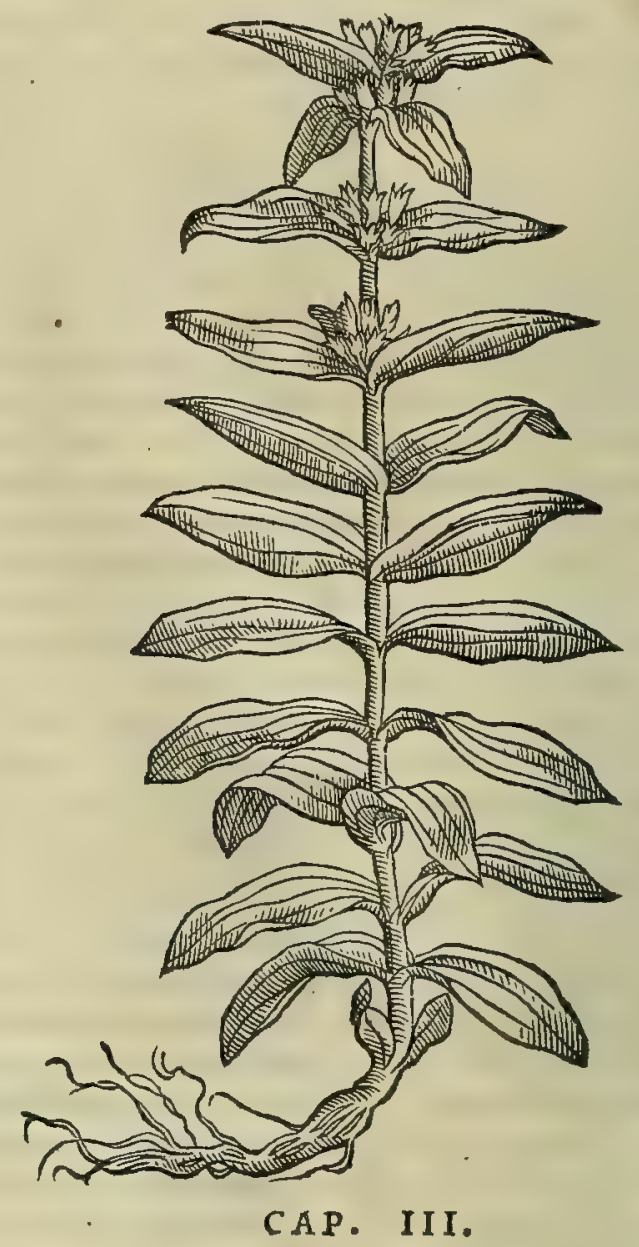

30

G E N T I A N AE inuentio prima afsignatur Gentio Illyriorum regi, à quo cognomentum habuit. Folijs partim proximè radicem, iuglandi, plantaginíve fimilibus, fubrubris: partim à medio caule, \& præertim iux ta cacumen, paulùm diffectis . caule cauo, \& læui, digiti crafsitudine, geniculato, \& ex interuallis maioribus foliato, binûm cubitorum altitudine. femine in calycibus lato, leui, 40 glumofo, fatis ad fphondilij femen accedente , radice longæariftolochiæ, longa, craffa, amara. Nafitur in fublimibus montium iugis, vmbrofis locis, aquofisq́ue. Vis radicis excalfactoria, \& adftringens : contra morfus ferpentium, duabus drachmis, cum pipere, ruta, \& vino pota auxiliatur . Extracti fucci drachma, laterum doloribus, \& ex fublimi deturbatis, ruptis, \& conuulfis prodeft : hepaticis, \& ftomachicis, pota cum aqua fubuenir. Radix collyrij modo fubdita, partus eijcit:impofita, vt lycium, vulneraria eft, \& ulcerum cuniculatim depafcentium medela. Succus præcipuè eodem effectu prodeft : oculis inflammatione laborantibus illinitur : pro meconio collyrijs acribus immifcetur. Radix vitiliginem abfterget. Succi extrahendi ratio hæc eft. Contufa radix quinque diebus aqua maceratur : poftea in eadem tantifper decoquitur, dum extent radices : \& vbi refrixit aqua, linteo excolatur : mox difcoquitur, dum mellis crafsitudo fiat, fictilique reconditur.

Gentianæ cófideratio.

G E N T I A N A planta eft uulgaris notitic. Frequentißima excelfis Tridentinis montibus prouenit, prefer = timq́; in Ananijs, in quorum cacuminibus Jepius eius effodi radices bracbiali craßitudine, o bicubitali longitudine . Hanc à Gentio Illyriorum rege inuentam, unde illi nomen, non modó Diofcorides; fed aliorum etiam ueterum monu menta teftantur. Plinio lib. X X v. cap.v I I. ea eft omnium preftantißima, qua in Illyrico nafcitur, ubi fortaffe pri= Gentiane ui- mim inuenta eft. Gentiane uires paucis admodum perftrinxit Galenus lib.v I. fimplicium medicamentorum, fic res. $\quad$ inquiens. Herbe Gentiana radix ualde efficax eft, ubi extenuatione, purgatione, abfterfione, obftructionis libera= tione opus fit. Nec mirum, /i hac poßit, cum impenséfit amard. Hec (ut Auicenna dit) excalfacit ordine tertio,

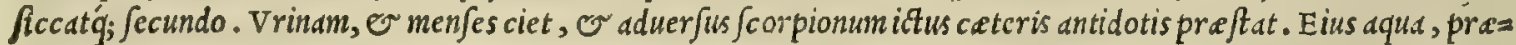
fertim qua uafe duplici balnei uapore uitreis organis elicitur, fibres (ut ego fapius expertus funn.) ab infarctu tum uifcerum, tum uaforum excitatas mirificé peilit . Alui tine as necat, maculas q́; in facie quale $\int c u n q$; detergit, fie ea frez 


\section{In Lib. tertium Diofcoridis. $\quad 347$}

quentius indcule abluantur. Eft preterea quedam uulgaris etiam planta, aliquibus CR V CI A I A dictu, que non Cruciatx con paruam cum Gentiana cognationem habere uidetur: quandoquidem E notis, o facultatibus illi plurimum refpon= fideratio. deat. Vide eos, non longe aberrare crediderim, qui banc Gentiandin minorem appellauerint. Hec in incultis pre= cipue loc is nafcitur, caule rotundo, dodrantali, ac etiam maiore, in cacumine rufefcente, paribus feré interuallis ab ino ad fummum geniculis inter feito : é quorum fingulis alis bina prodeunt folia fuppinguid, longa, unlgaris dicte Sa= pondrix emula, Gentime foliol is in fuminitate erumpentibus finilia. Flores, qui purpureo colore nitent, in fum= mo circum cuulem in orbcm exeunt. Radix illi alba, longa, amarißimo guftu, locis pluribus ab utroq; latere crucis inftar perfor ata: unde illi Cruciate nomen indiderunt. Sunt etiam in boc genere dux alia plante: : fed longé mino= res, tenuibus radicibus, ec caule admodum paruo. Harum, or predicte radices recentioribus magnis laudibus effe= uires.

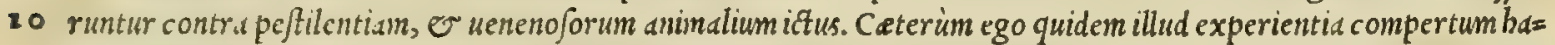
beo, quod radice tufa, or uentri emplaftrimodo impofita, uermes, qui in inteftinis fuerint, procul dubio necantur:

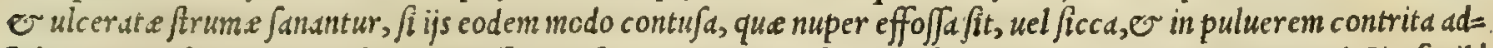
bibcatur. In fumma non defunt, qui afferant, bas ca omnia preftare poffe, qua Gentiana quod ex predictis facile. probaripotcft. Anamienfia rura Cruciatam uulgó uocant Pettimborfa. Ex quo quis conijciat, $f i$ iubet, hanc illis ins digenis, corrupta Italica noce Mctti in bor $\int a$, ideo Pettimbor $\int a$ nominari, quód to tuiribus commendetur, ut perinde. ac gemmat, crumenis afferuarimercatur: aut quod tantum uiribus excellat, ut medici ea utentes ingentem argenti,

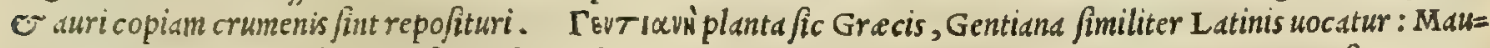
ritanis, Gentiana, Genthiana bafilica, feu Bafateca: Italis, Gëtiand: Germanis, Entzian, Bitter uurtz, fiue Creutz uurtz: Hipanis, Gentiana: Gallis, Gentianne.

\section{ARISTOLOCHIA ROTVNDA.}

30

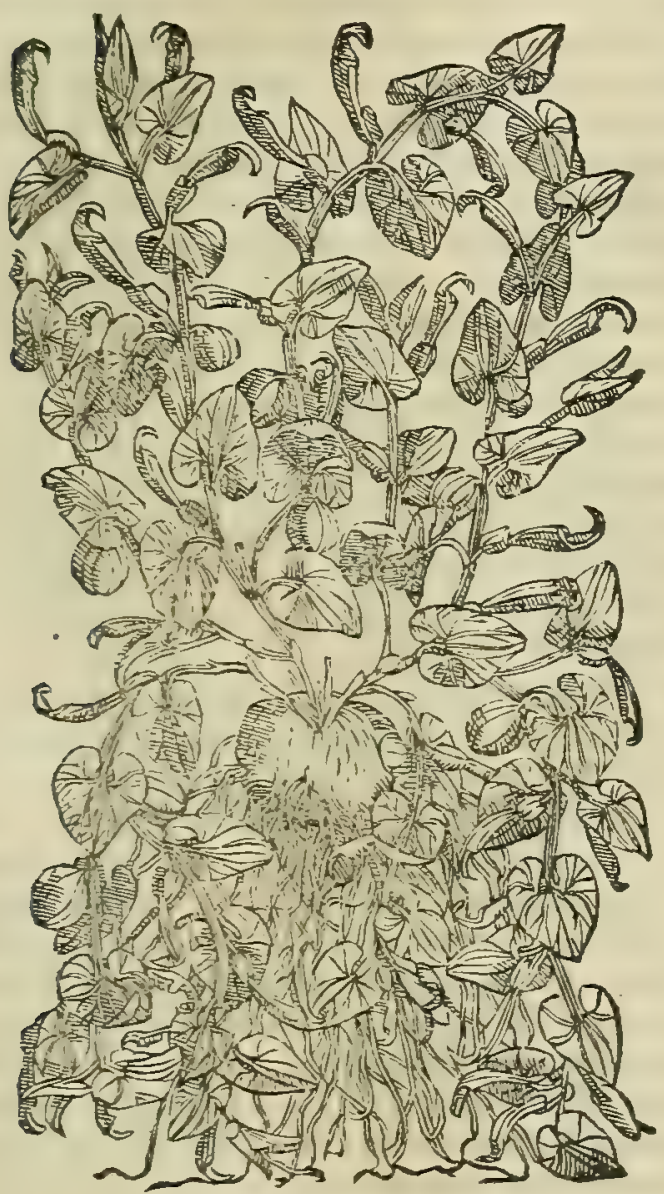

A'pisodoxí. ARISTOLOCHIA.
ARISTOLOCHIA LONGA.

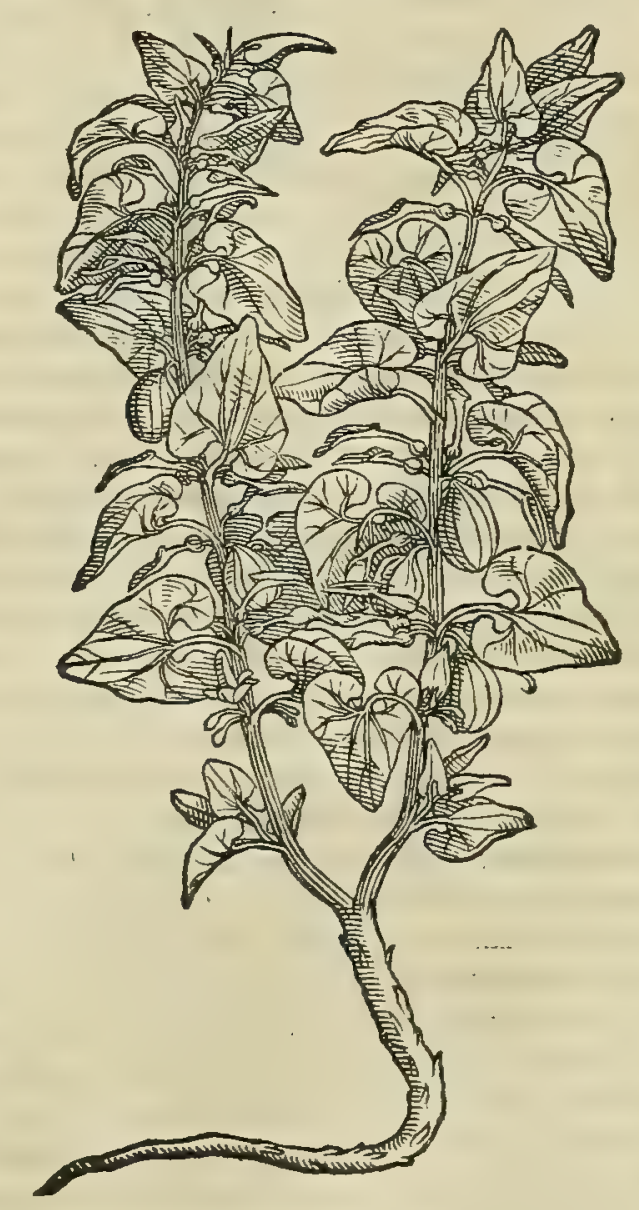

CAP. IIII.

Nomine.

Cruciate

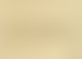

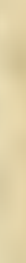




\section{And. Matthioli Comm.}

Eft etiámnum tertia longa, qux clematitis vocatur, ramulos habens tenucs, refertos folijs fubrotundis, minori femperuino fimilibus : flores rutæ: radices longiores, tenues, craffo cortice, odoratoq́ue veftitas, priuatim vnguentorum Ipiffamentis conuenientes. Rotunda cæteris venenis refiftit. Longa verò aduerfus angues, \& venena, drachmæ pondere ex vino bibitur, \& illinitur. Pota cum pipere, \& myrrha menfes, partus, \& omnia vuluarum onera eijcit : eadem efficit fubdita in peffo. Rotunda ad eadem pollet: infuper fingultibus, fufpirijs, horroribus, lieni, conuulfis, laterum doloribus, pota cum aqua, fingulariter auxiliatur. Aculeos, \& fpicula extrahic: ofsium fquamas illitu adimit: vlcera putrida exeft, \& fordida expurgat : caua cum iri, \& melle explet : gingiuas, \& dentes extergit. Clematitis ad eadem pollere creditur: viribus tamen inferior eft.

Arifolochix : A R I S T O L O C H I AE, quam officine Arifologiam uocant, triaftatuuntur genera, nempe rotunda, lon= confid. gd, o clematitis. Hec rara admodum, o paucis nota: ille ueró omnibus feré rei berbarie ftudiofis notißime. Que rotunda uocatur, et/i non ubiq; in Italia proueniat; in agro tamen Goriticnfi plurima, pulcherrima q́; nafcitur, pres= ftanti odore. Vtraque flores edit, of fructus : qui in long a pyri imaginem referunt, funt'́; iuglandıbus longé maio= plinij, \& Leo res: in rotunda ueró rotundiores, pauloó; minores ppectantur. Qua in re non potui non maximé Plinium admira= niceni laprus. ri,quód lib. $\mathrm{x}$ x v.cap.v I I $\mathrm{x}$.utranq; ferre bacculas paruas ueluti cappares tradiderit. nifi quis illud dixerit, quòd $\mathrm{Pli}$ nio contigerit, Ariftolocbie utriusq; fructus uidife, priusquìm ad fummum adoleuiffent. Sed certé is eodem in loco excufari, meo iudicio, non poteft, quin manifeste ballucinatus, o Grecifermonis non admodum peritus deprebenda tur, cum Ariftolochice nomen dediffe grauidas tradat. Quandoquidé non ab utero gerentibus mulieribus, fed ì puer= peris Ariftolochia ( ut Diofcorides fcribit) id nominis fibi comparauit. Cuius rei non modó indicium prabet nomen 20

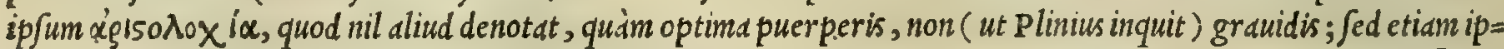
fius facultas, que ad remorantes à partu fecundas, menfesq́; ciendos magnopere commendatur. Quapropter fuerit hec pregnantibus procul dubio exitiale potius, quàm falubre medicamentum, cim ea fané omnid, que fecundas, or men $\int e s$ educunt, faetum ettam trabant, 0 quandog; interficiant, prefertim cim fuerint amara A riftolocbie modo. Nec minus pretered Leonicenum uirum alioqui noftre atatis doctißimum, fatis admirari polfum, quodd dum nimio fortaffe aliorum errata corrigendi ftudio, uel auiditate ductus, de cyclamino, $\mathcal{O}$ ariftolocbijs Plinium accufat, in ean dem, in qua Plinius, foue dm ceciderit, afferens cum Plinio Ariftolochiä à pragnantibus fibi nomen adinueniffe. Quod ne fine auctore pronunciaffe uideretur, Diofcoridem quidem adducit, fed eius biftoriam, quantum equidem fentio, Opinio quo- corrumpit, ac peruertit. Sunt é recentioribus Cordus, Adamus Lonicerus, o monachi illi, qui in Me fuem cömen= rundä repro- taria edidere, qui fibi certó perfuadent, eam effe Diofcoridi Ariftolochian clematitim, qux officinis omnibus paßim 30 bata. longa cognominatur : argumento quód bac radices proferat admodum longas, o farmentorum modo pratenucs. Quin $\mathrm{C}^{\mathrm{u}}$ u fuam tueantur, ac magis roborent fententiam, boc in loco Diofcoridis codicem omnino deprauatum effe

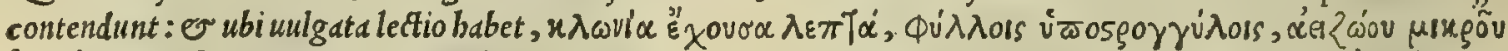

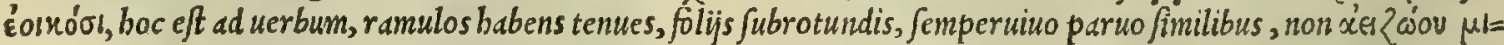

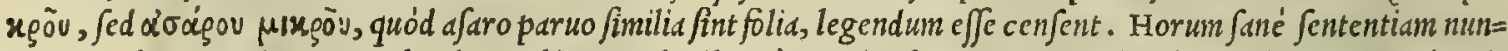
quam probare potui, neq; probandan arbitror, pluribus cim rationibus, tum auctoritatibus adductus . quandoqui= dem Oribasij lectio aliter non babet, quìm communis hac Diofcoridis, nec aliter legunt Serapio, o A A uicenila. Id quod maniffté oftendit, hoc in loco Diofcoridi nulldm fubefe inendam. Adde, quòd cün unum tantün Diofcoridi fit afarum, nec minoris afari is ufquam, quod legatur, meminerit, abfurdum fané uideretur, quód minori afaro Ariftolo= chiam clematitim comparaffet. Accedit er alia ratio, quód cum uulgaris Ariftolochia longa rute flores non edat, clematitis effe non poteft. Praterea fi Diofcoridislectionem accuratius perpédamus, nil aliud effe uidetur longa of= ficindrü, quàm longd Diofcoridis : aut fortaßis eius pecies, cuius nulld, quod extet, ab antiquis facta fit mentio. 2uip pe quod proferat hec folia longiora, Latior ág, quam rotunda: ramulos dodrantales: florem graniter olentem, qui fructum edat pyri modo turbinatum. Nam quód fructum ferat clematitis,non fcribit Diofcorides: nec folia longa, la= taǵ, ut uulgaris habet Ariftolochia, fed fubrotunda, er minori femperuino fimilia. At fi contrè dixerit quipiain, lon gam uulgarem Diofcoridis longam non effe, quoniam flos illi purpureus non fit, fed melinus, or radix non palmaris, nec digiti cra fitudine, fed longior admodum, e longé tenuior. Huic facilé repponderi poterit, id locorü regionumǵ;; uarietate euenire poffe, o quòd natura cum florum coloribus in quàm plurimis ludat: quód $\dot{q}_{\text {; }}$ uidimus etian nos Ari= ftolocbie long plantam à Calabris allatam, radice (ut in theriacis f cribit Nicander) cubitali longitudine, pollicari craßitudine : cuifolia erant, qua à 1 oft trate longa nullo difcrimine differebant. Ad hac Clematitidis radix Diofcoridi, so or Plinio craffo contegitur cortice: quod tamen in longa officinarrum, noft rateq'; non uifitur, ciun tenui cortice per = petuó ueftiatur, odore potius graui, quam odorato. Quamobrem inclinare nunquam potuit animus, ut crederem, $A=$

piftolochis. riftolochiam longam, cuius hic effigiem appinximus, effe clematitim. Sed potius eó deductus fum, ut fupicarer banc fortaffe effe Piftolocbiam fic Plinio uocatam, quód e ip fa puerperis commendetur. Nam preterquim quód bac illi quarto Ariftolochic generi a Bignetur, tenuior eft, quadm clematitis, denfis radicis capillamentis, iunci plenioris craf= Fitudine. Illud mibi fufpicionem auxit, quód uiderim etiam praeter hanc aliam, que radice palmari, $\sigma$ craßitudine di gitali conftabat : fed in omnibus alijs partibus alteri adeó perfimilis, ut nullam inter eas intercedere differentian com

Alia opinio pererim. Sunt preterea recentiorum quidam rei berbarix o ftudiofi, o periti, quibus per $f u a f u n$ eft, non tamen refutats. fine aliqua ratione, quód Ariftolochie longe preter clematitim duo babeantur genera: quarum altcra fit radice ( ut Diofcorides inquit) digiti craßitudine, $\mathcal{\sigma}$ dodrantis longitudine : altera uerò tenui ac longiore, qua (ut aiüt) ab Andro

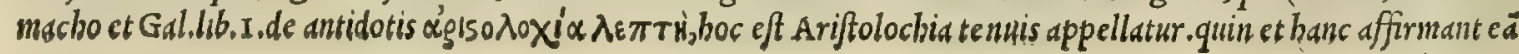




\section{In Lib. tertium Diolcoridis.}

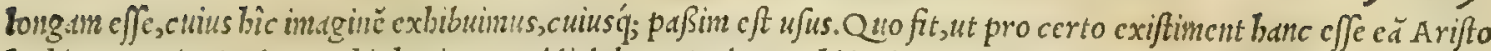
Iochiam, qu.e in Andromaclit theriacum addi debcat, Andromachi iunioris, et $\mathrm{D}$ amocratis teftimonio innixi, quód if in theri.ucs cöpofitionc buiufce tenis t.1ntum meminerint. Id quod (ut dicunt) pre fe forre uidctur, alterü etianmum ip= fius Ariftolochix longe genus cffe pr.eter clematitim, radice conftans tenuiorc ac longiore. Hoc autem comprobatiu

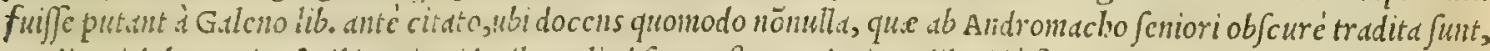
explicuri dcbesnt, itaf fribit. Siquid adhuc aliud fupereft, quod minus dilucide fit ab Andromacho feniori clegiac is

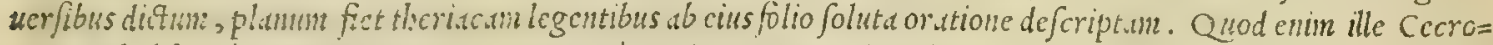

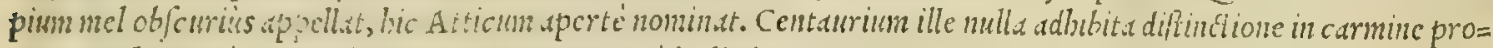
munciat, lic tecó in profateme apponit, eo quéd aliud quoque ecntaurium extet craflum appcliatum. Idem e to in ariftolocbia ficit, cum prater tenuem ariftolochian, alia quoque repcriatur, que craffam radiccm babeat, er rurfus tertid, que rotund.un. hatcenus Gallenus. Qübus nimirum uerbis illi credunt fuan fatis firmaffe fententian. Sed ego quidem aliter fentio, wi qui putem, Arifolochian tenuem non aliud Andronacbo es Galeno fuife, quàn clematitim cognomisatam. Etchin ut onittam, quód Diofcorides es Gdenus non plura, quantum inucncrin, quam tria Ariftolochix gencr.s commenorant, nempe rotumdan, longam. Or clcmatitin; clcmatitis priuatin a Diofcori=

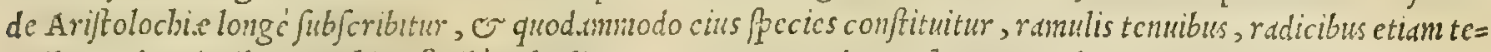
nuibus ac longioribus. Vt hinc ficile nobis lice at conijcere, Andromatbum o Galcnum non aliud fup:adicto loco per tenucm Ariftolochism intcliexife, quàsn clematitim. Adde quod $f$ ad omnium qualitates $\mathrm{E}$ facultates pectes, fanc clcmatitis dignior cft, qux in theriacam recipiatur. Hec chim radicem babet, Diofcoride tefe, cortice odo=

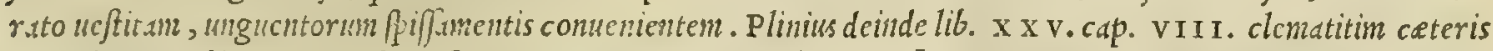
20 pretulit ijs uerbis. Tertiun !ongifina tenuitatis, uitis nouelle, cui fit precipua uis, que clematitis uocatur, ab alijs Cretica. Et pauli pojt iden ait. Odor omnium medicatus, fed oblonga radice tenuioriq́; gratior . bae ille. Qui= bus utique adfipulariwidetur etion Galcnus libro v I. fimplicium medicamentorum, ubi de Arifolocbiarum uiri= bus diffcruit, ut infrat patebit in earum commentatione. Quare non eft, meo quidemiudicio, afferendum, quod Ari= folochis $\lambda \varepsilon \pi T$ \& Andromacho o Galeno fit aliquod quartum Ariftolochie genus ita uocatum . quandoquidem $\lambda \varepsilon=$ $\pi T$ ' bic nullum facit per $\int e$ genus: neque folim tenuem indicat, fed etiam minorem. atque certè in longarum gene= re buiufmodi eft clematitis. Cetcrim . A riftolochia Gracis $\lambda \in \omega T H$ nominata effet aliud genus per $\int e$, neceffariỏ

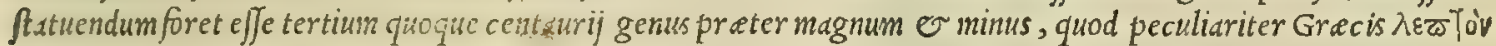
nocatur. Sed hoc dupliciter fal um effe conuincitur. Primó quód apud Diofcoridem, Galenum, aliosíq; antiquiores, qui de plantarum biftoria ac uiribus fcrip fcrunt, nufquam plura, quod equidem legerim, quàm duo centaurijgene= 30 ra fcripta reperiantur, fcilicet maius or minus. Secundó quód conftet, Plinio lib. $\mathrm{x}$ x v. cap. v I. centaurium co= gnomine lepton nullum per $\int e$ genus effe, $\int e d$ ea appellatione illud tantim centaurium de $\int c r i b i$, quod à Dio fcoride $\sigma^{\circ}$ Galeno minus appellatur. quinctiam idem de buius centaurij uiribus ea omnia tradidit, que illi centaurio minori red= diderunt. Sed quid tot uerbis opus erat, qubus noftran tueremur, ov aliorum refilleremus fententiam c cum buic difficultatifatis feré facere poßint uerba ipfius Diofcoridis, quibus Ariftolochix clematitidis radices expreßit in

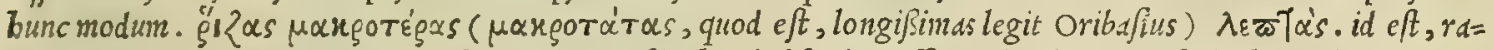
dices longiores, tenues. Vt uel ex his intelligi poß3it, haud abfurdun effe, quod aliquis A rifolochian clematitime= tiam tenuem nominet, quemadmodum ab Andromacho feniori, ov iuniori uocatan fuife exiftimamus. Ex bis itaq; omnibus colligendum effe arbitror, quód Ariftolocbia tenuis dictd ab Andromacho, non fit genus diftinctum ab alijs, fed eadem cum clematitide: $\odot$ quèd Jub Ariflolocbia tenuis nomine clematitim intellexerint Andronuchus, $\mathcal{G} \mathrm{Gd}=$

40 lenus. Erit igitur, mea quidem Sententia, Ariftolochia clematitis, utpote tenuior, odoratior, $\mathcal{O}$ praftantior, in theriace compofitionem addenda: non autem illa longa, quam bic depictam dedimus. Que tamen à nobis, forté rectius, Plinij Piftolochia cenfetur, ut fuprà dictum eft : aut certé aliud Ariftolochie genus ueteribus incognitum.

Veruntamen Fuclyfius medicus clarißimus, fuis de plantarum biftoria commentarijs, aliam plantam Piftolochiam Fuch. opinio putat : que tamen (cius pace dixerin) a Plinij Piftolochia prorfus ablorret. Eft enim Piftolochia Fuchfio mollis in uniuerfum planta, que uere prino und cum chelidonio exoritur, or maio, uel ad fummum iunio contabe fcit. Cree= fcithec tenellis, fubalbidiś,; folijs, coriandro, uel ranunculo primi generis proximis: radice tuberofa, inferiori parte feßili, Juperiori ueró monticuli inf tar elata, intus ubique concaua, nigro exterius cortice, buxea interius pul= $p a$, odore ariftolochie, $\in$ guftu anard. Quapropter Germanis hac, quód uera Ariftolochia rotunda fint deftitu= ti, eius uicem infeliciter explet. Non tamen ob id cenfendum eft banc effe Piftolochiam, qua à Plinio defcribitur. Si= so quidem bac illi tubero $\int$, o inani radice non conftat: $\int e d$ clematitide tenuior eft, denfis ( ut dictune eft) radicis ca= pillamentis, iunci plenioris craßitudine. Sed rectius, ueriusq́; quantum equidem fentio, dici poffet, hanc plantam effe Plinio fumarie alterum genus, quod ab eo lib. x x v.cap. $\mathrm{x}$ I I. ijs depingitur uerbis. Alia eft Capnos frutico $a_{2}$, pretenerd, folijs coriandri, cineracei coloris, flore purpureo. Nafcitur in hortis, es fegetibus. De hac etiam Ä̈= tiun loculum furffe exiftinauerim lib. X. cap. I I. in curatione obftructi iecinoris, ubichelidonij Capni meminit, eo quód (ut diximus) unà cum chelidonio primum erumpat birundinum aduentu, ut libro quarto latius differemus, ubi confulto fumarix biftoria tractabitur. Porró quód buius planter rdix Ariftolocbie rotunde uicem fupplere pof= fit, atque in buius penuria illa utiliceat, adnotatum reliquit Fucbfius in libro de componendis medicamentis, quem

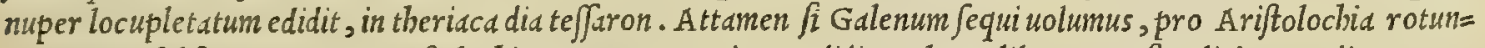
dalongam fubftituemus. Arifolochie generamemoria prodidit Galenus libro v I . fimplicium medic amento= rum, ubi corum uires explicauit ijs uerbis. Arifolochie radix ad medicationes utilißina eft, amara, or fubacris. sed exillis onnium fubtilißina eft rotunda, ad omnia efficacior. Aliarum ueró duarum, qua clematitis appella=

Ariftolochix uires ex Gal. \& Mefue. 
tur, fragrantior eft. Itaque ea dd unguenta utuntur unguentarij: Sed ad fanationes infirmior. At longaminus quidem tenuitat is obtinet, qu.im rotunda, fed nec ip fa inefficax eft: uerum abjtergendi, at $q$; excalfaciendi potentiam poßidet, minus quiden quàm rotunda abftergit, ac digerit, fed non minus cale facit, imó för fan plus quoq; . Itaq; in quibus ufus eft modica abferfionis, commodior eft longd, putd in carnium exulcerationibus, or fomentationibus ute= ri. At in quibus cr.tfum bumorcm ualidius extenuare oportet, illic ufus eft rotunda. Proinde dolores ab infaritu, aut craßstie crudorum flatum natos magis curat rotunda, er picula extrahit, or putredines fan st, or fordida ulcera re purgat, ac dentes, gingiuas q́; candidas efficit. Auxilio eft $\mathrm{O}$ afthmsticis, fingultientibus, comitialibus, podagricis, fi cum aqua bibatur: tum ruptis, er conuul/is, ut fi quod aliud medic amentum, idonea cft. baftenus Galenus. Arifto= lochia uim purgatoriain ine ffe (quod tamen filentio praterierunt Diofcorides, $\mathcal{G}$ Galenus) author eft Mefues, qui

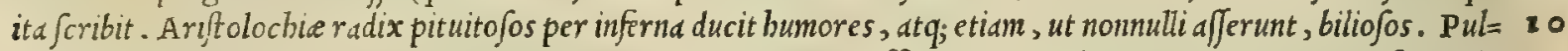
monesn, ac pectoris particulas ab bumorum lentore, ac putredine efficaciter mundat . cutus rei indicium eft, quod

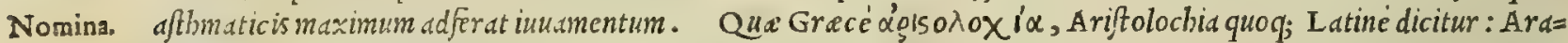
bicé, Zaraund, Mafmocra, feu Zaraued: Italicé, Ariftologia: Germanicé, Ofterlutey : Hifpanicé, Aftronomia: Gallice, Foterlle, aut de la sarafine.

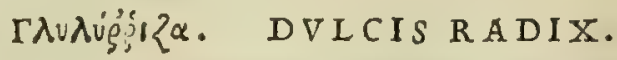

\section{CAP. V.}

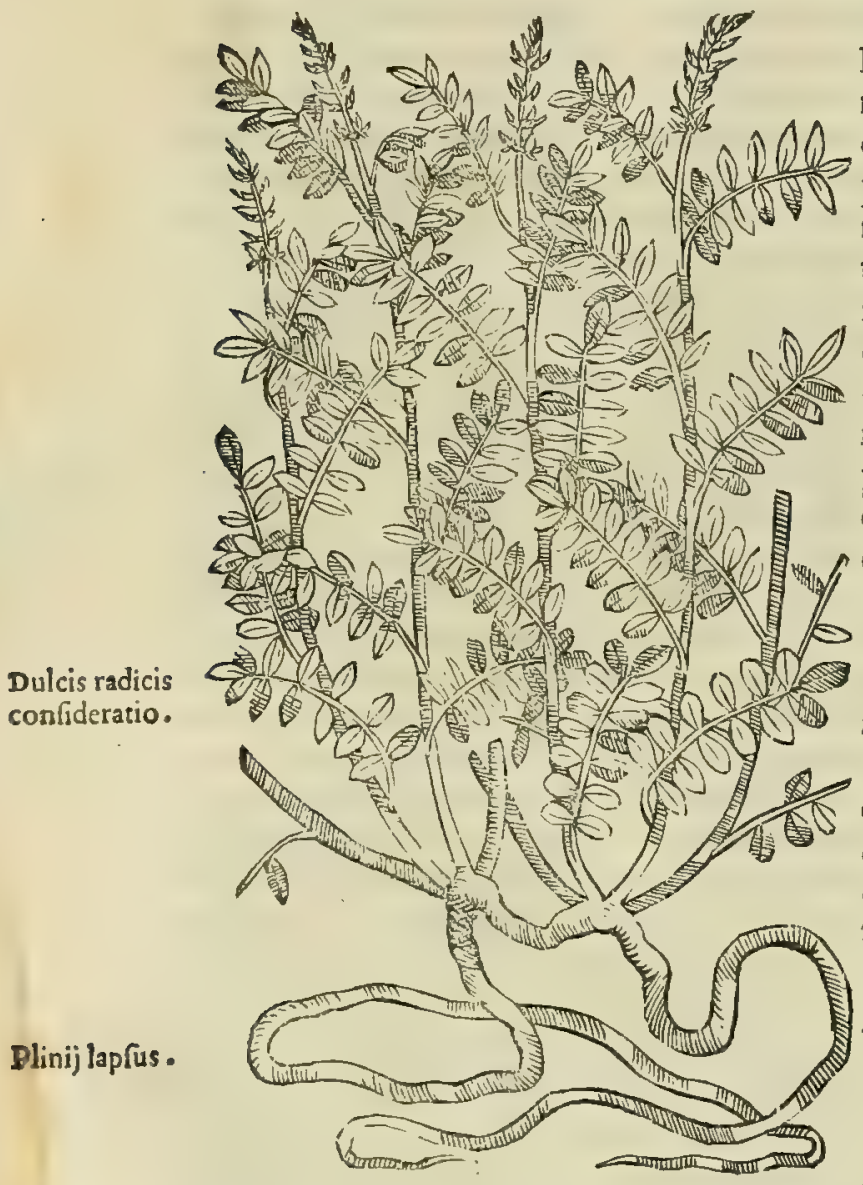

D v l C I s radix plurima gignitur in Cappadocia, \& Ponto. Fruticofa eft, ramis binûm cubitorum altitudine affurgentibus : fclijs lentifci, denfis, pinguibus, ta- 20 ctuque gummofis : flore hyacinthi : fructu pilularum platani magnitudinis, afperiore, qui filiquas lentium modo habet rufas, \& paruas : radicibus longis, ut gentianæ, coloris buxei, fubacerbis, \& dulcibus : qux denfantur in fuccum, lycij exemplo. Is in arterix fcabritia efficax habetur : verùm oportet, ut lingua fubditus eliquefcat : $x$ ftuanti ftomacho, thoraci, ac jocineri conuenit: fanat ueficæ fcabiem, \& renum dolores, cum paffo potus : idem eliquatus fitim fedat : uulneribus illitus accommodatur: commanducatus ftomacho prodeft . Re- 30 centis radicis dccoctum ad eadem cóuenit . Eiufdem farina pterygijs commodifșimè infpargitur.

D v l c I s radix, quam Greci Glycyrrbizam, o offici= ne Grecum nomen corrumpentes, uel potus Barbaros fecute, Liquiritiam uocant, $\sim$ Hetrufci uulgó Regolitia,planta eft pau= cis non cognita. Abundat bac A pulia, pre fertim Gargano mon= te, unde quotannis fuccus in paftillos condenfatus ad nos conue= bitur, er radicum quàm plurimum. vifitur etiámnum in uirida= rijs pluribus locis in Italia, non modó ad pectaculum fata; fed 40 or ad medicamentorum ufum. siquidem radix recenter effo fla, ficcalongé magis preftat, ev origratior in medicamentis habe= tur. Sed non pofjum non ualde admirari Plinium, quód Gly= cyrrbizam inter aculeatas numerauerit plantas lib. X X I I. cap. I $x$. fic inquicns . Glycyrrbiza fine dubio inter aculeatas eft, fo= lijs echinatis, pinguibus, tadu g; gunmofis. Et lib. $\times$ x 1 . cap. $\mathrm{x}$ v.dum catalogo quodam aculeatas commemorat firpes: Spinofarum, inquit, multa pecies. In totun pinofa eft apparagus, fcorpio, nullum enim folium babet. Quadan pinc fa foliata, ut carduus, cryngion, glycyrrbiza, O urtica. I is enim ommbus foligs ineft aculeata mordacitas. hac ille. Cun fit, ut fine controuerfia deci poßst, Plinium Glycyrrhizam minime nouife, cum certé nufquam gentium, quod cquidcm frim, aculeatts folijs proue= so

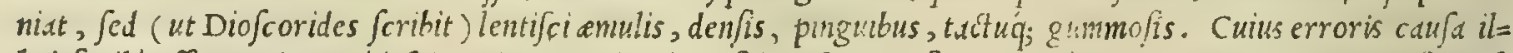
lud facile effe potuit, quodd fui potius Gracicodicis fidem fecutus fuerit, quin rei ueritatem, in quo fortaffe facil, lubricóque librariorum non aduertentium lapfu Éx ive pro oxive fcriptum legebstur: uel quéd orre= ca lingue non exacte peritus uocabulorum, uocumó; fimilitudine deccptus (ut allt quandoque démonftraul= mus) Plinius in boc errauerit. Nam buiufcemodi opinio adeo firniter ueritati coheret, ut facile if quoque deprehendi poßsint à ueritate defcifcere, qui credunt Glycyrrbizam olim ßinis fuiffe predican, fcd nangos nio longicultus edomito rigore pinarum aculcos amififfe, or tandem mitigatam effe: cim ea ctian, quic boc

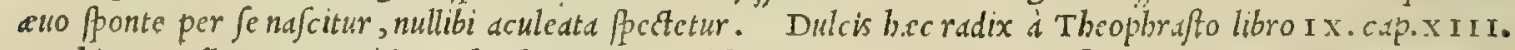
scythica appellatur, co quód scythe bac contenti abfque alio alimentorum prefídio deccm, duodecimq́; dies de= Flycyrhizæ gant. Nam (ut idcm teftatur) circa Meotim paludem plurimanafcitur. Glycyrrbize meninit Galcnushb. vi. u res ex Gal, fimplicium inedicamentorum, fic inquiens. Huius fruticis radicum fuccus in primis utilis eft, fimiliter ut cius radices 


\section{In Lib. tertium Diofcoridıs.}

dulcis, cum leti quad an adftrictione. Proinde afperitates lenire poteft, nec modó in arteria; uerim ctiam ucfica fca bra, id'; temperature mediocritute. Quocirca fucrit fane naturd cius familiaris noftre tempcratura : nam tale monfratum eft effe it quod dulce eft. Sed cime adfriftio quadam adiuneta fit, uniucr fum cius tcmpcramcutum, quan tum ex caliditate, or adftrifitone oft, tcpida potilimim caliditatis fuerit, quaim proxime accedcus ad yimmetrum, fiuc temperatum. Porró quonium tempcric quoq; bunidun eft, quod modicc dulce eft, iure fané ctian fitin cxe ilt= gue ns medic amentum cft, ninirum modtcé lumidum, fimul w bumana natura frigedius. Refert Diof corides, radiccne

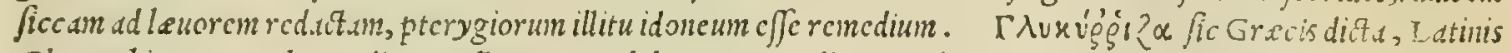
Glycyrrhiza, o Dulcis radix appcllatur : A rabibus, Sus: Italis, Regolitix: Germanis, Leckritz, fuic Sucfzlooltz: 10 Hipanis, Regaliza: Gallis, Rccliffe, feu Reygaliffe.

\section{KeVTxuǵgloy $\mu \varepsilon^{\prime} \gamma \alpha$. CENTAVRIVM MAGNVM. CAP. VI.}

20

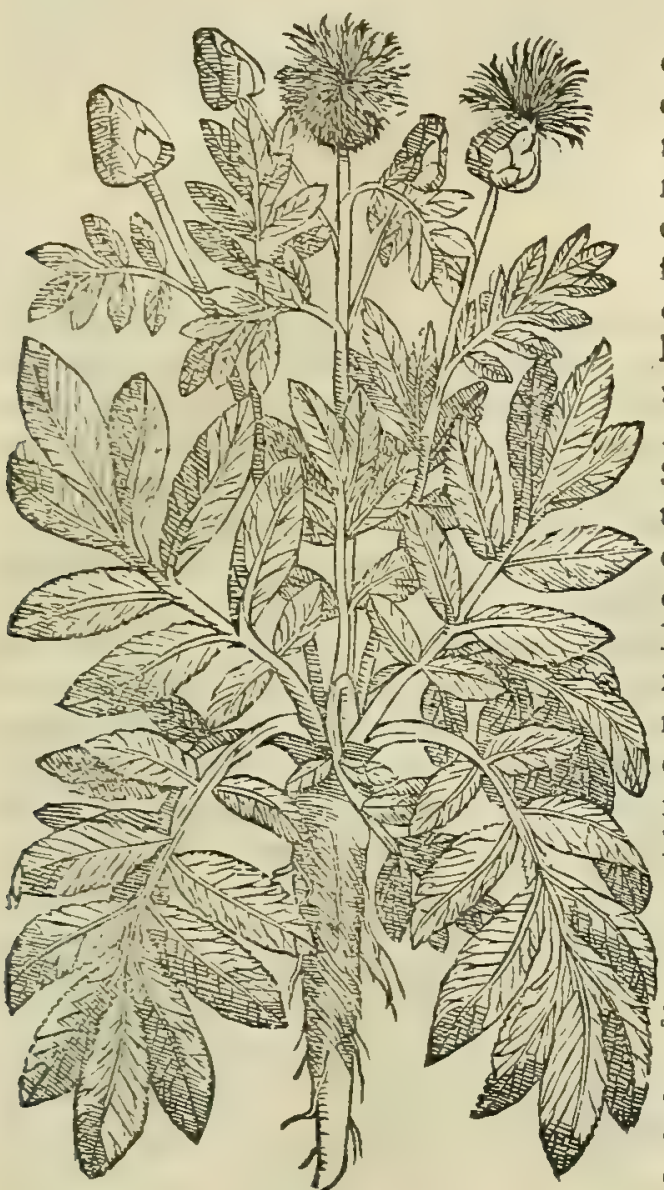

CE N T A V R I V M magnum folia habet iuglandis, oblonga, uiridi brafsicarum colore, ferrata in ambitu: caulem, ceu rumicis, binûm, ’aut ternûm cubitorum, multis ab radice adnatis, in quibus capita, ceu papauerum, in rotunditate oblonga. Flos cæruleus : femen cnico fimile, ceu laneis quibufdam inuolutum. Radix craffa, grauis, folida, tripedalis, fucco prægnans, cum aditrictione aliqua, \& dulcedine acris, \& rubefcens . Amat folum pingue, \& apricum, ac fyluas, \& colles. Copiofifsima eft in Lycia, \& Peloponnefo, in Arcadia, Helide, \& Meffenia, pluribusq́ue locis circa Pholoên, Lyciam, \& Smyrnam. Radix conuenit ruptis, conuulfis, pleuriticis, fpirandi difficulrati, neteri tufsi : fanguinem expuentibus, drachmis duabus tria datur, $f i f e b r i s ~ f i t$, in aqua; cæteris in uino: item ad tormina, \& vulux dolores. Ramenta eius in collyrij formam vulux fubdita, menles, atque partus extrahunt. Succus eadem præftat. Vulneribus prodeft: nam recens tufa, aut arida antè madefaeta , ea glutinat, \& coniungit. Carnes coalefcunt, fi tufa fimul decoquatur. In Lycia fuccum exprimunt, quo pro lycio utuntur.

CEN T A V R I V M magnum ( ut in Rhapontico fupe= rius diximus ) nil aliud, mea quidem fententia, eft, quidm illa infi= gnis admodum radix, quam preterita nuper etas Rhaponticum effe credidit: quamq́; etiam hoc tempore eodem nomine quidam appellant, qui cum imperitis Juperioris atatis errare malunt, quam cum peritis recentioribus uera cognofcere fimplicid me= dicamenta. Caterum contendat licet Mufa Ferrarienfis medi= Brafauoli Lacus clarißimus, radicem, qua R baponticiloco plerunt; officine utuntur, Centaurij magni radicem non effe; is ta= men hac in re decipi (pace eius dixerim) manifefté deprebenditur, cum ea radix, que uulgaribus $\mathrm{R}$ bapontici ui= ccm explet, omnibus fané notis Centaurium magnum reprefentet. Quippe quodd craffa fit, grauis, compactd, tri= pedalis, er rubco fucco pragnans, qui guftui non modó quadantenus fit acris; fed etiam cum aliqua adfrictione dulcis. Adde quodd O folia, caulis, capitula, flores, O Jemina illi pror fus fint eddem, quibus conftare Centau= rium magnum Diofcorides, 0 Galenus memorix prodidere. Ed, que bodie dd nos conuehitur, Gargano pr.t= clarijino Apulia monte numerofa nafcitur : quin $\mathbb{e}$ in alijs Italia locis, nempe in Veronenfi agro Baldo mon=

so te, quem Benaci alluit unda, fed infirma radice, $\sqrt{i}$ ad Apulam compares. Non defunt praterea bac tempeftate reiberbaris ignari nebulones, qui bonis quibufdam eplafiarijs perfuadere contentur, eam plantame effe Centauriuin magnum, qux in aquofis prouenit, caule quadrato, bicubitali : folijs falicis modo longis:flore rubenti, picato, quam quidam pro ly/imachia accipiunt. Neque alio, quod fciam, argumento nituntur, quim quòd hec plantaflore fit rubro, o caule quadrangulari, quemadmodum $\mathrm{e}$ Centaurium minus. Sed quantum ifti hallucinentur, quantaq́;

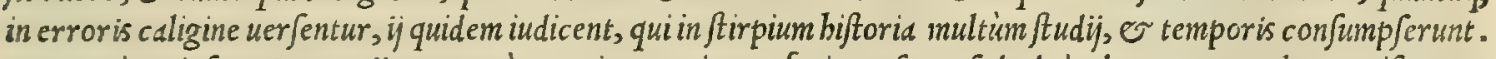

Porró utriufque Centaurij uno tantùm capite mentionem facit Mefues: $\int e d$ adeó alterum cum altero mifcet, dc confundit, ut mir andum non $f i t, f i$ a nonnullis at dtis noftre diligentifimis rei herbarie inquifitoribus acriter fuerit

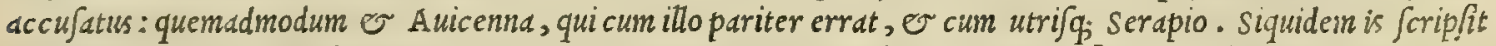
ex auttoritate Aben Mefuai, Centaurij magni radicem lentam trabere pituitam, fimul o bilem, o coxendicum doloribus opitulari. Qux tamen facultates Centaurij maioris non funt, Jed minoris, ut Sequenti capite explicabimus. Ceterum neq; Plinius ab errore uindicari poteft,qui tametfi in Centaurij magnibiftorial lib. $\mathrm{x}$ x v.cap. v I.

Centaurij me gniconfid. plus.

Quorundam hallucinatio. Arabum laplus.

Plinij error. 
in omnibus feré Diofcoridi fub fcribat; in facultatibus tamen erraffe uidetur, quod Centaurio maiori amaritudinem magni meminit Galenus lib. v I I. fimplicium medicamentorum, de eius uiribus iss differcns uerbis. Cent Centaurij Galeno. radix ficut guftu contrarias qualitates, ita in ufu contrarios effectus demonftrat. Guftrititaque acris fimul, adftrin= gensó;; apparet cum leviculla qladdam dulcedine . At in actionibus acrimonia quiden caliditatis opera oftentat, menfes

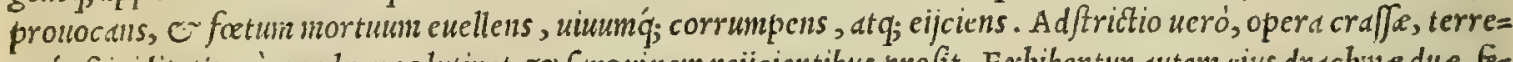
ne i; frigiditatis, cim uulnera glutinet, 0 fanguinem reijcientibus profit. Exbibentur autem eius dracbine due, $f e=$ brientibus qudem cum aqua, fébri ueró liberis cum uino. Porró fecundum omnium fimul qualitatun actionem, ru=

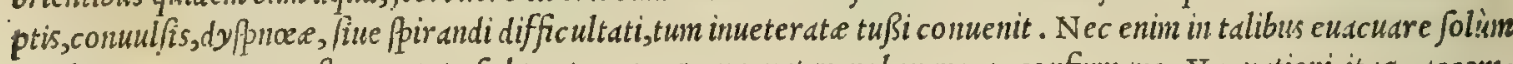
quod preter natur am efi, oportet; fed partem quoq; euacuatam roborare, ac confirmare. Vacuationi itaq; accom= 10 moda eft acriszonia, utiq; cum non fola fit, ac pura, fed aut dulcedini iuncta, aut certé non prorfum amaritudini: $l_{i=}$ quidem uebenentian tunc, atc; uiolentiam, mifta illi temperata quadam fubftantia, cuiufmodi eft dulcis, non obtine= bit. Porró ad ed, que euacuat a funt, roboranda, contrabendag;,adftrictione eft opus. Eadem que radix, o fuccus

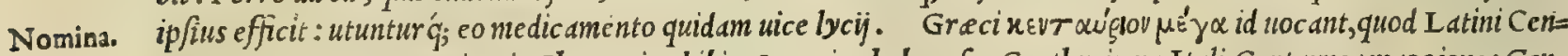
tauriusn magunn : Mauritani, Chanturion kibir, Sacurion babre, feu Cantburium : Itali, Centaurea maggiore: Ger= mani, non fine errore, Reupontic : ut etiam Hipani, Ruipontico : $\mathcal{G}$ Galli, Rhepontico.

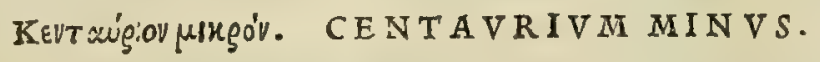

CAP. VII.

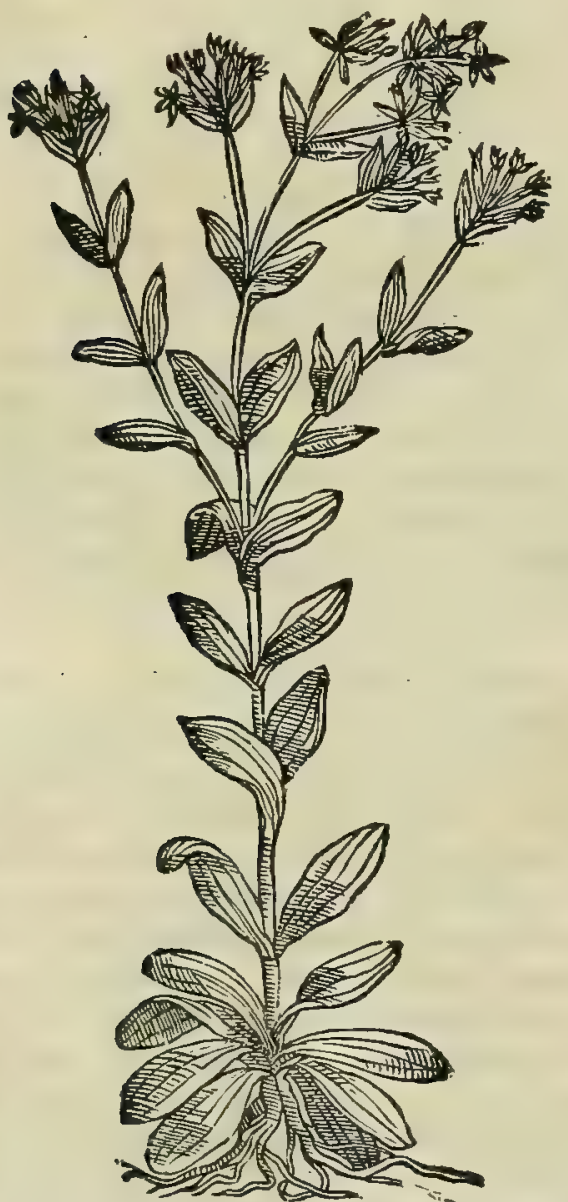

C E N T A V R I V M minus, limnefion aliqui nocaue- 20 re, quoniam rigua amet loca. Herba origano, aut hyperico fimilis, caule angulofo, palmum excedente: flore lychnidis, è puniceo in purpuram uergente: folijs rutx, prælongis, \& paruis : fructu tritico fimili : radice pufilla, læui,\& fuperuacua, quæ guftanti amaritudinem adfert.

Herba recens tufa fuo illitu vulnera conglutinat : uetera ulcera purgat, \& cicatrice obducit . Bilem,craffosq́; humores per aluum exigit, fi decoeta deuoretur. Ius decocti ifchiadicis conuenientifsimè infunditur: trahit enim fanguinem, \& dolorem leuat. Succus oculorum me $30^{\circ}$ dicamentis perquàm utilis : fiquidem cum melle caliginem oculorum expurgat.in uellere appofitus, menfes, \& partus extrahit: epotus peculiariter neruorum uitijs fuccurrit. Succi extrahendi ratio. Legitur herba femine prægnans. \& diebus quinque madefacta, decoquitur, donec fuperemineat aqua: mox ubi refrixit, linteolo exprimitur, \& eiecta herba, iterum decoquitur, ufque dum mellis crafsitudinem habeat. Nonnulli eam recentem, grauidamq́ue contundunt, atque fuccum fictili non picato exprimunt, \& in fole, lignea rude afsiduè mouentes, infpiffant.quòd fi quid concretum faucibus ualis adhærefcat, deradunt, reliquoque humori permifcent, noctu diligenter operiunt: nanque ros nocturnus liquores coalefcere non finit. Qux autem ficcis radicibus, aut herbis, liquamenta exprimuntur, decocta ( ut in gentianæ mentione retulimus) præparantur. Sed quæ ex corticibus humidis, aut contufis herbis factitantur, in fole, uti antè dictum eft, coguntur. Sic è thapfia, fic è mandragora, reliquisq́ue fimilibus fuccus : fic ex acerbis vuis melligo elicitur. Lycium tamen, \& abfynthium, hypociftis, \& confimilia, decocta, eo quo diximus modo, coguntur.

Centaurij mi noris confideratio.

C E N T A V R I V M minusnullis fercin non cognitum, in Hetruria unlgó Biondella nuncupatur: quoniam $a b=$ ftergendis, dealbandisq́; mulierum capillis ex lixiuio plurinum praftat. Quod paßinn in officinis habetur, uerum, or legitimum Centarium minus effe, omnibus, ut arbitror, exploratius eft, quàm ut a nobis oftendidebedt. Quip= pe quodd nullis in uniuerfum notis Centatrii natinoris biftoria refragetur. Galenus ob ingentes, mirasq́; cius facul=

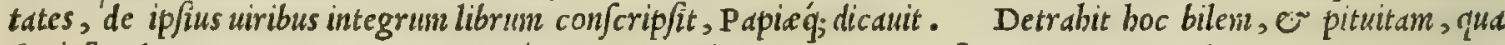
fané facultate Centaurium maius plané carere deprehenditur. Quo fit, ut non parum aberraucrint inter Maliz ritanos Mefues, Auicenna, $\mathcal{O}$ Serapio, quodd Centaurij minoris tires cum maiort turpiter confuderint.

Galenus prater ea, que de Centaurio minori ad $\mathbf{P}$ apian fcripfit, eius quoque meminit libro $\mathrm{V}$ I 1 . fims Centaurij mi
noris uires ex plicium medicamentorum, fic inquiens. Centaurij minoris radix prorfus inefficax eft. Sed ramuli cius, o po= Galeno. tißsimim folia, qux illi inherent, o flores, utiliß̣ina funt. Vincit in eis qualitas amara, paululum babens er adftri= 


\section{In Lib. tertium Diofcoridis.}

Gionis, atq; ob ciufmoditemperamĕtun admodum exiccatorium eft medicamen, expers mordacitatis. Porró quód ommia talis utilior a fint, fuprà commonui, e muc niblo fecius tamen nos repetere tempeftium cft, omnes cius particulatin actiones memorantes. Vulnera itaque magna berb.e ipfius recentis illitu glutinantur: or uetufta, quic = que egré ad cicatricem perduci queunt ulcera, cicatrice codem modo utentibus obducuntur. Arcfacta ucró gluti= natorijs, er deficcatorijs mifcctur facultatibus, ijs uidelicet, que finus, er fiftulas fanare funt nat.e, ucteresós duritias emollire, tum ulccrum maligna, que cacoüthe nocantur, fanare. Mifcetur etiam ijs, qua rbcumaticis affe= cibus medentur : in quibus ca medicamenta optima funt, qux uelsmenter deficcantia, cum quadam adfrictione nul= lam babent mordacitatem. Decoctum herbe quidam ifchiadicis infundunt, ceu bilio $a$, er crafja ducens : nam 0 talia purgat. quanquam cum adeó uebementer operabitur, ut cruenta euacuet, tunc plus proderit. Succus porró

20 cius, cum adfimilis fit facultatis, hoc eft, exiccatoria, ev abfterforix, ev catera iam dicta pulchré cfficere poteft: or cum melle oculis illinitur, menfesq;, $\mathcal{O}$ fotum appofitus euocat. Sunt qui ip fum prabeant $\mathcal{O}$ ijs, quibus nerui af $=$ ficti funt, ut qui cuacuet, $e^{-}$deficcet innoxiè que impleta funt. Quippe cum iecinoris quoque obftructiones optimé expediat, bonum $q_{;}$, it licni indurato remedium, foris impofitum, nec fecius, fi quis bibere fuftineat. KeVT av' $\mu$ re óv fic Grecé, Latiné ueró Centaurium minus dicitur: Arabicé, Chanturion fege, or fegir, feu Katarion fages: Italice, Centaurea minore: Germanice, Taufent gulden kraut, Fieber kraut, Erdtgall, feu Biber liraut: Hifpanicé, Fel de tierra: Gallicé, Centauree, aut Fiel de terre.

CHAMAELEON ALBVS.

20
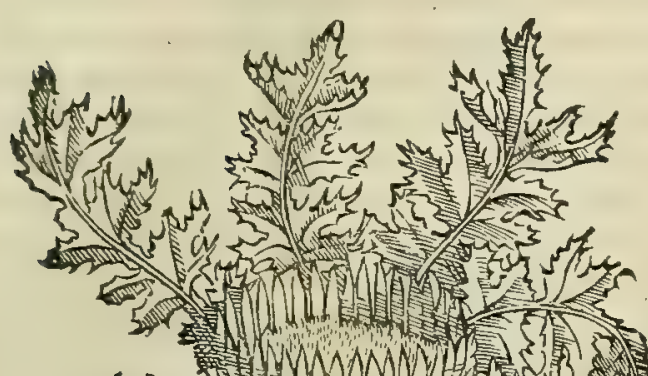

ing

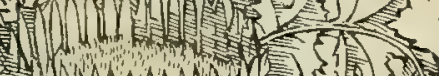

(1)

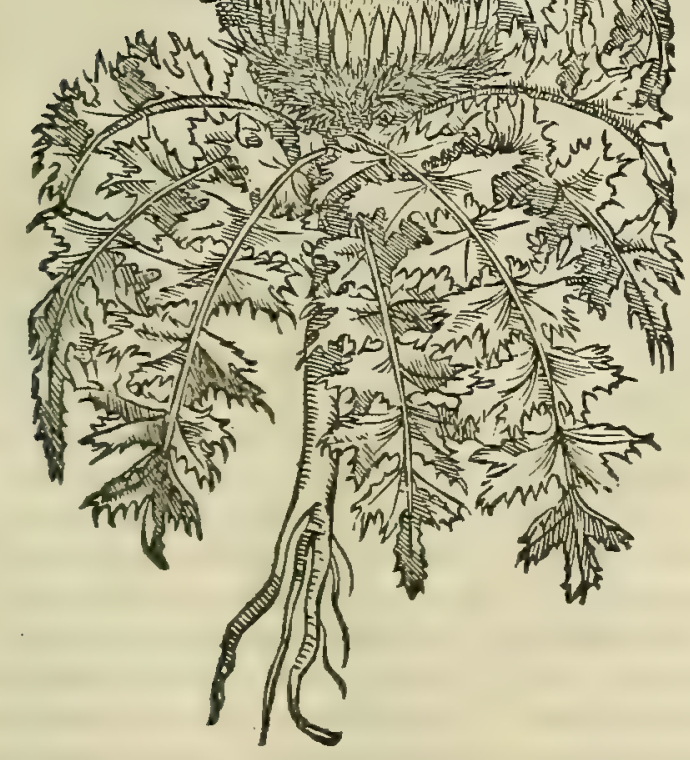

CHAMAELEON NIGER.

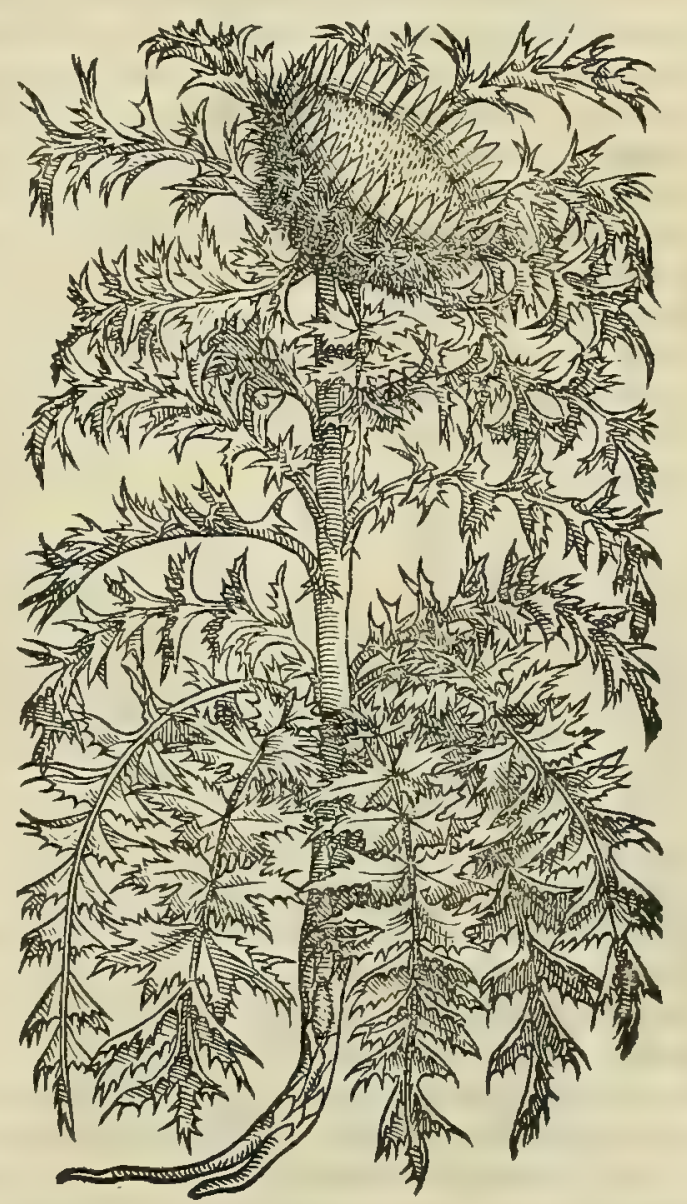

CAP. VIII.

Nomina.

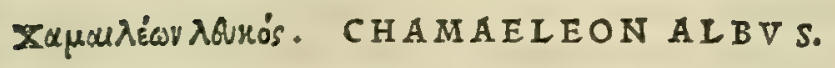

so $C$ H $\triangle A E I E O N$ albus, ixia ideo aliquibus uocatur, quòd quibufdam in locis uifcum circa radices eius inueniatur : quo pro maftiche utuntur mulieres. Folia habet filybo, aut fcolymo fimilia, afperiora, acutiora, nigroq́ue chamæleone ualidiora. Caulem non promit, uerùm ex medio fpinas, echini marini, aut cinaræ modo, erigit. Flores purpureos, veluti papporum lanugines emittit: femen cnico fimile: radicem in latis collibus craflam, in montolis verò graciliorem, in profundo albam, aliquátenus aromaticam, graui odore, dulcem. Quæ pota acetabuli menfura, latas interaneorum tineas pellit : bibitur autem in uino auftero cum origani feruefacti fucco. Hydropicis cómo difsimè drachma in uino datur : etenim eos extenuat. Contra difficultatem vrinx decoetum propinatur. Haufta in uino, ferpentium uenenis refiftit : occîdit canes, \& fues : mures item necat, fubacta cum polenta, aut aqua, \& oleo madefacta. 
C H A M AE I E ON niger folijs fcolymo fimilis effet, nifi minora, tenuioraq́ue, ac rubro diftinEta uiderentur. Caulem emittit dodrantalem, crafsitudine digitali, fubrubrum : \& in umbella flores. fpinofos, tenues, hyacinti æmulos, uerficolores: radice craffa, nigra, denfa, interdum exefa, qua diffecta flauefcit, \& commanducata mordet. Prouenit in campeftribus, ficcis, \& cliuofis tractibus, \& maritimis. Radix trita, addito atramenti futorij exiguo, cedrino oleo, \& axungia, fcabiem abigit: eadem, cùm libi fulphur, \& bitumen afciuit, \& cocta in aceto illinitur, impetigines abfterget . Decoctum collutione, dentium dolorem mitigat . Cum pari pipere, \& sera oblita radix, dolenti den ti auxiliatur. Radice concifa, $\&$ in aceto decocta, dentes fouentur : eos quoque frangit, fo fcriptorio ftylo feruens admoueatur : uitia cutis in facie, uitiliginesq́; cum fulphure emendat . erodentibus me. dicamentis admifcetur : phagedænas, tetraq́ue ulcera illitu fanat. Quare chamæleon uocetur,à uarietate foliorum euenit: mutant enim cum terra colorem : hîc uiridia, illic albicantia, alicubi cœrulea, nonnufquam rubra inueniuntur.

Chamaleontis utriufque confideratio.

Quorundam error.

C н A M A E L E O N albus tam ab Hetrufcis, quàn cateris feré Italic incolis unlgo Carlina uocatur.quod cre= dat uulgus (ut facilé folet) berbain banc nagrio olim Carolo regi ad fugandam fui exercitus peftem ab angelo demon= frratam fuife, tanquain antidotum omnium preftantisimum. Quo argumento freti uulgares quàm plurimi, ad arcen= dam peftilentian buiufce plante radices niris, magnisq́; laudibus commendant. Nec quidem ab re : quandó ènim pos ta radix (ut Diofcorides, er Galenus teftantur) latas interaneorum tine as interimat, et ferpentium uenenis refiftat, mirum utiq; non fuerit, quód eadé in peftilentia opem ferre ualeat. Falluntur nimirum, qui putant, ftirpem illam. pternici non abfimilem (noftri eam Carciofo unlgó appellant) aculeis borrentem, cuius flore coaguli uice Hetruria utitur, album effe Chamaleonem. Nam corum error ex eo maximé diluitur, quicd hac contra Chamalcontis albi de= fcriptionem, in longo admodum caule echinatos fuos proferat fructus. Porró Cbameleonem album nunquam Fu= cbfium (pace uiri aliogui eruditifimi dixerin) uidife exiftimauerim: quód libro fuo de plantarum biftoria primùm fcribat, nullum bunc edere caulem, fubinde bilus forte oblitus, eodem in loco eundem procero fatis caule depingat. Quin nec nigrum idem nouiffe uidetur, cim depictus ab co, quem tamen plané non probat, nullis notis legitimo, meo quidem iudicio, repondeat. Nafcitur niger in Tridentino agro, Ananienfibus admodum frequens tum montibus, tum Monachorü collibus, nullis reclamantibus notis. Qua in re haliucinantur monachi reuerendi, qui Me fuem commentati funt,
opiosplofa. cum certó fibi perfuddeant, Carlinam (ut corum utar diftinctione) caulem proforentem, quam legitimum Chamaleo=

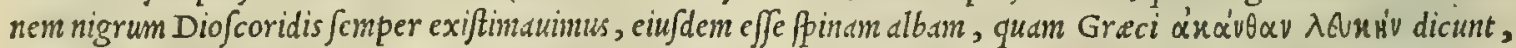
Mauritani ueró Bedeguar : itcm Carlinam altcram caule uiduame effo finam Arabicam ab A phris suchaa nocatam. Quippe cimn pina alba (ut Diofcorides eft autbor) bicubitalifit caule, ipfó́; albicăte, unde fortaffe nomen traxit,, inani, flore uerò purpureo nite $\int c a t$; Carlina uerò bac caule fit dodrante paulo maiore; pleno, non inani; fubrubro, non albicante, floribus byacinthi amulis, nulla ratione dicipoffe putauerim, Carlinam banc effe fpinam albam, fed po tius rufam. Cün nec finiliter monachi unquam probare poßint, Carlinam alteram caule uacantem Arabicam effe Binam: qućd nufquain Diofcoridem fcripfiffe inuenerim, 伍am Arabicain caule uacare, $\int e d$ pine albe potius effe perfinilem. Ex quo recté (ut arbitror) concludi poteft, quód cim pina alba procul dubio caulem edat, cundé quoq;

Quorundam Árabica promat. Sunt etiam qui uelint, Carlinam caulem gerentem nibil differre ab altera, qua caulem non fert, opınio repro nififexu, nempe quód altera mas, altera ueró fermina fortaffe fuerit: negantq́; omnino bus plantas effe Chamalcones, bata. illawíf; prafertim nigrun Chamaleonem effe nolunt, que caulem rufun gerit. Hocq́; argunzento nituntur, quòd fcri= p férit Galenus lib.v I I I. Implicium medicamentorum, Chamseleontis nigri radicem lethale quiddam obtinere : edin q'; ob caufam in extrinfecis tantum uenire medicamentis. Sed cum rapbani uice à compluribus copiosé cum acctarijs $e=$ datur nullo penitus incommodo, nec effe banc nigrum Chamalconem, nec eius peeciem probant. Quibus facilć refpon di poteft, quód fortaffe hac in re ( fit tamen cum uenia tanti medici dictum)errauerit Galenus, cùm omnibus in confeffo fit, quod $f i$ in altero duorum aliqua deleteria $u$ is infit, ea potius in albo, quam in nigro effe poßit. Quandoquidem non modó fcribit Diofcorides Ixiam lethale medic amentum in albo tantim Chamaleöte nafci; fed quód cius radix.canes, O fues, ac mures necet, $\sqrt{i}$ ab eis deuorctur. Qus fané euidens argunentum faciunt, qliód potius albus, quàm niger letbale quiddam obtineat : prefertim cum nigro null cm letbalem uin aßignancrit Diofcoridcs. Verim cnimuero, ne so cui tèmerttatis nomine fupectus fim, quòd di Galeno audeam diffentire, concedamus, non trecter rationcm id fcrip/iffe Galenum, quód Ixia etiämnum oriatur in nigri radice, ut Cretenfes affirmant, qui ex utriuf Ixiain colligunt ad pennas fagittis conglutinandas, quod di; fcriptun reliquerit Theophraftus, Chameleonis nigrira= dice canes pariter necari. Alia nobis fe e offert ratio, qua rectius, ut puto, illis refpondere po/fumus. Siquiden faci= le feri poteft, quod in Grecia, fortaffe in Ponto, alijsó; conterminis rcgionibus Chamaleontis nigri radix fit ueneno=

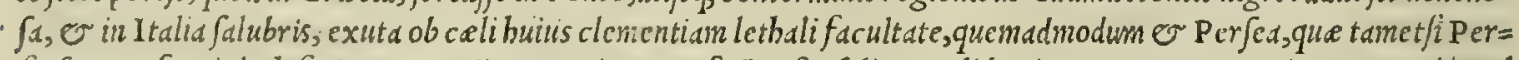
fis femper fuerit lethefera; Acgyptijs tamen innocua facta eft, foli o calibonitate. In Ponto enim non modómel

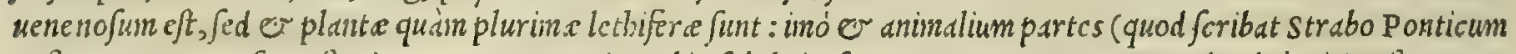
caftorcum ucricrofum e $\beta_{e}$.) qua tamen omnia nobis falubria funt. Arunz pratered Cyrenis adcó mitis eft, ut $r d=$ pi modo in ciborum ufum ueniat; cum tamen in Grecia, E I talia adeó acerrimum fit, ut ncc coctum, nec crudum edi poßit. Quin o fcorpiones in compluribus tcrrarum orbis partibus ittos interficiunt; in aliquibus ueró, ut in Tri= 


\section{In Lib. tertium D}

dentino traftu, nullumitn uenemun relinqunt : quo etiam in los teriun illud prater difa a me maximé ad credendum inducit, Carli quód bac planta omnibus in uniuer funt notis nigrum Chameleone noribus, tenuioribusq́, fubrubra per medium excurrĕte cofta :c floribus in umbella fpino/is, nerficoloribus : radice crafJa, exteri tus flauefcit. In qua certé deluteatione be plante ita ad.mußim fus fuerit, Carlinam, que caulesn mittit, Chaneleonem nigrum dem certior ob diligentior em inquifitionĕ fatus, boc tempore df, in fententia permanere decreu, donec aliquis reiberbarix dilig

- linis Chamelcones oftendat in Italia, qui rectius fuis notis Diofce alijs quoq; , non graubor mutare fententian. Explodendifun ftando errore, Grecorum uocabulorum uicinitate decepti, Chal Cbamsleone confundant. Nam Auicenua de Mezerio differen. errorem prodidit ijs uerbis. Mezerion bibitur cum uino ad morf uenenum mortiferum. Et quando mifcetur cum fauic, or coniunc or porcos. hac ille. In quibus duplici notatur errore: prinó qh leonireddidit Diof corides: deinde quod nigrum, non utiq; album. tiam. Meminit utriufq; Chameleonis Theophrastus lib. I x.ca meleonum, unus candidus, alter niger. Vires autem radicum int

30 Candidi enim candida eft, or dulcis, or craffa, or grauiter olen latim modo raphani decocta c/t, iunco transfixa in fericm. Vale come a acetabuli menfura é uino bibitur auftero. Occídit o can aqua, or oleo: fues cum braßica. Etfi boninem egrefcentem exi triduo iubent. Hoc enimf i tolerduerit, moriturum nequaquam e: mo fimili, uerim ampliori, o terra proximo: capite magno, dc6 ger folio conftat ad imili, preter quàm quód minori, leuioriq; . I radice craffa, or nigra cxtrinfecus, fubflaud intrinfecus nititur. nem abolet trita cum ace to, o ramentis illita: necnon er canes. super non ignorandum eft, uifcum fcilicet, quod Ixiam appellant.

30 mortifrum, cim tamen modica tantim quantitate fumptum fom mulieres fuarum lucubrationum gratia, ne fomnum inednt in ope: modo affumunt. Huius plerisq; locis meminit Plinius, or de eo n:

Wrown uifcum aliquod remedium protulit. Xapau a anis, Chemeleon leute, feu Chamalium: Italis, Carliura, or Chameleone bianco: Hifanis, Cardo pinto: Gallis, Car=

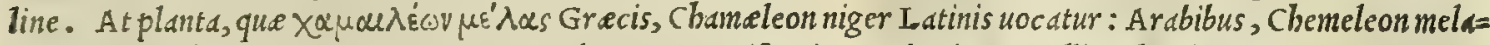
mos: Italis, Chameleone nero: Germanis, Eber uurtz: Hipanis, Cardo pinto: Gallis, Chardonette.

\section{Kporoféilov. CROCODILIVM. CAP. X.}

CROCO'D I L I O N chamæleontis nigri figuram habet. Nafcitur in fyluofis, radice longa, le40 ui, aliquantulum lata, odore, vt nafturtij, acuto. Feruefa\&ta in aqua, \& pota radix, fanguinem copiofum per nares pellit. datur lienofis, eos euidenter adiuuans. Semen ci rotundum ineft, duplex uti fcutum : quod fuapte ui vrinam ciet.

S v s T qui uelint, Carlinan uulgó uocatdm, eam inquam, qux caulem profert, legitimum effe crocodilium. sed corum opinio mini quiden nullo modo fatis facere poteft. Siquidem (ut pracedenti capite retulimus) Carlina, qua caulem emittit, adeó omnibus in uniuer fum notis chamaleontem nigrum reprefentat, ut uix unquă perfuaderipof= fim, eam efec crocodilium: prefertin cum facto periculo ijs fane uiribus careat, quibus crocodilium preftare $\int_{c r i=}$ bunt . nempe quéd radicis decozum potum fangumem per nares copiofum trabat. Adde quód Crocodilio radix fit lö ga, levis, aliquantulum lata, or odore, ut nafturtij, dcuto. Illi ueró Carline genericraffa, nigra, denfa, exe $\int a q_{;}:$

so non autem lata, nec leuis, nec nafturtij odorem pirans. Non de funt alij, qui Eryngium marinum Crocodilium exi= fiment. Verum cùm illud in litoribus maris nafcatur, chameleoni nigro fit abfimile, nec fanguinem é naribus eliciat; Crocodilium ueró proueniat in fyluofis, compluribus alijs reclamantibus notis, ijs etiam baudquaquă adftipulari pof= Jum. O' Guam magnifacerent medici Crocodilium, fi in Italia nafceretur, ubi tamen bactenus ipfum uidere non licuit, cim cius radicis decoctum tanta fit facultate preditum, ut potu tantum fanguinem copiofum per nares pellat . Croco dilij meminit Plinius lib. X X V I I. cap.v I I I. non tamen plura tradidit, quàm Diofcorides, à quo illa omnia accepiffe uidetur: quanquam in hoc ab co diffentit, quód Crocodilium in fabuletis nafci prodiderit, cum tanen in fjluofis nafci fcribat Diofcorides. Huius facultates lib. v1 I. fimplicium medicamentor um memorie prodidit Galenus, fic in= quiens. Crocodilij femen acre eft, atque odoratum, urinam, menfesq; ciens. Itaq; facultatem babuerit calidam, di= gerentem,er exiccantem. Succus tum caulis, tum feminis, ut qua fimilis fint facultatis, nepbriticos adiuuant. Radix petoris excreationibus ualenter conducit, minus quidem quàm femen acris, non tamen minus amara. Tr bit ueró $e=$

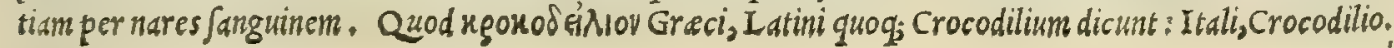
.
Crocodilijcó
fideratio.
Opinio ex-
plofa. .
Crocodilijcó
fideratio.
Opinio ex-
plofa. .
Crocodilijcó
fideratio.
Opinio ex-
plofa. .
Crocodilijcó
fiderstio.
Opinio ex-
plofa. Alia opinio Alia opini
reprobata.

Nomina. 


\section{ioli Comm.}

BRVM VENERIS. CAP. XI.

PSACVS aculeatarum generis eft. Caulem haum, fpinis horridum : folijs lactucæ, fpinofis, bi:nicula fingula complectentibus, prælongis, ceu Im bullas intus, \& extra aculeatas, in dorfi medio tibus, concauo alarum finu, in quo imber, aut ros tur: vnde dipfaci, quafi fitientis, nomen traxit. Imine caulis, fingula furculis capitula infunt, ob- echinata fpinis: qua arefacta, candida fpectanfrectaq́ue medulla tenus, vermiculos oftendunt. Io -imas fedis, fiftulasq́ue, fi tufa, \& decocta in vino ufque dum fit crafsitudo ceræ, immittatur. Meentum ærea pyxide recondendum . Aiunt formiibus, verrucisque penfilıbus remedio effe. Vercapitulorü in folliculo alligati collo, aut brachio $i$, produntur quartanis febribus remedio cfle.

P S A C V S, quem Latini Labrum Veneris uocant, in ulgaris eft planta, ijs pracipué locis, ubi lanificia exer=. . Siquidem echinato cius capitulo mangones rudem adbuc 20 : pectunt, expoliunt, detractisq́; floccis concinnant. In ia Dipfacum unlgo appellant Cardo da cardare, Foroiu= tero Garzo . Seritur is bodie in compluribus Italia locis, im'q; in agro Bononienfi, fingulari à cultoribus adbibita ia. Sed o . jylueftris quoq; ponte in campeftribus, in $\alpha=$ , o f crobium aggeribus, in vijs iuxta epes fiequentißi= citur, nullis pror fus repugnantibus notis, quas illi reddidit rides. Inucnitur autumni tempore (ut experientia quen= 'ere poteft) in eius capitulo iam exarefacto, nedullitusq́; - uermiculus ille, quem collo adalligatum quartanis febri 30 zedio effe produnt, pifcatoribus bamo affigendus maximé tus : et $\int \mathrm{i}$ Marcellus Diof coridis interpres, or commentat rmiculum bunc nunquam fibi compertum fuife fcribat.

Virga paftoris duplex.

Syluatici hallucinatio.

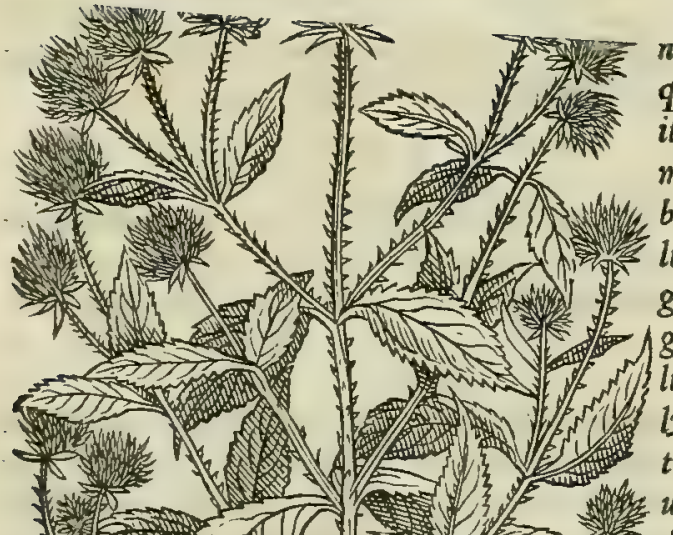

jacus officinis, or berbariorum uulgo virga paftoris maior nominatur. Quippe minorem etiam illius amulam oftendunt: quanquam non adeo ftriato caule, ac pinis borrido conftet, folijs item infirmioribus fit, er capitibus multo minoribus, ut que oliue magnitudinem non excedant. Sunt autem buius capitula tenui= bus capillis referta, ita ut feric is uiridi colore infect is floccis fimi lia uideantur. Caterim animaduertendum eft, neutrum Dip ${ }_{a c i} 4^{\circ}$ genus, quod tum Serapioni, tum Auicenne de cribitur, effe vir= gam paftoris. Quandoquidem ijs, quantum ex eorum friptis col= ligere potui, Paftoris uirgam nil aliud effe putauerin, quam po= lygonum, cuius tam fomine, quam maris biftoriam libro quar to tradidit Diofcorides. Quapropter illud mibi Jemper perfua fum uelim, quod non à Mauritanis Dip faco virge paftoris nomen in= ditum fit, fed d feplafiarijs ijs, qui fuis potius pandectis, qudm ca= teris caftigatißimis, ev probatißinis foriptorum monumentis, fi= dem preftare confueuerant. Nanq; Mattheusille Syluaticus pandectarum autor, Dip acum virgam paftoris appcllat: quide so inde in grauiorem errorem lap $\int u s$, Dip acum ip fum cum polygo= no turpiter confundit, utpote qui illud affequi non potuerit, quod Arabum $\mathrm{P}$ aftoris uirga, effet Diofcoridis polygonum, noin autem

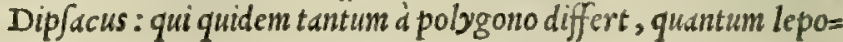
res aburfis. Dipfaci meminit Galenus lib. v1. fimpl. med. bis pancis. Dipfacipine radix fecundo ordine exiccatoria eft, ba= betó; nonnibil abfterforium. Planta, qux Gracis í axos, $L d=$ tinis Labrum Veneris nominatur : Mauritanis, Dibfacos:Italis,

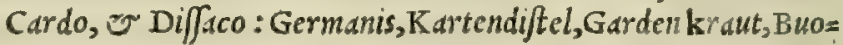
benfrel, e Vueber Larten: Hipanis, Cardencba, Cardo penteds dor: Gallis, Cardon à carder, er Verge à bergier. 


\section{In Lib. tertium Diofcoridis.}

A"rovod $\lambda$ Arrei. SPINA ALEA.
CAP. XII.

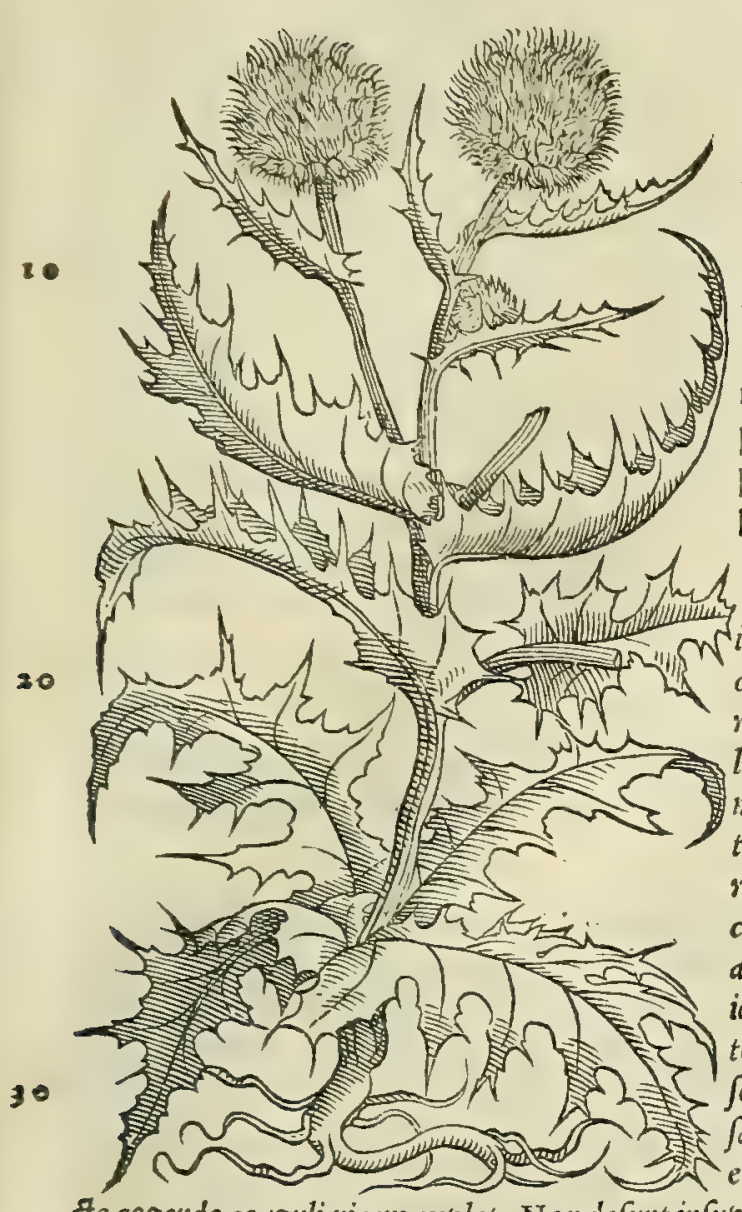

SP I N a alba nafcitur in montibus, \& fyluofis. Folia fert albi chamalconss, anguftiora, candidiora, aliquantum hifpida, \& aculeaca: c.ulem fupra bina cubita altum, poilicari, aut anspliore crafsitudne, albicantem, intus cauum: in cacumine capitu!um ineft fpinofum, echini marini semulum, fed minus, \& oblongum : fores purpurei, in quibus fenen, ceu cnicum, fed rotundius. Huius radix pota, coliacis, ftomachicis, \& ijs, qui cruenta extufsiunt, efficax eft: vrinam cit: tumoribus illinitur. Decoeto eius dentes in dolore collui prodeft. Epotum femen comuulfis infantibus, \& à ferpente demorfis auxiliatur. Geftatum proamuleto ferpentes abigere traditur.

S р I N A M alban feplaficrij Arabds (l:t plcrunc; folent) imitiati, Bedegl:ar appellant. Scd non parua inter hos, o medi= cos oritur contentio, quisnanin acule atarun genere, quas plit= rinas genuit natura, spina alba legitimé, notis omnibus adftipu= lantibus, appellari poßit. Verim etfi tantum liten tranfigere nequcant; interinz tanen pro spina alba alij alias herbas often= tant, o quif q, fuan ueran exiftinat. Quandoquiden funt $e 0=$ sun complures, qui fibi certó perfuddent, spinam albam eam as culeatdin berbam effe, quatin aliqui Carduum benedictum uocant, alijueró uulgóberba Turca. Sunt alij, qui Carlinam uocatam, id eft albun chamaleoittem, Spinam alban effe contendant. In= ter quos inuenio monachos, qui in Mefuem fcripferunt, quorum fententiam, Juperius in chameleontis utriusq; mentione, ut fal= fam reprobauimus. Sunt preterea, qui spinan albam effe uelint echindtanillam, ac fpinis rigentem berbam, que Hetrufcisin la= a cogndo coaguli uicem explet. Non de unt in uper qui unan, uel alteram fylueftrem, ac finins horrentem plan= tam, pro spina alba nullo difcrinine dccipiant. Duno fit, ut omncs ij nullo ueritatis lumine ducti, in huiufmodi tene= bris oberrent. Errat, ineo quident iudicio, hac in re Leonardus $\mathrm{F}$ ucbisin's etatis noftre medicus alioqui clarißimus: quippe qui ultino fuorum paradoxorum capite, spirain alban eam aculeat am berbain sppellat, que omnium in uni= uerfum aculeatarum plantart:in generum ampli ßimis confiat folijs, late buni fe pargentibus, ac crebris, albisq́; feu lacteis tota conperfa maculis. Virde apud quofdam Lactarie berbe nomen ddinuenit, etfi di quàm pluvinis, prafer= tim mulierculis, Carduns diue Marie dicatur. Hallucinatur inquan, pace eius dixerim, co quód inon animaduerte= 40 rit, hanc folijs albi chameleonis triplo, quadruplóq; maioribus iin campeftri planitie nafci, ut noftra teftatur Hetru= ria, ubi pafin feré frequens nafcitur, non autem in montibus, ac Jyluis, ubi spina alba Diofcoridis teftimonio prouc= nit. Ego ueró, qui a Diofcoride ne latun quiden unguen recedere foleo, in fyluofis montit!n iugis/punan albam le= gitiman oriri, mihiq, inibi compertan fuiffe exiftinto, folijs albi chainel conis finilibus, anguffioribus tanelt, ac candi= dioribus, fubbir futis, pinis rigentibus: caule ueró bicubitali, pollic dri, uel ampliore craßitudine, fubalbo, er inani : in cuius cacumine echinus fubalbidus infidet, fed minor, o oblongior, purpure is intus jloribus, o fenine crico finti= li. Huic plané defcriptioni, que etian Diof coridis eft, adftipulantur frequentißima plante, que fuis echinis, ac pinis rigentes, in excelfioribus Ananix uallis montibus lariceis, abieginis, @ piceis jyluis refertis I ulio menfe uifuntur.

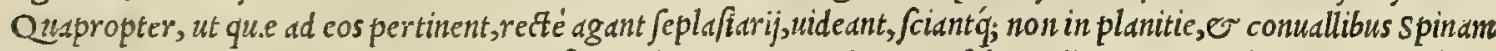
albam prouenire, fed in montibus: quorum fi quandoq; tum cacunina, tum fyluas adire non grauabuntur, procul du= so bio non magno etiam labore ip fan nancifcentur, quesiadmodum er ego inibi eam fapißimé reperi. Hac enim non mo

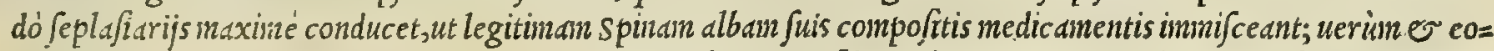
ruin errorem deprebendent (in hoc etiam R uellius uer fatur) qui fibi perfundent, Spinam albă illud effe cardui genus, quod à Tufcis, eo quód (ut pauló anté diximus) conguli vicem preffet, uulgó nocatur Prefurd. Error autem ijs facilé deprebendetur, fi illud adnotare noluerint, quód aculeata hac planta in hortis pa Sinn feratur, folijs albo chamelconti longé maioribus: E capitula fer at, quxe marinum echinum non parun excedant. . Commifcuit Me fues ßpinam albam, ac etian Arabican, quarun alter ani fuo diomate Bedeguar, alterain ueró suchad appellanit, fyrupo de eupatorio wocato, quem riris laudibus extulit ad diuturnas febres finiendas, ad eas prefertim, quibus naturalia uifcera, nempe uentriculus, $\odot$ iecur imbecillia fint redditd; $\odot$ ubi ì fua naturali temperie recefferint. Cuius tamen fententie non. parum refragatur Mufa Ferrarienfis : quippe qui longo fennone contendat, nec Arabican, nec albam findm buic fyrupo admifcerdam effe, quód utraq; adffritzoria ui polleat, qua (ut ipfe ait) fyrupi butus intentionibus admodum repugnat, cimm ad diuturnas obftructiones tanti:m referandas, Jernper buius apud inedicos fuerit ufus. Qud iin re inon. 
folim oftendit Mufa auttor is mentem non percepife, fed nec etian in boc (pace uiri alioqui clarißini dixerim) exd= ctan curandorum morborum rationem calluiffe. Nam cum Mefues fyrupum bunc compofuiffet ad illas curandas fex bres, qubus natur.alia uifccra imbecilla funt reddita, optima componendi methodo tam Spinam albam, quàm Arabicã illi in cruit, utpote que adftrictoria ui, qua pollcnt, languida illa, ac infirma membra, plurimium roborarent . quibus inconnnodis jolent perti, ac docti mediciijs medicaments occurrere, que odore fragrantia adftrictoria facultate comncndantur. Hinc itayuc facilé intelligi polfe crediderim:, quàm abfurda, explodendśc; fit bac Mufa fententia. Quin nec illud confiliun eius feplafiarijs accipiendum putaucron, quód ppine albes, or A rabica loco, filicule radi= cenz, ac fabine follia buic fyrupo Jubltituere poßint, er debcant, ut magis at q; magis tü uada, tum uifcera laxet. Quip pe quid fi tantim laxandi, ac re ferandi facultate hoc medicamentum debuilfet effe preditum, non modó barum pina rum radicibus carere debebat; fed etiam rofis, lentifcina refina, Indica nardo, es malabatbro expoliari: cum tamen bec onnia maturć, diligenter'́; cxaminata, non fine metbodo, ut qux robur bis uifceribus allatura fint, ab ip fo Me= Jue buic Jyrupo fucrint admit a, ne fcilicet natura diuturna frbre imbecillis facta, or à relaxantibus, ac admodum re= feran tibus medicamentis uexata, totam bumorum molem alui profluuio ob conteniricis facultatis amifum robur, tan=. Spinz albx ui quam uiribus omnibus defttuta ad mortem ufq; demitteret. Memint Spine alba Galenus lib.v I. fimplicium medi= resex Gal. camentorum, fic inquiens. Spine alb.e radix deficcatoria eft, er modic é adftringens. Quamobrem er caliacos, er ftomachicos iuuat, e fanguinis reiectiones colsibet, or ademata illita contrabit, ac dentibus dole ntibus prodc $f, f$ decocto eius collu.ntur. Semen tenuis efentie, e calide facultatis eft. Itaq; potum ijs, qui conuelluntur, conuenit.

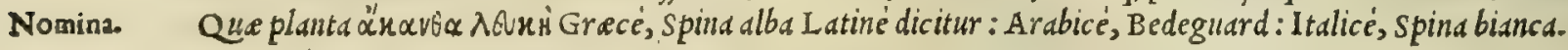

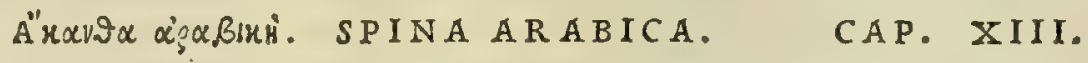

A R A в I C A M fpinam natura albx fpinæ fimilem effe conftat. Ipfa fiquidem ftringit. Ad fanguinis reiectiones, menfium abundantiam, cæterasq́ue fluxiones radix etiámnum valet. Prouenit in afperis.

Spinx Arabicx confid.

E R R A S S E cos nimirum crediderim, qui fibiperfuaferunt, A rabicam pinam, cuius bic meminit Diofcorides, eam aculeatam A rabie effe arborem, quam Acacian uocant. Cuius erroris illud in primis indicium eft, quód nufquam confueuerit Diofcorides alicuius ftirpis hiftoriam diuerfis capitibus repetere, nec etiam arbores berbis commifcere. Nam cim long a biftoria Acaciam arborem, qua etiam Aegyptia pina uocatur, prino libro inter arbores defcripfe= rit, abfurdum quidem uideretur, fi eandem preter morem bic inter aculeatas berbas repeteret. Ad loc indicium or illa ratio accedit, quód fi feor fum barum plantarum hiftoriam tradidit Diofcorides, diuer fas quog; plantas effe necef=

Ruellij hallu- $\int e$ eft. Quamobrem non parum Ruellius ballucinatus deprebenditur, quód non animaduerterit, in fua buiufce Ara= cinatio. Gice pinc mentione, Diof coridem boc loco aculeatam quandam Arabicam berbam albe pine in uniuer fum amulam intellexiffe, non altem (ut ipfe putat) acaciann nuncupatam. Qua in re non fatis uirum bunc adimirari poffum. quippe qui non modó 0 Grecis, e Latinis literis fit habitus peritißinus, ac inter eos, qui bac noftra atate de firpium bi= ftoria fcripfere, facile princeps; fed qui etiam Plinij biftoria fuerit ftudiofißimus : quem tamen fi accuratius perle= giffet, ac fcqui uoluiffet, nunquam arbitror in eun errorem incidıfet. Quădoduidem Plinius lib. X X I I I I.cap. X I I. alteram ab altera separauit. Et prinó huiks, de qua agimus, mentionem faciens, fic inquit. Spina Arabica laudes in odorum loco diximus : e ipfa piffat, ftringitó; diftillationes onnes, \& fanguinis excreationes, menfiumớ; abundan= tiam, etiámnum radice ualentior. Qulle ḋ Diofcoride uerbótenus tranftuliffe perpicuun eft. Mox meminit Arabice alteriuspine, qua in arborem afjurgit, bis uerbis. E/t e Acacie Bina. Fit in Aegypto alba, nigráq; arbore, item uiridi, fed longe melior eft prioribus. Eiufdem incminit etidm lib. x I I I.cap. I X.poftquàm Derfex arboris matericm miris laudibus conmendauit, ubibac babet. Nec minus Aegyptia pind celebratur in eadem gente, dintaxat nigra, quoniam incorrupta etiam in aquis durat: candida ueró facilé putrefcit. Quibus ex locis palime eft, non credidiffe $\mathrm{Plinium}$, unam tantim Arabicam, uel Aegyptiam effe pinam, quamuis $\mathrm{R}$ uellius non ita rem acceperit. $\mathrm{Q} u t$ item $\mathrm{Gd}=$ Ieni fententiam bac in re non animaduertiffe uidetur : fiquidem Galenus lib.v r. fimplicium medicamentorum ita fori=

Spinx Arabi- bit. Spine Arabice radix proflunium mulicbre iunat, o alia quecunq;, quibus auxilio eft que apud nos nafcitur ß cx uires ex na: fed efficacius tamen omnia iuuant tunn radix, tum fiuctus ipfius. Hic ueró $\sigma$ columelle prodeft, $\sigma$ ijs, que in Galeno. Sede inflata funt : tum ulcerd ad cicatricem ducit, mediocrem babens, o non moleftam adftrictionem. bec Galenus.

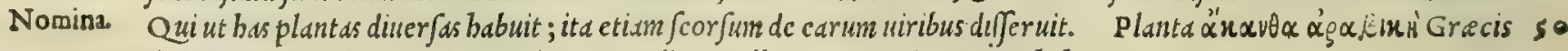
dita, Spina Arabica Latinis pariter er Italis appellatur : Mauritanis, Sucbaha.

$$
\text { ¿ródupos. CARDVVS. }
$$

CAP. XIIII.

CA R D v v s, Græci fcolymon uocant, folia chamæleonis habet, \& albx f pinx, nigriora, \& crafsiora: caulem longum edit, foliofum, capite fpinofo: radice nigra, \& craffa . Qux illita graueolentiam alarum, totiusq́ue corporis emendat : item fi decoeta in vino bibatur. copiolam autem vrină, foridamq́ue expellit. Herba cùm recens tencrefcit, in olera, afparagi modo, tranfit .

Carduorú có E T S I uniustantum Cardui breuiter etian boc loco meminerit Diofcorides; Theophrafto tamen, Plinio, ac a= genera. "lijs probatis auctoribus, plura Carduigenera traduntur. Verim ut primùn de bis, qui natura cultricc ponte prouc= 


\section{In Lib. tertium Diofcoridis.}

niunt. fermo fiat, fcire fané conuenit, quód eorum diuer fa funt genera:quorum tamen nomina propria, quod fiam, non babcntur. Atqui Plinio lib. X X.cap. X X I I I. duo tantum corungencra produntur: unum fruticofius ftatin $\dot{a}$ terra: alterun ueró unicaule, O crajhims. Satiuorum autem, quitum in bortis, tum in agris feruntur, multiplex eft genus. Horum principcm locum tenent, qui Hetrufcis unlgo uocantur Cardoni. Nanque ij diligenti cultura adea teneri, fiagiles, albiç; euadunt, ut magno quidem apparatu, fccundis canis pro bcllarijs cum $\int a l e$, or pipcre expe= tuntur. Quo arg!nnento dudus, cqudem putancrin de bis uerba feciffe Theoploraftum lib. vi. cap. I I I I. de plan=

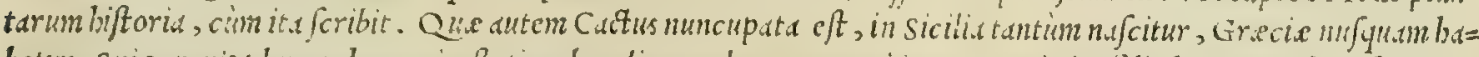

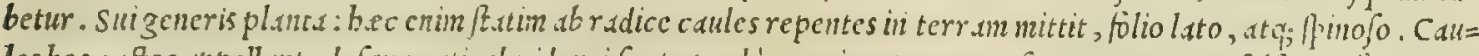

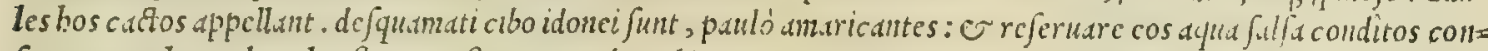

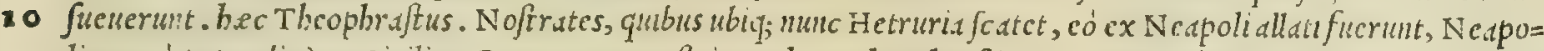
lim ucró (ut audio) ex sicilia. Qupropicr noftricun boc Theopbraftigenere maxine connenirc uidentur, quód feripscrit, Cactum sicili.e peculiarem effe plantan. Continentur preterea in Carduorum genere ctian ij, quos in Italia Hetrufcum un!gus appellat Carcioffi, alijs ueró inibi Archicbiochi dicuntur. quorum utem memuit Theopbra ftus codcin loco, cin Jubdit. Alium ucró cuulene ercatum producit, quem pternicem uocant. Is quoq; cibis aptus ex=

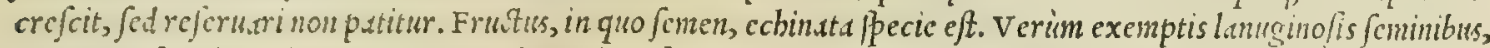
is quog; uefcendus relinquitur, or cerebro pulm.e fimilis eft. hactenus Tbeopbraftus. Qui pro pslme cercbro illud, quantim equiden reor, intelligit, quod Galenus cncep balon pluribus in locis appellari tradidit, er quod nunc corru= ptr uoce Neapolitanis, or siculis unlgó uocatur Cefaglione, de quo libro primo in Bdellij mentione abunde differui= mus. Carduorum autem, quos uulgó Carcioffi wocaridixinus, nobis plura funt genera, uaria capitis forma diftin= 20 et.t. Siquidem proferunt omies echlinata capituld, $\int e d$ aliqui pinis furfum repicientibus conftant, alij ucró ad terram ucr $\sqrt{i 5}$, nonnulh etian acule is uacant. Sunt preterea in boc poftremo genere, quibus ecbini in longum faftigientur, quibus ucró in globum extuberent, debifccntibus in altero fquamatim picis, in altero ijfdem fquamis, ueluticortico= fis unguibus in unum compactis, e codgmentatis, nucis pince inftar. Ex quo facilé in ean fententiam deductus fum, ut crediderin, hanc Cardui peciem poftrcmam nuc is pine e emulam, effe Carduum pineam Theophrafto uocatam, quód is loco anté citato ita de ea fcribat. Eft Carduus pinea ab radice foligerd: qua de media femindis acanus, uelu= tı malum, extuberat . bec ille. Ceterim Carduidculeati genus o illud eft, cuius echinati capitis floribus Hetrufci co.aguli uice utuntur, et/i Cardui fatiui onne genus idem fuis floribus praftet. Spinis carebunt, ut bortorum cultores teftantur, Carduorum capitula, fi priusquàn feratur femen, acumindta cius latera retundantur. Sine acule is ctian nafcentur, fi delibratis laquca radicibus, or diffectis femina integra condantur. Vnde illud facilé potuit factum effe,

30 ut ij, qui aculeis non rigent, bumano cultu mitiores euaferint, cum natura Carduorum omne genus pinis uacare ne= queat. Carduimeminit Galenus lib.VI I I. fimplicium medicamentorum: nec tamen plura de eius uiribus tradidit, Cardui uires quim frcerit Diofcorides. Sed de temperamento differens, ei caliditatis fecundum ordinem completum, aut tertium ex Gal. incipientem; ficcitatis ueró fecundum aßignauit. Et libro I I. de alimentorum facultatibus, Carduun Cinaram ap= pellauit, ac alimentum, quod corpori prebet, meritó damnauit, quód melancholicum fuccum generet. ¿xó $\lambda$ upos ea plinta eft Gracis, que Latinis Cardius, Cinard, or Strobilus nominatur : A rabibus, Raxos, Harxos, fiue Saco= lomas: Italts, Cardo, o Carcioffo: Germanis, Strobildorn: Hifpanis, Cardo de comer, feu Cardos: Gallis, Arti= chault, or Charchiophe.

\section{Potriglov, POTERIVM. CAP. XV.}

P O I E R I V M, Iones neurada uocant, largè fruticat, cortice obductum tenui, fpinis horridum, lanugine fpifia, ramulis longis, mollibus, lentis\}, tenuibus, tragacanthx proximis : folijs paruis, rotundis: fore exiguo, candidi coloris : femine nullius ufus, fed guftu acuto, \& odorato. 'Nafcitur in aquofis, \& cullibus. Radices demittit binûm, ternûmve cubitorum, neruofas, \& firmas : qux proximè terram recifæ, dant fuccum gummi fimilem. Tußx, pracifis neruis, \& vulneribus glutinandis illinuntur. Decoctum quoque cius neruorum affectibus prodẹt.

E X $\mathrm{R}$ E I herbaria peritis hactenus neminem reperi, qui Poterium in Italia nafci dixerit, atque ipfum oftende= Pnterij conrit. Quamobrem facilé crediderim, quéd illud non procreet Italia. $\mathrm{N}$ am fi inibi nafceretur, fieri quidem non potuif= fideratio.

so fet, qumbec etus, que rerum cognitioni maximé dedita eft, ipfum adinueniffet: prefertm cuin Diofcorides, cxte $=$ riq; friptores Poterij faciem clare fatis defcriptam reliquerint. Sed hic fubit nobis mirari Cornarium uirum alio= Cornarij opi qui eiatis noftre infignem, quód prunum fylueftrem putauerit uerum Poterium effe. Que certé fententia ut eft, nueo iudicio, abfurda; ita non immerito à Fuch/io medico clarißino refellitur. Caterim etfi nobis hactenus incomper= tum elt Poterium; non tamen omittendse funt eius uires, de quibus fub titulo Neuradis Galenus differuit lib. v I I I.

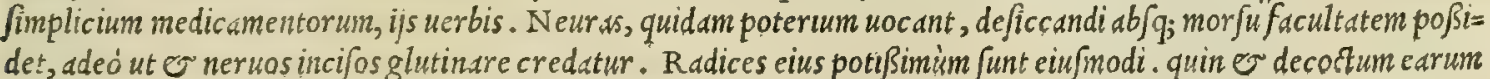
quidam cxlbibent ijs, quibus affectifunt nerui. Id Graci mot sioloy quod item Poterium Latini uocant: Itali, Po=

Nomina. terio. 


\section{A'x'́vitov. A CANTHIVM.}

CAP. XVI.

A C A N T н I v M albæ fpinx fimile, folijs aculeatis per extremitates, $t \&$ lanugine araneofa obductis . ex qua collecta, \& neta, ueftes bombicinis fimiles texunt. Folia, vel radices ad remedia opifthotoni bibuntur.

Acanthij con QV O'D Acanthium, cuius bìc inter aculeatas herbas meminit Diofcorides, in Italia nafcatur, equidēm affirma Gideratio. re non aufim. Qüandoquidem hactenus neminem inueni, qui folia dicuius aculeate berbe mibi oftenderit, que adeó aranco $\int a$, ac fubtili lanugine obducta $/ p e c t a r e n t u r$, ut ex ea neta ueftes bombicinis fimiles texere quis potuifet, ut bic

Quorundam Diofcorides, o lib. X XII I r.cap. XI I.teftatur Plinius. Quamobrem ingenué afferere non dubitauerin, eos error. magno in crrore uer $\int a r i$, qui pro Acanthio quandam Cardui montani peciem, echino lanugine quadam obducto, de= monftrant. Nam preterquàn quòd hec folia habeat nulla lanugine uelatd, nullo pacto qua echinatum capitulum cir=

Nomina. cuimueftit, depedit, uel neri poteft, utpote que tenuißima fit, fine uillis, fragilis, ac omnis lentoris expers. Quod Greci cércivarov, Latini fimiliter Acantbium, or Itali Acantbio dicunt.

+ Verba illa de lanugite non leguntur in Grecis Diofcoridis exemplaribus: que tamen bic defiderari oftendit abruptus auctoris fermo. Vnde ca non temeré ex Plinio ddiecerunt interpretes, eius tantüm, ut puto, auctoritate fre ti. Nos ueró é audacius illa addenda putamus, quód ea legantur in Oribasij codice manu fripto, in quo ex probac

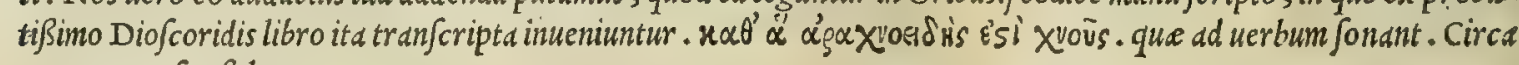
que araneo fa eft lanugo.

A'xurbos. ACANTHVS.

CAP. XVII.

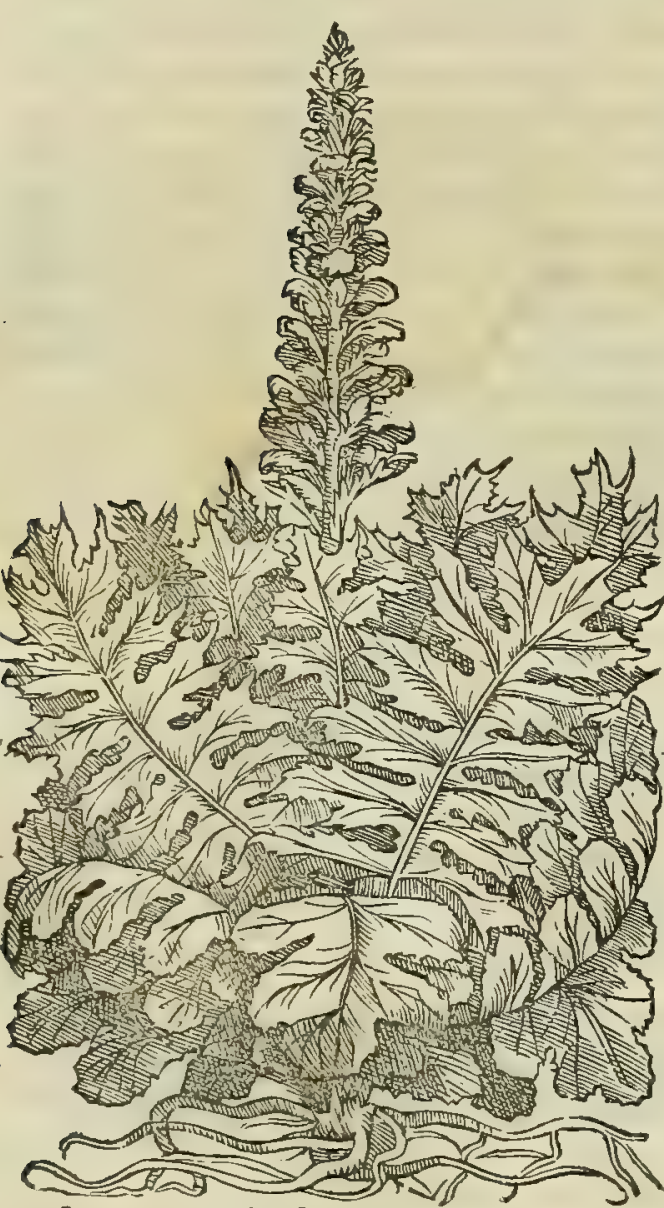

A C A N T H s, Romani pæederotam uocant, nafcitur in hortis, petrofis, \& riguis. Folia habet multò lactucaceis latiora, \& longiora, erucæ diuifura, nigricantia, pingtria, lxuia: caulem binûm cubitorum, digitali crafsitudine, læuem, prope uerticem ex interuallis circundatum foliolis, ceu nucamenta quxdam oblon gareferentibus, fpinofis, è quibus flos prodit albus: $\mathrm{fe}^{-} 30$ men oblongum, luteum : caput thyrfi fpecie : radicibus nititur longis, mucofis, rubris, \& glutinofis. Qux uft is igni, \& Iuxatis artubus illitæ fubueniunt: potæ urinam ciunt, fed aluum cohibent: ruptis, conuulfis, tabem fen tientibus, mirè profunt: Nafcitur $\&$ fylueftris Acanthus, fcolymo fimilis, aculeatus, breuior quàm fatiuus, $\&$ is qui in hortis prouenit. Cuius radix ad eadem ad qux fuperior efficax.

Acanthiconfideratio.
C R E D V N T omnes feré buinfce temporis rei berbarice 40 ftudiofi, Acanthum eame effe plantam, que nobis uulgó uocatur Branca orfina. Quorum fententie nec prorfus refragari, nec plane adffipularipoffum. Nam etfi in eorum opinionem:multis adducar rationibus, non folim quód ij magne fint apud me au= ctoritatis; fed etiam quód ipfe uiderin banc, que Branca urfina dicitur, folijs lactucalatioribus, longiorıbusíg, eruce modóla= ciniatis, nigricantibus, ac molli quodam lauore pinguibus : cau= leitem lavi, bicubitali, pollicaricraßitudine, per interualla fub ipfum ufq; uerticem foliolis quibufdam oblongis, ueluti nucamen= tis,circunidato: é quibus flos prodit candidus, o inde $\int e m e n o b=$ longum, lutcumíg: atq; etiam radice eadem conftet, qua Acan= thus; aliqua tamenrelinquitur dubitatio, an Branca ur ina legiti= mus fit Acanthus, cim foliold, que nucamenti inftar illius caulem cing unt, nullis pinis horrida confpiciantur, plan= táq; ip fa uideatur topiarijs operibus inepta: ad qua Acantbus olim (ut Plinius libro o cap. $\mathrm{x}$ x I $\mathrm{r}$. auctor cft) conue niens babebatur: ac ctiam ea bodie ab omnibus fré negligatur, e ucluti ignobilis planta, in perpaucis tum bortis, tü uiridarijs $\int$ cratur, cum apud antiquos Acantbus celebris, e in magno bonore babitus fit, ac plurimis ladibus fuerit decantatus, Neq; illud fupicionem noftram diluit, quodd dixerint aliqui Acanthina folid, que in quibufdam I talie locis marmoreis columnis, prefertimóq; Corintbias imitantibus, infculpta reperiuntur, nulla prorfus linca à Brance urfi= na folijs differre. Siquidem contrà ijs quipiam facilé reßłondere poffet, quód etfí utraq,; eandem retine ant forsnan; non ob id tamen neceffario uname ed endem peciem reprefentant. Quare quemadmodum dubium cft affererc, Brans cam ur/inam ab Acantho non differre; ita idem negare nitium effe uidetur. Ceterim ad băc tollendam dubitationem 


\section{In Lib. tertium Diofcoridis.}

illud non parum, meo iudicio, facit, quód ijfdem facultatibus Branca urfina predita fit, quibus pollere Acătbun Dio= fcorides, Ð Galenus memorie prodidcrunt. Illud infuper addiderim, quod et $f$ dicat Diofcorides, oriri Acantbum caule foliolis pinofis, ceu nucamentis, prope uerticem uf $q_{\text {; }}$ ex interuallis circumueftito; poteft tancn intelligi, quód non re uera foliola ill a aculcis horreant; fed quòd adeó acuminata erumpant, ut fanéfinis perfimilia uideantur. Id quod facilé credipoteft, cim cxteris ommibus notis Branca Vrfind Acantho a Diofcoride reprefentato adamußim refponde at. Neq; impedit, quodd loco citato afferat Plinius, A canthum in hortis crepidines marginum, affurgentumm; puluinorum toros ueftire. Quanuis enim necti haud facilé ex fe ualeat; tamen tum caulis, tum folia ob corum molli= tiem, lentoremq́; aded fle cti queunt, ut uimineo aliquo nex u topiario operi etian non incommodé aptari poßint. His

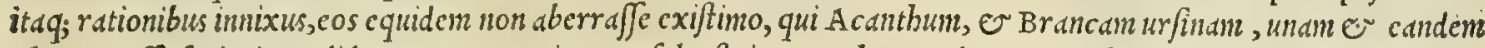
- plantam effe fcriptis tradidcrunt. Reperitur O fylueftris Acantbus carduo (ut Diofcorides inquit) fimilis, pino= fus, folijs tanten domeftico anguftio ribus. Cuiocirca non abre Plinius quoq; duo Acanthigenerd conftituit. Acan= thi meminit Galenus lib. V I. fimplicium medicamentorum, fic inquiens. Acanthos, alij quidem Meldamployllum nomi= nant, alij ueró Paderota. Folia quidem mediocriter digerentein facultatem obtincut. At radix exiccatoria eft, et le $=$ uiter inciforia, or tenuium partium. Planta, qua Grecé a'sav8os, Latiné fimiliter Acanthus nominatur: Itali= cé, Acantbo, or Branca orfind: Germanicé, Beren klauu: Hipanicé, Yerua giguante, 0 Branqua urfina: Galli=

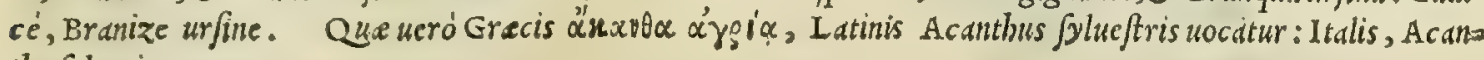
tho faluatico.

A'varis, "̈ OVavis. ANONIS, SIVE ONONIS.

A N o n I s, quam aliqui ononida áppellant, ramos habet fruticofos, dodrantales, aut maiores, fiequentibus geniculis cinctos, cauis alarum mulcis, capitibus rotundis : folijs lenticula, tenuibus, pufillis, ad rütx, aut pratenfis loti folia accedentibus, fubhirfutis, odoratis, non iniucundè olentibus. Muria condîtur, antequàm fpinofa fiat, cibis gratifsima . Rami acutioribus fpinis, \& ueluti fpiculis firmioribus horrent. Radicem mittit candidam. Quæ excalfacit, \& extenuat . huius cortex ex uino potùs urinam ciet, calculos com minuit, margines ulcerum erodit. Radix cùm decoquitur in pofca, dolorem dentium collutione mitigat. Decoctum eius potu hxmorrhoidas fanare creditur.

N A S C I T V R Anonis in pratis, cultis, atop etiam incul= Anonidiscötis locis, arido prafertim folo: folijstenuibus lentis modo, pufil = fideratio. lis, que ad rute, uel pratenfis loti cffigiem proximé accedunt, ac caleras omnes notas refert, quibus à Diofcoride depingitur. Ru= fticis ob id notißima eft, quód non modó fuo ramorum, ac radicum inplexu, aratra invitis bubulcis in medijs agrorum fulcis fapius remoretur, unde Refta bonis compluribus nominatur; fed quód $e=$ tiam mefforibus, o fänifecis pinis finis acutis admodum fit infes= fta. Nam et fit predurd, callofág; fit eorum cutis; eam tamen fuis perforat aculeis, quibus quafipiculis, cum maturuerit, horrida conpicitur. Infubres banc uulgó Bonaga nocant. Caterim quan. uisfloris eius nibil meminerit Diofcorides; conftat tamen flore plerunque purpureo fubalbicante, interdum tamen aureo. sed bec quibufdam in locis aculeis uacat. Mesininit Anonidis, ono=

nidis nomine, Theophraftus. Libro vi. cap. v. de plantarum his

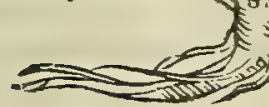

50 ftoria, fic feribens. Ononis ramis aculeigerum eft, anno tantum perdurans, folio ruta fimilis, fed per totum caulem appofito, ut ueluti coronam ex interuallis tota ßpecies reprafentet. Florem minutulum, o in filiqua non undique feptum edit. Nafcitur glutınofo, latog; folo, e precipue in fegetibus, atque cultis: qua de calufa agri= colis inimica exit. viuax admodum efl. Cum entm altam nacta tellurem fuerit, protimus fud infima pellit: $\sigma$ fin. gulis annis, furculis in latus emifsts, rur fus postero anno dcorfum uerfus pellere folita $e f$. Ideo ó; effodienda tota, extirpanda'; penitus eft. Incipit germinare astate, perficitur'; autumno. bastenus Theoplrastus. Huius quoque mentionem fecit Plinius lib. $\mathrm{x} \times \mathrm{V}$ I I. cap. I I I I. ubi fic inquit. Anonim, quidam ononida malunt uocare, ramofam, fimilem fano Graco, nifi fruticofior, hirfutior q́; effet, odore iucundo : poft uer pinofa . hec Plinius. Qui tamen bac in re erraffe deprebenditur : fiquidem non poft uer Anonis pinofa redditur, fed ( $u t$ Theophraftus author es?) in au= tumno. Id quod etian experinento comprobatur. A nondis radix uim maximam praftat ad renum calculos com= minuendos, expellendosq́;, obftructis prefertim urina meatibus . quod multorum tefimonio compertum eft qui cal = culo.affeçi, ubi tanium radices corticum puluerem ex uino diutius bibiffent, pristindm fanitatem recuperarunt. Noui 
quendam, qui buiufce radicis puluere duntaxat pluribus menfibus fumpto, carnofum ramicen abfumpfit, eri fai= natus eft: licet à medicis nullo alio medicamento, quàm fola fectione, uftionég, bunc curari poffe anted ftatutum

Anonidis ui- effet. Anonidis uires defcripfit Galenus lib. v I I I. fimplicium medicamentorum, fic inquiens. Ononis radicent ses ex Gal. bubet tertio quadantenus ordine excalfacientem. Cortex eius maximé eft utilis, habens quippiam er abfterforium; o inciforium. Proinde non tantum urinas prouocat; fed o lapides confringit. Eadem facultate er cruftas cito de= trabit. Vtuntur porró ea quoque $\sigma$ ad dentium dolores, in oxycrato decoquentes, $\sigma$ collui decocto iubentes.

Nomina. Huic plante nomen Grecum eft a’vavis, Ơ óvavis : Latinum item, Anonis, ơ Ononis: Italicum, Anoni= de: Gerinanicum, Haublechel, er Stallivaut:Hipanicum, Gatilhos, er Gathinos : Gallicum, Bugraues, er Bugrundes.

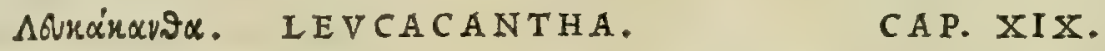

Leucacanth $x$ confideratio.

Ruel. lapfus.

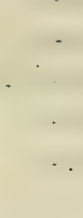

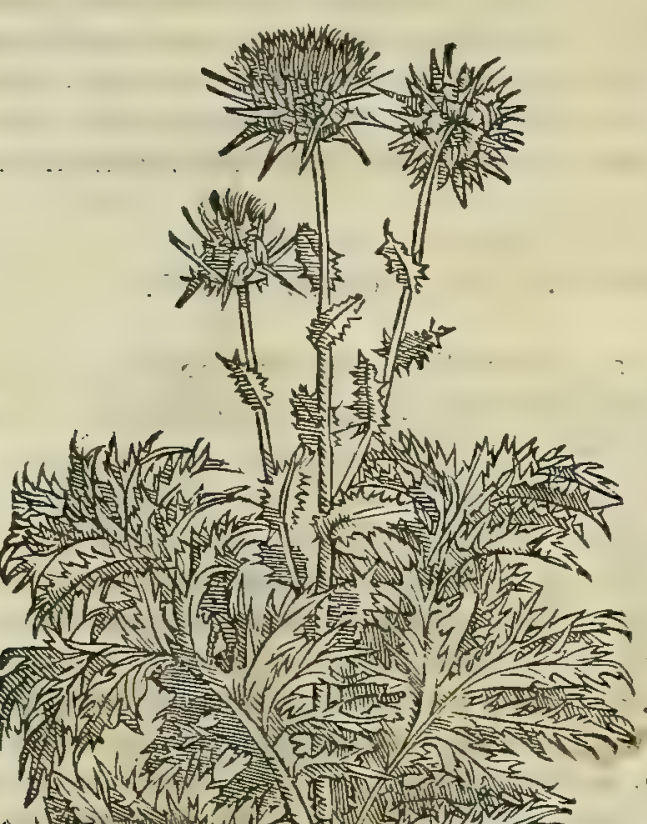

LE V C A C A N T HA, prædita eft radicecyperi, valida, \& amara. Quæ manducata dolorem dentiumfedat: ueteri laterum dolori, atque ifchiadicis prodeft, decocto cyathis tribus ex uino poto. Eadem ruptis, \& conuulfis medetur. Radicis epotus fuccus cofdem prat bet effectus.

In maniffto errore uer fantur, qui fentiunt, Leucacătham, 20 boc eft,albam fpindm, de cuius hiftoria, Ur uiribus hoc capite trat= ctatur, ab Acantba leuce, id eft, pina alba, de qua pauló fuperius diferuimus, nullo pacto differre. Qua in fententid, uel potius er= rore, fuere nonnulli ex recentioribus, alioqui rei berbarie peri= ti. In quorum etiam numero Ruellius fuiffe ex eo maximé de= prebenditur, quód cum debuifeet, more fuo, poft Anonidis tract a tionem, cuivs titulo pinam albam quoq; adiunxerat, quam, tamen albam pinami nominaffe rectius forté erat, eiufdem alba pine bi= ftoriam referre, ex induftria eam filentio preterijt. Nam cum exiftimaffet, alter am ab altera non diftingui, non opus effe iudi= 30 cauit, earum hiftoriam in Alba pina repetere, quam anted in spi= ne alba mentione tradiderat. Quo tamen in loco ab errore uin= dicari non poteft : quippe quoniam poftquàm pine albe, quam Mauritani Bedeguar appellant, meminerit, alteram eius nominis pinam fubdidit, quat cum in arbuftum undiq; dculeis armatum df furgat, fepibus extruendis rufticis noftratibus maxime expeti= tur. Nontdmen ob id declarat ip fe banc effe Leucacdntham; fed lubrico quodam lap $\int u, q u a f i$ fui ipfins, or cuius pine albe mentionem faceret, oblitus, in capitis calce aculeate illius arbu= fcula radicibus, qua ( $n$ ifallor) candida eft Diofcoridis rham $=40$ nus, omnes tribuit facultates, quibus legitima pina alba d̀ Dio= coride commendatur. Qui quidem Ruellij error omnibus euidentior eft, quàm ut pluribus refelli poftulet. Quód au= tem differant inter fe Acantha leuce, et Leucacantba, non modó Diofcorides inter cateros fimplicium medicamento rum foriptores facilé princeps oftendit; fed Galenus etiam, ev Paulus. qui practerquàm quód alteram ab altera diuer fis capitibus difinxerunt, earum fingulam differentibus facultatibus preditam effe tradiderunt. Quorum fententice

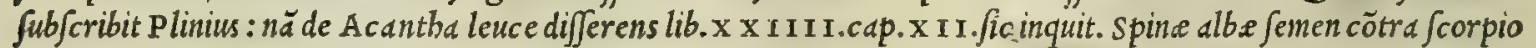
nes auxiliatur. Corona ex ea impofita capitis dolores minuit. Sed uires longé alias ab his L eucdcantha idem retulitlib. X X I I.cap. X V I .ubi fic habet. Leucacantham alij phyllon, alij ifchiada, alij polygonaton appellant, radice cy= peri, que commanducata dentium dolorem fedat. Item laterum, er lumborum (ut Hice fius tradit) femine poto drach= mis octo, aut fucco. Eadem ruptis, conuulfiś, medetur. bec Plinius. Que quidem uidiffe debuerat Ruellius, alioqu 50 Pliniane biftoria ftudiofißimus : aut certé Hermoldo doctißimo uiro credidiffe, à quo(etfi nunquam illum citet) integra quando $;$ capita, imó(pace eius dixerim) integrü feré furripuit opus, ita ut is omnibus illud fuum feciffe uideatur . siquidem Hermolaus, cum in Leucacantha, tum aliâs fepenunero commonuit in fuo Corollario, hanc ab acantba leu= Brafauoli er- cedifferre. Porró illud etiam nobis filentio non dißimulandum, ut ingenué quod fentimus de fimplicibus dicamus, ror. quód Leucacantba herba eft, non autem arbufcula fepibus conficiendis idonea, ut fal só, mea quidem fententia, Mufa Brafauolus fuo de fyrupis libello in eupatorij fyrupo exiftimat. Nam hoc loco de berbis tantim, er non de arbufculis fcribit Diofcorides : qui nimirum inftirpium hiftoria peritißimus, arbufculam illam fuprà libro primo inter R banni genera defcripfit, er fub candido, ut puto, complexus eft. Ceterim cimm nec Diofcorides, nec Plinius tradăt, quibus folijs, quo caule, flore, ac semine Leucacantha proueniat, difficile quidem fuerit inter tot aculeatarum ftirpium ge= nera, unam fecernere, qux ueré Leucacanthä reprefentet. tametfi damnandus ufquequaq; non effet, qui dixerit Leu cacantham effe fortaffe aculeatum illum Carduum,de quo in Acantha leuce diximus, cuius folia albis quibufdă macu= 


\section{In Lib. tertium Diolcoridis.}

tis depinguntur. Nimp preterquim quod coniectura quadam dici poffet, eam a maculis ill is albic antibus fibi Leuca= cant be nomen adinueniffe, radic is ctiam ipfius tum durities, tum amaritudo, etfi forma cyperinas non a mulctur, cons fentire uidentur. Sed hoc potius diffutandi, qudin afferendi gratia proponimus : cim adbuc mbil certi nobis comper tum fit. Lcucacunthe uires paucis perftrinxit Galcnus lib.v I I. Fimplicium medicamentorum, fic inquiens. Leu= cacamthon, quidan autem polygon.ton, alij if chiada nuncupant. Huius amara radix eft, ac proinde incidit, $\sigma$ exic

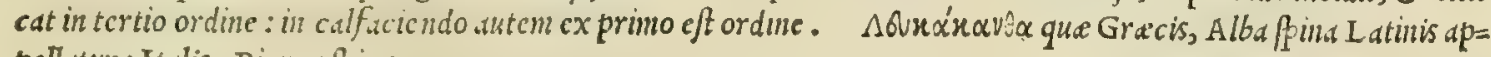
pellatur: Italis, Biancapina.

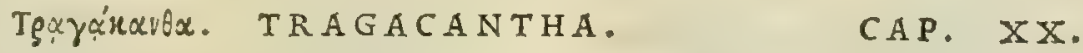

Nomina.

I.eucacanthx uires ex Gal.

T R A G A C AN T H A E radix lata, \& lignofa fummo cefpite nititur : unde furculos humiles, robuftos, latifsimè fundit: in quibus minuta folia, multa,nonnunquam tenuia exoriuntur: qux fub fe fpinas albas, rectas, \& firmas occulunt. Eft etiámnum tragacantha lacryma, quæ uulncrata radice manans, concreuit . Præftat pellucens, gracilis, læuis, fyncera, \& fubdulcis. Cutis fpiracula, ut gum mi, obftruit. Huius increbuit ufus ad oculorum medicamenta, ad tufsim, exafperatas fauces, recufas uoces, cxterasq́ue deftillationes, cum melle in delinctu: fubdita quoque lingux liquefcit. In paffo ma defaeta, drachmæ pondere bibitur,contra renum dolorem, \& ueficæ rofiones, mifto cornu cerui ufto, \& eloto, aut fcirsi aluminis momento.

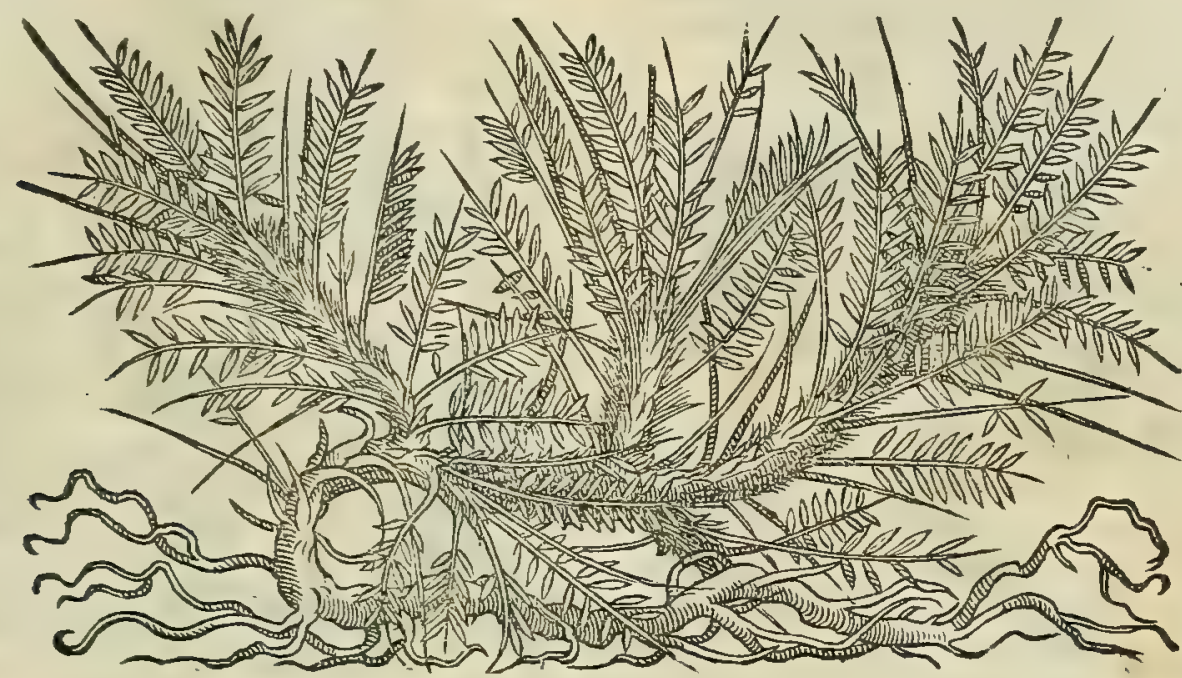

T R A C A C A N T H A E plantam, à qua effigiem, quàm bic exhibemus, deprompfinus,iampridem ad nos mifit quidam rei herbaria ftudiofus, qqui illam attulerat ex Apulia Gargano monte. Ea certé est, que nullis prorfus not is a Diofcoridis biftoria diffentiat, ut ex eius picfura omnibus liquidó conftare poteft. Ceterùm lacryma é uulnerata radice manans, quam feplafiarij uulgò uocant Gomma draganti, paßim in officinis concreta uifitur, $\dot{e}$ Creta, Afía, e Grecia adueța. At non modó hac (ut Diofcorides inquit) é unlnerata prius radice manat; fed etiam fponte (ut Theophraftus eft author) ab ea fcißo in latere cortice diftillat. Sed banc, qua utimur, Monachi illi reuerendi, qui in Me fuem commentarios ediderunt, ueram effe Tragacanthe lacrymam negant, quód legitima lingua fubdita faci= Tragacanthe confideratio. lé, Diofcoridis testimonio, collique $\int c a t$ : hec ueró nunquam, cum lingur fuppofita adeó lenta, tenaxó; euadat, ad= mista faliua, ut nullo feré temporis traftu diffolui liquariǵ; poßit. Qua quidem in re ij (pace eorum dixerim) toto crelo aberrant, ut qui Diofcoridis fententiam perperàm acceperint. Siquidem Diofcorides non de fola lacryma lin $=$ gua fubdita, fed in eclegmate cum melle conformata, itlud fierifcribit, cum inquit. Vfus eius ad oculorum medica= menta, ad tufes, exaperatas fauces, retufas uoces, cateras q; deftillationes, cum melle in delinctu: lique fcitó; fus biecta lingur. bec Diofcorides. Ex quibus palim eft uoluiffe Diofcoridem Tragacanthe lacrymam non folam, er

so per fe tantiom, fed in eclegmate cum melle paratam lingua effe fubijciendam, ut clarißinorum medicorum inftitu= tione fieri adfolet cun bechicis catapotijs, o diatragacanthe trochifcis, quibus ipfa commifcetur. Quippe cüm oporteat medicamenta, quibus afpera arteria, pulmo, ac pectus uniuer fum expurgari debent, quadam temporis diuturnitate ore retenta, uel lingua fubdita fenfim, leniter '́; lique fcere, ut commodé in tracheam percolentur ar= teriam, uoluit bic Diofcorides eelegmatis ufum recta methodo defcribere. Nam fi huiufmodi medicamenta de= uorarentur, nibil pror fus proficerent, cum ita non in pectuser pulmones deferantur, fed in uentriculum. Huic O alid accedit ratio, quód fí intellexiffet Diofcorides lacrymam per fe tantüm lingue fubmittendam, fubiunxiffet quidem, ut fui moris eft, quibus in morbis id factitandum effet. quandoquidem plane abfurdum uideretur fcribere, quód aliquod gummi lingue fubijciatur, paulatimi; lique fere cogatur, ac deinde filentio inuoluere, quibus in morx bis id faciendum. His itaque rationibus non modó recté, meo quidem iudicio, intelligi poteft uoluiffe Diofcoridem, ec= legma, quod Tragacanthe lacrymam exceperit, lingue fubijciendum effe, non ipfam tantum lacrymam; fed ex tiam MIonachos in hoc, ut alias $\int e p e$, deceptos effe. Tragacantha uires fcriptas reliquit Galenus libro v III. 


\section{4

Iragacanthre fimplicium medicamentorum, his paucis uerbis. Tragacantha fimilem gummi uim obtinet, emplaftican quandani,

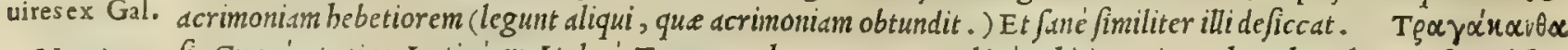

Nomina, fic Grecé, ut etidin Latine, er Italicé, Tragac antha uocatur: Arabicé, Chitira, Itica, Chatcth, Alcuted, feu Alcha= thad: Germanicé, Dragant : Hipanicé, Alquetira.

ER YN GIVM.

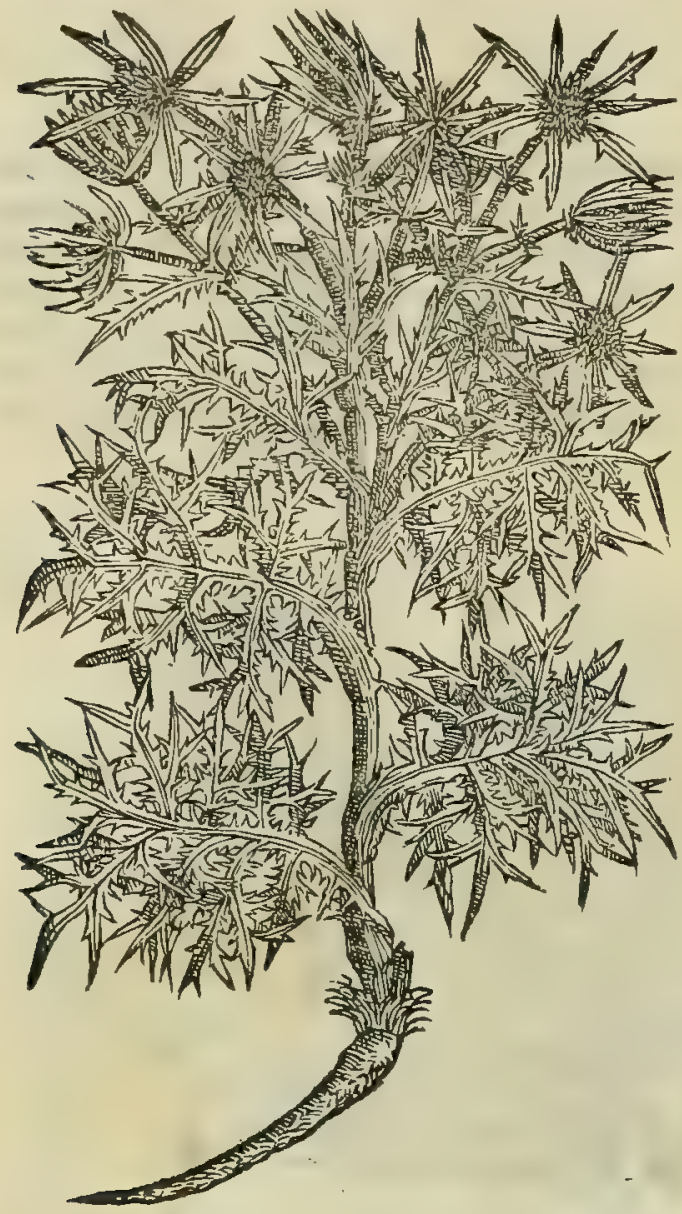

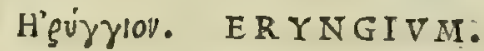

ERYNGIVM MARINVM.

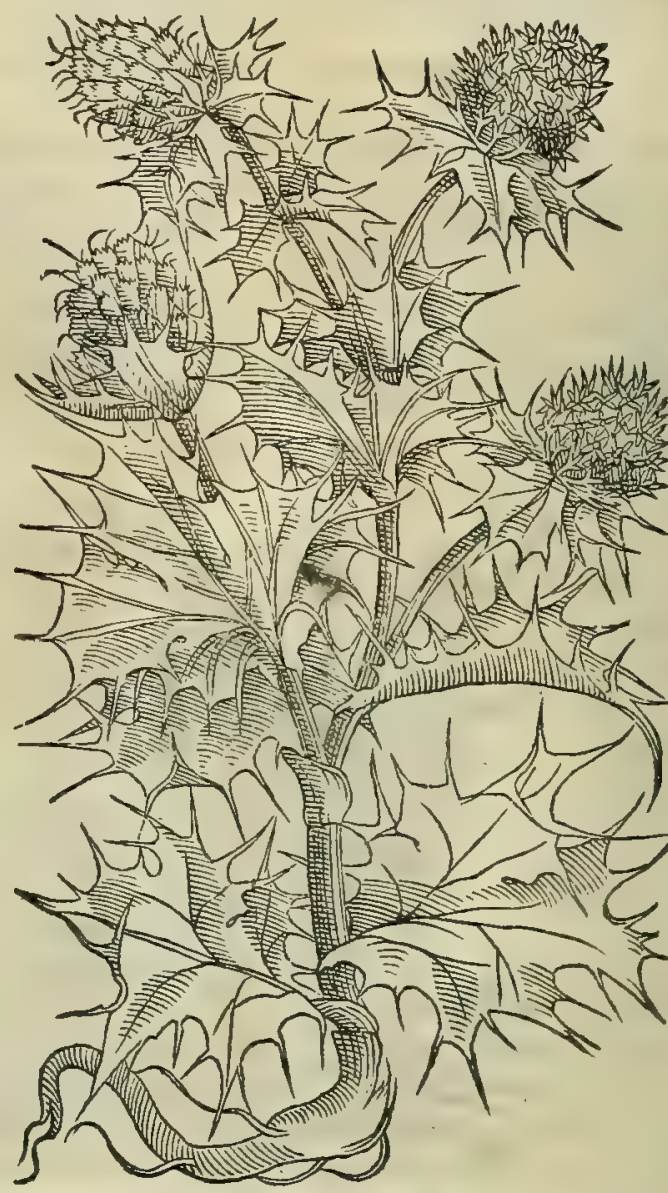

CAP. XXI.

ERYNGI O N aculeatarum gencris. Cuius folia in principio, fale condita, in cibos recipiun. tur. Lata autem funt, å extremo ambitu afpera, guftu aromatica: fed ubi adoleuerunt, circa com. plures caulium eminentias in fpinas aculcantur . in quorum fummitatibus globofa capitula, durarú, acutifsimarumq́ue fpinarum ambitu ftellatim circumuallantur, quorum colos aliàs uiridıs, aliàs albus, interdum coruleus inuenitur. Radix oblonga, lata. forìs nigra, internè candida, pollicis crafsitudine, odorata. Nafcitur in afperis, \& campeftribus. Vim habet' calfactoriam. Pota menfes, \& urinas pellit : tormina, inflationesq́ue, difcutit : contra iocinerum uitia, ferpentium, morfus, \& haufta uenena, cum uino prodeft : bibitur aduerfus plurima, cum feminis paftinacæ drachma una. appenfa, illitáve, tubercula difcutere proditur. Pota cum hydromelite radix, opifthotonicis, \& comitialibus medetur. Eryngiicon- LONGE' quidemaberrant feplafiarij Senenfes in Eryngij cognitione, utpote qui pro Eryngij radicibus afs so
fideratio.

fumant aculeat.e cuiufdam ftirpis radices, quam Cacatreppola uulgó uocant. Hinc error ommibus facilé depre= benditur, quód nulla pcnitus illius plante nota eryngio repondeat. Legitimunt Eryngiun, quod, meo iudicio, Dio= fcoridis de fcriptioni nibil refragetur, frequens inuenitur prope Tridentuna menia, ac in Goriticnfi agro, quin eo

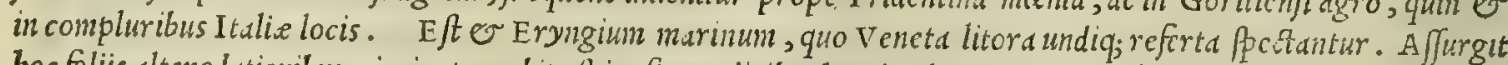
boc folijs altero latioribus, circinato ambitu pinofis : radicibus longioribus, mollioribusq́; , faccharo afferuandis lon = gém.tgis idoneis, quàn alterius. Huius tamet/i non meminerit Diofcorides; Plinius tainen lib. $\mathrm{X}$ X I I. cap. V I 1 .

Quorundam utriufque biftoriam tradidit. Quо fit, ut cortin fententiam minimé probauerim, qui Eryngium marinum Croco= errores. dilium effe exiftinant, ut in crocodilì mentione fuperius dixinus. Sunt 0 qui credant, Eryngium Mauritänis a Secacul non differre. Veruntamen ij quoque ballucinantur : nam chim serapio in capite de Sccacul, neque Diofco=

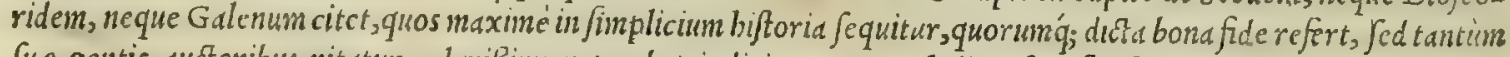
fue gentis auftoribus nitatur, clarißimum prebet indicium, secacul diuerfum fuife, o plantam Gracis inco= 


\section{InLib. tertium Diofcoridis. $\quad 365$}

gnitam . siquidem fipro eryngio secacul fcripfiffet Serapio, ei fané non fuiffet opus, paulo inferius de eryngio tra= care ex Diofcoridis, er Galenifententia, magno uirium o notarum difcrimine. Quamobrem non parum fallun= tur, qui secacul ab eryngio feccrnere nefcientes, Eryngij radices tum faccharo, tum melle afferuatas ucnereis in= feliciter cominifcent auxlijs, ut qui ederint, fortiores, falucioresq;; rcddantur. Quippe bac facultate Eryngiom preftare nufquam hactenus apud Diofcoridem, $\sim$ Galenum mibirepcrire licuit, qua tamen pollere Secacul memo= rif prodiderunt Arabcs. Cottcrim animaducrtendum eft Scrapioncm Aftera Atticum, fiuc Buboniun cum eryngio confudiffe, ftcllarum fimilitudine decptum, qua cerulco colore fe invicem cmulantur : ctfi qux Eubonio infunt, rullis acule is horreant. Meminit Eryngij Galenus lib. V I. fimplicium medic antentorum, fic inquicns. Eryngium Eryngij uires caliditate quidem aut parum, aut nibil, quxe temperata funt, fuperat. Siccitatem ueró in tenui cffontia confiftentem ex Galeno.

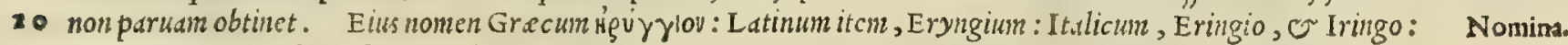
Germanicum, Brachendiftel, Manfreuu; Hifpanicum, Cardo corredor : Gallicum, Panicault.

A'入ór. ALOE.

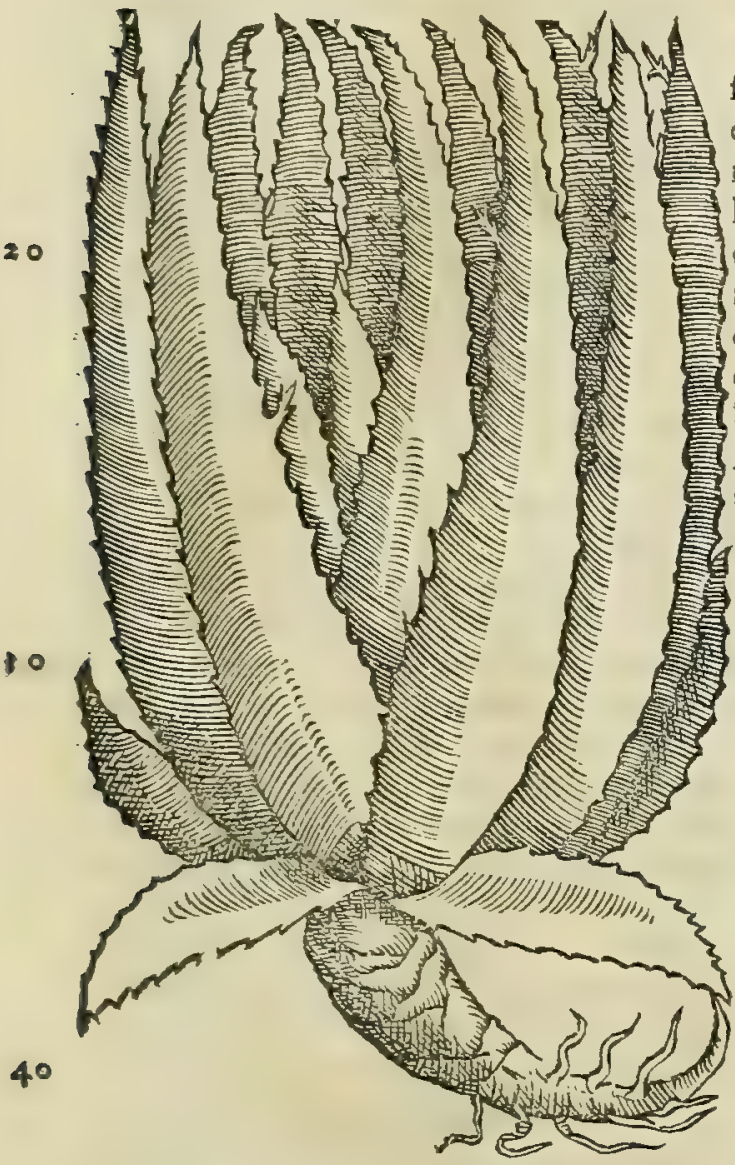

CAP. XXII.

A I o E S folium fcillx fimilitudinem habet, crafo fum, pingue, modicè latum, rotundum, retrorfus pandum : folia gerit curta, qux utrinque ex obliquo longio ribus interuallis ftriantur, \& in fpinulas definunt. Caulis emittitur non difsimilis antherico: flos albus: fruEzus haftulæ regix cognatus: graui tota eft odore, \& guitu amarifsima: radice una, ceu palo, in terram depacta. Plurima, prxpinguisq́ue in India gignitur, ex qua coactus fuccus adfertur. Nafcitur etiam in Afa, \& A rabia in locis quibufdam maritimis: 8 in infulis ( $u$ in Andro) non valde fucco extrahendo idonea, fed ad glutinanda vulnera fanè quàm vitilis, fi detrita illinatur.

Duo fucci genera : quoddam arenofum, quod fedimentum purifsimæ effe uidetur: alterum ad iecinoris imaginem uergit. Eligi debet boni odoris, fyncera, qux nihil doli fenfit, nitida, calculorum expers, rufi coloris, friabilıs, ac iecinoris modo coacta, facilè liquefcens, eximix amaritudinis. Improbatur nigra, \& fractu contu max. Gummi eam adulterant: quod deprehenditur guftu, amaritudine, $\&$ ualido odore: coq́ue argumento, quòd digitis friata non ad minima ufque frufta refoluitur. Nec defunt, qui acaciam immifceant. Natura eius eft ?piffare, exiccare, fomnum allicere, \& corpora denfare, aluum refoluere. Stomachnm repurgat binûm cochlearium menfura, in aqua frigida, aut egelida pota: fanguinis reiectiones fiftit : regium morbum purgat, tri bus obolis ex aqua,aut drachmæ pondere in potu: deuo rata cum refina, aur cum aqua, vel melle cocto fumpta,aluum foluit: purgationis perfectx caufa tribus drachmis fumitur. alijs purgatorijs medicaminibus admifta, præftat, ut minus ftomachum infeftent: ficca glutinandis vulneritus infpargitur : ulcera ad cicatricem perducit, cohibetq́ue. Eadem peculiariter exulceratis genitalibus medetur, \& difrupta puerorum preputia iungir: condylomata, rimasqque fedis ex paffo fanat; hæmorrhoidum abundantiam, \& fanguinis eruptiones fiftit: pterygia ad ciatricem ducit : liuores, \& infignita ex melle tollit. Priuatim fcabras lippitudines, pruriginesque angulorum permulcet: dolorem capitis fedat, tempori bus \& fronti illita, ex aceto \& rofaceo : capillum fluentem continet cum uino: tonfillis, gingiuis, \&

so omnibus oris ulceribus, cum melle \& uino proficit. Oculorum medicamentis torretur in munda, \& candenti tefta, pennaq́ue fubinde uerfatur, vt pofsit æqualiter torreri . Lauatur, vt quod fit arenofifsimum, tanquam inutile fubfidat, \& laeve, ac pinguifsimum affumatur.

N o N dubium eft, quin ea legitima fit Aloë, qua paßim officine utuntur. Nam electißima,ac purißima ddulterd= ta enim quandoq; etiam inuenitur) omnes preftat tum notas, tum uires, que fyncerifima ḋ Diofcoride a signantur. Aloë atate noftra in quàm plurimis I talize locis uire fcere confpicitur, prefertim Rome, $\sigma$ Neapoli, $u b i$ fuper adi= um feneftris, ac atrijs in fictilibus uafis terra plenis alitur, ac fouetur ad pectaculum potius, qudin ad medicum ufum. Quemadmodum o berba Plinio o P V N T I A dicta, folio Aloëlongé crajsiori,ac dimpiiori. Mirum quód ex bu= ius folio tantim plantato radices funt, ato; ed ita non fecus nafcitur, ac fi tota planta fereretur. Illud etiam eam Bectantibus permirum accedit, quod temporis \$atio fructus proferat ficis fimiles. unde d plerif $q_{\text {: }}$ Ficus Indica 110 minatur. Inuebuntur acerrime in Me fuem Manardus Ferrarien/is, o Eucb/ins ip fun fecutus, quód affirmauerit

Aloès confideratio.

Opuntia Plinij.

Mefues à calumnia uindi catus. 


\section{And. Matthioli Comm:}

O PVNTIA.

Aloếs uires ex Galeno.

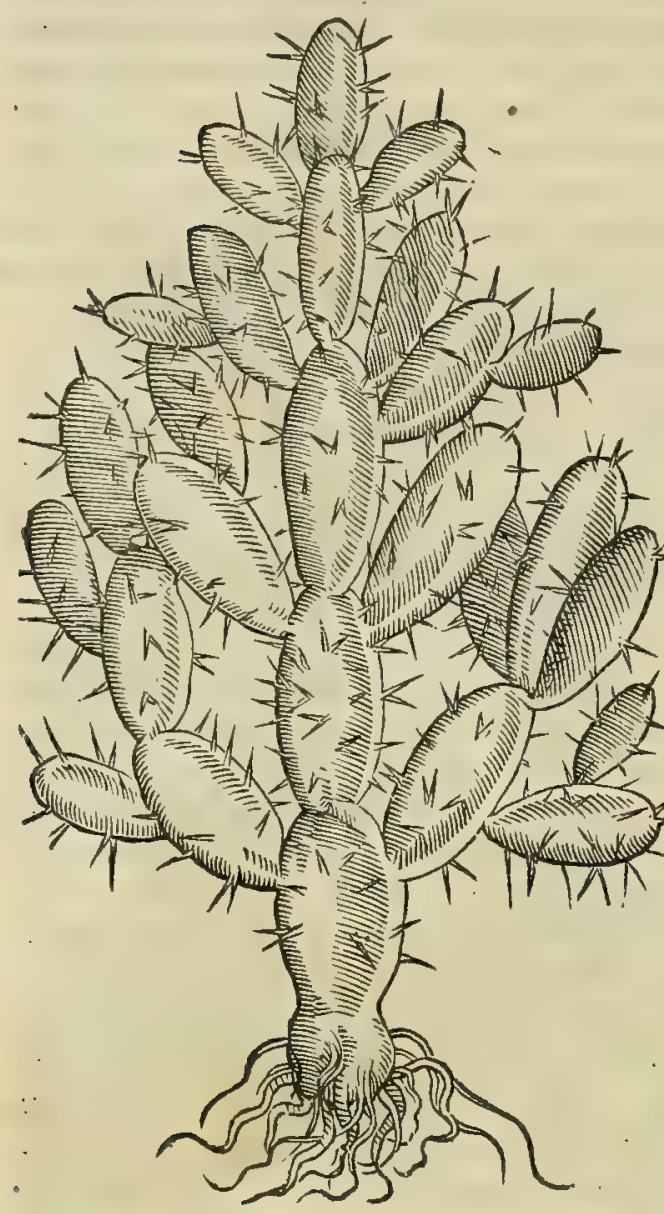

ille, Aloën per os fumptam uenarum ofcula adeò referarē, ut in= de poftea sanguis facilé exiliat, cùn id (ut ipfi aiunt) tum Diofco= ridis, tum Galeni placitis maximé repugnet. Verum quam longé ij, quorum pace dictum fit, à ueritate de fciuerint, non multo qui= dem labore demonftrare poffem, ni preter infitutum noftrum id effe cenferem, niq́; compertum baberem, illis prius recte, meo iudi= cio, repponfun fuiffe à Iacobo syluio clarifimo at tatis noftre me= dico in Mefuem fribentè, et à Gratianopolitano quod̄̄. qui tàm probatifimis rationibus Me fuem tuentur, ut non amplius Manar= do, ac Fucl)fio hic eum lacerandilocum relictum effe putem.

Aloës meminit Galenus lib.v r. fimpl.medic.ubific habet. H.o berba non admodum apud hos prouenit : 0 que nafcitur in mas gna syria, aquofior eft, \& facultatis imbecillioris: attamen ufq; adeó deficcare poteft, ut uulnera conglutinet. At in regionibus ca lidioribus, qualis eft Coelefyria, $\dot{\mho}$ Arabia, multó eft melior. Opti ma autem Indicd, cuius liquor $\mathrm{e} f \mathrm{t}$, id quod ad nos importatur, mes dicamentum Aloë cognominatum, ad plurimas res, propter fic = citatem mordicationis expertem, utile. Eft autem non fimplicis nature, fed ut indicio eft guftus, adftringit fimul, $\odot$ amara eft: adffring it quidem mediocriter, $f e d$ uebementer amara $\mathrm{e} t$. $s u b=20$ ducit o uentrem, utputa ex numero medicamentorum, que

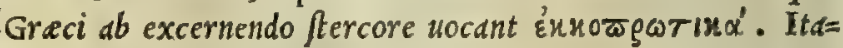
que ex dictis patet (fi quidem memoria tenemus; que in quar= to libro funt demonftrdtd ) quód tertij fit ordinis exiccanttum, calfacientium autem aut primi intenfi, aut fecundi exoluti. Sed o ipfius facultatis mifturam atteftantur particularia eius ope= ra: nam o vitle ftomacho medicamen eft, ut fi quid aliud: $\sigma^{\circ}$ finus glatinat. Sanat o ulcerra, que agré ad cicatricem duci poffeunt, $O$ maximé, que in ano funt, $\mathcal{O}$ pudendo. I uuat $\sigma^{\circ}$ corram inflammationes aqua fubacta, $\mathcal{E}$ unlnera eunden ad 3 modumglutinat: Congruit fimiliter utenti or ad inflammatio = nes in ore, ac naribus, 0 oculis. In fumma, repellere, $\sigma$ di= gereré fimul potest, cum hoc, ut paulim extergat, quantum uidelicet ulceribus puris non fit moleftum. Pr.e= terea idem Galenus lib. v I I I. de compofitione medicamentorum loc. in biere mentione, de Aloë ita fcriptun reli= quit. Atqui ipfan aloèn Andromachus quidem lotam, ex alijs autem aliqui etiam fic, aliqui uerò illotam adịciunt. Verim iam noffe oper epretium eft, ad uentris fubduftionem illotam aloën aptiorem effe, multum verò de medicamen taria ui deponére lotam, quam etiam febricitantibus dare aliquis audeat, fi non webiemens, fed ualde debil is fit febris. Quidam uerò etiam ex illota aloè pharmacum multis fic febricitantibus exbibuerunt, deinde cim nilsil manifefté $l_{\mathbb{R}}=$ fiffent, in alïs rurfus maximum experti funt nocumentum. Infeftißima eft enim aloë, etiam lota, bis qui citra uitia= tos bumores ex intemperie calida $\mathrm{O}$ ficcd affliguntur. Proximam ab his lefionem percipiunt, qui ficcam intempe= viem babent, etian cum frigiditate coniunctam. $e$ in uniuer fun qui ex fola qualitate particulam aliquam la $\int_{a m}$ ba= bent. Etenim in bumoribus intemperature, plarmac is ip fas eudcudntibus egent . que uerò ab fque bis confiftunt, pe nitus in tabem deueniunt ex pharmaci buius ex aloë conftant is $u f u$. Itaq; ubi bumiditas uitiata tuntcas uentris perris. gat, ex aloë picra utili is eft, expurgans bumiditatem. Omnino autem fic affectis acceßio naufea plus aut minus ad= eft. Eude uatio igitur affligentis bumoris per folam aloën contingit, qua purgatoriam uin non fortem babet; $\int e d$ ut ed; que circa aluuin funt, que etiam contingit, purgare poßit. Et $f i$ aliquando ampliori pondere exbibeatur, ufque ad locos circa hepar confcendit. non tamen totius corporis purgatoria aloë exiftit. Ceterum ex lis qua ei admifcen. tur, maftiche ut ftomacho commoda er odora, er que medicamentariam aloës uim frangere queat, admifcctur. Cin= namomum ueró eadem gratia, or praterea quód tenuißinnarum partium eft, ut aperire uentris meatus poßit, exter= gereq́; ac attenuare, fi quid uifcofum aut crafjum in bumoribus ferdtur. Craffos enim bumore sob purgatorie facul= so tatis imbecillitatem, aloe trabere non poteft . Quapropter biliofarum uentris affectionum optimum phatrmacum cft, adeó ut in uno die fape multos ftomacbicos creditos perfanet. Iunat autem $\sigma$ bos, $\sigma$ alios ornnes affectus ex uitid= tis humoribus ortos, cinnamomum admiftum: utpote quod alterantcm babet facultatem uitiofarum qualitatum in id quod fecundum naturam babet. Hactenus de aloë ex Galeno locis citatis. Deijcit Aloë (ut Mefues auctor eft) non

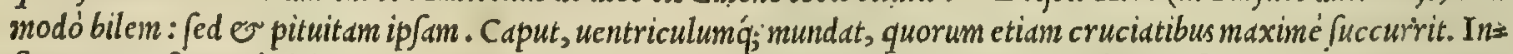
flammato, eft teantiğ; bilis redundantia uentriculo auxilio eft. Quotidianus eius ufus à mortiferis morbis tuetur. vin= dicat à putredine, addita myrrha, non modó uiuentium; fed etiam defunctorum corpora. Cum draconis fanguine, er myrrba ulcera contumacia fanat, quod fine morfu aliquo esiccare poßit. Scnfus omnes, intellectumiq; acuit, iecur ab infaretu purgat, of regio morbo medetur. Hamorrboidibus tamen, ac cateris fedis imflammationibus nocet: quă= obrem ijs ab eius affumptione abftinendum eft, qui aliquam in illis partibus noxampatiuntur. bxc Mefues. Caterum necat A loé uentris tineas ex lacte, uel melle fumpta: aut ombilico tenus appofitd, bubalo felle, or aceto Jubacta.

Planta, 


\section{In Lib. tertium Diofcoridis.}

A BSINTHIVM.

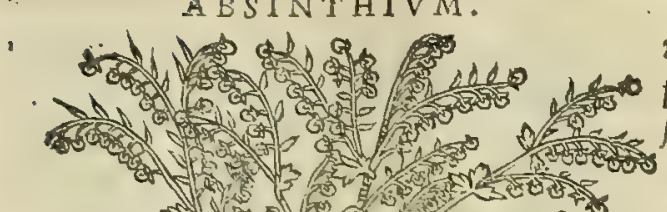

$\mathbf{2 0}$
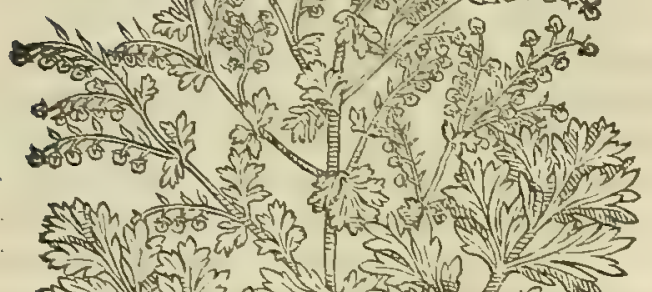

20

30

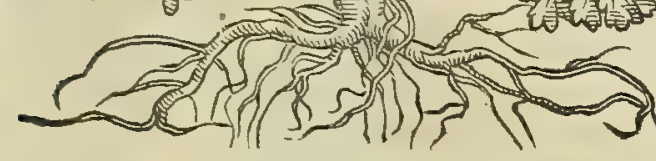

A BSINTHIVM MARINVM.

40

50

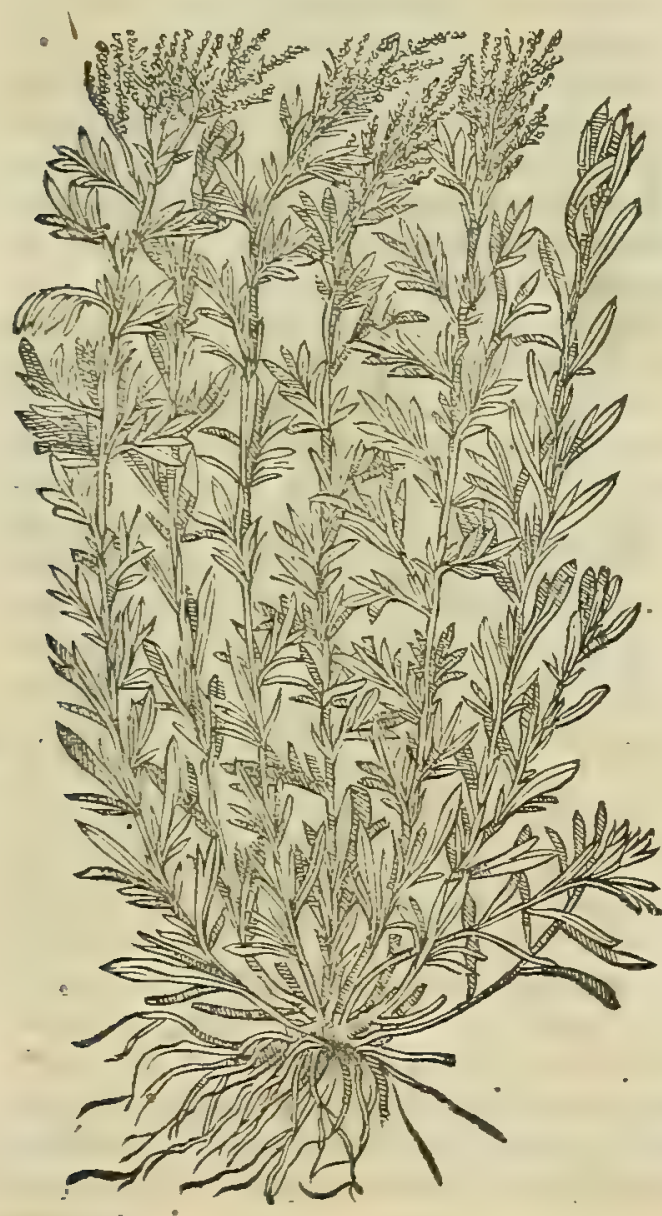

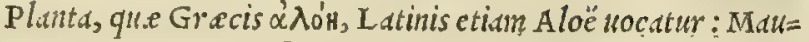
ritanis, Saber, Paber, fiue Sabar: Iralis, Aloc: Germanis, Ale= patic, O Bitter alocs: Hipanis, Hierua babofa: Gallis, Aloes, feu Perroquet.

\section{A'firgtov, ABSINTHIVM, CAP, XXIII,}

A B S I N T H I V M, aliqui bathypicron, herbavulgò cognita. Praftantius in Ponto, \& Cappadocia,ju mó te 'Tauro nafcitur. Vim habet calfaciendi, \&eadftringendi. Bilem expurgat, qux \& ftomacho, \& ventri inhre fit: vrinam cit, \& crapulam prefumptum arcet. ad inflationes ventris, \& ftomachi dolores prodeft, cum fefeli, \& nardo Gallico potum : faftidia difcutit, \& arquatos fanat madefacti dilutum, aut decocti jus, quotidie tri bus cyathis hauftum: menfes cit potum, aut cum melle appofitum. Contra fungoram ftrangulationes conuenienter ex aceto bibitur: aduerfatur ixia venenis cum vino : item cicutx, \& muris aranei morfibus, \& draconi marino. Anginæ eo cum melle, \& nitro perunguntur, \& epinyctides ex aqua. Ad fugillata, \& oculorum caligines, ex melle illinitur: item auribus, fi manat fanies . Dentium, auriumq́ue dolores decoctum vaporis fuffitu compefcit. Decoctum in paffo dolentibus oculis oblinitur : item præcordijs, \& iecinori, tritum cum cerato cyprino: ftomacho quoque longa valetudine laboranti cum rofaceo : cum ficis autem, aceto, \& loliacea farina, aqu $x$ inter cutem, lienofisque fubuenit. Vinum ex eo fit, quod abfinthiten yocant, præfertim in Propontide, \& Thracia, quo ad antè dicta vtuntur, cum febri carent: alioquin in aftate propinant, \& acceptam huic vino incolumitatem referunt. Infparfum arcis abfinthium, ve ftes ab erodentium iniuria vindicat : culices ex oleo perunctum abigit, \& à corpore arcet : atramentum librarium diluto eius temperatum, literas à murium erofione tuetur. Exiftimatur liquamentum eofdem præftare. effectus : attamen potionibus improbatur, quoniam fto machum malè habet, \& capitis ciet dolorem. Sunt qui. coeta amurca, liquamentum adulterant.

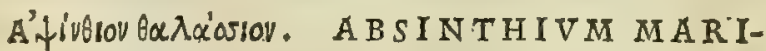 N V M. \\ CAP. XXIIII.}

A B S I N T H I Y M marinum, quod aliqui Seriphiú vocant, copiofifsimum in Tauro monte, iuxta Cappadociam, \& in Taphorifi Aegypti gignitur: quo Ifiaci pro oliux ramo vtuntur. Herba eft tenuis, abrotoni. parui fimilitudine, referta minutulis feninibus, fubamara, ftomacho inimica. Ea grauiter olet, \& cum quadam calfactione adftringit . Per fefe, aut cum oryza co$\mathrm{Cta}$, interaneorum animalia, teretesq́ue tineas, adiecto melle enecat . aluum læuigat: cum edulio autem, vellen ticula decocta, eadem præftare poteft. Pecora maximè pinguefcunt hoc pabulo. Tertium genus abfinthio affignatur, quo Gallia alpibus finitima fcatet. Id patrio nomine Santonicum vocant, regionis, in qua nafcitur, cognomento, abfinthio non difsimile: verùm fubamarum eft, non adeò feminis focundum. Eadem qux feriphium poteft. 
Ablinthiorŭ

A в S I N T H I I genera tria hic ḋ Diofcoride traduntur, nempe unlgare noftrum, marinum, quod seriphium confideratıo.

uocant, er Santonicum, quo Gallia alpibus finitima abundat. Abfinthium, quod in Pontonafcitur, cateris pre:= ftare ad iecinoris, of uentriculi inflammationes libro undecimo capite decimo $\int e x t o$. Methodi medendi prodidit $\mathrm{Gd}=$ lenus, fic fcribens. Cim autem duplex in omini Abfintbio facultas, or qualitas fit, ueluti in libris de medicd= mentis eft traditum, utique in Pontico adftringendiqualitus non parua eft. In reliquis osnnibus amara quidem qualitas eft uebementifina, adfrictio ueró (quam faltem guftu agnofcas) aut plane obfcura, aut prorfus nul= la fentitur. Proinde Ponticum ad iecinoris, ov uentris phlegmonas eligi praftat. Porró ideft tum folio, tum flore longé quàn catera abfintbia minore. Odor quoque buic non modó non infuauis; uerüm etiam aromatum quid prefirens: reliquis omnibus eft foedus. Quare bec fugere conueniet, or Pontico femper uti. bac Gale=

Quorundam nus. Cuius auctoritate fieti credidere recentiorum nonnulli, Ponticum abfinthium i communi noftrate fpecie non errores. parum differre, quemadmodum Seriphium, or Santonicum. Sed equidem nullo alio difcrimine alterum ab altero difi= dere crediderim, quàn quód Ponticum fit climatis illius temperie, er folijs, or floribus noftrate longé minoribus: quin $\sigma$ eam ob caufam adfrictoria facultate, ac etiam odore precellat. Quod abunde declarauit Galenus libro vi. fimplicium medic. ubide Abrotono dgit, cum inquit. Abrotoni dua funt pecies, altera quam marem, altera quam freminam nuncupant. quod ipfum dcfinitum eft, tum apud Diofcoridem, tum apud Pampbilum, aliosqi; innumeros. At aliud eft ab eo Abfintbium, cuius rurfum tres/tatuenda funt pecies, quarum unam eodem cum genere ipfo nomi= ne appellitant, cuiufinodi potißinuin eft Ponticum, alterum Seriplsum, tertium santonicum . hec ille. Quocirca re= eté quidem fenfiffe uidetur Diofcorides, quód in uulgaris Abfintbij genere Ponticum pre cæeteris commendauerit. Ex bis igitur palain effe puto, pecie quidem à noftrate non differre abfinthium, quod in Ponto gignitur; fed quibuf= dam tum facultatibus, tum qualitatibus tantum. Abfintbium autem buiufmodi, quod cateris prxftantius fit, non for lim in Ponto nafcitur; heriun etiam in Hungaria, Tranfyluania, eo Bobemia. Huic omnibus plané notis cum eo con= uenit, quod Galenus deliniauit. Etenim id folio, caule, flore, ac femine conftat longé, quim commune noftrum $A b=$ fintbium, minoribus. Saporem babet amariufculum, cui non parua adfringendi uis coniuncta eft. Odorem etiam pi= rat (ut Galenus teftatur) non infuauem, ita ut odorati nonnibil refipiat. Mefues, ut syluius doctißsine adnotauit, ne= jcio tamen qua ratione duCtus, Ponticum, Romanum appellat. Monachi ueró, qui in Me fuem commentarios frip $\int e=$ runt, putant magno quidem errore, id Mefui Romanum abfintbium effe, quod non modó in agro Romano, fed etiam in uniuer fa I talia prouenit. Plinius lib. $\mathrm{x}$ x V I I. cap. V I I. Ponticum fcribit multó I talico amarius effe. in quo fané Galenifententic or refiagatur, er errat. Ponticum abfinthium efficaccm uin obtinet ad aquan intercutem, ut mi= bi iam $\int e$ pius experimento compertum eft. Equidem quo $\int d a m$ noui bydropicos quafi deploratos, qui ex longo $c \int u c 0=$ marum clus, qux faccharo adferuate fuerant, fanitati reftitutifunt. Parandiratio bec eft: Sumito comarum recen= tium abfintbij Pontici libram unan: :acchari albißimi libras tres. Comas illas tundito in mortario lapideo: deinde ijs optime tufis faccharum in puluerem tritum adijcito . rur fus omnia fimul tantiper tundito, donec in unum corpus re= digantur: mox ad ufum recondito. Ex abfintbio ita faccharato femuncia quotidie afjumitur tribus boris ante cibum.

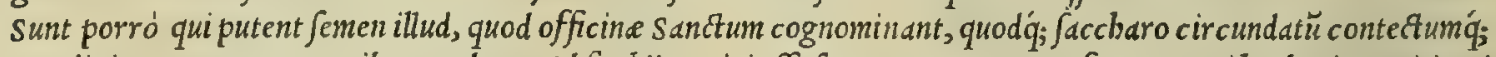
necandis interancorum uermibus prebent, Abfintbij marini effe femen. Attamen, ut fatentur rei berbaria periti, qui ex Gargano A pulix monte inter multa fimplicium genera, femen hoc ad nos comportant, à planta quadam profer= tur Abfinthio noftrati paululum abfinili. Ex quo facilé( (ut mea fert opinio) conijci poteft, id potius effe Santonici abfinthij femen, quàm Seriphij: prefertim quòd sanctum illud nomen non aliunde, quàm à Santonico deductum effe uideatur. Caterum procul dubio ballucinari deprebenduntur qui Canabel serapionis fomen fanctum interpretan= tur, cim longé admodum bec inter $\int e$ differant. Quippe serapioni nil aliud effe Canabel conftat, quàm terra tenuif= fimo fabulo perfimilis: quse (ut ipfe ait) und cumpluuia é calo decidit, cuius non modó apud A rabes ad interaned= Fuch. lapfus. rum tiness necandas; therum $\mathcal{O}$ ad fictilia fracta conglutinanda increbuit $u$ ius. Abfinthium marinum, fiue Seri= pbium, in quàn plurinis tam Tyrrbeni, quàm Adriatici pelagi litoribus prouenit, prefertimq́; A quilcicnfibus., er Tergeftinis. Sed Fucl. fium fupicor illud non cognouiffe : fiquidem quod in fuis clarißimis comincntarijs magno uo= Iumini appictum pectatur, abfinthium marinum non eit. Quod cum fortaffe e ip fe animaducrtiffer, in paruo fimpli= cium libello fententiam mutauit. Veruntamen non prius ab boc errore $\int e \int e$ uindicauit, quam in alium inciderit: quip= pe quod eandem plantam pro fylueftri nafturtio perperàm, meo iudicio, depinxerit. Marinum itaq; abfintbium cum primum é terra erumpit, folio eft abfintbio fimili, craßiore tamen. Scd poftquàm adolcucrit, er caules ediderit, mu= tatis in longum foliolis, ijsq; prefertim que ubiq; caulem ambiunt, abrotonum xmulatur, non tamen folijs cft adeo par uis. Semen profert exiguum, copiofumq; , abrotoni modo inter folia erumpens, at ; $_{\text {; }}$ fummitate caulis fré racemo= 50 Monachorú fum, ut hec pictura eius demonftrat, amari, e adftringentis guftus. Volunt patresillireuerendi, qui $\mathrm{Me}$ fuem cö= opinio falfa. mentati funt, tantim fuperficie tenus Abfinthium uulgare amdre fcere, imis ueró partibus dulcefcerc, ob id'́;; guftui gratum effe. Vnde etian aquam, que ab eo ignium ui diftillat, dulcem potius, qudin amaram fentiri contendunt. Qua in re ij parum rem naturalcm cullcre deprchendütur, nam quc่d Abfintbijftillatitia aqua fit dulcis, non cx co fit (quä= tum equidem fentio ) quòd Abfinthium ipfum conftet extima parte amarum, medullitus ueró dulce; fed quoniam cium exteriores ille partes, quibus amaror inclt, admodum fint tenucs; ac in uaporem facile re folubiles, ignis calore te= nuiores $f_{a c t}$, non magno quidem labore refoluuntur: euenitǵ; ob hoc, ut fillatitia, qua inde fluit aqua, omnis fit $a=$ maritudinis expers. Praterea dulcedo, qua in ip $\int a$ inuenitur, non ab intinis Abfintbij partibus emanat, $\int e d$ cam tan= tùn à plumbe is inftrunentis, qubus conficitur (ut diuturna docet cxperientia) prouentre comperimus. Nam ipfius dulcedinis qualitas non modo in Abfintbij fillatitia aqua fentitur, jed etian in quáuis alia, que ex berbis tempera= mento calidis extrabatur. siquidem cum plumbeum inftrumentum huiufcemodi herb.rmun uaporibus tum atu, tum 


\section{In Lib. tertium Diolcoridis.}

potentid excalfacientibus, terrena quadam fubftantia fuperficie tenus inficiatur, qux actutun in dulcißsimam ucluti cerulfam conuertitur, non mirmn quidem uidetur, $f$ aque inde manantes afcitilia dulcedine inbute, guftu dulces per cipiantur. Quod quidem ijs non euenit abfintbijftllatitijs aquis, que duplici uafe uitreisorganis, calcntis aque bal= neo conficiuntur. nam hic fufficicnter anarefcere cognofcuntur, nee tantillum quidem dulcedinis guftantibus pre $=$ bent. Euenit fanc hoc, quoniam balneum fue ip/ius aqux bumiditate, partes tcnuiores illas retinet, conferuat, ac co= bibet. Quo fit, ut non adeo in udporcm uertantur, qucmadmodum cumillis ficri folct, qua carbonum, or lignor um zuolento igne in auran cuanc ecere coguntur. Dulcedine praterea carent, co quód à uitrc is organis, quibus cliciun= tur, null.un afcitutiam qualitatcm rccipiant. Quare fatius, mea quidem fententia, effet, ut otium, quod fupereft, con= fumerent monschi in re chriftians, e medici in re medica, of finguli de arte fua bene mercri difcerent: ucl faltcm

10 quifq; quam recté infituit, uitan fequerctur. Abfintbij meminit Galcnus lib.v 1 . fimplicium medicanentorum, fic inquiens. Abfinthium adfrictoriam, $\mathcal{O}$ amaram, e acrem fimul qualitatem poßidet, excalfacicns pariter, er $c x=$ tergens, er roborans e deficcans. Proinde biliofos uentris bumores per egestionem infernam propellit, ac per uri= nas euacuat. Magis autem quod in ucnis oft biliofum, per urinas expurgat. Ob bec contentam in ucntre pituitam, oblatum nilil adiuuat. Sic neq; fi in thorace, aut pulnone contine atur: nam adftringens in co facultas, quain amara, ualentior eft. Porró quód in/it quoq; acrimonia, idcirco maiori portione calidum eft, quin frigidun. At fi opus cft generatin comprehenfan cius tempericm fecundim primas circumfcribere facultates ( milare fit ) calidum ipfun dixerim primi cxceffus, ficcum tertij. Succus autem eius longé quàm berba ip $\int_{a}$, calidior cft. Sed cum de Abfinthio marino, fiue Seripho ageret lib. v I 1. fimplicium medicamentorum: Seriphum, inquit, Apecic, er guftu abfintisio fimile cft. Id quod de Santonico fcripfit Diofcorides, cum tradiderit magis cum abrotono

20 conucnire Scripbium, quim cum ablintbio. Quamobrcm relinquitur fupicio, quod aut Diofcoridis, aut Galenifcri= ptura fit hoc loco librariorum incuria deprauata. Herba, que Gracis áfivaloy, Latinis item Abfintbium appel= latur: Arabibus, Afluthium: Italis, Affenzo: Germanis, Vuermuot, Eltz: Hipanis, Afentios, Alofna: Gallis, Aluyne, OO Abjince.

ABROTON VM MAS.

30

40

\section{ABROTONVM FOEMINA.}

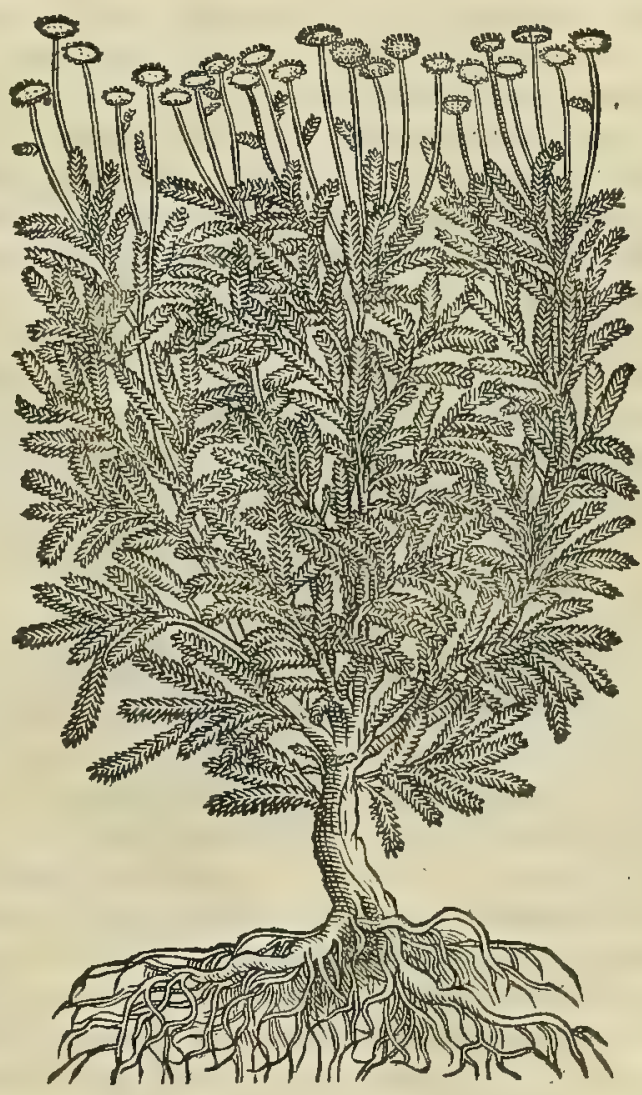

CAP. XXV:
Nomina.

Abfinthij ui res ex Gal.

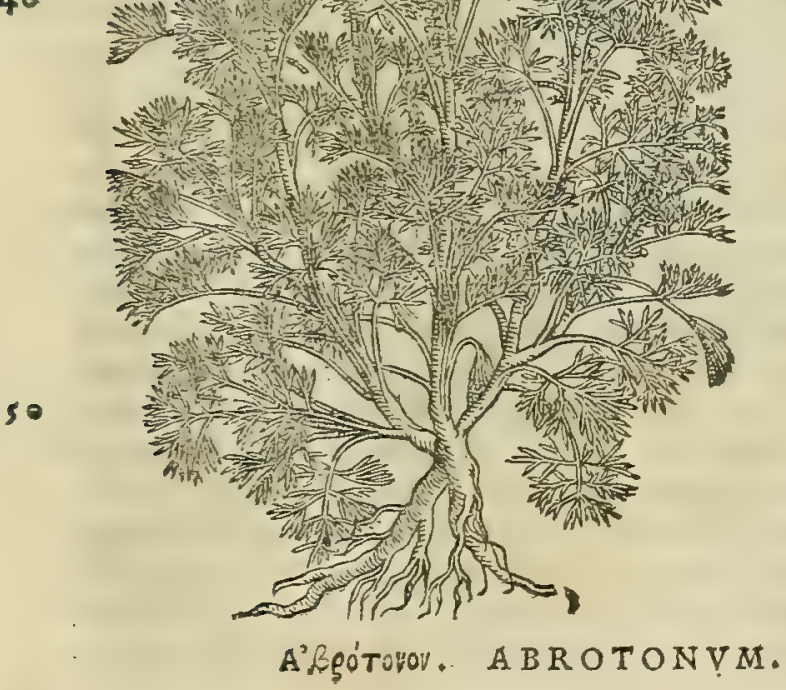

A в R O T O N V M duorum eft generum. Fœmina quadam arboris fpecie fruticans, candicat, circum ramulos folijs, feriphi modo, minutim incifis : floribus referta eft, comantibus in fummo, fulgore auri, corymbis . quod per æitatem prodijt, fuauiter olet, cum grauitate quadam, \& amaro guftu. Id genus Siculum efle conftat. Alterum mas uocatur, farmentofum, gracilibus ramulis uti ab- 
finthium. Plirimum in Cappadocia gignitur, \& Galatia Afiatica, atq; in Syrix Hierapoli. Vtriufque femen crudum tritum, \& feruefactum ex aqua, in potu auxiliatur orthopnoicis, conuulfis, ruptis, coxendicibus, vrinæ anguftijs, menfibus fupprefsis, aut remorantibus. In uino potum exitialium uenenorum antidotum eft : horroribus ex oleo illinitur. Serpentes \& fubftratu, \& nidore fugat: contra ietus eorum cum uino potum prodeft, priuatim efficax contra fcorpionum, \& phalangiorum uenena. Oculorum inflam mationibus commodè illinitur cum cotoneo cokto, aut pane . tritum cum farina hordeacea, decoetum qúue tubercula difcutit . Irini compofitionibus admifcetur .

Abrotoni có

A B R O T O N V M mas planta eft uulgaris notitie. Cuius duo ob eruauimus generd, bortenfe, or per fe in cam fideratio. peftribus nufcens, tenuioribus folijs, or minutiore fernine.' Quod ueró farmineo generi adfcribitur, non omnibus no= tum eft : non ideo, quòd er ip fun frequentißimum non feratur in bortis; fed quod ḋ paucis pro Abrotono fremina co= gnofcatur. Quandoquidens id alij cypreffum, alij Santolinam uulgó appellant, alij ueró marinum effe abfintbium exi

Quorundam ftimant. Sed ij profectó falluntur: quippe Santolina uulgò uocata, nil fané aliud eft, quàm Abrotonï foemina. Quòd srror. "primum (ut Diofcorides inquit) arboris peciem quandam reprafentet, unde $\sigma$ à quàm plurimis Cyprefjus uulgó di= cta eft. Deinde quód candicantibus conftet folijs, circum ramulos minutim incifis, floribus aureis, orbiculatis, caulem fummum, eftatis $\circlearrowleft$ autumni tempore, corymborum modo comantibus. Poftremó quód in uniuer fum fuauiter oleat cum grauitate quadda, or amaro guftu. Ex bac equidem delineatione adducor, ut decernere non dubitem, banc plan tam, quam unlgus Cypreffum, fiue Santolinam appellat, effe Abrotonum foemindm. Hinc itaq; Fucb/ium alioqui rei herbarie gnarum erraffe crediderim, quod pro forminei generis Abrotono plantam fubiecerti ab co longé diuerfam. Qui etfi Santolinam feorfum poftea depinxit; non tamen eam Abrotoni fremine nomine agnouit, fed berbariorum, ut 20 arbitror, unlgum fecutus, eam Chamecypariffum, hoc eft, pumilam cupreffum nuncupauit, eius'́; nullam ḋ Grecis $f_{a}$ Veronicęcó- Éam fuife mentionem falsó credidit. Caterüm quód Goritienfes Abrotonum marem Veronicam appellent, ea $\int_{a}=$ fideratio. néplanta mibi in mentem uenit, que recentiorum quibufdam VERONICA uocatur, magnis (ut aiunt)infignita ui= ribus. Heec duâm eff generum. Mus, que bumi repit, caule eft dodrante maiori, rubefcente, lanugino oó : folijs oblö= gis, nigricantibus, birfutis, er in ambitu ferratis. Flores edit purpureos circa fummum caulem emicantes, o femen in filiquis, loculi formam referentibus. Radice nititur tenui, que in plurcs diuaricatur partes. Fomina caule exit lanuginofo, folijs rotundioribus, minimé laciniatis, fub pinguibus. Flores profirt in luteo purpurafcentes: femen in uafculis rotundis inclufum: radicem ueró maris amulam. Nafcitur in loc is apperis, e incultis. floret I unio menfe. Guftu quidem adftringens, er amara eft : unde conijcere licet, edm effe tuin excalfaciendi, tum ficcandi ui praditam. Medetur cruentis unlneribus, ac etiam diuturnis ulceribus. Sunt, qui dicunt quiendan Francorum regem elephan $=3$ tiafl laborantem à uenatore fuo hac tantùm berba fuiffe fanatum. Tumores preterea in uniuer fum difcutit, praci= pué qui in ceruice emergunt. Nec de funt, qui illam fummis laudibus efferant ad peftiferas febres, ad tabidos, $\sigma$ io= Abrotoni ui- cineris, or lienis infarctus. Sed ut noftrum fequaimur inftitutum, iam Abrotono medicina reddenda funt ex Gale= resex Gal. no, quilib. v r. İmplicium medicamentorum, ita de cius uiribus pofteritatis memorie fcriptum reliquit. Abrotonum calidum, $\odot$ ficcum facultate, in tertio ordine. Seu receffu poft media fitum eft. Inueniemus autem eius temper amen= tumnon minimé quidem $\sigma$ ex guftu ducta coniectura, ut pote cum fit admodum amarum. Porró faporem eiufmodi, cùm terrene fit effentia, à largo calore extenuatum oftendimus. It $a q$; non inftrenue er excalf acit, er deficcat. $\mathrm{N} \vec{a}$ fiue comam cum floribus (reliqua enim eius palea inutilis eft) contufam ulceri puro illinas, mordax, or irritans uide=

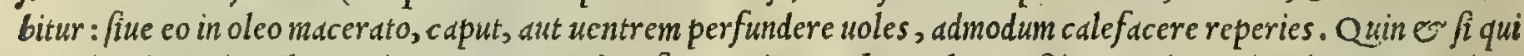
per circuitum rigoribus capiuntur, eos ante inuafionem rigorum hoc uoles confricare, minus utiq; rigore concutien $=40$ tur . imó er fenfus quidem protinus ubi admotum fuerit, ipfum calfacere percipit. Porró quód lumbricos interimat, par eft, nimirum cüm fit amarum. Scies autem protinus, quód o digerendi, o incidendi quandam uim babeat: Fed o quód magis quad Abfinthio id ipfi neceffariò infit, in promptu erit colligere. Prinim quidem ex guftu: paucißi= me fiquidem acerbitatis particeps Abrotonum eft, non pauce ueró Ab/intbiun. Deinde ex co quód inimicum fit fto= macho Abrotonum, uelut etiam Seriphum : gratum ueró, $\mathcal{O}$ amicum Abfinthium. Siquidem de sftis fuprà oftenfum eft, quodd amarum ipfum per fe omnifariam infenfum fit ftomacho : aufterum ueró, aut acerbum, aut in fumma adftrin= gens ftomiacho utile or amicum. Porró ubi qualitates ha inuicem permifte fuerint, qua uebementior fuerit, ea utiq; uicerit. Caterum Abrotonum ufum calidum, o ficcum facultate eft, magis adbuc qudm cucurbita ficca ufta, $\mathcal{O}$ a= netbi radix. Illa enim ulceribus humidis fimul e citra phlegmonem callo indur atıs conueniunt: ac proinde maximé ulceribus, qque in pudendorum praputijs funt, competere uidentur. At cinis A brotoni ulceribus omnibus mordax eft: 50 ac idcirco cum oleo tenuium partium, cicino fcilicet, aut rbaphanino, aut ficyonio, aut ueteri, e maximé Sabino, ad alopecias accommodatur. Barbam quog; fegnius tardius'́; enafcentem cum aliquo dictorum oleorum elicit: ed nec minus illis, lentifcino maceratum. Quippe pro eo quód tenuium eft partium, rarefaciendi uim obtinet, et mordax eft, o calidum. quas utiq; maxime eius facultates nouiffe oportet, nec quicquam pretered particulare in boc tractatu

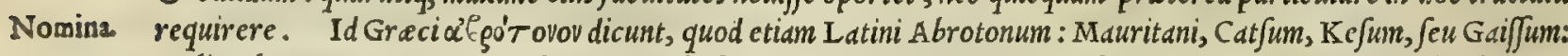
Itali, Abrotano: Germani, Stabuuertz, Schefzuunertz, O Gertuuurtz: Hipani, Abrotano, ${ }^{\circ}$ Hierua loinbrigue= ra: Galli, Auron, Auronne, שr Garderobbe.

\section{Y'arøळos. HYSSOPVM.}

CAP. XXVI.

H Y S S O P V M, herba nulli non cognita, duûm generum eft, montanum, \& hortenfe. Optimum eft Cilicium. Vim habet extenuandi, \& calfaciendi. Decoctum cum ficis, aqua, melle \& ruta, po- 
HYSSOPVM.

10

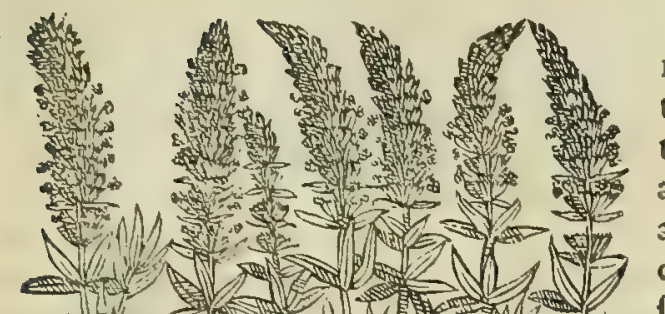

20

80

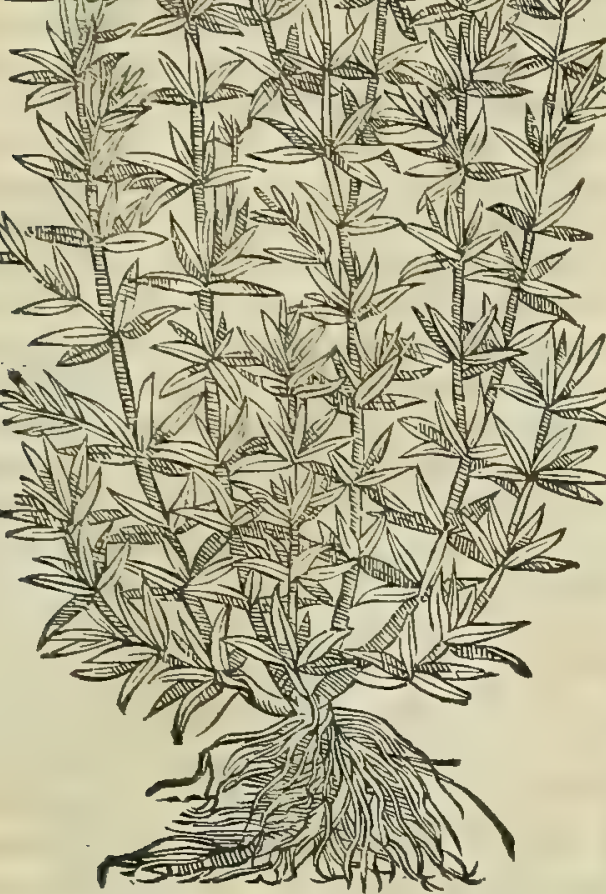

tumq́ue peripneumonicis, diuturnæ tursi, fufpiriofis, deftillationibus, \& orthopnoicis auxiliatur: tineas enecat. Idem facit, ficum melle delingatur . craffum humorem peraluum extrahit, decoetum ex aceto mulfo epotum. Ad fubducendam aluum cum ficis viridibus detritis manditur: vchementuusque addita iri, cardamomo, aut irione, deijcit : colorem in corpare fouet. Lieni, \& aqux inter cutem, cum fico nitroq́ue, inflammationibus quoque ex vino illinitur : cum feruéte aqua impofitum, fugillata difcutit. cum decocto ficorum, optimè anginis gargarizatur. Decostum cum aceto dentium dolorem in collutione fedat: inflationes auricularum uaporis fuffitu difcutit.

$\mathrm{N}$ o $\mathrm{N}$ modófunt, qui dubitent, ant uulgare Hyfopum legi= Hyffopi contimum appellari poßit; fed o qui certó credant, id ipfum cum Diofcoridis Hyfopo nullam habere cognationem. Horum opinio= nem fequuntur Monacbi illi, qui in Me fuem commentarios edide= runt, argumento quód fcrip ferit Diofcorides (ut Marcellus inter = pretatur ) origanum Heracleoticun folio effe bylfopi, non tainien habere umbellam by fopi modo rote figura in orben circuniactă, fed multifidam, o ueluti diuifam. Qux quidem nota non vifitur in noftrate $\mathrm{Hy}$ ffopo, ut quod flores picatos proferdt, non autem digeftos in umbellam rot.e modo circumactam. Quo fit, ut non ab re illi dubitauerint, an unlgare HyfJopum legitimum fit; hi uerò crediderint, eo omnino nos effe deftitutos. Ceterün mibi iam compertum effe puto, hos omnes in dubio, or errore uer $\int a r i$ per $=$ uer $\int a$ Marcelli interpretatione deceptos. quandoquidem fe ali= ter babet uulgata Diofcoridis lectio (cui etiam Oribafius, o ue= tufti quidam Grecicodices adffipulantur ) quàm uerterit $M$ ar= cellus: ita enim Grecé legitur. O'

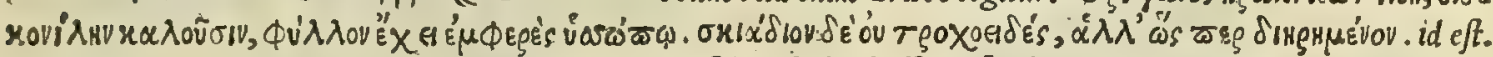
Origanum Heracleoticum, quod alij Cunilam uocant, folium babet byffopo fimile : umbellam autem non in rote $\beta e=$ ciem orbiculatam, fed uelutimultifidam. hee Diofcorides. Ex quibus palàm eft, non comparaffe Diofcoridemo origd= niflores ipfius hyffopi floribus, ut perperim Marcellus uertit, cum abfolute dixerit, nulla factx cum Hyffopo compds ratione, Origano unbellam effe non in rote modum orbiculată, fed ueluti multifidam. Illud infuper hac in re non par= uam ambigendi anfam prebuit, quód Diofcorides libro I I I I in Chryfocomes capite prodidit, cùm inquit. Chry foco= me palmi altitudine fruticat, comam babens pecie corymborum, by ffopo fimilem. Veruntamen fi quis preftanti iudi cio Diofcoridis uerba accur até perpenderit, ill a ané nibil eorum fententia refragaricomperiet, qui $\mathrm{Hy}$ fopum, quo

40 paßim utimur, legitimum effe contendunt. Siquidem in plantis coma, probatißimorum auctorum teftimonio, non $50=$ lim de floribus, er corymbis intelligitur; fed etian de folijs, er ramufcul is, dummodo bee bilari quadam uenuftate plä

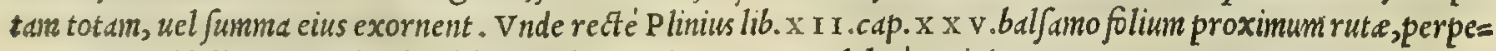
tua coma reddidit. Item virgilius lib. I I I I. Georgicorum perpulchré cecinit.

Ille comain mollis iam tun tondebat acanthi.

Ex his perpicuum fieri arbitror, Chryfocomen coma, hoc eft folijs, er ramufculis hyffopo effe fimilem, non autem ip= fis corymbis, quibus fortaffe in uniuerfum fcatet. Quanobrem bîc nullus, quätum equidem fentio, relinquitur amplius dubitandilocus. Sed quod Hyffopum communis ufus, uerum, legitimum'q; fit, nobis manifefté demonftrat symphytü petreum a me (ut pero) proximis annis repertum, quód folia uulgaribyffopo fimilia profr rat. Nam cùm fcribat Dio fcorides, symphytum petraum folio effe origani, Origanum ueró folia babere by fopi, clarifimum prabet argumen=

so tum, quód by ffopum, quo paßim utimur, fit uerum. Quinetiam cùm idem auctor tradiderit, Hy fopum duorum effe ge nerum, nempe montanum, $\mathfrak{O}$ bortenfe, $\mathcal{O}$ utrung; genus in noftrate paßim babeatur omnibus notis fimile, non modó opinionen auget, hoc legitimum effe Hyfopum; fed omnem quoq; litem dirimit. Huc pretered alia accedit ratio, quód cum Diofcorides congeneres, uel fimiles plantas feriatim coniuncte q́; de fcribere confueuerit, ftatim q́; poft hys= fopum ftoch adem reprefentaucrit, que folio, 0 picato flore by fopum noftrum admodum cemulatur, oftendit quidem ballucinari eos, qui hy fopum boc non legitimum effe bactenus iuerunt inficias. Adde etiam quód idem(ut experientia comprobat) ijs omnibus polleat uiribus, quas illi reddidit Diofcorides. Hyfopum montanum in comitatu Goritien/s Saluatino monte frequentifimum nafcitur, facie, floribus, or coma hortenfi non abfimile, rudiore tamen folio, or gu= ftu amariore, nec ufqueadeó acri. Mitefcit tamen, fit tranfplantetur in hortis, fit f $_{\text {; }}$ hortenfi fimile, exut a fylueftri ind= tura. Hyffopi paucis meminit Galenus lib. VIII. fimpl. medicamentorum, fic inquiens. Hyffopum deficcat, or

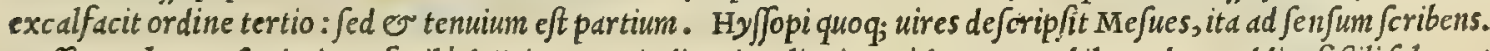
Hyy Jopum hortenfe pituitam facilé deigcit, quanuis dixerint aliqui, quòd ov atram bilem educit addito foßili fale, aut

Opinio re probata.

Marcelli mala interpretatio.

Hyflopivires ex Galeno, \& Mefue. 


\section{And. Matthioli Comm.}

\section{GRATIOLA.}

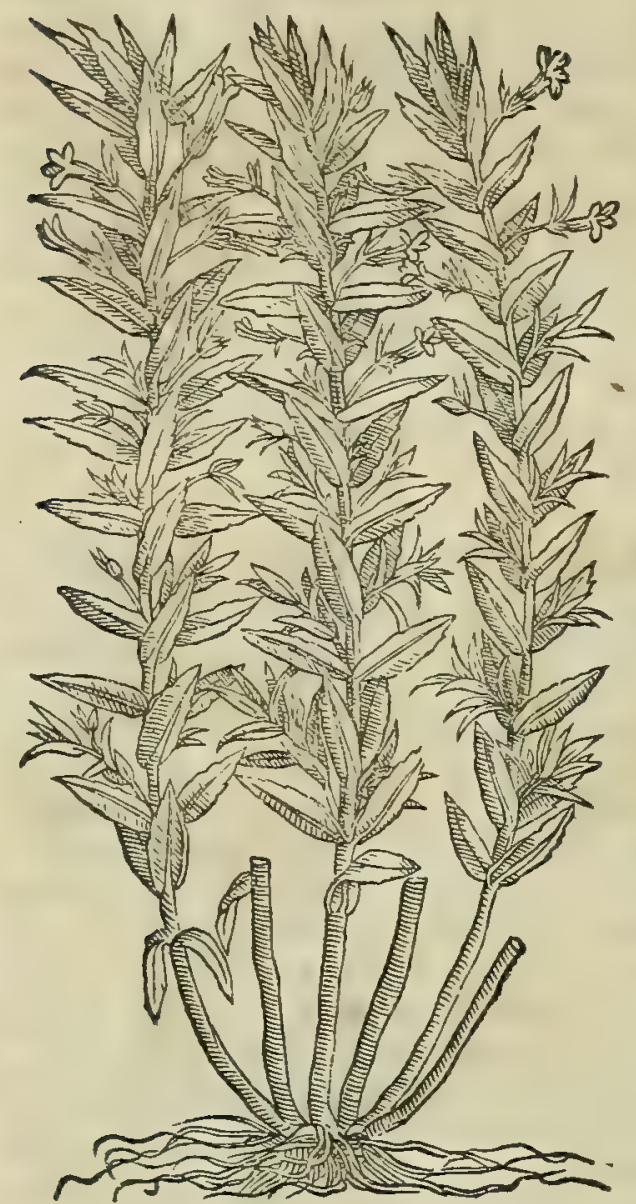

STOECAS.

Storehadis cö fideratio.

Stachadis vires ex $\mathrm{Gal}$.
Indo. At ipfum pituitam purgare manifefto experimento con= ftat, prex fertum que in pectore, ac pulmone continetur. Facit byffopum ad pituitofos tum cerebri, tum neruorü affectus: quód non modo mundet; fed quód etian roboret. Quin er pectus, or pulmonem detergit, prefertim fenibus, quorü pectus lenta, craf= $\int a q$; pituita refrertum cft: quo fit, ut afthmaticis, o tußientibus opituletur. Difcutit by/fopi ufus contumaces inflationes, cibi ap= petentiam inuitat, menfes $\sigma$ urinam ctet, $\odot$ febrium horrores excutit: uifum acuit. Melle commiftum interaneorum tineas ne= cat, nitri tamen addito momento. Oleum, quod tum: folijs, tum 10 floribus paratur, neruos algore affectos inunctum fanat, o robo rat. Poteft eadein e inontanum, atque etiam hec omnia effica= cius preftat. bactenus Mefues. Ceterùm nonnullicrediderüt berbamillam, qua unlgó ab aliquibus GRATIOLA uocatur, $a b$ alijs Gratiddei, ḋ quibufdam etiam, ut d Foroiulienfibus, Stan= ca cauallo, quód equi cius pabulo miré defatigentur, effe Hyfo= pum illud montanum, de quo Me fues in fuis fcriptis mentionem $f=$ cit. Sed ij, omnium feré iudicio, exidentius ballucinati funt, quàm ut pluribus demon/trare fit opus. Quoniä uerò in Gratiole her= ba fic ditze fermonem incidimus, bic locus poftulat, ut de ed ali= 20 quid dicamus. Nafcitur bac in locis humidis, pracipue in pratis uliginofis, prouenat etiam in paluftribus. Herba eft, que dodran= talem altitudinem excedit, caule quadranguldri, folijs by fopila= tioribus, or longioribus. florem fert in purpura albicantern, in= ter folis erumpentem que caulem ambiunt. Guftu berba bec ama rißima eft, quo etiam quadántenus adftringens fentitur. Aluum uelsementer purgat, tam recens quàm ficca fumpta. bilem, pitui= tam q́; trabit. Vulneribus celeriter medetur, trita $\sim$ fuperpofis ta. Herba varawos Gracis ditta, Latinis Hyffopum appella= tur: Arabibus, Cyfe, Iufa, feu Iabes: Italis, Hiffopo: Germa $=30$ nis, Firch byflop, 0 Hofter hyfop: Hipanis, Hiffopo hierua, et Hiffopilho hierua: Gallis, Hiffope.

\section{¿TolX $\alpha$ 's. ST.OECHAS. CAP. XXVII.}

S T OE C H A $S$, iuxta Galliam in infulis ciufdem nominis è regione Mafsilix gignitur: vnde cognomentum accepit. Herba tenuibus furculis, coma thymi, longiore folio, fubamara guftu, \& aliquantùm acris. Cuius decoctum, hyffopi modo, ad pectoris uitia efficax eft. 40 Antidotis utiliter mifcetur. Vifcera omnia, \& uniuerfum animantis habitum extenuar, confirmat, \& ab obftructionibus \& farctu liberat .

S T OE.C. H. D E M officinarum unlgus sticados appellat. Nafcitur bec non modó in Gallia (ut Diofcortdes fcribit) ex ads. uerfo Maßilie in infulis illis, quas stochadas uocant; Jed $\mathrm{O}$ in Arabia, unde cum alijs.mercimonijs; que ex Alexandria adue= huntur, Venetias cooportatur. Quapropter tam à medicis, quìm á $\int e p l a f i a r i j s$, indito ab A rabia cognomento, hodic Arabica nun $=50$ cupatur: etfí Maßilienfispelagi ftochas plerunque Arabica ui= cem expleat. Prouenit preterea in nonnullis I talie locis, uerum ea ceteris in Italia preftat, qua ex Gargano Apulie monte ad= uehitur . quanquam omnium probatifima eft peregrina, que ex Arabia defertur : banc deinde fequitur, que in siocbladibus in= fulis nafcitur, à quibus primim nomen adinuenit. De Stoch as de uires fcripfit Galenus libro v I I I. fimplicium medicamento=s rum, ubific inquit. Stæch hadis guftu quidem qualitas amara eft, - mediocriter fubaditringens. Céterim temperies compofita, nempe ex terrena effentia frigida exigua, unde fane adftringit: v exattenuata altera terrena copiofiore, à qua utiq; amara eft. 
ob utrortunque uerò conuenientiam er coitum, obftructione liberare, extenuare, extergere, roborare q́; tum uifce ra omnia, tum totius corporis babitum eft nata. Suprà nanq; ofteinfum eft, quòd qua ex ciufmodi effentijs conftant medic amina, dictos effctus reddere poßint. Huius quoque meminit Mefues, ita de eius uiribus differens. Stho= chas deijcit tum pituitan, tum atr an bilem : cerebrum, neruos, ac fenfum omnium organa mundat, ac roborat. Pro= deft contra frigidos morbos quale fcunque fint, ideoó; comitialibus conueniens remedium babetur, addita fcilla, aut eius accto. Balnea, fomenta, ac laconica, que ex ip/ius tun decodlo, tum uapore fiunt, occlufos nariun meatus ape riunt : neruorum, o comp.rginum criciatus mitigant: ac interna uifcera frigido bumore affecta roborant. Abfinen dum tamen ab ea biliofis eft, prefertim fi eorum uentriculus fit bile refirtus: nam eos maxiné turbat, naufeam com= mouet, fitim accendit, $O$ calore quodam moleftifimio uniuerfum afficit corpus. Que planta Gracé 5oixa's,

Ex Mefue.

10 Latiné itcm Stechas nominatur: Arabicé, Aftochodos, Aftuborados, fiuc Aftuchudes: Italicé, Stechade: Germas mice, Stichaskraut: Hipanicé, Cantueffo: Gallice, Stechados.

\section{ojiyxvos: ORIGANVM. CAP. XXVIII.}

O R I G N v M Heracleoticum, quod \& cunilam uocant, folium habet hyfopo non difsimile: vmbellam autem non in rotæ fpeciem orbiculatam, fed ucluti multifiam : femine in fummis uirgis haudquaquam denfo. Excalfacit : unde decoctum cum uino potum demorfis à ferpente conuenit. qui autem cicutam, aut meconion hauferunt, ijs ex paffo : fi uerò gyplum, aut ephemeron, ex aceto mulfo propinatur. ruptis, conuulfis, hydropicis cum fico efui datur . A ridum acetabuli menfura po2a tum in aqua mulfa, atros humores per aluum extrahit: menfes ciet, \& tufsi cum mellelinetum medetur. Ad pruriginem, pforas, regiumque morbum, decoeti ius in balneis prodeft. Succus uirentis, tonfillas, vuam, \& oris ulcera fanat, \& per nares ex olco irino infufum trahit . aurium dolores cü lacte mulcet. Conficitur ex en,\& cepis, \& rhoë, quo ad obfonia utuntur, uomitorium medicamentum, his omnibụs in cupreo uafe per dies bis uicenos infolatis, dum caniculæ fy dus flagrat. Herbæ autế fub. ftratu ferpentes fugantur. Quæ onitis appellatur, candidiore eft fo:io, \& hyffopo fimilior. Semen ueluti coniunctos cory mbos habet. Vis ei origani Heracleotici, fed multò ineflicacior. Sylueftre orjganum, aliqui panaces Heraclion, alij cunilam uocant, ex quibus eft Nicander Colophonius. Folijs eft origani: ramulis tenuibus, dodrantem altis : in quibus umbellæ anethi infunt, flores candidi: radix tenuis, fuperuacua. Peculiariter percursis à ferpente, folia, \& fores ex uino poti auxiliantur .
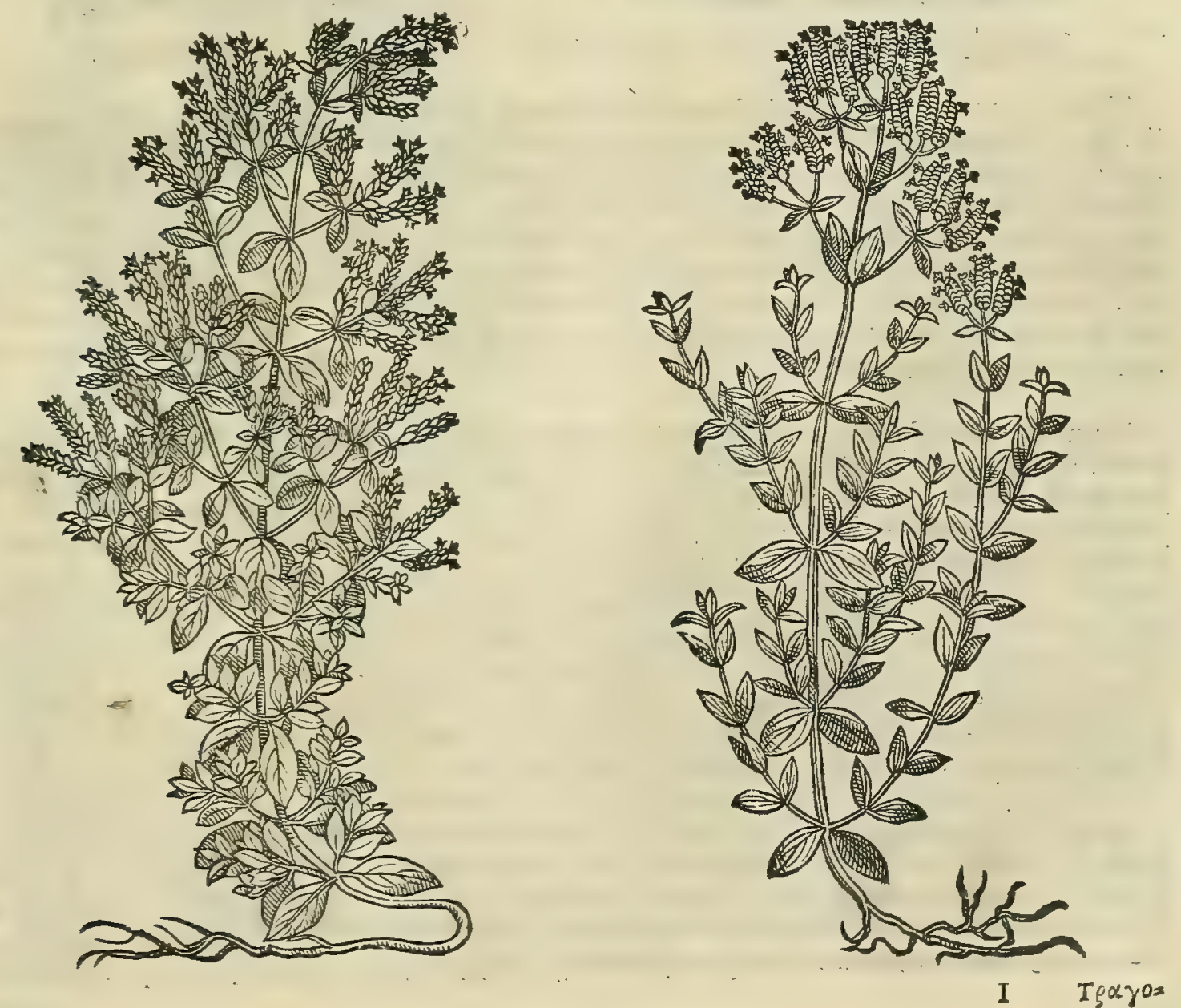

Nomin. 


\subsection{And. Matthioli Comm.}

ORIGANVM SYLVESTRE.

T RAGORIGANVM.

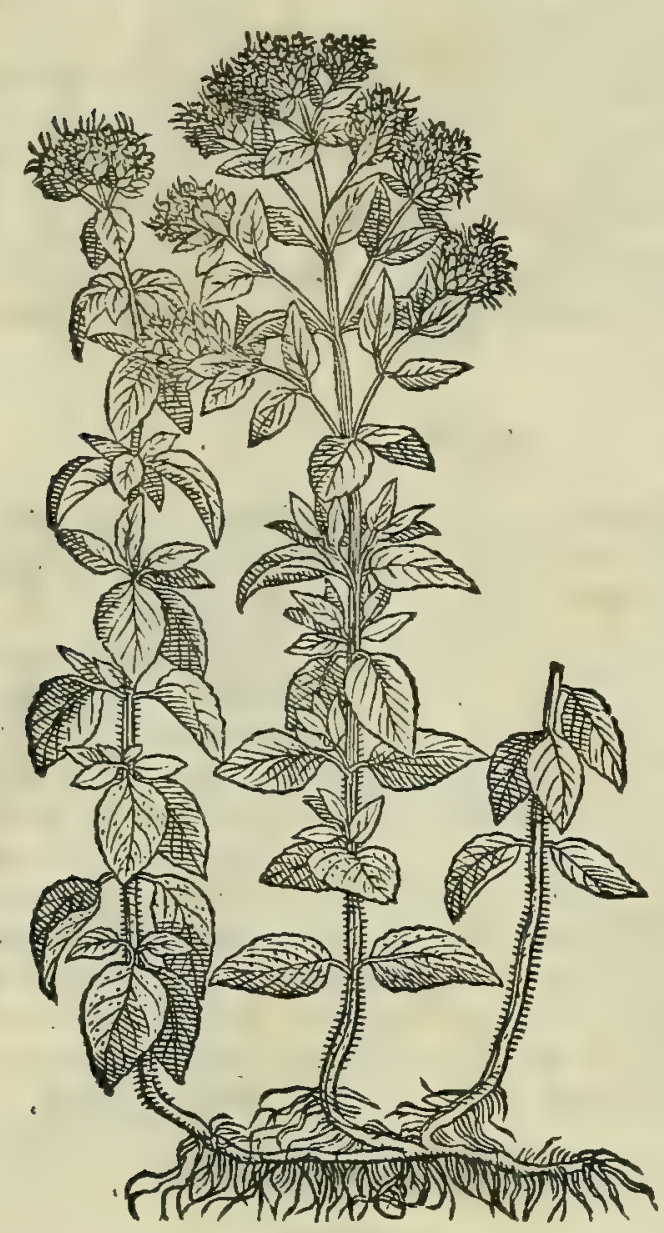

Texyogizavos. TRAGORIGANVM.

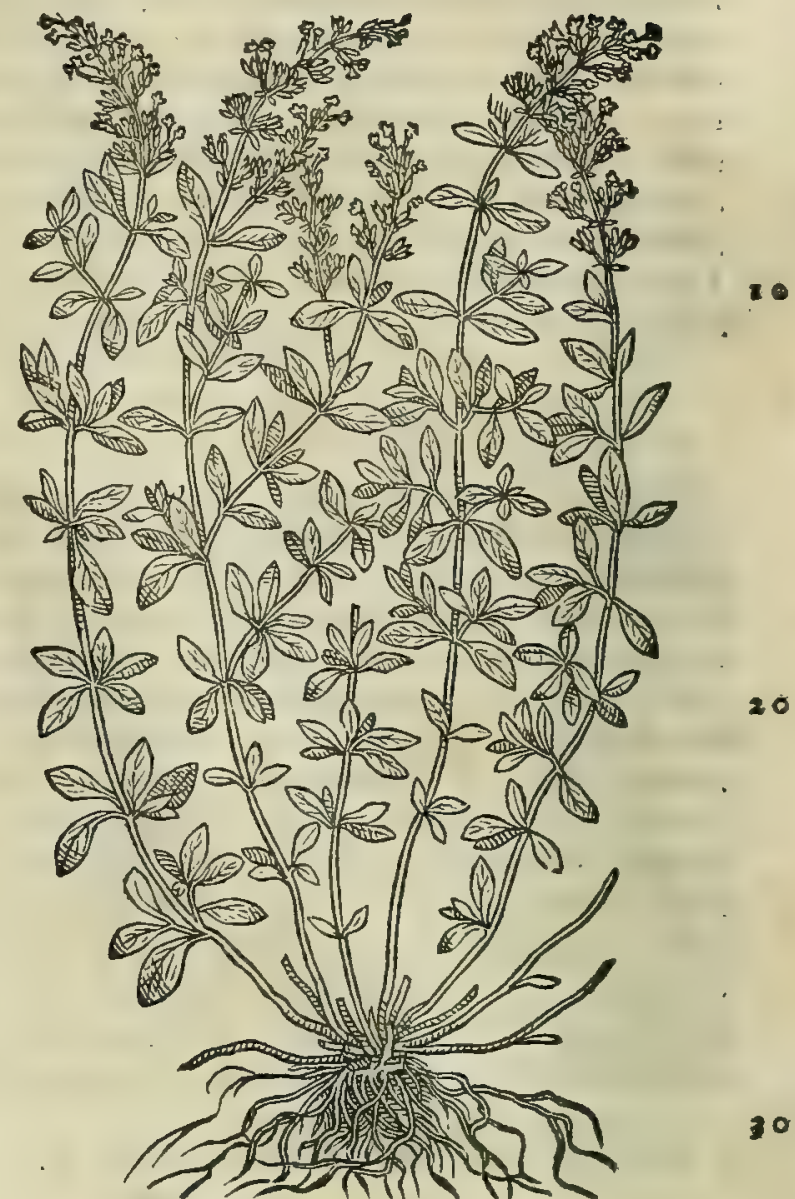

CAP. XXIX.

T R A G O R I G A N v M tenuis frutex eft, fylueftri ferpyllo, aut origano fimilis, folio, \& ramulis. Quibufdam in locis latius, uirentiusq́ue inuenitur, \& latioribus folijs, fatis glutintofum. Alterum exilibus furculis, ac tenuibus folijs, quod aliqui prafium uocauere. Optimum eft Cilicium, \& Cretenfe, \& Smyrneŭ, \& in Chio, Cooq́ue proueniens. Omnia excalfaciunt, urinam cient, aluo accommodantur. Decocto poto bilem deijciunt: lienofis ex aceto bibere prodeft : contra pota ixire venena in uino bibuntur : menfes trahunt: peripneumonicis, tufsientibus, ex melle in eclegmate dă- 40 tur. Grata, ac mitis eorum potio eft : quare cibum faftidientibus, \& ftomacho acida ructanti, imbecilloq́ue præbetur : item fi à maritima iactatione naufea, \& æftus præcordiorum cxcitetur. Tumores uerò cum polenta illita difcutiunt .

Origani hifto V A R I A, ac confufa eft apud antiquos reiberbaric authores Origani hiftoria. Quandoquidem Theoplraftus ria uaris. lib. v I. cap. I I. de plantarum hiftoria duo tantüm conftituit Origani genera, nigrum /terile, $\mathcal{E}$ candidum fructuo= fum. Plinius uerólib. x x.cap. X V I . poft Onitidis origani, e Tragorigani mentionem, Heraclium origanum fubiunxit, quod tria babere genera prodidit. Vnum nigrius, latioribus folijs, glutinofum. Alterum exilioribus, mollibusó;, , fampfucho non dißsimile, quod aliqui prafion uocauere. Tertium inter bac medium, minus quàm cate=

$p$ linij lapfus. ra efficax. In quibus uerbis $\mathrm{Plinius}$ deprebienditur non fine errore Tragoriganum cum Origani generibus confu= so diffe, quód Heraclij nomine, quod conftat Origánigenus effe, duas illas Tragorigani pecies, qua à Dofcoride red= duntur, huius feré imitatione exprefferit : licet tertium quog; addideritex alio forté authore . nifíi dixerimus, quód O banc pro aliquo Origani genere fump ferit, o fimul confuderit. Sed dimißis aliorum placitis, E Diofcoridem, quem nobis ducem, or auctorem propofuimus, duntaxat fecuti, dicimus tam Heraclcoticum, quàm Onition appel=

Bralauoli opi latum Origanum aut in I talia non oriri, aut inibi baftenus, quod fciam, ì nemine fuiffe repertum. I $t f i \mathrm{Br} a f a u o l u s$ no reiecta. Ferrarienfis medicus noftre etatis clarißimus aßerere uideatur, Heracleoticum illud berba genus c ffe, quod in It $t=$ lia paßim nafcitur, quodóf; perperàm Origanum uulgó ab omnibus uocitatur. Verüm buic (pace eitus dixerim) nun= quam aßentiri potui : quin potius eam plantam fylueftris Origanigenus effe femper exiftinaui, quod fua fponte in campeftribus ;a/peris, cliuofisq́; locis, o montibus proueniat, purpurafcenti admodum umbella. Nam quanuis d Diofcoride una tantum fylueftris Origani fecies defcribatur, floribus candidis; nil tamen obftat, quin in älijs quoq; ¿ Gracia regionibus una, uel altera eius pecies floribus differens gignipoßit. Siccum origanum, quod Venetias é 


\section{In Lib. tertium Diofcoridis.}

Creta dduchunt, flore eft albo, acerrimo guftu, fragrantiq; odore. Quo fit, ut hoc effe putem fylucfre Diofcoridis origanum (quanquam apud plcrofq; Heraclcotici,uel alterius nomen fibl falsó ucndicet) non folum quòd floribus fit candicantibus; fed ctinn quod gu/tutu linguam admodum uellicet. Siquidcn binc facilé conijcipotelt, fjlucftrc ori= ganum cxicris (ut Galcnus teftatur) ualentiorem effc. Heracleoticuntorigumm, itcm'́, Onitim mifit ad ine boc

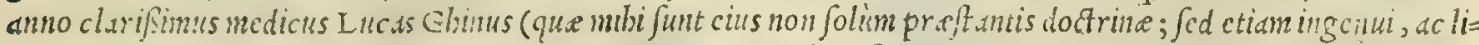

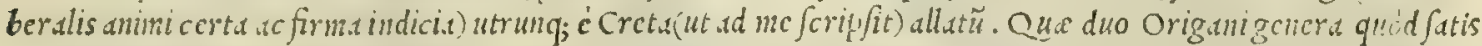
Diofcoridis biftorix refendeant, bic pidura exprimenda duximus. Tragoriganum ucró, cuius ctiam plantan picha exhibcnus, frequens nufcirur in Foroulicnfí agro, folijs ferpylli amulis, fed guftu pulcgij. Vnde non ab re ftatm poft ipsun pulcgij mentinit Diofcorides. De omm tam Origuni, quan Tragorigani genere differens Galcuuslib.

2 - V I I . fimplicimn medicamentorum, fic inquit. Origanus, Heraclcotica quidem efficacior eft onitide: fed agreftis, quàm quid.m p.tnaces Heraclium, alij conylen cognommant, ualentior utraq; eft. Omnes ueró incidendi, cxtenuädi, calfaciudiq; facultatcm posident: hecó; tertio cxeffu obtinent. Porró ca,quam Tragoriganum appellită, affum= pfit etian adfrictionis quippian . hec Galenus. Ex cuius doctrina patet, recté cum ijs agi, qui fylucftre ex Creta pe titum fuis medicamentis injerunt. Planta Grecis ó i youvos, Latims pariter Origanum wocatur: Mauritanis, Fan= denigi, Fudencgi, feu Fudenegi: Italis, Orig:no: Germanis, Vuolgemuot, Rottdoften, $\odot$ Coftentz: Hipanis, $\mathrm{O}=$ reganos: Gallis, Origan, ant Mariolaine baftarde.

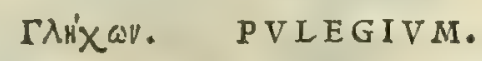

CAP. XXX.

20

30

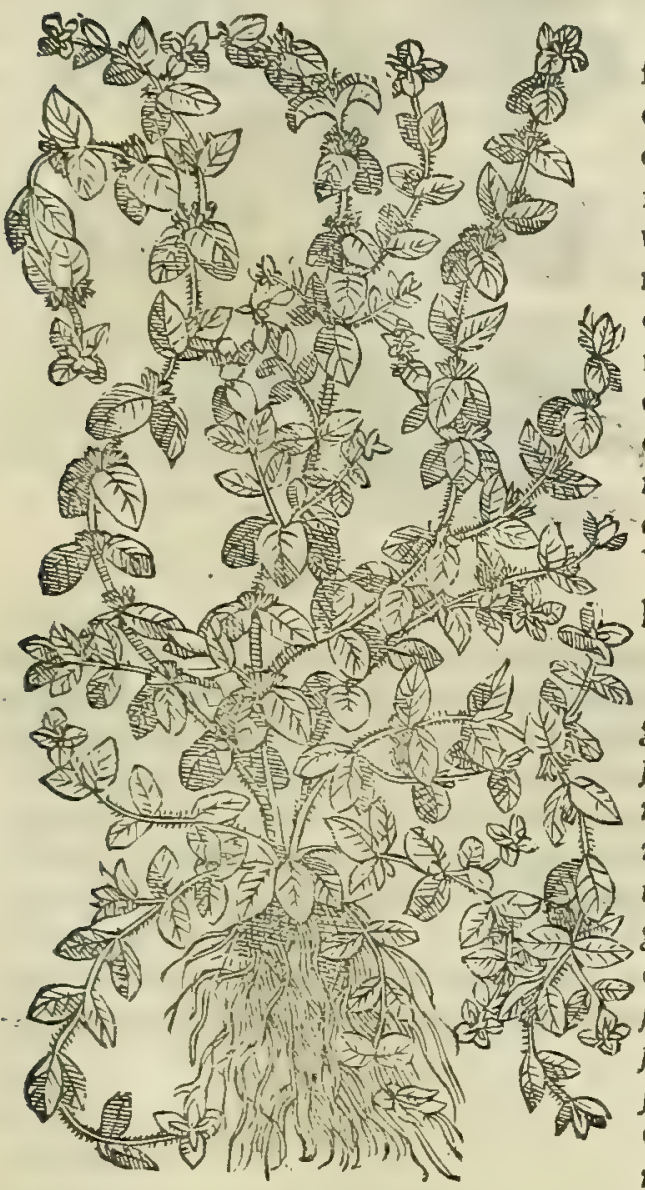

P V L E G I V M herbavulgaris notitix. Extenuat,calfacit,decoquit : potum menftrua, fecundas, ac partus eijcit. Pulmonis uitia ex melle, \& aloë potum extrahit , \& conuulfis auxiliatur. naufeas, ftomachiq́; erofiones ex po fca permulcet: atram bilem per aluum exigit . Bibitur in uino utilifsimè contra ferpentium morfus: defectos anino recreat,cum aceto naribus obicetum : gingiuas arefacti cinere corroborat. Illitum cum polenta inflam mationes omnes fedar : podagris per fe fubuenit, impofitú ufq; dum rubefcat locus : cum cerato varos extinguit: licnofis cum fale utiliter illinitur. Decoctum eius ablutas prurigi nes mitigat : conuer las uuluas corrigit cótra inflationes, duritiasq́ue vuluæ in defefsiones conuenienter adijcitur. Vocant aliqui blecchona, quoniam dum floret guftatum à pecoribus, balatum concitat. E T S I dubitauerint recentiorum quidam, an unlgare $\mathrm{P}$ ule $=$ deratio. gium legitimum fit, quodd ob eius unlgarem notitiam, nullis foliorü, florumq́; notis cius faciě defcripferit Diofcorides; non de funt td= menreiberbaris periti,qui uelint $\mathrm{P}$ ulegium unlgaris ufus Diofco* ridis, aliorumq́; antiquorum effe pulegium. Hocó; argumento ni= tuntur, quód non modó experientia compertum fit, uulgare $\mathrm{P} u l e=$ giun omnibus ijs uiribus effe preditum, quas fuo tribuit Diofcori= des; jed quodd etiam Pliniane hiftorice maximé repondeat. Plinio fiquidem lib: x x.cap. x I I I I.duo Pulegij produntur genera: foemind, cui purpureus flos: mas, cui albus. Horum utrung; fere folum Italicum, utrunque in Hetruria preftantißimum gignitur. Quapropter cos apertéballucinari crediderim, qui Pulegium cö= munis ufus unam, uel alterain calaminthe peciem effe contendunt. Quorundam Quippe quòd certó putem (ut infrà fuo loco dicetur)omnia calamin the genera, quorum meminit Diofcorides, à nobis error.

so iandiu fuiffe reperta. Quin e illud $\mathrm{P}$ ulegium noftrum le gitimum effe oftendit, quód folio fit Cretenfi dictamno fimi= le, cuifolia pulegio fimelia reddidit Theophraftus, item Diofcorides, qui tamen illa maiora fecit. Germanice mulieres Pulegium in hortis ferunt, ac ctiam in figulinis uafis fouent diligenti admodum cultura, fuis affectibus co confulen=

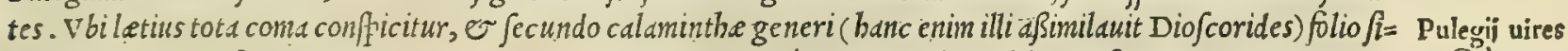
mile, acerrimo guftu, quadantenus amaro. Quamobrein recté quidem Galenus lib. v I. Jimplicium medicamen= ex Galeno. torum, de Pulegio differens, ita fcriptunn reliquit. Pulegium cum acre, $\checkmark$ fubamarum fit, ualde tum excalfacit, tum extenuat: Porró quód excalf aciat, abunde magnum eft fignum, quöd illitum rubrificat, or quód fi quis diutius toleret, exulcerat quoque. Quód uerò extenuet, fatis indicat, cum humida, craffa, ৩ lenta ex thorace, or pulmo=

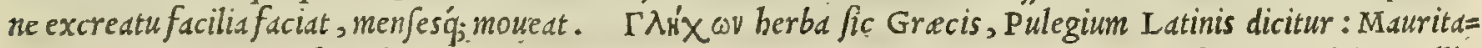
nis, Alnam, Alnegēn, feu Aluegen: Italis, Pulegio : Gernanis, Poley, $\odot$ Hertzpoley : Hipanis : Poleio : Gallis, Pulege, e Pouliot.
Nomine.

Pulegijconf

\section{Nomina.}




\section{$376 \quad$ And. Matthioli Comm.}

DICT AMNVM.

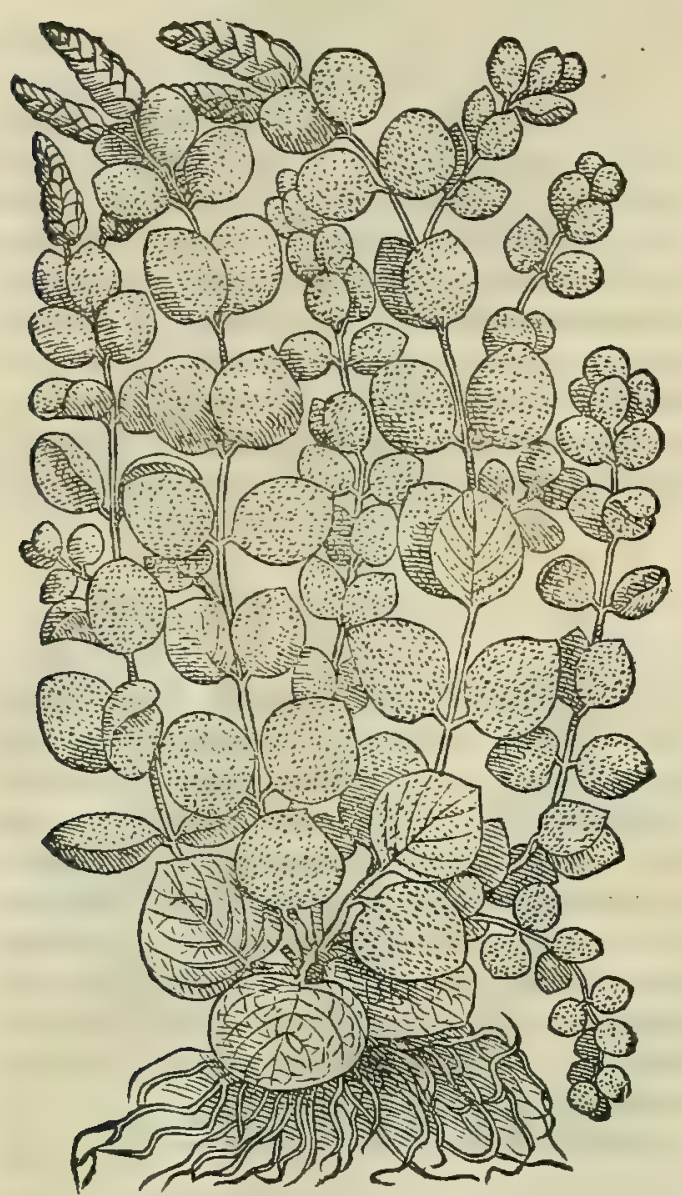

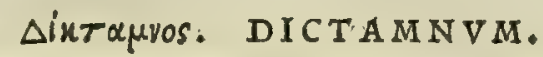

PSEVDODICTAMNVM.

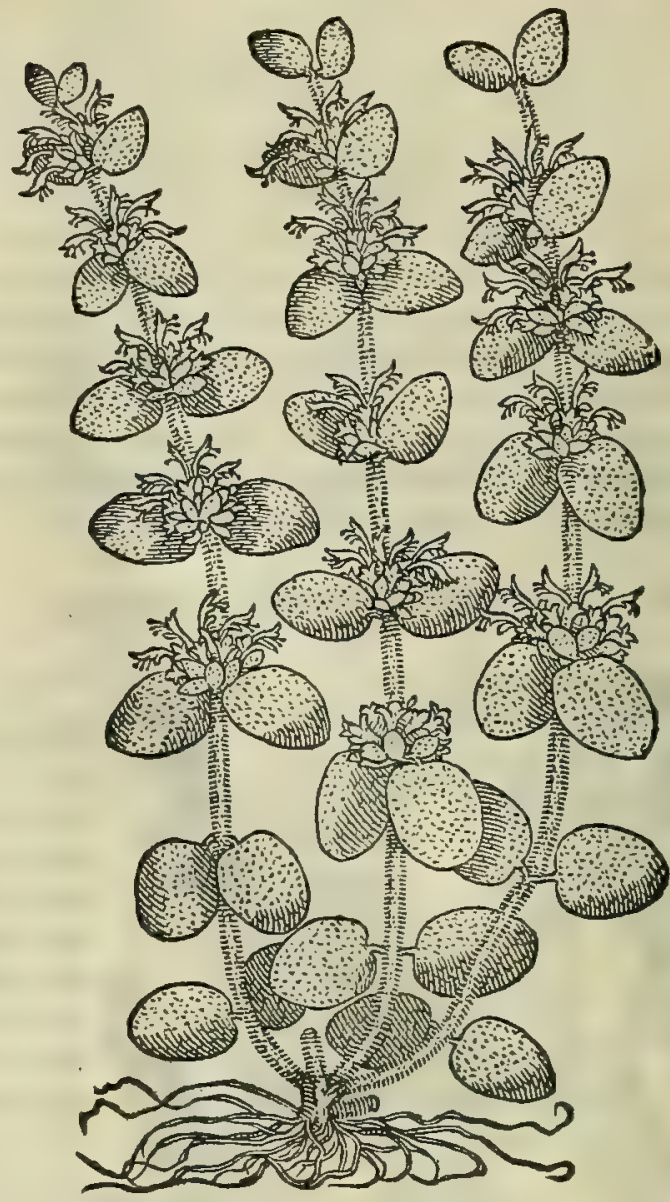

10

20

D I C T A M N V M, aliquibus fylueftre pulegium uocatur. Cretenfis herba eft, acris, lauis, pulegio fimilis, fed maioribus folijs, quæ tomento quodá, fpiffaq́; lanugine pubefcunt. Florem nullum, aut femen profert. Præftat omnia, quæ fatiuum pulegium, fed efficacius multò : nam non potum modò, fed appofitum quoque, aut fuffitum, defunctos partus eijcit. Produnt in Creta capras fagittis percuffas, huius herbæ paftu eas excutere. Purgandi uim habet fuccus illitus, aut cum polenta tri tus. Herba impactos pedibus, reliquóue corpori aculeos, illitu refigit . ad lienis dolorem efficax ha betur : fiquidem ipfum imminuit. Metunt $x f t a t e, \&$ autumno. Radix eius guftu calfacit : partus accelerat. Succus cum uino potus, contra ferpentium-morfus prxfidio eft. Tanta herbæ facultas eft, ut olfacta abigat beftias, qux venenato ictu fæuiant, appenfaq́ue contactu exanimet. Vulneribus ferro illatis, \& uenenatis morfibus infufus fuccus, præfentaneo eft remedio, fi etiam ab inftillatione ftatim in potuaffumatur.

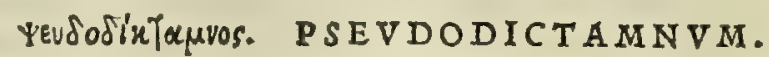

CAP. XXXII.

Qv o D Pfeudodiatamnum uocant, multis in terris nafcitur, antè dicto fimile: fed minus, quàm illud acre. Eofdem effectus præbet, fed inefficacius multò.

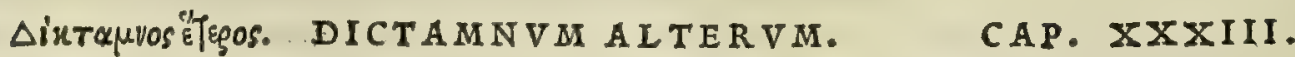

D E F E R T V R à Creta alterum dictamni genus, folijs fifymbrij, ramis maioribus : in quibus flo res fylueftris origani,nigri, molles. Odor foliorum inter fifymbrium, \& faluiam, iucundifsimus Efficax ad eadem, fed minus nares ferit. Mifcetur emplaftris, \& medicaminibus, quæ aduerfus ferpentium iniurias confinguntur, theriaca uocant. 


\section{In Lib. tertium Diofcoridis.}

D I C T A M V M legitimum, ac probatißimum in Creta infula tantim gignitur: neque tamen inibi paßsim, fed in angufto loco duniaxat prowenit, ut aut'sor eft Theophraftus. quilib. I x.cap. x x v I. de plantarum hiftoria Dict amnum pofteritatis menoric prodidit, his uerbis. Dictammum crete infula proprium eft, ui mirabile, er ad plura perutile, fed ad partwn mulierum potißimim pollet. Folio pulegio fimile conftat, nec fapore abfimile eft: ra= mulis tenuioribus conditur. Vfus foliorum, non ramorum, nec fouctus eft: ualcnt enim ad multa, o precipue ad difficiles partus mulierum, ut ditun eft : aut enim facilé poffe parere faciunt, aut certé dolores penitus fodät. Dan tur biberida cx aqua. Rarabec berbs: locus enim, qui fert, exignus admodun eft, eumq́; capre dep.1 cunt capef= fende caufa uoluptatis. Quod etian de telis firtur, ucrum effe affirmant: capras enin fagittatransfixas diftamno deuorato telum eijcere. Diftamnum tale eff, uiresq; eiufmodi poßsidet. Falfum dictamnum folio quidem fimile con=

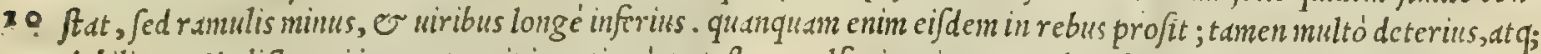
debilius. Vis dictamni in ore percipi continuó poteft : cxcalfucit enin ex paulo uchsmenter. Manipulos in firuld, aut canna intercludere folent,nc expirct: eft enin imbecillius, cum expirauerit. Non de funt, qui naturà Ditamni, o falfi Ditammi andem effe exiftinent. Sed quod locis letioribus exeat, degenerare, falfumíq; cognominart, ficuti etium alijs pluribus eucrit, ut uribus deterioribus ex loco reddantur. Dictamnum enin alperum folum uebementer amare inquiunt. Ef tetium aliud Dict.tmnum ueluti aquinocé appellatum : nec enim peciem, nec uim babet eandem. quippe quod folio fimilififymbrio conftet, e ranis condatur maioribus. vfus item, or uis non eifdem conueniunt. Hoc igitu. ( ut dictum eft) mirum, fimul'; proprium Cret.e infula dicitur. hac Theophraftus. Ceterim ut atati quoque noftre Dictami rationem aliquan reddamus, ut in omnibus ferc plantis facere confueuimus, non diu quidé eft, quód ex Creta infula Venctias legitinum Dictannum adferri coptum eft. siquidem Mandrdus Ferrarienfis, uir

20. non folim ingenio $\sigma$ doctrina celebris; fed etian fimplicium medic amentorum acerrinus indagator, lib. v I. epift. I I r. inquit. Di iamio, nifi camrur $\int u s$ Venus ab Ida fylua deportet, omnino deficimus. Sed certé (ut ingenué $f_{a}=$ tear ) ne cio, qua auttoritate, uel ratione fcripferit Dicfcorides, Cretenfe Dictamnum nec florem, nec femen pro= firre, cum id, quod creta ad nos aduebitur, und cum floribus deferatur, nullis preterea deficientibus notis, que in legitino requiruntur. nifi dic smus bunc locum deprauatum effe, ut fermé fupicor. Quód autem fructum ferat Cretenfe Diftmmum, or ex confequenti etiam florem, videtur fuprà declar affe Tbeophraftus, cium dixit. Vfus eft foliorun; non ramorum, nec fiuctus. Atquiid ipfun non ob furè à Damocrate explicatum eft, ut in Galeno legitur 7ib. v. de compofitione medicamentorum per genera, cap. x. in emplaftro ex dictamno, quod acceptum refert Da= mocrati. Hic nimirum dictumno Cretico florem aßigndut in illis Grecis uerfibus, quos folutis uerbis fic uertimus . His quoque omnibus addito dict amni berbe leuis ficce florem babentis drachmas uiginti. Hoc idem etiam credimus 2. Virgilium carminibus expreßiffe lib. X.1T. Jue Aeneidıs, ubi ita cecinit.

Hîc Venus indigno náti concuffa dolore,

Dittamnum genitrix Cretea carpit ab Idd,

Puberibus caulem folijs, er flore comantem

Purpureo: non illa feris incügitu estris

Gramina, cim tergo uolucres barere fagitte.

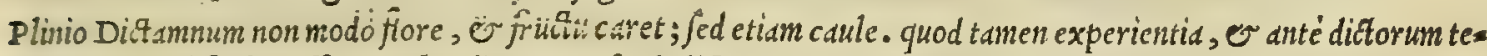
ftimonio plané falfum efe deprehenditur. Pfcudodidamnum porró hodie paucis (ut arbitror) notum, pifis lsoc tě = pore ad rne mifit claripimus medicus L ucas Glinus, caule dodrantali, lanugino $\int_{0}$, albicantég; : cui folia é caulibus erumpunt ex interuallis bina, dic amni tomento pubefcentid: é quorum omniü medio flores purpurei prodeunt, mar=

40 ruti, uel mely Jophylli modo, fapore pulcgij, minus tamen acri. Vulgare autem Difamnum, album uulgó co= gnominatum, quod folio fraxineo, floribus odore fragrantibus, citreis amulis, radice alba, hircinum uirus olente, e amara prouenit, nullis prorfus notis aliquod Creten/is dictamni genus reprefentat. viribus tamen quam pluri=

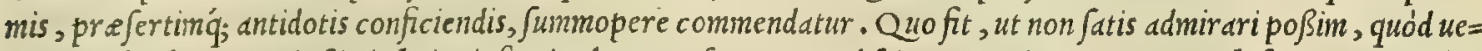
teres rei herbarie peritißini, huius infignis plante nufquam, quod fciam, meminerint. De eius hiftoria, ac uiribus libro primo latius differuimus . quare nunc ea repetere fuperuacaneum effe duximus. Difamni, ac falfi Dictamni Ditáni uires uires tradidit Galenus lib. v I . fimplicium medicamentorum, fic inquiens. Dictamnum tenuiore effentia conftat, ex Galeno. quam pulegtum : caterailli fimile. At quod uocant peudodictamnum, adomnia imbecillius dictanno eft. Que herba Grecé Sintauios, Latiné quoque Dictamnum appellatur: Arabicé, Mefcatremefir, Alnegem araba, fiue Nomine.

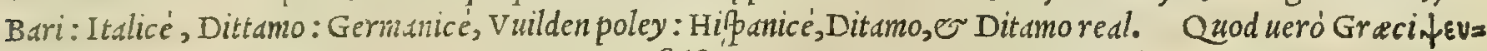

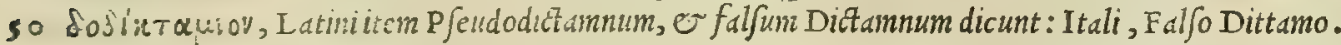

+ Hic locusithi prorfus ejt finilis, qui in uulgatis Dof foridis exemplaribus legitur libro primo in capite $\mathrm{N}$ ardi montani. Idcirco in boc fimliter, atc; in illo adnotauimus, mendum fubeffe arbitramur. Ergo communis quoq; erit uiriufque lociratio, qua uter"̨e fux, ut pero, integritati restituatur. Et quoniam fuperuacuum effet ea referre,

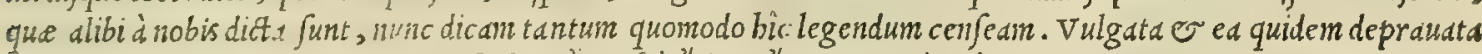

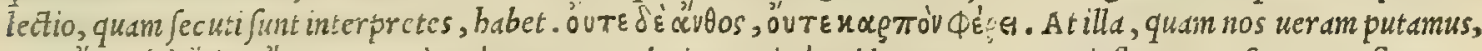

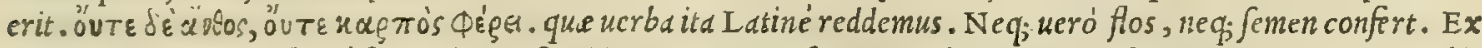
bac caftigatione illud facilé fiet, quód Diofcorides auctor grauißsinus non folum erroris fupicione non condemnabi. tur, fed etian maximé commendxbutur, quod ea foriptis tradiderit, qua cum alijs ueteribus conueniunt. 


\section{And.Matthioli Comm.}

SALVIA MAIOR.

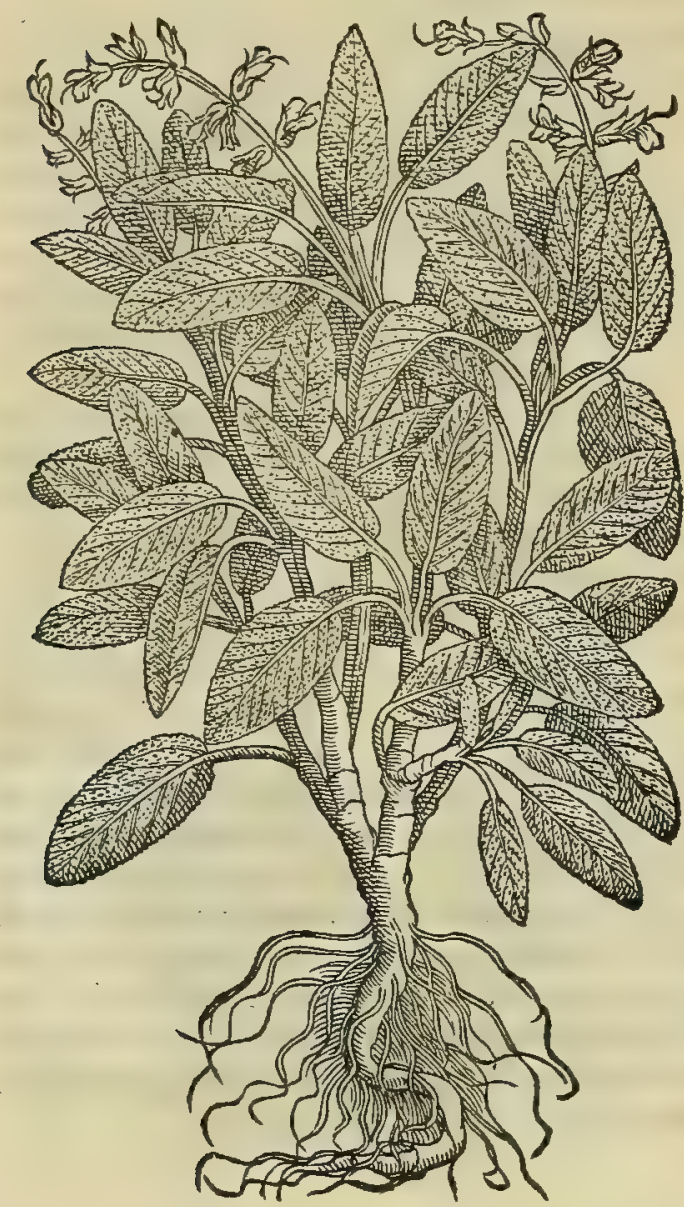

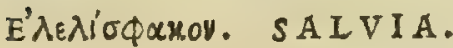

SALVIA MINOR.

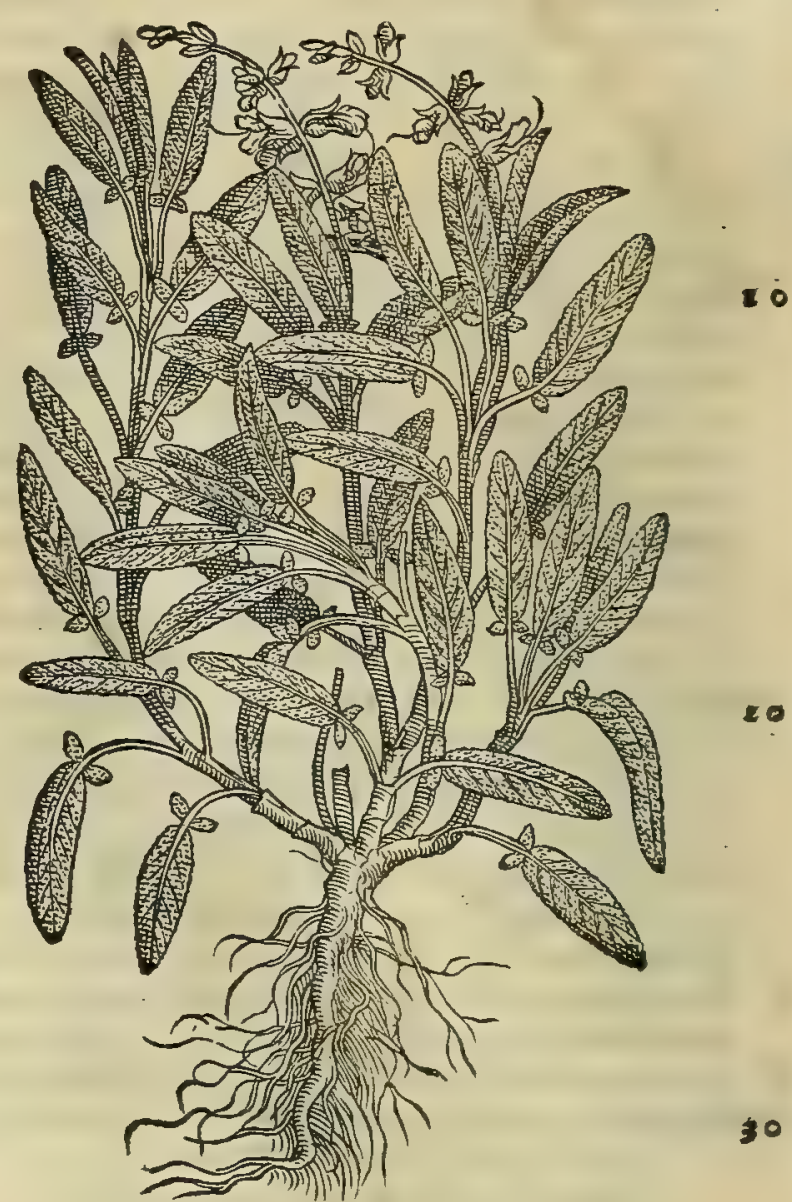

CAP. XXXIIII.

S A I V I A, fiue ele! i f̧̣̂hâcon, frutex eft ramolus, longus, uirgas habens quadrangulas, \& cañas folia mali cutonei effigie, fed longiora, alperiora, crafsiora, \& qux fenfim attritarum quafi ueftium fcabritiem referant, hirfuta, fubalbida, perquàm iucundo odore, fed graui : femen fummis in caulibus fylueftri hormino fimile gerit. In afperis nafcitur. Menfes cit, \& urinas decoctum foliorum,ramorumq́ue potum, \& partus extrahit,\& paftinacæ marın ictibus auxiliatur. Capillos denigrat,vulnerum fanguinem cohibet, tetra ulcera purgat. Teftium pruritus fedant rami foliaq́ue, fi eorum decocto cum uino foueantur.

Salnie confi- $\quad$ A D E o' eft uulgaris notitie Saluia borten/is, ut nulli prorfus reperiantur borti, in quibus hodie frequens paf $=$ deratio. fim non pettetur. Eft etiam preter banc saluia fyluestris, qua in campeftribus, apperis, incultis, or montibus pro= uenit folijs domeftice fimilibus, candidioribus tamen, ev hirfutioribus. Quo fit, ut longè aberrent, qui pro fylueftre Saluia, agreftem sclaream fic uocatam ufurpant, quam feplafiarij Centrum galli, o Gallitricum etiam appellant. Verim animaduertendum eft, quodd illa, quam jylueftrem appello, ea fane non eft, que in Hifpania campeftribus, et afferis locis, ac in Maßilienfi agro und cum noftrate nardo, o lauendula frequentißima nafcitur. Quandoquidem hee non fylueftris saluia eft, fed ea ipfa, quam domefticam uocant: nam qux in bortis habetur alia non eft, quàm campeftris in hortos translata. Ideớ; nõ fcribit Diofcorides, saluiä in hortis nafci, fed in aperis tantum locis. $C_{e}=$ so terim Theophrafto due Saluix produntur genera lib.v I.cap.I I de plant.hiftor.ubific inquit.sphacelus, et faluia in= ter fefe diftant, quafí alterü urbanum, alterü genus fylueftre dixeris. Sphacelo foliü lauius, contractius, minusó;; fqua Iens: Saluie fcabrius. hec ille . Porró genera hec Saluie, qua à Theophrasto reddütur, in Italia quoq; in bortis quàm plurimis inueniuntur : in eáqf; fum fententia, ut existimem fphacelum marem effe, faluiam ueró feeminam. In Creta, ac etiam in quibufdä Apulie, et Calabrice loc is saluia in cacumine gignit tuberculd quedä, gallarü inftar, fub= albida : quorum aliâs mibi copiam fecit Ioannes Baptifta Rbamnufius Illuftriß\}.Senatus Veneti fecretarius, uir mori= bus, ac doctrina preclarus: is enim (que fud eft bumanitas) cum ea ex Creta fibi allata effent, mibi uidenda tradidit. Saluiam Greci eleliffhacon uocant. Vnde factum effe puto, ut Plinius lib. $\mathrm{x}$ I.cap. X X v. uocabulorü cognatione Plinij laprus. deceptus, quod Gracis lens phacos appelletur, crediderit magno crrore eleliphacon lentis peciem effe. Saluia,

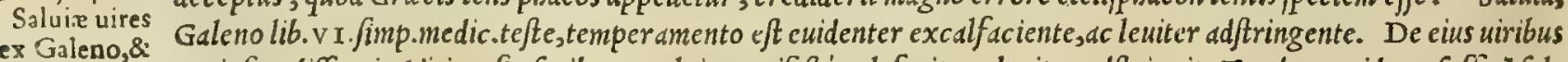
ex Galeno,\&: copiofius differuit Aëtius, fic fcribens. Saluid manifffté calefacit, o leniter adftringit. Tradunt quidam, fuffitä fal=
Aëtio. 


\section{In Lib. tertium Diofcoridis.}

uidm nenfes immoderaté fluentes, or omnino mulebre proflunium compefcere. Agrippa facram herbam uocauit, quam pregnantes mulieres, /i fluida, laxég; fuerint, utilißinc comedere prodidit: continet enim conceptum, uita= lemø̆; reddit. Ac fi fucci buius beminam cum modico fale, quarto à fecubitu die, mulier potauerit, deinde uiro mifces tur, procul dubio concipiet. A iunt in Copto Acgypti poft feuds peftilentias, ab bis qui fuperfucrunt, ad eum fuccun bibcndun mulicres coxt as fuife, plurimosí; indc produdtos fretus. Dato, inquit Orpbeus, fanguinem expuentibus fucci faluix cyathos duos, iciunis cum melle bibendos, o fanguis illico cobibebitur. Tabidis pilula in bunc modum pa rantur. Sumito pice nardi, gingiberis, fing. drachmas dus : feminis faluia affati, triti, or cribratidrach. octo: pi= peris longi drach. duodecim, or cum fucco faluix pilulas conficito, o mane iciunis drachm,am ună exbibeto, codem

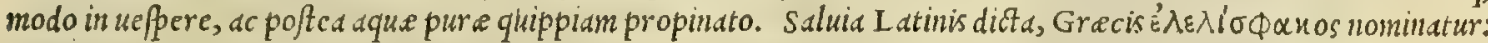

10 Mauritanis, Aelisfacos, feu Elifacos: Italis, Salua: Germanis, Salbey : Hipanis, Saluia, et Salua: Gallis, Saulgs.

Nomina.

MENTHA.

20

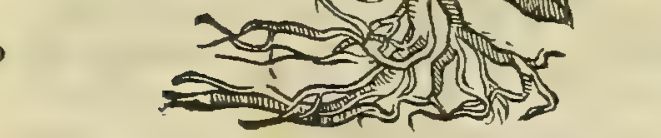

Hévioguos. M ENTHA.
MENTHA ALTERA.

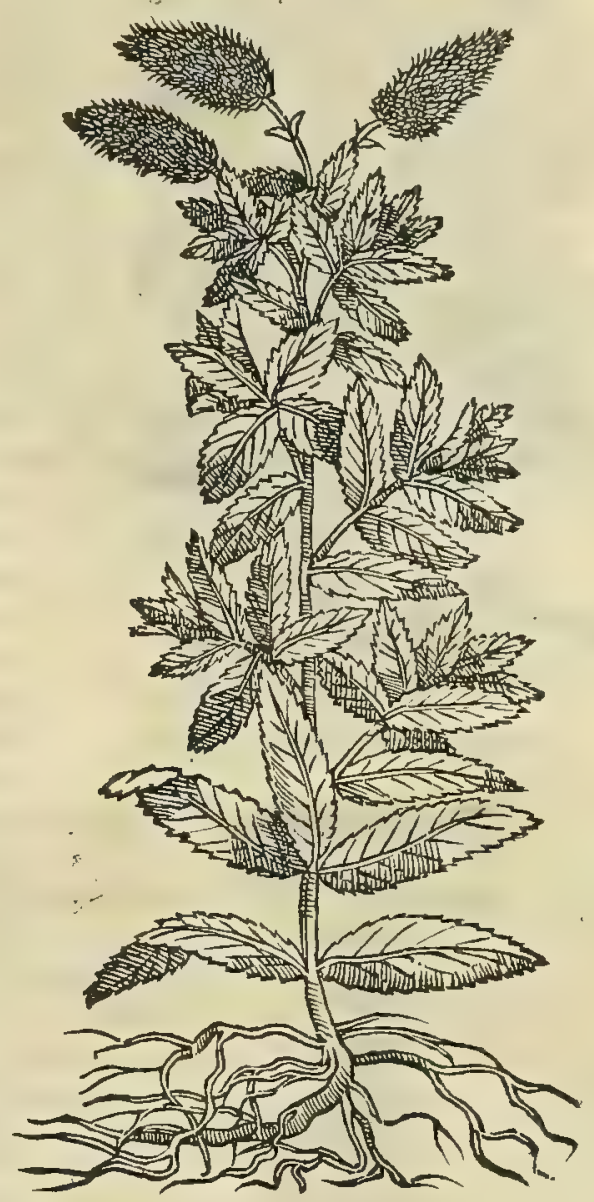

CAP. XXXV.

Me N т A cognita herba eft. Calfaciendi, adfringeudi, atque exiccandi uim habet. Siftit fanguinem, poto ex aceto fucco: tineas in ventre teretes enecat: venerem ftimulat. Singultus, vomitiones, cholerasque fedant terni ramuli cum acidi granati' fucco poti . Suppurationes difcutit, if cum polenta illinatur. Impofita fronti capitis dolores mulcet : mammas fi tendantur, aut lacte turgeant, compefcit: cum fale canum morfibus illinitur : aurium doloribus cum aqua mulfa fubuenit: 5o vuluæ ante coitum admota conceptioni refiftit: lingux fabritiem confrieta læuigat. Lac coire, denfariq́ue in cafeum non patitur, fi folia potionibus lactis immergantur. In fumma ftomacho utilis eft, \& in condimentis peculiarem gratiam habet. Sylueftris mentha, Latini menthaftrum uocant, hirfutiore eft folio, \& prorfus maiore, quàm fifymbrij, grauiori odore. quare minus ad fanorum ufus expetitur.

M E N T H A cimbortenfis, tum etiam Sylueftris, quam Hetrufci noftri Latinum nomen retinentes uulgó Men Menthe con thaftro appellant, adeo ommbus uulgaris, nota'; eft, ut fine uitio eius delineationem filentio pratermittipoffe pu= Gideratio. sauerim. Et quanuis plures, quadm bic fcribat Diofcorides, in bortis fint Menthe pecies (una enim breuioribuss o cripioribus conftat folijs, alia rubenti caule, er flore, alia uerò albicante) buiufmodi tamen pecierum differentia nŏ funt, meo iudicio, plurimi facienda. Viuax Mentha admodum eft: $n$ am in hortis femel tantum fata, tam reftibilifer = tilisate durat, ut uix in pofterum extirparipoj3it, quin renafcatur. Venereis uoluptatibus Mentha commendatd eft : 
Menthx uiresex Gal.

Menthx greCEmentio.

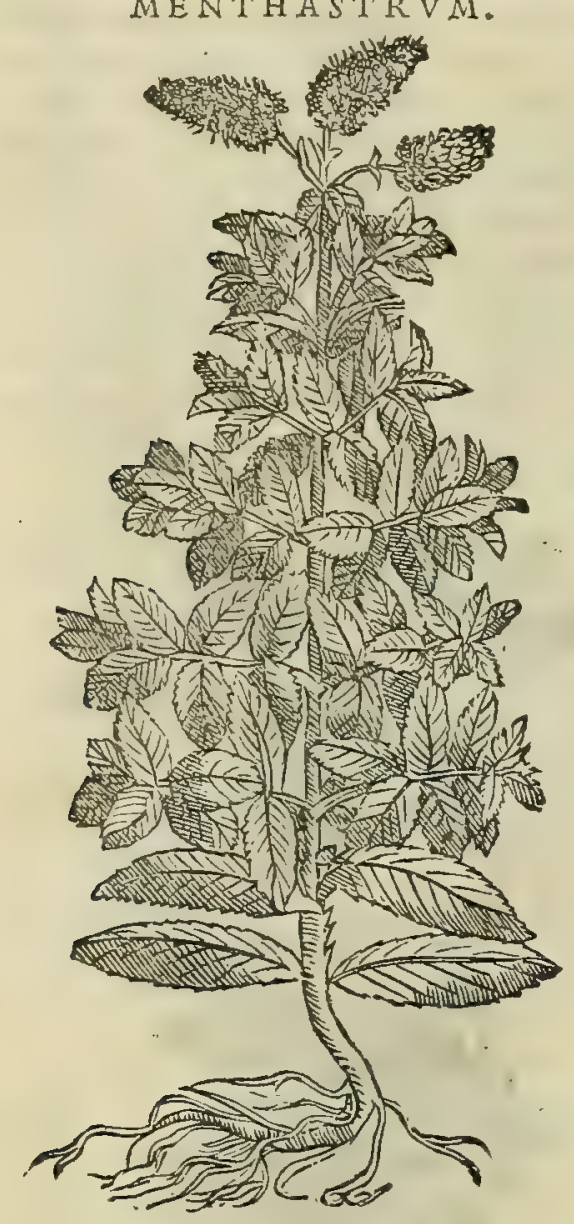

MENTHA GRECA.

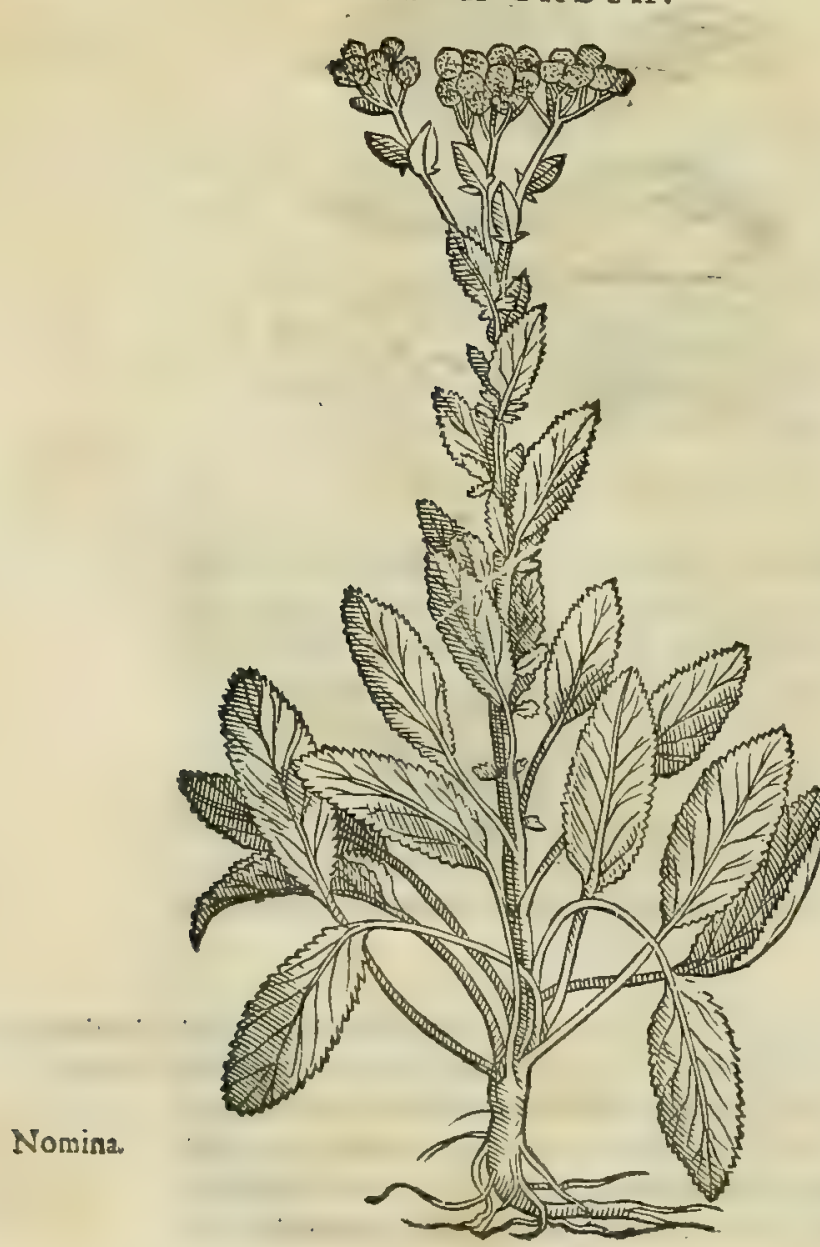

et $f \mathrm{P}$ linius non fine errore lib. $\mathrm{x} \mathrm{x}$. cap. $\mathrm{x}$ I I I I . plané contrds. rium fcriptis tradiderit. Huius menthe facultatis caufan fcite. reddidit Galenus libro.v r. fimplicium medicamentorum, ubi de ea ijs diffcrit uerbis. Hedio [mos, alï ueró minthen odoratam nun cupant. Eft enim alia quadam mintbe non odorata, quam ca $=$ laminthen wocant. Vtraq; guftu acris, $\sim \sim$ facultate calida eft, ex tertio ordine excalfacientium. Infirmior tamen ef mentha odo= rata, quim calamintha, or minus excalfacit. Vt enim in uniuer= fum dicam, bec ceu fylueftris quedam eft, illa ceu domeftica. Quamobrem fané ob eam, que ex cultu accedit, humiditatem, mediocriter item ad uenerem excitat. Id quod omnibus commu= ne cft, que humiditatem femic octam, o flatuofam continent. $O b$ talem ipfius berbx temperaturam in abfceßibus ea quidam cum polenta mifta utuntur. Id quod in Calamintha facere nequeas, propterea quód ualentius cum excalfaciat, tum deficcet, quàm id genus pofcant. Habet ueró etian quiddam amarum in $\int e, \mathcal{e}$ acer bum: $\mathcal{O}$ amaro quidem lumbricos interficit; acerbitate ueró ft cum oxycrato bibaitur, recentes fanguinis reiectiones reprimit. subftantia eft, ut fi qua alia berba, tenuium partium . bec Gale= nus. Veriun animaduertendum eft, boc loco Galenum per fylue= Arem Mentham non intellexiffe legitimam Calamintham, quod is de odorata Caldmintha (ut fequenti capite dicturi fumus) initio feptimi libri de fimplicium medic amentorum facultatibus copiose tractauerit. Ex quo facilé conijcere licet, Galenum in boc non Juam, er uerain appellationem retulifee, fed alior ü, or forté Gre ciuulgi, qui fylueftrem mentham calaminthe nomine appellare confueverit: id quod etiam Galeni locutio confirmare uidetur.

Ceterim cft or herba paßim in hortis crefcens, folio faluia lon giore, latioréq; , betonic e amulo, in uiridi albicante: caulibus cubitalibus, of aliquando maioribus : in quorum cacumine flores exeunt corymbacei, colore melino, tanaceti modo. Planta in uni uerfum amatra eft, fubadftringens, Er grauiter odorata. Gori= tiěfibus hec unlgó nocatur ME N T H A greca : in Hetruria ueró Saluia romana, qucd potius folijs faluiam referat, quain mentham:

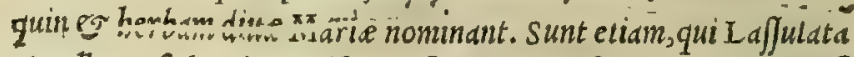
appellent: fed unde apud hos id fibi nomen afciuerit, ne fcio, ip/ $\mathrm{i}$ dicant. Porró Valerius Cordus in fuo dipenfatorio, in unguento starciati magno, duas profert Menthas, nempe cripam, er Sara= centicam: pro Saracenica autĕ mentha hanc, de qua prefens men= tio, imponendam effe cenfet. Sed quoniam id nulla comprobat au= thoritate, ucl ratione, eius quidem fententie adftipulari nõ tutum effe arbutror: prefertim cùm Nicolans nuper à Fucbjio latinus factus, nullam biriufce saracenic a menthe mentionem faciat, fed rubee, or agreftis tantim. Id quod facilé nobis indicat, ut liberé dicamus, Cordi dippen fatoriü quàm plurimis fcatere mendis. 'quip pequod non omnes medic anentorum defcriptiones ex bonorum duthorum fonte hauferit. Plantam banc (ut ip $\int e$ fcribit) Germani uocant Vnfer fraunen muntz, id eft, mentham fancte Maris. Ve rum Fuchfius aliam codem nomine ab hac longé diuer fam oftédit. Qui ueró horum errauerit, in bec Germanica lingua peritiores so iudices erunt. quanquam fi Hetrufcis Germanicd, uel Germanic is Hetrufca nomina reßpon dent, Cordo potius (quantum ad uocabu= lum ppectat) qudin Fucl, fio acceferim, quodd, ut modó diximus, ber ban diue Marie eă uocent in Hetruria. Huius epotus fuccus alui tineas, or lumbricos enecat : frigido utero fubuenit. Ventriculum roborat, tam bauftus, quàm illitus, or nomitiones compe $f c i t, T 0=$ ta planta tam fubftratu, quaim fuffitu ferpentes fugat, or corum uenenis refiftit quin es infarctus expedit, e capitirobur addit:

$\mathrm{E}_{a}$ Gracis idvoofuos, Latinis, pariter o Italis Mentba noca= tur: Arobious, Nabanaba : Germanis, Muntz: Hifpanis, Hierua buend, or ortelana: Gallis, Mente, 


\section{In Lib. tertium Diofcoridıs.}

CAIAMINTHA MONTANA.

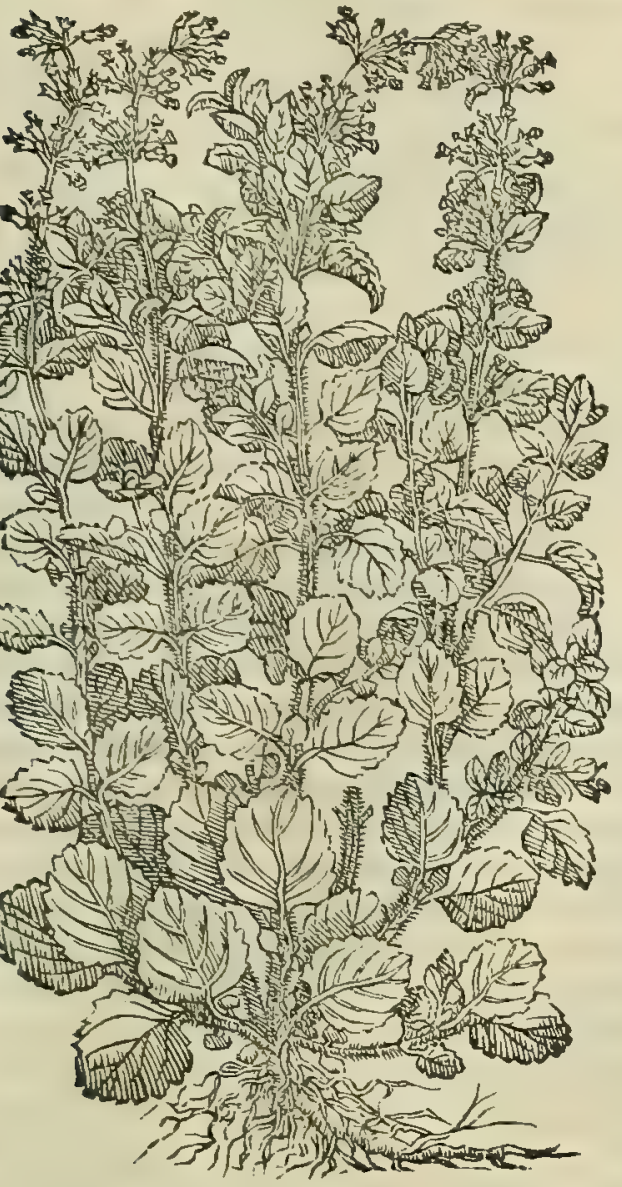

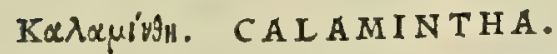

\section{CALAMINTHA ALTERA.}

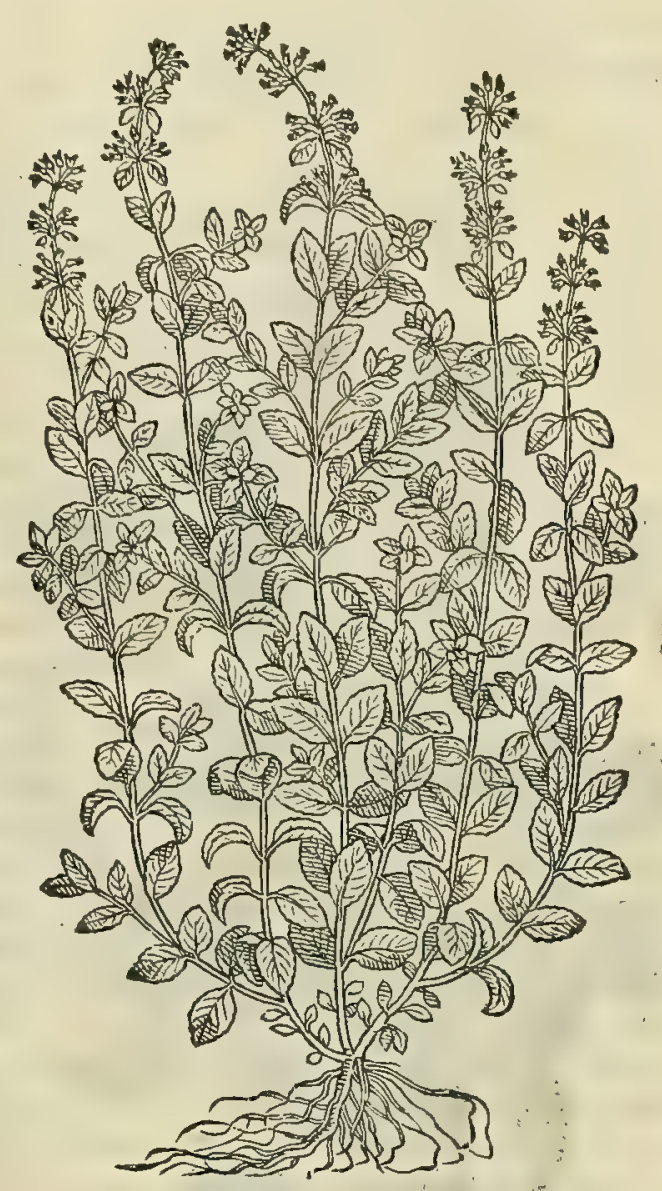

CAP. XXXVI.

EX CA L M I T HAE generibus quedam montibus familiaris, folia ocimi habens, incana: furculos, \& caules angulofos, purpureum florem. Altera pulegio fimilis eft, fed maior : quam fylueftre pulegium ideo appellarunt, quòd odore ipfum amuletur nepetam Latini vocitant. Tertia menthaftro cognata eft, folijs oblongioribus, caule \& ramis maioribus, quàm fuperiora, fed uiribus inefficacior. Omnium folia guftu impensè feruentia, \& acria : radix fuperuacua . Nafciturin campeftribus, afperis, \& aquofis. Potu, aut illitu demorfis à ferpente opitulatur. Decoctum potu menfes, \& urinas expellit : ruptis, conuulfis, orthopnœx, torminibus, choleris, horroribusq́ue auxiliatur : regium morbum expurgat . Prefumpta in vino venenis refiftit : tineas, cæterasq́; interaneorum animalia cum fale, \& melle pota, enecat: nec fecus cocta, crudáve, fi teratur. Elephanticos efitata adiuuat, fi poftea ferum lactis ebibatur. Folia detrita, fi in vellere fubijciantur, menfes extrahunt, \& partus enecant : accenfa, aut fubftrata, ferpentes fugant : nigris cicatricibus candorem reddunt, in vino cocta, \& illita : fugillata tollunt. Calamintha ifchiadicis imponitur, vt ex alto humores euocet, fummam cittem exurens. Vermes ne cat fuccus auribus inftillatus.

C A L A M I N T H A officinis Calamentum dicitur, cuius tres numerantur pecies. Sed cius frequentior eft ufus, que Lati= confideratio. nis Nepeta uocitatur, fecüdo loco bic à Diofcoride tradita. No= men bec apud Hetrufcosin bunc $u f q_{\text {; }}$ dicn retinct: fiquidesn no= ftrates eam, corrupto tamen nomine, uulgó appellant Nipotelld. 
Brafauoli er- C.eterim hac inre Brafauolus (pace eius dixerin) aperté hallucinari deprehenditur, quod pro certo cxiftimet ror. Calanintham fecundo loco is Diofcoride de fcriptam illam herbam effe, quan, eo quod cattimagna cius capiantur uo= luptate, Gattaria quidam uulgó nominant. Error binc manifefté proditur, quód G A T T A R I A, cuius hic imaginem

HERBA GATTA.

Ruellij erratum .

Monachoré lapfus.

Calaminthæ uiresex Gal.

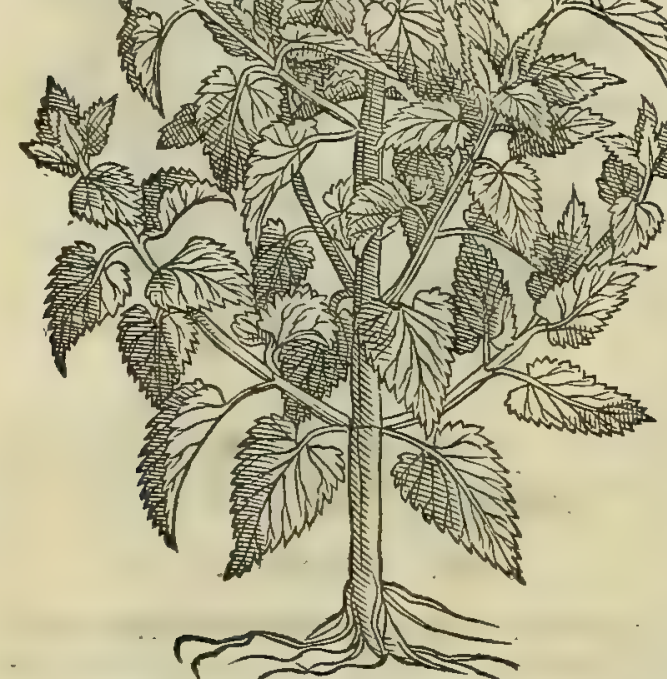
damus, fit herbof folijs urtice, aut apiaftro fimilibus, que quan= tum à pulcgij folijs dißíiedt, non modó ceteris notis; uerùm etian odore, in quo Brafauolus nititur, ij dijudicent, qui hus differëtias rectius norunt. Sunt tamen è unigaribus, qui Gattariam etiam Nepetam appell cnt, quorum nomenclaturam magis fortaffe fecu= tus Brafauolus, quain plante ip fius notas, ballucinatus deprehen ditur. Nepeta itaq; Diofcoridi nil aliud unquam, mea opinione, fuerit, quam uulgaris caldmintha, qua officina utuntur, quam'; nos unlgó uocamus Nipotelld. quandoquidcm unlgaris ufus $C_{d}=$ lamintha, non modó folijs pulegium smulatur; fed etiam fapore, er odoris fragrantia. Quo fit, ut mirum non fit, $/ 2$ Diof coridis te ftimonio, à quibufdam jylueftre pulegium uocata fuerit : nö enim odore tantum (ut Brafauolus uelle uidetur) Nepeta pulegium imi tatur; fed o folijs, o caule. Quamobrem dicamus licet, nullo pacto exift mandum effe, Gattariam berbam effe Nepetam fecun= dam Calaminthe pecien. Neq; ctiam putandum, eandem tertiă effe, quemadmodum falsó credidit R uellius, Quippe quoniam $f=20$ cerit banc Diofcorides mentbaftro fimilem, non autem meliffo= phyllo, aut urtice, quas (ut pauló anté diximus) Gattaria repres= fentat. Quapropter non modó ea de caufa cius fententiam explo dend am putauerim; fed ctiam quod fapius ip fe in locis aquofis re pererim tertiam Calaminiba peciem;mentbaftri anulam; fubal= bidioribus tamen folijs, ac guftu acriori. Non fecus er montana mibi frequens olim occurrebat in excelfis uallis Andinie monti= bus, folijs albicantibus, ocino fimilibus, caule quadrangulo, flore in purpura rufeccente. Quanquam in hoc errore, mea qui= dem fententid, verfantiu Monachi illireuerendi, qui in Mefuem 30 commentarios ediderunt, ut affercre non dubitent, montanä hanc Calaminthamilegitimam effe Nepetam. Calaminthe meminit Galenus lib.v i I. Jimplicium medicamentorum, fic de eius uiribus differens. Calamintha effentia eft tenui; $\sigma$ calida, ficca; tem= perie, ex tertio quodammodo ordine utraq; qualitate. Horum manifila funt indicid, partim guftu apparentia, par= tim experientia cognita. Guftu fiquidem acris, ev palan calida eft, ac paulun omnino Jubanari habet. Periclitan= tibus autem, or corpori admouentibus extrinfecus impofita, primim quidem ualde excalfacit, or mordicat, cutem $q_{;}$ laniat, poftremó etiam ulcus efficit. In corpus autem intró affumpta, tum ip faper fe fe ficcd, tum etiam cum melicra= sto, perfpicuó calfacit, er fudores ciet, omnéf; corpus tum digerit, tum exiccat. Ea ratione ducti quidam ip am cont= tha rigores per circuitum repetentes adbibuerunt, foris quidem oleo incoctam toti corpori inungentes cum frictione 40 non fegni, intró ueró affumentes, ficuti eft dictum. Quinetiam er coxendicibus eam quidam in egritudinibus if chia = dicis, tanquam ftrenumm remedium illinunt. Trabit enim qus in profundo berent ad fuperficiem externam, totum'; adeó articulum excalfacit, cutemó; non obfcuré adurit, men $\int \mathrm{es}$; t tum cpota, tum appofita adinodum efficaciter pro= uocat. Bonum etiam elephanticor um remedium, non co tantiom, quód frenué tenues bumores digerat; uerim ctiam quia extenuet, $\mathcal{O}$ incidat ualenter craffos, quales funt qui bunc morbum procreant. sic $\mathcal{O}$ cicatricibus atr is cando= rem reddit, $\sim$ fugillata digerit. Sed in talibus in uino coctan cataplafmatis modo imponere viridem magis, quim fic= cam preftat. Quippe arefacta uebementior redditur, or ad urendum promptior. Porró talis cim fit ad ue nenata= rum beftiarummorfus affumitur, uelut etiam cauteria, er quecunq; medicamenta calida funt, er acria, tenuium'́; partium, qué $q_{;}$facilé ex alto ad fe fe circumiacentem omnem qualitatem poffunt attrabere. Ceterìm que illi ineft d= maritas, plane exigua eft : uerùm ad quadam ita efficaciter agit, ut que ualentißima eft, nimirum cum coniuncta fit

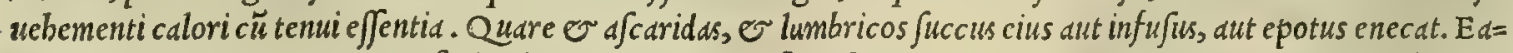
dem ratione aurium uermes, aut fi alicubi in corporis parte finuo ${ }_{a}$, aut implicata, qua putredine tentetur, talis pro= uenerit affectus. Sic 0 conceptum $\int e u$ pota, $\int e u$ admota interimit, $\sigma$ eijcit. I gitur incide ndi quidě ei uis adeft, pro= pter calorem eius, tenuitatem, $\sigma$ amaritudinem : abftergendi ueró propter unic an amaritudinem. Itaq; afthmaticis ob omnia anté dicta prodeft : iftericis ueró, fiue regio morbo laborantibus potißimùm ob anaritudinem, ficut alia $f=$ ré omnia amara, utpote abftergentia, or expurgantia in iecinore prouenientes obftructiones. Ad omnia iam dicta ef=

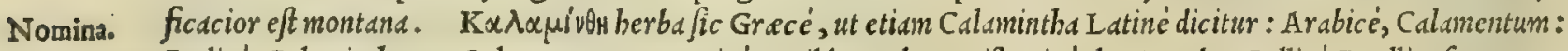
Italicé, Calamintha, o Caldmento: Germanice, Vuilden poley: Hipanicc, la Neuada: Gallicé, Poulliot fautuage. 


\section{Ovinos. THYMVM.}

10

20

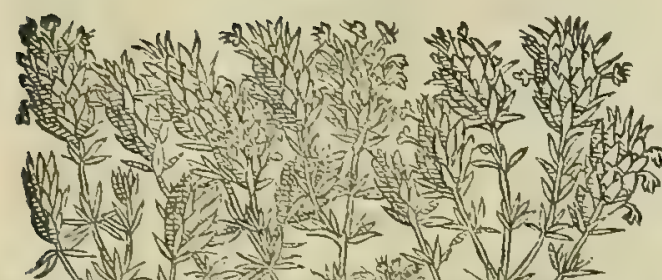

20

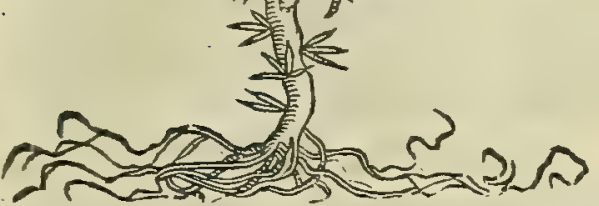

CAP. XXXVIY.

T н ४ $\mathrm{M} \mathrm{V}$ M ab omnibus cognofcitur, furculofus frutex, exilibus folijs, multis, \& anguftis circundatus: capitulis incacumine, flore purpurafcente refertis . Gra cili folo, \& petrofo prouenit : Vim habet hane, ut cum fale, $\&$ aceto potum, pituitam per aluum detrahat. Décocti ius prodeft orthopnoicis, \& anhelatoribus : tineas uentris exigit: menfes, partus, \& fecundas pellit: vrinas ciet. Cum melle in eclegmate faciles facit excreationes: recentes tumores difcutit, cum aceto illitum: concretum fanguinem diffoluit . verrucas thy mi colorem reddentes, penfilesq́ue tollit. Ifchiadicis cum uino, \& polenta impofitum fubuenit: hebetibus ocul is in cibo pro deft. Perquàm utile pro condimento, duntaxat ad ufus corum, qui recte ùalent.

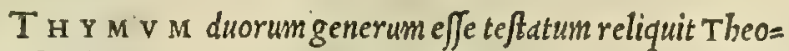
phraftus lib.V I cap. I I de plantarum biftoria, ubi de eo differuit bis uerbis. Quin o thymum candidum, nigrum $\dot{q}_{\text {; }}$ reddint. Scrò id admodum floret : nam circa diftium folftitium incipit. Meld= pes binc captint, o hoc algurio apiarij conftare affirmant, an probè melletur, nec ne. Etenim fi aliter defloruerit, mellatio mi= nus probé fuccedit. Deftruitur, perit $q_{5}$ flos, ${ }_{2} \mathrm{i}$ imber incefferit. Semen fac undum fatureia, atque etiam magis origani manifftó fentitur : thymi ueró nullum oftendi poteft, fed floribus quodam permifcetur modo. Flores etenim ferunt, itaque oritur thymum. bactenus Theophraftus. Ceterim nunc thymum in I talia notißi= mum eft. Prieftat autem quod ex A pulia fertur: quanquam laus datißimum eft, quod é Creta infula, alijsó; nonnullis Greciæloz cis aduehitur. Vnius tantum thymi, minoris uidelicet, mèminit hic Diofcorides. Verum cùm is libro quarto in epithymibiftoria, Epithymum florem effe fcribat é thymo duriore, fatu= reie fimili, haud dubié oftendit fe non fecus ac Theophraftum, duo Thymi genera obferuaffe. Vnum, quod mittit fur= culos complures exillbus folijs, anguft is, $\sigma$ numerofis circundatos : in quorum cacumine funt capitula flore purpu= reo referta. Alterum ueró lignofius, fruticofizus, ac durius, fatureia fimile. Thymo hoc duriore pa Sin feré fcatet Go yitienfis ager, cius precipué colles: in co q́; ( ut libro quarto fuo loco dicetur) legitimum epithymum oritur. Thy= mi meminit Galenus lib.v I. fimplicium medicamentorum, ubi de cius uiribus ita fcribit. Thymum incidit, er calfacit manifeté : ob id o urinam, o menfcs ciet, fretum euellt, o uifcera potum expurgat: educendis ex thorace, o pul 40 mone confert. Itaq; in excalfaciendo, e exiccando in tertio ordine ftatuendum eft. Preter has autem à Galeno de= - Scriptas, alids quoq;; Thymo uires reddidit Aétius fermone primo, fic inquiens. Hec ueró experimentis de Thymo cõ= perta funt. Dato ieiunis articulari morbo laborantibus, Thymi aridi minutißimi drachmas quatuor cum oxymelitis cyatho. Bilem enim, reliquosq; bumores, atq; acrem faniem euacuat: facit $\sigma$ ad uefice affectus. Ventre autem in $=$ flato, ubi fcilicet intume fcere caperit, drachmam unam dato ieiunis cum cochleari aque mulf $\int_{x}$. Ad lumborum co= xendicumg; dolorem, laterisq; $\approx$ thor acis, ac hypochondriorum fupenfiones ac inflationes, pondere trium drachme rum cum oxymelite temperato men fur a cochlearij ieiuno exhibeto. Similiter etiam o melancholicis, o mente tur= batis, timoreqy; detentis drachmas tres cum oxymelitis temperati cocbleari prabeto. Dato item ieiunis, $\mathbb{O}$ ante cax nam aduerfus lippitudinem, e uehementem oculorum dolorem. Praterea contra podagram, etiam qua motum om= nino interceperit, cum uino utilisiné propinatur. Poftremó ad tume factos testes ieiunis trium drachmarum pondere.

so exbibeatur. Verim ab atro thymo abftinere oportet: corrumpit enim temperamentum, bilemq́; gignit. Eligendum quod purpureo flore eft, preftantius tamen quod album illum babet. Planta, qua Grecis Oúuos, Latinisitem Thy mus, $\odot$ Thymum appellatur: Mauritanis, Hafce: Italis, Thimo: Germanis, Romifcher quendel, et Vuelfcher quen: del: Hifpanis, Tomilho fallero: Gallis, Thym, feu Mariolaine d'Angleterre.

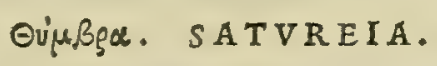

CAP. XXXVIII.

S A T V R E I A triuialis notitix eft. Gignitur in afperis locis, \& tenui folo, thymo fimilis, minor tamen, \& tenerior: defert fpicam florum plenam, coloris herbacei. Eadem poteft, qux thymum, fi modo confimili fumptitetur. Aptus fanis ufus. Eft etiámnum quædam fatiua, fylueftri prorfus minor , qux propter mitiorem acrimoniam commodius in cibos recepta eft.
Thymikftora.

Thymi uires ex Galeno,\& Aëtio.

Nomina: 


\section{4}

Thymbræcó

fideratio.

Thymbre ui res ex Paulo.

Nomine

Serpylliconfideratio.

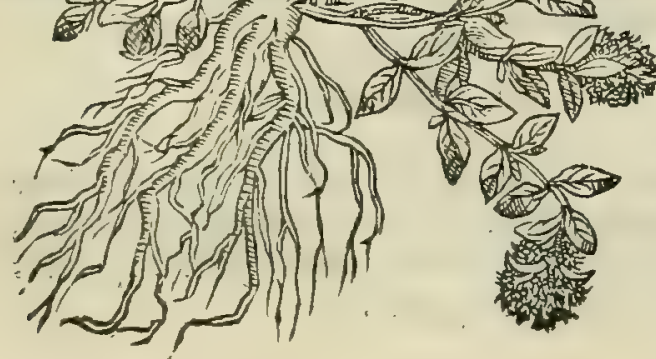

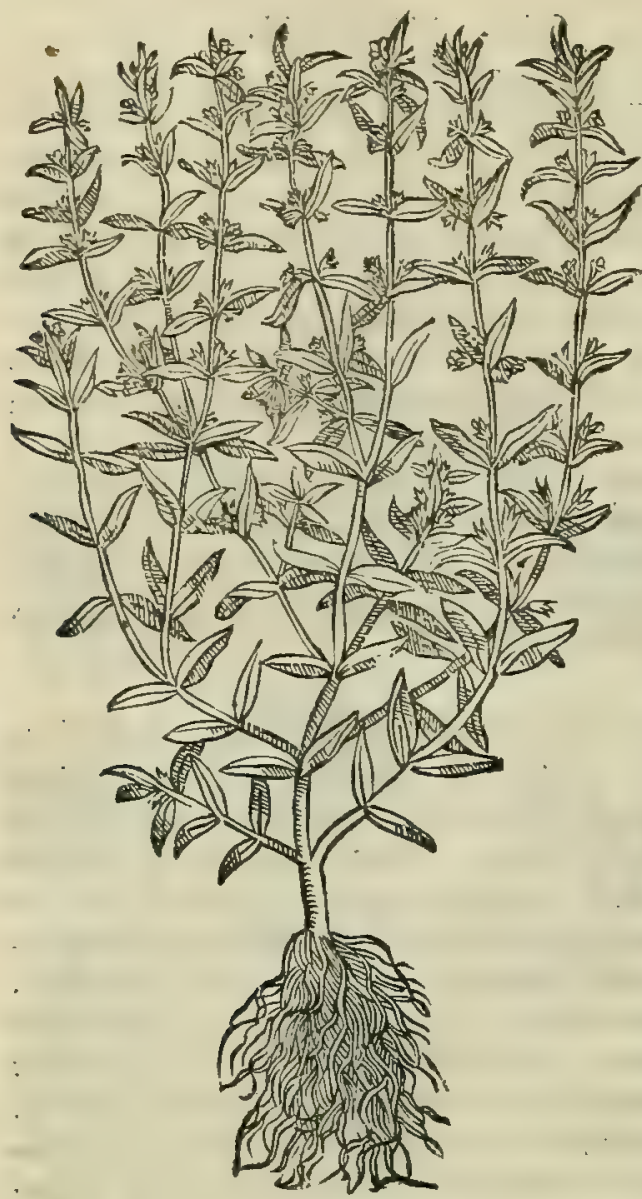

SATVREIA.

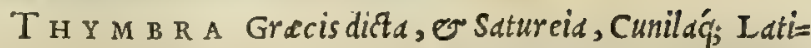
nis, nobis in Hetruria, corrupto ḋ Cunila nomine, uulgó uocatur Coniella. In alijs tamen plerifq; Italie locis,quod à Satureia uo= cem corrumpere inaluerint, appellatur uulgó Sauoreggia. Non defunt ctianinibi, qui ab acrimonia, quam piperis fere modo gu= Puirepra fentat, eam uulgó Peuerella, qua/i Piperellä nominent. Thymbre duo inueniuntur generd, fatiuum, or fylueftre, quod o guftu acrius, $\sigma$ odore fragrantius eft, in campeftribus, $\infty$ f $a=$ bulofis proueniens. Ideoq; Columella minimé damnandus uide= tur, quod Thymbram à Saturcia difcreuerit : quandoquidem is $0=10$ ptime nouerat hortenfem, ac fylueftrem Cunilam reperiri. quod o Plinius fatis notaffe deprebenditur. Ex quo facilè intelligi po teft, Columellam fylueftrem, thymbram nuncupaffe, hortenfem ueró Satureiam. Sed qux fit Thymbra illa, quam Diofcorides $f y l$ ueftrigeneri aßignanit, $\propto$ picam ferre prodidit floribus plenă. coloris uiridis, nondum fatis mibi conftat. neq; enim bactenus mi= bi contigit plantam fyluefrem aut fatiuam uidere, qua illi plané repondeat. Quamobrem non alterius imaginem exbibere potui= mus, quadm illius cunile, que paßim in nostris hortis nafcitur : lisec eft (ut equidem opinor) Jatureia, cuius d Columella fit men $=20$ tio. Ceterum quód in fimplicium cen $u$ ufquam Thymbra me= minerit Galenus, nondum compertum habeo. Paulus ueró eius mentionem freit libro v I I. ubi de utraque pecie ijs paucis diffe= rit. Thymbra fylueftris eadcm qua tlymum preftat. Hortenfis autem altera quidem inbecillior eft, fed ad ciborum ufum gratior, ש accommodatior. Quaberba $2 u ́ \mu \beta \rho \alpha$ Gracé, Thymbra, Cunild, Satureid Latiné uocatur: Arabice, Sabater, feu Sha= tar:Italice, Thimbra, Coniella, Savoreggid, or Peuerella: Ger manice', Kunel, Zuuibel byfop, ㅇ Saturey: Hifpanicé, Segu= relha: Gallicé, Sauoreie, Sarriette, or Satrea.

CAP. XXXIX.

SER P Y L L V M duorum generum eft. Hortenfeodore fampfuchum imitatur, atque in coronas addi folet. cui à ferpendo nomen inditum eft : quoniam fi qua ius particula terram attingat, inibi radices demittet. Folia, \& ramulos origani habet, fed candidiores, in macerijs multò procerius affurgit. Sylueftre, zigis appellatum, non ferpit, fed in altitudinem increfcit, ramulos edens tenues, furculofos, folijs refertos longioribus, $4^{\circ}$ quàm rutæ, \& durioribus, anguftis. Flores iucundè olent, guftanti acres. Radicis nullus ufus. Nafcitur in petris, fatiuo efficacius, atque magis excalfaciens, \& ad medendi ufum aptius. Menfes trahit, \& urinam potu ciet : torminibus, ruptis, vulfis, \& iecinoris inflammationibus auxiliatur: \& aduerfus ferpentes potu, illitúve prodelt . capitis dolores mulcet coctum, adiecto roraceo, \& madefactum in aceto: maximè uerò phreniticis, \& lethargicis conuenit. Cruentos uomitus fedat fuccus, drachmis quatuor ex aceto potus.

SE R P Y L L V M hortenfe in Hetruriabaud negligitur, fed in hortis feritur, or magna admodum diligentia colitur, quod etiam inibi ( $u t$ Diofcorides inquit) in coronamenta additur. Syl= ueftre duorum eft generum : unum flore candido, odore citrei ma li: alterum ueró flore purpureo, guftu perquàm acri, Satureice fimili. Vtrunq; copiofißimé najcitur apud Goritienfes Saluatino monte, quo mibi hactenus latius nufquam uidere contigit, nec itĕ odoratius. Serpyllum d Theopbrafto, cui hortenfe nil aliud effe cenfeo, quàm fylueftre in hortis fatum, de cribitur lib. V. I. cap. v I I. de plantarum biftoria, ubi de co differit ijs uerbis. Serpylli 


\section{In Lib. tertium Diofcoridis.}

fylueftre etiam genus cft, quoa' deforentes ex montibus ferunt, ut apud sycionem fierifolct, atque etiam Athe nis ex mante Hymet to: apud alios ueró, ut in Thracia, montes, or plana omnia serpyllo fatent. Peculiaris buic autio germinum : quippe cum in quätüm!is longitudinis procedere ualeat, nactum fcilicct adminiculum, aut iuxta fepes aliquas fatun. Genera ubuna reducre non eft, utrctulinus : frrocia cffe affirmant. Hoc cnin in montibus, tum fa= tureiatum quodd.m, atque uchcmentifitmum: tum gratum odore, molliusq; comperiri. Tempus fercndi plurimum autunnus : boc enim prinum fercre nimirum properant. hactenus Thcopbrafus. Ex cuius ctiam ucrbis fatis perfits cué colligi poteft, diu effe Jylucftris serpylli generd. Quare etfi paldm unius taintinn gencris mentioncm ficerit Diofcorides; duorum tamen obfcuré meminiffe potuit, cum inquit. Sylucftre, zygis appcllatsm, nan ferpit, fedin. altitudiucm affurgit. Nan fi unum tantim fyiucftris Scrpylligcnus Diofcoridi notum fuiffet, ci fanć neccffarium no.

\o erat addere zygis cognomen defferentie caufa. Satiuum radicibus quidem ferpit, fed ramulis atiollitur, amaraci. modo, quemadnodum fy! ueftris altera pecies, que malum citreum olct. Proinde fcité Plinius lib. X X.cap. X X I I. ita de co memorie prodidit. Serpyllum a ferpendo putant dictum. quod in fylucftri cucnit, in petris maximc. Sa= tiuum non ferpit, fed ad palmi altitudinem incre fcit. Serpylli uires paucisper, frinxit Galenus lib.v r. fimplicium medic amentorum, fic inquiens. Serpyllum ufqueadeó excalfacit, ut $\odot$ menfes, 0 urinas mouedt. cf autem et gu= ftu adnodum acre. Eiusnomen Gracun, हुछ erpylli uires ex Galeno. pillo: Germanic um, Quendel, or Hiener hoel: Hifparicum, serpollio, er Serpam: Gallicum, serpoulet.

Nomina.

$$
\text { ¿ápurov. SAMPSVCHVM. }
$$

CAP. XL.

$2 \cdot$

30

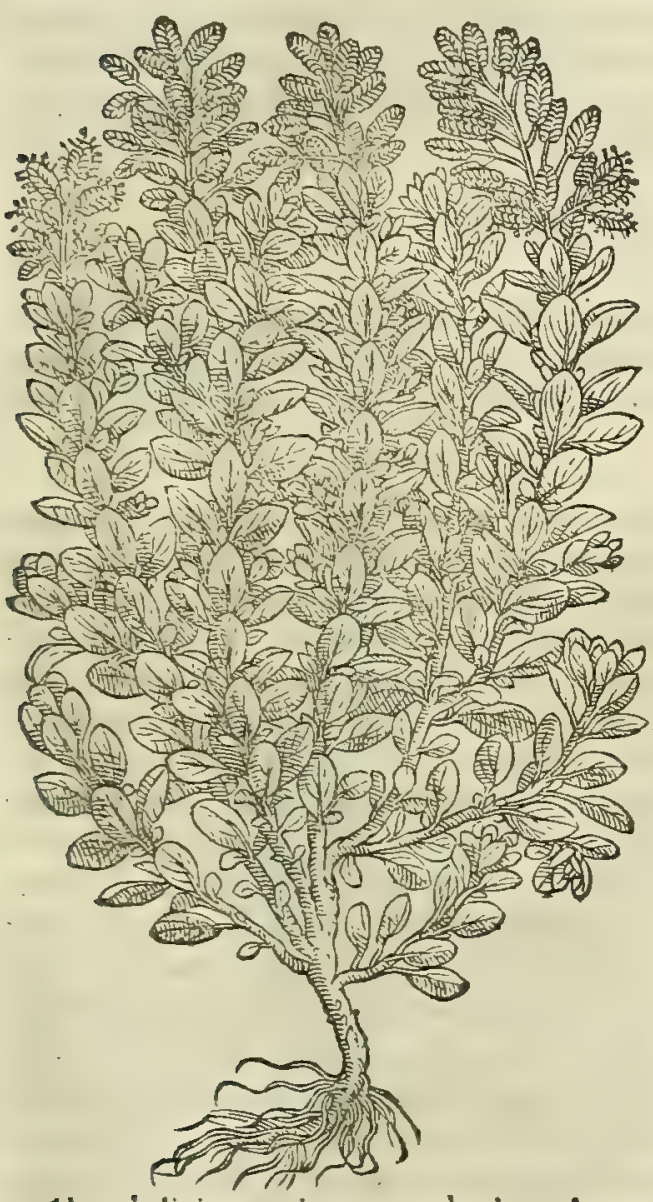

S A M P S. C H V M in Cypro, \& Cyziceno laudatiffimum. Secundum fibilocum uendicauit Aegyptium . Amaracum gens Sicula, \& Cyzicena appellat . Herba eft ramofa, per terram repens : folijs eius calaminthx, qux tenui folio conftat, hirfutis, \& rotundis. fuauifsimum odorem fpirat: ideo coronis inferitur. Vis eius excalfaciens. Succus decocti potus, conuenit incipientibus hydropicis, \& ijs quos urina difficultas, aut tormina excruciant. Illita ex melle arida folia, fugillata tollunt : menfes fubdita in peffo trahunt : contra fcorpionis ictum ex aceto,\& fale illinŭtur : Iuxatis, tumoribusq́ue cerato excepta, imponuntur : aduerfus oculorum inflammationes, cum polline polentre, illini prodeft. Acopis, malagmatisque calfaciendi gratia commifcetur.

Cv'M Juperius libro primo in sampfuchini unguenti come mentatione, Sampfucbim, or Amaracum idem effe latius often= derim, et $\{\mathbf{G}$ Galenus, ef Paulus diuerfis capitibus Sampfucbi, or Amaraci meminerint, eddem bic repetere fuperuacaneum duxi: quod ea buc facilé transferre poßint $i j$, qui rem bane fe aliter for $=$ taffe habere exiftimant. Sampfucbum in Italia Hetrufcis uulgo appellatur Per $\int a, q u d d$ forté illis é. Perfia fuerit allatum: ceteris ueró inibi Maiorana, nomine à Latinis mutuato. Herba bec tan= tam cum mulieribus iniuit gratiam fui odoris iucunditate, ut nul le feré reperiantur, que fuis in bortis, aut fictilibus uafis A mara= cum non ferant, uel plantas non transferant, ac diligenti admod $\vec{u}$ cultura foueant. Quo fit, ut putauerim ego, ex eo Maiorania fibi nomen adinueniffe, quod maiori cura, dic diligentia feratur, cold= turq;, quaim ceter $x$ plante. Neq; id ea folim ratione, quód, ut pauló anté diximus, odore perquàm iucundo commendetur; fed quód etiam perpetua uireat coma. Sampfuchi so meminit Galenus libro v I I I. fimplicium medicamentorum, fic inquiens. Sampfuchum tenuium partium, 0 dige=

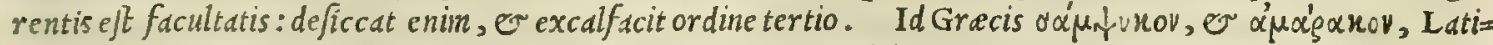
nis quoque Samp fuchum, Amaracus, $\mathcal{O}$ Maiorana uocatur: Arabibus, Merzenius, feu Morfangius: Italis, Md=

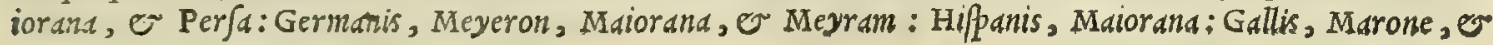
Mariolaine.

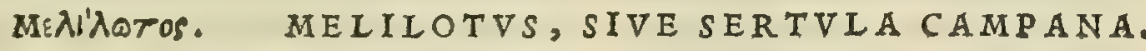

$$
\text { C A P. } \mathrm{X} \text { I I. }
$$

SE R T V I A campana laudatifsima in Attica, \& Cyzico, \& Chalcedone nata : cuius color uicinus eft croco, boni odoris. Nafcitur \& in Campania circa Nolam, colore in luteum languefcente, odore infirmo. Vim habet adfrictoriam. Inflammationem omné emollit, prxfercim qux in oculis, vul-

Sampfuchicö fideratio

\section{Sanupfuchi ui res ex Gal.}

Nomina. 


\section{6 \\ And. Matthioli Comm.}

ua, fedc, aut teftibus erumpat, fi ex paflo'cocta illinatur : interdum autem addito oui luteo affato,aut foni græci farina, lini femine, aut polline, aut capitulis papaueris, intybóue. Recentes meliceridas per fe cum aqua, \& ulcera manantia in capite illita cum creta Chia, vino, aut galla fanat : ftomachi dolores, \& cruda, \& cocta cum aliquo ex antè diEtis leuat: doloribus aurium mitigandis cruda ex paffo inftillatur: in aceto, aut rofaceo madefacta, capitis dolorem lenit.

Meliloticon

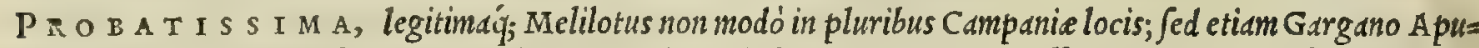
fideratio. lis monte prouenit. Cuius fenen in tenuibus corniculis inclufum nuper venetias afferric cepit. Quo factum eft, ut iam cognouerint medici uulgaris ufus Melilotum ill cgitimam effe, potiusq́; lotum urbanam referre, cuius biftoriam libro quarto tradidit Diofcorides. Mcliloti meminit Plinius lib. x X I. cap. I X. ubi ita fcriptum reliquit. Ergo in coronamenta folio uenere apiaftrum, meliloton, quod Sertulam campanam uacamus. Eft enim in Campania Italia laudatißima, Grecis in sunio, mox Chalcidica, er Cretica, ubicunque ueró apperis, e fylueftribus nata . Coro= nas ex bac antiquitus faftitatas, indicio eft nomen sertula, quod occupauit. Odor eius croco uicinus efl, or flos. Meliloti ui- Ipfa cana placei, maximé folijs breuißimis, atque pinguißimis. Melilotum, ut Galenus mennoria prodidit libra res ex Gal. VI. fimplicium medicamentorum, mifte facultatis eft : babet enim quiddane adftringens, fed $\mathcal{O}$ digerit, $\mathcal{O}$ conco= quit : copiofior enim in eo eft fubftantia calida, quam frigida. bactenus Galenus. Ceterim neminem inuenio é Gra: cis auctoribus, qui cxplicauerit, que Meliloti pars in ufum medicine recipiatur, anfolia, aut radices, aut caulis, an flores, aut cornicula, aut fcmen. Quod tamen docuerunt Matritani, prefertm Serapio, qui ex auctoritate If adc Eben ameram de Meliloto fcribit in bunc fenfum. Nelilotus berba cft, qua folia fert rotunda, o uiridia: r amulos emittit admodum exiles, in quibus folia rara. Senen gerit in filiquis tenuibus, ac rotundis : qua grana inclu dunt pauca, glauci coloris, rotunda, infra finapis magnitudinem. Porró in vieliloto ufum fibi uendicarunt filiqua,

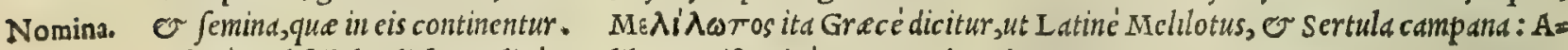
rabicé, Alchilelmelich: Italice, Meliloto:Hipanicé, Corona de rei.

\section{Mápol. MAR VM. CAP. XIII.}

M A R v M herba cognita uulgò, furculofa, flore origani, folijs multò candidioribus, flore odoratiore. Vim habet fifymbrio confimilem : fubftringit enim, \& modicè calfacit. Qua de caufa illitu ferpentia ulcera fiftit, \& in calidas illitiones additur. Iuxta Magnefiam, \& Tralleis copiofifsima gignitur.

Mari mentio ex Galeno.

E T I Galenus inter fimplicia medicamenta nufquam, quod equidem inuenerim, Marimeminerit; libro tamen primo de antidotis in Hedycllroi compofitione eius mentionem fccit, cum ita fcribit. Alix bcdychroi defcriptiones re periuntur, qua neq; A maracum, neq; Marum prorfus habent: quedam alterutrum tantìm continent. Neq; enim duo bec omnes nofcunt unguentarij, eo quód berbas folum é Creta aduect us emant und cum feminibus, at q; fuccis. Ego ue= ró er eafdem herbas foio in $\mathrm{A}$ fia nafci,ac in alijs quidem regionibus raras effe, in Cyzico autem frequentes. In Italia quoq; ut e alias quafdam berbas, ita e Amaracum uidi, que odore multum à Maro fuperatur. Marum enim ual = dé redolet, putaretg; aliquis fola nominis appellatione ductus, ungucntum amaracinum, quod in Cyzico faciunt, ama=

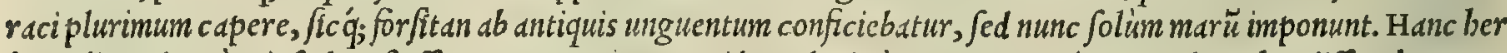
bam aliquoties cüm ipfe deguftafem, ac edm aniarain quidem plurinim, acrem ueró parum deprebendiffem, loortatus fum quendam eorum, qui Amaracinum conficere folent, ut amaraci tantum compofitioni imsnitterent, quantü or ma= ri. Ac mibi uifum eft id unguentum minus quidem odoratum, nibil autem uiribus inferius. bac Galeni uerba. Ex quibus palàm eft, Marum ab amaraco uiribus, of facie parum admodum dißidere, et fi tum amarius fit Marum, tum etiam odore fragrantius. Quapropter non plané corum Sententiam explodendam putarem, qui Marü amaracum illă effe arbitrantur, qua maioré pirat odorem, maioremq́; amaritudinem guftu prefert: qux q́; folijs uiret minufculis, candi= dioribus, of tenuioribus: unde non immeritó d noftris in Hetruria uulgó cognominatur Perfagentile. Sampfuchum enim, fiue Amaracum, inibi Perfa uulgó uocari fuperius indic auimus. Cuius illud genus, quod folijs conftat pinguiori bus, latioribus, uiridioribus, gustúg; acrioribus, minus tamen amaris, legitima ommibus Amaracus effe confetur. Illortmin inquam fententix fermé adstipularer, nifi eidem aduerfari Galenus inueniretur : quippe qui loco citato tefta= tus fit, fe in Italia amaracum uidiffe, nulla quód inibi Marum uiderit, facta mentione, fed tantum quód hoc in alijs so

Marum Italię ab Afia regionibus rarum oriatur. Hinc itaq; facilé adducor, ut exiftimem Marum non nafci in Italia. A uget nobis pregrinum. opinionem Plinius, qui quafi Galeno fubfcriberet, Marum duxit effe rarum inucntu, o Italix peregrinum . quare ipfum collocauit lib. X X I I. cap. X X I I I I. inter ea duntaxat odoramentorum genera, que ab externis regionibus in Italiam conuebcbantur, fic inquiens. In Aegypto nafcitur e Maron peius quàm Lydium, maioribus folijs.y ac uarijs : illa breuia, ac minuta, E odorata . bec Plinius. Caterim non ob id eos errare crediderim, quigraciliorem amaracum Mari loco fubftituunt. Quandoquidem teftatur Galenus, quód unguentum illud, in quo Amaracum pro

Nomina. Maro admifceri iußit, et $f$ minus quidem odoratum uideretur; non tamen uiribus inefficacius crat. Quod Greci

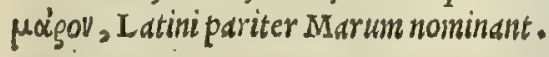




\section{InLib. tertium Diofcoridis.}

A"unos. A C I N V S.

CAP. XIIII.

A C I n o s, aut aconos a Grecis dicitur, tenui, ficcoq́ue ramulo herba, ocimo fimilis, odorata, fed hirfutior : qua coronx factitantur. à nonnullis olitoribus colitur. Menfes, \& aluum pota fiftit. Illita panos, ignemq́ue facrum fanat.

QV A N CV A M funt aliqui, qui Acinum eam ocimi peciem effe exiftinant, que anguftioribus conftat fo= liis, qué'; iucuidum effut odorem, cuius gratia, atque etiam umbra grate nirentis aftiuo tempore paßim in fi=

10 gulinis ualiss foutur extra fineftras cálim, $\sigma$ in atrifs, quan nos ob eius gracilitatem uulgó uocamus Bafilico gentile; horwnt tamen opinioni apertilimé refragatur Plinius lib. $\mathrm{x} \times \mathrm{I}$. cap. $\mathrm{x}$ v. ubi Acinum fcribit nunquain flo= rere. Id quod minori oc imo non eucnit: i iquidem boc aftate, o dutunno floret, floribusq́; ornatur albis, ac odo= ratis. Illud preterea ill is etian rcclimat, quod idem Plinius fcriptum reliquit lib. $\mathrm{x}$ x I. cap . X x v I I. cùm alt . Acinon o coronarun canfa, or ciborum Acgyptij ferunt, eadem q; crat, que ocimum, niff hirfutior ramis, ac folijs efet, $O$ admodun odorata. Ex his plinijuerbis abundé paldm fieri poteft, Acinum non effe ocimum tenuifo= Tium, cium hoc nec folid, nec caulem hivfuta proferat. Ceterim Mandardus Frrrarienfis, uir acri ingenio, or preftanti doctrina, nil aliud Acinum putauit effe, qudim berbam quandam, que in incultis proucnit locis, fed precipué in agrorus, ev uidrum aggeribus, ocimo birfutior ac fatis fudniter olens. que quód ocimum adino= dum emulctur, à quibufdan fyluftre Ocimum appellatur. Quibus fanè notis aliâs adduclus fum, ut Manardo

20 prorfus afenticudum putauerin. Sed cìn pofted animaduerterim, herbant banc flores emittere contra Plinij au= ctoritatem, nunc cogor nutare fententian. Nec me poenitet, quód noftra, aut aliorum diligentia futurum pe= rem, ut de hac, $v$ de alijs rebus dubijs quandoque certiora profirantur. Herba, qua Gracis ánivos, Latinis item Acinus appellatur.

De Acino opinio quorúdam explofa.

Manardi opi nio non acce pta.

Nomina. Bórkxopls. BACCHARIS.

CAP. XIIII.

B A C C H A R Is herba fruticofa, qux in coronas additur.cuius folia afpera funt, media uiolæ, \& uerbafci magnitudine: caulis angulofus,cubiti altitudiné petens, aliquantulum afper, non fine appendicibus adnatis : fore purpureo, fubalbicante, odorato: radicibus ueratro nigro fimilibus, quibus odor ineft cinnamomo proximus. Afperum, fqualidumq́ue folum amat. Radix in aqua decocta ruptis, uulfis, ex al to precipitatis, fpirandi difficultati, falutaris : item diuturnæ tufsi, \& urinæ diffcili : menfes pellit : contra ferpentium morfus utilifsimè datur in uino. Recens radix appofita partum extrahit. Puerperis eius decoctum in defefsionibus prodeft. In diapafmata utiliter inferitur iucundi odoris gratia. Folia, utpote quæ adftringant, capitis doloribus illitu profunt: oculorum inflammationibus, mammis tumếtibus à partu, ægilopijs incipientibus, ignibusq̣ue facris auxiliantur. Odor fomnum gignit.

D v M E A M de Paccharifententiam, qudm fuperioribus Baccharis con annis lingua Italica expreferam, nunc demum bis noftris Lati= fideratio. nis cominentarijs repetitam, excudendain tradidifern, confe]jus ingenué me nufqualm bactenus ueram Baccharim reperiffe, aut $a b$ alijs repertam uidiffe; accidit interea temporis, ut eam ad me Ronza miferit Andreas Lacuna Secobienfis, medicus hac noftra atate clarißimus. Cuius literas híc referre libet, quód ea fint, que mibi maximum faciant argumentum bumanitatis e $\mathrm{e}$ beneulo= lentixe fue, atque etiam rei fidem addant. Litere autem eius funt ita dd me $\int c r i p t e$. . Et $f$ i nos eidesn, cui tu, negotio illuftrandi, $l o=$ and. Lacunxe cupletandiq́; Diof coriderin nauemus aßiduam oper am, ob id q,; no= literæ.

bis ex ufu fit hanc ad reva extorquere facultates alien as potius, quàm dißipare noftras; uolumus tamen tibi or amico, et de materia medica quàm optimé merito commrunicare ueram Diofcorids Baccharim, quain baud ita pridem in bifce Romanis agris reperimus, quo poß ßis illam ad uiuam formă expreffam, in ufum bumanx falut is inferere tuis luculentif= fimis commentarijs, quos iam (ut fama eft) primìm Latiné fcriptos edere inftituis. Edm itaque charte alligatam ad te mitto, adeo per omnia reßpondentem defcriptioni Diofcoridis, ut in ip $\int a$ nulla nota poßit defiderari. Quippe folia eius funt afpera, media uiole er uerbafci magnitudine: caulis angulofus, cubiti altitudinem petens, aliquantulime 
aper: radices nigro ueratro fimiles, que odore, e fapore imitantur exquifitißinum cinnamomum. Porró flores, quos per inclementiam temporis nunc mittere ad te non licet, in nonnullis locis purpurei, in alijs lutei uifuntur: ita ut buius ftirpis effe dus pecies uideantur, uel fi meminerit unius tantiun Diofcorides. Poftremó buius plante uires, or facultales funt omnino eadem, quas fua Bacchari diuus tribuit Diofcorides. Hî amicus literis fuis finem impo= fuit. Sed certé illud mibi permirum acceßit, quód eadem die, or feré hora, qua Baccharim Roma accepi, candem Arimino ad me mifit I ulius Moderatus diligentißimus pharmacopola, berbarum'́, ftudio ws : id quod aperté teftatur bortus eius apud berbarios I talie non unlgaris, ut quifit uarijs ac nobilibus plant is refertus. Hanc fané compcri mullis prorfus reclamantibus notis, Diofcoridis Baccharim reprefentare. Nam praterquàm quód conftaret, ut illa, folijs apperis, magnitudincm inter uiolan $\mathrm{\sigma}$ ucrbafcum reficrentibus, caule angulofo, cubitali altitudine, aliquantu= lim affero; habebat etian in caulc fua adnata folia, non coliculos. Hinc obiter fupicor legendun effe $\varpi \alpha \rho \alpha \Phi v \lambda=$ $\lambda \alpha \delta \alpha s$, non $\pi \alpha \alpha \phi v \alpha \dot{\delta} \alpha$ s, ut uulgati Greci codices babent: quandoquidem illi lectioni adfipulatur etiam ori= basij manu friptus codex. Pretere a flores, quibus illa carebat, livic in purpura candicabant, odorati. Eius deniq; radices erant ueratro nigro fimilcs, er odore cinnamomo proxima. Huius igitur plante delineatione, que adanuf= fim biftorie Diofcoridis repondet, ut eius quoque effigies, quam pictam damus, affabré demonftrat, facile adducor, Leoniceni, \& ut affirmare non dubitem, hanc effe ueram, o legitimam Baccharim. Ceterum Leonicenus, Or Brafauolusip= quorüdā opi. fum $\int e c u t u s$, eam plantan magno errore putarunt Baccharim effe, quain quidam Sclarean, nonnulli ueró Matrifal= reprobata. uiam appellant. Sed cum buius radices non fit ueratro nigro fimiles, neq; minimum quidem odore cinnamomum imi= tentur, plané corum fententia improbanda uidetur: prafertin quód ueram Baccharim eam effe cen feamus, de qua fu perius differumus. Non defuerunt etian, qui crediderint, Bdccharim Diofcoridi accreuiffe, caput ó, boc adulterinit effe, eo fortaffe argumento, quód eam battenus inuenire non potuerint. quorum fupicionem augere potuit Galenus: quippe qui in /implicium cen $\int u$ de Bacchari quicquan,quod equidem legerim, memorix prodiderit. Vnde ij in eam fententiam deuenerunt, ut Baccharem eandem effe cum a faro certó putarent. Verim borum quog; error iam omni= bus euidentior factus eft, quàm ut bic à me explodi debeat. Neq; enim ea folim ratione proditur, quód pridem legi= tima Baccharis reperta fit; fed etiam quód legitimum boc Diofcoridis caput effe comprobet oribafius, in quo illud ex Baccharis ui- Diofcoride tranfcriptum legitur. Quinetiam idem confirmat Paulus Aegineta,qui Baccharis meminit lib. v I I.atque res ex Paulo. ea fcribit, que facilé, fi conferantur, Diofcoridiacceptaferrentur : fic cnim inquit. Eaccharis odorata eft herba, odo re cinnamomo proxima, coronaria, acris. Huius radicis decostum meatus obftructos aperit, urinam, er menfes ci=

Nomins. tat. Folia ipfius, cuimfint adftringentia, fluxionibus opitulantur. Huic berba nomen Gracum cft Bairxagss, Iatinum quoque Baccharis.

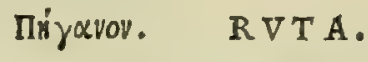

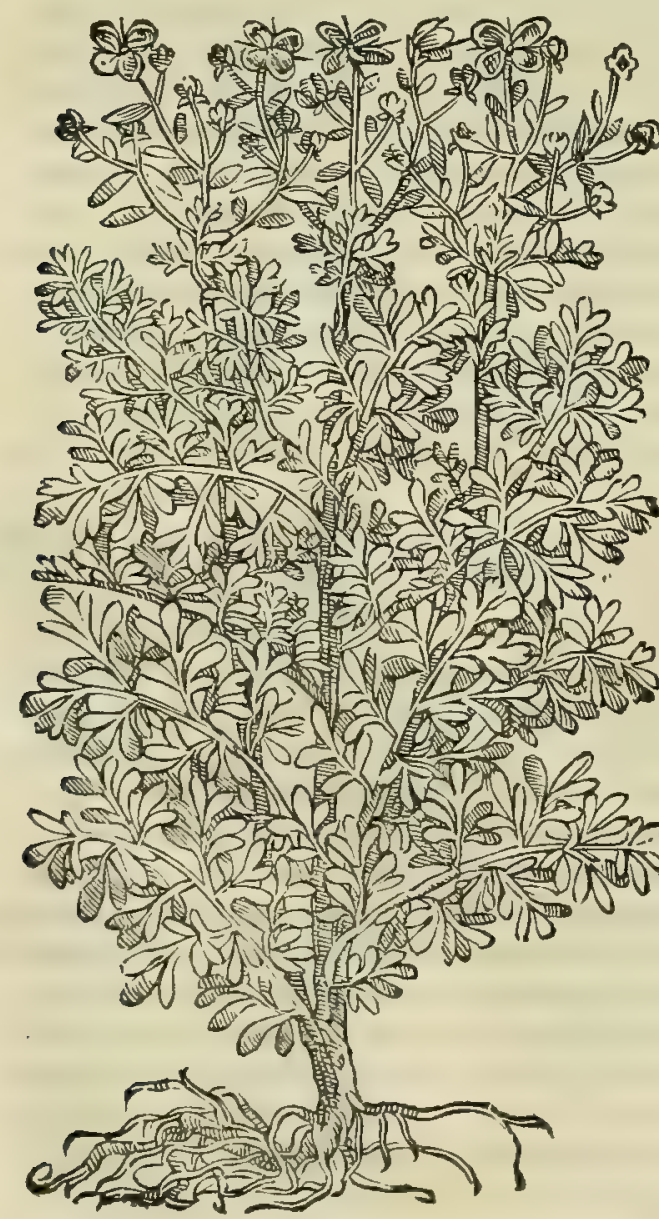

CAP. XLV.

R v T a montana, fylueftrisq́ue, fatiua, \& hortenfi acrior eft, \& in cibis damnata : fatiua uerò, quæ fub ficu arbore enafcitur, magis in cibos admittitur. Vtraque urit, calfacit, exulcerat, urinam ciet, menftrua pellit, aluum fiftit potu, cibóue. Lethaliurn medicamentorim antidotum eft, fi femen ex uino acetabuli menfura cbibatur. Folia per fe præfumpta, aut cum nucibus iuglandibus, aridisq́ue ficis, inefficaces uenenorum uires red- $4^{\circ}$ dunt : contra ferpentes fimili modo fumere connenit. Genituram cibo, potúue extinguit:cum anetho ficco decocta, tormina fedat. Facit ad pectoris, laterumque dolores, difficultatem fpirandi, tuffes, pulmonis inflammationem, coxendicum, articulorumǵue cruciatus, \& horrores febrium circuitu repetentes, pota, ut antè dictum eft. Item ad inflationes coli, vulux, rectiqque inteftini cum olęo decocta, \& infufa. Fœminas uuluæ ftrangulatu liberat, fi à genitali fedétenus cum melle fubjiciatur. Feruefacta ex oleo, \& pota, uentris tineas excu- 50 tit: articularijs doloribus ex melle, aquæ inter cutem cum ficis illinitur : eifdem in potu auxiliatur, decocta in uino ad dimidias partes, \& oblita. Cruda, conditaq́; cibo, uifus aciem excitat: dolores oculorum illita cum polenta lenit : doloribus capitis cum rofaceo, \& aceto illita, auxiliatur : profluentem naribus fanguinem fiftit trita, $\&$ indita. Teftium inflammationibus cum laureis folijs impofita, \&e eruptionibus papularum cum myrto, $\&$ cerato prodeft: cum pipere autem, uino, \& nitro affricta: albæ uitiligini medetur : cum eifdem illita formicationes tollit,\& uerrucas, quæ thymi floré repræéntăt. 


\section{In Lib. tertium Diofcoridis.}

contra impetigines cum alumine, \& melle utilifsimè imponitur. Succus in mali punici calycc calfaEtus,aurium dolori efficaciter infunditur. Idem oculis, qui hebetudinem fenfere, cum forniculi fucco, ac melle inunctus, opitulatur. Ignem facrum, ulcera qua ferpunt, aut in capite manant, cum aceto, rofaceo, \& ceruffa illitus perfanat o manfa alliorum, ceparumq́ue acrimoniam domat. Montana fi copiofius eftur, interficit. Dum florem promit, \& ad murias colligitur, cutem inflat, \& rubore quodam inficit, cum pruritu ac uehementi inflammatione. oportet itaque eam unctis antea manibus, \& facie colligere. Tradunt fuccum gallinaceis pullis in fparfum, feles arcere. Adijciunt eam, qux in Macedonia circa Haliacmon amnem prodeat, comedentes interimere. Montofus autern is locus, uiperis fcattet. Semen cius potum contra inteftina uitia efficax eft. In antidota commodè addi-

10 tur. Contra incontinentiam urinæ toltum femen feptenis diebus potui datur. Radix huius montanum moly uocatur. Sylueftris ruta fatiuæ fimilis eft. Prodeft comitialibus, \& coxendicum doloribus: menftrua mouet, partus enecat . Acrior eft uiribus, quàm hortenfis, \& ualidior. Sylueftris, utpote noxia, cibis abdicatur.

R V T A utraquc planta eft unlgaris notitix, tam fatiud inquam, quam fylueftris. Non tamen uelin de illa fyl= Rutx confueftri intelligas, de qua capite proximo differendum est, fed de ea tantium, cuius meminit Diofcorides in prafenti deratio. capite, quimí; in cius calce fatiua fimilem fecit: fiquidem bec ab illa plurimum differt. Nafcitur bec fylueftris Ruts in Goritienfíagro copiofißina, adeó ut qui circumftant montes, ea ubique fcatednt; prefertimó ; Saluatis nus mons, qui eadem firmé ueftitur. Facie bec bortenfi perqudm fimilis eft, graciliori tamen follio, $\mathbb{\sigma}$ guftu $d=$

20 criori, amurioriq;. Id quod Monachorum in Mefuem fcribentium (pace tamen eorum dixerim) ineptijs prorfus refragatur. quippe qui afferant nullam feré effe differentiam inter banc, 0 androfamum, fiue bypericum, ut qu:e in alterius locum fubftitui poßint. Qua in re manifefté deprebenditur magna eorum infcitid : quandoquidem hic (ut $e=$ quidem arbitror) in triplici uer fantar errore. Primin quód exiftimauerint, turpi nimirum lap fu, fylueftrem Ru= tam ab́ androfsmo, o byperico non dißidere. Deinde quód putauerint hallucinati etiam, andro femum, er bype= ricum unum o iden effe, cum tamen Diofcorides de his feorfum, tanquam de differentibus plantis tradiderit. Huc tertius accedit error, $\mathcal{O}$ is quiden, mea fententia, deteftandus, quód prodiderint, hanc fylueftris $\mathrm{R}$ uta hiftoriam bis à Diofcoride de fcriptam reperiri, magnamǵ; habere cum hyperico cognationem. Quod potius fomniaffe, qudm libero fenfuum iudicio fcripfiffe uidentur Monachi, cim non buius $\mathrm{R} u t e$ caput fit illud, in cuius fronte in qui= bufdam codicibus, ijsq́;; non probatis, illa legantur, que doctißimorum teftimonio bic afcititid, byperici autem

30 propria cenfentur; fed quod proximé fequitur, in quo alterius fylueftris Rute, qudin alij Moly, alij Harma= lam, alij ueró Befafan appellant, tractatur hiftoria. Quare caueant pharmacopold, quifortaffe horum patrum fcri= pta fequuntur, ne und cacutientes fepe ducantur in uarios errorum labyrinthos. Seritur Ruta (ut author eft Pliniuslib. X I x. cap. VI I I. ) fauonio, o ab equinoctio autumni. Odit byemem, e bumorem, ac fimum. Apri=

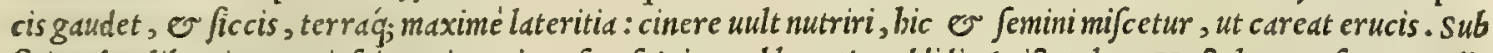
fici umbra libentius acquiefcit . cuius rei caufam fuis in problematis reddidit Aristoteles. Mustela cum ferpente di= micatura, in murium uenatu Rutam prius edendo fe munit, gnara hanc contra uenena pollere. Vtuntur $\approx$ ip $\int_{a}$ boc nostro tempore ad cacodemones depellendos, fortaffe quód contra fafcinationes eam commendauerit Aristoteles in problcmatis. Planta Rute mir abilis magnitudinis uifa eft (Flano Iofepho auttore) Macherunti, quod olim fuit mu= nitißinum I Ide e oppidum. Is elim Lib. $\mathrm{I}$ I.cap. $\mathrm{x} x \mathrm{v}$. de bello I udaico ita fcriptü reliquit. Erat autem in ipfa regia

40 Ruta mirabilis magnitudinis: a nulla enim ficu uel celfitudine, uel magnitudine uincebatur. Ferebant autem eam ex Herodis temporibus perfeueraffe: manfiffet q́; ultcrius profectó, fed à Iudais, qui locum ceperunt, excifa eft. Ru= t\& fylueftris, er fatiue meminit Galenus lib. V I I I. fimplicium medicamentorum, fic inquiens. Ruta agreftis ex quarto eft ordine excalfacientium: domeftica ueró ex tertio. Eft autem non fol im guftu acri; fed or amaro. Ex quo etiam fané digerere, atq; incidere craffos, lentosq; bumores poteft. Ob eandem uim er urinas mouet. Quin e tenuium eft partium, flatus $q_{\text {; }}$ extinguit. Quare ad inflationes competit, ac ueneris appetitum cobibet : digerit $\dot{q}_{;}$,at $=$ que exiccat frenue. Eft enin eorum ex numero medicamentorum, qux ualenter deficcant. Porró quod fuperius

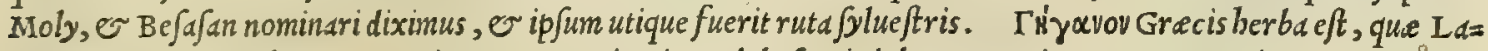
tinis, pariter e I talis Ruta nominatur : Mauritanis, Sadeb, feu Sedab: Germanis, Raut, Arruda: Gallis, Rue.

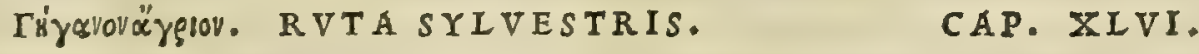

V o c A N T etiámnum fylueftrem Rutam, quod in Cappadocia, \& Galatia Afiæ finitima moly dicitur. Frutex eft, qui ab una radice multos emittit cauliculos: folijs multò,quàm alterius rutælon gioribus, tenerioribusq́ue, odore graui : flore candido : capitulis in cacumine paulò maioribus, quàm fatiux rutx, qux tribus maximè partibus conftant : in quibus triangulum femen, fubrufum, guftu amarum recluditur . cuius eft ufus. Semen autumno maturefcit quod cum melle, vino,croco, \& foeniculi fucco, ac gallinaceo felle, teritur contra retufam oculorum aciem. Sunt qui eam harmalam uocent, Syri befafan : qui Cappadociam incolunt, moly, quoniam quandam cum moly feruet fimilitudinem : radice nigra, flore candido. In collibus, \& læto folo prouenit.

Rutx uires
ex Galeno.

Rutx uires
ex Galeno.

Nomine.

Monachorú hallucinatio. 
Rutx fylue- IN V E N I V N T V R ex Grecis codicibus Diofcoridis, item ex Latinis illorum fidem dd unguem fecutis, qui Itris alterius uel maximo librariorum lapfu, ucl potius corum temeritate, qui nimis fcioli videri uolunt, plura de bac altera fylue= confideratio. Ari Ruta in capitis fronte fcriptd oftenduni, que do Ri ißinorun quorung; confenfu adiectitia funt, o byperico legi= timé debentur. Hac àeprauata, imó addititi, le tione decepti quidam rerum, literarumí; parum gnari, turpiter aber rarun:, certó crcdentes fylueftresi banc Rutam ab byperico nibil differre. Quorum error fimul deprehenfus eft, atyjic Diofcoridis lectio reftituta à pcritis this uiris, qui rei difcrimen exactißiné nouerunt, or uetuftißima Greca exempl.tria confuluerunt, in quibus nibil tali offenderunt. qucmadmodum neq; id fe fe offert lectitandun in Oribasij codice manu fcripto, bcrbarum de fcriptioncs Diofcoridi acceptas referente. Quo fit, ut nullus amplius fuperfit am= bigendi locus, quin ea afcititia fint, er ex byperico, cuius propria funt, bic perperim repetita. Sed bec iam miffa faciamu, or conftituamus duplicenz effe fylucftris R ute fpecicm: unam domeftice fimilem, de qua diximus in pre $=x 0$ cedenticapite: alteran veró, de qua nunc agimus, quam quidam Harnalam uocant. Hanc, ut ingenue fatear, $h a=$ ctenus non uidi: non defunt tanen, qui ean demonfrare promittant in Italia, ac etian iam oftendatur (ut audio) in publico horto Patauij. Quod non equidem negäterim, tanet fi fuerit hec peculiaris Cappadocia, O Galatis plan= Seplafiarionü ta. Apbri corrupta d Grecis appellatione Hajnzel pro Hamala dicunt. Verim enimuero grauißimo crrore du= grauis error. cuntur feplafiarij, qui Luminis apothectriorum frriptd fectiti, buius Rute, fiue Harmel loco, foetdis, er aggre= gatiuis dictis catapotijs, alijsq́; compofitis medicamentis cicute femen admifcent. Quod non folum fuis tum qualita= tibus, tun facultatibus Harmale onmino repugnat; fed etian uenerum lethale exiftit. Errandi caufam prabuit Qui ricus Auguftus Tortonen/is: quandoquidcm is, ubi in confrciendis fretidis catapotijs, quid fit $\mathrm{Harmel} \mathrm{explanare} \mathrm{con=}$ tendit, ait Syluatici Pandectarum autboris te ftinonio, quod quotiefcunq; reperitur Harmel cum appiratione nil aliud apud Arabes defignat, quàn femen cicute: Füe ueró afflatu, $R$ ute fylueftris femen. Quod euidens, ac execrandum 20 eft mendacium: fiquidem Harmel tam affatum, quam nudé foriptum Mauritanis perpetuó agreftem Rutä fignificat, ut Serapionis, Auic enne auctoritate facilé probari potef fuis in libris, in quibus implicium biftorias, et facultates pofteritatis memori.e prodiderunt. Nam qua illi de Harmel foripferunt, Diofcoridi, or Galeno R utam banc defcri= bentibus prorfus adftipulantur. Ceterün Auicenna ipfius Harmel ctian meminit libro quarto fui Canonis, ubi uipe= rarum morfus curationem tradens, fic inquit. Ruta folueftris ( - non cft albarmel, f ccundun quód exiftinatuerunt Fucl. lapfus, quidam, imó eft fpecies ruta ipfius) confert morfibus wiperarum . bec ille. Sed ne forté quis Auicennam non recté \& Auicenne intelligens, in bis uerbis decipiatur, ut fuis in Paradoxis Fuch, fint, uirum olioqui expertißimum, in Auicennam acriter defenfio. agentem, deceptum futfe deprebendimus, ut qui illum, ut puto, minus intellexerit, fciendum profectó eft (quemadmodü etiam anted aliquoties retulimus, or nunc, quoniam ad $r c m$ faciat, idipfum repetere non alienum erit) quòd non eiufdĕ utiq; generis eft fylueftris Ruta, de qua und cun domeftica fuperius tradidit Diofcorides, or hec, quam Gracorum 30 quidam Harmalam, Mauritani ueró Harmel, fiue Alharmel appellant. Ex bac omnibus perpicua Ruta fyluefris di= ftinctione, quantum equidem reor, liquido patebit, Auicennam haudquaquam errafje, ut errorem immerito illi iniungit Fuchfius. Quippe cum inquit Auicenna, Ruta fylueftris ( $O$ non oft albarmel, fecundun quod exiftinauerunt qui= dam, imo eft pecies rute ipfius) confert morfibus uiperarwn, ijs uerbis declarat fe illan bic fylueftrem $R$ utam in = telligere, qux domefticam amulatur : non autem illam, de qua hoc loco differit Diofcorides, quamí; fux Arabice fd= milix autbores $\mathrm{Harmel}$, fiue Alharmel wocant. Eius tamen loco citato, pauló anté meminerat, fic inquiens. Et al= barmel eft de medicinis liberantibus. Vbi per Alharmel ean fane R utam Jyluefrem intelligit, de qua prefens fermo eft . ob cuius differentiam, poftea alterius Ruta fylueftris mentionem faciens, fubiungit illa uerba, qux iam bis cita= uimus. Vt hinc paldim faceret, fe non modó de alio fylueftris Rute genere intellexiß̉e; fed etian occurriffe, ne quis,

Quorundam fif fine diftinctione locutus effet, fe idem fruftrà repetijffe calumnietur. Porró non de funt qui fuftinere contendăt, 4 error, \& lo- Harmel effe Cicutam, Auerroem in medium adducentes, quem lib. v. fuarum collectanearum ita fcriptum reliquiffe

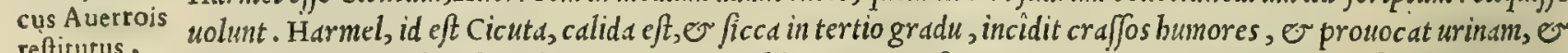
reftitutus. menfes, er ualet dolori f capularum, o purgat pljlegma. Hac ifti nituntur auctoritate. Quibus ita facilé refponderi potef, quod cum Cicute boc loco eas Auerroes tribuat facultates, quas ctiam Harmale, nomine tamen Moly, reddi= dit Galenus, maniffté deprebenditur Auerrois codex librariorü incuria fuiffe deprauatus. Neq; difficilis lap fus fuit, quód ij uocum finilitudine decepti Cicutam pro Rutalegerint, ac fcripferint. Adde etiam illud (boc enim medicorum neminem latet) quod tantum abest, ut Cicuta tertium caliditatis gradum obtineat, cui illam a Bignat deprauata Auer rois lectio, ut ne primum quidem attingat, cum Dio fcoridis, $\mathcal{O}$ Galeni teftimonio, in quar to frigiditatis ordine collo= cetur : ob id'c; eam lethale uenenum effe affirment. Quapropter quàm peßsime agatur ab ijs, qui Cicute formidandü femen ijs compofitis medicamentis addunt, quorum ufus eft dd deijciendos, incidendos, extenuandos q́; lentos humo= 50 res,ij dijudicent, qui ueritatis ftudio dediti huiufmodicauillationes, que fepe haminibus perniciem pariunt, tolerare Rutæ fylue- non poffunt. Rutam banc fylueftrem appellat Galenus Moly lib. v I I. fimplicium medicamentorum, ubi de ca dif= fris alterius ferit bis uerbis. Moly, boc quidan uocant peganon agrion, hoc eft, Rutam fylueftrem, nonnullibarmolan, syri be a $=$ uires ex Gal. fan, ficut Cappadoces moly, quia radicen babeat nigram, er flor em lacteum. vis cius tenuium eft partium, $\mathrm{O}^{*}$ calida

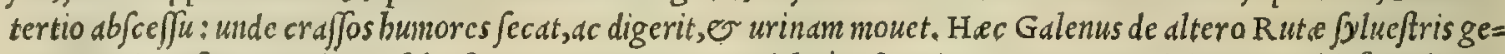
nere. Cui conftat o primum fylueftris Rute genus perpulchré refpondere. Ex quo crediderim, quód fine ullo er= rore feplafiarij alteram alterius loco fubijcere poßint, quoties A rabum barmel in fuis compofitis medicamentis admi Rutæ capra- fcendun reperiunt. Eft o alia Rutepecies, que recentioribusquibufdam CA PRA R A cognominatur, quibuf = rix mentio, \& dam ueró Galega dicitur, noftrates eam uulgó appellant Lauane $\int e . P$ aßin bec in frobium aggeribus, bumentibus $q_{2}$ uires. $\quad$ locis prouenit, fano greco perfimilis. Magnifaciunt ip fam nonnulli fuis experimentis nixi non modó aduer fus pefti= lentiam, e lethalia medicamenta; uerim etiam contra frarum ommium, que dentibus, aut aculeo uenenum emittüt, 


\section{In Lib. tertium Diofcoridis.}

tum morfus, tum ittus: in quem ufum herban uel eius fuccum bibendum prebent, ac etiam emplaftri modo unlnera= tis partibus impontunt. I audant aliqui fuccum fesquiuncix pondere haufum pueris comitiali morbo uexatis. Cete= rim apertißine falluntur, qui putant Rutam banc caprariam dictan Polemoniam effe, ut latius libro quarto fuo lo=

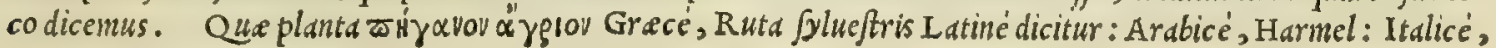
Ruta faluatica.
Mäßv. MO I Y.
CAP. XIVII.

M o I y folia habet graminis, latiora, humi fparfa : florem alba viola fimilem, fed minorem, magnitudine violæ purpureæ $æ$ mulum, lactci coloris : caulem candidum, quaternûm cubitorum : in cu ius cacumine ineft aliquid, quod allij fpeciem referat. Radix parua, bulbofa . qux mirum in modum valet ad vulux apertiones, fi trita cum irino vnguento, in peffo fubijciatur.

M $~ \mathrm{~L}$ Y, ut fcriptum reliquit Theophraftus libro I x.cap. x v.de plantarumbiftoria, apud pbeneum exit, atq; apud Cyllenam efe (qucmadmodum Homerus dixit) affirmant: radice rotunda, non abfimili cepa, folio fcille. V fum cius contra ueneficia fumma: non tamen effodi difficulter, ut ait Homerus. Moly quoque meminit Plinius lib. $\mathrm{x} \mathrm{x} \mathrm{v}$. cap. I I I . ita fribens. Laudatißima berbarum eff, Hontero tefte, quam uocari d dijs putant Moly. Aft inuentionem eius Mercurio aßign.t, contrá,; fumma ueneficia demonftrat. Nafcieam hodie circa Pbeneum, er in cyllene Arca= die tradunt, pecie illa Homerica, radice rotunda, nigraq́; , magnitudine cepe, folio fcilla : effodi autem difficulter . Greci authores foliun eius luteum pinxere, cum Honerus candidun fcripferit. Inueni é peritis berbarum medicis,

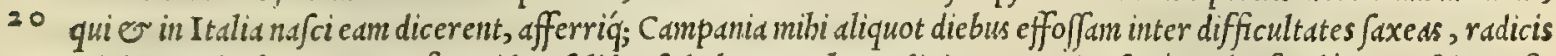
triginta pedes longe, ac ne fic quidem folide, fed abrupte. hec Plinius. Ex cuitus fané uerbis facilé cognofci poteft, Moly ab co fecundo loco redditum, quod in Campania effoflum, er fibi allatü fcribit, ab illo plurimum dißidere, quod Homertis, $\odot$ Diofcorides notis non plané confentientibus repra entarunt. Moly, cui Diof coridis delineatio repon deat, bactenus in Italia reperire non potui, neq; $a b$ alijs inibi repertum, aut aliunde aduectum fcio. Caterum ber bam Moly Diofcoridi appellatam, eandem nimirum efe putauerin cum illa, qua Galenolib.v I I. fimpl.medic. Myle uocatur, cum inquit. Myles radix paruo bulbo fimilis eft, facultatts contrabentis. nam cum farina erind, (hoc eft 1olij) appofita apertam uuluam fanare fcribit Diofcorides. His uerbis Galentes non folum quidem Mylen fuam Dio= fcoridis Moly dcceptam refert; fed etiam nos commonet mendi cuiufdă, quod bucuf $f_{\dot{p}}$ latuit in codicibus Gracis Dio=

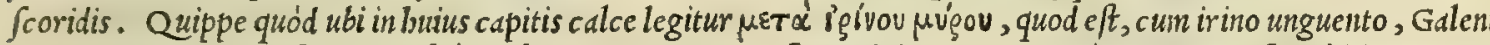

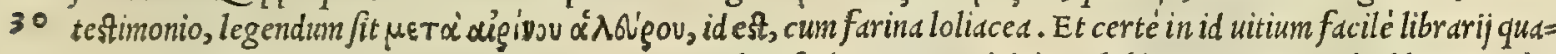

PANACES HERACLEVM.
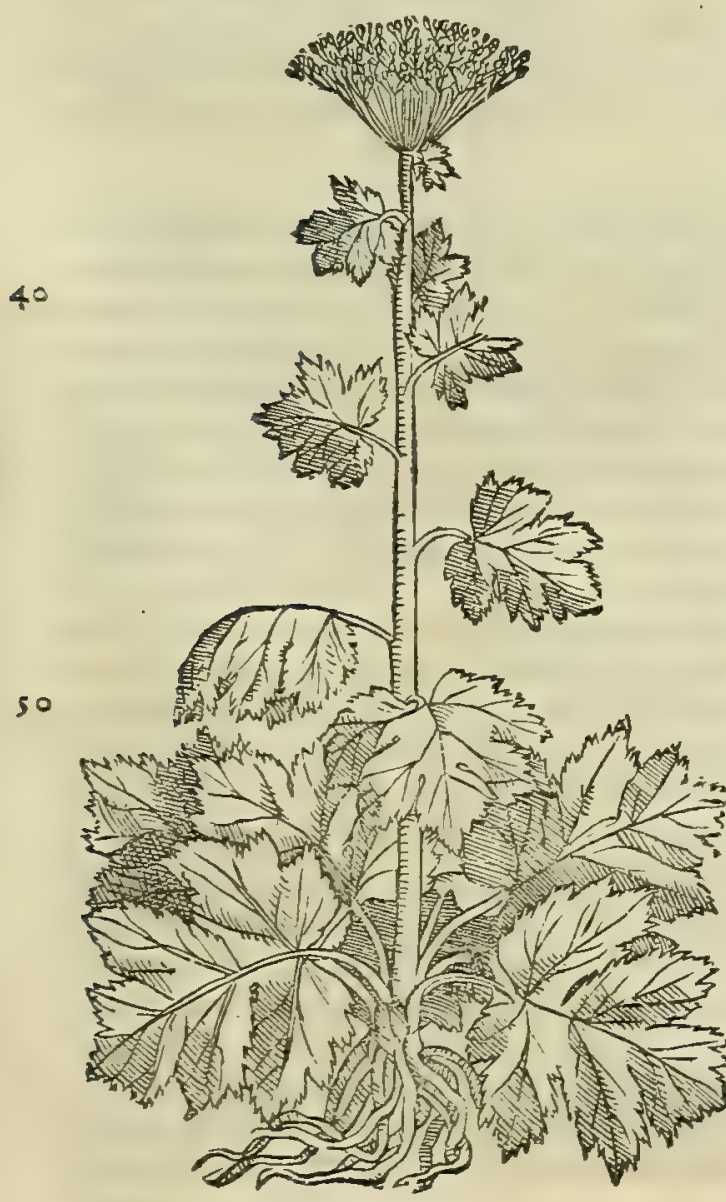

dam friptur arum uicinitate labi potuerunt. Sed addamus ratio= nem, qua unlgaris lectio deprauda manifefté deprebendetur. Nam fi unguentum irinum efficaciter aperit, non uideo quid $\mathrm{Mo}=$

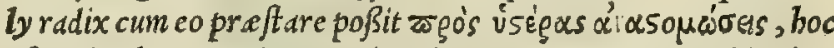
eft, ad unluse apertiones. Sic enim ex Greco rectius reddendum puto, qudim ad aperiédas uuluas, ut uerterunt Marcellus ó Ruel lius. qui tamen fecus facere non poterant, fi unguenti irini ratio nem babere uolebant. Id $\mu \tilde{\omega} \lambda v$ Graci dicunt, quod Latini itĕ Moly.

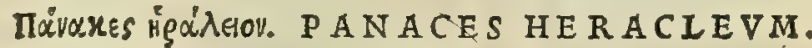 CAP. XLVIII.}

PAN A C E S nonnullis Heracleum dicitur: ex quo opopanax colligi folet. Plurimum in Bcotia, \& in Phiocide Arcadiæ nafcitur : ibiq́ue compendij, \& quæftus, qui ex eo liquore factitatur, gratia, ftudiosè colicur. Folijs eft afperis, in terra iacentibus, herbacei coloris, multum ad ficulnea accedentibus, in ambitu quinquepartitò diuifis: caule, vt ferulæ, altifsimo, qui lanugine quadam incanefcit, folijs etiam minutioribus obfitus : mufcarijs, ceu anethi, in cacumine : flore luteo, \& femine odorato, feruenteq́uc. Radices habet multas ab origine una, candidas, graueolentes, crafsi corticis, \& fubamari gultus. Nafcitur in Cyrene Libyæ; \& Macedonia . Excipitur fuccus incifa radice, recenti caulium pullulatu: Ea candidum fuccum emittit, qui ficcatus in fumma cute croceum colorem contrahit. Effluentem autem fuccú excipiunt, folijs excauato folo fratis, quæ ficcata tolluntur. Simili modo caule mefsibus incifo, profluentem fuc cum eximunt. Meliores ex radicibus, albx, rigentes, di-
Moly hiftor. ex Theophr. \& Plinio.

Moly uires ex Galeno.

Diofcoridis , locus caftiga tus.

Nomina. 
Atentæáue, ficcæ, quæ cariem non fentiant, aromaticæ, feruentes guftu. Fru\&tus ex media ferula cibo idoneus $\mathrm{cft}$ : fed ex agnatis ftolonibus, ab vfu cibario abhorret. Maximè in hoc fucci genere probatur, quàm amarifsimus, internè albus, aut fubfuluus, forìs ad croci colorem inclinans, læuis, pinguis, friabilis, tener, ftatim in aqua eliquefcens, graui odore. Niger improbatur, ac mollis. Adulteratur ammoniaco, aut cera. Sed fynceri experimentum eft, fi digitis in aqua friatus refoluatur, \& laetefcat.

Excalfacit, mollit, extenuat : horroribus febrium, circuitibusq́ue, vulfis, ruptis, laterum dolori, tor minibus, ftillicidio vrinæ conuenit. Contra veficx fcabiem ex aqua mulfa, aut vino bibitur : menfes trahit, fœtum enecat . Inflationes, quæ uuluam malè habent, duritiasq́ue, ex melle dilutus, difcutit: ifchiadicis illinitur . acopis, \& capitis medicaminibus admifcetur : carbunculos rumpit. Podagricis, cum vua paffa illitus fubuenit: dolore dentium liberat, cauis inditus : oculorum aciem illitu excitat. Ex eo, \& pice optimum fit emplaftrum contra beftiarum morfus, qux in rabiem efferantur. Radix in ramenta confciffa, vulux admota, partus extrahit: ad vetera vlcera efficax eft . nudata offa corpore operit, fi trita cum melle illinatur. Semen cum abfinthio fumptum, menfes pellit : cum arifolochia, prodeft aduerfus animalia, quæ venenum eiaculantur: \& contra vuluæ ftrangulatus in vino bibitur.

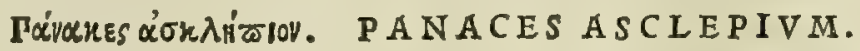

CAP. XIIX.

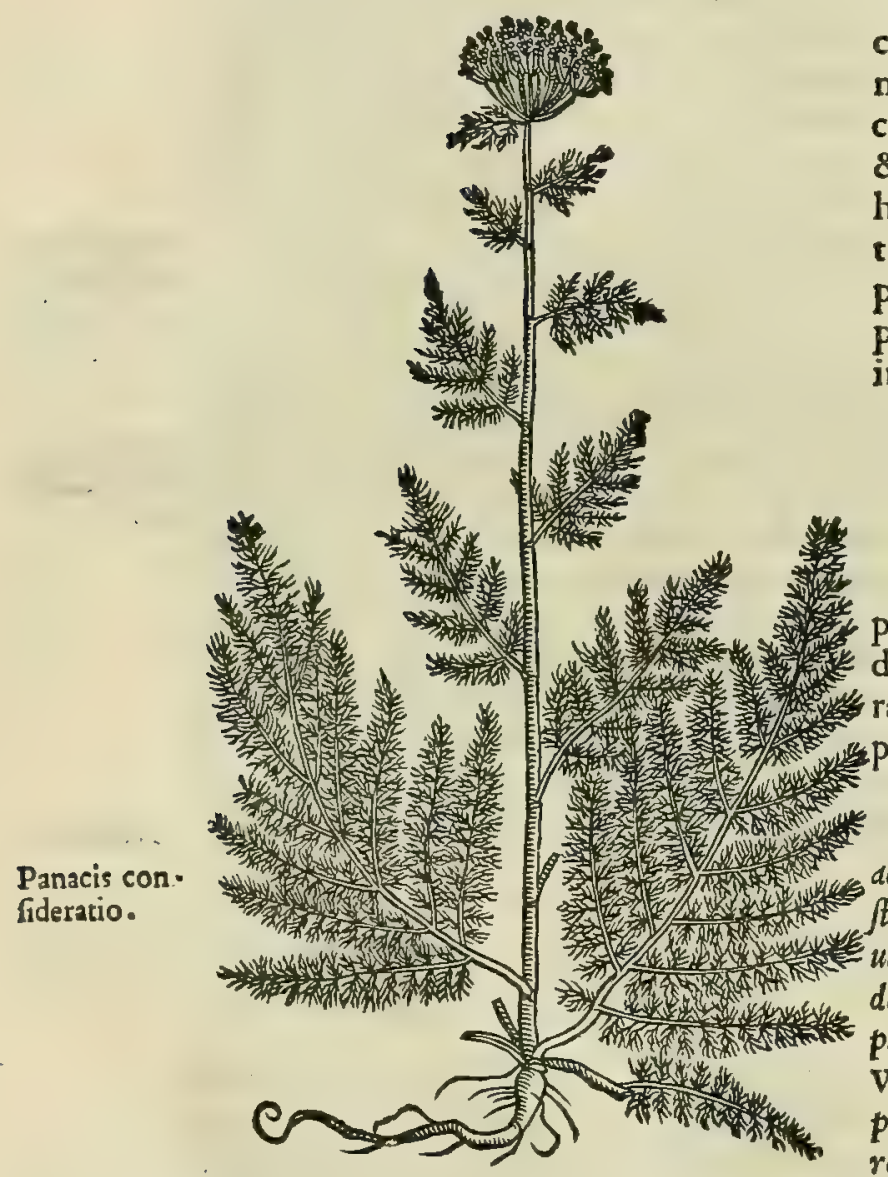

P A N A C E S Afclepij caulem à folo emittit tenuem, cubitalem, geniculatum : circa quem folia funduntur foe niculo fimilia, maiora tamen, \& hirfutiora, odorata : in 20 cacumine vmbella, vbi flores emicant aurei, acris guftus, $\&$ odorati. radix parua eft, \& tenuis. Auxiliarem vim habent flores, \& femina, contra vlcera, phagedænas, \& tubercula, fi trita cum melle imponantur. aduerfus ferpentes ex vino bibuntur, $\&$ cum oleo illinuntur. Aliqui panaces fylueftre origanum vocant, alij cunilam, de qua in origani mentione diximus.

\section{Iaróxes Xeigávion. PANACES CHIRONIVM. C A P. L.}

PANACES Chironium in Pelio monte maximè prouenit. folium eius amaraco fimile: flos aureus: radix parua, qux non altè demittitur, guftu acris. Pota radix ferpentium veneno refiftir. Illita coma, eadem præatat.

PANACES Herdcleum in Apulia frequens nd fcitur, quem= admodum in Apennini iugis, $\odot$ in Argentario promontorio in no frismaritimis Senenfibus. Habetur o in quam plurimis Italie 40 uiridarijs, ubi fumma diligentia colitur ab bis, qui fimplicium me= dicamentorum ftudiofi, ad fuum aliorum क् commodum innumera plantarum genera fuis in hortis, ac uiridarijs ferunt, ac.colunt. Verum non ob id affirmauerim, eius lacrymam, quam officine $\mathrm{O}=$ poponacum uocant, excipi in Italia. Nam que Venetijs uenalis reperitur, ex Alexandria Aegypti conuehitur. Legitima nŏ defit,

Mer.la plus. et/fadulterate frequentior fit ufus apud eos, qui ex quáuis herba manipulos colligunt. In $\mathbf{P}$ anacis biftoria aper=tißimé aberrauit Mefues: quippe qui initio capitis omnia eius genera confundat. Quod omnibus iam notius eft, quam ut à nobis oftendi debeat. Panaces Afclepium nuper uidimus, eiusq́; effigiem bic appinximus. Sed Chironium non prouenit, quod fciam, in Italia. Quanquam non defunt, qui pro Chironio panace oftendant plantam, qua folium ba $=50$ bet oblongum, hy ffopi feré modo : florem pentaphylli, fed maiorem, aureo tamé colore: furculos numero fos, tenues, lignofosqg; : radicem item lignofam, rufefcentem, guftu adftringentem. Verum quód Diofcorides panaci Chironio tri= buerit folia amar aco fimilia, é radicem guftu acrem, non video quomodo ingenué poßim eorum fentētia fubfcribere. Panacis genera ab inuentoribus cognominari tradunt. nempe Afclepium ab Aefculapio, Chironium à Chirone, or Heracleum ab Hercule : quare o Herculeum à plerisq; eft appellatum, cuius tantiom lacryma boc tempore officine utuntur. Semen enim, ac radix, etf in pluribus ualeant affectibus; ad nos tamen, quod uiderim, non ad feruntur. In quorum defectu optimi chirurgi, cüm denudata offa carne explere uolunt, radicum fegmenta, qua lacryma compd= Panacis uires cta reperiuntur, queque ill a fint, non paruo labore feligunt, or ad bunc ufum in pulucrem redigunt. Panacis ui= ex Galeno, \& res defcripfit Galenus libro v I I . fimplicium medicamentorum, his uerbis. Panaces Her aclium, inquit, ex boc fit Mefue. $\quad$ ucatus Opopanax, radicibus eius, o caulibus excifis. Porró opopanax ipfe longé eft ad plurimos ufus aptißimus, utpote excalfaciens, emolliens, 0 digerens : ponató; ipfum quipiam in calfaciendo tertij ordinis, in deficcando uerò 


\section{In Lib, tertium Diof coridis.}

fecundi. Cortex radicis exiccatorium fimul, or excalfactorium eft medicamcntum: fed minus quàn fuccus. quin or nonnull am habet abfergendifacultatem. 2uare co quoq; utimur $\odot$ ad of a denudata, et ad ulcera malignu, o con= tumacia. Sufficienter enim talia carnem procreant, fcilicet abftergendo finul, or deficcando, nec ita magnopere calfaciendo: que omnia ad carnem generandam neccfaria funt, uclut in libris de curandiratione cftendinus. Fru= ctus calidus e ip $\int e$ eft, ac menfibus mouendis medicamen accommodum. Caterim ne cio, quo pacto nunc ferć omnes ex more non panaces, fed panaca herbam hanc uocitent. Panaces autem A fclcpium minus eft calidum fuprà dicto pa nace: quamobrem eo, o foribus eius, e femine mellimiftis ad ulcera, phymata, or phaged.enas utuntur. Pana= ces ueró Chironium ipfum fimilem predicto facultatcm poßidet. hac Galenus. Porró dcijcit Panacis lacryma (ut author eft Mefues) is remotis corporis partibus, prefertinq, ab articulorum compaginibus, lentam, craffam, con

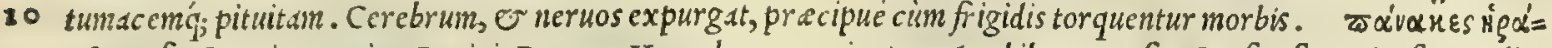
$x \lambda$ : ou fic Grecis, ut ctiam Latinis $\mathrm{P}$ anaces Heracleum, nominatur : Arabibus, Steufir, Ieufir, fiue Giaufir: Italis, Panace Heradeo. Huius gumni Grecis o’

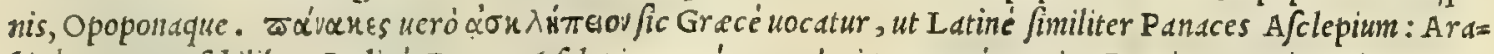
bicé, Pandx Afcbilibet: Italice, Panace Afclepio. $\pi \alpha$ úues denique Xe ces Chironium appellatur: Mauritanis, Panax caromon: Italis, Panace Chironio.

\section{Aryusiròv. LIGVSTICVM. CAP. II.}

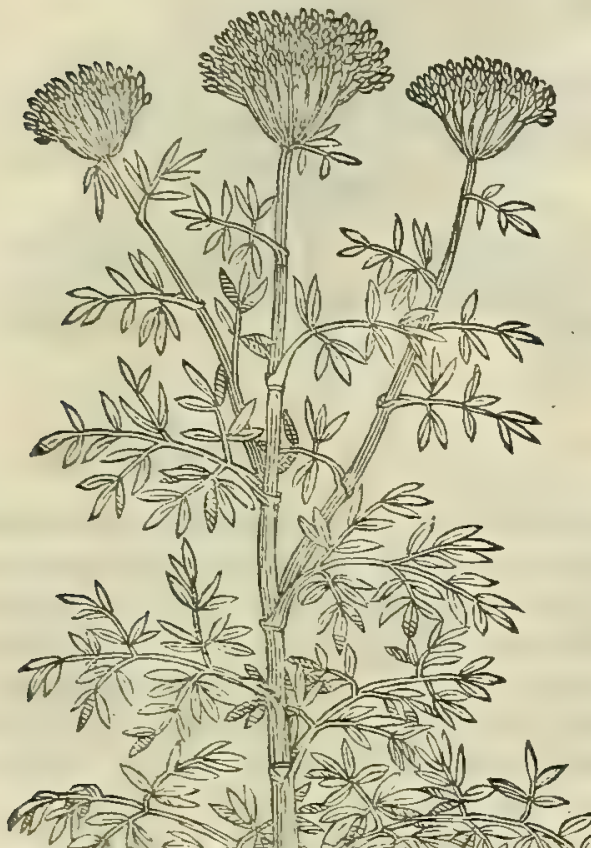

I I G V S I I C V M, quod alij panaceam, alij panaces uocant, plurimum in Liguria nafcitur, in monte $\mathbf{A}$. pennino Alpibus contermino: vnde nomen traxit. $\mathrm{Pa}-$ naces incolæ non ab re appellant, quoniam \& radice, \& caule Heracleotico panaci fimile fit, \& 2 niribus eifdē pręditum. Gignitur in altifsimis, afperisque montibus, ac vmbrofis, maximè iuxta fluenta. Cauliculum fert ancthi, geniculatum, tenuem, $\&$ in circuitu folia fertula Campanæ, molliora, odorata, prope uerticem gracilio$\mathbf{r a}, \&$ longè magis diuifa: in cacumine mufcarium, in quo femen dependet nigrum, folidum, \& oblongum, fœniculo proximum, guftanti acre, \& aroma olens: radix candida, Heracleotici panacis fimilis, odorata. Radicis, feminisq́ue uis excalfactoria, concoquens. Prodeft ad inteftinos dolores, tumores, concoctiones : item ad inflationes, præfertim quibus ftomachus turgeat : \& contra ferpentium ictus: vrinas, \& menfes potu trahit. Eofdem præftat effectus appofita radix. Semen cum radice oxyporis, \& medicamentis decoquentibus admifcetur. ori perquàm utile: quare pro pipere utuntur eo

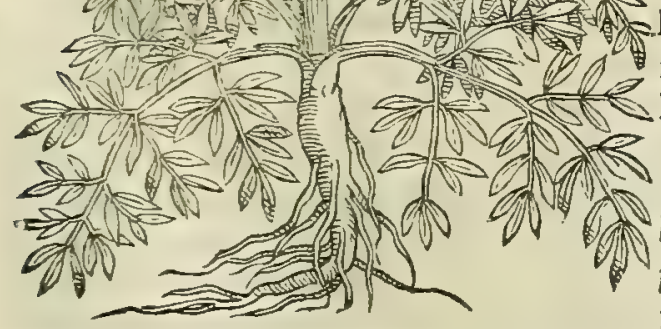
indigenæ ad obfonia. Adulteratur femine quodam fimili : quod fàcilè guftu difcernitur : amarum enim eft. Alij femen foniculi, aut fefelis admifcentes, ligufticum dolo uitiant.

F A L I V N T. V R aperté, ut mea quidem fert opinio, qui In Liguftico berbam uulgó bodie Leuifticum nominatam, quam legitimum hip pofelinum cenfemus, putant effe Ligufticum hìc à Diofcoride re= prafentatum, quod Galenus unius litere mutatione Libyfticum appellauit . Siquidem boc caule afjurgit tenui, o folijs fertule Campana fimilibus. Illud ueró caulem profert altum, craf Jum, concauum, er geniculatum : folla apij paluftris emula, maiora tamen, ac etiam crafiora. Ceterùm quan= uis legitinum, ac uerum Ligufticum in Liguria, cuius Genua metropolis eft, unde etiam nomen inuenit, frequentißi= mum proue niat, fitt'; inibi adeo uulgaris notitix, ut eius $\int \mathrm{emine}$ paßim utantur incole in ciborum condimentis; non ob id tamen per cater a Italia loca bactenus, quod fciam, deferri capit. Nafcitur in Ananienfibus montibus, quin er in Goritienfibus. Venetijs etiam uideripote? in bor to Maphei medici cldrifsimi. Galenus de Libyftico differens li= bro v I I. Jimplicium medic amentorum, fic breuiter inquit . Libyftici radix, \& femen ex genere excalfacientüu funt,

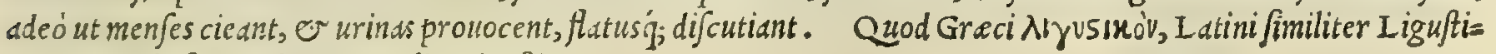
quorundam error. cuin, or Libyficum dicunt: Itali, Liguftico.

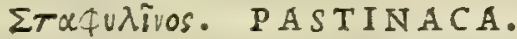

\section{CAF. LII.}

PA S I I N A C A fylueftris folia gingidij habet, latiora, fubamara : caulem reetum, fcabrum: vm. bcllam fimilem anethi : in qua flores infunt candidi, $\&$ in medio purpureum quiddam, ferme croceú. radix digiti crafsitudine, dodrantalis, odorata, quæ cocta manditur. Semen potum, vel impofitum, menftrua

Libyftici uires ex Gal.

Nomina 
PASTINACA SATIVA.

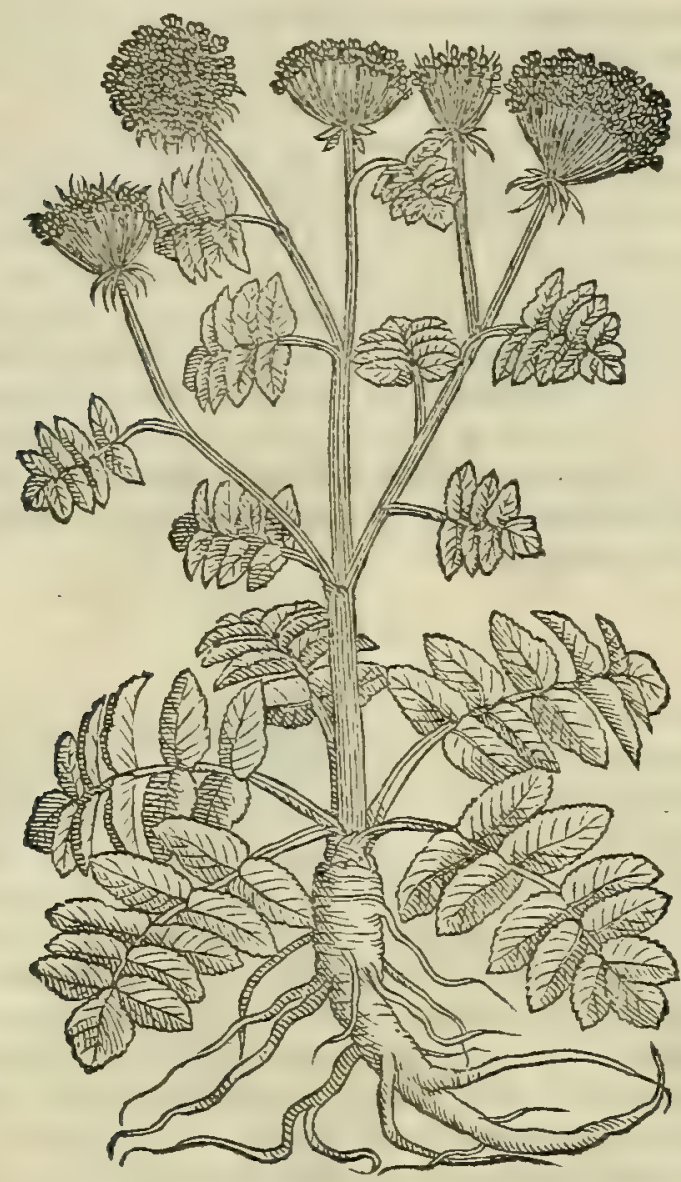

PASINACA SYLVESTRIS.

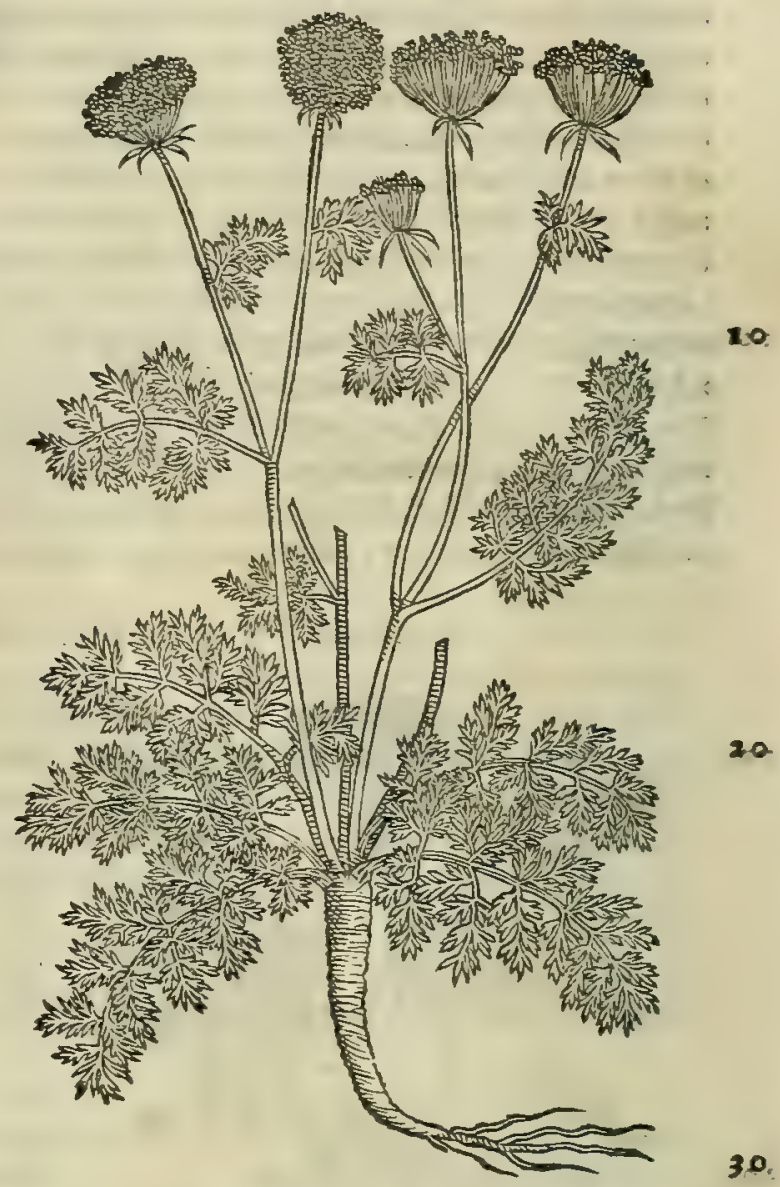

CAROTAE.

Pafinace cófideratio.

Ruellij erratum.

Quorundam etror. menftrua mouet. Iis conuenit in potione, quos vrina dificcultas torquet, aut lateralis dolor excruciat, aut fi aqua cutem fubijt : ferpentium morfibus, i̊tibusq́ue prodeft. præfumentes id, nulla affici iniuria à ferpentibus traduntur: conceptus adiuuat. Radix vrinam pellit, venerem ftimulat, partus appofita eiicit. Folia tria, \& cum melle impofita, phagedanas ulcerum purgant. Satiua ad cadem pollet, inefficacior tamen, \& cibo aptior.

V Y L G A R E S admodum funt in Italia tam fatiu.e, quàm 40. Jylueftris $\mathrm{P}$ aftinace radices, ut que paßinn quadrige find disiciu= nij tempore non ingraté in ciborum ufum recipiantur. Caterum quoniam fortaßis in Gallia non feruntur ii hortis, Ruellius mani= festo errore putakit, Carotas nobis unlgó nocatas, quas coctas, $\sqrt{a}$ $l e$, oleo, er aceto additis, byeme ufurpamus in acetarijs, fatiuds effe Paftinacas. Vt binc maximé admirari fubeat $\mathrm{R} u e l l i u m, u i=$ rum alioqui doctifimum. siquidem bactenus neminem inueni è rei berbaric fcriptoribus tam Grece, quam Arabice familie, qui memoris prodiderit, $\mathrm{P}$ aftinacam fatiuam radice niti adeó rufa, ut fanguineo fucco madeat, qualis Carote dicte ine $\int f_{e}$ deprelien $=50$. ditur. Satiua in Italia frequentißina feritur in hortis. Erratica ueró nonnunquam in campis ac incultis fua fponte nafcitur. Vtra que albicantibus conftat radicibus, que in locis quàm plurinis co. ta manduntur. nanque ex in quadragefimo prefertim ieiunio cü. farind, ov oleo friguntur, er ita fape, ubi defunt pifces, corum ui cen fupplent : licet pro ieiunantium inftituto, effent potius eorum cibis abdicanda : uenerem enim non obfcuré frimuldant. Fallun= tur praterea, qui Dauci loco,agreftis $\mathbf{P}$ aftinac e fenzen accipiüt, illius foilicet, in cuius florentis umbella inedio exiguum quid pur= purei emicat. Aliud enim eft à Paftinaca erratica Daucus, ut pau ló inferius fuo loco dicetur, ubi cius tres pecies à Diofcoride red= 


\section{In Lib. tertium Diofcoridis.}

duntur. Nam quanuis tan ex illius, quàm Galeni fententia libris tum de fimplicium medic amentorum, tum de almen= torum facultatibus, Daucus à Jylueftri $\mathrm{P}$ aftinded parum, uel porius nibil uiribus differat, ob id'́; alterum alterius ui= ce in medicine ufu capi poßsit; non tamell recté áci potcft, Daucum erraticam effe Paftinacam. Paftinace memi= nit Galenus libro v I I I. fimplic um medicamentorum, fic inquiens. Paftinaca fatiua imbecillior: agreftis ad asmix potentior eft. Vrinds mouet, or menfes prowocat cumberba quiden tota, tum maximé femen, ac radix. Habet por= ró etiam abferforium in fe quippian. quamobrent ulcerd phagedxnica quidam folijs cius uiridibus cum melle, quó

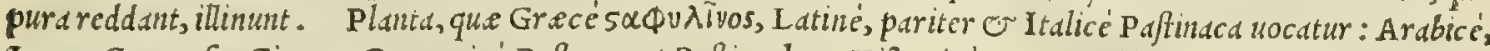
Iezdr, Gezar, feu Giezdr : Germanicé,Paftency, et Paftindcben: Hipanice, Canaoria blanqua: Gallicé,Paftenades.

Paftinace uires ex Gal.

Nomina

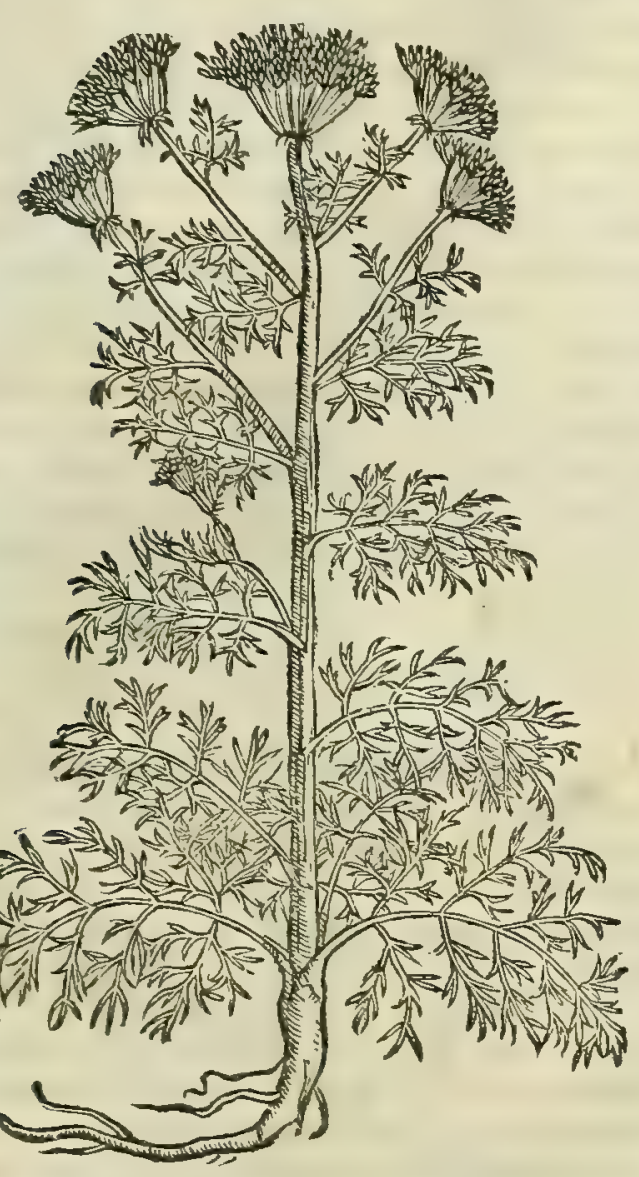

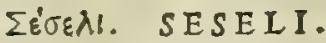

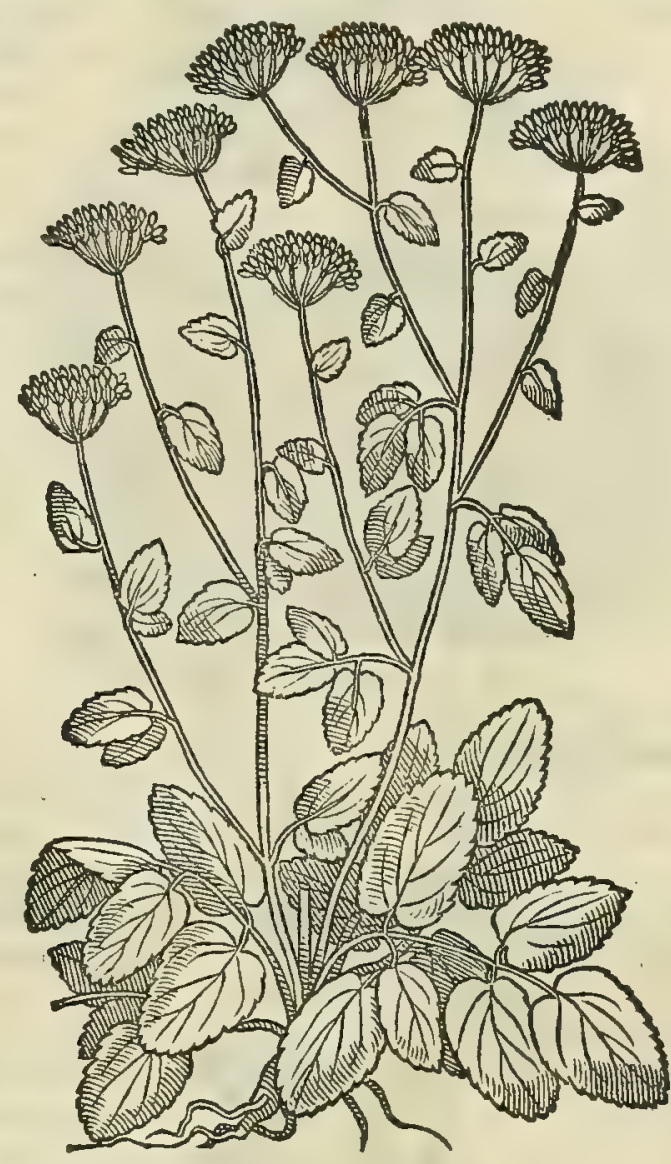

CAP. IIII.

SE S E I I Mafsilienfe folia foniculi habet, crafsiora : caulem uegetiorem : vmbellam anethi, in qua femen oblongum, angulofum, deguftantiftatim acre: radix longa eft, iucundi odoris. Semen, \& radix excalfaciendi uim habent. Potu ftranguriæ, \& orthopnœæ medentur : fuffocationibus mulierum, comitialibusq́ue profunt : menfes, ${ }^{Q}$, partus trahunt: ad omnia interna mala pollent : tufsim ueterem fanant. Semen cum uino potum, coscoquit, \& tormina difcutit : epialis febribus utile. contra perfrictiones in itineribus, cum pipere, \& vino bibitur. Capris, cæterisq́ue pecudibus datur in potu, quò facilius fuos fotus enitantur. Aethiopicum fefeli, folia habet hederx, minora, \& ad pe-

so riclymeni madum oblonga . frutex nigricar, palmitibus in bina cubita extenfis : ramis fefquipedalibus : capitulo anethi : femine in tritici morem denfo, nigro, amaro, Mafsilienfi odoratiore, \& acriore, multum fuaui. Peloponnenfe folia habet cicutæ, latiora, \& crafsiora: caulem fupra Mafsilienfis magnitudinem, ferulaceum : \& latam in cacuminc vmbellam, in qua femen latius, odoratum, \& carnofius pendet. Eifdem uiribus præditum eft. Nafitur in afperis, riguis, \& collibus . inuenitur etiámnum in infulis.

\section{TogSÜAlov. CRETICVM SESELI.}

\section{CAP. LIIII.}

T O R D Y L I V M, quod aliqui Creticum fefeli vocant, iuxta Ciliciam in Amano monte nafcitur, herbula furculofa, femine duplici, rotundo, fcutulorum effigie, odorato, fubacri . Contra vrinæ difficultatem bibitur: potı cit rienfes. Succo feminis, caulisq́; virentis, ternis obolis ex paffo decem diebus haufto, renes fanantur. Efhicax eft radix ad ciendas pectoris excreationes, in delinctum cŭ melle. 


\section{And. Matthioli Comm.}

Sefelis confideratio.

SESELI PELOPONNENSE.

Sefelis vires ox Galeno.

Nomina.

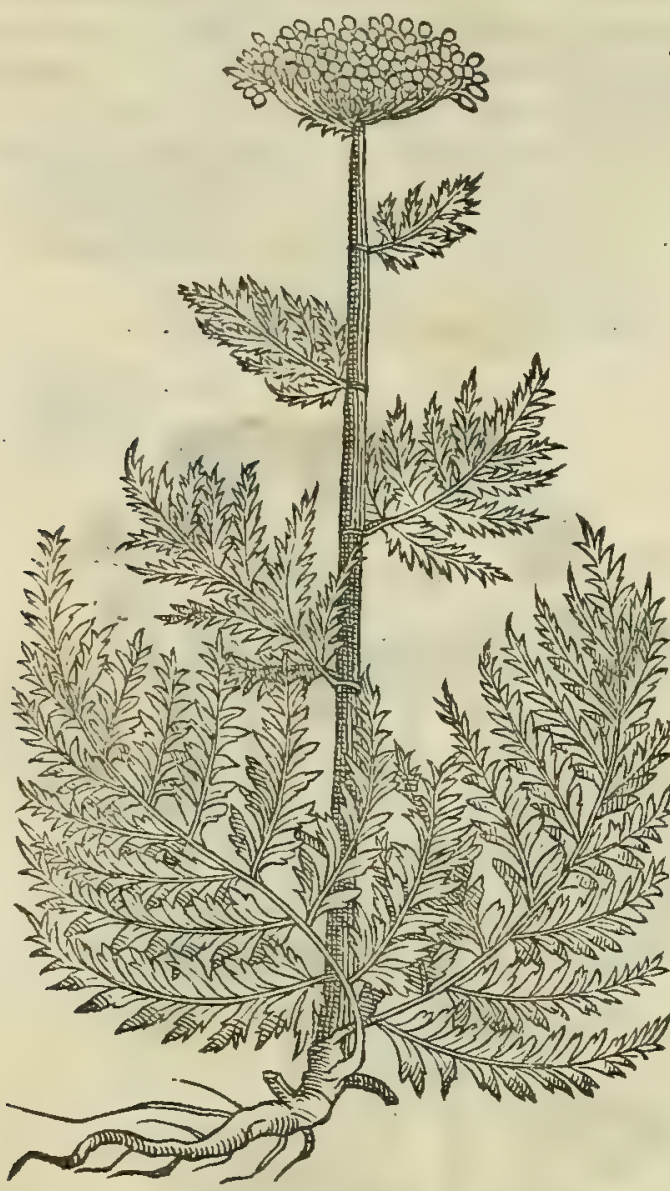

$A N$ I $\nabla M$.

Sifon femen incognitum.

Nomina
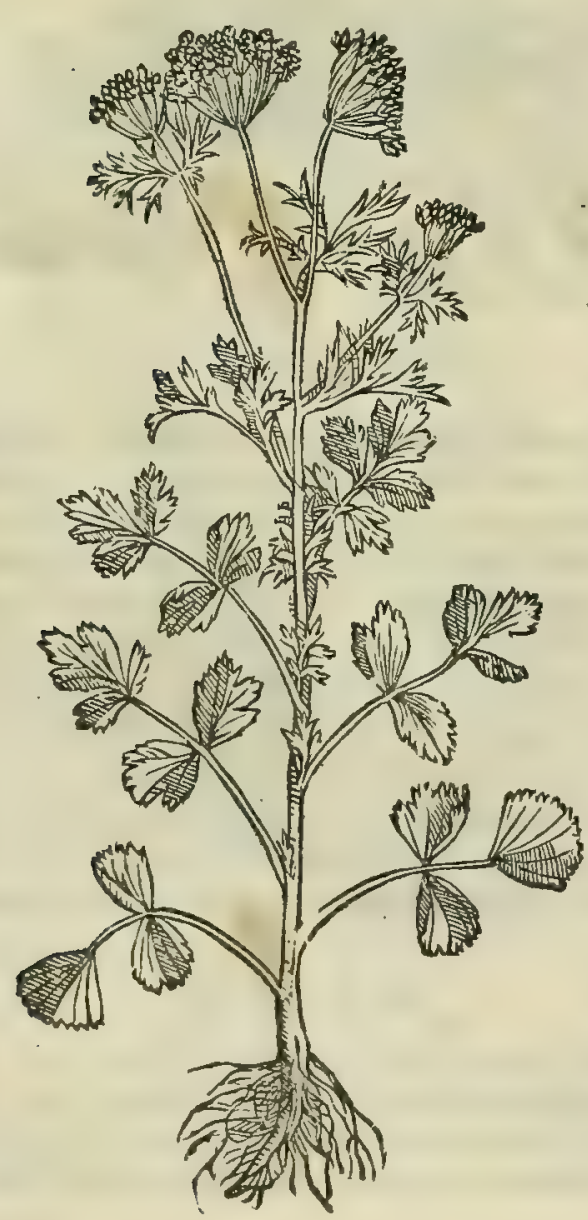

SE S E L I Arabibus sifileos dicitur. Officine uerò id siler montanum appcllant. Legitimum sefeli Maßilienfe in osnnibus fré Tridentinis montibus legitur. Sed maxine' animaduestendum eft, quidd quanquam in quibisdam Italie fharnacopolijs, uerum fit reperire Sefeli; in quam plurimis tamen quoddam $\int e m e n ~ S e f e=$ lis vicen explens ucnditur, quod nulit prorjus Se cli a Diofcori= de de fripto reppondet: quippe quod amaritudine tantum fit pree ditum, or olfaclui cinicum factorem repraentet. Porró sefeli Aethiopicum, ac Peloponnen $\int e, q u e$ prius in Italia non videran, boc anno i me, ut pero, reperta funt. Ceterim aliquando credi= dimus, Tordylium, fiue Cretic um sefeli in quodam noftro bortu= lo natum effe, quód eius fomen (ita enion aiebant) é $\mathrm{P}$ atanino fim= plicium uiridario allatum, terra connififfem. Verun cim po= flea accuratius eius faciem contemplatus effem, item q́; faporem examinafem, id d̀ legitimo longé admodun dißidere cognoui. sefelis monftratio prina aßignatur ceruis feminis. siquidem tra dit Ariftoteles lib.rX . cap.v. de hiftoria animalium; certias $f_{d}=$ tim à partu sefelim berbam petere, or cum eam ederint, ad pro= lem redire. Sefeli omne genus in uniuer fum memoria prodidit Galenus lib. v I I I. fimplicium medicamentorum, ubi ita fcribit. 20 sefeli er radix, atq; etiam $\int e m e n$ ufqueadeó excalfacit, ut admo= dum urinam mouere queat. Sed or medicamentum eft tenuium partium, ut $\mathrm{E}$ comitiali morbo, 0 or thopnoce competat. Que berba Gracis $\sigma \varepsilon \dot{\sigma} \lambda_{1}$, Latinis, ut etian'Italis Sefeli nuncupatur: Arabibus, sifalios: Barbaris, sifileos: Germanis, steinbrech: Gallis, Ser montain.

\section{¿icar. SISON. CAP. LV.}

S I s o N exiguum femen eft, in Syria natum, apio 30 fimile, oblongum, nigrum, feruentis naturx. Contra lienis uitia bibitur: vrinæ difficultatem potu emendat, remoratos menfes citat. Eo in condimentis, cum cucurbita, \& aceto indigenæ vtuntur. In cacumine gránula multa gerit.

S I s o N, ut hic Diofcorides teftatum reliquit, femen eft in syria proueniens, nobisq; incognitum: quandoquidcm plantam, que illud profert, apud ullum autborem fuis notis de fcriptam non inuenio : nec femen ip $\int u m, q u o d$ equidem $\int c i a m$, dd nos é syria de $=40$ fertur. Quapropter illius patrie gentibus relinquendam duxi= mus, ubi cius notitia, et eminis u us. Nan preterquim quád dif= ficile fit, etiam periculo fum iudico, de rebus peregrinis, quarum delineationes latent, aliquam proferre fententiam. Id oíw Gracé dicitur, quod Latiné quoq; sifon.

\section{A"ทซoV, ANISVM. CAP. IVI.}

A N I S V.M in fumma excalfacit, exiccat oris halitum iucundiorem facit, doloris leuamentum praltat. so Vrinam ciet, difcutiendi uim habet, hydropicis potum fitim éxtinguit. Animalium ven€nis aduerfatur: valet ad inflationes: aluum, \& alba fominarum profluuia fiftit:lac ad mammas elicit:venerem ftimulat. dolores capitis leuat, fuffitum naribus . cum rofaceo tritum, inftillatumq́ue fractis.auribus medetur. Melius femper recens, plenum, non furfurofum, odore præitans. Inter prima laudatum ett Creticum, proximo loco Aegyptium. 


\section{8}

\section{And. Matthıli Comm.}

te preditum. Vftun autem tertij ordinis tum excalfacientium, tum deficcantium fit: o proptered ulceribus nimis bumidis, mollibusǵg; prodeft, potißsmum ìs, que in pudendis confift unt. At que in preputio funt inueterata, ea probe

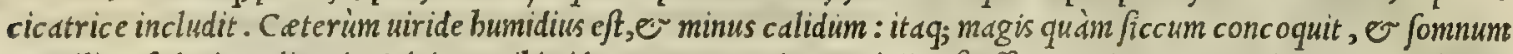
conciliat, fed minus digerit. Idcinco mibi uidentur ucteres in conuiuijs ufi effe coronis ex co concinnatis. Planta,

Nomina. que Grec is a'vrAol, Latinis item Anethum appellatur: Mauritanis, Xebet, Icbet, fiue Sebet: Italis, Anetho: Ger= manis, Dyllen, er Hocbkraut : Hißpanis, Eneldo : Gallis, Anet.

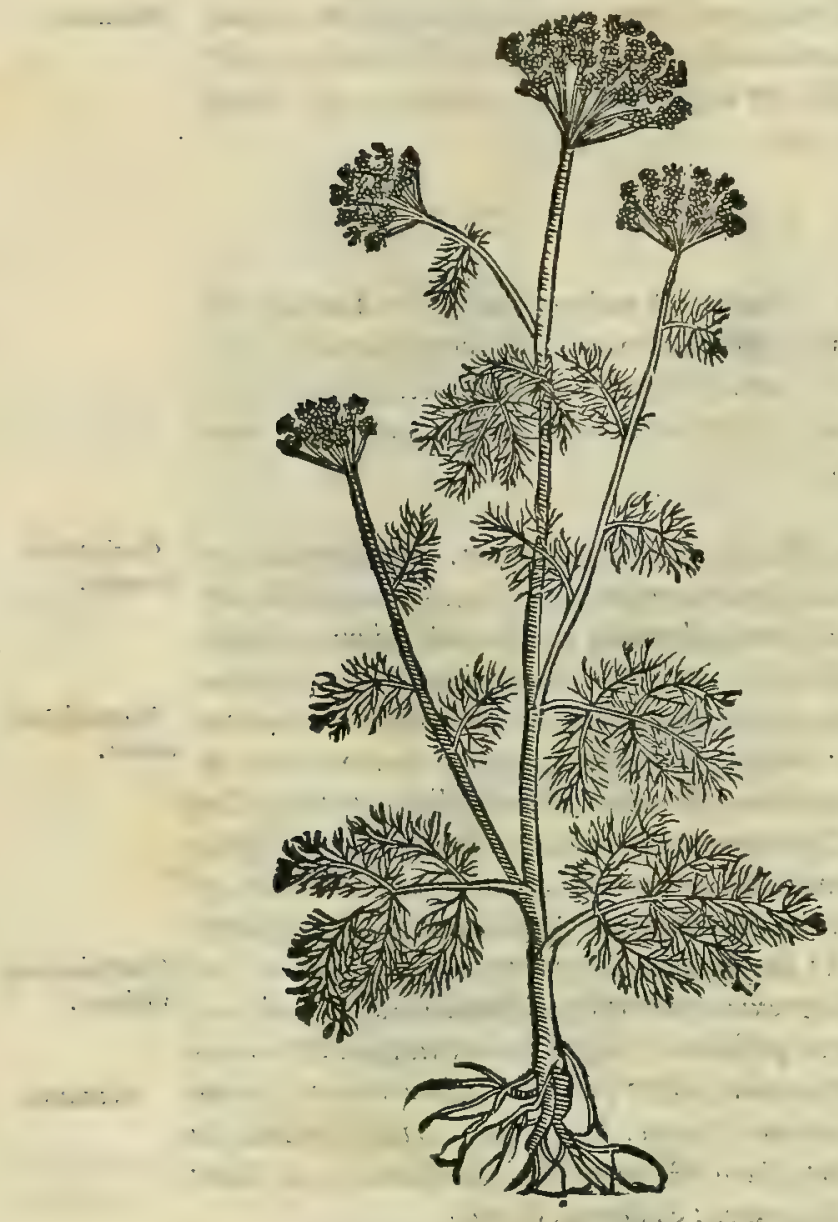

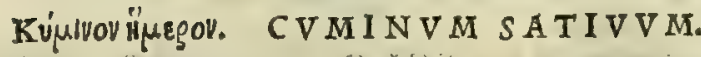

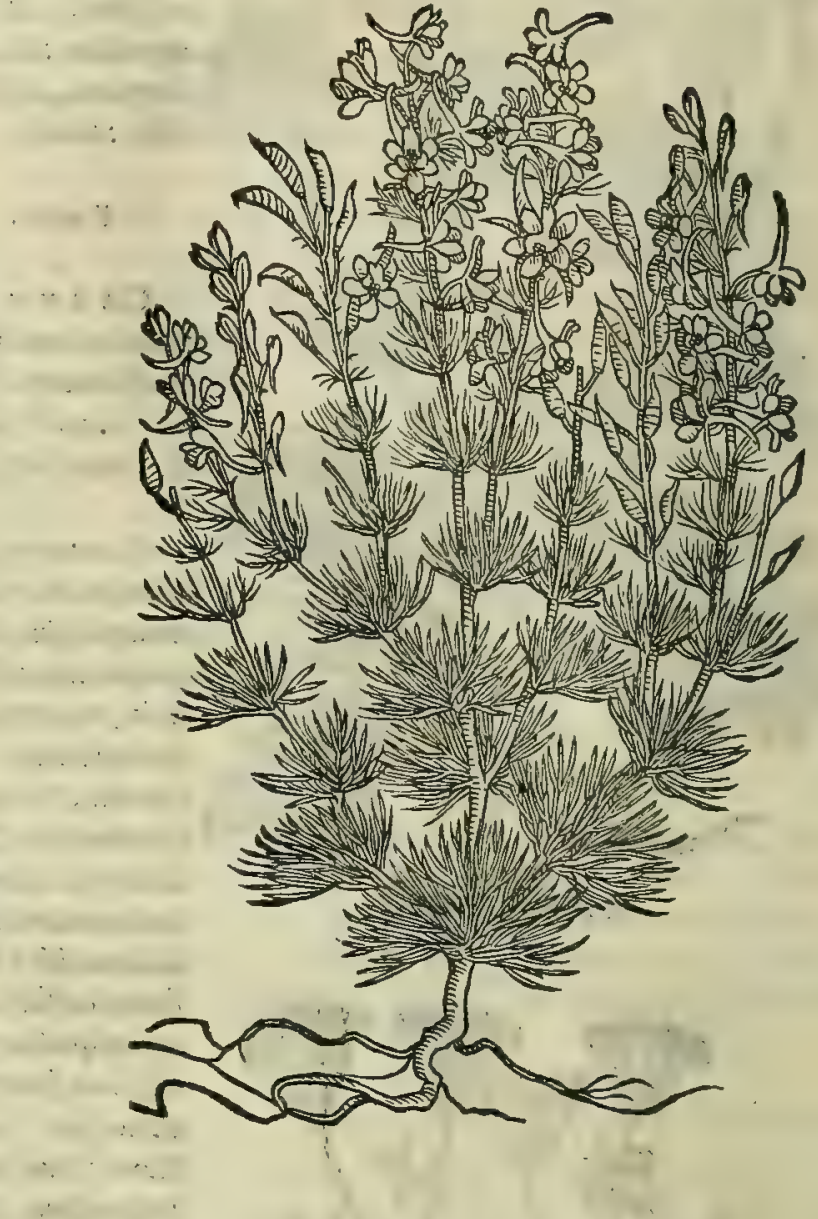

CAP. LIX.

C V M I N V M fatiuum ori gratum eft, fed multò magis Aethiopicum, quod Hippocrates regium appellauit: Secundum locum tenet Acgyptium : reliqua fequuntur. Prouenit in Galatia, in Afia, $\mathrm{C}$ licia, \& Terentia, \& plerifq; alijs tractibus. Excalfacit, adftringit,exiccat . ad tormina, inflationesq́; conuenit, coctum, \& cum oleo inditum,aut cum hordeacea farina illitum . orthopnoicis datur in po$\mathrm{fca}$ : demorfis à ferpente, in uino. teftium collectionibus auxiliatur, impofitum cum vus paffa, aut lolij farina,ceratóuc : menfium abundantiam inhibet. Contritum autem in aceto, \& naribus obięú, fanguinis profluiua fiftit. Colorem bibentium, aut perunctorum mutat in pallorem.

$$
\text { Kúusvov äYgrov. CVMINVM SYLVESTRE. C.. CAP. IX. }
$$

S Y LVES T RE Cuminum, plurimum, efficaciusq́ue in Lycia,\& Galatia Afix, atque Carthagine Hifpanix gignitur : frutice paruo, dodrantalı caule,ac tenui : quaternis, aut quinis folijs,tenuibus, ueluti ferratis, \& gingidij diuifura. In cacumine capitula quina, aut fena habet, mollia, rotunda : in qui bus eft femen acerofum, guftu fatiuo acriore. nafcitur in collibus. Bibitur femen ex aqua, aduerfus tormina, inflationesq́ue : item contra uenenatas beftias ex uino. Singultus ex aceto fedar: ftomacho utile, quem humor uexat. Sugillata tollit, fi manducatum cum melle, \& uua paffa illinatur : teltium inflammationibus, adiectis eifdem, illitum medetur. Eft \& aliud fylueftris Cumini genus, fatiuo non difsimile, quod à fingul is foribus elata promit cornicula, in quibus femen eft melanthio limile. Quod potum omnium ferpentium morfibus prafidio eft. Calculofis, \& ijs, qui urinæ ftillicidio uexantur, aut concretum fanguinem cum lotio reddunt, auxiliatur . fed apij femen feruefactum poltea bibendum eft. 
S A I I V V M Cuninum omnibss notum eft. Sed an fylueftre, id'; prefertim, quod primo generi a Diofcoride aßignatur, in Italia proueniat, ego quidem affirnare non aufim: quod nec illud uiderim, aut repererim unquam, neque praterea ab alijs repertum, uel ex $\mathrm{L} y c i d$, Galatia, o Hipania allatum audiuerim. Quod ueró fecundo afcribitur

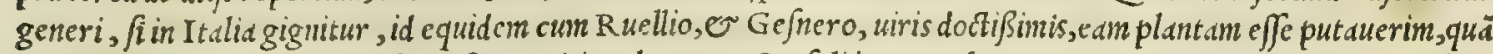
Germani unlgó Ritterporn, hoc eft, Equitis calcar, ON Confolidam regalem wocant. Quandoquidem planta bec nafcitur in fegetibus. Caulë profert fimplicem, ramulis multis, tenuibus, longis, diuifis, fylueftris nigetle modo. Flo= res edit purpureos, nigre uiole émulos : ex altera quorum parte prodeunt cornicula fur fum pectantia, que ueterü calc aris forman exprimere uidentur: unde $\sigma$ illi nomen à Germanis inditum. Semen firt melanthio fimile, in paruis corniculis conclufum. Vt $\mathrm{ex}$ bat defcriptione exiftimem, uix aliam reperiri poffe plantam, qua magis, quàm hac, po

20 Atremum Cumini genus referat. Caterimi Monachi ill reuerendi, qui un Me fuem fcripfere, flaui coloris Melan= thium, quod officine Nigellam citrinam uocant, primun fyiucftris Cumini genus effe contendunt. Sed ij, mea quidem fententid, in magno o aperto errore uerfantur. Nam, ut unufquisq; fane mentis per fe cognofcere poteft, Nigella ci trind fic feplafiarijs uocata, nil aliud unquam fuerit, quàm flaui coloris Mclanthium: cim omnibus paldm fit, non in alio Nigellam banc, $\sigma$ Mclanthium inter je pecie differre, quam in feminis colore : catera nanq; in forma, magnitu=

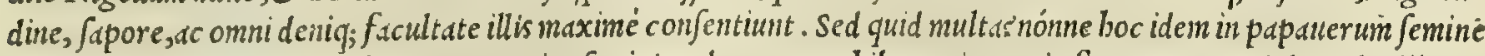
quotidie comeperimus: in quibus tamen uarius feminis color non probibet, quin omnia fint papauera. Id quod etiă per= picuum eft, in hy of cyamo, lactuca, e alijs pluribus plant is : quarum femina et fi alba er nigra inueniantur, non tamen aliud ab illis planta genus confrituunt. Hinc fit, ut in buiufec fylueftris Cumini biftoria patres illi, er qui eos fequun= tur, plané hallucinari de prehendantur. Quippe primi generis fylueftris Cumini femen in capitulis mollibus, ac rotun

20 dis acerofum gignitur, fortaffe (ut opinor) uulgaris pimpinelle modo, non autem in capitulis melanthij inftar, durum,

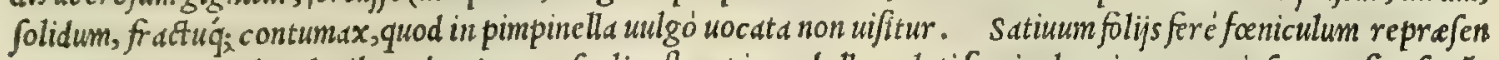
tat: unico exit caule, pluribss adnatis ramufculis : floret in umbella, ueluti feniculum, in qua copiofum profert femè: gadix ei albicans eft, fummo ceppite repens. Tractu gaudet calido, o putre fcibili : quamobrem frequentißimum in maritimis nafcitur. Cymini uires fcriptas reliquit Galenus lib.v I I. fimplic.medic. fic inquiens. Cymini femine po= tißimum utimur, quemadmodum anifi, liguftici, cari, $\odot$ petrofelini. Eft autem $\odot$ facultatis excalf acientis, ficut illo=

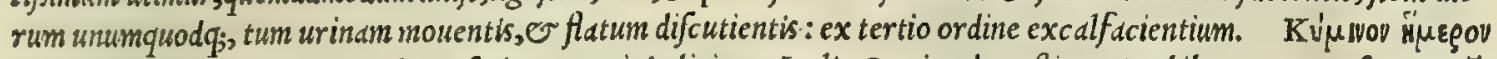
quod Gracis, Ciminum et Cuminum fatiuum Latinis dicitur: I talis, Cumino doneftico: A rabibus, Camum, Seu Kemü: Germanis, Kimmel: Hifpani, Comino: Gallis, Comin. Quod ueró Greci xíusvov ä'ygrov, Latini Cuminum fyl= 30 ueftre nominant: Itali, cimuno faluatico.

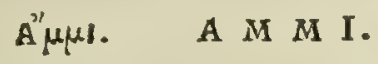

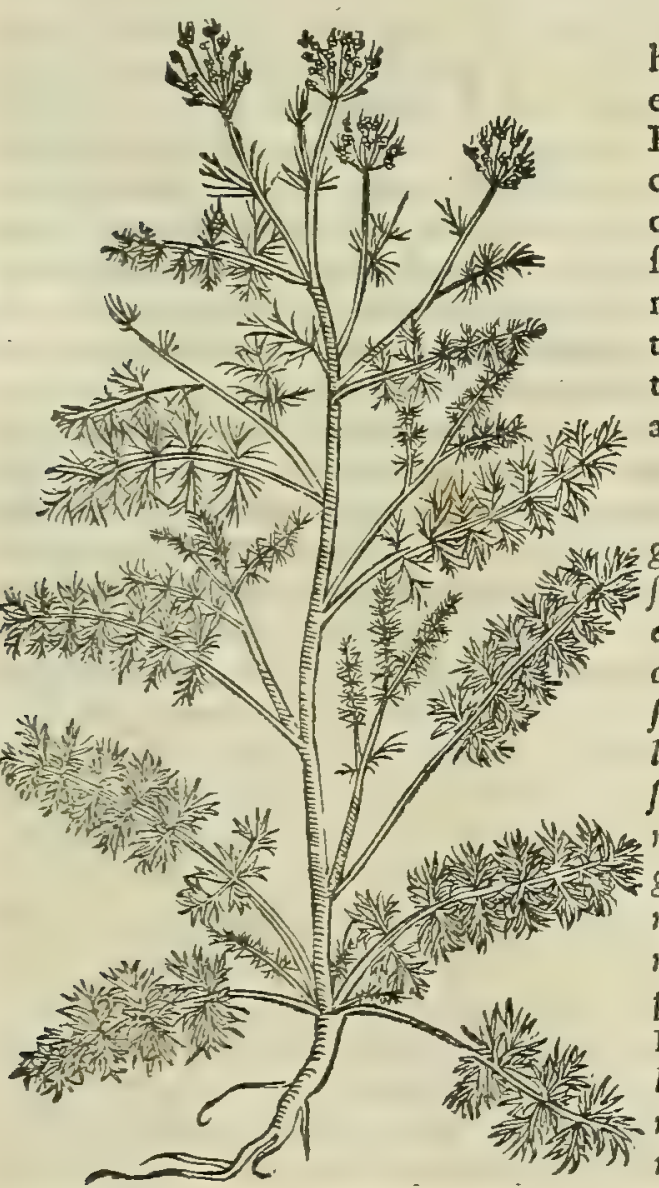

A M M I Aethiopicum cuminum appellant. Pleriq; hoc natura diuerfum effe ab illo exiftimant. Vulgò notü eft, femen exile, multò minus cumino, origanü refipiens. Eligendum eft purum, minimè furfurofum. Vis ei excalfactoria, feruens, \& exiccans. Facit ad tormina, urinæ difficultatem, ferpentium ictus, cum uino potum : menfrua ciet. Mifcetur derodentibus cantharidum medica mentis, qua ecdoria uocăt, ut inde exortis urinæ difficul tatibus refiftat. Sugillata cum melle tollit colorem potu; aut illitu mutat in pallorem. Suffitum cum uua paffa, aut refina, uuluas purgat.

Qv A N QV A M uaria, ac diuer $\int a \int e m i n d u i d e r i m, q u a l e=\Lambda$ mmios con gitimum Ammi mentiuntur; nullum tamen ex ijs bactenus mibi fideratio. Seec obtulit, quod animum ad credendum alliceret, uerum Ammi ex Alexandria Aegypti ad nos deferri: Quod Ameos nomine in officinis paßim babetur, cum probatißimum, Plinio tefte, cumino fit candidius, id nigricat, adeo ó; uulgaris petrofelini femen emu= latur, ut uifu ab eo dignofci minimé poßsit, fed in boc guftum con= fulere oportet. Nam cum baud leuiter fit acre, facultatis difcri= inen guftu facilé deprehenditur. Pretered cùm hoc nullum ori= ganifaporem guftui reprefentet, quem tamé referre uerum Am= mi Diofcorides eft auctor, adbuc clarius fit, id non effe legiti= mum. Veruntamen contrariü fenfiffe uidetur Ruellius: quip= Ruel. lapfus. pe qui minus fortaffe accuraté ea examinauerit, qua de Ammi, Hippocratis teftimonio, feriptis tradidit Plinius, ei alioqui fami= liarifimus, lib. X x.cap. x v.cum inquit. Eft Cumino fimilli= mum quod Greci uocant Ammi . Ruidam ueró Aethiopicum Cu= minum id effe exiftimant. Hippocr ates regium appellat, uideli=
Cuminicon. fideratio.

Monachorá error.

Cumini uires ex Galeno.

Nomine. 
cet qui.a cfficacius in Aegypto iudicatit. Plerique alterius natur in totun putant, quonian fit exilius, or candi= dius. Similis auten e buic ufus: nam e panibus Alcxandrinis fubigitur, e cum alinentis interponitur. hec Pli= nius. Ceterim non equiden negauerin, A nmi in Italia nafci, etfin officinis batcnus ucrun non reperiatur . Si= quidan Aloifius Anguillarius Romanus in berbarum cognitione diu ucr fatus, ex Patauo, ubi borti publici curan Monachorü gert, muper ad me mifit legitinum Ammi, nulla prorfus reclanantc not.s. Verini cuinuero buic fanć illud non error . adfipulariccrtun cft, quo magno, ut arbitror, errore ducti Monachilli, qui in Mcfuen commentarios edide= runt, fe ufos fuiffe affcucrant. nam pretcr rationcs, crror fatis ex fuis fcriptis exploditur, utpote qui fuum Ammi Ammios ui- nullo origani fapore commendari fatcantur. Herba, quan uocant Ammi, fcticnt, ut Galenus tcftatum reli=

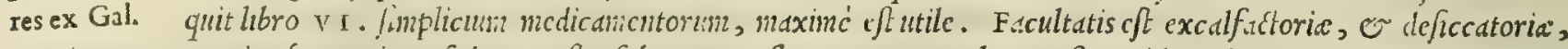

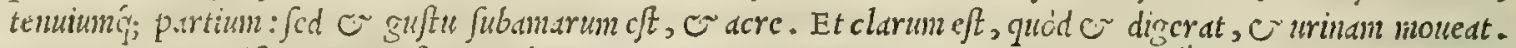

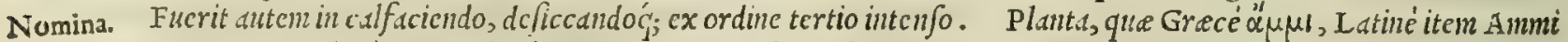
uocatur: Arabice', Nanochach, Anazuc, Nanachua, fcu Nanacbue: Italice, Anmi, ut ctian IHifanicé: Ger= Manice, Anncy.

\section{Kóglov, หै xogı'avvov. CORIANDRVI. C.A. IXII.}

Coriandri facultas ex Gal.

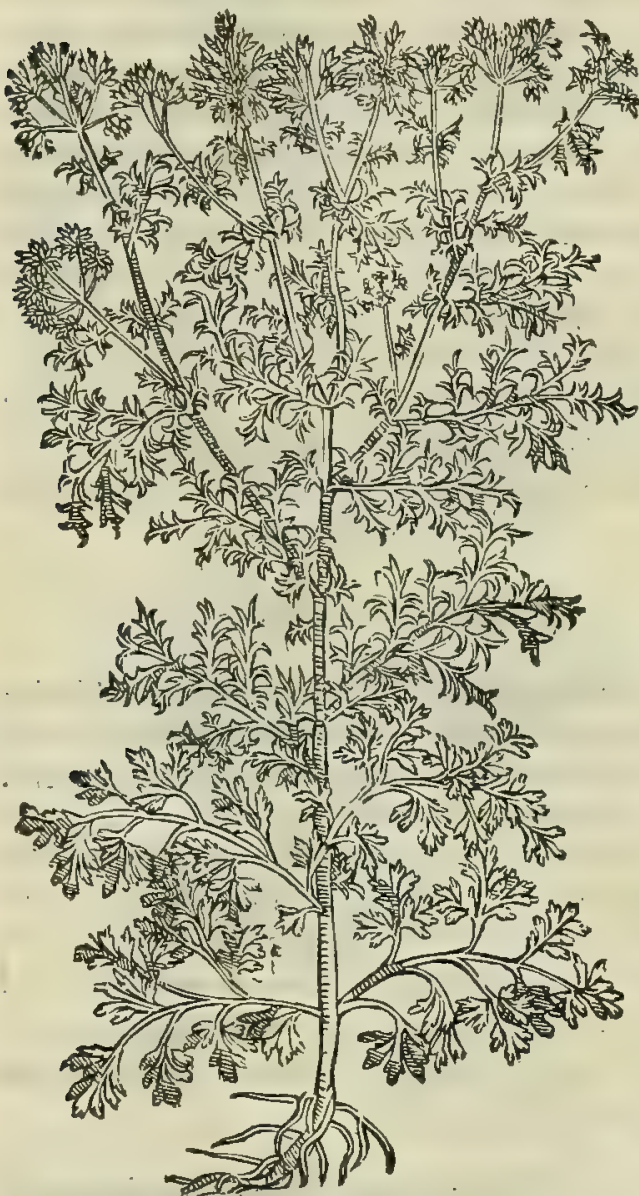

C O R I A N D R V M, aut coriannum uulgaris eft notitix: uim refrigeratoriam habens. Quare illitum cum pane, aut polenta, ignibus facris, \& ulceribus, qux ferpunt, medetur. Epinyctidas cum melle, uel vua pafla, teftium infammationes : carbunculosqúc fanat: cum faba frefa, ftrumas, \& tubercula difcutit. Tineas interanearum expellit femen,cum paffo modicè potum, \& genituram adaugct: largius tamcn fumptum, mentem non fine periculo mouet. quare continuo, \& copiofiore ufu abftinendam. Succus cum ceruffa, fpumáue argenti, necnon aceto, \& rofaceo illitus, ardentes fummx cutis infammationes emendat.

C O R I A N D R V M omnibusnotißimum eft. In cuius $f_{a=30}$ cultate indagands Galenis productus eft, ut longum fernone $f_{c=}=$ ceret contra Diofcoridis fententian lib. VII. fimpliciun medi= cantentorum, ubi ita fcribit . Coriannon, fiue Corion, aut utcun= que uocare Tubet. Vetuftiores Greci Coriannoit noninant: at recentiores mediciomnes Corion appellitant, ficut of Diofcoris des; refigeratorian efe berban dictitans, fed perperdm. siqui= dem ex contrarijs facultatibus componitur, plurinum babens ef= fentic aniara, quan oftendimus effe tenuium partium, o terre = nam. Nec partm etian aque a buniditatis obtinet, que tepentis eft facultatis. Habet autem er adfritionis paxillum. Ex qui $=40^{\circ}$ bus omnibus uarié quidem agit ea quse foribit Diofcorides, 0 non tantim ex refrigeratione. Caterum ego cuiufc; particulatin $d=$ ctionis caufam enarrabo, tanet f propofitu fuerat, mei unius dun= taxat boc in libro fententiam expromere. Sed forté nibil obfia= bit: imó, fi uerum fatendum eft, proderit nönibil, fuperiores me= thodos, que ad bunc modum in pucis medic amentis funt dicie, hic repetere. Primiun ergo non Diof corides tantum, fed er alij complures medicorum indeterminaté de morbis pronunciant, ficut fané bac quog; tempeftate non paucos inuenis medicos ucl infignes, prater alia, bac in re maximé ballucinantes. Interduni enin atra, liuida, frigidáf; red= dita parte, que cryfipclas habuit, nce amplius refigerantia pofcente medicamenta, cell anted, fed ea que infixü parti preter natur um bumorem cuacuent, ij tancn refrigerarc perfet:crant. Aliquando autem ad digerentia quidë tran = so

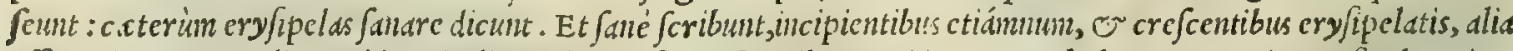
effe nedicamenta, alia ueró iam declinantibus, ac flaccefcentibus. Sed ita res non habet. Neq; cnin ery/ipelas etiam

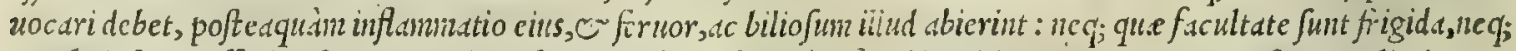

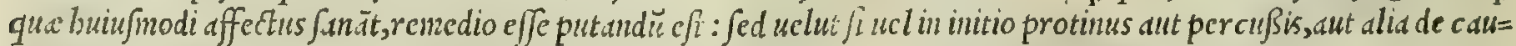
fa quáuis tumor un parte quapiă aut liuidus, aut niger extıterit, cum cl]c frigidum affectum exiftinabis, et que digerät excalfaciant'́; medic amenta pofcerc. Ad eundem nodum, fi calida affectio in frigidam reciderit, ncgligenda quidem

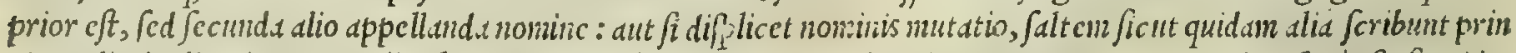
cipij, slia declinationis remedia, haud frigida cfje autumantes declinaticnis rentedia, concedendum fanc c $f$, fi cui ita

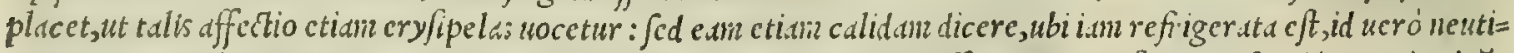
quan concedcndun. Itaq; ne quod tunc ei anxilio eft, refrizeratorium effe credamus, ficut Diofcorides Coriandrü, quod ut ipfe inquit, cum pane, aut polenta illitun, ery/ipelas curet. Nam quod exquifitum cft cry/ipclas, quod utiq; inflammatum 


\section{In Lib. tertium Diofcoridis.}

inflanmatum cf, o flaum, haud unquam fandre poterit cum pane Coriandrum, fed illud quod iam refigeratum eft. Proinde nos fuperioribus uoluminibus, cim determirata, ac definita experientia, cuiuf q; mcdicamenti facultatem ex= plorandum cenfuimus, quàm snaximé fieri poffet, fimplicißimum cligi affectun confuluimus. At plcriq; medicineqate quòd uel plurimi morborum protinus ab initio compofiti inusdant, norunt: nce; quod alius affectus fit cryfipelas exa= ctum, alius ucro is, qui uocatur ab ommibus nobis ufitaté, ut à uctcribus quoq; phlegmone : alij autcm inter hos shedif

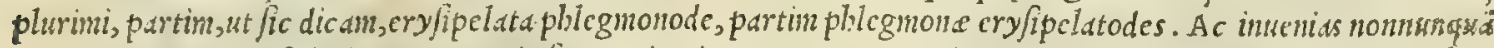
zibi neutrum uincat, $\int \mathrm{ed}$ ad ungucm paria fint. Quinetiam nonnunquam adcmatodes effe cryfipelas conpicitur, ficsse aliud fcirrhodes, ut compofitorum norborum non paruus aceruetur numerus. De quibus copio/ius, chim alibi difernis= mus, tum in libris de curandi ratione. Dicctur autcm o nunc quodd faltem eorum meminiffe neceffe cfis, quód cxactic

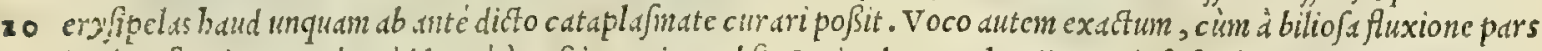
implet if fuerit . Porró quód longé à reffigeratione abfit Coriandrum, uel exijs, que ipfe fcribit Diofcorides, difcere Ticet. Nam frumiss, inquit, cum lonnento diffoluit. Cuód ueró nullum refrigerantium medicamentorum idoneum fit diffolueirdis ftrumis, ucl ipfum Diofcoriden non dubitaturum arbitror : quippe qui fexcenta fcripferit medicamenta frumas fundre potentia, qua omnia tum tempcric calida, tun actionibus digerentia effe confeffus eft. Hactcnus $\mathrm{G} d=$ le nus à Diofcoride in Coriandrif fucultate diffenticus. Porró uerò ac in re Galeno maxime refragatur Auicenna, qui in ipf fun aperté imulhitur lib. I I.cap. C X L I I I I. fic inquiens. Scripfit Galenus Coriandrum effe compofitum ex diuer fis facultatibus, ctfil terre a facultas in eo cateris cxcellat, fimul cun aqued quadain tepida, o adftrictoria pau= $c a$. Veriun, ut e go conijcio, aqucitds, que in ipfo reperitur, abfq; dubio frigida, non quidě tepida exiftit : nifí ei forfan

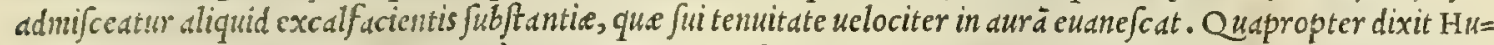

20 naym, remonet Galcnus frigiditatem à Coriandro, e Diofcoridirepugnat. At ego quidem aliter fentio, cum frigid. eius fubftantie mcminerint Archigenes, Rufus, o aliorum pofteriorünonnulli. Frigidum igitur eft Coriandrum na=

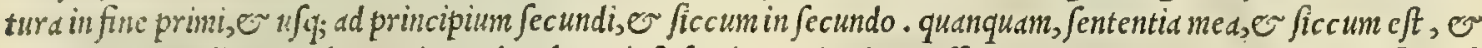
ad caliditatem aliquo modo uergit. Sed Galenus ipfe fentit, Coriandrum effe ex omniparte calidum. Id quod fortaffe euenife putandun ex a caliditatis particula, qua dum bibitur, aut comeditur, ab ipfo difperditur. Aliter nec neceffa= rium forct, fi homines fua frigiditate interficeret, ut in multa exhiberetur quätitate. Illud pratered fubdidit Galenus, fi Coriandrum trumas diffoluit, quónam igitur pąto frigidum erit? Cui facilè reßponderi poteft, id.agere Coriandrü fua quaddm occulta facultate, ac forma: aut quód reperiatur in eo aliqua tenuis facultas, que in prof undum penetra= re poßit, frigida fubftätia exterius relita. Sed cùm bibitur caliditas illa refoluitur. quo fit, ut fola frigida remaneat, o in corporibus agat. Hae Auicenna in Coriandro Galeni dicta refellens. Quxe et $\sqrt{i}$ aliquid in fe rationis, ac uerita= tis habere uideantur; tamen cim omnibus compertum putem, Galeno neminem adbuc parem extitife, quidiligentius ftirpium tum natur ds, tum facultutes inueftigauerit partim faporis guftu, partim odoris olfactu, partim fubftantia, et coloribus,partin deniq; ex longa experientia profundißima philofophie coniuncta, operapretiun eft eius potius ac= quiefcere fententie, qudin reliquorim omnium. Veruntamen Brafduolus in boc maluit fortafe cum Auicenna erra= re, quàm cum Galeno recté Jentive. Qui preterea cùn nefciuerit, Coriandrum in Hetruria paßim in pratis, o cam= peftribus fua Ponte nafci,afferit in fuo fimplicium uolumine, fatiuun tantim reperiri Coriandrum. Caterim quòd in hoc capite Diofcorides auctor fit, Coridndrum fumptum mentem non fine periculo commonere, guodd'; alij tum ex Gracis, tum cx Mauritanis memoria prodiderint, eiufdem fuccum potum interinere; ideo factume eft, ut multi, quor $\ddot{u}$ ego fententian antehac fecutus fum, coriandri ufum prorfus damnauerint. Sed id nune certe milhi uidetur iniufte $f_{a=}$

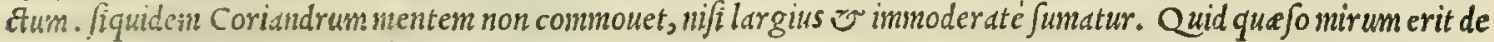
coriandro copiofius funpto, fi uinum etian, cuius tannen eft ufus quotidianus, liberalius epotum, dolores, morbos graues, ftr.ungulatus, e mortein deniq; infrat? quod fi moderatébibatur, prater alias utilitates, quas bumano corpori probet, wentriculum roborat, concoctiones adiuuat, excrementofa pellit, cor exhilarat, intellectum acuit, Piritus claros reddit $\odot$ uiuificat. Quare non equidem uideo, quid obftet, quo minus fimili ratione credamus, tan= tum abefe, ut Coriandri femen noceat, ut etiam maximé profit, fi tamen parcé $\sigma$ modicé fumatur. Quippe ab eius afu moder to non abhorruiße Galenum puto: nam lib. V I I I. cap. I 1 I I. de compofitione medicamentorum fecun= dum locos ex Archigene refert, ruitu acido affectis coriandrum cochlearij menfura exbibendum effe. Galeno autem aperitiline sdfipulatur é recentioribus Grac is Symeon Sethi, utpote qui in coriandri mentione fcribat, idftomacho bonun effe, er eundem corroborare: cibun in uentriculo retinere, donec probé concoquatur. Qưe auctorě bunc de temperato coriandri ufu tradidiffe, nulli dubium eft. Ex bis igitur facilé colligamus licet, quód non fit admittenda, fed potius explodenda illorun recentiorum opinio, qui coriandri ufum omnino fugiendum effe cenfent. nos enim iam hon osnnem eius ufum, fed immoderatum tantìm, ut nocuun, uitandum effe exiftimamus. Id Grecis róglov, er ro= piavvov appellatur: Latinis, Coriandrum: Mauritanis, Rusbor, Rasberd, Kuzbara, feuKuzibard: Italis, Corian= dro: Germainis, Coriander, e Coleander : Hipanir, Culantro, o Ciliandro.

\section{I'e⿻xius\%. HIERACIVM.}

\section{CAP. IXIII.}

H I E R A C I V M magnum caulem emittit afperum, fubrubrum, fpinofum, cauum : folia ex interuallis rariufculè diuifa, fimilia foncho per ambitum : luleos flores, in oblongis capitulis . Vim refrigerandi habet, \& modicè fubftringendi : unde illitum, ftomacho æftuanti, inflammationibusq́ue prodęt. Succus erofionem ftomachi forbitione mitigat. Herba cum radice illita, uibratis à fcorpione iftibus auxiliatur. Hieracium paruum, folia ex interuallis habet, diuifa in ambitu: cauliculos

Brafauoli error.

\section{Coriandrife-} minis ufus.

Nomine 
teneros, uirentes : in quibus lutei fores orbem circinantes, emicant. Vim fuam ad eadem, ad qua fuperiorimpendit.

HIERACIVM MAIVS.

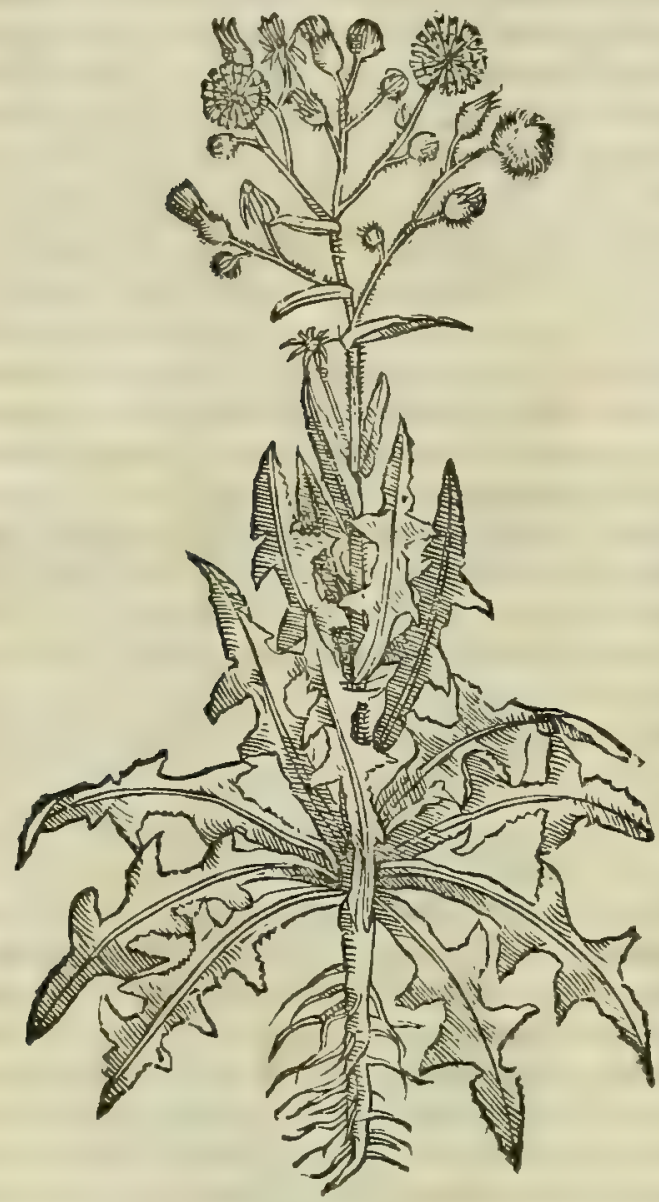

HIERACIVM MINVS.

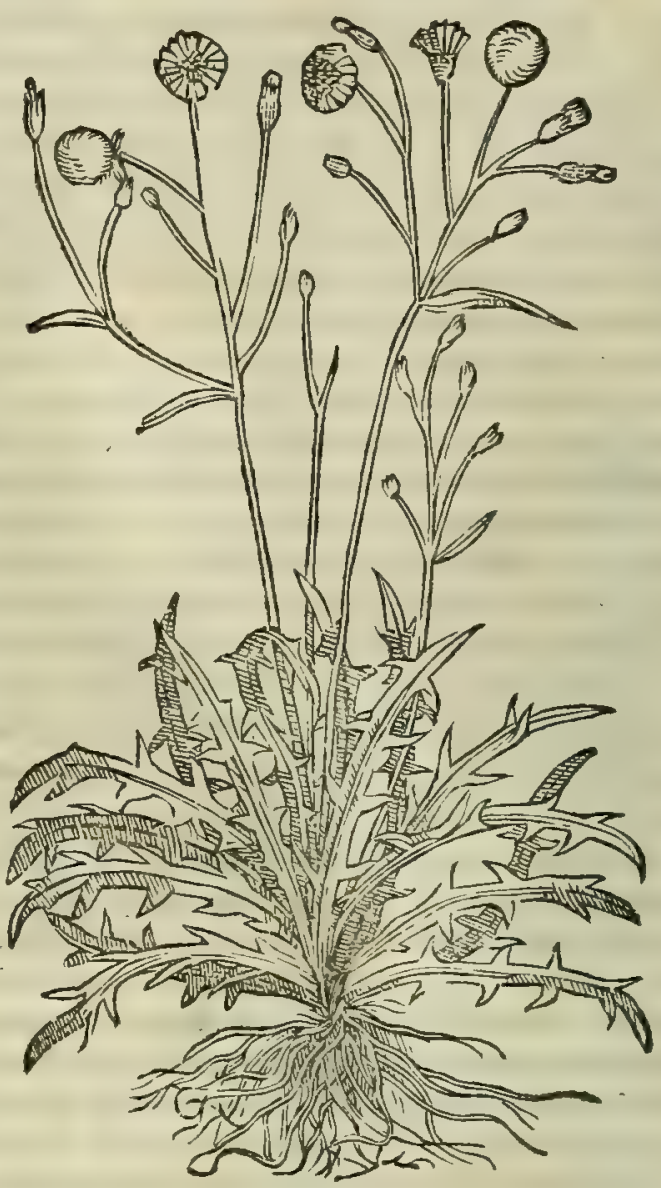

10

Hierscijcon:

H I E R A C I v м tam maius, quàn minus frequentißimum ubig; in I talia nafcitur, foncho non admodum dißi= fideratio, \& ui mile. Horum autem non reperio Galenum mentionem feciffe, nec etiam $\mathrm{Paulum}$, in libris de fimplicium medic amento= res ex Plı. rum facultatibus. Mesninit tamen eorum Plinius lib. X X.cap. v I 1 .inter lactucarum agreftium genera, fic inquiens. sunt, qui herbam Hieraciam uocent, quoniam accipitres fcallpendo eam, fuccóg; oculos tingendo, obfcuritatem cium fenfere, difcutiant. Succus omnibus candidus, uiribus quoq; papaueri fimilis. Carpitur per meffes incifo caule. Con= ditur in fictili nouo ad multa preclarus. Sanat omnia oculorunn uitia cum late mulierum. Arcet nubeculas, cicatri= 40 ces, aduftionesøi; omnes, precipué caligines. Imponitur ctiam oculis cum lana contra epiphoras. Idem fuccus aluum purgat, in pofca potus ad duos obolos. Serpentium ictibus medetzir in uino potus. Et follia tofta, thyrfiq; triti ex ace to bibuntur. Vulneri illinütur maximé contra feorpionum itus. Verum contra "phalangia commifto uino ex dce= to. Alijs quoq; uenenis refiftunt, exceptis que ftrangulando necant, aut i.j que uefica nocent, item pfimmythio ex= cepto. Imponuntur or uentri ex melle, dtq; aceto ad detrabenda uitia alui. vrine difficultates fuccus emendat. Cra= teuas eum er bydropicis obolis duobus in aceto, or cyatho uini dare iubet. Pe culiares earum uires partim iam dicte funt, fomnum faciendi, uenerem ó; inbibendi, \&f tum refrigerandi, stomachum purgandi, fanguinem augendi. Nunc nö pauc e reftant, quoniam inflationes difcutiunt, ructus lenes faciunt, concoctiones adiuuant: cruditatem ip $\int e$ nequa= quam faciunt. Nec ulla res in cibis auiditatem incitat, inbibet $q_{;}$: eadem in caufa alterntrinq; modus eft. Sic er aluñ copiofiores foluunt, modic. fiftunt, lentitiam pituite digerunt, at $q_{;}$, ut aliqui tradia'erunt, fenfus purgant. Stomachi so diffoluti utilißimé adiuuantur, in eo $u$ u, e oxypori obolis aperitatem addito dulci ad intinctum aceti temperantes. si craßior pituita fit, fcillite, aut uino abfintbite: fi $v$ tußis fentiatur, by fopite admifto. Dantur coliacis cum in= tubo erratico, or ad duritiam pracordiorum. Dantur or melancholicis. candide copiofiores, or ad ucfice uitia. Praxagoras or dy fentericis dedit. Ambuftis quoq; profunt recentibus, priusquim puftule fiant cum fale illite. Vl= cera etiam, que. ferpunt, coürcent, initio cum aphronitro . mox in uino tritc igni facro illinuntur. Conuulfa, er lu= $x$ ata caulibus tritis, cum polenta $x x$ aqua frigida leniunt : eruptiones papularü ex aino, or polenta. In cholera quoq; coctas patellis dederunt: ad quod utilißime, quaim maximé caule, fed amar.e. Quidam lacte infundunt. Defirucfari ij caules e ftomacho utilißimi traduntur. Has omnes Plinius tam Hieracijs, quàm S_lueftribus Lactucis uires contri

Noanina. buit. Quod Greci i f̧áusov, Latinifimiliter Hieracium uocant: Itall, Hieracio. 


\section{In Lib. tertium Diofcoridıs.}

APIVM HORTENSE.

20

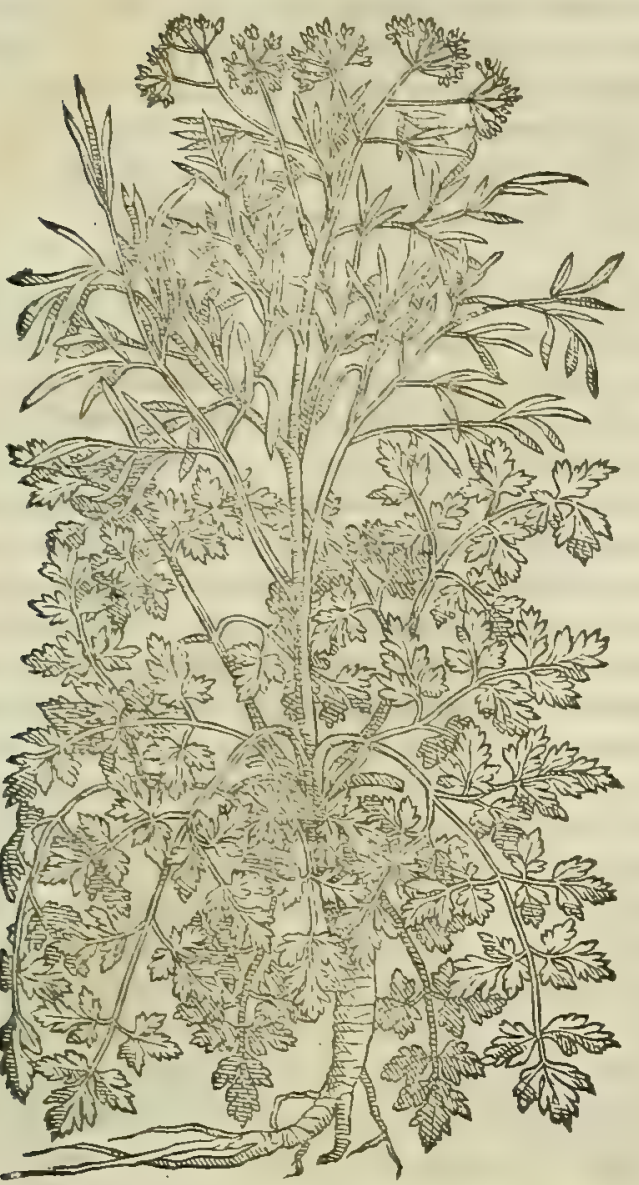

HIPPOSEIIN VM.

40

so
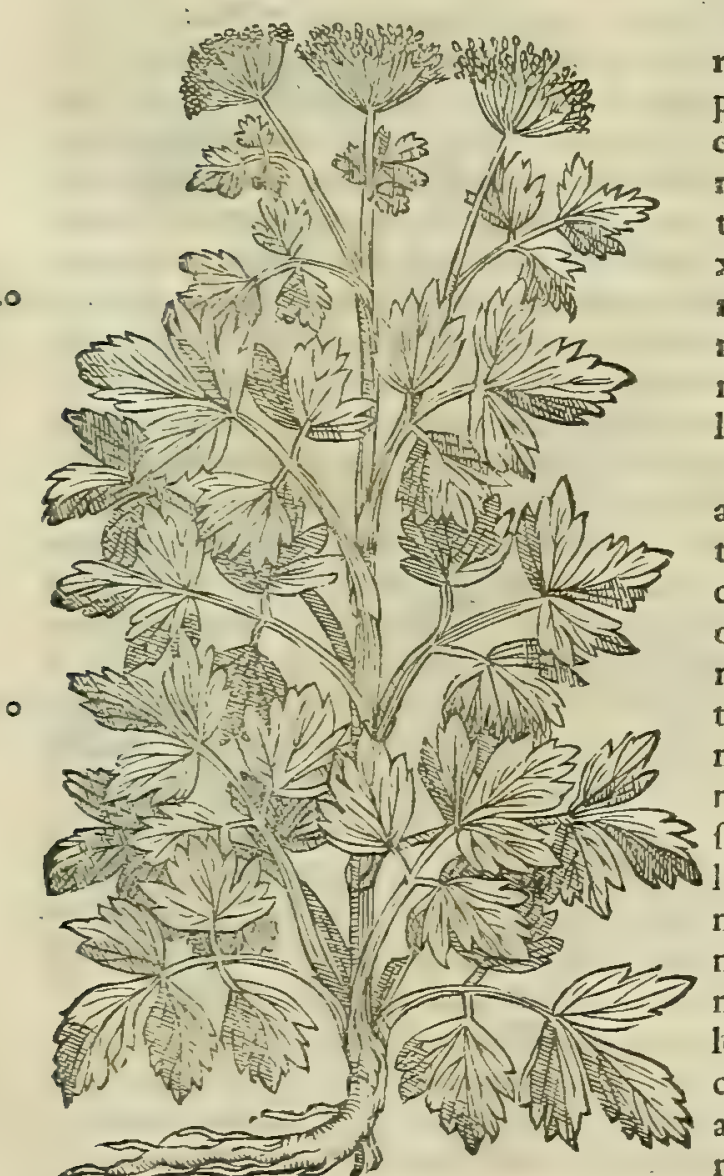

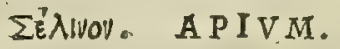

HorTENS Is Apij herba ad eadem, ad qux coriandrum conuenit. Inflammationibus oculorum cum pane, aut polenta illinitur : æftuantem ftomachum mulcet: mammarum duritiam ex lacte concreto contrątá, reprimit. Vrinam ciet, fiue crudum, fiue coctum edatur. Decoetum eius; radicisq́ue potum, uenenorum no$x \mathfrak{x}$ refiftit, cùm uomitiones excitet:aluum cohibet. Semen vehementius vrinam pellit: contra ferpentium uenena, aut epotam argenti fpumam auxiljatur : inflationes difcutit. Admifcetur medicamentis, quæ dolorum leuamenta præftant, theriacis quoq, ac tufs is remedijs . Eleofelinum in humidis nafcitur, fatiuo grandius, \& ad eadem efficax. Oreofelinum caule eft dodrantem alto; ab radice tenui exeunte : per cuius a mbitum rami , \& capitula cicutæ, multò tamen tenuiora : femine cumini oblongo, acri, \& odorato, tenui. Nafcitur in petrofis, \& montibus. Vrinam ciet, femine, ac radice in vino potis: menfes trahit antidotis, necnon medicamentis vrinam cientibus, \& excalfactorijs, inferitur. Nec hallucinari nos oportet, exiftimantes oreofelinum effe, quod in faxis prouenit:aliud enim eft petrofelinum. Petrofelinum in Macedonia prouenit, in præruptis locis, femine ammij, odoratiore, fapore acri, aroma olente. Vrinam cit, ac menftrua : contra ftomachi; \& coli inflationes, \& tormina prodeft : Laterum, renum, \& ueficx doloribus, in potu fubuenit. Admifcetur antidotis urinam cientibus. Hippofelinum Latini olufatrum appellant, aliqui fmyrnion, quanuis aliud fit, quod propriè fmy $\mathrm{r}-$ nion dicitur, ut paulò pòft referemus. Eft autem maius, 
\& fatiuo apio candidius : caule alto, cauo, molli, habente veluti lineas: folijs latioribus, in puniceum uergentibus : coma rorifmarini, florum plena: dependentibus in cacumine corymbis antequàm deflorefcat . Ea femıne turget nigro, oblongo, acri, folido, aromatico . Radix dimittitur tenuis, odorata, candida, qux os commendat . In vmbrofis, \& paluftribus enafcitur . olerum generis, ut apium . Ra dix cruda, coctáve eftur. Folia cum caulibus, decocta manduntur, \& per fe aut cum pifcibus præparantur, crudaq́; muria condiuntur. Vim hanc habet, ut poto femine ex mulfo vino menfes cieat : algentes calfacit potu, aut illitu : vrinæ ftillicidio auxiliantur. Radix cofdem præftat effeetus .

A pij hortëlis. P V T A N T dubio procul omnes frè atatis noftre medici, ij $q_{\text {; }}$ prefertim, qui diu uerfati funt in fimplicium confid. medicamentorum inquifitione, quiq́;; multum laboris ac ftudij impenderunt, ut banc medicins partenz pené abolitam reftituerent, nil aliud apud antiquos fatium fuiffe A pium, quim unlgare noftrum Petrofelinum, bodie bortis omni= bus frequentißimum. Quorum equidem fententiam nunquam aufim improbare: cum noftrum boc notis omnibus fit preditum, quibus conftare A pium ueteres tradidere. Plinius fiquidem libro x x.cap. x r.naturalis hiftoria ita fcri= bit. Apio gratia uulgo eft : nang; ramilargis portionibus per iura innatant, ev in condimentis peculiarcm gratiam babent, Hoc etiámnum confirmarc udetur Galenus lib. I I. de alimentorum facultatibus, cüm inquit. Apium inter caterd familiarißimum eft, or ori, ftomachó́; gratißimum. Que fané omnia in uulgari noftro Petrofelino cernun= tur : quippe quod nobis omnium olerum familidrißimum in ciborum condimentis perpetú babeatur. Caterùm quan= uis id uarios noftrarum menfarum cibos frequentißimé commendet; fcripfere tamen tum Cbryfippus, tum etiam Dio= nyfus ('ut Plinius autbor eff) A pium ad cibos non admittendum, imó onnino nef as : nam id defunctorum epulis ferali= bus dicatum. Ip fus quoq; nifus claritati inimicum. Caule famma uermiculos gigni. Ideo'g; cos, qui cderint, fterile $=20$ fcere mares, facminas q; . In puerperijs ueró ab eo cibo comitiales fieri, qui ubera bauriunt. Innocentiorem tamen ef= fe marem. Edq́g; caufd eft, ne inter ne faftos frutices damnetur. hec Plinius. Quare mirum non fuerit, fi recentio= Eleorelini có- res quog;; A pio comitialibus interdixerunt. Cìm igitur bis tum rationibus, tum auctoritatibus, notis praterea fuf= fiderstio. fragantibus, conftet uulgare Petrofelinum legitimum effe Apium, putandum quidem fuerit, quin potius affirmandü, id quod officinis omnibus fatiui A pij uicem explet, nil aliud effe, quam Paludapium, fiue A pium paluftre, Eleofeli= num Diofcoridi uocatum. Qudndoquidem boc in bumentibus, $\mathcal{O}$ paluftribus locis nd fcitur, caule, $\mathbb{E}$ folijs fatiuo ma=

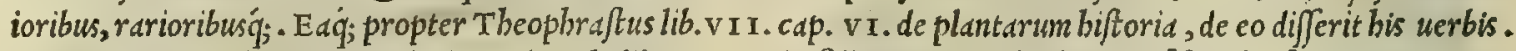
Paludapium, quod apud aque ductiu, et in paludibus prouenit, folio raro, nec hirfuto confiftit, fed fimile quodammo= Ruellij opin. do Apio eft, odore, fapore, figuráq;. Hinc itag; fit, ut Ruellio minimé adftipulandum cenfeam, qui plantam nobis non accepta. Italis Macerone uulgó appellatam, Paludapium effe putat. Quippe (ut pauló póft, atọ̆; etiam in proxima Smyrnij 30 commentatione dicetur ) non parud fané inter uocatum Maceronem, Eleofelinum, ev Hippofelinum intercedit diffe= Oreofelini có rentia. Apij porró in montibus nafcentis, quod ideo Gracis Oreofelinum dicitur, nulla à Diofcoride redditur fo= fideratio. liorum delinedtio, nifi in eo fcriptura fuerit depratuata, ut fermé fuppicor. Verim Theopbraftus, or Plinius oreofe= linun de fcripferunt folijs cicute, radice tenui, o femine unus, alter ueró caule anethi, minutiore tamen. Vnde factit eft, ut nonnullicrediderint $T$ beophraftum boc in loco deprauatum effe, $\sigma$ quód ubi in Grecis codicibus legitur, nat

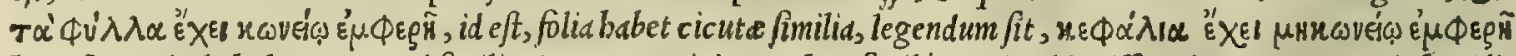
boc eft, capitula babet papaueri fimilia. In quam opinionem bos facile potuit adduxiffe unlgata Graca Diofcoridis lectio, in qua nimirum capitulorum papaueris, non autem foliorum cicuta mentio eft. Veruntamen ego potius (ut mo= dò dixi ) Diofcoridis lectionem uitiatam putauerim, quàm Theophrafti, licet contrà fenferit Hermolaus. Nam pres=

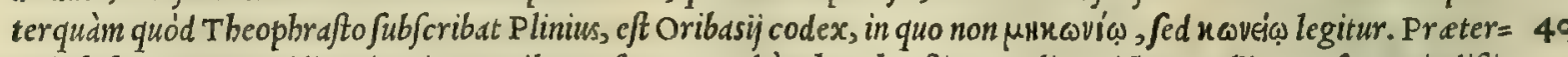
ed ipfe fepenumero uidi A pium in montibus nafcens, quod à Theophrafti, ev Plinï pictura nullis prorfus notis difi= det. Prouenit enim folijs cicute, radice tenui, e femine in umbelld anethi modo : que omnia Apij generi maximé $d d=$ ftipulantur. Illud infuper addiderim, quòd A pij longé magis proprium eft folijs confurgere cicute modo pèr ambi=

Petrolelinü. tum laciniatis, femine in umbella anethi inftar, quam capitulis paparuerifimilibus inclufo. Sed an legitimum Petro= felinum Macedonicum uocatum, in Italia proueniat, nö equidem afferere aufim, etfi Monachi illi, qui in Me $\int u e m$ fcri p fere, fe in Romanis quibufddm montibus illud adinueniffe teftentur. quod tamen ( fi uera referunt) Romanum qui= Hipporelini dem, non Macedonicum appellandum fuerit. Quod ueró Hippofelinum uocatur, nil certé aliud effe opinor, quàm confideratı. quod nonnulli bodie Leuifticum nominant, grandius plané inter omnia apiorum genera, adeó ut meritò Hippofelinum dicatur. Id fane notis omnibus refert Hippofelinum: licet Brafauolus Ferrarienfis berbain Maceronem uulgó woca= tam falsó Hippofelinum exiftimet, à peruer fa fortaffe Marcelli interpretatione deceptus, qui prater Diofcoridis $\int \mathrm{c} n=50$ tenttam, Hippofelino radicem intus candidam, foris ueró nigram reddidit, cùm tamen in Gracis Diofcoridis exempla

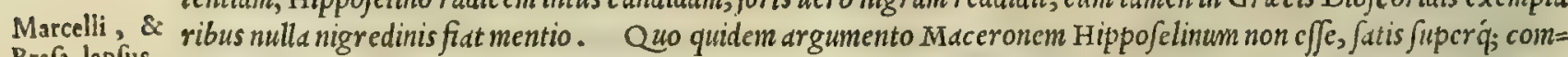
Brafa. lapfus. probatur, prefertim cum bec coloris radicum oppofita qualitate inter fe difcrcpent. Huius Marcelli lapfusillud cau fam fuiffe arbitror, quód legerit apud Theophraftum, nafci Hippofelinum foliys paludapio proximis : caule magno, ac birfuto: radice raphani modo craffa, fed nigra : nigróq; etiam fesmine, magnitudine eruo ampliore. Qula fortaffe au= thoritate fretus Marcellus, nigram Hippofelino radicem inc ffe addidit in Diofcoride. Sed animaduertendum eft Theo phraftum eo loco non defcripfiffe Diofcoridis Hippofelinum, cum altcrum ab altero pluribus differat notis, fcd Smyr= nium potius. Id quod ex eo conijci poteft, quód Diofcorides, itern'; Galenus affer ant, nomullos inucniri qui Hippo= felinum à Smyrnio non Separent. Quibus uerbis nil mirum inter cos, qui ita fentirent, Theophraftun quoque abillis

Fuch. error. comprehenfum fuiffe. Ceterum bac in re ctiam $\mathrm{Fuch}$ fius, cuius tamen pace dixerim, apcrté hallucinatur: quippe qui legitimum Hippofelinum Lenifticum unlgó nocatum, fimyrnij loco in fuis clarifinis de firpium biftoria comment= 


\section{In Lib. tertium Diofcoridis.}

tarijs depinxerit. Idcm preteres err.t/e deprehenditur in liöro de compofitionc nedic.mentorum, quem nuper au=

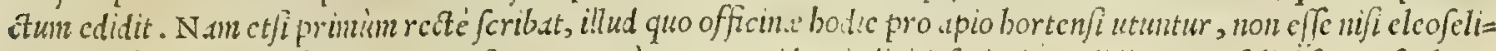

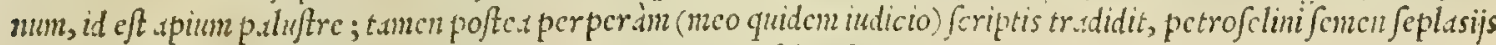

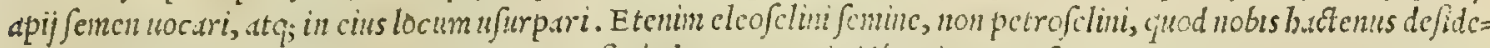

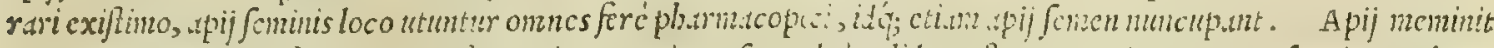

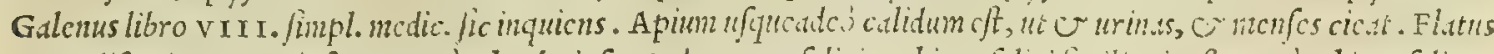

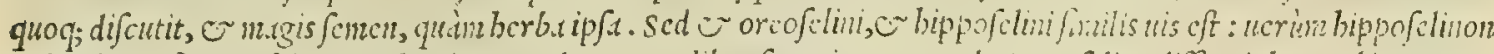

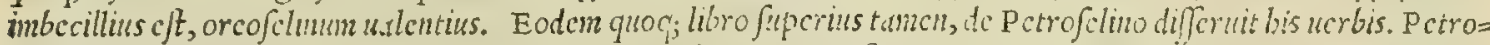

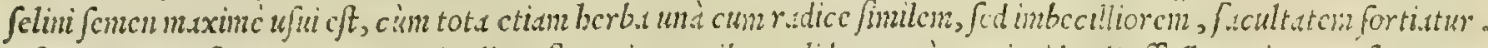

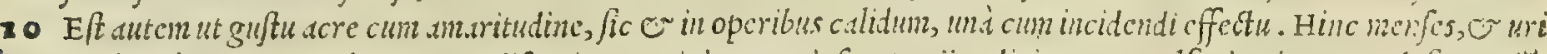

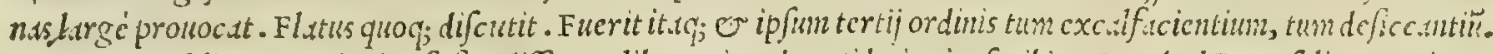

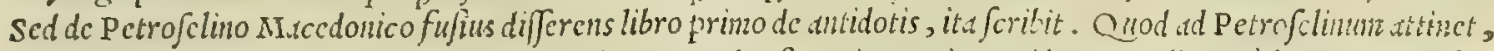

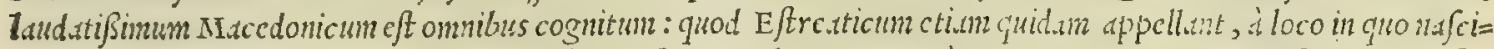
tur, nomen imponentes. Verime cxigum cft prorfus quod ibi proncnit, cum co prosuptus, or ansufus is locus fit a

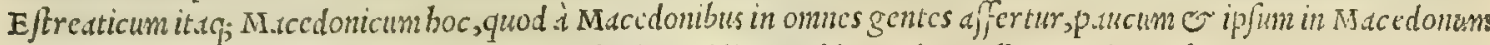
terra gignitur. Scd iácin in petrof clino Macedonio accidit, quol in Attico melle, er mino Falerno contingit. Merca tores fiquiden in onmem frrme orbis terram, ut mel Atticum, uinum F.lermum, fic petrofelinum Macedonicum adue= bunt, cun tamen in IIacedonia petrofelini tantum non oriatur, quantum gentibus ommibus fat is cffe queat. Verum in

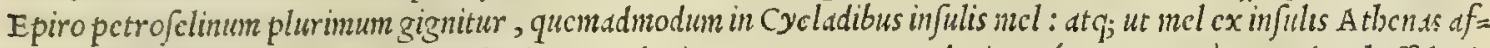

20 fertur; fic petrofelinum ex Epiro prius in Macedoniam comportatur, plurinumí;, o propc totum in Theffaloni= cam: inde ueró t.ınquam Macedonicum exportatur. Idcs in uino Falerno contingit . nan cun in cxiguo quodan Italia agro Falcrnum proucniat, complura alia uina in Falcrni pecien a uini magiftris concinnantur, quae perinde at ; Falcrnina, in onnes prouinciss Romano imperio fubiectas importantur. Tibi ueró fi petrofelinum Eftreaticum quandog; dccrit, ne peiorem exiftines theriacan futuram, fi alim impo fueris. Non enim fi mortiferis uenenis, $f i$ ue $=$ ncuatorum morfibus diud ab Efreatico petrofelinum minus congruit, propterea reliquis etian morbis, ut tormini= bus, ucntriculo dcbili, aque inter cutem, 0 id genus alijs, fcgnius opitulatur, quos in prinis fanare theriacd non pro mittit. Ad bee Eftreaticum petrofclinum theriacan plane anariorem facit, prefertim cum reccns adbuc imponitur.

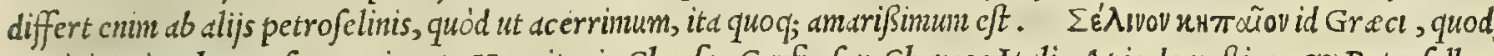
Latini Apium hortenfe, nominant: Mauritani, Charfs, Carfi, feu Chares: Itali, Apio doncftico, er Petrofello:

Nomina.

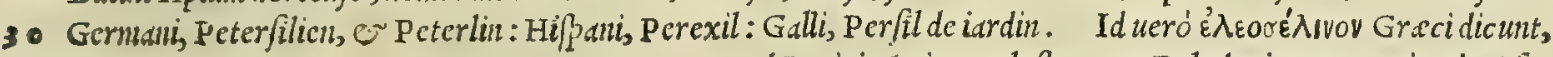

SMIRNIVII.

40

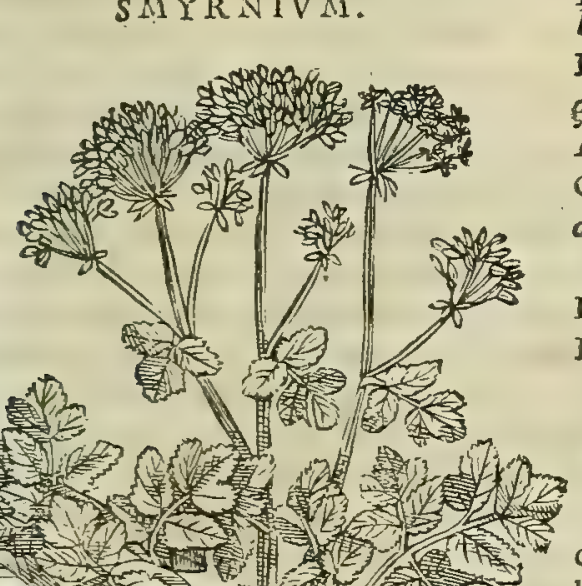

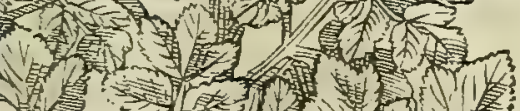

50

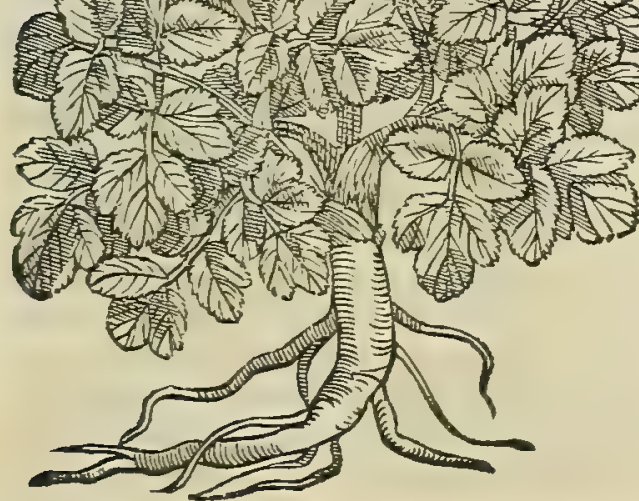

quod Latini, Apium paluftre, er Paludapium: Mauritani, $A$.

lis: Itali, Apio paluftre : Germani, Epffich, Cr Eppich: Hipan, Percxildagod, er Apio: Galli, Perfil de leau. 2uod autem os

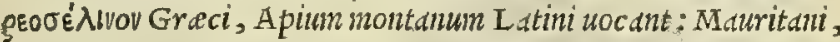
Acrafclinum: Itali, A pio nontano: Hipani, Perexil nontefino: Galli, Perfil des montaignes. Пєт citur , quoditem L stinis Petrofelinum, er Italis, Petrofelino.

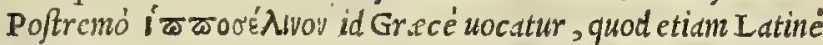
Hippofelinum: Arabicé, salis : Italicé,Hippofelino: Germanicé, Licbftocliel: Gallicé, Ache, Cr Ache large.

\section{¿uvंgriov. SMYRNIVII. CAP. LXV.}

S M Y R N I ON, quod in Cilicia petrofelinum nocant, plurimum in Anano monte gignitur. Caulem habet apij, \& ftolones multos : folia latiora, fuppinguia, ad terram infracta, robufta, odore medicato, cum quadam acrimonia iucunda, colore in luteum languefcente: capitibus caulium orbiculatis, vt anethi: femine brafsi$c x$, rotundo, nigro, acri myrrhæ fapore, ita vt alterum alterins loco cedat. Radix quoque odorata, guftuacri, fauces mordet, fuccofa, mollis. Cortex eius foris niger, intus viridis, aut fubalbidus. Nafcitur in faxofis, \& collibus, atque fqualidis, \& limitihus terrenis . Vis radicis, herbæ, \& feminis excalfacere. Folijs muria maceratis ad obfonia utuntur : aluum fiftunt. Radicem contra ferpen tium iEtus bibere conuenit: tuffes, \& orthopncas mitigat: vrinæ difficultati medetur. Illita recentes tumores, collectiones, duritiasq́; difcutit : vulnera ad cicatricem perducit. partus abortu uitiat, fi feruefacta fubijciatur. Semen lienis, renum, \& ueficx uitijs prodeft : menfes, \&

fecundas
Apiig generü uires ex Gal. 
fecundas pellit . commodè datur ifchiadicis in uino: inflationes ftomachi lenit : fudores ciet, \& ructus. Peculiariter datur hydropicis in potu, \& contra febrium circuitus.

Smyrnii conGderatio.

Ruellij opin. frum diqum Maceronem con/tanter afferuit . improbanda:

\section{IMPERATORIA.}

Smytrij uires ex Galeno.

Quorundan hallucinatio.

Imperatorix plantz defcri ptio, \& uires.

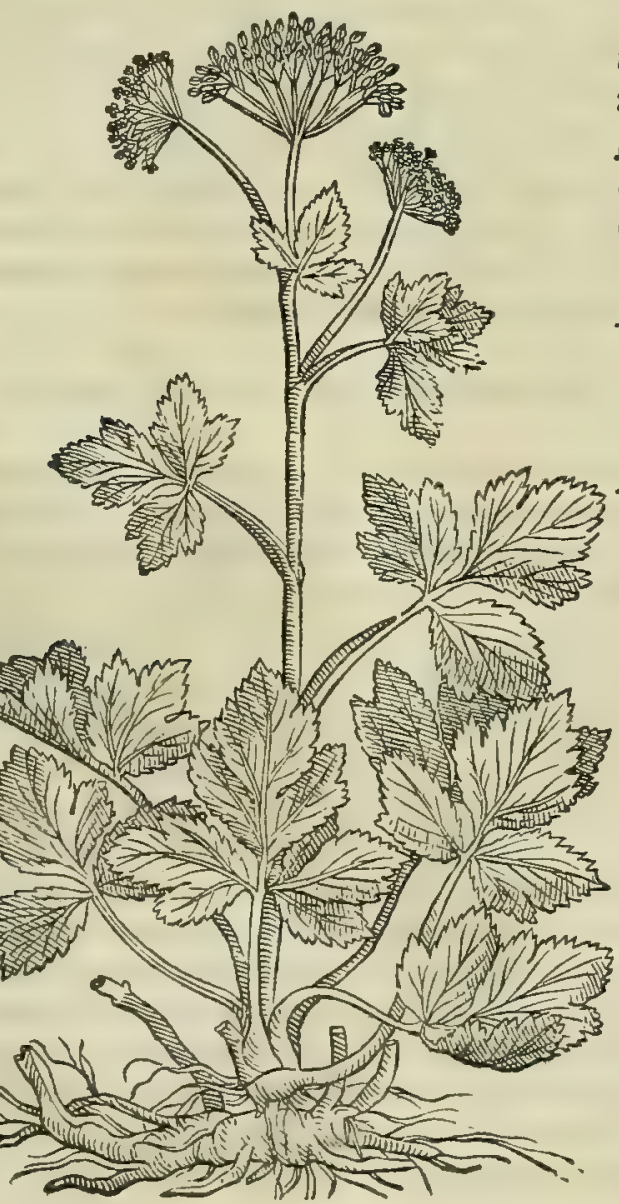

S I S M Y R N I I fingule noté, qux illi ḋ Diofcoride tribuntur recté, diligenter q́ éxpendantur, facilé qui= dem perfici poterit, smyr nium ei berbe fimilimum effe, que a noltris in Hetruria uulgó uocatur Macerone. siquis dem hanc nafci clarume e? caule apij, frolonibus mult is referto: folijs latioribus, fuppinguibus, robuftis, ad terră uer fis, odore medicato, cum quadam acrimonia iucundis, colore in iuteum langue fente. Praterea in caulum cacumini= bus umbellam gerit ane thi modo: femine braßice maiore, oblongo tamen, nigro, acri,odore myrrham referente. Ra= dice deniq; nititur odorata, acri, $\int u c c o \int d_{2}, a c$ molli, qua exteriore cortice nigricat, interiore ueró parte ex albo ui= refcit. Quss quidem notas fere oinnes conftat Smyrnio Diofcoridem reddidiffe. Verim quifiam, cui forté hac no= fra fententia minus arrided, obtrudet nobis femen, ut quod Maceroni noftro non infit rotundum, braßica modo. Huic illud reponfum uolumus, quód cum catere in uniuerfum note illi repondeant, facile in feminis delineatione mendum fubeffe poteft. Vel quod non in rotunditate, fed in alio uni cum altero femine intercedat fimilitudo. Porró quanuis memoria non prodiderit Diofcorides, quod smyrnium fer atur in hortis, in quibus bodie noftrum illud feritur, Jed quod pponte in Amano cilicie monte gignatur, tum etiam in collibus, incultis, ac faxofis locis; Plinij tamen atate pafim in hortis ferebatur. Id quod ip e Plinius manifefte demonftrat lib. X I x.cap. ultimo, ubi smyrniuminter bor=

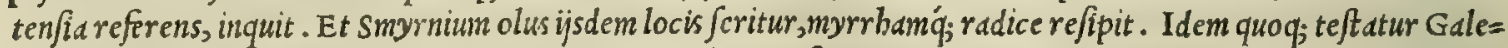
nus, quod ip fum inter olera connumeret libro I I. de alinent. facultatibus, e de eo foribat in büc modum. Smyrnin non eft infuaue. Ideón; Rome plurimum uenit. Multó autem acrius eft, er calidius, quàm apium : quin er odorati quidpiam habet. Quapropter efficacius urinam ciet, quàm apium, bippofelinum, or fion: Or mulieribus menfes mo= uet. Veris tempore caulem producit, qui crudus edendo eft haud aliter quàm folla, que fola per byemem inerant pla te, nondum caulem babenti, ficut neq; tum apium babet. Poftea ueró caule accedente, tota planta iucundior reddi= tur, fiue quis crudam ip fam, fiue coctam mandat, fiue ex oleo, or garo, fiue uinum, fiue acetum uelit adijcere. Non= nulli cum aceto, o garo tantùm edunt, ueluti apium : alij ueró paululum olci ijs adijciunt. bac Galenus. Ex cuius $\int_{a}$ né uerbis liquidó apparet, Smyrnium ueteribus etiam inter oler fuifje receptum. Galeno nimirum adftipulantur ed, qua de smyrnio mibi retulerunt siculi. nanq; ij affirmant, plantam Maceronem appellatam paßim coli in fuis bor = tis, $d t q ;$ edm ueris tempore ( $u$ t etiam Galenus perbibct) caulem tencrrimum emittere : qui non folum edendo fit, fed gratiam quoque ineat cum ore, prefertim fi cum fale o pipere cinare modo comedatur. His itaq; fortaffe, uel etiam ualidioribus rationibus adductus Manardus Ferrarienfis, uir quidem ingenio, or doctrina celebris, Smyrnium effe no 作 quód fupicetur (ut proxima commentatione diximus) Maceronĕ effe Paludapium. Smyrnium ueró eam effe ftirpeìn certó putet, quam in Gallïs uoc ant uulgó Leuecchid. Smyrnij tum biftoriä, tum facultates de fcripfit Galenus lib. v I I i. fimplicium medica= mentorum, fic inquiens. Snyrnium quidam Hippofeltnum agre= fte cognominant. Ex eodem genere $\sigma$ ip um cum apio eft, er pe=

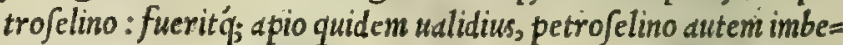
cillius. Menfes ita $q_{;}$, er urinas mouet; calidum, ficcum $q_{;}$tertio ordine. Cilices petro elimum nominant, quod in Amano monte na fcitur. Eft quidem or ipfum smyrnium, minus ueró petrofelino, 40 of fmyrnio acre. Proinde er ulceribus imponi poteft, quid uideli cet.fine moleftia deficcet. Sed $\sigma$ digerere, que indurdid funt, ua let. Reliqua uis cius apio, or petrofelino fimilis eft. Quocircd et femine eius utimur ad men $\int e s$, urinds, er afthmatd, fue arbelatio= nes. hattenus Galenus. Ceterim non de funt ex recentioribus, qui ballucinantes contendant, plantam Imperatoriam uulgó noca tam legitimum effe smyrniun, argumento quód eius radices exte rius nigrefçant, interius ueró uirefcant. Verùm ï ex co apcrté deceptideprebenduntur, quód non animaduerterint, an be plan= te ceteris inter fe notis conueniant. Sed pofteaquàm de Impe= ratoria berba incidit mentio, ob fui nominis maieftatem, uiriumi; preftantiam, pretereundum fané non duximus, quin bic cius tum biftoriam, tum facultates edifferamus. Preftantifima igitur I M= PERA T OR I A in Ananienfibus montibus fupra Tridentum fre $=$ quentißima nafcitur, folijs ßpbondylio minoribus, folo accubanti= bus, robuftis, lirr futis, ac afperis: caule bicubitali, purpurafcen: te, rotundo, birfutoó; : in cuius cacumine umbella floribus candi= dis ornatur: é quibus poftea femen prodit felelis modo acutum, pariterq; odoratum. Radix ineft ei non longa, mediocriter craf= $\int a$, rugof $a$, dura, ligno $a{ }^{\prime} \dot{q}_{;}$, qux foris nigrd eft, intus ueró fubui= ridis, Ea guftu admodum acris deprebenditur, ac mordax, fuba= 


\section{InLib. tertium Diofcoridis.}

mard, o odorata. Ex quo non temeré aliquis conijcere poteft, Imperatoris radicenn cxcalfacere tertio exceffu cö pleto, uel quarto inchoante: ficcare ueró fecundo. Difcutit bac nirifice tum uentriculi, tum inteftinorum, tum etiä uteriflatus. Quapropter colicruciatibus ac uentriculi torminibus maxime utilis eft. Cit itcm men fes, at f; urinan. Fouentur eits decocto utiliter in dolore dentes, prefertint fin uino auftero radix decoquatur. Eıdem ex uino pota uteriftrangulationibus prodeft. conceptum adiuuat, quem frigiditas intercipit: concoctionem roborat. Commanfa eft ueluti praftantipinus apophlegmatifnus, ut qux cfficaciter cerebri pituitan expurget. In pulucren ccnirita,

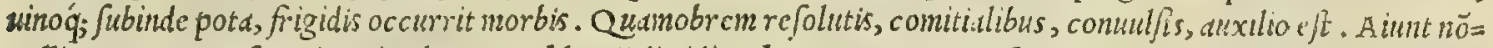
nulli quartana cos fanuri, qui pulueris cochlearij dimidiun bora una ante acceßioncm, ex incrobbcrint. Oris hali= tum commendat, $\mathcal{O}$ omes roborat fenfus. Epidemijs morbis, ucnenis ferć omnibus, ac uenenofor um animalium tuins

10 morfibus, tum idtibus opem preftat. Afthmaticos, feu anbelofos unat, obftructiones aperit, aqua intercute laboran=

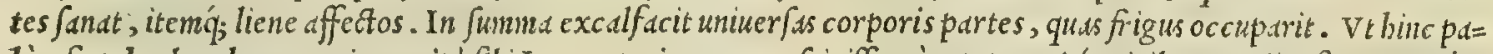

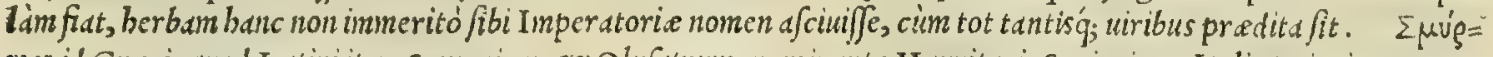
vov id Greci, quod Latini item Smyrnum, ON Oluatrum, nominant: Mauritani, Scniruion: Itali, Smirnio, $\mathrm{Or}$ Ma= cerone : Hifpani, Apio Macedonico.

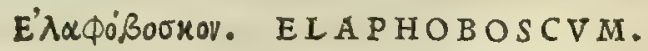

\section{CAP. LXVI。}

20

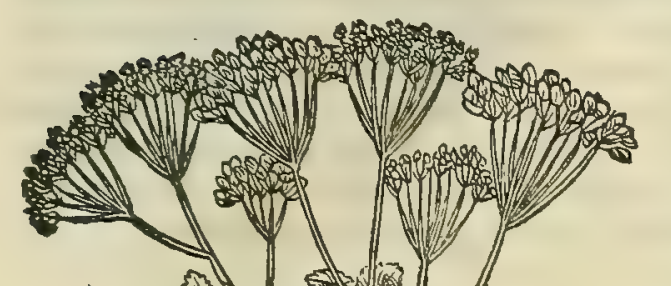

30

40

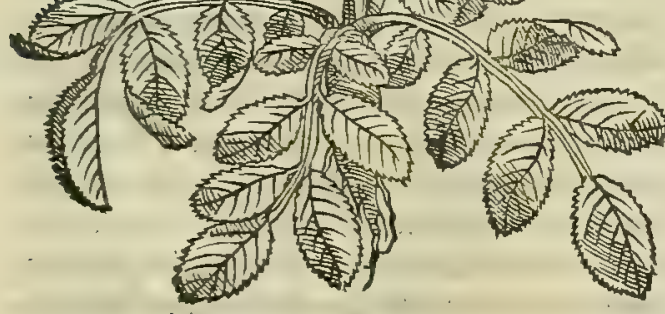

E L A P H O В O S C O foeniculaceus caulis eft, aut rorimarino frmilis, geniculatus : folijs duûm digitorum latitudine, vt terebinthi, prælongis, aliquantum afperis, circumfractis. Adnata multa habet, ferentia vm bellas anethi fimiles, \& femina eiufdem : florem fubluteum : radice ternûm digitorum longitudinis, \& $\&$ craffitudinis vnius, candida, dulci, efui apta . Caulis tener: pro olere manditur. Contra ferpentium ictus, datur femen in vino. Fama autem eft, hoc pabulo ceruas ferpentium morfibus refiftere.

QV A N QV A M aliqui profitentur, fe Elaphobofcumin Italia inreniffe, atq; etiam quibufdam in bortis oftendere; berba. Elaphoborci tamen, quam pro eo demonftrant, folia profert incifuris multis diuifa, leviaq́;. Adeó ut hinc perpicué intelligi poßit,edm à le= gitimo Elaphobofco plurimim dißidere, $/ f$ Diofcoridi magis, quàm Plinio fides eft adbibenda. Plinius fiquidem libro, or cap. X X I I. Elaphobofcum folijs fmyrnï, e femine corymbaceo de $=$ pinxit bis uerbis. Elaphobofcum ferulaceum eft, geniculatum. digiti craßitudine: :emine corymbis dependětibus, fimili effigie, fed non amaris: folijs olufatri. or hoc laudatum in cibis. bec Plinius. In quibus uerbis, quód ea plané à Diofcoride diffentiăt, Manardus Ferrarienfis Plinij codicem depraudtum effe exift $i=$ mat. Ceterum Ruellius tradit Elaphobofcum legitimü pau= Ruellij opin cis hodie cognofci, etfifrequens ubiq; reperiatur, illud'q; effe c fet, quod uulgó officinis fimul od berbarijs. Gratia dei nomina= tur, é qua fui nominis unguentum conficiunt: Sed hanc Ruellij fententiam non admittendain, quin potius explodendam putaue $=$ rim, fiper Gratiam dei eam plantam intelligit; de qua nos fupe= rius differuimus in by fopi commentatione, er qua officine utuntur. Quippe quód baec caule, 0 . folijs by fopo fit per= fimilis, non autem foniculo, ac terebintbo. Quamobrem aut aliam in Gallia plantam effe eodem nomine appellatam, aut Ruellium omnino deceptum exiftinauerim. Ip $\int e$ equidem berbam quandam fapius uidi, tum in Tridentino, tum 50 in Goritienfí agro, cuius etiam bic pitturam damus, que ita notis omnibus Elaphobofco refpondet, ut non potuerit a= nimus non inclinariad credendum, banc legitinum effe Elaphobofcum. Paucis admodum Elaphobofci facultates perftrinxit Galenus libro v. I. fimplicium medicamentorum, fic inquiens. Elaphobofcus facultatis eft calide, ev te=

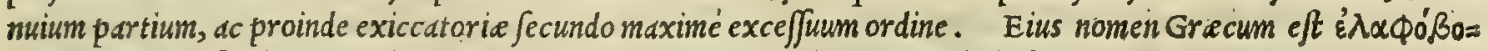
oxov: Latinum fimiliter Elapbobofcum, or Cerui ocellum: Italicum, Elaphobofco.

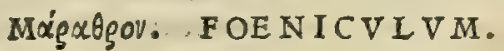

CAP: IXVII.

F OE N I C V I V M, fi herba edatur, aut femen cum ptifana bibatur, mammas lacte replet. Comæ decoctum in renum doloribus fubditum proficit, quippe quod vrinam excitet.contra ferpentium ictus in uino conuenienter bibitur : menfes ciet. in febribus naufeam, \& ftomachi feruorem ex aqua frigida potum fedat . Contritæ radices, \& cum melle illitæ, morfibus canum medentur. Succus cau- 
F OE N I C $I V M$.

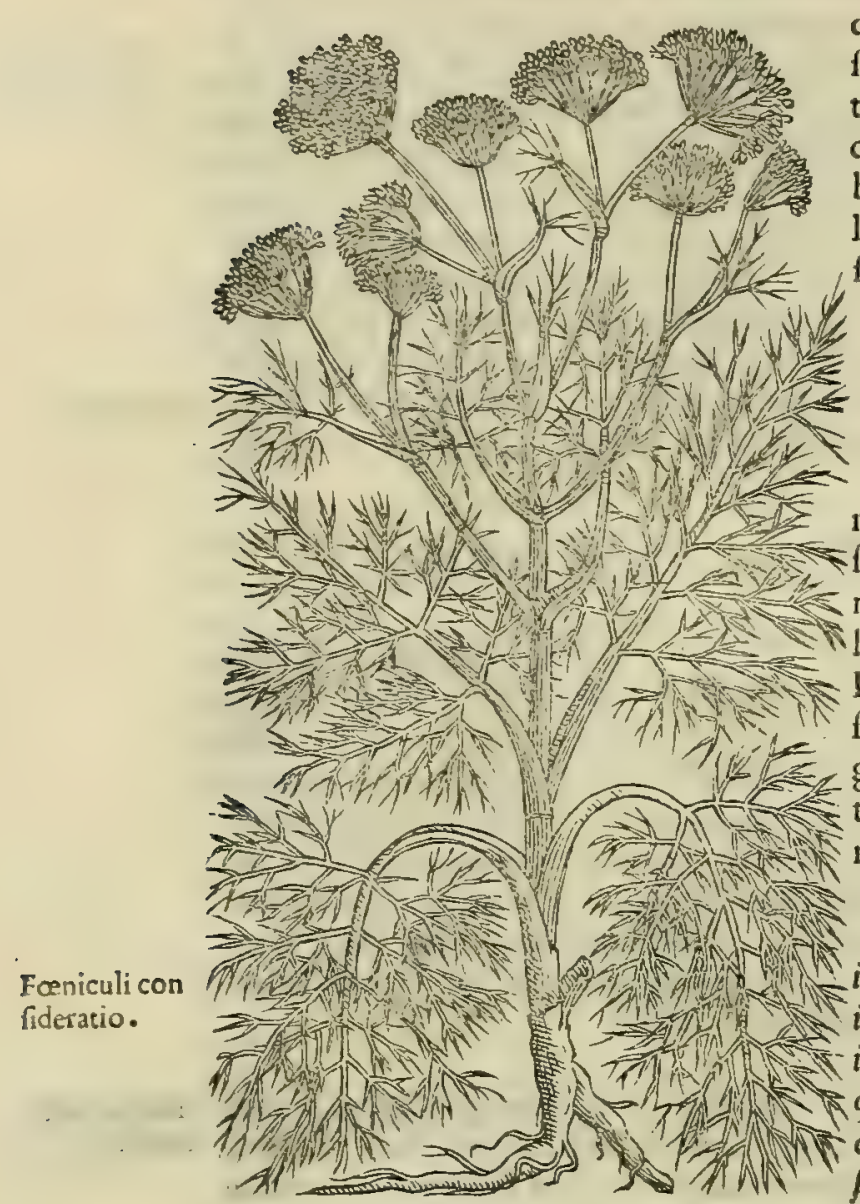

le, \& folijs exprimitur, \& in fole frccatus, in medicamenta adijcitur, quæ ad excitandam oculorum aciem commodè temperantur. Extrahitur fuccus ad eadem ualens,etiam femine uiridi, ramulisq́ue, \& radicibus prima germinatione incifis. In Iberia, qux ad occidentem fpectat, fuccum reddit gummi fimilem. Caulem medium, dum herba floret, ruftici demetunt, igniqúue admouent, quò facilius ui caloris exudans, gummi remittat : quod efficacius fucco eft, ad medicamenta oculorum.

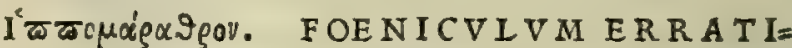 CVM. CAP. LXVIII.}

Es $\mathrm{T}$ \& fylueftre fœniculum, magnum : fert autem fe men cachryi fimile. Cuius radix iucundè olet, potaq́ue ftranguriæ medetur : méfes impolita ciet. Ventrem fiftit, radice, aut femine poto : contra ferpentium morfus auxiliatur, calculos comminuit, regium morbum expurgat. Lactis abundantiam facit, decoctum foliorum haufum: forminas à partu purgat. Traditur aliud hippomarathri 20 genus, longo, cxili, $\$$ angufto fclio: femine coriandri, rotundo, acri, odorato. Excalfaciendi naturam habet,\& uiribus foniculo refpondet, fed ad omnia in firmius.

F OE N.I C V L V M tam erraticum, quìn fatiuumomnibus in Hetruria notum eft. Seritur domefticum Februario menfe uere ineunte, locis apricis, o modicé faxofis . quippe quod non minus in ciborum condomentis guftui acuta quadam dulcedine placest, quìm utile fit in medic amentis. Faniculi meminit Plinus lib. $\mathrm{x} x$. cap. X X I I I. fic inquiens. Foeniculum nobilitauere ferpentes, gu=: 39 ftatu fenectam exuendo, oculorumí; aciem fucco eius reficiendo. Vinde intellectum eft, bominum quoq; caliginem precipué co releuari. Colligitur boc caule turgefcente. In fole fic= catur, inungitur q, ex melle. vbiq; boc eft : laudatißimum tamen in Iberia e lacrymis fit, ev ex fcmine recenti. Fit e= tiam é radicibus prima germinatione incifis. Eft e in boc genere fylueftre, quod alij Hippomaratbron, alij $\mathrm{Myr} / \mathrm{i=}$ neum uocant, folijs maioribus, guftu acriore, procerius, brachiali craßitudine, radice candida. nafcitur in calidis,

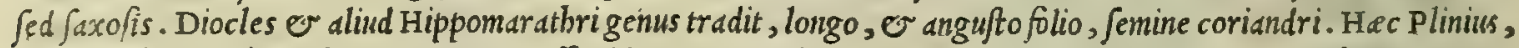
qui en ferè omnia à Diofcoride mutuatus effe uidetur. Porró alterum Jylueftris Fœniculigenus, cuius femen corian= Foniculi ul - dri efiggien refert, à nemine bactenus, quod fciam, in Italia cognofcitur, of oftenditur. Faniculum, ut memorie res ex Gal. prodidit Galenus libro vi I. Fimplicium medicamentorum, tam ualenter excalfacit, ut ex tertio ordine excalfacien= tium cen $\int e r i$ poßit. Deficcat ueró non equé, Jed ipfum quipiam in hoc prami effe ordinis pofuerit : proinde lac pro $=4^{\circ}$ creat. quodfi admodum deficcaret, non fane generaret. Suffufis eadem ratione auxiliatur. Vrinas, men fes q́; ciet. Eft $\mathbb{O}$ alterum Freniculum fylueftre, quod pra magnitudine bippomar athrum nuncupart, cuius radix ac femen am= plius quàm domeftici, deficcandi uin obtinet . quocirca uentrem quoq; eo nomine fiftere uidetur. Nec $\int a n e ́$ manifrfta illis ineft adstrittio. Huius non radix modó; ;ed or multó magis femen cacbryi adfimile eft : poteft'; $\sigma$ calculos fran gere, er auriginofos fanare, men $\int e s g_{;}$; mouere, or urinam excitare : non tamen lac congerere, ficut illud fuperius. Aliud eft Hippomar athrum, cuius femen rotundum eft, $\mathrm{E}$ acre, fimile femini coriandri, facultate quidem hippoma=

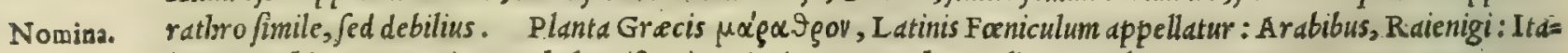
lis, Finocchio: Germinis, Fenchel: Hipanis, Hinoio, $\mathcal{F}$ Funcho: Gallis, Fenoil.

\section{$\triangle$ xи̃นоร. DAVCVM.}

\section{CAP. LXIX.}

D s v C v m aliqui daucium vocant. Creticum folijs foniculo fimile, minoribus ; tenuioribus: caule dodrautali, vmbella coriandri, flore albo: femine acri, candido, hirfuto, fuauifsimi odoris in mandendo. Radix digitali crafsitudine, \& dodrantis longitudine adolefcit. In faxofis nafcitur, $\&$ locis fole illuftratis. Aliud eius genus, fyluctri apio fimile, acre, odoratum, aroma olens, feruentis guftus. Probatifsimum Creticum. Tertium afsignatur genus folijs coriandri, floribus albis, capite, \& femine anethi, mufcario paftinac $:$ femine oblongo, ceu cumini, acri. Omnium femen excalfacit potum urinam, menfes, \& partus extrahit : torminibus liberat : veterem tuffim mitigat . phalangiorum morfibus potú in uino, auxiliatur : tumores illitu difcutit. Seminis duntaxat in alijs generibus inualuit ufus : in Cretico ctiam radicis, qux maximè contra venenatorum injuriam in uino bibitur. 
DA VCVM.

10

20.

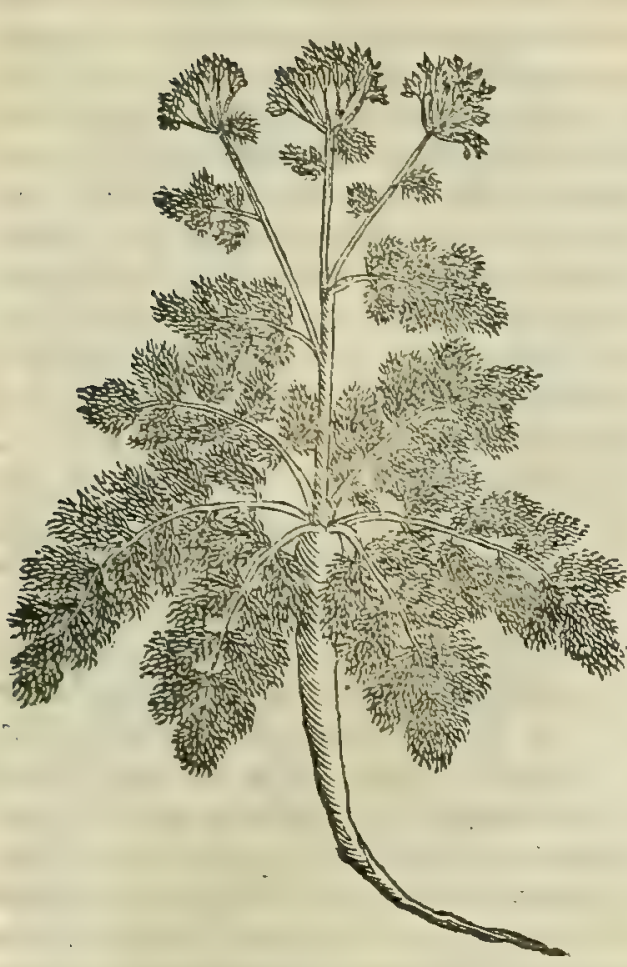

T A M E I S I nonnulli inucniantur plantarum cxplorato= res, qui Daucum ab erratica pastinaca nibil prorfus differre con= tendant, affirmantes, boc idem fenfiffe Galcnum, of poft ipfum $P$ aulum; ij tamen, quantunz equidem $\int_{c}$ ntio, matnififte falli depre benduntur. Nam etfi recte dici poßit, D.uncum effe fyluc/tr is pd= Pinace genus; non ob id tamen illa, inco iudicio, fucrit unquam fylucftris paftinaca, cuius pauló Juperius meminit Diofcorides.

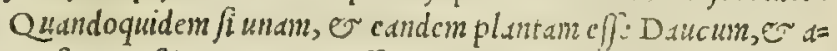
greftem paftinacam credidiffet Diofcorides, de iss fane feorfum non differuiffet, neq; alterum ab altera propiys capitibus difiun= xiffet. Ceterim cum non defint, quibus uideatur Galenus inter bas plantas nullam facere differentiam, uidendum $\mathrm{c} f$, an ita fe res babeat. Mihi quidem inter eas difcrimen fieri uoluiffe Galenum, illud maximun drgumentum eft, quod Diof foridem fecutus, or ipfe uarias utrisq́; tribuerit uires, edsq́; diuerfis locis de fcripferit. Dauci fiquidem libro v I. Paftinace ueró lib. V I I I. mentionem ficit in fimplicium cen $\int u$. Hinc itaq; fit, ut aperté conigcidm, Gd= lenum inter illa difcrimen noviffe: atq; cos decipi,qui in boc Mar cellum, or Ruellium fecuti, contrartum affermnt. Quorï pres terea fententiam, ipfius Galeni tcftimonio, facilé explodi poffe putaucrim, nec folim quód diuerfis capitibus utriusq; urres pee= ciatim tractauerit; fed quia libro vi. fimplicium medic amento= rum, Daucum non effe paftinacam clarißiné oftendit, cum in= quit. Daucus, quem quidain ftapbylinum nominant, agreftis qui= dem domeftico minus eft efuidoneus. In quibus fanc uerbis $\mathrm{G} d=$ lenus perfpicué fatis declarare uidetur, Daucum nö fibi, fed alijs paftinacam agreftem appellari. Quxmobrem cum Diofcoride non modó dixerim; fed etiam affirmauerim tria Dauci gener inueniri. quorum illud Italis frequentius eft, quod fylueftrem paftinacam emulatur. Hoc enim in Scnenfi agro, prefertim in maritimis, frequentipinum nafcitur. Creticun autem legitimum ex Creta tantim affcrri exiftimaue= 10 rim. Porró D.ucus, qui coriardri folijs prouenit, e femine cumino fimili, in qudin plurimis etian Italia loc is repe= ritur. Dauci uires tradidit Galenus lib. v r. fimplicium medicamentorum fuprd citato, ubi ita fcribit. Daucus, quĕ quidam ftaphylinum nuncupant, agreftis quidem domeftico minus eft efui idoneus, caterim in ommibus uebementior. At domefticus comeftilis quidem, fed iwabecillior. Acrem, or calefaciendifacultatem obtinet, ac proinde etiam ex= tenuandi. Certé radix preter ium comprebenfa flatuofum quiddam obtinet, ac uenereum. Semen autem domeftici

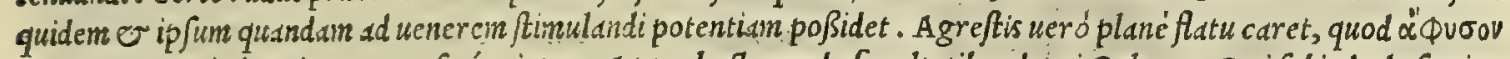
socant: ac proinde urinan, menfes q́; cict. Atque bactenus de facultatibus dauci Galenus. Qui fubinde de femiue ciufdem fcrip/it, eiq́; feorfum uires fus r reddidit bis uerbis. Dauci herb.e femen excalfaciendi uebementer facultatem babet, ut inter prima efficax fit Lum urine nzouende medic amen, tum menfibus prouoc andis. Multum etian digerere perbalitum poteft, foris impofitum. Ip $\int a$ ucró berba fimilem quidem uim obtinct, tamen femine infirmiorem, ni=

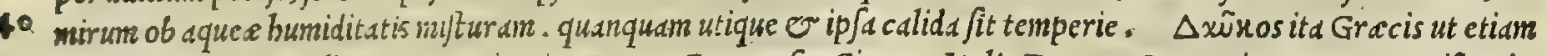
Daucus Latinis appellatur : Maritanis, Ducu, Gezar, feu Ciezar : Italls, Dakco: Germanis, Beruurtz: Hifpanis, Dauco Cretico: Gallis, Carote Jaurages.

\section{$\triangle E \lambda$ Fivior. DEI PHINIVM.}

\section{CAP. LXX.}

D E I F I N I V M furculos emittit à radice una fefquipedales, aut maiores : à quibus folia exeút parua, tenuia, diuifa, pralonga, qua delphinorum effigiem repræfentant: unde tractum nomen eft. Flos uiolx albx non difsimilis, purpureus : \& femen in filiquis, milio proximum : quo non aliud utilius bibi potef, ab fcorpione percufsis. Aiunt enim obiedta herba, fcorpiones refolui, atque ignaso uos torpefcere: femota uerò ea, fefe recolligere. Prouenit in afperis, \& apricis. Alterum eft delphi nium, quod Romani buccinum uocant, fuperiori fimile, fed folijs, \& ramis longè gracilius . Viribus eifdem pollet, fed non ita cfficacibus.

QV A N QV A M fcribit Ruellius, herbam in Gallia nafci, cui rura nullum adhuc nomen impofuerunt, que om= nibus prorfus notis Delphinio repondet; in Italia tamen nemo battenus, quod fciam, legitimum oftendit. Ex quo tantum abeft, ut putauerim unqudin, illud Ruellij uerum ac legitimum fuiffe Delphinium, ut etian fim plerunque fu= Ppicatus, hoc Delphinij caput in Diofcoride fpurium ac afcititium effe. Nec temeré, ut arbitror : nam fupicio inde ortum fum habuit, quód Delphinium nufquam, quantum equidem legerim, defcribatur à Galeno, Oribafio, , Paulo : cuin tamen borum alius biftoriam, alius uires plätarum ex Diofcoride bona fide in fuo quifq; fimplicium cenfu referat. Ceterum non defunt etiam qui uelint, eam plantam Delphinium effe, quam Germani uulgó uocant Ritter porn, id eft, Equitis calcar, herbariorum ueró uulgus Confolidam regalem: quam nos inter fjlueftris Cuminige=
Dauci confideracio.

Quorundam error.

Dauci uires ex Galeno.

Nomina.

Delphinijcófideratio.

Quorundam opiniones re probaca. 
ner s uperius retulimus. Verum cum hec unum tantion emittat d̀ radice caulem, non auten plures furculos; folia non ferat delphinorum effigie, nec flores alba uiole enulos, horum fententiam cur probem, non babco. Fuch, fius etatis noftre medicus preftanti cruditione o rerum peritia, antediforum opinionem fequitur in libro de compos nendorum medic amentorum ratione, quem iam recens locupletatum excudit. Sed ip $\int e$ quoque ( $f$ ref́té fentio) und cum illis in errore uerfatur . quandoquidem non foluin ( $u$ dixiseus) nufquam, quod ego inuenerim, Delphinij me= minerunt illi preftantifsimi medicinx authores, quos nominaui, qui tamen fimplicia ex Diofcoride tranfcribunt, es mutuantur; $\int e d$ neque etiam eius caput legitur in antiquißino Diofcoridis codice Longobardis literis fcripto, cuius fepe fidem citat $\sim$ probat Marcellus Virgilius, ut mibi licuit uidere in co, cuius copiam mibifecit Vienna clarif fimus iurifconfultus Ioannes Albertus Vuidman/tadus A uftriac orientalis cancellarius. Quod certé maniffto fatis argumento effe poteft, Delphinij hiftoriam plane fabulofam effe, uel faltem Diofcoridi adfcriptam er tllegitimam. Non defuere preterea, qui Senam Mauritanis uocatam, filiquarum conuexitate freti, or decepti, Delpbinium effecrediderint. Quorum grauis error ita euidens eft, ut iam ab omnibus cxplodatur. Id j; non iniuris, quod in Delphinio (demus eius caput legitimum effe) folda, non filique, que delphinorum formam reprefentent, requiran= tur :foliág; fint tenuia, longa, diuifa :flores ueró purpurci: $\widetilde{J}$ tota denique Delphinij facies ea depingatur, que cum sena quàm maximé pugnet, ut mox patebit. Nam quoniam Dclphinij occafione in Sene fermonem incidimus, cum buius nufquam, quod inuenerim, meminerint Diofcorides, Galenus, Paulus, o ueterum Gracorum alij, fit = que in repurgandis humoribus non modo innoxium, fed etiam funmé utile medicannentum, bunc locum non tranfe= undum duximus, quin de sena differamus, eiusó; hiftoriam, or uires cüm ex alijs, tum ex eo quod nobis compertum Senæ delinea- eft, defcribamus. Conftat itaq; s. N A, Mauritano nomine dicta, folijs glycyrrbiza craßis, fuppinguibus, fa= tio.

barum fapore : caulc cubitali, d quo ramuli exeunt in lorimodum flexiles. Floresci emicant aurei, uelutibraßic $x$,

$S E N A$. purpureis intercurfantibus utrulis: quibus fuccedunt folliculi falcati, adeog; natura compreßi, ut fuperior membrana inferio=

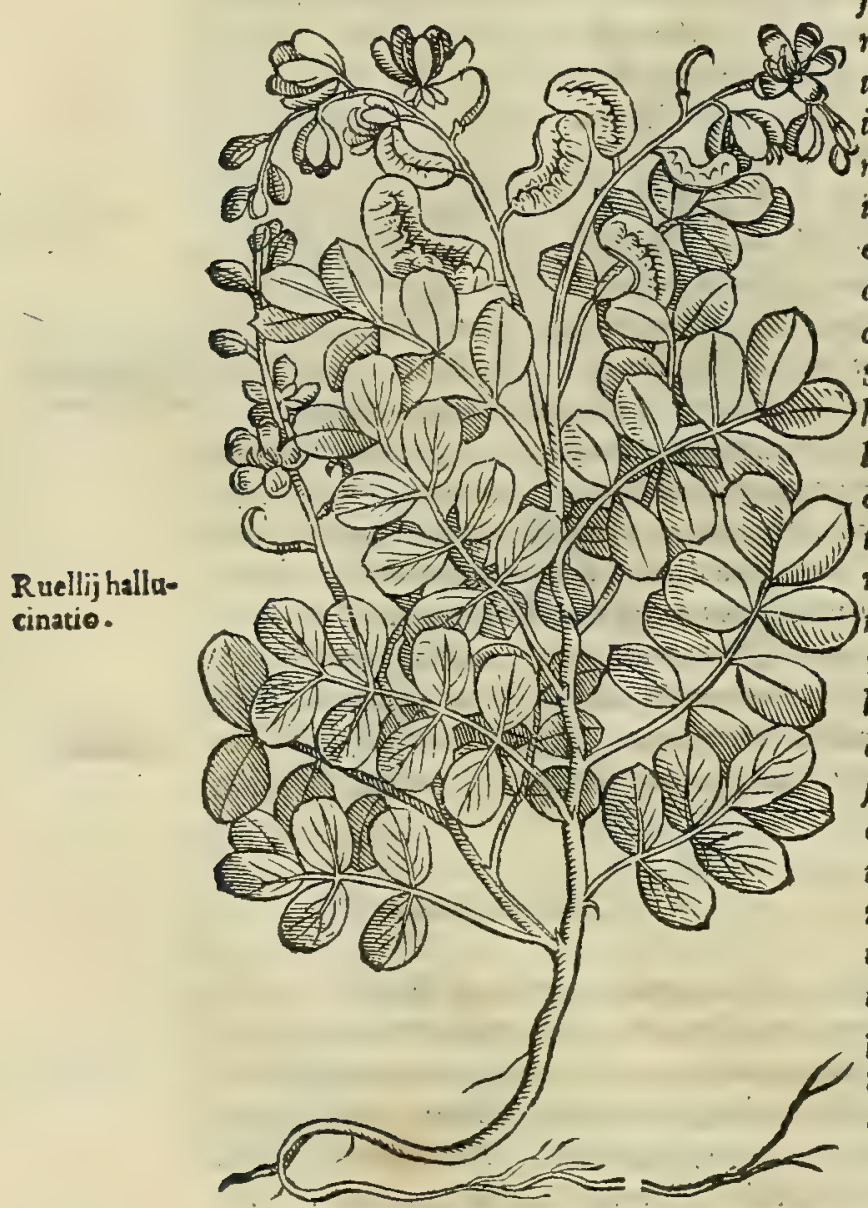
ri coblereat : in quibus femen continetur in nigro fubsirefcens, unarum uinace is ufqueadeo fimile, ut non facilé primo oculorum intuitu alterum ab altero difcernatur. Folliculi é rainufcul is pros minent, tenui pediculo appenfi. quo fit, ut maturefcentes, par= uo inentorim flatu facile decutiantur. Planta eft frigoris impati= ens . ob id q́; feri ualt maio, nec ultrd autumnum perdurat . Siqui= dem (ut pluries expertus fum) prius fata, facilé frigore deper= ditur ; ferius ueró byemem fimiliter non tolerat. Meminit sene. serapio in fuo de fimplicium medicamentorum uolumine, ubi fic babet ex auctoritate Abobanifa. Sena aferuatur ficca, filiquas. lunatas, ob oblongas profirt: in quibus femina in ordinem digefta ctauduritur. siliqux tenui pediculo pendent: ob idq́; facilè uen= torumi impetu deturbantur. Caducas opiliones colligunt . bec Serapio. Cuius poftremis uerbis fortaffe deceptus $\mathbf{R}$ uellius, se. nam cam effe arborem exiftimauit, quă Theopbraftus Tib.I I I. ca. $\mathrm{x}$ vi i. de plantarum biftoria Coluteam appellat . quandoquidem bec antiquis paftoribus fuit faginand is ouibus expetita. Vnde fat cile Ruellius, qui nunquam forfitan in Hetruria fuerat, ubi paf 40 fim legitina Sena feritur, prefertin in Florentino agro, magno errore putauit, senam non herbam effe, fed arborem Coluteam uocatam, ratus eafdem plantas effe. Sed cius error hinc pretea. rea apertifimé diluitur, quód coluteà filiquas proferat colore in purpuram primùm uergentes, mox albicantes, flatu turgens tes, que fi premantur, crepitum magnum edunt: femine intus paruo, rotundo, lentis effigie. Sena ueró filiquatur folliculis lu= natis, qui nullo feritu tumido diftenduntur; quibus femen inclu= ditur iuinacedrum inftar. Adde etiam, quód Coluted arbor fit mul tis perdurans annis, sena ueró non nifi paucis menfibas uiuat. Quofit, ut iam omnibus palim fit, Ruellium hac in re maniffete cecutiuiffe, ov inter senam, o Coluteam non paruam intercedere differcntian. It quanuis afferat $\mathrm{Fuch}$ fius in fuis de plantarum biftoria commentarijs, bas plantas facultate inter fe minimé differre; eum tamen in errore uer. Colutez, \& fari putauerim, quód certó fciam colute femen non minus, quàmgenifse uomitiones ciere. C O I V T E A, Colytę̨ mé- ut de ed quoq; bic aliquid dicamus, Theophrafto auCtore loco paulo anté citato, Lipar. propris traditur arbos ma= tio. gnitudine preftans, fructum in filiqua ferens, magnitidine lentis, quo oues inirum in mcdum pinguc cunt. Nafcitur femine, er fimo precipue ouillo. Tempus ferendi cim Arcturus occidit. Serendum femine pra'madef ftcto, cum iam in aqua pullulare inceperit. Folium babet non abfimile freno greco. Germinat primo unicaulis, triennio maxis mé: fpargitur deinde in ramos, quarto क्; anno arborefcit. hec Theophraftus. Ex quibus fané uerbis liquidà appd= ret, quam maximé d Coluted differat Sena. Fucbfits er medicine, o Graci fermonis peritijimus, plantam hanc non Colyteam, $\int e d$ Coluteam dे fuo fe errore uindicans, appellandam cenfuit. Et recte quidem, meo iudicio . nam 


\section{In Lib. tertium Diolcoridis.}

COLVTEA.

10

so

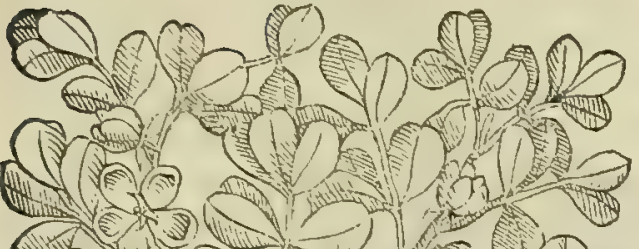

30

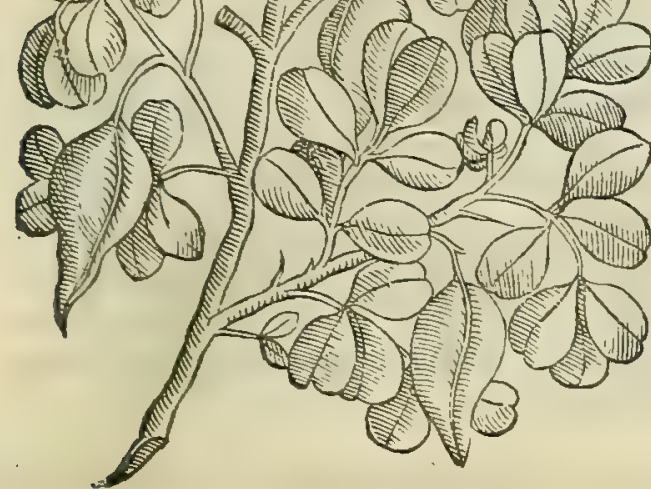

Colytea longé alia eft ab illa, Theophrafto tefte loco modó cita= to ubi eam ijs depingit uerbis. Arbor circd Idam prouenicns, quans CO L Y T E A M Hocant, genus aliud eft. Eft autch frutico $\sqrt{a}$, ramo $\int_{a}$, alo $\int_{a}$, inuentu rara, non crcbra: folio laturino, lauri latifolix, fed rotnndiori, amplioriq́; , ut uel wineo finile ap= pareat, oblongius tamen, colore parte alteraberbido, tergo au= tem albido, nerwofo q́; : cortice non leui, fed quafi uitigineo : ras dicibus per fumma gracilibus, o folutis, uerum ubratis, o ad= modum flavis. Fructu, flore ơ; carere putatur. Ex his Theophras= ftiuer bis perpicuum eft, Colyteam à Colutea plurimuim differre. Que tamen et/i. Theopbrafti a uo Lipare peculiaris fuerit; boc tamen tempore pluribus in locis ponte natam uidimus, prefer= tumq; in Tridentino agro apud Ananios, ubi ego primum eã quìm plurimis oftendi. Sed ut ed, unde digreffa eft, iam noftra redeat Mefuis, \& Bre oratio, credidit Mefues sene folliculos in deijcicnda aluo folijs lö= fauoli lapfus. gé preftantiores effe. Huic ueró reclamat non folum Manardus Ferrarien is uir doctisimus; fed etiam diuturna medicorum expe rientid: et/i Brafauolus, qui Me fuem tueri uidetur, contrarium putet. Ceterisin ne quis ex altercationibus confundatur, dicam ingenue quid bac in re fentio, nec quicquam ab eo recedam, quod experimento pluries comprobaui. Sciendun igitur eft, Sene fol $=$ liculos, qui ficcati afferuantur, duinin effe generum: alkerum per fe caducum, et in planta are factum, à quo femen eximunt, nigrum, er prorfus euanidum: alterum ueró, quod ante maturitatem dea metitur, crafjum, ponderofum, fucco pregnans, er tegetibus $\mathrm{ex}=$ panfum in umbra ficcatur, fed hoc uenundatu rarum. Cui fané, ut iam millies periculun fecimus, non minor deiectoria uis ineft, quadm folijs. Primum ueró genus, quo Venetijs omnes ferè officitie $\int c d=$ tent, non modò minorem buiujmodi uim babet; fed propé nullam. VE bint plané rolligere liceat, $\mathrm{Me}$ fuem bic non effe fine limitatio= ne damnandum : quandoquidem is, ut arbitror, de folliculis decer= ptis intelligat, non autem de caducis, quibus tantùm utuntur ij, qui Mefui falsó reclamant. In quorumz numero ego quoq; quandoq; fui. uerum cum poftea integrun sena campum feuiffem, ut folliculos decerptos uirentes, of fucco pregnantes, mox ficcatos experirer, rem aliter facto periculo fe habere facile comperi. Quiare noftro exemplo, qui folliculis uti uoluerint, senane ferant, ut folliculos optimos liabeant, wel faltem probatifimos emant, fit tamen eiufmodi reperiri poterunt: fin minus folijs tutius, or efficacius utantur. Obeft Sena (ut idem Mefues inquit) nonnibil uen=

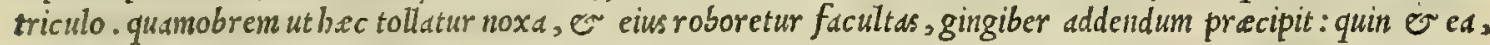
que cor, e uentriculum corroborant. Veruntamen non defunt, qui banc reprobent fententiam: quód deguftatis se ne folijs, aliquid adfrittionis, nonnibil ficcitatis, atque etiam tantillum amaritudinis perceperint . qua omnia potius

40 Senan roborare uentriculum indic ant, quàm ip sum perturbare, ac ïbecillum reddere. In quorun fententiam ego quoque pedibus eo : nam et $\sqrt{2}$ quibufdam, pre ertimó, mulieribus, quandoque contingat, ut epoto sene diluto, eorum inteftina torminibus uexentur, id nunquam ex Sene facultate prouenire exiftimaui, sed ex craßis, pituitofisó; excre= mentis, ab hoc pharmaco eo impulfis, qua fua crafitie inteftinorum meatus adeo replent, ut in eis non paruam ex= tenfionem faciant, dum uiam ad exitum querunt. Neque tamen me unqquam aliquem inueniffe memini, qui diceret $f e$ epota Send, uentriculi dolore laboraffe. Proinde Actuarius, qui folus, quantume extat, inter Gracos sena uires de= fcripfit, Senam citra noxam bilem, er pituitan deijcere memorie mandauit. Id quod non fine erube fcentia filere coë git quendam Pbilippum de Set medicum, qui (nifallor) ut fuam potius tueretur fententiam, quàm ueritatem, phar= masum quoddam improbaluerat ex Sene diluto, rhab.rbaro, atque ag arico conflatum, quod cuidam Illuftriß. ac Rex uerendiß.Cardinalis, ac Principis Tridentini nepoti in quadam quotidiana ficbre dederat clarißimus medicus Andreds

so Gallus Tridentinus. Is autem pharmacum illud damnandum effe cenfebat, quoniam sene dilutum, agaricum q́; exci= piebat, argumento quod hae duo (ut ip fe afferebat) maximé uentriculum laderent, immemar, ne dicam ignarus,quan tum preftantix, ac uirium agarico tribuerint in febribus diuturnis finiendis, à pituite prefertim infarctu exortis, Dio= fcorides, Galenus, Or Mefues, quantisq́; laudibus senam extulerit ACtuarius. Caterum é Sena, ea magis preftat, Sene, \& eiüs qux ex Alexandria A gypti, uel ex syria affertur, quanuis é noftrate adbuc in agro uirente, or rofarum diluto ego diluti uires. quotannis syrupum parare confueverin .qui tutó, largéq; omnes purgat bumores. Daturq́; commodé pragnanti= bus, e pueris,et cuiufcunq; atatis hominibus. Dilutü tamen magis preftat, quàm decoctum, quód nulld ex parte exha let: cuius uncis quinq, wel fex aluum modeftißine , o fine maleftia foluunt. Quód tutó dari poßit pregnantibus, o pueris, experientis docuit, cui fub fcribit Actudrius, qui senam citra noxam purgare tradidit. Redditur medicd= mentum hoc in deijcienda aluo preftantius, atque ualentius, fi caßi.e nigre, aut manne, aut rhabarbaro, aut ro $\int=$ rum diluto, aut rhodopharmaco, quod officine syrupum rofatum folutiuum uocant, commifceatur, aut fi maceretur Sena caprino fero. Preftantißimum dilutum boc modo paratur. Sumuntur folionum electißime sene drachme

$$
M=\int e x_{2}
$$


fex, gingiberis, aut cinnamomi contritidrachma una, florum bugloßi draclomx dux : mifcenturq́; omnia, er fittili uitro circumlito, fiuc ftagneo uafe anguftiorificij excipiuntur, et affufis ferucnt is aqua, aut feri caprini uncijs decem, uafis of culum adeo occluditur, ut nullus penttus pirandi pateat extus. His peract is puluinariplumis anferinis farcto, igniq́; cale facto uas inuoluitur, reponitur'q; ir arca, ubi pernoctare finitur. Sic enim conferuato calore dilutum omne facultatesn in fe recipit. Sunt pretcrea, qui uindemixe tempore sena folia in mufum conijciant, uinum inde confici= Senx uiresex entes, quod alui dciectorian uim obtinet. Educit Senaper inferna (ut Mefues teftatur) bilem tum atram, tumfla= Mel.\& Serap. uam, $\mathcal{E}$ (ut Actuarius ait) non bilem tantim, fed etiam pituitam : quod fané experientia comprobatur. Mundat Sena cerebrum,cor, tecur, licnem, pulmonem, o omnes corporis fenfus, confert $\dot{\text {; }}$ omnibus eorum incommodis. Vifcerum obftruftiones apcrit, alget iuuentutem, feniumq; retardat, e animibilaritatem affert. Folia in capitis perfufioni= bus utiliter decoquuntur, pr.certin addita anthemide. Roborat enim boc modo cerebrum, neruos, oculorum aciem, o auditoriam facultaten. Optima demum in uniuerfum eft medicina morbis omnibus diuturnis, or melancholicis. Quamobrem Serapio, sena, inquit, mirifice prodeft delirio, amentia, fcifjuris totius corporis, re folutioni neruo=

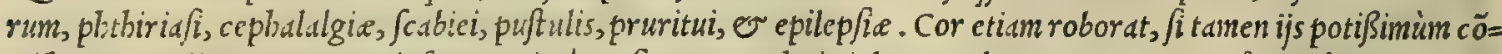

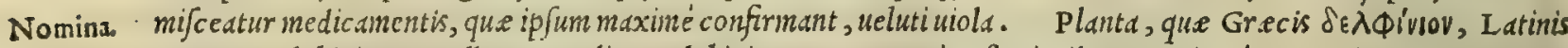
quoque Delphinium appellatur: Italis, Delphinio. Que ucró pofterioribus Gracis oéva, Latinis item Sena uo= catur: Arabibus, Sene : Italis, Sena: Germanis, senet: Hipanis, Sende Alexandria.

חuģér

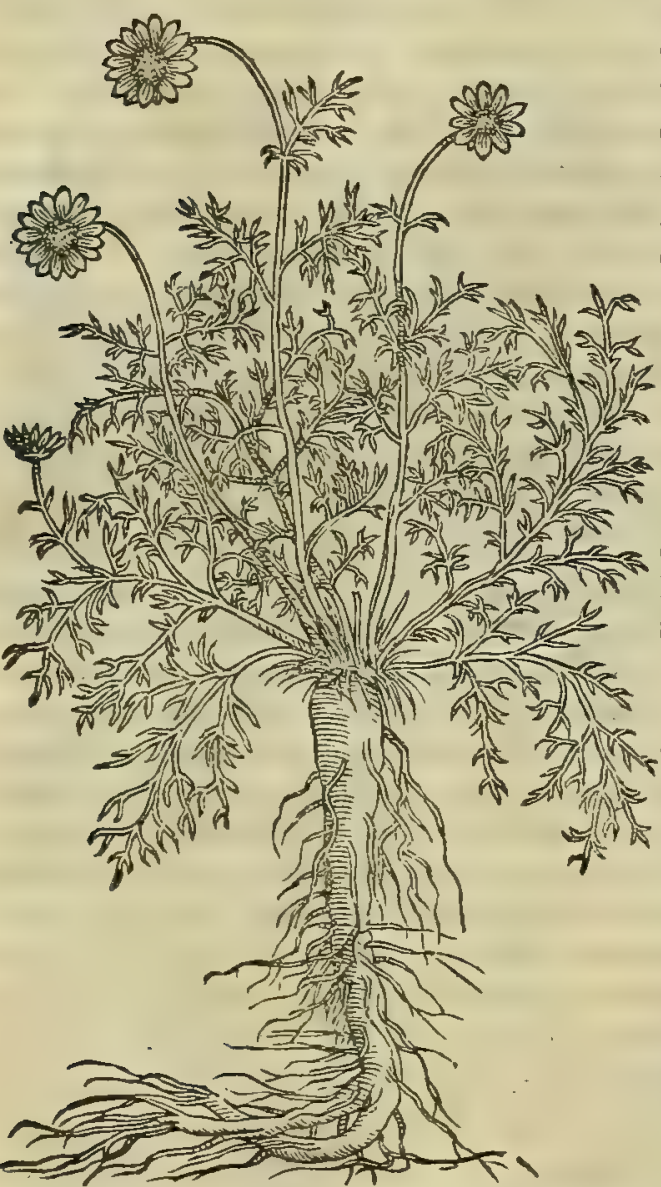

Py R E T H R V M Romani faliuarem uocant. Folia, caulemque emittit,ut daucum fylueftre, \& foniculum : vmbellamq́; anethi, circinatx rotunditatis . radix longa eft, pollicis crafsitudine, guftu feruidifsimo. Pituitam elicit : ideo in dolore dentium, decoeta in aceto, colluto inde ore, auxiliatur : manfa pituitam extrahit : Sudores ciet, peruncto ex oleo corpore: diuturnis horroribus efficax. contra perfrictiones membrorum, refolutionesq́ue eximiè conducit.

P Y R E T H R I radix officinis omnibus cft notd, in frequé tiq;; uJu habetur, prefertim in dentium cruciatibus. Nafcitur Pyrethrum in quibufdam quidem I talix montibus, $\int e d$ non. adeo acre, ut quod ex Orientalibus regionibus. Venetids aduebitur. Huius plantis vidi primùm ego in Baufano Tirolenfium emporio in bortulo quodam Blasij sbaicher medici in fimplicium faculta= te peritifimi, qux folijs, caule, radicéó; nullis difcrepantibus no= tis Diof coridis Pyretbrum referebant: Veruntamen noritlis $e=$ rant umbell e anctho fimiles, quales Pyrethro reddidit Diof $c 0=$ rides, fed potius flores anthemidis modo ppectabantur. id quod etiam teftatur Rucllius de Pyrethro, quod in Gallid prouenit. 4 Ex qua facilé adductus fum, ut. fupicandum putem, aht hoc in loco Diofcoridis codicem librariorum negligentia depraudum effe, aut plura Pyrethrigenera reperiri. Ceterim funt ex rel

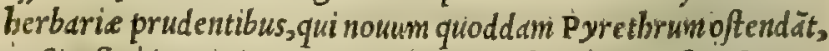
paßim feré in pratis, ac incultis nafcens, folijs hortenfi paftinace proximis: Cuius radix et/i primoftatim guftu acris non fentia= tur; poftea tamen cum diutius nididitur, tum lingian; tum faus ccs fina fruenti acrinonia mordet, ac quiodammodo incendit. sed tamen buius acrimonia non eft (nifi fallatur guftus) cum legitimi Pyretbri fapore comparanda : quippe qui $\sigma^{\circ} d=$ Pyrethri ui- marior, er multó acrior, er feruentior percipiatur. Pyrethri meminit Galenus lib. v I I. fimplicium med.ubi eius res ex Gal. uires ijs defcripfit uerbis. Pyrethri radice potißime utimur, caufticam, urentémue facultatem obtinente : qua utique etiam dentium refrigeratorum dolores lenit: 0 ad rigores ante periodum cum olco confricatur. Ad bac ftupidos

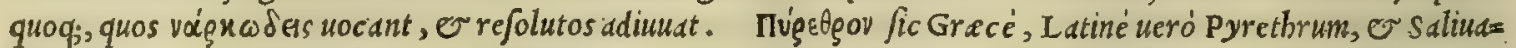
ris herba uocatur : Arabicé, Macharcaraba, feu Hacharcharha: Italicé, Pirethro: Germanicé, Bertram: Hipa= nicé, Pelitre: Gallicé, Pyrethre.

\section{MIBavaTis. ROSMARINVM.}

CAP. LXXII.

D vo Rofmarini gencra. Vnum focundum, frugiferumq́ue, cuius femen cachrys uocatur: Folia foniculi habet, crafsiora, \& latiora, in rotæ fpeciem, humi fparfa, iucundè olentia : caulem cubitali altitudine, aut maiorem, multis concauum alis: in cacumine umbcllam, in qua femen co- 


\section{In Lib. tertium Diof coridis.}

ROSMARINVM.

10

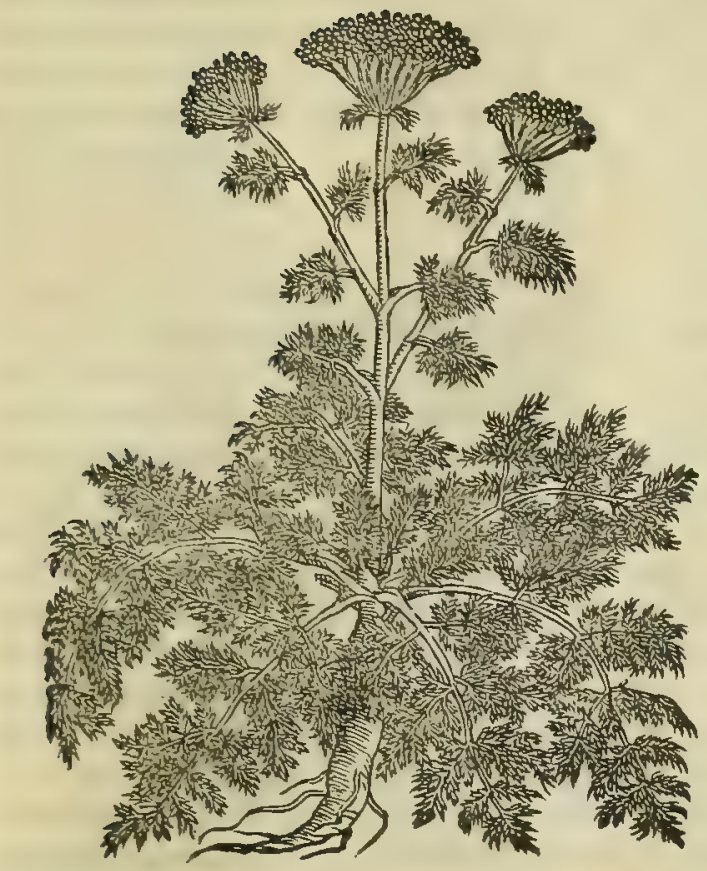

ROSMARINVM CORONARIVM.

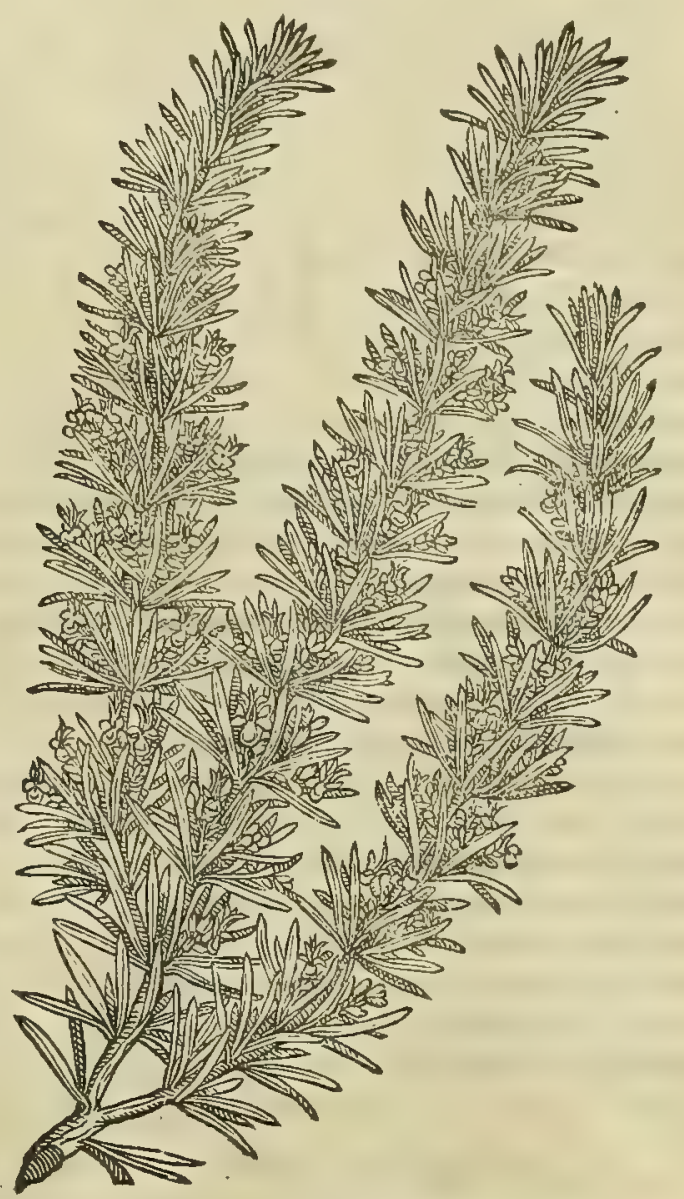

piofum, candidum, fphondylio fimile, rotundum, angulofum, acre, refinaceum, quod in mandendo linguam exurit. radix thus redolet, candida, prægrandis. Ett \& alterum omnino confimile, femen ferens latum, nigrum, uti fphondylion, odoratum, minime exurens : radice forìs, nigra, intus fi frangatur, alba. Verùm id quod fterile dicitur, illorum planè fímilitudinem refert: fed neque caulem, neque florem, neque femen promit. Nafcitur in faxofis, \& afperis. Trita omnium herba communiter hæmorrhoidum profluuia fiftit : fedis inflammationes, \& condylomata mitıgat : concoquit ftrumas, \& abfceffus, qui ad maturationem ægrè perducuntur. Siccæ radices cum melle ulcera

40 purgant: torminibus medentur cum uino potæ, \& contra ferpentium morfus conueniunt: menfes, \& urinas cient: ueteres tumores illitu difcutiunt. Tam radicis, quàm herbæ fuccus, adiecto melle, illitus oculorum acıem exacuit. Potum femen ad eadem pollet : fi comitiale malum fentiatur,aut uetus pectoris uitium, auxilio eft . regio morbo laborantibus cum uino, \& pipere datur : fudores mouet,cum oleo perunctum : ruptis, \& conuulfis prodeft . podagris, cum loliacea fárina, \& aceto tritum, illinitur: purgat uitiligines, addito aceto quàm acerrimo. Semine in potionibus utendum, eius quidem quod cachryn non ferat: quippe illud fua acrimonia arteriam exafperat. Rofmarinum cum erica nafci, folijs lactucæ fylueftris a marx afperioribus, candidioribusq́ue, radice breui, Theophraftus author eft : potuq́ue idipfum alterutra parte purgare. Cachrys uim habet excalfaciendi,\& uehementer exiccandi. Quare abftergentibus medicamentis inferitur . contra oculorum fluxiones caso piti illinitur, ita ut tertio die foluatur.

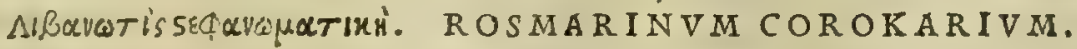 C A F. L L X X I I I.}

R O 5 M A R I N V M, quo coronarij utuntur, ramos mittit tenues, \& circa eos folia minuta, den$\mathrm{fa}$, longa, exilia, fubter incana, fupernè uirentia, grauiter odorata. Excalfactorıa ui præditum eft . Regium fanat morbum, $f_{1}$ decoetum in aqua, ante exercitationes bibatur : $\&$ ubi laborans exercitationi fe crediderit, in balnea defcendat, \& merum potet. Acopis, gleucinoq́ue vnguento admifceri folet. 
Rolmarinorum confid.

Rofmarini ui resex Gal.

Cachrys quid.

Nomina.

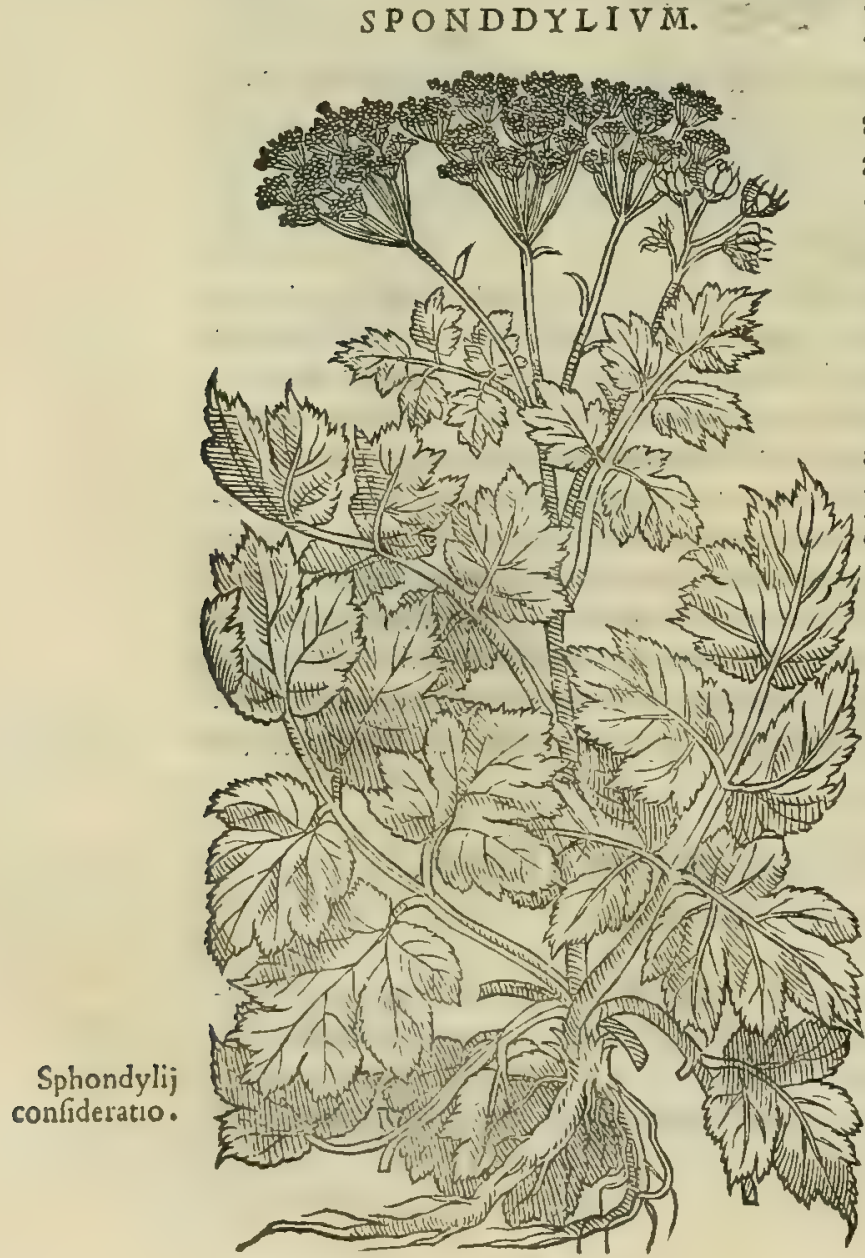

SPONDDYLIVM. in corylo, cui funt longo piperifimilia, item in nuce, ac' quercu. Nifí inter liec ueteres Grecos aüctores aliquam no= uiffe differentiam fit iudicandum, quód apud plerosq; non cachrys, fed canchrys, pro Ro fmarini femine fcriptum rez periatur . qua tamen uoces hactenus à rccentioribus confundi inuenio. Planta, qua $\lambda_{1} \beta \alpha \omega \omega T$ is Grecis, Libc= notis $\odot$ Rofmarinum $\mathrm{L}$ atinis dicitur: Mauritanis, $\mathrm{X}$ aier alme= riem, Alpinalfach, of Cachola: Italis, Rofmarino. Que

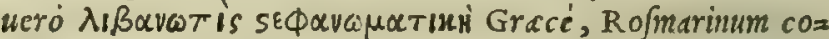
ronarium Latiné uocatur: Arabice, Elkialgeber: Italicé, Rof= marino coronario: Germanicé, Rofzmarin: Hipanicé, Rome= ro: Gallicé, Rofmarin.

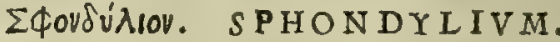 CAP. IXXIIII.}

S P H O N D Y L I Y M folia quadántenus platani, \& 40. panacis habet: caules foeniculaceos, cubitali altitudine, aut amplius affurgentes: in quorum cacumine femen du plex, fefeli fimile, fed latius, candidius, \& magis paleaceum, grauis odoris : flores eius albi, aut pallentes : radice raphani, candida. Nafcitur in paluftribus, $\&$ aquofis . Potum femen pituitam per aluum extrahit. medetur iocineris uitijs, régio morbo, comitialibus; orthopnoicis, vuluarum ftrangulationi : ueternofos fufitu reuocat: Cum oleo commodè infunditur capitibus phreneticorum, \& lethargicorum, item capitis dolori- 50 bus : cum ruta illitum, ferpentia ulcera cohibet. Datur radix cótra regium morbum, \& iocineris uitia : circüra fa eadem, \& iniecta callos fiftularum derodit . Recentis floris fuccus exulceratis auribus, purulentisque accommodatur : qui cæterorum fuccorum more exprimi, dein recondi folet.

R A R A admodum funt prata, uligine madentia, que inter alias complures herbas, innumeras quoq; sphondylij plantas non habeant: edq'; precipue, que in montibus potius, qudm in planis tie uirent. In bis fane sphondylium copiofum nafcitur, folio pla= tani, aut panacis: caule freniculi, cubitalem longitudinem exce= 
dente : in cuitus cacumine umbellu infidet, albis floribus refertu: ć quibus femen produt, fefcli non abfinilc, latius tu= men, ac fqumofum, fopore iniucundo, ut quod cinices forné refipiat. Radicem profert albam, raphani a'mulam, gu= fu non ingrato. Huus fenine utuntur quidun fefclis uice, quód altcrum alterius effectus preftare cxiftinent.

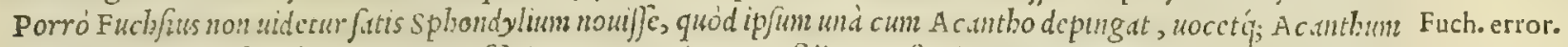

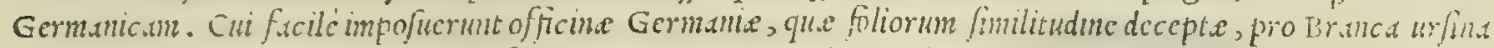

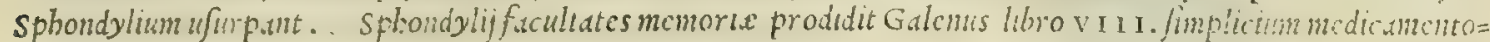

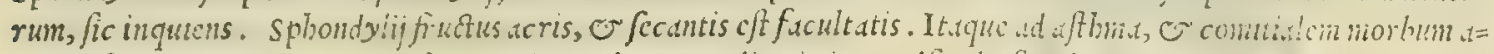

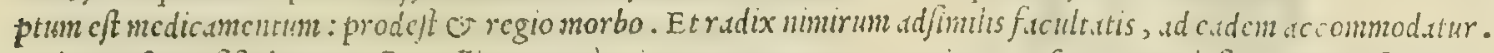
Sed o infuper fiftularun c.illos tollit: caterim imponcre cam oportet circumrafom. Porró floris ctivin fuccus ad

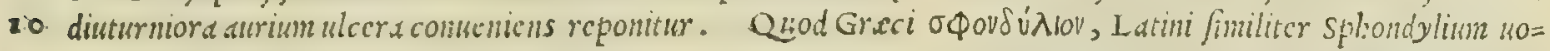
cant: Itali, Sphonditio.

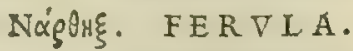

20

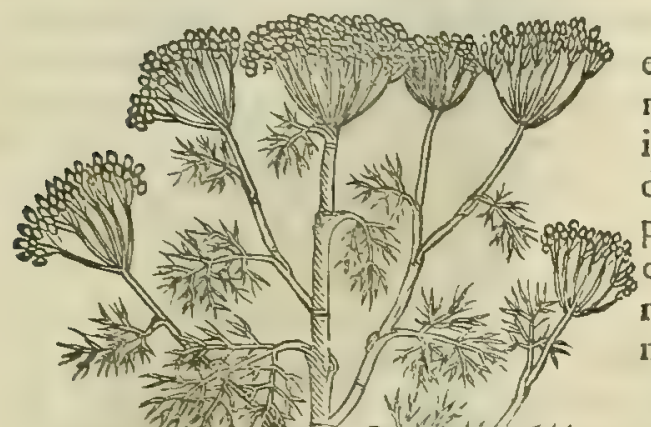

90

40

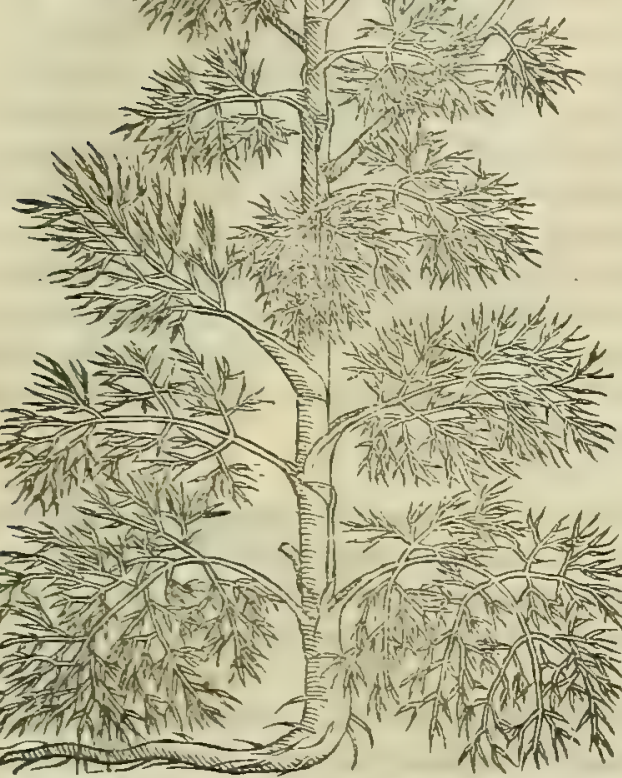

CAP. LXXV.

E' V I R I D I Ferula medulla pora utilis cft ad cruentas excreationes, cœliacosq́uc: contra viperarum morfus in uino datur: erumpentem naribus fanguinem indita fiftit. Semen potum torminofis auxiliatur: fudores cier, uneto ex oleo corpore. Caules fi edantur, capitis dolores faciunt : muria condiuntur. Ferula itaque caulem profert ternûm frepe cubitorum : folia fneniculi, longè afperiora, \& latiora . qua ab imo caule vulnerata fagapenum efficitur.

F I IR V I A aftuofis nafcitur locis: ideo ; nil mirum, quód A pulia Ferularum fit maximé ferax. Quinetiam frequens pro= uenit in Romano agro Tyrrbeni maris contermino, prafertim apud Centumcellds, é in uniuer/is Hetruric maritimis. $E^{\prime}$ qui= bus prima tantum germinatione corculum quoddam paftores exi munt ouiluteum induratum referěs, quod fub cineribus affatum, prius tamen charta, aut linteo madef actis conuolutum, mox pi= pere, o fale conperfum, non modó guftui gratißimus es cibus; Jed etiam ad excitaridam tenerein ualentißimus. De Ferulis ld= tius differuit Theophrastus libro v r. cap.: I r. de plantarum bi= storia, ubi ita fcribit. Feruldceum genus in plures $\beta$ argitur $\beta e=$ cies. Sed primum de eo, quod commune omnium constat, dicen= dum est, feilicet de Ferula, atq; Ferulagine: feu idem genus dm= babus, differens magnitudine tantim: :eu etiam alterum fit, ut nonnulli putarunt. Ergo natura earum,qu.e conßpici poßit,con= fimilis certé fentitur, pretcrquàm ratione magnitudinis. Ferula enim grandis admodum furgit, Ferulago autem bumilis. fed uni= caules ambe, es geniculate funt. Folia, er cauliculi quidam, geniculis erumpunt, ac alternatim exeunt folia: alternatim in= quam, quód non ex eadem parte geniculorum, fed permutatim, caulem magnd ex parte amplexd, ficuti arundinea proueniunt: nifí quòd deflexa brec magis, mollitie, magnitudinis'; caufa. Folium enim grande, molle, multifidum, ut capillamenti modo feré inpectetur : maxima, qua terrs proxima funt, o reliqud fubinde ad portionem. Flos melinus: femen obfcurum, anetho fimile, fed maius. Finditur cacumine, ov in stipites quofdam baud magnos dipergitur: quibus flos, femen;; infidet. nec flore, fructiue laterales caules carent, fed anetbimodo ferunt. Annuo caule con= Stat, er germinatio in uere primiun foliorum, tum caulis, ut etian in cateris fieri folet. Radice altédefcendit, ed=:

\$o dem q; fingulari irnititur. Talis Ferula cst. hec Theophrastus. Porró Ferule ( ut Plinius est author lib. X X I I I I. cdp. primo ) afinis gratißime funt in pabulo, cateris ueró iumentis prefentaneo ueneno. qua de cdufa id animal $\mathrm{L} i=$ beropatri aßignatur, cui e feruld. Natura Ferularum (ut idem Plinius libro x x. cap. X X I I I. testatur) mure=: nis infestipima est : tacta fiquidem ea moriuntur. In infula quadam ex fortunatis nomine Morion, ferulas in arbo=: rum amplitudinem grandefcere, fcripfere quidam. A puli lignorum uice, quibus maximé carent, ferul is ad ignem $u=$ tuntur. Ferulx meminit Galcnus libro v I 1 . fimplicium medicamentorum, fic inquiens. Ferule femen excalf $d=$ cit, $\sigma$ attenuat. At interna eivs pars recentis adbuc, quod medullam uocant, adstringentem qualitatem partici=

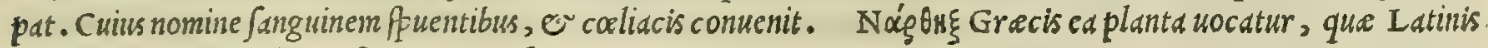
Ferula: Italis, Ferola: Hipanis, Cananbeia.
Sphondylij utresex Gal.

Nomina.
Ferulæ hiforia.

Ferulz uires ex Galeno.

Nomina. 


\title{
4I6 And.Matthioli Comm.
}

\author{
חЕU⿻Édavos. PEVCEDANVM.
}

CAP. LXXVII.

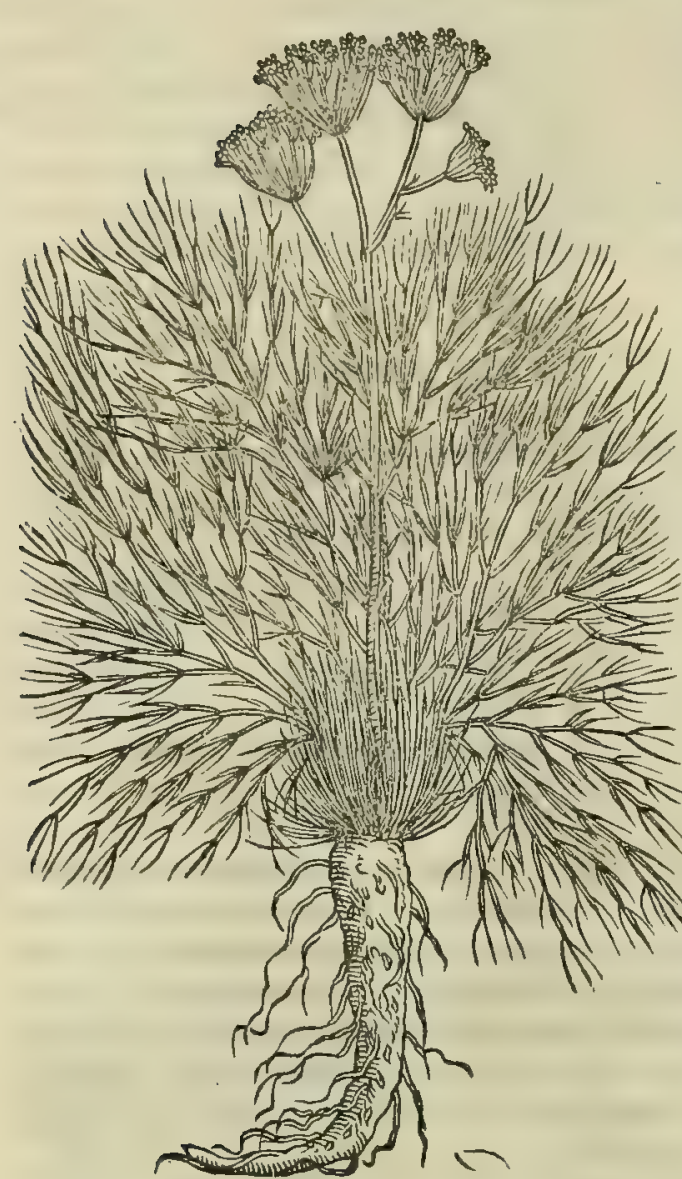

PE V C E D A V M caulem emittit tenuem, gracilentum, foniculo fimilem : comam habet ftatim ab terra copiofam, fpiffamq́ue: flore Juteo: radice nigra, craffa, graui odore, fuccofa . gignitur in montibus opacis. Tenera radix cultello conciditur, profluensq́ue è plaga fuccus umbre mandatur : in fole fiquidem confeftim euanefcit. Colligitur capite prius, \& naribus rofaceo perfufis, ne capitis dolor premat, \& uertigo fentiatur. Affatione radıx inutilis fit. Tam lac, quàm fuccus radice, \& caulibus extrahi folet, ficuti è mandragora: verùm inefficacior fucco lacryma habetur, \& velocius expirat. Interdum etiam concreta inuenitur lacryma, thuris fimilitudine, caulibus, radicibusque adhærens. Præfertur fuccus è Sardinia, \& Samothrace, colore rufo, odore graui, feruens guftu. Exaceto, \& rofaceo illitum Peucedanum prodelt lethargicis, phreneticis, vertiginofis, comitialibus, \& longis capitis do- to loribus, refolutis, ifchiadicis, conuulfis . omnibus, in uniuerfum, vitijs neruorum, ex oleo, \& aceto illitum, prodeft. Eius olfactu refpirant vuluæ ftrangulatus, \& $\$$ veternofi reuocantur. Incenfum ferpentes abigit. Aurium doloribus conuenienter ex rofaceo inftillatur: ca uernis dentium inditum, mitigat dolorem , contra tuffim efficacifsimè ex ouo affumitur: fufpirijs, torminibus, inflationibus fubuenit. Ventrem leniter emollit, licnem abfumit, difficiles partus mirè adiunat. $\mathrm{Fa}$ citad veficæ cruciatus, \& renum diftentiones potum: vuluam aperit. Radix ad eadem utilis eft, fed inefficacior : eius decoetum bibitur. Farina eius, fordida ulcera purgat, \& uctera cicatrice obducit : fquamas of sium extrahit. In cerata , \& calfacientia malagmata additur. Radix eligi debet recens, qux cariem non fenferit, firma, odoris plena. Succus ad potiones amaris amygdalis, aut ruta, aut pane calido, aut anetho refoluitur .

Peucedani cö QV o N I A M nullis prorfus foliorum, ac feminis, ov paucis admodum floris notis Peucedanum repre fentauit fideratio. Diofcorides, utpote plantam, que omnibus fortaffe fuo tempore notior erat, quàm ut longiorem defcriptionem poftu= laret; idcirco nobis quidem perdifficile effe iudico, decernere quódnam genus herbx bodie in medium afferri poßit, qua legitimum Peucedanum referat: prefertin cion Theophraftus, Plinius, A pulcius, ac antiquorum alij, qui fimpli cium hiftorias de fcripferunt, plura, quod legerim, de Peucedano memoria non prodiderint. Veruntamen cum fcri= bat Diofcorides, Peucedanum nafci coma ftatim à terra copio $\int_{\alpha}$ ac Biffa, hinc plané coniectandum uidetur, Diofco= ridem ipfum innuere, quod Peucedanum conftet multss folijs, capilluribus, tenuibus, ac long is, freniculi, aut anethi effigie. Huic coniectura illud eticm accedit, quód cum Peucedanum, Diofcoridis teftimonio, florem proferat meli= num, fiue luteum, non temeré credendum arbitror, bunc non in alio, quàm in umbella fuftineri, cùm omnes ferulace ftirpes, o que faniculo, o anetho fimiles babentur, cuiufmodi funt, qua boc in loco i Diofcoride recenfentur, um= bellas in caulium cacuminibus gignere conpiciantur, é quibus femen prodit faniculi modo. Quódfi ita fe res babet (ut equidem exiftimo ) afferere non dubitaucrim, me Sepenumero Peucedanumn uidiffe in Ananienfibus montibus, ubi buiujmodi plant e frequentißina prouenunt, que non folim predictis notis Peucedano adftipulantur; fed etiam rd= dice, quam habent nigram, crafsam, fucci plenam, grauiter'́; olentem. I $n$ hac itaq; fententia perfiftam, ut banc ber $=50$ bam, quam etiam pictam damus, uerum peucedanum putem, donec alian nictus cro, que certioribus notis illud ex= primat. Caterùm radices, quibus pro Peucedani radicibus unlgó officine utuntur, legitimas ementiuntur nam preter id quód exteriore parte non nigricent, nulla grakeolcntia, nullág; acri facultate Junt predite. Cuius ueró planta ba fint radices, ego quidem proferre non poffum; cas fiquidem bactenus non nifi ficcas, $\mathcal{O}$ fine caule, ac fo= lijs mibi uidere licuit. Pratulit Diofcorides Sardonium peucedanum, quod non magno quidem negọtio ad nos aduebi poffet, cim frequens, nec longa fit mercatoribus in Sardiniam nauigatio. Vnde feplafiarijs, fi rerum legitimarum ftu.

Peucedani ui dio caperentur, facile Peucedani radices conueberentur.". Pcucedani meminit Galenus lib. v I I . fimplictum me= res ex Gal. dicamentorum, ubi de cius uiribus differit in bunc modum. Peucedani radice quidem maximé, fed tamen ctiam. fucco, o liquore utimur. Sunt autem hec omnia eiufdem pecie faculcatis: fed ualcntior fuccus, admodum excalfaciens, $\mathcal{O}$ digerens. Quare affectibus ommibus circa neruos confiftentibus conuenire creditur, tum morbis in pulnone, or thorace ex craßitudine, or vifcofitate humorum prouenicntibus. Atque intró quidem in corpus fumptus, fed tame? 


\section{In Lib. tertium Diofcoridis.}

etiam olf actu prodeft. Porró quód incidat, e extenuet, fxpe etiam dentium perfor ratorum dolores cauitati impofi= tus protinus fedaut, quid uidelicet tenuium eft partium, o excalfutorius. Quinetiam lienes induratos iuuat, nem= pe incidendo, digerendo, atque extenuando craffos bumores. Sed or radice ad hec uti licebit: qua o fquamas ce= Ierrimé ab ofibus detrabit, quia uidelicet ualidé deficcat, minus tamen quàm fuccus excalfaciens. Et ulceribus inali= gnis remedium eft optimum arida illtta : ipfa enim expurgat, carnem gignit, o ad ctcatricem perducit. Excalfacit quidem ordine fecundo iam completo : deficcat ueró tertıo iam incipiente. Planta, que $\pi \varepsilon v x e ́ \delta \alpha v o s$ Grecé, Peu= cedanum Latiné dicitur: Arabicé, Harbatum: Italicé, Peucedano.
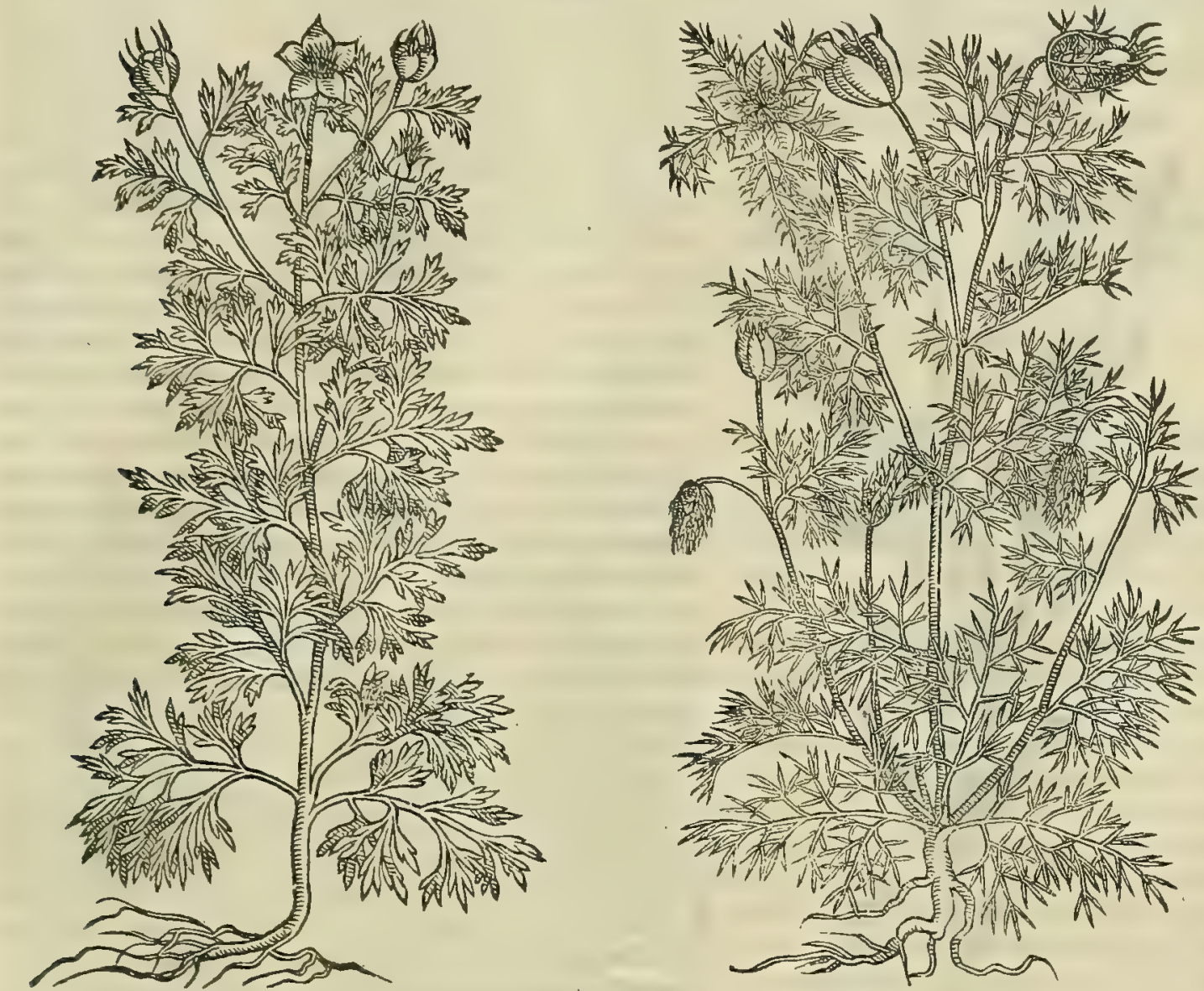

ME $\lambda x^{\prime} V$ Blov. GITH, SEV MELANTHIVM.

CAP. IXXVIII.

G I $\mathrm{T}$ н exilibus furculis fruticat, fxpe binos dodrantes excedens : folijs, ut fenecionis minutis, fed multò tenuioribus: capitulo in cacumine tenui, paruo, ceu papaueris, oblongo, intercurfantibus intus membranis: quibus femen includitur nigrum, acre, odoratum, quod panibus infpargitur. Capitis doloribus illitum fronti, fubuenit difcutit recentes oculorum fuffufiones, tritum ex irino, \& infufum naribus : tollit lepras, lentigines, duritias, tumoresq́ue uetuftos, cum aceto illitum : circum farificatos clauos cxcutit, cum uetere urina impofitum. Dentium doloribus, cum aceto, \& teda deco đum, \& collutum prodeft . teretes uentris tineas expellit, peruncto ex aqua umbilico. deftillatione laborantes adiuuat, tritum in linteo, \& olfactum. Vrinam, \& menftrua ciet, mulso tis diebus fumptum, \& lac extrahit: difficultatem fpirandi cum uino potum, leuat: phalangiorum morfibus ex aqua, drachmæ pondere, hauftum auxiliatur. Incenfo ferpentes fugantur. Tiadunt lartgiùs epotum enecare.

G I I $\mathrm{H}$, quod Greci Melanthium appellant, officinis Nigella uocatur. Legitimum folijs eft rinutim incifs, Melanthij cö ramulis tenuibus, capitulis in fumnitate oblong is : in quibus femen includitur nigrum, intercurfantibus membranis di= fideratio. ftinctum, acre, ac odoratum. Seritur in hortis, o uiridarijs, atq; etiam in alijs locis fatum prouenit. Qutod cium an= te nos probé animaduertiffent Hermolsus, $\mathbb{O}$ Ruelius, alferuerunt omnino ballucindri cos, qui putant edm ftirpem legitumum Melanthium effe, que inter fegetes in aruis paßim nafcitur, folijs fere porri : caule prelongo, hirfutoo;: flore purpureo, rofe parue effigie. Et recté, inca quidem Sententia, iudic arunt : fiquidem herba illd cum Diofcoridis biftoria quàm maxime pugnat, utpote que folijs, caule, ac floribus, nulla ex parte Melanthium referat, ficuti neque etiam femine . quod etfi nigrum Melanthij modo gignatur; non tamen guftui aliud repre e fentat, quàm amadritudinem 
Brafauoli er- fimul er apperitatent. Hinc itaq; peppicuum effe poteft, Brafanolum, alioqui medicum clarißimum, in fio fimplis ratum. cium uolumine Rome excufo manfefté cecutiuife . quippe qui affirmare non dubitauerit, illud uerum, legitimumiq. effe Melanthium, quod in fegetibus paßsim fua fponte nafci fuperius diximus, quodq́; uulgó Gittone à Ferrarienfibus appellarifcribit. Cuius crror non folum predict is rationibus; fed ea quoq; berbe appellatione facile deprebenditur, quod etium ij, qui ita eam appellant, illegitimum effe Melanthium exiftiment. Quandoquidem nil aliud Italis boc no= men Guttone denotare uide atur, qudin pursum Gith, quod idco Guthago, ev peudomelanthium uocari potef : quem= admodum $\odot$ id, quod rura Tridentina appcllant formentone, nil aliud fignificat, quam/puriam triticipeciem. Quod cim pofted ip $\int \mathrm{e}$ Brafauolus animaducrteret, noftris fortaffe, aut alio rum commentarijs adnonitus, fuan reuocauit fententiam. Quare pofthac Brafaroli quoq; fententix, ij damnandi erunt, qui in hac perfiftent opinione. Iam igitur conftetuamus licet, uerum Gith in bortis, o viridarijs fatum proucnire, in quibus frequentisimum feritur in Germa=.

Melanthium nia. Ceterim eft $\sim$ fylueftre Melantbium, quod in Hetruria reperitur, hortenfi non admodum disimile, captti=

fylueftre. Preudome lanthium.

$$
\begin{aligned}
& \text { bus tdunengrandioribus, e femine minus odorat } \\
& \text { PS.EVDOME L A N T HIO. }
\end{aligned}
$$

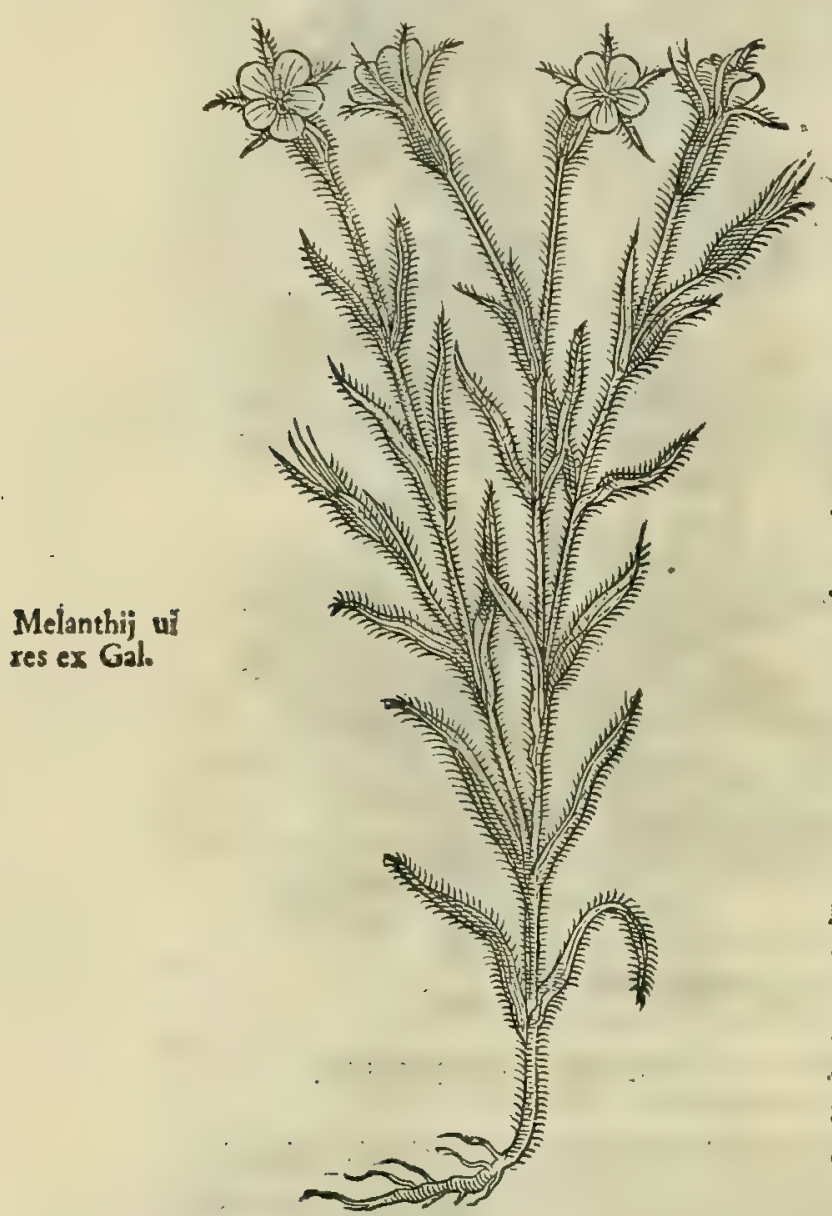

Melanthij uI res ex Galo. TH I VM ponte intèr fegctes nafcens, quod tocant uulgó Gitto= ne', cuius hic effigiem damus, nullo modo fylueftre. Melanthium effe. Sed longe minus id fuerit Lolium, ut apertißimé ballucina = tus credidit Fuch/ius, medicus alioqui peritißimus: cuius crror à nobis explofus eft libro fecundo in lolij mentione. Porró or illud Semen odoratum, fubrubrumí;, quod aliqui pro minori Cardamo= mo perperàm ufurpant. Seplafiarijs Nigella citrina nocatum,Me= lanthig genus eft . quippe ip $\int a$ feminis forma, odor, ac fapor nibil 20 prorfus à Melanthio difcrepant. Verum fi modó in aliquo dißidět, color eft, qui in altero niger, in altero ueró fubflauus conficitur. Quo fit (quod etian fuperius de Cumino differentes diximus) ut magno in errore uer fentur Monachi illi, qui in Mefuem commen= tarios edidere, quód prater rationem afferere fint aufi, Nigellam fubflaudm, nil diude fee, quàm Cuminum jylueftre primo generi a Diofcoride aßignatum. Melantbij meminit Galenus libro v I I. fimplicium medicamentorum, his uerbis. Melanthium excalfacit, atque deficcat tertio ordine. videtur etiam tenuium effe partium: unde etiam deftillationes fanat, calidum in linteo admotum, atque aßiduo olfactum . Quinetiam fi intrò in corpus fumatur, wel maxi= méflatus extinguit. Hinc conftat effentix ipfum effe fubtilis, er ad unguem d̀ caliditate elaborate. Propterea fane etiam amarum eft. Oftenfum teró in quarto horum uoluminum est , quód cùm $1 d$ extremam tenuitatem, atque elaborationem terrena pertingit $f u b=$ ftantia, amara proueniat qualitas. It taq; mirum non eft, $f i$ lum $=$ bricos interimat non efum modó, fed etiam foris uevitri impofitum. siquidem o id preftare poffe faporem amarum monftratum eft. Neque fané etiam mir andum, fi lepras, clauos, myrmecius eijciat, ei prefertim, qui in fuperior ibus libris comprelenforum baud eft immemor. Sic ueró etiam orthopnoam iunat, er menfes prous. cat, qui utique ob craßitiem, aut uifcofitatem bumorum retentifue= rint. In fumm, ubi incifione, exterfione, deficcatione, excal =

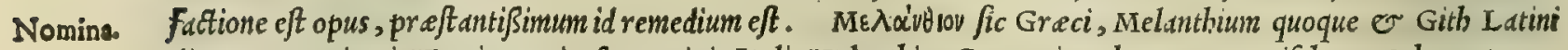
dicunt: Mauritani, Xamin, sunis, feu sunizi : Itali, Melanthio: Germani, Schuuartz roemifch, er schuuartz co= riander: Hipani, Neguillia, o Alipiure: Galli, Pourelle, o Nielle.

\section{$\Sigma$ ¿'A $\Phi$ 10\%. LASERPITIVM.}

\section{CAP. LXXVII.}

L A S E R P I T I V M in Syria, Armenia, Media, \& Libya nafcitur: caule ferulaceo, quem mafpetum uocant: folijs apio fimilibus : lato femine. Radix excalfacit, in cibis ægrè concoquitur, ueficæ noxia. Sugillatis illita cum oleo, \& ftrumis, ac tuberculis cum cerato, medetur: ifchiadicis conuenit cum irino, aut cyprino cerato : excrefcentibus circa fedem tollendis illinitur, cum putamine mali punici, \& aceto decocta. Venen is pota refiftit : os commendat, cibis, aut fali permifta .

Lafer è radice, atque caule fcarificatis colligitur . Præfertur autem rufum, translucens, myrrhæ $æ-$ mulum, nó porraceum, odore ualens, fuaui guftu, quod dilutum facilè albefcit . Cyrenaicum fi quis deguftauerit, humorem toto corpore ciet: blandifsimo odore, adeò ut ne os quidem guftanti nifi pau lulum fpiret. Medicum, \& Syriacum minus viribus ualent, \& magis uirofum reddunt odorem. Lafer omne antequàm ficcefcat, adulteratur fagapeno, aut fabæ lomento . quod maleficium deprehenditur guftu, odore, uifu, \& dilutione. Caulem aliqui filphion, radicem magudarin, \& folia mafpeton uocauere. Efficacifsimum lafer, mox folia, poftremò caulis. Acrem uim habet, inflationes fa- 


\section{InLib. tertium Diofcoridis .}

eit : perunctas cum aceto, pipere, \& uino alopecias fanat. oculorum aciem exacuit : \& incipientes fuffufiones, illitum cum melle, difsipar: cauernis dentium in dolorc inditur,aut cum thure in linteo circumligatur, aut cum hyflopo, \& ficis coctis in pofca, os colluitur. ijs prodeft, ques beftia in rabiem efferata momorderit, vulneribus immiflum. Valet aduerfus venena telorum, \& animalia omnia, qux uirus eiaculantur, potum, aut illitum: fcorpionum plagis olco dilutum circumlinitur. gangrenis pracoërcitis immitticur : \& cum ruta, nitro, \& melle, vel per fe carbunculis. Clausos, callosque prius circumrafos uellit, cerato, aut aridorum ficuum carne pramollitum. Recentes lichenas cx aceto fanat: \& excrefcentia in carne, poly posque, fi aliquot diebus cum atramento futorio, aut arugine illinatur . extuberantia cum forfice extrahit . Veteribus faucium feabritijs opitulatur : grauem, fubitoq́; 2o irraucefcentem uocem, dilutum aqua, forbitione confeftim expedit: vuam illirum cum melle reprimit:anginis ex aqua mulfa vtilifsimè gargarizatur. Vefcentes lixtiore colore mangonizat : tufsi commodè in forbili ouo datur, \& pleuriticis in forbitionibus: in fellis fuffufione, \& aqua inter cutem, cü aridis ficis. Horrores difcutit cum uino, pipere, \& thure potum . neruorñ contractionibus, opifthotonicisque datur oboli pondere deuorandum. hærentes gulæ hirudines, gargarizatum cum aceto decutit. Ad lac intus coagulatum bibitur: comitialibus ex aceto mulfo proficit : menfes ciet, cum pipcre, \& myrrha potum : coeliacos adiuuat, in acino vux fumptum : cum lixiuio autcm potui datum, repentè conuullis, ruptisque prodeft . ad potiones refoluttur amygdalis amaris, aut ruta, aut calido pane. Foliorum fucco eadem præftantur, fed multò inefficacius. Cum aceto mulfo manditur, ad expediendam arterium, maximè cùm uox retunditur. Eo cum lactucis utuntur, exitq́ue in uicem erucxe.

20 Fertur \& altera magudaris in Libya nafci, radix laferpitio fimilis, fed minus craffa, acris, \& fungofa, ex qua non profluit fuccus. Eiufdem cum laferpitio facultatis.

C R E D I D I M V S iandudum Laferpitij lacrymam nibil aliud effe, quàmillud iucundiac fuawis odoris gum= mi, quod pharmacopois atq; unguentarijs Belzoinum nominatur. Neque certé bactenus prater rationem in ea per= fitimus opinione . nam cim id mibi deprehenderetur odoratum, rufum foris, intus candidum, translucens, or quod di= lutum albefceret, non poteram non adduci, ut crederem boc effe legitimum Lafer. Huc illud quoq; accedebat, quód complures erant uiri docti or rei medica ftudiofi, qui idem mecum fentiebant. Verün cium poftea capiffem $\mathrm{L}$ a erpi= tij ac L ajeris biftoriam diligentius examinare, atq; plura ex Strabone, Theophrafto, Diofcoride, Galeno, $\sigma$ Plinio collegifem, que priorinoftre opinioni aperté aduerfari uidebantur, facilé in aliam deductus fum fententiam . etenim

so fic animum induxi me um, ut malim ueritati cedere, quàm pertinaciter (quod multifaciunt) falfa tueri. Strabo itaq libro ultimo Geographia teftatur, silphium fuo ufq; tempore Cyrenis defeciffe, his uerbis. Cyrenis finitima eft regio; que silphium gignit, o cyrenaicum fuccum, quem silphium pofterius effert. Id propenodum defecit, cüm aliquan= do barbari odio quodam ingruiffent, ac radices eius penc omnes eruiffent. Fuerunt bi Nomades uiri. bac ille. At Pli nius Cyrenaici fucci defectum non in barbaros ut strabo, fed in publicanos quofdam refert lib. $x$ I x. cap. I I I. ubi de co ita fcribit. Ab his proximum dicetur auctoritatc clarißimum Laferpitiun, quod Grecifilpbion uocant, in Cyre. naica prouincia repertum: cuius Juccum uocant Lafer, magnificum in ufu, medicamĕtisq́, $\mathcal{O}^{\circ}$ ad pondus argentei des. narij penfum. Multis iam annis in ea terra non inuenitur, quoniam publicani, quipa fcud conducunt, maius ita lucrum fentientes depopulantur pecorum pabulo. Vnus autem caulis noftra repertus memorid, Neroni principimiffus est. bactenus Plinius. Huic ueró cum Theophrafto fermé conuenit, quód lic fcribat pecus filphio purgari, pingue fceré⿱;

$4^{\circ}$ uebementer, or carncs mir abilen in modum fuaues reddi. Cum igitur strabonis or plinij teftinonio conftet, silpbiü Cyrenis corum u $q_{;}$atate defrciffe, neque inibi inueniri, nil mirum uideri de bet, fi noftra etiam tempeftate defecerit, atque nullum ism ad nos aduehatur, quod legitimum dici poßit. Quare id gummi, quod feplafie Belzoinum dicunt; meo quidem iudicio, ueruin filphij liquorem mentietur potius quàn fit. Sed bis illud quoque addamus, quód strabo au ctor eft, silphium adeó Cyrenenfibus olim cuftodibus fuiffe afferuatum, ut inde alio de ferri non porwiffet, nifi clam d mercatoribus, qui uinum apportabant. Plinius item silphum ad pondus argenti pendi folitum tradit . quin $\mathfrak{C}^{2}$ tantifa ctum fuiffe à Cefare, ut illud inter aurum argentunq́; protulerit ex erario. Ex quibus omnibus baud infirmum argu= mentum Jumi potef, quód Belzoinum noftrum non fit silphij liquor. quandoquidem id quotidie copiofum importatur non folum in Italiam, fed in uniuer fam fire Europam. Ad hac cum Diofcorides Cyrenaico fucco uim acrem tribuat.

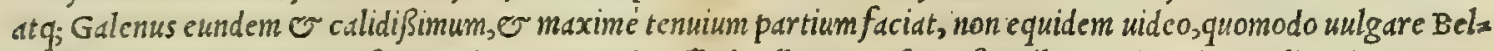
so zoinum poßit legitunum Lafer exprimere: quoniam illud nullam prorfug guftantibus acrimoniam relinquit. prete= red ualidi cortices, qui plerunq; Belzoino implicati repcriuntur, arguunt id arboris magne potius, qudim ferulacee plante lacryman effe. Quod ctiam nuper retulit mibi quidam medicus Cyprius, qui Belzoinum noftrun in Cypro ex arbore fatis procer manare affrrmauit : ubi tamë silphium nafci qui memorix prodiderit, hactenus inucni neminem. quemadmoriun neque in Ionti, neque in Peloponne fo id gigni, fed prope Cyrenas tantim, literis mandauit Hippocra tes. At tqui illud nobis obijcict aliquis, quod L a jerputium non modó in Cyrenenfium agro quondam proaenerit; fed ex tiam ( ut fribunt Theophraftus, Diofcorides, E Plinius) in Perfide, Media, Syria, e Parnafo monte : or quod of id ad nos aduehi poßst. Nos huic it a facilé repondebinus, quod silpbij illius liquor ad nos adferatur quidem, fed qui

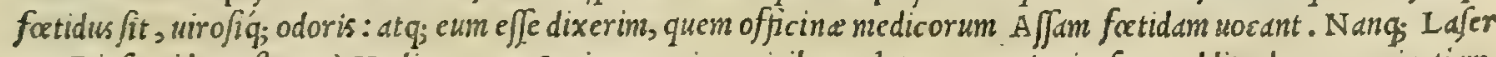
(ut Diofcorides tef.atur) Nedicum, of Syriac um minus uiribus ualet, of magis uirofum reddit odoresn. quinetiam.

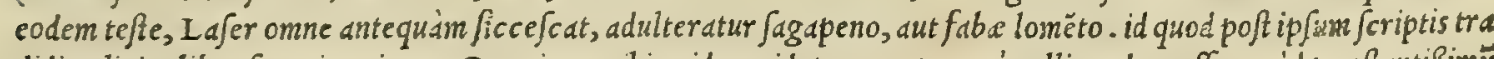
didit Plinius libro Juperius citato. Quocirca mibi quidem uidetur non temeré colligendum effe, quód preftantißimü

Laferpitij feu Laferis con Gideratio. 
Opinio quo- Iafer, quale Cyrensicum babebstur, à nobis omnino de fideretur. Cetcrim quid weteribus fuerit grimmi ithd eles rundan ex- gantiSimum, quod Belzoinum appellant, mili bactenus incompertum eft. In qua certé re non polfum corum opinio= plofa. ui fubfcribere, qui id putant effe probatißumam myrrham. Hex fiquidem, qux optins fit (ut Diofcorides inquit) prez ter aliss notas elfe debet undique concolor, que confrafta uenus unguium wodo candidas o lexues oftendat, minutis glebis, amara, 0 acris - quas tamen not as in Belzoino baudquqquam reperies. Nam etfi undique maculis conpergat $=$ tur, tamen fract as amygdalus reprefentat magis, quàn unguium quorumuis inaginem. Quin er macule ille tam in $=$ teriores, quàn exteriores partes obfident, adeó ut Belzoini gleba nibil aliud refrrat, quin delibratarum amygdalds rum acerum, copiofo nelle exceptum. Adde infuper, quód nufgusm, quantum equidcm inuenerim, memoria pro: ditume ef, myrrham in Cypro $\sim \sim$ syria fuis é plantis emanafe, fed in Arabia duntaxat (ut perbibent Theophraftus, Dicfcorides, $\odot$ Plinius) ijs in fyluis, in quibus thus etiam proucnit . quanquam Plinius myrrham quandam ex India Iaferpitij hi- adferit tradit, que ommlus imyrrha generibus deterior eft. Sed quoniam non iniucundam, quanuis longam, de Laz ftoriaex 1 he ferpitio biftoriam tradidit Theopbraftus lib.v r.cap. 1 I I.de plantarum biftoria ideo cius uerba bic fubijciam. De La ophrafto. Serpitio, inquit, nunc indicandum eft. Laferpitio radix multa, craffáq; : caulis quantus ferule, or craßitudine fré proximus : folium, quod mappetum uocant, apio fimile eft: :emen latum, foliaceü, quale quod folium appellatur: cau lis annuus, ficut ferule. Ergo uerc ineunte mafpetum hoc exit, o pecus eo purgatur, pingue citt; uchementer, or carnes mirabilem in modum fusues redduntur. Pofthac caulem edit bominum cibo idoneum omnibus modis, elixum, afum q́; , corpora co quoquc purgari ferunt, quadraginta diebus. Succus capitur duplex, alter ex caule, alter ex ra dice : qua de caufa alterum fcaparium, alterum radicarium uocant. Radix nigro cortice tegitur, eumq́; detrabere fa lent. Sunt ueluti certa menfur $x$ cadende radicis, quibus quantum conforre putetur ad futuram cofuram referualls tes, reliquum abfcindunt. Nec enin deuté, neq; plus confituto cedere licet: corrumpitur eninz, putre $f\left(i t \dot{q}_{;}\right.$, fi diu 20 manfit. Praparant id, conficiunt'; in Pyreeum portum aduectum hoc modo. Cim in uafis coniecerint, farinamiq; admifcuerint, quatiunt longo patio temporis : hinc etiam colorem capeßit, o conditum ism incorruptum perdurat. Preparatio, cesuráq; ita fe babet. Locum A pbrice amplum occupst, ampliorem, quàm quatuor ftadiorum millia in bortis Hepperidum frunt. Sed maiorem partem colligi apud syrtes. Peculiare buius culta fugere loca proditur: quamobrem, fi colatur mite cat $_{\text {; }}$ folum, deuiat; atque ommino degenerat: utpote natura culture apernans, feroci= tatisq́; conftans uernaculum. Cyrenen fes annis feptem prius, quim ip/i urbem babitarent, La ferpitium extitiffe off firmant. Habitant ueró annos maxime trecentos ufque ad simonide A thenis magiftratum. Ini fic referunt. Alÿ radicem L aferpitij cubitalem fieri tradunt, aut paulo maiorem. Hanc in medio extuberare in caput, quod fubline pe nitus extat, ut feré fuper terram effe appareat. Vude primim quad lac appellant, erumpit: dein caulis affurgit, ex quo magydaris, o quod folium dicitur, exeunt. Folium id femen est, quod cùm aufter ingenué poft caniculam flue= rit, difcutitur : atque ita L aferpitium nuscitur, codemǵ; anno radix con funmatur, e caulis. Sed hoc haud quicquä peculiare notetur: nam alijs quoque idem tribuitur . nidixeris,', quód difcufjum id protinus nafci poteft, ortum pecks liarem fortiri, fupradictiso; propterea diucrfum accipi poffe. Ad haec circunfodiendum id annuum cenfent. Nam fz relinquatur femen omne, c.1ulem '́; totum proferri, o deteriora tam bec, quìn radicem reddi exiftimant : defoffa as tem fieri melior a, fcilicet folo fubacto, benég; gluto . Sed huius contrarium illi uolunt; qui culta recufare id inquiunt . Mandi quoque radices in aceto recens decifas referunt. Folium colore aurum amulatur. Contrarium etiam, quód pe= cora folio efitato purgari minime indicant. Nam $\sigma$ uere, $O$ hyeme, pecus ad montem dimitti affirmant: cibus non folum hoc; fed etiam altero quodam abrotono fimili adminiftratur. Vim ambo cale factoriam fortiri plané uidentur, $\checkmark$ purgare quidem nequaquam ualere : exiccare autem, o concoquere unice poffe. Qùdd fi qua pecus agrefcens, aut aliàs minus bene fe babens ingreffa fit, mox eam fanari, aut emori aiunt, fed magna cx parte poffe feruari. Hac igitur utro tandem fint modo, quarendum. Quod ueró Magydarim uocant, nimirum à L aferpitio differt: tenerius enim, minusớ; uebemens, or fine L afere eft. necnon or afpetu manifefta experto homini conftat. Nafcitur in Sy= ria: nam apud Cyrenam, or monte Parnafo largé prouenire eandem affirmant. Sed quidam Laferpitium id appel= Tant. An culta id quog; , modo Laferpitij fugiat, quarendum. Quin $\sigma$ /i quid fimile, aut proximum habeat, ad folij, caulisq;; rationem, 0 fi quam ullo pacto emittat lacrymam, id inueftigandum. Ergo naturam ferulaceam, bijce con=

Ialerpitij ui- templari oportet . hac Theophraftus. Meminit Galenus Laferpitij libro v I I I. fimplicium medicamentorum, /ic res ex Gal. inquiens. Laferpitij fuccus calidißimus eft. Verim enimuero o folia, $\mathcal{O}$ caulis, $\mathcal{E}$ radix fat ftrenué excalfaciunt. sed omnia flatulente mag is effentie funt, ac proinde concoitu difficilia. Foris tamen impofita corpori efficaciora, et ontrium potißimum fuccus, admodum trabentem facultatem poßidens. Attamen $v$ excrefcentias amoliendi, $\sigma$ li= quandi uim quandam propter prediff am eius temperiem obtinet. I afcris quoque mentionem fecit, idem Galenus li= bro citato, fed antea feor fum, $v$ fub abfoluto ò où, hoc eft, fucci titulo, it a fcribens. Opus, fiue fuccus Cyrenaicus quidem omnium $\sigma$ calidifimus, $\sigma$ maximé tenuium partium $\mathrm{e} t \mathrm{t}:$ ac proinde omnium maximé difculit quanquam $\int_{d}=$

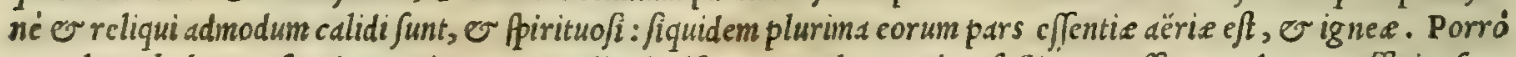
complures habentur fucci: quauis nanque radice incifa, aut caule, quod ex fectione craffum, ac lentum effluit, fuc= cus eft. Caterim pecialius, o uelut per excellentiam quandam Cyrenaicum ita nuncupant, er Mcdicum, or syrids

Nomina. cum. Planta, que Grecis $\sigma ' \lambda \Phi 10 V$, Latinis Laferpitium appellatur: Mauritanis, silfion: Italis, Laferpitio.

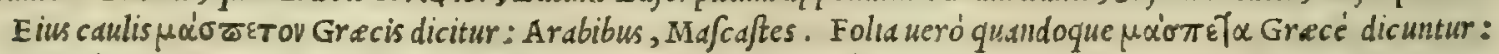
Arabice, Anuiden, $\sigma$ Mafcaften. Liquor feu lacryma Grecis $\lambda \alpha^{\prime} \sigma \in \cos$, Latinis Lafer nominatur. Radix $\mu \alpha \gamma y=$ Sajis Gracis Hocatur. 


\section{In Lib. tertium Diofcoridis.}

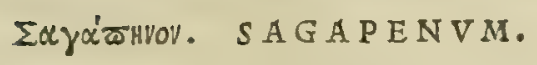

\section{CAP. IXXIX.}

SA G A EN V M ferulacex herbx fuccus eft, qua in Media nafcitur. Optimum ctt tranflucens, fuluo forinfecus colore, \& intus albo, nefcio quid inter lafer, \& galbanum redolens, guftu acri. Prodeft latcrum, \& pectoris doloribus, tufsibus uctuftis, conuulfis, \& ruptis. craftim pulmonis pituitam expurgat . Dutur comitialibus, opithotonicis, lienofis : itcm conera ncruorum refolutionem, perfrictiones, $\mathbb{a}$ fiobrun circuitus in potu. In unguenta probciadmitritur. menfes pellit, fed føtum exanimat, cum hydromelite potum. Prodeft ex uino haufum, ferpentitum iEtibus.

o olfactum ex accto uuluarum firangulatus excitat: oculorum cicatrices, offuram caliginem, hebetudines, fuftufionesq́ue detergit. Refoluitur ut lafer, ruta, aqua, \& amaris amygdalis, aut melle, aut calido pane.

S A G A P E N V M officine interpolsto uocitulo Serapinum appellant. Catcrim etfi cius adulterati frequen= Sayapeni con

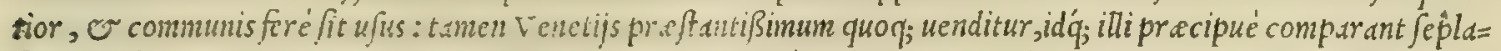
fiarij,qui bonorein diuitijs antcponunt. Ferulaceas plantas, é quibus sagapeni lacryma emanat, etiam in A pulia na=

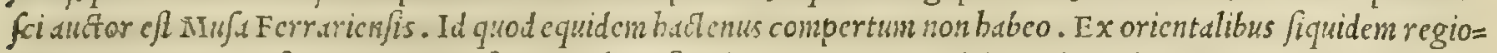
nibus all.tum, ut conftat, c.ectris proft.t. . Arabice familia auctores inter dciectoria medicamenta Sagapenum refic= runt : quanqu.un ea Sagupeni faculias, quantum extat, a Gracis filentio pratermiffa cft. Sagapenum itaq; (ut Sayapeni ui-

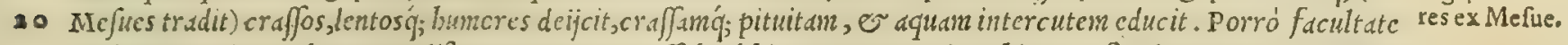

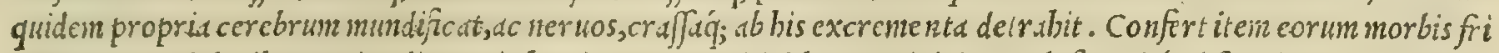
gidis, nempe doloribus capitis diuturnis, bemicranijs, comitialbus, uertigini, paralyfi, orisq́; diftentioni. Pectus. ud= lentißimé expurgat, eiusq́; ac etism lateris dolorcs tollit, prefertim fi bibatur ex belcnij, aut rute decocto . Foris em= plaftrimodo impofitum, aut intus afjumetun tußi diuturna ucxatis, ac difficulter firantibus, opem maximan fert. A qui intercute laborantibus finguldarc remedium eft, fi tamen flauis myrobalanis duplicato pondere additis exbi= bedtur. Difcutit compaginim duritiam emploffri nodo impofitum, addito aceto, er capparum fucco. Rute fucce, et

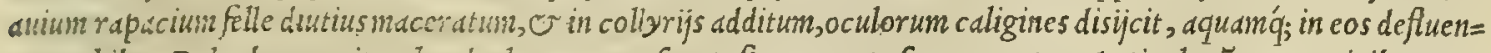
tem cohibet. Palpebrarunz item bord colos vocatos fanat, fi cum aceto fuperponatur. Articulor ̈̈ compaginibus quo= modolibet admotum, dolore s corum mirificé fedat: quippe quoniam ualentißimé bumorum lentores in his cruciatus

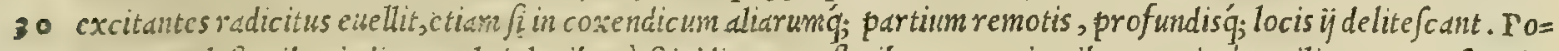
tum, aut clyfteribus inditun cole doloribus de frigiditate, ac flatibus prouenientibus maximé auxiliatur. Menfes cit, fed fretuin interficit, tam hauftum, quàn fuppofituin : contra utcri dolores, ftrangulatisó; prodeft. Ventriculo ta= men officit : ucrimn nox corrigitur lentif cina refina, E Indica nardo. Sagapeni meminit Galenus lib.v I I I. Fim=

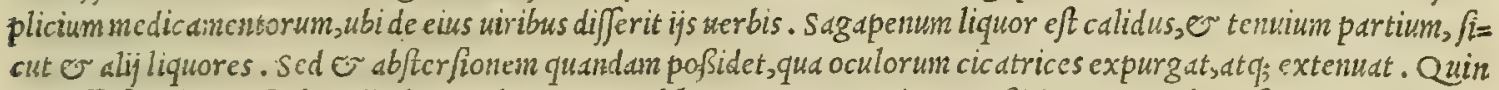

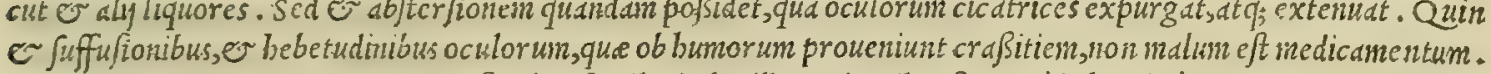
Porro planta ipfa, ex qua proucnit, frula aßimilis, imbecilla, E inutilis eft. Sane ipfa primisn Sag apenum appellat= tur. A: liquor eius abufiué hoc nomen obtinet, ceu alia quoq; multa ex nominis defifu per abufum nuncupamus. Per= fectius nang; foret ipfum cognoninare iron Sagapenum, Jed Sagapeni fuccum. Id oa yórs:ov Gracis dicitur, 40 quod Latinis etiam Sagapenum: Arabibus, sachabenigi, fiue Sechbinegi: Seplafiarijs, pariter or Hipanis, Sera= pino: Italis, Sagapeno.

$$
\text { E'U } 4 \text { O̊ßIO\%. EVPHORBIVM. }
$$

CAP. LXXX.

E v P H O R B I V M Libyca arbor eft, ferulæ fpeciem habens, quæ in Tmolo iuxta Mauritaniam inuenitur. Ea acerrimo fucco turget. Cuius eximium feruorem expauefcentes incolæ, ouillos uentres elutos, arbori circumligant, \& eminus caulem contis incidunt, confeftimq́ue è plaga, perinde atque uafe quodam, in uentriculos copiofus lactis humor effluit, præter id quod humi fparfum, uulnus ciaculatur. Duo fucci genera: vnum orobi magnitudine, farcocollæ modo emicat: alterum in uenso triculis concrefcit, atque uitreum fpectatur. Eligendum eft tranflucens, \& acre. Euphorbium adulteratur farcocollæ, \& glutini miftione. Sed difficile quidem experimentum : quippe cùm leui guftu, os accenfum diu detineat, adeò ut quicquid ori obijciatur, planè euphorbium refipiat . Eius inuétio tempore Iubæ regis Libyæ cognita extitit. Succus illitu fuffufiones difcutit. potus tota die exurit : quare melli, collyrijsq́ue pro acrimonix ratione admifceri debet. Coxarum doloribus prodeft in odorifera potione hauftus. fquamas ofsium eadem die eximit: uerùm eo utentes, neceffe eft linamen tis, aut ceratis communire corpus, quo offa conueftiuntur. Aliqui memoriæ prodiderunt, percuffos à ferpente nihil molefti paffuros, fi incifa offe tenus capitis cute, intritus fuccus infundatur, uulnusqque poltea confuatur .

N o $\mathrm{N}$ equidem dubitandun cenfeo, quin illud legitimum fit Euphorbium, quo pafim officine utuntur, cum tam Euphorbij cö guftu, quàm olf actu acerrimuin deprehendatur : ob cuius uiolentißimam acrimoniam nunquani, nifi inuito animo, d $\int e=$ fideratio. 
plafiarijs tunditur. Qusndoquidem tametfifibi nares, of os omni prorfus ingenio goßipio, o linteis aqua rofarum madefact is muniant; tanta tamé eft acrimonia vis tenuißima, ut onnibus und cum aëre penetratis munimentis, in co= rum tand em perueniat nares, ubi moleftißimun excitat ardorem, qui non facilé tollitur : quanquam etiam medicaměx tis adinodum refrigerantibus fuccuratur. Quo fit, ut folcrtisimi pharmacopols bailis, ac alijs uictum quarentibus boninibus id muneris obsundum tradant : interim tamen certó fciunt, non abfo; conuitijs, or maleditis opus boc ab illis peragi poffc. Qunanobrem mirmm fané non fuerit, fi qui ab arbore recentcm colligunt, eximium acrimonix fer

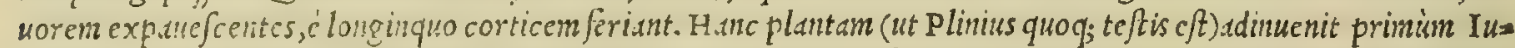

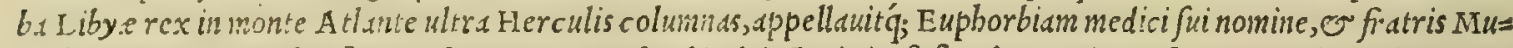
Euphorbif ui $\int x, i$ quo diuus Augufus fuit confcrustus. Euphorbio deicetoria ineft facultas. cuius nufquam, quod equidem inues

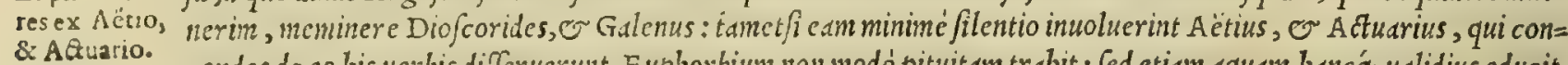
cordes de co bis nerbis differuerunt. Euphorbium non modó pituitam trabit; fed etiam aquam, hancó; ualidius educit. Eft autem acerrimum onnium, qu. ego nouerim, ardenti|ßimum $\dot{q}$; proptered colicis, e ucntrcm fïigidiorem baben= tibus ditur . cateros uebementer conturbat: fitim maxiné ciet. Nonnibil ex odoratis feminibus cieft commifcendum. Modus triobolaris, ex aq!la mulfa. Preft at tamen cum melle cocto ipfum in catapotia redigere. Id quod ctiam $\mathrm{P}$ au= lus annotauit libro feptimo, ubi inter ed $\mathrm{E}$ uphorbium recenfuit, qua aquam, ev pituitam deijciunt. Verum in fimpliciü Euphorbii ui cenfu, Diofcoridem, Galcnunq́; fecutus, de hac deicctoria facultate ip fe quoq; nibil memorix prodidit. Ceterim res ex Mefue. intcr Ajabcs MIefues fufius Euphorbij uires tradidit in foluentium medicinarum mentione, ubi ita, ad fenfum falteme jcribit. Euphorbium gummi eft, quod ufqueadeó excalfacit, extenuat $\dot{j}_{\text {; }}$ ut in boc catera gummigenera precellat. Excalfacit cnim ordine quarto: q160 fit, ut exulceret, ruborem, inflammationem $q_{\text {; }}$ infrrat, penetret, or uiolenter ab= ftergat. Euphorbium noxium admodum cft medic amentum, ita ut non fine labore, animi defectu, ac fudore frigido al= uum deijciat. Iocineriob id, uentriculó f fua ingenti acrimonia magnam infert noxiam. Quapropter exbiberi mini= mé debet, nifi prius ijs commifectur medicamentis, qua acerrinam eius uim retundere ualeant. Extrabit potum a

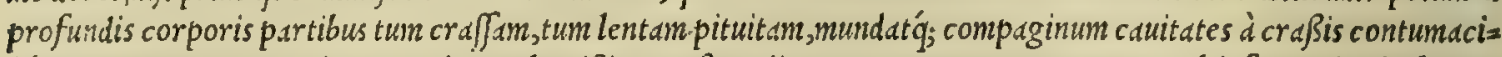
busue excrementis, qua in re omnium ualentißsinum eft medicamentum. Neruos expurgat ab infarctis iandiu bumo= ribus. Proficit ad hac refolutis, conuul/îs, Atupidis, tremulis, oris ;́; diftentionibus, ơ cateris neruorum morbis à fris gore obortis, /i ex leucoij oleo la uigatum exterius inungatur. Iocineri, lieniq; inunctum, mirificé corum dolores tols lit à frigore, ¿ flatu prouenientes. Stermutamenta ualentißimé cit . Occipiti autem confic $i c$ tum, ueternofos, obliujo= fos $\dot{q}$; iuudt. Aquam intercutem facilline extrahit duorum obolorum pondcre potum. Sed drachmarum trium pon= dere bauftum ( ut Serapio, of Auicenna fcriptum reliquerunt) potantem interficit, trium dierum patio erofis ab co inteftinis, U uentriculo. Euphorbium, tefte Mefue, quatuor edurat annis : neque eo prius utendum eft, quim annum integrum confenuerit. nanq; recens ob ingentem acrimoniam reprobatur. Seruatur conmodé milio, aut fabis, aut

Ex Goleno. Icntibus fepultum. Euphorbij facultates paucis perftrinxit Galenus lib. v I I. fimplicium medicamentortum, fic inquiens. Euphorbium cauftic $x$, fue urentis, or tenuium partium facultatis eft, alijs fuccis fimiliter. Et lib. I I. de compofitione med. localium, cap. I I I.tradens curam hemicranie, idem de Euphorbio ita fribit. Porró de cuphorbij facultate iam mibi relatum eft, quód citó exoluatur. quare in eiufinodi phamaca non uetus conijcere oportet. Dictü etiam recens albidius effe : quod ucró inueteratum eft, flatioris aut pallidioris coloris reddi. Planta, que Grecis G'фóşıv, Latinis item Enphorbium noininatur, quemadmodum fuccus cius: Mauritanis, Euforbion, feu Farbium: Italis, Euphorbio: Hipanis, Alforuiam, Alforfion, $\tilde{\sigma}$ Euforwio: Gallis, Euphorbe.

\section{X $\alpha \lambda B \alpha^{\prime} V A$. GALBANVM.}

C A L B A N V M fuccus eft nafcentis in Syria ferulx, quod nonnulli metopium uocant. Maximè laudatur cartilaginofum, merum, thuris effigitm prabens, pingue, minimè lignofum, retinens nonni hil adiecti f cminis, \& ferul $x$, graui odore,neque ualde humidum, neque nimis aridum. Adulteratur fa ba frefa,refina, 8 ammoniaco. Galbanum excalfacit, urit,extrahit, difcutit : inenfes, ac partus trahit appofitu, uel fuffitu. Lentigines aceto, \& nitro perunctas tollit . Deuoratur ad tufsim ueterem, difricultatem fpirandi, fufpiria, rupta, conuulfa. Aduerfatur toxicis, potum cum uino, \& myrrha: fimili modo fumptum mortuos partus extrahit. Imponitur lateris doloribus, \& furunculis: comitiales, \& uuluæ ftrangulatus, \& uertiginofos olfaetu fufcitat. Si uratur, fugat nidore ferpentes, \& perunctos feriri non patitur. Serpentes cum oleo, \& f phondylo circumpofitum, necat : dentium dolorem oblitú, aut cauernis inditum,mitigat . vrinæ difficili prodeffe cxiltimatur . Refoluitur ad potiones amaris amygdalis,aqua,aut ruta,aut calido pane, nulsáve: aliâs meconio,ære ufto, aut felle liquido. Si purgare Galbanum uoles, in feruentem aquam demittito. nanque cùm liquefactum fuerit, eius fordes fluitabunt: quas hoc modo facilè feparabis. Mundolinteo, raroq́ue alligatum in fistili, aut ærea pyxide ita pendeat, ut imum uafis ne tangat: opertoque uafe in feruidam aquam demittito: fic enim fyn cerum, ueluti per colum eliquefcet, \&lignofum in linteo remanebit.

Galbanicon. Qv A N v I s legitimum, optimumí; Galbanum in pluribus Italix locis, profertim $q_{\text {; }}$ Venetijs uenale reperia fideratio. tur; id tamen, quo paßin officine utuntur, nibil, uel fané parum Galbamum refert, q̧uod in laudatißini gencre à Dio fcoride reprefentatur. Siquidem illud non modó ab impoftoribus ddulteratum cft; fed etiam lignorum ferularumí; ramentis, lapidibus, ac alijs compluribus recrementis uitiatum. Quarant itdq; probifeplafiarij, quod optimum eft: 


\title{
In Lib.tertiumDiofcoridis.
}

alij uero, qui parfinonic, ne dicam auaritie ftudent magis, quam bonori, ut qui probatißimum uix nunquam af fequi polsint, id falten, quod impurum eft, purgare deberent à Diofcoride edocti. quippe quód ea ratione, facis lè $a b$ aduentitijs fordibus expurgari poßit. Galbuni uirestradidit Galcnus libro v I I I. fmpliciun medicancn= torum, fic inquicns. G.lbanum fuecus eft plantefrrulacex, molliendi, e digerendi ui. Fucritó; fané ex tertio ordine excalfacicntiun iucipiente, aut fecundo completo: in deficcando ucró ex fecundo incipiente. Id Grecé

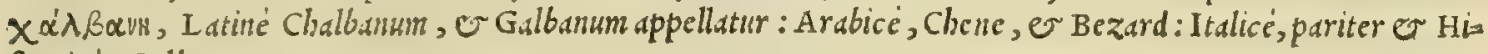
panicé, Galbano.

\section{A’unculxrór. AMIONIACVM. CAP. LXXXII.}

A M MON I A C V M ferulx fuccus eft, quam iuxta Cyrenen Aphrica gignit: cuius fruticem chm radice agafyllim uocant. Probatur bene coloratum, ligni \& calculorum expers, thuris frmilizudine; minutis glebis, denfum, fyncerum, nulla forde fpurcatum, caftoreum odore imitans, guftu amarum. Hoc gcnus thraufma, id elt, friaturam appellant: quod uerò terram, \& calculos collcgit, phryama a Gignitur in Aphrica iuxta A monis oraculum, fuccum ftillante ferulacea arbore. Mollit, exarahic, calfacit : tubercula, duritiasq́ue difcutit . potum aluum foluit, partus extrahit : lienem confumit, drachma pondere hauftü : articulorum, coxendicumq́ue doloribus liberat. Auxilio eft anhelaroribus, orthopnoicis, comitialibus : item quibus humor in pectore coit, fi cum melle delingatur, aut cü ptifana fucco forbeatur. Cruentam urinam pellit, albugines oculorum abfterget, genarum fcabritiam so abfumit : tritum autern cum aceto, \& impofutum, iocineris, lienisque duritias fedat . difcutit tophos, qui in artubus concalluerunt, cum melle, aut cum pice illitum . Lafsitudines, \& coxendicum dolores eo perungi utile eft, cum nitro, \& cyprino olco, uice acopi .

A M M O N I A C I Iacrymam oficiclite, mutata una litera, Armoniacum uocant. Cuius tamen fyncerißime pa= rnn ad nos conuebunt, qui ex Alexandria Aegypti cum mercimonijs Venetias redeunt. Quandoquidem rarıßimum Ammoniacum uifitur, quod fuis minutis glebis thus referat. Nam omne feré, quo officine utuntur, picea refine mo= do in maffam compactum cernitur, impurum, ac qudim plwrimis impoftorum adulterijs uitiatum. vt binc facilé dici poffe putauerim, hoc uel illegitimum, uel faltem deterins effe, id q́; fortaffe, quod Diofcoridi phyrama nuncupatur.

Cuius etiam meminit Plinius Lb. X I I.cap. X X I I I. ubi de Ammoniaco ita fcribit. Ergo Aethiopia fubiecta Aphrica 30 Ammoniacilacrymam fillat in arenis fuis. Inde etiam nonen ab Ammonis oraculo, iuxta quod gignitur arbor, quam Metopion uocät, refine modo, aut gummi. Generd eius duo, tbraufton mafculi thur is fimilitudine, quod maxime pro= batur: alterum pingue, or refinofum,quod phryama appellant. hec Plinius. Ceterum Ammoniaco ufi funt antiqui (ut Paulus eft author) in facrificiorum odoramentis, ac fuffimentis. In quem fane ufum illud ab ijs receptum fuiffe conijciendum eft, quod electißimum, $C$ thuri perfinile extitit. Huius rei illud maximo eft argumento, quod ab ipfo Paulo, itemi, Aëtio in fuis medic amentis Ammoniacum thymiama, boc eft, fuffimentum cognominatur, quafi Ammo: niacum preftantijimum ita intelligcre uoluerint. Ammoniacimeminit Galenus lib. v I. fimplicium medicamento= rum, fic inquiens. Ammoniacum liquor of ferule cuiufdam. Hoc babet emolliendi facultatem inten fam, adeó ut or

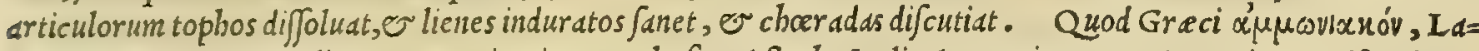
tini item Ammoniacun dicunt : Mauritani, Raxach, fiue Afach : Itali, Ammoniaco, or Armoniaco: Hipani, A= 40 guaxaque, o Armoniaque.

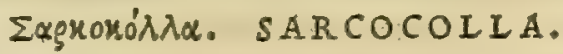

\section{CAP. IXXXIII.}

SAR C O COI I A lacrymaeftarboris in Perfide nafcentis, pollini thuris fimilis, rufa, guftu amara. Vulnera glutinat, oculorum fluxiones inhibet.emplaftris inferitur. Adulteratur admilto gummi.

L A C R Y M A M banc Sarcocollam dixere Greci, quoniam ficutiglutinum ligmum, ita bec fauciatam, exulce= ratámue corpork carnem agglutinet. Que autem ad nos aduebitur, non onnis legitima eft: quippe quód ea plerunq; so (ut de alijs quoq; pluribus lacrymis, refinis, or liquoribus fieri fuperius diximus) gummi, er alterius generis lacry= mis adulterata deferatur, $\sigma^{\circ}$ talis in officinis inueniatur. Verum fraus guftu facilé deprehenditur. quandoquidè que amara non eft, adulterium fenfit. Plinius lib. X I I I. cap. X I. albam cateris pratulit, fic inquiens. Fit er ex Sar= cocolla (ita uocatur arbor) gummi utilißimum pictoribus, ac medicis, fimile pollini thuris: or ideo candidum, quàm rufum melius. Et lib. X X I I I I.cap. X I I I I.idem ita fcribit. Sunt qui or sarcocollä pinx lacrymam putent, polli: ni thuris fimilem, cum quadam acrimonia dulcem. Cum uino tufa fiftitfluxiones: illinitur infantibus. Vetuftate es bec maximé nigre fcit . melior quo candidior. hec Plinius. Qui tamen in Sarcocolle biftoria ḋ Diofcoride, $\sigma$ Gale= no maximé diffentit, cimn bi sarcocollam guftantibus amaritudinem relinquere afferant, ille ueró contrà dulcedinem.

Sarcocclla Mauritanis pituito as cruditates, ac craffos, $\sim$ glutinofos de ijcit bumores, prefertin qui in compagi=

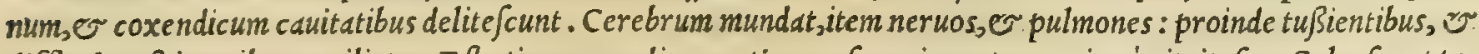
difficulter fpirantibus auxiliatur. Eft etiam ex medicamentis, qua fenes iuuant, precipué pituitofos. Calue $\int \mathrm{cunt}$ ta= men, qui frequentius ea utuntur. Praftat mirum in modum ad oculorum albugines, nubeculas, cicatrices, $\sigma$ id genus

Sarcocolle confideratio.

Ammoniaci uires ex Gal.

Nomina

Numina.

Ammoniaci confideratio.

$\mathrm{N} 2$ impedimenta,

Sarcocolle uires ex Ara-1 bibus. 
impedinenta, fi in craterc uitreo afinino lacte maceretur quinq; diebus: interea tamen noum lac quotidie eft infuns dendum, priore effiffo. Vulneraria preterea penicilla bydromelite prius madefacta, ac inde Sarcocolle puluere cir: cumlita duribus exulceratis utiliter imponuntur. Cruentis unlneribus, ac diuturnis ulceribus mirifice medetur : quip pe qux proprio fuo munere ea d̀ fordibus mundet, carne repleat, cicatriceq́; obducat. Aluă tardé deijcit, perturbat के cos, quorum ucntriculus bile redundat: quare cauendum eft, ne ijs exbibeatur. Roboratur eius deiectoria facultas, gin gibere, $\odot$ cardanomo additis. Hec ex Arabibus deprompfimus. que fané tam antiquis, quàm recentioribus incogni:

Ex Galeno. ta fuerunt, utpote qui ca nufquam, quod equidélegerim, fcriptis, tradiderunt. Sarcocolle uires retulit Galenus lib. VI I I. Iimplicium medicamentorum, ubi ita fcriptum reliquit. Sarcocolla lacryma eft arboris Perfica. miftam uims babet ex emplaftica quadain fubftantia, o paucula andara. Itaq; citra morfun deficcat, ac proinde glutinare uulne=

Nominz. raualct. Lacryma, que $\sigma \alpha \rho$ roxó $\lambda \lambda \alpha$ Grecis, Sarcocolla item Latinis, $\sigma-I$ talis appellatur : Arabibus, Anfa= rot, Anazaron, fell Auzurut: Hißpanis, I ancarotes: Gallis, sarcocolle.

\section{Гגxúniov. GLAVCIVM. CAP. LXXXIIII.}

G I \& v C I v M fuccus eft herbæ, quæ ad Hierapolim Sy riæ nafcitur, folijs ferè corniculati papa ueris, pinguioribus tamen, in terram fparfis, odoris tetri, guftus amari . tota croceo fucco madet. Folia in olla fietili femifrigidis clibanis calfaciunt indigenæ, ufque dum flaccefcăt : deinde contufis fuccum exprimunt. Cuius eft ufus ad oculorum medicamenta, utpote cùm inter initia refrigeret .

Glaucij confi G I A V C I v м medicorum, o officinarum uulgo, qui barbarorum, \& Arabum nomina ufurpare folet, sez 20 deratio.

rapionis, or Auicenne modo, Memithe dicitur. Id autem, quo pa\}sin Jepla fíarij utuntur, meo quidem iudicio, uerum

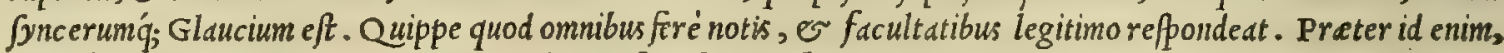
quód facto periculo, oculorum uitijs opitulatur; forinfecus rufefcit, intus ueró croceo colore pectatur, et guftu amds ro fentitur cum quadam graueolentia . tamet/i pharmacopolas nonmullos quandoq; deprebéderim, qui é maioris cbe= lidonij fucco Glaucium conficiunt. Sed animaduertendum eft, quód in Serapionis codice, prater proprium Memi= tha caput, quod Diofcoridis eft Glaucium, legitur etiam in capite de Curcuma (nifif fortaffe interpretis fuerit lapfus) Chelidoninn minus uocari Memithe. Qǘd in Serapione uel interpretis, uel alterius culpa, mendum fubfit, inde mibi quidem orta efl fuficio maxima, quód Diofcorides, cuius uerba ad unguem refert Serapio, Glaucij non meminerit in Chelidonijs. Quno factum eft, ut illi feplafiarij deprauata Serapionis lectione decepti, in bunc er alterum erroré in= ciderint: quod non folim ex chelidonijs fuum Glaucium eliciant; fed etiam maius chelidonium minoris loco fumant, 30

Glaucij uires quandoquidem illud fuccum croceum mittat Glaucio fimilem. Glaucij facultates memoria prodidit Galenus libro ex Galeno. VI. fimplicium medic amentorum, fic inquiens. Glaucium adftringit cum quodam faftidoo. Tum adeó maniffté rez frigerat, ut folum sepe cryfipelata, utiq; i fualentia non fuerint, curare poßit. Miftura eius compofita eft ex aqued

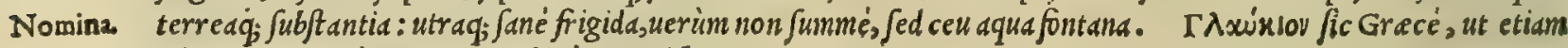
Glaucium Latiné dicitur : Arabice, Memithe.

\section{Kó $\lambda \lambda \propto$. GLVTINVM. CAP. LXXXV.}

G L V T I N V M, quod xylocollan, alij taurocollan uocant, præftantifsimum Rhodiacum, quod ex bubulis corijs conficitur. Id candidum eft, \& tranflucens . Nigrum uerò minus probatur. Refo- $4^{\circ}$ lutum in aceto, impetigines, leprasque cutis delet: ambuftis igni ex aqua calida dilutum, illutumque puftulas erumpere non patitur. Vulneribus prodeft melle, aut aceto madefactum.

\section{I'X 'Vóro $\lambda \lambda \alpha$. PISCIVM GLVTINVM.}

CAP. IXXXVI.

P I S C I.v M gluten, uenter eft pifcis cetacei . Præettat candicans, natione Ponticum, fubafperum, minimè fcabrum, \& quod celerrimè liquefcit. Vtile emplaftris capitis, \& leprarum medicaminibus, \& tetanothris, quæ cutem faciei erugant, \& extendunt.

Glutini con- N E M o eft, qui taurinum, or pifcium Glutinum non cogno fedt: quare bac in re non pluribus uerbis opus eft. so fideratio. Verüm fciendum, quód Glutinum taurinum bac atate non modó é taurinis corijs conficitur; ;ed ex omnium quadru= pedum pelltbus. Huius, neq; alterius non reperio meminiffe Galenum in fimplicium cenfu. quanquam inibi libro v I I. illius glutinis librarij mentionem fecerit, quod ex polline farina, o muria paratur, fic fcribens. Gluten, quod ad li= bros praparant ex fimilagine, $\mathcal{O}$ garo, emplaftice, concoctorix' $q_{\text {; }}$ facultatis eft, quibufcunque ipfum partibus illinas. Caterüm illud gluten, quod é pifcibus fit, inter cater a fimplicia Puulus quidem retulit, fed ea tantìm feré de eo fcri

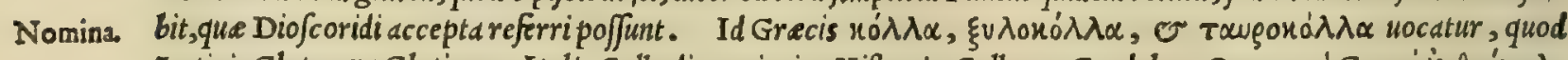
I atinis Gluten e Glutinum: Italis, Colla di carniccio: Hipanis, Colla, e Grudel. Que ueró Grecé ix Avóno $\lambda=$

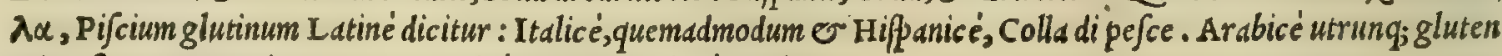
Zire, feu Gara nominatur : Germanicé, Leim: Gallicé, Colla. 


\section{In Lib. tertiumDiofcoridis.}

I'sós. VIS C V M.

CAP. IXXXVII.

V is C v M optimum eft recens, intus porraceum, extrà fuluum, quod afperi nihil, aut furfurofi conceperit . Fit ${ }^{2}$ acinis in quercu nafcentibus, buxco fruticis folio. Contufum acinum lauant, \& poftea in aqua decoquunt. Sunt qui commanducando ipfum efficiant. Gignitur quoque in malo, pyro,\& plerifque alijs arboribus. quinetiam inuenitur in quorundam fruticum radicibus. Emollit,difcutit, extrahit. parotidas, tubercula, cæterasq́ue collectiones ad maturitatem perducit,cum refina \& pari cera miftum : cpinyetidas in fplenio fanat : uetera ulcera, abfceffusq́ue, quos cacoèthes uo 10 cant, ex thure mollit . Lienem cum calce, gagate, aut Afio lapide coetum, $\&$ impolitum abrumit : cum fandaracha, aut auripigmento illitum, ungues extrahit . miftum cum calce, \& uini fxce, fuam uim intendit.

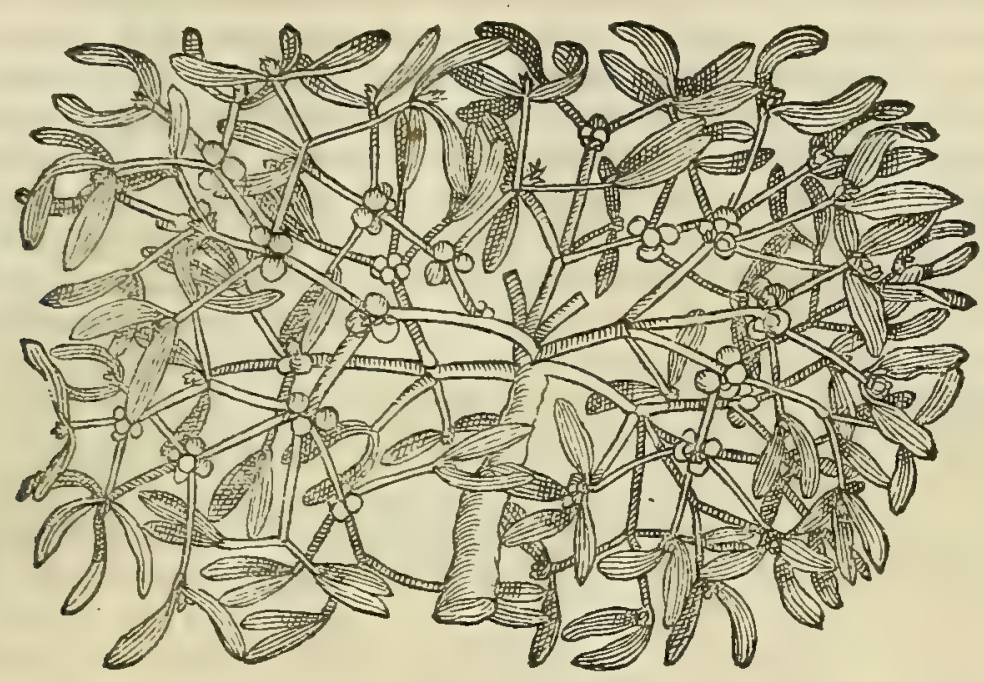

V I \& C v M fit plurilus, de diker/is modis. Verim omnium preftantifimum eft, quod égranis in quercu nafcen tibus conficitur . Huius preter id, anod inualidum in pyris, malisq; nafcitur, ingens in Hetruria prouentus. siqui= dem inibi non modo in quercu laudatifinzum prouenit, fed etiam in cerro, ilice, or caftaned, in noftris prefertim maritimis Senci:fibus, ubi uaftißime afjurgunt fylue, que non paruo pretio ïs locantur, qui uifcum efficiunt. Scans

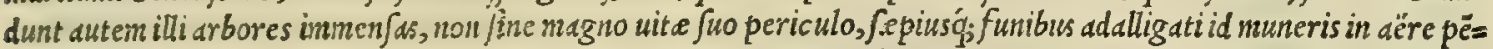
dentes obcunt. Grana, que legerunt, in aqua decoquunt, donec difrumpantur : poftea contundunt, or tandiu la= want in aqua, quoufque furfuraced exc:ementa eximant. Refert Plinius, nafci vifcum in quercu tantum, robore, ilis ce, fylueftri pruno, terebintho, pinu, o abiete. At in Hetruria gignitur etiam in caftanea, quod optimum eft, malo, ac pyro, non tantim fylucftri, fed etiand domeftico, quanuis penitus inutile. Vifcimaxima Hetrufcis utilitas eft:

40 nam preter eius ufum in aucupijs, quibus mirum in modun delectantur ob ingentem turdorum copiam, qui autumui tempore, in fyluis quibusdam cx iuniperis arte conftruftis, co capiuntur, id etiam in primis utile eft uitibus munien= dis, ne prima gcrminatione ab erucis, quibus omnia fattent, gemme denorentur. siquidem agricole vifco uites oms nes circundant, quo pofted erodentes uermiculi, qui tam preftantißimo latici infidiantur, é terra furfum petentes, meritó inplicantur. Qùjd cimm perßpexiffet naturd omnium rerum parens, uifci multum Hetrurie largita eft, ne hăc ob peftem uino deftitueretur. Vifci fruqu ue cuntur turdi, precipué magni, quos noftri uulgó turdellas appelz lant. Quorum ftercore uifci femine pleno inficiuntur, o Jeruntur arbores, in quibus pernoctant, or uititant: quo tandem femine nafcitur planta, que uifcun creat. Vnde fcite d Plauto dittum eft. Turdus exitium fibi cacat.

Caterim vifcum per fe non eft arbor, fed in arboribus wiuit, fronde plerungue perpetus. Id quod etiam teftatur virgilius lib. v I. Aeneidis, cimm inquit.

Quale folet fyluis brumali frigore vifcums

Fronde uirere noud, quod non fud feminat arbos.

Proinde Plinius lib.x v I.cap. ultimo ita fcriptum reliquit. Quedam enim in terra gigni non poffunt, $\mathcal{O}$ in drbox ribus nafcuntur. Nanque cum fuam fedem non babednt, in alicna uiunt, ficut Vifcum. Omnino enim fatum nullo modo nafcitur, nec nifi per aluum auium redditum, maximé palumbis, o turdis. Hec eft natura, ut nifi maturd= tum in uentre auium non proweniat. hec Plinius. Qux ante ipfum memorie prodidit Theophraftus libro I I. cap. XX II I de plantarum caufis, unde illa mutuatus eft Plinius. Porró id, quod in pinu, $v$ abiete nafcitur, quod (ut Plinius inquit) ftelin Eubred dicit, hiphear Arcadia, frequentißimum in Tridentino agro in uallis Ananix $\int y l=$ uis confpicitur, ubi ingens turdellarum copia uicittat. Sed hoc ad aucupia prorfus inutile eft: decoctun enint, ov de= inde elotum omnem amittit lentorem. Cuod autem in pinu,abiete, amygdalo, malo, pyroq ; prouenit, perpetua fronde wiret. Id ueró contrà, quod quercui, robori, of caftanee innafcitur, utpote cui appetente hyeme omnia folia deci= dant. Huius rei caufain reddere tentauit Theophraftus loco pauld anté citato, cum ita fcribit. Vifcum aliud folio effe

Vifei confideratio.

Víci utilitas in Hetruris. 


\section{And. Matthioli Comm.}

Theophrafti perpetuo, aliud deciduo, haudquaquam abfurdum eft . siquidem aliud uirentibus femper arboribus, aliud frondem fententia non accepta.

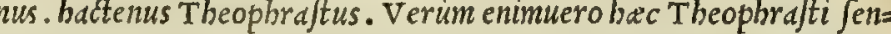
tentia non omni exparte probanda uidetur. quippe quoniam unuer fum Vifam, quod in amygdalo, pyro, maló,; in It alia prouenit, tam eftate, qudin byeme fronde perpetua uiret, cum tamen bx arbores byeme frondibus defti= tuantur. Quo fit, ut aliunde buius reicaufam petendam exiftimem. Fit preterea Vifcum auiculis tantùm capien= dis commendatum, in Syria ex myxis, qua Aphris sebeftena dicuntur, ut libro primo in prunorum mentione de ijs differentes retulimus. Vtuntur boc In übres fuis in aucupijs, quód arboreo uifco careant, illudó; $\dot{e}$ Venetijs defic $=$ runt, quó primim ex Damafco syrie aduchititr : unde Damafcenum uocatur. Sed id querno bonitate cedit. Fit quoque vifcum é quarundam arborum, radicibus, agrifolij prefertim, or uiburni, quarum etiam arborum biftoriam libro primo paliuri, o rbois commentarijs inferuimus. Qui autem ex buiufmodi arboribus uif cum conficiunt,cor= tices radicum fumunt, effoffá; ferobe inter fuarum arborum frondes bumido folo Sepeliunt, ibiq; tanto tempois re dimittunt, quoad computre fcant: mox eximunt, $\mathcal{O}$ tandiu in pila contundunt, donec lentorem concipiant: $d e=$ inde aqqua calida lauant, er manibus commifcent. Hac etiam ratione quibufdam in locis fit ex ibifci radicibus. Sunt qui querni uifci lignum in tenuißimum puluerem redigant, $\sigma$ comitulibus bauriendum prabeant . quo tantùm me= dicamento multos fuiffe fanatos pro certo affirmant. Sed noui ego complures, morbi, or medicamenti prorfus Vifci uiresex ignaros, quiligni loco vifcum ipfum in catapotijsdetorandum dederunt. Vifci meminit Galenus lib. vi. fim= Galeno. plicium medicamentorum, ubide eius uiribus differit ijs uerbis. Vifcum explurima dërea, er aquea calida, pau= cißima terrena fubftantia conftat. Nam acrimonia in eo amaritudinem excellit. Itaque etiam affectus fubftan= tie reßpondent. Siquidem ualenter ex alto bumores extrabit, nec cos tantum tenues, fed er craßiores, eósque 20 diffundit, ac digerit. Eft autem ex eorum genere, que non protinus poft primam appofitionem excalfaciunt, fed quat tempus requirunt, uelut thapfia. Sed o fuprà commonuimus, ineffe calidis facultate medicamentis, ubi

Nomina. largum continent bunorem recrementitium. Nomen illi Gracum, i'go's: Latinum, Vifcum: Arabicum, Dd= bach, feu Dibach: Italicum, Vifchio, er Pania: Germanicum, Vogel licin: Hipanicum, Vifco.

$\dagger$ Nulla bic in Graciscodicibus fit acinorum mentio, fed bac tantim leguntur. Yiver ac है $x$ Twos $x \alpha \rho=$

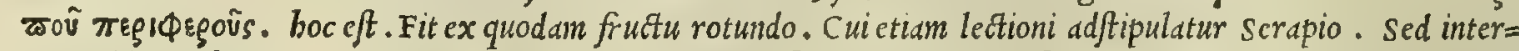
pres uidetur fecutus Plinium, qui lib. x v I. cap. ultimo fic inquit. Vifcum fit ex acinis, qui colliguntur meßum tempore immaturi.

A'zopitr. APARINE.

CAP. LXXXVIII.

A P A R I E ramis multis, \& paruis fruticat, afperis, quadrangulis, per interualla orbiculato foliorum ambitu,ut in rubia : flos albus : femen durü,rotundum, concauum,album,umbilici figura,afperitate ueftium te naci. Ea paftores coli uice utuntur ad eximendos è lacte pilos. Seminis, caulium, ac foliorum fuccus, potu contra uiperarum, phalangiorumq́ue morfus auxiliatur: infufu aurium dolori medetur. Herba cum axungia 40 trita, ftrumas difcutit.

A P A R I N E mufquam non prouenit, fed prefertim( $u t$ Theoplraftus inquit) inter lentes. Itali hanc uulgó uocant Spe ronelld, quód folia circd caulem ad calcarium ftimuli modum, afterifci inftar proferat. Tactu bac aperrima eft, quapropter cùm adoleuerit,attingentium ueftibus pertinaciter baret. Huius fuccum magnifaciunt quidam ad recentia uulnera glutinanda, et ad papillarum rimas. Aparines meminit Galenus lib.v I. fimp. medic.ubi fic breuiter inquit. Aptrine, quidam philantbropon, so alij omphacocarpum cognominant, modice extergit, et deficcat:

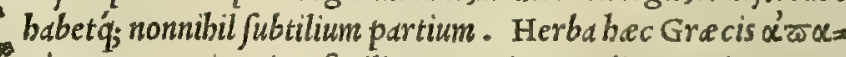
givn uocatur : Latinis fimiliter Aparine: Italis, Aparine et Spe ronelld : Germanis, Klebkraut: Hipadnis, Prefera : Gallis, Grda teron.

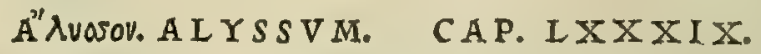

A I Y $S$ S o N exiguus frutex eft, unicaulis, fubafper, rotundis folijs : fructu duplicium fcutorum effigie, in quo eft femen quadantenus latum. In montibus, \& afperis locis emicat. Eius decoctum fingultus fine febri, 


\section{In Lib. tertium Diofcoridis.}

potu difcutit: idem efficit, fi quis cam aut teneat, aut odoretur. cum melle trita vitia cutis in facie, \& lentigines emendat. Contufa in edulio rabiei canis mederi putatur domibus appenfa falutaris effecreditur, $\&$ hominibus, atque brutis fafcini amuletum. Purpureo linteo circumligata, pecorum morbos abigit.

AL Y S S I uaria eft apud autbores biftoria. Nam f Plinio eft adbibenda fides, Alyfun ea plane fuerit berbi, quam Rubiam minorem wocxmus: que quidem, preterquàn quod folliaforat long é minora, prorfus Rubix fimilis cö= ftat. Ruod autem Plinio h.ec sibffon fit, eius uerba declarant lib. X X I I I I. cap. X I ubi de erytbrodano ita foribit. Erytbrodanus, quam aliqui ercuthod.num uocant, nos Rubiam, qua tinguntur lans, pellesó; perficiuntur, in medi=

20 cina urinam cict. Morbum regium fanat ex aqua mulfa: or lichenas, ex aceto illita: $\mathcal{O}$ ifchiadicos, er paralyticos, ita ut bibentes lauentur quotidic. Radix, fenenq; trabunt menfes, aluum fiftunt, or collectioncs difcutiunt. Contra ferpentes rami cum folijs imponuntur. Folid o capillum tingunt. Inuenio apud quofdam morbum regium fandri boc frutice, etian fi adalligatus pectetur tantion. Diftat ab eo, qui Alyffon nocatur, folijs tantum, er ramis minoribus. Quippe nomen accectit, quód à cane emorfos rabiem fentire non patitur, potus ex aceto, adalligatusq́;. hattenus pli=

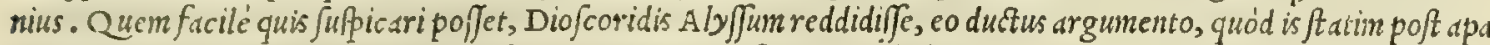

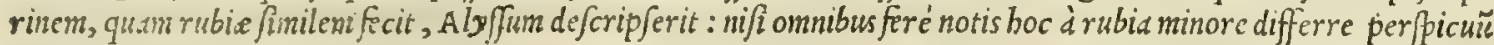
effet. Siquidem Diofcoridi Aly fum folijs eft rotundis, fructu duplicium fcutorum effigie, in quo femen quadantenus latum. in montibus, or aperis locis naf cutur. Que fané omnia in minori Rubiadefiderantur. Quod preterea Dio= fcoridi, wt Plinio, Rubia minor non fit Aly fum, ex eo aperté cognofcitur, quód is infrà de maiori, er minori $\mathrm{R} u b i \alpha_{,}$

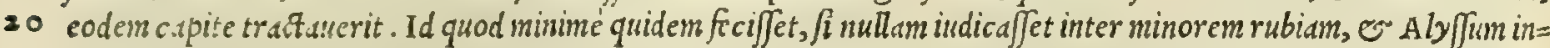
tercedere differentiam. Quare uel plinium bac in re ballucinatum, uel diuerfumà Diofcoride Alyfum accepiffe cre diderim. Porró magis adbuc Aly/i hiftoriam ea confundere mibi uidentur, que de co pofteritatis memoric prodi= dit Aëtius, cum inquit. Alyffum eam berbam effe aiunt, quam Heracleam fideritim uocant, qux propter uias ubique nafcitu", pur pureo flore, folijs craßioribus. Nomen traxit, quód à cane rabido emorfis mirum in modum opituletur. His uerbis Aètius non folim non refirre Diofcoridis Alyffum deprebenditur: fed neq; etiam fatis exprimere, quam fideritin pro Aly fo intelligat. Nam cum tres fint fiderites à Diofcoride monftrate, quarum dua, prima fcilicet, er

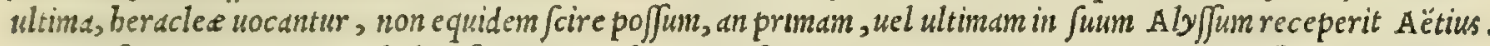
Florcm fiquidem purpureumbabet fideritis Diofcoridi poftrema, in uineis, o macerijs nafcens; folium tamen non crafjum, fed tcnuem, coriandri modo, in ambitu laciniatum, ut eam plané referat plantam, quam uulgus berbariorum

30 Rubertam appellat. Huic poftremó, ut alijs quoq; non confentiunt que de Alyffo retulit Galenus lib. I I. de antido= tis, ubi nomulla A fcle piadis medicamenta ad rabidi canis morfus commemorat. Aly ffum, inquit, berba eft marrubio adfimilis, afperior tamen, or magis aculeata circa orbiculos: florem ad caruleum uergentem profert. Hanc fub ca= nicule aftu colligere oportet: exiccata contundi, cribrari, er feruari debet, ne diffletur. Ex bis Galeni uerbis pa= $l$ line eft, Aly fum ab co ex A fclepiadc defcriptum, potius primam, quàm ultimam fideritim referre. Cùm igitur uaria adnodum fit de Alyffo authorum fententia, cim'q; eius biftoria tam uaria, incerta'́; babedtur, difficilé quidem fuerit

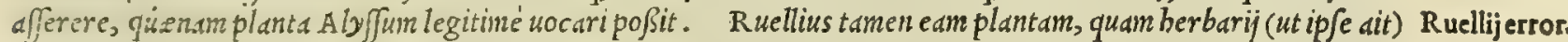
fy. Iucftrem cannabin uocant, putat effe Diofcoridis Aly fum, uel ad ipfum propius accedere. Quod, ne femper alio= rum errata corrigere uidear, ijs áijudicandun relinquo, qui in fimplicium hiftoria etiam mediocriter uerfati, bec or

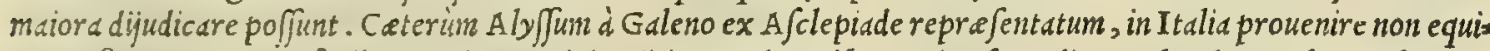
40. dem inficiar, neq; illud fimiliter, cuius meminit Aëtius. Sed quod horum in ufu medico probandum, uel reprobandum fit, non facilé decernere aufin. quanquam ḋ Galeno nunquain difcedendum putauerim. Qui preterea Alyßifaculta= tes tradidit lib.v I. fimplicium medicamentorum, bis uerbis. Nuncupata eft bec berba Alyffon, quód mirifice iuuet demorjos à cane rabido. Sed o rabienti quoque data, sepe in totum fanauit: atg; boc ex totius fubfantice fimilitu= dine efficit. Diatumí; prius eft talem facultatem ex fola percipi experientia, et plané nulla conftare metbodo. Quód fi quis ad multa experiatur, cognofcet faculiatem babere mediocriter ficcificam, or digerentem, cum boc ut abfter. forium nonnibil etiam obtineat. Hac, ratione or uitiliginem, or maculas faciei d fole prognatas expurgat. Herbas que $\alpha^{2} \lambda$ varov Grecé, Aly ffum quoq; Latiné dicitur : Italicé, Aliffo.

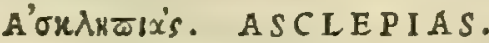

\section{CAP. XC.}

A S C I E P I A s, ramos emittit longos: folia hederx, longa: radices numerofas, tenues, odoratas: floris uirus graue: femen fecuridacre. nafcitur in montibus. Radices ex uino potx torminibus auxiliancur, \& contra ferpentium i\&tus. Folia aduerfus vuluæ, mammarumq́ue ulcera, quæ cacoẻthe uocant, illinuntur.

F A I L V N T V R, mea quidem fententia, qui A fclepiadis uice, quam in montibus nafci tradidit Diofcorides, necnon etiam Plinius, eam berbam accipiunt, quam uulgares quidam chirurgici Hederam terrestrem nominant: qua Flerunt; fecus uiss nafcitur, or perpetuó humi ferpit folijs rotundis, apperis, per ambitum quadantenus ferratis, lon= zo tenuiq; funiculo appen is : floribus exizuis, in purpura albicantibus : radicibus tenuißimis. siquidem preterquam quod Diofcorides criptum non reliquit $A$ clepiada in uijs publicis nafci, nufquam etiam, quod legerim, prodidit ean= dem tam longo repere tractu, er folia rotunda proferre. Nec minus etiam, ut equidem arbitror, hallucinantur ij

Aly si conideratio.

Varia de Aly fo fententua.

Alyfsi uires ex Galeno.

Nominas

Afclepiadis confider. Quorundam lapfus. 


\subsection{8 \\ And. Matthioli Comm.}

Fuch. error. (pace tamen Fucbsij eruditifimi dixerim, quem conftat ex fuis commentarijs hanc babuiffe fententiam) qui putant Afclepiada eame effe plantam, quàm uulgis berbariorum vincetoxicum uocat. que frequenter in $\int a x$ of is, $\mathcal{O}$ afperis locis prouenit, lieui admodum caule: folijs lauro acutioribus: flore albo, mufcofo: corniculis tenuibus, oblongis: $r a=$ dicibus innuncris, albicantibus. Quandoquidem buius cùm folia, tum radices nullo odore commendantur : flores ui= rus aliquod non redolent: femen non eft fecuridace fimile. Adde etiam, quód ex Oribasij lectione Afclepias nö pro= fret foliu longa . cui fubfcripfit Marcellus interpres, fretus fortaffe, ut folet, probatißimis exemplaribus. Praterea

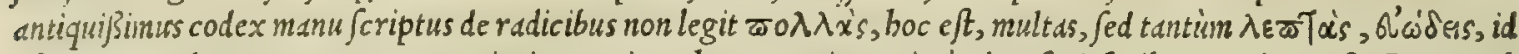

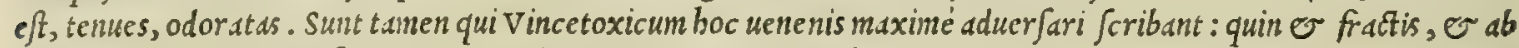
alto deuolutis auxiliari, fi contrite in puluerem radices $\mathrm{ex}$ uino fun antur. Has preterea laudibus efferunt ad mam= mas à partu turgentes, prefertim ubi lac in eis coierit: in quorum ufuradices ip $\int a s$ decoquunt, quas deinde cum po= lcnta mammis illinunt. Sed perperim, quòd boc Afclepiadis fit proprium. Ceterün non defunt, qui illam bumi re pentem berbam, de qua antea diximus, pluribus celebrent facultatibus, prefertim ad thor acis, o inteftinorum uul= ucra. quamobrem potiones ex ea magna opinione factitant, o fuccun eius in unguentis admifcent: nang; uulnerd= ria eft, er glutinatoria. Afclepiadis meminit quidem Galenus libro v r. fimplicium medicamentorum, fed nibil de eius uiribus differens, fic tantim inquit. In tertio Diofcorides de hac herba confcripfit. at nos eius nondum pericus

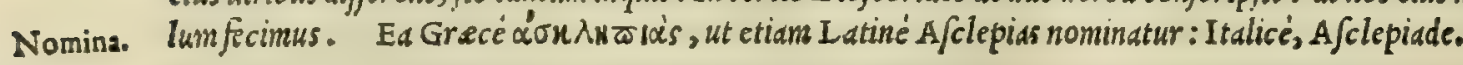

$$
\text { A'TgaxTuRis. ATRACTYLIS. CAP. XCI. }
$$

A T R A C T Y I I s, fpina eft cnico fimilis, folia multò longiora ferens in fummis uirgis, magna parte nuda, afperaqque, qua foeminæ pro fufis utuntur. capitula in cacumine fpinis horrent: flos luteus, quibufdam in locis purpureus inuenitur : radix tenuis, fuperuacua. Coma, femen, \& folia cum pipere, \& uino teruntur utilifsimè contra fcorpionum ictus. Percuffos tradunt, quandiu ea teneatur herba, nullum experiri dolorem, ipfumq́ue depofita ftatim recrudefcere.

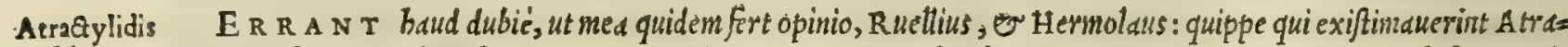
confid. atylida effe Cnicum fylueftrem, cuius primo loco meminit Theoftraftus lib.v 1 . cap. I I 1 I. de plantarum biftoria . Si= Ruel.\& Her- quidem magnam ego inter fylueftrem Cnicum, $\mathbb{E}$ Atratylida inuenio apud Theoploraftum effe differ entiam. Quod molai orror. ut omnibus perpicuum effe poßit, ijs prefertim, qui dliter fentiunt, bic Theoplbrafti uerba de Cnico, Acarnd, $O$ o $A=$

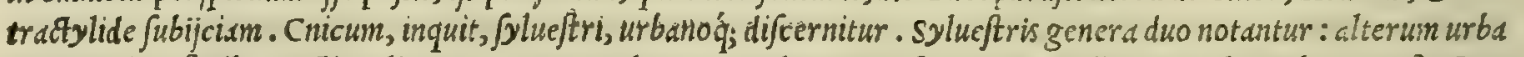
no admodum fimile, recticaulius tamen: quamobrem eo mulierum prifcarum nonmille pro colu utebantur. frudtum nigrum, maiufculum, amarum $q$; parit. Alterum genus denfun conftat, caulesqg; foncheos profert, quod aminodo bu= micaule fit : nam propter foliorum mollitiam declinatur, procumbit'́; ad arua. fructum amarum, frequentem, bar=

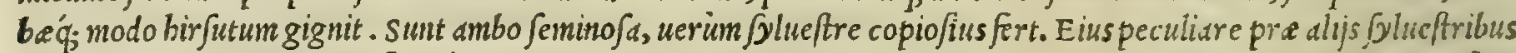
eft, quód illa duriora, pinofior áf, urbanis proueniunt: boc autem mollius, ac lacuius conftat. Acarna quoad fims plici ratione exprimi licet, appettu cnico urbano fimilis eft, colore flauicans, fucco pinguis. Fufus agreftis (fic cnims Atractylida Latini nominarunt) bis caindidior eft : babetó; peculiare, quod in folijs cuenit decerpta cnim, carniq́; al lata, fuccum fanguineum effund unt : qua de caufa Фo'vos, id eft, cruor à quibufdam pina hac eft nominata . gravis ex. tiam odore, cruorem q́; reprefentans. Seró perficit fructum, autumno enim. or quidem in totum (ut fummatim pros= ponam ) uniuerfa pinaceorum natura fructus ferotind exiftit. hac Theophraftus. Ex quibus uerbis facilé cognofci 40 poteft, in Atractylidis hiftoria aperté aberraffe Ruellium, cum in tertio fuo de natura ftirpium libro afferit, Fufum agreftem, boc eft Atractylida, nil aliud effe Theophrasto, qudim primum Cnici fylueftris genus. utpote qui non ani= maduerterit, quód A tractylis Theopbrafto alia eft à Cnico fylueftri planta : quanquam itlifortaffe non abfimilis, or cui ea tantum infit proprietas, ut é folijs fuccum fanguineum fundat: id quod nullo Cnicigeneri tribuitur. Errandi ei occafionem, meo quidem iudicio, prebuit Plinius, quód lib. X x I.eap. X v. Jylueftrem Cnicum à quibufdam Atracty= lida uocari tradiderit. v bi poftquàm commemor affet nomnullas pinofas plantas, quibus Aegyptì in cibis utuntur, de Cnico tandem in bunc modum differuit. Multas pratered, inquit, ignobiles habent plantds. Sed maximé celebrant: Cnicon Italie ignotam, ipfis autem oleo, non cibo gratam. Hoc faciunt ex femine cius. Differentia prima fylueftris, $\mathcal{O}$ fatiux. Sylueftrium dua pecies, una mitior eft, fimili caule, tamen rigido, exilis. Itag; $\odot$ pro colu antique mu= lieres utebantur . quam quidam atraftylida uocant. Semen eius candidum, $\sigma$ grande, amarum. Alter a birfutior, to = rofiore caule, er qui pené humi ferpat, minuto femine. hac Plinij uerba. Quse etfi quidem certam fidem faciant, priz mum fylueftris Cnici genus à quibufdam Atraftylida fuiffe uocatü; non tamen proptered affirmant, Atratglime effe Cnicum fyluestrem . Atrattylidis deinceps peciatin meminit ipfe Plinius cap. X v I. eiufdem libri, cum inquit. Acar= na colore tantum rufo (à fcolymo fcilicet) diftinguitur, of pinguiore fucco. Idem crat Atractylis quoque, nifi can= didior effet, or nifi fanguineum fuccum funderet . qua de caufa phonos uocatur ì quibufdam. Odore etiam grauis, ferò mature fcente femine, nec ante autumnum : quanquam id de omnıbus ßinofis dici poßit. hactenus Plinius. Ex ijs igitur omnibus meritó colligendum effe putauerim, legitimam Atractylidem nullum effe fylueftris Cnici gemus, fed $d=$ liam per fe plantam, nempe illam, qua pro fufis prifce utcbantur mulicres. Cuod fane animaducrtens Thcodorus fui Greci idiomatis peritißsimus in Theophrafti uerfione, Atractylida fufum agrestcm interpret.tur, non autem $c 0=$ lum, ut primum agrestis Cnici genus uertendo, ex antiquo ad colos ufu, id Colum agreftem recté cognominari poffe monftrauit. Qua inre is plane declaraffe uidetur, prifeds snulieres agrefti cnico coli uice fuiffe ufas, fuforun uerò 


\section{InLib. tertium Diofcoridis.}

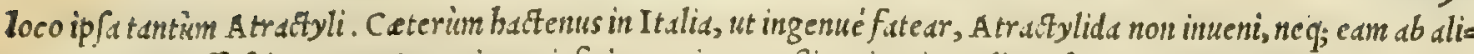
quo repertam cffe fcio . quahuis non iucro inficias, quin ea poßit ctian in Italia nafci. Equidem plures sidi plantas acule is horrentes, que illius not is pulchré repondebant: attamen ex ijs uullam unquan ractus fum, qux folijs carni adbibitis fanguineum fuccum funderct. Credidut Ruellus alteram Cnici fylueftris peciem cam nimirum effe flirpě, quam berbariorum uulgus Cardumbenedifum, uel futtum appellat. Quxn profectó optnionem baudquaquam in= probandann puto. quandoquidem Carduus benedictus uoc stus folo procumbit denfa foliorum com.x, o quodanmodo

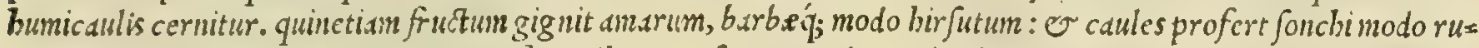
bentes. Vicxijs notis accuratius expen/is, quibus prorfus conucnit Carduo benedicto cum altero cnici fylucftris ge nere, nil mirum fi cogor mut.ure fententian, O boc quod aliâs negaueram, nunc plané afferere non dubitem. Scd Ruel. lapfus.

20 certé Ruellium mirari fubit, quòd tan facilé afferuerit Carduun benedictum uocatum fanguinem ex fe fundere. Nă etfí cgo millies periculum fecerin; nunquam tamen euulfo folio, ucl ramulo fanguinem é unlnere profucre comperi. Preterea fi concedamus, quód Rucllius uerarcferat, id maximé ipfius repugnabit fententix, cum tam Theopbrafto, quàm Plinio nullum Cnicigcnus fanguinem fundat: quonam id A tractylidis cft proprium. Hinc itaq; palam fieri ar= bitror, Ruellium, alioqui doctißimum, turpiter confiddiffe Atradtylidis biftoriam . Quippe $i$, , $t$ fuam tucretur fenten tiam, afferere woluifet, Atractylida effe primum fylueftris Cnicigenus, illud quidem fuccumfundere fanguinis inftar feribere debuiffet, non autem boc, quod Carduumbenedictum effe ccnfemus. Neque etiam mibi, ut liberéliceat quod quifq; fentit dicere, placet Fucbsij opinio. qui libro primo de compofitione medicamentorum, $\sigma$ in fuis de plan tarum biftoria commentavijs, Carduum beneditum unlgó nominatum A tractylidem bir futiorem effe exiftimat. birfu= tiorem dixi, quonian is duas effe conftituit Atractylidis pecies, nempe mitiorem alteram, alteram bir futiorem: $t a=$

to metfi tum Diofcoridi, tum Theopbrafto Atractylis unum duntaxat fit genus. quod, quantum reor, Carduus benedis ctus non eft. Siquidem bic nee fanguine um fuccum fundit, nec in inis uirgis unquam uifitur nudus: quinimó uirgas non profert, fed caules lentos, quibus humiferé reptat, uel potius folo procumbit. Sed poftqudin in bac noftra Atra= cylidis, or Cnicorum jylueftrium difquifitione, fermo incidit de Carduo benedicto, non ab re bic de miris eius atque

30

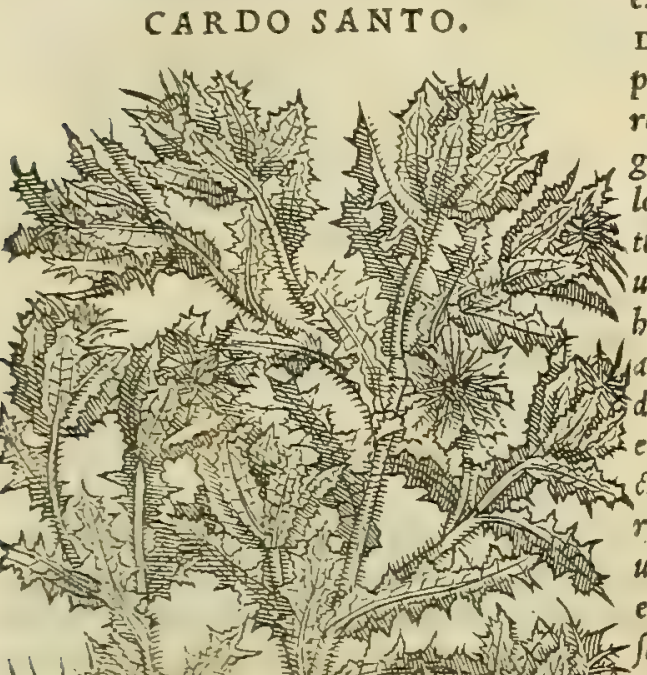

\section{CARDO SANTO.}

excellentibus dotibus nobis differendum eft. Eft igitur C A R= D v v s Benedictus ita uulgó nuncupatus, planta nullis hoc tem pore non cognita. Seritur paßim in hortis, fapore admodum amd= ro, quód terreis conftet partibus calore quodam attenuatis. Mas= gni nominis,magneó, exiftimationis planta eft non modó apud It los; fed etiam apud exteras nationes, prefertin contra peftilen. tian: item aduerfus uenena lethalia, tam interius fumpta, quà uenenoforum animalium ittibus, aut morfibus impo/ita. Sanantur hac berba quartana laborantes, aut alijs febribus detenti, quarum acceßsiones cum frigore adueniunt. Id enim preftatur haufto eiks decocto, aut fillatitia aqua, aut pulueris drachina pota. Praftant eadem comitialibus infantibus eodem modo bibita. Herbe deco. ctum ex uino fumptum iliusn, or renum dolores mulcet, or cate. ra uentris tormina fedat: fudorem cit, alui tineas necdt, er uteri uitijs auxiliatur. Herba ip $\int a$ tam recens, quam ficca er pota, er exterius admota, contumacia ulcera, er que cacoëtbe uocantur, fanat, cuteq́; obducit. Quamobrem decoctis mifcetur, que éli= gno Gualaco ex uino, et aqua ijs parantur, quos lues Gatlica cor

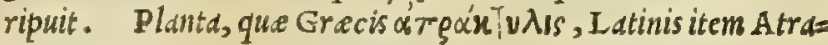
aylis, er Fufus agreftis appellatur: Italis, Atrattile.

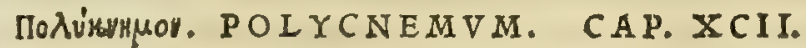

POL Y C E M O N, frutex eft furculofus, folijs origani : caule, ut pulegij, geniculis multis intercepto, fine umbella, tenui tamen in cacumine corymbo, boni odoris, \& acris . Vulneribusagglutinandis recens, aut aridum, cum aqua efficaciter illinitur : fed quinto die folui debet . ad urinæ ftillicidia, ruptaq́ue cum uino bibitur.

POL Y C E M V M bactenus, quód ego quidem ip um cos gnouerim, non reperi, neque uidi in Italia. Ceterim etfin inibi nonnulle inueniantur, atque etiam à quibufdam pro defint, que in Polycnemo requiruntur, quàm ut pro uero probaripoßint, non equidem quicquan in boc certiftatue= re aufim. Vude fatius ip fum inter alias ignotas plantas collocandum effe duxerin, donec aliud certius compertum fue rit. Sed fi quis interim Polycnemi uires ex Galeno quog; fcire defiderat, is lib. v I I . fimpl. medic. illas ita paucis

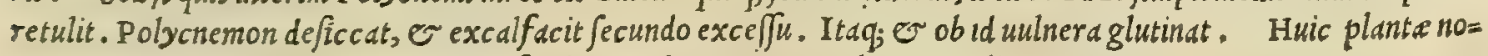

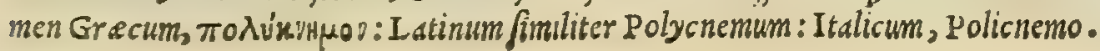

Fuchlij opin. reprobate.

Carduibene. diâti uires.

Nomine. confideratio. Vires ex Galeno. Nomina. 


\section{And. Matthiol Comm.}

CLINOPODIVM:

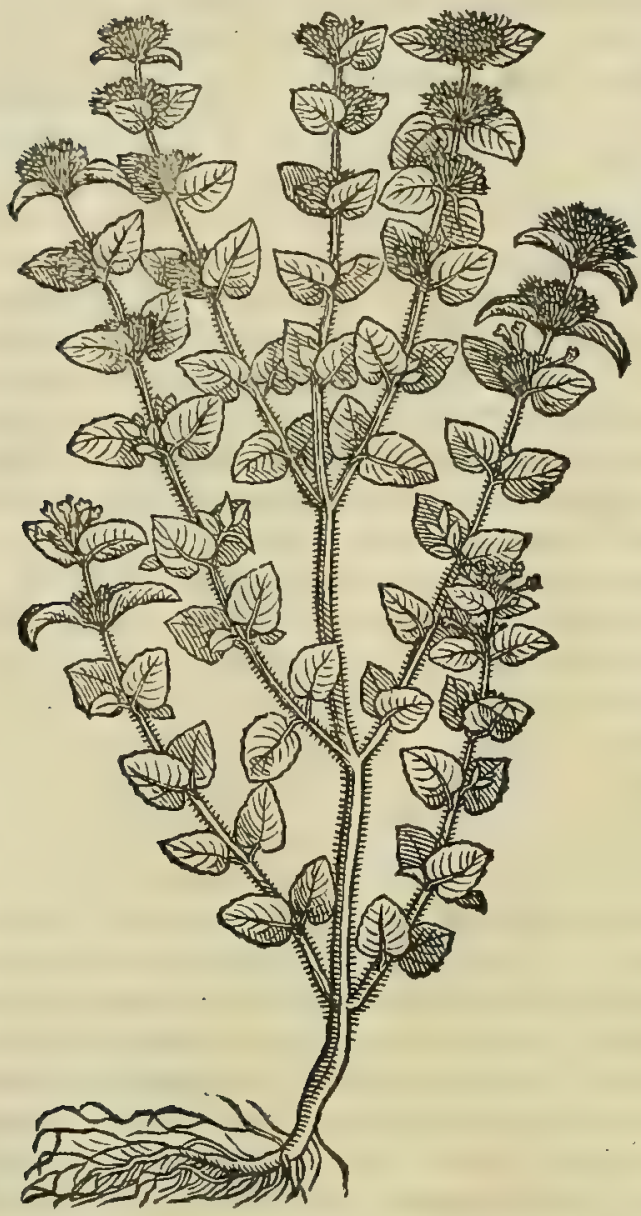

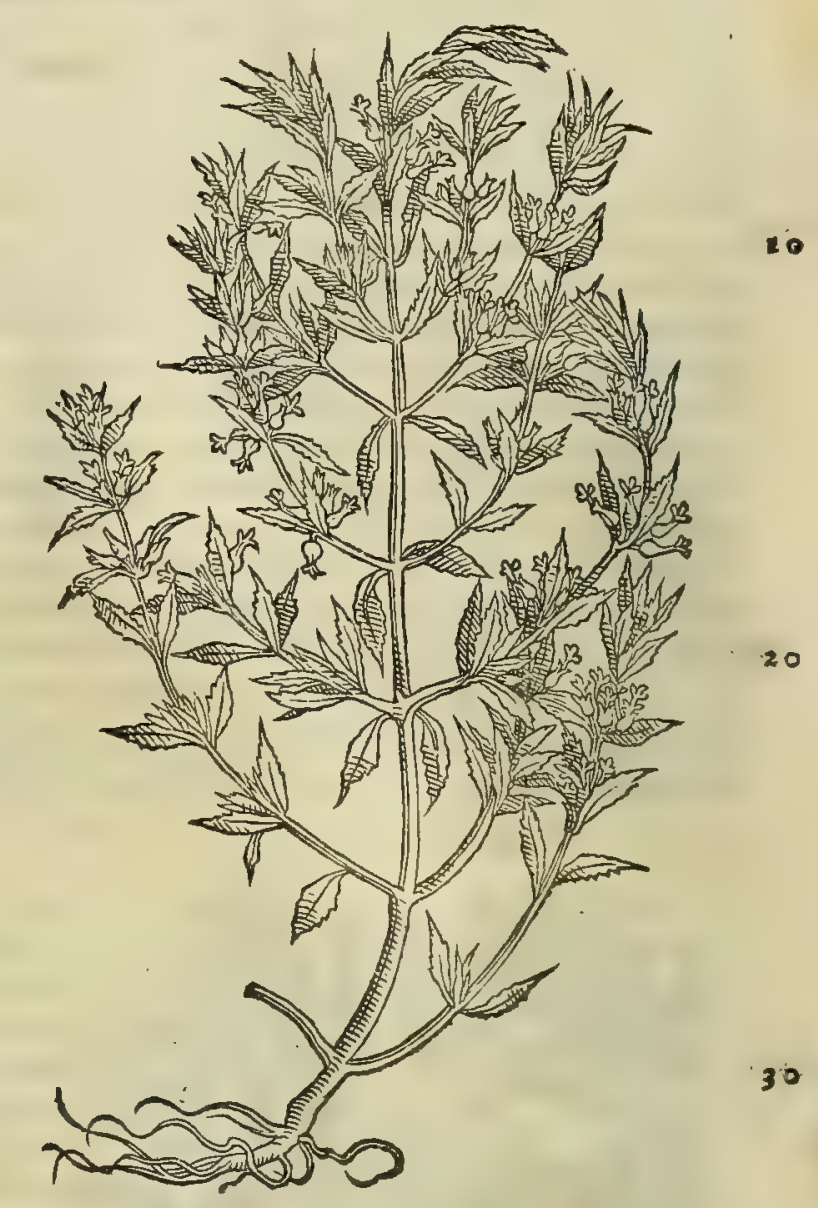

CAP. XCIII.

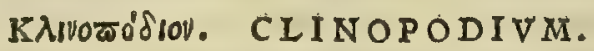

C I I N O P O D I O N frutex eft folijs ferpyllo fimilis, furculofus, duûm dodrantum altitudine. Nafcitur in petrofis. Flores, marrubij modo, ex interuallis diftincti f peciem lecti pedum præbent. Bibitur herba, \& fucci eius decoctum, ad conuulfa, rupta, ftrangurias, ferpentium ictus : menfes, $\&$ partus pellit : \& penfiles uerrucas, quas acrochordonas nocant, eijcit, aliquot diebus potum. Aluú 40 fitit decoßtum ad tertias, potumq́ue, fi febrim fentiunt, ex aqua; alioquin, ex vino.

Clinopodij C I I N O P O D I O N nil aliud nobis defignat, qudm lectice pedem, quód circinata florum figura, qui inter = confid.

cedentibus interftitijs caulem circumplectuntur, bafim lectica pedum referat. Nafcitur ubique frequens, folijs non

Clinopodij modó ferpyllo proximis; fed etiam montane calaminthe, quam maximé reprefentat. Huius meminit Galenus li=

facultas ex bro vir. fimplicium medicamentorum, fic inquiens. Clinopodium excalfaciendi uim obtinet, fed nondum aduren Galeno. di : eft ueró etiam effentia tenuium partium: ponatø̆; ipfum quipiam in tertio ordine tum excalfacientium, tum res.

Nomina. ficcantium. Kגivorósiov fic Grecé, ut Latiné pariter Clinopodium uocatur : Italicé, Clinopodio.

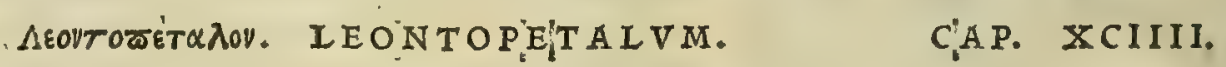

LE ON T O P E T A L ON, caulem emittit dodrantalem, aut altiorem, plurimis alis concauum, $\&$ in cacumine femina parua duo, aut tria, in filiquis, ciceris modo: Alores anemonæ fimiles, punicei coloris : folia brafsicæ, fed papaueris diuifura : raciicibus nigris, rapa fimilibus, frumofis. Nafcitur in aruis, \& fegetibus. Radix auxiliatur ferpentium ictibus, ex uino pota : nec alia res celerius dolorem finit . mifcetur ifchiadicorum clyfteribus .

Leontopetali L E O N T O P E T A L V M, eiusq́q; nigram, extuberantem q́; radicem, rapi inftar magnitudine, non modó confider. Venetijs, o Patauij in quibufdam hortis uidimus; uerim etiam in Hetruria aruis, alijs fr $_{\text {; }}$ Italic locis. Nafcitur fre $=$ quens in Apulia. Leontopetali meminit Plinius libro X X V I I. cap. X I. ubi ip fum ïs depingit uerbis. Leontope= talon, alij rbapeion uocant, folio braßsice, caule femipedali, alle multe, , Jemen in cacumme in filiquis cicer is mo= 


\section{In Lib. tertium Diolcoridis.}

IEONTOPETAIVM.

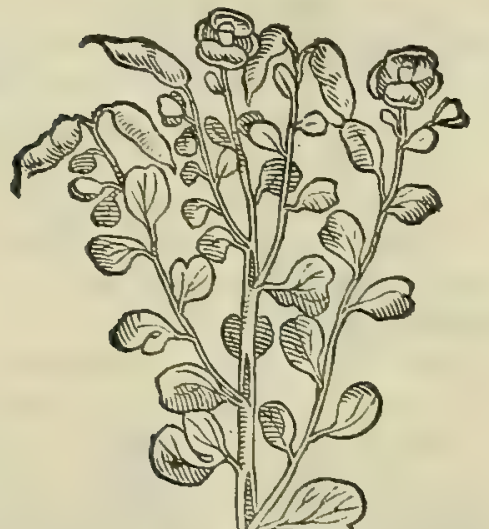

20

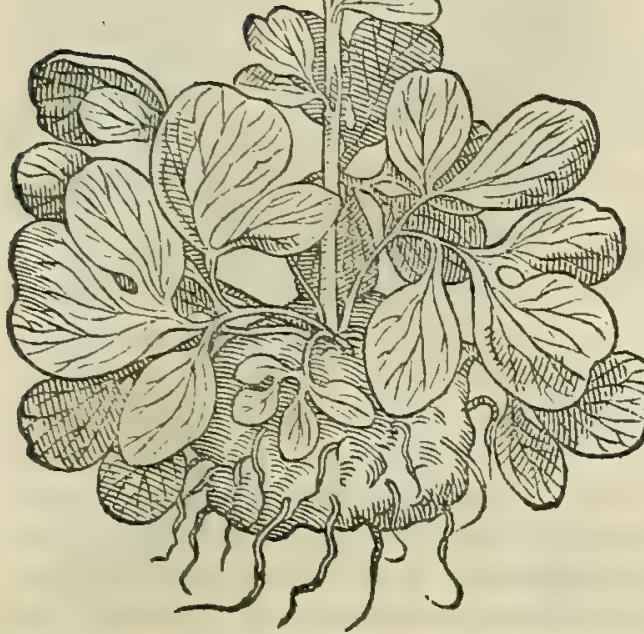

TEVCR IVM.
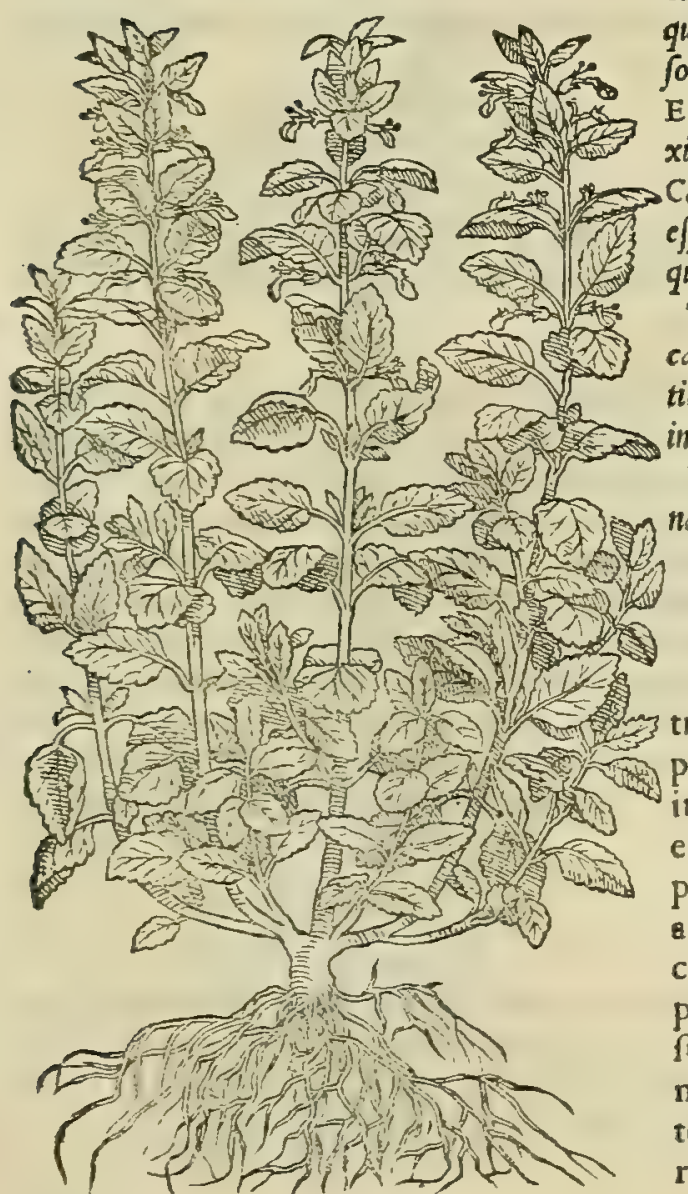

do. radix rape fimilis, grandis, nigra. nafcitur in aruis. Iex Icontopetall ontopetalifacultates paucis perftrinxit Galenus libro VII. fim = uires ex Gat. plicium medicamentorum, übi fic inquit. Leontopetali radice maximé utimur. Digerendifacultatem, $\sigma$ exiccandi, excalf $d=$ ciendig; in tertio ordine poßidet. $\Lambda$ eorTore't $\alpha \lambda$ ou quod Gre= ci, Leontopetalum qroq; Latini dicunt: : Leontopetalo, Itali.

$$
\begin{aligned}
& \text { TrixgloV. } T E V C R I V M . \\
& \text { C A P. X X V. }
\end{aligned}
$$

TEYC R I O N, fuc, ve alijs placet, tcucris, herba eft uirgx referens effigiem, triffaginis fimilitudine, tenuifolio, non multùm à cicere alicno. Hæc in Cilicia iuxta Gentiadem, Ciffademq́ue ubertim prouenit. Recens cum pofca, aut aridx feruefactx ius potu lienem po tenter abfumit . Licnolis cum aceto, \& ficis illinitur : ité ferpentium morlibus ex aceto folo line ficis .

H E R B A qued,rm nafcitur pluribusin locis, folijs quidem Teucrij conciceris, fed caule, er facie triffagini ideó finilis, ut fepe ex tem= fideratio.

pore uifa oculos decipiat. Hanc effe uerun Teucrium mecum femper exiftinaui, quéd ea mibi plané notis repondere uided= tur, quai Diofcorides Teucrio reddidit. Qui tametfi fcribat ubertion nafci Teucrium in Cilicia iuxta Gentiadem., $\sigma$ Ciffa dem; id tamen nibil impedit, quin or in Italis pronenire queat. Plinio duo Teucrij produntur genera libro $\mathrm{x} \times \mathrm{v}$. cap. v. ubi ita fcriptum reliquit. Inuenit e Teucer eadem atate Teucrion, quam quidam bermion uocant, pargentem iuncos tenues, folia parua: aperis nafcentem, auftero Sapore, nunquam florentem. neque femen gignit. Medetur lienibus. Conftat'q: fic inuentam. Cüm exta fuper eam proiecta effent, fertur adhefiife lieni,eum's exinanife. ob id à quibufdam ßplenion uocatur. Narrant fues, quiradicem eius edunt, fine plene inueniri. Quidam ramis byf= fopi plantam, furculofam, folio faba, eodemnomine appellant. Et colligiflorentem adbuc iubent, adeo florere non dubitant, me ximeó; ex Cilicijs, er pifidia montibus laudant. hac Plinius. Ceterum non defunt, qui putent alterum Plinio Teucriun eam effe plantam, que Italis uulgari fermone uocatur Faua grafa. quanquam hanc alij falso, ut opinor, Telephium effe contendüt: Teucrij uires defcripfit Gälenus libro v1 I I. fimplicium medi= camentorum, fic inquiens. Teucrium incidentis, o tenuium par

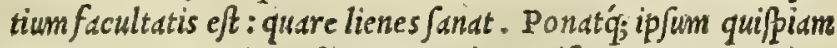
in tertio exiccantium, fecundo ueró excalfacientium ordine.

Hanc berbam Greci $T$ ṫungroy, Latini item Teucrium nomie nant: Itali, Teucrio.

\section{Xapxígus. TRISSAGO. CAP. XCVI.}

ChamaEdRy S Græcis, alijs chamædrops, Latinis triffago dicitur. Sunt qui eam teucrion appellauere, propter eam quam cú teucrio feruat fimilitudinế. Nafcitur in petrofis, \& afperis. Frutex eft dodrantalis, folia habés exigua, amara, effigie $\&$ diuifura quercus : flore paruo, penè purpureo. Carpitur femine prægnans. Recens in equa decoeta, potu tufsibus, indurato lieni, vrinæ difficultati, incipientibus hydropicis,auxiliatur: cit menfes, partus extrahit: lienem ex aceto pota confumit :aduerfus ferpentium venena ex vino, potu, illituq́; efficacifs:ma. Trita digeritur in paftillos, ad fupradicta. purgat ue tera ulcera,cum melle: cum oleo illita; caliginem oculorum difcutit . natura cius eft calfacere.
Teucrii uires ex Galeno.

Nomine 


\section{And. Matthioli Comm.}

chamxdryos confider.

chamędryos uires ex Gal.

Nomina.

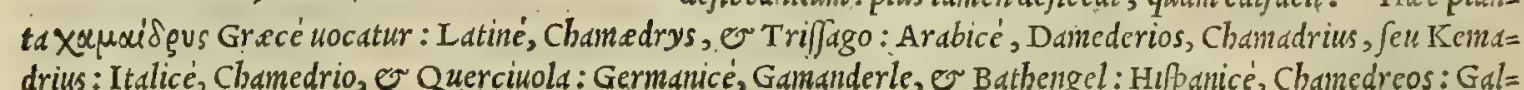
licé, Germandree.

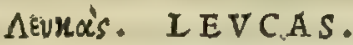

\section{CAP. XCVII.}

LE V C A s montana, latioribus quàm urbana folijs, femine acriore, amariore, ori ingrato. efficacior tamen quàm fatiua habetur. Vtraque ex uino contra animalium uenena, præcipuè marinorum; opitulatur.

Leucadis con Gderatio.

T A M E T.S I Hermolaus, er Ruellius contendant feriptis teftatum relinquere, berban quandam in uinetis ndfcentem mercuriali congenerem, effe Leucadd; ego tamen eam mercuriali con/imilem facere profecto non aufim, cum nullum bactenus ex rei berbaria authoribus inuenerim, qui cius faciem reprae fente t, plura' $q_{;}$de eius notis tradat, quàmfecerit Diofcorides: qui certé, quantum extat, nullis prorfus notis ip fan de fcripfit. Ca terùm recté, meo qui= dem iudicio, putat Marcellus Florentinus buic Leucadis capiti decurtatum effe principium. Id' quod nobis indicare uidetur ipfius Diofcoridis fermo : nam cum fatim ab ipfo capitis initio montanam L eucada urbane comparaucrit, nimirum oftendit à $\int e$ prius urbanam fuiffe defcriptam. Neque bac de caufa tantion adducor, ut Marcello adfripu Ier; fed quid etiam $\int e$ habuiffe teftatur Latinum Diofcoridis codicem uetuftißinum, in quo initium buius capitis ita legebatur. Leuca duo funt genera, una eft montana, $\sigma$ altera hortiua, Montana latiore quàm fatiua folio $\mathrm{e} / \mathrm{f} \in \mathrm{c}$. Que omnia maximo funt argumento, quód hoc in loco Diof çoridis codices fint deprauati, quodq; in ijs plurd adlsuc

Nomina. defiderentur, que faciunt ad perfectam buius plante hiftoriam. Sevra's herba fic Grecis, Leucas itcm Lati= nis appellatur.

\section{AUXvis. IXCHNIS.}

\section{CAP. XCVIII.}

L Y C H N I coronaria, flore eft albx uiolx fimili, fed purpureo. quo corollæ factitantur. Contra fcorpionum ictus femen in uino potum auxiliatur. Lychnis fylueftris, omnia urbanæ fimilis. Bilem per aluum detrahit, femine duabus drachmis poto. ictis à fcorpione fubuenut. Aiunt huius herba appofitu fcorpiones torpefcere, 8 inertes prorfus reddi. 


\section{In Lib. tertium Diof coridis.}

IYCHNIS.

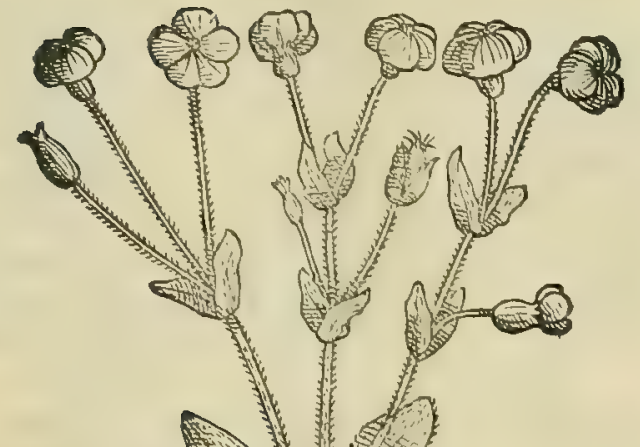

QV A N QV A M non facile eft hac atate plantus in Italia oftendere, qu.e legitimé referant utrang; L ycbnidem, horten $\int \mathrm{em}$ foilicet, o fylueftrem, cum earum folia, o caules tam i Diofco= ride, quàm ab alijs rei herbarix fcriptoribus, quod inuenerim, nul= lis prorfus reprefententur notis, utpote plant drum, que fortaffe olim omnibus erant notißime ob frequentẽ earum ufum tum ad lu cernarum lumina, tum etian ad coronds contexendas; attament in Tridentino, e Goritienfi agro planta qu.ed am in bortis, ac fictia libus feritur, coronis nectendis accommodata, quam equidem non dubitauerim pro legitima $I$ ychnide in medium afferre. siquidem flore exit purpureo, alb a viole fimili: folijs longis,tomento $i s, a l=$ bicantubusg;; : caule lanuginofo, cubito maiore, in cuius cacumine flos emicat, ut dixi, purpureus, inodorus tamen. Quód preterea planta bec uera fit L ychnis coronaria, illud nibi fidem auget, $f_{d=}$ cit $q_{;}$, ut in boc nibil fré addubitem, quód alter am eiufdem generis frequentißimam apud Ananienfes fylueftrem repererim, illifati= ua adeo per omnia fimilem, ut cism natalis duntaxat difcrimen ins tercedat, hac merito L y cbnis fylueftris appellariqueat. His acce dunt tomentofa earü folia, que ad lucernarum ufum pro ellychnio commodé ufurpari po fjunt. Vude apud ueteres Lychnidis fibi no= men afciuit . quippe lucerna Grecis $\lambda v$ xuav dicitur, quemadmo= dum er é $\lambda \lambda v^{\prime} \times$ vrov funiculus, qui é goß Bipio nobis boc auo para= tur, lucernisq; inferitur ad lumen edendum, flammam ǵ, nutrien= dam. Qutare cum goßipio, ut puto, carerent antiqui, tomentofis herbarum quarundam folijs ad hoc munus obeundum utebantur, nempe lychnidis, uerbafci,aliarum q́; nonnullis. Illud deniq; addis derim, ut noftra melius firmetur opinio, quód flos plantarum, quads Lychnides eße opinor, mirum in modum ruralibus, urbanisq'; uir= ginibus expetitur ad coronas factitandas: qua in re prifcam imi= tantur etatem. Caterum Plinius lib. X X I.cap.I I I I. Lychnis dë inter rofas retulit, fic inquiens. Eft e rofa, que Graca appels latur dे noftris, $d$ Grecis ueró Lychnis, nŏ niff in bumidis locis pro ueniens,nec unquasn excedens quing; folia,uiol e magnitudine, $0=$ dore nullo. Lychnidis coronarie Semen, ut Galenus eft author Jib.v I I. fimplicium medicamentorum, calidum eft fecundo quo= dammodo ordine, aut iam etiam tertio : ficcum fané eodem quoq; modo. Qua herba Gracis $\lambda v x$ vi's, Iychnis quog; Latinis di= citur: Italis, Lichnide.

\section{Kę? Vov. LILIVM. CAP. XCIX.}

L I L I A coronamentis fe dedunt, Liria à quibufdam uocata. E' quibus unguentum temperatur, quod aliqui lirinum, alij fufinum appellant, neruos, \& priuatim uulux duritias emolliens. Folia herbæ illita, contra ferpentium ictus auxiliantur : feruefacta ambuftis proficiunt: aceto condîta vulneribus opitulantur. Succus adiecto melle, aut aceto in æreo vafe coquitur conuenienti medicamento vetuftati vlcerum, \& ad recentia vulnera. Inaffata radix, \& ex rofaceo trita, igni ambufta fanat, vuluam emollit, menfes ciet, vlcera cicatrice obducit. Cum melle detrita neruis præcifis, luxatisq́ue medetur : vitiligines, furfures, \& lepras emendat: vlceraq́ue in capite manantia expurgat: abftergit faciem, \& erugat. teritur in aceto cum hyofcyami folijs, \& farina tritici mulcendis teftium inflammationibus. Semen potum morfibus ferpentium aduerfatur. Ignibus facris femen, \& folis cum vino illinuntur. Tradunt \& purpurea effe lilia. In Syria autem, \& Pifidia Pamphilize efficacifsima vnguentis nafcuntur.
Lychnidis co fideratio.
Lychnidis facultas ex Gal. Nomine<smiles>[Mg][Mg][Mg]</smiles> 
Liliorum có- L I I I A Italis notifina funt, atque adeó ommibus, ut plané fupcruacancum effe putem, exemplo Diofcoridis fideratio. addudus, uelex nobis corum faciem reprafentare, uel alterius biftoriam referre. Sed tanen quoniam ijs quando= que nos zerendus eft, qui femper bortis nouis ac uarijs floribus refirtis delectantur; idcirco filentio preterire non potui, quin bic in ererem, qua ratione, quóne mangonis alba litia (fi tanta fides prifcis reibcrbarice authoribus adbi=

Iiliorum hi- beripoieft) purpurea fleripoßint. Quod cum Plinius docucrit lib. $\mathrm{x} \times \mathrm{x}$. cap.v. ubi de Lilijs latius differit,

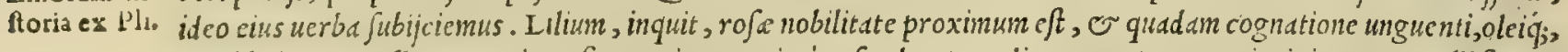
gilod lirinon appcllatur. Et impofitun etism maxiné rofas decct, mcdio prouentu earum incipicns. Ncc ulliflorum cxcelfitas in.ios, interdum cubitorun trium, languido femper collo, EN non fufficiente capitis oneri. Candor eius

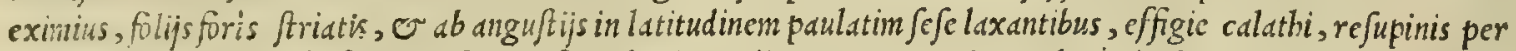
ambitum labris, tenuic; filo, 0 femine ftantibus in medio crocis. Itd odor, color q́; duplex, ut alius calycis, alius ftaminis : differcntia angufta. In unguenti ueró, oleiǵ; uju folis non pernuntur. Eft flos non dißinilis illi in berba, quam conuoluulun nocant, nafcens per fruteta, nullo odore, nec crocis intus, candorem tantum referens, ac ueluti natur a rudimentum lilia facere condifcentis. Alba lilia ijfdem omnibus modis feruntur, quibus rofa: o boc dinplius lacryna fua, ut bippofelinum. nibilí; eft frecundius, una radice quinquagcnos fape emittente bulbos. Eft 0 rubens lilium, quod Grecicrinon uocant. Alij florem eius cynorrbodon. Laudatißimum in An= tiochia, o L dodicea Syrix, mox in Pbafelide, quartum locum obtinet in Italia nafcens. Sunt or purpurea lilia aliquando gemino caule, carnofiore tantün radice, maiorisá; bulbi, fed unius. Narcifum uocant. Huius alterum genus, flore candido, calyce purpureo. Differentia a lilijs eft 0 bac, quód narcißis folia in radice funt, pro= batißimis in Lycix montibus. Tertio genericatera eadem. Calyx berbaceus. omnes frotini : poft ardurum enim florent, ac per aquinoctium autumnum. Inuenta eft $\mathcal{\sigma}$ in bis ratio inferendi, monftrific is bominum ingenijs. Colliguntur nanque menfe Iulio fcapiarefcentes, lilia';; fupenduntur in fumo. Dein: mundantibus fe nodulis, in fece nigriuini, uel Greci menfe martio macerantur, ut colorem accipiant, atque its in ferobiculis feruntur, be= minis fecis circunfufis. sic fiunt purpurea lilia, mirumq; ita tingialiquid, ut nafcatur infectum. bac plinius. Lilia (ut Anstolius teftatum reliquit) totum annum uiridia durabunt, fi cimocclufa filent, necdum patentia de= bifcunt, decerpta, nouis fictilibus non picatis indito diligenter operculo recondantur. fic cnim claufa perpetuum annum uegeta manebunt. Sed ut intermedio tempore ad ufum promuntur, ftatim ad folcm producta, cum fenferint cius calorem, aperta panduntur. Porró ut uicißin, or udrijs temporibus flores parimt lilia, bulbi ita feruntur, ut aliqui duodecim digitorum altitudine obruantur, alij octo tantim, alij quatuor duntax at profunditate mergantur. Martagon, \& fic diuerfis diebus dabunt lilia : quod $\mathrm{N}$ in alijs floribus fieri pollicetur. Caterum $\sim$ illud inter lilia meritó annu= eius delines- meraripoteft, quod M A R T A G O N cbymifte appellant. Hoc enim radice, etfi croceo colore infecta fit, ḋ lilio 30. t10.

MARTAGON.

Iiliorum uires ex Gal. candido non dißidet, ficuti nec caule. Folijs uulgarem faponariam imitatur, qux in'ftelle, uel ro $\sqrt{x}$ modum intercedente patio cau= lem ambiunt: in cuius cacumine tenui pediculo appenfiflores emi= cant liliorum effigie, minores tamen : quorum folia etian reflexa cernuntur, colore purpureo, punct is quibufdam rubentibus re= pperfa, er ipfi odorati funt, appectu $q_{\text {; }}$ iucundi. Lilijgenus boc in fuis de ftirpium biftoria commentarijs Fucb/ius, aphodelum fomi= nam putauerat effe, pro coq́; depinxerat: sed quia fui erroris con= fcius factus, banc ipfe fuam mutait fententiam, non cft cur iam nos eam pluribus refellamus. Lilionum facultates pofteritatis 40 memoria prodidit Galenus lib. v I I. fimplicium medicamentorum, fic inquiens. Lilij flos temperaturam miftam obtinet, partim ex tenui, partim ex terrens effentia, ex qua utiq; in gufu amaritudi= nem habet, partim ex aquea, ed'q; temperata. Itaque etiam quod ex co conficitur oleum, er unguentum, citra morfum digerendi, fimul'q; emolliendifacultatem obtinet. unde fit, ut uteri duritie= bus fit aptißimum. Porró radix, foliaq'; per fe trita deficcant, er abjtergunt, er digerunt moderaté. Proinde quoque ambuftis com petunt : fiquidem bec quog; moderaté deficcătem, extergentem q́; facultatem poftulät. Radicem ergo toft $a m$, ac deinde cum rof aceo contritam ambuftis, quodd obducatur cicatrix, imponunt. quippe cim alioqui or aliorum ulcerum onnium bonum fit inducenda ci= catriciremedium. Quinetiam uteros emollit, menfesóp prouocat . Folia ueró precoquentes, é ipfe ad obductam ufque cicatricem imponunt, non in ambufionibus duntax at; fed alijs quoque uulne= ribus. sed funt etiam, qui dceto ca condientes ad uulnera fuo tems pore utuntur. Plus tamen inef abfergentis facultatis in radice, quàn in folijs: quanquam tamen nec in ed i $\int$ a imultum infit, ficut prediximus nam primi ordinis abftergentium of nedicaminum. Itaque cum aut uitiligines, aut p foram, aut lepram, aut acbords, aut aliguid id genus extergere uolumus, commif cemus illi aliquid 


\section{In Lib. tertium Diofcoridis.}

Uliormm inedicamentorum ualidius extergentium, cuiufmodi eft mel. Ceterim fi id modcraté illi, ac conuenienter admifceatur, er ad nerworum diufiones competit; er ad alia uniucr $f$ d, que ualenter cxiccari poftulant ab $f ;$ mor $f u$. Impofuimus ueró etian quandog; er foliorum fuccum cum aceto, er mellc coctum: Quintuplus autem erat fuccus ad utrunq; atq; infigne medicumen fuit ad onmix ed, que exiccaripofulant abfo; morfu, ceu unlnera onmia ingentia, maxime que in cupitibus muf culorum cueniunt, or qux cunque ulcera bumida flaccidáue, $\mathcal{O}$ diuturnd funt, que $q_{;}$ egré ad cicatricen perducuntur. Sed hec iam ad medic anentorum componendorum inftitutum attunent, ì quo quans tum licet abfinere iit prefentis adnitor. caterim rerum ip farum natura fepenumero ut atting.ă adigit, celeriter ue=

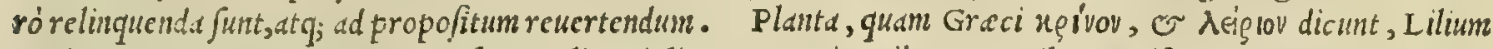
Latinis nominatur: Mauritanis, Sufen: Italis, Giglio: Germanis, Lilgen, $\mathcal{G}$ Gilgen: Hipanis, Azuccua, E Li=

Nomina. to rioblanco: Gallis, Lis.

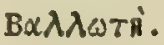
EALLOTE.
CA P. C.

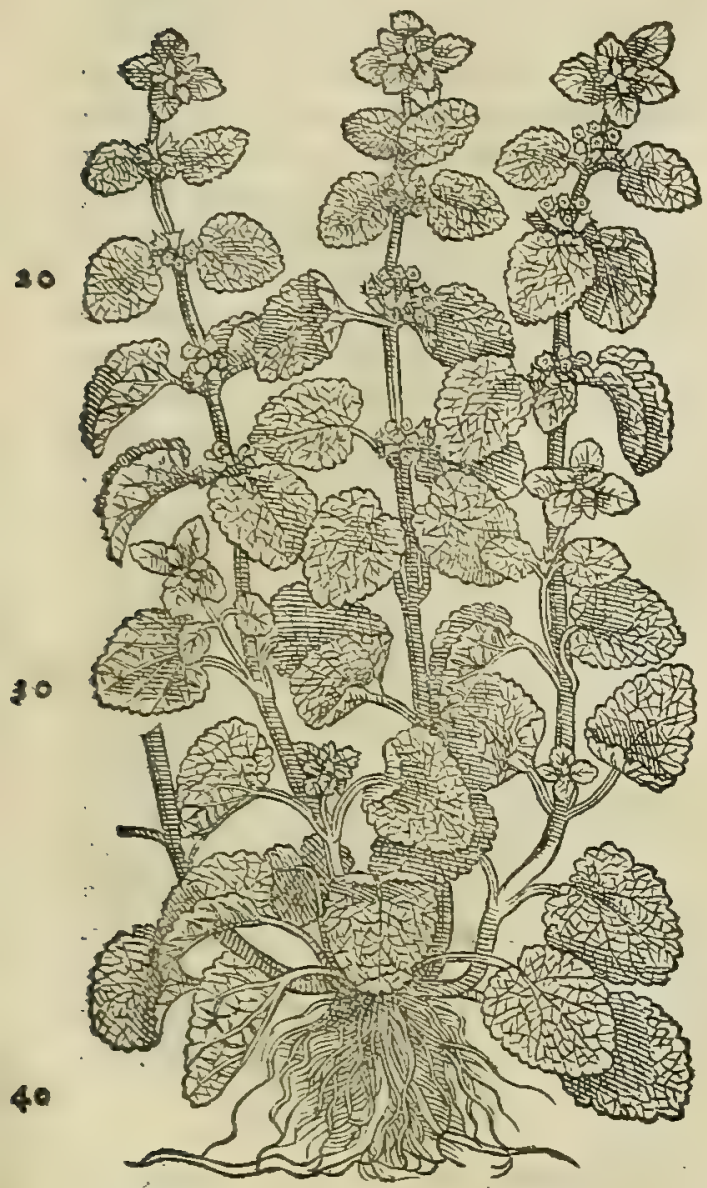

BALLOTEN, nomine alio nigrum marrubium uocant. Caules edit quadrangulos, nigros, fubhirfutos, cóplures ex una radice: folijs maioribus, quàm marrubij, hifpidis, per interualla in caule difpofitis, fubrotundis, t.graueolentibus, apiaftro proximis : unde aliqui apiaftrum eam uocauerunt. candidi flores uniuerfi uerticillato ambitu caulem coronant. Vis eius efficax aduerfus canis morfus, folijs ex fale illitis . Feruenti cinere flaccefcunt folia, ut condylomata reprimant : purgant \& fordida ulcera cum melle.

B A L L O TE, fiue Marrubium nigrum, quod etiam ob odoris Ballotes con: grauitatem dे quibufdam Marrubium foxtidum cognominatur, fre $=$ fideratio. quens in agrorum marginibus nafcitur, $\mathcal{O}$ paßim $\int e c u s$ uias. E/t autem boc apiaftro adeó fimile, quód facilé legentes falleret, nifs uares confulerentur : ita enin fua graueolentia citó innote fcit. In I talia nullis non cognitum eft, appellaturq́; ab dliquibus Mar rubiaftrum, ab alijs Marrubium purium. Huius meminit $\mathrm{P} a$ a lus (etfi uires eius filentio preterierit Galenus) lib. v I I. fic ins quiens. Ballote, quod alij marrubium nigrum dicunt, acris eft, o abfterforie facultatis. Illitum cum fale canum inor/ibus me=

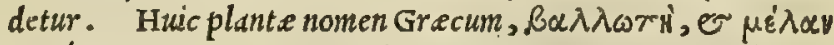

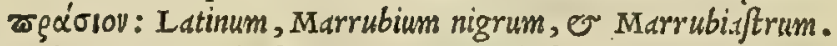
Italicum, Marrobiaftro, er Marrobio baftardo: Germanicum, Schuedrtz andorn: Hipanicum, Marroio negro: Gallicum, Marrubin noir.

+ In Oribasij codice manu fcripto hic interiectum legitur uer. bum $\mu$ é $\lambda$ ava , quod folia quoq; Ballote nigra reddit. Nec temea ré fortuß ßis illud quis adijciëdum putabit, quód pulcbré alteri cius nomini conueniat, quód $\dot{q}_{\text {; }}$ ipfius meminerit Plinius lib. X X V I I. cap. v I II. cüm inquit. Ballote folijs eft marrubij maioribus, or nigrioribus.

\section{ME}

MEI I S S O P H Y I I O N, fiue melittæna, id eft, apiaftrum, id fibi nomen ufurpauit, quoniam so apes ip/a herba delectantur. Cauliculi, \& folia ballotæ, de qua paulò antè diximus, fimilia cffent, nifi maiora,tenuioraq́;, nec ita hirfuta fpectarentur : citreú mâlım olent. Folia cum uino pota, aut illita profunt, contra ictus phalangiorum, fcorpionumq́ue : item aduerfus canis morfum . Decocto eorúdem gratia, foueri prodeft: defefsionibus fominarum ad ciundos menfes conuenit: dentes eodem in dolore colluuntur. dy fentericis infunditur. Fungorum ftrangulationibus folia, addito nitro, potu auxiliantur: torminibus, \& orthopnoicis delinetu. Illita cum fale ftrumas difcutiunt, ulcera purgant: articularios dolores illita fedant.

M E I I S 5 О Р H Y L L ON, quod Latinis Apiaftrum, o Citrago dicitur, Hetrufciab odore citri uulgó Apiaftri consocant Cedronella, item'́; Meliffa, ficut etiam Infubres. Herba eft uulgaris aqué notitia, atque odorata. Duo eius fideratio. babentur genera, unum fatiuum, alterum fylueftre. Fuchfius tainen medicus clarifimus, Melyffopbyllum in tria ge= nera dige Sit libro illo de compofitione medicamentorum, quem nuper auctum excudit. Sed cur is duo prima generd, 


\section{And. Matthioli Comm.}

A PIASTR V M.

Apiaftri usres ex Arabibus.

Ex Galeno.

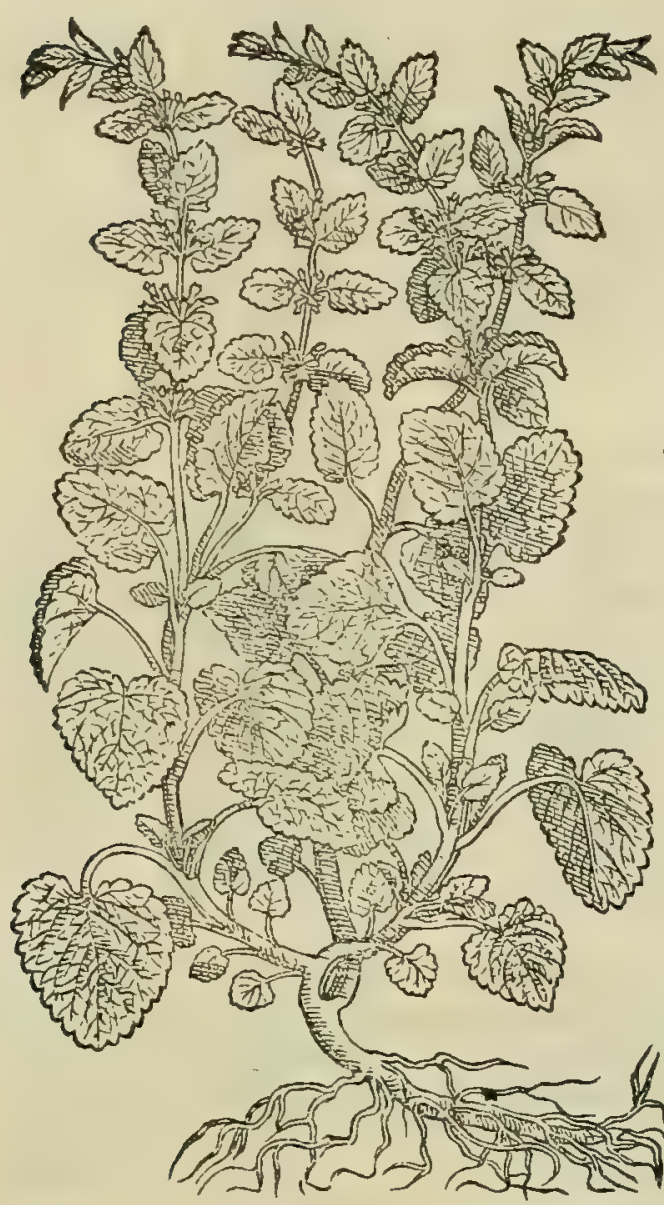

MAR R VBIVM.

Nomina.

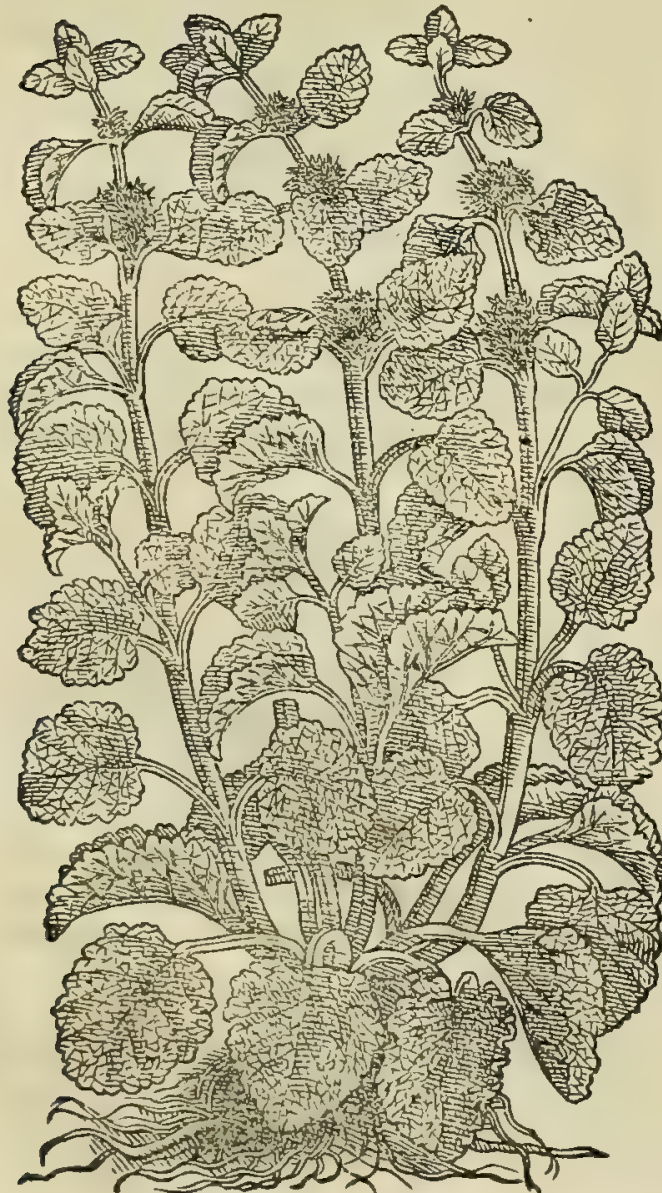

qux ( ut fcribit) grauiter odorata funt, er cinices uerius quaim citrum redolent, inter meliffophylli genera connumerauerit, ego nefcio, ipfe dicat. Mibi quidem (ut dicam ingenue quod fentio) plané abfurdum uidetur, quod meliffophyllum odore fuo aliud referat, quim citreum malum, chius tantim odorem pirare Diofcorides memoris prodidit. Meliffophyllum, ad cuius $f_{a}=$ cultates iam noltra progreditur oratio, in cordis affectibus Mall= ritani miris laudibus efferunt. tametfi id Greci,quod extet, filen tio preterierunt. Proinde bee Serapio retulit. Meliffopbylli, inquit, proprium eft animum bilarem reddere : bumenti, ac fri $=10$ gido uentriculo auxiliari, concoctionem adiunare, cerebriob= ftructiones referare, deficientem animum reuocare, cordis im = becillitatcs roborare, eamó; prefertim, qua fomnus frequentus nocte intercipifolet, quin e eius pulfum reprimere, animifoli= citudines fugare, ac folicitas imaginationes tollere, que tum $a b$ atrabile, tum $a b$ exufta pituita gignuntur. His preterea facul= tatibus pollere Mcliffopbyllon, comprobatur Auicenne quoque teftimonio, qui libro medicinis, que cordi conueniunt, dicato, ita de eo fcribit. Meliffophyllü excalfacit, ficcatớ; ordine fecun= do. Cor exbilarat, uitalesó; facultates roborat, odoris fragrana tia, faporis aufteritate, partium q́; tenuitate. Quibus facultati= bus cateris etiam uifceribus competit. Vires deietorias poßi= det, nee adeó imbecilles, quin atrablliarios uapores à piritibus, o d̀ Sanguine, qui cordi, or arterijs ineft, educere queat: quod in cateris corporis partibus, ac etiam in toto corpore efficere nequit. Meliffophylli meminit Galenus libro v I I. fimplicium ( medicamentorum, his uerbis. Melifoplyyllum marrubio fimile eft facultate, fed plurinum ab co uincitur : quanobrem nec uti= tur co quipiam. superuacaneum fiquidem foret prefente mar= rubio, cuius tantus eft ubiq; terrarum prouentus, uelle uti melif= fopbyllo. Caterim fi cuiforté ad manum quandog; marrubium non fuerit, illo utilicebit ad eadem, modo quantó ab hoc exupe= retur, cognitum habuerit . bec Galenus. Apiaftrum, Plinio li= bro $\mathrm{X} \times$.cap. $\mathrm{x}$ I.authore, in confe fa damnatione eft ucnenatum in Sardinia. Eaplanta Grecis $\mu \varepsilon \lambda i a r o ́ \phi u \lambda \lambda$ oy dicitur, que Latinis Meliffopbyllun, er A piaftrum: Arabibus, Bederangie, Bedarungi, Bederenzegum, Turungen, feu Trungian, o Mara macor: Italis,Meliffa,et Cedronella: Germanis, Meliffen,et Bi= nenkraut: Hipanis, Torongil, er Hierua cidrera. Gallis, Me= liffe; $\sim$ Pom cirade.

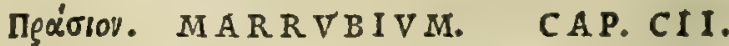

MA R R V B I V M, frutex eft ab radice ramofus, candicans,fubhirfutus, quadrangularibus ramis : folini pollicem equat,fubrotundum, hifpidum, rugofum,guftu amaro: femen in caulibus, \& ex interuallis : flores uerticillato ambitu, afperi. Nafcitur propter ædificia, ruinas, \& rudera. Huius folia ficca cú femine decocta in aqua, aut uiridium fuccus datur cŭ melle fufpiriofis, tufsienti so bus, \& ad tabitudinem redactis. Craffam è pectore pitui tam cum ficca Iri cijcit. mulieribus à partu non purgatis datur,ut menftrua, \& fecundas extrahat : item in dificili partu, $\&$ his qui uenena hauferunt,aut à ferpentibus demorfi funt. ueficam,renesq́; lædit . Folia cum melle illinŭtur fordidis ulceribus purgandis : pterygia,nomasq́; fiftunt. laterum dolores mitigant.Succus folijs contufis expreffus, \& fole coactus, ad eadem pollet : cum uino, \& melle illitus oculorum claritatem adiuuat: naribus regium morbum expurgat a aurium dolóribus conuenien ter inftillatur per fe, aut cum rofaceo. 
M A R R V в I V M uulgaris eft planta, notiorq́; omnibus in Italia, quìm ut pluribus indicanda fit. Eius duo Marrubijcon genera conftituit Theophraltus lib. v I. cap. I I. de plantarum biftorid, ubi ita fcribit. Sunt eo Marrubij duo genc= fideratio. ra. Aliud enin folio berbido, ferratiori, incifurisq́; profundioribus, o proinde conpectioribus ducrcto conftat, quo unguenturij uti ad nonnila confucuere. Alterum rotundius, fqualensq́; wcbementer, ficut phaceli, incifurss babcus obfcuriores, minusíf; fcrratum. hec Theophraftus. Ex quibus utique conftare potcf, Thcopbrafto altc= rum narrubium non alud clie, quain Diofcoridiballoten. Marrubij uires tradidit Galenus lit. v I I I. fimpliciun medicamentorum, fic inquicis. Marrubium ut guftuamarum eft, ita fi quis utatur, confentientem buic faporia= ctionem pofidet, iecur, ac licnem obftructione liberans, or thoraccm, pulnoncm'́; expurgans, ac menfes promo= ucns. Scd er illitum detergit, ac digerit. Ponató; ip $\int u m$ quipian in caliditate quidem fecundi ordinis iam completi:

x inficcitute uerò tertij medij, aut completi. Succo eius cum mellc ad uifus acumen utuntur. Qüinetiun o pcr nares morbum regium purgsnt, or ad aurium dolores inucteratos adbibcnt, in quibus fanć obfructioncs disijcere, mea=

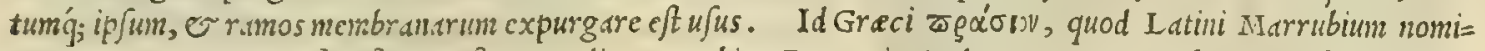
nant: Mauritani, Farafio, fue Frafum:Itali, Marrobio: Germani, Andorn, E L ungen kraut: Hipani, Mar= ruio: Galli, Marrubin.

¿rXXus. STACHYS.
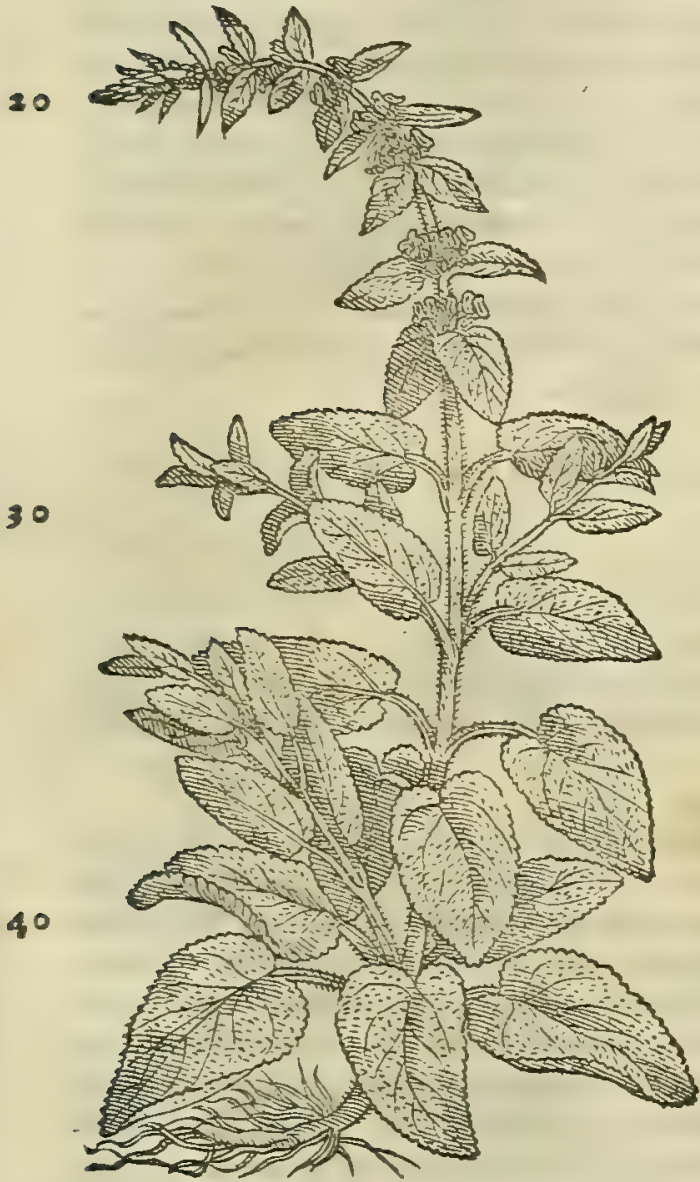

CAP, CIII.

S T A C H Y s, frutex eft marrubio fimilis, fed lógior, folia ferens numerofa, hirfuta, rara, prædura,cana,odoris iucundi : \& côplures uirgas ab una radice exeuntes, marrubio candidiores. Nafcitur in montibus, \& afperis. Vim habet excalfactoriam, \& acrem. Foliorŭ decoctum potu pellit menftrua, \& fecundas.

S T A C H Y S frequentißima in Italianafcitur . affurgit $e=$ Stachyos cönim uirgis compluribus, angulofis, ab una tantum radice exeunti= fideratio. bus, hirfutis,-marrubio tum longioribus, tum candidioribus: folijs numero/is, incanis, bir.futis, oblongis, preduris,odorisó; iucundi. Flores gerit in purpura albic antes, qui per interualla uerticilla= to ambitu caulem circundant marrubij modo. Ex quibus fanéno= tis fatis conftare arbitror, hanc herbam, qudm pictam exhibemus, effe ueram Staclyyn. Quibus etiam accedit, quod ea (ut Galenus teftatur) amara fit, et guftu acris. Plinius lit. X X I I I I.cap. X V. P linij lapfus. stachyn porri fimilitudinem habere tradidit, Gracarum uocum

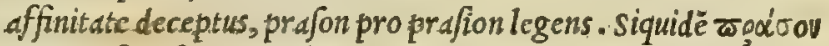

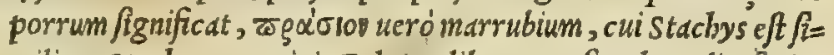
milis. Stacbyos meminit Galenus lib.v I I I. fimpl. medic. fic in= Stachyos ui . quiens. Stachys frutex eft marr ubio finilis, guftu acri, et amaro: res ex Gal. tertij eft ordinis excalfacientium. Quamobrem rationabiliter nŏ folum inenfes mout; fed or abortum affert, ov fecundas eij= cit. ETóxus ut Grecé, ita etiam Stachys Latiné Hocatur: Italicé, stachi.

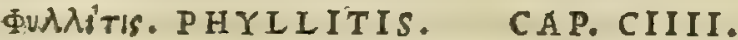

P. H Y I I I I $s$ folia promit rumici fimilia; longiora, \& uiridiora, fena, aut feptena, recta, qure parte anteriore læuia cernuntur, à tergo autem penfiles quafi uermiculos tenues oftendunt. In umbrofis, \& opacis hortorum locis emicat 。 guftu acerbo. Neque caulem, ncque florem, neque femen profert. Folia in uino pota ferpentium 30 morfibus aduerfantur quadrupedibus per os infufa auxilio funt: \& fi dy fenteria, aut refoluta aluus èxercet, potui datur.

Qv I notas omnes, qux Pbythitidi à Diof coride tribuuntur,diligentißimé expendere uoluerit, haud difficilé quis demfateri cogetur, $\mathrm{P}$ byllitin e fe eam herbam, quam aliqui Linguam ceruinam, nonnulli ueró scolopendriam perpe Gracis Aplenos, Nauritanis ueró ceterach dicitur. Quód autem itá $\int e$ res habeat, hinc in primis ad credendü im= pellor, quód umbro /is, opacis, bumentibusq́; locis proueniat : quód'q; folijs fit rumicimaioribus, longioribus, ac uiri= dioribus, rectis, anteriore parte leuibus, à tergo dutem eminentijs quibujä tranfuerfîm per interualla fignatis, $\sqrt{u b=}$ rubentibus, que (ut Diof corides inquit) penfiles uermiculos referunt: Opinionem deinde auget dcerbus fapor, qui guftu percipitur. Huc poftremó accedit, quód caule, flore, $\sigma$ femine nacet: $t$ amet fi non defint, qui credant, eius $\int e:$ men é penfilibus illis uermiculis prodire. Neque illud. fententie noftre quicquam obftare crediderin, quod huius ber

\section{Nomina.}

Marrubii uiresex Gal.

Nomina: 
PHYLIITIS.

Manardi,Leo nic. Ruellij, \& Fuch. laplus.

Phyllitidis ui res ex Gal.

Nomina.

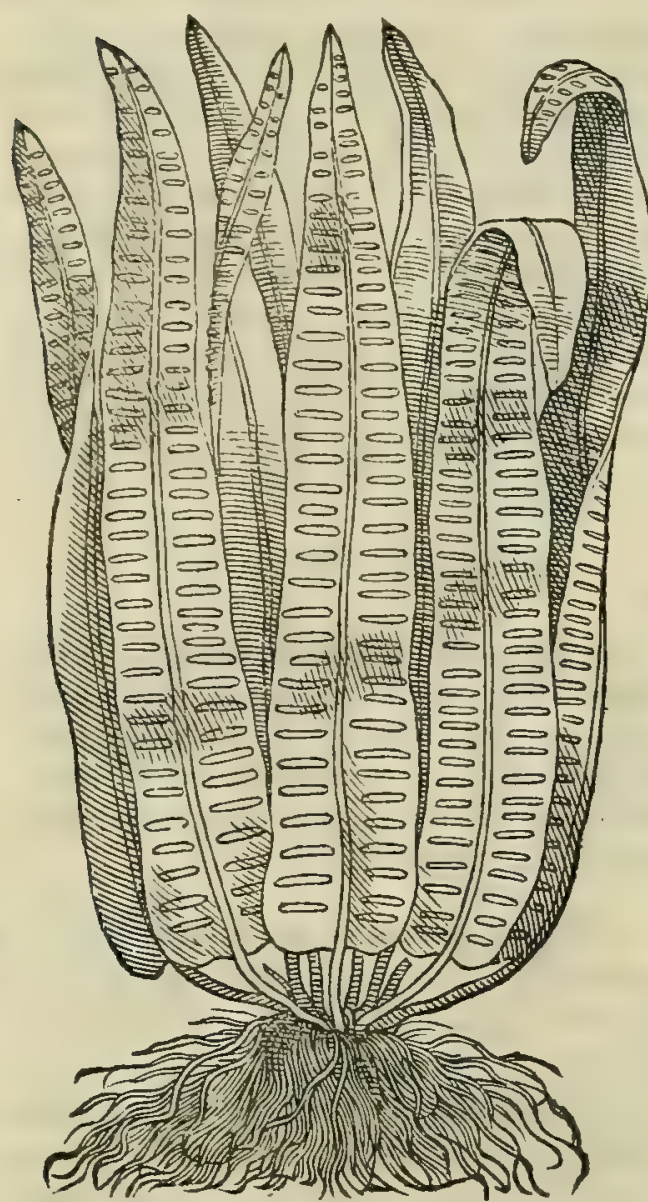

be complures reperiantur plante, que preter Diofcoridis au= Etoritatem ucl quinquaginta emittant folia. Quippe (ut expericn tia compertum habeo) effodientibus nobis è terra hane berbam nunquam ab una tantint radice to folia crumpere uifa funt, fed d quadm plurinis fe fimul tangentibus, ita tamen ut una ab altera feparari po/fet. Vnde facilé cognoui, quód fifingula radices $a b=$ inuicem diftincte confiderentur, non pluribus, quàm fenis, dut feptenis folijs refert.e inuenientur. His itaque rationibus, med quidem fententia, hac in re planc hallucinati deprebenduntur $M A$ nardus, Leonicenus, Ruellius, $\mathcal{O}$ Fuchjius, omnes alioqui cla $=\mathbf{0}$ rißimi nominis uiri, quód tam facilé crediderint, Linguam cer= uinam uocatam Pbyllitim nequaquam referre, fed Hemionitim. Nam etfi Hemionitis canle, flore, $\sim$ femine uidua fit; non ta= men folijs conftat rumicis, fed dracunculi, curuis, noue lune in = flar. Illud infuper addaidcrim, quod iam reperta fit Hemionitis, que omnibus prorfus notis legitimam refert. Sed ijs fortaffe er= randi occafionem prebuit uulgi opinio, qui Linguam ceruinam non inagno quidem negotio ad omnes lienis affectus affumere fua= det. quod tamen Hemionitidis eft proprium. Cuius forté uulgi opinionem ij potius fecuti, quàm quòd pbyllitidis lineamenta, notssó; diligentius perpenderint, in bunc facile lap runt. Pbyllitidis meminit Galenus lib.V 1 I I. fimplicium medi= camentorum, fic inquiens. Plyllitis cum qualitatis fit acerbe,no ab Jurdé diarrbods, fiue profluuia, o dy fenterias pota iuuat.

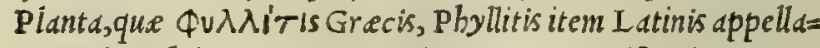
tur : Italis, Philite : Germanis,Hirtz zungen: Hipanis, Lengoa ceruina: Gallis, Lang de cerf.

\section{$\Phi \alpha \lambda \dot{x} \gamma \gamma$ lov. PHALANGIVM. CAP. CV.}

P H A L A N G I v M, à quiburdam phalangites, ab alijs leucacantha uocatur. Ramuli funt ei duo, aut tres, plurésve, in diuerfa tendentes : flos candidus, lilio fimilis, multas incifuras habens : femine nigro, †lato,ad lenticulæ dimidiatæ figuram, multò tenuiore: radice parua, tenui, herbacei coloris, dum à terra eruitur . prouenit in collibus. Huius folia, femen, flos cum uino pota, auxiliantur contra forpionum, phalangiorumq́ue ictus : tormina quoque difcutiunt.

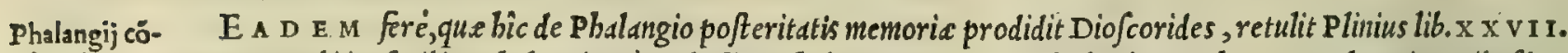
fideratio. cap. $x$ I 1.ubi ita fcribit. Phalangites à quibufdam phalangion uocatur, ab alijs leucanthemon, uel, ut in quibufdam exemplaribus inuenio, leucacantba. Ramuli Junt einunquam pauciores duobus, in diuer $\int a$ tendentes. Flos candi= 40 dus, lilio rubro fimilis : femine nigro, lato, ad lenticule dimidie figuram, multó tenuiore : radice berbacei coloris. Huius folio, uel flore, uel femine duxiliantur contra fcorpionum, phalangiorumó;, o ferpentium itus : itcm contra tormind. Hec Plinius. que omnia feré, fi conferantur, Diofcoridiacccpta referripoterunt. Ceterim etfi non de= fint bodie berbarij, qui in Pbalangï, ut in pluriü aliarum quoq; incognitarum plantarum locum berbas quafdă quales quales fint, fubftituant, atque rei berbarie parum gnaris pro legitimis fape oftendant; ipfe tamen bactenus, ut ins genué fatear, uerum Phalangium non uidi in Italia, neq; ab alijs inuentum frio. quanquam non equidem negauerim, Phalangij ui- ipfum inibinafci. Phalangij uires tradidit Galenus libro vix. fimplicium medicamentorum, fic inquiens. Pbas res ex Gal. langites fic appellata eft, quód morfis à phalangijs auxilietur. Eft autem facultatis tenuium partium, deficcantis. Nomina. quamobrem or tormina patientibus fuccurrit. Quod $\Phi \alpha \lambda x^{\prime} \gamma \gamma$ lov Graci, Phalangium quoque Latini dicunt : Pbalangio, Itali.

$\dagger$ siquis Greca Diofcoridis exemplarid confulat, hic non $\varpi \lambda \alpha \tau$, hoc eft latum, fed $\varpi \alpha x i$, quod eft craffum, fcriptum reperiet. Quód fi pretered ealegat, que ex Plinio in commentario rctulinus, deprebendet $\mathrm{R}$ uellium in uer tendo fecutum fuiffe Plinium, ex eo $\dot{q}_{\text {; }}$ uocem illam reddidiffe.

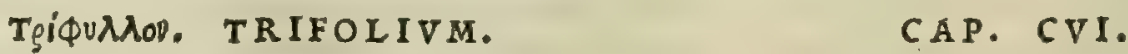

T R I F O I I v M, Gracitriphyllon, alij oxytriphyllon, alij menyanthes, alij afphaltion,uocant. Frutex fupra cubiti altitudinem attollitur, uirgas habens tenues, iunceas, \& nigras, unde ramulares enafcuntur appendicule, in quibus terna fingulis germinationibus exeunt folia, loto herba fimilia. ijs recenter enatis rutx odor inef, ubi autem adoleuerunt, bicumen olent. Florem edit purpureum: 

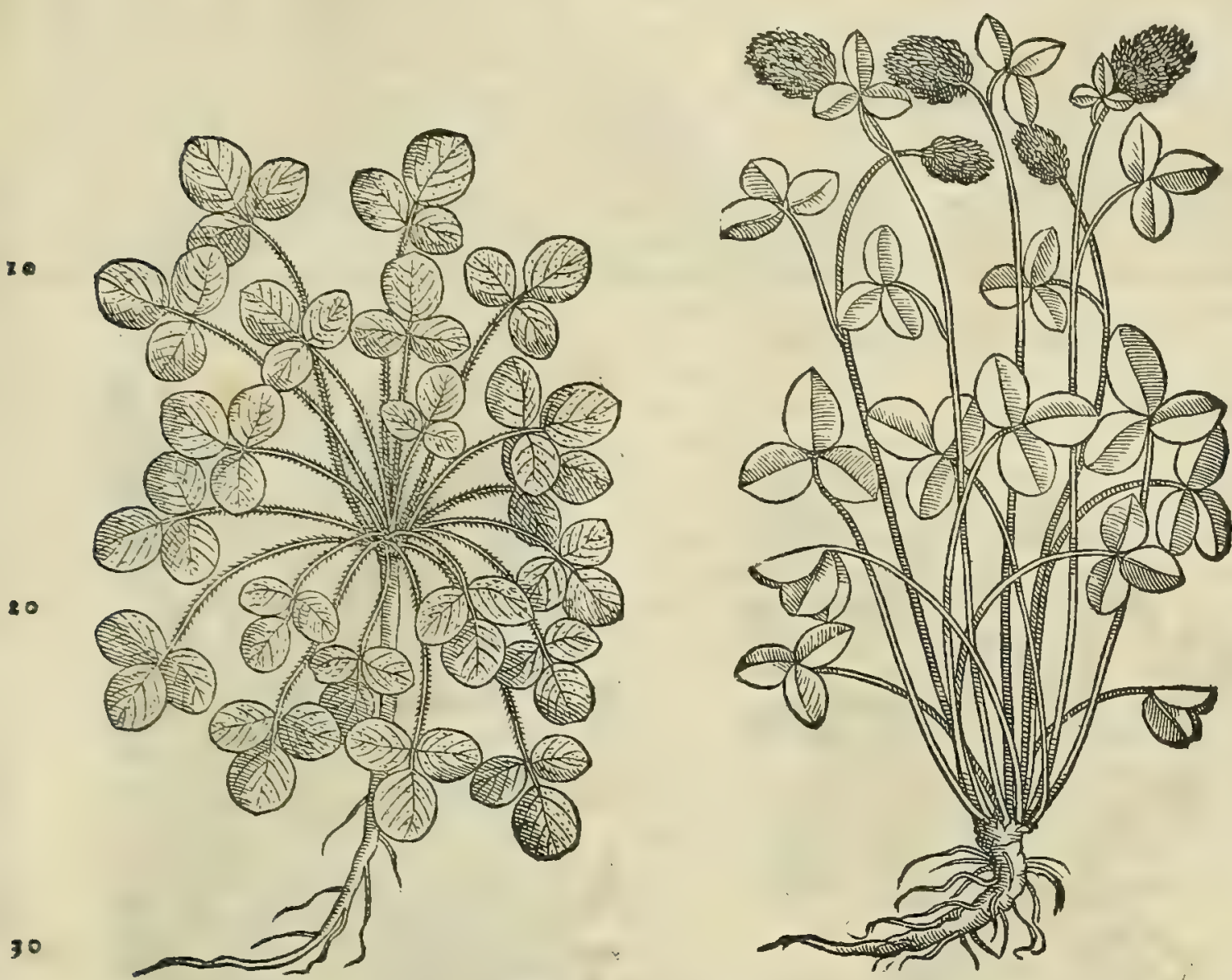

TRIFOL. PRAT. A ITERVM. femen quadantenus latum, fubhirfutum, ex altera ex-

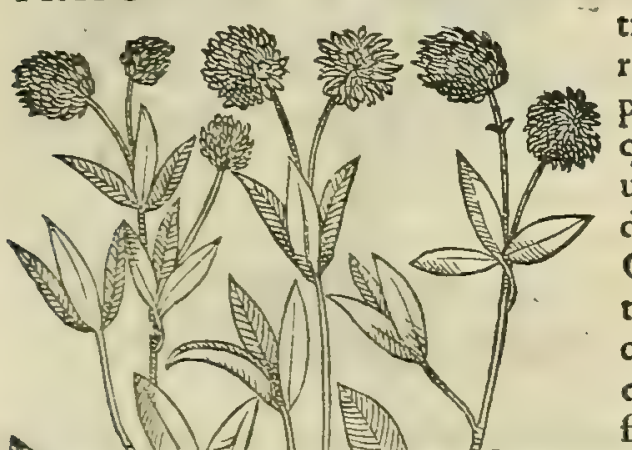
tremitate exertum, antennæ modo corniculum gerens. radix tenuis, longa, valida. Semen, \& folia in aqua pota pleuriticis, urinæ difficultati, comitialibus, \& ijs qui aqux inter cutem principia fentiunt, forminis quoq; vulux uitijs opportunis, auxiliantur: menfes ciunt. ternx drachmæè femine dari debent, è folijs uerò quaternæ. Contra ferpentium ictus trita folia, \& ex aceto mulfo po $\mathrm{ta}$, præfidio funt. Tradunt aliqui, totius fruticis, radicis, foliorumq́ue decoctum fotu dolores corum finire, quos ferpentes percufferint. qua auté aqua fanatus quis fuerit, fi ea quifpiam alius foucatur, qui vlcus habuerit, perinde afficitur, ut à ferpente demorfus . Quidam terna folia, aut femina in tertianıs, cum uino potui dedere': \& in quartanis quaterna, ut quæ febrium circuitus difcuterent. Radix antidotis inferitur.

T A M E T S I plura in Italia paßim in pratis, ac uiridarijs Trifolij conTrifolij inueniantur genera omnibus plané nota; non tamen de lideratio. bis tradidit hoc capite Diofcorides, fed de co tătum genere, quod àbituminis odore A pbaltitis dicitur, de quo etiam $\int c r i b i t$ Galet nus. Verism non ob id putandum, Trifolium pratenfe omne ges nus Diofcoridi fuiffe ignotum: fiquidem eius meminit libro quare to in fylueftris loti capite, dum ita fcribit. Sylueftris lotus plurit mim in Libya gignitur, caule bicubitali, o fepe maiore, alis multis, folijs trifolij pratenfis. Ex quibus utiq; Diofcoridis uere bis liquet, eos maximé hallucinari, qui recenter contendunt Trie folium pratenfe effe lotum fylueftrem, uel urbanam. Plinius lib. $\mathrm{X} \times 1$. cap.j $\mathrm{x}$. de tribus trifolij generibus differut in bunc moe dum. Folio coronat $\Theta$ trifolium. Tria eius genera . menyantbes 


\section{And. Matthioli Comm.}

uocant Greci, ali aphaltion, maiore folio, quo utuntur coronarij. Alterum acuto, oxytriphyllon cognominatum. Tertium ex omnibus minutifsinum. bactenus Plinius. Trifolij acuti meminit quoque Scribonius Largus, qut ita fcri= ptum reliquit. Trifolium acutum, quod oxytriphyllon appellant, nafcitur in sicilia plurimum. nam in Italie regio=

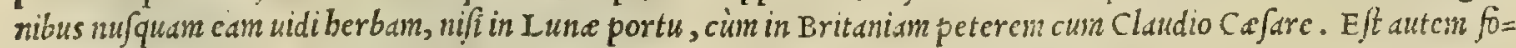
lijs, er fpecte communi trifolio fimilis, nifi quod pleniora funt folid, o quafi lanuginem quandam fuper $f e$ babent, er in extrcma parte uclut cminentem aculeum. Sed frutex huius duim pedum, interdum altior confricitur, o odorcm Trifolium a- graueme enittit, quorum mibl circa pratenfe trifolium inuenitur. bac ille. Eft $\mathrm{O}$ aliud trifolijgcnus fapore ace= cerofum. tofc, foliis fubpallidis, tenuibus, cordis effigie : quod à quibufdam Panis cuculus, ab alys Trifolium A C E T o 5 V M, o Allcliy a uoc atur. Plinius (ut quidam putant) hoc oxyn nominak libro X X v 1 r. cap. X I I. ubi fic inquit. Oxys folia tcrna babet. Datur ad ftomacbü diffolutum. Edunt o qui enterocelen babent. Nec plura de bac herba Plinius.

TRIFOLIVM ODORATVM.

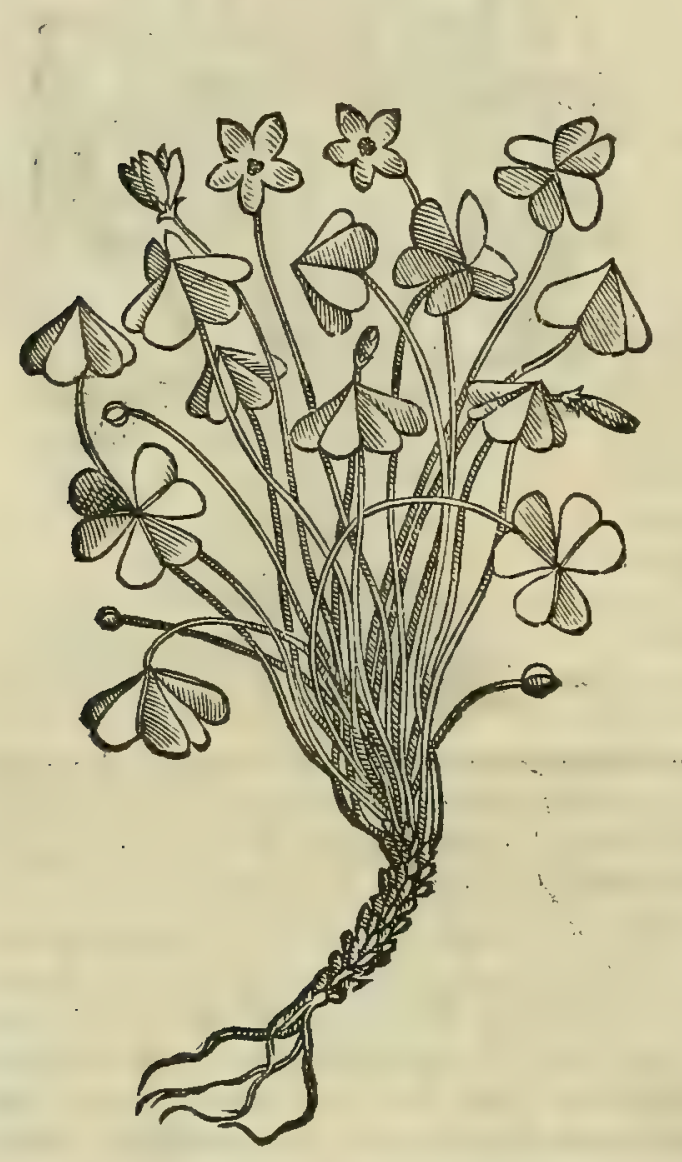

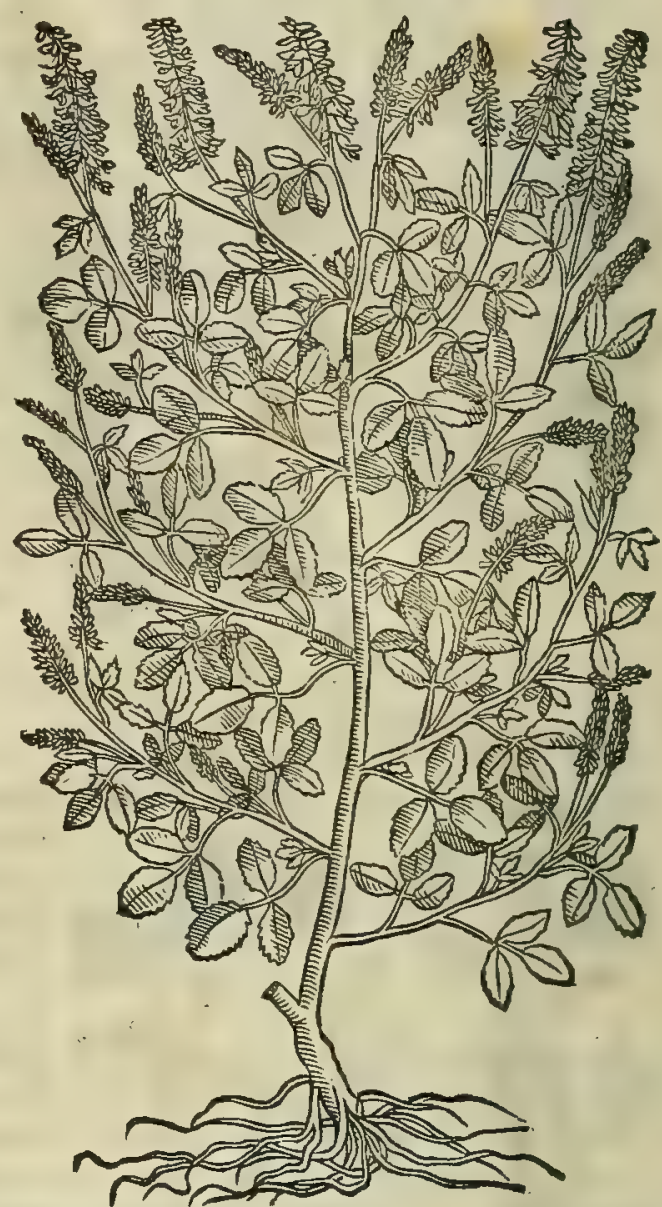

20

Trifolium o-

Porró buic illud quoque Trifolium addere pofjumus, quod nornulli Trifolium o D O R A T V м idco cogno= minant, quoniam eius tum folid, tum flores non iniucundum pirant odorem. Romani ac Hetrufci pariter id uulgo $u=$ cant Tribulo : atque ftillatitiam ex co aquam eliciunt, odoris tantùm gratia. Ha'ic plantam equi auidißimé in pabu= lum Juum fequuntur . unde factum eft, ut quidam eam Trifolium equinum appcllaucrint . Planta eft frutico fa, que ad trium cubitorum altitudinem attollitur, folijs trifolij pratenfis, caule lignofo, ramulis pluribus referto. Florem edit mufcofum, album, atq; etiam alicubi luteum. Radicibus nititur multis, albis, qua perifumma cefpitun diudgantur. bec de trifolio odorato, de quo etiam aliquid dicemus libro fequenti in Cytifi commentatione. Ceterìn Trifolium pratenfe in Italia trium eft generum. Primum folijs exit rotundis, or amplis: fecundum longiufculis: tertium ut pri= so mumcircinatis, fed breuioribus. Diftant o florum colore, quód in uno flores albicent, in altero rube fcant, in ter = tio lutei pectentur. Pratenfe trifolium tempeftates prenunciat. nam (ut Plinius cft author) inborre fcit, o folia contra tempeftatem fubrigit. Habetur pratered berbd, de qua ideo bic inter trifolijgenera differendum duxisnus, quód folio exeat triplici cornu diuifo : unde etiam apud quofdam berbarios fibi Trinitatis nomen comparauit. Haec itaque berba TR I I T As uulgo uocata, in locis prouenit uliginofis, o inter frutetd : gaudet cnim opacis. Folia

Trinitatis her fert triquetra, longis pediculis appenfa, qua auer fa parte cyclamini modo. fubpurpurafcunt, fuperiore uerò albis quibusdam maculis reperguntur. Caulem babet tenuem, in cuius cacumine primoftatim uere flos cinicat caruleus. Radicibus nititur numerofis, tenuibus, fubrubentibusq́;. Huiufce meminiffe Gracos, nec pariter Mauritanos, $h a=$ ctenus compertum non babeo. Probatur maximé recentioribus medicis ad unlnera glutinuida, tam extcrius illita, Quorundam quàm interius fumptd. quinetiam $\mathrm{e}$ ad enterocelas: in quem ufum puluerem dinidij cocblearis menfura ex uino aus
error. dicocan 
TRINITAS.

20

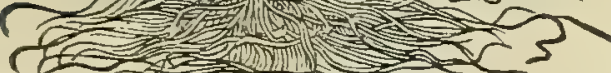

dacocam Aphris uocatam, ad quämuis trifolij Bpeciem referunt. Quandoquidem Andacoca (ut teftatur Serapio) nil aliud eft, quàm Diofcoridis Aegyptia lotus. E' cuius femine, quod papaue= rum modo capiribus quibufdam incliditur, A rabes fibi oleum con ficiunt, quod miris laudibus efferunt in neruorum morbis, prafer timı́; tremoribus : illud'́; oleum de Andacoca appellant. Id enim non defunt, qui credant é unlgari trifolij feminc fieri. fed quàm aperté decipiantur, uel ip/i uide ant, uel alij iudicent. Trifoliun fcript is tradidit Galenus lib. v I I I. fimplicium medicanentorum, fic inquicns. Tripbyllum, quidam aphaltion, quidan oxyplyllon, nonnulli miny anthes, funt or qui cnicium uocitent. Prina quidem tria $a b$ accidentibus frutici, reliqua duo nomina baud fcio unde. Vis plante eft calida, or ficca ut bitumen, cui odore of fimilis, utrinque tertio ordine. proinde pota laterum dolores ab obftru= étione natos iuuat, o urinam, menfesq́; prouocat . bac Galenus. sed animaduertendum eft, an Galenus ip $\int e$ in Trifolij facultatibus recte perceperit Diofcoridis fententiam. Quippe is in libro de theriaca ad Pifonem, ubi pluriummedicamentorum facit men: tionem, quibus contrarise infunt facultates, bec de eo memoria prodidit. Trifolium berba, qua byacintho fimilis eft, cum uere parturit, e femen agrefti cnico perfimile obtinet, decocta admo. dum, deinde morfibus aranei, uel uipere quoq; ex aqux fotu adbi= bita ipfis medetur, or dolores ftatim fedat. Sin autem in alio non commor fo fanum locum codem fotu circundederis, fimilem fens fum, fimiles q; dolores ïs, quos mor fus inuebit, omnes efficit. $\nabla t$ re uera miraculo dignum opus effe uideatur, uidelicet herbam $\mathrm{e}$ morfum fanare, o ferarum modo fanam partem praué afficere. bactenus Galenus. Verim id, $f \mathrm{f}$ Diofcoridis uerba recté expendan tur, nullo mir aculo fierifacilé conftabit, fed potius fecuntum ip= fius nature ordinem. Siquidem ( $u t$ Diof corides fribit) non oms= ne trifolij decoctumillud efficere poteft, fed tantim id, cuius fotu quiphiam a ferarum mor/ibus liber cuaferit, $\{$ eo alterius locus ulcere affectus perfundatur. Id quod aperté Diofco= ridis uerba declarant, cum inquit. Tradunt aliqui totius fruticis, radic is, foliorum '́; decoctum fotu dolores eorum fi= nire, quos ferpentes percufferint. Qua autem aqua fandtus quis fuerit, fi ea quifpiam alius foucatur, qui ulcus babuea rit, perinde afjcitur, ut de ferpente demor fus. Ex ijs Diofcorid is uerbis clarum fieri puto, bane rem in fe nibil adinirationis babere. Nam cum Trifolij ip/ius decoctum, quo dentorfi fouentur, uenenum à unlnere extrabat, ciq́; permis fceatur, haud dubié id uenenofum redditur. Quamobrem minimé quidem mirum uideri debet, fi idem decoctum, quo quipiann non demorfus foue atur, ubi perfufe partes aliquo ulcere laborauerint, ueneno per ulceris poros ingrediens te, ac fanguini fe commifcente, ed omnia excitet mald, quibus demorfi uexantur. idem enim uenenum cum fit, cosdem 40 quoque prabeat effectus neceffe eft. Vnde liquidó colligi poteft, quód uirus à Trifolij decocto euocatum, non autem Trifolium, fit illud, quod fimilem fenfum, fimiles,; dolores faciat. Quód autem uenenum exuctum à ferarum mor/ibus ulceratis particulis contactum necem afferre poßit, complures tam Graci, quàn A rabes authores, manifefte demon frant. Quandoquidem foribentes ore demor fos fugere preftantißimum effe remediun, ferio nos adinonent, ne id ore ulceribus affect o fiat: quoniam fi uenenum illud ulcus inficeret, fugentem in mortis difcrimen duceret. Hec itd. que funt, qux me maximé mouent, ut credan Galenum bac in re Diofcoridis mentem non accepilfe, atque etiam, fil $i=$ cet dicere, cecutiulfe . Ceterim non defunt, qui uelint, ut Galenum tueantur, librum de theriaca ad Pifonem non ef fe legitinum, id'; pluribus rationibus comprobant. Quibus an affentiendum fit, iudicent $\ddot{y}$, qui Gracam Galeni phras fim profitentur quiq; eius uoiumina diutius euoluerunt. Ego certé, ut dicam quod fentio, non poffum non illis fubfcribere, qui librum illum fpurium effe cenfent. Inter quos bic mibı bonoris gratia nominandus uenit Iulius Alexan= so drinus Tridentimus uir quidem fingularis ingenij er eruditionis, ac propterea maxime exiftimationis medicus apud Serenißs. Ferdinsndum Rom. Regem. Huius ergo uiri iudicium, ut quod multis er ijs quidem firmis argumentis ni=

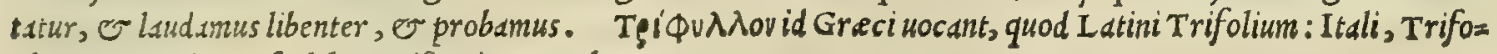
glo: Germani, Vuyenilee: Hipani, Treuol.

\section{ซóAIOY. POLIVM.}

\section{CAP. CVII.}

D v o genera polij. Montanum, cui teuthrio nomen eft, \& cuius eft ufus . tenuis frutex cft, candidus, dodrantalis, femine refertus: capitulo in cacumine quandam corymborum fpeciem pra fe ferente, paruo, cano hominis capillo fimili, grauiter olente, non fine quadam fuauitate. Alterum fruticofius, non ufqueadeò ualens odore, \& uiribus infirmius. Potum ferucfacti ius auxiliatur ferpentium ictibus, hydropicis, morbo regio: \& lienofis ex aceto: ftomachum male habet, ca- 
put doloribus afficit:aluum, \& menfes ciet. fubftratum, fuffitúmve ferpentes abigit: illitum vulnera conglutinat.

P O L I V M.

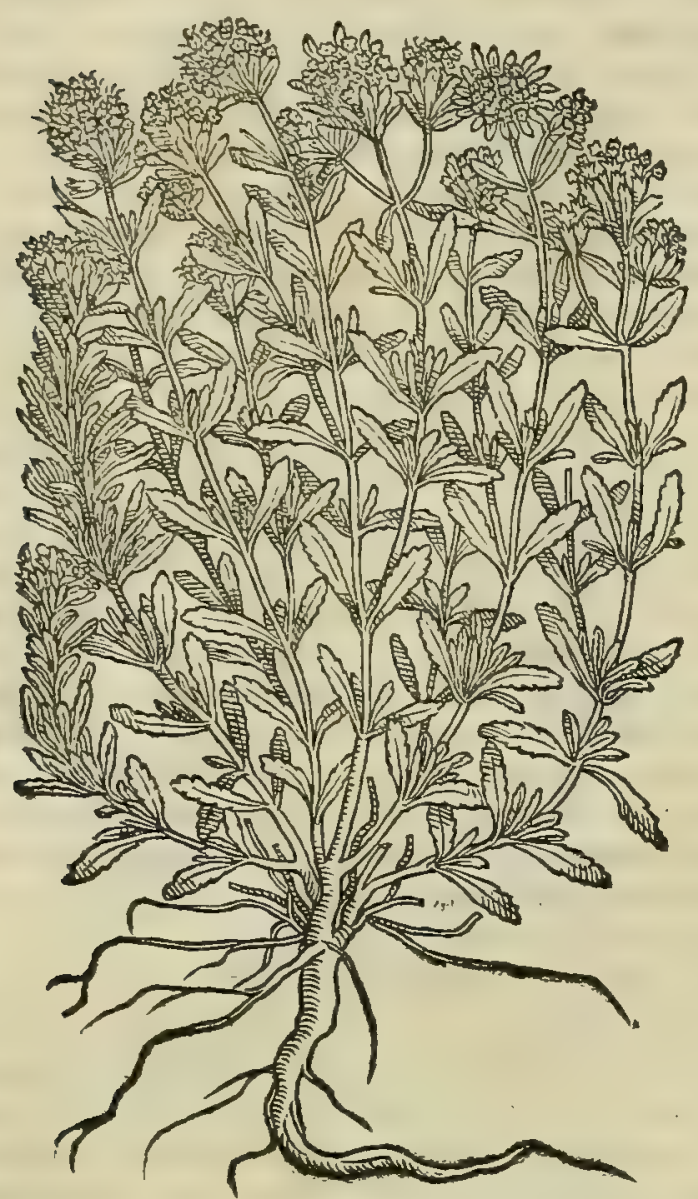

POLIVM ALTERVM.

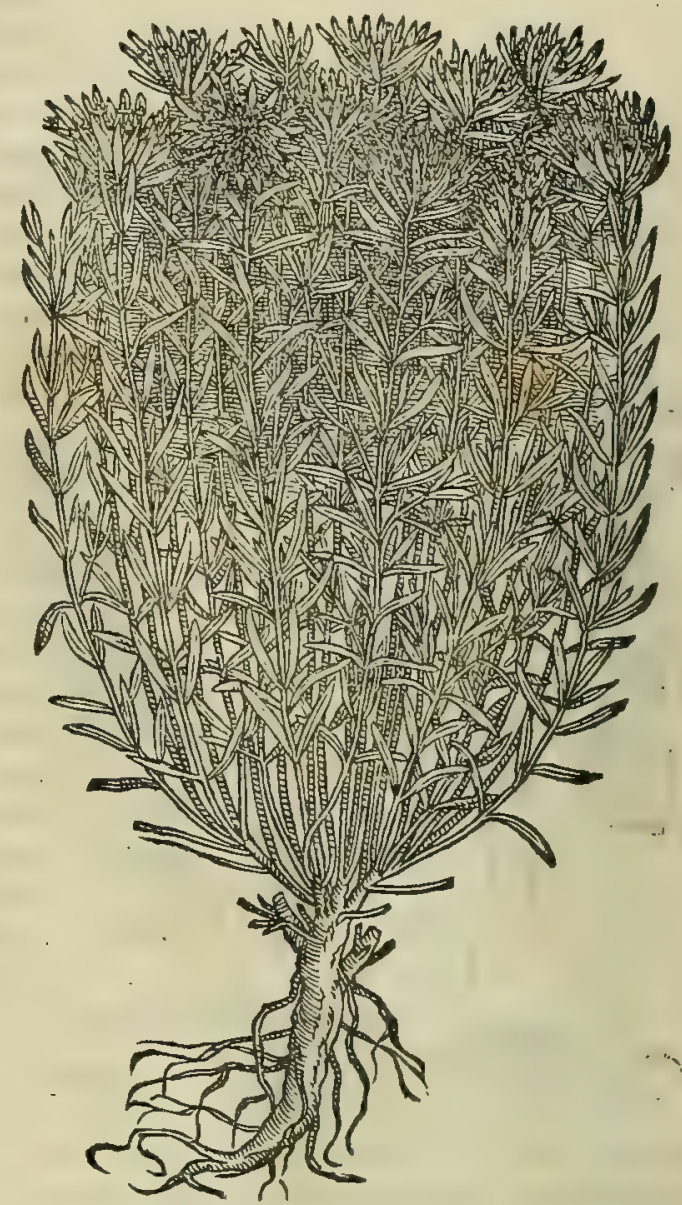

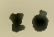

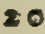

10

Polij conf- - SE P I A S I A R I I illi, qui pro Polio herbam quandam ufurpant, qua numerofos profert cauliculos, tenues, deratio. rectos, rotundo quodam femine undique refertos, euidentius, meo quidem iudicio, errant, quam ut corum erratum explodimereatur. quandoquidem berba bec nullis prorfus notis Polium reprafentat. Porró utrunque Polïge= nus, quod nulla reclamante nota legitimo refpondeat, in pluribus Italia loc is prouenit. Primum uulgus berbariorum I uam mufcatam appellat, à quo fecundum effigie non longé diftat, quanus non adeó fit odoratum. Secundi generis Polium, cuius etiam picturam adiecimus, uiret Venetijs in borto Maphxi cxcellentißimi medici. Polij meminit Pli= nius lib. X X I.cap.v I I. ubi ita fcriptum reliquit. A pud Gracos Polion berba inclyta Mufai, o Hefiodi laudibus, ad 40 omnia utilem predicantium, fuperớ; catera ad famam etiam dignitatis : pror $\int u s q$; miram, fi nodó ( ut tradunt) folia eius mane candida, meridie purpured, fole occidente caruled apiciuntur. Duo genera cius, campeftre maius, fylue= ftre quod minus eft: quidam teutbrion uocant. folia canis hominis fimilia, à radice protinus, nunquam palmo altiora. Plinij laprus. bec Plinius, quorum plura à Theophrafto mutuatus eft. Caterum in ijs Plinius aperté ballucinatus deprehendi= tur, quód turpiter Polium cum tripolio confuderit, cuius biftoriam libro quarto pertrątat Diofcorides. Siquidem Tripolij proprium eft, non autem Polij, tefte Diofcoride, ut colores ter in die mutet : neque id quidem ḋ Diof coride, ut à Plinio folijs, fed floribus adfcribitur. Preterea capitulum Polio ineffe cano hominis capillo fimile fcribit Diofco

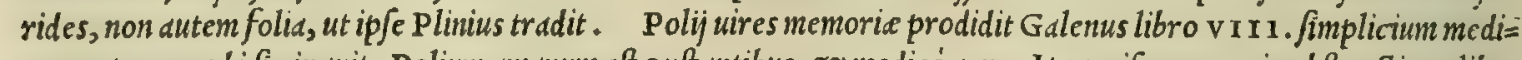
rat : urinamóf, or menfes ciet. Ac uiride etiámnum magna uulnera glutinat, maximé pecies eius fruticofa. A ridum $5 \circ$ cùm fuerit maligna ulcera fanat illitum: O magis hoc preftat quod minus eft. Polium minus, quo etiã utimur ad an= tidota, $\sigma$ acrius, $E$ amarius eft, quàm maius, adeo ut ex tertio fit ordine deficcantium, ex fecundo autem comple =

Nomina. to excalfacientium. Planta Grecis бód1ov, Latinisitem Polium appellatur: Mauritanis, Cahade, Iabade, jeu Giade: Italis, Polio.

\section{Exóp\$10V. SCORDIVM.}

CA.P. CVIII.

S C O R D I V M in montibus, \& paluftribus nafcitur, folijs triffaginis, maioribus, non fic in ambitu diuifis, aliquantum allia redolentibus, guftu amaris, \& adfringentibus: quadrangulis caulibus: fubrubro flore. Herba uim excalfąoriam habct: vrinam cit . Cocta recens, aridáve cum uino,aduerfus uenenatos ferpentium morfus bibitur : ad ftomachi quoque rofiones, dy fenteriam, \& urinæ difficultatem, binis drachnis cum hydromelite : craflamen purulentum pectore expellit. Facit arid $x$ 


\section{InLib. tertium Diofcoridis. $\quad 443$}

SCORDIVM.
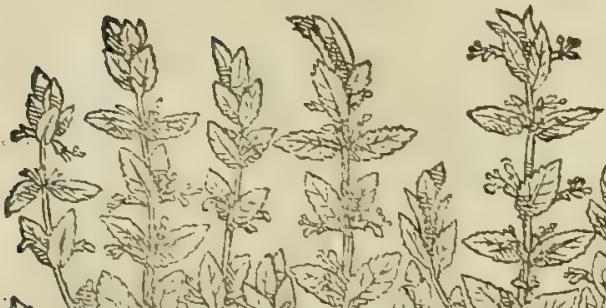

20
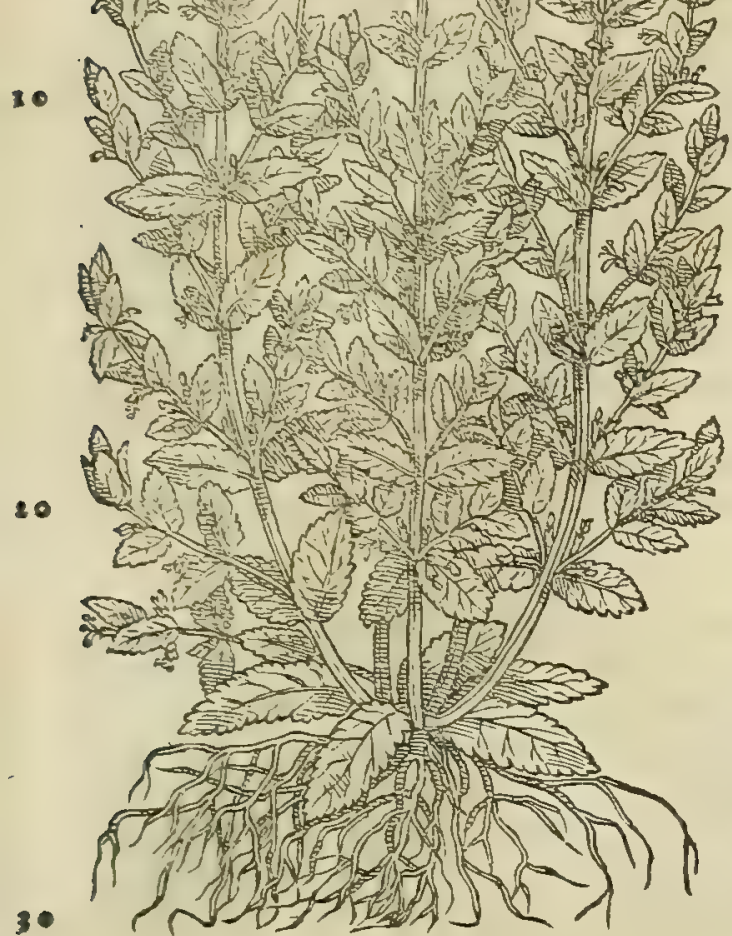

ALIIARIA.

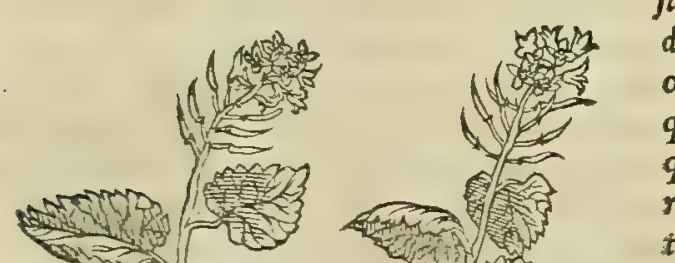

so

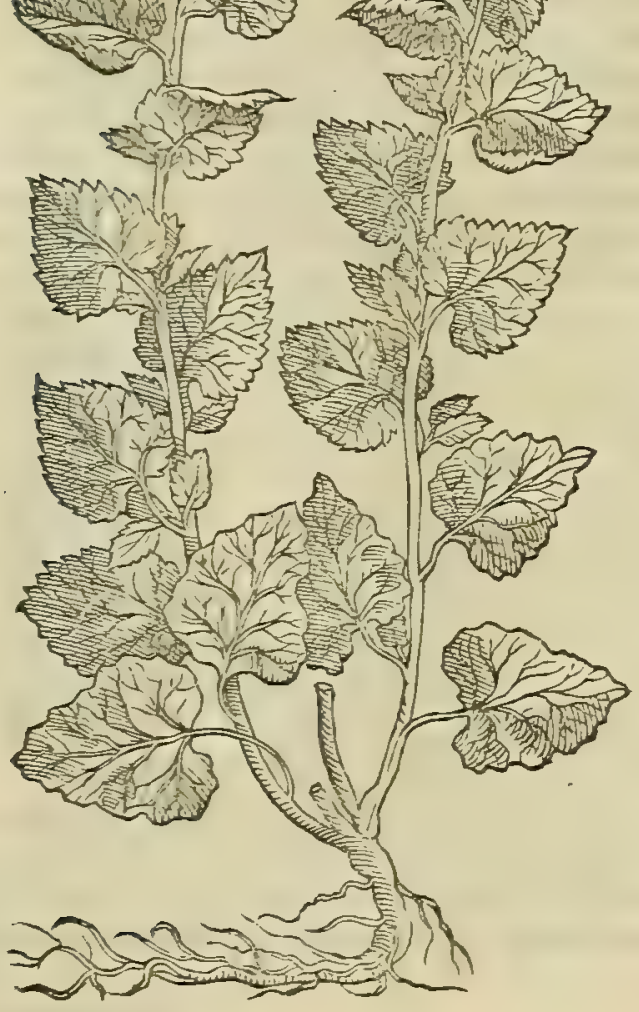

farina ad ueterem tufsim,rupta, conuulfa, fi cum nafturtio, melle, \& refina mifceatur in eclegmate. Inflammata modicè præcordia, cerato excepta, recreat : cum aceto acri, aut aqua, podagris conuenienter illinitur : menfes impolita mouet, vulnera conglutinat, vetera ulcera purgat \& cx melle cicatricem perducit . Sicca excrefcentias in carne cohibet. Succus ad eadem nitia bibitur. Inter prima efficax Ponticum natione, Creticumq́ue.

S C O R D I V M nonita pridem inueniri, O cognofcicx $=$ Scordij conpit in Italia. Siquidem praterita nuper atate omnes tum medi= fideratio. ci, tum Seplafiarij Mauritanorum monumentis decepti, fylueftri tantum allio, quód d Diofcoride ophiof corodon uocatur, pro le = gitimo Scordio utebantur. Neq; ijs folim rerum imperitia, sed ctiam uocabulorum uicinitas impofuerdt, ut qui Scordium à Sco= rodo, quod Grecis allium fignificat, diffinguere nefciuerint, pro unóg; acceperint. Sed illis potißimum errandi occáfionem dede= rat Auicenna, uel eius interpres; quód in alteram theriace com= pofitionem Scordium, in alteram ueró fylucftre allium addiderit. Quod cum uidiffent fuperioris atatis medici nonnulli rei, o prio risuocis ignari hanc ex altera expofuerunt, 0 Axicennam in bac re fui ipfius interpretem fecerunt. Vonde adducti funt, ut cer tó crediderint fylueftre allium, er Scordiun nibil inter fe differ $=$ $r e$, atq; unamer eandem plantam effe. Quo poftmodum factum eft, ut jylueftre allium apud omnes in Scordij locüillegitimé fuc= cefferit. Verim enimuero in bunc nunquam fortaffe incidiffent errorem, fi Diofcoridis, e Galeni fcripta diligenter perlegif fent. Porró uerum legitimumí; scordium, triffagini adeó fimile, ut Triffago paluftris meritó dici queat, bumentibus ac paluftri= bus locis proueniens, allij odore preditum, recentiorum diligen = tia iam omnibus magis innotuit, quàm ut fit ḋ nobis longiori hi= ftoria repreentandum. Pretulit Galenus libro primo de anti= dotis scordium, quod ex Creta aduehitur, ijs uerbis. Scordium optimum ex Cretd defertur: quanquam non fit improbandum quod in alijs quoque nationibus reperitur. Scriptum autem eft d quibufdam uiris granißimis, cum in bello interemptorum caddue= ra multos dies infepulta iacuiffent, quecun q; fupra Scordium for te fortuna ceciderant, multó minus alijs computruife, ea prö = fertim ex parte, qua berbam contigeraint: Ob quam rem $\int a n e ́ ~ o=$ mnibus per ruafum eft, tam putrefacientibus animalium uenenis, quàm medicamentorum deleterijs scordium aduerfari. Pr Scordii uires terea Scordij meminit idem Galenus libro v I I . fimplicium me= ex Galeno. dicamentorum, ubi de eius uiribus ita fcribit. Scordium ex mul= tiformibus id tun faporibus, tum facultatibus conftat. nam $\sigma \mathrm{o} d=$ snarum quid obtinet, o acerbum, or acre, or maximé fcorodo, hoc eft, allio adfimilis eius eft acrimonid: unde fane, med fenten = tia, nomenclaturam fortitum eft. Expurgat igitur; fimulg; ex: calf acit uifcera, tum men $\int e s$, urinamg; nioket. Praterea conuil $\int a$, ruptaq; , o laterum dolores ab obftructione, of frigore nas tos fandt epotum. Deniq; wiride quiden illitum magna uulnera conglutinat: fed fordida purgat, or maligna ad cicatricem per = ducit, illitum aridum. bactenus Galenus. Ceterìm herba qua $=$ Alliariz herdam iuxta fepes, o in agrorum marginibus nafcitur, quse of of bx mentio. dore, o fapore ita abunde allium refert, ut non temeré uulgó AL LIARIS fine Alliaria nocitetur. Huius folia cum primum erumpunt, feré rotunda pectantur uiole fimilitudine: poftquàm ueró ddoletuerint, per ambitum in ferre modum laciniata uifun= tur, ut quadantenus meliffophylli effigien reprefentent, leuiora tamen funt, nec adeó rugofa, or prope caulem latiora ; que digi tcrum attritu, guftatuç; allij odorem, o faporem reddunt. Cau= lem profert bicubitalem,rotundumí;: flores albos, er femen ni= 


\section{4 \\ And.Matthiol ${ }_{1}$ Comm.}

grum, minutumó;, irionis modo tenuibus filiquis inclufum. Radix, qux longiufcula eft, cundĕ cum folijs odorem res tinet. Vis plante huic calfactoria, o deficcatoria, uerum non adeo uelhemens eft, ut in allio. Attamen binc certó colligi poteft, quód ea craffos bumores extenuare, o lentos incidere ualeat. Semen emplaftri modo impofitum, uul=

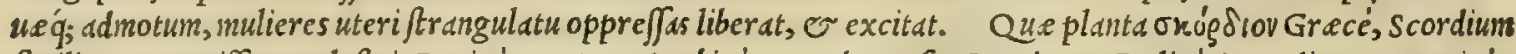
fimiliter, er Triffago paluftris Latiné uocatur : Arabicé, Scordeon, feu Scordeun: Italicé, 'Scordio: Germanicé, Vuaffer batenig, e Knoblochs kraut: Hipanicé, Scordio : Gallicé, Chamaraz.

BrixloV. TVSSILAGO.

CAP. CIX.

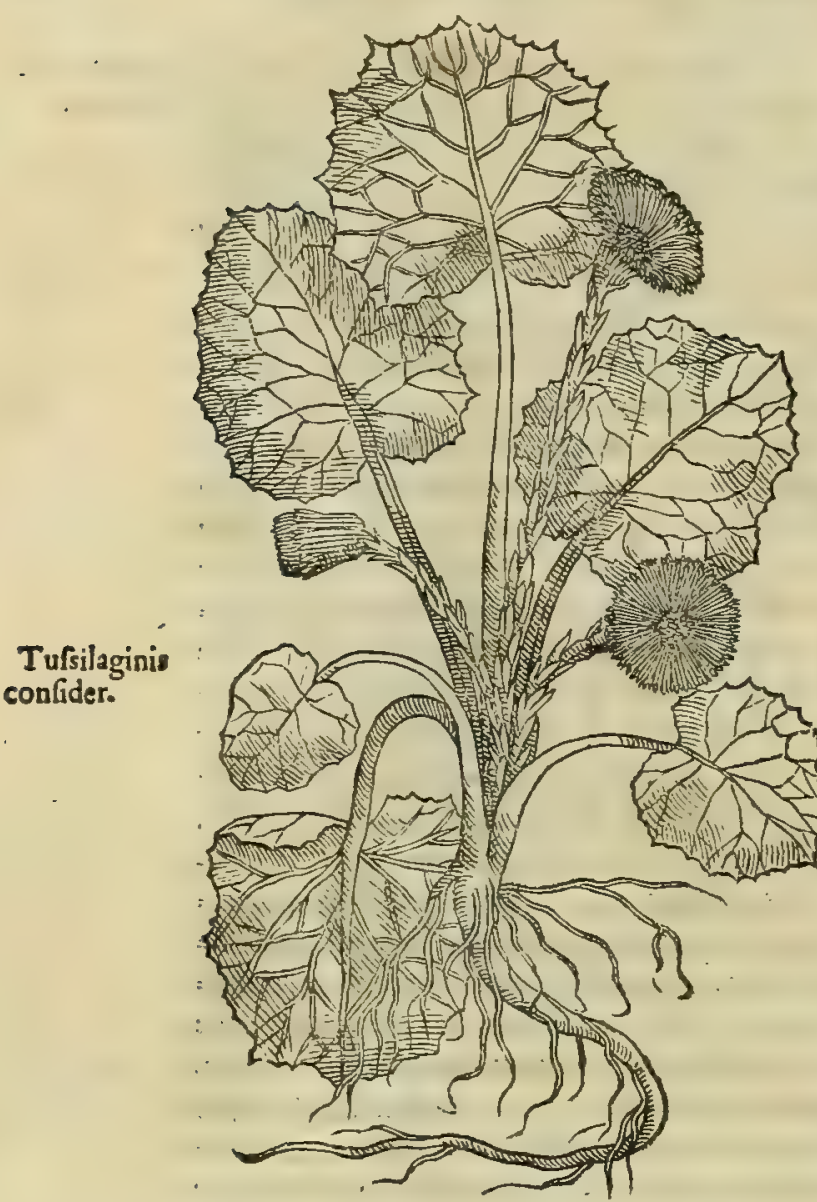

T V S S I I A G I N I folia funt maiufcula, quàm hederæ, fex aut feptem à radice, fubalbidà à terra, fupernè uirentia, in plures angulos exeuntia. Caulis palmum altus : flos luteus, nere prodit, quo unà cum caule confeftim exuitur: inde nonnulli his uacare exiftimarunt. Radix tenuis eft, $\dagger \&$ fuperuacua. nafcitur in amœnis, $\&$ riguis. Folia ex melle trita igni facro, \& omnibus inflammationibus illitu medentur. Arida fuffitu, ita ut fumus per infundibulum hianti ore rapiatur, hos fanant, qui ficca tufsi, atque orthopnœa infeftantur: pectoris uomicas rumpunt. Eundem effectum præbet fuffita radix . decocta in hydromelite, \& pota, emortuos partus eijcit.

T v S S I L A G o Hetrufcis unlgó dicitur Farfara, et Far= Farella, nomine à Romanis fortafe deducto : hanc enim ab ijs Far= fariam uocatdin fuilfe teftantur nomina Diofcoridi falso adfcri= pta. Officine hos, uel illos Secute eam Farfaram appellant, nec= non etiam Vngulam caballinam. Herbs eft uulgaris notitix. Cau= $l e$, o flore exit adeó fugacißimis, ut Plinius, qui corum tam fubi= tam iafturam no anmaduerterat, deceptus $T$ uß le, e fine flore nafci memoria prodiderit : cüm tamĕ ed uere pri= mo er caulem, or florem proferat, fed qui enatibreui admodum tempore durent : quo non nifi etiam à peritis, uel ab ijs, qui tunc fee e forté fortuna tulerint obuidm, conpici poßint, eoq́; magis, quod ijdem caulis, of flos prodednt, priusqudm folia enticent. Quare fcité fcripfit Diofcorides, Tußilaginem confeftim exui tums flore, tum caule, atque inde nonnullos bisuacare exiftimafe. sed certè uel bec non legit, uel illa non obferuarit Plinius, quod Tuf= Plinii lapfus. fildginem aperto errore o caule, o flore uidudm fecerit. Is Plinij error deprehenditur lib. x x v I.cap.v I.ubiip= fe de Tußilagine diferit ijs uerbis. Tußim fedat Bechion, qux er Tußilago dicitur. Duo eius generd. Sylueftris ubi

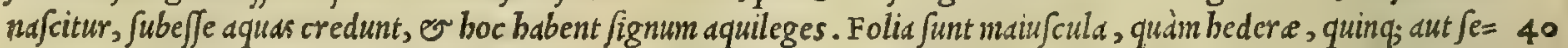
ptem, fubalbida ḋ terra, fuperné pallida : Fine caule, fine flore, fine femine : radice tenui. Quidă eandem effe bechiō, $\mathcal{O}$ alio nomine chameleucen putant. Huius arida cum radice fumus per arundinem bauftus, aut deuoratus, ueterem tußim fanare dicitur: Sed in fingulos hauftus pafjum guftandum eft. Altera à quibusdă faluid appellatur, fimilis uer= bafco. bec Plinius. Verùm alter a Tußilago, cuius nulla fit mentio à Diofcoride, utpote qui uno tantum eius genere contentus fuerit, mibi hactenus incomperta eft : nifi ea fortaffe fit, quam aliqui herbariorum Centrum galli uoc ant.

Fomes ignis. Porró nafcitur in $T$ uJildainis radice quadam fubalbida lanugo, que à radicum fegmentis prius repurgata, $\sigma$ dcin= ex tufsilag. de linteolis inuoluta, $\mathcal{O}^{\circ}$ in lixiuio parum decocta, addito falis nitri aliquătulo, ac demum fole ficcati ommium optimus eft fomes ad ignem é filice excuffum excipiendum. Quippe adeo rgnis eft rapax, ut ftatim primo tantùm chalybis con

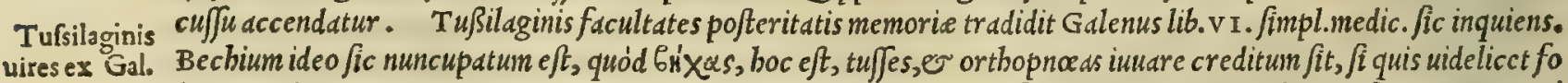
lia arida fumens, aut radicem in prunis accendens, afcendentem inde fumum infpiratu attrabat. Eft autem modice acris, ut fine moleftia noxáue omnes thoracis abfce fus creditafit rumpere. Sané folia uirentia partes cruda inflam= matione obfe fas illitu extrinfecus adiunant, propter aquex bumiditatis admiftioné : qua omnia uiridia, teneraq́; parti cipant alia plus, alia minùs.Nä ficca Bechij folia acrior a funt, quàm ut partibus inflàmatione laborantibus cöueniant.

Nomina, Quxe planta Brixlol Grecis, Tußilago Latinis uocatur: Officinis, Farfara, er Vngula equitina: Italis, Farfara, Far farelld, e Vnghia di cauallo: Germanis, Roßhuob, 0 B Brantlattich: Hipanis, Vnha de afno: Gallis, $\mathrm{P}$ as de afne.

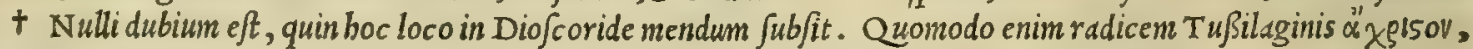
hoc eft, inutilem recté uocaucrit Diofcorides, /i paulo póft ei nonnullos ufus tribuit? Errorem bunc à nemine inter= pretum, quod fciam, animaduerfum, uidit Manardus, uidit item Fucb/ius, fed uterq; tamen locum inemendatum reliz quit. Equidern, ut dicam quod fentio, uerbum illud ut adfcititium delendum effe puto, Oribasij teftimonio nixus, in cuius codice manu fripto illa dittio non legitur. 


\section{In Lib.tertium Diofcoridis. $\quad 445$}

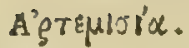
ARTEMISIA.
CAP. CX.

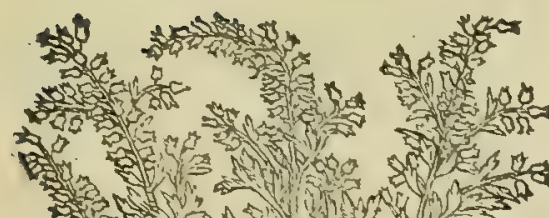

30
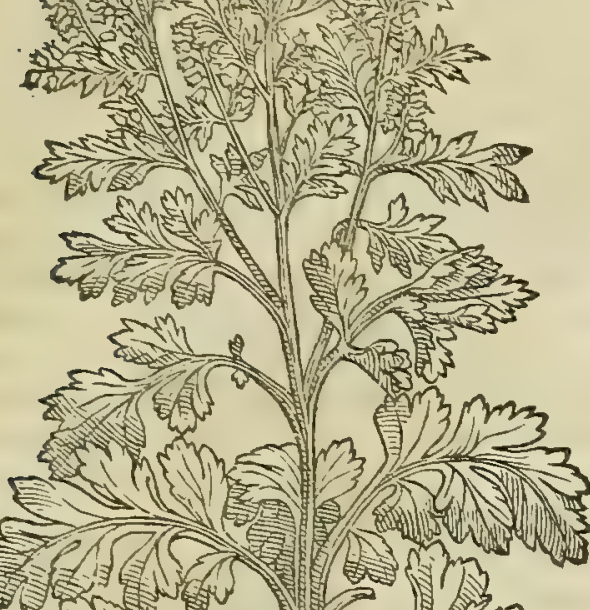

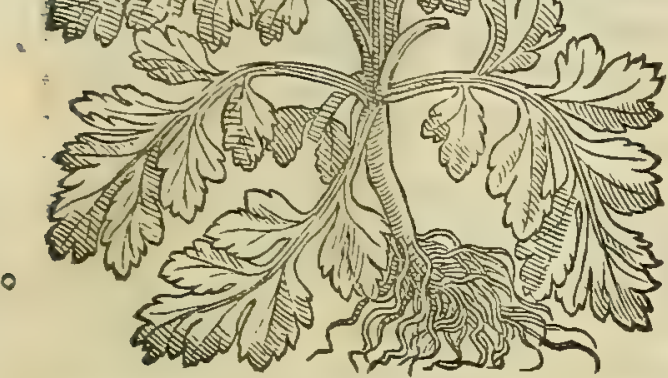

A R T E M I S I A magnaex parte in maritimis nafe tur, abfinthij modo fruticofa, maioribus, \& pinguioribus folijs, ramisque. Huius quidem genera duo. Vnum lxtius, habitiusque, folijs, uirgisq́ue latioribus. Alterum tenuius, flore paruo, tenui, candido, graucolente . aftate floret. Sunt qui in mediterraneis unicaulis nomine appellent tenuem herbulam, fimplici caule, \& minuto, floribus fcatente tenuibus, flauo colore . hæc iucundiorem, quàm præcedens efflat odorem. Vtraque excalfacit, extenuat . feruefactx conueniéter in mulicbres defeffus adijciuntur, ad detrahendos menfes, partus, fccundasque : item ad præxclufiones uulux \& eiufdem infam mationes : calculos cóminuunt, remoratam urinam cient. menfes pellunt pubi illitæ. Succus vuluæ inditus ex myrrha eadem, quæ inferfio trahit. Coma tribus drachmis eorundem educendorum gratia bibitur.

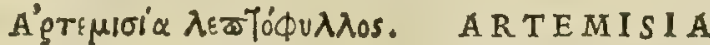 TENVIFOLIA. CAP. CXI.}

ARTEMISTA tenuifolia in fepibus, \& cultis iuxta aquarum ductus nafcitur. Eius flores, \& folia contrita fampfu chi odorem reddunt. Si quis ftomacho laborans, herbam cum amygdalino oleo bene contundat in malagmatis lentorem,\& ftomacho imponat, fanitati reftituetur. Qui neruorum quoque dolore cruciatur, fi fuccum eius cum oleo rofaceo mifcens illinat, fanatur.

T R I A ḋ Diofcoride recenfentur Artemifie generd. Verìm Artemifix cö prior a nullis inter $\int \mathrm{e}$ notis certant, nifi quód in uniuer fum altera maior eft, altera weró minor . que priuatim florem Gideratio. gerit candidum, paruum, tenuem, ac grauiter olentem. Que autem tertiogeneriadfcribitur, berbula eft fimplici, temuof caule, floribus plurimis referto, fluto colore. Id quod etiam confirmat Plinius lib. x x v. cap. V I I. fic in= quiens. Artemifía abfinthij modo fruticofa eft, maioribus folijs, pinguibusóg. Ipfius duo genera : alter a latioribus fo= lijs : altera tenera, tenuioribus, e non nifí in maritimis nafcens. Sunt qui in mediterraneis eodem nomine appellent berbam fimplicicaule, minimis foligs: flores copiofi erumpentes, cum uud maturefcit, odore non iniucundo, quam quidasn botryn, alij ambrofiam wocant. Talis in Cappadocia nafcitur. hec Plinius. Quitametfí in prioribus Arte= Plinij laplus.

$\$ 0$ mifie generibus, nibil i Diofcoride diffentiat; disidet tamen, er errat in tertio, quód in eius locum ambrofiam fe= quenti capite ab ipfo Diofcoride de fcriptam fubiecerit, crediderito ó;, deceptus hic ambrofiam, er tertium Artemifie genus, unam or eandem efe plantam. Caterim prima duo Artemifía genera Hetrufcis frequenti ßima funt, neque in alio inter fe diftant, quàm quòd in maiori omnes partes maiores ppectentur, in minori ueró minores : aliâs facie; $\checkmark$ forma fimilia conftant, quinetiann idem fapor, $\sigma^{\circ}$ odor, eddem $\dot{q}$; facultas utrique ineft. Quare equidem nefcto, qua ratione duttus Brafauolus Ferrarien/is in fuo fimplicium examene pro certo crediderit, eam berbam minorem effe Artemifiam que in Hetruria officinis Matricaria, er uulgó mulieribus Amarella uocatur. Sed eó magis uirun hune alioqui celebrem admir ari fubit, quod fcriptis tradiderit duas alias effe Ferraria Artemifie pecies nullis pror= fus notis diftinctas, proterquàm quód alteri unus tantùm fit ramus, alteri ueró plures. Eius uerba fubijcere lubet: Non dubito, inquit, ut nonnulli fecere, eam que apud nos corrupto nocabulo Arcemife dicitur, ac fi Artemifía dis so Etum fit, ueran Artemifiam effe, que folia ab/inthio fimilia habet, ut Diofcorides inquit, o eius duo genera facit Monoclonon, e Polyclonon, id eft, unun ramum, e plures ramos habentem. Ambas pecies Ferrarienfe uulgus

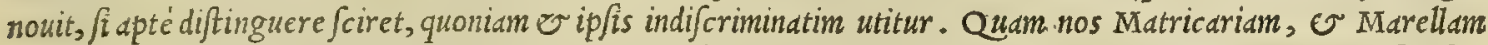
zocamus, Artemifie pecies eft, illa fcilicet, que malé olet. Nec obftat, quód Ferraris dua fpecies Artemifie fint per unum, o plures ramos diftincta, quoniam or hec in ppecie eft, qua plures babet ramos. bec Brafauolus. In quibus fané uerbis eius plurd, meo iudicio, deprehenduntur errata. Quorum primumillud eft, quód non fcripfe= rit Diofcorides, alteram primi generis Artemifiam multiplici conftare caule : alteram ueró fimplici tantìm uolierrata. confurgere, ut Brafauolus fwo modo interpretari uidetur. Sed author is duntaxat tradidit (ut etiam. Plinius refert) quód aliqui reperuntur, qui in mediterraneis unicaulis nomine appellent tenuem berbulam, fimplici caule, or minuto, floribus fcatente tenuibus, flauo colore . Verumbec tertio Artemifia generi aßignantur, non autem $\int_{e}=$ cundo, uel primo, ut Brafauolus exiftinat. Altero deinde errore notatur, quodd afferat Matricariam, fiue Marel = lam, quam legitimum Diofcoridis parthenium cenfemus, efe graueolentem Artemifiam. Quandoquidem minor illa, 


\section{And. Matthioli Comm}

que Diofcoridi fectudo loco redditur, grauiter olens, non quidem florem profert in nedio luteum, er per ambitum aibis foliol is cinctum Matricarie, uel A marclle modo: fed candidum, parum, ac tenuem. Tertius his accedit error, quód non affentire uideatur, duo illa Artemifie genera, que Ferraria perfiniles habentur, ea effe, quc it Diofcori= de primo loco reprefentata funt, magnitudine tantùm, ac paruitate differentia. Scd cinn porró feipfum bac in re deceptum deprebendeffet Brafaulus ( ut legitur in fuo ultimo uoluninc Venetijs impreffo) dum long a oratione con= tendit Amarellam, fet Matric ariam inter Artemifie gencrareponendan $c / f c$, Cotulam ueró fetidam Ferrarienfi= bus Brufciaculo uilgó wocatam effe legitimum parthenium, adco fsinfum ( pace eius dixerim) or fud fcripta confuns dit, ut nullo patio (dicans libere quod fentio, alijs tanten iudicandum relinquo) quid is tindem decernat, perctpi poßit. Nam cum afferit Anarelle, fine Matricari.s fuccum uiciarum quatuor pondcrc baufum utranque bilem, ac pituitan deijcere, aperté quidem fatetur hanc effe Parthenium, cuipriuatimea uis ineft. Attamen pauló póft eo= sun forté oblitus, arguncentis quibufdam fatis, mea quidern Jententia, levibus contrà affeuerat, nil aliud effe $\mathrm{Par}=$ Ruelij hallu- theniun, qua in fü̈ Brufaculum. Ruellius pratered quanuis in prinis Artemifie generibus plane Diofcoridi fub cri cinatio. bat; intertio tamen ballucinatus deprebenditur, quód tertij generis Artemifiam cann cffe putet, quan alij Athand= fism, alij Tanacetum appellant . siquidem $T$ anacetuin noftrum ftolonibus compluribus ab una tantum radice profi= lit, craßis, altis, ac firmis: folijs longis, amplis, crebris dinifuris diffect is : floribus luteis, in caulium cacumine grega=

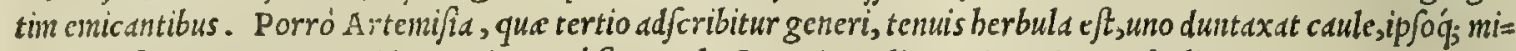
nuto confurgens. Hanc equidem (ut ingenué fatear) hactenus in Italia non inueni, neq; ab aliguo inuentam uidi. Quin potius eam inuentu difficillimaan duxerim. quippe ctim tam Diofcorides, quim Plinius fatis obfcurè, perplexéd; de ea fcripferint, e caulis, foliorum, florum, feminis, e radicis not ds filentio inuoluerint, non modó difficillimum uidetur ; fed uix etiann ficri poffe putakerim, , wt quis nunquam banc Artemifiam legitiné demonftret. Neq; tamen in hoc audié $=20$ dus eft $\mathrm{P}$ linius, qui (ut fuprà diximus) banc cffe A mbrofiam falsò memorice prodidit. Nam preterquàm quód rationi confentaneum non eft, quod Diofcorides duobus tam propinquis capitibus unius $\sigma$ eiufdem plante biftoriam tractaue sit, enidentißsimum eft, Ambrofiam fequenti capite defcriptam buius tertice Artemifie de fcriptionihaudquaquä re= Monachorü Prondere. Ad bee non in minori, quàm Brafauolus, e R uellius, uer antur errore Monschilli reuerendi, qui Me= \& Fuchfij er- fuem commentati funt. quippe qui $\odot$ bunc, E illun fecuti duplici ballucinatione fcriptis tradiderint, Matricariam ror. uulgó uocatam omnno effe minorem Artemifiam, Tanacetum ueró edm, qua unic aulis dicitur. In borun denique opinionibus, uel potius erroribus ipfe quoq; Fucbfius implicatur, uir alioqui ingenio, er eruditione preclarus, adeỏ ut etiam nemini dubitandum effe cenfeat in fuis de ftirpium biftoria commentarijs, quin Matricaria fit alterum Artemi= fie genus, Tanacetum ucrò tersium . qua in $r e$ is fortaffe fuit, qui malucrit cum alijs erraré, quaim folus rect ć fentire. Caterùm facilè credidere nonnulli diligentißimi fimplicium medicamentorum inquifitores, ac ctiam Diofcoridis fitu= diofi, qui fane nulli unquam labori pepercerunt, ut banc medicine partem fuperiori atati ob fcur an noftra illuftrem redderent, tertiü Artemifia genus in Diofcoride afcititium effe. Quód in buius capitis initio non trid, fed duo tantium effe Artemifla genera fcribat Diofcorides. Qứd praterea reperiantur buius auctoris codices antiquißimi, in quibus illa de tertio Artemufie genere non leguntur. quemadmodum etiam in noftro ex impreßis libro, in quem caftigationes ex uetuftorum excmplarium manu fcriptorum Diofcoridis, Oribasij collatione excerptas collegimus, quas acce= ptas refero Gabrieli Falloppio Mutinenfi medico clarißimo, nunc Patauif fumma cum omniun laude, er admiratione, corporis humani, er rei medice materiam profitenti. Cui certé ob eius fingularent in me amorem ac liberalitatě, at etiam in omnes bumanitatern, me plus debere fcio, quàm aut re, aut ucrbis repondere poßim. Cim itaq; (ut eo re= deam, unde obiter digreffus fum ) in Diofcoride fupecta fit tertia Artemifis, nil mirum uideri debet, fi in eius hiftoria cecutiuit Plinius. Neq; item mirandum eft, fi eius non meminerunt Galenus, $\mathcal{O}$ Paulus: qui tamen alioqui in fimpli 40 ciun cenfu Diofcoridis fcripta bona fide referre folent. Non defunt infuper doctifini uiri, o in plantarum hiftoria diutius uerfati, qui Artemifíe tenuifölix caput Diofcoridi accreuife, atq; adulterinusn cße cenfeant, boc ducti argu= mento, quód cim fuperiore capite de omni Artemifia genere differuiffet Diofcorides, ab furdum quippe effet, quód $\int \mathrm{e}=$ or fum Artemifia genus aliud fubiungeret. Addunt etiam, quód buius Artemifia inter fimplicia nufquam meminerint Paulus, Oribafius, or serapio : qui tamen (ut pauló anté dixi) illa ex Diofcoride tranfcribunt. Horum fentétiam etfi plané probandam exiftimem; cum tamen unlgati Greci codices hoc loco Artemifie tenuifolie caput babe ant, illud'q

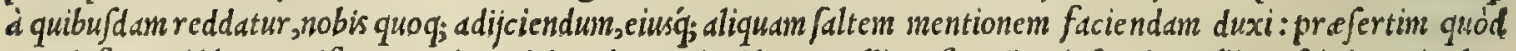
non defint, qui id Artemifie genus inueniri tradant. Siquidem $\mathrm{R} u e l l i u s$ cft austor, ipfum in Gallia nafci circa rikulos, aggeresǵ;, item in frumentaceis agris, atq; inibi uulgó diui Ioannis herbam nominari. Verìm cùm difficillinum effe putem, ut hac plantd ab aliquo cogno f catur, or legitiné demon/tretur, quód nullis prorfus not is depingatur, ne fcio $c=50$ Artemifix ui quidem quomodo Ruellio uiro alioquifide digno in hoc quis recté adftipulari de beat, aut meritó poßit. Duun tan= res ex Gal. tum generum Artemifiam fecit, corumq́; uires reddidit Galenus lib.v I. fimplicium medicamentorun, bis uer bis. Du= plex quidem eft herba Artemifia . Vtraq; excalfacit, 0 modice deficcat: $\odot$ funt, quòd ad calfactioncm attinct, ex= cefjus fecundi : quód uerò ad reficcationem, aut prinzi intenfi, aut fecundi incipientis. Sunt autem er modice tcruium

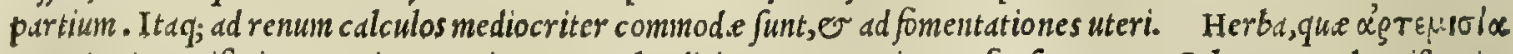

Nomina. Grecis, Artemifia item Latinis, pariter $\mathcal{O}$ Italis dicitur : Gcrmanis, Ecyfuofz, $\sigma$ Sant Iohahs gurtel: Hifpanis, Artemifla: Gallis, Armoife. 


\section{In Lib. tertium Diofcoridis.}

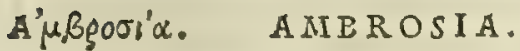 \\ CAP. CXII.}

so

20

$\$ 0$

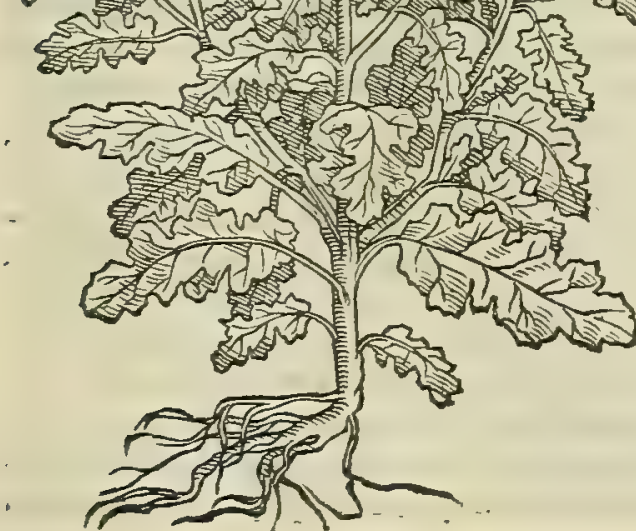

A M B R O I A pufillus frutex cft, ramofus, trium palmorum altitudine: folijs rutæ, circa imum caulem exiguis: cauliculi feminibus, perinde quafi racemulis grauidi, qui nunquam florem pariunt, odore uinofo, funui : radice tenui, fefquipedali. Coronantur ea Cappadoces. Vis eius reprimere,ac repellere, $\&$ illitu adftrin gere humores, qui in aliquam partem incumbunt.

E T S I in noftrisillis commentarijs, quos primün fuperio= Ambrofie cö ribus annis Italica lingua confcriptos edideram, ingenué cöfefus fideratio. effem, me nunquam uidiffe A mbrofiam in Italia; poftea tamen ea Rarijs in locis fe mibi obtulit infpiciědd, preferting.; fecus sindenia arcis Vipaci (loc us enim is diftat à Goritia circiter uiginti millia paffum) inter durißimos lapides orta. Cui cum inibi ex tempore

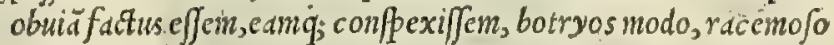
femine refertam, Itatim inclinauit animus, ut certó ducerem banc effe Ambrofiá. Ea quanuis a Diofcoride, o Galeno non alijs reprefentetur uiribus, qudm ut reprimere, repellere, et illituid= fringere ualeat bumores, qui in aliquam parté decumbunt, dixe= re tamen non poëta folum, fed plantarum quoq; fcriptores non contemnendi, nulla alia de caufa praftantißimam hanc plantame i ueteribus Ambrofiam fuife uocatam, quain quod fuo in cibis ufu longeuos faciat bomines, quemadmodum Ambrofiam illam, que Deorum fertur cibus, Deos immortales, perpetuos $q_{;}$con= feruare fabulantur. Ambrofie meminit Plinius libro $\mathrm{x}$ X $\mathrm{v}$ I I. cap. I I I I ubi eam ijs uerbis depinxit. Ambrofia uagi nominis $e f$, or circa alias berbas fluctuans, fruticem unum habens den= fum, ramofum, tenuem, trium feré palmorum, tertia parte radi= ce breuiore, folijs rute circa imum caulem. In ramulis feinen eft uuis dependentibus, odore uinofo, qua de caufa botrys à quibuf= dim uocatur, ab alijs artemifia. Coronantur illa Cappadoces. $\nabla$ fus eius ad ea, que difcutiopus fit. bec plinius. Ambrofie Ambrofize ui quoq; facultates, fed quàm breuißimé, tradidit Galenus lib. v I. res ex Gal. fimplicium medicamentorum, fic inquiens. Ambrofta cataplafs mate impofita vim babet adftringentem, ac repellentem. Ea ut Grecé áußpoor'a, ita etiam Latiné, er Italicé Ambrofia no=

Nomina. minatur.

\section{Bótgus. BOTRYS. CAP. CXIII.}

B o T R Y s fruticola herba eft,lutea tota, $\&$ in multas alas fparfa: femen circa totos ramulos prouenit: folia cichorio fimilia, tota fuauem odorem fpirat, qua re ueftimentis interponitur. Inuenitur in torrêtium ripis, \& conuallibus. Pota orthopnceas mulcet. Hanc Cappadoces ambrofiam uocant, alij artemifiam.

L E G I T I M A, er uera Eotrys fabulofis, er aridisgavi. Botryos códet, quin er glareo/is fluuiorum alueis. Ideoó; Tridentifrequen. Gideratio. tißima nafcitur. fecus Ferfinam, or Lauifium rapidißimos tor rentes, or in alijs quam plurimis locis. Goritix mulieres $B o=$ tryn in hortis ferunt, quód edm uteri affectibus opitulari exifti= ment. Fruticat bec folijs cichorij, laciniatis, finuofisq; quer= cutum foliorum fimilitudine: ramis numerofis, tenuibus, femine copiofifimo, racemofoó; refertis: Planta tota fucco quodam re= finofo madet, adeo ut comprebenfa refine modo manibus bareat. Odorem quidem acrem pirat, er qui nares quodammodo feriat, fed tamen is fuatitatem retinet. Plinius uidetur ex Diofcoride Botryn reddidiffe lib. X X V II. cap. V I I I. ubi eam in bunc mo= dum defcripfit. Botrys frutico of berba eft, luteis ramulis: femen 


\section{And. Matthioli Comm.}

circa totam nafcitur : folia cichorio fimilia. Inuenitur in torrentium ripis. Medetur orthopnoicis. hattenus Plinius. Ceterùm buius her bx, quod equidem legerim, non meminit Galenus in fimplicium medicamentorum cen $\int u$. Eius ta= Botryos ui- men facultates ex Diofcoride retulit Paulus lib. v I I. ubi fic inquit. Botrys, quam aliqui ambrofiam, alij artemifiam res ex Paulo. uocant, planta eft adnodum odorata. Hac cum uino pota non nifi recta ceruice pirantibus, quos orthopnoicos ap=

Nomina. pellant, auxiliatur. Ed Grecis sótęus, I atinis item Botrys dicitur:Italis, Botri: Germanis, Traben liraut, or Krotten liraut: Gallis, Pijmen.

GERANIVM PRIMVM.

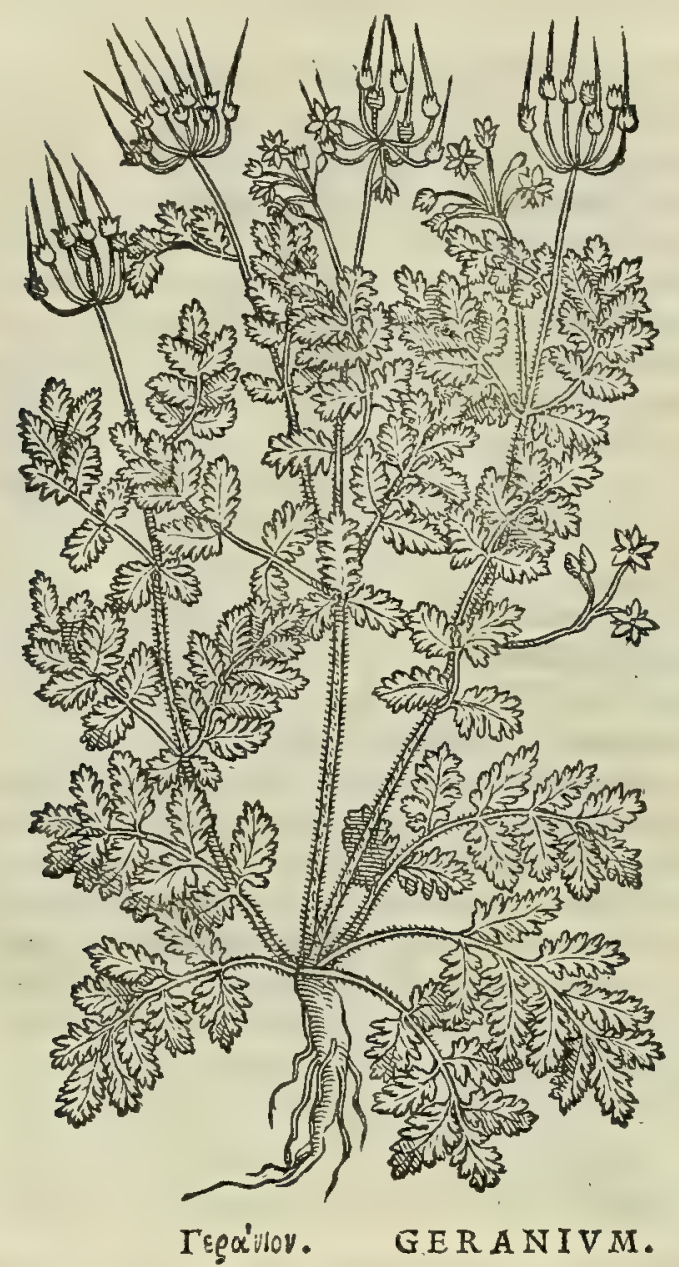

GERANIVMAITERVM.

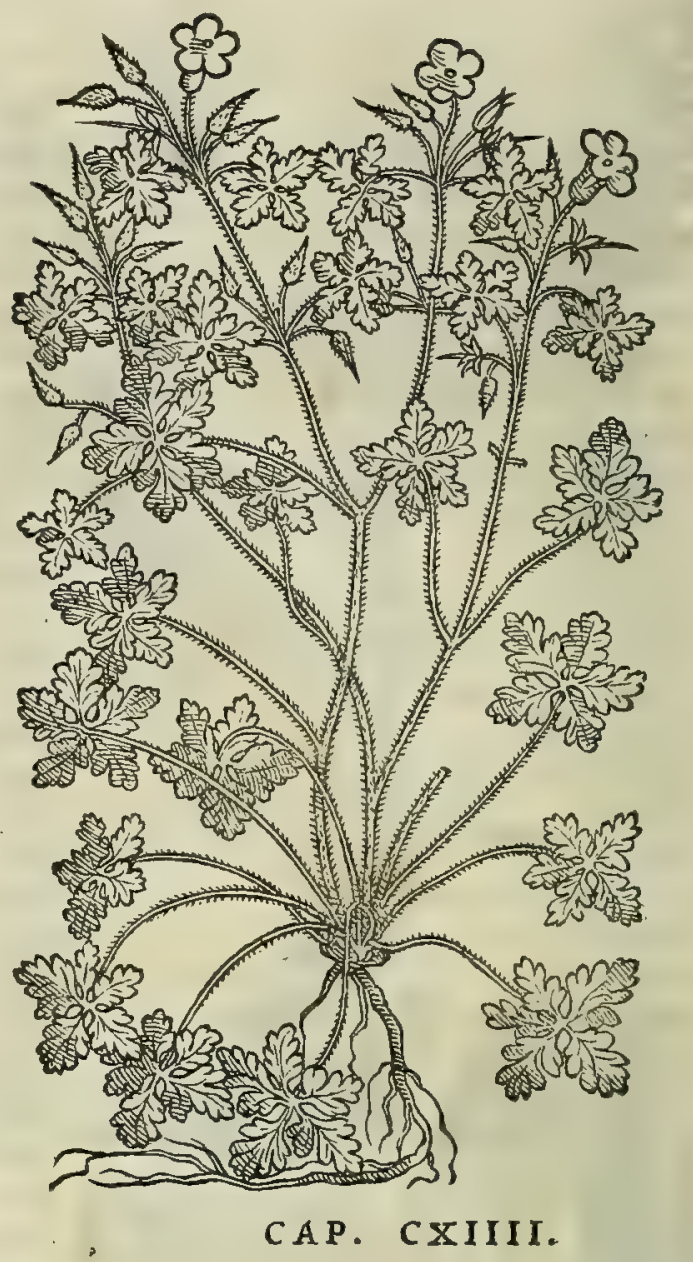

GER A I O N folijs anemones, diuifuris longioribus: radice fubrotunda,cùm efturdulci. Qux drachmæ pondere in uino pota uuluæ inflationes difcutit. Geranium alterum caulibus minutis, \& pilofis, fefquipedalibus : folijs malux . in fummis alis furfum fpectantia gruum capitula infunt, cum fuis roftris, autcanini dentes. Nullius in medicina ufus.

Geranii confị D v o tantùm Geranijgenẹra à Diofcoride traduntur. Verum Latini, Plinio authore, tertium genus addere deratio. uidentur, quòd alterum quidem eorum à Gracorum defcriptione differat. Id quod ipfe Plinius aperté teftatur libro X X VI.cap. X I. ubide Geranijs differit ijs uerbis. Geranion aliqui myrrbim, alij myrtbida appellant. Similis eft cicute, folijs minutioribus, e caule breuiori, rotundo, faporis, er odoris iucundi. Noftri fic eam tradunt. Graci folijs candidioribus, pauló quàm malue minoribus: caulibus tenuioribus, pilofis, ramo fam ex interuallis, binûm pal s so morum, es in ijs folijs, inter que in cacuminibus capitula funt gruum. Alterum genus folijs anemones, diuifuris lon= gioribus: radice mali modo rotunda, dulci. hee Plinius. Ex quibus facile colligi poteft, tria effe Geranij genera, Romanis unum, Grecis uer̀o duo. Que omnia bodie paßim feré uifuntur in campeftribus, fecus uias, $v$ iuxta $f c=$ pes. Porrò non defunt, qui putent eam herbam, quam fcribit Plinius Geranium à Latinis uocari,à Diofcoridis myr= rbide non differre. Ipfe tamen non dubitandum exiftino, quin bec ill fit berba, quam quidam Roftrum tun gruis, tum ciconix appellant, quidam ueró Acum mufcatam, eo quód (ut Plinius inquit) odorem iucundü piret. Nanq; af= furgit bee folijs cicute, minoribus tamen divifuris: caule breui,ac rotundo: Semine gruum capitulis contêto, à quibus Geranij nomen omnibus inditum eft. Ceterüm Geraniü, quod Diofcoridifecundo loco proditur, caulibus minutis, pi= lofis, fe fquipedalibus, folijs malue, in fummis alis gruü capitula gerens fur fum pectantia cum fuis roftris, nunquä du bitauerin eam effe berbam, que Pes columbinus uulgó nominatur, quód nullis pror fus reclamantibus not is bec illi

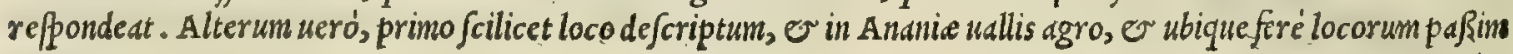




\section{In Lib. tertium Diofcoridis.}

GERANIVM TERTIVM.

10

20
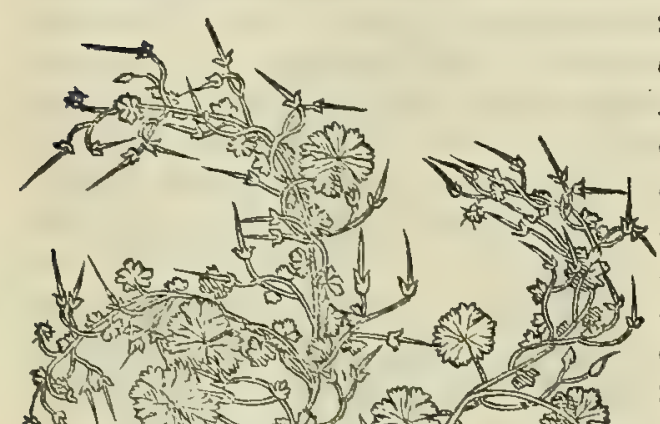

90
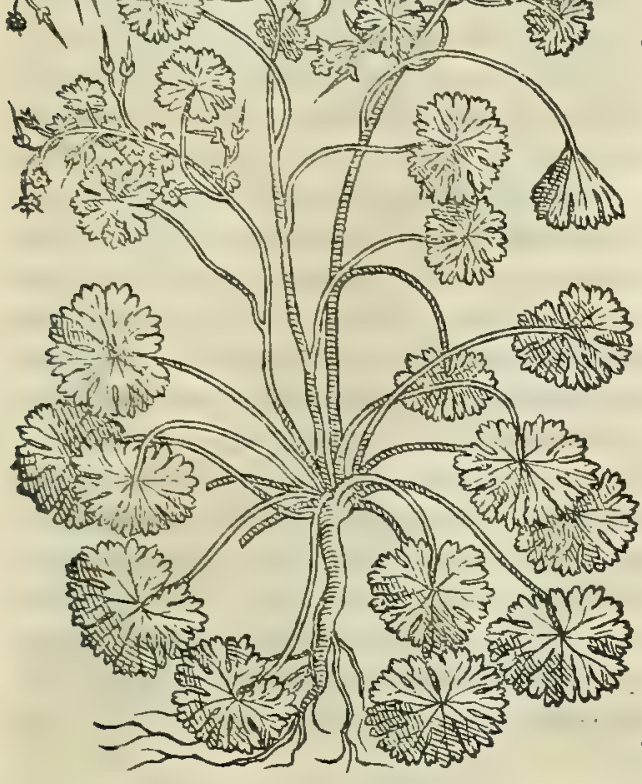

numera plantarum nomina leguntur. Fallitur quoque bac in biftoria Brafaulus, afferens nullo modo is offe adfi pulandum, qui Pedem columbinum uocatum Geranium effe contendunt, quòd Geranium folijs exeat maioribus ane= mones incifuris. Sed is, meo quidem iudicio, ignoraffe uidetur, quidd fecundum Geranij genus, non autem primo generi à Diofcoride aßignatum, eft illud, quod Pes columbinus cenfetur. Vel fortaffe dum bec fcriberet, alterum Ge= ranij genus non animaduertit in Diofcoride, quód tunc lectionis impatiens, totum illius caput non perlegerit. Aliam ab his Geranij plantam uidimus in pluribus bortis, ac uiridarijs Satam, folijs rotundis, fecundi Geranij modo per ambi= tum laciniatis, maluam magnitudine equantibus, fructu gruinis capitulis fimiti . Hanc herbariorum nonnulli Momor= dicam nuncupant, quemadmodum o Balfaminam alij eodem nomine uocant: eamq́; cateris praferunt in potionibus

40 ad interna uulner a glutinanda. Hec, mea quidem fententia, magis repondet alteri Diofcoridis Geranio, ut que folijs ad maluam propius eccedat. Quare or hanc magis eandem effe cum illo putauerim. Veruntamen haud eam inficias, quin Pes columbinus dittus idem fit Geranium: fed eum quis rectius forté Geranium minus dixerit. Primi Geranij ra dix (ut Plinius eft autbor) reficientibus fe ab imbecillitate utilisima est. Bibitur contra phthifim drachna in uini cya this tribus bis die : item contra inflationes . que or cruda idem praftat . Succus radicis auribus medetur . Opithoto= nicis femen drachmis quatuor cum pipere, o myrrha potum. Secundum ueró Geraniü et/i nullius effe in medicina ufus feriptis tradiderit Diofcorides; nö de funt tamen bodie berbarij, qui in internis unlneribus glutinandis, et fiftul is fanan dis ipfum in potionibus funptum, mirificé commendent. Sed equidem ue reor, ne ev hi decipiantur, Seraptonis inter: pretem Secuth qui A momum Pedem columbinum appellauit . quippe quoniam propria fit Amomi facultas internis cor porum uuineribus mederi. Geranij non reperio meminife Galenum in fimplicium medicamentorum libris. Eius qui= yo dem meminit Paulus, fed ea tantim de Geranijs pofteritatis memorie mandauit, qua ex ipfo Diofcoride fumpfit.

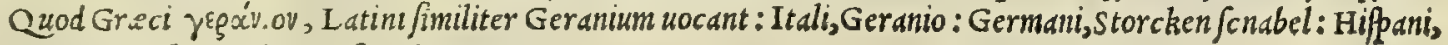
rico de cinguenha: Galli, Roftro de cicongie.

\section{ГV $\propto \uparrow \alpha \dot{\lambda} \lambda$ เov. GNAPHA LIVM.}

\section{CAP. CXV.}

G N A P H A I I I folijs albis, mollibusq́ue aliqui pro tomento utuntur. Bibuntur efficaciter folia in uino auftero ad dy fenteriam.

G N A P H A L I I hiftoriam adeó paucis perftrinxit Diofcorides, ut nobis non modó difficile, fed etiam impoßi bile uideatur, ut quifquam conijcere, ac decernere poßit, quianam planta fit, qua uerum Gnaphalium reprefentet: prefertin cum antiquorum bactenus repererim neminem, qui Gnaphalij faciem longiori hiftoria exprefferit. Ete= nim Plinius eadem, qua Diofcorides, brevitate ufus, Gnaphalï notas reddidit lib. X X v I I.cap. X. Fuch/ius tanen in fuis clarißimis de ftirpium hiftoria commentarijs herbam quandam pro Gnaphalio oftendit, quam ideo fortaffe Gnat=
Ruellij erratum.

Hermolailaplus.

Brafauoli error.

Momordics.

Nomina. phalium 


\section{$450 \quad$ And. Matthioli Comm.}

Impiaherbs

Plinij.

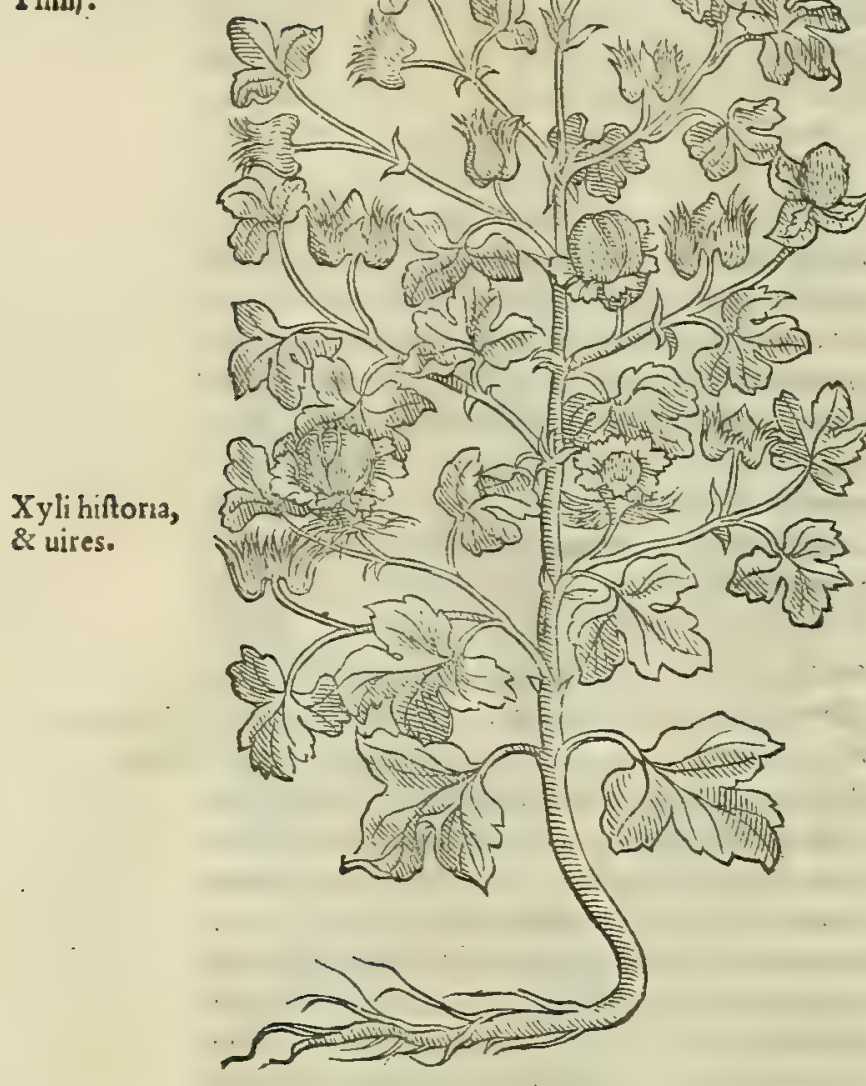

T Y P H A.

Gnaphalij uires ex Gal.

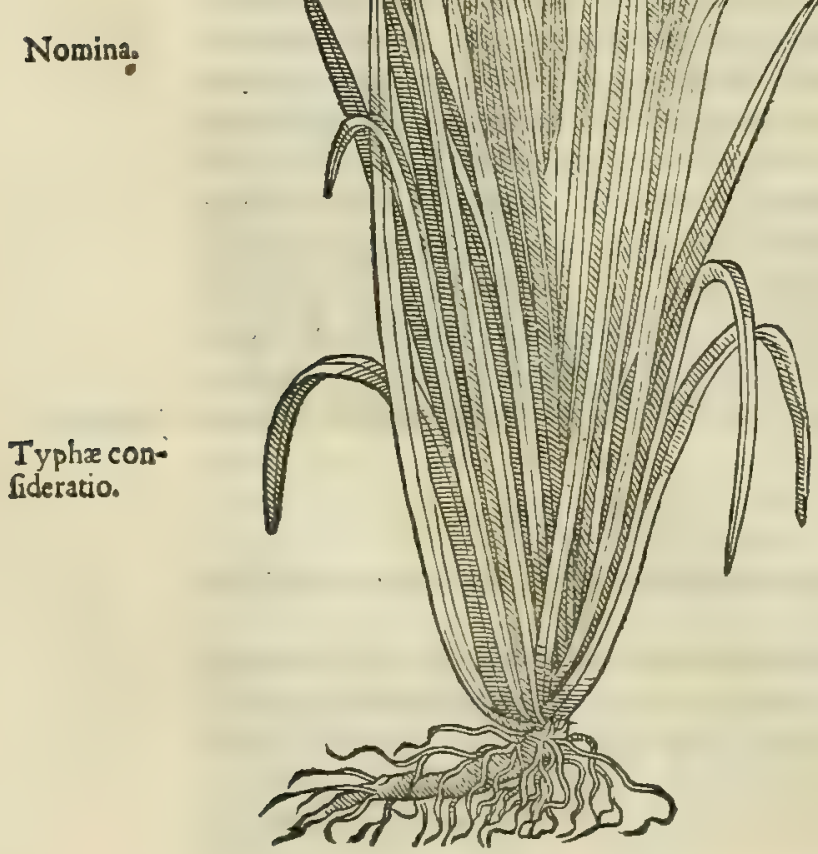

phalium exifinauit, quód incana, tomento dáp. conpiciatur. Sed mibi plane cam Fuchjius pro Gnaphalio depinxiffe uidctur, quain Plinius lib. X X I I I I.cap. x I X. Herbxim impiam uocari trudit: que meritó IMPIA Plinij dicipolfet, quód cius $\tilde{\text { I }}$ ucte $=$ ribus nemo, qiuntü equidem legerim, preter ipfum meminerit. De qua is diffcrens loco modó citato, eã ijs notis, ct uiribus de frripfit. Herba imapia uocatur incana, roris marini apectu, thyrfin modo ue

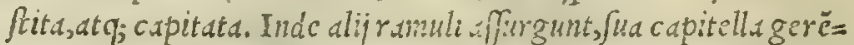
tes. Ob id imoian appellauere, quoniă liveri uper parenté excel= lant. Alij potius ita appellatan, quód nullum animal cam attin= gat; exiftimaitere. Hac inter duos lapides trita fruct, praci= puo aduer Jus anginas fucco, lacte e uino admifro. Mirumí; tra $=$ ditur, nunquam ab co morbo teitari, qui guftauerint. Itdq; or Suibus dari, que ó; id medic dnentum noluerint baurire, co mor= bo interire. Sunt qui o in auium nidis m eri aliquid ex ex putent, atque ita non ftrangulari pullos auidius deuorantes. hactenus de Impia Plinius. Caterim quoniam Gnaphilium ob cius tomen= tum, illud candidißinum uellus, quod uulgo nos appellamus Eam=

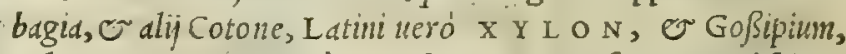
mibi in mentem redegit, à uetertbus Grecis nufquam, quod fciam, 20 defcriptum; ideo bic de eius biftoria, ac uiribus latius differen= dum duxi, quàm feccrim in linimentione, ubi cius quoque memi= ni. De boc itag; Plinius lib. X I x. cap. I. fic loquitur. Superior, inquit, pars Aegypti in Arabiam uergens gignit fruticem, quem aliqui Goßsipion wocant, plures Xylon, or ideo lind inde fatta xylind. Paruslis ef , fimilemí; barbate nuci defert fructum: cuius ex interiore boinbice lamigo netur. Nec ulla funt ei in can= dore, mollitiáueprofirenda. Vefies inde facerdotibus Aegypti gratißima : bec Pilinius. Hac atate Xylon feritur etiam in $\dot{C} y=$ pro, Creta, sicilia infulis, ubi copiofißimum prouenit: quin 30 or in Apulisalijsóf; regionibus na citur. Huius lanugo manifffé excalfacit, ac ficcat. Gue fi comburatur, wirum in nodum ma nantem è unlneribus fanguinem fiftit: Seminis medulla tußi, or difficulter Pirdntibus auxiliatur : genitde femen procreat, pro= inde uenerem ftimulat. Oleum ex ed exprimitur, quo tum lentigi= nes in facie, ttum etian cater cutis macula optimé delentur.

sed ut iam Gnaphalio fuas ex Galeno reddamus uires, ês. ip $\sqrt{e}$ lib. v I. fimplicium : medicamentorum, bis uerbis retulit.: Gnat phalium ideo. fic nominatun eft, quód folijs eius mollibus a'vтi $\gamma^{v} \phi_{\alpha} \alpha \omega y$, hoc ef, pro tomentis utantur. Sunt autem candida, 40 o mediocriter adfringunt: ac proinde quidan id exbibent, ex aufterorum uinorum quopiam, dyfentericis. :Herba Grecis

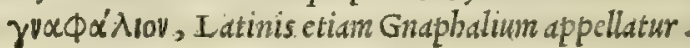

TUंфH. TYPHA.

CAP. CXVI.

T Y P н A folium edit cyperidi fimile : caulem album, lauem, xquabilem : flore in cacumine ambientem, denfum, qui in pappos foluitur, quod paniculam aliqui nominant. Huius herba flos fuillo adipe eloto exceptus, ambuftis medetur. Gignitur in paluftribus, \& 50 aquis ftagnantibus.

T Y P H A planta eft in Italia uulgaris, notioró; onmibus, quàm ut eius effigies explicaridebeat. Ea in paludibus, ftagnis, o lacubus frequentißina prounit, ita ut rars admodum fint flagnantes aqua, qua Typha non fcateant. Claud, quan in le= uißjino caule gerit, à noftris Hetrufcis Mazza forda unlgó dici= tur, quod cius lanugo, $f i$ in aures decidat, furditatem afferat.

Expetuntur clauarum pappi infine gentis hominibus pluma= rum uice ad grabatos farciendos. Foliorun ueró ufus ad contue= ftienda uitrea uafa, or ad muliebres cathedras texenda: quin or ad tegetes parandas. Typha pappis, additis betonic a folijs,

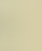

10




\section{In Lib. tertium Diofcoridıs.}

orgladioli, achippogloßiradicibus, ommibus in puluercm tcnuifimum redactis, of affatis onorun lutcis cxceptis, utuntur quidam feliciter ad cnterocelas. Id autem medicancntum cxbibent quotidic icimis drachna pondcre trigin

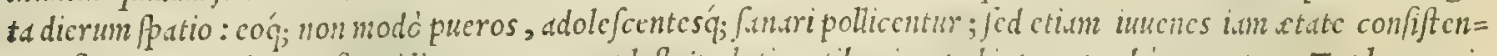
tes: fi tamen intcrim preftantiligatura, ac emplaftris glutinantibus ina pubis pars probc muitutur. Typhe memi=

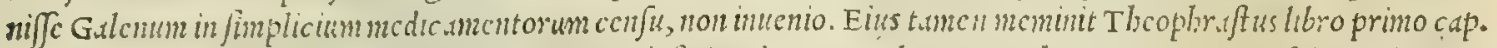

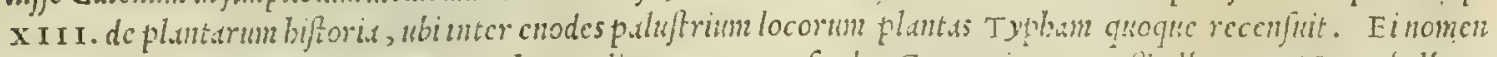

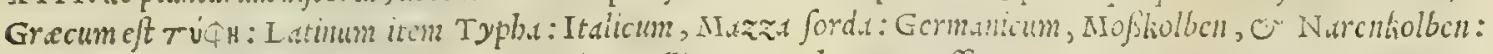
Hifparicum, Bohordo, or Imico amacorocado: Galicum, Nache, Or Naffi.

Kigraia. CIRCEA.

C A P. CXVII.

C I R CE A, quam \& dircxam aliqui uocant, folijs eft hortenfis folani, agnatis crebris: flore nigro,pulillo, copiofo: femine milij, nafcente in quibufdam ueluti corniculis : dodrantal radice, triplici ferme, aut quadruplici, candida, odorata, excalfaciente. Nafcitu in apricis, faxis, \& nento perflatis. Radicis tufre pondo quatmor, in fextarijs tribus uini dulcis per dicm, Le noetem maccrantur, potuq́ue triduò vuluas expurgant. Semen in forbitionibus datum lacte mammas nutricum cxplct.

H A V D equidem aufin affumare, an Circes hodie inuenivi poßit in Italia: quanuis ed antiquis fortaffe notißi= Circxx con-

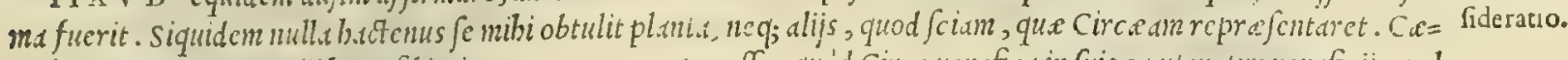
terum credidere nomulli bunc fibi circe a nomen comparaffe, quod Circc ucnefica in fuis ea uteretur ueneficijs, uel 20 quod fortaßis cius fuerit inuentrix, à sole patre plantarun omniun genitore cdocta. Quod ct $\mathrm{i}$ nonnullis uerifinile

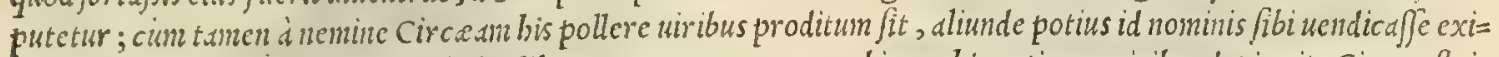
fimandum. NIeminit Circes Plinius lib. x x v I I.cap. VI I I. ubi eam bis notis, ac uiribus depinxit. Circsedtri= chno (hoc eft, folano) fatiuo finilis eft: flore ingro, pufillo: parno femine, ut milij, nafcente in quibusdan cornic wlis: radice femigedali, triplici frrme, aut quadruplici, alba, odorata, guftus calidi. Nafcitur in apricis faxis. Diluitur in uino, bibiturq́; ad dolorem unlue, or uitia. Macerari oportet in fextarijs tribus quadrantem radic is tufa per noctë, $\checkmark$ diem. Trabit cadem potio fecundas. Semine lac minuit in uino, aut mulfa aqua pota. Hac Plinius, qui illa omnia feré ab ipfo Diofcoride nutudtus eft. Etfi ab co in boc magno, ut puto, errore diffentiat, quod Circa 2 femen in uino, aut mulfa aqua potum luc minuere tradat, cùm potius, tefte Diofcoride, ipfum eliciat. Qua in re Plinius nŏ modó Dio fcoridi refrag atur, fed ipfi quoq; Galeno . qui de Circa a uibibus differens lib. v I I. fimpl. medic. fic inquit. Circea 30 herba radicem fribit Diofcorides ex uino dulci potam fecundas expurgare. Eft enim boni odoris, ex excalfactoria.

\section{FIL I P E D L L A.}

40

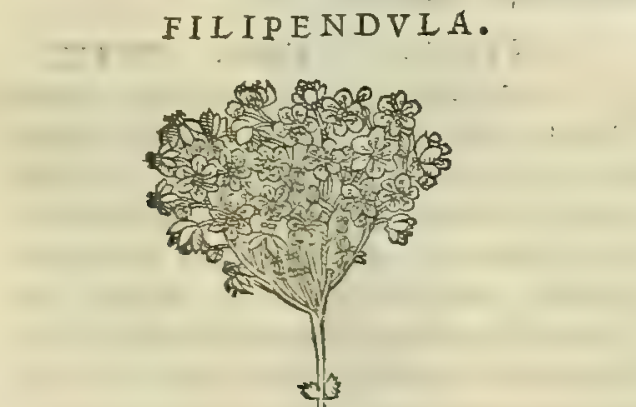
semen autem eius in forbitione exbibitun, ad lact is generationem conducit. Que Grecé u!puaia, Latiné finiliter Circea, es Itd= licé Circea wocatur.

O’พั่ทタ. OENANTHE. CAP. CXVEII.

OENA N T H E folia habet paftinacx: florem candidum : caulem craffum, palmi altitudine : femen atripličis: radicem magnam, in multa rotunda capitula extuberantem. nafcitur in petris. Huius femen, caulis, \& folia cum mulfo uino pota, fecundas eijciunt. Radix è uino urinæ fillicidio conuenit.

OE N A T H EN, cuisshic Diofcorides meminit, Theo= phraftus libro v I. cap.v I I. de plantarum biftoria, $\mathcal{O}$ Plinius lib. $\mathrm{X} \times \mathrm{I} . c a p . \mathrm{X} \times \mathrm{I} I \mathrm{I}$. non equidem hactenus reperi, ac uidi in $\mathrm{I} t a=$ lia, etfi in ea indaganda non parum laboris infumperim. Fuch/fius, or recentiorum herbariorum plerio; Oenanthen eam effe berbam exiftintant, que hodie paßim F I L I P EN D v L A uocatur. Quorü certé Sententix, quanuis uirorü magne apud me auctoritatis, nun= quam potui fubfcribere q quód Filipendula bac magna nufquam, quod inuenerim, radice nitatur, que rotundis extuberet capitibus: quod femen non ferat atriplicis: quòd denique non in petris, fed in

50

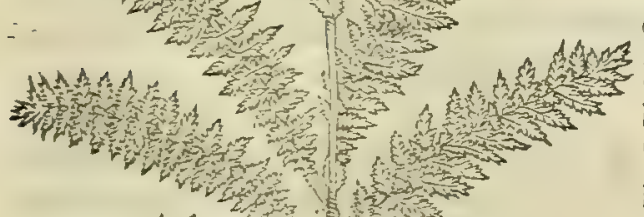
pratis, er lato ubique folo proneniat. Quibus fané rationibus non potui non adduci, ut apud Diofcoridem aliam omnino à Filipendula Oenanthen femper effe crediderin. Oenanthes wires, quas de feri= p $\int$ erit Galenus in fimplicium cenfu, non licuit mibi reperire. Cate= rum Filipendulam non unlg aribus pollere uiribus, teftantur recen= tiores. Ea enim urine remoratui, eiusq, ftillicidio auxiliatur : item renum tum calculis, tum doloribus. Eadě fromdehi inflationes difcu tit. Medetur fupirio/is, o anbelantibus, omnibus'; in uniuerfum morbir, quos caufa frigida excitauerit. Prodeft comitialibus infper fo cibis radicum puluere. Planta, que Grecisólyo'vor, Latinis $e=$ tiam Oenanthe appellatur: Italis, Enanthe.

Oenanthes confider. Filipendula uires.

Nomina. 
CONYZA MAIOR.

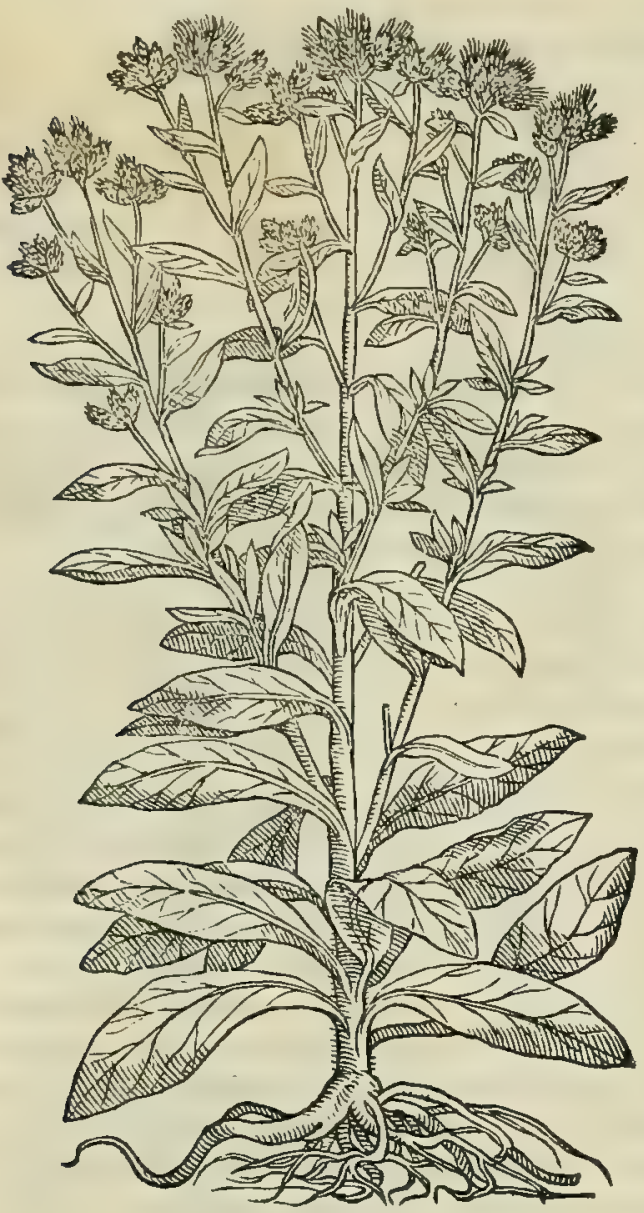

CONYZA MEDIA.

Conyra con Gideratio.

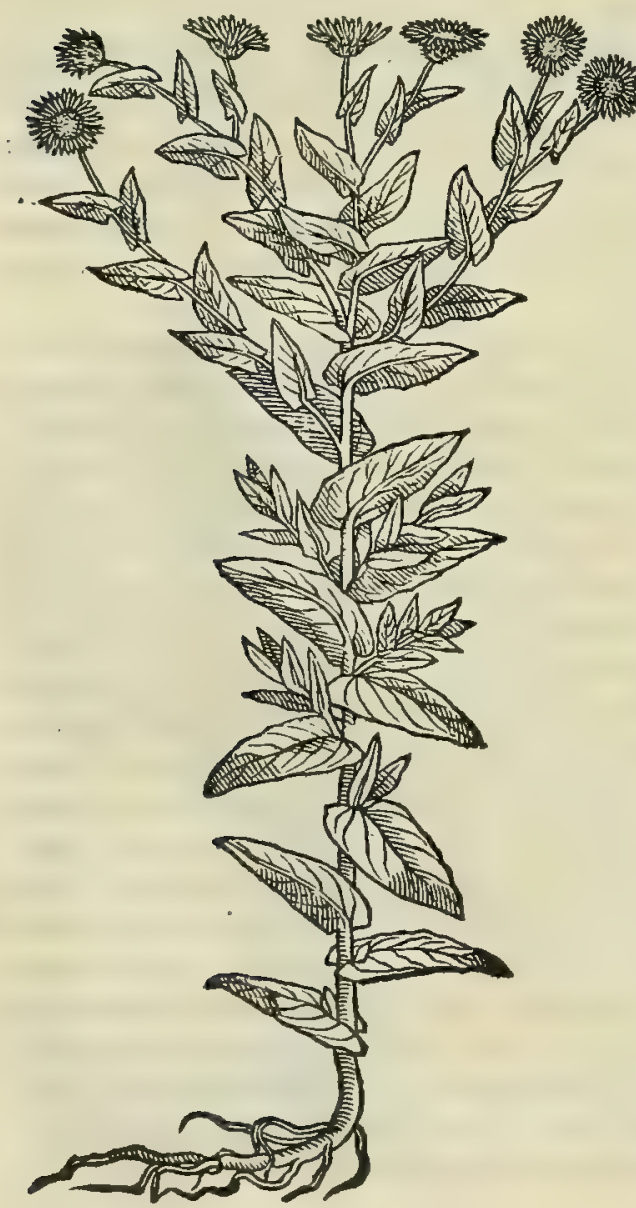

CONYZA MINOR.

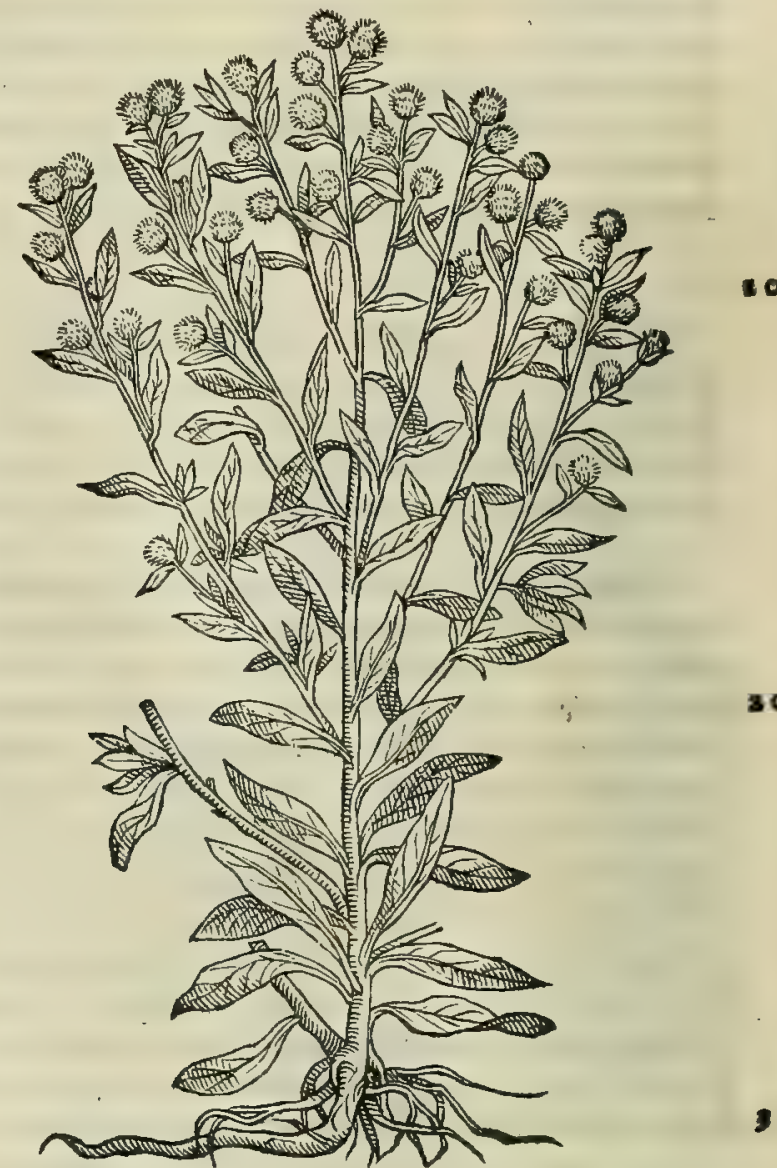

Kóv? 2 . CONYZA. CAP. CXIX.

C ON Y Z AE duo genera.quæ parua uocatur, odore præftantior eft: maior uerò frutice altior, \& folijs latioribus, graui odore. Vtriusque folia oliuæ fimilia, hirfuta, pinguia . in maiore caulis binûm cubitorum altitudine at tollitur, in minore pedem æquat. flos fragilis, lutei coloris, qui in pappú abit . radices fuperuacua. Suffitu, fubAtratuque frutex totus ferpentes fugat,culices abigit, $\&$ pu lices necat. Folia conuenienter illinuntur ferpentium pla $4^{\circ}$ gis, \& tuberculis, ac vulneribus . Flores, \& folia cum uino ad menfes, partusq́ue eijciendos bibuntur : item contra urinæ ftillicidia, arquatum morbum, \& tormina : comitiales pota ex aceto adiuuant . Decoctum in defefsionibus medetur vulux malis. Impofitus fuccus abortum facit. Herba ex oleo efficaciter horroribus oblinitur. Capitis dolores tenuis illita fanat. Eft \& tertium conyzx genus, caule crafsiore, ac molliore : folijs medix inter ma iorem, \& minorem amplitudinis : minimè pinguis, multò tamen grauioris odoris, \& iniucundioris, fed ineffica- 50 cior. Prouenit locis humentibus.

C O N Y Z AE omne genus non in Hetruria folim, fed alibi quoq; paßim feré prouenit, nullis prorfus reclamantibus notis, que earum fingulis à Diof coride tribuuntur. Conyza maior uulgó $\mathrm{P} u=$ licaria dicitur, quia fubftrata (ut Diofcorides inquit) pulices necat. Quafortaffe ratione adductus Theodorus in Theophrafto Cony= zam $\mathbf{P}$ ulicariam interpretatur. Meminit autě Conyza Theopbras ftus lib.v I.cap. I I. de plätarum hiftorid, ubi de eius generibus dif= ferit his uerbis. Conyzd ma fculd, $\sigma$ fromina conftat. Diftant quë= admodum cetera, qua fic difcerni defiderant. Fomind enim te= 


\section{InLib. tertium Diofcoridis.}

nuiori ueftitur folio, er compreßior eft, at in $_{\text {in }}$ totum minor. Mas amplior, craßioriq; caule, atque ramofior, er fo=

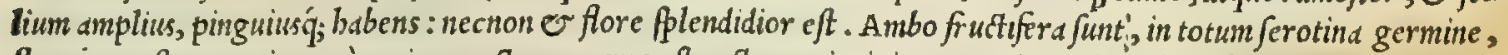
flore $\dot{q}_{;}$conftant : quippe cum circa arcfurum, $\mathcal{O}$ poft arcturum incipiant. Marigrauior odor : fomince acrior, ideó, contra beftidrum morfus commodior eft. hae Theophraftus de duplici tantim Conyze genere. Caterim tertid eius Ppecies, cuius d Diofcoride fit mentio, inter marem, $\mathcal{O}$ fomina media est. Nafcitur bec in Andrix uallis agro, o in Goritienfi comit dtu copiofisind, bunentibus prefertim locis, ev fecus uids, ubi ex agrorum marginibus aqueus bumor fillicidio quodam in proxintos defluit canales. Conyze uires pofteritatis memorie prodedit Galenus libro VI I. fimplicium medicamentoruni, fic inquiens. Conyza er maior, ov minor adfimilis funt tum tcmperature, tum facultatis: guftuiamare, er acres apparent. Excalfaciunt'́; admodum luculenter, fiuc quis folia lacuigata cum te= 10. neris ramulis (eft enim fruticofa planta) particuipiam illinat, fiue ubi in oleo coxerit, co utatur. Siquidem concußio= nes, fine rigores per circuitum redeuntes, tale fanare oleum uidetur. Flores quoq; corum adfinilis funt facultatis. Itaque quidan, ơ ip fos cum folijs tritos in uino bibendos exbibent ad menfes fortiter ducendos, ciendumí; fotum. Eft er tertium Conyza genus, in locis humidioribus proueniens, utrisq; illis tum graueolentius, tum imbecillius. Sed prime memorate tertij funt ordinis in excalfaciendo, er exiccando. Kóv $2 \alpha$ fic Grecé, ut etiam Conyza Lati= the dicitur: Italicé, Coniza, er Pulicaria: Germaricé, Geele muntz, or Durruurtz: Hifpanicé, Attadcgua.

Conyzx uires ex Gal.

\section{HEMEROCALLIS.}

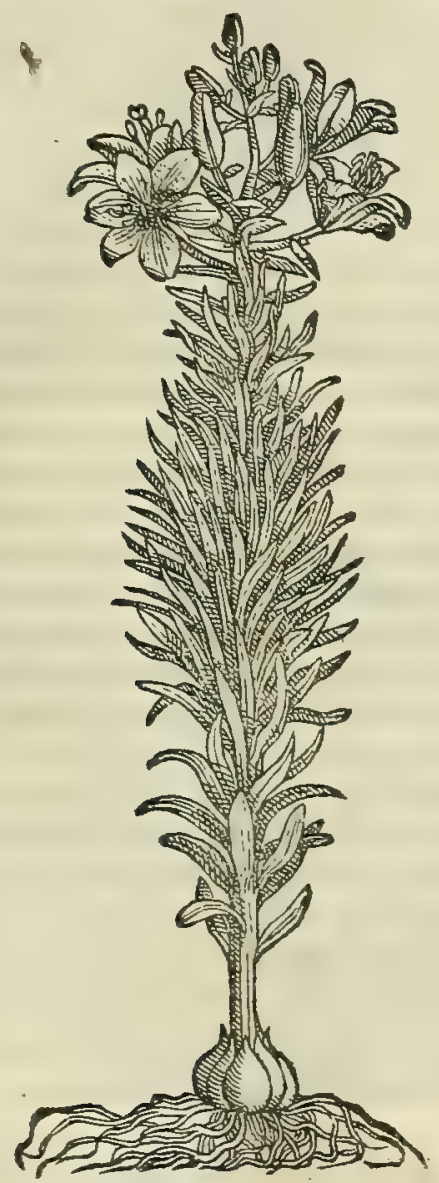

Héєон $\alpha \lambda \lambda$ is. HEMEROCALLIS.
HEMEROCALIIS ALTERA.

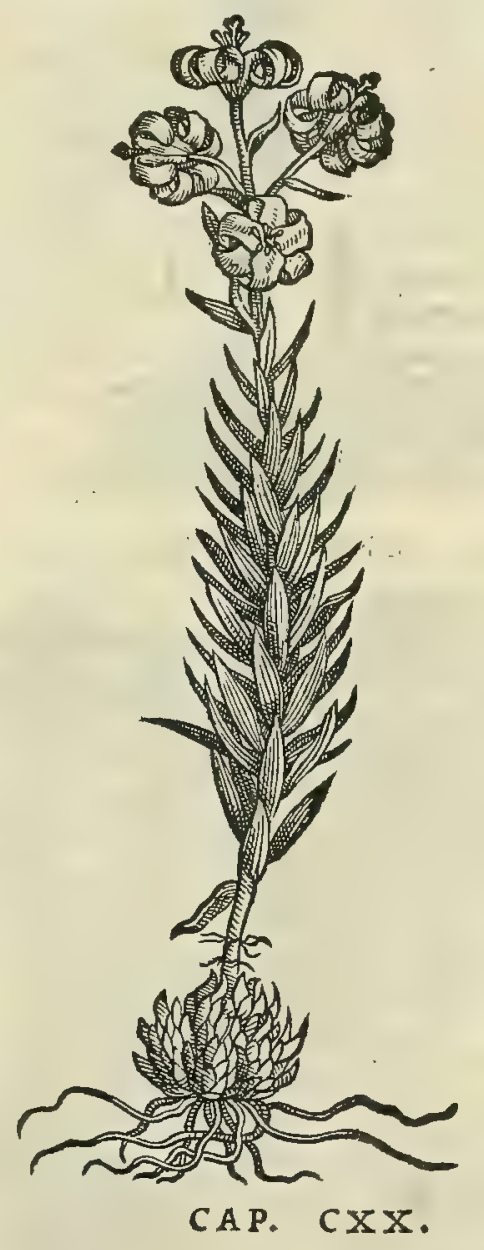

5. HEMEROCAL I S folium, \& caulem habet lilij, herbacei coloris ut porrum: flores in caule per fingulos exortus, terni aut quaterni erumpunt, lilij diuifura, quoties dehifcere cœperunt, colore perquàm pallido: radix magna cft, atque bulbofa. Qux pota, aut cum melle, \& lana in peffo appofita, aquam educit, \& fanguincm. Folia trita mammarum inflammationes à partu contractas, oculorumq́ue collectiones mitigant . Radix, \& folia igni ambuftis utilifsimè illinuntur .

H E M E R O C A I L I S mufquam non prouenit in Italid. quandoquidesn circa meffem in aruis inter fegetes, Hemerocallis in pratis, in montibus, o in uallibus aurco colore emicat. $V$ ulgus Lilium jylueftre nominat. Radice nititur bulbofa, confider. bortenfílilio perfimili, fed colore diver $\int a$. Flores, cim fuo tempore dehifcunt, colore perquàm pallido (ut Diofcori= des ait) conpiciuntur, adeo ut fulgentis auri modo rutilent. Hemerocallis genus er illud effe non diffiteor, quod ego inueri in montibus I apidis. id nang; facie alterum emulatur, fed radicem babet, que pluribus er paruis coagmen= tatur bulbis: quinetian flores profert aliam fortitos diuifuram, ut eius effigies, quam hic adiecinus, aperté demon= 


\section{And.Matthioli Comm.}

Quorundam error.

Lilii conualJij méntio, \& uires.

\section{LILIVM CONVALIIVM.}

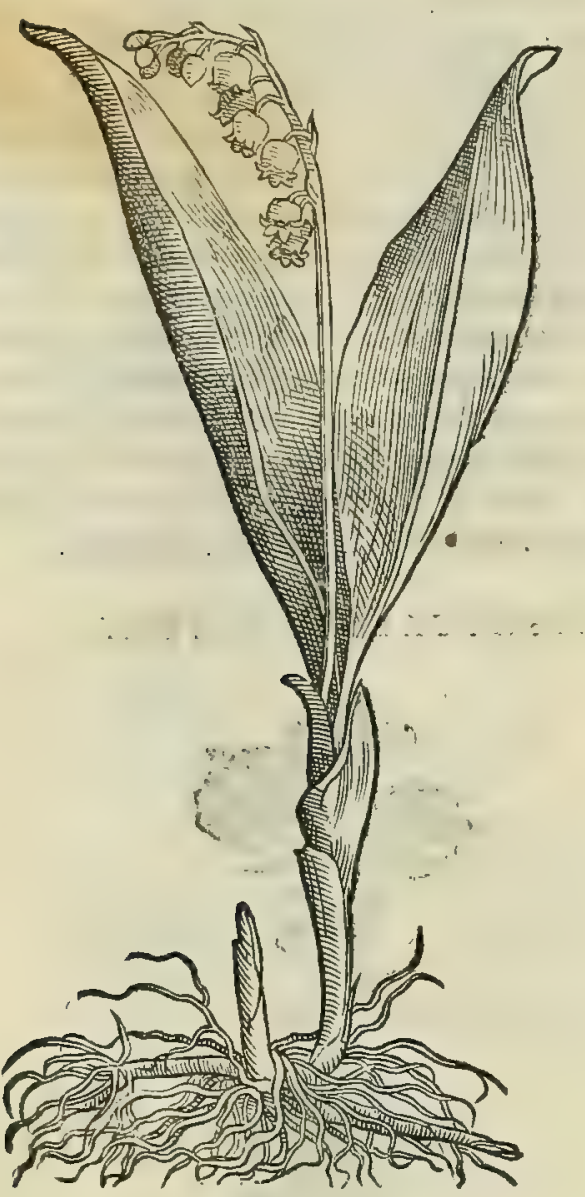

LEVCOIVM.

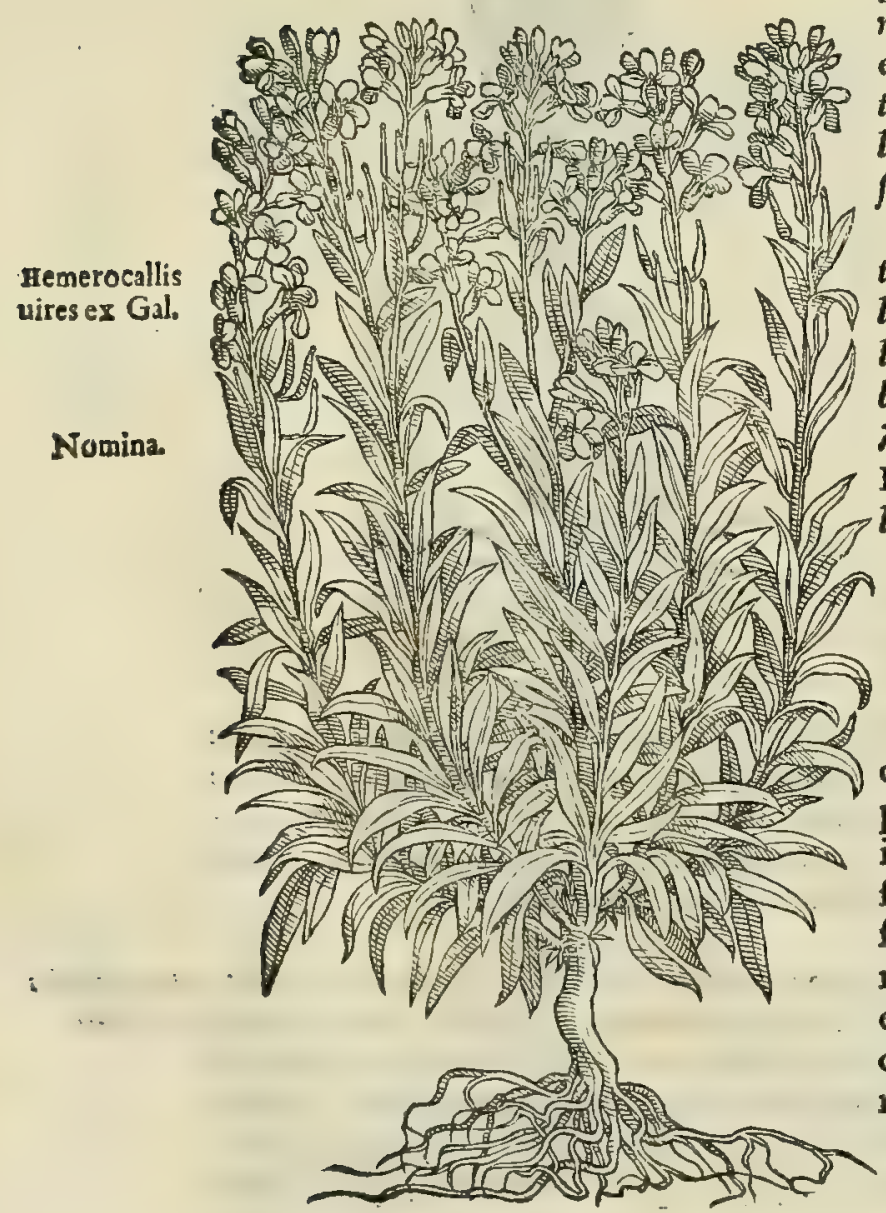

frat. Hinc itaque corum error, ut arbitror, evidentifine de prehenditur, qui I ilium conuallium uulgó dicfum Hemerocallim effe exiftinant. Nanq; illud folijs conftat fe ré plantaginis, tenuio ribus tamen, minusq́; ftriatis caulic ulis iunce is, tenuibus, ac mol libus: in quibus cacumen uer fus plures prodeunt flores albican= tes balauftij, or arbuti effigie, odore perquàm iucundo. Radi= ces demittit laxas, longas, fibris, capillamentisq; refirtas, nullis adiacentibus bulbis. Hemerocallis ueró, Diofcoride tefte, folia, or caulem profert lilio fimilia: flores colore admodum pallido: radicem magnam, bulbofaní;. Que fané not æ, fi diligenter con 2 ferantur, manifeftißime indicabunt, cosballucinari, qui Lilium. conuallium Hemerocallin effe contendunt. I I I I conuallij. magnus apud Germanos in medicamentis eft ufus (abundat cnim eo maxime Germania) ad uarios corporis morbos. Aiunt co ro= borari cor, cerebrum, o omnes principes facultates. Idcirco refolutis, conitialibus, conuulfis, uertiginofis, animi deliquio cor reptis, er cordis pulfatione concu/3is, ipfum exbibent. Quin er $i t$ is, feu commorfis a uenenofis aninalibus prabent. Itesn agré parturientibus, oculorumg; inflammationibus maximo effe auxi= lio pradicant. Conficiunt autem ex floribus per aftatem ficcatis $₹ 9$ uinum uindemiarum tempore, ip fos calcatis unis admifcentes, quo pofted utuntur dd predicta. Sunt or quirecentes flores uetere uino macerent, or in uitreo uafe diu infolent, admift is lauendule uocate, or roris marlnifloribus, additis $q_{\text {; }}$ odor dmentis nonnul= lis: deinde ex ijs fillatitiam aquam in calenti's aqua balneo ui= treis organis eliciunt, eam q́; aureis, argenteis f; uajculis repo= nunt. Hanc aquam auream appellant: qua utütur ad omnes pra= dictos corporis affectus. Quinimó eam iamiam animam expiran= tis ori inferunt,rati $x$ cius affumptione homines morientes in ui=

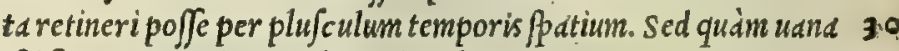
iftifrantur opinione, mibi quidem fepenumero experimento de= prebenfum eft. Quod etfi ijs quoq; irritum comperiatur ; ed $t=$ men eft buiufce aque apud omnes authoritas, ut plerique ab cius exhibitione abftinere nequèant, etiam in morbis calidißimis. C $\mathrm{C}=$ terim non fine errore Fucfibus, uir alioqui doctißimus, putat $\mathrm{L} i=$ lium conuallium e fe Ephemerum, de quo Diofcorides agit libro fequenti. Sed quam is aperté decipiatur, nos Juo loco dicemus. Hemerocallis meminit Galénus lib. $\mathrm{v}$ I. fimplicium medicanen= torum, fic inquiens. Hemerocalles radicem babet lilij radici fimi= lem, non figura tantum, fed v uiribus. prodeft non fecus atq; il $=40$ la,igni ambuftis : quippe que leuiter digerentem facultatcm ba= beat, 0 cum boc repulforiü quiddam. Que Gracis ípsore $\alpha \lambda=$ $\lambda$ is, Latinis quoq; Hemerocallis, er Lillum jylueftre vocatur: Italis, Hemerocalle, o Giglio faluatico : Germanis, Heydnifch lilien: Hipanis, Lirio amarilho: Gallis, Lis gaulne.

\section{AEUróiov. LEVCOIVM, SIVE ALBA VIOLA. CAP. CXXI.}

L E V C O I O N vulgaris eft notitix. fed in floribus differentia quædam : nanque aut ccrulei, aut albi, aut purpurei, aut lutei inueniuntur. Luteum nerò præcipui in medicina ufus. Huius aridi flores feruefaci in defeffionibus, valent contra vuluæ inflammationes, \& men." ftrua expellunt : fanant oris ulcera, cum melle : cum cerato, rimas fedis: Semen duûm drachmarum pondere ex uino potum, aut cum melle inditum, menfes, fecundas, \& partus extrahit. Radices cum aceto illitæ, lienem reprimunt, \& podagricos iuuant. 


\section{In Lib. tertium Diofcoridis.}

LE v C O I O N et/i Latinis albam tantim uiolam ipfo nomine fignificat; tamen à reiberbarie authoribus on Leucoii conpro cateris uiolarum generibus, luteo fcilicet, purpureo, coruleo ơ colore diftinctis, fepe ufurparifolet. Id bodic fideratio . officinis, atg; etian medicis ijs, qui A rabum factionem fequuntur, horum uoce Cheiri nuncupatur. Leucoium omne ferégenus un Italia in hortis, ac uiridarijs, in adium feneftris, parietibusq; frequentifimum uifitur : ubi illud in figu= lixis, ac ligneis uafis mulieres ftudiosé colunt, ac fouent. Nang; eius flores cum coloris uarietatc, tum odoris fuanitd= te tantam cum oculis, $\mathcal{O}$ naribus ineunt gratiam, ut in coronamenta frequentißimé addantur. Porró non tenteré omne ferc genus Letcoij in I talia nafci modó diximus. quandoquidem caruleü inibi, quod fcium, non proucnit. Qü̆= obrem Marccllo Diofcoridis interpreti fubfcribendum puto, qui Leucoium caruleum boc loco dccreuife fufpicatur, uetuftißimi Latini Diofcoridis Longobardis literis fcripti teftimonio nixus, in quo multum planc de creruleo Leucoij 20 colore uerbum legebatur. Sufpicionem banc augent, itaq́; effe comprobant Oribafius, o serapio, quos item id uer bum boc loco non habere comperio in fimplicium cenfu, cim alioquin reliqua Diofcoridis refer rant. Caterim ex Leucoio, fiue ex albis uiole floribus, utpote quicateros odore precellant, Perfe odoratum illud unguentum parăt, quod I f fininum appeilant, "tt primo libro in ipfius Ia fimini unguenti mentione oftendinus, ubi corum fententiam re fut aumus, qui éfloribus Gelisinnini uulgó uocati id fieri contendunt. Leucoij uires tradidit Galenus lib. v I I. fims plicium medicamentorwm, fie inquiens. Leucoij frutex uniucrfus extergentem facultatem poßidet, ac tenuium par= tium eft: plus tanten flores, o inter los qui funt ficciores, magis etiam quàm uirides, adeó ut $\odot$ oculorum cicatri=

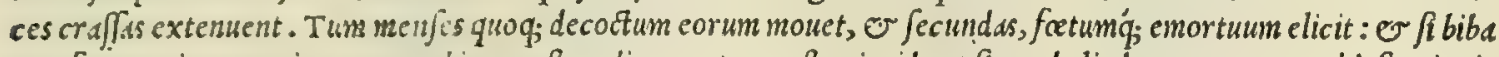
tur, faxtum uinum perimens, or abigens cft medicamentum: eft enim id, ut fi quod aliud, amarum. Quód fi quis ui= rium eins uebementism sults aqua admifta retundat, ac mitiget, aut certé id genus aliquo, habebit er ad phlegmone

20 bonum medicamentum. Sic decoctum eius \& non merum fuerit, uteri phlegmonas identzdem perfufunn fanat, potifi= miun que diutino tempore ad fcirrbi modum induruere. Sic cum cerato ulcera agré ad cicatricem perkenientia cu= rat. Sunt ucró etian, qui cummelle ad oris ulcerd adhibeant. Semen cion eiufdem fit facultatis, aptißimum eft duds rum drachnarun menfura potum : tum mentibus ciendis appofitum cums melle, conue nire creditur, fretum'q́; uiuen= tem interficere, ac mortuum eijece. . Radices fimilis quoque facultatis, nifi quatenus craßioris funt effentie, or ma gis terrene, cum aceto lienes indur atos fanant. Nonnulli ueró $\mathrm{e}$ phlegmonas in articulis induratas ijs curant. Id $\lambda$ Eukóïo Grecis dicitur, quod Latinis Viola alba, (quanquam eo nomine Greci o luteam, o purpuream uiolam comprehendunt:) Mauritanis, Keiri, Cheiri, fiue Alcheiri: Italis Viola bianca: Germanis, Gelb uiolen, or Vuyßs weil: Hifpanis, violetas amarilhas, or violetas blanquas: Gallis, violettes, $\mathbb{O}$ Giroflecs.

\section{KgaT aló yovov. CRAT AEOGONVM.}

CR A T AE O G O N v M, fiue, vtalijs placet, cratzonon, folijs melampyro fimile eft, multis calamis ex una radice emicantibus, multorumq́ue geniculorum : femine milij. Nafcitur in opacis, \& frutetofis parte plurima: fummopere acre. Traditum eft à quibusdam, hoc fi bibat ieiuno ore, ter die poft menfes purgatos, tribus obolis, in cyath is aqux duobus mulier, ante conceptü quadraginta diebus; \& uir modo confimili, totidem diebus ante coitum hauriat, virilis fexus partum futurum.

QV A v is putent nonnulli Crateogonum effe quandam Perficarie uocate feciem; ego tamen eorum fen= tentie non aufinz fub fcribere, quód Perficaria nullis feré notis Crateogonum amulari mibi uideatur. Neq; ueró aliam o bərbam, que Crat:ogoni effigiem reprefentaret, hactenus reperi, aut repertam uidi in Italia ; ubi tamen ipfum na= fci non negauerim. Sed certe id inuentu defficile fuppicor, quoniam eius de fcriptio , quemadmodum e Sequentis, ab

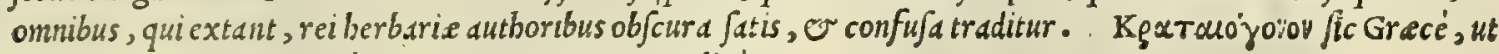
Crateogonum item Latiné uocatur: Crateogono, Italicé.

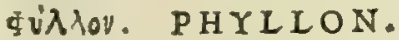

\section{CAP. CXXIII.}

P н Y L L V M, quod elæophyllon uocatur, in faxofis nafcitur. duâm generum eft. Quod autem thelygonum appcllant, prouenit mufci modo, folio olex, fed colore magis herbaceo: caule tenui, breui: radice exili . florem album profert : femen papaueris, maiufculum. Sed arrhenogonum cate50 ra huic limile, folo fructu diftat : habet enim racemofum quiddam deflorentibus oleis non difsimile. Arrhenogonon potu, mafculi fexus facere partus, ut thelygonon fæminei, proditur. Horum Crateuas author eft. Sed huiufmodi hiftoriátenus mihi produxiffe uifum eft.

L E G I T I M V M Phyllum nondum bac atate, quod fciam, in Italia compertum eft: quanquam uidetur $\mathrm{R}$ uel= lius exiftumaffe, Perficariam, quam maiorem cognominant, effe Phyllon. Qua in re is, meo quidem iudicio,aperte fal= litur : Fiquidem Perficaria ill a bumentibus, ac uliginofis locis prouenit; Phy yllum ueró in faxofis nafcitur, ut Diofco= rides teftatur. Cui tamen, fi eius uerba accuratè expenduntur, nullam buius berba cognitionein babuiffe depreben ditur, nifí eam, quam ex Crateux herbarij biftoria habere potuit, unde forté ea amnia fumpfitt. Quto fit, ut mirari no liceat, , i nobis quo q; Phyllum cognitu fit difficile. De quo nibil d Galeno, e P Pulo proditum inuenio : id quod haud dubiain fidĕ facere poteft, non fecus illis, ac nobis Phyllum fuilje incognitum. Cäterimin non de funt qui uelint Phyl lum à Lizonofit, boc efi, MIercuriali non differre, quòd pluribus tum notis, tum facultatibus fibi inuicem repon=
Dioforidis locus LufpeQus.

Leucoii uires ex Galeno.

Nomins.

\section{Cratxoyori} confid.

\section{Nomina.} dedint.
Phylli confderatio.

Opinio quorundam. 


\section{6 \\ And. Matthioli Comm.}

deant. Verum quòd cum ijs non poßim liberé confentire, hec me maximé animo fupenfum detinent, quoniam Mers curialis folia bubet ocimi, helxine cognata, non autem oline: florem berbaceum, non album. quód preterea Mercu rialis nafcatur palsim in bortis, or uineis, non in faxofis tantum . quod de bis deniq; feorfum dinerfis q $_{3}$ capitibus fcri= pferint Diofcorides, $\mathcal{O} \sim \mathrm{Plinius,} \mathrm{utpote} \mathrm{de} \mathrm{rebus} \mathrm{inter} \mathrm{fe} \mathrm{differentibus.} \mathrm{Equidem} \mathrm{hoc} \mathrm{anno} \mathrm{plantam} \mathrm{inueni} \mathrm{inter} \mathrm{faxa}$ ii Saluatito monte non longé à Goritis, folio mercurialicrafsiore, breuiore, aliquantim in ambitu ferrato: femine ian deflorentis olius fimili. Quibus utique notis ea mihi uifa eft fatis Arrhenogono fuffragari. Sed an uerum fuerit. Phylli métio Arrbenogonum procerto afirmare nonaufim. Pbyllimeminit Theophraftus lib. Ix.cap.x Ix.de plantarum hi ex Theophr. ftoria, ubi ita fcriptum reliquit. Qusdam ad procreandum marem, aut femmam ualcre traduntur. Quamobrem pbyllon tum arrbenogonon, boc eft, marificum, tum thelygonon, id eft, fominificum uocant. Ambo inter fe finilia funt, or ocimi pecicm refirunt. Fructus thelygoni modo mufcioleaginci, uerim pallidior : arrbenogoni ucro ficut oliua, cum primim ex mufcofo flore emergit: geminus modo tefticuli bominis. bec Theoplbraftus. Excuius nimi= rum uerbis colligi poteft, Diofcoridis codiccm boc in loco deprauatum effe. quandoquidem Theophrafto theligonum non nafcitur mufci modo, neq; folium habet olec uiridius, ut in Diofcoride fcriptum legitur: fed fructum quidem fert in modum mufciolex, pallidiorein tamen. Quse certé theligoni notarum diuer fitas facit, ut planc fufpicer in Diofco= ridis potius, quàm in Theopbrafti uerbis mendum aliquod fubeffe. Atque adeo fit, ut quafi iam non dubitem afferere eam plantam, quam ego reperi (ut anté dixi) in Saluatino monte, uerum Arrbenogonum effe : non folum quod defcrie

Nomina. ptioni pulcbréreßpondeat; fed etiam quód in notis ferénon diffentiant auctores illigrauißimi. Herba, que Gras. cis $\phi u^{\prime} \lambda \lambda o v$, Latinis or Pbyllum, er Folium appellatur: Italis, Pbillo, er Folio.

\section{O"PXIs. TESTICVLVS.}

\section{CAP. CXXIII.}

TE S T I C V l v s, quem Græci cynoforchin uocant, folijs circa caulem, \& ima eius parte in terra ftratis, olex molli fimilibus, longioribus, anguftioribus, læuibus : caule dodrantali : floribus purpureis : radice bulbofa, oblonga, oliux modo angufta, duplici ordine: fuperiore, qux plenior eft: inferiore, quæ mollior, ac rugofior. Eduntur radices coctæ, vt bulbi. Ex quibus fi maiorem edant uiri, mares generari dicuntur : fi minorem fominx, alterum fexum. Addunt, in Theffalia mollem mulieres in lacte caprino bibere, ad ftimulandos coitus : aridam uerò ad inhibendos . \& alterum alterius potu refolui . Nafcitur in petrofis, \& fabuletis.
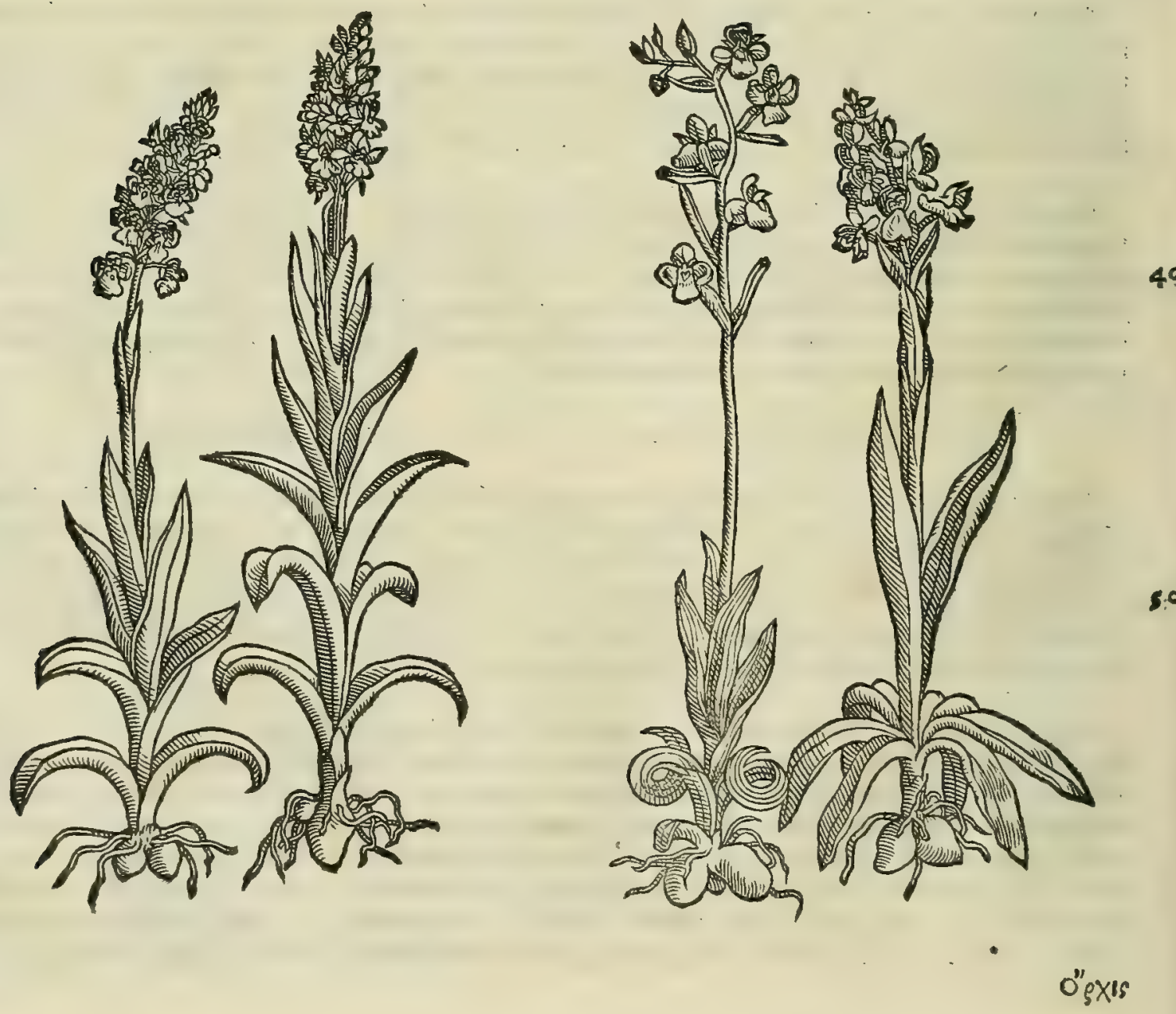


\section{In Lib. tertium Diofcoridis.}

\section{TESTICVLVS.}

20

se

30
TESTICVLVS.

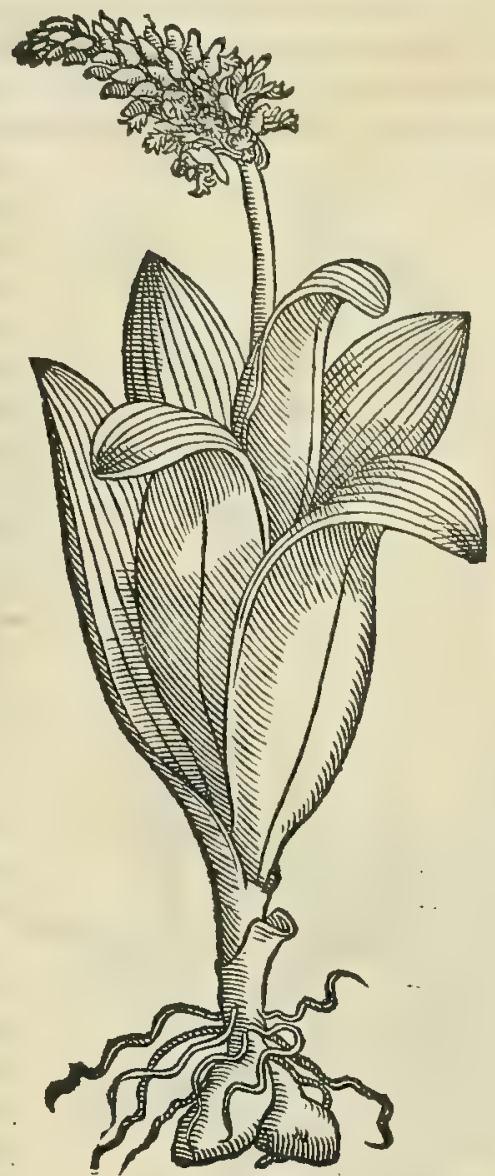

CAP. CXXV.

T E $S$ I I C V L v $S$ alter alio nomine ferapias, Andrea authore uocatur : quoniam radix ad multa utilis fit. Folijs eft porri, latioribus, oblongis, pinguibus, ex alarum finu inflexis : caule palmeo : floribus penè purpureis : radice tefticulis fimili. Qux illita tumores difcutit, ulcera purgat, \& ferpere eadem non patitur: abolet fiftulas, \& illitu inflammationes lenit. Aridæ radices nomas inhibent : fanantq́ue putredines, \& oris ulcera cacoëthe: aluum fiftunt è uino potx. De hac, eadem qux de tefticulo canis, produntur.

$$
\text { Extigrov. SATYRIVM. }
$$

CAP. CXXVI.

S A T Y R I V M aliqui trifolium uocant, quoiam tria fert folia, ad terram infracta, rumici, aut Iilio fimilia, minora tamen, ac rubra : caulem cubitalem, nudum : florem lilij effigie,candidum : radicem bulbofam, mâli magnitudine, fuluam, intus ut ouum candidam, guftanti dulcem, \& ori non ingratam. Quam in uino nigro auftero bibere conuenit, contra opifthotonum. Vtendum ea dum concumbendi incelsit cupiditas : fiquidem ea proniores ad uenerem fieri affirmant.

\section{CAP. CXXVII.}

E S I 1 T alterum Satyrium erythronium, fiue erythraicon, id eft rubrum, femine lini, maiore, duro, leui, fplendente. quod fertur non fecus atque fcincus, libidinem excitare. Cortice radicis graci li, rufo . intus autem album includitur, fapore dulci, non ingrato ori. In montofis, \& apricis enafcitur. Venerem, ut produnt, fr omnino manu teneatur radix ftimulat : eoq́ue magis, fi bibatur in uino.

E R R A N T, mea quidĕ fententia, omnes ferè huius atatis medici,ac feplafiarij: quippe quòd Canis tefticulis le= Satyrij,\& $\mathrm{Te}$ gitimi Satyrij uice paßim in medicamentis utantur. Nam be plante (fi Diofcoridicredimus) notis, ac facie maximé fticuli consiinter fe diftant quanuis uiribus, o facultate non longé fint difimiles. Tefticulorum enin radices, preter id quód deratio. animealium teftes repre eentant, oblonge Junt, bine, utring; pendentes: Juperior tamen altera, que plenior eft : inf $\varepsilon=$ error. 


\section{$45^{8}$

rior alterd, que mollior, or rugofior. Satyrij ucró radix bulto $\int_{a}$, mliq́; modo extuberans de fcribitur, colore extcrius fulua, interius ut oum candida, guftantidulcis, or ori non ingrata. Caterum uerum Satyrium, ut ingenue fatear, hadc locis non modó duo imneniuntur genera; fed alia quoq; longé plura. qubus er illud addendum effe cxiftimauerim, cuius radix bun ana manus fimilitudinem refert. Vulgus à pradicta radicis figura id Palmam $\mathrm{C}$ H $\mathrm{R}$ I $S$ T I ap= pellat. Auiccnna bafec radices Digitos citrinos nuncupat . etfi eds Digitos citrinos c fe perperàm, nulla $\dot{q}_{\text {, }}$ quod in

Palme ChriAtigenerz.

Fuch. errata,

Monachorú laplus.

\section{PALMA CHRISTI.}

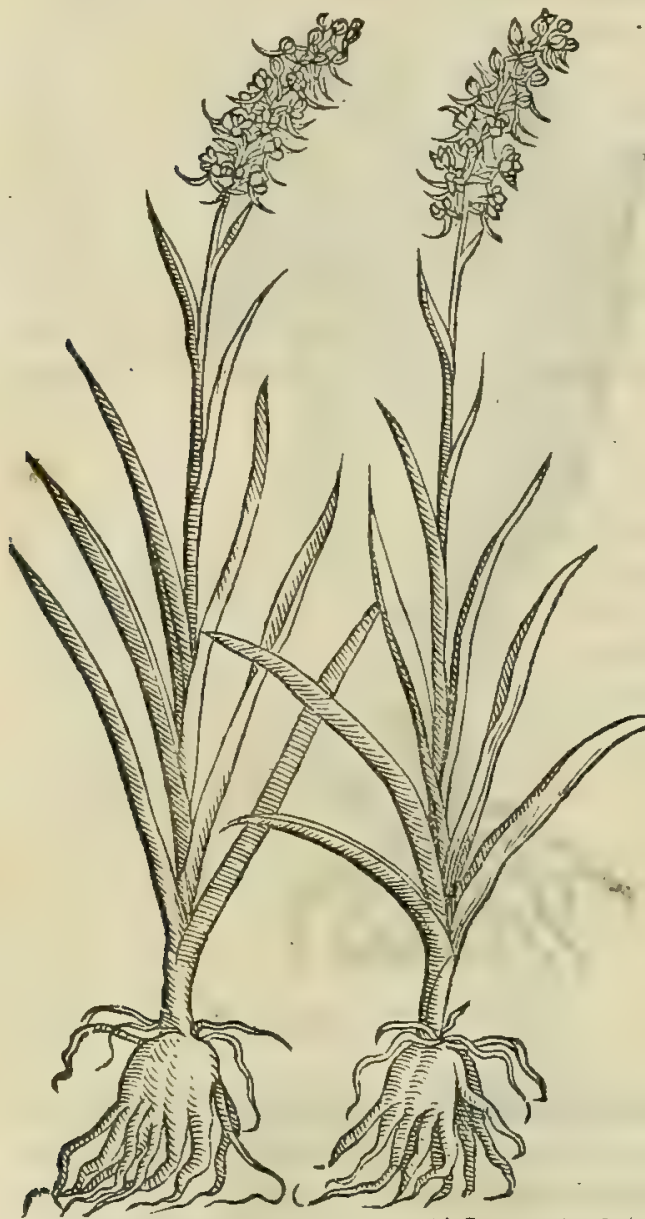
libro fuo legerim, ratione ducti negent Monacbi illi, qui in Me= fuem commentarios ediderunt. Huius duo in Ananie uallis montibus habentur genera. Vnum maius, quod folia feré lilï ba= bet, leuix, patula, maculis quibuddam nigris reper $\int a: c a u l e m$ ro= tundum, lcuem: florem picatum, uarium, in purpura albican= tcm, odore non ingrato: radices duds, qua fané tefticulos caninos referrent, nifi ramis quibufdam quafi digitis, bumanam ma= num exprimere uidexentur. Alterum minus, quod folijs conftat croci: caule dodrantali; iunceo, leui $q_{;}$: in cuius cacumine flos emicat purpureus; amaranti amulus, qui recens odorem quam fuarißinum reddit. Huius exiccati puinis ex aqua ignitum chaly= bem experta, epotus (ut perbibent $i j$, qui itd effe experimento comprobarunt) dyfentericis maximé prodeft. Idem aquam pre= ft are aiunt, qua per uitrea organd ex ijs clicitur: Radices buic fimiles, fed quie alteri magnitudine cedunt. Excalfaciunt utra q;

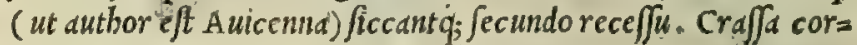
poris excrementa pellunt, faciem '; detergunt. Dantur maniack magno iunamento: quine in neruorum affectibus. Seminis pul= uis drachme pondere ex uino potus, comitidibus Jubuenit. Item radicis decoctum uino diutius commiftum, quod bibendum pard= tur tam in prandio, quam in cona. Radices, Nicoli Florentini teftimonio, febrem quartanam fugant: is nanque earum tant ìm ufu Biliotum quendam curdtum retulit. Fucb/ius Palman Chri finon recté, pace cius dixerim, inter Satyrijgenera depinxit: 30 fiquidem ea potik, meo iudicio, inter Canis tefticulos erat repre fentanda. Quinetiam in eo mihi plane erraffe uidetur, quód Saty rium tripbylton, perinde atq; canis tefticulos, cuim dicabus. radi= cibus piatura exprefferit contra Diofcoridis delineationem: qui unam tantün radicem Satyrio mâli magnitudine reddidit, Nifi fortaffe is potius fuerit piforis lapfus. Hallucinantur pretes rea und cum Mefue Patresilli reuerendi, qui eius antidotarium commentat funt. quippe quimale fibi perfuaferint, tot effe satyrio radices, quot Canis tefticulis. Verum ij Diofco= ridem confulant, o binc quàm aperté decipiantur, intelligent. Sed bis facile errandi occafionem potuit dediffe Pli= nius, quem lib. x x v I. cap. x. Orchin, id eft, tefticulum, cum fatyrio turpiter confudiffe conf at. Caterim quoniam legitimo satyrio deficimus, officine, ac medici eius uice Tefticuli radices fuppeditant, infelicitamen, nec pari fuc= ceffu. Nam etfi ad prolem gignendam tefticuli radices pretulerit Diofcorides, quod maior à uiro deuorata mafcu= lum gignat, minor uerò à famina foeminam: detur'q; mollis fominis bibenda in lacte caprino ad ftimulandam uene= rem, arida ueró ad inbibendam; non tamen ob id unquam comperi quenquam, qui ex earum largiore efu refirret, fe magis ad uenerem fuiffe excitatum, quàm effet, priufquìm eas comediffet. Sed id forté fortuna illis accidit, quòd utrafque finul radiccs ederint medicorum imperitia. quo factum fit, ut altera alterius uim deftruxerit, cum alteri. uis infit, ut uenerem ftimulet, alteri ueró ut eandem inbibeat. Id quod fortafe ijs non eueniret, fi legitimumbabere= mus Satyrium : uel ff berba illa inueniri poffet, que bomines falacißimos reddit. Cuius Theophraltus meminit lib. I X. cap. $\mathrm{x}$ x. de plantarum biftoria, ubi ita fcribit. Ad rem autem ueneream mir um in modum berba pollebat, quam In= dus attulerat. Non enim folum edentibus, fed etian tangentibus tantum genitalibus uim dixere uebementem adeo fie $=$ so ri, ut quoties uellent, coire ualerent. Et quidem qui ufi fuerunt, duodectes egiße dixerunt. Indum autem ip um $_{\text {, qui }}$ uel magno, atque robufto corpore erat, feptuagefies aliquando coiviffe fatentem lickit audire . uerim emißioncm feminis guttatim fuife, demumó; in fanguinem deueniffe. Mulieribus uerò ucbeme ntius etiam . citari libidinem, cùm Canis teficu comedicamine ufa fuerint, dicebatur. bactenus Theopbraftus. Canini tefticuli uires pofteritatis memorix man= li uires ex Ga dauit Galenus lib. v I I I. fimplicium medicanentorum, fic inquiens. Orchis, nuncupatur or Cynos orcbis eadem Jeno. berba. Radici eius bulbofe, ac gemine uis ineft bumida, or calida, ac guftantibus dulcior apparet. Ceterim maior. radix multan uidetur babere bumiditatem excrementitiam, e flatuofam: quapropter epota uenerem excitat. Al= tera ucró, minor uidclicet, contrà admodum elaborata eft, ita ut eius temperamentum ad calidius, $\sigma$ ficcius ucrgat. Vnde hec radix non modó non fimulat ad coitum; fed ctiam plané contrà cobibet, ac reprimit. Eduntur tolte bul= borum more. Orchis ucró, quem $\sigma$ serapiada nuncupant, /icciorem facultatem obtinet, qudim ut primi ordinis ha= beri mereatur: quocirca ad uencrě non fimiliter accommodus $c f$ : Oedemata illitus difcutit, 0 ulcera fordida pura 


\section{In Lib. tertium Diofcoridis.}

gat, o lierpetes fanat. Sicc atus multó etiam magis deficcat, adeó ut o putrefcentia, contumaciá," ulcera fanet. Habct etiam quidpian fubadftringens, ac proinde uentreme ex uino potus ffftit. Meminit item Satyrij Galenus eo= dcm libro. Satyrium, inquit, aut Tripbyllum bumidum, c calidum tcmperatura eft: qudmobrem guftu quoq; appa= ret dulce. Attamen recrementititum, o flatuofam humiditatem poßidet: quocirca ad uenerem incitat. Hæc ucró et berbe ipfins ratix preff are poteft. Porró, ut quid an fcribunt, ex uimo nigro anffero potum fanat opifthotonon.

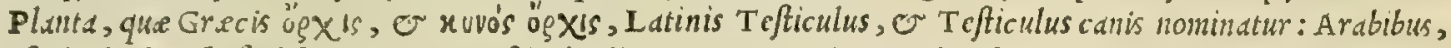
Chafialkcb, fcu Chafialchelb: Italis, Tefticolo di cane: Germanis, Kuabcn kraut: Hipanis, Coyon de perro:

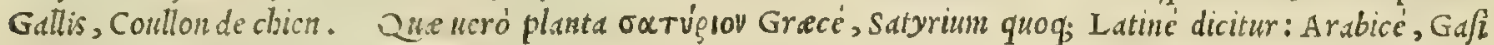
alchaleb, Cbafi altraleb, fiuc Taturich : Italice, satirio, or Satirione: Germanicé, Stcndel uurtz: Hifpanicé, Sa=

so tyrion, or supinos de Rapoja: Gallicé, Satirion.

\section{Ögusvov. HORMINVM. CAP. CXXVIII.}

Ho R M I N V M fatitum herba eft folijs marrubbio fimilis : caule femicubitali, quadrangulo,circa quem eminentix filiquis fimiles prodeunt, quæ ad radicem fpectant, in quibus diuerfum femen re cluditur. Siquidem in fylueftri rotundum, fufcumq́ue inuenitur: in altero nigrum, \& oblongum, cuius eft ufus. Ad uenerem ftimulandam, cum uino bibi uolunt. Purgat cum melle argemas, albuginesq́ue: illitum ex aqua tumores difcutit : eo etiam extrahuntur aculei ex corpore. Idem effectus so fcetur. eft illitæ herbæ. Sylueftre magis uiribus pollet : quare unguentis, præfertim gleucino, permi-

$H \circ R M I N$ V M.

30

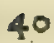

50

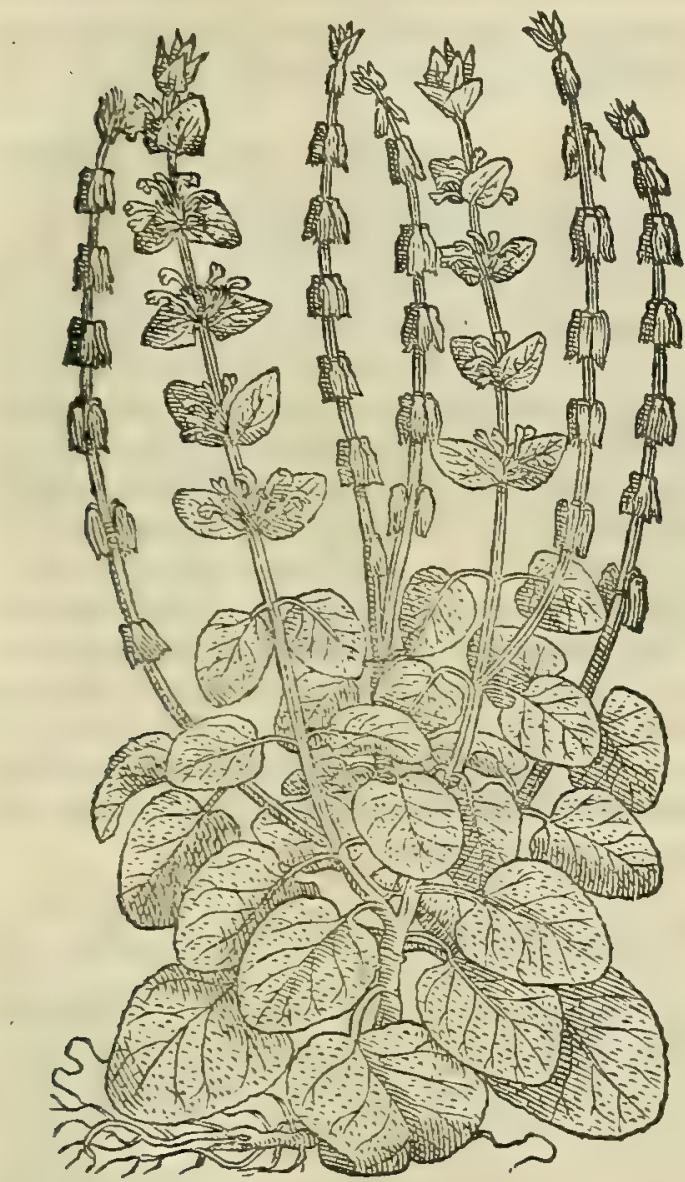

S C L A R E A.

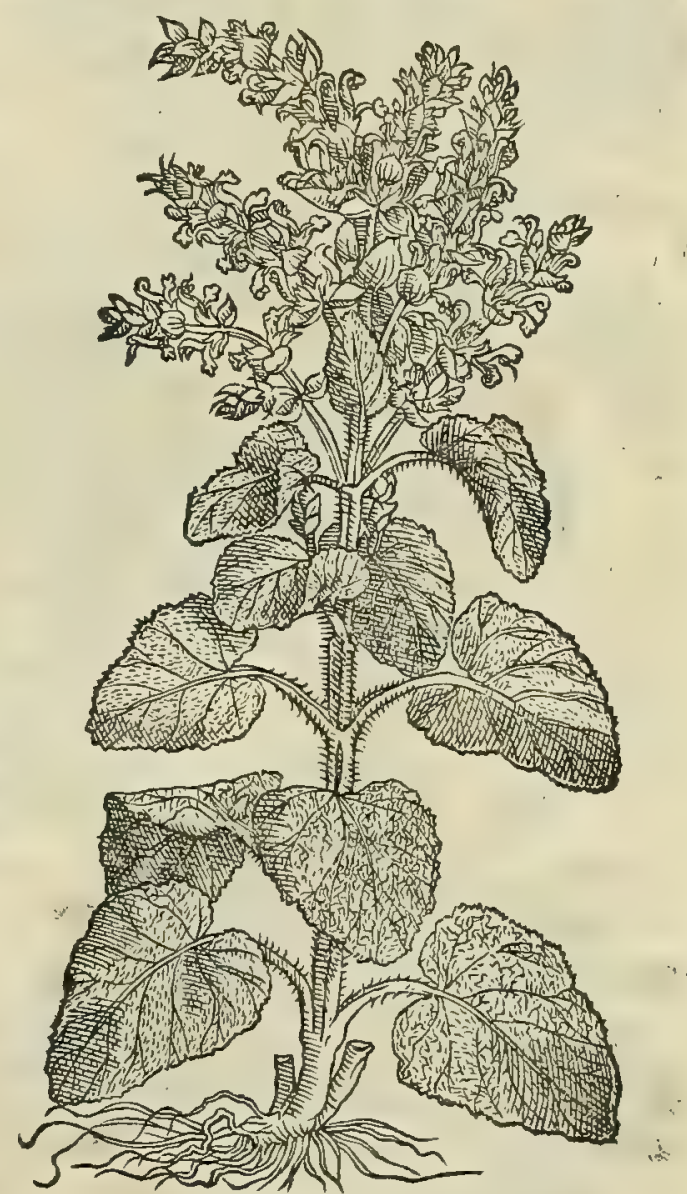

R V E I I I V s, e bunc, ut arbitror, fecutus Fuchfius in fuis quîsq; de ftirpium biftoria clarißimis commen= Hormini con tarijs, certó credunt Horminum fatiuum edm perquàm odoratam berbam effe, qua uulgo aliquibus sclarea, quibuf= fideratio. dam Matrifaluid, of nonnullis Herba fancti Ioannis appellatur. Sylueftre ueró borminum illan effe cenfent, que. pafim in pratis nafcitur, quam officine Gallitricum, e Centrum galli nominant. Sed certé borum, licet doctif= Ruelli,\& Fufimorum uivorum, fententiam ut minus probem, multa mibi occurrunt. Primùm quód contrà Hormini utriusq; de= chsij opin.refcriptionem ille plante confent caule plerunq; bicubitali, folijs marrubio quàn longé maioribus, er calyculis, in qui= probata. bus Semen recluditur, fur fum ppectantibus. Deinde quòd in utrifq; illis plantis rotundum femen inveniatur, non au= tem in uno oblongum, in altero rotundum. Illud pretered addiderim, quodd Diofcorides nunquam, meo iudicio, Hor mini odorempretermififfet, fi ei sclarea dicta Horminum fatiuum fuifet, ut illi exiftimant: ea enim adeó odorata 


\section{0

eft, ut eius odor infignis fine uitio preteriri nö poßit. Huc de niq; illud accedat, et eos plané, ut puto, refellet, qui fecus opinantur, quód nuper plantam, cuius bic effigiem damus, Pifis ad me mifit L ucas Ghinus medicus clarißimus, ত̃ rei

Plinij lapfus. herbarie peritißimus, que adamußim Horminum fatiunm reprefentat, ut pictura affabre demonftrat. . Hormis ni utriufque meninit Plinius libro $\mathrm{x} \times \mathrm{x}$. cap.ultimo. ubi in eum errorem lapfus deprebenditur, in quem er in Jtaclyc eunden incidife fuperius oftendimus. Nam ubi Horminum folijs marrubio funilibus depinxiffe opus erat;

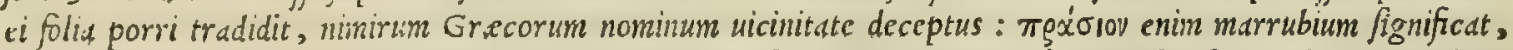

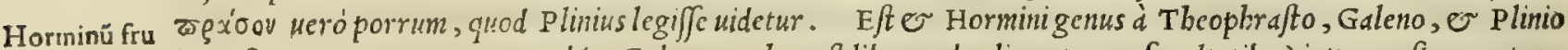
gis genus. inter fiuges anmumeratim: quod (ut Galenws author ef libro r, de alinentor um facultatibus) inter eryfimum, et cuz

\section{HEDYSARVM.}

Nomina.

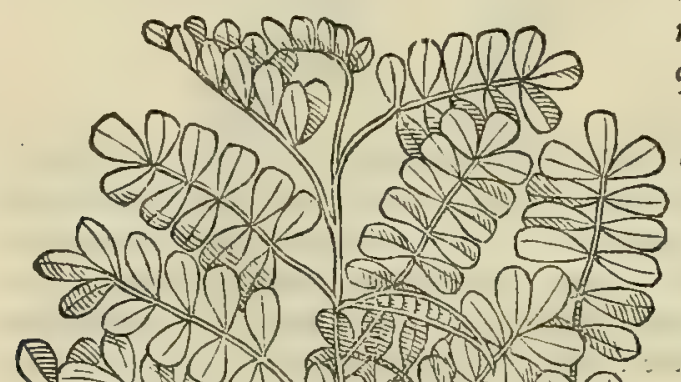
minum median naturam obtinet. Caterùm Hormini, de quo bic nobis eft fermo, meminiffe Galenum in libris fimplicium medicas mentorum, non reperio . quanuis cius mentionem fecerit $\mathrm{P}$ aulus, qui tamen illd tantim refert, que à Diofcoride mutuatus eft.

Graci eam plantam óguvev nocant, ut etiam Horminum $L a=$ tini: Itali, Hormino.

\section{H'sioagov. H E D Y S A R V M. \\ CAP. CXXIX.}

HE D. Y S A R ON, quod unguentarij pelecinum,id eft, fecuridacam uocant, frutex eft, folijs ciceris: femen 2.9 rufum in filiquis fert, corniculorü modo aduncis, quod incipitcm fecurim zemulatur, unde nomen accepit : ama rum guftu. Stomacho utile in potu. Additur in antidota. Cum meile ante coitum fubditum,concipiendi fpem adimit. Nafcitur in fegetibus, \& hordcis.

HedỵaricóGderatio.

Hedyfari uires ex Gal.

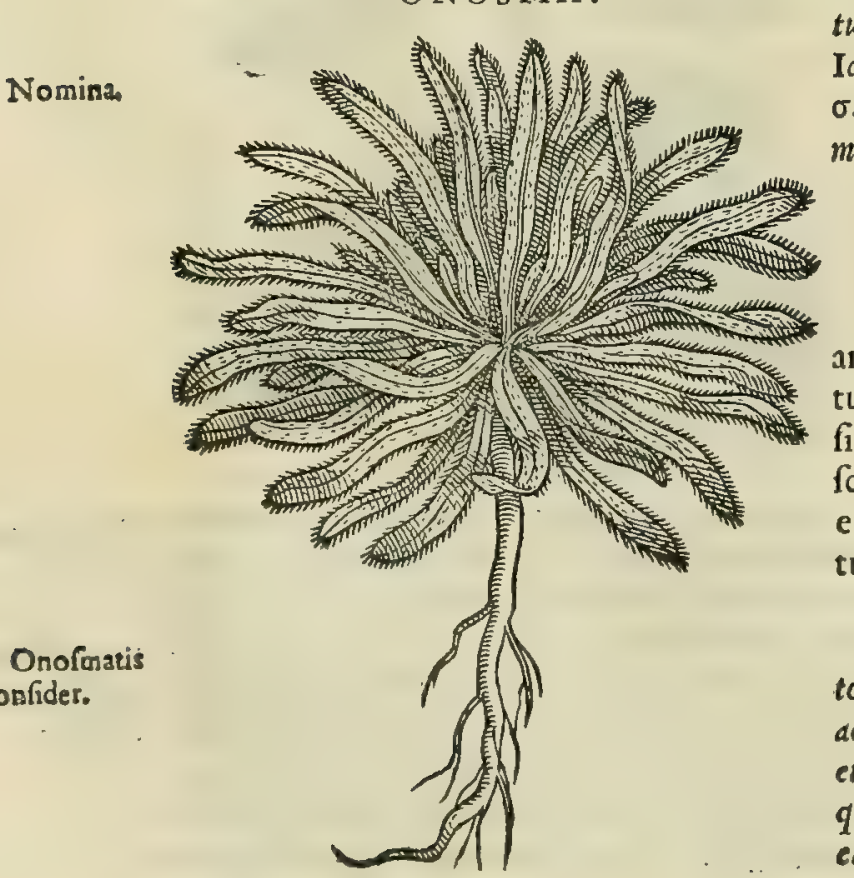

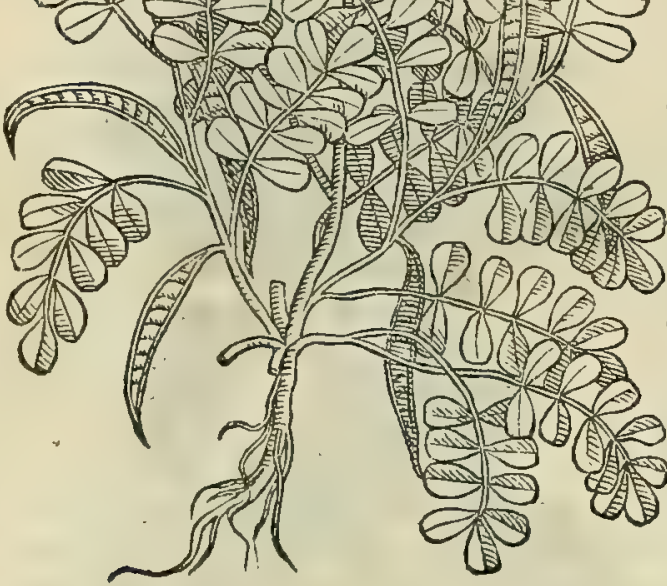

ONOSMA.

QV A N QV A M Securidacd inter triticum, e bordeum quando ; proueniat; frequentior tamen inter aphacam nafcicer nitur. Id quod etiam teftatur Theoploraftus lib. $\sigma$ cap. v I Ir. de plantarum biftoria, ubi securidacam in aphacis gigni, edq; apbacen neçari prodidit. Plinius fimilitudine uocabulorü dece ptus lib. X v I I I.cap. X v I r. Securidaca lentem complexu ftran gulari foirbit. In eo autě error deprebenditur, quód phacon pro aphace legerit, or uerterit : nam Grecis lens фaxio's, uocatur,

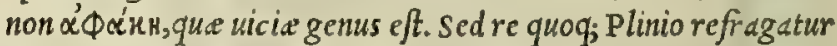
Theophraft tus, qui loco citato aracum, non autem fecuridac älen ti innafci,er inimicari tradidit. Hedyfari meminit Galenus lib. V I. Fimplicium medicamentorum, fic inquiens. Hedy farum, aut pelecinus. Huius fruticis femen colore rufum eft, utrinq; anceps, uti fecures. Amarum, of fubacerbum apparet . quamobrem $p o=4^{\bullet}$ tum gratum eft ftomacho, o vifcerum obftructiones expurgat . Idem preftant totius fruticis ramuli. Planta,que Grecis nisu $\sigma \approx \rho \circ v_{2}$ Latinis Hedyfarum, $\sigma$ Securidaca nominatur : It alis $f i=$ militer Hedifaro, o Securidaca.

\section{O"vooux. ONOSMA. CAP. CXXX.}

O N o s M A oblonga folia habet, ad fimilitudinem anchufe, longitudine quatuor digitorum, \& unius latitudine, mollia, in terra iacentia, fine caule, fine femine, 5 ? fine flore: radice nititur oblonga, tcnui, infirma, rubefcente.gigniturin afperis. Folia in uino pota, partus extrahunt. Prægnans, fi eam fupergrediatur, abortum facere dicitur.

P I A N T A quadam ex collibus, quos uarijs berbis refer tos circa Goritiam natura collocauit, in aperis natd iampridem ad me allata eft, que folia habet minoris ancbufe: radices ueró eius ita rubefcunt, ut quafi rubia uideantur. Ex ijs notis, quie quidem pulchré Onofinati reßpondent, non potui non adduci, ut eam uerum Onofina putarem. Vnde ctiam eius piạuran addenx 


\section{In Lib. tertium Diofcoridis.}

dan diligenter curaui, ut de al aliorum quoque fit iudicium. Sed certé, ut uerum fatear, milhi adhuc incom= pertum eft, an heec caulem, flores, ov femen proferat: fiquidem eam hactenus non mifi caule, or reliquis uiduam aidere mibi llcuit. Onofmatis uires tradidit Galenus libro v I I . fimplicium medicanentorum, fic inquiens.

Onofma, kel ofmas, ucl phlonitis, uel ononis, $c x$ acri, O amara conftat fubftantia: proinde quoque creditur fatus necare, $\odot$ eijcere, folijs eius in uino potis. Vt Grace övoopa, ita etian Latiné, paritcr or Italice, $0=$ nofima uocatur.

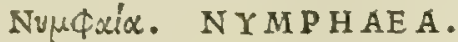

CAP. CXXXI.

10 N Y M P H AE A nafcitur in paludibus, \& fagnantibus aquis, folijs fabx Aegyptix, minoribus, \& longioribus, alijs in fumma aqua, alijs demerfis, pluribus ex radice eadem prodcuntibus : flore lilio fimili, albo, $\&$ in media crocos habente. cùm defloruerit, ut rotundum malum, aut papaueris caput, extuberat: nigro femine, denfo, \& lato, lenti guftus. Caulis eft læuis,nigcr, minimè craffus, Acgyptiæ fabæ cognatus : radix nigra, fcabra,clauæ fimilis, qux autumno fecatur. Sicca cum uino pota coliacis, dy fentericisqueauxiliatur, \& lienem abfumit. Radix ftomachi,ac uefica doloribus illinitur: uitiligines ex aqua emendat : impofita cum pice,alopecijs medetur . eadem contra ueneris infomnia bibitur: fiquidem ea prorfus adimit pota âsiduè aliquot diebus, genitale infirmat. Idem femen potum efficit. Ny mphæx nomen fibi uendicaffe uidetur, quoniam aquofa amet. Plurima inuenitur in Elide, in Anygroamne, \& in Bœotix Aliarto.

20

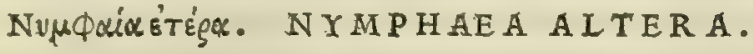

CA P. CXXXII.

E S I E T altera nymphæa, cuius flos blephara dicitur, folijs antedictæ: radice alba, fcabra: flore luteo, nitente, rof fimili. Huius femen, \& radix contra fominarum profluuia efficaciter ex uino nigrobibuntur. Nafcitur in Theffalia, amne Peneo.

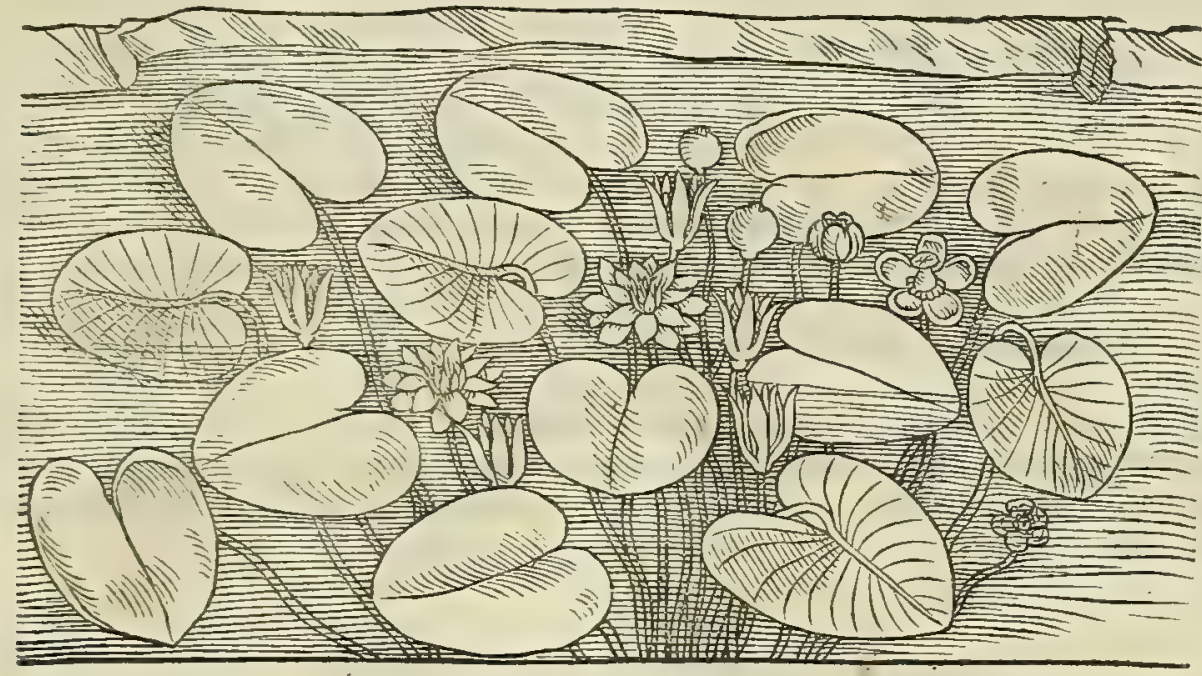

N Y M Р H AE A utraq; Seplafiarijs Mauritano nomine Nenuphar appellatur. Nafcitur ubiq; frequentißima in paludibus, lacubus, $\mathcal{O}$ aquis stagnantibus. Vnde non mirum, fi ea fit uulgaris admodum planta, $\widetilde{J}$ omnibus notior, quam ut indicari deceat. Veruntamen Fuchfius medicus atatis noftre clarißimus in libro illo de compofitione me= dicamentorum, quem nuper auctumedidit, putat alias effe Gracorum Nymphe as, alias Arabum, ut eius uerba, qux bic fubijciam, aperté fatis declarant. Nymphees inquit, feplasijs Nenupharis. Facultatis tamen florum eius Dio= fcorides er Galenus non meminerunt. De illorum itaq; Jententia Jemine potius er radice medicis utendum erit, que,

50 ut ijdem teftantur, refrigerandi es exiccandi poteftatem obtipent. Arabes contrà floribus effe utendum pracipiunt, illis $q_{;}$refrigerandi in tertio, in fecundo autem bumectandi uim tribuunt. Atq; bos quidem flores quarta $\beta$ Pecies Nea nupharis producit. quandoquidem illi preter binas, quas Greci commemorant, duas alias recenfent. Vt hinc con= ftet, edin $\mathrm{Nympheam,} \mathrm{cuius} \mathrm{flores} \mathrm{humectare} \mathrm{Arabes} \mathrm{memoria} \mathrm{prodiderunt,} \mathrm{hodie} \mathrm{effe} \mathrm{omnibus} \mathrm{incognitam.} \mathrm{Qua=}$ propter toto calo errant nofri temporis medici, quód fuis Nympheis, qua funt Gracorum, humectandi etiam fa= cultatem aßignant. Ita A rabum fcripta fepenumero errandioccafionem medicis prabent. Et mirum plané eft, se= rapionem etiam inter $\mathrm{N} y m$ phe as numerare, quam calidan effe e tenuium partium foribit. Adeo nibil eft in uniuer= $\int_{a}$ Arabum dottrina certum ac folidum. Factenus Fuchfius. Huius equidem uirialioqui eruditi iudicio tantum abeft ut bac in re fcribere uelim, ut potius cogar ip fum refellere, atq; Arabum doctrinam tueri: utpote qui Grecorum fcri= ptabona fide referant, atq; ijs etiam addant fi quid boni babent fua induftria er experientia compertun. Id quod uel hic fiet perpicuum omnibus, qui equo animo rem iudicabunt, Quód igitur A rabum nymphea, et $\sqrt{i}$ cas bunecta= re tradont, ubi de earum floribus mentionem faciunt, eadem fint cum nymphais Gracorum, qui uim illam intactam

Nymplaxe confid.

Fuch, opinoi reprobata.

$Q_{3}$ reliquerunts 


\section{2 \\ And. Matthiolı Comm.}

reliquerunt, facilé probari poteft serapionis, ac Auicenne teftimonio. Hinanque, ut omittam quodd omnid feré ex Diofcoride tranfcribunt, non folum utuntur floribus, ubibumed and um fit, fed etiam feminc or radice, ubi adftrin= gcre e refrigerare fit opus. Neque mirum certé, quod Arabcs fus nympheis figidum e bumidum temperamen= tum adfribunt, quando fic allis, ut etian nobis, experimento compertum eft, illarum flores bunectare or refrigerd= re. Atque adco boc mibi non uidetur Gracorum fententie aduerfari. quippe Greci foribunt nymphas exiccandi

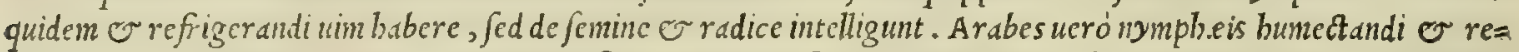
frigerandi facultaten tribuunt, quan tanc nfores fortitos effe uolunt, ut clarißimé foribit A uicenna. Illud addam, quod nibil prorfus fit alicnum à ratione, ut una eademí; planta fuum uariet temperamentum pro diuerfa uniufcu= iujq̨ue partis naturd. Huius rei Galenus teft is effe poteft in inandragore mentione, ubi fcriptum reliquit eam ra= dice refrigerarc or exiccare, fructu ucró refrigcrare or bunectare. Quare, meo quidem iudicio, Arabes erunt in hoc landandipotius, quain odiose (quod uidetur facere Fuch/ius) exprobrandi: ut qui non fine magna morta= lium utilitate Nymphx: flores in ufum medicum afferuerint. quód a ucteribus Gracis, quantum nobis conftat, pratermifun cfl. Porró ucrifinile non cft, quòd Árabes ignorauerint, que in nymphx is fuerint feminis or radi= cis facultates. Nam fi Auicenna cxiftinalfet earum femen er radicem eiufdem effe cum floribus temperamenti, il= lis utique non fuifet ufus ad dy fentericos, ad ueneris infomnia, ad muliebre profuuium, $e$ ad alios morbos, qui frigida ficcág; requirunt medicamenta. Sed illud nobis obijcietur, ut contendant non eas effe Arabum, qua Graco= rum rimphxas, qucd serapio ex auctoritate Albafaris inter nymphas recenfeat plantam, qua tenuium partium

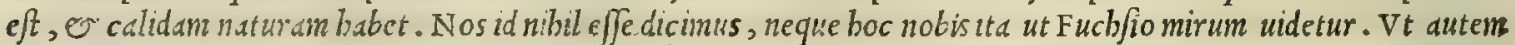
non miremur Arabihus traditan effe nymplixam, cui uis infit calida, facit tertij femperuiui exemplum in Diofcori= de . etenim is tertiun fedigcmus ácpinxit, eiq́; uim exculfactoriam, acrem or exulcerantem reddidit: tametfi reli= 20 qua duo fedigenera eidem. Diofocoridi refrigcrent, atque ijfdcm Galenus tertiam refrigcrandi fedem aßignet. Cie= terum in quibufdam Bohemix lacubus Nympha a paruanafcitur, folio quidem nympbse , fed braßica marina paulá maiore : fiore candido: capitibus exiguis, ut in cappari: Semine intus papaucris magnitudine. Hanc tamen plantam

Vires ex Ga- hactenus, quod meminerin, mibi non licuit alibi uidere, quaim in Bobemia. Nymphxx facuitates retulit Galenus leno. libro vi Ir. fimpliciummedicamentorum, his uerbis. Nymphex tum radix, tum fenen deficcandi uim babet ci= tra morfum. Itaque uentris profluuia cobibet, femen'́; fiue per infomnia, fiuc alio pacto immodicé profluens retinet. Iuuat porró ctiam dyfentericos. Ceterim Nymphed, que candidan radicem habet, potentioris cft facultatis, ut o muliebri profluuio nedeatur. Verim o bec, or ea quoque, qua atram habet radicem, ex uino nigro auftero bibutur. Porró nonnullam etiam abflergendi uim obtinent, ita ut er alpbos fanent, 0 alo= pecias. Ad alphos ucró macerantur aqua, ad alopecids pice liquida. Sed ad bac aptior cft ea, cuius radix ni= 30

Nomina, gra eft, ficut ad alia, cuius alba. Nvuфaia Grecis, Nymphea item Latinis appellatur: Mauritanis, Ni= lofar, Ninofan, feu Nilufar: Italis, Nimphed: Germanis, Gelb, Vueifz fcebluomen, e Haruurtz: Hipanis, Efcudetes del rio, er Higos del rio: Gallir, Blanc de eau, Launet de eau, $\mathrm{O}$ Lis deftang.

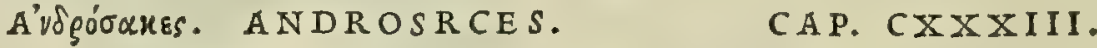

A N D R O S A C E herba eft amara, t tenues fpargens iuncos, fine folijs, folliculos in capitulis habens, in quibus femen continetur. Gignitur in Syriæ maritimis. Ea drachmis duabus in uino pota, copiofam hydropicis urinam ciet. Idem effectus eft lemini poto, \& herbæ decocto: podagris utiliter illinitur.

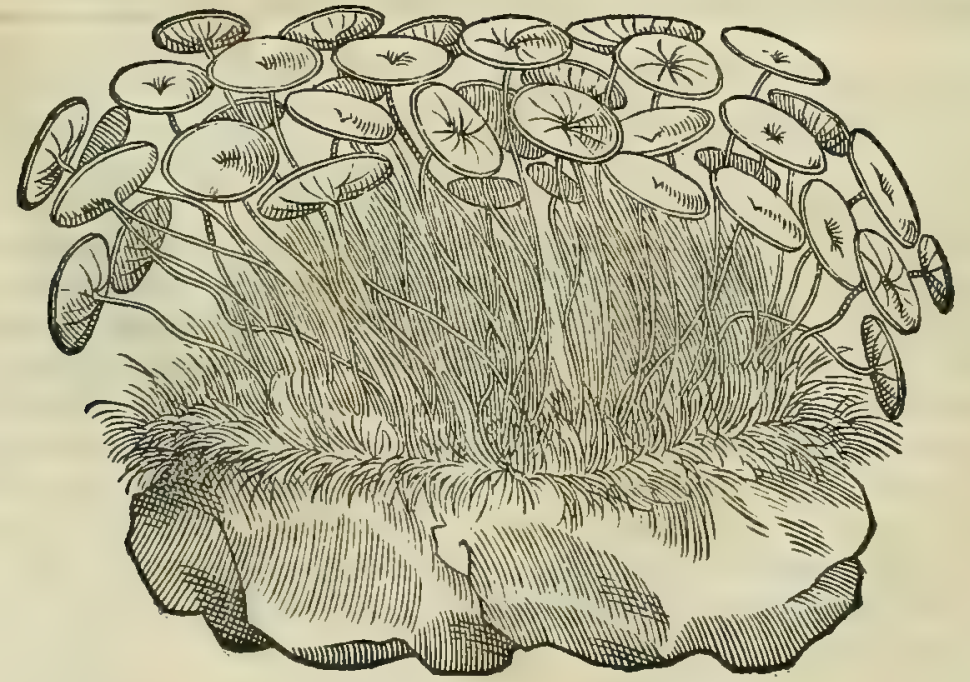




\section{InLib. tertium Diofcoridis. $\quad 463$}

A N D R O S A C E ex Syria, quod fciam, non defertur in Italiam. Verim, quia eam berbam inibietian nat= fcipoffe mbil probibeat, quoddam plante genus nuper inuentum eft in Hetrurie meritimis, cuius bic puturam ideo exhibere libuit, quód id a quibusdam Androfaces exiftinctur. Idipfun ad me mifit hoc anno Pifis Luc as Gbinusme= dicus clarißimus, or reiberbarix peritißimus: a quo ( $\mathrm{f}$ is illi opinioni fubjcriberet, $\mathcal{O}$ Androfaces in Italia nufce= retur) non mibu ex co diffenticudun effet, quód prater alias notas bec planta (ut Oribafus cx Diofcoride tranfcri= bens habet) tota candida pectutur. Androfacis meminit Galenus libro v I . fimplicium medic amcntorum, ubific inquit. Androfaces bumida, or acris herba cft. Poteft autem reficcata, cxbibitá; tum ip a, tum fructus eius magno= pere urinam moncre, or nimirum difcutere, eo deficcare. Hac planta ut Grecis ávidsóoanes, ita Latinis An= drofaces dicitur: Italis, Androface.

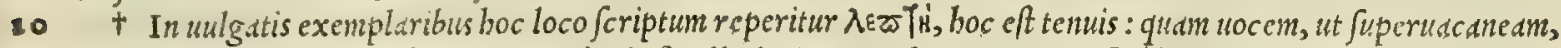
omift Ruellius. In Oribafio ueró $\lambda$ Qux', id eft, alba legitur: er banc ex aliquo forté antiquo codice uertit Marcel $=$

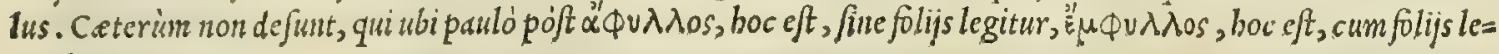
gendum putent.

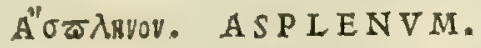

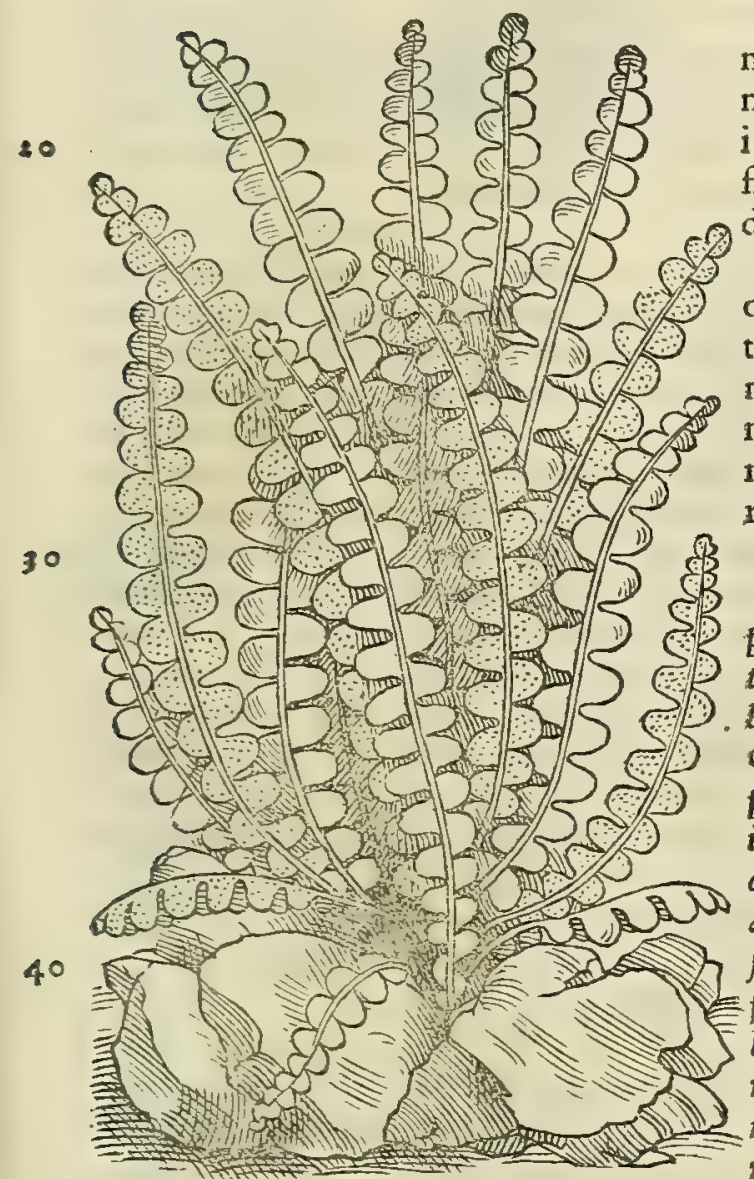

\section{CAP. CXXXIIII.}

ASPLENVM aliqui fcolopendrion vocant, alij fplenion, alij hemionium : folijs eft multis, fcolopendrea nimali fimilibus, ab radice una prodeuntibus. Nafcitur in parietibus, faxisq́ue filiceis, \& opacis : nec caulem,nec florem, nec femen habet. Folia polypodij modo diuiduntur, fubter flauefcentia hirfutaq́ue, fupernè uiridia. Vim hanc habent folia in aceto feruefacta, ut per dies quadraginta pota lienem abfumant: quibus etiam contritis lienem ex uino illini: oportet. Atrangurix, \& regio morbo predeft, fingultum fedar, calculos in uefica comminuit. Conceptum adimere creditur, per fefe, aut cum muli liene appenfa. Tradunt noctu, filenteluna, huius rei gratia effodiendam.

A S P L E N V M, fiue Scolopendrium tan àmedicis, qudan Afpleni conpharsnacopolis, qui plané Mauritanorum fcripta fequuntur, $C e=$ fideratio. trach barbara uoce uocatur. Nec diu eft, quód nouere rei her= barie periti Arabum Ceterach effe legitimum Scolopendrium. Quandoquidem antea uniuerfa herbariorum fchola Apleni loco phyllitim, quam etiam uulgó Linguan ceruinam appellant, fuis immiscebant medicamentis. Verum enimuero quanquam boc a = deó clarum eft, ut nullus ampiius dubitandi locus relinquatur; adhuc tamen inueniuntur é ueteribus noftris feplafiarijs, qui ut fuam potius pertinaciam, quam ueritatem ip $\int a m$ tueantur, nullo pacto fibi perfuafum effe uolunt,phyllition non efe le gitimum Sco lopendrium : eo lantum argumento pertinaciter innixi, quòd fui maiores phyllitim Scolopendriam appellawerint, quódq'; eam $\beta l e=$ ni feraper inaxime profuiffe experimento cognouerint. Quatd= men in re pror fus aberrant, ut ex Apleniy notis facile ab omni= bus inteligi poteft: ex quibus apiertißimé cogno fcitur, nil aliud effe Aßlenum, quamipfum Cetrab uocatum. Nec dejunt preterea, qui obnixé contendant, Cetrach non effe Afplenum, quod foripferit Diofcorides nafci A plenum fo= Iijs polypodij, fiue filicule, quibus tamen ipfius Ceterach folia non undequaq; repondere uidentur, veruin fi ij, qui ita obijciunt, cam sidiffent filiculan, que in montibus pronenit in itinere, quo Goritia per montes in Carniolam itur,

so folijs angufioribus, or adinodun uirentibus, ijs in pofterum, quantum equidem reor, onnis dubitandi occafio fublato. elfet . Siquiden filicula hec folio exit Ceteracho perquàm fimili, quanquam pauló ampliore. Tantáq, eft fimilitudo, ut mibi primum banc berbam inqpicienti ea fermé uifa fit uerum Aplenum: que tamen effoffa radice ftatim pro fili=. cula agnofcitur. Preftantifinum aplenum in Creta nafcitur, ubirepertum vitruuius offfrmat circa Potercum amo nem, qui duas urbes Gnofon, o Cortynam interlabitur : parte qua ad Cortyndm pectat, pecoribus fine liene inuen= tis, quis herbain banc roderent: altera ueró parte, que ad Gnofon eft, lienem babentibus, quia ibiberba illa non ap= pareat. A, Leni tures paucis perflrinxit Galemus litro v I. Fimplicium medicamentorum, fic inquiens. Aplenum

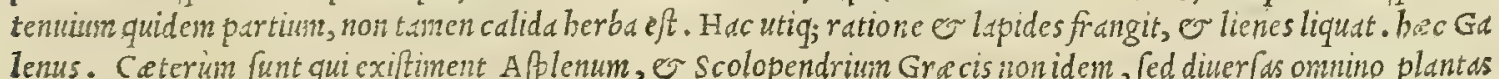
lenus. Caterum funt qui exiftinent A plenum, os Scolopendrium Gracis ion idem, fed diuer as omnino plantas
reprefentare, Galeni autboritate fieti. Quippe qui libro v. cap.x I I. fimplicium medicdmentorun de his differens, que obftrutco lieniconferunt, Scolopendrium ab A Ple leno fegregaffe manifefté uideatur, cim inquit. Maiores licnis obftrutcones uelicmentio a de fiderant medicament ta nempe capparis cortic $\mathrm{w}_{2}$, tamaricis radices, folopendriunt,

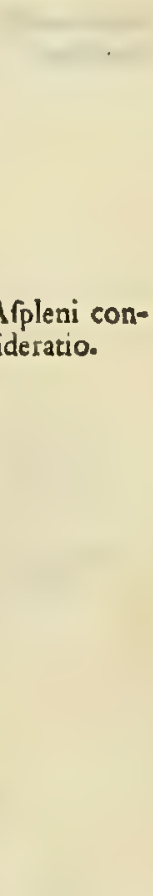

Quorundam error. Afpleni uires
ex Galeno.
Androfacis confider.

Androfacis uires ex Gal.

Nomina. $\sim \int$ cilldin, 


\section{4 \\ And. Matthioli Comm.}

ipfum nomine reprefentat aplenos appellata. Hec certé uerba different fuppectus.

declarant. Sed, meo quidem iudicio, credendum effe fupicor, quód boc in loco preter Galeni fententiam accre: uerit scolopendrium, deprauatd'q; in eo fit fcriptura uel librariorum incuria, uel nimia alicuius fcioli daligétia : quód in fequentibus libris, in quibus de fimplicium omnium, quorum cognitionem babuit, facultatibus figillatim differit Ga lenus, nufquam, quod inuenerim, Scolopendrij meminerit, Sed tantim Apleni, cuius etiam uires (ut fuprà retuli= mus) Sané quim paucis perftrıxit. Aut rectius forté crediderim, quód co in loco per scolopendrium, uel per Aples num bemionitım intellexerit Galenus, de qua in fequenti commentatione dicemus. quandoquidem bemionitis (ut ip. fe Galenus fcribit lib. I x. cap. I I. de comp.medic. Secundum locos, ubi ea pharmaca ab Andromacho confcripta rez cenfet, qua epota (plenic is fiue lienofis opem ferunt) ab aliquibus ex antiquis A plenum, ab alijs Scolopendrium ap= pellata eft. Quare non effet mirum, fi loco predicto Galenus accepiffet afplenum pro bemionitide: prafertim quod sa

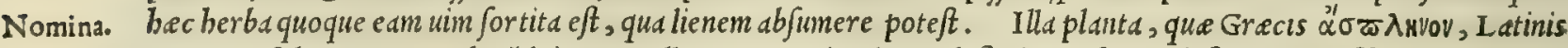
quoque Aplelcum, or Scolopëdrium appellatur : Mauritanis, Scolofendrion, feu Sculufendrium: officınis, Cetrach: Itatis, Apleno, Scolopendria, e Herba indorata: Hifpanis, Doradilha: Gallis, Ceterach.

HéenViTIS. HEMIONITIS.

CAP. CXXXV.

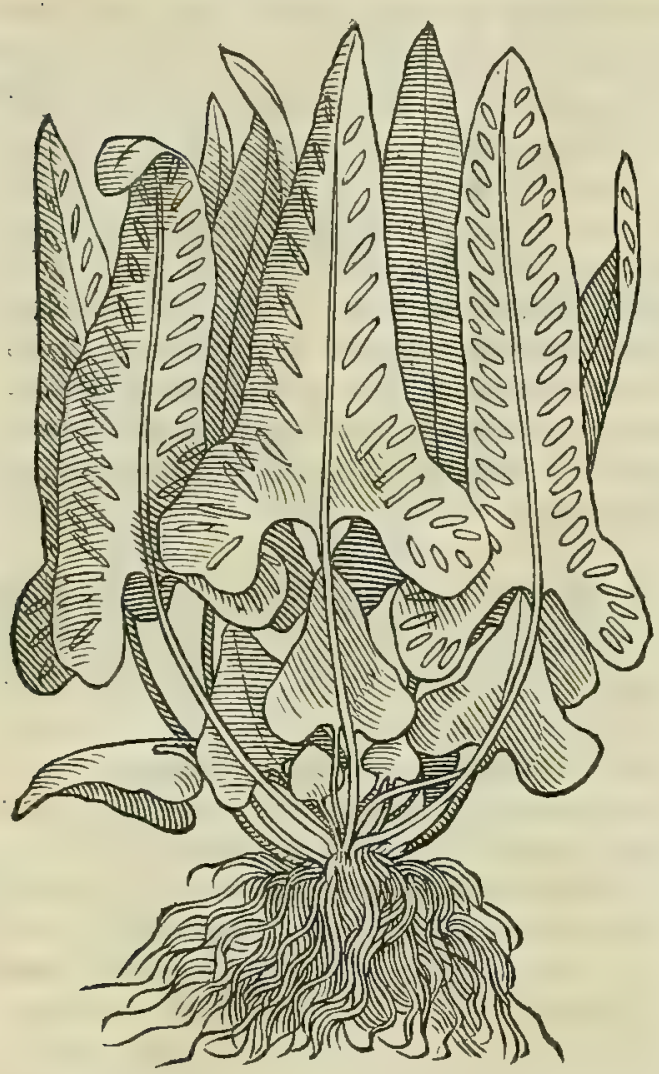

HE M I ON I T S , quam aliqui fplenion usocant, folium cmittit dracunculi, lunatum : radicibus cohxret multis, tenuibus: nunquam flores, neque femen, neque caulem gignit. in petrolis nafcitur, auftero fapore. 20 Ea ex aceto pota lienem abfumit .

F A L L V N T V R procul dubio (ut in Phyllitidis commen= tatione fuperius diximus) Leonicenus, Ruellius, o Manardus: quippe qui fibi certó perfuaferint, Hemionitida edm effe plan= tam, quam Seplafiariorum uulgus Linguam ceruină, perperamó, Scolopendriam nominat. Sed quoniam in predicto loco bos ui= ros alioqui doctißinos, or Fuchfium pariter eos fecutum errare euidentißimis, ut puto, argumentis oftendimus; idcirco fuperud= canteum effe duximus hic eadem repetere, prafertim quód nemi= nem futurum perem, qui eó fe conferre grauctur, fi cupiat no= ftras contra wiros tam celebres rationes audire. Porró non mo= dó idm nobis compertum eft ueram Hemionitim, que à Diofcori= dis biftoria nibil prorfus dißsdet, Rome nafci in quibusdam ru=

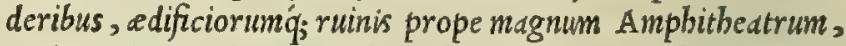
unde quidam rei berbaria ftudiofi eam in fuos tranftulerunt bor tos; fed nos quoque boc anno eam accepimus ab Aloyfio Anguil lario Romano reiberbarie peritißimo, qui Hemionitidis plan= tam, cuius pictură damus, ad nos $\mathrm{P}$ dtauio mifît. . Equidem cre= didimus iamdudum und cum Hermolao, $\sim \sim$ R uellio teucrium, $\sim 4^{\circ}$ bemionition unam tantum Plinio plantam effe, depranatis eius exemplaribus decepti, qu.e lib. x x v.cap.v. ita criptum babe= bant. Intenit er Teucer eadem etate teucrion, quam quidam bemionion uocant. Veruntamen cüm poftea tractu temporis Plinij codex mendis quàm plurimis expurgatus ad manus effet, non bemionion legendum fuiffe comperi, fed bermion. Quo factum eft, ut omnino fuerim coactus in hoc mutare fententiam, contráq; afferere teucrium à Plinio defcriptum à Diofcoridis teucrio nullis notis differre. Caterùm inter bemionium, o aplenum Plinio nulla interce = dit differentia, quodd fcrip ferit libro x x v I I. cap.v. A plenum funt, qui hemionion nocant. Sed equidem uereor, ne o ipfe in errore uerfetur . quandoquidem Diofcorides non modo utriufque biftoriam diuerfis capitibus defcripfit; fed etiam a plenum nusquam, quod fciam, hemionitim appellari ait : tametfi contrà Hemionitin non applenum, fed plenion à quibufdam uocari tradiderit. Sed pofteaquam Hemionitidis lunata folia mibi ad memoriam renocarunt so

Lunarix mi- berbam illam, qua à chymiftis L V N A R I A minor, ev ab alijs ob femen raccmofum Lunaria botryitis cognomi= noris defcri- natur, cum $\sigma$ ip $\int a$ miris in medicamentis polleat uiribus, non pretereundum duxi, quin bîc de ea aliquid differerem. ptio, \& uires. Hæc itaque breuis eft planta, dodrantaliffré altitudine. Caule conftat fimplici, rotundo, lento, ac gracili : é cuius medio in latus exit ramufculus, cofte effigie : cuifolia funt utrinque feptem annexa, lunata, craffa, firmá'; , braßjica marine modo. Flores profert in fummitate caulis, oxalidis minoris inftar: Semine rufo, rotundo, minutóg, in uue modum racematim cobarente. Vis totius plante miré efficax unlneribus glutinand is, item q; intrinfecis, at $q$; extrin= fecis corporis fradturis fanand is : quare miris celebratur laudibus d puerorum enterocolds. Datur utiliter, commo dé; dy fentericis, planta tota in puluerem contrita. Albas uterifluxiones fupprimit, quemadmodum or rubentes. Ferunt equos, qui in montibus berbas depafcuntur, ubi h.cc copiofa prouenit, auulfis ab ed clauls, fuos firreos calcea tus amittere, ơ ob id unlgó à nomnulis sferra cauallo appellari. Sed perperain, meo quidem iudicio, quód alia fit planta, qua uel ab ipfo effectu legitimé fic fuerit appellata, uel quód femen proferat ferreis equorum calce is fimile. 


\section{In Lib. tertium Diofcoridıs .}

IVNARIA MINOR.
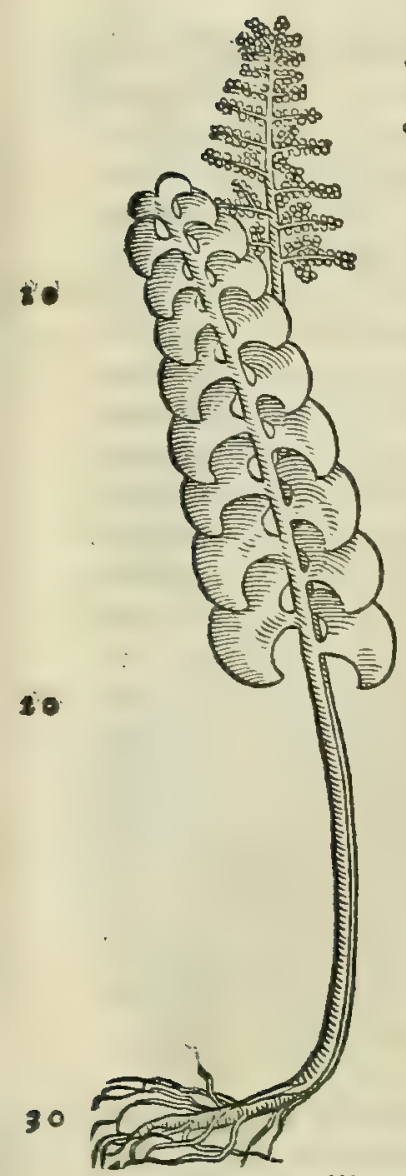

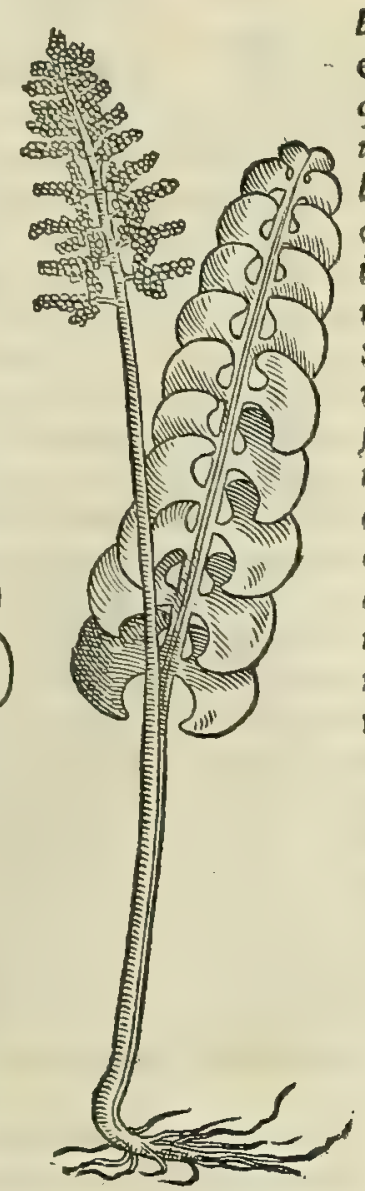

Magnifaciunt banc quidam, prefertin chymici, eamó; pluris for= me aftimant, quim aurum. Sed quàm ifti in fuis uanis opinioni= busdeludantur, ipfimagno Гape fuo dunno experiuntur. Eft o aliaberba, quam aliqui fimiliter Lunariam minorem nominät, que in fcrobium ripis, of aggeribus uligine madentibus, fecus uias plerung; nafcitur. Serpit bec bumi iunceis cauliculis, cubito longioribus, clematidi illifimilibus, que vinca peruinca uulgó uo catur", in quibus à radice ad fummum ex utroque latere brevibus interffitijs folia exeunt cr a $3 i u f c u l a_{2}$,rotund $d_{2}$, aruorum nummo= ruin peciem referentia : unde à nonnullis Nummularia dicta eft. sunt qui exiftime nt, banc effe Elatinem. Veriun quia Nummuld= rie ditt a folia pilof a non funt, fed levid : quid preterea non nd= ccitur in fegetibus or cultis, fed in fcrobium aggeribus or uligi= nofis locis; ideo ijs non poffum adffipuldri. Hec quog; glutinan= di, o cohibendi facultate predita eft. Sed iam, ut noftri moris eft, Hemionitidi fue reddantur uires ex Galeno, qui eas retulit li bro v I. Fimplicium medicamentorum, his paucis ucrbis. Hemio= nitisfimul or adftriftionem, or amaritudinem poßidet : quamob= rem cum aceto pota lienofis auxilio eft. Ea ut Grecis íms $\omega=$ ViT Ts, ita etiă Hemionitis Latinis, o Hemionite Italis uocatur.

\section{A'Yง Aגis. ANTHYLLIS. CAP. CXXXVI.}

AN TH Y I I I duplex eft quædam enim lentifimillima, folijs mollibus, rectis ramulis, palmi altitudine: radice parua, tenui. Nafcitur in falfis terris, \& à fole illuftratis, non infulfo guftu. Altera eft folijs, ramulisqúu aiugx fimilis, hirfutioribus tamen, breuioribus, $\&$ afperioribus : flore purpureo, odoris admodum grauis: radice cichorij. Pota drachmis quatuor, vrinæ difficultati, renibusque plurimùm prodeft. Tritæ, vulua pitutas emolliunt, cum rolaceo, \& lacte impofitæ . vulneribus medentur, Qux autem aiugæ f1militudinem refert, præter.alia pota cum aceto mulfo, comitiales fanat.

P R I M A M, aut alteram Anthyllidd, que Diofcoridis hiftorixe reßpondeat, non equidem bactenus in Italia re= peri, aut repertam uidi: quanquam non negauerim, quin ea inibi proueniat. Ruellius banc pofteritati salfolam uo= catam fuiffe tradit, quód ex ea falem fieri memorice proditum fit. Fucbjius ueró in libro illo de componendis me= dicamentis, quen locupletatum nuper excudit, putat eam herbam, qua Kali Mauritanis dicitur, de qua nos differui= mus libro fuperiore in Atriplicis commentatione, Anthyllidein effe. nam ubi Aluminum genera expendit in fine fer= 40 mé fic inqutt. Alumen, quod Catine appellant, ex lerba combufta conficitur, Cali Mauritanis dita, Grecis Antbyl lide $\sigma$ Trago . Sed, meo quidem iudicio, in hoc aperté hallucinatur Fucb/ius una cum Amato Lufitano, à quo illum hanc uanam opinionem accepiffe facile fupricor. In primis nanque non uideo ego, quomodo fieri poßsit, ut Cali Mau= ritanorum duas poßit legitime Grecorum plantas representare, Antbyllidd $\sim$ Tragum. qux quidem genere, for: ma, notis ac uiribus inter fe maximé differunt, ut in ed A pologia, quam in illum Lufitanum fcripfimus, latius often= dimus. Deinde nobis plane fubit mirari Fuchfium, uirum alooqui doctißimum e in re medica adeó clarum, ut primes ferat in Germania, quod Lufitani illius ineptias tam religioséfit fecutus, ut bịc contentus protulife Anthyllidem ef $=$ fe herbam Cali, neglexerit pratered Anthyllidis genera, que Diofcorididuo funt, expendere : atque genus explica= re, quod Calie fe putabat. Atre uera Cali (quantum ego Sentio) nec primam, nec alteram Anthyllidem exprimit, neque etiam Tragum. Etenim boc fine folijs nafcitur, fed eorum uicem explent aculei, adeó ut tota planta pinis bor.

so rida fpectetur. Illa ueró Antbyllis, quam primo generi adfcribit Diofcorides, lenti fimillima eft. Porró alterum eius genus (tefte Dicfcoride) folijs rumulisq́; aingam emulatur, birfutioribus tamen, brevioribus or aperioribus: flore purpurco, odoris admodum grauis. Que nimirum note in berba Cali, guftantifalfa, prorfus defiderantur. Vtriuf= que Anthyllidis memenit Galenus libro v I. fimplicium inedicamentorum, fic inquiens. Antbyllis duplex efts, fed utrd= que inodice deficcat, ut er ulcera glutinet. Ceterim alterd, ed fcilicet qux chama pityi adfimilis eft, quadantenus fubtilioruin eft partium, quinu altera, sdeó ut e comitialibus competat. Quin o ipfa magis quàm altera exterge=

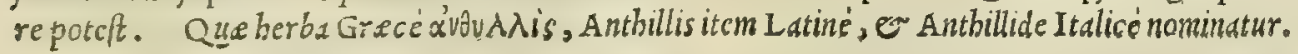

Anthyllidis confideratio. Fuchfii opin. damnats.

\section{Viresex Gal.}

Nomina. 


\section{6 \\ And. MatthıliComm.}

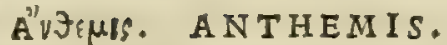

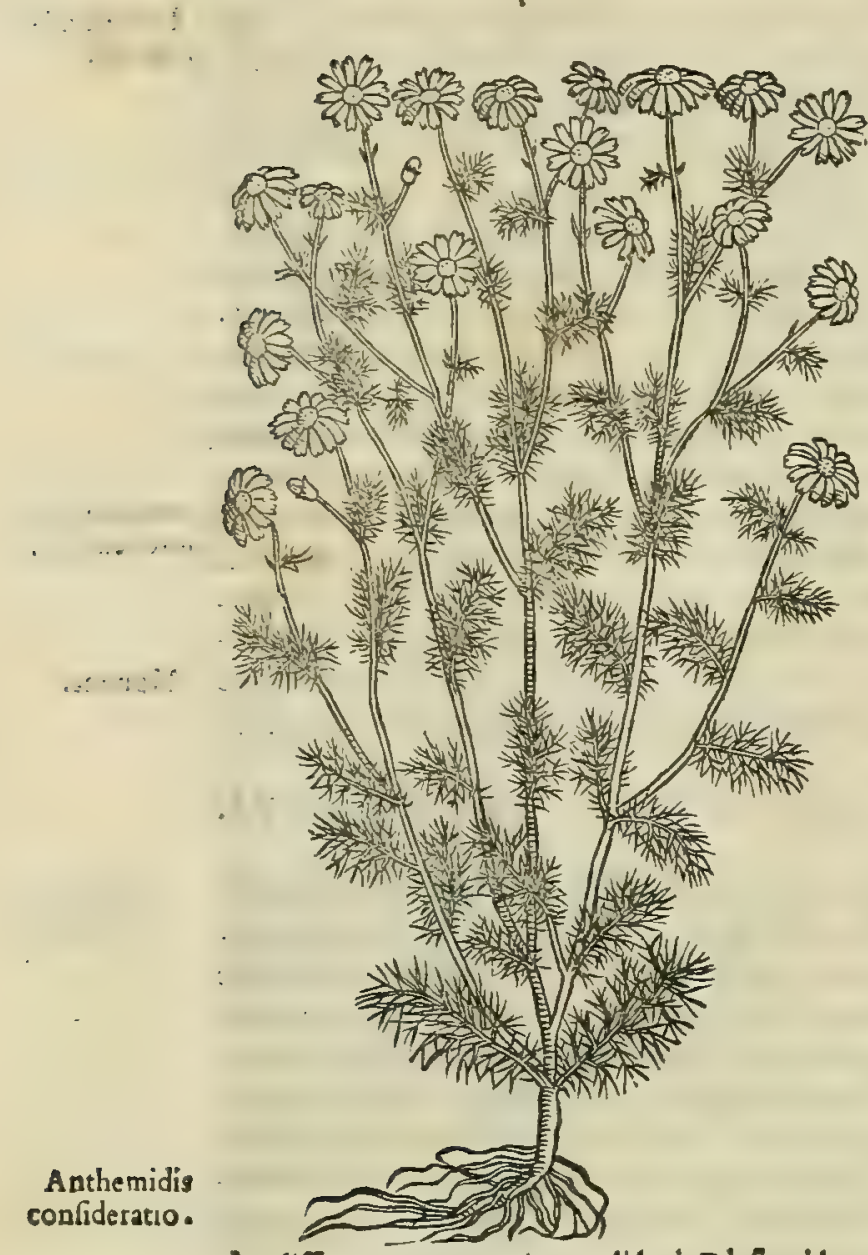

A N T H E M I D I S generą tria, tantùm flore diftantia: rami dodrantales, truticofi, alis mulkis concaui: tenuibus foliolis, paruis, numerofis : rotundis capitulis: foribus in medio aureis, forinfecus orbiculato ambitu candidis, melinis, aut purpureis, magnitudine foliorum rutæ. Nafcitur in afperis, \& iuxta femitas. colligitur uere. Vim habênt radices, flores, \& 39 herba excalfaciendi, extenuandiq́ue. Potu, \& infefsione, pellunt menftrua, partus, vrinam, calculosq́ue :aduerfus inflationes, \& ilei tormenta bibuntur : bilem fuffufam expurgant: iocinerum uitia fanant. Decocto earum veficæ fouentur. Ex omnibus his generibus:ad calculos efficacifsima eft, qux florem purpureum habet, cu ius amplitudo maiufcula eft. Hanc propriè heranthemon uocant. Ea cui leucanthemo nomen eft, item quar chryfanthemon dicitur, vehementius vrinam ciunt. Aegilopijs illitæ medentur: commanducat ulcerum eru- 20 ptiones in ore fanant. Nonnulli in clyfteribus ex oleo vtuntur, terunturq́ue in farinam, ad abigendos febrium circuitus. Flores, \& folia recondi debent, \& priuatim tu$\mathrm{fa}_{2}$, in páftillos digeri : radix quoque ficcari, dumqque ingruit necefsitas, binæ partes herbæ dari, modò floris aut radicis pars una, modò contrà floris partes dua, \& herbæ una, permutatim duplicato pondere', alternis diebus. bibere autem oportet in uino mulfo diluto.

A N T HE M I s, qua er Chamemelon abodore mali Grec 3 ? cis difta eft, oficinis, of uulgo corrupta noce Camomilla nocde tur. Verim quanuis tres Anthemidis pecies florum colore tan= tüm differentes, memorie prodiderit Diofcorides, eamq́; cateris ad calculos preftare tradiderit, cuiflores in media aurei, per ambitum ueró purpurei bubonij modo infunt; pharmacopols tamen in Italix illam duntaxat fibi compa= rant, que floribus conftat intus aureis, foris folijs albicantibus circumfeptis: quodd bec ceteris frequentior, copio=

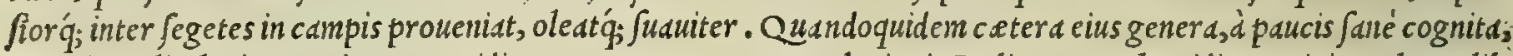
Anthemidis in raris Italia locis reperiuntur. Vidinus tamen nos utrasque pluries in Italia. Anthemidis meminit Galenus lib. uires ex Gal. I I.I. fimplicium medicamentorum, fic fcribens. Chamemelum tenuitate quidem rofe perfimile eft, calore ueró ad olei facultates magis accedens, animali tum familiares, tum temperatas. Quapropter laßitudinibus, ut fi quid aliud

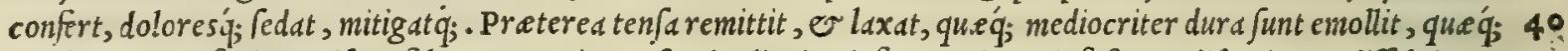
conftipata rarefacit. Ad hec febres, que citra uifceris alicuius inflammationes infeftant, difcutit, ac diffoluit. ac prefertin qua cx bunortbus biliofis, aut cutis denfitate proueniunt. Qua de re ev ab Aegyptiorum fapientibus foli confacratum eft, febriumq;' omnium remedium putatur. Verüm bac quidem in re à ueritate aberrant: folas enim, quas dixi febres fanare poteft, eaśq; qux iam concoct $x$ funt. I uuat tamen pulcbré reliquas etiam omnes, que melancholi= ce funt, dut pituito fe, aut ex uifcerum inflammatione prognata. Nam or harum remedium chamemelum uel ftre= nuißimume eft, ubi iam concoctis adbibetur: quapropter $\mathcal{E}$ bypochondrijs, ut $/ \mathrm{i}$ quid aliud, gratum exiftit. Meminit etiämnum libro v I. corundem fimplicium medicamentorum, fic inquiens. Dictum quidem in tertio libro de hac berba copiofius eft, dicetur,; nunc fummatim, quód calefacit, $\sigma$ deficcat in primo ordine. Eft o tenuium partium, ac pro

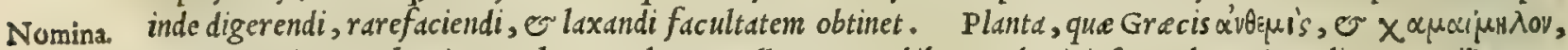
Iatinis pariter Anthemis, o Chamemelum appellatur: Arabibus, Debonigi, feu Babunegi: Italis, Camamilla: Ger 50 manis, Camillen : Hipanis, Manzanilld: Gallis, Camemina, or Camomille.

\section{Magdéviov. PARTHENIVM.}

\section{CAP. CXXXVIII.}

P A R T H E N I V M, aliqui amaracon uocant, folijs eft coriandri, tenuibus : flore per ambitum albo, intus melino, odore fubuirofo, fapore amaro. Siccatum, cum aceto mulfo, aut fale potum, non fecus atque epithymum, \& bilem, \& pituitam detrahit : fufpiriofis prodeft, \& melancholicis. Herba fine flore à calculofis, , \& anhelatoribus magna utilitate bibitur. Valet decoctum ad infidendú in duritia vuluarum, \& inflammationibus . Illinitur facro igni, \& collectionibus cum flore. 


\section{InLib. tertium Diofcoridis. 467}

PARTHENIVM.

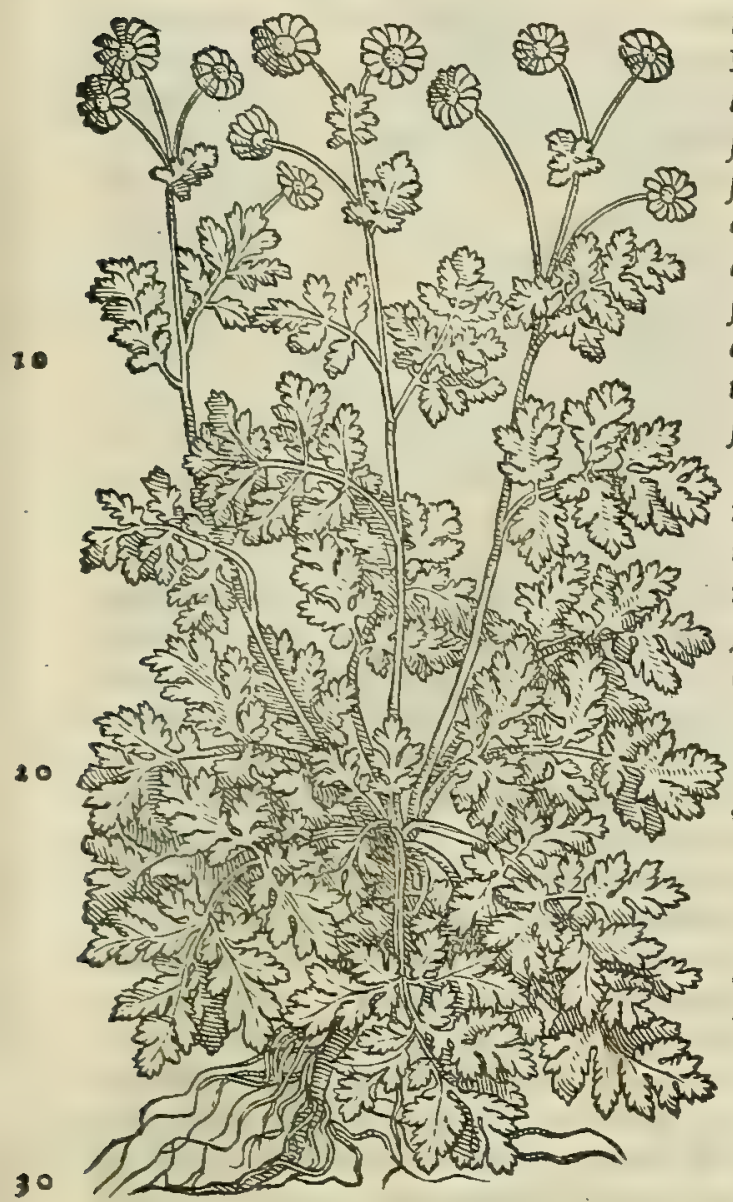

TANACET $\nabla M$.

$4^{\circ}$

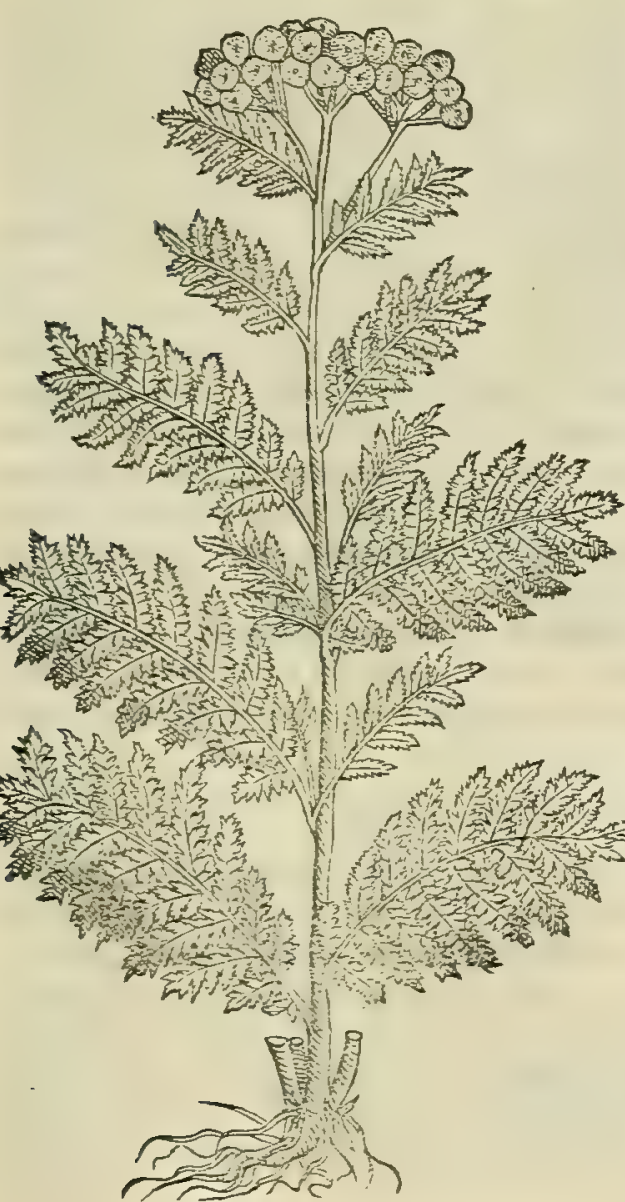

S E R I I V R Parthenium in Italia in hortisferé omnibus, Parthenii cōneque modó in ijs fatum; fed in alijs quog; locis ponte prouenit. Folio eft coriandri, amaro fapore, odore graui : floribus per am= bitum albis, intus melinis. Hetrufci Matricariam, or ab amaro fapore, Amarellam uocant. Ceterim ballucinantur, mea quidem fententia, in Parthenij biftoria Brafauolus, o Fucljius, uiri alio qui doctißimi : quin or Mondcbi illi reuerendi, qui in Mefuem commentarios ediderunt, quód concordes fibi perfua ferint ( $u t$ fuperius in Artemifie commentario, corum error explodens do, diximus ) Matricariam, fúe Amarcllam uulgó uocatam effe illud Artemifie genus, quod fecundo loco à Diofcoride repres= fentatur: utpote qui non recte expenderint banc effe legitimum Parthenium. Porró contendunt Brafauolus, o Fuchjius eam $0=$ mnino plantam uerum referre Parthenium, quam berbariorum uulgus Cotulam fretidam appellat. Sed quàm ift clarißimi medici magno in errore uerfentur, iudicent ij, qui probé fciunt Cotulan fatidamfolio effe freniculi, aut anthemidis potius, quàm corian= dri : neque apore ufqueadeo amaro, ut in $\mathrm{P}$ arthenio requiritur. sunt preterea antiquor um nonnulli, qui Helxinem quoq; $\mathbf{P}$ artbe= nium uocauere, illam fcilicet, que in parietibus nafcitur deter= gendis uitreis ua/is aptißima, ut Galenus ip $\int e$ teftatur lib.v I. fim plicium medicamentorum, or Plinius libro X X I I. cap. X V I I. naturalis biftoria. $\mathrm{N}$ ec de funt etiam, qui uelint mas $\mathrm{P}$ arthenium appellare Athanafiam, quam er TANACETrM uocant $\int e p l d=$ fiarij, cuius etiam fuperius de Artemifadifferentes mentionem fecinus, or bic modó effigiem damus. Quorum equidem fenten= tiam magis probandam cellerem, quàm corum, qui tertium $\mathrm{Ar}=$ temifíe genus $\mathrm{T}$ anacetum effe contendunt. Vtuntur $\mathrm{T}$ anaceto recentiores ad uentriculi, o aluiflatus difcutiendos, item ad lum bricos ex uentre pellendos. Vtuntur et ad fiangendos renum cal culos, $\sigma$ ad ciendam urinam. Sed id uiris magis, quam mulieri= bus commendant: contrà uerò Matricariam dictam fominis tar= tùm exhibendam precipiunt. Parthenij in fimplicium medica= mentorum cenfu Galenum meminiffe non reperio. Eius nomen Grecum eft wapgéviov, Latinum fimiliter Parthenium.; Arabi= cum, Achuen, Vcbuen, Achuan, fiue Alachuam: Italicum, $\mathbf{P} a r=$ thenio, Matricaria, e Amarella: Germanicum, Muotter kraut, or Mettram: Gallicum, Matricaire.

\section{Bov' $\phi \theta \alpha \lambda \mu o v$. BVPHTHALMVM. CAP. CXXXIX.}

B v P H T H A I M N, quidam cachlam uocant, cau les emittit tenues, mollesq́ue: folia fæniculi : luteum flo rem, antbemide maiorem, oculi fimilitudine, unde nomen traxit. Circa oppida nafcitur, \& in campeftribus. Flores cum cerato triti, tumores, duritiasq́; difcutrint. Aiunt epotam polt exitum à balneis, regio morbo correptis, colorem tractu temporis reddere.

No N parum profecto inter fe udriant de Buphthalmore= centiorum fententix, ut herbam, que ip Jum legitine reprefen= tet, decernant, or oftendant. Nam aliqui putant, berbam quan= dam cubito altiorem, in pratis ov agrorum marginibus nafcen= tem, qux ( ut equidem opinor) Bellis maior eft, folio nonnibil in ambitu ferrato, flore intus melinto, extrà ueró candidißimis fo= liolis undiq; circundato, anthemide maiore, effe legitimum $\mathrm{B} u \mathrm{ph}=$ thalmum. Alijueró, quibus adfipulatur Fuch/ius, aliam ab hacherbain uerum Buphthalmum effe contendunt, uulgaris an= themidis cognatam, quam officine Cotulam non fretidam uocant. sed cur borum fententias comprobem, fane non babeo. quippe quanuis Cotula non fatida dicta foliorum facie quadantenus $\mathrm{E} u=$ phthalmuin

Tanacetum; \& eius medicin $x$.

Nomina.

Buphthalmi confider. 


\section{And.Mathiols Comm.}

BVPHTHALM VM.

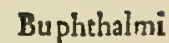
uires ex Gal.

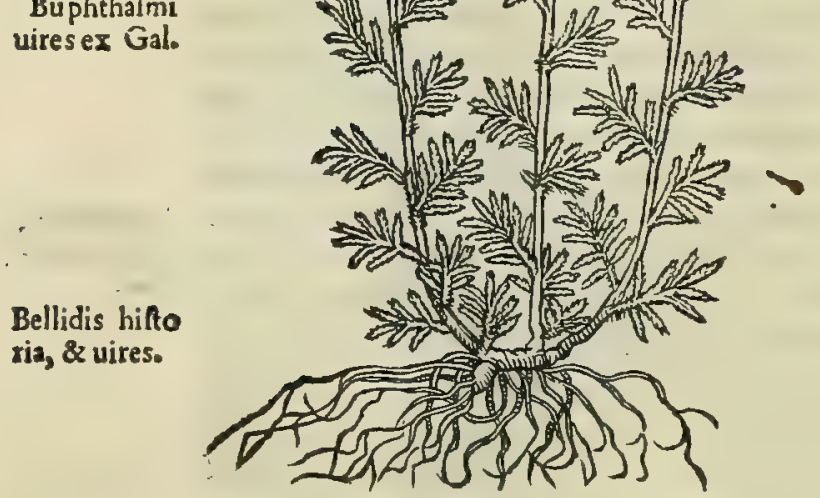

B E I I I $S$.

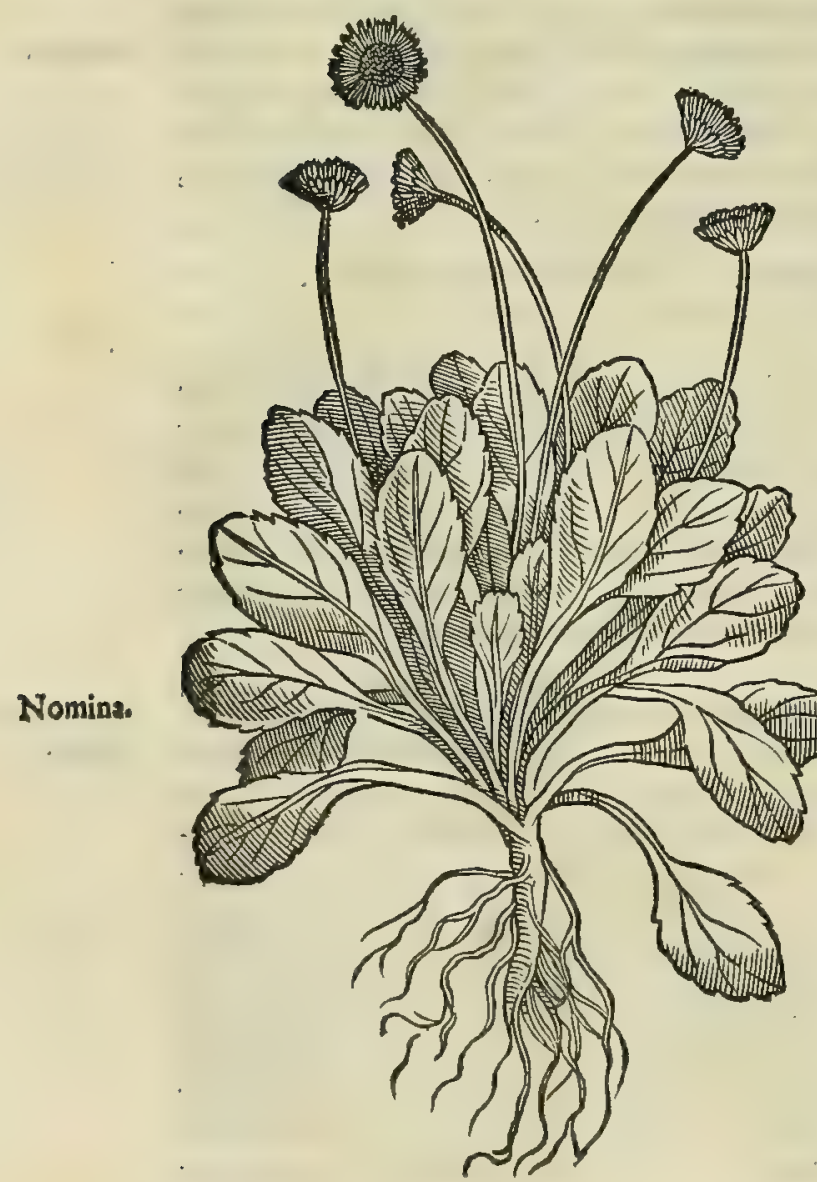

phthalmum referat; flores tamen in medio melini; 0 in ambitu anthemidis modo candidi, Diofcoridis pictura non utiq; refpon= dent. Quemadmodum o binc perpicuum eft alteram plantam, cuius primo loco meminimus, non effe Buphthalmum. siquidem cum diligentißime fcripferit Diofcorides unlgaris anthemidis, tum etiam parthenij flores intus aureo micare colore, per ambi= tum ueró candido, dubitandum quidem non eft, quin 0 cadem fuerit ufus diligentid in de fcribendo Buphthalmi flore, quem td= men luteum in uniuerfurn facit, non autem in ambitu candidum; qualis in unlgari parthenio conpicitur. Cùm itaq; Buphthalnam luteo plane flore praditum effe debeat, haud dubic errant, meo quidem iudicio, qui pro Buphthalmo predictss, aut fimiles plans tas accipiunt. Caterum legitimum, nifallor, Buphthalmum ad me attulit boc anno Patauio Ioannes Odoricus Melchiorius $\operatorname{Tr}^{2}=$ dentinus, inuenis pectate in philofophid, ac medicina eruditio= nk, mibio'; perinde ac filius charißimus, quod in nutlis pror fus no= tis à Diofcoridis de fcriptione dißidet, ut eius effigies, quàm bic damus, abunde demonftrat. Buphthalmi uires retulit Galenus lib.vr. fimplicium medic. ijs uerbis. Buphthalmum, inquit, fic ap pellatum eft a floribus, qui figur a quidem boum oculis uideantur 20 adfimiles, colore autě anthemidis floribus fimill imi funt, fed mul tó illis tum maiores, tum acriores. Proinde $\sigma$ uehementius di $=$ fcutiunt,adeo ut duritias fanent cerato mifti . hec Galenus. Vbi, ne quid nobis obftet, animaduertendum eft, quòd Galenus, qui $\mathrm{B} u=$ phthalmi flores anthemidis floribus fimillimos reddit, de ea tatum anthemide intelligit, que lutcos flores profert. Sed quoniam de Buphthalmi flore differenti mibi B E I I I s fic d Plinio uocatd oc currit, cuius etiam initio commentarij memini, non alienum effe duxi, boc in loco eiusbiftoriam, or uires recenfere. Bellis igitur in Italia trium eft generum. Primum in bortis feritur : ceterd in 30 pratis, e campeftribus nafcuntur. Hortenfe berbula eft folijs longiufculis, in cacumine fubrotund is, folo procumbentibus, et in rote modum radiantibus, craßiufculis, per ambitum minutim fer ratis : é quorum medio cauliculi prodeunt uillofi, flexibilesós: in quorum cacuminibus anno feré to to flores emicant, centró tenus aurei, per ambitum ueró foliolis duplicibus in purpuram rubenti bus circundati,coronis texendis aptißimi. Alterum in pratis ple= runq; nafcens, folijs, $\sigma$ cauliculis conftat bortenfi fimilibus, ma= iufculis tamen : Sed flore intus melino, circùm ueró cădido, dnthe midis modo. Hoc, quod primo ftatim uere floredt, Hetrufci appel 40 lant uulgó Primo fiore, ê Fiore di primanera. Tertium cateris maius affurgit, flore predicto non dislmili, fed maiore : folitis e=

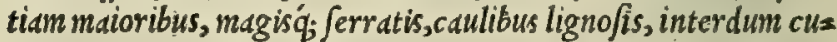
bito altioribus, non nifi aftate florentibus. Facultas omnibus ea= dem: nam (ut recentiores perbibent) ualent in strumis, e capitis fracturis: quinetiam in uulneribus thoracis, que in pectoris caui tatem ufq; penetrarunt, in quem ufum Bellim potionibus inferiut: sunt 0 qui Bellidis genera laudent ad ifchiada, or paralyfin.

Bov' $\phi \theta \alpha \lambda \mu o v$ fic Gracé, Latiné ueró Buphthalmum, $\odot$ Ocu= lus bouis dicitur: Arabicé, Bihar: Italicé, Buphthalmo, $\mathcal{O} \mathrm{O} c=50$ chio dibue.

\section{ГAuหvoín. PAEONIA. CAP. CXL.}

PAE O N I A, fiue glycyfide, Græcis alıquibus pentoboron dicitur: funt qui Idxos dactylos radicem pæo niam uocant. Caulis altitudine fefquipedis adolefcit, comitantibus multis ftolonibus. Huius duo genera: mas folia iuglandis habet : in fomina uerò fmy rnij more diuiduntur. Summo caule filiquas emittit amygdalis fimiles : in quibus, cùm dehifcunt, multa grana, exigua, rubra, acinis punicorum fimilia inueniuntur, $\&$ in medio 
P AE O N I A.

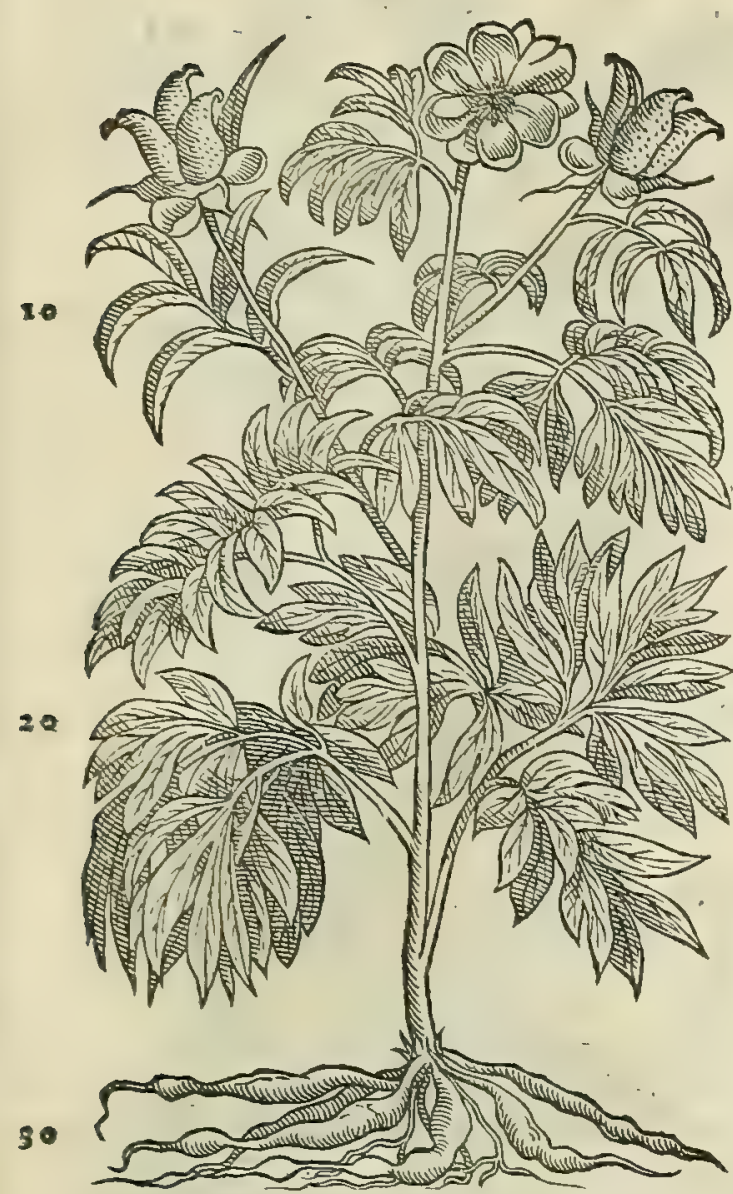

medio nigra, purpurea quinque aut fex. Radix maris di gitali crafsitudine, \& palmi longitudine, gufu adftringens,alba. fæminæ radicibus ceu glandes circiter feptem aut octo inharent, ut in hafula regia. Forminis à partu non purgatis ficca radix datur: ciet menfes amygdalx magnitudine pota: uentris doloribus cum uino potanu xiliatur valet contra regium morbum, \& renum,ac ueficæ dolores . decocta in uino aluum fiftit. Rubra grana rubentes menfes fiftunt, docem uel duodecim pota in uino auftero, \& nigro: fto machicis, \& erofionibus ea effe prodeft : a pueris pota initia calculorum eximunt. Grana nigra auxiliantur fupprefsionibus nocturnis, vuluæ ftrangulationibus, \& matricis doloribus, quindecim numero pota, in aqua mulfa, ant uino. Nafcitur in altifsimis montibus, \& præruptis.

P A E O I A fremina planta eft uulgaris notitic: mas ueró Pxonix concontrà,quód paucis in Italia locis proueniat. Hanc Pifis ad me fideratio. Goritian mifit hoc anno I ucas Glinus Forocornclienfis, uir er doctrina, o rei medica cognitione praclarus. Sed o eam anted é Germania allatam uidumus. Paonie uires pofteritatis memo Viresex Gal. ria tradidit Galenus lib. v I. fimpl.med. ubi ita fcriptum reliquit. Glycy/ida, quam pentorobon,è peoniam nuncupant, radicê bd= bet leuiter adftringentem cum quadam dulcedine : etfi plufculum dentibus mandas, acrimoniam item quampiam fubamar am fubeffe percipies. Proinde menfes ciet ex melicrato amygdala pota quä= titate. Sane tundere eam oportet, ac cribrare, er fic inpergere. Expurgat porró etiam iecur obftructum, or renes. Sed hac effi= cere nata eft, quì acris, et fubimara eft: qua ueró quiddam etiam adftriftorium obtinet, uentris fluxiones fiftere poteft. Verùm eä tunc in aufterorum uinorum quopiam decoctam bibere conuenit. Galeni hiltoEf autem facultate omnino refíccatoria uebementer, ita ut non deßperauerim eametiam adalligatdm, quod meritó ria . creditum eft, puerorum epilepfias fanare. Equidem uidi puellum quandoq; octo totis menfibus morbo comitiali libe= rum, ex eo quo geflabat radicé tempore : ubiueró forté fortuna quod à collo fupenfum erat decidifet, protinus mor= bo correptus eft. rurfusí; jußpenfo in locun illius alio, inculpaté poftea fe babuit. Porró uifum eft mibi fatius effe de= nuò id collo detrabere certior is experie ntix gratia. Id cüm feciffem, ac puer iterum effet conuulfus, magnam recen= tis radicis partem ex collo cius fuppendimus: ac deinceps prorfum fanus effectus eft puer, nec pofted conuulfus eft. Rationabile itaq; erat aut partes quafpiam à radice defluentes, ac deinde per infFirationem attactas, ita affectos lo= cos curare, aut aerem à radice aßidue mutari, o alterari. Nam boc pacto fuccus Cyrenaicus columellam phle= $4^{\circ}$ gmone affectam iunat, $\mathcal{O}$ melantbium frictum palain destillationes, $\mathcal{O}$ grauedines deficcat,,$\sqrt{i}$ quis id in calidum linteum rarum liget, aßjiduéq; calorem ex co per infirationem, qua per nares fit, attrabat. Quinetiam $f \mathfrak{f}$ complu= ribus linis, or maximé marine purpure, collo uipere iniectis, illis uiperam prefoces: edq́; pofted cuiupiam collo obuincias, mirificé profuerit tum tonfillis, tum omnibus ijs, qux in collo expullulant. Sed de talibus prituatim aliquan do forté confcribam. Nunc ueró fciendum est P eonix temperamentum tenuium efe partium, ov exiccatorium, haud

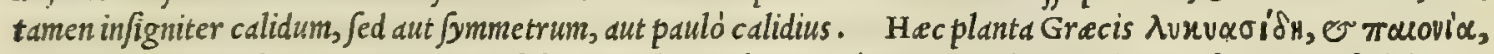
I atinis item Poeonia nuncupatur : Arabibus, Feonid: Italis, Peonia : Germanis, Peonien: Hipanis, Rofa del mon=

Nomina. te, er Rofa albardeira: Gallis, Penoefne, er Pinoine.

\section{AHóógęuOV. LITHOSPERMVM. CAP. CXLI.}

L I T H O S P E R M ON à feminis duritia nomen accepit. Folijs eft olex longioribus, \& latioribus, mollioribus, iacent humi, qux ab radice exiliunt : ramulis reetis, tenuibus, firmis, crafsitudine acuti iunci,lignofis : in quorum cacumine bifidi exortus cauliculorum fpeciem exhibent : folijs longis, inter quæ paruum femen, rotundum, erui magnitudine, duritia lapidea . Nafcitur in afperis, $\$$ edi tis locis. Vim hanc habet, ut femine cum uino albo poto calculos frangat, pellatqque urinam.

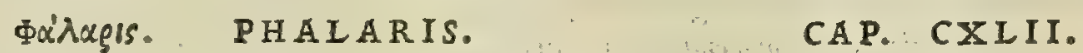

P F A I A R I 5 cauliculos emittit zex culmis fimiles, à minutis, ac nullius ufus radicibus, multos, duûm palmorum geniculis cinctos, graciliores tamen, ac dulces : femen candidum,oblongum, milij magnitudine. Tunditur, $\&$ in aqua aut uino fuccus ad ueficæ cruciatus utilifsimè bibitur. Semen cochlearis menfura potum, ad eadem efficax elt.

R IIтнов 

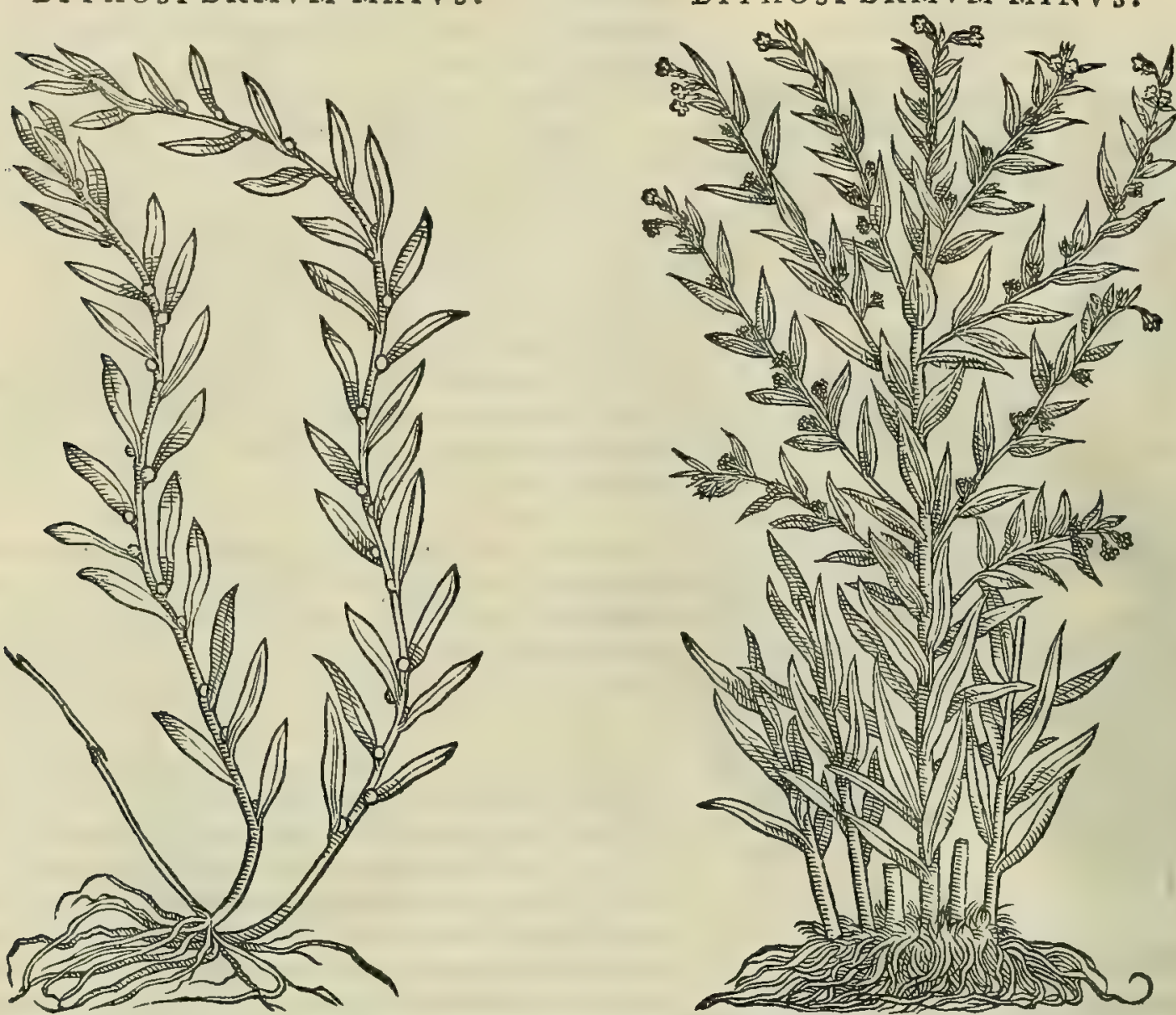

Lithofpermi

L I T H O S P E R M O N hodie feplafiarij, or omnes feré medici Barbaros fecuti Milium folis nominant. Licet confider. rectius fortaffe Mauritanorum quoq; imitatione ab illis Milium soler nocaretur. Quandoquidem bec planta (ut fcri= bit Serapio teftimonio A ben 1 ultel ) frequens $n$ afcitur in montibus soler : unde illi aptius forté à loco, quàm à fole co= gnomentum imponeretur. Huius milij, utcunque cognominetur, duo oftenduntur generd. maius, quod legitimum eft Lithopermon, quóue Hetruria fat is referta eft. minus, quod longé frequentius ubiq; in It alia gignitur. Hoc utiq; non temere exiftimauere nonnulli effe Pbaldrida, quod femen proferat milio perfimile, fubcandidum, er oblongum. Qui= bus facilé fub cribi polfet, /i planta bec culmis geniculatis, ac etidm folijs zee finilis pectaretur, quód Oribafto Pha= laris non modó culmos fundat zex fimiles; fed etiam folia. Ex ijs equidem notis, qux plané in Milio folis minore defi= derantur, cogor itlis non adftipulari. Quin potius adducor, ut certó credam Phalarim effe plantam ab illa diuerfam: eam'; fortaffe, cuius aliquando picturam dabimus, que in fylueftrium frugum genere, dquibufdam recenfetur, adeo ut 40 non defint etian quibanc appellent sylueftre milium. Eft enin culmo, er folio zed, o femine candido or oblongo,

Fuch. error. milij feré magnitudine. Ceterüm Fuch fium, uirum alioqui doctißimum, Lithoßpermum Dio coridis omnibus propé nunc compertum, non cognouife arbitror, quod in fuis clarißinis de ftirpium biftoria commentarijs pro uero Litho= permo, illud quod officinis Milium folis minus appellatur, depinxerit. Idem mbil minus deinde mibi quidem uidetwr erraffe in libro de compofitione medicamentorum, quem nuper auctum edidit : ubi fcriptis tradidit Lithopermi genus effe plantam illam harundinaceam, ex cuius Seminibus, qua nos Lacrymas uocamus, fiunt orbiculi, quibus filo traiectis utuntur mulieres ad fuas preces numerandas. Hanc autem opinionem quoniam confutauimus in Apologid, quam ad= uerfus Amatum $\mathrm{L} u$ fitanum, quem forté fecutus eft Fucbfius, fcripfimus, bic ut fatis alibi explofam relinquimus. I $i=$

Lithofpermi thopermon, ut herbam fumma admiratione dignam, eleganter de fcrip/it Plinius lib. x x v I 1. cap. x I. cuins bic uer= hıt. ex Plin. ba fubijciam. Inter omnes berbas, inquit, Lithopermo nibil eft mirabilius. Aliqui egonychon uocăt, alij diopyron, alij 50 ber aclcon. Herba quincuncialis feré, folijs duplo maioribus, quàm ruta, ramulis furculofis, crafitudine iunci. Gerit iuxta folia fingulas ueluti barbulas, et earum in cacuminibus lapillos candore, et rotunditate margaritarum, magni= tudine ciceris, duritia ueró lapided. Ip $f i$, qua pediculis adhareant, cauernulas habent, er intus femen. Nafcitur et in Italia, fed laudatiSimum in Creta. Nec quicquam inter berbas maiore quidem miraculo conpexi. Tantus eft decor, uelut aurificum arte altcrnis inter folia candic antibus margaritis, tam exquifita difficultas lapidis ex herba nafcĕtis. Idcere, atq; bumi ferpere autbores tradunt. Ego uulfam,non berentem uidl. hactenus Plinius. Litbopermi in fim

Phalaridis ui plicium medic amentorum libris, Galenum meminife non inuenio. Verum $\mathrm{Phalaridis,quam} \mathrm{phalerim} \mathrm{nuncupat,uires}$ resex Gal. reddidit libro VIII. corundem, fic inquiens. Phaleridis herbe tum fuccus, tum femen, tum folia potu auxiliari cre=

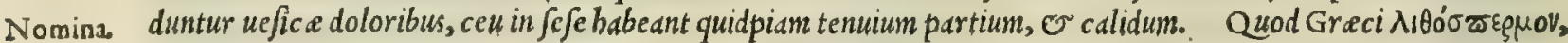
Latini quog; Lithopermum uocant: Mauritani, Kulb, Culb, Calt, feu Calab: Itali, Lithopermo, or Milium folis: Germani, Meerhir $\int z$, Steinfomen: Galli, Gremil, oN Herbe aux perles. 


\section{In Lib. tertium Diof coridis. $\quad 47^{\mathrm{I}}$}

RVBIA SATIVA.

20

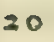

30

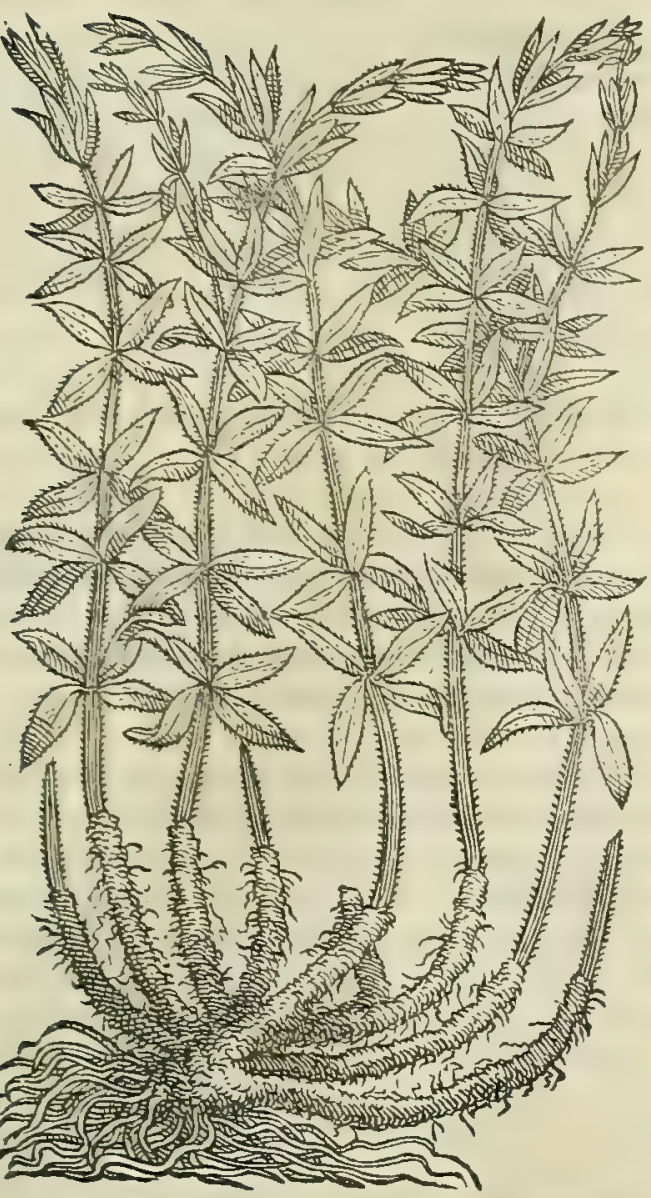

E'ęuģo'd avov. R V B IA.
RVBIA SYLVESTRIS.

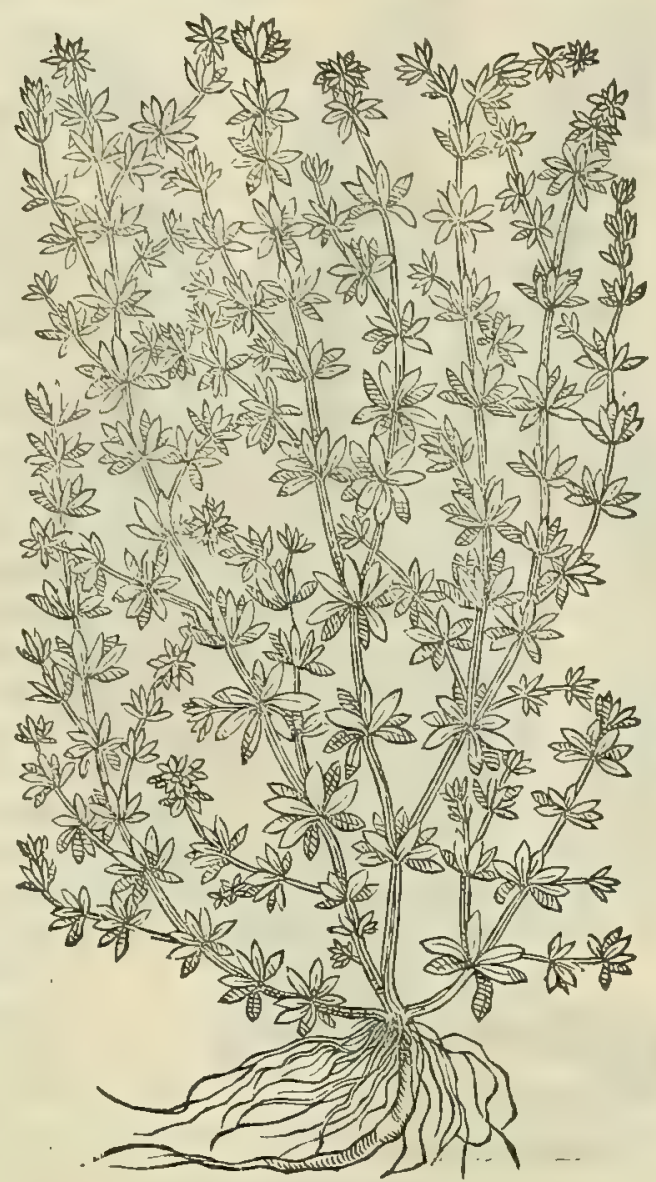

CAP. CXIIII.

E R Y T H R O D A N V M radix rubra eft, qua tinguntur lanæ. Vna sponte prouenit:altera feritur, ut in Thebana Gallix, \& Rauenna Italiæ: in Caria inter oleas, ut in aruis, folo creditur. Hanc non fine quæftu ferunt : nanque maximum ex ea fentiunt prouentum. Afperi caules, \& quadranguli, longi, aparinæ non difsimiles, robuftiores, \& multò prorfus maiores : folijs per interualla circum articulos, ftellatim decuffatis. Semen eius rotundum, inter initia uiride, mox rubrum, poftea cùm 40 ematuruit, nigrum: radix tenuis, longa, rubra. Vrinam ciet: qua de caufa regio morbo opitulatur, pota cum aqua mulfa : item ifchiadicis, \& refolutis. Craffam, copiofamq́ue urinam pellit, nonnunquam \& fanguinem : bibentes tamen quotidie lauari oportet, \& excrementorum quæ redduntur differentiam fpeetare. Aduerfus ferpentium morfus, ramulos cum folijs uino bibere prodeft. Semen ex aceto potum, lienem abfumit. Impofita radix trahit partus, menfes, fecundasq̨ue .albæ uitiligini illita ex aceto medetur.

R V B I A, quam Greci Erythrodanum dicunt, Hetrufcis nullis non cognita: neq; medicis folù, ac feplafia= Rubix confi rijs cognofcitur: Sed etim mulierculis, ac rufticis, ijs prefertim, qui in locis babitant, ubi lanificio opera impenditur. deratio. quandoquidem inficiendis tingendisq;; lanis aptißina eft. Quapropter ruftici, e agreftes mulieres, quód lanarü in= so fectores Rubie quotann is plurimun emant, buius radices effodiunt, o uendunt, unde tantum queftur faciunt, ut fibi fuisq́; uiftum fuppeditent. Nitttit hanc abunde Hetrurid, pracipué senenfis ager. Expetuntur folia noftratibus mu= lieribus, quód afperrina fint, ad ftagnea uafa detergenda: fiquidem inirum ditu quàm pulcherrimé nitefcant, que Rubiam fuerint experta. Rubie menninit Galenus libro $\vee \mathrm{I}$. fimplicium medic amentorum, ubi fic fcribit. Eft au= tem Rubia tinctorum radix acerba, or guftu amara. Itaq; quecunq; agere dictum eft fuperiore libro, ubi in unum ciufmodi coiuerint facultates, ed omnia in bac radice luculenter conpicies, Quippe cum er lienem, ev iecur expur=

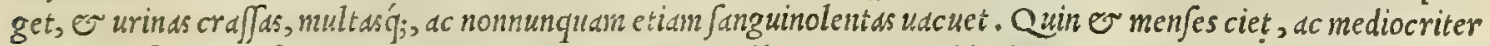
que exterfionem poftulant, extergit: proinde uitiligines albas ctm ace to illita iunat. Sunt qui eam ifchiddicis, hoc

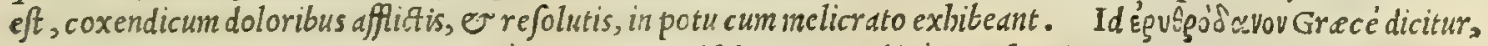
quod Erythrodanum, o Rubia Latiné : Paue, Fue alfabagin, Arabicé: Ertthrodano, $\sim$ Rubbia, Italicé : Ferber roet, Germanicé : Ruuid, Hipanicé: Garance, Gallicé. 
LONCHITISALTERA.

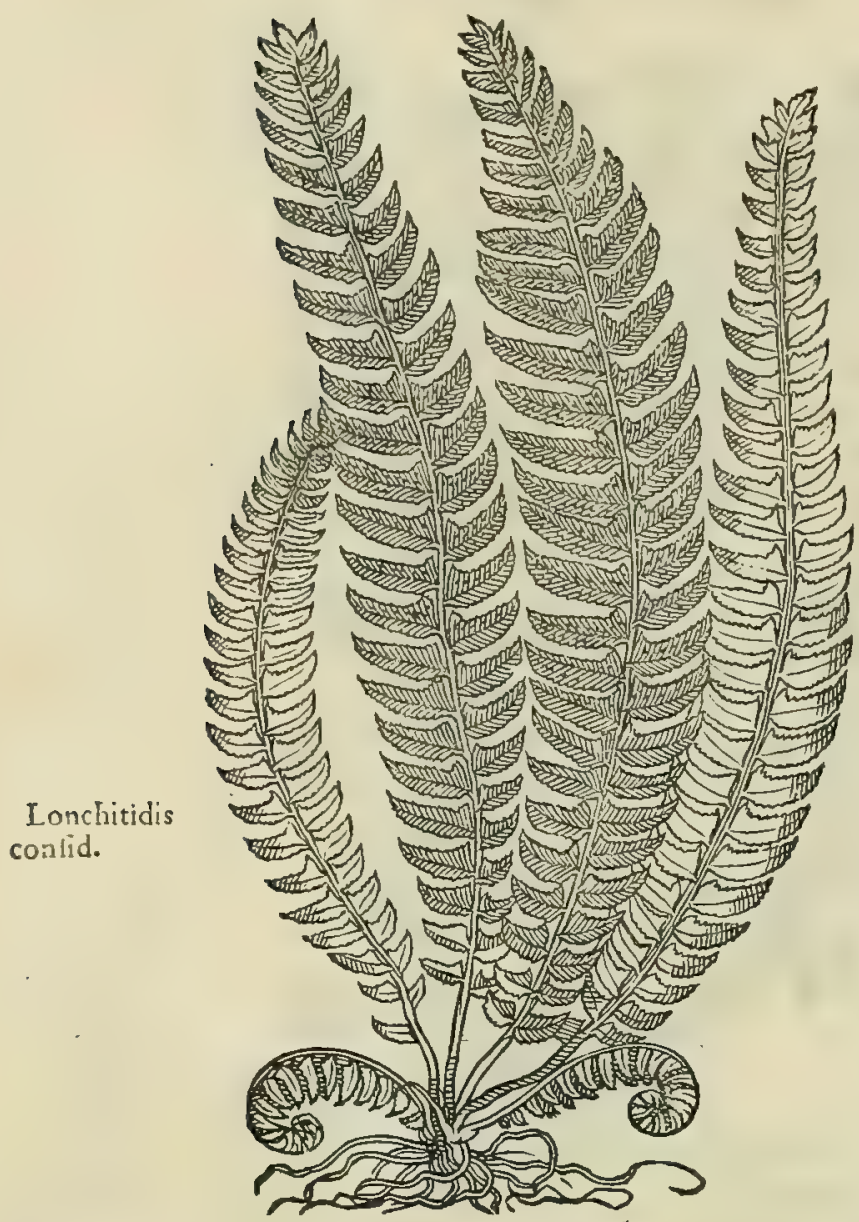

A L T H AEA.

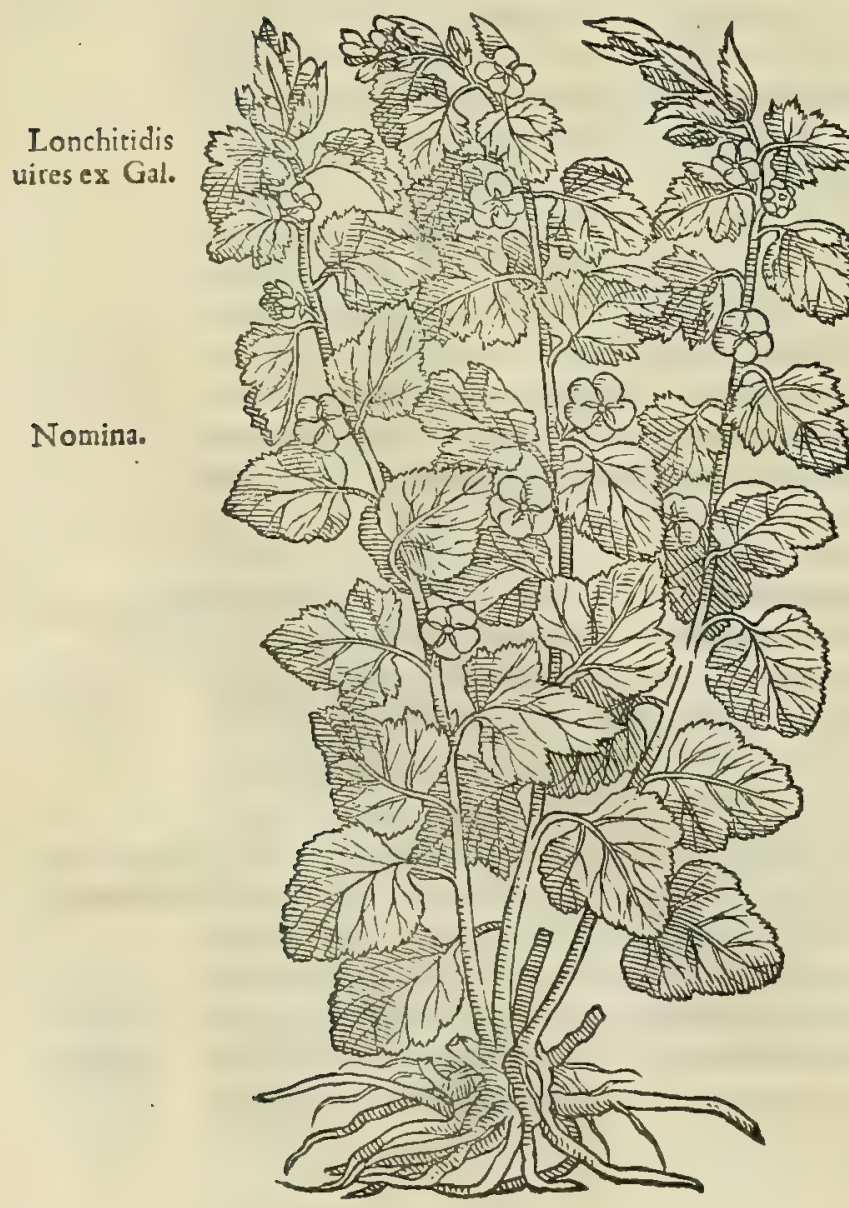

\section{SOYXITIS. LONCHITIS. CAP. CXIIII.}

L ON CH I T I s folia habet porri, latiora, rubentia , plurima, ad radicem circunfracta, ueluti in terram procumbentia, pauca in caule : in quo flores, ceu galericuli, hiantibus comicis perfonis fimiles, nigri, \& è riEtu albam exerentes uelut lingusm, quæ ad labrum inferius fpectet . femen inuolucris claufum lancex fimile, triangulum: unde fibi cognomentum arrogauit. radix dauci. Nafcitur in fitientibus, \& afperis. Radix ex ui- $\mathbf{z}_{\mathrm{S}}$ no pota urinam ciet.

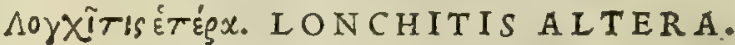 C A P. CXLV.}

A L T E R A eft Lonchitis, quam aliqui afperam lonchitin dicunt : folia fcolopendrij emittit, fed afperiora, maioraq́ue,ac multò magis diuifa. Vulneribus mirum in modum prodeft, in eisq́ue in fămationes excitari non patitur. Pota exaceto lienem abfumit.

ET 5 I in compluribus I talie, ac Germanie montibus, alijsq̆; apperis, e aridis locis diu multunó, perquifiuerim primü Lon= chitidis genus: ipfum tamen bactenus mili non licuit reperire, neq̧; etiam ab alijs inuentum viderè. Caterium Lonchitim alte= ram iampridem uidinus ftudio, ac liberalitate $\mathrm{L}$ uce Gbini medi= ciclariBini, qui eam $\mathrm{P} i \mathrm{fis}$ ad nos mifit. Hac folia babet $\int c 0 l o=$ pendrij, aperiora, maiora, magis q́; diuif a, ut eius pictura, quam exhibemus, probéoftendit. De prima Lonchitide differuit pli= nius lib. $\mathrm{x} \times \mathrm{v}$. cap. $\mathrm{x} \mathrm{I}$. ubific inquit. Lonchitis non, ut ple $=30$. rique exiftinatuerint, eadem eft, qua xyphion, aut phafganion, quanquain cupidi fimilis Semine. Habet enim folid porriruben= tia ad radicent, o plura quan in caule, capitula perfonis comi= cis fimilia, paruam exerentibus linguam, radicibus pralongis. nafcitur in fitientibus. Hactenus Plinius, qui borum pleraque d Diofcoride mutuatus eft. . Lonchitidis utriuf q; meminit Gale= nus lib. VII. Fimplicium medicamentorum, ubi de edrum uiribus ita fcribit. Lonchitis, eius uidelicet, que femen habet triangula= re, figura lances fimile, radix potißimum quodammodo fimilis eft radici dauci: proinde urinam ciet. Porró eius, qu.e fcolopen $=40$ dria fimilia habet folid,ea ad glutinand a unlnera idone a funt ui= ridia: Sed ficca cum ace to pota, lienes induratos fanant., $\Lambda 0 \gamma=$ XîTıs ut Gracis, ita etian Lonchitis Latinis, $\mathcal{O}$ Lonchite Italis uocatur.

\section{A'Aoxia. AITHAEA. CAP, CXIVI.}

A L T H AE A, quam alij Ibifcum uocant, in fylueftrium maluarum genere eft, cui folia ut cyclamino rotunda, lanugine canefcunt : flore rofaceo: bicubitali caule: radice lenta, intus alba. Althæa appellatur; s:o, quòd inter primas fit utilis, \& pluribus polleat remedijs. Decocta enim in uino aut aqua mulfa, \& perfe cum imponitur tufa, efficax eft contra uulncra : item ad ftrumas, parotidas, abfceffus, mammarum inflammationes, fracta fedis, inflationes, neruorum rigores: frquidem difcutit, \& excoquit, rumpit, \& ad cicatricem perducit. Cocta, ut dictum eft, adiecto fuillo adipe, aut anferino, terebinthináve, ut malagmatis lentor fiat, facit ad vuluæ inflammationes, præclufionésque, in pefsis fubdita. Decoctum eodem fungitur munere: onera vulux, reliquiasqúue à partu extrahit. Decoctx 


\section{In Lib. tertium Diofcoridis.}

coctx radicis fuccus ex uino potus, fuccurrit urinx difficultati, calculoforum cruditatibus, dy fentericis, ifchiadicis, tremulis, ruptis . dentium muicet dolorem, cum aceto dccocta, colluto inde ore. Viride femen ficcumq́ue tritum, uitiligines in fole cum aceto perunctas emendat. Eodcm cum oleo $\&$ aceto peruncti, à uenenatis non feriuntur. valet contra dy fenteriam, \& fanguinis reiectiones, aluiq́ue profluuium. In pofca, aut uino decoftum bibitur, contra omnes uefparun, apum, fimiliumọ́; aculeatos ictus. Folia cum olci momento, morfibus, \& igni ambuftis illinuntur. Conftat aquam, trita radice addita, fub diuo addenfari.

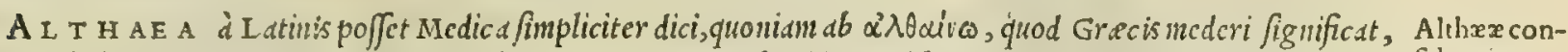
to etymon babere uidetur. Qüocirca meritó fcriptum religuit Diofcorides, Altha din id nomen traxiffe à multitudine fideratio.

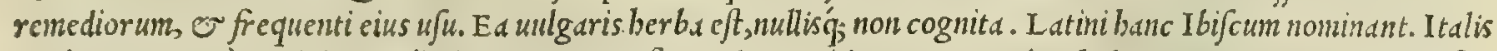
weró, corrupta à L atinis appellatione, o prepofita malua, quód cum ea quandam babeat cognationem, compofito nomine Maluauifco unlgó uocatur. Althedm memoria prodidit Theophraftus lib. I X. cap. X I X. de plantarum bi= ftoria, ubi de ea diferit ijs uerbis. Et radicem Ibifci aquam poffe addenfare aiunt, fi tritam inicccrix, fub diuoq, $b u=$ morem pofueris. Conftat Ibifcus folio malux maiori, pilofioriø̆; : caule molli: flore lutco: radice neruofu, alba: fructu malue . caul is quoque guftu maluan reddit. vfus eius ad rupta, o tuffe é uino dulci, o ad ulcera in oleo. Aliam quandam fi carnibus concoquas, in idem aggregare, ac ueluticonglutinare poffe affirmant: alias uin attractoriam poßidere, modo magnetis lapidis, atque fuccini . hac in inanimatis. hactenus Tbeophraftus. Mcminit Ibifci $\mathrm{Gd}=$ Ienus libro v r. fimplicium inedicamentorum, ubi eius uires ita defcripfit. Ebifcus, fiue althea (eft autem malua

20 agreftis) facultatem babet digerendi, laxandi, phlegmone leuandi, mitigandi, concoquendidifficilia coctu tubercu= 1a. Radix porró cius, o femen catera quidem fimiliter agunt, ut herba uiridis, fed tenuiorum partium, magisq; $e=$ xiccatoriam, ad hec magis exter foriam qudm illa facultatem oftendunt, ut o uitiligines detergant, o femen re= num calculos confringat . Radicis ueró decoctum dyfenterix, alui proflunio, o fanguinis reiectioni utile eft, nem=

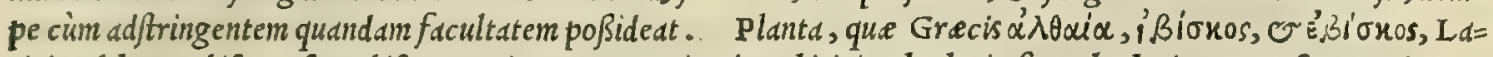
tinis Althed, Ibifcus, feu Ebifcus nominatur: Mauritanis, Cbitini, Chatbmi, fiue Chatbmie, O Rofa zaueni: Ita= lis, Maluarifco: Germanis, Ibifch, o Heyluurtz: Hipanis, Hierua cannamera, 0 Marmaie : Gallis, Guimaunes.

Althxx uires ex Galeno.

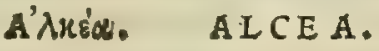

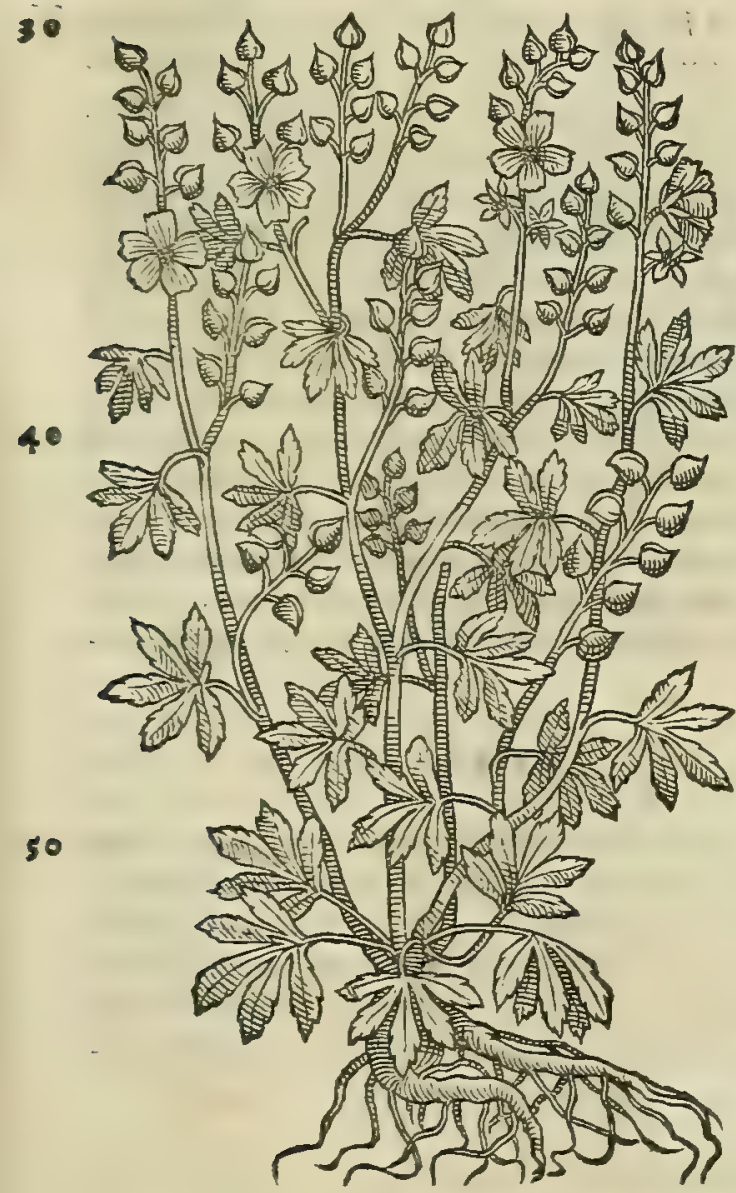

\section{CAP. CXIVII.}

A I C E A fylueftrium maluarum generi afsignatur. folia habet diuifa, uerbenacx proxima: caules tres aut quatuor, cortice cannabino ueftitos: florem rofx, par-uum : radices albas, latas, quinque aut fex,cùm plürimùm cubitales. Qux cum uino, aut aqua potx, dyfentericis, ruptisq́ue medentur.

A L C E A M bodie pasim feré in Italia aliqui Bifmaliam, Alcex confsalij Maluam fylueftrem;nonnulli etiam Maluauifcum agrefte no= deratio. minant. Herba eft caule, floribus, ac femine bortenfi malua per= quàm fimilis, fed folijs longiori incifura laciniatis, ranunculimo= do. Nafcitur in incultis, campeftribus, er agrorum, fcrobium 'q; marginibus, iuxtafepes, titas, ac femitas. Alcea radicibus non defunt, qui altbex loco utantur, cum buius copiam non babeant, ad tumores tum foluendos, tum emolliendos. Porró Alcee pe= culiari capitememiniffe Galenum non reperio, nifi hanc fyliseftrë maluam akpellauerit, dum malue facultatés libro vi.i. fimplie cium medicamentorum defcribit, his uerbis. Malua fylueftris qui dem digerentis paululum, er emollientis leuiter eft facultatis. Hortenfis uerò quantó plus babet aquea bumiditatis, tantó facul $=$ tate imbecillior eft. Fructus eius tantó ualidior eft, quantó o ficcior . bec Gdlenus. Caterum Paulus feorfum Alceam retus

lit lib.vi I. ubific inquit. Alced fylueftris malua genus eft. In ex Paulo. uino pota dyfenteris, or erofionibus medetur, potißimùm eius

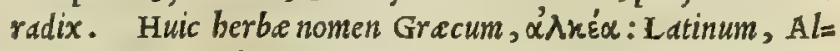
cea: Italicum, Bifmalua,Malua faluatica, er Buon vifchio: Ger= manicum, sigmars kraut : Hipanicum, Malua de Vngria, Or Mal ua montefina: Gallicum, Bimauue.
Nomina.

Nomina. 


\section{$474 \quad$ And. Matthioli Comm.}

KQ'WW Bis. CANNABIS.

C A N N A B I $S$ fatiua planta magni in uita ufus ad robuftifsimos funes factitandos : folijs fraxini, graui odore: caulibus proceris, inanibus: femine rotundo. quod largio re cibo genituram extinguit. Succus ex ea recente conuenienter aurium doloribus inftillatur. Sylueftris cannabis uirgas fert althæx fimiles, minores, nigriores, 8 afperiores,cubiti altitudinế æquătes : folio fatiux, nigriore, \& 20 afperiore: florelychnidis, fubrubro: femine, \& radice althxæ. Decocta radix, illitu inflam mationes mulcet, tumores difcutit,tofos articulorum difsipat. Huius cortex torquendis funibus accommodatus .

C A N N A B I S fatiua planta eft adeo unlgaris notitie apud omnes Europe nationes, ut omnino fuperuacuum fit eius faciem uerbis reprefentare. Sylueftris autem quanquam in multis Italie locis proueniat cum fyluofis, tum etiam campeftribus; paucos ta $=$ men effe puto, qui legitimam oftendant. Ceterim fatius femen in 20 cibis fumptum plané contrarium efficit in gallinis, $\sigma$ in nobis: $f i=$ quidem largius commanducatum nobis genitur am extinguit : gallia nas ueró ouiferaciores reddit. Experientia enim compertum ha= beo, gallinas, qua byeme, quo tempore algoris Seuitia raró oua parere folent, Cannabis femine ue cuntur, numerofiore ouorum partu gaudere: id quod frequenti cantu fuo declarant. Illud pre= terea mibi non abierit indictum, quód Cannabis recentis decoctum, expreffa deinde fortiter berba, terreftriuns Lumbricor um cauernu= lis inperfum, ftatim cos euocat. Quod pifcatoribus acceptum re= ferendum eft, qui hoc ingenio uermiculos capiunt fuis hamis inf $i=20$ gendos. Verüm non modó terrenos uermes euocat $\mathrm{Cannabis} \mathrm{deco=}$ ctum, er fuccus eius expreffus, fed etiam (ut Plinius lib. $\mathrm{x}$ X.cdp. $X$ X.III. author eft) uermiculos, o quodcunque animal in aurem intrauerit, eijcit. Hinc itaque quipiam conijcere poteft, eius facultatem ad interaneorum uermes haud imbecillem Cannabis ui- fore. Cannabis meminit Galenus lib.vi I . Fimplicium medicamentorum, fic inquiens. Cannabis femenflatus difcu= resex Gal. tit, adeoó; deficcat, ut fi plufculum edatur, genituram exiccet. Sunt qui ex co uiridi Juccum exprementes ad au= rium dolores ab obftructione, ut mihi uidetur, natos utantur. Et libro primo de alimentorum facultatibus, idem de Cannabi ita fcribit. Non quemadmodum planta ipfa cannabis uitici quodammodo eft fimilis, ita femen femini fa= cultate eft fimile : fed plurimum ab eo difidet, ut quod concoctu eft difficile, ftomacho' $\mathfrak{q}_{\text {; }}$ ac capiti noceat, prauiq; fit fucci. Sunt tamen qui eo quoque frixo cum alijs tragematibus uefcantur. Tragcmata autem uoco ed, que poft 40 conam, uoluptatis inter bibendum excitand a gratia manduntur. Multùm autem calefacit : ideó́; fumptum pauló largius caput ferit, uaporem furfum ad ip fum mittens, calidum fimul ac medicamentofum. bec Galenus. Exqui=

Mulierum er bus liquidò apparet, quàm grauiter errent mulieres, qua pueris comitiali morbo laborantibus Cannabini feminis sor.

Nomina decoctum exbibent. quo tantum abeft, ut morbum curent; ut etiam eius augendioccafionem prabeant: Qua planta roivvaßis Grecé, Cannabis item I atine dicitur : A rabicé, Scehedenegi, o Canab: Italicé, Canape: Ger= manice, Zamer hanff: Hifpanicé, Canhamo: Gallicé, Chanure.

\section{A'vózugis. ANAGYRIS. CAP, CXIX.}

ANAGYR Is frutex eft arboris inftar, perquàm grauis odore: folijs uiticis, uirgisque: flore se brafsicx : femen in corniculis non breuibus gignit, fubrotundum, firmum, uerficolori facie, fimile renibus, quod durefcit uu maturefcente. Tenera folia trita tumores illitu reprimunt: fi partus hæreat, \& fecund $x$, menfesq́ue morentur, drachmæ pondere bibuntur in paffo : fic \& fufpiriofis dantur, \& contra capitis dolores in uino . difficulter parientibus adalligantur, ita ut à partu ftatim auferantur. Radicis cortex concoquendis, difcutiendisque adhibetur. Semen commanducatum uomitiones uehementer ciet.

Anagyris có- QV A N V I s ueteres unius tantuma Anagyris meminerint; duo tamen in Italia uifuntur genera. Maius in A pu fideratio. Lia frequentißimum nafcitur, et eo Campania tractu, quo Terracind itur Fundum ad Tyrrbeni litus : folijs uitici pro= ximis : flore braßice raccmofo: fructu bortenfifmilaci fimili, amplioribus tamen, er breuioribus pauló filiquis ins clufo, colore purpurafcente, $u \int q u e a d e o ~ d u r o, u t ~ a q u a ~ m a c e r a t o$, fua in pertinaci duritie confiftat. Ninus, qüod ru= 


\section{In Lib. tertium Diofcoridıs.}

ANAGYRIS.

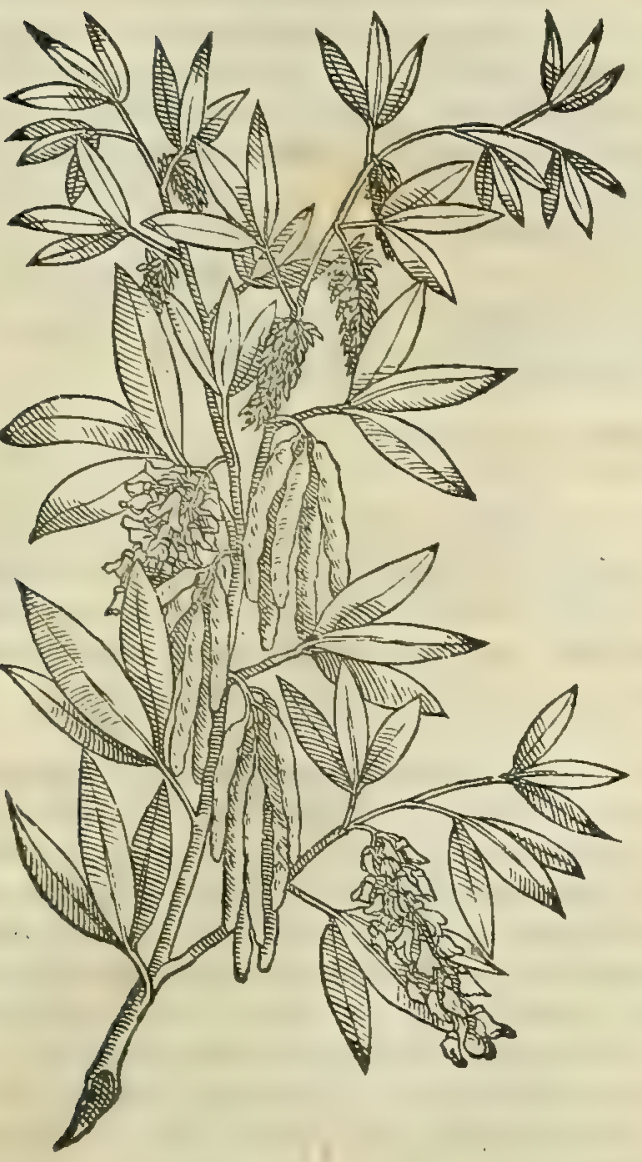

ANAGYRIS ALTERA.

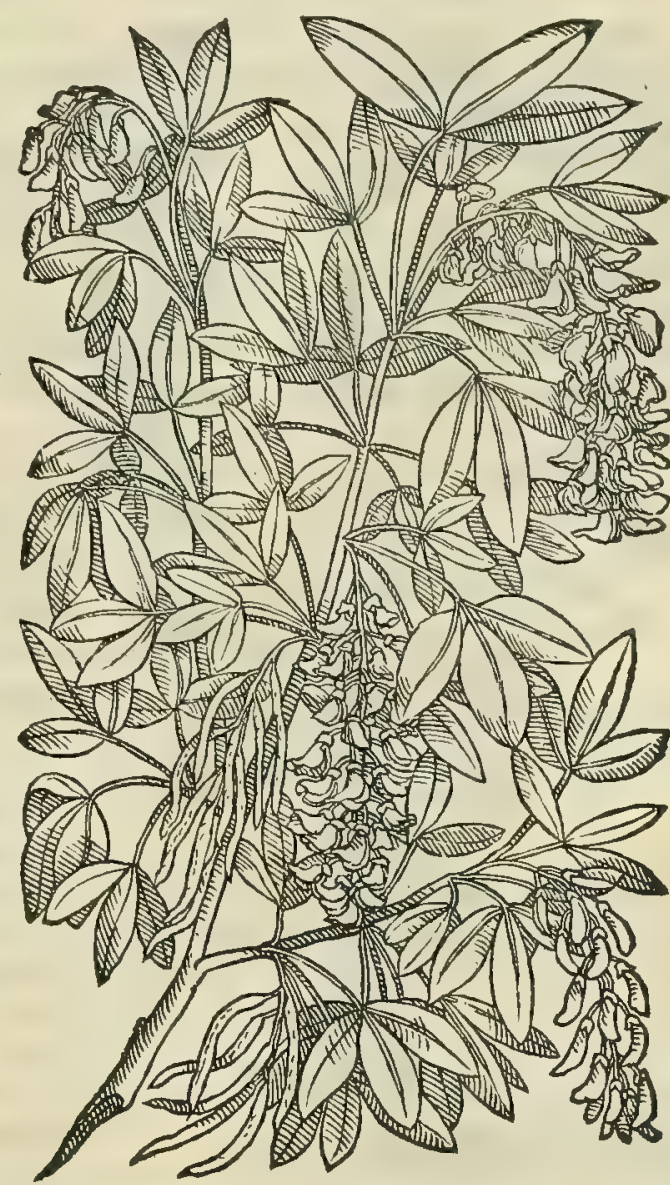

ra Tridentina uulgó uocant Egbelo, maio or iunio men/ibus grato in montibus pectaculo floret. Micat enim aureo flore, alteri omnino fimtli, odore tamen ingrato. Hinc cornicula prodeunt genift a amuld : in quibus femen cötinetur eiufdem genifte magntudine, fed oblongum, phafeoli modo, colore fubnigro. Quod comedentes quandoq; ignari pas ftores, ueluri le gumin $x$, crebris adeó uomitionibus afficiuntur, ut nonnunquam uiderin ego quofdam, qui fanguinem ufque euonuerunt. Materies ligni durißima, qua guaiaci modo exterius lutea eft, interius ueró nigra. Incorrupta diu dur at: proinde uintores ex Anagyri palos factitant fuftinendis uitibus aptißinos, bosq́; cateris praferunt ex $d=$ lijs arboribus fact is. Quin o fagittarij ex ea ualidißumos arcus conficiunt. Hac planta fcatet ualli is Anania, ac uni= uerfus Tridentinus ager. Caterim non defunt è recentioribus berbarijs baud obfcurinominis (quòrum opinionem

40 tuetur. Conradus Gefnerus Tigurinus uir magne lectionis in fuo libro animalibus dicato ) qui putant, ac potius pro Opinio reprobata. certo affirmant, alterum Anagyris genus, quod in montibus Tridentinis uulgarifermone Eghelo appellarifuprà di= ximus, eam fine controuerfia arborem effe, quam Plinius lib. X v I.cap. X v I I I. L aburnum uocat, ubi ita fcribit. $A=$ quas odere cupreßi, iuglandes, caftanea, laburnum. Alpina e bec arbor, nec unlgó nota: dura ac candida matee rie : cuius flor em cubitalem longttudine apes non attingunt. Exijs Plinij uerbis abunde, ni fallor, çognofcitur, quód ut falsa, reprobanda fit illorum opinio. Siquidem Laburni materies à Plinio candida de cribitur : llon contrà meduls litus nigra, corticé tenus lutea, in modum Gudiaci, qualis Egheli wocate materies plané cernitur. Preterea eghelus arbor eft omnibus feré cognita, quòd frequentißima in fyluis reperiatur: non ea quidem uulgó incognita, ut de $\mathrm{L}_{d=}$ burno refert Plinius. Ad hec Egheliflores, qui in arbore racemorun inftar pendent, palmi longitudinem non exce dunt : quos tamen L aburno Plinius cubitales reddidit. Illud infuper experientia compertum habeo (etfi contrarium

so affer at Gefnerus) qujd apes Egheli flores attingunt, nec eos appernantur. Hec nimirum funt, que, meo quidem iu= dicio, refragantur tum Ge fnero, tum omnibus ijs, qui cum co bac in re fentiunt. quinetiam oftendunt, qua m magna fit differentia inter Laburnum e Eghelum. Hanc tamen plantam idem Gefnerus montani cytifi genus effe cenfet, argu mento quid folia ferat terna uclut cytifus, quod'; cytifi modo fit apibus ingrata. Sed is (pace uiri eruditi dixerin) in hoc maxiné ballucinatus deprehonditur, Marci Varronis, Columellx. \& Plini teftimonio : ut qui inter catera feri iubeant iuxta aluedria cytifum, quód buius flore magnopere delectentur $\&$ alliciantur apes. Hoc fimiliter teftatur Galenus libro primo de antidotis, ubi cytifi hiftoriam o uires de fcribit. Et miror certe, Gefinerum illa non widiffe, qux tamen debuerat, fi omnes, qui extant in Europa, libros perlegit, ut perlegiffe conijcitur ex Bibliotheca, quam edidit. Quare equidem non pofjum non in ea perftare fententia, quam iampridem habui de planta Eghelo rocata, cum nulla fit firma ratio, que me cogat illorum fubfcribere iudicio, qui eam Laburnum Plinij effe exiftimant. Quan= tum igitur ego Jentio, Eghelus erit Anagyris minor, aut Anagyris montana, fita nobis liceat eam nominare. Nang: non folim folijs, floribus, corniculis, ,emine, O omnibus deniq; notis Anagyrim prorfus amulatur, ut cius cffigies, 


\section{$476 \quad$ And. MatthioliComm.}

Anagyris uires ex Gal.

Numina.

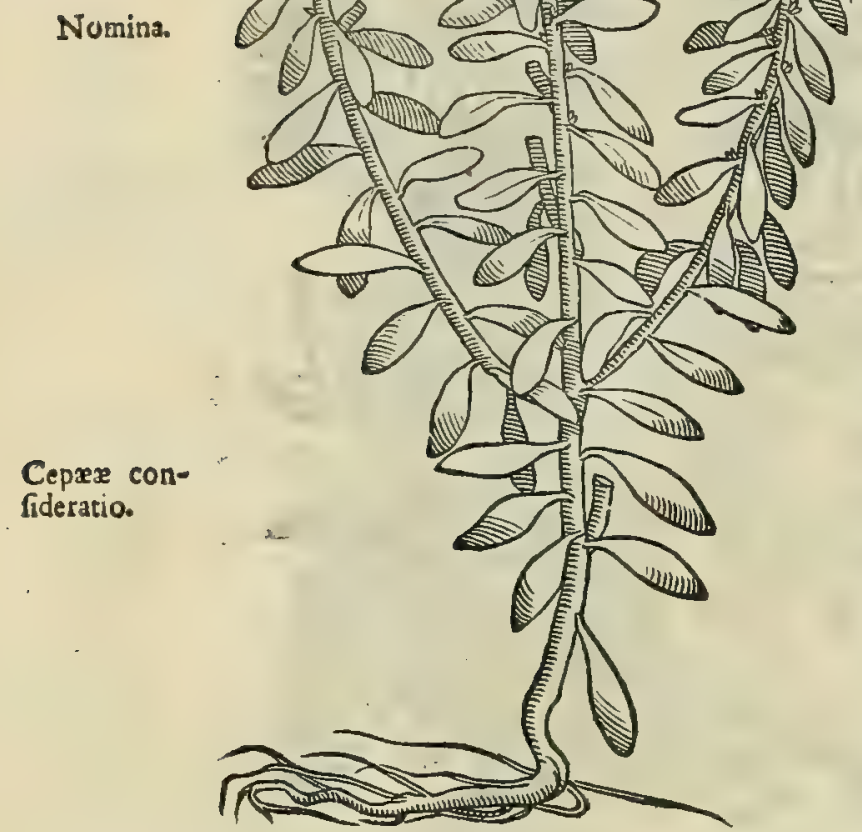

Cepax uires

A IIS M A.

expaulo.

Alifmatis cófideratio.
C E P AE A:

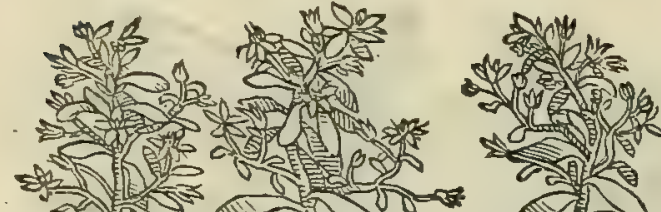

quam hic damus, pulclré demonftrat ; fed etiam uiribus er odoz $r e$, utpote qui in tota planta teter e grauis admodum fentiatur.

Anagyris uires menoris prodidit Galenus ibro v $\mathrm{r}$. Fimplicium medicamentorum, his uerbis. Anagyrus frutex eft graniter $0=$ lens, o acris, digerentis, excalfacientisq́; facultatis. Sed folia etiámnum uirentia, cimm propter bumiditatis admiftionem minus fint acrid, idcirco tumentia reprimüt: At ficcata incidentis funt, exiccantisq; ìalenter facultatis. Similem feré facultatem habet radicis cius cortex. Semen autem magis fubtilium eft partium:

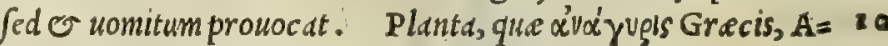
nagyris etiam Latinis dicitur : Anagiri, Italis.

\section{KHW Ciq. CEPAEA. CAP. CL.}

CE P AE A portulacæ fimilis eft, fed nigriora habet folia, \& radicem tenuem. Folia in uino pota urinæ ftilli cidio, \& veficæ fcabie laborantibus opitulantur. maximè id præftat,fi cum decocto radicum afparagi eius, qué myacanthon, hoc eft, corrudam uocant, bibatur.

C E P AE A M, quam anted in noftris commentarijs Italica lingua confcriptis, ingenué confeffus eram me nŏdum comperif= Se, aut ab alijs compertam uidife, boc tempore Venetijs ad me mi fit Iodnnes Odoricus Melcbiorius Tridentinus medicus pro eta $=$ te fua non imperitus, reiq; berbarie non ignarus, mei adeó ftudio fus, ut fi aliud non effet, boc nomine tantim mibi plurimùm dilis gendus fit, ato: etiam in filium babendus. Ad Cepeam banc re= deo. Ea fané mibi uifa eft ita adamußim Diofcoridis de fcriptioni repondere (id quod cius pictura, quam hic damus, graphice $0=$ flendit) ut non dubitdndum putem, quin hac fit uerd ac legitima 30 Cepea. Huius, quod equidem legerim, Galenus non meminit in fimplicium cenfu. Veruntamen Paulus eius mentionem fecit li= bro v I I. inter fimplicid, ubi eam retulit his uerbis. Cepea por= tulace fimilis eft. Folid ipfius contra uefica fcabies utiliter bibü tur . Radix cum apsarago, quem myacanthinum, hoc eft, corru= dam appellant, pota, urine ftillicidia, que ex obftructione funt. abigit. Krwaix ut Gracis, ita Cepea Latinis, o Cepea Ita lis appeillatur.

\section{A"Niouse. ALISMA. CAP. CLI.}

A I I S M A, alij Damafonion appellant: folia ei plan taginis, nifi anguftiora effent, $\dagger$ laciniofa, conuexaque in terram: caule fimplici, tenui, cubito altiore: capitibus thyrfi : flore tenui, candido, pallefcente: radicibus tenui bus, vt ueratri nigri, acribus, odoratis, modicè pinguibus . aquofos amat tractus. Radix, fi drachma una, aut altera bibatur, his conuenit, quileporem marinum deuorarunt, aut à rubetis ranis demorfi funt,aut opiú hauferunt : torminibus, atque dy fenteriæ, per fe,aut cú pari so modo feminis dauci; potui datur . conuulfis , \& contra uitia vulux prodeft. Herba fiftit aluum, menftrua pellit, tumores illita mitigat :

QV A N QV A M affirmat Ruellius, cui etiă Fuch/ius fub= fcribere uidetur, Alifma fibi cognitum effe, uocarió, à nonnullis Paftoralem fiftulam, à quibusdam ueró Plantaginem aquaticam; tamen plantago hec, quam etiam aliqui Barbam fyluanam appel lant, nullis notis cum A lifmate conuenire deprehenditur . Siqui= dem Alifma folia fert plantagini fimilia, fed anguftiora, or in ter ram reflexa: caulem mittit fimplicem, ac tenuem. Plant.ıgo au= 


\section{InLib. tertium Diofcoridis.}

tem aquatica folijs prodit plantagine maioribus, lancearum cupidum inftar acuminatis, furfumq́; pectantibus : mul= tiplici caule, adnatis pluribus referto. Cum itaq; ex ijs notis collatis conftet, Alifna, E Barbam fjluană inter fe plu= rimuin differre, non temeré facere uidcor, quód illorum fententie non aujim adfipulari. Porró plantam, quam lìc pro Alifmate depingi curauimus, mihn prinum Prage oftendit Ad.mus Leonorus, iunenis pectate doctrina, or rei berbarieftudiofis. Quód enim hec onmibus, nifallor, notis Alifma reprafentet, meritó fit, ut iam non dubitem af= firmare can effe legitimum All]ina : aut faltem cus cffigiem exbibere, ut aliorun quoq; de ca fit iudicium. Corterum

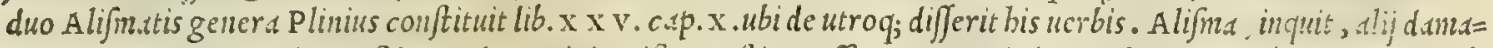
fonion, alij lyron appellant . folia ci plantaginis, nifi anguftiora effent, er magis laciniofa, conucxá́; in terram, aliâs etiam uenofa fimiliter : caule fimplici, e tenui, cubitali: capite thyrfi: radicibus denfis, tenuibus, ut weratri nigri, 10: acribus, odoratis, pinguibus. najcitur in aquo/is. Alterum genus elufdem in fyluis, nigrius, nuxioribus fölijs. bee $\mathrm{Pli}=$ nius. Alifina mentoria prodidit Galenus libro $\mathrm{v}$. fimplicium medicamentorum, fic de cius uiribus differens. Dd= mafonium, aut Ale ina. De hac herb.i in tertio libro tradit Diofcorides, quod radix eius epota dy fentcrias fanet, er aluum fiftut, atq; cedemata mitiget. Sed nos ca quidem experti non fumus. Quód autem conftitutos in renibus calcu= los aqua, in qua decocts fuerit, pota comminuat, cafu experti fumus. Ex quo liquet, quód abfter forian quandam fa=

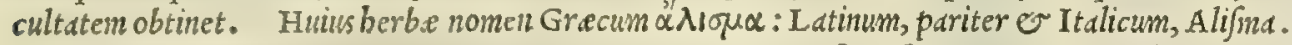

† Hec nox non legitur in Grecis codicibus, neque ab Oribafio refertur, neque etian à Marccllo uertitur. Vnde plané fupicor, quód Rucllius ita uerbum boc ex Plinio adiecit, ut reliqua etiam ex eodem reddidit.

$$
\text { O'voßguxis. ONOBRYCHIS. _ _ _ _ CAP. CIII. }
$$

20. O N O B R Y C H I folia habetlentis, longiora paulò: caulem dodrantalem: florem puniceum radicem paruam. nafcitur in uliginofis, \& incultis. Herba fuapte ui, fi trita illinatur, tubercula diffipat : cum uino pota, ftrangurias fanat: illita ex oleo, fudores mouet.

N A S C I T Y R Onobrychis, Plinio libro X X 1 I I I.cap. X v I. authore, circa fontes. Folia babet lentis, pau= lólongiora: florcm rubentem : radicem exiguam, o gracilem. Sunt qui Onobrychin uelint eam effe herbam, quam aliqui Rutam caprariam, alij Galegam uocant: nos ueró uulgó Lauane $\int e$. Verùm bac notis, qua Onobrycli tribuun tur, baudquaquam refpondere deprehenditur . quippe que folia ferat lentis quadruplo maiora, caulem plerunque bi= cubitalem, flores purpureos, e radicem non paruan. Vt binc mibi plané uideatur, quód illorum opinioni nemo re= cté poßit, aut debeat ad/tipulari. Onobrychidis uires tradidit Galenus libro v I I I. fimpliciummedicamentorum, 30: - Iic inquiens. Onobrycbis rarefaciendi, digerendiğ; uim obtinet: proinde folia eius uirentis etiámnum illita ad morem

H Y P ERICVM.

40

50
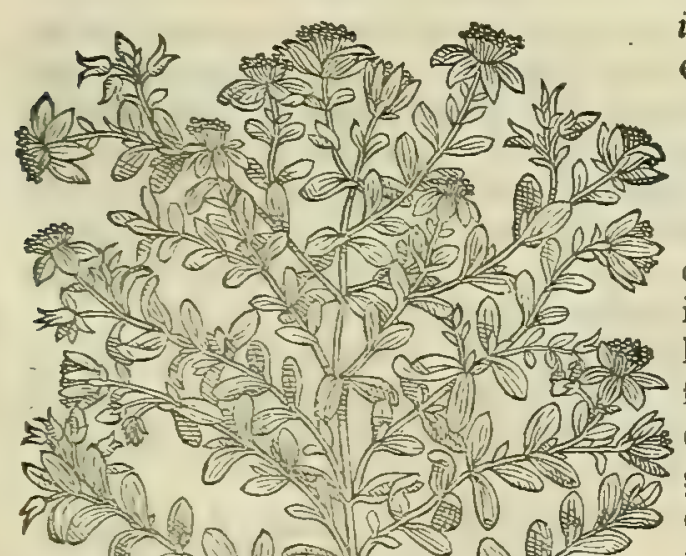

cataplafinatis tubercula difcutiunt:arefacta ueró, fi cum uino bibantur, frangurids fanant. Quinetiam fudores elicit cum oleo inuncta. Que óvoßpux is Grace, Onobrychis item Latiné, o Onobrichi Italicé uocatur.

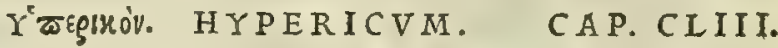

H Y PE R I C V M alij androfrmon, alij corion, alij chamæpityn appellant, quoniam femen odore refinam imitatur: furculaceo frutice, dodrantali, tubefcente: folio rutæ: flore luteo ${ }_{9} \dagger$ leucoio fimili, qui digitis attritus fanguineum fuccum remittit,qua ex caufa androfemon cognominatur: fubhirfuta filiqua, \& in rotundo oblon ga, hordei magnitudine: femine intus nigro, refinofi odoris . gignitur in locis cultis, \& afperis. Vrinam cit; menftrua pellit appofitum : tertianis, quartanisq́ue cum uino potum liberat. Scmen quadraginta diebus hauftum, ifchiadicis medetur. Folia cum femine illita, ambufta fanant.

\section{Äбxч९or. ASCYRVM. CAP. CLIIII.}

A S C Y R ON, fiue afcyroides, hyperici genus eft, magnitudine dif́ans, fruticofius, maiores habẽs ramos, furculofiores, rubentesq́ue: folia tenuia : flores luteos, \& fructum refinofum, hyperico non abfimilem: cuius attritu digiti ferè cruentătur, qua de caufa androfæmon vocauere. Vfus feminis ad ifchiadicos, porum in hy dromelitis fextario:nam biliofa recrementa amplifsimè detrahit . fed a fsiduè dare oportet, donec fanitati re-

fituantur. Illinitur \& ambuftis efficaciter.
A'v $\delta g^{\prime} \sigma \alpha u \mu \%$.

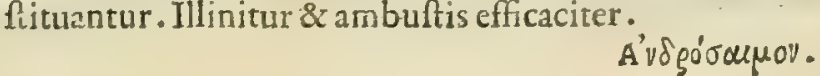

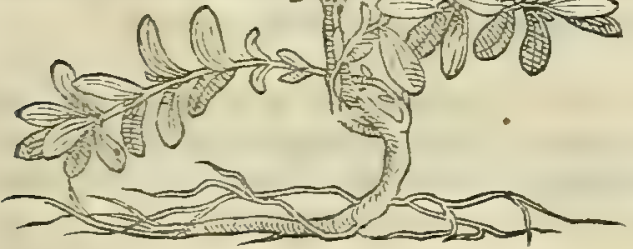

Alifmatis uires ex Gal.

Nomina.

Onobrychis confideratio.

Vires ex Galeno.

Nomina. 


\section{And. Matthiol ${ }_{1}$ Comm.}

A SCYRVM.

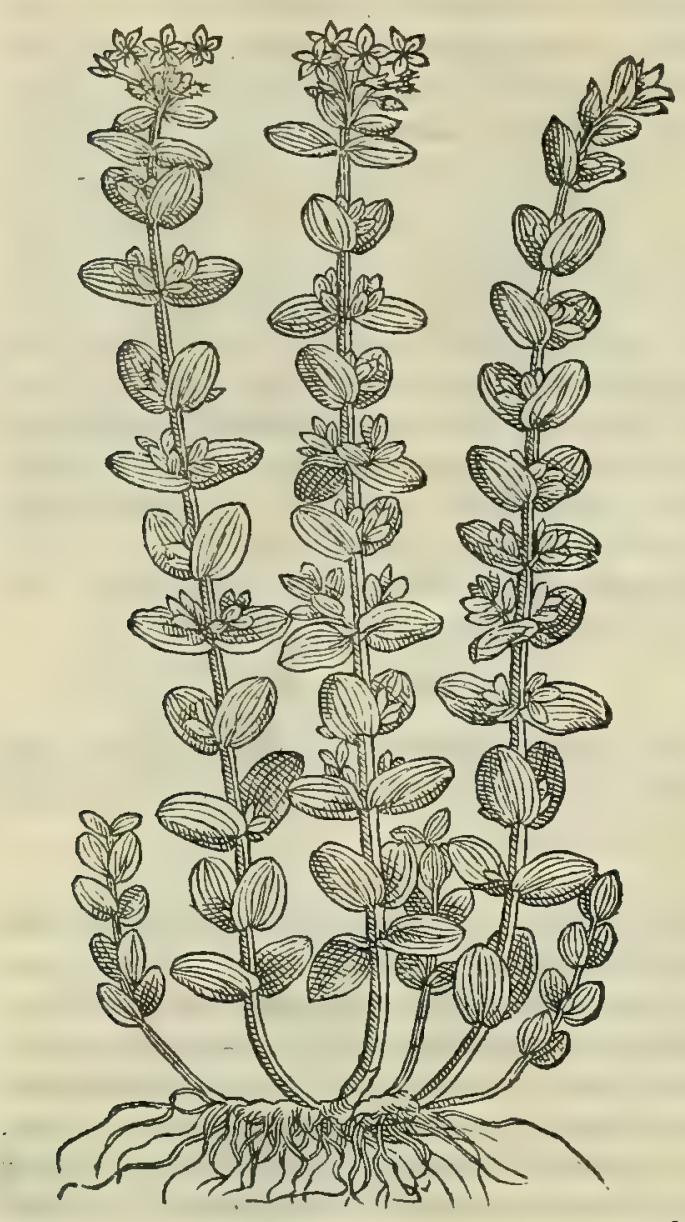

C O R I $s$.

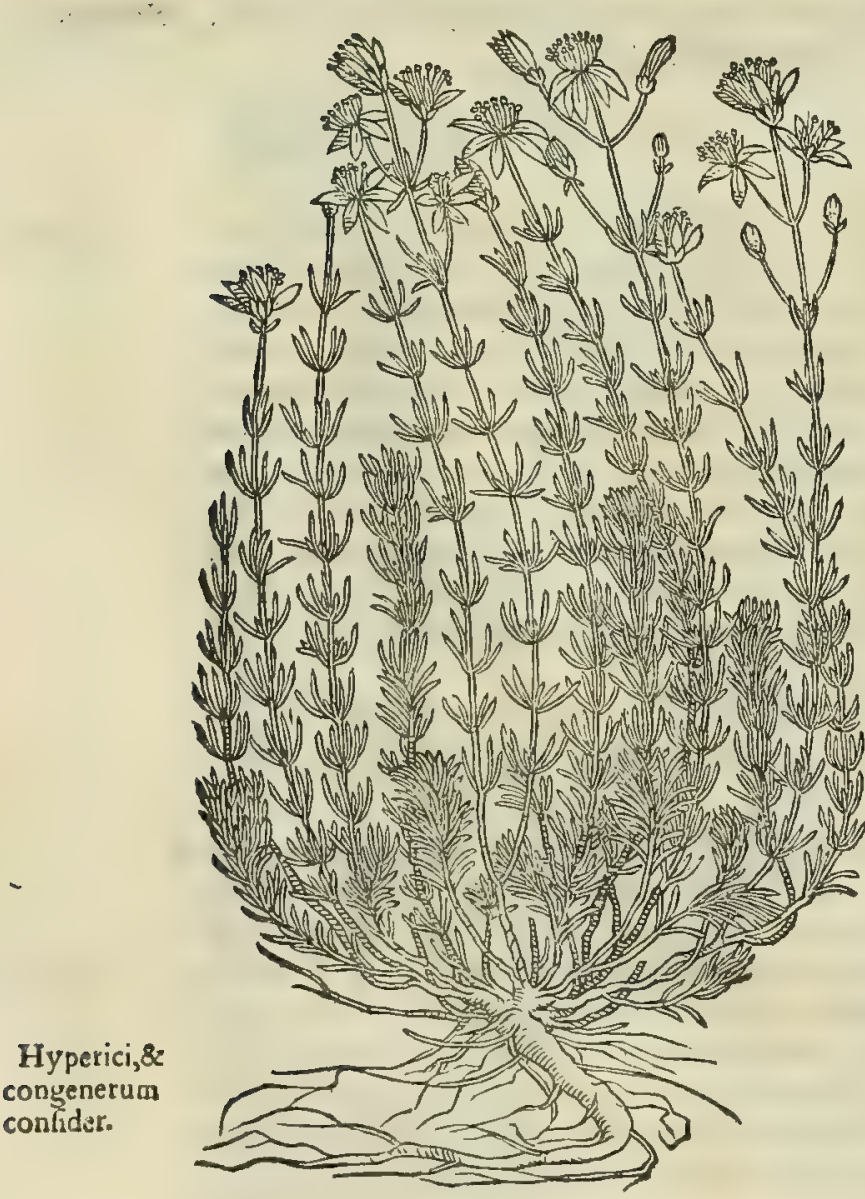

A N D ROSAEMVM.

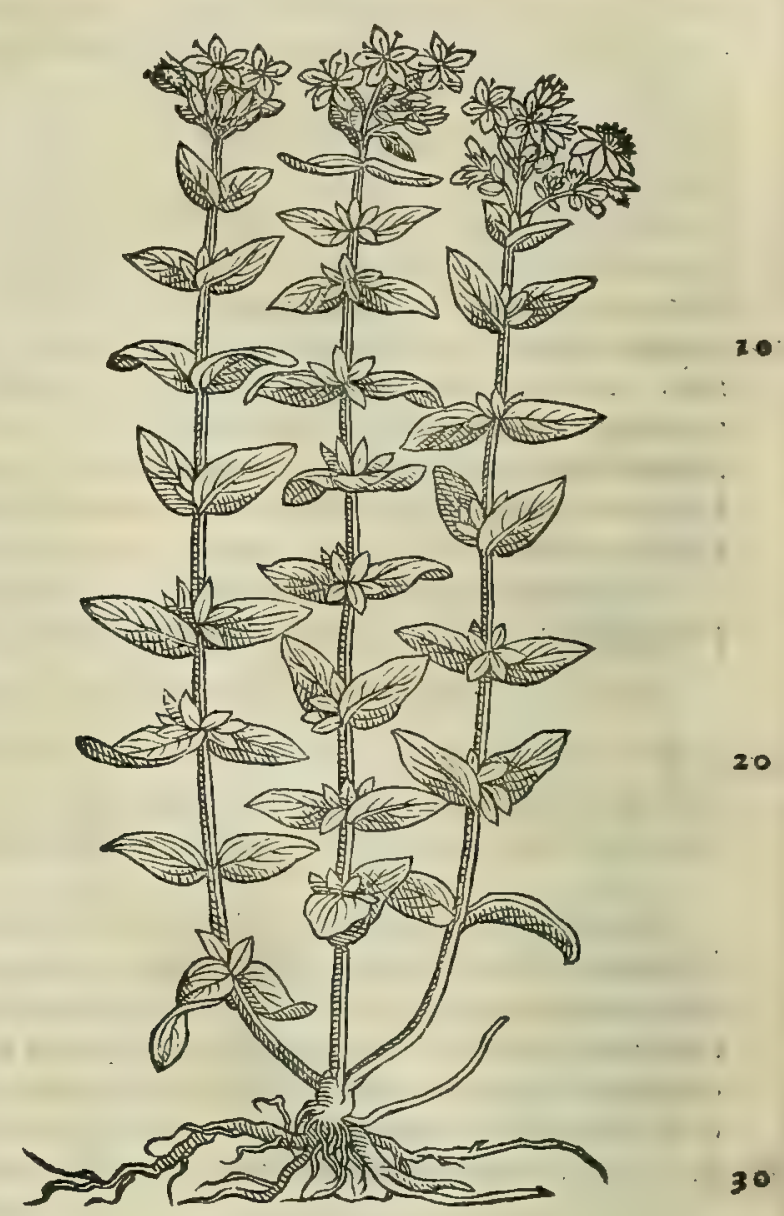

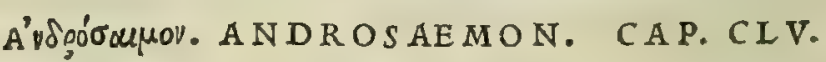

AN D ROS AEM ON ab hyperico, afcyroq́ue differt, quòd fruticet ramulis furculofis, ac tenuibus : rubentibus uirgis, \& folijs rutæ, triplo aut quadruplo ma ioribus, qux trita uinofo fucco manant . complures alas habet in çacumine, utrinque expanfas, pinnatasque: cir ca quas fiores pufilli, lutei : \& in calyculis femen papaueris nigri, inligne lineis. Huius comæ tritæ refinofum odorem reddunt. Semen tritum drachmis duabus po- 40 tum, biliofa alui excrementa pellit. ifchiadicis maximsè medetur: fed à purgatione aquam exorbere oportet. Herba ambultis illita medetur, \& fanguinem cohibet.

$$
\text { Kộs. CORIS. CAP. CIVI. }
$$

C o R I s, quod aliqui hypericon uocant, frutex eft folio ericx, rubro, pinguiore, ac minore, non altior dodrante, fuauis, odoratus, acris. Potum femen menfes tra hit, \& urinas : contra phalangiorum morfus, ifchiadi- so $\cos$, \& opifthotonicos ex uino potum auxilio eft : horroribus ex pipere, fed opifthotonicis ex oleo, aptifsimè illinitur. Radix uino decocta potaq́ue, defectis opem ferre creditur: fed laborantem inter potandum quàm optimè cooperiri licet : fiquidem corpus totum defuda bit, ex qua re priftinam agilitatem recuperabit.

H Y P E R I C V M, A fcyrum, O Androfemum, eiusdem plane generis plante (ut Diofcorides inquit) effe videntur. Ve= rum in earum caulibus, \& folijs aliqua notatur differentia : nam bac folla babet rubétior a, illa uiridior d, uni maiora infunt, atteri 


\section{In Lib. tertium Diofcoridıs.}

minord. Similis difcriminis ratio in caulibus. Omnes ba congeneres plante bodie ab omnibus unlgó cognof cuntur: ea nanque iunio, or iulio mensibus, diuer/is in loc is aureis floribus ornate conpiciuntur, ijs adamußin diftuncte de predite notis, qux fingulis : Diofcoride tribuntur. Ceterum que Coris uocatur, non ita Hypericum refert, quem= admodum Andro femum, o A cyrum. quippe que non altior dodrantali altitudine affurgat: folijs erice, minoribus tamen, of fubpinguibus : caulibus ruffecntibus, odore fuau, ac grato. Hac ad me pluries allata eft a noftris berbd= rijs. nafcitur ficquentißima in Italia. Hypericum à perforatis folijs à no/tris unlgo Perforata uocatur : folia cnin innumeris fattent for ammibus, ijsó; adco minutis, ut uifum effugiant, nifi ipfa folia fole obict, infpiciantur . id quod

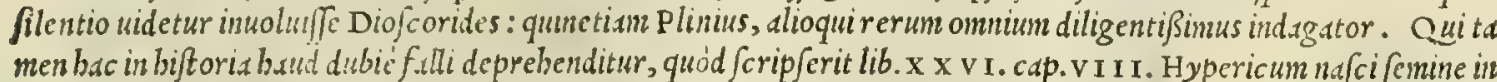
so filiqua, nigro, m.turefcentc cun hordeo. Siquidem Diofcorides non tradit Hypericum cum bordeo maturefcere, fed contineri eius nigrum femen filiqua fubbirfuta, o in rotundo oblonga, bordei magnitudine. Conftat praterca annua experientia maturefcere bordcum plerunque abcunte maio : uerium Hypericifemen non perficitur, nifi iulio, $\mathbb{E}$ au= gufto menfibus. In bac quoq; Hypericibiftoria errat Brafauolus medicus licet clarißimus, quód uelit Hypericum ex Diof coridis auctoritate florem album babere : exmq́; ob caufam, id quod circunfertur, cumflore fit melino, illegi= timum efe putat; inó non aliud, quàm Rutam fyluefrem, pro qua pharmacopolan fecum colloquentem, id ipfum afe feriare admonet. Neque in bis uno tantum, $\int_{e d}$, quantum $\int \mathrm{e}$ ntio, duplici notatur errore. Primum quod Hypericum

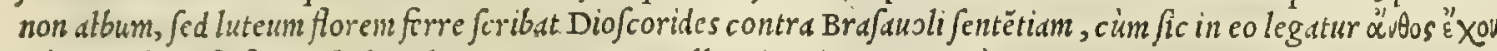

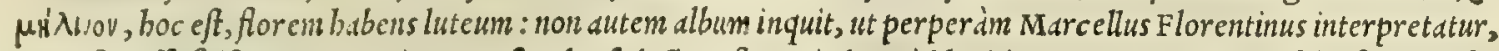
cuius fortaffe falfa interpretatione Brafaulus feductuseft. Deinde quód legitimum Hypericum pro fylueftriruta fer

20 uandum cenfuerit, cium tamen in calce feré fui uoluminis prioris fententix oblitus, dum olei ex Hyperico parandi $\int e=$ niori inyropole rationem explicat, communis usus Hypericum A fcyrum effe declarat. Nec fecus quàm Brafauo= lus ballucinantur, pace corum dixerin, Monachi illireuerendi, qui in Mefuem commentarios ediderunt, quód non re

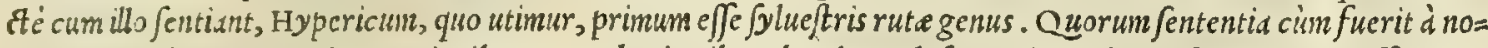

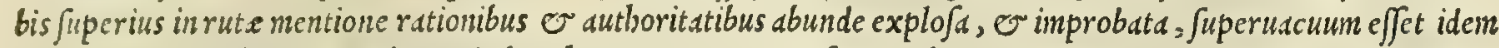
nunc repetere : é enin accedet, qui plura horum crrata cognofcere uolet. Hyperici uires memorix prodidit Ga= lenus lib.v I I I. Fimplicium medicamentorum, fic inquicns. Hypericum calefacit, e deficcat, tenuisq́; fubftătice eft, adeó ut or menfes, o urinds prouscet. Sed ad bee totus fumendus eft fructus, non tantün femen. Porró cum folijs illitus uiridis ad cicatricem ducit cum alia, tum etiam ambufta. Ceterim fificca contufa inpergas, fanabis bumida, ew putredinofa ulcera. Sunt er quilifcbiadicis bibendum exbibeant. Idem lib.v I. de Androfemo ita fcribit. Andro

30 femum planta fruticofa, natura duplex : unum ènim Afcyron, $\mathcal{O}$ Afcyroides nuncupatum eft, Ppecies byperici. Al= terum ueró à quibusdam Dionyfís appellatur. Eft autem femen eorum purgatorium. Foliorum ueró facultas modi= cé extergens $\mathcal{O}$ deficcans, ut $\mathfrak{E}$ ambufta fanare credantur. Caterùn in uino auftero decocta, uinum ip fum magno= rum uulnerum glutinatorium efficiunt. Sed quòd de Cori mentionem fecerit Galenus in fimplicium medic amentorum

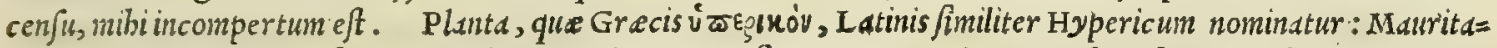
nis, Reiofricon, $\int e u$ Reiof aricon: Italis, Hiperico, $\sim$ Perforata: Germanis, Sant Iobans kraut: Hipanis, Coraion=

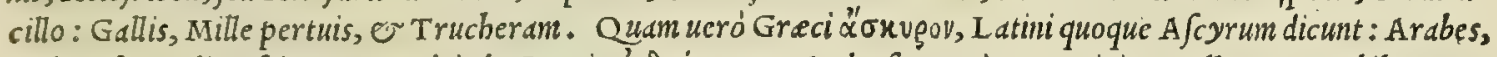

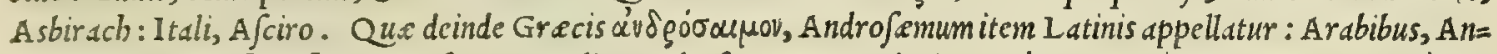
drofeman, Androfion, fiue Andrefagian: Italis, Androfemo. Quxe denique Hógs Grecé, Coris ctiam Latiné, er Cori Italicé nocatur.

+ Quoniam boc loco in uulgatis exemplaribus Grecis nulla fit albe uiola mentio; idcirco funt qui illorum tefti= monio freti, uerbum illud auferant ex interpretibus. Sed quomodo id recte factum fit, non uideo : fiquidem in Oriba

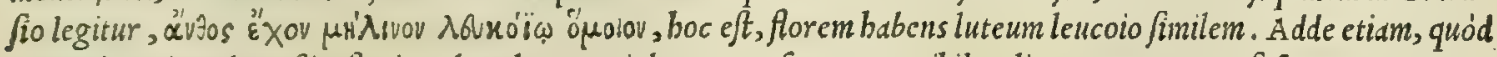
Hypericum ita adamußin floris colore luteam uiolam reprefentat, ut nibil melius. Nos autem ufi fumus uoce Gres= ca, ne ex albo, quod forté Marcello impofuit, aliqua poßit oriri difficultas.

$\dagger$ Que bic Jequuntur, in Grxcis codicibus impreßis non boc loco, fed in fine inter notha, of Diofcoridi falsó ads fcripta leguntur, ut que adfcititu fint habita. Nos ueró illa buc admifimus Ruellij, ut facimus, interpretationem fe= cuti: necnon etian fidem codicis manu fcripti.

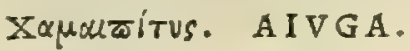

\section{CAP. CLVIT.}

so A I v G A herba in terra repens, fubcurua : folijs femperuiui minoris, multò tenuioribus, hirfutis, \& pinguioribus, circum ramos frequentibus, odore pinus : flore tenui, luteo, uel candido: radicibus cichorij. Folia feptem diebus in uino pota regio morbo medentur : \& quadraginta diebus ex hy dromelite, ifchiadicos fanant. Dantur peculiariter urinæe difficultatibus, iecinoris, \& renum uitijs: torminolis profunt. Ea apud Heracleam Ponticam, perinde atque antidoto, contra aconitum utuntur, bibentes decoßtum. Ad antedicta illinitur, cum polenta iure decocti fubacta. Trita in farinam,\& cum fico in pilulis fumpta, alu'um emollit : excepta melle, cum æris fquama, \& refina deijcit : appofita ex melle, vulux uitia extrahit: mam marum duritias difcutit, vulnera glutinat: vlcera quæ ferpunt, cum melle illita, cohibet. Alterum eft genus aiuga, cubitalibus ramis, in anchorx fpeciem incuruatis, prætenuibus : coma fupradictæ, flore candido, femine nigro. hæc etiam pinum redolet. Tertia mas nominatur, paruula, folijs exilibus, albis, fcabris: caule afpero, candido : luteis flofculis, femine iu $x t a$ alas . refspit \& hæc pinum. Hx duæ uim fuperioris abtinent, fed non ufqueadcò cficacem . 


\section{And. MatthioliComm.}

CAMAEPITYS PRIMA.

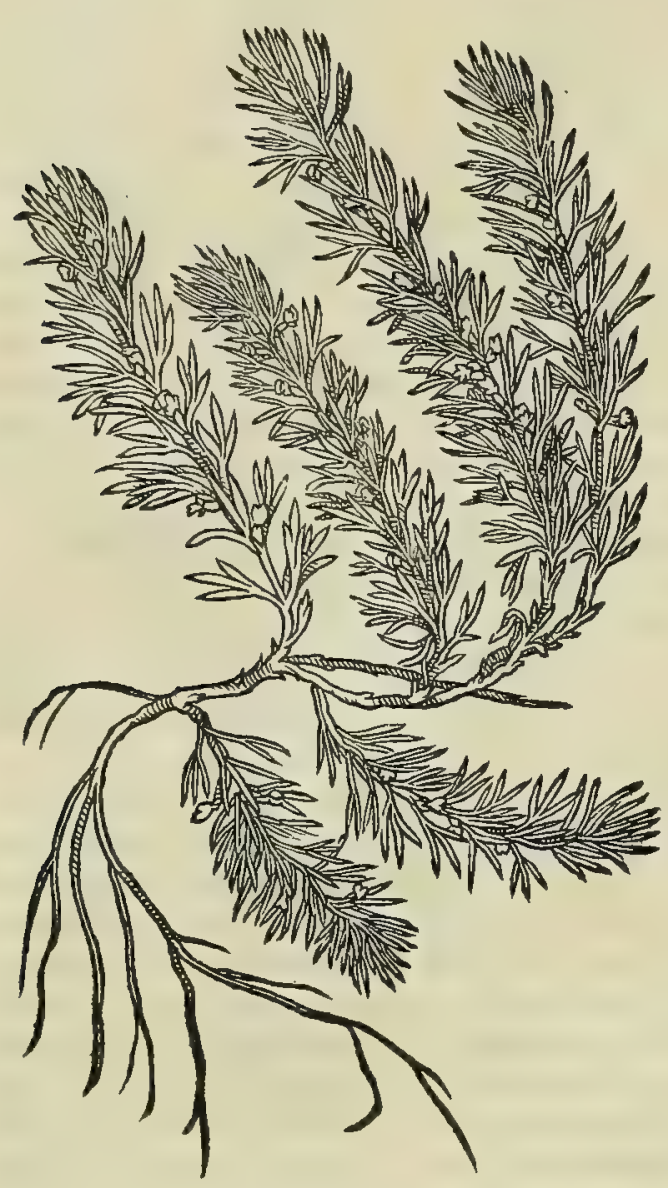

Aiuge confideratio.

AI VG AM, quam Greci Chamepityn uocant, quonian folijs, or odore pinum refert, herbariorum uulgus I uami arthritic am appellat, quód ifchiddicis, or alijs articulorum doloribus opem ferat non obfcuram. Vulgaris eft notitive Aiuga, qua primo generi adfcribitur. Verüm poftrema, quam $\int a p i u s$ etiä uidimus, non adeo omnibus eft nota. quem: Cuiuddä Ger admodum nec media, quam bactenus mibi quidem uidere non licuit. Caterùm in aperto errore uerfabatur Germa= mani errox. nus ille pharmacopola, qui Brafauolum docuit Aingam Germanica lingua uocari Vergiß mein nicht. Quandoquidem berba buius nominis mibi cum Germanis iandiu uerfanti notißina eft: que tamen nulla prorfus ex parte quámuis Aiu Chamepity- gamreprefentat. Chamapityos meminit Galenus lib. v I I I. Iimplicium medicamentcrum, ubi de eius uiribus ita $4^{\circ}$ os uires ex fcriptum reliquit. Chamapitys guftu quidem amarum faporem acri ualidiorem obtinet. Effectu ueró expurgat, ab= Galeno. ftergitó; uifcera plus quàm calfacit. Proinde regio morbo laborantibus, Er omnino quibus facilé iecur obftruitur, bonum eft medicamentum. Quin er menfes ducit tum potd, tum appofita cum melle. Sed $\sigma$ urine mouende aptum eft medicamen. Sunt autem qui etiam eam exhibent decoctam in melicrato ijs, qui coxendicis doloribus torquentur: Herba porró ip $\int a$ uiridis uulnera magna conglutinat, or ulcera putrefcentia fanat. Preterea mammarum durities

Nomina. difcutit . Eft enim in ficcando ordinis tertij, in calfaciendo ueró fecundi. Qua berba Gracis $\chi \alpha \mu \alpha u$ ítvs, $L d=$ tinis Chamepitys, Aiuga, \& Abiga nuncupatur: Mauritanis, Hamefitbeos, feu Chamafithius: Italis, Chamepitio, $\mathcal{O}$ Iua: Germanis, Ye lenger ye lieber: Hippanis, Pinilho, $\mathcal{O}$ Yud artetica: Gallis, Iue mufcate, aut arthetique.

LI B R I TER TII FIN IS. 


\title{
$48 \mathrm{I}$ PETRI A NDREAE MATTHIOLI MEDICI Senenfis Commentarii,
}

\section{IN LIB. QVARTVM PEDACII DIOSCORIDIS}

\author{
A NAZARBEI, DE MEDICA MATERIA.
}

$T$

R I B V S A N T E' libris, amantißime Aree, tradidimus odoramenta, olea, arbores, vnguenta, animalia, frumenta, olera, radices, fuccos, herbas, feminaqúue. In hoc autem quarto differemus de radi-

cibus, oveis, que reftant, herbis.

KÉsgov. BETONICA.

so

40

so

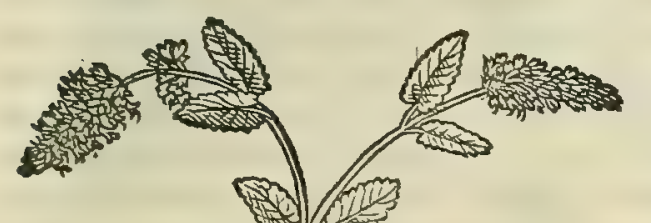

CES T R ON pfychotrophon uocitatur, quoniam frigidis locis inueniatur. Latini Betonicam appellant. Herba eft caulem ferens tenuem, cubiti altitudine, aut maiorem, quadratum : folia quercus, mollia, longa, in ambitu diuifa, odorata, prope radicem maiora: in fummis caulibus femen, ueluti fatureix, fpicatum eft . Decerptahuius folia ficcantur, plurimos ad ufus . Radicibus nititur, ut ueratri, tenuibus . quæ ex hydromelite in potu, pituitofam uomitionem euocant. Folia dari debent ruptis, conuulfis, mulieribus vuluæ malo opportunis, 8 ad laxandos uteri ftrangulatus, denarij pondere cum hydromelite : tres in uini fextario drachma cốtra ferpentium morfus ebibuntur. Herba magna utilitate illatis à ferpente vulneribus illinitur.aduerfus etiam uenena drachma ex uino pota conuenit: præfumpta ea, fi uenenum hauriatur, nihil nocebit. vrinam ciet, aluum fubducit. Medetur comitialibus, $\&$ infanis pota ex aqua : $\&$ iecinoris, lienisq́ue uitijs drachmæ pondere in aceto mulfo . concoktionem adiuuat, fi quis fabæ magnitudine fecundum cœenam cum melle cocto deuorauerit : modo confimili acida ruktantibus propinatur. ftomachicis eam manducare, \& fuccum deuorare proderit, fi poftea dilutum uinum forbeatur. Datur fanguinem excreantibus, tribus obolis cum diluti uini cyatho: ifchiadicis; renum, \& ueficæ doloribus ex aqua. aqux inter cutem binis drachmis ex hydromelite, fi febricitant: fin aliter ex mulfo. regio morbo laborantes recreat: menfes pellit drachmæ pondere cum uino pota. aluum purgant drachmæ quatuor potæ in hydromelitis decem cyathis . facit cum melle ad tabem, \& purulentam excreationem. Folia ficca, tritaq́ue fictili uafe rẹconduntur.

B E T O N I C A herba eft nullis non cognita, or innumeris predita uiribus. Vnde Itali, cüm aliquem laudibus familiariter extollere uolunt, uulgari prouerbio dicunt. Tu bai piu uirtu, che non ha la Betonica, id eft, $T$ u pluribus preditus es uirtutibus, qudm Betonica. Scripfit de Betonice viribus proprium libellum Antonius Mufa clarißimus Augufti $C$ faris medicus, in quo bec de ea memorix prodidit. Herba Betonica nafcitur in pratis, e montibus mun=

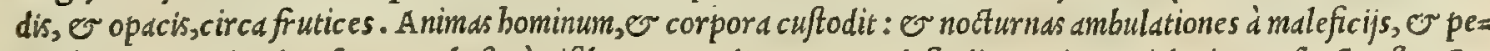
riculis. Loca quinetiam $\int a c r d, 0 \sim$ bufta ḋ uifibus metuendis tuetur, ac defendit : 0 in onni deniq; res $\int a n c t a$ eft. Ce= 
fron uocdtur, 0 jynchotrophon : fiquidem frigidis reperitur in locis, radicibus tenuibus, thyr $\int o$ pariter tenui, $c u=$ biti altitudinem excedente, quadrangulo. Folia profert quercus, odorata: fenen in fummitate thyrfipicato, thism= bre modo. Pollet uniuer fa planta dotibus fere innumeris. quandoquidem tufa capitisq́; uulneribus illita, ea mira ce leritate conglutinat. proftat id tamen efficacius, fi tertio quoq; die iterum, atq; iterum imponatur. Aiunt pretcrea tam ualentioris effe facultat is, ut offa quoq; fract a extrahat. Radicum ex aqua decoctum ad tertias fotu oculorum do= loribus medetur. quod item praftant contritafolia, e fronti fuperimpofita. Succus à folijs per fe tritis expreffus, aut prius aqua maccratis, aurium dolores mulcet, fi tamen addito rofaceo in aures egelidus infilletur. Idem drach= me pondere bauftus in aque calide cyathis quatuor, fanguinem illum per inferna trabit, cuius redundantia caligines oculis offundit. quo fit, ut etiam uifum acuant comefta folia. Eadem cum falis momento contufa, naribusqj; immiffa fanguinern inde flucitem fiftit. Betonice decostum ex uetere uino, aut ex aceto dentium dolores finit, $f i$ co os fepius 20 colluatur. Herba ip $\int a$ ex tepenti aqua pota fupirio/is, er anbelofis inaximé proficit. Folia melle excepta tabidos iu= uant, prefertim qui purulenta cxtußiunt. Eadem tribus continuis diebus deuorata draclmarum quatuor pondere, aut ex frigida aqua cyathis quatuor ebibita, uentriculi dolores mulcet: iecinoris ueró, $f$ ex calida bauriatur. Ex uino decocta lienis uitijs medetur. Sanat or renum uitia ex mulfo bibita, duarum drachmarum pondere: ex uino au= tem ueteri trium drachmarum pordere, additis piperis granis feptem $v$ uiginti, ad lateris, lumborum $\dot{q_{;}}$dolores uti= lißstmé bibitur. In duobus aque calida cyathis fumpta, alui es inteftinorum tormina remouet, fi tamen à crudis non

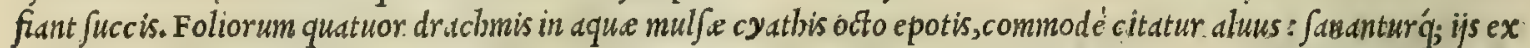
uino fumptis coli inflammatione uexati. Betonic a in eclegmate cx melle fumpta nouem diebus, tußsin fedat: Pota in aque calide cyathis quatuor duarum dracbmarum pödere, addita plant aginis dracbina, febres quotidiands expellit, quod tamen in acceßionibus tantum fieri debet. Idem preftat etian in tertianis; fi cum pari pulegio affuinatur. Sandt ipfo quoq; ordine etiam quartanas in tribus aque calide cyatbis baufta, trium drachmarum pondere, addita mellis uncia : calculi franguntur. Betonica ex tepenti aqua feliciter bibitur bydropicis. Pariendi celeritatem affert, uteriq; cruciatus a frigiditate conceptos mulcet, fi ex calida aqua, aut mulfo duarum dracbmari pondere propinetur. Con= trita folia illita, precifos glutinant ne ruos, or refolutos iuuant. Eadesn triun dracbmarum póndere ex caprillo

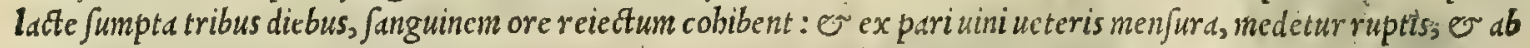
alto dewolutis. Prefumpta ebrietatem arcet. Ex uino frequeter baufa, ifericos fanst: O fullo adipe admifta, car= bunculos curat. Potu ex ace to mulfo unius drachme pondere, uiatoribus longo itinere defatigatis uires mirificé refi= cit. Faftidia abftergit, e ftomachicos recreat. Aduerfatur uenenis, o ferpentium, o uenenoforum rabidorumq́; quorumcunq; animalium mor fibus non modó intus fumpta, $\int e d$ etiă extrà emplaftri modo impofita. Cuniculofa, finuo= fáq. fanat ulcera cum fale indita. Ex uino haufta men fes ciet. Potu dolores podagricos lenit, prafertim radicum de= Betonicx ui- coctum potum. idemó; preftant contrita folia impofita. Betonic a uires memoria prodidit Galenus lib. v I I. fim= res ex Gal. plicium medicamentorum, fic inquiens. Cefron, aut $\mathrm{P} / y$ chotrophon, Ronané ueró Betonica, uim babet incidendi, ut guftus indicat. Amarior enim eft, or fubacris ip $\int a$ berba : id quod o particulatim edita actio oftendit. Nam conf $i=$

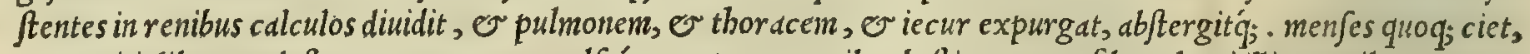
or comitidlibus prodeft : tum rupta, conuulfáq; curat, o omnibus beftiarum morfibus ulceri illita duxiliatar. Po=

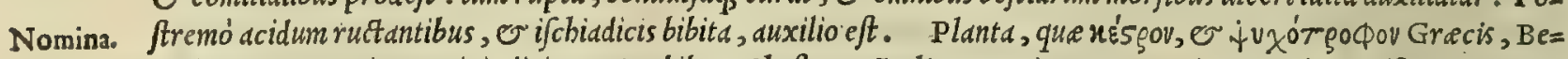
tonica, o Vetonica Latinis dicitur: Arabibus, Chaftard:Italis, Betonicd: Germanis, Betonien: Hipanis, Breto= nica: Gallis, Betoefne, or Betoine.

\section{B९єтаиหน่. BRITANICA.}

CAP. II.

B R I T A N I C A, aut Vetonica, folia habet fylueftris lapathi, fed nigriora, \& pilofiora, guftu adAtringentia : radicem tenuem, \& breuem caulem paruum emittit. Folijs exprimitur foccus, qui igni aut fole cogitur. Vim habet adfringentem, priuatim depafcentıbus oris, \& tonfillarum ulceribus accommodatam. Valet etiam ad reliqua, quibus adfrictione eft opus.

Britanicx có- Q Q A N Q A M tradit Ruellius Britanicam effe plantam Italia cognitam, dtq; ibi uulgó appellari Piatama= fideracio. no; mibi tamen hactenus non folim nomenillud incompertum eft, fed nullum etiam inuenire obtigit, qui Britani= cam oftenderet. Hanc autem fcriptis celebrauit Plinius libro $\mathrm{x} x \mathrm{~V}$, cap. I I I . bifce uerbis. In Germania trans Renum castris à Germanico Ca fare promotis, maritimo tractu fons erat aque dulcis folus, qua potadentes intra biennium deciderent, compagesq́; in genibus foluerentur. Stomacacem medici uocabant, or fceletyrben ea mala. Reperta auxilio eft berba, que uocatur Britanica, non neruis modó or oris malis falutaris; fed contra anginas quoque, o ferpentes. Folia babet oblonga, nigra: radic em etiam nigram. Flos ci, qui (ut certó proditur) col= lectus priusquàm tonitrua audiantur, er deuoratus fecuros in totum reddit bomines. Frisij, quà caftra erant, no= ftris demonftrauere illam. hec Plinius. Ceterum non defunt, qui Britanicam cenfeant cam cffeftirpem, quam

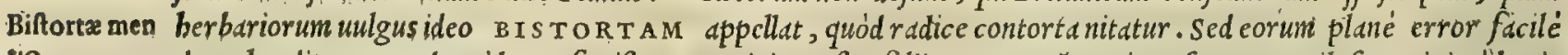
tio. deprehenditur. quandoquidem etfi Biftorta rumicis conftet folijs; non tamĕ ea nigra funt, neq; pilofa : quinimo' lauia apparent, supernè rufefcentia, or ḋ terra quadantenus cafia. Ad bec Britanic radix fubeft tenuis, breuisí;: $\mathrm{Bi}=$ ftorte ueró craffa, ferpentis iacentis modo contrasta, er intorta, colore rubio, non (ut Plinius inquit) nigro. Sed praterea non de funt etiam, qui Tormentillam fic officinis, $\mathcal{F}$ uulgó uocatam Biftorte generi adfcribant, quód non facie, fed fortaffe uiribus illi repondeat. Que quoniam hic nobis occurrit, or quàm plurinis effertur laudibus, ideo 


\section{In Lib. quartum Diofcoridis. $\quad 483$}

\section{BISTORTA.}
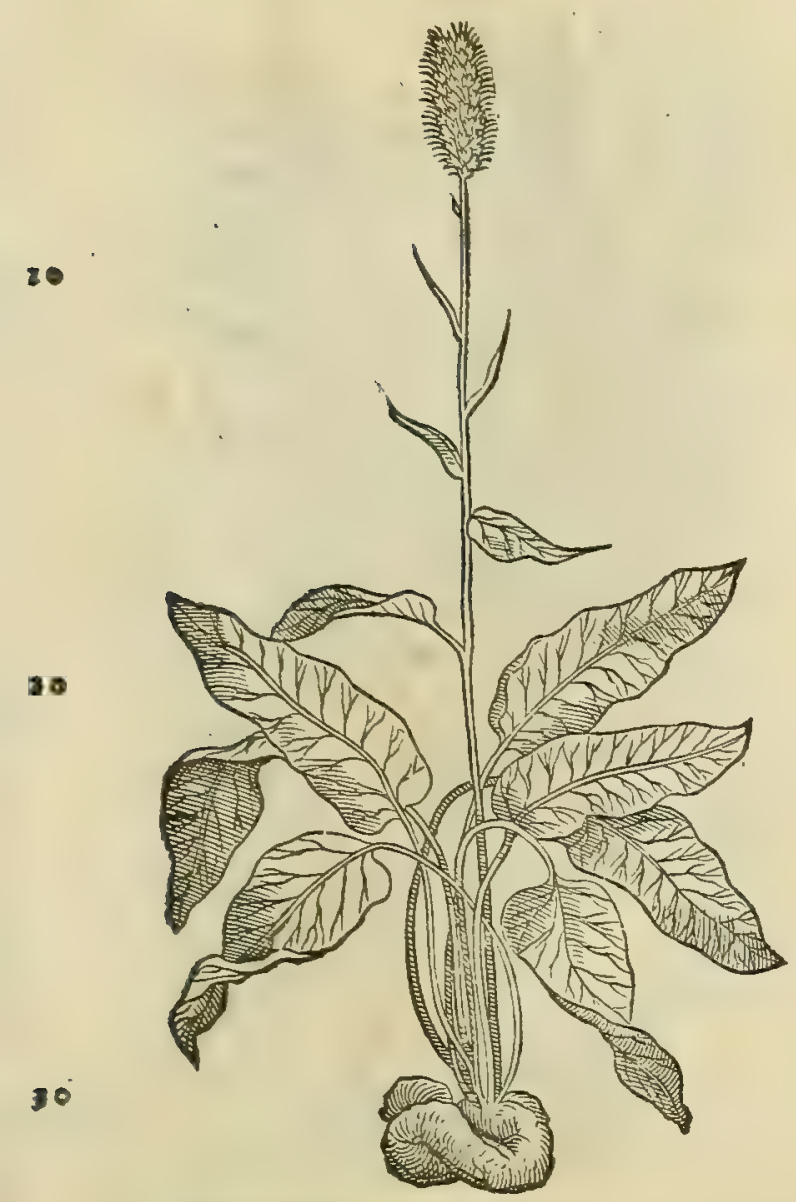

TORMENTILLA.

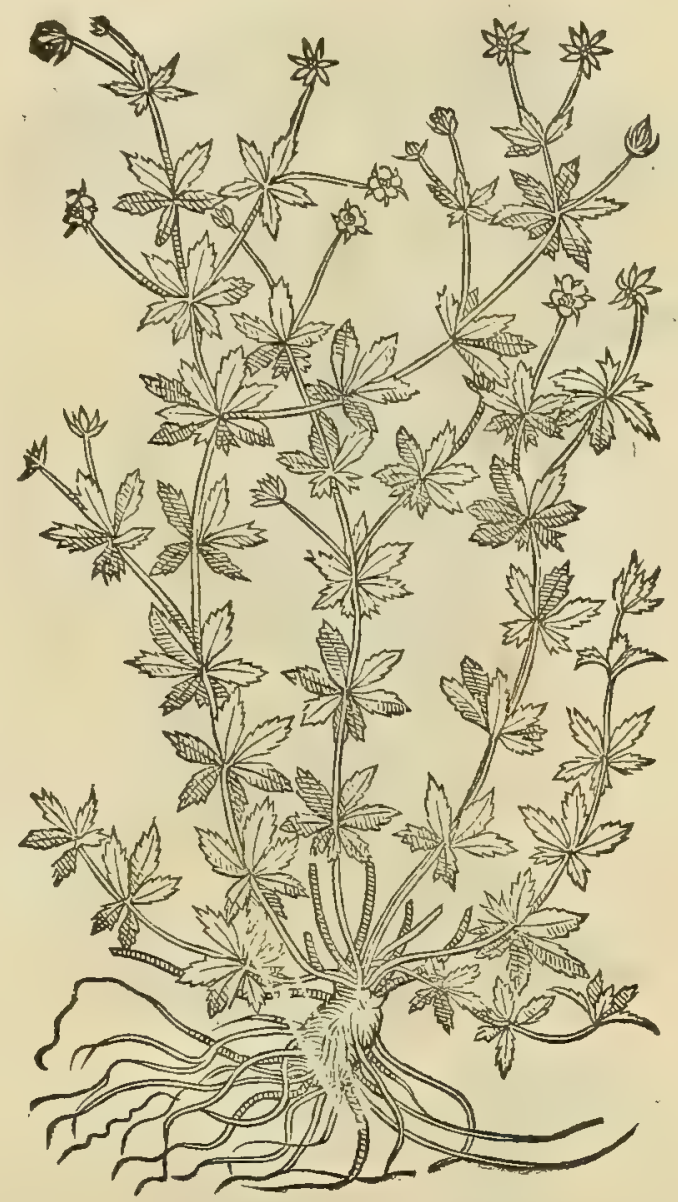

bic locus expofcere uifus est, ut de ea aliquid differdmus. Eft itä̈; T O R M E N T I I I A folio pentaphylli Tormentillx minore, feptenis incifuris diuifo: radice breui, nodofd, compdetd, rubeo colore, fapore adftringenti: cauli= hiftora, \& ui culis tenuibus, fubrubentibus : flore melino, adeo ut in pentapbylli genere fit reponenda. sunt qui à feptenis fo= liorum diuifuris Heptaphytlon hanc uocent. Herbarij compertum babent, hanc ijsdem pollere facultatibus, quibus Biftorta predita eft. Quamobrem utreq; abortum probibent bibite, ac uentri renibus's; ex aceto illite : urine incon= tinentiam fupprimunt, cum fucco plantaginis pote : fiftunt menfes, fi in earum decocto ad umbilicum usq; confederint 40 famine. Idem preftant (de radicibus tamen intellige) fi trite, o exinelle atque fica fubacte, uentri ac pubi illi= nantur. Sanguinem é uulneribus inanantem cohibent, Juper aperfo earum puluere. Qui item potus biliofas coércet uomitiones, fi ouorun albo exceptus fuper fictili teguld inaffetur, mox comedatur. Aqua, qua ex bis dupliciorga= no elicitur, fiuc é radicibus decoctum, uenenis omnibus remedio est. Ex quo tantum apud nonnullos Tormentille

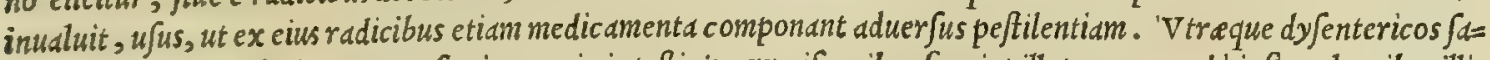
nant, ev uulnera glutinant, prefertim qua in inteftinis, er uifceribus fuerint illata, non modó ipfis uulneribus illi=

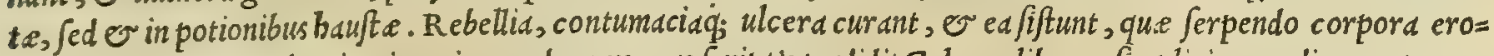
dunt. Sed ut iam ad Britanice uires redeamus, eds fcriptis tradidit Galenus lib.v r. fimplicium medicamentorum, Britanicx uiubific inquit. Britanica herbe folia adftringentia funt, o unlnerum glutinatoria, fimilia folijs fylueltrium lapatbox res ex Gal. sum, nifi quatenus atrior a funt, magis q́; birta. Sed $\mathfrak{N}$ expreffus ex illis fuccus perinde natus eft adftringere. it qque so cottum quiddm reponunt, tanqudm inter ftomatica medicamenta efficacißimum. Videtur enim fanare iam etiam pu= trefcentid. bactenus Galenus. Ceterùm non eft filentio pretereundum, quód Diofcoridis codices inueniuntur, in qui= bus poft Britanicam alterum per fe de Betonica caput legitur. Quod quoniam pluribus indicïs in Diofcoride afciti= tiume effe conftat, atque in bunc autborem ex libello Antonij Mufa Augufti Cafaris medici fuiffe translatum; idcirco

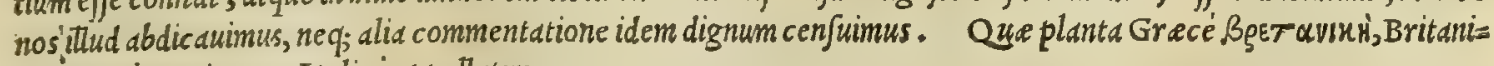
ca Latiné, pariter $\odot$ It alice appellatur.

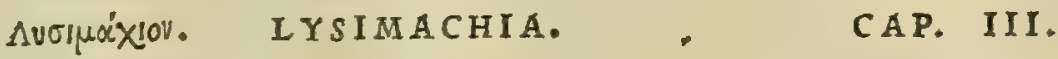

L y S I м A C H I A, quam aliquilytron appellant, caules emittit cubitales, altiorésue, fruticofos, tenues: prodeuntibus geniculatim, folijs tenuibus, falicis figura, guftu adfringentibus : flore rufo, aut aureo gignitur in aquofis, \& paluftribus. Foliorum fuccus adftringente fua ui, fanguinis $\mathrm{S} 2$ reieftionem 


\section{And. MatthioliComm.}

IYS IMACHIA.

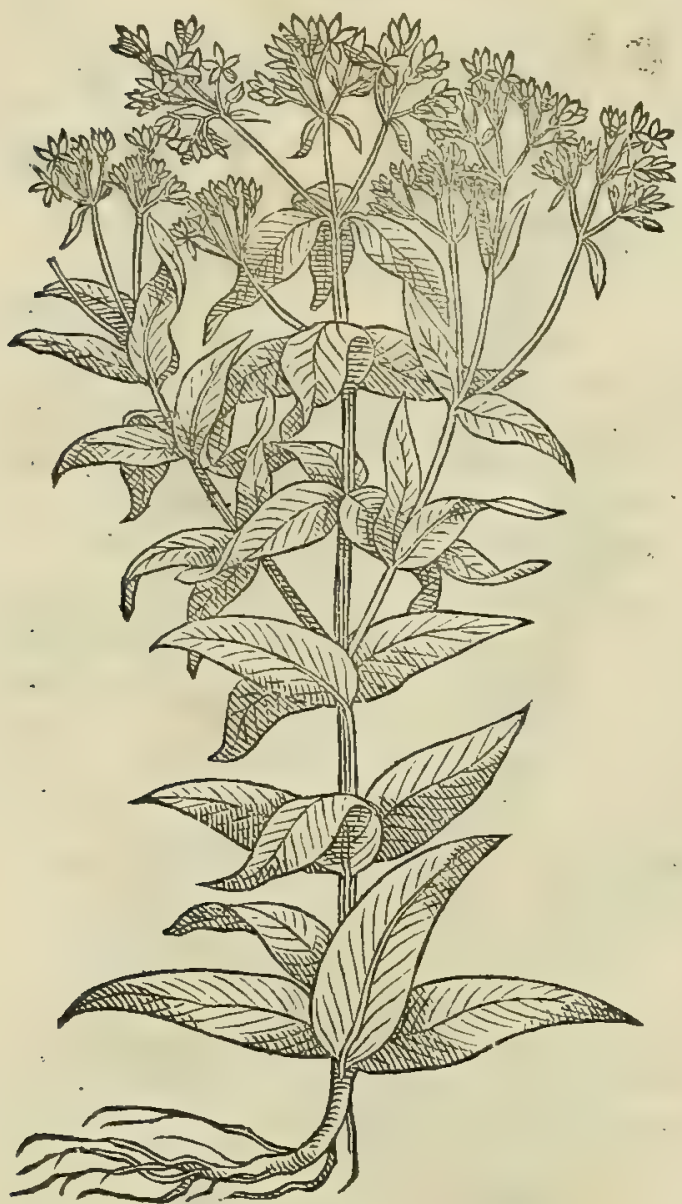

IYSIMACHIA AIIA.

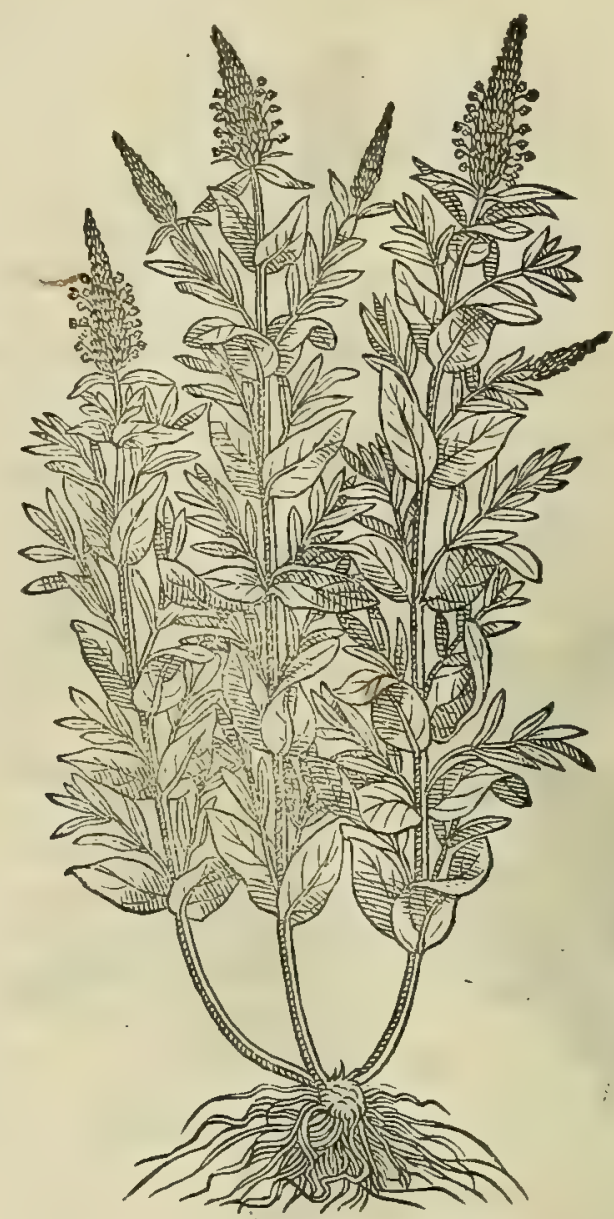

20

10

reiectionem fupprimit: dyfentericis potui datur, aut infunditur : menfium abundantiam fiftit, in peffo. fanguinis profluuio fubuenit, fi nares ea herba obturentur : vulnerum cruorem cohibet. Acerrimum nidorem fuffita reddit : qua de caufa ferpentes fugat, \& mufcas interficit.

Lyfimachix

L Y S I M A C н I A d̀ Ly/imachorege inuentore nomen accēpit, ut Plinius eft autbor libro x x v.cap. v I I. confid. ubi de ea ita fcriptum reliquit. Inuenit $\mathrm{L} y$ fimachus herbain $\mathrm{L} y$ fimachiam, qua ab eo nomen retinet,celebrata $\mathrm{E}$ raf $\mathrm{l}=$ frato. Folia habet falicis, uiridia : florem purpureum: fruticofa eft, ramulis erectis, odore graui . gignitur in aquo Ruellij erra- fis. Vis eius tanta eft, ut iumentis difcordantibus ingo impofita apperitatem cobibeat. hec Plinius. Ruellius $\mathrm{L} y / \mathrm{i}=49$ tum. machiam eam berbam putat effe, cuius eft ufus apud infectores ad inficiendos uiridicolore pannos: ubi enim bos gld= fto tinxere, eam fuperinducentes uiridem colorem efficiunt. Hanc Hetrufci,qui lanificio dant operam, uulgó appel $=$ lant Cerretta, fiue Braglid, Foroiulienfes ueró Cofarid. Sed hac in re Ruellius, meo quidem iudicio, aperté fallitur: fiquidem Cerretta, quam ipfe rufticis Corneolam wocari ait, caules profert, o folia lino maiord, non autem falicis: florem luteum, femen folliculis genift e efigie inclufum: ndfcitur in pratis, nullaq; eft, quod guftu perceperim, ad= ftrictione predita. Non defunt preterea alij, qui pro Ly/imachia aliam plantam oftendant, que quadrato exit caule, folijs falicis, flore in purpuram rubefcente, , picato . uerum in hac quoq; nibil adjtringens guftu deprehenditur. Iyfimachidin legitimam, ni fallor, Roma ad me Goritiam mifit Vincentius Cantonus ciuis meus, medicus eruditus, ơ reiberbaria ftudiofus : qua mibi plané fingulis notis, quas Diofcorides I yfinachie tribuit, uidetur adftipulari. Nd= Ruellii alius Scitur bec in Romano, er senen/i agro. Ceterim quanuis Ruellius in mentione Lyfimacbia exiftimauerit (ut fu= so lapfus. prà diximus) Corneoldm effe ueram Lyfimachiam; in fine tamen eiufdem capitis quandam aliam berbam à rufticis fibi demonftratam fuiffe teftatur, ad fuganda peftilentie efficacißimam, buboni tantim adalligatam, quam etiam pro Ly= fimachia afferuit. Ex quo palàm eft, Ruellium duas pro I y fimachia plantas defignafe, ea fortaffe ratione adductus, quòd Diofcorides flore rufo, aut aureo conftare Iyfimachiam memoria tradiderit. Iyfimachia meminit Galenus

Iyfimachix lib. vIr. Fimplicium medicamentorum, ubi de eius uiribus in bunc modum differuit. Iy fimachios fuperantem babet uires ex Gal. qualitatem adftrictoriam: per quam o uulnera glutinat, erumpentemq́; ex naribus.anguinem emplaftri modo illita compe $\int c i t$ : quin er reliquas $\int a n g u i n i s ~ c r u p t i o n e s$ fiftere poteft cum ip $\int a$, tum fuccus eius multo magis. Pota dyfen=

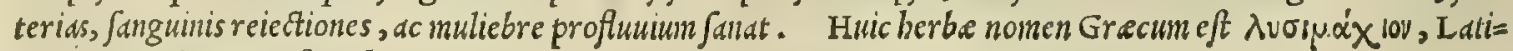
num, $\mathrm{O}$ I talicum Lyfimachia. 


\section{In Lib. quartum Diofcoridis.}

POLYGONVM MAS.

20

$30^{\circ}$

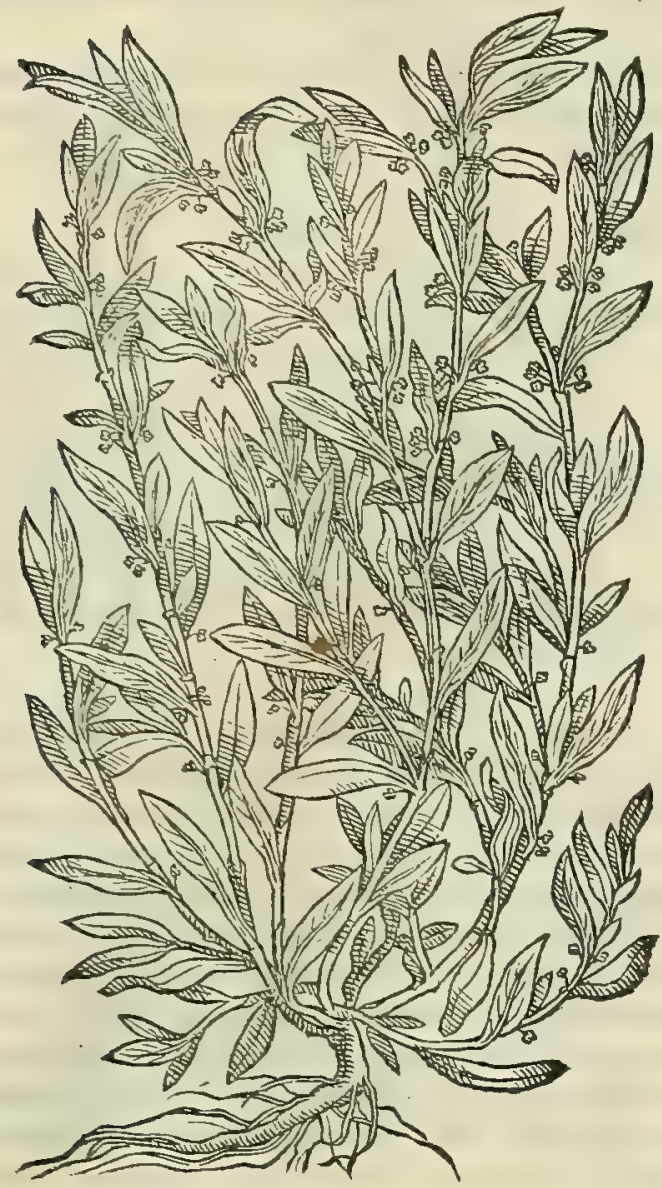

Poגن่วovov. SANGVINARIA.
POLYGONVM FOEMINA.

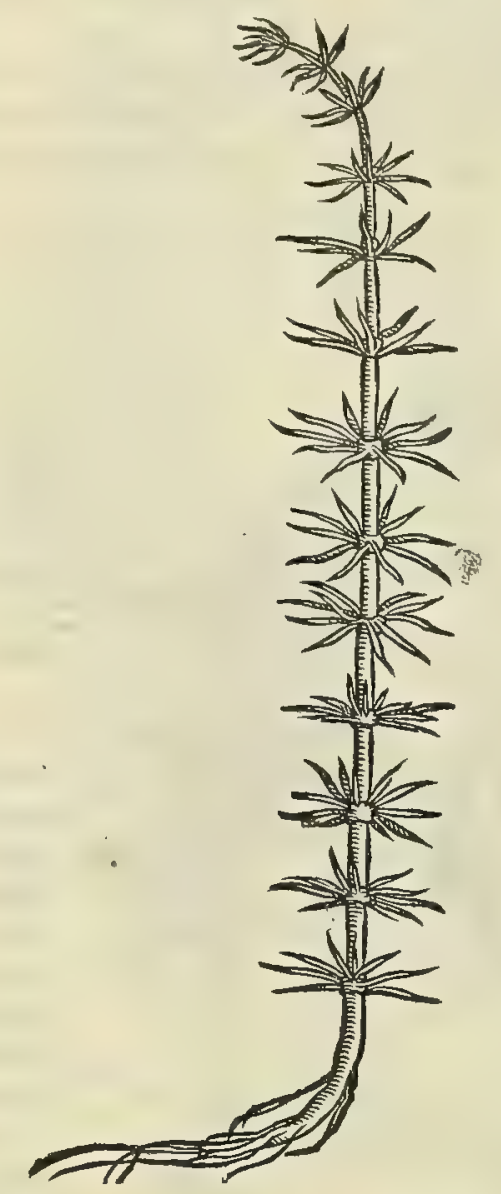

CAP. IIII,

PO I Y G ON V M mas ramos habct teneros, \& exiles, copiofos, geniculis cinctos, qui per terram, ut gramen repunt : folia rutæ, fed $†$ molliora, longioraque : femine fub omnibus folijs turgefcen te, unde marem appellari uolunt: flos ei candidus, aut puniceus. Vis epoti fucci eft, fpiffare, ac refrigerare. prodeft cruentæ excreationi, choleræ, alui fluxionibus, \& urinæ ftillicidio : nam urinam apertè ciet. Cum uino potus, contra ferpentium morfus auxiliatur: datur in febribus per horam an40 te fignificationes . fæminarum profluuia impofitu fiftit. Idem fuccus aurium doloribus, ijfdemq́ue purulentis inftillatur. Facit eximiè ad genitalium ulcera, cum uino adiecto melle decoctus. Stomachi feruori, fanguinis reiectionibus, ulceribus quæ ferpunt, ignibus facris, collectionibus, tumoribus, \& recentibus uulneribus folia illinuntur . Sanguinaria foemina fruticat uno caule, arundini teneræ fimili, denfis geniculis, \& in fe tubarum modo faretis : articulos in orbem cingunt apices, foliolis picex frmiles: radicis nullus ufus. nafcitur in riguis. Huic quoque fpiffandi, refrıgerandiq̨; natura ad eadem ualens, fed inefficacior.

PO I Y G ON ON mas, quod ab Italis uulgó nocatur Coreggiold, er Centinodid, in campis, edificioruni Polygoni có areis, o uijs publicis frequens ubique nafcitur. Fomina ueró, que non adeó frequens eft, or copiofa, in ri= fideratio.

so guis humentibus; loc is inuenitur. Mari polygono Proferpinaca nomen tribuit Apuleius, quód bumi cauliculis repat. Polygoni meminit Galenuslibro VI I I. fimplicium medicamentorum, ubi eius uires reddidit his uerbis. Polygonum, inquit, uti adftrittionem quandam obtinet, ita fané uincit in eo aqueum frigidum, ut uidelicet fecun= res ex Gal. di fit ordinis medicaminum refrigerantium, aut etiam quodammodo in initio teriij. Proinde fane quibus ftoma= chus feruet eftu, foris frigidum illitum prodeft : uelut etidm eryfipelata, or calidas phlegmonas iunat. Porrò tale cum fit, or fluxiones repercutit, er hac ratione uidetur effe exiccatorium. Quare cim berpetum, tume ulcerum, aliorum: ;́; bonum eft remedium: efficacißimum autem inflammatione, o fluxione laborantium par= tium. Eft o cruentorum unlnerum glutinatorium. Sed 0 aurium ulceribus prodeft : $\mathbb{O}$ fi uel plurinum infit puris, hoc tamen etiam deficcat. Eafdem ob facultates o proflunium muliebre fiftit, Oo dyfenteriam, $\mathcal{O}$ fanguinis reiectiones, $\sigma$ undecunque aliunde immoderatiores impetus. Refert Diofcorides, quód $\mathbb{e v}^{u}=$ rinam prouocet exbibitum fillicidio feu ftranguria affectis. non tamen affectum exacte difcriminat, in quo ipfum dari expediat. Porró mas ad omnia diata, quam formina, ualidioris eft effectus. Herba, que Grez 


\section{6

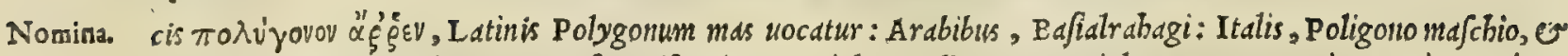
Correggiola: Germanis, Vueggrafz: Hifpanis, Corriola: Gallis, Coreggiole. Que neró Grecé ๘oגúyo= nov $จ \tilde{H} \lambda$, Latine Poligonum fermina dicitur: Italis, Poligono foemina: Germanis, Kantten liraut: Gallis, Pin aquatic.

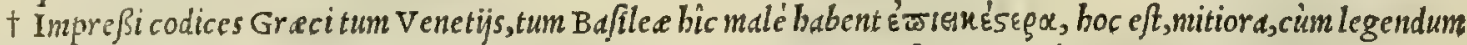

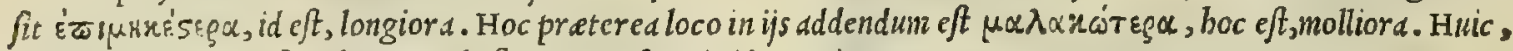
o alteri lectioni adftipulatur Oribafius, quem fecuti uidentur interpretes.

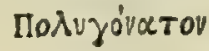
POLYGONATVM.
CAP. V.

Polygonati confideratio.

Manardierra tum.

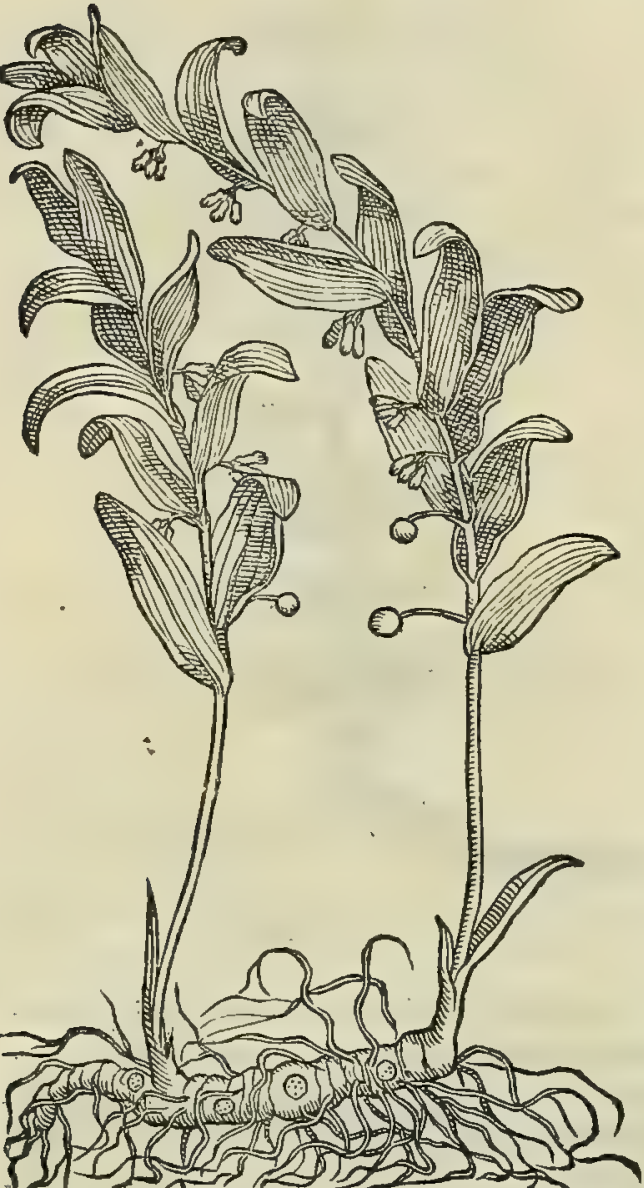

POLY G ONAT V M nafcitur in montibus, frutice cubito altiore, folijs lauri, latioribus, \& læuioribus , fapore mali cotonci,aut punici, cum quadam adftrictione. Flores per fingulos foliorum exortus promit, candidos, folijs numcrofiores, incepta à radice fupputatione. $\mathrm{R}_{\mathrm{a}}$ dicem habet albam, mollem, longam, crebrò geniculatam,denfam, graueolentem, digitum crafsitudine æquan tem. Qux uulneribus efficaciter illinitur: quinetiam maculas in facie delet.

P o I Y G O N A T V M Hetru cisuulgó Fraßinella nomi= natur. Alij keró Italia populi quafi d Gracis docti, id Ginochiet= to uulgari fermone appellare didicerunt, ac fi geniculatam radi= cem dicerent. Mulieres é Polygonati radicibus aquam ftillatitiă Itudiosé conficiunt, qua ad faciem detergendam, poliendamǵ; pro fuco utuntur. . Sunt preterea, qui Polygonatum figithum fancte Marie, o 'qui figillum Salomonis uocitent: uerim ipfe quidem harum nomenclationum caufam adbuc affe qui non potui. Nee defunt etiam, qui afferant, ueluti Manardus Ferrarienfis, eam plantam Polygonatum effe, quam nomine secacul defcribunt 30 Mauritani. Sed ij haud dubie, meo indicio, falluntur : fiquidem perpicuum eft, serapionem fidelem Diofcoridis interpretem, nullis fuum secucul reprefentare notis, qua d Diofcoride $\mathbf{P o}=$ lygonato tribuuntur. Huc accedit, quód Serapio eo in loco nun= quam Diofcoriden citat, ut fui moris oft in alijs fimplicibus me= dic anentis, que ipfi Diofcoridi refert accepta. Illud infuper, $f$ particulatim libeat percurrere, Manardi errorem maniffefté de= prehendet, quòd serapio non folia lauri fuo reddidit Secacul, Sed piforum inftar. Neque Polygonatum, or secacul eifdem uiribus pollere conftat inter authores: quandoquidem illud Greci commendant ad uulnera, $\mathcal{E}$ ad maculas in $f d=$ cie delendas. Hoc autem Arabibus laudatur ad prolifici Jeminis ubertatem, $v$ ad uenerem conciliandan. Qua in re nonnulli falfa Manardi opinione ducti, fe delufos inuenerunt, qui Polygonati radices faccharo conditas ad ue=

Polygonati nerem excitandam auidißimé deuorarunt, nullo tamen rei fucceffu. De Polygonati uiribus differuit Galenus li= uires ex Gal, bro v I I r. Fimplicium medicamentorum, hunc in modum. Polygonatum miftam babet tum facultatem, tum qua= litaten : habet enim adftrictionis pariter o acrimonie, $\sigma$ amaritudinis quippiam, o indicibilis cuiufdam infuaui= tatis. Quocirca nec admodum eft ufui, fed tantüm quód radicem eius quidam uulneribus illinunt. Sunt etiam qui ne: uos maculdsq́; in facie illo detergunt. Hac planta ut Grece roju yovoctov, itd etiam Latiné Polygonatum nominatter: Italice, Fraßinella, o Ginochietto: Germanice, Vueifz uurtz: Hıßpanicé, Fraßinella: Gallicé, Genijculiere.

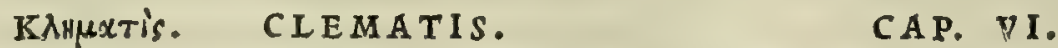

C I E M A T I S humi ferpit. lato, pinguique folo prouenit, uiticulas fpargens crafsitudine iunci, exiguas : folio lauri figura \& colore, \& multò minora. Ea cum caulibus in uino pota alui profluuia, \& dy fenterjas fedant: fubdita in peffo cum lacte, \& rofaceo, aut cyprino, cruciatibus vuluæ medentur: dolores dentium commanducata finit. impofita ferpentium morfibus iuuamentum præftat.Fertur etiam contra afpidum ictus ex aceto pota opitulari. Gignitur in terrenis. 


\section{InLib. quartumDiofcoridis.}

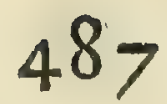

\section{CIEMATIS.}

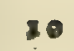

20

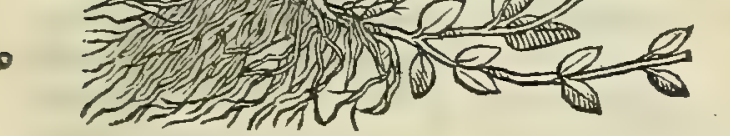

CLEMATIS ALTERA.

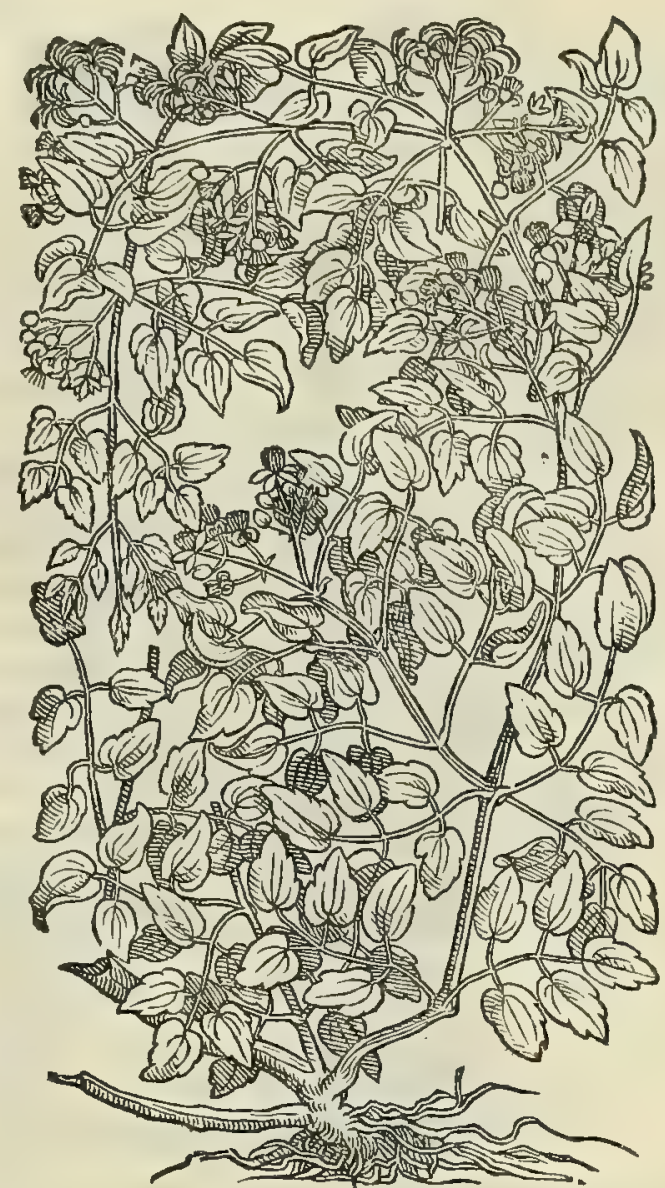

CAP. VII.

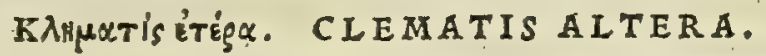

Es T \& altera Clematis, quæ uiticulofum emittit ramulum, rubefcentem, lentum : folium guftu admodum acre, ac exulcerans . repit per arbores, vt fmilax. Semen tritum pituitam, bilemq́; detrahit, in aqua aut hydromelite potú. Folia eius illita, lepras purgant. Cumlepidio conditur ad cibos.

C I e M A I Is, que primo loco defcribitur, aliquibus vinea peruinca dicitur, nobis uulgó appellatur Pro= 40 uenca, cuius fronde mulieres pueris, ac puellis uirginibus, funeft as texunt coroll as. In hac fiquidem nullam reperi no tam, que Clematidi primi generis reclamare uideatur. Quamobrem eorum fententiam explodendam putauerim, qui noftratem Peruineam chamedaphnem effe fibi perfuadent, quam uulgó Laureolam appellamus. Nam bae uirgas $e=$ mittit cubitales, finguldriftipite à radice exeuntes, rect ds, tenues, leues $q_{5}$ : Semen rotundum, rubens, inter folia re $\Rightarrow$ fidens, que facie laurina emulantur. Porrò Clematis, quam fecundo loco reddidit Diofcorides, nimirum à prima quàm maximé dißidet . Et $\int a n e ́$, ut ex quibufdam notis, qua probé adftipulari uidentur, colligi poteft, hac nostr is $v i=$ talbis uulgó uocatis plurimùm facie repondet. quandoquidem be uiticulis exeunt rubentibus, ac lentis: folijs funt fimilacifimilibus, que fi linguam confulas, o uebementer acria, or exulcerantia deprebendes. Ambiunt he mire in=

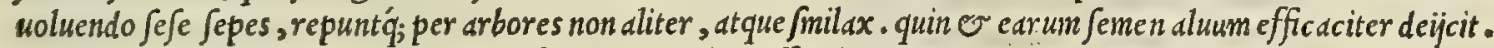
Quo fit, ut mihiomnino perfuaferim, noftratem vitalbam effe clematidem alter am contra corum opinionem, quid= 50 crem Clematidem eam plantam putant effe, que nafcitur in $\int e p i b u s$, flores proferens candidos, calathi effigie, quos quidam reiherbaris imperiti Liguftra falsó nocant: falso inquam, quoniam Diofcoridiliguftrum arbufcula eft, non berba, ut fuperius libro primo monuimus. Fuchfius tamen medicus doctifimus noftratem Vitalbam, uitem nigram effe exiftimat . Sed errat, mea quidem fententia, ut infrà fuo loco dicemus. Floris alterius clematidis figuram non reprafentauit Diofcorides: tamet fi vitalba uocata florem album, ov odoratum proferat, fit $q_{\text {; }}$ alia butc fimilis, qua purpureumflorem promet, facie tamen ab altero diuerfum. Ceterimberba, quam quidam F L A M M V L A M dicunt, folijs, floribus, ac femine nibil ab hac clematide differt, quemadmodum nec acerrimo guftu. Attamen neque Sepibus circumuluitur, neque arbores fcandit, cum recticaulis afjurgat. Plures autem baec $\mathrm{cx}$ fe mittit caules bicu= bitales, fubrubentes, $\mathbb{E}$ in bis folia fmilacis, quibus intoler abilis ineft acrimonia, unde Flammuls fibinomen afciuit. Ex bac ego fepius aquam elicui, demiffo uitreo organo in calentis aque balneo: que eadem, qua berba ip $\int_{a}$, pollebat acrimonid. Hanc compertum eft efficacißimam effe in morbis frigidißimis. Flammula (ut Platedrits eft author) ex= calfacit, ficcató; ordine tertio. sed quód impolita carnem non fecus exulceret, ac ignis, calidam ordine quarto re =

Clematidum confideratio. Quorundam error.

\author{
(n)
}




\section{8

F L A M M V A M.

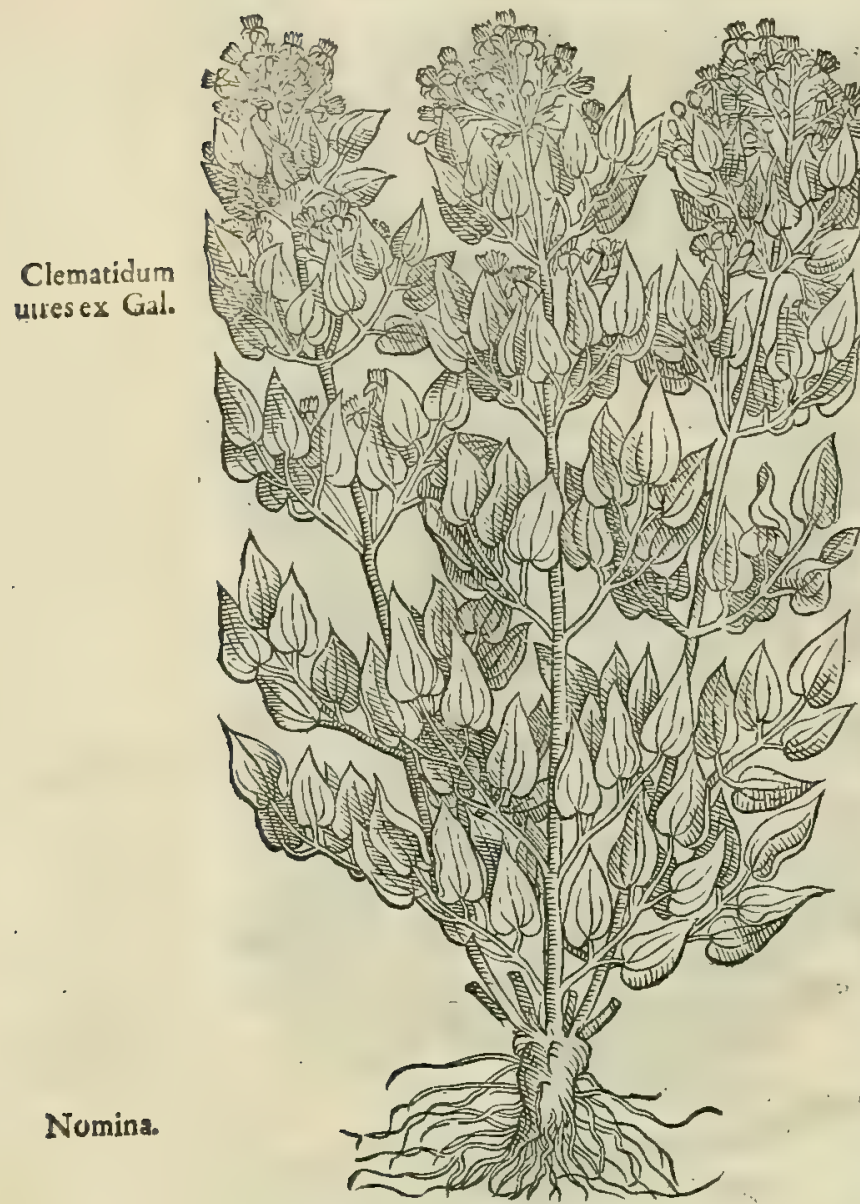

ctius crediderin. Sunt qui Flammulam quartanarijs cdendăpre: beant magno (ut front) iuuamento. Alij eius oleum commen=

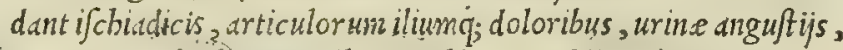
er renum calculis, in quibus morbis aut calidum illud inungunt, aut clyfteribus infundunt. Id autem praparant boc modo'. Flam= mula folia tenuilimé concifa in ro aceum imponunt, quod uitreü uis exceperit, ac inde per aftatem infolant obturato uafe. Datur etiam in cibis bifce morbis affectis, trium drachmarum pondere. sed ut iam ad Clematidum uires reucrtanur, ea de bis fubijciam, que Galenus lib.v I I. fimplicium medicamentorum adnotata re= liquit. Clematidis, flia, inquit, acrem o adurentem fiue caufti= cam facultatem obtinent, adeó ut $\sim$ lepras excorient. Fuerit ita que in quarti ordinis excalfacientium initio. Vocatur autem cle= matis $\sigma$ daphnoides, quod quidam myrfinoides, alij polygonoides appellitant. Caterim id nec exulceratorium oft, nec acre, ficut quód anté dictume eft, inno profluuijs, or dy enterijs cum uino po= tum prodeft, dentiumq; dolores manfum mitigat : tum uteri quoq; doloribus in peffo admotum, ufui eft, tantum abeft, ut perinde $u=$ rat, ac ulceret, ceu illud fuperius. Sed Junmé nobis fupiciendus pamphilusille, ficuti in reliquis nugatur de ijs, que nunquam ui= 20 dit, literis ea mandans, fic hac ambo in unum confudit. At Dio= fcorides utriusque in quarto meminit, or eius que fimpliciter uo catur Clematoides, id 'q; in fine libri, er alterius, fed in principio. Quamobrem neceffe non eft, me etiami de cribere pecies ambas, ficut nec in alijs feci. bec Galenus de utraque Clematide. Ex qui bus palam eft exulcerantis clematid is caput ab aliquo curio fo ex buius quarti libri calce, ubi commodé inter aluum de iycientia me= dicamenta, fibilocum adinuenerat, exemptum fuiffe, er bic alte= ri Clematidi adiunctum ob eam, quam inuicem babent nominis con uenientiam. Prima clematis Gracis $x \lambda \mu \mu \alpha \tau i$ ' $\delta \alpha \phi v o l \delta$ is 30 appellatur: Latinis, Clematis, er vinca peruinca: Italis, Cle $=$ matide prima, o prouenca: Germanis, singrien: Hipanis, Peruinqua: Gallis, Ly feron. Secunda ueró $x$, $\mu \alpha \alpha=$

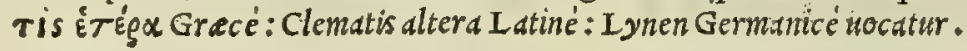

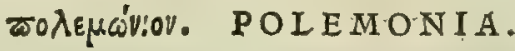

\section{B CAP. VIII.}

POL E M O I A, alij philetæriam, Cappadoces chiliodynamin appellant, ramis exilibus, utrinque pinnatis : folijs paulò quàm rutæ maioribus, aclongioribụs, calaminthæ, aut fanguinariæ, proximis : quibus in fummis velut corymbi dependent, nigro femine: radice cubitali, albicante, radicula fimili. nafcitur in montofis, \& afperis. Bibitur in vino radix contra ferpentes, \& dy fenteriam : \& 40 ex aqua aduerfus vrinæ difficultatem, \& coxendicum cruciatus . datur ex aceto drachmæ pondere lienofis. Eadem fcorpionis plagæ alligatur. Tradunt eum, qui radicem guftauerit, à fcorpione non feriri : eumq́ue, fi ictus fit, nihil molefti paffurum. Dentium dolorem manfa mitigat.

Polemonix CRE D o equidem me iam fepe uidife Polemoniam in altioribus, or apperioribus uallis Ananix montibus, kes confider. nui, er quadrangulari caule, utrinque pinnato : folijs effigie nepete : corymbis quadantenus dependentibus, nigro femine refertis : radice pralonga, albicante. Hinc itaq; non facilé adducor, ut credam, quemadmodum cenfet Brat fauolus, eam effe Polemoniam, quam noftrum Hetruria uulgus appellat Lauane $e$ : alij ueró Galegam, alij Rutan caprariam nominant. Quandoquidem bac omnibus feré notis fanum grecum refert, in cuius ramorum fummitatibus cornicula dependent, in quibus femen recluditur fubrubeum, non autem corymbi. Radix illi ineft breuis. Nafcitur $\mathrm{se}$ leto folo, er plerunque in frobium marginibus, alijs $\dot{q}_{;}$uliginofis loc is : non autem in montibus aperis, ubi inafci $\mathrm{Po}=$ Fuchfij opin. lemonian tradidit Diofcorides. Ceterim Fuchfius libro primo de compofitione medicantentorum, eam Polemo= niam putat effe, quam officine Ben album uocant. Sed ab eo, pace uiri eruditißimi, plane diffentio, quod boc ramulis non fit utrinque pinnatis : quod corymbos nullos proferat, fed filiquam, uel calycem ocimoidis modo: quod denique

Polemonij ui non folim in montibus, or apperis proueniat, fed ubique, prafertim in pratis. De Polemonio differens Galenus liz res ex Gal. bro v I I I. de fimplicium medicamentorum facultatibus, fic inquit. Polemonium quidam philetserium, quidam (ue= lut Cappadoces) chiliodynamon : tenuium partium eft, $\mathcal{O}$ deficcandi uim obtinet. Quamobrem quidam radic em eiis Nomina. cumuno ad ifchiadicos, dyfenteriam, lienem q; induratum potui exbibent. कo tinis Polemonium, e Polemonia nominatur. 


\section{In Lib. quartum Diofcoridis.

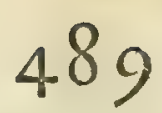

\section{SYIIPHYTVM PETRAEVM.}

10

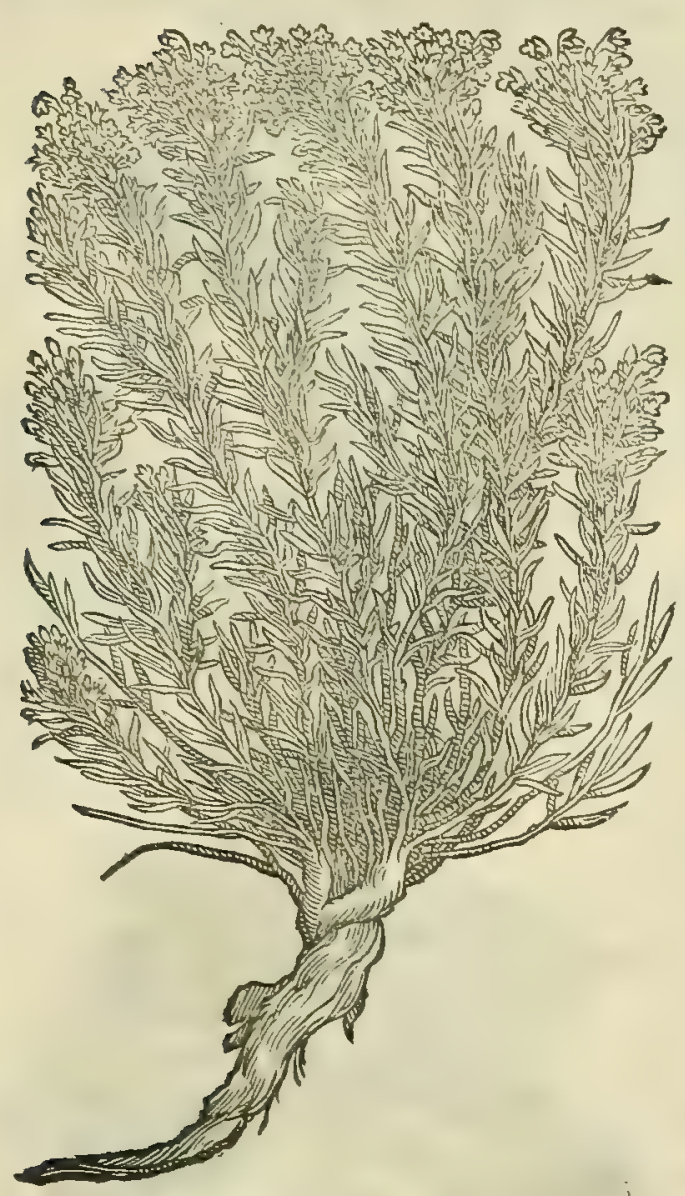

Eupqútov. SYMPHYTVM.
SYMPHYTVMALTERVII.

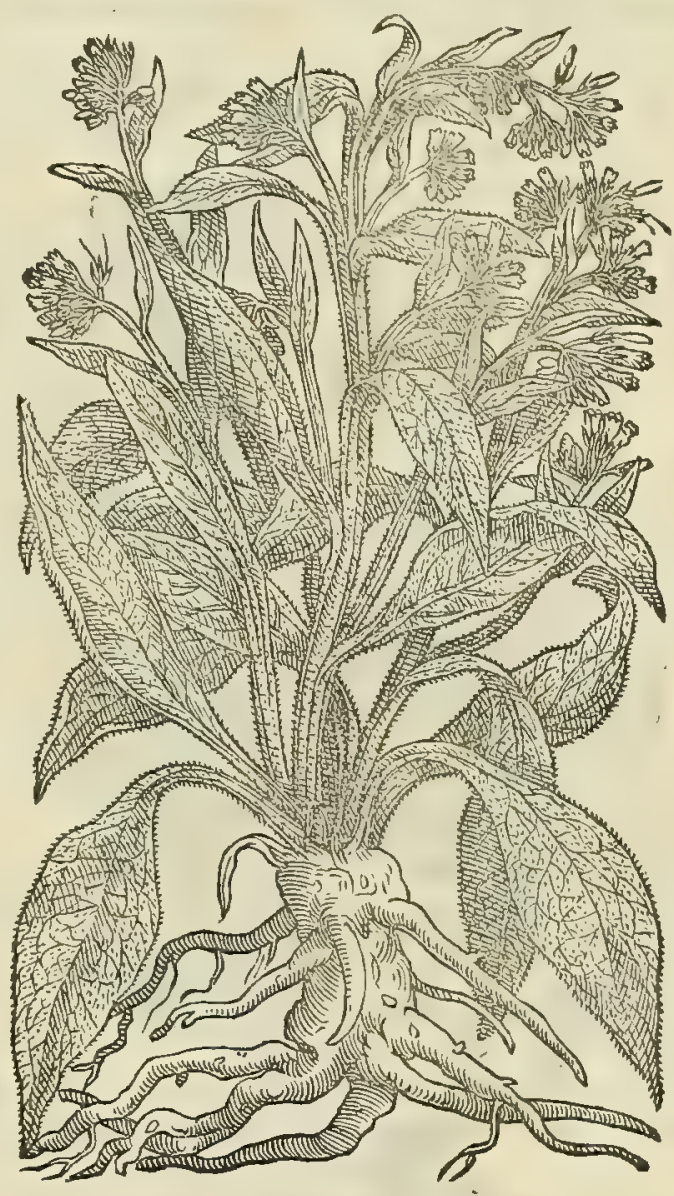

CAP. IX.

S Y M P H Y T O N petræon nafcitur in petris, ramis tenuibus, paruis, origano fimilibus: capitulis, \& † folijs thymi : lignofum totum, odoratum, guftu dulce, f faliuam ciens : longa radice, fubrufa, digitali crafsitudine. Decoetum in aqua mulfa \& potum, pulmonis vitia purgat: fanguinem reijcientibus, \& renum malis ex aqua datur : ad dy fenteriam, rubraq́uc freminarum profluuia in vino de coctum: ad conuulfa uerò \& rupta, ex aceto mulfo bibitur. Quin \& commanducatum fitim fedat, 40 faucibus afperis fubuenit, vulnera recentia, enterocelasq́ue conglutinat, \& illitu cohibet. Carnes autem cum fymphy to decoctx coalefcunt. Elt \& alterum fym phyton, quod aliqui pecton uocant. id caulem emittit bicubitalem, aut maiorem, craffum, leuem, angulofum, vt fonchi inanem : circa

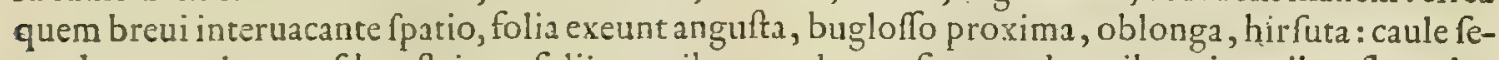
cundum angulos quofdam ftriato: folijs tenuibus, ex alarum finu prodeuntibus : in quibus flores lutei , \& circa caulem uelut verbafci femina emicant. Tam caulis, quàm folia afpera lanugine horrent, tactıque pruritum concitant. Radices demittuntur forìs nigræ, intus candidæ, uifcofre quarum eft: ufus. Tritæ, \& potæ cruentis excreationibus, ruptisq́ue proficiunt : recentia vulnera illizæ conglutinant. carnes quoque fi concoquantur, cogunt additæ. In flammationibus præfertim fedis, cum fenecionis folijs, vtiliter illinuntur.

Q V A N V I S in noftris commentarijs, quos multo anté tempore Italicé confcriptos edidinus, ingenué confef= Symplyytorú fus effem, ine non anted adinueniffe symphytum primi generis petreon cognominatum; id tannen pofted reperi menfe confid. Septcmbri fuis floribus esnicans, longè a Goritia circiter uiginti nillia palfuum, in latere magni montis vipacipauló fupra arcem, ac deinde in alijs ip/îus montis partibus, alijsq́; I apidie locis, prefertim eo tractu, qui uulgó sclauis di= citur Gabernich, quin er in nonte illo ciusdem tractus, quem uocant Sanffi Vrbani, nullis prorfus deficientibus notis, que illi à Diofcoride tribuuntur. Eft profectó planta, prefertim ubifloriterit, uifu iucundisina, ita ut maxima cum uoluptate ad je uidendt!m uidtorum oculos alliciat, argumento quidem quód etidm uiribus polleat in/ignibus. Por= ró sympbytum alterum, quod fectundo loco reddidit Diofcorides, nulli dubiun cft, quin ea fit berba, quse hodie pasim Confolida maior nominatur, quain etiam nonnulli berbariorum Alum falsó appellant. Eüippe quód cius note fingu= la Diofcorid is biftoria ad unguem berere deprebendantur. Hec frequentiBima nafcitur in pratis, floribus non modỏ luteis, ut Diofcorides inquit; feder candidis, o purpureis, eadem fané facie, ac forma. Ceterim hallucinantur, 


\section{0 \\ And. Matthioli Comm.}

Quorundam meo quidem iudicio, qui symphytum petreum putant eam effe plantam nullis non cognitam, qudm officine $\mathrm{C}$ o $\mathrm{N}=$ errores. $\quad S$ O I I D A M, O Solidaginem minorem uocant. Siquidem eam nibil pror fus symphyti petrai notis reßpondere, omnibus rei herbari.e etiam mediocriter gnaris euidentius eft, quàm ut à me indicari deceat. Neq; etiam ftatuendum

CONSOLIDA MINOR.

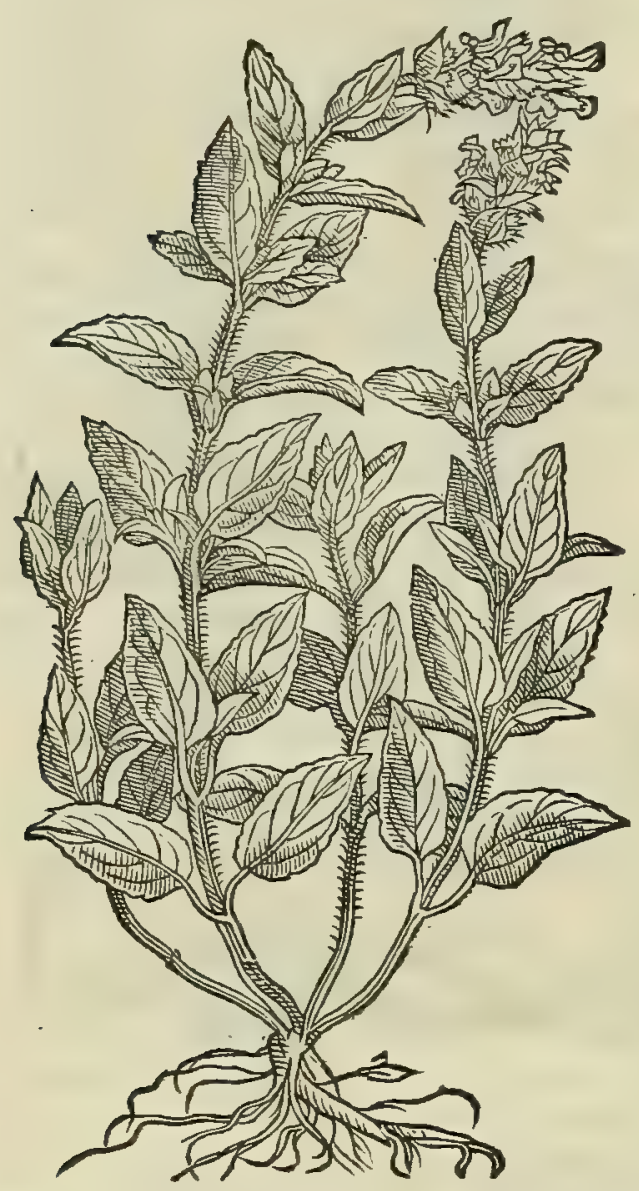

CONSOLIDA MEDIA.

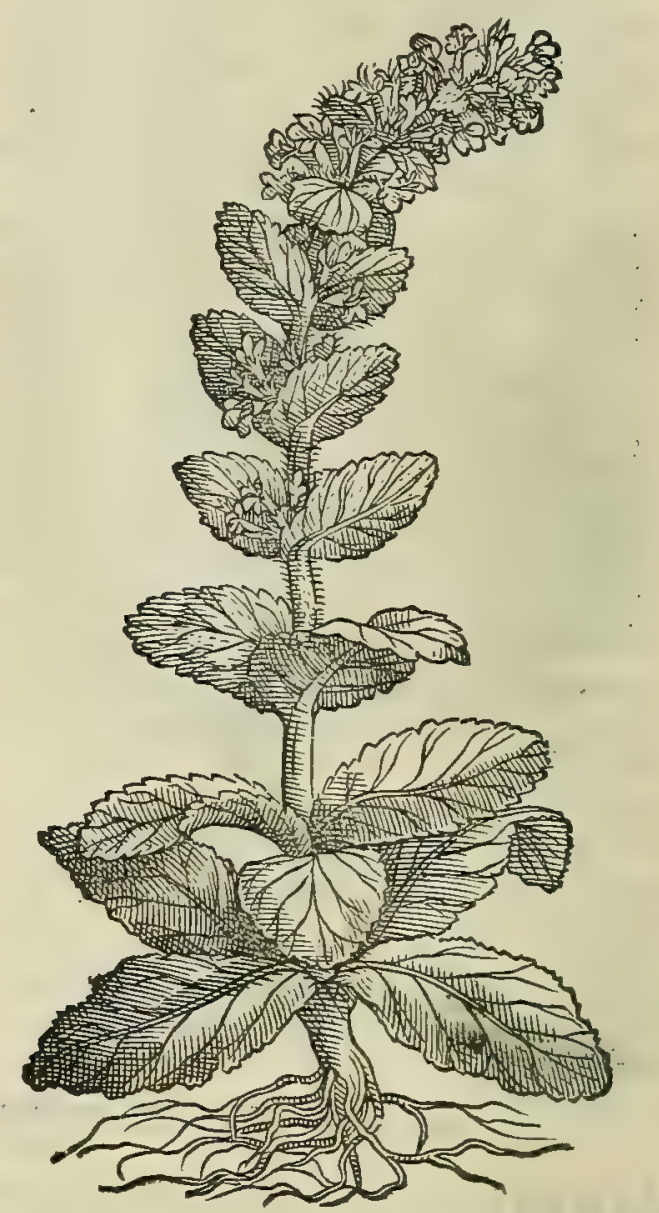

10

20

30 ab alto deuolutis, ac etiam ijs, qui interna, inteftináue uulnera acceperint : nanque illa, fint uel exterius, uel interius $4^{\circ}$

Solidaginis SOLID A media nuncupatur, ab aliquibus ueró Laurentina, é ḋ Senenfibus Morandold. Harum modó dicta= minoris, \& rum ftirpium et $f \mathbf{i}$ nusquam, quod battenus inuenerim, meminerint Greci, aut Mauritani ; ex tamen mirum in modum medix uires. prodeffe exiftimantur difruptis, fractisó; internis, ov externis corporis partibus. Idcirco utiliter dantur potanda illata, mirifice fanant. Tradidere nonnulli, qui rerum experimenta profitentur, Confolidam mediam uocatam potu fanguinis grumos in uentriculo, uel in alia corporis parte concretos disijcere, o diffoluere. Illita ueró folia, uel eo= rum fuccum efficax medicamentum effe predicant ulceribus omnibus in ore manantibus, exedentibusó; , ac etiam te $=$ ftium, pudendorumq́; uirilium, or muliebrium. His omnibus facultatibus ea quoque predita eft, quam solidagimem minorem uocant, ut quidam exiftimant. Etenim ubi uulnera glutinare, adftringere, ev reprimere fit opus, minorem ufurpant, quam etiam altera longé preftantiorem effe fepenumero compertum eft. Recenfetur praterea Germa= Saniculx unú nisinter symphytigenera quedam ipfis uulgaris berba, quam S A N I C V L A M appellant. Exit hac folijs pen= genus. $\quad$ tapbylli maioribus: radice candida, tam miro nature ipfius artificio nodulis, ac lacinijs quibusdam elaboratd, ut non parum admirentur, qui tantum nature opus diligenter intuentur. His utuntur in potionibus ad enterocelas, or ad

Sanicule al 1 - interna unlnera, prefertim ad ed, que in thordcis cauitatem penetrauerint. Plura infuper Sanicule oftendunt ge $=50$ ud genus. nera. quorum unum, quod aliquibus berbarijs A uricula urfi nominatur, folia fert plantaginis magnitudine, fed craf= fiora, uelutifabarie uulgó uocate, lacinijs circim magno artificio factis à natura, colore in album flaue fcente. Id genus copiose nafcittur in agro Goritienfi monte Saluattmo. Hoc cateris praferunt ad enterocelds, or thoracis uul=

Solidago alia. nera, fi quotidic in potu fumatur: quin $\mathcal{O}^{\circ}$ ad alia uulnera, tam intus fumptum, quàm exterius illitum. His aliame denique annumerant solidaginem, quam uulgus medicorum Confolidam regalem, o tp/i fua uulgari lingua Ritter= porn uocant, quod fonat nobis sperone da caualliere, o Latinis equitis calcar. Huic funt caules cubiti altitudine: folia oblonga, tenuia : flores plané purpurei, magnitudine uiole : é quorum bafi corniculum eminet, antiqui calcaris effigie, unde illi à Germanis inditum eft nomen. Laudantur flores ad rubentes, or inflammatos oculos triti, er aqua rofacca illiti. Herba auxiliatur ardoribus, tußi, inflammationibus, uenenis, uomitionibus, bilio/is affectibus, Jupprefs Se urine, calculofis, ifchiddicisq;; : quin o aluum citat. Verùm boc Solidaginis genus magis, quantum cquidem reor, Cuminum jylueftre, quod à Diof coride fecundo loco de fcribitur, reprafentat, quàm aliam quámuis plantam, ut fupe= 


\section{InLib.quartumDioicoridis. $\quad 49 \mathrm{I}$}

\section{SANICVIAM.}

20

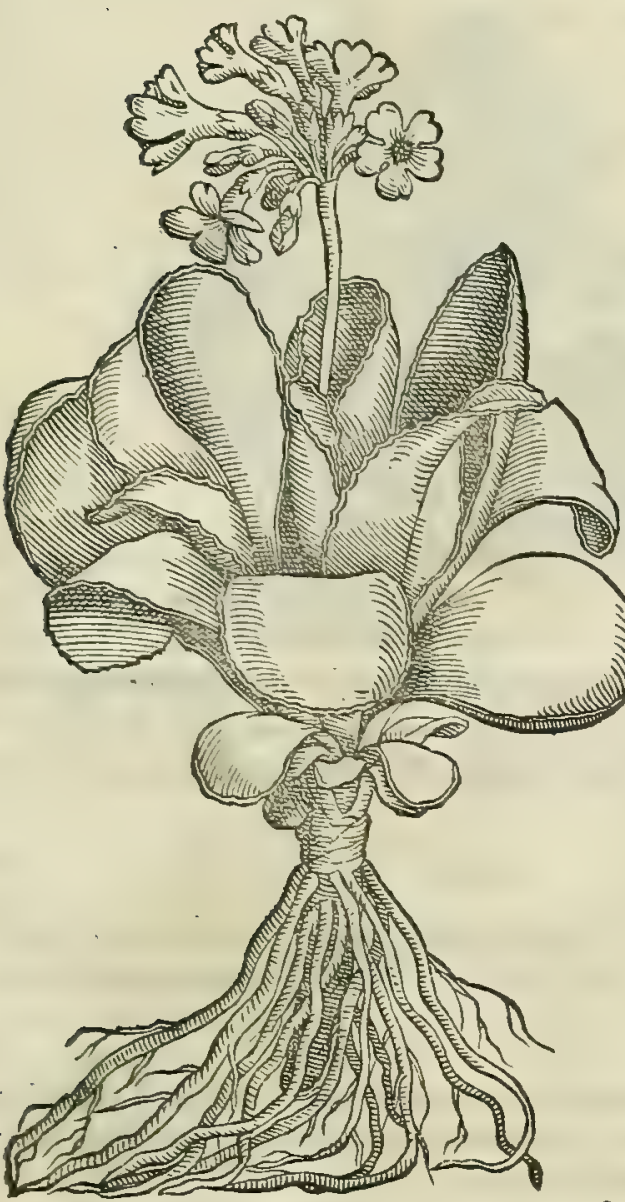

rius in Cumini commentatione diximus. Meminit utriusq; sym= phyti Galertus libro v I I I de fimplicium medicamentorum fac ul= tatibus, ubi ita fcriptum reliquit. Symphytum petreum ex con= trarijs conftat uiribus: babet enim incidendi uim quampiasn, qua collectum in thorace, o pulmone pus expurgare poteft. Habet etiam quandam contrabendi uim, qua eiectionibus fanguinis auxi= liatur: o tertia ad eas ineft bumidit ds quadam non immodicé $c d=$ lida, per quam guftantibus dulce apparet, o odoratu iucundun. Commanducatum fitim extinguit, o arterie apperitates fanat. Porró fecundìm onniun dictarum uirum miftionen fimul dige = rere abunde poteft, finul'; corpor a contrabere, or conftringe = re. proinde enterocelis imponitur, or ad conuul $[a, c r$ rupta cum oxymelite bibitur. Porró qui ipfum in uino decoctun ad dy fente= riam, or rubrum profluuium exbibent, utuntur tanquam deficcan te, o contrabente. Quitueró ad nephritin renimue dolorem, tanquam expurgante, e incidente. Symphytum ueró alterum, puta magnum, fimilem diffo uim babet: non tamen guftantibus dulce elt, nec odorantibus odoratum. Sed lis fanè à modó fcri= pto diuerfum eft. Caterim quatenus uifcofitatem quandam, er mordacitatem obtinet, fcille fimile eft. Vtuntur co ad omnia, ad

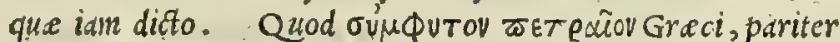
Iatini symphytum petreum, $\mathcal{O}$ I tali simphito petreo uocant.

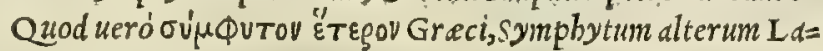
tini appellant: Itali, Confolida maggiore: Germani, Vual uurtz: Hipani, suelda maiore, er confuelda maior: Galli, Oreylle d'afne.

+ Ne quis commoueatur, quód nos lic folia adiecimus pres= ter Ruetlij, $\sigma$ Marcelli interpretationem. Id enim ea ratione $f e=$ cimus, quoniam in Aldino codice boc loco $₫ \dot{v} \lambda \lambda \alpha$, boc eft, folia babetur. Tum ueró quia folia thymi pulchré illi berbe quadrant, quam uerum symphytum petr aum cen $\int e m u s$.

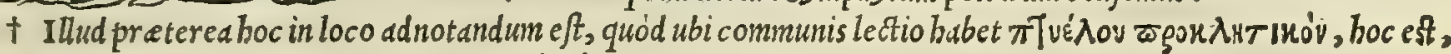
faliuam prouocans, in oribafio legitur su - Tiróv, quod eft adftringens.

O'Aós10\%. HOLOSTIVM.

CAP. $\mathrm{x}$.

HOLOS T I ON quadrantalis herba eft pufilla,tribus quatuórve digitis fupereminens extra terram : folijs, viticulisq́ue coronopo, aut gramini proximis, guftu adftringentibus : radice alba, prætenui ufque in capillamenti fpeciem, longitudine quatuor digitorum. nafcitur in collibus terrenis. 4. Vfus eius ad rupta in uino pota : nam \& carnes coguntur decoctionibus addita.

H o I O S I I V M etfía nemine, quod equidem fciam, cognofcatur in Italid; eam tamen plantam illi confimi= Holofii con lem effe crediderim, quam libro fecundo in Coronopi mentione à Goritienfibus ideo Serpentinam uulgó uocari dixi= mus, quód mirum in modum ferpentium morfibus opituletur. Hac fiquidem herba eft exigua, bumi procumbens,

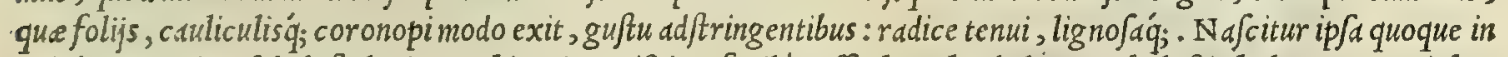
collibus, ac etiam fabulofis locis. Ex bis utiq; quifpiam facile poffet banc berbulam pro boloftio babere : quanuis boc ego pro certo affirmare non aufim. Recenfetur Holoftium inter fymphyti generd. Sed ballucinătur had dubié qui credunt eam berban effe Holoftium, quam Pilofellam berbariorum unlgus appellat . nam quanquam Pilofella dicta frequers nafcatur in collibus; folia tamen edit olex proxinid, albicantibus pilis horrida, unde illinomen. Iifdem ue= 5o ftuntur pilis $\odot$ caules, qui humi ferpunt, ac reptant, é quibus poftea prodeunt flores aureo colore. Radicibus ni= titur breubus, er tenuibus. Sed hac eius delineatio nibil prorfus Holoftio competere uidetur. P I L OS E L L AE plur a funt genera, quorum unum nafcitur inter $\int a x$ a Saluatino monte in comitatu Goritienfí : folijs in terram parfis, longis, echij inftar, pilis innumeris, lanuginég; ob́ductis: caule duûm palmorum longitudine : flore cyani fimilitudi= : ne, maiore tamen. Preftat hec planta ad uulnera glutinanda: quinetiam ad enterocelas, tam illita, quàm pota. Hăc nobis Pilofellaminaiorem liceat appellure, quando nondum conftet, an ueteribus Grecis, aut Latinis cognita fuerit, à quibus nomen mutudri po Simus. Tota Pilofells planta uehementer adftringit : quapropter huius rei non ignari pd= ftores inaximé cauent, ne ouium greges in illis pafcuis immorentur, ubi buiufce plurinum gignitur. Quandoguidem depafcentes oucs tant alui adftrictione afficiuntur, ut inde facilé emoriantur. Hinc didicerunt medici, eam mederi

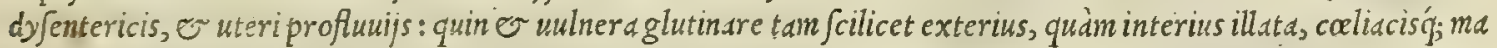
gno effe auxilio, e biliofis uomitionibus: cruentis item putitis, enterocelis, o o onnibus in uniuer fun fra:turis open ferre, fed precipué caluarie. Caterim ut ad Holoftium noftra redeat or atio, ingenué fateor nulla hadtenus plan=
Symphyti utriulque vires

Nomina. fideratio.

\section{Quorundam} error.

Pilofellx defriptio, \& ui res. ex Galeno. 
P I L O S E I A.

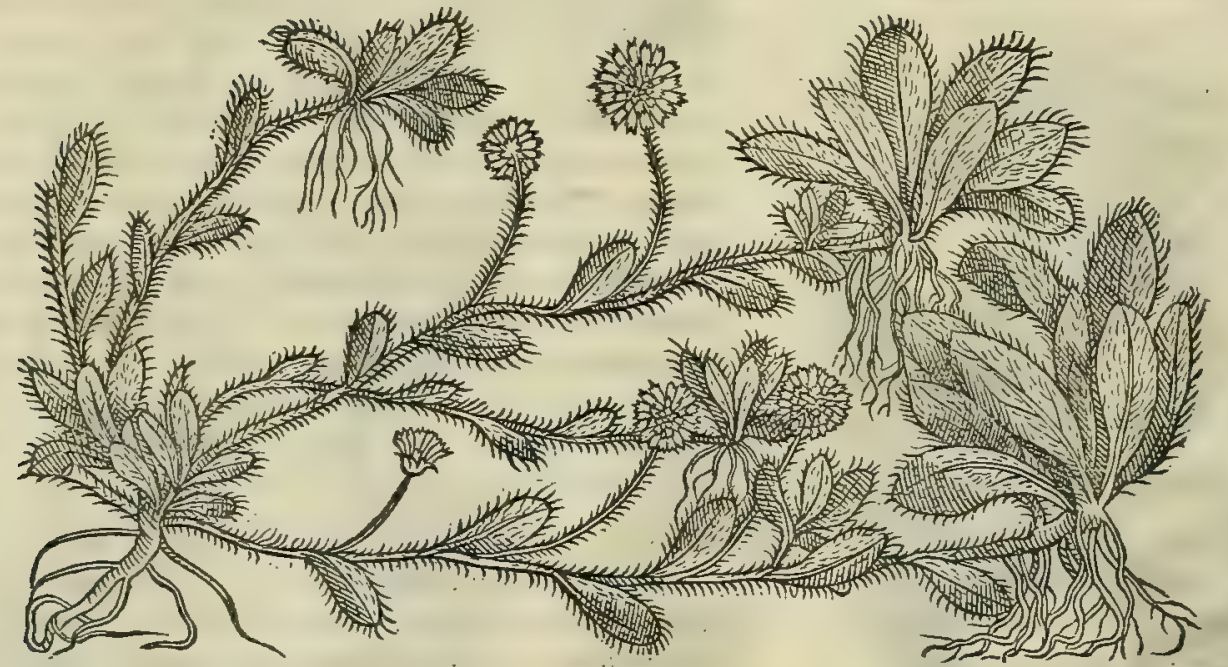

tam fe mihi obtuliffe, que magis Holeftium referat, quàm ed, qux Serpentina, ut diximus, ḋ Goritienfibus uulgó uo=

Holefij vires catur. Holeftium ( ut author eft Galenus libro v Ir. fimpliciun medicamentorum) deficcandi uim habet cum ad= 20 ex Galeno: friftione: quamobrem ipfum ad rupta potui exhibent. Quod. Graci ó $\lambda$ Ésiol, Latini item Holeftium, Or Holo= ftium dicunt: Itali, Holeftio.

\section{$\Sigma T O \& B S . \quad S T O E B E$.}

CAP. XI.

S T OE B E vulgaris eft notitix. Cuius femen, \& folia fringunt quapropter decoctum dyfentericis infunditur : auribus quoque purulentis inftillatur. Illita folia oculis ab ictu cruentis profunt, $\&$ erumpentis fanguinis impetus cohibent.

Stæbes confi S T O E в E N Diofcoridis tempore omnibus unlgó cognitam fuiffe, illud maximo argumento eft, quód eam nullis deratio.

prorfus notis reprafentauerit. Hinc certé nobis faceßitur negotium, quó minus fcire poßimus qúenam fit illa inter

SCABIOSA.

Matthei Syluatici error.

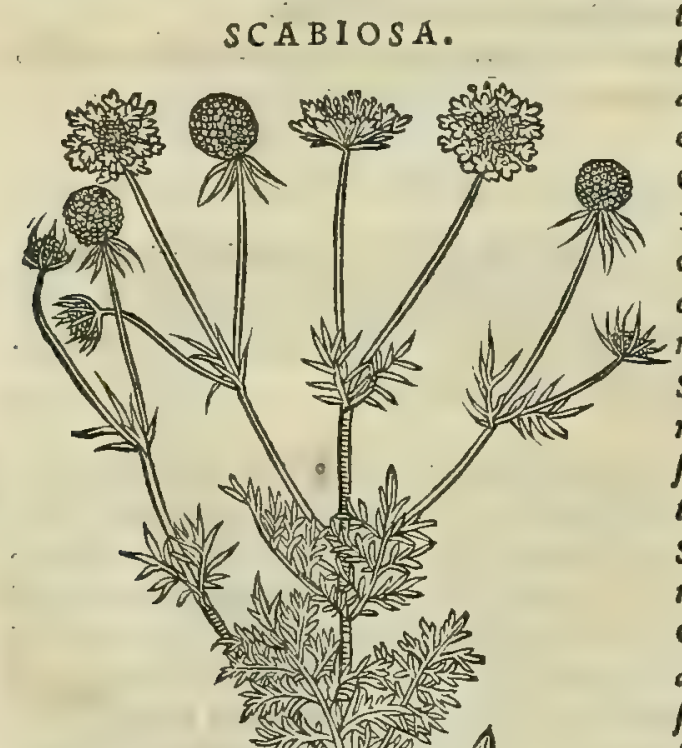
tot plantas, cuius nomina, er facultates ignorantur. Plinius li= bro $\mathrm{x} \times 1$. cap. $\mathrm{X}$ v.stceben inter aculeat as herbas retulit (id quod à Theophrafto lib.v I.cap.IIII. de plantarum hiftoria mutuatus eft) fic inquiens. Quedam funt berbe, qua pinas in folio babent, e in caule, utphleos, quod aliqui staben appellauere. Idem lib. $\mathrm{x}$ X I I.cap. X 1. Stacbe, inquit, quam aliqui pbleon uocant, deco= Ata in uino precipuë auribus purulentis medetur : item oculis itu cruentatis: bemorrboidi quoque, o dyfenterie infufa. haec Pli= nius. Ex quibus equidem uerbis plané afferere aufim, Phleon, or Staben eandem plantain effe. Hanc in Orchomeno lacunafci $\int e=40$ mine placentaceo, o molli, colore rubido, author eft $\mathrm{Theophra=}$ Atus lib. I I I I.cap.x I. de plantarim biftoria. Hinc itdq;.Mat $=$ thei syluatici error maniffte deprebenditur, qui in fuis pandectis stoben eam berbam interpretatur, quam uulgus scabiofam nomi= nat. cuius, quod fciam, nec Greci, nec Mauritani meminerunt. Quanquam non defunt, qui scabiofam eam effe contendant, que $a b$ Aëtio uocatur $\mathrm{P}$ fora: quam tamen is nomine tantùm expref \pm fit, nulld adiecta defcriptione, ex qua aliquid certiconftitui pof= fit. Ceterum Scabiofam uocatam non effe Stoeben illud abunde $0=$ ftendit, quód hec folijs conftet laciniatis, fubbirfutis : caulibus te $=$ so nuibus, cubitali altitudine, atq; etiam maiore : in quorum cacumi ne flores emicent in caruleo albicantes: $\sigma$ in pratis, or campe= frribus proueniat. At Stobe folia fert aculeatd, o in lacubus, fta gnis, paludibus, alijsí; locis aquofis nafcitur. Vnde Ariftophanes comicus recte in comedia ranas inter fe loquentes adducit, qua admodum latabantur, quód totam confumpfiffent diem inter $c y=$ perum, o phleum faltantes. Sed quoniam nufquam reperio ue= teres $S$ C A B I O S AE meminiffe, ne d̀ nobis quoque filentio pretermiffa in pofterum deperdatur, bic eius facultates explica= bo. Pollet in primis bec aduerfus fcabiem, unde illinomen: in quem ufum non modó eius decoctum quotidie potandum praci= 


\section{In Lib. quartum Diofcoridis.}

piunt; feder berb.e ip/ius fucco, per $\int e$, aut in unguentis addito, $\int c$ abio $\int a$ corpora illinunt. Prodeft omnibus pecto= ris uitijs, or refpirationi inferuientibus organis : quippe que er corum inflammationes purulentas disijciat, er om= nia pectoris excrementa expurget. Antloracibus, fiue Carbunculis peftiferis utiliter illinitur : adeo ut illita bos lctha les abfceffus trium borarun patio prorfus abolere exiftimetur. Scd iam ad Stcebes uires redcamus, de quibus Galc= Stobes uires

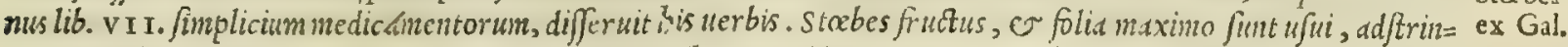
gendi uim babentia mordacitatis experten. Sed er deficcant euidenter in tertio feré ordine incivicnte. Quamobrem decoqum corum dy fentericis inijcitur, o auribus pure flue tibus, tum uulnera magna conglutinat. Euidcritius hec preftat cum uino atro auftero: udenter enim deficcat omnes prater naturam bumidiates. Preterea folia uiridia, fillinantur, uim babcnt crumpentis fanguinis fupprimendi : denique o oculorum ex idtu fuffuliones illita iuuant.

20. Qua planta sosßri Grecis, fimiliter stebe Latinis, or stebe It lilis appellatur.

Nomina.

$$
\text { K入ứevor. CLYMENVM. CAP. XII. }
$$

C L Y M E N V M caulem fert fabr, quadratum : folia plantaginis: folliculis fupracaulem fefe inffe xis, ut in poly porum cirris. Probatifsimum eft è montibus. E' frutice toto cum radice fuccus exprimitur : qui ad fanguinis reiectiones, in potu efficax eft : cœliacos,rubraq́ue foeminarum profluuia,refrigerando infrænat : fanguinem naribus erumpentem fupprimit. Trita folia, aut filiquæ recentibus vulneribus impolitx, ea ad cicatricem perducunt.

S I C A V L E S, itemíg; flores berba, qua Saponaria unlgó uocatur, Clymeni delineationi reponderent, Clymeni cóquemadmodum folia illi quadrare uidentur, quippe que plantagini prorfus referant imaginem, cum Ruellio uti= fideratı. que fentirem, fatererǵ; Saponariam legitimum effe Clymenon. At certé neque caulis, quem rotundum profert, Ruellij, \& $\mathrm{Pli}$ or per interualla geniculatum, neque flores illi quicquain adftipulari deprebenduntur . Quamobren qúenam ber= ba Clynenum in Italia bodie referat, battenus non fatis compertum babeo. Hanc (ut Plinius memorice prodidte libro X X V.cap. VII.) inuenit rex Clymenus, unde o nomen herbe. Qulo in loco idem Plinius clymeno perpe= ràm illd omnia reddidit, que Diofcorides periclymeno aßignanit. Huius nufquam, quod inuenerim, meminit $\mathrm{G} d=$

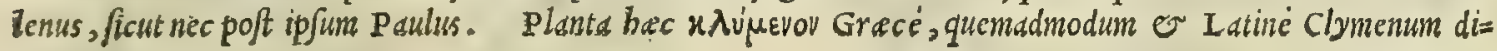
citur.

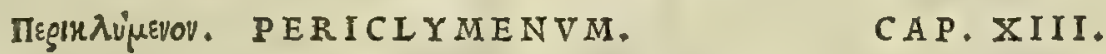

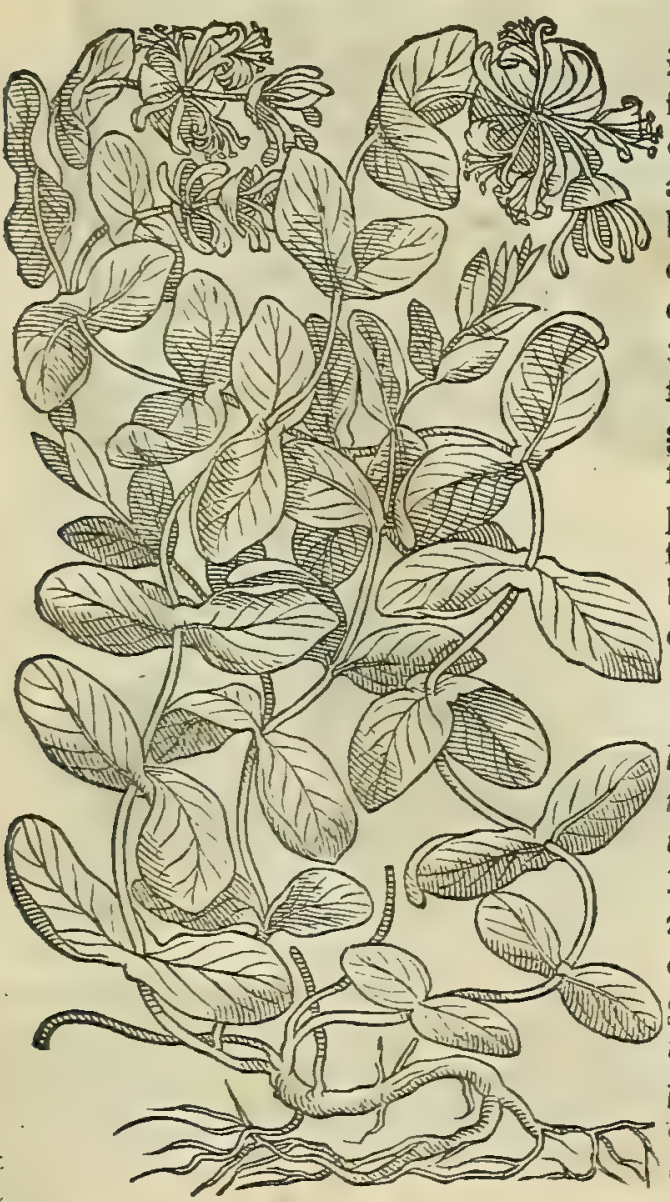

PE R I C I Y M E O N fimplex fruticat, ex interuallis parua folia habens, ipfum amplectentia, fubcandida, hederacea : inter folia furculi exeunt, in quibus bacca hederæ fimiles : flos fabæ, candidus, aliquantùm rotundus, \& quafi in folium procumbens : femen durum, \& quod difficilè euellatur : radice rotunda, craffa. Nafcitur in aruis, ac fepibus, conuoluens fe adminiculis proptèr afsidentibus. Semen eius poftquàm ematuruit collectum, \& in umbra ficcatum, fi drachmæ pondere detur in uino, quadragenis diebus, lienem abfumit, lafsitudinem difcutit: fed urinám ciet, ftatim à fexto die cruentam orthopncx, \& fingultui prodeft: partum accelerat. Folia funt eifdem uiribus prædita : quæ tricenis feptenis diebus epota, fterilitatem facere produntur : perunctis ex oleo, febrium algores abigunt.

SV N T qui Periclymenum perperàm Caprifolium appel= Periclymeni lent: officine Matrijyludm uocant: nos tueró, quòd propinquas confider. uinciat plantas, uulgó appellamus vincibo $\int c o$. Caterüm id po= tißimùm nos ad credendum impellit, unlgatam Matrifyluame efe Periclymenon, quodd non folim omnes buiufce atatis reiberbd= ris peritißimos in banc fententian deueniffe compererim; fed quod etidm ex notis, quds illireddidit Diofcorides, ita effe co= gnouerim. Quandoquidem Matrifylud unico tantùm caule fru= ticat, qui ex interuallis gemina tantùm folia mittit, ipfum am= plectentia, fubcandida, bederacea q́;. Flos eifabe non dißimilis, candidus, cum adoleuerit, in folium procumbens. Semen bederd= ceum, predurum, $\sigma$ quod difficile euellitur, in furculis quibufs 
dan connexum, qui inter folid erumpunt. Conftat preterea eius caulem, qui ab radice fimplex affurgit, arbufculis; o fruticibus miré $\int e \int_{e}$ conuoluere, ubi in fepibus, or frutetis nafcitur, adeo ut fape tam pertinaciter inhereat, li= Quorundam getóg; adminicula, ut in ea manifftum imprimat uestigium: unde à nobis meritó vincibofco dicitur. Porró plané, error. mea quidem fententia, ballucinantur, qui Caprifolium, or Matrifyluam feu Periclymenum idem effe exiftimant: in quorum numero effe deprebenduntur $\mathrm{R}$ uellius, $\mathrm{O}$ Fuchfius, alioqui uiridoctißimi, In bunc autem lapfum bos fortaffe deduxit Mattheus syluaticus pandectarum autbor . Siquidem is fuum Caprifolium Matrifyluam nominat, cium tamen, ut fubinde legitur, nil aliud Syluatico Caprifolium fuerit, quàm Diofcoridi pyxacantha, feu lycium, non autem periclymenum, de quo feor fum fub titulo Matrifylux Syluaticus ipfe differuit .'Quod forté non animaduer tentes ij, Caprifollum, or Periclymenum idem effe putarunt. Caterùm Matrifylua in corum unguentorum ufum uenit, qux ad capitis uulnera parantur. Nanque hac in re efficacißimum eft medicamentum . quanuis é ueteribus a. nemunem bactenus inuenerim, qui Periclymenon ea ui pollere, memorix prodiderit. Hanc etiam berbam com= mendauit Iodnnes de vigo clarißimus clirurgicus,ad crurum ulcera, quodd eam ad boc (ut ipfe inquit) utilem effe tradiderit Galcnus lib. V I I . Fimplicium medicamentorum. Veruntamen id non legitur in meo Galeno: nam loco Periclymeni citato Galenus de Periclymeno ita feriptum reliquit. Periclymeni tum fructus utilis eft, tum folia, adeó uebe= uires ex Gal. menter incidentis, fimul ev excalfacientis facultatis, ut fi plufculum bibantur, urinam fang:inolentam efficiant: principio quidem urinam tantim mouent: porró foris cum oleo illita excalfaciunt. Inuant $\mathcal{\sigma}$ lienofos, $\sigma$ difficul= ter pirantes. Competens potionis menfura eft, drachme unius pondus cum uino. Porró deficcat quoque $f e=$ men. Et quidam aiunt, fi copiof fius bibatur, fierilitatem omnino bibentibus afferre. Sed 0 funt qui certum die= rum numerum ad tulem potionem prefiniunt, ut Diofcorides, qui feptem $\sigma^{-}$triginta eos tradi refirt. Hic etiam

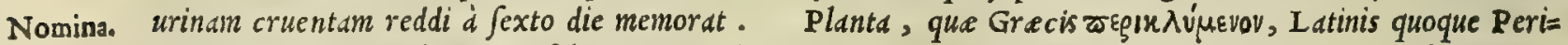
lymenum dicitur: Iralis, Matrifelua : Germanis, Geiszblatt: Hipanis, Madrefylua: Gallis, Vincibofje.

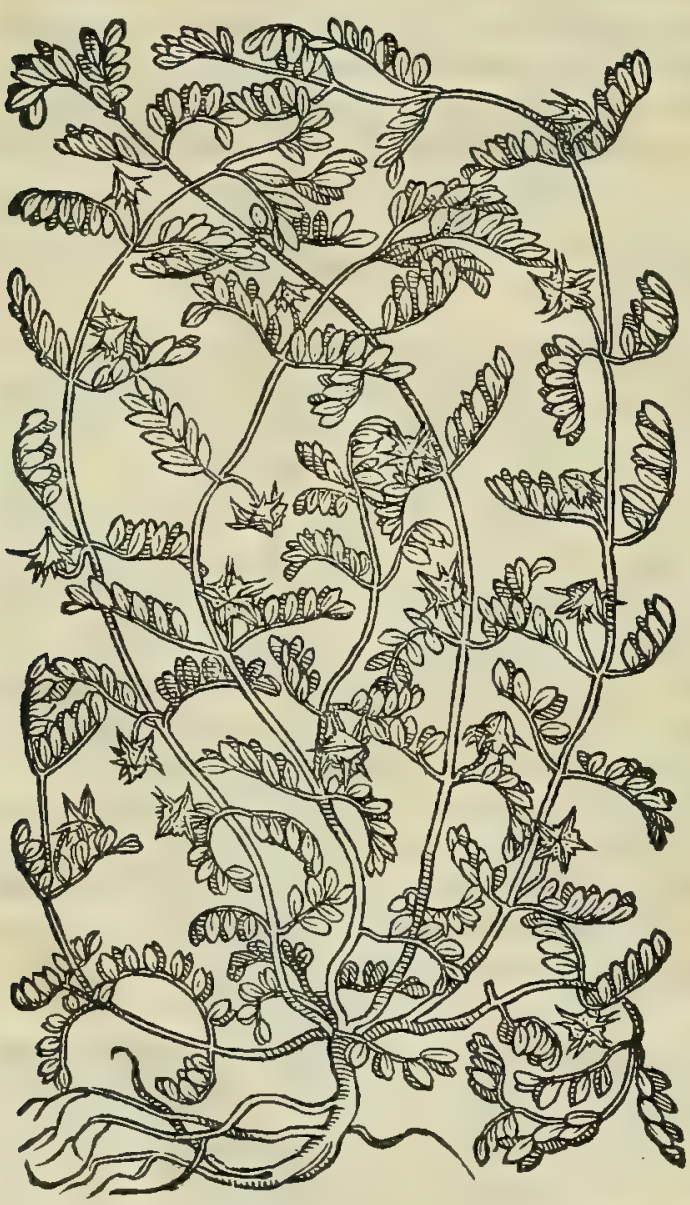

Tpißoגos.

TRIBVLVS.

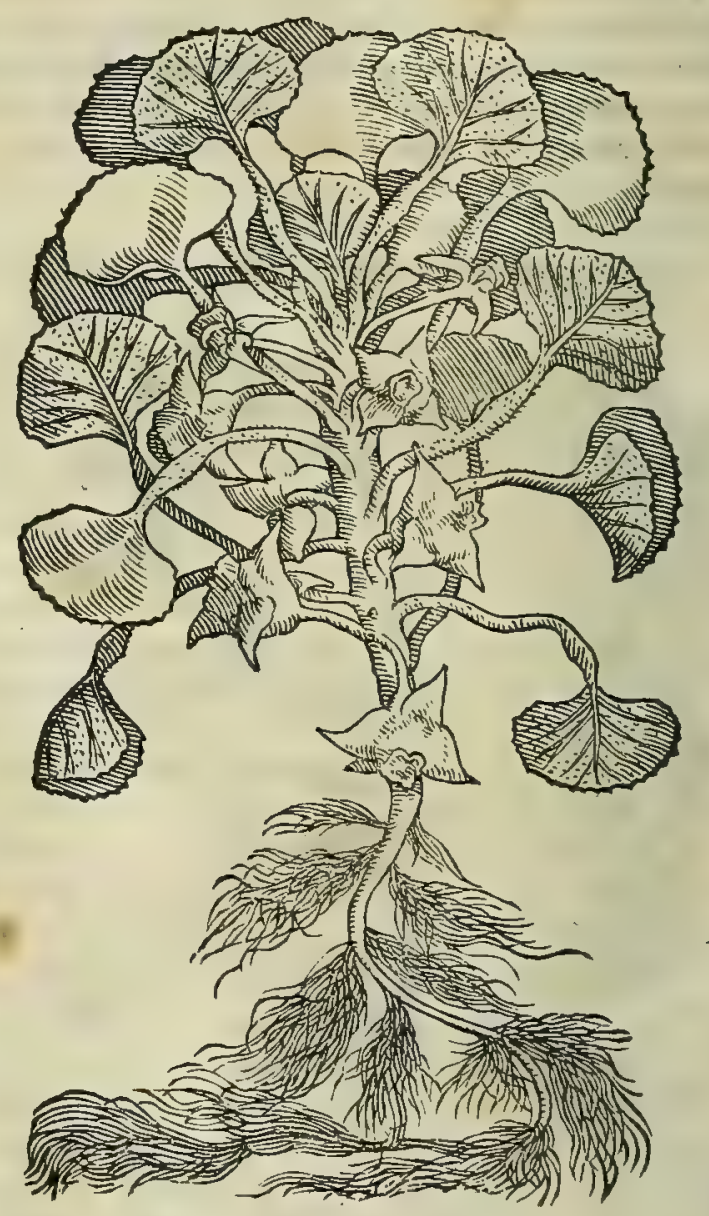

CAP . XIIII.

T R I B V L I genus unum terreftre, folijs ad effigiem portulacx, tenuioribus : viticulis in terra ftratis: (pinis fecundum tolia rigidis, præduris. iuxta amnes, \& rudera nafcitur. Eft \& alterum genus, aquis familiare, quod in fluminibus natum comam exerit, aculeos condens : folijs latis, \& pediculo longo : caule parte fumma, quàm ima crafsiori : adfunt ei \& capillamenta quædam fpicacea : femen durum, ab altero non abhorrens. Vterque refrigerantis, \& infpiflantis eft natur $x$ : 


\section{In Lib. quartum Diofcoridis.}

ideo inflammationes omnes cataplafmate adiuuat. ulcera in ore erumpentia, putredines, gingiuas, tonfillasq́ue perfanat. Succus ex his colligitur ad oculorum medicinas. Semen dum recens bibitur, calculofis iutuamentum affert. Drachma terreftris tribuli pota, illitáve, ictos à uipera recreat: contra uenena cum uino aptifsimè bibitur. decoctum cius fparfum pulices necat. 'Thraces qui ad Strymona amnem habitant, virenti tribulo equos faginant : \& è dulci femine \& efculento panem,quo vefcuntur, faciunt .

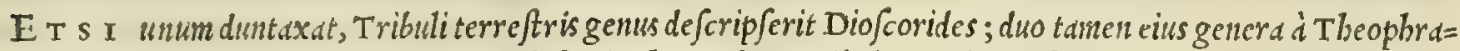
fro redduntur lib.v I. cap. v. de plantarum biftoria, his uerbis. Tribulo peculiare eft, ut fructum gerat aculc atum. Tribuliconfideratio.

- Eius duo funt generd: uni folium eft ciceris, alteri aculeatum. Vtrunque terreftre, o furculofum: ferius germinat, cui in folijs funt aculei, magisi, hoc apud fepta villarum erumpit. Semen precoci fe fame figura cernitur : alteri, hoc eft ferotino, rotundum, nigrun, filiquis inclufum. Hec duo terreftris genera Theophrafto. Tribulum, cuifolia por= tulace Diofcorides aßsignauit, memini me uidife Venetijs in maris litore propé diui Nicoldi faccllum. At bunc, cuius bic figuram expromp/inus, Pifis mifit ad me Lucas Ghinus Forocornelien/is medicus rei berbaria peritifimus.

Rucllius Tribulum aculeatun Thcophrafti eam plantam effe arbitratur, quam Hetrufci uulgó nocant Cacatreppo= Ruel. error . $\mathcal{L}$, ea fortaffe ratione ductus, quód prope torrentium, o fluminun ripas proueniat. Verün cum lateat nos foliorum effigies, que à Theophrafto illi tribulo non redditur, atque etiam conftet hanc plantam furculos non mittere, neque filiquam ferre, in qua intus claudatur femen, cogor onnino d Ruellio diffentire. Noftrates feplafiarij huius radices melle, O facclaro condiunt, eryngij eas effe exiftimantes. Qua in re haud dubie illifalluntur, ut fuperiorilibro in

so eryngio oftendimus. Sed ad Tribulos redeamus. Aquaticum genus in plerisq; It alia fluminibus, o lacubus prove nit, prefertim in agro Mantuano, o Ferrarienfi: neq; folum in dulcibus dquis gignitur; ;ed etiam in mari. Hos tri= bulos venetijs in foro uendunt, quos marinos appellant, ut qui in lacunis illis uicinis enati inueniantur. Ex his porró qui péregre proficifcuntur, uerticillos faciunt, quibus fuas preces enumerant, collo ${ }^{\prime}$ geftant, ut maiorem pra fe frrant religionem, ne dicam bypocrifim. Nonnulli fructu, qui caftaneis refert fimilitudinem, fub cineribus calidis cocto, non fecus, atque illis pro belldrijs ue fcuntur. Tribuliutriufq; facultates perstrinxit Galenus lib. vi I. fim = plicium medicamentorum, ubific inquit. Tribudus ex bumida effentia modice frigida, E ficca non mediocriter o ip $\int$ a frigida componitur. In terreftri tamen fuperat terreum frigidum, quod $\sigma$ adftringens oftendimus : in aquatico ueró aqueum. Propter utrunq; itaque o contra phlegmonarum generationes, o omnino contra omnes influxus con

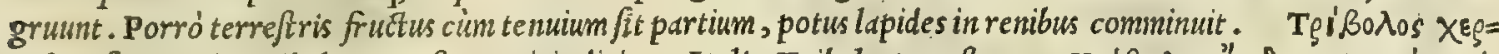

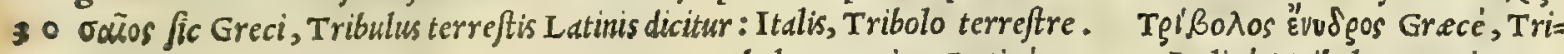

SAXIFRAGA.

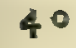

so

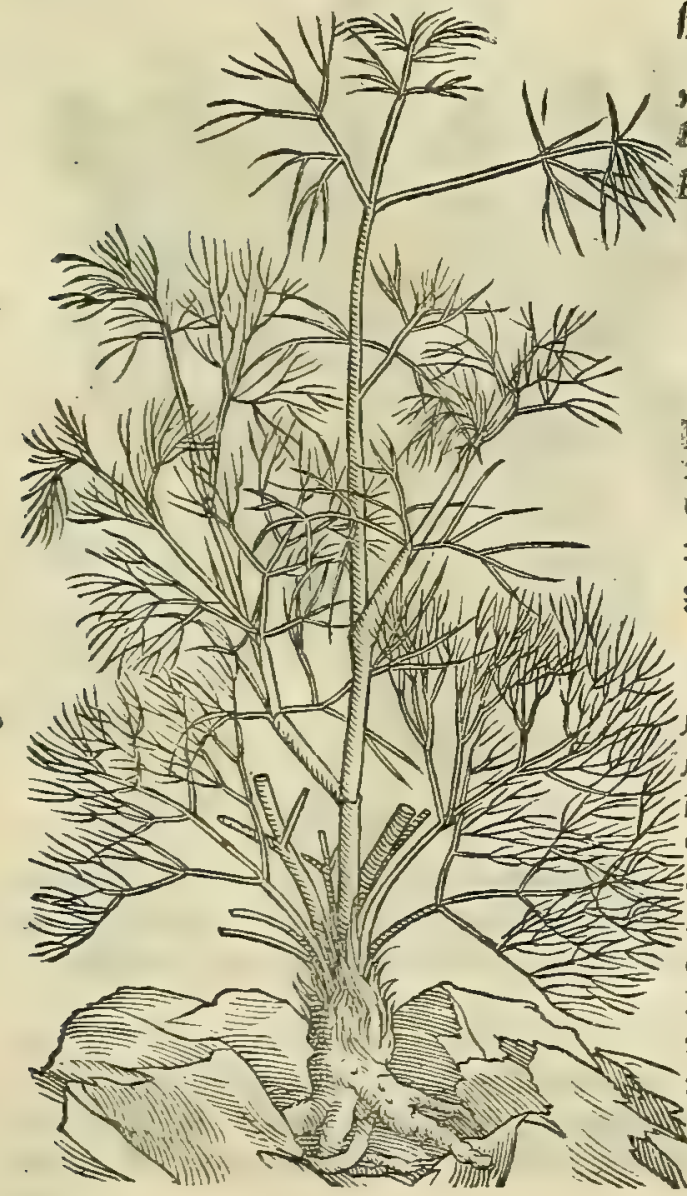

bulus aquaticus Latiné uocatur : Italicé, Tribolo acquatico. $A=$ rabicé fimpliciter tribulus $\mathrm{H}$ a fach, feu Haferk appellatur: $\mathrm{Hi}=$ Aanicé, Abroyos, 0 abrolbos.

† Hoc in loco ita equidem legunt unlgata Greca exempla= ria, fed Oribafius lib. x I I ittemó; uetuflus Diofcoridis codex ba= bent $\mu \alpha \mu \rho \alpha$ qua noce Tribulum terreftrem uiticulis long is $r e=$ praesentant. Id quod etiam satis plante pictura demonftrat.

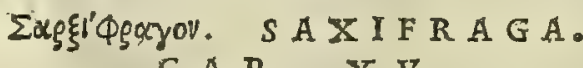 C A P. X X.}

† S A R X I P H A O N aliqui farxiphragon,alij empétron, Romani faxifragam vocant . frutex eft furculofus, in petris, \& afperis locis nafcens, epithymo fimilis . Coctus in vino, mox potus, febricitantibus opitulatur: ftrangurix prodeft, fingultum fedat,calculos veficx frăgit \& urinam ciet.

L I C E T omnibus buius etatis rei herbarie peritis fatis Saxifragx cöfuperq́; perfuafum effe non ignorem, boc saxifrage caput Dio= fideratio. fcoridi illegitimum effe, quodd Lidtind nomenclatura contra $\int c r i=$ ptoris moré Gracé proferatur; tamen cùm in omnibus feré Gre= cis exemplaribus habeatur, id mibiquog; disimulandum non $p u=$ taui : eaq́; maximé ratione, quòd eam plantam babet, nouitó; Italia. cuius ufus precipué expetitur ad renum, or uefice call culos comminuendos, of ad urinam remoratam ciendam. Ea in Hetruria pluribus locis è durißimis erumpit faxis, folijs capilld= ribus, epitbymo non dißimilibus, prefertim Argentario pro= montorio in maritims noftris. Inuenitur quinetiam in agro Goris tienfi quibufdam $\int a x i s$ enafcens, iuxta sontij fluminis ripam, qua salicano rure itur Canalum. Sed aliquis fortaße obijciet, hane
Tribuli uires ex Galeno.

Nomin. 


\section{And. Matthioli Comm.}

tlin:am non effe legitimum saxiphragon hoc loco defcriptum, quod ea nullis feré notis epitbymum reprafentet. Nes que id quidem temere obijcietur : etenim non uideo ego, quomodo saxipbragon recté epithymo aßimilaripoßit,quód illud fiutex fit furculo $\int_{u s}$, boc autem tantum abfit a frutice furculofo, ut uideatur poțius effe quoddam capillamen= tuin. Idcirco facilé adductus fum, ut fupicer codicem boc in loco deprauatum effe: aut saxiphragon frutex erit, qui folijs duntaxat epitbymum amuletur, ut illa fọlia fatis oftendunt, qua in bac planta, cuius imaginem bic expreßcmus, Plante faxi- capillorum inftar tenuißima conpiciuntur. Ceterum funt $\sigma^{2}$ alla berbarum genera, qua fub saxifrage nomens frog e dictx. clatione uulgaribus demonftrantur, nempe Trichomanes, Adiantum, A plenum, Filipendula, Maßilienfe fefeli, Pimpinella que bircum redolet, $\sigma^{-}$alie plures berbs : qux ideo saxifrage nomine infigniütur, quód omnes urinam

Saxifraga al- cieant, o calculos frangant pellantq́;. E/tporró alia quoq; planta Germanis berbarijs notißima, quam Saxifra $=$

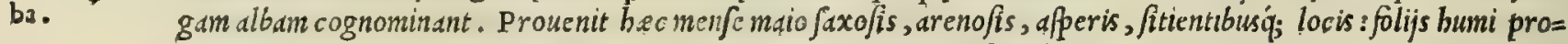
cumbentibus, exiguis, rotundis, in ambitu ferratis, uulgaris terreftris bedere modo ; pinguioribus tamen, $\mathcal{O}$ mol= lioribus. Caulem profet tenuem, iunçi modo, birfutum, cubitalem : in cuius cacumine flores prodeunt albi, candidis uiolis non abfiniles, qui menfe I unio absq femine decidunt. Radix buic exilis, granulis quibufdam coberens, coris andri magnitudine, qua partim albicant, partim ueró rufe fcunt, er pro femine feruntur, amaro guftu. Folia cum

Nomina, radice in uino decotta urinam cievit, renum, or ucfice calculos pellunt. Idem praftant er granula, que radicibus adberent, fi tufa deuorentur. Planta, que Grecis $\sigma \alpha \rho \xi i \phi x \gamma o v$, et $\sigma \alpha \rho \xi i \phi \rho \alpha \gamma o v$, Latinis Saxifraga, $\sigma$ Italis Saßifragia nominatur.

tQui poltremó impreßi funt Greci Diofcoridis codices non bic, fed in fine feparatim fcriptum habent hoc caput de saxifraga, inter ea relatum, que in boc authore adfcititia cenfentur. Hoc dictum fit, ut omnibus conftet, illud nö folum Latiné, Jed etiam Grecé fcriptum reperiri.

\section{I MO N I V M.}

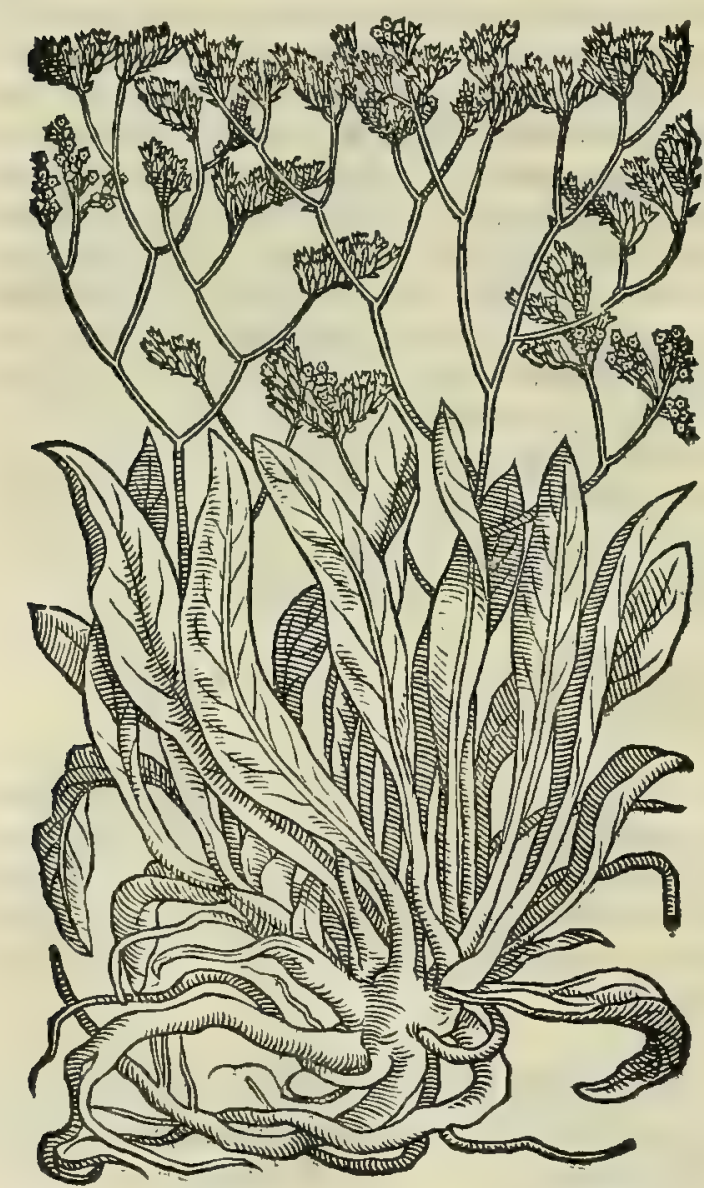

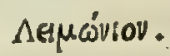

LIMONIVM.

\section{IIMONIVM A I IVD.}

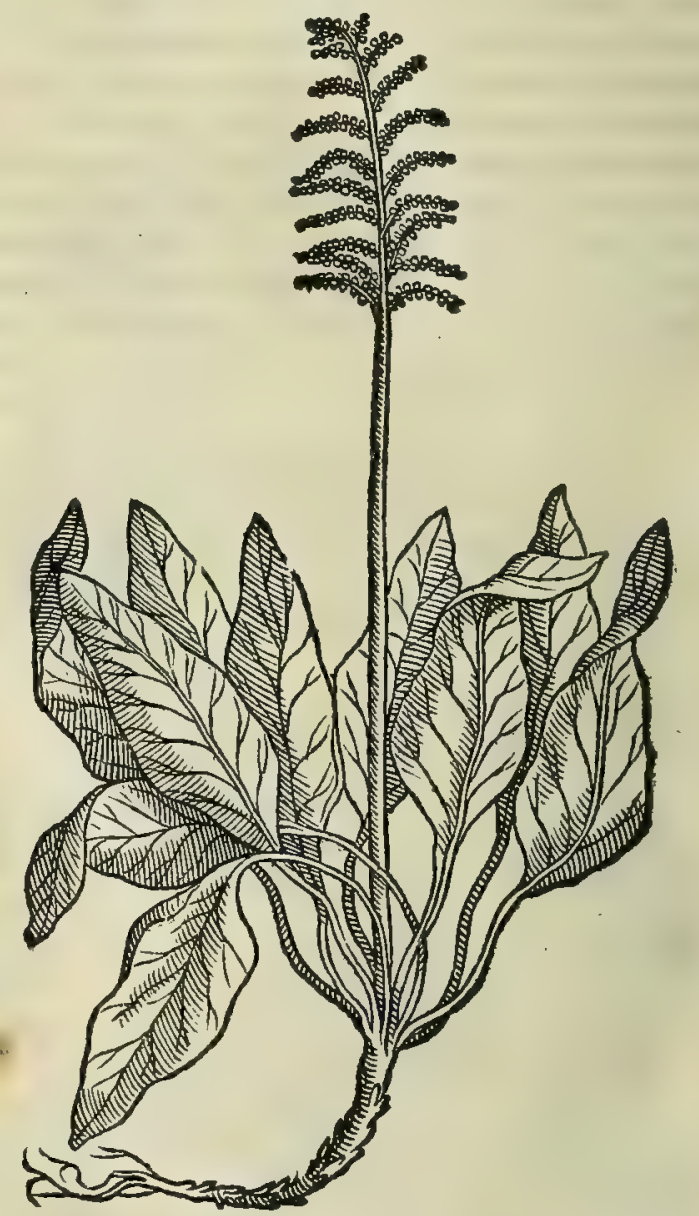

CAP. XVI.

L I M o N I o N folia habet betæ, tenuiora, \& longiora, decem, \& frpe plura: caulem tenuem, reEtum, lilio xqualem, feminibus rubris fcatentem, qux guftata adftringunt. Semen tritum, \& ex uino acetabuli menfura potum, dy fentericis, coeliacisq́ue prodeft : rubra fominarum profluuia fiftit. Nafcitur in pratis, \& paluftribus.

Limonii con P R O V E N T L Limonium, nullis prorfus reclamantibus notis, innumeris fré plantis in paludibus, que Ti= fideratio.

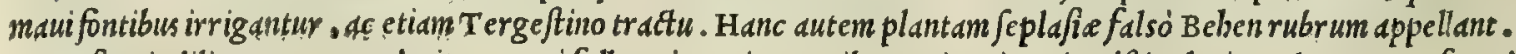
quam fi quis diligenter expenderit, edm, ni fallor, inueniet omnibus notis Limonio adftipulari : unde cogetur fateri 
aut hane uerum Linonium effe, aut faltem eius genus. Siquidem berba eft (ut imagines dux, quas bic damus, aper = té demon/trant) folijs bete, tenuioribus or longioribus, decem, fepe plursbus: caulibus item tcnuibus, in quibus fe= men rubrum, quod g!!ftatum adftringit. Preterea in pratis, prefertim uligino/ts, er paluftribus prouenit. Addan etiam quod experincuto compertum cft, Bebcn boc adulterinum preditum cffe facultatibus or uiribus, quas Limo= nio.reddiderunt Diofcorides 0 Galenus. Quare non temere me facturun putaui, fi proucro Limonio hic eds plan= tas depizas exbiberem, que in officinis Behen rubri nomen perperam acceperunt : quod iam mita perfuafum fit ( ut in glandis ungucntarie commentatione dicetur) cas plane Bchen illud ementiri, de quo d Nauritanis mentio facta cft. Plinius libro x x.cap. v I I r. Limonium fylueftrem bctam nocari tradit. Sed buic, ut in beta notaumus, refiagatur Galenus libro fecundo de alinentorun fucultatıbus, ubi fe mullam unquam fylueftrem betam nouife fcribit: nifí quis

to proea rumicem accipiat. Atq; adcó hine colligamuslicet, Limonium effe per fe genus berbx. Limonij uires me= morie prodidit Galenus libro v I I. finplicium medicamentorum, fic inquicns. Limonij fenen utpote austerum, ca: liacis, dy fentcricis, $\odot$ fangunem ? Puentibus cum uino exhibent. Iuuat $\odot$ profluuium mulicbre. Satis autcm cft ace= tabulimeafurd. Quod Graci rejuáviov, Latini item Limoniun dicunt: Itali, Limonio.

\section{4ywitrous. LAGOPVS. CAP. XVII.}

L $A$ G O V s herba fiftitaluum in uino pota:aut in febri, ex aqua. Eadem inguinialligatur in in flammatione. Nafcitur in fegetibus.

20 S A N E' tam pancis Lagopam perftrinxit Diofcorides, utpote quine ullam quidem eius imaginis notam defigna wit, ut arduum eque, atque difficile fit afferere, quinam fatuendus fit in tan ingenti plantarum multitudine, quar $\tilde{u}$ nulla apud homines extat cognitio. Ceterim Matheus Syluaticus parum reate, meo quidem iudicio, tradidit Lago= pum cam effe berbam, quam herbariorum unlgus Caryophyllatam appellat: quandoquidem bec non gignitur in $\int e=$ getibus, fed in montibus, or in uijs iuxta fepta. quod mirum in modum fepibus opacarigaudeat. De hac ueteres, quod fciam, nibil memoria prodiderunt. Nifífortaffe fuerit Geum à Plinio deferiptum libro x x v I. cap. V I 1 .cuira

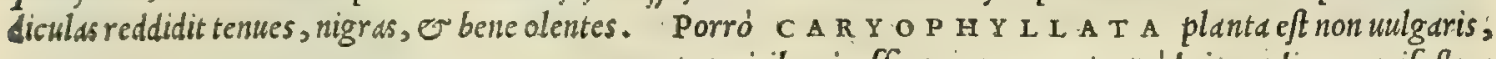

CARYOPHYILATA.

30

40

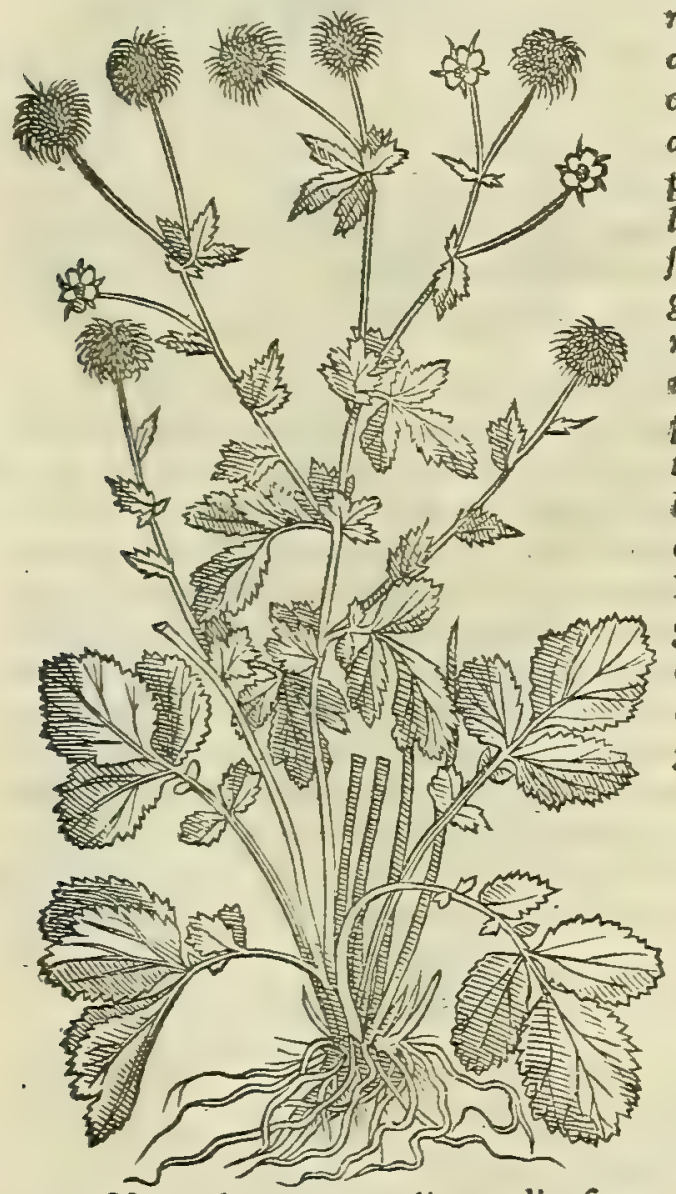

vieq; uiribus inefficax, argumento quód eius radices manifeftum caryophylli pirent odorem. Ea recentiores utuntur pota ad tho= racis interna unlnera. Quin er cius fuccum, admifta erugine; cuniculofis, contumacibuś; ulceribus utiliter inijciunt. Eaden - Ifactu piritus recreat, o frigidü roborat cerebrum. E pota pro. deft coeliacis, dyfentericis, fominarim profluuijs, or cruenta ex puentibus. Tam intus fumpta, quàm foris illita enterocelis auxi= lio eft. Temperamentum ei excalfaciens, or exiccans, ut manife fto funt indicio eius radices : quippe que guftu odorate, adfrin= gentesq́; deprehendantur. Quibus qualitatibus non modò attenua rè, difcutere, er adfitringere ualent; fed etiam roborare. sed, at ad noftrum infitutim reuertamur, Germanorum uulgus $\mathrm{L}$ ago pü appellat herbä, qua folia babet trifolio fimilia, oblonga: caulem tenué, rotundum, birfutum'; : Semen in paniculis paruis, mufco/is, lanugino/isóf; : cui nort obfcura adftringẽdi uis ineft. Proinde funt é Germanis, qui ea utantur ad detergendam fedem in dy fenterid. Nafcitur hac quidem in fegetibus. uerum an ed legitima fit $\mathbf{L} d=$ gopus non aufim affirnare: nullus enim, quod fciam, Lagopifa= ciem reprafentauit. Lagopi uires fcriptas reliquit Galenus li= bro $v$ I I. fimplicium medicamentorum, his paucißimis uerbis. La gopus facultatis eft deficc antis, adeó ut fluxus alui probé exiccet.

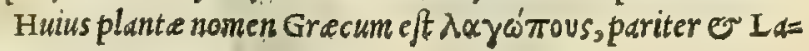
tinum Lagopus.

\section{Mrídoy. MEDIVM.}

\section{CA P. XVIII.}

M E I O N in faxis, \& opacis nafcitur. folia habet iridis : caulem tricubitalem, \& in eo florem grandem, purpureum, rotundum : femine cnici, minuto : radicem dodrantalem, crafsitudine baculi, guftu acerbo. Quæ trita in farinam, \& ex melle decocta, rubros menfes fæminasum fiftit, eclegmate per aliquot dies fumpto. Semen in uino potum, menftrua pellit.

M E D I O $\mathrm{N}$ in Media duntaxat nafci quibufdam proditum eft. Quód fíta fe res baberet, mirum profictó non Medii confieffet, finon proveniret in Italia, ubi ip $u m$ bactenus fateor me non reperiffe, aut uidiffe. Sunt qui eius folid intubof $f=$
Lagopi confi deratio.

Syluatici opi nioe xplora.

Caryophyl latæ uires.

Lagopi uires ex Galeno.

Nomina. deratio. 


\section{8

milia fuciant, non autem iridi, ut communis habet lectio, quibus etiam oribafius adstipulatur. Et certé facilis potuit

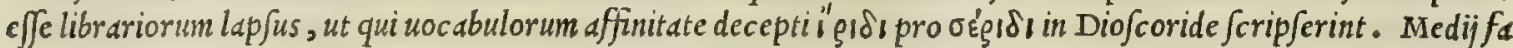

Medii uires cultates tradidit Galenus libro $\mathrm{v}$ I . fimplicium medicamentorum, fic inquiens. Medij radicem contrà at $q_{;}$femen ip ex Galeno. fum, temperatam effe contigit. nam illa quidem auftera eft, of fluxiones cobibet cim alias, tum proflunium muliebre quod uocant. At femen tantum abclt, ut tale quid efficiat, ut ctiam menfes cieat, utpote quod tenuium partium, $\sigma^{-}$

Nomina. incidentis eft facultatis. Vt Greci hanc plantam $\mu$ sis 10y, ita etiam Latini Medium uocant.

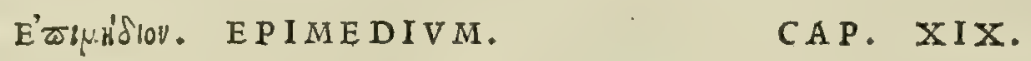

E P I M E D I V M, caulis eft non magnus, hederæ folijs, denis atque duodenis, neque florem, neque fructum ferens : radice tenui, nigra, graui odore, guftu fatuo . nafcitur in humidis. Folia cum oleotrita, impofito cataplafmate, mammas increfcere non finunt. Radix conceptum adimit. Folia trita quinis drachmis, polt mentruas purgationes; quinque diebus in vino pota, preftant mulieribus, ne concipiant.

Epimediicon QV I Epimedium in I talid, quantum mibi perquire licuit, boc tempore cogno $\int$ cat, demonftret $q_{;}$, bactenus repe= fideratio. ri neminem. Quarc putauerim alijs in regionibus hanc plantam prouenire : uel fi fortaffe nafcatur in I talia, nondum Opinio cuiur ad nostram perueniffe cognitionem. Non tamen nos fugit medicum effe in I talia materiam medicam profitentem, dam medici cuius nunc nomen libet filentio dißimulare, qui Epimedium eam plantam effe cenfet, que à triquetra foliorum figura
explofa.

Epimedii uiquibufdam recentioribus Trinitas appellatur : id'ǵ; illis constantcr affirmat, o perfuadet, qui maiorem for $\int a n$ ei fidĕ preftant, quàm ip/i Diofcoridi. Sed quód bis aperté ballucinetur, etfi unicuiq; mediocriter etiam in re herbaria uer fato perpectum eße poßit, pro alijs tamen iam nobis oftendendum eft. Quod facile conftabit, fi expendatur utriusq; plante defcriptio: fiquidem Epimedium, Diofcoridis teftimonio, caul is eft non m.g gnus: folia babet beder a fimilia, de na aut duodena. Trinitas ueró nullo conftat caule, fed folijs tantìm modó uicenis, modó tricenis, modó quadrige= nis, pluribusq́; d radice cyclamini modo excuntibus. Pretered Trinitas primo statim uere floren edit caeruleum, mox Jemen. Epimedium ueró, Diofcoride authore, neq; florem, neq; $\int e m e n$ profert. Adde quód Trinitas radice nititur mul rifida, odore non ingrato, e fapore adftringente. Radix ueró Epimedij tenuis de fcribitur, graui odore, o infipido ac fatuo gustu. Ex quibus omnibus, ni fallor, harum plantarum difcrimen luce clarius oftenditur, o medici illius opinio uana apertißimé exploditur. Caterüm Plinius libro x x v. I I. cap. I X. Epimedij biftoriam ad uerbum ferme ḋ Diofcoride mutuatus eft : cui item Galenus fuam acceptam referre poteft libro v I. fimplicium medicamentorum, ubi

res ex Gal.

GLADIOLVS.

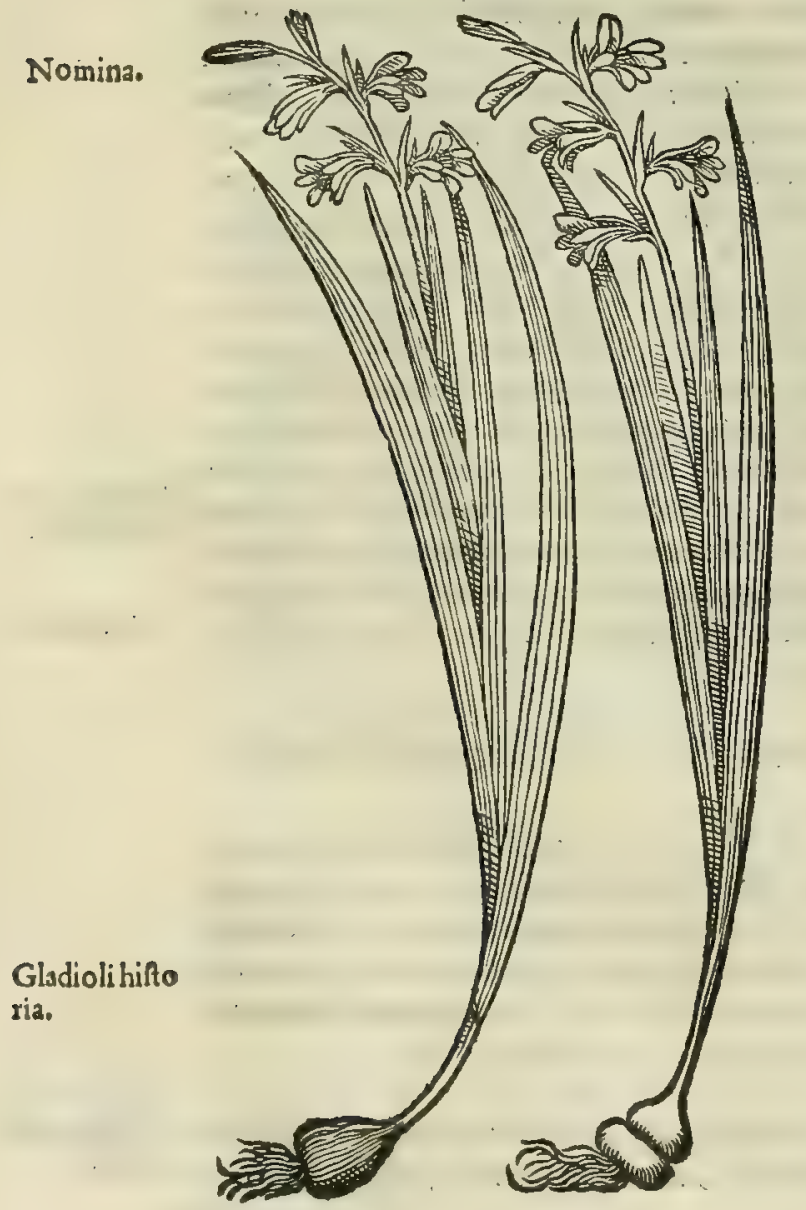

ita fcribit. Epimedij uis eft moderaté refrigeratoria cum aqued bumiditate. quadre nullam habet in/ignem qualitatem. Mammas cataplafmate impofitum rect as feruare poteft. A iunt ueró epotï concipiendipem adimere."Planta, quam Greciē̄ Latinis fimiliter Epimedium appellatur.

\section{ElQIOV. GLADIOLVS, CAP.XX.}

XI P H I O M, alij phafganon, alij machæronion, Romani gladiolum uocant. nomé inde accepit,quòd fo lium gladij prabeat fpeciem. Iridi fimile erat, nifi mi- $4^{\circ}$ nus, $\&$ anguftius uideretur, \& gladij modo mucronatum, neruofumq́ue. In caulem exit cubitalem, in quo purpurei flores, in ordinem digefti, inter fe diftant: rotundo femine: radicibus geminis, vna paruorum bulborum modo, fuper alteram infidente'quarum inferior gracilis eft, fuperna uberior. nafcitur in aruis. Superior cum thure illita, admifto uino, fpicula \& aculeos è corpore extrahit: panos cum lolij farina, \& hydromelite difcutit: qua de re huiufmodi emplaftris inferi folet. menfes impofita trahit. Superiori radice ex' uino 50 pota, venerem ftimulari, \& inferiore fumpta fterilefcere tradunt. Superiorem quoque utiliter infantium ente rocelis, cum aqua potui dari præcipiunt.

NA.s C I T v R Gladiolus, quem Grecixiphion uocant, frequens in Hetruria, $\sigma$ in comitatu Goritienfi, in pratis, $\mathcal{O}^{\circ}$ in aruis inter fegetes: unde segetalis pleri /q; dicitur. Inuiusflo= resnostri uulgó appellant Mondcuccie. Folia ei iridıs, brenio= $r$ a tamen, $\mathrm{O}$ anguftior, lineis neruorum modo ftriat a, mucro= nataq́;. Caule attollitur cubitali, fuccofo: in quoflores emic ăt purpurei, paribus inter $\int \mathrm{e}$ patijs dettantes, qui etiam iridisfo=

\section{0}

(1)

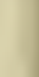




\section{In Lib. quartum Diofcoridis .}

$S$ P AR GA N V M.
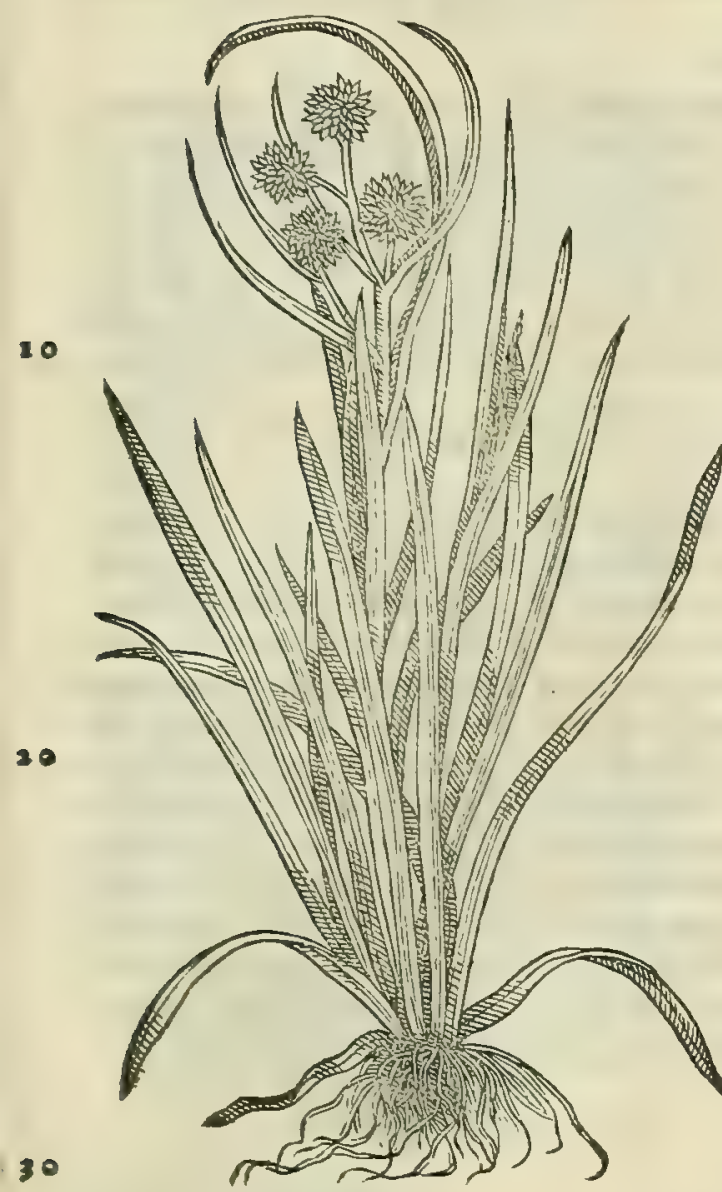

$X Y R I s$.

res forma effigieq; plurimim emulantur, quanquam Gladiolo mi= nores funt, O uno tantim colore conftant . Prodit ex bis femen (ut Diofcorides inquit) rotundum. Radicibus cobaret geminis, rotundis, preßisí; vierticllorum nodo, uñ fuper alteram infiden= tc , albicantibus, bulbofisiog. He obteguntur capillaceo imolu= cro, in nigrü purpurafcente, ueluti crociradices. Caterùm quă= uis tradiderit Diofcorides, quòd fuperior radix magnitudine infé riorem fuper dt; plerunq; tanen contrarium uifitur. Plinius por $\Rightarrow$ Plinius à Dio róbse in biftoria à Diofcoride diffentit: fiquidem Gladiolum, qué fooride diflen in aruis nafcifcribit Diofcorides, in paluftribus is o aquofis int= ueniri exiftimat. Ex quo facilé crediderim, Plinio illum uocdri Gladiolum, quem paßim officine Acorum nominant. Gladioli meminit Galenus libro V I I I. Fimpliciun medicamentorum, ubi fic inquit. Xiphij rddix, o maxime altera, que fuperior eft; $a t=$ trabentem, digerentem, 0 exiccantem $f$ cilicet facultatem etiam poßidet. Hac planta छ̧i申 Ius: Arabicé, Kafiflon: Italicé, Gladiolo:: Germanicé, Schuner= tel: Gallicé, Glais, er Glaitel.

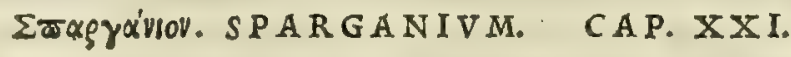

SPARGAN I ON, aliqui xiphidion uocant . folia habet gladioli, fed aretiora, \& in terram magis procumbentia: in fummo caule ueluti pilulx prominent, in quibus femen. Contra ferpentis uenena, radix cum uino datur.

E X I S T I M A T Ruellius eam plantame effe sparganium, Sparganii cöqua in aquofis locis prouenit, quam berbariorum unlgus $S p a t u=$ fideratio. lam foetidam appellat. Verum bec, ut in proxima commentatio= ne dicetur, nil aliud eft, quàm Diofcoridis xyris. Quare mibi pla né refillenda uidetur in boc $\mathrm{R}$ uellij opinio . siquidem herba bec, quam ideo spatulam foetidam cognominant, qkid grauem exha= let odorem, folia quidem babet gladioli; fed latiora, longioraq́; , minimé in terram procumbentia. Adde etiam quód illd in fummo caule non pilulds, que femen contineant, fed folliculos, aut fili= quas profert . syluaticus spatulam foctidam defcribens, eius bisto Syluatici er riam $\mathrm{P}$ aulo Aeginet perperàm acceptam refert $:$ id enim ipfe in Paulo nusquam potui reperire. Sed ad Sparganium noftra re= deat oratio. Vidimus hoc primim in agro Romano apud Tolpham propé aluminis fodinas ad pedem montis Ronconi, 0 deinde in $a=$ lijs plerisq; locis, folins gladioli, arctioribus : pilulis in caulis cd= cumine platani proximis, berbaceo colore, in quibus femen con= tinetur. Sane qudin paucis de Sparganio differuit Galenus libro VI I I. fimplicium medicamentorum, fic inquiens. Sparganium O ipfum deficcantis eft facultatis. Nomen Grecumbabet plă

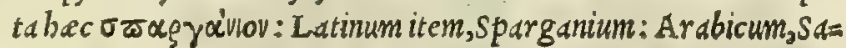
farhe ramon: Italicam, sparganio.

\section{Eugis. XYRIS.}

X Y R I S folia habet iridis, latiora, \& in cacumine mucronata: quorum medio caulis erumpit, fatis craffus, cubitalis, ex quo filiquæ triangulares dependent : in quibus purpureus flos, in medio puniceus : femen in folliculis, fimile fabis, rotundum, rubrum, acre : radix longa, geniculata, rufa. Contra capitis vulnera, fractaque efficax eft : aculeos, \& fpicula omnia, citra moleftiam extrahit, adiecta floris æris tertia parte, $\&$ radicis centaurij, ac mellis quinta: tumoribus, \& collectionibus illita cum aceto medetur. Radix ex paffo bibitur, ad conuul-
Gladiols uires ex Gal.

Numina. ratum.

Sparganij facult. ex Gal. Nomina. 
fa, rupta, coxendicum dolores, ftrangurias, \& alui profluuia . Semen tribus obolis potum, vrinam vehementiùs impellit : \& cum aceto, lienem abfumit .

Xyridisconfideratio.

$\mathrm{Xyridis}$ uires ex Galeno.

Nomina.

$\mathrm{X}$ Y R I s pluribus locis prouenit in Italia, prefertim in Hetruria, nullis deficientibus notis, quas ci tribuit Dio= fcorides. Eam uulgus spatulam foetidam appellat, quód eius folia, fi manibus atterantur, grauem or ingratum red= dant odorem. Sunt qui buiufce fucco utantur ad fcabiem, uitiliginem, es lichenas. Hanc memoria prodidit $\mathrm{G} d=$ lenus libro v I I I. fimplicium inedicamentorum, ubi de eius uiribus ita differit. Xyris tenuium partium, attracto= rix, digerendi, ac nimirum etiam deficcandi eft facultatis, cim radix, tum multo etiam magis eius fructus: qui qui=

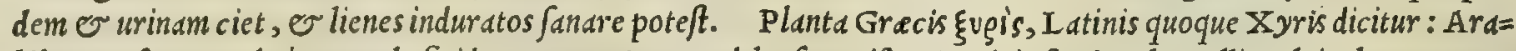
bibus, Caforas : uulgó, spatula fetida: Germanis, Vuandtleufz: Hipanis, Lirio ßadanal : Gallis, Glaieul Sauuage.

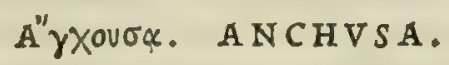

CAP. XXIII.

A N C H V S , quæalio nomine calyx, aut onoclea appellatur, folia habet lactucx, in acumen faftigiata, hirfuta, afpera, nigra, multa, ab radice quoquo uerfum humi fparfa, fpinis horrida : radici crafsitudo digitalis, quæ æltatc prouenit, \& manus inficit fanguineo colore. læto folo nafcitur Radix adfringit : ad ambufta, \& uetera ulcera, ex oleo \& cera efficax eft : igni facro cum polenta medetur : lepris, \& uitiliginibus. illinitur ex aceto : partus extrahit,vuluæ indita . Eius decoctum renum uitijs, lieni, \& bile fuffufis datur: $\&$ fi febris fit, ex aqua mulfa. Siftunt aluum folia in uino pota. Radice pigmentarij vtuntur ad unguentorum fpiffamenta. Eft $\&$ altera, quam aliqui alcibiadion, aut 20 onochiles appellarunt. Hæc à priore diftat, quòd minora habeat folia, fed fimili modo afpera : ramulos exiles, in quibus flos purpureus in puniceum uergens confpicitur : radices habet rubras, prælongas, quæ mefsibus fanguineum fuccum fundunt. in fabulofis nafcitur. Vis ei, folijsq́; ineft, quæ contra uirus cùm reliquorum ferpentium, tum maximè uiperarum auxilictur, frue cibo, fiue potu, frue alligatu : nam fr quisquam mandens, in ferpentis os infpuat, eum necabit. Eft \& alia huic haud diffimilis, femine puniceo, minore. Cuius femen manducatum, $f i$ in ferpentis fauces infpuatur, eam interficiet. Radix acetabuli menfura cum hyflopo, \& nafturtio pota, latas uentris tineas excutit.

ANCHVSA PRIMA.

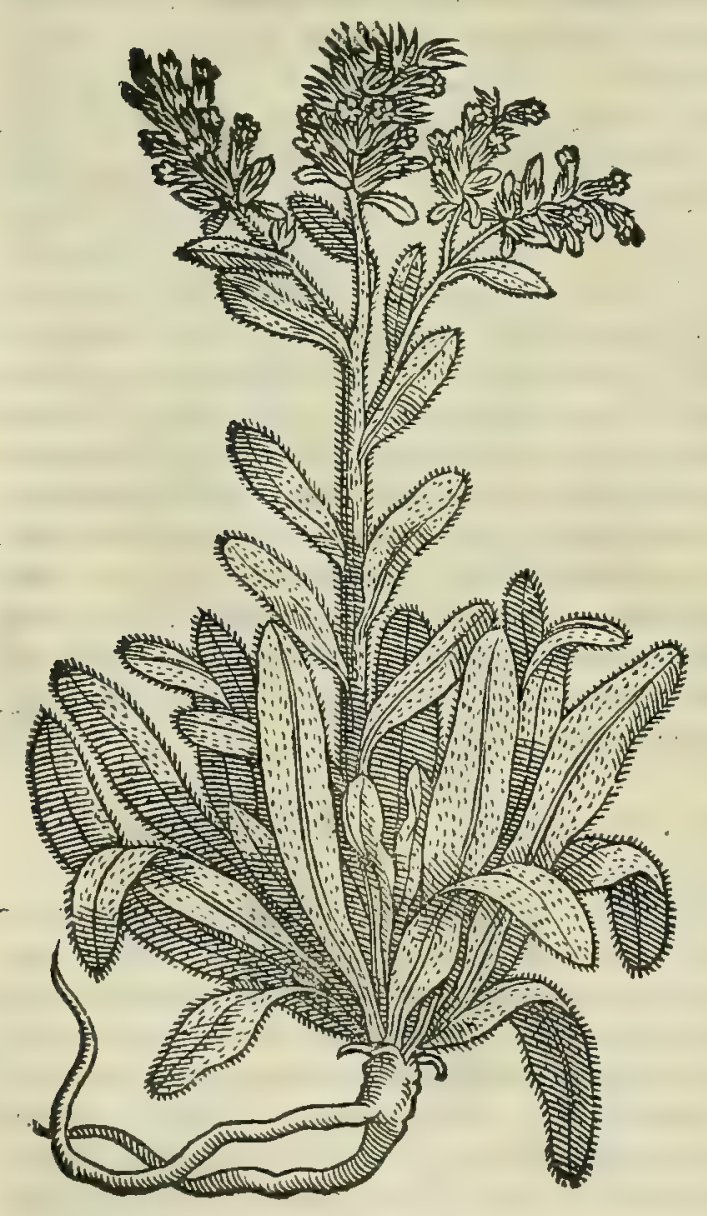

ANCHVSA AITERA.

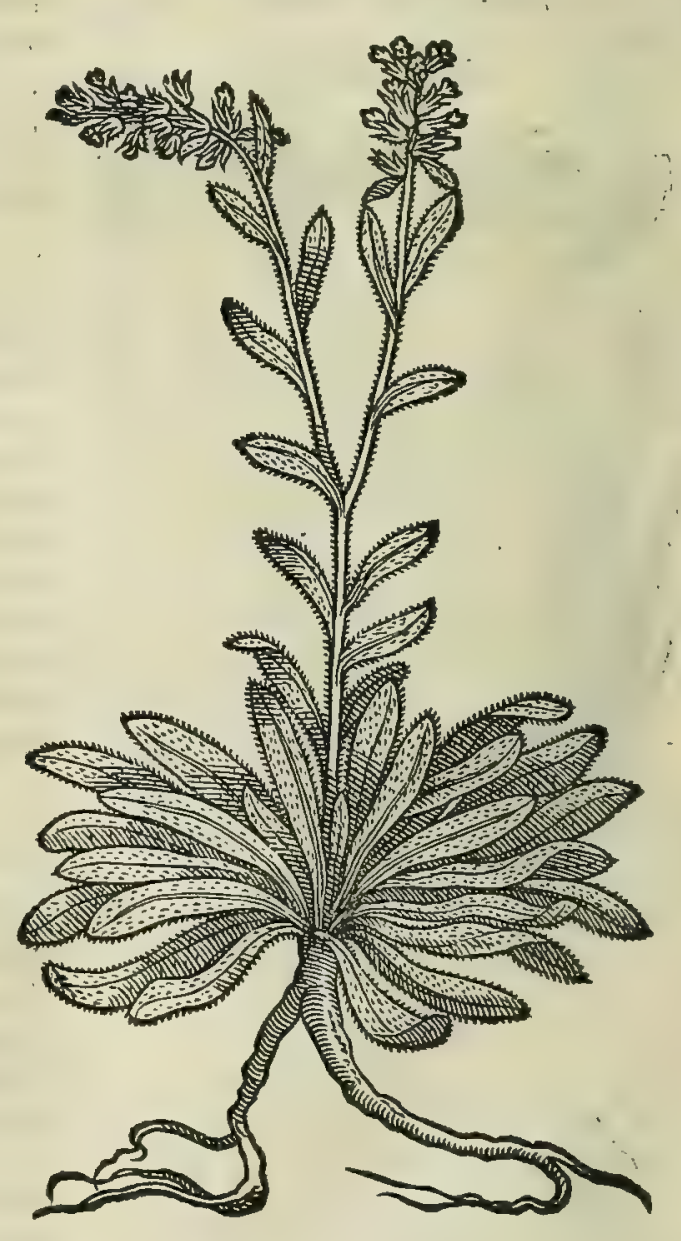




\section{In Lib. quartum Diofcoridis.}

ANCHVSA TERTIA.

20
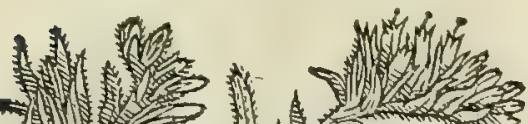

政

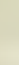

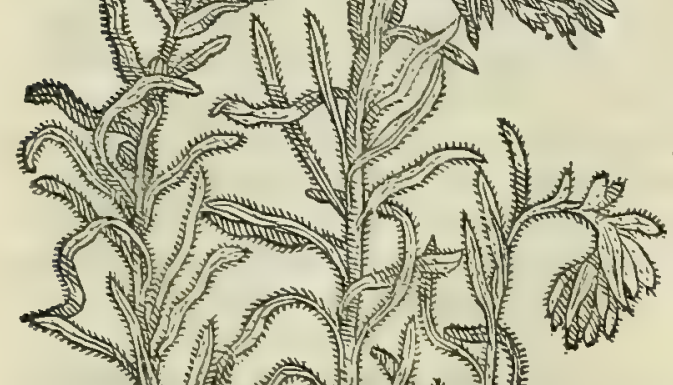

20

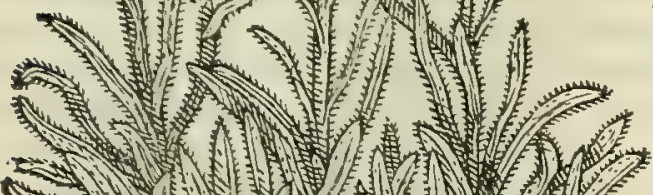

30

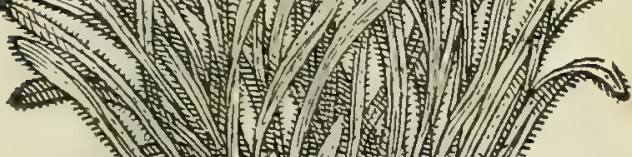

T R I A funt Anchufa generd, qua bic d̀ Diofcoride fcri= buntur : quanquam Plinio libro $\times 1$ II. cap. $\times$ X.quartum quog; genus additur, quod p $\int c u d o a n c h u f a m$ ob id appellatan ait, quo= miam printo aliarum generi quadantenus fimilis eft, birfutior ta= men bac, lanuginofior, or minus pinguis, foliis tenuioribus, or languidioribus. Sed banc nufquam equidem uidi, cum tamen alias oinnes loc is compluribus in Italia inue niffe me certo fciam. An= chufe onne genus in toto feré caule purpureos explicat flores à unlgari buglofjo non longé dißimiles, quanuis Anchufis magis fubrubentes, magisó; expanfi pectentur. Galenus inter An= chufas $\mathrm{L}$ ycopfin quoque recenfet libro $\mathrm{v}$. fimplicium medica $=$ mentorum, ubi ita fcriptum reliquit. Anchufe quadruplex pe= cies cft. Quarum onoclea quidem radicem babet admodum refris gexantem, $\odot$ deficcantem, tum adftringentem, o Subamaram, tum que fufficiat extenuandis, or extergendis bumoribus bilio= fis, corporibusq́; condenfandis. Caterim folia baber imbecilliora quidem radice, adftringunt tamen $\approx$ ip $\int a, \sigma$ deficcant. Porró lycop/is cognominata refrigerat, et deficcat, magisó; radix eius, quim onoclex adjtringit. At onochelos calidior eft, er magis me dicatd. nam plufculum babet or guftu ip $\int 0$ protinus acrimonia. Hac ueró etiam calidior eft parua, que o amarior, o magis $e=$ tiam medicata eft. Anchufe non omnes easdem uires obtinent. Nam onoclea quam nocant, radicem babet fimul adftringentem, O fubamardm, corporibus condenfandis, er modicé extenuan= dis idonedm: tum abftergendis quoque, er abluendis biliofis, or fal/is fuccis. Dictum enim fuprà eft, quod qualitas acerba mifta amaritudini ea preftare queat. Sic fané regio morbo, o lieno= fis, er renum affectibus eft utilis. Sed o refrigerare idonea eft. Or fane cum polenta illita iunat ery/ipelata, 0 abftergit non mo= dó epota, fed e foris impofita. Proinde uitiligines, $\widetilde{O}$ lepras $\int a=$ nat cum aceto. At radicis quidem bec opera funt, $\sigma$ operum $f_{a}$ cultates, quas diximus. At folia ipfius berbe radice quidem funt imbecilliord, non tamen aliena funt à reficcatione,

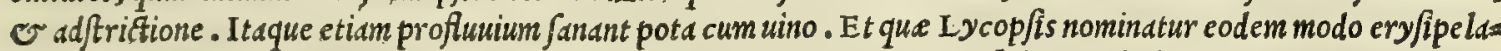
tis congruit, o radicem habet qudm onocled magis adftringentem. At onochili, or alcibiadij cognominate uis ma= gis eft medicata. Nam er guftu protinus maiorent babet acrimoniam, or cos qui à uiperis morfi funt, admodum iu= wat tum illita, tum fupenfa, tum efa. Reliqua ueró, nempe quarta, qua parua eft, o feré nomine caret ex illis fold,

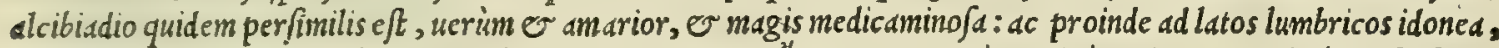

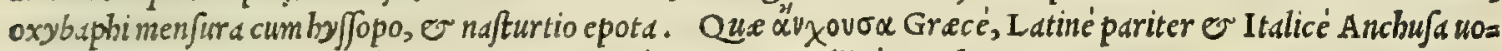
casur: Germanicé, Rodt och/en zung: Hipanicé, sodgem: Gallicé, Orchanette.

\section{Aن́ronts. IYCOPSIS.}

CAP. XXIIII.

L y C O P S I s, quæe \& anchufa à nonnullis uocatur, folijs eft lactucx, longioribus, afperioribus, latioribusque, crafsis, ad radicis caput recidentibus : caule longo, recto, fcabro, hirfutis adnatis, multis, cubitalibus : flore in ijs paruo, purpurafcente : radice rubra, \& adf tringente . nafcitur in campeftribus. Cum oleo radix illita, vulneribus medetur : \& cum farina hordeacea, ignibus facris : fudores peruncta mouet, adiecto oleo.

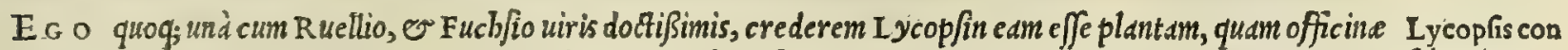
legitimi Cynog lo Si uice paßim ufurpant, uocant'́, Cynogloffam; $f i$ tamen bec radice rubra, non autem candida nite fideratio.

so retur: Fi folijs uire fceret afferis, non autem leuibus, ad terram recidentibus, non fur fum pectantibus: fic caule affur= geret $\int c a b r o$, non molli : fi denif; Plinus buic fententie non prorfus refragaretur . Porró çùm Plinium uideam libro

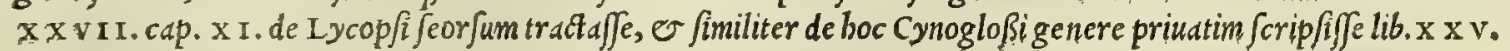
cap.v I I r. cogor omnino, ut ingenué dicam, ab illis diffentire. Potius enim adducor, ut credam, I ycopfin berbam ef= $\int e$ anchufe non abjimilem: quam ideo non temeré Galenus, $\sigma$ Aẹtius sum fecutus in anchufarum genere retulerunt, ut fuperiori commentatione diximus. Lycopfin, quam ego legitimam effe exiftimo, uidi $\int_{x}$ pius in campeftribus, $f i=$ tientibus, aridisq́; locis enatam, anchufe adeó fimilem, ut uix ab ea difcerni poßit. Caterüm quoniam in buius libri quarti progre fu, Deo iuuante, nobis de Cynogloffo differendum eft fuo proprio capite; idcirco dißutatio quódnam

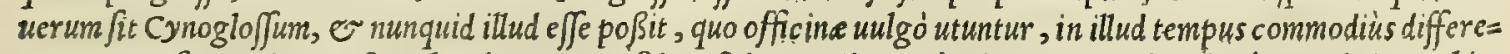

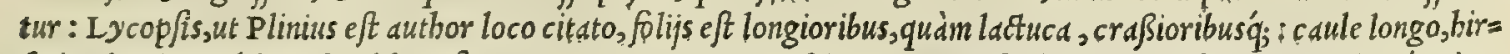
futis adnatis, multis, cubitalibus: flore paruo, purpureo nafcitur in campeftribus. Hẹc berba Grecis $\lambda$ úrofis, Iatinis item I ycopfis, e I talis Licop/ide appellatur.
Anchufarum conlideratio.

Anchufarum uiresex Gal.
Opinio reprobata. 
E'X10\%. ECHIVM.

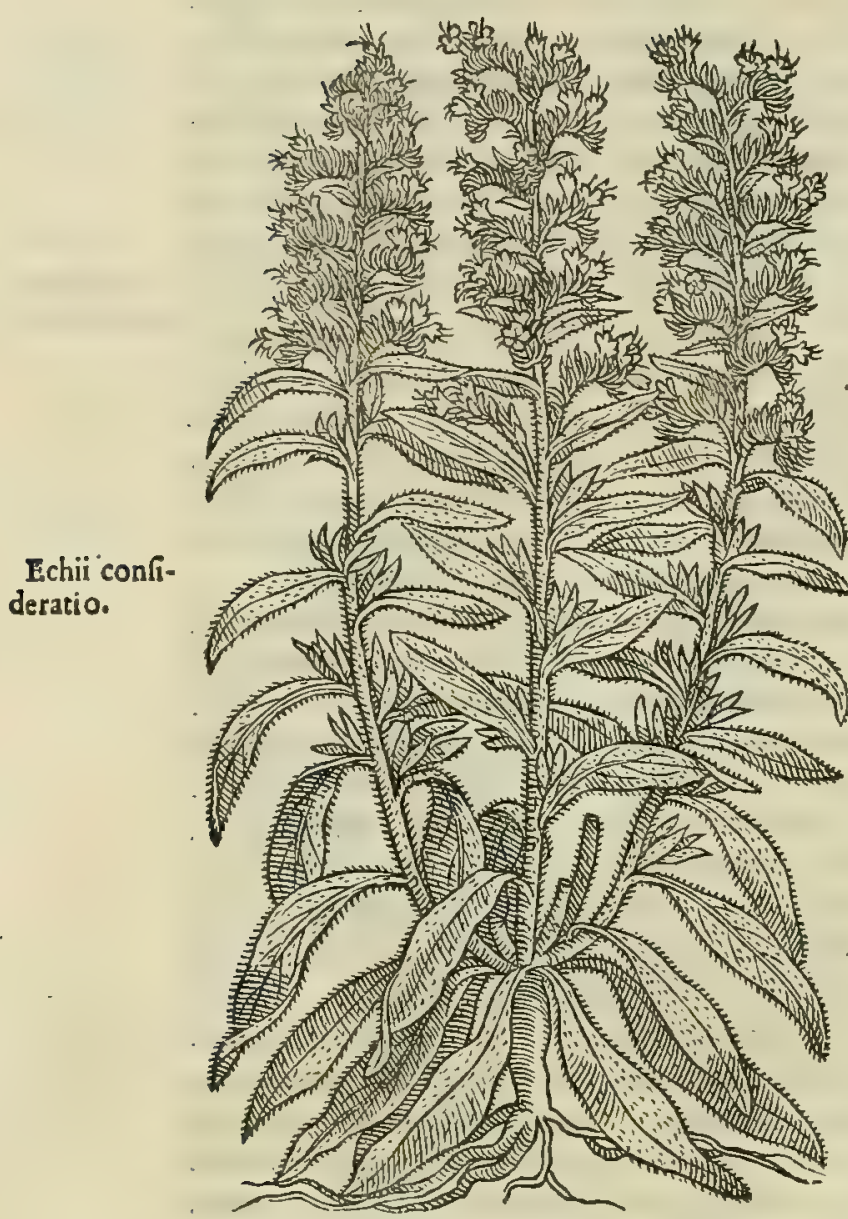

\section{$C A P, X X V$}

E C H I o N folia habet prælonga,afpera, aliquantùm tenuia, anchufx proxima, minora tamen, fubirubra, \& pinguia, fpinulis tenuibus horridula : cauliculos exiles, numerofos : minutaq́; utroque latere folia, expanfa, pinnataq́ue, nigra, in fummo caule proportione minora: flores fecundum folia purpureos, in quibus femina capiti uiperarŭ fimilia infunt : radix nigricat, digito tenuior: : 0 Quæ non percufsis modò à ferpentibus ex uino prodeft; fed eos qui antea biberine, feriri non patitur. Folia, \& femen idem præftant munus. Lumborum dolores fedat: in uino, aut forbitione fumpta, lac extrahit.

E C H I O N d̀ uiperis omnino nomen adinuenit suiperd ènim Gracis "'X's dicitur)uel quód Jemen proferat capitibus uiperinis fimile, uel quod uiperarum mor fibus preftantißimum fit medicas= mentum: Hanc herbam ab Alcibio quodam fuiffe inuentam author eft Nicander in theriacis, 0 proinde à pofteris cognomine Alci= $=0$ biacum appellatum. Is enim dam fecus aream dormiret, à uipera in extremo inguine ictus eft excitatusog; d fomno ex bac herba fuccum commanduc ando palato oo dentibus expreßit, baufitog; in corpus. Manfe ueró berbe reliquum uulneri fuperimpofuit contra dolorem.quo medicamento liber euafit. Vnde pofted Ecchio nomen inditum eft Alcibion ab eo, qui primus oftenderat, quantum uiribus polleret contra uiperarum iđus. Numenius fcriptor grauifimus duo Ecbijgenera inuenirifcriptum reliquit . quorum alterum Ocimoides appellari inquit, quód folia ocimo fimilia has beat : alterum ueró,quod folio eft pinis borrido, priuatim Echion nominari. Id fané quod in theriacis ante ipfum fcripferat Nican= der. Quibus uidetur etiam Diofcorides adftipulari, quippe qui Echio ftatin fubiecerit Ocimaftrum. His quoque fubfcribit. Plinius libro $\mathrm{x} x \mathrm{~V}$. cap. I $\mathrm{x}$. fic inquic ns. Echios duîn eft generum: altera folijs coronata, pulegio fimilis : altera lanugine diftinguitur pinofa, cui o capitula ui=

Plinij laplus. pere fimilia funt. Sed tamen ignoraffe Plinium Alcibion, ev Echium idem effe, fatis manifeftum eft: fiquidem is lib. $\mathrm{x} \times \mathrm{VII} . c a p . \mathrm{v}$. Alcibios, inquit, qualis effet herba, apud authores non comperi. Ex cuius uerbis illud facilè colligi poteft, quod fcilicet Plinius non fatis dccuraté Nicandrum legerit. Caterim non parud admirda= tio eum capiet, qui in Echio diligenter opus prudentißime natura perßpexerit, nempe quód ipfum genuit uiperi= nis capitulis, ut ita apud homines, quorum potißimum curam gerit, teftatum relinqueret, eam berbam preftantif= findm effe ad buiufcemodilethalium ferarum morfus. Echium, quod ubique feré proueniat, dridis prefertim locis, fepe in Hetrurid, in agro Tridentino, o Goritienfi uidimus, femen'q; eius uiperinun decerpfimus ad antidota . Her ba eft ancbufa, que fecundo loco Diofcoridiredditur, non abfimilis. Vocant quidam fylueftre Bugloffum. Flores profert bec in rubeum purpurafcentis inter minuta folis à medio caule ad fummum : è quibus femen prodit nigrum; birfutis, pinofisö́; inuolucris inclufum, uiperarum capitibus fimile. Non inuenio Galenum ullam Ecbij mentionem Echii uires ex feciffe in libris, quos de fimplicium medicamentorum facultatibus edidit. Paulus tamen eius uires defcribit Diofco= Paulo. ridem fecutus libro v I I. ubihac refert. Echion, alij doriada, nonnulli alcibiadion uocant. Spinofa berba eft, quae non modó à ferpente commorfis cum uino pota auxiliatur; fed prafumentes quoque ex ictu nibil moleftum pati finit.

Quod Greciéx $10 \mathrm{~V}, \mathrm{~L}$ atini quoq, Echium dicunt: Itali, Echio: Germani, Vuild ocbJen zung: Hipani, Yeriua della biuora: Galli, Bugloffa faundge.

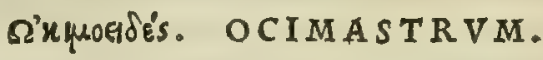

CAP. XXVI.

O C I M O I D E S, Latini ocimaftrum uocant, folia fert ocimi, \& ramos dodrantales, hirfutos: filiquas hyofcyamo fimiles, femine, ut gith, nigro pragnantes. Vim habet femen in uino potum, qua uiperarum, cæterarumq́ue ferpentium morfibus medeatur. Datur ifchiadicis, cum melle, uino, myrrha, \& pipere. Radice nititur tenui, \& fuperuacua.

Ocimaftri có- O C I M A S T R V M, fiue fylueftre Ocimum idipfum nobis appellare liceat, paßim copiose nafcitur in Italid, Gideratio.

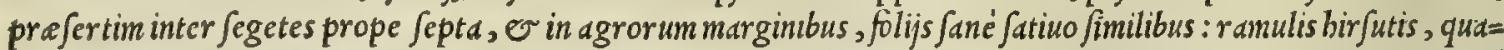
dratis, dodrantali, uel cubitali longitudine : in quorum summo flores emicant, candidi, quandoque ueró purpurci, id quod filentio preteriyt Diofcorides: é quibus uafcula erumpunt byofcyami figura, capaci uentre, arctis faucibus, 


\section{In Lib. quartum Diofcoridis.}

OCIMASTRVM.

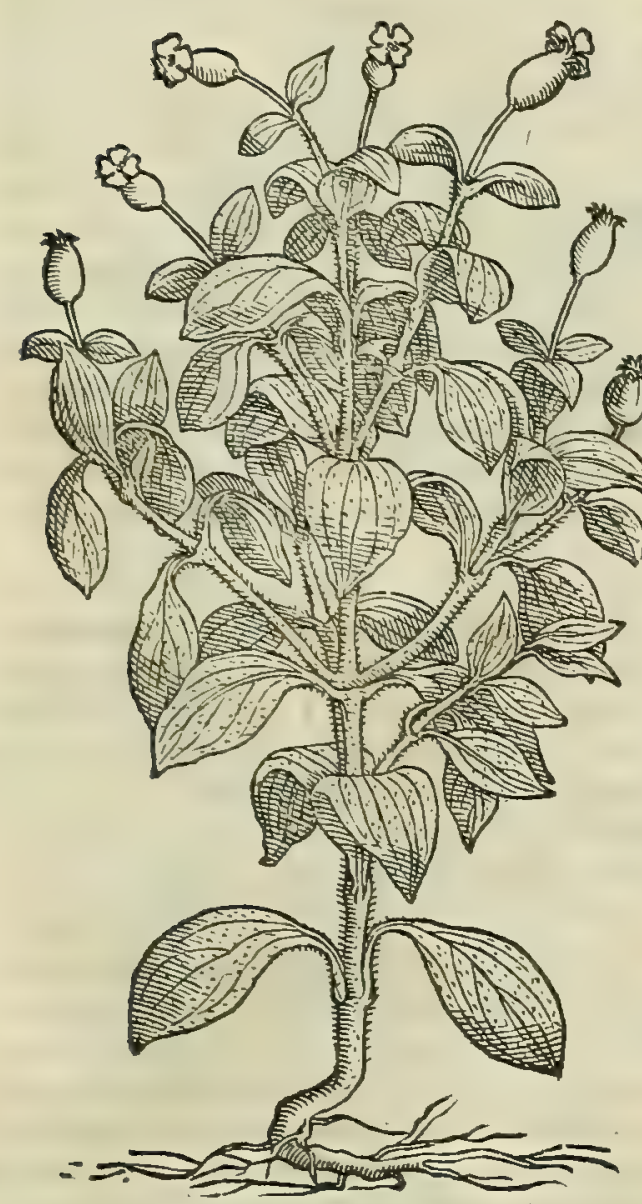

E R I N $\mathrm{N}$ :

50

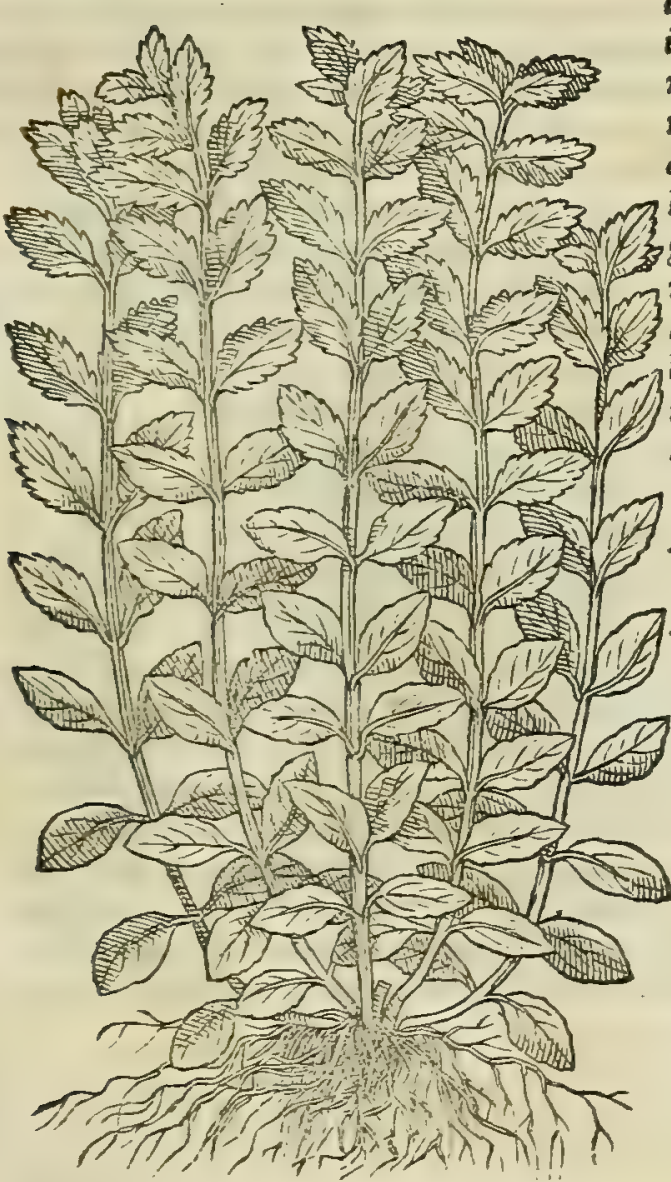

per ambitum denticulatis, uiperinis capitibus fimilia: in quibus femen includitur nigrum, melanthio firme finile. Hec uafcula ita a natura farta pueri noftrates colligunt, ubi exarucrint: $f=$ quidem, cum fenen exciderit, ijs intus fufflantes acutißins edüt fibila: fic enim natur a pueris interdum ludendi prabuit inftru= menta. Meminit buius Nicander in theriacis inter echijgenera, fic inquic ns. Ecbijgeneraduo : alterum pinofo folio, anchufe finile: altcrum minoribus folijs, or purpureo flore, apero la = miginofoq; caule, capitulis uiperarum figura.. Ocimaftriu = res iradidit Galemus in calce libri v I I I. fimpliciun medic anen torum, uói fic inquit. Ocimoides quidam Pliliterium cognomi= nant. Radix fupernacanea eft. At femen tenuium partium, er deficcantis citra mordacitatem facultatis elt. Herba Grecis ákjuoes $e^{\prime}$, Latinis Ocinoides, or Ocimaftrum appellatur: Italis, Bafilico faluatico : Hipanis, Albabaqua montefina : Gal lis, Bafilic fanuage.

\section{E" piros. ERINVS. CAP. XXVII.}

E R I N V s nafcitur apud fontes, \& fluuios, folijs ocimi, fed minoribus, parte fuperna diuifis : furculis quinis, fenísve, dodrantalibus: flore candido: femine nigro, \& acerbo: folia, \& caules lacteo fucco turgent .

Semen drachmis duabus in quatuor mellis cyathis oblitum, oculorum fuxiones cohibet. Succus cnm fulphure, \& nitro inftillatus, aurium dolores fedat .

E T $s$ I nonnulli Diofcoridis codices babedntur, in quibus non legitur Erinum diquo ladeo fucco turgere; non de funt $t a=$ men er in quibus plané oppofitum friptum inueniatur, quorum lectio mihi mag is probanda uidetur non infirmis, ut arbitror, ni= xus rationibus. Quippe quod berbam banc apud aquarum riuu= los uiderim, legerimí; lacteo fucco manantem, adeo ut co manus inficeret. Quód praterea Plinio reddatur Erinus berba lat $t_{a=}$ ria, feu lacte madens libro $\mathrm{x}$ X I I I. cap.v I I ubi de ea bac me= moris prodidit. Herba, inquit, quam Greci Erinon uocant, red= denda eft in boc loco propter gentilitatem. Palmo alta eft, cause liculis quinis, feré ocimi fimilitudine, flos candidus: femen ni= grum, paruum, quod tritum cum melle Attico oculorum epipho=" ris medetur. Manat lacte multo, $\sigma$ dulci. Herba perquam uti= lis aurium dolori, nitri exiguo addito. Folia refiftunt uenenis. ba'c Plinius. Caterüm Erinifacultatis aduerfus uenena non me= minit Diofcorides, quanquam Nicandro, ut que ad id prestet, addatur in antidotis. Galenus hanc berbam non Erinum, $\int e d \mathrm{E}=$ cbinon appellat: neq; id fané mirum eft, quandoquidem in uetu= ftis aliquot Diofcoridis codicibus Echinos legitur; De qua differens ipfe Galenus libro v r. fimplicium medicamentorum, fic inquit . Ecbiniberbe femen acerbum eft : ac proinde repel lentis, o exiccatoria facultatis, Vtuntur co ad oculorum, $\sigma$. narium fluxiones. Qua herba Gracé É or Ocimum aquaticum nominatur : Italice, Erino: Hipanicé, Bafilgo de lbagod.

\section{A" Yousis. GRAMEN.}

\section{CAP. XXVIII.}

G R A M E N geniculatis ferpit ramulis, à quibus radices fpargit dulces, articulis pracinctas: folı acuminata, dura, \& ut arundinis paruæ lata, eaq́ue iumenta, \& boues pafcunt. Trita radix illitu vulnera conglutinat. Decoctum eius in potu, torminibus medetur, $\&$ vrinæ difficultatibus: calculofa etiam veficæ excrementa
Ocimattri uires ex Gal.

Nomina.

Erini confideratio.

Erini uires ex Galeno.

Norrina. 


\section{4}

\section{And. Matthiol ${ }_{1}$ Comm.}

GRAMEN.

Graminis hiftoria ex Pli.

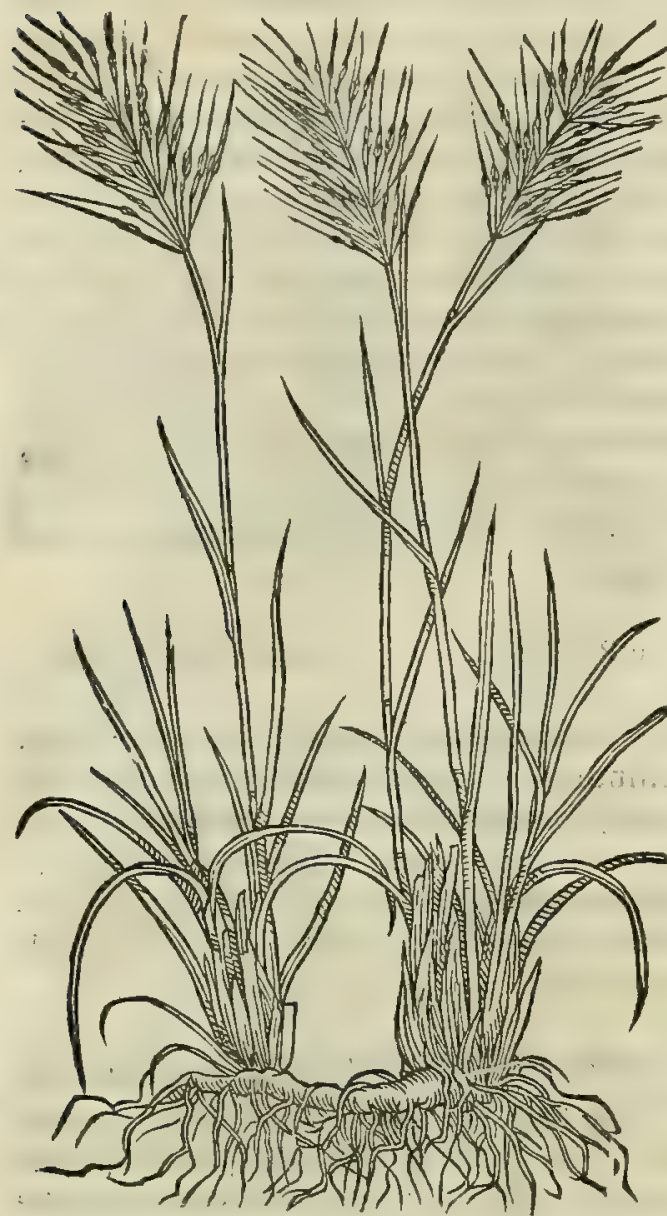

comminuit. Eft \& arundinaceum gramen, priore multò maius, quod iumenta necare traditur, præfertim in Babylone: idq́ue iuxta uias nafcitur. Quod in Parnafo monte gignitur, denfius fruticat : folijs hederaceis : fore odorato, candido : femine paruo, non inutili : radicibus quinis, aut fenis, digitali crafsitudine, candidis, mollibus, \& admodum dulcibus. Succus $f_{1}$ in vino cum melle pari, \& myrrhæ dimidio decoquatur, adijcianturque piperis, \& thuris tertiæ portiones, probatifsimum erit oculorum medicamentum : id in ęrea pyxide recon. ditur. Decoctum radicis idem, quod herba, præflat. Semen vehementius vrinam impellit : aluum, vomitionesque fiftit. Natum in Cilicia gramen, quod incolx $\mathrm{Cin}-$ nam appellant, boues inflammat, fi eo uirenti fape pafcantur.

P L V R A, dc udria funt Graminis genterd: fiquidem pres = ter bec tria, quorum meminit Diofcorides, alia quoque'tria acu= leatigeneris Plinio redduntur lib. X X I I I I.cap. X I X. natural is biftoria, his uerbis. Gramen ip fum, inquit, eft inter berbas uul $=20$ gatißimum: geniculatis ferpit internodijs, crebroó; $a b i j s$, e ex cacumine nouds radices pargit. Folid eius in reliquo orbe in exi= litaten faftigiantur. In Parnafo tantim bederacea pecie den= fius, quam ufquam fruticante: flore odorato, canidido ${ }^{\prime}$. I umen= tis berba non alia gratior, fiue uiridis, fiue in foeno ficcata. Tun= ditur apperfa aqua. Succum quoque eius in Parnafo excipi tra= dunt propter ubertatem: dulcis enim bic eft. In vicem eius in re= liqud parte terrarum fuccedit decoctum ad unlnerd conglutinan= da. Quod o ip a berba tufa preffat illtta, tuetur '́, er ab inflam mationibus placat. Decocto adijcitur uinum, ac mel ab aliquibus, 30 o thuris, e piperis, myrrha q́; tertie portiones. Rurfusó; co= quitur in ereo uafe; ad dentium dolores, $\sigma^{-}$epiphoras. Radix decocta in uino torminibus inedetur, or urine diffi= cultatibus, ulceribus uefica : calculos frangit . Semen uebementius urinam impellit: aluum, uomitiones q́; fiftit . pri= watim autem draconum morfibus auxiliatur. Quod è graminum genere feptem internodia babet, cfficacißimé capiti contra dolores adalligatur. Sunt qui o aculeatum gramen wocant triun generum, cim in cacumine aculei funt plu rimüm quini, dactylon uocant. Hos conuolutos naribus inferunt, extrabuntó; fanguinis ciendigratid. Altero, quod eft aizoo finile, ad paronychia, o pterygia unguium, or cum caro unguibus excreuerit, utuntur cum axungia .

Tertiun genus, quod tenuius eft, nafcitur in parietibus, or tegulis. Huic cauftica uis eft. Siftit ulcera, qua fer= punt. Gramen capiti circundatum, fanguinis é naribus fuxiones fiftit. bac Plinius de graminibus. Caterium binc omnibus plane perpicuum effe puto, Gramen, quod in Babylone, quod'g; in Parnafo monte prouenit, non gigni in Italia : quanquam illud primum, ac unlgatum genus nobis paßim fiequentißimum nafcatur. Neque illud quoque om= nibus non cognitum or unlgare eft, cui in cacumine caulium quini sunt aculei, uelutidigiti, quos pueri naribus infe= runt extrabuntó;, ut fanguinem eliciant. Hanc berbam Hetrufci ab effectu uulgó appellant Sanguinella, alij Caprio= Ia. De qua latius in Coronopo diximus, ubi Leoniceni, o Ruellij fententiam reprobauimus, qui banc e Coronopum Diofcoridis unam $\mathrm{\sigma}$ eandem herbam effe afferuerunt. Verum de Coronopo feparatin differuit Plinius libro $\mathrm{x} \times \mathrm{I} \mathbf{\mathrm { I }}$ : Graminis ui- cap.X I X. fure naturalis hiftoria. Sed iam Graminibus fuas reddamus uires ex Galeno, qui de ijs agens libro v I. res ex.Gal. fimplicium medicamentorum, ita fcriptum reliquit. Graminis radix mediocriter frigida eft, o ficca, mordacitatem quandam exiguam, o partium tenuitatem obtinens. At herba ipfa primo quidem exceffu refrigerat, in bumiditate ueró, of ficcitate moderata. Porró femen alibi quidem imbecillum eft, in Parnafo ueró deficcatorium, or tenuium partium, o fubacerbum. Gramen efculentam habet radicem, ubi mollis fuerit, dulcem quidem inftar aqua, fed acre quiddam exiguum, o fubacerbum obtinentem. Hac herba plané aqued guftantibus eft . Ex quibus apertum eft, $r a=$ dicem modice effe tuin frigidam, tum ficcain: ac proinde cruenta ulcera glutinare. At ip fa herba illita,non uebemen ter refrigerat, in medio conftituta bumiditatis, $v$ ficcitatis. Porrò mordacitas $v$ tenuitus, qua radici ine $f t$, exigua eft quidem, fed interdum tamen lapides frangere affolet, $\sqrt{i}$ quis eam decoctam ebibat. At femen alterius quidem im= becillum eft, eius ueró qua in Parnafo nafcitur, urinan ciet : $\sim$ fluxus uentrił, o ftomachi reficcat: uis enim cius

Nomina. eft exiccatoria, tenuium partium, o fubacerba. Herba, qua Grecis $\alpha^{\prime \prime} \gamma \rho \omega 5 i s, \mathrm{~L}$ atinis Gramen appellatur: Arabibus, Vagem, Negen, feu Negien, Thel, Kel, E Negil:Italis, Gramigna: Germanis, Grafz: Hipanis, Gra= ma, o Gramenha: Gallis, Dent de chien. 


\section{In Lib. quartum Diofcoridis.}

SIDERITIS PRIIIA.

Io

so

30

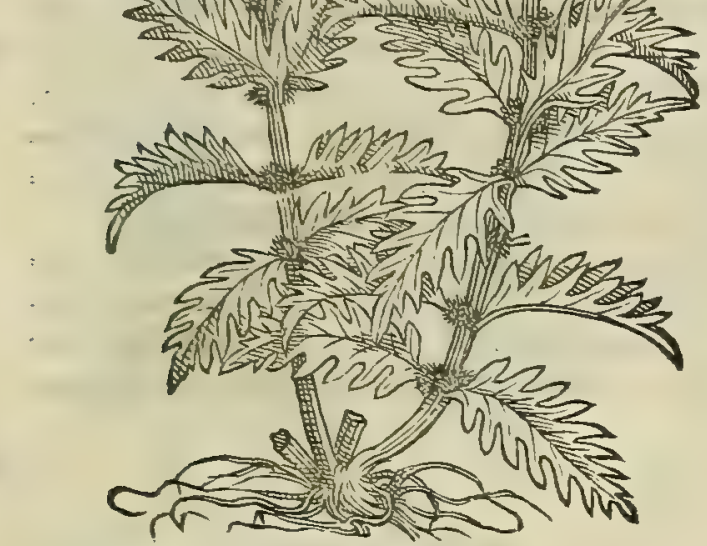

SIDERITIS TERTIA.

$4^{\circ}$

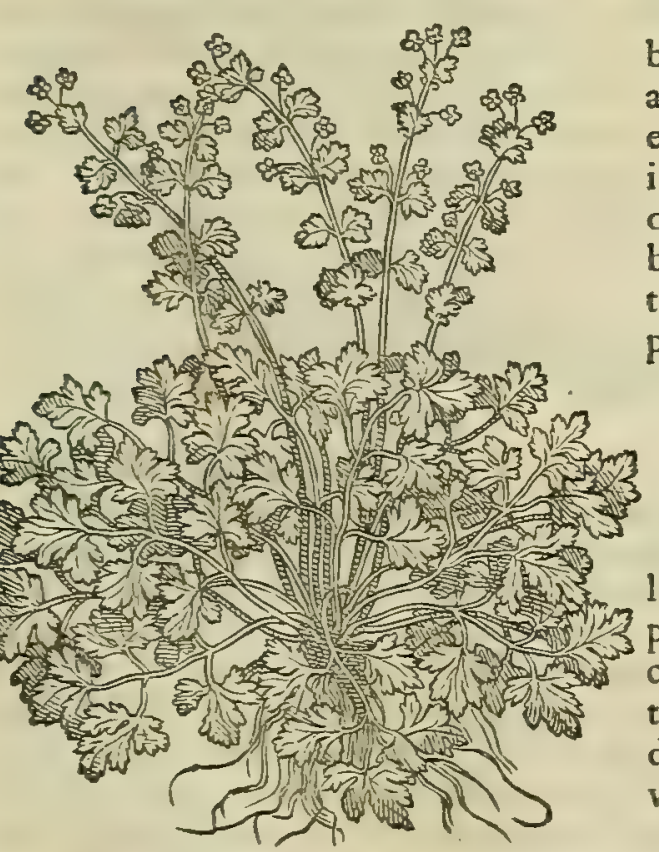

SIDERITIS ALTERA.

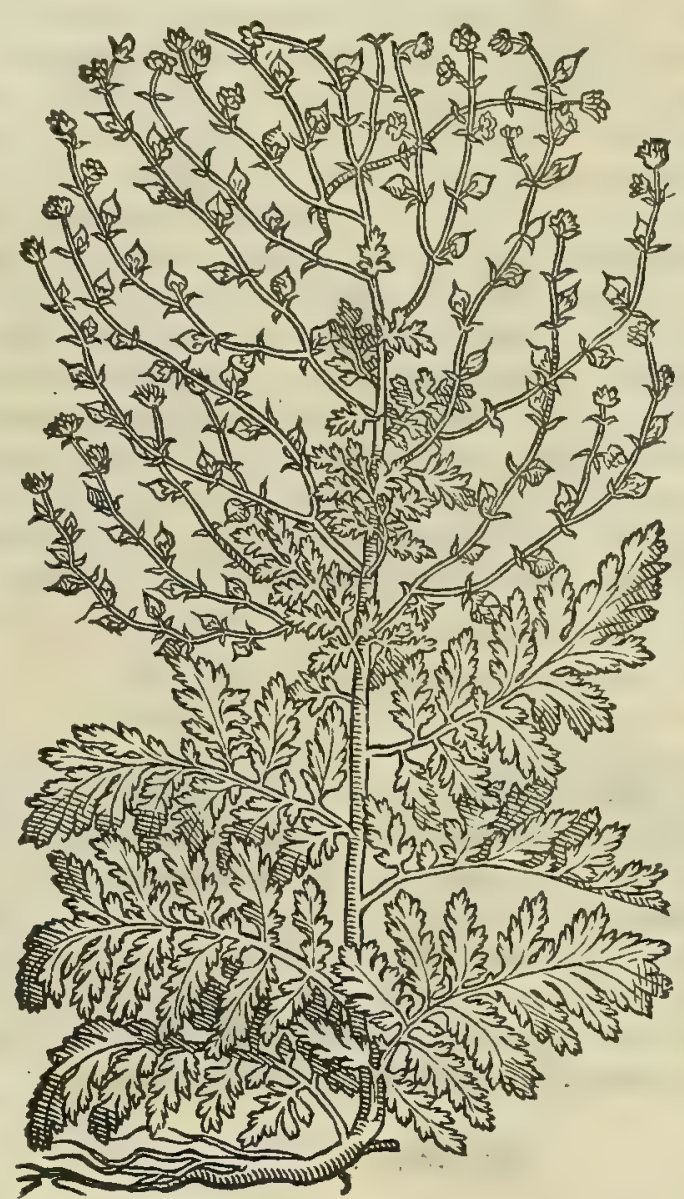

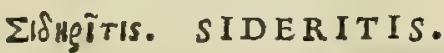

CAP. XXIX.

S I D E R I I I N aliqui heracleam uocant, folia habet marrubij, fed longiora, fatis ad frondem quercus, aut faliuæ accedentia, minora tamen, \& afpera: caules edit quadratos, dodrantem altos, aut etiam maiores,non iniucundi guftus, aliquantumque fubfringentis : in quibus per interfitia orbiculatæ uertebra, ut in marrubio fpectantur : \& femen in eis nigrum :nafcitur in petrofis. Illita folia, fuapte ui uulnera line inflammationis periculoiungunt:

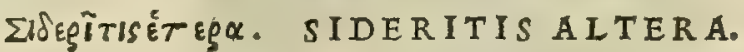 C A P. X X X."}

A I T E R A Sideritis binûm cubitorum ramulis, exi libus : folio filicis, numerofo, utrinque per oras diuifo, pediculo longō, prodeuntibus è fummo alarum finu fur culis, longis, tenuibus : capitulo in cacumine orbiculato, afpero : in quo femen continetur, quàm betx rotundius aliquantò,ac durius : Huius uis, foliorumq́ue ad vulnera, præcipua eft.

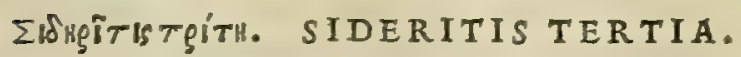

CAP. XXXI.

S I D E R I I I N aliam effe tradunt, quam Crateuas heracleam uocat, in macerijs, $\&$ uineis nafcen tem : folijs, ab una radice multis, coriandro fimilibus, circa coliculos dodrantales, læues, teneros, fubcandidos,atque fubrubicundos : flore puniceo, paruo, guftanti amaro, \& lento. Huius ea uis eft, ut quanuis recenti vulneri impofita, fanguinem fupprimat. 


\section{6

Sideritidis có T R I A sideritidis genera preter Achilleă,de qua equenti capite dicetur,"hic à Diofcoride rèpre entari cons

fideratio. ftat. Quorum etfi illam, que fecundo loco defcribitur, antea in noftris I talicis commentarijs me nuutquam inuenife, ac uidife tradiderim; ea tamen boc anno Pifis ad me mifit $\mathrm{L} u c$ as Ghinus Forocornelicn/is uir rei medicx peritißinus. Reliqua ueró gencra iandiu noniffe nos putamus, quód ea omnibus notis fuam qua q; biftoriam fequi deprebenderi= mus. Catcrum nemini mirü fit, quòd tam uaria effigie prime Sideritidis folia reddiderit Diofcorides, ut qui ea modỏ marrubij, modó quercus, modó faluix figura depingat. Quippe corum longitudo Saluix accepta refrratur oportet: fcabrities dcindc Juperficiétenus, ac fubalbidus color tum eidcm faluix, tum marrubio : quercui poftremó, qua in am= Fuchsij erra- bitu eft diuifura. Sed ea mihi quidem nibil prorfus prima sideriti adftipulari uidetur, cuius imaginem expreßit $\mathrm{F} u=$ tum. chfius in fuo infignide firpium hiforia commentario. Siquidem perpicuum eft, quód eius pictura non folum non pre Se fert folia, e caules, que sideritim ucram referant; fed etiam flores cius psicati in cacumine, non in caulibus inter a

Ruellii opin. folia marrubij modo, plané uer.e sideriti refragari conßpiciuntur. Ruellius porró sideritim banc nonnullis herbam reprobata. Iudaicam appellari tradit. Verim $f i$ is I udaicam illam intelligit, cuius libro II. meminit Auicenna, nullo modo erro= ris culpa uacare poteft. Nam Auicenne Iudaica berba nil fané aliud defignat, quàm eruum. Sunt tamen aliqui,qui Virgx aurex bcrbam Indaicam, itemiq; Paganam eam nominant, que berbarijs, or medicis quibufdam v I RG A aurea dicitur, fácies, \& ui- caule rubente, bicubital, levi : folijs oliux latioribus, circùm minutißimé ferratis, in fuperficie leuibus : floribus in res. Sunmitate caulium picatis, colore aureo, non tamen anthemidis modo rotundis, radiatisq,; ut eam ininus reàté depin git Fuchfius. flores ij, ubi maturuerint, in pappos abeunt. Hanc chirurgici in Germania, alijs quibufdam additis, ijs filiciter potandame exbibent, quibus intrinfecus inflcta fint uilnkrd, o ad fifulas. Quinetiam eam in unguenta, que ad id conficiuntur, utiliter addunt. nam, ut ipfi refirunt, glutinandis uulneribus tam intró in corpus fumpta, quàm exterius illita, cfficax admodun oft medicamentum. Extulit banc Arnaldusinter recentiores clarißimus author, ad 20 urinam cicndam, comminucndos'g; calculos. quod tamen apud dlium fcriptorem bactenus mibi non licuit reperire. Pota hac aluifluxiones cobibet: id quod etiam preftat clyfteribus infufa. Eius decotto fanantur oris ulcera, firman= tur'; dentes. Idem gargarizatu anginam, o columelle inflammationem arcet, $v$ faucium morbis medetur. Verun= tamen hec, ut ad inftitutum noftrum redeamus, non erit sideritis primi generis, ut fortafe Ruellius exiftimauit .

Sideritidis ui- Sideritidis uires mentoric prodidit Galenus lib.VII I. fimplicium medicamentorum, ubi ita fcriptum reliquit. Side= res ex Gal. ritis babet quidem etiam abjtergendi quandan facultatcm: Sed plurima eius pars bumida eft, o mediocriter frigi= da: palcula ueró ineft adflrictio .quare phlegmonem fedat, or glutinat. Hac Galenus, de una tantìm sideritide

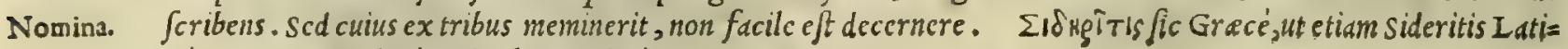
né nocatur: Arabicé, sidrichis: Italicé, siderite.

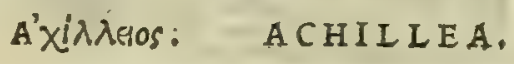

Achillex cófideratio.

Multorum error.

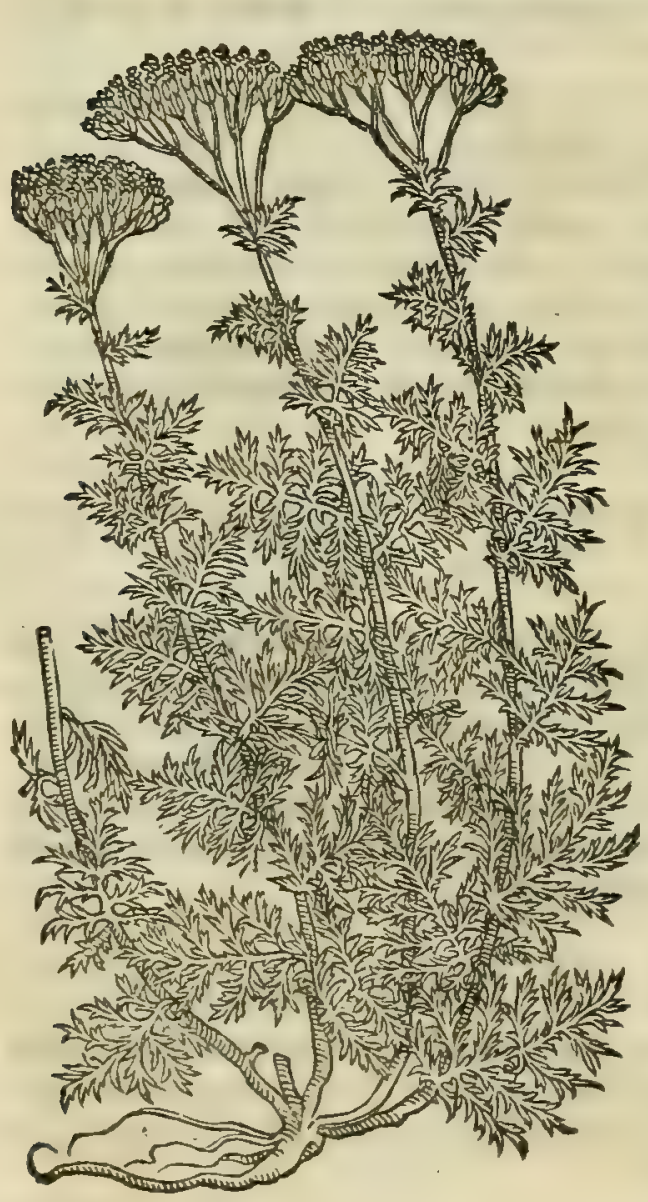

A C H I L L E A, quibufdam Achillea fideritis, dodrantales, aut maiores gerit fcapos, fuforum effigie minutulis folijs circundatos, ex obliquo crebras incifuras habentibus, coriandri fimilitudine, fubfuluo colore, lentis, odore multo, non infuaui, verùm medicato: umbella in cacumine rotunda : floribus candidis, purpureis, $\&$ aurum $æ$ mulantibus . prouenit læto folo. Trita coma fanguinolenta glutinat, \& ab inflam mationum 40 periculo tuetur: erumpentem fanguinem inhibet, \& cruenta vuluæ profuuia in vellere. Decoeto quoque infident foeminx fluxione vulux laborantes . ad dy fenteriam bibitur.

Qv i unlgaris ufus Millefolium Achilleam effe exiftim ant haud dubiè, mea quidě fententia, decipiuntur. Siquidě id (ut infrà latius dicemus de Stratiote millefolio differentes) folia non pro= fert crebrik ex obliquo fectionibus, coriädri fimilitudine, sed aui culdrum penuas amülantia. Porró tametfi conftet, Millefolium sa umbella coronari modó alb $\alpha_{2}$ modó purpurea, modó aurea; non kumen propterea colligendum eft Millefolium, ev Achilleamu= nam $\mathcal{G}$ eandem herban effe. Qzandoquidem non putawerim ego fuiffe Diofcoridis inftitutum (ut Ruellio placet) quod bee Achillea umbellam ferdit candiddin, illa ueró purpuream, alia denique auream : fed quód omnibus in uniuerfum Achillece plantis eadem infit umbclld, que tantum predict is coloribus di= ftincta pectetur. Nafcitur in Hetruria planta, nafoitur o in Goritienfi agro, fcapis feré cubitalibus: follins coriandri pro* ximis, odore quddantenus graui, nan tamen ingrato : umbella in cacumine rotunda, amplá; , colore in purpura candican = 


\section{In Lib. quartum Diofcoridis.}

te, purctis quibufdam aureis depict, , quam femper putaui effe legitiman Achilledm. Atque in bac perfiftam fententia, donec quis certiorem plantum protulerit: quód hec mibi plané omnibus notis A chilleam Diofcoridis reprefen= tare uideatur. Caterim in bunc forté errorem, ut crederent noftrum millefoliun cffe Achilleain, illos deduxit Pli= nius, quilib. $\times \times$ v.catp.V. Achilleam Latinis nillcfolium uocari tradidit. Vcruntamen is, quantum uidcre eft, co in loco non Achilleam banc defcribit, fed eam omnino plantam, quam Diofcoridcs myrioplyyllum appellat. Quarc patt= ló póft bac uerba fubiunxit. Sed alij, inqut, fatentur ueram Acbilleam effe fcapo carulco, pedali, fine ramis, $c x$ omi parte fingulis folijs rotundis eleganter ueftitan. Ex quibus uerbis liquidó apparet dubitaffe flinium, qualis les gitima effet Achilled: O idco ita indeterminaté locutum fuiffe, ut mbil in co perpetuum fratui poßit. Serapio, au= thoritate Conftantini, Achilleam, quód (ut ipfe ait, licet falsó) rubeum fuccum fundat, Sanguinem draconis appel=

Serapionis

- lat. fed fortajfe bic interpretis lapfus fuus factus eft. Siquidem fuccum rubcum fundere A chlleam non tradidit Dio= fcorides: ne ơ ction (ut omnes compertum babent) lacryma, quam officinx Sanguinem draconis appellant, berba fue cus eft, fed Arabice cuiufdam magne arboris gummi, uch, ut aliqui uolunt, draconis animalis eft fanguis ab elepbante collifi. Cuius loco illius plurimum ucndunt inpoftores, quem birci fanguine cum refind quáuis, forbis ficcis, alijsq.; nonmullis adulterant, o in rotundas placentas conformant. Achillea meminit Galenus lib. v I I I. fimplicium sned. fic de cius uiribus fribens. Quidam etiam uocant Achilleam fideritin, qua propofit a quidem, quod ad iam ditta atti= net, uiribus eft non dißimilibus: ceterim adfrictione exuperat .quare ad fanguinis eruptiones, dy fenterias, or mu=

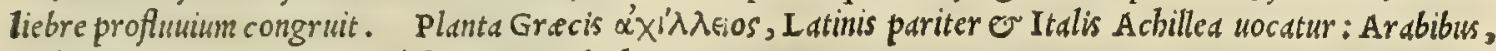
siclritis, Or Egilos : eius ueró fuccus Demalochotten.

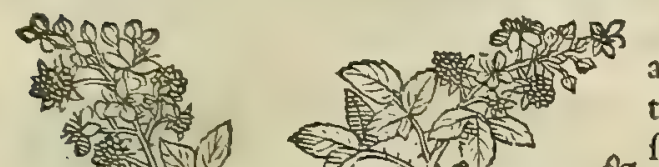

R v.B v S notitix uulgaris. Vim habet ficcandi, \& adfringendi : capillum tingit. Ramorum decoetum,potualuum fiftit, \& fominarum profluuia : præfteris morfui accommodatifsimum. Gingiuas firmát, \& oris vitijs medentur folia commanducata: cohibentulcera quæ fer punt : ulceribus in capite manantibus, oculisque procidentibus, remedio funt : condylomatis, \& hamorrhaidibus folia illinuntur . cardiacis, \& ftomachi doloribus, trita conuenienter imponuntur. Caules cum folijs tunduntur, exprimiturq́ue fuccus, mox fole cogitur, fingulari remedio contra omnia, quæ modò dicta funt . Mori in rubo nafcentis quàm optimè maturi fuccus, ad oris medicamenta conuenit. Siftituraluus præmaturi cibo, necnon flore in uino poto.

\section{Baitosidaia. RVBVS IDAEVS. CAP. XXXIIII.} ID AE v S Rubus appellatus eft, quoniam copio-
fus in Ida prouenit. Eft autem longè tenerior priore,

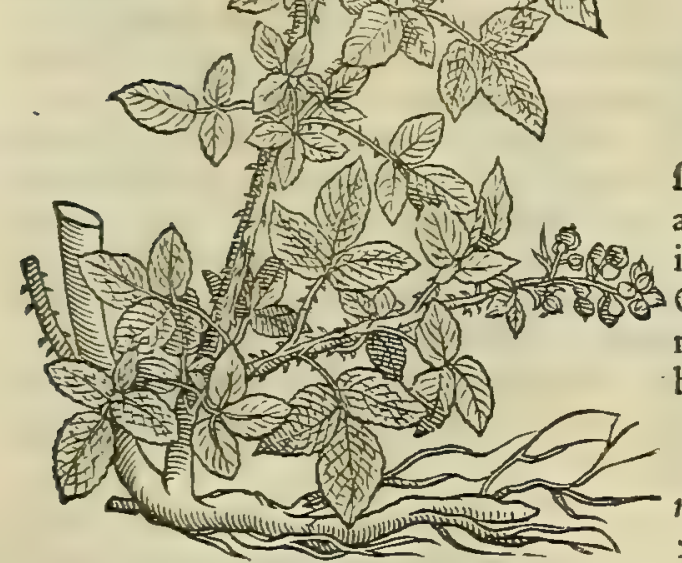
ac minoribus fpinis horrens: quanquam \& fine fpinis inueniatur. Infuper eadem præftat, quæ fupradictus. Cæterùm flos cum melle oculorum collectionibus illinitur . ignem facrum extinguit, ftomachicisque ex aqua bibendus datur.

$R$ V $\dot{B}$ I unlguris plante, plurd apud nos reperiuntur ge= Ruborum có nerd . quod etiam teftatum reliquit Theophraftus libro I I I. cap. fideratio. crafe feens, in altum attollitur : alius fepibus, frutetisq́; implicatur : alius humi ferpit, radicatur'q; graminis mos do, quem ideo humirubum appellant: alius denique alys modis in fyluis, or montibus uagatur. In montibus fiqui= dem Tridentinis, prafertim $\dot{q}$; Ananienfibus Rubi quoddam genus nafcitur, rubra proferens mora, fragis non dif= fimilid, nullis intus oßiculis, que ab incolis uulgó uocantur Ampomele, guftui per aftatem non iniucunda. Is maxi= mé delectantur urfí: qui hac de caufa eo potißimum tempore, quo illa mature $\int c u n t, d$ uenatoribus captantur. Hoc rubi genus funt é recentioribus, qui pro certo crediderint effe I deum rubum. Sed equidem non uideo, quomodo illorü fententia pror fus recté probari poßit: nam fi Idsus rubus dictus eft (ut interpretatur Diofcorides) quod in Ida pro= weniat, hine nimirum colligi poffe putauerim, ut Plinius lib. x x I I I I.cap. x I I I I non temeré fortaffe collegiffe uide tur, quód is in Ida tantum, non aliâs naf catur, quemadmodum etiam radix, qua Idad dicitur, or dictamnum in Cre= td. nifi forté quis I deum pro montano accipiat. Fuchfius rubimora (ut libro primo in liguftri mentione diximus) uacinia e fe putat. Sed quare ab co diffentiam, ibidem diffufius oftendi, quód fciticet uacinia flores, non fructus effe

Achillex uiresex Gal.

Nomina. 


\section{8 \\ And. Matthioli Comm.}

Rubi uires ex cxiftimèm. Rubi uires defcripfit Galenus libro vr. fimplicium medicamentorum, fic inquiens. Rubi folid, germi=

Galeno. $n a$, flos, fructus, or radix qualitate adftringente participant, eá; non obfcura. Sed bocinter fe differunt, quód folix, mollia potifiniun, or recens nata, plurimum in fe babent fubstantie aquex, parum ueró adfrictionis : eddem

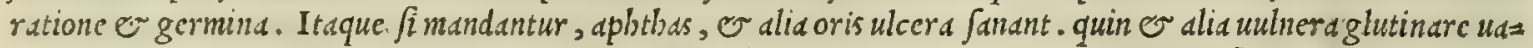
lent. Eft cnim corun temperies $\sigma$ ex terrea frigida effentia, o aquea tepida. At frutus, fiquiden maturus fue= rit, non parum babet fucci calidi tesnperati, qui dulcis eft, uti monftrauimus. Proinde ob hoc, o propter modic am adftrictionem, efui non infuauis eft. At iminaturus à frigida fubftantia terrea uincitur: 0 propterea acerbus eft; O ualde exiccatorius. Et fané uterq; ficcatus reconditur, ualidius quàm recens deficcans. Sed o flos eandem frus Etui immaturo facultatem poßidet: utraq; ad dyfenterias, $\mathbb{E}$ uentris profuuium, tum robur deperditum, o fangui= nis expritiones, idonca remedia. Porró radix preter adfrictionem non paucam in $\int$ labct fubftantiam tenuem, pro= Norsina. pter quam e lapides renum comminuit. Hac plenta Gracis Ba'Tos appellatur : Latinis., Rubus: Mauritanis, Buleich, feu Halcich: Italis, Rouo: Germanis, Carza: Gallis, Ronce. Eius ueró fructus Grecé bativa et bas= rwía dicuntur: Latiné, Miora rubi: Italicé, More dirouo: Germanicé, Bramber, o Kratzber.

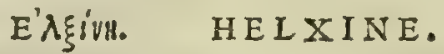

Helxinis con fideratio.

Helxines uiresex Gal.

Nomina.

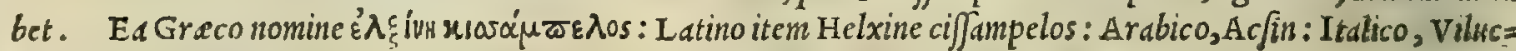
chio minore: Germanico, Mittel uuind: Hipanico; Campdiela yerua.

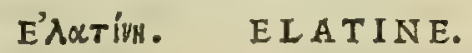

CAP. XXXVI.

E I A T I N E folia habet helxinæ fimilia, minora, rotundiora, pilofa: tenuibus, \& dodrantalibus ramulis, quinis, fenísve, à radice foliofis, guftu adftringentibus . nafcitur in fegetibus, \& cultis. Ocu lorum fluxionibus, \& inflammationibus auxiliatur, folijs cum polenta tritis, \& impofitis. Fadem cocta forbitionis ufu dy fenteriam fiftit .

Elatines confideratio. ijcitaluum.
S v N T qui uelint Elatinen cam efe plantam, quam quidam Numinulariam uocant. Alij ueró non banc uos lunt, fed eam quam nos uulgó uocamus solbaftrella, officinx Pinpinellam, er alij quidem Sanguiforbam dicunt. Sed mibi quidem, ut dicam quod fentio, neutrorum placet opinio. Siquidem $\mathrm{N}$ unmularia in primis non fort folia pilofa, neq; in $\int e g c t i b u s_{2} n e q_{;}$in cultis prouenit, fed plerunq; in fcrobium marginibus, prefertim uligine madentibus:
HEI X I N E cognomento ciflampelos, folijs eft hederæ: minoribus: ramulis exilibus, quibus complectitur quodcunque contigerit adminiculum. Nafcitur in 20 fepibus, uinetis, \& fegctibus . Foliorum fuccus potu de-

N v. I I I certé dubium effe putauerim, quin Helxine cogno mine ciffampelos, quafi bederace am uitem dixeris, fpeciesfit Con uolundi. Sed qua ea fit, non facile cxplicari poteft. Verum cum cam reddiderit Diofcorides folijs beder a fimilibus, minoribus $t a=$ mcn: ramul is exiguis, quibus quodcunq, contigerit complectatur: detur, edme effe Helxinen, que quidem in aruis tum fegetes ip $\int a s$, tum linum, tum legumina omnia irretit, ac tuncit, $\mathfrak{E}$ in ninet is, palis; Or nitibus circumuôluitur. Hanc Hetrufcum unlgus fno idlomate nominat vilucchio minore, Tridentinis ueró Minutola diciur. Quniquam non defunt, qui putent Helxinem eam effe tices, flores illos candidos aftate oftentans, quos noftri ualgo ap pellant Campanelle. Hanc Plinius conuoluulum uocat lib. X X I. cap. v. wbieam his uerbis depingit. Eft, inquit, flos non dißsinilis lllo in berba, quam Conuoluulum uocant, nafcens per fruteta, ing odore, ncc crocis intus, candorem tantùn referens, ac uelu 40 tes hanc berbam, o eius florem liguftrum uocent : in qua appellaz tione deceptus fuit Seruius grammaticus. Hunc errorem explofi= mus libro primo, ubi ueri liguftrimentionem fecimus. Helxinen perpaucis perftrinxit Galenus lib.v I. fimpl. medic. fic inquiens. Helxine, que e ciffampelos nuncupatur, digerendifacultatem ha 10

.




\section{In Lib. quartum Diofcoridis.}

NVMVIARIA.

10

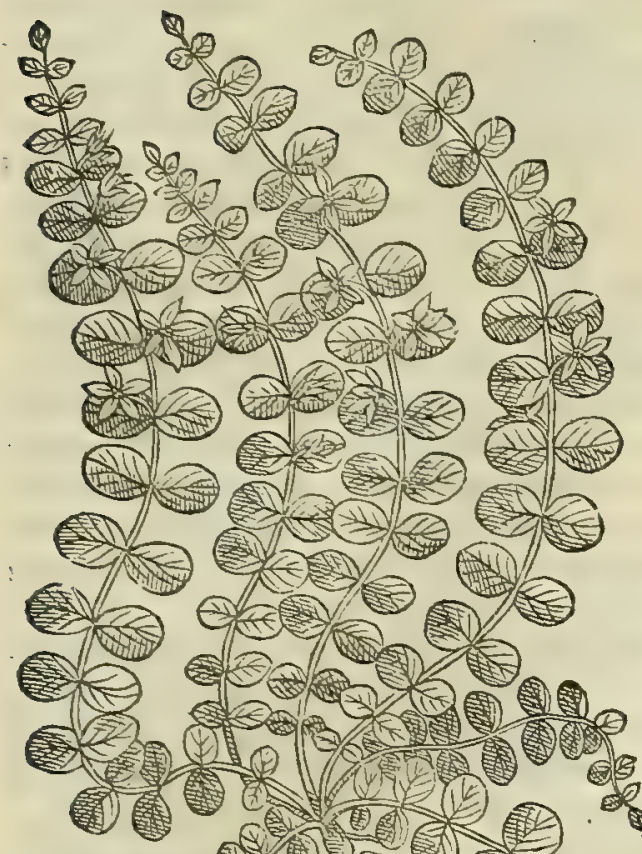

30

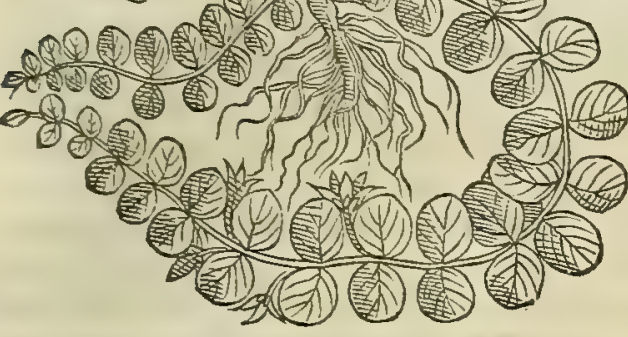

EVPATORIVM.

40

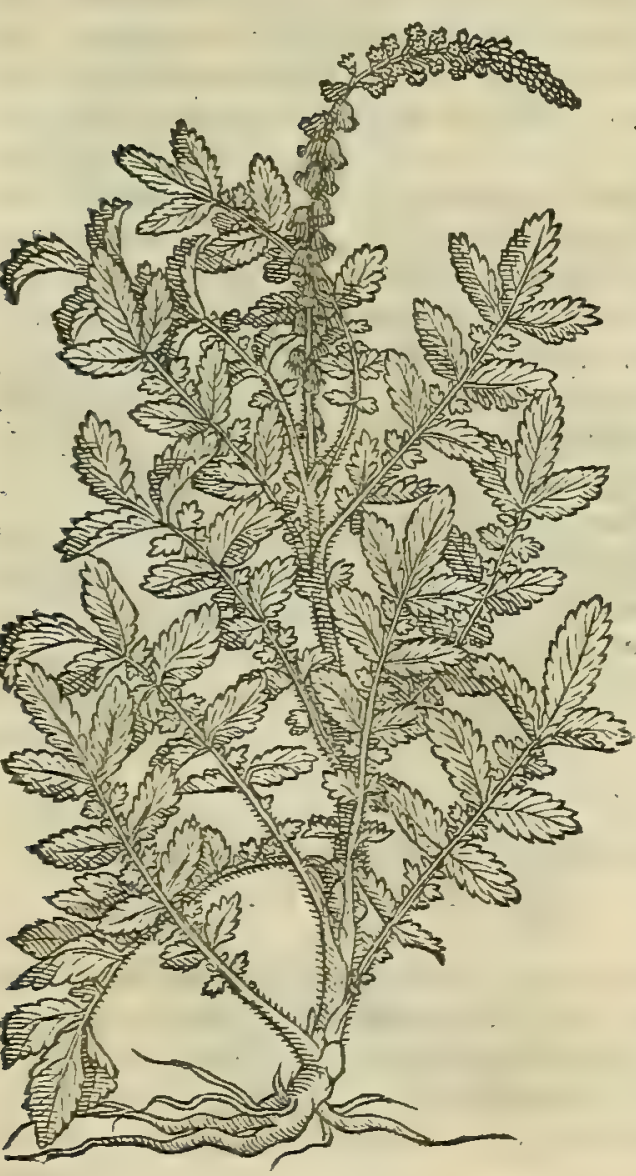

Deinde Pimpinella uocata ramulis exit longé pluribus, quaim $\mathrm{f}_{\mathrm{e}}=$ nis in terram procumbentibus, or folia habet undique in ambitu laciniata, afterifci modo. Rucllius porró Elatinen in Gallia unl= go Rapiftrum uocari ait, co $\dot{q}$; ut rapo fylucfri in ucrnis accta= rijs rura uti. Verim fi rapiftrum id Hetrufcis oft, quod Gallis, certó fcio, Elatinen effe non poffe. Que tamen quód nafcatur in Italia, nec negarequidem, nec affirmare aufin, cum bactenus plantam non uiderim, qua illam legitime referat. Galenus de Elatines uires Elatine quàm breuißsinc differuit libro v 1. fimplicium midica = ex Galeno. mentorum, fic itquiens. Elatine modic é tum refrigerat, tum ad=

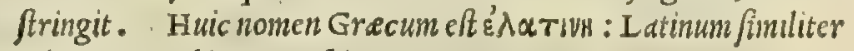
Elatine: Arabicum, Athin.

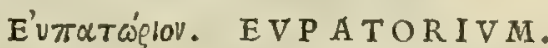 \\ CAP. XXXVII.}

EV P A T O R I V M fruticofa herba eft, unicum efferens caulem, lignofum, nigricantem, retum, tenuem, hirfutum, cubitalem, interdum ampliorem : folijs per interualla quinquefolij,aut cănabis potius fimilibus, quinquepartitò, aut amplius diuifis, nigricantibus \& ipfis, per ambitum ferratis : femen medio caule erumpit, pilofum, deorfum fpectans, quod ficcatum ueftibus inhæret. Contrita huius folia, \& cum fuillo adipe impolita,vlceribus, quææ grè cicatricem trahunt, medentur. Herba, aut femen in uino potum, dy fenteria, iecinoris uitijs, \& ferpentium ictibus liberat. Nec defunt, qui aberrantes argemonem hanc appellarint, cùm tamen longè alia fit, uti expofuimus.

S v M V N T nonmuli, imó uniuēr fa feré feplafiariorum turz Eupatorii cöba,legitini Eupatorij uice quandam appectu infignem plantä,qua fideratio. plerung; in uliginofis locis, ev in frobium marginibus enafcitur, tricubitali longitudine, folijs cannabinis amulis, maioribus $t d=$ men, fubalbidis, hirfutis, o amaro guftu: caule fubrubeo,rotun= do, firmo, hirfutoơ;, mult is aldrum cavis, multisó; adnatis re $=$ ferto. Huic flores in umbellam exeunt, non tamen fimul cohes= rentem, fed diuulfam, origani uulgaris modo, colore in purpu=

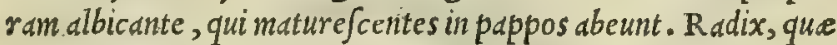
inplures diudricatur partes, illi inutilis eft, nulliusó; in medicina ufus: Et quanquam ij fciunt, legitimum Grecorum Eupatorium eame efe plantam, qua unlgo Agrimonia uocatur, corum forte imitatione , qui Diofcoridis et tate eandem perperdmargemonems appellabant; cum tamen animis imbibitos iandiu errores reijcere nequedint, uel potîus nolint, difficile quidem adducipatiuntur, ut unlgarem Agrimoniam Gracorum medicamentis, que Eupato= rium excipitunt, ddmifceant. Non tamen biec proptered dici= mulexipan proprium fic Auccenin Eupatorium; fed ut unumquodq; fuo red = datur atuthori. Paldm etenim eft, ut ex foliorum amaritudine, or odoris preftantia, quo buius Eupatorij tota redolet planta, per= cipi poteft, id er obftructiones aperire, er craffos, lentos ö; humo= res mirificé incidere poffe. Veruntamen nunquiam eó deueniam, ut affeuerem, hoc apud Grecos legitimi Eupatorij nomen fibi afci uiffe: tantum illud abeft, ut etiam à nullo, quantum equidem inue= nerim, ueterum fub alio nomine pofteritatis memoris proditum fit, preterquàm ab Auicennd. Ruellius tamen nefcio qua $r a=$ tione ductus in fuis de natura firpium commentarijs non fine magno errore fibiperfuafit, unlgare hoc Eupatorium dubio pros cul bydropiper effe d̀ Diofcoride libro fecundo defcriptum. Sed nos ibi in noftra bydropiperis commentatione Ruellij erro= rem latius explofimus, quam ut quicquam fuperfit addendum.
Nomina.

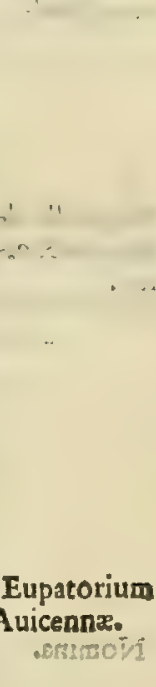


Eupatorium Mefuis.

Cordi \& Fuchsij error.

Eupatorii uíres ex Gal.

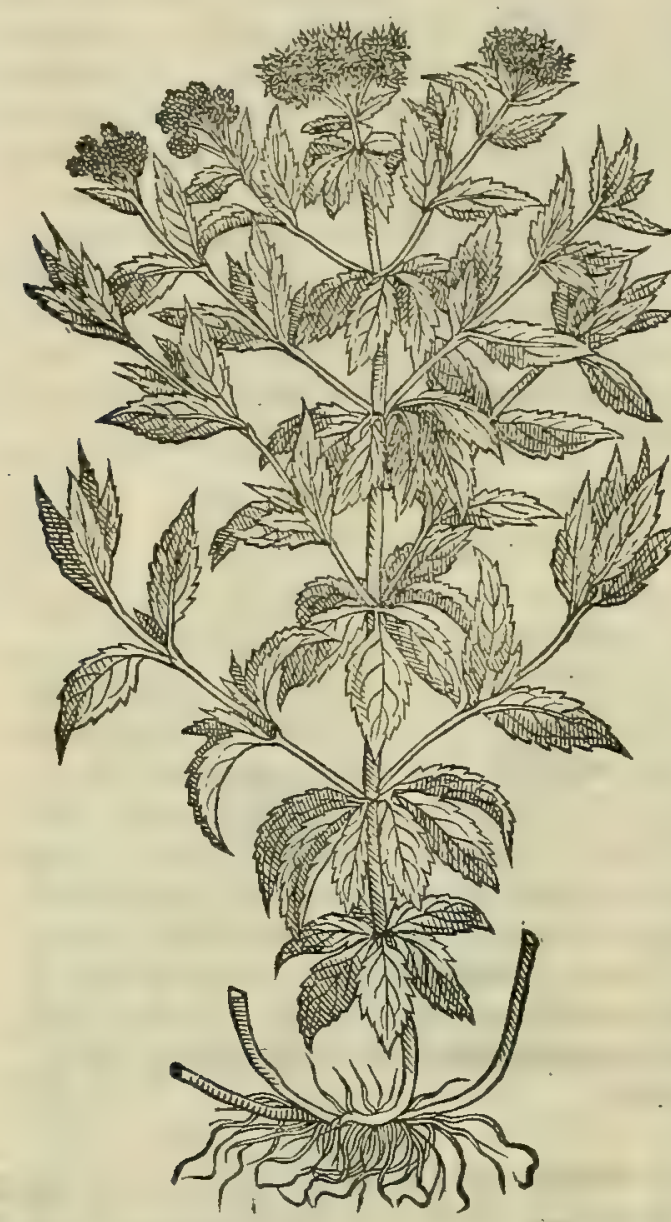

POTENTILLA.

aterim Mejues quoque babet Jum peculiare Eupatorium, quod, ut ex cius de $\int$ criptione apparet, à predict is longé diuer= fum eft. Id nanque plures ab radice emittit caules: folijs mino= ricentaurio fimilibus, per ambitum laciniatis: floribus aureis, in umbellam coberentibus, belichry/i modo. Hoc noftratibus senenfibus uulgó nocatur berba Giulia. Huius comam mulieres per noctem uino albo macerant, ac fubinde dilutum pueris po= tandum prabent dimidij cyathi men ura ad necandos uermes ad= mirabili fucceffu. Nafcitur bec in campeftribus: atque, ut med frt opinio, ea eft planta, que Diofcoridi ageratum dicitur: quippe qua omnibus notis illi reßpondeat. Hinc itaque addifcant Mauritanorum fequaces, cum tres babeantur plante nomine Eupatorij, in medicamentis à Mefue relictis fum interponere Eupatorium : in Auicenne remedijs fuo item uti : $\mathcal{O}$ in $\mathrm{Grec0}=$ rum compofitiones Agrimoniam uulgó uocatam addere. Sed animaduertant uelin, ne in hoc valerij Cordi dipenfatorium fequantur, quod perperdm, meo quidem iudicio, fribat in confectione pilularum aggregantium, quin er in fyrupo de $\mathrm{Eu}=$ patorio, pro ipfius Me fuis E upatorio admifcendam effe Gratio= lam. siquidem bec preterquìm quód aluum magno incommodo 20 deijciat, nullis etiam plané notis, ac reliquis facultatibus illud reprefentare deprchenditur. Nempe fua deiectoria ui, qua ma= gno cum impetu uentrem foluit, iecur imbecillum, atque infir= mum reddit. Cordum fecutus uidetur Fuchfius, uir alioqui do= ctißimus, in libro de compofitione medicamentorum, quem po= ftremó auctum edidit, ubi in antidoto é lacha magna illud Eu= patorium ufurpandum effe tradit, quod à Me fue de cribitur, or Grecis ageratum, Italis ueró gratia Dei nominatur. Qua in re

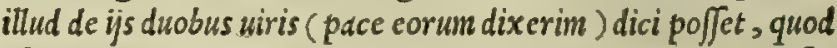
eft in communi prouerbio: Cacus coccum ducit, $\mathcal{O}^{\circ}$ ambo in $f 0=3^{\circ}$ uean cadunt. Eupatorij meminit Galenus lib. v. r. fimplicium medicamentorum, ubi ita fcribit : Eupatorium berba tenuiü par tium, incidendi extergendiǿ; facultatem citra manifeft am cali= ditaten obtinet . quocirca obftructiones iccoris expurgat. Ineft ci oradfrictio modica, propter quam robur uifceri addit. has= Eenus Galenus. Eft 0 berba Agrimonix non dißimilis, que nonnullis P O T E N T I L L A uocatur, tametfí birfutiori= bus fit folijs, fuperné uirentibus, inferné ueró albicantibus. Cau= liculas profert, qui bumi repunt, pilofelle nocate modo: aureis floribus ornatur, fingulari pediculo pendentibus, ranunculo bor to? tenfi cemulis. Radice nititur exterius purpurafente, interius ue rócandicante. $\mathrm{N}$ afcitur in uliginofis locis, er propter femitas. Vniuer fa hec planta adfrictoria, 0 exiccatoria facultate pol let. Idcirco mulierim profluuia, or dy fenterias cobibet, et uul= nexa recentia agglutinat. Prodeft item $\checkmark$ fanguinem reijcienti= bus, Pudendorum, $\mathcal{F}$ oris ulcera $\int$ anat. Firmat commotos den= tes, ftringitóf; ging iuds, or dentium dolorem mulcet, fi eius de=

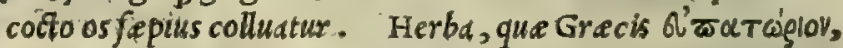
$\sigma$ í⿴囗大 pellatur: Arabibus, Cafat, Cifit, $\int e u$ Gafet: Italis, Agrimo= so nia: Germanis, Odermenig: Hipanis, Agramonia : Gallis, Aigremoine.

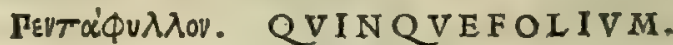 CAP. XXXVIII.}

QV I N QV E F I I V ramulos fert feftucarum fimilitudine, tenues, dodrantales, in quibus femen ; folia menthr, quina fingulis pediculis, rarò plura,in ambitu ferrata : florem ex candido pallefcentem,auri æmulum. Nafcitur in riguis, \& aquarijs ductibus. Subrubram 


\section{InLib. quartum Diofcoridis.}

QVINQVEFOLIVM.

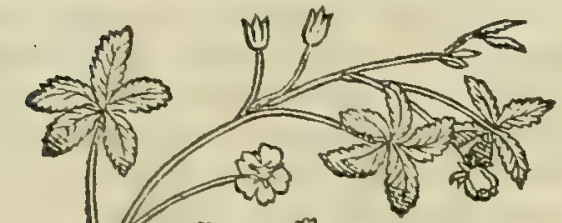

20

30

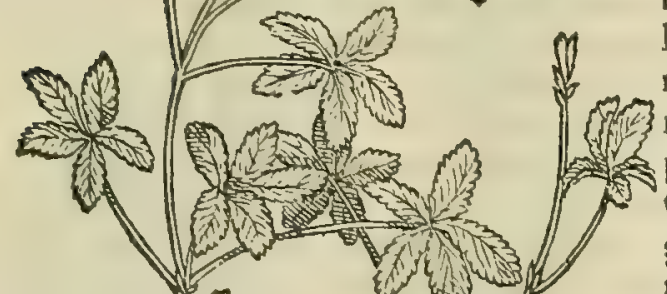

$4^{\circ}$

50

\section{DIAPENSIA.}

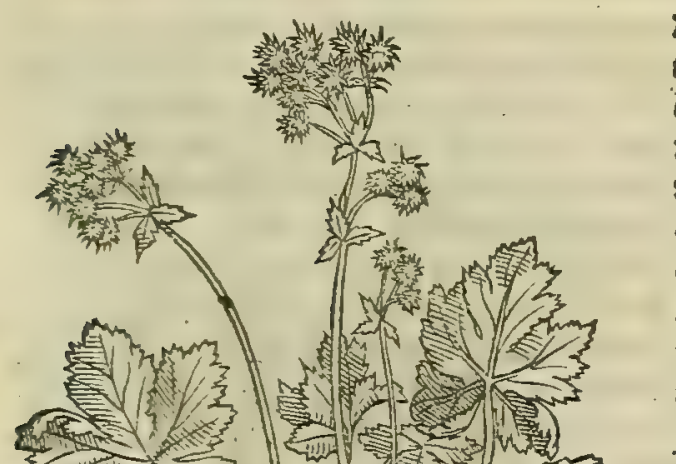

bram habet radicem, oblongam, ueratro nigro crafsiorem. plurımis poller remedijs. Ius radicis decoctx ad tertias, fi in ore contineatur, dentium dolores fedat: putrida oris ulcera ${ }_{3}$ collutione fiftit : arteriæ fcabritias, gar garizatu laxuigat: contra alui profuuia, \& dyfenterias auxiliatur : item articulorum, coxendicumq́ue cruciatibus potum. Cocta in aceto, \& illita, ferpentia ulcera cohibet: Atrumas, tumores, duritias, abfceffus, \& collectio nes difcutit : ignes facros, reduuias, condylomata, p forasque fanat. Teneræa radicis fuccus, contra jecinoris, pulmonumque vitia prodeft:itcm aduerfum uenena. Cum hydromelite autem, uel diluto uino, \& piperis exiguo, bibuntur folia contra febrium circuitus: in quartana quidem, quaternûm ramulorum folia : in tertiana uerò, ternûm : in quotidiana, unius. Ea quoque folia tri cenis pota diebus, comitialibus profunt. Foliorum fuccus tribus cyathis aliquot dies potus, celerrimè regio morbo medetur. Illita cum melle \& fale, tam vulneribus, quàm fiftulis remedio funt : enterocelicis auxilium præetant. Quinquefolium fanguinis profluuia \& potu, \& illitu fiftit. Ad expiationes, caftimonias, \& incantamenta inciditur.

T A M E T S I unius tantum Pentaphylli, fiue Quinquefolij meminerit Diofcorides; nos tamen quatuor eius genera uidımus in Italia. Quorum utiq; prinum à Diofcoridis biftoria nibil pror fus diffentit . Secundum à primo differt, quod folijs fit albic anti= bus, hirrutis, of flore candido. Tertium folio erumpit paruo, fubalbido, per terram repit. Vltimum ueró folia fert uitigined, in partes quinque diui $\int$, quod aliqui D I A P EN S I AM, alij Sa= niculam appellant. Huic încauliculorum fummitatibus, or adna= rorum faftigijs, capitula prodeunt fubalbida, facie frag is fimilia. Primum prouenit in riguis, o fcrobium marginibus, cauliculis tenuibus, floribus aureis, é quibus fubinde femen oritur. Pedicu= los é fe mittit, o in fingulis quina folia oblonga, menthe feré $=$ mula, in ambitu tamen magis serrata. Radix illifubrubens appd $=$ ret, quod quanuis negat Brafauolus; id tamen alijs, ut mibi eam effodienti, uerum effe deprebendetur. Hac in plures radiculas diuiditur, elleboro nigro craßiores. Hinc autem mirari fubit Manardi erra Manardum Ferraric nem uirum alioqui buius noftre etatisinge tum. nio, er doctrina infignem: quippe qui tam faclé fibi perfuaferit, id legitimum effe Quinquefolium, quod Grecibeptaphyllon, of = ficina ueró berbariorumós, unlgus. Tormentilldm dicunt. Siqui= dembec feptem ex uno tantìm cauliculo profert folia: Penti= pbyllum uéró quinque, unde ev illi nomen. Hoc radices elleboro fimiles babet, craßiores tamen, oblongas : illa ueró admodum bre ues, ftrumo Jas, fimuló; in unum compactas globum. Gignitur hec plerunque in incultis, fiticulofis ; locis, in altis prefertim mon: tibus: illud uero in campeftribus, er prope aqua ductus, 0 in riguis. Que fané omnia aperté declarant, hac in re Manardum cacutiuife. : Ceterum nunquam admiratus fum Plinium in hoc (in quo tamen à Leoniceno, ut arbitror, immeritó reprebëditur) quód libro $\mathrm{x} \times \mathrm{v}$.cap. I x. tradiderit reperiri Quinquefolium. quod fraga gignendo commendatur. Quandoquidem ( $u t$ paulo anté diximus) $Q$ uninquefolijgenus eft, quod à quibusdam Diapen= fla nominatur, in cuius fümis cauliculis capitula feectantur fro gis non difimilia. Verumet et afferat Brafaulus in Veronen $\sqrt{i} d=$ gro nafci Fragariam, cui quinque unicuique pediculo infunt folia, or que fraga gignit, in cibis gratißima, putetó; de bac intellexif= fe plinium, quod d̀ Verond, ut ipfe inquit, fuerit oriundus; non

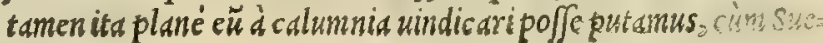

Quinquefolij genera. . 
FRA'GARIA.

Quinquefo lii uires ex $\mathrm{Ga}$ leno.

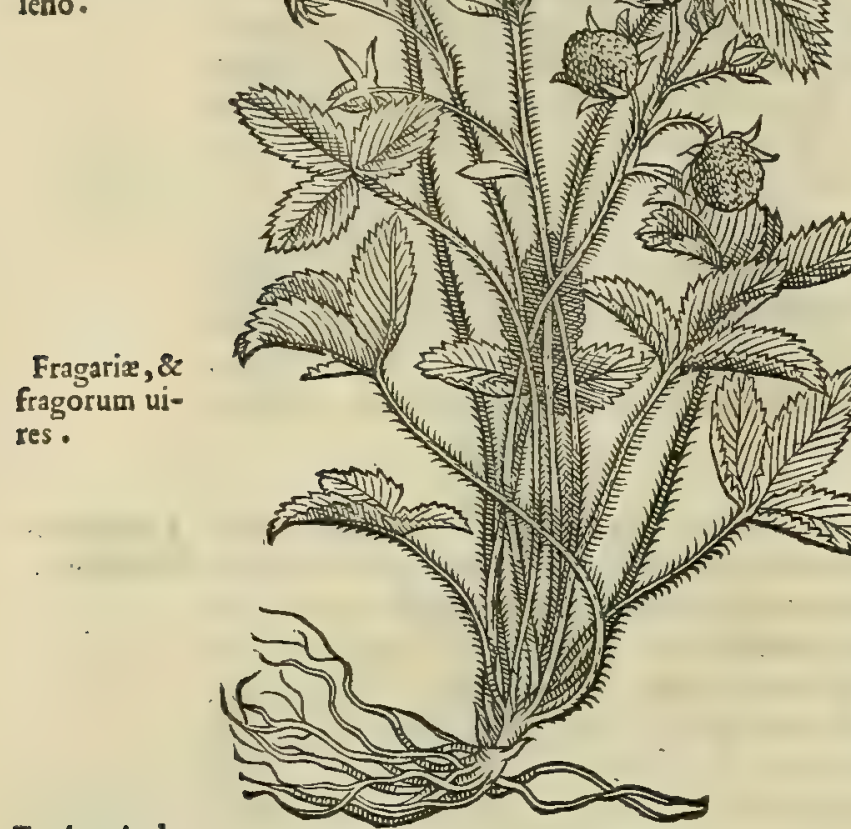

Euphragię de lineatio, \& vi res.

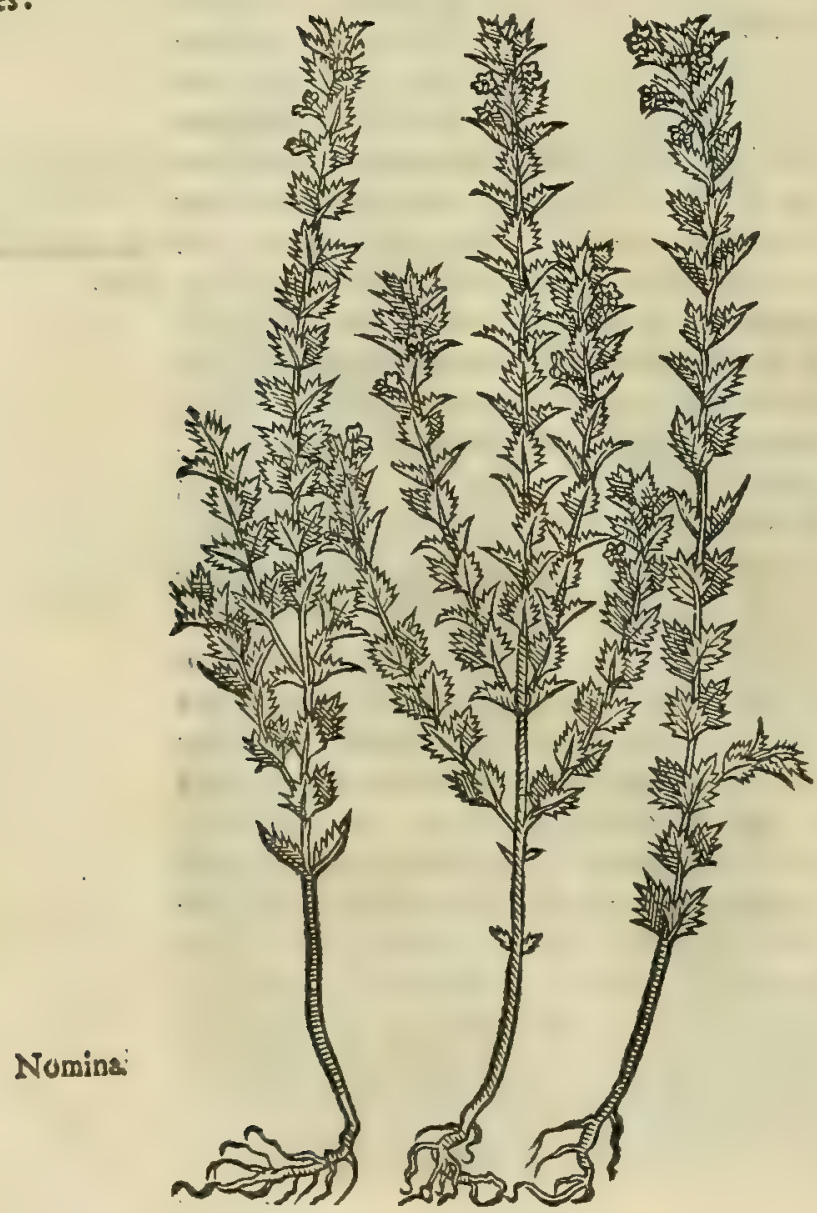

tonius Tranquillus fuo de illuftrium uirorum eatalogo, Plinium Nouocomenfem ficerit, non Veronen $\int e m$. Quarta bac Quinque= folij Pecie Germania chirurgici maxime utuntur ad intrinfecd uulnera, enterocelas, or fiftulds, eius puluerem, uel decocium po tui exbibcntes. Quinctiam ad morbos omnes, ubiadftringenti, folidantí; medicamine fit opus. Eft tamen non ignor andum, boc non effe Saniculan illam, que etiámum quinis exoritur folijs, ra= dice alba, miro nature artificio laciniatd, de qua fuperius in sym= phytimentione differuimus: fed aliud longé differens. Quin= quefolij uires retulit Galenus libro v I I I. fimplicium medicamen to torum, bis uerbis. Pentapbylliradix, inquit, deficcat uebenent= ter, minimim ueró acris eft. Quare in multo eft $u \sqrt{ }$, uelut alia quoque onnia, que cim fint tenuium partium, citra morfun de= ficcant. Eft enim bec radix deficcatoria ex tertio quodammodo ordine, minimum babcns euidentis caliditatis. hac Galenus. $C_{e}=$ terum quoniam Pentaphyllum Fraganobis in mentem redegit, cum ea fint tam cibis, qudin medicamentis idoned, ideo or res, o locus mibi expetere uidetur, ut hic tum plante, tum fructus eius uires perftringamus. FRAGAR I itaque planta ef neminife= ré non cognita, adeo ut boc nomine fuperuacuum putem, eius $f a=20$ ciem reprafentare. Refrigerdt ordine primo, ficcat'́; fecundo . Folia, er radix uulnerd, or ulcer a fanant: muliebres fluxus, dy fenterias cobibent, urinam cient, e lieni conferunt. Herbe, or radicum decoctum potum; auxiliatur iecinoris inflammationi= bus, mundató; renes, er ueficam. Idem ore contentum, collutio= nisq́;; modo agitatum, gingiuas roborat, dentes commotos firmat, ordefillationes fiftit. At Fraga prater id quód gufui aftate in cibis arrideant, biliofis, eftuantibus'́; uentriculis profunt, fiti= culo/is q. fitim fedant. Vinum, quod ex ijs elicitur, ulcufculis, que in facie à caliditate proueniunt, mirifice medetur : item $\phi_{\$}$ ua 30 ros, e: oculorum nubeculas, calidas'; defuxiones impofitum tol= lit. Neque etiam hic filentio difimulanda uidetur Euphragia, quam nobis Fraga nunc ob uocabulorum uicinitatem ad memo= riam reuocarunt, cum er ip $\sqrt{a}$ miris ad oculorum morbos uiribus pradita fit : etfia a ueteribus Gracis nusquam, quod legerim, de= fcriptareperiatur. Eft itaque EVPHRAGI A temuis planta, que ad palmi altitudinem affurgit : folijs minutis, cripis, per am= bitum ferratis, gultu adftringentibus, paululumí; amaris : caule exit tenii, rubentiq; : flore inter purpurain or aurum albicante, quem emittit abeunte aftate . nafcitur in pratis. Preftat bec quo 40 cunque modo fumatur tam in cibis, quàm in medicàmentis recens, uel exiccata ad omnia impedimenta; que oculorum claritati off $=$ ciunt, prefertim cim in cibis diutius fumitur Fit ex ca uinum uin demiarum tempore, unis er nifto inacerata. de quo Arnaldus iu bunc modum differuit. E uphragia uinum, inquit, fit ad oculos po nendo berbam in mufto donec fiat uinum. Cuius ufu oculi fenum reiuuelte cunt, $\mathcal{\sigma}$ aufert impedimentum corum, $\sigma$ defectum uifus in quocunque cuiustis atatis bomine, praestim ubi pinguedo, or pituita redundent. Et eft qui permanfit wibil uidens per long $\tilde{u}$ tempus; er infra annum, eius ufu reftitutus cfl ad uifum. Ip $\int \mathrm{e} e=50$ nim berba calida eft $\mathcal{O}$ ficcd: $\mathcal{O}$ babet boc a proprietate, quód quando puluis eius comeditur cun ouorum uitellis, idein mirifice preftat, uel quando puluis idem recipitur cum uino. Et fuper Junt teftes fide digni, quifecerunt in $\int e \mathrm{ip} / \mathrm{is}, \mathrm{er}$ qui non poter ant lege= re fine ocularijs, o legerunt poftmodum absque ip/is, etiam li= teram fubtiliorem. Et ufus uini Euphragiati non babet par in proficiendo uifui. Si autem uinum effet nimis forte, temperetur cum aqua foniculi : $e^{-f i}$ opus eft, addatur zuccharum nece $\int a=$

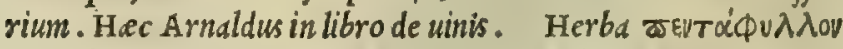
Gracé, Quinquefoliü Latiné dicitur : Italicé, Cinquefoglio:Ger= manicé, Vucis funf,er Fingerl'raut: Hipanicé, Cinco en rama: Gallice', Quinte fueille. 


\section{In Lib. quartum Diofcoridıs.}

\oivin. PHOENIX.

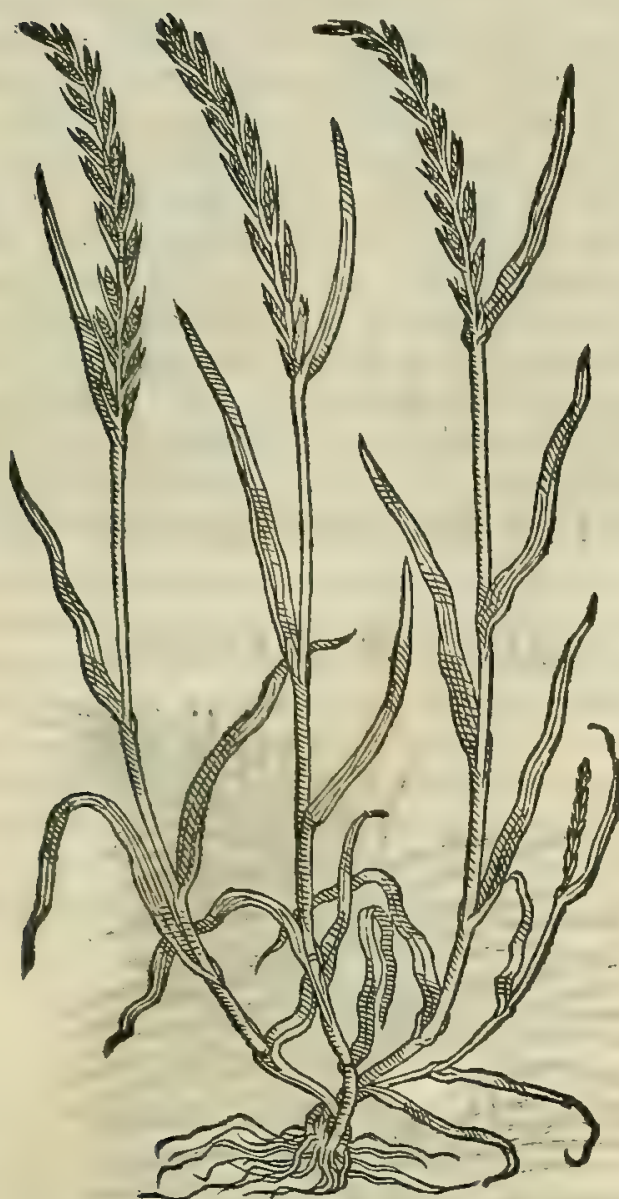

RADIX RHODIA.
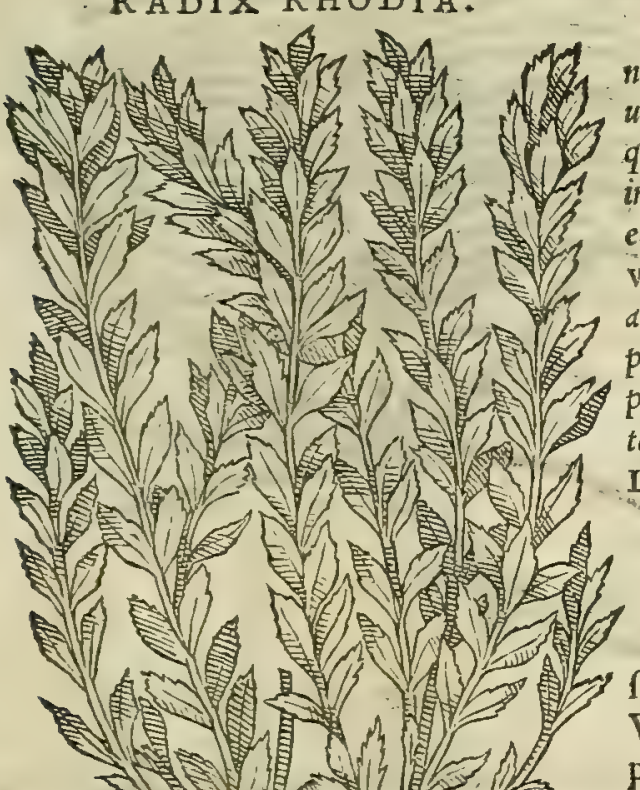

D AE A radixhcdic, quod fciam, ad nos non conuebitur: nec quenquam bactenus reperi, qui fcribat, ubibec planta pro= ueniat : etfi cognomine natale eius folum faclléindicari uideatur, quód fcilicet in Idamonte, qui ad Troadem $\beta e c t a t$, nafcatur : uel in co eiufdem nominis, qui in Creta babetur, ut etiam Idro rubo euenire fuperius diftun eft. Huius uires tradidit Galenus libro v. Iimplicium medicamentorum, fic inquiens. Idea radix guftus adinodum acerba eft : ac fi opere periculum facias, eandem uim preferet, nimirum fanguinis profluxia, aluifluxus, dyfenterids, proflumium multerum, or quecunq; cius funt generis tum pota,

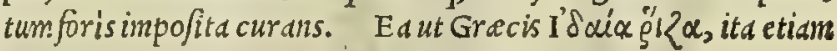
I atinis Idea radix uocdtur: Iralis, Radice Ided.

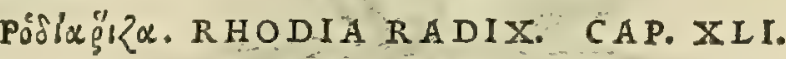

G I G N I T V R Rbodia radix in Macedonia, colto fimilis, leuior, inæquabilis : qua contrita rofas redolet . Vtilifsima capitis doloribus, fi madefacta fronti,\& temporibus cum rofacei momento imponatur.

$\mathrm{R}$ H O D I A radix planta eft non omnibus plane uulgaris, Rhodix radiO cognita in Italia: et fiè facilé in A pennino, Gargano mon cis confid tibus nafci, er inue nimi poßit. Qude in noftro barto Goritie ui= ret, iandiu eam Gratio Styriz oppido Petrus salicetus medicus clarißimus, or in fimplicium facultute non imperitus, ad nos prie mìm uidendam mifit: quam tamen pofted frequentißimamireperi in monte magno fupra vipacum, qui circiter uiginti millia paffuts ¿ Goritia diftat. Ceterùm quoniam paucis fane notis eam perftrin xit Diofcorides, ut ab omnibus facilius $\mathcal{O} \operatorname{cog} n o f c i$, o reperiri
Phøenicis côfideratio.

Nomins

Idxax radicis confider.

Idxx radicis uires ex Gal.

Nomina. poßsit, 
poßit, nos non temeré facturos duximus, fi eius hiftoriam hic diffufius tradamus. Radix itag; Rhodia caules emittit rotundos, quadantenus concauos, cubitales, dे quibus circunquaq; folia prodeunt longiufculd, in dcutum definentia, portulaca, aut fedi inftar pinguia, minutim q́; per ambitum ferrata. In caulium cacunine unbellam profert, uiridem tithymali cyparijij modo, fed que, ubi defloruerit, rube $\int_{c a t}$. Radix ei inequalis, ftrumofa, craffa, qualis cofto, leui cortice que recens eft, exterius $\beta$ lende fcens, o intus fubalbida : que ueró ficca eft, leuis percipitur, intus rubens,

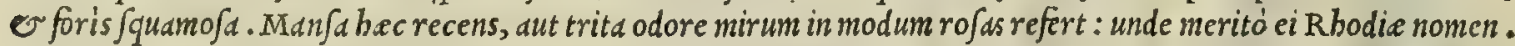
Preterea omnium radicum uiuacißima eft : quippe qua é terra effo ofa, nifil locis perquìm ficcis reponatur, poft mul= tos menfes rur fus plantataftatim repullulat. Nafcitur in altißimis montium rupibus faxofis, praruptisg; locis, ubi uix tantum terre circum babet, ut illi inherere poßit. Valet hec ad capitis dolores a quacung; caufa prouenientes, fi recens confracta, or rofacea aqua perfufa, ubi calidus fit affectus, aut cum amaraci aqua, fi frigidus fit morbus,

Rhodizeradicis uires ex Galeno.

Nomina. fronti temporibusq; illinatur. Cercbrum roborat odoris iucunditate, conuenitg; (ut diximus) onni capitis dolori, ut = pote que temperatis fit qualitatibus predita : id quod indicat rofaceus eius odor, quo mirifice redolet. Rhodie ra= dic is meminit Galenus libro VI I I. Fimpliciun snedicamentorun, fic de eius utribus fcribens. R hodia radix ea uideli= cet, qux in Macedonia nafcitur, tenuium partium, o difcutientis eft facultatis. In calef acie ndo ueró fecundi recef=

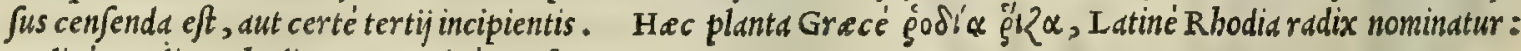
Italice, Radice Rhodia : Germanicé, Rofen uurtz.

EQVISETVM PRIMVM.

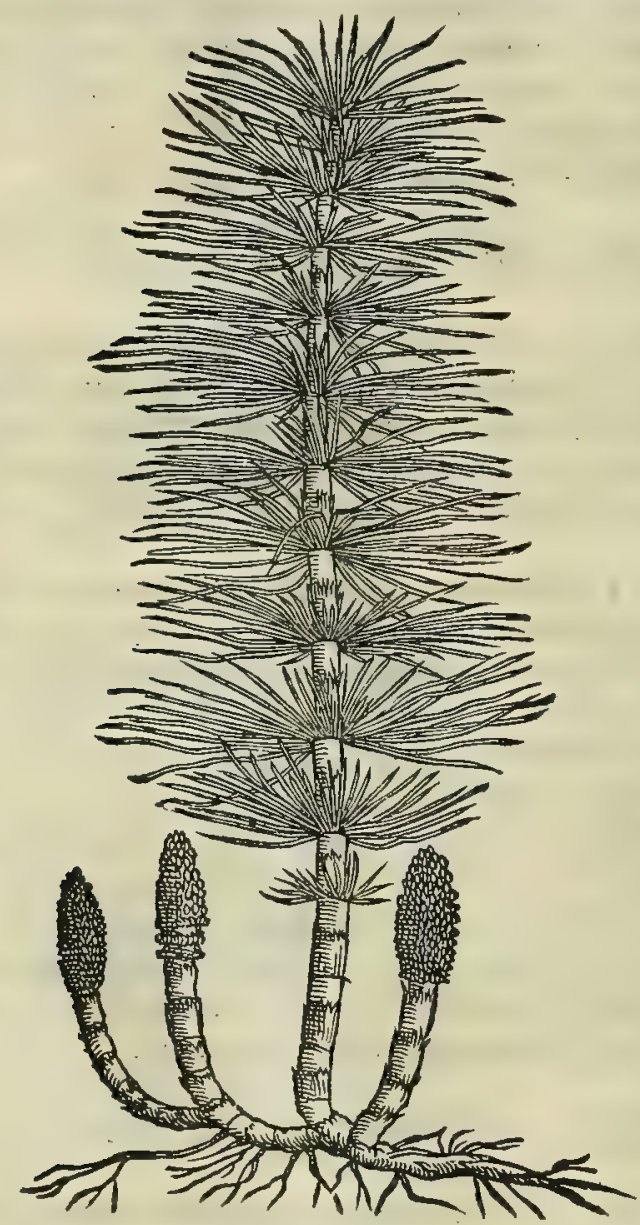

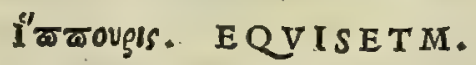

EQVISETVM ALTERVM.

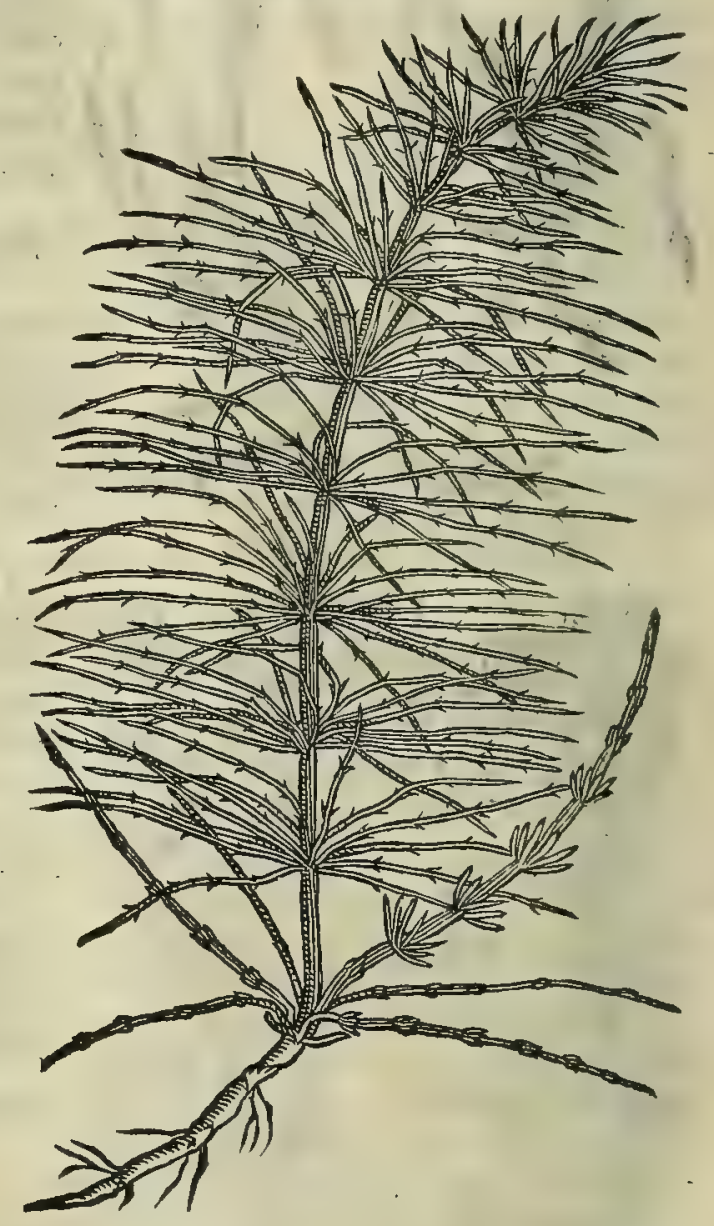

CAP. X.LII.

E QV I S E T V M in riguis, \& fcrobibus nafcitur . cauliculi prodeunt inanes, geniculati, in fe farCi, rubefcentes, leniter fcabri : \& iuncea circa eos folia, crebra, exilia. In fublime attollitur, vicinos arborum caudices fcandens, obuolutumq́ue dependet, comis multis, nigris, ut equorum cauda : radix lignofa, dura. Vis herbæ fpiffare : quare fanguinem naribus erumpentem fuccus ipfe fiftit : prodeft dyfentericis in uino potus : vrinam cit . Sanguinolenta vulnera glutinantur, tritis folijs, \& illitis. Radix cum fua herba tufsim, orthopnœam, ruptaq́ue adiuuat. Foliis in aqua potis, diffectıones veficæ, \& inteftinorum, enterocelæq́ue in vnum coalefcere, cogiq́ue feruntur. Alterum Equifetum caulis eft rectus, cubito maior, inanis : comis per interualla breuioribus, candidioribus, \& mollioribus. Id cum aceto tritum, vulneribus remedio eft, eademqque fungitur facultate. 


\section{In Lib. quartum Diofcoridis.}

E Qv'I s $x$ T v u officinis, o berbarijs plerisque uerbum Grecum reddentibus Cauda equina nominatur. $V=$ trunque eius genus uulgaris eft notitie. Alterum, quod apero fit caule, à quibusdam uulgó Apperella uocatur. Ex=

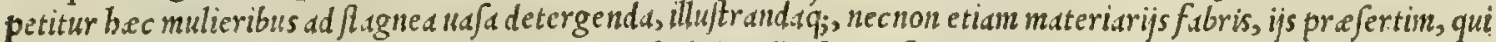
torno opera fud conficiunt: fiquidem buius berb.e fa abritia ill.e fuis uafis fplendorem, nitorem'q; conciliant : ifti ucró fimiliter fuorum operum ruditatem expoliunt. Primum autem Caudam equi omnes feré appell snt, quód facie equo= rum caud as referat, unde O Grecis Hippuris dicta eft. Profert h.ec, cüm primim ć terra erumpit, quoddan tener = rimun germen, oblongum, inglandium iulo non abfimile. Hoc ruranoftra uulgó uocant Paltrufalo, in cibumq́; affu= munt, ieiuni quadragefimalis tempore. Etcrim illud prius elixant, mox farina circumpergunt, o oleo in $\int a r t a g i=$ ne frigunt, inandunt ơ; pifcium uice. Ex quo cibo aluus quandoo; corum adeo conftringitur, ov conftipatur, ut in co= so li cruci.tum facilé.incurrant. Sunt qu primum boc Equifetigermen ficcum afferuent per aimum, quo fubinde aftc= te utantur ad dy fenterism. Cuippe quod aqua calida nocte maceratum eo modo decoqunt, quo dictum eft, ov in ci= bum magno fucceffu exhibent. Vtrunque Equifctum eleganti admodum pidturd expreßit Eucb/fius clarißimus in fuis Fuch.lapfus. magnis de ftirpium bistoria commentarijs. Sed nefcio qua poftea ratione duct us, is in paruo libro, in quem plantarum imagines duntuxat depingi, o imprimi cur auit, primigeneris Equifetum pro $\mathrm{p}$ olygono faimina aperto lapjureddi= derit. Equifeti meminit Galenus lib. $\mathrm{V}$. Fimplicium medicamentorum, ubi eius uires retulit bis uerbis. Hippuris, inquit, adftringentem cum amaritudine facultatem poßsidet, ac proinde ualenter, fimul'́f citra mordacitatem exic= cantem. Itaq; unlnera maxima catapla finate impofita conglutinat, etiam fi prefectos effe neruos contingat: prete= rea uocat as enterocel ss glutinat. Caterim ad fanguinis reicctionem, ad profuuium muliebre, potißimüm rubrum, ad dy fenterias, 0 ad alios uentris fluxus generofum est remedium berba ip $\int a$ aut ex aqua, aut ex uino pota. Sunt qui so de ea fcriptun reliquerunt, quód nonnunquam etian ueficx, ac tenuium inteftinorum uulner a fuccus ipfius fanaue= rit. Prodeft etiam profluio fanguinis ex naribus, tum fluxui obnoxijs in uentre affectibus ex aufterorum uinorum quopiam potus: ac fifrbre teneantur, ex aqua. Que planta Grecis i' A rabibus, Dhenben alchail, Dbenib alchi, fiue Daneb alchail: Italis, Coda di cauallo: Germanis, Roßz fchumantz: Hifpanis, Coda de mula, o Rabo de mula: Gallis, Queue de cheual, o Prela.

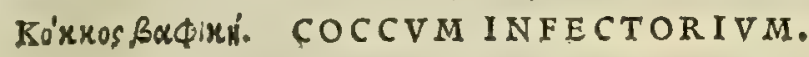

\section{CAP. XLIII.}

C o C C v M, quo infectores vtuntur, frutex eft fur-

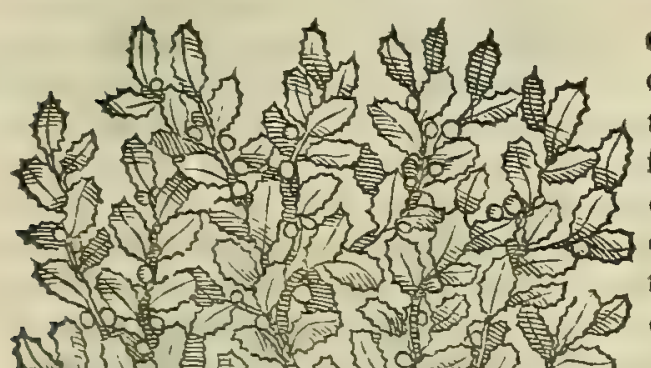
culofus, paruus, cui grana ceu lentes adhærent', qux eleEta congeruntur. Optimum gignitur in Galatia, \& Armenia : deinde Afia, \& Cilicia : vltimum ex omnibus Hifpanicum. Vis huic f piflandi : vulneribus, neruisq́ue præ cifis, conuenienter ex aceto tritũ illinitur. Nafcitur quoque in Cilicia è quercubus, cochlearum exilium fimilitudine, quod illius regionis mulieres ore legunt, \& coccunı vocitant.

E $\mathrm{s}$ s I Coccum feugranum tinctorium feplaftarijs, or infe= Coeci infecto

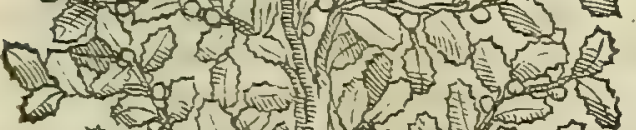

ctoribus:notißimum fit, quód $\sigma$ medicamentis admifcedtur, er eo rij confid.

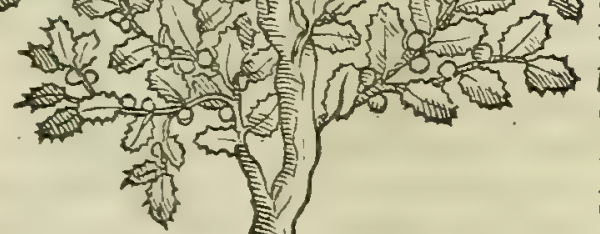

plurima tum fericed, tum lanea ftamind infici foleant; ne fcio td= men an eius arbufcula in Italia proueniat. Nos autem eam, cuius picturam danus, uidimus ex Byzantio allatam. Porró Coccum tin ctorium communis ufus conftat rotunda, inaniq́, bacca, que nul= lam profectó lentis faciem refert, ut Diofcorides afferit. $V t$ binc plané conijcere liceat, Coccum boc diuerforum effe generum, no= ftrum $\dot{q}_{5}$ facilé tlud effe, quod Plinius in Attica, O Aphrica pro= uenire tradit, Scolecion ideo nocatum, quonidm ex eius medulla te nues exoriuntur uermiculi : argumento quód boc inane intus de= prehendatur. Huius puluer e non infeliciter utuntur mulieres Ita= lice ad probibendum aborfum, ip fum grauidis in ouo forbili propi= nantes pauco addito thure, uel maftiche. Coterim contendunt Monachi ithi reuerendi, qui in Mefuem commentarios ediderunt, aliud effe Coccum, aliud ueró Cherme finum unlgá uocatuin, quo ferica stamina rofeo colore inficiuntur. Etenim afferunt ijlegitimum cbermefinum é quibufdam fieri granulis, que ut plurimum uulgari Pimpinelle radicibus adherentia reperiunur, uocariq́; bec proprie Mauritanis Chermes: O binc isti deinde colligunt, minimé credendum êfe, quód Gracorum coccum uulgó grand tinctorü nun cupatum, fit Mauritanorun chermes : quandoquidem magna omnino inter colorem coccineum, e cherme finum in= tercedat differentia. Sed hos patres hallucinari ( pace tamen eorum dixerim) ex eo equidem euidentiBimum fieri ars bitror, quòd hactenus neminem A rabica fecte inuenerim, qui eorum adftipuletur fententia. siquidem serapio per chermes nil aliud intelligit, quìm coccum tinctorium d̀ Grecis appellatum, cüm de Chermes agens ea Jané omnia in eius hiftoris refer rat, que Diof corides fuo cocco tribuit. Quapropter fcirem libentifiné qua ratione, quáue autho= ritate nixi ij reuerendimonachi in hanc uanam, et ęrroneain deuenerint opinionem. Verum non ob id negauexim ego
Equireticonfideratio.

Equifetivires ex Galeno.

Nomina. 
nostrum Chermefinum à cocco minimé differre, quód certó fciam, aliud effe coccum, aliud chermefinum, unde ê in= fectores differentie caufa coccum Grandm nuncupant, Chermefinum ueró, quod è pimpinelle radicibus decerpitur: fed negauerim quidem Mauritanorum chermes noftri ufus chermefinum effe, quod nil aliud Chermes effe putem, qudm Coccum, cuius hic meminit Diofcorides. Chermefinum nouum iampridem conuebitur in Italiam ex Hipanijs ab occiGrani tincto- dentali India importatum, quod cum copiofißinum afferatur, Chermefinaftamina nunc vile fecere caperunt. Cocz rij uires ex cifeu Grani infectorij uires de cripfit Galenus lib.v I I. fimplicium medicamentorum, bis uerbis. Granum tinctorium Galeno. adftringentem, fimulq;; amaram facultatem poßidet. Vtraque fine morfu deficcat. proinde ad ingentia uulnera con=

Nomina. gruit, prefertinǵ; neruorum. Sed tunc ipfum quidam cum aceto terunt, alij cum oxymelite. Qux róxuos $\beta x \Phi 1=$ หH' Grecé, Latine pariter Coccos baplica, o Granum infectorium nominatur : Arabicé, Charmen, Kermes feu Chermes:Italicé, Grana de tintori: Germanicé, Scharlach ber: Hipanicé, Grana para tennir, er Grana en gras no: Gallicé, Vermillon.

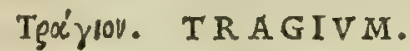

\section{CAP. XLIIII.}

T R A G I V M nafcitur in Creta tantùm infula, lentifco femine, folio, \& ramis fimile, fingulis tamen minoribus : fuccus ei lacteus, gummi non difsimilis. Semen, folia, lacrymaq́ue illitu fpicula è corpore ejjciunt : omnia quoque corpori impacta, euocant : pota ftranguriæ medentur, calculos ueficæ frangunt, menfes trahunt. modus in fumptione eft, drachma vna. Fama eft fylueftres capras fagittis confoffas, eius herbæ pabulo fpicula excutere.

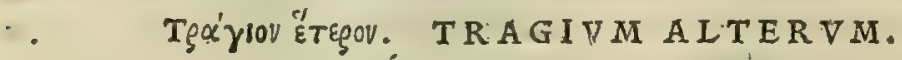

CAP. XLV.

Es.T ET alterum Tragium, quod tragoceros aliqui vocant: folia fcolopendrij habet, \& radicem fylueftris raphani, tenuem, candidam. Quam crudam vel coctam effe dy fentericis prodeft. Folia au= tumno, hirci virus olent : exinde fibi tragij nomen adoptauit. Prouenit in montibus, \& præcipitijs.

Tragii confi- T R A G I V M, quod in Creta tantùm nafci tradit Diofcorides, quod'ǵ, in uniuerfum lentifco fimile facit', pli=

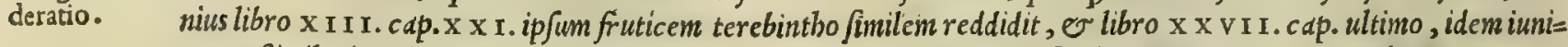
pero a ßimilauit . Id quod dubio procul oftendit, Tragium boc omnino illi fuiffe ignotum, or quòd tantüm id de co me= morie prodiderit, quod ab alijs authoribus non minus fortaffe bac in re cecutientibus mutuatus eft. Hoc atate noftra, 3

\section{PIMPINELIA SAXIFRAGIA.}

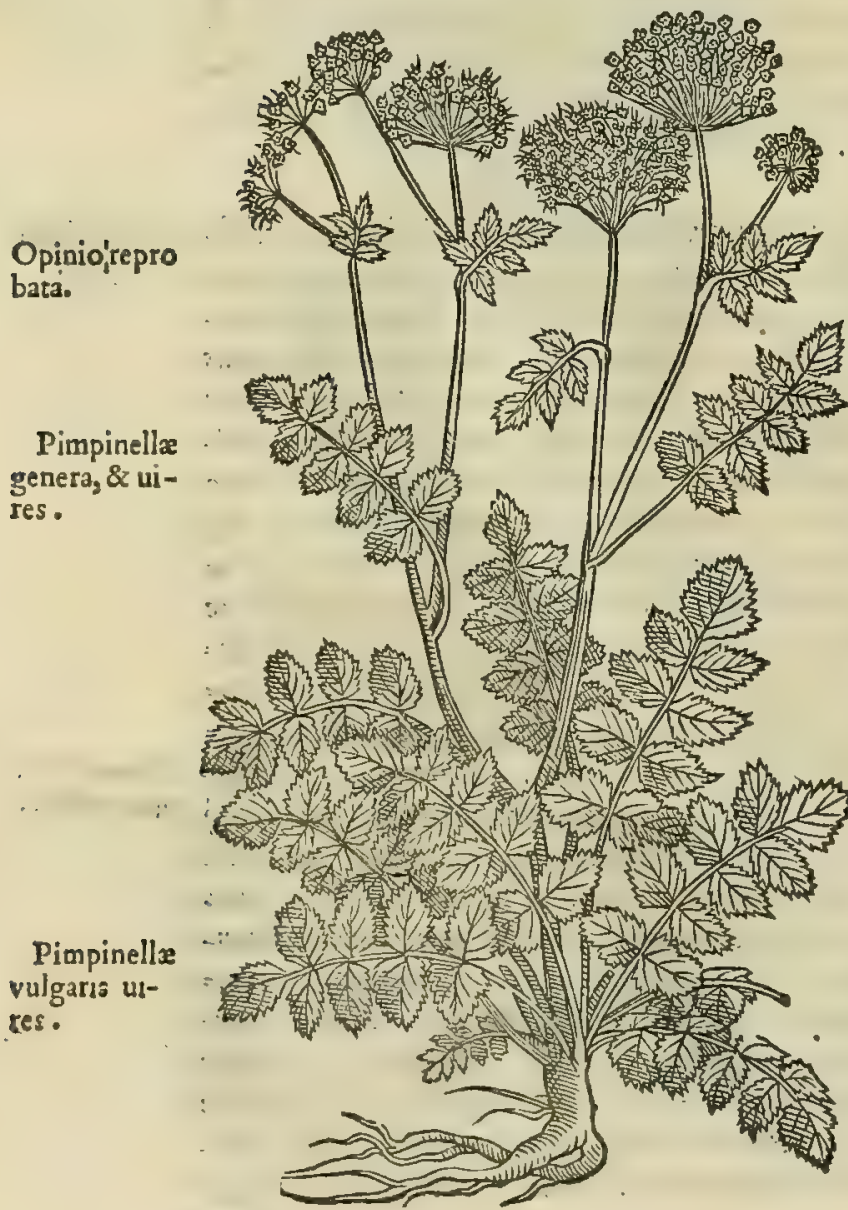

non defertur, quod fciam in Italiam. Quo fit, ut id mibi batte = nus ficut o creteris herbarum ftudiofis, ut ferme fuppicor, fit in Italia incognitum. Quod autem fecundo loco d Diofcoride re= prefentatum eft, id potius berbam effe crediderim, quam arbu= fculam, cim eius radix tam cruda, qudm cocta in cibum ueniat, fit q́; jylueftriraphano proxima. Veruntamen nondum reperi qui plantam mili demonftraret, folijs fcolopendrio fimilibus, qua bir= ci uirus oleant. Ex quo adducor, ut ab ijs plané diffentiam, qui putant Tragium hoc eam effe plantam, quam quidam Pimpincl= lam, quidam ueró ab odore saxijragiam bircindm appellant. Quandoquidem buic fcolopendrij folia non infunt, nullusó; eius ad dyfentericos ufus, tamet fi ad ciendam urinam, expediendosó. uifcerum infarctus plurimìm preftet. Huius P I M P I N E L = L AE duo habentur generd. Maior radice nititur longa: folijs circumquaque folo procumbentibus, diffectis, per ambitumig; fer= ratis: caule quadrangulari: floribus in umbellam coharentibus, tenuibus, albicantibusó; . Minor caule exit rubenti: folijs mino= ribus, minus diffectis, minutius $q_{;}$ferratis. Vtraque tamen bircum redolet. Radix, in qua uis tota confiftit, excalfacit, ficcat'; or = dine fecundo compleio, aut fane tertio incipiente. Préftat hac 50 -ad renum, ov uefica morbos; quorum calculus eft caufa. Obid enim renes à calculis expedit, $\mathcal{O}$ urinam remoratam pellit. Pro= deft expreffus è radicibus fuccus ex uino bauftus, deleterijs medi= camentis, $\mathcal{E}$ ucnenoforum animalium morfibus. Qu defunt, qui ad peftilentiam, radicem banc miris laudibus effen rant. Eft er alia Pimpinella, qua à noftris uulgó $s$ o $\mathrm{L} \mathrm{B} \mathrm{A}=$ S T R E L L A nominatur, nullis non cognita, utpote qua ace= tarijs frequentißime inferatur. Verim bec ab antedictis longe diftat uiribus, etfi foliorum facie fatis inter fe conueniant . Siqui= dem ultima hac guftata non leviter adftringens percipitur, o len toris copiam prabet. Vude facilé conijgitur, eã effe adftrietoria 


\section{In Lib. quartum Diofcoridis.}

PIMPINELIA.
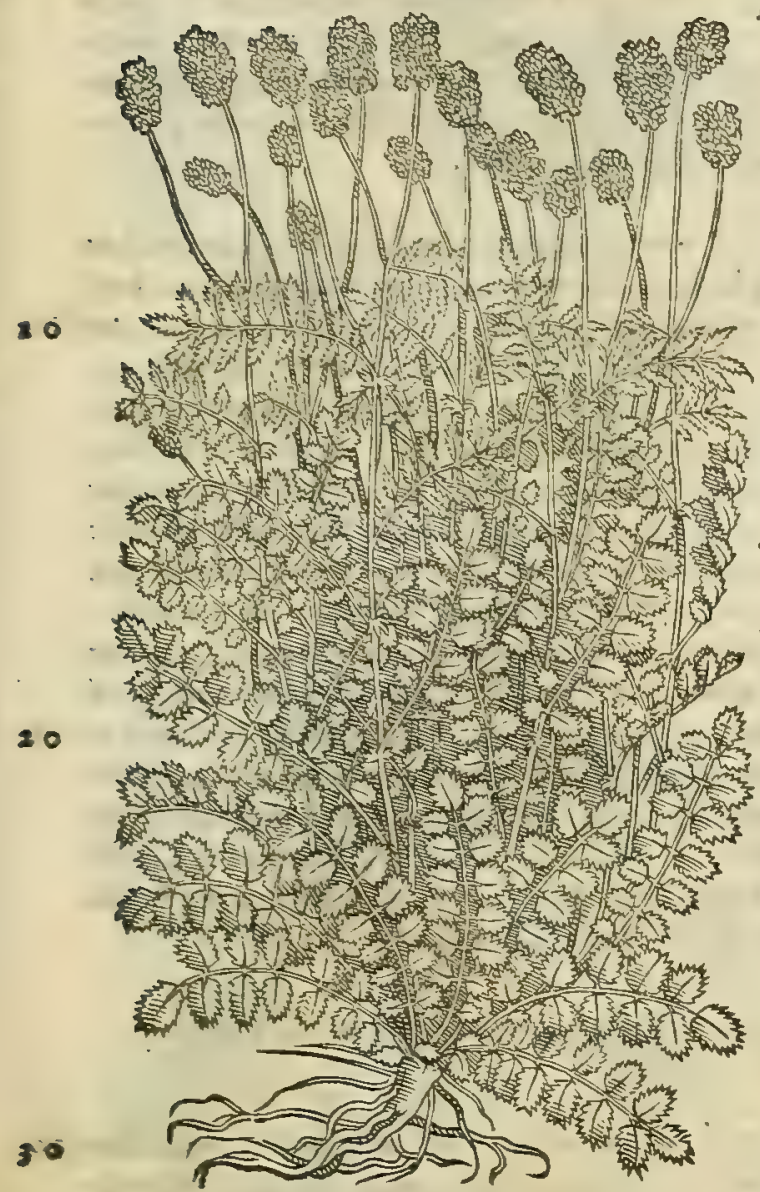

TRAGVM.

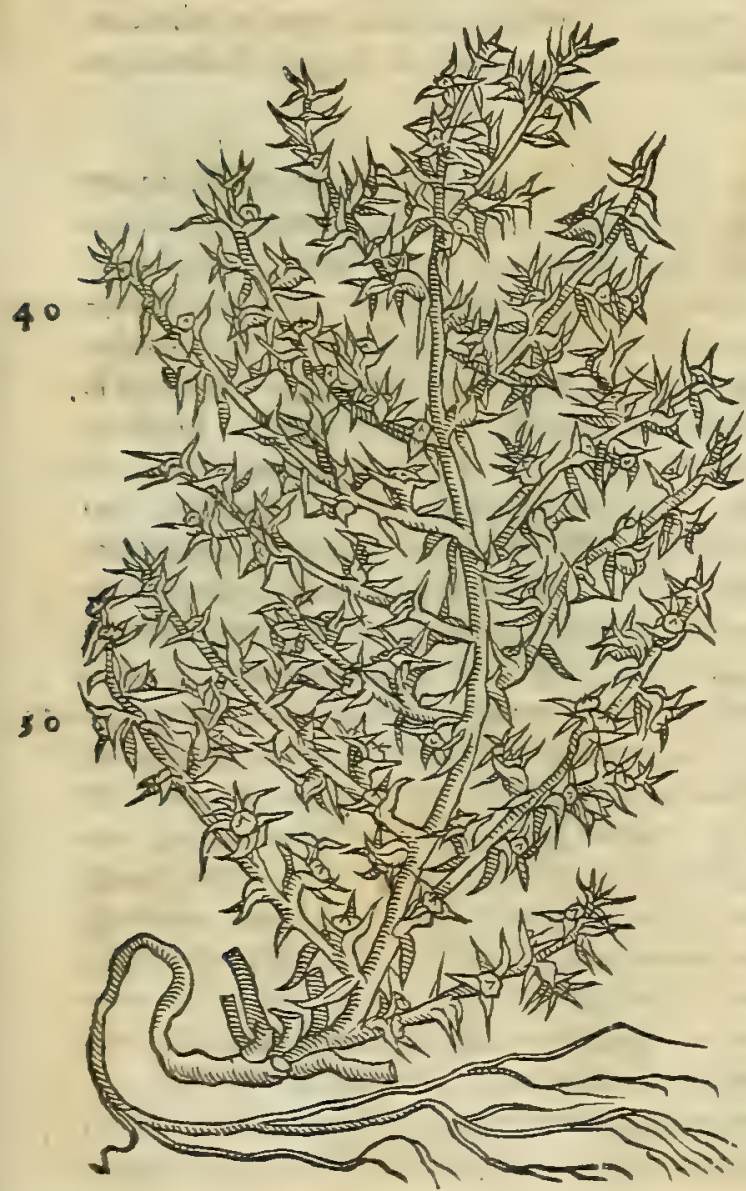

facultatis. Hinc itaque fit, ut muliebre profunium efficacif= fimé fillat: dy fenteriam, $\sigma$ céteros alui fluxus cobibeat: quin o buliof as nomitiones reprunat. Herba ipfa uulnera, o ulce= ra fanat: mifceturq'; unguentis, qua tum ad capitis uulnerd; tum ad carcinomata parantur. Hanc Mattheus Curtius clarißimus etatis noftrxe medicus, contagiofis, peftilentibus q́; fibribus ma $=$ ximé commendauit. Sunt qui esm Elatiien effe putent. Sed ii, meo quidem indicio, aberrant, ut fuprd̀ ctiam in fua mentione do cuinus. Tragij meninit Galcnus libro v I I I. fimplicium me= dicamentorum, ubibec de eius uiribus tradit. Tragi, inquit, fo= la, femen, o lacryma trabentis, digerentisq́; funt facultatis . Eft uero e tenuium partium, o facultate in principio tertij or dinis calida. Corpori infixa extrabit, lapides frangit, menfes mo uet drachme pondere potum. Porró in Creta fold nafcitur tra= gion lentifco fimile. Ceterum alterum Tragium boc minus, cu= ius folia fcolopendrio fimilid funt, vifitur quidem multis in locis: fed non parum babet facultatis adftringentis, ut $\sigma^{2}$ ad fluxio= num affectus conueniat. Vtraq; planta Gracis T $\alpha^{\prime} \gamma$ jov, qué= admodum er Latinis Tragium appellatur.

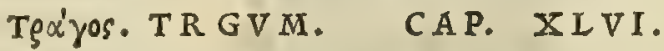

E s $\mathrm{T}$ etiam herba tragos, quam aliqui fcorpion,aut traganon uocant: maximè in maritimis nafcens, palmü alta, aut amplior, fruticofa, humilis, oblonga, fine folijs: pufillis circa ramos acinis, rufis, multis, magnitudine tritici, acuto cacumine, guftu multùm adftringente.

Racemorum acini decể ex uino poti , cœliacis, \& fœıni nis fluxione vulux laborantibus, auxiliantur. Tundun turà plerisque, \& in paftillos digefti afferuantur : quibus utuntur, cùm opus eft.

T R A G V M aliquibus Scorpion uocari non modó tradi= Tragi conf dit Diofcorides; fed etiam Plinius lib. $\mathrm{x}$ x $\mathrm{V}$ I I. cap. ultimo, his deratio. uerbis. Eft or berba Tragos quam aliqui scorpion uocant, $\int e=$ mipede alta, frutico $\int a$, fine folìs : pufillis racemis, rubentibus, grano tritici, acuto cacimine, or ipfa in maritimis nafcens. Et lib. X X I.cap. Xv. Spinofarum, inquit, multe pecies. In totum pinofa eft apparagus, fcorpio: nullum enim folium babet. İd quod ante ipfum pofteritatis memorie prodiderat $T$ beophra= ftus libro vir. cap. primo de biftoria plantarum, cum inquit: Aculeatorum alia ex toto aculei funt, ceu corrudd, et fcorpitus: hac enim nullum preter aculeum folium gerunt. Hinc itags om= nibus abunde conftare arbitror, herbam, cuius bic effigiem da= mus, legitimum effe Tragum. Ea fiquidem in maritimis nafci= tur (plurima enim in Tergeftino litore prouenit, $\sigma$ ad Argen= tarium promontorium in Hetruria) nulla prorfus reclamante no to ex ijs, quas rei herbarie authores Trago reddiderunt. Hiius tamen nufquam, quod inuenerim, meminit Galenus in fimplicium medicamentorum cenfu. Herba bac тек'yos or oxog-ios Nomina Grecé dicitur : Latiné item Tragus o scorpio.

\section{¿roînos. I VNCVS.}

\section{CAP. XIVII.}

I v N C I duo genera. vnum lauis nominati: alterum acuti, qui in mucronem faftigiatur. Cuius etiam duo afsignantur genera. vnum fterile: reliquum fert fe men nigrum, rotundum, \& crafsiore conftat calamo, carnofioreque. Tertius eft iuncus, qui uocatur olofchœnos, prioribus carnofior, afperiorq́ue : is fimilem fupradicto fructum in cacumine parit. Semen utriuf-

Tragi uires ex Galeno.

Nomina. 
IVNCVS.

Iunci confide ratio, \& uires ex Galeno.

Nomina.

Lichenis con fideratio.

Lichenis genera ex Pli.

Pulmonarix depitio, \& uires.

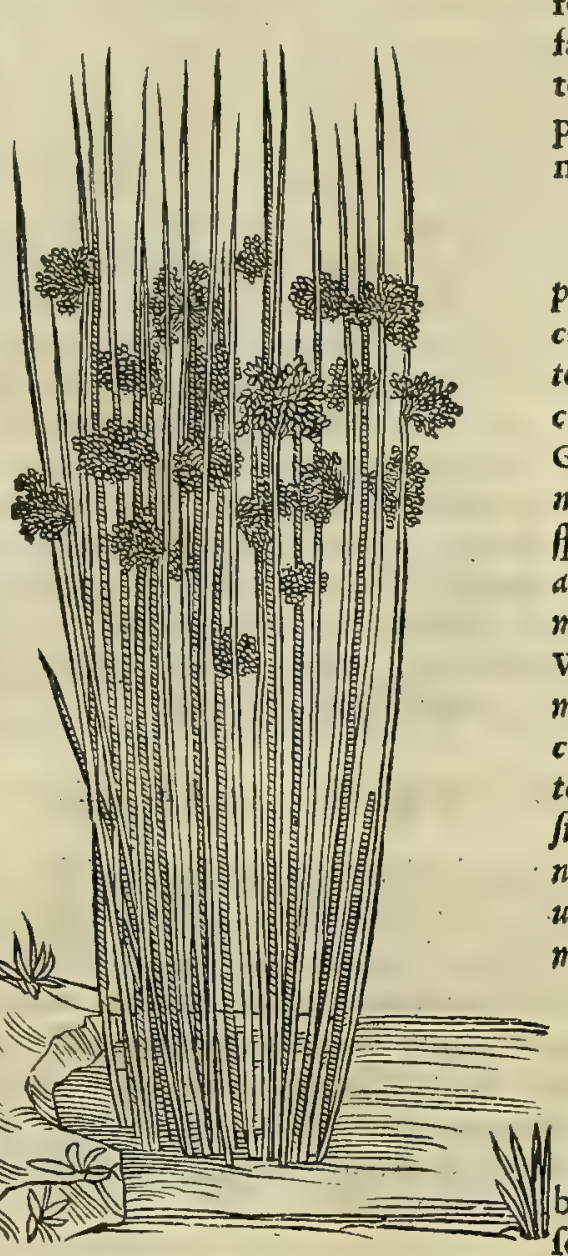

que toftum, ex diluto uino potum, fiftit aluum, \& rubra fominarum profluuia: vrinam cit, capitisq́ue dolores facit. Qux proxima funt radici folia tenera, conuenienter illinuntur aduerfus phalangiorum morfus, Aethiopici iunci femine fomnus allicitur : fed modus in potione feruandus eft, ne fopor fiat.

I v N C v ș omne genus unlgaris eft notitie: quandoquidem propter ftagnantes aquas omnes eius reperiuntur pecies. I un= cigenerum meminit Galenus lib. v I I I. fimplicium medicamen= torum, ubi de ijs itd f criptum reliquit. Schoenos leta, boc eft, Iun= cus lauis, quadam oxyfchoenos, alia oligof choenos nuncupatur.

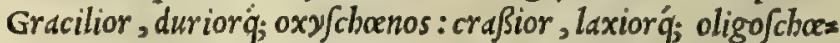
nos. Fructus oligo f choeni fomnum affert. At oxy fchoeni dux funt ßpecies: alter afterilis, cuius quidem in medicina nullus ufus eft: altera ueró femen fert, cuius etiam femen fomnum conciliat, fed minus quàm oligofchoeni : quanquam tamen boc caput tentet. Vtrunq; fi frictum cum uino bibatur, uentris fluxus deficcat, er muliebre proflunium rubrum fiftit. Ex quibus clarum eft, quód compofita corum temperies eft ex terrena uidelicet effentia leui 2.0 ter frigida, or aquea leuiter calida : ut 0 inferna deficcare pof= fint, $\mathcal{O}$ fenfim frigidos ad caput uapores fubmittere, quibus fom= nolentos efficiant. Exölvos fic Grecis, Iuncus ueró Latinis uocatur: Arabibus, Dis: Italis, Giunco: Germanis, Bintzen fcho melen: Hifpanis, Iunco: Gallis, Ionc.

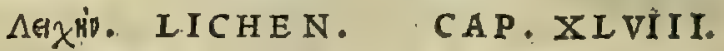

L I C н E $\mathrm{N}$, qui faxis eft familiaris, aliquibus 20 bryon appellatur, afperginofis petris adhæret, ut mufcus. Is illitus fanguinis profluuia fiftit, inflammatio-

I I CHEN.

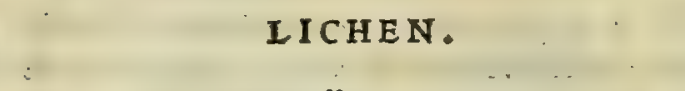
nes atcet, impetigini medetur. Inuat regio morbo correptos, cum melle illitus: oris, \& lingux defluxiones inhibet.

L I C H E N procul dubio ed eft plantd, quam officine, or herbarij bodie Hepaticam uocant. Hanc autem Greci Liche= na appellarunt, quod lichenas ferpentis morbi genús, impo= fita fiftat, o fanet. Lichen in aperginofis, or rorulentis pro $=49$. uenit locis, nudis petris adherens, mufai modo. Folio conftat suppingui, cartilagineo, prope radicem angufto, in latum $f e$ pandente, triplici uel quatriplici lacinio interfecto. Prodeunt a radice cauliculi tenues, quibus capitula infunt parua,ftel= larum effigie. Lichenis Plinius libro X X v I. cap. I I I I. duo produntur generd, que his uerbis depingit. Lichen, inquit, her= ba omnibus bis prafertur, unde nomine inuento. Nafcitur in $f_{a}=$ $x o /$ is, folio uno ab radice lato :calle uno, pario, longis folijs de= pendentibus. Hac delet é ftigmata : teritur cum melle. Eft aliud genus Lichenis petris tantùm adherens, ut mufcus, qui $\mathrm{\sigma}$ ipfe il 50 linitur. Hic Janguinem fiftit unlneribus inftillatus, et collectio nes illitus. Morbum quoq; regium cum melle fandt ore illito, er lingua. Qui ita curantur, aqua falla lauari iubentur, ungi oleo amygdalino, bortenfibus abfinere. bec Plinius. Caterum eft berba Licheni non longé disimilis, que in quercuum, aliarum $\dot{q}_{\text {; }}$ fylueftrium arborum caudicibus nafcitur, in opacis prefertim fyl uis. bac tamen aridior, ơ ambitu latior, superiore parte uirez frens, inferiore uerò pallefcens, maculis quibufdam referta, adeo ut formam pulmonis referat: unde plerifque $\mathrm{P} V \mathrm{I} M \circ \mathrm{N} \mathrm{A}=$ I A ditad eft. Vtuntur bac nonnulli mag is fortaffe nomine, quàm ipfis uiribus freti, ad tabem, pulmonum ulcera, or cruenta puta. Nec defunt, qui laudibus eam efferant ad uulnera $\int a n a n d a_{2}$ ad pudendorum ulcera, $\sigma$ ad $u=$ 


\section{In Lib. quartum Diolcoridis.}

POLMONARIA.

20

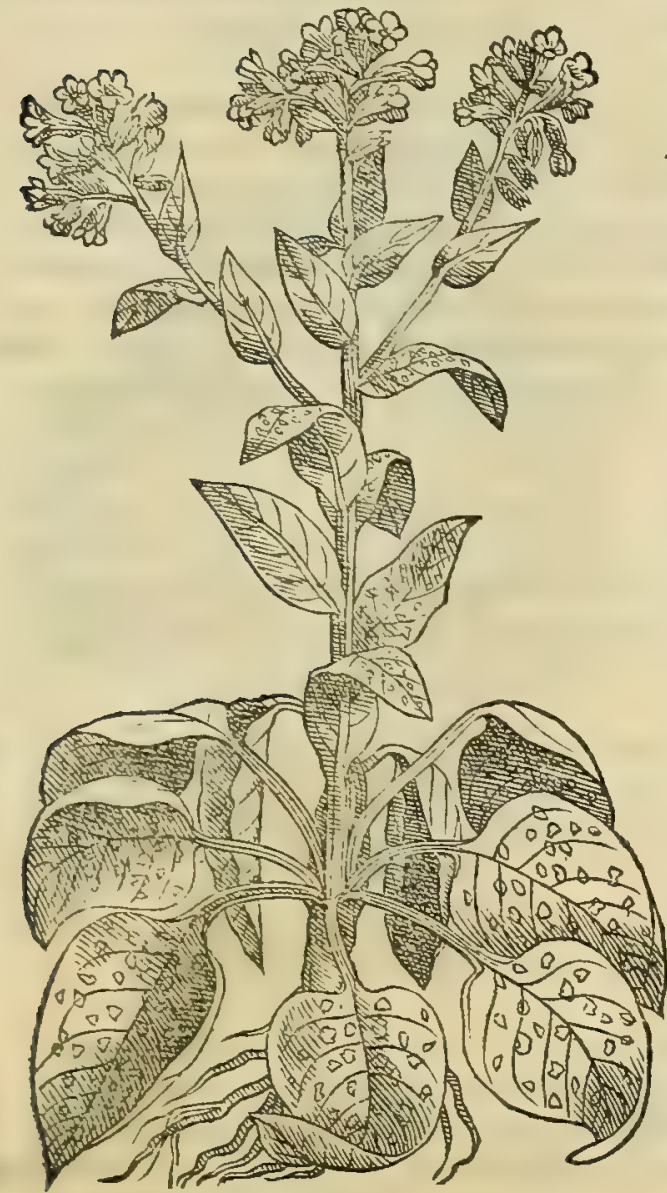

ad utrunq; mulicbre proflunium, cui mirifice mederi aiunt. Ouin o cam dyfentericis exbibent, o biliofa cuomentibus. Eft $\mathcal{O}^{\circ}$ alia berba, qua etiam $\mathrm{P}$ ulmonaria uulgó nominatur, ab illa tamen maxime differens, in opacis proueniens, folio bugloßi, appero, bir = futo, albis maculis circumperfo. Caulcm gérit hac ineunte ue= re, in cuius cacumine flores erumpunt purpurei, perinde ac in uulgaricynogloffo. Huic plante reiberbarie periti non contc= menendas uires tribunnt, ad pulmonis ulcer a funanda. Qua in re, itemós in fanguinis reiectione mirabili fucceffu fe eã exbibuife mi bi fep pius retulit I ulianus à Maroftica Teruifič fis medicusperitiß̨i mus: decoquitur enim ad medias, daturq'; decoctum potandum addito faccharo: uel fuccus ex ea expreffus fer apij modo cum $\int d c$ charo paratus. Preftant bec onnia berba ip $\int a$, e flores, quoquo modo à tabe affect is fumantur decocta. Lichenis meminit $\mathrm{G} a=$ lenus libro v II. fimplicium medicamentorum, fic inquiens. Li= chen, qui in petris nafcitur, eft uelut mufcus quidem, fed recte ex plantarum genere cenferipoteft. Sic dutem nominatus uide= tur, quód lichenas feu impetigines curet. Extergentem, ac modi= cérefrigerantem facultatem babet, utrang; weró reficcantem. Abftergentem quidem, dtque exiccantem à petra obtinet, refri $i=$ gerantem uerò ab bumre aqueo: nafcitur enim in bumidis, or grauiter olentibus faxis. Porró quod ex talibus fubftantijs cont $=$ ponitur, aduer fum effe inflammationi, nibil mirum eft. Caterim an fanguinis profluuia fiftat, ut refert Diofcorides, id neuti= quam dicere queo. Quod Grecis $\lambda e x$ Hiv, Latinis item $\mathrm{L} i=$ chen dicitur: Arabibus, Azez alfacher: Italis, Lichene: Officinis, Hepatica: Germanis, stein laber kraut, $\mathcal{O}$ Brunnen leber liraut : Hifpanis, Hepatica, or Figadelda: Gallis, Hepati= que, $\odot$ Porcorau.

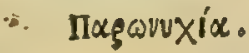

PARONYCHIA.

CAP. XLIX.

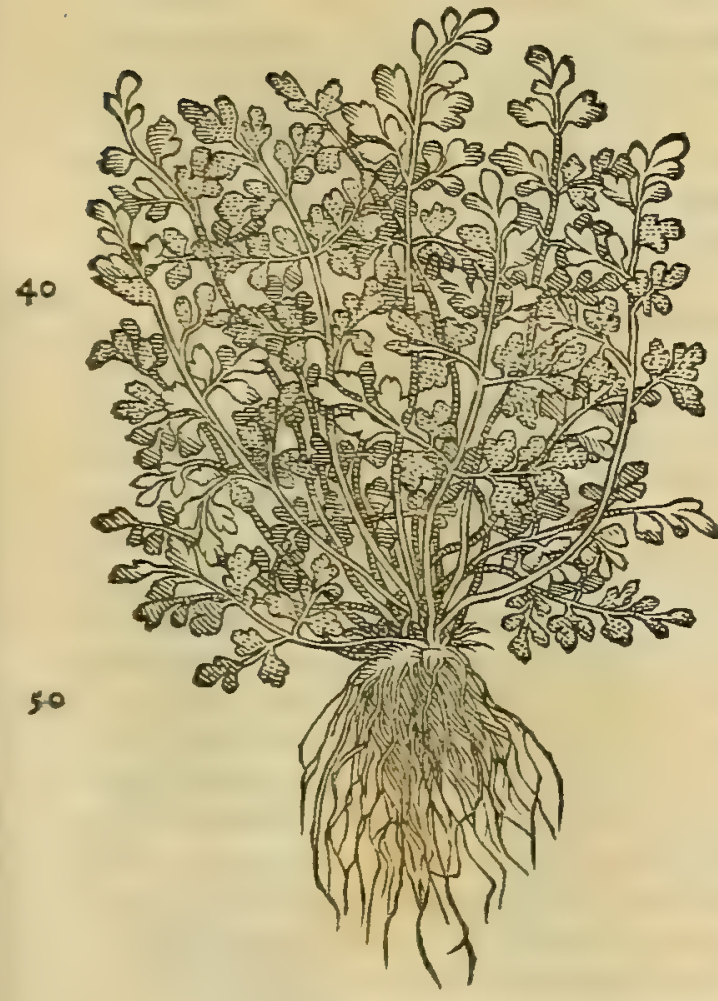

PARON Y C H I A exiguus frutex, in petris nafeens, peplo fimilis, minor longitudine, maioribus folijs . Illita paronychijs,atque fauis remedio eft .

P A R O N Y C H I A non modó in faxis gignitur; fed etiam in ueterum adificiorum parietibus, folijs peplo, aut rute fimilibus, aduerfa parte pallentibus, paruisó; maculis refertis, phyllitidis uel hemionitidis modo. Hanc aliqui parietum $\mathrm{R} u t a m$, alij Saxi= fragam appellant. Copiofisima prouenit hec in ingentifylua, quae in itinere eft , quo Goritia difcedentes petunt $\mathbf{L}$ abacum Carniole

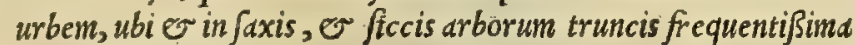
uifitur. Meminit Paronychia Galenus lib. v I I I. fimpl. medic. ita de ea fcribens. Paronychia ab effectu nominata eft: fanat enim paronychids, er ut refert Diofcorides, fauos quoq; . Vis eius eft te nuium partium, et exiccatoria mor fu udcans : talid enim fint opor= tet, qua paronychias fanant. Porró fatis conftat tale effe idoneum ad digerendos affectus omnes, qui digeri poftulant. Siquidem eius= modi funt, qua cum ex tertio fint ordine excalfacientium, $v$ de= ficcantium, uelut o hoc, effentix infuper tenuium partium funt.

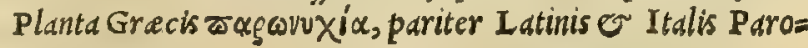
Paronychix confider.

Noming nychia nomindtur.

\section{Xочокоцн. CHRYSOCOME.}

CHRY S O C O M E palmi altitudine fruticat: coma fpecie corymborum, hyfopo fimili : radic hirfuta, veratri nigri modo, tenui, cyperum æquante: guftu non iniucundo, ex dulci auftero. in petro-
Lichenis uires ex Gal.

Pulmonaria alia.$$
\text { ex Gal. }
$$ 
fis,opacisq́ue nafcitur. Radix excalfacit, \& adfringit : his conueniens, quos iecur, aut pulmonis inHam matio malè habet. contra purgationes vulua, decoeta cum hydromelite affumitur.

Chryfoco- Qv I Cbryfocomen in Italia mibioftenderet, Fditenus reperineminem. Quamobrem in eo natures uirida= mesconfid. rio, plantis compluribusnobis incognitis referto, quod tantim in fui ipfius ufum colit natura, ne omnibis exuta medicanentis, firis ctian languoribus mederi nequeat, cam or uirefcere, or florefcere omittamis, donec nobis, aut alijs compertam in communem quoque cognitionem, ov ufum prodere contingat. Interim tamen, ut noftrum Vires ex Ga- infttutum fequamur, uires cius ex Galeno fubijciam: quas ipfe libro v I I . fimplicium medicamentorum, ijs uer= leno. bis defcripfit. Cbryfocome uocatur o cloryfites. Radix uincentes acrem fimul, o adfringentem qualitates ha= bct: quare neque multiulus eft. Vfui tanc neft decoda in melicrato im peripneumonijs, of morbis bepaticis. Sed

Nomina. o menfruce pitrgationis prowocanda uim quandan obtinet. XovoorópH fic Gracé, ut etiam Chryfocome I dtiné dicitur.

$$
\text { Xguóyovor. CHRYSOGONVM. CAP. II. }
$$

C H R Y S O G O N V M densè fruticat, quernis folijs, flore coronarij verbafci:radix vt rapum extuberat, intus ruberrima, foris nigra. Quæ trita cum aceto, atque impolita, muris aranei morfibus auxiliatur.

C H R Y S O G O N V M, nifi dliunde in Italiam defratur, inter plantds, que minimé cognofcuntur; or ip fun 20

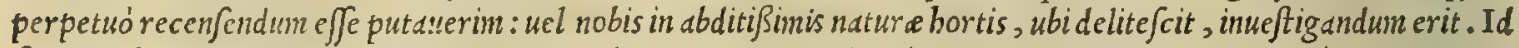

Nomina. fiquidem hactenus mibi neq; inuenire, neq; ab alijs compertun uidere licuit in Italia. Quod xpvóyovov Greci, Latini quoque Clryfogonum dicunt.
E'ríxp̧oov.
HELICHRYSVM.
CAP. III.

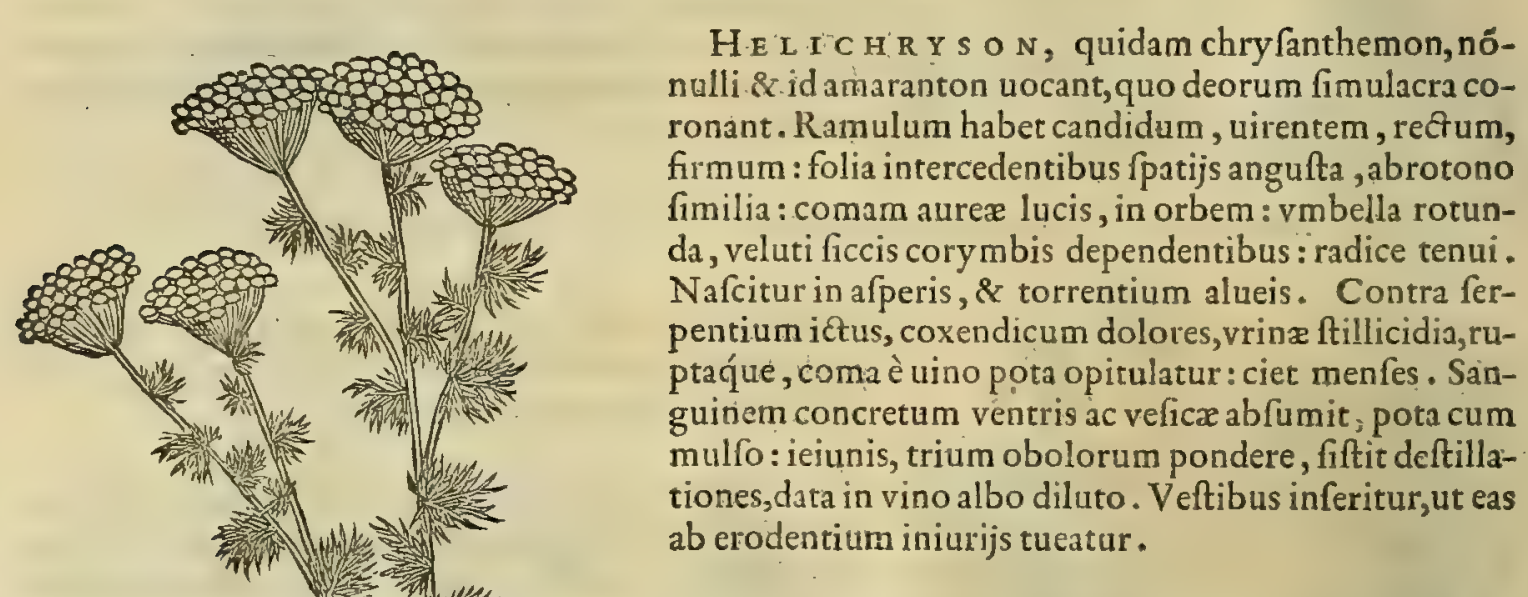

Helichry fí cỏ fideratio. etiam in fluminum alueis. Caule conftat recto, equali, ac ligno=
Fuch. error.

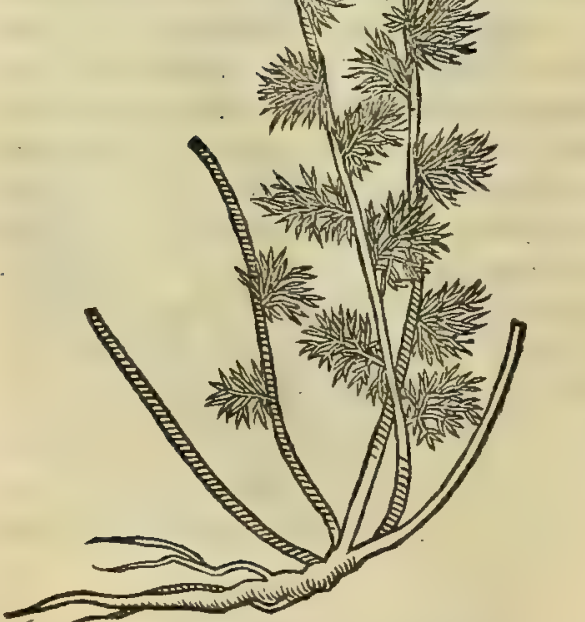

HELICHRY SON copiosé prouenit in Hetrurid in pratis gracili folo, incultiś; locis, fiticulo/is collibus, necnon fo, cubitalem longitudinem non excedente: folijs per interualla emergentibus, abrotoni emulis: comantibus in cacumine flori= bus, aureo colore fulgentibus, o in orbem umbella modo cobe $=$ rentibus, corymbace a facie, ueluti myriophylli, uel agerati : qui exiccati aureum coloren diutius retinent. Proinde commode bye me, quód eo tempore flores deficiant, puelle ficcum Helychry fum coronamentis fuis inferunt, quemadmodum e Amarantum pur $=50$ pureum, quod noftris Hetrufc is unlgó dicitur Fioruelluto. Heli= chryfum depinxit Fuch/ius in fuis clarißimis de ftirpium biftoria commentarijs, folio echij aculeato, er floribus buphtbalmi. Qua in piqura ipfum deceptum fupicor, quód ea Helicbryfo minimé repondere deprebendatur. Helichryfimeminit Plinius lib. $\mathrm{x}$ x $\mathrm{I}$. cap. $\mathrm{x} \times \mathrm{v}$. ubi de co differuit his uerbis. Heliochryfum, inquit, quod alij Chry fanthemon uocalt, ramulos babet candidos: folia fubalbida, abrotono fimilia: ad folis repercuffun aure lucis in orbem ueluti corymbis dependenti= bus, qui nunquam marce fcunt. qua de caufa deos coronant illo. Quod diligentißimé obferuauit Ptolemeeus rex Ae= Helichryf ui gypti. Nafcitur in frutetis. Helicloryfi Jub Amaranti nomine mentionem fecit Galenus libro v I. fimplicium mediz camentorum, $\sqrt{i c}$ inquiens. Amarantum facultatis eft incidentis, er extenuantis. Coma igitur eius men es cun uino pota cducit: er grumos fanguinis liquare creditur, non folim in uentre, fed $\widetilde{\sim}$ in uefica: fed tunc potius cum mulfo 


\section{In Lib. quartum Diofcoridis.}

AMARANT VM.

10

$\$ 0$

so

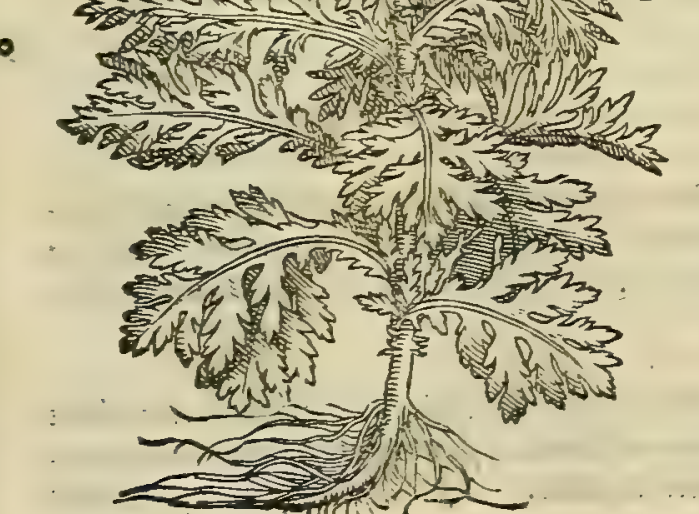

CHRYSANTHEMVM.

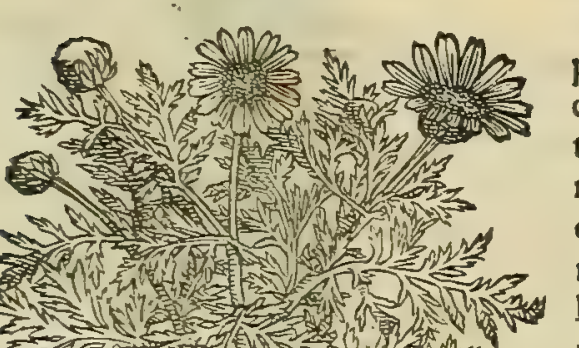

bibenda. Et omnes fimpliciter fluxiones, potadeficcat, ftoma cho inffita.bac Galenus. Ceterim cum Hclichry/um tan Amarät pur Diofcoridi, quàm Galeno Amarantum dicatur, opportuna no= purei méso, bis fee offert occafio, ut bic A M A R A N T I purpurei, quod, ut pauló anté diximus, à nof tris unlgó noc atur Fiorucllu= to, hiftoriam, uires tradamus, pre ertin quod puellis gratif fimum fit byeme in fuis texendis corollis, utpote quod tam re= cens, quim ficcumpurpureum, ac flammeum colorem diutius conferuet. Hoc itaque folia profirt ocime maiora: caulem craf= fum, pinguem, fubrubentem : florem ficatum, admodum purp:t= reum. qui quanquam dis ficcatum ( $u t$ fuprd̀ difum cft) affer= uatur, haudquaquam tamen fuum deperdit colorcm. Amaran= tum boc, quantum equidem reor, memoria prodidit flinius lib. X X I.cap.V I I I.cum fic inquit. Amaranto non dubié uincimur. Eft autem fpica purpurea, uerius quim flos aliquis, or ipfe fine odore. Mirumq́; in eo gaudere decerpi, E letus renafci. Pro= uenit augusto menfe : durat in autumnum. Alexandrino palma, qui decerptus afferuatur. Mirumq́; poftquàm defecere cuncti flores, madefactus aqua reuiuifcit, er bybernas coronas facit. Summa eius natura in nomine eft, appellato quoniam non mar= cefcit. Hactenus de amaranto Plinius. Huic facultas ineft (ut recentiorum quorundam fert opinio ) frigida $\sim$ ficca: proinde flos cius potus caliacos, er dy fentericos iuuat. Men/íum abun= dantiam cobibet, $e^{r}$ albas uteri fluxiones. Quinetiam cruenta expuentibus prodeft, prafertim fi in pulmone, uel pectore, uds

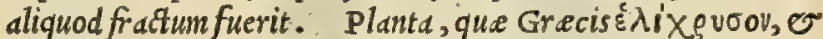

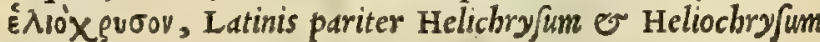
appellatur: Italcs, Helichrifo.

\section{Xguóinguov. CHRYSANTHEMVM。 C A P. LIII.}

CHRTS ANT H E MON autcaltha, nonnullis buphthalmos . herba eft tenera, fruticofa, læues proferens caules, \& multifida folia : flores fupra modum fplenden tes, luteos, orbem oculi imitantes, unde buphthalmi nomen traxit. propter oppida nafcitur . cuius caules oleris uice manduntur. Flores cum cerato triti, fteatomata difcutere produntur. Regio morbo correptis,colorem bonum breui reddunt, fi fequente longo balnei ufu, poft exitum ebibantur.

Q v A N QV A M non defunt, qui crediderint Buphthalmü, er Chryfanthemum unam, er eandem plantam effe, quód pa= ribus notis inter fe cerțire uideătur; tamen fi particulares que= dam note in utrifque diligenter expendantur, facile inter bas plätas difcrimen aliquod notari deprebendetur. Quód cùm opti mé fciret Diofcorides, diuerfis libris, diuerfisq́; capitibus de his peciatim differuit. Quod utiq; minime feciffet, fi compertum habuiffet, nullam inter cas intercedere differentiam. Qux tamen binc cognofci poteft, primum quód Buphthalmo folia infint for niculo finilia, que plané capillaria conftant: Chry fanthemo ue= rò tenerd, multifida, minutinós per ambitum laciniata. Deinde Chry anthemi caules in cibis mädi aliorum olerum-modo fcribit Diofcorides : id quod de Buphthalmo agens filentio preterijt. Preterea flores Buphthalmo reddidit anthemidi fimiles: Chry= fanthemo ueró luteos, er uehementer plendentes. Caterim de horum uiribus differens, Buphthalmi flores, cum cerato tritos, tumores, duritids q; difcutere tradidit in uniwerfun, affir= matiué locutus. Verum pofted de Chry anthemo fribens, buius flores, inquit, fteatomata difcutere produntur; particulariter,
Nomina.

Chryfanthemi confid. 
er dubiè locutus. Hec fané barum plantarum maniff fta difcrimina faciunt, ut credam, quód aliquis antiquorım cus. riofus, nimis q́; fciolus Buphthalmum, er Cryjanthemum unam tantün referre plantam forté exiftimans, omnia in Chry antbemo adiecerit, 0 confuderit, que libro tertio de Buphthalmo memorise prodidit Diofcorides. quemad= modum imprudenter de Ruta 0 Hyperico, A faro er Bacchari ab alijs factum cfe in precedentibus oftendimus. Hoc Chryfanthe- itaq; argumento fretus crediderim ego boc inodo Chry fanthemi caput effe legendun. Chry fanthemon berba eft te= mi caput refti nera, frutico $a_{a}$, leues proferens caules, or folia multifida: flores luteos, admodum fplendentes. Eius caules man= tutum. duntur olerum modo. Flores cum cerato tritifteatomata difcutere produntur. Hinc itaq; , fic Chryfantbemi capite reftituto, facilé patebit, quantum aberrauerint ij, qui Cbry fanthemum cum Buphthalmo confuderunt. Chryfan= themon, cui nulla prorfus ex modó traditis reclamet nota, fregucntißimum prouenit in Senenfi agro prope Montem nigrum oppidum ita appellatum, efurq́; ibi à rufticis ueluti beta, \& braßica. Buphthalmum ueró et fi antea à me nö uifum in noftris commentarijs Italica lingua confcriptis confeffus cffem; ad nos tamen hoc anno uerum $\mathrm{P}$ atauio alla= tum effe fuperius in fua mentione indic auimus . quod etiam pofted accepimus Pifis à Luca Gbino medico clarißimo,et

Fuch. error. reiberbaria peritißino, omnibus prorfus adftipulantibus notis, qua illi tribuuntur. Quo factum cft, ut certius au= fin affirmare Chry fanthcmibiftoriam auctam, depraudam $q_{;}$effe in Diofcoride. Credidit Leonardus Fuch/iusme= dicus doctifimus in fuo de plantarmm biftoria commentario, chry fanthemumillud effe ranunculigenus, quod folio

Nomina, apiy, luteis flombus, in prat is plurinum nafcitur. Qua in opinione quantum, pace eius dixerm, hallucinetur, euiden= tius omnibus effe puto, quàn ut à nobis oftendi debcat. Chryfanthemi meminiffe Galenum in libris de fimplicium medicamentorum facultatibus, hactenus incompertum habco. . Eius nomen Gracum eft X iten cloryfanthemun: Italicum, Clrifantbemo.

A GERATVM.

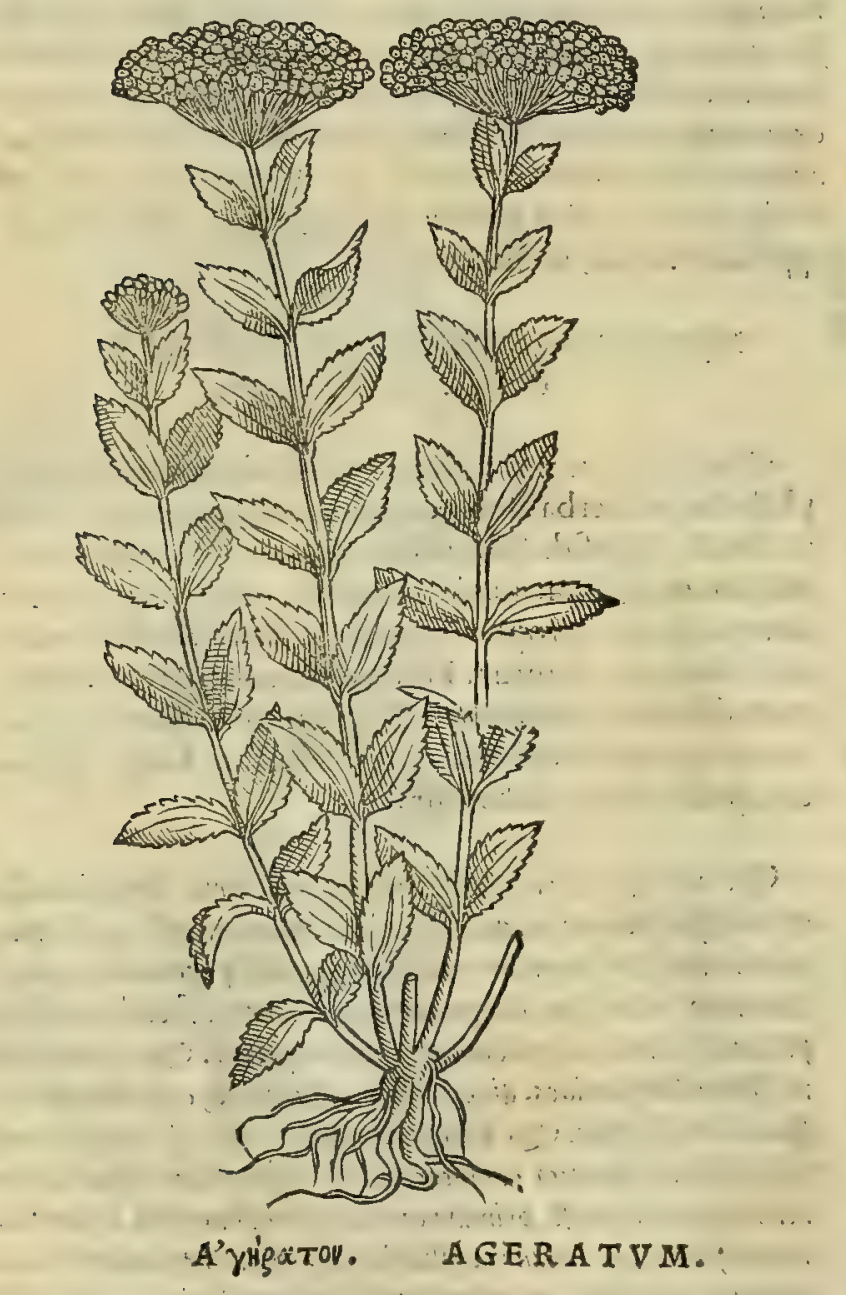

AGERATVM ALIVD.

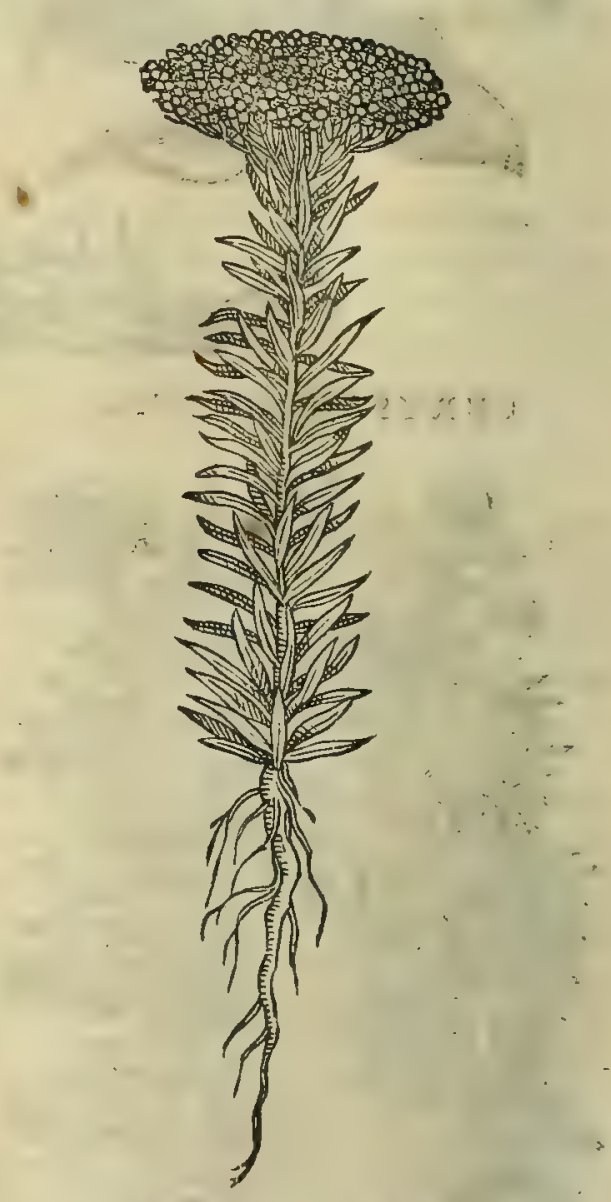

C A.P. LIIII.

A G E R A T O N fruticofa herba ef, palmari longitudine affurgens, fimplex, humilis, origano maximè frmilis : vmbellam gerit,in qua flos bullis aureis emicat, helicry fo minor. Nomen ei inditum eft, quoniam diutifsimè flos in fua coloris fpecie conferuetur. Vis decocti feruens : huius uftæ nidor vrinam cit, \& vuluæ duritias emollit.

Agerati confideratio.
N. A S C I T.V R Ageratum paßim in uniuer a Hetruria, folijs origano proximis: floribus aureis, in umbella emicantibus, belichtyfi modo. Hanc herbam Mefues Eupatorium exiftimat, ut fuperius in Eupatorij comnenta= tione abunde diximus $\mathrm{Ea}$ à noftris SenenGbus uulgó appellatur berba Giulia. Agerati uires paucis perftrinxit 


\section{In Lib.quartum Diofcoridis.}

Galenus libro v I I. fimplicium medicamentorum, fic inquiens. Ageratum digerit, or inflamnationes leniter quo= danmodo refoluit. Qula berba á y'

Nomina. Pigisigrciv. VERBENACA.

CAP. L I .

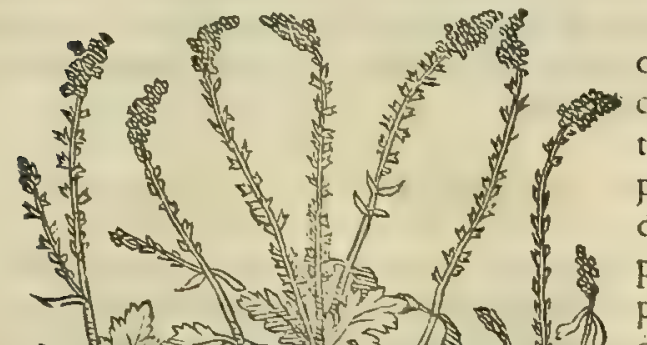

PER I S TERE ON, fiue verbenaca, nafcitur in aquolis. Nomen ex eo duxiffe uidctur, quòd columbx cir ca hanc perquàm libenter uerfari toleant. Dodrantis altitudine, $\&$ interdum amplius adolctêt. Folia è caulc prodeunt incira, \& fubalbida . ea lingulari ramo, radiceque fola, conftare frepius inuenitur. Folia cum fuilla adi pe recebti, aut rofaceo inspofita, vuluarum dolores finire putantur: ignem facrum illita ex aceto reprimunt: putri da vlcera cohibent : vulnera glutinant, veteraq́ue ex melle ad cicatricem perducunt.

\section{İร९ं Вот $\alpha^{\prime}$ H. SACRA HERBA. CAP. IVI.}

20

30

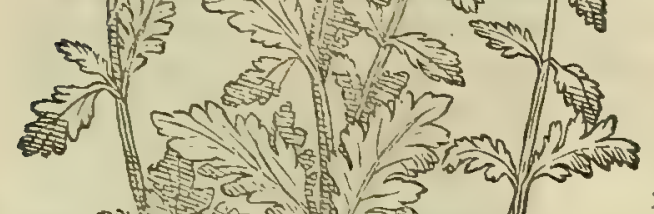

SACR A H E R A, qux \& periftereon nominatur, ramulos emitcit cubitales, aut maiufculos, angulofos : in quibus ex interuallis folia quercus, fed minora, anguftioraque, eifdem diuifuris in ambitu, colore aliquatenus cæfio: radixlonga, tenuis: flores purpurei, graciles. Folia cum radice in vino pota, illitáve aduerfus ferpentes pollent . eadem drachm $m$ pondere cum thuris obolis tribus in vini veteris hemina, quadragenis diebus, ieiuno ore, contra regium morbum bibuntur veteres tumores, \& inflammationes mitigant : fordida vlcera purgant. To ta in vino decoeta, tonfillarum cruftas abrumpit: oris no mas gargarizatu cohibet. Aiunt fi aqua fpargatur triclinium, qua maduerit, latiores conuißtus fieri . Datur potandum in tertianis febribus tertium à terra geniculum, cum folijs circundantibus: quartanis quartum. Sacram vocant herbam, quoniam multùm ad amuleta, expiationesq́ue commendetur.

V E R B E N A C A Hetrufcis uilgó Verminacola, alijs ueró Italis Berbena, er Berbenaca dicitur. Huius (ut ex bis duobus capicibus elici potc $f$ ) duo babentur generd, que boc tantim inter fe differunt, quód alterum caulibus in altum attollatur, rara ex interudllis proferens folia. Alterum ueró refupinatis caulibus bumi procumbat, er nu= merofioribus folijs confet. Nec fane alis inter hee turs foliorum, tum florum deprebenditur differentia. Hinc fit, Fuch. error.

40 ut in fwo infigm de firpium hiftoria comnentario Fucb/ium virum alioqui eruditisimum, aperté erraffe exiftimem: quippe qui difcriminiscaufa Verbenace recte florem luteum tribuat. Quod tamen in Diofcoride mibi nunquam li= cuit inuenire: quemadmodum neque in Plinio, qui utranque Verbenace peciem libro $\mathrm{x}$ V. cap. I $\mathrm{x}$. his uerbis de= fcripfit. Nulla tamen Romane nobilitatis plus babet quain bierabotane, aliqui periftercon, noftri uerbenacam uo= cant. Hac ceft, quam legatos ferre ad hoftes indicaninus. Hac. Ionis menfa uerritur, domus purgantur, luftranturq́;. Genera cuus duo funt: foilo $\int$ a, quam freminam putant: mas rarioribus folijs. Ramulis utriufque plures, tenues, cubi= tales, angulofi. Folia minora, quàm quercus, anguftioraq́; , diuifuris maioribus: flos glaucus: radix longa, tenuis. $\mathrm{N}$ afctur ubique in planis aquofis. Qinidam non difinguunt, sed unum ommino genus faciunt, quoniam utraque eof= dem cffectus labcat. Vtraqiie fortiuntur Galli, or precinunt reponfa. Sed magi utique circa banc infaniunt. Hac perunctos impetrare qua ueitint exift inant, febres abigere, amicitias conciliare, nulliǵ, non morbo mederi. Colligi so circa canis ortum debere, ita ut ne luna, aut fol conpiciatur, fauis ante, o melle terre ad piamentum datis. Circum fcriptain ferro effode fin:ftra manu, es in fublime tolli: ficcari in umbra feparatim, folia, caulem, radicem. hac Pli= nius. Ex quibus uerbis, ut arbitror, facilé deprebendi poteft error Fuchsii Brunfillium forte fecuti, quód in fuis de plantarum biftoria cosmmcutarijs primó editis, pro verbenaca formina eam plantam depinxerit, qua à Diofcoride, ceterisf; antiquis foriptoribus Erigeron, fiue Senecio nuncupatur, tamet fi mutata fententia libro primo de compo= fitione medicamentorum in ultina methodo, rcct am uerbenacam perperàm, meo iudicio, alteram finapi peciem effe contendat. Caterim baud ne fcius Galenus nullum, uel paruum inter utrasque uerbenacas difcrimen effe, breui= ter de e arum uiribus fub una tant im pecie differnit libro v I I . fimplicium medicdmentorum, fic inquiciss. Verbe= naca ideo periffereon appellafa eft, qućd in ea periftera, boc eft, columbet uerfentur. Vim habet adeo deficcantem, ut uulner a conglutinet. Et libro fecundo de compofitione pharmacorum fecundum locos, de antiqú capitis dolore fcribens, fic inquit. Omnium porró longé maximé difcutit, e perfęté corroborat uerbenaca recta, maximé uiri= dis : ino or arida cum radıcibus, or fimul cum Serpyllo, oleo incotta. Conijcienda etiam ad ea crocodiliadis muxime 

Nomina. pitis dolori antiquo ex frigiditate, aut ex craßis humoribus oborto medeberis. Primum Verbenace genus Gracis

ASTRAGALVS.

Afragali con fideratio. Aftragali ui-
resex Gal.

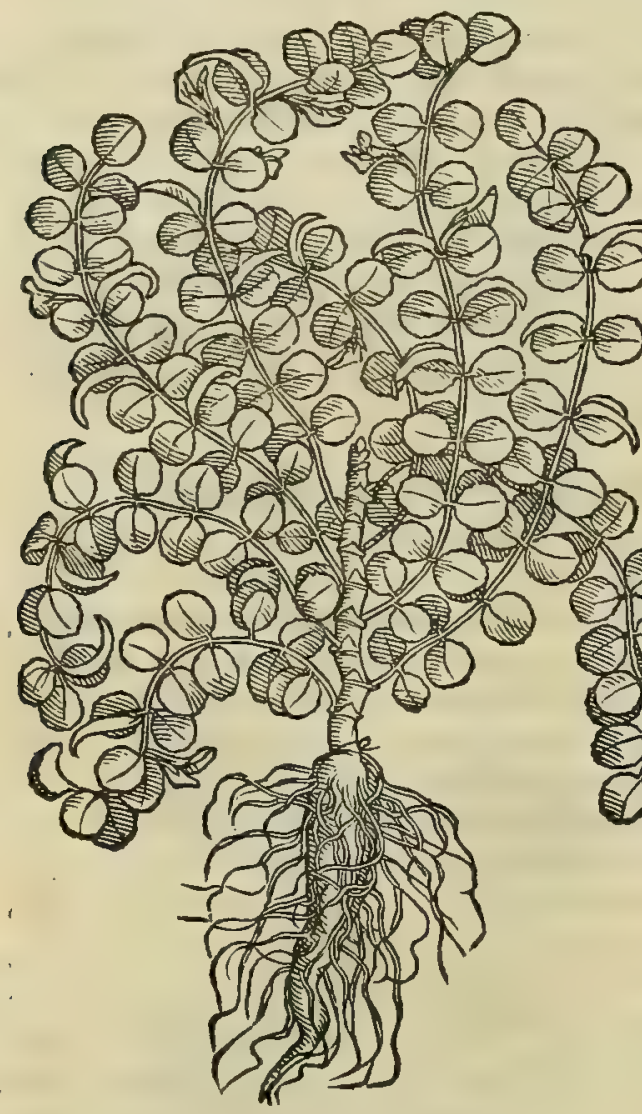

HYACINTHVS.

Nomina.

Hyacinthi cö fideratio. ఐE

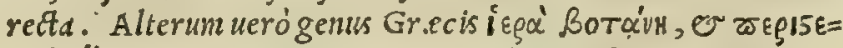
geciv "TTlos appellatur: Latinis, Vcrbenaca fupina . In uniuer= fum Italis Verminacola, Berbena, o Berbenaca nominatur: Germanis, Eifen Lraut.

\section{A'sg $\alpha \gamma \alpha \lambda$ 's. ASTRAGALVS. CAP. LVII.}

A S T R A G A I v S paruus eft à terra frutex, folijs, \& ram is ciceri fimilis : flore purpureo, paruo : radicé rotunda, raphani modo grandi, quæ adnatas appendices firmas habet, nigras, præduras, veluti cornua, inter fe implicatas, guftu adftringentes. Nafcitur in ventofis, opacis, \& in niualibus. eo Memphis Arcadix fcatet. Aluum fiftit radix in uino pota : vrinam mouet: vetuft is vlceribus ficca efficaciter infpargitur: fanguinem fupprimit. ægrè propter duritiam tunditur.

A S T R A G A L V S frequens nafcitur in agro Tridentino, in uallis Ananix montibus, folio ciceris maiore, floribus purpys = reis: radice raphani emula, adnatis appendicibus firmis, nigris, preduris, inter fe implicatis, o guftu adfringentibus. Affra= galus aliter dे Plinio, quàm à Diofcoride defcribitur. Plinius $f=$ quidem libro $\mathrm{x} \times \mathrm{v}$ r.cap.v $\mathrm{r}$ I. Aftragalum bis notis reprefen= tauit. Aftrag alus, inguit, folia habet longa, incifuris multis, $o b=$ liqua, circa radices : caules tres, aut quatuor : florem byacinthi: radices uillofas, implicatas, rubras, preduras. Nafcitur in petro fis, apricis, o ijfdem niualibus, ficut Pheneo Arcadie. $\quad M e=30$ minit A/trag ali Galenus libro v $r$. fimplicium medicamentorum, ubi ita fcriptum reliquit. Aftragalus frutex eft exigurs, radices habens adf trictorias: quamobrem etiam in numero eft non instre nué exiccantium. Nam ulcera uetera cicatrice obducit, et aluum fluxu tentatam fistit, $f$ quis in uino decoctam radicem bibat. Plu= rimus buius fruticis proùentus eś in Pheneo Arcadic. Is Gr.s=

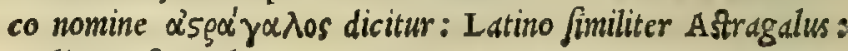
Italico, Aftragalo.

\section{Y์ณ่นNฟิัง. HYACINTHVS. CAP. IVII.}

HX A C I T H V s folia habetbulbi:dodrantalem caulem, læuem, minimo digito tenuiorem, herbacei coloris : comam procumbentem, florum purpureorum plenam, incuruam : radicem quoque bulbaceam. Qux, vt creditur, pueris cum vino albo illita, pubertaté coër-cet, \& non patitur erumpere : fiftit aluum pota, \& vrinam impellit: phalangiorum morfibus auxiliatur. Semen aditringentius eft, theriacis expetitum : regiũ morbum emendat, cum vino potum.

HY A C IN T H V S in uniuer fum in campestribus inter fegetes, $v$ in fyluis prouenit: folijs, or radicibus bulbaceis : call le dodrantali, uiridi, tenui, lauiq; : floret cum uiolis circa finem Martii, $\odot$ Aprilis initium : florentem emittit comam, ab ip $\int 0$ cau lis medio ufque ad fummum purpureis circundatum floribus, qui maturefcentes ad terram incuruantur, perdurant $t_{;}$diu anted qudir contabefcant. Hetrufcis no/tris Hyacintbi uulgó uocantur Cipolle canine. Flores primo statim exortu noftrates pueri col= ligunt ob purpurei coloris prestantiam. Caterum fcire conues nit, quód Hyacinthus bic non est ille, quem ex Aiacis fanguine. 


\section{In Lib. quartum Diofcoridis.}

editum poëte fubulantur, in cuius flore ipfius Aixcis nomen primis literis expreffun legitur. Siquidem is (ut poëte canunt) florem profert rubentem, lilio adfimilem. Hyacinthi uires memorie prodidit Galenus libro $\mathrm{V}$ I I $\mathrm{I}$. fimpli= Hyacinthi ui cium medic ansentorum, fic inquicns. Hyscinthi radix bulbofa cft, ordinis primi in deficcando: fecundi ueró comple= res ex Gal. ti, aut certe tertij incipicntis in refigigerando. Itaque pucros diutißimé feruate impuberes illita cum uino creditur. Semen leuter extergit, or ad/ringut: quanobrem 0 ip $c$ regio morbo laborantibus exbibctur in uino, ordine qui= dem tertio quabantenus ácficcans, cetcrim in medio confiftens caliditatis, ac firigiditatis. planta Grac is váulv= Cos, Latinis item Hyacinthws applhitur: Italis, Hiacintho: Germanis, Mertzen bluomen: Hipanis, Mayos flores: Nomina.

PAPAVER SATIVVM:
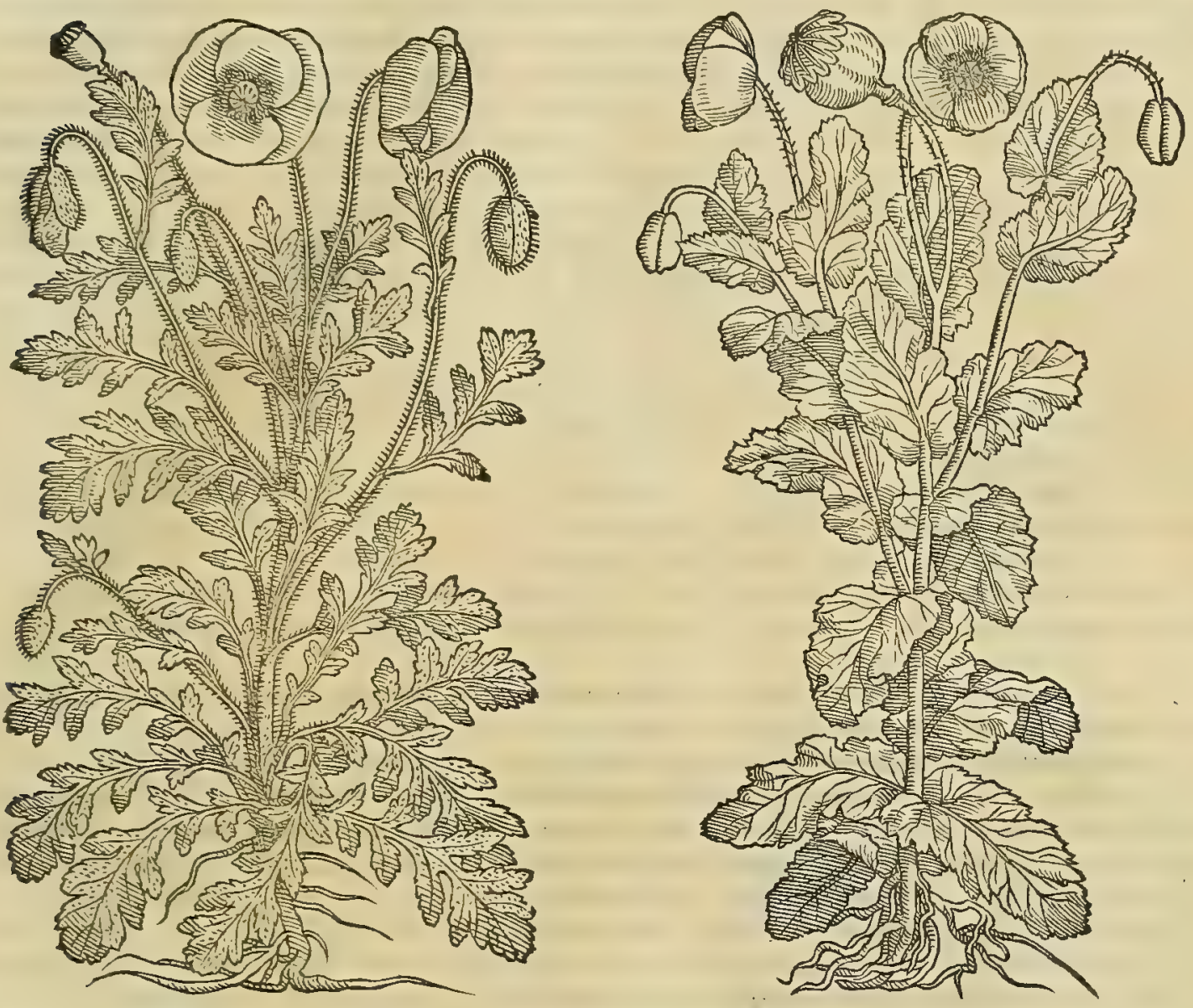

MH'rwy gooris. PAPAVER ERRATICVM.

CAP. LIX.

PA P A VE R erraticum, quod rhceada vocant, vere quidem in aruis cum hordeo nafcitur: flore protinus deciduo, vnde \& nomen apud Græcos accepir. Folia erucæ, aut origano, aut cichorio, aut thymo fimilia fpectantur, fed longiora, diuifa, fcabra: iunceus ei caulis, rectus, cubitalis, afper: flos fylueftris anemones, puniceus, interdum albus : oblongum caput, fed quàm anemones minus : femen rufum : radix longa, fubalbida, minoris digiti crafsitudine, guftu amara. Huitus capita quinque, aut fex in vini cyathis tribus ad dimidias decocta, potui dabis, quibus fomnus accerfendus eft . Semina acetabuli menfura ex aqua mulfa pota, aluum leniter emolliunt: ad idem præftandum mellitis placentulis, \& dulciarijs libis admifcentur . Folia cum calycibus illita, inflammationes fanant : eorundem fotu, \& perfufione fomnus allicitur.

$$
\text { MH́roy Ḧurgos. PAPAVER SATIVVM. }
$$

CAP. IX.

E' S A I I V I papaueris genere, quod hortenfe eft, femen in panem denfatur, qui fanis in vfu fit: eo etiam ex melle pro fefama vtuntur : thylacitin vocant. Capitulum habet longum, \& femen candidum. Sylueftre uerò caput habet infidens, demiflumq́ue, \& nigrum femen : quod pithitis nominatur:nonnullis tamen \& ip fum rhceas dicitur, quoniam eius fcapo lacteus fuccus emanat. Tertium magis fylueftre, \& ad medicinas valentius, multo his longius, productiore capitulo. Omnium in commune natura refrigeratrix . quare $f_{1}$ capita ip $f a, \&$ folia decoquantur in aqua, fomnum fotu conciliabunt. Bibitur decottum contra vigilias. Calyces cum polenta triti, \& cataplalmatis admifti,igni bus facris, \& inflammationibus profunt. Tunduntur quoque virides, \& digeruntur in paftillos, qui 


\section{And. Matthioli Comm.}

ficcati ad ufum reconduntur. Capitaquoque per fe in aqua coquunturad dimidias, iterumque adiecto melle, dum humor coëat in eclegmatis lentorem. Id medicamentum in tufsi, arteriæ fluxionibus, ac coliacorum affectu, doloris leuamentum præbet . efficacius tamen redditur, addito hypociftidis fucco, \& acacia. Papaueris nigri femen tritum cum vino bibitur, contra citam aluum, \& foe opium. minarum profluuia . in peruigilijs fronti, temporibusq́uc illinitur exaqua. Opium eius magis retrigerat, infpiffat, ficcatq́ue. Sumptum erui magnitudine, dolorem finit, concoquit, \& fomnum allicit: tufsi, atque cceliacorum valetudini auxiliatur: verùm fi copiofius hauriatur, nocet, cùm lethar gicos efficiens interimat. Ad dolores capitis cum rofaceo perfufum, efficax eft : aurium dolori cum amygdalino, myrrha, \& croco inftillatur : inflammationibus oculorum cum torrefacto oui luteo proficit : igni facro, \& vulneribus cum aceto : podagris, cum lacte mulieris, \& croco. fomnum accer- 20 fit fubditum fedi pro balano. Optimū habetur graue, \& denfum, guftu amarum, odoratu foporiferú, quod facilè aqua diluitur, Ixue, candidum, neque afperum, neque grumofum, quod inter colandü non vt cera coëat, \& in fole diffundatur: dein admotum lucernis, non atra luceat flam ma : extinetum denique odoris uim conferuet. Sed opion glaucio, gummi, aut fylueftris lactuca fucco adulterant. Verùm glaucio fucatum, in dilutione croci colorem reddit: lactucaceo fucco fictum, exiliter fpirat, \& a sperius fpectatur : gummi uitiatum fplendefcit, \& infirmum eft. Nec defunt, qui cò dementiæ deuenerint, ut adipem ei admifcerent. Fictili nouo torretur ad oculorum medicamenta, dum mollius, atque rufius appareat. Diagoras, vt Erafiftratus author eft, ufum eius damnanit, oculorun lippitudinibus, \& aurium vitijs infundi uetans, quoniam uifus aciem hebetaret, \& foporem gigneret. Addidit Andreas, illitos eo protinus excæcari, fi non adulteraretur. Mnefidemus ufum duntaxat 2 olfactandi probauit, quoniam ad conciliandum fomnum conueniret: alioqui nobis vt noxio interdicit. Quæ commentitia effe experimento deprehenduntur : fiquidem effèctus, uirium huiufce medicamenti fidem faciunt. Quare non alienum fuerit fcriptis mandare, quónam modo is excipiatur fuccus. Aliqui capita ip $f_{3}, \&$ folia tundunt, \& prælo exprimunt, terentesq́ue in mortario digerunt in paftillos : id meconium uocatur, multùm opio ignauius. Porrò opij faciundi ratio hæc eft. Cùm ros in eo exaruerit, cultro decuffatim in ftellas, ne penitus adigatur, ex obliquo in rectum fummam cutem incidere oportet, lacrymam exeuntem digito in concham abftergere : nec multò pòft redire, ut concreta inueniatur: ctenim qux tum, aut poltero die etiam offenditur, in uctere pila teri dcbet, \& in paftillos cogi. cùm tamen inciditur, retrocedendum eit, ne ueftibus fuccus deradatur.

Pepaueris erratici confideratio.

Papaueris fatiui confideratio.
S P E C T A N T V R Maio menfe Papauera erratica rubentibus floribus nitèntia, in aliquibus campef tribus lo= cis adeo numerofa, ut deceptis oculis, campi uideantur coccineis uelaminibus uestiti. Horum flores non dc $\int u n t$, qui affirnét lateris dolori, qui Gracis $\bar{\nabla} \lambda$ evpitis dicitur, mirıfice mederi : in quem ufum eos ficcatos in puluerem redi $=$ gunt, $\sigma$ in potu exhibent. A b boc experimento nonnulli medicorum edocti, ex ipforum florum recentium fucco ter, aut quater iterato diluto, ferapium conficiunt : quo poftmodum magno, ac proppero fuccefju in plcuritic is utuntur. Tridentina rura Papaueris erratici folis prima ftatim germinatione olerum modo decoquunt, fumuntó; in citum ca= feo, o buty ro admistis. Nec mirum fané, cùm etiam Theophrafti atate (ut ipfe fcriptü reliquit lib. I X.cap. X I I I. de plantarumbiftoria ) eadem fumerentur in cibis. Loco enim citato ita de eo fcribit Theophrastus. Papauer crrd= ticum uocatum non abfimile intubo erratico conftat: quare in ufum uenit cibarium. Nafcitur in aruis potisimim int= ter bordea. Florem rufum producit: caput pollicaris unguis magnitudine. Legitur ante hordei me fe $n$, atque uiri $=40$ dius etiam . purgat inferius . hec Theorbraftus. Sed iam de Papauere fatiuo, fiue domeftico nobis differendum eft. videtur Diofcorides cum fatiuo duo fylucftris Papaueris genera tradidiffe, et boc nomine bac á́ illo diftinxiffe . Qulda in re animaduertendum eft, ne aliquis fortaffe decipiatur, quód omnes bx papauerum ppecies ab agricolis fermntur. Verum illud duntaxat, mea quidem fententia, hortenfe appellauit Diofcorides, quod albo conftat $\int \mathrm{cmine}$, quoniam hoc frequentius in uiridarijs, or bortis prope ades feritur. Catera ueró fylueftria nominatuit, non quód pponte, or per fe nafcaltur ( feruntur enim omnia) ) ed quod afperior a, birfutiora $\dot{\text {; }}$ proueniant tum caule, tum capitibus, tum etiam folijs: quód preterea nigrum, aperumq́; proferant femen : quodd deniq; ferantur in campestribus fegetum, or legu= minum modo . Rem autem fe ita babere testari uidetur Plinius libro X I X.cap. $v$ I I I. cum fic inquit. Papaueris fa= tiui tria genera. Candidum, cuius femen tofum in fecunda menfa cum melle apud antiquos edebatur. Hoc e panis ruftici crufte infpergitur adfufo ou inberens, ubi inferiorem cruftam apio, gith'̆; cercali fapore condiunt. Alterum so genus P apaueris nigrum, cuus fcapo incifo lacteus fuccus exprimitur. Tertium genus rhoeam uocăt Greci, id noftri erraticum dicunt. Sponte quidĕ, fed in aruis cum bordeo maximé nafcitur. hactenus Plenius. Papauere candido paf= fim abundat Hetruria. Vtrisq; ueró nigris $\int c$ atet uniuer $\int_{a}$ Infubrium tellus: fed precipué apud gentes, qua Triden= tinas incolunt ualles, ubi $\mathrm{P}$ apauera bec copiosé feruntur in canpis, er inter legumina, prefertim inter fabas. Ibifi= quidem eius femine ue cuntur homines, inmifto placentulis, quas ex pafta foliofa multiplici inuolucro conficiunt. Comedunt illi quidem bafce placentas ad Jaturitatem ufque : nec ob id tamen unquam (quod mirum alicui fortafje ui= debitur) diuturniore fomno capiuntur, neq; ueternofi fiunt. Quin nec illi ctiam, qui stiriam, fuperioremq́; Auftriă incolunt, in ueternum incurrunt: etfi oleum è nigri papaueris fenine expreffun in cibis continué affumant, oliuarum olei vice. Ea demum experientia fecit, ut intrepide quandoq; aufus fim Papaueris feminis cremorcm bordei decocto expreffum in ardentißimis frbribus ad fitim extinguendam, fomnum q́; conciliandum etiälargius exhibere. Hinc pra tered factum est, ut eum metum excufferim, $\sigma$ depofuerim, quem mihi olim preceptorum meorum graues admoni= 


\section{In Lib. quartum Diofcoridis.}

tiones incufferatt, or ingeferant. Caterim ex incifis Papaucrum capitibus opos, fiue fuccus manat, qui in Opium Papaueris fuc uocatum addenfatur, ut fcité docuit Diofcorides. Et quanuis Opium quarto exceffu frigidum ftatuatur; tamen fi ex ci, fiue Opij fapore, of effectu rerum temperamenta, or qualitates cognofcuntur, opium noftri ufus (quantum equidem depre= bendere potui) non modó guftu amarum percipitur; fed etiam acre, adeò ut paululum in ore decentum linguam, or palatum exulceret. Vude had dubic colligi polfe putauerim, calidißimas illi iueffe qualitates. Cuius reifidem auge= re poteft, que ex eo prodit odoris grauitss. Veruntamen ne impudentis, atque arrogantis nonen fubeam, quod in hoc omnium frè medicorum fententiam defruere uelun, eorun iudicio rem banc aftimandan velingutu, qui ante nos opij tum qualitates, tum facultates diligentißimé expenderunt. Sed forté ea acris, amaraq̧; facultus in opum facilé inuebitur ex glaucij adulteratione, quod illi fepius admifecnt, ut Dtofcorides adnotauit. Illud'́; argunento effe po= 10 teft, quód aqua colliquatum croceum colorem reddat. Adde quód opium, quod bodie ad nos conucbitur, non est il= lud uerum er legitimum é lacryma, que ex incifo papaueris capite exicrit, concretum, fed potius hoc é foliorum, $\mathcal{E}$ capitum contritorum fucco confectum eft: id q́; meconiun uocatum erit, opio longé deterius. Papauerum uires ine= morix prodidit Galenus libro v I. fimplicium medicanentorum, fic inquicns. Papauer alterum R ha as nuncupatur, quód filicet celeriter flos cius defluat. Alterum domefticum, quandoquidem colitur. Quin or altere dux funt pre = ter baspecies fylueftris papaueris : alterum uelut incidentem calycem fuftinens: alterum longiorem quan ithd ca= lycem obtinens, totum autem procerius, ac fqualidius. Ab boc fuccus defuit, atq; binc eft, quód banc peciem qui= dam R basda nominent. Porrò omuium facultas refrigeratoria eft. Ceterim fatiui $\int \mathrm{emen}$, quod or thylacite cogno= minant, mediocriter fomnum conciliat, uifu candidun: proinde pani ipfum inpergunt, ac melle maceratum edunt . At eius, quod primo lcco recenfuimus, cuius florem celeriter decidere pofuimus, ualidius femen refrigerat, ita ut ne=

20 quaquam eo quis innoxie folo uti poßit, ficut fatiuo fiue domeftico melli admifcens. Admodum uero', fi ita fumptum fit, fommum conciliat. Ceterim pufillum eius inpergunt ijs, qui ex melle conficiuntur bellarijs, atque placentis, pd= nibusq́;. Porró tertio loco difi femen atrum etiam medic amento $\int u n$ eft, admodum refrigerans. At quod quarto lo $=$ co pojitum eft, omnium eft medicatißimum, tum in femine, tum in calyculis, tum in folijs, tum in fucco. Validé enim refrigerat, ad fuporem ufque, or mortem perducens. quare medici quó probé co utantur medicamentis mifcentes, frigiditatis uebementiam retundunt. Eft enim ex quarto, $\mathrm{O}$ ultimo refrigerantium ordine. Porró quo pacto maxi= mé ex me thodo mistionem facere oported, non eft prefentis tractationis proprium. Et lib. I I. de compofitione me= dic amentorum fecundum locos, de dolore capitis agens citra manifeftas caü fas oborto, ita de opio differit. Raró, in= quit, cogimur pladrmacis ex opio uti, cum uidelicet pre doloris uebementia bomo de vita periclitatur. Quanquam E tunc folide partes ex eius uJu offendantur, adeó ut poft bec correctione opus babeant. Sic $\sigma$ ex opio collyria 30 multis detrimento fuerunt, adeo ut debilem oculum reddiderint, ovifus hebetudinem, amblyopiam Gracis appelld= tams induxerint: uelut etiam auditus grauitatem inducunt quecunque ad uebementem aurium dolorem ex papauéris fucco funt compofita. Idem Galenus lib. I I I eiufdem tractatus, de aurium inflammationibus agens, fic inquit . Pbar maca ex papauer is fucco omnia fenfun ftupefaciunt: O ob id fané neceffarió cogimur ip/is uti ubi nullum aliud miti gatiuum opem tulit. hec Galenus. Ex quibus fané omnibus admoniti effe debent medici, ne temeré, aut inconfulté ad ufum opij fe conferant. Sed ratio, qua id corrigendum, adminiftrandum $q_{;} /$it, ex ipfo Galeno colligi poteft, libro VI I I. de compofitione pharmacorum $\int e c u n d u m$ locos, ubi ita fcriptum reliquit. Calefacientia mifcentur, qua refri= gerantium ftupefactionem deducere pofjunt, cum illa ip a per $\int e$ tardi tranfitus exiftant. Hac igitur ubi quis inaudi= uerit, quantitatem confideret fimplicium pharmacorum, que in compofitiones mifcentur. Ex bac enim fciet num ma gis, an minus efficere poßit compofitum pharmacum, ea qux promittit. sinanque refrigerantia plura apparuerint, 40 fen fum affectorum magis obtundit, er quantum caloris in ip $\int a$ particula fuerit, etiam bunc extinguit . vbi ueró cal= facientia fuerint aucta, minus quidem hec efficiet ipfum pharmacum, innocentius autem reddetur. Noffe enim opor= tet, corpora uiuentium mortificationi fimile quippiam perpeti ab omnium ex opio, byofcyamo, er mandragora com= pofitorum pharmacorum ufu : nimirum caufis dolorem infligentibus infenfibilibus factis, or multi fané qu aßidué ta

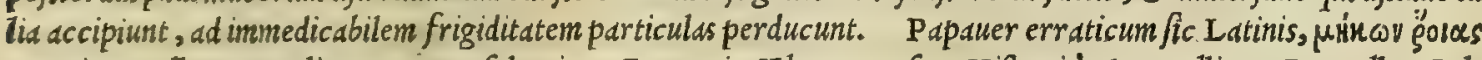
Grecis appellatur : Italis, Papauero faluatico: Germanis, Klapper rofen : Hifpanis, Amapollia ON Papoulla: Gal Tis, Coquelourdeis. Papauer ueró fatium Latiné dictum, $\mu$ in Chafchas: Italice, Papauero domeftico : Germanicé, Magfomen : Hifpanicé, Dormidera: Gallicé, Pauot . Quod

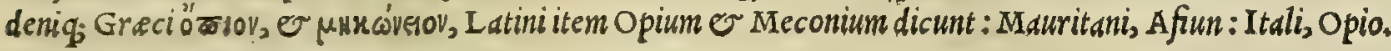

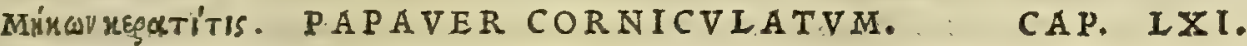

P A P A V E R ceratites, id elt, corniculatum, folia habet candida, hirfuta, verbafco fimilia, in ambitu fylueftris papaueris more ferrata: caule non difsimili : flore pallido : calyculo foni græci,in corniculorum modum inflexo, vnde nomen mutuatur: femine papaueris, pufillo, nigroq́ue: radice pet fumma cefpitum, nigra, crafla . nafcitur in maritimis, \& afperis. Radici ea vis inelt, vt in aqua decotta ad dimidias coxendicum, \& iecinoris affectus potu fanet - prodeft his, qui craffa quxdam, \& araneofa cum lotio reddunt. Aluum leniter purgat femen, acetabulo in aqua mulfa poto. Cruftas emarginant, illita ex oleo folia floresque : argema ac nubeculas iumentorum, perunctas abftergunt . Sunt qui glaucium hoc papaueris genere factitari exiftimarunt, falf quadam foliorum cognatione. 
PAP. CORNICVLATVM.

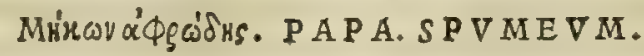

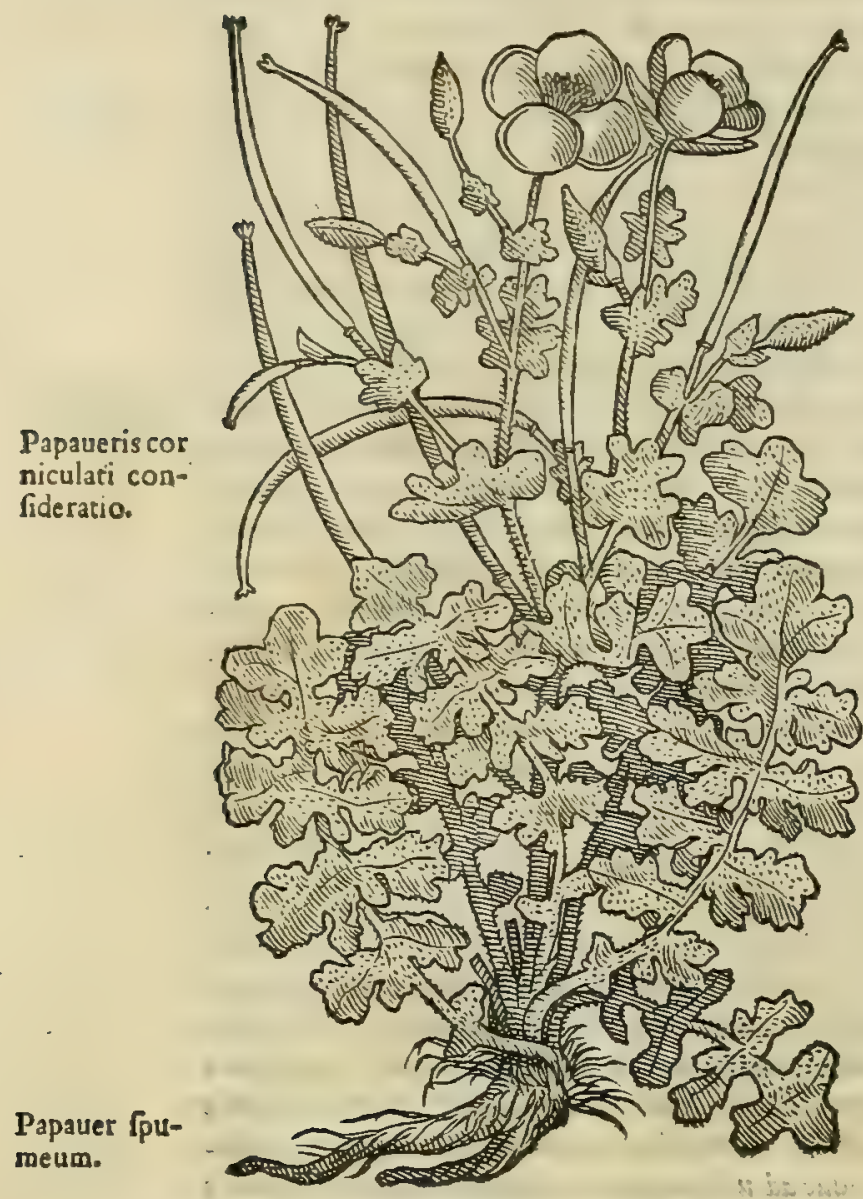

A L I V D Papaueris genus aphrodes, id eft, fpumeũ vocatur, ab alijs heracleum, caule dodrantali : folijs admodum paruis, radiculæ fimilibus : fructu inter ea candido. nam herbula alba eft, \& fpumea tota: radice in fummo cefpite. Legitur æftate femen, cùm integrè ado leuit, deciditq́ue exiccatum. Datum acetabuli menfura in aqua mulfa, vomitione expurgat . priuatim huiufmodi purgatio, comitialibus prodeft.

P A P A V E R corniculatum in maritimis noftris senenfi= bus Craffetano, or Orbetellano agro, or circa Herculis por= tum Argentario promontorio, itemó; in Adriatici maris litore non longé à Timauo fonte, er Tergefto faxofo litor is tratu, ubi Sepius ipsum legimus, frequentißimum prouenit: quanquam $e=$ tiam in alijs Italie locis nafcitur, fed quod potifimùm in bortis, o viridarijs ad publicum omnium commodum, or ßpectaculum fuerit fatum. Huius meminit Theophraftus lib. I X.cap. X I I I I. de plantarum biftoria, fic inquiens. Papaueris quoque Jylueftris 20 genera plura notantur : quoddam enim corniculare appellatum: quoddam autem nigrum eft, folio conftans uerbafci nigri, fed minus nigro: cauli altitudo cubitalis : radix breuis, per fummáq cepitum: fructus inflexi, ut corncula figurantur. Legitur cir= ca meffes. Alum purgare poteft : folium albuginem ouibus au= fert. inafcitur iuxta mare, faxofis locis . hac ille. Crediderenönulli Glaucium, quod Matiritanis memithe nocatur, fieri e corni culati Papaueris fucco. Verum ij (ut Diofcorides aft author) procul dubio decipiuntur. Ceterim Papaluer fpumeum, quod aliquiberacleum uocant, nondum mibi compertum $\mathrm{e} f \mathrm{t}$, neque $e=50$ tiam bactenus aliquem reperi, qui illud legitimum oftenderet. Quo fit, ut ipfum quoq; inter tot alias nobis incognitas plantas relinquere malim; quàm aliquod incertum proferre, Plinij lapfus. ut quidam faciunt. Verıntamen non mibi uidetur filentio pretereundus fatalis feré Plinij lapfus, in $\mathrm{P}$ apdueris $p$ pu mei mentione lib. X x.cap.X I X. Quippe qui huius papauer is folia.peciem paffer rm auium reprefentare tradiderit; deceptus nimirum duplici eiufdem nominis Gracifignificatione. Spovétov enim Gracis non modó paferem auiculam fignificat; fed o plantam eam, quam Latini radiculam, fiue lanariam herbam appellant: cui quidem Diofcorides, non autem auiculis, quas pafferes Latini dicunt, Papaueris pumei folia fimilia reddidit. Quemadmodum 0 Theo= phraftus, qui de eo loco citato ita fcriptum reliquit. Papauer ber aclion nuncupatum folio conftat ftrutbij, hoc eft ra dicule, qua linteis candorem conciliant: radice candida, in fumma terra eunte: fructu albo. Huius radix purgare

Papaueris Juperius nata eft. Non defunt, qui contra comitiales ea utuntur in uino mulfo. bac Theophraftus: Papaueris cor $=40$ corniculatt ui niculatimeminit Galenus lib.v I I. fimplicium medicamentorum, de cius uiribus in bunc modum differens.: $\mathbf{P}$ apauer res ex Gal. corniculatum nominatum quidem eft à femine leuem inuerfionem habente, ueluti oo fanum gracum, ut bovis cornu uideatur effe fimile. Vocatur porró à quibufdam paralium, quandoquidem ut plurimùn iuxta mare nafcitur. Vim ba bet incidendi; er abftergendi. Itaque radix herbe in aqua decoctd dd dimidium, hepaticos affectus adiunat. Porró

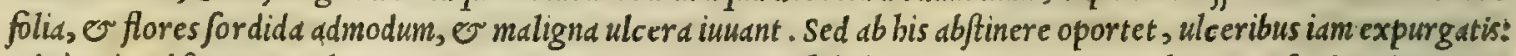
adeó enim abftergere ualent, ut er pure quoque carnis nonnibil eliquent. Hoc uirium robore non fordem duntaxat; fed or cruftam ulceribus detrahit. Papauer ueró Herculeum, quod er aphrodes, hoc eft, ßpumeü noc atur, eo quòd

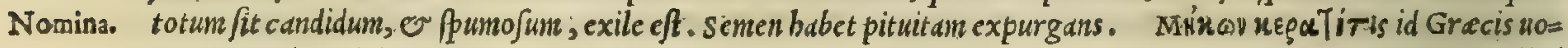
catur, quod Latinis Papauer corniculatum: Arabibus, Almacharam: Italis, Papanero cornuto : Germanis, Gelbol

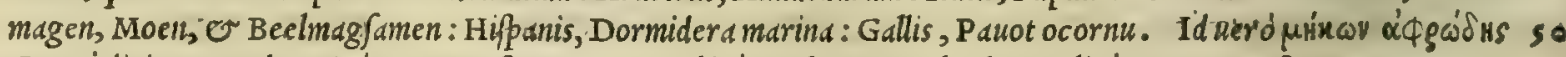
Grece dicitur, quod Latiné Papauer ßumeum: Arabicé, Dabre, or zebeolij: Italicé, Papauero pumeo.

$$
\text { Y'ธixoov. HYPECOVM. CAP. LXIII. }
$$

H Y P E C O ON, aliqui hypopheon vocant. nafcitur in fegetibus, aruisq̨ue, folijs rutæ, exilibus ramis. Natura eadem, quæ papaueris fucco.

Hypecoi con H Y P E C o v M ijs facilé fe fe offeret, qui inter fegetes, o legumina ipfum perquirere non grauabuntur. Hoc fideratio. pro fylueftri ruta olim Petrus spezzalancia Clesij uallis Anania oppiduli pharmacopola compater meus, mibi oftenz dere folebat. Quandoquidemid prouenit in aruis, folijs rute paulo maicribus : caulibus exiguis, mollibus, hirfutis : in

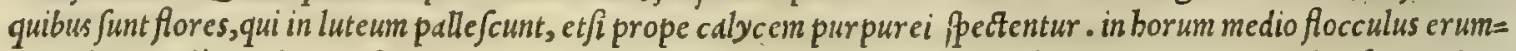
pit colore aurü a mulans, uifu iucundus. Floribus fuccedunt capitula, tenui inuolucro contecta : in quibus femen clau= 


\section{In Lib. quartum Diofcoridis.}

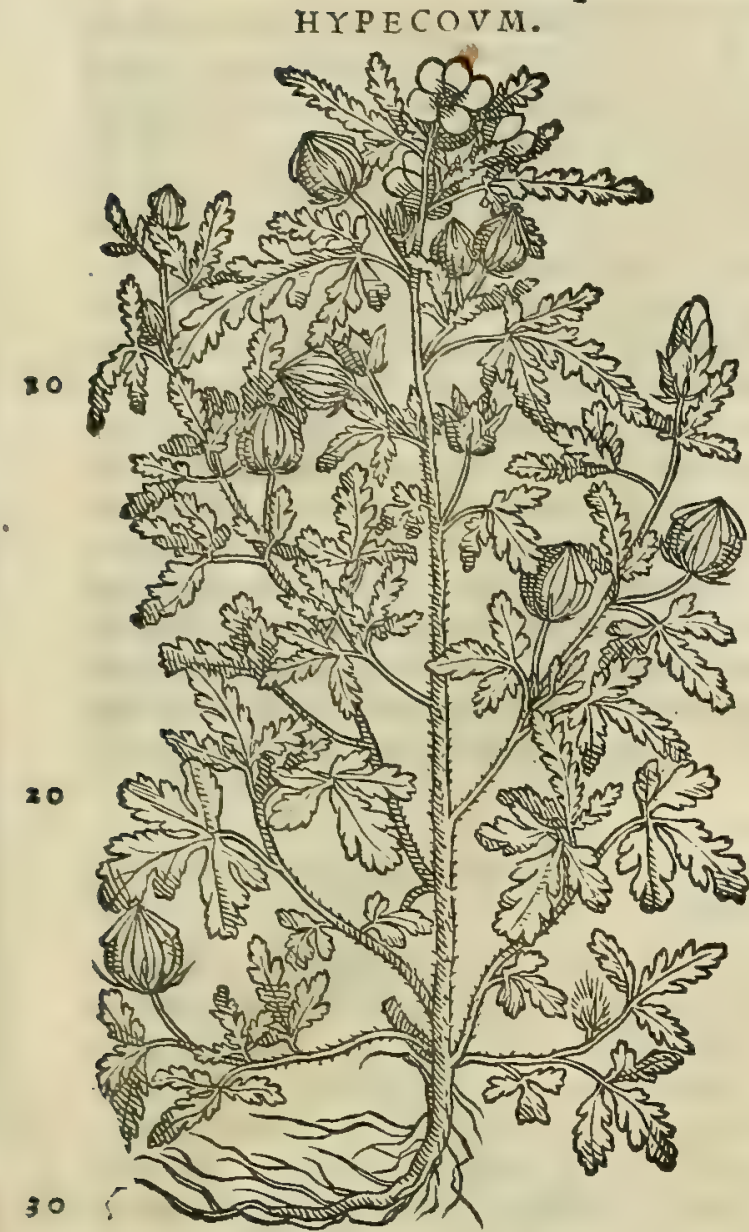

HYOSCYAMVS.

50

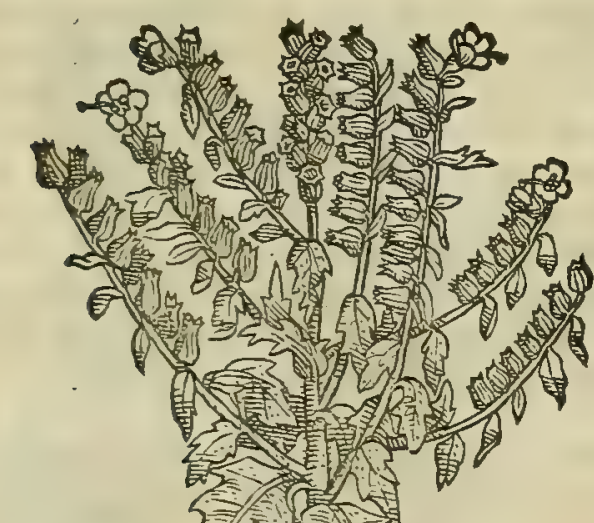

buius Galenus libro v I II . fimplicium medicanentorum, bis Hypecoi uipaucis ucrbir. Hypecoon, inquit, refriger andi uim babet, exter= res ex Gal. tio firé refrigerantium ordine, adeo ut parum abfit à papauere.

Quod Graci vंáxoov, Latini quoque Hypecoun uocant: Itali, Hipecoo.

Yoorviaus. HYOSCYANIVS, SIVE A POLIINARIS. CAP. LXIIII.

HY O S C Y A v S frutex eft caules emittens craffos: folia lata, oblonga, diuifa, nigra, hirfuta: Hores è latere caulis, ordine prodeunt, tanquam punicorum cytini, fcurulis fepti feminum plenis; ut papaueris. Tres eius differentix. Vna femine nigro, floribus penè purpureis, fmilacis folijs, cytinis præduris \& fpinofis. Alterius femen fubflauum ut irionis. flores lutei, folia \& filiqux fimpliciores ambo infaniam gignunt, \& foporem : ideo in communi ufu damnantur. Tertium genus, ut quod mitifsimum effet, medici recepere : pingue, lanuginofum, molle, candidi floris feminisq́;, in maritimis ruderibusqque, nafcens . cuius occafio fi non adfit,rufum ufurpari oportet . niger, ut deterrimus, improbatur.

Recenti femine, caulibus, folijsq́ue tufis fuccus in fole exprimitur, \& exiccato humore, ufus ad annum ufque prorogatur:nam facilè corruptionem fentit. Extrahitur etiam ex ficco femine feparatim in aqua calida tufo, \& expreflo. Liquamentum autem fucco lacteo pręftantius eft, \& magis dolores finit. Contufa herba recếs, addita trimeftri farina, digeritur in paftillos, \& reconditur . Liquamentum primum, \& quod à ficco femine exemptum eft, collyrijs, quæ doloris fenfum auferunt, cómodifsimè inferi folent . contra acutas, calidasq́ue fluxiones, dolo res aurium, atque vulux mala profunt: cŭ farina autem, aut polenta, oculorum, pedum, cæterarumque partium inflammationes placant. Semen eadem præbet : tufsi, deftillationibus, oculorum fluxioni, \& do loribus efficax : contra menfium abundantiam, \& erumpentem aliunde fanguinem, oboli pondere cum papaueris femine, \& aqua mulfa bibitur: podagris fubuenit: teftrbus inflatis, mammisque tumentibus à partu, tritum ex uino illinitur. Alijs quoque cataplafmatis, qux doloris leuamentum præftant, admifceri folet. Folia omnibus medicamentis dolorem fedantibus, per fefe, \& ex polenta utilifsimè imponuntur. recentia ad mitigandos omne genus dolores oblinuntur: cum uino terna, quaternáve pota fanant algidas febres, quas epialos uocant . Cocta olerum modo folia , fi acetabuli menfura manduntur, mèdiocrem infaniam gignunt. idem efficere tradunt, fi colo vlcus fentiente, infundantur. Radice in aceto decoeta, dentes in dolore colluuntur.

E T S I trid Diofcoridi Hyo cyami tradantur generd; id Hyolcyami tamen folum mibi uidere lic uit, quod aureum florem profert, or confider. femen in uafculis fubflauum potius, quàm nigrum : nam reliqua, quanquam diligenter inquifiuerim, qui mibi oftenderet, bactenus reperi neminem. Hyofcyami meminit Scribonius Largus, in= quiens. Altercum, quod Grecis byofcyamus uocatur, qui bibe= rint, capitis grauitate, $O$ uenarum diftentione laborant, ment= teóg; abalienantur cum quadam uerborum altercatione : unde er 


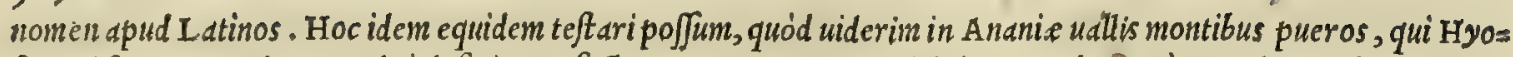
foyamifemen comederant, adeó defipientes factos, ut parentes, or uicini eos crederont à cacodamonibus uexatos effe. Hinc eft, quód eius regionis incole Hyofcyamum uulgari fermone appellant Difturbio, ut quod mentem maxi= mé turbet. Aues, que buius berbe femen ederint, pracipué qua in gallinacco babentur genere, non multo póft té= pore pereunt quemadmodum e pifces. Hyofcyamus uidetur Gracis dicta, quafi faba fuilla: propterea quód ( $u t$ Helianus inquit) buius berbe paftu re foluantur., er conuellantur apri. Sed remedium nouere, aquas enim ftatim Hyofcyami adcunt, o cancros uenantur, atque ita protinus faluti reftituuntur. Hyo fcyami uires.recenfuit Galenus lib.v I I I. uires ex Gal. fimplicium medicancntorum, bis uerbis. Hyofcyamus, cuifemen atrum eft, infaniam, ac foporem affert. Huic au= tem is, cui femen med tocriter flaum cft, propinquain facultatem obtinet. Verum uirique fugiendi funt, ut inutiles, o ucnenofi feu deleterij. Ceterum cuius femen, ac flos candidus eft, ad fanationes uel maximé idoneus eft, ex tertio quodammodo ordine refigerantium. Porró flos eius quidem, cuifemen eft nigrum, mediocriter purpureus eft : eius ueró, cui cft fubflauum, leuiter mâli colorem refert. bac Galenus. Ceterù, ut ad byofcyami biftoriam noftra re= uertatur oratio, mibi quidem non videtur pretermittenda fupicio, que eft, quód in buius capitis initio, ubi de flori= bus fit mentio, mendum aliquod Jubfit. Ea nanque inibifloribus tribuuntur, qua filiquis legitimé debentur. Etenim filique funt, qua fcutulis conteguntur, atque femen intus continent, non autem flores. Auget banc nobis fupicio= nem Serapio: quippe qui illud de fructibus $\mathrm{H}$ ycfcyami Diofcoridi acceptum referat, quod bic de floribus fcriptum le= gitur. Quare non temere, mco iudicio, conijcere poffumus, bunc locum in Diofcoride depraudtum aut mutilatum

Nomina. cffe. Planta, que Gracis vंockvauos, Iatinis appellatur Hyofcyamus, A pollinaris berba, Altercum: Arabi= bus, Pengi: Italis, I ufquiamo: Germanis, Bilfomen, or Bilfen: Hifpanis, Velenbo: Gallis, Iufquiame, $\circlearrowleft$ Ha= neballe.

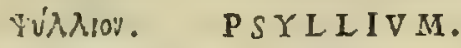

CA P. IXV

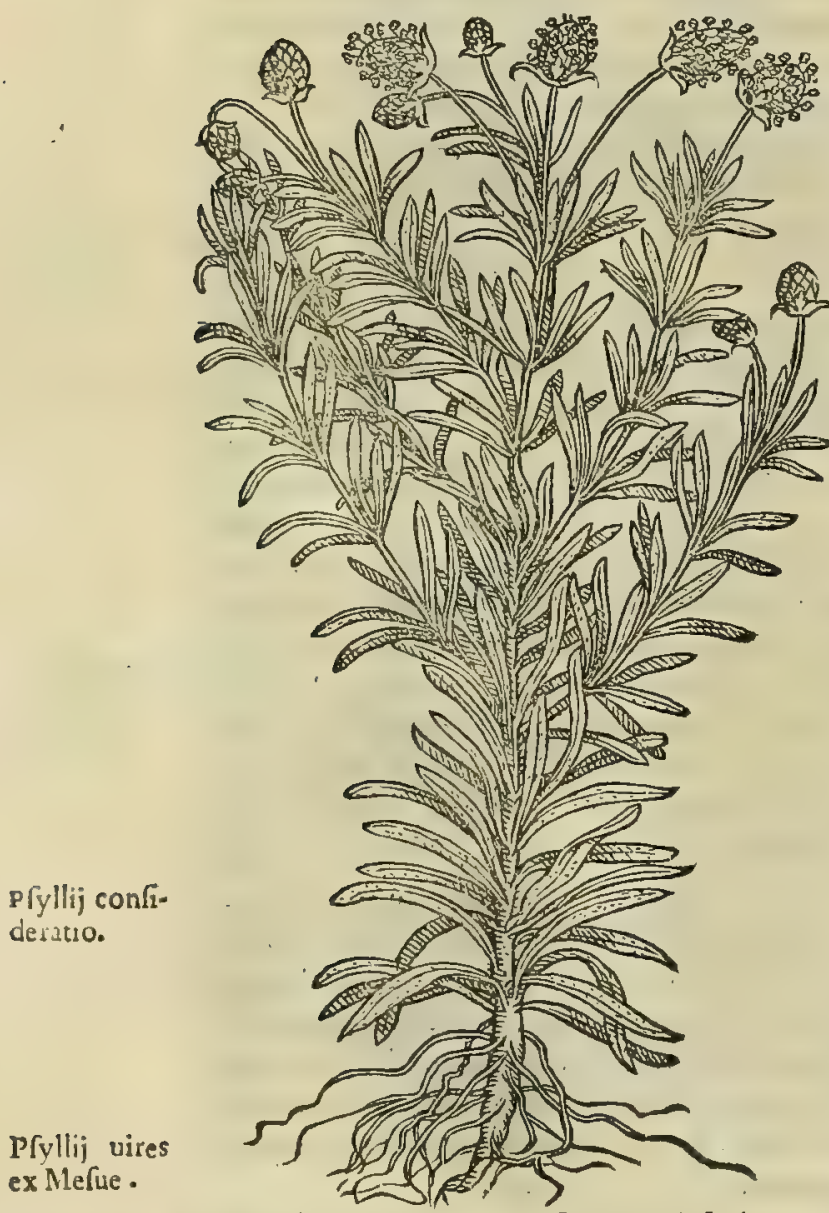

PS Y L L I ON folijs eft soronopo non difsimilibus, hirfutis, longioritus. farmentofa fœni modo in totum herbula, ramis dodrantalibus : coma à medio caule exoritur, duobus tribúsve conuolutis in cacumine capitulis: $n$ his femine duro, nigro, puticum fimili, unde \& nomen. in aruis, \& incultis nafcitur. Vis ei ad refrigerandum, infpiffandum, \& molliendum conue- 30 niens : articulorum morbis, parotidibus, tuberculis, tumoribus, luxatis, illitum auxiliatur : imponitur in dolore capitis, cum rofaceo, aqua , aut aceto: enterocelis infantium, \& prominent umbilico, illitum ex aceto me detur. Tcritur acetabuli menfura, $\&$ in aqua fextario madefactum, ubi concreuit aqua, illinitur : fiquidem uchementer refrigerat, $\&$ in feruentem aquam deiectum calorem reprimit contra ignes facros efficax eft. Fama eft, fi uirens domutm importetur,non finere in ea pulices gigni. Cum adipe tufum fordida ulcera, \& quę 40 cacoêthe uocantur, expurgat. Succus uermiculofis auribus, aut fluxione laborantibus, ex melle prodeft.

P S.Y I I I V M, quod OO Pulicariam herbam nuncupant, ubiq; feré prouenit, fed in maritimis frequentius. Seplafie femen recondunt ad glutino fos liquores conficiendos, quibus in infrigi= dandis inflammationibus, probibendisq;; calidis defluxionibus, or ad extinguendam fitim, leuigandam '́; linguam, or faucium $\int_{c d}=$ britiem; in ardentißimis fe bribus utuntur medici; quinetiam ad al= uum emolliendam. Psyllij uires retulit Mefues inter ea medica= menta, que deictoria ui pollent, ubi hec ad fenfum faltem babet. Psyllium de bis eft, qua temperamentum immutant, 6 qua emol= licndo aluum citant. Huius feminis tria babentur genera, candic ans, fubflaum, ơ ad purpuram, uergens. Preftan= tius perfecte maturum, ponderofum, $\mathcal{O}$ quod in aquam demiffum fatim inum petit. Contrarijs conftat cum uiribus, tum fubftantijs: ea fiquidem, que in medalla continetur, calida $c f$, e ficca ordine quarto, adinodum acris, inci= dens, cxulcerans, feptzca, or deleterix facultatis. Que ueró in cortice refidet, tefte $\mathrm{R} u$ fo, infigidat, humectatí;

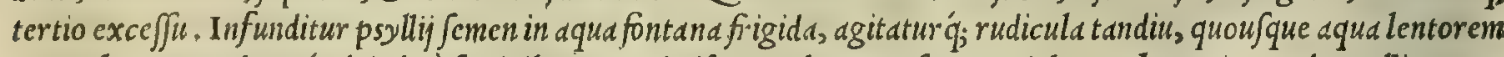
contrabat, percolatur'́; deinde à feminibus, er admifcetur olco, aut fyrupo violaceo . boc enim modo psyllium po= tu aluum mirificé emollit, er deijcit. Verim fi frixum prius fcmen rofaceo adinifum eodem modo agitetur, tunc fumptum dyfentericis remedio eft, $\sigma$ cateris alui fluoribus, prefertiniq; ijs, qui deiectorio medicamento exu= perante baufto fuperueniunt, fed pracipué acri, qualc eft fcammonium. Caterum maxiné animaduertendum est, ne 


\section{In Lib. quartum Diofcoridis.}

Psyllij femen (id quod tamen detefantur recentiorum quidam) tufum in puluerem potandum exhibeatur. Quippe quod, attrita medullari fubftantia, uentriculum, e intestina exulcerat: iecur, ev fanguincm inflammat, e omnia deniq; wifcera ledit. Intcgrifeminis dilutun co modo, quo diximus, paratum bilem deijcit: eáq; propter ardentifi= mis febribus, intolerabili fiti, inflamnatis ualde piritibus, or fauciun, or pectoris appertatibus mirifice medetur. In aceto diu agitatum infanmatione, igni jacro, o berpetc laborantibus auxiliatur, exterius illitum: priuatim, pro deft capite dolentibus fronti impo/itum, fi tamen dolor à caufa calida fuerit excitatus. Hec ex Mefue decerp/imus.

Psyllij uires puxcis perftrinxit Galcnus libro v I 11 . fimplicium medicamentorum, fic inquiens. Psyllij femen ad= Pfylliis uires modum utile cft, ex fecundo refrigeraitium ordine a in deficcando ueró, e bumectando medium quodammodo cft, ct ex Galeno.

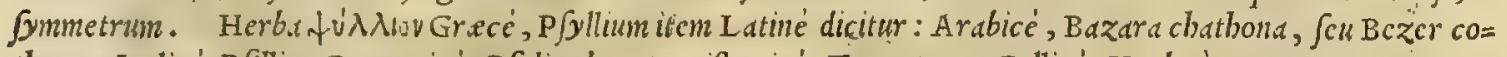
1. thume:Italicé, Pfillio: Germanice', Pfylienkraut : Hifpanicé, Zargatona: Gallicé, Herbe à puces.

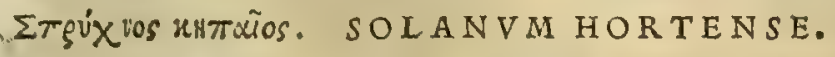 \\ CAP. LXVI.}

HoR T E N E Solanum frutex eft cibis idoneus, exilis, pufillus, multis concauus alis : folio nigro, maiore quàm ocimi, \& latiore: fructu rotundo, uiridi, qui poft maturitatem nigricat, aut fuluefcit: herba innocentis guftus. Natura ei refrigerandi : quare folıa vlceribus qux ferpunt, \& ignibus facris, conuenienrer cum polline polentre illinuntur . æagilopia, capitisq́ue dolores, trita \& impofita per fe fanant: $x$ ftuanti ftomacho auxiliantur : parotidas cum fale detrita illicu difcutiunt. Valet fuccus eius aduerfus ignem facrum, atque ulcera qux ferpunt, cum cerufla, rofaceo, $\$$ argenti fpuma :

20 ad agilopas cum pane : infantium aduftioni, quam fyriafin vocant, cum rofaceo perfufus proficit: in collyrijs, aqua vel oui vicem exhibet, contra acutas fluxiones illitus : aurium dolori inftillatus prodeft . menfium abundantiam fiftit in vellere fubditus. Succus fuluo gallinarum cortalium fimo fubactus, '\& linteo appofitus, ægilopijs prafentaneo eft remedio.

SOLANVM HORTENSE.

ya

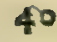

so

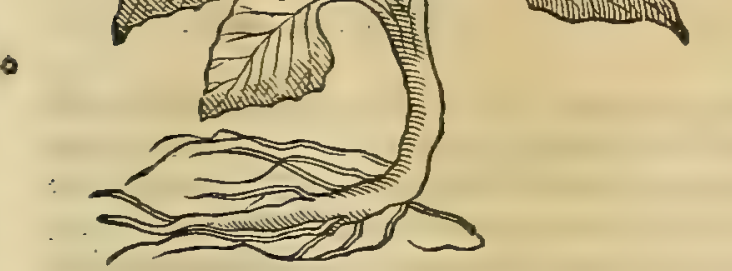

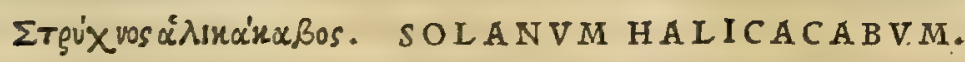

SOLANVM HALICACABVM.

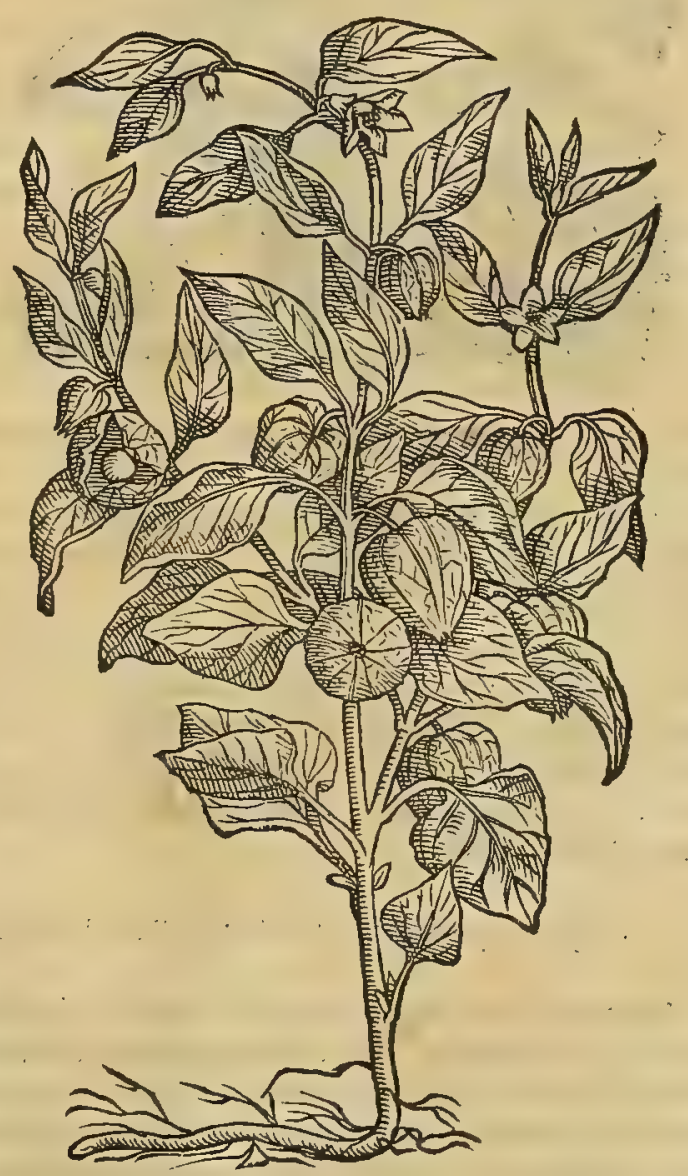

CAP. IXVII.

ES T E T aliud Solanum, quod peculiari nomine halicacabon, aut phy falida, id elt veficariam vo cant, folijs antedi\&to fimilibus, verùm latioribus : cuius caules, pofteaquàm adoleuerunt, prona terram fpectant : folliculis orbiculatis, veficulis fimilibus : in quibus femen continet fulüum, rotundú, læue, acinorum vux figura: quo coronarij vtuntur, corollis intexentes. Vim, vfumq́ue hortenfis 
folani habet:verùm cibis nequaquam expetitur. Regium morbum purgat, femine poto, \& $v$ rinam pellit. Ex utraque herbą fuccus extrahitụr, qui ficcatus in vmbra reconditur, ad eadem. valens.

SOLANVM SOMNIFERVM,

SOLATRVM SOMNIFERVM.

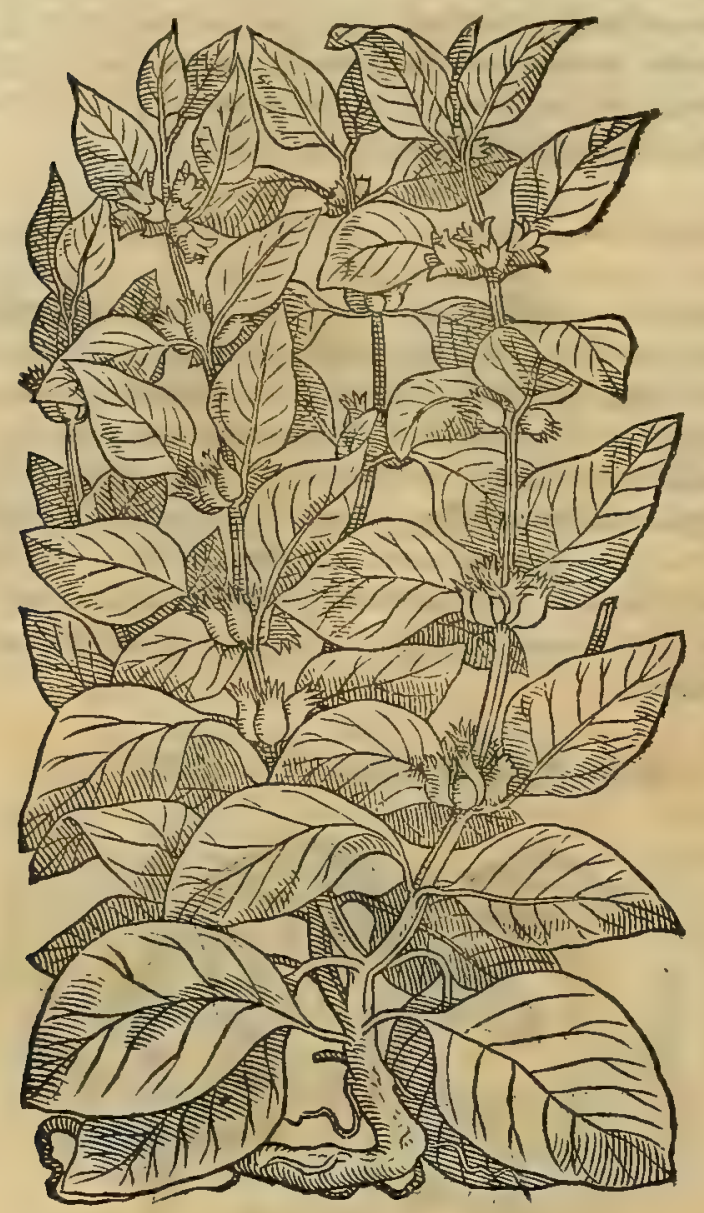

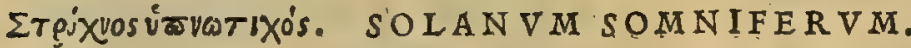

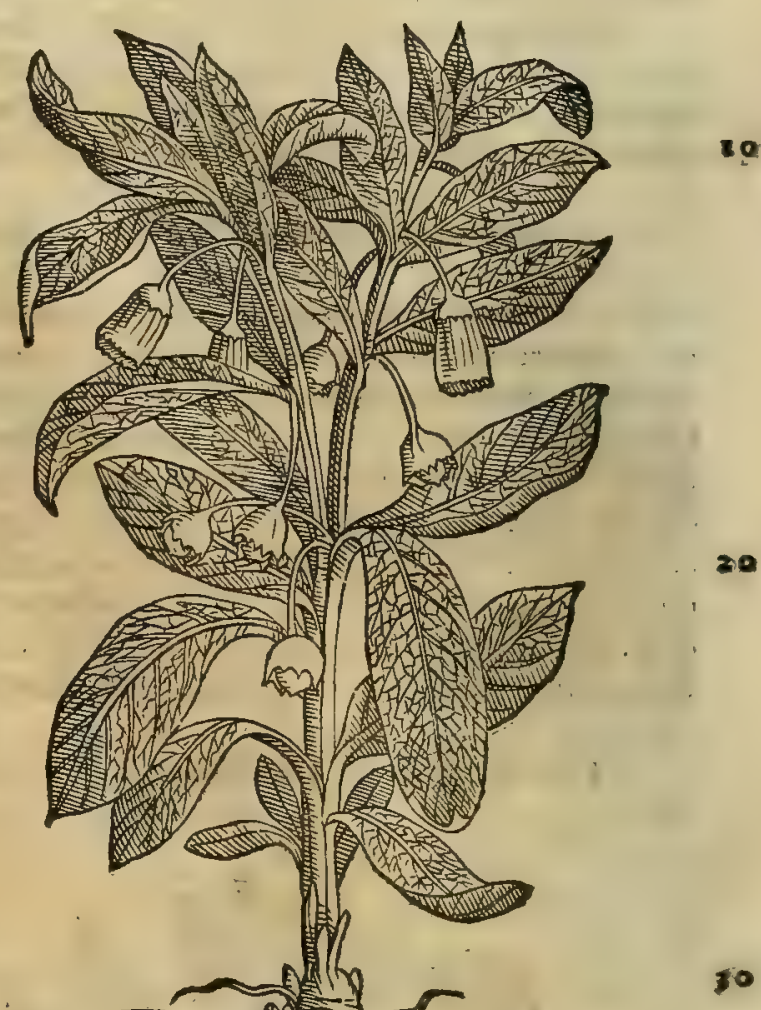

CAP. LXVIII.

S O L A N V M fomniferum, aliqui etiam halicacabon appellant, fruticat multis ramis, denfis, caudicofis, fractu contumacibus, pinguium foliorum, cotonexáue mali fimilium plenis : flore grandi, rubro: fructu in folliculis crocato : radice grandi, fubrubro cortice veftita. nafcitur in faxis, non procul à mari. Radicis cortex, in uino drachma pondere potus, fomnificam uim habet, opio mitiorem. Semen vehementer urinam cit. Corymbi duodecim hydropicis dantur: fi quid numero adijciatur, alienationem mentis faciunt. Remedio eft aqua copiofa mulfa, potui data. Succus paltillis inferitur, \& medicamentis, quæ doloris leuamentum præbent . decoctus in uino, fi in ore contineatur, dentium doloribus auxiliatur. Radicis fuccus, cum melle illitus, oculorum hebetudines tollit.

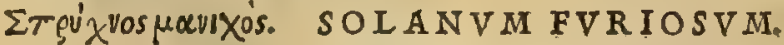

\section{CAP. IXIX.}

So I A v M manicon, aliqui perfion, alij thryon appellauere. Huic folium erucæ fimile, maius aliquantò, fatis acantho, quàm paderota vocant, accedens: caules à radice proceros emittit decem aut duodecim, vlnx altitudine adolefcentes: caput in cacumine oliux figura, fed ut platani pilul $x$ hirfutius, uerùm maius, latiusq́ue : florem nigrum : poftquàm eo exuitur, racemus exit rotundus, niger, denis aut duodenis acinis cóltans, fimilibus hederæ corymbis, vt uux mollibus : radices firmatur candida, craffa, calı, cubitali. gignitur in montibus, vẹnto perAatis, \& plataneatis. Radix drachmæ unius pondere pota ex uino, facit fpecjes vanas, imaginationesq́; non iniucundas abuerfari: fed duplicatus hic modus, ad tres vfque dies mentis alienationem affert : quadruplicatus interimit. Remedio cft aqua mulfa copiofiùs pota, \& vomitione reiecta. 


\section{In Lib. quartum Diofcoridis.}

$\mathrm{E}^{\prime}$ QV A I V O R Solanigeneribus, que hic ḋ Diofcoride defcribuntur, etfi in commentarijs, quos antea I td= Solani generû lico fermone confcripfi, me duo tantim genera nouiffe prodiderim, bortenfe fcilicet, $\sigma$ quod aliqui Halicacabum, confideratio. alij Veficariam uocant; hoc tamen anno tertium, quod Somnifirum appellat, $\mathrm{p}$ ifis ad nos mifit uir reimedica eru= ditione clarus Lucas Ghinus Forocornclienfis: id q́; mihi plane ommibus not is legitimo reftondere üidetur. Verime quartum Solanigenus, quod Municum cognomiliant, bactenus me non uidife fateor. Caterimeriant, med quidem fententia, qui eam pluntun, quam berbariorum uulgus Solatrum maius nominat, Veneti ueró unlgó Herba

HERBA BELIA DONNA.
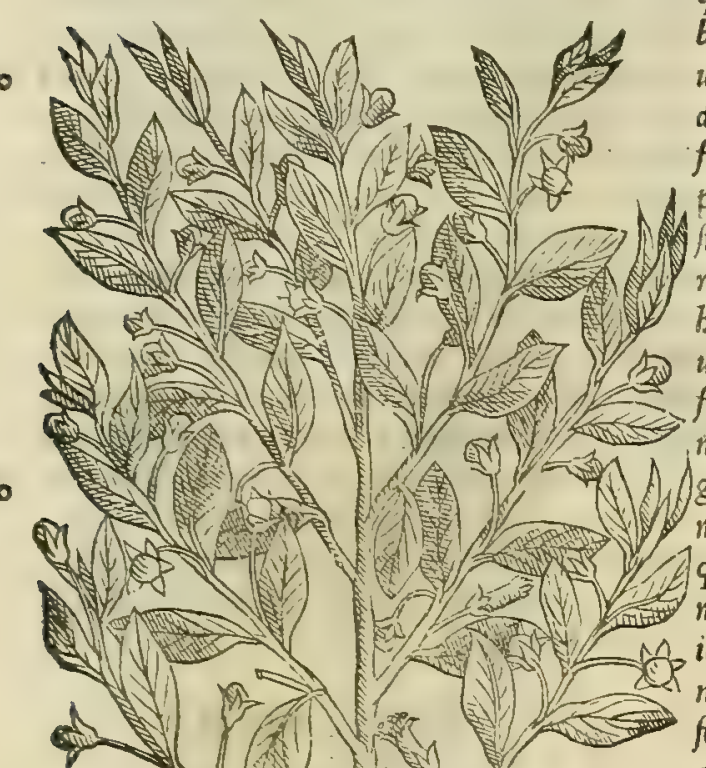

bella donna, Solanum fomnificum Diof coridis effe existimant. Si= quidem id fructum non profert in folliculis croceum, tanetficius baccee largius fumpte interficiant, facto inexpugnabili fomno, ut quandoque accidit pueris, qui difcriminis ignarieas unc uice devorarunt. Vnde quanuis be plante uiribus conuenire poßint; facie tamen inter fe maximé diftant. Horum fententie adfti= Fuch. error. pulatus eft Fucb/ius medicus alioqui peritißimus, in fuo magno de firpium biftoria commentario. Sed cum in boc fe manifeste er= raffe deprebendifet, in fuo poftea paruo plantarum libro, hanc berbam in Mandragoras repofuit, eam q; Mandragore peciem uoluit effe, quam Diofcorides Morion uocari tradit, lapfus, ni fallor, de uno in alterum errorem. Mandragora fiquidem nomi= ne Morion, folia fert mandragore mari fimilia, dodrantali lon= gitudine, terre procumbentia, circa radic is fummum. Id quod manifftum prebet indicium, hanc perpetuó caule uiduam effe, quemadmodum catera mädragor genera. nam pediculi, quibus mandragore fructus fuftinentur, caules dicinon po funt. Hinc itaq; fit, ut plantam banc, qua uulgó Bella donna uocatur, in nullo Mandragora genere legitiné referendain putem : cum bec folia emitat hortenfi solano maiora, palmi menfuram nunquame excedentia, minimé candicantia, nec bumi ftrata, fed in caulibus exeuntia, adnatis plurinis refertis, bicubitalibus, o ligni modo preduris. Quinimó crediderim ego, banc effe soldni quintam ßpe ciem, antiquis friptoribus incompertam . Nam, quantum equidĕ longa experientia comperi, uaria ac diuerfa Solani reperiuntur genera. Somnifici, er manici solani meminit Theophraftus lib. I X. cap. X II. de plantarum biftoria, ficcinquiens. Solano= rum genera duo. Alterum fomnificum, radice rubra, fanguinis modo, ed candida cum ficce cit : fruotu cocco rubriore : folio ti= thymalo fimili, aut malo dulci, fed pilofo, o parte ima magno. Huius corticem radicis tundentes admodum, $v$ in uino meracu= to madefacientes dant; atque ita dormire faciunt. Nafcitur in rupibus, of faucibus, at $q_{;}$fepulchris. Alterum genus infanire facit . id alij Bryoron wocant, alij periffon. Conftat radice candida, or longa ad cubitum, atg; caua. Dabi= 40 tur cius radicis dracbme pondus, fi ut quis ludat, fe q, pulcherrimum putet, placuerit : at fi magis infaniat uis, drachs= mis duabus opus ef: : in autem nunquam infania folui malueris, tres dabis: 00 quatuor, fi interimendum fit. Habet folium eruc proximum, maius tamen: caulem longitudine feré quatuor cubitorum : caput gethyi, fed maius, atque pilofius: nec fructui platani abfimile conftat. Eft or aliud Veficarie genus, quod bac tempeftate fcenas, atte= gias, tuguria, o pergulas inumbrat: quinetian adium feneftr as topiario opere contexit, or opacat. Constat hac fo $=$ iijs oblongis; per ambitum laciniatis: floribus candidis, é quibus ueficula prodeunt, in quibus femen includitur albü, pifi fimilitudine, in cuius medio ueluti humani cordis effigies uifitur, obfignata nigrocolore. Nec fine ratione id \& natur a fafum conijci poteft, quod fortaffe huiufce cordis nota nobis infinuet, banc ftirpem ad cordis affectus maxi= mé preftare. quemadmiodum er in Echio herba contra uiper arum mor fus celeberrima, femen uiperinis capitibus fi mile procreauit. Refertur etiámnum inter solani genera alia quadam planta S T R A M O N I A multis wocd= so $t a$, adeó Solano fimilis, ut nil aliud, qudm ip fum reprefentet, uerum eius folia opium redolent. Flores, qui fuauem lilij odorem pirant, gerit hec albos, emulos conuoluuli illius, qui compluribus reiberbarie imperitis Liguftrum falsó dicitur. Fruizus eicircunquaq; pinofus, umbilicatusóp, colore uiridi. Folia folanum quadantenus refrunt, maiora tamen. Quo factum eft, ut quidam exiftimaucrint, banc uiribus foldno non dißimilibus preditam effe. So= Iani fingulis generibus uires reddidit Galenus libro v I I I. fimplicium medicamentorum, ubi itd fcriptum reliquit. solanum efculentum, quod in bortis na fcitur, notum est omnibus, utuntur '; ad omnia ed, qua refrigerari, or ad= ftringi poftulant: poteft enim bae duo ordine fecundo. Ceterorum uerò non efculentorum unum quidem nuncupatur Halicacabum, fruttum babens rufum, dcino uus tum figurd, tum magnitudine ad/imilem: quo etiam ad coronas u=

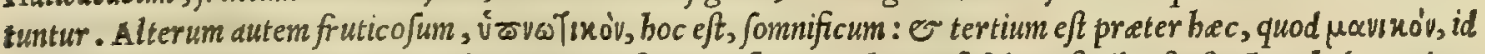
eft, furiofum appellitant. Halicacabum igitur in foliorum facultate bortenfif folano fimile eft, fructum babens ciens de urine idoneum : proinde multis compofitis facultatibus, que ad iecur, ad ueficam, $\mathrm{e}$ renes accommodantur, wijcetur. Solani ueró fomnifici cortex rddicis, /i cum uino bibatur, fomnum accerfit drachma pondere fumptus. 
STRAMONIA.

Nomina.

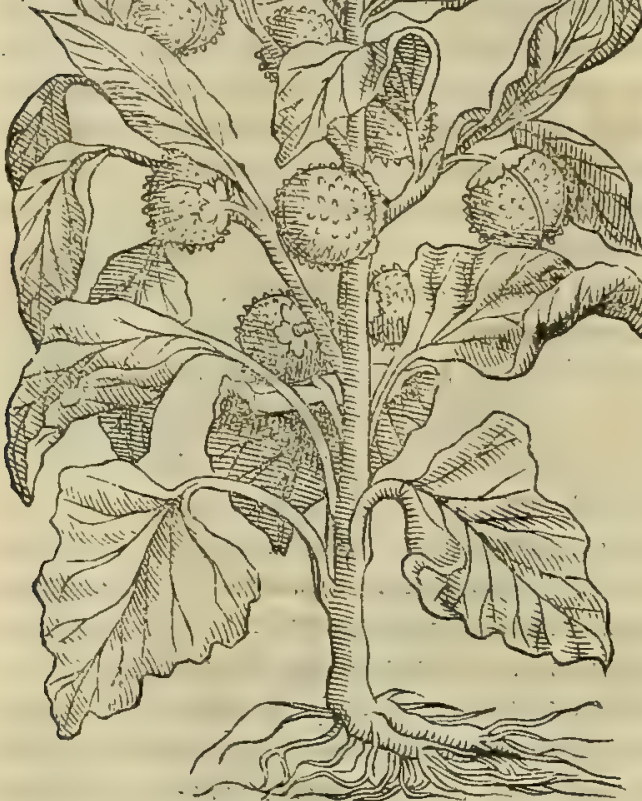

Sed o ad catera quoq; papaueris fucco perfimilis eft : nifi quodd coufque imbecillior eft, ut ipfe tertij babeatur ordinis refriger an tium, cim bic in quarto fit conftituius. Huius foldni femen urinam ciendi uim habet. Verum fi plus duodecim corymbis hau feris, de= mentiam furiánue adfcifcet. Porró quod reliquum eft ex dift is Solanis, ad medicationes, que intró in corpus adbibentur, inutile eft. Nam fi quatuor eius dracbin.e fumpte fuerint, mortem infe= rent: fi pauciores infaniain. Vna certé innoxie fumitur: cete= rim nec ipfa utile quid obtinet. Verim fi foris corpori emplaftri Amodo illinatur, ulcera maligna, er depafcentia curat. Sed ad 10 talia radicis cortex optimus eft, deficcans fecundo ordine iam cä= pletó, or tertio incipiente : refriger ans ueró fec undo incipiente.

Illud folanigenus, quod Gr.ecis spúxyos xнтта丿іоs, Latinis Solanum bortenfe nominatur: Arabibus, Hamebathanaleb, $\mathrm{Ha}=$ meb alchabaich, fiue Hanab althaleb: Italis, Solatro hortolano: Germanis, Nacht fchadt: Hipanis, Yerua mord: Gallis, Mo=

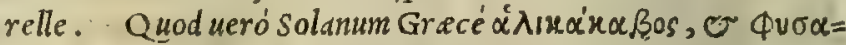
$\lambda$ is, Latine Halicacabus, et Veficaria appellatur: Arabicé, Ke= liengi, Alleliengi, fiue Kekenegi: Italicé, Halicacabo: Ger= manicé, I uden Lirfen: Hipanicé,Bexiga de perro: Gallicé, $\mathrm{B} e=20$ guenaudes. Quod deinde Gracis sevixvos vínvatixo's, Lati= nis solanum fomniferum dicitur: It alis, soldtro fonnifero. Quod denique Grecé spí $x$ vos pavirós, Latiné Solanum furiofum uo catur: Italice, solatro furiofo.

\section{$\triangle 0$ รุixuloy. DOR YCNIVM. C A P. I XX.}

D.OR Y C N I o Crateuas halicacabon, aut caleam vocat . frutex olex nuper prodeunti fimilis, Nafcitur in petris non proculà mari, ramis cubito minoribus : folijs olex fimilibus colore, minufcul is, frrmioribus, præter modum fcabris : flore candido: filiquis in cacumine, ceu ciceris, denfis, rotundis : quinis intus aut fenis feminibus, exigui erui magnitudine, lxuibus, firmis, verficoloribus . radix ad digiti crafsitudinem, \& cubiti longitudinem adolefcit. Id fomniferum cfle conftat. Copiofius hauftum mortem adfert. Nec defuere qui dicerent, femen in amatoria expeti.

Dorycnii cöfideratio.

D ค R Y C N I V M, Crateud teftimonio, inter faxa in maritimis nafcitur, folijs cum forma, țum etiam "colore olius proximis. Verim mibi hactenus non contigit ipfum inuenire, aut inuentum uidere: quanuis in eo quoq inquiren do multum laboris infumpferim. Caterumballucinantur, meo quidem iudisio, qui putant Dorycnium effe eam Ve=40 ficariam, que femine eft rotundo, albo, macula cordis effigie infignito : cuius hiftoriam inter solani.genera prece=

Vires ex Ga- denti capite retulimus. Siquidem hac Dorycnio omnibus feré notis repugnare deprehenditur. Dorycnij meminit leno. Galerus lib.v I. fimplicium medicamentorum, ubi de eius uiribus ita fcrit . Dorycnium temperamento papaueri fimi= le eft, o mandragora, o ijs qui fic refrigerandi uim habent: excellit aquea frigiditate admodum efficaci. Quam=

Nomina. obrem modicum quidem foporem conciliat : largius ueró fumptum interimit. Id $\delta$ o $_{3}$ vinviov Graci, quod Dorycnium quoque Latini wocant.

\section{Mävógxyópxs. MANDRAGORAS.}

CAP. LXI.

M A N D R A G O R A M, aliqú antimelum, alij circæam uocant, quoniam videatur radix ad amatoria conducere. Duo eius genera . niger, quæ fomina exiftimatur, thridacias appellatus, anguftioribus folijs, ac minoribus quàm lactuca, uirofis ac graueolentibus, in terra fparfis : mâla gerit forbis fimilia, pallida, odorata, in quibus femen ueluti pyrorum : radicibus inhæret bene magnis, binis, ternísve, inter fe conuolutis, nigris forìs, intus albis, craffo cortice veftitis ; caulem non fert. Alter candidus, qui mas dicitur, nonnullis morion uocitatur . huius folia magna, alba, lata, læuia ut betæ: mâla quàm alterius duplò maiora, colore in crocum inclinante, iucundè cum grauitate quadam olen tia, quorunı pomorum cibo aliquantùm opiliones foporantur : radix alterius limilis, maior \& candidior, orbata \& hæc caule. Succus fit è cortice recentis radicis tufo, \& prælis fubiecto: qui. infoJatas, vbi concreuerit, fietili reconditur. Mâlis quoque fuccus depromitur, fed aliquantò ignauior. Delibratur radix, \& traiectus lino cortex, ad ufum fufpenditur. Aliqui radices in uino ad rertias coquunt, \& defæcatum ius feruant, cyathoqque vno utuntur in peruigilijs, \& doloribus, \& ante fectio- 


\section{In Lib. quartum Diofcoridis.}

MANDRAGORA MAS.

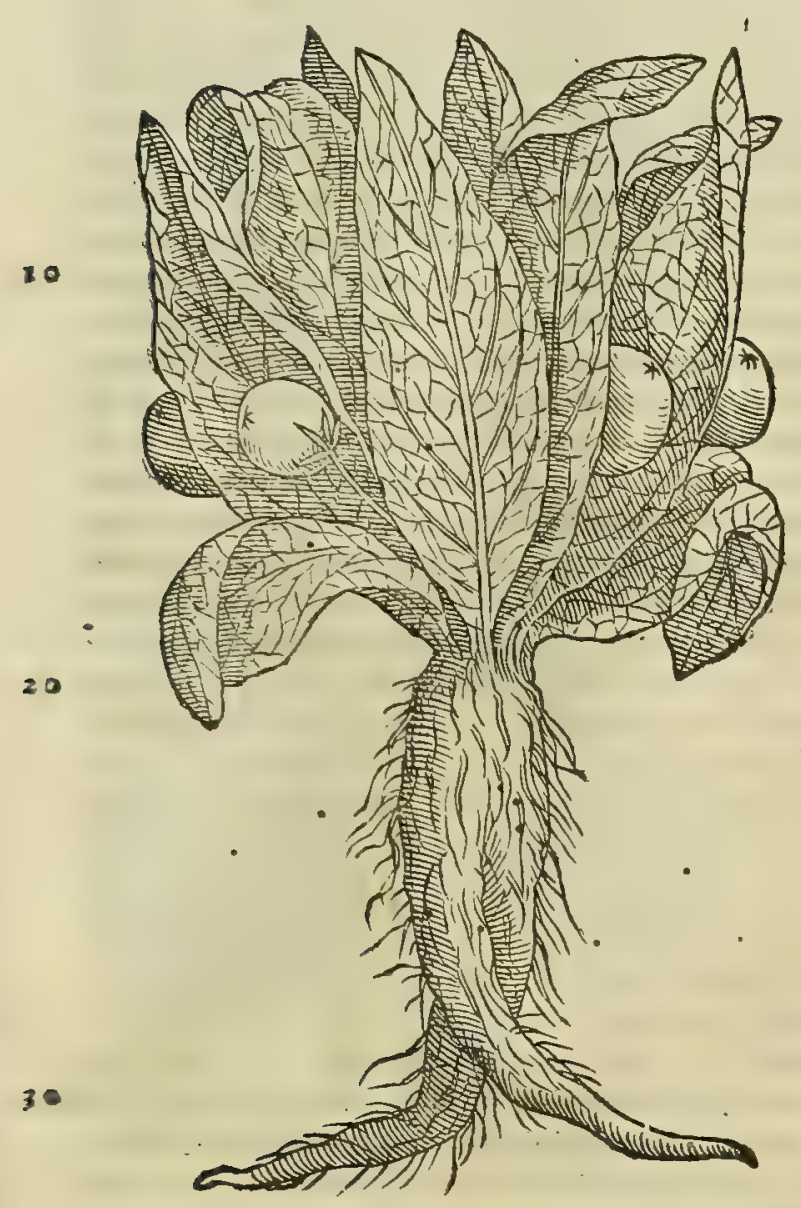

MANDRAGORA FOEMINA.

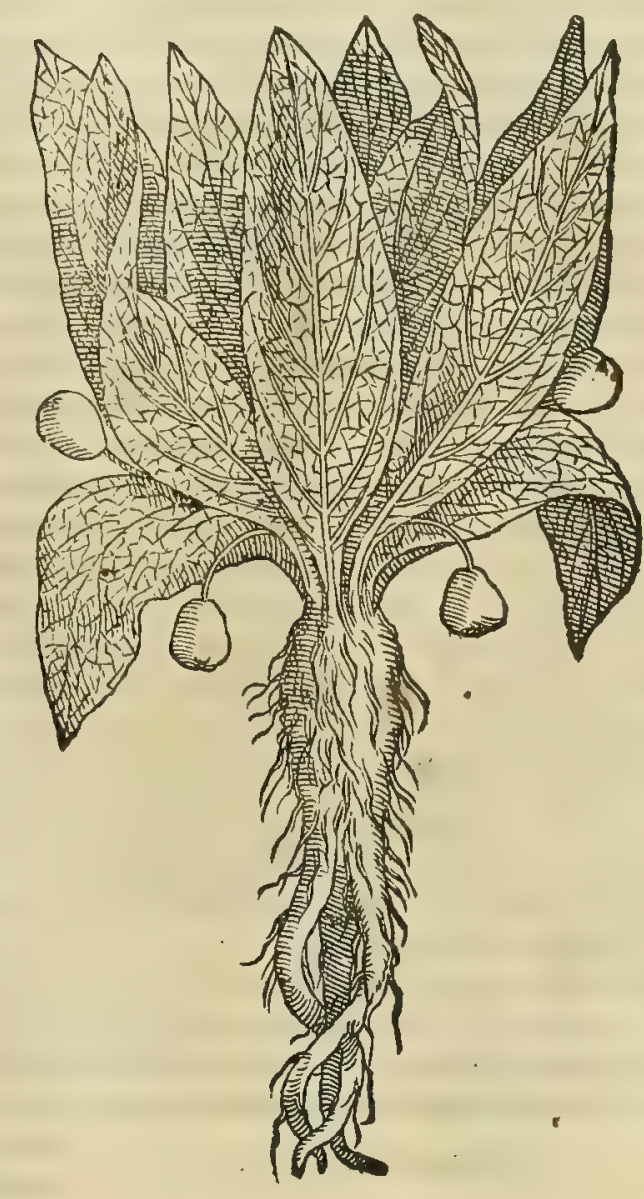

nes, vftionesq́ue, ne fentiantur. Succus duobus obolis ex mulfo potus, vt ueratrum, per uomitiones bilem atram, pituitamq́ue extrahịt: verùm potu largiore vita adimitur. Medicamentis ocularibus, $\&$ his quæ dolores finiunt, pefsis quoque emollientibus, admifcetur : femioboli pondere inditus, per fe r.enfes, \& partus expellit : fubditus fedi pro balano, fomnificus eft. Radix ebur emollire fertur, quæ fenis horis cum eo decocta fit: \& ad accipiendam quam effingere optaueris formam ipfum facilè præftat. Folia recentia conuenienter oculorum inflammationibus, \& collectionibus, quas 40 vlcera citarunt, cum poienta illinuntur: duritias omnes, fuppurationes, ftrumas, \& tubercula difcutiunt: Atigmata fine exulceratione delent, fi quinis, fenís ve diebus fenfim perfricentur. Folia feruantur in murijs cofdem ad vfus. Trita radix ignibus facris ex aceto, \& ferpentium ictibus ex melle, aut oleo medetur: ftrumas, atque tubercula cum aqua difsipat : articulorum cruciatus, cum polenta fedat. Fit citra coctionem vinum è cortice radiciş, ad hunc modum. Ternæ minæ in vini dulcis metretam conijciuntur. Dantur ex eo terni cyathi, ijs qui fecari, aut amburi debent, vt antè dictum eft: fiquidem nullo tunc afficiuntur dolore, fed veterno quodam prefsi torpefcunt. Mâla foporem afferunt olfactu, \& etiam fi mandantur : item expreffus ex eis fuccus . nimio tamen odore percufsi, abmutefcunt. Semen mâlorum potum vuluas purgat : appofitumq́ue cum fulphure ignem non experto, rubra fominarum profluuia fiftit. Scarificata, punctisq́ue multifariam aperta radice erumpens

so lacryma, cauo vale recipitur. Liquamentum autem fucco lasteo præftantius eft. fed non vbique, vt experientia docet, radices lacteum fuccum dclacry mant. Alium tradunt effe mandragoram, nomine Morion, in opacis iuxta fpecus enatum : folijs albi mandragoræ, minoribus, albis, dodrantalibus, radicem ambientibıs: qux mollis eft, \& candida, paulò maior palmo, pollicemq́ue crafsitudine æquat. Tradunt eam in pane, offa, obfonióve drachmæ pondere deuoratam, vfum rationis intercipere. obdormifcit enim homo, eo ferè quo comederit habitu, fenfus impos, ternis quaternísve, ex quo data elt, horis. Hac medici vtun tur cùm fcindendi, vrendívenecefsitas adeft. Antidotum effe volunt radicem, cum manico folano potam.

MA IT D R G O R AE utrunque genus frequens nafcitur in compluribus Italia locis, prefertim in Apulid Mandragore Gargano monte, unde radicum cortices, $\odot$ poma berbarij quotannis ad nos conuebunt. Habentur $\odot$ in uiridarijs Ppectaculigratia . etenim Neapoli, Rome, $\mathcal{E}$ Venetijs utranque. Mandragoram in bortis 0 uafis fictilibus fatam ui= 
dimus. Sed profectó uanum ac fabulofum eft, quód Mandragore radices ferant, qua humanam effigiem repres: fentent, ut ignarum uulgus, or fimplices muliercule certó credunt, or affirmant. Quibus etiam perfuafum eft, eds effodi haudquaquam poffe, nifi cum magno uite periculo, cane qui effodiat, radicibus adalligato, er auribus pice Mandragors obturatis, ne radicis clamorcm audiant effodientes, quod audita uoce periclitentur, pereant $\dot{q}$; foffores. Quippe ra $=$ humana for- dices ille, que bumanam formam referunt, quas impoftores, ac nebulones quidam uenales circunferunt, infocundas mafactitia. mulicres decepturi, factitia funt cx barundinum, bryonia, aliarum'; plantarun radicibus. Sculpunt enim in bis ad= huc uirentibus tam uirorum, quàm mulierum formas infixis hordei, $\sigma^{\circ}$ milij granis, ijs in locis, ubi pilos exoriri uo= lunt: deinde facta: fcrobe tandiu tenui fabulo obruunt, quoufque grana illa radice smittant: id quod fiet uiginti ad fummum dierum patio. Eruunt eds demum, $\sigma$ adnatus é granis radices acutißimo cultello fcindunt, aptant $\dot{q}$; ita ut capillos, barbam, or ceteros corporis pilos referant. Huius fané rci certam fidem facere poffum, quód cùm Rome 0 effem, impoftorem quendam circunforaneum lue Gallica correptum nobis curare contigit, qu pratcr alias innume= ras impofturas, quibus circumuentis bominibus multam pecuniam extorquent, docuit $\sigma$ artem, qua factitias fibi com= parabat Mandragoras. quarum complures mibi demonftrauit, afferens unam tantum interdun diuitibus uendidiffe quinque or uiginti, nonnunquan etiam triginta aureis. Quamobrem nos, qui omnium utilitati er faluti quantum pof= fumus confulimus, bec filentio baudquaquan inuoluenda duximus, ut palam omnibus fiat, quibus fallacijs ac fraudi= bus maximo cum detrimento, or uite e epe difcrimine homines ab bis impoftoribus, or nebulonibus decipiantur. Qui ut antiquorum quoque authoritate fuas impofturas adftruant, pradicant Pythagoram uocaffe Mandragoram Anthro pomorphon, quód eam humanam formam reddere uoluerit. Veruin fciendum eft, non fine ratione Mandragoram ita ¿' Pythagora dictam fuiffe quippe quód in uniuerfum omnes feré Mandragore iradices à medio ad imum bifurcate proueniant, adeo ut crura hominum modo babere uideantur. Quapropter fi eo effodiantur tempore, quo fructum 10 gerunt, qui mâli instar fuper folia ad terram procumbentia breui pediculo appen fus, parum à radice distat, hominis, cuibrachia defint, éffigiem quadantenus reprafentant. Hanc quidem rem nulli, quod fciam, uel pauci funt, quire= Á acceperint. Quin potius plerique buius fententic ignari ddducti funt, ut Pythagore, or Columelle id maxime uitio uerterint, ut qui cos de Mandragora fabulatos effe crediderint. Sed ut ad fabulam illam redeamus, qua pericu= lum denunciat ignaris radices Mandragore effodere uolentibus, ijs cane qui effodiat, non adalligato, ea mibi qui= dem defumpta uidetur à Flano Io epho: qui et fi de alio radicis genere fcribat, ea tamen potuerunt facilè ab impo= ftoribus in Mandragore radices transferri. Quod ut omnes clartus intelligant, bic Iofephi uerba fubijcian, qua lib. v I I. cap. X X v. de bello I udaico ita fcripta funt. Vallis, inquit, qua ciuitas à parte feptentrionali cingitur, quidam locus Baaras appellatur, ubiradix codem nomine gignitur, que flammx quidem adfimilis est colore, circa uepperam werò ueluti iubar fulgurans. Accedentibus, eamó; cuellere cupientibus facilis non es, , fed tandiu refugit, nec prius

MEIANZANE.

Hermolai $t$ u tela.

Mâla uulgò Melanzane.

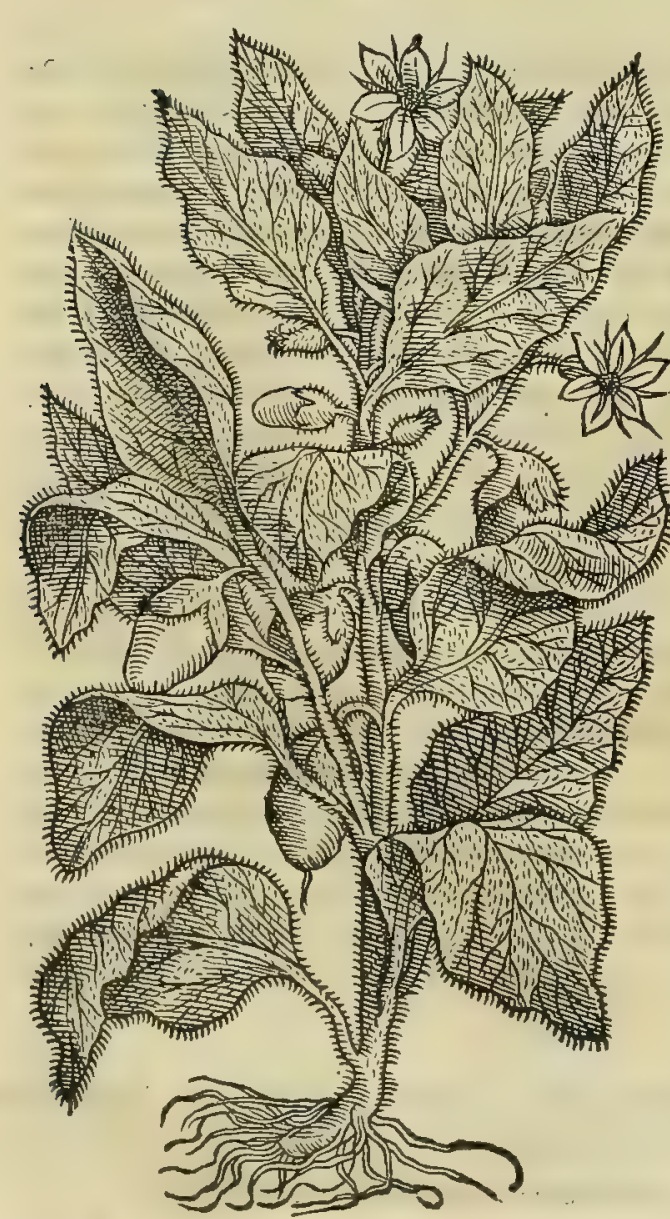

manet, quam-fi quis urinam muliebrem, uel menftruum fangui= nem fuper eam fuderit. Quinetiam tüc fiquis èm tètigerit, mors certa e/t, nififorté illam ipfam radicem ferat de manu pendentem. Capitur autem alio quoque modo fine periculo, qui talis est. To: tam cam circunfodiunt, ita ut minimum ex radice terra fit condi= tum: deinde ab ea religant canem, illoq́; fequi eum à quo religa= tus est cupiente, radix quidem facilé euellitur, canis ueró conti= nuó moritur, tanquam eius uice, à quo tollenda erat, traditus: nullus enim posted accipientibus metus est. Tantis autem pericus. lis propter unam uim capi ean operapretium est. Nam que uo= 40 cantur demonia, peßimorum bominum piritus, uiuis immer $\int a$, cosq;; necantid, quibus fubuentum non fuerit, bac cito, etiam/i tan tummodo admoueatur egrotantibus, abigit . bactenus Iofephus. Ex cuius utiq; uerbis onmibus perpicuum effe potest, quod binc impostores occafionem acceperint, qua postea uanam ac falfam de Mandragora radicibus commenti funt bistoriam. Caterum tertium Mandragore genus, quod Diofcorldes Morion appella= ri tradit, in opacis iuxta pecus proueniens, qui mibi ostenderet in Italia, bactenus reperi neminem. Brajarolus, item $q_{;}$Fucb= fius Hermolaum immeritó, meo quidem iudicio, damnant, quod ui rum bunc in ea fententia fuiffe uelint, ut putauerit mâla illa, que Infubribus M E L A Z A N E unlgó nocantur, noftris ueró Hetrufcis Petranciani, effe buius tertic Mandragore fructus. Sed quod hec non fuerit certa ac firma. Hermoldi fententid, cius uerba abunde testa ri poterunt, qua in fuis corollarijs de Morio ita fripta inuenio. De Morio, inquit, mandragora nibil babeo quod addi poßit ïs, qux à Diof coride notantur. Sed quoniam ma la terreftria $\sigma^{\circ}$ canina Mandragore fructus appellantur, in men tem fubeunt, que uulgó Melanzand uocitamus, boc cft, ut ip $\sqrt{e}$ puto, mala infana: de quibus nibil ueteribus fcriptum fuiffe iam defino mirari, quód multa buiufmodi reperio, ficut bercle multa 


\section{In Lib. quartum Diofcoridis.}

quond an fuetre, qua modó uel ignorantur, uel certé non habentur. Mala ergo infana é frutice unlgari funt, paßim majcente, ut inelones, o cucurbite: parı quow; cultu, folijs propé ficulncis : flore oblongo, ßpeciofo, candido. Man= ditur uulgó poinum ex oleo, file, pipere, fungorum modo coctum. Hac ad uerbun Hermolaus. Ex quibus equidem ommbus palim fieri arbitror, quód perperdin tum Brafauolus, tum Fucb/us bac in re Barbarum infinulauerint.

Sunte noftratibus, qui Malis infanis uejcantur ad wencrem excitandan. Quod forté ideo prestant, quonidan fla= Mâlorum intus gignunt, concoctu'̆, contumacia cxiftunt. Verüm cüm fiequentius monduntur (ut teftıs eft A uicerna) biliofos fanorú uires. generant bunzorcs. Qunetime pariunt nifcrum ob/tructiones, carcinomata, clephantiafin, capitis dolores, trifti= tiam, o iecinor is o lienis inf arctus: unde poftes diuturne proueniunt fibres, o babitus malus. Hinc itaque fit, ut Auerrcen mirari fubeat, quód libro v.collceq aneorum, mala infana commendauerit fuo quodam modo parata. Iam Mâla aurea.

so or aliud horum genus importari capit, prefjum, orbiculatorum malorum modo, melopeponum more fectum, colore primum uiridi, deinde ubinaturitatem fenferit, in qubusdam plantis aureum, in quibusddm ueró rubeum uifitur. Ideó, uulgóappelluntur P O M I d'oro, hoc eft, mala aurea. Eduntur O hace quemadmodum illa. . Mandra= Mandragor

\section{ACONITVM PRIMVM.}

gore uires defcripfit Galenus libro V I I. fimplicium medicamen torum, bis uerbis. Mandragora uincentem habet facultatesn re= frigeratoriam, adeo ut tertij fit ordinis refrigerantum. Verun= tamen $\sigma$ caliditatis cuiufdam particeps eft, $\sim$ in pomis bumidi tatis : proinde foporem conciliandi uim ea babent, Radicis cor= tex, cum fit ualentißimus, non tantim refrigerat; fed $\sigma$ defic= cat. reliquum quod intus eft, imbecillum exiftit. Hec plantd, que Grecis $\mu \alpha v \delta \rho \alpha \gamma o \dot{\rho} x$, , Latinis item Mandragoras appella= tur: Arabibus, Iabora, feu Yabrobach: Italis, Mandragora: Germanis, Alraun : Hipanis, Mandracola : Gallis, Mandrago= re, $\sim$ Mandegloyre.

\section{A'róvitoy, ACONITVM. CAP. IXXII.}

A c o I I Y M, aliqui pardalianches, alij cammoron, alij thelyphonon, alij myoctonon, alij theriophonon uocant. Folia habet cyclamini, aut cucumeris, tria aut quatuor, minora, \& fubhirfuta: caulem palmo al-
A CONITVMSECVNDVM.

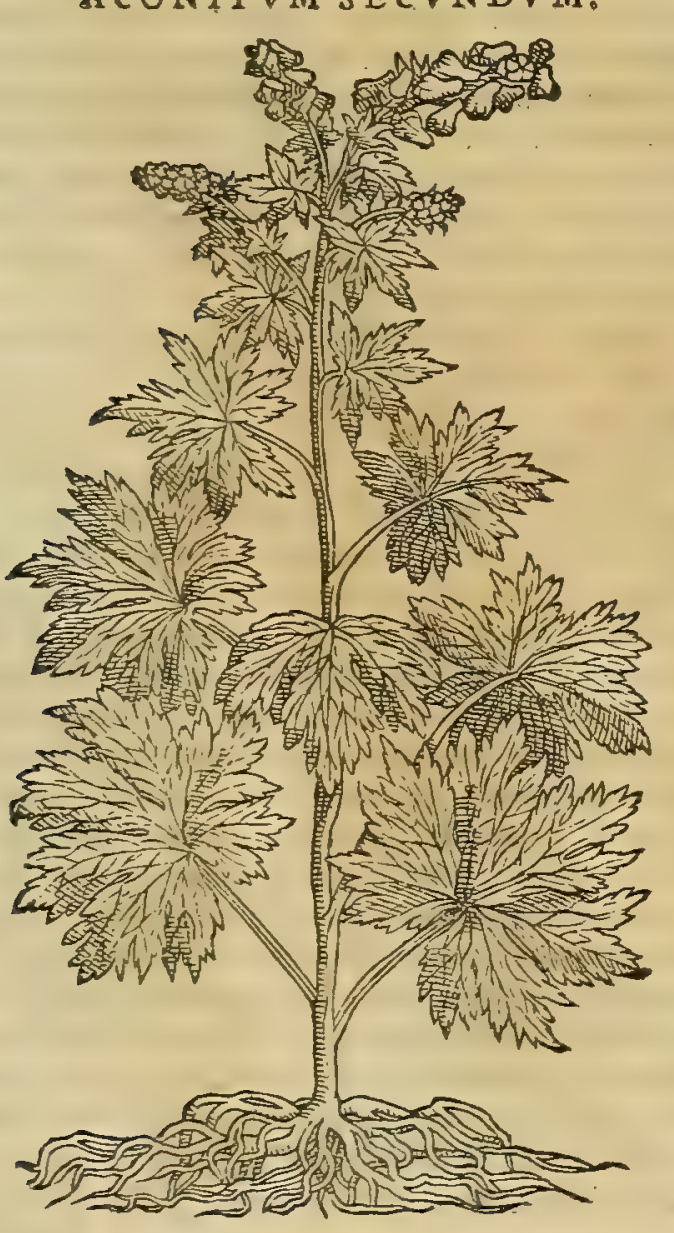

ACONITVM TERTIVM.

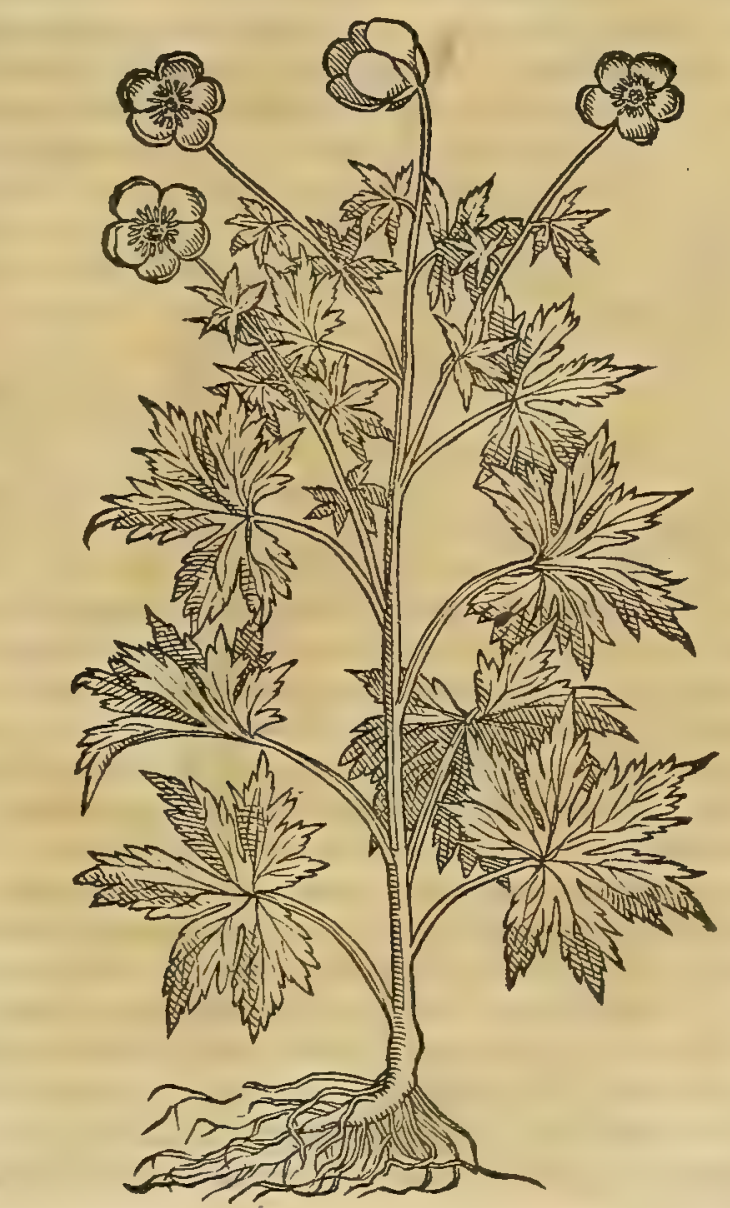

Nomina. ires ex Gaeno. 


\section{And.Matthioli Comm.}

\section{ACONITVM QVARTVM.}

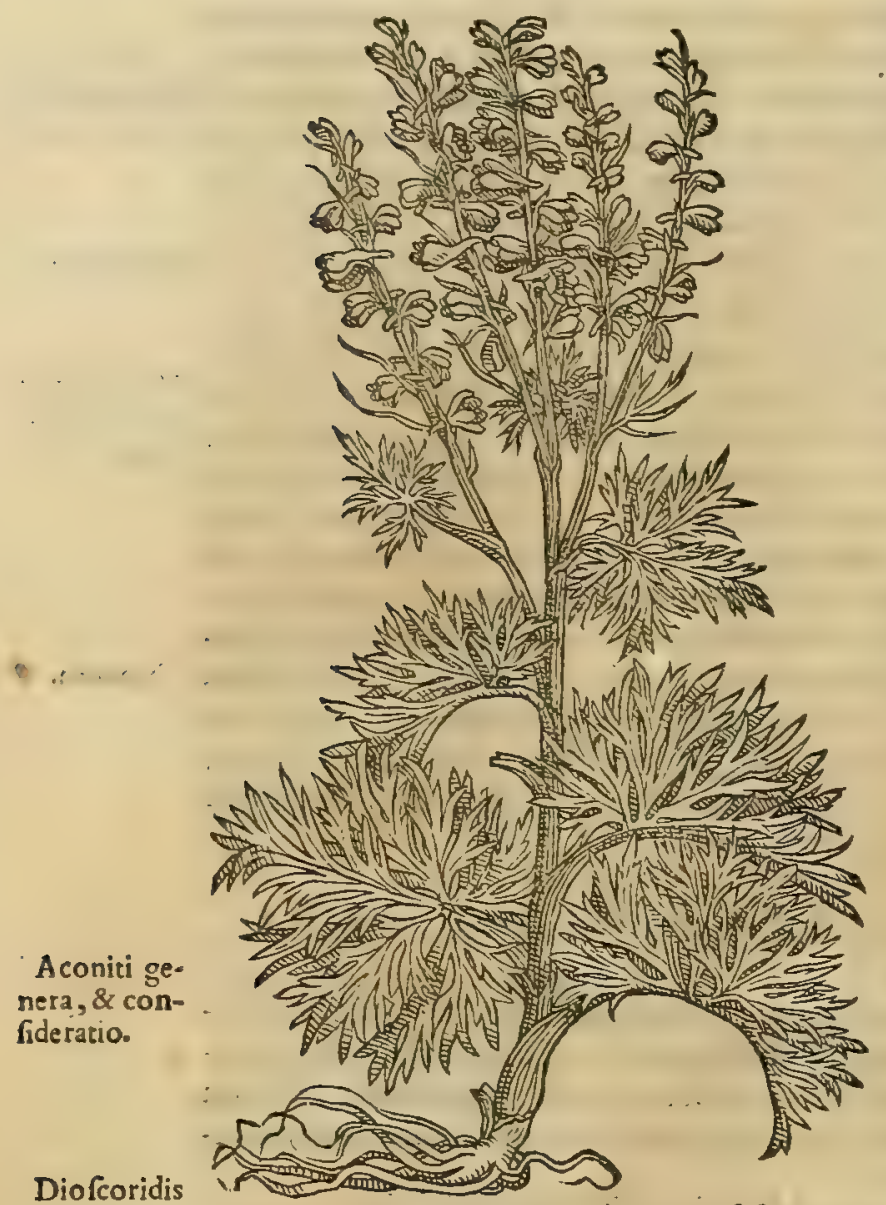

tum : radix fcorpij caudam remulatur, \& alabaftri modo fplendet. Torpefcunt, ut fama eft, fcorpiones admota radice,ftupentq́ue: qui rurfum ellebori contactu, excitantur. Oculorum medicamentis leuandi doloris gratia adijcitur . Enecat pantheras, fues, lupos, \& feras omnes, in carnibus obieftum.

\section{A'uóvitov ÉTEgov. ACONITVM ALTERVM. C A P. IXXIII.}

Es T E T.alterum Aconitum, quod aliqui cynoctonon, alij lycoctonon-appellarit. Huius genera funt tria: vnum, quo utuntur uenatores: alia duo in ufum fuum uertere medici.è quibus tertium, quod Ponticum nominatur, plurimum in Italia, montibus Iuftnis exilit, à priore diftans, quoniam folia faciat effigie platani, crebriore diuifura, longiora, \& multò nigriorascautem filicis pediculo fimilem, nudum, cubitali altitudine, aut ampliorem : femen in filiquis oblongis recóndit: radices in modum fquillæ marinæcirrorum nigrefcunt . Quibus ad uenationem luporum utuntur : infertx fiquidem crudis carnibus, \& deuorat lupos enecant.

Dí o D I S C OR I D I produntur Aconitigenera, quanquam poftremum triplici diftinguit differentia. Primum, quód pardos enecet, Pardaliancben : alterumueró,quód canes, luposq; conficiat, Cynoctonon, Lycoctonon q; noc ari dit. Hoc (ut diximus) in tria genera diftribuit : ueruntamen poftremun tantum defcribens, duorum priorum biftorian, or uires filent 39 tio praterijt. Quo fit, ut Hermoldi, o Marcelli fententiä pro= locus fufpeaus.

bandam putem: qui non temeré quidem fupicantur, in altero capite plura defider ari, quibus es priorum biftoria, or quónam pato tum medici, tum uenatores ijs antiquitus utercntur, jalàn fieret. Huius diminute lcctionis illud non parum fupicionem auget, quód in tertio genere, quod Ponticum appellauit, nibil fit ab ip fo Diofcoride preter= mifjum. ex quo quis forté conijcere poteft, in ceteris quog; eum quicquam non pretermififfe. Tertium boc genus paßsm in Italia omnibusferé montibus nafcitur, folijs que platanum quadantenus amulantur, magis tanen per ambi= tum ferratis, albis quibufdam maculis reperfis: caule filicis, bicubitali: floribus fubluteis, acutis galericulis facie finilibus : é quibus filiqux prodeunt, femen continentes: radice multiplici, ac nigra. Habetur or aliud genus ijsdem feré folijs, ơ caule, floribus tamen melinis, ranunculo non dißimilibus, longè tamen maioribus, adeó ut fylueftres ro

Gefnerus de- fasbic equet amplitudine. Quanquam Gefinerus in fuo magno libro de animalibus infcripto (in quem is mibi qui= 4 a ceptus. ius flores lutei fint, atque rofas emulentur : ut qui fibi fortaffe perfuaferit omnia natur o opera fe nouife er uidiffe. Attamen in boc, pace eius dixerim, decipitur: Jiquidem plures extant montes, qui cum boc Aconitigenere fcateant, nos bic uera fcrip/iffe, Gefnerum contrà ueritati reffagari, pofteris omnibus teftatum relinqucnt. Sunt qui hoc Aco nitum ab effectu Lupariam uocent: at rura Tridentina, in quorum montibus copiosé prouenit, ip $\int u m$ paßsin Vulpa=

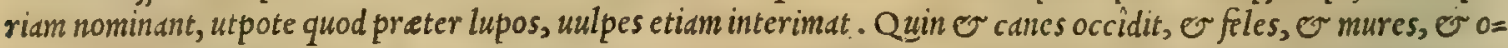
mnia denique animalia, que fuo exortu tanquam ceca producuntur. Primum genus thelyphonon appellatum, quo uenatores pantheras, o pardos interficiunt, fe pius leginus in Tridentinis montibus. Huius generis cft or illud, quo utuntur quidam in Romano, or Neapolitano agro, lupis eo tantum cadem procurantes. Radices eius pluries uend= les uidimus Rome in Aurelio ponte iuxta molem Adriani: quandoquidem non de funt, qui eas expetant, ad mures,ca so nes, "E lupos enecandos. Primigeneris A coniti, quod thelyphonum uocant, meminit Theophraftus libro I X. cap. $\mathrm{x}$ I x. de plantarum biftoria, ubi ita fcribit. Thelyphonum, quod alij forpionem appellant, quia radicem fcorpioni fimilem babet, admotum, fcorpionem occidere tradunt: $\sigma$ cum reuiuifcere poffe, fi elleboro candido linatur. Ene=

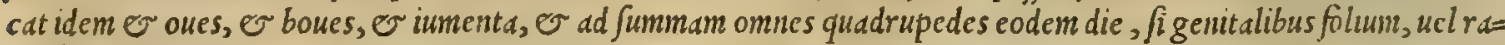
diculd imponatur. Proficit potum contra fcorpionum iftum. Folium habet cyclamino fimile : radicem, ut difum eft, fcorpionis effigie. Nafcitur graminis modo, or geniculis conftat. loca amat umbrofa. Quód fi uera fint, quae de fcor pione narrantur, iam or reliqua ciujmodi haudquaquam incredibilia, o fabulo a dici debent. Hac Theopbraftus de thelyphono. qui alterius quoque Aconiti mentionem fecit cap. X v I. elufdem uoluminis, fic inquicns. A contitum na= fcitur in Creta, atq; Zacyntlio: Sed plurimum, optimum q́; in Heraclia Ponti. Conftat id folio intubacco, radice tum Ppecie, tum colore nuci proxima. uim illam mortifer sm in bac efe, folium, or fructum nibil noccre affirmant. Frti= ctus herbe eft, non bumilis materie: herba ea breuis eft, ov nibil fuperuacui habens, fed frumento fin ilis: fcmen non 


\section{In Lib. quartum Diofcoridis.}

piceum. Nafcitur ubiq; or non in Aconis folum, à quibus habet appellationem : is autem uicus eft periandinorum. Amat autem loca potisimim faxo $a$. P afcitur eo neq; pecus, neque ullum animal. Praparari ad afficiendum modo quodam enarrant, nec nolfe que nquam: quamobrcm medicos, quoniam componere ne ciant, pro putrefactorio uti. Hec ille de fecundo Aconitigenere. quod duorum altcrum Diofcoridi effe poteft, er illud fortaffe, quod (ut ipfe in= quit) in ufun fum uertere medtci. Sed $\sigma$ de tertio Aconiti genere differuiffe Theophr aftum equidem crediderim, cum eodem locopanló póft bec uerba fubdit. Aliud quoq; ucnenum uim diurnariam enccandi fortiens compertun affirmant : effe nanq; radiculam quandam, qiae codem die poßit occidere: folium banc babere ellebori, notanq́; om= nibus effe . bactenus Theophraftus. In quo nibil moweor, quod buic Aconito, quod tertium fufpicor, ueratrifolla tri= buerit. nam o Diofcorides nigro ueratro folia platanireddidit, quemadmodum etian tertio Aconitorum generi.

so Fuchfius in fuis claris de ftirpium hiftoria commentarijs, primi genteris Aconitum eam plantam effe cenfet, quan Fuch. error.

HERBA PARIS.

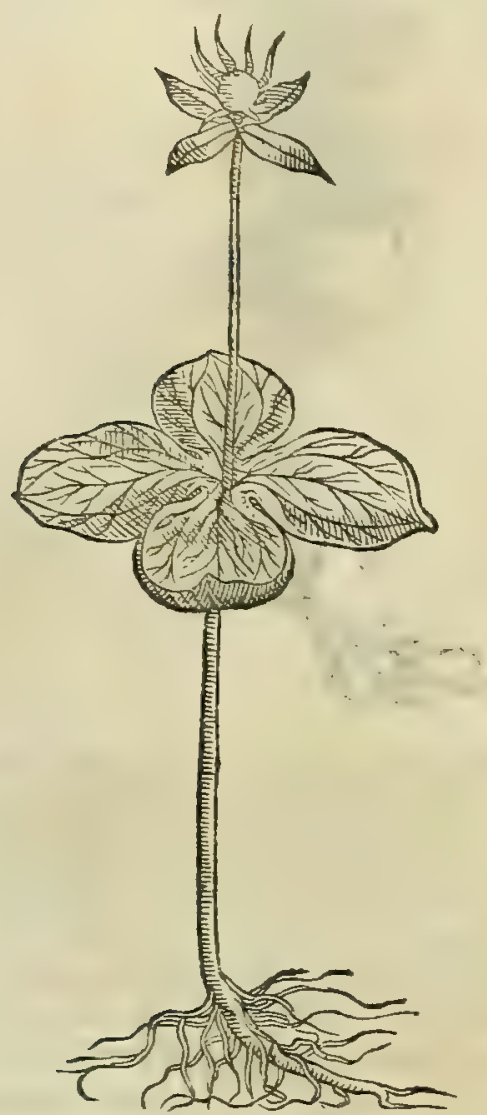

berbariorum uulgus H E R B A M Paris appcllat. Sed is pla=
né, mea fententid, aberrat: fiquidem bec uno tantum conftat cau $l e$, rotundo,duorum palmorum altitudine : é cuius medio quatuor erimnpurt folia, codem ambitu, crucis inftar patentia, fanguinese uirge fimillima: alia preterea quatuor codem modo prodeunt prope caulis fummitatem, fed hec minima funt, o longiufcula: in quorum medio purpureus, ninofusq́; extat globulus, acino une fimilis, in quo femen concluditur album, minutum, copio fum q́; , balicacabi modo. Radix, que illi fubeft tenuis, in capillares fere particulas diffecta, palle fcit, nulla fcorpionis cauda effigie, nec alabaftrimodo aliqua ex parte nitet, ut primum Aconiti genus à Diofcoride representatur: cuius folia (ut etiam Plinius libro $\mathrm{X}$ X V I I. cap. I I I. eft.author) preter id quód cyclamino, aut cucumeri fimilia funt, nunquam, quod uiderim, in caulis medio fuam babent originem, fed ftatim ab ip fa radice exeunt, hirfuta, humiq́; recumbentia. Semen buic nullum, quod fciam, ḋ rei her= barix fcriptoribus redditur. Sed ex berba Paridis acino femen colligitur, cui non modó nulla deleteria uis ineft; fed etiam con= tra ueneficia praftantisimum eft medicamentum. Noui eninn ego quofdam, quorum aliqui morborum diuturnitate, alij ueró uene= ficijs Semiftulti facti erant, hoc tantum $\mathbf{P}$ aridis berbe femine ad uigefimum ufq; diem in puluerem baufto drachme pondere, pri= ftine fanitationnino reftitutos effe. Porrò idem Fuch/ius in Fuchfij error fuis paradoxis nil aliud Aconitum effe putat Mauritanis, e pre= alius. Sertim Auicenne, qudm Napellus. Qu in re rur Jus, meo quidem iudicio, fallitur . quippe quód reperio Auicennam de utroq; Aco niti genere fcriptitaffe, or alterum appellafe ftrangulatorem adib, alterum uerò ftrangulatorem leopardi, que nomina eadem funt, que apud Grecos lycoctonos, o pardalianches: at q; eun= dem prius inagna differentia peciatim de Napello egiffe conftat.

Preterea N A P E L L V S radicem Aconitis. longe dißimilem profert : ficutio folia, que potius artemifiam, quàm cyclaininum, $\sigma$ platanü re ferunt. Flores idem edit purpureos, qui anteaquàm debifcant, mortuibominis caluariam reprefentant, debifcentes ueró pandunt fe es urtica mortua mo do. Caules e bicubitales, $v$ aliquando maiores: femen paruum, nigrum, corniculis conclufum breuibus. Qua certé omnia e harum plantarum difcrimen aperté oftend:tnt, fimul $\odot$ Fuchsij fententiam refellunt. Hinc itaq; colligendü putauerim, Aconttum cuirfque generis nullam habere cum Napello cognationem. Napelli uis in necandis hominibus adeó immanis, feuá,; exiftit, ut null is fr ré antidotis occurri poßit, nifi qudm primùm, of fatin fuccurratur, quod ta men Aconitum fumentibus non euenit. Napelli immanitate uidimus nos Rome anno ḋ Chrifto nato 1524 . menfe no= uembri in Capitolio Clementis v I I. Pont. max. anno primo. Nain cum decreviffet experiri olei cuiufdam praftan= so tißimi uires, 'quod Gregorius Carauita Bononienfis chirurgicus tunc preceptor meus contra deleteria medicamenta, o uenenoforum aninalium quorume unq; mor fus parauerat, iußit Pontifex uenenum dari duobus latronibus, quos le= ges damnauerant, quo fuorum facinorü poends luerent, laqueo uitam finire, ut in ijs olei buius experimentü fieret. Ho rum alterum, qui plurinum $\mathrm{N}$ apelli fumpjer at dulciarijs panibus cömiftum, pontificij mediciftatim oleo inungendum prebent, qui poft tertium dicm sepius oleo perunctus euafit incolumis: quanquam non fine magna formidabilium fym= ptomatum acceßione. Alterum ueró, cui longé minus uenenati panis exbibuerant, oleo inungi uetant, ut afjumpti uene ni effertun, feuitiam q́; cernerent. Id quod illis rei exitus facilé comprobauit : quandoquidem paucis pôft boris obijt

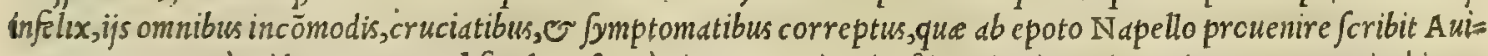
cenns. Ceterim idem quoq; Fuchfius loco fuprà citato Leoniceni teftimonio nixus, in Auicennam acerrimé inuez hitur : nec fane eum, ut noftri recentiores, principem, fed tyrannum, er bomicidam nuncupat, eos'́; pariter detefta $=$ tur, qui cius fectantur doctrinam . quippe quodd A uicenna frripferit (ut ipfe inquit) Napellum perniciofum, effe uene= num : mox fubdiderit,quód linitum, e bibitum delet albaras cutanei morbi genus. Qua in re rö poffum non admirari 


\section{And. Matthiolı Comm.}

N A P E L L V S.

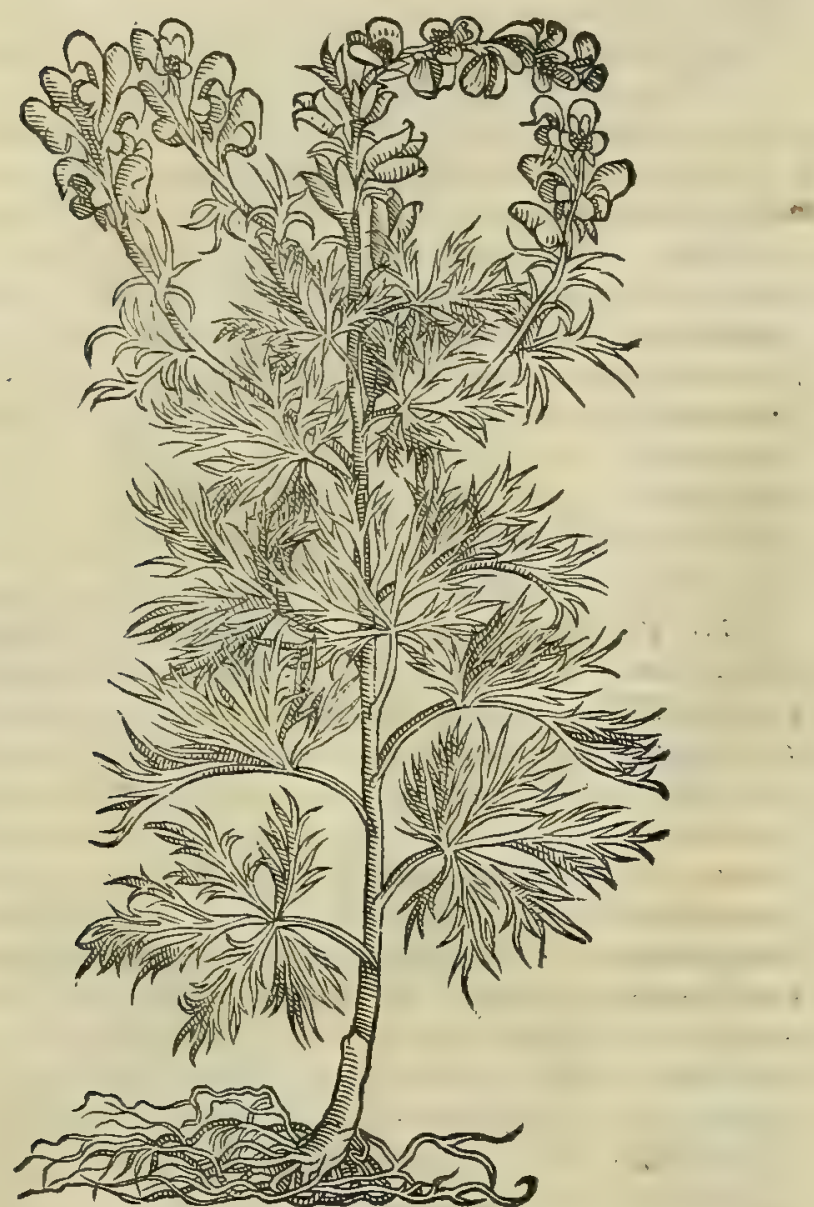

NAPELLI GENVS ALTERVM.

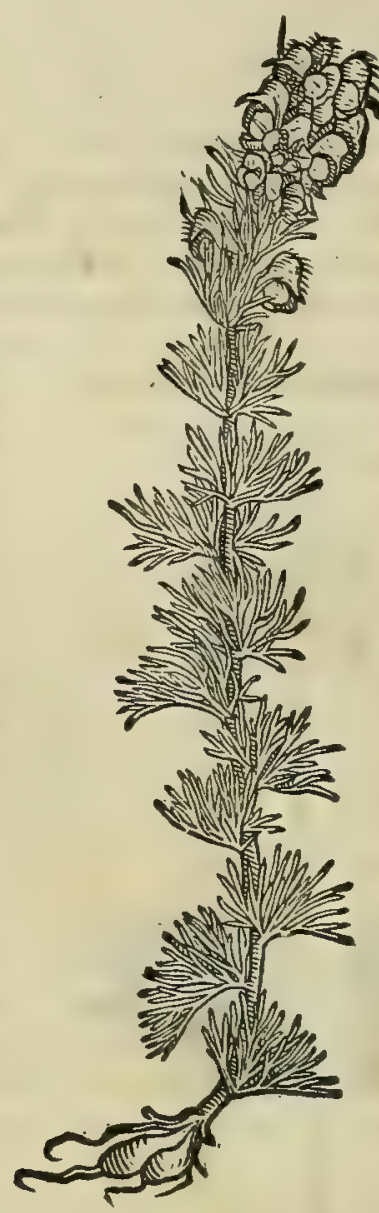

20

Fucbfium, uirum alioqui ingenio or eruditione clarum, quem etiam boc nomine plurimìm diligo, quód in tam cele= brem o antiquum fcriptorem paulo acrius or immodeftius egerit. Hominum enim eruditorum partes effe femper exiftimaui, etfi ego eas ufquequaq; feruare non potuerim, ut non uanis contentionibus, neq; conuitijs aliorum $\int$ cripta

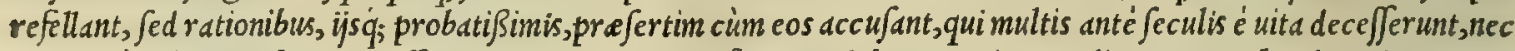
amplius ḋ calumnijs fe tueri pofjunt. Qui pratered confiderare debent, an in quo aliquem reprebendunt, in eo pro= prius fit autboris lapfus, an interpretis, aut librarij, anteaquàm ullü iurgijs potius, quàm rationibus inuadant. Quip= pe relictis tam Mauritanorum, quaim Grecorum fectis, quarum uni magis quadm alteri addictus effe nolo, mibi quidem non uidetur exiftimandum, quòd Auicenna uir fané fingulari doctrina, $\sigma$ admir abili ingenio ab omnibus recentiori $=40$ bus noftris maximé commendatus, codem in loco fibi onnnino contraria fcripferit in ueneno tam feuo, cui exitiales for midandasq; uires tribuit. Cuius reifirmißimum prabet indicium fcriptura Auicenne ab Andrea Bellunenfi castigat: ta, in qua nufquam legitur $\mathrm{N}$ apellum bibitü albar as delere, fed quód boc efficit quxdam eius confectio in potu fumpta. Verba enim Auicenne fecundum caftigationem Bellunenfis ita fonant. Napellus delet albar as linitum, ficut er con= fectio eius dictat alberzacali in potu fumpta. Ex quibus uerbis plura mibi fe fe offerunt conijcienda, ut tuear Auicen= nam, aut quód confectio illa tam exiguam Napelli partem excipiat, aut ea, quam recipit, adeo antidotis correcta fit, ut non folum necem non inferre poßsit, fed ne tantillum quidem obeffe. Aut quodd Napellus in illam additus, is forté est, quem Auicenna appellat Napellum Moyfi, aliqui ueró Antoram. quandoquidem bac planta antidotum fit admodum efficax contra Napelli uenenum, pree ertim quód dicat Auicenna, ine fe fimiliter buic plante uim ad albar as, ov le= pras : aut in eadem confectione fortaffe mus ille interponitur, qui Napelli radicibus utctitat, à nobis pluries inuentus in Ananienfibus montibus, quód etiam mus iste $\mathrm{N}$ apellus Moyfi ab Auicenna dicatur, quoniam ijfdem contra Napelli ue nenum polleat uiribus, quibus er eiufdem nominis planta. Hec fortaßis fu/ius, quim decebat, perfecutifumus. Sed tamen eo confilio id libenter fecimus, primim ut quantü per nos fieri poffet, Auicenna d̀ calumnia uindicaretur. Des inde ut ingenue dicerem quod de ijs omnibus fentio, qui optimos etiam quosq; autbores, prefertim Arabas, lacerant ac difcrepunt, quorum pleriso; magna eft babenda gratia : tantum abeft ut eos odio perpetuo profequi debeant . Ve= rüm cur id faciant, non uideo, nifít quòd tutum fit in mortuos inuebi, quando bodie pauci fint, qui eos tueri uelint. Caterum exiftimarunt Manardus Ferrarien/is, $0 \mathrm{~L}$ Leonicenus, quód Napellus, of Toxicum Gracis uocatum inter fe non differant . Sed quantum o ifti uiri grauißimi aberrauerint, inferius libro fexto in toxici mentione latius offers: Aconiti vires demus. Aconitorum uires tradidit Galenus libro vi. fimpl. medicam. ubi ita fcriptum reliquit. A conitum parda ex Goleno. lianches putrefaciendi facultatem obtinet, o lethale eft. It $d q_{;}$in cabo potúf, fugiendum : attamen ad putrefaciens dum externas corporis partes, aut circa fedem idoneum eft. Herbe ueró radix ad bac utilis est. Quod autem $\mathrm{L} y \mathrm{cos}=$ 


\title{
In Lib. quartum Diofcoridıs.
}

Stonon vocatur, fimilem alterifacultatem babet, fed peculiariter lupos, ficut illutp ardos, interficere confuerit . Ha= ctenus Galenus. Meminit Aconitietiam Plınius libro Xx VII. cap. I I. bis ucrbis. Sed anuquorum curam, dili=

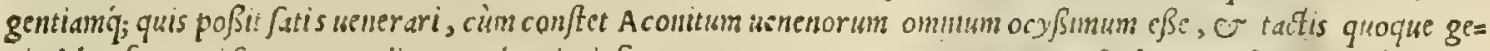
nitalibus fonumeifexus anumalium, cotem die inferre mortem. Hoc quoque tumen ill ufus bumanc fautus uertêre for= pionum thibus aduerfare experiendo datum in uno calido. Ea eft raturs, wh bonmen occhtat, nifi inuenut, anod in bo= mine perimat. Cum eo folo colluctatur, uclut pari intus inuento. Sola hec pugna cs?, quun ucnenun in uifceribus repes rit : mirumq́; cxitialia per fé ambo quum int, duo uenena in bomme commorimntur, ut bomo fuperfit. Torpefcunt Scor=

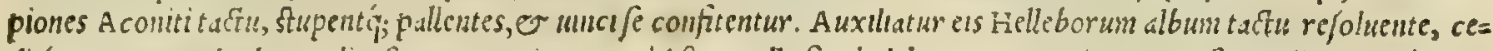
ditị; A contimn dwobus malis, fuo, o omniume. Quod fi quis illa forté ab bomme excogitart potußse credit, ingrate Deo=

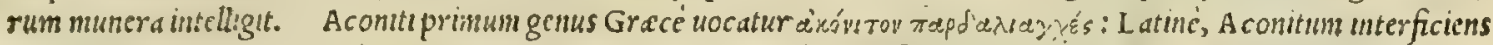
pardos ac pantheras : Italice, A conito pardalianche: Germanice, Vuolffs beer, o Doll uurt: Hijpanice, Centelba: Gal=

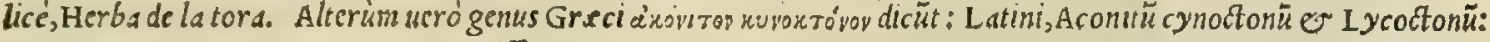
Itali, Aconito cinoctono: Germam, Vuolffs uurtz: Hifpam, Yerwa mata louo, it Yerua de ballsestcros: Gall, Patelouine.

\section{Appendix.}

Con r a v s Gefnerus hac xtate eruditione, ac copia rerum clariffmus medicus fuo, quem de raris, \& admirandis herbis appellauit libello, de primo Diofcoridis Aconin diferens, quod ipfe vuigus fequutus Toram appellat, non folùm imaginem noltram in huius capicis initio appietam plursbus impugnare nititur, fed (ve arbitror) inuidorum piotius quorundả fuafionibus, quàm fux ipfus genio excitatus eò immodeltix, iniurixq́; perueniffe demonftrat, quò haudquaquam decere crediderim honeftos quofque viros deflectere. Quamobrem non pofum non admirari, Gefnerú, quem hactenus modeltiffmè de omnibus feripfifle conltat, nunc primuñ longè aliter fe gerere, præfercim cùm certò fciat fe iam plura magna edıdıfe volumina, qux cenfuris innumeris non uacabunt. Ecquid profertò turpius, detettabiliusq́; Gefnero cuenire potuit, quàm infidelitatis illum arguere hominem, cuius authoritas, integritasq́; tanta iamdudum fuit apud ipfum, vt innumeris ferè locis in libris de animalium hiforıa,alijsq́; voluminibus non folum illum laudauerit,probauerit, ac etiam obfertasuerit, fed illius fcriptis, inuentisq́; pro fui commodo vfus fit, ac multa illi acce pta referre poffit? Etenim non abeft lufpiqio, quin eius fynceritatem vafer quifpiam labefactauerit maleuolus, (nam \& alios fynceros, ac probos viros ab iplo deceptos fcimus ) quo poftea factum fit, ve dum is immerito noftram accufat imaginem , aliam iple in medium afterat, qux (pace eius dixerim) meritò damnari poffit, quum planta, quam ipfe pro primi genęris Aconito pingic, de quo Diofcorides, \& antiquorum alij meminere, nullis prorfus notis legitimum illud Aconitum referát. Adeò vt à genuino non minus ḋfferre videatur, quàm coruus à cygno. Nain vbı hisfuta folia ? vbi Cucumeris, aut Cyclamini facies? vbi plura quàm vnim tantùm folium ? vbi radix caudæ Scorpionis æmula ? vbi (Dij boni.) alabaftri fplendor? Nullum penitus talitum notarum apparet veftigium. Quamobrem plurimùn nirari fubic, quòd quafi $f_{2}$ fcinatus maluerit Gefnerus imperitifimi olitoris, cuius balifte fe telun effecit, contra nos probare fententiä, quàn Theophraftum, Diolcoridem, Plinium, Oribafium, \& alios quot quor funt clarifimi nominis authores admittere.Adhxc non video, cur ea ratione adducatur $G$ efnerus, vt non putet i maginem noftram nifi fictitiam, quòd fcilicet nimis artificiola fit radix, \& quòd abfque vllis videatur fibris, quum aliarum etiam plantakum habeantur radices omninò glabre artificio editx longè maiori; ve in Dențaria vocata, \& in eo Saniculæ genere, quod album Gerniani voçán, cuius fuperius inter fymphyta meminimus, uideri poteft. Sed dicat Gefnerus, obfečro, quot nain in fuis de animalrbus libris fiAirias appinxit imagines? longum fanè eflet recenfere. Recenfebo fortâfsè aliàs. Qunippè nil minus ferendum, quàm Gefizerus no

rationem ab altero repofcere eum, qui fux reddere non poffir. Sunt enim in promptu doctifimi viri, \& in plantarun tatur. hiftoria, ac facultate exercitatifimi, qui rertum ueritatem optimè norunt, quorum nomina, etfí copiofum non efficiät numerum, fatius mihi fuerit ijs commendari labores nottos, quàm à cæereris improbari . Equidem Gefinero alioqui viro doAifimo noltri Aconiti ftirpem mittere poffern, nec me tæderet ad montes illos me iterum recipere, licet magna intercedat itinevis diftantia. Atqui quun plantam non requirat, féd duorum,aut trium eruditorum teltimonia, hæc fem per in promptu erunt. Viuit Georgius Liberahis pietor, qui plantam delineauit; Viuit Petrus Spezzalancia, qui eam effodit; V1uit Francilcus Melchiorius medicus Tridentinus, qui nobifcum ierat. Viuo ego ( Dij boni) qui adhuc fidei aliquid prxita re poftum; \& montes vıunt, \& extant, qui tales nobis alune plantas. Murum fanè, quòd iam tam morofi fint homines, vt nil aliud extare terris; marıbusq́; cenfeant, quàm quod ipfi tantìm viderint. Verum enimuerò non poflum fatis explorare Gefneri mentem, quippè qui hxc, \& a lia nonnulla aduerfum me prius fcripferıt, \& nunc primùm nos honeftè benigneq́; defenderit aduerfus Guilandinum quendam Boruftum, qui ad ipfum epiltolam quandam fcribens de Bulbo Caltaneo, Trafis, Moly, alijsq́; nonnullis barbara quadam inuidia fauciatus citra caufam omnem, ac rationem temulentı hominis inftar, acrius, immodeftiusq́; , quineriam iniquius quàm parfuerar, in nos inuehitur. Sed Jicet etiam nobis; obfecro, parumper vaà cum Gefnero, quem tamen fuis inaledictis fautorem fperabat, tam impuden tis hominis rabiem repellere. Nam quis hoc pati poffrt? Quis non modeftix fines prxtergrediarur, vbi tantum concumelijs, calımnjjs, \& impofturis fuerit laceflitus ? Nihil eft, quod bono, doftoq́; uiro grauiıs, moleftiusq́; contingat, quàm fi fenferir labores fuos ab imperitifsimis hominibus rabidis morfibus carpi, \& prarer equum impugnari,Id, quod fi aut noftro tantùm æuo, aut mihi folı euenire perfpectum haberem, dolerem primùm horum temporum nequitiam, indè uerò fortunam meam deplorarem. Verùm quum id omni tempore fuiffe commune animaduertam, eamq́; fuiffe femper bonorum, doctorumq́; virorum conditionem non ignorem, ve inuidorım tela euitare, rabiemq́; effugere neuri quam pofsint, facilè xquo anımo patior quorundam audaciam, infignemq́; temeritatem. Inter quos nulli mihi fecundus videcur Borullus ille,quem potius (ve ita dicam) Marafium vocauerun. Quid? Mihi blatero inuidiam parare credit, quòd me herbariorum Deum appellat? An nefcit rabula , non aliam ob caulam labores noftros in omnium ferè ftudioforum manibus florefcere, \& legi, Jaudari, foueriq́; ab onnibus, quàm quòd ij de re herbaria benemeritum me iudicent? quinetiam ob id mihí tantas agant, habeantq́; gratias, quatıtas mihi uix meritus effe uideor? At qui is, tamerfi tzaleiffimus fit, in hoc tamen (me hercule) fapere videtur, quod corsum illud fuum tanti faciat, vt Matthioli pelli anteferen dum iudicer, quod fibi aliquandò ex vú fore putat. Seruet ille fuum corium diligenter jnunctum, \& magno exiftimet pretio. Quippè nifi proprio fuerit adiutus corio, parum aberit, quin liunris intumefcentia rumpaturmedius. At videant candidi, pijá; lettores, qua hipocrifi inceperit in nos inuehi Guilandinus, quum primùm inquit. Non is fum, qui cauillis, \& impofturis inanem gloriolam aucupari velim. Mentiri nefcio, nec fi fcirem, velim, quum tamen nil magis proficeatır, quàn calumnijs, maledictis, \& impofturis fynceritatem, \& modeftiam noftram impugnare; \& id me fcri pfile afferat, cuod nufquam in noftris legitur cominentarijs. Sed nefcio quomodo turpiora fint uıtia, quam qux virtusum jpecie celantur. Porrò fi quandoque fortafsè nonnullas bonas horas malè confumpfero, ut huic impudentifsino

Gefineri lapriss.

Matthioli te

ftimonia aduerfus Gef nerum.

\section{Melchioris}

Guilandini explofa reme ritas.

\author{
(1)
}

$$
\text { .. }
$$


C I C $\nabla$ T A.

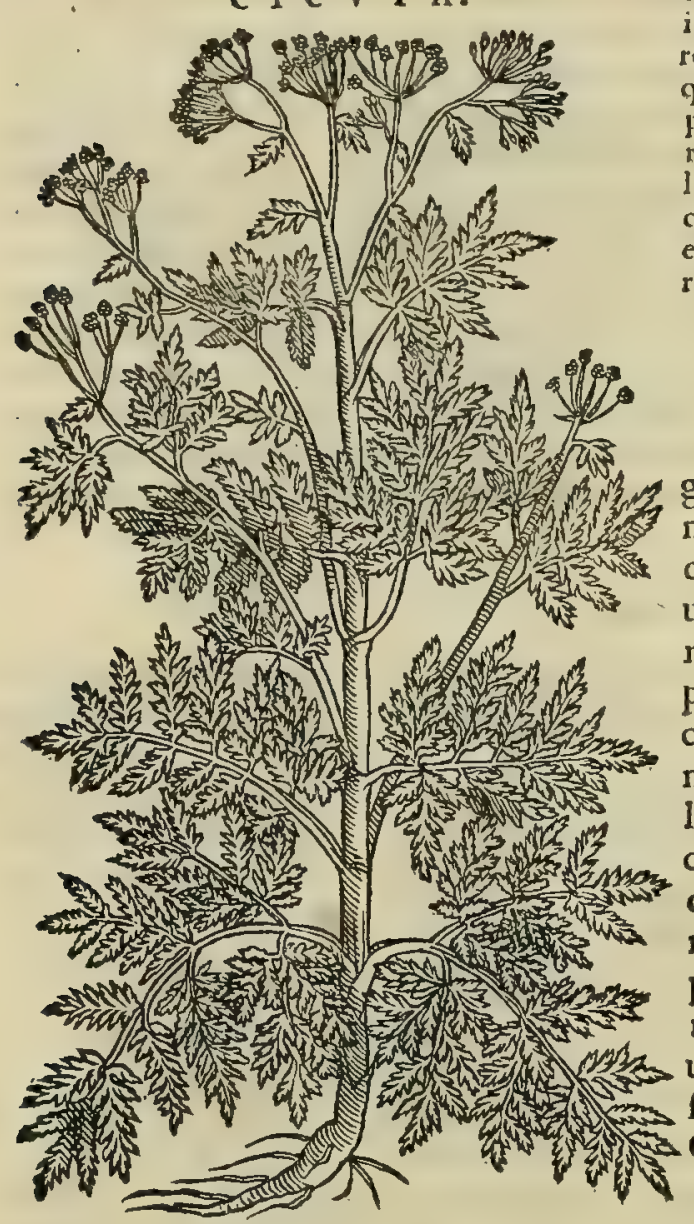

Cicutæ confideratio.

T A X V S.

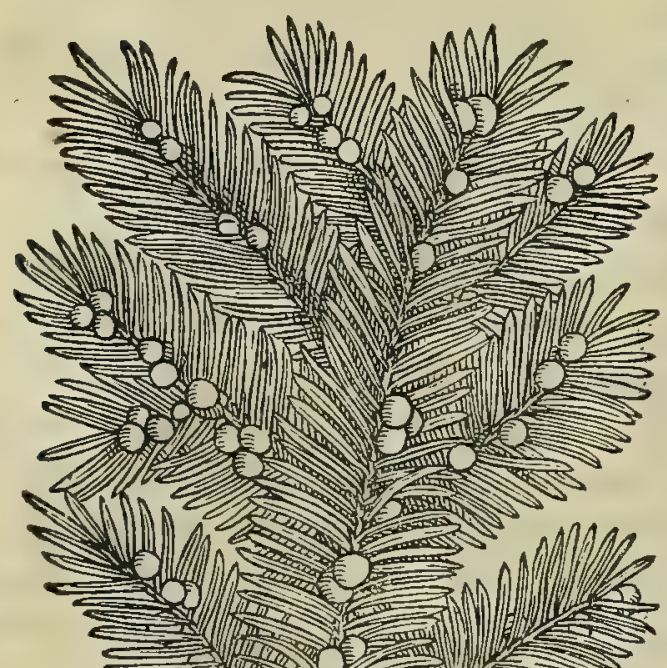

Nomina.

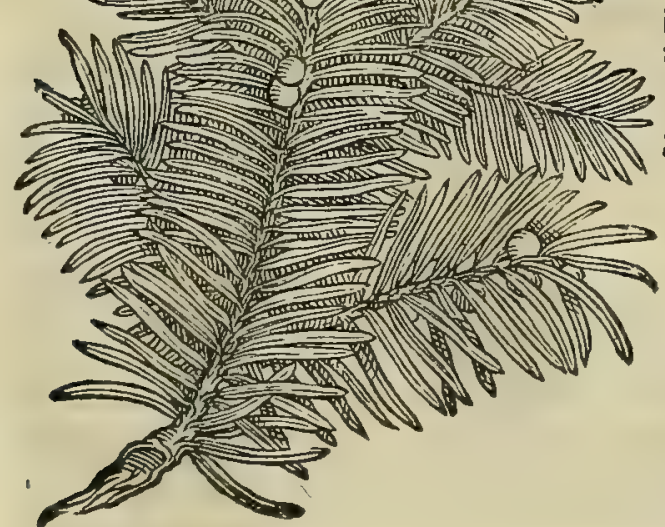

conuitiatori refpondeam (id enim hic non expoltulat locus; the hu ius futilitate, \& fruool is ineptijs noltra defodentur comınentar ia) rogatos velim ftudıofos onnes, ne id à me factum putent, ut aliquam mihi exindè laudem requiram, quæ nulla mihi tam diu efle poreft, quàm diucum homine tam impudenti negotium eft : qui ravquam lutulentus fus cum quouis volutari cupir, fed fi quam ille maledicendo uoluptatem accepit,eam malè audiendo amittat; cæteruqu; eius fimillini apertè omnes intelligani, plusele bonis, eruditisá; viris in fe defendendo prafidij, guam uạns obtrectatorsbus in calumniando fraudis.

\section{Káneroy. CICVTA. CAP. IXXIIII.}

10

C I C V T A caulem edit geniculatum, ut foniculi, grandem : folia ferulx, anguttiora, graui odoratu: rami, mox umbellæ in fummo prodeunt : flores quoque albicantes, \& femen anifo candidius : radice non alta, conca ua. Cicutæ lethale nenenum ineft, fuaque ui refrigerato ria necat. Remedio eft uini meraculi potus. Succus exprimitur contufis cacuminibus, priufquàm femina, $\&$ comę ficcefcant,qui fole denfatur in paftillos. Multus ad medëdi rationem ufus eft aridi : commodè mifcetur col 20 ly rijs, qua leuandi doloris gratia temperantur : ignes fa cros, \& ulcera qux ferpunt, illitu reftinguit. Herba cum coma trita, \& teftibus circumlita, libidinum imaginatio nes in fomno compefcit, fed genitale refoluit. lac puerperarum mammis appofita extinguit : in uirginitate má mas coercet, \& increfcere non patitur . pueris præftat, ut eorum tefticuli cibum non fentientes intabefcant. Ef ficacifsima uis Cretic $x$, Megarenfi, mox Atticx, \& in Chio \& \& Cicilia nafcenti.

C I c v r A uulgaris notitice eft planta, utpote que pleruncs. prope urbium, or oppidorum meenia proueniat, ferule adfimilis, cdore tamen admodum graui. Maxima uis Cicute, ut Plinius refrrt, que nafcitur in terra Parthorum, mox Laconice, Cretice, Aflatice. In Gracia ueró Megarice, deinde Attice. Ceterùm in Italia conftat Cicutam non adeó exitialem eßse. Eam in Hetru-. ria fi afini depafcantur, profundißimo omno, or torpore capiuns. iur, ita ut non tantùm stupidi, fed plané mortui uideantur. Id quod a'iquando rufticos buius rei ignaros fifllit: nam dum afinis, quos mortuos credebant, pellem ad ufum detraberent, accidit mirum, quód in medio feré operis afini experrecti funt, non fine ma gno ex= coriantium terrore, atque ingenti pectantium rifu. Cicute breuis ter meminit Galenus lib. V11. fimplic. medic. ubitantùm omnibus notum effe fribit, quod ed extremé refrigerantis fit facultatis. Et in libro quód animi mores corporis temperaturam fequantur, $\mathrm{Ci}$ cutce potu illam fieri amentiam tradidit, quam à cicuta ip/a Greci conion appellant. Hoc nobis contigit uidere, ut latius libro fes xto explicabimus, in quibufdam, qui imprudenter cicuta radices pastinace uice decoctas conederant. Planta, que Gracis nés= verov, Latinis atque ctiam Italis cicuta uocatur : Arabibus, Sucară: Germanis, Ziger laraut, Scbirling, $\mathcal{O}$ Vuetterich: Hipanis, $C$ guda: Gallis, Cigue, Cocue, er segue.

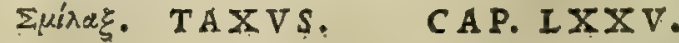

S M I L A X à Græcis, Taxus à Latinis appellatur, arbor abietis magnitudine, \& foliorum eiufdem figura, in Italia, \& Narbonenfi Gallia Hifpaniæ contermina nafcens. Auicular qua Italicæ taxi baccas deuorant, denigrantur: \& qui ederint eafdem homines, alui proftuuio corripiuntur.Narbonæ tam præfentis eft veneni, yt fi qui dormiant 


\section{In Lib. quartum Diofcoridis.}

dormiant fub ea, aut in eius umbra fubfideant, lædantur, \& fxpenumero moriantur . quare de taxo hrc traduntur, ut ab ea caueamus.

N A S C I T V R Taxus frequens in Ananic uallis snontibus, faxofis ac praruptis locis, inter abietes, $\mathrm{O}^{2} \mathrm{i}=$ ceas,quibus folio, ac forma non longe dißimilis uifitur : quanquam bec illarun proceritatem non nifi rarißine equet. Baccas frertrubentes, agrifolij modo, dulces, uinofas q; : quas quandoque mandentes tum paftorcs, tum qui in fyluis

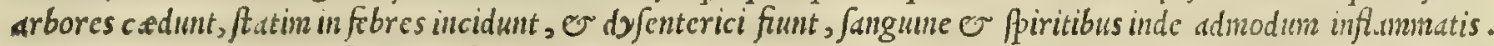
Iignimateries, quod rufercat, quàm plurimis intercurfantibus ucnis, incorruptag; fit, lignarijs fabris maximé expetitur, or plurimi fit, prefcrtim concinnandis men/is, $\mathbb{O}$ haftis, telisq;; conficiendis. Quanobrem Germani

20 huius arboris affercs ad fua conftruenda bypocaufta non exigua fibi comparant pecunia. Taxi meminit Theo= plraftus libro I I I. cap. x. de plantarumbiftoria, fic inquiens. Taxus quoque gencre fimplex, procerd, auctu

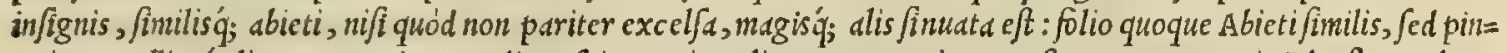
guior, molliorq'; ligno. Quse in Arcadia nafcitur, nigro ligno, aut puniceo conftat : que autem in Idd, flauo ddmo= dum, er cedro fimili . propter quod uendentes fraudare dicuntur, tanquam cedrum uenundent. Totum enim cor effe, cortice detrafto : corticem fimilem cedro babere tum fcabritia, tum colore: radices breues, graciles, per fummáq; ceßpitum . rara bac circa Idam. At in Macedonia, Arcadiaq́; uel fructum abunde proferre, rotundum, faba pauló maiorem, colorem rufum, tactu'q; mollem. Aiunt, quód fi iumenta folia comederint, emoriuntur : fi ruminan= tid, nibil putiuntur . Fructus er ab aliquibus bominibus snanditur, fuauisq; eft, atque innoxius. bactenus Theophra= ftus. Cuilus fententix illud obftare uidetur, quód no/tra Taxus fructum fer at non innoxium, ut ipfe ait, sed noxium,

20 ut fuprd diximus. Taxi Plinius quoque meninit lib. x y r.cap.x. ubi de ed ita fcribit. Abieti, o picea fimilis $e=$ tiämnum apectu cft Taxus, minus uirens, gracilisq́;, of triftis, ac dird, nullo fucco, ex omnibus fola baccifera. Mas noxio fructu: letbale quippe baccis, in Hipania pracipue, uenenum ineft. Vafa etiam uidtoria ex ea uinis in Gallia factis mortifera fuiffe compertum eft. Hanc Seftius fmildcem d̀ Grecis nocari dixit: $e^{2}$ effe in Arcadia tam prefentis ueneni, ut fi qui dormiant fub ea, cibúmue capiant, moriantur. Sunt qui er taxica hinc appellata dicant wenena, qua nunc toxica dicimus, quibus fagitte tingantur. Repertum innoxiam fieri, fi in ipfam arborem clauks areus adigatur . hec Plinius. Foliorum fumo mures necantur. Taxi preterea nocumenta tradidit Diofcorides libro fexto, ubide noxijs medicamentis pertractat .quó cìm perwentum fuerit, de ijs diffufius nobis differendum erit.

Taxi uires quìm paucis reddidit Galenus lib.v I I a fimplicium medicamentorum, fic inquiens. Smildx, aut taxus arbor eft uenenofe facultatis. Huic arbori nomen Gracum eft $\sigma \mu \mathrm{i} \lambda \alpha \xi$ : I atimum, Taxus: Italicum, Taffo : Ger= 30 manicum, Eiben baum: Hipanicum, Texo: Gallicum, If .

\section{A'øóruviov. : A POCYNVM. CAP. IXXVI.}

$4^{\circ}$

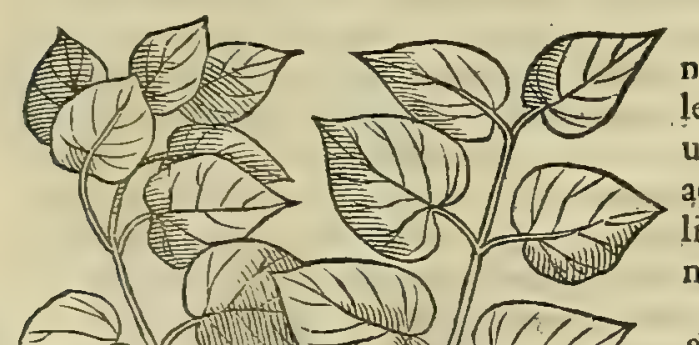

A POCYNON, fiue cynocrambe, brafsica cani na, frutex eft longis uiticulis conftans, malè olentibus, lentis, uitiliumque modo obfcquiofis, fractu ferè in. uictis : folio hederæ, molliore tamen, \& per extremüm acutiore, lento, graui odore: id luteo fucco turget. Siliqux ceu fabarum, folliculari f pecie, digiti longitudine protenduntur: femine intus duro, paruo, nigro.

Folia cum adipe in panes coacta, canes, lupos, vulpes, \& pantheras enecant, in cibo data, \& protinus corum co xendices refoluunt.

A p o C Y N O N, quod Or Braßicam caninam appellant, Apocyni có etfi iandiu mihi quidem incognitd fuerit, adeo ut inter alias incom fideratio. pertas ftirpes in amplißimo nature uiridario pofteris reliquerim explorandam; boc tamen anno é Pifis medicus eruditione, $v \sigma$ in re berbaria clarus, Lucas Ghinus Forocornelienfis duas ad me mifit plantas, quarum una per omnia Diofcoridis Apocynon re= prefentat. Scribit enim uir ille, duds à quodannobili amico fili= quas dono accepife e syria allatas, quarum alteri infcriptum erat Periploca repens, alteri ueró Periploca nion repens, fortaf= fe quód ita Syri eas plantas nominět. Subdit practerea, has filiquas rbododendri filiquis admodum fuiffe fimiles : inter quas tamé bec

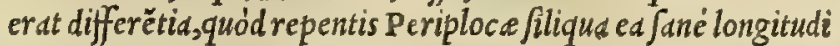
ne conftabat, qua et rhododendri, gracilior tamen erat: alterius ueró breuior. E' longiori fata plantam prouenife ait qua no mo dó bumi repit; fed et arbores quantumuis procer as fcädit : é bre uiori ueró aliă, que notis omnibus A pocynon refert. Vtraq; por= rò non minus lacte turget, ut fcribit, qudin titbymali omne genus: uerùm id repenti omnino album ine fe : non repenti ueró fubcros

50

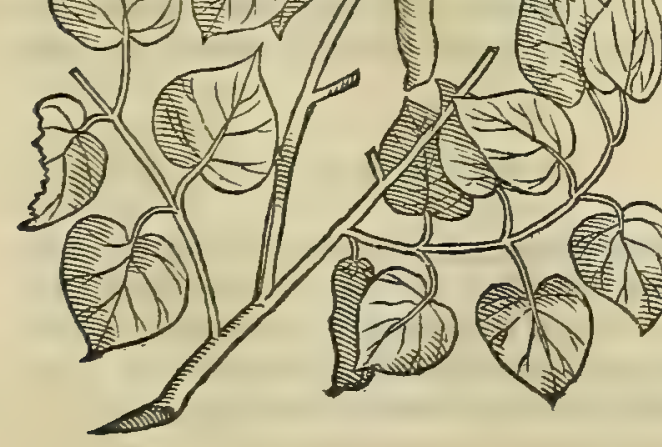


Apocyni uires ex Gal.

\section{Nomina.}

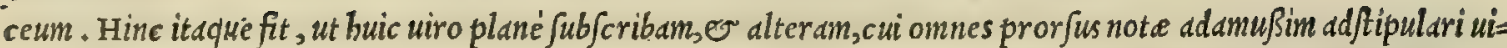
dentur, Apocynon effe certócredam. Neq; hanc facilé mutabo fententiam, nifí aliam plantam proferri uidero, que clarioribus notis, quàm hec, cuius picturam exbibemus, A pocynifaciem exprindt. Apocyni uires memoric pro= didit Galenus lib. V I. fimplicium medicamentorum, fic inquiens. A pocynum, aut Cynocrambe. Vocant autem quidam eam Cynomorum, quandoquidem canes celerrime interimit, fic ut Lycoctonon lupos. Eft autem bominibus uenenum, berba multim grauiter olens: proinde omnino calida eft non inftrenué, non tamen proportione deficcat. Itaq; illi=

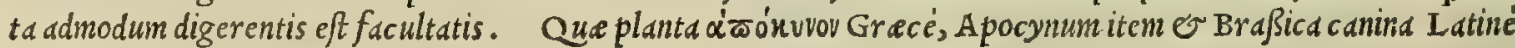
dicitur: Italicé, A pocino.

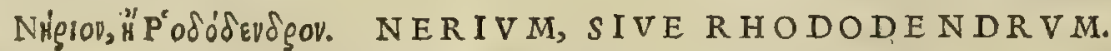
C A P.

\section{X X V I I .}

NE R I O N aliqui rhododaphnen, alij rhododendron vocant . frutex eft uulgaris notitix, longioribus quàm amygdala folijs , crafsioribusquue: flore in rofam conformato : fruĉu amygdalx fimili, corniculato, qui patefactus quandam lanofam naturam oftendit, $\mathrm{fpi}$ narum pappos repræfentantem: radice longa, acuta, lignofa, guftanti falfa . nafcitur in amœnis, maritimis, \& fecus amnes. Flores, \& folia mulis, canibus, afinis, \& quadrupedum plurimis uenena funt hominibus uerò contra ferpentium morfus præfidia, è vino pota, eò magis ruta addita. Imbecilla etiam animantes, vt pecus, \& capr $x$, fi aquam bibant, in qua folia ea maduerint, moriuntur.

N E R I V M, quód florèsrofarum effigie proferat, lauri= nisí; folijs conftet, Griecorim quidam $\mathrm{R}$ bododendron; $a l i j \mathrm{R} h \mathrm{O}=$ dodaphnen appellant. Italis oleandro unilgó dicitur. Vidimus nos boc primum ad Benact ripas, $\sigma$ in Argentario promonto= rio in maritimis noftris. Planta eft laurif facie, fpectabilis, $\sigma^{\circ}$ u $=30$ funon iniucunda, prefertim cim rofeis emicat floribus. Horum fimilitudine deceptus quondam fuit I ucius Apuleius fub afini me tamorphofi, dum rofas quareret, quarum paftu in priftinam formam reftituendus erat. Nam cum procul uidiffet Nerium fuis floribus refertum, ratuis eos effe ueras ro $\int a s$, eo dperto ore $d c=$ currit tanta auiditate, ut parum defuerit, quin eas primo occur= fu imprudens deuorarit. Verum is, ut quin plantarum bifto= ria, or uiribus earum indag andis diligentißimis author extitit, non immenor Nerij flores depaftos afinis uenenum prefenta neum effe, ita deceptus labra fabmouit, demißisq; ad terram au $=4^{\circ}$

Nerij uires ribus abijt. Nerij uires defcrip/it Galenus libro v I I . fimplicium medicamentorum, fic inquiens. Nerium, ut ex Galeno. Rhododaphne notus omnibus eft frutex. Foris quidem corpori illitus, difcutiendi uim obtinet. Intró autem in corpus afjumptus, perniciofus, ac uenenofus non tantum bominibus eft; fed plerifq; etiam pecudibus. bxe Galenus. Que

Conciliatio maximé repugnant Diofcoridis, e plinij placitis: quippe qui Nerium porum commendauerint bominibus contra Diofcoridis ferpentium uenenoforum morfus. Nifi dicere uelimus, quod Nerium fumptum fecundum Galenum fit bominibus non cum Gal. demorfis perniciofum: fecundum ueró Diofcoridem idem ïs remedio $f i t, q u o s$ ferpentes momorderint. Id $q_{;}$ed rd= tione frat, qua or cantharides ( ut inquit Auicenna) à cane rabido demorfis medentur, er euphorbium à fcorpionibus $i c t i s, \mathcal{O}$ dlia deniq; lethalia medic amenta alijs item uenenis aduerfantur, ut inferius libro fexto latius dicetur. Si= quidem mibi non uidetur uerifimile, quód prater rationem id prodiderit Diofcorides in fimplicium materia omnium

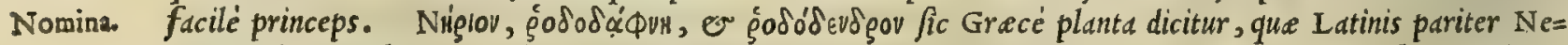
rium, Rhododaphne, er Rhododendrum: Italis, Oleandro: Germanis, Olander: Hippanis, Adelfa, er Eloen= dro: Gallis, Rofagine.

\section{MURห่TES. FVNGI.}

\section{CAP. IXXVIII.}

F V N G O V M differentia duplex: aut enim manduntur, aut perniciales funt. Multis de caufis venenofi gignuntur, vbi videlicet clauus ferreus, in quo fic rubigo, aut panni marcor adfuerit: aut fi iuxta ferpentis cauernam, arborésve, quæ priuatim pariunt noxios fructus, erumpant. Continent qui tales funt, nefcio quod ftrigmentum, concretamq́ue pituitam, terraque eruti, quàm celerrimè computrefcunt, atque marcore: vitiantur. Sed qui veneno imbuti non funt, fuauem in iuribus gratiam habent; largius tamen fumpti nocent, $\&$ xgrius conco\&i ftrangulant, aut chole- 


\section{In Lib. quartum Diofcoridis .}

ram morbum citant. Remedio eft nitri potus, aut lixiuium cum acida muria,aut feruefąt fatureiæ, aut origani iufculum: debellantur etiam gallinacei fimi potu ex aceto, aut eiufdem delinctu cum melle multo. Corpus alunt, fcd xgrè diffoluuntur; cùm magna ex parte integri jpfi cum recrementis alui deijciantur.

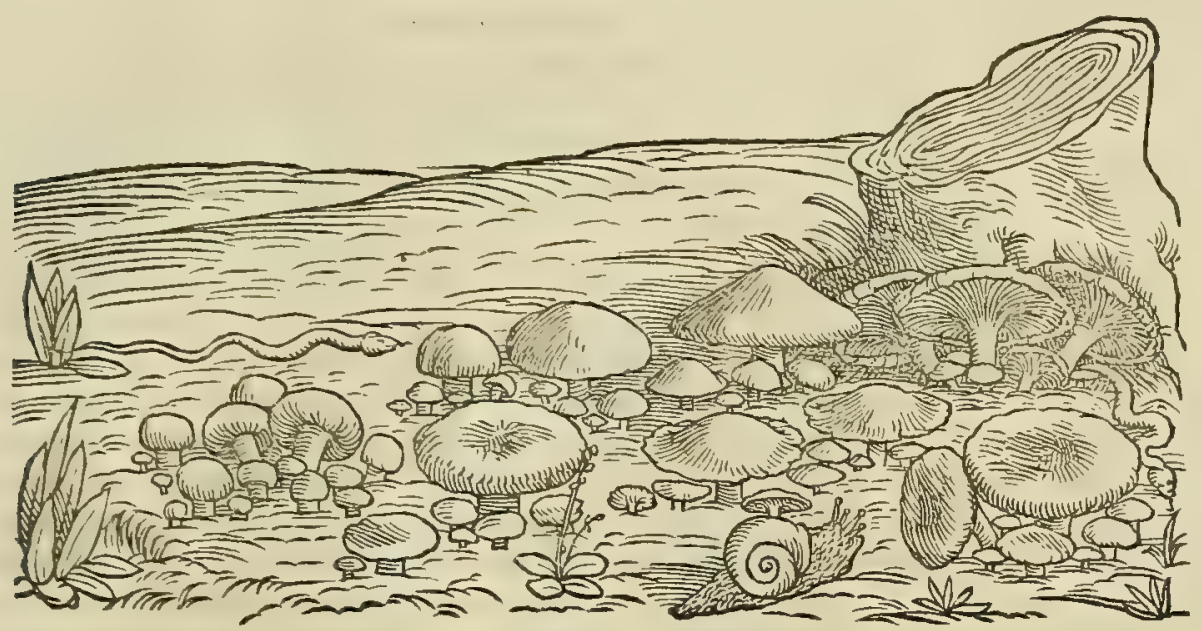

T A M E T S I duo tantùm Fungorum generd bic uidedtur recenfere Diofcorides, ad fungos duntaxat innoxios, Fungorú geor perniciales refpiciens; tamen, ut omnibus paldim eft, plura ac diuerfa corum, qua in cibis expetuntur, difcrimi= nera, \& conna notantur. Horum inter omnes I $t$ dlia regiones feracißlima eft Hetruria, ubi illi Fungicateros antecellunt, qui uul fideratio. gó dicuntur Prignoli : ij fiquidem fingulis annis primis A prilis imbribus erumpunt, neq; folùm odorem eximium $\beta_{i=}$ rant, guftuiǵ; gratißimi funt : Sed etiam omnino innocui babentur. Sécundum uerò locum apud noftros Hetruf cos te nent ij, qui uulgó Porcini, boc eft, fuilli nuncupantur : quippe qui prius elixi,ac demum farina circumliti, ov oleo uel butyro frixi, magnam cum palato ineant gratiam. Verüm bi non adeo tuti funt, quodd in fuo genere perniciofi plures, quàm in alijs reperiantur. Caterìm periculofi ac malefici à peritis, er oculatis niris facile dignofcuntur, cùm à ter=

30 ra o cortice purgantur, inciduntur'; decoquendi . Nam cultello diffecti illicó (ut Plinius inquit) dilutus eius adue= nit rubor, rancidus fubinde afpectus, liuidus intus color, rimofa ftria, pallidum per ambitum labrum: poftremó accé dit nigredo, o ita protinus computre fcunt. Quamobrem recte fcribit Auicennd libro I I I I, fin V I.eos nocentio= res effe, qui nigri, uel uirides, uel in nigro purpurafcentes uifuntur. Proinde amens quidem, er plané ftupidus, or ftipes fuerit is, qui tam repentinas mutationes uiderit, or non cognouerit bis not is eorum uirus patefieri. Sed accidit plerung;, ut illos potißimün $\mathrm{F}$ ungi interimant, aut faltem in magnum difcrimen adducant, qui eos fuper ferrea crati= culd, aut pruius, calentibuśf; cineribus affatos deuorant. Hoc enim modo decocti, cum in taleolis non fecentur, non tam facilé cognofci poffunt, ut ij qui diffecti parantur. Adbxe non femper officiunt Fungi,quód per fe lethiferifint, fed quód copiofius, quim par fit, ingerantur. Quandoquidem cum lenti admodum, craßißjimiq́; fucci exiftant, arte= giarum ofcula ufqueadeo obftruunt, ut conclufis intus piritibus fuffocent. Quod cim probé norint agreftes in Hetru

ifo ria mulieres, rarißimé fungos mandunt, nifi allio, eo pipere adiectis. Afjeruantur Fungi muria, prefertim qui uulgo Porcini dicuntur: $n a n q$; boc modo paratiinnocentiores redduntur amiffo lentore. Preter hac multa alia fungorun genera apud nos inueniuntur, ut ij qui nobis uulgó appellantur Prataioli, Turini, Boleti, Orcelle, Cardarelle, $M d=$ nine, Ordinali, Parigiole, Vefcie di lupo, o complura alia, que, cim nihil uel parum ad rem faciant, filentio inuol $=$ uenda duximus. Ceterum Fungi non tantùm bumi proueniunt, fed et in arborum caudicibus, qui omni feré periculo uacant (dummodo non fint arbores noxia) quód é cortice profiliant, cui nec ferrum, ntec tabefactus pannus, nec fer= pentis cadauer fubefe poteft. Ex hoc genere quidam, preter agaricum, laricibus innafcuntur in Ananienfibus inon= tibus triginta librarum pondere, aureo colore, per ambitum difJecti, in cibis gratißimo, nullo amarore prediti, ticet agaricus ab eadem arbore productus fit amarißimus. Hîc certé mirarifubit, quòd tanta bominibus inferitur gula li= bido, luxus, er incontinentia, ut adeó inconfultó, duideǵ; fungis ue cantur, in quibus fapius immatura mors delitee

50 fcit. Tanta bodie interceßit gratia Fung is cum menfis in Italia, ubi corum frequentißimus eft ufus, ut Neapoli inuenti fint lapides, qui defoßi, $\mathcal{O}$ in cell is uinarijs translati, terra aliquantulum operti, et fubinde tepida aqua inperfin, intra quatriduu fungos non ingratos procreant. Hos et Roma, et Neapoli uidimus, ubi magna feruantur diligentid,nempe quorum merito quolibet tempore fungos edant. Sunt e lucernarum $\mathrm{F} u n g i$, qui in ellycbnio funt, prefertina cüm Fungi luces aér bumorem contraxerit, er ad pluniam preparatur. Fungus itaq; lucernarum, meo quidem iudicio, fuerit is car= narum. bonis globulus, qui fungi faciem reprefentans, in ellychnij extremitate concre fcit, $\dot{\sigma}$ flamms lumen obumbrat.

Neq; enim in boc fubfcribam Cornario, uiro alioqui ingenio o doctrina celebri, qui in commentarijs, quos in ter = Cornarij opi tium Galeni librum de compofitione medicamentorum fecundum locos edidit, cenfet fungum illum effe ellychnium lu= nio exploci. cernarum ex quodan fungigenere factum, quod facie (ut ipfe inquit) marinas emulatur pongias. Siquidem apud ue= teres nufquam me legiffe memini, é fungis ellychnia fieri: cum tamen legerim apud Virgilium, e Pliniun, cium fungi generantur in lucernis, futur.e pluuix effe prefagium. Nanq; Virgilius libro primo Georgicorum, ubi futur e plu= uis figna recenfet, id apertißimé teftatur, ïs carminbus. 


\section{6 \\ And. Matthioli Comm.}

Tum cornix plena pluniam uocat improba uoce,

Et fold in ficca fecum patiatur arena.

Nec nocturna quidein carpentes penfa puelle

Ncfiucre bycmem, tefta cim ardente uiderent

scintillare olcum, 0 putres concrefcere fungos.

Eorum porró generationis caufam fcité quidem reddidit Seruius Grammaticus in commento bifce uerbis. Nam(ut in= guit Plinius) cum acr bumidus effe coeperit, fauilla, que cü fumo folet egredi, probibita dëris craßitate in lucernis re . Fitet, o quirfdam uclut fungorum imitatur imagines. bec ille. Sed prèterea ipfe Plinius virgilio, or nobis quoque adftipulatur lib.x V I I I. cap. ultino, cium it a fcribit. Falladinanque ignes, murmur antes $\dot{q}_{\text {; }}$, tempeftatum nuncij fen tiuntur : plunia ctiam, fi in lucernis fungi. bictenus Plinius. Ex qquibus omnibus luce clarius fieri puto, bac in re Cor Fungi corpo- nariun cecutiuife. Fungi pretered apud Hippocratem o Galenum lib. E comm.iji. de morbis uulgaribus, funt sis aftectus. excrefcentix, qua quandoque in palpebris, quandoque in pudendis enafcuntur. Quin $\widetilde{\sigma}$ Fungidicuntur à Galeno lib. I. de locis affectis adnafcentie capitis, ubi hoc fracto, meninx, que eft membrana cerebrum cuftodiens, fuerit

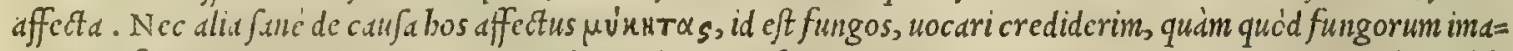
Fungorum ui ginem referant: quemadmodum et ij qui in lucernis concre $\int c u n t$. Fungorum uires memoria prodidit Galenus lib. res ex Gal. V I I I. fimplicium medicamentorum, fic inquiens. Fungus figida, bumidá; admodum planta est. quamobrem etiam proximé ad deletcriam, enecantémue facultatem accedit: e fané inter eos funt qui interficiant, potißimìm qui ex natura miftam habent qualitutem putredinofain. Et libro fecundo de alimentorum facultatibus, idem de fungis ita duferit. Inter fungos Boleti, fi belle in aqqua elixi fuerint, propé accedunt ad cibos infipidos. Non tamen fic folis ip= fis unlgó utuntur, fed adparant uarie $\sigma$ condiunt, ut alia omnia, qus nulla infigni qualitate funt predita. Alimen= tum autem ex ip /is eft pituitofum, o frigidum uidelicet, prauiq;; eft fucci, fi quis ip/is lirgius utatur. Omnium igitur fungorum ì minimum funt noxii. Secundi autem poft bos funt Amanite. Reliquos ueró tutius eft omnino ne attinge= re quidem: multi cnim cx ipforum c fu interierunt. Equidem noui quendam, cui poft Bolctorum non fatis elixorum

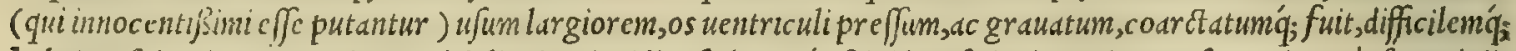
b.buit refkirationem, o in anmi deliquium incidit, fudoremq́; frigidum fudauit, ac demum feruari agré, fumptis ijs qua bumores craffos incidunt, potuit: cuius generis eft oxymeli infum per $\int e$, o cumbyfopo, or origano ipfi me: diocriter incoct is. Is cnim tum bac fumpfit, tum nitri pumam ipfis infperfam: poft qua fungos, quos comederat,

Nomina. uomuit, qui iam quodammodo in fuccum pituitofun, frigidum'́; admodum ac craffum erant mutati. Muxk่тยs qui Gracis, Fungi Latinis appellatur : Arabibus, Hatar feu Father: Italis, Fongbi: Germanis, Pfifferling, er reysken: Hipanis, Hongos, Cogomelos, o Cylherquas: Gallis, Champignon, er Potyron.

COLCHICVM.

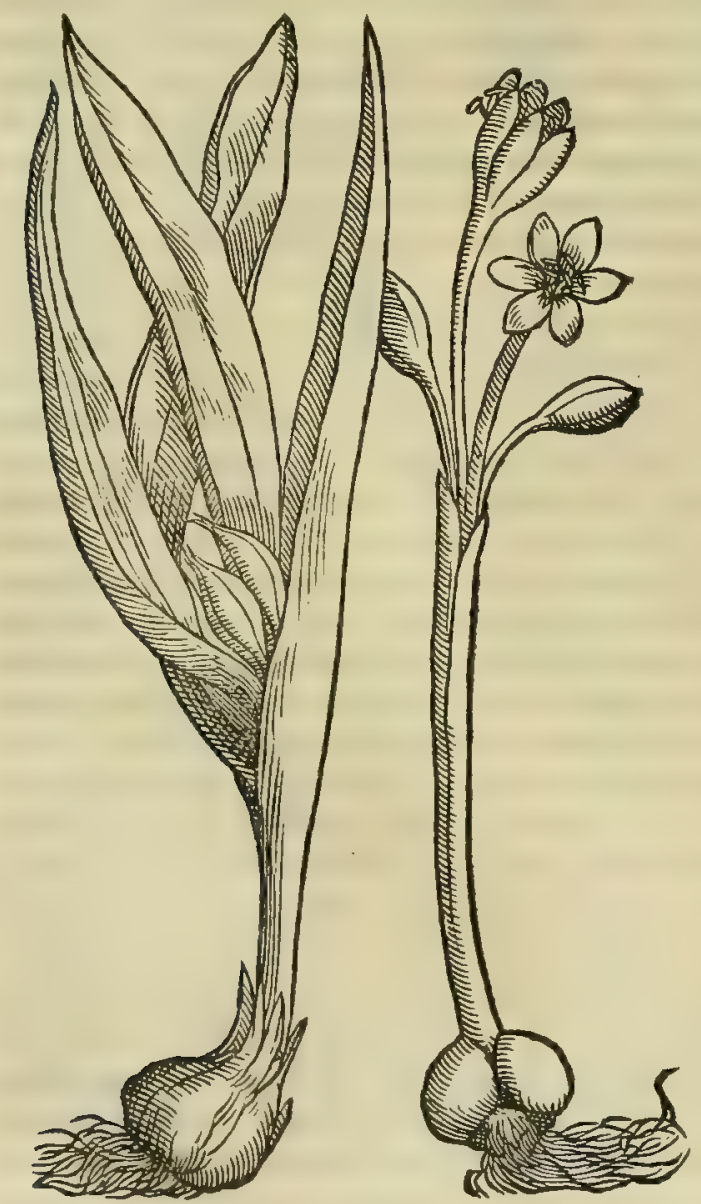

E P HE MER V M.

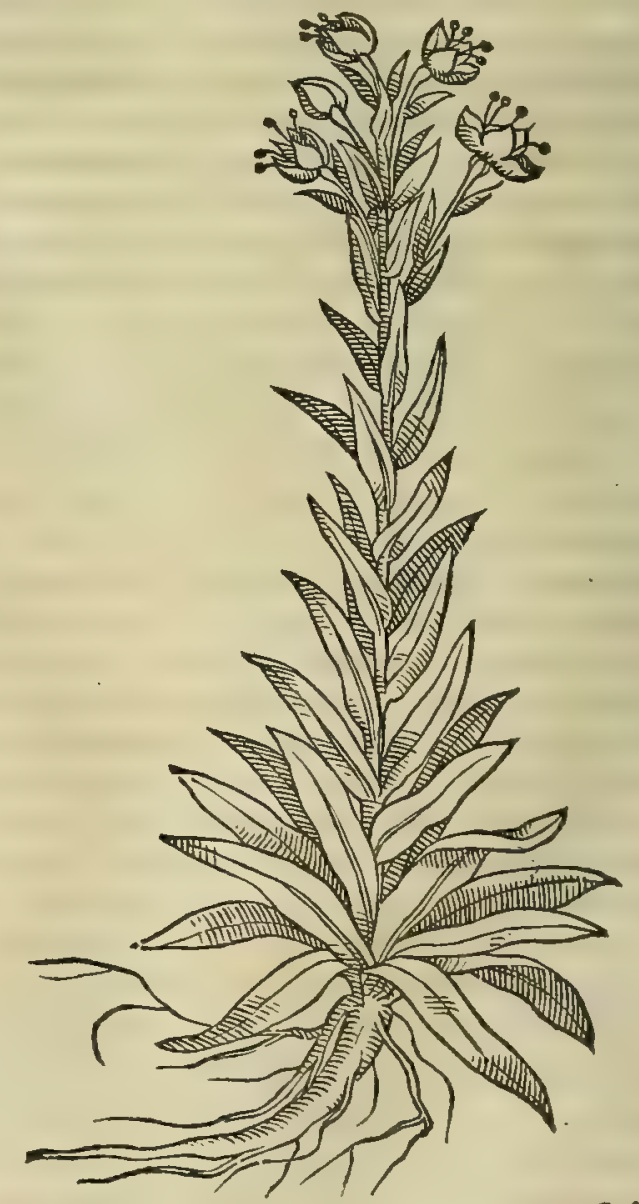




\title{
In Lib. quartum Diofcoridis.
}

\author{
KoגXIKóv. COLCHICVM.
}

CAP. LXXIX.

C O I CHI CON, aliquiephemeron, funt qui agreftem bulbum uocant. Autumni exitu florem edit croci, candicantem : ab co tempore folia bulbi, fed pinguiora : caulem palmo altum, ferentem ru fum femen : radicem foris è nigra rufićcentem, quæ delibrata, candida, \& mollis fpectatur, lactco fuc co madet, atque guftaiu dulc ss inuenitur : bulbus cius mediam habet rimam, fiffuramquc, qua floserumpit plurimum in Mcflenia, \& Colchis enafcitur. Ea comefa, fungorum more, ftrangulando enecat. Hanc autem depinximus, ne à quoquam imprudenter pro bulbo deuoretur: mirum enim in modum faporis uoluptate imperitos allicit. Remedio funt eadem, qux fung is : bubulum etiam lac po 20 tum auxilıatur. itaque cùn adfucrit, non aliud defideratur auxilium.

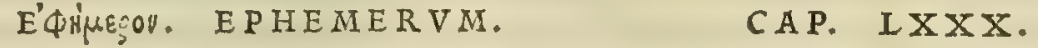

E P H E M E R O N, aliqui fylueftrem irin appellant. Folia habet lilij, fed tenuiora : caulem parem: florem candidum, amarum : femen molle : radicem unam, digitali crafsitudine, longam, adfringentem, odoratam. naficitur in fyluis, \& opacis. Huius radix dentibus pracipua, fi decocto colluantur. Folia in uino coEta, difcutiunt tumores, \& tubercula, qua nihil adhuc humidi contraxcrunt.

E P H E M E I I duogenera conftituiffe uidctur Diofcorides, unum, quod Colchicon, $\sigma$ agreftem bulbum: al= 20 terum, quod Irin fylucftrem cognominant. Quod primo loco de fcribitur, ufqueadeo perniciofum affirmant, ut uno die fumptum interficiat: unde ill Ephemeri nomen. Ea dutem ratione illud fe depinxiffe tradit Diofcorides, ne ab ali= quo imprudenter bulbi uice deuoretur : mirum enim, inquit, quantum faporis uoluptate imperitos alliciat. Verün cum boc duinum Diofcoridis infritutum non animaduerterint, uel forté neglexerint Mauritani, oo eos fecuti medici Juperioris noftre atatis, non modó fcipfos, of fequaces mifere deceperunt; fed of cateris omnibus errandi anfam facilé prebucrunt. Siquiden Colchicum ephemerum deleterium medicamentum, fi cius note diligentißimé expendan tur, nil aliud, meo quidem iudicio, reprefentare deprehendetur, quàm candidum illum bulbum, quem uulgó officine Mauritanos fecute falsó Hermodactylum appellant. Sed quantum deteftandus fit error is, or abolenda praud, ac per nicio a bec confuetudo, quantumue difcriminis, or incommodinoftris corporibus binc imnineat, aftimabunt $\ddot{j}$, qui recté diligenteró; eaperpenderint, que non foluin Diofcorides, e Galenus; fed e Paulus, er Nicander, er Pli 30 nius de Colchico ephemero pofteritatis memorix prodiderunt. quippe qui affirmauerint, id deuoratum eadem die ho= mines interimere. Quem effectun et/i hac tempeftate ab hoc manifefte preftari non conftet experimento in bis, qui ip fum in medicamentis affumunt; id tamen non alia de caufa fieri putauerim, quàm quod fortaffe in Italia, ut in Col= chide, mortiferum non proueniat: aut quod ed, que fumitur quantitas, exigua fit, neque ad perdendum fufficiens. sed non propterea dubitandum eft, quin boc fumentibus grauid o periculo fa incommoda inferse ualeat. Erroris occafionem dediffe uidetur Serapio, utpote qui confusé uno tantün capite de utroque Ephemero, er de Hermoda= Atylo fcrip ferit, nomine duntaxat Hermodactyliomnibus infcripto, immemor, uel potius ignarus, apud Gracos, d qui= bus tanen quicquid feré boni habet, mutuatus eft, eds plantas inter fe maximé differre. Quód autem in hoc deceptus Serapio bas herbas turpiter confuderit, fidem inanifeftam facit Paulus Aegineta, qui libro v I I. de Ephemeris, er de Hermodactylo fcparatin tanquam de diuer/is differuit: 0 primum de Hernodactylo, fic inquiens. Hermodactylira=

40 dix - per $\int e$, o ip/ius decoctum uim babet purgandi: priuatim artbriticis tunc, cim bumores defluunt, exbibetur. uerim ftomacho nimis quainaduer $\int a t u r$. Mox paulo inferius, fex tantün interiect is capitibus, de Ephemeris ita fori= bit. Ephemeron non uenenum illud, fed quod iris fyluatica nominatur, mifte potc $f$ atis eft, o r repellentis, $\mathcal{O}^{\circ}$ difcu= tientis per halitum. hactenus Paulus. Ex quibus fané palàn fit, non modó Hermodactylum cum Colchico nullam ha= bere cognationem; fed etiam hac in re plané ballucinatum fuiffe Serapionem, quem fecuticateri Mauritani, qui poft ip fum libros confcrip ferunt, atq; etiam ex noftris plerique, qui fuperiore atate claluerunt, ut cacicacos fequentes

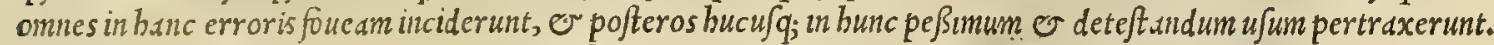
Iam itaque refipif cant tum medici, tum feplafiarij, qui Colchicum fuis medicamentis, or catapotijs inferunt, er ipsum iam non fecus ac fcopulum euitent, utpote quod, omnium probatißimorum authorum teftimonio, mortiferum fit me= dicamentum. Que autem radix nobis hodie Hermodactylus dicipoßit, difficile quidem fuerit decernere, quód ex

so probatis reibcrbatis fcriptoribus hatenus neminem inuenerim, qui notis ullis eius tradiderit biftoriam. Verunta= men, fi $\mathrm{ex} \mathrm{uocabuli} \mathrm{c}_{\mathrm{y}}$ mo conijcerc licet, nil aliud fignificare uidetur Hermodactylus, quàm digitun Hermi, aut Her = metis. Vnde factun $c \hat{i}$, ut aliquando cogitauerm, an illa bulbacea radix, que manus bumana formam refert, quam $q_{;}$ uulgo Chrifti palinain appellaitt, ad Hermodactylum accedere poffet, quód bulbacea fit, quemadmodum er Colcbi= cum, quod'́g fumpta non modó uomitiones, fed $\sigma$ aluum cieat, ut teftis eft Nicolus Florentinus, qui hac radice plu= ribus factis uomilionibus, Biliotum quendam quartanarium curauit. Hac in medium proferre libuit, non quod ita ef fe certó a ferere aufim, fed ut rei herbaria ftudio fis res bec melius aftimanda proponeretur. Nec illud fané hoc lo= co pretereundum duxi, quod Hernodactyli Actuario, er Nicolao Myrepfico, qui albi, or rubri Hermodactylime= minere, nil aliud repre entant, quim Beben album, o rubcum Mauritanis appellatum. Siquidem ex de fcriptione auree Alexandrine apud Nicolaum, er diamofchi antidott apud Actuarium id liquidó conftat. Sed non ob id dicen= dum eft, hermodactylum Pauli, er Serapionis idem cum illis effe : bis nanque altcrius generis radix eft, qua uim ha= bet deictoriam ad articulorum defluxiontes precipuam. Fucbjus medicus etatis noftre celebris, in libro de com=

Colchici, \& Ephemeri có fideratio.

Mauritanoná \& lequacium error.

\section{Serapionis la} plus. 


\section{8

pofitione medicamentorum, quem non pridem locupletatum edidit, hermodactylum Pauli defcribens, inquit. Vnus babet radicem alban, crafjam, ac modice duram . atq; is est, qui in bodiernum diem nomen bermodactyli in officinis snedicorum retinet. A' Paulo quoque bermodactylus appellatur. Ex ijs nimirum uerbis Fuchfius fibi perfudfiffe ui= detur bermodacfyl:un communis ufus cundem effe cum $\mathrm{P}$ auli bermodactylo : cum tamen omnibus fic ré conftet, illum nö aliud effe quain Colchicum. Qusocirca nulli cquidem dubium effe puto, quin Fucb/ius bac in re deccptus fit . nifi fepla fix Tubingenfes probermodactylo aliam ufurpent radicem ab ea, quam hactenus in reliquis Germaniz pharmacopo= lijs ufurpari uidimus. Caterim Ephemerum, quod fylueftrem Irin appellant, in Ananienfilbus montibus tam in prad= tis, quàm in fyluis copiosé nascitur, ubi indigenis uocatur uulgá Giglio matto, boc eft, Lilium ftultum. Huic certe, Fuchai erra- nifi me fallit iudicium, omnes prorfus note conueniunt, qua alteri Ephemero ḋ Diofcoride tribuuntur. Hinc ita= tum. que fit, ut in boc Fuch/ius, uir alioqui doctißimus, aperté erraffe deprehendatur, qui plantam mulgó Lilium conual= lium uocatam Ephemerum alterum, or non letbale effe contendit. Quandoquidem illud folia litio latiora, non autem anguftiord, $\mathcal{G}$ dißimilia profert : caulem non lilij modo, fed gracilem, of ftaminis inftar tenuem : radicem itcm exi= lem, que capillaribus diuiditur fibris, tantum abeft, ut digiti craßitudinem aquet, qualis in Ephemero requiritur. Praterea neminem adbuc reperi, qui tradat Ephemerum flores ferre fuauiter olentes: cum tamen Lilij conuallï di= ctiflores adeó iucundum pirent odorem, ut eius gratia ab omnibus maximé expetantur : id quod nunquam filentio praterij]fet Diofcorides in re herbaria grauißimus author, prafertim quòd ea nota fuiffet Ephemero infignis, $\circlearrowleft$ no tabilis. Ex his igitur colligendum effe putauerin, non folum Fuchfium in aperto errore uerfari; fed reliquos etiam, qui Lilium conuallium uocatum Ephemerum effe contendunt. Sed ad Colchicum reuertamur. Floret boc autumik tempore, floribus croco amulis, nullis tamen emißis folijs, nifi appetente uere, quo tempore fubrubeum gignit femen, quibusdam folliculis inclufum, iuglandium fimilitudine. Verum boc tempore radix ei dulcis non eft, quemadmodum in 20 autumno, fed lacte pragnans, $\sigma$ amar inuenitur. Quare bic cogimur dicere, o fateri, quód boc non ob eruaue= Monachorũ rit Diofcorides, uel faltem, quód indictum id omiferit. Porró in communem illam ballucinationem anté explofam hallucinatio. deducti funt er patres illi reuerendi, qui in Mefuem commentarios ediderunt : quippe qui nullam faciant differentiä inter Colchicum, e Hermodactylum, id'q; aperté afferunt. Quorum etiam auctoritate freti pharmacopole adduci pofjunt, ut cum maximo bumane uite detrimento colcbicum catapotijs immifceant. Quare caueant meo confilio fe= plafiarij, neque facilé fidant ijs, quos magis decet libros facros, quàm medicos euoluere, ut aninabus potius, quàm corporibus mederi fciant. Caterum colchicifloribus, ut audio, utuntur Turce, cim inebriari uolunt: cos enim ui= Ephemeri ui- no macerant, cóq; poto adeo ftupidi redduntur, ut in ccftafin abeant. Vtriusque Ephemerimeminit Galenus libro res ex Gal, VI. fimplicium medicamentorum, fic inquiens. Epbemerun non illud lethale feu deleterium, quod $\sigma$ Colchicon uo= cant, fed alterum, quod $\widetilde{\sigma}$ Irin agreftem cognominant, folid, or caulem litio fimilem obtinet : radicem oblongam, 30

HEIXINE.

Nomina:

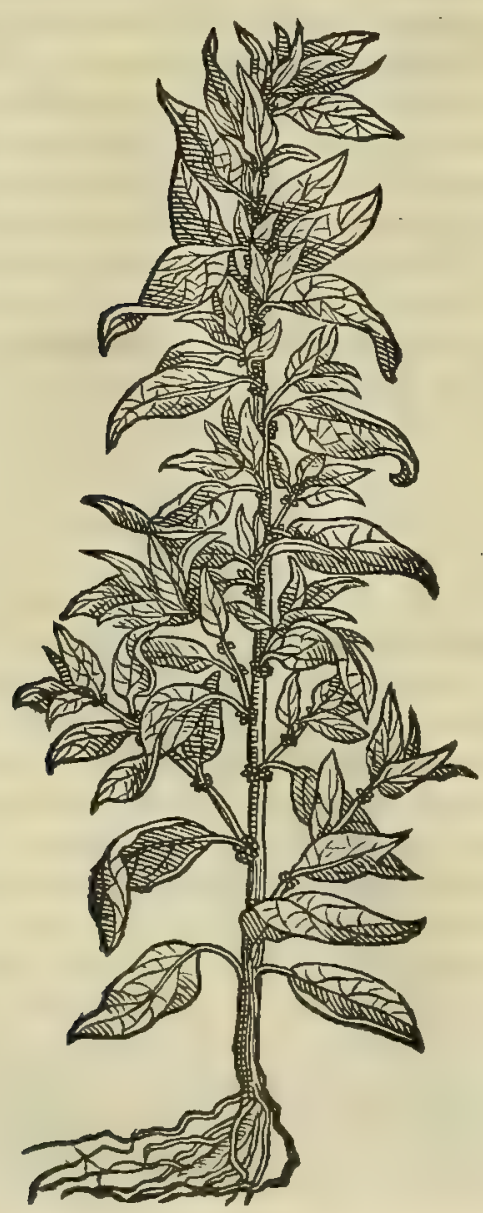

non rotundam ceu colchicun, digiti potißimuini craßitudine : eft autem adstringens, $\sigma$ boni odoris. Ex quibus paldin fit, quód mi= ftefit facultatis, temperaturéq, nempe repellentis, or balitu digerentis. Teftificantur ueró id operd, qua particulatim edit. siquidem non inefficaciter radix eius in dentium doloribus collui= tur : O folia tuberculorum tum augmento, tum uigori congruunt. Oportet autem ed in uino decocta, priusquàm pus moueds, illine= re: Planta, qua Gracis ro $\lambda \times 1 x^{\prime} v_{3}$ L dtinis Colchicum, er Bul= bus agreftis uocatur: Arabibus, surugen: Italis, Colcbico: Ger= manis, Zeitlofz, $v$ Vuild faffran bluom: Gallis, Mort au chin, 40

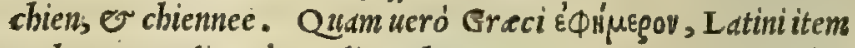
Ephemerum dicunt: Itali, Ephemero. At que recentioribus

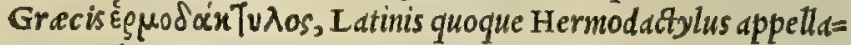
tur : Italis, Hermodattilo: Mauritanis, Surugen, uel surengiam, ita tamen ut hanc cum colchico aperté confundant.

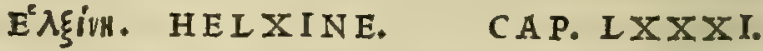

HE L X I E nafcitur in parietinis, fepibus, \& macerijs . folia ei mercurialis infunt, hirfuta: cauliculi fub- 50 rubentes, \& circa eos ueluti femina afpera, adhærentia ue ftibus. Folia refrigerandi, fpiffandiq́ue naturam habêt. qua ex caufa fanant illitu facros ignes, adufta, condylomata, panos incipientes, tumores, inflammationesq́ue. Succus eius cum ceruffa, ignibus facris, \& ulceribus quæ ferpunt, commodè illinitur : imponiturq́; podagris cum hircino adipe, aut cerato cyprino: veterem tufsim emen dat, inftar cyathi hauftus : tonfillis inflammationem fen tientibus utiliter \& gargarizatur, \& oblinitur : aurium dolorem cum rofaceo, inftillatus leuat. 


\section{In Lib. quartum Diofcoridis.}

HE I X I N E N, que hic d Diofcoride defcribitur, officindrum unlgus Parietariam appellat, quód in adifi = ciorun parietibus nafcatur. Alij, quod detergendis uitreis poculis/it aptißima, vitreolam nominant. Hac planta omnibus notißima eft: quatre fupcruacaneum effet, eam longiore hiftoria reprafentare. Verium alia ab hac, e lon= gé diuer $\int_{a}$ eft Helxine, quam Plinius libro $\mathrm{x} \times \mathrm{I}$. cap. $\mathrm{x}$ V I. inter aculeata retulit, o depinxit his werbis. Helxine gara uifu eft, neque in onmilhus terris eft: radice foliofa, ex qua media ueluti malum extubcrat, contectum fua fronde. Huius uertex funmus lacryman continet, iucundi faporis, acanthicen maftichen appellatan. hiec Plinius. Helxi= nes uires tradid t Galenus lib.v I. Fimplicium medic amentorum, fic inquicns. Helxinen aliqui perdicium nominant, alij partheniun, alij fidcritin, funt qub bcracleam appcllitent. Caterim uis ci ineft abftergendi, o leniter conftrin= gendicum bumiditate fubfrigida. Cuamobrem pblegmonas omnes in initio, $\sigma$ augmento fanat ufque adftatum, $v$ 20 maximéfi calide fucrint. Quinctian incipientibus phygethlis cataplafmatis ritu illinitur. Succus quoque eius cum rofaceo ad aurium dolores phlegmonofos, mediocriter profuerit. Gargarizandum itcm nonnulli exbibent ad parifth= mix. Sunt uerò etiam ex medicis quidam, qui ijs, qui diutina tußi uexantur, illam exhibucrint. Certé enidens exter=

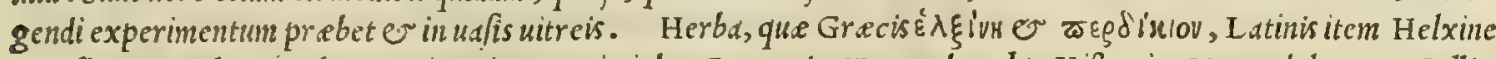
appclatur: Italis ac uilgo, Parictaria, o vitriola: Germanis, Tag und nacbt: Hipanis, Yerua del muro: Gallis, Paritoire.

A'AJin. ALSINE.

CAP. IXXXII.

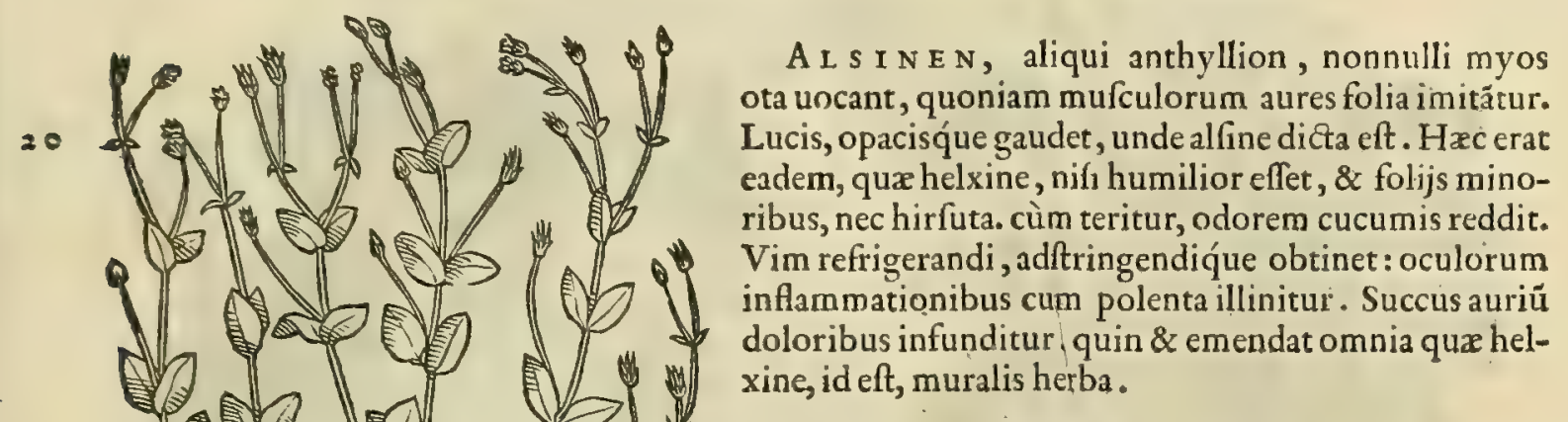

A I S I N E eanimirumberba eft molliufculd, qux Hetru= Alfines confcis Centone, alijs ueró Pauarina, alijs Pizza gallina, alijs Cen= fideratio. touice uulgó appellatur. Et qranuis Diofcorides uname tantüm Alfinen reprafentauerit; plurt tamen eius reperiuntur generd. Porró babentur quadam Dioforidis exemplaria, in quibus $c d=$ put hoc legitur in calce libri fe undi ftatim poft Muris auricule mentionem. Sed nos, ut eo in loco latius diximus, hanc fudin ue= ram ac germanam fedem effe renfemus. Alfines meminit $\mathrm{G} a=$ Vires ex $\mathrm{Gal}$. lenus libro vi. Fimplicium medicamentorum, ita de eius uiribus fcribens. Alfine, dut Myos ot fimilem belxine facultatem ob= tinet, nempe refrigeranten, o bumectantem: eft enim elfentix aquex frigide: quare er itra adfrictionem refrigerat. Quo= circa ad fruentes phlegmonas, or mediocria eryfipelata com= petit. Hac á̉ Italice, Centone, or Paturina: Germanicé, Huener dorm, Vogel kraut: Gallicé, Murronem.

IENS PALVSTRIS。

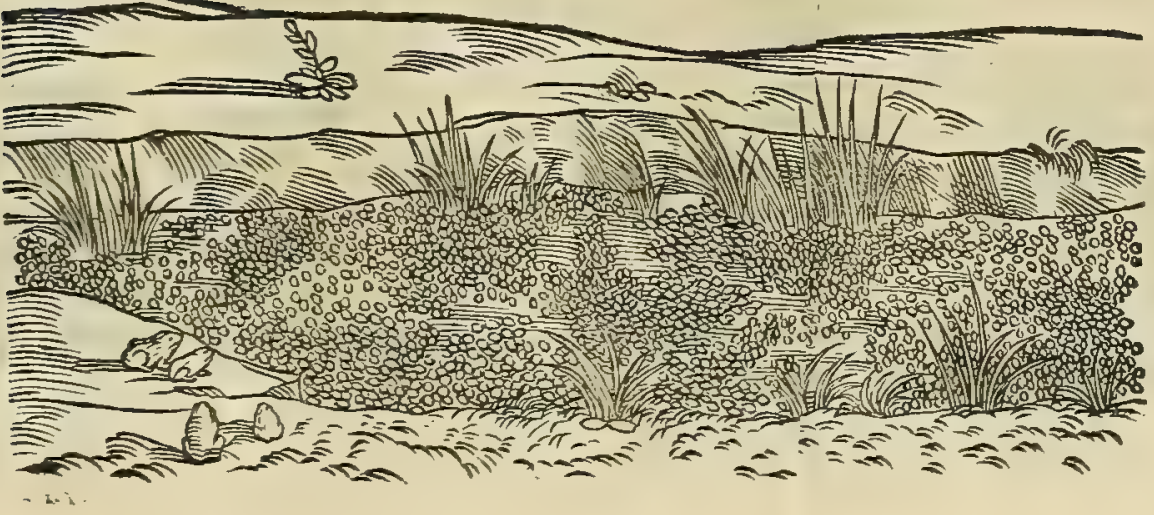




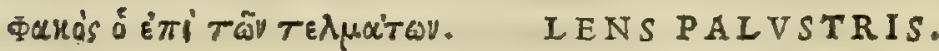 CAP. LXXXIII.}

LE N 5 paluftris inuenitur in aqua non fluente, mufcus lenticulæ fimilis, refrigeratoriæ naturæ. Propter quod conuenienter collectionibus, igni facra, \& podagris illinitur per fe, \& cum polenta: glutinat \& procidentia puerorum interanea.

Ientis palu- P A L V S T R I s lens, quam officine, or berbariorum uulgus Lenticuldriam appellant, notior omnibus eft, ftris confid. quàm ut pluribus defcribi mereatur. Ea plerunque flagnantibus aquis innatat, ijs ; $_{\text {; }}$ prà fertim, que urbes, or oppi= 20 Facultas ex da cingunt. Ientis paluftris non nifi temperamentum prodidit Galenus libro v I I I. fimplicium nedicamentorum, Galeno. ubific inquit. Lenticula paluftris bumida, frigidéq temperatura eft, utrinque ex fecundo quodammodo ordine.

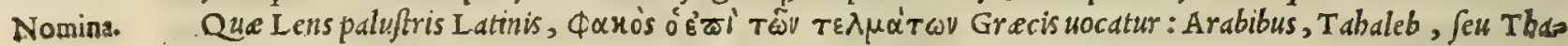
leb: Italis, Lente de i paludi: Germanis, Vuaffer linfen: Hifpanis, Lenteya dellagoa : Gallis, Lentille de mer.

SEDVM MAIVS.

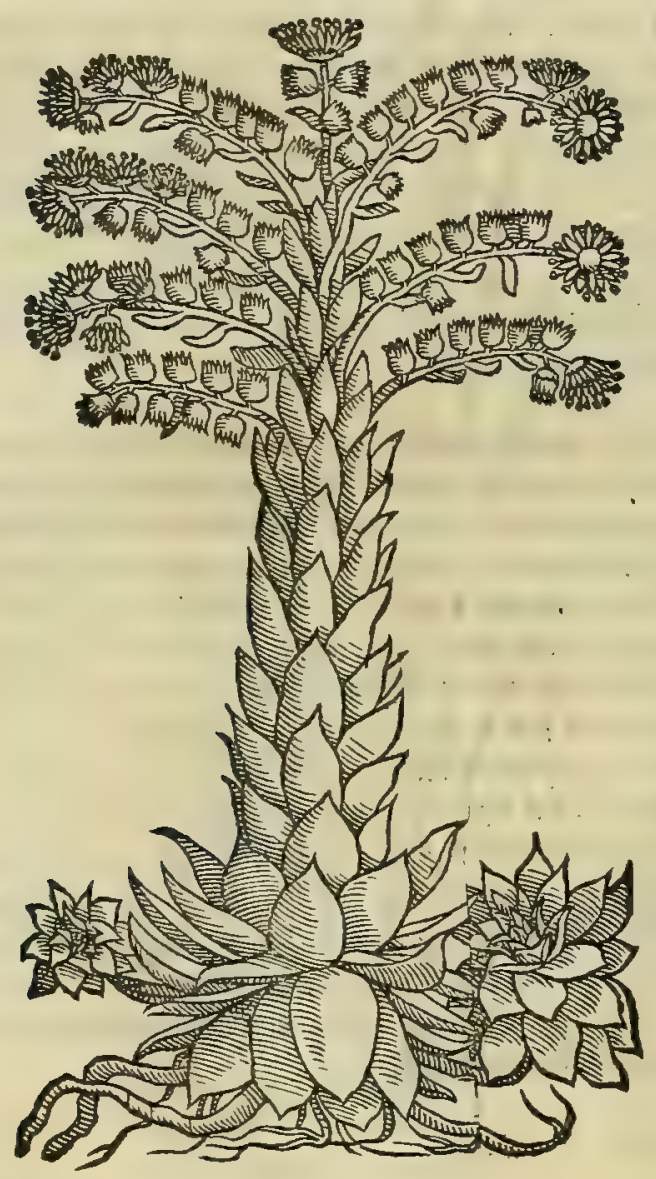

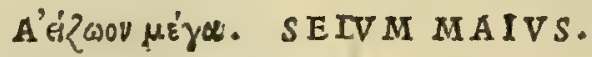

SEDVM MINVS.

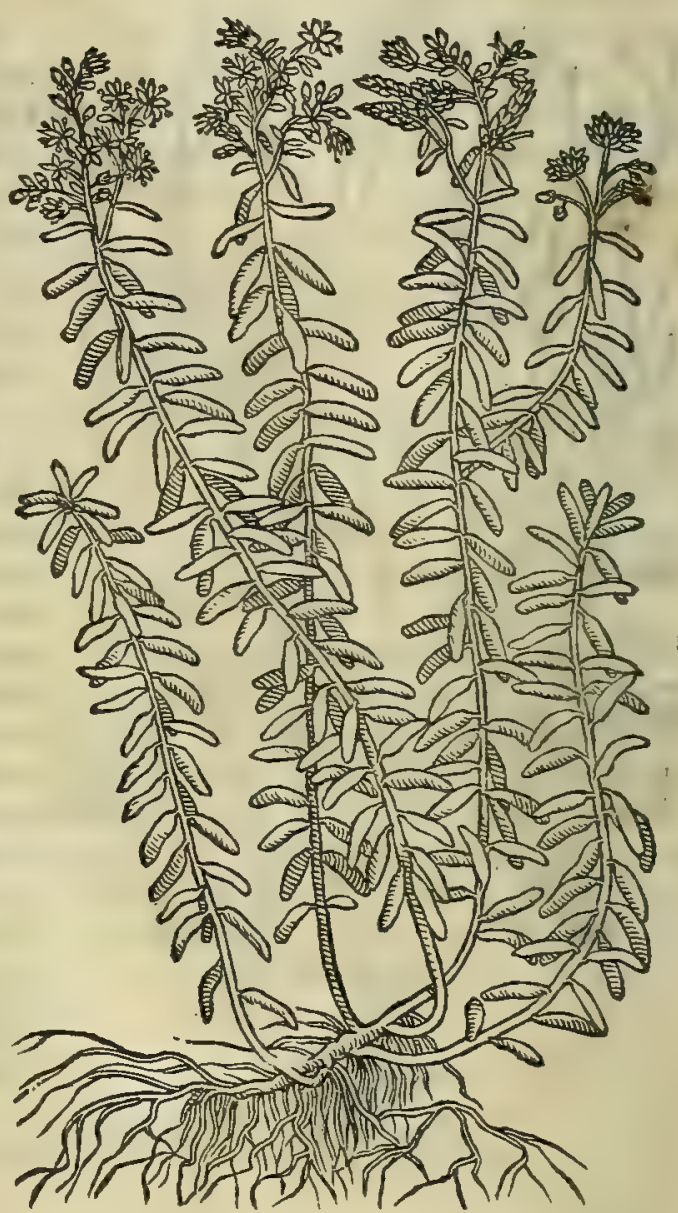

CAP. LXXXIIII:

SE M P E R V I V V M magnum ideo nominatur, quoniam perpetuò folia uireant . cuius caules so cubiti altitudinem implent, interdm excedunt, pingues, crafsitudine pollicari, uirentes, characix tithymali modo infecti : folia pingia, carnofa, longitudine pollicari, in cacumine linguæ fimilia, alia in terram conuexa, alia in capitiftantia inuicem, ita ut ambitu effigiem imitentur oculi . nafcitur in montibus, \& teftaceis : fupra dohicilia etiam feritur.' Eius uis refrigerare, \& adftringere. Medentur igni facro, nomis, ulceribu qux ferpunt, oculorum inflammationibus, a mbuftis igni, podagris per fe, \& cum polenta illita llia . Succus capiti in doloribus, cum polenta, aut rofaceo perfunditur : datur in potu contra phalanţorum iztus, dy fenteriam, aluiqúue profluuia : teretes tineas potus in uino excutit : fubditus in uelire, mulierum abundantiam fiftit. Succus oculorum lippitudinibus, fanguinis uitio conceptis, inuritur. 


\section{In Llbr. quartum Diofcoridis.}

\section{A'écorpurpòv. SEDVM MINVS. CAP. IXXXV.}

SEM P'ER V.I V V M paruum in petris, parietinis, \& macerijs, necnon fcrobib us opacis nafcirur, caulibus ab una radice multis, tenuibus, crebrè foliatis : exilibus folijs, rotundis, pinguibus, mucronatis : caulc à medio emicante, palmum alto, umbellam, herbidosq́ue flores, s tenues gerente. Folia eifdem cum priore uiribus prædita funt .

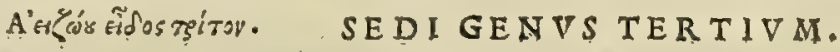

\section{CAP. IXXXVI.}

TE R T I V M uidetur femperuiui genus, quam aliqui andrachnen agriam, aut telephion uocauerunt, Romani illecebram, pufillis, crafsioribusque folijs, hirfutis, portulacx proximis, nafcitur in faxis. Vis ei excalfactoria, acris, exulcerans . illita cum auxungia ftrumas difcutit.

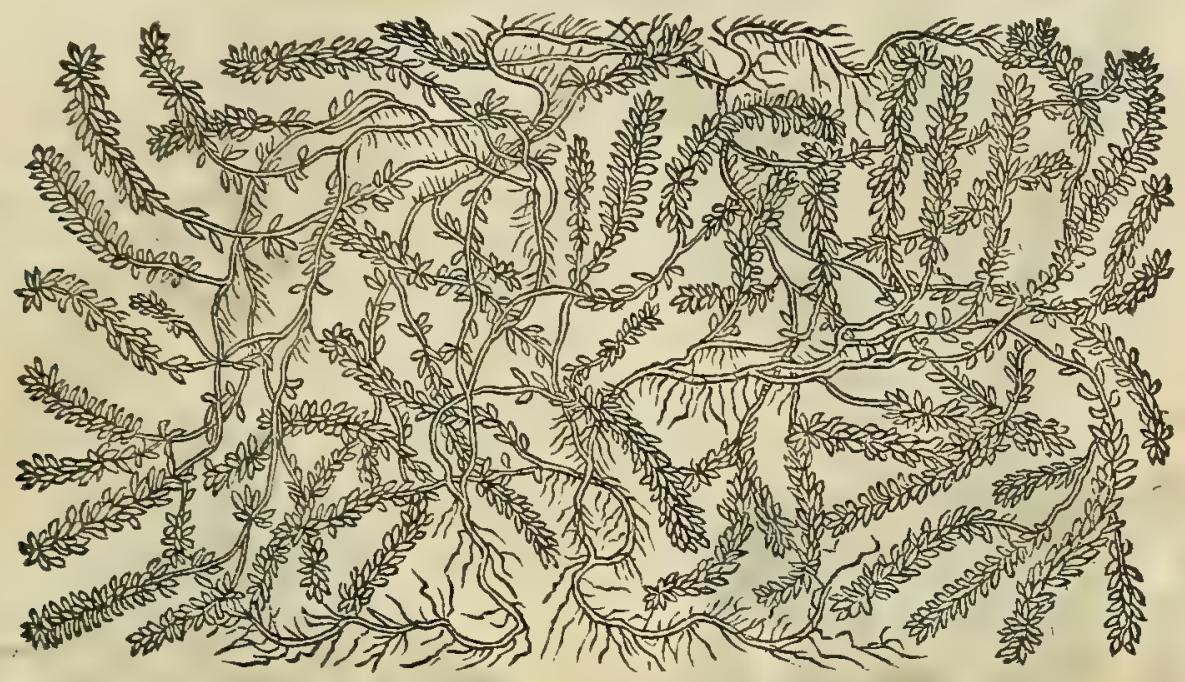

E $\mathrm{x}$ T R I BVS sedi, fiue semperuiuigeneribus, qus boc loco d Diofcoride pinguntur, primum, er alterum Sedigenera, omnibusnota funt. Vtrungine officine Semperuiuum appellant, addita maioris, er minoris differentis. quanuis non \&icoulader. defint, quiminus Vermicularem, Crafulan'q berban uocent. Minoris duo uifuntur genera. Alterum, cuius Dio= fcorides imeninit, folijs craßsioribus, longioribus, rarioribusóf, facie nucleis pineis à putaminbus repurgatis fimli= bus, unde quibusdan uulgó etiam Pignola dicitur. Caules fert tenues, pluresq́; : in quorum cacumine flores excunt berbacei, feu Jubcandidi, umbelle diuulfe modo. Alterum folijs brevioribus, angustioribus, copiofioribusí;: floribus melinis, codem ordine prodeuntibus. Hoc marem, illud foeminam recentioruin quidam exiftinant. At tertum, quod 4o mibi iandiu incompertum extitit, cum ufqueadeó excalfaciat, ut carnem exulceret impofitum, d̀ ceteris longé facul= tatibus difidet. Huius uaria in Diofcorịdis codicibus legitur biftoria: caterum nos Aldinum exemplar fecuit, hinc ed abdicauimus, que adulterina cenfentur. Nec defunt qui crediderint, tertium boc Dio/coridi effe fpurium, çuod duos sum tantum meminerit Galenus. Veruntamen é Pifis boc anno tertium sedigenus, guftu fané acerrino, adeo ut lin= guam exulceret, ad me mifit Lucas Gbinus Forocornelienfis medicus rei berbarie peritißınus. qui ull plinte bac werba fubiccerat, que bic referam eius bumanitate fretus. Vifitur, inquit, in uiridario illustrißani Ducis flarentice quoddam tenuißuni sedi genus, gustu nibiló minus acri, quàm ranunculi omne genus. quodetiam in antiquis edifi= ciorum parietibus, or faxorum rimis prouenire conpexi. Hoc, meo iudicio, tertium eft medum. Sed cüm Diofcort-

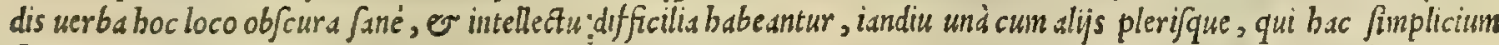

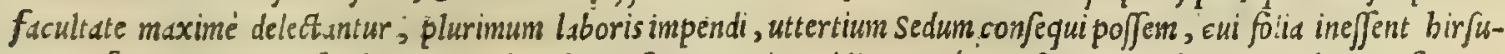
so ta, or facie portulace fimulia. Ceterum cùm poftea attentius, diligentıus q́; Diof coridis uerba perpenderem, fic $L a=$ tiné. fonare uidentur. Efter tertium fedigenus, quod portulac a repectu, folia edit pinguiora, denfiorá́;; , erc. Quibus cum bunc dederim fenfum, qui, mea fententia, propriam Diofcoridis mentemexplicat, tertium. boc fedum facile mbi $\int e$ e obiulit cognofcendum, ut ommbus quoque idip fum euenire haudquaquam dubitauerim, qui Grecam difionem

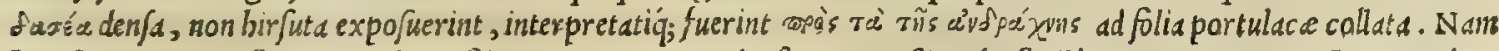
buiufec tertij fedı folia, portulace folijs compara:a, ijs denfiora, craßiorá; facilé cernuntur. Hactenus amiṣs ille. Cuius certé fententia non poffum non adştpulari. quippe quxe doctißsmis rationibus nitatur, or ip/e fit apud me grauis teftls. Semperuiui mentionem fecit Theopbraftus lib. X V I I. cap. V I I I . de plantarum biftoria, fic inquiens. Semperuiuo datum à naturd est, quòd humidum, uiridéq; femper durare ualeat. Folio carno 0 , leui, atque ob= longo id conftat. Planis parietinis nafcitur, necnon er in tegulis, chin terre confluuium quoddam arenaccumfactum eft. bec Theopbraftus. Sediuires defcripfit Galenus ll6.V I. fimplicium medicamentorum, bis uerbis. Aezoon utrunque, tum maius, tum minus, deficcat quidem leuiter, quandoquidem or mediocriter adátringit, omnis alterius

Sedi uires ex uibimentis 
webementis qualitatis expers: quare in co plus cateris abundat effentia aquea. Caterum non mediocriter vefrigerat: est

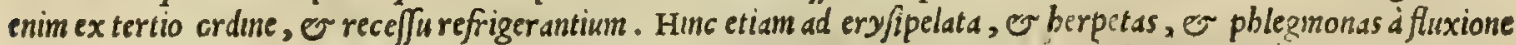

Nomina. natas accommodatur. Semperuiuum fíue Sedum maius quod Latini uocant, Grecic'és' wov $\mu \varepsilon^{\prime} y a$ : Mauritani, Beiabalalen, feu Hai alhalez: Ital, sempreuiuo maggiore: Germani, Grofz baufz uurtz: Hypani, Sempreuiua, or yerua

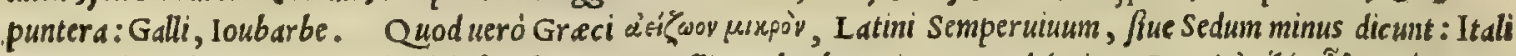

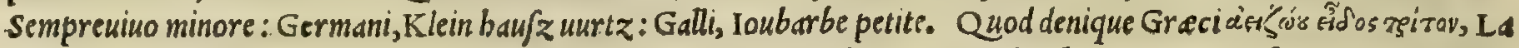
tinis Semperuinifiue Sedi genus tertium appellatur: Arabibus, Alfebram, Handracbabara, o Tilafon: Italis, sempres uimo terzo.

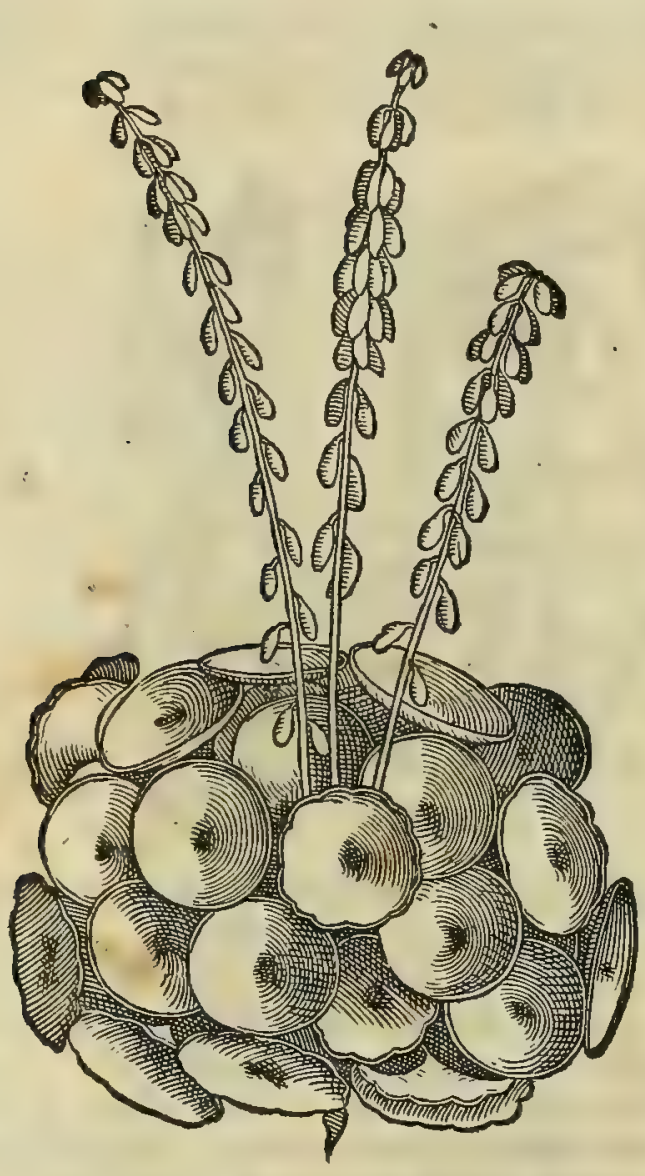

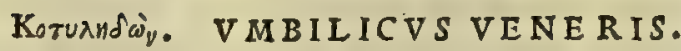

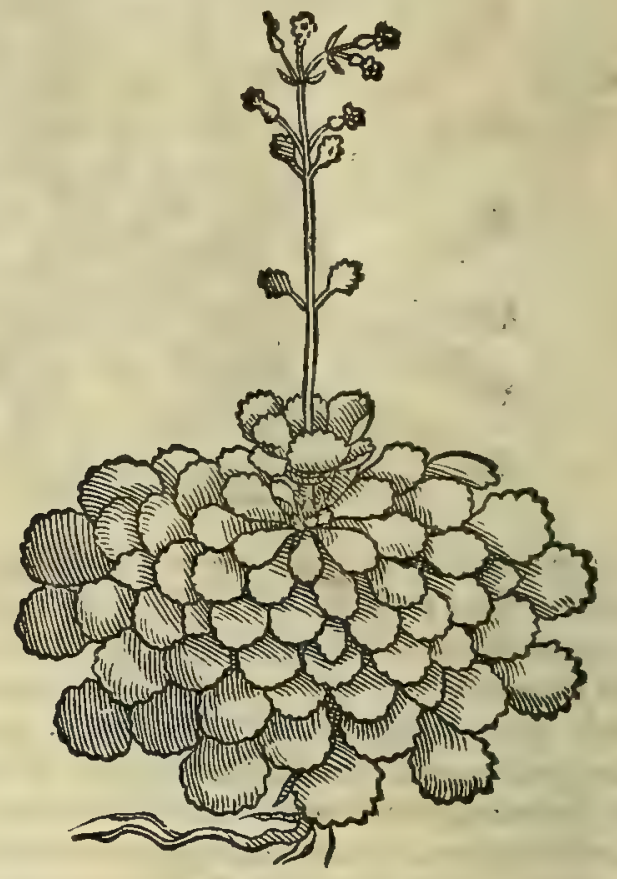

CA P. LXXXVII.

CO TY LE D ON, fiue vmbilicus Veneris, folio eft in acetabuli formam tornato, ineuidenter concauo, breui in medio cauliculo, in quo femen ineft: radice oliuæ modo rotunda. Succus cum uino circumlitus, inftillatúsve contecta genitalia nudat: inflammationibus, facris ignibus, ftrumis, pernionibus, illitu auxiliatur : ftomachi ardorem refrigerat. Folia cum radice comeła, calculos frangunt, urinam cient : hydropicis cx melle dantur. Herba utuntur ad amatoria .

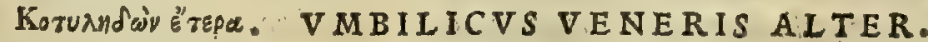 CAP. LXXXVIII.}

E S T E T alterum vmbilici Veneris genus, cy mbalion aliqui uocant, pinguibus folijs, latioribus, ligularum modo, denfis circa radicem, medium oculi ambitum defcribentibus, ut in maiore femperuiuo, adftringentis guft us : cauliculo tenui, in quo flores \& femina hyperici : radice maiufcu1. Facit eadem, qua femperuiuum.

Vnibilici Ve nerisutrufo, confider.
V M B I L I C V S Veneris, quem prinnogeneri aßignant, frequens nafcitur in uniuerfa feré Hetrurid, faxis, er uetustis adificiorkm parietibus. Huius folia, quód fictlium operculis fimilia fint, uulgó senenfes appellant Copertow ivole. Alterum ueró eius genus a quibufdam Cymbalion uocatum, uidimus primum in Foroiulienfium ciuttate Aue Stribe, in bortulo quodam excellentißstmi medici Iuliani d̀ Maroftica Teruifienfis. Hanc porró plantam in pluribus mon tibus faxis inherentem inuenimus. Cui, meo quidem iudicio, omnes prorfus conueniunt note, que alteri umbilica 


\section{In Lib. quartum Diofcoridis.}

Veneri tribuntur. Caterim apud Infubres officina legitime Cotyledonis, ftue umbilici veneris loco, berbam quandam in parietinis, or macerijs nafcentem ufurpant, qux ex ijs cminet, or cone modo dependet, caule tenui, folijs bederaceis, per ambitum mucronis inftar laciniatis. Hanc forté, quód Cymbalaria uulgó uocetur, putant à cym balio corrupté nomen traxife, or ideo uerum Veneris umbilicum effe. Sed euidentius errant, quim ut oftendide= beat. Fuchfius quoq;, cuius uiri alioqui eruditi pace dixerim, in bac re ballucinatus deprehenditur, quód in paruo fuo libro, in quo plantarun duntaxat imagines expreßsit, pro utroq; unbilico Veneris eas nimirum plantas depinxe= rit, que nonmullis uulgó Faburi.e, o Fabe craffe appellattur: quis tamen prius in fuo de ftirpiun biforia commen= tario pro telephio oftenderat. Verum tam primid, quàm altera eius opinio, ut dican quod fentio, mili plané repro= banda uidentur. Quemadmodum er tertia ciufdem de cadem re fententia, quam non ita pridem protulit in eo libro 20 de compofitione medic amentorum, quem poftremó auctum excudit. Ibi enim putat Fucbjius Acetabulum alterum, fiuc alterum umbilici Venteris genus, effe Fabariam, quam uulgus e feplafie Craffulam maiorem nominant. Sed quód is in magno werfetur errore, manifift um fit fatis ex Diofcoride. Quippe qui cymbalio, feu alteri veneris umbilıco, folia reddiderti denfa circa radicem, que medium oculi ambitum defcribant, ut in maiore femperuiuo : cauliculum ueró tenucm, in quo flores of femina byperici. Que tamen note in Fabaria, aut Craffula maiore defiderantur. Si= quidem hee folijs conftat horten is portulaca maioribus, qua cum femperuiuo mullam habent feré fimilitudinem, nec oculi formam defcribunt: caulem preterea enittit craffum of firmum . radicibus denique nititur pluribus, afthodeli proximis. Vmbilici veneris meminit Galenus libro vi I. fimplicium medicamentorum, fic tnquicns. Cotyle= don facultatis mifts eft, nempe bumide, fubfrigide, or cuiufdam obfcuré adftringentis, or cum ca leuiter ama= re: : unde refrigerat, repercutit, abftergit, or difcutit. Itaque phlegmonds eryfipelatodes, 0 eryfipelata phleg =

20 monode curat: o maxime ftomachi ardore aftuantis admodum utile eft epiplafma. Putantur folia cum radice manducata calculos confringere, or urinam monere. Koт $\checkmark m b i l i c u s$ ueneris nominatur: Italice, Ombilico divenere: Hifpanicé, Scudetes: Gallicé, Efcudes. Qua uerò

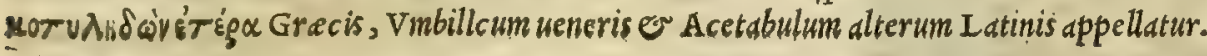

Officinarum error.

Fuchsij hallu cinatio.

\section{VRTICA PRIMA.}

VRTICA SECVNDA.

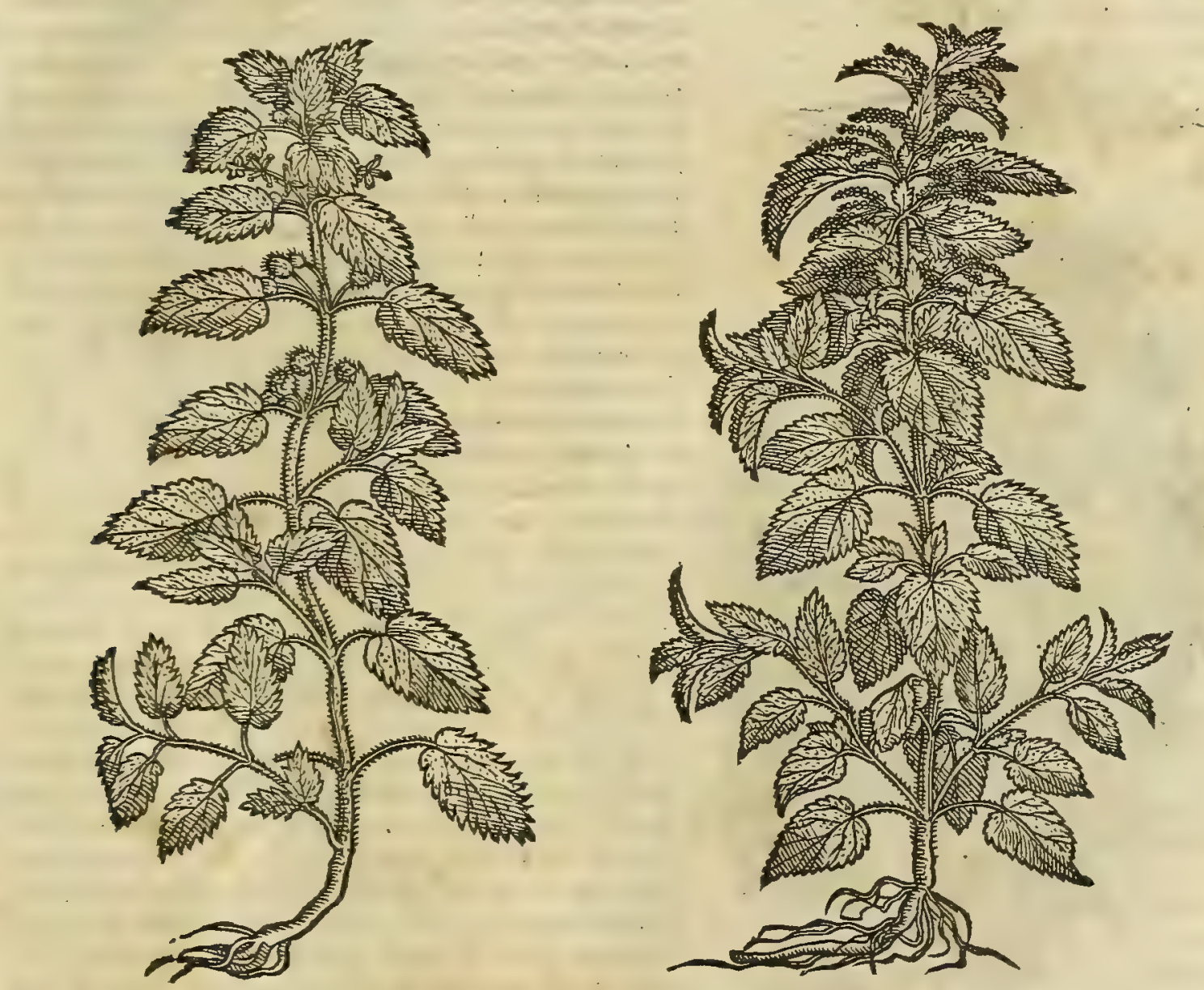

A'x

CAP. IXXXIX.

D v 0 V R I I A Eenera. Altera fylueftrior, afperior: latioribus, nigrioribusque folijs : femi nelini, fed minore. Altera non zquè afpera, minuto femine: Folia utriufque illita, canis morfibus addito fale, medentur : gangrænas, carcinomata fordida ulcera, \& quæ çacoéche uocantur, item lu- 


\section{4 \\ And. Matthioli Comm.}

VRTICA TERTIA.

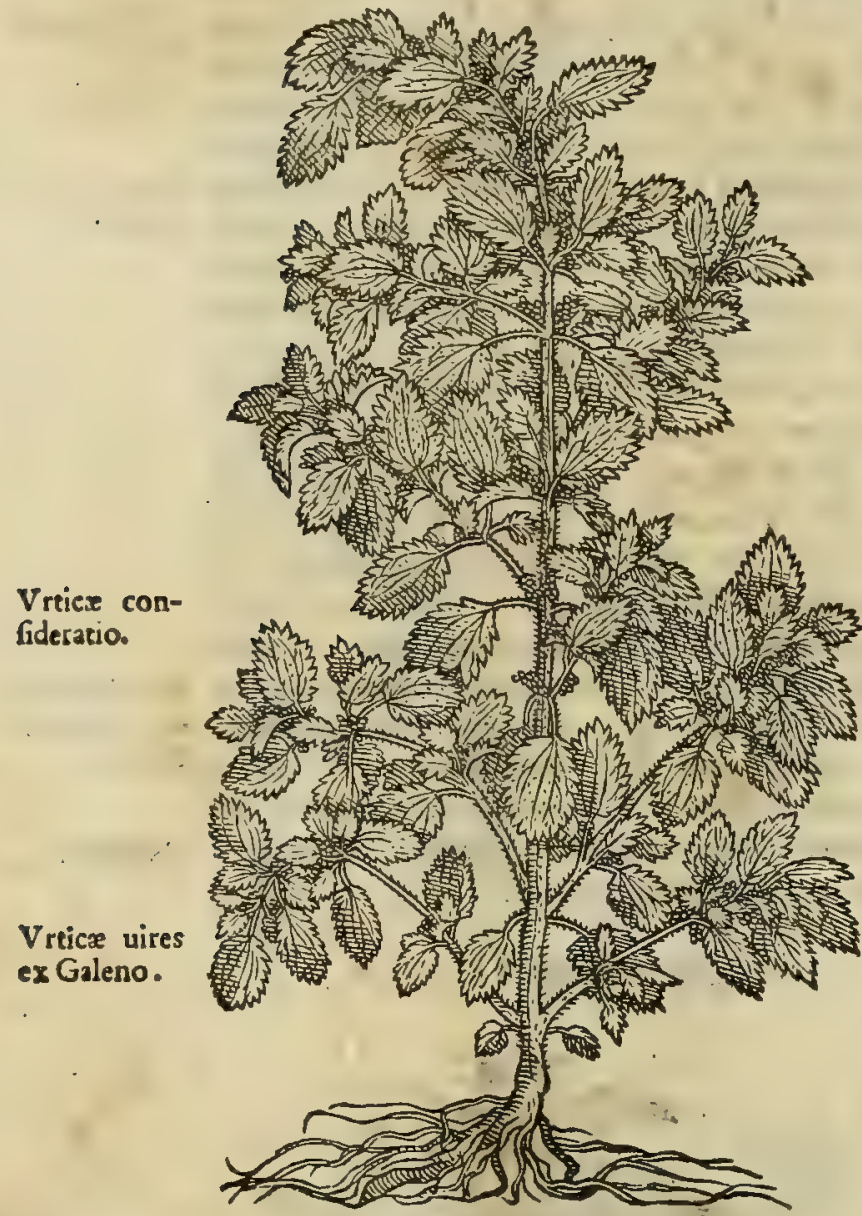

CARDIACAM.

Cardiacx hiftoria,\& uires

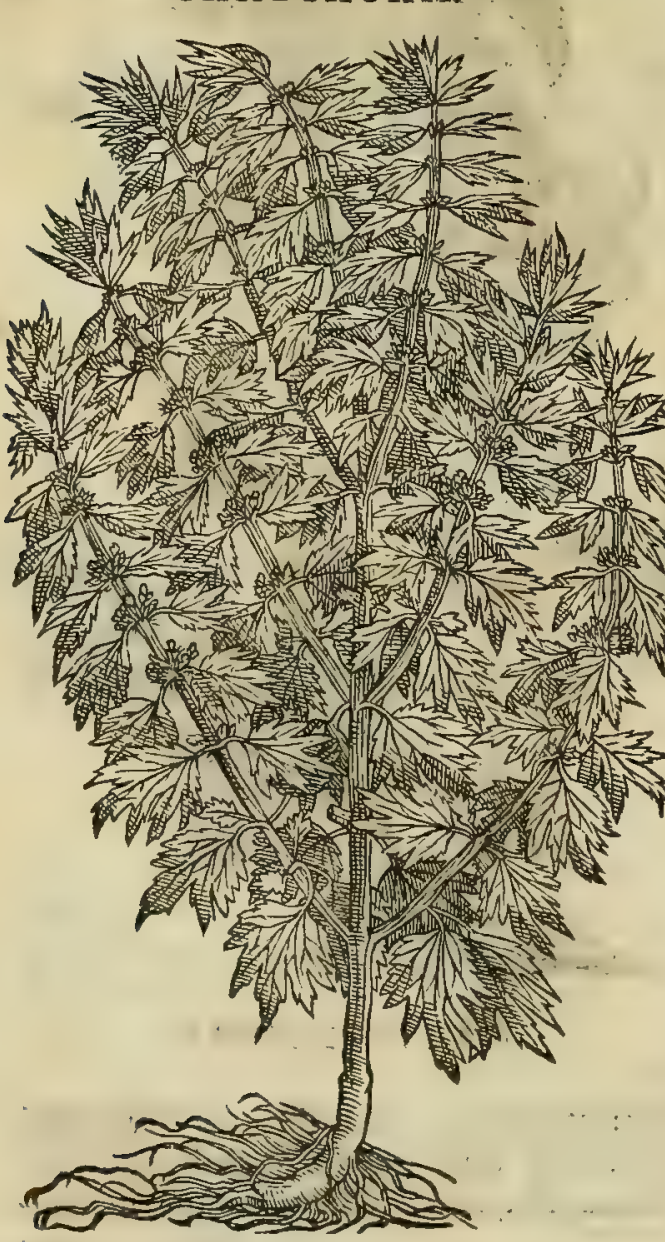

xata, panos, tubercula, parotidas, fuppurationesq́ue fanant : lienofis cum cerato imponuntur : faciunt ad profluuia narium cum fucco trita, \& naribus indita: menfes ciunt eadem detrita cum myrrha, \& impofita : prociden tes vuluas recentia contactu refilire cogunt. Semen potum ex paffo uenerem ftimulat, \& vulux ora patefacit ; cum melle delinctum orthopnœex, lateris \& pulmonum inflammationibus prodeft : thoracem expurgat . eroden tibus medicamentis admifcetur. Cocta cum conchis folia aluum emolliunt, vrinas mouent; inflationes di- 20 fcutiunt : decocta cum prifana, uitia pectoris extrahunt: mulierum menfes euocant, cum my rrhæ modico pota : Inflammatione turgentem vuam, gargarizatus fuccus reprimit.

V R T I C A adeó unlgaris notiticeft, ut non modó inter= diu; fed etiam noctu in tenebris folo tactu ab omnibus facillimé co gnofcatur. Proinde operepretium non eft, ut hic pluribus eius faciem depingamus. Veruntamen ignor andum non eft; quodet $/ 2$ Diofcoridi deo tantùm Vrtice a ßignentur generd; trid tamen in It alia reperiantur. siquidem preter Vrtiods d Diofcoride tras ditas; alia eft; quam aliquifylueftrem appellant, cateris derior; o mordacior, falijs parvis, birfutioribusí; caulibus +omnibus o hec nota. Vrtica utres memoria prodidit Galenus libro V I. Iimplicium medicasnentorum; ubi fic inqiuit . Vrtica, er huius berbe tum femen, tum folia(nam hec potißimium in ufum ueniunt) digerentis funt facultatis, adeo ut $\sigma$ phymata, $\sigma$ parotidas $\sqrt{a}=$

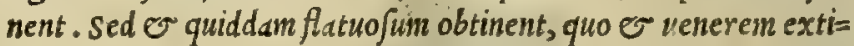
mulant, e maximé ubi curt mufto femen bibitur. Porró quód non uebementer calfaciat, féd admodum tenuium fit partium, te $=$ zo ftimonio eft crafforum, uifcoforum '́; humorum ex pectore, pul= mone q́, eductio, tum quod partes, quas contigerit, pruriant. $\mathrm{C}_{e}=$ terim flatuofum eius, cuius particeps effe dicta-eft, dum concoqui tur, nafcitur: non enim actu flatuo fa eft, sed poteftate. Ventrem autem modicé fubducit, duntaxat abftergendo, ac uelutititillan= do, non purgando Et gangrano $\int_{a}, \sigma$ cancrofas $\sigma$ in totum qua exiccari citra mordicationem poftulant, ea conuenienter fandt. nimirum cùm fubtilium fit partium, er temperature ficce, non tamen tantim babens caliditatis, ut iam mordicet. Et libro Ir. de alimentorum factiltatibus, idem de urtica ita fcribut. Vr $=40$ tica, berbarun agreftium una etiam bac eft, tenrium partium uim obtinens. I ure itaque nemo ip $\sqrt{a}$, ut alimento utitur, nif $\mathrm{ma}=$ xima prematur fame. Vtilis autem eft obfonium ac inedicamen= itum, quod aluum deijcit. bactenus de urtica Galenus. - Sed quo= niam berba illa, quam bodie herbarï CAR D I A CAM nominăt, nunc ob cognationem, quam cum Vrtic a babere uidethr, mibi in mentem uenit ; ideo non alienum puto, quód bîc de eà quóque ali= quid differ amus. Hac itaque urtice proxima eft, tametfi folijs, qua prope terram prodeunt rotundioribus conftet, ranunculi modo per ambitum laciniatis. Eicaulis eft quadrangulus, in quo so bina ubique folia paribus interuallis exeunt, oblonga, urtica fimi= lid, fed per ambitum ferratiord. Flores; qui in purpura albicant, urtic c feetid $a$, de qua eequenti capite decturi fumus, non disimi= les profert, minores tamen : qui uerticillato ambitu marrubij mo= do caulem circundant in ipfo foliorum exortu. Radix in rubro pallefcit, alijs pluribus paruis radicibus adnatis. Prouenit ubiq; iuxta fentitas, circa fepes, $\odot$ poft urbium mania. Guftu ufque= adeó amarefcit, ut facilé exiftimari poßit ad fecundum excalfo= cientium ordinem, e ad tertium ficcantium accedere. Preftat bac; ut recentio res quidam tradunt, ad cordis affectus, unde etia apud unlgares nomen accepit. Medetur item conuulfis, ac refo= 


\section{In Lib. fecundum Diofcoridis :}

AGLIOPSIS.

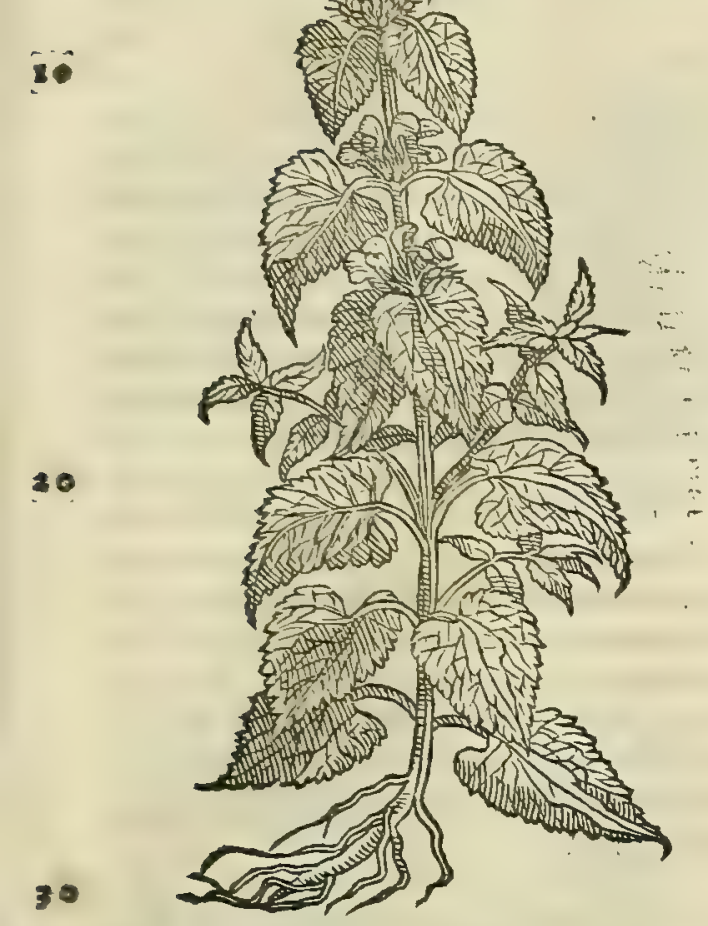

SCROPHVIARIA.

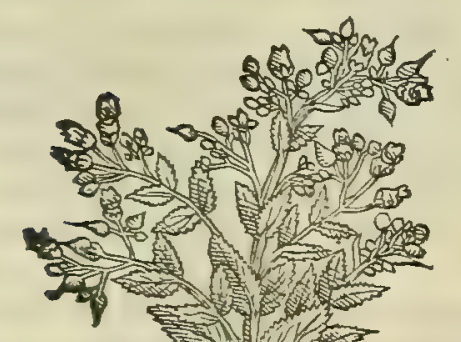

so

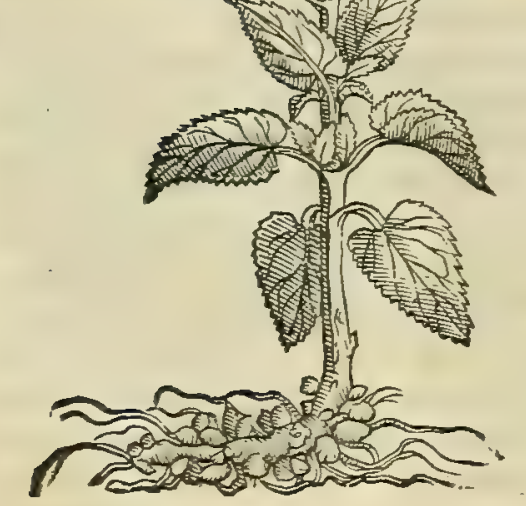

lutis. Obftructiones aperit, ques caufa frigida induxerit: urinam cit, o menfes. Pectus à pituita detergit, e lumbricos necxt. Caterim in puluerem contrita, or cocblearis menfura ex uino baufta, difficilé parientibus mirum in modum opitulatur. Vr= tica fic Latinis dicta , $\alpha^{\prime} r \alpha \lambda v^{\phi} \phi$ Grecis nominatur : Arabibus, Huniure, Vraith latum, 0 Angiard: Italis, Ortica: Germanis, Neffel: Hiffanis, Ortiga: Gallis, Ortic.

\section{TQNiow's. GALIOPSIS. CAP. XC.}

GAI I O P S I s, frutex in totum caulem; \& folia habct urticx, læujora, \& qua graucm odorem erita reddant: flore purpureo, tenui . nafcitur circa fepes, adificiorum areas, ac femitas ubique. Folia, caules, femen, fuccusque, duritias, \& carcinomata difsipant: ftrumas, panos, \& parotidas difcutiunt . Oportet bis die tepidum ex aceto cataplafma imponcre, \& eius decocto foucre. ad putrefcentia, gangrænas, \& nomas, cum fale efficaciter illinuntur.

GAI I O P S I N edin equidem plantam crediderim effe, quam nos in Italia Vrticam fretidain appellamus, que ubiq; feré prouenit, in edificiorum areis, in plateis, iuxta femitas, $\sigma^{2}$ circa hortorum Sepes, odore ingrato: unde e foetide cognomeriadin= uenit. Quiandoquidem bec folijs, o caule conftat urtica fimili= bus, taltu tamen non mordentibus: floribus item purpureis, te= nuibusq́g. . Hinc itaque fit, ut ij, med quidem fententid, in errore uerfentur, qui putant Galiopfine fe herbam illam unlgarem, que officinis, er berbariorum unlgó Scropbularia maior, Millemorbia, Ferraria, atque etiam Caftrangula dicitur : boc fortafe argumen to nixi, quodd ea flores ed at, qui galex fimilitudinem referunt. Sed corum error ex eo, ut arbitror, aperté diluitur, quód scropbula= ria maior ditta folia non proferat urtice admodum amula, nec ea graui odore predita fentiantur. Adde quód buic radix fubfit ind $=$ gna, alba, undique frumo $a$, unde forté scropbuldrix nomentra $=$ xit, adeó notatu digna, ut non uideatur verifimile, quód eius $f_{a=}$ ciem non depitam reliquiffet Diofcorides, quando fenfiffet hanc berbam effe Galiopfin. Huc etiam illud accedat, quod illa ut plu= rimùm in. fcrobium marginibus, in riguis, or uliginofis locis na=

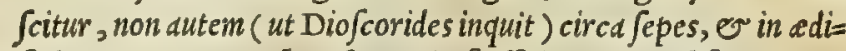
ficiorum areis. In bac fententia fuife inuenio Fucbfium, uirum Fuch. erratí. alioqui eruditum, qui d̀ galed, cuius effigiem scrophuldria flores reprefentant, hanc fibi nomen afciuiffe exiftimat. Id quod mihi plané non uidetur effe rationi confentaneum, quód non fit ex mo= re Grecorum, ueterum prefertim, apud quos nulld uerborum ino= pia fuit, ut ex Latinis, o Grecis dictionibus plantarum, or alid= rum rerum nomina componant: galeam enim Grecum nomen nö effe conftat. Ex his igitur adducor, ut in boc neque Fucbfio, neq; alijs adfipulari poßim, quorum potius fententiam ex fuprà diti is reprobandam effe cenfeo. Eft preterea dia planta Vrtice foc= Vrtica lastea. tide non ab/imilis, que d̀ lacteis maculis fingula folia in longü pro currentibus Vrtica latted d noftris senenfibus uulgó cognomina= tur, quam rectius forté quis Galiop/in dixerit, $\sqrt[f i d]{d} \gamma \alpha \dot{\lambda} \lambda \alpha$, quod uocabulum Grecis lac /ignificat, Galiopfin diftam effe ftatuat. Quód autem res hac ita effe poßit, ex Diofcoridis ordine, conie= Atura quadam colligi po fet. nam quod ftatim poft Galiop/in Galiö defcripferit, cui ex eo noment inditum effe tradidit, quód in cogen do latte codguli uicem expleat, uidetur innuiffe, inter atrunque magnam effenominis cognationem. Hanc itaque legitimam effe Galiop fin quafi affirmare non dubitarem, nifi Plinius lib. XX II. cap. X I I I i eam Lamium appellari prodidiffet, laudibusqjás extu=
Galiopfeos confideratio.

Opinio quorundä reprobata. Lanium Plinij.

$$
\mathrm{Al}_{2}{ }_{2} \text { liffer }
$$




\section{$55^{6}$ And. Matthioli Comm.}

G A I $I O N$.

Scrophularix

uires.

Galij confideratio.

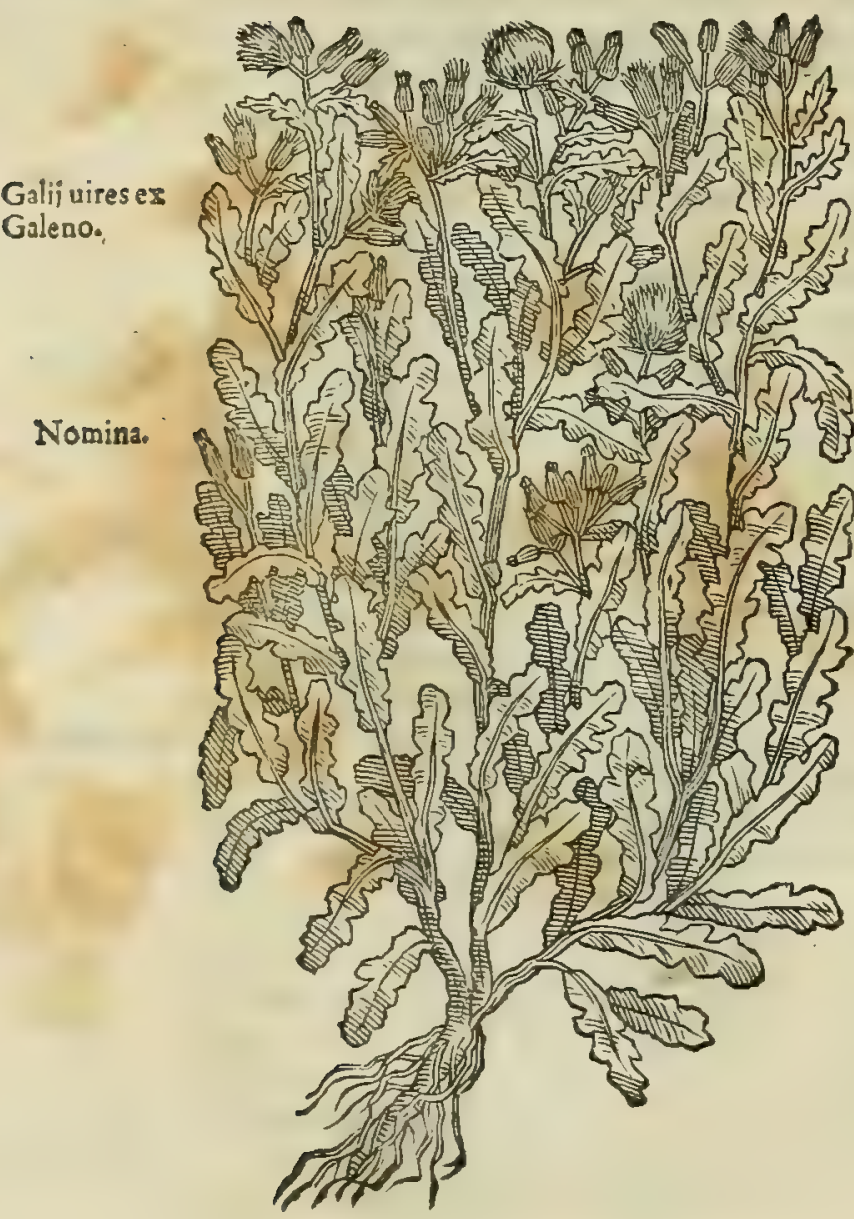

liffet albunt, quod babet in medio folio, ad facros ignes, er folio= rum reliquum cum uniuer fa planta, addita mica falis, ad contu= $\int a$, incufa $\dot{q}_{;}$, ad ambufta, frumas, tumores, podagras, er uulne= ra. Quibus fane Plinij placitis decernere coginur, primam, quan Vrticam foetidă diximus, effe Galiopfin : alteram ueró Pli nij Lamiü. Sed fi fuftinere uclimus bane fecindam effe ueră G.t= liopfin, dicere nobis liceat, Pliniü nö cognouife Gdliop/in.neq; id fortaffe temeré diceretur, quód in multis alijs Plinius euiděter er rafe deprebendatur. Ceterim quanuis ex rationibus fuperius adduct is perpicuum, ni fallor, factum fit, s CROPHVLA= RI AM non effe Galiop/in; ed tamen uiribus pollet non conte= mnendis . naniq; eius radix frumas, ow bemorrboidas fanat. In quem ufum radix effoditu* autumnali tempore, o repurgata tunditur cum recenti butyro, operculato q́; fitili in uliginofolo= co reponitur, ubi dimittitur per quindecim dies. Deinde lento igne butyrum illud liquefit, er percolatum afferuatur . quo pre=

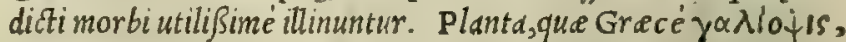
Latine item Galiop/is, Vrtica labeo, et Vrtica fatida nominatur: Italice, Ortica fetida : Hipanicé, Ortiga muerta.

$$
\Gamma \alpha \dot{\lambda} 10 v . G A L I O N . \quad C A P . X C I .
$$

GAL I o N nomen ex eo traxit, quòd in contrahendo lacte, coaguli uicem impleat ramulum,foliumq́; habet aparinx fimillimum, rectum : florem in cacumine lu teum,tenuem, denfum, copiofum, odoratum. Flos igni ambutis illinitur, \& fanguinis profluuia fiftit. Cerato rofaceo galion admifcetur, infolatum ufquedum albefat; \& fic lafsitudines reficit. Radix uenerem concitat. Nafcitur in paluftribus.

G A I I v M ubiq; copiosé na feitnr prope fepes, of fecus uid, folijs aparine minoribus: flore tenu, picdto, partim luteo, partim albo:Verim non proptered omnibus notd cft uis, quan coagulandi latis bet: nam fi ea paftoribus innotuifet, non mi= nus apud eos buius berbe inualuiffet ufus, quam cinar apud $\mathrm{He}=$ trufcos: qui eius flore, ut dulcior Juanior q; cafeus euldat, tum ouillü, tum etiam caprinum lac cogunt, ac piffant. Galio uires reddidit Galenus lib.v I. fimplicium medicamentor ü, fic inquiĕs. Galium inde adeó nomen fortitum eft fuun, quód lac coagulet. A dfimile autem eft aparine, facultatem obtinens exiccatoriam, 40 or fubacrem. Flos eius fanguinis proflunijs competere uidetur, or combuftis mederi. Eft autem boni odor is, er coloris lutei.

Huius herbe nomen Gracum yó̀ $10 v$ : Latinum, Galium : Ita lic $\vec{u}_{2}$ Galio : Germanicum, Vnfer frauuen, Vuegftro: Hipanicum, Coaia leche yerua: Gallicum, Petit muguet.

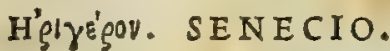

CAP. XCII.

S E N.E C I o cauliculo eft cubitali, fubrubro: folijs continuis, per extremitates erucæ modo diuifs, fed mi- so noribus multò:luteis floribus, qui celeriter diffecti vanefcunt in pappos Nomen uerò fibi uendicauit, quoniam flores capillorum ritu canefcant . radice fuperuacua. Nafcitur maxımè in macerijs, \& circum oppida. Folia cum floribus refrigerant: quare illita cum uini modico, vel per fefe, teftium \& fedis inflammationes fanant : quin \& ex manna thuris medentur, cùm reliquis vulneribus, tú jis quæ nerui acceperunt. Illi per fe cum aceto pappi,idë munus præftant: uerùm recentes epoti,ftrangulant. Totus caulis, fi coctus in paffo potui detur, ftomachi dolores à bili contractos perfanat. 
S E N E C I O, qux Gracé Erigeron dicitur, aliquibus unlgó Cardoncello, alijs ueró spellicciofa uocatur. Senecionis"có plana eft uulgaris notitis. Cauliculis exit ( $u t$ Diofcorides inquit) fubrubentibus: folijs laciniatis, trucx enulis, fideratio. minoribus tumen, $\sigma$ apperionibus : floribus lute is, qui dchifcentes in pappos abeunt. Nafcitur paßim, adco ut etian fuper urbium mania, o in p.rictinis proueniat. Hanc berban Otho Brunfelfius effe Verbchacam fupinam magno Brunfelsij eraperto crrore cxiftinauit. Senecionis quàm breuem mentionem fecit Galcnus lib. v r. fimpliciun medicamen= torum, cius tuntim ficultaten refrens bis uerbis. Erigeron, fiuc Senecio facultatem mift an obtinct, fimul refil

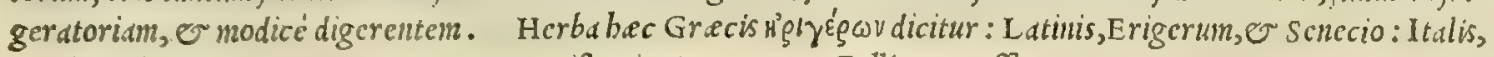
Cardoncello: Germanis, Creuz uurtz: Hifpanis, Bon uaron: Gallis, Seneffon.

T H A L I C T R O N fulia coriandri habet,pinguiora paulò : caulem rutę crafsitudine, in quo folia, Qux trita illitu antiqua vlcera ad cicatricem perducunt. Naf́citur maximè in campeftribus.

T н A I I C T R O N, fi Ruellio credimus, berbarij in Gallia Argentinam appellant, quód drgenteo micet co Thaliatri con loratu, ceteris notis Thalictripicture adftipulantibus. Hec (ut ipfe fcribit) inuenitur ubique, fepe in campeftri=. fideratio. bus, or macerijs. Veriun cum mibi bactenus non contrgerit eam berbam uidere, idcirco R uellij fententiam non aufim probure, neque etiam refellere. Thalictron Thalietron nominat Galenus lib. vi. fimplicium medicamentorum, ubi Vires ex Gade eius uiribus in bunc modum differit. Thalietrum folla babet coriandro fimilia, caulem craßsitudine rute. Vis ei in = leno.

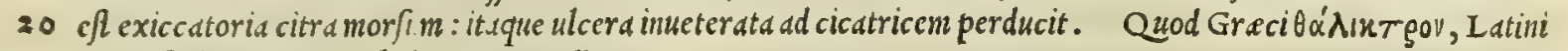
item Thaliarum, or Tbalietrum appellant.

\section{Bgiov $\theta \alpha \lambda$ xisır. MVSCVS MARINVS.}

\section{CAP. XCIIII.}

M A R I N v s mufcus nafcitur in fcopulis,teltaceisq́; haud procul à mari, gracilis, capillaceus, caulis expers . Præcipua ei fpiftandi uis, \& collectiones cohibendi, \& po dagras, quas refrigerare opus fit .

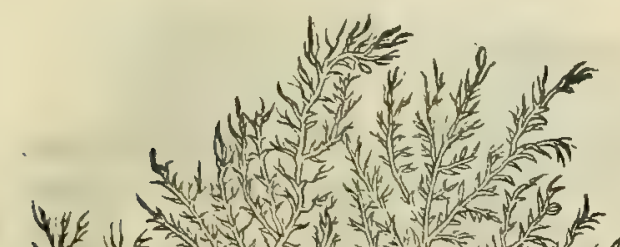$$
\text { }
$$

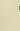

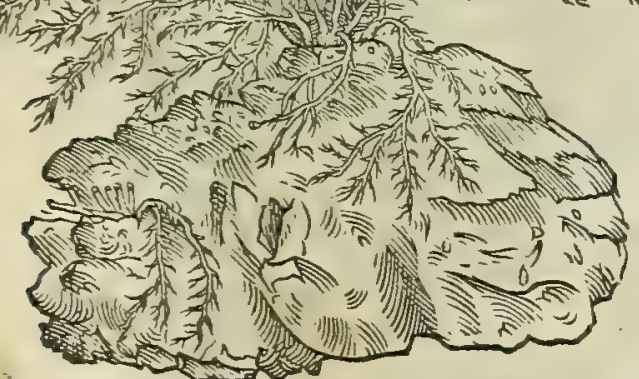

$\mathrm{N}$ o $\mathrm{N}$ poffum corum non probare fententiam, qui dicunt $\mathrm{M} u$ - Cum marinume eam capillaceam effe plantam, quam of ficine $\mathrm{Co}=$ rallinaim appellant. Hâne circunforanei in puluerem contritam in plateis uenditant ad puerorum uermes necandos.miris q́; laudi= bus efferunt. Quia in re nimirum cateris preftat medicamentis: fiquidem non modò interficit lumbricos, fed cos quoque eadé die expellit, magna fape cum aftantium admiratione, quòd quan= doque uifus fit puer, qui ex afjumpta huius pulueris dracbina cen tum uermes excreuerit. Crediderim itaque Corallinam banc effe Mufcum marinum, quod certó fciam, eam ab ïs reperiri, qui co= rallia expifcantur, corallijs; ficuti etiam fcopulis, pifcium teAtis inberentem, co fane modo, quo arboreus mufcus arboribus ipfis innafcitur. Is utique ceteris prefertur, qui cor allijs adna= fcttur, unde ei nomen. Probatur fecundo loco, qui faxis adbaret, colore rubicundo : cincreus ueró improbatur. Sed marinum mu= fcum bac pollere facultate non nouere ueteres: quandoquidem nufquam apud ip $\int$ os legerim marino $m u f c o$ interaneorum uermes necari. Mufci marinibiftoriam (longé tamen ab ed diuer $\int a m$, quam paucis perftrinxir Diofcorides.) profectutus eft Plinius lib. x X V I I. cap. V I I I. bis uerbis . Eryon marina berba fine dubitatione lactuca folijs fimilis, rugofa ueluti contracta, 50 fine caule ab ima radice exeuntibus folijs. Nafcitur in copulis maximé, teftisó, terra comprebenfis. Pracipua fic=

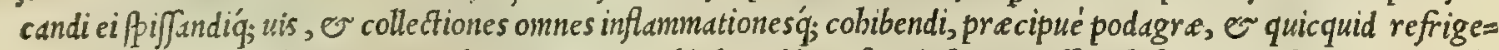
rare opus fit . hac Plinius. Ex quibus nimirum uerbis liquidó conftat ipfum erraffe in biftoria Mufci marini, quód bunc perperàm fecerit folijs lactuce fimulem. Caterüm Mufci marini meminit Galenus lib.v I. fimplicium medica= mentorum, fic inquiens. Mufcus marinus compofitus eft ex terrena, $\sigma$ aqued effentia, utraq; frigida. Siquidem $v$ guftum adftringit, or calidis quibufuis illitus, ed euidenter refrigerat, or adiuuat. Id Grecis Boviov $9 \alpha \lambda x^{\prime a r r o v}$ quod Latinis Mufcus marinus uocatur: Tabaleb, fiue Thabel Arabibus, quibus tamen mufcus is cum lente paluftri, confunditur : It alis ac officinis, Corallina : Germanis, Meermiefz, feu Mermoeßs: Hifpanis, Malborquiana yerud: Gallis, Coralline. ror. Nomina.

Nomina. 


\section{$55^{8}$ \\ And. Matthioli Comm.}

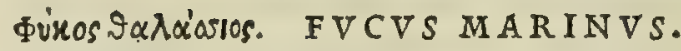

CAP. XCV.

E' P H V C I marini gencribus, quoddam latum, \& alterum fublongius, \& rubens : tertium candidum, nafcens in Creta, floridum ualde, quod nulla corruptionis labe polluitur. Omnia uim habent refrigeratoriam, non podagræ modò, fed etiam inflammationibus, in cataplafmatis efficaciter utilem : uerùm ijs uti humidis conuenit, priufquàm exarefcant. Nicander puniceum aduerfus ferpen tes dedit. Hoc fuco quidam putant mulieres fuum colorem mentiri, cùm tamen fit radicula eiufdem nominis, qua fefe fucant.

Fuci marini

D E F V C o marino locutus eft Plinius libro X I I I. cap. X X I I I. ubi ita fcriptum reliquit. $\mathrm{N}$ afcuntur in ma 10 hilt.ex Plin. rifiutices, arboresó;, minores in nof tro. Rubrum enim, of totius orientis Oceanus refertus eft fyluis. Nö babet lin gua alia nomen quod Greci uocant phycos, quoniam alga berbarum magis uocabulum intelligitur : hic autě eft fru= tex. Et lib.x x v1.cap.x.Tria, inquit, Pbycithalaßij, id eft, Fucimarinigenera, latum, er alterum longius, qua= dantenus rubens : tertium crifis folijs, quo in Creta ueftes tinguntur. bactenus Plinius. Ceterum cum Fucigenera mibi plané incomperta fint, quid de ijs dic am non babeo. Non tamen deeft fupicio, quin Fucus marinus fi alga non eft, in eius faltem genere recenferi poßit et debeat: nam Theodorus in Theophrafto non aliter Fucum marinü inter= pretatur, quàm alge nomine. Adde quod er Plinius alijs in locis Fucum marımum algam maris aliquando uocauit, ut. etiam adnotauit Marcellus. Sed non ob hoc exiftinauerim, Fucum marinum eam uulgarem effe algam, in qua Veneti uafa uitrea recondunt, ne inter uebendum collidantur, or confringantur. Quód preterea Fucus marinus alga effe. poßit, illud argumento fit, quód nullun aliud, quod fciam, apud L atinos nomen inuenerit. Alge pecies eft, que er 2.0 vlua dicitur, hoc tantum inter fe differentes, quód bec paluftris, lacuftris, fluniatilis'́; fit : illa uero tantum in mari proueniat. Quod difcrimen illo uulgari uerficulo indicatur.

Alga uenit pelago, fed nafcitur ulua palude.

Vnde etiam Virgilius libro fexto Aeneidis ita cecinit.

Tandem trans flumium incolumes, uatem $q_{;}$uirum $q_{\text {;", }}$

Informi limo, glaucs'; exponit in ulud.

Lino fo g; lacu per noctem obfcurus in ulua. Delitui.

Et libro fecundo ciufdem.

Fuci matini Fucimarinimentionem fecit Galenus lib.v I I . fimplicium medicamentorum, bis uerbis. Phycos humens etiännum, uires ex Gal. er uires ex mari exemptus deficcat, e refrigerat ordine fecundo : babet enim quiddam modicé acerbum. Nomi=

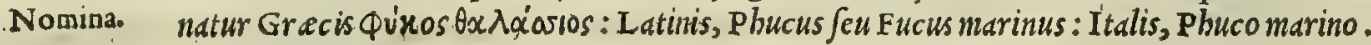

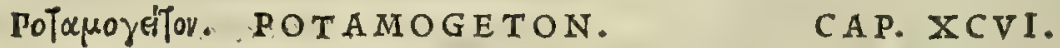

P O T A O G E T ON, foliumbetæ fimile; hirfutum, pàlulum lupereminens extra aquam. Refrigerat, \& infpiffat : pruriginibus utile, \& contra ueterum vlcerum nomas. Nomen ex co inditú cft, quòd paluftribus, \& aquofis enafcatur:

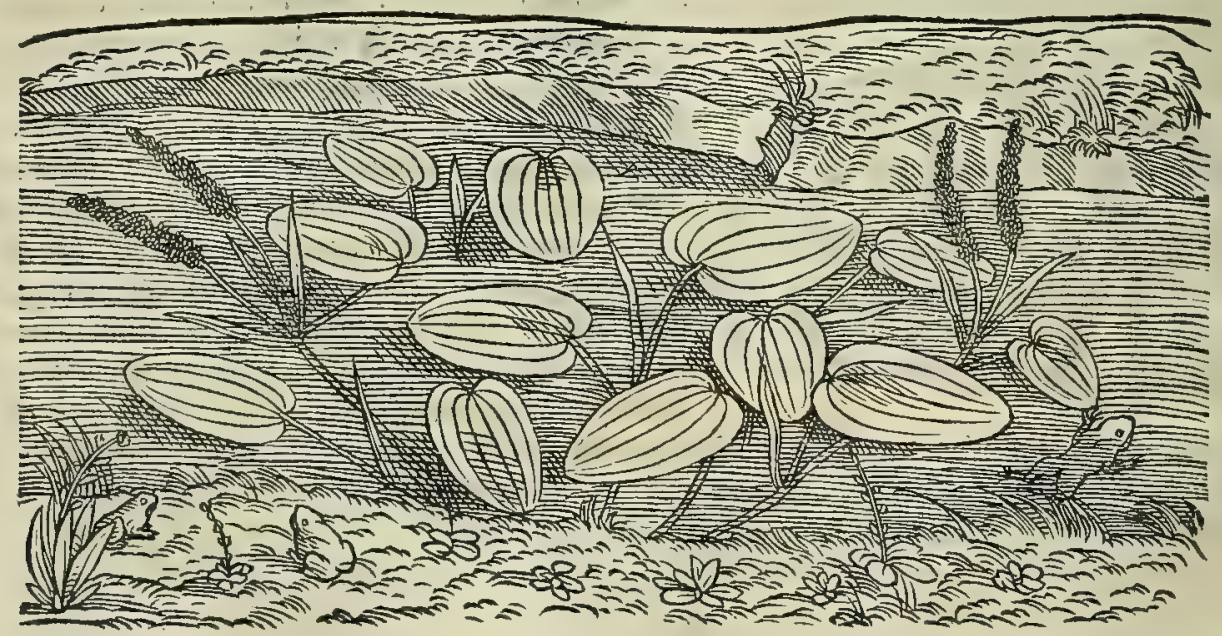

P O T A M O G E T O N lacubus, o paludibus innafciamat, ubi folijs bete proximis, fuper aquam expanfis. Potamogeto in compluribus locis emicare inuenitur. Hanc berbam nos fepe uidimus, or legimus, priuatim in lacubus quibufdam
nis confid.

Vires ex Gal. in Ananienfium agro, quam ibi unà cum nympbed aquis fupernatantem deprebendimus. Potamogeton, ut teftatur

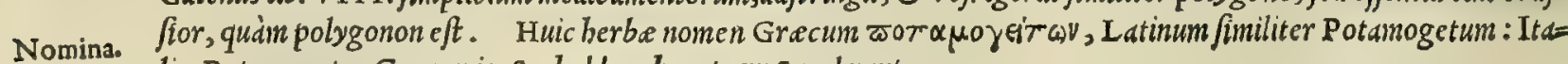
lis, Fotamogeto : Germanis, Sechalden kraut, or sam kraut. 


\section{In Lib. quartum Diofcoridis.}

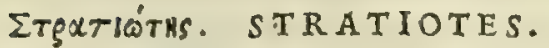

CAP. XCVII.

S T R A T I O T E S in aquis nafcens, ijfdem fupernatat, \& fine radice uiuit: vnde cognomentum traxit. Herba femperuiuo limilis, ni maiora haberet folia. Qux refrigerant : fanguinem, qui defluit à renibus, pota fiftunt: vulnera, quæ inflammationem minantur, intumefcere non finunt:ignibus facris, \& tumoribus ex aceto illinuntur.

N o N ES T profectó quód miremur, fi stratiotes in Italia non prouenit. Quădoquidcm cd, ut lib. X X I I I I. 10 cap.X V I I. Plinius teftatum reliquit, eft in Acgypto tantim, 已 inundatione Nili nafcitur, dizoo fimilis, ni mato= rahaberet folia. Vocatur Gracis sgatióths envigos: Latimis, Stratiotes aquaticus.

Nomina

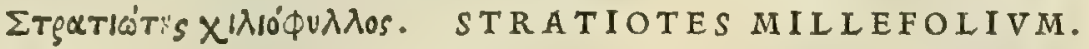 \\ C A P. X X VIII.}

S T R A I O TES millefolium exiguus frutex, palmi altitudine, aut amplius affurgit: folijs auium pulli pennas imitantibus, breui admodum, diffectoq́ue foliorum exortu. Folia fyluefte cuminum fimulant, præfertim brenitate, atque fabritia, breuiora paulò : denfiore vmbclla, \& pleniore. Surculos in cacumine gerit exiguos, \& capitula in modum anethi : Alores paruos, \& candidos. $\mathrm{Na}-$

20 fcitur in afperis agris, præcipuè circa femitas. Eximij vfus ad ulcera vetera, recentiaq́ue, profluentem fanguinem, \& fiftulas.

MILLEFOLIVM MAIVS.

30

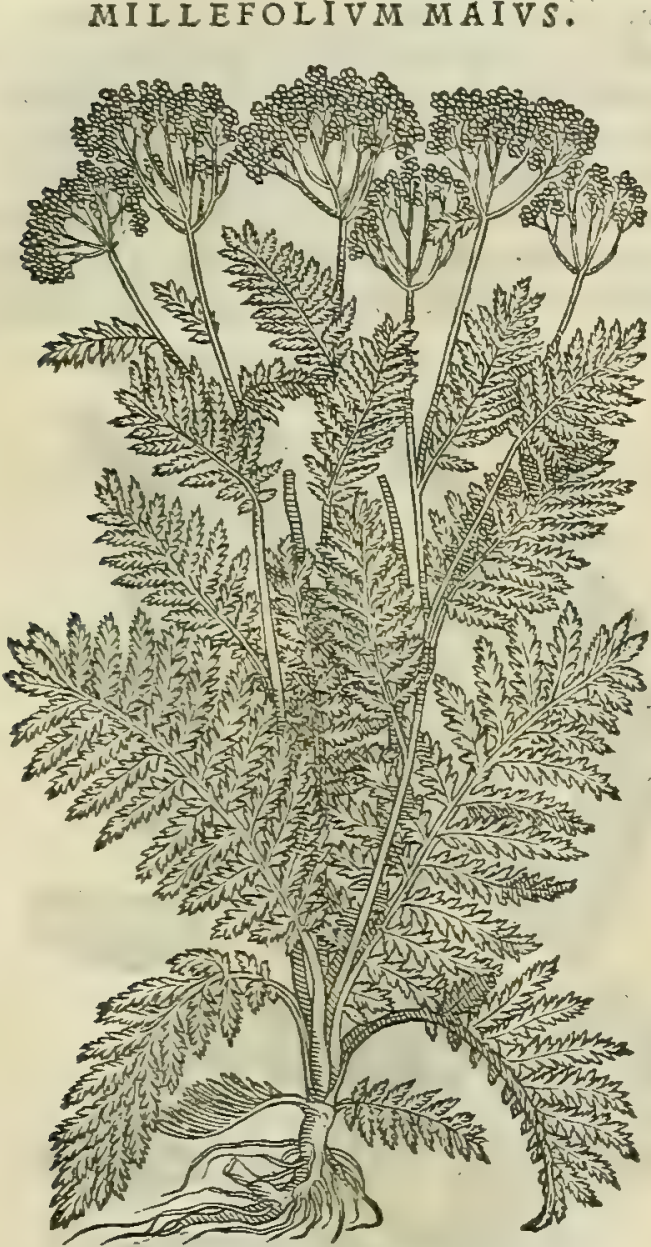

MILLEFOLIVM MINVS.

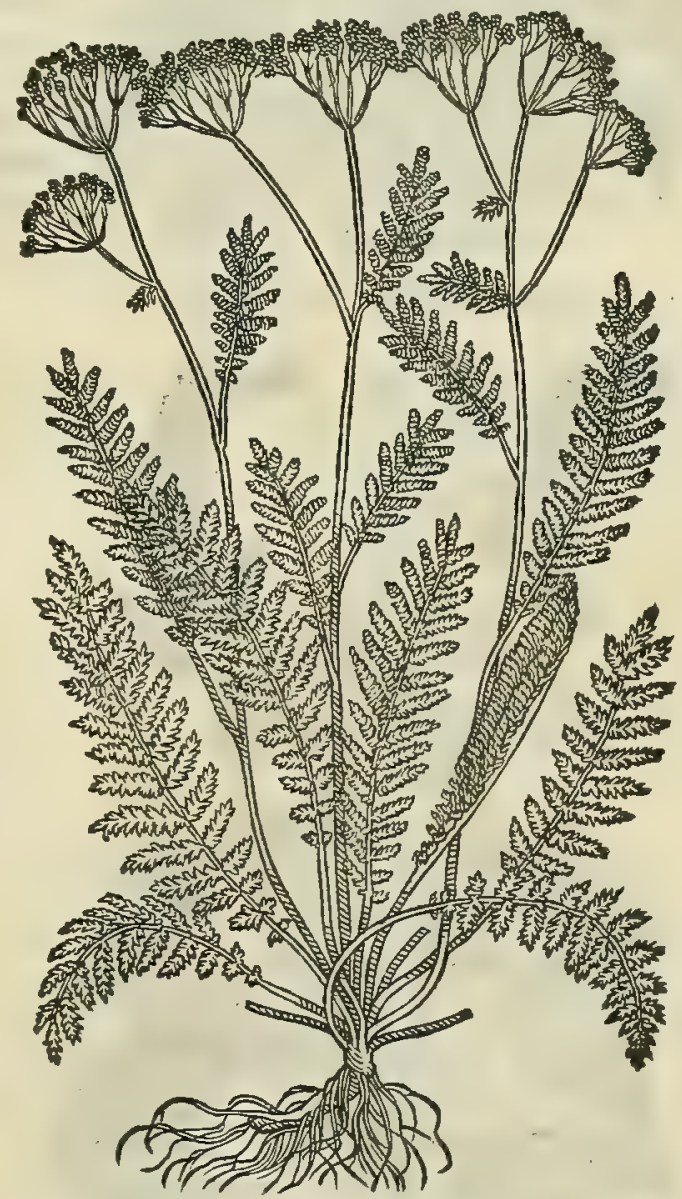

S T R A T I O T E S in bunc ufque diem Millefolij cognomen retinet. Planta eft officinis notißima, in incultis Stratiote mil proueniens, in pratis, er circa femitas, ligno/is caulibus, dodrante maioribus, pluribus ab una radice prodeuntibus, lefolix conaquibus folia in funt auium nouellar um pennis fimilia, fylueftriq́; cumino amuld. Flores eius denfiore umbella fuftinen= deratio. tur, candidi, et fi nonnunquam in purpura rubefcant. Ex bis utique notis paläm eft, communis ufus Millefolium nil aliud dici poffe, quàm stratioten, de quo hic agitur, non autem, ut Brafauolus exiftimat, Myriopbyllum infrà dे Dio= fcoride defcriptum. Siquidem Niyriophyllum caulis eft tener, fingularis, unica nixus radice : folijs plurimis, leuibus, foeniculo fimilibus. Que fane omnia, ni fallor, apertißimé oftendunt, Brafauolum bac in re ballucinatum effe. Mil= lefolij genus quoddam najcitur in Goritienfi agro Saluatino monte prope facellum diux Marie uirginis, eo tantim 


\section{And. Matthioli Comm.}

VER B A S CVM PR I M VM. faxofo tractu, quo ad sontium flunium defcenditur. Id quoniam a=

Stratiote uires ex Gal.

Nomina.

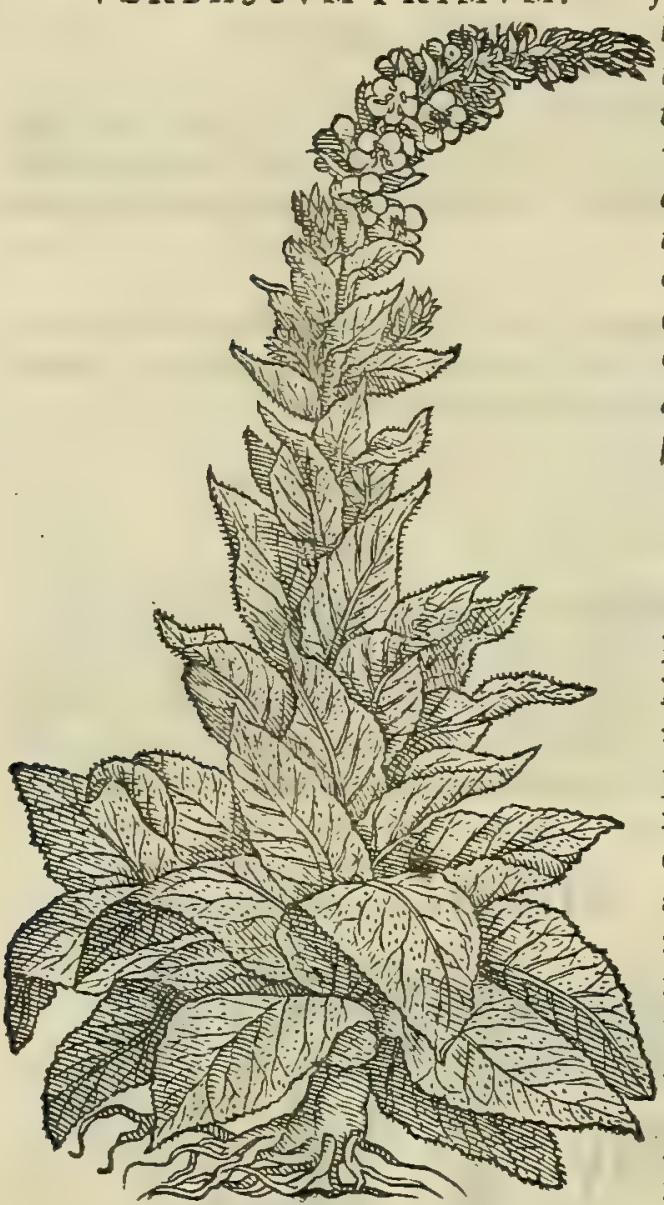

VERBASCVM SECVNDVM.

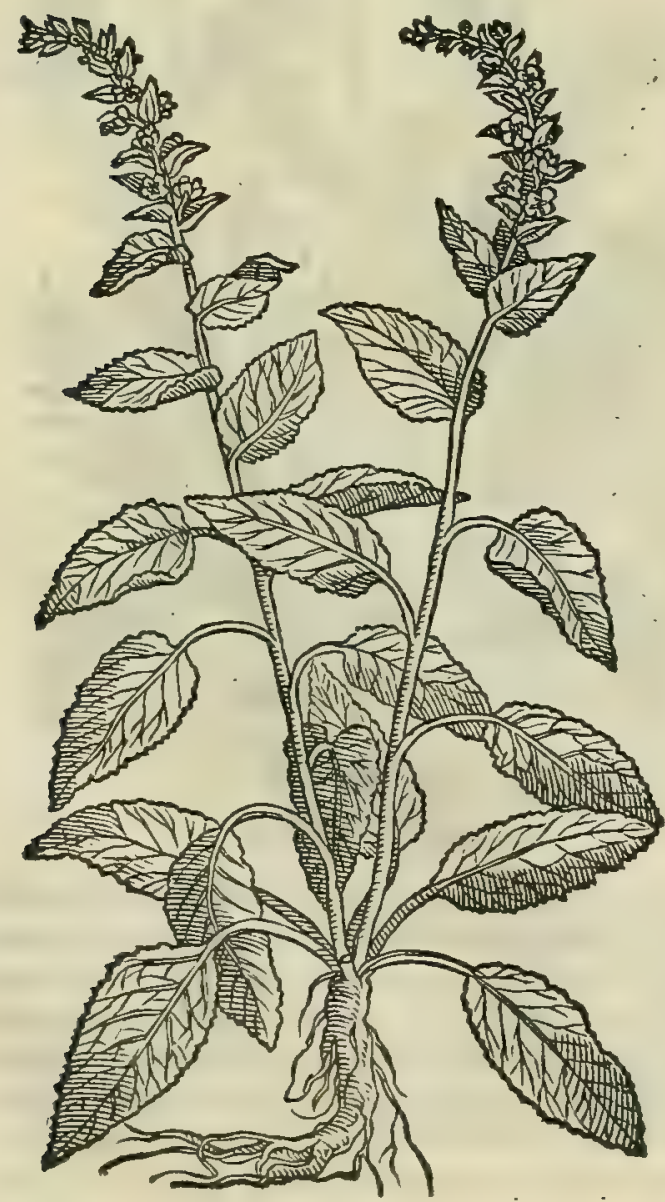

liud preftat magnitudine, ut eius effigies, quain bic damus, aper= té oftendit; ideo nobis iure liceat ip fum nominare Mille folium ma ius. Stratioten bunc, of fuperiorem perftrinxit Galenus libro V I I I. Jimplicium medicamentorun, ubide utriufque uiribus ita differit. Stratiotes aquaticus quidem bumida, o frigida faculta= te eft: terreftris uerò nonnibil habet adfrictionis: proinde fane, O ulcera glutinare potest, 0 ulceribus effe utilis. Sunt qui eo o ad angumis eruptiones utantur, o ad fiftulas. Herba, que

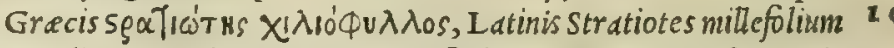
appellatur: Italis, stratiote millefoglio: Germanis, Garben: $\mathrm{Hi}=$ Ppanis, Milhoyds yerua: Gallis, Mille fueille.

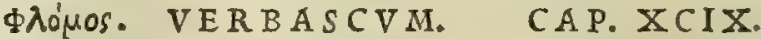

VER B A S C V M differentias fummas: habet duas, hoc nigrum, illud album : in quo mas, \& fømina intelligitur. Fœminæ igitur folia funt brafsicæ, pilofiora mul tô, \& latiora, candida : caulis albus, cubitalis, aut amplior, fubhirfutus : flores albi, aut ex luteo pallefcentes: 20 femen nigrum : radix longa, guftu acerba, crafsitudine digiti.nafcitur in campeftribus. Verbafcum, qui mas appellatur, oblongius, albis folijs, \& anguftioribus, tenuiori caule. Sed nigrum prorfus albo fimile effet, nifi nigriore, latioreq́ue conftaret folio. Syluêftre folia fert faluix : altas uirgas, \& lignofas, \& circa eas ramulos, qua les marrubiŭ : flores lutcos, auri xmulos. Sunt \& phlomides duæ, hirfutæ, rotundis folijs, humiles. Tertia lychnitis appellatur, ab alijs autem thryallis, folijs ternis, aut quaternis, uel paulò pluribus, hirfutis, crafsis, 30

VERBÁSCVM TERTIVM.

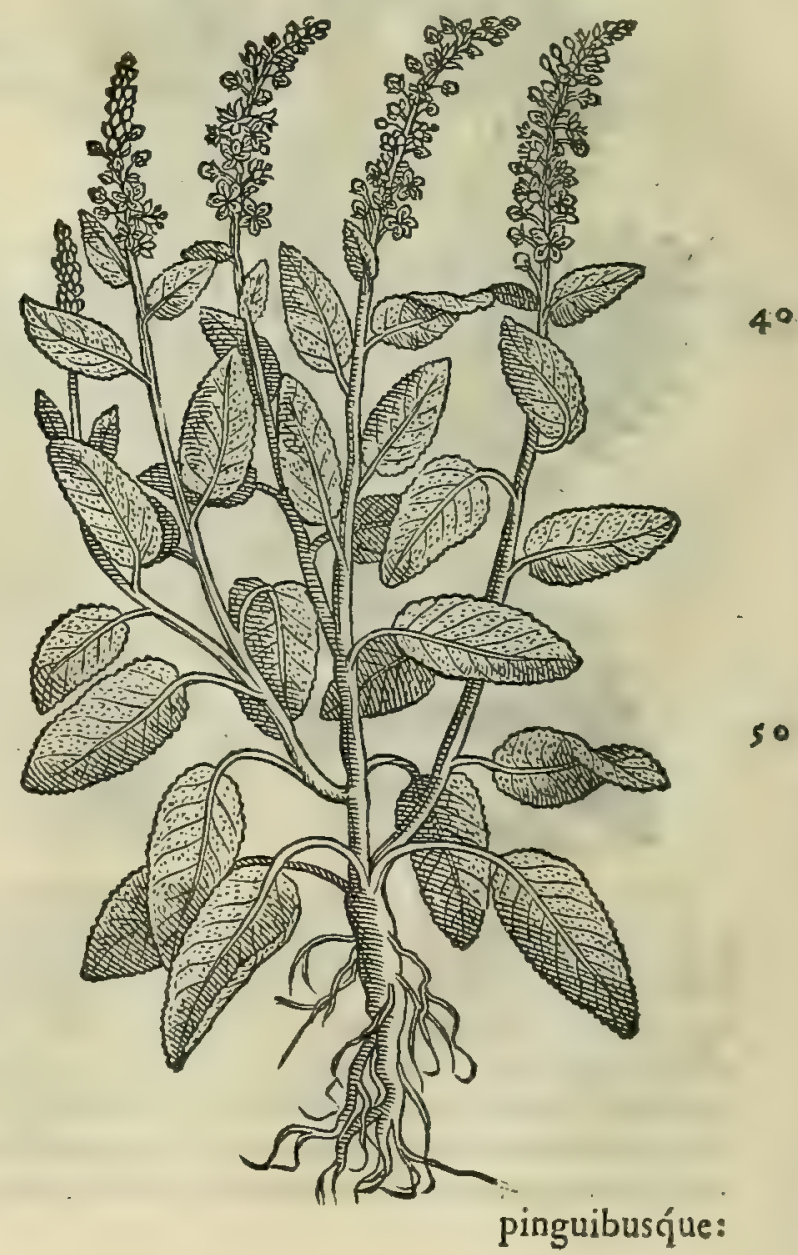




\section{In Lib. quartum Diofcoridis.}

VERBASCVM SYLVESTRE.

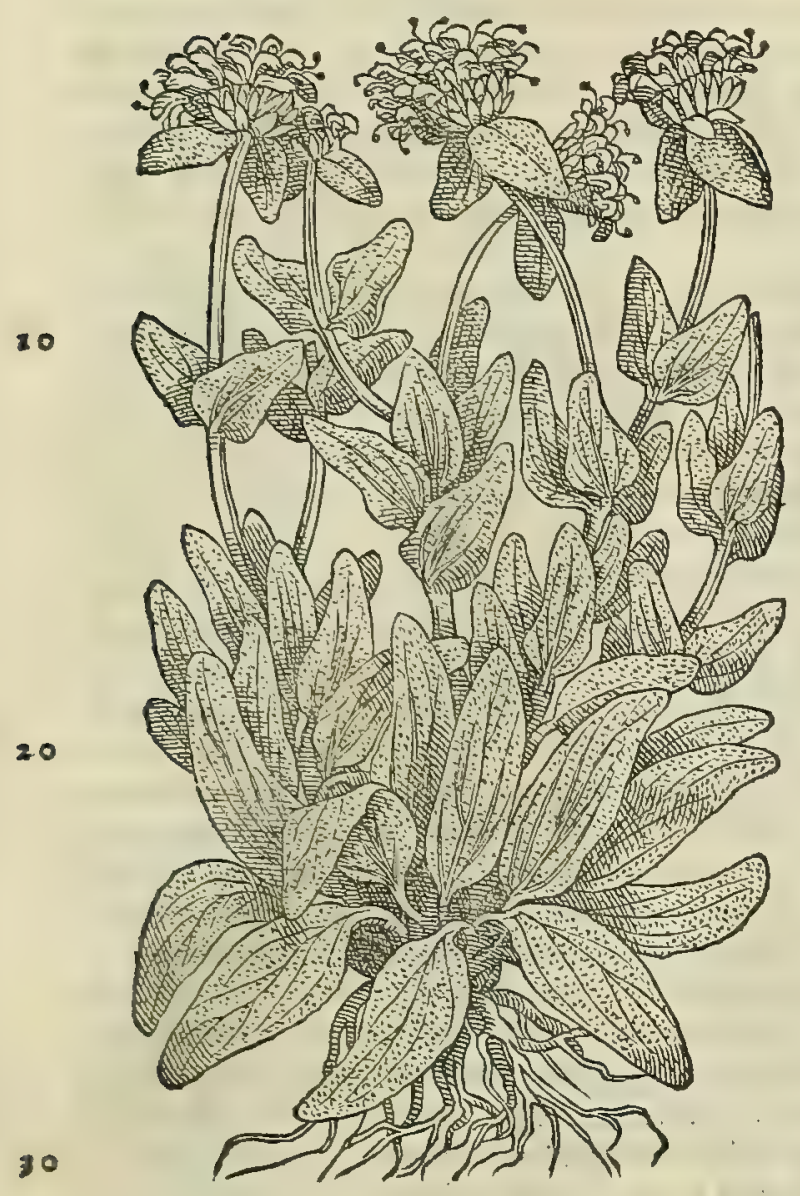

PRIMVIA VERIS.

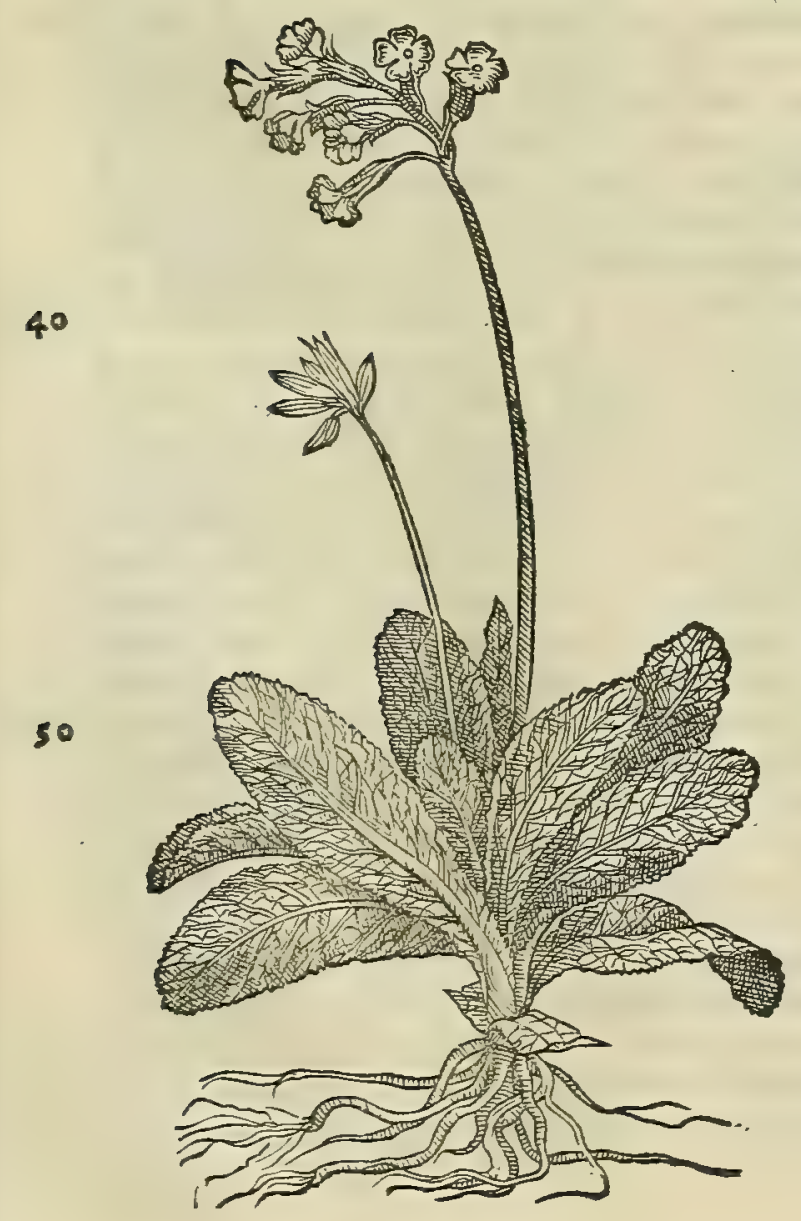

VERBASCVM LYCHNITIS.

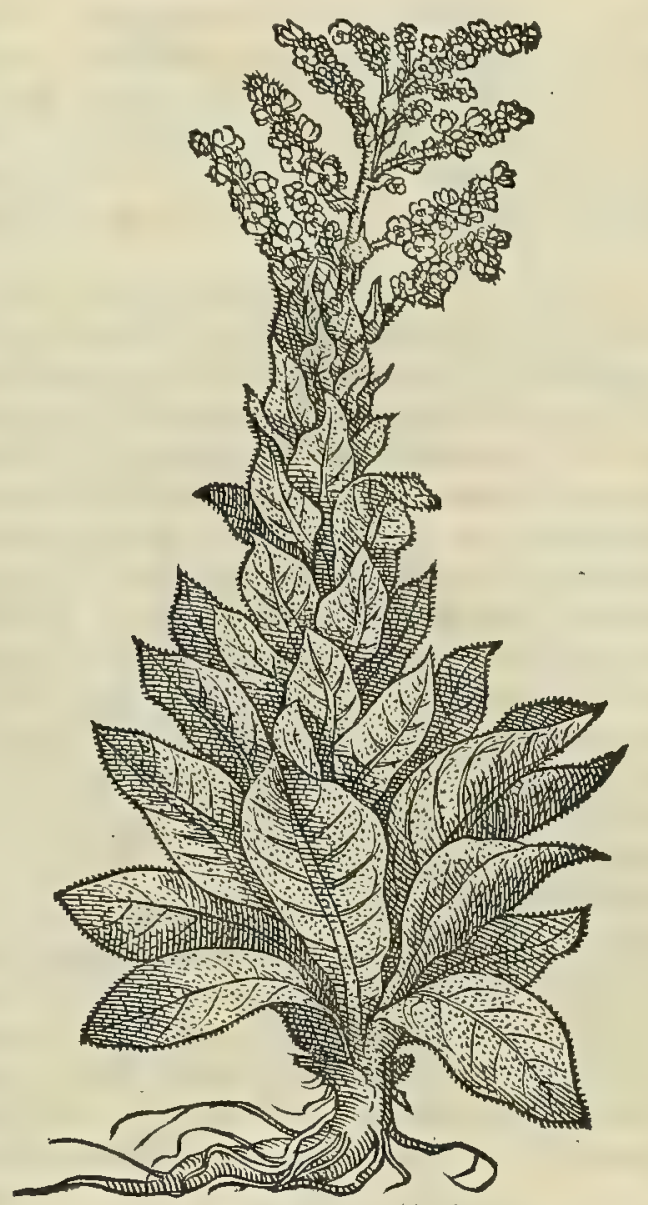

PRIMVLA VERIS ALTERA.

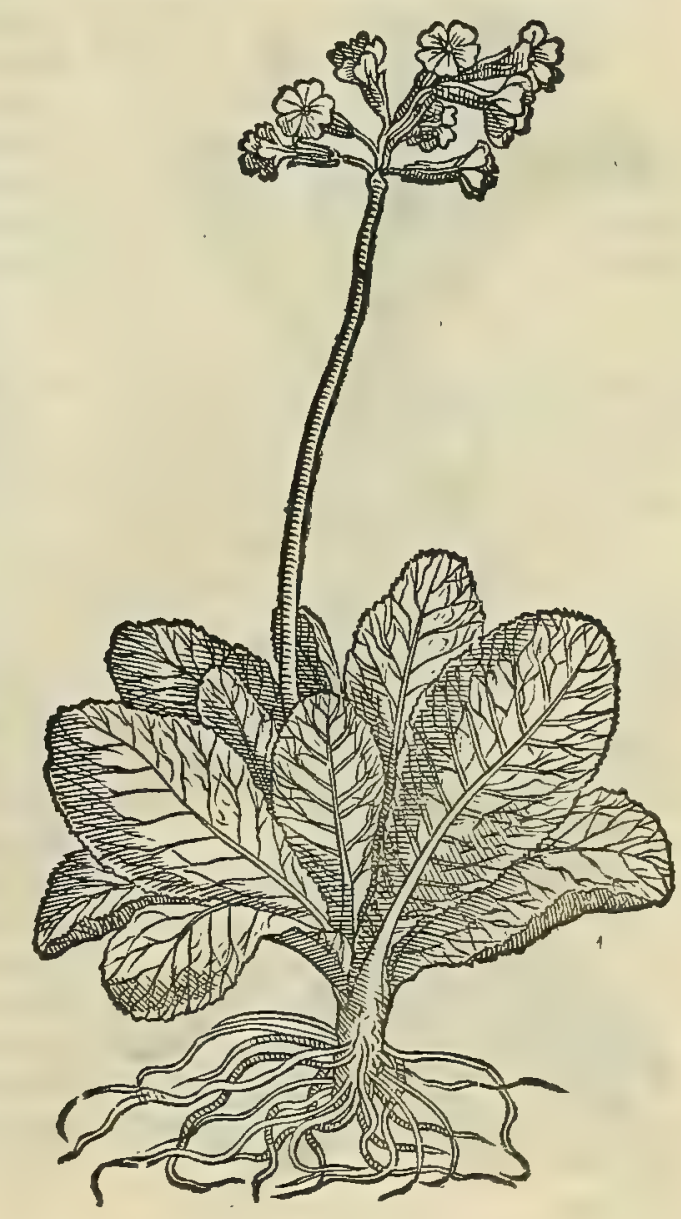




\section{2 \\ And. Matthiolı Comm.}

pinguibusq́ue: apta ad lucernarum lumina . Radix priorum duarum adfringit:quare quod magnitudine ludicrum talum æquet, in alui profluuio, conuenienter ex vino datur. Decoctum ruptis, conuulfis, fractis, antiqux tufsi auxiliatur : dentium dolorem collutione mitigat. Verbafcum, cui flos aureus, capillos tingit, \& quocunque abijciatur, blattas in fe contrahit. Cocta in aqua folia aduerfus tumores, \& oculorum inflammationes illinuntur: fyderatis ulceribus ex uino, \& melle, cum aceto autem vulneribus medentur : cótra fcorpionú ictus funt auxilio. Sylueftris folia ambuftiśngni funt cataplafmata. Aiunt in folijs eius, quam fæmină dicimus, aridos ficus omnino non putrefcere .

Verbafe1 ge nera, \& confideratio.

Ruellij, \& Fu chfij opınio reprobata.

Blattarix hiStoria, \& uires.

Verbafci ge nera, ix uures ex Galeno.

Nomina

P R I M A V̈erbafcigenerd, domeftica fcilicet duo, nulli non cognita funt. Verùm fylueftre, quod folïs faluix fimilibus, aure iś'; floribus prouenit, non omnibus fané notum exiftimo. Viret tamen bodic Pataui in nobilißimo/im= plicium borto, quen ad commune ftudioforum commodum Illuftrißimus Venetorum Senatus conftrui curduit . Quin nec fortafe Lyclnitim, cuius etiam figuram bic damus, nouere multi. Reliqua ueró, qui mili demonftrauerit in Ita= lia, hactenus repcrinesninem. Et quanuis fint, qui putent, ut Ruellio, Fucb/io, ev recentiorum alijs placet, eds uulgaris notitix plantas, que quibusdas Brache cuc uli, officinis Primule ueris, Germanis claues fancti Petri, non= nullis ueró herba paraly is appellantur, effe Diofcoridis Pblomides, qua hirfutis, rotundisq́; folijs, bumiles profiliüt; corum tamen fententie, licet eruditorum uirorum, baudquaquam adftipulari polfum. siquidem plantis ijs folia non in= funt birfuta, nec etiam rotunda, fed alteri le uia, alteri ueró cripa, lactuca, aut dip faci modo. Adde quód florum, quos hac Phlomidum genera proferant, nufquam, quod fciam, meminit Diofcorides, neque é ueteribus alius, qui ver bafcigenera recen $\int e a t$. Id quod in berba paraly/i, meo quidem iudicio, filentio inuoluend um non fuerat, cumbac $0=$ mnium prima fuis aur eis floribus emicet, uer'q; noum pronunciet: unde illi officina nomen impofuerunt. His recen $=20$ tiores uin efficacem tribunit ad articulorum dolores. Radicis earum decoctum ad renum, o uefic calculos com= mendant. Succum quoque tum potum, tum exterius illitum fractis, luxatis q́; oßibus utilem effe tradunt. Quo item ex

Verbarci ui- floribus expreffo utuntur mulieres ad erugandam faciem; eiusq; maculas detergendas. S'ed ad legitima Verbafci res quædam. genera redeamus. Hac omnia in uniuerfum, ut plurimis factis periculis conftat, omnibus feré fedis morbis mirifice fubueniunt : adfringunt enim, or exiccant. Qudmobrem feminis, or florum puluis, additis chamamalifloribus, $\mathcal{O}$ laric is refina, procidentem fedem fuffitu cobibet, or tenafmum procipué dyfentericis tollit. Verbafci foemine folia inter lapides contufa, $f i$ equi claudicantis ex claworum noxa ungui prius excallato imponantur;mirum dictu quàm bre ui tempore is liber euadet. Radicis eiufdem fuccus, antedquàm caulem proferat, duarum drachmarum pondere ex Cretico uino bauftus, in ip $\int a$ acceßionis bora ( ut Arnaldus refert) quartanam fugat, cum boc tamen, quod tribus, aut quatuor iteratis uicibus hauriatur. Sticcustam florum, quam foliorim apperis uerrucis illitus, eas facilé delet, et $=30$

B L A T T A I A.

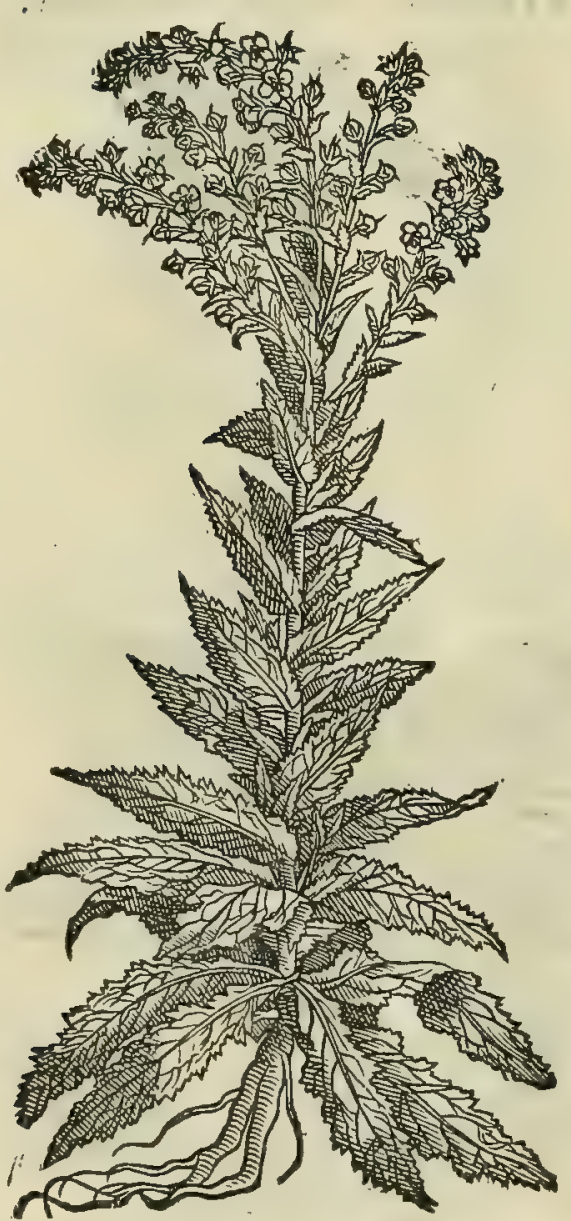

fi leuibus nibil proficiat. Eft er herba fimilis verbafco, qua B I A T T A R I A Plinio nominatur libro $\mathrm{x} \times \mathrm{v}$.cap. I X. ubi cam ijs uerbis depingit. Eft fimilis yerbafco berba, qua expe fal= lit pro ea capta, folijs minus candidis, cauliculis pluribus, flore luteo. Hec abiecta blattas in fe contrahit, ideó; Rome Blatta= riam uocant . hec Plinius , Eundem ueró effectum Diofcorides il= li verbafcigeneri aßignauit, quod floribus aureis defcrip/it: Que certé resfacit, ut credam, quod non aberrarent ij, qui fibi animü inducerent, blattariam Plinij, or uerbafcum illud Diofcoridis, cui flores infunt aurei, unam er eandem plantam effe. Porró Blatta $=40$ ria paßim feré nafcitur : folijs oblongis, per ambitum ferratis : flo ribus tertium Verbafci genus maximé amulantibus. Quibus de= cidentibus circa caulem folliculi exoriuntur parui, lini inftar, $d u=$ riores tamen, ac leuiores, in quibus femen continetur. De hac berba plures, quod inuenerim, facultates non produntur. Sed cum ed guftu amara deprebendatur, binc certó colligere licet, quód eadem $\sigma$ aperire, $\sigma$ abftergere poßit. Verbafci gene= $r d$, or uires memorie tradidit Galenus lib.V I I I. fimplicium me= dicamentorum, ubi ita fribit. Verbafcum, quoddam folijs album eft, quoddam ueró nigrum. Et albi aliud quidem mas eft, cuius fo $=50$ lid anguftiors: aliud fremina, cuius maiord. $\mathrm{E}$ f pretered aliud Verbafcum fylueftre cognominatum, quod floribus conftat aureis, o luteis. sed $\mathcal{O}$ preter bas pecies alia eft, quam proprie phlo= mida, $\sigma$ thryallida nominant. Priorum itaq; duarum radix \&uftu acerba eft, or fluxionis affectibus prodeft : $\int e d \sigma$ ad dentium do= Torem eam quidam colluunt. Attamen folia digerendi uim babent: fic or aliarum folia, or maximé eius, qua aureos flores obtinet: qua etiam capillos rufant. Omnium enim folia deficcandi, $\sigma$ dige rendimoderaté uim poßident. Qux planta Gracé $\phi \lambda$ ju.os, Verbafcum Latiné dicitur: Italis, Verbafco, er uulgó Taffo bar bafjo: Germanis, Vulkraut: Hifpanis, Verbafco:Gallis, Bouillon. 


\section{In Lib. quartum Diof coridis.}

\section{A จิง}

CAP. C.

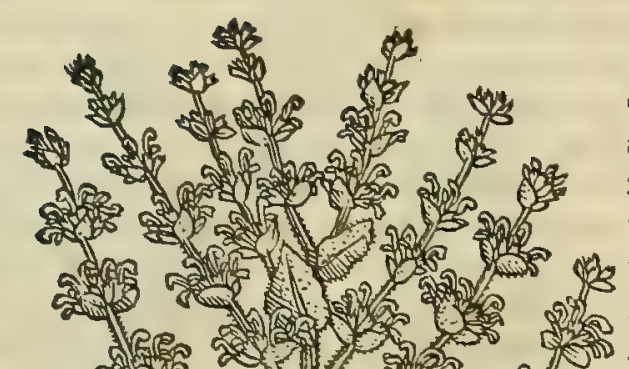

AETHIOPIS folia habet verbafco fimilia,perquàm hirfuta, denfaq́; , in orbem circa radicem imam redacta: caulem quadrangulum, $\dagger$ fcabrum, fimilem apiaft ro, aut arćtio, multis concauú alis : femen erui magnitudine,ge minum, in uno conceptaculo: radices ab eodem cerpite numerofas, longas, plenas, glutinofas guftu : quæ ficca nigrefcunt, duranturq́ue, ut cornua pofsint uideri. Plurima nafcitur in Ida monte Troadis, \& in Meffenia. Auxiliatur purulentis excreationibus, ifchiadicis, pleuriticis, arterix fcabritijs, deco\&ta radix, \& pota : quin \& cum melle, eclegmatis uicem prabet.

T A M E T S I iampridem exiftimauerim, Aethiopidem her bam in Aethiopia, o Ida Troadis tantum nafci, quód eam inibi plurimam gigni testentur Diofcorides, et Plinius; boct tamen an= no legitima, nif allor, Aethiopis ad me allata c'st Patalio ab eru= dito inueni medico Io anné odorico Melchiorio Tridentino, quä, nulla prorfus reclamante nota, Aethiopidem referre deprebendi, ut eius pittw a quan bic damus pulchré demonftat. Aethio= pidis non reperco merniniffe -Gatenum in fimplicium medicamen= torum cenfu. quanquam eam memoria prodidit Paulus lib.V I I. 4bi no.plures de bac berba uitres tradit, quàm quie Diofcoridi ac= cepta referripoffunt, gam ita fribat. Aethiopis fimilia uerbd= fco babet folia. Radicis decoctum potum auxiliatur ifchiadicis, pleuriticis, o fanguinem reijcientibus arterise etiam aperita= tescummellelenit. Vt Gräcis hec planta díb10 tis ita etiam Latinis Aethropis nominatur: It alis, Etbiopide.

T. Hoc toco in unlgatis Grecis codicibus legitur w $\alpha \times v^{\prime}$, boc eft, craffum. Qulam uocem interpres Plinjum forte, ut folet, fe= cutus omifit . Sed cur nos eain non ddiecerimus, fecit Oribajius, quem in boc Plinioadftipulari inuenimus.

Águrloy. ARCTION. CAP. CI

A R C T I O N, aliqui potius Arcturon uocant, fimilis eft verbafco folijs, nifi quòd hirfutiora, \& rotundiora funt : caule longo, molli: femine cumini, paruo : radice tenera, alba, dulciq́ue: Decocta cum femine radix in uino, dentium dolorem mulcet, fi contineatur ore decoctum: ambufta, pernio40 nesq́ue fouentur eodem : bibitur aduerfus coxendicum dolores, \& ftranguriam è uỉno.

C R E D I D I T Ruellius, Arction eam effe plantam, qua o fecus uids, $\mathcal{O}$ in fcrobium marginibus nafcitur,

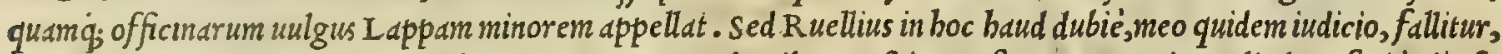
nec; audiendus est. siquidem, ut diligenter notas expendentibus perpicuum fiet, $L$ appa minor aliud prof ectó nŏ eft, quam $x$ anthium inferius à Diofcoride reprafentatum. E tenim L appa minor. folio uerbafci, cóg; birfutiore non uif $t=$ tur : neque caulem profert longum, or mollem: quin nec femen cumino fimile, neque radicem teneram, ac dulcem. Ex quibus. fané notis repugnantibus $\mathrm{R}$ uetlij opinio euidentißimé refallitur. Nullam equidem bactenus herbam reperi, ac uidi, qua Arctium legitmé referat. Huius meminit Galenus lib. VI. fimplicium medicamentorum, ubi de eo ita fcriptum reliquit. A rction illud, quod uerbafco eft fimile, radice tenerd, candidd, dulci: caule oblongo, or molli: $\int e=$ so mine cymino /imili, facultatis eft admodum tenuiü partium, or ob id exiccantis, extergentisq́, tamen modice. Quam obrem radix, ac femen eius coita cum uino, quadantenus dolores dentium mitigant. Porró ambufta, er chimetbla, non bor um modó decoctum neerfufum, fed er caules teneriores fanare poffunt. Quod ägutiov Graci, Arttium quoq; Latini dicunt: Itali; Arctio.

\section{Äprevor. PERSONATA.}

CAR. CII.

PE R S ONA T A folia habet cucurbitz, maiora tamen, hirfutiora, nigriora, \& crafsiora : caulem albicantem, quanquam \& interdum uidua caule reperiatur : radice intus candida , forìs nigra. Hæc drachmæ unius pondere pota cum pineis nucibus, purulenta, \& cruenta extufsientibus auxiliatur: trita dolores à contorfionibus artuum contractos, illitu fedat. Folia utiliter antiquis ulceribus illinuntur. Artiii confifideratio.

Aethiopidis confider.

Aethiopidis vires ex Pau.

Nomina. Ruellij error.

Artii uires ex Galeno.

Nomina. 


\section{And. Matthioli Comm.}

Perfonatx có

fideratio.
PERSONATA.

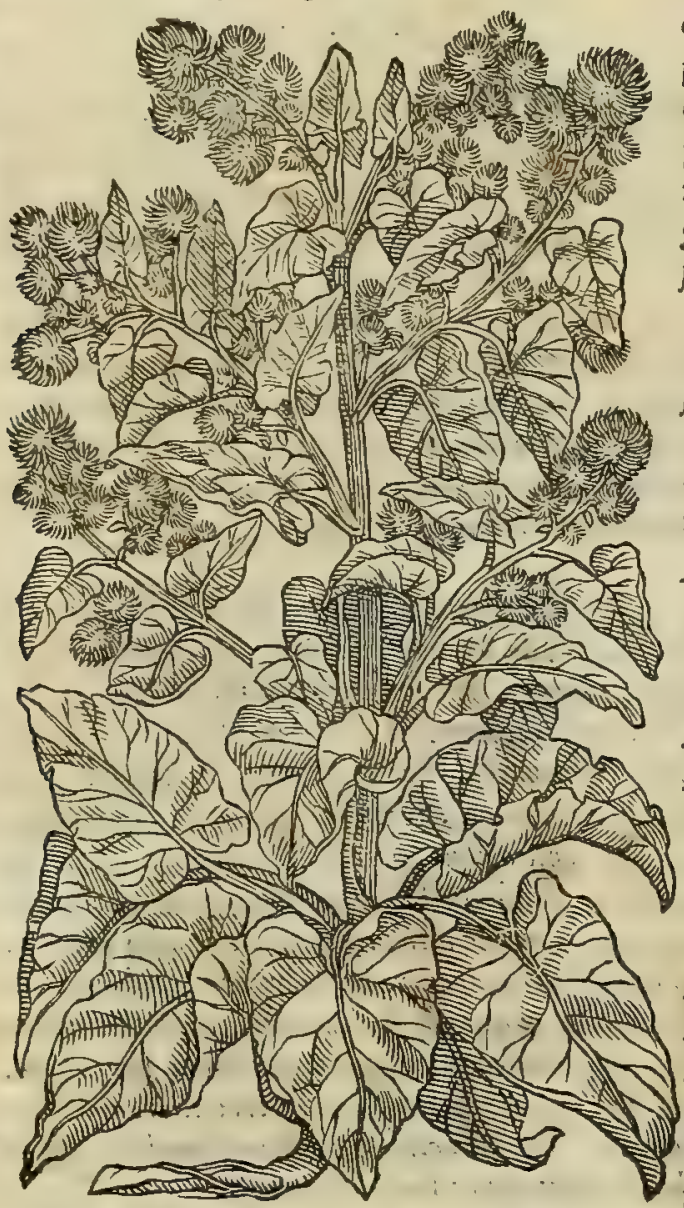

PER S O N A T M, Pliniolibro $\mathrm{x} \times \mathrm{v}$.eap. Ix.tefte, quidam Arcion uocant, cuius folio nullum eft latius, grandes lap= pasferentem. Ex quibus Plinij uerbis planum fit, Perfonatam eam nimirum plantam repree entare, quam officine uulgó $L$ ap= pam maiorem uocant, quod buic folia infint berbarum omnium inaxima, longeq ; cucurbitina excedentia: quódq́; bec lappas grandiores ferat. Huius altera babetur pecies, que quideme folijs cucurbitas magis amulatur, ijs tamen maioribus, in riguis, $\mathcal{N}$ fcrobium marginibus proueniens, caule interdum uidua, non tamen perpetuó, quoniam ueris initio or caulen, flores pro $=20$ fert, licet ijs fubinde confeftim exuatur. Ex buiis folijs noftrd= tes ruftici pileos fibi conficiunt, quibus à folis radijs fe tuentur. dum sirio ardente fegetem uel metunt, uel triturant. Huius item meminit Plinius loco citato, ubi eam non quidem Perfonatam, fed Perfolatam appellat, fic fcribens. Perfolatam, quam nemo ignorat, Graci ueró Arcion uocant. Folia habet maiora etiam cucurbitis; $\widetilde{\sigma}$ birfutiora, nigriorá, or craßiora : radicem albam, or grandem. Hac Plinius de Perfolata. Ex cuius notis facile cognofcipotelt, Plinium hic fecundum Perfonate genus de fcripfiffe. Quofit, ut maximé redarguendum putem Leoni= 2 ? cenum, utpote qui Plinium in hoc perperdm damnauerit, afee= rens non nifi unum Perfonata genus reperiri., Fuchfius, $\mathcal{O}^{\mathrm{r}}$ re= centiorum nonnulli non dubitant, quin boc Perfonate genus fit Petafites. Sed omnes, pace eruditorum dixerim, in errove uer = Santur, ut proxima commentatione liquebit. Caterim Bra= fauolus in fuo fimplicium examine Lappam credidit effe Dio= coridis Aparinen, in boc evidentius ballucinatus, quam ut $e=$ ius crror explodi debedt, ut etiam ij dijudicare poterunt, qui in reberbaria etiam mediocriter uerfati fuerint. De Perfonata fub alterius Arctij nomine differuit Galenus libro vi. fimplicium 30 PERSONATA ALTERA., medicamentorum, bis uerbis. Alterum ueró Arctium, quod Profopida uocant, ctius'q́; folia cucurbita fimil= lima funt, nifi quatenus tum maiora, tum durio= ra, difcutit fimul or deficcat, fed or adftringit mediocriter. Quamobrem folia eius ueteribus ulceribusmederipoffunt. Que planta Grecis

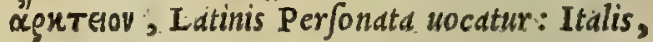
Lappold maggiore: Germanis, Groß kletten: Hipanis, Bardand, e Pagamacera mayor: Gal= lis, Gloteron, $\mathcal{C}$ Bardand.

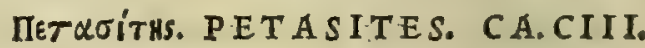

PETASITES pediculus eft cubito maior, crafsitudine pollicis, à quo prægráde folium, galeri modo amplum, ceu fungus dependet. Contra phagedænas, \& ulcera qux cacoëthe vocantur, efficaciter illinitur.

Petafitis confideratio. Ruellii,\& Fuchlii opinio.

QV A N QV.A M feribit Ruellius, nafci Petaften in Gallia; non tamen uideo, quomodo quis recté eius fenten= tie Jubfcribere poßit ac debeat. Quandoquidem is Perfolatam, de qua fuperiori capite differuimus, pro Petafite fum so pfiffe uidetur, quam etiam ipfum forté fecutus Fuchfius pro cadem depinxit. Sed quoniam Petafites pediculum fun= dit cubito proceriorem, d quo amplum folium, galerifigurd, tanquan fungus, dependet, cui folium buius Perfolate, uel Arctijgeneris minimé repondere deprebenditur; binc fit, ut borum alioqui doctißimorum uirorum fententian improbandam effe exiftimem. Nobis baEtenus ueram Petafiten non licuit inuenire. Atque adeó mea fententia eft,

Vires ex Gal. quodd bec non nafcatur in Italia, argumento, quod tam grande folium tandiu nunquam latere potuifet. Petafiti ui= res paucis reddidit Galenus libro v I I I. Fimpliciun medicamentorum, fic inquiens. Petafites ex tertio eft ordine de=

Nomina, ficcantium. Quamobrem ad maligna, qua cacoëthe uocantur, er phagedanica ulcerd, ed utuntur. Non fecus $L$ a

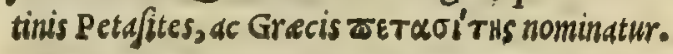




\section{In Lib. qua rtum Diofcoridis.}

E'कlTarTis. EPIPACTIS.

CAP. CIIII.

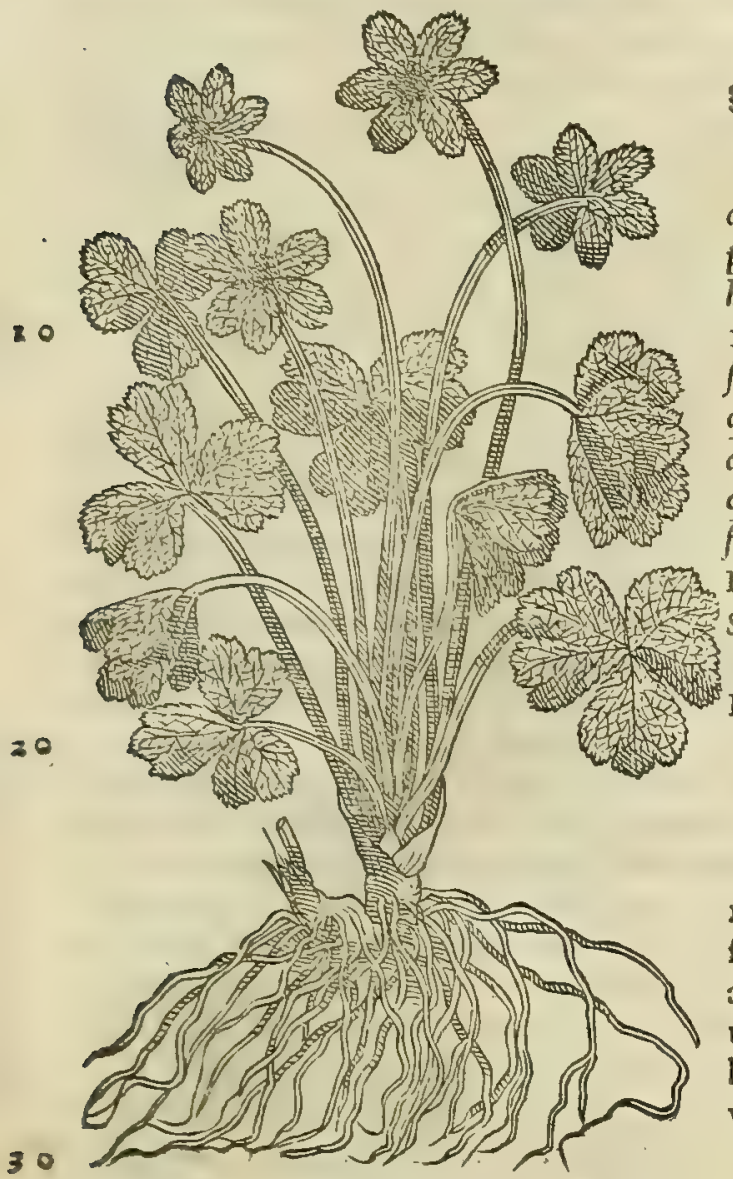

F $M A R I A$.

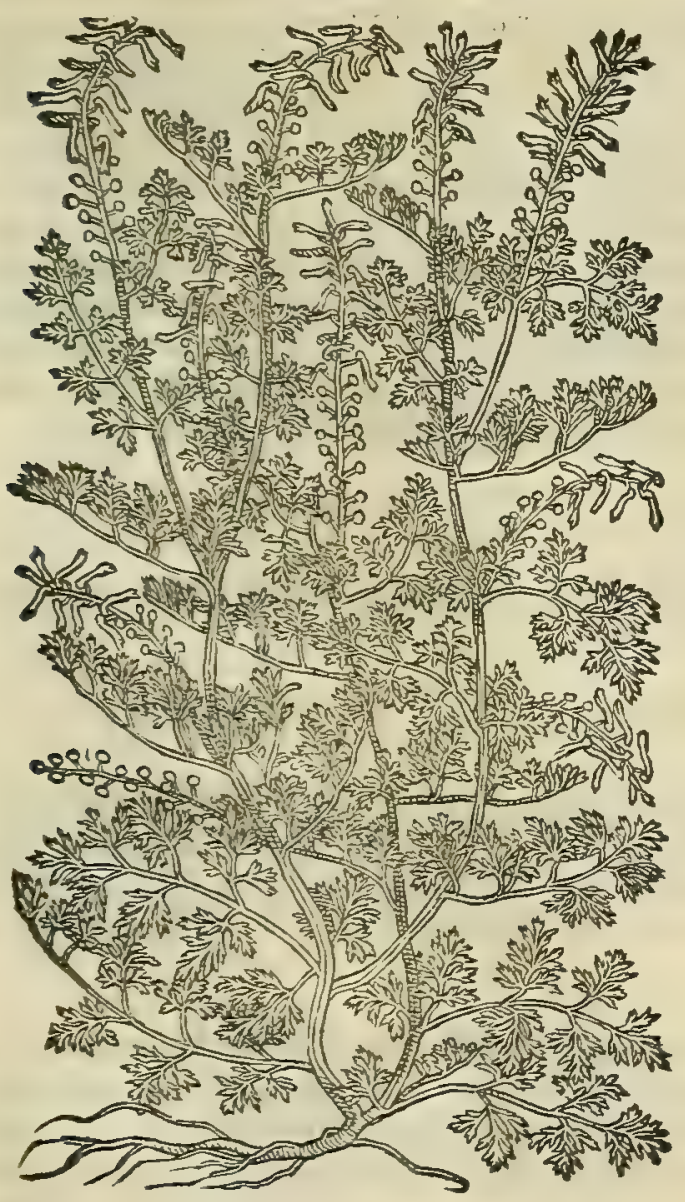

E P I A C I Is ab alijs elleborine, parua herba,exiguis folijs . Iocineris uitijs vtilis, \& contra venena pota.

E P I P A C T I D A ader paucisperftrinxcrunt Diofcori= des, acceteri, qui ante er poft ipfum de plant:urum biftoria fcri= perunt, ut difficilé admodum fit decernere, quienam planta fit hec in Italia, ubifortafe ea non prouenit. Nain, ut Plinitus lib. $\mathrm{X}$ I I I.cap. X X.commemorat, Epipact is in Afid, er Grecia nd= fcitur. Verim enimuero fi Epipactis Ellcborinc cx co didta eft, quód cum Elleboro nigro fimilitudinem babeat, edin equidem cres diderim nafci in Goritienfi agro. Quandoquidem inibi frequens quedam parua berba reperitur, cuius bic figuram damus, que folijs, floribus, es radicibus elleborum nigrum reprafentat. Epipactidis inter fimplicia,quod inuenerin, non meminit Galenus. Sed $\mathrm{P}$ aulus idem, quod Diofcorides, de cius uiribus tradidit.

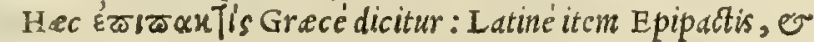
Elleborine.

\section{KaळVós. FVMARIA. CAP. CV.}

F v M A I A fruticofa herbula eft, prætenera, coriandro fimilis : folijs candidioribus, undique numerofis, cineracei coloris : flore purpureo. Huius fuccus acris eft : claritatem facit oculis, delacrymationemq́ue: unde nomen traxit. Illitus cum gummi, euulfas palpebras renafci prohibet. Commanducata herba biliofam vrinam trahit.
Epipactsdis conliveratio.

Nomina.
FVMARIA ALTERA.

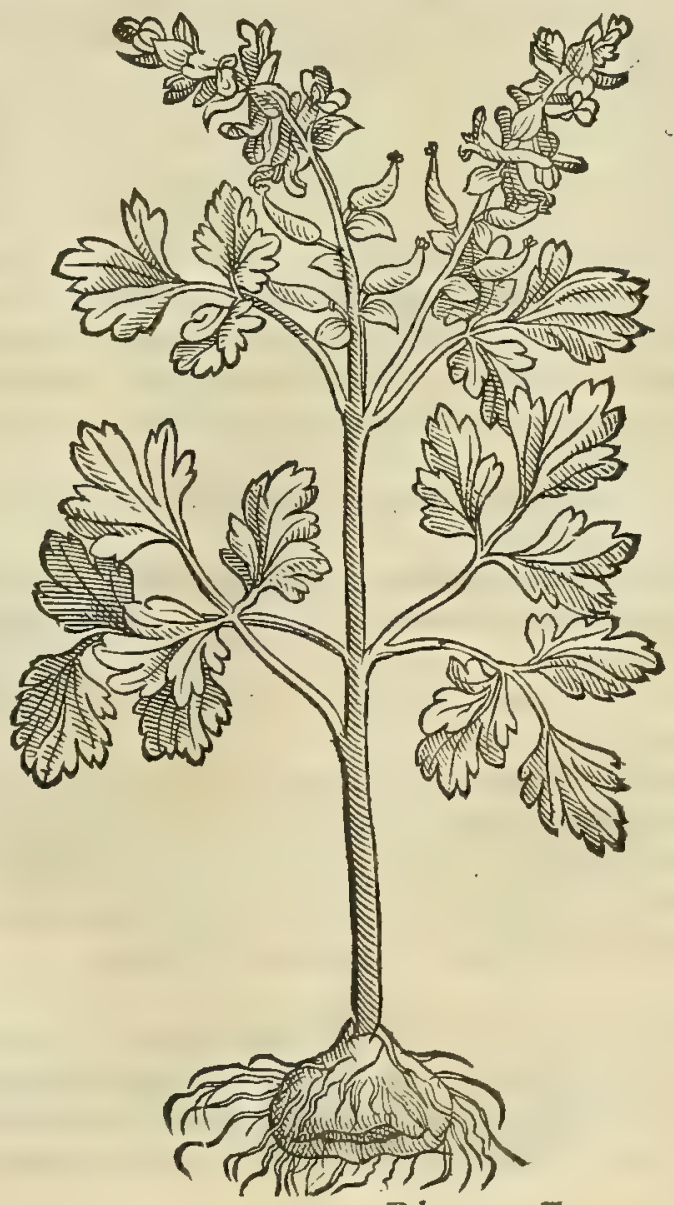

$\mathrm{Bb}$ 
Fumarix con F V M R I A, berbauulgaris admodum notitic, officinis paßim uocatur Fumus terre. Fumarie uerò nomen fiúeratio. fibi afciuit, quód cius $\int u c c o$ oculis iminiffo, quibus mirifice claritatem conciliat, lacrymas, quemadmodum $\sigma^{2}$ fu= mus, cieat. Debet bec Mauritanis longé magis, quàm Grecis, quód illi eam pluribus commendauerint uiribus, nec

Fumarix ge- eisquidem conteinnendis, ut Serapionem, Auicennam, or Mefuem legentibus facilé patebit. Fumarix Plinio nera ex 'lin, duo traduntur genera lib. $\mathrm{x} \times \mathrm{v} . c a p . \mathrm{x}$ I I I. ubi ita fcriptum reliquit. Capnos prima, quam pedes gallinaceos uo= cant, nafcens in parictinis, of epibus, ramis tenuißimis, parfis $\tilde{q}_{;}$, flore purpureo, uiridis, fucco caliginem difcu= tit: it sque in medic amenta oculorum addiur. Similis or nomine, o effectu alia eft Capnos fruticofa, pretenera, folijs coilandri, cineracei coloris, flore purpureo. Nafcitur in hortis, $\sigma$ fegetibus bordeaceis. Claritatem facit inun ctis oculis, delacrymationem '́; , ceu fumus, tunde nomen accepit . eadem euu' fas palpebras renafci probibet. bec plinius. Creterim qúcenun altcra fit Capnos, que etian ab Aëtio defcribitun, fuperius libro tertio de Ariftolo= 10 chia, or Pifolochia differentes latius expíicauimus. Eó igitur illos remitt. is s, qui plura de altero Fumaria ge= nere fcire defiderant. Hic fatis nobis fit cius tantum imaginem exbibere, fumaria alterius nomine infcriptam. atque eius notws, quas loco citato retulimus, omittamus, ne idem fruftrì repetere uideamur. Porró in nothis, e Diofcoridi adfcripris fimplicium nomenclaturis reperio Capnon quibufdam Corydalion appellari. Vnde fa= Eume $\mathrm{ft}$, ut in fupicionem uenerim, an de Capno intellexerit Galenus libro x I . fimplicium medicamentorum, ubide galerita fcribens, qu.e Greciscorydos dicitur, Corydalios herbe meminit, fic inquiens. Adieci hac fer= moni, quòd uellem claré hoc animal, nempe galeritam, manifitare, quos ferat in capite pilos erectos: quandoqui= dem expcrtus fum eius aduerfus colicos utilitatem, ueling; qui ip fum non norunt, ijs bene monftratum. Nam er ip=

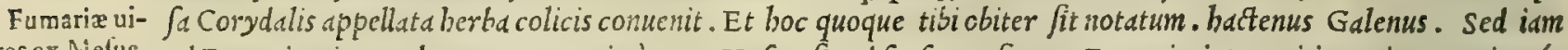
resex Mieluc. ad Funarie uires redeamus, quas primùn ex Mefue fic ad fenfum referam. Fumaxia inter mitiora, innocentiord'́; recenfetur medicamenta, quibus deiectoria uis incft. uerim nimia buius berbe copia facit, ut eius quoque aluctoritas

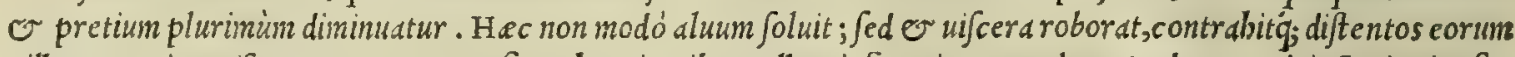
uillos. Omni prorfus noxa caret : quo fit, ut baurientibus nullum inferat incommodum. Roboratur deiectoria eius $f a=$ cultas, quod non admodum fit ualcntior, additis myrobalanis, fend, caprino fero, infectorio cocco, aut uuis paßis . Preftat que uirentior, folijs extenfis, non fané cripis, o que uiola:eo fit flore. Colligi debet uerno tempore, $\sigma$ ex co fuccus exprimi. Sunt quibanc in uniuer fum temperamento frigidam dixerint. Sed aberrarunt, quoniam in ip= fa foliorun fuperficie reperitur or calidttas, que tamen eius frigiditatem non fuperat. Siccat preterea ordine fecun do, fed femen calidum eft. Deprebenditur fané cius caliditas ex amaritudine, er acredinis parte quadam modica, que guftu percipiuntur. Quapropter attenuat, penetrat, obftructiones aperit, ac deie ctorie eft facultatis. sict: tifi-igiditatis, er acerbe qualitatis adminiculo colibet, aggregat, or roborat. Aluum facilé deijcit; bilem trahit, 30 $\mathcal{O}^{-}$aduftos bumores. Eius uis non modó ad bepar; fed or ad uends diffunditur. Quamobrem fanguinem expurgat, onnibusq́; incommodis medetur à bile, aut exuftis humoribus prouenientibus. Proinde elephantiafí medetur, ad= uerfus carcinomata efficax eft : lichenas, or alia cutis uitia mirificé emendat: quin or omnibus morbis auxiliatur, qui ex uifcerum infarctu originem ducunt. Roborat Fumaria uentriculum, iecur, e cetera interna uifcera, bilio=

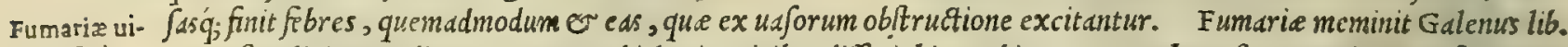
res ex Gal. VI1. finplicimmedicamentorum, ubi de eius uiribus differit his uerbis. Capnos, boc eft, Fumaria acris fimul, er anar qualitatis eft particeps, nec tamen plané expers eft acerbe. Quamobrem urinam bilio am multam prouocat, fanat'́, iecinoris obfrutiones, er debilitates. Succus eius oculorum aciem acuit, non paulum trabens lacrymarum, uelut ipfe fumus: nam binc ei appellatio indita. Plebeius quidam ea uti folebat ad ftomachum roborandum, unáq; ucntrem lubricandum. Siquidesn berbam primim deficcatam condebat: porró cuin uti uolebat, fubductionis quidem 40

Nomina. gratia, melicrato inpergebat: at roborare uolens fomachum, uino nimirum diluto. Herba, qux Grecis now vós, Iatinis quoq; Capnos ef Fumaria nominatur: Arabibus, Scchiterig, fiue Sabeteregi: Officinis medicorum, Fumus terre: Italis, Fumaria, en Fumoterra: Germanis, Erdtrach: Hifpanis, Palomilha: Gallis, Fumeterre.

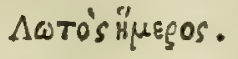
LOTVS VRBANA.
CAP. CVI.

L o T v м vrbanam alij trifolium uocant. nafcitur in hortis. Extractus fuccus, addito melle, ocu lorum argema, nubeculas, cæterasq́ue caligines difcutit.

\section{IDTÒs äyglos. IOTVS SYLVESTRIS.}

S Y L V E S T R I S Lotus, quam trifolium minus appellant, plurimum in Libya gignitur, caule bicubitali, \& fxpe maiore,alis nultis : folijs trifolij pratenfis : femine foni græci, multò minora, guftu medicato. Vim calfaciendi, \& leniter adftringendi obtinet : vitia cutis in facie, maculasq́; cum melle peruncta expurgat . Trita per fefe, aut cum malux femine, in uino, aut paffo bibitur aptifsimè contra dolores, qui ueficam malè habent.

Loti utriufg; confideratio. GeIneri, \& aJorum opin. reprobata.

N V L I A certé hactenus nobis $\int e \int_{e}$ obtulit herba, cui meritó $\int u b f c r i b i$ poßit : hec eft uera ac legitima Lotus $\int_{d}=$ tiua. Caterim non de funt è recentioribus,quorum opinionem tuctur Ge fnerus uir doctißimus in fuo libro animalibis dieato, qui putant, Lotum fatiuam effe Trifolium illud, quod in pratis paßum atque alibi etiam prouenit: 20 fortaffe argumento adducti, quód Diofcorides fcripfcrit Lotum tam urbanam, quàm fylueftrem ab aliqubus trifolium appel. 


\section{In Lib. quartum Diofcoridis.}

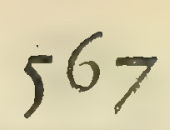

IOTVS VRBANA.

LOTVS SYLVESTRIS.

10
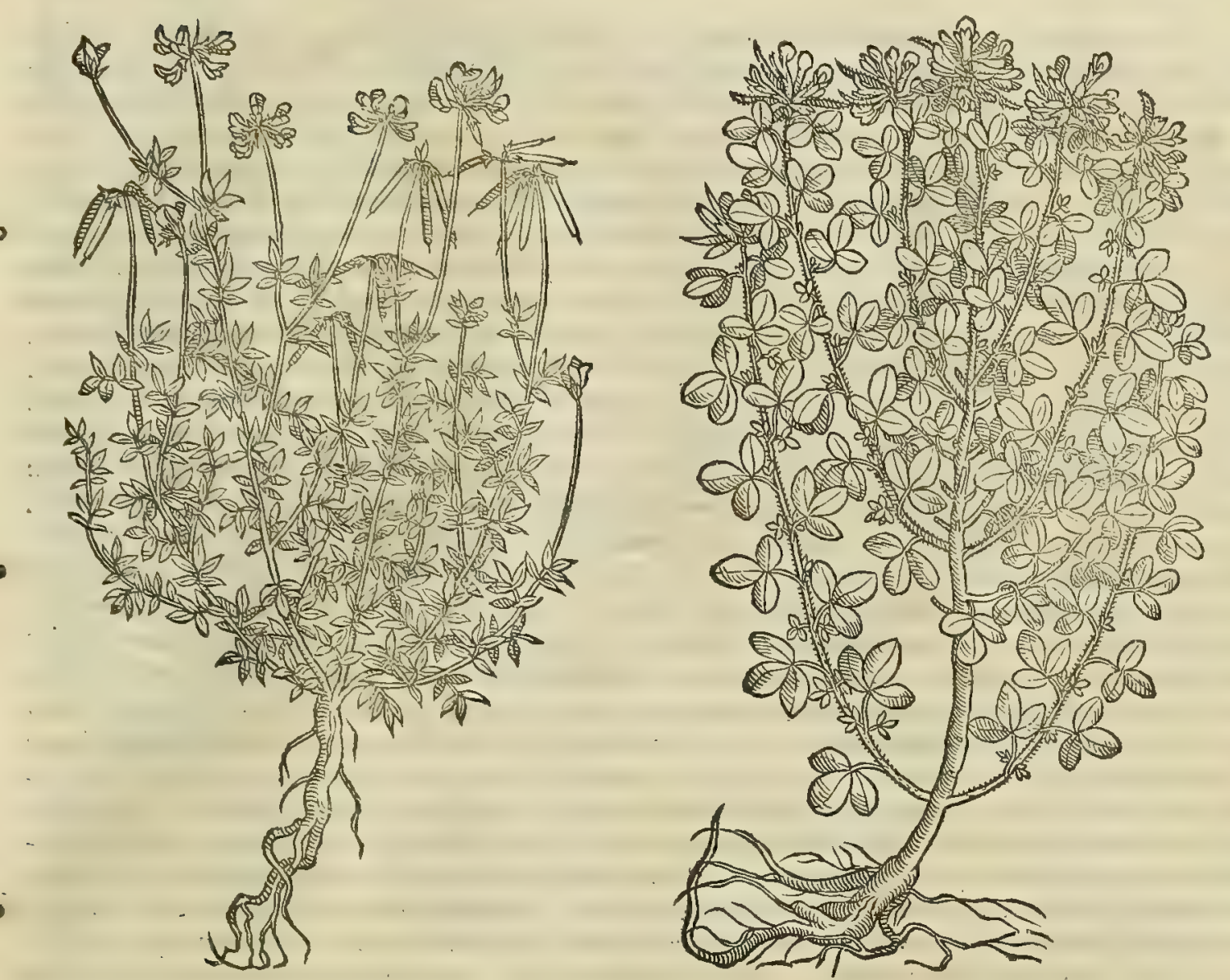

Idri. Sed quòd errent ij, qui itd fentiunt, ex eo maniffté cognofcitur, quód à Diofcoride Loto fylueftrifolid trifo= lijpratenfis tribuantur. Nam fi Diofcoridi Lotus fatiua fuiffet trifolium pratenfe, is nimirum fcriptis tradidifet, eam in pratis nafci, non in hortis: atque fatis illi fuiffet $\mathrm{L}$ otum fylueftrem fatiux fimilem reddere, omiffa trifolij pra= tenfis mentione. Hinc ergo colligendum arbitror, I otum effe plantam aliam à Trifolia : eosq́; in errore uerfari, qui fecus opinantur. Sunt porró alij, qui exiftinant, eam plantam effe Lotum urbanam, quam uulgares berbarij, eN officine Melilotum falsó appellant, utpote qua folijs conftet trifolij effigie, nd fcaturớ; non in pratis tantim, fed etiă in uiridarijs ac hortis. Verum borum fententiam cur plané probesn, aut refellam, nibil equidem habeo, cum ij fua

40 potius opinione duci, qudin rationibus aut auctoritatibus niti uideantur. Inclinat tamen animus ad credendum, quodd ita, ut illi rentur, facilé effe poßit. quandoquiden unlgaris Melilotus o in bortis prouenit, o folia trifolio proxi= ma profert: quin e omnibus notißima eft berba, quemadmodum Lotum urbanam olim fuiffe aperté innuit Diofcos rides, qui eam ut triuialesn ideo non depinxit. His illud etiam accedit, quód in bunc ufque diem proprium feré ferud= uerit nomen, co tantium aucto ex Loto in Melilotum. Vinde poftea facilé factum effe poteft, ut eadem legitime me= Tiloti locum occupauerit. Sylueftris ueró Lotus, quàmcopiofam in Libya gigni tradidit Diofcorides, an nafcatur in Italia, non anfirn affirmare. Equidem herbam quandam fapius uidi, ac legi in incultis, o pratis nafcentèm, folijs trifolio emulis, bicubitali caule, quàm plurimis adnatis, luteisfloribus, é quibus cornicula prodeunt femine plend, feeni greci modo, odore non ingrato. Sed an hec fit uera Lotus fylueftris, nondum compertum, ov exploratum bd= beo. Loti utriufque uires reddidit Galenus libro v I I. fimplicium medic amentorum, fic inquiens. Lotus domeftica,

so quam quidam triphyllon, boc eft, trifolium nominant, ut mediocriter concoquendi uim poßidet, fic etiam exiccan= di : in caliditatis, frigiditatisq; coniugatione media quodammodo eft, es temperata. Lotus autem agreftis plurima in I ibya prouenit. Semen eius fecundi eft ordinis excalfacientium, babetó; nonnibil abfterforium. $\Lambda \omega$ To's que

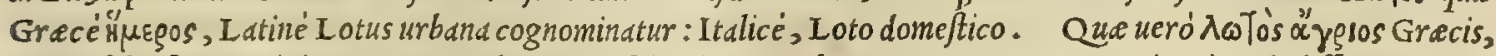
Iotus fylueftris Latinis nocatur : Italis, Loto faluatico. Arabes utrunque cun Aegyptia etian indifferenter no= cant Handachocha, Garch, er Thusf.

\section{Kítoos. CYTISVS.}

CAP. CVIII.

C Y T I S v frutex eft albus in totum, ut rhamnus, ramos fpargens cubitales, \& maiores: in. quibus folia foni græci, aut loti trifoliæ, minora, dorfo medio prominente. Ea digitis trita erucam olent, guftataq̣ue ciçer recens fapiunt. Folia refrigerant: tumores inter initia difcutịunt, ff 


\section{And. Matthioli Comm.}

cum pane trita illinantur : decoctum potu vrinam ciet. Nonnulli, quòd apes alliciat, prope aluearia ferunt.

Cytifi confideratio.

Cytifus fru tex elt, non herba.

Cytifi hiftoria ex Col.

Cytifi hifto ria ex Plin.
C R E D I D I M V S iandudum Cytifum, fi tamen is in Italia proueniret, non aliam effe plantam, quam eam Tri= folij odorati foecicm, que Romanis uulgó appellatur Tribolo, alijs ueró Trifoglio cauallino, hoc eft, Trifolium equi= mum,co quód equis gratisinum fit pabulum, cum nulla anté mibi occurreret planta, que mag is not is omnibus Cytifum pre fe ferre videretur. In banc opinionem me primim deduxerat Plinius, quód fcripferit, iumenta deguftato Cytifo bordeum fpernere. Nam cün certó fcirem, equos adeó buius Trifolij zenere auidos effe, ut co inagis delectětur, quàm bordeo, allena, or reliquis frugibus; idcirco uidebar non temere adduci, ut crederem, banc ftirpem legitimum effe Cytifum, presertim cum pluribus conftet notis, que cytifo repondent. Huc praterea alia accedebat ratio, quód no cum Dio fcoridem uiderem de Cytifo inter berbas, non autem inter frutices, $\sigma$ arbores differere, non aliud quidem mibi perfuadere poteram, quàm quód Cytifus effet berba potius, quàm arbor: precipué cùm palàm fit, iumenta berbas, $\sigma$ fonum potius depa $\mathrm{c} c i$, quin arborum frondem. siquidem eruo, et medica berbis antiqua atas armenta, o pecora alebat, ac faginabat. His itaq; rationibus fretus (tunc enim plura neglexeră inueftigare) adductus eram, ut exiftimarem, illud Trifölij genus odor atü omnino effe cytifum. Verüm enimuero cum poftea rem hanc accuratius, rectiusq; expendiffem, me in errore uer fari deprebendi. Proinde in pr efentia non grauabor priorem mutare fenten= tiam, constanter ${ }^{\prime}$; affirmare, aliam ab illa planta Cytifum effe : nec eam quidem berbam, fed fruticem, qui cultura arborefcat. Non enim is fum, qui opinionis alicuius fuftinenda gratia adeo pertinax effe uelim, ut falfummagis, quàm uerum tueri contendam. Sed quód iure putemin aliam me deueniffe fententiam, facit in primis Galenusli= bro primo de antidotis, ubi cytifum frutic em effe myrti magnitudine fcribit, bis uerbis. In Myfia quog; qua parte nusfre prouincis finitima eft, tractis occurrit, quem Britton nominant, in quo mel Attico per fimile magna cum ad= miratione conpexi. Extabat enin ibi quoque collis quidam non magnus, faxo fus totus, thymo, $\mathcal{N}$ origano refertus: alibi locus erat Cytifo plenus. A pes plurimun mellis ex Cytififloribus excerpere fcriptores uno ore tradunt. Fru= tico a ueró planta Cytifus eft, eam altitudinem attingens, ad quam myrticre $\int c u n t$. bec Galenus. Eft deinde Plinius, quem Galeno fub fcripfiffe inuenio hibro $\mathrm{x}$ I 1 . cap. I I I. cuim inquit. Alterum eft ebeni genus frutico fum, Cytifi modo or tota India difperfum. Et libro X V I. cap. x x x v I I I. ubi inter arbores Cytifumenumerat, fcribens. Totd offed eft, ilex, cornus, robur, Cytifus, morus, ebenus, lotus, or que fne snedulla effe diximus. Accedit bis etiam Colu= mella, qui idem teftari uidetur in calce libri v. ubi cum longius de cytifo differuiffet, demum inquit. Hattenus de ar= boribus precepiffe abunde eft. Horum itaque probatorum authorum teftinonio planum fieri arbitror, Cytifum arbo= refcentem effe fruticem myrtimodo, ut Galenus fcriptum reliquit . Sed mihi quidë battenus inter Italicos frutices, qui 30 arboris inftar adole fcunt, nullum contigit inuenire, qui legitine cytifum referret. Caterum non de funt, qui fibi perfaladeant, atq; etiam fcriptis tradant ( $u t$ Ge nerus in libro magno, quem de quadrupedibus edidit) fe (ytifum vidiffe, legifféq; in Italia in fyluis, alijsó; fylueftribus locis, qui per fe tantum proueniat. Sed cquidem dubitatuerim; ne, or ip/i decipiantur : quandoquidem ij, quantum ex eorum fcriptis colligi poteft, Coluteam fic Theophrasto uo= catam fumunt pro cytifo. Neq; propterea illud dixerim, quodd putem cytifum fua ponte non prouenire, ciun tefte Columella lib. $x$ x. cap. I I I I. de re ruftica, duplex fit cytifus, una fatiua, et altera fuc pontis: fed quód fcribat Plinius, raram effe in Italia. De fatiua autem cytifo diligentißime fripfit idem Columella lib. v. de re rustica, capite ultimo, cuius bic uerba fubijciam. Cytifum, inquit, in agro eße quim plurimum maximé refert, quod gallinis, apibus, capris, bubus quoq;, or omnigeneri pecudum utilißimus $\mathrm{e} f$, quód ex co citó pingue fcit, $\mathrm{O}^{\prime}$ lactis plurimum prebet ouibus : tum ctiam quód octo menfibus uiridi eo pabulo uti, o poftea arido poßis. Preterea in quolibet agro, quanuis inacerrimo, celeriter comprebendit: omnem iniuriam fine noxa patitur. Mulieres quidem fi lactis inopia premuntur, cytifum aridum in acqua macerari oportet, ov cum tota nocte permaduerit, poftero dic expreßi fucci ternas heminas permifceri modico uino, at $q_{;}$ita potandum dari: fic $\mathcal{O}$ ip $\int \mathfrak{a}$ ualebunt, o pueri abundantia lactis confirmabuntur. Satio autem Cytifi uel autumno circa idus octobris, wel uere fieri poteft. Cum terram bene fube= geris, areolas facito, ibiq; uelut ocymi femen cytifi autumno ferito. Plantas deinde uere dipponto, ita ut inter fe

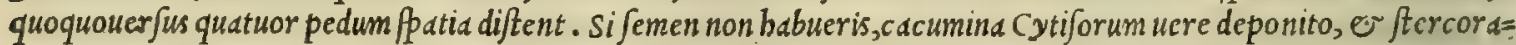
tam terram circumaggerato. Si pluuia non incefferit, rigato quindecim proximis diebus, fimul atque nouam front dem agere coperit, farrito, or post triennium deinde cadito, or pecori prabeto. Equo abunde ef uiridis pon= do $\mathrm{x}$ v. bubus pondo uicena, caterisq́; pecoribus pro portione uirium. Poteft etiam ante Septembrem fatis commodé ramis Cytifus feri, quoniam facilé comprebendit, ev iniuriam fuftinet. Aridum fi dabis, parcius prabeto, quoniam uires maiores habet, priusóp; acqua macerato, or exemptum pale is permifceto. Cytifum ciim aridum facere uoles, circa menfem septembrem, ubi femen eius grandefcere incipiet, cadito, paucisq́; boris, dum flaccefcat, in fole has. beto: deinde in umbra exiccato, $\sigma$ ita incondito. bactenus Columella. Plinius quog; Cytifi biftorian copiosé pro= fequitur libro x I I I. cap. $x$ x I I I I . ubi bec habct. Frutex eft $O$ Cytifus ab Ariftomacho Atbenienfi miris laudibus predicatus pabulo ouium, aridus ueró etiam fum: Ppondet $\dot{q}$; ingero cius annua $\mathrm{H}$ __ S. MM. uel mediocri folo redi= tus. Vtilitas qua eruo, fed ocior fatietas, perquàm modico pingue fente quadrupede, ita ut iumenta bordeum per= nant. Non ex alio pabulo lact is maior copia, aut melior : fuper omnia pecorum medicina i morbis omni ufu praftan= te. Quin er nutric ibus in defectu lactis aridum, at q; in aqua decoctum, potui cum uino dari iubet, or firmiores, cel= fioresq́; infantes fore. Viridem etiam gallinis, aut $\sqrt{2}$ aruerit madefactum. Apes quoque nunquam defore, Cytifi pax bulo contingente, promittunt Democritus, er Ariftomachus. Nec aliud minoris impendij eft. Seritur cum bordeo, aut uere femine ut porrum, uel caule autumno ante brumam. si femine madidum: er fi defint imores, fatum frar. 


\section{In Lib. quartum Diofcoridis.}

gitur. Plante cubitales feruntur frobe pedali. Seritur poft equinoctia tenero frutice: perficitur triennio: deme= titur uerno aquinoctio, cum florere desijt, uel pueri uel anus uilißima opera. Carus appectu, breuiter $q$; $f$ quis ex= primere fimilitudinč uelit, anguftioris trifölij frutex. Datur animalibus poft biduum femper: byeme neró quòd ina= ruit, madidun. Sutiant equos dene libre, e portione minora animalia: obiteró,; inter ordines allium, er cepe feri fertile eft. Inuentus bic frutex in Cytbno infula, inde translatus eft in omnes Cycladas, mox in urbes Greeds, mas= gno cafei prouentu. Propter quód maximé miror rarum effe in Italia. Non aftuum, non frigorum, non grandinum, aut niuis iniurian expauefcit. hec Plinits. Ex quibusbic certé fubit nobis mirari Gefnerum, uirum alioqui eru= ditione clarum, quód in fuo magno libro de quadrupedibus, ubi probare contendit arborcm, quan rura Tridentin. Eghclum uocant ( nos edm Anigyris generi ddfcripfimus) cffe Laburnum, feribdi ex auctoritate Democriti Cytifum

so apibus aduerfari. Qua in re is mibi quidem uidetur ( pace cius dixerim) non fuife memor illormm uerborum, quibus pauló anté afferuerat ciusdem Democriti teftimonio, apes nunquam defore, cytiff pabulo contingente. Id quod nos quoq; ex plinio paulo fuprà retulimus. Ceterùn de Trifolio illo odorato, cuius initio buius comnentationis, at ${ }_{;}$ etiam fufius libro tertio in Trifolijs mentionem fecimus, neq; Diofcorides, neq; Galenus, quod fciam, quicquam me= morix prodiderunt. Nondefunt, qui id uclint effe Theophrafto plantam Mel frugum appellatam, quam ipfe inter lotigenera recenfet libro V I I. cap. X I I I . de plantarum biftoria, ubi fic inquit. Quedam enimformis pluribus conftant, quanquam nomen unum fortiantur, ut ita frme aquiuoca fint, ceu lotus. Huius enim genera plura re= dundant, folio, caule, flore, fructúq; difcreta. Inter que uelillud redditur, quod Mel frugum appellatur, diuer= fum tum uiribus in ufu cibario, tum quód non eaden loca defideret . bec Theopraftus. Qux fané illorum fententiam mibi probare non uidentur, quód Trifolium odoratum minune in cibis ueniat, er ijsdem in locis nafcatur, in qubus

2a lotorum omne genus uire cere conpicitur. A tqui Plinio libro x X I I. cap. ultimo, nil aliud eft Mel frugum, Dio= clis teftimonio, quàm panicum. Cytifi uires Galenus libro v I 1 . fimplicium medicamentorum, reddidit his paucis uerbis. Cytififolia digerendifacultatem obtinent aque temperate miftam, ficut or malue folia. Planta ut Gre= cé xútroos, itcetiam Cytifus Latiné, er Citifo Italicé dicitur.

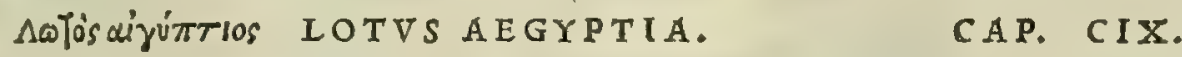

ES T E T in Aegyptolotus, quæ in campis flumine inundatis prouenit, caule fabæ: flore paruo, candido, lilio fimili, quem tradunt occidente fole comprimi occludiq́ue, ad ortum autem aperiri :adduntq́ue, caput ipfum uefpera aquis condi, \& ad exortum folis emergere. Caput quaso le papaueris, maximum : \& intus grana, ceu milij, quæ Aegyptij exiccant, \& in panes cogunt. Radice $m$ lotos hæc habet, mali cotonei fimilitudine, qux cruda coctaqque manditur : decoctaq́ue lutei oui qualitatem exhibet.

L O N G A M Satishiftoriam de Loto Aegyptia pofteritatis memorie tradidit Theophraftus libro I 1 I I.cap. x. de plantarum biftorid, cuius hic uerba referam. Qui Lotus, inquit, uocitatur, planis parte maxima pronenit, cùm

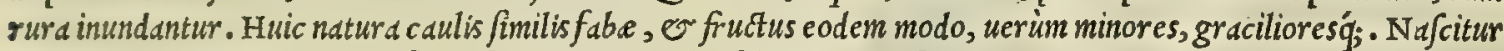
frutus in capite, modo quo in faba: flos candidus, lilijs foliorum anguftia proximus: multi, ac den/i promifcui exe= unt. Sole occidente fe comprimunt, caputóg, integunt, ad ortum aperiuntur, o fuper aquam afjurgunt: id ${ }_{j} f f_{d}=$ cit, dum caput perficiatur, floresó; defluant. Capitis magnitudo quanta papaueris maximi, er percingitur incifuris

40 non alio modo, quam papauer : nifi quod in his fructus frequentior babetur, qui milio non abfimilis eft. In Euphra $=$ te caput, floreso;; mergireferunt, at q; defcendere ufq; in medias nottes, tantum q; abire in altum, ut ne demiffa qui= dem manu capere fit, diluculó deinde redire, 0 ad diem magis: fole oriente iam extra undas emergere, florem $\dot{q}_{5}$ patefacere: quo patefactó amplius infurgere, ut plané ab aqua abfit alté. Aegyptij capita ipfa aceruis putrefaciunt, cumq́; tegumenta putruerint, in flumine lauando feparant fructum, $v$ ficcantes, pinfentes q́; panem faciunt, eoq; cibo utuntur. Radix loti Cor/ion appellata, rotunda eft, cotonei mali amplitudine, cortice nigro, quali nux caftanea tegitur. Corpus internum candidum : elixum, a fJum ; $_{\text {; }}$ in pecimen albuminis uertitur, gratum cibis : manditur etiam crudum, Jed gratius decoctum feu aqua, feu pruna. Haftenus de Loto Aegyptia Theoplraftus. Caterum banc, or fupradictas Loti pecies Ser apio fua lingua Handachocham indifferenter nominat. E' cuius femine oleum expri= mitur Mauritanis ad articulorum dolores expetitum. Neq; enim fit Handachoche oleum ex unlgaris trifoij Semine,

so ut quidam abẹrrantes exiftimant, fed ex omnium Lotorum femine, $\sigma$ ex eo tantùm trifolio, quod aphaltiten Greci uocant. Ioti Aegyptia breuiter meminit Galenus inter alias lotos, libro v I I. fimplicium medicamëntorum, fic Lotus segyinquiens. Loti Aegyptia femen in panes quidem cogitur. Planta $\lambda \omega r$ òs aúyviَT Iatiné, Handachocha Arabicé, e L Loto d'E gitto I talicé appellatur.

Loti Aegye ptix hiftoria ex Theophr.

\section{Mug̣ó}

M Y R I O P H Y L L V M, fiue millefolium, caulis eft tener, fingularis, unica nixus radice: plurimis folijs, læuibus, feniculo fimilibus, unde nomen accepit . Caulis flauefcit, uarius, ac ueluti ex induftria deliniatus. nafcitur in paluftribus. Vulnera recentia ab inflammatione uindicat, fi uel uiride, uel ficcum ex aceto oblinatur : pracipitatis in potu cum aqua, \& fale datur .

A rabum Han dachocha. 

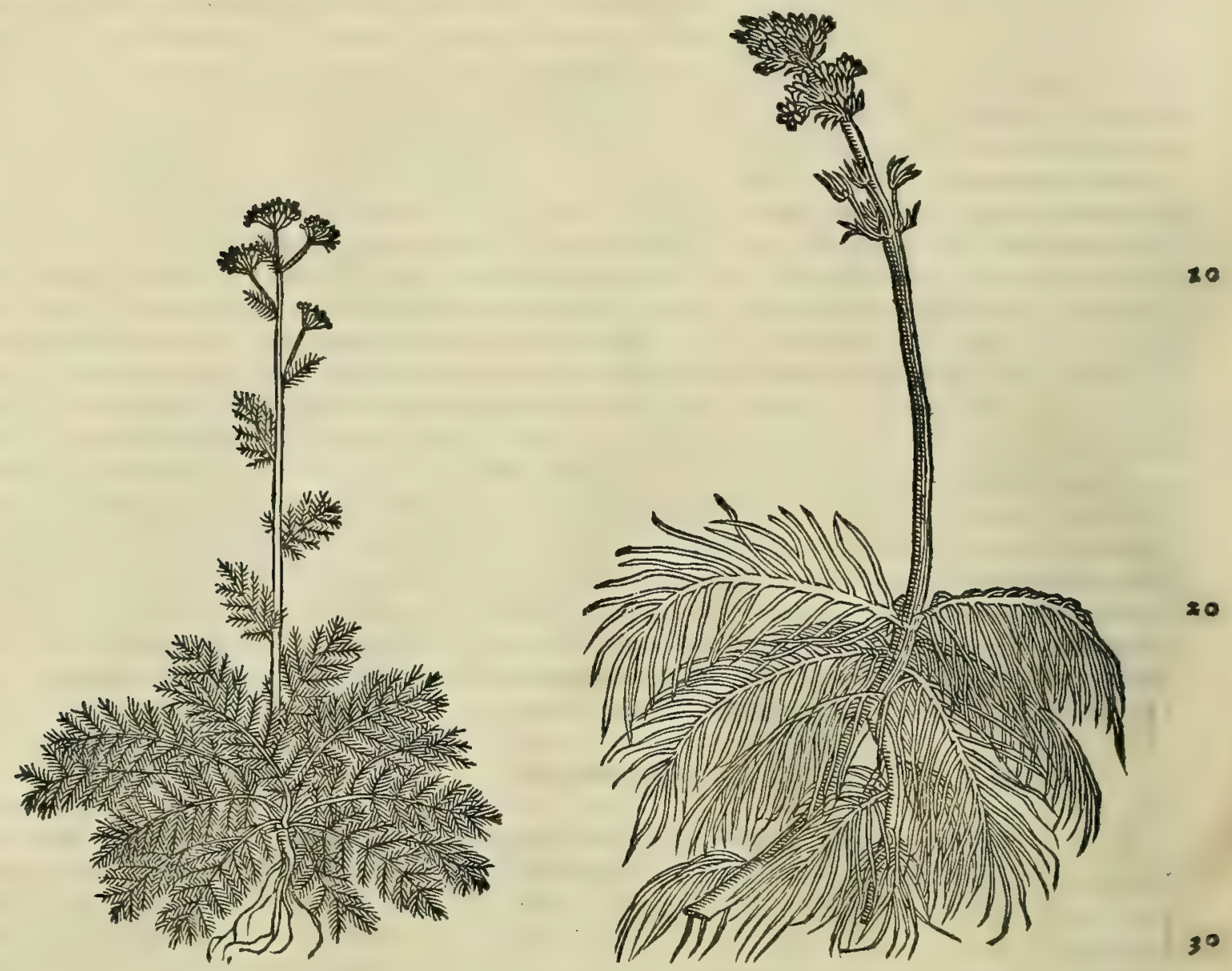

Myriophylli confider.

Myriophylli vires ex Gal.

Nomina,

Myrrhidis cő fideratio.
MYRRHIS.
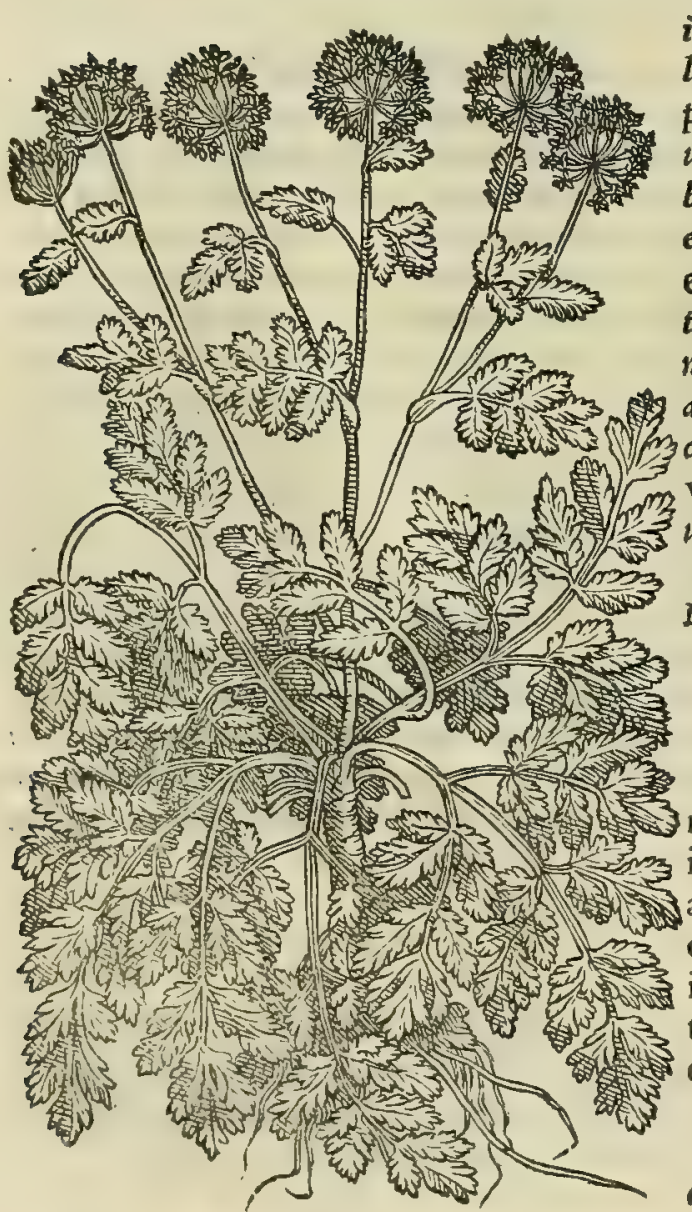

E T S I nondefunt, qui uelint Myriopbyllum, ut fuperius in stratiotis millefolij commentatione diximus, effe unlgare Mil lefolium, quo omnespaßim utuntur in Italia; tamen cum boc plurimis caulibus à radice profiliat, folijs conftet à forniculo di= uerfis, nafcaturq; in pratis $\mathfrak{O}$ incultis, non autem in paludi= bus, binc fatisperpicuum fieri puto, bos qui ita fentiunt, in errore uerfari. Equidem legitimum Myriophyllü me inuenife, or sepe uidiffe crediderim in uallis Anania paluftribus, unico tantium caule, innumeris foliolis referto, capillaceis faniculi to modo, odore non ingrato. Huius plante bic picturam damus, aliam $\dot{q}_{\text {; }}$ appinximus ad nos Pifis miffam ab eruditißimo uiro $\mathrm{L} u=$ ca Ghino. Myriophylli uires paucis perftrinxit Galenus lib. VI r. fimplicium medic amentorum, fic inquiens. Myriophyllum ufqueadeo deficcatoria eft facultatis, ut uulnera glutinet.

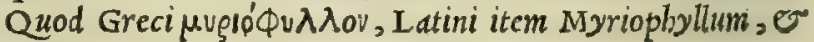
Millefolium aquaticum uocant : Itali, Miriophillo.

\section{Mų่̧̣́s. MYRRHIS. CAP, CXI.}

M Y R R I s fimillima eft cicutre, caule, folijsq́ue: radix ei oblonga, mollis, rotunda, odorata, cibo non infuauis. Quæe pota in uino, phalangiorum morfibus auixiliatur: cit menftrua, \& partus fecundos, purgátque à puerperio foeminas : fubuenit \& phthificis cocta in forbitione. Aiunt quoque eandem bis die térve potam ex uino, in peftilentia falutarem effe, \& ne morbi contagia fentiantur, obftare.

GIGN I T VR in quàm plurimis Italie locisplanta ques dam cicute faciem reprefentans, minor tamen, miniméq; $g r a=$ ueolens 


\section{In Lib. quartum Diofcoridis.}

ueolens, Cicutaria nonnullis uocata, quam quidam cenfent legitimam effe Myrrbin. Sunt deinde, qui pro Myrrbide Angelicain uulgo appellatam accipiant. Alij ueró, ut Manardus, illud oleris genus intclligunt, quod cherefolium uo cant. Veruntamen boc, meo iudicio, nullis notis Nyrbida refert, ficuti nec illa: tamet/f buius radix d recentioribus in peftilentia miris laudibus commendetur. Quód autem Angelica non fit Niyrrbis, ex co eudentißimum effe arbi= tror, quód eifolia fint fatiue paftinace ftmilia, non quidě multifida, ueluti cicute. Caterum fi Myrrbis in Italia pro= uenit, mulla fané mibi battenks $\int c f e$ obtulit planta, que magis illi reppondeat, quàm bac, cuins bic cffigiem pict am ex= bubemus, que quidem longé ab Angelicadiffert. Sed quoniam A N G E I I C A mentio incidit, ne tampre=

A NGELICA.

2.

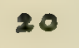

30

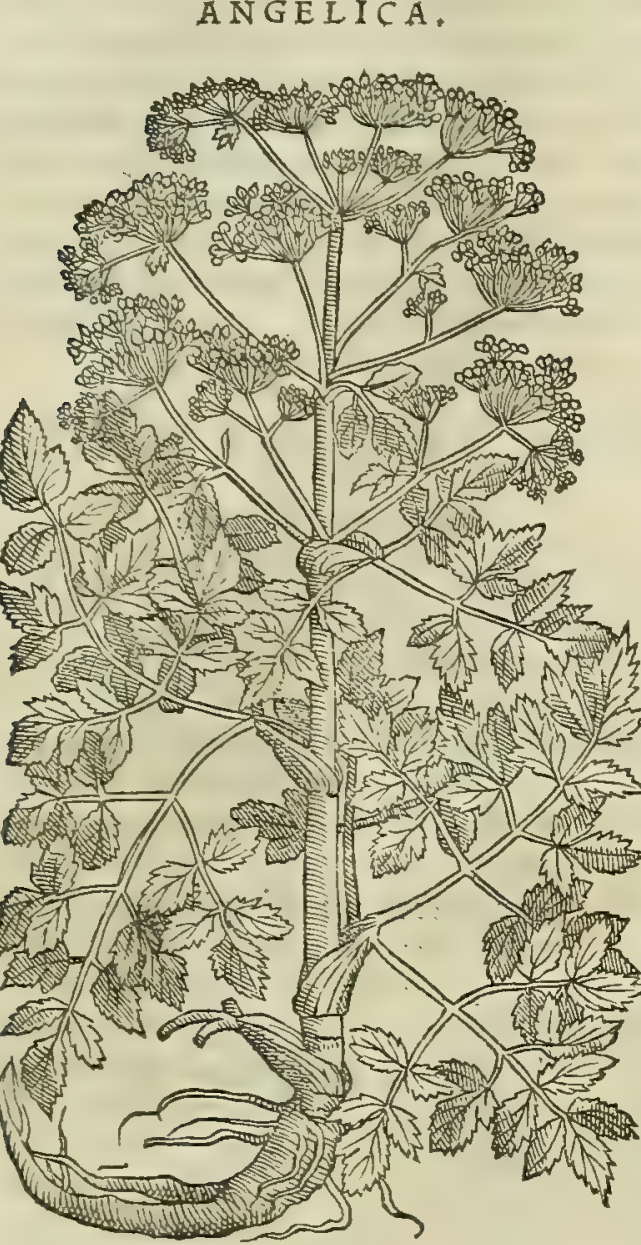

ftantisimam plantam filentio pretereamus, bic fufius de ea nobis differendum eft. Hac itaq; planta cubitalem excedit altitudinem, caule geniculato, inani, mult is al arum cauis referto : folia profert oblonga, per ambitum ferrata, in nigrum uircfcentia: flores al= bos, in umbellan cobrerentes: é quibus femén prodit tenue, len= tium modo compre fjum. Radix eifubeft craffa raphani modo, qua in plures diuaricatur ramos, guftu acris, $\sim$ fuauiter odorata.

Excalfacit, pariteró; deficcat ordine fecundo completo, aut ter tio incipiente. Proinde aperit, attenuat, o difcuttt. Venenis mi= rifice aduerfatur: quare peftilentiam arcet baufta, aut frequen=

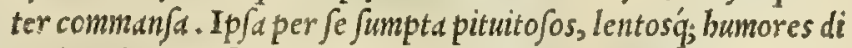
gerit. Idem preftat or radicis decoctum . quod etiam celerius ex frigore tußientibus auxiliatur : expectorat enim efficaciter craf fam, lentam'q; pituitam. Sanantur eodem ex aquat, aut uino inter= na uifcerum ulcera, concretus'q; fanguis diffoluitur, or roboratur uentriculus. Radix in puluerem trita animi deliquijs, or cateris cordis affectibus opem unicé preftat. Valet ad rabioforum, or ue nenoforum morfus, exterius cum ruta impofita, or intró in cor= pus affumpta. Hinc fit, ut recentiores quidă magnd opinione banc fuis inferant antidotis.: Myrrbidi iam fud reddanus uires ex Myrrhidis ui Galeno, qui eas lib. v I I. fimplicium medicamentorum, bis uerbis res ex Gal. defcripfit. Myrrbis, quidam myrrbam nominant. Radicem babet odoris iucundi, er dulcem, que men fes mouet, or ea que in tho= race, ac pulmone funt, expurgat. It aque ex fecundo ordine fue= rit excalfacientium, adiuncta quadam partium tenuitate. Mv' $\rho^{\prime}=$ ९́s ita Grecis, Myrrhis quoq; Latinis dicitur : Italis, Mirrbide.

\section{Múxyos. MYAGRVM. CAP. CXII.}

M Y A G R O N, aliqui melampyron uocant, herba eft furculacea: folijs rubiæ, pallidis, tripedanea : femen oleofum, fœno græco fimile. Quod contufum igni torrent, perunctisque uirgis ad lucernarum lumi40 na utuntur. Hoc pingui, fcabritias corporis læuigari, atque expoliri conftat.

S C R I B I T Ruelliu, Myagrum frequentifimum nafci in Gallia, eius q́q femine agros bene fubactos perinde Myagri conquafi napis feri : quin $\odot$ Jue Ppontis inter fegetes inueniri. Ex femine autem oleum exprimi ait, quo non ad lumina fideratio. tantum lucernarum; sed ad ciborum quoque condimenta pauperes utuntur. Addit id à fuis Cameliam, aut Camami= nam uocari. Sed ip fe non equidem Ruellio aufim fub fribere: quandoquidem non pudeat fateri me hactenus Mydgrü non uidife in Italia, quod Diofcoridis delineationi repondeat. Ceterum cos baud dubié fallicrediderim, qui pu=

non uidife in Italia, quod Diofcoridis delineationi repondeat. Ceterum eos baud dubie fallicrediderim, qui pu= Quorundam mum referre Myagrum. Siquidem boc folijs rubiam non emulatur, fed fylueftrem erucam, ut que laciniatd pecten= tur : nec femen profert foeno greco fimile, fed papaueris modo exile. Mydgrifemen, ut teftatum reliquit Galenus

so libro v I I. Fmplicium medicamentorum, pingue eft. Quare fi tundatur, oleofum quid effundit, quod emplafticam

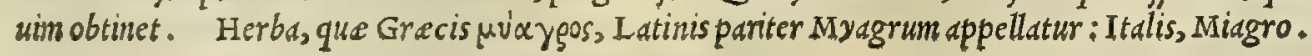

Nomina. error.

Myagri uires ex Galeno.

Nomina.

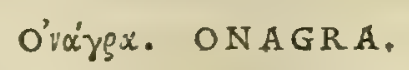

\section{CAP. CXIII.}

ON A G R A, fiue onothera, aut onuris frutex:ft arboris inftar, prægrandis, amygdalino folio, fed latiore, lilio non difsimili : Alore rofaceo, macno: radice candida, longa, cùm ficcata eft, uinum olente. nafcitur in montibus. Aqua, in qua radis maduerit, in potu data, feras mitigat, \& cicures facit. illitu quoque tetra ulcera mulcet .

T A M E T S I memorix prodiderit Theophraftus lb. I x. cap. X x I. de plantarum biftoria, Oenotbera radic Onagræconcem é uino poram mitiores, hilarioresó; mores conciliar; nutlum tamen, qui eam mibi os?enderet, hadtenus licvit re= fideratio. 


\section{And. Matthioli Comm.}

Onaurr uires ex Galeno.

Cirfijconfideratio.

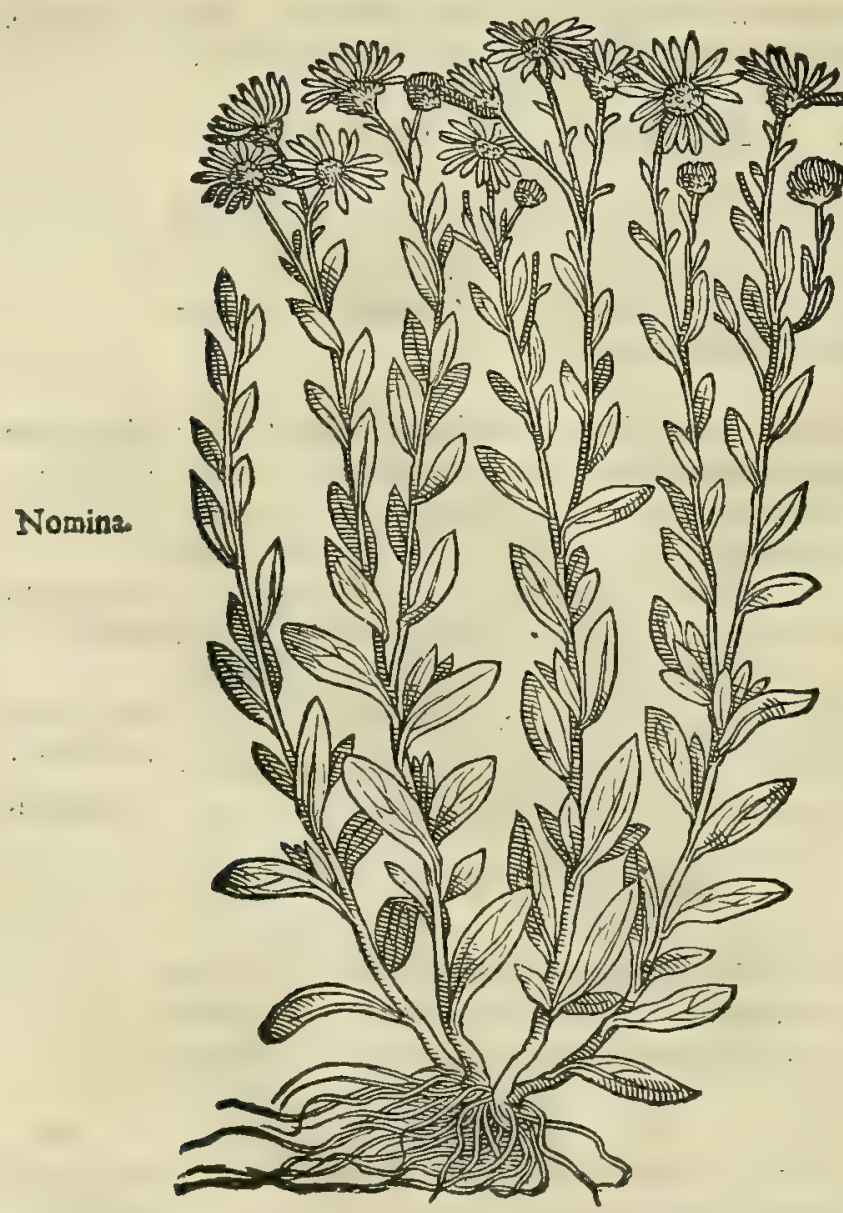

perire, quanuis ad mitigandan omnium animalium feritatem,ne dum bominum quorundam, effet optimum, utilißimumí; reme= dium. Ceterum ad me fripfit clarißimus medicus L ucas Gbinus Forocornelien is, fepius ex Apennino in uiridarium fuum tran ftulife plantam bomine proceriorem : folijs amygdale, maiori= bus tamen: flore rbododendri: femine perquàm minuto, exili= bus teretibusás filiquis contento, molli ac candida lanugine obuo luto: radice fubalbida, longa, fubter bumum repente. Qux $\int a=$ né omni ex parte Onagram referre uidetur, etffi ipfe quoque pro certo non aufit afferere, bane legitimam effe Onagram, cum ha to ctenus experientia comper tum non babedt, an buius radix ficca uinum redoleat, mitiget '; ferds aqua, in qua maduerit, pota, ut Diofcorides teftatur, Onagra meminit Galenus libra v I I I. fimplicium medicamentorum, ubific inquit. Onagron, aut ono= thera, aut onotburis, buius radix are fact a unofum quiddam re= dolet: fed er uini maximé facultatis eft. Que óva' $\gamma \rho \alpha$ Gre= $c_{\dot{3}}$, Onagra item, fiue Oenagra Latiné dicitur.

\section{KígroV, CIRSIVM. CAP. CXIIII.}

C I R S I V M, caulis eft tener, duorum cubitorum, triangulo fimilis : ab imo foliola, rof $x$ fpeciem referen tia: anguli fpinofi, per interualla molles : folia bugloffo fimilia, longiora, fubcandida, modicè hirfuta, partibus extremis aculeata: cacumen caulis orbiculatum, hifpidum : in quo capitula in fummo purpurea, qua foluuntur in lanugines. Radicem huius loco laboranti adalligatam, dolores uaricum fedare Andreas fcripfit.

CRE D I D E R E recentiores quàm plurimi rei herbd $=20$ ria periti, nil aliud effe Cirfium, quàm uulgare Bugloffum. Sed mibiplané bac fententia, pace corum dixerim, refillenda po= tius, quàm probanda uidetur: quód Bugloffo caulis triangulus non infit, fed rotundus: quod ab mo foliola per ambitum acu= leda rofe peciem non referant, fed longa, o continua pro= deant: quodd deniq; Bugloffo flores non euane $\int$ cant in pappos, fedlangue fcentes integri decidant, relito in folliculis femine. plantam, quam proculdubio Cirfium referre putamus, nuper Pifis ad me mifit clarißimus medicus L ucas Gbinus, cuius etiam hic figuram damus. Nafcitur, ut ip $\int e$ fcribit, in uliginofis locis. 40 Ed, meo quidem iudicio, Cirfio maxime adftipularideprebendi= tur. Cirsij nufquam, quod legerim, meminerunt in fimplicium cenfu Galenus, or Paulus. Id equé xigorov Graca uoce. atque Latina Cirfium appellatur.

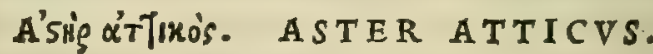 CAP. CXV.}

A s T E R Atticus cauliculus lignofus, florem in cacumine habens purpureum luteúmve, per ambitum di- 50 uifum, anthemidis modo, capitulum, foliol is ftellæ mo do radiatis : qux autem caulem ambiunt folia, oblonga funt ac hirfuta. Feruenti ftomacho, oculorum inflam mationibus, procidux fedi, ac inguinibus illitu auxiliatu: . Tradunt purpureum florem, li ex aqua bibatur, anginis, \& pueris comitiale malum fentientibus, opitulari. Inguinum inflammationi recentem illinire con uenit. Si aridus flos finiftra dolentis manu decerpatur, \& inçuinibus adligetur, dolore liberat. 


\section{In Lib. quartum Diof coridis.}

A s T E Atticus, qui $\approx$ Bubonion, hoc eft noftris Inguinalis, dicitur, fibi Atticinomen afciut, quod in Athe= Afteris Attinienfi agro frequentior, quim alibi proueniat. Bubonion uero, $\mathcal{O}^{2}$ Inguinalis dica a ft berba, quod bubonum, fiuc in= $\mathrm{cr}$ confid. guinum precipuun fit remediun. Afteris porró appellationcm accepit, quoniam cius capituld, in quibus flores cha= memali inftar emicant, per ambitum diuifa foliolis ftellse modo radiata pectantur. Planta cf bodic non paucis cogni ta. Nafcitur in afperis, incultis, o conuallibus. Hanc serapio (ut libro tertio in eryngij mentione prodidimus) cum Eringio confudife deprebenditur, florum fimilitudine falfus, qui in utraq; planta ftella figuram pre fe firunt. Ces= terùin non cft pretereundun, quód nonmulli Diof coridis codices reperiuntur, in quibus boc capite plura leguntur, quàm fuprifint reddita. qua quonian à doctißimis uiris Diofcoridi accrcuiffe comperta funt; idco nos quoq; ed, ut= pote adiectitia omifmus. Quód autem adfcititia /nt, tefimonio effe poffunt Galenus, Oribalius, $\mathrm{P}_{\text {sulus, }} \mathrm{O}$ Serapio,

to in quorum libris illa, que redundant, $n u f q u a m$ leguntur, ctfi reliqua, ut folent, bona fide reforant. In cuiusdam ta= men A puleij libello de plantarum biftoria er uiribus frripto, nonnulla babentur capite de Aftere A ttico, qua inde fa rile, quód feré eadem effe uideantur, huc adiccta funt: fic cntm uerba illa fonant. Stellarum radij noctibus collucent: quare qui naturam ftirpis ignorant, inane finulacrum fe uidere putant. Repcritur à pajtoribus pecudum. Aftera Amellus Vir Atticum à Virgilio quoque cclebratum fuiffe exiftimo lib, I I I . Georgicorum, ubi. Ancllum, qucm florem ita $a b a=$ gricolis wocariait, berbam '́; cius defcripfit. Id quod Juis luculentißimis carminibus aperté tefatum reliquit, dum ita cecinit.

Eft etidm flos in pratis, cui nonzen Amello

Fecêre agricole, facilis quarentibus herba:

Narque uno ingentem tollit de cepite fyluam.

A ureus ipfe, fed in folijs, que plurima circum

Funduntur, uiole fublucet purpura nigre.

Sepe deum nexis ornate torquibus are.

Afper in ore fapor: tonfis in uallibus illum

$\mathbf{P}$ aftores, er curua legunt prope flumina Melle.

Afteris Atticirecens berba ( ut Crateuss tradit) cum axungia fenio tufa rabio/i canis norfibus utiliter imponitu" . Turgentia guttura difcutit, ej incenfa ferpentes fugat. Huius meminit Galenus libro v I. fimplicium medicament= torum, ubi eius uires retulit bis uerbis. After Atticus, alij bubonium uocant, non ob id tantüm quod illitum, fed etiä quód fufpenfum bubonas fandre creditur. Habet quiddam etiam digerens, babet ueró non minimé $\sigma$ refrigerans quiddam, ac reprimens, adeó ut mifte fit facultatis, utirofa: uerùm id non adstringit. hactenus Galenus. Sed quo= 30 niam Attica ftella mihi in menten redegit Stellariam recentioribus unlgó uocatam, cum or ip $\int a$ uiribus non unlgari=

STELIARIA.

40

50

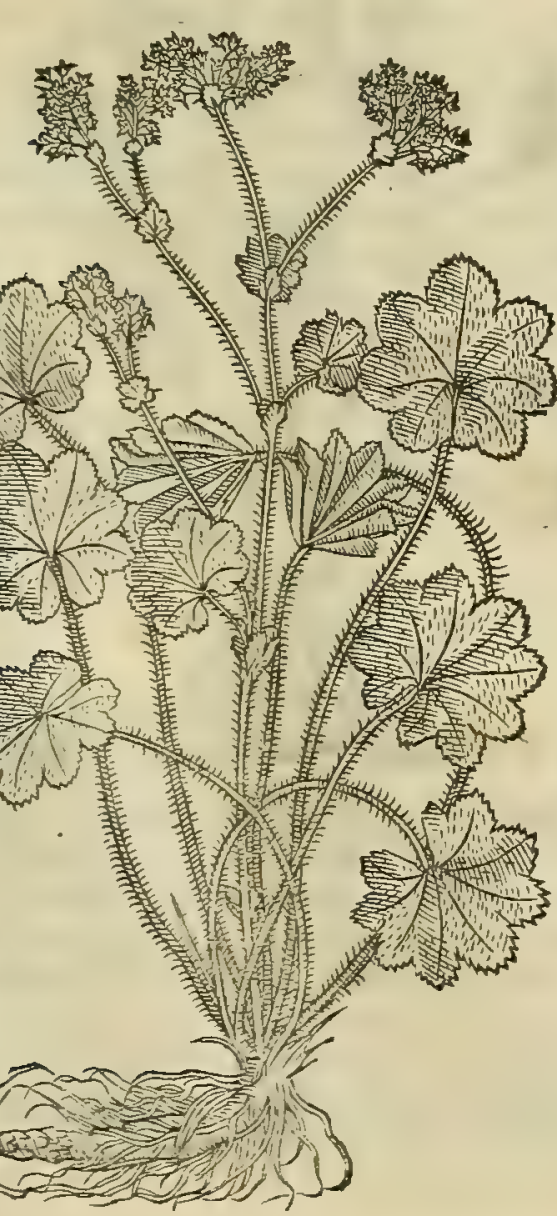

bus fit predita, eam miniméfilentio dißiniulandam duximus. Es? igitur S T E I L A R I A, quam alij Pedem leonis, alij Alcbi= millam uocant,planta, que ut plurimum in mantibus prouenit, pres fertim in pratis, folijs malua ferme fimilibus, durioribus tamen, cripioribus, angulis octo diftinitis, prominentioribus, er per am bitum ferratis, adeo ut latius apertaftelle formam referant. Cau= lis ei tenuis, femicubitalis, a quo plures exeunt ramuli, in quorum fummo flores emic ant Jubpallidi, tenues, ftellarum effigie. Radi= ce nititur, qua craßitudine digitum aqudt, et longitudine palmum excedit . Erumpit hec Maio men $\int e_{3}$ I unio ueró floret. Efficax eft pota fanandis non folum internis uifcerum uulneribus, fed $\mathbb{O}$ fi= nuofis ulceribus : quinetiam extrinfeca uulnera glutinat. Expeti= tur Germanis chirurgicis,miris $q_{\text {; }}$ laudibus celebratur:quippe qui

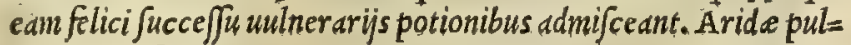
uis in fui ipfius decocto, dut cum aqua eius ftillatitid fumptus, ente rocelis medetur. Datur idem puluis ex uino, aut iure cochlearis menfura, quindecim aut uiginti diebus, mulieribus, qubus adem= pta fit concipiendi facultas à nimia uteri humiditate, que iniectum femen contineri probibet. Stillatitid eius aqua epota, tum etiam in uuluam indita; alba mulierum proflunia mirifice fiftit: adeo ut eius quoq; diutina inietione corrupte ab incorruptis uix dignofci poßint, restrittis mirum in modum foemineis tocis: quod tum cele rius, tum efficacius preftatur, $f i$ in eius decocto infideant. Quir or laxas procidentes f; mulierum mammas contrabit, et duras $\int_{0}=$ lidasó; efficit, fi linted in cius decocto, aut ftillatitia aqua intincta mammis fepius imponantur, diutiusó; importentur, prefertim by pociftide, equifeto, fypteria, ficciś; rofis admiftis. Planta, que Gracis assig Q'T Tixo's Latinis item After atticus nomina= tur : Arabibus, Aftaratico : Italis, After attico: Germanis, Stern kraut: Gallis, Afpergoutte mineur.
Serapionis er ratum.

Afteris Attici uires ex Gal.

Stellarix hiftoria, \& uires.

Nomina. 


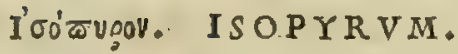

CAP. CXVI.

Is O P Y R O N aliqui phafiolon ob fimilitudinem vocant, quoniam folium, quod eft anifo f1mile, in pampinos torquetur: capitula funt in fummo caule, tenuia, plena feminis, melanthij guftum imitantis. Contra tufsim, \& catera pectoris vitia, femen ex aqua mulfa bibitur : hepaticis, \&z fanguinem excreantibus vile.

H A C T. E N v S, ut ingcnue fatear, mibi non contigit uerum Ifopyrum inucnire, neq ; $_{\text {ab aliquo compertum }}$ uidere . non tamen ncg xucrum, quin illud nafcatur in I talia. Quare fi bac noftra atate nobis non fefe offeret, id po= $\mathbf{2} \theta$ fteris inquire ndum relinqucm:ls, quipörtaffe diligentius in bec ftudia incunbent, ut earun rerum, qua nos latent, ali

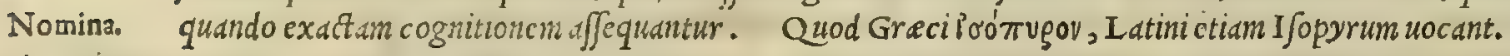

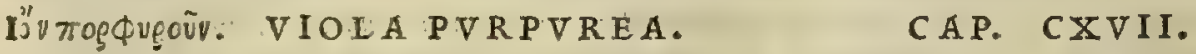

V I o I A purpurea folium habet hedera minus, tenuius, ac nigrius, nec multò difsimile: cauli culus à radice medius prodit, in quo flofculus fuauifsimè olens, purpureus opacis, \& afperis nafcitur. Refrigerandi naturam habet. Folia per fe, \& ex polenta illinuntur aptifsimè ftomacho aftuanti, \& oculorum inflammationibus, fedique procidenti.

VIOLA PVRPVREA.

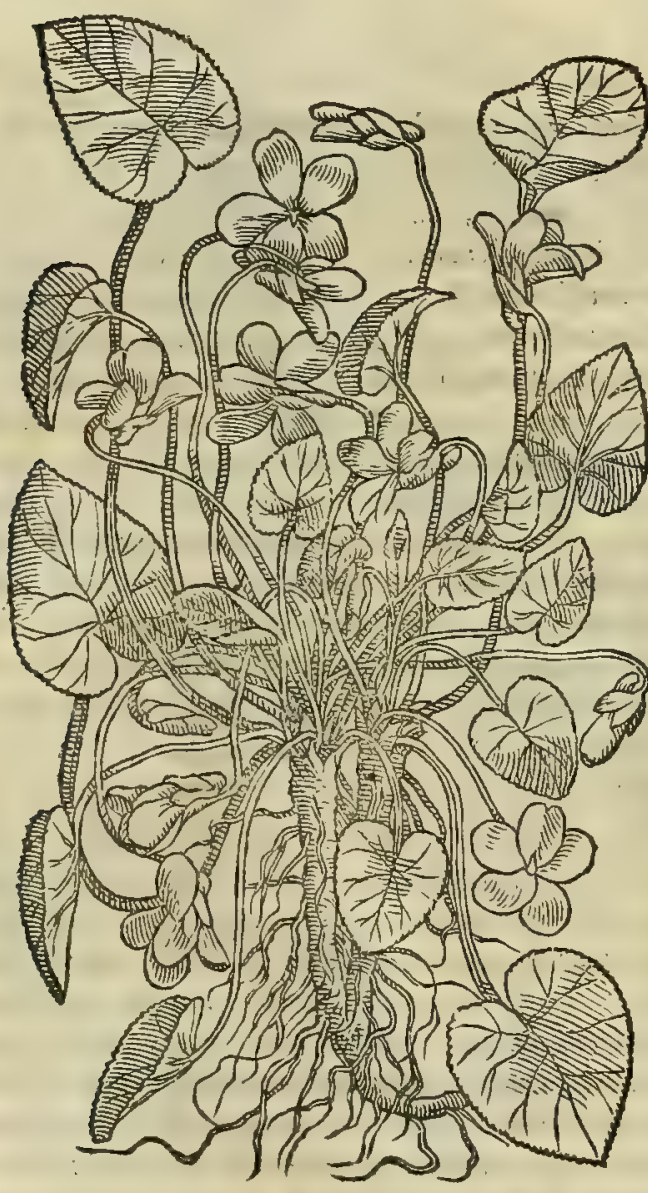

I A C E A.

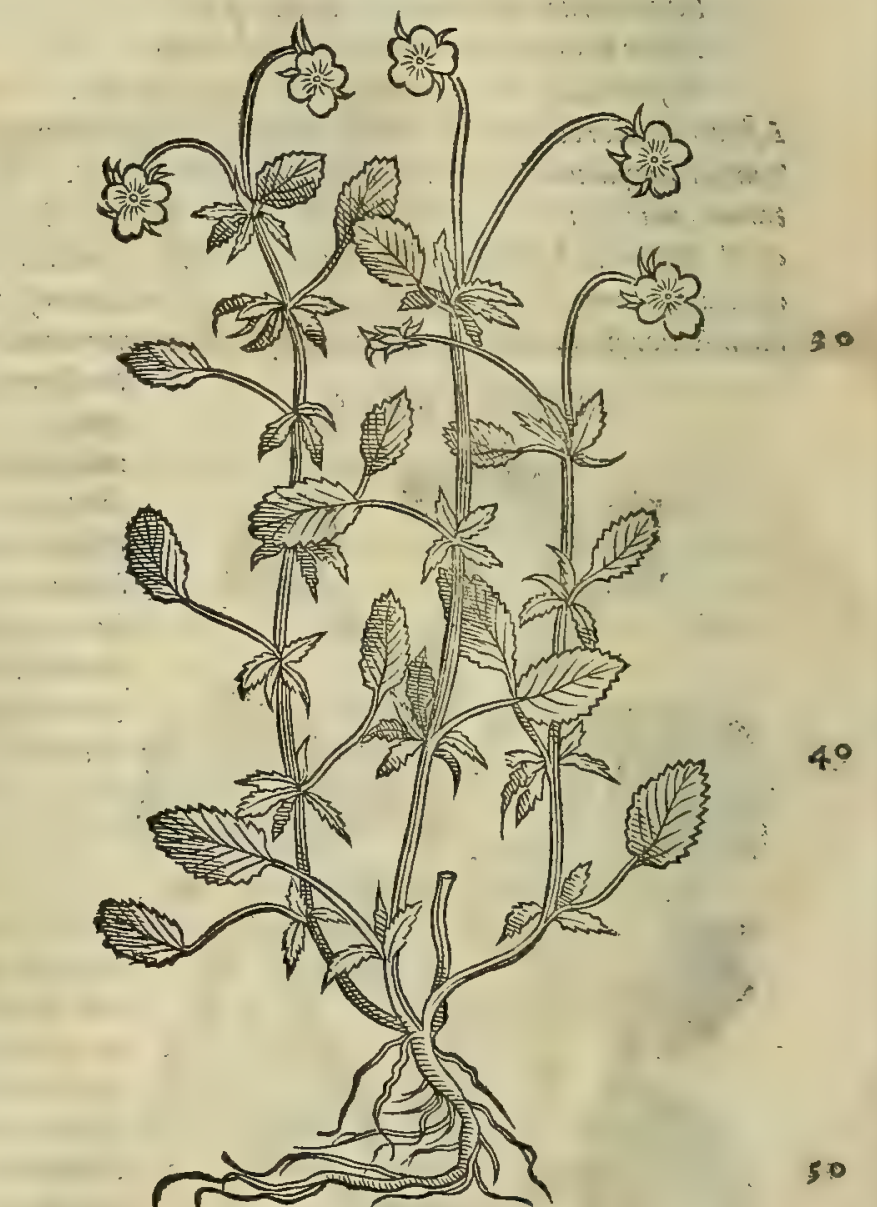

Viola purpu rex confideratio.

S V N T in Violarum genere non modó purpurea, fed etiam candide, frigidis er uliginofis locis nafcentes, pror= fus tamen inodore, de quibus nibul, quod extet, memorie prodidit Diofcorides. Ha numero a proueniunt in And=

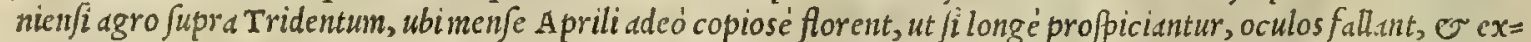
tenfa linted uideantur. Alij preterea flores per elatem Maio, es Iunio menfibus uifuntur fuperné purpurei, in me= dio candidi, inferius ueró lutei, forma purpureas uiolds referentes, apectu gratißimo, cum tamen nullo $\sigma$ ipfi come mendentur odore. Prodeunt bi ex quadam planta, cui primo cxortu folia infunt rotunda, per ambitum ferrata, qu.e tamen per increme ntum in longitudinem def cifcunt. Conftat bac caulibus triangularibus, quadantenus friatis, 0 in $=$ tus concauis, quibus paribus interuallis genicula fupereminent, è quorum concauo ranufculi exoriuntur, quibus flo= resdependent. Vocant hanc.nonnulli I A C E A M. Verum an bec illa fit Iacea, quam ad inteftinorum ramtices magnifaciunt recentiorum quidam, nondum fatis compertum b.,beo. Quanquam non dcjunt, qui affirment, hanc cfec 


\section{InLib. quartum Diofcoridis.}

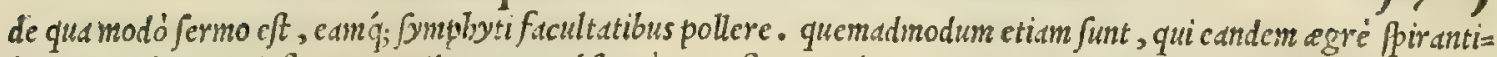
bus, e pulmonum imfanmationibus, non obfcuré opem ferre tradant: quin o fcabien fanare, o catera cutis ui= tia delere. Violarum purpurearum facultates exquifite de fcripfit Mefues inter fimplicia foluentia, unde bec de=

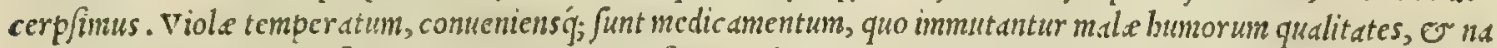
turd corum foluitur. Pr.eferuntur que primo uere florent, folis ardorem, qui uim refoluit, minimé experte, nec ims= bribus dilutex. viole refrigerant, o buncit ant ordine primo, cum tamen ficca minus refitgerent, o minus bume= ctent. Recentibus quaddm inest bumiditas, qux obtundit caliditatem, à qua potior cft uis. Quapropter ficcata bu= miditate, que. in fuperficie continetur, guftu an aritudo deprebcnditur, que à calido prowenit, qui prius fub bunido delitefcebat. Quo fit, ut cxiccatex magis calide, minusq; bunnidx babeantur. Humiditas, qux fuperfut reccntibus 20 ineft, alumm emollicndo ciet: ucrim arefact.e, deicetorie funt facultatis, non quód cinolliant, fed guod diffoluant. Viole un fumma foportfere funt, refrigerant, calidos dolores mulcent, inflammationes extingume, leniunt, o fol $=$ uunt. Earum fuccus, o fyrupus ex co factus uentrem leniunt. Macerantur in aceto, quód ualentius ardentisinis conferant fetribus. Fit ex wiolis oleum, ifs in eo diutius maceratis: cateris tamen praftat, quod ex immatturis oliuis, aut ex dulcibus anygdalis exprimitur. Viole bilen educunt, eius f; feruorem mitigant. Conferunt capitis doloribus, quos caliditas excitauerit : fommum conciliant : pectoris, er appere arterie fcabritiem leniunt : nedenturq́; anginis, $\mathcal{O}$ columelle uitijs : precipuo autem auxilio funt pectoris, $\mathcal{E}$ later is inftammationibus: fittim;; arcent. At que fic= ce funt, iecoris obftructiones referant, inflammationes difcutiunt, $\bullet$ morbo regio labor antibus opitulantur. Hd= atenus de uiolis Mefucs. Parant hac atate é uiolarum recentiundiluto, quo pluries niole fucrint macerate, deie= ctorium syrupum, quemadinodum ov ex rofis rofaceun, quo deijciende alui gratia recentiores medici in pleuritide

20 utuntur, uncias quaternas, uel quinds exlibentes. Violarum uires tradidit Galenus libro v I. fimplicium medica= mentorum, fic inquiens. Viole folia aqueame fubfrigidam fubftantian fuperantem poßident: proinde tum per fe, tum cum polenta illita calidas phlegmonas mitigant. Imponuntur o ori uentriculi aftuanti, er oculis. bac Galenus. Ex quibus abunde paldim eft non nouiffe Galenum, ficuti e ceteros ueteres, Violas deiectoria facultate citra noxam

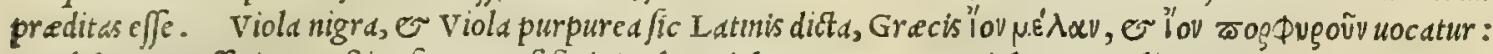
Arabibus, seneffigi, sonofitig, fiue Benefffrgi: Italis, Viola porporea, ev viola mammola : Germanis, Mertzen uio len: Hiftanis, Violeta : Gallis, Violetes, Violes de martz, 0 Carejme,

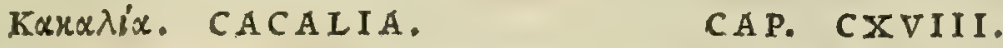

30 C A C A I I A, qux leontice uocatur, folia fert magna, alba : è quibus medius caulis emicat, reçus, albus: florem ferens robori, aut olex fimilem. nafcitur in montibus..: Radix in uino madefacta, ut tragacantha, delinctu aut manducatu per fe tufsibus, fcabritijs arteriæ medetur. Grana, qux poft excuffum Horem innafcuntur, trita $\&$ cum cerato illita, faciem erugant, \& cutem extendunt.

C A C A I I A, Plinio libro $\mathrm{x}$ v v.cdp. X I. authore, uocatur femen margaritis minutis fimile, dependens inter. foliagrandia, in montibus firé. it Plinius. Sed non propterea mihibactenus contigit Cacaliam reperire in Italia,

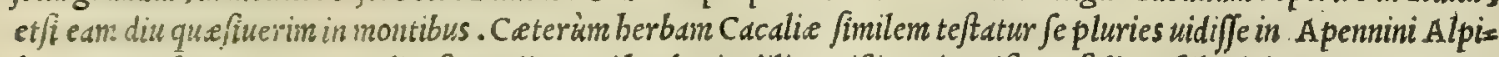
bus Luc.as Ghinus Forocornelienfis medicus reiberbarix diligentißimus inquifitor, folio tußilaginis, maiore tamen, aueva parce candidiore, minuś; per ainbitum angulofiore : caule palmi altitudine, refto, fubcandido: in cuius $c d=$ 40 cumine flores exeunt panicule facien referentes, mufcofi, olius inftar. Hanc ip $\int e$ Cacaliam fu/picatur. Equidem bu ius uiri iudicio facilé aufin fub fcribere, quód is in fimplicium cognitione diligenter uer fatus fit, atq; inter Italos inea maxime preftet. Cacaliam cancanon uocauit Galenus libro v I. . fimplicium medicamentorum, ubi cius uires red= didit bis werbis. Cancani radix facultaten babet morddcitatis expertem, o modicé exiccantem : effentiam craffam, $\mathcal{O}$ emplasticam. Quapropter macerata uino, ficut tragacantlia, o lincta arterie afperitates fanat : nec minus, fi quis eam commandat. Succus eius defluens prodeft arterie, fimiliter ut glycyrrbiza. Kainaia ita Grecé, ut $e=$ tiam Cacalia Latiné dicitur.

\section{Bớviov. BVNIVM.}

\section{CAP. CXIX.}

So B v N I o N caulem edit quadrangulum, procerum, digiti crafsitudine: in quo ramuli minutis folijs, ac floribus fcatent : folia proxımè radicem, apio fimilia, longè tenuiora, coriandrinis proxima: flores anethi : femen odoratum, hyofcyamo minus. Vrinam ciet, excalfacit, fecundas euocat: lieni, veficæ, renibus utile. Tam humidi, quàm ficci, exprefsiq́; fucci caulibus, folijs, radicibusq́ue, ufus inualuit ex aqua mulfa.

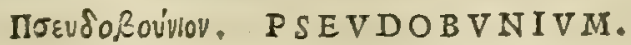

\section{CAP. CXX.}

P S E V D O B V N I O N palmi altitudine fruticat in Creta, folia, ramulosq́ue napi ferẹns, acri guftu. Tormina, atque ftranguriam, laterumq́ue dolores fanant quaterni rami eius poti in aqua : illiti quoque cum fale, \& uino tepentes, ftrumas difcutiunt.

Cacalix confideratio.

\section{Cacaliz uires} ex Galeno.

Nomina.
Violarum ui res ex Mefue.

Syrupus uioaceus.

Violarumuires ex Gal.

Nomina, 


\section{$576 \quad$ And. Matthiols Comm.}

Bunii conf. " B v N I v M, quod noftri Napum fylucftrem uocant, Plinius uidetur pofteritatis ntemorice prodidiffe lib. $\mathrm{x} x$. deratio. cap.I I I I. ubi de napis ita fcriptum reliquit. Naporum duas differcntias e in medicina Greci feruant. Angulofis foliorum caulibus florentis, er quod Bunion uocant, purgationibus freminarum, or uefice, er urine utile decoctum, potum ex aqua mul $\int a$, uel fuccidrachma. Semen dyfentericis toftum, tritumi; in aqua calida é cyathis quatuor: fed urin an inbibet, fi non lini fenen und bibatur. Alterum genus Buniada appellant, er raphano, or rapo finile. Semi= nis prechari contra ucnens: ob id $\mathcal{O}$ in antidotis utuntur illo . hec Plinius. Ex cuius fané uerbis palam fieri arbitror, cam nobis plantan effe Bunium, que Napum fylueftrem rura in Hetruria appellant. Nafcitur bec inculto folo, fri $=$ gido precipué tractu. Verim P feudobunium, quod Greci uocant, nondum mibi in Italia compertum eft. Quod nul= li mirum uideri debet: nam quod planta hac fruticet in Creta, ut Diofcorides tefatur, uidetur potius Cretenfium pro. pria, quaim aliarum gentium. Bunium, ut Plinius tradit, antidotis admifcetur: quare or in ip $\int a$ Andromachi theria=

Bunii uires ca Bunium expctıtur. Vtriusque uires fane paucis tradidit Galenus lib. v I. fimplicium medicamentorum, fic in= ex Galeno. quiens. Bunium, alij areticon, adeo excalfacit, ut er urinam moucat, or menfes prouocet. Sed o P Peudobuniun

Nomina. adfimilis illi caliditatis eft. Quod Greci Bov'vıv, Latinifimiliter Bunium uocant: Itali, Nauone faluatico. Quod ueró illi ł ev́doßovivov, bi Pfeudobunium, er Bunio falfo.

\section{Xapuixioros. CHAMAECISSVS. CAP. CXXI.}

C H A M AE C I S $S$ o $S$ folio eft hederæ, tenuiore, longiore: ramulis à radice quinis fenísve, dodrantalibus, foliofis : flore uiolr albr fimili, candidiore, ac tenuiore, guftu fupra modum amaro : radice tenui, candida, inutili . nafcitur in cultis . Bibunt conuenientifsimè ifchiadici folia, tribus o- 20 bolis in aquæ cyathis tribus, tricenis, quadragenísve diebus : eodem pota modo, fenis aut feptenis diebus, regium morbum purgant.

Cliamecifsi C R E D I D I T Leonardus Fucb/ius, medicus etatis noftre celebris, in fuo de ftirpium biftorid commentario, confider. nihil differre Chameciffum ab ea uulgaris notitia planta, quam, ut fuperius libro tertio in Afclepiadis mentione dixi= mus, herbariorum uulgus Hederam terreftrem nominat. Sed cur eius fententiam comprobem, fané non babeo . Siqui= dem uulgaris hedera terreftris folio conftat rotundo, quadantenus ferrato : caulibus, uel potius funiculis uitilium mo do longis, bumi longo trattu repentibus. Chamecifus ueró Diofcoridi folijs eft bedere, tenuioribus, longioribus: ramulis à radece quinis fenisue, dodrantalibus, foliofisq́;. Adde quód Chamacififlores uiole albe fimiles facit Dio= fcorides, ac etiam candidiores. Sed terreftris bedera florem profert pufillum, in candido purpurafcentem. Quibus 30 utique rationibus ducor, ut putem, banc herbam non effe Chamaciffum, quòd notis inter fe plurimim pugnare depre= hendantur. His etidm accedit, quód Chamecilfos ( fi plinio credimus lib. x x I I I I. cap. X v.) Picata eft tritici mo= do: ev cùm floret, exiftimari poteft alba uiola. Ruellius hanc in Gallia nafci fcribit. Sed eam aliam effe à Chamecif= fo bic reprafentato perßpicuum eft : ea enim, qua Plinius refert, à Diofcoride diffentiunt, quem nutlam fpicarum mentionem feciffe conftat . Equidem, ut ingenué fatear, nullä hattenus in Italia herbam.comperi, quam legitimum

Chamæcifsi effe Chameciffum aufim affirmare. De uiribus Chamecißi breuiter differuit Galenus libro v I I I. fimplicium me= uires ex Gal. dicamentorum, ubific inquit. Chamecißiflos, cum fit admodum amarus, iecur obftructione liberat. Sunt wr qui if= Nomina. chiadicis ipfum exhibeant. Hec planta ut Grecis Xapairsaros, ita etiam Latinis Chamaciffus nuncupatur.

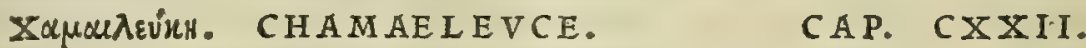

$C$ H A M AE LE V C E lumborum doloribus propitia eft. herba uirens, incuruis folijs, furculísque: flore rofaceo:

Chamęleuces S A N E' quàm paucis Chameleuces hiftoriam përftrinxit Diofcorides. quare difficillime quidem decerni poteft, coafid. quảenam in uniuerfo plantarum genere Chamaleucen referat. Caterim bic filentio non dißimulandum puto, quód

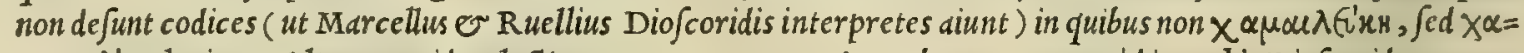
$\mu$ auto'xn legitur. Alteram quidem lectionem nos quoque magis probamus, tum quód in nothis Diofcoridis nomen= claturis Cbameleuce nul aliud fit quàm tußilago, quemadmodum $\approx$ apud Plinium libro X $x$ I 1 I I. cap. X v. ubi eam Farranum fiue Farfugium uocari tradit: tum etiam quód eodem loco Plinius idem feré fcripferit de chamapeuce, so quod de cbamaleuce in hoc capite fcriptum reperitur. Quod haud dubie oftendit, huius capitis initio mendumn $j u b c f=$

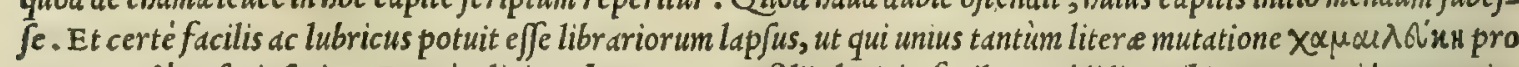

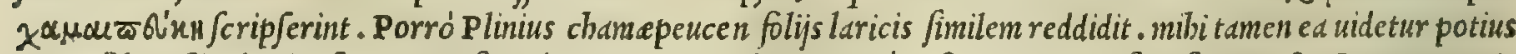
picex folijs a ßimilanda, fi in compofito plante nomine uolumus recté pofterioris uocis fignificatum fpectare: nam pi=

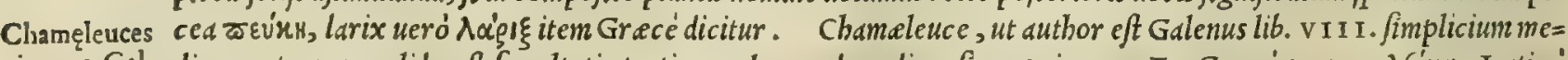

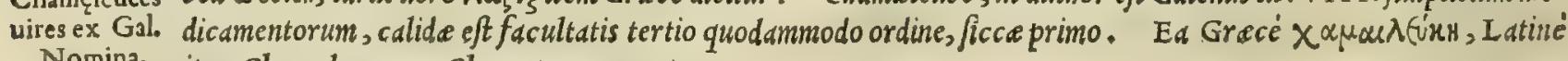
Nomina. item Chameleuce, or Chamapeuce uocatur. 


\section{InLib. quartum Diofcoridis.}

BVGLOSSVM, BORRAGO.
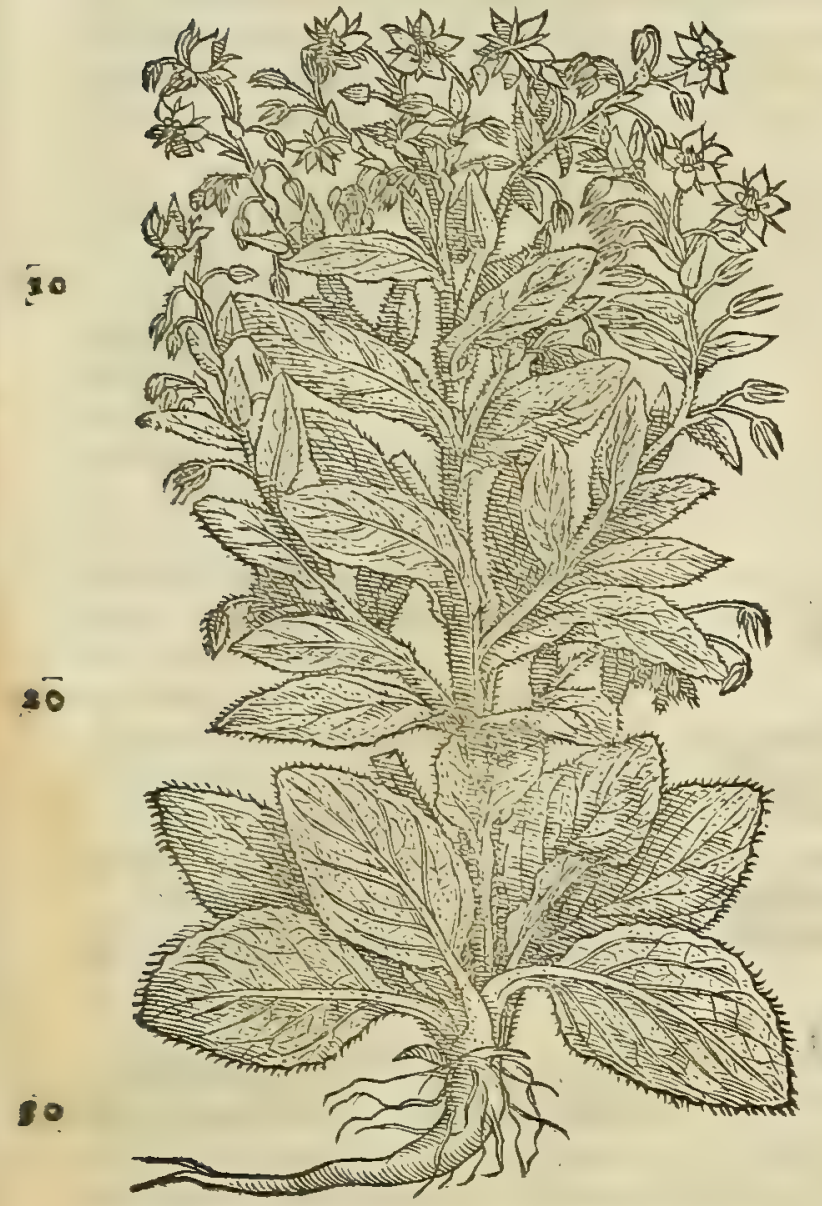

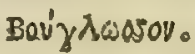

BVGLOSSVMVVLGARE.

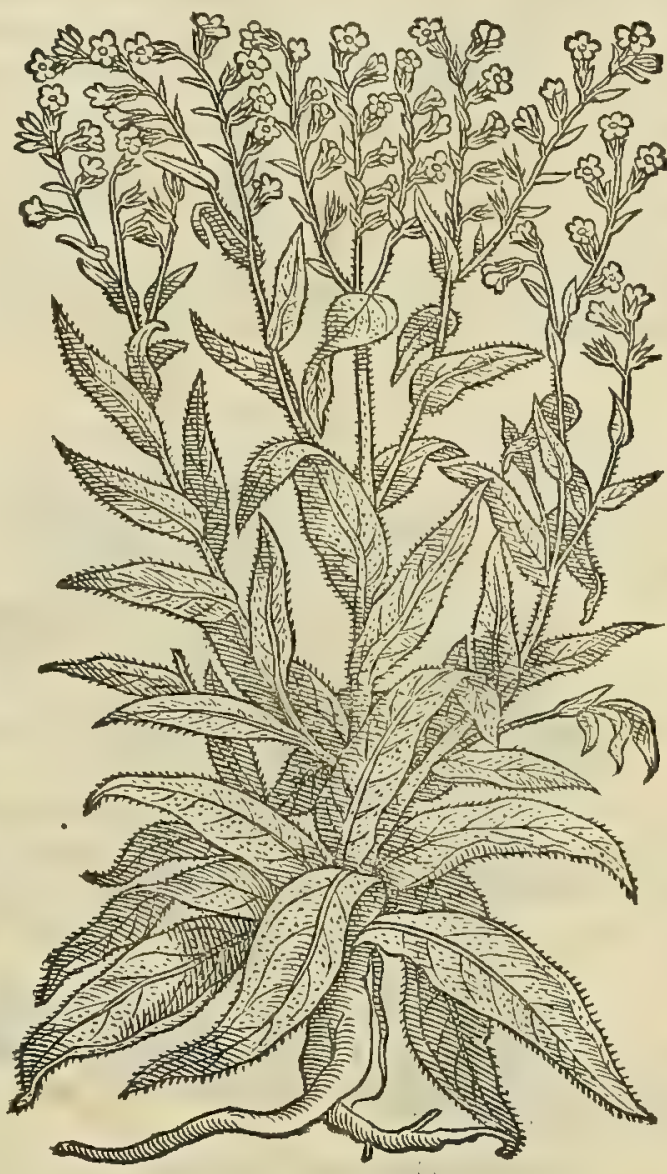

BVGLOSSVM, LINGVA BVBVLA, CA P. CXXIII.

B V G L OS S V M nafcitur in campeltribus, \& fabulofis. Iulio menfe colligitur . Alunt eam; qua tres thyrfos emittit, cum femine, \& radicc tritam, potamq́ue contra tertianos horrores prodeffe: quæ quatuor, ad quartanos: ea in uino decoquitur. Herbam abfcefsibus utilem effe uolunt. Verbafco fimile eft, folium in terra fparfum, nigrius, a Tperum, bubulas imitans linguas. Quod in uinum 40 deiectum, animi voluptates auget.

Qv I diligenter Bugloßi hiftoriam expendunt, onnes herbam Borraginem uulgó uocatam, in bortis, alijsó; $l o=$ Buglolsi con cis nafcentem, potius legitimum effe Bugloffum cenfent, quàm illam, qua Bugloffa uulgó nominatur, cuius in officinis fideratio. communis eft ufus. Quorum equidem iudicio non dubitauerim fubfcribere. Fiquidem Eorrago dicta folijs eft in uni= uerfum uerbafco fimilibus, nigrioribus tamen, o apperioribus: quibus etiam hec fymphytum alterum amulatur, quod folia buglofo proxima ferre fuperius prodidit Diofcorides. Adde preterea, quód folia Borraginis in terram pro= cumbunt, o bubulas linguds tum forma, tum apperitate imitantur. Contrà qua Bugloßi nomen fibifalsò uendicauit. folia habet longa, echio fimilia, non ufqueadeo lata, ut bubulas referant linguas, minus'; bumi depreffa, que potius $\dot{e}$ toto ferme cepite furfum afpiciunt, nec aliqua ex parte uerbafcum, aut fymphytum alterum reprefentant. Non ob so id tamen negare auferim, quin uulgare Buglofjum in campeftribus nafcens, ijfdem cum Borragine polleat uiribus: quandoquidem eadem utriufque aperitas, idemq́; fapor guftui manifeftum prabent eiufdem facultatis indicitm. Atq; facie non multum dißidere ea inuenias, fi illud genus pectes, quod bodie in hortis feritur ex Hilpanijs allatum: boc enim etfi uerbafcum adeó adamußim non repra sentet, quemadmodum Borrago; foliorum tamen effigie bubulas lin= guas maximé imitatur. Sed quoquomodo hec fe res habeat, concedam facilé Borraginem, or uulgarem Buglofjam o pecie, of forma inter fe differre : attamen crediderim alteram ad alterius uires proximé accedere, or fi non ece= dem utrifque, fimillimas tamen ine $\iint e$. Caterum non de funt, qui his rationibus neglectis affer ant unlgare Bugloffum Echij omnino genus effe, quòd illud omnibus notis referre putent. Alij uerò funt, qui idem Buglofjum Cirfium exifti mant. Verumnos aliud a uulgari Bugloffo er echium, or cirfium effe cenfemus, ut abunde fuis locis docuimus.

Quód infuper Borrago facilé fit legitimum Bugloffum, A uicenns teftimonio comprobari poteft, qui libro I I. fui Buglofsi decanonis it a fcribit. Iingua bouis eft berba lata, babens folia ficut almaru, or ad tactum apera, or rami cius apperi, cennx. ficut pedes locuftarum. Oportet autem, ut illa adminiftretur, qua eft in Corafceni, craffa babens folia, fuper quortmo 
faciem funt punct, qua funt radices fpinarum, of pilorum exeuntium ab ea. Quibus notis adeó cuidenter noftram Borraginem exprefit Auicenna, ut nemo non intelligat, hane effe Iinguam bubulam. Eum preter morem defcri= p fit Aucenna, quid fuo quoque tempore non decfsent, qui ucri Bugloßi loco aliam quandam futftituerent plantam, ut aperte eins ucriba declarant, dum fubdit. Que autem in hac terra reperitur, 0 qua utuntur medici, plurimum eius cft genus almaru, o non eft lingua bouis, o neque confert, ut iuramentum illius eft. bactenus A uicenna. His onnibus illud denique accedit, quód apud A pulcum in eo libcllo, qui de berbarum medicanninbus infcribitur, inue= nio Bugloffum Lucan is Corraginem nuncupari prioris tantim litere mutatione, quod cordis affectibus quàn maxi= mé opituletur. Que Sané omnia, ni fallor, clarißsimic oftendunt, Borraginem effe uerum ac legitimum Buglofjum.

Buglofsi ui- De cuius viribus differens Galenus libro vi . fimplicium medicamentorum, fic inquit. Bugloffum bumide cali= res ex Gal.

Nonina. deq́; tempericieft. Itaque unis iniectum, letitie ac bularitatis caufa cffe creditum eft. Sed o ijs, qui ob faucium Grecis Bovighwarov, Latinis itcm Buglof Jum

\section{CYNOGLOSSVM.}

Cynoglofsi confider.

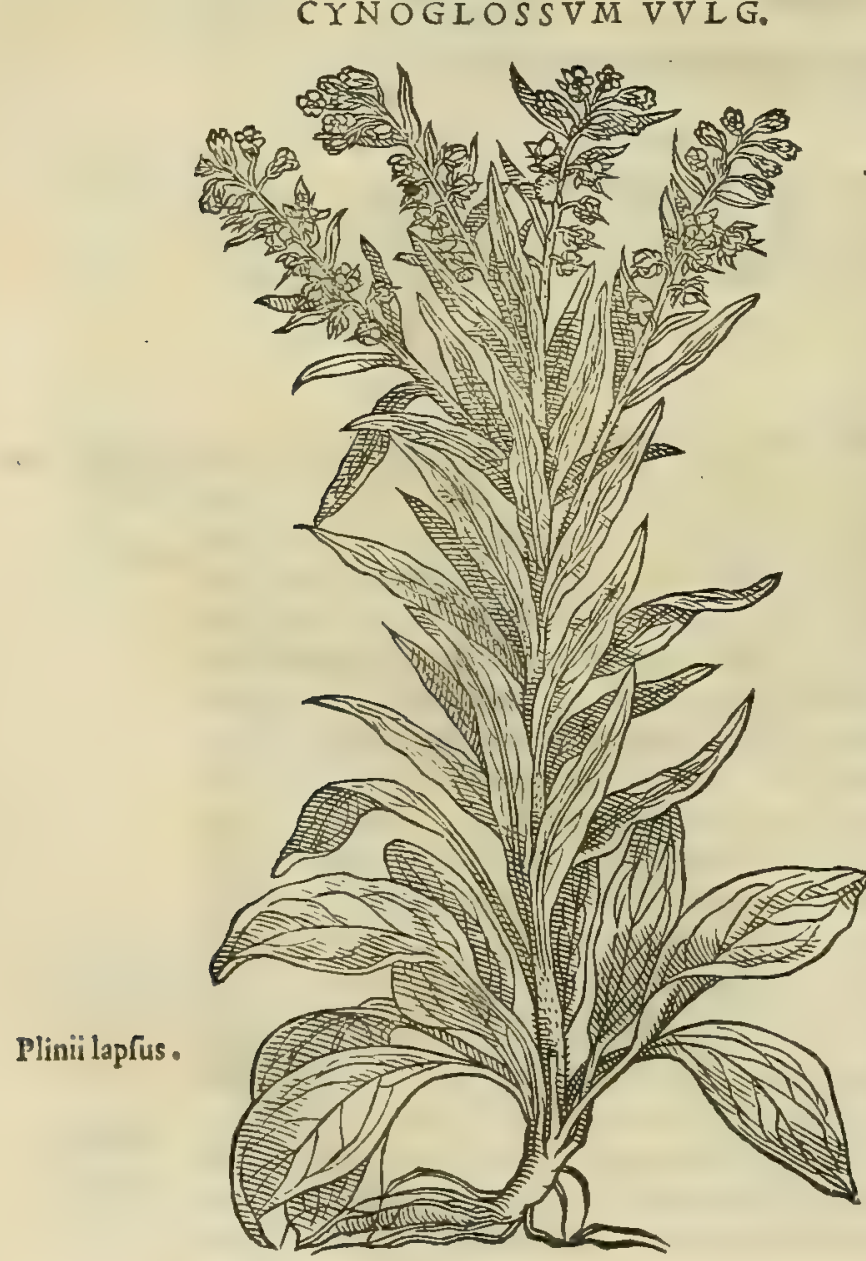

fen althaur, feu Lefan althaur: Italis, Bor= ragine: Germanis, Burret $f$ ch: Hipanis,Bor= raia, o Borraienes: Gallis, Borrache.

\section{KU10' $\gamma \lambda$ oosov. CYNOGLOSS VM. CAP, CXXIIII.}

CYNOGLOS S ON folialatifolix 20 plantaginis habet, arctiora, minora, lanuginofa : caule vacat, \& humi fternitur prouenit in fabuletis. Folia cum fuillo adipe veteri, medentur morfibus canum, alopecijs, \& ambuftis . Emollit aluum, decoctum herbæex uino potum.

L E G I т I м v м Cynogloffum, quod, Diofcoride tefte, neque caulem, neque flores, neque femen gignit, pluries non modó uidinus; fed etiam legi= mus Rome poft Adriani molem in fabulofis quibufdam locis ena tum. Hoc duulgari Cynoglofjo, quo paßin officine utuntur, perquàm longę diftat: quippe quod in radiant is folis morem folia fert, Juppinguid, tenui lanugine albicantia, bumiftrata, o cau= le perpetuó uiduum eft. Illa ueró planta, que cynogloß̧i ufum omnbus praftat, plurimos emttit caules, cubito fepius longio= res, adnatis in cacumine ramis: quibus flores infunt purpurei, echio fimiles: é quibus deinde quadam parue prodeunt lapper, nö fine magno nature artificio facte, que contactu ueftibus per $=40$ tinaciter adharent. Meminit Cynogloßi Plinius libro $\mathrm{x} \times \mathrm{V}$. cap.v I I I. bis uerbis. Iungitur er Cynogloffos caninas imitans linguas, topiarijs operibus gratißima. Aiunt' '́; que tres thyrfos feminis emittat, eius radicê potam ex aqua ad-tertianas prode $\iint$ : que quatuor, ad quartands. Eft $\mathrm{\sigma}$ alia fimilis ei, que ferat lappas minutas. haec Plinius. Ex quibus fat is perpicuum effe pu to, quód neutrum Cynogloßigenus à Plinio traditum, Diofcori= dis Cynogloffo repondet. Siquidem primü Plinio caules uel thyr fos edit adeo flexiles, ut ij topiarijs operibus maximé conicniăt. Diofcoridi ucró pläta efl fine caule, que bumifternitur: ut binc. so apertißimé conftet, hanc operi topiario, ut aliquid conueftiat uel contexat, prorfus ineptá effe. Adde quód Diofcoridi Cynoglof= fum medetur canum morfibus, alopecijs, er ambut is : quinetia aluum emollit. Plinio autem ad tertianas tantim, or quartands prodeft. Id quod de Bugloffo intelligitur, ut fuperioricapite te $=$ ftatur Diofcorides. Hinc itaque palim fieri arbitror, Buglof= fi hiftoriam, os uires cum Cynogloffo tur piter confudiffe Pliniü. Cuius certé lap fum non animaduerterunt recentiorum nonnulli, qui P linij auctoritate freti contra Diofcoridis grauem fententia probare contendunt, Cynogloffun caules, flores, $\sigma$ femen pro $=$ ferre; Quod autem fecundo loco à Plinio defcribitur, lappas mi 


\section{In Lib. quartum Diofcoridis.}

nutas ferens, tuil aliud, meo quidem iudicio, fuerit, quàm unlgare cynogloffum ommibus notum. Quo fit, ut omnino erraffe exiftimem Ruellium, o Fuchfium uiros alioqui doctiß3mos: quippe qui crediderint, uulgarem Cynogloffam Ruel.\&Fuch. effe L ycopfin, ut etiam fupra fuo loco monuimus. neq; enm bos animaduertiffe uideo de bac cum alio Cynoglofjo error. fcripfiffe Plinium, ac deinde peciatim de Iycop/i lib. X X v $\mathrm{I}$. cap. X I. Cynogloßi in libris de fimplicium medic.

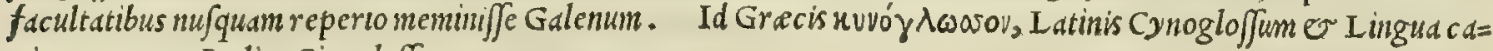
nina nocatur: Italis, Cinoglofja.
фúT\&ux. PHYTEVMA.
CAP. CXXV.

20 PH T TEV A folia habet ftruthij, minora:copiofum femen, perforatum: radicem paruam, tenuem, per famma terrx nitentem. Quam ad amatoria conuenire, nonnulli fcriptum reliquerunt.

C v'M fit ufus Pbyteumatis ad dmatoria duntaxat, exemplo plinij ductus, plura bic de co referre fuperuacuum babeo: prafertin quod nulli rei berbarie fiudiofo id bodie compertum effe fciam. Mibi quidem bactenus berba bac incomperta eft. Quare eam relinquamus in bortis Veneris, quos ip $\int a$ ad deficias o damatoria tantum colit, donec quis Dee charißimus hanc herban edoctus, eam nobis quoque indicare poßit. Huius, tanquam fuperuacur, or inutilis

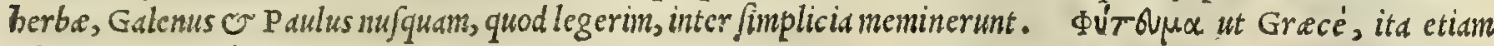
Phyteuma Latiné dicitur.

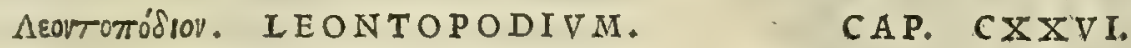

L E O N T O P O D I O N duûm digitorum herbula eft, folia ferens angufta, longitudine ternûm, quaternúmve digitorum hirfuta, quæ iuxta radicem lanofiore flocco canefcunt: capitula in fummo caule quali perforata: flores nigri : femen vfqueadeo fpifla lanugine inuolutum eft, ut fre fallat : radice parua cohæret. Quam tradunt appenfam ad amatoria prodeffe, \& tubercula difcutere.

VE R V M Leontopodium bactenus non folium mibi incompertum eft; fed alijs quoque ignotum effe arbitror: 30 nullum enim inueni, qui ip fun hodic oftenderet. Neque propterea boc multum curare debent medici, cum er co

HIP P O LOSSVM:

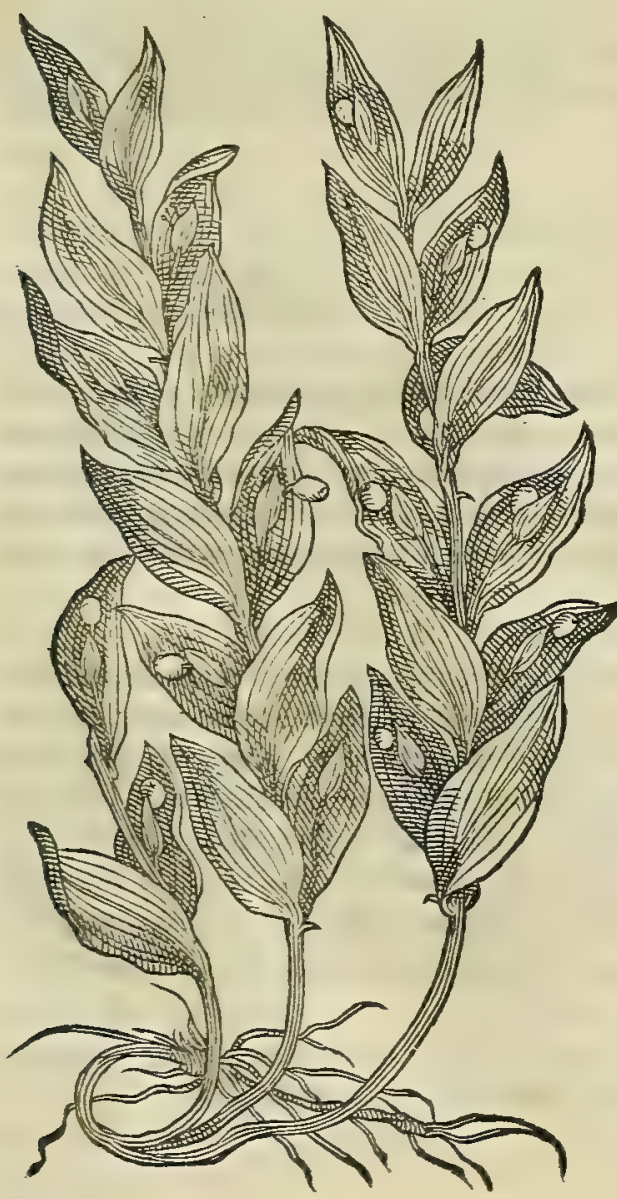

adalligato ad amatoria tantünafa fuerit antiquitas. Caterùm bic Brunfelfij ernon eft:audiendus Brunfelfius, qui stellariam berbam uulgo uocd= ratum. tam in fuo onomaftico Leôtopodium effe: fcribit. Qüa in re nö mi= nus ballwcinatus deprebenditur, qudm in alijs compluribus.

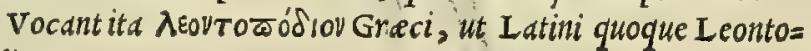
podium.

\section{Iळळóy \\ CAP. CXXVII.}

H I P O G L o s o N, frutex eft folia habens rufci tenuis figura, $\&$ fpinofam comam, $\&$ in fummo ceu linguas è folijs exeuntes - Capitis dolorem corona ex comis impofita minuit, malagmatis radix, fuccusá; admifcetur.

H I P P.O G L O.S S. V M, quód in folijs tueluti prominentes linguas proferat, Bislinguam uocat Hetrurid, alij ueró Bonif $d=$ ciam. Nafcitur hec frequentißinid in Liguria Alpibus; Vrbind= ti agro, er quibufdam fyluofis inontibus non longe à Goritienfi comitatu; qua iter eft in $\mathrm{H}$ ydriara ard argenti uiui fodinas verun= tamen non eft hec Latus Alexandrina, aut Ided, de qua infrd fuo loco differemus, ut in fwo infigmi de plawtarin biftoria com= mentario exiftimat Fucb/fis. Qudndoquidem Laturus tezandri na é foliorum umbilico nullam aculeatam exerit ling iam, fed tan= tìm fructum rotundum tilie modo longio ri pedictulo dppenfum pro fert. Hippoglo/fun recéntiores longé pliribus commendant ui= ribus, quàm fecerint antiqui fcriptores. ndm, ut illitradunt, in $u=$ teri affectibus magno datur iuuamento. Quo fit, ut frangulatu uulue laborantibus mulieribus radic is, aut berbe puluis cocbled= ris men $\mathrm{urd}_{2}$ ex uino, uel iure bauftus, prefentaneo remedio opem

C 2 ferat.
Hippoglorsi confideratio.

Hippoglolsi uires.
Nomina. 


\section{And. Matthioli Comm:}

ferat. Eft on ad puerorum enterocelas praftantißimum medicamentum, fi diutius diluculó haurialur puluis idem fes= quidrachma pondere ex maioris fymphyti decocto. Verùm id fumentibus euenit, quód primis tantum diebus adeó ra= micem pulfare percipiant, ut inteftina for as prolabi uelle uideantur : quare fubcingulis, fafcijs, $\sigma$ fibulis reprimen=

Nomina. tibus, roborantibusq́; primis diebus uti opus eft. Que planta Grecis i gloffum appellatur: Italis, Bislingud, Or Bonifacia: Germanis, Zepfflir kraut: Hifpants, Lengoa de cauallo: Gal = lis, Lingua pagana.

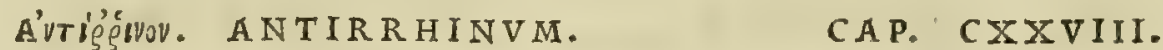

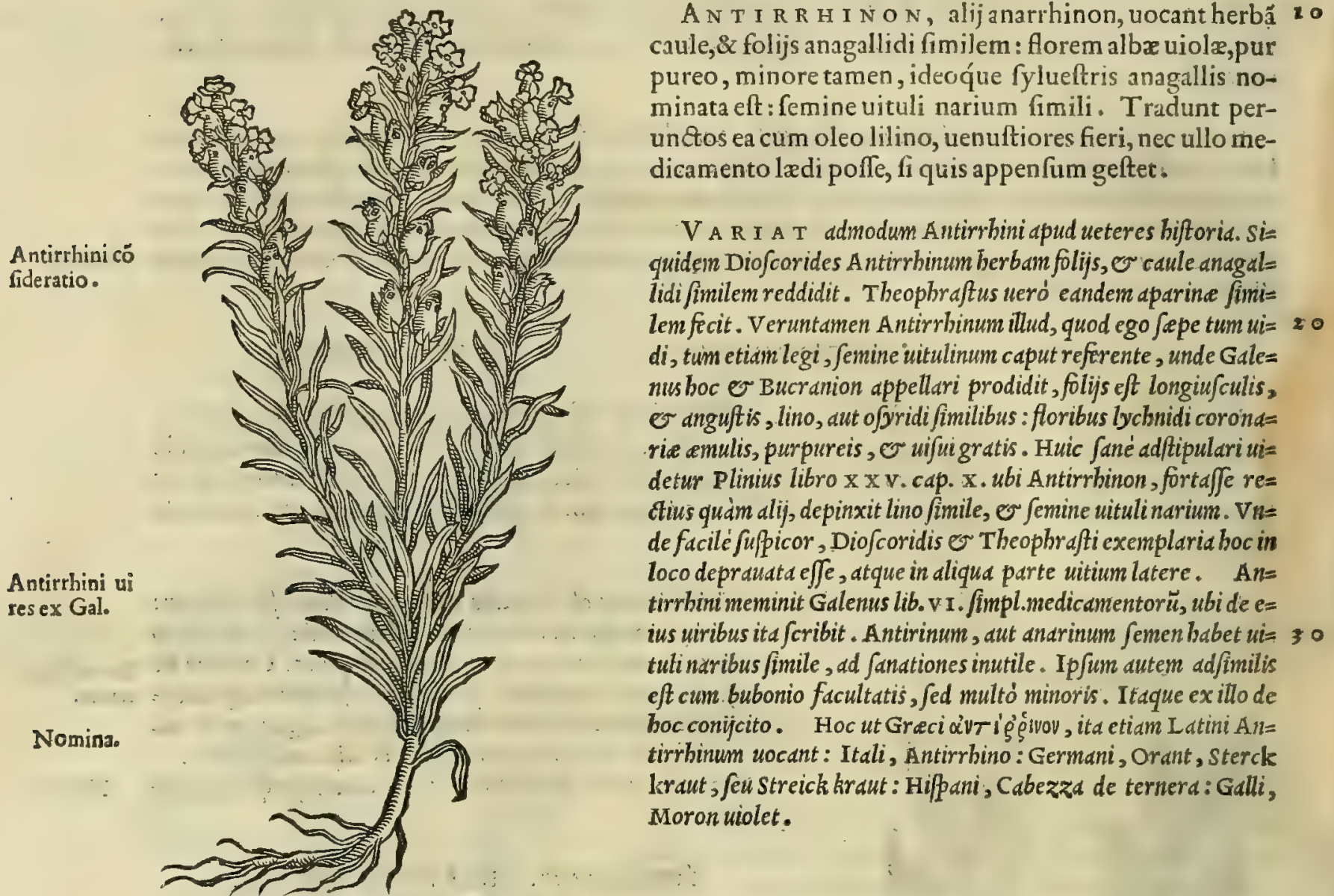

A N T I R R H I N O N, alijanarrhinon, uocant herbạ́ 20

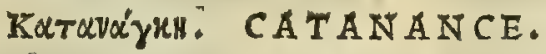

CAP. CXXIX.

E x : E o genere una, folia coronopi habet, longa : radicem iunci modo prætenuem : capitula fena, feptenáve, in quibus erui femen ineft. Arefcens in terram flectitur, \& fe contrahit ad fpeciem unguium milui exanimati. Altera mali parui magnitudinem explet, radice exiguæ oliuæ magnitudine: folijs quoq; oliuæ colore, \& figura, mollibus, diuifis, humi inclinatis : femen ut cicer, minutum, in uirgulis dependet, punicei coloris, multis foraminibus pertufum. Vtranque narrant in amatoria expeti. Theffalic mulieres his uti traduntur.

Catanances

NE V T R V M equidem Catanances genus battenus me comperiffe fateor, ne ; $_{;}$aliquem fcio in Italia, qui alte= confider. rum faltem legitimé nouerit. Sed nibil certé referre arbitror : quippe quód ea rebus uenereis tantùn conucniant, or amatorijs naf cantur. Proinde mulieribus The ffalicis relinquenda funt, quibus olim fuit ufus: prefertim cium bac $\&=$ tate homines in uenterem admodum procliues fint, atque etiam multi nimis calleant dinatorid . tantum abeft, ut etian

Ruellij error. buiufcemodiberbarum, fi cognofcerentur, auxilia ijs indicaridebuiffent. Caterum exiftimat Ruellius in hoc fub=

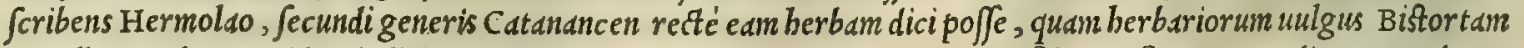
appellat. Sed meo quidem iudicio errat Ruellius, quód Bistorta dicta rumicis folia proferat, or radices quandoque bumani brachij craßitudine, anguium modo contorta, non autem paruas oliua magnitudine, uclut altera Catanance.

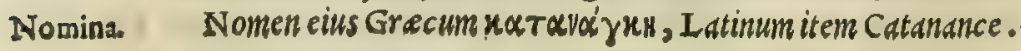




\section{In Lib. quartum Diof́coridis.}

T R I P O I I O N in marinis nafcitur locis, qua allidit unda, recedensq́ue dimittit, neque in mari, neque in ficco: folio glafi crafsiore: palmeo caule, in mucrone diuifo. Eius, ut tradunt, flores colorem ter dicmutant, mane candidi, meridie purpurei, fero punicei confpiciuntur. Radice alba, odorata, calidi guftus. Quxedrachmis duabus in uino pota, aquam, tirinamque per aluum extrahit. In medicamenta digeritur, quæ uenena arcent .

20 T R I P O I I M scrapioni Turbit appellatur. Quapropter credidere nonnulli, Turbit uulgó 110 atum Dio= fcoridis effe Tripolium, prefertim quód ipfum $\mathrm{E}$ album, $\mathrm{O}$ deicctoria facultatis effe deprebendercnt. Veruntanen gem aliter fo babere illud argumento eft, quodd communis ufus Turpetum nullo commendet thr odorc, nec guftui acre= dinem relinquat, fed tantum falfedinis, o apperitatis quidpiam. Ex quibus fane notis afferere licet, Tripolium in Italia non reperiri, neq; aliunde aduebi: quemadnodum nec Turbit, de quo differuit A uicennt, quem etiam Diofco= ridis Tripolium intellexiffe rcor. Ceterum ab his longé differre uidetur TVR B I T, quod à LVe fue de fcribitur, noftrati Turpeto ontnibus prorfus notis reffondens. Ait enim Turbit radicem effe berbs folia ferula minora frent= tis, triplicíg; notari differentia, nempe alba, fubcinerea, o nigra. Que quidem omnia in noftri ufus Turpeto dili= genter intuentibus facilé $\int e$ e offerunt. Siquidem in Turpeti radicibus, que ex orientali plaga ad nos defrruntur, $0=$ mnes hi reperiuntur colores: non tamen quód putem, cos ita factos effe tantum ex ipfius planter natura; fed quód ob

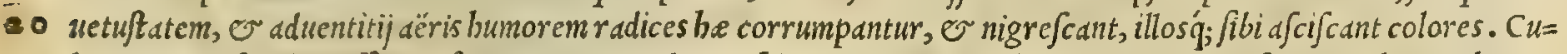
ius rei in caufa etisin efe poteft maris, per quod conuebitur, exorta procella, undis triremes fuperuntibus, quibus ma defacte radices facile fitum, ucl nigredinem contrabunt. Preterea cum afferat Actuarius, nil aliud effe album $\mathrm{T} u \mathrm{r}=$ petum, quam alypie radicem, corum plané refellitur opinio, qui Mefuem erraffe exiftimant, quód album Turpetume dixerit planter radicem effe, que folia ferret ferulaced . quandoquidem alypum, fiue alypia, ut in fequentibus docebit Dioferides, folijs tenuibus profilit, quemadmodum e ferula. Ex bis igitur, ut arbitror, abunde liquet, Turpetum tam $\mathrm{Mefui}$, quain Actuario alypix effe radicem. Eft $\mathcal{G}$ aliud $\mathrm{T}$ urpetum, quod potius p peudoturpetum dixerim, craf= fius, er cortice nigrius, quod ex Gargano Apulie monte conuebitur duplicigenere, quoniam unum é thapfie, alte= rum é pityufa radicibus concinnant impoftores, d quibus hec omnia didicimus. Non itaq; ab re fcrip/it Actuarius, ni= grum Turpetum radicem effe pityufe. Verüm boc (ut mea fert opinio) Me fuis Turpetum baudquaquam fuerit, cim

so ipfius Turpetum nil alivd êfe exiftinten, ut paulo anté diximus, qudin alypie radicem. Quanquam putat Brafauo= lus, nulla tamen, quod cquidem fciam, ratione uel authoritate nixus, apud Mefuem Turpetum omnino tithymali myr= finitis radicem effe. Sed quantum myrti folid d frula folijs differant, qui ne fciunt, rei berbarix peritos confulant.

Fuchfius porró libro de compofîtione medicamentorum Turpetum, de quo Mefues egit, $\dot{e}$ Thapfie radicibus exem= Fuch. opinio ptum exiftinat. Sed ipfius quoq; fententia mibi plané, ut liberé dicam, reprobanda uidetur : nam é ueteribus nullum reiecta. bactenus reperi, qui Thapjiam lacteo fucco turgere fcribat: cim tamen Mefui Turpetü à planta eximatur, qua plu= simo lacte madet. Preftat in Turpetigenere album ex orientali plaga allatum, refinofum, minimé cariofum. Deij= cit hoc pituitam, craffos lentosq́; bumores ad articulorum compagines defluentes, remotiores $\dot{q}$; corporis partes. ventriculum expurgat, or qua illi. penitus inharent excrementa detergit : item o pectus à pituite lentore. Datur magno iuuamento aqua intercute laborantibus : item elephantiacis, o Gallica lue affectis : quin $\sigma^{\circ}$ ijs, qui morbis ab 40 exuft is humoribus prouenientibus. Junt obnoxij. Prodest diuturnis febribus, ov in uniuerfum ubi pituita redundet . ue rùm qui fumunt cauere debent d’ pifcium e $\int u$, or auftraliflatu. Sed iam ad Tripolium noftra redeat oratio. Repe= Plinij lapfus: gio hac in biftoria non parum hallucinatum effe Plinium libro x X I.cap.V I I. ubi turpiter Tripoliun cum polio ber= ba confudit, aded ut afferere non dubitauerit, polium ter in die foliorum mutare colorem. Id quod de Tripolijflori= bus tradidere tun Diofcorides, tum antiquorum reliqui. Tripolij quàm breuißimé meminit Galenus libro v I Ix. fimplicium medicamentorum, ita fcribens. Tripolij radix gustanti acris eft, or facultate calida in tertio exceffu.

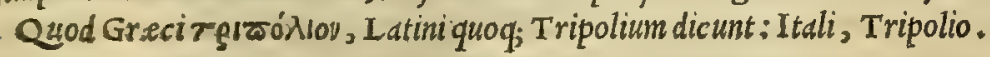

\section{A'sixvTov. ADIANTVM.}

CAP. CXXXI.

50 D I A N T O N, polytrichon, pufillagerit folia, fimilia coriandri, in fummo incifuris diuifa: cauliculi, quibus exoriuntur, nigro colore nitent, prætenues, palmum alti : radice fuperuacua : neque caulem, neque fructum, neque florem profert. Decoctum herbæ potum, prodeft f́pirandi difficultati, furpiriofis, lieni, \& felle fuffufis, \& urinæ difficili : calculos frangit, aluum fiftit, ferpentium mor fibus auxilio eft: contra ftomachi fluxiones in uino bibitur: fecundas ciet, \& menftrua : fanguinis reiectiones inhibet. Contra ferpentium morfus cruda herba illinitur, alopecias denfat, ftrumas difcutit: furfures, \& manantia capitis ulcera ex lixiuio emendat: defluentes capillos continet, cum la.dano, \& myrtino, \& fufino, aut hy ffopo, uinoq́ue. Decoztum eius cum lixiuio, \& uino infufum, ide præftat . Coturnices, \& gallinaceos pugnaciores facit, in cibos eorum additum. Seritur gratia utilitatis pecorum circa ouilia. Vmbrofis, \& paluftribus, circa pariețum afpergines, \& fontium fpecus enafcitur.

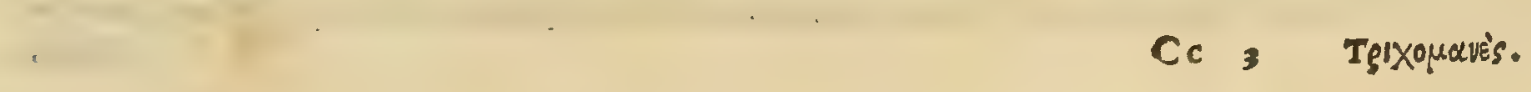




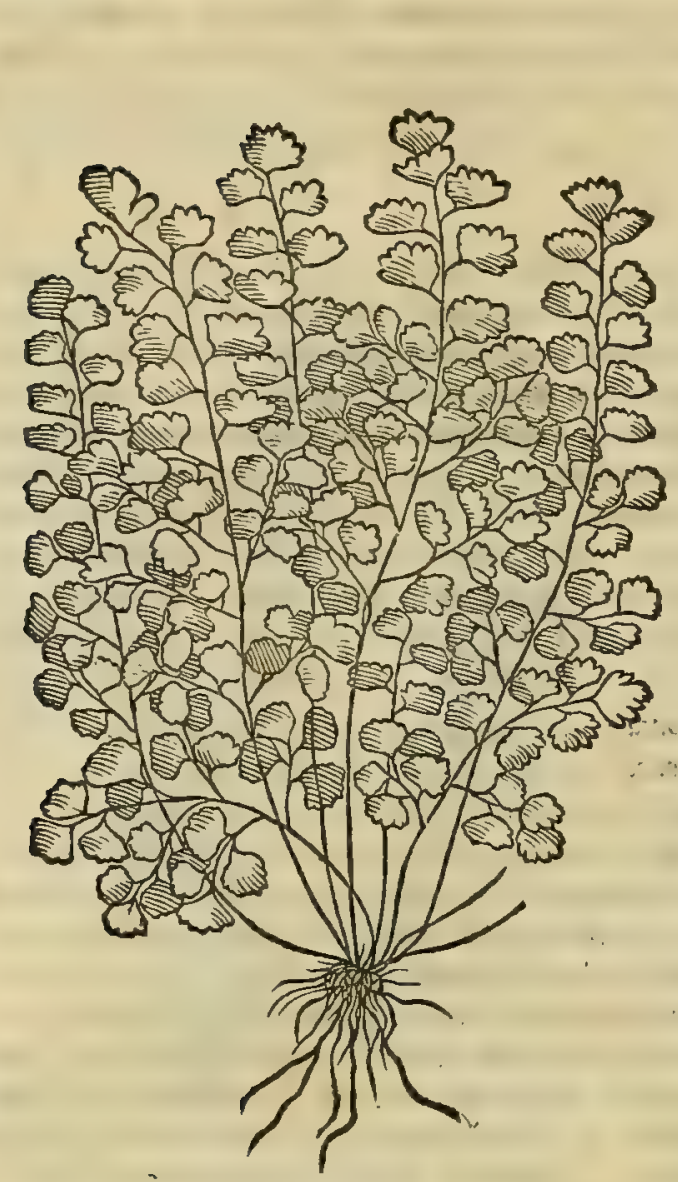

TęXquVE's. TRICHOMANES.

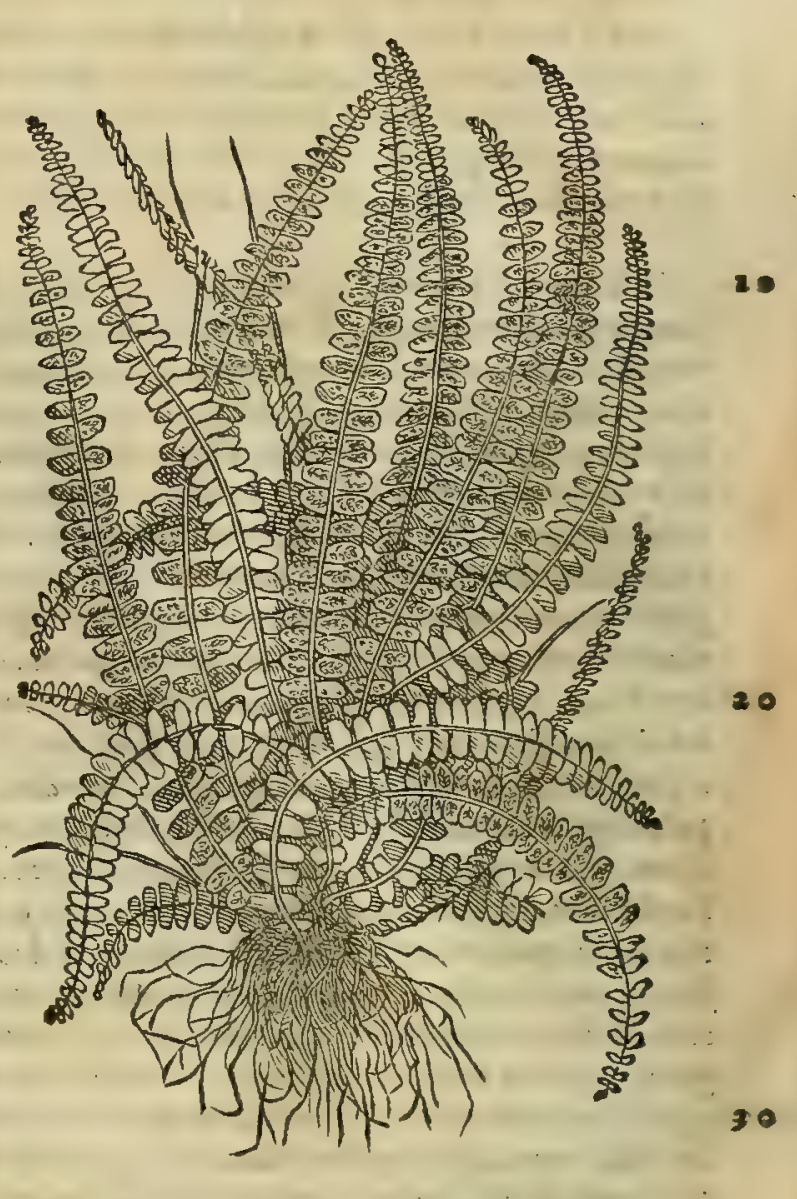

CÁP. CXXXII.

TR I C H O M A E S nafcitur eifdem in locis, quibus adianton: filici fimile, fed exilius : folijs lenticula, tenuibus, in ordinem utrinque digeftis, aduerfis in $f e$, in ramulis tenuibus, acerbis, fufco colore fplendentibus. Eadem qux $\&$ adianton præftare poffe conftat.

Adianti, \& Trichomanis confideratio.

A D I A N T V M officine Capillum Veneris appellant. Duo eius generd Theophraftus aßignauitlibro vi I. cap. $x$ I I I de plantarum hifforia, ubi ita fcriptum reliquit. Adiantifolium in aqua nunquam madefcit, nec quic quam adhafiffe bumoris conftat: unde $\sigma$ nomen berba accepit. Genera eius duo, candidum, atque nigrum : Ambo ad de= Aluuium capillorum utilia, oleo trita. Nafcuntur maximé locis bumidis. hac Theopbraftus. Cuifubfcribit Plinius, licet confusé fatis, libro x x I I. cap. x x x. dum fic inquit. Aliud Adianto miraculum, aftate vinet, bruma non mar cefcit, dquas reßpuit: perfufum, mersumue, ficco fimile eft, tanta diffociatio deprebenditur, unde er nomen i Gra? cis. Quidam callitrichon uocant, alij polytrichon, utrunque ab effectu. Duo eius genera, cadndedius, er nigran, breuius'; . Id quod maius est Polytrichon, aliud Trichomanes uocant. Vtrique ramuli nigro colore nitent, folijs fi一 licis, ex quibus infrriord appera, ac fufca funt: omnia auté contrarijs pediculisidenfa inter fe ex aduer fo: radiox nulla. Vmbrofas petras,parictum q; appergines, ac fontiü maximé ppecus fequitur, er faxa nanantia. quod miremur, cìme $a=$

Plinij lapfus. quas non fentiat. ita Plinius. In quibus nimirum uerbis maniffte deprehenditur iffe plinius, Trichomanes, quod o Filiculam appellamus, in fecundi Adianti locü retuliffe. quippe qui perper àm fortaffe acceperit Theophrafti fenten= tiam, d quo illa mutuatus eft. Nam Theophraftus ubi de utroq; Adiantigenere differviffet, eodem loco citato ftatme de Trichomane hac uerba fubiunxit. Trichomanes uel ad distillationes urina unicé facit, ut aliqui exiftinant. Caulé bee

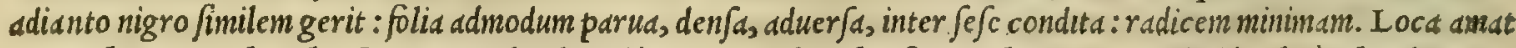
opaca. bactenus Theophrastus. Ex quibus liquidó apparet, Theophrafto Trichomanes, quod: Fidicula d Theodoro uer titur, nullu Adiantigenus effe, fed per fe fuí,; generis plantam : quód enim Fidiculara dixerit cauliculum ferre nigro adianto fimilem, clarißimé oftendit, candidum Adiätum cum Trichomane nullă habere cognationem. Hinc itaq; facile crediderim, Adiantü nigrum, quód caule filiculam referat,nobis legitimum effe, id fané intelligens, quód Capillü Vene ris paßim nominant. Candidum ueró eam plantam effe aliquando putaui, qua unà cum Trichomane in petris, pariet ac fontium aßperginibus, ßpecubus, or bumentibus locis nafcitur : folijs nigricantibus, minutim laciniatis, luteas macus las quàm plurivess aucrfa parte habentibus : caule viridi, gracili, flexiliq;; : quam nonnull, có quód folijs rutam a mua 


\section{In Lib. quartum Diofcoridis.}

letur, or in muris proueniat, Rutam murariam cognominant, alij saxifragan dicunt. Sed nunc cquidem banc can= dem cum $\mathbf{P}$ aronychia Diofcoridis effe opinor, ut etian fupcrius in fua mentione mostuimus. Cateriun Fuchfius me= dicus clarißinus, banc herbam pro Saxifrag a Diofcoridis depinxit in fuis de firpium biftoria commentarijs. Verum quód bac folio conftet rute, illa ueró cpitbymi, capillorumó; modo tenui, cur plané cius fententiam comprobem, non habeo. Adiunti meminit Galenus libro v $\mathrm{I}$. fimplicium medic dinentorun, fic de cius uiribus fcribcns. Adiantum in caliditate quidem, er frigiditate fymmetrum elt, uerim deficcat, en extcnuat, or difcutit. Etcnin alopecias capill is

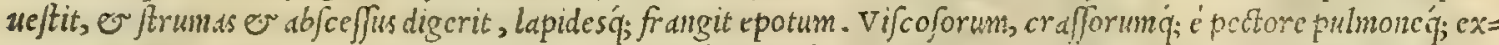
creationibus non mediocriter confret, ơ uentris proflusium fiftit : non tanen ullam manifeftan caliditatem affert, ficut nec frigiditatent. Verim pojuerit ip Jum quiplam fecundum banc oppofitionem or tcmpericm in ordine medio.

20 Trichomanis autem meminit libro v I I I. corundem fimplicium medicamentorum, nbi fubfribens Diof coridi, bxc tantum retulit. Trichomanes caden preftat, que adiantum. bactenus Galenus. Porró Adimum, ut Mefues in= ter fua fimplicia refert, aluum fubducit, bilem, or pituitan deijcit, craffá,; excrementa, qua diu interioribus inbe= fere. Pectus, or pulmonem detergit, fanguinein clarificat, bonum facit babitum, animan dilat at, o iecur $\sigma$ uen= triculum purgat, prefertin fi obltructione laborent: tanet fi ad eorum infarctus potétitus fit cius dilutum cx apij, aut endiuie aqud pardtum, aut ex ciccrumnigrorum iure, aut caprino fero. Sed fi addatur faccharum, lateris inflamma= tiontes fanat, or urinam trahit. Eius praterea decoctum frequentius potum calculos frangit, e faninas à partu pur gat. Hos autem effectus prebet calida tantum facultate, qux illi ineft. At adfringente ui, qua etráminn pollet, de= fluxiones inbibet: fuentem fangunem fiftit, uentriculum roborat, or capillorum defluium ufqucadco esuendat, ut non modó cos colibeat, fed er rena ci faciat, prefertim emplaftri modo impofttum, myrtino olco, ladano, or aufee=

20 ro uino additis. Idem preftat et combufti cinis: quinetian eius ex uino decoctum. Fur fures reiteratis lotionibus de= pellit. Eius cinis bec omnia poteft, o a gilopds curdt. Ipfius diluti libra epota commodifiné aluus fubducitur.

Herba, que Grecis a'd íavtov, Latinis pariter Adiantun nominatur: Arabibus, Berfcegnafcen, feu Berfaufan, or Chulbare albir: Italis or alijs uulgó, Capel uenere: Germanis, Frausenhar: Hifpanis, Culantrillo de pozo: Gal

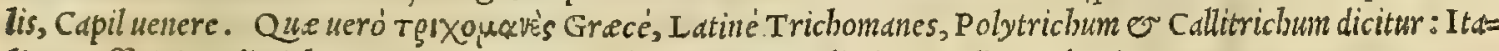
lis or officinis Politricho : Germanis, Steinbrech: Hipanis; Politrico: Gallis, Polytricen.

इaivblov. XANTH I V M, SIVE IA P P A.

CAP. CXXXIII.

30
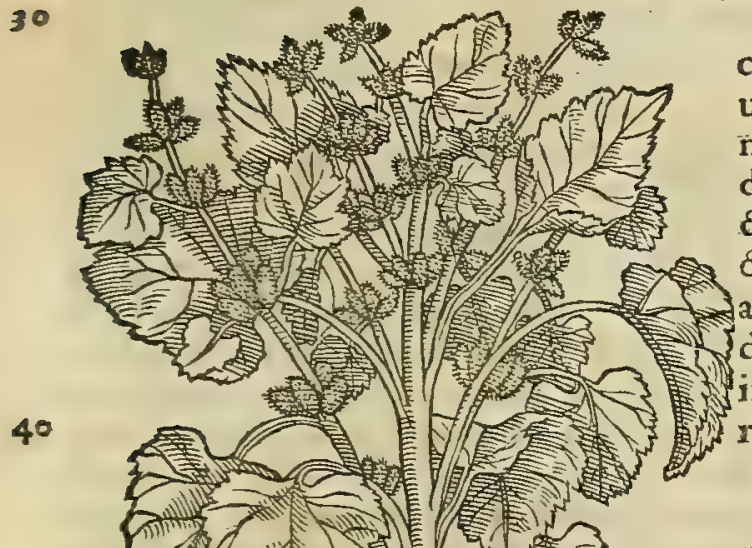

XA.N T H I v M nafcitur lato, \& pingui folo, \& lacubus exiccatis, caule cubitali, anguloro, pingui, prodeuntibus ex eo crebris alis : folia atrip licis habet, infecta, nafturtium odore imitantia: fractum grandis oliux modo, rotundum; \& ut platani pilula; fpinofum, qui contactu ueftibus adhærefcit: Is antè collectuis quàm perfeCtè ficcefcat, tunditur, \& fictili uafe reconditur. Flauos autem facit capillos, fracetabuli inftar tepida aqua madefcat, mox caput, nitto antè perfrictum, illinatur. Alij in uino tumdunt; \& ita afferuant. Semen aptifsimè tumoribus imponitur.

X A N T H I V M, qtod unlgus Lappam minorem cognomi= Xanthii connat, omnibus unlgarißimuon eft: quandoquidesn publicis ubiq; $f e=$ fideratio. mitis, er exiccatis fcrobibus, lacubus q́; naféctur. Huic, meo qui= dem iudicio, omnes comieniunt notr, nulla pror fus reclamante", que Xanthio dे Diofcoride tribuuntur. nam preterquàm quód caulem gerit angulofun, ac pinguem, folid, que ei fubalbida funt, atriplicis effigiem referunt, per anbitum ferrata, nafturtium odo re innitantia. Prodeunt etiam é caule ramuli, quibus racemation frutus oliue figura deperidet, aculeditus ceuplatani piluld, qui maturefcens, cum tangitur, ueftibus pertindciter adbaret. $\mathbf{P} d u=X$ Xnthii uires cis admodum buius berbe uires defcripfit Gälenis lib.v r 11 , finte ex Galeno. plicium medicamentorum, fic inquiens. Xanthitum uacatur etiam phasganium. Fructus difcutiendi uim obtinet. Hecplantd Gro= cis $\xi \alpha$ 'v Iov appellatur : Latinis quoq; Xanthium :Italis, Lappo= la minore: Germanis, Bettlersleijz, or spitzkletten:Hipsmis, Lappa menor : Gallis, Gloteron, $\mathbb{E}$ Grapellis.

Nomina. 


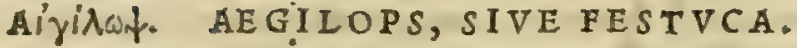

CAP. CXXXIIII.

Aegylopis có fideratio.

Error quarundam.
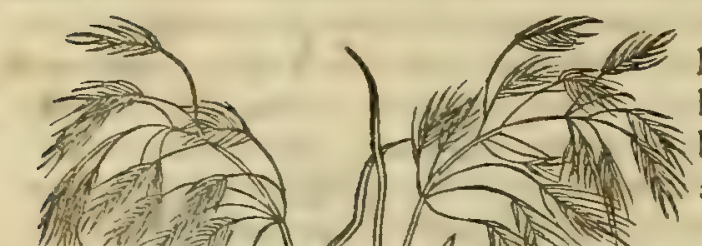

AE G I I O P S herbula folia tritici habens, fed molliora, in fummo capite femina bina ternáve rubra, quibus ariftæ quafi capillace exeunt. Illita cum farina herba xgilopijs medetur, duritias difcutit. Succus farinx admiftus ficcatur, \& eorundem gratia reponitur.

N A S C I I v R frequens Ágilopsinter Jegetes, fed fre $=\mathbf{x}$ quentißima inter hordcuin, or zeam, folio tritici, culmo prete $=$ nui, in cuius cacumine bina ternáue rubra femina dependent, ob= longa : é quibus arifte prodeunt longe, capillorum modo tenues. Hanc non modó uidimus in Ananienfi agro, or ubiq; feré locor fed etian.fepißimé legimus. Eam rura Ananienfia uulgó squa lam appellant. Proinde errant ij, ut equidem arbitror, qui Ae= gilopem, er auenam idem effe contèndunt. quandoquidem etfî primo ftatim intuitu Aegilops auene faciem referre uidedtur; di= ligenter tamen fingulas eius notas expendenti, facilé er difcri= men, $\sigma$ error deprebendetur. Etenim Auena inftipule cacumi= 20 nibus grana profert, longiufculis appenfa pediculis, oblong is fol $=$ liculis contecta, bipedum locuftarum effigiem reprefentantibus. At Aegilops tenuißimas fert picds, tribus, aut quatuor tantum granis contentas, auene feré modo dependentibus: é quibus ari= fte prodeunt capillorum infar tenues, rubentes, or auena lon= giores. Quód autem ita fe res babeat, manifeftum prebet indici= um ipfe Diof corides: utpote qui de auena l bro fecundo inter ce= realia abunde fripferit, neq; bis feor Jun $q_{;}$e iufdem plante bifto= riam tractare foleat : fuperuacaneum enim fuifet idem repetere, crinordinatum eidem inconfultó addere. Huc accedit, quód $\tilde{I}_{30}$ note, qua utriq; plante à Diofcoride redduntur, inwic eñ confe $=$ rantur, haud dubie alteram ab altera tum facie, lim uiribuis, lon=

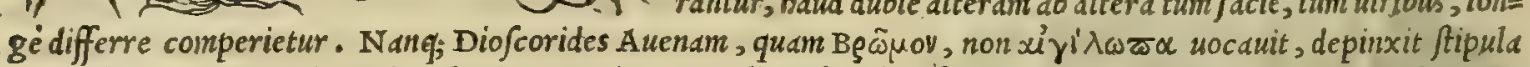
geniculis intercepta, dependentibus in cacumine paruulis ueluti locuft is bipedibus, in quibus femen concluditut. Aegilopa ueró in fummo capite femina bina, aut terna rubra babentem, arift is capillaceis. Porró cum libro fecundo de uiribus Auene differeret, inquit. Huius femen non fecus atq; bordeum, utile eft ad cataplafinata. Pulte eius aluus fiftitur . prodeft tußientibus in forbitione fuccus. Verim bic de uiribus Aegilopis fcribens, berbam eius ad $f=$ nuofos oculorum abfeffus, quos Greci egilopas uocant, $v^{\prime}$ ad duritids difcutiend ds commendauit: fuccum' fari= ne admiftun ad idem ualere prodidit. Que fané omnia, nifallor, apertißimé demonfrant, agilopem auene quàn Aegylopis maximé repugnare. Aegilopem ex bordei uitio fieri, ficut lolium ex tritico nimia uligine, teftis cft $\mathrm{G}$ alenus libro 40 ex hordeo ge primo, capite ultimo de almentorum facultatibus, ubi ita fribit. In tritico quidem, frequens lolium fepe inuenineratio. tur: in bordeis ueró reperitur, fed paucum : quam autem agilopem appellant, ed in hordeis frequens inuenitur, cùm prima generatio, uel incrementum ip/is non recté fuccefferit. Porró pater meus atate ian declinante, cùm agricultura delectaretur, triticum, ac bordeum aliquando feminauit, omnibus diuer fi generis feminibus, qux ipfis crant admifta, diligenter felectis, quó certó cognofceret, num ex ipforum mutatione lolium er agilops nafceren= tur, an propriam hec quoq, femina naturam haberent. Cùm autem forté und cum puris feminibus in tritico quidem frequens lolium, in bordeo autem parum, fed magnam agilopis uim cnatam conpiceret, in alijs quoque fcminibus. itidem experiri eft aggrefjus. hactenus Galenus. Caterum ip $\int e$ quoq; teftari polfum, me fapenumero in Anania ual= Aegylopis ui . le audiuiffe agricolas conqueri, quód bordeum degeneraffet in Squalam: fic enim ip/i Aegilopen uocant. Acgilo= res ex Gal. pis uires retulit Galenus libro $\mathbf{v}$. fimplicium medicamentorum, his uerbis. Acgilops digerendiuim poßsidet, id quod ex guftu patet : leuiter enim eft acris. Verum er ex co liquet, quód phlegmonas induratas, er xgilopas fanat. bec Galenus. Cuius etiam teftimonio fatis planum fieri potelt, Auenam, or A egilopem inter fe dißsdere, quód de

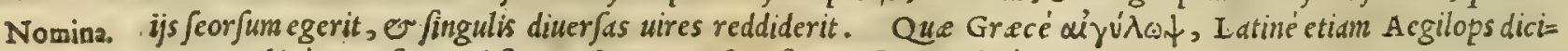
tur: Arabicé, Daufir, Dalifit, Dofana, Daufer, fiue Dußer : Italicé, Egilopa.

$$
\text { Bō̃us:- BROMVS. }
$$

CAP. CXXXV.

B R O M v 5 herba xgilopi fimilis, exiccatoriam uim habens. Decoquitur cum fua radice in aqua ad tertias, \& iuri colato par modus mellis adijcitur: rurfus incoquitur, dum liquidi mellis craf́situdo fiat. Linteum eo humore imbutum, \& naribus inditum, contra graueolentiam ulcerum efficax eft. Aliqui tritam aloën addunt, $\&$ eo modo utuntur. Cum ficcis roils cofta in uino, grauem oris halitum emendat. 


\section{In Lib. quartum Diofcoridis.}

\section{$\int 85$}

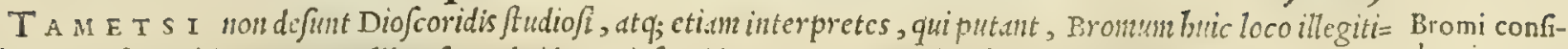
mé accreuife, quód de ca quoq; libro fecundo idcm Diofcorides tractauerit, aliud'q; nonfit Bromos, quàm Aucna; deratio. nos tonen longé aliter fentimus. Mcafiquidem fententia eft, critq́; donce melior ab alijs profir.sur, quód Diofco=

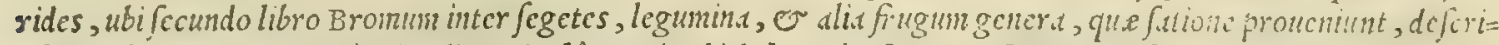

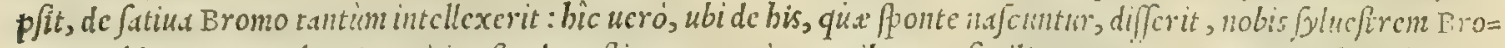

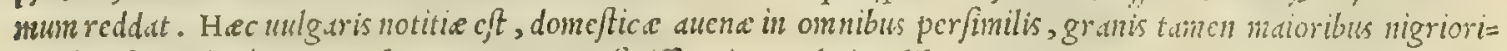
bus, 'birfutioribusq; . Promit.uius mentionem ficiffe opinor Plenium libro $\mathrm{x} \times \mathrm{I}$. cap. $\mathrm{x} \times \mathrm{v}$. dum fic inquit. Ero= mos femen cft picun fercntis berbx. nafcitur inter uitia fegctis auenc Grace genere, c folio, or fipula triticum imitatur. In cacuminibus depcndentes paruulas uelut locuftas babet. Semen wille ad cataplafinata, atq; bordcun,

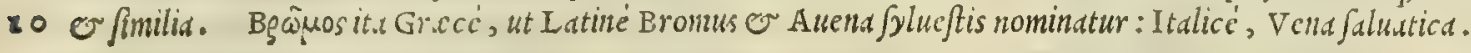

Nom

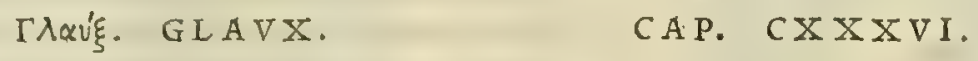

G I A v x cytifo, aut lenticulx folijs fimilis, quæ fupernè uirent, auerfaq́ue candidiora fpectantur: ramuli à terra exiliunt quini feníve, tenues ab radice, dodrantem alti: flores uiolre albx, purpurei exeunt, minorcs tamen . nafcitur iuxta mare. Coquitur cum hordeacca farina, fale, 品 oleo in forbitione, ad reuocandam extincti lactis ubertatem .

Qv A N QV A M fribit Diofcoridesiuxta mare nafci Glaucem; eam tamen ipfe hadtenus mu fqum reperi, ne= 20 que ab aliquo compertan audiui. Nifi Ruellio adfipulari uelimus, qui eam berban Glaucem putat efe, quxe fiuti= cat multis caulibus: folijs oblong is, in ordunem utrinq; digeftis, ciceris modo, fubter cesijs, fupcrné uiridibus: flore purpureo, paruo, filiqua terete, non in aduncum ut fonigreci corniculata. H.ec, etfi Rucllio tcfte nullum apud Gallos inuenerit, nomen à quiburdan G A EG A ab alijs Ruta capraria, in Hetruria ueró unlgó appellatur Laua=

G A LEGA.

30

40

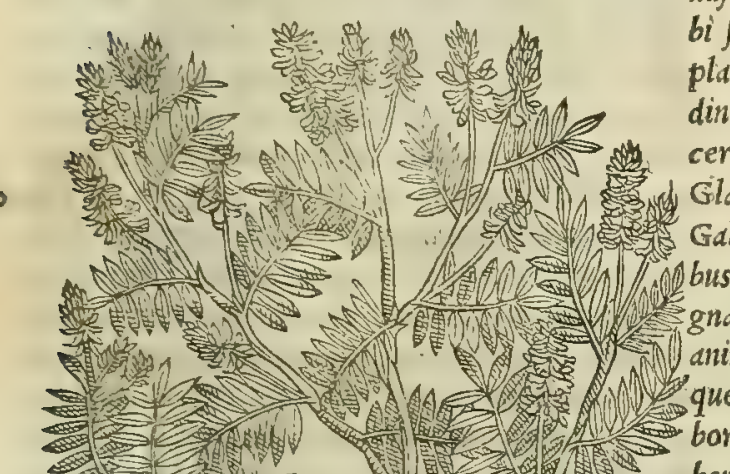

50

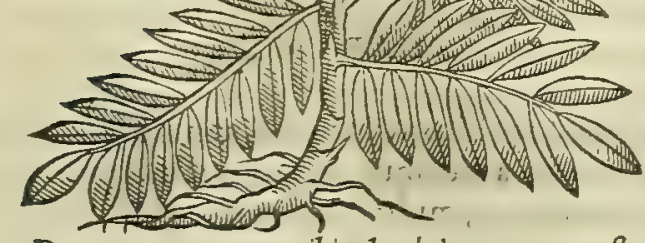

nefe; fiue ut quidam alij Lauamani, quod prope riuos aquarum nafcatur, ubi manus lauantes ruftici, bac planta faponis uice $f=$ bi fordidum lutum abftergunt. Verum cum uidedmus buiufce Ruellii opin. planteflores, er caules, qui fe quando ; $_{\text {; }}$ ad bicubitalem altitu= explofa. dinem attollunt, Glaucis faciem non repre entare, cogimur di= cere $\mathbf{R}$ uellium bac in re hallucinatü deprehendi : praesertim quód Glaux, Diofcoride et $\mathrm{Plinio}$ authoribus, inuenitur iuxtamare. Galega ueró in uliginofis locis, in frobium aggeribus, in monti= bus, e deniq; paßsim feré provenit. Huic plante recentiores aßi gnant uires non uulgares contra peftilentiam, or uenenoforum animalium morfus. in quorum remedium berba per fe eftur, at= que etiam exterius illinitur. sunt $\sigma$ qui eam morbo comitialila= borantibus auxiliari predicent : in quem ufun eius fuccum exbi= bent, drachmarum quatuor pondere. Quod autem bec extin= ctum lac reuncet, ad quod Glaux do Diofcoride commendatur, non equidem aufim afferere, cùm nullum inueniam, qui Galegam his uiribus preftare testetur. Glaucis meminit Galenus lib. VI. fimplicium medicdmentorum, de cius uiribus differens in bunc jmodum. Glaux herba, or ip fa lactis generandi uim obtinere ui= detur. Quodfita fit; calida quodammodo, bumida' q $_{;}$fuerit tem $=$ peramento. Ea equé Grecis $\gamma \lambda \alpha v^{\prime} \xi$, atq Latinis Glaux ap: pellatur.

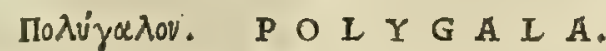 CAP. CXXXVII.}

POI G A A palmi altitudinem petit, folijs lenticulæ, gultu adfricto. Quæ pota, lactis abundantiam facit.

P O L Y G A L A mihi plané incomperta eft. neq; id temeré faterilicet, quód tam pauce eius tradantur noto tum à Diofcoride, tum etiam à Plinio, ut admodum difficile fit decernere, qua nobis bodie fefe offerat planta, cui

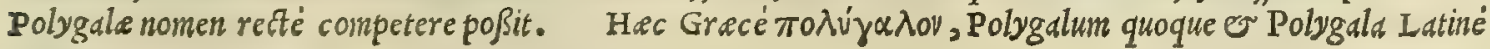
Nomina. dicitur. 


\section{And. Matthioli Comm.}

O"ouģs. OSYRIS.

\section{CAP. CXXXVIII.} fideratio.

Plinij lapfus.

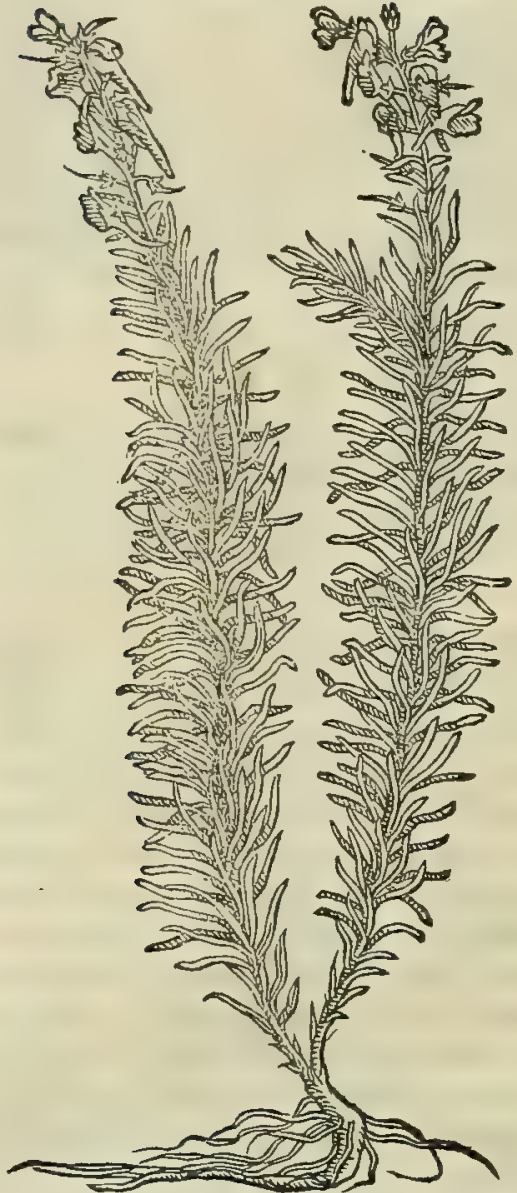

Ofyridis con

O S Y R I s frutex elt niger, ramulos ferens tenues, lentos, fractuque contumaces : $\&$ in his folia quaterna, quina, fenáve, ccu lini, nigra in initio,dein colore mutato rubefcentia. Decoctum eius potú, iuuat arquatos.

O S Y R I $s$, quódfolijs, o caule linifaciem representet, officinis Linaria appellatur. Huius flores, quos tamen omifit Dio 10 fcorides, numerofi à medio ufque ad fummum uifuntur, fylueftris cumini fecundigeneris modo, uerum in boc purpurei funt, in illd fublutei. Sunt tamen qui uelint, ofyrim edm effe plantam, quam unlgó nos appellamis Bel uedere, quód bellé, denfißimé,; fruticet, uireat $\dot{q}_{\text {; }}$ per aftatem, non folum in hortis, $\sigma$ uiriddrïs fata; fed etiam in fictilibus ornandi feneftras gratid. Qui neró ita exiftimant; co ducuntur argumento, quód bac nón modó cre $\int c a t$ folijs lino fimilibus, fed quodd etiam nunc feratur ḋ multis ad fco= pas ex ea parandas. Quandoquidemid d Galeno dictum volunt in fimplicium cen $\int_{u}$ ubt uerbum หogriex $\tau \alpha$ (itd enim legendum eft, 20 non autem $и \alpha$ кен $\mu \alpha \tau \alpha$, ut male habent codices) non folum me dicamenta, que faciem uenuftant; uerum etiam fcopas Grecis $l=$ gnificare arbitrantur, quemadmodum er Cornarius in Aétio in $=$ terpretatur, Quorum equidem Sententiam non prorfus impro= bandam cenfeo, quoniam paldim eft, banc plantam folijs linum re= ferre, $\sigma$ ad fcopas conficiendas aptifimam effe. tamet $f$ Diof $c 0=$ ridis placitis ea non admodum adftipuletur, ficuti nec alia uoca= ta Linaria, quód neutrius folia é nigro, quod uiderim, in rubrum mutentur, quodd ǵ; harum ramuli longé plura habeant folid, quàm quind, uel fend. Ofyridis biftoriam tradidit etiam Plinius lib. 30 $\mathrm{X} X \mathrm{X}$ I I.cap. X I I, ubi ita fcriptum reliquit. Ofyris ramulos fert

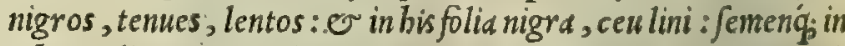
ramulis nigrum initio, dein colore mutato rube $\int c e n s$, hec Plinius. In quibus, meo iudicio, lap $\int u s$ deprehenditur ip $\sqrt{e}$ plinius, quód ijs notis depinxerit huius plante femen, qua folijs reddidit Diofcorides, à quo tamen Plinius illa mutud= Ofyridis ui - tus eft. De uiribus ofyridis Galenus lib. v I I I. fimpliciummedicamentorum differuit, ijs uerbis. Ofyridi, inquit,

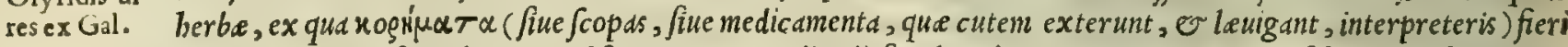
folent, amara ineft qualitas, e obftructiones expediendi facultas . 'quare $\widetilde{c}$ in iecinore confiftentes obftructiones adiunat. Herba bac óvugi's Gracis, Latinis item Ofyris dicitur: Germanis, Harn Lraut: Italis pariter or $\mathrm{Hi}=$ Bpanis, Linaria.

\section{$\sum \mu i \lambda \alpha \xi T \rho \alpha X \tilde{E}{ }^{2}$. SMILAX ASPERA. CAP. CXXXIX.}

S M I L A X afpera, folia habet periclymeni : farmenta tenuia, multa, rubi modo, aut paliuri aculeata : arbores fcandit, ab imo ad fumma perreptans, fe conuoluens eis : fert racemos exiles, qui maturi rubefcunt, guftumq́ue leniter mordent. Nafcitur in paluftribus, \& afperis : radice dura, craffaq́ue. Folia, \& acini, \& antè, \& pòft epoti, uenenoforum antidota funt. Tradunt, 11 infantibus nuper in lucem editis, quid ex his tritum propinetur, nulla poftmodum venena nocitura. Inciditur etiam ad alexipharmaca, id elt, ad ea medicamenta, quibus venena arcentur.

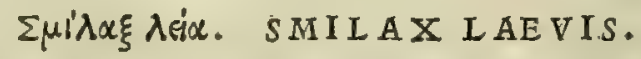

CAP. CXL.

L AE v I s Smilacis folia hederæ fimilitudinem habent, molliora, lieuiora, tenuiora : huius farmenta fupradictæ fimilia, nullis horrent fpinis : conuoluitur arboribu's, ut prior : fructum parit lupini modo nigrum, exiguum : floribus in cacumine perpetuis, mult's, rotundis. Hac fmilace, quadam topiariorum arte, tentoria contra xftus moleftiam factitantur:: folia per autumnum decidua. Semine cum dorycnio poto, ternis fingulorum obolis, varia \& tumultuofa in fomnis obuerfari traduntur.

Smilacis afperæhiltoria ex Theophr.
S M I L A X apera Hetrufcis Hedera ßpino $\int a$, fiue Rubus ceruinus nominatur. Hanc diligentißimé perfecutus eft Theophraftus lib. I I I. capite ultimo de plantarum hiftorid, ubi ita fcriptum reliquit. Smilax, id eft, bedera Cali= cid, amplexicaulis ipfa quoque affurgit, frutex aculeatus, o uelut praborridus: folium bedera, paruum, fine an= 


\section{In Lib. quartum Diofcoridis.}

SMIIAX ASPERA.

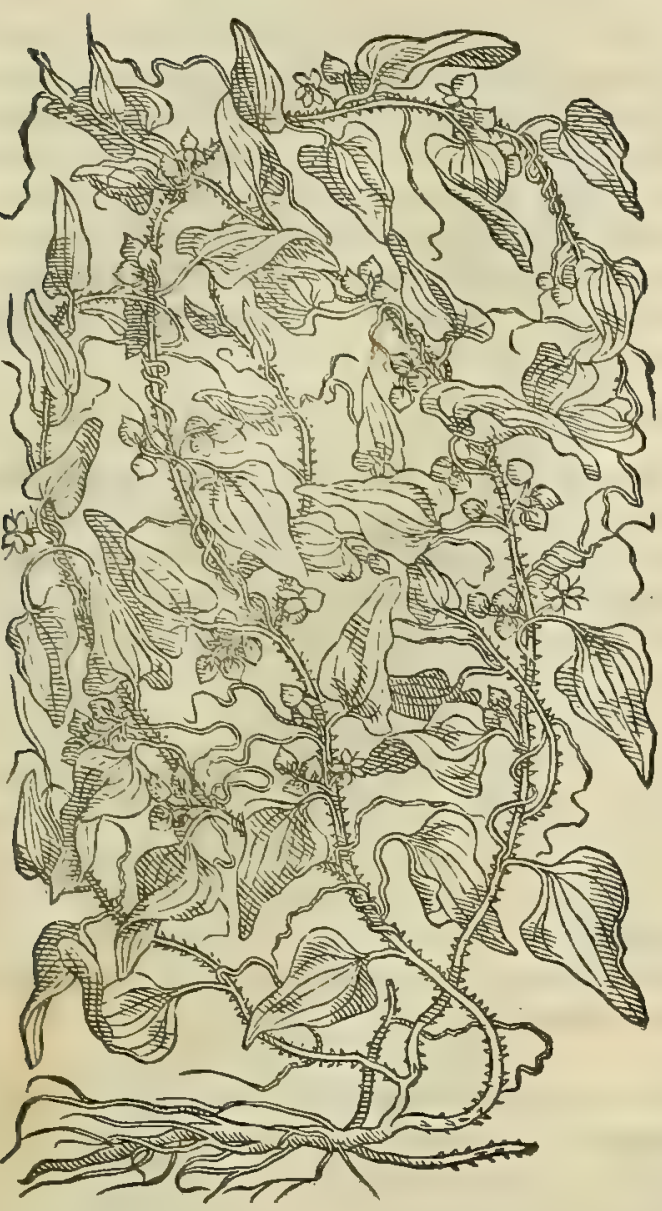

SMILAX LAEVIS.

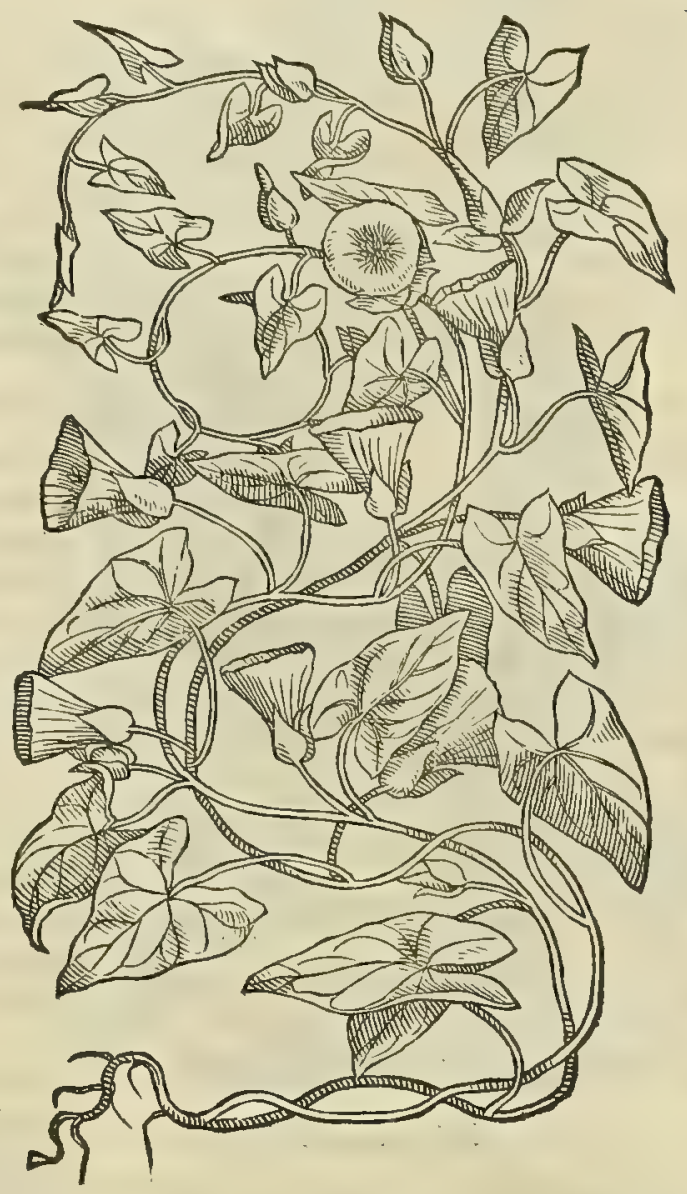

gulo, iuxta pediculi retinaculum bumcetum: peculiure, quód medium illum callum, qui inftar fpine animantium fe= cat, pratenuem babet, ov interuall staminea, non ex co porrecta, ut cater, , fed circa eum in orbem circumacta, $a b$ annexu pediculi ducit, ad caulem ueró foliorum internodia con funmantem: iulus ab eisdem pediculis atque folia, tenuis, féq; conuoluensdcpendet. Flos candidus, fuallter olens, uerno proueniens tempore : fructus proximus fo= lano, atque melotbro, e maxiné uux labrufca nocitate. Racemi penfiles ut hedere funt, uerum ad labrufcam po= tius accedunt : nam de codem puncto pediculi acinorun exeunt. Colore fructus rutilus eft: nucleos in uniuerfum qui= 40 dem binos continet, quanquan grandior ternos, e paruulus unum. Nucleus durus admodum eft, or colore form= fecus niger. Peculiare racemis, quòd per latera caulium fepiunt, poftremo $\dot{\text {; }}$ caulis racemus omnium maximus pro= pendet, Sicut in rhamno, er rubo: unde fit, ut extremo fructifera, , v latere largé fructifera iftapectetur. Hacte= nus Theopbrasii de fmilace apera fententia. Que autem Smilax lauis appellatur, ubiq; feré prouenit, fed pres= Smilacis lęuis Sertim in Hetruria, ubi paßin frequentißima inucnitur. Incole eam unlgó uocant Vilucchio maggiore. Hac folijs hiftoria.

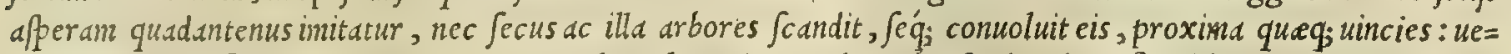
rim farmentis, fiue ramulis constat, non ut altera borridis, aculeatisq; , fed lauibus, flexilibus, ac lentis. Flores profert candidos, calatble figie : é quibus femen prodit atrum, le ntibus maior, fed lupinorum figura. Officine hane plantam Volubilem nuncupant. Cuius tamen plura Mauritanis babentur genera, quorum unum illud est, quod Lu= pulum appellant. Huius etfi apud medicos atatis nostre frequentißimus fit ufus, adddturq; abijs in quàm plurima

50 medicamenta; nibil tumen de co, quod equidem inuenerm, Galenus, o Diofcorides, alijq; ueteres tam Graci, quàm Latini authores, posteritatis memoric prodiderunt . quanquam non de funt, qui uelint, , bunc Plinio effe Lu=

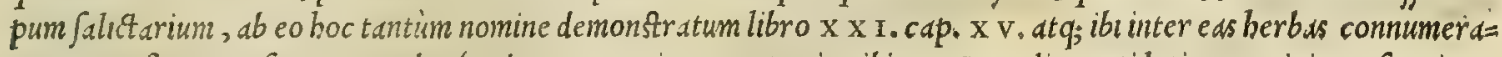
tum, qux ponte nafcuntur, qubusq́; plereq; gentium utuntur in cibis. I upuli uocati latius meminit Me fues inter fua deiectarief facultatis medicancnta, ubibec ad fenfumbabet. Est or aliud Volubilis genus, quod L V PV L v S appellatur, folla habens a,pera, cucumeris modo : flores exilibus folliculis fquamatim compactos, racematim $q_{;}$de $=$ Cupuli hiftoria,et uires ex Mefue. pendentes, colore fubcinereo. Hic flauam bilem detrabit, fanguinem ab ea expurgat, er eius inflammationes ex= tinguit. Sero caprino maceratus, ualentior redditur. Succus cum faccbaro decoctus fyrupi modo, regio morbo la= borantibus medetur. Sed profectó mirum est, quód eo noftra etatis medici tam parcé raroó; utantur, cium tamen preftantißimum fit medicamentum . quandoquidem tum berba ip $\int$ a per $\int e$, tum etiam fuccus polente ddmistus, capi= tis dolorem à caliditate contractum tollit. Iecinoris, or uentriculi estus mitigat. Syrupus ex faccharo, or eius fuc= coparatus, urilißimé exbibetur in febribus à bile, or fanguine excitatis, hec Mefues de Lupulo. Ceterùm ad insti= 
Smilacis utriufq; uires ex Galeno.

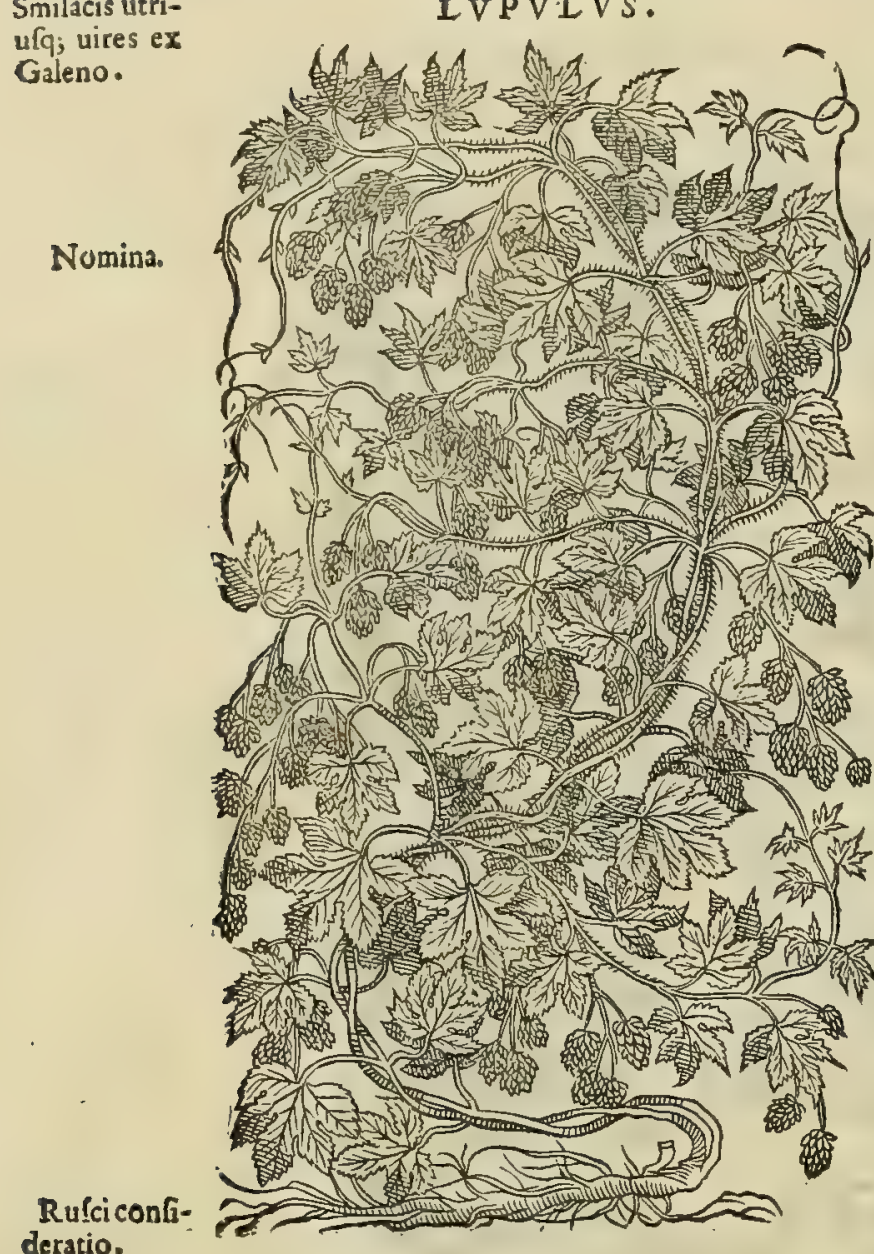
deratio.

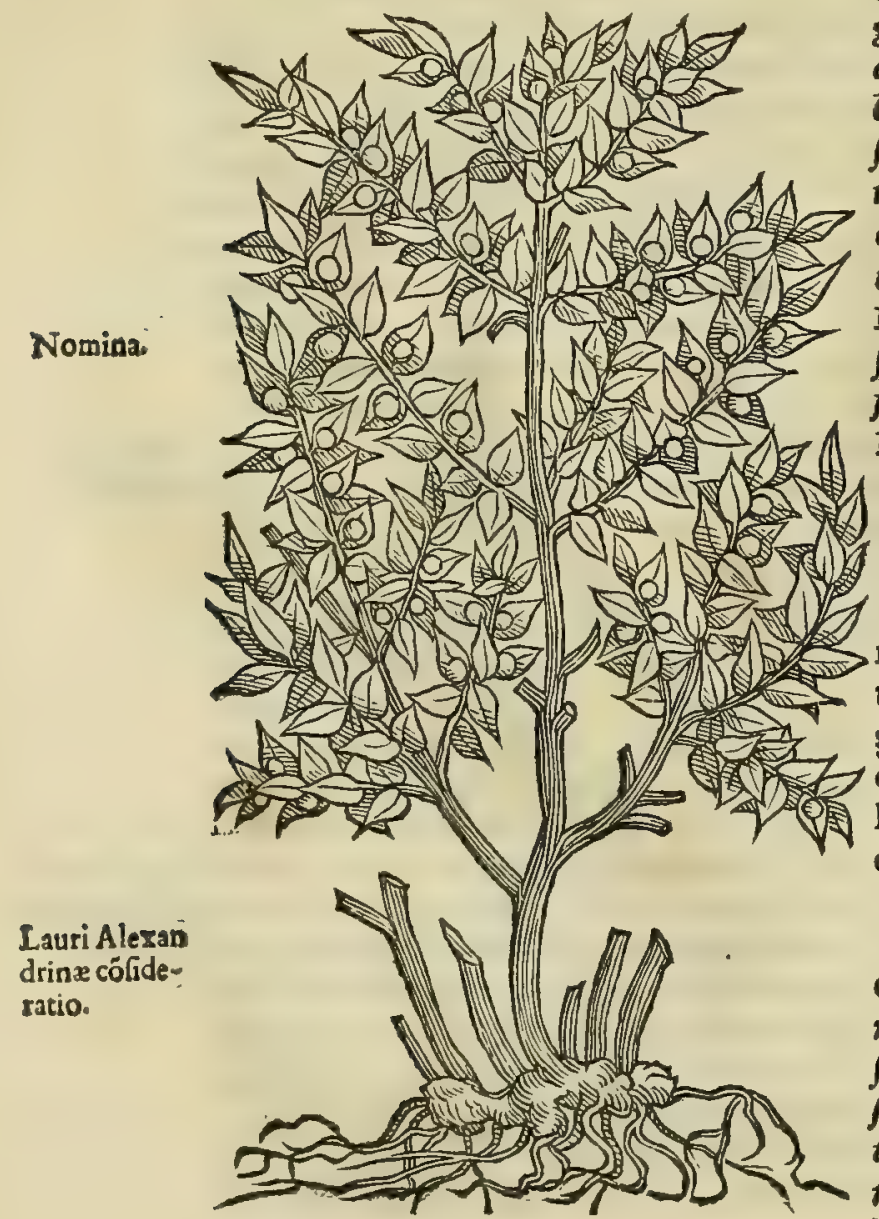

IVPVIVS.

RVSCVS.
R v S C V M officine corrupto nomine ex litere additione 30 Brufcum appellant. Nos ueró, quód arcendis muribus is aptißi= mus fit, i falitis appen/is carnibus funiculo circunligetur, Pun= gi topi Hetrufca lingua dicimus. Germinat bic uere aparagimo= do, turionibus tamen breuioribus, craßioribus, hirfutisg;: qui $e=$ lixi manduntur ex oleo, fale, or aceto. Ceterim, quód non ob= fouré amarorem guftui relinquant, in medicamentis potius, quàm in cibis expetuntur : funt enim cienda urine, aperiendisóf; obftru ctionibus perquàm idonei. Gracis, quód folijs fit acutis, $\widetilde{O}$ myr= tum emuletur, oxymyrfine, boc eft, acuta myrtus appellatur.

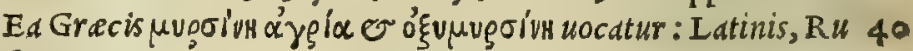
fous, er Myrtus fylueftris: Arabibus, qui Cubebas cum rufcocon fundunt, Cubebe:Italis, R ufco et Pongi topi: Germanis, Bruofcb: Hippanis, I Ius barba, o Gil barbera: Gallis, Brufco.

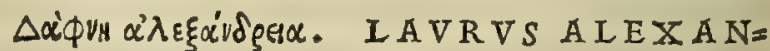
DRINA.

\section{CAP. CXLII.}

LAVRVS Alexandrina folio eft rufci maiore, molliore, \& candidiore : femine inter folia rubro, ciceris magni tudine: ramos fpargit in terra dodrantales, interdum lon giores : radice fylueftri myrto fimili, maiore, molliore, so odorata . inuenitur in montofis. Difficiles partus accelerat, radice pota fex drachmarum pondere in uino dul$c_{i}$ \& Atillicidio urinæ auxiliatur, fed fanguiné extrahit.

S I L A V R V M Alexandrinam, or Hippogloffum unam er eandem plantam effe fenfiffet Diofcorides, ut quidam exifti= mant, nulli quidem dubium eft, quin fuperuacuum erat, $d e$ ijsdem feorfum, diuerfis att; etiam proximis capitibus Diofcoridem dif= ferere , uel nulla in earum notis, er uiribus reperiretur differen tia. Sed quoniam eas feorfum tanquam diuer as retulit,diwerfasq; utrisq; notas aßgignauit; idcirco bas plantasinter fe differre dio 


\section{In Lib. quartum Diofcoridıs.}

\section{9}

IAVRVSALEXANDRINA.

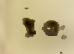

20
LAVRVS ALEX. A ITERA.

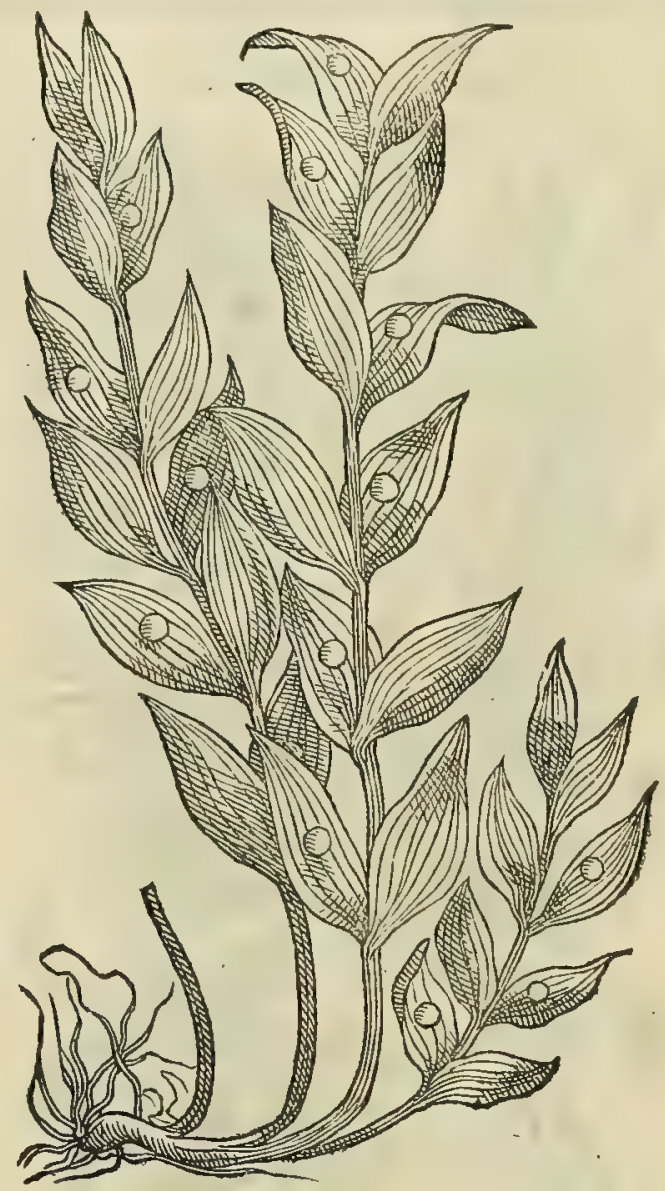

catur, neceffe eft. Namet fi utriq; folia rufci reddiderit Diofcorides; tamen Hippogloffum ftatuit aculeatan geverë coman, o in fummo ceu linguas é folijs exeuntes: commendauitớ; comain ad dolorem capitis corone modo impo/i tam : e radicem, fuccumíg; malagmatis admifceri feripfit . Verim bic in $\mathrm{L}$ auro Alexandrina nec linguarum memi nit, nec acaleorum é foliis prodeuntium : tradidit quidem banc folia babere rufco fimilia, fed maiora, molliord, or candidiora: ramos dodrantales, in terrain parfos: radic em rufco fimilem, maiorem tamen, molliorem, or odord= tam. Cui uires tribuit ad difficiles partus, ad urine ftillicidium, er ad fanguinem exirabendum. His accedit, quód ("ut Diofcoridesteftari uidetur) Laurus Alexandrina fructum fert rubrum, ciceris magnitudine, inter folia, non autem in medijs folijs, ut bippoglofjum, or rufcus. Ex bis itaq; tum notis, tum uiribus, que in bifce duabus plantis 40. maximé pugnare deprebenduntur, omnibus abunde conftare arbitror, hallucinari $\mathrm{cos}_{2}$ qui putant $\mathrm{L}$ aurum banc, $\mathrm{C}^{-}$ bippogloffum unamer eandem effe plantam. Nos equidem bane, cuius bic figuram damus, ueram ac legitimam $L d=$ urum Alexandriname effe cenfemus, qua (ut pictura pulchré demonftrat) non parum ab bippogloffo differt. Huic. alteran adiecimus, que o ip $\int a$ baud dubie, ni fallor, fuerit Laurus Alexandrind, $\sqrt{2}$ buic fructum in medijs folijs innafci concedamus. Lauri Alexandrine uires memorie prodidit Galenus libro vi. Simplicium medicamentorum, ficinquiens. Lauri herbe, quam 0 Laurtom Alexandrinam appellitant, temperatura euidenter eft calida, o gu= fantibus acris finul e fubamard eft: pota q́; tum urinam, tum menfes prolicit. Planta Grecis $\delta \alpha^{\prime} \Phi u$ a $\alpha^{\prime} \lambda \boxminus \xi \alpha^{\prime} y=$ Sesso, Idtinis Laurus Alexandrina dicitur: Arabibus, Gar Alexandria : Italis, Lauro Aleffandrino.

Iauri Alexan drinęivires ex Gal. Nomina.

\section{$\triangle Q \Phi$ VOE $\delta \dot{s}$. DAPHNOIDES.}

CAP. CXIIII.

D A P H N O I D E S cubiti altitudine fruticat, ramis flexilibus, oblequiofisqque, multis, à medio furfum verfus foliofis : cortex fupra modum vifcofus ramos veftit : folia lauri, graciliora, \& molliora, fractu contumacia, quorum guftatu os \& fauces incenduntur : flores candidi : bacca, cùm ematuruerit, nigra : radix inutilis . nafcitur in montofis. Pituitam extrahit folium recens, vel aridum in potu : menfes ciet, \& vomitum : caput inanit commanducatum : fternutamenta mouet. Bacca quindecim potæaluum refoluunt.

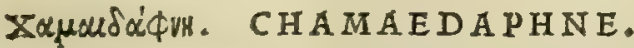

CAP. CXIIII.

C н A M AE D A P H N E virgas emittit cubitales, fingulari ramulo conftantes, reetas, tenues, Laues : folia lauri fimilitudine, læuiora multò, ac viridiora: femen rotundum, rubens, annexum 
folijs . Illinuntur capitis doloribus trita folia , \& ftomachi ardores mulcent: ad fedanda tormina cum vino bibuntur. Potus cum vino fuccus menfes, \& vrinam ciet: idem facit peffo appofitus.

DAPHNOI DES.

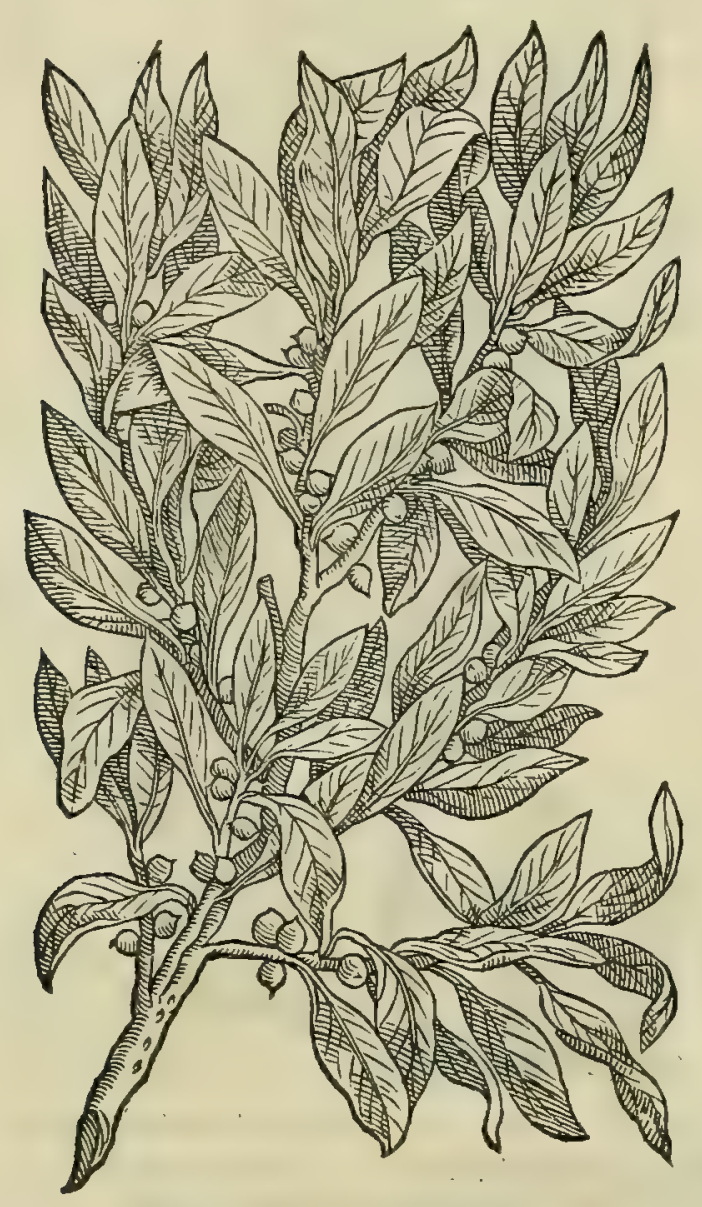

CHA MAEDAPHNE.
Daplinoidis, \& Cham edaphnes cófid.

Multorumer ror.

Daphnoidis, \& Chamædaphnes uires.

Nomina.

D A P H N O I D E S, quam officinx, o herbariorum unlgus $L$ aureolam uocant, frutex eft uulgaris notitic: Prouenit bec frequens in uallis Anania montibus Tridentino agro, nullis prorfus reclamantibus notis. Cubitalibus enim afjurgit uirgis, flexilibus, obfequiofis q́; : folijs numerofis, fur fum ppectantibus, lauro fimilibus, gracilioribus tamen, ac mollioribus, acerrimo guftu: quin o ramorum cortex admodum tenax eft. Hinc itaq; fit, ut eos errare. toto calo deprehendantur, qui putăt Mezereum Mauritanis uocatum effe Daphnoidem. quandoquidem Mezereon Cbamelea eft, de qua fuo loco differèmus. Porró Chamedaphne, quam Laureolam marem pleriq; cognominant, 40 folijs ac fructu à Daphnoide non longé differt : uerùm biec tantum intercedit differentia, quòd Chamedaphne fingu= lari rectoó; caule conftat, cui folia circumquaq; prominent, adeo ut in cacumine in orbem umbelle inftar diradien= tur: femine inde prodeunte Daphnoidis modo. Caterim, quód uocauerit Plinius Chamedaphnen eam clemati= dem, quam aliqui vincam peruincam appellant, credidere quidam hanc Diofcoridi effe Chamedaphnen. Sed pro= fectó y falluntur : error q́; omnibus etidentior fiet, qudm ut, pluribus explodi poftulet, fi modó contemplentur,

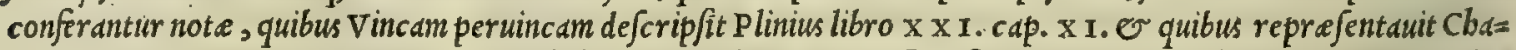

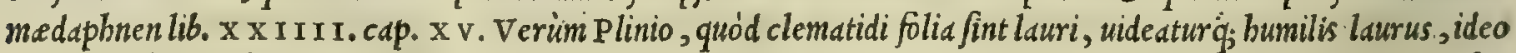
non temeré eam Chamedaphnen diciplacuit. Sunt, qui Laureole fructum Piper montanum uocent, quanuis rufti= cis Ananien fibus nil aliud fit piper montanum, quàm Diofcoridis granum Gnidium, ut infrà fuo loco dicemus. Da= phnoidis, e Chamadaphnes uno tantùm capite meminit Galenus libro v I. fimpl. medicamentorum, fic inquiens. Chamedaphnes germina tenera edi quoq; affolent. Eft autem perfimilis viribus lauro Alexandrina : ficut fané o

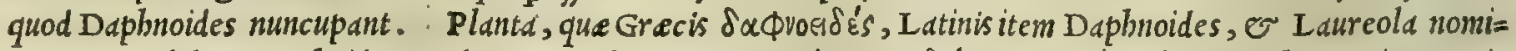

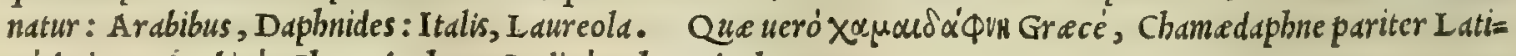
né dicitur : Arabicé, Chamedaphnes: Italicé, Chamedaphne.

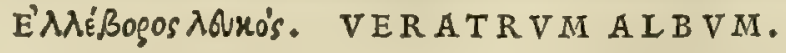

CAP. CXLV.

E L I E B O R V M album, Latini veratrum album uocant, fert folia plantaginis, aut betæ fylueftris firmilia, fed breuiora, \& nigriora, rubefcentia : caulem cauum, quadrantalem, tunicis conuolutum, quas abdicat, cùm arefcere incipit, radicibus nititur multis, tenuibus, ab oblongo, \& exiguo capite ceparum modo exeuntibus. nafcitur in montibus, \& afperis. Radices mefsibus colligendæ . Opti- 


\section{In Lib. quartum Diof coridis.}

mum habetur candidum, friabile, carnofum, modicè extentum, nec tamen iunci modo mucronatum, quod fiangendo puluerem emitcit, \& tenuem habet medullam, guftu non admodum feruens, neque faliuam fubinde cicns. huiufcemodi autem ftrangulat. Primatum Cyrenaicum tenet. Galaticum autem, \& Cappadocicum candidioră, \& puluere quodam obfita, celcrius ftrangulutus mouent.

Vomitione autem uarios extrahit humores. Collyrijs admifcetur, quæ caliginen oculorum difcutiunt . partus impofitum nccat, menfes pellit, fternutamenta excitat: mures interficit, cum melle, \& polenta fubactum : ablumit carnes, fi coquatur unà. Datur per fe iciunis, \& cum fefama, aut ptifanæ fucco, aut halicx, aut lcntis cremore, cum aqua mulfa, aut pulte, aut quauis alia forbitione. Cogitur cum pane, \& ita inafiatur. Præparatio corporum, ac uictus ratio diligenter tradita cft, cùm $20 \mathrm{ab}$ his qui de medica eius potione fcriptitarunt, tum maximè à Philonide Siculo Ennenfi, cui nunc affentimur: quippe longum nimis effet in hac prafertim editione de materia, fimul nedicam curandi rationem exponere. Dant nonnulli in pultis forbitione, aut copiofo halicæ cremore, aut paucum antea cibum dari præcipientes, ftatim ueratrum offerunt, ijs præfertim, quibus frangulationis fufpicio imminet, aut fi ualetudo corpus infirmat: hocenim modo deiectio nihil periculi minatur, quòd cibo munitis non intempeftiuè medicamentum corporibus offeratur. Vomitiones concitant fubditæ cx co balani cum aceto.

VERATRVM ALBVM:

20.

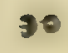

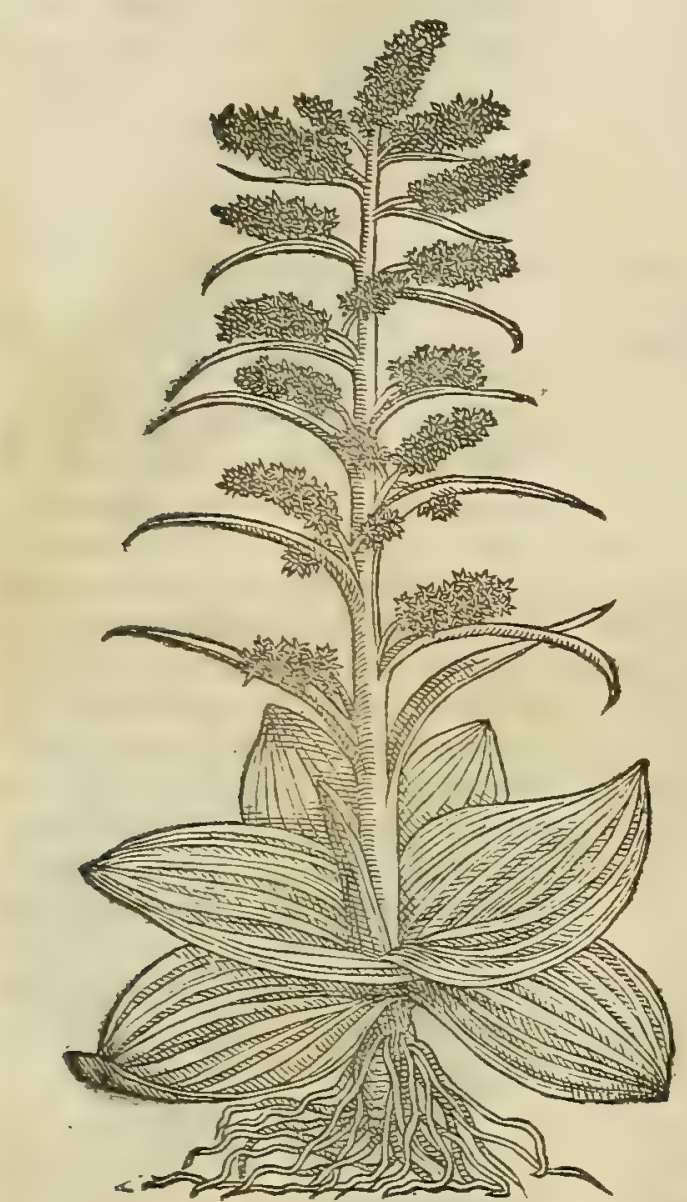

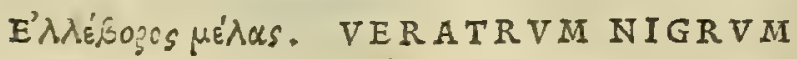

VERATRVM NIGRVM.

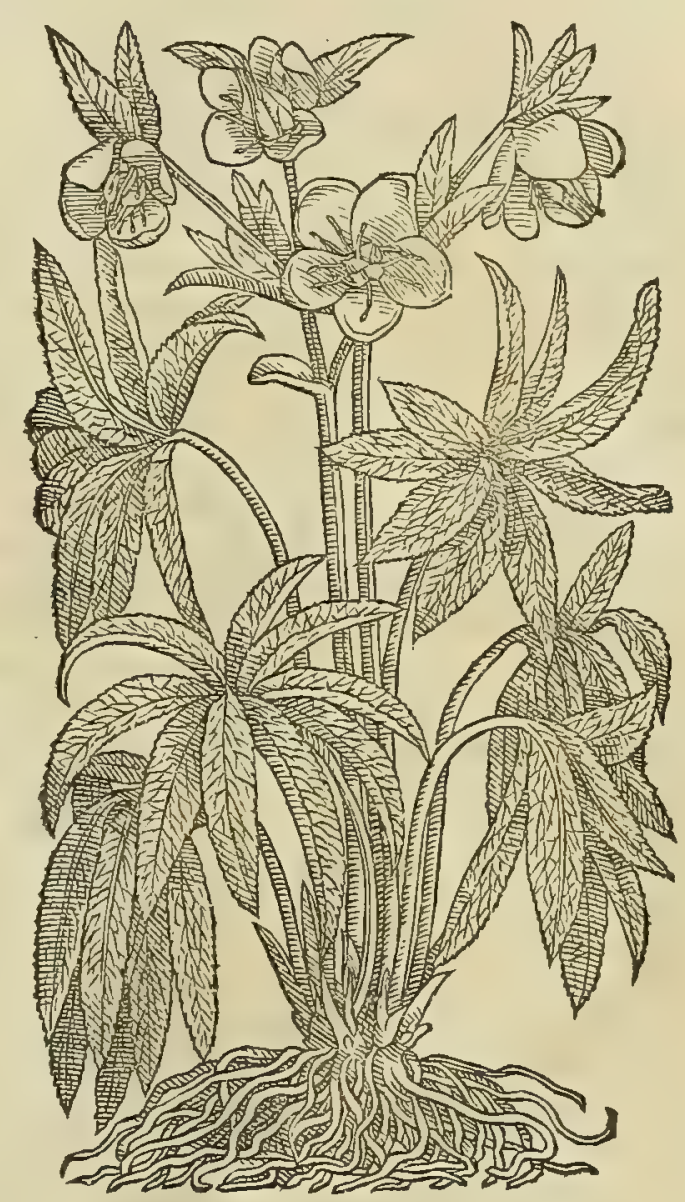

CAP. CXLVI.

E L L E B O R V M nigrum appellatur melampodion, quoniam caprarum paftor nomine Melampus furentes in fe Prœtidas primus purgaffe, \& fanaffe fertur . Folia ei uiridia, platani fimilia, minora, fclijs fphondylij proxima, fubafpera, nigriora, pluribus diuifuris incifa: caulis afper: flores in purpura albicantes, racematim cohærentes : femen cnici, quod in Anticyra fefamoides uocant: quo deiectiones moliuntur. Radicibus cohæret nigris, tenuibus, à capitulo cepæ fimili confibratis, qua rum eft ufus . In collibus, afperis, \& fitientibus locis enafcitur. Optimum eft, quod ex huiufmodi petitur terris, ut ex Anticyra. Nigrum inibi probatifsimum gignitur. Eligi debet corpulentum, \& plenum, in quo tenuis fit medulla, acre guftu, feruensq́ue : cuiufmodi eft in Yelicone, Parnafo, \&r Aetolia natum : attamen Heliconium præcellit. Veratrum nigrum purgat uentrem, detrahit bilem pituitasque, datum per fe, aut cum fcammonia, \& tribus obolis fiue drachma falis. decoquitur uel cum lente, \& iufculis, quæ purgationis caufa fumptitantur. Prodeft morbis comitialibus, melan-

D 2 cholicis, 
cholicis, infanientibus, articularijs doloribus, \& refolutis. Menfes inditum trahit, partus necat: pur gat fiftulas impolitum, \& tertio die detrątum. Item contra grauitatem auditus in aurem demittitur, ibiq́ue in alterum, aut tertium diem effe finitur. Scabiem fanat illitum cum thure, aut cera, \& pi-: ce, \& cedrino oleo : vitiliginibus, lepris, impetiginibus ex aceto medetur: dentium dolorem collutione mitigat . Erodentibus medicamentis commifcetur: hydropicorum ventri utilifsimè imponitur fątum ex eo, farina hordcacca, \& uino, cataplafma. Confitum proximiè radices uitium, uinum purgandi facultate donat. Huius refparfu domos expurgari arbitrantur: quare inter fodiendum ftan tes Apollinem, Acfculapiumçue precantur, ac uitant aquilæ uolatus : aduolare enim non fine periculo tradunt. nanque fi auis effofsionem ellebori confpexerit, moriturum qui fuccidit, auguriug eft. Celeriter efiodiatur oportct, quoniam halitu capur aggrauat : quapropter ad id arcendum, foffu- $\mathbf{x}$ ri allium præfumere, \&̈ uinum bibere confueuerunt: nulli ita noxæ opportuni redduntur. Veratri albi modo emedullatur,

Lllebori utriufq; confid.

Herophilifen tentıa dảnata.

Opinio quorúdan reprobata.
E I I E B O R V M, quod बr Veratrum Latinis dicitur, tam albun, quàn nigrum omnibus, ni fallor, notum eft in Italia. Et quanuis inibi unum tantimn Ellebori albigenus inueniatur; nigri tamen tria nobis comperta funt ge nera, flcre duntaxat inter fe diltincta. Vnumi quidem flores profert purpureos, quales fuo reddidit Diofcorides: alterun ueró candidos: tertium deniq; berbaccos. Hec ut flore diftinguuntur; ita etiam uiribus inuicem differunt.

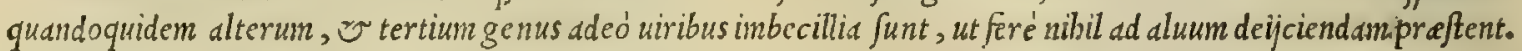
Id quod ficto periculo didici, cum primunt elleborigenus flores ferens purpurcos nobis non effet ad manus. Huius radicum diluto ex more noftro parato, byeme ctiam media, of m.tgis urgente frigore (etfilid improbent medici) praparata prius diutitus materia decoctis, ac Jyrupis ad id facientibus, plures quartana febre laborantes Sanauimus. Nunquam cnin, quod meminerim, boc ellebori dilutum dedimus quartanarijs noftris, quin ex unica affumptione, uel Saltem altera, Deo iunante, fuerint ad fanitatem reftituti. Catcrim albi quoq; ellebori dilutum exhibuimus quibus= dam m: lancholicis, magno fané fucceffu: nullo tamen agrotantiun incommodo, null aq; noxa. Quod non alia ex cals fa eucniffe putauerin, quàm quód in Tridentino agro, alijsq; circim finitimis locis, ea fortaffe fit illius creli tempe $=$ ries, ut non adcó pernicio is facultatibus fcateat utrung; ellcborum, quemadmodum illud, quod in cafidioribus proue = nit regionibus: tamet fi non dubitaucrim etiam utriusq; accrrimam uim reprimi,ac corrigi proprijs quibusdam addi= tis medicamentis. Vifuntur nigri uniuer $\int a$ genera Martio, o Aprili menfibus unto o eodem loco florere in amplif= fima fylua, per quam tranfeunt, qui Goritia Labacum Carniole urbem proficifcuntur, ubi er nos preft antißinum $\int e$ pius legimus. Purpurci radices nigriores, carnofiores f́, cxtcris babentur : cùn aliorum generum radices ut pluri $=3 \sigma$ mim fubalbida pectentur : omnibus tamen in uniuer fim eadem cft foliorum facies. Heroplilus antiquißimus me= dicus clleborum fortißinn duci equabat: concitatis enim intus onmibus, ip fum in primis cxire dicebat. Ideo erranif= fe antiquos parcius id prebendo, cisn celerius erumperet, quod darctur largius. Sed hec Heropbili fententia nó pla cet noftra etatis medicis, neq;; etiam nobis, ut qux pluribus damnari, or explodi poßut. Elleborus mger. boues, $c=$ quos, o fues necat; proinde id in pafcuis caucnt, quanuis album innoxic depafcantur. Nigri radices denor fis à fer pente quadrupedibus mirifice medentur, fi recentes in uulneris ofculum, fublata d̀ carne cute, immittantur, quód tta eidculatum rcuocent uenenum : quin or illud idem prodef, fi gregi peftilentia ingruerit, in auribus traiecta, uel pe= Itori infixa radice. Qua ratione ducticredidere nonnulli, id etiámnum in hominibus ficri poffe, quód fi in perforatam calcanei cutem nigrum elleborum inferatur, cos omnino à peftilentia tutos reddat, qui geftauerint. Elleborifemen, Ariftotele autbore, coturnicibus gratißimum eft: quam ob caufain antiqui eas abdicarunt menfis. que tamen bodie 40 imagnopere expctuntur. Porrỏ nondefunt é recentioribus, qui putcnt nigrum communis ufus Elcborum, cuiflo= resherbacei infunt, non elleborum, nec eius peciem effe, fed eam fane plantam, quam Columella, $\sigma$ Plinius Confili= ginem nocant, quam q́; ad pecorum pulmonarian curandam, peftilentiamí;; arcendam funmis laudibus efferunt, boc tantum puto argumento freti, quód fcrip ferint ij, fi in morbofi quadrupedis auricula cöfiliginis radix infer atur, per= forata ferro prius aure, omnem inorbi uin é confluere, o per illud for amen peftilens uirus elici. Siquidem cüm pare ftores buius atatis obferuatuerint, id totum (ut nos quoq; pauló anté diximus) praftari tantim illius ellebori radici= bus, exftimaucrunt boc ueratri nigrigenus, quod flores rubentes non proferat, uel (ut Diofcorides inquit) in pur=

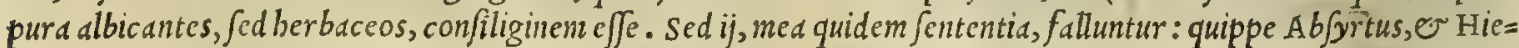
rocles idem praftare nigrum ueratrum affirmant, Quibus etiam fubfcribit Pliniius lib. $\mathrm{x} \times \mathrm{v}$. cap.v. bis uerbis. Ni= grum elleborum pecorum, e iumentorum pituit as fand, furculo per aurem traic $c_{0}$, $\odot$ poftera die eadem bord ex $\tilde{c}=$ pto. bec Plinius. Ex quibus utiq; perpicuum fit, non modó confiliginis, fed etiam nigri ueratri radicem hac omnis efficere poffe. Vanum profectó effet dicere, exempli gratia, fabinam effe calamintbam, uel contrà, quòd utra $q$; $r e=$ moratos menfes eliciant . quafi natura adeó fuerit auara, ut unicuiq; morborum generi unum tantùm genucrit medis camentum, cum tamen nullus fit morbus, cui innumer as non creauerit meáicinds, uno $\mathbb{E}^{-}$codem ordine adbibend ws. Adde etiam, quód cum nullus extet author, quod ego inuenerim, qui Confiliginis biftoriam defcribat, neq; kna quidé nota eius faciem reprafentet, non uideo, quomodo recté ij afferere poßint, ueratrum noftri ufus effe confiliginem. sciant itaq; uelim, qui nigrum herbaceifloris Elleborum ideo Confiliginem effe contendunt, quód pefilentibus peco $=$ rum morbis prefens remedium fit, fi eius radix auriculis, of alijs corporis partibus inferatur, id fucceffu longé me= Viori effici, fi rubentis floris elleboro idem fiat, cituusqi; expurgari uirus illud peftilens, quód buic uires infint ualentio res. Horum quidem opinionem ut plané fequitur Fuch/jus uir doctifimus in libro de compofitione medicamentorü, quem poftremó auctum ediäit; ita etiam idem, meo iudicio, in manifffto illorum errore uerfatur. Catcrum hic non 
eft filentio dißimulands inepta fatis, Er una, meo quidem iudicio, de nigro ueratro opinio Vgonis Solerij, uiri alio= qui doctißsimi, ut cius tcftantur fcholia, que nuper in priores Ačtij libros cdidut. Is cmim in predittis fcholijs cenfet, Elleborum noftru ufus twun illud, quod flores fret rof arum modo purpureos, quàm quod albos, effe lycoctoni, uel cyno etoni aconiti fpecies: quod uerò berbidos babet flores, Plinij $\sim$ Columelle Confiliginem, aliorum iudicium fecutus. Quod quibus rationibus comprobct, ex cius uerbis, que modó referam, cognofci poterit . si quis, inquit, commemo= ratarum iam plantartum radices diligenter expendat, nibul illas cum nigri ueratri radicibus ( $q u c$, tcftc Diofcoride, cep $x$ modo bulbo fe fint, erumpentibus ab ino car un bulbo multis radicibus ) commune babcrc multó cuidentius com periet, quàm ut pluribus demonftrari nunc debcat. Taceo nullum cx his plantis dum uclluntur, capitis dolorem ob uaporum halitum concitari, ut ip fe millics fum expertus, id quod in nigri ueratri eunlfione tc fatur Diofcorides. Ex

to bis igitur conftat, nullan barun trium plantarum ad nigrum ueratrum fatis apté poffe reduci. quin duss priores aco= niti lycoctoni poftremss pecies effe, poftremam berbam Juigeneris. hec solerius. Quibus ucrbis eum inme egiffe, licet non aperté, mestmi; oppugnaffe fententiam ex hoc plané conijcio, quód nullus, quod fciam, ante nos feripferit, tria in I talia, ac priuatim in Carnol reperiri nigri ueratri geneva, florun tantum colore diftantia. Neque id certe agréfero, quód libenter dudium, indics noun in re berbaria proferri fententiss. Velim tamen id liberius, apertius, Cirmioribus tun rationibus, tum auctoritatibus fieri. Redeo ad Solerium, cuius fané hac in re argunenta inc faci lé diluerc poffe pero, utpote que (pace eius dixerim) leuia fat is fint, or prorfus à ueritate defcifcant. Nam falfum. cffc, ac nimis fort.tfe temeré dictum arbitror, quód Ellebori genera illd, quorum fuperius meminimus, ncn mittant ra dices ( $u t$ Solcrius afferit) tenues, nigras, à cepacco quodam capitulo pendentes, ac confibratas : cum omnibus non modó reiberbarie peritis; fed etiam pharmacopols, ne dicam lippis, e tonforibus, manifftum fit, nigri ueratricom=

20 munis ufus radices non aliunde, quim àbulbaceo quodam tuberculo omi cx parte pendere nigras, ac graciles: non autcm cepe modo bulbofas $\mathrm{e} \int_{\mathfrak{e}}, \mathrm{C}^{\sim}$ ab imo bulbo multas erumpere, ut ille pronunciauit. Vnde facilé adducor, ut cre $=$ dam, fi licet ingenué dicere quod fentinus, solerium aut Diofcoridis lectionem luxaffe, aut cam minus reate perce=

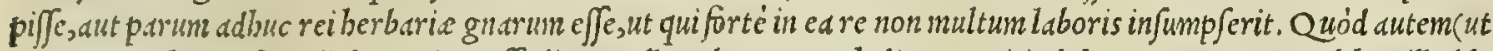
idem ait) ex hoc noftro elleboro, dim effoditur, nullus ob usporum balitun capitis dolor concitetur, or ob boc illud le gitimum cffe non poßit, nulla bee cft ratio apud me. Neq; enmmirum alicui effe debet, cur id non faciat: quoniam Diofcorides non dicit, quod Elleborum nigrum effodictibus capitis dolorem inferat, fed quód balitu caput aggrauat : Quam nimirum grauitatem id, cuiflos purpurafcit, tanquan cateris acrius, apud nos fapius cxcitat, prae fertim fi li= gone unlnerentur radices, $\mathcal{O}$ uentus aduer $\int a$ parte piret. Id quod fortaffe in Anticyra, Helicone, Parnafo, O Ae= tolia ualentius presat. quandoquidem, Diofcoridis tcftimonio, ijs in locis acre guftu, feruens q́; , er omnium proba= 30 tißinum gignitur climatis illius ratione quod in Gallia fortaffe, $\sigma$ in Germania coeli inclementia non euenit. Ca $=$

\section{CONSILIGO.}

40

50

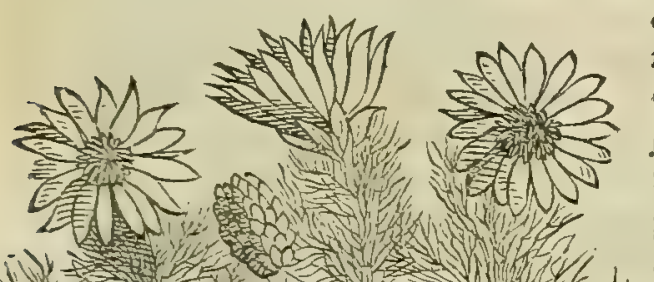
terum quód priora nigri Ellebori generd, que flore tum purpu= reo, tum albo conftant, aconiti cynoctoni, uel lycoctoni fint pee= cies (ut Solerius fibiperperàm, med quidem fententia, perfuafit) mibiplané abfurdius uidetur, quàm ut ab aliquo approbari poßut, o debeat. Ea fiquidem aconitorum genera iam omnibus clarif= fimé innotuerunt, funt '̆́, caule filicis fimili, cubito longiore, or radicibus adeó tenuibus, ut fquillarum marinarum cirris eas com= parauerit Diofcorides. Que fané omnia in nigro veratro commu nis ufus nüquam quis inueniat. Huc preterea illud accedit, quód nobis idm millies experimento compertum eft, nigrum communis ufus ueratrum, quod proprio fungatur munere, atrabiliarios $0=$ mnes fandre morbos: fiftulas callo induratas tribus diebus impoof tum emollire, er purgare: in aurem demiffum auditus grauitate auferre: : Fabiem, uitiliginem, lepras, er impetigines illitum emé= dare: $\sigma$ carnem in ulceribus excrefcentem abfumere. Quibus tamen uiribus non Aconitum cynoctonon, fed Elleborum predi= tum e effe, in confeffo eft . Ex his itaq; omnibus abunde perpicumm fieri puto, in hoc solerij opinionem prorfus explodenda a efe : et/f idem in aliys quog; nion paucis, meo iudicio , falli deprebendatur.

sed iam nos quoque de CONSILIGINE noftram proferd= mus fententiam. Ea quidem nobis hatenus incomperta fuit, quód neminem ex fcriptoribus tam ueteribus, qudm recentioribus inue nerim ( ut fuprà dixi) qui eius not as memorie prodiderit. At $\dot{q}^{\prime} d=$ deóbinc fit, ut non au/im ego afferere plantam illam, quam bic de pingicuratuimus, effe ueram ac legitinam Confiliginem. neq; $e=$ nim eft, cuius auctoritate fretus poßim eam radicibus, foliis, cau= libus, floribus aut feminibus comprobare. Verum quoniäbuiufce planteradices per auriculam perforatam inferte, pecorum pul = monariam atque etiam alios morbos curant, ellebori nigrimodo, facilé adducor, ut fermé Juficer can effe uerain columelle or plinij Confiliginem. Hanc ueró plantam Hieronymus Tragus, 


\section{And.Mathioli Comm.}

cuius fape teftimonium adfert er probat Ge finerus, putat effe legitinum Veratrun nigrum. Sed is ut in hac eviderts tius errat, qudin ut mediocriter etiam in re berbaria uerfatis oftendi debeat; ita in multis alijs plantis, quorum nume= rum referre longum effet, à peritis bexbarum facilé cognofcitur uanum atg; leue iudicium babuiffe. Plantan, chius bic inaginem exbibuimus, coniectur a quadam ducti ean Confiliginem effe, defcribamus. Hac ad duûn palmorunn lon gitudinem affurgit . cauliculos emittit tenues ac molles. folia babet longiufcula, tenuia, quadantenus abrotoni . flo= res profert buphthalmi, paulo maiores.: ex quibus prodeunt capitula oblonga, ruborum moris fimilia . radicibus ni= titur nigris, nigrum ueratrum cmulantibus, tenuioribus tanen, or aliquantó nigrioribus. Flurima nafcitur in Bobe= mia, prefertim in agro Pragenfi. Ea utuntur onnes illius regni tum inedici, tum pharmacopæei pro elleboro nigro: Elleboriutri- priuxtim magno fucceffu ad pecorum morbos. Reliquum autem eft, ut de utriufq; Ellebori uiribus iam aliquid di= ufque uires. camus. Album, ut Me fues in fuo de medicamentis deiectorijs cenfu prodidit,mortiferun çt, quód facilé bomines fuf= focare poßit : idcirco omnino reijciendum efe precipit. Nigri tamen ufun prob.ti , Sed in ualidisimis tantium corpo= ribus. Quzod fané decretum nonnullos adeo perterruit, ut non modó fuis medicamentis Elleborum admifcere non au=. deant; fed o nomen abhorreant. Verüm ij ridendo potius timore quodam ducuntur, quàm quòd iure ufqueadcó $\mathrm{pl}=$ leboro refragari debeant. Siquidem ego teftari pofjum, me fexcentis ferme hominibus nigri ellebori dilutül exbibuiffe. nullo prorfus incommodo: atq; etiam eiufdem diluti faciendirationem quàm plurimos docuiffe medicos, qui, facto fubinde periculo, effectum confecutif funt, unde ingentes mibi gratids retulerunt, qua meritó debétur elleboro. Pre $=$ stat quod, euulfis ftatim radicibus, interna repurgatur matric,, ficcaturó;; in umbra. Harum puluis diluto longé for = tior eft : ob id enin non datur nifis robuftis, es ubiobcalluerit morbus. Proinde de eo ita criptum reliquit Actuarius in libro de compofitione medicamentorum. Veratrum nigrum, atram bilem flauam '́ é toto trabens corpore deor= fum, nec tamen citra ullam difficultatem pellit. Ideo fibribus circuiturepetentibns, e diuturnis obijcimus. Datur quoq; infanientibus: altera caluaric parte, o fubter caput diutiné cruciatis commodißimum : prefertim uifceribus, utero, o uefica deicctorium medicamen poftuldntibus. Maxima autem eius uis eft peculiariter educere, quicquid. fanguini commiftum, eum corrumpit. Ideo ueterafcentibus arquatis morbis utlle : $\mho^{\circ}$ quibus in fuperficie fummatim aperitudines emerferunt, uelut lepris, impetiginibus, er horum fimilibus : elephantia quog; laborantibus accommo= datune eft. Datur fcrupulorum termûm pondere, aut paulo plus minusue. Fit é ficcis radicum fibris, aqua paulim ma ceratis: poflea cortice detracto, e in umbra ficcato, proiect a'́, tenui, que in ipfa fubeft, medulla. Exbibetur auten ex paffo, a aceto mulfo : uerüm fuauitatis gratia, quedam ex odoratis feminibus inferenda. Si ueró efficacioré alui

Ellebori vtri- deiectionem molirifit in animo, $\int c a m m o n i j ~ p a u x i l l u m$ adijcito. baderius Actudrius. Ellebori utriusq; uires pofle $=$ uโq; uires ex ritatis memorix tradidit Galenus lib.v I. fimpl. medic. fic inquicrs. Elleborus uterq; tum albus, tum niger extergen
Galeno. tis fimul er excalfacientis eft facultatis. Quamobrě ad alphos, impetigines, fcabies, lepras ǵ; accommodi funt. Quin= 30 etiam niger, fi in fiftulam callo induratam demiffus fuerit, duobus tribusue diebus calli detrahit. Dentibus prodeft $c \tilde{i t}$

O P H R I .

Ophris defcri

prio, \& uires.

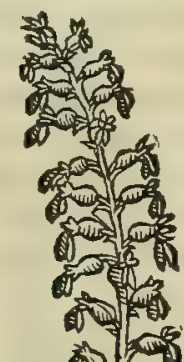

Nomin: aceto colluentibus. Sunt autem intertio ordine excalfacien!ium, o deficcantium. Porró niger guftu calidior eft, cädidus fubdma rus.Hactenus de utroq; Elleboro Galenus. Celerim quxdä plä= ta reperitur i recentioribus O P H R I s appellatd, que folijs ma= ximé album ueratrum reprafentat. Duo tantim bec folia pro= fert: inter que caulis erumpit, capitulis quibusdan oblongis in uniuer fum refertus : é quibus flores exeunt cădidi, exiguis linguis fimiles. Radice nititur gracili, non fine multis appendicibus, odo re praftanti.Prefertur uniuer da planta ad denigrandos capillos, fracturas $\int a n a n d a s$, et uulnera glutinanda. Illa planta, qua Gre cis $\varepsilon \lambda \lambda e^{\prime}$ 'bogos $\lambda$ Euno's, Latinis Elleborus albus, et Veratrü alb appellatur: Arabibus, Cherbachem, Jeu Charbech abaid : Italis, Elleboro bianco:Germanis, Vuc is nie $\int z$ uurtz:Hifpanis, Verde gä bre blanquo, et yerua de ballefte: Gallis, viraire, Vcrarum, Verd=

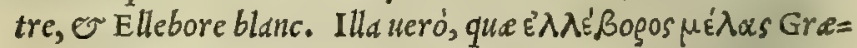
cé,Elleborus niger, $\mathcal{O}^{\circ}$ Veratrum nigrum Latiné dicitur: Arabi= cé, Cherbachem, feu Charbech afued:Italicé,Elleboro nero: Ger manice, Chrift uurtz: Hipanicé, Verde gambre negro, or Elle= boro: Gallice, Viraire, $\widetilde{E}$ Ellebore noir.

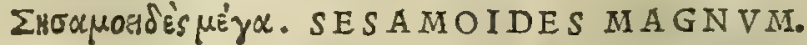 CAP. CXIVII.}

S.ES A M O I D ES magnum in Anticyra clleborum uocant, quoniam albo ueratro in purgationibus mifceatur. Simile cft fenecioni, aut rutæ: longo folio : fore cădido: radice gracili, ignaua : femen guitu amaro, cætera fefamæ fimile. Ventrem detrahit datur tritum ad bilis, pituitæáue deiectionem, quantum tribus digitis capitur, addıto ueratri albi féquıobolo, ex aqua mulfa. 
SE S A M O X D I paruo cauliculi funt dodrantales: folia coronopi, minora, hirfutiora : : 2 in cauliculorum cacumine capitula florum penè purpureorum, medio eorum albo: femen fefamæ, fuluum, amarum : radix tenuis. Detrahit bilem, pituitasque femen ex aqua mulfa potum dimidio acetabulo : illitum ex aqua tumores, ac tubercula difcutit. Nafcitur in afperis .

$\mathrm{N}$ o $\mathrm{N}$ eft, quód in rebus incompertis longiorcm mor am nos ducere oporteat. quandoquidem bactenus non fo=

o lim ipfenon reperiun Italiamaius, aut minus Sefanoidis genus, etfin corum inquifitione multum laboris ac ftudij impciderim; fed neque etian ullum inucnire contgit, qui unum, uel alterum legitimé oftenderct. Quare bas plant= tas deinecps perquirendicuran ijs relinquemus, qui nauigationibus Anticyram petunt. Illud Graci onopuoet=

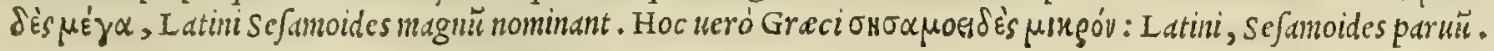

Nomina. sinusäygros. CVCVMER SYLVESTRIS. CA P. CXLIX.

C v C V M I s fylueftris fructu folo diftat à fatiuo cucumere, quem longè minorem parit, oblongis glandibus non difsimilem : folia, atque farmenta fatiui refert : radicc candida, magna. Nafcitur in fabuletis, \& ruderibus. frutice in totum amaro. Inftillatus foliorum fuccus aurium dolori conuenit. Illita ex polenta radix, ueterem omnem tumorem difcutit: impofita cum refina terebinchina, tubercula rumpit:ifchiadicis infunditur: podagras difcutit, decocta ex aceto $\$$ illita. Eius decocto dentes in dolore colluuntur. Arida farina impetiginem, lepras, \& uitiligines abfterget: nigris cicatricibus colorem reddit, \& in facie maculas expurgat. Radicis fuc cus fefquioboli pondere, \& item cortex acetabuli quarta parte, bilem, pituitamq́; deijciunt, præfertim in hydropicis: deiectiones autem citra ftomachi iniuriam mo uet. Radicis felibra, in uini præfertim Lybici hemina conteritur, danturq́ue ex eo terni cyathi tiiduo, dum tumor abunde deprimi cernatur. E'fructu huinfce cucumeris fit medicamentum, quod Elaterium uocatur, ad hunc modum. Decerpti cucumeres, qui tacti protinus exiliunt, feruantur nocte una poftride impofito fupra craterem rariore cribro, utrisque manibus prehenfi, figillatim fupino cultro, furfum uerfus aciem habente, finduntur, atq; per cribrum humor in fubie?tum uas exprimitur : fimulque carnofum, quod hæfit cribro, quò facilius excidat, eliditur - quod ita preffum eft, refidere finitur, atque in uicinam peluim demittitur . Coaceruata autem in cribro fegmina dulci aqua perfunduntur, \& linteo opertus, foli exponitur: dumq́; fteterit, tota fupernatans aqua cum humore concreto, effunditur. Hoc uerò identidem fieri folet, donec exiftens aqua liquefcat : qua ftillatim exhaufta, fedimentum mortario fufcipitur, \& conterendo cogitur in paftillos. Sunt qui ad hauriendam protinus fucciabundantiam, cribratos cineres humi infpargant, \& medium cauantes, triplicatum linteum ob-

so tendant, per quod elaterium cum fua humiditate diffundunt, ficcatumq́ue in pila, ut dictum eft, conterunt. Aliqui pro dulci acqua marinam perfundentes, ita eluunt. Alij in nouifsima lotione mulfam aquam refpergunt. Elaterium optimum effe conftat, laue, non ponderofum, cum candore leniter humectum, guftu amarifsimum, quodq́ue lucernarum luminibus obiectum, facilè flagret. Porraceum tamen fabrumq́ue, fi turbidum fpectetur, atque erui cinerisque plenum fit, graue $8:$ uritiofum effe folet. Nec defunt, qui cucumis fucco amylum immifceant, vt candorem ipfum, \& Ixuitatem imitentur. A'bimatu ad decennium deiectionibus utile eft. Integer modus obolus eft, minimus femiobolus, pueris chalci duo, fiquidem copiofius, periculum adfert. Bilem, ac pituitam utráuis parte extrahit. optima fufpiriofis elt purgatio. quòd fi in animo fit deicetionem moliri, adięto falis duplo, \& ftibij-quod colorare fufficiat, ex aqua, erui magnitudine catapotia dato, poftea cyathus unus aquæ tepidæ forbeatur. Ad citandas tamen uomitiones aqua diluens elaterium, fubiectas lingux partes penitissimè penną oblinito. quòd fi quifquam difficilius euomat, oleo, aur 
unguento irino refoluito: fomnum inhibeto. Porrò his, qui cximiè uacuantur, continuè uinum, \& oleum dare conuenit : etenim uomendo reftitunntul. Quòd fi uomitiones non finiantur,aqua frigida, polenta, polca, poma, \& quæ ftomachum denfando corroborant, offerenda funt . Ciet elaterium menfes, \& partus enecat, in peffo fubditum. morbo regio medetur, cum lacte naribus infufum, \& diuturnis capitis doloribus liberat. efficacifsimè anginis illinitur, cum uetere oleo, melle, aut felle taurino.

Cucumetis fylueftris cófideratıo.

Elaterij uires ex Mefue.

Cucumeris fylueftris uites ex Gal.

Nomina.
S Y L V E S T R I S Cucumis frequens in Hetruria prouenit, prefertim agro noftro Senenfi in oppidorum pld= teis, e fecus monix, e femitas. Ex cius fructibus fuccum exprimunt officine, at f $_{\text {; }}$ Elaterium uocatum parant. De quo differens Theophraftus lib. I X . cap. x I I I I. de hiftoria plantarum, ita fribit. Sed omnium medicamento= rum diutumißimum Elaterium eft, optimum q́; quod uetuftißimum. Itaque medicus quidam, uir baud infolens, ne= que mendax, elatcrium ducentorum annorum, uirtute mirabili ferudre apud fe retulit, eo ḋ quodam munere dond= tus. Caufa, ob quam tam longo ferustri tempore poßst, bumoris copia eft: quamobrcm ucl cum praciderint, in cine= re bumidum ponunt, or tamen ne ita quidem ficcari poteft, fed $u \int_{q}$ ad quinquage fimum annum lucernis admotum lumen extinguit. Hec igitur uis peculiaris ift tribuitur. hactenus Theophraftus. A' quo maximé diffentire uidetur Diofcorides: quippe qui Elaterium dixerit à bimatu ad decenniü deiectionibus utile effe. Theophraftus ueró, idem ducentis annis mivibili uirtute feruatum $e$ ße. Quin et in eo difcordare deprebenduntur,quod alter tradiderit tantum bumoris in fe continere Elaterium, ut ufq; ad quinquagefimum annum lucernis adinotum lumen extinguat. Alter ue= ró probatißinum illud effe Elaterium, quod lucernarum luminibus obiectum, faciléflagret. Theopbrafto fubfcribit plinius lib. x x. cap. I. ubi fic inquit. Elaterium ufq; ad quinquagc fimum annum lucernarum lunina extinguit. Hoc enim veri experinentum eft, $f i$ ddmotum prius quam extinguat, fcintillare furfum ac deor $\int u m$ cogat . bac Plinius Theophraftum fecutus. Caterum hac in re facilè crediderim, Dio fcoridis codicem boc in loco omnino deprauatum effe. Quippe preter Theophrafti, or plinij Jententiam, cum omne bumidum, quod pingue non fit, ignis flammam protinus extinguat, nulli profectó dubium eft, quin Eldterium, in quo bumiditas aqued multim exuperat, potius flammam extinguat, quàm flagret: nanq; flamma admotum, excitato in bumido à calore flatu, lumen extinguit . id quod nobis aliquando experinento compertum eft. Elaterij uires defcripfit Me fues inter fua deijcientia medica= menta, ubi in hunc fenfum inquit. Cucumis fyluefris, fiue afininus abradit, $\sigma$ uaforum of cula aperit: proinde er inte ftinorum tormina excitat, or dia adfert nocumenta. Sed tolli bec omnia polfunt, $f i$ addatur aut bdelliu aut tragacan:= the lacryma, aut aqua mul a cum falis modico, aut fi ex lacte bibatur. Roboratur elaterij uis, addito foßstij falis mo= mento, aut odorato puluere, quem officine pecies elcphanginas uocant: ijs enim admiftum felicius quo ;; operatur. Purgat, ut quidam ferunt, $\int$ cammonij modo. At re uera magis pituitan dcijcit, quim bilem : quanuis o banc quan

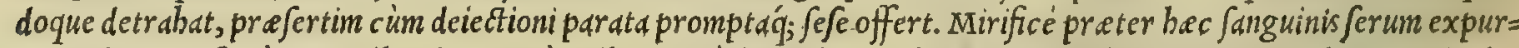
gat, ab ijs potißimim partibus ducens, d quibus egré decumbentes bumores detrabifolent ; quamobrem articulo= rum dolore uexatis opem non modicam preftat. Radix in aqua elixa, tufa, or olco fubacta cum abfintbio, diutur= nam bemicraniam fanat fincipiti, or loço dolenti illita, fi tamen prius cius decocto fouedtur locus. Preftat idem er fuccus ex lakte naribus imm /fus, quód cerebrum purget; idcirco or narium tedia delet, or comitiales iuuat. Idem obduratos refoluit abfceffus, quemadmodum er ftrumas, prefertin addito melle, or caprino ftercore. Radicis, or cucumis ipfius fuccus aqua intercute laborantibus preftantißimum eft medicamentum, quód flaudm proprie educat aquam. Ad idem ualet $\mathrm{E}$ radic is decoctum. Prodeft preterea arquatis, o iecoris, e licnis obftructioni= bus. Item ifchidicis, tum clyfteribus infufum, tum etian fi decocta radix cxterius imponatur. siccate radicis pul $=4^{\circ}$ uis, uulnerum cicatrices attenuat exmelle impofitus: or fugillata exictu delet. Eiufdem fuccus fabdcea farina ad= miftus, or linimenti modo adbibitus maculas omncs, que cutis nitorem uitiant, mirifice detergit. Sed animaduerten= dum eft, ne plusquam par fit hauriatur : quod referatis uaforum of culis fanguinem eliciat. C Cucumeris agreftis uires reddidit Galenus libro v I I I. fimplicium medicamentorum, his uerbis. Cucumeris agreftis, or fructus ip fius fuccus, quem uocant Elaterium, or non minimé radicis, acfoliorum, ad medicationes accorimodus eft. Elate $=$

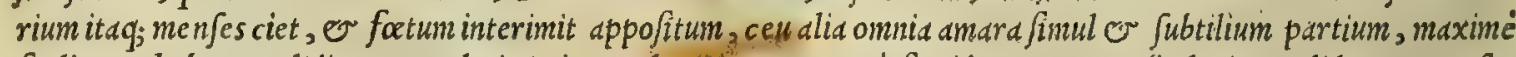
fi aliquam babeant caliditatem, ueluti nimirum Elaterium. Summé fiquidem amarum eft, leuiter calidum, ut ex fe= cundo fit ordine excalfacientium. Porró tale protinus quoq; digerendi uin poßidet. Sic igitur eo angina laboran= tes inungunt quidam cum melle, aut oleo uetere. Bonum item eft regio morbo affectis, fufun cum lacte in nares. Hoc etiam ufu dolores capitis fanat. Atq; Elaterium quidem eiu fmodi eft. At radicis fuccus, ut er foliorum, licet so elaterio fimilem uim babeat, imbecilliorem tamen. Sed or ipfa radix adfimilem facultatem poßjidet: abftergit nan= que, digerit, atque emollit. Porró cortex ea potentius deficcat. Huius planta Gracis oirus à y glos appellatur: Iatinis, Cucumis anguinus, Jylueftris, or erraticus: Arabibus, Chefe allimar, Kate alhenei, feu Chetha alhamar: Italis: Cocomero faluatico: Germanis, Vuilder cucumer, e E fels cucumer:Hipanis, Cogombrillos amargos:

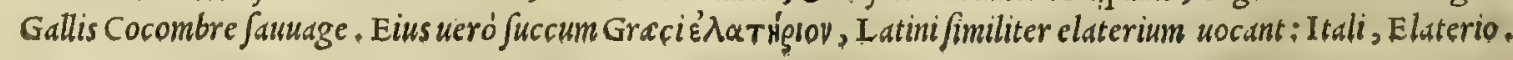

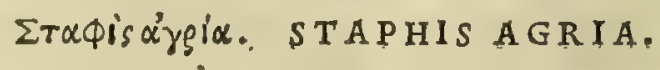

CAP. CL.

S T A P H I S agria, fue herba pedicularis, folia habet labrufcæ, diuifa: \& cauliculos rectos, mol. les, nigrosq́ue :fert florem glafti : \& folliculos uirides, fimiles ciceri, \& in his nucleum triangulum, fcabrum, ex nigro fubfuluefcentem, intus album, guftu acrem. Grana quidecim, li trita in squa 
STAPHIS AGRIA.
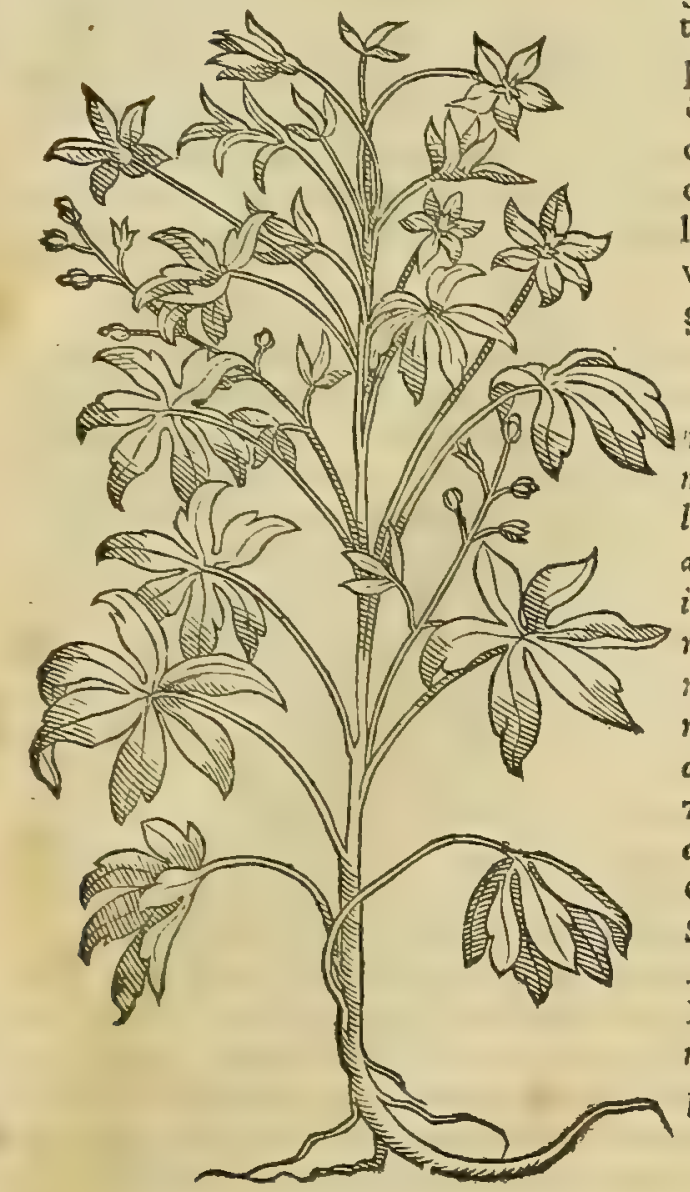

THA PSIA.
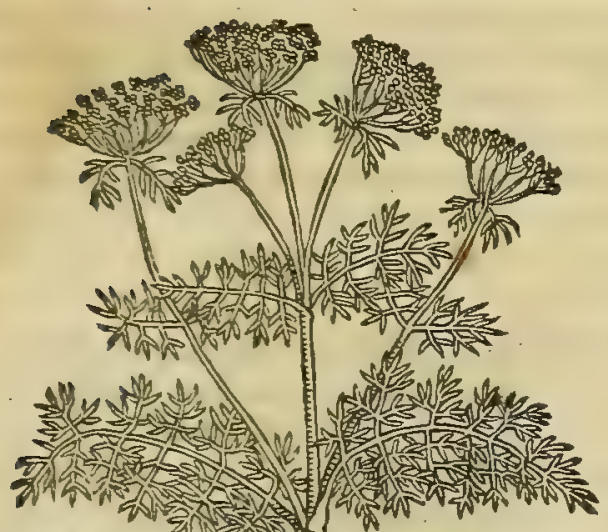

in $>140$
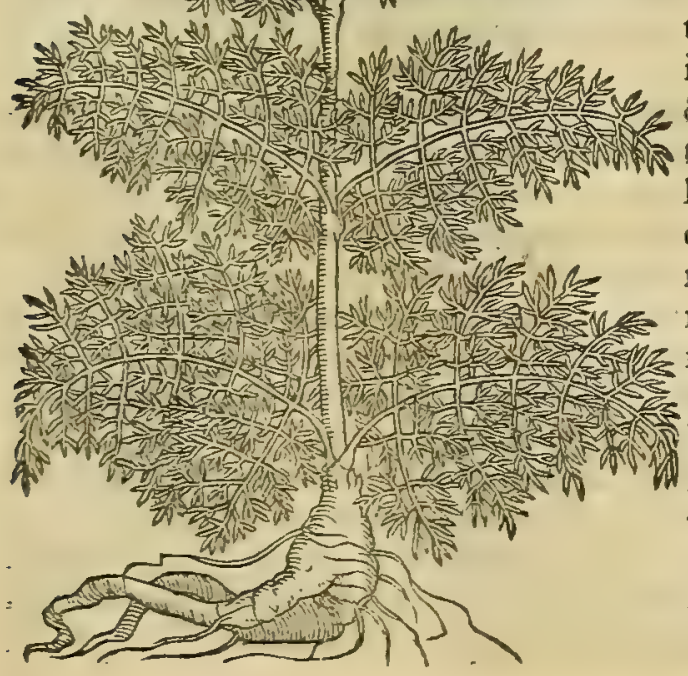

mulfa dentur, craffum humorem per uomitum purgant: fed qui hauferunt, ambulare debent. Prudenter tamen attendere oporter, \& aquam mulfam continuò potui dare : quonian pericula frangulationis inferunt, \& tauces adurunt. Trita, \& ex olco illita phthiriali prodeft : item prurigini, \& pforis. Cit plurimam pituitam commanducata : decocta in aceto, dentiu m dolori, colluto ore, fubuenit: rheumatrfmum gingiuarum filtit: vlcera oris manantia cum melle fanat. Vrentibus malagmatis imponitur.

S T A P H I agria, quam officine Greca uoce corrupta Staphidisaulgó Staphufarian uocant, Latinis ab effectu, quòd pediculos gria confid. necet, Herba pedicularis dicitur. Hec in iftria, Dalmatia, A pu= lia, o Calabria, frequentißima prouenit. Eius Semen copio $u m t$ apud feplafiarios inuenitur: nanq; co frequenter utuntur medici in apophlegmatifmis. Id quod etiam plurimim expetitur mulie= ribus ad pediculos, o lendes necandos. Staphidis agrie me= Staphidis agr. minit Galenus in Aftaphide libro v I. fimplicium medicamento= uires ex Gal. rum fic inquiens. Aftaphis agria uebementer acrem obtinet $f a=$ cultatem, adeó ut ex capite pituitam purget, quod $\propto$ ๘० $\varnothing \lambda \varepsilon \gamma \mu \alpha$

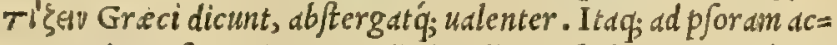
commodata eft. Sed $\widetilde{c}$ urendi uim aliquam babet. Eaplanta

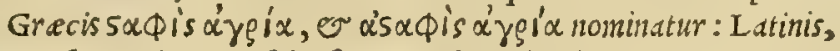
Staphis agria, Vua fylueftris, Herba pedicularis, or Pituitaria: Arabibus, Alberds, Habelras, Mubazagi, fiue Miubezegi: Italis acofficinis, staphufaria: Germanis, Bifzmijntz: Hif $d=$ nis, Fabaraz Paparraz: Gallis, Eftaphifagrie, on Herbe au poulx.

\section{Exłí. THAPSIA. CAP. CII.}

T H A P S I A nomen ideo accepit, quod in Thapfo eiufdem nominis infula, primùm inuenta fit. Tota uerò natura ferulæ fimilis eft: graciliore caule: folijs fœeniculi : umbella ancthi in cacumine, à fingulis furculis erumpente: flore luteo: femen quale ferula, latiufculum, fed aliquantò minus : radix forís nigra, intus candida ${ }_{3}$ longa, acris, crafsiore libro ueftita. Succi extrahendi ratio hæc eft. Facto in a mbitu fcrobe cortices incidútur, aut radix in fornicis fpeciem in fe excauata cooperitur , quò merus fuccus confluat oportet illuc fequenti die fe conferre, $\&$ congeftum fuccum extrahere: Tunditur etiam radix in pila, \& fuccus organo per quallum expreffus, fictili craffo infolatur . Aliqui folium unà terunt: fed inualidior huiufcemodi fuccus. Hoc autem intereft, quoniam qui ab radice manauit, grauius olet, \& humidus permanet : è folijs autem extra\&tus exiccatur, atque teredinum iniuriam fentit. Qui fuccum colligit, ftare debet non obuerfus uento: aut potius cùm dies apricus eft, \& à flatu filet : quoniam ob halitus acrimoniam facies uehementer intumefcit,nudaq́ue corpora inuadunt puftula . ob id prius liquido cerato, $\&$ adftringente, nudas partes illinunt, \& ita muniti accedunt. Tam cortex radicis, quàm fuccus purgandi uim habent, \& lacteus fuccus in aqua mulfa potus : nam utrinq; bilem extrahunt. Radicis modus, quaterni oboli, cum tribus feminis anethi drachmis: fucci, terni oboli: laEtis, obolus unus . quod eo amplius affumitur, pericuculofum eft. Huiufmodi purgatio conuenit fufpiriofis, $\&$ diuturnis laterum doloribus, reiectionibusque:

Nomina. 


\section{8 And. Matthioli Comm.}

datur in cibis, aut obfonio, quibus difficile fit uomere. Tam radix, quàm fưccus omnium maximè, qux pares cum eis uires adepta funt, uim habent extractoriam exalto, ubi ex imo aliquid enocandum eft, aut meatuum laxitas aliò transferenda eft. vnde fuccus illitione, aut radix recens affrißu alopecias explent. Radix, fuccusque cum æquis ceræ, thurisque portionibus, fugillata, liuoresq́ue tollunt: fed non plus binis horis dimittantur: locus deinde aqua maris calida foueatur. Vitia cutis in facic emendat, cum melle illitus fuccus : lepras tollit : tubercula difcutit, perunctus cum fulphure. In diuturnis pulmonum, laterum, pedum, articulorum q́ue ualetudinibus utiliter illinitur. Valet ad integendam colis glandem ijs, qui natura, non circuncifione curti funt: tumorem enim excitat, qui pinguium fotu emollitus, præputij iacturam refarcit.

Thaplį̧ con-

DE T H A P I A E viribus locutus cf Thcophraftus libro r x. cap.x x I I. de plantarum biftorid,ubitita fcri Gderatio. bit. Thap/ic radix uomitoria $e f t, \sigma$ fi quis continuit, tam fuperius, quàm inferius purgut. Ad bec liuida tollere po= teft: fuppurationes tamen aliás exalbidas facit. Succus cius ualidior eft, $\sigma$ quidcm tam fuperius, quam inferius pur= gat. Nullus feminis ufis. Nafcitur tum alibi, tun in terra Attica, in qua pecudes incole edm non tangunt, peregri= ne ueró depafcunt: Oo aut aluus foluitur, aut intereunt. baftenus Thcophrastus. Thapfiam autbor eft plinius libro

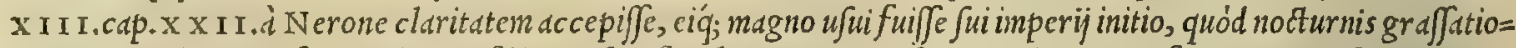
nibus conuerberatan faciem illinens fibi cum thap/ia, thure, or cera, fequenti die contra famam cutem fynceram cir cunferret: etenim ea mirum in modum fugillata delet. Thapfia plirima najcitur in A pulia, prefertim Gargano mon te, inter complures ferulaceigeneris plantas. Prouenit $\sigma$ in noftris maritimis locis adeó ferula adfimilis, ut non $f_{d}=$ cile, nifi à rei herbarie peritis, una ab altera digno catur. Vifitur etiam bodie in bortis ad pectaculum plantata. qua 20 ratione iam ferme omibus innotuit in Italia. Ceterum non defunt impoftores, qui $\mathrm{T}$ bap fie radicum cortices pro $\mathrm{T}$ ur peto uenditent : que quidem à peritis feplafiarijs in ea medicamenta iure optimo addi polfunt, que Thapfiam expo= fcunt: $\int c d$ in turpeti locum non funt, meo iudicio, recipiende. Qudpropter maximé in hoc (ut fuperius diximus in Tripolij conmentatione ) ḋ Fuchfio diffentimus, qui Turpetum d. Mefue defcriptum, nil aliud effe cenfet, qudm Tha=

Thap fix ui- pfia radices. Thap/ia uires incmorie prodidit Galenus lib. v. fimplicium medicamentorum, fic inquiens. Tha= res ex Gal. pfia dercm babet, ac uchementer excalfacientem facultatem cum bumiditate. Quamobrem ex alto uiolenter extra= hit, or ip um quod extraxit, digerit. Verim plufculum ad ea efficienda tcimpus poftulat, ut que largé excrementi= tia bumiditate impleta eft, ob quam celeriter corrumpitur. Et lib. primo de compofitione medicamentorum fecun= dum locos, fic inquit. Qui Thapfia utitur, fciat opus cst, maximam, differentiam effe recentis ad uetuftiorem. Vis $e=$ nim buius pharmaci poft annum multum exoluitur, atque amplius adbuc poft duos annos, aufimó, feré dicere cam pe= so

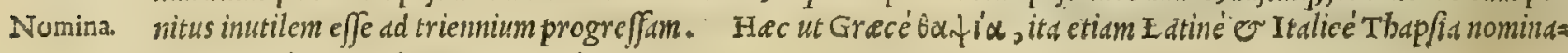
tur: Mauritanis, Hiantum, or Driz.

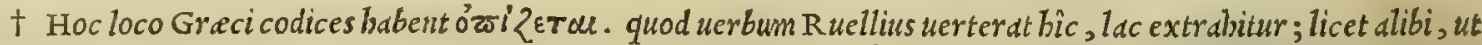
in panace Heracleo, iden uertat, fuccus excipitur. Nos ueró, quód ómò's, à quo ucrbum illud defluxit, fuccum, li= quorem, er lacrymam fignificet, maluimus reddere, fuccus cxtrabitur. Neq; certé temere, quód non folum nobis con ueniat cum Marcello interprete; fed quód etiam arbitremur banc effe germäliam illius uerbi fignificationem; atque melius rem exprimere, de qua fermo eft. Huius tamen mutate à nobis uér fonis lectorèm admonendum effe duximus.

\section{¿ragtiov. SPARTIVM.}

CAP. CIII.

S P A R T I O N frutex cft longas ferens virgas, fine folijs, firmas; fractu contumaces, quibus uites vinciuntur : femen lenticulæ, in folliculis phafiolorum modo nafcents; fiorem, vt albæ violæ, luteú. Purgant per fuperna veheméter ellebori vice, citra periculum fores, \& femina quínis obolis in aqua mulfa pota. Semen deiectionem mouet. Ramis in aqua maccratis, mox tufis, extractus fuccus, ifchia dicis, \& 2 angina laborantibus auxiliatur, fi cyathi modum ieiuni bibant. Quidam marina aqua macerare malunt, \& infundere ifchiadicis clyftere : ftrigmenta autem elicitoruenta .

Spartij conf- T I T A nimirum inter spartium, fiue spartum, o Genistam intercedit fimilitudo tum facie, tum ctiam uiri= deratio. bus, ut corum affinitate deceptus iam crediderim omnino erraffe eos, qui alterum ab altera feccrnerent: prafcrtin cum bac in re deprchendiffem Plinium dubitaffe libro'x x I I I I.cap. I x . wbi ita fcriptum reliquit. Gcnista quog; uin= culi ufum prestat. Flores apibus gratißimi. Dubito an bec fit, quam Grecianthores sparton appellituere, cimn ex calina pifcatoria apud cos factitari docuerim: or nunquid banc defignauerit Homerus, crim dixit: Nanium ffarta diffoluta. Nondum enim fuiffe Aploricanum, zel Hifpanum Partum in ufu certum eft : o cim futiles fierent 11 ares, Jino tamen, non Parto unquam futas. bec Plinius. Verum cum accuratius Diofcoridem perlegiffem, bac de re prius admonitus à clarißimo medico Petro Cannizero Hipano Serenijimi Ferdinandi Romanorum Regis Protophy/ico, qui in Hipania copiofißimum Spartum, numerofanq; Geniftam fe uidefe teftatus eft, comperi plané inter lias plan= tas difcrimen effe. Quippe quód spartium Diofcoridifrutex fit folys uiduus : cr floribus con/tet albe uiole fimili= bus. Genifta ueró folia proferat longiufcula, liniferé modo: er flores luteos, ipfí modo lunatos. Hinc itug; factum est, ut nunc in corum fententia confiftam, qui Spartium à Genifta differre existimant. Non tamen quód diuerfi pror fus generis has plantas effe putem. num tanta, ut dixi, uni cum altera cognatio eft, ut etfinon exdem fint; tancs cö Sparti ufus ex genereseffe videantur, Sparti quidem ufus (ut Plinius eft author lib. . I x, cap. I $x$, ) multa poft fecula ceptus cf,
Plinio. 


\section{In Lib. quartum Diofcoridis.}

SPART IVM.

20

30

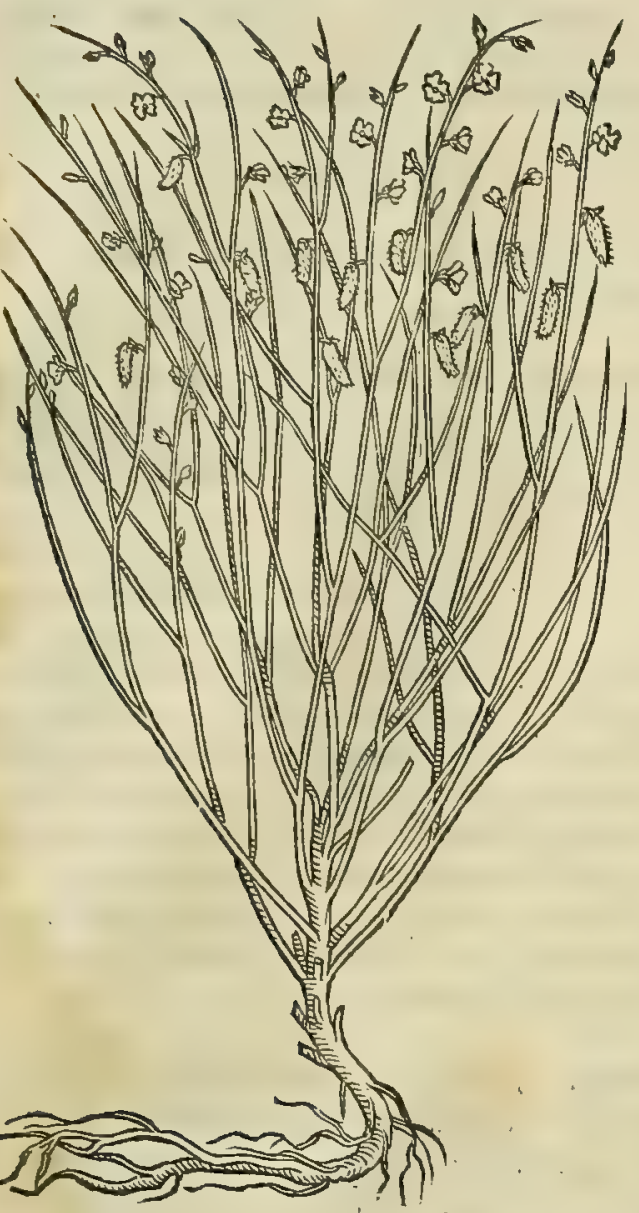

GENISTA.

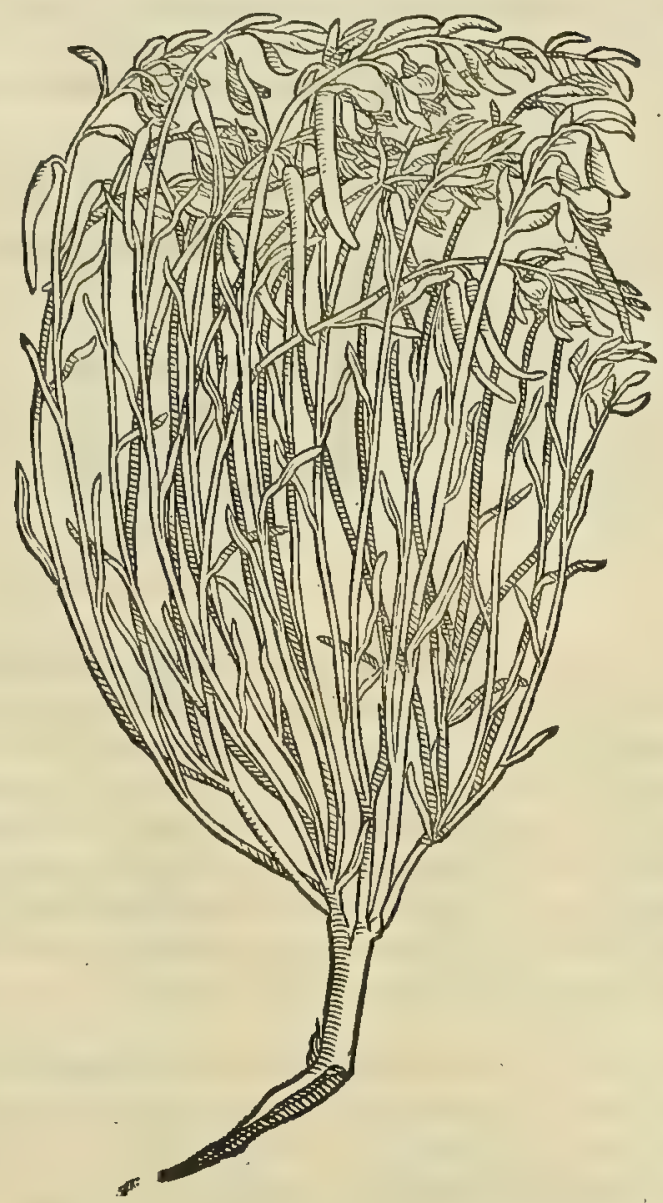

nec ante Ponorum arma, que primum Hipanix intulerunt. Herba or bec ponte nafcens, or que non queat feri: iuncusós; proprie aridifoli, uni terre dato uitio. Nanq; id malum telluris eft, nec aliud ibi feri, aut nafci poteft. In $\mathrm{A}=$ phrica exiguü, $\sigma$ inutile gignitur. Carthaginenfis $\mathrm{H}$ ipanie citerioris portio, nec bac tota, fed quatenus parit, mon tes quoque Sparto operit. Hinc ftrata ruftic is eorum : binc ignes, facesó; : binc calceamina, \& pastorum ueftis. $A=$ nimalibus noxium, preterqudm cacuminum teneritate. Ad reliquos ufus laboriosé euellitur : ocreatis cruribus, $m a=$ nibusq́; tectis manicis: conuolutum offeis, ligneisq; conamentis. Vulfum fafcibus in aceruo adunatum biduo, tertio refolutum. Spargitur in fole, ficcaturg, , o rurfus in fafcibus redit fub tecta. Poftea maceratur aqua marina opti= 40 mé, fed er dulci, fi marina defit. Siccatum f; $_{\text {; }}$ fole iterum rigatur, fi repenté urgeat defiderium, perfufum calida in $f o$ lio, ac ficcatum ftans compendium opere fatetur. Hoc autem tunditur, ut fiat utile, pracipue in aquis mariq́; inuistum. In ficco praferunt é cannabi funes. At $\$$ artum alitur etian demerfum, ueluti natalium fitim penfans. Eft qui=

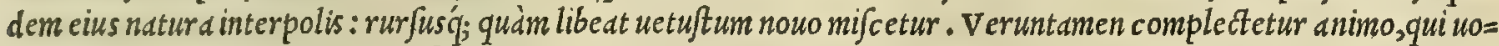
let miraculum aftimare, quanto fit in ufu omnibus terris nauium armamentis, machinis adificationum, alijsq́; de fide= rijs uite. Hactenus de parto Plinius. Caterum Genifte in Hetrurid adeo frequentißime proueniunt, ut Maio, et Genifx conI unio menfibus magnum $\sigma$ iucundum pectaculum prabeant uidtoribus, quoniam tam copiosé fuis peciofis, ac ful= fideratio. gentibus floribus ornantur, on ueftiuntur colles, ut procul aurei videantur. Gaudent earum floribus apes, ut Plinius inquit : proinde aluearijs.circunferuntur. Genista nobis ligandis uitibus falicis uiceme explet, maceraturóg; etiam can= nabis modo, funtớ; inde funes, Ev rudia linteamina, qua conficiendis accis aptißima funt. Expetitur Genista lignit so etiam figulis. qui un It alia id uaforum fictilium genus conficiunt, quod uulgó de maiolica uocant: quippe quód (ut ip= fiaffirmant) mullo alterius arboris ligno fornax fuccendi poßit, quo aureus ille color conferuetur in opere. Ge= niftam recenfuit Mefues inter fua fimplicid deiectoria facultat is, ubi hae ad fenfum fcribit. Genistd arbor eft montd= ud, é cuius caudice quàm plurime funduntur uirga, recta, flexiles, fractu contumaces, quibus uites, er alia ligan= tur. Flores edit flauos, lunari figura : é quibus filiqux prodeunt, erui magnitudine: 0 femina in eis lenti fimilia, in= teruallis diftinta. Planta tota perturbat, prouocat, incidit, attenuat . Obeft cordi, o uentriculo. Sed tollitur no=

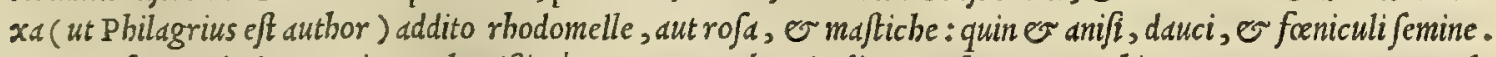
Epotum emen pituitam utrinq; ualentißimé purgat, $\sigma$ ab articulis quoq; bumores trabit. Renum excrementa pel $=$ lit, urinam cit efficacißimé, ev calculos difrumpit tam in renibus, quam in uefica : nec in his materias figi, er in cal=

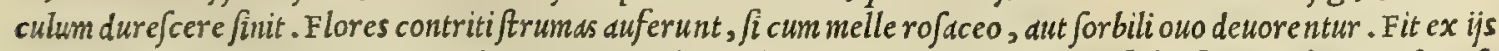

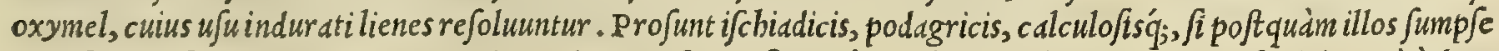
vint, Jubinde frequenter enomant agri. Modus, prefertim floris, àdrachmis duabus ad quinque : feminis ueró à dra= 


\section{And. Matthioli Comm.}

chmis duabus ad quatuor. bec Mefues. Quit tamen Genifte femen non recté obferlidfe videtur. quandoquidem id ey= Sparti uires ui, uel uicie faciem potius referat, quam lentis. Sparti, ut iam ad eius uires rededinus, meminit Gälemus lib.V I I I. ex Galeno. fimplicium medicamentorum, bis paucis uerbis. Sparti, quo er uïtes apud nos alligant, tum femen, tum uirgarü fuc=

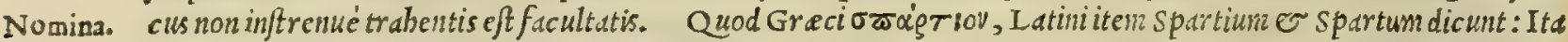
li, spartio. Que ueró Latinis Genifta, I talis Geneftra nocatur : Hifpanis quoq; Geneftrd, Giefta, er Giefteira.

$$
\text { ¿íUBOV. SILYBVM. }
$$

\section{CAP. CLIII.}

S I I Y в o N lata fpina elt, folia ferens chamæleonis albi. Hæc recens cum fale oleoq́ue cota eftur. Radicis fuccus drachmæ pondere potus uomitiones ciet.

H A C I E N v non ex noftra tantim, fed neq; ex aliorum quoq; inquifitione uerum ac legitimum silybum in It talia nobis licuit reperire. Et quanuis inter tot alias plantas aculeatas inibi nafci, 0 e efe poßit; tamen tam paucis eius notas explicatiit Dio fcorides, ut difficile admodum illud inuentu iudicem: neq; enim ipfe, ut ingenué fatear, quod Nomina. exillisfit, aufim decernere. $v t$ Grecis $\sigma i \lambda u$ Bov, ita pariter Latinis silybum appellatur.

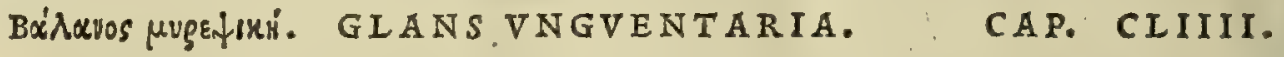

G I A N S vngùentaria fructus eft arboris myricæ firnilis, magnitudine auellanæ nucis. cuius nucleus amygdalarum amararum more tritus, humorem reddit: quo ad pretiofa unguenta pro oleo utuntur. Náfitur in Aethiopia, Aegypto, Arabia, \& Petra oppido fecus Iudæam. Præfertur plena, recens, candida, qux facilè delibretur. Ea drachmæ pondere pota lienem abfumit: cum lolij farina, \& aqua mul ra podagricis illinitur. Pforas, leprasq́ue, deco\&a in aceto: vitiligines, \& nigras cicatrices cum nitro emendat: \& cum lotio lentigines, uaros, \& papulas in facie, \& cutis uitia tollit . Vomitiones mouet, \& aluum cum hydromelite refoluit : ftomacho aduerfatur · Oleum, quod ea exprimitur, aluum potu ciet . Cortex eius magis adftringit: verùm tufx, \& expreffx fuccus abftergentibus medicamentis adijcitur, quæ aduerfus prurigines, \& fcabritias idonca funt.

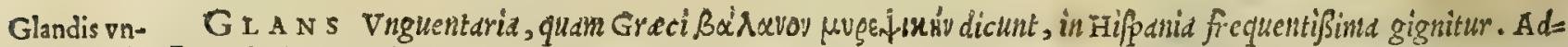
guentarię cö- fertur bodic copiofa in Italiam. Vnguentarij, ac feplafiarij Mauritanorum nomind fecuti, eam Ben appellant. Forma lideratio. hec piftacia maximé refirt, albo cortice, triquetro, fractu facili, nucleo intus confer to, 0 admodum pingui : ex quo oleum exprimitur, quod de Ben uocant. Magnifaciunt id unguentarij, quód quámuis diu inueteratunt, nunquain ran= corem fentiat, ut etiam libro primo fuo loco monuimus. Arabice familia autbores (ut modó dittun cft) unguenta= riam glandem Ben nominant. Proinde de ea inter fua foluentia fimplicia fcribens Me fues, in bunc fenfum inquit. Ben duorum eft generum. Maius eft nucis auellane magnitudine, triangulare. Minus ueró cicerifunile. Vtriq; ineft oleo= fa medulla, lenis, or alba. Praftat maius, quod noxa uacet : minus fiquidem noxium eft. Prefertur in maiorigene= re, quod putamine fit albo, leui, tenui : nucleo fragili, albo, oleofó $\dot{q}_{\text {. }}$. Vetuftum recenti melius. In minori autě pre $=$ cellit in cinereo albicans, fragilis pariter, o pinguis. Diofcoriditamen in maiori genere (ninoris enim non meminit, quemadmodum nec Theophraftus, neque Plinius) preftantius eft recens, etfi contrarium afferat Me fues. Oleum ab. unguentarijs hoc tempore é nucleis tantum exprimitur, ut Diofcorides docuit, non autem, ut quidam exiftimant, ex $4^{\circ}$ putaminibus, quód dixerit Theophraftus, unguentarios putamine fructus contufo utifolere. Plinius, ut Theophrafti, o Diofcoridis fententiam comprobaret, unguentarios prodidit é putaminibus, medicos ueró é medulla oleum elicere. quód boc medicamentis, illud odoramentis ufum prebeat. Vertuntamen bac atate (ut diximus) ab omnibus tantume uucle is d̀ putamine repurgatis exprimitur. Nec crediderim unquam, quód ex folis putaminibus oleum effluere pof= fit, quanuis diligentißimé comprimantur, or conftringantur prälo etiä grauißimo : quoniă bec putamina arida funt, o omni pror fus bumore carent. Illud quog; fidem non dubiam facere poteft, quod lianc parandi olci rationem fillen= tio pretermifit Diofcorides, non modó in boc loco, fed etiam libro primo, ubi tamende oleis, o unguentis conficien

Manardi du - dis latius differuit. Cuius forté doctrine immemor Manardus Ferrarienfis, uir alioqui noftre atatis celebris, dubitat

bium folutú. in adnotationibus, quas in Me $\mathrm{Muem}$ edidit, an Vnguentarie glandis oleum é nucleo, an é putamine exprimi debeat, af= ferens quanquam in quibusdam Diofcoridis codicibus legitur, oleü boc é nucleis exprimi debere, in aliquibus tamen 50 nec nucleorum, nec putaminü ullam fierimentionem. Verime etfi ambigendi non defuertt occafio,prefertim ex Theo phrafti teftimonio, qui putaminibus uti unguentarios tradidit; aderat tamen grauißimus autbor Ģalesus, qui rem hanc abunde enucleauit, cüm conftanter affeueret, Balanitrum oleum unguentarijs ex carne nuclcoruni, non ex putd= minibus exprimi . Id quod etiä facilé ex Diofcoride colligi poteft, cum dicat confimili modo fieribalaninum or amyg= dalinum. quod autem boc ex amygdaldrum nucleis fiat, nemo efl qui dubitet. Hac fané nobis non leucm faciunt fupi cionem, quod aut eo in loco Theophrafti exemplaria fint depraludta, aut minus integri, er ueraces fuerint authos res, dquibus fortaßis unguentarie glandis biftoriam accepit. $H$ is porró accedit buius olei communis ufus, $G$ cius pas randi ratio . Siquidem Baldninum oleum plurimi faciunt unguentarij, non quód aliqua odoris praft antia comnendes tur (inodorum etenim eft) Sed quód nunquain uetuft ate rancorem contrahat. Id filicet quod é nuclcorum medulla, non autem ex putaminibus conficiunt. Nain rancor is expers cum fit, omnium aptißimum babetus" ad odoratißsina un= guenta (mifturas Hocant) temperanda, que ex mofcho, zibetto, er ambaro, illinendis chirothecis, er alijs, quorum 


\section{In Lib. quartum Diofcoridis.}

in delicijs, or laf ciuid omnis eft ufus or gratix, parantur. Quandoquidem fi bec alio quónis olco liquefcerent in un= guentum, contracto inde non multo póft tempore rancore (atate cnim onne olcum pretcr Baldninum rancefcit)

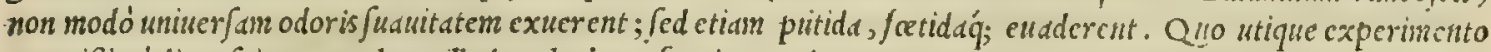
apertifimé dignof citur, an olcum illud Balaninum fuerit, quod ex unguentarix glandismaleisfierifolet. Cate= rum de uiribus Ben bec fubiuxit Mcfues. Maioris, inquit, generis fructus incidit, affergit, attemudt, cxpurgat,

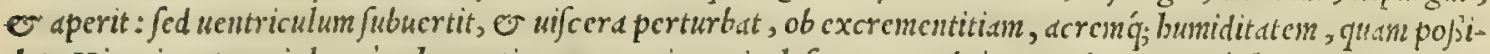
det. Minoris autem uis longe uchementior, đ magis periculofa: nanq; adcó perturbat, agitató; bumores, ut fapius anime deliquium faciat, e frigidos fudores cöcitet. Proinde non in alios ufus is admittc ndus oft, qudnin ungucritu, - cataplafinata. Maioris noxa demitur, cum igne torrefcit: fiquidem ignis calore exuperantcm deperdit busmidita=

ro ten, que uomitionem mouet, fitǵ; medicamentum tantum deictoriun. Decoquitur ctian cum anifl, $\sigma$ feniculi femine: quoniam boc modo prior noxa corrigitur. Tam in potu, quim aliter fumptus lcntam, craffám; pituitam somitu, et deictionc purgat. Ideóq; aptißimum medicamentum eft colicruciatibus non modó bauftus, fed ctiam cly= fterthusinfufus, prafertim ubi d flatu, e pituita ortum babuerint. Fit ctiámnum ex contritis ipfus nuclcis, polenta, o melle admiftis, cataplafma ad frumas, durosq́; tumores admodum utile, o ad neruorum morbos à frigiditate excitatos, addito tantim melle quo fit, ut conuulfis, refolutis, of contractis opem ferat non obfcuram. Pollet pre = terea ad iecinoris, e licnis infarctus duritics f; , fi addita lupinorum farina, er nardo cmplaftrimodo imponatur. Nucleorm oleum uunersm cicatrices attenuat, o delct: item lentigines, alias q́; cutis foditates emendat. Auri= bus infufus non modó doloribus lewamentum praftat; fed $\mathcal{\sigma}$ furditatem, $\sigma$ timitum curat. Glandis ungucntaria uires memoria prodidit Galenus libro v I. fimplicium medicamentorum, his uerbis. Balanus myrepfice, loc eft,

so glans unguentaria, adfertur ex barbarica regione. Vtuntur unguentarij carnis cius fucco, qui facultate calidus eft. Reliquix autem, unde expreffus eft fuccus, terreftres fcilicet, or dur:, uincentem habent qualitatem dinaram. sed or admifta eft qusdam adfritio. Proinde extergentem fimul, e incidententem, contrabentem $q_{;}$, o ftipan= tem effectum poßident. Itaq; ad ionthos, lentigines, ephelin, ev pruritum, deinde $\mathcal{O}$ ad pforam, er lepram conuc= niunt. Verim enimuero o lienes liquant, iecur ; $_{\text {; }}$ indurefcens. Quód fiquis carnem eius draclma pondere cum me= licrato bibat, medic amen experietur komitorium. Sepe etiam per infernam alutm largiter fubducit. Itaq; cum boc. medicamento utimur, ad uifcerum expurgationem, or maximé iecinoris, lienisó;, ex oxycrato ip um exhibere con= fueuimus. Gaudet ueró ucl maximé alioqui aceto ad extrinfecas actiones. Adeó enim effic ax efficitur,"ut o p foras, copras extergeat, or multó etianmag is que his funt minora, lentiginem, uitiliginem, ionthos, ephelin, exan= themata, achords, tum ulcerofa, e que craßsi funt fucciomnia. Sed e cicatricibus decorem adfert. Porró quod 30 cim illinenda eft lieni, praftet admiftam effe farinarum quampiam exiccantium, cuiujmodi eft erui, ac lolij farina, id iam potius ad compone ndorum medicaminum tratationem, haudquaquan ad prafens inftitutum pertinet: $\int e d$ o in par atu facilibus ipfum dicetur. Verum in pra fens fufficit abftergentem, ev incidentèm cum adfrictione quapiam propofitimedicaminis dixiffe facultatem, ac fic ad aliud tranfgredi. Cortex tamen eius admodum adfringit: itaq; eo poßit quis ad ea uti, ad que ualida ufus eft adftrictione, hattenus Galenus. Sed quoniam Baldmus myrepfica Mauritanorum Nyrobalana nobis ad mcmoriam reuocauit, quorum ijdem quin q; faciunt generd, cùm ed in medica= menta frequenter; 0 commodé ueniant, nec corum, quod extet, meminerint uetères Graci; ideo nunc de ijs nobis differendum eft : neq; enim ob conum ufum filentio erant difimulanda. Sunt itaq; , ut diximus, M Y R O B A L A NOE R v M genera quinque: nempe Flaud, Chepula, Indica fue nigra, Empelica; Bellerica qua omnia facie inter fe diftant, ut etiam uiribus. Quamobrem omnino cenfendum effe putauerim, ea à diuerfis produci arboribus. quan= 40 quam non defint, qui affirment, flaua fimul, or chepula ex und $\sigma$ eddem arbore nafci, exiftimantes flaua decerpi ab arbore immatura, chepula ueró cum ultimam adepta fuerint maturitatem. Verum cim horum fructuum ortus, $\mathcal{O}$ arbores nos prorfus lateant, non eft quod illorum fententiam probare, aut refellere aufin. Recenfentur genera omnia inter ea medicamenta, que aluum citra noxam deijciunt: nam etfi purgatoria ui polleant; nulla tamen uiriume imbecillitate, aut moleftia fumentes afficiunt, fed potius fua adfringentifacultate, quam poßident, cor, iecur, er uentriculum roborant, quinetiam uniuerfum corpus. Id tantim illis noxa adfcribunt, quód obftructiones, $\mathbb{C}^{\circ}$ uifce $=$ rum infarctus augeant: proinde ne obfructis exhibeantur precipiunt. Infrenantur Myrobalanis medicamenta om= nia, que deijciendo laborem inferunt: quo fit, ut utiliter admifceantir fcammonio. In flauorum Myrobalanorum genere ea ceteris preftant, que in uiridi plenéflaue $\int u n t$, pondero $\int a, f a r c t a, g u m m o \sqrt{a}$, craßi corticis, er quibus pumulum oßiculum inest. E' Chepulis ea probantur, que ceteris craßiora funt, colore nigro purpurafcente, corti= so ce craffo, 'o que in equam deiecta fundum quàm citißimé petunt. Inter Indica excellunt, qua maximé nigricant, craffa, pondero $\int a$, uillo intus offe, er que confracta in unum compacta cernuntur. In Empelicorum cla $\iint_{e}$ laudan= tur, que in maiora, craßiora, denfiora, pronderofiora $\dot{q}_{;}$frufta diuiduntur, or que minus oßis, qudm pulpa habent. Bellericorum uero illa in fuo genere praferuntur, quibus craßities, denfitas, grauitas $\dot{q}_{;}$non defit, $\mathcal{O}^{\circ}$ quibus craffus in uniuerfum fit cortex. Flaua, Indica, Chepula, Bellerica refiigerant ordine primo, ficcant $q_{;}$ fecundo. Empelica ueró primo tantìm tum refrigerant, tum exiccant. Vim obftructoriam exuunt omniagenera, additis aperientibus, or urinam cientibus medicamentis: uel fi macerata caprino fero, aut fumaria fucco exbibean= tur : uel fi cum abfinthio, aut agarico, aut rbabarbaro bauriantur. Perfunduntur amygdalino, $\sigma$ fe $a m i=$ no oleo, ut contratta inde pinguedine, uentriculo non inbereant. Quin er id noxe pariter tollitur, ubi cum caf= fie nigre medulla, aut manna, aut acidis palnulis deuorentur. vbideicctione fit opus, corum tantum dilutum prebent: ubi autem adfrictione in puluerem conterunt, of fubinde propinant. Chepula que faccharo condiuntur magis roborant, quain deijciant. Contrarium efficiunt, que cruda ficcataque reponuntur. Myrobalana omne

Glandis unguentarie uires ex Mef

Glandis ynguentariæ uires ex Gal.

Myrobalano rum geners.

Myrobalano rum uires. 


\section{2

genus (ut Me fues ift author) corum fenectutem remorantur, qui ipfis frequenter utuntur : coloren faciunt elegan: tiorem, corporiodorem iucundum conciliant, bilaritatem afferunt, or uentriculum, cor, or iecur roborant con= ferunt bemorrboidibus, o bilis feruorem reprimunt: ad quod flaua cxeteris preftant, ut que priuatim bilem detrd= hant: $\sigma$ eos peculiariter iunent, qui temperamento calidi funt. Fricantur cote ad oculorum collyria, cum uue acer = be, aut ro arum aqua, aut faniculi fucco, quód oculorum inflammationes reprimant, lacrymas fiftant, dcfluxio= nesq́; cobibeant. Sanantur hor um puluere ulcerd, addita lentifcina refind. Chepuld pituitam exhauriunt, intelle= Etum clarificant, or uifum, prefertim faccharo alferuata : uentriculum tum mundant, tum confirmant. Dantur uti= liter aqua intercute affectis, o diuturnis frbribus laborantibus. Nigra utranque bilem trabunt, prafertim exu= ftam. Conferunt membrorum tremoribus, coloris nitorem conciliant, elcphantiacos iuuant, morores auferunt, $\sigma^{\circ}$ quartanam fugant. Empelica pituitam educunt, cor, 0 cerebrum, corroborant, intellectum augent, uentricu= 0 Ium à pituita, alijsq́; noxijs bumoribus expurgant, ac etiam confirmant, ac fitim extinguunt, womitiones cobibent,

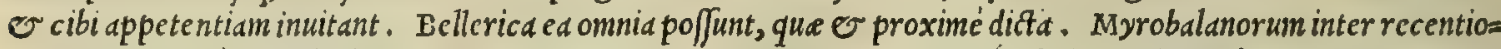
res Grecos tantim, quód fciam, Actuarius meminit : qui tamen ea, qua de illis fripto reliquit, di Mauritanis (ut ip= fe quoq; fateri uidetur ) mutuatus est. Sed profectó ne (ciuerim, qua ratione ductus inter ed medicamenta, qua uo= Chry lobala. mitum eliciunt, myrobalanarepofuerit, cüm omnia corum genera plané uomitiones compefcant. Porró bodíe igno=

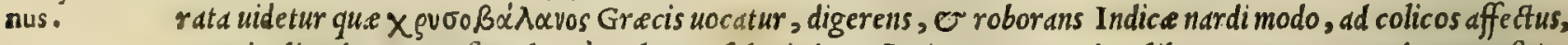
uentriculi ardores, $\sigma$ fingultus a Galeno A clepiadis ductoritate commendata libro v I I I. Cr I X. de compo/itio= ne medic amentorum fecundum locos. quanquam non defunt é recentioribus, qui fibi perfuadeant Chryfobalamum effe mucem myrificam : cum tamen plura fint, que corum deftruant fententiam, nempe cinereus color, acutus ori fapor, ev quod myriftica nucis niiquam meminerint ueteres Graci. Nullam buiufce, quod legerim, mentionem fez, 20 cit Galenus in libris fimplicium medicamentorum. Id quod argumento effe poteft, Galenum ip fum non babuiffe com=

Behen album, pertum, quid effet Chry fobalanus. Sed de bis bactenus. Ceterüm quandoquidem Balanus myrepfica, quam ab Ara \& rubeum. bibus Ben appellaridiximus, nobis in mentem redegit radicesillas, quas officine Behen album, er rubeum uocant, ad cordis affectus ijs, ac etiam recentioribus expetitas, bunc locum non pretereundum effe duxi, quin de ijs quoque aliquid differerem, prefertim quód é Gracis non inueniatur, qui illa pofteritatis momoria prodiderit. Sed illud in primis animaduertendum eft, quód communis ufus'radices, quas uulgó Beben nuncupant, ea quidem non funt, de. quibus Mauritani fcripfere, imó eds prorfus ementiuntur. Siquidem fcribit Serapio, Beben radices proferre minoris paftinace fimiles, contortas, odoratas, er manfulentas, ov in Armenia nafci. Auicenna dutem radicun lignofa frufta Beben effe ait, in fe contracta, or ficcitate exoleta. At noftrates, qua in Italia, non in Armenia effod un=

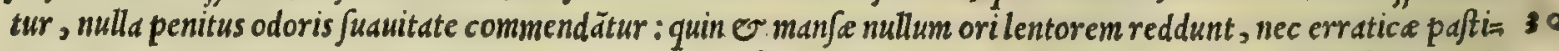

\section{NARCISSVS.}

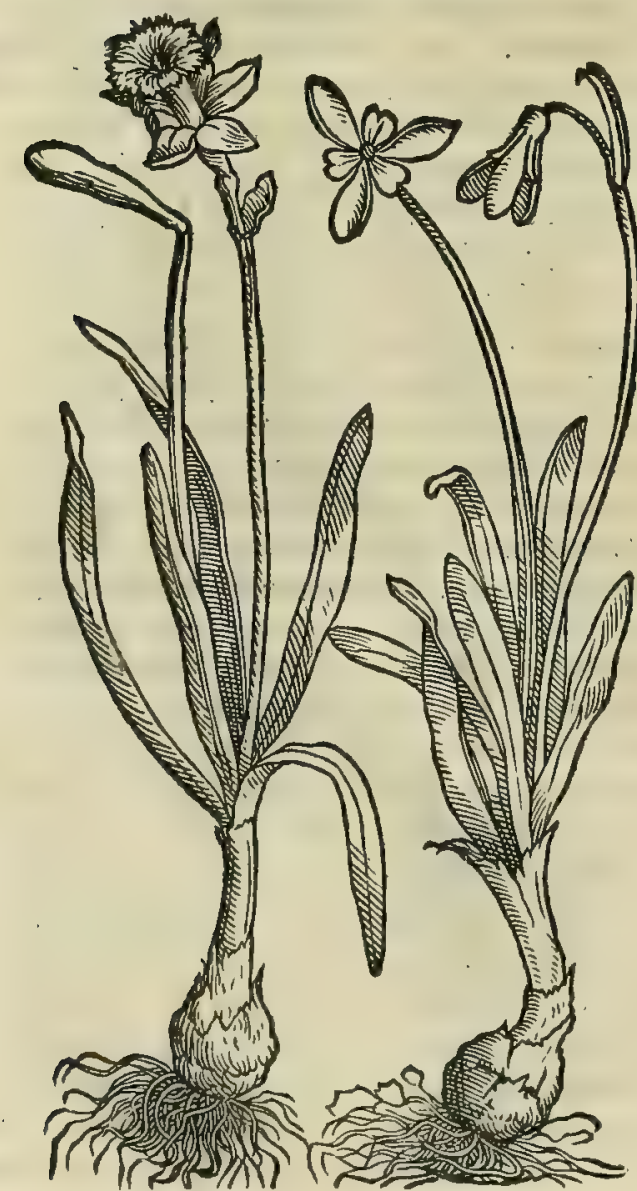

nac a faciem reprafentant: cum tamen Arabicum Behen radici= Lus adeó paftinac am referat, ut fcripferit Haliabbas clarißimus Mauritanorum author, Beben $\sigma^{-}$jylueftris paftinace radices nullum inter fe difcrimen babere: Quo fit, ut nulla fefe offerat nobis ratio, qua probare proßimus, Behen communis ufus effe Arabum legitimum, quanuis er ip/i inter fe bac in biftoria non parum diffentiant. Nicolaus Myrepficus, itemós. Actuarius Be= ben bermodactylum uocant, nefcio tamen qua ratione, cùm alia fit radix apud Paulum, $\mathcal{O}$. Arbes bermodactyus. Beben adulteri$n a$, tam album, quàm rubrü, paßim in. Italia proueniunt. sed qui 40 bus polleant uiribus, nondum mibi compertü effe ingenué fateor.

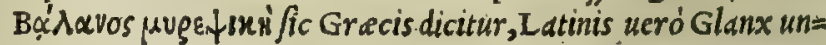
guentaria: Mauritanis, Habben, feu Ben: Italis, Ghianda un= guentaria: Hifpanis, A uellana de la India,Tartago; 0 Muia. Nógriasos. NARCISSVS. …CAP. CLV.

NA R C I s $s$ v funt qui ut lilium lirium appellarint folia profert por ro fimilia, tenuria, multò minora, $\&$ anguftiora : caulis uacuus, \& fine folijs, fupra dodrantem attollitur : flos albùs, intus croceus, in quibusdam purpureus : radix intus alba, rotunda; bulbofa: $f_{e}-5 a$ men uelut in tunica, nigrum, longum. Probatifsimus nafcitur in montibus, fuau odore cateri porrum imicantur, atque berbaceum uirus olent. Radix cheta, fiue eftur, fuc bibitur, uomitoria eft : ambuftisigni prodeft cum exiguo melle trita.præcifos neruos illitu glutinat: luxatis malleolis, diucurnisq́ue articalorum doloribus trita ex melle, \& impofita fubienit. Vitia cutis in facie, uitiliginesq́ue cum femine urtic $x, \&$ aceto emaculat : cum eruo, \& mellé, ulcerum fordes expurgat :abfceffus rumpit concoctioni repugnantes, infixa corpori extrahit, illita cum lolij farina, ゙̌ melle . 


\section{In Lib. quartum Diofcoridis.}

NA RCISSV s, inquit Theophraftus libro ercap. VI. de hiftoria plantarum, ucl lirium (alijenim boc, alij illo nomine wocunt) folium albuci, terre proximum gerit, Jed long clatius, li modo. Habet caulem fine follo, berbaceum, florem fwo ferentem cacumine, im membrana ueluti uafculo inclufun, iargc anplum, coloréq; nigrum, figura oblongum. Hic á cidens ponte germinat, catcrin 0 qui legunt defigere cum folent. Quin er radiccm fe=

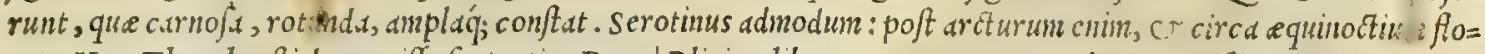
ret. Hac Theophrafti de narciffo fententia. Porró Plinius libro x x I. cap. x I x. duo Narciß̧i genera prodidit, que bis uerbis etiam depinxit. Narcißiduogencra in ufu snedicirecipiunt. Vmun purpureo flore, alterum berba= ceum. Hunc fomacbo inutilem, or ideo uomitorium, aluos quoque foluentem, nernis inimicun, caput grauantem, or à narce narciffum dictum, non à fubulofo puero. bec Plinius. In quibus plane de prebenditur à Diofcoride diffen to ture, quó neutrum Narcifígenusflore albo de fripfcrit. quanquam idem Plinius cap. v. eiufdem libri inter lilijge= nera Narciffun connumerans, bunc flore candido conftare tradidit. Veruntamen nulli ex boc mirari licet, nco; pro= pterea Plinium damnandum effe cenfeo, quód uiderin ego plures Narcißifpecies florum tantum uarictate diftin= ctas. Narcißi wires retulit Galcnus libro v I 1 . fimplicium medicamentorum, fic inquiens. Narcißiradix ufqued= deó exiccandi facultate pollet, ut $\mathrm{O}^{\circ}$ maxina uulnera conglutinet, uel ad incifiones ufque, que circa tendones acci= dunt. Habet ucró quiddam abfterforium, ov attractorium. Planta, que Griecisvígularos, Latinis item Nar= ciffus appellatur: Arabibus, Narces feu Nargies: Italis, NarcifJo: Germanis, Vebtblumen, Hornungsblumen, c.Zzitlofen.

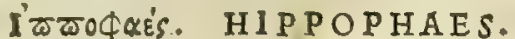

\section{CAP, CLVI.}

H I P P O P H A E S, quo fullones veftes interpolant, in fabulofis, maritimisque nafcitur, fúrculaceo fiutice, undique denfo, \& largo: folijs oleæ longioribus, mollioribusq́ue : inter quæ candican tes fpinx emicant, ficcx, angulofæ, interftitio quodam diftantes : flores hedræ corymbis fimiles, racematim cohxrent, minufculi tamen, \& molles, candidi, ex parte rubefcentes : radix lacteo fucco madet, craffa, mollis, amara guftanti : ex qua perinde ac thapfia, fuccus eximitur . qui per fe; \& cum erui farina fubactus, ficcatur, \& ad vfum reconditur. Syncerus pituitas, bilem, aquasque deijcit, oboli pondere: erui vẹoò farina fubactus, quatuor obolis, cum aqua mulfa. Frutex cum radicibus ficcatus tunditur, \& cum aqua mulfæ dimidia hemina tritus datur. Radice, \& herba liquamentum depromitur, vti in thapfra. huius io purgationibus modus eft drachma.

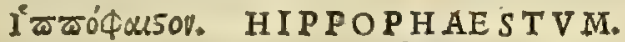

\section{CAP. CLVII.}

H I P P o P H AE S T o N, id quodaliqui hippophaés appellant, nafcitur eifdem locis, quibus hippophaes, efq́ue fpinæ fulloniæ genus, humilis herba, fine cauliculo, fine flore: inanibus tantùm capitulis : folijs paruis, fpinolis : radiculas habens molles, craflas. Succus radice, folijs, \& capitulo exprimitur, \& exiccatur. Datus, cui voles, tribus obolis in aqua mulfa, aquam pituitasq́; detrahit: priuatim comitialibus morbis, neruorum vitijs, \& orthopnœæ conuenit huiufcemodi purgatio:

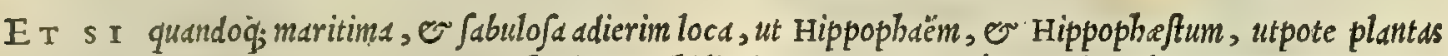
40 inibi nafcentes, inquirerem; neutrum tamen bätenus mibilicuit inuenire. Caterùm retulit nobis Hieronymus Amal= beus Opitergen/is, medicus ingenio, er eruditione clarus, fe olim Venetijs plantam accepiffe ḋ Ioanne Baptifta Zopiffo $\mathrm{P}$ apienfi clarißimo medico, que non modó not is omnibus Diofcoridis Hippophä̀m referebat: fed etiam uiri=

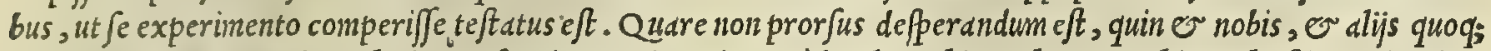

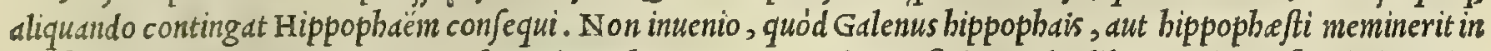
fuo fimplicium medicamentorum cenfu. Hippophais tamen mentionem fecit Paulus lib. v I . inter fimplicia. Hip=

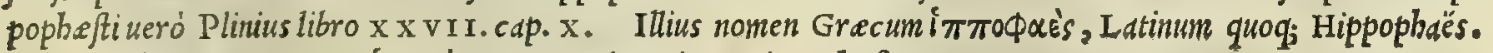
Huius ueró nomen Grecum iø

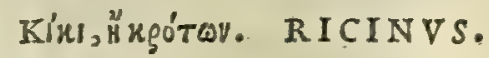

\section{CAP. CLVIII.}

50

C I C I, aut croton, nomen accepit à ricini animalis fimilitudine. Arbor prouenit paruẹ ficus altitudine, folio platani, maiore, læuiore, \& nigriore: ramis, caudicibusque cauis, in arundinis morem : femine in uuis afperis, quod corticibus exutum ricinum animal repræfentat. ex quo oleum nomine cicinum exprimitur, cibis foedum, lucernis emplaftrisq́; vtile. Grana triginta numero purgata, trita potu pituitas, bilem, aquamq́ue per aluum extrahunt, vomitionesque mouent . fed iniucunda admodum eft, \& molefta purgatio : fiquidem ftomachum vehementer fubuertit . Tufa \& impofita, vitia cutis in facie, varosq́ue expurgat. Folia cum polenta trita inflammationes oculorum, tumoresq́ue leniunt: turgentes mammas cohibent. eadem exaceto illita, ignes facros reftinguunt. rex ex Gal.

Hippophais confideratio.

Nomina.
Narcifsi ui-

Nomina.

rcilsi hifto ria ex Theophrafto.

Nomina. 


\section{$604 \quad$ And. Matthiols Comm.}

Ricini confideratio.

Ricini vires ex Galeno.

Nomina:

\section{RICINVS.}

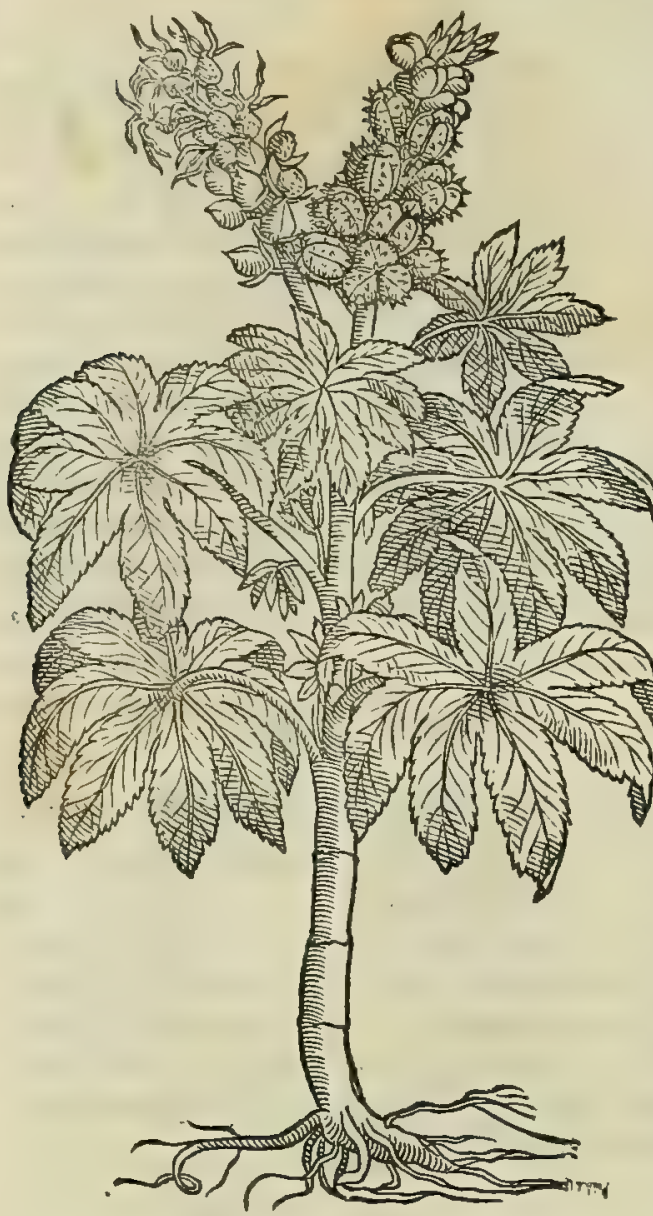

RICINVM uocaluere Latiniplantam, que Grecisuin di= citur, à fimilitudine, quam cius femen habet cum ricino liuido ac fodo animali, quod canibus, bubus; capris, alijś; quadrupedibus adberet: neque prius decidit, qudm pleniis fanguine faginatum. rumpatur. In Hetruria planta bac à quibufdam uulgó uocatur. Gir afole, aliquibus ueró Fagiuolo Turche $\int c o$. Apud Infubres a $u=$ tem pluribus in locis Mirafole. quanquam id nominis potius Helio tropio cŏuenit, de quo in buius libri calce diferemus. Scmen of= ficine Cheruam maiorem appcllant: tametfi ab ip $\int 0 \mathrm{Me}$ ue, cuius ueftigia pharmacopole maximé fequntur, Regium granü appel to lari conftet. Ricinus copiosé eritur in Aegypto, ubi ex eius femi ne plurimum olei exprimitur, cibis quidë fadum (ut inquit $\mathrm{P}$ linus) fed lucernis utile. Deijcit aluum, perinde ac balanus myrepfica. tolliturá; eius noxa ïfdem medicamentis. Quamobrem de eo fic loquitur Mefues. Regiun granum ( hoc eft Ricini femèn) pituită tam per uomitum, quàm per aluum extrahit, fed non fine affumen tium moleftia: quinetiam bilem, or aquam inter cutem deijcit: $\mathrm{et}$ ea fané omnia excrementa purgat, qua ad articulorum compagi= nes defluunt. Confert item coli, $e^{\circ}$ articulorum doloribus,nempe podagricis, et ifchiadicis, $\mathfrak{i}$ ex iure ueteris galli decoctum baturia 2 a tur. Hydropicis ueró decoquitur cü caprino fero; aut emulfo re= center lacte maceratum. - Ricini utres memorix prodidit Galé= nus lib.v I I. fimpl. medic. fic inquiens. Ricini femen, quemadmo. dum expurgat, detergit, ac digerit; fic quog; folium, fed undequa que debilius. Oleum, quod ex femine conficitur, tum calidius, tum tenuiorum partium eff, quàm oleum commune, ac proinde etiam

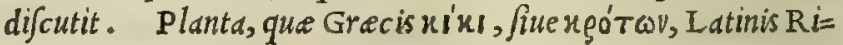
cinus appellatur: Arabibus, Cherua: Italis, Girafole: Germa= nis, Vunderbaum, or Creutzbaum: Hipanis, Figueira de lbinfer. no: Gallis, Paulme dieu.

TITHYMALVS CHARACIAS.

TITHYMALVS MYRSINITES.
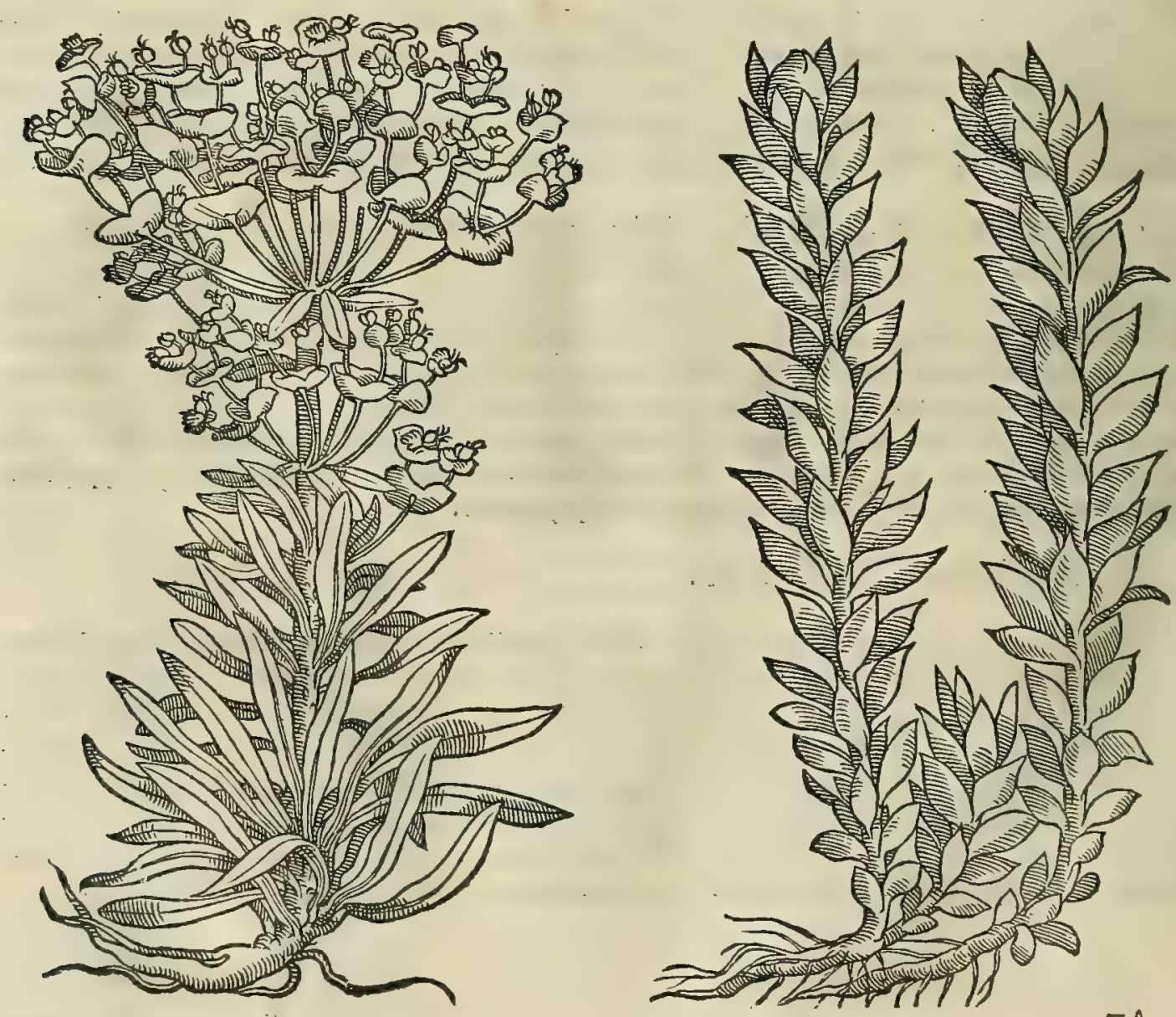

40

Tilupa'ros. 


\section{InLib.quartum Diofcoridis. 605}

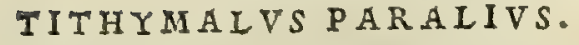

Notur

-5y Hef In

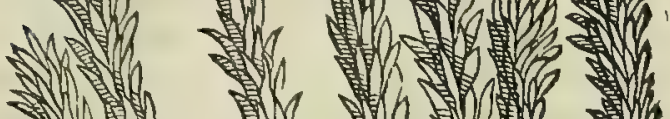
*

1) (

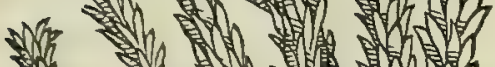

20 1 -

3

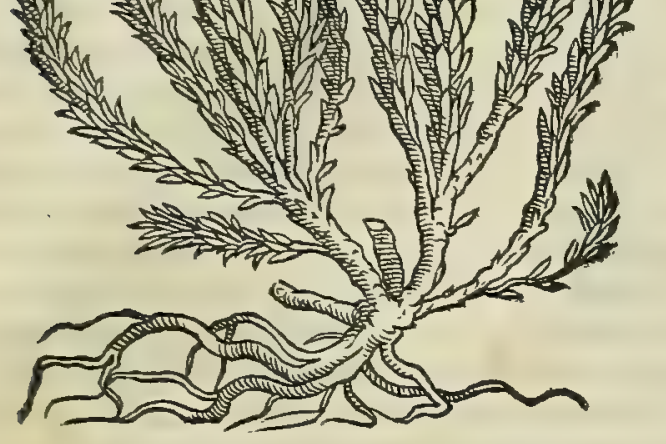

TITHYMALVS CYPARISSIAS:

so
TITHYMALVS HELIOSCOPIVS.

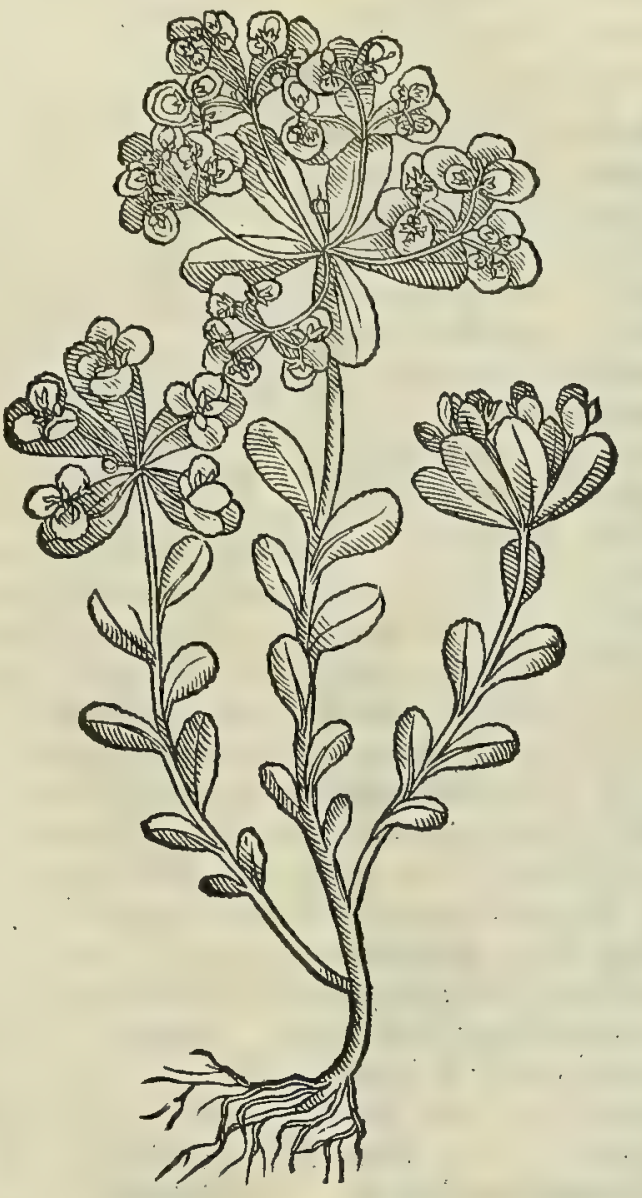

TITHYMALVS DENDROIDES

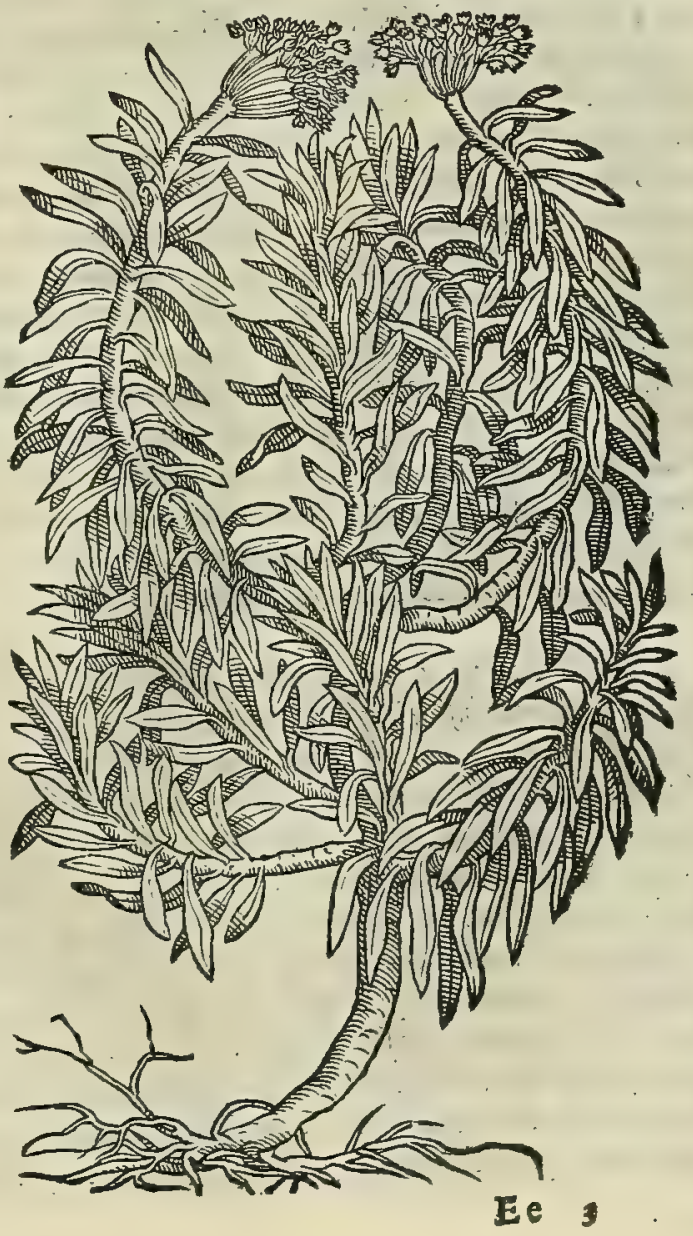


T I T н Y M A I I genera feptem, quorum mafculus characias appellatur, abaliquibus amygdaloides: alter myrtites, qui fæmina exiftimatur, eumq́ue myrfinitem, aut caryitem vocant: tertius paralius, quem tithymalida appellarunt : alius heliofcopius : quintus cyparifsias : fextus dendroides: feptimus platyphyllos dicitur. Characix caules fupra cubiti altitudinem attolluntur, rubri, lafteo fucco, atque acri madentes : folijs olex circum ramos, anguftioribus, \& longioribus : radice craffa, lignofa : pendet in cacuminibus caulium coma iunci, fub qua caueolx foliclis balnearum fimiles, in quibus femen continctur . nafcitur in afperis, \& montibus. Succus aluum purgat, trahit pituitam, bilemque binis obolis in pofca fumptis, \& cum aqua mulfa vomitiones mouet. Appetente vindemiarum tempore fuccus, congeftis ramulis, mox diffectis, \& vafe conclufis, excipitur. Aliqui adijciunt farinam erui, \& in paftillos digerunt, qui erui magnitudinem impleant. Alij in aridas ficos ternas quaternásve guttas inftillant, vt cum his inarefcant, quas ad vfus recondunt. Per fe etiam tufus in pi1 a, $\&$ in paftillos coactus reponitur. Porrò cùm extrahitur lac, neque quò ventus afpiret, ftare quenquam, neque manus oculis admouere conuenit, fed antequàm colligas, corpus, præfertim faciem, collum, fcrotumáue genitalis, adịpe, aut oleo cum vino perungere. Fauces autem exafperat : quapro pter catapotia cera, aut decocto melle oblini par eft \& \& hoc modo dari. binas tamen ternásve ficos purgationis gratia fumpfiffe, fatis eft. Recens lac ex oleo, perunctos in fole capillos euellit, renafcentesque flauos, \& exiles efficit, denique omnes perimit. dentium cauernis inclufum, leuat dolores: $2 \%$ fed cera dentes oblinendi, ne fuo delapfu fauces, \& linguam vitiet. Tollit illitu impetigines, formicantes verrucas, penfiles, \& qux thymi florem repræfentant . valet aduerfus pterygia, carbunculos, phagedænas vlcerum, gangrænas, fiftulasq́ue. Legitur femen autumno, \& ficcatum fole leuiter tunditur, feruefactumq́ue loco mundo reponitur. Folia item ficcantur. Semen, \& folia lactei fucci effeEtum præbent, dimidio acetabulo pota. Sunt qui inueterant, admifto cum lacte lepidio, \& cafeo con tufo. Radix drachmx pondere in hydromelite pota, per inferna trahit . decocta cum aceto, dentium dolori auxiliatur, colluto ore. Fomina, quam myrfiniten, aut caryiten vocant, fimilis fuapte natura daphnoidi : folijs myrti, fed maioribus, firmis, in cacumine acutis, \& pungentibus : ramulos ab radice mittit dodrantales : fructum fert alternis annis, nuci fimilem, mordaci guftu . nafcitur in afperis . Succus, radix, femen, folia, confimilem antedicto fortiuntur facultaten : fed ad citandas vomi- yo $^{\circ}$ tiones inualidior hæc eft. Aliud tithymali genus dicitur paralios, quem tithymalida, aut mecona aliqui appellauere. Nafcitur in maritimis, ramis fubrubentibus, palmum altis ; quinis, fenísve à radice exeuntibus : folijs lini,anguftis, paruis, oblongis, in uerfus quofdam digeftis : capite in cacumine orbiculato, in qua femen, vt eruum, vario colore emicat: fos albus. Frutex totus cum radice lacteo fucco turget. Similes ad ufus reconditur. Heliofcopius dicitur, folijs portulacæ, tenuioribus, rotundioribusq́ue : ramulis prodeuntibus à radice, quatuor aut quinque, rubentibus, dodrantali altitudine, tenuibus, lactis copiof plenis : capite anethi : femine uelut in capitulis inclufo. He. liofcopij nomen accepit, quoniam comas cum fole circumagat. circa oppida nafcitur, potifsimùm in ruderibus. Colligitur fuccus, femenq́ue, ut aliorum. Eædem, quæ fuperioribus uires, non tamen úfqueadeò ualidx. Cyparifsias in caulem exit dodrantalem, uel maiorem, fubrubrum: ex 49 quo folia pini fimilitudine exoriuntur, molliora tamen, \& tenuiora : \& in totum nafcentem pinum æmúlatur, unde nomen traxit. Candido fucco madet : cui eadem uis, qux fuperioribus. In petris nafcens dendroides cognominatur . ampliter opacat, in cacumine frondofam fpargens comam, fucco làcteo prægnans, cauliculis rubentibus, folijs myrti tenuioris, fructu characiæ. Eiufdem effectus, cuius fuperiores, fimiliq́ue modo reconditur. Platyphyllos uerbafco fumilis eft. Radix, fuccus, \& folia per inferna trahunt aquas. Pifces necat, tufus, \& aqux infparfus. Reliqua tithymalorum genera, qux fuprà Icribuntur, idem efficiunt.

Tithymalorum confid.

I I T \& Y.M A L O R V.M omne genus officine Efulam indifferenter appellant, quanqudm plura funt titbymd ligener d, quoram biftoriam fatis confusé Mauritani tradiderunt. quo fit, ut apud hos non fine magno labore tithyma so lorum genera recté, er diftincté cognofci poßint: qua tamen ḋ Grecis ordine pulcherrino defcripta inueniuntur. Ob id igitur mihi quidem difficile uidetur decernere que Titbymaligenerd ex ijs, qüe dे Grecis reprefentantur, ed duo fint, qua à Me fue, $\odot$ A Aicenna Scebram, $\odot$ Alfebram nominãtur : quoniam borum neuter, quod extet, earum Brafauoli opi plantarum faciem notis explicauit. Credidit Brafauolus illud effe Mefui alfebram minus, er Auicēna fcebram, quod nio explofa. Diofcoridi paralius. Sed equidem ab co diffentio, quód nufquam in borum monumentis legerim, Alfebram minus in maritimis nafci :quin nec ramos ferre fubrubentes, nec linifolia, nec femen eruo fimile, capitulis conclufum: :ed tan tum repererim memorie prodidife Mefuem, Alfebram effe plantam lacteo fucco refertam, radicibus tenuibus, qua= rumbe preferuntur, que fubrubeant. Auicenna uerò Scebram nafci ait in hortis, non autem in maritimis, caule te= nui, hirfuto, folijs tarco fimilibus. Qux fané omuia Brafauolifententix aperté refragarideprebenduntur. Nec poss fum praterea cum eodem fentire, quód Alfebram maius apud Mc fuem, or Mebezeberegi apud Auicennä idem fint Mauritanis, quod Grecis Tithymalus platyphyllos. quandoquidem in corum foriptis nu!quam reperi maioris gene. 


\section{In Lib. quartum Diofcoridis.}

ris Alfebram folis edere uerbafco fimiila: nec quód tufum, or aque infparfum pifces interficiat, fed quód rectius (ut inquit Auicenua) eius folia minori scebram fint fimilia. Porró fi mbibac in re conicctandum effet, putarem equidem nil aliud Mauritanis effe minoris generis Alfebram, fiue Scebram, qudin plantam illam, que officinis E fu= laminor uocitatur, quód (ut inquit Auicenna) in hortis, or ubig; proueniat. Hac autem, ni fallor, ed eft, quam nocat Diofcorides Titbymalum cyparıßiam : quippe que pinum arborem nuper natam folijs pror Jus imitetur. Quin= ctiam cenferem Alfebram maius, fiue Mehezeberegi eam omnino cffe plantam, qua Gracis dicitur pityufa, utpo= te que Tithymalo cyparißix folijs fit fimilis, quanuis magnitudine excellat: non enin defunt, qui inter titbymalo= rumgenera etiam pityufain recenfeant. Proinde non ab re dicebat A uicenna, Mehezebcregieffe finile Scebram, fed nuius, or colore fubcineritio. Mefues ueró, quód radicibus effet rotundis, craßis, craffo q; cortice obductis,

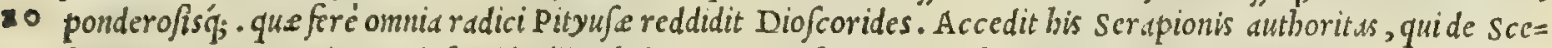
bram agens, ed omnia ex Diofcoride illi tribuit, qux pityufe idem Diofcorides aßignawit. Ex bis itaq; perpicuum fieriarbitror, piryufam Mauritanis fcebram maius appellari:minus uerò id, quòd Gracis titlymalus cyparißias dicitur. Ceterum Characiam uocatum,poftquàn multum laboris in eo indagando fruftrà impendifem, hoc anno mi= fit ad me Pifis clarißimus medicus I ucas Ghimus Forocornelienfis: qui, meo quidem iudicio, omnibus prorfus not is legitimo reßpondet. Myrfiniten quoq; boc tantum anno reperimus, folijs circa caulem totum craßis, acutis, myrto fimilibus. Paralius ueró in maritinis tantim nafcens, quem unlgaris ufus titbymalum putat Brafasolus, in mariti= mis noftri senen/ibus, Argentario promontorio, ov in uniuer fo illius regionis tract $u$, item in Aquileienfi agro fre= quentijimus inuenitur. Huic folio fimilis uifitur quedan alia planta, qux in Hetruria uulgó appellatur Herba mora. Cuius radicibus prius contufis, ac deinde fluminibus demerfis, pifces protinus enecantur. Sed caret bec lacteo fuc=

20 co.quapropter eam inter tithymalorum generd iam non effe adiumerandam cognofcimus: etfialias aliter fenfimus, quod, alijs notis neglectis, linifolia uiderentur, or caules fubrubentes. Si hec defuerit, Platyphylli radices fu= munt, quo uniuer $\int a$ regio $\int$ catet. Porró Helio fcopius, fic ditus, quod cum fole comam circunagat, omnibus uul= garis notitie planta eft. Prouenit enim hecpaßim prope urbium, or oppidorum mania, in campis, incultis, bor= tis, collibus, or ubique tam culto, quam inculto folo. Cyparißias deinde (ut Jupràdiximus) ea eft planta, quam E fulam minorem wocant, cuius pro omni Titbymalo inualuit ufus. Dendroidem uidimus primum in regno Neapoli= tano extra Terracinam urbem inter faxa antiquißimi pecus in itinere Neapolim uerfus, planta arbore fcentis effi= gie. Hunc dum contemplari capiffem, fuperuenit peritißimus medicus Hieronymus Drogus Parmen/is, er doctißi= mus Hieronymus Rorarius Portonouenfis ( tunc omnes und fequebamur Bernardum Cle fium amplißimum Candina= Iem Tridentinü ad Cefarem pergentem) quibusmagno folatio Dendroidem tithymalum ibi à me primùm repertums

so oftendi : erant enim ambo rei herbarie ftudiof $i$, atq; etiam gtari. Nafcitur idem titlymalus etian in Tergeftino li= tore non longé a Timauo fonte, in faxofis quibufdam rupibus arbore fcens. Theophrafto tria tantum Tithymalo= rum genera produntur libro I X. cap. X I I. de biftoria plantarum, ubi ita fcriptum reliquit. I actariarum (fic e= nim tithymalum uertit Theodorus ) quod naritimum granum appellant, folio eft rotundo, caule, tóta ó; magnitudine ad palmum, frustu candido. Demetitur, cùm uua nigrefcere incipit: or ficcatus fructus tritus potui datur acetabu= Ti tertia parte. Mafcula autem uocitata olee folio conftat, or magnitudine cubitum aquat. Huius lac, cuim uinde= mia incipit, exprimunt, or preparato utuntur : purgat inferius. Myrtaria ueró cognominata, candida lactaria e,t, folijs myrti condita, uerüm aculeatis parte poftrema: farmentula in terram demittens, longitudine palmi, que non finul, fed alternatis annis fructificant, alia hoc anno, alia poftero, quanquam omnia eadem radice exorta. Loca mon swofa defiderat. Frutus nux appellatur . demetitur, cùm bordeum turgefcit, or exiccatus, purgatusó; datur elotus

40 ckm papaueris nigri duabus partibus, ita ut totü modo acetabulifit: irahit pituitain per aluum. At ueró finucem ip-

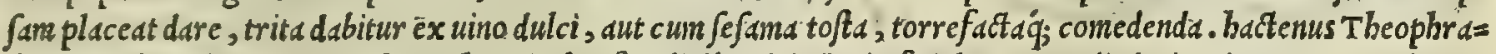
ftus. Tithynali omnes, Mefue authore in fuis fimplicibus deiectoria facultatis, cardi, iecinori, er uentricolo mas xime officiunt: uafa difrumpunt, inteftina abradunt, uniuer fum excalfaciunt corpus, adeo ut inde febres facilé cons citentur. Tollitur prima tithymali noxa ijs admiftis, que cor, iecur, vo uentriculum roborant. Secunda ueró, or tertia ijs, que agglutinatoria facultate pollent : cuiufmodi funt tragacantbe lacryma, gummi, bdellium, psyllij feminis piffamentum, er portulace fuccus. Tollitur e quarta, admiftis frigidis, e bumidis: proinde arit fonchi fuccos aut intubi aut portulace, aut hortenfis folani, aut ace to cum cydoniorum feminibus diutius rudicula agitato, com= mifcent. Vulgaris ufus Tithymalus pituitam uebementer deijcit, of atrü quem uocant fuccum, pariter q́; pituitss ad articulos decurrentes. A quam inter cutem ualidißime extrahit : nihilo ecius exiccat uniuer fum corpus, $\sigma$ geniturä

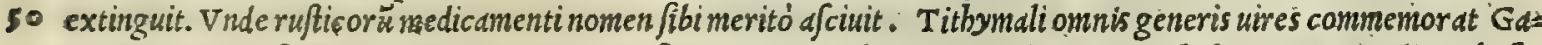
lenus lib.v I I I. fimplicium medicamentorum, fic inquiens. Tithymali omnes uincenten babent acren, calidam q́, fa cultatem, ineft ueró $\sigma$ amaritas. Validißimus itaq; eft eorum liquor. Secundum locum tenent femen, or folia. Sed or radix dictarum facultatum particeps eft, fed non ex equo. Sané ip fa cum aceto decocta dolores dentium fanat; maxime qui illis erofis proueniunt. At liquores, ut qui ualentiorem uim babeant, in fordmina quidem ip a dentium in duntur : ceterim fi aliant corporis partem contigerint, continuo adurunt, ulcerant ǵ $_{\text {: }}$ proinde foris illis cera cir a cumlinitur . quippe cum ex quarto fint excalfacientium ordine, quem efe adurentium po fuimus . sic pilos quo of fuc= cus inunctus tollit. Porró cùm uehementior fit, oleo mifcetur: $\mathcal{E}$ fi id fepe fidt, tandem prorfum pilorum radices adufe extirpantur, corpusq́; depile reddetur. Eddem facultate uerrucas; quas acrochordonas nominant, $\sigma$ myr: mecias, o pterygia, fiue oculorum ungues, or thymos auferunt, detergéntque lichenas or p foras quia fcilicet $\sigma^{\circ}$ abftergendifacultas ineft proptcr amaritudinem. Pratered ulcerum phagedanica, anthrachode, et gangrenode, quia walenter cum excalfaciunt, tum extergunt, fi in tempore, o moderate utare, iuware aliquando poterunt. Ve=

Tithymalico gniti.

Tithymalo rum hiftoria ex Theophra fto

Tithymalo rum vires ex Mefue.

Tithymalo rum uires ex Galeno. 
rùm enimuero, fof fularum callos eximunt eadem facultate. Caterim bec omia gencre quidem fimiliter, imbes

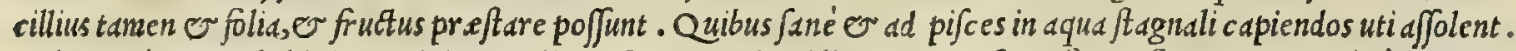
Celerrimé nanq; ab illis in uertiginem acti, ac femimortui redditi, ad aqux fuperficiem feruntur. Porró cùm feptem fint corum generd, ualentißimus eft quem characian nominant, qucm utiq; etiam quidam snarem cognominant, $\mathfrak{V}^{\circ}$ fomina nuncupata myrfintes, $\mathcal{O}$ qui in petris nafcitur ad modum arboris: deinceps qui uerbafco adfimilis eft, $\mathcal{E}$. cyparißias: deinde paralius, fiue marinus : denique beliofcopius. Proportione ueró comprehen fe illorum facultatis

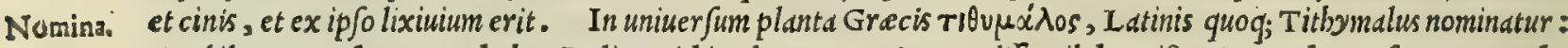
Arabibus, Xaufer, Er Ethuba: Italis, Tithimalo: Germanis, Vuolffs milch: Hifpanis, Leche trefna, er Leche tregua: Gallis, Gerbe à lach.

IITViovo'. PITYVSA.

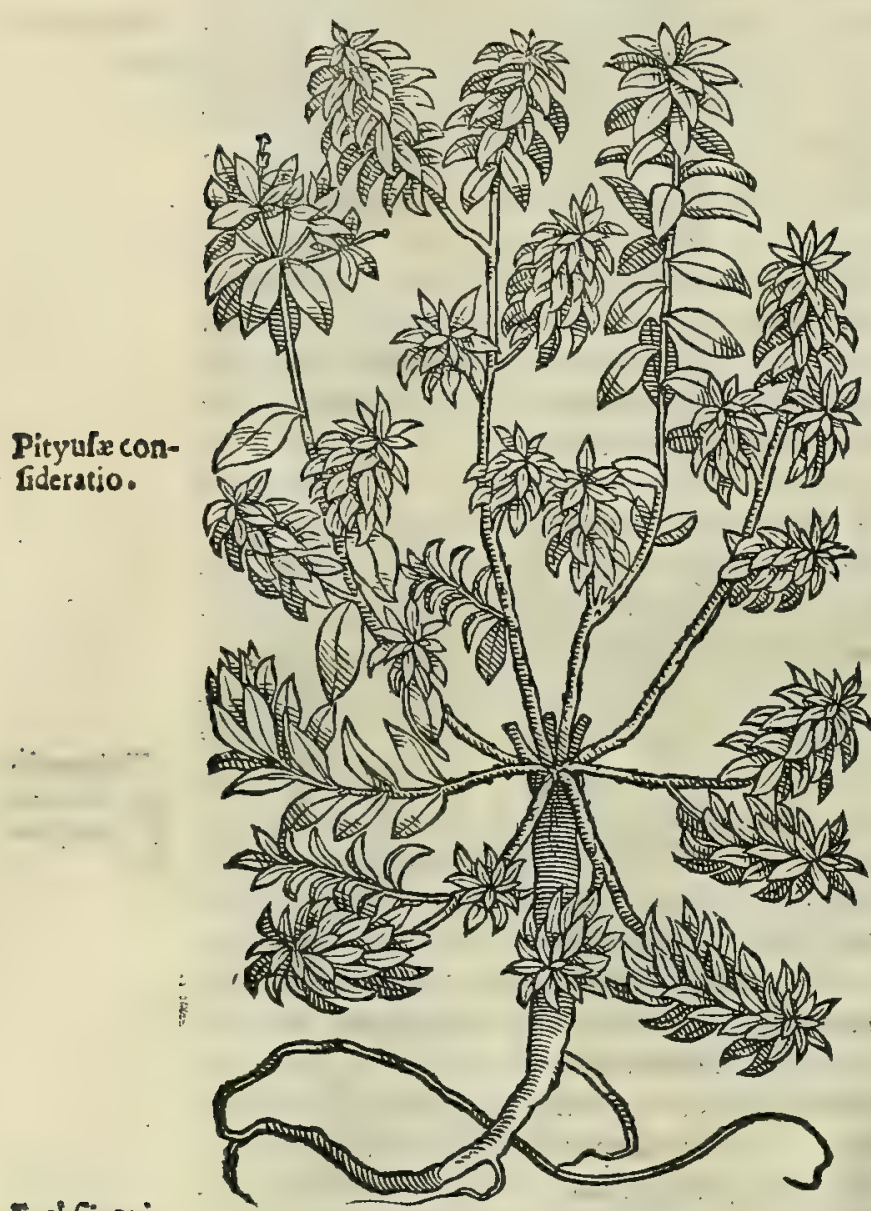

\section{CAP. CLX.}

Pityvsam fpecie à cyparifsia differre conftat, etfi tithymalorum generj afsignetur. Caulis fupra cubiti altitudiuem affurgit, geniculatus : folijs picex, acutis, exilibus : flore paruo, velut purpureo: femine inftar len ticulx: lato: radice craffa, candida, fucco referta . quibufdam in locis frutex hic prægrandis inuenitur. Detrahit per aluum radix drachmis duabus data in aqua mulfa : item feminis drachma. fucci cum farina fubaeti 20 cochlearium in catapotio datur. modus foliorum drachmætres.

P I T.Y. V S A, ut latius precedenti capite retulimus, ea nimirum fuerit planta , quam of ficine Efulam maioré nominant. Huius radices herbarij, qui quotannis é Gargano A pulia monte fuccos, $\mathbb{E}$ alias radices ad nos comportant, magna impoftura pro Turpeto uenditant, quemadmodum o thapfie radices pro codem fubijciunt, at fuperius in tripolij mentione diximus: Quod cum fua atate non ignoraffet Actuarius, album turpetam $A l y=30$ pie effe radicem prodidit, nigrum ueró $\mathrm{P}$ ityufa. Nec bis obftat, quód dixerit Diofcorides, Pityufa radicem fubeffe candidam: nam is de interiore fubftantia tantìm intellexit, non autẽ de exte riore corticis membranul a, que uiridis ruffescit; ficcata nigrefcit. Porrò quód Efula maior:fit Mauritanis alfebram, uel febrä, fatis liquidó ex Serapione colligi.poteft, utpote qui integrum de $\mathrm{P}_{\mathrm{F}}$ tyufa caput ex Diofcoride fumpfit, $\mathcal{O}$ in fuum Scebram repo= fuit. Quo fit, ut plané falli putem Brafauolum, quippe qui cer= tófibiperfuadeat, Alfebram maius Mauritanis effe tithymalum platyphyllon. Nicolaus Myrepficus quibufdain in antidotis, $\sigma$ 4.0 catapotijs aluum foluétibus Efulam imponit cognomine chame= seprobata.

pityn. Vude Fuchfius in fuis doctißimis adnotationibus nil aliud efulam Nicolao referre fcribit, quàm Chamexpityn, non autem tithymali fpeciem. Qua in re Fuchsij opinio(pace eius dixerim) mibinon plané fatisfacit. Nam cùm plu= rafint tithymalorum genera, que in uniuer fum Efula nomine appellantur, de ea tantum intellexiffe Nicoldum exi= ftimo, quam Diofcorides à foliorum forma Pityufam wocat, eo quod pini, uel picee arboris folio conftet : que ob id efula chamepitys differentix caufa Nicolao appellata eft. Paruam enim pinum pityufa reprefentat: quare non ab re efula quoque chamepitys cognominari potuit. Pityufa in Italia paßim fere prouenit, facie minoris efule, fed longè in omnibus maior, adeo ut quibufdam in regionibus, ut in Apulia, arbusci ppeciem referat. vifitur copiofa in Veronenfi agro, ed immenfa planitie, per quam ad Benacum tranfitur. Sed quod aridifimum ibifit folum, non ad= modum adolefcit: Hac (ut Mefues eft author) agreftium bominum medicamentuu eft: multa enim fumentibus ad= 50 Frt incommoda , proinde eius ufus apud medicos peritos prorfus exoleuit, quemadmodum, $v$ turpeti ex buiufce ras dicibus parati, poftquàm detecta eft impostorum fraus: etfi non defunt improbi pharmacopole, quipityufe radices legitimi turpeti uice fuis inferant medicamentis: fintó; etiam circunforanei, qui barum radicum puluere plures ingu= lent rufticos, quàm fanent. Adfcribunt quidam Pityufam tithymalorum generibus, quoniam o ip $\int$ a fimiliter lacteo Pityufa uires fucco madeat, purget'́; corum modo. Id quod Galenus aperté teftatur lib. v ₹ I I. fimplicium medicamentorum, ex Galeno. dum fic inquit. Pityufd, o banc quidam peciem putant effe tithymali, quód fuccum babedt, ut illi, quód'; fimilie Arabicé, Scebram, $\mathcal{E}$ P thias; officinis, E fula maior: Italis, Pitiufa, E Efula maggiore. 


\section{6ro And. Matthioli Comm.}

Jijs rotundo, vti in peplo, feruente guftu : radice fingulari, fuperuacua, tenui. Colligi, \& reponi, ac dari, vti peplos, \& fale condiri folet. Eafdem habet vires.

Pepli,s pepli dis confiú.

Vires utriuf que ex Gal.

Nomina.

Chamafyces confider.

Chamxfyces uures ex Gal.

Nomina.
P E P \& V M berbariorum sulgus, quòd orbiculata confet coma, Efuldm rotundam uocat. Prouenit non mo= dó in uinetis, fed etian in agris cultura deftitutis, lacteo fucco pregnans. Peplida uerò, qua Peplion dicitur, in ma= ritimis na ccentem, non prius quin hoc anno eunlfam uidimus. Sed nobis non licuit hoc tempore eius effigiem pictam cxhbere: tamen, Deo concedente, aliquando dabitur. Vtriufque uires reddidit Galenus libro v I I r. fimplicium medicamentorum, ubi premian de Peplo ita fcribit. Peplos, quidam ueró papauer pumeum, o bic frutex paruus fuccun babct finilem tithynal is, cim in alijs, tum quia purgat, ceu illi. Mox de Peplio idem Galenus baec uerba fub= iunxit. Peplium, e bic quoque frutex exiguus fuccum obtinet, ficut tithymali : nafcitur $\dot{p}_{\text {; }}$ plerunque ad mare, radi= cem habcns inutilem, ut er peplos: fuccun uerò ualidum, non tamen admodum utilem. Sed femen utile eft, $\sigma$ fld=

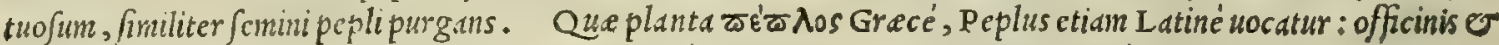

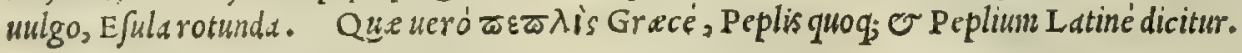

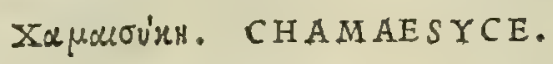

\section{CAP. CLXIIII.}

C H A M AE S Y C E N aliqui fycen nominant. Ramos emittit quaternûm digitorum, teretes, fuccofos, in terram deiectos: folia lentis, parua, peplum planè referentia, tenuia, qux à terra non attoiluntur: femine fub folijs rotundo, vt in peplo : neque caulem, neque florem promit: radice firmatur tenui, fuperuacanea. Rami ex vino triti vulux dolores fedant, in peffo appofiti : tollunt tumores, ac verrucas omnium generum illiti . Decoctorum cibo aluus refoluitur. Succus fimilieffeetu prodelt. Illitus contra fcorpionis ictus auxiliatur: aduerfus caligines oculorum vtilis, \& hebetudines, incipientes fuffufiones, nubeculas, cicatrices, cum melle inunctus. In fqualidis, petrofisçue nafcitur.

N A S C I T V R Chame $y$ yce, quemadmodum er peplus, in uineis, petrofis, er fqualidis monticulis. Hac, ut ex totius plante defcriptione colligi poteft, in pepligenere enumeranda uidetur: quippe que ramulis exeat bumi

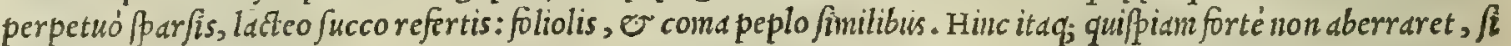
cenferet Chame $\int y c e n$ e $\int e$ minorem peplum : ego tamen id plané afferere non aufin. Chanefyces uires tradidit $G d=$ lenus lib. v I I I. Fimplicium medicamentorum, his uerbis. Chaimefyce abftergendifimul er acremuim poßidet. Ita= 30 que acrochordonas, or myrmecias caules eius teneriores in modum cataplafmatis admoti, or ex eis liquor auferunt. Cum melle ueró crafdas oculorum circatrices detergunt. Sed or bebetudinem uifus à craßitie natam adiunant, ficut

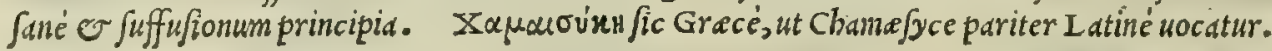

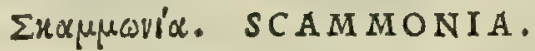

\section{CAP. ' CLXV.}

S C A M M O N A ramos ab vna radice emittit trium cubitorum, multos, pingues, \& qui nonnihil crafsitudinis præ fe ferant: foljis helxinæ, aut hederaceis, mollioribus tamen, hirfutis, \& triangulis : flore candido, rotundo, in calathi modum cauo, graueolente : radice prælonga, crafsitudine cu bitali, candida, graui odore, fucco grauida. Legitur ad hunc modum fuccus. Capitc exempto, ra- 40 dix in teftudinis f peciem cultro excauatur : quo fit, vt in cauum confluat fuccus, qui conchis demum excipitur. Alij fcrobes in terra concamerato finu fodiunt, in quos fubiectis iuglandium folijs, profundunt fuccum, ficcatumq́ue extrahunt. Laudatur autem Scammonium leue, nitidum, rarum, \& colore quàm fimillimum taurino glutini, fungofum, tenuibus fiftulis, quale ex My fra regione Afix deportatur. Nec attendere folùm par eft, fi lingux tactu albefcat ( hoc enim euenit adulterato, quod admifto fit tithymali lacte) fed longè magis anteà narratis . item fi non vehementer linguam exurat, id quod mitti tithy mali argumentum eft. Natione autem Syriacum, \& Iudaicum deterrima habentur, grauia, denfa, erui farina, \& tithy malo vitiata. Succus drachmæ vnius, aut quaternûm obolorum pondere hauftus ex aqua pura, vel mulfa, per inferna bilem, \& pituitam extrahit. Ad refoluendam aluum binos obolos cum fefama, alióve femine fumpfiffe fatis eft. Dantur efficacioris purgatio- $s$ nis caufa, fucci tres oboli, cum duobus ueratrı nigri, \& aloës drachma una. Fiunt purgatorij fales, drachmis uiginti fucci fcammonix in fenos falis cyathos adiectis. Horum modus proportione uirium : integer quidem, tria cochlearia : medius, duo : minimus, vnum. Radicis drachma una, aut altera purgat cum jjs, quæ retulimus . Nonnulli decoctum radicis ebibunt. Coquitur in aceto, \& cum hordeacea farina teritur, cataplafmate ifchiadicis utili. Partus enecat fuccus, vulux in lana fubditus: tubercula difcutit cum melle, aut oleo illitus . decocto in aceto perunctx lepr $x$ abiguntur: diuturni capitis dolores ex aceto, \& rofaceo perfunduntur.

Scammonix, eiusáue fucci confider.
S C A M M O N I V M, quod cft Scammonia fuccus, copiofum quidem in Italiam aduebitur, prefertim vene= tias, quó ex Alexandria Aegypti, e syria importatur : Sed quod probatifimum fit, rarum admodum inuciltur. Si= quidem quod omnibus ijs notis, ac dotibus praditum fit, quas optimo tribuit Diofcorides, hactenus nunquan, ut ingee 


\section{In Lib. quartum Diofcoridis.}

mué fatexr, fun confecutus. Nec mirum mibi quidem uidetur, cum id, quod àmercatoribus ad nos defertur, syrid= cum plurimum fit, ON I udaicum, compactum, den $\int u m$, graue, or erui fortafe farind, titbymali lacte, alijsó; impoftu= ris uitiatum, er illud denique, quod ut olnniun deterrmum, Diofcoridi improbatur. Verum boc parum expendentes plerique pharmacopol.e, illud preft antißimum scamnonium exiftimant, quod lingue faliua madentis contactu, $f_{a}=$ cile, confrftim $\dot{q}_{\text {; }}$ albefcit. In quo Diofcoridis doftrinam bi negligere maniffté deprebcnduntur : quandoquidem ip= fius Diofcoridis admonitio eft, ut non folim illi experimento fidere conueniat, fed etiam alijs, certioribus q $_{3}$ : id nan= que euenit adulterato quoque lactis tithymali admiftione. Quamobrem medici, qui Cbriftianam religionem, dc pieta= tem colunt, $\sqrt{i}$ probé, fancté ; artem medic am exercere cupiunt, pro uiribus fuos quisque pharmacopolas moneat, ir:= ftetq ; , ut laudatißimum querant, habeant' ó; f ammonium. Nam cum boc medicamentum omnium feré electariorum, - catapotiorumg;; , quorum paßin eft ufus ad humores in morbis deijcicndos, fit bafis, qui ijs adulteratum immifccnt, nulli dubium eft, quin peßima, or plerunque exitio a conficiant medicamenta. quo certe nibil deteftabilius, nibil'̆; execrabilius effe poteft. Sed caueant feplafiarij, ev peritorum admonitus libenter audiant: aliâs enim fciant, erro= rum pernicioforum, quos lape committunt, tandem meritas panas luent. Quód autem fcammoniun illud, quo om= nes feré officine refrete funt, tithymali fucco fit uitiatum, binc liquidó patere arbitror, quód decen, uel quindecine cius grand aluum pluries refoluant, cim fynceridrachma, Diofcoridis teftimonio, id uix preftare poßit. Plantam, é cuius radice fcammonium colligitur, uidimus primum Neapoli, allatam (ut quidam feplafiarius afferebat) ex Gar= gano Apulie monte, qux omnibus notis, meo quidem iudicio, legitimam scammoniam referebat. Sed profectó mira= rinobis fubit, quod Galenus in libris de fimplicium medic amentorum facultatibus, nibil de Scammoni uiribus memi= nerit, củm tamen pleraque alia fcriptis tradiderit longè etiam minoris momenti, atque aliâs fapius obiter Scammo=

20 nij mentionem feccrit in fuis alijs monumentis. Scammonium, authore Mefue in fuis fimplicibus deiectorijs, quinque corporibus lxfiones inferre poteft. Prima eft, quód flatus quosdam mordaces gignit, ufqueadeo uentriculum lacef= fentes, ut fumentibus naufeam commoueat. Noxabec tollitur, fi in excauato cydonio malo, clibano, aut prunis in= afetur, pafta undiq; circumlita, prefertim additis, aut foeniculi, aut dauci, aut apij femine, aut galanga. Inflam= mat deinde acredinis exuperantia corporis fpiritus: quo fit, ut facilé febres excitet, ijs precipué, qui obftructionibus wifcertm, er humoribus putrefcentibus obnoxij funt. Sed id nocumenti aufertur, admistis inter coquendum, que re= frigerant, er feruorem extingunt: cuiufmodi eft psyllij feminis fpiffamentum, prunorum decoctum, feu potius pul= pa, ro farum or uiolarum fuccus, aut dilutum, aut aqua : quinetiam $f$ ante coctionem maceretur oleo ro faceo, aut uio Iaceo, aut cotoneorum miftifaporis fucco, aut admifto rboë, aut factitio ßpodio. Ad bee quód magua tum attraben= di, tum aperiendifacultate fit preditum, immoderatas alui fluxiones facit : uaforum enim of cula plufquàm par fit $a=$

30 perit. Hec lefio adimutur admiftis rebus ad/tringentibus, cobibentibusq́;, nempe maftiche, cydonijs malis, fuccóq; ab cis expreffo, or myrobaldnis, prefertin flauis. Abradit preterea acrifucco; quo fcatet, inteftina : proinde er tor =

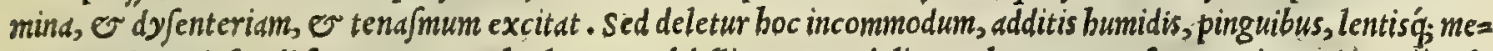
dicamentis : cuiufmodi funt, tragacantha lacryma, bdellium, amygdalinum oleum, aut rofaceum: item prunorü pul=

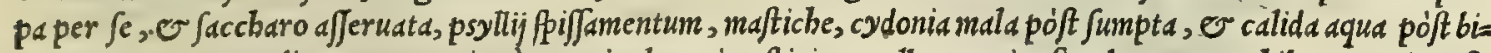
bita : utpote que medicamentum ocius a uentriculo er inteftinis expellant, evita fimul noxam prohibeant. Hinc eft, quód prudentes medici, quó celerius scammonium à uentriculo, $\sigma$ inteftinis deijciant, bordei iufculum, cum facchas ro Juperbibendum prebent. Obeft poftremó fcammonium cordi, iecori, ac uentriculo, fubftantia füe totius proprie= tate. Vitium boc aboletur, filli tum calida, tum frigida admifcedntur medicamenta, que cordi, iecinori, uentriculó= que opem fuam preftant. Deijcit fcammonium ualentißimé bilem, quam $\mathrm{e}$ d̀ udfis, et à fanguine exhaurit. Eius deij= $4^{\circ}$ ciendi facultas haud fané alijs medicamentis abfimilis eft, qua purgant cum labore or moleftia. Planta. Gracis on $\alpha \mu \mu(2)$ ia, Latinis item Scammonia uocatur : A rabibus, Scammoned? fiue Sachmunia: It alis, Scammoned.

\section{X $\alpha \mu \varepsilon \lambda \alpha i \alpha$. CHAMELAEA.}

CAP. CIXVI.

С н А M E I AE A furculofa fruticat, ramis dodrantalibus : folia oleæ fimilitudinế habent, tenuio. ra, \& amara, quæ guftata linguam mordent, \& arteriam deradunt. Detrahit pituitạ bilemq́ue, folijs præfertim in catapotio deuoratis . nanque duæ abfinthij partes, adiecta chamelæx una, hydromelite excipiuntur, \& in catapotia coguntur. ea autem in uentre non liquefcunt: fiquidem quotquot fuere deuorata, regeruntur. Folijs cum melle tritis, fordida ulcera, \& cruftofa repurgantur.

T H Y M E L AE A eft, ex qua granum Gnidium, quod eft femen ipfuus, colligitur. Hoc Syri apolinum uocant, quoniam fatiuilini frutex fuapte natura fimilitudinem referat. Virgas edit pulchras, multas, tenues, binûm cubitorum : folijs chamelæa, anguftioribus, \& pinguioribus, uifcofis, gummofisque, fi mordeantur: flore candido: fructu myrti in modum rotundo, qui inter initia uiret, \& tandem rubefcit : inuolucrum fructus durum, foris nigrum, intus album. Hoc per inferna bilem, pituitam, aquasq́ue detrahit, fi uiginti granorum pars interna bibatur : verùm fauces adurit. Itaque cum farina, aut polenta, aut in vux acino dari debet, aut melle cofto obductum deuoram ri. Qui agrè defudant, trito femine cum nitro, \& aceto inunguntur. Folia, quæ peculiariter cneorum appellantur, per melfes colligi debent, \& ficcata in umbra recondi, Quibus dare libeat, antea 
tundere, \& neruos eximere conuenit. Illitum acetabuli modo cum diluta uini potione, aquam extrahit: mediocrius purgat, addita lente cocta, aut contritis oleribus. Thymelææ farina vuæ acerbæ fucco excipitur, \& in paftillos diuiditur. Herba ftomacho infefta. partus impofita necat. Nafcitur in montibus, \& afperis. Hallucinantur, qui coccon Gnidium fructum cffe chamelæx exiftimant, decepti quadam foliorum fimilitudine.

CHAMELAEA.

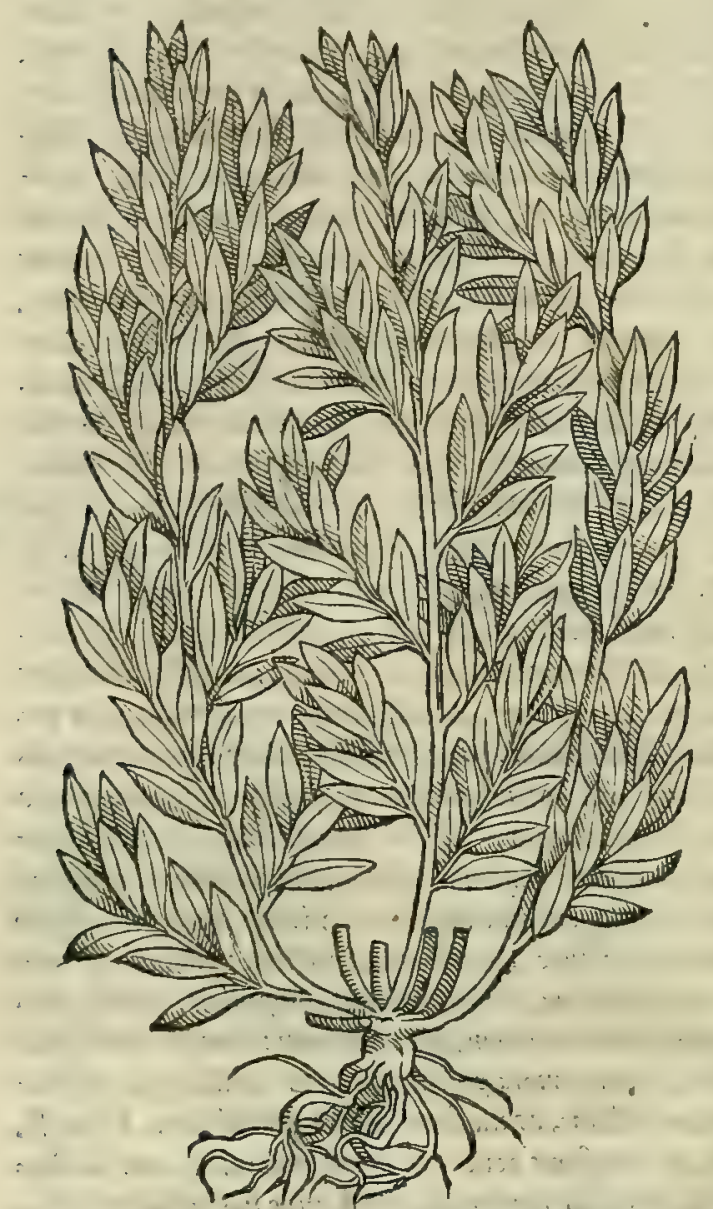

THYMELAEA.

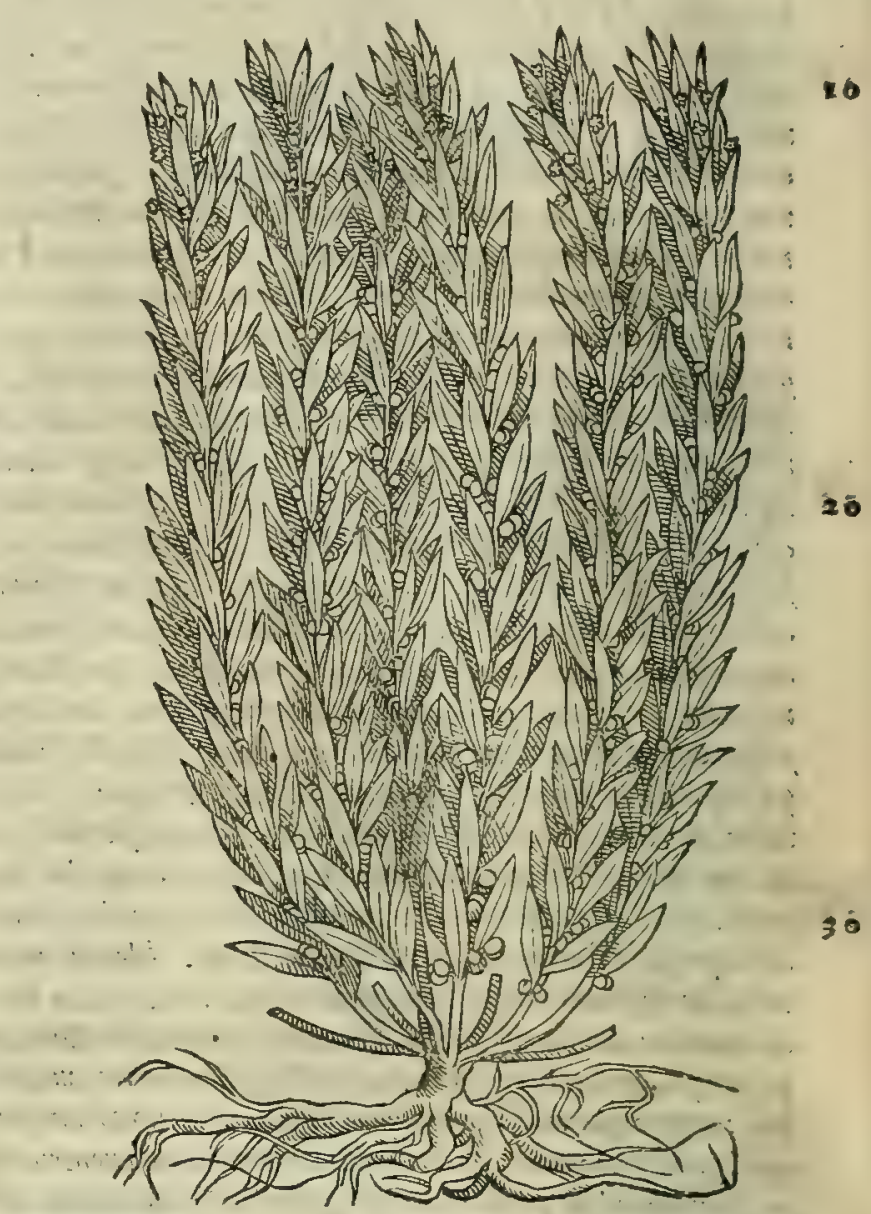

Chamelex; \& Thymelęx confid.

C н A M. L AE A M, pariter U Thymeleam Arabesconfusé fatis, ac perplexé Mezereon appellant. Cuius et $f i$ duo faciant gener ${ }^{2}$, unum album, alterum nigrum; tamen ijs etiam Daphnoidem admifcent, ov hac onnia adeó confundunt, or implicant, ut hac in re nibil certi, nibilig; perpetui ac tuti ex eorum fcriptis elici poßit : Illarwin plan $4^{\circ}$ tarum uis in exoluendo corporis bumores; tam uebemens, uiolenta, ac furiofa exiftit, ut nifi robuftißimis bomini= bus tutó in medicamentum dari poßint: plerunq; enim imbecilles confecerunt, abrafis uifceribus, apertisq́; uaforum ofculis. Quare non temere eas Mauritani of terra leones, of plantas uiduificas cognominarunt. Proueniunt he plante numerofa in uallis Ananie montibus Tridentino agro: of utreq; (licet hoc in chameled preterierit Diof $c 0=$ vides ) fructums firunt myrti baccis fimilem, quanuis chamel a e quadantenus longior fit, ev oliux formam reprêen= tet. Vtrique fructus initio fui exortus uire fcit, mox per maturitatem rube fcit, denique exiccatus niger confpicitur: - Caterum baccam, que é Thymeled decerpitur, quoniam ficcata piperis faciem pra e ferat, acrimoniamíg non obs: Fouram guftantibus relinquat, rura Ananienfiá, und ctiam cum Laureole femine, Piper montanum indifferenter no= minant. Nec-fané mirum, quandoquidem e Theophraftus libro I X .cap. X X I I.de plantarum biftoria, ubi de pipe= re differuiffet, ftatim Cnidij grani meminit :utpote quod maximé piperis imaginem refer at, o admodum etiam acre fentiatur. Sumunt boc piper (ut coruminomine utar) frequenter incole in fuis purgationibus aduerfus omnes feré mor bos, ita medicos, $\sigma$ pharmacopolas fallere credentes. Sed Sepe euenit, ut cim futuram noxam non preuideant (que cörum multorum imperitia eft) non folum jeipfos decipiant; fed etiam fibi mortem confcifcant. Et certéboc teftari poffum, quodd ex riontani illius piperis a Jjumptione plures perijfent, nifi antidotis noftris fuccurriffem, eosóg; in uita feruaffem. Proinde fcite pofteritatis memorie prodidit Me fues, nemini Mezereon prebenduin c $\int f e, m f i$ ijs admiftis antidotis, quibus eius deleteria facultas infrenari poßit, qua omnia corporis principalla membra corrumpat, ac de= fruit . Habentur tamen paßim in pharmacopolijs catapotia, que de Mezereo appellant, quibus aliquando utuntur. medici, ad aqudm inter cutemextrabendam. Verim ea non audent exbibere (quanquam medicamenta fimul recepe $=$ Chamel xx ui rint, quibus corum malitia reprimitur) nifi robuftis, ac fortioribus bominibus. Chameleam tantim, quod fciam, cŏ= res ex Gal. memorauit Galenus in fimplicium medicamentorum cenfu, de cuiusuiribus libro v I I I. cornndem ita fcribit. Chame lea uincentem babet qualitgtem amaram. Quamobrem admodum fordida ulcer, o que maximas babc nt cruftas, 


\section{In Lib. quartum Diofcoridis.}

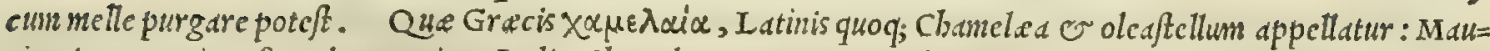
ritanis, Mczcrion, fcu Alcmezerion: Italis, Chanclea : Germanis, Zylandt: Gallis, Boys gentil. Qu\& ueró Gre-

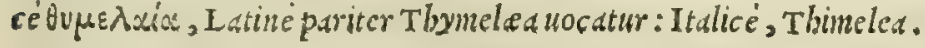

\section{$S A M B V C V S$.}

20

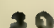

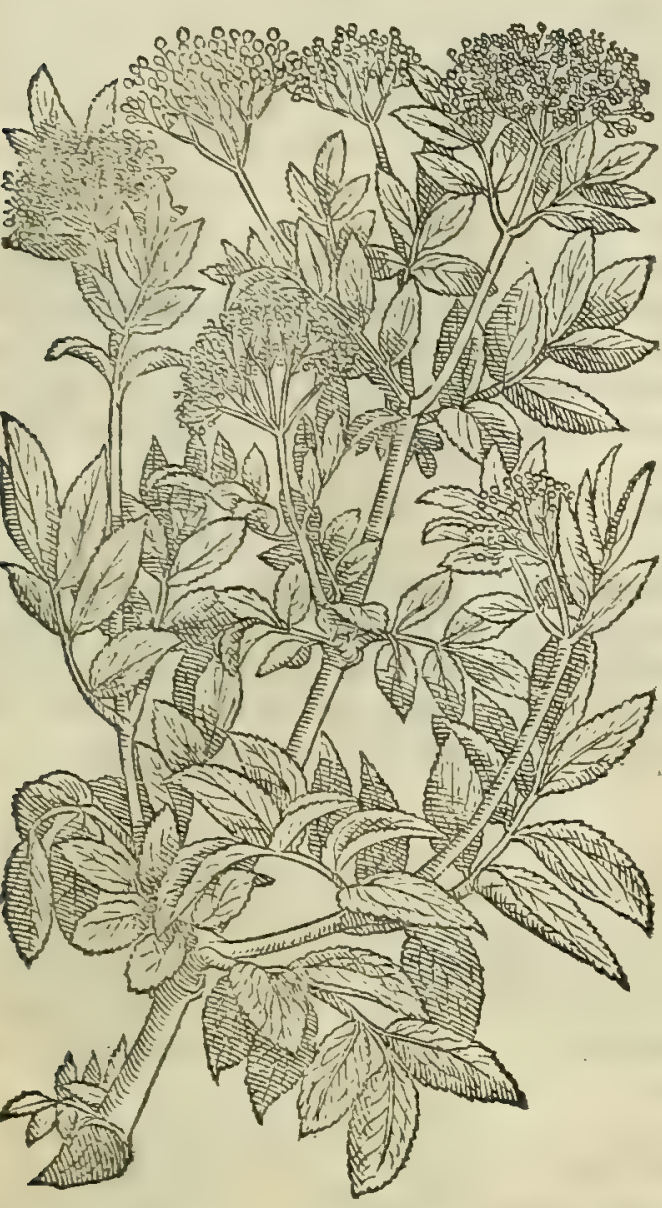

A'rth. SAMBVCVS.
EBVLVS

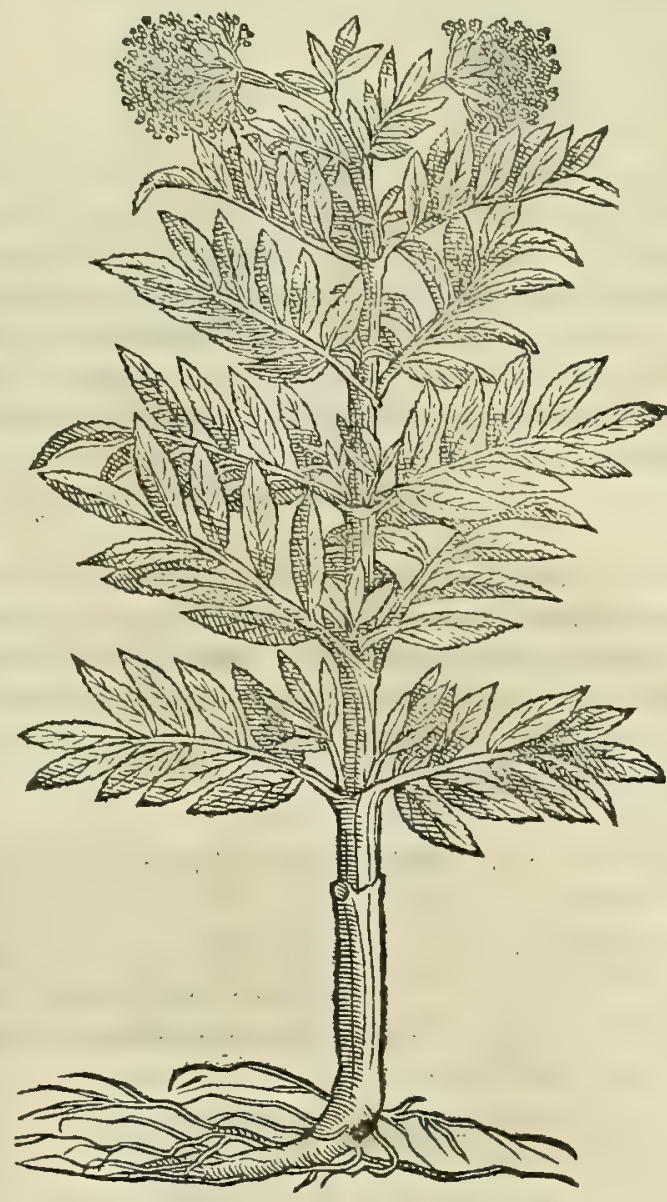

CAP. CLXVIII.

S A M E V C I duo genera. Vnum in arborem affurgit, furculos fpargens arundinaceos, teretes, cauos, candicantes, proceros : folia juglandis, terna quaternáve, ex interuallis circa ramos exeunt, 40 grauia odore, minutim in ambitu fecta : \& in ramulorum cacuminibus, cauliculisq́ue circinatæ umbellx, qux florem candidum pariunt : mox acinum terebintho fimilem, in nigredine fubpurpureü, raccmofum, fucco madentem, uinofumq́ue. Alterum genus chamæacte uocatur, Romanis ebulú, longè humilius eft, magisq́ue herbaceo generi afsignandum : caule quadrangulo, geniculato: folijs amygdalx, ex interuallo longioribus geniculatim expanfis, pinnatisq́ue, graueolentibus, in ambitu ferratis : mu fario fambuci : flore, \& acino eiufdem : radice nititur, longa, crafsitudine digitali . Eadem utriufque uis, \& ufus exiccans, aluo detrahens aquam, ftomacho inutilis. Folia olerum more coquuntur, ad pituitam, bilemq́ue detrahendam. Caules teneri in patinis cocti, eadem efficiunt. Radix in uino decocta, $\&$ in cibis data, hydropicos adiuuat : prodeft uiperarum morfibus, eodem pota modo. vuluas emollit infidentium, decoeto : patefacit eorum fpiracula : \& uitia corrigit . Acini 30 in uino poti, eodem funguntur munere: denigrant capillos illiti. Folia, fi prætenera ac mollia ex polenta illinantur, inflammationem mitigant : ambuftis, \& canum morribus illitu profunt : vlcera qux dehifcunt in fiftulam, agglutinant. ijs, qui podagra tentantur, cum feuo taurino, aut hircino profunt illita folia.

$S$ A M в V C V $S$, 厄 Ebulus plante funt nutlis non cognite. Prioris etfin unun tantùm genus prodatur à Dio= fcoride; nobis tamen duo eius obferuata funt genera: alterum quidem montanum, ov fylucftre : alterum uerò urbd= num, plerung; in hortorum, o uinearum fepibus proueniens. Hac genera fructu inter fe differunt: fiq:idem monSambici, \& Ebuligeners, tano baccs perpetuó rube fcunt. Illud etian difcrimen facit, quód urbanum in maiorem proceritaten adole $\int c i t, o r$ Teuiore conftat materie. Sunt pretered: qui paluftrem Sambucum oftendant, nempe arbufculam uliginofo, er pa= 1uftrifolo enafcentem, uirgis fambuci emulis, geniculatis, alba intus medulla, fed caduca, or frogili materie :fo= lio uitigineo : flore albo fanbucimodo, odore non prorfus iniucundo: i quo baccse prodeunt rubcntes, oxyacunthe 


\section{I4 And. MatthioliComm.}

magnitudine, uinofo fucco referte. qua deuorate uomitiones cient. Aqua é ambuci floribus fronti, er fyncipiti illita, capitis dolores mulcet, qui ḋ calido bumore prouenerint. Succus è radicis cortice expreffus, nomituin ualen= tißimé commouet, er aquam inter cutem pellit. Preftat idem é radicibus ebuli extractus fuccus. Quin or craffam pituitam ad articulos decurrentem extrabit. Ebulifemen per diutinus aque lotiones à nigro circumftante fucco ex= purgatum, datur utiliter drachme pondere ex chame pityos decocto, podagricis, ifchiadicis, $\mathcal{O}$ Gallic a lue labo= rantibus: mulcet enim deiectoria ui mirificé corum dolores, cum bumores é fluentes tum reuocet, tum deijciat . Sunt qui ex ebuli radicibus fuccum eliciant, infolentó; fubinde, ov in paftillos diger ant, feruentóf; ad u us. Hic clystere infufus tam inteftinorum, quàm coxendicum dolores tollit a frigiditate, er flatu genitos. Supponitur conuenicnter faininarum locis ad cuocandos mereses, prefertim fi lana exceptus intromittatur. Suffuntur ebuli decocto commo= dé ij, qui diuturna fibre uexati ad malum deuenerunt babitum, fi tamen uentriculus, or iecur interea roborentur 10 Sambuci utri odoratis adstringentibus, o ad id confrentibus medicamentis. Meminit Sambuciutriusque Galcnus libro v I. fim=

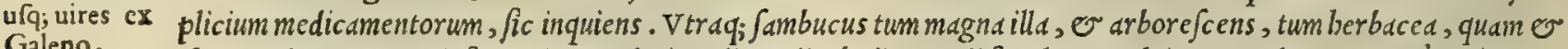

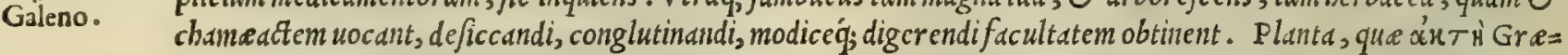
cis, sambucus Latinis appellatur: Arabibus Iafacti: Italis, Sambuco, Germanis, Holder, feu Holler: Hipanis',

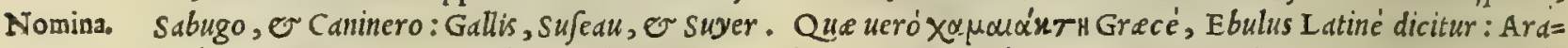
bicé, Kameatis: Germanicé, Attich, $\mathcal{\sigma}$ Niderer holder: Hipanicé, Hiezguos, or Sabugo pequenno: Gallicé, Hyeble.

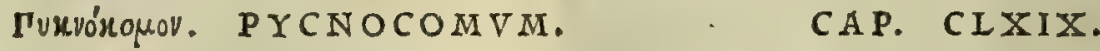

P y C N O C O M O N conftat erucx folijs, acrioribus, fcabris, \& crafsis : caule quadrangulo: flo- 20 re ocimi : femine marrubij : radice nigra, aut pallida, rotunda, exigui mali figura, terram redolente. inuenitur in faxofislocis. Semen grauia fomnia, \& tumultuofa facit, drachma inftar potum. tumores difcutit, illitum cum polenta: $\&$ fpicula, adactosq́ue corpori aculeos extrahit . Folia illitu tubercula, panosq́ue difcutiunt. Radix eius in aqua mulfa duûm drachmarum pondere, aluum foluit, \& bilem extrahit.

N V L L A M equidem usquam plantam bactenus fum confecutus, qua facie Pycnocomorepoinderet. Quare e hoc mibi, ut ingenue fatear, referendum eft inter alias berbas, quas bodie ommibus incompertas effe arbitror. Ita enim fiet, ut $\mathcal{O}^{\circ}$ pofteris, quos ßpero futuros reiberbarie diligentiores inquifitores, fuus relinquatur foribendi locus. Nec fané quenquam pigere debebit, cum ex bis, que nobis uel incognta, uel incerta funt, aliquid inuenerit, 30

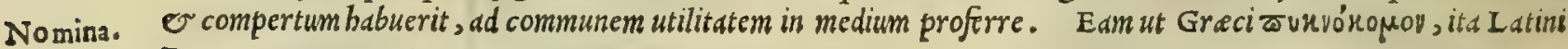
Pycnocomum uocant.

A"Tlos. APIOS.

Apij, fiue Ifchadis confideratio.

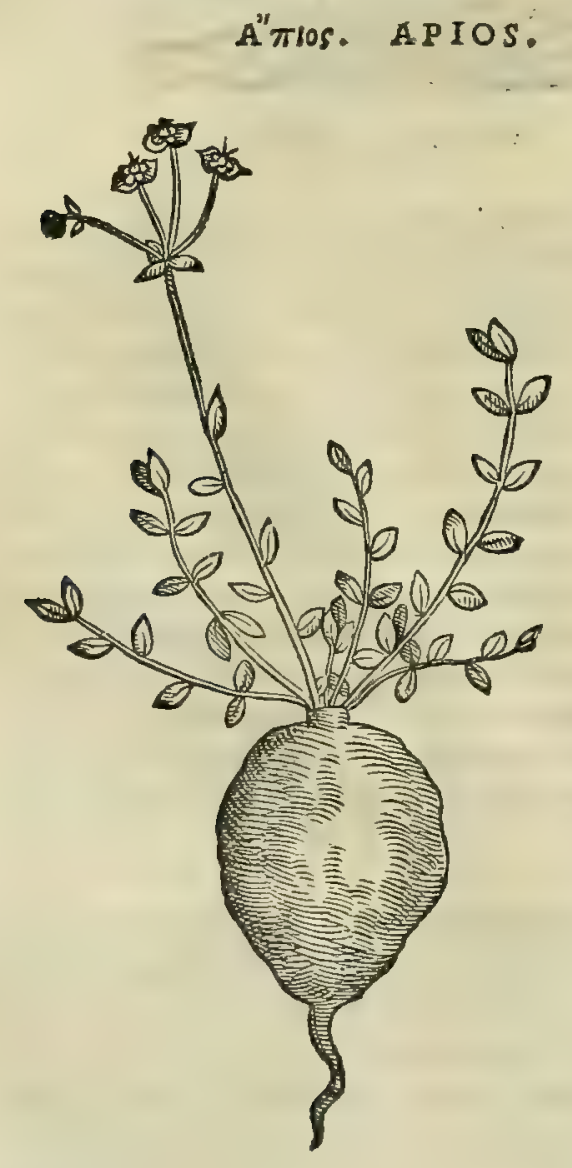

\section{CAP. CLXX.}

A P I o s ramulos duos fiue tres iunceos fpargit,rubros, tenues, qui à terra parum attolluntur : folijs rutæ, oblongioribus tamen, \& anguftioribus, herbacceis : $\mathrm{fe}$ mine paruo: radice haftula regiz in formam pyri turbinata, rotundiore tamen, fucci foccunda, intus habet corpus candidum, extrà cortices nigros. Superior pars 40 eius uomitione bilem, pituitasque extrahic: inferior per aluum : tota utrinque purgationes mouet. Succum fi libet eximere, tufa radix in fictili mergitur, \& agitata aqua, quod fupernatat penna felęum; exiccatur. Purgat utraq; parte is fuccus, fesquiobolo potus .

A P I os, qua r Ifchas appellatur, nafcitur in Creta(quă quam non de funt qui uelint eam quoque protienire in Italia, pra= fertim in Apulia) folijs exiguis, rute, uel byperico proximis, pri mo statim uere abradice erumpentibus, nigrioribus tamen, alba so quadam lined in lognitudiné percurrente: cauliculis iunce is $\int u b=$ rubentibus, lacteo fucco madentibus: radice exterius nigra, interius cädida, pyri effigie, unde or nomen : a' cis nil aliud fignificat, quain Latinis pyrum. Theophr.libro Ix. cap. $\mathrm{x}$. de plant.biftoria, Apion bis notis reprafentauit. Ifchas, fiue Apios folio conftat rutaceo, breui, caulibus ternis, aut quas= ternis, bumi proftratis: radice, qua aphodelus, uerim fquamo/a. Nafcitur in montibus. Legitur uere. Datur ad expurgandum corpus, quod altera radicis parte fuperius, altera inferius pur= get. hec ex Theoplbrafto. Apion legitimam, quam primim me uidiffe recordor, ad me mifit Venetijs Nicolaus à Sïto Michiè= 


\section{In Lib. quartum Diofcoridis. $\quad 615$}

Ie Nouocomenfi, medicus fingularis ingenij, atg; eruditionis orizei berbaric peritus. Caterim fcribit Rucllits Ruel. laplus Apion frequentißimam in Gallia nafci, eiusq; radice ruri pauperes per inopian fiugum ue $\int c i$. Sed R uellij fontentiz non effe fubfcribendum iudico: nan chin Apios per fupernd, or inferna purgationem moliatur, malé nimirum cos baberet, qui nulla buius facultatis babita rationc copiose ( ut ruftici facere folent) cius radices funerent in cibis. Apil buius mufquan, quód inucncrim, mentionem fecit Galcnus in fimplicium medicamentorum cenfu. Hac plantw non fecus Latimis A pios, at q; Grecis äw los nominatur.

Kororiveis. COLOCYNTHIS.

\section{CAP. CIXXI.}

CoL OCYNTH I S farmenta, foliaque fatiuicucu meris emittit, per terram repentia, diuifa: fructum in fpeciem mediocris pil $x$ conglomeratum, vehementer amarum . quem legere oportet, cùm cœperit in pallidum colorem permutari. Medulla fructus purgatoriam vim habet, fi quatuor oboli cum aqua mulfa, melle cocto, myrrha, \& nitro excipiantur, \& cogantur in catapotium. Arefactæ pilæ teruntur, \& infufæ cly lteribus profunt ner uorum refolutioni, coxendicum doloribus, \& coli vitijs, vt quæ bilena, pituitam, \& ftrigments, interdum etiam criorem eliciant. fortus admotx enecant. Dentium dolorem tollit,fi vna repurgetur, \& luto oblita cum áceto $\&$ nitro inferuefcat, hocq́ue iure decocti dentes colluantur. Si aqua mulfa, aut paffum in eadem incoquatur, $\&$ fub diuo refrigefcat, potu craffum hum orem, \& ftrigméta aluidetrahet : ftomacho fupra modum aduerfatur . fubdita ex ea balano alui excrementa eijciuntur. Virentis fucco vtilifsimè ifchịadici perfricantur.

C O I O.C Y N T H I s plantd eft tam medicis, quàm fepla= fiarijs unlgaris notitice. Verim etfi ( $u t$ Mefuies eft author) pre $=$ ftantißinum ex eits fructu paretur medicamentum ad uaria nor= borum genera; ea tamen cordi, iecinori, "ீ uentriculo naximé aduerfatur, quin or uniuerfum perturbat corpus, faftidium, or inteftinorum tormina excitans. Abradit enim: inteftina, er ud= forum ofculd aperit, adé ut etiam cruenta fape cliciat. Hinc merito fit, ut edin dari prohibeant, nifi prius malefica eius wis prorfus aboleatur, ïs additis antidotis, qua ad id praftant : cuiuf= modi funt illa, que uentriculü, iecur, er cor tum roborare, tü theri

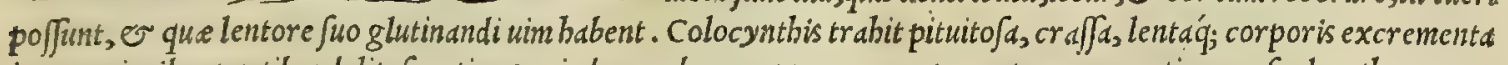
40 in remotioribus partibus delite centia : proinde cerebrum, er neruos expurgat, nec non etiam mufculos, thor acem, e pulmonem. Eam ob caufam uertigino is, comitidlibus, refolutis, conuulfis, hemicranid, diuturnog;; capit is dolo= re affectis, afthmaticis, or egré pirätibus utiliter in catapotijs exbibetur. Collacbrymantes adiunat oculos, et diu= tind tußi laborantes. Eft prixterea uis eius efficax ad omnes frigidos articulorum dolores, prefertim podagricos, et ifchiadicos: ad que non modó in catapotijs deuor atur, fed etidin clyfteribus infunditur . quibus fané nil pr.eftanti= au eft ad coli cruciatus ex flatu, et frigiditate prognatos. Pellit aquas tam bibita, quim per fedem infufa. Fit é co= locynthid is fructu oleum, ad retardandam canitiem, denigrandos capillos, et corum deflunium cobibendum, $\sqrt{i}$ exem= pta é fructu pulpa, eauitas oleo repleatur, et in cineribus decoquatur. Eodem mulcentur aurium dolores, et eartm incerti fonitus difcuttuntur. Colocynthidis uires retulit Galenus lib.v I. fimplicium medic amětorum, his uerbis. Colccynthis guftu amar a eft, fed quze dmarifino medicamento epoto adfunt opera, ea enidenter efficere nequit, ob.

so purgatoriain facultatem, quam ualidam in fe fe continet, nimirum cum ïs, que expurgat, anté et ipfa per aluum excerni preuertens. Viridis ipfius fuccus intritus ifchiddibus prodeft. Ko Korvvois fic Grecis, Latinis item Colo= cynthis, et Cucurbita Gylueftris appellatur: Arabibus, Chandel, Handel, feu Handal: Italis, et Hifpanis, Colo= quintida: Germanis, Coloquint, et Vuilder kurbfz: Gallis, Coloquinte, et Courle faunage.

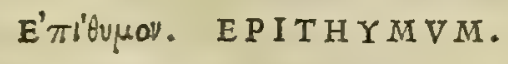

CAP. CL XXII.

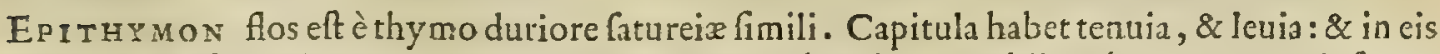
caudiculas, quafi capillamenta. Potum cum melle detrahit pituitam, bilemq́ue atram per inferna. Priuatim prodeft melancholicis, \& inflatis, acetabuli menfura ad quatuor drachmas, cum melle, fale, \& aceri exiguo. Plurimum in Cappadocia, \& Pamphylia gignitur .
Colocynthidis confidera tio.

Golocynthidis uiles ex Galeno.

Nomina. 


\section{I6 And.Matthioli Comm.}

Epithymi cófiderauo.

Multorü opi nio reprob.
E P I T HYMVM.

IN H A C equidem opinione uer $\int a n t u r$ complures buius atatis medici rei herbarie periti, quemadmodü $\mathrm{Br}$ rauolus $\mathrm{Fer}=$ rarienfis, ut credant, Diofcoridis, aliorumó; Grecorum Epi= thymum magno difcrtmine ab eo diuerfum effe, de quo fcrip $e=$ runt Mauritani, prafertim $q$; abillo, cuius meminit Mefues. Quippe qui afferdnt, nil aliud Arabicum epithymum effe, quàm capillaris caffutbe genus quoddam, quod thymo circumuolui= tur. Grecum ueró idem effe uolunt cum proprio flore durioris thymi fatureia fimilis. Suam autem fententiam hoc argumento comprobare uidentur, quód fi unlgaris ufus epithymum, Ard= bicum fcilicet, illud effet, de quo differit Diofcorides, is non di= xiffet, Epithymum florem effe durioris thymi, fed alterius plan= te thymo adnafcentis, eiǵ; fe e conuoluentis. Id quod etiam Pli= nij auctoritate confirmant, ut qui eorum opinioni ex eo maxi= mé adftipulari uideatur, quód duo Epithymi genera prodiderit 7ib. X X V I. cap.V I I I. ubi fic inquit . Epithymum eft flos è thy= mo fatureie fimili . Differentia, quód bic berbaceus eft, alterius thymi albus. Quidam aliter epitbymum tradunt fine radice na= fci, tenuis fimilitudine pallioli (rectius forté pili legendum effet) rubens. bac Plinius. Ex quibus utique planum fit, duo effe $\mathrm{E}=20$ pitbymi genera : quorum alterum illi ad Grecos, alterum ad Arabas referunt, er ita fuam tuentur fententiam. Horum certé iudicio ego quog; facilé fubfcriberem, nifi quedam $\int e f e$ no bis offerrent, qua aperté reclamare uidentur, atque etiam often dere, Plinium ipfum Diofcoridis codicem, unde ill mutuatus eft, deprauatum baburfe, uel alium auctorem in hoc minus grauem fecutum fuiffe, uel feipfum deceptum, ut in alijs compluribusitli cueniffe adnotauimus. Pald̀m etenim faciunt, quantum equidem reor, noftri ufus, o Diofcoridis epithymum, unum er idem effe medicamentum, que de eo Aëtius, e Actuarius, Diofcoridem,

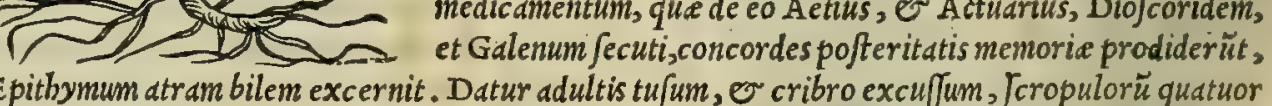
cüm ita fcribunt. Ep pithymum atram bilem excernit. Datur adultis tufum, ov cribro excuffum, Jcropulorü quatuor

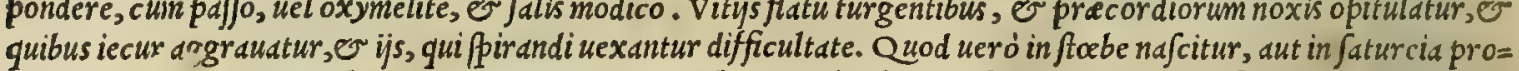
filit, Epiftcebe, atque Epitbymbrum inde appellatum, thymi modo aluum refoluit: Sed utrunq; facultate cen $\int$ etur in= firmius. bec illi ambo. Que fané liquidó oftendunt, quód non fecus Epithymbrum thymbre, er Epif trebe ftebe in= nafcatur, atq; Epithymum in thymo ndfcitur, uel profilit. Hoc idem prater Aëtium, or Actuarium longé anted te= ftatus eft grauißimus author Paulus. Diofcorid is, o Galeni fectator acerrimus ijs uerbis. Epithymum inter ea, qua atram bilem extrabunt, praftantißimum eft remedium. Dantur ipfius drachma quinque lauigate ex lact is hemina. Epithymbrum ueró, quod thymbre itnafcitur, epithymo fimiliter euacuat, fed imbecillius eft. bactenus $\mathrm{P}$ aulus. Ex 40 bis itaq; omnibus non dubitauterim afferere, unum tantium effe epithymum, non autem plura. Quandoquidem fi Pak= lus, Aêtius, eN Actuarius pro certo non habuifent, legitimum Epithymum effe illum thymi florem, de quo fcribit Dio= fcorides, putaffentó; duo eius genera reperiri, nulli dubium eft, quin $\sigma$ ip/i explicafent duplex in thymo nafci epi= thymum. Verum cum compertum haberent, unum er idem effe medicamentum capillamentumg; , quod in thymo, thymbra, or fteebe profilit, ijsó; nullo radicis adminiculo conuoluitur, $\mathcal{G}$ implicatur, fibi uifum eft, quod fuo tem= pore Epithymum unlgaris notitie medicamentum effet, fat fore declar affe non modo id in thymo gigni; fed etiam in ftabe, thymbra, o ( ut nos Sepe uidimus) in polio, et chamedry. ut binc fcirent medici, in epithymi defictu, epithym brum, uel epiftcebem fubritui poffe: quinetiam ut non ignoraret, id capillamentum barum plantarum propriam non effe partem, neq; fuam habere fedem, fed afcititium quoddam effe exterius adueniens, $v$ in ijs profiliens, $\mathfrak{e}$ uiuens. His igitur rationibus adducor, ut non temeré exiftimem, Diofcoridis codicem, quem Plinius habuit, fuiffe (ut diximus) so deprauatum, $\sigma^{\circ}$ ob id ipfum Plinitu deceptum effe: aut bunc aliunde accepiffe occafionem, ut duo magno errore $f a=$ ceret Epithymigenera. Quód autem Diofcorides epithymum florem thymi dixerit, haud inepté dictum putauerim: nam cum is fciret E pithymum thymo innafci, nulla radice propria, fed thymi adminiculo fultum, floresó; per fe albos frre, qui cum in thymo funt, huius plante proprij uidentur; ideo non abfurdum fore duxit fcribere, Epitbymum effe florem durioris thymi. Sed quód Epithymum flores albos freat, declaraffe uidetur Diofcorides, cum dicit. Capitu= la babet tenuid, e leuid, caudicul as babentia capillorum modo. Siquidem bis notis non defcripfit Diofcorides thymi florem fuperius libro tertio ( $u t$ Brafauolus afferit) fed capitulis in cacumine, flore purpurafcente refertis, nulla caudicularum, neque capillorum habita mentione. Pretered conijcere licet Diofcoridem epithymum thymi florcm appellafe, quód à thymo decerpatur co duntaxat tempore, quo epithymum ipfum largé floret. Nam quòd pro cpi= thymo non intellexerit is purpureum thymiflorem, hinc perfpicuó apparet: quoniam de epithymi uiribus libro I I $\mathrm{r}$. ubi de thymo, o eius floribus egit, nibil in medium protulit, nimirum eam ob caufam, qquod epithymum propriam 


\section{In Lib. quartum Diofcoridis.}

thymi particulam non exiftimakerit effe, fed (ut fuprà dictum est) afcititium quoddam, ut in arboribus inucus, or uifcum: que tanten legitime arborum partes non funt, fed uiribus o facultate diuer $\int e$. His igilur rationitus, ut ar= bitror, ductus Diofcorides, egit de tbymo, ev cius floribus libro tertio inter odoratas plantus: de cpitbymo uero', tanquam de re à thymo diuer $\int a$, differuit in boc libro quatrto inter decictoria medicanenta. Similiter de arboribus, quibus nifcum innafcitur, difputaut libro primo: de ip $\int 0$ autem uifco libro tertio cum ijs medicamentis, qux fuo len= tore glutinant. Aáde quód idem indicarc uidctur nomen Gracun écí, quod Latinis modó fub, modó in fignificat. Vnde nil aliud nobis epitbynum infort, quàm in thymo, ucl fub thymo. Id quod flori tlymi quomodo conucnire pof= fit, non uideo: utpote qui non in thymo, neque fub thymo nafcatur, fed fuper thyno, ea cminentiori parte, qua capitula cmergunt. His alia accedit ratio, quod cum feripfcrit Diofcorides Epithymum plurinum in Cappadocia, $\mathcal{O}^{\circ}$

ro Pamplyyliagigni, facilé colligi potest, ipfun de Epithymo uulgaris ufus effe locutum. Quippc fi cpitlymmm pro= prij thymi florem effe duxiffet, cifane opus non fuiffet fcribcre, quod magis ijs in locis cpithymum copio fum proueni= ret, quam alibi: quoniam fcripfilße fat erat, oriri epithymum, ubicunque thymum proueniat, boc argumcnto, quód thymum ubic unque nafcatur, eft ate fwos edat flores. Epithymum in tbyno fatureia fimili nos fepißiné lcgimus pro= pe Goritiam Saluatino, e Gargaro montibus fupra Salicanum, quico durioris thymi genere copiosé uestiuntur, fed cui cpithymum infideat co tantium tractu, qui ad meridicm pattat. Et/i enim montes illi thymo omni ex parte fatent, nufquam tamen thimi plantas mibi licuit inuenire, in quibus Epithymun pectaretur, nifi in anneniore mon= tis parte, "lbi herbe enate austro perflantur. Quamobrem nil nirum efe debet quód in Pampbylia, or Cappado= cia epitbymum frequentißimum proueniat. Sed quoniam tot fcio me frustrà buc adduxiffe argumenta, quibus ineam firmauifententiam, nfi ctiam Plinnij autboritati, qua nititur Brafauolus, clarius refponderem: id circo illi ita re=

20 Pponfun uolo, quód cum Plinius Diofcoridis mentem, a quo priorem fuorum uerborum partem fump/iffe uidetur, non recté perceperit, ideo non affirmaté, $\int e d$ dubiè duo fecit Epithymigenerd, or aliorum potius, quàm fuam opi= nionem retulit, cum inquit. Epithymun eft flos è thymo fatureix fimili. Differentia, quód bic berbaceus eft, alte= gius thymi albus. Quidain aliter epithymum tradunt fine radice nafci, tenus finilitudine pili, orc. Porró ueró idem $\mathrm{Plinius} \mathrm{in} \mathrm{ijs} \mathrm{uerbis} \mathrm{erraffe} \mathrm{deprehenditur,} \mathrm{quod} \mathrm{maiori,} \mathrm{durioriq;} \mathrm{thymo} \mathrm{berbaceum} \mathrm{florem,} \mathrm{minori} \mathrm{ueró} \mathrm{al=}$ bum reddiderit : cum tamen minoris flos purpureus $\sqrt{i t}$, alterius autem modó candidus, modó in candido purpurafcés. Hinc itaque perfpicuum fit, tam confusé, $\sigma$ inconftanter de epitbymo, e thymo tradaffe Plinium, ut nibil certi in bac re ex eius uerbis elici poßit. Ceteriun ballucinantur, mea quidem fententia, in Epithymi biftoria, etiam Monschi illi reuerendi, qui in Me fuem commentarios ediderunt : quippe qui Diofcoridis uerba perperàm interpre= tati deprebendantur, etfiut forté alijs doctiores uiderentur, fuam in Epitbymo fententiam proferant ijs uerbis. Cer=

30 tißimé à paucis uerus fenfus uerborum Diofcoridis de epithymo percipitur. nam cim ipfe Diofcorides dicat capitu= lo de epithymo, epithymun flos eft é thymo fatureix fimilis, non per boc intelligit Epitbymum, fcilicet capillamen= tum thymi effe finile berb e fatureie, fed afferit illud dictum capillanentum thymi effe fimile capillamento fatureix, fcilicet thymbre. quia etiam e fupra thymbram generatur huiufmodi capillamentum, ficut fupra thymum. bac pa= tres illi. In quibus facilé cognofcitur borum inanis quedam iactantia, ne dicam, pace fua, ignorätia. quód fenfus uer borum obfcuros, claros reddere profiteantur, atque ijs Jubinde, ut mibi uidetur, maiorem caliginem offundant. Quód enim Diofcoridis fententia hoc loco euidentior fit, quam ut exponi debeat, quódq́; aperté Monachis refrage=

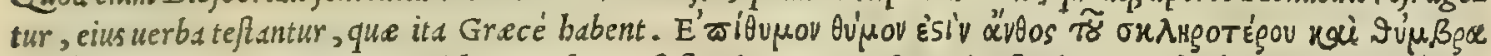
Éoixótos. hoc eft ad uerbun. Epitbymum thymi eft flos durioris ơ fatureix fimilis. His fané uerbis liquet, quód Diof corides non comparat Epithymum, quod florem thymi wocat, flori fatureia, ut Monachi illi malé interpretan=

40 tur, fed illud genitiunum colno'Tos ad thymum tantum refert: ita ut tbymum, cui Epithymum infidet, fatureiz fimile faciat. Thymi nanque duo babentur genera. Vnum maius fatureic fimile, in quo epitbymum profilit. Alterum mi= nus, tenuißsinis folijs re fertum, in quo nullum nafcitur epitbymum. Hoc certé non latebat Diofcoridĕ. quare ne quis= piam fortafe putaret utriq; thymo epithymum inna fci, id tantum in thymo duriori inueniri prodidit. Sed fat is fuper $\dot{q}_{;}$ de Epithymo difputatum eft : iam medicine reddenda eft ratio, er de eius uiribus agendum. Illud fibi peculiare afci= uit Epithymum (ut teftatum reliquit Me Jues in fuis fimplicibus) quód ualentius ceteris medicamentis atram bilem ex= cernit, id'́, facile, er citra ullam moleftiam praftat. Efficax eft ad morbos cerebri, nempe melächoliam, epileppiam, diuturnos capitis dolores, alids'́; atrabiliarids ggritudines. Confert cordis tremoribus, er animi deliquijs. Prete= rea cunttis lienis affectibus miré opitulatur : item renum uitijs, or bypochondriaca melancholia uexatis. Frequens

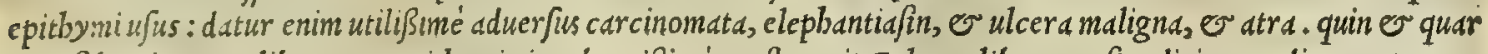
so tana febre detentos liberat. Epithymi uires breuißimé perftrıxit Galenus libro v 1. finplicium medicamentorum, fic inquiens. Epithymum thymi facultaté babet, ad omnia efficacius exiccat, or excalfacit ordine tertio . hactenus Galenus. Verün quid Epithymum ob fimilitudirem mibi ad memoriam reuocauit c A S V T H A M ita à peritiori= bus medicis uocatam, licet officinis, er berbariorum uulgo Cufcuta nominetur, cim à ueteribus Gräcis nibil, quod conftet, de ea memorix proditum fit, bic locus pofcere uidetur, ut de ea aliquid differamus. Cufcuta igitur, fiue Caf= futha eius generis eft, ut in frutices, $\sigma$ berbas epitbymi modo profiliat, or uiuat earum adminiculo fulta, nulla radi= ce nixa, fed uelut ab alarum finu prodeuntibus cirris, capillamentisue longi istmis. Hac ftatim ab exortu plantarum ramulis $\int e$ implicat, or adeó crebris inuolutionibus bis fe circumuoluit, ut breui plantas ip $\int a s$ frangulet, atque ene=cet. Folijs nullis unquain ueftita uifitur. Flores ámen edit albos, quàm plurimos, à quibus senen tenue prodit. Cirri rufefcunt, uitium capreolis crajitudine, o facie pares. Sunt qui putent', admirabile boc plante genus Plinio Caf= $\int y$ tam appellari libro $\mathrm{x} v \mathrm{I}$. capite ultino, ubita fcriptum reliquit. Eft $\mathcal{O}$ in Syria berba, qua uocatur $C a \beta y t a s$, non tantim arboribus, ed ip fis etiam pinis circumuoluens $\int e \int e$. Nec plura Plinius. Ex quibus equidem, quód repe=

Epithymi uires ex Mefue, \& Galeno.

Caffuthæ hiAtor. \& uires. Monachorü expolitio uana.

Epithymum ubi plurimú.

Plinij lapfus.

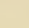




\section{And. Matthioli Comm.}

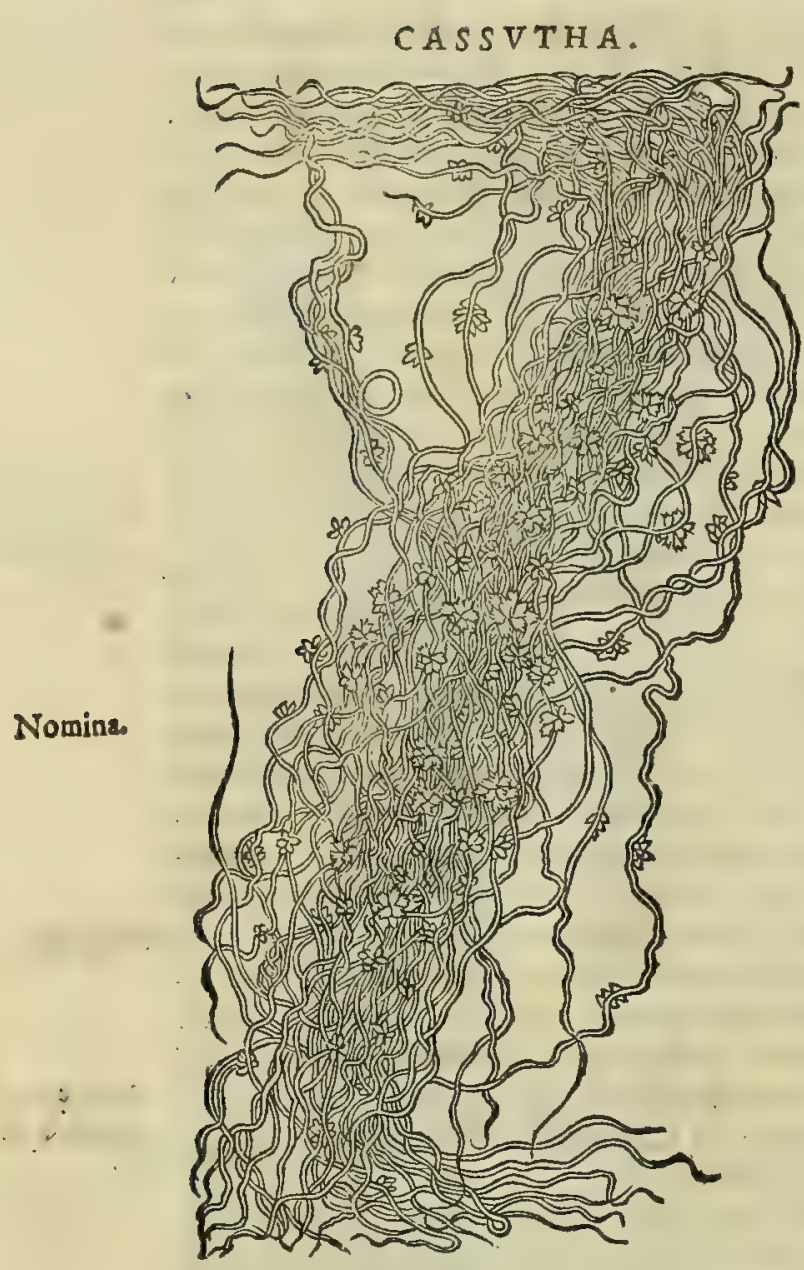

A L Y P VM.

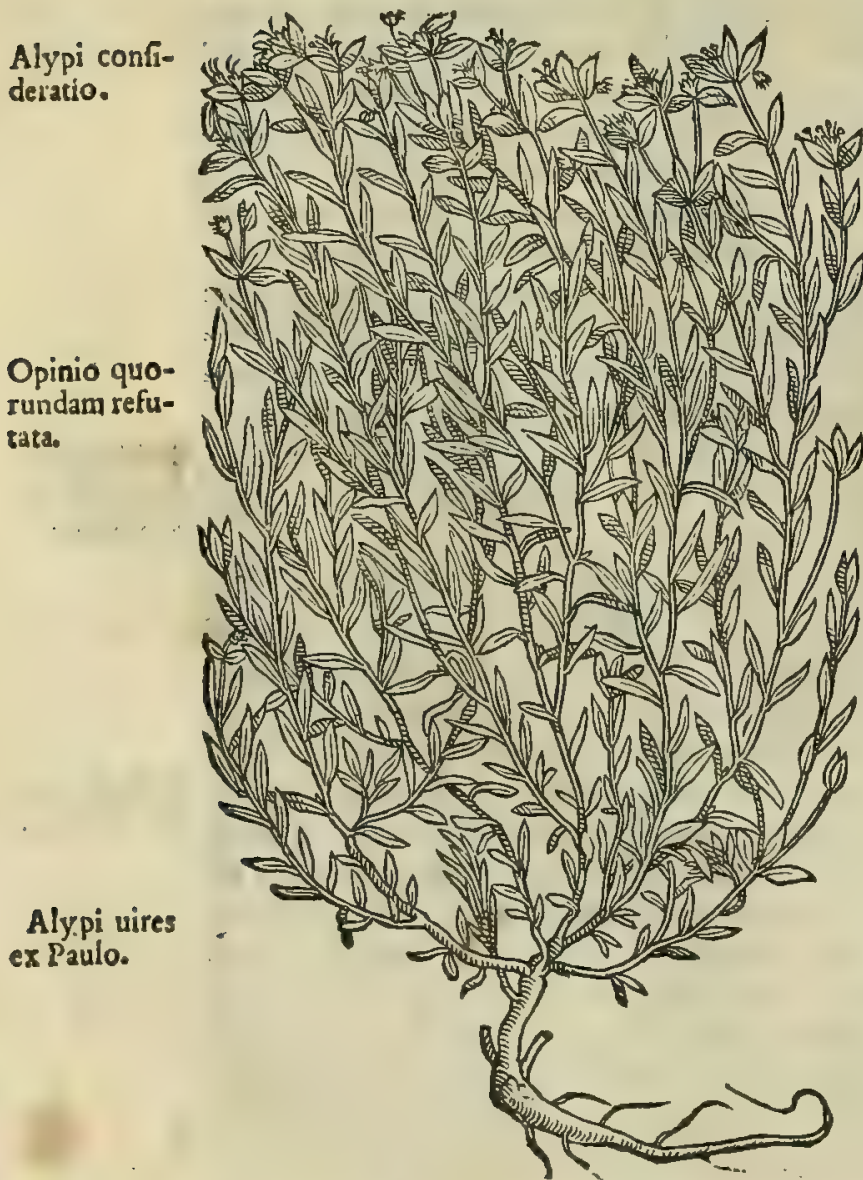

riantur Plinij codiccs, in quibus cadytas, non caßytas legitur, quód q́; hec arboribus tantum, or pinis fe circumuoluat, nofira werò $C$ affutha duntaxat herbas, o frutices, non arbores com= plectatur, or irretiat, non aufin affirmare uulgarem cufcutam effe Plinij caßytam; prefertim cum in Syria tantum nafci fcribat ipfe Plinius. Credidere preterea plerique $\mathrm{C}_{\mathrm{a}}$ Jutbe eandem ine ffe facultatem, que o plantis ineft, in quibus nafcitur. Quo= rum utiq; fententiam potius proband $\vec{s}$ qudim refellendam cenfeo, argumento quòd Epithymum iffdem, Galeni authoritate, polleat uiribus, quibus o thymu. Excalfacit $\mathrm{Caffuth}$ ordine primo, fic: catớ; fecundo. Abftergit, o quaddan cum ad Strictione roborat. Iecoris obftructiones aperit, infarcti lienis uitia expedit: uenas pituitojis, ato; biliofis cxonerat bumoribus : urinam pellit, er re gio morbo fubuenit . Puerorum febribus auxiliatur : fed diuturno ufu uentriculum grauat, que tamen noxa tollitur, fi anifi momen tum adijciatur. Bilem deijcit, prefertim abfinthio admifta. In quem ufum decoquitur, bibiturq́; eius decocti felibra, cum fac=

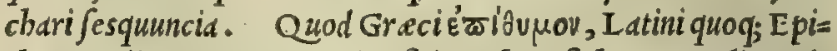
thymum dicunt: Mauritani, Efitimo, feu Efichemo: Itali, Epi= thimo:Hifpani, Cabellos, feu flores del thomilho: Galli, Tei= gne de thyn.

\section{A'AUळOV. ALYPVM. CAP. CIXXIII.}

A L Y P O N furculofa herba eft, fubrubra: gracilibus ramulis: tenuibus folijs: flore molli; leui, \& . copiofo : radice betæ, tenui, referta acri fucco: femine epithymi. Gignitur in maritimis, maximè Libyx, quàm largifsima, quanquam alibi quoque plurima prouenit. Semen atram bilem deijcit, fi menfura epithy- 30 mo pari cum fale, $\&$ aceto fumatur : verùm interanea leuiter exulcerat.

A I Y P V M, eiusó; radix ( $f i$ A ftuario credimus) nil aliud Sanéfuerit, qudm ofjicinarum Turpetum, turbit Arabibus di= ctum, quod album uocant. Ipfe enim fuo de compofitione medi= camentorum libello, ubi minoris paranda triphera rationem do cet, fic inquit. siboc medicamento pituite deiectionem moliri inftituis, alypum, id eft, album turpetum addds. Idem póft , ubi de fimplicibus medicamentis uomitü cientibus tractauit, ita $f c r i=40$ bit. Turpetum, quod radix eft pityufa, or album alypie, glu= tinofam detrahit pituitam. verüm quia idem Actuarius, paü= ló anté Alypum defcribens, prodidit eius femen atram bilem per aluum ducere, putauere quidam A Atuario dlypiam ab alypo dif= ferre, quód buius feminis tantum uires reddiderit: Sed ijs reßpon di poteft, quód cum probé fciret Açuarius aliam uim ine ffe femi ni, aliam ueró radicibus, proinde de radicibus fub turpeti, o de Semine fub Alypi nomine differwit. Plante enin babentur, que, alium folijs, alium femine, alium radicibus effectum prabent. Me= dium berba nobis exemplo erit, qua, Diof coridis teftimonio,men so Ses fiftit, cum tamen eius femen contrarium efficiat. Quasnob= rem facilé crediderim Alypum, o Alyplam nullisinter fe notis dißidere : nec modó bis rationibus fretus; fed etiam $\mathrm{P}$ auli autho= ritate . quippe qui libro v I I. Alypum inter ed, que atram bilem depellunt, commemorauit ijs uerbis. Alypi femen inferius aträ purgare bilem pari epithymo menfura, cum falc, $v$ aceto dictum cft: inteftina ueró, $\sqrt{f}$ fidem Diofcoridi accommodamus, leuiter. cxulcerat. Eft autem, meo iudicto, que nunc Alypias uocatur. bec Paulus. Ex quibus pal dim eft, $\mathrm{P}$ aulo nullam inter Alypü, en Alypiăfieri differentiam. Cacteriun ad nos folü radicem deferri, neq; ullum bactenus qui plailä, uel femen oft end crit, sme nactum 


\section{In Lib. quartum Diofcoridis}

fuife, antea prodtderdm in commentarijs noftris Italica lingua confcriptis. Verum hoc tcmpore Lucus Ghitus uir reimedice eruditißimus, Pifis berban hanc pro Abpo ad nos mifit, cuius bic piaturam damus, qux quiden de cri= ption pulchré quadrare deprebenditur. Alypi, quod legerim, nosmenimit Gdlenus in fimplicium nacdicanentorie cenfu. Hic de Turpeti uiribus nobis differendum effet, mfifuperius in Tripolij conmentatione, cius biftoriam, ac $f_{a}=$

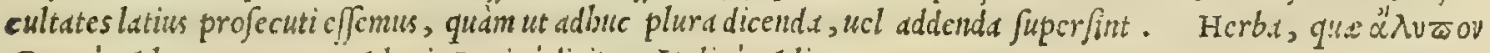
Grecé, Alypum quoq; $\mathrm{O}$ Alypis Latiné dicitur : Italicé, Alipo.

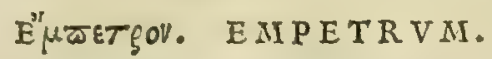

\section{CAP. CIXXIIII}

20 EM PETROM aliqui phacoides uocant. nafcitur in montibus, \& maritimis, falfo gufu: fed quò propius terreno fuerit, amarius fentitur. Trahic bilcm, pituitam, \& aquam, fr bibatur in iure aliquo, aut hydromelite.

E M P E T R I berbs facicm nullis prorfus notis depinxit Diofcorides. Vnde folo nomine nobis de bac herba po= tius diuinandum effet, quàm quód aliquid certi, ac perpetuiftatui poßit. Non defunt tamen qui Oedipum fe faciant, o hec Diofcoridis ob f cura quafi anigmata audeant folvere. Hifiquidem Empetron edin planta putant cffe, quan bodie Romani Faniculun marinum appellant, alij uulgari fermone berba difan Piero. Sed banc nos fupcrius libro fecundo legitimü effe critbmum, pluribus probauimus. Porró er ubi na catur Empetron, er qu ibus facultacibus fit preditum, Plinius quoq; tradidit lib. X X V I 1. cap. I X. ita ut ea plané à Diofcoride mutuatus deprehendatur. Ve Plinij error.

to rim in reddendis medicinis, nominis fortafe fimilitudine deceptus, quód Empetron faxifragam effe exiftimauerit, ui= res, quas utriq; feorfum tribuit Diofcorides, ipfe uni Empetro aßignauit, addens huic, quod urinds cieat, or calcu= los frangat: que medicine faxifrage debentur. Qua in re Plinimm omnino erraffe fatendum eft. Empetrimemi= nit Galenus libro v1. fimplicium medicanentorum, ubide eius wiribus in bunc modum differit. Empetron ad folds

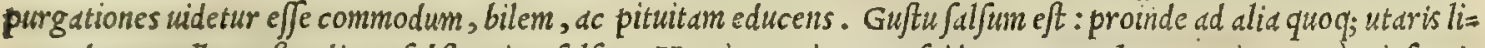
cet, ad qua pollere oftendimus fubf antiam fall am. Nominatur item prafoides. Hec Galenus. qui temen a Diofcori= de in nomenclatura difcordat: quandoquidem alter Empetron phacoides à quibusdam uoc dri prodidit, alter ueró pra foides dici ait. Quare non deeft Jupicio, quin aut borum alter errauerit, aut alterius codex boc in loco fit depraua= tus. Non enim uideo, quomodo recté idem Empetron fimile reddi poßit, or lenti, or porro, ut illa nomina denons

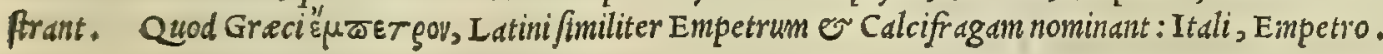

Empetriconfideratio.

Empetri uires ex Gal.

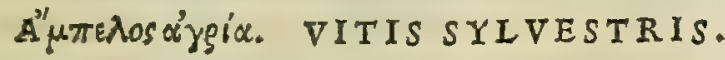

CAP. CEXXV.

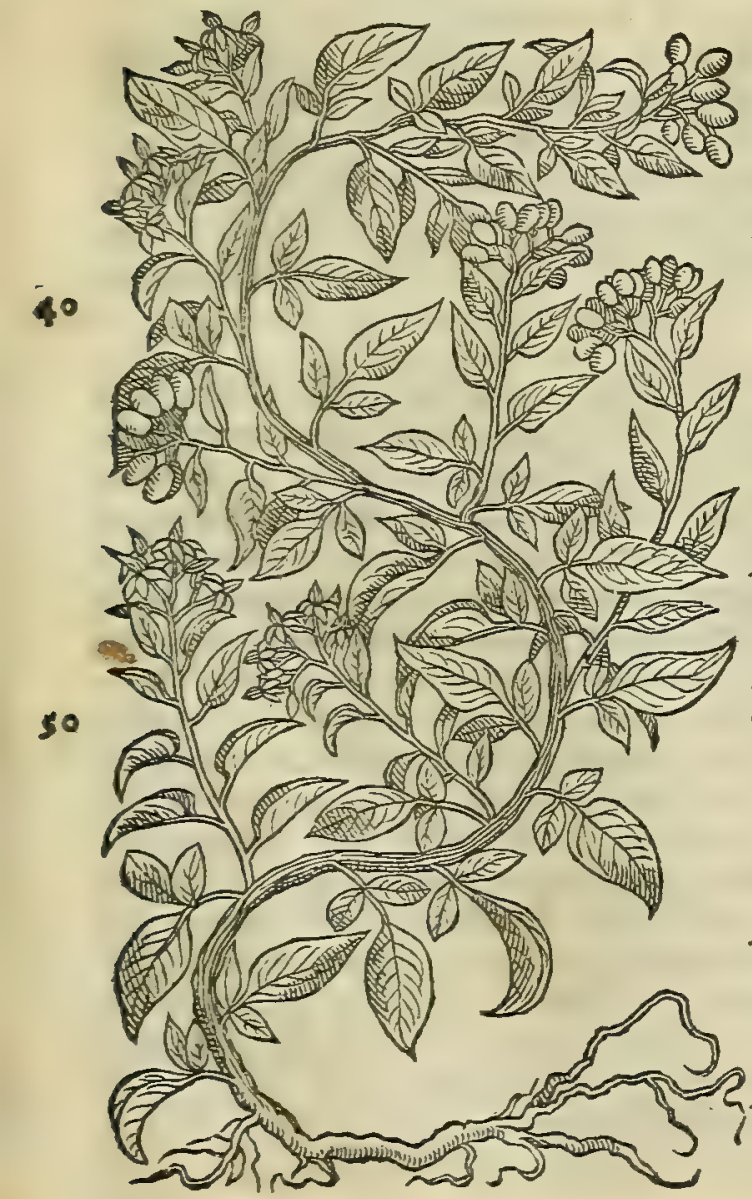

V I i Is fylueftris farmenta uitis modo prælonga emittit, afpera, lignofa, rimofo cortice, folijs hortenfis folani, longioribus, ac latioribus, mufcofo flore, \& capillaceo: fructu exiguis uuis fimili, poft maturitatem rubente : rotunda eft acinorum facies. Feruefacta radix in aqua, $\&$ in cyathis duobus uini aqua marina diluti, pota, humorem alui ciet:ideo hydropicis datur. Vux eius uitia cutis in facie, \& maculas omnes expurgant. Enafcentes uiticulæ, cibi gratia, fale condiuntur.

V I T I s fylueftris planta es in Hetruria mulieribus notif= ma: utpote qua eius uuis, quibus lentigines, or maculas in facie emendant, plurimim utantur. Hec conftat foliys bortenfis folani; fed longioribus, ac latioribus: floribus racematim coherentibus (ita enim legendum cenfeo in Diofcoride, non mufcofis, ut unls gata habent exemplaria, Oribasij teftimonio fretus, qui hoc loco non Bevádess, fed Bot pucídas legit) capillaceis,purpureo colo= re: fructu exiguis unis fimili, rubente, ac vinofo. Illud porró no= bis obftare poteft, quóminushac fit uerd vitisfylueftris, quod et fi eius farmentd, quibus uinifere uitis modo uicinas arbores $\int c a n$ dit, ac uincit, quadantenus aperd uidedntur; nion tamen, ut in Diofcoridis codicibus friptum reperitur, rimofo funt cortice, fed albo. Huic obiectioni ita repondere polfum, quód ca non fit

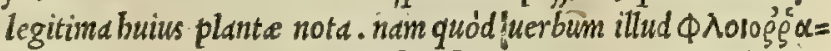
yoũvt a non legatur in Oribafio, facit ut fupicer in Diofcoride hoc loco mëdum ac uitium fubeffe. Hinc itdq; moveor, ut hanc pro fylueftri uite nune proferre non dubitem, donec alia nobis, aut alijs cöperta fit planta, que magis notis omnibus illi repondeat. Theophraftus uitem fylueftrem Atragenă yocaffe videtur lib. v.

Vitis fyluefris confide. ratio.

Numina.

(n) 


\section{And.Matthioli Comm.}

cap. ultino de planturum biftoria, ubi de fomitibus ad ignem concipiendum egit. Antiqua enim atas chalybem fortaf= fe non experta, ex ligno duriore, er fungofo ignem parabat: ad quod, meo iudicio, fylueftris uitis materies admo= Vitis fylue- dumapta fuit. De buius uitis fylueftris uiribus fcripfit Galenus lib. v 1 . fimplicium medicam. his uerbis. Vitis agre= fris uires ex fis racemi cxtergendi uim babent, ut eplseles, $\sigma$ neuos, er id genus omnia in extima cute exiftentid curare poßint. Galeno.

Nomina.

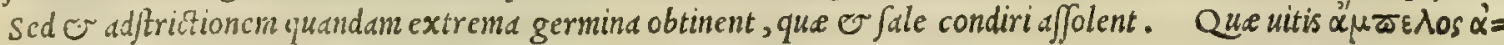
yeia Grecis, Vitis fylueftris Latinis uocatur: Vite faluatica, Italis.

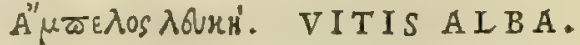

\section{CAP. CLXXVI.}

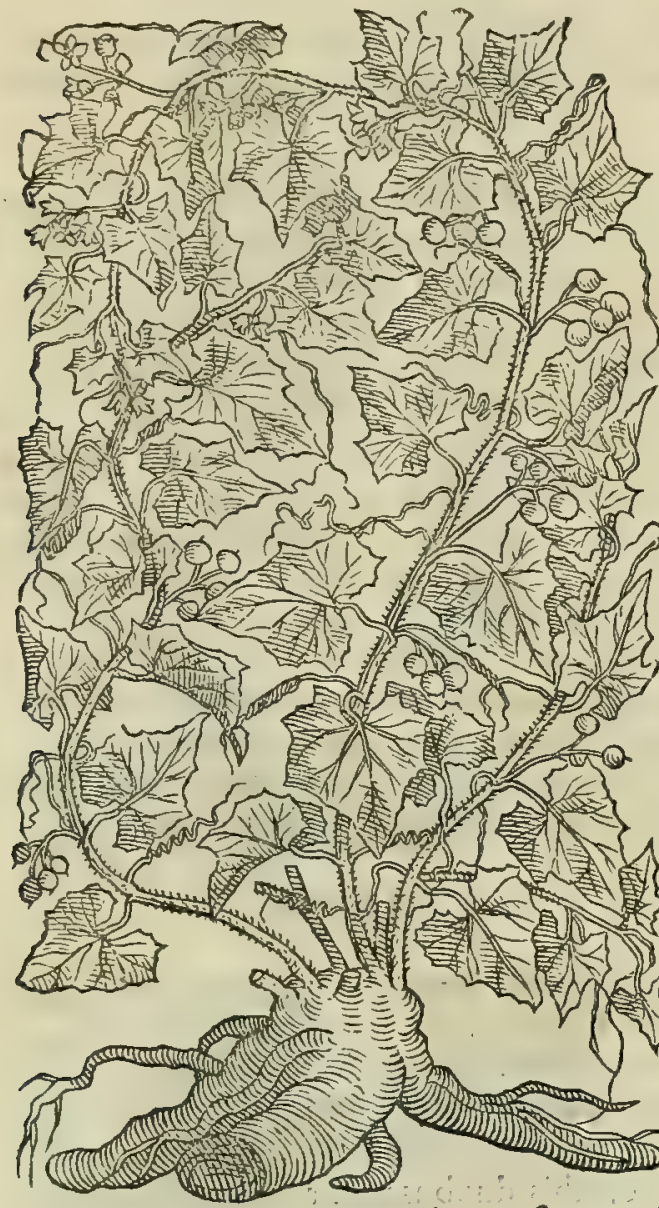

V I T E M albam aliqui bryoniam uocant. Folijs, ui- 2 ticulis,pampinisq́ue fatiuam uitem imitatur, fed hirfutiorafunt omnia: ea, quos propefe natta fit frutices, fuis clauiculis complectitur: fructus rubens in vua dependet, quo coria pilis fpoliantur.' Ex ea afparagi, qui prima germinatione exeunt, decocti in cibo, aluum, \& urinam cient. Folia, fructus, radix acrem uim fortiuntur : itaque ulcerum phagedænis, gangrænis, chironijs, putrentium tibiarum tædio, efficaciter ex fale illinuntur. Radix corpus abftergit, \& cutem erugat : uitia cutis in facie, uarosq́;, lentigines, \& cicatrices nigras emé- 20 dat, cum eruo, creta Chia, \& fæno græco. Eodem effectu prodeft decocta in oleo, ufque dum liquefcat: fugillata tollit, \& reduuias committit inflammationes difcutit illita ex uino: fuppurationes rumpit. medicamento aptè immifcetur, quod carnem exeft : infracta offa extrahit, trita, \& impolita. Datur comitialibus in potu, drachmæ pondere, quotidie anno toto: prodeft attoni=. tis, \& uertigine laborantibus, confimiliter affumpta. Contra uiperarum ietus pota drachmis duabus, auxiliatur: partus necat: mentem interdum fubturbat. Fœmi- 30 narum locis appofita partus, fecundasque morantes trahit : cit urinam pota. Eclegina ex ea fit cum melle, difficilè fpirantibus, ftrangulatu opprefsis, tufsientibus, vullis, ruptis, \& laterum doloribus. Lienem ternis obo lis pota ex aceto triginta dıebus, cófumit : illinitur ad ea dem cum fico. Ad muliebres quoque infeffus decoquitur : fiquidem vuluas purgat, fed abortum facit . Succus è radice uere exprimitur, qui trahit pituitam cum aqua mulfa potus. Ad pforas, \& lepras femen efficaciter illinitur. Lactis abundantiam facit fuccus eius, fi cum tritico decacto forbeatur.

Vitis albæ cö fideratio, \& urres.

V I $\mathrm{I}$ is alba officinis, or berbarijs Bryonia nominatur. Vulgó mulieribus Cucurbita fylueftris dicitur. Nota oinnibus fr ré planta eft, quód paßim fecus uias, er propter fepes proueniat. Hanc inter fua deiectioria medicamen= ta repofuit Mefues, qui de ea bec ad fenfum fcribit. vitis fylueftris, quód haufts, quemadmodum o dracunculus, uentriculo, c iecinori noxam inferat, darda non eft, nifí aromatum puluere permifta, aut addito maftiche, $c y d o=$ niis snalis, aut alijs adftringentibus, roborantibusó; medicamentis. Succus é contrita radice expreflus pituitam eij= cit, urinam remorantem trabit, o cerebrum mundat, quinetiam pectus, et neruos à pituitofis, putridisq́; excremen= tis : uifcerum obftructiones aperit : renes à calculis expedit: Jubuenit item uertigino/is, comitialibusq;. Prestat o=

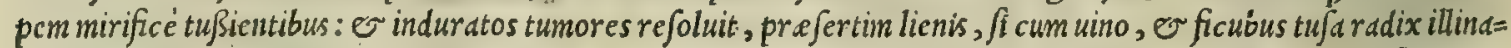
tur. Menftrua elicit, o uniuer fum purgat uterum, atq; etiam foetum expellit, fi in eius deccito infideant foemine . so Succus fabarum, autcicerum farina exceptus, maculds in facie, o uulnerum cicatrices emendat, linimenti modo adbibitus. Oleum excaudtis eius radicibus immifJum, cineribusó; incoctum, fugillata delet. Praterea mulieres unl= ue frangulationibus.obnoxias mirum in modum iunat, adeo ut cas à trangulatu liberet, er fanet. Equidem noui mulierem quotidie frré per annos boc morbo uexatain, qua tandem à quodam uulgari herbario edocta, ut uinum al = bun biberet, in quo uitis albe radicis uncia efferbuiffet dormitum itura femel in hebdomada, cum bac medicina per Vitis albx ui- annum ufa fuiffet, optimé ex illo morbo conualuit. Vitis albe meminit Galenus libro v I. fimpliciun medicamen= res ex Gol. toruin, de cius uiribus ita fcribens. Vitis alba, quam 0 Bryoniam, o $\mathbf{P}$ filotbrum uocant, prima quiden germina ab onzribus pro more in uere eduntur, utpote edulium ftomacho, eo quòd adftringat, gratum. Habent etiam fubama= ram, o modice acrem adftriftionem: quare $\mathcal{O}$ urinam moderate cient. At radix $\mathcal{\sigma}$ abftergentem, o deficcanté, ov tenuium partium, ac moderaté calidam uim obtinet: quamobrem $\mathcal{O}$ lienes induratos liquat, tum epota, tum for is cum ficubus impofita: o p poram, o lcpram fanat. Porró fructus cius racemi pecien preferens, ijs qui coria tine 


\section{In Lib. quartum Diofcoridis. $\quad 621$}

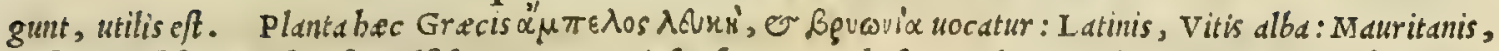
Fefire, Alfefire, Feffera fiue Alffecera, Nezargicfan feu Nezarchafen: Italis, vitc bianca, $\sigma$ Zucca faluatica: Germanis, Stickuurtz, or Teufol Lirbsz: Hipanis, Nuexa or Anorca: Gallis, Colubrine, Or Couluree.

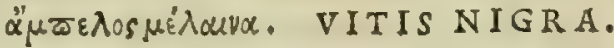

CAP. CLXXVII

20
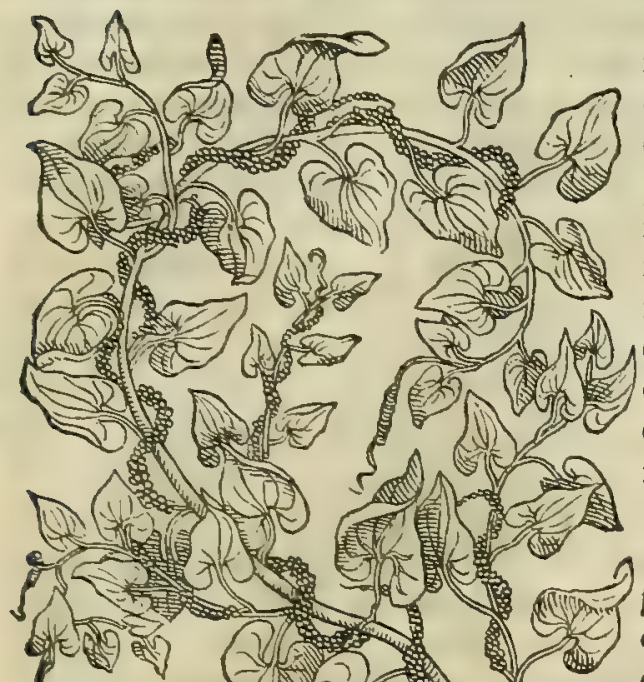

N I G R A uitis, quam aliqui nigram bryoniam uocăt, folia ferthedcrx, fimilaceis proxıma, fed maiora: caules etiam cognatos: capreolis fuis arbores, quafi adininicula, comprehendit : fructus racematim cohærent, qui inter principia uirent, \& polt maturitatem nigrefcunt : radix foris nigra, intus buxeo colore nitet. Viticulx, qux primo germinum partu erumpunt, in olera recipiuntur. méfes pellunt, urinas cient, lienem abfumunt : uertiginofis, comitialibus, neruorú refolutione tentatis profunt . Radix eadem, quae uitis alba praftat, fed inefficacius. Folia cum uino exulceratis iumentorum ceruicibus commodif frmè illinuntur : luxatis itidem imponuntur.

V I I s nigra Hetrufcisulgó appellatur Tamaro, corrus pto d tamno uocabulo. Sunt enim qui hanc tamnum, fiue tamun etiam uocent, unde Latinis eius una Taminia dicta eft. Huius uiti= culx, qua uere primim é terra erumpunt, quod afparag is fimiles fint, ,orum more decoctie, bac etiam tempeftate manduntur, quă= uis non eam, quam aparagi, cü palato ineant gratiam. Frequentisima hac in Hetruria prouenit, quin o in Goritien/i comitatu, ubi Martio or Aprilimenfibus, eius cauliculi in fafciculos digefti in foro ueneunt ad ciborum ufum. Huic tamen, que in Italia nafci= tur, illud tantim obijci poffe putauerim, quod in uuarum colore ab illa dißidere inueniatur, quam Diofcorides representauit, quód buic una poft maturitatem nigrefcant, noftre ueró perpetio ru= bentes pectentur : catera enim, meo quidemiudicio, inter fe mas ximé conueniunt. Sed illud nibil me mouct, neque facit, ut mutare debeam fententiam, o credere banc aliam eße à vite nigra, quód Sape uiderim foldnum hortenfe quibufdam in locis uuas ferre modó nigras, modó rubentes, modó croceas : quandoquidem natura plerunq; cum florum, or fructuum colore ludere $\int 0=$ leat, ut in uuis, cerdfis, moris, ficubus, prunis, malis, o dijs cöpluribus perfpicuó cernitur. Idcirco nil mirum effe debet, fi in Italia vitis nigra rubentes uuds proferat, alibi ueró nigras, ut in Gracia, A fia, alijs ; calidioribus, quòd buiufmodi difcrimina sapenumero cceli, ac foli diuerfitate contingant. Hac igitur ratione fretus, qux, ni fallor, illans 40 obiectionem diluit, non dubitauerim afferere, hanc plantam, cuius etiam bic effigiem pictam damus, effe ueram ac genuinam Vitem nigram, quoniam cetere omnes prorfus note illi adstipulari deprehenduntur. Caterim credidit Fuchfij opin. Leonardus Fuchfius, medicus nostre atatis celebris, eam ftirpem effe legitimam Vitem nigram, qua noftris in $\mathrm{He}=$ reprobata. truria uulgó vitalba dicitur, quamq́; alteram effe Diofcoridis clematidem fuperius huius libri initio abunde ostendi= mus. Verim bac eius opinio nobis, pace fua, plané reprobanda uidetur. Siquidem nostra Vitalba non babet radicem foris nigram, intus buxeo colore: non fert folia bedere maiora, fed potius minord, $\mathcal{O}$ per ambitum laciniata: nec femen edit in racemi modum, fed fimul compactum, nulla cum uuis fimilitudine. Adde, quód eadem fua facultate exulcerat. vitis ueró nigra exulceratis boum ceruicibus medetur, o luxatis ob adfrigentem uim, quam babet, uti= lifimé imponitur. Vitis nigre uires paucis perftrinxit Galenus lib. v I. fimplicium medicamentorum, fic inquiens. Vitis nigra: uocatur autem hec proprie bryonic, uiti albe ad omnia fimilis, nifi quód imbecillior . bactenus Galenus so de uite nigra. Huius autem fucco (ut eft author Mefues) nihil ualentius adftrumas fanandas, fic cum uini, o mellis equali portione is hauriatur. Preftat ad idem radix quoo; $f$ tufa, er melle excepta illinatur. Sed quoniam vites Viticellx, fiue

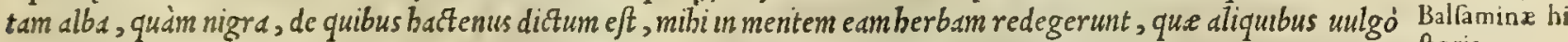
uocatur B A L S A I N A, alijs viticella, alijs Momordica, alijs Caranza, cum ueteribus nibil de éa posteritatis me= morie proditum fit, fitq;; dotibus qudm plurimis non obfcuris predita, hunc locum opportunum duximus, in quo bu= ius herbs biftoria pertractetur. Eft itaque VI I I E L IA, fiue Balfamind, planta, que prelongis, tenuibusq́. uiticulis, ultro citró,; reptantibus, proximas tum berbas, tum arbufculas comprebendit: folijs uitis alb a aut uini= fere fimilibus, fed longé minoribus magisq; per ambitum laciniatis: capreolis tenuibus ex alarum finu prodeuntibus quibus fe e e implicat appofitis adminiculis. Floré promit cucumeri fimilem, colore fubluteum: fructum utrinq; turbi

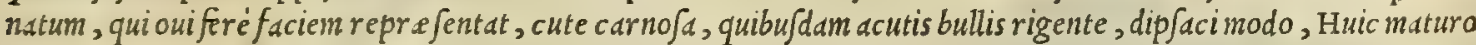
puniceus color, qui preterea facilé disilit ultumam maturitatem adeptus. Semen includit angurie uocata fimile, mi nus tamen, cötectum cute cr affa, pingui, lubrica, er perquàm rubente. Planta hec gracili nititur radice, nec ci= 


\section{And. Matthioli Comm.}

BAISAMINA.

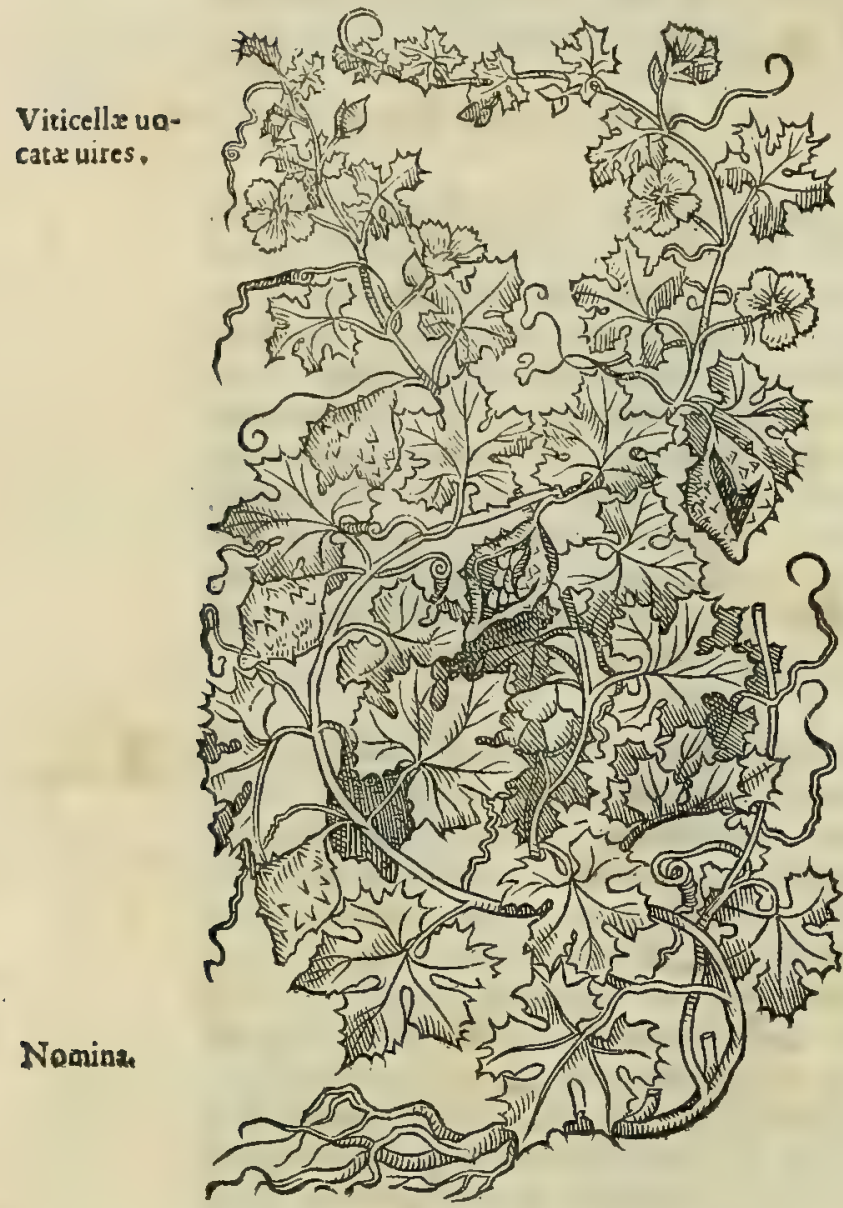

FIIIX MAS.

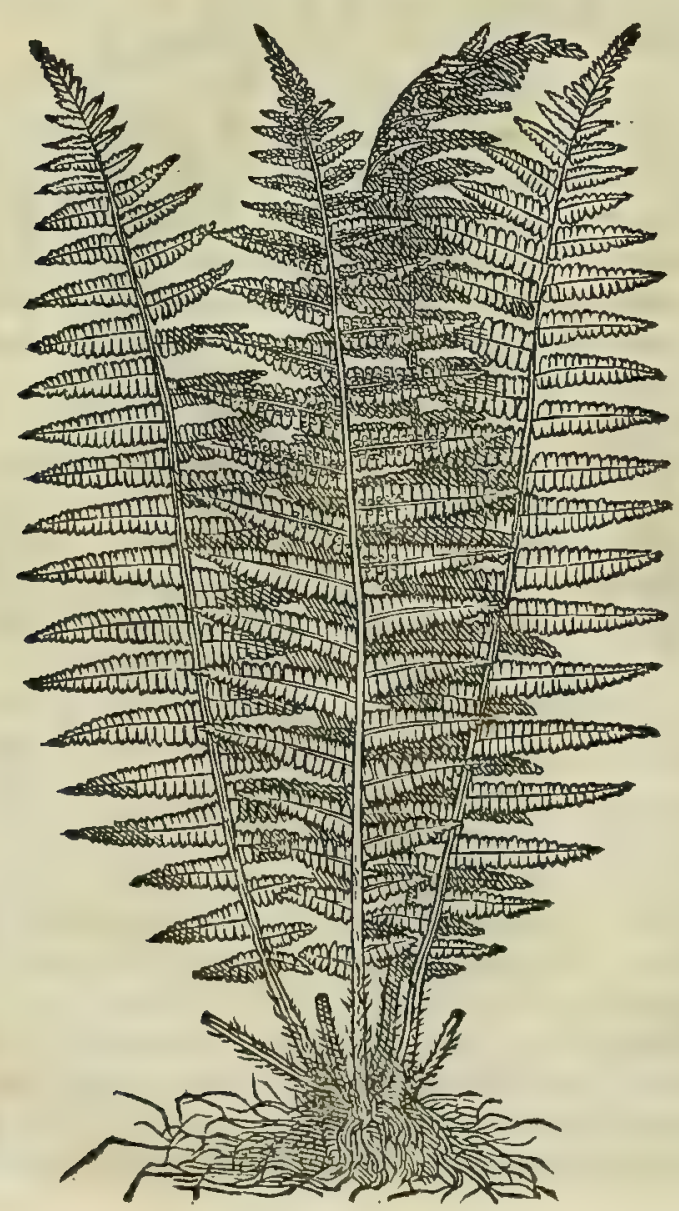

tius fructum perficit, ac matur at, quàm aduentante autumno, Aus gufto, er septembrimenfibus. Nu uquam nifi fatd, quod fciam, in Italia prouenit: pluribus autem in locis inibi plantatar, o nafci= tur. Folia ulner a recentia glutinant. Fructus exempto Semine in folantur diu in olco omphacino, aut macerantur codern oleo in bal= neo calentis aque, aut equino calente fino, fit $\dot{0}$; inde oleum pre= ftintißimum ad arcend as uulnerü, mamillarumiq; inflammationes, doloresq;; mulcendos. Valet idem ad exulceratos, inflimmatos q; uteros fiphone iniętum. Doloribus hàmorrboldum miré auxilia= tur: in quem ufum macerantur fructus (ut dixinns) oleo amygdd $=0$ lino dulci, aut é femine lini expreffo, addita ad unamquanf; olei li= bram, liquida hernicis uncia. Medetur hoc amibuftis tam igne, qudim aqua. Punctis, Jauciatisq; neruis utiliter illinitur: quin o uulnerum cicatrices tum attenuat, tum etiam prorfus delet. Scri= bunt recentionum quidam, fteriles mulieres faccundas fieri, fi a bal neo medicamentis utero conferentibus parato, boc oleo uteri ofou lum fibi perunxerint, ac demum fuis fe iunxerint viris. Ramico/is pueris efficax remedium eft, fi co locus fapius perungatur. Folio rum puluis (ut ij affirmant, qui periculum fecerunt) cochlcar is më furd ex plantaginis, fiue equifetidecocto, inteftinorum wulnera $\int_{a}=0$ nat. Nec defunt qui eundem puluerem laudibus efferant, ad coli dolores, $v$ inteftinorum tormina. Porró illud hic pratereund $\breve{u}$ non êf, ne forté buiufce plante nomina alicui imponant, quòd funt qui Momordicam etiam appellent geranij genus quodda $m_{2}$ illud $f c i$ licet, quod maiora inter cetera folia profert, malue amplitudine, de quo libro tertio in Geranijs abunde differuimus. Qua vitis

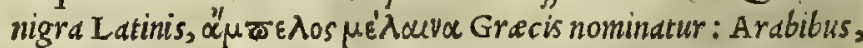
Fefirefentanim, Fefirefim, Alfifirefim, fiue Faferfin : Italis, vile nera, E Tamaro: Hipanis, Congorca.

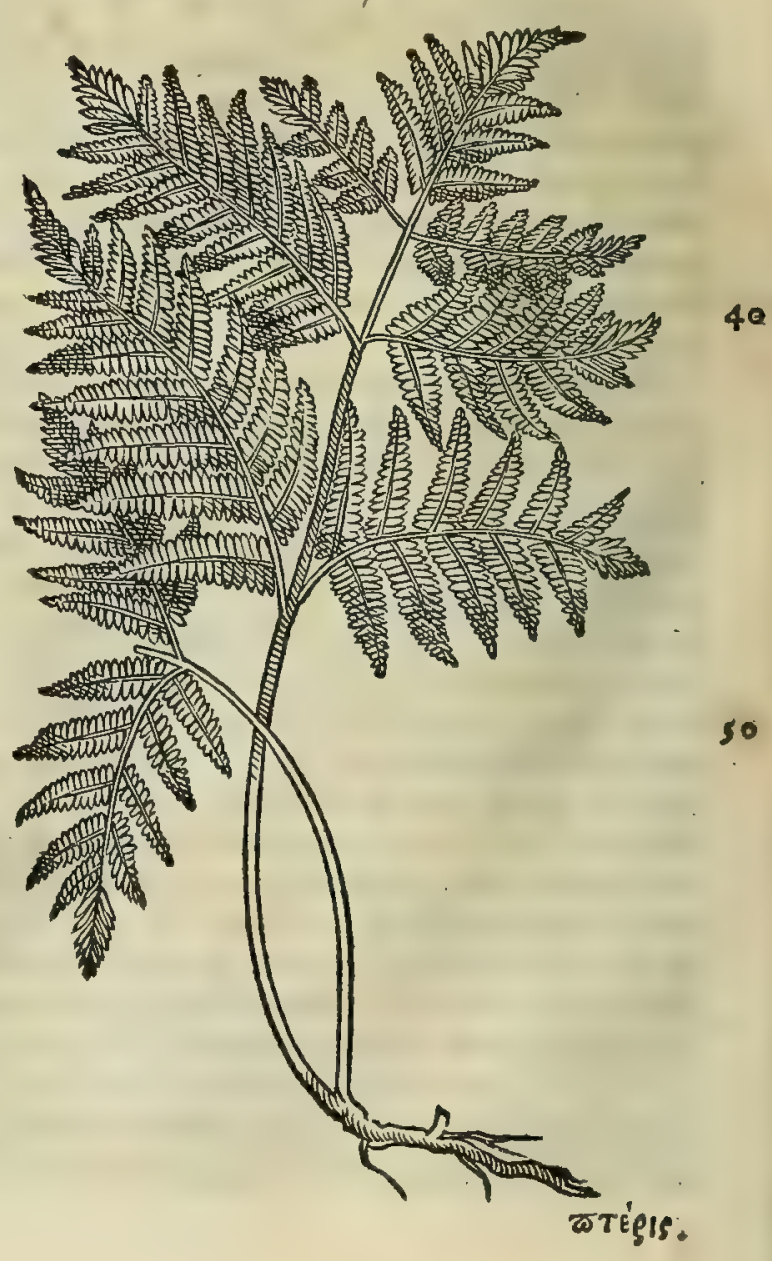




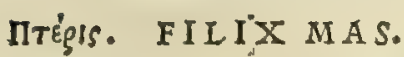

\section{CAP. CLXXVIII.}

F I I I C I folia fine caule, fine frufu, fine flore, ex uno pediculo cubitali longitudine exeunt, multifida, \& lateribus pinnata, fub graui odore: radice per fumma cefpitum, nigra, oblonga, filices multas fundente, fubaftringente guftu . nafcitur in montibus, \& faxofis. Radjx latas tineas excutit, fumpta drachmis quatuor ex aqua mul fa : melius fi cum fcammonix, aut ueratri nigri totidem obolis detur : fed qui fumunt, alia præguftare debent . laborantes lienis incremento recreat. Radix \& potu, \& illitu cum axungia, vulneribus fagitta arundinea factis, eft auxilio .cuius rci probatio talis 10 fertur. Pcribit filix, quam per a mbitum fata copiofior arundo coronet: \& contrà euanefcens abibit arundo, quam obfepiens multa filix in orbem cinxerit.

\section{EHAvæTegis. FILIX FOEMINA. CAP. CIXXIX.}

F I I I X fomina folijs eft filicis, furculofis, altioribusque, \& quæ non fingulari, vt illa, pediculo fulciantur: radicibus longis; pluribus, obliquis, qux ex nigro in lutenm flauefcunt: aliqux ctiámnum rubrx inucniuntur. Pellunt lata interaneorum animalia, cum melle, eclegmate fumpto: potx cum uino drachm is tribus teretes tineas cijciunt. Datæ fominis fterilitatem faciunt: \& prxgnantibus abortum, is fupcrgrediantur. Farina humidis ulceribus, \& cicatrici repugnantibus in20 fpargitur: iumentorum ceruicibus medetur. Folia recentia in oleribus cocta manduntur, ut uentrem emolliant.

F I L I C I s tam maris, quàn femine, quibus fcatet uniuerfa Italid, mesninit Thcophraftus lib. I x.cap. x x. Filicis utriusde plantarum biftoria, his uerbis. Filix fremina utilis contra interaneorum animalia lata, melle fubatda : er contra que hultoria. tenuis, in uino dulci cum farin hordeacea data. Si mulieribus grauidis detur, abortum facere: fic cateris, fteriles in totum reddere aiunt. Differt feemina flix à mafcula, quód folium unico artu porrectum bec habeat, radicem ueró craffam, longam, o nigram. Harum igitur uires fterilitati addixiffe natura putatur. Hactenus de filicibus Theo= phraftus. De ijs etiam fcripfit Plinius lib.x x v I I. cap. I X. Fic inquiens. Filicis duo generd, nec florem babent, nec fennen. Pterin Greci wocant, alij blechnon, cuius ex una radice complures exeunt filices, bind etiam cubita longitu= 30 dine excedentes, non graues odore. Hanc marem exiftimant. Alterum genus thelypterin Graci tuoedut, alij myn= pheam pterin. Eft autem fingularis, atg; non frutico fa (fortè rectius non fingularis, atque frutico da) brevior, mol= lior $\dot{q}_{;}$, $\sim$ denfior, folijs ad radicem canaliculata. Vtrius $q ;$ radice fues pingue $\int$ cunt. Folia utrius $q_{;}$; lateribus pinna= $\boldsymbol{t} d$, unde nomen Greci impofuere. Radices utriq, longe, in obliquum, nigres, precipué cün inaruerc : ficcari autem eas fole oportet. Nafcuntur ubiq; , fed maximé frigido folo. Effodidebent Vergilijs occidentibus. vfus radicis in tri= matu tantiun, neq; ante, neq; poftea. Pellunt interaneorum animalia : ex bis pteniws cum inelle, ceter as ex uino dul= ci triduo potse. Vtraq; ftomacho inutilifima. Aluum foluit, primó bilem trabens, mox aquam . melius ptenias cuns fcammonij pari pondere. Radix eius duîm obolorum pondere ex aqud, poft unius diei abftinentiä bibitur, melle pre = guftato, contra rheumatifmos. Neutra danda freminis, quoniam grauidis abortum, cateris ueró ferilitatem facit. Farind edrum ulceribus tetris inpargitur, iumentorun quoq; ceruicibus. Folia cimicem necant, Serpentem non re=

40 cipiunt. Et libro X V I I I. cap. v I . idem de Filice hac scripto reliquit. Filix biennio moritur, fi frondem agere non patiaris. Id efficacißimé contingit germinantis ramis baculo decußis: fuccus enim ex ipfa defluens necat radices. Aiunt $\sigma$ circa folsitium auul as non renafci, nec arundine fect as, aut exarat as uomeri arundine impofita. Fili=
cem utranque prodidit Galenus lib. V I I. fimplicium medicamentorum, ubi de exrum uiribus in hunc modum diffe: cem utranque prodidit Galenus lib. v I I I. Iimplicium inedicamentorum, ubi de exrum uiribus in bunc modum diffe= dere in aqua muls sump ferit. Ad cundem modum foetum uiuum quidemnecare, mortuum autem eijcere miruin non eft: eft enin amara, paulim habens adftriftionis. Quamobrem ulceribus impofita ualenter deficcandi fucultatem

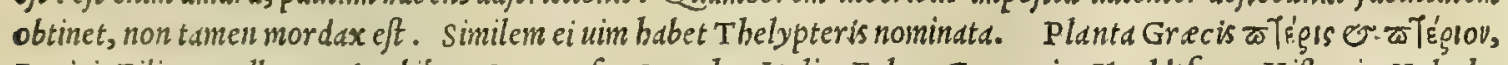
Iatinis Filix appellatur: Arabibus, Sarax, feu Sarachs: Italis, Felce: Germanis, Vualdtfarn: Hipanis, Helecho yerua: Gallis, Ofmunda regale.

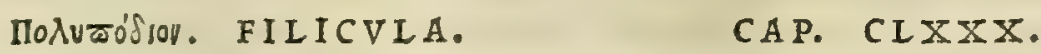

F I L I C V I A nafcitur in mufcofis petris, \& uetuftis arborum caudicibus, præfertim quercuú, palmi altitudine, filici fimilis, fubhirfuta, non tenui perinde diuifura. Radix pilofa, in qua continentur cirri, ceu poly porım, crafsitudine digiti minimi, coloris intus herbacei, auftera aliquátùm, \& guftu fubdulcis. Purgandi uim habet. Coquitur cum gallina, aut pifcibus, aut beta, aut malua, ad aluum foluendam. Aridx farina aqux mulfæ infparfa, detrahit bilem, \& pituitam : trita lixatis efficaciter illinitur, \& aduerfus rimas, quæ inter digitos fiunt.

P O L Y P O D I V M Iatinis Filiculd nuncupatur. Recentiores medici, atque etiam of ficin.e Grecumnomen Polypodij co retinent. Eius diro reperiuntir genera. Alterum, de quo hic Diofcorides differit, omnibus notum cet, quód ubiq, lo= fideratio. 


\section{And. Matthiol, Comm.}

POLYPODIVM.

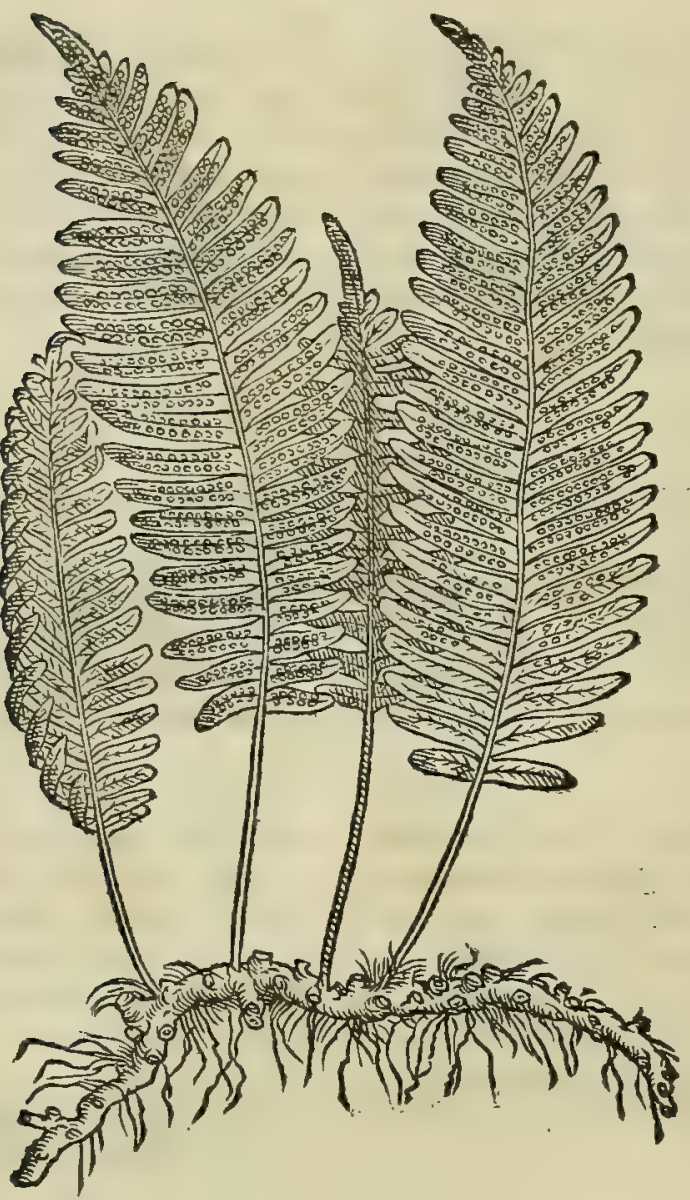

POIYPODIVM ALTERVM.

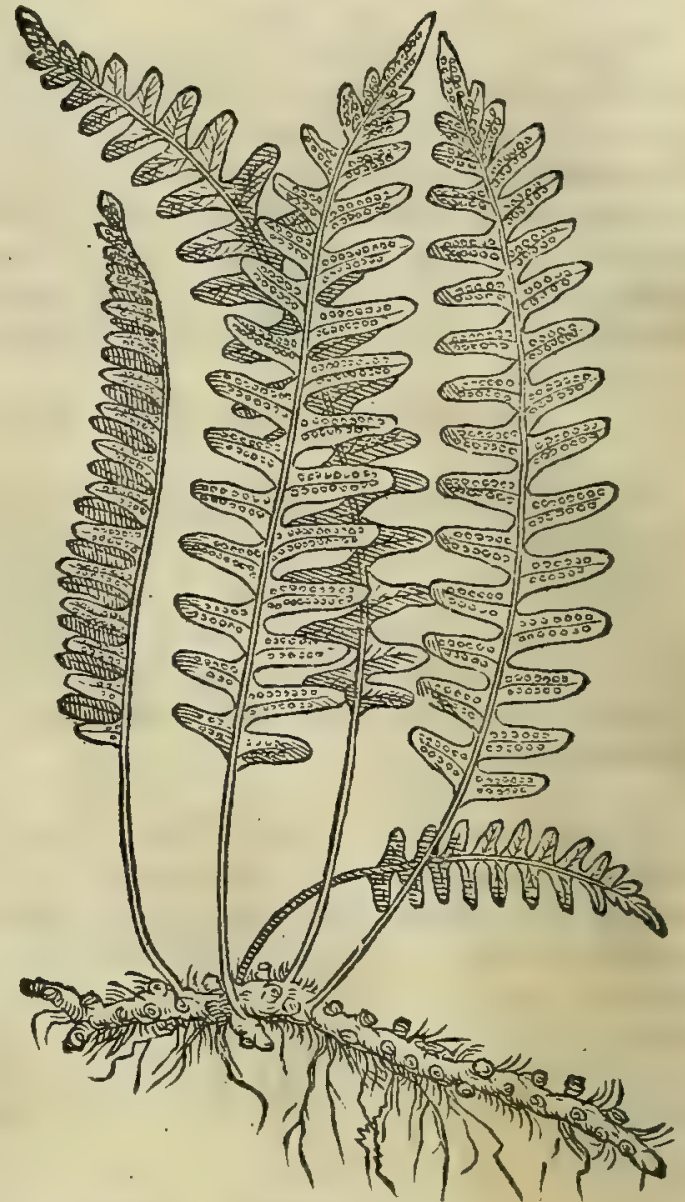

2

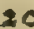

30

corum frequetts proueniat. Alterum uerò non nifípatucis cognitum effe reor, folio apleni, fed longiore, uiridiore, magisós per ambitum laciniato: radice priorifimili, graciliore tamen paulo. hoc plurimum nafcitur in montium $\int y l=$ uis. Nos copiofum uidimus, legimusq́; quibusdam in montibus, per quos iter breue, ac compendiofun faciunt, qui Go ritia Labacum contendunt. Pretulit Me fues filiculam, que in quercuum caudicibus gignitur, quód ed, qua folo, aut mufcofis lapidibus innafcitur, fuo quodam exubcrante, inconcocto ó; bumore maximé uentriculo fit noxid, quód's; ip= fum flatibus repleat, ac etiam fubuertat. Id quod poftea in uniuerfum de omni Filiculd fubiunxit, dicens. Polypodium inter ea recenfetur medicamenta, que uel inaxime corpord exiccant, $\sigma$ extenuant: fubuerfionem, o naufeam $f a=$ cit. In quo tamen Me fui refragatur doctißimus Manardus Ferrarienfis, afferens, quód polypodium, cùm imbecilli= 40 ter leuiteró; purget, corpora extenuare non poßit: addens fe certò fcire, quód idem per $\int e$ exbibitum, nullam ftomd= cho inferat iniuriam. Proinde Auerroi in boc mag is adstipulandum cen $\int e t$, quàm alteri :quandoquidem Auerroes au Polypodij ui thor eft, Polypodium tutum effe medicamentum, on epitbymo preftantius. Polypodium (ut teftatum reliquit $\mathrm{A}=$ res ex Actua- ctuarius in libro de compofitione medic amentorum) bilem, o prefertim atram, e pituitam extrahit. Dantur pur= vio, \& Gal. gate radicis feni fcrupuli adfufa aqua mulfa. Mediocriter ueró aluum ciet, o citra moleftiam, tum in gallinaceo iu= re, tum in cremore ptifane cocta radix. Polypodio facultatem duntaxat aßignauit Galenus libro v I I I. fimpli= cium medicamentorum, ijs uerbis. Polypodium dulcem fimul o aufteram babet uincentem qualitatem, ut facultatis fit admodum deficcantis, citra morfum tamen. bec Galenus. Ex quibus fane fatis conftare poffe arbitror, Me fucm recté dixiffe, $\mho^{2}$ in hoc immeritó à Manardo reprebenfum fuijfe. Nam quód Polypodium abundé exiccet, Galenus testis eft grauißimus. Ex quo cur etiam efficaciter extenuare non poßut (ut inquit Me fues) non equidem uideo. Qua $=50$

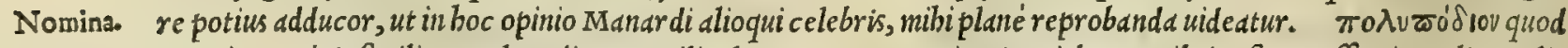
Grecis, Latinis fimiliter Polypodium o Filicula wocatur: Mauritanis, Bisberg, Aibeig, fiue Beffalgi: Italis, Poli= podio : Germanis, Engelfuesz, Baumffar, er Dropffanuerz: Hipanis, Filipodio, or Polipodio: Gallis, Polypode.

\section{$\triangle$ ŞOTIEgis. DRYOPTERIS.}

CAP. CIXXXI.

DR Y O P T E R I $S$ nafcitur in veterum quercuum mufco, filici fimilis, multo minore foliorum incifura: radicibus inuicem implexis, hirfutis, guftu acerbis, in dulcedinem uergentibus. Pfilothrum eft cum radicibus trita : illinitur enim primùm ufque dum fudorem ewocet, mox fudor abluitur, \& recens imponitur. 


\section{In Lib.quartum Diofcoridis. $\quad 625$ \\ DRYOPTERIS.}
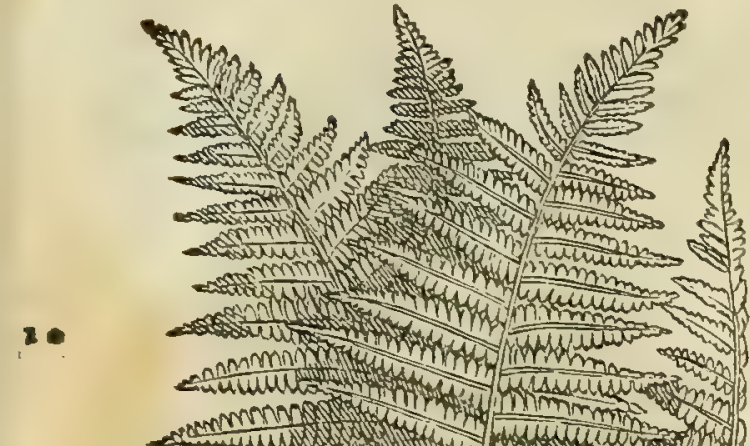

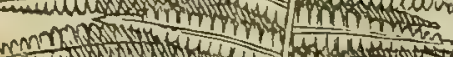

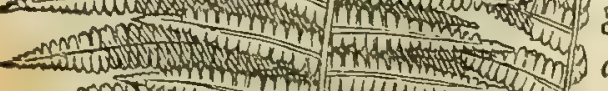

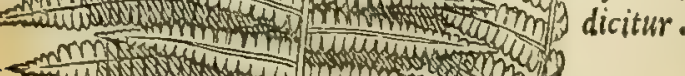

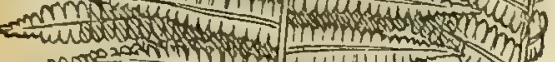

mat

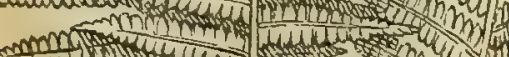

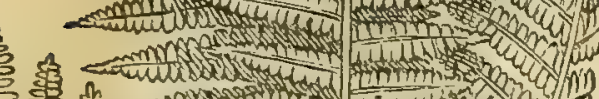

s.
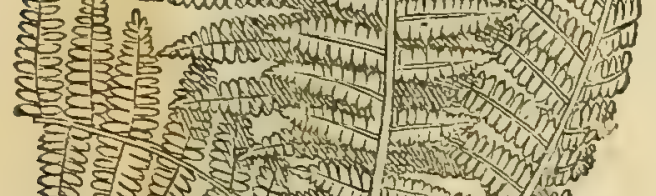

25 है

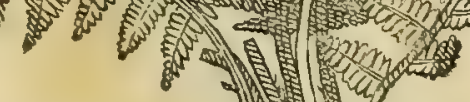

Jath
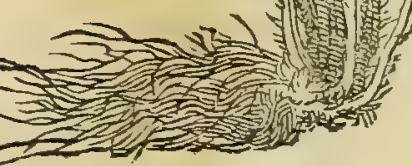

CNICVS
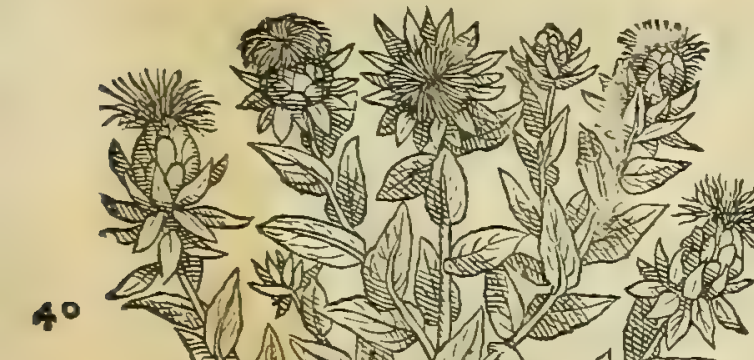
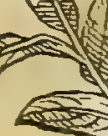

.
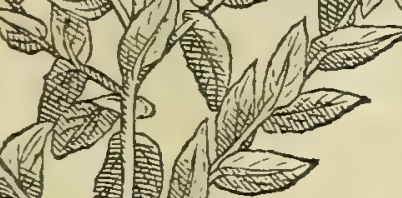

\section{Kuiros. CNICVS.}

C N I C.v 5 folijs conftat oblongis, perambitum diuifis, afperis, fpinofis : caule fesquipedali : capitulo magnitudine grandis oliuæ: flore croci : femine candido, alioqui rufo, longo, angulofo. Hui us flore in obfonijs utuntur. Seminis tufi, \& exprefsi fuccus, cum aqua mulfa, uel iure gallinacei, aluum purgat: fed ftomacho aduerfatur. Ex co autem fiunt offulx, quas placentulas uo cant, adiectis fucco amygdalis, nitro, anifo, \& melle decoeto, quæaluum emolliunt. Hæ in partes quatuor finduntur, quæ nucis iuglandis magnitudinê impleant: è quibus ante conam duas, uel tres fumpfiffe fatis eft. Ratio tếperandi hæc eft. Cnici candidi fextarius,amygdalarum tofarum \& delibratarum cyathi tres, anifi fextarius unus, aphronitri drachma una, cum carnibus triginta caricarum. Seminis fuccus lac cogit, \& magis ipfum refoluendæalui facultate donat.

S v N T in Ytalia, qui Cricun Crnctun Saracenicum appel= lent, quod :iusflore plerung; crocilocs rurd utantur : tametfi officine Mauritanos fecute Cartamum vocent. Cnicus (ut du= thor eft Theophraftus libro v I. cap. I I I I. de plantarum bifto= ria) duorum eft generuin, fatiutom unum, alterum fylueftre, ut latius libro tertio in Atractylidis mentione retulinus. Porró in ufum medicine femen tantün uenit. Quod (ut Mefues inquit) hauftum fuperné, inferne $\dot{q}_{\text {; }}$ purgat. Pituitam, er aquas extrabit: quo fit, ut coli dolore affectis, $\mathcal{O}$ aqua inter cutem laborantibus opem inirificé preftet, non modó bauftum, fed o clyfteribus infufum. Seminis medulla d̀ putaminibus repurgata, er faccharo eclegmatis modo excepta, pettus, or pulmones abftergit, $u_{0}=$ cem clarificat, prolificumó; femen auget. Cnici uires paucis perftrinxit Galenus libro v I I. fimplicium medicamentorum, fic inquiens. Cnici Semine duntaxat ad purgationes utimur. Tertij eft ordinis excalfacientium, fi quis foris co uti wolet. Eius plan ta xvixos Grecis, Cnicus, er Cnecus Latinis appellatur: Mau= ritanis, Kartam, fiue Charthom: Italis, Zaffarano Saracinefco: Germanis, Vuilder Saffran : Hiptanis, Alacor, 0 Semente de papagaios: Gallis, Saffran baftard, o saffran $\int a u$ age.

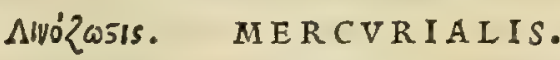 \\ CAP. CLXXXIII.}

LINOZOS TIS, aliqui parthenion, alij hermû botanion appellant, folijs conftat ocimi, helxinæ cogna-
Dryopteridis confuderatio.

Dryopteridis facul. ex Gal.

Nomina.

Cniciconfideratio.

Cnici uires ex Gsleno.

Nomina. $\mathrm{Gg}$ tis, 


\section{And.Matthioli Comm.}

tis, fed minoribus : ramulis duplici geniculorum modo cinctis, alarum cauis multis fructu freminx, copiofo, quandam racemorum îpeciem præbente: mari è foliorum finu dependente, paruó, rotundo, ceu binis tefticulis vnà cohærentibus: frutice dodrantali, aut maiore. Vtraque in oleribus manditur, ad aluum ciendam . cocta in aqua, epoto iure, bilem aquamq́; detrahit. Conftat, vt mares gignantur, hunc facere : vt fœmin $x$, illam, fi à purgatione bibantur, \& trita folia gentalibus admoueantur.

MERCVRIALIS MAS.

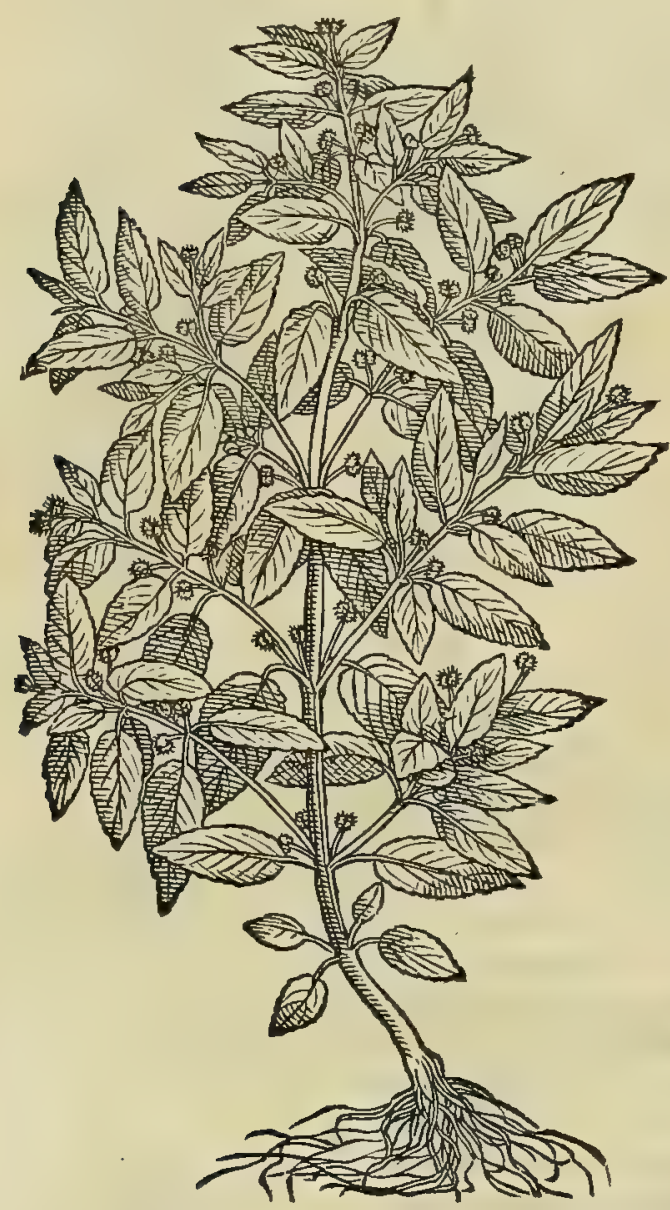

\section{MERCVRIALIS FOEMINA.}

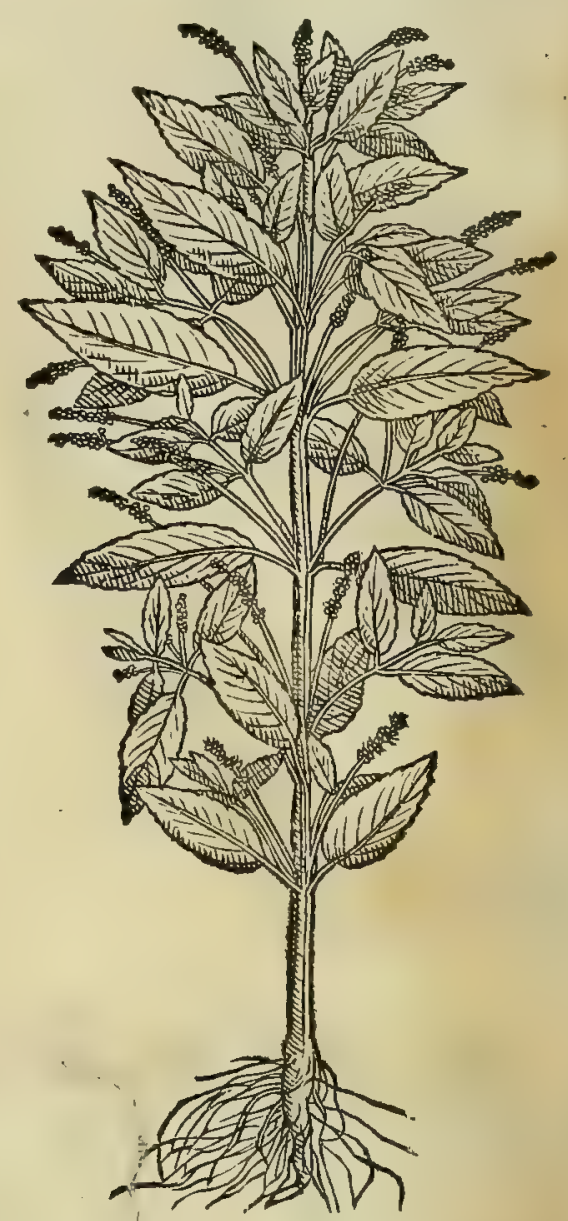

Mercurialis confid. \& hiftoria ex $\mathrm{Pl}_{\mathrm{i}}$

M E R C V R I A I E M, que Grecis Linozostis appellatur, duorun generunt effe conftat: unum mus, alte= rum foemina. Vtraq; non modó medicis, ac feplafiarijs unlgaris admodum eft notitix; fed etiam mulierculis, $\sigma f c=$ ré omnibus, quód in clyfteribus plerunq; imponatur. Qüare non eft, cur de Mercurialibic pluribus differamus. subijciam tamen que de ea memori.e prodidit Plinius lib. $\times$ x v.cap. v. ijs uerbis. Linozoftis, inquit, fiue parthe= nion, à Mercurio inuenta eft, ideo apud Grecos berimú poan multi uocant eam, apud nos omnes mercurialem. Duo eius generd, mafculus, of foemina, que efficacior : caule cubitali interdum, ramofo in cac umine, ocimo anguftio= ribus folijs, geniculis denfis, alarum cauis multis: femine in geniculis dependente, foemine copiofo, turi iuxta ge= nicula ftante, rariore, ac breui, contortoo $q_{b}$, f cemine foluto, $\sigma$ candido : folia maribus nigrior a, farminis candidio $=$ ra: radix fuperuacua, pretenuis. Nafcuntur in campeftribus cultis. Mirum eft, quod de utroque eorum genere proditur: ut mares gignantur bunc facere, ut foeminx illam. Hoc contingere, $f i d$ à conccptu fuccus protinus bibd= tur in paffo, edanturue folia decocta ex oleo er fale, uel cruda ex ace to. Quidam decoquunt eam in nouo fictili, c beliotropio, e duabus, aut tribus picis, donec decoquatur. Decoctum dari iubent, e berbam ipfam in cibo, al=. tero die purgationis mulierıbus per triduum, quarto die à balneo coire eas. Hippocrates miris laudibus in mulierum so ufu predicauit illds:eas ad hunc modü adbuc medicorum nemo nouit. Ille eas uulue cü melle, uel rofaceo, uel irino, uel lirino admoutt.Item ad ciendos men $\int e s$, fecundas q.;. Hoc idë preftare potu, fotúq; dixit. Inftillauit auribus furdis fue cum, inunxitó; cùm uino uetere. Aluo folia impofuit, epiphoris, Atranguria, o uefice. Decoctum eius dedit cum myrrha, ov thure. Aluo quidem foluendie, uel in fe bri, decoquitur quantum manus capiat, in duobus fextarijs aque ad dimidias, bibitur fale, er melle admifto, necnon cum ungula fuis, aut gallinaceo decoctum falubrius. Purgatio= nis caufa putauere aliqui utranque dandam, fiue cum malua decoctum. Thor acem purgant, bilem detrabunt, fed Mereurialis ftomachum ledunt. Hattenus de mercuriali Plinius. Eius quoque uires defcripfit Galenus libro v I I. fimplicium uires ex Gal. medic amentorum, /ic inquiens. Mercuriali utuntur omnes ad uentris purgationes duntaxat. Verìm enimero fi quis Nomina. eius facere periculum uolet in catapla fmate, ,ané ean digerentis admodum facultatis effe experietur. Avvo'zosis fic Gracé, Latiné ueró Linozoftis er Mercurialis uocatur : Italicé, Mercorella : Germanicé, Bingel kraut: Hi= Panicé, Mercuriale, er Vritigua muerta: Gallicé, Mercuriale. 


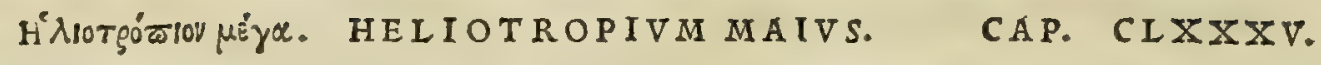

HE L I O T R O P I O magno flos eft effigie fcorpionis caudx, vnde fcorpiuro ei nomen: \& quoniam folia cum fole circumagat, heliotropion dicitur. Folia ocimi habet, hirfutiora, candidiora, \& maiora : ramuli à radice terni, quaterni, aut fxpe quini exiliunt, multis alis concaui : flos in cacumine candidus, aut fubfuluus, incuruatur ut fcorpionis cauda : radix tenuis eft, $\&$ inutilis . nafcitur in afperis. Decoctum herbæ ex aqua, fafciculo manus plenæ, potu pituitam, bilemq́ue per aluum extrahit: contra fcorpionum ictus in vino potum, \& illitum prodeft a adalligatur ad conceptus arcendos. Aiüt per horam vnam ante accefsiones, feminis grana quatuor cum vino quartanas finire, tria verò tertianas. Illitum femen formicantes verrucas, penfilesq́ue, \& thymos, \& epinyctidas exiccat. Folia infantium deftillationibus, quas fy riaféis uocant, podagricis, luxatisq̨ue vtilifsimè illinuntur . menfes cient: partus trita, \& impofita pellunt.

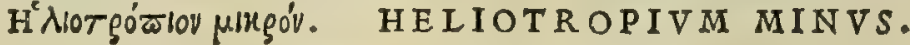 CAP. CLXXXVI.}

HE L I O T R O P I V M paruum nafcitur in paluftribus, iuxta lacus, folijs antedicto proximis, rotundioribus: femine acrochordonum verrucarum modo, penfili, rotundo. Herba cum fuo femine pota, adiecto nitro, hyffopo, nafturtio, \& aqua, latas tineas, teretesq́ue excutit . Penfiles verrucas, quæ acrochordones uocantur, cum fale illita tollit.

Heliotropij utrsufy; con-

H E I I O T R O P I O N maius, licet in afperis nafci Diofcorides tantim prodiderit; tamen in Hetruria, 0 in Gderatio.

comitatu Goritienfi, ubi frequentißimum uifitur, paßim feré prouenit, in campis, [ecus uids, in oppidorum plateis, et circa adificiorum areas, dridis item, E fabulofis locis. Herba bac apud Hetrufcos officinis Verrucaria appellatur, quod uerruc as, myrmecias, ov thymos affricatd ualenter adimat. Quare mibi, ut Ruellio quoque doctiß3imo, pluri= mim errare uidentur, qui cenfent Calendulam officinis dictams, qua e neotericis Caltha exiftimatur, effe Heliotro= pium maius. nanq; omnes prorfus illius nota buic reclamare deprebenduntur. Neq; corum opinioni illud quicquam addit, quòd buius Calthe femen quadantenus fcorpionum caudiculas referat, quonidm Diofcoridi Heliotropij flos, non femen fcorpionis caude effigiem reprefentat. Porrò Ruellius beliotropium boc uocari ait berbann cancri, quód

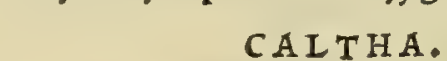

Catherenfideratio, \& vi res.

Nomina.

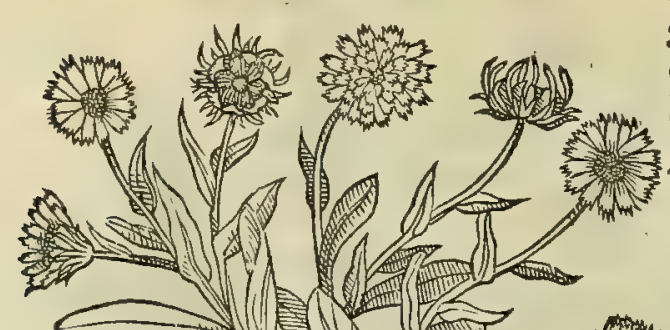
eius flores in caude cancri (qui nobis aftacos effe putatur) fini= litudinem inflectatur. Verìm, hae nominis ratio à Ruellio a $\beta i=$ gnata mibi non plané fatisfacit, quòd fcorpionum, or aftacorum caude forma inter fe maximé differ ant. Vndè potius crederem, boc Heliotropium berbe cancri appellationem traxiffe, quód ef= ficacißinum fit aduerfius carcinomata, ev ulcera gangrenofa ad que magno admodum fucce fu eo utuntur chirurgici, yiuto plan= tam, or eius uires compertas habent. Ceterum Heliotropium minus uidimus, ac fape legimus in Tridentino agro, in paluftri= bus quibusdam locis, id q́; compluribus oftendimus, ut quod piftu= 40 rae fatis repondere mibi uideretur. Quód autem buius Heliotro= pij, aut alterius mentionem fecerit Galenus', non inuenio in fim= plicium medicamentorum cenfu. Paulns tamen utriusque memi= nit, fed non plura de bis tradidit, quidm que Diofcoridi accepta referre poteft. Sunt érecentioribus (ut fuprd diximus) $q u i C_{d}=$ lendulam uocatam, virgilij or Plinij C' A I I н A M exifti= ment, boc argumento nixi, quód flores aurcos luteósue profe $=$ rat. Quorum equidem fententie non aufim omnino fubfcribere, aut refragari. Ea in Hetruria à florum colore unlgo Fior rancio nominatur. Hanc inibi paßim acetarijs adbibent. Guftu eft ad=so fringenti, cum quadam leuiufcula amaritudine. Ex quo non ui= deo, quomodo bec, ut quidam fcriptis tradiderunt, menfes ciere poßit, nifi id fortaffe fiat ab occulta quadam facultate. Siccate puluis cauis dentium immiffus, dolorem leuat. Vt Graci i $\lambda 10=$ T ģóซ เov, ita etiam Latini Heliotropium dicunt : officina e unl= gus, Verrucariam. 
EKOgতIOAdÉg. SCORPIOIDES.

CAP. CIXXXVII.

20

20

3
SCORPIOI D E herbula eft, folijs paucis: femine caudx fcorpionis effigie. Illita fcorpionum ictibus præécraneo eft auxilio.

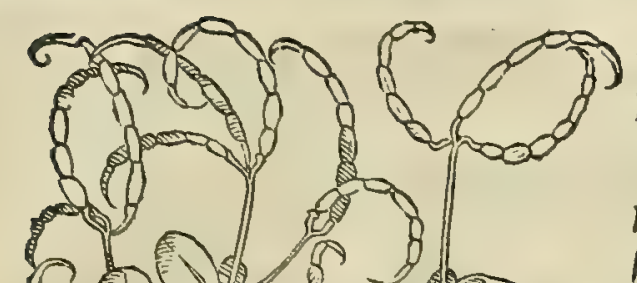

S C O R P IO I D I Peciem Calcndulam nominatam baud dubic effe cenferem, fi folli, ficuti femen, Scorpioidi re= pponderent. Verimm, cimm hec folijs pasucts, illa ueró multis, lon= gisó; profiliat, ij aperté falli deprebenduntur, qui in bac opinio= ne uerfantur. Equidem veram, ut arbitror, Scorpioiden uidi primism fuperioribus annis in Foroiulien $\sqrt{2}$ agro in Ciuitate $A u=$ Arix quodam in bortulo clarißimi medici Iuliani d. Marofitica Teruilienfis. Hanc eandem, cuius bic effigicm pictan damus, dun boc tempore diligenter curarem, ut fingulis plantaruin de= fcriptionibus, quarum cognitionem babemus, pitara accede= ret, ad me mifit quidam ex ijs, qui rei berbaria dant operam. Qunin fane fuis notis uerami scorpioidem referre putamus: erfí non defunt uiri doctißimi, qui aliter fentiunt. Scorpioidenz brevißimé perftrinxit Galenus libro v I I . fimplicium inedic $=$ mentaruim, fic inquiens. Scorpioides excalfacit quiden ordine tertio, deficcat ueró fecunda. Ea non fecus Latinis Scorpioi=

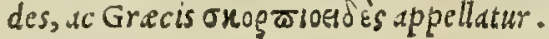

LIBRI QVARTI FINIS.

Scorpioidıs contider.

Scorpioidis facul. ex Gal.

Nomina. 


\section{PETRI ANDREAE MATTHIOLI MEDICI Senenfis Commentarii,}

\section{IN LIB. QVINTVM PEDACII DIOSCORIDIS A N A ARBEI, DE MEDICA MATERIA.}

CV P E R I O R I B V S quatuor libris, amicißime Aree, tradidimus de aromatibus, oleis, vnouentis, Darboribus, d- earundem lacrymis, ac fructibus : item animalibus, melle, lacte, adipe, cerealibus, oleribus : necnon de omni radicum, herbarum, fuccorum, feminumq́ue ratione. In hoc autem totius operis quinro differemus de uinis, Er metallicis, à vite noftram commentationem aufpicati.

\section{COMMENTARIVS MATTHIOLI.}

Varia de generatione lapidum fenten tia.

Ariftotelis opinio.

Theophrafti opinio.

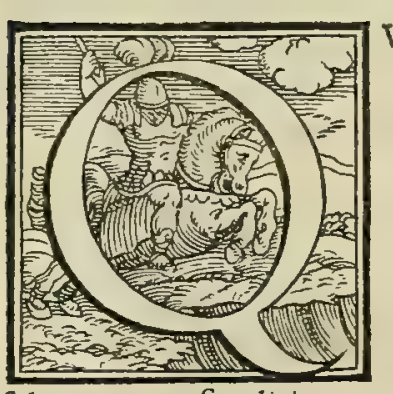

$\nabla$ O N I M non difficile tantium, fed quafi etiam impoßibile effet, ut cuiufcunque fcientie, aut facultatis principijs, ac fundamentis uniuerfalibus ignoratis, fciri perfe= cte poßint illd, que deinceps peciatim in ea con/ider and d ueniunt; ideo non minus ne= ceffarium, quàm utile fore exiftimaui, fi hic in uniuer fum foßstium, ac metallorum ma= teria tractaretur. Nam etfí in boc quinto libro nonnullorum foßilium medicamento= rum cùm biftoriam, tum facultates tradiderit Diofcorides, o ipfun fecutus Galenus in libris fimplicium medic amentorum; cum tamen corum neuter originem, materian, cau $\int d s$, ac alia plura in bis aftimanda, dc cognofcenda explicuerit, illa quidem boc $l o=$ co filentio inuoluenda non duximus, ut quantum per nos fieri potcft, nibil quod ad $a b=30$ folutam rerum fimplicium cognitionem, or communem ufum faciat, à nobis intactum relinquatur. Cim itag; plu= restam antiquos, quain recentiores, qui de foßjilium, ac metallor um materia fcripferunt, diligenter fatis perlege = rim, eos utique non modò inter $\int e$ differentes reperi, fed in aliquibus etiam contr arios. Nam licet corum quidan de ueritatis tramite parum deflectant : uidentur tamen non exadte ea omnia explic auiffe, que hac in re maximé neceffa= ria cenfentur. Fieri enim lapides, Arifoteles author eft, igne non liquefcentes ex ficca ignefcente exbalatione. Ex quibus deduci poteft, exhalationem bumidam materiam effe lapidum liquefcentium, é quibus metalla conflantur. quo fit, ut ex Ariftotelis fententid, lapides igne non lique fentes fiant ex calido, ev ficco uapore: Lique fcentes ue= ró ex bumido balitu tantün. Sed opinionem bane, qui rent altius, diligentiusqg; inuestigarunt, mininé probındam exiftimant, cum lapides longé minus, quàm terre ex uapore fieri queant. Siquidem puluis, qui fic gigneretur, unü aliquod ex pluribus fieri nunquam poffet, nifi bumor illi commifceretur. O omnespariter lapides non lique fcentes 40 $a b \int_{q} ;$ mult ta bominum opera, ac tundendi labore facile in arenam, uel puluerem tran $/$ irent, $\sqrt{i}$ tantum $c x i j$ s nullo ac= cedente bunore efficerentur. Quod proféctó haud ita fe habet: lapides nanq; feré innumeros admodum compactos, folidosq́; uidemus. id quod haud dubié ostendit, exillo tantüm uapore eos nequaquan genitos effe. Quód/i ex eo lapides eiufmodiprocredrentur, magis ominino fierent in Juperiore dëris regione, ut que facilé ignis contactu incen= datur, quàm intra terră. Qutandoquidem omnibus liquidó conftat, quàn fuperior illa aëris regio ex uelocißima aftro rum conuer/ione, citius accendatur. Ac certé fi non alids, faltem quoties gignerentur comet.e, faces, flamme, clypeiǵ; ardentes, deciderent lapides é calo, aut terra . quód tanen fieri non uidemus. Et quanuis tradiderint pro= digior un fcriptores pluiffe quando q; lapides, ut Plinius, or alij quidan teftantur; non tamen ob boc opinatus cst Ari foteles in ä̈re lapides gigni poffe. Nempe is lapidem é calo delapfunt uentorum ui in aërem fublatum fcribit. At fí lapides in ä̈re fiunt (quòd plane negare non aufim) quid obstat, cur dici non poßit, bos ex eadem fieri materia, ex so qua illi fub terra generantur ? quam quidem materiam facilé produxiffe potuerint uiolentiSime tempestates : utpote que repentino aliquo motu dum oriuntur, ex reliquorum elementorum mutatione terrena illa corpora genuerint.

Theophraftus ueró non lapides foliun, fed terras etiam conftare fcribit ex pura, ac aquali materia, que confluxu quoddin, fiue percolatione fit effecta, alióne modo excreta. Quod etfí iure aliquo probari poßit, non tamen ijs duo= bus modis tantum talis efficitur. Nec ea quanuis proxina fit materia terre infignis, onnis etidin eft lapis, ueriun a= lijs quoq; modis fit pura, or equalis materia, ut cum fucci nafcuntur. Interdum quoq, neceffe eft, ut calor materiam ijs duobus snodis genitam, prius coquat, ut inde efficiat fuccum, $c x$ quo tandem lapis, qui liquefcat ignis calore, fie= ri poßit. Verim enimucro multó magis in hoc erraffe Theophr aftus deprebenditur, quód fcilicet omnes lapides etiä pretiofos terra abundare crediderit : is enim ita inquit. Eorum, que in terra confiftunt, alia dquea funt, alia neró terrend. A quea quidem funt metalld, nempe aurum, argentum, o reliqua. Terrena ueró lapis, o lapidum pe= cies pretiofe, ac etiam terrarumpecies onnes, que colore, uel loxore, uel pißitudine, aliáue facultate funt in= 


\section{In Lib. quintum Diofcoridis .}

fignes. Qundoquidem fi uera effet bec Theopbrafti fententix, nulla quidem inueniretur gemma, que transluce= ret, cuin tamen uarise, ac ferme innumere reperiantur, que maximé pellucent. Hinc itaq; fit, ut citra iniurian de= ci poßit, non ommes pretioforum lapidum pecies effe terrenas, fed aqueds, id eft, ex lumore quodam conflat us, cui aque pondus longémxius, quim terre infit. Catcriss Aurcenne opinio, quam fequitur Albertus, multò magis weritati, ac rationi coherere uidetur, quan aut Ariftotel is, aut Theoplorafti. Qutippe quăquan non explicucrit ip= fe, quibus modis futura lapid is materia congregetur; dixit tamen lutum effe in primis lentum, or aquam non fim= plicem illam, fed cum terra permiftam. In qua permiftione fi plus terre, quim aque confluxcrit, lutum dicitur, fin aqus, fuccus. nibil enin aliud eft lutum, quam terra, que persnaduerit aqua : nec fuccus aliud quidem explicat, quim aquxm, que forbuerit terrain, uel abraserit, tetigeritó; metallum. L utum cnim, cx quo lapis futurus eft, len=

so tum, ac tenax effe oportet, cuiu/modi illud eft, ex quo lateres e fictilia funt: nam ab alterius gencris luto, quod penitus lentore careat, haud difficulter feparatur, ac diffoluitur bumor, tumq́; non lapis cx co efficitur, fed pul= wis. Lutum ueró tentix calor prinime exiccando conpetfat, efficitớ; medium inter lutum, or lapidem : deinde quia diutius idem agit, uel acrius, lapidem gignit. Quinetiumfuccus craffus, o lentus facilé conuertitur in lapidem. quod in animantibus eft euidens, prefertim q; in nobis, cum iandudum ueteribus medicis, ac etiamnum recentioribus decretun fit, tum renum, tum ueficx calculos non aliunde progigni, quim ex lento, crafo ó; bumore temporis tras= ctu à caloris noftri facultate confto. Ob id igitur translucentes gemmas non ex aqua tantum fieri confat; fed ex pu= ro, liquidóq; fucco, qui aque multum, terre ueró tantillum refer.at. Siquidem fi ex aqua tantùm buitucentodi lapi= des efficerentur, non utiq; mergerentur in ea proiecti, fed ed fupernatarent, non fecus ac glacies, er grando. At cùm omme lapidum genus demergatur aqua, ac etiam cryftallus, er beryllus, que tamen, quoniam glaciem colore

20 reprefentant, omnino uidentur ex aqua conftare, fatis mtelligimus, ex fola aqua non gignilapides illos. Quapro= Plinij opinio pter (ut in fequentibus fuo loco diccur) plané explodenda uenit Plinij, o aliorum quorundam fententia, quibus explofa. certum eft, cry/tallum glaciem effe, que niue in algidißimis montibus concreuterit, cüm aqua non fupernatet. Ge= nerantur pretered lapides ex lapidibus ipfis, cim flutiorum, riuulorum, ac fubterraneorum fontium aqua per faxa excurrentes, ab corum fuperficie aliquid lapidofi abraferint, qtod cum refederit, folis calore ficcatur, ac lapide fcit. Hoc enim euidentißime apparet in canalibus, ac foli patentibus aqueductibus, quibus nonnulle aque calida ducuns tur. I inimirum lapideis quibusdan cruftis oblinuntur, que cim tenuifinis ramentis compacte fint, cateris mollio= res, infirmioresq́; habentur. Hoc idem apertißimé conpicitur in quibusdam balne is aquarum ßponte nafcétizun, pres= fertimǵ; in balneo fancti Pbilippi comitatus noftri senenfis. Qudndoquidem ex buiufce balnei aqud, particula quae= dam gignuntur lapidex, faccharum tum candore, tum etiam materia referentes, que ufqueddeó imitantur femina 30 faccharo contecta, er afia id genus, qua in officinis faccharo fimiliter conteguntur, nempe anifum, coriandrum, ac etian plerunt; cimramomum, ut ijs capfule à quibufdam impleantur, itág; aptentur, ut folatij caufa aliquos faccha-

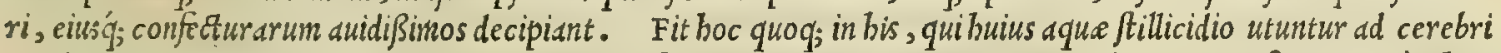
morbos curandos, illi quotidie caput fubijcientes. fiquidem lapidofa illa materia, capillis circumcifis continue inhse= rens, in granula quedam cogitur, ac coale fcit, ab anifo faccharo contecto nibil feré dißimilia, que non nifi tractu temporis inde fe explicant, $\sigma$ diffoluuntur. Idem pratered euenit in montiun concauitatibus, ac peluncis, qux ex faxo potißsinum calcario conftatt. quippe aquarum ex faxor um commißuris ftillicidio lapidea concre fcit materia, que é caultatum illarum cameris non aliter pendet, qudm ftirie byberno gelu é domorum noftrarum tectis prominent. Ex codem etiam faxo calcario oritur \&yp $\int u m$, melitites, galactites, $\sigma$ alij quidam lapides: $\sigma$ ex fucco, qui ex eo= dem $\int a x o$, o aqua contemperatur, lapis pecularis, o gyp fum, quod raró translucidum inuenitur. Eodem modo 40 ex ramentis rubei lapidisfit bematites, $\sigma$ fchiftos : item in commiffuris marmoris maculofi, aut eius, quod in can= dido cinereum colorem refert, reperiuntur dactyli Idai, lapides Iudaici, trochite, er confiniles. Verum enimue= ro fuccus lapide fcens omnino differt ab aqua, qux faxorum ramentis referta est, uel quodd plus habedt fedimenti, uel quòd calor talem coquendo aquam, eam denfiorem effecerit, uel quód aliquid is fuccus contineat, quod uehementer adftringat. Ex quo (ut opinor) corallium maris planta, or antipathes oriuntur. Poftremó materia lapidis erit quicquid babet meatus, per quos fuccus lapidefcens imbibi poß3it, fîue is à terrd contineatur, fine cum aquis miftus ex ea effluxerit. Quamobrem multoties arbores, frutuces, animantes, offa, ov alia in lapides uertuntur, ut Bolie= mi aperte teftantur. Quandoquidem in eorum regno pluries in fubterraneis fodinis (Georgius Agricold auctor eft) arbore sinuéte fuerint in lapidem cöuer $\int e$, ftantibus adbuc ramis, cortice, medulla, ac radicibus. Equidem ipfe quoq; ingenue fateri poffum, arboris ramü ex lacus cuiusd am litore mibi allatum effe, qui altera parte lapideus, altera ueró

so ligneus cernebatur. Venetijs item in magno Germanorum emporio, quod uulgó uocant il Fondaco de Todefchi, equi tefticulü lapidem factum, Antonius Golb mercator ibi pro Fucharis agens, iucundo omniü pectaculo, or admiratione oftendebat. Id quod animalium quorundam carnibus, er oßibus, tum etiam teftaceis pifcium operimëtis eueniffe conn= perimus. nanque in Hetruria quàm plurimis in agris, buccina, cocblex, conchule, ec eiufmodi multa aratro ab agri colis eruuntur in lapidem conuer $\int a$. Que Janè omnia haud dubiam fidem faciunt, ita fe rem băc babere, uti dixi= mus. Sed ut ex predittis omnem lapidun materiam paucis perftringamus, ed in primis eft lutum, in quo multó plus fit tenacis terre, quàm aqus. Deinde eft fuccus, qui uebementi frigore congelafcit, in quo aqua $i p \int a$ terrä $\int u p e r d t$. Süt preterea ramenta $\int a x o r \tilde{l}$, que aquarum decurfus abradit. Quinetian fuccus lapide fcés, qui cüm in aérem effluxit, in lapidem concre fcit. Omne deniq;,quod habet meatus, in quibus lapide fcens fuccus facilé excipiatur. Nibilo $\int$ ccius in metallorü ortu et materia, de quo iam nobis differend ü eft, autbores inter fe diffentire inuenio. Alia etenim eft philoso

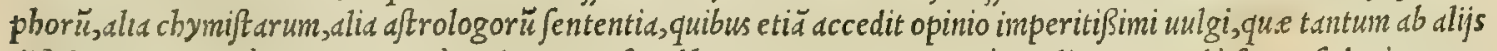
dijlidet, quantum à ueritate, er à ratione prorfus abborret. Is nanq; certó credit, non modó faxa; fed etiain me-

Auicennx 0pinio coprobata. 


\section{2

talls omnia, pretiofos lapides, or gemmas, ac terrarum uaria generd, in ipfa tantum mundi creatione Deum opti= mum snaximum talia finxiffe, atque creaffe, qualia nunc reperiuntur: nec medio temporis lap $\int u$, ullam ex materijs ad id difpoftis effe natam, tel renatam, neq; aliquam uim naturs, ad eorum perennitatem fummum rerum opificem tribuife. Qui certé uulgus ita temeré pronuncians, non uidet quàm maximam natura inferat iniuriam, qua nunquă aliquo temporis momento quic fcens, nil aliud agit, quàm ea femper regenerare, que aliâs genuit, que etiam noua multa producit. Vude bec uulgaris opinio prorfus explodenda, at $q_{;}$exibilanda $\mathrm{c} f \mathrm{Q}$. Quam infuper ut uanam ac ridi= culam, illud maximé diluit, ac demolitur, quod in antiquis metallorum cuniculis fole clarius uifitur. Siquidcm innu= mere inueniuntur metallorum fodin $x$, tanquam inutiles à fofforibus derelicte, quód inde omne metallum effoderint, per quas etfi prius longé, latéq; patebat tranfitus, ita ut liberé, or abfq; ullo impedimento non modó foffores ipfi, fed uebicula, ac curriculi per eas difcurrerent; tract u tamen temporis factumeft, quód materia lapide fcens in ipfis adeo 10 creuerit, ut fofforibus denuo ingredi uolentibus ob cauitatis anguftiam denegaretur aditus. Sed praterea metalla. continué generari, ferrum indicio eft. Id quod in Ilux infule metallicis fieri (ea enim à maritimis noftris non longé diftat ) non modo probatißimi foriptores memorix prodiderunt; fed foffores ipfi, qui diutius in ip is uerfatifunt, uer= bis referunt . quippe quód ferrex ille fodina mult is iam annis deftitute, iterum atque iterum ferrea materie implean= tur. Porróphilofophi, or chymifte aliter fentiunt. Ariftoteles lapidum materiam halitum tantum exiftimat. Chymiftarum ueró nonnulli omnino afferunt, metalla in uifceribus terr a gigni ex fulphure, er argento uiuo: alij ex quadam cinere aqua madefacta. Quorum fententia, cum non folim fupecta, fed ctiam plané falfa babeatur, eos ni= mirum omnes decipit, qui horum lubricis fundamentis nixi philo ophantur, ut firmis tum rationibus, tum argumen= tis probare non uererer, nifi id preter noftrum inftitutum eßset, qui hic harum rerum capita tantum percurrinus. Verum fi quis rem hanc fufius enarratdm, atque exactißimé difcuf)am babere cupit, librum legat Georgij Agricole uiri eruditisimi, à quo nos plura mutuatos effe ingenué fatemur. Caterùn illud omnibus, ut mea quidem fert opinio, perfuafum effe debet, quod nil aliud fit metallorum materia, quàm fubftantia elementaria, que tanto perfectius me= tallum efficit, quantó magis in aquali proportione tum qualitatis, tum quantitatis impense depurata conftat. Quip= pe inmetallarum materia aquam effe, maximo argumento eft, quód ignis calore liquentur, ac fluant: frigore ueró tum déris, tum etiam aque rurfus denfentur, ac coëant. Id quod claré oftendit, ed aque multum, terr ae ué parum obtinere. Simplex enim aqua non eft corum materia, fed mifta cum terra : atque terre quidem portio tanta in miftio= ne exiftit, quanta aque perfpicuitatem ob $\int$ curet, fulgorem ueró non auferat. Quinetiam miftura quó purior fuerit, có pretiofius ( ut diximus) metallum conflat, idó; magis ignis patiens redditur. Sed quota terra portio infit cuique humori, ex quo efficitur metallum, nemo mortalium unquam mente concipere poteft, nedum uerbis explicare. Id tantum nouit Deus optimus maximus, quicertas, ac definitas quafdam leges nature tribuit, quibus res inter fe mi= fcet, ac temperat. Succus igitur eft, ex quo formatur metallum, quem pariunt uarij motus, quorum proxini funt aque defluxus terram mollientis, aut fecum rapientis: terra cum aqua permiftio : o vis caloris agens in mifturas,

Caufa metal- ut id genus fuccos gignat. Sed cum de metallorum materia fatis dictum fit, ian caufam efficientem prof cquamur. lorú efficiens. Ea autem nil aliud nobis effe cenfetur, quàm calor, $\mathbb{N}$ frigus, qui in ipfius terre uifceribus reconduntur. Calor inquam is eft, quibumoris metallici miftionem coquit, ac purificat; figus ueró, quo eadem denfatur, or duracf $=$ ficitur. Hoc equidem experientia facilé comprobatur, cim neminem lateat igni metalla liquefcere, ac etiam tractu temporis poft liquaticnem, ipfius ignis calore contabefcere, auro excepto : Quamobrem deteftanda uidetur eorum opinio, qui tantum calore fubterraneo metalla confici crediderunt. Sunt er qui putent, metalla omnino eficifide= rum errantium influxu. Soli nanque auri generationem aßignant, I une argenti, Marti ferri, Mercurio argenti uiui, Iouiftagni, Veneri eris, Saturno denique plumbi. Addunt'́;, quód ficuti metalla ab errantibus fellis ful ortus 40 principium babent; ita pretiofi lapides, ac gemme, a fixis fuam effectricem caufam fufcipiunt. Huic autem fentens tia plerique non acquiefcunt, quoniam bas cau das nimis remotas credunt, er propinquioribus caufis inbarendum effe arbitrantur. Ego tamen inficias non eundusn reor, quin omnia bec inferiora terrena, ac finita regantur, guber= nentur, es producantur à fuperioribus cceleftibus, ac fempiternis : que tandem diuturno orbium circumuolutione, omnium caufarum tam remotarum, quàm propinquarum caufa exiftunt. Ita pariter dicendum exiftimo lapidum gi= gnendorum caufam non femper à folo frigore, uel calore, fed modó ab boc, modó ab illo prouenire. Nam lapides, quos aqua humectando diffoluit, calorem exiccando compegiffe intelligimus. Contrà ueró, qui calore ignis lique cüut, ut fluniorum, $\sigma$ torrentium filices, quibus igne liquatis uitrum conficiunt ar tifices, eos frigore conereuiffe certum efl. Concretio enim, ciq́; oppofite affectiones, re folutio fcilicet, atq; liquefactio, oriuntur à caufis inter fe contrarijs. Etenim calor à materia bumorem extrabens, edm efficit duram: at frigus eandem, aére maxima ex parre exclufo, so webementer conftringit, quemadmodum agit, cum aquam in glaciem, uel niuem cogit. Hinc eft, quód memoria pro=, didit Galenus, eam aquam corporibus prorfus inimicam effe, que à niue, uel glacie colliquatis fluxit: quoniam omne, quod in ea tenuißimum erat, à gelu expreffum fuerit. Duabus bis caufis tertia quog; accedit, que eft fuccus ille lapi= defcens, de quo fuperius diximus, qui uel folus, uel cum aquis permiftus inftirpium meatus, aut in animantium partis culas recipitur. Nam preterquàm quod fit lapidum materia, caufa etiam efficientis partes fubit: quando fcilicet in corpus aliquod per meatus penetrat, id'́, totum fecum in lapidem uertit. Quód fi in lapidem concreuerit zuttatim ca dens, aut in urceos diffufus, tunc materia tantium, non caufa efficiens dici mercbitur. Gignitur bic (ut Juprà dictum

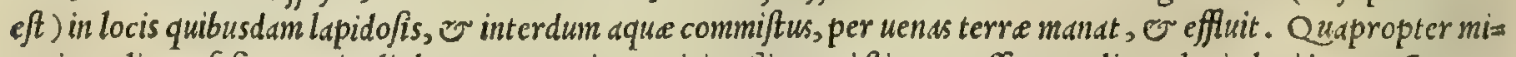
rarinon licet, fi fontes, riuuli, lacus, ac putei reperiri pojsint, quiftirpes, offa, or alia multa in lapidem tractu tem= poris uertant. Verüm non eft ignorädum, quód fuccus is lapide $\int c e n s$ motu aliquo agitatus, non facilé in lapidem dens

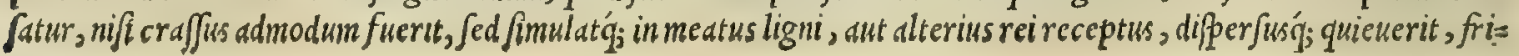




\section{In Lib. quintum Diofcoridis.}

gore cogitur, or concre fcit, mutat q́; resillas, quibus continetur, in lapides, ut in quodan Gotbix finte enenire pro= batißimi authores teftantur. Cuins gutt.e folo perfuf $x$, cim moneri, aut agitari nequeant, $a b$ ambicnte ä̈re denfan= tur, $\sigma$ lapidefcunt. Quod fi pretered uerum eft, in montibus pyreneis cffe loca, in quibus aqgue pluuiales lapide= fcant, id ideo ficri polfe uidctiu, quod aquas cum terra permiltas uel folis calor paulatin concoquat, ucl infignis pro= per calorem ficcandiuis, que terre in/it, confpiffet: utroque cnin modo ex cis poteft cfficilapis. Neque necc/fe eft

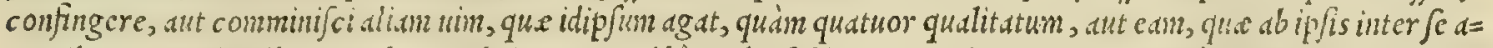
gentibus, or patientibus orta loco tribuitur. Sed hic nobis fubit inquirendum, cur unus tantiun quandog; gignatur lapis, cur ueró plures wno loco cficiuntur. Fit igitur, ut arbitramur, unus tuntim lapis, cun locus, qui concepit mat= teriam, folidus fucrit, ac meatibus carens. Quppe conclufus calor onncm tum operan, tum ficultatem tudique in

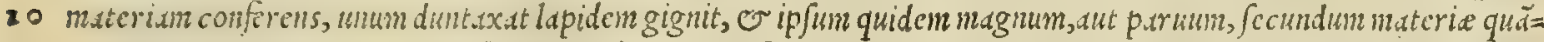
titstem . quapropter plerunque fingulares d frigore fficiuntur, cim purißsini fucci, cx quibus conftant, rarius mul= ti ac ingini in locum unum coirgregentur. Terum contrà plures gignuntur lapides, fi locus non fucrit planc folidus, fed meatibus refirtus, per quos culor ip $\int \mathrm{c}$ difcurrere quedt: nam if meatus patucifucrint, calor matcrian diuidens pulucos efficit líbides; fin multi, multos. Ad bec plwes generantur lapides non nodó ex preditis, fed etiam ex ma teriu diuer/it.ate. quandoquiden calor partem unius generis fecernens ab alterius generis parte, plures efficit lapi= des. Itcm plures eficiuntur ex mult is unius loci receptaculis, in quibus infufa materia in plures partes diuiditur: $f i=$ quidem in ca figus non minus, quim calor uires fuas exercere poteft. Quilapides preterea pro diuer fa matcrix mo le magni, aut exigai redduntur. Iifdem modis quoque glared, or filices fiunt : et fi ij fapius aquarum impetu, qui faxa frangit, or coinninuit, efjiciantur. Hactenus caufas explicauinus, qua lapides, or metalla efjiciunt . nunc ad eo= 2o rum differentius progredismur. Colorum itaq; difcrimina, qux in lapidibus fpectantur, materie, ex qua gignul= tur, diuerfitaten indicunt. unde unus, er idem lapis fepe uarios colores confequitur, quód fiat ex diuerfí coloris ma teria. Dinde calor, cum ipformm lapidum fit opifex, coloribus materiam inficit : nam obfcuros ipfius colores illuftra re, illuftres ueró obf curos reddere poteft. Cuius effectus exemplum clarum babetur in coloribus iis, quibus fictilia ua fapingmntur. nunque colores omnes, qui ad uasafictilia pingenda, uel inficiendaparantur, anteaquam in fornacem conijchntur, ab bis plurimim diftant, qui in fictilibus ip/is igne torrefactis, pofted uifuntur. Quandoquidem et fi fi= ctilia aris fquma fupcr porphyrite lapide leuigata, admista aqua, infecta rufo colore, aris feré modo, appareant; ignem tamen fornacis experta, uiridia efficiuntur. sicut er color, qui ex ferri fquama paratur, melinus efficitur. I apis etıánnum, quem figuli noftrates unlgó uocant zaffara, porpbyrite lapide lauigatus, colore fubnigro cruda adbuc fictilia tingit: fed igne percoctus, in caruleum preftantißimum mutatur, ut nobis aperté declarat ceruleus,

30 ac pulcherrinus ille color, quen uulgó pictores uocant smalto: is enim ex ipfo lapide zaffara nominato, cum uitro mifto in uitriarijs fornacibus efficitur. Verum hanc colorum permutandorum facultatem in frigore non inuenix. quare lapides ab ip fo coacti colorem eundem feruant, quo prius eorum materia infecta fuerat. Ex bis adduci poffu= mus, ut non temeré credanus, quód plerique fluniorum, ac torrentium filices coloribus in fuperficie tingantur: quo= niam modó aquarum inundatione madefiant, modá folis calore ficcentur. Solis enim calor, d̀ quo filices ipfí aftate si= rio ardente adeó incale (cunt, ut uix tangi poßint, ipfor um quidem colores ( ut fictiliun fornax) facilé immutare po= teft, licet id inagis euenire conftet in eorum fuperficie, quain in centro. Differunt or metalla inter fe colore, pplen= dore, fapore, odore, pondere, or facultate. Color primim uarius in metallis conpicitur, nam unumquodque fuum fortitur colorem. Aurum fiquiden inter metalla ideo fului coloris eft, quod calor uel terram in flauedinem quandam fynceram uerterit, anteaquám cum aqua mifceretur, uel fuccum ip fum mox futurum aurum. Aes ueró fuum colo= 40 rem habet, or eum quidem fubrubrum, eo quód terram nonnibil impuram aduferit calor. Ferrum autem fubnigrum $e f$, propter terrami ualde impuram, er aduftam. Argentum porró candidum est, quód terra cius fuerit alba. Ed= dem in ceteris fingulis colores inueltigandi ratio. Sequitur deinde corum plendor, of nitor, qui ab aqua tantum (ut anté diximus) prouenit. Ex quo fit, ut quantó bumor ipfe tenuior, denfior, purior q́ fuerit, eó metallum niti= dius, ac plendidius efficiatur. quamob caufam reliquis bac in parte preftat aurum. Atq; linc etiam faporem odo= remí; fibi metalla afcifcunt: dum enim aurum igne comburitur, terre ip fius fynceritate, qua optiné cum aqua com= mifta eft, fumum perexiguum, $\in$ uix fenfibilem emittit, $\mathcal{O}$ dulcem, ac fuduem magis, quàm fretidum. Argentum ue= ró contrà, quód terram impuram, licet combuftu difficiliorem obtineat, plus fumi eructat, quim aurum, $0 \sim$ fub= fciduin quoque odorem exbalat. Sed tam ferro, quàm eri multó maior fumi copia effunditur, atque und̀ odor lon= géfxtidior, quód fcilicet adustain contineant terram. Plumbum denique ac ftagnum, ob aque redundantidin, bebe=

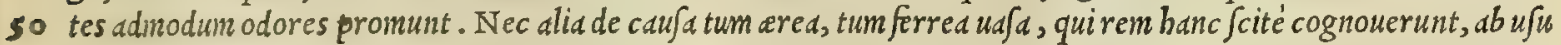
coquinario abdicauere, quaim quod adufte terre, quasn poßident, ualde amara qualitate cibi omnes, qui in buiusce= modi uafis uel coquuntur, uel parantur, uel aportantur, uel reponuntur, facilé infici poßint. Id quod non modo gufturi malé afficit, ev exaperdt ;ed etiam in uentriculo naufeam, or fubuerfionem commouet. In hoc ergo admo= nitos feplafiarios wolumus, ut ab horum uaforum ufu cauednt: nam quandoque compertum eft, quodacida medica= menta in cacabo areo (qua fuit pharmacopole uel ignauia, uel imperitia) decocta, faua ac periculofa intulerunt $a=$ gris $\int y$ metomata. Preterea metalla omnia ponderofißima funt: cuius rei cau $\int a$ eft denfitas ip $\int a, q u a$ fequitur bonan terre cum aqua permiftionem. Hinc fit, ut grauißima quaque ponderd metallis liqucfactis fupernatent, modó ma= ior fit metallorum quantitas, quain rerum, que ipfis demerguntur. At buius rei cxperimentum quotidie facere li= cet, $\sqrt{i}$ argentun uium in aliquod uas infundatur, ei $q_{\text {; }}$ metallica pondera fuperpondntur, auro excepto, quod fo= lum inter cetera fundum pettl, quoniam plus cateris ponderet: argento enim niuo ipfa pondera non aliter fuperna= tare deprehendentur, quam aque ligna. Caterim aurumin ipfo mergttur, non modó quód ponderofius fit; fed

Cur pauci, curmulu lapi des fiant.

Lapidum colores unde ua ij.
Metallorú dif ferentix plures. 
etiam quód cogntitionem quandam, or quafi confenfun cun ipfo habere uideatur. Metalla infuper, que liquéfcunt, iis qux atingunt, minime adberent, nec eadem bumect ant, neque etiam labuntur, ut cateri aquei liquores tam fof =

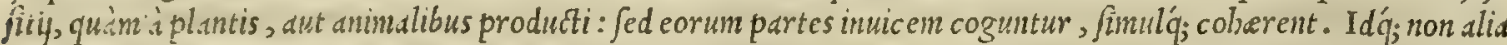
ratione fiericonftat, quisin quód tam bona, firmáq; miftio rci ficce cum bumid a fact a fit, ut ficca obftet bumnide, ne adherefcat, o bumectet: liumida ueró contrà impediat, ne ficca prorfus conquiefcat. Cux quidem miftio quoniam in auro perfectifina reperiatur, ideo hoc igne nunquam abfunitur. nam cim eius purißina terra fit optime cum as qua permifta, humorem ftringtt, or continiet, ne ui ignis expiret : bumor weró contrì tuetur, ac defendit terram, ne accendatur. Idcirco munquan comburitur aurum, ut cetera faciunt metalla. que quandoquidcm impuriorem fortiantur terram, deteriorénque miftionem, proinde ignis uiolentia facilé rapiuntur, er conficiuntur : cum enim terraflanminis accenfa fucrt, bunorem celeriter deperdit. Attanen metallum unum alio magis, er citius comburitur, prout hoc illo plus terre, camq́; minus probé miftam obtinet. Etenim fi libeat experiri, in prinis ferrum depres bendetur igni confumi, propter nimidin, quam babet, terre impure copiam. Mox plumbum, o ftagnum, quód ijs non fatis firmum fit cum terra temperamentum. quam ob caufain poftqudm bumorem exhauferit ignis, terram confumit. Deinde as, quod cim terra purioris, ac etiam paucior is particeps fit, quàm ferrun, etfi ea non atis ex= quifuté mifta it cum aqua, diutius igni refiftit. Poftremó argentum, quod quia puriore terra confat, ac melius $d=$ que conmifta, non nifi longiori tempore famme cedit. Verüm plumbum, ac ftagnum non ob id igne tam facilé uin= cuntur, quòd multun impure terre contineant, fed folum ob niftura uitiun, quonian in bis imperfectior inueni=

Iapidum di- tur. Sed ad lapides noftra rewertatur oratio de quortin quoq; luciditate, fiue perßicuitate, ac nitore, uel ho= uerfa difcrimi rum oppofitis obfcuritate, ac fqualore iam aliquid nobis differendum eft. Expredictis itaque onmibus clarum effe na. arbitror, lapides aquain magis, ac terrain participare, quam catera elementa. Sed quoniam non terra, fed aqua 20 cernitur effe perpicua, ac pellucida; ideo ab ea tantùm perpicuitatem, luciditateríg; ijs adueniffe confrat. Vude ex fuccis claris, 0 perlucidis conftare lapides, que translucent, affirmamus. quemadmodum ex terra eos, qui quda litatis perpicuitati oppofite reperiuntur : bi cnim ex claris fuccis gigni nequeunt, fed ex impuris, ac turbidis ucl lu= to, wel nigriore infectis. Quidd ueró alij lapides magis, alij minus pelluceant, non aliunde fiericertum eft, quàm $\dot{e}$ Juccorum diuer/itate, cum fcilicet alij alijs clariores, ac lucidiores exiftunt. Ex quo fequitur, quòd albs gemme gignantur ex fucco, cui aqua color infit, atque adeó ceteris clariores, ac illuftriorcs appareant, ut cryftallus, on iris, gemma fie ex arguniento uocata : nam fub tecto percufa fole ob angulos, quos habet, colores ex opaco reddit, Apeciesq́; arcus calestis in proximos (ut Plinij uerbis utar) eiaculatur p.rietes. At adamas ex fucco minus claro progignitur, ideoǵ; tain iride, quàm cryftallo obfcurior eft. Non dißimili uarietate notantur aliorune colorum gem= me translucentes, fiue ortse fuerint é fuccis uiridibus, ut fintragdi, ac prasij: fiue é ceruleis, ut fappliri, cyanei, or iapidum quoddam genus: fiue é rubris, ut carbunculi : fue é purpureis, ut ancethyfti, or by.cintbi: fiuc ex au= geis, ut chryfolithi, or chryfopatij: fiue ex mifti coloris fuecis, ut opali. Hinc igitur colligifacilé poteft, quód cre= tera gemmarum generd, que perfpicuitate carent, é fuccis concrefcant impuris, atris, $\mathcal{O}$ obfcurss : quando nec $d=$ qua quidem limpidißima, cui ater fuccus infufus fit, clara ac purd perpici poßit. Nitent tamen gemme non translu= centes propter infignem leuorem, qui lucis continuitatem, er denfitatem parit. Quem quidem l.evorem aut fibi na= tura comparant, aut artificum inallgonio confequuntur. Iifdem de caufis marmor:a quor'; radiant. Porró lapides, o gemine pellucentes nomnunqu.in coloris labem, aut uitium aliquod contrabunt: $\int e p e$ enin aut umbra, aut nul= beculis, aut capillamentis, aut fale, aut plumbagine uitiantur. Qune fane omnia non alia ex cuufa proueniunt, quìn ex coloris fuccidiuerfitate. Gignitur quidem umbra, cum fuccicolor aliqua parte obfcurior fuerit: nubecula neró ob partem albidioris coloris. At capillamentun, quo prefertim fapphirus inficitur; $\int a l, q u o$ opalus; palumbago, quo findragdus, ex alieno prorfus colore funt, non autem proprio gemmarum. Quinetiain fibigemine frabriticne indunt, cum ob fucci diuerfitatem partes inequaliter coalefcunt. His ergo rationibus nixus, nemo non audebit di= cere atq; afferere, lapides omnes, ac faxu, que neq; nitent, neq; pellucent, ex craßißino fucco, er terrena materis fieri. Differunt preterea lapides pißSitudine or raritate, leuitate er grauitate. itaq; ponderofis, ac compactis $1 \mathrm{l}=$ pidibus pauci, er admodum occulki funt meatus : raris ueró, ac lcuibus contra multi, $\sigma$ patentes. Qunapropter $d t=$ cendum effe reor, quòd rari, ac leues efficiantur lapides, ubi eorum bumor cü terra non probé fucrit miftus . is İqui dem d̀ calore ficcatus locum, in quo confederat, uacuum relinquit, ut in topbis, o fimilibus con/picitur. Iden quor; euenit, cum ponte flagrant montes, ut Aetna in Sicilia, $\mathcal{O}$ Ve fuuius in Campania Plinij tempore, ac etiam bac noftra atate . nam cim ibi magnis incendijs terra cremetur, eddem ratione ex ip $\int$ a fint meatuum pleni, caucrnofi, o leuif= fimi pumices. Contrarium plané fieri con/tat, fi bumor undiq, in terram penetret, o illi optimé mifceacur : is cnìn boc modo lapides graues, compactos, ac duros generat. Quod autem lapides duri, uel molles fiant, partim materia in caufa eft, partim uerò id, quod materiam fingit, $\sigma$ format. Nam fi fuerit materia tcnax, $\sigma$ calor tantus, ut cx ip= fa bumorem exbaurire queat, uebementer conftringitur, $\sigma$ in $\int e$ cogitur, fit $q_{;}$ex ea lapis denfus, $\sigma$ durus. Sin len= toris parum admodum, aut nibil habuerit, $\odot$ calor fuerit multus, aquam etiamfi probé terre permifta fit, abfumit, ${ }^{\circ}$ refoluit, terrain ueró comburit. quo fit, ut lapis adeó mollis fiat, or friabilis, ut facilé in puluerem redigatur. Obdu re $\int$ cunt ad hec lapides frigore, utpote quod fuccum ualidißimé cogat, o conftringat. Atq; ij lapides, qui ex buiuf= modi fuccis coadtis concreuerint, in fornaces ardentes coniecti lique cunt, flunt' '́; ob conclujos hunores. Qui ueró igni admotifranguntur, e disiliunt, non quidem tantum bumoris in $\int \mathrm{e}$ continent, quantum priores, ut co terren.e par tes coliberi poßint. Quos autem ex luto genuit calor, ignis terit in puluerem, propter terrenam ficcitatcon. Cate= rim qui ex fuccis pinguibus, o bitumino fis conftant, accenfi non fecus ac ligna ardent. Cuius generis eft gagatcs la= pis, quo Cimbri, er alij plerig; Germania inferioris populi a asim lignorum uice, quorum inopiam babcut, sid ignen 


\section{In Lib. quintum Diofcoridis.}

utuntur. Verim cnimuero non ob id tanta eft ignium uis, ut adamantem uincat: quandoquidem buius bumor ignis ca= lore fortior exiftit. Eandem etiam ob canfam amiantus non modó non comburitur igni, fed ne quide diffoluitur. Vter= que cnin etfificcus, cim tangitur, efe fentiatur; tamen bunorem immiftum obtinct, non alter ato; metalla. Porró lapides, qui corpora erodunt, ut in Lycia inuenti, ucl abfumunt, ut A Bius, in quo corpora de funitorum condita $a b=$ fumi tradunt, unde illi farcophigi nonen, ex materia admodum acri gignuntur, ut in fodinis quibufdam cadmia que= dam inuenitur, que fofforibus ipfis manus erodit, er exulcerat. Poftremó nonnulli lapides funt, qui ueluti praegnan= tes lapillum, uel argill.m, ucl liquorem in utero gerunt. Cuius rei caufa eft or materix diucr fitas, er quód cadcn magna ex parte figuram globofan referat, aut quàm proximé accedat. Materie enim pars interior ab exteriorc diffe rens, aut calore cocta mox diuiditur, aut aliquo póft temporis patio feparatur, non fecus ac are fat e nucis aucllane 20 mucleus a putanine. Quod fîfuerit Juccus, vel lutum tenax, ip $\int a$ etiam pars intcrior in lapidem cogitur, ut in ačtite uifitur: fi ueró lutum non tenax, uertitur in terram plerunque argillacedm, ut cernere licet in gaode: fin fuccus te= nuis, ucl aqud, liquor interdum remantet, ut in enbydro, in quo ad motum fluctuat intus, ucluti in ouis liquor, ut inquit Plinius. Caterum cochleas in axis repertas, calor conclufus, ex materia pingui, er lenta efficere uidetur, $\mathrm{Cr}^{\mathrm{ex}}$ eadem gignere mufculos, or conclylia': Sed terra quantó eft craßior, quam mare, tantó ea migis imperfict. zignit. Nec mirum cuipiam effe debet, quód ciufinodi concbylia in lapidum medio orta, ibi diutius conclu $\sqrt{a}$, ip is cedente $l=$ pide, crefcant, er uiuant. Siquiden ego certò teftaripolfum, me uidiffe non longè à Timauofonte prope Duinum ca= frum in Adriatici litore fitum, ubi inaris alluit unda, lapides à focijs malleisferreis frangi, ato; in illis plurima repe= ririconcbylia, que dacty los a forma, er colore uocant: funt cnin palmarum caryotis fimilia. Hac eadem me ali= quando comediffe memini in caftro Goritix in opiparis men/s illuftris, ac clari comitis Francifci à Turri noftrorum

20 fludiorum (qua cius cft fingularis bumanitas) fautoris, promotorisq́; maximi : qux fanc non minorem quàm oftrea, in cibis grati.m habere comperi. In ipfo quoq; Duini caftro ijsden ue $\int i$ mibi contigit apud magnificum Matthiam Hofferum, uirum sané nobilitate er moribus infignem. Neq; me fugit, bis nuper elapfis annis uirum magnificum atq; prxclarum Didxcum Mendozium Hipanum, lapideds quafi tabellas mibi oftendife ex Veronenfi agro (ut afferebat) delat.ss, que in longum fciffe uarios intus pifces ueluti infculptos habebant, cum omnibus fuis particulis quámuis mi= nimis, in lapidem uer fos. tot tam q; admirabilia funt opera nature. Huc preterea illud accedat, quód pifces foßiles

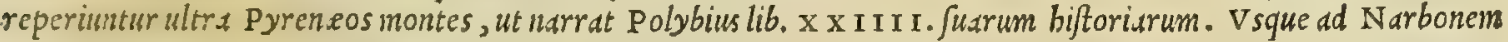
ammem, inquit, planities eft, per quam flunij feruntur Illiberis o R hof cinus, fluentes propter urbes eiufdem nomi= nis, qux babit.ntur d Celtis. In hac igitur planitie funt pifces foßlles diqti. in ea enim eft terra tenuis, ubi multum n.s fitur gramen, fub quod altitudine duorum uel trium cubitorum per arenam aqua fluminit deidta fluit: or fi quan=

30 do inund auerint, cun aqua pifces terram fubeuntes ( nam mirific é appetunt graminis radices) planitien efficiunt re= fertam piccibus Jubterraneis, quos incole effodiunt. bec Polybius. Quibus adde, quód etian pifces foßiles inueniun= tur circa Heracleam, atq; in alijs plerisq; Ponti locis, ut Theopbraftus eft auctor . quin et in Germania ultra Albim fluium quibusdsın in locishac elate effodiuntur. Verùm quandoquidem Diofcorides in boc quinto libro fcrip/it Terrarü bretratakitg; etiännum de uarijs terrarum generibus, qux in medicum ufum ueniunt, non alienum fore iudico, quód de uis enarratio. bis quo.; uniuer fim aliquid differanus. Terram itaque aut fimplicem, aut compofitam effe oportet. Simplicem nunc eam intclligo, que cum nulls re foßili, neq; cum aliquo liquido fucco fuerit permifta: non autem eam, que à cateris elementis fit penitus munds. quippe ob continuan elementorum miftionem uix ullam reperiri poffe putauerim, que nonnilil aqux, aëris, uel ignis non complectatur. Quamobrem eam fimplicem dixerim, que nullam prorfus alumi= nis, aut falis, aut nitri, aut chalcanthi, aut bituminis, aut cuiusuis alterius rei inetallice miftionem admiferit. Con=

40 trà compofiasm appellauerim, que unum, uel plura ex bis in fe receperit. Simplex autem terra, de qua nunc fer= monem habesnus, mod' grauis, modó leuis confat, pro maiori, aut minorielementorum mistione, quxe illi ineft. quis enim dubitet, qum ea fit leuior, ac rurior, que plus aĕris, aut ignis participat, quḋm aque? Ad hec terra ip a per fe omnis exiccat, fed urius fortitur facultates pro uxia eorum, que ei ddmifcentur, qualitate. Namillx, in qua fit aque frigus, adftringit: que ignem accepit, acris eft: que dërem, glutino $\int_{1}$, or leuis: que aërem er ignem, les uis, or acris. Ills ueró, qua' fibifulphur adiunxit, aut alumen, aut chalcantbum, aut metallum aliquod uel fo $\beta$ illem fuccun, facilé quidem guftu, ac etiam olfactu cognofci poteft. Nec de his plura dicenda funt, quód mihi plané perfua= deam buiufinode qualitates nulli non cognitu faciles futuras, guftuduntaxat iudice, qui tamen dulcia ab amaris, acria $a b$ acidis, falfa $a b$ infipidis, acerba i maturis difcernere fciat. Terre autem, quarum in medicina eft ufus, fua mu= tuantur nomina partin à locis, ubi effodiuntur, or aportantur: partim à coloribus, quibus inficiuntur: partim àfaso cultatibus proprijs. A locis enim denominantur Lemnix, quód ex Lemno infula deferatur, Samia quód ex Samo, Cbiaquod ex Chio, Cimalia quód ex Cimo, Eretrisquód ex Eretria Eubare ciuitate, or Pnigitis quód ex Pnigite Iibye pazo. A' colore appellationem trabunt rubrica, or alie nonnull.e. A facultate deniq; nomen accepit ampe= litis, quod eius fit ufus ad illinëdas uites fub germinationis tempus aduerfus erucarum iniurias. Et ut aliorum quo= que foßlium colores percurramus, colore albo conftant, creta, qua farcinatores utuntur, gyp $\int u m$, alumen, dmian= tus, Arabicus lapis, Iudaicus, melitites, galadites, alabaftrites, cryftallus, argentum, argentum uiuum, ftagnum, et Syncery/3imum marmor. Colore cinereo produntur melia terra, ov Evetria altera. Ceruleo uero colore pectantur Sapphirus, cyanus, er lapis proprié ceruleus diatus. Virent fmaragdus, praßius, cbryfocolld, er chalcantbum. Flawo luteóue colore funt aurum, ochra, cbryfopatius, chry folithus, or auripigmentum. Rubeo tingunturrubini, granati, fandaracha, corallium, hematites, fcißilis lapis, minium, cinnabaris, rubrica, or Lemnia terr 1. Quxdam colore purpureo fulgent, ut byacinthus, er amethyfus. Alia caruleo diluto uifuntur quemadmodum ixpis, quem bo= ream dicunt. Nonnulla ceruleo uire fcente, ut arugo, en Armenius lapis. Alia albo rufefcente, ut aphrodifiace. 
Folsilium facultates.

Quedam rufo candicante, ut $x$ anthos. Quedam nigro ruff $\int$ cente, ut tertia batrachitis pecies. Aliqua atro purpue rajcente, ut aldbandicus lapis. Alia aureo candicäte, ut topatius. Sed plura feparatos colores babent, ut nigro, al $=$ bo, or quóuis uerficolore, ut achates. Apficton ueró nigram rubentes uene diftinguüt . Contrà nafomonites, cum fit fanguinis colore, nigris ucnis decoratur. Vene autem, quse peciem pre fe ferunt fanguinis intexte, quodammodo funt heliotropijs, corpore porracei coloris. At in ceruleo fapphiro aurea puntta collucent. Quinetiam quxdä funt, qux tres feparatos habent colores: nam per album agyptelle corpus dus uene permeant, altera nigra, altera ru= bra. Porró eupetalos, or orca quatuor habent colores : eupetalos enim caruleun, igneum, minij, mali: orca ueró nigrum, fuluum, uiridem, candidum. Verficolores poftremó nonnulle babentur, non aliter, ac collum galline Nu= midice, uel pauonis, aut columbe in fole apricantis, ut eriflalis, or pederotum genera: ea enim ad inclinationem colores permutant. Ceterim fciendum est,quód ex foßilibus, que in medendi ufum recipiuntur, alia quidem corpo= ra fanant, alia ueró eadem affligunt, in cibis uel potionibus data. At qua remedia corpori funt, medentur ci partim proprietate totius fubftantia, partim qualitate aliqua, qua profligantur morbi. Que autesn proprictate ualent, ed= rum quedam refiftunt uenenis, quedam morbos fanant. Quibus natura dedit uires fuperandi uenena, eorum alia corpora, qua peftilentia funt affect $a$, curăt, ut fmaragdus, figillum Lemnium, gle ba Armenia. Alia fingulari uc= neno medentur, ficuti f corpionum ictibus fappbirus potus, fulpbur plaga illitum : fung is ftrangulantibus nitrum po= tum, ac pariter atramentum futorium. Alia pluribus aduer fantur uenenis, ut fal morfibus uipere, cerdftis, dc cro= codili . his enim emplaftrimodo imponitur: fed potum opio, es fungis prefidio eft. Quibus ueró foßilibus compara= tum eft, ut morbos proprietate fugent, corum quadam fanguinis profluuium fiftunt, ut hieracites. alia os uentriculi geftatu or appofitu robor ant, uelut iapis. alia finiftro mulieris brachio adalligata abortum probibent, ut aëtites. alia item ad femora pregnantis alligata partum accelerant, ut idem aëtites, er iapis. sunt que craffa écorporibus 20 deijciunt, ut magnes: alia atram bilem, ut Armenius, or ceruleus lapis : nonnulla uomitü faciunt, ut idem Armenius lapis, chryjocolla, or chalcanthü. Sed inter ed, que elementaribus qualitatibus agunt, calefaciunt alumen, chal= canthü, chalcitis, mify, fory, melanteria . refrigerant terra Eretria, molibdoides, ftibium, argentifpumd, ceruffa. Que autem fecundis qualitatibus operantur, quadam molliunt que dura funt, ut gagates: quedam contrà indurant que mollia funt, ut lapis plumbarius, or ftimmi. Sunt $\mathcal{\sigma}$ que infenfibiles feré poros aperiant, o que claudant: $a=$ perit enim nitrum, puma nitri : claudit terra Samia, er in fumma ormis terra glutinofa. Alia, que corpori coierŭt, nempe glandulas, đ nodos, difcutiunt, ut pyrites, molaris, bitumen. Aliqua cicatricem inducunt, ut clsalcitis, mify, alumen fciffum. Nonnulla carnem excrefcentem minuunt, ut aßij lapidis flos, erugo, chalcăthum, chalcitis, mify, calx uiud, auripigmentum, fandaracha, cbryfocolla. Non defunt etiam, qua deuerfis uiribus predita fint, ut

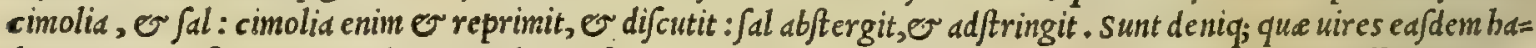
beant, ita ut deficiente und, altera eius locum suppleat. Siquidem cbyfocolla, e lapis Armenius cundem effectum pre=

VITIS VINIFERA.

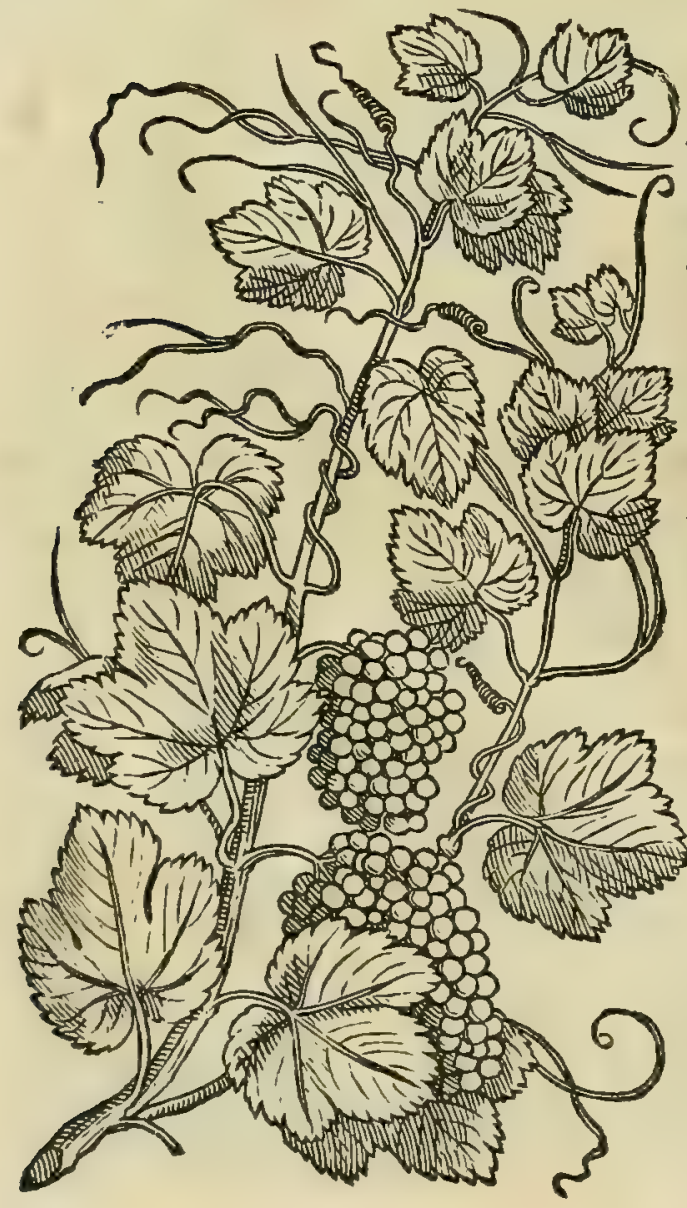
bent: auripigmentum, or fandaracha: bamatites, or fcluftos: atq; hec quinq; chalcanthum, mijy, chalcitis, fory, melanteria inter fe uiribus confentiunt. Veruntamen ex bis chry focolla uim efficaciorem obtinct, qudim lapts Armenius : auripigment ü, quàm fandaracha: hematices, quim chiftos : chalcantbum, quain re= liqua fibi cognata. Cettrum non pauca reperiuntur foßilia $m e=$ dicamenta (ut fufus libro fexto dicetur) qua in cibo, aut potu frequentius, aut copiofius fumpta, uel maximé fumentes affligüt, uel ijs mortem inferunt. Id 'q; efficiunt, uel quód uifccra erodant, 40 uelutifandaracha, or auripigmentum : uel quod pirandi orga na occludant, ut gypfum, or ceruffa. Sed hec de fo ßilium facul= tatibus. Nam de concretis fuccis, cuiu fmodi eft fal, nitrum, dlux men, chalcantbum, ov cetcra, que cum eo cognationem babét, fulphur, fandaracha, auripigmentum, cbryfocolld, er alia nons nulla, in buius libri proce $\int u$ Juis loc is latius tractabimus.

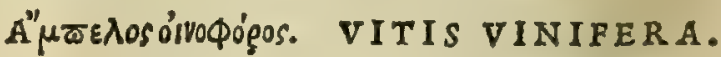 CAP. I.}

F o I I u uitium, \& triti capreoli, capitis dolores illitu mitigant: \& inflammationcm ftomachi,ardoremq́ue cum polenta. Folia etiam per fe, ut quæ refrigerent, $\&$ adfringant, imponi folent. Potus eorum fuccus : $d y-$ fentericis, fanguinem excreantibus, ftomachicis, \& grauidarum malaciæ medetur. Eadem efficiunt madefacti in aqua capreoli, \& poti. Lacryma uitium, quæ ueluti gummi in caudicibus concrefcit, ex uino pota calculos pcllit : illita lichenas, \& p foras, leprasque, nitro prius perfrictas, fanat: eadem cum oleo fxpius pilis illıtis, plilothri effectum habet: maximeque ranies, quam ac- 


\section{In Lib. quintum Diofcoridis.}

cenfa farmenta uitium uiridia exudarunt: qua \& peruncte uerrucarum informicationes extrahuntur. Cinis farmentorum, \& unaceorum, detractis in fede condylomatis, \& thymijs, illitus ex aceto medetur: prodeft luxatis, $\mathbb{S}$ uiperarum morfibus: contra lienis inflammationem illinitur cum rofaceo, \& ruta, \& aceto.

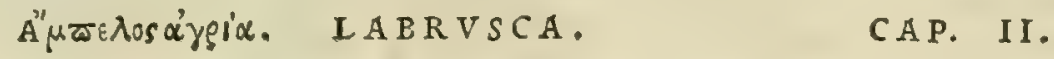

L. A B R V S C A duorum generum eft. Alterius vua non maturefcit, fed florétenus œnanthen nominatam perducit. Altera ad frugem peruenit, paruis acinis, nigra, \& adftringens. Folia, caules, \& 2. clauicula, quibus repunt, uim habent cultæ uiti fimilem.

$$
\Sigma T \propto ф \vee \lambda H^{\prime} . \quad V V A \text {. }
$$

CAP. III

V V A E recentes aluum turbant, \& ftomachum inflant . innocentiores, qux decerptx diu pependere, ideo quòd in eis copia humoris exiccatur, utilesque fiunt ftomacho, xgrisque, atque cibi auiditatem excitant. In uinaceis, \& ollis feruate, ori \& ftomacho gratx funt, aluum fiftunt, fed ueficam, \& caput tentant: \& fanguinem excreantibus conueniunt. Similesq́ue, quæ in mufto fuere. Sapa, aut paflo condit , ftomachum magis infeftant. At quæ folem prius paffæ, in aqua coleftı conduntur, minus uinofe funt, fiticulofis, ardentibus, \& longis febribus falubres . Rcconditi uinacei 20 inflammatis mammis, rigentibus, ac præduris, cum fale illinuntur. Decoctura eorum dyfentericos, coliacos, \& fominas fluxione vuluæ laborantes iuuat infufa: ad defefsiones, ac fotus affumitur. Nuclei acinorum aditringendi nim obtinent: Itomacho utiles funt Infpargitur farina toltorum,polentæ modo, dy fentericis, \& coliacis, \& folutis ftomacho .

V I T I V M omnium generd, que non modógratißinas, dulcißinds $q_{;}$utad ad cibos proferunt; uerum etiam ex Vitis uinifebis uinum precipum bumane uite bonum, fuauißinumg; potum largiuntur, quot er qualia fint, bic jcribere fuper= uacuum effe puto. Quandoquidem earundem dulcedine bumanum genus allectum, adeo és fibi conciliauit, familiarés= que reddidit, ut mullus tam clarus quàm obfcurus, tam nobilis quaim ignobilis, tam deniq; urbanus quàm rufticus in= ueniatur, qui de uitium generibus, earumiq; hiftoria non poßit apté, atq; etiam diftincté loqui. .Vt autem er uites ip=

30 $\int e$, e uinum a quorundam uermiculorun erodentium uindicentur inuria, illud omnino filentio inuoluendum non du=

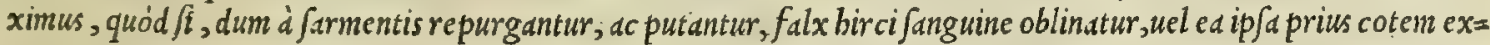
perta, caftorei corio affricetur, nuper emife gemme ( $i$ tanta rei agraria authoribus fides adbibenda. eft) ab eru= cis mininé erodi pofjunt : neque etian emiffa iam folia, ab alijs quibufdam uermiculis conuolui. Praterea non ignor $\breve{a}=$ duin eft, quod magna admodum iniuria witibus infertur, atq; uuis maximum detrimentum, $f$ braßica feratur inter ui= tes. Fiquidem perniciale uni cum altera odium intercedit. Quod cumanimaduerterint rei medice fcriptores, praci= puun ebrietatis antidotum in braßica collocarunt. Ea enim fi cruda pre fumatur (ut apud plerasq; nationes in cae= ne initio capitatam brafsicam minutim re (cifsam, lactuce or intubi loco in acetarijs recipi obferuauimus) ebrietatem futuram mirum in modum arcet, quemadmodum etiam póft fumpta crapulam difcutit. Quo fit, ut Germanix populi uino admodum addicti, femper fuis men/s braßicam interponant, uel recentem, uel muria aferuatam. Ad Elephan=

40 tinem (ut Theophrascus est author) item '; circa Memphin, uites perpetua froade girent: tamet $f i$ annuds tantim pro= fer ant uus. In Italia ueró uites habentur, Plinio infane appellate, que ter in anno florent, fed primas tantum ma= turant uuas. Vuas fine uinace is quidam prouenire affirmant, fi propaginum ima pars, qua terra in fcrobe obrui de= bet, ante plantationem adeo fecetur in longum, ut medulla utrin $q_{;}$eximatur, ac deinde cöiunctis partibus, or ulineo cortice circumuolutis, propagines ip $\int e$ fuis fcrobibus implantentur. Sed ut iam uuis fuas reddamus facultates, Vux (ut Galenus libro I . de alimentorum facultatibus memoria prodidit) quemadmodum inter fructus autumnales prin=

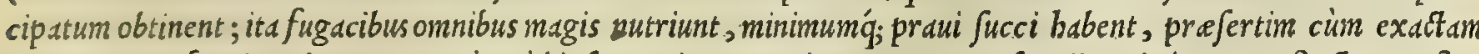
maturitaten fuerint adepte. Porró quód ip $\int e$ nutriant, maximo argumento. funt $i \bar{j}$, qui uinearum fructum cufto= diunt: quippe qui tunc temporis uuarum efu admodum pingue fcant. Ceterùm non omnes uno quidem modo nutriunt, quoniam que dulces existunt, ceteris fuccum babent calidiorem : ob id funt fiticulofa, ac uentriculum inflant, or

so aluun fubducunt. Contrarium efficiunt austere: fiquidem, or uentrem cobibent, parum nutriunt, egre ó;; conco= quuntur. Acerbe autem uitari pror fus debent, utpote que uentriculo aduer fentur. Vue eó laudabiliores, quó car= nofiores fuerint, prefertim cum probé matura d̀ uite decerpuntur. At penfiles, fi prius matura fint, er dulces, ce=

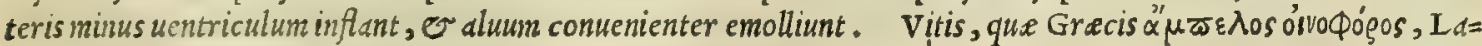
tinis Vitis uinifera appellatur: Arabibus, Harin, Karin, feu Karm:Italis, Vite uinifera: Germanis, Vueinreb:

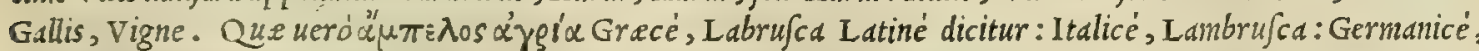

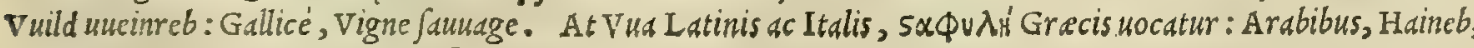
Germanis, Veinbeer: Gallis, Roifin. rx, vuxạ; cöfideratio.

Vuarum facul. ex Gal.

Nomina. 
Vv A P A S A alba adftringentior eft. Prodeft efitata caro earum tufsi, faucibus', renibus, ac veficx. Eftur in dyfenteria per fe cum nucleis : $\&$ deco $t a$ in patinis cum melle, admifta milij, ac hor dei farina, so oue, valet ad purgandum caput: eirifdem gratia cum pipere commanducatur. Teftium inflammationes fedat, illita cum lomento fabarum, \&c cumini farina. Fauos, epinyctidas, carbinnculos, enatas in articulis putredines, \& gangrænas, fine nucleis trita, \& cum ruta impofita fanat - podagræe conuenicntẹr cum panaçis fucco illinuntur : mobiles vngues illita, celerius extrahit,

Vux pal̂x có fideratio.

V V A S P A S S A S, qutrum ubique uulgaris er frequens eft ufus, omnibus notißimas effe arbitror. Verunta= men non eft, meo quidem iudicio, credendum, quód cum de Vuis paßis mentionem faciunt Galenus, oo ueteres alij, paruulas illas tantum intelligant, que boc tempore ex quibufdam Aeg ei infulis, ac Peloponnefo Venetias conuchuntur, er in quibufdam etiam Italix locis infolantur. Siquidem Galensus nulla magnitudinis, uel paruitatis babita ratiox ne, omites in uniuer fum unas folis calore ficcatas, paffas appellat. Id quod ipfe Galenus libro fecundo de alimento= rum facultatibus ijs uerbis declarat. Porró quemadmodum pafarum differentia, que àcolore fumitur, nihil ad paf= farum facultatem confert, ita nec magnitudo: fola autem qualitatis, que gustui ineft, differentia poteft omnia. Ex bis nimirum Galeni uerbis fatis colligi poteft, ipfum omnis generis uuds, que folis feruore flaccefcunt, nullo pror fus difcrimine palfas appelladfe, nempe Damafcends ceteris grasdiores (zibibum officine uocant) ac pariter bis conge $=20$ neres, qua é Smyrnis (ut aiunt) Cypro, o Creta comportantur. Preterea loco citato idem Galenus ita fcribit.

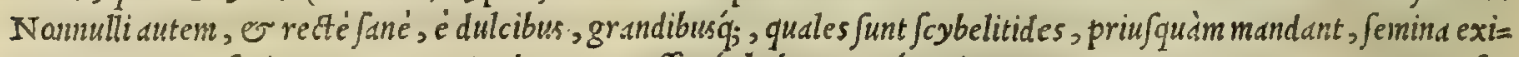

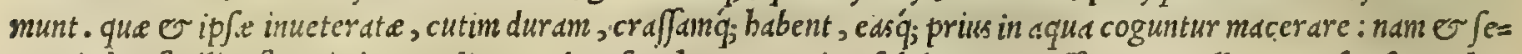

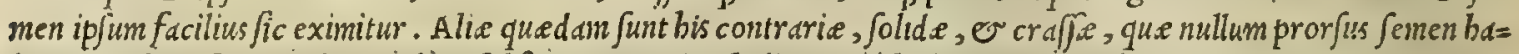
bent. Crefcunt be in cilicia, colore fubflawo. In Pamphylid dutem f cybelitice, er colore nigre: : que, wit dixi, funt maxime. hec ille. Caterim fciendum eft, non omnes. Vuas paffas eiufdem effe facultatis. alia nanque facultas ineft dulcibus, alid aufteris, alia uinaceos babentibus, alia non babentibus. Cue itaque uinaceis carent, uel quód ita natu= ra producantur, wel quód ij arte fuerint exempti, $f i$ dulces fint, adftringente facultate ufqueadeo priuätur, ut etiam mirificé leniant . quamobrem petor is anguftie, tußi, exaßperatis faucibus, o renum, ueftex'́q; uitijs maxiné conue= niunt. Id quod plané comfirmat Galemus libro feptino, e octauo de compofitione medicameniorum fecundum locos, ubi uuas paffas fine uinaceis leniendo pectori, ac iecinorofis plurimim commendat. Contrà ueró facultate omnino adftringente cenfentur, que cum fuis uinaceis manduntur : Quód cim non ignoraret Diofcorides, Vuam paffan cum

Medicorum erros. mucleis in dy fenteria edendam effe tradidit. Hinc itaque fit, ut maximo in errore uerfari exiftimem medicos alioqui etatis noftre celebres, qui alui deijcienda gratid, Vuam paffariparuam unlgarem, que ex locis fuprà dictis is Italiam defertur, fimul cum uinaceis deuorandam exbibent. quippe cùm aluum fluidam facere in anino fit, eam pos

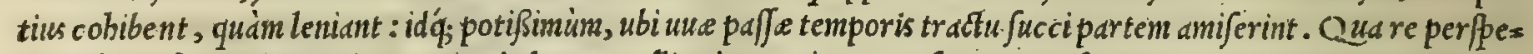
Ita in banc fententiam deducor, ut ad aluum emolliendam aptiores cenfeam Damafcenas, Cyprias, ac Creticas (qui= bus tamen prius nuclei exempti fint, uel ea fumantur; qu.e fine nucleis nafcuntur) qud̀m que minute pafsim in officis nis inueniuntur . quandoquidem ba fucci longé minus, quàm corticis, E uinaceorum continent, nifi fint omnino re= centes, $\sigma$ diligenter afferuate: : Quapropter $f i$ boc tenui unarum paffarum genere uti quandoque coginur ad emol: Tiendam aluum, eas eligi preftat, qua fine uinaceis proueniunt : uel fi be defint: fuppleant ills, qu.e à nucleis fuerint

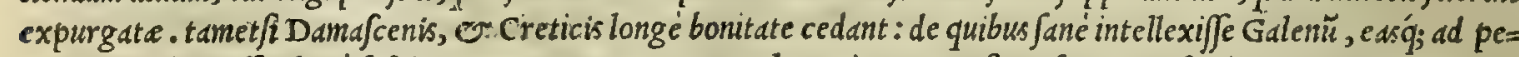
Etoris uitia laudaffe plané fupicanur. In quorum genere hac etiam tempeftate funt, que femine carent, quemadmo= dum que Galeni atate ex Cilicia conuebebantur. Illud porró animaduertendum eft, quód ubi quis aluum bonam facere contendit, non debet paßis uti, qua guftui acerbitatem, uel dufteritatem relinquunt: : funt enim tales frigide, ac terreftres . quibus utique facultatibus cohibent, adftringunt, e roborant, prefertim fi cum uinaceis nucleis come dantur. Vnde fcité Galenus libro fecundo de alimentorum facultatibus, hac prodidit. Vue paffe cum alijs suis ean= dem babent rationem, quam carice cum ficubus. Multe enim fiunt dulces, acerba autem omnino pauce: plurime ueró ex dulci, ov auftera qualitate funt mift . quanquam dulces nonnibil quoque auftere qualitatis habent: $\sigma$ au= ftere, dulcedinis. Caterim ut dulces temperamento funt calidiore, ita aufter frigidiore. Ad boc aufter a ftomachit roborant, o ventrem conftipant, o bis multó magis acerba : mediam autem quodammodo inter ipfas conftitutio= nem dulces obtinent, ut que nec ftomachum diffoluant, nec aluum fubducant. Dulcibus tamen, ut uis quadam femper ineft contemperandi, ita $v$ mediocriter detergendi : quibus duabus facultatibus exiguas mordicationes, qua os uen= triculi infeftant, obtundunt. Et libro v I I I. cap. VII . de compofitione pharmacorum feciudum locos; idem Gd= lenus fic inquit. Vua pajfa contemptilis uideri poßsit, ob familiarem eius ufum. At ueró boc ipfum eam facit utilioré: nam cum familiaris nobis fit, in tanium adjtringens est, quantum opus babet uifcus affectun. Habet autem er uim concoctoriam crudorum bumorum, o uim coërcendi maligna, fitq́; ip $\int a$ haud facile putredini obnoxia: E ultra kec fec undum totam fubftantiam, uifceri ipfi, boc eft iecinori, familiaris eft, o propria. I tem libro de attenuante uictus ratione, fic habet. Vux pasfe fi non fint adftringentes, lieni quidem, $\sigma$ bepati tunentibus non conducunt, thoracis tamen, o pulmonis affectibus conducunt. De unis autem paßis, ut cibus funt, locut:ls eft ipfe Galewus li= bro fecundo de alimentor um facultatibus, his uerbis. Alimentum ex paßis uuis tali qualitate in corpus dętribuitur, 


\section{In Lib. quartum Diofcoridis.}

ipfarum natura fuerit, dulce ex dulcious, dufterum ex aufteris, miftun cx ijs, que utriufque qualitatis funt partici= pes. Quantitate ueró copiofius expingubus, ac dulcibus: parcius ex auftcris, or macris. Quód fi paffarum pin= guium, ac dulcium, a quibus femina fuerint cxempta, parcm molem cum pari uuarum mole contulcris, p.rffas ualen=

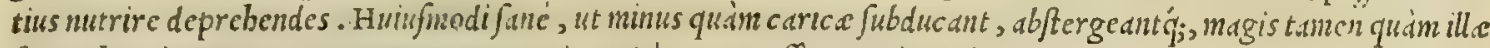
ftomachum iuuant. Hec uua, quex Grecis $5 \alpha \Phi$ is, Vua paffa Latinis pariter ac Italis wocatur: Arabibus, Zibib: Germans, Vueinbeerlen, Mertreubel, $\mathcal{O}$ Kofein: Hipanis, Pafas: Gallis, Roifins en captz.

O'WX'vGr. OENANTHE.

CAP. V.

2. OE N A T H E vocatur vitis fylueftris fructus, cùm floret. Recondi debet fictili non picato, collectaq́ue fubftrato linteo, in vmbra ficcatur. Laudatifsima in Syria, \& Cilicia, \& Phonice. $V$ is ei adfriftoria : quare pota ftomacho, ac ciundæ vrinæ vtilis . aluum filt 1 , ac fanguinis excreationes. Contra faftidia, \& acorem ftomachi, ficca, \& illita eflicax cft. capitis doloribus tam viridis, quàm ficca ex aceto, \& roljcco perfunditur: fanguinolenta vulnera cataplafmate, \& incipientes agilopas, oris vlcera, \& genitalium nomas, trita cum melle, croco, my rrha, \& rofacco ab inflammatione vindicat. Pcfsis mifcetur ad fiftendum fanguinem : contra oculorum delacrymationem, \& ftomachi ardores cum polline polentæ, \& uino illinitur. Cinis crematæ in tefta candentibus prunis, facic ad oculorum medicamenta : reduuias, \& pterygia, abfedentes gingiuas, cruentasque cum melle fanat.

OE N A N T H E N non itlus labrufca modó florem efé, qux uuds ad maturitatem non perducit; uerum etidm oenanthes có alterius, que fructum perficit, afferere non dubitamus. Nam etfi fuperius fripfit Diofcorides, labrufcam duorum. generum $\iint c$, atque alterius unam non mature $\int c c r e, \int e d$ florétenus Oenantben nominatam perduccre: nibil tamen proptcrea probibet, quin alterius quoque labruf ce florentis uua Oenanthe pariter dici quedt, chim non aliud ueteri= bus fignificet Oenanthe, quàn uitisflos. Quód in prefenti capite ipfe Diofcorides manifefte declarat: quippe qui tradat Oenanthen uocari uitis fylueftris frutum, cum floret, nullius fata generis diftinctione. Quin er idem in fe= quentibus confirmat, ubi uini oenanthinimeminit, é feracis fylueftris uit is floribus fieri fribens. Ex bis itaq; abunde conftare arbitror, nö tantum infructifere, fed etian fructifere labrufce florem Oenanthen uocari poffe. Adde quod id quoque aperté teftatur Galenus lib. V I I I. cap. I. de compofitione medicamentorum fecundum locos, his uerbis.

- At ueró quemadmodum omphacium, fic etiam abfinthij fucco adnifceo, quandoque etiam ambo, er tertium infuper bypocifidis, of quantü oenanthes. Fic autem appello uitium jylueftrim germen una cum floribus, ex quo fucceden= tibus diebus unafit. Plinius lib. XII. cap. XX X I I.. Ocnantben uuan, non florem effe cenfet fic inquiens. Eo= dem $\sigma$ Oenanthe pertinet. eft autem uitis labrufce uua. Colligitur com flore, cum optine olet. bac Plinius. In

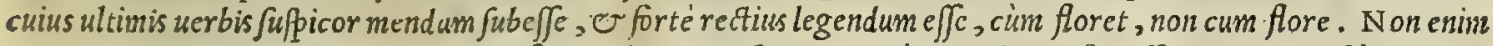
uideo, quonodo quis unquam unam cum flore colligere poßit. Ceterim ne aliquis fortafe decipiatur, bic non du= Marcelli Ver

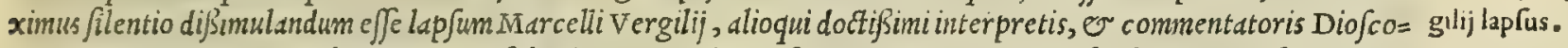
ridis. Is autem ex eius uerbis, que nunc fubijcian, magis innotefcet. Monemus, inquit, fcribere in v. I. fue medici= ne Paulum Aeginetam plurimum quidem ex labrufa Oenanthes ufum effe, quoniam egregié adftringit, ftomachúm= que, alumm maximé firmat. Veruntamen traditis bis, iden ftatin fubijcit. Diofcorides autein alian defcribit $\mathrm{O} e=$ o nanthe u contrarias buic uires habentem . ideo f́;ecundis, ftillicidio uefice, er follis fuffufionibus eam mederiait. Quorum nibil in capite boc legitur, neque in fcriptore boc alibi legiffe me memini, E nibilominus non negligenda Aeginete authoritas, or teftinoniun eft. quem credere oportet uerd, or que aliquando legiffet, teftari. hec Mar= cellus. In quibus Jané uerbis euidentißimé deprebenditur bullucinatus, uel potius eorum oblitus, que de Oenantbe herba uiribus buic cötr arijs predita, memoria prodidit Diofcorides libro tertio. Neque folùn huius, quam tamen Iatinam fecerat, non meminiffe uidetur ; fed neque corum quoque, que ibidem in fua commentatione docte fatis fcri= pfit. Sed aliquando etiam bonus ( ut aiunt) dormitat Homerus. Illud poftremó sddiderim, quód etiam domeflic ui= tus flos Oenanthe dicitur. Verum qua Jyluefris uitis ui multo magis adfrictoria pollet, is per excellentiam Oenan=

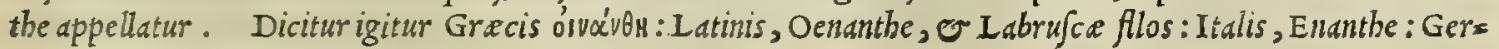
manis, Vuild reben: Gallis, Grappe de uigne faumage.

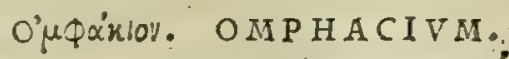

CAP. VI .

O M P H A C I V M fuccus eft acerbæ vuæ nondum maturefceritis, è Thafia vite, aut Aminæa. Oportet autem ante Canis ortum, expreffam melliginem in rubroxre, linteo cooperto, infolare, vfque dum cogatur : femperq́ue quod ceruici vafis concretum hælit, reliquo humori permifccre: noctu uerò à fubdialibus locis in tectum referri; quandoquidem nocturnı rores ipfum concrefcere non finunt. Eligendum eft flaum, friabile, vehementer adfringens, \& linguam mordens. Sunt qui coquendo melliginem cogant. Prodeft contra tonfillas, vuam, ulcera oris, humida gingiuarum vitia, purulentas aures cum mellc, aut paffo : item ad fiftulas, vetera vlcera, nomásque ex aceto. dyfentericis, \& mulieribus fuxione vulux laborantibus clyftere infunditur : oculorum claritati, \& tca britia, \& crofionibus angulorum conuenit. Bibitur ad recentem fanguinis excreationem, etiam fi rupta parte aliqua contingat: fed pauco, \& aquatiore eft vtendum, valde fiquidem exurit .

Hh 2 OMPHACIVM 
Omplacij có fideratio.

О M P H A C I V M ex Omni inmaturarum unarun genere parat Italia, cum Thasijs, $\mathrm{O}^{-}$Amineis carcat unis, é quibus ueteres fuum Omphacium conficiebant, ad medicine duntaxat ufun, id in fole cogentes, ubi uidclicet adftri ctione opus erat. Que tamen parandiratio boc tempore feré prorfus exoleuit. Sunt qui ut maiorem omphacio ad= frifionen comparent, éfylueftrium uitium uuis illud exprimant, non ad medicamenta tantum, fed etiam ad ciborum condintenta. Verum omphacium noftrum fole non cogitur, etfi pluribus diebus ip fum infoldri dimittamus fuis cum ui nxce is in cado, craffo lintedminc cooperto, donec excrementa fubleuentur, fex ueró fubfidat, or inclarefcat fuccus. siquidem bac parandi ratione $a b \int q ;$ fale per annum incorruptum afferuatur tam ad ciborum, quàm ad medicanicnto= Omphacij ui- rum ufum. Omphacium ( ut Galenus memoria prodidit lib. 1 I I . Fimpl. médic.) calidis morbis omnibus magno iu= jes ex Gal.

Nomina uamento adluberipoteft. quippe cum id ommino acidun fit, perfect cetian refrigerat, unice ó; ardoribus prodeft, fiue ori uentris impofitum, fiue totis bypochondrijs, fiuc cuilibet alij, quód refrigerare uelimus. - Id.Greci ó $\phi \alpha \dot{ }=$ xsov dicunt, quad Latini item Omphacium: Itali, Agresto: Germani, Agreft: Hipani, Agraz: Galli, Veriuft.

\section{Olvov фứrs. VINI NATVRA.}

V I s o uetere nerui læc่untur, \& reliqui fenfus, quod tamen guftu fuavius eft : quare cauendum jjs, qui inteftinæ alicuius partis imbecillitatem fentiunt . attamen in fecunda ualctudine paucum aqua dilutum, innoxiè fumitur. Nouum inflat, xgrè coquitur, infomnia parit grauia, $\&$ vrinam ciet. Aetate medium utraque ùitia fugit: quare ad uictus fanorum, xgrorumq́ue ufurpatur. Album, tenue, ftomacho utile eft, ac facilè in membra diftribuitur. Nigrum ucrò crafum eft, \& concoctu difficile, carnem alit, \& ebrietatem creat. Giluum, urpote quod medium eft, medias inter u- 20 trunque uires habet. In fecunda tamen, \& finiftra ualetudine, cùm primis laudatur album. Quin \& uina fapore diftant. fiquidem dulce crafsis partibus conftat, \& difficilius à corpore exprrat: Itomachum inflat, aluum \& interanea ut muftum turbat, fed minus incbriat : renibus, \& ucficx aptifsimum. Aufterum per urinam celerius tranfit : fed capita dolore tentat, \& temulentiam gignit. Acerbum ad ciborum per membra digeftionem accommodatifsimum : aluum, \& cxteras fluxioncs cohibet, minusque urınam expellit. Nouum neruos minus tentat. Vinum aqua marina factum ftomacho aduerfatur, fitim ftimulat, neruos infeftat, aluo aptum, à ualetudine fe recolligentibus inutile. Paflum, quod vuis fole ficcatis in area, aut in farmento torrefact is exprimitur, Creticum cognomine, aut pramnion, aut protropon : \& fapa, qua fit multo igni decocto; Graci firion, aut hepfema appellant : nigra quidem, \& qux dicuntur melamp fithia, craffa funt, \& corpora multum alunt : can- $\neq 0$ didum tenuius : $\&$ heluola inter hæc media, medias fortiuntur uires. Omnia tamen aditringunt, \& pulfus reuocant. faciunt aduerfus uenena, qua exulcerando necant, ex uleo pota, \& uomitionibus reddita : contra cicutas, meconium, pharicum; toxica, $\&$ concretum in grumos lac: item contra renum, \& ueficæ pruritus, rofiones, exulcerationesq́ue . inflat tamen, \& ftomacho aduerfatur. Priuatim, prodeft melampfithium, fi uenter rheumatifmum fentiat . Album magis cæteris emollit aluum. Gyp fo conditum neruis officit, captit aggrauat, \& incendit, ac ueficæ aduerfatur : contra uenena cateris aptius. Picata, aut jefinata excalfaciunt, concoquunt: fanguinem excreantibus inimica. Qux uerò aparachyta uocant, vt qux admiftam fapam recipiunt, caput implent, temulentiam gignunt, ægrius in halitum expirant, ftomachum malè habent. Inter Italica uina Falernum principem locum obtinet : quod inueteratum perquàm facilè coquitur, pulfus exufcitat, aluum anffringit, ftomacho utile: fed veficæ nocet, atque ijs qui uifus hebetudinem fentiunt, \& ad potus crebros minimè idoneum. Albana crafsioribus conftant partibus, dulcia : ftomachum inflant, ventrem cmolliunt, fed concoctionem non æquè adiuuant, \& neruofa minus infeftant : vetuftate eadem aufterum faporem concipiunt. Cecubum, cùm fit dulce, eft \& Albano crafsius : corpus, \& colorem alit : :grè tamen coquitur. Surrentinum ualde aufterum eft: quare inteftinorum, \& ftomachi fluxianes cohibet, $\&$ cùm tenue fit, caput minus tentat : inueteratum fuauius redditur, \& ftomacho utile. Adrianum, \& Mamertinum in Sicilia æquè crafsis partibus gignuntur: modicè adftringunt, \& ocy fsimè inueterantur, minusque ob fuam tenuitatem neruos tentant. Parætypianum, quod ex Adriatico finu defertur, odoratum, àc tenuius eft : quare liberaliter epotum fallit, diu feruat ebrietatem, \& foporem adfert. Iftricum Parætypiano fimile eft, fed urinã uchcmentius pellit. Chium tamen antedietis mol- so lius, \& aptum potui elt . bene alit, \& minus inebriat, fluxiones cohibet, oculorum medicamentis utile. Lesbium facilè membra fubit, Chio leuius, \& aluo idoneum. Ephefium eandem uim habet, quod Phygelites nominatur. Verùm Afianum è Tmolo monte, Mefogites appellatum, capitis dolores ciet, \& neruos ladit. Coum uerò, \& Clazomenium, quoniam multam fibi maris aquam uendicant, facilè corrumpuntur : flatus mouent, aluum turbant, neruis oficiunt. Vinum omne (ut reliqua in commune dicantur) merum, ac fyncerum, \& fua natura aufterum, excalfacit, facilè in mébra diftribuitur, ftomachum adiuuat, appetentiam ciborum inuitat : vires alit, ac robur auget : fomnum conciliat, \& commendat colorem. Potum liberalius auxilio eft contra affumptam cicutam, coriandrum, phaticum, ixiam, meconium, argenti fpumam, taxum, aconita, fungósve : contra ferpentium morfus, \& omnium ictus, qux refrigerando necant, aut ftomachum in uomitiones effundunt . Facit ad longas inflationes, rofionesq́ue præcordiorum, ac diftentiones, fomachi rc folutionem, \& fi 


\section{InLib. quintum Diofcoridis.}

uenter, aut interanes theumatifmum fentiant. Conueniunt fudatoribus, \& quibus corpus immodico fudore digeritur, maximè alba, uetera, \& odorata. Quæ tamen uetufate dulcefcunt, renibus, ac ueficæ accommodatiora redduntur: vulneribus, inflammationibusque in fuccida lana imponuntur: tetra ulcera, \& phagedanica, \& Aluxionibus obnoxia commodè perfunduntur. Qux marinam non receperunt, auftcra, \& alba, ad fanorum uictus vfurpantur. In his præftant Italica, Falernum, Surrentinum, Cecubum, Signinum, \& permulta Campaniæ, \& Parætypianum ab Adriatico fuu, \& Siculum, quod Mamertinum appellatur. Lx Græcis Chium,Lesbium, \& Phygelites ex Ephefo. Craffa uerò, \& nigraftomacho negotium exhibent, inflationem pariunt, corpus augent. Tenuia tamen, \& auftera ftomacho profunt, \& minus carnes alunt. Vetera valde tenuia, \& candida uehementius u-

2 rinam ciunt, \& dolores capitis mouent, neruosq́ue largius pota centant. In media xtate, ut à feptimo anno, potui falubcrima funt. Modus autem pro etate, \& tempore anni, \& confuctudine, \& qua litate uini definiatur. Non fitire, \& modicè çbos proluj, optimum eft præceptum. Nocet ebrietas omnis, \& maximè afsidua : fiquidem obfeffos neruos quotidie remittit : largiorq́; potus acurorum morborum ad'fert initia. Mediocris tamen uinolentia aliquot diebus, maximè polt aqux potus, vtilis : nanque modo quodam ex alto cuocat, fenfilesq́uc expurgat excretus, \& per cæca corporis ducit fpiracula. Sed aquam pott uinolentiam bibere oportęt fiquidem ualętudinis alicuius gratia factæ te. mulentixe remedium adfert trigida.

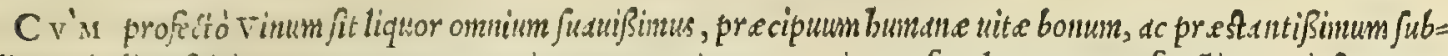
o fidium, witalim firitum regcnerator maximus, ac omizim corporis tum facultatum, tum functionum itstaurator optimus, cor litificet tueatur q́: fummopere, mulli mirum effe debet, quód plantam, que fructum fert, ex quo uinum exprimitur, uitcm, quafi uitam, appellauerint ucteres. Verim non ob id gaudeant, iubilent $\dot{q} ; \dot{\eta}$, qui uino nimis indul= gent, quod cgo ipfum to laudibus extulcrin. quippe cum omne extremum ( ut in communi prouerbio eft) fit uitio= fum, fininum inmoderaté, or plus quàm deceat, bibatur, periculofos atque horrendos (ut mox dicetur) procreat morbos. Alis $f i$ in cius $u$ lu temperantia adbibeatur, tum ad alcndum, tum etiam ad roborandun corpus omnium ef= ficacißinum babetur . quandoquiden purißsimum generat fanguinem, ocy/3imé in alimentum uertitur, concoctionem in quáuis corporis parte adiuuat, animum addit, cerebrum purgat, intellectuin excitat, cor exbilarat, piritus uiui= ficat, urinain ciet, flatus difcutit, innatum calorem auget, conuale fcentes impinguat, cibi appetentiam inuitat, fanguinem turbidun clarificat, obftructiones aperit, alimentum in uniuerfum corpus defert, colorem conciliat, or omne

30 in corpore excrementofum deijcit. Sed fi modus abfit, er fine ratione, ac temperanento fumatur ingurgiteturue (quod facere folent cbrio/i) ex accidenti totun refrigerat corpus. neque enin fecus nimio eius potu (ut Galenus in= quit) imatus corporis calor fuffocatur, atque paruus ignis magna lignorum ftrue extinguitur. Praterea cerebro, fpinslimedullse, ac neruis inde exoricntibus obeft. bine fit, ut principe bac parte affect d, temporis tractu maxini, ct perriciofi concitentur morbi, nempe apoplexia, cpilepfia, paraly/is, tremor, ftupor, epbialtes, catalcp/is, con= "ullio, wertigo, articulorum contractio, lethargus, phrenitis, deftillatio, furditas, cxcitas, er oris labiorum q́; di= stcntio. Quinetian uinum intemperaté baufum, bonos corrunpit mores. nan quód homines contentiofi, loquaces, cffrencsí; fiant, quód fur ant, menté'; noue antur, quòd deniq; ale a, libidini, ac rei ucnerex femper feré indulgeät, ac nonmunguam homicidia committant, nulli uerius adfcribcndun $\mathrm{c} f \mathrm{t}$, quàn uino immodicé fumpto. Adde quod me= moriam dißipat, fen $u s$ omnes perturbat, aßiduos morbos parit, or repentinas mortes adfert: ne fingula perfequar,

40 qux reccnfere longum effet, Ev audire moleftum ijs, qui nimium uino dediti funt. Caterum vinum magis fenectuti, quan reliquis aetatibus conuenit. id fiquidesn frigidam fenum temperiem, talcm annorum multitudine redditam, tem = perat, ac mulcet. Verim pueris, ac adolefcentibus ad uigefimum annum ufq; minimé concédi debet, $f i$ Galeni fen=

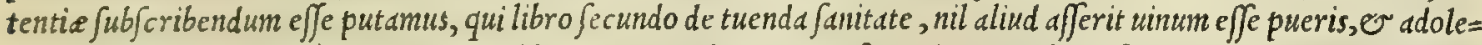
fentibus exhibitum, quain ignemigni additum. Cauendum quoq; eft, ne in ardoribus elt atis uinum niue, aut glacie, aut gelidijima aqua perfrigeratum hauriatur: quód cerebro, neruis, pectori, pulmoni, uentriculo, intestinis, ple = ni, iecinori, rembus, uefice, utero, dentibus q́; maximé nocest. Quare admirari non licet, fi tempore uimum arte frigefactum bibentes coli, or uentriculi cruciatibus afficit, iten conuulfionibus, refolutionibus, apoplexia, pirandi difficultate, urinx fuppreßione, calculo, uifcerum obftrutione, aqua intercute, ac pluribus alijs grauious, er per= nicialibus morbis. Proinde fcitißiné Galenus libro de cibis boni, or malifucci, bec prodidit. Qui non exercentur

so fumma aftate, cum uebementi calore urgentur, fontis aquam bibant, niuisq; er uini refrigerati ufum uitent. Hac $e=$ nim quanuis protinus nullam iunenum corporibus fenfibilem lafionem inferant; fen/im tancn, occultéq; crefcente ui tio, cum iam atas progreffu temporis inclinauerit, articulos,neruosq́;, er uifcera ijs morbis uexat, qui uel difficulter admodum, ucl omnino tolle non poffunt. Ad bec in tuenda fanitate diligenter procurandum eft, ut uinum, quod in potu alvmentigratia quotidie fumitur, fit inundum, purum, clarum, odoratum, es fapore iucundum: nanque corru= ptum, turbidum, impurum, odore graui, er guftu ingrato, non modó toti corpori noxan infert; fed etiam fanguinem corrumpit. Quapropter felicißime fuam tuentur fanitatem, qui regiones incolunt, in qubus optina uind proue= niunt . quemadmodum in Goritien/i comitatu, ubifané generofißima uina nafcuntur, nimirum Pucinumillud antiquis adeó celebratum, necron vipacum illi bonitate proximum. Hac quidem parcé modefté,; pota, ad tuendan fanita= tem minlficé conferunt. Id quod ip $\int e$ experientia in me facta comperi, atque etian omnibus ingenue testaripofjum. nan clim multis anté annis diuturnus uentriculi dolor male me habuiffet, quem totius corporis inbecillitas confecuta crat, ex Pucini, er Vipaci tantim u. $u$, me priftinan mean fanitatem, er integrum robu adeptum effe ccrtó fcio.

Vini facultates uiriz fro modo vlus.

Vinú cui ętati conueniat. 


\section{2 \\ And. Matthioli Comm.}

Ob id ergo mirandum non eft, fi Plinius magnis laudibus predicauit $\mathrm{P}$ ucinum libro $\mathrm{x}$ I I I $\mathrm{x}$. cap. v $\mathrm{x}$. ubi ita friptum reliquit. Liuia Augufta octuaginta duos annos uite Pucino retulit acceptos, non alio ufa. Gignitur in finu Adriati= cimaris, non procul d̀ Timauo fonte, faxeo colle, maritimo afflatu, paucas coquente amphoras. Nec aliud aptius me= dicanentis iudicatur. Hoc effe crediderin, quod Grecicelebrantes miris laudibus pyctanum appellauerunt ex $\mathrm{A}=$ driatico finu. bec Plinius. Cuius certé teftimonio plane fub cribunt ruftici Iapidie incole : quippe cùm ij uinis $\mathrm{P} u=$ cino cognatis in quotidiano potu utantur, rarißimé agrotant, e longxuam adnodum uitam traducunt, adeó ut plus rimi reperiantur, qui nonage finum, or centefimum annum attingunt. Eft autem uinum boc tenue, clartum, lucidum, colore aurcum, odoratum, guftuí,; gratißimum. Potum ualenter excalfacit, nifi dilutum fuerit, faciléq; in uniuer= fum permeat corpus. Quamobrem (ut libro tertio fimplicium medicamentorum fcribit Galenus) tale natura uinum, non modó perfrigeratorum omnium, fed corun etiam, qui aut ex oris uentriculi, aut cordis dolore animi deliquium $\mathrm{c}$ patiuntur, prefentaneum fuerit remedium. Ex quibus facilé colligi poteft, flicißinos effe cos, qui un regionibus, que uind optima ferunt, oriuntir, fi tamen modefté (ut fieri decet) eis utantur. Caterim qua uina in uniuer fun quotidia no ufui mag is conueniant, hic longiori fermone commemorare fuperuacuum duximus, cum boc à Diofcoride latius fit proditum, atq; etiam de omnium uinorum uiribus diligentius fcriptum, quàm ut plura à nobis referri debeant. Vinum fic Latiné, olvos autem Gracé nocatur: Germanicè, Vuein : Italicé, pariter o Hifpanicé, vino.

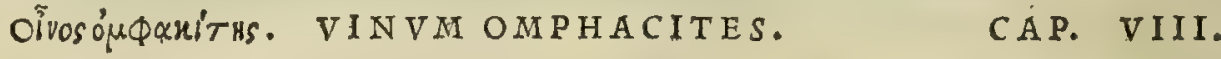

O M Р H A C I T E S nomine, peculiariter fit in Lesbo, ficcata fole acri vua, paulò ante maturitatem decerpta, triduo aut quatriduo, donec racemi in rugas contrahantur : expreffumq́ue vinum ca- 20 dis infolatur. Vim adfringendi habet, prodeft diflolutis ftomacho, \& ilei dolore laborantibus: item prægnantium malaciæ, \& crudis . in peftilentia quoque forptum auxiliari dicitur. Huiufmodi yina non nifi poft multos annos bibi poffunt.

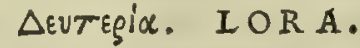

CAP. IX.

L o R A, quam deuterian, alij potimon appellant, fieri folet adiectis metretis tribus aqux in vinacea, quibus triginta vini metretæ extractæ fuerint: calcatis vinaceis, expreffoq́ue decoeto ad tertias partes, \& additis in fingulos congios modi eius qui remanfit, binis falis fextarijs, poft hyemem transfunditur in vafa. Lora intra annum vtendum : etenim celeriter exolefcit. Conuenit $x$ gris, qui- 30 bus timemus noxam vini, coacti fæpe defiderijs eorum obtemperare : item à longa valetudine fe recolligentibus. Fit $\&$ vinum, quod adynamon uocant, loræ vires habens, hoc modo. Pares aqux, $\&$ mufti menfuræ coquuntur molli igne, donec abfumatur ayua : quod, vbi refrixerit, elutriatum picato vafe reconditur. Alij marinæ, \& cœleftis aqux, mellis, \& mufti pares mifcent portiones, decapulant, \& quadraginta diebus in folant . quo ad annum vtuntur ad omnia eadem.

Loræ paran- Lo R A dlia ratione Galeni etate; qudim Diofcoridis parabatur. Ille fíquidem loram faciendi modun libro I r.

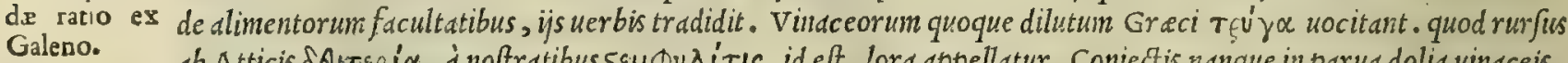

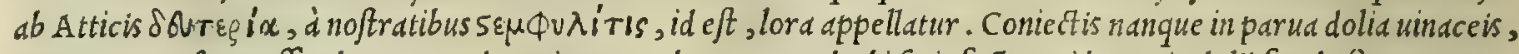
tantum aque superaffundunt, quodd omnia permadeant. Quod ubi fatis factum uidetur, in dolij fundo for amen ape $=40$ riunt, ut dilutum effluat, id's; pro uino bibunt. Perpicuum autem eft, quód pro racemorum copia aquam affundunt, experientia docti: quó uidelicet neque aquofa adinodum, neque meraca fit lora. Deinde rur fum alum aquam, par= ciorem tanen priori, uinace is affundunt, fic ut boc quoque potioni fit attcmperatum: quod quidam Attice proprie=

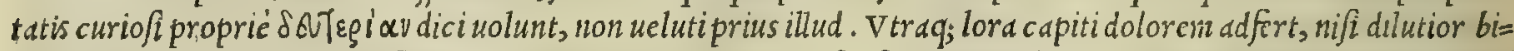
batur, fed prior magis caput ferit. Dos una buic potioni conceffa eft, nempe quod ocyus per urinam reddatur : $\int e d ~ n \vec{o}$ pauca fubeft diucrfit as ex uaria uuarum pecie, é quibus uinacci funt relicti. Etenim fi dulces fuerint, potus multỏ crit fuatuior, citius'; per urinas excernetur : fin uero acerbe, o acida fuerint, infuauior longé, ac minus ciens uri $=$ nas. Porró dilutum hoc ualentius uinofussǵ;; efficitur, cim uinaceus ad uer, aut aftatem fucrit afferuatus. Hyemis autem tempore fi quis utatur, ut caput minus tentat, ita 0 per urinas minus expellitur. Haec de lora Galenus. Ea

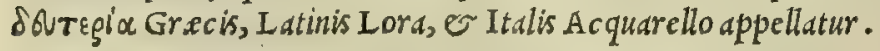

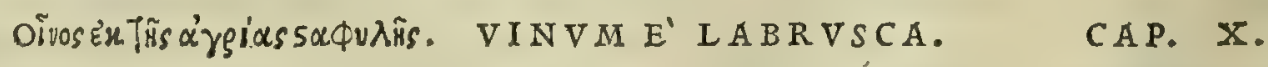

V I N y м è fylueftri vua nigrum, adfringit: prodeft alui, \& ftomachi fluxionibus, \& cxteris, quibus conftrictione, \& contractione opus eft.

$\mathrm{N}$ o $\mathrm{N}$ defunt in Hetruria, qui uinum é Labrufce unis exprimant, colore admodum nigro, id q́; giluo admifcent, ut rubicundius reddatur. Vtuntur co ruftici in alterius uini penuria. fiquidem conftat dulce fimul, or austerum: ve rüm tractu temporis dulcedinem facilé deperdit, fit $\dot{q}_{j}$ tune gülui omnino infuaue, adeó ut tantùm medicamenti uicem

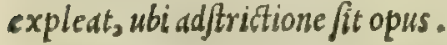




\section{In Lib. quintum Diofcoridis.}

MELITITES datur in longis febribus, qux ftomachum infirmarunt. nanque aluum leuiter emollit, vrinam ciet, ftomachum expurgat. prodeft articulario morbo, renum vitijs, inıbecıllo capitı, \& mulieribus abftemijs :odoratum liquidem eft, \& corpus alit. Diftat à mulfo, quod fit è uino vctere, auftero, \& melle exiguo. Melitites autem adiecto ad quinque congios aulteri mufti mel! is congio, \& falis cyatho. Cortinis magnis, quò magis ad cfferuefcendum locus patcat, fieri o20 portet, fenfim afperfo âle :cùmque efferuere defierit, in alia vafa transfunditur.

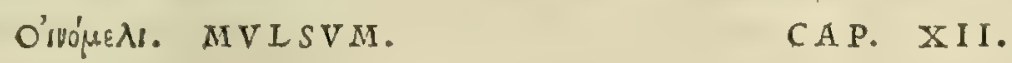

M V L S V M è vetere vino, aufteroq́ue, \& bono melle factum, prafertur: minus enim inflat, ac celeriter id genus in vfum uenit. Vetus, corpus alit . media ætate, aluo prodeft, vrinam pellit: à fur:mo cibo fumptum, nocet: \& inter initia potum, implet: dein appetendi auiditatem renocat. Fit mulfum duabus vini metretis, admifta vna mellis. Aliqui, quò celerius præberi pofsit, mel cum vino coquunt, \& ita transfundunt. Alij vtilitatis gratia, ad fextarios fex mufti feruentis vnum mellis adijciunt: \& ubi ferbuerit, vafe recondunt, dulce autem permanet.

A C v a mulfa eafdem, quas mulfum vires pofsidet. Cruda vtimur cùm moliri deiectionem, aut vomitionem incitare volumus : vt ijs, qui venena hauferunt, ex oleo. Decocta datur imbecillis , $\&$ hominibus elanguefcentis pulfus, quos illi dixere microf phyctos, tufsientibus, peripneumonicis, \& ijs, qui immodico fudore digeruntur. Iam paratum, conditiuumq́ue, quod aliqui hydromeli propriè vocant, media ætate adynamo vino, aut loræ in recreandis viribus refpondet, \& fimilem vim adipifcitur . quare inflammationibus alicuius membri plusquam lora prodeft. Inueterati tar men vfus damnatur inflammatis, aut conftrictis : fed laboranti ftomacho, aut cibum faftidienti , fudatoribúsve conuenit. Fit duabus pluuix aqux veteris ad vnam mellis partem additis, $8 x$

30 infolatis. Alij fontanam aquam adijciunt, \& ad tertias partes decoquunt, \& ita recondunt. Nec defunt qui hydromeli appellent, quòd à mele elutis aqua fauis confici ac feruari foleat: fed meraciuss confieri conuenit, aliqui id coquunt. Aegrotantibus noxium eft, quoniam plurimum ceraginis $\mathfrak{f}_{\mathbf{f}}$ bi vendicat,

A I I A fanc A que mulfe ratio conficiendxe cf apud Mauritane familic authores, ab hac que bic à Diofcoride traditur. Inter Arabas nanque Mefues de ea ita fcribit. Aqua mul $\int a$, ex antiquorun fententia, inagnis utique uiri= bus predita cft. Sitim etenum arcet: frigidis affectibus, prefertim cerebri, $\in$ neruorum, $\mathcal{E}$ articulorum, auxilia Aqux mulfx ratio facientur. Loco sini pota, humida extußrentibus prodeft : quin o pus, o lentam, craffaní; pituitam épcétore trabit. Inteftina, uifcerd, urinariosq́; meatus purgat, terget, ac lauat: quapropter fubuci it coli doloribus, aluum fubducit, 40 o calcultem gigne prohibet. Fit é libra laudatißimi mellis, non tamen ueteris, colore pallido, odore iucundo, Japore cum dulcedine modicé acri, cum aque fontana libris octo, in uafe lapideo, uel fictili witreato, lento igni decocta, de=

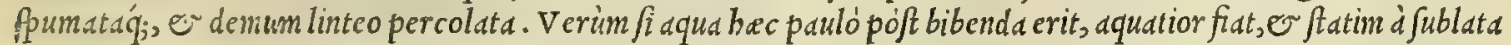

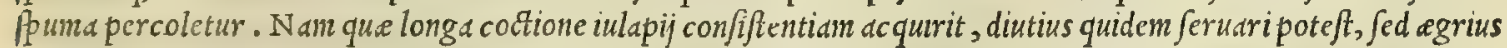
penetr at in remotas corporis partes, facile q'; in bilem uertitur, ob fuam exuperantem dulcedinem. unde fitim accen= dit, ni/i plurinza affufa aqua dißoluatur, adeo ut aque feré modo reddatur infipida. Variant autem mul 5 a facultates pro diuer $\int e$ cottionis ratione .quippe qua breui coquitur tempore, flatus in uentriculo parit, aluum magis mouet, er munus nutrit . qua ueró longiori coquitur tempore, flatus difcutit, magis nutrit, minusq́; aluum ftimulat. Sunt qui mulle aromata etian addant, nempe gingiber, crocum, cimtamomum, macim, o id genus alia. Alij galliam mofchatam officinis uocatam, $\mathrm{\sigma}$ agallochum adijciunt. Fit pratered ex parte una mellis, o aque fontana partibus

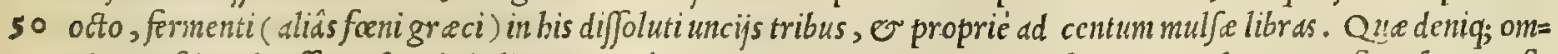
nid, mufti modo efferue fcenda in ligneum cadum conijciuntur, non tamen ad fummun repletum, ne feruefcens refi= liat. Vbi ueró deferbuerit obturato uafe, afferuetur uini modo ad potandum, ueruntament non bibatur, nifí tertio menfe tranfacto. Huic mulfa aromata quoque admifceri poffunt linteolo inclufa, ơ adalligata in cadum demiffa. hec Mefues. Cuius ultimam mul $\int_{e}$ paranda rationem, Germani Medonem uocant. qui tamen fermentum addunt, non excerealium genere aliquo paratum, Sed ex uinimufti recremento, o lupi Salitarij floribus, quibus etiam utun= tur ad zythum conficiendum, quod Ceruifiam appellant. Medonis plurimum bibunt Poloni, dc Lituani, quód mel= le plurimo abundent. Q Q qua melata.

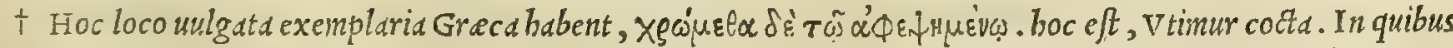
nimirum uerbis uitiun aliquad latere $\int u$ picor. nan contextus uerborun o res ip $\int_{a}$ poftulabant, ut prius Aque mulfe crude, inox cocte ufum traderet Diofcorides. quod hunc feciffe puto, fed librariorum culpa eueniffe, ut fit

Nomina. 


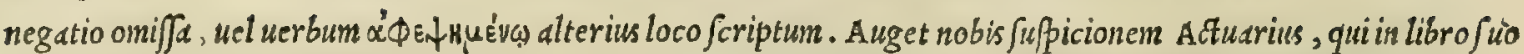
de compofitione medicamentorum, ubi ea de Melicrato, id est Aqua mulfa fcribit, que Diofcoridi decepta referri poffunt, inquit primium, Cruda utuntur ij etc. deinde, Cocta uero exbibetur erc. Hunc fecutus fortaffe Ruellius uir do etißimus, uulgatam illam lectionem ut deprauatam reliquit, or alteram ut ueriorem accepit. Addam infuper, quód

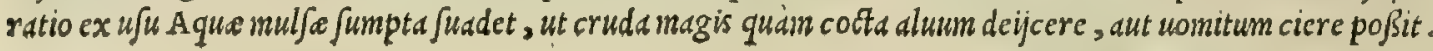

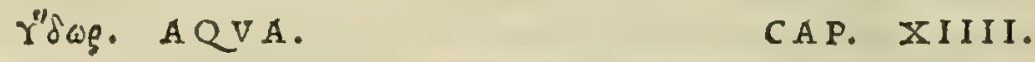

DE A QV I s in vniuerfum decernere, propter locorum proprietates, $\&$ peculiares naturas, crelum, \& alia pleraque, difficile eft. Magna tamen ex parte optima eft dulcis, fyncera, nullius omnino qualitatis particeps, \& quæ ne minimo quidem tempore in præcordijs com moratur . ad hæc quæ $\&$ facili uia fertur, \& citra inoleftiam, nec inflationes creat, \& minimè computreficit .

Aquarŭ diffe rentix, \& facultates.
PA V C I S S I M I s quiden uerbis de potabili in uniuerfum aqua differuit Diofcorides, ita tamenut nullam plane notam pratermiferit ex bis, qux in optima aqua requiruntur. Quare fi nobis effet ijs tantum faciendum fatis, qui rerum natur alium periti unt, non oper pretium cxiftimarem, boc in loco plur a de aquis commemorare. Verim quia bofce commentarios in ftudioforum, of imperitorum potißimum gratiam condimus; ideo non folim aquarum omnium, qua in communem tam cibi, qudim potus ufum ueniunt, tum qualitates, tum facultates hic breuitcr perftrin= gam; fed etiam earum, qux ponte nafcuntur, or fibi metallorum, ceterorusnq́; fo ßilium udrias ucndicant faculta = tes. In primis itaque illa aqua ad potandum laudatißima cenfetur, qua clara, pellucida, tenuis, pura, fruftillorü,

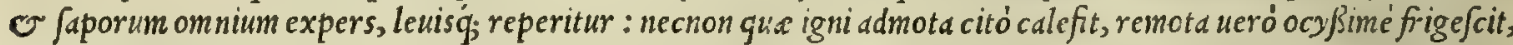
guftu iucundo: que denique celeriter pracordia pertranfit, 0 fine ulla uentriculi moleftia labitur, o fecedit. Talis autem ea effe folet, cuius fons ad orientem folcm erumpit, currit $\dot{q}_{;} \int u p e r$ lapides, aut arenam, aut purißimam tcrram:

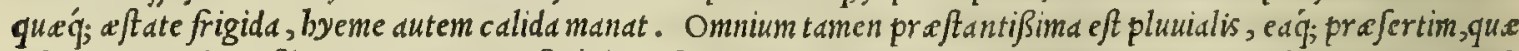
aftate media pluit, filente calo. Huic feré illa repondet, que codem tcmpore cum tonitruis defcendit, tonitruc $\sqrt{a}$ proprié appellata. At ea, qua maxima aëris, ac uentorum procella, terrifico tonitruum, fulgurum, $\sim \sim$ grandin is impetu, ex uelociter concitatis nubilus colo demittitur ( $u$ in commentario libri fexti epidemiorum foribit Galcnus) in bumana uite ufum admitti non debet. Porró aqua cifternarum non tot fané laudibus commédanda uidetur, licct $\dot{\alpha}$ quàm plurimis medicis laudetur. Siquidem non modó noxia cxiftit, quód mifcella quadam fit diucr farum aquarŭ, qua in diuer fis anni tĕporibus inibi colliguntur ex pluuid, tum ex grandine, er niuibus byemali tempore in tectis colliynatis fed etiam quod aqua omnes ftationarie putref actionifacile fint obnoxix. Quo fit, ut aqua in cıfternis collect a ( $\mathrm{fi}$ rcm recté expendamus ) Syncera pluuiali minimé fit comparanda. Dicendum igutur erit, aquam fic afferuatam có pluuiali fyncera detcriorem effe, quó magis fuerit niuium, $\mathcal{O}$ grandinum liquationibus commifta. Quandoquidem ( ut in libro de bonitate aque fcribit Galenus) qux à niuibus or glacie collique cit, concoctionem impedit, urinam cobibet: pe= atus, pulmonem, ac uentriculum malé habet, conuulfiones, laterum dolores, ơ flatus generat. Quod dlia de caula non euenit, quàm quód cum in glaciem, uel niuem concreuit, omne, quod tenue inerat, deperdit. Pute alis praterea grauis quidem eft, egréq; conficitur, nec ftatui quidem pott ft, quód fit putredinis omnis expers : ueruntamen tantó minus fuerit damnanda, quantó frequentius bauritur, uel fi é Jubterraneo fonte fcaturiat. Sequuntwr lacuftres, or paluftres, que omnino funt improbanda, nifi cocte; uel igne deftillate fuerint. Fluuiatilis deindc probatur, ucl in=

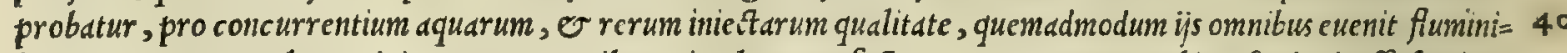
bus, que magnas perluunt ciutitates. Nam quibus animalla putrefacta, excrementa, $\mathcal{O}$ urbium fordes ine fe fentiun= tur, ex ab alimentorum u fu abdicande funt, nifi longo temporis tractumag nis fictilibus aßeruate, dc defacate cla= refcant, or prorfus expurgentur. ut Romani faciunt cum fui T iberis aqua, qua pra ceteris bac facultatc pollct, ut clara fata, ad centum, $\mathcal{O}$ plures annos perduret incorrupta. Ad bac noxia funt, qux plurimam terre mifionem confequuntur, quód non modó ui[cera obftruant; fed or calculos in renibus; or uefica procreent. Cetcrum aqua,

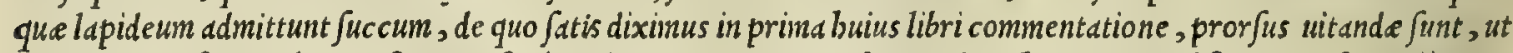

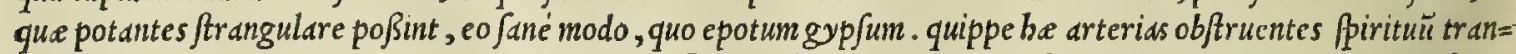
fitum intercipiunt: quin $\mathrm{O}$ alimentum in corpus deferrıprobibent. Quocirca buiufmodi aque potabiles non funt, neq; in ciborum coquendorum ufum recipiendse. Quemadmodum nec illx fanis probantur, qux fal, nitrum, chalcan= thum, alumen, $\sigma^{r}$ alia id genus concretifucci continent. quanquam omnes in medicina ufum ueniunt. Nam quod $0=50$ mnes predictis excalfacientibus medicamentis referte fint, frigidis, 0 bumidis morbis laborantibus utilißime exli= bentur : ijs ueró noxie funt, qui à bilio/is uel acribus proueniunt bumortbus. Salf $\mathfrak{x}, f$ bibantur, pituitam eijciunt, fanguinem in uentriculo concretum diffoluunt, aquam intercutem exiccant, or obefa corpora extenuăt. Scd his confumptis potantes fiticulofos reddunt, uentriculum ledunt, inteftita abradunt of fcabiem, ov pruritum excităt, utpote que non obfcuré fanguinem acuant, o fua falfedine adurant. Clyfteribus infu $\int x$ pituitam attenuant, $\sigma$ de $=$ trabunt, or ex ea prognatos dolores mirifice tollunt. Factis ex ea balneis aque cutem $\int u b e$ untes refoluuntur, $f i$ no= uus fuerit morbus : frigidi neruorum dolores mulcentur, pectoris fluxiones cobibentur, excalfir q́; uentriculus figidi tati obnoxius, e bumiditate langue fens : quin er pituito a f cabies curatur. Tollitur quoq; uapore ex ijs calentibus accepto, tum capitis grauitas, tum aurium cruciatus: fotu ueró frigidi tumores, ov totius corporis fugillata delentur. Nitrofe, fi bibantur, corpus perturbant, pituitain deijciunt, frentinas prolific ds reddunt, $O$ (trumas abfumunt.

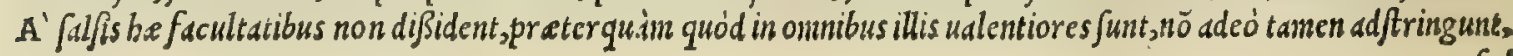

30 


\section{In Lib. quintum Diofcoridis.}

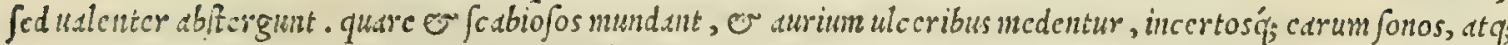
tumores difcutiunt. A luminofe admodun adltringunt. proinde mirum non eft, fi ucutriculun roborent, qut crebris uomitionbus inbecill!s cficiatur. Vterifluxiones cohibent, abortum probibent, $\sigma$ in bis prefertin fominis, que antc fetus maturitaten plerunc; abortiri confueucrunt. uefice ulccrbus medentur: or oris, gingiuarumq́; inflant= mationibus, /i ex cis fi.cquens collutio fiat, Gargarizatu non modó deftllationes ad fauce inbibcnt, fed ctian conflu= xos rejolumit bumores. Idem preftat balnewmex ijs paratum: confert cuin magno iunanento cxterioribus totius corporis cxslceratis, particulis, ijsq́; prefertim, que defluxiombus tentantur. Crucntis itcm expuitionibus fubuent, anum procidentem reprimit, or fudorem jupcrfluum cobibet. Nocct tanen tam in potu, quim bulnco, iis qut uifce= rum infartsu laborantes in frbrss fucilé incidere poffunt. Porró aqua, quibus chalc antbum, aut mify, aut fory, aut

so melanteria immifectur, ciss omnia eadem facultate conftcnt, sluminofis fane perfiniles funt: ueruntamen he ualcn= tius fuust obeunt mun, itcmpe quod preter adfriftoriam facultatem, fuccum etiam admodum acrem obtineart. quamobren ferpëtibus ulccrbus,ac phagedxnis opitulantur. Sulphurofe excalfaciunt, ac cfficaciter neruos cmol liunt . proinde refolittis, conuulfis, tremulis, ftupidis, contractis q́; peridonee inueniuntur. Exdem comprginum tu= mores difcutiunt, ¿ dolores mitigant; 1 um ubi quipian coxcndicum dolore, aut podagra, uel chiragra uexctur, ful= plunrofa aque balincamagnopere iuuatur. Praftant preterca ad iecinoris, lienis, ac uteri dolores, atque tumores in jis genitos mirifice re foluunt: uentriculü tamen laxdit, or infirmant. Bituminofe, etfi pote internis quibusddm mor = bis conucniant, $c^{\sim}$ balncis adhibita alıquo temporis traltu neruos emolliant, ac excalfaciant; attamen caput replët, fen ws hebetudine afficiunt, praferting; oculos. Que auten Armenij, aut carulei lapidis, aut aruginis, aut chryfo= colle aliquid sdmiftum babcnt, $/ \mathrm{i}$ bibantur, womitiones concitant: ablutionibus weró phagedanca ulcera fiftunt. Qua

so preterea auripigmentum, aut fandarachan contincnt, pectus dilatant, aftbmaticis, o fufpiriofis profuit, or onniGus frigidis in uniuerfum morbis open frunt, quibus repir andi facult as impeditur. Aered ori, 0 genitalium mem= brorum ulcera fandnt: quin o faucium, or oculorum deftillationibus auxiliantur. Qux deniq; ferrex funt, uentri= culi, licniś; uirijs, femmis profluuio, $\sigma$ menftruis albis utiliter adbibentur. Et ut rem banc fummatin cöplect amur, aqua omis, cui quóduis fojile medicamentum adnifceatur, eandem facultatem prebet, quam quodilli admifcetur. Qus mimirun vatrone ducor, ut fuperuacum putem, rcliqua figillatim profequi, ut taceam id nims longü futurum.

Aqua Latinis dicta, Gracé údog appellatur: Italicé, Acqua.

$$
\check{X}^{\prime} \delta \omega \rho \text { g } \alpha \lambda \alpha i \tau \text { Tlov. AQVA MARINA. }
$$

\section{CAP. XV.}

30. AQV A maris calida eft, \& acris. ftomacho aduerfatur, aluum enim conturbat : pituitam expellit, si verò calida ad fotus adhibeatur, elicit, \& difcutit, neruorum vitijs, \& pernionibus, ante vlcera prodeft. Mifcetur catapldfmatss ex hordacea farina, \& cmplaftris, \& difcutientibus malagmatis. Ad mouendas deiectiones tepefacta infunditur, \& ad tormina, calida . pforas, pruritus, imperigines, lendes, \& mammas rigentes, foueri vtile éft: liuores fotu difutit. ad venenatos ictus, qui tremorem, \& refrigerationem adferunt, falutaris intelligitur: maximè fcorpionum, phalangiorum, afpidumque: etiam liquis in calidam defcendat, auxiliatur. \& malo habitu confectis iandiu corporibus, neruisque, balneæ ex ea utiles . hydropicos, capitis dolores, aurium grauitates, feruentis uapor leuat. Syncera, \& line potabilis aqux mitione repolita uirus deponit. Sunt qui etiam præcoquant, \& ita recondant. Datur ad purganda corpora per fefe, aut ex pofca, aut cum uino, aut mel40 le: verùm polt deiectionem dant gallinx, aut pifcium iufcula, ad domandam morfus acrimoniam.

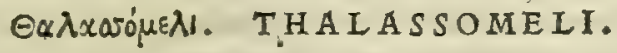

CAP. XVI.

Qv o D thalaffomeli vocatur, vehementer purgare conftat. Temperatur autem æquis portionibus maris, mellis, \& imbris ex alto, defæcatis, $\&$ picato vafe per Canis aftus infolatis. Alij ad binas marinx coeta fingulas mellis adijciunt, \&x. vafe condunt huiufmodi moderatius eft aqua marina, S mitius.

\section{Ö६os. ACETVM.}

\section{CAP, XVII.}

50

A C E T V M refrigerat, \& adfringit. Stomacho vtile, appetentiam excitat: erumpentem vndecunque fanguinem, potu infeffúve fiftit - prodeft alui fluxionibus coctum cum cibis: çruentis vulneribus inditur: inflammationes arcet, in fuccidis lanis, aut fpongia impofitum : reprimit procidentia fedis, vuluxq́ue: item abfedentes gingiuas, \& fanguine manantes. Ad nomas, \& ignem facrum, vlcera qux ferpunt, lepras, impetigines, pterygia, cum aliquo conuenienti efficax eft: phagedanas vlcerum, nomasq́ue fotu continuo cohibet:podagricis calido fotu, cum fulphure auxiliatur : fugillationes rapit, cum melle illitum. Contra capitis ardores cum rofaceo in fuccidis uelleribus, aut fpongia imponitur. Ad aquam intercutem, grauitatem aurium, \& fonitus fibilosq́;, ferventis vapor proficit, inftillatum quoq; aurium vermes necat. Panos coërcet tepidi fotus, aut fi imbuta aceto fpongia admoveatur : pruritus permulcet. Contra venenatos ferpentium içus, qui refrigerando nocent, calidum commodè fouetur: \& frigidum ijs, quiæ exurens virus ciaculátur.

Calidum 


\section{6}

\section{And. Matthioli Comm.}

Calidum potum, atq; vomitionibus redditum, aduerfus omnia venena efficax eft, præfertim contra meconium, \& hauftam cicutam, conglobatum in ventre fanguinem, lac coagulatum, fungos, ixiam, taxumq́ue, cuin fale. hauftu voratas hirudines, fi forbeatur, eijcit: tufsim veterem mitigat, \& recentem lacefsit. In orthopnœa calidum com modè forbetur : gutturis fluxiones gargarizatum inhibet: anginis, \& vuæ procidenti conuenit. contra dentium dolorem, calidum colluitur.

Aceti miltre facultatis con fideratio.

Q V A N V I s Diofcorides fimpliciter pronunciauerit Acetum effe frigidum, quod fortafe in eo magis frigiditas exuperet, quàm caliditas; $t$ amen Galenus qualitatum medicamentorum omnium indagator maximus, ex contrarijs qualitatibus, calidis fcilicet of frigidis, acetum conftare docuit libro primo de fimplicium medic amentorum faculta= tibus, nec effe homocomeres fimilaréue, quemadmodum nec lac uniuerfum. Id quod ipfe Galcnus lib. v I I de corun= dem facultatibus, apertifimé confirmauit his uerbis. Acetum primo horum commentariorun mijta effe fubftantia, nempe frigide, pariter o calide, ciusq́; utriusq; tenuium partium demonftratum eft: caterim calidam frigida exk= perat. Porró magnam deficcandi facultatem obtinet, adeó ut fit tertij ordins de ficcantium iam completi, utic;; clim ualidum extiterit. Et libro primo de compofitione pharmacorum fecundum locos, idem fic inquit. Atqui Acetune ex incidentium ordine exiftens, ultra boc quód difcutit, pracipuum quiddam in $\int c$ liabet, quod reprimit, ac quod in= fluit, or repellit: utpote quod fubltantia fua parum calidum eft, plurimum ueró frigidum, or partium tenuium. Idë quoq, libro I I I I. fimplicium inedicamentorum, ita fcribit. At frigiditas, que ab aceto proficifcitur, tanto eft ud= lidior, quantó er tenuior. Ineft ueró illi o acrimonia quedam excalfaciens, qua tamen fatis non fit ad fuperandam $a b$ aciditate prouenientem frigiditatem: uerùm que tranfitus modo celeritatem promoueat . nam quantó calidum frigido facilius penetrat, tantò acris fuccus aptior eft, qui fenfibilium corporum meatus tranfeat, quàm acidus. Itd= que ille, uelut pracedens uiam fternit, hic uerò baud ita tardé infequitur: quo tempore fenfus perficitur miftus, or. qui agrè exponi queat, utpore qui nec plané frigidum effe acetum denunciet, quippe cum in eo ignea quedam per= cipiatur acrimonid, nec plané calidum. N am perpetuó, qua ex precedente fit acrimonia, calefactionem. Frigus ab infequente aciditate occupans, obfcurat, protinusq́; extinguit . quo fit, ut maior multó ex frigore percipiatur fen= fus, quàm ex calore. Hac ad literam Gälenus. Ex quibus abunde liquet, quód acetum etfic ex contrarijs qualitatibus con/tat; plus tamen frigidtatis, quàm caliditatis particeps eft. Quod cum recté animaduertiffet Diofcorides, ace= tum fimpliciter (ut fuprà diximus) refrigerare pronunciauit. Veruntamen illud ignorandum non eft, quód acctum nimirum eó calidius crit, quó uetuftius, o acrius extiterit. Siquidem ex Galenifententia, libro x I. fimplicium me= dicamentorum capite de adipe, item tertio de compofitione plarmacorum fecundum locos, uinum, snel, acetum, oleü, adeps, uetuftate calidior a fiunt. Ex quo faciléfieri poteft; ut reperiatur acetum adeó uetuftate acerrimum, ut plus

Nomina. babeat caliditatis, quim frigiditatis. Acetum quod Latini uocant, Gracis o' os dicitur: Arabibus, Chal : Iralis, Aceto: Germanis, Eßig: Hipanis, Vin agre: Gallis, Vin aigre:

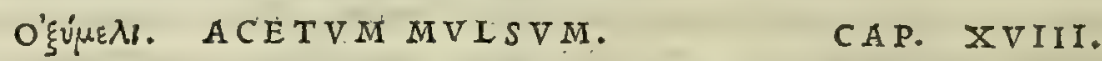

A C E T v M mulfum, quod oxymel uocant, hoc modo temperatur. Aceti heminas quinque, falis marini pondo, mellis minas decem, aquæ fextarios quinque pariter coquito, decies efferuefcente cortina : atque vbi refrixerit, diffundito. Sumptum craffos humores extrahere, \& ifchiadicis, comitialibus, \& articulorum morbo confictatis prodeffe creditur. Contra morfum eius viperæ, quam fe$\mathrm{pa}$ vocant, hauftum meconium, ixiámve auxilio eft . Anginis vtiliter gargarizatur.

Oxymelitis confectio triprex Galeno.

T R I P I I C E M oxymelitis componerdirationem pofteritatis memoris tradidit Galenus libro I I I. de $\int_{t}=$ nitate tuenda .qui tamen fal nulli commifcuit, ut eius uerba loco dicto aperté teftantur, que ita fequuntur. T'ni aceti parti, mellis, dq quo detracta puma fit, duplum ef mifcendum: deinde ambo in leni igni coquenda, donec corum qud= litates in unum coierint : ita enim nec acetum àmplius crudum apparebit. Cum aqua ueró ftatim ita facies oxynzcli. Melli quadruplum optime aque mifcebis: dein coques modico igni, quoad pumare definat. Ac malum quidem mel multam egerit $\beta$ pumam. quo etiam diutius coqui debebit: Optimum ueró, ut breuißimo tempore coquitur, ita minimü pume euomit, unde nec pari ei coctione eft opus. Plurimum certé quartam partem eius, quod ab initio cft inditum, amittit : poft ueró dimidio aceti adiecto, rurfus coquendum, donec qualitatum omnino fit unitas, nec acetum crudum etiam appareat. Conficitur fane oxymeli etiam tribus ftatim ab initio miftis, ad bunc modum. Aceti uni parti addi= tur mellis duplum, o aque quadruplum: atque hec ad tertiam partem coquuntur, uel etiam quartam, puma inte= Oxymelitis rim detracta. Quód fi ualentius id facere studes, tantundem inijcies aceti,quantum mellis . hadtenus. Galenus. Qué confectio ex fecutus Mefues, ipfe quog; de oxymelite fic fcripfit. Oxymelifit ex aqua, aceto, o melle. Aqua ueró mifcetur, ut Mefue. longa coctione refoluatur id, quod in oxymelite flatus excitat; ut etiam promptius de $p$ pumetur, ut deniq; medicamen ti huius facultas, aque miftione tenuior facta, facilius in corpus diftribuatur. Mel ueró additur, ad oppugnandam pi= tuitam. Ex melle denique, o aceto miftis, facultas quadam tertia, qua neutri corum ineft, tanta confurgit, ut effic cacißima fit, atque certißima ad attenuandum, incidendum, refoluendum '; craffa, lenta'́; excrementa, qux in uen=

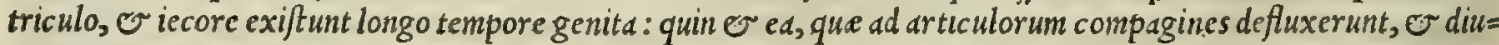
turnas procrearunt fébres : ea nanque o incidit, e coquit. Fit ex aceti parte una, mellis partibus duabus, aque par tibus quatuor. Primum autem mel, $\sigma$ aqua fimul coquuntur, ubi de $\beta$ pumata probe funt, addito aceto percoquuntur,

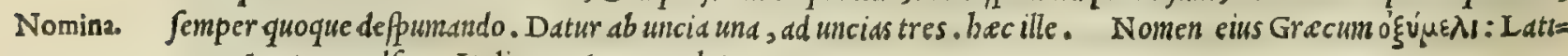
num, Acetum mulfum: Italicum, Aceto melato. 


\title{
In Lib. quartum Diofcoridis.
}

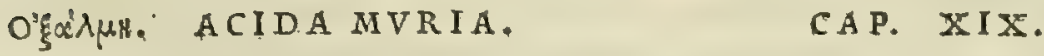

A C I D A muria, quam Graci oxalmen uocant, contra nomas fotu, putrida ulcera, canum morfus, \& venenatos $\mathrm{j}$ \&us auxiliatur. Sanguinis fuxiones polt excifos ealculos fiftit, fi ftatim calida in vuhus inijciatur: \& prociduam fedem reprimit. dyfentericis, fi nomas fentiant, infunditur: oporter autem ex lacte inftillare. Hirudines forbitione, aut gargarizatu necat , furfures, \& manantia capitis ukera exterget.

30 A C I D AF murix, que Gracis oxalme appellatur, ufis atate noftra prorfus exoleuit. Parabatur autem ue=

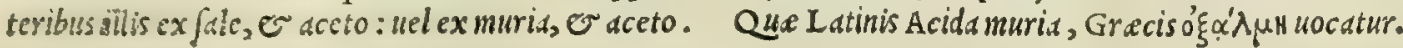

Nomina.

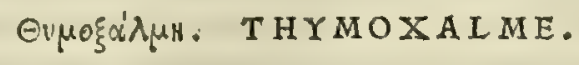

CA P. XX.

Т н Ү M Х A L M E veteres vtebantur, dabantq́uelaborantibus imbecillitate ftomachi, ternos quaternósve cyathos, aqua calida dilutos : item in articularibus morbis, \& inflationibus. Craffos hu mores, atrosq́ue trahit. Hoc modo factitatur. Thymi triti acetabulum, falis jdem modus, rutx, pulegij, polentx, fingulorum exigux portiones in uas conijciuntur, aquæ tcrni fextarij, \& aceti terni cyathi infunduntur, \& circumpofito linteo fub dio madefcunt.

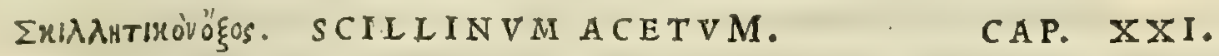

SCI L I I V M acetum hoc modo fit. Scilla, qux candida fuerit, expurgata conciditur, traieêaque lino fegmenta modicis interuallis, ne fe contingant, ficcantur in umbra quadraginta diebus: mina corum in aceti boni fextarios duodecim immergitur, \& uafe diligenter operto feptenis diebus in fole madeficit: poft cum dierum numerum frilla eximitur, \& expreffa abijcitur : defacatum acetum transfunditur, \& reponitur. Aliqui fcilla minam quinque aceti fextarijs mifcent. Alij citra exiccationem repurgantes, parem menfuram adjjciunt, \& fenis menfibus macerari patiuntur. Id multò magis humorum lentitias digerit. Singiuas humore prægnantes collurione ftringit, firmatq́ue, \& ₹ o motos dentes ftabilit. putredines oris, \& graues halitus tollit durat fauces forbitione, $3 x$ callofas facit: vocem expedit, \& ly mpidam, canoramq́ue reddit. Datur ftomachicis, agrè cibum concoquèntibus, melancholicis, comitialibus, vertiginofis, mente captis : item vuluarum ftrangulationibus, lienis incremento laborantibùs, ifchiadicisq́ue. Imbecillos admodum recreat, corpus fanum reddit, \& bonum colorem preftat : oculorum aciem exacuit : tarditatem quoque aurium infulione purgat . In fumma ad amnia efficas. Cauendum tamen inteftinis exulcerationibus, in capitis dolore, aut neruorum uitijs. Datur quotidie ieiunis forbendum inter initia exiguum, paulatim adaugendo, ad cyathum ufque. Nonnulli binos dant cyathos, aut largius.

QV A N Q $\mathrm{V}$ A M fatis fuperg; de Scillino aceto d Diofcoride dictum eft; non tamell alienum fore cxiftino com= $4^{\circ}$ memorare boc in loco, qua de co miris laudibus feripfit Galenus libro I I I. de medicinis paratu facilibus, fic inquiës. Salubre optimum acetum Scillinum i Pythagora fcribitur, quo omnes Imperatores ufi funt. Ab ip fius authore fer= tur, quicunq; boc utatur long wite fore, $\mathcal{O}^{-}$eius extrema integra, $u f q$; ad finem permanfurd. Et ipfe quidem Samitis fenex buiufmodi extitit: quditum enim temporis uixerit, baud ignoras. de ipfo in libro traditum eft, quod cumfuis

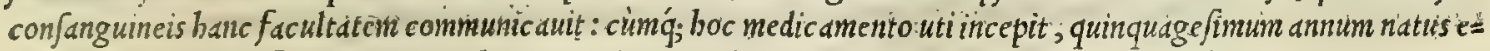
rat, $\mathrm{O} u f q$; ad centefinum decimum feptimum uitam produxit integer, er nulla unquam aduer $\int_{a}$ ualetudine tentatus. Hec dné medicamentiautbor differuit, quod fortaffe uir philofophis erat, mentirine cius. Nos autem uiri buitu fi= dei periculum fecimus, ac firmam, conftantem'́, buiufce medicamenti facultatem effe teftamur. Oportet igitur $\int u=$

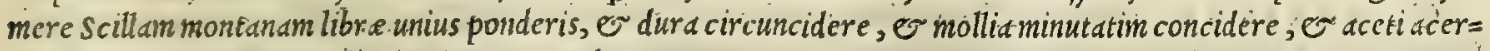
rimi fextarios ofto in uitreis usis mittere atq; obturare, ac per triginita dies in Canicule caloribus, ut maceretter, per= so mittere: deinde fillam extractam exprimere. Id genus aceti parum mane forbeto. Tibi autem hec euenient, ut ne fauciun orisq́; partes ünquart rèmolle ćcant, os uentriculi bené ualebit, facilé fpiritum duces, tox recté babebit, oculi dcutißimé cernent, aures in offacio manebunt, nullusó, flatuofus uapor in uentre unquam excitabitur, nullum uifcus fupenfum erit; $\circlearrowleft$ bene pirans, bète coloratus deges. Ad ciuilia negotia recté affectus, non acidum, non falfum ru= ấabis, fi aliquid aceti buius affumpferis: er ieiunus ut affumas pracipio, feptemóq; poftea ftadios deambules. ita enim diffoluetur. Hoc aceto qui uttur, in uictu quanuis lic entiofus efto: omnid enim cibaria conficiet, er à nullo unquam offen am patietur, neq; ualde implebitur, fed in melius proficere uidebutur. ubil fuperuacui in corpore refidebit, nö flatus, non bilis, non ftercus, non ürina, fed omnia facile excernit, atque educit. Aluus lubricdomnino est, totius corporis purgatorium medicamentum, etiam fi in o/ Sibus fordes inhareant. Item phthificos ab onnibus deploratos, Ђoc medicameuto fanitati reftututos nouinus. Morbo comitiali diuturno efficaciter profuit, ut nif poft longa tempo= ris interualla, non redicrit: incipientem ueró ac noumm perfecté difcutit, neque reuerti amplius lune affectum per=

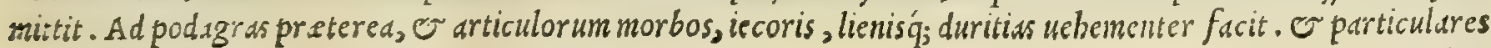

Scillini aceti uires mirabıles. 
quidem acetifcillini effectus hi funt. Communes autem quàm plurimi, quibus nos commoti falutare boe nedicamen= tum, fanitatis, integritatisq́; caufa, tibi tradidinus. Hec ille, quicunque fuerit. nam liber is mter nothos, or Galeno

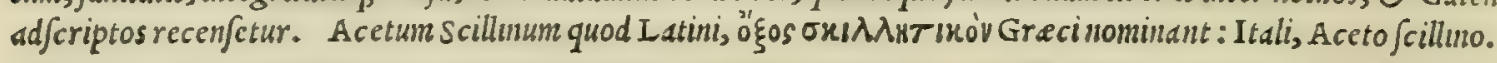

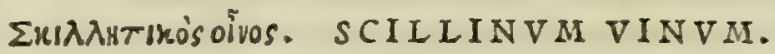

CAP. XXII.

S C I L I I N V M vinum fit hoc modo. Diffeetam, vti diEtum eft, fcillam, \& fole ficcatam con * tundito: minam eius tenui cribro incernito, \& linteo raro illigatam in uicenos fextarios mufti recentis, ac boni demergito . vbi trimeftri fpatio maduerit, elutriatum uinum, obftructo diligenter uafe, recondito. Licet quoque fic humida fcilla uti. In orbiculos, rapi modo, diffectam duplicato ponde- $o$ re, quadraginta diebus infolari oportet, \& ualde inueterafcere. Alia parandi ratio. Scillæ diffectx, \& repurgatæ tres minas in Italicam metretam mufti demittito, \& fenos menfes in uafc obftructo macerari finito polt id tempus defæcatum, \& excolatum uinum recondito. Vtile eft contra cruditates, $\&$ ciborum corruptiones : item ijs, qui reuomunt cibum: \& fi pituita in ventre, aut ftomacho coierit. Prodeft lienofis, malè babitis corporibus, aquæ inter cutem, regio morbo, difficili urinæ, torminofis, inflationibus, refolutioni neruorum, horroribus longis, vertiginofis, \& vulfis . menfes pellit: minimè neruos infeftat. Hoc uinum vetuftate fit melius. Cauendus in febre ufus, aut fi interanea ulcus fentiant.

Scillini vini

S C I I I I N I uini meminit Galenus libro tertio de medicamentis paratu facilibus, his uerbis. Vinum boc po $=20$ usres ex Gal. tui datum, omnem fanitatem adfirt. humores enim attenuat, fed maxime pituitam, neq; ip fam in ftomacho, aut uen= tre, aut capite, aut iecore, aut liene, aut neruis, aut oßstbus confiftere permittit, neq; alium id genus tenacem bumo= remobftructiones facientem: Fed omnia diffoluit, o uentrem lenit, atque it a fubducit, o urinam monet, o per ip= fam caufas attenuat, excernit $q_{\text {; }}$. Adeó ueró caput purgat, ut nares humiditate uacent. Commodum eft podagra, ar= ticulari, or comitiali morbo: denique omnis fanitatis est author. Ix bis conftat. Scillam albam, montanam circiter Canis exortum accipito in libre pondere, per dies decem in umbra refrigera: deinde fcille laminas refrigeratas in uitreum uas mitte, 0 uini albi ueteris fexturios duodecim fuperinfunde, o fupenfum uas per quadraginta dies ba = beto: poftea fallam exime, o abijce, $\sigma$ uino ad antediata uitia utere, $\sigma$ cius uin percipies. Subinde ante cibunt uini duas uncias exhibe, fin à cibo unciam mediam. Quodd fí ipfum potui commodum efficere uclis, ut magis delectet, mellis fextarios duos, dut tres admifceto. Quod Grece ộ tur: Italice, vino fcillino.

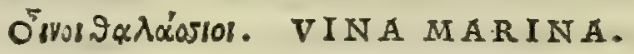

CAP. XXIII.

V I N A ex marina aqua, uariè faetitantur. Aliqui enim ftatim cùm decerptæ funt vux, aquam maris admifcent. Alij in area vuas fole ficcant, quibus calcatis marinam adijciunt. Alijpaffas prius vuas in dolijs marina aqua macerant, mox całcatas exprimunt. id magis pifsi generibus adfcribitur. Quæ tamen aufteriore guftu temperantur, contra febrium aduentantium indicia ualent, fi modò meliora non adfint : aluum fubducunt : profunt purulenta extufsientibus, \& fi dura aluus exerceat. Qux ex Aminxis vuis fiunt, caput tentant, ftomacho aduerfantur, flatus creant . Verùm quiè plenior habeatur hiftoria, ijs qui huius ftudio tenentur, non inutile exiftimamus uarias vinorum compofitio nes adferre, non quòd frequens eorum, aut neceffarius exiftat ufus; fed ne quid omifụfe uideamur, quod ad eorum rationem attinet. Sunt autem quædam ex ijs factitia, minoris curæ ac impendij, qua cadunt in ufus : vti qua cotoneis malis, pyris, filiquis, item myrti baccis componuntur.

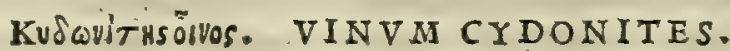

\section{CAR: XXII.}

CY D O I T ES, nomine alio melites appellatur, \& ita fieri confueuit Mala cotonea exemptis feminibus, fruftatim rapi modo fcinduntur, \& duodecim minarum pondo, in mufti metretam, triginta diebus macerantur: poftea defæcatum uinum reponitur. Alia faciendi ratio. Oportet ad fin- so gulos mellis fextarios denos fucci cotoneorum tuforum prefforumq́ue adijcere, \& ita recondere. Vinum hoc adftringit: prodeft ftomacho, dyfenteriæ, hepaticis, renum vicijs, \& vrinæ difficultati.

Melomeli, quod \& cydonomeli nominant, fic fit. Cotonea mala feminibus fuis caftrata, in quàm plurimum mellis, quo penitus demerfa contegantur, conijciuntur :id polt annum mitefcit, mulfo non difsimile. Præltat eadem, quæ fuperior-compofitio.

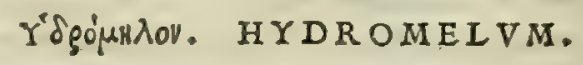

CAP. $X X V$.

F I T hydromelon duabus menfuris aquæ coctæ, \& fub Caniculx fydus infolatx, additis ad vnå melomelitis facti ex cotoneis. Vis huius eadem eft. 


\section{In Lib. quintum Diofcoridis.}

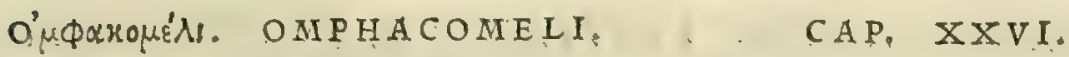

O M P H A C O E I I T I faciendiratio hre ett. Acerbr vuæadhuc immaturx, \& tribus diebus infolatx exprimuntur, \& ad ternas fucci partes, mellis optimi defpumati fingula partes adijcrun tur: \& inlolatur in vafa transfufum. Vim reprimendi, ac refrigerandi habet. ftomachicis, coeliacisq̇ue conuenit. V fus palt ạnự eft.
A'कiThs Õ:Vos. VINVM EX PYRIS.
CAP. XXVII.

F I r \& è pyris, perinde atque cotoneis, vinum, apijtes nomine, fed ita ut pyra non magnopere maturefcant. Ex filiquis etiam, mcfpilis, forbis, limili modo temperatur. Omnia hæc genera acer ba funt, \& adfringunt . ftomacho utilia funt, atque inteftinas fuxiones cohibent.

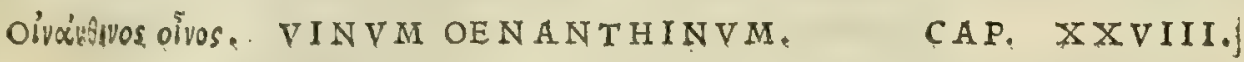

F I r è feraci uite fyluefri, quod uacatur œnanthinum. Sicci flores minis duabus mufticado ma: cerati, polt triginta dies mutantur, mox colatum uinum reconditur. Facit aduerfus ftomachi imbecillitatem, cibi faftidia, coliacos, \& dy fentericos

\section{Pöfns osvos. VINVMEX PVNICIS. CAP. XXIX.}

F I T è punicis malis maturis; quod thaten nominant, fucco expreffo ab açinis ẹorum, quibus lignofus nucleus abeft, apyrena uocant, ac decocto ad tertias, \& ita repofito. Eflicax eft contra fuxiones internas, \& febrim cum alui profluuio exortam. ftomacho utile, adfringit aluum, \& urinam mouet.

V I N V M é $\mathrm{P}$ unicis malis multifariam conficitur in Italia. Aliqui enim repurgatos punicorum acinos prelo Vini è puni-

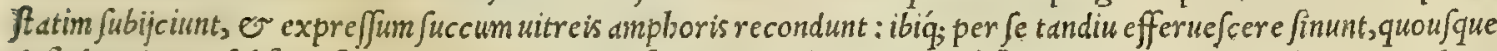
30 deferbuerit, $\sim$ fubfidat fex. deinde in alids trăsfundunt amphoras, quod à fecibus repurgatum eximunt, 0 oleum fuperinfundunt, ne euane $\int c a t$, er corrumpatur, uel ace $\int e a t$. Alij, quimagis punicis abundant, acinos in ligneum cadum altera parte patulum conijciunt, 0 unarum modo pedibus calcait, donec uniser fis exiliat fuccus : deinde per fe in fole cfferue fere finunt, cado linteo pifiore coopcrto, $u$ fquedum f $x x$ uniuer fa refidat, nuclei fupernatent, $\sigma^{\circ}$ uinum defecatum, ac pellucidum reddatur. Vbi autem bec falta funt, perforato paulo fupra fecen urase, uinum exi= munt, $\sigma^{\circ}$ cadis ligneis afferuant. Huic oleum Juperinfundere non opus cș : feruatur enim fic par aium per fe, modo Hafis of culum pite, uel cera obturetur. Sunt preterę, qui epurgatos punici acivos, cu, parimenfura nigre une austeriufculi saporis commifceant, calcent, er per fe efferue cere finant, quo ad winun claritatem confequatur. Sub inde in doliolis afferuant: fiquidem hoc guifui plurinum arriadet.

\section{PódithsoíVos. ROSACEVMVINVM.}

CA.. $\quad$ XXX.

RHODITES fic fit. Rofarum ficcarum, tufarumáue minam linteolo deligatam in fextarios ofto mufti demergito: \& poft tres menfes defacatum uimum transfundens, recondito. Vrile ijs, qui febri carent: \& ad ftomachi coctiones, \& dolores, à cibo potum : \& contra humidas aluos, $3 x$ dy fenterias . Fit quoq; ex fucco rofarum addito melle, quod rhodomeli uocant : quod arteriæ fcabritijs cónenit.
MUgTiTHS oivos. MYRTITES VIIVM.
CAP, XXXI.

M Y R T I T E s fit, baccis nigris, qua maturitatem excefferint, tufis, \& organo exprefsis . Aliso qui ad tertias coquunt. Alij baccas prius fole torrent, \& quaternis fextarijs contufarum, ternas aquę heminas adijciunt, \& uini ueter is parem modum : poftea exprimunt, \& feruant. Magnopere adftrin git. ftomacho utite: fluxionibus uentris, ac ftomachi prodeft, \& contra inteltinas ulcerationes, \& profluuia denigrat capillos.

\section{MUgowitss õvos. MYRSINITES VINVM.}

\section{CAP. $X X X I I$.}

M I R I I I TES fictemperatur. Raminigræ myrticum fuis baccis, \& folijs tufi, decem minarum pondo, in tribus multi congiis feruefcunt, donec duo fuperfint, aut certè dimidium. id uinum colatum ad ufus reconditur. Contra furfures, ulcera in capite manantia, eruptiones papularü, gingiuas, tonfillas, \& puruleritas aures efficax eft : fudores fiftit. 


\section{0 And. Matthioli Comm.}

\section{EXivvos, kei Tęquivarvosölvos. LENT I C INVM, ET TEREBINTHINVM V I N V M. \\ CAP. XXXIII.}

LE N T I S C I N V M fimiliter vt myrfinites temperatur. Nec fecus terebinthinum. nanq; bacciferi eorum rami fumi debent. Similes infunt vires adftringunt, ftomacho accommodantur, \& deflu xionibus inteftinorum, veficæ, \& ftomachi, \& fanguinis profluuio. Vlcera omnia fluxionibus obno $x i a$, fotu ad cicatricem perducunt: fluxiones vulux, ac fedis, infefsione cohibent .

ФonvixiTHsoĩvos. PALMEVM VINVM.

CAP. XXXIIII.

PA L M V L A S maturas, quas uocant chydxas in urceolum imo pertufum, \& obftructum picata arundine, demittito:lino foramen fit obturatum, \& quadragenis fextarijs ternos aquæ congios infundito . quòd fi ipfum ita dulce effe non libeat, quinque congios infudiffe fatis eft. poft decé dies detracto $a b$ arundine linteo, affumito vinum craflum, \& dulce, \& reponito. Suaue illud quidem, fed capiti noxium. contra fluxiones propter adftriftoriam vim efficax: ftomachicis, cœliacis, fanguinem expuentibus conuenit. Aliqui idem addita aqua iterum capiunt, \& tertio, quarto, quinto, fextóvefaciunt, quod tandem acore uitiatur.

KメTOgX'THS ÖIVOS, VINVM EX CARICIS FACTVM.

\section{A P. XXXV.}

C A T O R C H I T E S, aliquibus fycites vocatur, in Cypro fit, ita ut palmeum: fed hoc interef, quoniam pro aqua tantundem humoris adijciunt, in quo recenter preffa vinacea maduerint. Caricæ, quæ chelidoniæ, aut phœnicex appellantur, præfertim nigræ macerantur,vti diximus : \& poft decem dies humor excipitur, atque iterum, aut tertio, idem modus aquæ, in qua uinacea maduerint, infunditur . fimili modo intercedente fpatio, quarto, aut quinto affumitur. Demaceratorum liquor non fecus acorem contrahit, \& aceti ufum prabet. Id tenue eft : flatus gignit, ftomacho aducrfatur, faftidium parit, aluo tamen prodelt, vrinam ciet, menfes trahit, lactis vbertatem facit, vitiofum fanguinem creat, \& elephantiafin adfert, vt potio, quam zython appellamus, Aliqui fex amphoris, decem falis fextarios adijciunt. Alij murix am phoram. quod non facilè uitiatur, \& aluo idoneum fore cenfent. Alij thymum, \& foniculum imo fubijciunt, \& caricas fuperponunt: \& ita vicifsim, donec uas expleuerint. Fit \& è fycomoris eodem modo uinum, fed in acetum acre degenerat : quonıam nó ita praualet vis eorum, ut fluentis liquoris dulcedinem retinere porsit.

\section{P'kTivithsoivos. RESINATVM VINVM. CAP. XXXVI.}

RE S I N A T V a vinum populatim factitari folet. copiofum in Galatia : quoniam uinum illic coacefcat, vua non maturefesse, ob cœli algorem, nifi picea refina temperetur. Refina autem cum cortice tunditur, \& amphoræ dimidiata hemina permifcetur. Aliqui ubi efferbuit, excolant, feparan 40 tes refinam : alij relinquunt. Hæc vina uetuftate dulcefcunt. O mnia capitis dolorem, \&c uertigines faciunt : coctionem tamen adiuuant, \& vrinam cient: tufsientibus, ac deftillatione uexatis conueniunt : item cœliacis, dy fentericis, \& hydropicis, \& fœminis fluxione vulu $¥$ laborantibus : altis exul cerationibus infunditur. In hoc autem genere nigricans magis albo conftringit.

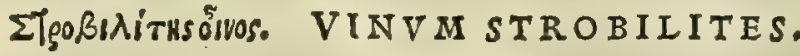

'CAP. XXXVII.

S T R O B I I I T E S fit maceratis in mufto nucibus pineis, recentibus, fractisq́ue : præbetque refinati effectus. Siquis madefactas nuces pini mufto decoquat, potum affatim conuenit ijs, qui tabitudine conficiuntur.

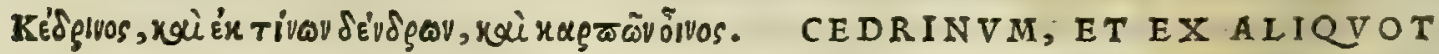 ARBORIBVS, ACFRVCTIBVSVINVM. C.AP. XXXVIII:}

C E D R I N V M, iuniperinum, cuprefsinum, laurinum, pineum, aut abiegnum, fimili ratione funt. Diuifos recenter ramos, cùm fructum edunt, aut foli, aut balneo, aut igni admouere oportet, uti confudent, congioque uini minam unam permifcere, \& poft duos menfes transfundere, \& antequàm recondantur, infolare. Factitiorum uinorum uafa impleri debent : nanq; non plenis uafis, uina in acorem corrumpuntur. Medicata autem uina reetè ualentibus infalubria. Omnia excalfaciunt, urinam cient, \& fubltringunt. Laurinum tamen uehementius excalfacit. Fit quoy; è fructu cedri maioris uinum, congio munti, a diecta tufarum baccarum felibra. diebus quadraginta infolari debet, $\&$ defæcatum 


\section{In Lib. quintum Diofcoridis.}

\& defecatum in vafa transferri, Fit etiam vinum è baccis iuniperi, non aliter quàm cedrites, \& ad eadem ualens. Cedrites hoc modo fit . Cedriam dulci aqua lauant, \& lingulas amphoras lingulis cya this diluunt, \& ita mufto replent. Hoc genus unni excalfacit, extenuat: tufsi antiqua vilie fine febre, pectoris laterisq́ue doloribus, torminibus, ventris, \& interaneorum ulceribus, purulentis excreationibus, mulieribus vulux caufarijs, hydropicisq́ue : facit aduerlus ventris tineas, $\mathrm{N}$ horrores. Contra venenatos ictus auxiliatur : ferpentes necat: aurium doloribus inftillatum medetur.

\section{Tiarithsoivos. PICATVM VINVM. CAP. XXXIX.}

1a Pr C A T V M ex liquida pice, \& mufto temperatur. Picem autem primùm marina, aut muria tantifper eluere oportet, dum inalbuerit, \& fyncera maris aqua defluat : mox aqua dulci prolucnda : congijs ozto multi vncia picis una, aut al tera adijcitur: vbi efferbuerit, \& conftiterit, in vafa diffunditur . Hoc genus vini excaltacit, concoquit, purgat, abftergit: vtile doloribus pectoris, alui, iecinoris, lienis, \& vulux, fi line febre fint, veteri rheumatifmo, exulcerationibus in altum recedentibus, tufsi, fufpirijs, concoctionibus tardis, inflationibus, \& luxatis, præfertim in fuccida lana impofitum.

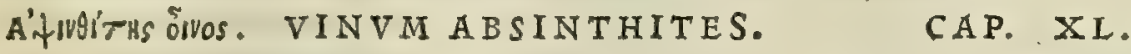

A в S I N T H I T AE faciundi ratio euariat. Aliqui enim duodequinquaginta fextarijs Italicarum 20 amphorarum, admiftam ablinthij pontici libram decoquunt ad tertias : \& vbi infuderint fex aceti fextarios, \& abfinthij felibram, ac diligenter permifcuerint, diffundunt in uas : dumq́ue conquieuerit, defæcant. Alij ablinthij minam in amphoram demittunt, tufamque, \& raro linteo deligatam, in cado mufti macerant binis menfibus. Alij ablinthij quadrantem, alij trientem, \& nardi Syriacx, cinnamomi, cafsi $x$, floris iưnci odorati, calami, elatæ, palmarum fingulos fextantes inijciunt in metretam mufti, \&r tundentes prius pila, obftru\&to vafis 〔piraculo, binis ternísve menfibus dimittunt: poftea defæcatum uinum transfundunt ad ufus. Alij addunt in mufti cadum Celticæ nardi drachmas quatuordecim, \& abfinthij drachmas quadraginta, linteo inuolutas : \& poft quadragefimum diem elutriant. Alij in fenos fextarios mufti, abfinthij libram, \& ficcx pini refinæ fextantem immittunt: \& poft decem dies excolant, \& recondunt. Vtile eft ftomacho, vrinam cict, tardam concoctionem

30 accelerat: hepaticis, regio morbo, \& renum vitijs auxiliatur: faftidia difcutıt .ijs prodeft, quibus ftomachus negotium exhibet: valet contra longam præcordiorum diftentionem, $\&$ inflationes, teretesq́ue uentris tineas, \& remoratos menfes . contra haufta ixiæ venena quàm plurimum potum, is uomitionibus redditum, auxiliatur .

\section{Y゙ڤڤTITHS ÕNOS. VINVM HYSSOPITES.}

CAP. XII.

H y 5 s o P I I E s è Cilicio hyffopo maximè laudatur. Fitq́ue fimiliter, foliorum hyflopi tuforum libra in amphoram mufti coniecta : linteolo raro cum quibufdam lapillis folia inuoluuntur, ve degrauatus pondufculo fafciculus fidat : vinum poft quadraginta dies defæcatum elutriatur. Con40 tra peetoris, laterum, \& pulmonis vitia, veterem tufsim, \& fufpiria prodeft : vrinam cit: torminibus, \& horroribus febrium circuitu repetentibus auxiliatur . menfes mouet .

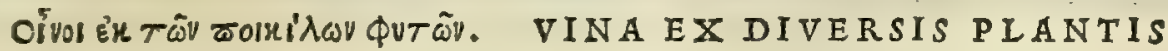 FACTA. CAP. XIII.}

S I M I I modo chamædryites fieri folet. Excalfacit, difcutit: conuulfis, regio morbo, vulux inflationibus, tardæ concottioni, incipienti aqux inter cutem fubuenit. Inueterafcens melius redditur. Stœchadites non fecus temperatur. Congij fex ftœchadis minam addere oportet. Crafsitiem, inflationes, lateruın neruorumq́ue cruciatus, \& perfrictiones difcutit . comitialibus commodè daso tur cum pyrethro, \& fagapeno. Fit ad eadem acetum è ftoechade herba, vt paulò antè diximus, aceto macerata, quod eofdem implet effectus. Fit vinum è betonica, quam ceftron pfychotrophon appellant. Herbam femine maturo prægnantem, cum fuis ramulis minx pondo, congijs duobus vini macerant, \& poft feptimum menfem transfundunt. Ad multa interaneorum vitia, vt frutex ip fe, pollet. Et vt in vniuerfum dicatur, factitia vina fibi mifturarum uires adfcifcunt . quare non difficile fuerit ijs, qui illarum naturam norint, vinorum vires coniectura quadam confequi : veruntamen vinorum vfus febricitantibus abdicandus. Fit etiámnum è betonica acetum ad eadem vitia vtile.

Tragoriganites fit quaternis tragorigani drachmis linteolo colligatis, in quaternos mufti fextarios coniectis, \& poft tertium menfem transfufis . Prodeft torminibus, vulfis, ruptis, laterum doloribus, fpirituum difcurfationi, ægris concoetionibus. E'napis fit vinum, nomine bunites, drachmis duabus tufi napi in fextarios duos mufti additis, \& cæteris eodem modo factis. Prodeft ftomachicis, \& dimicatione, aut longo equitatu fatigatis. Dictamni drachmas quatuor macerato quaternis mufti 
fextarijs. Facit aduerfus ftomachi faftidia : menfes, \& purgamentum à partu fubducit. Marrubijadulci folia tundito, \& fextarios octo in mufti metretam demittito, \& reliqua cöfimiliter facito. Conuenit hoc vinum pectoris vitijs, \& omnibus, quibus marrubium. Thymi tufi, \& cribrati vncias centum lintcolo colligatas, in amphoram mufti adijcito. Valet contra ægras coetiones, faftidia, dyfenteriam, neruorum \&x præcordiorum dolores, hybernos algores, \& venenata animalia, quorü mor fus frigus infequitur, aut putrefcit locus. Simili modo è fatureia vinum fit . quod eadem, quæ thymites præftat. Sic quoque origanites ex Heracleotico origano conficitur fimiliter cum fupradizto. Facit eadem, quæ thymites. E' calamintha, pulegio, \& abrotono vina fiunt eodem, quo thymites, modo. Profunt ftomachicis, cibum faftidientibus, \& regio morbo: quòd vrinam moucant. Fit itế è conyza vinum contra venenata ante alia efficax .

\section{A'guHaTiths ónOS. VINVM AROMATITES. CAP. XLIII.}

Aromati tes ita fit. Palmæ, afpalathi, calami, nardi Gallici, fingulorum quatuor fextarios fumito: poftquàm contriueris, paffo fubigito, coactis ingentibus offis, ik in fextarios duodecim aufteri mufti deiectis, operculato vafe, quadraginta diebus quiefcere finito: deinde vbi frece ex purgatum fuerit, recondito. Alia eius ratio. Calami vncia, phu drachmæ feptem, cofti drachmæ dux, nardi Sy riaci drachm $x$ fex, cafsiæ vncia, croci drachmæ quatuor, amomi drachmæ quinque, afari drachm $x$ quatuor. Omnia fimul trita , \& linteo colligata in cadum mufti demerguntur: $\&$ poltquàm vinum deferbuerit, transfunditur . Facit ad pectoris, \& laterum, \& pulmonis dolores, difficili vrinæ, horro- 20 ribus, retardatis metifibus, atq; ijs qui per frigora iter faciunt, potú conuenit. pituitæa crafsitiem extenuat, colorem alit, fomnum conciliat, dolorem finit renum, \& veficæ vitijs auxiliatur.

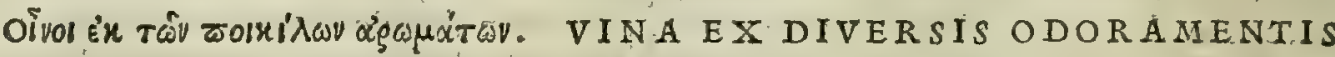 F.ACTA. \\ CAP. XLIIII.}

FI $\&$ vinum ad deftillationes, cruditates, tufsim, inflationes, \& fi humor in ftomacho coit. Myrrhæ duæ drachmæ, piperis candidi drach ma vna, iridis drachmæ fex anifi drachmæ tres o omnia plenius tufa, \& linteolo inuoluta in fex vini fextarios conijciuntur: vinum poft triduum colatur, \& in: lagena reconditur. Datur poft deambulationem meraculum, cyathi vnius menfura. Fit quoque ne- $3: 0$. ctarites ex helenio herba, radice fieca pondo quinque drachmarum linteolo colligata, $\&$ in congios fex mufti addita, \& poft tres nenfes effufa. Facit ad ftomachi,\& pectoris vitia : vrinam pellit. E'Syriaca nardo, \& Celtica, malabathroq́ue vinum factitatur, hac ratione. Singulorum felibram in binos mufti congios mittito, poft menfes duos colato. Datur cyathus vnus cum tribus aquæ. Hoc vinum efficax eft contri vitia renum, hepaticos, regium morbum, \& vrinæ difficultatem : prodeft ftomachicis, atque jjs quos pallor decolorat . Alij vnciam, aut fextantem acori \& Celticæ nardi quadrantem in mufti amphoram adijciunit. Afari quadrantem in fenos mufti fextarios itidem demittito. Id víni genus vrinam ciet : hydropicis, \& regio morbo laborantibus, hepaticis; ifchiadicisq́ue conuenit. Radicis fylueftris nardi recentis, \& tritæ, cribratæáuc beffem in congium mufti conijcito: duos mêfes quiefcere finito. Vtile eft hepaticis, difficili vrinæ, inflationibus, ftomachicis.

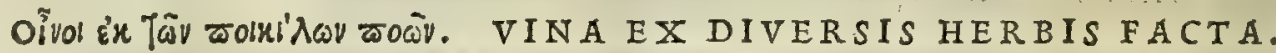
C A P. XIV.

R A D I C I s dauci contufre drachmas fex in multi amphoram imponito, \& fimiliter transfundito. Facitad dolores thoracis, præcordiorum, \& vulux: menfes pellit, ructus ciet, \& vrinam : prodeft tufsi, ruptis, vulfisque. Saluiæ vnciam in mufti amphoran, quod idem cum ceramio eft, mittito. Valet contra renum, veficæ, \& laterum dolores, reiectiones fanguinis, tufsim, rupta; vulfa, \& fup-, preffos menfes. Panacis vneiam in mufti congium mittito, \& transfundito. Prodeft ruptis, vulfis, contufis, orthopnœx: lienis crafsitiem extenuat : contra tormina, coxendicum dolores efficax eft: so tardas concoctiones accelerat: menfes, \& partus extrahir : aqux inter cutem, \& ferpentium ictibus. auxiliatur. Vína ex acoro, \& dulci radice confimili modo fiunt. Oportet enim fingulorum vncias octo in fenos-congios mittere, tribus menfibus macerare, mox in vas transferre. Faciuntad pectus, \& latera, \& vrinam mouent. Seminis apij recentis, maturi, \& cribrati vnciæ nouem in linteo colli-: gatæ in mufti amphoram demittantur. Appetitum excitat: Atomachicis, \& difficili vrinæauxiliatur: faciles fpiritus facit. Ex foniculo, anetho, \& petrofelino, vina eodem modo fiunt, \& adeadem efficacia. Fit \& è flore falis vinum, multò ad purgandum efficacius, quàm vinum aqua marina temperatum. Fauces, veficam, renes, \& ftomachum infeftat: quare neq; in fecunda, neq; aduerfa valetudine prodeft. Fit etiam vinum, quod phthorion vocant, quoniam partus necat, $\&$ abortus facit, veratro, aut fcammonia, aut fylueftri cucumere, iuxta radices vitium fato: fiquidem vites fibi illorü vires adfcifcunt. Id vinum partus enecat: datur ieiunis mulieribus, quæ antè vomuerunt, cyathorum octo menfura 


\section{In Lib. quintum Diofcoridis.}

menfura, dilutum. Ramorum thymcl.xæ cum fuis folijs, \& fructu triginta drachmas mittito in congios tres mufti, \& laui igne coquito, donec congij duo fuperfint, duficatugique recondito. Aquofa purgat excrementa, \& lienem abfumic. Chameliea dum floret, cum tolijs rufa, \& cribruta docem drachmarum pondere, in mufti congium addıtur: polt duos menfes vinum in vas transfurtur. Aquæ inter cutem, hepaticis, \& lasitudine confraftis, cficax eft : itcm mulieribus, yıæ à partu $\mathfrak{x}$ grè purgantur. Chamapityinum fimili modo fit, ad eadem conuencens: vrinam quoque ciet. Librum radıcis mandragoræ concidito, fegmenta lino traijcito, quod fclıbram æquat, in mufti cadum demitrito, ibiq́ue clle finito ad menfes tres, deinde transfundito. M-dia potio, hominæ dimidium: bibitur, paffo in duplum addito. Aiunt heminam vini congio miltam, potu foporem adfirre. cya-

10 thus vnus cum fextario uini potus, enecat. Mediocris ulus elus doloris fenfum aufert: Auxiones incraffar olfactu, potuq́; , \& cùm inditur, idem preltat. In congium mufti aqua marina diluti, drachmas duodecim nigri veratri triti in linteo mundo mittito : dumq́ue cfferbuerı, in marinæa aqux congios quatuord cim, vbi pleniufculè fregeris, inijcito: poft aliquot dics colato, \& vtitor. Dato cyathum vnum ex aqua balnei, in potu ad aluum foluendam, ijs qui enomucrunt à cœens. Alia ratio. Veratri drachmas viginti, iunci odorati vncias duodecim, fpicæ Sy riacæ vncias tredecim . cribratas, \& linteo colligatas, in feptem vini Coi fextarios, diebus quadraginta macerandas indıto, poftmodü colato. dabis in potu fefquiheminam. Aliter. Decoctx marina aqux ex al to petitx fextarios duodecim, veratri candidi libras fex, in mufti amphora quadragefimo dic quàm madefeceris, colato, \& vtitor. Alia ratio. Veratri drachmas duodenas, \& aphronitri quaternas in fenis mufti fextarijs die20 bus quinifdenis macerato, mox colato: \& femeftri exacto, vtitor. Id vini genus abortus facit, \& partus necat. Aut vuas in fole ficcatas imponito in muft metretam (implet autem metreta congios duo decim ) \& gypfum in vinum mittito pondo drachmarum viginti, \& biduo refidere finito : conijcito veratri nigri drachmas triginta, iunci odorati, calami, fingulorum drachmas triginta, baccarum iuniperi fextarios duos \& trientem, myrrhæ, \& croci fingulorum diachmam : inuolucns linteolo diebus quadraginta appendito, poftea colato. dabis heminas tres, aut duas dilutas. Purgat à partu, \& abortu fœminas: foctus extrahit : contra ftrangulatus vulux efficax. Scammonites fic fit. Radicis $f$ cammonix per meffes effoftx, tritx, \& linteo colligatæ drachmas quinque in mufti congium mittito ad dies triginta. Aluum purgat: bilem, \& pituitam extrahit .

30 V I N a factitia parandi ratio diuer $\int a$, quam superius ab initio propé buius libri ad bunc ufque locun pluribus capitibus diffusé diligenteró; tradidit Diofcorides, nobis quidem clarior, ev euidentior nifa eft, quàm ut operapre= tium effet, fingula corum capita noftris commentatcontbus profequi, profertim c um omnium ferè lam ufus apud nos. exoleuerit. quanquam non equidem dubitauerim, quin efent buiufmodi uina, i co modo parata in promptu effent, ijs morbis profutura, quibus predeffe produntur. Vnde pluribus adbuc rationibus nixus, primus cgo, ut arbitror (quod etian lib. I in Ebeni mentione diximus) è ligno Guaiaco uinum confeci, $\sigma$ alijs quoq; conficiendum effe fcriptis tra= didi. Cuius poftea ufu innumeros Gallica lue correptos, nos, $\sigma$ alij medici fanitati reftituerunt. Videmus enim Eu= pbrafiatum ad oculorum claritatem effic acißsimum effe, Myricinum lienis morbos fanare, er quod ex fena paratur, atrabiliarijs morbis, o cutétenus exulcerantibus, nempe fcabiei, lepris, uitiliginibus, lichenis, $\odot$ id genus alijs, com= modißimum effe medicamentum. Quod cùm animaduertiffet magnus philofopius, o medicus non pernendus. Ar=

40 naldus de villa noud, de factitijs uinis, que medicine ufuiconueniunt ad uarios corporis morbos, copiofißsimum edi= dit libellum. In quo qui uinis medicamentofis delectantur, e hac conficiende modum, ov corum facultates, facile d= dipifci poterunt. Nam apud Germanos, $\mathbb{O}$ alios illis conterminos, medicamenta uinis commifta in frequentißimo ba= bentur ufu, quód magis, quàm nos odoratis, of concinnatis delectentur potionibus.

\section{De Metallicis Lapidıbus.}

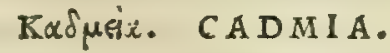

\section{CAP. XIVI.}

so FX C A D I AE generibus optima eft Cypria, botryitis nomine, denfa, modicè grauis, \& in leuitatem magis declinans, racemofa facie, colore fpodij, quæ fracta cinerulenta eft, \& æruginofa. Proxima habetur foris cærulea, intus candidior, internatis venarum difcurfibus, onychitæ lapidi fimilis, cuiufmodi funt quæè veteribus metallis effodiuntur. Quædam etiam placodes, id eft, cruftofa dicitur, fegmentis quibufdam perinde quafi zonis cincta, ob quod eam zonitin appellauere. Alra oftracitis nominatur, gracilis, \& magna ex parte nigra. Sed quæ teftaceam faciem habet, ter am amplexa eft. Improbatur candida. Oculorum medicamentis botryitis nomine, \& onychitis, vtiles: reliqux ad emplaftra, \& farinas, quæ cicatricibus inducendis infparguntur. Ad eadem $\mathrm{Cy}-$ pria prodeft. Ex Macedonia verò, Thracia, \& Hifpania delatæ improbantur. Cadmix effectus adftringere, caua explere, fordcs expurgare, exiccare, corporis meatus infarcire, excrefcentia in carne coërcere, cruftas creare, \&i vlcera, quæ cacoethe vocantur, ad cicatricem perducere. Gignitur cadmia ex ære in fornacibus candence, fuligine egefta $\mathrm{H}_{a t u} \&$ lateribus, camerisq́ue fornacum inhærente.

Vinorum faEtıtiorum cófideratio. 
Prxgrandes autem, ac ferreæ fune rudes, ab officinis appellatx aceltides, per fumma faftigia conne: $x æ, \&$ concameratæ, kt quæ ab ære iactantur furfum corpufcula, cohæreát, \& inibi detineantur : quæ cùm fpifsius infident, in corpus concrefcunt, \& modò genus vnum eius, modò duo, modò omnia perficiunt. Extrahitur \& cadmia in Cypro è monte, qui Solis incumbit, cremato lapide, cui pyritæ cognomen eft. in quo etiam monte quadam quafi venæ chalcitis, mifyos, foreos, melanterix, cœrulei, chry focollæ, atramenti futorij, diphrygisqque inueniuntur. Nec defunt, qui cadmiam in lapidum fodinis inueniri tradant, falfi quadam lapidum cognatione: qualis inuenitur, \& apud Cumas lapis, nullam fui vim oftendens. Ii eo deprehenduntur, quòd funt cadmia leuiores, nullumq́; alienum man dentibus faporem exhibent: commanducatus item lapis dentes offendit : cadmia, vtpote cùm cedat, efum non refpuit. Alio autem difcerni poffunt argumento. Cadmia in farinam detrita, \& aceto fuba io eta, atq; in fole ficcata, coit: quod in lapide non accidit. Item tritus, \& igni appolitus lapis profilit, \& fumum igni fimilem eiaculatur: cadmia verò quieta manet, fuliginemq́ue luteo colore, aut æreo fplendentem expuit, vario zonarum difcurfu. Infuper lapis ignem expertus, atq; refrigeratus colorem mutabit, ac leuior multo fiet: fed cadmia nihil euariat, nifi quis eam multis diebus cremauerit. Fit $\&$ in argenti fornacibus candidior, ac minus ponderofa, fed uiribus nequaquam comparanda $x$ rariæ. Vritur cadmia fuperior carbonibus obruta,donec trắslucida fpectetur, \& ferrei ltercoris modo bullet: mox extinguitur vino Aninæo, quæ ad emplaftra præparatur : fed quæ ad p forarum medi camenta præparatur, aceto. Alij hoc modo exuftam conterunt in vino, rurfumq́; fiftili crudo torrét, donec pumicofa videatur : iterumq́; tritam ex virio, tertio vrunt, donec prorfus in cinerem redigatur, nihil fcabritix retinens. hac fpodij vice utuntur. Lauatur autem in mortario trita, effufa fubinde aqua, dum fordium nihil emergat : dein coacta in paftillos reponitur.

Cadmię confiderario.

C A D M I AE duogenerd. nanque non modó factitia, fed etiam foßilis reperitur. Arte quidem éafit, qux in fornacis teftudine, ubi er is materia comburitur, coalefcit, ut ed que Diofcoridis, $\sim$ Galeni atate in Cypro co mon= te, cui sole urbs adiacet, ex pyrite lapide in fornacibus concremato conficiebatur. Verim foßjilis (ut Ealenus eft au thor libro I x. fimplicium medicamentorum) in ararijs ipfius montis fodinis frequentißima habcbatur, de qua ita fcri= Hiltoria ex ptum reliquit. Cadmia fit, ubi in fornacibus as paratur, nempe tota terra illa, ex qua es generatur, in fornacibus in Galeno. altum egerente, uelut fuliginem quampiam, er fauillam, fiue utcunque appellare licebit. At fi non terram, fed lapi= dem nuncupare uelis, ex quo in fornacibus fecernendo partim fit as, partim cadmia, partin dipbryges, nihil fané retulerit. Sed erin argenteis metallis efficitur fimili fecretione, fiue generatione, aut quomodocunque nocare no= 1es. Quin er expyrite lapide in fornacibus ufto fit cadmia. Caterim atfque fornace in Cypro cadmia inuenitur : ac iure quipiam illam lapidem nuncupet. I taque in solis, quo tempore cgo in infula peregrinabar, paucißimum etiam reliquum erat cadmix, qua in fornacibus fit. Verum lapidibus, qui in montibus, or ruis reperiebantur, a metallis profectó acceptis, cos in A fiam, Italiamíq; portaui ad annicos, à quibus funmam inibam gratiam, qućd fe uel maximu munus accepiffe dicerent, $\mathcal{O}$ que alid omni cadmia multó effet preftantior. Et talem certé meritó quis lapidofam uo cet cadmiam. At cius, qua combufta eft, aliam botryitin, aliam placitin medici nuncupant. Botryitin quidem, qux in editioribus domorum, in quibus fornaces extructe funt, partibus colligitur. Placitin ueró, que in infritoribus. Ac liquet fané botryitin effe tenuiorum partium, craßiorum ueró placitin: utranque autem ui deficcandi, ceu alia me= tallica omnia, er lapido $\int_{a}$, terrená,;. Porró preter deficcandi facultatem, mediocriter item extergit. Attamen; qua in fornacibus colligitur, ignex facultatis aliquid babeat neceffe eft. Merito itaque lauantes eam, medicamcntum efficiunt mediocriter tum deficcans, tum extergens abf $q_{\text {; }}$ mordicatione, utile ad ulcera impletionem expofcentia, $\sigma$ in oculis, $v$ in toto corpore. Porró ulcera magnopere bumida, aut putrefcentia, in corporibus impendió mollibus; qualia funt eunuchorum, puerorum, ac mulierum., eiufmodi cadmia adiunat. At in durioribus, $\mathcal{O}^{\circ}$ contentioribus.; que ualentius deficcant, requiruntur. Itaq; illud femper memoria tenendum, fermonem ad temperatam, 0 mediam exceffum naturam, in ijs que ita fimpliciter efferuntur, referendum : puta cum dicimus medicamentum, aut ulccra carne implere, aut cicatrice claudere, aut aliud quiduis eits generis preftare. ad quam utique or nos nunc refpi= cientes, leuiter deficcatoriam, abster foriamq́; cadmie effe facultatem dicimus. In caliditatis autem, or frigiditatis Cadnix hi- differentia, temperata quodammodo exiftit cadmid, nempe neutrum infigniter efficiens. bec Galenus. Quibus ma= foria ex Pli- ximé adftipulatur Plinius lib. $\mathrm{x}$ x x I I I . cap. x. fic inquiens. Metalla eris multis modis inftrunt medicunam, ut= nio. pote cum ulcera omnia ibi ocyßime fanentur. Maxime tamen prodeft cadmia. Fit fine dubio bac o in argenti fornd= cibus, candidior, ac minus ponderofa, $\int e d$ nequaquam comparanda ararie. Plura autem genera funt. Nanque ip $\int e$ lapis, ex quo fit es, cadmia uocatur, fufuris neceffarius, medicina inutilis. sic rurfus in fornacibus exiftit, aliamiq. nominis fui originem recipit. Fit autem egefta flammis, atq; flatu tenuißima parte materia, o cameris lateribuisue fornacium pro quantitate leuitatis applicata. Tenuißima eft in ipfo fornacium ore, qua flamme eluctantur, appellata capnitis, exufta, or nimia leuitate fimilis fauille. Interior optima cameris dependens, $\sigma$ ab eo argumento botryi= tis cognominata. ponderofior hec priore, leuior porró fecuturis. Duo eius colores deterior cinereus : puniceus melior, friabilis, oculorumं; medicamentis utilißima. Tertia eft in lateribus fornacium, qua propter grauitatem, ad cameras peruenire non potuit. Hec dicitur placitis, $\mathcal{O}$ ip $\int a$ ab argumento, crufta uerius, quàm pumex, intus uaria: ad $p$ foras utilior, $\sigma$ ad cicatrices trabendas. Fluunt ex ea duo alia genera. Onychitis extra pené corulea, intus $0=$ nychis maculis fimilis. Oftracitis tota nigra, o caterarum fordidıßima : uulneribus maxime utilis. Omnis autem cadmia in Cyprifornacibus optima, hec Plinius. qui $a$ Galeno in hoc diffentit, quod dixerit. foßilem cadmiam fufuris 


\section{In Lib. quartum Diofcoridis.}

tantim neceffariam, or medicine inutilem, cim tamen Galenus contrarium fcribat. Cadmix omne genus uidimus $\int_{s}=$ p.e nos in pluribus Germania locis, ubi as, argentum, or auricbalcum conficttur. Sed peciatim botryitin apud Per= zc num quinto it Tridcnto lapide, er apud sbozium in Tirolenfi comitatu, ubi in quà plurinis fornacibus as, ac alia metalli fundeutur. Eotryitis cadmic fruftulum fané pulcherrimum nouißimé ad me mifit Sagabria Dalmatic urbe clarifimus medicus Iofeplsus Sulundius Bergomenfis : qua adeó in racemi modum congelta eft, ut plané uus pecicm referat. Porrò officine omnes Tutiam, qux pomplolyx cft, Cadmiam perperian nominant. Quandoquidem Tutia illis uocata (nifi mea me fallit opinio) Cadmis cft c' botryitis genere. Neque enim mirum effe debet, quod Cadmia pro= prio amifo nomine, in pompholyg is locum fuccefferit, cum etiam Diofcoridis tempore podij loco uterentur medici.

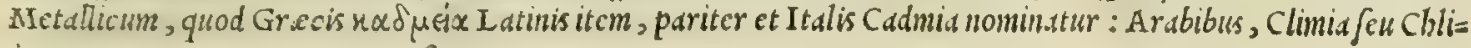
10 mia: Germsnis, Grauker, Auguftem.

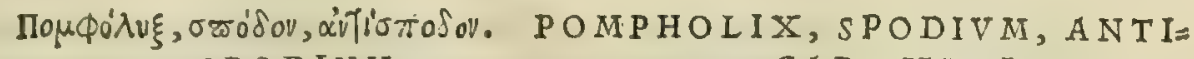 $S$ PODIVM. \\ CAP. XIVI.}

POM P H O I Y X fpecie fola, non genere à fpodio diftat. Siquidem fpodos nigricat, \& p!erunque ponderolior eft, palearum pilorumque plena, quafi purgamentum quoddam, quodab æras riarum officinarum pauimentis, \& fornacibus euerritur. Pompholyx uerò pinguis eft, \& candida, vfqueadcò leuis, ve in auras euolare pofsit. Cuius duo fluxerunt genera. Vnum ad aéris colorem vergens, fubpingue: altcrum magnopere candidum, fummamq́ue leuitatem nactum. Candi-

zo: da fit pompholyx, quoties in perficiendo ære, fabri præftantiorem facere volentes, detritam cadmiam cumulatius infperferint. nanque tenuifsima faulla, qua eflertur, in pompholygem coit. Cæterùm pompholyx non ex xris modò materia, \& fabrili induftria factitatur; fed ex cadmia quoque, ad gignendam ipfam eximiè follibus proflata. Cuius faciundx ratio hæc eft. In domo gemina contignatione operta, fornax extruitur, iuxta quam mediocris feneftra, ad tabulatum à fupernis partibus pateat domicilij paries fornaci proximus, tenui foramine ad fornacem vfque perforetur, ad excipiendam follis narem : oftium mediocre habeat, pro exitu ingrefluque artificis fabricatum . domunculs altera huic coniuneta fit, in qua \& folles, \& flator fuo munere fungantur. deinde carbonibus in camino fuccenfis, afsidens artifex cadmiam particulatim fractam infpargit, à locis fupra infurnibulum extruß̨is . idem negotium obit infernè artificis minifter, fimulq́; carbones adijcit, vf30. que dum indita cadmix copia prorfus abfumatur. Itaque egefta fuffitu tenuis pars, \& leuis materix in fummam domum cuolat, \& parietibus, tectis, fornacique adhærefcit: conflatum autem inde corpus, inter initia erumpentibus aquarum bullis fimile prodit , poftea maius incrementum capeflens, glomufculis vellerum limile redditur. Ponderofus autem in ima loca fe recipit: fed hoc fornacibus offunditur, illud domus pauimento cohæret : quod tenuiore deterius exiftimandum eft, ideo quòd multum terræ collegerit, \& fpurcitia in aceruatione referciatur. Sunt qui hoc modo tantum fieri fpodium arbitrantur, de qua antè dictum eft. Optima creditur Cypria, quæ accepto aceto halitum aris præftat, colore aliquantùm piceo, fapore cœni horrido: et fi fraudem non experta, flagranti carbone inferuefcit, aëreum colorem contrahit . Antedictis autem notis diligenter attcndendum elt. siquidem à nonnullis adulteratur taurino glutine, ouillo pulmone, aut marino, aut crematis grof40. fis, \& quibufdam confimilibus . quod facile cognitu fuerit: quippe nihil in ijs probandis inuenietur corum, quæ antè diła funt. Pompholygem in commune ita lauari oportet. Ligatam linteo mundo, modiceque raro, aut ficcam, aut aqua refperfam in labellum demittito, quod imbrem contineat, \& hucatque illuc fafciculum dcferens, immergito: ita enim limofa pars eius, ac utilis effluet; \&: omne fedimentum in lintcolo remanebit . poftea refidere finens aquam cum cinete colis incernito \& nouam infundés, agitato, \& effundito : mutata tantifper aqua, \& colata, dum arenofi nihil fidat. demum aquam exprimito, \& ficcatum cinerem recondito. Alij quantum maximè fieri poteft ficcant, manibus in aqua conterunt, dum mellis craffamentum imitetur: deinde linteo faucibus excepturi vafis obtento, aut laxius illigato, colant, \& quò facilius traníeat, infufa per linteum largiore aqua, cincrem conturbant : mox fpumofum, quod traiectum eft, \& fupernatat vafi, concha ex-

50. cipiunt, \& fictili nouo ad vfus recondunt. Quod verò refedit, fenfim cribratum, in aliud vas transfundunt, relicto arenofo, quod peffum ierat: rurfus lapidofa fidere patiuntur, \& in vas aliud excolant : hoc identidem faciunt, donec cinis merus, \& arenæ expers inueniatur . Alij paulatim integram in aqua refpergunt, arbitrati arenas, lapillosq́ue fuo pondufculo degrauatos, peffum ire: pilos autem, \& paleas leuitate fua in fublime attolli. Cæterùm cinerem medium feparant, \& in pilam coniectum, vt cadmiam, eluunt. Quinetiam lauatur vino chio marina aqua diluto, modis quos fuprà diximus : $\&$ ita redditur adftringentior, quàm aquis elota. Vis pompholygis adftringere, refrigerare, explere, purgare, obftruere, \& aliquantùm exiccare. Inter medicamenta numeratur, qux leniter cruftas obducunt. Quòd fi fpodon torrere libet, diligenter tritam, \& irrigatam aqua, colliges in paftillos, fietiliqque no'so, fubiectis leuibus prunis orbiculos continuò verfabis, dum a ficcati fuluefcant. Neque ignorandum ex auro, argento, plumboq́ue fieri fpodium : uerùm poft Cyprium, plumbeum maximè commendatur. Quoniam fpodos fxpenumero defideratur, neceffe elt often- 
dere, qux fimili virtute polleant, vt in fpodij locum fuffici pofsint, antifpoda vocant : quoq́ue modo runi debeant. Folia itaque myrti cum floribus, \& immaturıs, in fietile crudum conicta, indito operculo continua foramina habente, vruntur fornacibus, donec figlinum percoquatur. iterum in fictile aliud crudum transferuntur, quod vbi peraffatum fuerit, exempta lauanturad vfus. Idem quoque fit è termite fylueftris oliuæ, fi habeatur: fin fecus, fatiuæ cum fuis floribus, aut malis cotoneis diffettis, \& detractis of sibus, aut gallis, aut laceratis linteolis : item ex mor is immaturis, id cit candidis, in fole prius arefactis, aut terebincho, aut lentifco, nenanthe, aut mollibus rubi folijs, vel è è buxi coma, vel è preudocy pero cum fore. Alij ficulneas frondes in fole antea ficcatas, eodem modo parant : alij taurinum glutcm : alij fuccidas lanas afperas, pice aut melle irrigatas. Qur omnia in fpodij vicem viurpastur.

Pópholygis conlideratio.

Manardi erra tum .

Brafauoliduplexerror.

Fuchlij opi-

P O M H O L Y G E M officina Mauritanos fecute Tutiă dicunt. Ita cnim pompholyx appcllatur Serapioni, or Auicenne. Verum quam feplafiarij Tutiam exiftimant, legitima non eft, fed cadmia potius pecics. siquidem cum bec lapidis modo crufto $\int$, preduraif; fit, pompholygem, fiue tutiam dictam pror fus mentitur. Pompholyx nanq; Diofcoride, e Galeno authoribus, ex aris, uel cadmia fauilla in glomufculos uellerum fimlles coit, o farine modo contacta dipergitur. Id quod recenticrum nullus, quod fciam, animaduertit, fortaffe quód onmes rei berbarie inda= gande magis infudauerint, quàn in inucftiganda fojilium materia. Quamobrem Manardum Ferrarienfem, medi= cum etatis noftre clarißimum, hac in re deceptum fatis reperio. Quippe qui, dum A uicennam redarguit, quód $\beta 0=$ dium é combuftis arundinum radicibus conficiat, feduló nos admoneat, ut f c cuti Guleni fententiam, in Ppodij defictu, tutia potius utamur, qua feplafia abundant, quàm Auicenne antippodio . Sed in boc Manardus plané ballucinatus de= prebenditur, quód procul dubio crediderit,uulgarem officinarum tutiam legitimam Diofcoridis, $\sigma$ Galcni $f \int e$ pom= pholygesn, cum tamen legitima Tutie nullis in officinis fit ufus, çud ( ut iam diximus) omnes fompholygis loco cad= mia tantum utantur. Porró legitimam tum pompholygem, tum podium, que a Diofcoridis, Go Galeni hiftoria nullis

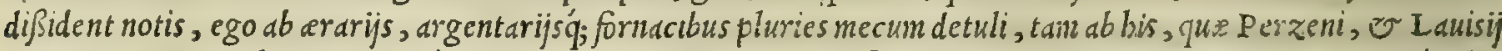
in Tridentino agro habentur, quam ab illis, que sbozij in Tirolenfi comitatu Germania lnueniunsur, ubicerté cele = berrime funt metallorum feré omnium fornaces, ac fodine: $e$ quibus non modó pompholygis, or podij quantum fat is

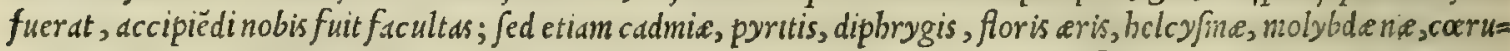
lei, er Armenij lapidis. Quorum ne minimam quidem particulam apud I talia feplafiarios reperi unquam, prater= quàm apud eos, qui uel à me, uel ab amicis meis admoniti, legitima bec metallica medic amenta, adulterinis ex fuis of $=$ ficinis abdicatis, in medicum $\int u$ ceperunt ufum. Nunc ueró amicos intelligo (quos tamen uerius fratres amantißimos 30 appellare poffem, ut qui $\odot$ retate, $\sigma$ longa confuetudine, o ftudiorum communione mibi coniundißmi fint) clarif= fimos medicos Tridento oriundos Andrean $\mathrm{Gallum}, \mathrm{E}$ Iulium Alexandrinum, qui iandudun ob fuam tum doctrinam,

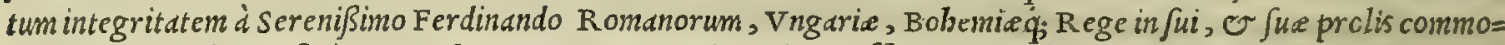
dum in medicos honorifice receptifunt. Hoc itaq; pacto cadmia officinis pompholyg is uicem explct: quibus etiam antipodia quedam ex arundinum radicibus, er boum oßibus concrematis facta, podium fal só referunt. Quod tamé non omnino fuerit rcprobandum. nam, Diofcoridis teftimonio, ubi legitimum defideretur fpodium, antifedijs uti $\int_{a}=$ né licebit: nempe qux fieri po/3int è myrtifolijs, floribus, baccisq; : ex oliux frödibus, cydonijs malis, quercuum gal = lis, attritis linteaminibus: item moris nondun maturis, terebintho, lentifco, buxo, $p$ feudocyperc, fici fronditus, tau= riglutino, fuccida lana, pice aut melle perfufa. Quo fit, ut mibi plané inmeritód Manardo reprebéfus uideatur Aui= cenna, qui ex combuftis arundinum radicibus fibi podiun confecit, medicinis commifcendum, qux ad cordis robur 4 : parantur, $\mathcal{O}^{\circ}$ intus in corpus Jumuntur. His enim longé melius, ac conjultius fuerit arundinaceum admifcere ppodium, quàm eius uice tutiam feu pompholygem imponere. licet hec quog; fit Brafauolifententia. Sed equidë bactenus nun= quam me legiffe recordor, pompholygem feu podium ijs nicdic amentis tutó admifceri poffe, que intus in corpus fu= muntur : cim neq; Diofcorides, neq; Galenus, nec qui poft ip fos diuerfis temporibus clarueriut, tam ex Grecis, quám Maurttanis, ufquam, quod inuenerim, memoric prodiderint, citra uit.e periculum hec bauriripoffe. Nam ficri non poteft, quin tam pompholyx, quism ffodium uentriculo, $\sigma$ ceteris uifceribus, mirum in modum noceant, cum ex te= muißina aris fubftantia uebementißima ignis ui conficiantur, o ob id deleterij aliquid habeant. 2uod maiori quidem diligentia expendere potuifet Brafauolus, cum interrog atus à fuo fene pharmacopola, quid podij loco in compofitis medicamentis imponendum foret, inconfulté $\int a t i s$ repondit, pompholygem, ut faciebai Galenus. Qüa in re duplici, meo quidé iudicio, notatur errore. Primùm, quód repondens non diftinxerit, an boc uel alio modo agendum fuerit cü so medicdmentis, que ore fumuntur, quibus myropole podium quandoq; cominifcent, omnino bac in re concludere ui= detur, pompholyge indifferenter pro ppodio utendum eße, tam in bauriendis, quim exterius admouendis medic amé= tis. Deinde ueró cum pompholygem, fiue (ut ip fe babet) tutiam podij loco fumendan satuit, in codem uer fari erro= re depbrebenditur, in quo Manardum cius ciuem uer atum oftendimus. Quandoquidë fi recté nouifet tutiam commu nis ufus, legitimam non effe pompholygem, omnino (ut femper in ceteris tam adulterinis, quàm fuppofititijs medica= mentis facere adfolet) errorem hunc fuo feni pharmacopole indicaffet. Nec obftat, quód dixerit Galenus in ftodij de fectu, pompholygem fupplendam . Siquidem is in ijs tantum medicamentis id factitandum uoluit, que exterius illinun= tur. Nam Galeni atate nullus podij uel antipodij extitit ufus ad medicamenta, qux intus in corpus fununtur, ut lon= go poff temporè à Mauritanis factum effe reperio. Ceterum Fucbfius medicus a tate noftra celebris, libro de com= ponendorum inedicamentorum ratione, Agricolam forta]fe fecutus, preter illud spodium, quod in fornacibus fit.

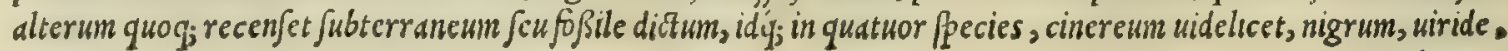




\section{In Lib. quintum Diofcoridis.}

or luteum digerit: quod quidem folis Arabibus (Agricola foli serapioni) notum effe fribit. Veruntamen serapio ubi de pompholyge agit cap. 422 . ubi item de spodio cap. 34 2. nullan, quod legerim, podij foßilis mentionem $f_{a}=$ cit : quem.dinodum neq; Autcona, neq; etiam alij Arabica familix audores. Porró meminit tum Pompholygis, tum etian spodij Galenus lib. Ix. fimplicimm medicancntorum, fic inquiens. Pomploolyx fit in aris fornace, uelut or cadmia: fity; or dum in fornacibus cadmia uritur, ut in cypro. Cum enim prafectus ad eris fornacem inftructas res non baberet, precepit cx ip fa cadmia prepararl (prefentibus, atg; inpectantibus nobis) pomplolyga, uideli= cet minutis cadmice fragmentis in ignem conicctis, qui ante ararium iacebatfollem. Canera erat incurud, nusquam

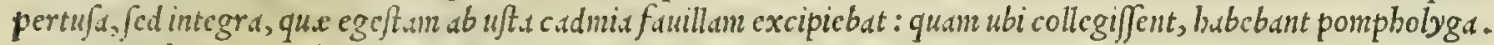
At quod reflectens infi i in panimentum recidebat, podos eft quam wocant, qua plurina, ubias in fornacibus uri=

to tur, colligi a folet. Quidan eanz podium neutro genere pronunciant: cui uidetur fmilcm babcre facultatem quod nocant Antippodium. At cgo illo ufus fun nunquam, cum largé mibifemper pomplolyx fuppeteret. Nec enim quis= quam, ubi biec adfit, podio uti uelit, nedum antipodio. Eft autem pomplolyx medicamentum propé omnium, qua. cutra morfun deficcant, fi clota fucrit, preftantißinum, quamobrem ad ulcera cancrofa idone $a$ eft, er ad alia om= nia maligna. Itag; inditur collyrijs, qua ad oculorum imponuntur fluxiones, quáq; bullas, feu puftulas in eis natas curant. Praterea ad pudendorum, ac fidis ulcerd optimum eft medicamentum, nimirum fine morfu deficcans. Sed non eft huius negotij in iftis diutius immorari. Idem lib. I I I I. de compofitione pharmacorum fecundum locos de pompholyge ita fribit. Pompholyx lota mulli plarmacorum mordacitati expertium inferior ef: ato; ob id ea utimur ad acres, $\odot$ tenues fluxiones, capite uidclicet prius finul'; uniuerfo corpare eudcuato. At ueró maniffftum eft, quód per uch.e fictionem, ac purgationcm totum corpus euacuamus, per apophlegmatifmos ucro caput à pituita

so undic.amus. Poteft enim poimphorlyx lota, quemadmodum etiam podium, atq; amylum fimul, er moderaté bumo=

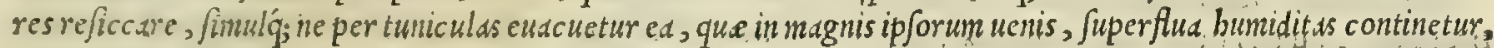
probibere. Quire fi quis prius, quàm caput ab bumoribus ad oculos defluchtibus expurget, obturantibus pharma $=$ cis utatur, uchementem dolorem ex diftentis tunicis efficiet, or ex multitudine influentium buntorum aliquando ru= pturam, aut corrofionem inducet. : Пouфó $\lambda v \xi$ fic Grecis, ut etiam Pompholyx Latinis e . Bulladicitur : Arabi=

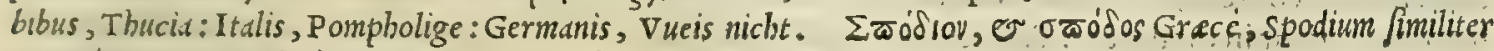
Latiné nocatur: Italicé, spodio: Germanicé, Grauknicht.

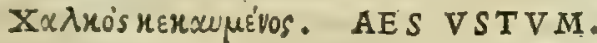

CAP. XLVII.

3o AEs ufum probatur rubrum, \& quod contritu colore cinnabarim imitetur : nigrum uero plus quàm deceat, exuftum eft. Fit autem è clauis folutarum nauium, fietili crudo compofitis : fubfperfo fulphure cum fale pari, omnibus uicifsim infparfis, fictile, circumlito figularicreta fpiramento, fornacibus inditur, donec figlinum percoquatur. Quidam pro fulphure, \& fale alumen infpargunt. Alij fine lulphure ac fale, fictili multos dies urunt. Al lij fulphure folo utuntur, fụliginem tamen excutiunt. Alij oblitos fcifsili alumine clauos cum fulphure \& aceto, fictili crudo cremant. Alij in ænea olla aceto iefperfos urunt, \& iterum ac tertio idem efficiunt, poltea recondunt , Principem locum tenet, in Memphide cóbuftum : proximum in Cypro. Adftringit, exiccat, reprimit, extenuat, attrahit: vlcera purgat, \& ad cicatricem perducit: vitia oculorum emendat, excrefcentia in carne confumit, nomas cohibet: vomitus ciet cum hydromelite potum, aut cum melle delinatum, illitúmve.

40 Lauatur ut cadmia, mutata quater die aqua, donec nulla prorfus fordes emergat. Aeris recrementum; ftercúsve, quam fcoriam uocant,eodem modo lauatur : \&eandé uim, fed imbecilliorem, habet.

A E S V S.T V M, quodin officinis paßim babetur, pauci fané ualoris effe exiftimauerim, cùm nigrum fit, $O$. plufquàm oporteat, igne exolutuin. Verim facilé quipiam buic malo mederi poterit, , fi Diofcoridem fecutus, ip $\int_{u m}$ conficiendi laborem fubierit. Qüd fi erei claui é navigijs folutis exempti non adfint, es aliud omne uetuftate expurgdtum, commodé affumi poterit. Vfti aris meminit Galenus libro I x. fimplicium medicamentorum, bis uerbis. Aes

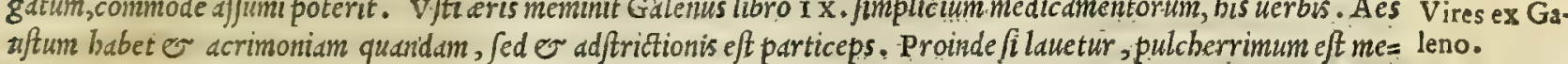
dicamentum cicatrici ulceribus inducendx : quanquam idip um praftare, er antequam lauetur, poßit, potißimum in

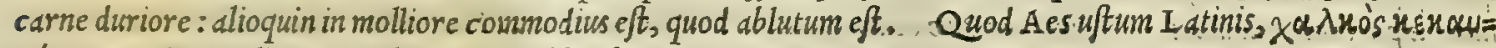
so pívos Grecis appellatur: Italis, Rane abbrufciato:

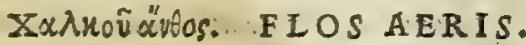

\section{CAP. XIVIII.}

F L O s xris, quem nonnulli clauorum veterum pfegma, quafi refegmen aut fegmentum, nominarunt, optimus eft friabilis, in attritu fuhuefcens, milij effigie, \& numero, brẹis, ponderofus, modicè fplendens, atque conftringens, qui delimatam aris fcobem non recepit; qua fxpe adulteratur. Sed id facilè deprehenditur, cùm dentium illifu dilatantur ramenta : Fit autem, cùm æs fornacibus fufum, in receptacula delabitur, per cola fifularum ad ea pertinentium . tum huic negotio addicti miniftri, fordes expurgantes, aquam clarifsimam infundunt, refrigerandi propofito: itaque repentino concretu, ac addenfatione, velut expuitur, \& erumpit antedictus flos . Adftringit, \& excrefcentia coërcet : offufam oculis caliginem emendat, fed magnopere mordet, Quaternúm obolo-

Aeris ứticófideratio.

Nomina.
Pópholygis, \& fpodii hi-foria,et uires ex Galeno.

Nomina. 


\section{8}

\section{And. MatthioliComm.}

rum pondere datus, craffum humorem extrahit . carnofa narium, \& fedis vitia abfumit : eruptiones papularum cum vino cohibet. Candidius contra diuturnas aurium grauitates tritus, in eas per fiftulam flatu impellitur: vuam, tonfillasq́ue reprimit , farina eius cum melle admota.

Floris arishi FI OR E M A E R I 8 uerum ac legitimum in fornacibus, ubi es ipfum funditur, in Tridentino agro, fapius thoria. collegimus, in bunc modum. Cum es fornaciliquatum, in paratum receptaculum extrafornacem diffunderetur, an= teaquàm omnino coiret in ma $\iint_{a} m$, frigidam fuper ipfum adhuc ignitum infundebam: ftatim q́; uapor magnus excita= batur, Jub quo mox ferream laminam, e cam quidem amplam, fubijciebam, tandiúq; tenebam, donec ceffabat uapor. It taque demum aris flos, qui fuper lamina illa ferrea deciderat, milhi fefe oftendebat granulis milio proximis, minori= bus tamen, fed colore rubicundo plendentibus, Quandoquidem tenuißima eris pars, quo d̀ uapore in fublime fertur, aěris frigiditatem experta, facile in eiufmodi exigua grana concre fcit. Is nufquam, quod fciam, in officinis reperi= Vires ex Ga- tur. quapropter eius uice erugine perpetnó utuntur. Florem er is paucis perftrinxit Galenus libro I X. fimplicium leno. medicamentorum, fic de eius uiribus differens, Flos eris tenuiorü partium facultatis eft, quìm aut as uftum, aut $\int q u d=$ ma. Merito itaque ex eo factis collyrijs, extergunt, aufrunt qٔ; fupereiliorum magnas afperitates, quas uocant $f y=$

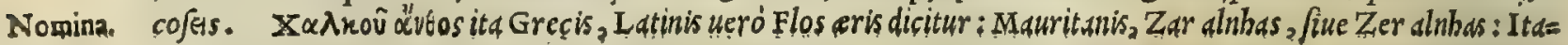
lis , Fiore del rame.

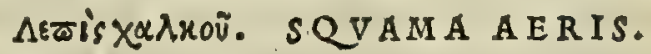

\section{CAP. XLIX.}

S Qv a m a æris excuffa ex Cyprijs officinarum clauis, craffa quidem ipfa præftantior, quæ heli- 20 tis, id eft, clauaris nominatur. fed ex vili promifcuoq́ue ære, aut candido, vitiofa intelligitur : quam, vtpote tenuem, \& inualidam, damnamus, maximè approbantes craffam, rufam, præfertim fi aceti refperfu æruginem contrahat. Vim habet adltrictoriam, extenuantem, reprimentem, \& erodentem : nomas coércet, vlcera ad cicatricem perducit. pota ex aqua mulfa, aquam trahit. Aliqui farina fubactam, dant in catapotio. Additur ad oculorum medicamenta : genarum nanque fcabritiam abfumit, \& fuxiones exiccat. Lauatur hoc modo. Siccæ æris fquamæ expurgatæ felibra, cum nitida aqua in mortario manu diligenter conturbatur, quoufque peffum ierit : abijcitur, quod fubfidit, \& effufa aqua, hemina coeleftis imbris adijcitur, \& diftenta manu, fquama , quafi deftringenda fit, vehementer confricatur : dumque lentorem emittere cœperit, aqua fenfim ad fex heminas vfque fuperinfunditur, terendo validè : fquama ad latus mortarij colligitur, ibiq́ue apprimitur. quo facto, ex- 30 preffus humor pyxide ex ære rubro facta, excipitur. Hoc eft enim velut fos fquamæ, valens viribus, \& ad ocularia medicamenta cùm prim is efficax. Inutile, imbecillumque quod fupereft, lauatur donec nullam prorfus lentitiam excernat : \& linteo opertum biduo conquiefcere finitur, effufáque extante aqua, vbi ficcatum erit, reconditur pyxidicula. Alij vt cadmiam lauant, \& reponunt.

\section{AETiŚsomujuTos. SQVAMA STOMOMATIS. CAP. L.}

S QA M AE eX acie, aut mucronibus decuffa, quam vocant ftomoma eadem vis. Lauatur modo fimili, \& reconditur: fed ad moliendam alui deiectionem inefficacior eft.

Squanz xris, \& Ptomomatus confider.

Plinij, \& recentiorú quo rundä error.

AE R I S S QV A M A malleis ex co decuffa, res fané unlgaris notitice eft : tamet/i ea praftătior. fit, qua ab are excutitur, quo claur füt, , belitis proprié dicta. Siquidĕ cùm buiufmodi es rude impurum $q_{\text {; }}$;it, craßiorem, uegetio= remó; fquamam reddit, quàm id quod pluries ignem expertum, in uarid uaforum genera conformatur. Eius praterea abluende ratio adeo Diofcoridiclar a diftincta ó; traditur, ut nibil addendum fuperfit. Squame omnis in uniuerfuim meminit Galenus lib. I X. fimp. med. ubi ita fcriptum reliquit. Squama alia eft eris, medicamen ad multa utile : alia ferri, et flomomatis. Quidă ueró nominant 厄゙ belitin lepida, fiue fquamă. Omnes fané uebementer deficcant. At inter fe diuer fe funt, tum quód alia magis, alia minus exiccat : tum quòd alia crafioris, alia tenuioris fit effentia: qućd'q; plus, minusue adftrittionis fint participes. Helitis certé principem in deficcando locum obtinet. name te= nuiorü partium, quàm alie eft, nimirum que $\$$ eruginis nonnibil affumpferit. Maiorem obtinet adftrictionem fqus= ma ferri, er bec etiam inaiorem ftomomatis. quamobrem ad contumacia ulcerd, meliores funt, quàm fquama aris. Detrabit, o liquat carnem potentius fquama aris, or bac ctiam ualentius belitis. Omnes autem fquame non in= frenué mordaces funt. Ex quo clarum eft, quỏd effentix ipfarum confiftentia non admodum tenuis eft, fed potius craffa : fiquidem inter qua eandem uin obtinent, minus eft mordax, quod eft tenuius, ut fuperioribus libris oftendi= mus. hrec Galemus. Ex quibus utiq; liquidó conftat ftomomatis fquamam, eris fquamam effe nequaquam : etfi contra= rium memoria prodiderit Plinius errore ductus, at $q$; etiam idem affirmauerint recentiorum quidam, eius fidem magis fortaffe fecutti, qud̀m quòd altius rem banc inueftigauerint. Quandoquidem non de funt, quiftomomatis fquamă, aris fquamam omnium tenuißimam effe contendant, ut Marcellus Diofcoridis interpres. Sunt etiam qui putent eă= dem modó aris, modó ferrifquamaim tenuiorem defignare, ut Brafauolus. quanquam bec nullis, quod equidem $\int_{c i}$ am, rationibus, mullis q́; authoritatibus probent. Brafauolus tamen, ut fuam tueatur fententiam, Dio fcoridem in me $=$ dium citat . Sed qua ratione ego profectó nefciuerin, cim nufquam repererim fcripfiffe Diofcoridem, quod ftomo: matis fquama promifcué, aris e ferri fquama effe poßit. Verum ne quippiam forté putaret, me bec meo tantum ara 


\section{In Lib. quintum Diofcoridis .}

bitrio proferre, id fané quod fentio, primum non obfcuris, ut puto, rationibus aperiam: mox probatißimorum autho= rü teftimonio illud apertißimé cöfirmabo, quod fcilicet ftomomatis fquana nec aris, nec fimplicis ferri fit materia, fed chalybis tantum. In primis itaq; dicimus, quód cum fcribat Galenus aris fquamam principem locü in deficeando inter cateras obtinere, ferri ueró m.iore adfringendi ui quim hec pollere, or bac etiam maiore fomomatis, manifeftum prebet indicim, , Romomatis fquan.um nec ab ere, nec a fimplici ferro effe decuffan, fed di duriore ac terreftriore metallo, nempe ab ip fo chalybe : quippe cum ftomomatis fquand longè mugis adftringat, quain ferri, buius ueró plus adfring at quàm eris, rationiminime confonum uidetur, ftomomatis fquanan effe aut eris, aut fimplicis ferrifco= bem, fed pottus ( ut ditum eft) puribini cbalybis. Ad bec cum Galenusin capitis fronte fcribat, Squama alia eris cft, alia firri, alia fromomatis, omnibus fane palim facit, ftomoma aliud effe metallum ab ipfo are, or à fimplicifer=

- ro ommino diuerfun. Nam fi fenfij]et Galenus, quódftomoma in eris genere, non autem ferri, fuiffet reponendum, dixiffet haberi fquanam aris, ftomomatis, ac ferri, neq; it apeciem à fuo genere difiunxiffet. Sed quoniam recté no uerat ftomom gomu effe frriarte facti, ob id fuo illud adfcrip/it generi, quemadmodum o paulus ipfun fecutus. Caterum prater rationes addulas, ftomomatis fquamam à chalybe tantün decuffam effe, nihilǵ; aliud Gracis fto= momatis nomine indicari, quàn chalybem, confirmatur Aëtij o probatißimi, o Graciauthoris teftinonio . quipe pe qui libro I X . cap. X I V I I I. de ijs agens, que in corpus fumpta dy fentericos iuudut, quidnam Gracis effet sto= moma, bis uerbis aperté declarauit. Deinde uinum purum uetus, quantum fatis uidebitur, in noum uafculum infun= dito, o lamman ignit am ex ferro, quod fomoma uocant, non minorem libra in uino extinguito. Item libro x. cap. $\mathrm{x}$. ubi indurati lienis curam agit, fic inquit. Sit auten ferrum, quod in ipfis extinguitur, ftomoma. Ip/ius autem ftomomatis ferrifquand, quan in fabrilibus officinis ferrum, dum ignitur, or malleo tunditur, abijcit. Poftea agre=

20 ftioribus hominibus utiliter exbibetur. Et lib. x I I I I. cap. x x I I I 1. idem ait. Squama frri, prae fertim ftomoma= tis, amplioris adfrittionis particeps eft. bec Aëtius. Ex quibus fané perpicuum fit, nil aliud Grecis effe ftomoma, quàm Latinis fit chalybs, qui é puriore ferrifubftantid, arte fit in fornacibus. Quo factum eft, ut omnes in uniuer=

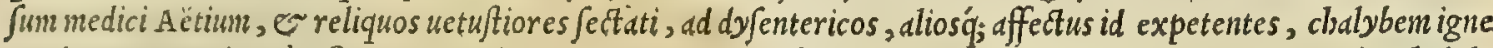
candentem, magis quàm ferrun, modó in aquam, modó in aufterum tinum, modó in lac extinguant, quòd chalybs maiore adfringendi ui polleat, quaim ferrum. Hinc itaq; omnino affirmare licebit, nil aliud extitife uetuftioribus, ac recentioribus Grecis fomomatis fquamam, quàm qua à cbalybe decutitur, eius क́ prafertim, qui malleo ferra= rijs in officinis acuitur, dum gladijs ac telis aciem, uel mucrones coaptant artifices: quinetiam dum alia funt inftru= menta inateriarijs fabris, er terre cultoribus expetita. Porró hanc rem quog; Actuarius abunde expreßit fuo de compofitione medicamentorum libro in Aegyptia Andromachi, dum inquit. Multó reddetur utilior, $f$ fquamam

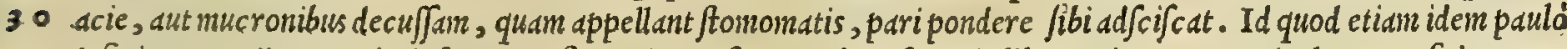
infrius repetijt. Hoc in infuper confirmari poteft ex Galeni fcriptis libro primo, ac tertio de compofitione me= dic amentoruin $\int$ ecundum locos, ubi diuer is medic antentis, pre $\int e r t i m$ ' ad alopeciam facientibus, stomomatis fer ri fquamam immifcet. Sed fi forté reperiretur aliquis adeo ceruicofus, er.peruicax, ut tot clarißimorum uiro= rum autboritatibus non acquiefceret, audiat quefo Ariftotelem philofophorun omnium principen, qui libro I I I I.

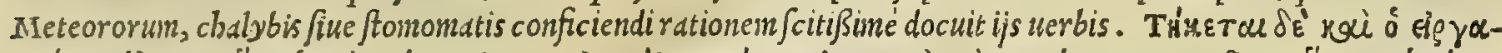

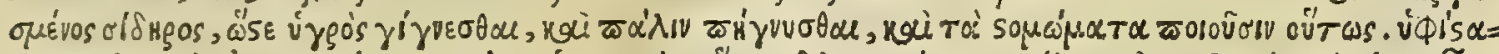

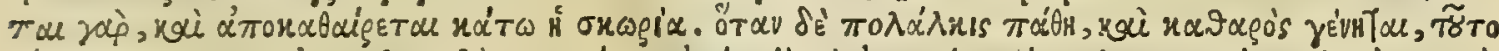

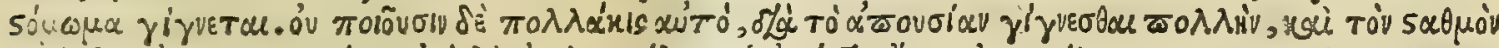

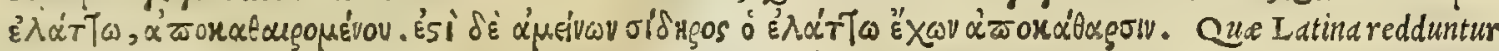

40 in bunc modum. Porró o ferrum elaboratum lique fcit, ita ut fluxum reddatur, or rurfun concre fcat, at $q_{5}$ in bunc modzin faciunt f tomomata: fiquidem fcoria in fundum fubfidet, $\mathcal{O}$ defecatur ferrum. Cùm ueró id fape factum eft, er purum euafit, fomoina efficitur. Hoc autem non $\int e p e$ faciunt, co quod repurgatum multum deperdat, er. pon= dere imminuatur. Atqui ferrum illud melius eft, quod minus excrementi retinet. bactenus Ariftoteles. Cuius nimi=

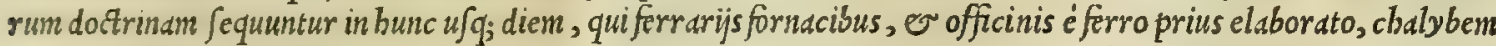
conficiunt in Italia, or in alijs uniuer $\int e$ Europe regionibus. Quxpropter eos pror fus ballucinari euidentißimum eft, qui aliter fentiunt: nempe inter antiquos Plinium, or inter recentiores Marcellum, ow Brafauolum. His omni= bus accedit Serapionis authoritas, magni inter Arabes Diofcoridis interpretis : quippe qui quadringentefimo tertio fui operis capite de fimplicium medicamentorum hiftoria er uiribus, id totum quod à Diofcoride proditü eft de fqua= maftomomatis, de ferrifquama pofteritatis memaria prodidit, ferrum tanquan genus, chalybis loco accipiens.

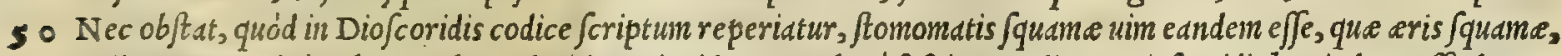
quă quam non adeó ualenter aluum deijciat. Siquidem ego plané fupicor, codicem Diofcoridis hoc in loco effe depra= uatü, ut in alijs quoq; pluribus deprebenditur, prefertin cum nec à Galeno, nec ab alijs ueteribus recentioribusí; Grecis prodttun fit, ftomomatis fquamam eris fquame uiribus effe fimilem: bec nanq; aluum deijcit, illa ueró con= tra eam cohibet. Ad hec nu $q$ quam memini apud quenquam legiffe, alio metallo roborari poffe ferrum in aciem uel mucronem elaboratum, nifí chalybe, qui Gracisftomoma dicitur. Quo fit, ut illorum pertinaciam mirarinon de= finam, qui aliter fentiunt. Ex bis itdq; haud dubié credendum arbitror, non aliud efe ftomoma, quà chalybem, qui cum d primordijs femper fuevit expetitus ad ferreorum inftrumentorum aciem roborandam, quam aciem Graci sóuoux uocant, pariter chalybem ftomoma uocarunt. Quapropter dicebat Aëtius, fit ferrum, quod in ipfis ex= tinguitur, stomoma. Hoc autem uocabulum putauerim ego ortum effe à só $\mu \alpha$, quod Latinis os fondt. Acies enim, item'́; mucrones, gladijs, er telis, alijs q́; ferreis inftrumentis ufum nullum alium prabent, quim oris . unde Latinis quandog; dicifolet, eos, quibus ob malefacta caput abfcinditur, in ore gladij perijfe. Plinius quoq; licet ignoraue=

Stomoma effe chal y bis lqua mam confirmatur authositatibus. 


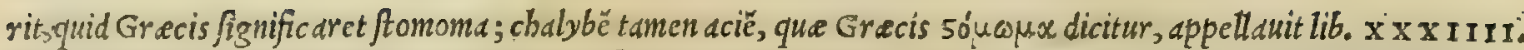
cap. X I I I . fic inquiens. Exomnibus dutem ferrigeneribus serico palma eft. Scres boc cum ucftibus fuis, pelli= busq; mittunt. Secunda $\mathrm{Parthico}$, neq; aliagenera ferri ex mera acie temperatur: ceteris enim admifcetur. hec plinius. Ex quibus palain eft, id hoc loco Plinio aciem uocari, quod chalybem etiam Latini appellant, quod'q; nos

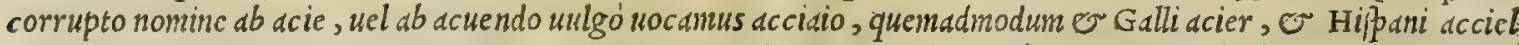

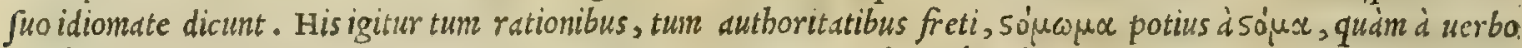

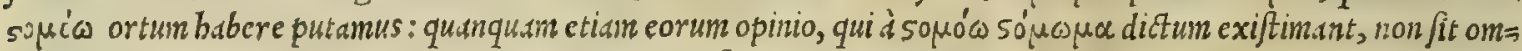
sino improbanda, quod id uerbun roborare, durum facere, dciem er mucronem inducere Grecis defignet. Sed neq; illos quoq; prorfus aberrare crediderim, qui fcobem ab acie, or mucronibus, dum fuper lapide rotante acuun= tur arma, derafam, ftomomatis fquaman effe cenfent. uerü tamen bec, quodd fit lapidis illius ramentis admifta, non 10

Nomina: perinde ac fyncera probanda uidetur. Squama, que Gracis $\lambda \varepsilon \pi i s \times \propto \lambda x_{0}$, Latinis Squama aris appellatur: Italis, squama del rame: Germanis, Kupfer fchlag: Hıpanis, Efquana de cobre. Qua ueró Gracé $\lambda \varepsilon \pi i s: 50=$

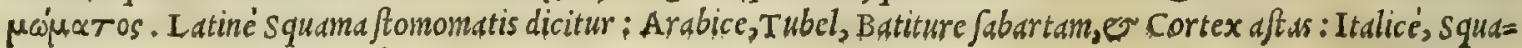
ma dello ftomoma: Hipanicé, Esquama de szero.

\section{I'ơ EูUSo'v. AERVGORASILIS. CAP. LI.}

AE R V c o rafa fit ijs modis. In cadum, aut aliud confimile uas, acetum quàm acerrimum infunditur : fuperponitur inde inuerfum $æ$ neum uas, præfertim concameratum, fin minus, planum : fitq́ue obftruetum, nullumq́ue habeat fpiramentum : exempto, quo doliolum obturaueris, operculo, $2 \theta$ decimum poit diem infidens ærugo deraditur. Aut æris lamina in cadis fuper acetum ita furpenditur, ne ipfum attingat, \& totidem polt dies raditur. Aut maffula æris, aut lamina una plurésve uinaceis non recentibus, fed iam acefcentibus conduntur, \& fimili modo uerfantur. Quinetiam ex delimata. æris fcobe æruginem facere licet: necnon è laminis, quibus bracteæ auri cóclư malleo ducuntur, fi quis eas aceto refpargat, \& ter aut quater uerfet, donec æruginem contrahant. Tradunt æruginem in Cyprijs metallis gigni, lapidibus quibufdam nonnihil æris habentibus, qubus ærugo efflorefcit: adduntq́ue per Caniculæ æftus è quodam fpecu manare: fed illam paucam, \& optimam effe: hanc speluncis effluentem, copiofam quidem, \& boni coloris, fed uitiofam, quòd lapides multos collegerit. Pluribus autem modis adulterant, aliqui pumice admifto, alij marmore, alij atramento futorio. Sed deprehendemus pumicem, aut marmor, dum pollice finiftræ manus madefacto, xruginis 3 a portiunculam altero atterimus ; fiquidem eam difundi conftat : marmoris autem, pumicisqúue partes coëunt non difsipatæ, demumq́ue tractarione crebra, \& humoris complexu dealbefcunt q quin \& dentium appreflu : fiquidem fyncera cedit, lacuis, $\mathbb{3}$ fine afperitatc. Atramentum uerò futoriú igne coarguitur : nanque fi fictile, aut lamina adulterata arugine illinatur \& feruenti cinere, aut carbonibus incalefcat alterutrum, mutabitur, rubefceț̣́; id, quod atramentum futorium acceperit: quòd id uftum fuapte natura țalem fortitur colorem.

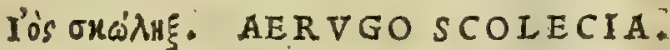

CAP. LII.

AE R V G I N I S , quam uocant fcoleciam, duo funt genera . quædam forsilis eft, altera factitia ad $4 \circ$ hunc modum. In mortario Cyprij æris dimidiam heminam aceti albi acrisq́; , piftillo cupreo conterito, donec ftrigmenti crafsitudinem imitetur: deinde aluminis rotundi drachmam unam, cum falis fofsitij translucentis, aut marini quàm albifsimi, folidiq́ue, aut certè cum nitri pari pondere teritur in fole æftuofifsimis diebus, fub fydus Caniculæx, donec colorë æruginis contrahat, \& concretu Atrigmentofum fiat: vbi autem fe in uermiculorum Rhodiacis frmilium fpeciem coëgerit, recondito. Efficax, \& ualde boni coloris redditur, fi duas partes urinæ ueteris, cum una aceti adieceris, \& alia, quæ dikta funt, peregeris . Sunt qui ruginem rafilem, quæ in apparatu non refpondit, gummi mifto digerant in formas, \& ita uendant . quod genus, ut uitiofum, improbatur. Fit $\&$ quxdam ærugo ab aurificibus, mortario, \& piftillo Cyprij aris, cum urina pueri impubis, qua aurum ferruminant. Antedicta ærugınum genera ufto æriomnino refpondent, fed magis effectu ualent . Sciê-dum fofsilem fcoleciam præftantifsimam effe: derafam fequi : poftremo loco factitiam . mordacifsima tamen eft hæc, \& magis adftringens. Aurificum:atem ærugo rafæ refpondet. Aerugines omnes adftringunt, extenuant, excalfaciunt . oculorum cicatrices emendant, lacrymas cient, nomas fiftutt, vulnera ab infla mmatione tuentur : vlcera ex oleo ceraq́ue ad cicatricem perducunt : callos, \&r fordida ulcera purgant, cum melle coetx : callum fiftularum crodunt cum ammoniaco, colly rii modo in eas adactæ . ad gingiuarum autem excrefcentias, \& extuberationem utiles . Magnopere extcnuant genarum crafsitiem, cum melle illitæ : verùm poft illitionem fpongia ex aqua calida locus fouendus eft . refina terebinthina exceptæ, cum ære \& nitro lepras abigunt. Vritur arugo, quancunque uclis, minutifsimè fracta, comminutaq́ue, in fictili patina, flagrantibus prunis fuperpofita : verfaturq́ue donec fe mutet, \& colorem cinereum concipiat: poltea refrigerata reponitur ad ufum. Sunc qui cruda olla eam urant, uti dictum eft : fed non prorfus eundem colorem cremata reddit . 


\section{In Lib.quintum Diolcoridis. $\quad 66 \mathrm{r}$}

AE R V G I N E M, quód colore fit uiridi, officine, ac medici in I talia as uiride nuncupant, or unlgarifernone aterde rame. Verim quanuis officine eo in muiuerfium abundent; fynceri tamen parum oftendunt. Scolecia arugi= ne, ac fofitia defituimur : quód alterd, quod fciam, boc tempore non paretur, altera ueró ab utrarijs fodints, ubifor taje plurima repcritur, a fofjoribus non defratur. Proinde cum barum copia non fit, ca tantim utinus, qua are in acctarijs cadis demij]o, aut uinace is iom acefcentibus obruto, conficitur. Hallucinantur, qui eredunt arugincm, or eris florem unan, $\mathcal{O}$ candem $r \mathrm{~cm}$ cffe, ut fuperius de eris flore differcntes latius ostendimus. Acruginum uires reddidit Galcnus libro $\mathrm{x}$. fimplicium medicamentorum, fic inquiens. Acrugo guftantibus acrem qualitatem offert,

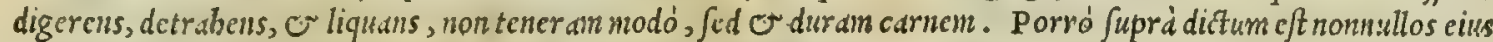
generis medicament:, epulotied, hoc cft, que cicatricen mducant, appellare, cum ijs in tenuißinum pollinem trit is - per pecilli cupiden contigerint ulccra excrefcentia, ac poftridie contracta reperiant tametfi illos baud lateat, fi pauló plus impofitum foret, fe fe ulcus non contrattum, fed erofun inuenturos. Siquiden colliquat, or digerit car: «m : cuim medicantenta epulotic a contrabant, conftipent, conftringant, or calli in morem illan indurent. Quin er guscus mordicat ermgo, non tantim ipfa wleerd. quód fi pauculum eius cerato non pauco admifceds, id quod ex an= bobus miftum eft, citra morfum exterget: Dictum ueró fuprì eft de talium modic amentorum natura, tum ut fe fe qui= dam fallunt ex talibus compofitionibss, aut farcoticam, aut epuloticam ad fcribentes facultatem medic ameritis, qui= bus minime oportet: utpote cum infa id preftare nequeant, uevimed, que ex ipfiscöpofita funt: Que arugo io'v

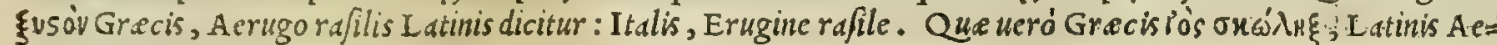
rugo fcolecia nominstur: I talis, Erugine fcolecia. Arabibus, Ziniar, feu Zengiar: Germanis, Spangruen: Hipa= nis, Cardenillo: Gallis, Verderis or Verdet.

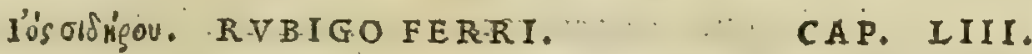

R v в I.G o ferri,reftringit: fiftit fominarum profluuia admota, potuque praftat ne concipiant. Illita ex aceto, ignibus facris; \& papularum eruptionibus medetur. Perquàm utilis ad feabritias genarum, reduujas, \& pterygia. Condylomatis prodeft, gingiuas firmat, podagras illita lenit, alopecias replet. Vinum aquáve, in qua candens ferrum fit reftinftum, potu coliacis, dy fentericis, lienofis, cholera laborantibus, \& diffolútis fomacho auxiliatur.

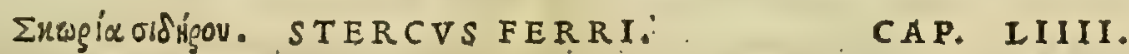

IS T E R V S ferri, quam fcoriam uocant, eadem potef, quæ rubigo, fed ineficacius. Aconito ex aceto mulfo potum, opitulatur.

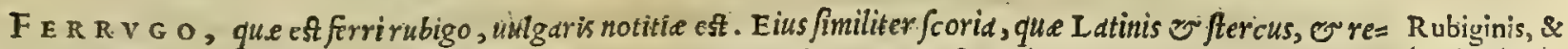
crementum ferri, e nostris uulgó fpiuma difirro appcllatur; omnibus notiór ét, quàm ut maiore indigea decla= ratione. bac nanque prope ferrarias officinas paßim in aceruum congefta.pcctatur ab omnibus. Veruntamen ne ali= quis fortaffe decipiatur, illud nobis indict um non abibit, quíd ferri, aut aris, aut argenti fcoria non eft fquama, qqia malleo decutitur. Siquidem hec ferrarips fornacibus', qubus ferrimetallum funditur, indita liquef cit, $e^{\circ}$ iterum in ferrum coit . Scorid ueró, quód inutile fit ferri recrementum, inane, e pongiar um modo pumofum, nunquam fe40 rum efficipotest. Scoric mcminit Galenus libro I x. fimplicium medicamentorum, fic inquiens. Scoria omnis re= ficcatorium admodum medicamentum eft, potißimuim autem ferri. Siquidĕ ad lauorem redigens ip fan in aceto quàm acerrimo, pofteáq; decoquens, ad aures, que longo iam tempore pure fluxerunt, ea utor, medicamento maximé exic= catorio, adeo ut mirentur, qui preparantem me uident, $\sigma$ ante rei periculiun fidem non habeant, aures tale poffe ferre medicamentum. Porró argentifcoriam propriéhelcy fma appellant. Verim emplastris quibufdam reficcatorice facultatis commifectur. Rubigo firri Latinis dicta, lo's ol frigov Gracis appellatur: A rabibus, seda albadid: Ita=

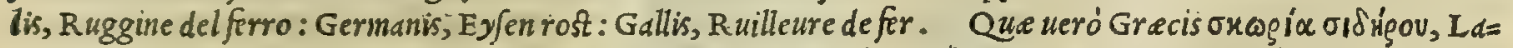
tinis, Scorid, Stercus er Recrementum ferri dicitur: Arabibus, Chabt allsadid: Italis, Spiuma de ferro: Germanis, Schalken: Hipanis, Mozo de herreraj er Mozo de fragua.

L O I $\nabla$ R A plumbi fic fit . In mortarium plumbeum aquam inijciens, piftillo plumbeo terito, donec nigrefcat aqua, \& limi modo craffefcat, aut lutulenta reddatur : linteo deinde colato, aquam fuperinfundens, quò facilius quicquid eft refolutum incerni pofsit. hoc iterum facito vfque dum fatis tibi habuiffe videatur . vbi confederit priore aqua effufa, nouam adijciens, vt cadmiam lauato, donec nulla extet nigritia: poftea in paftillos cogens reponito. Quidam fcobem mundi plumbilima quxlitam, mortario piftılloque lapideis terunt, atit manibus cum aqua paulatim adiecta fricant, donec nigrefcat: mox vbi id peffum ierit, effufa aqua, colligunt in paftillos.nam tritum vehementer, ceruff frmile redditur. Alij elimatæ fcobi modicam plumbaginem adijciunt, affirmantes ita elo tum phumbum praftantius effe. Potelt refrigerare, adftringere, inducere, mollire, explere caua, fiftere oculorum fluxiones, \& vlcerum excrefentia. Sanguinem fupprimit : prodeft contra fedis vltcorie terri confider.

Seorix uires ex Galeno. 


\section{2}

cera, condylomata, \& hæmorrhoidas, ex rofaceo : item ad ea, quæ ægrè cicatricem ducunt: \& in totum fpodij effectus præbet, nifi quòd non obducit cruftas. Syncerum plumbú affrietu, mạini fcorpionis, draconisque plagis auxiliatur.

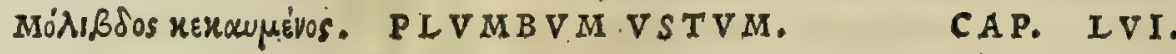

V R I T V R plumbum fic. Super quàm tenuifsimas plumbi laminas, fietili nouo inditas, fulphur infpargito: additisque alijs rurfus laminis, interiecto femper fulphure, vfquedum vas expleueris, fuccendito. flagrante autem plumbo, ferrea rude verfato, donec perfecè redigatur in cinerem, nihilque è plumbo non vftum hæferit. tum demum obftructis naribus eximito: alioquin halitus plumbi noxius fentitur. Aut elimatam plumbi fcobem in olla fulphure vrito. Alij laminas in factili crudo, vt dictum eft, imponunt fornaci, aut foco, \& circumlinentes operculum, dato exili fpiramento, vrunt . Alij pro fulphure ceruffam, aut hordeum infpargunt. Alij integras laminas imponentes, acri igne vtuntur, \& rudicula ferrea continuè mouent, dum in cinerem foluantur. Sed difficilis huiufmodi vftio, \& fi vehementius uratur, contrahit fpumx argenti colorem. Magiș tamen nobis placet prima vrendi ratio. Plumbum vitum lauatur vt cadmia, \& reconditur. Eofdem cffectus habet; quos plumbum elotum, fed multò acriores.

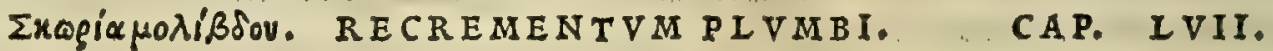

RE C R E M N T V M plumbi, quod fcoriam vocant, optimum eft, denfum, fractu contumax, ceruffam planè repræfentans, nihil plumbofi habens, quod adluteum colorem accedit, \& uitri fplendorem imitatur. Eadem, qux plumbum exuftum poteft, fed magis adftringit . Lauatur in mortarijs infura aqua, \& refufa fumma aqux parte, quæluteum colorem duxit; idq́ue fxpius, dum recrementum abfumatur. Dein vbi confederit craffamentum, aqua effufa, digeritur in paftillos.

\section{MOAIBSOESIS, MOLYBDOIDES, SIVE LAPIS PLVMBARIVS. CAP. IVIII.}

M O I Y B D O I D E S lapis à plumbi fimilitudine dictus, refpondentem recremento uim habet, 20 \& eodem modo lauatur.

Scorix plumbi confid.

Lapidis plum di barii confid.

Plumbi facul tates ex Gal.
P L V M B I abluendi, dt qं; etiam comburendi ratio, adeó lucidé constat à Diofcoride prodita, ut oper eprez tium non fit plura de ea referre. Veruntamen animaduertendum eft, plumbi recrementum, quod Diof coridi fcoria uocatur, non effe plumbaginem, que excrementi instar, ubi plumbum igne lique fcit, ab eo fecedit. Quippe quód hec nil aliud /it, quàm purißimum plumbum, quod ignis ustione, cineris peciem induit. Hac enim in plumbarijs officinis in purißimum plumbum facilé redigitur, quemadmodum or argenti puma. Plumbi itaq; foria fit tantim in fornaci= bus, ubi plumbilapis metallicus funditur. siquidem boc probe fufo, artifices plumbum, quod inde effluxit, in frabi= culam extra fornacein delabi finunt. vbi uero adbuc calens concreuit, aqua frigida perfunditur, quousque fcoriam exuat : que (ut Diofcorides inquit) den fa admodum est, or fractu contumax, colore in luteü uergente, er uitri plen 40 dorem pra fe ferens. Huius complures uidimus aceruos in Tridentino agro, ac etiam in comitdtu Tirolenfi, ubi in = numere metallorum fornaces, die noctú; ignibus aguntur, nanq; in ijs locis metallorum recrementa, extra officinas abijciunt, monticulos ex his fruentes. Quód $f i$ accidat metallicos lapides agré igne in fornace lique cere, $f$ corie bu iufce partem admifcent, quoniam buius adminiculo citius metalla ignibus cedunt. Reperi ego fepius plumbi, argens tíg; fcoriam adeo uerficoloribus line is interfectă, pellucidam'́; ut id uitri genus,quod uulgó Venetijs appellant smal to, omni ex parte referret. Quare oportet eos, quibus in animo eft, certam et exquifitam barum rerum cognitionem affequi, metallorum fodinas, e fornaces adire, nö autem e in pharmacopolijs iuserere, ubi omnia feré metallica me= dicamenta ßpuria, $\mathcal{O}$ adulterijs uitiata reperiuntur. Caterum qui Lapidem plumbarium, fiue molybdoidem hodie legitimé oftendat, habeo profectó neminem, ni forte foßilis quoddam cadinia genus demon]trent, quod plumbum colo re imitetur, qualis illa, quam uulgó uocant Margheßita diftagno: quanquam banc equidem molybdoidem effe non au= so fim affirmare, quod nullum latius Molybdoid is biftoriam friptis mandaffe compererim, quim ipfe fecerit Diofcori= des. qui tamen eius hiftoriam tam paucis perftrinxit, ut difficile admodum fit decernere, quinam lapis nobis legitimam molybdoidem reprafentet. Etfi fortaffe non aberrarent, qui dicerent, plumbi lapidem ignem in fornacibus non expertum, ueram effe molybdoidem. quippe quód bic colore,'er pondere plumbum maximé referat. De plumbo diffuse fatis differuit Galenus libro I X. fimplicium medicamentorum, ubi ita fcriptum reliquit. Plumbum facultatis eft refigeratoria. Siquidem non modó multam babet fubft antiam bumidam à frigore congelată ; fed ơ dëream, pal cam autem terream. Igitur quòd plurimum babet effentią bumide à frigore coacte, indicium tibiesto, quód ubi ad= motum est igni, celeriter fundatur, fluató;. Quód ueró or aërex fit particeps, hoc habeto fignum omnium, que nox uimux, unicum plumbum tum mole ip $\int a$, tum pondere augetur, fi condatur in adibus fubterraneis, dẻrem habentibus turbidum, ita ut quacung; illic ponantur, celeriter fitum colligant. Tum etiam plumbea ftatuarum uincula, quibus earum pedes annectuntur, se penumero creuiffe uifum est, er quedam adeó intumuiffe, ut ex lapidibus dependerent cryltalli 


\section{In Lib. quintum Diofcoridis. 663}

eryftatli modo. At tq, he probabiles quidem funt bumiditatis cius, frigiditatisq;, note, priusquàm cxperime ntum fiat: caterim fcientificx, or certe per experientiam cognofcuntur. Preparato igitur mortario, fimulg; piftillo, utrisq; explunbo, infunde quemlibet liquorem: itaq; terito, ut $\mathcal{O}$ piftillus, or plumbe um mortarium fuccum quendan red=

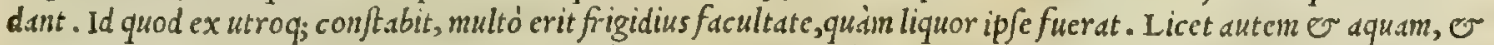
uimum tenue aquetum, or olcum inijcere, aut quiduis ciufmodi. At fi etiam plus efficcre fuccum uoles refrigeratoriü, olcum omplsacinum fit, aut rofaccum, aut mclinum, aut myrtinum. Porró $\int \mathrm{i}$ fucco, qui proueniet, uti uoles, optimum b. abebis remedium -0 ad phlegmonas in fede cum ulccre, aut rugis, or ad cas, qua in pudendis, tcftibus $\dot{q}_{;}$, Or uberi= bus confiftunt: fimiliter aduerfus ceteras omnes fluxioncs incipientes, que aut in inguina, aut in pedes, aut in alium quémuis articulum dccumbunt. Sed or ulceribus rebcllibus utile eft. Nam or ad cancrofa co utens, uirtutem medica.

- menti mirsbere. Quod fi celeriter multum plumbei fucci colligere noles, conare in fole terere, aut quocunq; certé modo ä̈re excalficto. Ad multa autem utilc habcbis medicamentum, fi adfufo rcfrigerantium fuccorum quopian te ras, cen fempcrwini, cotyicdonis, intybi, lactuce, chondrylla, $p$ fylli, ompbacis, portulace. Porró fiqua horum non facile in fuccum fo'uuntur, uclut portulaca, mifceto illis alorun fuccorum quempiam, uclut omphacis, qui er ip $\int e$ per $\int e$ e predicto mortario inditus, medicamentum efficit refrigeratorium longé pulcherrimum. Quin $\sigma^{\sigma}$ in $l_{a}=$ minam diductum plumbum absq; dito ullo, ip fum per fe fe athletarum fe fe exercitantium lumbis infternitur, ubi uene= reis fomnijs uexantur fcilicet: nimirum baud obf curé cos refrigerans. Sed er bractea cx plumbo tenuis facta, probé ganglio illigata, plané ipfum dißipat. Illig abit autem probé quisquis ab Hippocrate didicerit, in ip ain noxam potius firmandum, quàm binc ucl inde. Mirum ergo non eft, fi plumbum crematum, ac rur fus ablutum, re frigerantis efficis= tur facultatis, cim ante lotionem mift a fuerit. Et bec ipfin medic amen, nempe plumbum combuftum, bonum eft ad

20 ulcera rebellia. Vbi ueró lotum fuerit multó optimum medicamentum eft, er ad ulcerum impletionem, er.ad eadem cicatrice obducenda. Conuenit $\mathcal{O}$ chirone is que uocant ulceribus, or cancrofis omnibus, or putredinofis, tum ip=

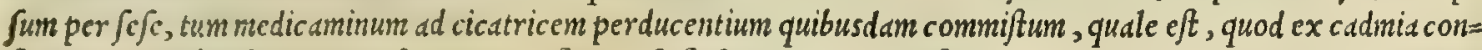
ficitur. Ceterim foluendum eff principio, /f copiofa fit $\int a n i e s, ~ q u o t i d i e:$ fin minus tertio, aut quarto quoq; die. Ve $=$ rim for is pongiam imponito aqux frigide, qux fi deficcetur, rurfum mergatur. Sed bec fufius, quàm pro inftituto diximus, plufculum fermonis affinitate prouecti. At tempus iam cft fequentia deinceps perfequi. bactenus Galenus.

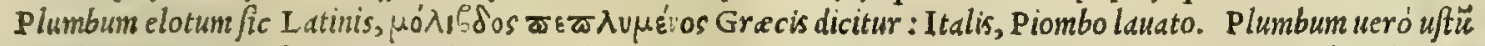

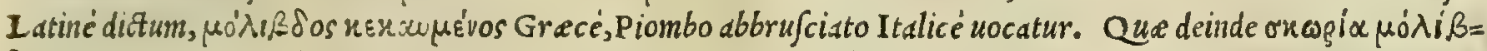
Sov Grecis, Latitis Plumbirecrementum, er plumbi fcoria appellatur : Italis, spiuma del piombo. Que denique 20

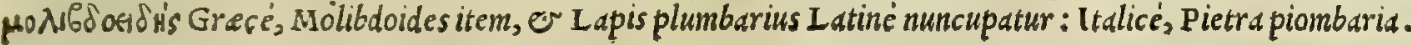

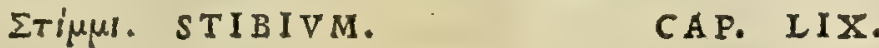

S T I. M M I optimum, quod fplendidifsimum eft, modoq́; nitedularum emicat,confractu crufto-

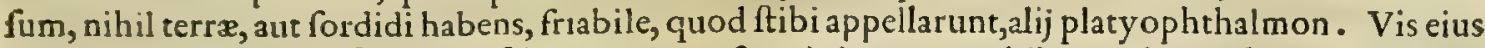
adfringere, meatus obftruere, refrigerare, excrefcentia in carne cohibere, vlcera ad cicatricem perducere, fordes, \& ulcera oculorum expurgare : fiftit \& fanguinem è cerebri membrana profluentem. $\&$ ut in uniuerfum dicatur, vis ufto plumbo fimilis eft. Priuatim, ambufta igni in puftulas erumpere non patitur, cum adipe recenti illitum . cruftofas exulcerationes ad cicatricem perducit, cum cera, $\$$ exigua ceruffa. Torretur pinlita farina circumlitum, \& carbonibus obrutum, donec carbuncule40 tur crufta, exempeumq́ue reftinguitur mulieris lacte, quæ marem peperit, aut uetere uino. Vritul etiam carbonibus fuccenfis efflatum, quoad igni deflagret: fi enim paulò magis concremetur, plumbum fit. Lauatur ut cadmia, \& 2 s. Sunt qui ut plumbi recrementum eluant.

S I I M M I, fiue Stibium, recentioribus medicis, chyshiftis, ac feplafiarijs, qui Mauritanorum doctrinam fe= Etantur, Antinonium dicitur, quód hoc nomine Serapio, or Auicenna stibium appellauerint. Huius fodine pluribus locis habentur in noftro senenfi agro, fed preftantißimum foditur in maritimis nostris Mafjano folo, ac Suanenfi: quineriam in comitatu fanct. $\mathrm{F}$ lore prope Syluendin oppidum. Venetids adfertur ex Germania, fornacibus prius fu= fum, $\sigma$ in maffas concretum. Aiunt artifices, qui campanas conflant, has edere fonitum magis concinnum, magisq́; auribus gratum, ac fonorum, $f i f t i b i j$ nonnibil cateris admifceatur metallis, dum und in fornace liquantur. I is etiam

so expetitur, qui uaja éftagno conficiunt: item ijs, qui metallica faciunt, er poliunt peculd: ijs preterea, qui chalco= graphis characteres, 0 typos effing unt. Id tantum differentice effe inter plumbum, or ftibium ait Brafauolus Fer= Brafauoli esrarienfis, quód plumbum ignium ui lique $\int$ cat, ftibium ueró nunquam, fed facilé teratur in puluerem. Sed eius opinio= ratum. nem falfam effe deprebendit experimentum . quandoquidem ftibium igni admotum, perinde ac plumbum colliquefcit, or fluit. Cuius rei nos $\int x$ pius periculum fecimis, dum ole um noftrum ex ftibio conficeremus, quo quidem magno fuc= ceffu utimur ad contumacia, finuo $a \dot{a} ;$, ulcera $\int$ ananda . ad id fiquidem ftibium pluries fundere oportet, ut fyncerius, puriusq́; reddatur. Ceterùm admonitos lettores nolumus, oleum hoc noftrum é ftibio paratü, non illud effc, quo chy= mifte argentum in aurun mutarı fabulantur, fed aliud ab eo longé diuer fum: tamet $f \hat{i}$ boc noftrum ex fe $\int e$ plus auri fundat, quàm illud chymiftarum. Sed ut ad inftitutum noftrum reuertamur, mibi plane uanum uidetur afferere ftióiu igne haudquaquam liquefcere. Nam cum quolibet metallo, fiue ferrum fit, fiue chalybs, in fictili fuforıo persniftum, ea celerius eliquand prebet materiam. Quam ob caufam qui ferreos, pbericosq́; globos bombardis inmittendos e fufo ferro conformant, nifi fibium ferro admifcerent, nunq̨uam fané (ut pro certo affirmant) id fiuxum facerent.

Stibij confideratio. 


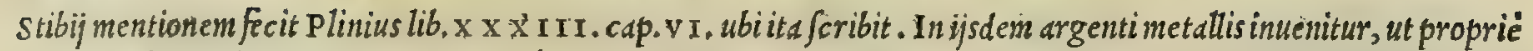
dicamus, fpume lapis candide, nitentisq́; , non tamen translucentis, fimmi appellant, alijfibium; alij alabaftrum, alij larbajon. Duo eius generd, mas, er foemina. inagis probant fominam. Horridior eft mas, fcabrior $q_{;}$, er mi= nus ponderofus, minusq;; radians, er arenofior. Famina contrà nitet, friabilis, fiffurisq́; non globis debifcens. ba= Stibii uires'ex clenus Plinius. Stibijuires retulit Galenus lib. I x. fimplicium medicamentorum, bis uerbis. Stimmi ad facultatem Galeno. deficcantem adiunctam habet boc medicamen :adfrictionem: quamobrem rocularibus medicinis commifcetur, er: illis filicet, que conformantur in collyria qua uocant; er ficcis, que utique ficca collyria cognominant. hec Gale=

Stibij uis de- nus. Catcrum ftibium uim deiectoriam fortutur praftantißimain: quanquam nullus (quod ego fciam) antiquorum, iectoria. neq; recentiorum, prater unum Theophraftum $\mathrm{P}$ aracelfum, boc literis memoriáq; mandauit. Quare non equiden grauabor in ftudio forum gratiam ea bic commemorare de buius medic amenti uiribus, que uidi, atg; ctian a medicis quibusdam fide dignis accepi. Etenim Andreas Gallus medicus Tridentinus, qui iandudum bonoratißimé medicinam facit Serenißimo Ferdinando Arcbiduci Auftrie, apud quem me nunc collegain babet, ex multis uigilïs magnisq́; la= boribus, quos infudia or feruitium infumper at, inciderat in malan ualetudinem, nempe in pulmonun, cordis, er uentriculi inflammationem : unde uebemens admodum fitis confequebatur, que nullo quidem potu extingul poterat. Preterea epiglottidis tumore, e tanta palatificcitate uexabatur, ut uix laqui poffet. Quinetiani cordis palpitatio= nem patiebatur adeó magnam, ut nocte repente expergefactus putaret per cubiculum aliquem obambulajfe. His de=

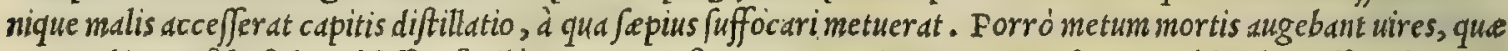

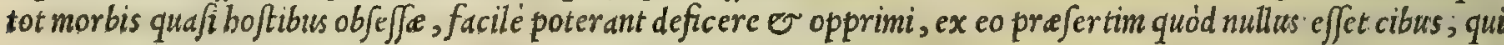
appetitum langue fentem excitaret, atq; ita uires inftauraret, uel faltem conferuaret. Addan quód os er guttur. cius $\int a p o r e m$ tetrum or carbonibus fimilem reddebant. que fané omnia dicte inflammationis erant indicium nonob= fcurum. Cum igitur res fua per aliquot dies ita fe baberet, at $q_{;}$in maximo uer faretur difcrimine, neq; ullum percipe ret leuamentum fuarum agritudinum ex multis medicinis factis, ad Stibium, quod Mauritani Antimonium uocant, me. nefciente, confugit: quoniam fape audiuerdt medicamentum boc fibi mirificé commendatum fuiffe d Georgio Hansd= fchio medico familiarifuo, qui illius experimentum fecerat in morbis difficillimis. Hac itaq; ratione ductus stibij in tenuißimum puluerem redacti, or rbodo acchari exiguo admifti, tria tantum grana fumpfit . atq; paruo póft tempo= ris patio fenfit medicamentum illud uentriaulifubuerfionem snoliri, ac leuem quendam calorem cxcitare. Nox eru= pit uomitus, quo folum quasdan cibi particulus reiecit, etff fuperiore die non conaffet. Hunc pauló póft alius fecutus eft uomitus fimilis : cui fucceßit bilis flaue reiectio ad unciarum feré quatuor pondus. Hac autem omnia euenerunt bore tantim dimidie patio. Ex quibus nimirum illud cepit iuuamenti, quód fatim omnis uentriculi labor fedatus eft. Ex eo ueró quód hora póft ter biliofa inferné excreuit, in quibus craffa quedam refidebant (bec fimul duarum libra $=3$ a rum pondus equare poterant) factum $\mathrm{e} f$, ut ab illa cordis palpitatione, capitis fluxione, or epiglottidis tumore fta= tim fit liberatus. qui preterea neq; fitim moleftam babuit, neq; cibifaftidium perpe ffus eft. Quamobrem is corporis falutem ip Sam; uitam in tot morbis deploratain, Deo primum, deinde buic medicdmento acceptam retulit. Alium quoq; stibij intus a fumpti effectum filentio non dißimulandum milhi narrauit idem Georgius $\mathrm{H}$ ansdfchius, cuius fupe gius memini. Is enim cum effet peftilentia correptus, ob id oj; maxima totius corporis imbecillitate affectus, cordis tre more, pirandi difficultate, capitis dolore, or finiftri inguinis abfceffu, circa noctis crepufculum stibij rhodofaccha= ro admifti triagrana fump/it . atq; poft bore dimidium uomitionibus reiecit magnam pituite, , bilisq́; tum flauce, tum porracee quantitatem, cum propero ddmodum fucceffu. Siquidem ex uomitu (fic ille dicebat), ftatim fublata eft fpi= randidifficultas, ac cordis tremor ceffauit. Vomitum deinde fubfecuta eft copiofa alui deicetio fine ulla egrotantis moleftia. poft quam reliqua peftis fymptomata pror fus euanuerunt, atque adeo breui is fuit integra fanitati reftitu $=4$. tus. Id quod etiam alijs contigife fcio, qui boc admirabili medic amento funt ufi. Praterea stibium opitulatur omni= bus in uniuerfum morbis, quos atra bilis excitauit, ijs'q; prefertim qui hypocbondriacam obtinent inflationem : equi= dem uidi Praga Bobemorum parocbum, qui melancholicus factus plané defipiebat, multág; ftulté loquébatur. Huic fane exbibitum fuit stibium granorum duodecim pondo: quod paùló póft copiosé atram bilem per aluum eduxit, cui erant admifta ( ut ego, qui uidi uocatus tanquàm ad miraculum, teftari poffum) ramenta ueluti carnis, que magnos uarices in particulas diffectos pre fe ferebant. nanque excrementa illa fanguinem nigerrimum reprefentabant po= tius, quàm ullum ex alijs bumoribus. Hoc utiq; illi tantam opem tulit, quód poftera die uifus eft belle priftinam mentis Jue fanitatem recuperaffe. Et quoniam is erat corpore robusto, or anino forti; ideo non eft mirum, fi facile er fine ullo incommodo tulerit tantam illius medicamenti quantitatem. quanquam audax nimis forté babendus eft ille, qui eă exbibuit. Datur etiam stibium utilißime diuturna febre confumptis, o ijs quifpirandi difficultate luborant, praci= so pue afthmaticis. Prodeft item conuulfis, comitialibus, ueternofis, refolutis, o ijs qui coli dolore cruciantitn. Cate=. rim funt qui aferunt Stibium fumptum non fecus bumana corpora ab omnibus excrementis cxpurgare, atque idem reliqua omnia metalla, infrumentáq; metallica, quibus adïcitur, ab ommi forde purificat. Atqui in cius exhibitione diligenter animaduertere oportet, ut illud quod exhibetur, fit praparatum. Hanc ob caufam nos bic cius parandi $r a=$ tionem fubijciemus. Eligito Stibium optimum, quod (ut Diofcorides tradit) Plendidißimum eft, modóq; nitedul arum emicat, confractu crustofum, friabile, nibil terre aut fordidi habens. Id primum in puluerem facito: deinde in fictile $u a s$, quod amplum fit, conijcito : tum demum carbonibus fuccenfis ad calcinandum (ut cbymiftarum ucrbo utar) fub dio exponito, atque interim cochleariferreo continué moueto. Hoc ueró dum fit, fumus exhalat tenuis, fulphur $\mathcal{O}^{-}$ auripigmentum redolens, quifi ore attrahatur, crebras interdum ( ut audio) excitat uomitiones, quapropter qui uer fant, uentis terga opponunt. Ver fare autem aßidué expedit: nam $f i$ pauliper ce $\iint e s, u e l$ comburitur stibium, uel li= quefit, atque iterum coalefcit in glebas. Vix tamen fieri poteft, etfiperpetwo uerfes, quin aliqua parua glebe cons crefcant: 


\section{In Lib. quintum Diofcoridis.}

crefcant . quas cun uideris, fublato ab igne fictili, quod concreuit, rur fus in pulucrem redigito, at q $_{\text {; }}$ ciden fictili in= pofitum carbonibus reddito, afsiduo $\dot{q}_{j}$ uer $\int a t o$. Id quod toties repetendun cft, quotics coalcfccntcs glebula poftula= uerint. Ita quoq; tandiu uerfare conuenit, quoad corpufculailla, qua emic ant, pplcndoren fuum anifcrint, uapor omnis cefaucrit, foctor obfoleucrit, er stibiun in calcen conuerfum fubalbicantis citeris colorem cötraxerit . per= fecti autem operis fignum crit, /i prunis ardentibus inpergatur, nibil', pror fus funi cmittat. Poft bac fumito buiu= fce calcis, exempli gratia, libram mediam: ftbij crudi, boc eft, non calcinati, unciam : chryfocolle factitie, fenun=

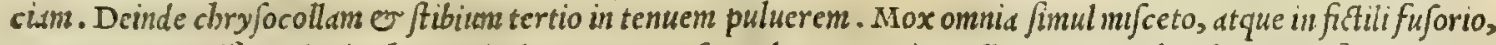
quo utuntur aurifices, igni uebcmenti admoucto: uas fuper laterem prius collocatum, carbonibus accenfis circunda= to. Veruntamen oper epretium eft in hac magnam adbibere diligentiam, ne res ille comburantur. Quocirca babcn=

20 da eft rudicula ferrea, or cim uas fictile candefcit, ea immifja, an stibium liquefiat, periculum facicndum cft. nam fi rudicule aliquid hef crit, ectum liquefactionis erit indicium. Hoc cum uideris, ftatim à rude tllud quod befit, abra= dito. Id dutem prixion cffe jalet coloris pallidi. Sed pauló póft eodem experimento utendum cft, id'q; repetendum, $\$ \int q_{;}$dum illius, quod abraditur, color appareat flauus, wiuidior ac pellucens. Qua re perpecta nulla eft trabenda mo ra, fed ftatim uafe ab igne excmpto cum forcipe igniario, res liquefact e funt fuper lapidem por phyreum ucl marmo= reum guttatim proijcienda . quamprimim cnim concrefcent in lapillos, qui colore $\sigma$ nitore chryfopatios, atg; etiam nonnunquan granatos referunt. Hos autem repones in ufum, or cum ijs uti uolueris, in pulueré redigito, dato $q_{\text {; }}$ triä ucl quatuor grancrum pond ere : id tamen pondus in robustioribus nonnibil augeri potcft. Stibium ita preparatü com modifimé admifcetur rhodofaccharo, cui etiä mastiches modicum adijcitur. Atq; bactenus de stibij non uulgari ef= facacia ac preparatione q que equidenn omnia (ut ingenué fatear) in primis debeo Andrea Gallo uiro clarißımo, cu=

so ius fupra mentionem feci. Stibium quod Latinis, si'uul Gracis uocatur: Arabibus, Aitmad, feu Atimad: Italis,

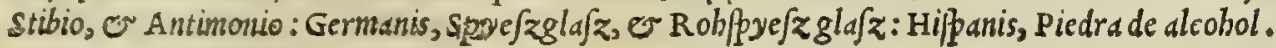

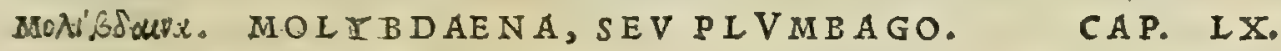

MOLY B D AENA optima eft flau, argente $x$ pumææxula, modicè fplendens, cùm teritur rufa,co eta cum oleo iecinoris colorem trahit. Vıtiofa eft, quæaèrem, aut colorem plumbeum refert. Gigni tur ex auro, \& argento. Eft etiam quædam folsilis, ad Sebaftiam, \& Corycum inuenta. Q iro in genere probatur, qux lapidofa non fie, aut recrementofa, fed nitens, \& flaua. Vim habet fpumæ argenti, aut recremento plumbi fimiler 1. Vritur, lauaturq́ue eodem modo. Mifcetur conuenientifsimè me30 dicamentis, qux liparas vocant, atque emplaftris minimè mordentibus. Carnem recreat, \& ulcera ad cicatricem perducit : glutinant, ibus tamen medicamentis, aut abftergentibus non conuenit.

M O I Y в D A N A, ut Diof corides testatum rèliquit, factitia eft, o foßilis. Factitia fit in fornacibus, ubi auri, o argenti met allum funditur - quandoquidem ubi auri, uel argenti uena, fiue materia, plumbi tantum fibi admi= Aum non babet, quantun ad eius liquationem moliendä fatis effet, qui operi prefunt, aut lapidem, à quo plunbum eli citur, aut plumbum ipfun fuperaddicnt: quod tamen ignium ui partim eum admifis nzetallis coit, partim uerò argen= ti fpune modo fornacisfolio coharet, o in molybdenam uertitur. Hoc itaque cum probé nouifet Plinius, libro X XXIIII.cap.X V I. de hac Molybdena defferuit ijs uerbis. Plumbi nigri origo duplex eft: aut enim é fua proue= nit uena, nec quicquam aliud ex fe parit : aut cum argento nafcitur, mift iśg; uenis conflatur. Eius, qui primus fluit

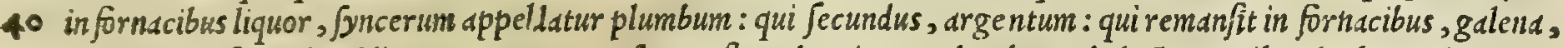
que portio eft tertidaddita uene. Hec rurfus conflata dat nigrum plumbum, deduct is partibus duabus. Idem pres= bet argenti $\beta$ pura, que Grecis lithargyros dicitur. hactenus Plinius. quantobrem facilé afferere aufim, nil aliud ef $=$ fe Molybdenam, quam lithargirij fpeciem, que poftquim é fornace fluxere metalla, in ipfius forndcis fundo concre= ta, peruftáq; refidet. Proinde non ab re dixiffe uidetur Galenus, quód Molybdena ijfdem polleat uiribis, quibus e argenti fpuma. Que autem in terre uifccribus foßilis nafcttur, nil aliud fané fuerit, meo iudicio, quàm metallicus ille lapis, qui plumbum, $\sigma$ argentum fimul continet. Hunc equidé teftari poffum uaria fe facie oftendi : quippe quód alius fit colore luteo, alius cinereo, alius caruleo, alius ueró f́ cintillans cernatur, atque nitorem prese ferens, pro uarijs, ac diuer fis terre uaporibus, qui in metallicos lapides feruntur. Quod autem eiufmodi fit Molybdana fößitia, teftis eft Plinius lib. X x X I I I 1. cap. X V I I 1. ubificinquit. Eft so plumbi, or argenti uena comnzunis. Et libro X X X I I I. cap.v I. ita fcribit. Argenti metallum terra eft, alia rufa, alia cinerea. Excoqui non poteft, nifi cum plumbo nigro, aut cum uena plumbi, quam galenam uocant. bec Pli= nius. Ceterum palìm eft, molybdanam factitiam nihil à lithargyro differre. Hoc non latuife Galenum, eius uer= ba declar ant libro I X. fimplicium medicamentorum, dum ait. Molybdana fimilem lithargyro uim poßidet, tantum à media temperie ad frigidum paululum quid recedens. Sed nec abftergentis facultatis eft particeps. Vtraque autem hec medicamina liquari pofunt : ac non ut lapides, o cadmia, or arena liquationem re $\beta$ uunt, fed celerriné liquan= tur, ubi oleo additun nonnbil aceti eft : liquantur tamen etiam admista aqua, fed diutisina coctione. Porró ceu in Cypro cadmiam, que in montibus, o riuis nafcitur accipteban, que e ipfa lapidis, ut dixi, pecies est; ad etundem modum molybdenam multsm, cum alijs proiectam lapidibus conpexi in uia, qua ad Ergafteria ducit à Pergamo. vocatur at!temi Ergafteria pagus quidam, in quo or metalla funt inter Cyzicum, o Pergamum quadringentis, o

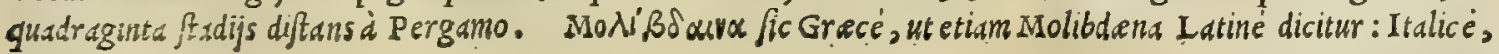
Piombaggine.

Molybdene confider.

\section{Molybdænx} uires ex Gal.

$$
\text { KK } 3 \text { Ágyugou }
$$




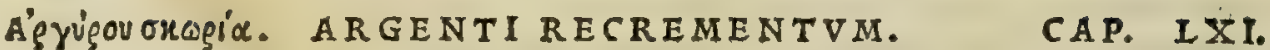

REC RE M E T V M argenti, quod fcoriam vocant, aut helcyfma, aut encauma, molybdæna vim habet. quare em plaftris, quas phæas appellant, additur, ac medicamentis, quæ cicatricem obducunt, vtpote cùm adftringat, extrahatq́ue.

Argenti feo- C O M P L V R E argentifcorice acerui, quam uulgó Loppa uocant artifices, extra fornacum domos wifune rix confid.

tur in agro Tridentino prope Perzenum, e L Luifum, o in comitatu Tirolenfi, ubi perpetuó argenti metallum in fornacibus uritur, ut in precedentibus diximus de plumbifcoria differentes. Facie bac uitrum, quod Veneti ab indi= tis quibusdam uulgó Smalto dicunt, adeó refert, ut perdifficile fit alterum ab altera dignofcere. Varijs bac colori= 10 bus conpicitur, pro admiftorum (ut opinor) foßjilium uarietate. nigricat tamen cum plurimum, $\odot$ quibufdam exar $a=$ tur lineis cùm ceruleis, tum etiam uiridibus. Nec deest etiam que uiridi tantüm, o que folim caruleo fectetur co=

Vires ex Gal. lore. Huic uires reddidit Galenus lib. Ix. Fimplicium medicamentorum, his uerbir. Argenti fcoriam proprié bele Nomina cyfmam appellant. Emplaftris quibufdam reficcatoria facultatis commifcetur. Quod Latinis Argenti recremene tum, Grecis ágyujov orogi a uocatur: Italis, Scoria dell'argento.

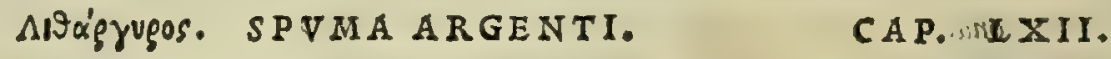

S P V M A argenti quxdam gignitur ex arena, quam molybditin uocant, in fornacibus conflata,do nec perfectè igni incandefcat : altera ex argento : tertia ex plumbo. Probatifsima eft Attica : fecunda 20 Hifpanienfis : has fequitur, quæ fit Dicæarchiæ, id eft Puteolis, Bajjs, in Campania, \& Sicilıa . plurima enim hifce locis è flagrantibus laminis plumbeis gignitur. Qux flauo colore fplendet, chryfitis appellatur, omnium optima : quæ in Sicilia, argyritis : quæ ex argento, cảlábritis. Vis autem adftrin gere, mollire, explere caua, excrefcentia in carne reprimere, ad cicatricem ducere, refrigerare, \&c occludere. Vritur argenti fpuma, confractis partibus ad magnitudinem iuglandium prun $x$ fuperpofitis : ita accenfa follibus, ut conflagret, abftergitur infidens fpurcitia, \& reconditur. Aliqui ter aceto, aut vino reftinguentes, rurfus vrunt, \& eadem profecuti, reponunt. Lauatur vt cadmia. Vt argyritidi nominatæ, aut, fi defideretur, alteri candor detur, ea in partes magnitudine fabarum confracta, chœnicis Atticæ menfura, fictili nouo fuperfufa aqua, addito candidi tritici pari pondere, priuatimq́ue pugillo hordei, linteolo puro, raro, anfulis valis alligato, coquitur, donec hordeum fraetum diffiliat. deinde omnia in nouum craterem oris ampli transfunduntur : triticum abijcitur, fpuma argéti vehementer manibus affricando, infufa aqua lauatur, afsiccataq́ue in Thcbaico mortario teritur, affufa feruente aqua, donec foluta fatifcat. Excolata aqua, iterum tota die teritur, \& vefperi infufa calida aqua finitur: mane colis excernitur, alia infunditur, atque ter die excolatur. Id feptem diebus fieri folct: poltea additis ad fingulas minas fpumx argenti, quinis falis fofsilıs drachm is, infufaq́ue calida aqua, ter die teritur, \& addita aqua excolatur : cùmq́ue inalbuerit, calida infufa, idem facito, dum nullam prorfus falfedinem refipiat demum ardentifsimo fole ficcata, eiecto prius humore reconditur. Sin minus mina fpum argyritidis diligenter teritur, addito fale forsilitrito, triplicato pondere, in fictile nouum conijcitur, aqua infunditur, ita vt fuperemineat: mouctur quotidie mane \& vefperi, aquaque fuperinfunditur, priore nequaquam effufa. hoc fit triginta diebus : nanque nifi moueatur, 40 craffefcit ufque ad duritiem teftæ. Poft hæc effufa leniter muria, in Thebaico mortario fpuma argenti teritur, coniectaque in fictile aquam continens, manibus diligenter agitatur, mutata fubinde aqua, donec nullum falfuginis indicium præbeat . deinde quod ex argenti fpuma candidum apparet, in vas aliud transfertur, \& redactum in paftillos, plumbea pyxide conditur. Alij fpumam argenti in fabarum magnitudines confractam, in ventre fuillo crudo ex aqua co quunt, dum vifcus eliquefcens contabefcat, exemptamq́ue cum fale pari terunt, \& ve fuprà dictum eft lauant. Sunt qui falis libram vnâ, \& fpumæ argenti tantundem, in fole terant, aqua continuè mutata, dum candor ei detur. Alia ratio. Sumito quantam vis argenti f pumam : vbi lana candida inuolueris, fietili nouo indita aqua, cum pugillo fabarum recentium, repurgatarumq́ue decoquito: cùmq́ue fabæ difruptæ dehifcent, lanaque non denigretur, exemptam argenti fpumam, \& altera lana inuolutam, iterum coquito, cyathum a- sa quæ, \& parem fabarum modum adijciens . eadem tertio, qux fuprà, facito $:$ in fumma tantifper, dum lana iam non inficiatur. Infuper transfundens in mortarium, ad fingulas falis forsitij libras, adijcito octogenas fpumx argenti drachmas Atticas, \& terito : intermittensq́ue nitri quàm albifsimi cum aqua diluti drachmas quadraginta feptem indito : iterum terito, donec fatis candoris contraxiffe videatur. Ita autem fundens eam ex al to in fictile oris ampli, adiecta largiore aqua, vbi confidere defierit, colato : tum nouam fuperadijciens aquam, manibus probè verfatam, finito ut confidat, ac rurfus per colum traijcito. Alternis eadem profequere, dum pura aqua, dulcisq́ue eftuat, \& nullam falfedinem præ fe ferat. Poftremò in fictile nouum translatam, colato fenfim omni humore, foli quadraginta diebus fub Caniculæ fydus exponito, \& ficeata vtitor. Elotam autem cóftat ad oculorum colly ria prodeffe, \& ad cicatricum foditates tollendas, ad rugofas facies, \& cicatricofas, laceratasq́ue, \& macularum plenas. 


\section{InLib. quintum Diofcoridis.}

F I T P L E R V N QV E Argentifpuma, quam Grecilitargyrum uocant, ea inquam, cuius hodie apud $\int e=$ Spumxargěti plafiarios eft ufus, iu metallorum fornacibus, ubi repurgatur argentum, i plumbo argenti rccrementis .tdmifo. Si= confideratio. quidem cum artifices argenti maffam à fua uella defluxam à commiftis metallis, nempe plumbo, ercá; repurgare no= Iunt, in alneum é cincre fuo more paratum, plumbi multum conijciunt, adcó ut ui fubditi ignis colliquatum, balnei ppeciem referat. In boc demun argentum repurgandum immittunt, quod plerunque (ut diximus) aut plumbum, aut as habet admiftum. Dum autem hec perficiuntur, uifitur plumbum in lique fentium metallorum fuperficie, ignium uifolliumflatu continué excitat, , olci modo fupernatans. quod tandem poftquàn es, aut plumbum, quod prius ar= gento fuerat admiltum, in fe contraxit, corundem follium flatu ad cinerci aliv oras pedetentim cxpellitur. Hoc cum uident artifices, alueun in lutus fecunt, labig; finunt in bumum: fit ; boc modo lithargyrus, coctionis diuturnitate,

to metallorum aliorum miftone, caforma concepta. Huic, poftquam refrixit, quandoque aureus, qualdoque ars genteus emicat fplendor, Quo factum eft, ut hune argenteum, illum aureum paßim feplafisrijs ac medic is dicatur, $0=$ mnino exiftimantes, alterum ex auro, alterum ex argento conflari. Ceterim coloris buiufce uarictatem lithargy= rus baudquaqualm ex auri, uel argenti puma contrabit, fed quód plus, minusue arei uaporis ab argento detracti, in $=$ tra fe receperit. siquidem ( ut ego plurics experientia comperi, or ipfi quoq; teftantur artifices) argentun depu= randum fi plurimum fului sris contineat, buius or plumbi miftione, lithargyrus aureus red ditur: in minus, argen= teus efficitur. Quare nobis affimare licebit, nil aliud effe litbargyrum, quain plumbum aris uel argenti uaporibus commiftum. Non itaq; temere prodidit Diofcorides fieri argenti ßpumam aut ex arena, quam molybditin uocant, aut ex argento, aut explumbo. Cui ubfcribut Plinius libro x $\mathrm{x}$ x. cap. v I: Meminit argentifpume Galenus libro I x. Lithargyri ui fimplicium medicamentorum, fic de cius uiribus foribens. Lithargyrus deficcat quidem, welut alia omnia metallica; res ex Gal.

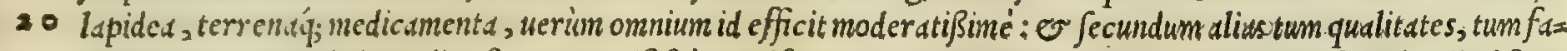
cultates, qrodămodo in medio eft, neq; manifefté excalfaciens, ne q; re frigerans s modica tamen adfringendi, abfter: gendiq; facuitas ei inest. quamobrem infrior eft $Q$ Jarcoticis medicamentis, que mediocriter extergentia ostendi= mus, of contrahentibus, atq; adftringentibus. Cełerum ad intertrigines femorum utilis medela eft: quandoquidem utriusq, ian diff f facultatis leuiter eft particeps. I ure itaque medij ordimis in metallicis babebitur?: Proinde ea fre= quenter utimur cek materia ijs mifcentes, qu\& udentem facultatem obtinent sifue mordicantem; fiue adftringétem, uel aliud quippiam efficientem, ficut in lique centibus ad pleraque-medicamenta ceram adbibemus tanquam materiä,

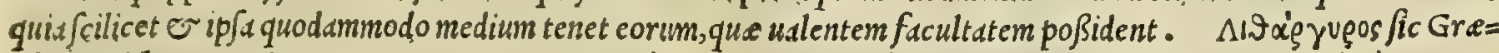
cé, ut Lithargyrus item er Spuma argenti Latiné dicitur: Arabicé, Martech; fine Merdafengi: Ibalicé, Spuma 30 d'argento: Germanicé, Glett: Hifpanicé, Almartaga, Litargirio, er Yezes de oro.

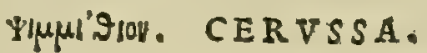

\section{CAP. IXIIT.}

CER VSS A fit hoc modo. infuro in urccum oris lati, aut fetile labellum quàm acerrimo acëto, laminam plumbeam fupra fictilis fpiraculum, fubiecta prius arundinea tegete, firmato: fuperiectisq́ue velaminibus, ne halitum expiret acetum, vbi refoluta fuerit, defluensq́ue deciderit, humorem purum ad fumma delatum colato, craffamentumq́ue transfundito debet quoque ficcari in fole, mox trufatili mola teri, aut aliâs tritum cribrari. poftea quod fupereft duri, in tenues partes redigendum, cribrandumáue. vicifsim eadem tertio, quartoq́ue facienda. Melior, qux primò cribrata eft, \& medicamentis oculorum affumenda. Secundum locum tenet fequens, \& reliquæ fuo or-

$4^{\circ}$ dine. Nec defunt, qui ligneas rudes in medio vafe appendant: $\&$ derafo ceu fitu impófito, ita vt acetum non contingat, inditoq́ue operculo circumlinentes dimittunt. Poft dies decem laxato obturamento vifunt: cùmq́ue refoluta materia fuerit; reliqua, vt fuprà diximus, exequuntur. . Si autem quis in paftillos velit digerere, aceto acri fubacta, diuiditur in paftillos, qui in fole ficcaritur : Aeftate tamen fuprà dictum opus obeundum eft : ita enim candida, atque efficax redditur. Quinetiam hyeme paratur, urceis fupra furnos, balnea, aut fornaces impofitis : afcendens enim calor idem, quod fol præftat. Laudatifsimam fierı putant Rhodi, \& Corinthi, aut Lacedæmone: proximam Puteolis . Torretur hoc modo. Flagrantibus igni carbonibus, fictili nouo, maximè Attico, tritam ceruffam imponito, \& afsiduè verfato: cùmq́ue cinereum colorem traxit, eximens refrigerato; \& vtitor. Eft $\&$ aliud vrendi genus. Trita patinis nouis fupra prunas imponitur, \& ferulacea rude mouetur, doso nec colore fimilis fandarachæ frat, extractaque ad vfus minifratur. Quæ verò ita paratx elt, Sandyx à quibufdam dicitur. Lauatur ceruffa cadmix modo. Vis ei refrigerare, occludere, emollire, explere, extenuareque: infuper excrefcentia leniter reprimere, \& ad cicatricem perducere. Mifcetur ceratis, \& emplaftris, quæ liparæ vocantur, paftillisq́ue. Elt autem lethalis eius potus.

C ER V S A medicamentum eft omnibus notum. Fattitia tamen res eft. Venetijs plurima conficitur, ficutior in alijs compluribus Italielocis:quód non folum in medicamentor um ufus expetatur feplafiarijs, ac medicis; fed etiam pictoribus, qui ea frequentißımé in fuis operibus utuntur. Paratur ex cerufa (ut Diofcorides inquit) Sandyx, quod officinse Serapionem fecute miniun appellant, non autem Sandaracha; auripigmentigenus, ut libro de compo: fitione medic amentorum exiftimat Fuchfius. Siquidem sandaracha, ut fuo loco dicetur, fo ßilis res eft, non autem fa= ctitia. CerufJe meminit Galenus libro I $\mathrm{x}$. de fimplicium nedicamentorum facultatibus, ita fcribens. P/immythiü, id eft ceruffa, er boc medicamen teftimonium prabet modó dicte facultati. Nam fi ex acri ace to foluatur, guftu td=

Cerufle, \& fandycis cofideratio.

\section{Ceruffevires ex Gal.}




\section{And.Matthioli Comm.}

men neque aere erit, neque mordax, neque difcufforium, fed emplaficum, er refrigeratorium : facultatis arugini

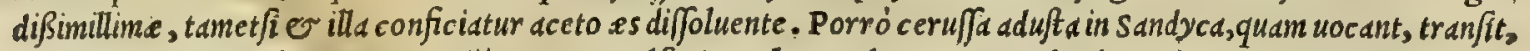
medicamentum feipfo tenuius, nondü tamen excalfaciens. bec Galenus. Ex quibus liquidó patet, Sandycem, e $\int a n=$ daracham maxime inter fe facultatibus pugnare . bec nanque Galeni, $\mathcal{O}$ Diofcoridis teftimonio ar fenici modo cars nem exurit, o cruftas fua uehementi uredine, ac caliditate, mor fuq; uiolento excitat : illa ueró nulla fui parte ex= calfacit, fed potius refrigerat. Id quod in uulgari officinarü minio facilé deprebenditur. Sandycis meminiffe uidetur Vergilius in Bucolicis, dum bis uerfibus cecinit .

Ipfe fed in pratis aries iam fuaue rubenti

Murice, iam croceo mutabit uellera luto.

Sponte fua Sandyx pafcentes ueftiet agnos.

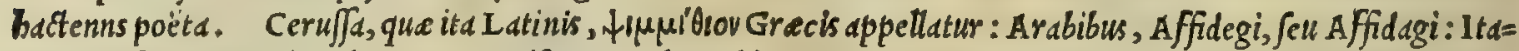

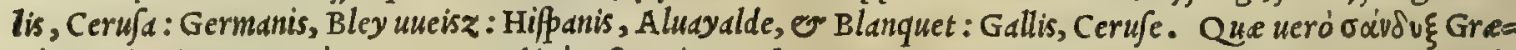

Nomina. cié, sandyx item Lattné uocatur : Arabice Afrengi, Sarchon, sandicon, sandax, syrengi, fiue serengi: Italice, Sandice: Vulgus, Minio.

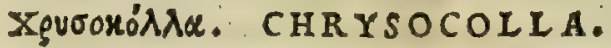

\section{CAP. LXIIII.}

C H R Y S O C O L L A laudatifsima Armeniaca, colorem porri quàm fímillimè reddếs. Secundú locum fibi vendicat Macedonica: \& proximum Cypria . quo in genere præfertur pura: damnatur, quæ terram, aut calculos collegerit. Ratio lauandi hæc eft. Tufam infufa aqua, mortario expaffa 20 manu ad pilam vehementer fricato, \& ftatim quàm confederit, colato. Alteram infundens aquam, rurfum terito. hæe vicifsim profequere, donec pura, fynceraq́ue fpectetur. dein ficcato in fole, \& ad vfus recondito. Luòd ii vrere uolueris, ex ea terens quod fatis effe videbitur, patinis fupra carbones adponito : \& alia fácito, qux fuprà diximus. Dos chry focollæ ad purgandas cicatrices : excrefcêtem carnem coercet, adfl ringit; purgat, excalfacit, \& modicè cospus mordendo exeft. Inter medicamenta intelligitur, quæ vomitiones concitant, \& necem inferre poffunt.

Chry focolle C hiltoria. per uenam auri defluens, craffefcente limo rigoribus bybernis, ufque in duritiam pumicis. L audatiorem eandem in ararijs metallis, e proximam in argentarijs fieri compertum eft. Inuenitur $\sigma$ in plumbarijs, uilior etiam auraria . 30 In omnibus autem ijs metallis fit er cura, multum infra naturalem illam, immi|3is in uenam aquis leuiter byeme tota, ufque in Iunium menfem. Dein ficcatis in Iunio, 0 Iulio : ut plane intelligatur nil aliud chryfocolla, quàm uena pus tris. Natiua duritia maximé diftat, lutedm uocant. o tamen illa quoque berba, quam luteam uocant, tingitur. Na= tura eft, que lino lanaúe ad fuccum bibendum. Tunditur in pila, deinde tenui cribro fecernitur, poftea molitur, ac deinde tenuius fic cribratur. Quicquid non tran $\int m e a t$, reperitur in pila, dein molitur. Puluis femper in catinos di= geritur, of ex aceto maceratur, ut omnis duritia foluatur. Ac rur fus tunditur, deinlauatur in conchis, ficcatur $q^{\prime}$. Hactenus de chryfocolla Plinius. Ceterim feplafiarij, quemadmodum aurifices, Chryfocollam unlgó Borrace uo= cant, Maurttanos fecuti : cumt tamen pauca admodum in officinis reperiatur, qua fyncerißima dici poßit, er que co= Iore fit uiridi, porraceo ó;, ut Diofeorides inquit, of preft antißima expofcit. Siquidem subnigricat bec, nec ulla ex parte uirefcit. Que faturato colore uiret (ut mea fert opinio) in a rarijs tantim metallis foditur: que nigricat, in 40 plumbeis: que albicat, in argenteis : er que pallefcit, in aureis. Vnde mulifacilé perfuafum eft, Chryfocollam fibi uarium colorem uendicare, pro metallorum, in quibus foditur, tatione. Porró factitic ex alumine rupeo, fale ni= tro, ac etiam alijs quibufdam admiftis, copia non deficit. Idcirco aurifices, qui ea ad aurum ferruminandum frequen= tißime utuntur, ip $\int a m$ magna quidem diligentia $\int e$ ligunt. quanquamer ipfi plerunque decipiantur : tanta in omnibus eft impoftorum aftutia. Preferunt auro ferruminando illam, que lutea eft: tametfi in medicamentorum ufu, pres: ftantior fit uiridis. Fit etiámnum chryfocolla (ut Diofcarides prodidit libro fecundo in urine mentione) ex puero= Chryfocollse rum urina in areo mortario, piftillo item areo fubcalenti fole tandiu ducta, ut unguenti modo craffe fcat. Q Quod pas. urres ex Gal, riter literis memoriég; mandauit Galenus libro $1 \mathrm{x}$. fimplicium medicamentorum, fic inquiens. Chryfocolla, . O boc medicamentum ex ijs eft, que carnem liquant, non tamen ualenter mordicat, quanquam fit facultate admodum dige: rente, de ficcantég; . I gitur quidam id modó, quod in metallis inuenitur, ita nominant : alij ueró id, quòd in areo mor $=50$ tario, piftillog; areo, ex pueri urina preparatur : id quod quidam inter aruginum differentias numerant. satius ues ró eft ip sum preparare tempore aftiuo, aut certé aëre prorfum calido, urinam in mortario terentes. Praftat aus tem as, ex quo mortarium piftillum'́; conficias, rubrum fit. Nam quo as tenerius fuerit, eó plus circumagendo pis ftillo deteritur. Hoc medic amentum aptißimum eft ulceribus contumacibus, tum per fe, tum alijs miftum, ut in opere de componendis medicamentis referetur. Nunc autem id nouife fat eft, quòd quantó plus quàm Chry focolla met allis ca deficcat, minus'́; mordicat, tantó etiam ipfam excellit tenuitate. I f fan tamen Cbryfocollam illam fi uras, muls

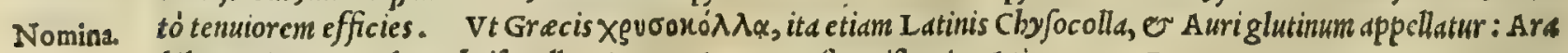
bibus, Tincar: Italis, Chrifocolla: Germanis, Borraßs: Hifpanis, Atincar, $\sim$ Borrax. 


\section{In Lib. quintum Diofcoridis.}

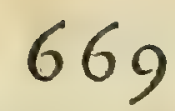

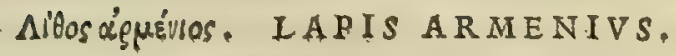

CAP. LXV.

A R M E N I S lapis præfertur læuis, colore ccruleo, perquàm æquabilis, calculo carens, \& friabilis. Eadem, qux chryfocolla præltat, fed inefricacius. Quinetiam vlum habet ad pilos in palpebris alendos.

A R M E N I A, ut lib. x X x v.cap. v r. teftatum reliquit plinius, lapidem mittit, qui eius nomine appellatur. Lapis est bic quoque cbryfocolle modo infectus : optinum q́; $\mathrm{eft}$, quód maximé uiride eft, communicato colore cum 10 carulco. Plinio Jubfcribit Auicenna, fic inquiens. In lapide Armeno eft aliquantulum azuli coloris, non tamen eft in colore azuli, or non eft in eius foliditate, fed eft in eo drenofit as quedam: ON quandoque utuntur co pictores loco azuli, 0 est lenis tactus. Ex horum /ané uerbis perppicutun fit, lapiden Armenium colore effe uir idi, ad ceruleum inclinante. Talis autem effe compcritur, qui in argentifodinis, in compluribus Germania locis foditur : ov é quo co= loren illum ad pictorium ufum parant, quem uulgò uocant uerde azzurro, ac fi diceres uiride cxfium, uel uiride cox= ruleum. Nanque is colore chryjocollam refert, fed duritie precellit. Qu amobrě crediderin ego, cos non longé ab= effe à ueritate, qui dicerent, Germanicum bunc lapidem illi congenerem effe, quent Armenia mittit. fiquidem patriü A rmenij nome ng genus non immutat . neque etiam obftat, quin er in alijs regionibus, lapis bic gigni poßit. Quippe Phrygius lapis is Phrygia regione difus, optimus in Cappadocia foditur, ut Diofcorides ef author. Id quod facile o= ftendit, Armenium preter Armeniam, alias quoque regiones gignere poffe. Necrefert, quód fcripferit Mandrdus

20 Ferrarien/is libro I I I. epiftola I I 1 . Armenium lapidem bodie non facile inneniri poffe. Qu andoquidem cùn certó fciam, mulcs in officinis feré omnibus dec fe medicdmenta, dóg, prefertim, que ex metallorum fodinis expetuntur, que tamen fua nat ali folo, ubi proueniunt, copiofareperiuntur, mirum certé non fuerit, fi Armentio etiam lapide careant

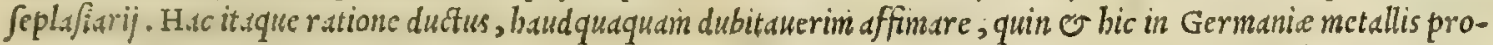
ueniens, in Armenij lapidis genere legitime recenferi queat . quemadmodum in Gagatis, Phrygï, A Bijq;: genere nobis recipiuntu", qui alibi, quàm in Gaga flutio, in Pbrygid, 0 Affo inueniuntur . prefertim cüm notis omnibus ac niri= bus Arnenio per omnis fimilis hic habeatur. Notis quidem, quód fummé uireat, oo ad cafsum colorem proximé ac= cedat. Viribus autem, quód ( ut equidem teftari poffun ) atra bile uexatis maxiné conferat, ijs nomitum, or aluun ciens. Porró feplafí.e (ut omnibus conftat) non modó mult is deftituuntur fo Bitijs medicamentis, fed continue alte: rum alterius loco fupponunt : nempe cadmiam pompholyg is loco, podij uice complura antifpodia, o pro flore aris

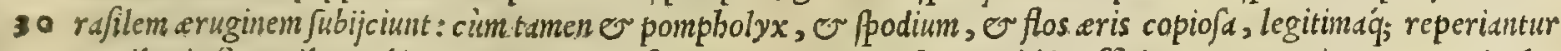
omnibus in fornacibus, ubi argentum, or es funduntur. Nam ex boc, quód in officinis non reperiatur A rmenius $l d=$ pis, quemadmodum alia complurd, baudquađquan colligere licet, quod hec omnia fuis in fodinis förnacibusq́; non ha= beantur. Preftat mirum in modun Armenius lapis (et/id Galeno, Paulo, alijsq;; ue teribus incognitum exiftimetur) ad atram bilem deijciendam, ut teftis eft Alexander Trallianus clarißimus author, libro primo capite de melancholia, wbific inquit. Quid/îbiera data melancholix inaginationes nibilominus infeftare videantur, tunc fine ulla cuncta= tione lapidem Armeniacum dare ffftinato. Noui enim cx ueteribus antiquiores ad ueratrum album properaffe, ubi affectum ab alijs purgationibus nihil pené imminui conppicerent. Verüm ego lapidem Armeniacum ueratro albo pree fero, atq; licet utentem ipfo experientia cognofcere, quomodo preterquàm efficaciter, etiam fine moleftia, er peri= culo purget . quorum nibil album ueratrum habere nouimus. Si igitur res poftulat, non modó infrià per aluum, $f e d e=$

40 tiam per womitum purgationem fieri, lapidem illotum exhibere conuenit. Sit autem modus ipfius fcrupuli tres, dut quatuor, aut pauló amplius, minusue, pro uirium fimul, o copia bumoris noxij ratione. At fi ager purgatione per uomitum non admodum indigere uideatur, , Sed per imum uentrem totum uitiofum bumorem exire conducat, tunc ld= pidem eluere oportet usque ad duadenas (uetus legit quinquagenas) uices. vbi enim fic fecerimus, ineque turbatio= nem ftomachi, aut compreßronem lapis excitare poteft, fed etiam minori cum moleftia nigrum terreftrem uccuabit, ut paucis preteritis dicbus adiumentum ex co nobis acceßiffe percipiamus. Dato autem ex eo $f$ crupulos quinque, aut $\int e x$, ut uliurinum ex aqua tepida, femper ex cognatis dictis coniectura deprehendens an plus, minisue exhibere debeas. Quod fi egrum etiam bis adbuc requirere fuppiceris, cum fiducia rurfus exbibeto . neque enim $c d=$ lorem babet, aut ficcantem admodum, aut aliam quampiam ip/s infidentem, amaram, or uenenafam qualitatem, ut ager ideo medicamentum bibere detrectet. Sin autem nonnulli bumidum aliquod medicamentum fumere aduer fentur

so (multi enim in totum non fuftinent liquidum medic amentum affumere) in catapatia lapidem redigere oportet. Si ue: ró libet, etiam picre aliquam infignem partem admifceto, dut etiam ex alijs quibufdam, que purgationem magis pro= mouednt, er non renitantur. Ne autem is, qui parare uelit horum confectionem, inquirendo laboret, uifum milhi eft ea de caufa etiam horum compofitionem meminiffe. Habet autem in hunc modum. Picre femuncia, epithymi femun= cia, agarici fcrupuli qustuor, fcammonix uncia, garyophyllorum grana uiginti. Contufa excipiantur rbodomelo, aut fucco citrij, aut rbodomelite. Dentur fcrupuliduo, plurimum quatuor. Notandum ueró eft, praterquàn quód. uentriculum corroborant, fimul etiam uarios bumores, prefertim terreftrem, o melancbolicum, citra moleftian purgare poffe. hactenus Alexander. Ceterim Armenium lapidem deiectoria facultate pollere in atrabiliarijs mor bis, nauit etiasn Ac̈tius. quippe quil lib. I I. cap. X L V I I. ex Nicheffonis medici authoritate, fic de eo fcriptum re=. liquit. Armerium, quo piffores utuntur, duodecima drachme parte melancholicis, er craffun fanguinem habenti= bus dato. Datur o pueris pectoris morbo infeftatis : reuomunt enim, nam uomitoriun exiftit. Datur or morbo fa= cro obroxijs, ac furiofiss, hoc modo. Centaurij faf ciculos manipulares tres in aqua marina heminis tribus coquito,

Armenij lapi dis vires ex Alexandro.

Vires eiusde ex Aetio. 
donec una fuperfit, es cum excolato decocto, Armutbei lapidis, quem Greci Armenium uocant, tertiam drachme partem terito, ac confidenter cxbibeto. nibil enim periculi eft. I taque noffe operepretium eft, quod Armeninm pes nitus reuomitur, nibil memorabile furfum efferens, fed $\mathrm{V}$ inferné modicum quid paulatim, or in pluribus feceßi= aus effert. hec Aëtius. Nouit pretered Armenij uires deiętorias inter recentiores Gracos Actuarius, ut uidere Armenii lapi eft in fuo de compofitione medicamentorum libello. Verim alias ab illis Armenio lapidi uires reddidit Galenus li-

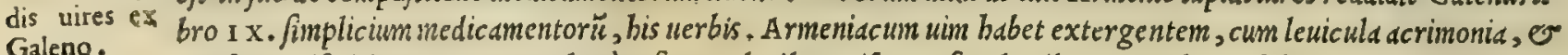
Galeno. leuißima adftriftione. Itaque tale ciun fit, ocularibus mifcetur facultatibus. Et ipfo per fe $\int e$ quoque ad pollinis lae= uorem redacto, utimur ficco ad pilorum in palpebris incrementum : nempe ubi pre bumorum acrimoniapartim ex= cidunt, partinz ueró nec crefcunt, nec aluntur. siquidem depaft is bis acrimonijs, in bonum nature babitum pars re= ducitur : cuius cum alia fint muncra, tum etiam producendi, incrementum prebendi, ac roborandi, qui in palpebris 10 Junt pill . quippe cium prima, Er ex profe fo, quedam fint medicamentorum opera : quedam ueró mediante natura, que animantium corpora dipen fat, eduntur, uelut que in bis ip/is calliblephara nuncupant. Ip $\int a$ enim partes mode= raté le fas mediocriter deficcant, pilos corrumpentem bumiditatem abfumendo . qua ubi abolita cft, tum natura ad

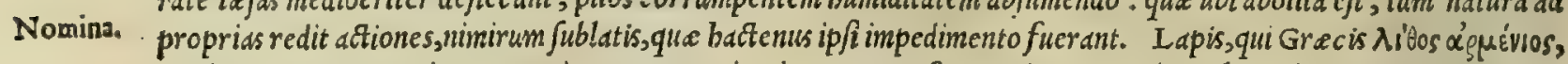
Latinis Lapis Armenius cognominatur : Mauritanis, Hager, feu Hogiar Armeni: Italis, Pietra Armenia.

\section{Kuavòs $\lambda$ ítos. COERVLEVS LAPIS.}

\section{CAP. IXVI.}

COE R V E I origo ex ærarijs metallis in Cypro. copiofior ex arena litorali fecundum quofdam fubcauatos fpecus maris inuenitur, qui magis probatur. Eligi debet inebriatus. Vritur vt chal- 20 citis. lauatur vt cadmia. Vim haber reprimentem, \& modicè erodentem . cruftas gignit,\& exulcerat.

Corulei lapi dis confid.

C OE R V L E V M officine Auicenne doctrindm recute, lapidem Azuli, uel Lazuli uocant. Probatißimus,qui fintillis aure is emicat. Lapis bic ( ni fallor) cum Armenio non obfcuram babet cognationem, quód non modó utriq; fimul in ijsdem proueniant metallis, promifcuéq; oriantur; fed quód etiam ijsdem feré uiribus prediti fint ad atram bilem deijciendam. quo factum eft, ut Mauritanorum quidam alterum cum altero ineptißimé confuderint. Cate= rim quoniam tradidit Auicenna, cui fubfcribit Mefues, corulcum fiue (ut corum nomine utar) Azulum feptica, de putrefacientis effe facultatis, non de funt é recentioribus, qui eum deteftentur, quemadmodum $\sigma$ c catapotia, que ad atrabiliarios affectus ex lapide ip $\int 0$ caruleo paßim in pharmacopolijs parantur: é quorum numero eft Fuchfiusme= dicus noftre etatis celebris, in fuis paradoxis. Verüm quanuis confuse fatis de Caruleo, er Armenio fcriptita= uerint Mauritani; non tamen obftat,quin ij bilem atram pellere queant. Id quod priores ucteresq́; Graci,uelignorauerunt, uel filentio dißimulduerunt. Porró Galenus, etfi non explicuerit caruleum atrabiliarios humores ducere; tamen fcripfit deijcientem babere facultatem. Quód cuim fortaffe perpenderent Arabes, qui multorummedicamen= torum, qua Gracis incognita fuiße uidentur, diligentißimi fuere indagatores, inuenere tandem facto pluries pericu=

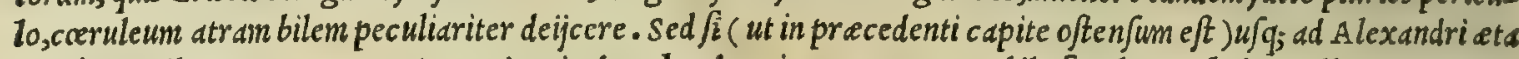
tem é ueteribus nemo nouerat Armenium in detrabenda, citra noxam, atra bile facultatem babere albo ueratro pa= rem, mirum quidem non fuerit, fi etiam longo póft tempore, id fcripferint Arabes, $u e l$ quód ab co fortaffe acceperint,

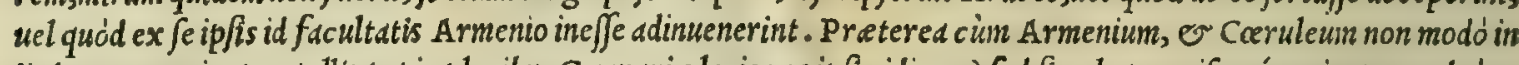
ijsdem proueniant metallis (ut in pluribus Germania locis nos ipfi uidimus) fed fimul, promifcué; oriantur, adeo ut

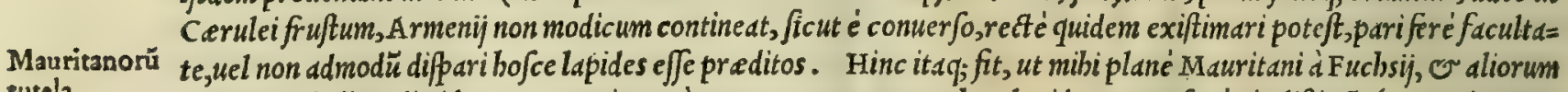
surela . calumnia uindicandi videantur. Quippe cum cernerent naturam hos lapides promifcué, indiftinctéq; progignere, quid mirum $/ \mathrm{i}$ ip $\int_{\text {am }}$ imitati, corum biftoriam or facultatem indifferenter tradiderunt? cum pro certo ex his exifti= mandum fit, nil aliud effe Armenium, quàm coerulei materiam, nondum à calore in terre uifceribus ad fummun per= fectég. coctam . quenadmodum chalcitis, mify, fory nil aliud effe creduntur, quàm chalcantbi materiam. Hac igitur cim accurate perpendiffet clarißimus Manardus Ferrarien/is, ubi in fimplicia medicamenta à Me fue confcripta di= ligentißimé adnotauit, eorum fententiam refllit, qui corulei ufum fua tantùm ducti opinione tam acriter uituperăt, bis uerbis. Caruleo Graci nullam uim deie toriam adfcribunt, fed uidentur be uires ab Armenio deriuate. Arabes cnim utrunque confundunt. Serapio quidem, $\mathcal{O}$ Auerroes fub lazuli nomine de Armenio tractantes, Auicenna de Azulo fcribens, feré ei omnes uires attribuit, quas Greci utriq;. De Armenio ueró ea fcribit, que Gr aci: folum ad= so dens, quód atram bilem magis purgat, quàm cyaneus. Qus omnia licet uer a fint, non tamen ego bis accefjerim, qui nö fecus ac perniciofißimum uenenü bunc formidant. Experientia enim certa fcio, quód fi bené abluatur, multum iuuat, or uel nibil, uel parum ladit . bec ille. In cuius certé fententiam unusquisq; medic us facilé deueniet, qui potius ra= tionalis fit, quaim pertinax. Nam etfi dixerit Auicenna caruleum exedentis effe facultatis, hoc quidem non impedit, quin bauftum atrain bilem deijcere poßit absq; noxa, fi diligenter fuerit ablutum. quandoquidem eius peracuta fepti= cd'q; facultas pluribus lotionibus ab eo facilé tollitur. Prefertur in bunc ufum quod aureis maculis pellucet: nanque id, quo feplafie abundant, or quo in Germania pictorios colores parant, tum facultatc imbecillius, tum ignobilus, habetur. Memini me ad nonnullas tam aris, quäm argentifodinas acceßiffe, in quibus e carulei, or Armenij in $d=$ ceruos congefti plurimum uidi : attamen nullum mibi in ijs locis cxeruleum repertum eft, quod aureis fulgeret fcins tillis, eo quód non proueniat hoc nifi tantum in durifodinis. Idcirco caruleus ille color, qui uulgó nobis dicitur $\mathrm{Az}=$ zurro oltramarino ab omnibus magno aftimatur pretio. Fit cnim is ex carulco lapide, quitantium in anri metallis in 


\section{In Lib. quintum Diofcoridis.}

orientalibus regionibus foditur, omnium praftätißimus. De illo autem, qui ex arena in maris litoribus inuenta confis citur, quid plura dicam non babeo, quain fcripferint Dicfcorides, $\odot$ Plinius. Carulei uires retulit Galenus lib. IX. Fimplicium medicamentorum, fic inquiens. Cyanos medicanentum acrifacultate eft, tum detrabendi, $q u a m \times x=$

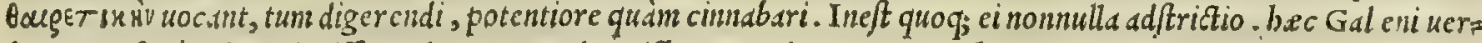
ba. Que fuce uel non legife, ucl non anmaduertiffe Manardus ex eo deprehenditur, quod carulco Gracas nullam

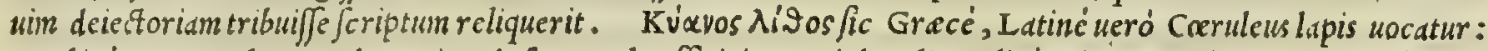
Arabicé, Hager alezioard, Laziuard, feu Azul: officinis, L apis lazuli : Italicé, Pietra cerulea : Germanicé, La faurftein: Hipanici, Azul.

I N D I C I duo genera vnum fua fponte nafcitur, tanquam fpuma, germinatione Indicis arundinibus exiens. Alterum infectoria dant officina: \& eft fuma purpurea innatans cortinis, quam detractam artifices ficcant. Optimum exiftimatur, quod cœrulei fpeciem prabet, fuccum fuum forbet, \& leue. Inter medicamenta eft, qua leuiter adfringunt, \& inflammationes, tumoresq́ue rumpunt. purgat, \& reprimit ulcera.

I N D I C V s color, quo bodic pictores utuntur, tametfi in eplasijs ubique uenalis habedtur; fit tamen in in= Indici confifectorijs officinis ex glafti recremento, e puma, cum lane glafte ipfo inficiuntur. Quod autem pponte nafcitur, deratio.

20 tanquä puna germinatione arundimibus exıens, quod Iciam, ad nos non defertur. Plinius libro $\mathrm{x} \times \mathrm{x} \times \mathrm{V}$, cap. V I. $f a=$ ctitium Indicü in purpurarijs of ficinis fieri ait, ex purpura-puma cortinis innațäte. Qua in re Diofcoridis uerba no recté accepife uidetur Plinius. Siquidem author non ex purpurarum $\beta$ uma fieri Indicum fcribit, fed ex purpurea fpuma ( talis etenin eft qua ex ifatide prouenit) innatante cortinis in infectorijs officinis. Nulla nanque, quod mibi compertum fit, ex purpurarum fanguine, quo regum ueftes olim tingebantur, Puma proferebatur. Quod Gre= ciivinino'v, Latini quoq; Indicum uocant: Itali, Indico.

$$
\text { O"X X⿻一. OCHRA. }
$$

\section{CAP, IXVIII}

O с H R A leuifsimam, \& omnino luteam eligere oportet, faturatam, non lapidofam, friabi30 lem, natione Atticam. Vritur hac, \& lauatur cadmix modo. Vis eius adftringere, erodere, collectiones \& tubercula difsipare. Excref centia in carnereprimit, caua cum cerato explet, \& articulorum tofos comminuit.

O C R H A foßilis, qua pictores utuntur, cur legitima non fit, quid obftet non uideo: quăquam bac (quod fciam) ex Athenis laudati(Sima non adferatur, quemadmodum nec Vitruij tempore, qui ochra Attic ufum in Italia iam exoleuife fcribit. Eft itaq; Ochra terra, que in plumbifodinis aureo colore reperitur. Quamobrem qui rerum cau= fas perfcrutantur, arte etiam ochram ex plumbo ipjo conficiunt, que coloris nitore foßitiam fuperat. Praftantißix mam ochram non longè d Tridēto effo/fam, mifit ad me hoc anno Martinus Guidottinus Tridentunus, eplafiarius has rum rerum diligens inquifitor, qua nullam bactenus uidimus meliorem. Ocbra in libris fimplicium medicamentorum

40 non reperio meminife Galenum : tamet fi eius mentionem fecerit commento I $\mathbf{I}$. in Hippocratis prognoftica de uomis tione agens, cim inquit. Ochra enim genus quoddam terre eff, cuius potißimùm Attica probatißima eft. Que ¿x $\rho \propto$ Grecé, ochra item Latiné $\mathrm{O}$ Italicé appellatur.

Kuwa'Bapls. CINNABARIS.
Cœrulei uires ex Gal.

Nomina.

Nomin.

Ochrę contsderatio.

H A I I V C I N A I Y R qui cinnabarin minio eandem efle exiftimant. Minium enim in Hifpanijs ex lapide quodam argentex arenæ permifto, temperari folet ; alioqui non dignofcitur. Fornacibus autem in florentifsimum, flagrantifsimumq́ue colorem permutatur. In metallis uerò ftrangulantem halitum eructat . itaque facies incolæ uefrcis obuelant, ut per illas fpectent, nec refpirando 50 noxium aërem attrahant. Eo pictores ad fumptuofa parietum ornamenta utuntur. Cinnabaris uerò ex Aphrica defertur, \& magno conftat . hactenus inuenitur, ut uix uerficoloribus pictorum lineis fatisfaciat : intento colore, nec diluto præditum : quare quidam fanguinem effe draconis exiftimauerunt. Vim habet cinnabaris hæmatitæ lapillo eandem. Conuenit ad oculorum medicamenta, uerùm efficacius : magis enim adftringit, \& fanguinem cohibet. Ambuftis igni, \& papularum eruptionibus, cerato excepta medetur.

C I N N A B A R I s, qua officine, o pittores utuntur, longé fané differt (ut plane conftat) à Diofcoridis Cinnabari . quandoquidem noftri ufus cinnabaris res fattitia eft ex Julphure, $E$ argento uino diu arte quadã igne tor refactis. Eft $\mathcal{O}$ aliud cinnabaris genus foßile, $\mathbb{O}$ fponte per $\int e$ nafcens, ut poftea dicetur: uerim non ut facitium copiofum, nec ad eó colore pracellens. Que autem à Diofcoride defcribitur, ex A phrica defertur, eadem facultate pollens, qua hematites lapillus, quem nö modó pretulit ipfe foris appofitum ad plures oculorum morbos; fed etiam 


\section{And.MatthioliComm.}

intus affumptun, ad urine angufti is, muliebrium locorum defluxiones, or cruentas expuitiones. Quibus utique afs fectibus unlgaris ufus cinnabaris nullo pacto competere poteft, quód proprid ui erodat, exulceret, $\sigma$ hanfum pers niciem adferat, or proinde fit oculis, o internis uifceribus inimica. Ceterim quidnam inter ea, qua bac cete in ufum medicum ueniunt, Diof coridis cinnabaris effe poßit, non equidem au/im decernere, fed potius quod fentio, addu cor, ut coniccturis quibusdä afequar. quippe quód Diofcorides Cinnabarin mullis notis de fcripferit, neq; tradiderit an factitia res fit, aut foßilis, an ex plantarum materia proueniat. Sed anteaquàm coniectur as eas afferam, quibus cö= ftare uidetur Diofcoridis cintrabrifeplafias noftrates non deftitui, Plinij fententia cognofcëda eft, quilib. X X X I I I. cap. v I I. affirmaté fcribit, nil aliud effe cinnubarin, quàm draconis faniem, elifi elephantorum morientium ponde=

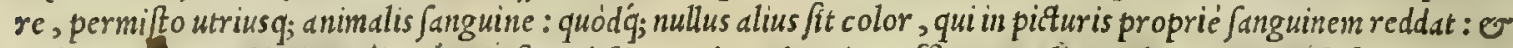
quód ea ctian antidotis medicamentis fit utilißima. Id quod pariter affirmat Iulius Solinus in uarid hiforiarum le = co ctione. Ad hac fcire conucnit, gummi cuiufdam arboris in Apbrica nafcentis ad nos deferri, quod etiam hoc euo fan= guimis draconis lacrymam officine tioc ant, colore fanguinis, pellucidum, leue, er fractu minimé contumax. Hoc no= frates officine unlgó úocant Sangue di drago in lagrime, alterius differentia, qui pluribus impofturis paßim in orbi= culos coactus vienditur. Priorem itaq; non ab re lacrymam appellant, quod fcribat Aloifius Muftus patritius Vcne= tus in fuis in A pbricain natuigationibus; ex arbore quadam boc gummi collacrymare, colore, or fubftantia, fanguini fimili : incifo tamen ab incolis prius arboris cortice, $u$ fufius inde effluat. Hoc ( $u t$ idem fubdit) eneis cecabis excipiunt, e igni re fine modo decoquunt, quousque confiflat, draconis fanguinem, néfcio qua ratione ducti, ipfum ap= fellantes : nifí id étieniat, quód fortaffé fú lingua plantam, à quia defluit, draconem appellent. Ex bis itaq; nobis iure conie Etare licebit, gummi hoc Diofcoridi facilé cinnabarin elfe, quod primuin non aliunde, quìm ex Apbrica defera= fur, nec inde copiofum. quód item pittoribus expetatur, ut intento eius colore, purpurcas, rubentes q́; conciunent i zimbras, ubi prius picturds'rubro, wel purpureo infecerint .quód dcinde ob raritatem, etiam hoc tempore, qquo fre quentius in A pbricam náuigatur, nò uili ueneat pretio . quód deniq; ( ut Diofcorides inquit)uiribus hamatite lapil= to per omnia repondeat. Nam, ut périculum facientibus liquidó patcbit, adftringendi ui pollet, o maiore quidem quam hamatites. quo fit, ut felicius eo utantur medici ad muliebres, $\sigma$ dy fentericas fluxiones, ad cruentas excred = tiones, ad firmandos commotos dentes, $v$ robor andas gingitids. His acccdit, quod fi Diofcoridis atale non deerant, qui Cinnabarin efe draconis fanguinem exiftimarent, mirum fané non fuerit, fi per plurcs atates producta baec falfa

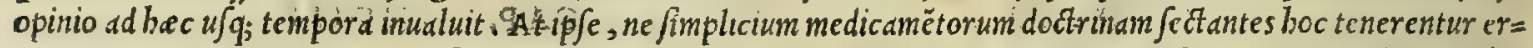
rore, inanem corum fententiam filentio inuolvendam non duxit, qui cinnabarin draconis fanguinem appellabăt, cùm inquit. Hactenus inuenitur cinnabaris ut hix uerficoloribus piftor lineis fatisfaciat, intento colore, nce diluto pre= ditum: quare quidam fanguinem e fe draconis exiftimauerunt. Ex bis igitur cum conieffuris, tum rationibus ćlligen 3 o dun effe putaucrim, hanc lacrymam, colone. fanguinem pre fo ferentem, legitimam effe Diof coridis cinnabarin. Ce= terum uidetur bac in re manifefté aberraffe Plinius. quandoquidem etfi afferat is cinnabarim nil aliud effe, quàm draconis ferocißime bellue fanguinem, elife clepbantorum morientium pondere; củn tannen dixerit nullum alium reperiri colorem, qui in picturis magis aduiuum fanguinem reddat, quàm cinnabaris, facile de prebenditur error. Quippe neceffarium fane fuerit, ut de bac lacryma omnino intellexerit, putaritó, falfus unlgari appellatione, lacry= man banc illum draconis fanguinem effe; ab elephante ( ui referunt) collifi. Nam confentaneum minimé-uidetur, ut buiujce bellux fanguis extrd uda in terram diffufus, puluere lapillis commiftus, fitu er putredine obduttus cont= täbe factusq́;, uiuim, ac tuerum fanguinis coloren referre poßit quemadmodum nec ille fyncerum fanginis colorem prabet, quem impoftores $\int 10$ arbitrio factitant, ex bircino fanguine, rubrica sinopica, ucl fabrili, contufis lateribus er forbis, diutius infolatis, illius pro poffe colorein, $\int$ fubitantian imitantes, qui ex collifis fimul draconibus, $\sigma$ ele phantibus (fi tamen vier a narrant) emanare folet: :quióg iam longo tempore ad nos aduehi de sijt. Q uo poftea factum effe opinor, ut in eius defectu factitium fuppofuerint impoftores, bä fraudem excogitauerint: neq; follum eard= tione, quam modó diximus, ip fum parant; fed etiam modis alijs compluribus, refinas, rubia infectoria radices, bra=

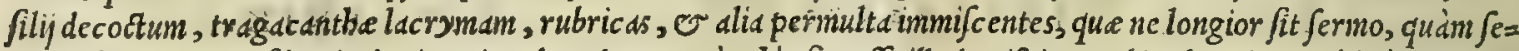
Obiectiosis ries ip $\int a$ expofcat, filentio duximus inuoluenda. Verum bic fortaffe illud quipiam nobis obtrudet, quód cum hoc los dilutio. cofcribat Diofcarides de metallicis tantum; ac foßitijs tum coloribus, tum medicamentis, confentaneum miniviz uidea tur, $u$ t bis inferuerit arborum lacrymas, quarum hiftorias, $e$ facultates, diffufius libro primo pertractauit: 0 ob id omnino credendum fit; cinnabarim fojsile effe medicamentum: Heec obijcienti ita reponfun uolumus, quód cum ca Foc loco recenfeat Diojcorides, que ob calorum nitorem, in pictorium ueniunt ufum, nempe cerufaun, chryfocollä,

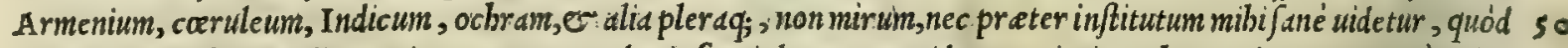
bis etiam cinnabarim adiunxerit, quanquamarboris fuerit lacryma. Videmus enim inter bec Indicum quoq; dे Dio= fcoride connumeratum effe, quod tamen nec foßile, nec metallicum eft, fed in India pume inftar, ex arundinum qua rundam germinatione ponte prouenit : at; etiam arte quadam fit ex ifatide berba in infictorijs officinis. Ex bis ita= que omnibus palàm fieri arbitror, quód communis ufus cinnabaris., quam Diofcorides Miniü, quòd in fornacibus fiat, o florentißimo, flagrantißimóf; colore ßpectetur, effe mibi femper perfuafi, ab ea longé diuerfa fit, de qua author nofter hic mentionem facit. Est enim, ut fuprà dictum eft noftri uJus cinnabaris foßjilis, or factitia : nota bec omni= bus, o frequens : illa ueró rara, nec multis cognita. Fopilem (ut proxima coinmentatione latius dicctur) uidimus frequenter nos in argenti uiui fodinis, Hodria monte, qui una tantum dieta à Goritia diftat, circa Carniole fines. La pis eft purpureus ad rubedinem declinans, hematte lapidi emulus, non admodum durus, impensé tamen grauis, tan tóg; plerung; argento uiuo pregnăs,ut per $\int e \int e$,nulla ignium ui guttatim exiliat. Factitic codem loco plurimum $e=$ $i$ am paratur ex argento uiuo or julphure, fictilibus quibusdam conclufis, er flagrantißimo igni admotis, donec ad 


\section{In Lib. quintum Diofcoridis. $\quad 673$}

faituritatem rubcfcant. Id quod fieri a natura crediderim in ed, que foßsilis fucrit, in terre uifceribus. Nullus barum ufus in medicanent is, que utus in corpus fumuntur, quod perniciofs fint, er uencnofe. Hinc forte factum cft, Fuchfij opin.

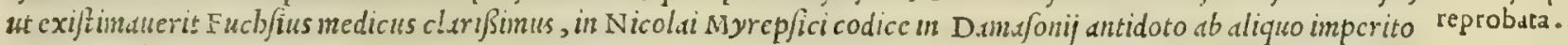
addutan cffe cinnab.urin. Scd in boc alix plané di Fucb/o opinio noftra cjt. quippe quod putcon Nicolaum eo in loco

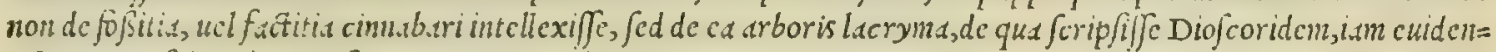
tifimum, nifullor, i nobis fuctun est. Nam cum cimabaris hec, Diofcorid is teftimonio, bematita lapillo pares ba= best wires, probsucritó; is bxemstité ad urinte difficultstem, dubitandum fané non cft, quin confultó antiquorun cin=

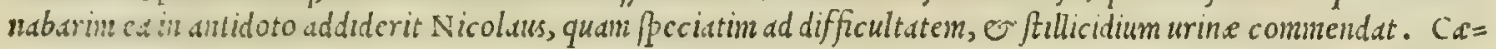
terim quasuis communis ufus cinnabaris in medicamentis, qux fumuntur in corpus, omnino le thalis, o pevinens fir;

20 con:jat tanten ijs utiliter admifceri poffe, qua exteriks adisbentur, nempe fuffimentis, que funt ad delendan Galli= can lucm, ubic atera non profucrint rcm:dia, ungucntis item nonmullis ad idcm facicntibus, $O$ ad contumacia ulce= ra, alijsi; medicamentis, quorum uires longum effet in prefentia recenfere. Porró cùm dic at Diofcorides balluci= nari cos, qui cimabarin minio candem effe exiftimant, cuimi; etiam foribat fequenticapite argcntun uiuum cx minio ficri, quod abu/üc cimuburis diciuur, omnino mihi perfuafum uolui, thil aliud Diofcoridi effe miniü, quam fosile boc, quod diximus cinnsbarm foßsitian bodie appellari, à quo argenti uiui plu imü eliciunt in Hydrix fodinis. Auxit pre= terea opinionesn ip $\int \mathrm{c}$ Diofcorides, quippe qui aferat Minium in metallis ftrangulantem balitum eructare, ob idó; fof= fores ucficis fibifaciom obuclare, ut per ullas fpectent, nec repirando noxium uaporcm attralant. Quandoquidem *bi cimub.tris in Hydria monte fodtur ( ut ego uidi, er tcftari poffum ) artifices eam decoquentes fictilibus quibus= dam ad id conflatis, or conuer fo fimul ore argilla circumlitis, ut inde argentum uiumm cliciant, nares, $O \sim$ os linteis

- fibiob,truunt, ne noxio uaporiliber pateat aditus: quod non modó buiufce balitus noxa, anbelofi fiant, qui baufe= rint, ed plerunq; dentes uniucr fos amittant, putrefcentibus circumquaq; gingiuis, ut quidam apertijime tcftantur, qui preto narium, or or is uelamento, ut ceteris uiderentur fortiorcs, edentuli prorfus facti funt, continuo trenore concusi. Accedit buc Vitruil authoritas, qux fentcntiam noftran maximé tuetur. Ipfe enim feptimo uolumine fuxe ardbite đure, ita de Minio difèrit. Ingrediar minij rationes explicare. Id autě agris Ephefiorum Cilbianis primim

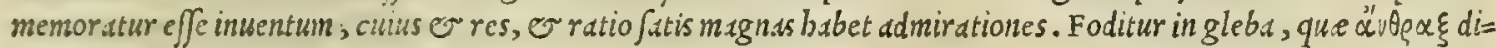
citur, antequam tractationibus ad minium perueniat, uend utiferro, inagis fubrufo colore, habens circa fe rubr un puluercm. Cim id, foditur, ex plagis ferramentorum crebras emittit lacrymas argenti uiui, qux à fofforibus fatim colliguntur. bac Vitruuius. Nos equidem hoc idem uidimus in Hydria montis fodinis : ubi plerunque eucnit, ut ul= nerat a ferramentis uens, argentum uium fonticuli inftar, in fubfratam defluat bumum. Caterum Plinio minium di=

30 ner forum cft generum, ut loco fuperius citato legitur, ubi cuncta eius genera retulit bis uerbis. Inuenitur in argen= tarijs metallis minium quoq;, er nunc inter pigmenta magne autboritatis. Theopbraftus tradit inuentum minium aे Callia A thenien fe initio fuperante aurum : poffe excoqui arcna rubente in metallis argenti : băc fuiffe originem eius. Reperiri autem iam tum in $\mathrm{H}$ ipanijs, fed durum er arenofum. Item apud Colchos in rupe quadam inacceffa, ex qua iaculantes decuterent : id efe adulicrum. Optimumucró fupra Ephefun Cilbianis agris. A renam cocci colorem bas bere, banc teri, dein lauari farinam, or quod Jubfidat iterum lauari. I ba minium nafci in Carmania tradit. Hermo= genes $\approx$ in Aethiopia. Sed reutro ex loco inuchitar ad nos, nec feré aliunde, quàm ex Hiffania. Sed adulteratur multis modis, unde preda focietati. Nanque est alterum genus in annibus feré argentarijs, item '; plumbarijs metal= lis, quod fit exufto lapide uenis permisto, non exillo, cuius uomicam argentum uium appellauimus, fed ex alijs $f=$ mul repcrtis. Steriles etiam plumbi fuo colore, nec nifin in fornacibus rubcjcentes, exustio; tunduntur in farinam. Et

40 hoc est fecundarium minium perquàm paucis notum, multum infra naturales illas arenas. Syncero cocci nitor effe debet. Probatur auri modo. A uro candente fucatum nigre $\int c i t$, fyncerum colorem retinet. Inuenio or calce adul= terari. Ac fimili ratione ferri candentis lamina, fi non fic aurum, deprebendilllico. bactenus de minio Plinius. Hinc igitur palain eft antiquis minium $\sigma$ foßjile, o factitium extitiffe. Nec fané dubitauerim, quin in factitijgenere ac= ceperint ipfi cinnabarim factitiam, que paßim in feplafiariorum officinis inuenitur. Id minium bodic appellant pliar= macopolx, tum etiam pittores, quod ueteres Greci sandycem nocauere, ex plumbo, aut cerufa in fornacibus peru=

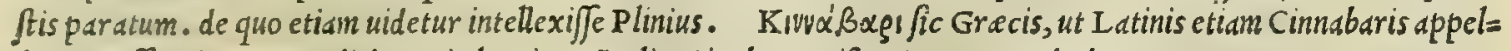
latur: Officmis, Sangue di drago in lagrime; Italis, Cinabro: Hifpanis, Sangre de dragon.

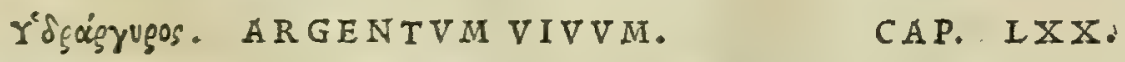

ARGEN T V viuum fitex minio, quodabufuè cinnabaris dicitur, patinis fictilibus impofita, ferrea concha cinnabarin continente, \& calice cooperta, argilla fuperlita, carbonibus fuccendunt. : frquidem deterfa fuligo, quæ calici infidet, refrigerata in argentum viuum coit. Quinetiam inuenitur in argenti fodinarum tectis ftillatim concretum. Alij per fe in metallis inueniri tradunt. Serua tur in vitreis, aut plumbeis, aut fagneis, aut argenteis vafis : fiquidem aliam materiam omnem exedit, \& defluere facit. Potum vim pernicialem habet : fuo enim pondere interna exeft. Remedio eft lac multum fubinde potum, \& vomitionibus reiefum, aut vinum cum abfinthio, aut apij decoetum, aut femen hormini, aut origanum, aut hyffopum cum vino. Auri limata fcobs, id eft, ramentum quàm tenuifsimum epotum mirabili eft auxilio. 


\section{4}

\section{And. Matthiolı Comm.}

Argenti uiui A R G E N V M uium omnibus notißimum, corpus eft é foßilium genere, liquidum, or aque modo fuidum, conlid. colore argenteo, liue cente, pellucidum q; : fubftantia ueró lenta, tenui, in qua tam frigiditas, quàn bumiditas exupez rat. Hac igitur fymmetria ( ut chymiftarum, qui fe philofophos cxiftimant, fert opinio) res eft fané admodum dipo= fita ad metallorum oinnium generationem. quamobrem ipforum tum originem, tum femen argentum uiuum appella= uere. Quinetian non addenfari putant, quod ei non infit caliditas, v ficcitas tanta, que ad id muner is obeundü fuf= ficiant. Addunt temporis defectu id etiam euenire : ideoq; inmatur um, indigeftum, imperfectumí; reddi. Cateriun relicta chymiftis difceptandi materia, an ipfun metallorü quor umcunq; prima fuerit materia, an aliter fe res habeat, dicam, philofophorum tantim, qui de eo foripferunt, fententiam fecutus, facilé Argentum uiuum effe materiam ad metallorum generationem proximam. Quippe cum facillimé omnibus fe coniungat metallis, palàm nimirum fit, ijs gi= gnendis aptißinam effe materiam, ijsq́; prafertim, quibus facilius contactu inbare fcit: quandoquidem in babentibus

Quorundam Jymbolum ( ut uulgata propofitio eft ) $v$ in confimilibus facilis eft tranfitus. Hanc itaque ob caufam cos balluci= error. $\quad$ nari putauerim, qui dicunt, quodd $\hat{f}$ argentü uiuum in terre uifceribus ufqueadeó decoctum effet, ut in aliquod fixum, firmumiq ; uerteretur metallum, in ferrum potius, $\sigma$ in plumbum uerti deberet, quàm in argentum, uel in aurum. Si= quidem certum eft, quód id facilius argento, auróq; contactu inbaret, quàm cateris. Hic autem eft chymiftarum ludus, qui tempus conterunt, or oleum $\mathrm{C}^{\mathrm{o}}$ operam perdunt, id arte reficere exiftimantes, in quo natura ipfa defecit: quam (ut liquidó conftat) nemo unquam ita ad unguem imitari potuit, quin ab eius mira folertia aberrauerit. Oms nia metalla in argentum uiuum coniecta, fupernatant, ut lignum in aqua, preter folum aurum, quod fi inijciatur, ftas tim petit fundum, quód hoc magis amplexetur, quàm ceterd. Amplißima argenti uiui metalla (ut etiam in fuperio= ri capite diximus) uifuntur in Hydria monte, qui quadraginta millia pafjuum ḋ Goritia diftat, ubi continuó copiofun

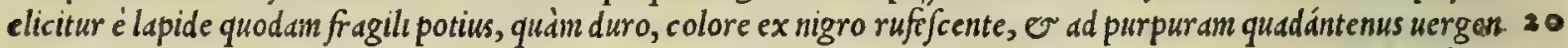
te, ponderofo plumbi inftar, er argento uiuo f cintillante. Hanc uenam poftquadm effoderunt, conterunt, $v$ in ficti= lia quedam angufti orificij conijciunt, or recenti arborum mufco obturant : deinde fictile alterum buic fimile, latiox ris tamen oris, in terram fepeliunt, or alterius pleni inuer fum orificium, in illud in ferunt, $*$ argilla circunquaque muniunt obturant $\dot{q}_{;}$of cula, $\mathcal{O}$ uafa fimul connect unt, o firmant, adeo ut uacuum fictile totum fub terra fidat, ple= num ueró totum fuperemineat. Itá;; in aperta area quàm plurima feriatim collocant fictilia, or deinde ignem in am= bitu fuccendunt, cuius wi calefacta uend, argentum uiuum guttatim difillat in fubftratum.fictile. Hinc fuo tempore eximunt, $v$ in utriculos quosdam reponunt, quód uda feré cuncta exedat, ac dilaceret, preter uitred, uel fictilia ui tro circumlita. Quo fit, ut Diofcoridem mirari fubeat, qui argentum uium in argenteis, aut plumbeis, ftagneisue, aut uitreis tantim uafis feruari pofe $\int$ cribit, quod aliam materiam omnem erodat, nifi codex hic deprauatus fit. Si= quidem id falfum deprehenditur: nam argentum uiuum exeft, ac destruit omnia metalla, quibus inhe erit. Ex quo 30 potius, cum bec à serapione non fcribantur, qui tamen Diofcoridis omnia feré fcripta bona fide reddidit, plané fu= ficandü fuerit, buic capiti plura fubeffe menda. id quod etiam uaria in hoc loco oribasij lectio confirmare uidetur. Reperiuntur autem in argenti uiuifodinis inter ipfius uenam peculiares quadam lapidis illius rufizona, quem fof= fores foßitiam cinnabarim uocant, de quo etiam in precedenti capite diximus. Hic adeó argento uiuo $\int$ catet, ut $\int$ epius $a b f q u e$ alio igne, inde per $\int e \int e$ guttatim defluat. Euenit praterea dum foffores mucronatis in/trumentis, uenam ef= fodiunt, ut purum profiliat argentum uiuum, decurrat q́; celerius, ueluti é fonticulo quodam. Porró rari admodum funt foffores, or buiufce materie artifices, tametfi robuftißimi fuerint temperamenti, qui eo in opere ad quartü uf= que annum incolumes perdurare udle ant : quippe ob noxium metallibalitum, partium omniü tremore concutiuntur.

Galenus no- Ceterùm Galenus libro I x. fimplicium medicamentorü fcribit, contraillud quód experimento comprobatur, Ar= gentur. Gim uium ex ponte nafcentibus non effe, fed ex ijs, qua preparantur, uelut ceruffa, erugo, pforicum, lithar= gyros : fateturq; fe nullum buiufce medicamenti feciffe periculum, an interimat, fi deuoretur, uel ubiforis fuerit ad= Argenti fubli motum. Fit ex argento uiuo $\sim$ fale, quod ammoniacü uocant; lethale illud medicamentum, quod officine clymi= mau cöfetio. Stas fecute Argentum fublimatum appellant, utrifque fimul admiftis, or in uas uitrcum coniectis, ac inde in fornacem deductis, ut hac ignium ut in uafis fublime tollantur, ubi falis modo concre fcunt, lapide fcunt'́; faccharicolore. Fit

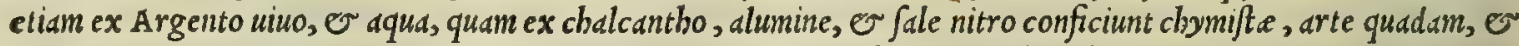
ignium ui, id quod recentiores quidam Pracipitatum uocant. Cuifac ultas ineft fné admirabilis ad contumacia ulces

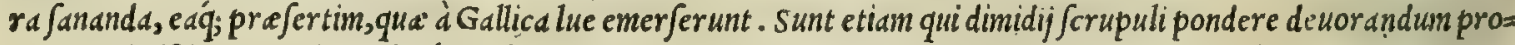
pinent admistis margaritis, alijsq́; quibusdam, que cor tueri non ambigunt, ubi quis Gallicis doloribus circa articü= los conflictetur. Datur etiam melancholicis, Armenij lapidis modo, ut libello, quem de morbo Gallico fcripfimus, $a=$ bunde dictum eft : nanque cofdem prabet effectus, uomitionibus expurgans. Sunt pretered qui purum fyncerumq́; Argentum uiumm hauriendum prabeant non modó adultis, fed pueris, er infantibus atate tenellis. Siquidĕ Brafa= uolus Ferrarienfis uir fané hac etate clarißimus, fuo de ftirpium examine pro certo fcribit, fapius fe dediffe Argen= tum uiuum infantibus deuorandum ui uermium femimortuis, qui illico fanati funt: id q́; feciffe ait in ultima deperatio= ne. Sed quomodo, uel qua menfurd, uel pondere dandun fit, filentio inuoluit. At Goritienfes obftetrices, ubigraui= de diu in partu laborauerint, ftatim Argentum uiuum fcrupuli pondere nullis incommodis potandum exhibent. Quo fit, ut facilé mihi perfuaferim, Argentum uiü̈ potantes baud necare, nifi pondus, uel menfuram excefferit. Non ta= men crediderim, quód folo pondere interinat, ut quidam putant Diofcoridĕ tantùm fecuti, ut latius libro fexto dif= Auri hiltoria, feremus. Sed quoniam Argentum uiuum nobis in nentem reuocauit A V $\mathrm{R}$ V M omnium metallorum pretiofißji= \& praftant12. mum, prestantißimumq; , cim eius nufquam, quod extet, meminerit Diofcorides, crederem profectó non paucam natur e rerum iniuriam à me illatam iri, fi buius tam pretiofi nnetalli, cuius inextinguibili fiti uniuer fus astuat mun. dus, biftoriam, or facultatem filentio preterijfem. Quandoquidem ob ipfius plendefcentem coloris nitorem, opise 


\section{In Lib. quintum Diofcoridıs.}

nati funt nattre operum indagatores, admirabiles auro incffe facultates, quibus bomines non modó incolumes tueri poßit, fed $\sigma$ longewos reddere. Quapropter mirkn non cft, fi ipfum tanti faciat mundus, $\sigma^{\circ}$ ante catera cxtol= lant bomines. Auri itaquc matcriam nil aliud c ffe fcribunt, quam fubftantie clementaria fibiinuicem proportione refpondentes. He autem fimul conmifte, cum pari fint uirtute conformate, aliud fanégignere nequennt, quaim amicabilcm quandam, or optimam miftioncm, qua firmcntatione, or costione perficitur . quo fit, ut inde tam in= diffolubili nexu uniantur, ut permanentes, $\sigma$ feré indiffolubiles fiant, adeó quód, fiue id eucniat colcftium corpo= rum infuxu, aut tcmporis ui, dut agacißime nature opere, aut his omnibus uni concurrentibus, conucruntur ex= den fubftutive in boc metallicum corpus, quod uocant akrum. Hoc enim ( ut dixinus) ob fui tum ingentem tempe= ricn, tum unit stem, tum optin.tn mistionem, adeó denfiun euadit, quód non modó quandam communem confequitur

to permanfionem, fed incorruptibilem feré tempericm, or caufan quandam, ob quam fuperflui mbil continere poßjit. Hinc igitur cft, quod quanqum longioribus feculis atrum in terra, ucl in aqua fepultum permaneat, nunquam ru= biginen contrahit : ficutinigne diutius permanens, non modó aliqua ex parte non comburitur; fed $\mathcal{O}^{\circ}$ depuratius, or Plendidus cfficitur. Ad bec ob optinxm fui unitatem, nullo phlegmate, nullo'́; pingui redundut : ita ut perpe= tuó fulgeat, fplcudidifimum,; pendwret. Quinetian tractantium manus mullo colore tingit, nempe crocco, aut nt= gro, quemadiuodum c.etera faciunt met alla. ne $\phi_{;}$etian aliquo odore, aut fapore guftantium, aut olfacientium tum nures, tum palatum inficit. A urum intus in corpus fumptum, fue ex induftria, fiue infcijs deuorantibus, nullam pe= nitus infert nox.m, ut complura fuciunt metalls: fed mirum in modum cor, Er uitalen facultaten roborat. quod folis infuxuiacceptum pleriq; fipientes retulcrunt. Qutmobrcmiure quidem dici poteft, aurum omniun metallo=

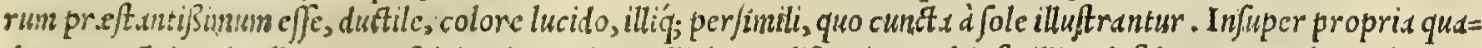

to dam attraftrice ui pollet, qua refpicientium animos alicit, $\sigma$ diponit, ut ab ip/s illico defideretur. unde quidan exi ftinauerunt duro proprias quimplurimas ine fe dotes. In Italia proprie fynceriaurifodina ( quod fcians) nullibi extant. Atqui in Germania, Psnnonia, ac Tranfyluania ex pluribus in locis babentur. Auri uenam ijs onmibus lo= cis crediderun gigni, ubi calun at caufe clementaris influat, ac diponat, de quibus antea differuimus. Huius uena uarijs lapitibus impata uifitur in afperrimorum montium uifceribus. Verim ed omnium preftantißima auri uena cenfetur, cui coruleus lapis fuerit admistus: tuntó enim melior bec, quantó ponderofior, er colore uigentior: d= deo ut illa ceter as precellat, qux pluribus auriguttis fcintillet, uel in qua plures auri line intercurfantes conpi= ciantur. Ef etian auri ferax diuerfor ifuminum arend. Siquidem proculdubio conftat in Hipania Tagum, in Thra= cia Ebrum, in India Gangem or Pactolum, in Pantonia Ifrum, in Germania R benum, in Italia Padum er Ticinü, aure ducere arenas, à quibus arte quadan aurum omnium probatißtmum elicitur. uer unt dmen non omnibus eorum

9 - litoribus aurea exdem funt drene. Auri uires prodidit Auicennd fecundo fui operis volumine, fic inquiens. Au= Auri uires ex rum in onnibus fuis partibus equale eft. Inferitur medicamentis, que atrabiliarijs competunt morbis. Ad bec ubi Auicenna. actuali cauterio fit opus, ignitum aur um cateris preftat metallis, quod ulcus inde cxortum citius confancfcat. In ore contentum, anbelitus graueolentiam tollit. Auri fcobs porpbyrite lapide leuigata in ea medicamenta additur, que ad alopeci.ts, o lichenas parantur, tain intus in corpus fumptum, quàm extrà medicamentis exceptum. Hac item eo. dem modo diutius leuigata, adeó ut tactum feré effuglat, oculis immittitur ad roborandam corum acicm. Bibitur au=

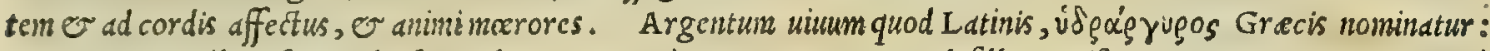
Mauritanis, Zaibar, feu Zaibach: Italis, Argento viuo: Germanis, Queckfilber: Hipanis, Azogue. Aurum veró Iatinis, X juoo's Gracé dicitur: Germanicé, Guld: Italicé or Hipanicé, Oro.

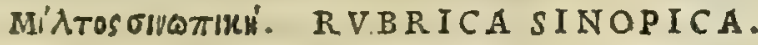

CAP. LXXY.

R V B R I C A S I N O P I s maximè probatur grauis, denfa, ad iecinoris imaginem uergens, calculorum expers, concolor, cùm diluitur, impendiò fufilis. Effoditur in Cappadocia, fpeluncis quibusdam, expurgataque defertur in Sinopem urbem, in qua uenditur : vnde cognomentum accepit.

Vim habet exiccatoriam, quafi inducendo obftruentem, \& adfriftoriam . quapropter vulnerarijs emplaftris, \& paftillis exiccantibus, \& adfrictorijs commifceri folet. Aluum fiftit, in ouo fumpta, aut clyftere infura . datur iecinoris uitio laborantibus .

H D I E profectó neminem inucnio, qui doceat, os explicet, qua nobis legitima fit Rubrica sinopica. Sed 50 quantum ego conijcere potui ( etfi id procerto afferere non aufin) nullum é foßilium genere occurrit, quod magis sinopic am rubric am nobis reprefentet, quam uulgarißimus bolus Armenus uocatus, is nimirum, qui in quadratas defertur mafjas, quiq́; maxime uulnerarijs medicis expetitur ad fanguinis profluuium cobibendum, er fractd offa fer $=$ ruminanda. Hec rubrica ( $u$ t Georgius Agricols maximus foßilium indagator inquit) etfi iandudum ex sinope Cap= padocix urbe, unde nomen inuenit, cantum importabatur; conftat tamen alibi etiam reperiri, non modó in proprijs uenis; fed in aurarijs, arzentarijs, ararijs, ferrarijsó; metallis. Hanc omnino mibi opinionem illud auxit, quód certó fciam plurimum p feudoboli Armenij ex ferrarijs Iluse Tyrrbeni inful.e fodinis ad nos quotidie conuehi: quod deinde colore fit iecinoris, pondere grauis, futftantia denfus : quód etiam in aquam coniectus facilé diflliat : quód deniq; fua ui exiccet, adftringat, $\sigma$ cogat. Hec enim gleba, cim uerusbolus Armenius non fit, nil aliud (meo iudicio ) ejfe poterit, quìn rubrica sinopica, quanquain à sinope non deferatur. Species sinopidis (ut plinius eft aubbor libro

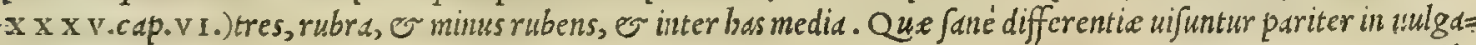
ri Arnenico bolo. Porró IIanardus Ferrarien is libro tertio epiftola quarta, sinopica rubric meminit, qua albo

RubriceSinopica confideratio.

Nomina. 


\section{And. Matthioli Comm.}

glebam Rubricam appellari. Rubrica, que Grecis $\mu$ i pica uocatur : Arabibus, Mogar, Jiue Magra: Hifpanis, Almagra.

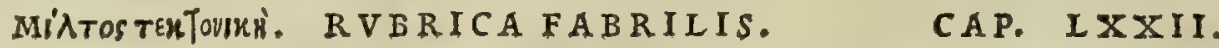

R v B R I C A fabrilis ad omnia Sinopide inferior eft. Optima Aegyptia, \& Carthaginenfis, lapidum expers, friabilis . Gignitur etiam in Iberia, quæ ad occidentem fpectat, ochra exufta, \& degenerante in rubricam.

Rubricx fa- $\quad$ R V B R I C A M banc ideo fabrilem appellauere ueteres, quód ea plerunq; uterentur materiarij fabri ad lineas brilis confid. protrabendas infertis in ea funiculis. Nafcifabrilem rubricam in Lemno memoria prodidit Galenus, cum libro nono fimplicium medicamentorum, tum ettam primo de antidotis, fed à Lemnia phragide plurimum differre. Verìm an communis ufus rubrica, que uulgó Italis proprié dicitur Terra roffa, ed fit fabrilis rubrica, de qua bic meminit Dia

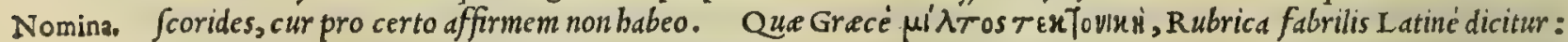
Arabibus, qui nullam faciunt differentiam inter hanc $\mathcal{O}^{\circ}$ sinopicam, Mogar or Magra: Italis, Rubrica fabrile: Germanis, Roetel ftein.

\section{$\triangle H \mu V V^{\prime} \alpha \gamma \tilde{H}$, LEMNIA TERRA. CAP. IXXIII.}

LE M N I A terra cuniculofo in fpecu nata, è Lemno infula, paluftri loco defertur, inibi electa \& caprino fanguini permifta. quam incolæ cogunt in paftillos, \& imagine capræ fignant: vnde \& fphragida xgos, hoc eft, figillum caprx appellauere. Vim antidoti habet contra perniciofa uenena fingularem : pota cum uino, \& præfumpta euomi uenena cogit. Contra ictus morfusq́ue animalium, quæ exitiale virus eiaculantur, prodeft. Antidotis familiaris. Sunt qui hanc ad facrificia utantur. eft \& dyfenterix utilis.

Lemnix terrę hiftor.ex Galeno.
L E M N I A E terre amplam in Italiam notitiam fuo tempore attulit Galenus medicamentorum omniuni diligen tißimus inquifitor . quippe qui, ut hac (jncerißima tandem potiretur, atq; ut omnem impoftorum fraudem detegeret, qui eam adulteratam uendebant, bis in Lemnum infulam nauigauit, ut eius uerba teftantur libro I x. fimplicium me $=38$ dicamentorum, ubi ita criptuin reliquit. At alie funt terra differentixe ex diuerfi generis corporum nate commiftio ne, qua ratione lapidofa, o archofs babentur : atque admistam talium fubftantiam fegregant larga aque effufione ac maceratione, dum totum bumidum efficiatur. Cüm enim id effetum eft, id quod defertur, atque ineft lapidofum, atque arenofum, id omne fubfidit, e terra exacta fupernatat. Tale quiddam 0 in Lemnia terra uifitur, quam co= gnominant quidam milton Lemniam, id eft, rubric am Lemniam, $\mathcal{\sigma}$ alij quidam fthragida Lemniam, hoc eft, figils lim Lemnium, ob impreffum uidelicet illi figillum Diane facrum. Siquidem hanc terram facerdos cum patrio quo= aam bonore fumens, baud mactatis animalibus, fed tritico, atg; bordeo piamenti gratia loco redditis, in urbem com= portat: quam deinde aqua maceratam, atque in lutum bumidum redactam, ubi ualenter conturbauit, paulumq́; inde quiefcere fuit, primìm aquam, qua fupernatat aufert, or mox quod fub ed eft lutum tollit, ac reliqum duntaxat, quod ad imum fubfedit; lapidofum fcilicet, er arenofum relinquit, ut inutile, ac fuperuacaneum. Porró lutü illud pin= 40 gue $u f$; ; eò deficcat, dum mollis cere confiftentiam accipiat: huiusq; exiguis acceptis particulis, facrum Diane $f i=$ gnum imprimit . Ac poftea rur fum in umbra ficcandum reponit, donec omnĕ plané bumiditatem amittat, fiatq;; illud medicis omnibus cognitum medicamen Lemnia flbragis, fiue figillum . Sic enim quidam illam cognominant; ut dixi,ob impreffam illi fphragida,boc eft, figillum: ceu etiam nonnulli ob colorem Lemriam milton fiue rubricam appellitant: eundem enim, quem rubrica, colorem babet. Verùm ab ea differt, quód contactu non contaminet atque illd : $\sigma \int e=$ cundum collem in Lemno, qui totus colore fuluo eft, or in quo neque arbor, neque faxum, neq; planta nafcitur, tan= tìm buiufmodi terra uifitur. Porrò tres eius fignantur differentie: una quam pofuimus terre facr $x$, quam alij nemi: ni prater unam facerdotem contingere fas eft : altera uerò cius, qua re uera miltos eft, fiue rubrica, utuntur autem ea potißimim fabri: demum tertid eius, que extergit, qua utuntur, qui lintea, on ueftes lauant, quibus utigue colli= bitum eft . Caterüm cùn o apud Diofcoridem, e alios quofdam fcriptum legiffen, Lemnix terra hircinum mi= fcerifanguinem, atque ex luto, quod ea miftione conficiebatur, facerdotem quas uocant Lemnias phragidas tum conformare, tum confignare, cupiebam profectó er ipfe miftionis modum inpicere, atque fymmetriam. Itaq; quem= admodum in Cyprum nawigaucram uidendorum, qua in ea funt, metallorum gratia, ev in cauam syriam Paleftine partem profectus fueram, bituminis er aliorum quorundam infpiciendorum caufa; ita nec in Lemnum enatigare pis guit, ut quantum fanguinis terre admifceretur, con/picerem. Nam cùm iterum ex A fia Romam pedeftri petercm itinere, per Thraciam, $v$ Macedoniam, prius à Troade Alexandrea in Lennum adnauigaui, nactus illic nauem, que ad Theffalonicam curfum deftinabat. Conueniebam autem cum nauclero, ut in cur fu Lemno appelleret. Et $f a n e$ ille preftitit, fed non ad eam ciuitatem, ad quam oportebat. Antea enim ne fciueram duas cffe in infuld ciuitates, fed credebam, ut Samus, Chius, Cos, Andrus, Tenus, O omnes adeó, qux in Aegeo funt mari, unan duntaxat ciui= tatem habent, toti infule cognominĕ ; ita $\sigma$ Lemnum unam nominis fui habere ciuitatem. Porró ut ex nauidefcen= deram, intellexi ciuitati nomen effe Myrine, nec in regione ciuitatis illus aut Pbiloctetis templü effe, aut facrum $\mathrm{Ne}=$ 


\section{In Lib. quintum Diofcoridis.}

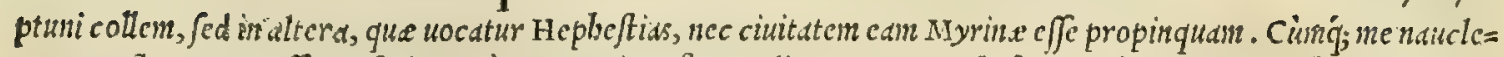
rus expectare non poffet, diftuli, ut cim Roma in Afiam redirem, tunc Hepbsfiada uiferem: id quod feci, prout pe= raucram, or propofueram. Nams ubicx Italia in Nacedonian traiccifen, cam q́; pené totam pedeftri itinere per=

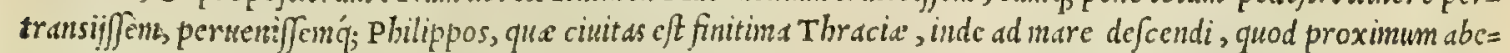
rat centum uigintiftadijs : primum;; Thafon tranfmifi, diftantem plis minus duccntis ftadijs, atquc illinc in Lcmumn feptingentis, ac rurfum firme feptugentis in Alexandream Troadu traicci. Ac proinde fané ex unduftria tum de nauigatlone, tum de fladijs adfcrip/i, ut fi quemeadem, que me caperet Hepheftiada uifendi cupiditas, cognito cius fitu, fic maigationem inflitueret. In tota nanque infula Lemno orientem fpectat Hepheftias, occidentem ueró My= rina. El quod i poëta dictum de Vulcano cft, qui Grece dicitur Hepheftus, Decidit in Lemnun, propter collis na= 20 turan occafionesn fumpiffe fabulse crediderim. Apparet enim combufto fimillimu, tum colore ipfo, tum etian quia whil in eo $u$ afcutur. In hunc itaq; collem facerdos, quo tempore ego ad infulam acccfferam, egreff, certo quodan tritici, hordeiq; numero in terram coniccto, alijsq́; quibusdam pro religione patria perpetratis, plauftrum totum terra inelevit. Atq; ubi in urbem conueniffet, quo dixt modo, illas fama bominum adeó celebratas Lemnias pbra= gidus preparabat. Vifum ergo mili crat percontari, nunquid unquam antea bircinum, aut caprinum fanguincm buic terre mifcerifolitum, memorix proditum accepiffet. Quo audito, omnes in rifum foluti funt, nec ij fante quiuis ex aulgó, fed uivioppido quàm cruditi, cum in alijs, tum precipué in uniuer $\int a$ patrie biftoria. Quin 0 à quodam li= brum accepi, quondam ab incolarum quopian de friptum, qui omnem Lemnie terre ufun edocebat. Quamobrem nec me quoq; piguit buius medic amentı periculun facere, acceptis pbloragidum uigintimillibus. Sed o bis, ḋquo Lemnix terrę librum dono accepi, inter principes habitus, ad multa boc utebatur medicanine: fiquidem ad uulnera tum uetera, uires.

20 tum cicatrici inducende contumucia: ad bec ad morfus uipera, atque adeo omnes ferarum morfus, necnon aduer $=$ fus medicamentalethalia, non anté modó exhibere, fed $\sigma$ póft ßibragide uti confueuerat. Addebat porró fe $\int e$ pe=

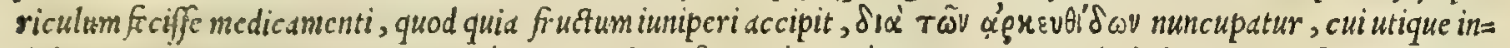
debatur o terra Lemnia: uonitum'q; ciere aiebat, fiquis cim etiámum in uentre lethale uenenum bereret, ale= xitcriun fime amuletum ebibilfet. Et fané nos quoque buius ficimus periculum in lepore marino, or cantharidibus, cim fe fe tale quippiam accepiffe homines fupicarentur: uerim baufto, quod Lemniam phragida babebat medicas mento, protions omne euomuerunt, nec po/ted ullum illis accidit fymptoma eorun, que ad leporem, er canthari= des comitari confueuerunt: tametfi conuicta effet pernicioforum medicaminum exbibitio. Caterum an ad alia mor= tifera medicaments, hxe inquam, que nocant deleteria, eandem uim babeat medicamentum, quod ex fructu iunipes ri, or terra Lemnis conficitur, mibi utiq; ignotum eft. At ille ab Hepheftiade profectó afferebat, adeo ut 0 rad $=$ 30 bientis canis morfum eam fanare diceret in uino diluto epotam: at ulceri ex aceto impensé acri impofitam. Sed er aliarme ferarum ifus, ex ace to fanare referebat, extrinfecus folijs herbarum infuper impofitis, qua putredini refi= fere didicimus. In primis ueró predicabat fcordium, deinde centaurium exile, inde marrubium. Porró fi quando nos face ad ulcera cacoëthe, or putrida terram Lemniam adbibuimus, magnifice profuit. Vfus autem efl, pro pra= witatis ulceris magnitudine. Quippe id, quod grauiter olet, impendio $q_{;}$laxum, molle $q_{j}$ eft, ac fordidum, fuftinet ut wel per acerrimun acetum Lemnia terra in luto fan foluatur confiftentiam, aliorum more paftillorum, quorum alius alio whitur : dico autem Polyide, or Prafionis, ev Andronis, or qui nunc dictus eft, quem Betinum uocdnt. siqui= dem hionnes ualenter deficcantes profunt ulceribus contumacibus, foluti interim quidem in uino dulci, interim fapa, ìterin cenomelite, nonnunquam etiam alborum uinorum quopiam, aut fuluorum, aut flakorum, prout nimirum ufus poftulat. Nam de talibus alibi definietur. similiter ueró quando q; foluuntur aut ex aceto, aut uino, aut aqua, aut o= 40 xymelite, aut oxycrato, aut melicrato. Porró Lemnia terra ex aliquo comprebenforum foluta, inedicamentum fit idoneran tum recentibus glutinandis unlneribus, tum medendis inueteratis, ogré ad cicatricem tenientibus, 0 con= tumacibus. Hactenus de Lemnia terra Galenus. Ex cuius quidem uerbis facilé conijci poteft, Lemniam terram, quan ad nos hoc tempore conuebunt mercatores $T$ urcic is charatteribus obfignatam, illegitimam effe, or minime fynceram. Quandoquidem conftat Galeni teftimonio, Lemniam ßpbragidem impensé rufefcere, non autem fubrufe= fere, qualis bec uivitur, que paßim pro legitina, fyncerd $\dot{q}_{;}$circumferunt impoftores. Quamobrem corum fen= tention minimé improbandan cen $\int \mathrm{emus}$, qui nil aliud effe Lemniam terram putant, quàm bolum A rmenium, qui of ficinis Seplafiariorum Orientalis cognominatur : prefertim quód certó compererim, bolum bunc non aduehi ex Ar = menia, ubi legitimum jyncerißinumo;; A rmenium lutum nafcitur, fed tantim ex infula Lemno, ex eodem fané colle, cuiks meminit Galenus. siquidem Armenium lutum, quod bolum quidam uocant, preterquàm quód ex Armenia ads

so ferridebeat, $f i$ Galeno medicorum principi credimus, colore eft pallido ochre inftar, non autem impensé rubro. Id quod ipje Galenus libro nono fimplicium medicamentorum in Samia terre mentione teftatur, his uerbis. Caterum durante hac immani, er graui peftilentia, ex Armenia ed, que Cappadocia fintima eft, data nobis eft terra, etiam ficcantior, colore pallido. Lapidem qui donarat, non terram appellabat: promptißiméq; in lauorem foluitur, ceu etian calx: fic enim uidelicet nuncupo petram combuftam. Verum utinec in illa arenofum quippiam admiftum eft, ita nec in Armenia. Nam poftecquam in mortario piftillo comminuta est, adeo est lou is, nec plus cft lapided, quaim aut calx, aut samius after: tametfi non equé ut after leuis est. Itaq; illo etiam mag is confpifata eft, minuśq; aëria: quä= obrem opinionem, ac phantafiam prebet ijs, qui negligentius intuentur, quafilapis effet. bac Galenus. Ex quibus fane perfficuun fit, quod Armenia terr a, fiue lapis, uel lutum, ab Armenio bolo oricntali uulgó nocato, qudm ma= ximé dysidet. Atqui, ut fraus, er impoftura detegatur, atque palàm fiat, non eft filcntio dißinulandum, quód qui Lemnum incolunt mercatores, cum fciant Armeniam terram ad nos non aduchi, lucri proinde dulcedine allceti, $e x$ was iantim terra duas conficiunt. Quippe fyncerißsimam terram Lemniam extra infulă Conftantinopolim compor=

I.emnia terra quid cenfeatur.

L1 3 tants 
t.unt, $\mathcal{O}$ pro Armeniaca uendunt, emptoribus fuadentes candem có ex Armenia comportari. Quxm uerò in Lemí no pro Lemnia exhibent, ut colore ab altera differat, eam cuidam albe terre inibi nafcentis admifcent: quo fit, ut longé minus quàin fynccra rufefcat, Hanc it dque legitime fphragidis loco fupponunt, hifce adulterijs permiftam: quam etiam figillis obfignant, ut inde impofture maius lucrum accedat, figno magis, quam medicamento fidentes. Caterum cium bec impoftura à pluribus modó depreben a fit, qui fraudem non ignorant, relicta unlgaribus medicis, qux obfignata conuebitur, ubi Lemnia ßphragide fit opus, A rmenium bolum falso uocatum fumunt, preftantißsinü fcilicet. quód procertó babeant, bunc legitimam effeßpbragidem Lemniam, quam miris laudibus extulere ueteres ad uenena, o uenenoforum animalium ictus. Quare inuigilent diligentißimi inedici, quibus cordi est hominum $\int a=$ lus, ne bac in re dectpiantur, cum perdifficile fanéfit ( ut libro primo de antidotis memoric prodidit Galenus) fyn= Armenix cer ceram fobragidem cognofcere ab adulterina. Verim quandoquidé in A R M E N I A terra fermonem deueni=. ræ feu boli ui mus, non alienum fuerit, eius etiämñum uires referre ex Galeno, qui eas loco nuper citato in fimpliciü medicamento= res ex Gal. $\quad$ rum cenfu fubdidit, fic inquiens. Armenia terra, quód fummé deficcet, ad dyfenterias, er uentris profluuia, tum fan=. guinis expuitiones, or catarrhos, ad bec ad putre centia oris ulcera in primis competit. Quin eo cos magnificé $t u=$ uat, quibus ex capite in thoracem fluxio decumbit: quamobremillis, quibus ex tali occafione aßidua difficilis eft an= belitus, ualidé prodest. Sed or eos, qui phthoè laborant, adiuuat: ulcus enim eorum deficcat, ut baud etiam tußiant, nifi in uiftu peccetur non leuiter, aut ambiens de repente ad intemperiem recidat. Ac mibi uidetur, quód ficut in fia. ftulas fepe conppeximus, non in alijs partibus duntaxat, fed in ipfo etiam ano, ut citra collyrij immißionem, quod for. dem, aut callum auferret, ipfo duntaxat exiccante medicamine, contraberetur, ac clauderetur; ita quoq; in pulmo= nis eueniat ulcere. Siquidem o ip um ab exiccantibus iuuarimedicamentis perinde confpicitur, utique cium medio= cre eft, non admodum magnum. Itaque uif funt quidam corum, qui taliababebant, prorfum effe liberati. Ac qui= 20 dam, qui Romain Libyam talem ob caufam profecti funt, plané fe fanos effe credidere: o fané ufque ad amos ali= quot inculpaté tranfigebant : poftea ueró sum non pari degerent cura, $\widetilde{\sigma}$ cautione, reditus morbi apparuit . Hos er = go, ut dixi, bolus Armenia euidenter adiuut. Quin v cos qui Rome agunt, qui aßiduó difficultate ßpirandi difcrus ciantur, magis etiam. Porró in magna bac pefte, cuius eadem facies fuit, atq; eius, que Thucydidis memoria graf= fabatur, quotquot hoc medicamen bibêre, celeriter cur ati funt. At quibus non profuit, omnes interiere, fcilicet cum nec alio quóuis iuuarentur. Vnde colligitur, quod ijs duntaxat non fuerit auxilio, qui plané erant incurabiles. Cea terium bibitur ex uino confiftentia tenui, modice diluto, fi aut plané febri careat, aut leuiter ea teneatur: fin gra $=$ uius frbriat, admodum aqueo. Non tamen calore uebementes funt fibres peftilentiales. Porró de ulceribus reficcas ri poftulantibus quid attinet dicere, quantam uim babeat bolus hec Armeniaca? Liberum eft autem utcunque appel= lare uelis, fiue lapidem, ut is qui mibi donauit: fiue terram, ut ego; quandoquiden humidis rigaripatitur. Hactenus jo

Lapidis Bezar de Armenia bolo Galenus. Sed quoniam Lemnia pbragis, er Armenia terra, quód uenenis maximé refiftant, mi=

har hiftoria, hi in mentem redegerunt lapidem, quem Arabes fuo idiomate Bezahar uocant, Er contra deleteria medicamenta mi \& uires. ris admodum laudibus celebrant, bic locus opportunus nobis uifus eft, in quo de buius lapidis biftoria, ac uiribus ali= quid differamus. Lapisitaque B E Z A A R, Mauritanorum teftimonio, antidotum cft omnium praftantißimum, fua fpeciali dote, contra omnis in uniuer fum uenena : utpote qui non modó, bauftus; fed etiam adalligatus, ita ut nus dam finiftrilateris carnem contingat, omnia fuperet uenena. Lapis bic plurium eft generum, nempe flauus, pulue= rulentus, qui ex albo uire $\int$ cat. Preftantißimus eft flauus, deinde puluerulentus, Verim enimuero diligenter inpi= cere oportet, ne impoftorum fallacijs decipiantur, quibos lapides inquirunt. Sunt enin nonnulli alij lapides, qui hos facie reprafentant, Sed uiribus nullis prediti. Hunc Rafis experinento ductus, miris extulit präconijs, ita de eo fcribens. L apis Bezahar eft mollis, colore flauo, fapore nullo. Cuius peculiaris uis eft, ut wenenis omnibus aduer $=40$ fetur . quandoquidem ego contra bauftum napelluin boc lapide ufus fum felici admodum fucceffu. Erat autem bic co= lore flauo albicante, leuis, or luminis modo plendens. Equidem certó teftari poffum (boc enim pluribus experimen= tis compertum babeo ) lapidem bunc longé magis preftare aduer fus deleteria uenena, quàn catera non modó fimpli= cia buiufce facultatis medicamenta; fed etiam theriaca dicta, er alia quixuis antidota. Subdit preterea Abdalana= rach. Lapidem, quem uocant Bezahar, iam ipfi uidimus apud filios Almirama cuftodis legis Dei: pro quo lapide is magnificam, ac propé regiam adem Cordube rependit, initio belli. Lapis bic (ut diximus) ita uiribus contra uene= na omnia pollet, ut non folum bauftus duodecim granorum pondere; fed uulneri impofitus à mortiferis quibuscung; ferisitios, ftatim liberet, ueneno fudore expulfo. Idem pariteriuuamenti adfert, fi ore aliquo tempore fugatur. Verum lapis bic inuentu difficilis fuerit, quod non defint paribus notis lapilli, qui tamen nullam uim babent aduerfus

Iapis in ocu- uenena. Sunt etiam, quimemorix prodiderint, in ceruorum oculorum angulis lapidem gigni, uiribus Bezahar so is ceruorum pradicto baud abfimilem. Aiunt enim in orientali plaga ceruos longo fenio confectos ferpentes deuorare, quorum matus. $\quad e f u\left(f i u e r a \int c r i b u n t\right)$ reiuuene $\int c u n t$. At ueneni fuperandicaufa, ferpentibus devoratis, in fluuiorum aquis ceruos illos mergi tradunt, capite tantum extra aquas exerto. Iis autem fic permanentibus, bumorem quendam lentum ab corum oculis deflui, qui tandem folis ardoribus in lapillos inibi concrefcit, glandis inaginem referentes. Hic itaque lapis ipfis é fluminibus egredientibus, ab corum oculis ( $u$ taiunt) ftatim decidit in humum: ubi ab ijs facile reperitur, qui rem omni diligentia obferuarunt. Sed an hec biftoria uel fabula dici mereantur, rerum naturalium ftudiofis, er

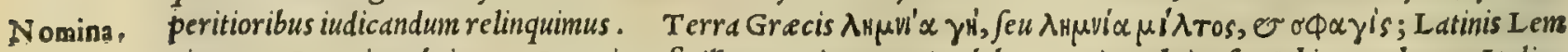
nia terra, L emnia rubrica, $\mathcal{O}$ Lemnium figillum nominatur : Arabibus, Teri machtim feu Thim machtum: Italis, Terra Lemnia : Hifpanis, Tierra fellada. 


\title{
In Lib. quintum Diofcoridis.
}

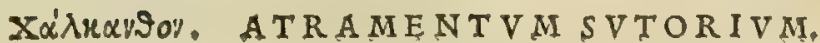

C A P. IXXIIII.

A T R A M E N T M futorium genere quidem vnum \& idem eft, molle, \& concretum: fed in fpecie differentias tres habet. Vnum nanque humoribus ftillatim in cuniculos quofdam colatis, concrefcit: quare ab ijs, qui Cypria metalla conficiunt, ftillatitium appellatur. Peteefius ipfum pinarion vocat: alij Italacticon, id eft, Itillatitium. Alterum fimplici ratione fit in fpeluncis : poltea transfufum in excauatos fcrobes, concrementum capefsit, quod petton, id eft, concretitium, propriè nominatur. Tertium dicitur coctile, $\&$ in Hifpania fieri folet : fed inutile, ac inualidifsimum effe con-

20 ftat. Ratio parandi hac eft. Aqua madefactum decoquunt, mox in pifcinas transfundunt, \& relidere patiuntur. Hoccertis diebus coalefcit, in complures formulas digeftum, teferarum fpeciem reddentes, quæ raccmatim inter fe cohærefcunt. Optimum efle creditur cœruleum, graue, concretum, translucens: cuiufmodi ftillatitium eft, ab alijs lonçhoton nominatum. Proximum concretitium. Coctile uerò ad infectus, \& denigrationes, aptius cxteris effe compertum eft : fed ad medicinæ ufum inualidius effe, experimenta docent. Valet adftringere, calfacere, \& cruftas inducere , latas uentris tineas necat, drachmæ pondere deuoratum, aut cum melle linctum : uomitus ciet aduerfus haufta fungorum venena, ex aqua potum auxiliatur . purgat caput aqua dilutum, $\&$ in vellcre naribus inftillatum. Vritur, vt paulò pòft in mentione chalcitis oftendemus.

C H A L C A N T H V M, quod Latini Atrantentum futorium uocant,quoniă uitrimodopellucedt, Itali vitreo lum nominant. Duo eius generd in Hetruria. Vnum foßlle, per fefe in terre uifceribus concretum, quod unlgó ap= pellant Copparofa. Alterum factitium, cuius paßsin eft ufus, infectoribus expetitum. Praftat boc plus, minusue tam pro regionum, locorum, ac coli dipofitione, quim ip/ius fo/3ilis matcrix, à qua arte conficitur. Veruntamen com= pertum cft, Romanum cognomento ( quanquam colore conftet dilutiore) catera fattitijgenera precellere. Secun= dum locum obtinet Cyprium, tametfí buic apud antiquos palma. Quzod autem é Germania adfertur, omnibus in Ita= lis infirmius babetur: fed quód fit colore caruleo, nonnullos fallit. Caterim chalcanthi materiam, quonian guftanti= bus linguam uellicet, appero, adftringentiq.; fit fapore, putauerunt quidam fulphureis, ferreis, ac areis conftare qua= Titatibus, quinetiam aluminis, nitri, falisq;. Chalcanthi uena, qux foditur in agro noftro senenfi pluribus fané locis, prefertim maritimis in fylueftribus plerunque uallibus, terrea potius, quim faxea uifitur, colore fubcinereo, macu=

30 lis nonnullis refper $\int$, quarum alie ferri rubiginem, alia aruginem, colore refer rnt. Hac dum fodttur, fretidum, gra ueolentemí; balitum eructat, fulphuris fere inftar q quam ob caufam in conclufis, coneameratisq; cuniculis nufquam foditur, fed aperto undique calo. Quippe $f i$ in fubterrane is foderetur peluncis, metallorum modo, ob acerrimum, fatidißimumiq; uaporem, foßores noxio conclujo ßpiritu facile interirent. Effo/fam itaq; chalcanthi uenam in aceruĭ in longitudinem protractum, quandam fuper aream exaggerant, ubi aperto colo fex ad minus menfibus, imbribus, roribus, pruinis, folibusq́; die noctuqq; macerandan relinquunt: quo tempore ftatutis quibusdam diebus ligonibus, or raftris acerum dilacerant, fubuertunt ó; or iterum in eandem congerunt aceruationem, ut facilius bec imbribus maceretur, coquaturq; folis ardoribus. Poft bac tectum aceruo fuperponunt, ne amplus in pofteruin pluuijs dilua= tur, neque folibus plusquam par fit, inare $\int c a t:$ or ita alijs fex menfibus materiam banc fermentari patiuntur. Eli= gunt deinde locum, quó facilius é propinquis fluijs, uel fontibus ducantur aque : ibiq;; fub conftructo tecto foditur al=

40 ueus, qui ligneis afferibus, uel lateribus, er calce adeó ftipatur, ut indita intus aqua nullo pacto prolabi poßit. In bunc igitur alueum purißiman aquam deducunt, cui demum tantum illius cbalcanthimaterie addunt, quantum buic negotio addicti miniftrifatis effe cen $\int e n t:$ poftea mifcent aliquo tempore ligne is quibusdam infrumentis ad id paratis, quoufque aqua in fe omne quod ineft chalcanthi receperit: deinde excrementa fubfidere finunt, donec aqua cbalcan= tho pregnans claritatem concipiat. His peract is foramina quedam prope aluei fundum in latere facta, recluduntur: $\sigma$ inde exiliens aqua in magnum excipitur receptaculum. Hanc ttaque fumunt, $\mathcal{O}$ in plumbeos alueos conijciunt (caterea enim metalla ab ea eroduntur) fornacibus quibusdan fuperpofitos, or igne fubdito feruorem excitant, ftatutis horis. Demum ferri fruftum inmittunt, uel eris: /iquidem aiunt chalcantbum nunquam concrefcere, nifs buiufmodi imponantur metalla, qua iniecta paruo tempore collique cunt in aquam. Poftquàm autem dehito tempore coxerint, igncn quìm primùm é fornace eximunt, permittunt q́; quie fcere decoctum, quoufq; egelidum reddatur, ne

so plumbeus alueus, eo Jublato, fornacis calore collique ceret. Omnibusitaq; tepefactis, decoctam materiam exımüt, orin alueolos quofdam ligneos digerunt, ubi tandem concrefcit, aluminis rupei modo, fit $q_{;}$chalcantbum. Si ueró aliquid fuperfit decodti, quod concrefcere nequeat, id totum iterum recoquunt, eadem feruata ratione. Sed longe ali= ter olimficbat cyprium chalcanthum, de quo Galenus libro I x. fimplicium medicamentorum, in hunc modum fri $=$ bit. Forte fortuna o chalcanthum in chalcitin tranfire conpexi. Apportaui enim ex cypro o buius medicamenti ingentem copian. Extimum eius omne poft annos plus minus uiginti chalcitis effectum elt, intima eius parte chalcan= thi peciem feruante. Quamobrem $\sigma$ ufque in bunc diem quod fic mutatur, afferuo, ob feruans dum ad imum ufque ano quoque anno pioced at mutatio, ceuchalcitidis in mify, ut eft anté pofitum. Caterim mirari fubit de hoc mrdi= camento, quo pacta uebementißtme adfrictioni admifta eft caliditas non inftrenua. Conft at ergo quod omnium ma= ximé condire, Serwaréq; carnes bumidas poteft, nimirum caliditate bumiditatem abfumens, atq; adftrictione fubftan= tian contrabens, atq; conftipans: boc enim opere nonnibl etian buniditat is ip/ius exprimit. Constringit uero, de= ficeat, atq; contrahit in $\int e \int e$ totius fubftantiam carnis. Rorró quo tempore in Cyprodiuer fabar, bunc in modum me $=$

Chalcáthi ge. nera, \& hilto ria.

\section{Chalcảthi ui- res, \& hiltoria ex Gal.}


dicamentum hoc colligi compexi. Domus erat magna quidem, non tamen alta, ingreffui in metallum obiecta. Ad pas rietem autem domus finiftum, qui erat ingrediĕtibus ad manum dextram, effolfus erat $\beta$ ecus in continentem collem, ca latitudine, ut tres $\int e \int e$ uiri in co contingerent, tanta ueró altitudine, ut uiro fumné procero recto liceret incedere. specus bic decliuis quidem erat, fed non planus, of multis locis preruptus. Porró ad finem eius quafi in ftadiü por= recti, lacus crat aque uiridis, or craffe tepentis plenus. At in toto defcenfu calor fimilis, qualis in primis balneor edibus percipitur : quas, quód in cis corpora pramollirifoleant, promalacteria appellare confueuerint. Aqua ueró quotidie guttatim ex pertufo colle deftillans, quatuor er uigintiboris diei, ac noctis colligi affolet ad amphoras Romanas quasi octo. Eam aquam uincti quidam in urnas quasdam quadratas fictiles in domo ad ingrefjum pofita fi=

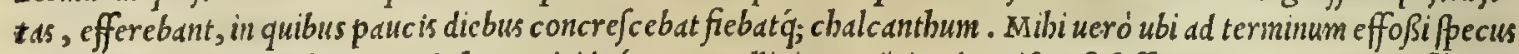
defcendiffem, ubi uidelicet tepida bec, uiridisq́; aqua colligitur, aëris odor uifus eft fuffocans, or toleratu difficilis, chalcitin, aruginemó; redolens. Hac aqua quoq; guftu praferebat qualitatem eiufmodi. Ea propter, $\odot$ nudi,et cü fflinatione amphor ds uincti exportabant, nec longiorem illic moram perferre poter ant, fed celeriter recurrebant. Accenfi autem erant mediocribu in pecu interuallis lycbni, qui nec ipfi longo tempore durabant, fed celerrimé ex= tinguebantur. Hunc ergo pecum pedetentim excauatum mult is annis ab ijs tunc audiui. Hec enim, inquiebant, aqua uiridis, quan uides ex colle in lacum manantem, fenfim fe ip a minor effici folet. At ubi prope adeft ut definat, rurs Jum uincti, quod continens eft ipfius collis, perfodere pergunt : euenitǵ; aliquando olim, ut fubitó quicquid perfofjum efet, concideret, omnesóf; ad unum occideret, ac totam uiam corrumperet. Id ubi fit, alia foramini fodiendo eousque infiftunt, quoad rurfum aqua illis adfit. Hec habui, que tibi de chalcantho exponenda cenferem, $\mathbb{C}^{-}$fané fortaffe non neceffaria, caterum que fcire preftaret, quàm ignorare. Memineris auten, quód ad finiftram manum ingredientibus conpectum nobis dixerim metallum foreos, chalciteos, $\mathcal{O}$ mifyos. ut ex bis conijcere liceat, aquam pliuiam totius 20 collis terram illam colluere, atque abluere, ex qua fponte quidem fiebat fory, mify, or chalcitis: o per fornaces as, cadmia, pompbolyx, ppodium, er diphryges. Hac de calcanthi biftoria Galenus. Ex quibus paldim fit, aquam uire= fcentem illam, que é monte in peluncam continuo ftillicidio defluebat, nil aliud extitiffe, quàm aquam, annuis imbri=

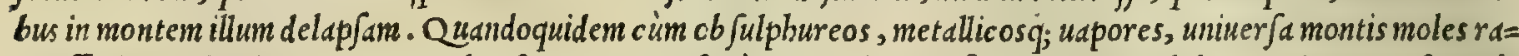
ra effect d, undiq; innumeris meatibus fcateret, non fane mirum uidetur, fi tractu tëporis laberetur in imum, fecum q́, deferret tenuiores chalcitis, mifyos, foreos, tum etiam ar arie materie partes : ibidem q́; calefieret, ac decoqueretur, fulphureis, bitumino/is, alijsq́; metallicis ignibus in terra uifceribus conclufis : adeó ut tandem in cauern illam de ccěe= dens, nature operd id fuerit affecuta, quod factitium chalcantbum arte confequitur. Eam igitur ob caufam in qua= drat is uafis extri parat is proiecta ea uiridis aqua, in chalc anthum coibat nulla adhibita coctionis ratione. Quinetiam opus non erat ferrum, uel es in eam inijcere liquandum, ut concrefceret, quemadmodum in factitio fit chalcantho. 30 quippe quod dum per erarij montis medtus laberetur, eris innumera ramenta fecum deferebat, que chalcitidis, $\mathcal{O}^{\circ}$ mifyos, ui ab ip $\int a$ aqua contracta, in eandem lique fcebant, argumento quód aruginis modo uiridi effet colore. Ob id itaq; fatuendum fuert, Cyprium chalcanthum coneretum eß3e medicamentum ex chalciti, mify, fory, or erc confld= tum. Id quod manifefte declarat Galenus, cum ait . Memineris autem, quod ad finiftram manum ingredientibus con= pectum nobis dixerim, metallum foreos, chalciteos, et mifyos. ut ex bis conijcere liceat, aquan pluuiam totius collis terram illam colluere, atq; abluere, ex qua pponte quidem fiebat fory, mify, er chalcitis: $\mathcal{O}$ per fornaces as, cad= mia, pompholyx, podium, or diphryges. Hoc ego quoq; maxime ob feruaui in quibusdam cbalcantbi fodinis in Tri=

Brafauoli uana accufatio.

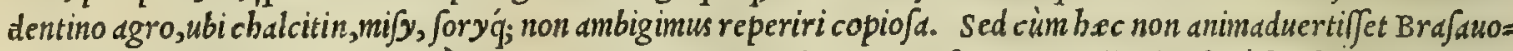
Tus, uir alioqui buius atatis clarißimus, dum imprudentia Gdlenum a ccu fare contendit, eius fané feip fum magis accu= fat. Quandoquidem ubi Galenum fibi examinandum proponit, co fcilicet loco, in quo feribit chalcanthum é Cypro a $\int e$ aduectü, trattu temparis confene fcens, factum effe chalcitin, dicit $\sigma$ fictitium uulgare noftrun illud idem effice= re : ueruntamen $\sqrt{2}$ in aqua re foluatur, iterum in chalcantbum concrefcere, quod maniffté indicat in ueram non tran= sijffe chalcitin : afferens boc non expédiffe Galenum. Verim in boc uidetur Brafauolus Galeni uerba haud recté per= cepiffe, cùm inqut, quód aqua, ex qua Cyprium fiebat cbalcantbum, terram uniuerfam diluebat, é qua chalcitis, mify, fory $q_{;}$fiebant in terre uifceribus. Siquidem nil aliud dixiffe uoluit Galenus, quàm quód chalcanthum effet chalcitis aqua diffoluta. Nam fi chalcitis ponte proueniens in aqua re foluta chalcantbum efficitur, mirum fané non eft, fi ed que tractu temporis fit ex chalcantho, eundem prabedt effectum. Neq; his objtat, quód quis dicat Cyprium chalcás= thum non folum ex chalcitifieri, fed ex mify fimul, er fory. Quandoquidem (ut in proximo commentario dicemus) tria bec chalcitis, mify, fory, ex ipfius Galenifententia, eiufdem tum generis funt, tum etiam facultatis. Cbalcantbu ponte, E per $\int e$ in terra uifceribus conflatum, uifu fane pulcberrinum mifit nuper ad me Tridento Martinus Gui:

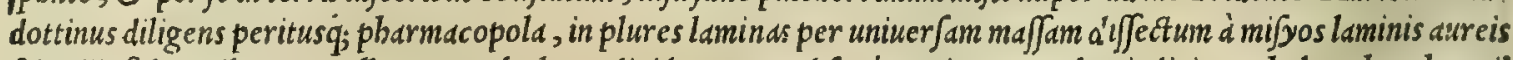
fcintilis fulgentibus, que illas unam ab alter diuidunt. 2uod fané maximum prebet indicium, cbalcanthum boc nil prius extitiffe, quàm chalcitin, que Galeno tefte, mify femper fuperftat. Caterùm ial'ud nil mirinobis adfert, quód conmendauerit Diofcorides chalcanthum potun ac deuoratum ad latas alui tineas, or ad fungorum uenena, etfi me= decamentum erodens, er feptic a facultatis babeatur. siquidem ad cofdem, er alios ufus bor tempore non modó chal canthum ipfum quidam potui exhibent in peftilentia; fed etiam cius oleum, quod cbymifte uitreis organis magna ignium ui ab ipfo chalc antho eliciunt, nullo fane incommodo. Qui illud in pefte propinant, quod uulgó uocăt Coppa rofa, in aqua rofarum diffoluunt, et iterum cogunt, reiteratis tribus, aut quatuor uicibus : dant'́; , obolum, nomitum

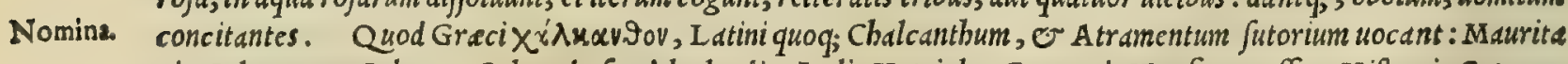
ni, Calcantum, Calcant, Calcand, feu Alcalcadis: Itali, Vetriolo: Germani, Kupfer uuaffer: Hifpani, Caparos $\int d:$ Galli, Copero $\int e$. 


\section{In Lib. quintum Diofcoridis.}

C H A L C I I s prefertur fimilis xri, friabilis, nec lapidof, necinueterata, intercurfantibus oblongis venis, fplendentibusąue. Huic abfterforia vis ineft, excalfaciens, \& cruftas vlceribus obducens: purgat, qux oculis, \& eorundem angulis harent. In genere leuiter erodentium clt . Ad igné facrum, \& viccra, qux ferpunt, cflicax eft. Sanguinem è vulua, \& naribus erumpentem, cum fucco porrififtit. Gingiuarum vitia, depafcentia vlcera, tonfillasq́ue eius farina compefcit. Vfta, \& cú melle trita oculorum medicamentis longè vtilior redditur. Callum genarum, \& fcabritiam abfumit,

2 abßtergetq́ue. Fiftulas tollit, collyrij modo in eas adacta. Fitcx chalcite mcdicamentum, quod Pforicon. Pforicon vocant, duabus cius partibus, cum vna cadmix additis, \& ex aceto tritis . oportet autem in fictili obruere fimo dicbus quadraginta, per Caniculæardores : fic enim fit acrius . idem quod chalcitis potett. Alij pares veriulque portiones in vino terunt, \& eadem profequuntur. Vritur chalcitis fictilinouo, viuis carbonibus fuperpofito. Modus autem vltionis in humidioribus cft, dum ip a chalcitis bullas excitare defierit, \& perfętè inaruerit : in reliquis verò, dum mutata in floridum colotem fucrit, \& fanguineum aut miniatum colorem contraxerit, tum demum eximenda eft. Inlidens autem fpurcitia Hatu expellenda, mox reponenda. Torretur etiámnum perflatis carbonibus, ufque dum luteo colore pallefcat: aut fictili fubdıtis candentibus prunis, fubinde verfata, donec igni conflagret, \& colorem mutet.

\section{Miou. MISY.}

\section{CAP. IXXVI.}

M I s y affumendum natione Cyprium, auri fimile, durum, quod friando auri colorem imita. tur, \& ftclle modo fplendet. Vim habet, \& vftionem, cum chalcitide eandem, praterquam quòd p foricum ex eo non conficitur, exceffus, defectusq́ue ratione tantùm differens. Aegyptium autem cæteris prattat, utpote quod efficacius habeatur, fed ad ocularia medicamenta multo fupradicto inferius.

\section{MEגarthgix. MELANTERIA.}

\section{CAP. IXXVII.}

M E I A N T ER I A geminæ eft originis. quædam in faucibus cuniculorum, quibus æs eruitur", falis modo concrefcit : Alia uerò in fumma facie fupradictorum locorum coit, qux terrena eft. Qui-. netiam inuenitur in Cilicia, \& alijs quibusdam regionibus, fofsilis quxdam. Præftat quæ fulphuris colorem trahit, 'Iæuis, pura, æquabilis, \& qux contaktu aqux confeftim nigrefcit. Vim caufticam eamobtinet, quam \& mify.

$$
\Sigma \text { Ege. SORY. }
$$

\section{CAP. IXXVIII.}

SOR Y exiftimarunt aliqui melanteriam effe, aberrantes: fiquidem fui generis eft fory, ei non 40 abfimile. Verùm forei uirus ineft graue, \& naufeam mouens. Inuenitur etiam in Aegypto, $\&$ alijs quibusdam regionibus, utin Libya, Hifpania, \& Cypro. Prafertur Aegyptium, quodque frianti nigrius apparet, inmulta furamina dehif́cens, fubpingue, infuper adfringens, \& olfactu deuorationeque magnum uirusolens, ita ut ftomachus in uomitiones effundatur. Quod autem friatum fcin tillas mifyos modo non emittit, \& alterius generis effe, \& inualidum, cenfendum eft. Vim, \& uftionem fupradıctis fimilem habet . dolori dentium cauernis inditum medetur : eosq́ue labantes firmat: ifchiadicis ex uino infu fum auxiliatur: illitum cum aqua, uaros extinguit. Medicamentis admifcetur, quæ capillos denigrant. Hæc autem ferè omnia, \& alia, quæ uftionem expcrta non funt, peruftis ualidiora effe exiftimantur : præter falem, \& uini fæcem, nitrum, calcem, \& confimilia, quæ cruda remifsiora funt . combufta enim uiribus efficaciora redduntur.

50

C н A I C I T I s, Mify, er Sory, longis iamifeculis latent, adeó ut perpauci, uel potius nutli fint in Italia, qui bec legıtima fe uidife affirment. Et quanuis ego iandudum pluribus in pecubus, cauerniś́;, ubi aris uena foditur, di ligentißimé inueftigauerim, atq; nullum ex bis, preter melanteriam, fuerim confequutus; boc tamen anno Mifyos fruftum fané pulcherrimum, aureis emicans fcintillis,quin or Chalcitidis, er soryos, quibus etiam chalcanthum ad= diunctum er at, mifit ad me Tridento Martinus Guidottinus pharmacopola reiberbarie, or metallica ftudiofus. In= uenta autem hec funt in quibusdam chalcantbifodinis in. Tridentiro agro, quibufdam montibus non longé à Leuigo pago. Verum legitimam Melanteriam iandiu muenimus in compluribus metallorum tumulis. Porró putat $\mathrm{M} u \int a \mathrm{Bra}$ fauolus, medicus noftri temporis celebris, chalcanthum nobis Romanum uocatum, uerum effe Mify, quod tamen ueritai, o rationi maximé repugnare uidetur. Qusndoquidem prater id quód aurum colore minimé imitatur, mi= nus'; cum frangitur, aureis fulget fcintillis, fed uitream tantum refert fubftantiam, palìn certé ommbus eft, $G d=$ leni teftimonio, sify factuium non effe medicamentum, fed pponte 0 per $\int e$ factum in terra uifceribus: Itpfe enim

Chalcitis, $\mathrm{mi}$ fyos, foreos, \& melanterix confider.

Brafauoli error. 
7ibro I x fimplicium medic amentorum, de chalcantho fcribens inquit. Memineris autem, quód ad finifr.tm manum ingredicntibus confpectun nobis dixerim metallum foreos, chalciteos, or mifyos. ut ex bis conijcere licedt, aquam pluuiam totius collis terram illum colluere, atque abluere, exqua ponte quidem fiebat fory, chalcitis, er mify: per fornaces es, cadmia, pompholyx, podium, er diphryges. Praterea idem de fory, chalcitide, or mify differens tcftatur (ut latius inferius patebit)dum in eorü ingrederetur metallum, quasdam intus fe conppexiffe ueluti zonds, alids. fuper alias in longum porred as, numero tres: quarum infima erat ipfius foreos, fuper quam erat altera chalciteos, fuprema ueró mifyos. Id quod manifefté oftendit, tria hac pponte in terre uifceribus fieri, non autem ullo drtificunt ingenio, ut Romanum chalcantbum fieri nemo nen intelligit. Conftat praterea nullă factitij chalcantbi peciem effe

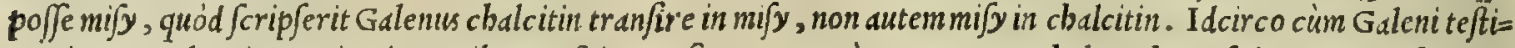
monio, er uulgari experientia onnibus perpicuum fit, , non tantum Romanum chalcantbum, fed onne, cuiufcunque 0 generis tractu temporis degenerare in chalcitin, nullo pato fuerit cenfendum, Romanum chalcantlam effe mify. Vnde rectius fortaffe dicere potuiffer Brafauolus, chalcantlun foreos magis peciem referre, quisn mifyos. Nam ( fi tante authoritatis apud doctißinos quo $\int q_{\text {; }}$ medicos fuerit Gralenus) quemadmodun chalcitis ucrtitur in mify, ita

Mifyos, \& co gnatorum hiitoria, \& uires ex Galeno. audiant, quefo, Galenum de re hac differentem lib. I X . fimplicium medicamentorum bis uerbis. In me cuius modó mentionem feci, in montibus solor um, domus erat ingens, cuius ad parietem dextrum, fed ad nos utiq;, qui ingrediebamur, finiftrum, introitus erat in ipfum metallum, in quo quafdam conpexi in longißinum porrectas veluti zonas, alias fuper alias numero tres : infina erat ip/ius fores, fuper quam erat altera chalciteos, fuprema mifyos. Ceterim id temporis prefictus metallibis commoftratis : sicui, inquit, nunc aduenis in cadmice fornacarie inopla, ita borum trium admirandas has uides diuitias. Itaque ego cum eius multum accepiffem, primisn quidcm in 20 Afiam, deinde Romam attuli, or ufque modó babui, elap/is iam annis plu's minus triginta. Et forte quadam abfolil= tum fuit hoc opus ad ufque octaum librum, ante annos uiginti, nec adie.tus, fuit nonus bic, partim quód lipides quof= dam nondum co: $\beta$ :xiffem, partim ob alia negotia, qua mibi intered temporis obuenere. Nunc autem cum nonum bunc librum cater is addere pararem, interea forté fortuna mibi accidit res pect. ttu longé pulcherrtma, ac fi quifpiam coftudio, ac induftria magno cum artificio effeciffet. Nam cum mify opus baberem, ad medicamen quodpiam pre= parandum, bolum eius accepi, quam feré plena manu teneas, qualem fané confiftenti.m mify non adinodum folet ba= bere, cum in parua fruftula diuidatur. Muratus itaq; infolitam cius condenfationem, bolo facta extinum quidem mi= fy circunquaq; reperi, eiks quod intus erat, uelut efflore fcentiam. Porró $\int u b$ eo inter chalcitin uidelicet, $\sigma$ mify, quiddan erat medium uergeris ex chalcite ad mify, ex dimidio iam commutatum : principio enim bolus fuerat claalci= teos: ceterum quod in alto erat, perfecta erat chalcitis, nullam dum alterationem experta. Hoc igitur ubi uidiffem, cogitatione repetens; $\sigma$ in metallo itd fuper chalcitin nafci ip fum mify, ut arugo fuper as, in mentem fubijt irpicere, quod feruabatur adbuc apud me reliquum ipfius foreos, nunquid or ip fum ullain accepif, $r_{\text {et }}$ mutationem in chal

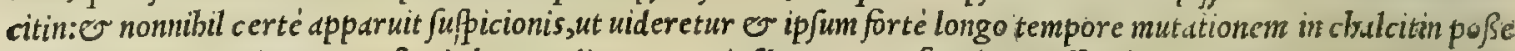
dccipere. Itaq; mirum non eft tria bec medicamenta eiufdem gentere facultatis effe; fory dico, chalcitit, $\mathcal{C}$ mify;

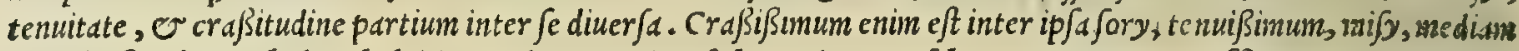
utriu $\oint_{q}$ facultatem babet cbalcitis. Adurunt uniuer $\int_{a}$ bac tria, $\mathcal{O}$ efchards quas uocant, efficiunt. Attamen etiă fi urant, nonnibil quiog; adfringunt. Caterim mify admotun carnibus duris, minus chalcite mordicat, tametfi ea non minus fit calidum : uerim id babet, quod tenuium partium effentia fit. Porró cùm utrá,; $b_{x} c$ in decoctionibus fundantur, o magis chalcitis, quam miy ; fory tamen non. Tiquefcit, nimirum quod lapido/ius fit, ac uebementius compactum: ficut rurfum mify, quia à cögentto calore elaboratius eft, ac proinde ficcius cbalcite, idcirco merita 4 quoq; agrius lique cit. Et libro i I I de compofitione medicamentorum per generd, idem Galenus ita fcribit. My= $\int_{y}$, fory, ut dideciftis, chalcitidi genere cognata funt, ex una ut dicam radice producta, tenuius tamen apparet

Nomina. mify, ac minus mordax $\sigma$ urens, craßius fory eft, ov utroque ficcat imbecillius. Xa Chalcitis Latinis dicitur: Arabibus, Colcotar, feu Cholchotar: Italis, Chalcitis. Mív ueró Gracé, Mify item Iatiné nocatur: Arabicé, Zeg, fiue Zagi: Italice, Mifi. Que deinde Grecis $\mu \in \lambda \alpha V T$ egi $\alpha$, Melanteria pariter.

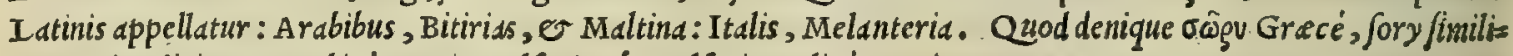
ter Latine dicitur: Arabicé, surie, Alfurie, feu Alfuri: Italicé, Sori.

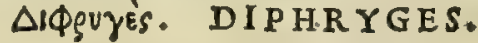

\section{CAP. LXXIX.}

D I P H R Y I s triagenera effe creduntur. Quoddam enim mettallicum eft, quod in Cypro fola gignitur: lutofum nanque extrahitur, ex luto cuiufdam inibi fpecus: extractum fole ficcatur; mox circumpofitis farmentis vritur . diphryges ideo uncatum eft, quòd \& à fole, \& à farmentis vratur, arefcat, \& ferme torreatur . alterum perfecti æris quafi fubfidens fæx eft : fiquidem poft frigid $x$. aquæ offufionem, vt fuprà retulimus, cùm de flore æris differeremus, fublato ære, fornacum ima parte cohærens id genus inuenitur, \& adfrictionem, $\&$ guftü æris habens. Tertium fic fit. Lapidem pyriten, vt calcem multos dies cremant in camino: cùmq́ue colorem rubricæ contraxerit, eximētes recondunt. Quidă tradunt hoc ex fola materia, qux lapidem xris gignit, fieri : quando in dictis areis. affata, $\&$ in fcrobes tumulata peruritur. tunc enim ambientem fcrobis locum comprehendit, \& exéptis lapidıb nihilominus inuenitur. Præfertur, quod faporem æris reddit, æruginisque, adftringens, \& vehementer exiccans linguam : quod fibi exufta ochra non vendicat, qua cremata diphrygis 


\section{In Lib. quintum Diofcoridis.}

vice urnit. Vis eius adftringere, perpurgare, extergere, ficcare, excrefientia confumere, vlcera ferpentia, \& qur cacoëthe vocant, ad cicatricem perduccre. Suppurationes terebinthina, aut cerato exceptum difcutit.

D I P H R Y G I s genus illud, quod perfecti aris quafi fubfidens fex eft, poft frigide aqua offufionem, ut Dio, ¿i Diphrygis.co

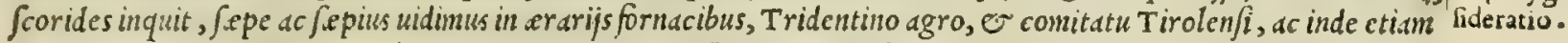
nobifcum detulimus. Sed quod è luto in Cyprio illo pecu foditur, urituró, farmentis : quod item é pyrite lapide calcis modo exufto conflutur: quod demum ex fola eris materia fit, cum in arcis afjatur, er in fcrobes translata peruri= tur, bactenus mbil uidere non licuit : nec cortum, quod fctam, peciatim meminit Galenus . quil libro I x. fimpliciums

10 medicamentorum de Diphryge in bunc modum differuit. Diphryges miftam babet tum qualitatem, tum facultatem : habet enim in fefe quidd.m er mediocriter adftringens, o mediocriter acre. quamobrem ulccrum rebellium opti= mum medicanentum eft. Conuexi autem o buins medicamenti uim ingentem ex Cypri solis, ubi metallum ab urbe abeft, quafi triginta ftadijs. Proiectum erat enim in medio patio adium, qua ante metallum cxtructe erant, or ui= ci, qui ci fubiacet. Cat terun prefectus, ac procurator metalli, id quod poft cadmiam reperiretur, effe dicebat inuti: le: itaque abijci, non cccus atche uftorum in foco lignorum cinerem. Verum boc mibi ad multa utile factum eft medis. camentun, tum ad putrefcentia oris ulcerd, fiue per fe, fiue cum melle, cuidetracta fit $\beta$ uma, tum ad anginam, ui= delicet ubi ism per adftringentium medicaminum auxilium conftitit, quod influcbat. Preterea columellam ubi prez:

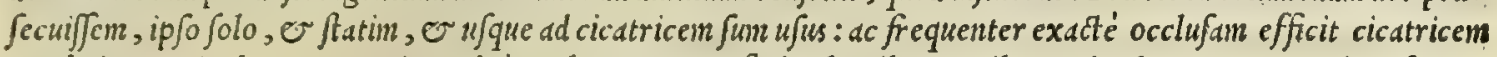

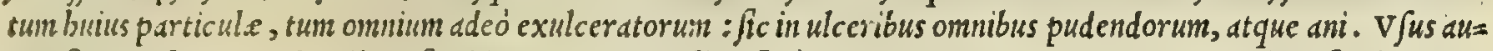
20 tem fimilis eft in oris ulceribus: fiquidem ex partes eifdem feré medicamentis gaudent, nimirum calida fimiliter , O humide. Et libro I I I I. de compofitione medic dmentormm fecundum generd, fic inquit. Porró diphryges appella= tum pharmacum, ulceribus egré bumiditatis uitio ad cicatricem uenientibus aptißimums eft : ualidé nanque ficcat, et is modicé mordeat. Eninueró id quoque preter acrem tum qualitatem, tum potentiam uim babet adftrictoriam.

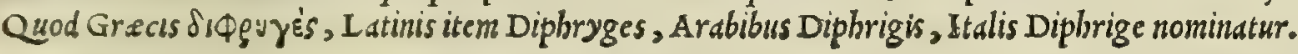

Hiftoria, \& vi resex Gal.

\section{A'gơVIxò. AVRIPIGMENTVM.}

CAP. LXXX.

A V R I P I G M E N T V M in eifdem metallis, quibus fandaracha, gignitur. Optimum exiftimatur cruftofum, aureo colore micans, nulli materix permiftum, in fquamas fifsile : quale in $\mathrm{My}$ fra Hel 30 lefponti nafcitur. Huius duo genera fluxerunt. vnum fuprà dictum eft. Alterum glandis effigie, pallidum, \& colore fandaracham imitans, glebofum ex Ponto, \& Cappadocia defertur : quod etiam fecundum locum tenet. Torretur in tefta noua, viuis carbonibus fubiectis, afsiduoq́; verfatur, donec igne flagret, \& mutet colorem : deinde refrigeratım, tritumq́ue reconditur. Vim habet adftrietoriam, \& erodentem. Cruftas cum uehementi vredine, \& violento morfu excitat. reprimit qux excrefcunt, \& capillos euellit .

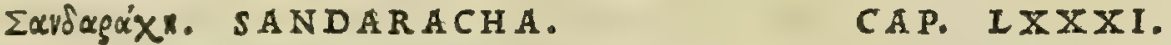

SAND A RACHA probatur rufa, \& faturatior, \& aliena materia uacans, friabilis, cinnabaris 40 colore, fulphuris uirus redolens. Dos eadem, \& vftio, qux auripigmento . Explet alopecias, refina excepta : \& fcabros vngues cum pice eximit: contra phthiriafin ex oleo efficax eft : tubercula cum adipe difcutit. Prodeft ad narium, oriş̧que vlcera, \& cæteras papularum eruptiones cum rofaceo : ité códy lomata. Datur ex mulfo, purulenta extufsientibus , fuffitur quoque cum refina, aduerfus veterera tufsim, rapto per fiftulam nidore: vocem expedit cum melle delincta : fufpiriofis cum refina in catapotio optimè datur.

A V R I P I G M E N T V M, Co Sanddracha, medicamenta funt eiufdem tum generis, tum facultatis, nec inter Auripigmenfe in alio differunt, quàm quòd alterum magis, alterum ueró minus excoctum fuerit in terr a uifceribus, ubi gignun = ti, \& Sandaratur. Vnde etiam Sequitur, quód alterum altero tantùm uirium tenuitate praftet. Quandoquidem nil aliud eft fanda= chx confide-

so racba, quàm auripigmentum, quod maiori nature coctione colorem rubeum contraxit, E tenuius effectum eft. Id quod periculo arte facto uerum deprebenditur. quippe i fictili: uel uitreo uafe uratur auripigmentum, fubftratis can dentibus prunis, breui (ut mibi pluries experientia compertum eft, flammeum, $\odot$ fummé rubens contrabit colorem, perinde ac fandaracha : coó; magis, quó plus calorifici ignis arte fuerit expertum, quàm ipfa fandaracha natura ui fuerit affecutd. Sandaracham fumme rubens uidimus primisn Venetijs in officinis, ubi auripigmentum, or exteri ueneunt colores pittoribus expetiti. Veruntamen animaduertendum eft (ut $\int u$ perius libro primo diximus) quód hac illa uulgaris Sandaracha non eft, quam Vernicem fcriptoriam officine appellant: fiquidem nil aliud bec eft, quàm gummi iuniperi. Errorem autem fecere neoterici illi, qui Mauritanorum nomina fecuti (ijs enim gummi iuniperinä fandar sx dicitur) idein gummi fandaracham nominauerunt: uta nomina turpiter confundentes, ut imperitis fape grauiter in rebus ipfis errandi prebeant occafionem. Quamobrem ubi in Arabum monumentis, ucl eorum, qui $\mathrm{Ar} d=$ bicam factionem in omnibus sequuntur, medicamentum aliquod repertum fuerit, quod sandaracham excipiat, de iuniperigummi perpetwo intelligendum erit : ubi ueró id in Grecis codicibus inuentum fuerit, eq quidem fine contros 
uerfia erit affumenda, de qua bic differit Diofcorides. Vocauerunt preterea recentiorum nonmulli sandarachant quoque sandycem, quam é combufta ceruffa conficiunt, quód fortaffe hec colore admodum rubefcat. Sed bec ab il= Ta (ut Juprà retulimus, cum de ceruffa fermonem baberemus) uiribus, or qualitatibus plurimiun dißidet. E/t or sindaracha ceragino/is mellis genus, $/$ i Plinio credimus, qui libro x I . cap. v I r. eius mesninit. Ceterim illud non atct flentio pretereundum, quod Arfenicum officinis cryftallinum uocatum, ideo quód cryftallimodo pelluctat, non fit per fefe, nec Ponte nafcitur in auripiginentifodinis, ut fcribit Vannoccius ciuis me us in fua pyrotecbnia, qui nos alixis eius fidcm fecutos, in bunc funn errorem deduxerat, fed arte ex auripigmenti fcobe adinifto fale. Sumunt enim artifices auripigmenti fcobem, or cum parifalis pondere mifcent, terunt'́; finul, or fubinde operculatis fictilibus huic operi inferuicntibus, ignium ui tandiu coquunt, quoufque id onne in fublime feratur, 0 operculo adbareat, con=

Auripigmen ti, ix Sandarache uires exGaleno.

Nomina. crefcató; in lapidem: id q́; toties repetunt, donec adeó purum efficiatur, ut cryfallum referat. Auripigmenti uires reddidit Galenus lib. I x. fimp. med. fic inquicns. Arrbenicum, fiue arfenicum facultatis eft cauftica, fiue urentis idq; tam combuflum, quàm uftionis expers. Coterim id confat uftione reddi tenuiorum partium. Vtuntur porró $c o$, ceu adurente ad denudandam pilis partem quámuis: Verün fï diutius inhareat, nec cuti etiam ipfi parcet. Idë de fandaracba codem libro fcribens, inquit. Sandaracba urentis eft facultat is, ceu ar fenicum quod uocant. $\mathrm{Merito}$ ita=

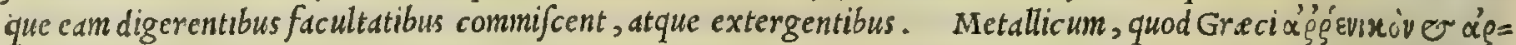
бevixo'v, Latini Arfenicum, Arrbenicum, Auripignentum uocant: Mauritani, Harnetb, feu Zarnich: Itali, òpimento: Germani Auripigment, or operment:Hipani, Oropimente. Qux ueró $\sigma \alpha v \delta \rho \alpha x^{\prime}$ Gracé, Sanda racha Latiné pariter et Italicé nocatur: Arabicé, non fecus at g; auripignentum, $\mathrm{Harnet,} \mathrm{O} \mathrm{Zarnich}$.

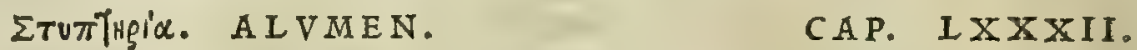

A L V M I N I s omne ferè genus in Aegypto, \& in eifdé metallis inuenitur: etenim fcifsile quoddam; quafi flos glebofi intelligitur. Signitur \& in alijs quibufdam locis, in Melo, in Macedonia; in Liparis, Sardinia, Hierapoli Phrygix, Aphrica, Armenia, \& plerifque alijs regionibus, ficut- $\&$ rubrica. Plurim $x$ eius fpecies : verùm ad medendi vfum fcifsile, rotundum, \& liquidum expetuntur. Optimum eft fcifsile, præfertim recens, candidifsimum, guftu perquàm adftringens, graue olens, calculorum expers, nec glebulosè aut afsulosè compactum, fed figillatim in capillamenta quxdam canefcentia dehifcens: quale eft, quod trichites, quali capillare nominatur, in Aegypto natum. Reperitur quoque lapis huic alumini perfimilis, qui guftus iudicio dignofcitur, quòd non adftringat . Damnatur in rotundi genere, quod manu confictum eft : fed ex figura dep rehenditur . Affumendum autem fuapte natura rotundum, bullis turgens, albo propius, atque ualidius adftringens, præterea nonnihil palloris cum quadam pinguitudine præfe ferens, fine arenis, friabile, natione Aegyptium, aut ex infula Melo. Liquidi probatio, ut fit lympidum, lacteuni, æuvale, \& femper fucco madens, fjne lapidibus, atque quendam coloris igniculum expirans. Vim habent excalfaciendi, ftringendi, \& expurgandi, qux caliginem pupillis oculorum offundunt. genarum carnem, cxteras que excrefcentias extenuant. Scifsile rotundo efficacius intelligitur. Vri, \& torreri chalcitidis modo debent. Putrefcentia ulcera compefcunt : fanguinis fluxiones inhibent : gingiuas humore pragnátes comprimunt: motus dentium cum aceto, \& melle firmant. Profunt cum melle ulceribus or is, eruprionibus papularum, \& fluxionibus auriuḿ, cum fanguinalis herbæ fucco. Lepris conueniunt cú brafsicx folijs, aut melle cocta: item pruritui, \& unguium fcabritijs, pterygiis, \& pernionibus, afperfa cum aqua. Valent cum aceti fæce, \& galla, pari pondere cremata, ad phagedænas ulcerum : \& cum falis duabus partibus, ad uitia, qux pafcunt . furfures, cum eruo, \& pice illita abftergunt: ad lendes, pediculos, ambufta, cum aqua illita auxilio funt. Contra tumores, \& graue alarum, inguinüq́ue uirus illinuntur. Ex Melo autem aduectum, mulieribus præftat ne concipiant, ante coitum ori vuluæ inditum : partus quoque extrahit. gingiuis, fi caro excreuit, vuis ac tonfillis accommodantur: ori , auribus, \& uerendis, cum melle illinuntur.

Afumintícon

T A M E T I I fcripferit Diofcorides plurima effe Aluminis genera; non tamen plurd, quaim trid boc locoftd= fideratia. tuit recenfenda, nempe fcißile, rotundum, or liquidum: quód fortaßis fuo tempore ijs tantìm uterentur medici. Ve= runtamen bac atate officine complura habent genera, quanuis rotundo, o liquido careant: nimirum $R$ upeum, quod uulgó uocant Alume di rocca: fquamofum, quod uulgó dicunt Alume fcagliolo: item é uini fece confectun: necnon illud, Catinum ïjsdĕ uocatum: quibus accedit, quod plumeun appellant . quod tamen legitimum fcißile nö eft, et fi iandudum cum cateris rei metallice ftudiofis crediderim fcifile alumen nil aliud efe, quàm quod unlgó officinis uocatur Alume di piuma. Sed boc (ut poftea dicetur) nil aliud nunc effe cenfemus, quim lapidem amiantum: quód guftu non fit adftringenti, fed acri, quoddó; igne nunquain comburatur, quod eft amianti lapidis proprium. Legitimü alumĕ fcißile Pifis mifit ad me hoc anno clarißimus medicus Lucas Ghinus, notis omnibus refertum, quas illi reddidit Diofcorides, o guftu admodum adftringens. Quo poftea factum eft, ut diligentitus exploratis plumei aluminis tum

Brafauolio pinio reprobata: item Fu chfij error. 'notis, tum qualitatibus, facilé deprebenderim plumeum hoc non effe fcißlle. Caterum Brafauolus de alumine diffe= rens in fuo fimp. med. examine, nil aliud liquidum effe contendit, quaim rupeum. Sed ab eo, licet uiro eruditißimo, uariat opinio noftra. Nam quód ego in Alumerijs Pontificis maximi in Romano agro prope Tolfam per bicnniü mo= ran duxerim, co nimirum tempore, quo Auguftinus Chifius opulentißimus mercator ciuis meus, illas aluminis fo= 


\section{In Lib. quintum Diofcoridis.}

dines à Pontifice cmerat, ampla fanè milhi fuit facultus twm uidendi, tum ctiım difcendi, quo artificio, quáue ratio= ne, rupeum confarctur alumen. Quamobrem facile teftari poffun rupcialuminis materian liquidun, fluxilcniq;

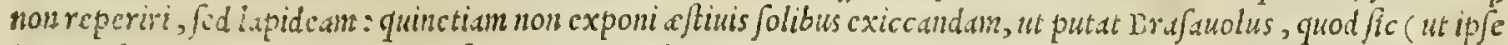
ingust) feripferit P linius liquidum fieri, o addenfari. In codem Brafanoli crrore uer fatur ctiun Fuclifus medicus

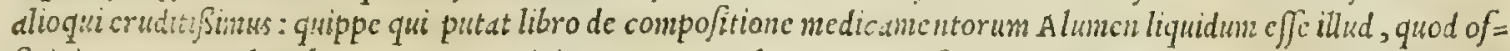
ficinis rupeun, ucl roche uocatur. Fit itaq; $R$ upcum dumen cx durifino quodam lapide, cuilu duo ob eruauimus gencs: $x$ : alterum durius, or rufeccens : altcrum ucró mitius, or candicans. Quod autcin é candido fit lapide, albe=

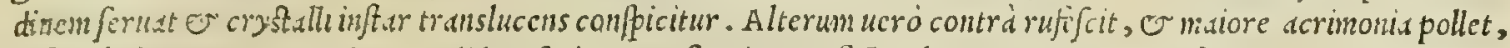
infiturij; fordidius. Expetitur candidum fericeormm ft sminum infectoribus: itcm ijs, qui preftantion lanarum uclle= 2o rúcoccinco colore tingunt, quód altcro nitidius, minusq́; acre babcatur. Foditur aluminis lapis ć rupe quad.m aper 50 undique celo, non ałem in concameratis cuniculis. Ingens ibifofforum catcrua perpetwó combinoratur, qui par= tim mucrontis ligonibus cx ualidißimo chalybe temperatis, partin ferrcis nulle is, ipfisó; ingentibus, purtin acutif= firits calis, chincis đ̆, bunc lapiden frangunt, lacerant, fcindunt, conterunt, ac diducunt, ca demum ratione, qua la= picide operantur in ingentibus lapidum, marmorum qj; fodinis, que ad magna effodiuntur adificia. Transferuntur deinde confoatil lapides in fornaces calcarijs fimiles, ubi ualidisimis ignibus, eo fané modo, quo calx, nocturno pra fertim tcmpore inuruntur duodccim, aut ad fummum quatuordccin borarum ßpatio: quippc fi diutius urerentur, cun= cta aluminis inutcria inarefecret. Poftquaim autem refrixcrint, plaultris in amplifimas areas $f u b$ dio, or folibus eos comportant, ibiq; in planos componunt aceruos, hortorum toris perfimiles, fed longé, laté'; grandiores, latiore fun damento, quam ucrtice. Compofitis igitur boc modo in arcis aceruis, aquam qua utring; continuó excurrit, in lapi= 20 dum aceruos mittunt, quibusdan cxcauatis inftrumentis, éligno conflatis, ijs perquàn finilibus, quibus naute fuis é faphis aquam eximunt; id tribus, aut quatuor uicibus quotidie repetentes, doncc diuturna aqua affufione, peru= filapidcs wföeadco' macerentur, ut in terram quandas lentore madide argilla finilem, permutcntur: quod tanen non fit, nifi squa pcrluantur, ad trigcfimum fcxtum, aut quadragefinum ufq; diem. Excauant praterea ligonibus terram hanc, er ad fornaces cortinaśg; , quas caldarias uoc ant, curribus item conuebunt . Sunt autch caldaria fic di cte cortine admodum capaces, or fuper amplißimum eneum fundun patine inftar, fuppofitan fornacem prias ex= tructam undiq; opericntem, cx lateribus, o calce fabricate, o crufta quadä pertinaci undiq; circumlita. Has itu= que aqua replcnt, aque ductibus eo deducta: deinde in fubfidentem for nacem, ualidißimum fuccendunt ignem, ut de= mifa firusest aqus. Hoc cim fartun fucrit, comportatam ex areis terram in feruentem aque alueum conijciunt . $A=$ ftant utrinq; bini robuftifini artifices, qui uelutiremigantes, magnis quibufdan ligne is inftrumentis (palas uocant) 30 continuó immifam terran aqua commifcent, quousq; aqua omnem aluminis materiam in fe conceperit. Subinde ter re recrementum, inftrumentis iam ditis trabunt ex alueifundo, es per propinquam ibifeneftram in quendam aque riumlun proijciunt dilo deducendü. Qüo facto iterum nousm fuperindunt terram, modo quo diximus commifcentcs, er recementum auferentes. quod tandiu profequuntur, quoufq; intelligant aquam tantum aluminis matcrie fibi afci uiffe, quantum fat fucrit. Demum parumpcr quie fcere dimittunt, ut fi quid recrcmentifit, in imum defcendat. Mox calentem aquam dlwmine refrtam extrahunt, o fuis aquaductibus ad id paratis in magnas quasdam cap as ex quer= namateric factas transf r rint. Iti enim ofto dierum termino alumen conficitur internis parietibus inharefcens add= mantinis mucronibus fintle, er crysalli inftar pellucidum, ad quatuor, aut quinque digitorum craßitiem. Alumine porró it a concreto, lixiuij reliqum (fic enim uocant decoctum) ḋ quo feceßit alumen, ijsdem aqueductibus è cap/is ithis cximentes, ad caldarias ita cis uocatas, remittunt, id fcilicet, quod clar un defacatumíg; fit : nam turbidum, er 40 recrementitium, aperto foramine in receptaculi fundo, tanquam inutile per riuulum deferri, or delabi finunt. Post hec aluminofum recrementum, quod minutis particulis granorum tritici inftar ad fundum refedit, ad cortinas illas magnas iterum difcoquendum comportant. Demum capfe fundo fcopis omni ex latere mundato, quibusdam ferreis, ligneiśq; instrumentis concretum in parietibus alumen diducunt, diductum'q; eximunt, er exemptum in uimineas fi= fcellas conijciunt, or in quodam aqua alueo laulant, fifcellis in aquam demerfis. Eximunt poftca, er aqua excolata in aceruum domibus afferuant, falis modo. Ex bis itaque omnibus apertißimé cognofci poteft, rupeum alumen nullam babere cum liquido cognationem. Quandoquidem afferit Plinius libro $\mathrm{x} x \mathrm{x} \mathrm{v}$. cap. $\mathrm{x} v$. fieri liqudum ex aqua li= moq́; , hoc eft terre cxudantis natura : corriuatum byeme, eftiuis folibus maturari. probari autem quod limpidum 1ateum'; fit, fine offen/is fric antium, cum quodam igniculo caloris. si ueró adulteratum fit, deprchendi fucco mali punici: quod Jyncerum ed miftura nigrefcat. Sed bec non inueniuntur in rupeo, ut quod magis glacicm, cryftalluní

so referat, quàm lac : fiat item ex durißimo lapide, non ex limo: nec affufo punici fucco mgrefcat, fed longé magis pel luceat. Hinc igitur fit, ut non modó à Brafauolo diffentiam, er à Fuchfio uiris alioqui citra controuerfiam doctißi=

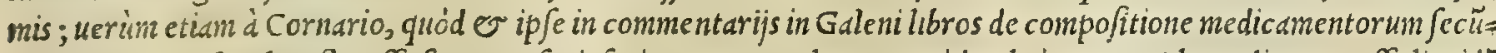

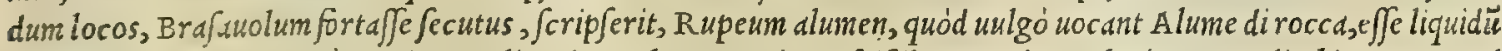
Grecis uocatum. Verim enimuero liquidum Alunen, quin o fcißile, rotundum, placites, e plintbites nuper ad me mifit Bartolome us Maranta A pulus, medicus apprimé eruditus, or medic materia ftudiofus, at $q$; diligčtißimus Alumina co. inquifitor, qui ex fe e Puteolis Campania idmpridem bec omnia aluminum genera comperit, que fané nullis, ni nze falit iudicium, notis a legitimis dißident. Huic ergo uiro eorum aluminum cognitionem libentißime acceptan refero, $\mathcal{O}$ quas poffum ago gratias. Scio tamen ijs ingentes deberi, qui ut ipfe fua inhenta cum alijs quoq; conmunicarc non grauantur. Iiqudum item Alunen ex Ilua Tyrrheni infula aduectum, quod' ; $_{\text {; }}$ nanibus duct um lente cit, antea ad ine miferat clarijßimus medic:s Lucas Gbinus, Pliniane defcriptioninotis ommibus reppondens, adeoó; adfringens, ut nunquam meminerim medic dnentum aliquod deguftafe, quod guftui tantü adfitrictionis relingueret. Porró quod ro:

Aluminis rupei facięda ra tio. 
tund um Greci uocdnt, tamet fi non defint, qui fibi per fuadeant, id efe quod officine à facchari effigie zuccharinum appcllant, ex crudo alumine rupeo, ouorum albo, er ftillatitia rofarum aqua paratum; cum tamen non inueniatur ru= pcum ueteribus cognitum fuif $e_{2}$ cur corum iudicio fub fribam non babeo, prae fertim quód legitimü nunc apud me fit. Quod praterea Catinum appellant, ex cuiufdam planta cinere, chali Mauritanis uocate, conficitur ad uitra in for = nacibus expurganda. Plantam hanc nos uulgó uocamus Soda. Prouenit bec (ut alibi fcrip/inus) in litoribus maris, falfo admodum fapore. Caterum quod ex uini fece paratur, fit conformatis é face panibus, deinde fole ficcatis, er igne tandiu peruftis, quou $q_{\text {; }}$ candorem conceperint. Poftremó squamofum (fic enim uoco alumen illud, quod uul. gó dicitur Alume fcagliola) ex fquamofo quodam fit lapide, or uitri modo pellucido, qui nonnullis pecularis appella tur, quod fortaffe felenitis modo peculi prebeat effigiem. nos Afini peculum dicimus, Hunc itaque in ignem conij= ciunt, aut ferri laminis igne candentibus fuperimponunt. Incenfus enim illico claritatem deperdit, difilit'́; in tenuif= fimas laminas, or gypfi modo albefcit, eius q́; induit ßpeciem. Quamobrem maximé falluntur, qui fibi perfuadent, in= ter lapidem pecularem, \& Talcum uocatum nullam intercedere differentiam. Quippe ( ut mibi quidem experien= tia compertum eft ) non fine magno labore, o flagrantißimo fornacis igne, Talcus imuripoteft. Specularis lapidis puluis nondum ignem experti, miris laudibus quibufdam effertur ad dy fentericos, in uino auftero potus : exuftu cnim

Aluminŭ ui- non probauerim, quod gyp/i pecie induta, fumentes ftrangulet. Aluminum uires paucis perftrinxit Galenus lib. resex Gal, Ix. fimplicium medicamentorum, fic inquiens. Stypteria, buius medicamenti nomen ab adfriclione deductum eft: nam adeft illi uebementißima. Caterum cum fit crafjarum partium, tenuior quodammodo eft alïs aluminü generibus, quod uocatur fchifte, hoc eft foßjilis: proxima eft frongile, id eft rotunda, or aftragalote. Admodum autem craffa eft tum liquida, tum placites, of plintbites appellata. Et libro i I I I. de compofitione medicamentorum fecundum ge nera, idem ait. Omnes aluminis differenti ulcera fatis exiccant generosé adftringentes: quare nemo folis ijs ad ul= 20

Opinio qux cerautatur. bec Galenus. Sed non defunt, qui Diofcoridem fecuti, alumen omne non parum excalfacere opinen= dam diluta. $\quad$ tur ; contrạ ueró qui contendant id omnino effe fal fum, potius frigefacere ip fum exifimantes, Galeniauthoritate fre

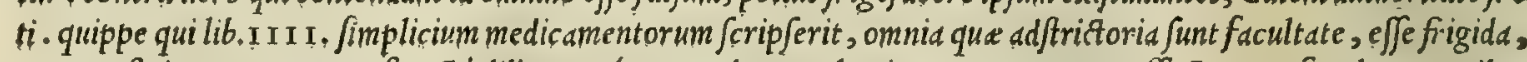
ac terr ffria. Veruntamen fi recté diligenterq,; expendantur alumin um quoruncunq; effectis, er facultates, quibus in corpus noftrum agunt, nemo quidem inficias ire poterit, quin aluminis omne genus non obfcuré excalfaciat, quem= admodum chalcanthum, cbalcitis, or mify : que cum ualenter adfringant, non tamen refriger ant, fcd maximé excal faciunt, ut idem teftatur Galenus libro primo de fimplicium medicamentorum facultatibus, dum inquit. Quin ueró ct A fclepiades Metrodorus tanquam illum etiam fuperare contender et afferendis de fenfu mendacijs, cùm alia qued a, tum refinam, o bitumen excalfacere nos denegat, at $q$; adfringentia omnia refigerare dictitat, chim fi nibil aliud fal tem chalcitis, chalcanthos, or mify, que ualenter adftringunt, tantam affecuta fint caliditatem, ut nos etiam exu= 30 rant. Nibil eft ergo mirandum, fi prolixa quedam nugentur, feipfos'́; nonnulli fallant, cùm de manifeftó apparenti= bus, uerum fateri non audent. Et libro I I I I. de compofitione medicamentorum per gener a capite primo itlud idem affirmauit, bis uerbis, Porró diphryges appellatum pharmacum ulceribus agré bumiditatis uitio ad cicatricem ueni= entibus aptisimum eft: ualde nanq; ficcat, etfi modice mordeat. Enimuero id quog; preter acrem tum qualitatem, tum potentiam uim habet adfriftoriam, quas tamen ambas fortiores, er chalcitis cruda, er chalcanibum reprefen=

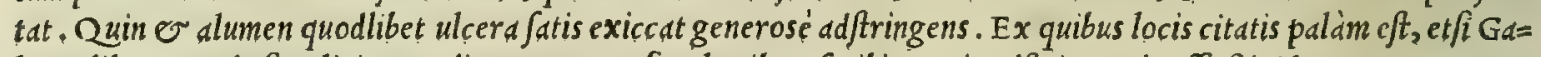
lenus lib. I I I I de fimplicium inedicamentorum facultatibus, fcribit omnia adftringentia effe frigida; non tamen eun inter ea recipife chalcanthum, chalcitin, mify, diphryga, eruginem, o alia quxdă, ut alumen omne genus: prafer= tin quod facilé compertum babeam, aluminis cuiufcunq; fillatitiam aquam, maximé rupei, non modó carnem cxede=

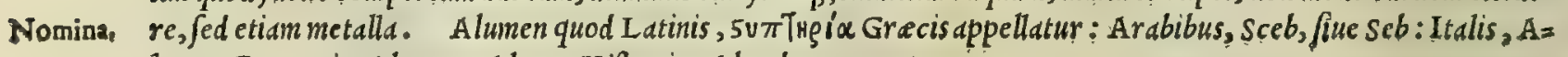
lume: Germanis, Alun, er Alaun: Hipanis, Alumbre.

\section{అย̄ंoท. SVLPHVR.}

\section{CAP. IXXXIII}

S V L P H V R optimum exiftimatur viuum, quod apyron uocant, nitedulæ modo fplendidum, perlucens, minimè lapidofım. Probatur in genere fulphuris ignem experti, quod uiret, ac prapingue fpectatur. Plurimum in Melo, \& Lipara gignitur. Supradictum fulphur calfacit, difcutit, \& celeriter concoquit. Prodeft tufsibus, fufpiriofis, purulenta extufsientibus in ouo fumptum, aut fuffitum : prxterea partus ufti nidore extrahit. Lepras, lichenas, fcabros vngues, cum refina terebinthina miftum aufert : cum aceto autem illitum, ad lepras efficax eft : vitiligines tollit. Scorpionis ictibus, addita refina, medetur : cum aceto uerò, draconis marini, fcorpionisque plagas fanat. Pruritus toto corpore erumpentes, cum nitro deterfum fedat : regium morbŭ emendat, infparfum fronti cochlearis menfura, aut in forbili ouo fumptum. Facit ad grauedinem, \& deftillationes; fudores quoq; confperfum inhibet , podagriçis cum aqua \& nitro illitum, conducit . grauitatem auditus, futfiti nidorem raptim per fiftulam haufto, fanat, Lethargicos fuffitu excitat : erumpentem vndecunque fanguinem fiftit . Contufis auribus, cum uino \& melle illitum, medetur .

Sulphuris cô. S V L P H V R tam ponte er per fe nafcens, quod uiuum appellant, quàm arte in fornacibus factü, frequentifs fideratso. fimum babetur in Italia: Sed non omnibus unus tantum color quippe aliud uiride, aliud luteum, aliud cinereum, aliud pallidum pectatur. Quod autem ponte fit, uiuum appellatum, exterius colore est fubcinereo, interius ueró cum frangitur, fubluteo, nitedula modo $\beta$ lendens, ut Diofcorides inquit ; ijsdem q́, oritur locis, ubifactitij uena foditur. $\mathrm{E} f$ 


\section{In Lib. quintum Diofcoridis.}

autem sulpibr foßtium medicamentum è pingui quadanterre fubfantit prognatum, ut in compluribus uifitur lo= cis, que impensé calida fit, er ficca: adeó ut à chymiftarum authoribus, igni natura fimile sulphur dic atur. Vocant id ij mafculum femen, or primum nature agens ad omnia metalla procreanda. Ciun autem calidum fit, $\mathcal{C}$ ficcun, quinetiam pingue (ut diuturna conftat expcrientia) maxinam cum igne trabit cognationem : /iquidem non flamme igrium madó; fed prunis quoque adnotum, ftatin accenditur, nec unquan accenfum extinguitur, quousq; pinguis, or oleofa cius fubftantia in uniuer fun igni abfumatur. Verun cnimucro ctfi pre fe ferat sulpbur tempcramentume

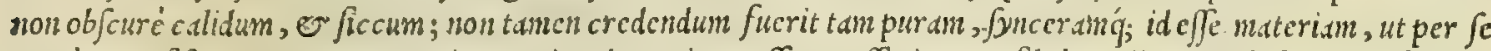

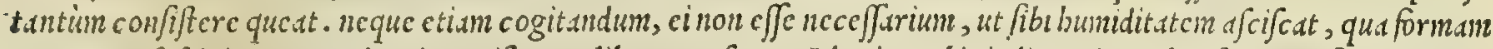
congruan fufcipiat, qucmadmodum mifta qualibet expofcunt. Id enim nobis indicat cius uclocißsina, ac facillina dif =

xo fufio, cimftstim igni adnotum colliquefcat, metallorum modo. Foditur aperto undiquc crelo, non autem in $c u=$ niculis, or Jubtcrrancis lpecubus. In bis nunque tum ucbementi calore, tum factidißimo terre halitu, foffores illico depcrirent. Porró effoffa Sulphuris ucna, fictilibus quibufdam magnis imponitur Romanis bydrijs non abfimilibus, longo ab ore dependente roftro, intus uacuo, ac in bumum pectante, uitrci pilci inftar, quo fillatitie aqua confi= ciuntur. His it.ąuc fictilibus fulphurea ucna repletis, fictilibus pariter operculis ad id duligenter conflatis, conte= guntur, ftipsnturq; ten.tcißino luto, cretd, o cquino ftercore compofito, ne tantillum quidcm expirare poßit ful= plurcus uspor. His perafis in fornacen crates duds ferreas intus babentem fictilia de feruntur, or in fuperiore cra= tem firmantur, coden luto undique fipata, adeo ut ignis flamma, qui in infina accenditur cratc fub fictilium funio, nullo pxito in fublime frrripoßit. Ad bxe fictilium roftrum in aliud uacuum fictile inferunt, per quoddam in latere orificium, - cadem creta quàm diligentißimé circumlinut, obducunt q́; maximé. Demumignem fuccendunt fub fi=

=0 Gilim fundo, cuius ui depuratum fulphur in fublime fictilium fertur, er per roftri concauitatem in udculdn fibi ad= nexum de fcendit receptaculum: à quo tandem fluens cximitur, aperto in fundo foramine, er alijs uafis excipitur, ubi in magnos coit globos. Hac fané ratione sulphur fieri conpeximus in agro noftro sersenfi in montibus non longe $\dot{a}$ bslneis dui Phlippi, or in maritimis apud Petriolum. Sulphuris uircs memorix prodidit Galenus libro $\mathrm{IX}$. fim= Sulphuris uiplicium medicamentorum, fic inquicns. Sulphur omne trabendi uim poßidet, eft'́; temperamenti calidi, dtq; effen= res ex Gal. tie tenuis, adcó ut ad multa uenenatorum animalium refiftat. Siquidem ego aduer fus paftinacam marinam, $\sigma$ dra=

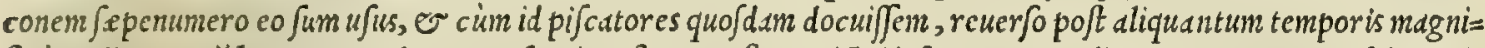
ficé medicamentü hoc commendarunt. V fus cius eft, ut $\sigma^{\sigma}$ ficcum ictui inpergatur medicanentum, Or cum faliua mi= ftum: nam cum o boc excogitaffen, ab experientia comprobari reperi. Sed o urina maceratum idem effccturü ex= cogitaui. Docebam enim pif catores medicamenta maximé parabilia, dixiq́; pulchré illos er cum oleo ueteri, $\sigma$ mel=

3० $l e$, o refina terebinthina uJuros. Et fané horum omnium experientidiudicium preftitit. Quin or p fords, $0 *$ liche= nas, $\sigma$ lepras; non raró boc medic amento cum refina terebinthina Janaui. Extergit cnin omncs id genus affectus, abfq; ut in profundum repellat, cim alia multa medicamenta, que illos curant, miftam habeant potentiam, nempe ut digerant pariter o repercutiant. Pratcrea, ut idem Galenus inquit lib.V I.cap. I I.de compofittone medicamento=

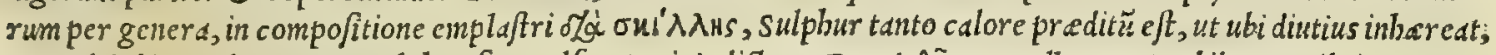
procul dubio exulceret. Sulphur fiue Sulfur Latinis dictum, Grecis Oẽov appellatur: Arabibus, Cribrit, $\sigma \mathrm{R} d=$ bric: Italis, solfo: Germanis, Schuuebel, $\mathcal{O}$ Lebendiger: Hipanis, Piedra azufre.

\section{Kiosrgls. PVMEX. CAP. IXXXIII.}

40 Pv M I C I s probatio, vt magnopereleuis, fpongiofus, fcilsilis, necarenofus, item teri facilis, $\&$ candidus. Crematur flagrantifsim is carbonibus obrutus, \& vbi canduerit, extractus, vino reftinguitur odorato : iterumque incenfus, reftinguitur : \& tertia uftione exemptus, \& per fe refrigeratus, ad vfus conditur. Vis eius adftringere, gingiuas abftergere - purgat cum calfactione, quæ pupillis caliginem offundunt : explet ulcera, \& ad cicatricem perducit : excrefcentia cohibet. Fit ex farina eius dentifricium. Corpori cruftam obducit: auellendis capillis aptus. Theophraftus author eft, fi quifquam in bullientem urceum uini pumicem iniecerit, feruorem ftatim fedari .

P V M I C E M ambuftum effe lapidem in montium concauitatibus, onnes feré fatentur nature operum explord= Pumicis contores. Ob id enim punices fepius eructat mons Aetna in sicilia, er in Campania Vefunius, qui hoc tempore, annis fideratio.

so nuper elap/is, non fecus quadm Plinij etate, ingentibus flammis exarfit, cum magno Puteolorum, or adiacentium lo= corum detrimento, igne in terr 2 uifceribus genito, é fulphureis uaporibus, or bitumine, quo quàm plurimi referti funt montes, cóq; prefertim, quod Graci piffappaltum dicunt. Pumicis uires duobus locis reddidit Galenus libro pumicis vires I X. Fimplicium medicamentorum, ubi de eo primim ita fcribit. si pumex inter lapides recenfcri poteft, et ipfe eius= ex Galeno. dem eft facultatis, quod certé ad abftcrfionem attinet, uelut etiam figulina teft $c_{3} a c$ multó mag is ca, qua fornaciü eft.

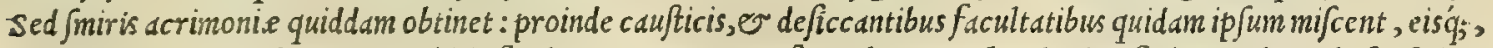
que curant gingiuas laxas, ac mollitie fluidas. Pumex autem fi comburatur, baud erit inferior eosdem ad ufus finire. secundo autem loco idem de punice differit bis uerbis. P umicem fi inter netallica recenfeas, calumniabuntur, qui

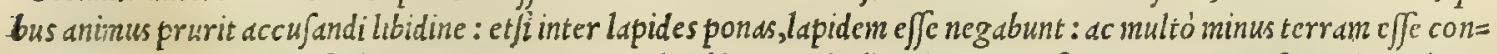
cedent, nec marinorum baberi quodpiam. Atqui alicubi tamen de illo dicendum eft: quippe qui in farcotica indatur medicamenta, $\widetilde{J}$ ea q!x dentes extergunt, partim ustioncm non cxpertus, partim etiä ustus, quando uidelicet alijs omnibus combuftis fimiliter Jutšătiz efficitur tenuioris. Caterùm uftione quiddan acquirit acrinonia, quam rur= 
fus lotione exuit. Videri autem poterit plendorem conciliare, non tantum facultate; sed etiam aperitate, uelut etiă

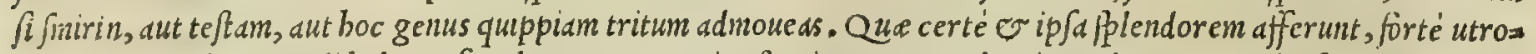
que, tum quia detergendi habeant facultatem, tum quia aperitatem. Eundem in modum cornua deuftadentes plen=

Nomina, didosefficiunt. Pumex qui Latinis, Grecis xiasmgs uocatur : Arabibus, Fanech: Itulis, Pomice: Germanis, Ein bims: Hipanis, Piedra pomez.

$$
\text { A }^{\prime \prime} \text { S. SA L. }
$$

\section{CAP. LXXXV.}

S A:L folsilis efficacior eft. communiter, fi eft candidus, calculis uacans, \& perfpicuus, denfus, zequali compage. Peculiariter Ammoniacus natione laudatur, fi modò findi facilè pofsit, \& in recta 10 fegmenta diduci. In marino fale eligendus eft candidus, æequalis, denfus. Probatifsimus in Cypro fit, \& Salamine Cypri, \& Megaris, in Sicilia, \& Aphrica. Sed inter dicta falis genera lacuftris prafertur: fed multò ualidifsimus eft Phrygius nomine tapeus, aut tritæus, aut gantæus. Salis natura in commune perquàm vtilis eft : adltringit, abfterget, expurgat, difsipat, reprimit, extenuat, \& cruftas inducit. fed hoc intereft, quòd alius alio fit præltantior. Quin \& à putredine vindicat. Admifcetur medicamentis pforas abftergentibus . excrefcentia in oculis reprimit, \& pterygia confumit, cæterasq́ue carnis extuberationes tollit. Cly lteribus infunditur: difcutit lafsitudines ex oleo illitus . Contra hydropicorum tumores auxiliatur: dolores in faccis fotu mitigat: \& pruritus fedat, ex oleo \& aceto infriôus ad ignem, donec fudent: item lichenas, lepras, pforasq́ue . Anginam ex melle, aceto, \& oleo illitus leuat : tonfillis, vuxq́ue cum melle toltus. Vlceribus in ore manantibus, gingiuis, quas 20 humor vexat, \& phagedænis vlcerum, cum polenta crematus illinitur. Aduerfus fcorpionum ictus cum lini fcmine : contra ferpentium morfus, cum origano, melle, hyfopo: aduerfus ceraften cum pice, aut cedria, aut melle auxiliacur : contra fcolopendr inorfus, cum melle, \& aceto : aduerfus vefparum ictus, \& teredines, albidasq́ue capitis puftulas, thymos, \& tubercula, cum feuo vitulino : furunculos, cum vua paffa, aut fuillo adipe, aut melle difcutit: teftium tumores, cum origano \& fermento maturius concoquit. Crocodilorum morfibus auxiliatur, tritus in linteolo, \& intinctus aceto, ita ve vinculis loca confringantur. Prodeft ad beftiarum morfus, \& ad fugillationes in facie ex melle contra hauftum opium, \& fungos, cum aceto mulfo bibitur. Luxatis imponitur cum farina, \& melle. ambuftis igni cum oleo impofitus, puftulas erumpere non patitur. Podagricis itidem imponitur, \& aurium doloribus, cum aceto , ignes facros, \& vlcera, qua ferpunt, cum aceto, aut hyf- 30 fopo illitus fiftit. Vriturfictili, diligenter opertus, ne exiliat, conditusque prunis, vfquedum efferuefcat . Aliqui forsilem fubacto polline obliniunt, \& carbonibus fubijciunt, vfquedum eius crutta exuratur. Solet \& fal communis hoc modo vri. Aqua femel abluitur, \& ficcatus in ollam coopertam mittitur fubdito igne, moueturq́ue, donec.iam non exiliat.

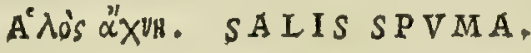
CAP. LXXXVI.

S P v m a falis fpumofi maris lanugo, fiue ramentum eft, in exilibus petris inuentum . cui uis eadem, qux falis.

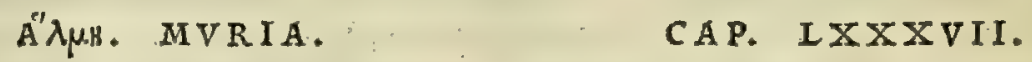

M v R I A effectus falis præbet, abftergitć; : dy fentericis infunditur, etiamfi nome inteftina corripit : $\&$ ifchiadicis veteribus. Ad fotus, aquæ marinæ vfum præftat .

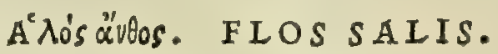

\section{CAP. LXXXVIII.}

F L o s falis flumine Nilo defluit: lacubus tamen quibufdam innatat. Affumendus qui crocei coloris eft, odore ingrato, ceu gari . interdum longè magis uirus olet, guftuq́ue mordacior, \& pinguiter lentus. Fucatus autem rubrica, aut fcrupulofus, improbatur. Præterea fy ncerus non nifi oleo refoluitur:adulteratus nonnulla ex parte, etiam aqua, diluente factitium colorem. Ad ulcera, qux cacoëthe uocantur, \& phagedænas, genitalium nomas, \& purulentas aures, cficax eft: oculorum hebetudines, cicatrices, albuginesque tollit. Emplaftris ; unguentısq́ue coloris caufa, ut rofaceo, mifcetur. Sudorem cit, aluum turbat, in uino aut aqua fumptus : ftomachum malè habet. Additur acopis, \& fmegmatis, quæ albandi capilli gratia componuntur. Et in vniuerfum acris eft, \& feruentis naturæ, ut fal.

Salis omnis generis conlideratio.
SA I, quo frequentißimé in omnibus feré cibis utimur, or fine quo uiuere ne fcimus, quo item ad annos afferuari= tur carnes, pifces, alia'q; complura, nullis fane non cognitus eft. Plures tamen in falis genere funt differ entiz: quă= doquidem prater marinum, fluuiatilis, lacuftris, foßjilis q; reperitur. Marino utitur uniuer a fr ré I talia, cxceptis Ca= labris, qui foßitio quàm pulcherrimo abundant. quo etiam utitur uniuerfa Panonia. In Germania hauritur é falfis quibusdam 


\section{In Lib.quintum Diofcoridis.}

quibusdum fontibus, quor̆̈ aqua diu ignium ui cxcold in falem cogitur. Fofsitum officine Arabus fecute faleng gem= me uocant. Huius fodinas undinus apud Calabros agentes, loco, qui unlgó dicitur Alcomonte, ubi lapidun modo $\mathrm{ex}=$ ciditur, translicidus cryftalli modo. Hic in ignen coniectus preter caterorm naturan nec dißilit, nec crepitai, fed

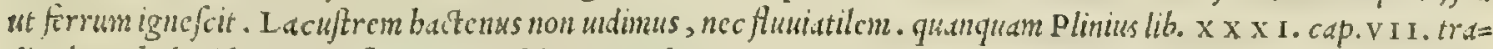
dit plures baberi lacus, ac flunios, qui falen copiofun reddunt, ut cius ucrba, quxe fubijcian, aperté tesh.ntur. Sal ommis, inquit, aut fi $i$, aut gignitm. Vtrwnq; plunbus modis, fed caufigcmina, coudto bumore, aut ficcato. Siccatur in lacu T. arcutino aftiuis folbus, totung; ft.gnum in falcm abit, modicun alioquin, altitudine gcnua non excedcus. Itcm in Sicili.1 in lacu, qui Cocanicus nocutur, or alio iuxta Gelam. Horum extremitates tantiun inarcfcunt, ficut in

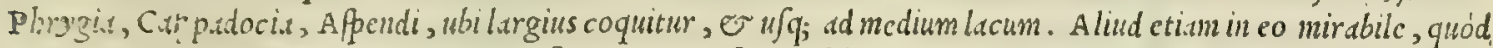

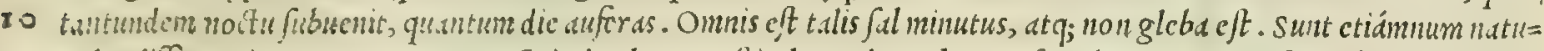

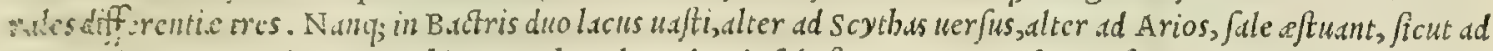
Cirtum in Cypro, et circ. Mcmphin, cxtrabunt lacu, deinde fole ficcunt. Sed or fumma fluminum derfantur in falcm, anne reliquo uclutifub gelu fluente, ut apud Capius portus, qua falis flumina appellantur. Item corca Mardos, er Armenios. Praterca apud Bactros ammis Ocbus, C Oxus ex appofitis montibus deferunt falis rantenta. Sunt $\mathrm{CO}^{\text {in }}$ A plvicalacus, er quidem turbidi, falcm ferentes. Ferunt quidem o calidifontes, ficuti P.rgufei. Et hacte int ba=

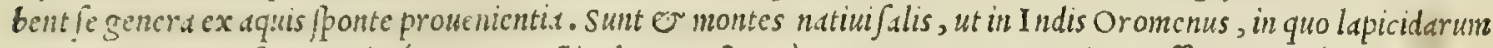

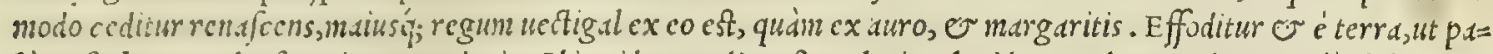
lin eft, humo"e denfato, in Cappadocia. I bi quiden caditur ppecularium lapidum modo. Pondus magnü glebis, quas micas unlgus appellat. Carrbis Arabie oppido muros, domosq́; majsis falis faciunt, aqua frrruminantes. Inuenit or 20 iuxta Pelufium Ptolemeus rex cinn castr. faccet. Quo cxcmpto postea inter Aegyptum, or Arabian ctiam fqud= lentibus locis ceptus est inueniri, decractis arenis. qualiter o per Apbrice fitientia, ufque ad Ammonis oraculum.

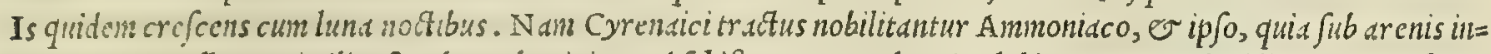
ucritusur, appelluto. Similis est colore alumini, quod fchifon uocant, longis glebis, neque perlucidis, ingratus fapo=

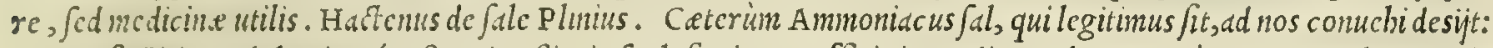
quppe frctitius, adultcrinusq́; eft, qui paßim in feplafiariormofficinis venditur, plerunque é Germania allatus, ni= gricuntibus exterius glcbis. Non defunt tamen, qui credant conflari bunc ex camelorum urinis, artificio quoda con= cretis. Scd cur lis adftipularidebean, non equidem uidco, prefertin cion Germania, unde Venetias conuchitur fa= etitius, camelos non babeat. Seplafiarij, pariterq́; chymifte Sal Armeniacum appellant, quód fortaffe exiltiment ex Armeniadferri, ubi innumeri funt camelorum greges. Sed ifti, mea quidem fentenita, hallucinantur. Serapio

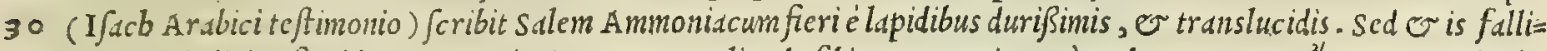
tur, meo iudicio: fiquidem Ammoniaci nomen non aliunde fibi comparauit, quìm ab arena, que aupos Grecis di= citur, fub qus in laminas concretus, inuenitur in Cyrenaica regione. Venit praterea in nedicorum ufun Sal, qucm Arabes Alcb.li cognominant, itein Alumen catinum, de quo fuperius in alumine diximus. Sal autem Indus appella= tus (ut libro fecundo retulinus) nil aliud antiquis extitit, quam faccharuin in facchariferis arundinibus in India gum= mi modo concretum, cuius nunc loco utimur $\int u p p o f i t i t i o$, quod feplafie zuccharum canditum uocant. Veruntamen animadlucrtendum of, quòd quanquam Paulus, O Auicenna eum fortaffe fecutus, concretum natura faccharum fas lem Indum appellant; non tamen fuerit putandum, quod Indi legitimum falem non babeant. Quandoquidem (ut.Pli= nius eft auctor) in Oromena India monte lapicidinarum modo foditur ingentibus glebis proinde dicebat Mcfucs de Jale fcribens, Napbthicum, o. Indicum cateros fales precellere. Quod autem Salnitrum uocant, tormentorü belli= 40 corum pulueribus expetitum, uulgaris notitix eft, de quo tamen latius fequenticapite fermonem facicmus. Ceterim falis puman pluries legi quibusdam in fcopulis Tyrrbenimaris. Cum enim procella exoritur, intune fcit q̧; pelagus, Ppunantes afu in altum fublate, fcopulorum cauitates replent. quo fit, ut ibi fub dio renanentes folibus, or rore, aftiuis caloribus, in falem album concrefcant. Muria porro, qua innumera afferusntur edulia, nota oinnibus res eft, ut que fale tantion, or aqua conficiatur. Sed quidnam ueteribusflos falis fuerit, decernere non aufin, neque plu= ra quod fcribam babeo, quàm que à Diofcoride produntur. Eius tamen meminit Plinius loco fuprà citato, fic in= quiens. Salinarum fynceritas fumman facit fwam differentidn. Quxdam enim fauilla falis, qua lcußjina cx co eft,

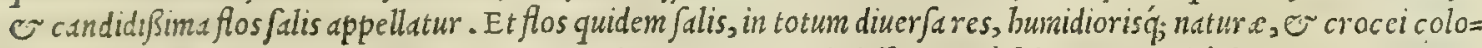
ris, aut rufi, ueluti rubigo falis. Odore quoque ingrato, ceugari, diffentiens a fale, non modó à pund. In Acgypto inuenitur, utdetur $q_{;}$Nilo deferri. of fontibus tamen quibusdam innatat. Optimum ex co, quod olei quandan pin= so guitudinem reddit. bec Plinius. Porró color rufe rubiginis inftar pictoribus expetitur, $\dot{e}$ Germani.e falints adue=

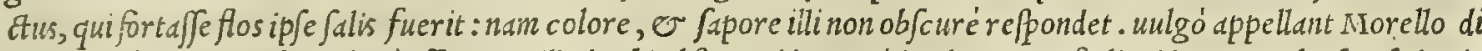
fale. Verun cur non boc plane affirmem, illud mubi obftare uideo, quod color is non fit liquidus, neq; olcolus, fed ari $=$ dus. quare potius inclinat animus, ut ip fum credam effe falis rubiginem, de qua ex Plinio pauló ante mentionem fecimus. Fuchfius medicus ingenio $\sigma$ eruditione clarus, in libro de compofitione medicamentorum, quem auctum $\int e=$ Fuch. opinio

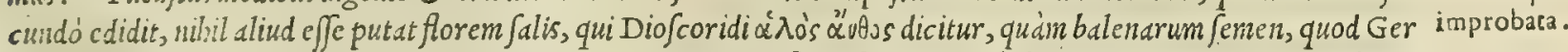
manis medicorum officinis Sperma ceti nominatur. Cua in re is fortaffe fecutus eft fententian Georgij Agricolerci metallice accrimi indagatoris. Sed utcunq; fit, non equidem poffum borum quanuis eruditorum uirorü iudicio fub= fcribere. nam res illa tantsm abeft, ut fit crocei aut rufi coloris, ut etiam candida confeiciatur. Adde, quód flos fal is D!of coridi e Plunio fumine Nilo defuit, o lacubus feu fontibus quibusdam innatat : boc autem sperma ceti uocas= tum in sari colligitur, atq; etiam in paludibus maritinis inuenitur. Id forte a maxinis illis pifcibus effunditur: quod Salis uires ex tamen non ie liquidum apparet, ut de flore falis Galenus memoris prodidit. Salis autewi meminit idem Galenus Galeno.

$\mathrm{Mm} \quad 3 \quad$ tum 


\section{0

tum inter foßitit medicamenta, tum etiam inter ea, qua in marinafcuntur libro I x. or x 1 . fimplicium medicamens torum, fic inquiens. Sal eiufdem genere facultat is eft, fiue foßilis fit, fiue marinus: ucrum boc differunt, quod fal is $\dot{e}$ terra effoßif fubftantia magis fit compacta: ac proinde in boc maior eft, or partium craßitics, $O$ adfingingendi poten= tia. Itaque marinus affufa ipfi aqua protinus liquefcit, at foßili boc non eucnit. Porró eiusdem peciei cum marino eft, qui inftagnis quibusdain falfedinem babentibus nafcitur, aftate uidelicet aquis aftu ex ijs abfumptis, cuinfmodi cft Tragafius non procul à sminthio. Confluit enim illuc ante aquas ppontaneds, qua admodum funt calida, copio $\int a d=$ quaftagnans, non amplo in loco: er ed aftate omnis abfunitur, df fole uidelicet arefacta. Porró quoniam locus ip $\int e$ falfedinem natiuam continet, quod reliquum est eius omne, fal eft, cognominationem à loco pariter o aquis forti= tus. Nam pontanea er ip fa illis in locis aque Tragafia nuncupantur, potentia fummé exiccatorid: or fané, qui in ea regione funt medici, ad hoc ill as accommodant. Porró dictum eft $\widetilde{\sigma}$ de Sodominis in mari mor tuo prouenientibus $\$$ in quarto libro, quem fiquis librum diligenter perlegerit, illi tantim refricare memoriam nunc opus eft, ut expofita gustus qualitate, ip fe medicamenti facultatem $\operatorname{cog}$ no $\mathrm{cat}$. I gitur cim qualitas falfa digerat, fimul $\sigma$ contrabat con= tact am ab ip a fubftantiam, wocatum apbrolitron in boc differt, quód in ipfo unum modó faporem exuperantem ex= preßéfit uidere, quem uocant amarum, uim babentem digerendi, baud etiam contrabendi, uti fal. Nam bic quicquid in corporibus bumidum ineft, id totun quodammodo abfumit: $\mathcal{O N}^{\circ}$ quod reliquum eft fubftantix folid $x$, adftrictionc cŏ= trahit : ac proinde etiam conditura fua corpora ficcat, of d putredine tuetur. Quippe qua putre cunt, excremen= titium continent bumorem, fubftantiamq́; tum diffolutam, tum minimé compadfam. Quibus ergo corporibus nulla prorfus eft bumiditus fuperflud, ceu melli optima, $\sigma$ corpus folidum, or compactum eft, ceu lapidibus, ca ut putre= $\int c a n t$ eft impoßibile: ac proinde in bis falis non probatur ufus, uerim in ijs, in quibus fupecta eft putredo. Spumo=

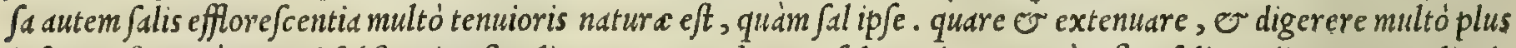
ipfo poteft: uerum quod Jubftantice eft reliquum, contrabere ut fal nequit. Caterim flos falis medicamentum liqui= dum eft, tenuius etiam quàm fal ustus: tum acris qualitatis, $O$ admodum digerentis facultatis. bactenus de $\int_{\text {ale }} \mathrm{G} a=$

Nomina. lenus. Sal Latinis dictus, ¿iss Gracis appclatur ; Arabibus, Melech, feu Melha: Italis, Sale: Germanis, Salz: Hipanis, sal.

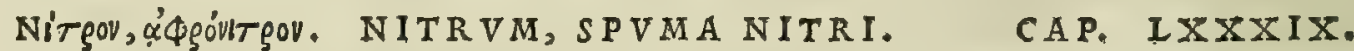

P R AE F E R T V R Nitrum leue, rofeo colore, aut candido, in foramina dehifcens, perinde quafi fpongiofum quiddam, quale ex Bunis adfertur. Humores euocat, qui in alto concreuerunt. Spuma

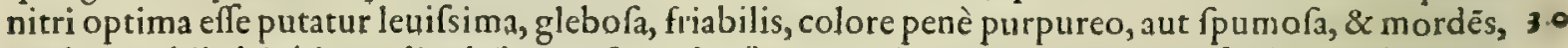
qualis ex Philadelphia Lydiæ defertur. fecunda eft Aegyptia. quin $\&$ in Magnefia Cariæ gignitur. Vim, \& vftionem falis habet, tam nitrum, quàm fpuma eius. Præterea nitrum tormina fedat, fi tritú cum cumino bibatur in hydromelite, aut fapa, aut aliquibus, quæ inflationes difcutere poffunt, uti ruta, uel anetho. Febribus circuitu redeuntibus illinitur, ante fufpeetam accefsionem. Mifcetur emplaftris, quæ extrahunt, \& difcutiunt, extenuant, \& lepras abftergunt. Cum aqua autcm calida,aut vi no infufum, inflationes, purulentas aures, \& fonitus earundem fanat : fordes expurgat, cum aceto inftillatum. Canum morfibus ex afinino adipe, aut fuillo medetur. refinx terebinthinæ admiftum furunculos aperit : aqux inter cutem cum fico illinitur: oculis ad claritatem uifus cum melle fuccurrit: $\&$ venenis fungorum, ex pofca potum : aut fi bupreftis momorderit, ex aqua : ijs uerò qui taurinum fanguinem biberint, ex laferpitio : ijsq́ue qui cibum non fentiunt, vtiliter obducitur : opifthotonis- 40 q́ue iam remifsioribus, \& luxatis cum cerato: in lingux refolutione, pani commodè permifcetur. Aliqui fupradicta carbonibus urunt, fubiecța prius teltạ noua, donẹc incandefcant .

Nitri, \& fpumę nitri con-

N I T R V M, oritrifuma, quorum antiqus maximus fuit in medicamentis ufus, diu fane eft, quód ad nos fideratio.

conuehi defierunt. Proinde hallucinantur, mea quidem fententia, qui putant Salnitrum uocatü, quo ad tormentorum bellicorum pulueres utuntur, or ad fortifimas aquas conficiendas, quibus argentarij fabri aurü ab argento feparant, uerum ac legitimum effe nitrum, cuius meminere Theophraftus, Diofcorides, Galenus, Plinius, o antiquorum alij. siquidem id manifefte demonftrat Plinius lib. X X X I.cap. X. ubi de nitro ita criptü reliquit. Non eft differenda $\sigma^{\circ}$ nitri natura, non multü à fale diftans, er eó diligentius dicenda, quia palàm eft er medicos, qui de co foripfere, igno= raffe naturam, nec quenquam Theophrafto diligentius tradidiffe. Exiguum fit apud Medos, cane fcentibus ficcitate so conuallibus, quod uocant halmirhaga. Minus etiam in Thracia iuxta Philippos, fordidü terra, quod appellant agriü. Nam quercu crematd, nunquam multum factitatum eft, ov iampridem in totum omifjum. Aqua ueró nitrofa plu= ribus locis reperiuntur: fed fine uiribus denfandi . Optimum copiofumí; in Clytis Macedonix, quod uocant caldflici= cum, candidum, purum q́; , proximum fali. L acus eft nitrofus exiliente é medio dulcifonticulo. Ibi fit nitrum circa Canis ortum nouenis diebus, totidem $q_{;}$ce $\iint a t, a c$ rurfus innatat, $\mathbb{E}$ deinde ceffat. Quo apparet foli naturam effe, qua gignat: quoniam compertü eft, nec foles proficere quicquam, cüm ceffet, nec imbres. Mirum cft $\mathrm{o}$ illud, $f_{c a}=$ tebrafonticuli emper emicante, lacum nec augeri, nec effluere. I is autem dicbus, quibus gignitur, if fuere imbres, falfius nitrum faciunt, aquilones deterius, quia ualidius commouent limĭ. Et bìc quidem nafcitur. In Aegypto autem

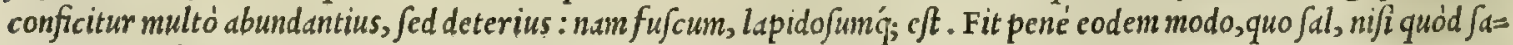
linis mare infundunt, Nilum autem nitrarijs. Excedente Nilo ficccantur, decedente madent fucco nitri quadraginta diebus continuis, non ( ut in Macedonia) ftatis, si autem imbres adfuerint, minus de flumine addunt, ftatinǵ;, ut den= 


\section{In Lib. quintum Diofcoridis.}

fari fft coptum, rapitur, ne refoludtur in nitrarijs. sic quog; olci nutura interncnit. Ad cabicm animalium utilis. Ip fum autem conditum in aceruis durat. Mirumin lacu A feanio, e quibust.me circa Cbalcida fontibus, funmas d= $q$ lus dulces cffi, potariq́; inferiores nitrofas. In nitro optimum, quod tenuißimum, er idco puma melior. Adali= qua tantiun fordidum, tanquan ad inficiendas purpurds, tincturasq; onnes. Magnus or nitro ufus, qui dicetur fuo loco. Nitr.urix cgregite Aegyptijs: nan circa Nattcratin, ON Mempbin tantim folcbant effe. Circa Memphin detc= riores: nam er lapidc/çt ibi in accruis,multiq; funt tumuli ea de canfaf.xxci. Faciunt ex ijs uafat. Necnon fiequčter liquatun cum fulfure coquentes in carbonibus. Ad ca quoq; que inuetcrari uolunt, illo nitro utuntur. Sunt ibi nitra ria, in qubus or rufum exit à colore terre. Spunam nitri, que maximćlaudatur, anliquincgabant fieri, nifi cim ros cecidifet, pregnantibus nitrarijs, fed nondum parientibus. It.dq; non fieriincitatis, etianfi caderet. Alij operi= 30 mentorum fermento gigni cxiftimaucre. Proxina atas medicorum Apbronitrum tradidit in A fia colligi in pelunc is mollibus difr!hans, pecus cos Calycas $10 \mathrm{cant}$ : dein fole ficcant. Optimun putant L ydium. probatio, ut fit minime pondcrofum, muxinzé frisbile, colore pené purpurco. boc in patellis affertur. Aegyptium in uafis picatis ne li=

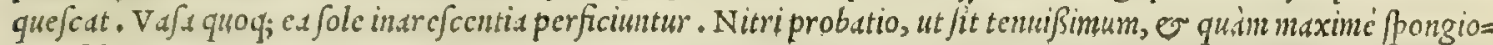
fum, filtulofumig. Adulteratur in A cgypto calce. Deprebenditur guftu: fyncerum cnin facilé refoluitur : adultera= tum pungit. Calce aperfun, reddit bunorem uebementem. bec Plinius. Ex quibus liquidó cons?at, nofri ufus Sal= nitrun, antiquorum nitrun non cffe, etfi inficias eundum non fit, quin aliquas nitri babeat qualitates. Veruntamen ncmini unquam perfux un uelin, ut medicanentis, qux intus in corpus fumuntur, nitriloco salnitrum abfque noxa imponi pojsit. Et quamis contrarium afferant, fcriptisó; tradant Monachi illi reuerendi, qui Me fuem commcntati funt; non tancu credo, hoc id prius in fe ipfis expertos effe. Quod nibilominus cos facere decebat, $\sqrt{i}$ fraterna chari= 20 tate ducti funt, ut alijs fuaderent falnitrum tutó affumi poffe, cum prima charitas (quod dictum frequenter ufurpant) incipiat de fe ipfo. Nitrimeninit Galcnus lib. I x. fimpliciun medicamentorum, fic inquiens, Nitrum dictum eft fu= prà in nedio effe aphronitri, e falis uiriun : ceterün uftum propius ad aphronitrum accedit, utpote exuftione te= nuius red dutum. Deficcat itag;, or digerit: o fi intró in corpus fumatur, fecat, e extenuat craffos lentos q́ fuccos potentius multó quam fal. A phronitrum ueró nifigrauis urgeat neceßttas, nemo deuorabit, nimirum ininicum Ito= m.acho: quandoquidem plus ctiam litro incidit. Sané ad fungos Juffocantes, rufticus quidam co uti afjolet, er femper profuiffe probutum eft. Caterum nitro ufto, fimul or non ufto, or multó ctiam magis eius puma, er nos in talibus uti confucuinus. haq enus Galenus. Qui tanen uidetur ijs, qui codicis mendam non animaduerterunt, maximam fa= cere differentiann inter A pbrolitrum, $\sigma$ Apbronitrum, licet bac re diuerfa non fint. Nam ubi de A plbrolitro libro

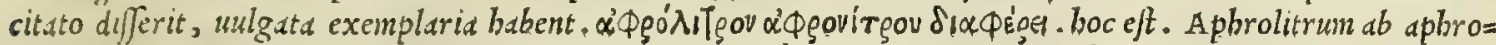

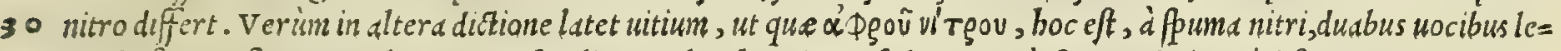
genda fit. I a fict, ut Gsleno non apbrolitrum ab apbronitro, fed utrunq; a Puma nitri apté diftinguatur. Id quod $\mathcal{O}$ Augu/tinus Ricchus Lucenfis, E Leonardus Fach/ius, medici etatis noftre celebres, doctißsimé adnotarunt. Ceterum cim Galeno aphrolitrum, fiue aphronitrum puma nitri non fit, quid aliud fit, ingenue fateor me ignorare:

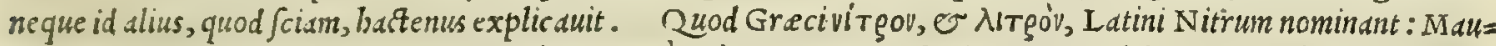

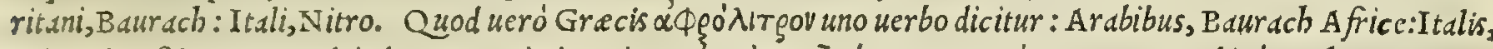
Nitro di Africa. Que deinde Spumanitri Latine, a $\$$ go's Toü vírgov Grecé nocatur: Arabicé, A phronitrum.

Monachorú error.

Nitri, \&apluronitri uires ex Gal.

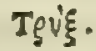
F A X.
C A P. X C.

40 E I I G E D A Fex maximèà uino uetere, Italico: fin minus, ab alio confimili. Fxx aceti uiribus longè acrior eft. Crematur, ut alcyonium, antè diligenter ficcata. Sunt qui noua tefta jgni largo urant, ufquedum penitus incendatur. Alij uiuis carbonibus fæcis glebam obruunt, \& idem opus profequuntur. Experimentum eft legitimæ uftionis, ut aërio nitore inalbefcat, linguamáue tactu urere uideatur. Eadem urendæ facis aceti ratio. Vis ei fupra modum urens, \& abltergens, vlcera ad cicatricem perducit, adfringit, uehementer exeft, ficcatq́ue. Sẹd recenti vtendum eft, quóniam celeriter exanimatur: proinde non nifi in reconditorio, \& uafe aliquo reponi debet. Lauatur ut pópholyx. Quæ uftionem experta non eft, tumores \& per fefe, \& cum myrto cohibet . ventris, ftomachique fluxıones illita fiftit : muliebre profuuium imo uentri, aut genitalibus impofita mitigat : panos difcutit nondum exulceratos, \& tubercula: rigentes mammas, fuique lactis impatientes, cum so aceto peruncta extinguit. Cremata uerò, ungues fabros cum refina aufert. Addito lentifcino oleo, illita nocte tota, rufat capillum. Elota oculorum medicamentis, ut fpodos, adijcitur : cicatrices corum, \& caligines eadem abftergit.

F A E x uini uulgaris notitie eft, quin er ipfius adurende ratio nota, ijs prefertim, qui ex hac alumen, quod uocant fecis, confictunt. Porró uini recrementum, quod uinarijs cadis agglutinatum, crufte lapidofe inftar inue $=$ nutur, officinarum uocabulo Tartarum wocatum, aluum non obfcuré fubducit. Proinde nö de funt, quifibi adftrictam aluum citĕt $t_{2}$ aufto tartari puluere ex gallinaceo iure, addito maftiches momento, o faccharo: nibil enim incommodi adfert bac ratione paratum. Additum in deiectoria diluta, que ex fena, uel polypodij radicibus, uel epitbymo paran= tur, uim eorum deiectorian adauget. Sunt qui album Tartarum faciant, diu ip fum in aqua decoquentes, atque fub=

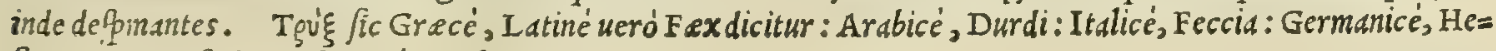
fin, or Vueinftein: Hipanice, Rafura de uino. (ack
Fæcis, \& tarta
ri dicti colid.
\&uires. (ack
Fæcis, \& tarta
ri dicti colid.
\&uires. (ack
Fæcis, \& tarta
ri dicti colid.
\&uires.

Nomine

Nomina. 
C A I x uiua hoc modo fit. Marinorum buccinorum teftas igni condito, aut feruenti dibano, nocte dimitrito : poftera die, fi candidifsimæ fuerint, extrahito : fin aliter, iterum urito, ufquedum. uchementer inalbuerint. Dein ubi in aquam frigidam demerfx fuerint, in fietile noum conijcitor, \& exactè pannis operiens, noetem unam conquiefcerc finito : mane eam extrahens, ubi perfecto omni opere elaborata fuerit calx, recondito. Fit \& è litoralibus calculis igne crematis, necnố è uili, \& fufaneo marmore, qux cæteris prafertur. Vis omnicalci in commune ignea, mordens, adurens, \& cruftas inducens : quibusdam alijs immifta, ut adipi, oleo, concoquendi uim alfumit, mollit, \& difsi- 0 pat: ulcera ad cicatricem perducit . Efficacior exiftimatur recens, nee afperfa aquis . Calcis confi- C A I x, cuius paßim ufus ad adificiorum nuuros ftruendos, nota omnibus eft. Prater hanc fit etiam priuatim
deratio. ad uaria medicamentd é purpurarum, buccinorum, cochlearum, oft reorum, ouorum $\dot{q} ;$ teftis. Non defunt tamé, qui etiam eam, que fit ex calcario lapide, unguentis, e emplaftris admifceant, eam primum demergentes in aquam, us= quedum pror $\int u s$ dißiliat, ac fubinde laudntes dicbus pluribus, affuf $\int$ Sepius recenti aqua pluuiali, uel fontana . Valet enim fic elota ad contumacia ulcera, quód abfq; morfu ualenter ficcet. Ob id itaq; unguentis expetitur, quibus utun tur ad pudendorum ulcera, edq́; prefertim, que uenerea lue contrabuntur. Quinetiam prodeft ad ambafta, o alia, que non facilé curationem admittunt. Sunt ctiam qui extinttam prius calcem, lauent deinde diutius rof arum ftillati=

Calcis uires ex Galeno.

Nomina.

Cypis hifto-

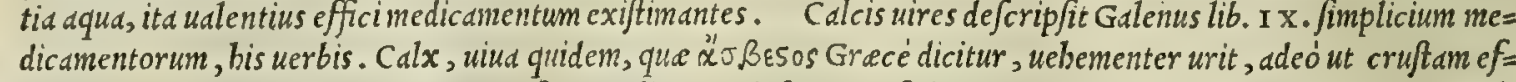
ficiat : extincta ueró protinus etian cruftam molitur e ip $\int_{a}$ : at poft diem unum, aut alterum minus urit, minus $\dot{q}_{5}$ inducere cruftam poteft. At ueró temporis progrefju prorfum nec cruftam quidem gignit tamet $\sqrt{i}$ etiámnum calf $a=$ ciat, carnemó; liquet. Porró fíl lauetur in aqud, fuam mordacitatem exuit, efficit'́; nuncupatam noviov, boc eft li= xiwium : at ip $\int a$ abfque morfureficcat. Ac fibis, ter q́; aut amplius abluta fuerit, plané mordacitatis expers confti= tuitur, ac ftrenue absque mordacitate exicat. Calx uina Latinis dicta, $\alpha^{\prime \prime} \sigma \beta \varepsilon S O S$ Grecis appellatur: Arabibus, Horach, Nura, feu Nure: Italis, Calcina uiud: Germanis, Vngelefclyter, er Kalk: Hipanis, Cal.

$$
\text { rúfos. GYPSVM. }
$$

\section{CAP. XCII.}

G Y P s V M uim habet adftringendi, obftruendi : fanguinis eruptiones, fudores que cohibet . fed potum, ftrangulationis modo iugulat.

ria.

G Y P S V M quid fit, nemo eft qui nefciat. Abundat gypfo uniuer fa fere Hetruria, ibique commodé frequen= terơ;; expetitur cementarijs ad rediu fabricas. Fit gyp $\int u m$ é quodam candido lapide, inlaminas facilé fcißili : qui ta= men non longa ignium ui torretur, $\odot$ excoquitur. Quandoquidem in calenti furno coniectus, quatuor, aut ad fum= musn quinque borarum patio perurttur. Tunditur deinde in puluerem, o incerniculis excutitur. Preftantißimum eft recens: nam diu afferuatum, aque immiftum agré lapide fcit, ac coit. Fit etiam Gypfum é peculari lapide, qui

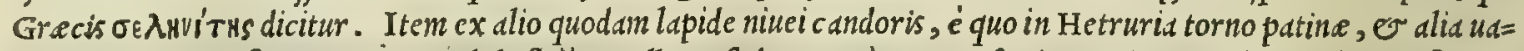
Gypfi uires forum genera conficiuntur. Hunc alabaftrü appellant, fed perperdim. Gypfo uires reddidit Galenus lib. I x. fimpli= 40 ex Galeno. cium medicamentorum, ita differens. Gypfum o ip fum ad communem omnium terrenorum, lapidoforum q́; corpo= rum facultatem, qua deficcare dicta funt, infuper boc adiunctumbabet, quód eft facultatis emplaftice. Vnitur e= nim ipfum ad fee e, e cogitur, lapidefcit; ; maceratum. Quamobrem ficcis medicamentis, qux ad fanguinis eruptio= nem accommodantur, commifcetur. Nam ipfum per fefe lapidofum fit, o durum coactum, ac congelatum. proinde rigare, dilueréq; illud excogitaui, tenui albo q; oni liquore, quod ad ophthalmias utile eft, admisto quod in farina triticea eft puluilli tenuißimi, qui in parietibus molendinorum refidet. Excipere ueró, quód fic fubactum eft tenellis 1eporis pilis, aut qui perinde funt molles, expedit. Gypfun combuftum non equé emplafticam uim babet: ceterime tenuiorum eft partiun, o valentius deficcat. Quin $\mathcal{O}^{-}$repercufforium eft, maximéfi maceretur oxycrato. Гvं= tos ita Grecis, ut Gypfume pariter Latinis appellatur: Arabibus, Gepfim, feu Giepfin:Italis, Geßo: Germanis, Gyps: Hifpanis, Yefo, E Alges.

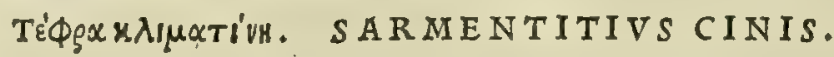

\section{CAP. XCIII.}

S'A R M EN T O R VM cinis vrendi uim habet: cum axungia autem, uel oleo illitus, fractis ner uis, articulorum collíín ibus, \& neruorum nodis prodeft : curn nitro, \& aceto excrefcentias carnis in fcroto reprimit. Serpentium, canumq́ue morfibus illitus ex aceto medetur. cruftas obducentibus medicamentis admifcetur . Fit ex eo lixiuium contra præcipitationes, \& fungorum uenen 3 , cü aceto, fale, \& melle. 


\section{In Lib.quintum Diofcoridıs. $\quad 693$}

Ci n is omnis quid fit notius eft, quin ut pluribus explic ari debeat. Quure ad cius uires properemus: de qui= bus in uniucrfun differens Galenus lib. V I I . fimplicium medic amentorun, /ic inquit. Conis combuftorum lignorĭ reliquia fic muncup.untu, compo/ite ex contrarijs tun qualitatibu, tum fubftuntijs. Habet enisn in fc partin terrenü, parcin uelut fuliginofun, quod Grecé dicitur athalodes, fune lygniodes, fiue quomodocunque quis appellare uolet: atque be jane purtes funt tenues, or que maceratk aqua cineribus, or percoiatis, und apportantur, atque abeunt. Quod uerć reliquun clt, terrenum eft, infirmum, er morfucarens, calidu fucultate in liximilin depofita. Sed non onmus cimis caden tempcratura preditus eft, fed pro combufte materive diucrfitate uariatur. Atnefcio quo pacto Diofeorites onmes cincres adjtringendibibere uim prodiderit, cumficulneus curmodi onnis qualitatis fit expers, utpote cim 0 ipf arbor null f fui parte acerbum qualitatem prefirat, ceu quercus, ilex, arbutus, fagus, lcntifcus, - o bedera, $c$ boc genus alix: uerim plent fucco ualido tota fit cóf acrier calido. Ergo cx accrbis utique lignis fa= ctus cinis, non purum adftringit: meniniq; me quandoque, cim aliud ad manum non effet medicamen, per bunc fan= guinis fuppreßiffe eruptionem. Verium nullus unquan ad tale utificulnco audeat. siquidem bic acrimonixe multun, adurentisq; facultatis obtinet, mifte abftcrfioni : o utroq; differt ab eo, qui ex quercinis lignis conficitur, tum quód in eo fuliguneum multo cf acrius, tum quod in illis terrenum quodammodo fubad/tringens $c f t$, in boc abftcrgens, uc= lut in cinere tithinalorum. Eft or culx cineris quxdan pecies, cetertim tenuioris elfentia, qudin qui ex lignis fit: nimirum quantó lapides exactius torreri, ut cinis fiant, poftulant: non tanen multum reliquum in fe babet, uclut

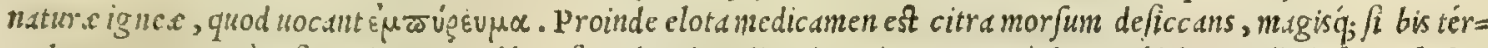
we lanetur. Ceteriun fi marina aqua abluta fit, adnodun digerit. Dicetur porró de ca, ubi de metallicis fermo babe=

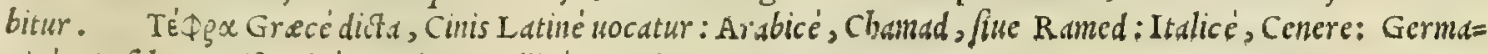
20 nicé, Aefchen: Hipanicé, Ceniza: Gallicé, Cendre.

A'Arvóviov. A L CYONIVM.

A L C Y O N I quinque effe genera compertum eft. Vnum enim fpifum, acerbi faporis, fpongiofa facie, item tetri odoris, ponderofum, \& pifcem olens, quod plurimum in litoribus inuenitur. Altcrum pinnulæ oculorum, aut fpongiæ fimile, fifulofum, \& leue, odorem algæ referens. Tertium vermiculi forma, \& colore magis purpureum, quod Milefium quidam vocanc. Quartum fuccidis velleribus non difsimile, multis inanitatibus hians, leue. Quintum figura fungi, finc odore, alperü, parte interna quodammodo pumicofum, foris læue, acre, quod plurimum in Propontide iux ta in30 fulam Besbicon appellatam gignitur, patrio nomine halos achnen vocant. Duo priora in fœeminarú finegmata aflumuntur, contra lentigines, lichenas, lepras, vitiligines, nigritias, \& maculas in facie, reliquoçue corpore. Tertium ijs, qui difficili vrina uexantur, aut arenulas in uefica colligunt, idoneum elt : item renibus affectis, aquæe inter cutem, lieni. Vftum autem, \& ex uino illitum, alopecias replet. Poftremum dealbandis dentibus aptum eft . in alia fmegmata, pfilothraq́ue affumitur, cum fale miftum. Si quifquam alcyonium cremare velit, cum fale in crudum fictile mittat, \& oblinens vafis firiraculum luto, ita fornaci mandet, \& cùm figlinum percocțum fuerit, extrahens ad vfus recondat . Lauatur ut cadmia .

A I C Y O N I VM (ut Plinius est author lib. $\mathrm{X} \times \mathrm{X}$ I I.cap. VI I I.) fit in mari ex nidis, ut aliqui exiftimant, 40 alcyonum, o caicum: alij ex fordibus fpunarun craffe fcentibus: alij è limo, uel quadam maris lanugine. Quatuor eius genera. Cinereum, piffum, odoris apperi. Alterum molle, lenius, odore feré alg $x$. Tertium candidioris uermi= culi. Quartum punicofius, pongis putrifimile, pené purpureum: quod optimum, boc er Milefium uocatur. Quo autem candidius, hoc minus probabile elt. hec Plinius. Qui tamen quintum fungifigura, cuins meminere Diofcori= des, $\odot$ Galenus, filentio preterijt. Sunt pretered, qui Alcyonium ita appelldri tradant, non quód ex alcyonum ni= disfiat, ut Plinius fcribit, fed quód alcyones fuper illud marinis und is fimul congeftum nidificent. Quorum fententiä magis probandan cenfemus. Alcyonium officine Spumam maris uocant : quód fic idem uocent Arabes, Diofcoridë Secuti . quippe qui fcripferit quintum Alcyonif genus in Besbico balos achnen, hoc cst, maris pumam uocari. Cete= rum rufum Alcyoniwn corallii inftar, coaceruatis in globum ueluti uermiculis, lapido $\int a$; materie, Venetijs primuita uidimus. Quutium uerò reperinus copiofum in Tergeftino litore uelleribus fimillimum, album, ac levilsimum. Piso featores boc cochlearum marinarum, que dculeis rigent, $\sigma$ uulgo appellantur Garufe, nidum effe affirmant. Primum, er ultinum geitus pluribus in Jeplasijs inuenitur. Porró in boc capite in uulgatis Diof coridis exemplaribus nonnulla ( ut plune fupicor) uerba defiderantur, cùn de uiribus quarti alcyonij nilit in ijs fcriptum legatur. Au=

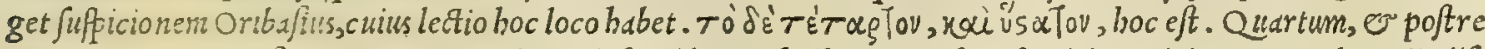
muin e c. Idenz confirmat Serapio, qui ex Diofcoride tranfcribens utriufque Pecici meminit. De Alcyonijs dif= ferult Galcnus lib. X I. fimplicium medicamentorum, bis uerbis. Alcyonid omnia detergunt, ac digerunt, quali= tatem babentis acrem, o calidam facultaten: uerim aliud alio non parum plus minus $q_{;}$, e in bis $i p /$ is, que dixi= mus, fectudum partium effentix totius tenuitatem. Eft autem eorum unum denfum, or graue, odoris praui: olet e= nim pifces putres, Ppongie in $\beta_{1}$ ccic fimle. Secundun ueró aliud figura longiore, leue, o rarum: odorem habens fimilem phycijs. Aliud tertivin uermi fimile eft ßpecie, colore purpureo, confistentia molli: uocant id Milc fum . Poft que quartum fccundo quidem iam pofito fimiliter o leue, e rarum, uerum lanis fuccidis fimile. Denique er quin= tum extina fuperficie leui, caterum interna fubftantid aperum, nullius odoris, guftu tamen apparens acre: er fané
Cineris omnis uires ex Galeno.

Nomina.
Alcyonij hinoria, \& conGideratio.

Locus Diol Iufpectus.

Alcyonij uires ex Gal. 


\section{4

omnium alcyoniorum cft calidißimum, adeó ut e pilos urere poßit. Itaq; cùm duo prima lichenss, alphos, pforas, leprasq́; adiuuent, proterea cutem plendidiorem competentia uirium efficiant, idem praftare non poteft boc ultimo loco pofitum. Nec enim perinde ut illa, cutem duntaxat fummam extergit, fed etiam excoriat, usque in profundume cutis penetrans, ut etian ulcera moliatur. Porró quod terłio ordine recenfuinuts, omnium eft teinißimum. Itaque. uftum alopecids curat illitum cum uino, colore quidem fuluo, tenui tamen effentia. Quartum autem eiufdem cum boc. Nomina. Pecici uires obtinet, uerum haud parum imbecilliores. Quod Greci a' $\lambda$ xงóvrov, L atini quoq; Alcyosium dicunt: Arabes, Zebotbalbahar, feu Zebd albhar: Itali, Alcionio.

$$
\text { A'dóguss. A DARCES, }
$$

\section{CAP. XCV.}

F I $\mathrm{T}$ in Cappadocia, quodadarces appellatur. Eft autem tanquam concreta falfilago, humidis \& paluftribus locis ficcitate emergens, \& harundinibus, ac herbis agglutinata, colore flori lapidis Afij fimilis, \& omni forma mollialcyonio, \& aliquantùm cauo proxima, ut uideri pofsit lacuftre alcyonium. Ad euellendas lepras, lcntigines, lichenas, \& uitia cutis in facie, fimilia, accommodatur . Et in fumma uis ei acris. Humorem euocat, qui in alto concreuit, \& ifchiadicis prodeft.

Adarczcon- L E G I T I M A M Adarcen, que Diofcoridis, es Plinij placitis refpondeat, battenus non uidimus, etfi in

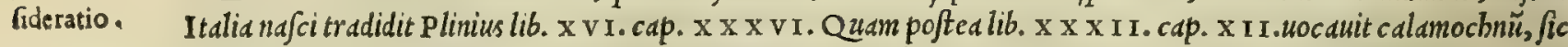
inquiens. Inter aquatilia dici debet 0 calanochnus, Latiné adarca appellata. Nafcitur circa arundines tenues, $\dot{e}$ puma aque dulcis, ac marine, ubife mifcent. Vim habet caufticam, ideo acopis additur contra perfrittionum uitia. bactenus Plinius. Porró ueró cos ballucinari crediderim, qui fibi perfuadent id effe Adarcen, quod uulgó Italis dici= tur Palla marina. Siquidem hec in mari tantimn nafcitur, non in paludibus aqua dulcis: er ibinon arundinibus, neq; berbis inberens uifitur, fed in ficco reperitur litore, undis fimul cum alga proiectd, pilx omnino fimilis, que in la= Eentiinn bedorum uentricul is, ex exuct is uni cum lafte pilis, plerunque reperitur. Adde quod bec, quantum gufta= uerim, nec acris, nec cauftica (ut Plinius inquit) deprebendatur : neque etiam, quod fciam, in paludibus inuenia= tur. Huius tamen meminit Galenus libro primo de compofitione medicamentorum fecundum locos, referens qua Cri=

Cornarii lap- to ad conferuandos, augendos, ikemq́; à defluuio preferuandos capillos fcripfit. Vbi cum interpres Cornarius uir

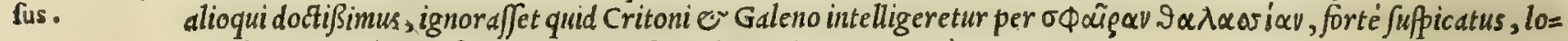
cum lbunc in Galeno cffe depratatum, ßpangia marinam perperàm interprekatus eft : quandoquidem lectio illa uera eft, o uertendum erat pilam marinam. Id quod etiam Fucbfius doctißimé adnotauit in fuis de compofitione medicd $=30$ mentorum libris. Marinam pilam addit Nicolaus Myrepficus in quodain unguento ad lumbricos, ubi fic habet. Pile

Adarcx uires marine, que reperitur in mari rotund a, ut lana congefta. Ceterum Adarca uires retulit Galenus lib. $\mathrm{x}$ I. de fimpli= ex Galeno. cium medicamentorum facultatibus, ita fcribens. Adarcion aliqui mafculino genere adarcon, alij forminino adarcen dicunt, effentia quidem fua uelut $\beta$ uma eft aque falfe concreta, circd drundines, $\sigma$ farragines concrefcens. Acer= rimü boc eft, fimul'́; calidißimum medicamentum. proinde or per fe inutile eft, uerum commifcetur ijs, que uim eius

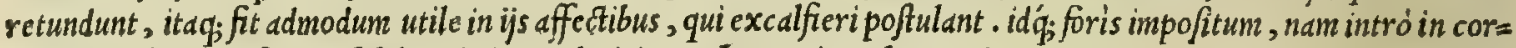
pus ipfum fumere eft impoßibile, nimirum ob uirium uebementiam. beec Galenus. Ex quibus liquidó apparet, $A$ dar=

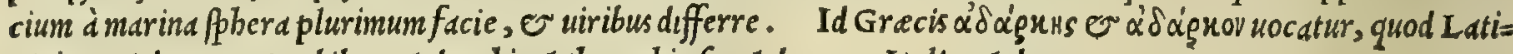
nis item Adarces: Arabibus, Adarcbi, Atharachi, fell Adaraca: Italis, Adarce.

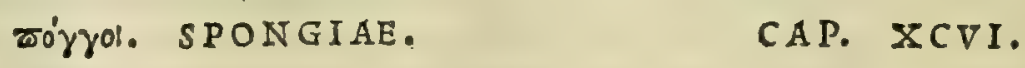

E S P O NG I I S alias mares appellauere, tenui fiftula, fpiffas : quarum duriores tragos nominarunt. Fœminas autem, quæ contrarias dotes habent. Vruntur ex, ut alcyonium. Recentes fine pinguitudine vulnerarix funt, \& tumores reprimunt . recentia vulnera ex aqua pofcáve conglutinant: veteres finus ex decocto melle iungunt. Vetuft $x$ autem inutiles. Aridæ ligat $x$ lino, fi penicilli modo adigantur, occlufa ulcera, callosq́ue laxant. Siccæ recentes, \& uacux, fenilia vlcera, \& que fluxione laborant, aut cuniculatim exedunt, impofitu ficcant. fanguinis profluuium fiftunt. Crematarú cinis ex aceto,arid $x$ lippitudini auxiliatur : \& ubi quid abftergere, aut adftringere opus eft. Vtilius in oculorum medicamentis lauare cinerem. Omnium cinis cum pice crematarum, proflucntem fan- so guinem fiftit. Candidæcura fiunt, è mollifsimis recentes per xftus tinctæ falis fpuma, qux petris cohæret : infolantur inuerfr, hoc eft, parte caua furfum fpectante, \& qua abfciffe fuerunt, deorfum . Si uerò xftiua ferenitate ad lunam fternantur, perfufæ fali fpuma, aut maris aqua, maximum candorem referent.

Spongiarũ hi foria ex Ari ftotele.
S P O N G I A R V M genus (inquit Ariftoteles lib.v. cap. X v I. de biftorid dnimalium) triplex ftatuitur : name

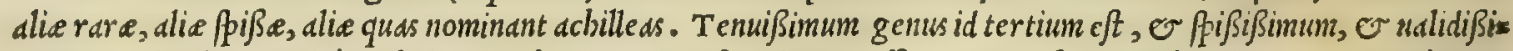
mum, quod galeis ocreisq́; inferitur, eo f; minus ciere ftrepitum pofe notatum cft. genus boc inuentu perqudm rax rum eft. Que autem in genere illo piffo predur a funt, atque afpere, nomine birci nuncupantur. Que quidem om= nes aut ad faxa nafcuntur, aut iuxta litus, lutoó;; aluntur. Cuius rei argumentunt cft, quód capte limo referte om= nes cernuntur . quod certé indicat cateris quoque adharentibus cibum per ipfum adnexum bauriri. Imbecilliores 


\section{In Lib. quintum Diofcoridıs.}

propterea funt ßpiffe, quim rare : quia minus albo radicis be fu innituntur. Scufum etiam pongijs effe aiunt : argumento quód ad cuulforis acceffun contrabuntur, ita ut euelli difficile fit . quod idcm ctian faciunt, quotics flatus, tempeftasq;; urget, ne fua de fede pellantur. Sed funt, qui de boc dubitent, ut qui Toronä incolunt. Narrant tamen procul dubio beftiolas quafdam uelut tine as, lumbricósue, or eiufmodi alias confiftere intra ftongias, atq; ali: quas $\mathfrak{O}$ cuulfis ppongijs, pifciculi faxatiles devorent, qui uel radices abfumunt totas, qux inharentes faxis rimanferint. si euenerit forte, ut pongis abrumpatur, refiduo item renafcitur, et completur. Magnitudine amplifina folute ille,

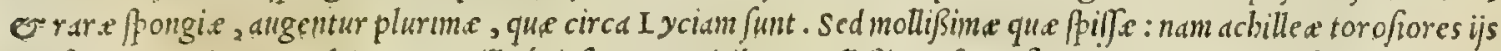

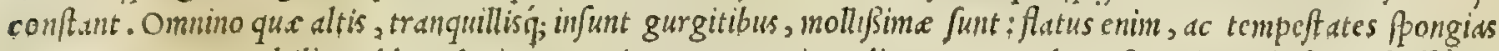
guoque, ut c.etera altilia reddunt duriores, o incrementum impediunt, Quamobrem pongix Hellefrontiffiffe, dc 20 dur s funt, $\sigma$ omnino quas marc ultra Maledm promontorium, citráf; refert. Differunt inter fe mollitie, duritie $q_{;}$. nec calorem immodicum pongix patimitur : fit enim co, ut more pullulantiun putrefcant. Quocirca optime iuxta

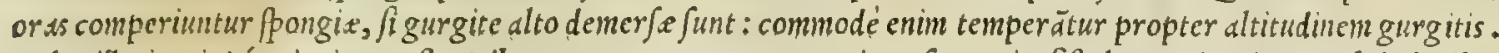
Color illatis, niuisq́; nigricans eff. Adberent nec parte, nec toto: inter funt enim fiftule quedam inanes, fed pluribus paßim particulis halitant, o quafi membrand extenta fubeffe radicibus carum uidetur. fuperné autem cateri med= tus concreti propenodum latent: at ucró quaterni, aut quini patent, per quos pafci exiftumantur. Hactenus de pont= gijs A riftoteles. Cui quiden Plinius fuam de fpongijs biftoriam acceptam referre poteft, quam libro I X. cap. L x v . fcriptis tradidit. Spongisrum uires memoria prodidit Galenus lib. x r. fimplicium medicament. bis uerbis. Spongia ufta acris cft, or digerentis potentic. Vtebatur ea preceptorum meorum quidam ad fanguinis eruptiones, que ma= muali opura indigent. In quem ufum femper eam paratam babebat ficcam, er exarefactam; cum ueró res pofceret,

20 bituminc in primis imbuebat, fin co careret, pice. Porró admoucbat cam partibus fanguine profluentibus etiámnum drdenten, ut o crlifa parti inducerctur, o ip Jum pongie ufte corpus, ceu operculum quoddam acciperet. Ce=

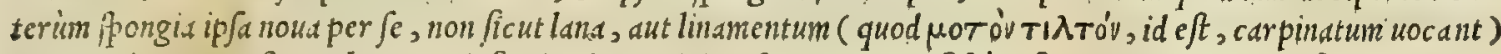
materia dumtuxat eft, que bumores infundendos excipiat, fed etiam manifefté deficcat. Id quod fcies, fie ea fola utaris in unlnere, cum aqua, aut oxycrato, aut uino, prodiuerfitate nidelicet corporum, uti eft anté dictum. Glutinabit fi= quidem ca fimiliter atque medicamenta, que uocant enema. At fi non noua fit, fed ufui accommodata, palàm cogno= fces, quantum à noua fuperetur, fiue uulneribus eam imponas, fiue aqua proluens, fiue oxycrato, fiue uino. Nec mi= rum c/t, crim in pongia noud feruetur etiámnum ed, quam d̀ mari accepit, facultas modic é corpora cxiccandi. Atq; bec quidem preftare poteft. cùm etiámnum feruat maris odorem. Nam temporis fpatio, etiamfi nunquam ufui ac=

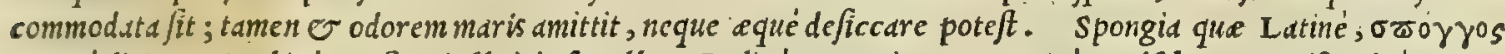
30 Grecé dicitur: Arabicé, Asfrmgialbairi, feu albar: Italicé, Spognia: Germanice, Badfchuuam: Hipanicé, Spon gia: Gallicé, Eßponge.

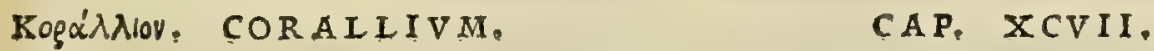

C O R A I I I v , quodaliqui lithodendron appellarunt, marinum effe fiuticem conftat, qui alto extrątus, duratur ftatim atq; emergit, tanquam offufo aère protinus concrefcat. Plurimum inuenitur ad Sy racufas, in promontorio, cui Pachyno nomen eft. Laudatifsimum rubens, colore antheric1, aut fandycis faturatæ, nec fecus terenti facilè cedens, æquabili ufquequaque concremento, rurfus algx, aut phuci mariniodore, quàm ramofifsimum, forma fruticis, cinnamomi æmulum. 40 Qud autem in lapides duritiam coit, fcrupulofum, inane, \& lacunofum, uitiofum exiftimaturl. Adftringit, \& refrigerat mediocriter ; excrefcentia coërcet: oculorum cicatrices abftergit: vlceru m caua, \& cicatrices explet. Contra fanguinis reiectiones magnopere efficax eft: vrin $\mathbb{x}$ difficultati auxiliatur. quin \& potum ex aqua lienem abfumit. Quodantipathes uocant, corallium effe arbitrantur, fpecie tantùm diftans. Eft autem colore nigro, arboris figura, ramofum magis, Vires fupradiktishabet.

COR A L L I V M, quo ufqueadeo abundat Italia, ut feré nulli ibi reperiantur infantuli, nulle q́; pue lle, qui= busnon geftentur Coralii monilia aut collo, aut bracbijs $\int u$ penfa, quo item utuntur famine in templis ad fuas pre= ces numerandas, ex Tyrrbeno, e siculo mari extrabitur, at $;$; inde ad nos defertur. Ceterum etfirubri tantum, $\sigma^{-}$ so nigrimenunerit Diof corides; reperitur tamé quod niuei fit candoris in ijsdem pelagis, non autem ut rubrum compa

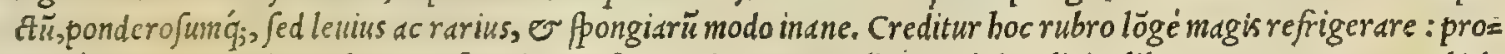
inde co utuntur medici, ubi opus cf maiore refrigeratione. Corallij meminit Plinius lib. $\mathrm{x}$ x X I I. cap. I I . ubide co ita fripium reliquit. Quantum apud nos Indicis margaritis pretium eft, tantum apud Indos in Corallio: nanque ifta perfuafione gentiun confant. Gignitur quidem et in rubro mari, fed nigrius. In Perfico uocatur Iace. Lauda= tifimum in Gallico finu, circa Strechadas infulas, or in siculo, circa Hcliam, or Drepanum. Nafcitur et apud Gra=

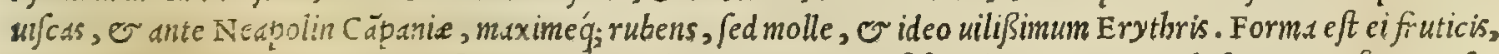
color uiridis. Dacce cius candide $\int u b$ aqua, $E$ molles exempre confeftin durantur, er rubef cunt, quafi corna $\int_{a}=$ tiua, Pecie, at \%;

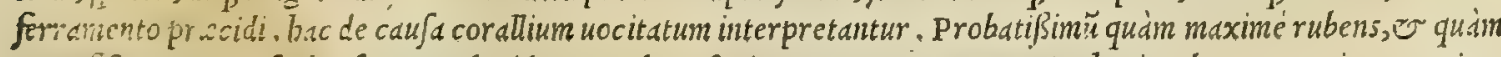
ramcjpim!'m, rec fcit:o oum, auk lapideum, uel rurfus inane, aut concaumm. Authoritas baccarum eius non minus Indorum wiris quoq; pretiofa eft, quam feminis noltris uniones Indici. Aruppices eorum, uatesq́; in primis religio=

Nomina.

Spongiarum uires ex Gal.

\section{Nomina.}




\section{5

fum id geftamen antoliendis periculis arbitrantur. Itag; o decore, or religione gaudent. Galligladios, fcuta, ga: leas adornabant co. nunc tanta penuria eft uendibili merce, ut perquàm raró cernatur in fuo orbe. Surculi infantice

Plinii lapfus. adalligati, tutelam babere creduntur. bec plinius. Quem tamen mirarifubit, quod tam facilé fibi perfuaferit, coe rallium per fe baccas ferre, quafi corna fatiua pecic at g; magnitudine, perinde ac catera arbores fuos proferunt fructus. Quandoquidem, ut fatentur $\ddot{y}$, qui corallia expifcantur, ov in ijs mercaturam exercent, itullas per fe bac= cas edunt. Bdcce enim, que in cordliorum monilibus cornis, ac cerdfis fimiles uifuntur, ex ip forum truncis torno, $\mathcal{O}$ lima prius parantur : mox Jmyridis lapidis puluere, of terra quadam, qua é Tripoli A plorica adfertur, expoli= untur, or lucidum leuorem contrabunt, cum ijs diutius fricantur. Adbac Corallia é mari circunquaque mufcofa eximuntur, nec tunc ulla ex parte rubefcunt, uerim inde artificibus tradita, derafo cortice rubent, es perpolita ni= tefcunt. Nigrtm Corallium, quod Diofcorides Antipatbes uocari dit, primum uidicgo Neapoli ebenum colore $z$ Corallii facul referens. Corallium comitialibus commodé adalligatur, hauriendumq́; prabetur. Corallium ades ( $u t$ aiut $)$ d ful= tates. Minum iniuria tuetur. Idem menfium abundantiam cobibet, dentes commotos firmat, defquamatas gingiuas emendat, item $q_{;}$oris ulcer a fanat. Potum dy fentericos iuuat, feminis profluuium in uiris, nocturnas q́; pollutiones, er in mu= lieribus albos uterifluores reprimit. Recenfeturinter ea (Auicenna tefte) qua cordibilaritatem adfrunt. Auxilia= tur praterea ( $u$ t Plinius inquit) contra torminum ac uefice calculi mald in puluerem igne redactum, $\sigma^{\circ}$ cum aqua potum. Simili nodo ex uino potü, aut fi febris fit, ex aqua fomnum conciliat. ignibus diu repugnat. Sed eodem me= dicamine fapius poto, tradunt lienem quoque abfumi. Sanguinem reijcentibus aut excreantibus medetur. Cinis cius mifcetur oculorum medicamentis: pifjat enim ac refrigerat, ulcera caua explet, cicatricesó; extenuat. Corallij me= miniffe Galenum in libris legitimis de fimplicium medicamentorum facultatibus, bactenus non reperi: tametfi libro Septimo de compofitione medicamentorum plura de fribat medicamenta ad incipientem phtbifin, hxmoptoicos, er

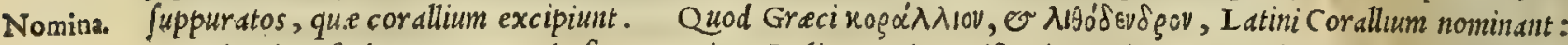
Mauritani, Baßad, Mergen, Besd, fiue Morgian : Itali atq; etiam Hipani, Corallo: Germani, Coraln: Galli, Coral.

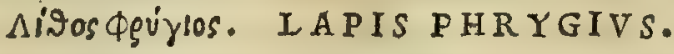

\section{CAP. XCVIII.}

P H R Y G I V S lapis, quo infeetores in Phrygia utuntur, à qua nomen accepit, nafcitur in Cappadocia. Optimus habetur pallidus, modicè grauis, non folida corporis compage, intercedentibus albis fegmentis, ut in cadmia. Vritur autem uino optimo perfufus, uiuisq́ue carbonıbus obrutus : perflatur afsiduè follibus, donec mutato colore rufefcat : rurfus extractus eodem uino reftinguitur. Hoc iterum, \& trinis uicibus faciendum : attendendum tamen ne minutim confringatur, \& in 30 fuliginem euanefcat. Vis crudo, uftoq́; adftrictoria, expurgans : vlceribus cruftas quadantenus inducit : ambuftis cum cerato medetur. Lauatur, ut cadmia .

Phrygiilapidis confid.

Phrigij tapidis uires ex

Galeno.

Nomina.

Qv I mibi Pbrygium lapidem oftenderit in Italia, battenus neminem inueni . quippe cum nee noftratibus medi= cis, nec lanarum infectoribus, ullo fit ufui, ex Cappadocia ad nos deferridesijt. Plinius, cum ignor affet, pbrygi= um lapidem medicamentis, etiámnum expeti, tingendis tantüm ueftibus commerdauit. De huius lapidis uiribus dif= feruit Galenus lib. I x. fimplicium medicamentorum, bis uerbis. Pyrite facultatem habere exiftimatur et Phrygius, quem nocant. Sed eo femper utor combufto quidem ad ulcera putrida, idq́; aut ipfo per fe, aut ex aceto, aut ano= melite, aut oxycrato: ad oculos ueró medicamentum ficcum efficiens : quod multi nunc acceptum à me obtinêt. Mi= fentur eier alia quapiam. Dicetur autem de ipfo in opere de componendis pharmacis. Nunc fat is eft de gener alie = ius facultate explicuiffe : ualidé enim deficcat, habens quiddă adftrictionis, fimul ev mordicationis. Dictum ueró fu= perius eft, ed effe omnia optima medicamina, plurimiq'; ufus, qux mift as in fe fe hafce duas facultates babent, nem=

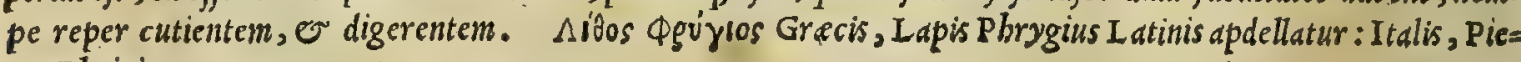
tra Phrigia.

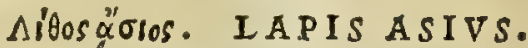

\section{CAP. XCIX.}

A $s$ I $s$ lapis affumi debet pumicis colore, leuis, fungofus, item friabilis, fcifsiles uenas lutei coloris ad imum actas habens. Eius flos falfugo fubflaua eft, fummo lapide infidens, compage tenui, colore in aliquibus albo, in alijs pumici fimili, ad luteum uergente: admotus linguæ aliquantùm 50 mordet. Vim habet uterque adftrictoriam, \& modicè erodentem . admiftus liquidæ pici, aut terebinthina, tubercula difcutit. Longè ualidior flos exiftimatur . De cætero ficcatus flos uetera ulcera, \& cicatrici repugnantia fanat . excrefcentia cohibet : tetra ulcera, \& fungis fimilia, cum melle expurgat : ulcerum caua explet, \& expurgat cum melle : depafcentiaq́ue cum cerato fiftit. Fit cataplafma ex eo podagris, mifto fabæ lomento: \& lienofis ex aceto, \& uiua calce. Prodeft flos ex melle phthificis linctu. Podagrici iuuantur, pedibus in folio ex eo lapide excauato inditis. Fiunt quoque ex eo loculi, qui corpora erodunt : \& luxuriantem carnem, \& corporum crafsitiem abfumunt, cùm uice nitri in balneo f parguntur. Si lauare libet, cadmix modo lauatur.

Afii lapidis confider.
T A M E T S I in commentarijs noftris fuperioribus annis Italica lingua confcriptis, Afium lapidem mibi incos gnitum effe ingenué confefus fuerim; legitimum tamĕ nuper Tridento ad me mifit Martinus Guidottinus feplafiarius 


\section{In Lib. quintum Diofcoridis.}

diligens wqué ac peritus: qui quidem lapis, nifullor, mullis prorfus notis ac nivibus Diofcoridus defcriptioni recla= mat. Foditur in Iridentino agro quibudam chalcanthi fodinis, quodam in monte non procul à pago, qucm Lcuigum nominant. Eft cnim lic pumices inftar lcuis, fungofus, filabilis, lutci coloris intercurfuntibus wenis. Hoc, quod car=

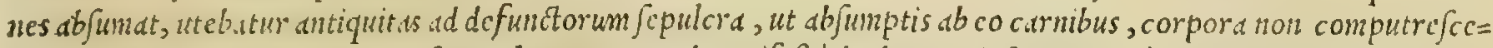

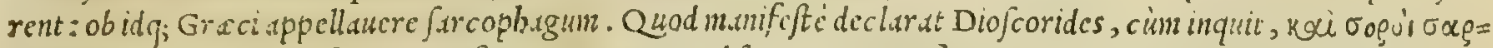

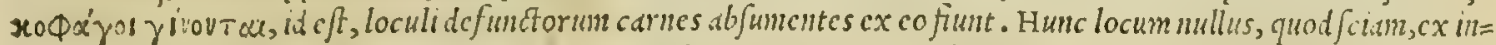
terprettbus ita ut nos accepit: fid omnes ad aliud refpicientes nocent ongo'l pulucrem uertcrunt. In quo mibi plané nou aidentur merten Diofcoridis affecuti. Qiam probc affecutis, noftréq; fententice adfipulari cognofcitur pli=

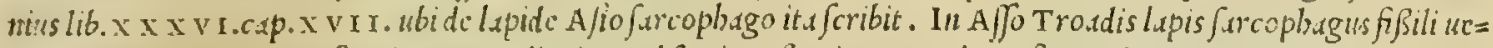
so na fcinditu. . Corpora de functorum condita in co abfumi conftat intra quadragefimum decm, exceplis dentibus. beec Plinius. Cetcrum A sijlipidis hiftori.m, or uircs defripfit Galenus lib. I x. fimplicium medicamentorum, fic in

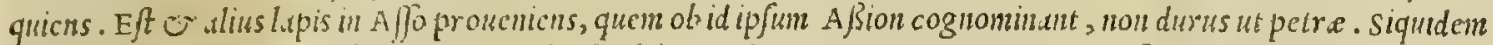

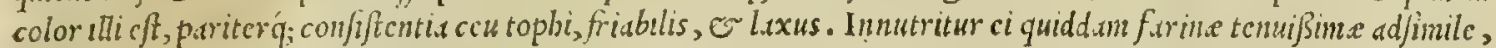
qualis in piftrinorum parietwus adhercre uifitur. A ppellant boc medicamentï petre Afia florcm. Eft ueró $\mathrm{C}$ fub tilium partum, ut finc morfuninis molles carnes, ac fluidas cliquet. Pctra ueró, in qua nafcitur, tametfin uim liabedt illi finilent, attionis trumen uchementia infrior cft. Hoc enim ca potior eft flos, non tantum quód magis colliquet, ac

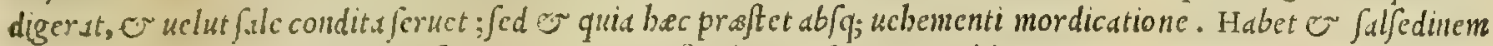
quandan in guftu bic A fie petreflos: ut conic ctura fit, illum nafci ex co quód ros ex imari in petran refidens, pofted

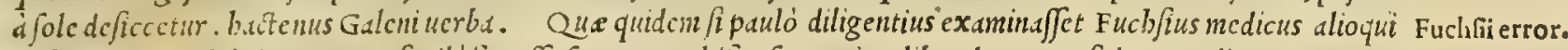

- noftre atais celiaris, nan tam facile fortaffe fuam protulyjet fentenitam libro de compofilione medicamentorum: quodfcilicet A/ise petra flos fit illa mollis, albs, e temißina materia, quant farine, qux parietibus mol trum inhe= ret, îmilen cxudsut uctercs muri, rupes, fuxiq́; montium : ex qua fit quod salnitrum uocant. Porró quód hec non weré fit Asil lspitıs flos, omnibus ijs perfpicumnfict, quirem banc accuratius expendent. Nam pr.eterquain quod ed diucrforum lıpidum flos $c f$, millam babct cognationcm cun Afio lapide. qui folus, Diofcoridis or Galeni teftimonio,

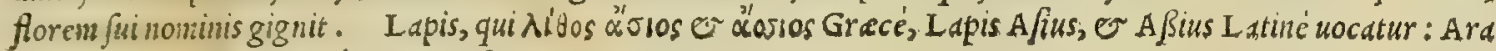
bicc, Hager A fos: Italice, pictra A Ria.

\section{Míos ซ!gitTH. IAPIS PYRITES. CAP. C.}

30 PyRITES lapidis genus eft, à quo æs conflatur. Eligi debet æris fimilitudine, facilè fcintillas edếs. Vritur fic. Mclle irrigatus, molli pruna continuè flatur follibus, donec rufefcat. Alij in multos carbones igni candentes, lapidem copiofo melle perfufum deijciunt, \& vbiad fuluú colorem vergere coeperit,extrahurt: efflatoq́; cinere, rurfus madefuctum cremant,donec æquabiliter afsiccatus, friabilis red datur: fiquidem fixpe facies fumna folum vritur. ita crematus, ficcatusq́; reconditur. Si eloto opus fit, lauari debet, vt cadmia. Tam crudi, quàm vfti uis eft excalfacere, abftergere, offufam oculis caliginem expurgare, duritias concoquere, \& concostas difcutere. Refina exceptus excrefcentia in carne cohibet, fed calorcm quendam,\& adfrictionem parit . Ita uftum nonnulli diphryges appellant.

L A P I D E M, quem Greci Pyriten dicunt, officine cum Mauritanis Marchefitam uocant. Verum quanquam 40 uniucrfi lapides, à qubus ignis chalybe excutitur, pyrite appellari poffunt; cim tamen Marchefita appellata cate= ris in.xgis fcintillet chalybe aut ferro percuf $\int_{\text {, }}$ per antonomafiam ip fa fold uocdtur Pyrites, tanquam cateris praftan tior. Foditur bec in omniun metallorum feré fodmis, genere, or colore diuer $\int a$, plerunque tamen (ut Plinius inquit lib. $\mathrm{x} \times \mathrm{x}$ V I.cap. $\mathrm{x}$ I x.) aureis fcintillis, uel argenteis reper $\int a$. Gignitur, ut rei metallic.e periti tradunt, ex impu= ro metallor um balitu. quo fit, ut feré femper reperiatur in nzontium cacuminibus, ubiauri, er argenti uena, in pro= fundo delitcfcit. Sterilis bec magna ex parte, quod (ut cbymifte exiftimant) ex impuriffino fulphure, alijs'́f; incon= coctis partibus metallorum fit confata. quimobrem foffores is Germania, extra cauernas pyriten tanquain inutilem proijcunt. Veruntamen quandog; Pyriten inueniunt, qui aurum, argentum, uel as intra $\int c$ continct. Idcirco recté prodıdit Diofcorides, Pyriten lapidis effe genus, ex quo es conflatur. Quod cum ignoraffet Albertus, onnem Mar= chefitam inutilem effe a]Jeruit. Pyrita uires reddidit Galenus libro I x. fimplicum medicamentorum, bis uerbis. Pyrite uires so Vnus corum, qui ualidali facultatem poßident, elt e pyrites quem uocant . quo utimur digerenti emplaftro admifto: ex Galeno. adijcitur ei er foriftos. Ab boc medicamine, o pus fepenumero, er confiftentia grumofa in patijs intermedijs mufcu Zorum nata, per balitum digefta funt. Ceterim ubt in ufu uocantur lapides omnes admodum ucbementer contufi, atö;; ad leuorcm redati fint oportet, fimiliter atque ea, que in ophtbalmic ws facultates admifcentur, Etenim nifi pollinis inftar comminuantur, adeo ut in profundum corporum, quibus applicantur, fubeant, aßimiles manent iftis marinis, o fluviarilibus arenis, que o ip $\int e$ communem omnium lapidum uim poßident. siquidem exiccant tumentem ex by= drope carncm, uidelicet laborante in eis excalfattis decumbente. Non tamen ad aliud quippiam eis utimur, tanquä prsedetis, ad ophthalmucas, o fistentes tum anguirem, tum mulicbre proflunium facultates, praterea ad glutun $\bar{a}=$ da ulcera, cicatrice claudenda, carne implenda. Nam qui ex eis acresnon funt, adbec onnes funt utiles, uelut c acres, quorum pofterius mentionem faciam, ad detergendum, abstergendun' $;$, tum detrabendwin, extcnuan=

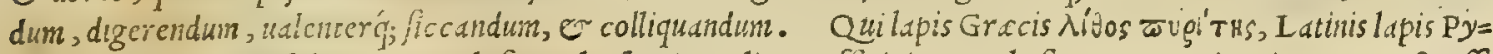
gites nombia! ur : Arablous, Hager al, Jüe Alrufenai: Italis er cfficinis, Marchefita: Germanis, Kis, or Ertz stuoff.

Nn Míos 
AíbosqipxtitHs. IAPIS HAEMATITES. CAP. CI.

H AE M A T I T E's optimus habetur friabilis, faturato colore niger, durus, \& fuopte ingenio $æ-$ qualis, nulla forde admifta, nulloq́ue zonarum difcurfu. Vim habet adftringentem, \& excalfactoriá aliquantùm, extenuantemq́ue. Oculorum cicatrices, \& fabritiam cum melle purgat : cum lacte autem muliebri, lippitudini, fractis, \& oculis cruore fuffufis conuenit . Bibitur contra difficultatem vri

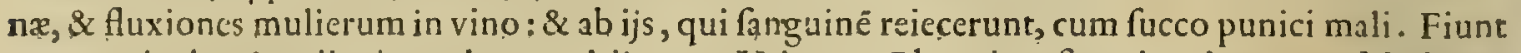
ex co coticule, it collyria oculorum vitijs apta. Vritur ut Phrygius, fine vino duntaxat. Modus vftionis eft, ye modicè leuis fiat, \& bullis quibus dam intumefcat. Sunt qui hæmatiten ita adulterant. Denfam glcbam, rotundamq́; fchifti lapidis, cuịufmodi funt, quæ eius radices vocantur, in urceum. figlini operis, qui feruentem cinerem contineat, condunt : paucaque interiecta mora eximunt, experiunturque fi trita ad cotem hæmatitæ collorem reddat . quòd fi ita res fe habet, reponunt: fin minus; iterum obruunt, \& fubinde confpicientes, periculum faciunt : fıquidem in cinere diu dimiffus, colore mutato diffunditur , Coarguitur malè confiẹtus, primùm fcifsilibus venis : quippe in reetos uenarum difcurfus refringitur. At hæmatites longè fecus $f e$ in colore habet: nanque hic floridum reddit, hæmatites verò faturatiorem, atque cinnabarin imitantem. Inuenitur in Sinopica rubrica, Fit \& è magnete lapide, vehementer ambufto. In Aegypto fponte naturæ cum metạllis ẹnafcitur.

Hematite la- Н A M A T I T E s lapis, quo omnes in unituer fun medice officine abundant, quoq; pictores, or lignarij $f_{a=} 20$ pidis confide bri utuntur, uulgó uocatus $L$ apis, legitimus non eff, de quo meminerunt Diofcorides, $\sigma$ Galenus. Quippe hic $f_{a}=$

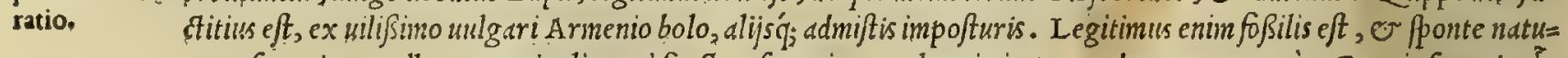
ra nafcens in metallorun cuniculis : qui fractus, fanguinem colore imitatur, unde e nomen, cim Grecis fanguis $\alpha^{?}=$ $\mu \alpha$ dicatur. Huic perfimilis eft, quem Schiftum uocant, cuius biftoriam, o uires ftatim poft bunc fcribit Diofcoria des ob cog nationis uinculum. Foditur hematites non modó in Aegypto, fed in pluribus Germania, $\sigma$ Bobemie mö $=$ tibus, prafertim in Hercynia fylua : quin $\sigma$ in I talid Brixienfi agro, fed percgrinis bonitate cedentes. Variat tamen buic lapidi color, quoniam e niger, o flauus, ef frruginis inftar, qubbufdam infit, ut peritißimus aqué ac doctißi= Hæmatię vi- mus A gricola in fuis de foj̧ilium natura libris diligenter adnotauit. Hematite uires memorie prodidit Gal :mus lib. res ex Gal. IX. fimplicium medic amentorum, ubific inquit. Porró talium quog; unus eft bamatites, quem uoc ant, ic coloris $f=$

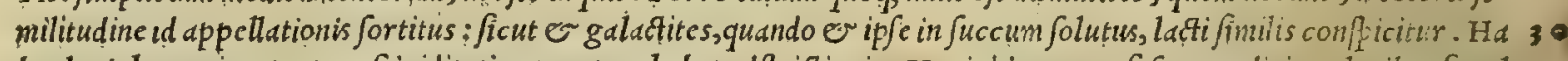
bet lapis bamatites tantum frigiditatis, quantum babet adftrictionis. Meritò itaque aufi funt meñici oçiaribus facul tatibus lapidem mifcere hematiten. Ac folo co uti poßis palpebris exafperatis : $/ i$ quidem cum plilcgmone apper a fint reddite, ex ouo ipfun diluens : ac fi magis etiam, per frenigreci decoctum. sin ueró citra phlcgmonem, ex aqua. Incipito ue rò femper à modicé bumidis, per ßpecillum infundens, vbi autem, quód uires eius frat, conpexeris, nid= gis ac magis craffum efficies, ac tandem adeó craffum facics, ut pecilli nucleo inung as, fecundum fubiectionem, aut cuerfionem pal pebre, Hic idem lapis fimiliter in cote contritus, fanguinis expuitioni conucnit, omntbusă; ulceribus: Porróficcus, fi ad tantum redact us fuerit lauorem, ut puluillum referat, reprimit excrefcentia, at ij; co nullus folo, atque per fe fe utitur. Ego ueró ad ea, que dixi, ufus fum facultate eius ex guftu qualitate comperta, cim mox cxpe= rientia periclitari uellcm, nunquid recte conieciffem. Et ip $\int a$ quidem oculorum ulcera, folus per $\int$ e cicatrice includit (ut paulo anté comprehenfum eft) attritus, caterim aut affufus, aut inunctus . nam o id experientia exploratum Hæmaritz ui babeo. hactenus Galenus. Miris item laydibus extulit hamatiten lapidem Alexander Trallianus, fic inquicns. Ego fané nouifrequenter me fine theriaca, alijs f́; pretiofis antidotis multos curaffe, lenibus ufum medicamentis, o pra= fertim lapide bamatite. vfus autem co fum in his, qui largius fanguinem reijciebant, cum fucco punici mali, or gra= nis, ucl cum fucco polygonij : in quibus autem janguis non copiosé euacuabatur, etịtam ex aqua fold egelida. At le= uigare ipfun curiosé oportet, ut in tenuißimum puluerem redigatur, fit q́; dëreus, o uento perfinilis. Dedi ego ex co fcrupula quatuor, or pauló amplius minúsue. Exhibui etian ijs, qui pus expui inceperant, ac mirum eft, quomo= do ulcus exiccarit fanaueritó;, ut non amplius pus generaretur, neq; eger tußi infeftaretur. Spcctai autem $\sigma$ aliu quendam ex his, quibus uas exefum erat, non modo particulds quasdam ex faucibus, fed etiam apperam arteriame ex= puentem, ac mirum quoinodo in boc quoq; lapis hic maximam efficaciam indicauerit. Nam e hic curatus cft nobis non admodum etiam pernentibus . Exhibui autem agro potui medicamentum frequentius, ut commodius diftribuere=

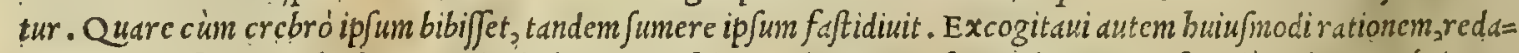

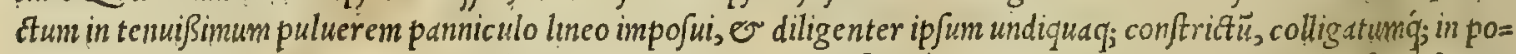
culo, quod uinum odoratum modicum baberet, fupendere permifi, id q, per totam nociem iam inde ab is fo vepere: cxtraxi autcm tenucm, ä̈ream'; eius partem, ut ager folam uini qualitatem perciperet, Ex hoc biberc quantum ma= ne libenter babebat, ci precepi, atq; boc fané agendo, bibendoó; continué, fanitatem recepit . Hoc autcri morbo libe ratus, idem praferuationis caufa facere pergebat, bibebat q́;, donec etiam corpore probe permutato, confueta agens

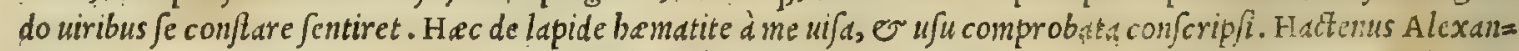

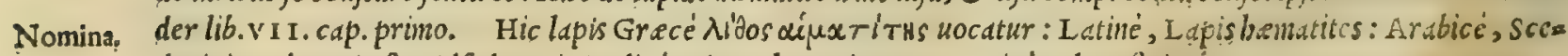
denigi, Sadenegi , feu Aljadenegi : Italicé, Pietra hematite : Germanicé, Bluot ftein." 


\title{
In Lib. quintum Diofcoridis.
}

\author{
Aíos oxisòs. IAPIS SCHISTVS. \\ CAP. CIY.
}

SC H I S T o lapis in Iberia Hifpanix gignitur. Probatur maximè, qui croci colorem $æ$ mulatur, friabilis, fuapte natura fifsilis, concremento, \& alterno cohærentium venarum difcurfi, pectinum moda, Ammoniaco fali fimilis. Vim exhibet hæmatitx, fed ad omnia infirmiorem. quin \& caua replet muliebri lacte perfufus . ad procidentia, rupta, item genarum crafsitiem, \& vuas oculorum, nagnopere cfficax eft.

S C F I S T V M lapidem, quem tradidit Diofcorides gigni in Iberid, bactenus allatum in Italiam non uidimus: Schifti lapidis 20 Fodi tamen bunc in pluribus Hercynix fyluc locis in Germania, quin er in Bobemia author eft clarifinzus Agricola: Caterisn è̀m de uiribus citm hermatite certet, hic cius uires nobis fupplere poterit. Neminit scbifti lapidis Gale= nus lib. IX. fimplicium needicamentorum, fic de eius uiribus differens. Lapidi bematite per/imilem uin obtinet, ue= rim infirmiorem, is qui thocatur fchiftus; ac poft eum galdstites. At melitites caliditatis etian nonnibil, ut dixi,adiun= xit. Vritaque unufquifque ipforum leuiter, ac $\int \mathrm{en}$ fim ab hematite facultate recedit, ita ad oculos fimiliter in ufum ducitur : cft tamen mitior. Porró mitior.t remedia partibus etiámnum pblegmone afflictis femper gratio a funt, atque

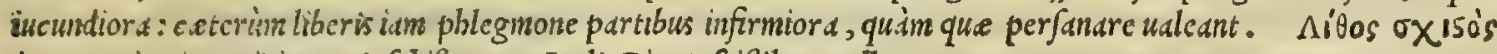
ita Grecis, ut Latinis Lapisfchiftus; er Italis Pietrafcißile appellatur.

\section{Aítos yayithS. LAPIS GAGATES. CAP. CIII.}

IN G A G A T A R V M lapidum genere, præferendus qui celeriter accenditur, \& odorem bituminis reddit. Niger eft plerunque, \& fqualidus, cruftofus, perquàm leuis. Vis ei molliendi, \& difcutiendi . deprehendit fonticum morbum fuffitus : recreatq́ue vuluæ ftrangulationes : fugat ferpentes nidore. podagricis medicaminibus, \& acopis additur. In Cilicia nafci folet, quà intluens amnis in marecfunditul, pioximè oppidum, quod Plagiopolis dicitur . vocaturr autem \& locus, \& amnis Gagas, in cuius faucibus ij lapides inueniuntur.

L A P I D E M, quem Gagaten wocant, in comitatu Tirolen $/ i$ Germania non longé ab Aeniponte (Germani Ifpruch dicunt) in quodan torrentis alueo repertum, oftendit mibi primim clarißimus medicus Iodnnes Petrus Me= خo renda Brixianus, nullis pror us notis d̀ Gagate hiftoria dißidentem. Nam preterquàm quód igni admotus confeftin

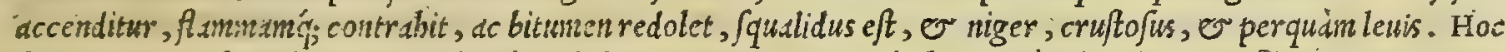
featet in uiniuer fum Flandria, Cinbbritóg, wbi lignorum penuria incole boc tanticm lapide ignem fibi comparant. Fo= ditur boc tempore etian in I talia Brixiano agro, é cuius foduris nuper ingentem glebam mifit ad me Tridento San= tus Santinus diligens plsarmacopola ad Corallij infignium. Fuchjius tir alioqui eruditißimus magno errore putat Fuchajerros.

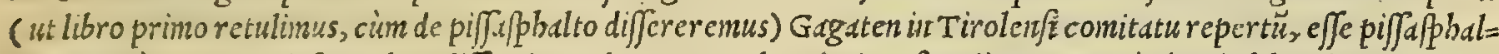
tum. Veriun cur ezo in boc ab co diffentian, citato nuper loca latius oftendinus. Porró idem in libro de componen= dis medicumentis, quen nuper auctum edidit, Gagaten cen fet effe fuccinum illud nigrum, quod nobis unlgò Ambra ne ra uocatur. Sed in hoc fimiliter eum ( $p$ ace fua dixerim) ballucinari clarius effe opinor, quain ut pluribus demonfere= twr. Nam ut omittan abfurdum mibi plané uideri, quód fuccinum lapitis nornire dignetur, illud non eft fqualiáum,

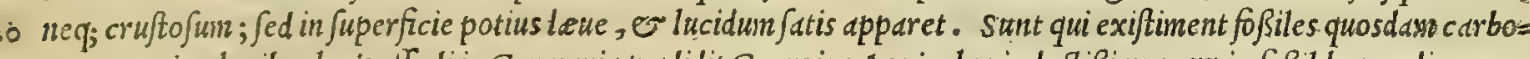
nes, quos in pluribus locis effodi in Germania tradidit Georgius Agricola uir doctißimus, or in foßillbus medicamen= tis indagandis hodief. cendantur. Veruntamen cum hi flammam ron ed ant, nififollibus excitentur, nec ullum bituminis odorem fpirent, co= -jum opinio platié refellenda uidetur. siquidem Gagates adeó bitumine pragnans eft, uit acceilfus picis feré modó flac gret, o ngerrimum emittat fumum. Quin o oleum copiof am reddit, ubi uitreis organis conclufus, ignium ui peris= gitur. Hoc commendauit Me fues denzoniacis, epilepticis, paralyticis, $\beta a$ fmicis, tetanicis, arthriticis, ab wtero $\int u f=$ focatis, er conceptuin non admittentibus. Quod tamen à carbonibus ijs elici non poteft, cim omini penitus bunore deftituantur. Gagata hiftoriam, ov vires tradidit Galenus lib. I x. de fimplicium medicamentorum facultatibuis, bis uerbis. Efter alius lapis colore atro, qui ubi igni admotus fuerit, perfimilem bitumini odorem exbibet .quem Dio=

'50 fcorides, nonnulliq́; alij in Lycia inueniri prodiderunt, ad fluxium nomine Gagatem, unde or ipfi lapidi nomenclatu= ram inditam dicunt. Ego tamen eum fluuium non uidi, tamet $f i$ parua nauicula totius $\mathrm{L} y$ cia litor legerim, quó uide= licet, que in ea funt, infpicerem. Cruftaceos uerò lapides nigros, or qui in ignem additi exilem flammam ederent, complures Coele syria apportaui, natos in colle, mari mortua, quod uocant circundato, qud orientem pectat, ubi er bitumen eft : eratq́; lapidum odor fimilis bitumini. Vtebarq, eis ad flatuofos tumores in genu dituturnos, o egré cu= rabiles, miftis uidelicet facultatibus, que ad hoc fymptoma probate fucrant. Planéq; uifum eft mibi euidentiorem exrum facultatem reddidiffe. Miicui ueró ipfum $\sigma$ Barbaro quam uocant, o palain medicamentum effectŭ eft exic= cantius, adeó ut $\odot$ finus contraberet, nedum cruenta uulnera glutinaret, ad que competere maxime creditur. ba=

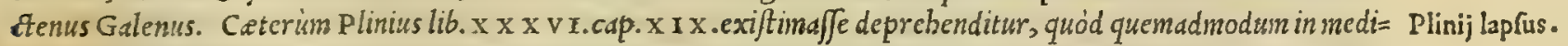
camentis fibi uiribus mutuis refpondent Thracius lapis, $\odot$ Gagates; ita uterque in aqua demerfus accendatur, or conflagret, reftinguatur uero in oleo. Quod tamen falfum eft: quandoquidem Diofcorides ubi ntemoria prodidefet Thracium lapiden ijsdem uiribus effe preditum, quibus er Gagatcs; fubdidit Tbracio allud peculiare adfcribi, quod

$$
\mathrm{Nn}{ }_{2} \text { aqud }
$$

Gagatæ lapidis confideratio.

Gagatx hifto ria,ŭs uiresex Galeno. 
aqua demerfus aceendatur, er oleo restinguatur. quod tamen in Gagate non accidit. .vim Gagate adnirandam efe fe Aëtius testis eft lib. I I. cap. X X II I I. quippe fi igne inflammetur, meroq́; reftinguatur', exbibeatur q́; id uinum cardiacis potandum, confsftim leuantur, repreffo fudore, excitatoq; arteriarum pul $\zeta$. Nonnulli Gagaten ad polli= nis tenuitatem terunt, feptem q́; continuis diebus colicis é uino propinant dracbme unius pondere, er integram refti= Achatx lapi- tuunt ualetudinem: poculum interim, quo laborantes bibunt, eiufdem uapore fuffientes, Sed quoniam. Gagates ab dis hiftoria, \& quandam nominis fimilitudinem, lapidem A C H A T E N. ita ueteribus appellatum, mibi in mentem redegit, cüm uires.

is laudetur ad uaria bumani corporis incommoda, meritó bic aliquid de co nobis dicendum effe duximus. Repertus primism Achates eft in Sicilia, iuxta Achaten fluuium, à quo nomen fibi uendic auit. Lapis hic uarijs conftat coloris

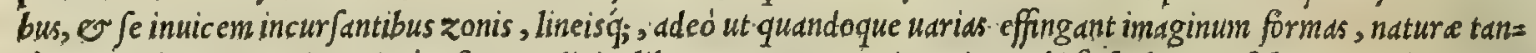
tùm penicillo. Id quod maximé teftatur Plinius lib. $\mathrm{x} x \mathrm{x}$ V I r. capite primo, ubific babet. Poft hunc annulum regid so fama eft gemme Pyrrbi illius, qui aduerfus Romanos bellum geßit. Nanque babuiffe traditur Achaten, in qua no= uem $M u f \int_{2}, \mathcal{G}$ Apollo citharam tenens fpectarentur, nọ arte, fed ponte nature, ita difcurrentibus macul is, ut $M u=$ fis quog; fingulis fua redderentur infignia. Hinc igitur creditum eft antiquos uocaffe Achaten uarijs, ac diuerfis now minibus. Vocatur enim phafjachates, cerachates, dendrachates, leucacbates, bamachates, corallachates, 0 id gew nus alijs : quód quidam columbos, quidam cornud, alij arbores, alij anguinem, nonnulli cor allium coloribus pre $f e f e=$ rant. Prodeft Achates ( ut Plinius eft author) contra f corpionum ittus. Quod in Siculis utique crediderim, quoniam primum eius prouincis afflatu fcorpionum peftis extinguitur. Et in India inuenti contra eadem pollent, of alijs ma gnis miraculis, spectaffe etiam prodeft oculis. Sitim quoque fedant in os additi. Leonine pelli fimiles, potentiam ceteris ualidiorem babere contra forpiones dicuntur. In Perfis ueró fuffitu, earum tempeftates auerti, e prater= eafumina fifti. Argumentum effe, fi in feruentes cortinas additi, refrigerent. Sed ut profint, leoninis iubis alligan $=20$ dos. Abominantur hy ne pelli fimiles; quiod domibus difcordiales fint. Sed qui unico tantum colore notatur, inui=

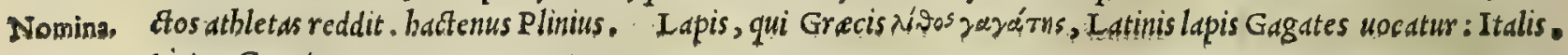
pietra Gagate.

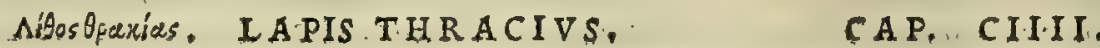

L A P I S Thracias dictus, nafcitur in flumine quodam Scythiæ, cui Ponto nomen eft. Vis ei gagatx. Traditur aqua accendi, \& olco reftingui : quod in bitumine accidit.

Thracii lapi- QVI TH RACI vM lapidem oftenderet in Italia, hadtenus profectọ neminèm inueni: nec qui illum alijs in regio 39 dis mentio ex nibus fe uidife, aut inuenife teftetur, compertum habeo. Eius inentionem fecit Galènus und cum gagate lib. I X. de Galeno.

fimpl, medic. facultatibus, ubi ita fcribit. Eft or alius lapis, cuius meminit Nicander bunc in modum.

si lapis uratur candenti Thracius igne, or.

Póft madefiat aqua, flagrabit totus : at idem

Mox oleo affufo, penitus reftinguitur, adfert.

Thracius bunc ad nos paftor de flumine, nomen

Cui Pontus.

Verum nullus eius in medicina ufus: neq. Nicander prater graueolentiam, que fuffitu feras fugat, quicquam ei ado

Nomina. fcripfit. bec Galenus. Ceterüm nos Thracijlapidis hiftoriam potius fabulofam, quàm ueram cen femus. : Eius no=

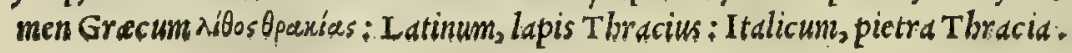

$$
\text { AíPospecziñtis. LAPIS MAGNES. }
$$

CAP. CV.

M A.GN E S lapis optimus elt; qui ferrum facilè trahit; colore ad coruleum vergente, denfus, nec admodum grauis. Datur cum aqua mulfa trium obolorum pondere, vt craffos humores eliciat. Sunt qui magnetem crematum pro hæmatite uendant.

Magneris la-

M A G N E S lapis Heraclius, or sideritis quoque dicitur. Magnes quidem ab inuentore (ut Nicander eft alli=

pidis hiltoria. thor) nomine Magno, qui primus in Ida monte lapidem bunc adinuenit: aut à Magnefic regione, ut Lucretius fuis in poëmatibus fcribit. Heraclius ueró, uel $a b$ Heraclia urbe, uel $a b$ Hercule : ut enim Hercules immanes domuit bel $=$ so luas, uiribus ǵg; fubegit; ita Magnes ferrum.uictricem rerum materiam ad fe trabens, fubigit, er tenet. Quas ob ui= res sideritis quoque dicitur. quippe ferrum Gracis oíspos appellatur. Nos autem uulgari idionate appellamus pie= tra Calamita. Foditur in Cantabria Hißpanie, ov in uarijs Germanie, ac Bobemia locis, etfi fape cafu inueniatur inferrifodinis. Preftat, qui ex Macedonia, o Magnefia ill contermina conuebitur: fed omnium praftantißimus eft Indicus, $\mathcal{O}$ Acthiopicus. Differunt Magnetes colore, qui in ijs aut niger eft, aut coruleus nigricans, aut in ni= gro rufus, aut contrà. Optimus eft mas; qui non modó celerrimé trabit ferrum; fed etiam uim fuam in id adé transfundit, ut poßjit alterum inherens ferrum ad fe trabere, quo fit, ut $\int$ epius acus acum trabat, adeo ut altera alte= ri fubpendeat, nullis appofitis adminiculis, ad duodenum usq; numerï. Qüod item ferreis fit anulis, qui alter alteri inbarentes catena inftar dependent . tamet fi poftremius non tam pertinaciter inhereat, uti primus, o fecundus. Ratio autem cur Magneti tantium facultas infit trabendi ferrum, nulli fané, quod fciam, adbuc comperta est , nec ulla. cam philofophorum inucftigatio unquam affequi potuit. Proinde neceffarium fucrit dicere, illi uim banc peculiarem 


\section{In Lib, quintum Diofcoridis.}

tribuiffe calun, or rerim ommium parentem naturam, ut $\mathrm{R} b a b a r b a r o$ uim detrabendi bilem, o Torpedini mavine fupidam reddendi manum, qux ipfam uiucntem tetigerit. Nec fané aliud quic quan inucniri putaucrim, quod uiribus Magnetem inagis a muletur, quàm Torpedo pifcis. Quandoquidem ut Magnetis adıiranda facultas cx una pendens te acu in alism tranfit acum, or ex anulo in anulum; idem fimiliter efficit Torpedinis uirtus. Quippe hamo capta, obftupefaciens cius facultas adcó confrftin per fetus uirgamí; excurrit, utftatim pifcatoris manum miro fanéftupo= re corripiat. Idem '́; fficit retibus comprehenfa, ui per funem aura inftar excurrente. Caterim Dinocrates Ale= xandrinus ( Plinius author eft lib. $x$ x X I I I I.cap. X I I I I.) Arfinoés de Magnete lapide templum concamerare inchoaucrat, ut in co fimulacrum cius ć ferro pendere in dëre uiderctur. Cuius forfitan rationcm fecuti A rabes, Tur= carumg; facerdotes (if tamen uera refrunt, qui talia fcribunt) Mabumeti facellum é preftantißimo Magncte cons

to camerari uifferunt, ut impojita in co. Mabumeti arca c purißino ferro conflata, tanquam diuino quodam miraculo in. ac̈re penderet, ita deceptis populis. Trabit itaq;. Magnes propria ui ferrum, excepto co, quod rubiginem cötraxerit, uel ubi lapis is allio fuerit conficicatus, aut ubi adanas prope adfratur. Magneti uin fane contrariam babet Thea= medes lapis in Aethiopie montibus nafcens; non procul à monte magnétis : quippe quód appofitum fibiferrum confe lapis.

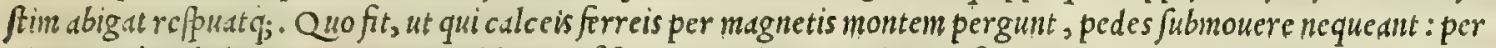
alium scró ambulantes, nunquan pedibus con/iftant, or ueluti tripudiantes fiant. Magnetis breniter meminit Ga= Magnetis uis lenus lib. I x. Fimpl.nicd. fic inquicns. Ex lapidibus unus eft or magnites, er beraclea,quam uocant, ad/imilem bema ex Galeno.

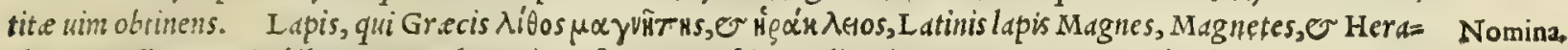
cleus appell.tur : Arabibus, Hager almagritos, feu Magnathis; Italis, pietra Magnete, er Calamita.

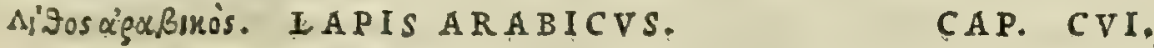

A R A B I C V s lapis maculofo ebori limilis. Is tritus illitus hæmorrhoidas exiccat, Eius cinis dentifricio oprimus :

N V L L. M bactenus uidi, necreperi lapidem, qui eburneam mibi oftenderit faciem , quapropter non credi=

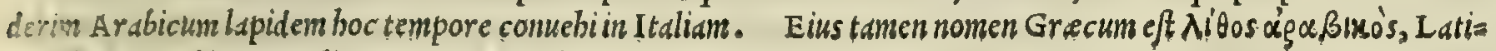
whin lapis A rabicus; Italicum, pieța Arabica.

\section{Aigoș $\gamma \alpha \lambda x x$ TírHs, IAPIS GALACTITES:}

G A L A C T I T s appellatur, quod lacteum fuccum réfudet : cinerei tamen eft coloris, \& guftu dulcis. Ad oculorum fluxiones, \& vlcera conuenienter illinitur. Oportet autem in aqua tritum, pyxide plumbea recondere, propter vim glutini, quod ei obharet .

\section{N'ÖOS MEגITITHS. LAPIS MELITITES: CAP. CVIII.}

M E I I T I TE S omnia galactitx fimilis, hoc tantùm intereft, quòd dulciorem fuccum remittit. Eiufdem vt galactites effẹtus.

G A I A C T I I E N, item Melititen qui mibi oftenderet, hactenus non reperi. Alter tamen (ut Galenus int quit lib. I x. finplicium medicamentor um) Galactites uocatur, quód in fuccum folutus lactis peciem reddat . quem= sdmodum alter melitites, quod fucci dulcedine mel guftu reprefentet. Galactitx meminit Plinius lib. x x x v I I.cap. $\mathrm{x}$. fic inquiens. Galactites ex uno colore lactis eft. Eandem dicunt leucam, er leucographiam appellant, $\sim$ fynne= phiten : tritam latis is ucco, e fapore notabilem. In educatione nutricibus lactis facunditatem : infantium quoq; ad= alligatd collo, faliuam, facere dicitur: in ore autem liquefcere. Edndem memoriam adimere dicunt. Mittit eam er Achelous aminis . hec Plinius. Caterim, ut teftatur Agricold, non folum reperitur Galactites in quibufdam $S$ axos

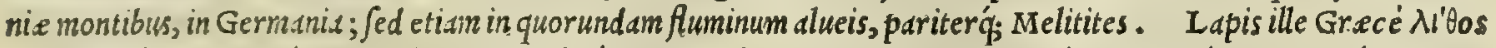

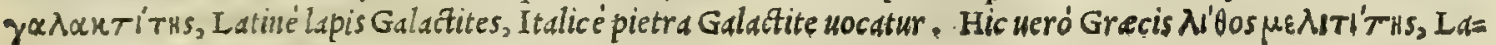
50 tinis lapis meltites, Italis pietra Melitite nominatur.

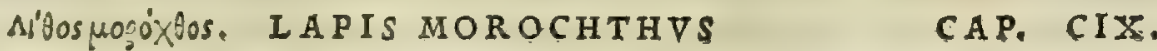

Mo R O CH T H S Japis, quem aliqui galaxiam", aut leucographida uocauerunt, in Aegypto nafcitur . quo, vtpote riolli, \& facilè liquefcente, linteones dealbandis ueftibus utuntur. Spiracula corporis obftruere uidetur : conueniens ijs, qui fanguinem expuunt, cœliacis, \& veficæ doloribus, cum aqua potus. itidem fluxionibus vuluæ, \& impofitus uelleri . Mollibus oculorum collyrijs mi. fcetur : explet enim caua, atque delacry mationes fiftit. Idem cerato exceptus, ulcera, qux fiunt in teneris partibus corporis, ad cicatricen perducit .

M ० R ० с н T H V M lapidem nonnullis galaxiam wocatum nafci, fodiq; in saxoñia Germanie teftis eft Geor gius Agricola maxinus foßilium indagator. Veruntamen cim nec inde, nec ex Alegypto, quod fcidm, in Italiam de=

Galatitis \& melititz hifto ria.

Nomine. 
Morochihils frratur, cur plurade eo dicam, non habeo. Morochtbi meminit Galenus unà cun fcißili lapide lib. $\mathbf{x}$. de fimpli= pidisurres ex cium medic amentorum facultatibus, fic inquiens. Sunt et alij laptdes in fuccum folubiles, ut qui in Acgypto nafcitur, Galeno. quo utuniur ad piendorem lintcis conciliandum. Eft dutem omnium dictorum minimé qualitatis particeps, nec adftri Gionem, nec morfum, nec abfterfionem pre fe ferens . quocirca boc ipfum duntaxat lapidi buic ineft, quód deficcet. uidelicet : proinde cerato eum mifcentes ad cicatricem ulceribus inducendam in mollibus corporibus ufurpant. sed. or ocularibus mifcetur facultatibus, perinde ut modó dicti. At quantó eft maiore emolliendi ui, quàm pradicti,quód: nullam uidclicet effectricem qualitatem babeat; tantó etiam moderatior eft, magisá; dolorem leuat. Hunc lapidem quidam moroxum, nonnulli leucograplida nuncupant. hactenus Galenus. Sed certé ne cio qua ratione, aut author ritate ductus fibi perfuaferit Plinius lib. $\mathrm{x}$ X V I I. cap. $\mathrm{x}$ I. bunc non effe lapiden, fed herbam, ubi una cum leuca de:

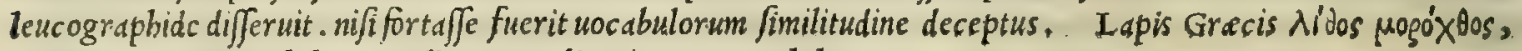

Nomina. Iatinis Lapis moroclbtbus appellatur: Italis, pietra Morochtho.

\section{LíBosa'r $\alpha$ Busgiths, IAPIS ALABASTRITES, CAP. CX.}

A L A B A S T R I T E S vocatus onyx, crematus, refina aut pice exceptus, duritias difcutit. ftomachi dolores cum cerato lęuat : gingiuas comprimit.

Alabaftritz A L A B A S T R I T E S notißimuslapis eft ijs, qui Romana inuiferunt edificia. Hallucinantur tamen, qui confider. credunt lapidem illum Alabastriten efe, quó bac tempestate torno uaria finguntur ua $\int$, quibusdam fubnigricantibus uenis difcurrevitibus, pellucido leuore, materix ueró adea imbecilli, ut parum collifa facilé frangantur. Quando= 20 quidem lapis bic Alabastrite pecies non est, fed potius gypfi materia. Alabaftrites enim, quem antiqui ad uafa un=

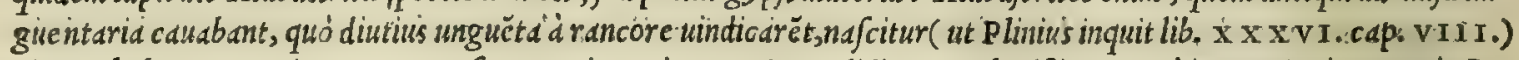
circa Thebas Aegyptias, en Damafcum Syria. Hic cateris candidior. Probatißimus ucró in Carmania, mox in In

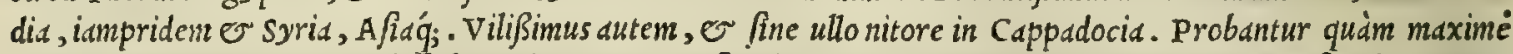
Alabaftritęvi mellei coloris in uertice maculofi. bec Plinius. Huius facultates memorie prodidit Galenus lib. ix: fimplicium me= res ex Gal. dicamentorum, fic iñquiěs. Et alabaftrites uocatus unguis.in medicine ufum ingreditur combufus. Quidam eum bia

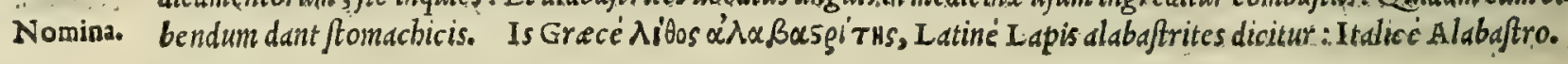

\section{AITOS GuITRS. LAPIS THYITES:}

C.A. C.X. C.

I A P I s nomine thyites, in Aethiopia gignitur, fubuiridi colore iafpidem imiratus: cùm diluitur tamen, lacteum fuccum reddit. Vchementer mordet: tenebras, qux pupillis obuerfantur, expurgat .

T н Y I. T E N lapiden neq; ipfe hattenus inueni, neq; ab alio compertum fcio: Quifortaffe ex Aethiopia tan= Fuch. opinio tum petendus $\mathrm{eft}$, ubi eum gigni prodidit Diofcorides. Veruntamen Fucb/us medicus fingularis doctrine, libro il= reprobata. To de compofitione medic amentorum, quem collucupletatum fecundó edidit, lapidem Diofcoridi Thyiten dictum; ni= bil aliud effe cenfet, quàm lapidem illum corulcum, qui Italis uulgó Turchina, alijs ueró Turcicus lapis appcllatur, ut eius uerba, qua fubijciam, aperte declar ant. I a pis, inquit, Galeno duplex eft. Vna fubuiridis, que Diofcoridi Thyites, ut alibi diffusè monftrauimus, dicitur. Thyites autem non eft nifi ea Iapidis ffecies, que quód aérie coelo 4

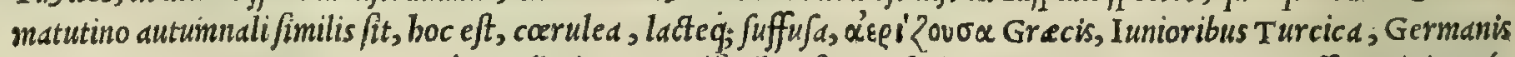
Turckes nominatur. Qudm certé appellationem uerifimile eft ex Thyitis deprautata uoce promanaffe, originem $q$; fuam duxiffe. Altera uiridis, que fic dicta eft; quia uiret. Eius duodecin funt generd, quie alibi ḋ nobis funt ordine explicata. Quintum autem genus eft Turcica uocata Iapis, de qua iam diximus. Hactcnus de Thyite lapide Fuchsij fententia. Que fané mibi nonnullis rationibus refellenda uidetur. Primùm nanq; non inuenio, quód Galeno Iapis in duo genera digeratur, in uiridem fcilicet, $\mathcal{V}^{2}$ fubuiridem, ut illi Fucb/ius adfcribit. Sed ipfum uiridis tantùm meminif= fe conftat lib. I x. fimplicium medicamentorum, ubi de euss facultatibus differuit. Nec obftat, quód Galcnus codem libro in commemoratione Thyitis lapidis ex Diofcoride, hunc coloris effe fcribat fubuiridis quodammodo, ut iapis. fiquidem Galenus eo in loco Diofcoridis uerba refert, ut ex capitis illius titulo quisq; certior fieri poteft : id cnim ita

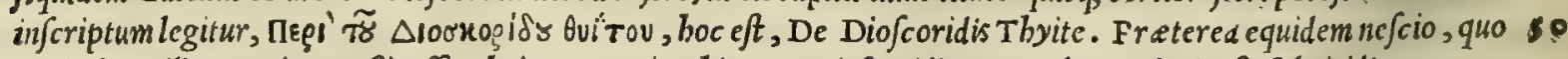
pacto lapis ille Turcicus poßit effe Thyites: quoniam bic tum Diofcoridi, tum Galeno coloris eft fubiiridis, non au=

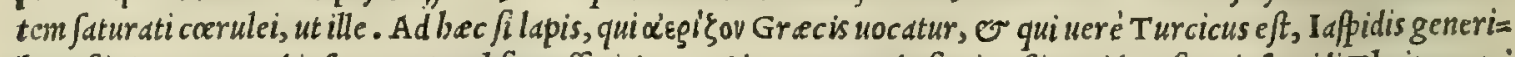
bus aßsighatur ( quod ip $\int e$ quoq; Fuch/ius afferit) non uideo, quo modo fieri poßit, ut idem fit Diofcoridi. Thyitcs : qui a nemine, quod fciam, inter iapidum genera recenfetur. Poftremó mibi quidem non uidetur uerifinile, quód Turcie cus lapis a Thyitis deprauata uoce nomen acceperit . quam enim, que fo, ille uoces babent inter fe finilitudinem? ccrté nullam. Quare potius adducor, ut credam eam appellationem fluxiffe ab Italica noftra lingua. nam quemad= modum in Italia cceruleus color, quem proprié coeli colorem effe uolunt, uulgó turclino vocitatur; ita etiam inibi la pis is, de quo fermo eft, d̀ colore, quem coerulcum habet, Turchind nominatur. Ex qua nomenclatura poftea facile factuin cffe arbitror, ut eundem lapidem iuniores Turcicum appcllauerint: atq; adeó fimili initatione fortaße ducti

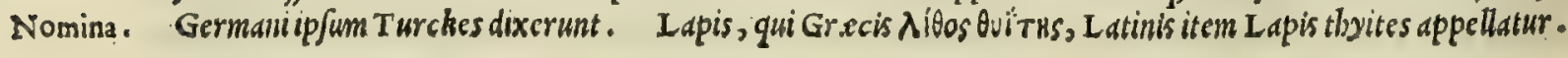




\title{
In Lib. quintum Diofcoridıs.
}

\author{
Nitosiousairós. LAPIS IVDAICVS.
}

CAP. CXII.

I v A I C v s lapis in Judæa nafcitur, glandis effigie, candidus, fcita admodum configuratione, lineis aqualiter inter fe diftantibus, quali indultria detornatis. Solutus nullam qualitatem manifeftam guftui repræentat. Potéf ciceris magnitudine tritus ad cotem, ut collyrium, cum calidx aqua cyarhis tribus, potu difficultati urinæa auxiliari, \& calculos in uefica comminuere.

L A $P$ Is é Iudxa allatus, unde or illinomen, paßim in officinis habetur. Vtuntur co medici nö modò ad uefice Lapidis Iudai

to calculos; fed ctiams ad cos, qui in renibus fiunt, Galenum fecuti, qui libro nona de /implicium medicamétorum facul= tatibus, cius faciem ac uires defcrip/it, bis uerbis. Eft $\mathrm{O}$ dlius lapis uiribus ualentioribus in $P$ alleftina syria prouc= niens, colore candido, ßpecie concinna, line as babens ceu torno ductas. A ppellitant eum à loco, in quo nafci confue=

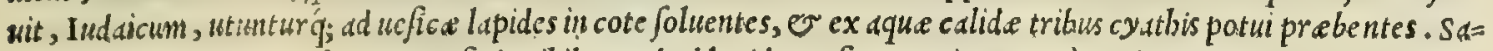

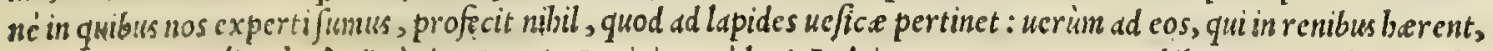

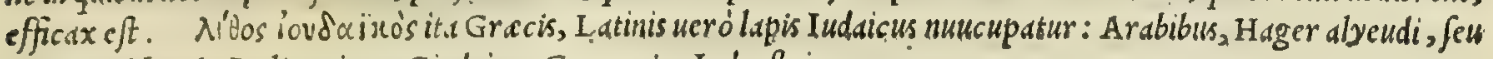
Hagiar aliheud: Italis, pietra Giudaica: Germanis, Iudenftein.

Niqosáuizuios. LAPIS AMIANTVS.

CAP. CXIIY.

to Am rantys lapis in Cypro nafcitur, fciffo alumini fimilis . quo, utpote flexili, telas \& uela tantùm fpectaculi gratia texunt, qux ignibus iniecta ardent quidem, fed flammis inuicta fplendidiora exeunt.

L A P I D E A Amidntum (ut in alumine retulimus) officine ac medici Alumen pluneum uocant, id effe exiffi= Amianti lapimantes, quod Grecis fciptle dicitur. Sed, meo quidem iudicio, falluntur, cim plunteum alumen ijs uocatum nulla dis confid. adftringenti ui polleat, fed acri, nec in ignem coniectum comburatur, quod Amianti eft proprium. In hac uulgari opinione, ego quoq; uni cum plerisq; rei metallice fudiofis iampridem uer fatus fum, donec clarißimus redicus Lu= cas Ghinus legitimum alumen fcißile Pifis ad me mifit , facie adeó Amianto fimile, ut nifi adftrictoria uis, qua pollet, ipfum ab Amianto plurimim differreguftui indicaffet, alterum fané ab altero difcernere nefciuiffem. Nibilominus.

3. - ex eo difcrimen cognofcitur, quód boc in ignem proiectum ftatim exuritur, ille ueró nequaquam. Hinc itaq; fit, ut haud dubie credendum jit Alunzen plumeam wocatum legitimum effe Amiantum. Ceteriun non defunt impoftores (ut auctor eft Erafauolus Ferrarienfis) qui lapidem Amiantum fimplicibus mulierculis oftendant, uendantq̨; $\int a p e n u=$ mero pro ligno Crucis seruatoris nostri. Id quod facile credunt, cum igne non combur atur, quòd $\dot{g}_{\text {; }}$ lign modo plu= rimis conftet line is intcreurfantibus. Memenit Amianti Plinius libro X X X V I. cap. X I X. ubific inquit. Amiantus alumini fimilis nibil igni deperdit. Hic ueneficijs refiftit onnibus, priuatim magorum. Eius nomen Grecum $\lambda i$ inos $^{2}$

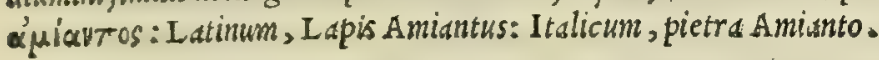

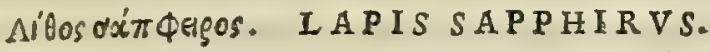

CAP. CXIIII.

40 S A P P H IR V S lapis perculsis à fcorpione, potu prodeffe exiftimatur. Contra inteftinas exulcerationes bibitur. Excrefcentia in oculis, vuasq́; , \& puftulas inhibet, \& ruptas membranas cogit .

S A P P H I R V S gemma colore conftat cy, aneo, perquàm tratslucido. Lapis est omnibus notus, quod dimulis, o torquibus, que collogeftantur, frequenter inferatur. Plinius sapphiros aureis punct is collucere fcribit libro X X X V I1. cap. I X. Veruntamen bac at ate nullum bactenus tidi sapphirum, qui aureis colluceret faintillis, $\int e d$ co= lore tantim cyaneo, adamantis modo translucido. Qu o fit, ut putandum fit aut noftri ufus fappliros effe cyanos ge $\bar{e}=$ mas Sapphiri emulas: aut hac inre erraffe Plinium fatendun, quòd fortaffe coerulcum lapidem peculiariter uoca= tum, quem Mauritani azulum, uel lazulum dicunt, pro Sappliro acceperit. Nam nullus prater hunc inter gemmas aureis emicat fcimtillis. Sapphiri uires perquàm breuiter perftrinxit Galenus, cuim tantìm ad fcorpionum ictus bau=

Atum prodeffe fcripferit. Caterim adduntur boc tempore in medicamenta ad cor facientia, o in antidota, qua aduerfus uenens, er peftiferos affectus parantur, norimodó fapphiri, fed fmaragdi, carbunculi, granati, fardōnij, hyacintbiq;: tamet fi prater medic orum $\$$ pem, potantes plerung; fallant : quod rara admodum fint feplafia, qua bus

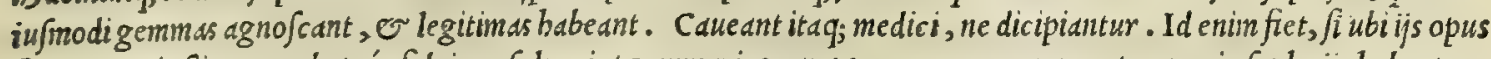
fuerit, peritzfinos probatég; fidei confuluerint genmarios . quippe gemmarum ramenta, qux in feplasijs babentur, adulterijs, $\odot$ impcfturis non uacant. Adde, quood plerunq; alterum alterius uice fupponunt. P utant enim clory fopa= tios aureo colore nitentes byxcinthos effe, qui tamen ame thy fum colore referunt. Pretered obferuandü eft, ut gemmarum ramenta, fiqua legitima, preclará, inueniuntur, quin e margarita', e corallia fuper lapide porpbyrite tandiu attcrantur, ufquedum redigantur in puluerein tenilsimi pollinis inftar. Et fané aduertant medici, quibus cu= re eft, ut plus bo:soris, quim auri lucrentur, ne corallia in eneis mortarijs conterantur. Nan fi id inconfulte fiat,

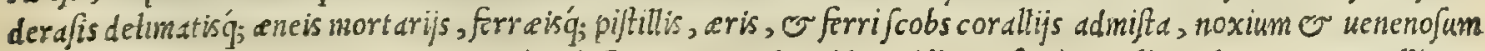
geddet medic smentum, magna egrotantium iaf wira. Quandoquidem uidi ego fepius mulierculas, qua corallia er.

Nomina. 


\section{4 \\ And. Matthioli Comm.}

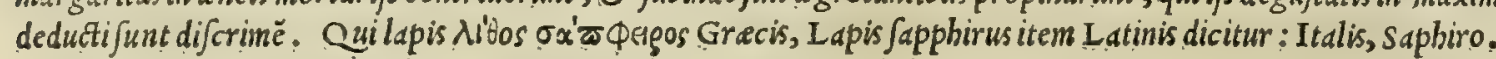

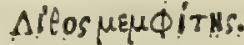
LAPIS MEMPHITES.
CAP. CXV.

M E M P Y T E S in Aegypto iuxta Mcmphin inuenitur, calculorum magnitudine; pingtis, uerficolor. Tradunt trito, \& 1 llito, qux urenda, aut fecanda funt, fine periculo obftupefcere, ita ut non fentiant cruciatum .

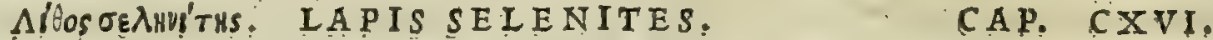

SE L E I T E S lapis; quem aliqui aphrofelenon appellarunt, quoniam noctu inuenitur luna imaginem rcddere, qux cum ea quidem augetur, \& decrefcit. Nafcitur in A rabia, candidus, translucens, leuis . Huius ramenta comitialibus in potu dari iubent. Eo ceu geftamine ad amuleta mulieres utuntur. Arbores adalligato eodem frugiferæ redduntur ,

Memphitx,\&

M E M P H I T E s lapishodie, quod fciam, ad nos ex Aegypto non adfertur, tametfi uulnerarijs medicis fe Selenitx con pißimédefideretur, ubi integra partium fectione fit opus. Seleniten veró etfí anted non wideram; cmi tamen hoc fideratio. anno à peregrino quodam, qui é Galitia Hipania, ubl diui Iacobi templum inuiferat, in patriam reuertcbatur, Hic lapis uitri modo translucet, of facilé initenues finditur laminas. quo fit, ut ijs in locis, ubi frequentißimus babetur. uitri uices expleat, ad concludendas edificiorum feneftras. Quidam, quód peculi inaginem reddat, specularem la=

Cryftslli hi- pidem uocant. Ceterim quoniam hic translucidus lapis Cryltallum nobis in mentem redegit, cim expetatur id fe=

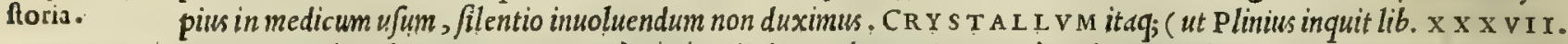
cap. I I.) gelu uebementiore concrefcit, nec aliubi certẹ reperitur, quàm ubi maxxiné byberne niues rigent, glaci= Phnii sétětią evíq; cfe certum eft, unde er nomen Gracidedere. Hac Plinij de cryftallo fententia. Nos ueró contrà rationibus nö explofa. obfcuris innixi (quod etiam peritißimus Agricola fentit) Cry/fallum cen emus nec glacie, nec niue fieri unquam: fed eo ipfo bumore, quo in terre uifceribus gignitur beryllus, adamas, er alijid genus lapides. Gigni autem cryftallum ex humore omnium purißimo fané conftat, quodd omnium gemmarum clarißimum, translucidißimun'̧; fit. Probatur fic gigni, non autem (ut Plinius inquit) ex glacie, uel niue : quoniam unaqueq; glacies quantumuis longo tempore concreta in algidißimis montibus, à quibus nec byeme; nec aftate nix unquam recedit, etiamfi é profundis partibus eruatur, lique fcit tamen in calidis locis repofita, non modó ignis, fed folis etiam calore. Nanq; id ip fum cryftallo eueniret, igni uel folibus admoto, fi è niue aut glacie concrefceret: reperire tur q́; tantim in montibus perpertuó ni=

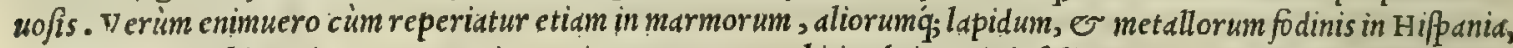
Germania, scytbia, Cipro, Carmania, or in Nerone, er Chitirubri maris infulis, quin or in agris, ubi feges $\int e=$ ritur, ubi aratro fe pius magnas cryftalli glebas fodêre bubulci,liquido fané cöftabit, ex alia materia gigni cryft allum, quàm glacie. Siquidem id, quod in prer uptis montium fcopulis inuenitur, Juperficie tenus coherens, ex purißimo ld= pide cente bumore in uifceribus terre concrefcere non dubitauerim : quod tamen trac $u$ temporis à pluuiarum impe= tu, que inpreruptis inontium uniuer fan deradunt terrà, denudari crediderim. Quapropter non temeré dixit $\mathrm{Pli=}$ nius, liquido $\int e$ affirmare poffe in cautibus alpium nafci adeo inuijs, ut plerunque fune pendentes id extrabant bomi= nes. Huic alia accedit ratio, quód glacies per aquas innatet, cryftallum ueró illico fubfidat. Praftantißimumillud 49

Cry talli ui- exiftimant, quod album er aqua clarißime modo pellucidum uifitur. Vis cryftallo adftriltoria: proinde datur in res. puluerem tenuißimum tritum utiliter dy fentericis ex uino auftero. Alba uteri profluuia fistit, lac ueró nutricibus au= get. quod à Tridentinis mulieribus didicimus. Fiebat quondam antiquis é Criftallo pila, qua aduerfis folis radijs ex= pofita medici corpora urebant, tgne inde concitato. Sed ijs tantùn id cauterij genus admouebant, qui candente ferro perterriti curari reformidabant. Sed $\mathcal{O}$ nos buiufce cauterij periculum fecimus, non fine egrotantium, er aftanti=

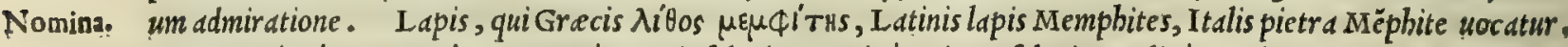

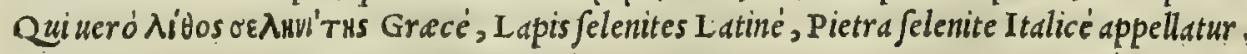

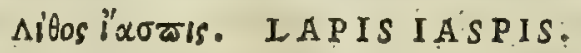

CAP. CXVII.

I A 5 P I D V M quædam fmaragdum imitatur : alia cryftallum, colore fimilis pituite: alia non difsimilis aëri , ob id uocatur aërizufa : alia ueluti fumo infecta, qux capnịas ex argumento uocatur . quædam lineis albis refplendentibus præcingitur, Affyrios appellata . alia terebinthinæ fimilis, qux terebinthizufa dicitur alia colore callaida gemmam æmulatur. Omnẹs ạmuleta effe traduntur, \& accelerare partum femoribus appenfæ.

lafpidumge- IA S P I D V M generalonge plira recenfentur, quàm que d̀ Diofcoride de fribuntur. Quandoquidem ques nera. dam uifitur caruleo copiofo, aut glauco pingui fimilis, id eft, uiridis lacte fuffufa. Alia purpurea, qualis nafcitur in Phrygia. Alia rofed, er quafifloribus tincta, qualis in Ida monte profundisimis pecubus foditur. Alia ex purpura carulea, qualis inuenitur in Cappadocia. Alia ex rubro nigra. Alia iecoris imitatur colorem, qua fi faturatiore co= lore reperiatur, lineis ciufdem coloris diluti, e nigri cingifolet. Quedam niuem imitata rutilis punitus repergitur. 


\section{In Lib, quintum Diofcoridis.}

cued am onyche pungitur, ane cx alteru parte iapis eft, cx altcra onyx; proinde iafponyx uocatd. Alia cuius alte= rit parte fit purpureas, al lere uiridis, nec utrinq; pellucens, fed qua parte uirefcit. In fumna uaria eft I afpidum nas tura. Sufpenfas ad plura ualere siunt, nempe ad omnem fanguinis fluorem, ad protegendum conceptum, e partum

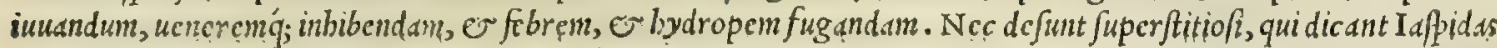
bomines reddere gratos, potentes, ac tutos, /i quibusd.m magicis uerbis admurmurentur, priusquàn fupendantur.

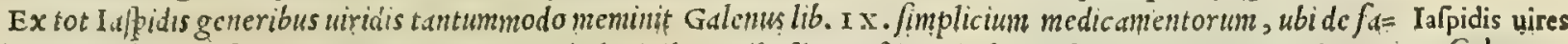

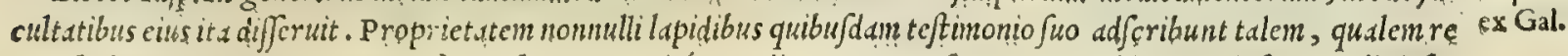

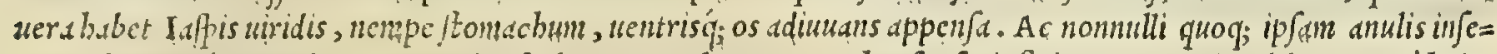
rent, fcalpuntí; in eadraconens radios habentem, uelut rex Nechepfos fcripfit in quartodecimo libro. Sané buius 10 ego quoque lapudis abunde periculumfici. Torquene enim ex buiusmodi lapillis confectum à collo fuffendi, ita ut $l_{a}=$ pides os wentris canting crent. A pparebant qutcm nibilominus prodefe, etiam if fculpturame non baberent, quam

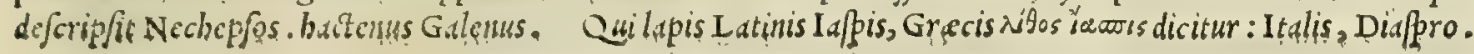
Lifoscistitus.
LAPIS AETITES.
CAP. CXVIII.

AE TI TE S Japis eft uelutiprægnans, cùm quatitur, alio in 'utera fonante. Grauidis continet partus, cùm lubricx funt vulux, « parum tenaces, liniftro brachio adalligatus : fed parturientibus è brachio amoueatur, \& feminibus alligetur, ut fine doloribus pariant. Furem deprehendit, fi quis in pane conditum offerat : fur enim manfum deuorare non poterit. Quinetiam concoctus furem co20 arguit: quippe decocta cum eo deuorare non poterit. Tritus, \& cerato exceptus, cyprino, aut gleucino, aut alio excalfaciẹte, comitiales magnificè iuuat. xiliari.

AE T I T E N Greci, Latini Aquile lapidem dicunt, quód aliquando in extrum reperiatur nidis. Variat lapis

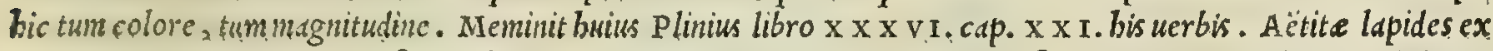
a gunento nominis magnam fanambabent. Reperiuntur in nidis aquilarum, ficuti in decimo uolumine diximus. Aiunt binos inucniri, marcm, of fominam : nec fine ijs parcre, quas diximus aquilas, o ideo binos tantün. Gene= ra eorum quatuor. In Aphrica nefcentem, pufillum, o mollem intra $\int e_{2}$ ac uelut in aluo habentem argillam fuatem, candidam: ipfum friabilem, quem freminei fexus putant. Marem autem, qui in A rabia nafcitur, durum, galle fimi= lem, aut fubrutilum, in aluo habentem durum lapidem. Tertius in Cypro inuenitur, colore illis in A plorica nafcen= 80 tibus fimilis, amplior tamen, atq; dilatatus . ceteris enim globofa facies. Habet in aluo arenam iucundam, ev lapil= los: ipfe tamen mollis, ut etiand digitis frietur. Quarti generis Taphiufius appellatur, nafcens iuxta Leucadem in Taphiufa, qui locus eft dextra nauigantibus ex hac ad Levicadé. I nuenitur in fuminibus candidus, $\odot$ rotundus. Huic eft in aluo lapis, qui uocatur callimus, nec quicquam tenerius. Hactenus de aquilinis lapidibus Plinius. Sidosástín Tis Grecis difus, lapis Aëtites Latinis uocatur: A rabibus, Hager achtamach: IItalis, pietra d' Aquila.

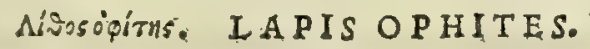

CAP. CXIX.

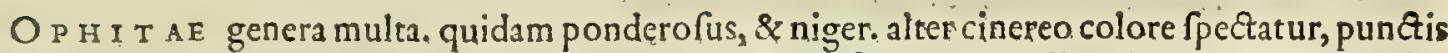
diftinctus. tercius lineis quibusdam candidis intercinctus eft. Omnes alligati contra capitis dolo40 res, \& ferpentium iatus profunt. Feruntur, qui lineas habent, lethargo \& capitis doloribus au-

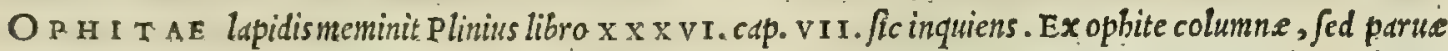
admodum inueniuntur. Duo eius genera, molle candidum, nigricans durum. Dicuntur ambo capitis dolores fedare adalligati, $\approx$ Serpentiun itus. Quidan phreneticis, ac lethargicis adalligari iubent candicantem. Contra ferpen= tes autem à quibusdam laudatur, precipué ex his quem tepbriam appellant à colore cineris. bac Plinius. Veriun Opbites marmor ${ }_{2}$ quod ualgo noc amus serpentino, porphyrite feré lapidis instar durißimus eft, cotore minimé ni= gricante, nec candido, nec cinereo, ut in fuo requirunt Diofcorides, E Plinius, Sed uiridifaturato dilutis einfdem coloris maculis reßperfo. Ex quo fané conftat añtiquorum Ophiten à noftrate maximé fuiffe diuerfum. O Ophite la= so pidis uires tradidit Galenus lib. I X. Fimplicium medicamentorum ${ }_{2} u b i$ fic inquit. Ophites quem uocant lapis uftus ex= tergendi confringendiǵ; uim poßidet, ceu etiam uitrum. Admodum enim e ip $\int$ wm ex uino dlbo ac tenul epotumi lapi= des uefice comminuit. Verum ipfum in lapidibus quipian forté non numeret. Et infrà in Iafidis uirrdis mentio-

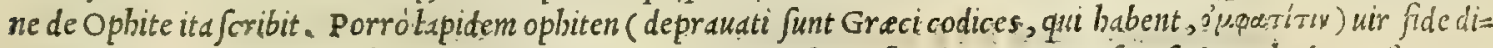
gnus re sera iuuare mor fus à uiper a fupenfum retulit. Sed eiufinodi facultates extra ufun funt methodo con/t antern:

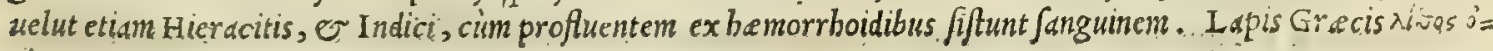
gims, Latinis Lapis ophites, Italis pietra Serpentina uocatur.

Aëtita lapidis hiltoria,\& uires.

\section{Nomina.}

Ophitze lapidis luftoria.

Ophites $m a n$ mor.

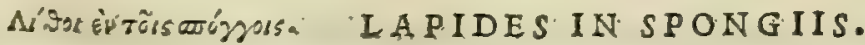
C.A. 
Lapidú Spon- L A P I D E S in pongijs reperti, omnibus notifimifunt: quippe quód rarißime fnt pongie, que bifce lapidigiram uires busuacent. Horum uires retulit Galenus lib. I x. fimplicium medicamentorum, his uerbis. Lapides, quireperiun= ex Galeua. tur in Pongijs, frangendi uim obtinent, non tamen itd ualidam, ut lapidem in uefica comminuant, unde qui id fcris ptum reliquerunt, mentiti funt: uerüm qui in renibus confiftunt rüpunt, uelut qui ex Cappadocid conuebuntur, quos in Argeo nafci aiunt. Soluuntur autem bi in fuccum colore lacteum. ex quoliquet, quód extenuandi uin obtinent.

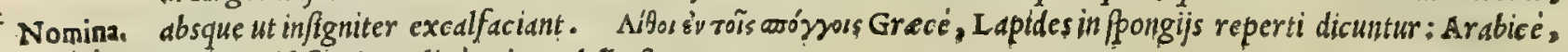
Hagiar alsefengi: Italice, pietre delle ppugne.

\section{A Toxónre, IITHOCOLLA. CAP. CXXI.}

LI т н O C O L L A glutinum, quolapides coniunguntur.conflatur autem ex marmore, lapide Pario, \& taurino glutine. Poteft candente fpccillo admotum, incommodos oculis pilos replicare.

\section{NHosósparitils. IAPIS OSTRACITES. CAP. CXXII.}

O S T R A C I T Es teft fimilitudinem habet, cruftofus, \& in laminas fifsilis. quo mulieres ad detrahendos pilos, pro pumice utuntur. Menfes drachmæ pondere potus ex uino fiftit. Si quatuor diebus à purgatione bibatur ficilici pondere, foeminis præftat ne concipiant. Cum melleautem impofitus, mammarum inflammationes lenit, \& nomas cohibet.

O s T R A C I T E N lapidem, quo pumicis uice ufa eft antiquitas, bactenus mibi uidere non licuit: quanquam

Ofracit $x$ lapidis confid. \& uires.

reperiri hunc in Holdesheimio circa antrum à nanis appellatum, colore fubrubeo, or oftracorum teftis fimilem, libro quinto de natura fo ßilium foribit Agricold. Eius uires tradidit Galenus lib. I x. fimplicium medicamentorum, fic inquicns. Porró oftraciten uocatum lapidem predicare quosdam audio, quafi deficcandi ualenter facultatem ob: tineat, temperatam ex adftrictione, er acrimonia, uelut $\mathcal{\sigma}$ Geoden nomine, pupillas expurgare, $\mathcal{\sigma}$ uberum teflium:

Nomina. que phlegmonds fanare, ex aqua uidelicet inundtum. Idpis Latinis oftracites, Gracis aígos o'sparizns dicitur: Itas is, pietra oftracite.

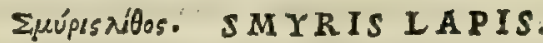

CA P. : CXXIII.

S M Y R I s lapis eft, quo annularij fcalptores lapides expurgant,ad erodendum,\& urendum utilis: gingiuis, quas humor uexat, prodeft : dentifricio commendatur.

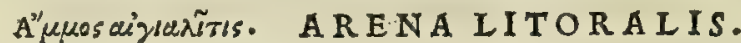

CAP. CXXIIII.

A R E N A è litoribus fole feruefacta, hydropicorum tumores exugit, fi capite tenus in ea obruantur. Torreri folet ad aridos fotus, pro milio aut fale.

Smyridis con fider.\& uires ex Galeno.

S M Y R I s uulgó nobis smeriglio, notißimus eft lapis, prefertim quód eius puluere expoliantur gemme, er armorum omne genus, vitrum quoq; Smyride lapide firiditur, quemadmodum er adamante, tanta ineft ei durities. Huius uires Galeno lib. I x. fimplicium medicamentorum, bis uerbis defcribuntur. Sed er smyris uocata, quoda multum abftergentem babeat facultatem, clarum eft uel ex co quód dactylioglyphi, hoc eft, qui anulos exculpunt,

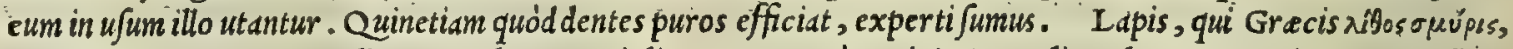

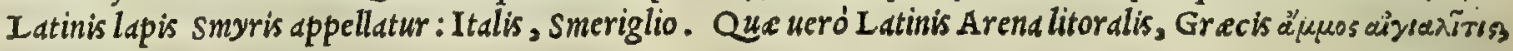
Italis Arena marina dicitur.

\section{A'xóvnvakia. IAPIS NAXIVS.}

CAP. CXXV.

E' c o T E Naxia, quod exacuendo ferro deteritur, illitum alopecias ad pilum reducit. uirginum mammas cohibet, nec increfcere patitur. Potumex aceto lienem abfumit, \& comitialibus prodelt.

\section{Nílos yeẃdis. IAPIS GEODES.}

\section{CAP. CXXVI.}

GE O D E lapis adftringit, ficcat, caligines oculorum difcutit. Illitus autem ex aqua teftum, mammarumque inflammationes fedat.

N A X I v M lapidem, item q́; Geoden, nullus eft, quod eqquidem friam, qquibodic cognofcat oftendat $q_{;}$in Itac lia uel ibi inuentos, uel aliunde allatos: tametfí in Mifnia, o saxonia nafcibos fcribat Agricola. Naxius autem, Galcni teftimonio, non folum uirginibus mammarum incrementum probibet; fed er pueris teftes crefcere non pati=

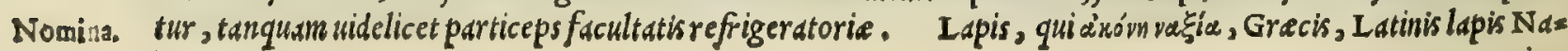




\section{In Lib. quintum Diofcoridis. $\quad 708$}

xius, ut etiam Italis pictra Naxia nominatur. Quiueró dívos zeódns Gracé, lapis Geodes Latiné, pietra Geode Italicé dicitur.

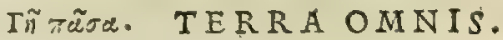
CAP. CXXVII.

O M N I s tcrra, ad medendi ufun recepta, fummam \& primam uim habet refiigerandi,meatúsque ohducendı, occludendiç;: fed fpecie diftat, cùm alia adiunctis quibusdam ad alia fit utılis.

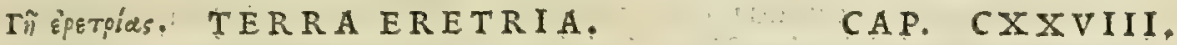

ERETR I A E S duxfunt, una uehementeralba eft, altera cinericia. Optima habeturad cinereum colorem uergens, perquàm mollis : qux fi per aramenta tractim ducatur, lineam uiolaceam refert. Lauatur, ut ceruffa, aut hunc in modum. Tcritur feorfum, \& cum aqua, \& ubi peffum ierit, humor lcuiter excolatur: ficcata folibus, iterü teritur interdiu, adiecta aqua, ut uefpere confidat: antelucanis colo excernitur, \& demum in fole trita, fi fieri poteft, digeritur in paftillos. Quòd fi tolta defideretur, paftilli magnitudine ciceris in fictile perforatum conijciuntur, oreq́ue uafis diligenter obturato, fupracarbones candentes continenter follibus perflantur : vbi uerò cinis in faullas fe conuertit, auc aẹreum colorem contraxit, exempti reconduntur. Vim habet adfringentem, \& refrigeratoriam, leuiter mollientem : caua explet, \& fanguinolenta conglutinat:

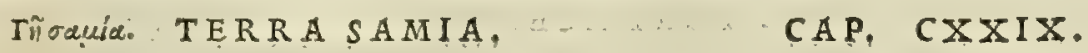

SA M A præfertur candida, leuis, tangentilingux glutinis modo adhærefcens, mollis, fuccofa, friabilis : cuiufmodi eft, quam aliqui collyrion uocant. Dux enim fpecies eius : unam antè diximus: altera after appellatur, cruftacea, \& cotis mado pradenfa. Vritur, ac lauatur, ut eretria, uimq́ue contimilem habet. Sanguinis reieçtiones fiftit : foeminis fuxione vulux laborantibus, cum flore fylueftris punicre datur. Teftium, \& mammarum inflammationes, illita ex rofaceo, \& aqua, refrigerat: fuddores arçet. contra ferpentium morfus, \& ụenena pota ex aqua auxiliatur.

\section{CAP. $C \times \times x$.}

S A M I v s lapis in Samia terra inuenitur, quo aurifices utuntur poliendo auro, ut refplendeat. Probatur candore, \& duritia. Vis ei adfrictoria, \& refrigerans . prodeft ftomachicis potus . fenfus hebetat: verùm ad fluxiones oculorum, \& ulcera, cum lacte efficax eft. Partus, ut tradunt, adligatus accelẹrat; \& conceptus tœminarum cuftodit

T E R R A, quam Samidm uocant, all ex Samo deferatur in Italiam, non equidem aufim affirmare : tametfi bec ufum in medicina maximum preftiterit Galeni tempore, qui ed, que after appellatur, tanquam preftantiore femper uj:s eft - huic tumen Diofcoridi prefertur illa, quam aliqui collyrion uocant. Sunt qui putent Samium aftera illum Terræ Samix lnigne contsctu nunquam glutinis modo adheret, attritu contumax eft, nec cotis inftar predurus wifitur. Adde qucd Talchws non fit cruftofus, fed fquamofus, translucidus, ut uitrum, ac leuis: or quód non nifi niagno labore, or diutino igne comburi poßsit: nec id quidem per fe fieri poteft, nifi quibusdam admiftis. quod tamen samio afteri non ellenit, utpose qui facile, tcfte Diofcoride, eretria terra modo comburatur. Ad bec fciant medici Talchum ebibitü.

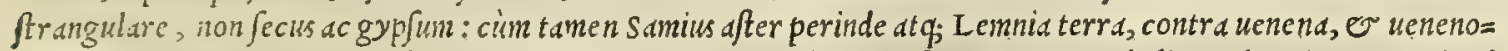
forum ferpenilum ifus maximé auxilietur, or ut illa labijs e lingue inhereat. Id quod aliquando animum traxit ad credendum, eam terram uel samiam, uel samix fimilem effe, quam magnifaciunt circulatores, qui ferpentes circü= frrunt, ¿̀ Melita infula allațm: quámque uulgó uocant Pịtra di fan Paolo. Siquidem h.ec colore candeda pecta=

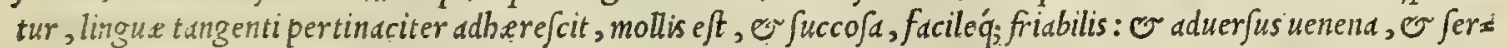

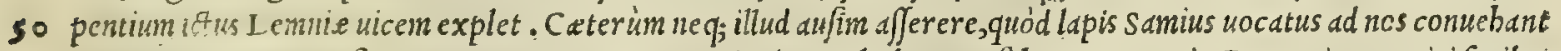
mercaicres, auo aurifices aurum, o argentum antiquitus poliebant: et/i bunc quoque in Germania reperirifcribat

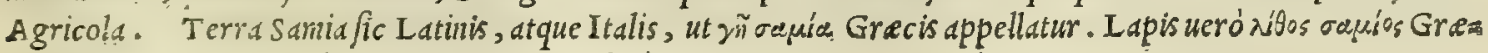
$c \dot{e}, \mathrm{~L}$ apts Samius Latiné, ơ pietra Samia Italiç é nominatur.

$$
\text { Tringer. TERRA CHIA. }
$$

\section{CAP. CXXXI.}

C 1 a eligi debet candida, uẹgens ad cinereum, Samix fimilis. Eftautem cruftofa, albaq́ue, fed fictitijs formis differens. Vis eadem, quæ \& Samix . extendit faciem, \& erugat, atque fplendida reddit: colorem in facie, \& corpore toto commendat . in balneis pro nitro deterget. 
E A D E M præftat Selinufia.maximèlaudatur, quæ uehementer refplendet, candida, friabilis, \& humore dilui celerrima.

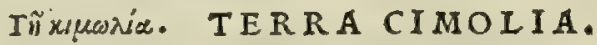

\section{CAP. CXXXIII.}

C I M O I I AE duogenera, candida, \& ad purpureum inclinans. Optima cxiftimatur, quxin natam habet pinguitudinem, tactuq́ue frigida fentitur. Vtraque aceto diluta, parotidas, \& alia tu- $10^{\circ}$ bercula difcutit. Ambufta igni, fi ftatim cimolia oblinantur, puftulas non fentient : teftium duritias, \& totius corporis collectiones cohibet: igni facro imponitur. In fumma, utraque multùm in medicina commendatur, fi incorruptæoriginis, nec fpuria affumatur.

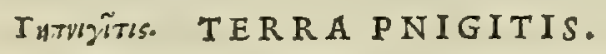

CAP. CXXXIIII.

QV AE pnigitis dicitur,colore ferè eretrix fimilis eft,grandioribus tantùm glebis : manum fi quis admoueat, refrigerabit : tactu linguæ ufqueadeò glutino â, ut penfilis hæreat. Cui effectus idem, qui cimolix, paulò tamen infirmior. Hanc aliqui pro eretriade uendunt.

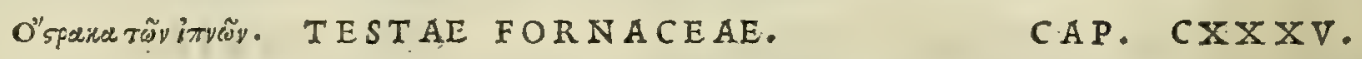

F OR N A C E AE teft $x$ uehementer toft $x$, cruftas ulceribus obducunt: quare prurigini, \& papularum eruptionibus, medentur. Podagricis profunt : Atumas difcutiunt, cerato exemptæ.

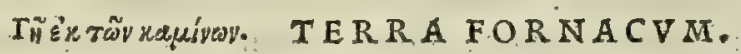

CAP. CXXXVI.

F O R N A C M terra, quæ retorrida fuluefcit, ciufdem cum tefta effectus .

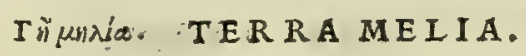

CAP. CXXXVII.

M E I I A colore cineream eritream imitatur, afpera tactu : ea digitis friata, derafi pumicis modocrepitat. Vim habet aluminofam, fed remifsiufculam, id quod guftu deprehenditur: modicè linguam ficcat : purum corpus reddit, \& colorem commendat : pilos extenuat: vitiligines, \& lepras abltergit. Pictoribus ufum præbet, ut colores diutius perennent. Emplaftris uiridibus, qux chloræ dicuntur, efficaciter inferitur. Ex omni melia terra, \& omni alia in uniuerfum, eligi debetrecens, mollis, non lapidofa, friabilis, qux cùm humorem attigerit, facilè refoluatur.

QV A N v I s terra Erctria, Clia, Selinufia, Cimolia, Pnigitis, or Melia antiquis notißime fuerint, ov in ufu medico frequentißime, ut author eft Galenus; tamen ab bis, qui nos pracefferunt, adeó neglectas fuiffe conftat, $4 \circ$ ut nulla amplius, quod ciam, ad nos adferatur. Quamobrem non operapretium duxi, ut in fingulis moram trabe=

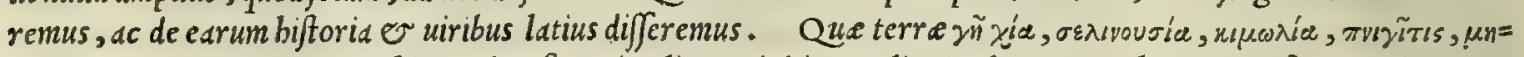
nia Gracis, Latinis, terra Chia, Selinufia, Cimolia, Pnigitis, Melia: Italls, terra Cbia, selinufia, Cimolia, Pni= gite, Melia uocantur : Arabibus uerò terra Cinolia Teri chimolea, feu Thin chimulia : Pnigitis, Terilanem.

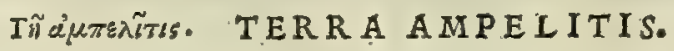

\section{CAP. CXXXVIII.}

EX A M P E L I T I D E terra, qux pharmacitis nomine in Seleucia Syrix nafcitur, laudatur in primis nigra, piceæ longos carbones referens, modicè affulofa, æquabili fplendore, quæ detrita, accepto oleo, ftatim eliquefcit. Vitiofa cenfetur candida, \& cinerea, qux in liquorem non refoluitur. s. Vim difsipandi, \& refrigerandi habet . ad calliblephara additur, tingendis capillis idonea. Vfus eius ad illinendas uites, fub germinationis tempus, utpote cùm innafcentes uermiculos enecet.

Ampelitidis terra confid.

A M P E I I T I s, ut author eft Galenus libro nono fimplicium medicamentorum, boc fibinomen iure uendi= cauit, quód antiquis in frequenti baberetur $u \int u, a d$ praferuandas ab erucis uitium gemmas prima earum germinatio= ne, quemadmodum nos uifco circumlito noftras tuemur in Hetruria. Pharmacitis ueró dicitur, quód medicamento $\int a$ maximéft. siquidem non modó uermiculos aduites afcendere inbibet; fed etiam eos interficit. Hac ufqueadeo bitu= mine refirta eft, ut Plinius, or Poßidonius, bitumini fimilem ipfam fecerint. Cuius experimentumeft, $\beta$ facile in ol:a impofita, liquefcat. Quamobrem credidere nonnulli Ampclitin terram cruftofum illum fuiffe lapidcm, quenz $\int c$ ibit Galenus $\int_{e}$ inueniffe in I ycix litoribus, $\sigma \sigma$ in Cole Syria, qui in ignem coniectus leuiu fculam edebat flammă. Hoc argwnĕ to nixi, quód idem fcripferit fe reperiffe lapidè illum in quodam colle omniferé ex parte circüdato ab $\mathrm{A}=$ 


\section{In Lib. quintum Diofcoridis.}

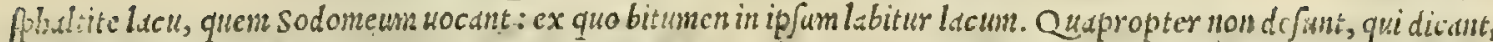
Galcrium baudquaquan nouiffe, cos lapides nil aliud effe, qualm terram ampelitiden. que cim piceum refr rat carbo= new, ut Diofcorides ipfe teftatur, non mirum, fi potius lapidis, quìn terre fpeciem pre fe ferat. Non ab re itaq; ere dendum fuerit, Ampelitim terranz non adinodum à Gagate lapide diffcrre quippe quód utreque ex terra co bitus mine furm traxerint originem. Ampelitis muperrimé $\dot{c}$ Carniola, ubi foditur, ad me allatd eft, nullis reclamunibus

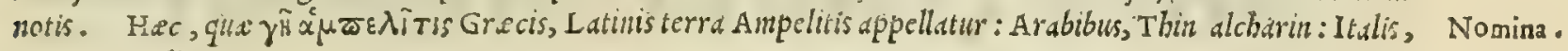
Terris ampelite.

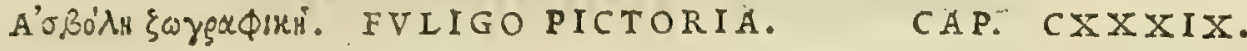

F v L I G o, qua pictores vtuntur, ex uitrarijs officinis colligi folet : fr quidem ci palma tribuitur. $V$ is ei ad adtringendum, \& erodendum efficax. fracta, cum rofaceo cerato ad cicatricem perducit.

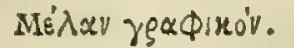
ATRAMENTVM LIBRARIVM.
CAP. CXL.

A T R A M E N T V M, quo fcribimus, fuligine è tedis coacta colligitur. In fingulas libras gummis, ternx fuliginis uncix adijciuntur. Fit ctiam è refinarum, \& pictoria fuligine, de qua paulò antè diximus. Affumitur autem fuliginis mina, gummi fesquilibra, glutinis taurini, atramenti futorij, fingulorum fescuncia. Additur conuenienter erodentibus medicamentis a ambuftis, ex aqua com-

2o modè crafsius illinitur, fed non antè foluatur, quàm cicatricem induxerit: fanatis fiquidem ulceribus, fua fponte decidit. Cæterùm habes, amicifsime Aree, ferè quæ tradenda duximus pro operis modo, quem deftinaueramus, \& materix, aixiliorumq́ue medicinalium copia .

DE F V I I G I N E pifforia, ațue ctian de Atramento librario latius or apertius d Diofcoride fcriptum eft, quam ut de bis plura nobis fuperfint dicenda, uel declaranda. Quare iam und cum authore nostro, buic quinto libro finem imponamus. atque infuper D EO, cui omnia, que à nobis fiunt, dut dicuntur, dcceptaferre par cft, imt=

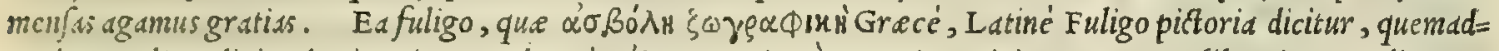

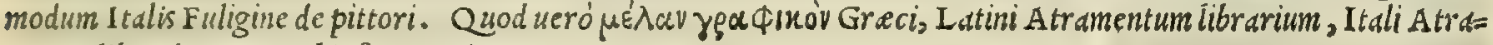
mento librario a aut Inclioftro nominant. 


\title{
PETRI A NDREAE MATTHIOLI MEDICI Senenfis Commentarii,
}

\section{IN LIB. SEXTVM PEDACII.DIOSCORIDIS}

\author{
A N A Z AREI, DE LETHALIBVS VENENIS, \\ EOR VM'QVE PRAECAVTIONE, \\ E T C Y R T I O NE.
}

\section{Prafatio Diofcoridis.}

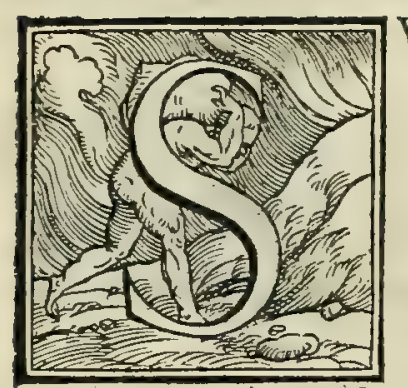

V P E R I O R I B V $s$, amicifsime Aree, libris tradidimus dearomatibus; oleis, vnguentis, arboribus , \& earundem frußtibus, lacrymisçue : item animalibus, melle, lacte, feuo, frumentis, oleribus, herbis, radicibus, liquamentis, vinis, metallisq́ue. In hoc verò totius operis vltimo, facultates me dicamentorum recenfebimus, quæ prodeffe nobis, aut officere poffunt.

Vitata igitur orationis prolixitate, opus inftitutum profequamur. Huiufcemodi autem tractatus cùm bifariam diftributus fit, in partem venena præcauentem, ita vt ne fallant fumentes, aut fi quando per imprudentiam dentur, yt tum quoque innoxia fiant, irritaq́ue : $\&$ in rationem ijs fuccur- 0 rendi, qui iam noxam fentiunt: primùm differam de præcauendi modo, quem effe difficillimum ple rique maiorum arbitrantur, quòd dantes clam venena ita infidias temperant, ut peritifsimum quenq́; decipiant. Siquidem venena fua amaritudine, permiftis dulcibus, fpoliant, \& graue odoris virus miftura odoramentorum eximunt. Aut medicamenta immifcent, quæ tuendæ fanitatis giatia dari purătur, \& præfertim in valetudine, vt abfinthium, tragoriganum, fatureiam, aut hyffopum, quinetiă thy mum, irim, origanum, abrotonum, caftorium, aut fi quid medicamentis purgatorijs cognatam habere qualitatem videatur. Aut potionibus inferunt, yt uinis afperis, iuribus, paffo, mulfæ aquæ, mufto: fuccis, ut in cremore lentis, polentis: aut medicaminibus, aut alijs, quæaffumuntur, edulij fpeciem referentibus. Quare qui in ea fufpicione funt, conditos cibos vitare debent, omniq́ue intenfo fapore dulcium, aut falforum, aut acidorum abftinere : nec fitibundi affatim bibcre, aut efurientes voraciter $4^{\circ}$ comefle, femperq́ue ad faporem horum diligenter attendere, præfertimq́: potu frigidam aquam præfumere. Satiato enim appetitu, qualitates ægerrimè poftea concoquuntur. In ægris quidem facilè cauemus potiones auxilij prætextu dari folitas, quas offerunt improbi vencficiorum artifices: itaq; ob id laborantes morbo non perinde audentium iniurijs patent. Et hæc quidem ne facilè incauti feduEtiq́; homines capiantur dolis yeneficorum, ratio eft, \& facultas. Sed alia fupereft expeditior, vt fufpiciofi aliqua præfumant, quæ yenenorum vires hebetent, \& inefficaces irritasq́; reddant: cuiufmodi caricæ funt cum iuglandibus nucibus manducatæ, \& quæ cedromela uocant, id eft citria, feminisq́; napi drachma cum uino. Item folia calaminthæ, aut creta, quæ Lemnia fphragis appellatur, pondcre pari cum vino: aut rutæ folia , \& nucis iuglandis nucleum: aut caricas duas, \& falis callum ieiuni fumant, \& nullo yeneni genere lædentur. Antidota ex vino fumpta, eundem effectum præbent: inter so qux intelligitur magnum Mithridatium, \& quod fcinco, \& quod fanguine temperatur. Quin \& frepe venenis obfiftunt peculiares quidam corporum affectus certo quodam modo confitutorum, cum quadam cibi, potusque qualitate, tum vini copia ita temperatorum, vt cum uenenis diffentiant. fiquidem ingefti veneni vires frangunt, atque iam priore alimento faretis, præclufisque meatibus, obftant, ne membratim per digeltionem infinuetur. Verùm enimuero, quoniam fortunæ necefs $j$ tas interdum fimilia difcrimina peregrè agentibus adfert, abfque vllis infidijs hominum, nonnihil differendum mihi de hac re neceffarium duco. Iam primùm igitur culinam apparare loco fubdiali conuenit, cibosqúue $\&$ potus in huiufcemodi loco ftruere. Si id fieri commodè nequit, fecunda erit conditio hæc, apparandi, apponendiq́ue fub tecto. Sed tum diligenter laquearia animaduertenda: frequenter enim à fuperioribus contabulamentis animalia decidunt exigua quidem, fed qux non modicam pernịciem moliantur, vt phalangia, ftelliones, \& alia quædam reptilia. Porrò uinaria uafa diligenter 


\section{InLib. fextum Diofcoridis.}

diligenter intueri oportet : nanque reptilia odore vini illiciuntur, qux interdum forbendo, noxium virus erućtarunt, interdum verò delapfa immerfaque expirarunt, \& exitij caufas haurientibus atıulerunt. Sed hæc hactenus dicta fint, ne cauti, \& prouidi infidijs pateant. Qiòd fi qui fua fponte, aut exquorundam infidijs fumpferunt, auxiliari primo quoque tenopore oportebit. fiquidem dum comites lingulorum vencnorum notx expectantur, immedicabile fit venenum, \& paulifper neglectum, medicamentis agrè cedit. Quare fi yui pro comperto fe uirus fumpfiffe intelligunt, \& fateantur, aut eorum, qui aderant, teftimonio conftet, protinus ad idonea remedia tranfeuntes, facilè peculiari, natiuxq́uc conftitutioni reftituemus. Neque enim ijs affentimur, qui prorfus auxilia in hujufcemodi fruftrà adhiberi contendunt. Quo enim modo morbi, quorum caufx cæcæ, latentesq́ue 10 corporibus infident, mcdicinam admittunt, \& qux forinfecus incurrunt venena, medendi rationem afpernantur? Aequè vcrò omnes morbi pro caufarum ingruentium magnitudine, proq́ue antecedentibus affectionibus, qualitatibusque, quibus fit opportunum corpus, vcl medicabiles funt, uel nullis cedunt medicamentis. Quòd fi qui forfan obmutefcentes, aut temulenti, aut nolentes alioqui venenum à fe egeri, nullam nobis eius cognitionem præbeant, tum protinus accedenduma ad ea, quæ communiter cpotis quibufcunque venenis opitulari confueuerunt. Atqui nullum magis in omnia ualens auxilium dari poteft, quàm ut proximo loco uirus foràs exhauriatur, priufquàm inualefcat : Quare fine mora calidum oleum ex aqua, aut feorfum, vt uomitare cogantur, dari conuenit. Aut li oleum natura loci negat, buty rum cum aqua calıda, aut malua, aut lini femine, aut trago, vrtica, freno greco, aut halicæ dccocto, vicem eius exhibebit. Hæc enim non modò uomitionibus exigent vi 2o illa lua laxatrice, aut naufeam ciente; fed aluum quoque fubducent, \& corporum inanitione ita aduerfabuntur, vt acrimonias venenorum hebetent. Id quod euidenter huiufcemodi argumento deprehendere licet. Efto, vt quifquam viua calce, vel frece, aut cantharidibus, aut alio quouis acri, corpus cxulcerare ftatuerit, is fi ipfum oleo leniter illinat, exulcerationem non accipiet. Atqui ne-que vehementer adftringi corpus, neque refrigerari poterit, fi antea perungatur. Quinetiam uomitus non ob id modò, quòd vaçuet, $\&$ noxium humorem excernat, iuuamentum adtert; fed quòd affumptum virus nonnunquam odore, coagulatis grumis, aut colore prodat, quippe cùm odore, 8 . amaritudine, meconium : colore, ceruffam, gyplúmve: grumis, lac aut fanguinem animalis recens iugulati oftendat. Nam grauis odor regeftorum, leporis marini, aut rubetx veneficia deprehendit: ita vt nonnnulls $\mathrm{ab}$ ijs remedia peti pofsint, ad idonea fingulorum auxilia tranfeuntibus. Oleo e-

30 tiam malux dccoctum admifcetur, aut glaucium, aut adeps anferinus, aut pinguium carnium iura, aut lixiuium lignorum cinere factum. Vbi verò uomitus diligenter citatus fuerit, ne quid in uentre coierit, quæ bæferunt inteftinis reliquiæ, clyftere acri deuocentur. Facit \& nitrum tritum cum hydromelite fumptum, \& vina vetera liberalius epota, gallinacea iura, præpingues pifces, vetuftæ carnes pinguesq́ue, \& qua adipe aut recenti buty ro parantur. Aluum nanque fubducunt, uti diximus, \&. ftomachum refoluentia, proniorem ipfum ad vomitum reddunt: \& venenorum acrimonias hebetant, atque meatus obftruentia, celerem virium penetrationem inhibent. Quinetiam medicamenta dantur, quæ communi dote profunt, vt Lemnia terra, agaricum, abrotonum, irio, radix eryngii, femen paftinacx, \& calamnth $x$, nardum Gallicum, caftorium, ferulæ virentis medulla, flos rhododendri, fuccus marrubij, lafer, aut laferpitium, fagapenum, peucedani fuccus, aut panacis, \& ra$40 \mathrm{dix}$, quam magudarim appellarunt, ariftolochia longa, fylueftris rutx femen, \& betonicx, quam celtron nominant, folia . fingula cum vino drachmæ pondo fumi debent. Effeatum præbet polij decoftum, \& fefeli, \& liquida pix lincta. Magnificè ferunt opem antidota, quæ in calce operis feripta reliquimus . Communis ratio præftandi auxilij ita fe habet. Cæterùm ab ijs, quæ confueuerunt euenire, communia rcmedia fumptitari poffunt. Ferè enim uires venenorum quàm plurimorum in affectus confimiles corpus tandem redigunt. Quam ob caufam plerifque communia conducunt auxilia. varia etenim funt venenorum genera, communes tamen, nec multi ijdem affectus oriuntur. Neque fieri poteft, vt omnes concurrentesq́ue cafus, quæ fy mptomata vocant, vnum uenenum fequantur. slioquin fuperuacanea fuiffet venenorum fingulorum traditio, cum fuis remedijs ab authoribus defcripta. Neque uerò in vno eodemq́ue promptum eft inuenire, ut quis ftomachi, alui, inteftinorum, iecoris, renum, \& veficæ dolore vehementer crucietur, vt fingultiat, erodatur, contremifcat, refrigeretur, obmutefcat, conuellatur, pulfus elanguefcat, fpiritus difficilis fiat, veterno prematur, vertigo obuerfetur, caligent fenfus, ftranguletur, fitiat, fanguis crumpat, febre conflictetur, zgrè lotium reddat, torminibus uexetur, crebrò vomitct, naufea prematur, rubefcat, liuore fugilletur, pallefcat, delipiat, ftertat, viribus deficiatur, \& pleraque alia faciat, patiaturq́; . fingula enim in genera les affeetus deducta, pauca numero, \& communia ea demonftrant, qux euenire confueuerunt. Qilare in fingulis, qux fuprà diximus, non facilè fuerit deuoratum uirus cognofcere. Nam oris \& lingux erofio, ttomachi, ventris, veficæac renum inflammatio, vehemēs vrinæ difficultas, \& interdam cruoris cum co exirus, lancinatio, \& in pluribus partibus quidam aduftionis fenfus, non in cantharidibus modò potis reperiuntur; fed in erucis quoque pinorum, \& buprefte, \& falamandra. Porrò non modòcos, qui meconium hauferunt, veterno, aut fopore premi, ftertere, liuore fugillari, torpere, refrigerari, ftupefcere, to to corpore pruritum fentire, fenfu priuari conltat; fed cos ctiam, qui man- 
dragoram, aut cicutam deuorarunt. Delirium non hyofcyamus tantùm infert; uerùm etiam, qux toxica appellantur : jtidem aconitum, \& $\mathrm{mel}$, quod in Heraclea Pontica gignitur. Strangulatio non minus in fungis, quàm in fanguine taurino, lacte, aconito, ceruffa, gyp fo confpicitur. In fumma, difficile vnum vni uencno proprium inuenire fignum, quod hauftum, guftatumq́ue uirus prodere poffit : maximè, quòd hæc cæterorum etiam vitiorum, quæ in corpore exoriuntur, communia fequi folent. Caterum in his, quæ ccleriter enecant, noxam fignis forlitan indicare pofsis, fi ad ca refpexeris, quæ fumus dicturi. Sed in ijs, qui ad longas ægritudines fpectant, nihil ad medendi rationem difricile, duntaxat quod pertineat ad indicia noxæ, vtpote cùm uenena ftatim, atque præfentaneam vim illam perdiderunt, tranfmutata in longos affectus, communia reliquorsm vitiorum remedia, compolitionesq́ue flagitent, cùm venefica proprietas non amplius infit. Si uerò longa fit affectio, in aliquod diuturnorum morborum genus recidet, à quibus facile fuerit medendi rationem affumere. Sed de ijs, quæ generaliter auxiliantur, hactenus. Confequenter qux priuatim lingulis profunt, fcriptis mandabimus, fi prius figillatim expofuerimus, quæ ex fingulis ordinibus exitialem, aut maleficam vim fortiuntur, vt medicinx ftudiofi ea cautè obferuent, qux ad rationem falutis fcripta inueniuntur: quòd nonnulla eorum, quibus utuntur, venenis fint commifta. Incuria enim magnas adfere noxas, \& fæpe continuo vfu corum, homo in perniciem agitur. Proinde anımalia, qua exitiofam uim babent, hæc funt: canthaxides, bupreftis, falamandra, pinorum erucx, lepus marinus, rubeta, \& rana paluftris muta, deuolatx hirudines. Semina funt, hyofcyamus, coriandrum, cicuta, gith, pfyllion. Liquamenta, meconium, opocaspafon, thapfie fuccus, elaterium, mandragoras. Kadices, quas mittit chamæleo, aconitum, thaplia, veratrum, ixia, agaricum nigrum, ephe- o merum, quod aliqui Colchicum uocant, quod in Colchide nafcitur. Arbores, herbx, oleraque: fmilax, quam aliqui tithy malum appellant, Romani taxum : folanum manicum, quod \& dorycnium dicicur: fardonia herba, qux ranunculi genus elt: corniculatum papauer, pharicum, toxicum, ruta fylueftris, fungi. Abanimalibus, taurinus fanguis recens, lac intus coagulatum, mel Heraclex in Ponto genitum. Metalla, gy pfum, ceruffa, calx, auripigmentum, duo fandarach $x$ genera, fpuma argenti, adarce, plumbum, \& quod argentum viuum dicitur. E' liquoribus domefticis, uinum abunde polt talneas potum, aut paffum, \&̀ frigida aqua fimiliter.

\section{COMMENTARIVS MATTHIOLI.}

Beneficium i Diofc. in poiteros coll2sum.

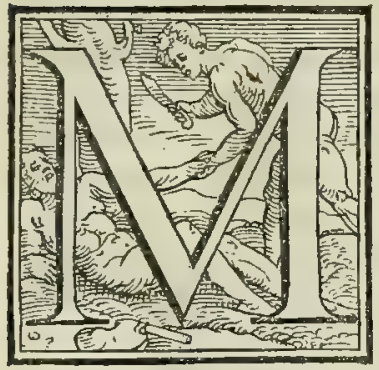

A G N.VM SANE', O immenfum beneficiun acccptum referre debent fapientißi= mo Diofcoridi non folum medici orbis uniuer $f i$; ed etian uniuer $\int$ a fimul bumand natu= ra. quippe quod is artem medicam illuftrauerit quinque Superioribus libris, in quibus infinitorum impliciun medicamentorum hiftoriam, ac facultates miro ordine tradidit: fine quibus inullo quidem paśto agritudines propelli poffent, nullá;; earun noxa deles ri, quibus uita noftra conflictatur, ac tollitur. Sed longè plura adbuc beneficia eidem accepta referri debent, quód deinceps in boc fexto uolumine, exactifina fcientid, mi:

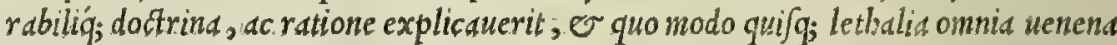
precauere poßit, o qua etiam ratione fuccurrat, ne eadem perniciern, uel aliquam in = ferant noxam, qua prus per imprudentiam, aut malitiam, uel dolum intus in corpus affumpta fuere. Nametfi medi= camenta tam ad uniuerfales, quàm ad particulares morbos, qui quotidic inuadunt, afflogntq́; humanü corpus, necef= Jaria plurimim. femper extiterint, appriméq; utilia; innumeri tamen babentur morbi, qui feruata tantum uictus ratio= ne, nature duntaxat ope pelluntur. Secus autem euenit ijs, quibus uenenum exbibitum fit . quandoquidem nifi prius bauftis preftantibus admodum antidotis ueneno preuenerint, ucl poft ipfum affumptum remedia non admiferint, $r a=$ rißime ucl nunquam natur, x uiribus feruantur. Quin potius eos plerunq; wita deficit, qui uenenü batuferunt, nul iquàm primùn fuccurratur remedijs. de quibus ita abunde, accurate ö; fripfit Diofcorides, ut Galenus e grauißimus au= thor, E medicorum facile princeps, necnon tota pofteriorum Grecorum, $\sim$ Mauritanorum fchold, ip fum in hoc $a=$ deò diligenter fint imitati, ut ab eo omnem buiufce facultatis doctrinum didicerint. Cuius rei cimplijimus teftis cft $\mathrm{Ga}$ lenus libro primo de antidotis. Quanobrem omnibus perpicuum effe poteft, Diofcoridem in bac uenenorum, equé

Ratio commentariorum in librum fex tum. ac in illa medicamentorum facultate, omnium facile principem,et magiltrum extityfe. Itaq; cum in alios eius quin que fuperiores libros, commentarios (ut puto) non inutiles confcripferim, me equidein oper epretium facturum pu= taui, fi libro quoq; fex to commentarios adderem : prefertim cum nouerim quim utile fit, ac neceffariu bomines in uni uerfum affequi tum modun, tum rationem tam pracauendi, quam cur andi uenena, non folim ea, que intus in corpus fununtur; fed etiam que uenenoforum animalium mor $\int u$, uel iftu eiaculantur, o relinquuntur. siquidcm malefica ucnenorum uis, adcó grauis, o potens bumane nature femper extitit inimica (buic enim magis, quaim cateris aduer fatur) tantá;; uclocitate fuum exequitur munus, ut $\int e$ pcnumero cundem preftei effectum in corporibus noftris, qucm praftat uoracißimus ignis, fi quando ad aridißimas peruencrit paleas. Fit enim, ut plerung; uenena, dum iubent qui fump ferunt, uel ictilanguent, medicos accerfiri, coujq; corporis bumores inficiant, atque criam princepes partes, ut fubinde nibil, ucl parum profint remedia, o quam praftantißsuna antidota. Quapropter recté Gale nus lib. I I I. de fimplicium medicamentorum facultatibus cap. $\mathrm{x}$ x I I I. fcriptum rcliquit, quodd quando uenenum putredine, ev eros fione enccans, graucm corpori intulerit noxam, fieri quidem non potc]l, ut amplius uncatur, fupereturq;; , tel ui= 


\section{InLib. fextum Diofcoridis.}

atus ratione, uel gencroforum medicaminum ope. Ex boc itaque accepi, clareq́; cognoui, quód fi in bunc quoq; li=

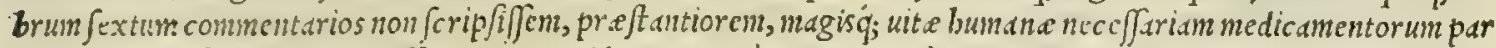
tem, intad.um filcutio preteriffem. Que quidem pars, cum praterca a nobis ex'Diofcoride pluribus ante annis in Italican linguan werfa babedtur, ac ctiam bis noftris commentarijs enarrata, caufa nimir um erit, qua potißimim in= numeri homincs, non modò à mortiferis fe tucantur uenenis; fed à morte quog; liberentur. Nam quicunc; in bos no= fros inciderit commenturios, qui Italici, aut Latini fermonis non fuerit prorjus ignarus, quanquam non fuerit mes dicus, non tantum fibi ips; uerum ctian aliis adiumento effe poterit. Nempe quodd ufus medicamentis tum fimplici

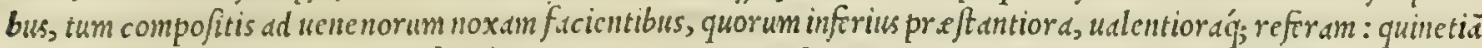
comuenicntibus ufus cautionibus, facile aliquando uensno prorfus medebitur, aliquando autem tandiu a gros uinos tra

to ducet, quandiu diligentiß̧inis medicis accerfitis, qui non femper preftó funt, fed magna ex parte uel longé diftant, uel abfint, integrum medendi locum relinquet. Sed anteaquam modum, ac rationem pracauendi uenena in medium afferan, non alichum duxi ad ampliorcm buiufce rei doctrinam, nonnulla in unituer fum pramittere fcitu, ut arbitror, neceffaria, ut fine quibus tractatio bec dimmuta, ov imperfecta uideri poffet. Primum itaque dixerin (ut etian Conciliator inquit in lióro, quem de ucnenis edidit) uene num onne intra corpus noftrum affumptum omnibus fuis $f_{a}=$ cultatibus pror fus op poni cibo, quo nutrimur. Nam quesnadmodum cibus in noftri corporis fanguinem uertitur, firq; in omni fui parte membris, qux pracipué nutrit, fimilis, locumillius, qnod continuo in nobis exoluitur, fubin= trans; ita ucnenum contrario modo fe babens, corpus, ac membra, quibus primó adberet ( ut infr ḋ latius dicetur) in fibi peculi.rem ucucnatam naturam transfert. Vude quemadmodum animalia omnia, omnesc;; fructus, que terria parens gignit, qué q; in nutrinentun uerti poffunt, fi i nobis edantur, in noftrum tranfeunt alinentum; fic per oppo

20 fitum modum, weverats intró in corpus fumpta, unuerfa corporis noftri membra uenenata reddunt. 2uippe cum omne agens fuo p. ffo fit fortius, ucnenum ui fus agendi ualida, noftram uincit fubftantiam, uertitó; in fuam uenend= tam naturam, ca fanératione, qua ignis fua ui agendi potentißima paleas celerrimé in $\int \mathrm{e}$ ip fun conuertit, or confi= cit. Ob id itar; dixere antiqui rerum saturalium exploratores, quód uenenum bomines interficit corrupta corporis temperic, $\odot$ compofitionc. Id quod naximé comprobat Galenus lib. I I 1. de fimplicium medic amentorum faculta= tibus, ubi in hoc', inquit, differt alinentum à medicamento, quód boc noftrum corpus alterat fuis qualitatibus, illud ueró conuertitur, fitć; Jubjtantie corporis fimile. Porró fcire conuenit (ut Auicenna, er Auerroes pofteritatis memorie prodiderunt) uenena in uniwerfum trium effe generum : ut enim aut à plantis, aut ab aninalibus, aut à me= tallicis exitio am uim babent; ita inde difcrinina fortiuntur. In plantis igitur ce omnes inter uenenata recenfentur, que ciborum nature omnino repugnant, $\odot$ aduerfantur: que natura non eiufmodi funt, ut efitate in alimentum con 30 uerti poßint. quinimo contrariam obtinent facultatem, ita ut membra iam nutrita in fe ip as conuertant. Cuiufmo= di eft elleborus, aconitum, cicuta, napellus, sardonia berbs, nerium, er alia quàm plurima plantarum genera, de quibus in proceffu pluribus feor fun agemus. In animalibus ca omnia ueneno inficiunt, cuius natura bumane prorfus aduerfatur. Patet id in uiperis, apidibus, bafilifcis, lepore marino, rubeta, fcorpio, phalangio, falamandra, rd= bidis quadrupedibus : item in morticinis carnibus, aut à fulmune occifis, aut d̀ uenenofis, or rabidis animalibus. Ce $=$ terim hac in re, licet nonnulli dicant uenenum cum uita animalis confumi, eo ducti exemplo, quód cerui, lupi, apri, o relique fire, que uenenatis Sagittis conficiuntur, innocue comedantur; fcire tamen oportet, hanc regulam defi= cere in bis, que peftis, aut rabies, aut fulminis iftus, aut uenenofor um morfus enecat. Quandoquidem complures ui= di mortwos effe, qui tantum boues pefte confectos excoriauerant, baud aliter toto corpore tumentes, ac $f i$ in bydro= pem incurriffent. In metallicis denique illa omnia produntur uenenata, que malefica, ac lethaliconftant facultate . 40 Qualia funt argentum uium, aurtpigmentum, fandaracha, magnes, o fimilia. Ad hec fctendum eft uenena non folim interficere per os fumpta, fed interdum etiam extrinfecus applicatd, uarijs ac diuerfis rationibus. Porró qua per os fumpta uenena vitam adimunt, fub ciborum, aut medicinarum pecie plerung; propinantur. Quxe ueró exte= gius tantim admota inficiunt, ut plurimium à uenenatis, or mortifer is animalibus de fumuntur. Siquidem hac bomines non mor fu modó, uel itu necant; fed uifu quoque, fibilo, or tactu (ut quidam fcribunt) interimunt. Quinetiam non defunt uenend, que guftatu, olfactú; tantim ftatim hominem in perniciem agant nulla temporis mora. que quidem inter catera malitis, 6 atrocitatis principem locum obtinent: quippe quód fecum deferant prefentaneum interi= tum, ex quo nullum fubinde fiat reliquum infelicibus moribundis fuccurrendi tempus. Caterum morfu, itu' inter= ficiunt uipere, apides, fcorpiones, phalangia paftinace pifces, rabidicanes, er alia id genus plura. vifu autem,er fibilo (ut author eft Galenus labro de theriac a ad Pifone, fi tamen Galeni legitimus eft liber) ftatim inficit bafilifcus.

so Tactu alius ferpens enecat, de quo agens A uicenna lib. I I I $x$. fen v 1 . narrat, quód is à milite quodam hafta infixus uirulentam uim per baftam tranjmifit ad manum, quam primum infecit, er deinde totum corpus corrupit. Ad buiufce rei comprobationem illud fané compertum habeo, quod in agro Tridentino eueniffe fcio. Nempe cùm rufticus quidă fuis effet in uinetis, paruum quendain collem $\int$ epius a fcendebat, ut ibi uuarum cujtodiam ageret. Hinc quadam die ad collis pedem magnum, er borrendum uidit ferpentem, cuius capiti fuperné baftam fatis longam infixit: at dum fixam Fram $\int \mathrm{e}$ binc inde fortiter contorquentem, e bafte circumuolutam, pro uiribus teneret, magno ftatim trenore cor $=$ reptus eft, quo maximé deterritus uociferans, wiatores, er circunftantes colonos ad fe ire rogabat. Quam uocifera= tionem audientes, qui non longé aberant ruftici, eó curfu uelociter contenderunt, or ip fum feré femimortum inuc= nerunt. Cognits tamen ex occifo jerpente fui infortunij cav $\sqrt{a}$, ad theriacam, or alia antidota confugerunt, quibus eum ad !nitam reuocarunt. Teruntamen duobus anns poftea is uniuerfi fere corporis ftupore in lecto femper decum= bens egrotauit, or co prefertim brachio, quo perniciofum animal hafta occiderat. Nec admodum mirari rem banc nobis licet, cim uideanus ( ut etian literis mandauit Galenus lib. v I. de locis affectis) torpedinem marinam derc=

Venenorum genera unde. 
pentć pifcatoris mamum obfupefacere, ac torpidam reddere, ubi primim is tridente eam tetigerit. Id quod finnilis ter effict, tran [miffa per funem retis qualitate, dum trabitur in litus. Proinde id experientia docti pifcatores, $f i d u n$

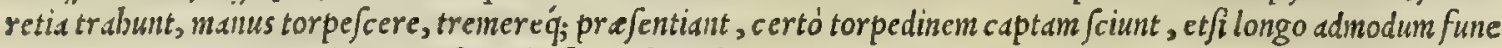
trabutur. Vnde illud perfpicuum eft, quod fi buiufce pifcis qualitates per tridentis baftan, or retis quàm longi|simum funem tranfmiffe ad manum, inficiunt or corrumpunt bomines, có magis id ip fum fieri poterit, fi antinalia ip $\int a$, aut nuda manu, aut alia corporis parte tangantur. Idcirco manifefte conftat nullum effe brachium tam ualidum, or ro= buftum, quod torpedinem adbuc uiuentem diutius fuftinere poßjit. Quare admirandum fané non erit (ut tcftaiur $G_{d}=$ lenus libro nuper citato) quód fputum canis rabidi, fi bumanum corpus contigerit, perinde ip/ um rabic afficiat, ac if ab ipfo cane effet demor fum: nam o buiufce effectus hac noftra etate plura afferri poffent exempla. Neque etidin alicui mirum efe debet, quód putum apidis cognomento Ptyas, omnes ueneno unficiat, quos contigcrit. Hoc idem fi= 10 militer efficiunt queda m Seuißima uenena arte conflata, tanta permeandi er penetrandi ui predita, quód illitis (ut ferunt) fellarum pediferis, infefforum ocreds penetrant, donec ad nudas ped is plantas peruenta, or inde per cutis fpi= racula in corpus ingre $\iint a$, uniuer $\int a$ eius membra corrumpunt, or abfiomunt. Horum ufus (ut audio) frequens apud Turcas, o alias ferinas gentes. Ex bac autem re nullam quis capiat admirationem oportet. fiquidem arterie core poris noftri (tefte Galeno lib. I I I. de fimplicium medicamentorum facultatibus, ac alijs in locis) ad fe intus trahunt quodc unque proximé circundat eas, dum continué dilatantur. Id quod quotidie liquet ex inunctionibus, ac fuffitibus ad morbum Gallicum paratis . quippe eedem ab arterijs attrafte, ubi argenti uini, cinnabaris, uel fublimati officinis uocati plurinum admiferint, feuißina fepe pariunt fymptomata. Sunt $\mathrm{O}^{\circ}$ alia uenena, qua olfactu tantim (ut quo= rundam fungorum meminit Rafis ) prefentaneam afferunt mortem ijs, qui ea naribus admouerint. Huius funme malitie fedem illud fané tenere debebat, quo florem recentioribus uetonicum uocatum, senis quidam circunforaneus 20 infecerat, ex bis qui innocué uenenum deuorare profitentur. Quem cum olfaciendun exhibuifet fuo concurrenti in publico senenfiforo, is ex folo olfactu derepente concidit mortuus. Pretered uenena quedam funt, qua folo gufta= tu, quanquam non deglutiuntur, perimunt : idq́; preft at apidis furdiputum. Quo memini quofdam imprudenter in= fictos effe. Inter quos uidi go rufticum in ualle Anania, qui dum foenum fecaret in pratis, feram falce per medium fecuit, er cum pofted capitis truncum manu cepiffet, ut focijs aftantibus oftenderet, utpote qui iam feram demortuam fortaffe cenfebat, fuppenfus manu truncus caput retorfit, er rufici manum feuicns momordit. At ille credens fuitu unlnerifuccurrere, os itatim morfui admouit. Quo facto derepenté in terran cecidit, ubi illico mutus factus depes

Venenorum rijt. Infuper fciendum eft, quód uenena non uno eodemó; modo, neq; ab una eadem q́; caufa fuos pariunt effectus. effectus à di- siquidem (ut fapientes quidam memoria prodiderunt) quedam agunt exceffu qualitatum elementorum, quarum mi= fione conftant. Quedam ueró propria tantium qualitate aut forma, quam occultam proprietatem medicorum qui=30 dam appellant, in miftis inferioribus introducta ex influxu linearum rectarum radicalium, que ex jyderum fixorum fplendore proueniunt, pro materix miftorum proportione feu conftitutione. Alia denig; utroque modo fimul agunt, A' qualitatibo nempe er qualitate elementari, e propria, quam formam pecific am nominant. Porró uenena,que cxceffu tantum excedētibus. Suarum qualitatum operantur, fuas uariant actiones, prouatrictate ip farum qualitatum. quippe quód unum fit cali= dum, aliud frigidum, aliud ficcum, aliud humidum. Que igitur caliditate excedunt, duobus modis perimunt. Vno, quód intus in corpus fumpta, excalfaciant, urant, corrodant q $_{\text {; }} u f_{q}$, ad cor. Alio, quód extrinfecus appofita corro= dant, or exedant carnes u que ad offa: id quod lepori marino adfcribitur. Vel quód funné cale facientia tam intus, quam extra corpus adurant, quemadmodun euphorbium, of elleborus, donec inflammato tandem corde intcrimant. Frigida fimiliter bifariam necem adferunt. Vno modo, quód exuberante frigiditate fua, ufque adeó corpus gelidum, fupidumíg reddunt, quód fimul etiam cor congelafcit, ut ijs euenire fepius compertum eft, qui opium deuorarunt. 40 Altero, quod obftructis ingentifigiditate meatibus, anbelitum intercipiunt, or proinde fuffocant, or ftrangulant: id quod praftant exuftum plumbum, of fungi uenefici. Duplicem o ficcum uenenum babet operandimodum . quan doquidem uel bumidum fanguineum cordis ab fumant, ut calx uiua : uel feparent ac diuidant partes abinuicem, quouf= que onmia membra ad cor ufq; in minimas diuidantur partes: quem effectum prabet rifagallum uocatum. Humi= dum poftremó, etfi aliqui tradant non inueniri, quoniam nullum fit bumidum reperire, quod ad quartum bumiditatis exceffum peruenerit; oppofitum tamen declaratur exemplo illius, qui nocte dum dormiret, i. ferpente quodam de=. morfus ( ut Gilbertus Anglicus narrat) mortem obijt: cum'; mane à puero per brachium traberetur ( fic enim arbi= trabatur dominum dे fomno excitare) caro iam uniuer fa putredine confecta, tractu illo concidit, oßibus remanentibus carne prorfus exutis. Quod certé non alia de caufa contigiffe potuit, quàm ab excedente ueneni bumiditate, que fumma fané inerat fer allius dentibus. Eundem effectum preftat etiam falamandra; fi in puluerem redacta bibatur, so ut in proceffu fuo loco docebit Diofcorides. Nec fecus illi accidit, quem cenchris ferpens momorderit. Quocircare= cté proditum eft a Galeno ex autboritate Hippocratis libro primo de temperamentis, quód cim anmi conftitutio plu= uialis, bumida, $\sigma^{\circ}$ auftralis fuiffet, ea potißimim bumidit as fecit, ut fuccedente aftałe carbunculi orirětur : quibus ob corruptam uenenatam q́; bumiditatem eoufque in aliquibus brachia putruerunt, quad deniq; tota bac ip a putredine correpta, ḋ cubitis diuifa deciderunt. In alijs ueró tantam coxarum, crurium, or pedum caro putredinem fenfit, quód plané offa carne deftituta remanferunt. In alijs denique non caro folum computruit; fed fimul etian nerui, ofa, corum compagines, nexusq́; contabuerunt. Ex boc itaque aperté oftenditur reperiri uenena, tanta bumiditate exube rantia, ut homine interintere poßint, utpote qua membra putrida efficiunt: fic ut argentum uiuum, quod fua humidi= tate modum excedente, infitum cordi natura bumidum fepe corrumpit, ut quotidic uidemus in ijs, qui co unguentis ex= cepto fe inungunt ad luesn Gallicam delendam. in quibus preterquàm quód femper gingiuas, dentes, palatum, alias $q_{;}$ uicinas partes putredine afficit; fepe etiam ubi uberius quaim par fit, inunaum fuerit, cos in perniciem ducit : quippe 


\section{In Lib. fextum Diofcoridıs.}

quod uniuer fo anguini putredinem inferat. Idq́; extrinfecus duntaxat adhibitum. quanquă or id ipfum intus affum= ptum occidit, fi modum quend sm exce ferit, ut libro fuperiore tradidimus. Siquidem pre nimia fui frigiditate uitales piritus, cordis q; fubftantian congelat . quod cuidam feplafiario, qui illud imprudenter biberdt, eueniffe narrat Cü= ciliator Petrus A ponen/s. Hoc igitur modo, alijsğ; prodict is fuos uenena praftant effectus, que fuis modun exce= dentibus qualitatibus mortcm bominibus adfrunt. Caterim uenena, que propria fuifucultate, uel (ut dicunt) pro= pria forma cuccsint, id non cfficimt, quod caliditatis, figiditat is, bumiditatis, aut ficcitat is modü cxccdant, fed quód

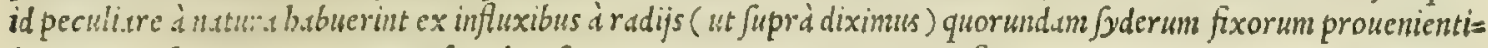
bus, qux e.t bunatic natur.e prorfus aduerfa genuerunt. Hec propterea et fi tam pauca quantitate fumantur, ut uix

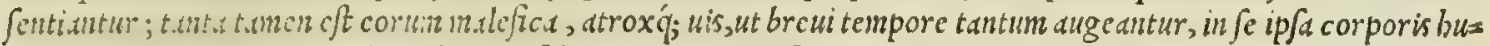

- miditaten conuctendo, qivod po/tea qua/i hore monento diffoluunt, or ad nortem trabunt homines, à quibus halk=

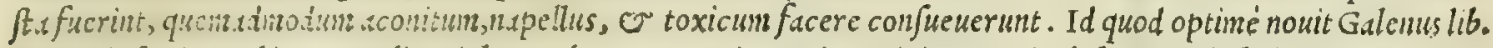
primo de fenise, ubi rem cxplicatuit his uerbis. Qua ratione etiam minima particula bumoris lethalium uenenorum, que deleterita apellunt, ubi in animalis corpus ingreffa fuerit, totum id mome nto temporis inmutat, fibiq, fimili af = fictions alterat. Nec fecusfit curatio, que per uenenorum remedia, or antidota adbibentur, quxe alexipharmaca

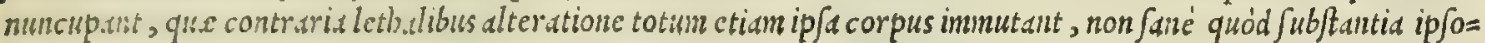
rum per totam penctret corpus (neque enim potcft tam p.ucus fuccus tam breui tempore corporis interdum maxi=

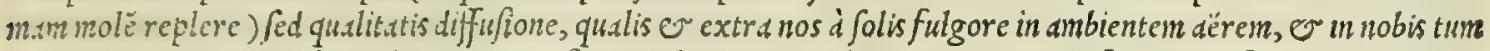
- corde in arterias, tum à cercbro in neruos fieri conpicitur. Er lib. v. cap. $\mathbf{x}$ I x. de fimp. med. facult. idem inquit. At nsedicament.1 funt que tota effentia nobis contraria funt. proinde fo uel minimum eorum affumptum fuerit, omnino

20 ledat neceffe cft. bxc Galenus. Ex quibus facilé conftat, ip fum uelle quód antidota nö fecus at q; uenena agät in cor= pora noftr.. Idem Galenus tertio fimplicium uncdicanĕtorum cenfuc cap. X x I I. in predictorum teflimoniü ita fcri= ptum reliquit. Medicamenta crodentia, et putrefacientia etiamfi quantitate minima funantur; omnino tamen corrü = pust, quis undelicet, que putredini obnoxia funt, calore, bumiditateq́; putrefcere folent. Atqui calidus, bumidusq;

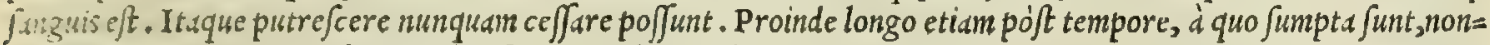
nu!la interimunt, potißimùn que crafja, terrenáque effentia funt. hatenus Galenus. Sed ad antidota redeamus. Vbijciendun clt, quód ex bis ea tutius operantur, qux precauendi gratia anted affumu ntur, quàm qux póft: ndin ut: :cnenum, quanquan efficax, nibil aut parum nocet ijs, qui prius $\int_{e}$ antidotis muniuerunt (ut contigit Mithridati) itr pari ratione mulum, aut paucum adferunt auxilium, que poste cexbibentur, nifi fapius, maioriq; quantitate fus= mintur, ut in corporibus maius corum uis capiat incrementum. His adftipulatur Galenus libro primo de antidotis d

30 priticipio, fic inguiens. Mitbridatica antidotus, item'; theriaca non eam uim habent poft uenenum accepta, quim an= te jumpta habuijjent . nam portio antidoti qua prius, e femel baufta tutum a morte quempian preftitiffet, ea uene= num fub fecuta nifi ob quadruplum, quincupliunue auqd, non iuuabit: neq; id femel tantum, fed bis, fingulis qubusó; diebus baufa, faciet. bactenus Galcnus de bis differens. Caterim uenena, que o manifeftis, or occultis fimul qua= litatibus agunt, id preftant utroque modo, quo predicta duo. quemadmodum agit euphorbium, quod licet uenefica ui, quan ab exceffu caliditatis obtinet, inficiat; inficit tamen or ui alia, que a propria fui forma, or latente qualitate procedit. Cuius reilllud indicium eft, quód exbibita theriacs, cuius proprium eft ed ommia fuperare uenena, que pro= pris formu $e r$ totapecie operantur, efficacißimé ualet aduerfus euphorbiü hauftum. Quódfi fola excedente calidi= tate euphorbium nox in inferret, tantum abeft, ut theriaca, que non parum caliditatis obsinet, auxilio futura $\sqrt{i t}, u t$ etiam illius noxam foueat, er augeat. quod tamen non facit. Scire etiämnum conuenit nö omnia uene na cor primùm

40 petere, or illi noxam inferre . Siquidem reperiuntur, quibus ita natura comparatum eft (id enim claret experientia) ut intus afjumpta feparatim noceant uno tantum corporis membro, alia ueró alteri. quemadmodum etiam junt medi= cine, quarum alie precipue cordi opitulantur, ut crocus, byacinthus . alie cerebrum, $\sigma$ caput iunant, ut $\int \mathrm{marag}=$ dus, fiechss, betonica. alix uentriculo precipuam opem ferunt, ficuti corallium, cinnamomum, gingiber . alie de= niq; alijs corpormm membris anxiliantur. Idcirco Galenus libro de theriacd ad Pifonem: Sunt (inqut) plura media camenta, qu.e quibusdam corporis partibus eximié curandis funt idoned. Patienti igitur iecinori fepe eupatoria ber= ba auxilixisel, : glans unguentaria (myrobalanon uocant) lienem adiuuat: Sarxifragon, o betonica renibus pul= chré faciunt: fimiliter alia aliarum (ut experientia obferuauimus) propria funt medicamina. Tales igitur proprie= tates in uenenis quoq; reperiri affirmauerim. quädoquidem plane conftat cantharidas precipué noxam inferre uefl= ce, cicutan cerebro, leporem marinum pulmoni, $v$ alia item alijs corporis membris particularibus, ut in boc lib.

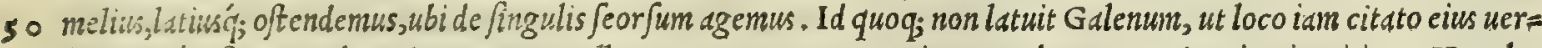
ba sperté iefantur, dum ait. Sunt nomulla uenena, qua partes etiam quasdam corporis priuatim uitiant. Nam lea pusnusinus p:imonem cxulcerat, cantharis ueficam peculiariter afficit. Porró non ignorandum, quod et/i uenena

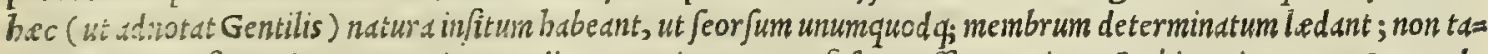
men prosterea fit, quin noxam etian cordi communicent, nam $f i$ fecus e fet, neminem fané interimerent: Quamob= rem baid mibi diflicet corum fententia, qui ideo uolunt omnia uenend perniciofa effe, quód cordis facultatem oppri= mant. Siquidcm parunt refert, an illud efficiant, quod primo cor ip sum opprimant, aut aliquo alio mediante. Huius rei manifeftain fidem facit Galenus lib. v. cap. I. de locis affectis, ubi fic habet. Quxnam ipfi cordi proprié uel pri= marió affects fiperueniant accidentia: quienam uero ipfo ceteris partibus confentiente, id ex ijs intelligi poteft, que prius in 1 lijs libris demonftraimus, ubi iam declaratun efi innatic aloris cor uelut fontem effe, neq; animal mo= gi omnino polfe, ni cor afficiatur. bec Galenus. Ceterum illud etiam in diputationem uenit, nunquid fieripoßjit, ut uenens in diem exhiberi poßjint, $\sigma$ certis occidere tcmporibus, hoc cft, quód certo, er prefixo tempore morten . d=

A' forma pro pria.

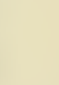




\section{6}

\section{And. Matthiol ${ }_{1}$ Comm.}

ferant: exempligratia in uno mene, uel pluribus, ucl ad annum ufque, non celerius, neq; tadius determinato tempos re. Qua in re in primis aufcultandus eft Theopls aftus grauißimus, er antiquißimus author, qui libro I X. cap. X V I. de biftoria plantarum de aconito differens, ita fcriptum reliquit. Componi auten ita ferunt, ut certis occidere tempo= ribus poßit, uidelicet bimeftri, trimeftri, femeftri, anno completo, nonnullum etiam biennio. Peßimé illos de uita di= fcedere uolunt, qui plurimum temporis refiftere poßint: paulatim enim tabefcat corpus, ov languore pereat diutur= no cffe n:ceffe. Facillimé illos, qui confeftim obeunt. bec Theophrafti fententia. Veruntamen omnes feré rei medice studiofos in banc conclufionem conuenire reperio, quód quanuis in uenenorun numero inueniantur (ut Theophra= fus inquit) que celerius, $\sigma$ que tardius interficiant ; non propteréd tamě prafciri poteft terminus certus, $\sigma$ dies, quo mortem inferre debent, ut quidam exiftimant. Nam quod uenena citius, aut ferius occidant, non tantiun ex innna= ta e propria corum ui prouenire cenfent; fed etian quód magis, uel minus refiftat eius natura, qui uencnum afjum= 0 pfit. Id autem plané docet experič tia: fiquidem conftat idem uenenum eodem pondere, uel eadem quantitate diuerfis natura exhibitum, alios in bora tantum perimere, alios in quatuor boris, alios in die, of nonnullis mif $\mathrm{paruam}$ affer $=$ re noxam. Id quod etian quotidie experimur in medicamentis, que ad deijcicndam aluum exbibentur. quandoquidé idem medicamentum codem pondere, uel quantitate à diuerfis bominibus acceptum, in aliquibus fum celeriter pre: ftat effectum, in alijs tardé, in aliquibus parum efficit, in alijs plurimum, in alijs nibil, in aliquibus citra omnem mole= stiam deijcit, in alijs ueró magno cum labore. Neq; tamen id alia de caufa accidere maniffetum eft, qudin ex uario, di= pariq́; agrotantium temperamento: quod non ita ad unguem deprebendi potest, ut certó $\int c i r i$ poßit, quandiu inna= tus eorum calor ueneno refiftere ualeat. At quanuis concedi poßit, quód quis adeó peritus ueneficus reperiatur, ut ex longa experientia, ac pariter fcientia tam exacte naturam, $\mathcal{G}$ robur uitalis facultatis calleat in unoquoq; bomine, ut conijcere poßit, quousque perdurare ualeat, ubi uenenum illi fua arte preparatum exbibuerit; non tamen pro= 20 pter boc is determinate fcire poterit diem, neq; boram mortis illius, qui uenenum affumpferit . non enim fieri poteft, nifi diuino iudicio, aut afflatu, ut aliquis medicus, uel philofophus adamußim expendere poßit, ac metiri, quantum bu= midi fubftantifici, quantumí; caloris innati in quocunq; fit corpore, prefertim quod non femper in eodem ftatu per = fiftant principes facultates : quo fit, ut quipiam modó plus, mndó minus fortis appareat. tum ctiam quód corpor is temperamentum plurimum immutent caufe extrinfece, quas Greci quod antidota, qua à medicis buiufcemodi uenenatis continué propinantur, etfi ueneni uim ob fui contumaciam fupe= rare nequeant; impediunt tamen, ne id tam breui tempore perimat. Vanum igitur crediderim e efe, quód internds no= fri corporis facultates, ac functiones poßint ( ut quidam rentur) iudicio duntaxat ita exquifité expendi, ut läce ex= penditur crocus. Atqui fcire etiam oportet, quód etfi boc magna ex parte euenire poßit nature ip/ius robore, in boc magis, in illo minus exiftente; co etian tamen prouenit, quod aliqui conftent arterijs, quibus uencnum in cor fer $=30$ tur, admodum anguftis, alij contrà admodum amplis. Nanq; uenenum ubi uias latas expeditas'q; inuenerit, non fo= Iüm celeriter permedt; fed longé etian facilius unà cum dëre prouebitur, qui cordis refrigerio continué ingreditur. Id quod ijs minimé contingit, qui propterea quód cor minus calidum obtineant, arterijs potiuntur longé anguftiori= bus, quin $\sigma$ pirituum uitalium facultatem ualde imbecilliorem babent. Quocirca Galenus tum tertio fimplicium me= dicamentorum cenfu, tum libro fecundo de alimètorum facultatibus, tradidit cicutam hominibus in cibo lethalem cffe, sturnis autem nutrimentum. Quandoquidem bi arterijs adeo anguftis pr.eclufis $\dot{q}$; conftant, ut nullo pacto per eas ad cor letbal is cicute uis, progredi poßit . quanquam boc de frigidis potius, quam de calidis uenenis intelligi debedt.

Huc illud fcitu dignum accedit, quod perfudfu difficillimum eft, uenena, que ab impijs ueneficis in dicm exbibentur, alterius generis effe $a b$ bis, que fuarum tantum qualitatum excefju perimunt. Nam qua propria forma ac ui necant, in minima etiam quantitate exhibita ( $u t$ Galenus inquit) difficile cobibentur, quin breuißimo tempore lethale munus 40 obeant fuum. Non de funt kamen, qui pro certo affirment, quacunq; uenena adeo tĕperari poffe, ut illa celerius, bac tardius interficiant . quibus equidem refragari non aufim, cum fciuerim admiranda admodum efje fecreta nature.

Vtrum quis affueferi poffit, ut uenena innocuè lumat.

Quasi preterea folet, num fieri poßit, ut quis ita ueneno affue fcat, minimü quid de eo quotidie affumens, ut co tan=

dem innocué nutriatur, quemadmodum R ufi teftimonio fcribit A uicenna, olim puellam nutritam effe ueneno, ed tă= tim ratione, ut reges quosdam, er principes (quód formofißina effet) qui fecum rem baberent, inficeret. Qud in re

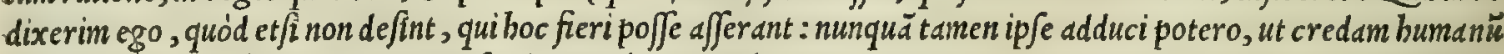
corpus nutriri poffe ueneno, N prefertim napello, quo plerig; rem exponentes eam puellam nutritam effe interpres tantur. Siquidem ea biftoria Arabic ds potius fabulas imitatur, quàm rem aliquam, qua omnibus naturalis philofo= phice rationibus comprobari poßit. Quamobrem confat Gentilem Fulginatem in hoc Auicenne loco adnixum quidem fuiffe, ut banc opinioné feruaret integram. quod nimirum fidelis cuiusq; expofitoris effe debet. Nam poftquam so eam fententiam ualidis, uerisóg; rationibus primum improbafet, denuo (ut affolent) Auerrois, Diniq́; authoritate innixus Auicenne, $\sigma$ Rufi opinionem probare non dubitauit quibufdam argumentis, quanuis nidis, $\sigma$ infirmis. Quorum illud uidetur fortius effe, ubi autboribus magis, quàm rationibus addįus inquit, Aequum non effe, quód aus thores tam graues, tam q́; Japientes, mendaces uocentur, uaniq;; babeantur . quippe quód certó crediderit ip $\int e$ Gentilis $\mathrm{R}$ ufum, item $q_{;}$A uicennam in ueram hiftoriam hanc rem recepiffe, non autem in fabulam. Sed quoniam fuperuaca= neum duco in boc conterere tempus, longa contradicendi oratione, prefertim quód uenenorum mcdcle ca nullă aut paruam afferat utilitatem : ideo relictis alijs, in Galeni fententiam facile deucnio. Qui tertio fimpliciun medicamentorum cenfu cap. X V I I r. tradit uenena calida, ficca ( qualem effe napellum, quo puellam illam nutritam uolunt, non ambigo ) nullo modo poffe in nutrimentum redigi, etiam quod in quantitate minima fumantur : tamet fi frigida ue= nena quandog; in alimentum uertantur. Quandoquidem bac (ut idem author eft exemplo cicuta, papaueris, byo= fcy ani, or mandragore ) non fui natura interficiunt, fed qualitate duntaxat frigida. Quibus adijcit ipfe Galenus bi= 
forian anus cuiusdam Athenienfis, que cicustä in cibo funebat mullo foné detrinento accepto. Ed enimt ut idem fori=

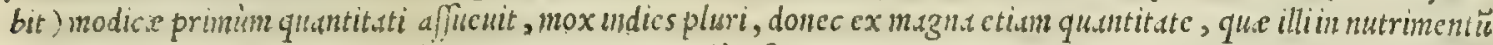

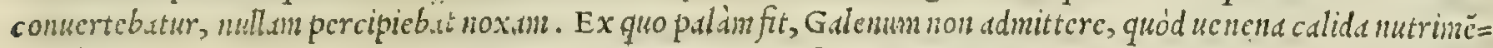
to effe poßent. Id qrod nimus ctiun ill is concedit, que propria peci, aut occulta caufa, ucincni inaturan fortiuntur. Inter qux principé locum obtinct nxpellus. Qusure longé aberrant nonnullinterpretes, utpote qui illud napello tri= buant, quod plune cicute reddidit G.lenus : itug; fit, uc (qux corum infcitia cft) buftorian banc confundant, Galeni

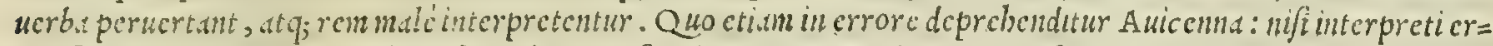

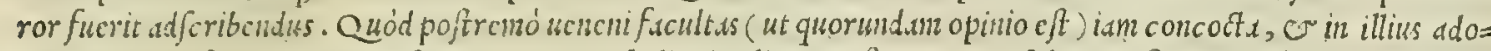
lefcentula fubftuntan conucr fa, potwerit cx anhelitu in alios tranfire, ac cos fubinde inficere, fane perridiculü ui=

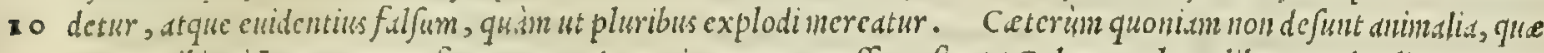

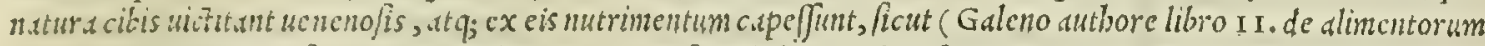
facultatibus, $\mathcal{O}^{-}$I I I. finplicium medicancutorum) fturni cicutan depafcuntur, o coturnices ueratrum, $O$ ut nos

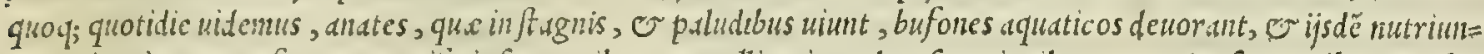

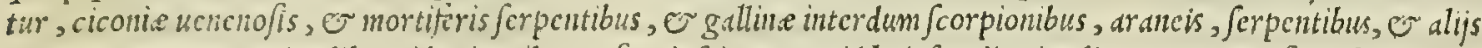
id genus ucnenatis animalibus; idco inutile non fuerit fcirc nunquid buinfmodi animalia, qux ucncnofis uc fcuntuf, ab bosnimbus cibo acceptu, inde ucnenum inferant, co q; inficiunt. Hac in re plerosq; inuerio, inó feré omnes recentiores, qui de uenenis foriffermt, firmiter alferere, quód fi buiugmodi animaila cdantur, non modó ucneno non inficcre polfunt, fed nullum prorfus inferre noxam: quin potius corpus nutrire, non fecus atq; alia. quippe quód conftct (ut dicunt jea $m$ fusm naturam uencnatos cibos reddere. Qua ratio, op opinio etfi non abfurda, neq; incongrua uided

20 tur; tamen credidesim, quód licet uenenum concoquatur, $\sim$ tranjmutetur in eorum aninalium fubfantiam, quorum

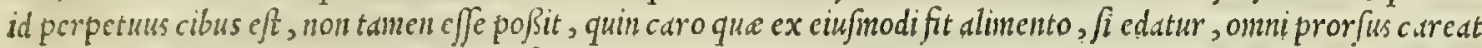
socumcnto. Quinimo putauerin, quod fi ea in fiequentioresn cibum ucnerint, poßint quandoque morbos $\int_{x} u i \beta i n o s$ excitare, $\circlearrowleft$ jubinde neccm infirre. Siquidem buius reinobis teftimonium prebent Diofcorides, $\circlearrowleft$ Galenus. quippe qui pariter affintent iac, quod uil aliud cft, qudim fang uis bis costus, ex animalibus emunchü,qux fcamoniam, aut ue= ratrum, aut tithymalum depaf cantur, potum mirificé uentrem dẹjcere. Ex quo omnibus perfpicuun eft, quód omnes in uniucr fun plante, quibus nis deiectoria, er perniciofa incft, quanuis fapius concocia fuerint, non prorfus tamë fuan deijciclidi, ac necandi facultatem deperdunt. Id quod fimiliter manififum deprehenditur in turdis, qui iuniperi baccis uc cuntur: item in gallinis, que deuorant abfintbium. Quandoquidem illor un caro imiperum non mediocri= ter redolet gustatu: harum ucró tion paruam abfintbij amaritudinem refrt. Ab bis itaque edoctimedici diligentißi=

30 mi mandant nutriendas effe capellas herbis accommodatis, ubi animus fuerit earum lac exbibere becticis, aut alijs d= lio morbo affectis, quibus tamen conueniat. Hoc quoq; teftatur Galenus de uipera fermonem babens lib. $\mathrm{x} x$. de fim= plic um medicamentorm facultatibus. Ibi cnim de dipfade differens, fe non ignos are memorix prodidit, animantiü carnes alterari is cibo, er alinento, quod capiunt. Quare ut fummatim quod fentimus dicamus, nullo modo buiufino= di animalia in cibos admittenda efe putauerim, quanuis à nonnullis frequenter recipiantur. Illud porró fciendum. relinquitur, quód nonmunquam uenera, quin os medicamenta uenendia tam interius fumpta, quàm exterius appo= fita morbis fuccurrunt, qui aliud curationis genus non admittunt, interdum ctiam aduerfw alia uenena theriace ui= cem fupplent. Nanq; aperté uidemus, quod ubi quipian afficiatur diuturnis uigilijs, aut fuffocanti deftillatione, aut menfium profluwio, aut dy fenteria, aut colidolore, aut renum, aut uteri, ubi alia non contulerint medicamenta; $\sqrt{f} 0=$ pium, mandragor $a_{2}$ byof cyamus, uel dntidota aliáq; compofita medicamenta, qua bac exceperint ( Junt enim talia in

40 of ficinis femper parata) exhibeantur, fepenumero agros à morte uindic ant. Quemadmodum etiam fif fcammonium, colocyntis, turpetum, ueratrunq́;, $\sim$ aliaid genus deijcientibus pharmacis addantur. Nam quanuis hac omnia ma= lefica qualitate pollcant; in contumacibus tamen morbis ov curationi refragantibus, tantan afferunt utilitatem, ut egris deperditam fré falutem reuocent. Cantharides praterea ad mor jus canum rabidorum utilißimé exbibentur. cuphorbium fcorpionum itibus medetur, o fcorpiones ipfifuis iftibus remedio funt. Sicut etian uiperd, dempto cas=

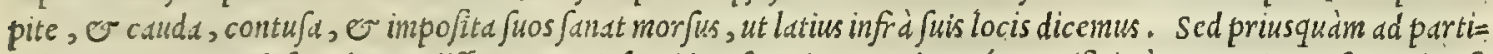
culares curationes defcendamus, differemus Diofcoridem fecuti, quomodo, quóue artificio à ueneno ij prx feruari pof= fint, qui perpetuo ueneni timore premuntur. Quin or rationem docebimus fuccurrendi ijs,qui ian uenenum baufiff fent. Atc; buc onmia preftantiora vemedia afferemus, tam que fimplicia funt, quàm qua cöpofita, nö folim à uste= ribus inuenta, atq; experimento comprobata, fed etiam à clarißimis quibusdă recentioribus. De quibus probatis an=

so tidotis, et $\sqrt{i}$ polliciius fit Diofcorides fe omnino traditurum in ultima buiufce uoluminis parte, pollicitis tamè non fee tit, ut X X X I I I . buius libri capite conpicitur, ubi excufatione ufus, mutati confilij rationem reddidit. Vcrum us iam ad rem nobis propofitam accedamus, primó modum aperiam, quo bomines fupiciofi ueneficia prac cauere poßint.
pleriq; igitur funt, qui putant, non paruam effe principibus cautionem, mandare minifris, ut edulia, qua preponit=pleriq; igitur funt, qui putant, non paruam effe principibus cautionem, mandare miniltris, ut edulia, qua pr:eponit=
tur edenda (mos ifte bodie frequentißimus eft) prius deguftent. Quse tamen res in fupicione ucneni tribus manifi= fis de caufis nibl, aut parum aftinanda uide tur. Siquidem $f i$ pincernd, fiue qui cibos fuis dominis apponunt, uenefi= ciü committcre dccrcucrint, fe ipfos facile prius preparare poffunt ualentißsimis antidotis, ueneno illi accommodd=
tis, quod exbibere in arimo eft. Vnde fibi ipfis precauebunt, dominum autem intcrficient. Ex quo fatis liquet nibil prodefe ad precautendum, quod pocillator in feruate fideifignum domino prabibat, or eduliorm diffector praco= medat. Adde deinde, quód quanuis ille, qui edulia miniftrat, menfé q́; apponit, à coquo uencficiun faciente deceptus; citos uenenatos prezufrando afiumat; ; eorum tamen adeó modicam quantitatem preguftat, ut nullam, aut paruan co temporis momento poßsit moleślam percipere. Vltima accedit ratio, quód feré ommia uenend, que ut interimant ci=

Venenú quan doq; morbis, \& alteri uene no remedium elt.

Modus præca uédi uenena. Precautio vul garis explofa. 


\section{And. MatthioliComm.}

barijs admifcentur, ed arte, coó; ingenio paratd funt ab implis, o f celeftis heneficis, ut not nifil temgoris interuallo furm triffe perficiant opus. His igitur de caufis illud libere proferre non dubitauerim, quod nullam sueliorem, ac tutiorem precautionem fíbi ccmparare poffunt pritcipes, quim curare, ut uitam cbriftianam, or integranducant, iufitiámque regant, ita ut populi cos uererentur, pariter o timeant. Curent deinde, ut miniftros babeant, quo= rum manibus edulia adminiftrantur, non ignobiles, nec obfcuro loconatos, fed preclard $\dot{e}$ firpe genitos, fideles, nec auaritix addictos, nequc inuidos, 0 qui diu anted uita ac moribus probatt fint. In quos preterea debent fres = quenter noula parua conferre beneficid: itd enim femper gratos e fideles miniftros babebunt. Quin er medicos fibi adiungant, quimedic materic peritißimi habeantur, ut antidota, que contra uenena parantur, quemadmodum funt theriac a, $O$ antidotus Mithridatica, ex legitimis, non ex adulterinis fimplicibus medicamentis, per fe ipfos (ut ipfe faciebat Galenus) componere ualcant: nam fi hacc legitime parata fucrint, haud dubie poterit unufquif que faci= 0 le uenena precauere. Ex his certémaius percipicnt emolumentum, quam fi mille alijs pracautionibus uterentur. Nec minor fané cautio adlaberidebet, ut uafa ex auro er argento conflata, munda, nitidáq; feruentur, e hominum fidelium manibus committantur . quandoquidem in eiufmodi pretiofis uafculis, quorum apud principes quofq; preci=

Abfurda quo puus eft ufus, uenena facilius abduntur, quim in uitrcis aut fictilibus uitro circumlitis. Sunt nonnulli ex recentio= sundam opi- ribus, rerum prorfus imperiti, qui ( $(f$ uerum fateri liceat ) co dementie deuenerunt, ut praceperint in liqustum igne nio. aurum, uel argentum, ex quo uda confici debent, theriacam, aut Mithridatis antidotum, o alia adiungi dcbere, ut afcita inde antidoti facultate, uenenis repugnent . Sed quàm abfurda, ridendxí; fit horum opinio, ij dijudicèt ( $e x$ enim eft, qua non indigeat clariori reprobatione) qui mediocrem etiam rerum naturalium, ac metallorum precipué peritiam funt affecuti. Caterim fupellectilium non negligenda cura, ut fcilicet uafa, quibus ciborum condimenta reponuntur, claufa, or cooperta feruentur, ut neq; aranei, neq; fcorpiones, nec aliquod uirulentum reptile, uel infe $\Rightarrow 20$ ctum ingredi poßint. Admonet Diofcorides, ut etiam uafa uinaria diligenter claufa cuftodiantur . nanq; wipera fum= mo uini amore alliciuntur, qua fi uafa aperta offenderint, cò facilé contendunt. Quo fit, ut interdumbibendo exi= tiofum uirus eructent, interdum uerò in uino immerfa expirent. Quamobrem Ariftotcles lib. v I I I cap. I I I . de biftoria animalium, quofdam uiper as vino in fictilibus ad fepes diff ofito ucnari, or eas ebrias capere, memoria pro= prodidit . Galenus item lib. $\mathrm{x}$. Fimplicium medic amentorum, eam narrat hiftoriam, quam nos libro fecundo in uipe= rarum mentione retulimus. nempe de illis uiperis, qua pponte fe uino immerferunt, unde etiam fibi mortem confciue= runt. Quo uino duos homines clephanto affectos fanit ati reftitutos effe, iden eft author. Quibus cx ucrbis pal am eft Galeni teftimonio, uinum in quo fint extinta uiper a, noxium non effe, quin potius adeo falutifrum, ut effic dcifime clephantiafin curet. Quod tamen Diofcoridis fententie refragari uidetur . nifi dicamus uipereum uenenum ele phans to laborantibus praft ans effe auxilium, cateris autem exitium. Qui iten in uenenifuppicione uer fantur, cibos uita= 30 re debent, qui candido, uel oler aceo colore fuerint: necnon etiam ab bis abfinere, qui ex animalium fanguine par an= tur. Siquidem albedine, uenena quedam metallica facile occultantur : cibis berbaceo colore, uaria lethales plante commodé admifcentur : fanguini etiam animaliï, quibus uefcimnr, commodißimé uenendorum fanguis inferitur. Il= lud etiämnum apprimé utile atque neceffarium effe duco, ut coqui, or reliquiculina inferuientes, non modó fideles fint, $\mathbb{O}$ incorrupti; fed etiam mundi, cauti, ac prouidi, ne ullus ueneficorum infidïs relinguatur locus : tum ctiam ut

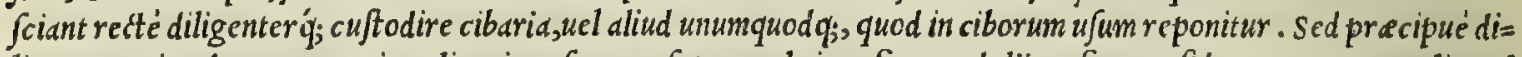
ligenter animaduertant, ne in culinaria ua $\int a$, qua fuper, uel circa foc um edulijs referta refídent, uenenatum aliquod animal à tecto per caminum decidat, ut quidam exigui apides, qui fub tectorum tegulis, er contabulamentis fe reci= piunt, phalangia, ftelliones, fcorpiones, or fimilia . Nang; Florentia ( ut Nicolus eft author) canobum monacho= rum ueneno infectum eft, quod araneus niger admodum in olla decidiffet, dum coquerentur iufcula. Ad bac princi= 4o pes maxime curent oportet, ut perquàm fideles habednt cubicularios. Nam (ut fuperius dittum eft) quodan ueneni genere cubilia, interule, ceteráq; ueftimenta infici poffunt. Quare nonnulli faccre folent, ut diu, priufquàm ueftes induant, cas manibus pertractent ferui . Quin e pueris fimiliter iubent, ut fape equis infideant, ijs fuper fellis, qui= bus ipfi uti confuetuerunt. Tum etiam ftabuli prafict is mandant, ut tam caute fell ds, babenasgig; recondant, ut ignotis; Qux res ve- $\mathcal{O}$ bis quibus fidendum non fit, cas non intueri, ne dum tangere licedt. Infuper illud fcire conuenit, quód quredam. nena prodăt, quxá; furpen fxeiftem aduerfentur. res fimplices funt ( ut pleriq; inculpat e fidei medici fatentur) qua fua peculiari natur $x$ dote prefens uenenuin fignis imanifftant. Inter quas cornu, feu lingua, quam ferpentis linguam uocant, refertur, qua (ut Conciliator Petrus $\mathrm{A}=$ ponenfis tradit) prefente napello, aut uiperd, aut pardi felle, exudat : quod tamen non prodit, cátcris uenenis pres= fentibus. Sunt alij, qui procerto tradunt, praßium lapidem, quein Plafma unlgus appellat, ftatim flendorem amits tere, ubi in prefentia ueneni cuiusq; fuerit. Addunt pretered, quod fi lapis rane terreftris anulo aureo infcratur, ita so $u t$ is digiti carnem contingat, quam primum prafenferit adc $\iint_{e}$ uenenum ( $f \mathrm{t}$ credimus bis, qui hoc fcriptum relique= runt) tanta digitum afficit caliditate, ut carbonem accen $\int u m$, ipfum q́; digitum urentem pre $\int e$ ferat. Q Quibus fane et $f$ parua, mea quidem sententia, fit adhibenda fides; ea tamen, quo omnibus fatisfiat quintum poteft, non duxifilentio difimulanda. Non defunt etiam, qui contra leth alia uenena pollere contendant figilla quedam, fiuc char afteres, five imagines, quomodocunque eas appellare libeat, precipue fi collo fufpenfa geftentur, uel digitorum anulis infer ätur. Quzccirca prodidit Albertus libro imaginibus dicato, quód fi Serpentarij imago cum fuisftellis cuiuis lapidi pretiofo. infculpatur, eam utilißimé geftari aducrfus omnia uenena, eág; prefertim, que uenenoforum animalium iflu uel mor= furelinqumntur. Proinde Petrus Aponenfis fcriptunt inueniffe tradidit in quodam libro, quen reges Perfarum olim babuffe refert, quod fi in bamatite lapide fculpatur bomo genibus flexis ferpente cinctus, ctuius caput dextra teneat, caudam uero finiltra, o lapis ille anulo ex auro purifimo confecto inferatur, geftatu bomincin à quocund; uelleno tuetur. Que imago fi modó aliquem praberet effectum (non enm bac in re certi quicquam profirre alfim) mea fert. 


\section{In Lib. fextum Diofcoridis.}

opinio, quód iempore, quo fculpitur, neceffaria fit qudpundăf ellurum obferustio, d̀ quibus ca uis influat in fculptann imaginem. Porrạ tradidere fapicntum ueterum nommulli, reperiripretiofos lapides, quibus folis a natura largitum cft, ut uencnorun malitiun cfjicacişimé diffoluant, o deftruqnt . Ob id itaq; fcriptum reliquit Albertus cognomĕto Nagnus adanuntem orientalcn geftatum biachio finiftro inter bumerum, or cubitum adnexum, omnium ucnenorum win denolivi. Id quod etian idem tribuit achatte, by.1cintho, $\sim$ fapphiro orientali. Alij eandem facultate aßignant fmardgdo, alij lapudi, quem in capite draconum inuenvi tradunt, unde draconitis nomen accepit. Caterum (ut inge= nue fateur quod fentio ) parum fidcndum cffe credidcrin bis fupenfionibus. quippe quod nunquam uiderin buiufce rei cxperimentum tan clurum, ut fyncerafides adbibcri poßit: quanuisillud facilius perfuaderi poßim, quod fma= r.gdus, Jy.acunthus, ach.utes, fupphtrus lapides in tenuißimun puluerem redacti, poßint per os fumzti ueneno infe=

to Etos fepe liberare : utpote qui cam fortiantur maturam, ut cordis uiribus fubueniant. Sed quód giftatilapides ueneni.

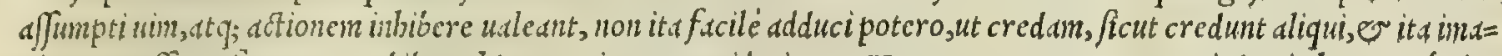

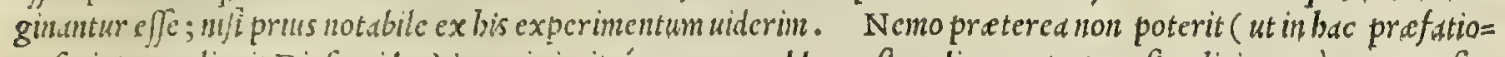
ne fcriptum reliquit Diofcorides ) imoxia irrita q; uencuareddere, fimedicamenta tam fimplicia, quàm compofita prefumperit: que uiribus pref, tuntisimis pollecnt, quibus póft affumpta uenena facilé ualeant fuperare . Simplicia autem nedicanentas Diof coriti comprobata, funt carica cumiuglandibus nucibus efitat a, citria mala cruda mandu= cata, napig; fonen ex uno potum. Itcm calaminthe folia, er L emnia ploragis, quan fummis laudibus extulit Gale= nus: fed que pro fingula uice dracbm.e pondus non excedant. Idem fimiliter fummis laudibus conmendauit rute fo= lia, cum nucis iuglandis nucleo accepta: quin o duas caricas, faliśq; momentum. Ex compofitis autem non immeritó c.eteris antidotis Nutbrid wtiun antecellere fcribit. quädonuidem ex frequenti cius ufu (ut ex antiquorum monumen=

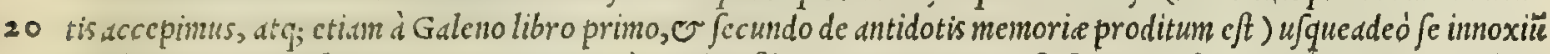
prebuit ucneno Mithridutes Ponti rex, ut cum uellet fibi necem ueneno confcifcere, ne fe Romanis dederet, nullum cx aflumpto ucneno percepit incomnodun. Qua in re poftea Galenus theriacam praftantiorem effe tradidit, affe= rens fieri non polfe, ut ijs uenenun ullum noceat, qui eam quotidic fabe Acgyptia pondo fumere confueuerint, quo modo fwo tempor"c Aurclius Antonimus Imperator facerc folebat. Cateri pofteriores, qui Diofcoridem, ${ }^{\circ}$ Galennm fecutifint, prefcrtin Arabes, $\mathcal{O}$ ipfi ad idem caftaneas plurimim ualere tradiderunt : quin er mefpila, piftacid, al= lium, raphamm, $\sim$ nuces Ponticas addiderunt, omnibus his tamen optimam theriacain praferentes. Et hac bacte= mus dict. fufficiant de modo precauendi uenena. Reliquum eft, ut curandi ordinem, ac rationem ineamus, qua ijs fuccurrere poßsinus, qui cibo aut potu uenenum fumpferint. Primum igitur ( ut paucis etiam fuperius dictum eft) fcire conuenit, quod ingeftum intus uenenum, non fatim, ut quidam uolunt, ad cor ipfum contendit, quin prius alias 30 internas partes percurrat, $\mathcal{O}$ ledat, $\odot$ fanguinem inficiat. Sed quia maxima pollet agendi uiob propriam fui for $=$ mam, uel temperamentum, quam obtinet atrocißimam, quancunque corporis bumanipartem contigerit in fuam uiru= lentame conuertit naturam, er ita cousq; procedit multiplic ando, inficiendo, at $q_{;}$fanguinem cum-reliquis bumoribus in uenenum uertendo, quousq; accefforla quantitate ad autum, cor ip fum attingat, quod tandem breui tempore in ue= nenatam picciem tranfmutat. Hinc deinde fit, ut piritus uitam fouentes, loco proprio ac naturali expulfi, fuam fedem cedant ueneno: atq; ita fubinde corpus piritibus, or uitd fimul deftituatur. Illud pratered non ignorandum, quód arterix und cum cordis uentriculis (quibus natura datus eft motus dilatationis, or confrictionis, ut ex illo quidem attrahut tur aër circundans, quo indiget cor ad refrigerădum fummum perituum uitalium calorem: cx hoc autem pars aè is fuligino a expellitur, pro cordis item refrigerio ) quemcunq; flatum extrdे offenderint, intus attrabunt, ita ut arterie, quamuis minutißime, qux per totum corpus dipergütur etiam fub cute, per meatus quos habent, dérem nos 40 circund.ntem attrabant, ip funq; prouebant ad cor, quod quidem pofted per easdem uias calorem fumum Alum reijcit. Quo fit, ut fi nos circundans ä̈r fuerti infectus, uenenatus, es perniciofus, ed ratione dicta cor ipfum inficit, atq; corrumpit. Id ǵ; non euenit propterea quód arterijs atq; cordi natura infitum fit, ut uenenum attrabat, fed quodd ser ren continuo infpirent, quo mediante natura etiam repugnante fua, uenenum quo op; trabunt. Hinc itaque eft, quod quid am, dum ( ut contingit) fommum caperent fub arboribus uenenatis, ceu taxo ac nerio ; uel bumi cubarět fuper planis noxijs, uelut napello, $\sigma$ açonito; uel propter uirulentorum ferpentium pecus quie fcerent, impruden= ter uenenum contraxerunt, non alia de caufa, qudm ex dëre loca illa ambiente, plantis illis uenenatis infecto, e pes cuum uivilento piritu. Ceterim iam tempeftium erit ad generalem corum curationem accedere, qui ueneno infe= Eifunt, corumć; precipué, in quibus non adeó manifefa figna conpiciuntur, ut quódnam fit affumpti uenenigenus, dizno $\mathrm{ci}$ poßit. Nullus ita $q_{\text {; }}$ medicus ingenio preditus eft, qui non protimus uideat o intelligat ex feuis acciden=

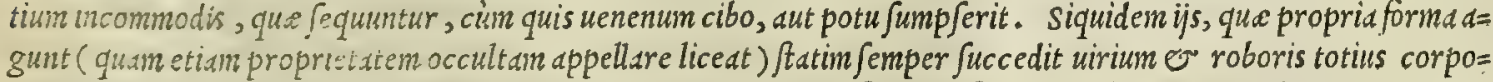
ris proftratio : egri ea nagia cordis moleftia fiequenter animo deficiunt: facies liue cit: quin $\sigma$ lingua, or labia nigrican : item extrema corpor is, prefertim ungues, plumbeo colore liue fcunt. Ad hec qui hauferint, uertiginoft

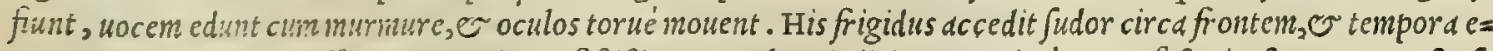
rumpens. Qus omnia alfumpti ueneni manifftißimum prebent indicium, maximé autem fi satim fequantur post af= fumptum cibum, ijsq́; contingant qui fibi rectan quotidiani uictus rationem adbibeant. Quandoquidem tam mala ef= fe boffet in aligno utaus rstio, quód bunores inde geniti, tractu temporis ufqueadeo corrumperentur, ut contract a z:cneni viatura, uim nature inferrent, $\sigma$ eadem iam dicta cierent fymptomata. Id quod maximé teftatur Galenus li= bro iexto de locis affectis, tum etiam libro de cibis boni ac mali nutrimenti. Quapropter medicos cautos, ac prudé=

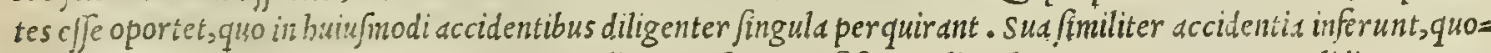

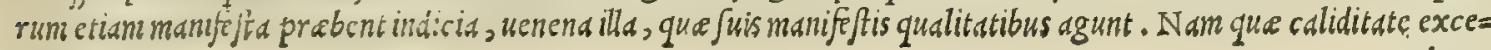

atio curan


dunt, omnia menbrd interna celeriter inflammant, fitin ingentisindin excitant, oculos inflammatione malc' babent, inquie tudinem continuam inducunt, or continuun fudor cm cient. Si ueró praterquàn quód calido excef fu polleant, excellant etiam ui tum erodendi, tum putrcfaciendi, ut arfenicum fublinatum, auripigmentum, fandaracha, er id ge= nus alia, punctione, atque dolor intoler abili uentriculum or inteftind afficiunt, in quibus etiam frequenter murmura fentiuntur. Hac autem accidentia fape fequntur uomitus, faftidia, Sudorcs modó calidi, modó frigidi, uari.c deniq; coloris mutationcs. Que ueró nimia frigiditate excellunt, pleruny; fosnnum inferunt adeó profundum, ut $\int x$ pe non fine magno labore excitari poßint affecti. Nonnunquam ucró cerebrum obftupefaciunt, ita ut affecti cogantur qudin plurimos incompofitos edere motus, tum corpore toto, tum etian oculis, ore, manibus, reliquisq́; corporis partibus, non fecus ac fiftultifacti effent, uel temulenti. Huc illa preterea accedüt, frigiditas fcilicet totum corpus occupans, frigidi fudores, or color in facic liuidus adnzodum, o terrificus. Ad fummun totum corpus torpidun afficitur.

Ex ficcis auten uenenis lingua arcfcit, guttur fiti inextinguibili afficitur : aluus adfricta redditur, cgré redditur urina : omnia deniq; membra fiunt drida, or uigilie inftant longisina. Foftremó bunida inexpugnabilem fonmun adferunt, alui fluxiones, articulorum, nernorumq; luxationes. Ita quod quandoq; oculorum nerui, ac nexus in tant $\ddot{u}$ laxantur, ut ponte fua é cauitatibus exeant, capitiq; propendant. Plerunque etiam extremx corporis partes putre= fcunt, ut in preccdentibus dictum cft. Porró $\sigma$ illud adnotandum eft, quód uenend, que er manifefta, or occulta qualitate agunt, if fuerit hac uivibus altera imbecillior, in fine fux actionis eadem pariunt accidentia, que proueniunt ab bis, que occulta duntaxat proprietate munus fumm obcunt. Vis ctenim qualitatü elementarium, qua illis ineft, uine illam propriam occultam ';, quam hec pariter fortiuntur, antecellit. Proinde primùn qualitatis elementaris exce= dentis effcctus prebent, cosq́; fubinde, qui proprix corum forme attribuuntur. Sed buius rei clariorë notitiam tra= demus, ubi fpeciatin fingulorum nneminerimus. Hac igitur funt omnium uenenorum indicia uniuerfalia, cateris que 20 explicari poßint, certiora, ac manifftoria. quibus peritißimi medici tutó dijudicare poffunt. Nam cum conftet acci= dentia pradicta non folim perdurare; fed etiam augeri, ac continue in deteriora labi, nullóg; modo auxilijs cedere, neg; nature repugnanti obfequium preflare, clarum profectó mortis indicium eft. Contrà falutis, fi quando remitti

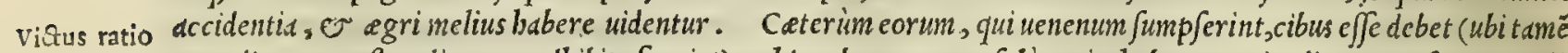
corü qui ue- remedia,quse poftea dicentur adbibita fuerint) ex bis rebus, que non folum uim babent nutriendi corpus; fed qua ctiă sena lumple- uenenorum noxie refiftere ualent. Quo in genere lac dininum fummopere laudatur: item caprinum, ouillum, bubu= runt.

lum, at q; ettan humanum, prafertim fi recenter emunctum bibatur. quanquan lac onne effic acius cxhibetur cötra uenend calida;, erodentid, quam ad reliqua uenenigenera. Ad boc or butyrum facit. Faciunt $\sigma$ inf cula tum car $=$ nium pinguium, tum pifcium, quibus addi poffunt, ut pinguiora reddantur, butyrum crudum, or pinguedo animaliu, quorum eft ufus. Siquidem pinguia hec ideo conueniunt, quod uids obftruant, ex quo nenenitranfitus inbibetur. 30 Quinetian ubi uenend excdfaciunt, erodunt, pinguia hec acrimonian corum bebetant. Idcirco boc in cafu, ani= malium cerebrum, atq; oßium medulle aptißine pariter cenfentur. His fimiliter berbe quain plurine opein ferre polfunt cibis admifte : equarum numero probatur caldmintba, origanum, ferpyllum., fifymbrium, ruta, bugloffum, echium, filipendula, fonchus, pimpinella, ali.é; quàm plurims : quarum uim uenenis, fuperioribus libris, aduer fari retulimus, quarum etiam catalogum pauló infra recenjebimus. Locus deinde, in quo re fidere debent, qui ucnenuin fump ferint; lucidus fit oportet: ibi aćr quoq; fit mulla mald qualitate affectus. Paretur autem corum cubiculum odo= ramentorum fuffitu,quibus uis ineft propulfandi uenena. Id enim preliant fantalum omme, myirha, ftyrax, $l l o e^{2} l d=$ ferpitij lacryma, agallocbum, fcordium, caßia odoratd, citrcimali cortex, iuniperi bacc \&, ciuś; ligntum ficcum, ơ: id genus plura. Infuper affecti ueneno (Galeno authore lib. I 1 . de antidotis) nibil aut parum dormire finuntur. So= mnus nan q; uevenum retinet in internis partibus, e facilius ad cor deducit. Contrà uerò uigilic, quippe qua id a 40

Remedia có- centro ad corporis fuperficiem, nempe ad externas partes, retrabunt. His ita inftitutis in primis onani indultria, tra venena. ac diligentia curädum eft, ut deuoratum uènenum ford̀s exhauriatur. Qua in re nullum fané ualentius anxilium per= bibetur, quàm ut fine ulla mora agri uomitum ciere cogantur : fi tamen ue nenum adbuc in uentriculo refideat. Quód fi iam in inteftina defcenderit, illud quàm primum clyfteribus infufis extrabatur. A tqui in boc onni diligentia ordi= nem ac modun inire debemus, quem in buiufce uoluminis prefatione nobis reddidit Diofcorides: siquidcm is de hac re ita exquifite differuit, ut pofteriores omnes ommia feré que de ea fcriptis tradiderunt, illi accepta referre poßint. Verum boc unum ipfe addiderim, quod fi fortè is, qui uenenum fumpfiffet, ex ommibus uomitum cientibus auxilijs uo= mere nequiret, tunc ( $u t \mathrm{R} d$ fis author eft) medic amentis foluentibus, itemq́; clyfteribus erit procedendun. Mcdicd= menta autem, qua deic ctoria potiuntur facultate, ad hoc idonea funt agaricum er rbabarbarum. Quandoquidcnu $u=$ trunque preterquàm quód deiétoria ui preditum eft', facultatem etian uenenis maximé repugnantem fortitur. Id so quod etiam quidam minori centaurio attribuunt. Neque prorfus ab re effet ad idem Aegyptie filiqua atram medul= lam, aloëm q́; ufurpare. hac nanq; preter deiectoriam fac ultatem, feorfum plurimim pollet aduer fus humorum pu= tredinem, que femper, uel plerung; ingefta fequitur uencna: illa ueró quód aluun mirificé emolliat, uenentm ucu= triculi tunicis adberens abluit or abftergit . quin er erodentium acrimonian obtundit, ev ea deniq; per aluum fecun cducit. His autem perattis, ed certé cly fmata competere uidentur (ut Diofcoridi placet) que acria funt er traben= di ui prodita. Quibus fi ea fuccefferint, que é iuribus pinguibus, adipe, aut pinguedine, aut butyro, aut lacte paran= tur, ne ultevius uenena penetrent, ut in dy fenteria fieri folet, nequdquam ea inutilia forc putaturim, prx fertim ubi compertum baberetur, uenenum inteftina exulceraffe. Quamobrcm lac copiofus cpotum poft uonitioncs, $\sigma$ cly= ftcria utilißinü efe prodidit Auicenna: nempe quód ucteni noxian frangat, o fanet. Quinctian fummopere pro= funt, premißis tamen uomitionibus, on clyfteribus, fortes, ac ualide diterfiones: utpote qiin non modo probibeant

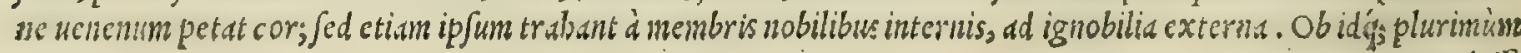

prode $\iint c$ 


\section{In Lib. fextum Diof coridis.}

prodeffe crediderin cucurbitulas, fi ex igne natibus, or crurium pulpe applicentur. Ferunt fimiliter opem frictio= mes ex apseris lintesminibus, quin or fibule ftrictun facte, ita ut dolorem excitent, manuum, pedumiq digitis, item bracbijs, cre cruribus. Mirificé ctian uenemum auertitur à partibus intrinfecis, fipaticntes in balneo aque calide $\mathrm{ex}$ medicamentis accomnotatis confutto, uel in luconico ficco fudoren ciente imponantur. Quandoquidem buinfmodi

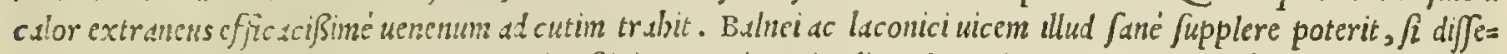
cto wiui nulli, aut equi aluo exertis statin inteftinis, ager in animalis cadauer intromittatur: $\sigma$ cum refrixerit cadd= uer, idem etisn di alio fixt, quoueque fat fucrit. Ad hoc autem muli, mulxq; ( ut unlgi fert opinio, fortaffe quod bec animalia plurinum caloris babeant) cateris prapollent aninsllbus. Hoc enim auxilio a ueneno liberatum narrant $V a=$ Ientinums Alex.tn:tri fexti funmi Pontific is filum. Is eninz (ut ferunt) cuim in quadan coend aliquot Cardinalibus uente=

to mum exbiberc uellit, fibi ipfi, ac putri it imprudenter exbibuit. Ceterim fcire ethan conuenit, quód quanuis pres= ditis remedis onnis communiter uenenis opitulentur, non propterca est dinittenduns, quin continue infectis propinen= tur omnia probsta antifots, tam fimplicia, quim compofits, que cuinfcunque ueneni noxam auferre poffunt. Sinn= plicia quiden medicamenta, qua ad boc idonea Diofcoriti, reliquisq́; Grecis posterioribus celebrantur, funt unum uctus copiofius cpoium, Lemnix fihragis, agaricun, abrotonum, irio, eryngij radix, napier paftinace femen, ca= Ismintha, nardum Celticum, castoriunn, ferule uirentis medulld, flos rbododendri (quanquam is Galcno, alijsó; ipfum fccutis in antidotun minime recipiutur, fed potius inter uenena dnnumeretur) fuccus marrubij, laferpitij, of panacis, fazapenum, arifolochis longa, femen rut:e fylucftris, betonica, pix liquida delincts, polij, ש feelis decoctum, plou, cimnansomum, caßsia, iuniperi bacce, citria mala, o que limonia, o atrantia uocant, or eorum femen. Item glan= des, prefertum querne ex bund ano late cpote, quinquefolij radicis: fuccus, leporis coagulum : muftelle caro' fale inue=

20 terata, or in unnbra ficcata, cum uino pota, lac canis ex primo feetu acceptum, capparis, channaleonis albi radix, apii decoctun, polemonie radix, tribuli terreftris fuccus, fmilacis apere acini, fcordium, thlappi, o cratenfe didtamnum. His Arabes, or recintiorum nonnellic aftaneas addunt : iten ponticas nuces, me pila, piftacid, zedoariam, lau=

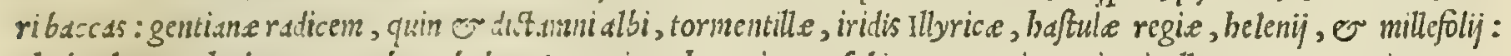
rhabarbaram, bedere corymbos, bolum Armenium, bypericum, fabinam, mumiam, pimpinellam, Imperatoriam, cen= tauriun maius, angehcam, uerbenace fuccum: mures, qui napelli radices depafcuntur, o mufcas grandiores, que cius folijs ui.titant, filipendulan, cxrpobalfamum, nufcum odoratum, ambarum, os in corde ceruirepertum, ev ceruinun cornu, quin $\mathcal{F}^{2}$ monocerotis, urfi teftes, $\mathrm{e}$ arietis, origanum, fmaragdum, lapidem bezahar, er carduum, quen fanctum, wil benediaum dppellant. Et heec de cenfu omnium fimplicium medicamentorum, que contra wene= na pollent, que nobis tum weteres, tum recentiores fcripta reliquerunt, dixiffe fufficiant. De compofitis autem

30 medicamentis illut proferre non dubitauerim, quód fi theriaca legitime parata reperiretur, non effent aliunde peten= da auxilia contra uenens. Set quonian mibi plané difficillinume effe uidetur, ut ea reperiatur, que quemadinodunt eius exigit apparatus, confects fit, cimn nobis defint cimtinomum, ballamum, petrofelinum Nacedonicun, myrrha, folium, chalcitis (quan tamen iamnobis compertan putanus) anoinum, afpalatbus, er caldinus odoratus, que $0=$ mnix perq:àn maxini funt momenti; idctrco nunquam adducar, ut credam uenalem theriacam poffe fibi locum er ufibn illius antique legitiné uenticare: prefertim cinn conftzt ternpore ufque Galeni, quo Romani fumino imperio pos tiebditur, theriacain omnibus nuneris ab jolutsin confict inon potuiffe (ut ipfe Galenus testatur libro prino de anti= dotis) nifíab Imperatoribus. qutliquam non deefent tempore Antonini Cejaris diuites primates, qui eam conficez

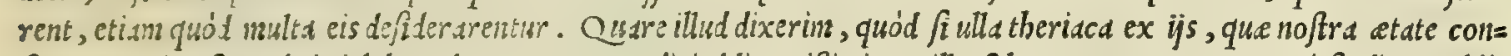
ficiuntur, in ufuns admitti debet, dent operam medici deligentißimi, ut illa faltem utantur, que omni ftudio ac dili= 40 gentia parata fit, clarißimorum er peritißimorun uirorum testimonio : quéf; eo modo experientia comprobata fit, quo docet Galenus libro quem ad Pifonem fcripfit: quin er alio, quem Pamphiliano dicanit. Hoc iten faciant de Mitbridatio, quod nibil minus quin theriaca presist aduerfus uenena, quodq́; 0 facilius parari potest. Qud in re caueant homines ab adulterates theriacis, quas in publicis foris uendunt crrculatores, etf $f$ plerunque ab his, quos eo=

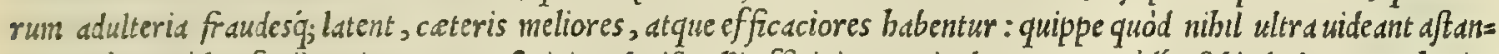

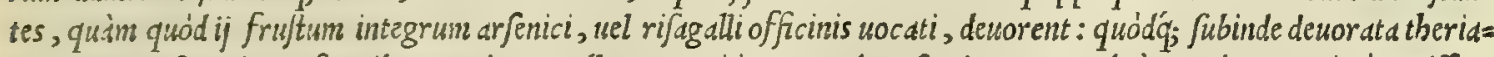
ca, quam postea circumftantibus uendunt, nullum ueneni incommodum fentiant. Quod cum Galenus optimé nouiffet, libro Pifoni dicato, ita fcriptum reliquit. Multe dे fubdolis improbisọ, in boc quoque fraudes funt, ac unlgus fola antidotiopinione deceptum, ab yjs qubus ars est mercenaria, plurima pecunia medicamentum, uel praue confectum redinit. Ceterum ut quifque flagitioforum impostorum fallacias, o dolofas merces euitare poßit, o debeat, nunc

so mibi in animo est ad commune rei publice benefficium corum ingens, ac fcelestum facinus pofteritaki prodere. Nam cum ifti fugzesta afcendunt corain populo, quem dolis capere intendunt, oftenfuri quód uenenum aqué dc panem innoxie fumunt, multis caullationibus, atque injidijs utuntur. Inter quas bas duas babent fraudes, quas modó omnibus aperiam, quas'; ; retinent illi in fuos chariores ( ut ita dicain) lenones. Frimus itaque dolus, quo nituntur buiufmodi fraudulenti

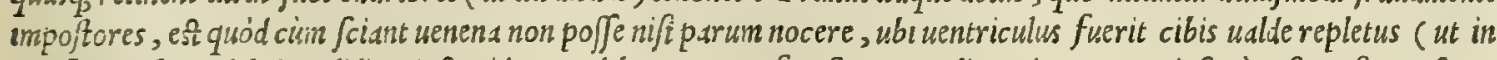
prefatione huius libri tradidit Diofcorides, 0 libro quarto fen fexta retulit Auicenna) priufqudm fuggefusn afcen= dant, ad faturitatem ufque, prefertm estate, lactucas crudas deuorant fale, aceto, ש oleo conaitas : verum olei tan= tumn imponunt, ut feré in eo innatent lactuce. Et quia byeme, maximé urgente bruma, tenclle lactuce difficile paßina inseniri poffunt; ideo earum nicein bis prebent interanea boum prepinguium, quorum tantan comedunt copian, quost uentriculus ueluti tympanus extendatur. Id autem eo conflio factunt, ut hec quidem iurium pinguedine, eo=

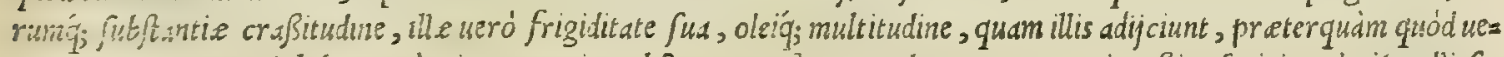

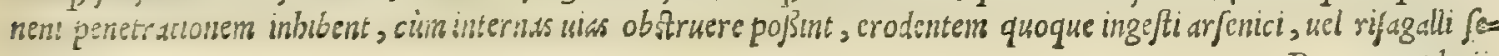


plasijs nocati, acrimoniam obtundunt, or bebetant. Cum igitur uenenum fumperint, quodillis ob preaffumpti alis menti uin, mulam, aut paruamnoxam adfert, nempe quóduentriculus fit tenfus, er pinguedine imbutus, mox fium adulteratum antidotum, quod onnino legitimam theriacam mentitur, afununt, idq́; impune. Quo fit, ut facile pos sted populo aftanti perfuadeant, id effe antidotum omnium preftantißunum contra omnia uenend, quod in untuerfo orbe reperiri poßit. Hisleues unlgi animi perfuafi accenfig;, maiori multitudine, ac impetu feruntur, ut adulter as tam, inualidam, ueramg; mentientem theriacdn emant, quam ij qui in maxima annonx penuria có catcruatim concura runt, ubi plurimum panis gratis onnnibus exbibetur. Itaque cum temporis momento capfulam hac impostura exhaus= ferint, statimí; $\dot{e}$ Juggefto defcendunt circunfor anei, fefég; in bofpitium recipiunt, ubi cum primim fuerint, arfenis cum pauló anté fumptum und cum lactucis aut bubulis interaneis arte quadam exomunt, neque aliud ills dic affumunt, quàm lac, quod tamen fapius alternatim potant, uomuntq́; , or reuomunt. tantum potest in improbis hominibus auri 10 Altera impo cupiditas, ut fponte confultóg; in manifefta uite difcrimina frantur. Fraus altera, quam isti facinorofi perpetrant,

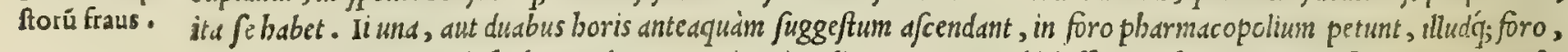
in quo fermonem populo babere uolunt, propinquius eligunt. Atque ubi iufferint pharmacopola fibi arfenici cap use lam adferri, eius duo dut tria fruftra feligunt, prout fibı magis expedire uidetur . que pofted charta inuolui, or in ea dem capfula reponi mandant. Quo facto pharmacopolam rogant, ut cum in fuggefum afcenderint, ar fenicum illud repofitum dare uelint puero, quem ad eun miferint. Forró in forum abeunt uerba facturi, ubi corum fiuriam therias. cam, ad crelum ufque mivis laudibus efferunt admentientes. Ad bec ut rem magis uerifinilem reddant, puerum uelé cir: cumftantibus quempiam ad pharmacopolium mittunt, qui uenenum antea ab ipfis felectum defrat. Interea ingentem capfulam in fuggesto ftantes aperiunt, quam babent uafculs praue illius theriaca plenis refertam, cuius operculo in= tus adberent cera Jubpofita, uaria cuilijdam mifcella fi usta ex faccharo, quod canditum uocant, amylo, alijśg; inno= 20 xijs medicamentis miro quodam artificio conficte, que prorfus of facie, er magnitudine refirunt illa ueri ar fenici fru= Pta, que prius ij in pharmacopolio felegerant. Leuant autem ist hominum proditores operculum à capfula, quó frau= dem melius occultent, in fuggesco ftantes. fiquiden fummo cum artificio internam operculi partem, cui adberent illius mifcelle frusta arfenicum mentientia, uerfus $\sqrt{e}$ trabunt, ne quis fuam fraudem deprehendere poßit. Deinde statim in manu focij, aut pueri, quos doli miniftros babent, capfule operculum collocant : quod eorum alter aperta manu pere quàm eleganter fuftinet, parte plcudoarfenicum continente colum uerfus repiciente: id'q; ne quis doimm intueri pof $f i t$. Interea redit nuncius arfenicum legitimum à pharmacopolio deferens. Alqui iftud accipicns aris captiofe magis fter, ftatim illud populo oftentat longa atque mendacioratione. Qua perfecta ad experimentum tranfit, perpetuo do= losé procedens. Quandoquidem fimulans fibi opus effe expedutis manibus, manicas ex murice, ulel ferico prodicore, quo plerunque ueșiuntur, ad cubitum ufque conuoluit, ea tantum ratione, ut arfenicum uerum, dum bac agit, fuper o= 30 perculo predicto peudoarfenicum continente, reponat, abdatq;: quod cb operculicirculi altitudinem inullo paito int= ferné à circumftantibus uideri potes?. Obuolutis itaque manicis, bracbijság; denudatis, ac tenuilinteolo bumeris ins pofito, iubet aque uel wini poculum adferri, or relicto in operculo arfenico uero, factitium innoxium frauduienta mas nu capit. quod gladio minutim incidit, er uino, uel aque parati cyatbi commifcet, o denique tutißimé bibit. Atque ita fraudem bifce coloribus exornatam pectantibus perfuadet, ut nullus dubitet, quin ille mortifrum ar fenicum han!= Hiftoria frau ferit, quodex medica of ficina delatum fuerat. Memini me olim unum ex his uidiffe, qui uenenum fimitimo do adulte dis. $\quad$ ratum puero exbibuerat fwo: or cum fimularet fe ei open ferre nolle, donec pulfun dunififfet, or in mortis dif crimi= ne uerfaretur, ut fue falfe atque adulterina theriace maiorem compararet exiftimationem : cim praterea prius uer = futum puerum admonuiffet, ut anhelitum compefceret, idq'; ut facies eius colore mutaretur, quin $\odot$ interim oculos obuerteret, er os ac ceruicem contorqueret; ad fe uocauit aftantem nzedicum baud acris callidig; ingenij, in ea ciuita= 40 te, ubi id mibi contigit uidiffe, receptum babentem, qui pueri pul/sun tangeret, ut omnibus testaretur, quód pulfum amififet. Quod cum fecißet bonus ille medicus iam imprudenter factus circulatoris leno, omnibus tefimonium perbi=

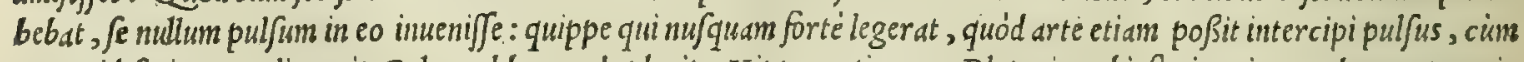
tamen id fcriptum reliquerit Galenus lib. v s. de placitis Hippocratis, or Platonis, ubi fic inquit. Eadem natura in arterijs cersitur, nametiam ip $\sqrt{e}$ perinde ac nerui, aut incife, aut laqueo interclufe pulfu ommi, micationé; orban= tur. Ex quibus fané uerbis tunc comminifci potuiffet, quód facilé buic puerolaqueata eßsent brachia, er proinde in: terceptus arteriarum pulfus, qua per brachium ad manum excurrunt. Siquidem adstringentes laquei ab ijs nebuloni= bus adé callidé fubdoléque aptantur, ut uerfato quodam ferreo globulo fupra cubitum extra manicas latente, ftrin= gantur admodum, ac relaxentur. Id quod facile ab eo fieri potest, qui puerum feminortuun fe fimulantem, brachijs ad jpectaculum fuftinet. Tali igitur fraude adfringebantur fibula, ubi pulfum intercipere animus cffet, laxabantur so autem lenté, cum ian uerfutißinus puer ex theriaca illa affumpta, in pristinam fuam conftitutionem resticui fimula, $=$ fet. Hactenus de fraudibus borum carnificum, quas pluribus profequi libuit, ut quifque eas euitare fciat, dc poßst. Qua de re morbo Gallico quàm plurimum certé debeo: fiquidem unus, isíg, infignis, ex bis qui uenenum innocué dcuo= rare profitentur, cuius offa lues illa non immcrito depafcebatur, cum à me in fanitatcm redigi exoptaret, inter curan= dum, mibi id ab co expetenti, omnes has fraudes, quibus boc flagitiofum bominum genus utitur, ut pecuniam extor= queat, libentißime patefecit. Caterim fraudes, ac mendacia, quibus ij pariter utuntur, qui é diui Pauli profapia or= tos fe predicant, qua tamen de re mentiuntur, bic confultó dimittam . uerùm intactas eas non relinquam, ubi in procef= Antivota no fude ijs differemus uenenis, que morfu, uel iffurelinquunt innumerd exitiofa animalia. Sed ne aliquod pres?ans anti= fra prę̧ätif- dotum defideretur in bis noftris comnenterijs, me probi, ac fidelis medici munere funftum exiftimauerin, $f i$ boc in loco fima cótra ye quedam antidota suthi longo labore comparata, magni ad uenena momenti, defcripfero. que non modó ijs, que per os affumuntur; fed ijs etiam, que animalium morfu, uel idtu eïciuntur, fummo, ac prefentanco fuife remedio comperi. 


\section{In Lib. fextum Diofcoridis.}

Iicet autein bate etatc rari admodim babcantur medici, qui fua pandere arcana uelint, fi quod nacti funt pulchrum o fingulare auxilium; tanen cum mibi confilium ab initio fuerit, mea opera quantulacung; fit omnibus generatim prodeffe, alicnum quidem inbumanumiq, foret, fi modó uel inuidia ucl auaritiu compulfus, aliquid filcntio inuolucrem, quodin artentedica ufuifuturum putem. Prinum igitur antidotum, cuius admirandas in ucnena uires fepius ex= Primi antido

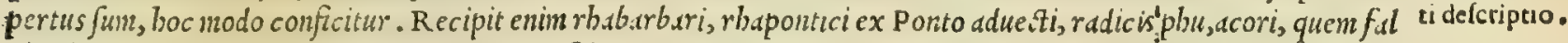
só cal amuan odoratum uocant, cyperi, quinquefolij, tormentille, ariftolocbie rotundx, peonix, belenij, cofti, iridis Illyrice, chamelcontis albi, cuiusq; drachm.s tres. Itcm galange, Imperatorix, dictamni albi, angelica, millefolij, filipendule, doronici, zedoarix, gingiberis, fingulorum drachmas duas: agaricidrachmas tres: libanotidis maris, gentiana, morfis diabolific berbarijs difti, cuiusq; drachmus dus $\mathcal{C}$ femis. Ad bec fominis citrei mali, uiticis, cocci 2o infictorij, fraxini, oxalidis, p.sfinac e fylucftris, hapi, nigelle, peonie, ocimi, irionis, thlapis, feniculi, anmi, fingu= lorum drachmas duas . preterea baccarum laturi, iuniperi, bedere, appere fmulacis, cubeba, fingulorum fefquidracb= man. Foliorun fcordij, chumedryos, chame pityos, centaurij minoris, ftachadis, nardi Celtici,calamintha', rute, mé

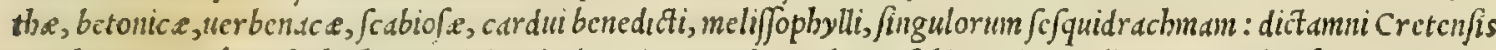
drachmas tres. Jampfucli, byperici, iunci odorati, marrubij, galege, fabinx, pinpincile, cuiusq; dracbmas duas. Ca ricarum, mucum iuglandiun, piftaciorum, fingulorum uncias tres : myrobalanorum enepelicorum drachmas quatuor.

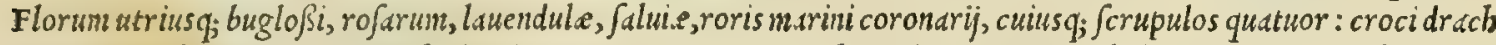
mas tres. Caßjie odorats, quam bodie cinnanomum nocant, drachmas decem. Caryopbyllorum, nucis inyriftice, mas cis, fingulorum drachmus duas er femis. Piperis nigri, ac longi, fantalorum omniü, agalloch, fingulorü fefquidrach mam. Cornu cerui crudidracbmas quatuor : unicorni diacbm.m unam. oßis cordis ceruini, ramentorum cboris, uir=

20 ge ceruine, caftorij, fingulorum fcrupulos quatuor : terre Lcmie dracbmas tres: opij fe quidracbman . margari= tarum orientalium, ramentorum fmaragdi, byacinthi, cor.llij rubri, fingulorum fe fquidrachmam: capbura dracb= mas duas. maftiches, thuris, Ayracis, myrrhe, gummi Arabici, refine tcrebinthina, fagapeni, opopanacis, laferpi= tij, fing ulorum draclumas duas or femis . mo fchi odorati, ambari, cuiusq; drachmam : olei é chaleantho confecti unciă median. Pulueris cordialis temperati, diamargariti, diamo fchi, diambari, electuarij e gemmis, paftillorum capbu= $r \mathscr{e}$, fcille, fingulorum drachmas duas or femis: $p$ ftillorum uipere uncias duas. Succi oxalidis, fonchi, fcordij, e= chi, , bugloßi, meliffopbylli, fingulorum felibram: bypociftidis dracbmas duas. Theriace electe, Mitibridatij optimi, cuiusq; uncias $\int e x$. Vini uetcris albi odorati librus tres: facchari é Medera infula, uel optime mell is libras octo or un cias $\int \mathrm{ex}$. Ex ommibus bis fumma diligentta, or ratione inquifitis, at $q_{;}$felectis fiat electuarium, eo modo quo theria= $c d$, aut Mithridatis antidotum conficiuntur. Sumendiquantit is eft à dracbma una ufque ad tres pro atatc, $O$ con=

30 ftitutione patientis. Atque ita omnibus perfuadere poteris, antidotumboc non folim preftantißimun effe (ut anté diximus) contra omnia uenend, que per os fumuntur, item $\dot{q}$; duerfus ed, qux morfu uel ictu relinquntur; uerim

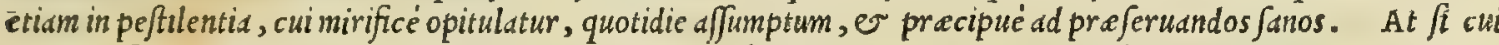
in animo fuerit, ut prefentaneum adferat auxilium, bec faciat oportet. Antidoti prefcripti libram accipiat, libram item fyrupi é citrei mali cortice parati, or libras quinque aque uite uocate, ex optimo, odoratón; uino confecte,

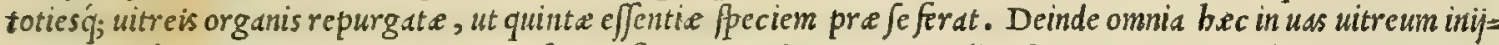
ciat duple à rebus inditis capacitatis. poftea uafis ore ita obturato, ut nullus pirandi meaíus relinquatur, magna cum dexteritate aquam in uafe cum electuario tandiu agitet, donec totum diffoluatur. Atque tum uds ore cera, uel pice obducto in menfem integrum reponat. Quod tamen bis in bebdomada agitari conuenit eo modo, quo antea di= ctum eft : fit enin, ut electuarium facilé refidat in fundo, fi dinittatur. Exatto denique menfe claram aquarn auréó=

40 que colore nitentem, electuario fupernatare inueniet, or que iam onnem illius uim in fe contraxerit. Tum itaque uas ip fum aperiat, $\mathfrak{e}$ in uas aliud item uitre um lympidam aquam paulatim effundat, cuius os cum cera, er membra= na accuratißimé obturet. Nain fi illud dieiffatio apertum fineret, omnis conclufa aqua in auram euane faret. Tan= ta bee aqua uirtute pollet (quod millies expertus fum) ut quatuor drachmarum pondere pota uel per fe, uel cum pa= riodorati uini quantitate, uel fillatitie cuiusuis aqux ad cordis robur facientis, ubi quis iftus, uel demorfius d quo $=$ cunque uenenato animali, in tanto mortis difcrimine uerfaretur, ut uocem, uifun, ac reliquos feré fenfus amififfet; agrum ingenti adfantium admiratione à longo ueluti fomno excitat. Quin er uomitione plerung; plurinam infe cto rum humorum copiam exhaurit. Cuius rei exemplo (preter alia innumera) nuper mibi fuit prafecti oppidi vipaci uxor, quam à uipera in dextra manu demorfam, o iamiam de naulo rationem cum Charonte inituram, bec aqua in uitan à morte reuocauit. Id quod etiam pauló póft contigit cuidam mifere sclaue ab alia non dißsimili wipera in ma= so nu demor $\int e$. Hec idem fimiliter preftat contra uenena, que per os fumuntur: fiquidem ea adeó tenuis effentix, ef $=$ ficax, er pentetrans eft, ut momento uifua in omnes corporis uenas permeet. Quin er eofdem prabet effectus in $a=$ lios quadm plurinos morbos, quos breuitatifudens pretereo. quandoquidem prudentes, or periti medicl, habita bu= iufce uirium exacta ratione, eam adbibere poterunt, ubilegitimé conuenire cenfebunt. Porró antidotum alterum generofum, pariter $\odot$ fingulare, oleum illud eft, cuius fuperius libro fectundo capite de fcorpionibus, item quarto ca=

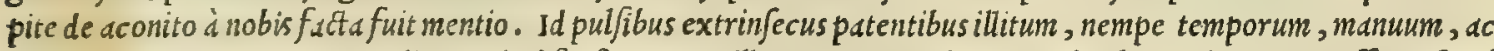
pedum, quitetian extime cordis parti ad finif tram mamillam, repetita alternis tribus horis illinitione, efficacißime - Juecurrit ommibus uenenis per os fumptis, que tamen ex crodentum genere non fuerint. Similiter uiperartim, appi= dum, $\sim$ cuikf cknque deniq; uenenati animalis morfibus fingulari auxilio eft, ut in proceffu latus explicabimus. Vt atem omnes intelligant quaim maximum fit in me iuuand pofteritatis ftudium, modum, quo illud conficitur, hic de= fribere nongrausbor. Sumantur itaq; ineunte menfe maio, quo tempore confici debet, olei communis centum anno= run, fin minus fui temporis uetuftißimi libre tres: foliorum byperici uirentis manipuli tres. Olcum in uas uitreum

Potio expre dicto antidoto.

Alterius anridoti deferiptio,\& uires.

$$
\text { PP } 2 \text { duple }
$$


duple a contento capacitatis imponatur, in quo bypericum aliquantulum anted contufum infundatur. deinde us ce= $r a$, o membrana obturetur, o medium in tenuißimam arenam condatur, loco ubi tota die infolaripoßit, at $q$; inibi finatur ad decimum, ucl duodecimum diem $u \int_{p}$. Cuo exacto tempore, mergatur uas in calentis aqua balneo ad uigin ti quatuor boras : nox olcum ab herba exprimatur. Hoc facto fumatur byperici,chanedryos,caliminthe, cardui bc nediati, fingulorum manipulus. Que omnia prius diligenter contufa oleo admifce antur, ac fubinde uas in predictun mergatur balneum tribus continuis diebus. Extrabatur deinde, $\mathcal{O}$ ab incoct is herbis exprimatur. Polt bac accipian tur florum byperici manipuli tres, qui à caulibus probè repurgati, or contufi in predictum oleum infundantur, ac in idem balneum per triduum reponatur. poft id tempus eximantur, $\mathfrak{F}$ ut prius exprimantur. Idem fiat ter, aut qua ter, $u$ fquedum olcum fanguineum colorem referat. H is peract is fumatur bypericum, quod iam dcfloruerit, $e^{\circ}$ ab eius cacumlne grand illa uiridia excerpantur, que hordeaceis granis fimilia deprcbenduntur, in quibus fcinen continetur. Ex ijs itaq; tres confertim manipuli decerpantur: qui poftea tufi, or uino meraco albo aliquantulum perfufi in olcum predictum infundantur, or cum eodem uitro, in arena fepulto, odto diebus continuis infolentur. Quo tempore trane fatto tridui patio in balneum immittantur, póft colentur, or modo predicto exprimantur : tertio, aut quarto fimlis ter dictum femen in oleo macerari debet, donec $\downarrow d$ ob f curi fanguinis colcrě reprafentet. Ad bac fumatur fcordij re* centis, calaminthe, centaurij minoris, cardui benedicti, werbenaca, dictamni Cretenfis, fingulorum medius inanipu= lus : tundantur omnia, mergantur in oleum predictum, or uas in balneum iterum imponatur per biduum continuun, dein colentur, of exprimantur, ut fuprà. Poftea fumantur zedoaria, radicum dictamni albi, gentiana, tormenillle, ariftolochia rotunda, fingulorum drachine tres, fcordij manipulus. Tundantur item omnia, infundantur, er immit: tantur in balneum, ibig; permanednt tribus diebus continuis : colentur deinde, ex exprimantur. Infundantur denuo ftyrac is calamiti, la eris, cuiusq; dracbme fex, baccarum iuniperidracbme quatuor, melantbij draclome due, caßixe 20 odorate (cinnamomum officine uocant) draclmme nouem: imiciodorati, cyperi, fingulorum fefquidrachma: fanta= lorum alborum femuncia. Tundantur omnia (ut pluries de alijs ditum eft ) ev in idem oleun infundantur, or per tri duum continuum in balneum macerentur, demum colentur, or exprimantur, modo quo anté dictum eft. Poftremó adfint oportet trecenti fcorpiones uiui diebus canicularibus collecti. Ii in uafe uitreo conclufi, cineribus calidis $\int u=$ perponantur, er cim eos pre calore fudare, atq; irafci conftet, omne iam dictum oleum calidum fuperinijciatur. sed aduertendum eft, ne id adeo feruens fit, ut uas difrumpat. obturato ftatim uafis ore in balneum tribus continuis diebus contineatur: deinde coletur, $\sigma$ exprimatur. Proiectis intere a corpionibus, rur fum in ole ü infundantur rhs barbari laudatißimi, myrrbe communis ufus, aloës bepatica, fingulorum dracbme tres : nardi Indici dracbme dus, croci drachma una: theriace elect e, electió; Mithridatij, cuiusq; femuncia. Que ex bis tundëda funt, terantur, mox ultimó infundantur in oleum, quod per triduum continuum contineatur in balneo. Quo facto oleum non amplius per $=30$ coletur, fed deinceps recondatur, perinde ac opobalfamum. quippe quod mirandum fit remedium ad iam dicta ucne= $n a$, e prectpué contra napellum, quo infecti fuere, ut experimentum ficret, Corfi illi duo uiarum ob $f \int f o r e s, ~ q u o=$ rum biftoriam fuprà retulimus libro quarto in aconti mentione: ad cuius lectionem, ne idem bis repetamus, cos reij= cimus, qui eius defiderio capiuntur. Preter autem Mitbridatium, antidota alia duo generofa Dio fcoridi p:obantur in prefenti prefatione, unum fcilicet quod é fcinco, alterum quod é fanguine nuncupant: fed quod is eoril conficien dorum rationem tradiderit, nufquam hactenus reperi. Quamobrem illa duo in multor um gratiam bic ad]cribere, non alienum fore duximus, co tamen modo, quo lib. I I. de antidotis $i$ Galeno feriatim de fribuntur, ubl bac $\int c r i p t a$ reli=

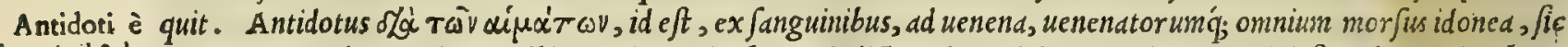
fanguinib' de habet. Piperis longi, piperis albi, acori, croci, phu, mei, dictamni Cretici, ammoniaci, agarici, fingulorum drachmas
fcriptio.

duas : amomi, opobalfami, feminis rute fylueftris, cymini Aethiopici, anifi, fanguinis anatis maris, or famine ficci, fanguinis bedini, fanguinis anferini, feminis naji fylueftris, fingulorum drachmas tres : gentiane, trifolij, florum iun ci odorati, thuris, rofarum ficcarum, fingulorum drachmas quatuor, petrofilini drachmas quinc; , polij Cretici tens tundem, cinnamomi drachmas fex, florum fcordij drachmas octo : myrrha, nardi, fing ulorum dracbmas decem, cro: cidrachmas duodecin, caßia dracbmas octo. Omnia bec diligenter contufa, ac per excufforium cribrum traiecta melle Attico deßumato, commifcebis, commiftá; in argentea pyxide repones, at $q_{;}$bac ut maximo medicamento ute= Antidoti c̀ ris. Caterim que é fcinco temperatur antidotus, d Galeno bunc in modum redditur. Antidotus Mitbridatis Eupds

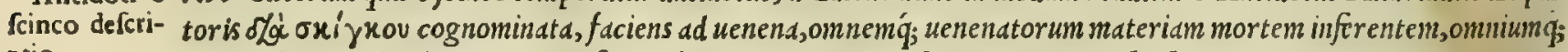
ptio. uentenoforum animalium ittus, conficitur bac ratione. Scinci, fagapeni, acori, phu, byperici,acacia, iridis, mei, gum= mi, fingulorum dracbme due : rofarum ficcarum, gentiane, cardamomi, fingulorum drachme quatuor, opij oboli duo, ftyrac is dracbme octo : polij, caßie nigr.e, fe elelis, bdellij, bal fami, piperis albi, fingulorum drachme quinq; $\mathcal{O}^{-}, 50$ oboli duo : fuccibypociftidis, opopanacis, myrrbe, thuris mafculi, caftorij, piperis longi, cypheos, foliorum malaba= thri, fingulorum dracbme fex: fcordij, cofti, florum iunciodorati, galbani, refine terebinthine, fingulorum draclis me fex èr oboli duo : nardi syriaca, opobalfami, thlapis, dauci Cretici, fingulorum draclime fex er oboli tres: cro ci, cinnamomi, zingiberis, fingulorum drachme fex e oboli duo : fucciglycyrrbize, agarici, fingulor um draclume feptem er oboli tres. Conftruitur autem boc modo. Cyphi, bypociftis, fagapenum, gummi opium, flyrax, opopi $=$ nax, uino Chio macerantur die noct úq; , quodd penitus diffoluta fint. Reliqua ueró interim contufa tenui cribro ex=

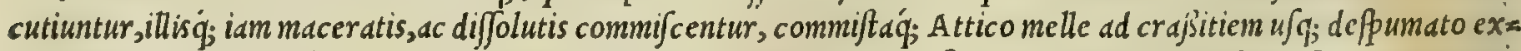
cipiuntur, opobal famóq; fuperimmiffo. demum in uas argenteum transferuntur, atque ad multos ufis reponuntur. Datur autem ex bac antidoto quantum ager tolerat. Hec de duabus antidotis, quas non inmerito quidem probauit Diofcorides, quasq́; ut efficacißimas in aliarum cenfum retulit Galenus, atque defcripfit. Sed quoniam (ut fuprà in theriace mentione dictum fuit ) multa nobis de funt fimplicia medicamenta, que in eis expetuntur; idcirco non uideo 


\section{In Lib. fextum Diofcoridıs.}

quomodo poßint legitinc confici, nifi ijs uti uelimus, qute cormn uiccm fupplent, ita ut unum fimplex medic amentum in alterius locum fuccedat. Id quod medicorum, ac fepldfiariorum plerisq; ficriadfolct. Quorum fententie ct/i cui= pian uideretur Galenus adftipulari, quippe quód feriptis tradiderit in cinnamomi defictu duplum caßsie fubijcı poffe; non tamen proptcres inde colligi poteft, quód idem ficri poßit de quocunq; alio fimplici medicamento, quod defide= retur, ut quidan exiftimant, non recté, meo quidem iudicio, Galeni mentem affecuti. siquidem is fecus de bac re diffe git libro prino de antidotis, ubific inquit. Quod ad caßsim ucró attinet, ed me commemorare nunc opus cft, qux in multis de medicina libris foripta funt, duplum caßex fiquis cimnamono cgedt, inijcicndum. Hoc dictum irridens Saty= rus magifter mcus, unatm cx Quintifacetijs ipfum effe dicebat, affeucrans cos, qui duplum caßia imponcre iubcut, $f 2$ cimanomo carcamus, fimilia llis fac ere, qui nos cenfent, $f$ q quando Plalerno caruerimus, illus quod in cauponis uen

o ditur, duplicata menfur a bibere: fíg; panis filigineus defit, fur furacci duplum comedere. Mubi ucró bac Quinti face tia, fi de re una quapiant, qua per fe fola uti uclimus, afferatur, uera irreprebenfibilisq́; widecur: fin de re, qua in $0=$ cietstem multorum uciuist, non eft codem pafto uera. Nam criufcunq; quod folum corpori admoucri debct, ut pu= ta thus, abfinthium, iris, gentian., uel id genus alia aliqua medicina, fiquis minus boni duplum loco praftantißimi ac= cipiat, o corporiuel extri, uel intri admoucat, duplicato etiam noc cbit: at fi multis aliquod optimum commifcen=

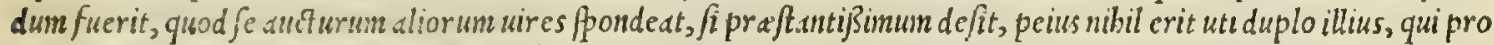
prictates ciufdem generis babeat, criamfi deterius boc illo uideatur. Caßsia quiden cinnamomo genere proxima ufq;

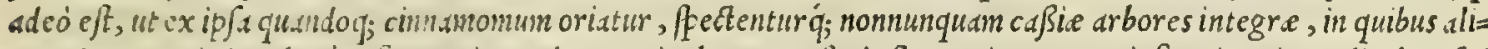
qua cintmomi uirgulte é cafie ramis prodeant. Simle autem iftud eft non uino aut pani, ficuti Quintus dicebat, fed uite functionibus in extruend.e domo, in fabricanda nati, in tollendis, o tranponendis oneribus, in omnibus dentiq;

20 wite afrionibus, in quibus quod per.gendun erat ab uno bomine robufto, fi $a b f i t$, d duobus imbecillioribus perficiu= tur. b.ec G.denus. Ex quibus uerbis onmibus palin cft, Galenum non affentire, ut in compofitis medic amentis unum fimplex pro alio Jupponatur, nifíf ex ijs fint, qux eandein naturam fortiuntur, ut caßia, es cinnamomum. Quarc illud inde colligesdun c/)e putanerim, quód perperàn faciant ij, quirembane aliter intelligunt. Porró o illan anti= dotum, que iunipert bsccas, terramó; Lesniam recipit, fummopere laudauit Galenus, amnó; lib. I I de antidotis me moris prodidit, bifee uerbis. Antidotus, que exbibuta accipientem tutum à uenenis reddit, fic babet. Bdccarum iu= niperi drachinas dus, terre Lemin drachinas duas er obolos duos. Hac ubi in puluerem redegeris, olco, aut melle commifecbis, o repones: atque cim opus fuerit, ex aque mulfe cyathis duobus quantum eft aucllana dabis. Hac an= tidoto Nicomedes rex utebatur, fi quando fupectos babuiffet, qui fe uocarant. Nam fi uenenum non fubfit, quieta manet: [in adfit, nue can concitat, o cuomere cogit, ita ut uenenum quoq; cum antidoto reijciatur. Sed bxc bacte=

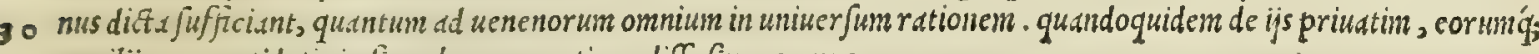
akxilijs, $\mathbb{C}^{\sim}$ antidotis in jingulorum mentione diffufius agemus.

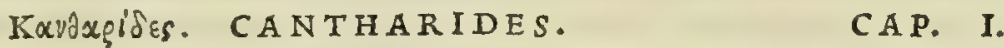

Qv I B y s datæ funt cantharides, figna eueniunt grauifsima. Ab ore enim ad veficam ufq; cuncta erodi fentiuntur : picem, aut fimile quiddam cedrix refipiunt : dextra præcordia inflammantur. vrinam ægrè reddunt, \& fubinde cum lotio fanguinem emittunt : ftrigmenta non fecus atque dyfentericis, aluo deferuntur: faltidis urgent: animo linquuntur, obortaque uertigine concıdunt. poftremò mente abalienantur. Ergo antea quàm tale nonnihil accidat, dato oleo, aut fupradictorum 40 aliquo, uomere cogantur . mox vbi uomitione plurima reiecerunt, halicæ aut oryzæ, tragi aut ptifanx cremor, aut decoctum ma!uæ, aut feminis lini, aut fœni græci, aut radicum althæx, quam Latinus fermo ibifcum appellat, clyftere infundatur . Præterea nitrum eisdem dandum, ex hydromelite, ut qux ftomacho adhuc, aut inteftinis adhærent, eluendo excernantur, ac defcendant. Qux nifific difcutiantur, ingefta in aluum ex nitro aqua mulfa, uacuari debent. Detur deinde uinum, aut paffum, in quo pineoli nuclei, aut cucumeris femina contrita fint, aut ex lacte, aut mul $\sqrt{a}$, aut anferinus adeps in paffo liquefsctus. Inflammatx autem partes, hordei farina cum mulfa decoeta perungantur. Ab initio admota cataplafmata nocent, quòd citatus ab eis calor, illapfum uirus ita remoratur, ut in prin cipes fe partes infinuet : ipfa tamen interiecto tempore, moleftifsimis inflammationibus opitulantur, vtpote quæ dolores \& permulceant, \& leniant. Tum ubi corpus calfaciente olco inunctum fueso rit, in folium defcendere oportet, ac lauare, ut per cutem fummam, quæ corpori noxia inhæferunt, etiam excernantur. Et deiectiones multifariam moliri oportet, ne affectus infigatur, \& ftabilitatem capeffat. Gallinaceis carnıbus, \& hædinis, aut fuillis catulis, maximè pinguibus, \& tenerrimis, ac cum lini femine coetis, uefci debent: fiquidem aluum cient, atque tenenorum acrimonias hicbetant. Vinum dulce liberalius ebibatur. Prodelt thuris cortex, \& Samia terra, quæ after appellatur, fi quaternæ fingulorum drachmæ cum paffo fumantur. item pulegium ex aqua tritum : irinum, aut rofaceum, cum rutæ decocto : recentes uitis ramuli, cum paffo detriti. Longè omnium potentifsimè antidota auxiliantur, cum aqua mulfa, drachmis quatuor pota.

C A N T H A R I D V MI tumbifforiam, tum etiam facultates fuperius libro fecundo, ubi o earum piaturam ex= bibunus, adeo dififusé làcég, tradedimus, ui fuperuacuum ducerem boc in loco plura de eis remernorare, nifi nunc de earammalefic 10 noxia ui notis differendum effet. Curn igitur Cantharides exculf aciant receffu quarto, o exic=

Cätharidum malefica \&zno yıa uis. 
cent fecundo, nil fanè mirum fuerit, fi erodant, ulcerent, er denique fumentes interimant. Nocent priudtim uefic $e_{\text {, }}$ omnbusq́; urine inferuientibus membris, non modó baufte; fed quandoque etian exterius illitie, ubi exulcerare fit opus : prefertim cum amplis admifcentur cataplafmatis, locisq́; illinuntur uefice propinquioribus: nempe coxendi= cum articulis dolore diutius tentatis, uel pubi, uel renibus, uel teftibus. Quo fit, ut qui bas baufcrint, exulcerata in= de uefica, magnis in urina reddenda excrucientur dolorbib. quanquam preter id omnia in uniuerfum ladant uifce= $r a$, quód fuapte natura erodant, o poftremó necenn inferant: nang; fua uenefica, o perniciofa ui deradunt internos Symptomatú mealus omnes, qubus obulant. Proinde nec mirum fi cum lotio fanguinem extrabunt, erofis ab eis $u a /$ is : neque $f i$ caufx. $\quad$ quando (ut recentiorum quidam dixere) penis ipfe, teftes, pubes, or uefic ceruix intolerabili inflasmmatione uexen tur. Hinc enim plerunque euenit, ut qu bauferint, urine ftilltcidio afficiantur non fine intolerabil ardore anguftiá,.

Caterim picis, ơ cedrix odor, quem à cantharidibus malé affecti guftu, eo olfactu percipiunt, aliunde, meo qui = 10 dem iudicio, non prouenit, quaim a uxporofis bumoribus in uentriculo, er iecinore aduftis, inten a buiufce ueneni ca= liditate. Ab ea fiquidem dum exuruntur bumores, quedam inuicem fit commiftio, que proprian tum guftum, tum odoratum inficiendifacultatem adipifcitur. Inflammantur preterea dextrilateris pracordia . quippe cim ueneni uis in iecur facilius, qudin in lienem excurrat, mirum utiq; non eft, fi concitatis ibi inflammationibus, potius dextrum, quim finiftrum xgrotet latus. Nec alia ratione fit inde fluxio dy fenterice finilis, fecum deferens inteftinorum ra= menta, quàm quód cantharides ip $\int e$ ad linteftina defcendentes acerrima fua ul, ea exulcerent, or abradant. De=

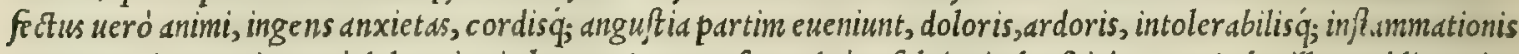
exuperantia: partim ueró deleteria ui plsarmaci, que ufqueadeó re foluit uitales piritus, o imbecillos reddit, ut ins de affecto corde, bac tam feus oriantur fymptomata. Cuin er ob id uertiginofi fiunt, delirio, amentiáq; capiuntur; qui eas fump ferint, quòd ueneno $x$ exhalationes, que à colliquatis bumoribus in inferioribus membris furfum in cere $=20$

Cantlaridü brum fermitur, adeó ipfum inficiunt, ut facile animales facultates corrumpantur, ratioǵ; ip a pereat. Sed ut bis $0=$ veneni cura - mnibus fuccurratur incommodis, primùm fané neceffariun fuerit (ut etiam Diofcorides inquit) canth.aridas ip as ex= tio. tra corpus ducere, crebris excitatis uomitionibus, ys nimirum medicamentis, quorum in buius libri prafatione me= minit Diofcorides, at q; etiam nos mentionem fecimus in noftra in eam longa commentatione. Quinetidin acribus clyf= matis opus eft, ut per bec deuocentur, qua ad inteftina defcenderunt. Fit enim ut saliaufis é corpore cantharidibus, non magno poftea ncyotio accidentibus, inconnodisi; prefidia adbibeantur. Quandoquidem exulcerata uefic $R_{2}$ cui Juapte natura plus nocent cantharides, quan cateris internis uifceribus, fuccurritur refrigerantibus, lentis, $\mathcal{O}$ pin $=$ gubus fimul miftis medicamentis. frigida nanque inflammationes extinguunt, mulcent'́; earun dolores: pinguia ueneni acrimoniam obtundunt: lenta ueró, ac vifcofa cum internis partibus pertinaciter inbarcant, non modó diu me dicamenta in exulceratis retinent locis; fed etiam fanas partes muniunt, ne uencui uim admuttant. Idcirco ad hoc mi=

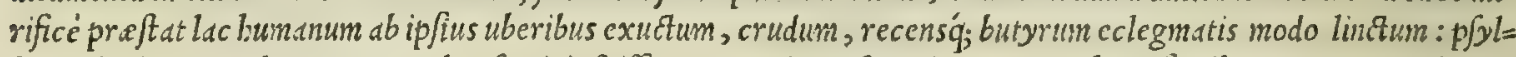
lij, cydoniorum malorum, of malux feminis ßiffanentum: item ferapium ex nymphex floribus, $\sigma$ purpureis uio =

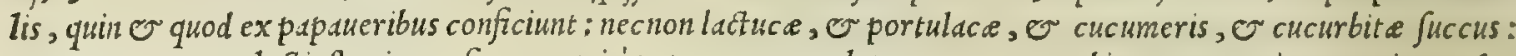
preterea cremor, lactis peciem referens, qui é papauerum, melopeponum, cucurbite, cucumeris, anguria, $\sigma l_{d}=$ auca femine exprinifolet, affuf uiolarum, aqua, aut radicis al theee, aut folani, quod ueficariam, or halicacabum nocant . cuius etiam rubentes bacca decem, uel duodec im numero frata, or ex aqua portulace, uel ptifana bordea= cea pote, boc in negotio praentaneo rentedio profunt. Facit ad boc er amygdalinum oleum, quod filicet ex dulci= bus elicitur nucibus, unciarum fex pondere baufum. Huic autem prefertur, qkód é recentibus pineis nucibus expri= mitur. Sed omnium pr.eftantißimum ef , quod e femine albi papaueris eximitur. quandoquidem boc prater id quod tanquam pingue plurimum conuenit, poteft fuapte natura inflammationes extinguere, wencni acrimoniam retunde= re, ơ dolores quantúmuis uehementes fedarc. Sunt etian qui proferant aquam, que feruentis balneicalore uitreis inftrumentis elicitur è malua folijs, ibifciradicibus, or recentibus cucurbita ramentis: quód propria ui urine ardo= ribus opem ferat, e inteftinorum inflammationtes repellat. Porró fuccurritur exulceratis inteftinis, ijsdem fane medicamentis, quibus ad dy fenterian utimur : nempe pinguiun carnium iuribus clyftere infufis, addito birci, ceruiq́; adipe : om omphacino rofaceo, plantaginis aut portulace aqua prius cloto. Probibentur balitus cerebrum petentes, diffoluuntur'q; alfumptis antidotis, que uenenis refiftunt, O bumores putre fcere non finumt . quinetidm cataplafma= tis $\mathrm{ex}$ frigidis, repellentıbusq́; fuccts, finctpiti, or coronali future illitis. In funma frangitur, atq; demolitur ueneni uis, Diofcoridis teftinono, u.lentibus antidotis, ueluti theriaca, aut Mitbridato, aut (ut fcribit Galenus lib. I x. fin= plicium medicamentorum capite de terra Lemmia ) eo antidoto, de quo $\sigma$ nos fuperius locutifunus, quod fit ex ip $\int a$ Lemnia phragide, e iuniperi baccis. Profunt infuper cpitbesnata cor roborantia, item $\dot{q}_{\text {; }}$ inunctiones, que ex odo= 50

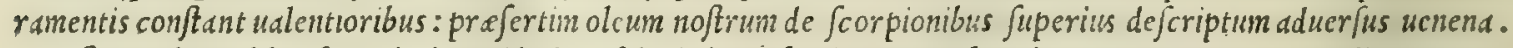

Cótrouerfia Refert Galenus libro fecundo de antidotis Afclepiadis autboritate, cantharidas proprio ueneno remedium or an= inter Gręcos, tidotum e fe, $\int i$ earum pedes,, alx trita cum inclle eclegmatis modo paulatim affumantur. Id quod etiam afferuit li= \& Arabas. bro x r. fimplicium medcamentorum, ut fuperius libro fecundo in carum quoq; mentione retulimus. Hoc idem fori= bit Aètius à Galeno fortaffe mutuatus lib. x I I I. cap. $\mathrm{x}$ L Ix. fic inquicns. A t ueró contrariae affectionis ratione, quantum nibil aliud his auxiliantur cantharidum alx, or pedes cum pafjo pota. hec Aëtius. Veruntamen cum buiu= fcemodiremedium fupicione non uacet (non propterea Galcm teftunonium reijciendum putauerim) ctmn'q à multis

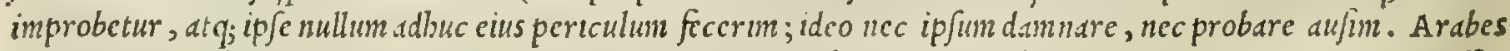
nanq; pro certo babent, onme uencnum, quod canthardibus in/it, carum tantum alis, pedibus, or capitibus ineffe. Quare cum cantharid as fuis inmifcent medicamentis, tam intus fumendis, qudm cxirà adhibendis, iubent contra Gra= corun fententian, ut captta, ale, ac pedes abjctndantur. quanquan credendum arbitror Arabas Hippocratem per= 


\section{InLib. fextum Diofcoridis.}

peram intellexiffe, ut ultimo commentario de ratione uictus in morbis acutis feribit Galenus. Sed quoquomodo res fe babeat, ambarum partiun placita in medium attulimus, ut unufquifq; fum in bac re fequatur fententiam. Nos ta= men fupecta medic anenta fenter dinittenda iudicaumus, atq; bis utcndum, de quibus inter probatos authores, edoctos uiros conuenit. Sunt ć uulgaribus, qui ad cpotas Cantburidas acetum continendent. Sed id equidem probare non aufim, quod antiquorum, recentiorumí; repercrin neminem, qui foripis tradiderit acetum contra cantharidas auxiliari. Quinctian medentur urine drdoribus, or pudendorum influmnationibus, non tantum ca medicanenta, que per os fumuntur; fed ea quoq; que exterius illinuntur. Preftant igitur ad hoc rof,aceum, omplacinum oleum, uiolaceum, o quod fit ex nymph.ex floribus : iten quod cx papatuerum femine conficitur, quod '́; ex ijs paratur fru= ctibus, quosum plantam appell.nt aliqui Balfaminam, alij ucró Caranzam, cuius biftorian, ac facultates fuperius li=

20 bro quarto defcripfinus, cun de uite nigra differcremus. In qucm ufum bec non modó exterius illinuntur pubi, peni, or teftium; fed etian in pudendimeatum clyftcre inijciuntur, prafertim addito oui albo diutius rudicula agitato,aut fedifucco, aut byofcy dmi, aut portulaca, dut lactuce. Maximé etian prodeffe compertum cst, fi ad umbilicum ufq; dusbus aut tribus boris federint patientes in aque tepentis balneo, cuibifciradices, malue folid, er fonind, wioldrumflores, $p$ fyllij, cydoniorum m.lorum, fanigraci, o lini femen, bordcum, or byofcyamum, or id gen!s alia fue= rint incocta. Poftremó ad omes buius ucneni reliquias, qux corpori befißent, eradicandas, la $\int a_{\text {q }}$; membra robo= randa, $\sigma$ ad priftinun temperamentum reftituenda, probatißinum erit medicamentum bis in die inane, er ueperi, clectarium mox de fcribendum, uncie pondere ex bundno, ucl caprillo, uel afinino lacte potum. Fit autcm boc mo= do. Accipe nucleorum pincorum uncias tres: nucis Indice rccentis uncias duas : piftaciorum $\int e f$ cunciam: $\int e n i n u m$ melopeponum, cucurbite, cucumeris, papaueris albi, inalux, fingulorum uncic dimidium: corticis arboris tburis,

20 drachinas tres: inargaritarum, coralliorum amborum, fantalorum alborum, fingulorum fe fquidracbmam: fuccigly= cyrrbize drachmas duas: baccarumiuniperi drachmam undm: gummi Arabici fe fcunciam:terre Lemnie drach=

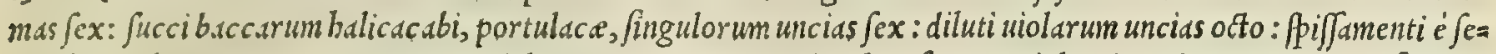
minibus malorum cotoneorum, aqud uiolarum maceratis, uncias $\int e x$ : ferapij uiolacei uncias quatuor; de floribus nymphex, de papaucre, cuiusq; uncias decem. Que terenda funt, conterito, deinde commiltis omnibus fecundum $\int e=$ plaliariorum regulam, electarium facito : quo utitor, ut anté diximus.

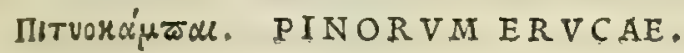

\section{CAP. II.}

I I qui erucas pinorum hauferint, illico dolor in ore \& palato exoritur : vehemens alui, lingux, 30 ac ftomachi, inflammatio torquet : inteftina dolor excruciat, ita ut pruriginem fentire uideantur: corpus totum exaltuat : faftidium urget . Quibus eft fuccurrendum remedijs, quæ deuoratis cantharidibus dantur. Peculiariter tamen pro fimplici oleo \& irino, melinum, quod è cotoneis pomis $\&$ oleo temperatur, accipiemus .

\section{Bovं๘̧Rsis. BVPRESTIS.}

\section{CAP. III.}

Q v I bupreftin biberunt, non difsimile nitro uirus fapiunt: ftomachi, uentrisqúue uthemens dolor in fequitur : tam uenter quàm ftomachus mirum in modum, ut in aqua inter cutem, difflatus, inturgefcit vniuerfa corporis facies contenditur : vrina fuprimitur. Quibus eadem, qua potis can-

40 tharidibus auxiliantur. Priuatim polt uomitus, \& uacuationes, quas clyfteribus molimur, aridæ ficus profunt: item earum decoctum, ex uino. Vbi uerò iam ferè pericula inclinantur, Thebaicarum palmularum cibo, aut earundem tritarum in mulfo, aut lactis potu, iuuantur. Pyrorum etiámnum omne genus effe, \& lac humanum bibere, conuenit.

D E B V P R E S T I B V S, e pinorum erucis fuperius libro fecundo fatis differuimus, quantum adearü bi= ftoriam attinet: nunc harum uim ueneficam profequimur. Hec igitur animalia etfi pota, aut aliis in uentriculum in= gefta, quedam fymptomatd, or incommoda pariant, ab bis plané diuer $\int a$, quse ab epotis cantbaridibus inferuntur; tamen er ip fa eandem expetunt curationem, eadem'; poftulant medicamenta, quibus in epot is cantharidibus utimur. Verüm aduerfus hec quoq; nonnulla propria, peculiariá, habentur antidota, quorum cùm latius meminerit Diofco= 50 rides, non eft cur nos de ijs plura dicamus.

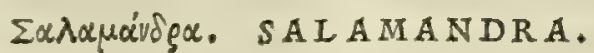

\section{CAP. IIII.}

SI S A L A M A D R A M hauferunt, lingux inflammatio confequitur: mens, \& fermo prapeditur : tremor cum torpore, aut horrore quodam, ac exolutione accedit: partes nonnulla corporis liuoribus circunquaque fugillantur : frepeque, diutius immorante ueneno, putrefcentes defluunt. Quibus præftabimus cuncta, quæ potis cantharidibus. Pecularia uerò remedia, refina pinus, aut galbanum ex melle linftum, \& aiugre decoctum, in quo nuclei pinei conterantur : urtic $x$ quoque folia, cum lilijs \& oleo decocta. Profunt etiam oua teftudinis marinæ, aut terreftris cocta : item ranarum ius, cum quibus eryngij radix incoßta fit. 
Salamandrx $\quad \mathrm{N}$ o $\mathrm{N}$ folun ucneno inficit, or necem adfert Salamandra ficca, or in puluerem pota, liel clam cibis admifta; fed uenefica natu etian mor $\int u$, uiperarum modo, ceterorum'́, ferpentium uenenum eiaculantium. Quin or fructus, or berbas inficit ra. tun falius quad.un, tun nucofa pecie, que $c$ toto cius corporc fudat, nagno de guft antium difcrimine: fiquidem ple= rique reperti fint, quiboc tantum ueneno periere. Proinde mirum non effe uidetur, fi recentiorum quidam tradide= runt, integras quandog; interijfe familias: quód aquas bibifent, in quorum puteos forté salamandra ceciderat: uel quod panem tantim ccmediffent furno incodum, qui lignis ed infect is concaluerat. Quibus tamen non ufquequaque credendun existino, cum ignium ui uenena omnia abfunantur. Sed potius adftipulandun fuerit Plinio, qui libro X X I X.cap. I I I I.non ex pane furnis incolto, in quibus ligna falamandra ueneno infecta, accenfa fuiffent, quosdame ian fuiffe necatos prodidit, fed ex panis crufta lignis inafata pede tantim falamandra contactis, ut eius uerba te= stantur, cum inquit. Inter omnia uenenata falamandra fcelus maximum eft. Catera enim fingulos feriunt, nec plu= $\mathrm{x}$ res pariter interimunt, ut omittam, quodd perire confcientia dicuntur bomine percufo, neq; dmplius adinitti ad ter= ras. Salamandra populos necare improuidos poteft: nam fi arbori irrep/it, omnia poma inficit ueneno, vo cos qui ederint, necat frigida ui, nibil aconito diftans. Quinimo fi contacto ab e ligno uel pede, quo crufta panis incoquatur, idem ueneficium eft, uel fi in pute um cad.at. Quippe cum faliua eius quacunq; parte corporis, uel in pede imo reper: $\int a$, omnis in toto corpore defuat pilus, bactenus Plinius. His igitur, quibauferint (ut Aétius eft autbor lib. X I I I.) preter ea que à Diofcoride fcribuntur, macule in totum corpus exoriuntur albe, deinde rubea, poftremó nigre, Salamandre que tandem putrefcentes, uniucrfun deglabrant corpus. Sic uenenat is fuccurritur (ut Diofcorides ait) ijsdem rez uenevi cura- medijs, que ad cantharidus preftant. Quod tamen diqquibus minimé uidetur rationi confonum. quandoquiden cum tio. falamandrä uenenum maxiné frigidum, bumedun' fit, canth.sridum contrà calidißimum, er exiccans, nullo quidé patfo confentaneum cen $\int e n t$, quód ijsdem utrisq; fuccurratur medicamentis. Verim bis illud recté, mea quidem $\int e n=20$ tentia, reponderi poteft, quód ubi Diofcorides falamandris cantharidum commendat medicamenta, de generalibus, que in uniuerfun fiunt, duntaxat intelligit, nempe ut quìn citó fieri poßit, uenenum é uentriculo, or inteftinis ex=

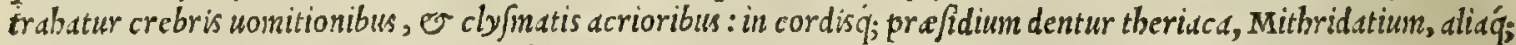
generofa antidota, que pota cor ip um a uenenatis omnibus tuentur. Siquidem in cantharidum capite, qnod ommium primum babedtur, general is methodus Diofcoridi tradenda fuit, ne eddem per fingula capita fope fruftrd or incpte repeterentur. Quare fcité cum ad cantharidum remedia legentes reijcit, de genter alibus tantum intelligit. Auic enna eandem falduandris adbibet curationem, quam opio, qudd tam hoc, quam ille frigidisimo int tenperamento. pra= ferti; ceteris theriacam, Mitbridatis antidotum, refinam terebintbinam, ftyracem, urtic e femen, or cupreßi fron= Stellionti con des. Caterum quoniam falamandra fui corporisforma 5 I E I I I N E $S$ mortiferi etiam morfus animalia mi= fideratio.

bi in mentem reuocauit, cim eorum peculiarem mentionem non fecerit Diofcorides, non alienum fore duximus, eo= rum primum biftoriā defcribere, deinde uenenati norfus remedia in mediun adducere. Sed an lacertarum generile= gitime stclliones adfcribi poßint, profectó non aufim decernere: quanquam non defunt, qui afferant, maiores lacer= tos, quos uuigó appellamus Ramarri, alij Liguri, alij ueró Lucerti, ueros effe ftelliones. Quorum tamen fententice

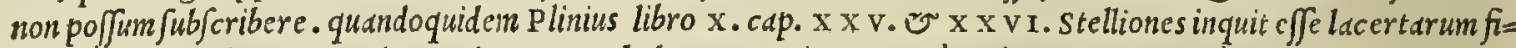
gura, O chameleonum quodaminodo naturam babere, ut quirore tantim uiuant, preterquàm araneis. Ex quibus fateri licebit, ftelliones non effe noftrates lacertos. nanq; bi cocbleas, cicadas, locuftas, or papiliones deuorant, er if genus animalcula. Ad bec copiofum in uenis continent fanguinem, or amplo referti funt iecinore, hominibusq́. baudquaquam inimic antur, quin potius cos amant. Contrà ueró ijs aduerfantur ftelliones, Plinio authore lib. $\mathrm{x} \times \mathrm{x}$. cap. $x$. ubi nullum animal fraudulentius inuidere bomini tradidit. Pretered (ut idem codem loco fribit) ftelliones byemant in domibus in locis oftiorum, or feneftrarum, aut cameris, fepulcrisue . quapropter uenatores obferuant cubile corum af atibus. I bi uere incipiente fißis barundinibus textas opponunt cafas de cipularum modo, quarum an= guftijs etiam gaudent. Venantur auté cos, ut eorun fenect.tm, qua ut ferpentes quotannis exuuntur, facilè confequă= tur: quód nibul ei remedio in comitialibus morbis preferatur: ex more enim exutdm fenect dmillico deuorant. Hine igitur fané perpicuum fuerit, ftelliones à maioribus I talicis lacertis differre : hifiquidem in campeftribus, in frutetis, fepibus, or macerijs degunt, illi ueró in fepulcris, or domibus nostris oberrant. Proinde iubet Diofcorides, ut qui in ucnenorun timore uer fantur, o culinam fubdiali loco apparare nequeunt, fub tecto apparent. Sed tum diligenter laquearia animaduertenda, quód frequenter à fuperioribus contabulamentis animalia decidunt, exigua quidem, fed qua non modic am perniciem moliantur, ut phalangia, ftelliones, ev alia quadam reptilia. Qubód autem ftelliones in I talia proueniant, teftis eft Ariftoteles lib.V I I I. cap. $\mathrm{x} x$ I x . de biftoria animalium, afferens in quibusdam Ita= lia locis ftelliones morfu bomines perimere. sed qui fint, nullam babeo hiftoriä clariorem. Quanquam bis coniectu= ris iandiu exiftimatuerim ea lacertarum genera effe ftelliones, que in Hetruria in noftris morantur domibus, pre= fertim quibusdam prope terram foraminibus, i nobis uulgo Terrantola appellata, de quibus fuperius libro fecundo latius diximus, de lacerta Calcidica differentes. $2 u$ andoquidem boc animal lacertis perfimile uifitur, or arancos ma ximé uenatur, ut Plinius inquit, item Ariftoteles lib. I x. cap. primo de biftoria animalium. Dorfo praterea macus= lis quibusdam nitet fellarum modo radiantibus, unde or fortaffe nomen. Quinetiă, quòd uenenum morfu relinquant, cime é cauernis exeunt, ftatim in Hetruria necantur. His (ut audio) abundat Syria in caminis potius, quàm aliubi commorantibus. Varia fané Junt buiufcemodi anmalium genera, de lacertis, chameleonibus, fcincis, crocodilis, fellionibus, $\odot$ falamandris loquentes: quippe quoniam in unoquoq; borum genere babentur differentic tum forme, tun coloris, tum magnitudints. ob feruau ego falamädras in quibusdam Germania fyluis uniuer fo dorfo nigerrimas, pectore lleró, er uentre admodum rubentes. Sunt 0 in Vtinenfibus aquis degentes, cauda anguillarum modo lata, et rotundo roftro, aluo adnodum rubente, nigricante dorfo, mullis maculis reperfo. Quod ctiam fcincis euenit : nam 


\section{InLib. fextum Diofcoridis.}

or bi in It.lis babentur vicentino agro, purui o nigricantes, ijs utiq; abfimiles, qui ab Alexandria Aegypti vene= tias comportantur. Sicuti o in A rabia lacertx funt bicubitales. In Nifa Indie monte X X I I I I. pedum longitudine reperimitur. Et in ea fortunaturum infula, que Capraria nuncupatur, migne admodum, or coptofe. Sed ut ad ftellionesian nofter redeat fermo, eorum morfibus fucc urrendum eft theriacd, Mithridat is antidoto, 0 . alis, quice in unsuer fun uenenoforum animaliun morfibus opitulantur. Impoinutur priuatin maximo prefidio, demor/is iam lo= cis.contriti fcorpiones. Proinde oleun noftrum de fcorpionibus, de quo abunde in prima buius conmentatione dixi= mus, ijs precipuun fucrit antidotum. Si weró quis ucnenum boc in potu cibóuc funpferit, primùn tum uomitione, tum clyfteribus extrubendum erit : mox uslentioribus antidotis cordi fuccurrcndum. Illud poftrcmó non ignorandum eft, quod (ut plinius inquit) ex ftcllionibus fit malun medicanentun : nam cim ftellio immortuus eft uino, faciem eo=

ao rum, qui bibcrin, lentigite obducit. Ob id in ungucnto necant cun infidiantes pellicü forme. Remediun cft oui lu= teum, or mel, ac nitrum.

\section{E'фripegar. EPHEMERVM. CAP. V.}

S v м т т ephemero, quodaliqui Colchicon, aut fylueftrem bulbum appellant, pruritus in toto corpore excitatur, non אecus atque ijs, qui vrtica, aut filla laceffuntur : interna rofionem fentiunt : ftomachus cum ingenti grauitate exæftuat . cæeterùm inualefcente morbo,cruor ftrigmentis ad'miltus, per aluum exigitur. Quibus, vt ijs qui falamandram hauferunt, uomitione aut clyfteribus auxiliari conueniet : fed antea quàm venenum inalefcat, dandum eft decoctum frondium quercus, 20 aut glandium, aut malicorij: lac bibere prodeft, in quo ferpyllum fit decoctum : item fuccum fanguinalis herbx, aut ramorum vitis, aut rubi, aut medullæ recentis ferulæ, aut my rti cum uino. Bac‘æa atem myrti tufe tricæéue, \& aqua maceratæ, vt liquor inde fumatur, opem ferunt. Media caAtanearum tunicula, fimilem eflectum præbet, fi cruda in aliquo fupradictorum fucco fumptitetur : origanum quoque cum lixiuio epotum . eximiè iuuantur afinini lactis, aut bubuli calidi potu etiamfi in ore contineant: ita vt quibus copia lactis huius adfit, non aliud defiderctur.

C O I C H I C I Ephemeri hiftoriam picturam $q_{;}$reddidimus libro quarto, ubi ea attulimus, qua in ipfo cö $i d e=$ rand a nobis occurrebant. Eius autem ueneno medendi rationem boc loco adeó diffusé tradidit Diofcorides, ut plura Ephemeri ue $\$ 6$ alijs, qui poft ip fum claruerunt, confequi mibi non licuerit. Danda igitur opera est, ut primum (quod in alijs quo= \$o que fepenumero dictum eft) crebre uomitiones, or clyfteres fuum preftent auxilium . deinde propria antidota ex hibenda funt, prafertim bumanum lac, afininum, bubulumq́;. Nec tamen omittenda, qua in uniuerfum omnibus ue= nenis refffunt, de quibus iam fepius diximus. Sed quoniam inter uenenata recenfentur Anacardia fic Mauritanis : uocata, formu ephemero quadantenus proxima, quanuis colore diß3imilia : item'; Staphis agria, qua er perniciofa babetur, or eiusdem fere cum anacardijs temperamenti ; cum bae Diofcoridi pratermiffa uideantur, fint $\phi_{\text {; }}$ medica $=$ , menta, quibus quotidie ad uarios humani corporis norbos utuntur medici, ab inflituto nostro defeciffe putarem, nifi horum quoq; nature uenefic propria aßjignaffem remedia. Prefertim cùm fepe contingat, quód bec medicamenta (que craffa quorundam circunforaneorüignorantia eft, qui non modó non mederi, fed uix etiam legere fciunt) pro= pinätur, nullis feruatis ponderibus, nec menfuris, nullis $q_{;}$additis medicanentis, que illorum uim maleficam frangant: unde nonnunquam miferi grotantes in tain magna incidunt difcrimina, er tan faud fequuntur fymptomata, ut nift

40 poftea à peritis medicis remedia er antidota adbiberentur, facilè deperirent. id quod pluri mis eueniffe fcimus.

A N A C A R D I A igitur tam in potionibus baufta, quàm aliâs ingefta prater quàm quod fauces, guttur, $\sigma$ uen= triculum inurunt, o ufqueadeo uniuerfum excalfaciunt corpus, ut inde fibres oriantur, excitant $\mathcal{O}$ paraly/im in quibusdam corporis membris, Er ratiocinatricem facultatem corrumpunt, quòd fua calorifica ui atrum fuccum exu= rant. Quibus eft fuccurrendum, factis anted uomitionibus ac clyfterijs, oleo amygdalino dulci, aut é pineis nucleis, aut é nucibus Indicis, aut é papaueris femine, aut recentibutyro, o bubulo lacte. Dantur bec affatim in potu, ma= gno fané iuuamento. Quin o alia pinguiamedicamenta conueniunt : nempe pinguium carnium iura, fuillus, $\mathcal{O}^{\circ}$ an= ferinus adeps liquefactus, quadrupedum, o uolatilium cerebrum, or oßium medulla . quandoquidem bis amplißis ma ineft facultas (ui pluries diximus) qua uenenorum calidorum omnium feruor extinguitur, retunditurq́; acrimo= nia. Preterea ijs auxiliantur omnia, que fuapte natura refrigerant, uel que arte fuerint refrigerata. Proinde Aui-

so cenna Anacardiorum ferwori extinguendo cateris pretulit bubulum lac ace fcens, uiolaceum oleun; or bordeaceam ptifanam, pritu tamĕ glacie, uelsuue frigefactam. Veruntamen proprium Anacardiorum antidotum funt Iuglandes, E pinorum nuclei aliquantiper torrefacti. Ceterim S T A P H S A G R I A, anacardiis (utpaulo fupe= rius diximus ) temperamento reppondet, quod admodum calida fit, ac urens. Quare eadem fané adfert incommoda', que andcardia, or cantharides. Adurit enim fauces, or palatum, uomitiones commouet, uentriculi erofiones facit, e dy fentericos fuxus ciet, poftremó frangulat, nifi ftatim fuccurratur. Sed cum bac fua ponte or propria faculs tate uomitiones moliatur, non aliter eft prouocandus uomitus. Verim animaduertendum eft, an ip $\int$ a reijciatur. quod ubinon euenerit, dulce amygdalinum oleum in potu fuerit dandum, admifto bydromelitis plurimo: atgue interim co: gantur agri, ut continuó inambulent, nanque boc tantum medicamento ualentißimé per uomitun esigitur. Nec td= men ob id negligantur clyfteres, quorum pluries meminimus, ut fi ramentum ipfius aliquod ad intefina defcenderit, bis extrabi poßit. Reliqum ueró curationis fumatur é cantharidum curatione, non omißis uniuerfalibus antidotis. 
D O R Y C N I ON, quod aliqui manicon folanum appellarunt, epotum, lactis faporem in guftu refert: continentes fingultus ciet, humor linguam uexat, fanguis confertim reijcitur: mucofa quædã perinde quali dy fentericis, aluo egeruntur. Itaque antequàm aliquid ex ijs eueniat, auxilio funt antedicta, uomitus, clyfter, \& quæcunque potum uenenum expellere poffunt. Priuatim ijs opitulatur, aqua mulfa, lac caprillum, aut afininum, dulce uinum, quod tepidum cum anifo bibatur, amygdalæ amaræ, gallinacea pectora deco fts . quinetiam conchylia omnia, tam cruda quàm tofta effe, falutare eft . conueniunt \& locuft $x$ marin $x, \&$ gammari, \& pota eorundem iufcula .

Dorycnij ue

DE D ORY CN I o fatis differuimus libro quarto, quantum que noftra effet de co fententia, ingenue dicendum neni confid.

erat. Hoc tamen loco non taccéo, quód idem effe non arbitror Dorycnium, ev manicum folanum . quandoquidĕ duow bus capulibus libro quarto, de bis tanqua de diuerfis differuit Diofcorides. Verum enimuero et/it boc in loco dixerit is reperiri quosdam, qui Dorycnium manicum folanum appellarunt; non tamen id effe uerum afferit, fed aliorum tan*

Solani manici tüm refert opinionem, quam nec probandam cenfet. Ceterùm Solano manico ueneficam uin ineffe conftat, utpote veneni noxa, quod cos, qui ipfum hauferint, maximis efficiat incommodis, ut ip $\int_{e}$ Diofcorides teftatur loco citato, cum inquit. So= \& curatio. lani manici radix drachma unius pondere pota ex uino, facit pecies uands, imagines'́; non iniucundas obuer $\int a r i: \int e d$ duplicatus hic modus, ad tres usque dies mentis alienationem adfert : quadruplicatus ueró interimit. Remedio eft $d=$ qua mulfa copiofius pota, e uomitione reiecta. Has perniciojas facultates, earumí; remedia loco dicto reddidit Diofcorides Solano manico: cuius tamen bic inter uenenatas plant as poftea non meminit. Ibidem libro quarto non $d=$ liam uim maleficam Dorycnio aßignauit Diofcorides, quàm quód copiofius hauftum mortem adfrat. Hinc itaque conijcere aufim, quòd eadem utrisq; medicament 1 facilé competere poßint. Dorycnium Auicenna uuam uulpinam focat, nec tamen plura de co retulit, quàm fcripferint Diofcorides, $\odot$ Paulus. Idcirco hoc in negotio à Diofcoride minimé difcedendum erit, nec ab ijs preterea medicamentis, que à uobis inferius in opij curatione def cribentur.

\section{A'KóvTOV, ACONITVM.}

CAP. VII.

A c O N I T V M ftatim in lingua inter bibendum, cum adftrictione quadam dulcefcit : \& fubinde, potifsimum cùm exurgere conantur, vertigines offundit: lacrymas ciet: grauitatem pectori, \& 30 præcordijs adfert, fimulq́ue crebri fpiritus deflantur. Quare venenam uomitione abigi, aut clyftere per aluum egeri opus eft. Vtimur inter propinandum, origano, ruta, marrubio, uel ablinthij decokto, cum vino abfinthite, vel femperuiuo, vel abrotono, chamela'a, aut aiuga. Prodeft etiámnum opobalfami drachma, cum melle aut laffe cum caltorio, pipere, \& ru ta, æquis ponderibus ex vino. congulum hædi, leporis, aut hinnuli cum aceto: ferri quoque ftercus, item uinum in quo aurum; ferrum, argentúmvecadens reftinguatur, potum : lixiuiaque cum gallina, \& vino decocta, aut carnium bubularum præpinguium iura, cum uino fumpta. Fertur \& aiuga priuatim ipfis fubuenire.

Aconiti ueneni conlideratio.

Scillęueneno fęnoxa, \& cu ratio.
T A M E T S I plura fint, ut fuperius libro quarto retulimus, Aconiti genera: nempe tria, qua cynoctona, lys coctonaq́; appellantur, o quartum pardalianches uocatum, qua omnia ueneficam uim fortiuntur; unam tamen, or candem expofcunt curationem. Refert Aëtius, preter Diofcoridem, eos qui haufere, poft diulcedinem, $\sigma$ adftrictio= nem amaritudinem percipere : adftring untur deinde maxille, fubfequuntur mor fus, o erofiones ftomachi. Quibus mffi illico fuccurratur, caligant oculi, o fubcruenti uifuntur. Oboriuntur tremores, corpus'ós uniuer fum intumes fcit, fiunt $\tilde{q}_{\text {; }}$ gri bydropicis fimiles. Medendi ratio à Diofcoride petenda : quippe qui ufqueadé preftantia defcri= p fit medicamenta, ut Aëtio, $\sigma$ Auicenne plura non reliquerit addenda. Attamen Conciliator A ponenfis, qui inter recentiores de uenenis luculenter fcripfit, aconitum bibentibus phbragidem Lemniam commĕdauit drachmarum duas rum pondere ex calida potam: dein uomitum excitari iubet: $\dot{a}$ uomitu theriac am eodem pondere exhiberi, ex uino in quo incoltd fuerit gentiand. Atq; adeó putat Aconiti pracipuum effe antidotum longa arifrolocỉie radicem. Ce= terim dum hac fcriberem, mihi in mentem uenit nonnunquam inter uenenatas plantas baberifcillam, flammulam, ur= tice, e dracunculi femen, que cum hic filentio pretermiffa fuerint dे Diofcoride, optimum inftitutum effe putaui, nunc de fingulorum ueneno, eiuś; ; remedijs nönulla commemorare. Sunt igitur in s C.I L L ARVM genere, que fuapte natura uenenofa proueniant : funt etiam contrà qua nullo imbute ueneno in medicum ueniant ufum. Ho po= te, uel aliâs ingefte, nullam pariunt noxam, nifi earum plus, quam par fit, affumatur. Illa ueró fua malefica ui, etfî quàm parce deuorentur; illico tamen bominem torquent, quemadmodum fungi. Venenofa autem fcilla (ut Mefues, ac ceteri Mauritanorum tradidere) fola nec alteri annexa prouenit, locis q; oboritur fadis, ac graucolentibus, ut apud thermas. Difcant igitur diligentißimi feplafiarij ijs uti fcillis, que fimul connafcuntur, fapore amaro, acri, fie mul $\sim$ dulci, ßplendentibus undiq, laminis. Quandoquidem nulla bis facultas ineft, qua corpus ledi poßit : nifi for taffe, ut dictum cft, plus earum affumeretur, quaim ferre poffet natura. Quamobrem de his differens A uicenna inter uenenat as plantas fen feptima quarti noluminis, fic inquit. Scille male, aut probate longior ufus, quam par fit,

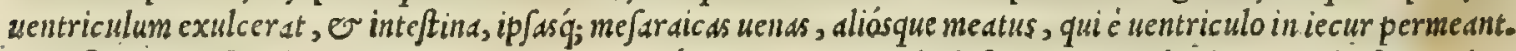

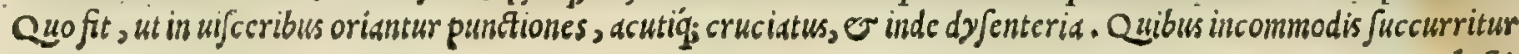




\section{In Lib. lextum Diofcoridis.}

lacti is potu, in quo frrmum, quod Graciftomoma, nos ucró chalybĕ appellamus, pluries reftinctum fuerit, deuoratis= que onorun uitellis, in aceto decodtis. Quinetian ijs frix a cibaria confrrunt, pinguia carnium iur a, recens, crudumí;;

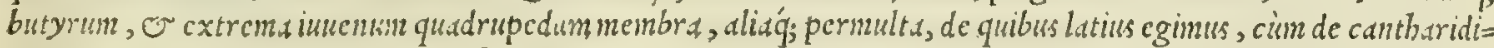
bus fermo baberetur. Nec minora facit incommoda F L A M M V L A locath, cuius biftorian fcripfinus libro

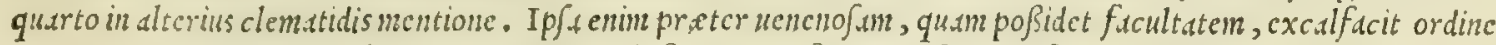
qurrto, adcó utualentisiné corpus exulceret, ubifwert impofita. Ingeft. ueró funces, guttur, uentriculum, e in=

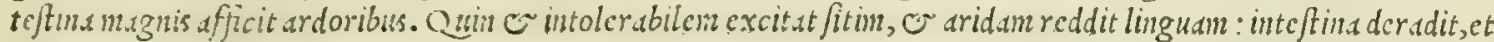
ardentem pellit urinsin. num quandoque tam alté excoriat, ut crofis unforum tunicis, mictufanguis reddatur intole $=$

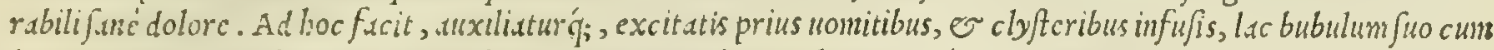

20 butyro potum, aut alio reccnti admstum, itcm amygdalinum olcum, aut é pincis nucleis, aut Indicis nucibus, aut $p, t=$ putcris fentine expreffun. Quippe(ut ian fxpenumero diximus) buinfccmodi acutorum curatio, non cft aliunde pe=

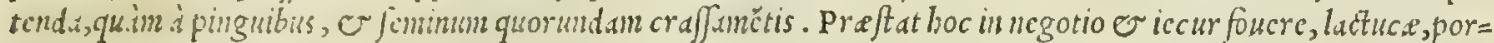
tulace, e intubl hortenfis fucco: itcm funtalis aqua rofacea m.tceratis: quin ct halicacabi baceas deuorare prodeft.

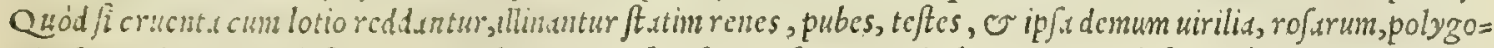

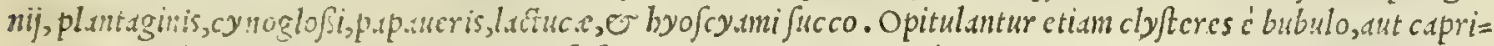

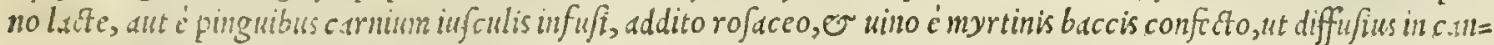
tharidum curatione retuimus. Sequitur V R T I C A E S E M E N, id prefertin, quod lini femen refert, quo ex= citand $x$ ucneris gratis. quidan utuntur. Sed cim $\mathrm{O}$ ip fum in medicum ueniat ufum, ac etiam quorundan cibis admifcea

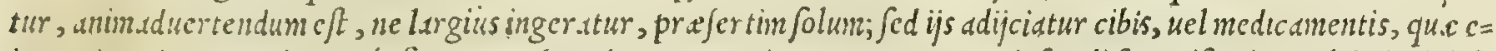

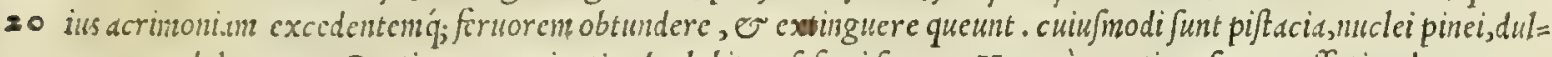
ces amygdale, muces Pontice, er priustin deglubitum fefani femen. Nam cuin urtice femen affatinz deuoratur, non folim (ut Auicenna eft author) onnes fcille malos prebet effectus; fed priuatim etiam continentcmexcitat tuf=

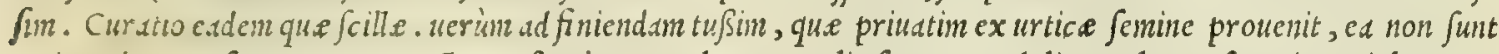
onittend, qux fupte viatura pectoris apperitates mulcent: qualia funt amygdalinum oleum, ferapium uiolaceum, o cx zizyphis, faccharun quod canditum uocant, diatragac anthum firgidum, hordeacea ptifana faccharo inper= $\int i, \sigma$ id gcmus alia. Praft ant pre cateris ( ut fcribit Conciliator) ad epotum urtice femen, malorum cydoniorum

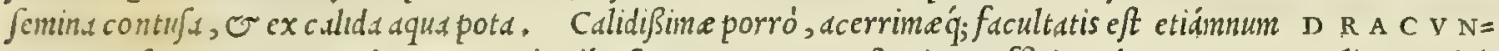
C V I I femen, utpote quod potum, aut in cibis fumptum, guttur afperitate afficiat, adurat, ac pungat: linguam itĕ, gingiuss, o dentes uexat: quin e corpori uniuerfo ingentem calorem inducit. His noxis auxiliatur recens buty=

30 rum bauftum. Priuatin tamen precipuum remedium adfert hordeacea farina in pultem conformata, additis pinidijs,

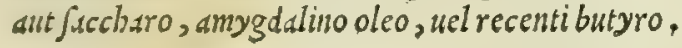

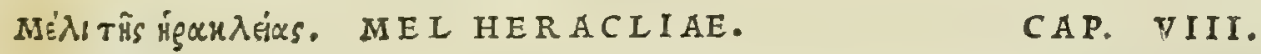

M E I I N Heraclia Ponti, ubi aconitum gigni folet, inuenitur quod qui edunt, bibúntve, non fecus afilictantur, quàm qui aconitum ebiberunt. Iis eadem, qux poto aconito conueniunt. Adiuuantur in primis continuo vini mulli potu, cui rute folia fint adiecta.

M E I I I S Heracleoticibiftoriam, or uires fufius libro fecundo retulimus. Quo in loco tradidit Diofcorides -4 (etf $\mathrm{i}$ id poftea bic filentio inuolverit) eos mente abaliendri, ac fudore diffluere, qui illud comederint : remedio aute effc ruc.me efitatain, o falfamenta, aut epotumnul Jum. Sed cum iandiu in I taliam non adferatur; ideo nec curee $e=$ ius infiftendum eft, prefertin quodd eandem cum aconito uenenatam fortiatur facultatem, er curationem.

\section{Kóglov. CORIANDRVM.}

CA. IX.

COR I A N D R M obodorem latêre non poteft. epotum autem vocem exafperat: infaniam adfert, à temulentijs non abhorrentem . qui fumplerunt, pudenda diatu blaterant, totiusque corporis odore, uenenum fatentur. Quibus poft uomitionem irino oleo concitatam, vti retulimus, merum. $\&$ per fefe, \& ex abfinthio potum auxiliatur : item oleum : nec fecus oua in eodem exinanita, fi lique-

so facta in muria forbeantur: \& epota muria, \& ius falfum ex gallina, \& anfere: paffum quoque cum lixiuia fumptum.

DE C O R I A N D R O libro tertio abunde diputauimus. Et quia non folum de facultatibus coriandri, qus.

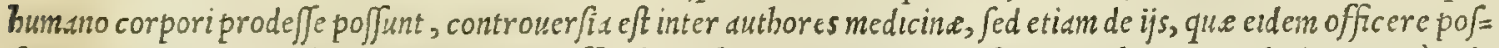
funt, idcirco loco antedicio q'id de prima difficultate fentirem, o cui potifimun adharerem, dixi. Caterün de fecunda difï̌cultate nunc equidem fecus fentio, atq; olin. Aliâs enim multorum fententiam fecutus, coriandrum ab

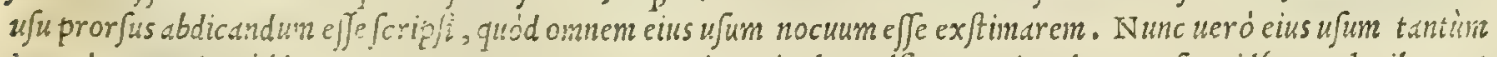

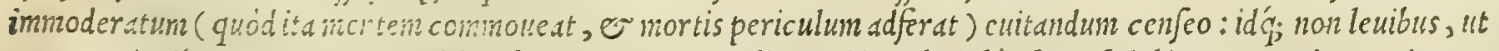
puto, rationibus. Quas quoniain libro fig-rius citato retulimus, ideo ab eis hic fuperfedcbimus, er ad rencdia ac=

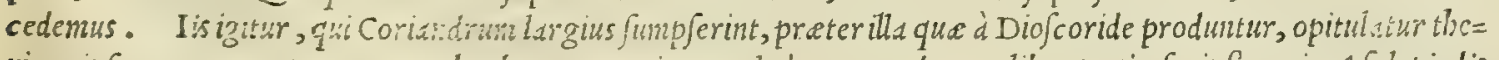

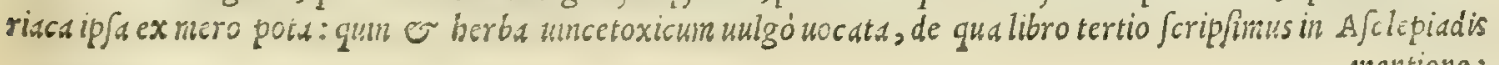

Flammulx ve neni noxa, \& curatio.

\section{Vrticx femi-} nis noxa, \& curatio.

Dracüculi feminis noxx, Si remedia. 
mentione : nan, hec proprium coriandri antidotum eft. Subueniunt preterea raucedini, uociq́; exaperate gargas= rizationes ad id experte: item ed, que pectori conueniunt. Ad cerebri ueró noxam preftat dianofchum, o diama barum, er id genus alia, que cordi, or cerebro auxiliantur.

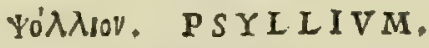

CA P. X.

PS Y L L I O N epotum, corpori totifrigus, \& torporem cum exolutione, \& mcrore quodam adfert, ita vt animum defpondeant . Cui omnia, qux exhaufto coriano auxiliantur.

Pryilii ueneris noxa, \& cu ratio.

Cicita uene fica uis.

Hîroria cuiufdam cafus.

Cicutæ fumprex curatio.

fertin pracordia. quamobrem ad uebementiorem motum, ac curfum ( ut ip $\int e$ inquit) cogendi funt agrotantes. Cons = gentiane radicem ex uino. Nang hoc cicute uerum effe antidotum putat.

\section{$\sum \mu i \lambda \propto \xi$. TAXVS.}

\section{CAP. XII.}

S M I I A X, à quibufdam tithymalum, à Latinis taxus appellatur. frigus vniuerfo corpori, ftran gulatus, \& celerem interitum infert. Cai eadem, qux cicutæ conueniunt.

uenefiura.

P S Y I I I V M, cr eius femen, cuius in pharmacopolijs frequens eft ufus ( ut fuperius libro quarto diximus) 20 notum omnibus eft. Hoc in potionibus baufto preter ed, que ¿ Diofcoride illi a Signantur indicia, conf cquitur anbeli= tus difficultas, alui tunor, $\mathcal{O}$ tanta deniq; cordis anxiet.s, ut plerunque oborto fudore frigido commoriantur agri. Curantur qui bauferint, primum uomitionibus, or cly finatis. Poft bec antidota illa exbibenda junt, qux in uniuerfum Dnibus uenenis aduerfantur. Sed er ed omnia ijs maxime fubueniunt (ut Diofcorides eft author) que er ijs, qui

\section{Káveror. CICVTA.}

\section{CAP. XI.}

C I C V T A pota uertiginem excitat, oculisq́ue caliginem offundit, ita vt ne minimum cernatur: fingultus ciet, mentem turbat, extremi artus gelantur : denique conuulf, fuppreffo arterix fpi- 20 ritu, ftrangulantur. Quare inter initia, uti in reliquis, cicutam vomitu, excutiemus:poftmodum deieftionem moliemur, ut quod ad inteftina prolapfum fit, excernamus: tum demum in meracam potionem, qux maximo eft auxilio, deueniemus. repetendum per interualla, in quibus proderit, Jac afininum, aut bubulum potui datum, ut abfinthium cum pipere \& uino, caftorio, ruta, mentha cum uino, aut amomi, cardamomi, aut ftyracis vncia, aut piperis, cum femine urticæ \& uino, aut lauri folia. Item lafer ex oleo, \& paffo, \& paffum per fefe largiùs potum proficit .

C Y V T A E bistoriam, Or facultates, quibusá; in locis magis exitidis proueniat, ita copiosé retulimus libro quar to, ut opus non fit, ed boc loco repetere, nec plura nobis reftent addenda. Sed iam ad uires eius ueneficas tran= feundum eft. Pota bec, uel in cibis. fumpta (ut Diofcorides inquit) uertigines excitat, uifum adimit, oculis caligine 30 offufa, or mentem ufqueadeó perturbat, ut in furorem agi uideătur, quibauferint. Que omnia experimento no= bis comperta funt. Quippe cum rufticus quidan magnifict Ioannis à Turri uinitor non longè d̀ Goritix arce fuds co= 作, ligone forte fortuna erutis cicute radicibus, fecumq; domum delatis, paftinace radicis loco decoxit, co= (que rufticorum cofuetudo eft) ambo iuere cubatum. Media dutem no=

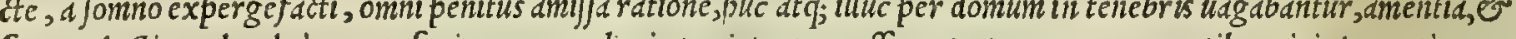
furore ducti: unde adeo caput, faciem, $\mathbb{C}^{\circ}$ oculos in parietes percuferunt, ut mane accurrentibus uicinis, partim per cußionibus tumidi, partimq́; effufo fub cute eanguine liuentes, tumentibus admodum oculorum palpebris, barrendă 作 列 Tia emittere incipiebant. Qua re perpecta celeriter ad agros redij, quos quidem non multo póft tempore, Deo adiu= uante, in priftinam mentem er fanitatem reftitui tamet fi percußionum curatio multó longior fuerit, quàm ueneni.

Decepta quoq; bifce radicibus eft Juperioribus annis quedam nobilis matrona a Coloreto Vtinen/is, qua cicute ra= dices proprio in horto effo/fas totifamilie decoxit, prebuit'; efitandas carotarum loco. Quinetiam monachum Francifcanum curauimus, qui pluribus menfibus modó amentia, modó furore agebatur, quód cicute folia bortenfis petrofelini uice pifcium quorundă iufculis impo/ita comediffet. Caueant igitur omnes, ne in bec ueniant difcrimina. Exhibet Aëtius, preter Diofcoridis antidota, cicutam baurientibus apij femen, ex uino potand ü, aut iridis radicĕ, aut $\int e$ eli Maßilien $\int e$ : item nitrum ex aqua copiofiore potum. Totum praterea corpus calefacere conducit, $\mathrm{e}^{\circ}$ pres=

T A x v s arbor, cuius biftoriam fuperius libro quarto retulinus, ubi er eius plante pizuram adiecinns, non folim cos perdit bomines, quifolia or fruttus efitauerint, uel biberint foliorum fuccum; fed etiam (ut aiunt quidã) gu.ddrupedun omne genus, quod prefumptum pabulum non runinat: cuiufmodi funt equi, afini, muli, or id genus alis. qhansudin fcribit Plutarchus, tertio fympofiorum commentario, Taxum co tantüm tcmpore noxiam, quo ian 


\section{In Lib. lextum Diofcoridıs.}

Rorere inceperit, quód fucco fit maximé pregnans. Diofcorides libro quarto de taxo age ns, inquit. Narbone tam

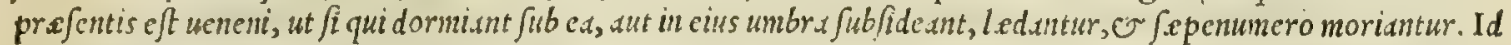
guod Scftins (authore Plinio lib.x v I. cap. x.) in Arcadia quoq; cuenire foribit. Vafa etiam uiatoria ex ed uinis in Gallia fatis mortifera fuiffe compertum $\mathrm{cft}: \mathcal{O}$ in Hipania lecbales effe baccas. Prouenit arbor bec frequens in Tridentinis montibus, profertin Ananic uallis, $\mathcal{O}$ Flemarum, ubicainter ingentcs abietum, picearun, pinorum,

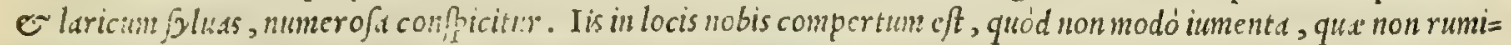
nant, deuorata taxo, moriuntur; ;ed ctian qux rumindnt. quandoquidem boucs complures uidimus à rufticis deplo=

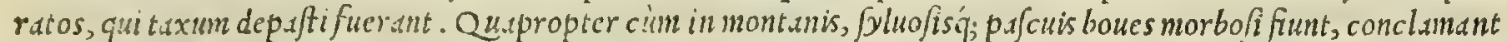
ruftici, animaduertendum c/je, ne $\mathbb{N}$ axuin deguftaucrint : ita enim taxum corrupto uocabulo nominant. Nibil minus

10 eius bucce ijsdcm in locis noxix ac perniciof.e deprebenduntur : quippe quód curaucrin ego paftores, aliosí; in $\int y l=$ uis lignic cedentes, qui faporis dulcedine alle $i i$, baccas ipfius comederant. ex quarum efu non modó in ardentes fe= bres inciderant; fed o ur alui proflinium, adé ut in maxuno uerfarentur difcrimine. Caterim non parum dubi= tandun uide rur, an inter plantas calidas, ucl inter frigidas $T$ axus fit reponenda. Diofcorides quidern, er cius fequa= ces onucs cxiftinarunt Taxum effc frigidi temperamenti, arg umento quód afferucrint, ïsdem remcdijs taxi venemum fupcrari, qub:is er cicuts. Quorun tamen fontentia, omnium pace dixertm, mbi plane non probanda uidetur. nan= que amstor, qui cortici, of frondibus ineft: coms perpctud uirens, pinorum, abietum, er picearum modo, quibus fronde finilis pectatur : b.scarum tun dulcedo, tum acrimonia quedam : or quod auicule eas depalte nigrefcant; manifc ftè indicant infignem temperamenticaliditatem. Atq; binc eft, quod $\sigma$ febribus, er alui proflunio tentanur, quibacc.s cfitarunt, inflammatis eo cibo piritibus, or fanguine. Veruin quanuis aliquis repondere poffet, dccendi in

so bis fibres, gigniq; alui profluium, exlumorum putrcdine, qucmadmodum in aftate eneniunt bec ex frigidorum fru ctuun c fu: nigrun ucró colorem inauculis contrabi poffe non minus à frigido, quàm à calido; ex eo tamen adbuc fupccta $\sigma$ improbanda relinquitur eorum fententia, quod frondium, $\sigma^{-}$corticis amaror, baccdrum dulcedo, $\sigma^{\circ}$

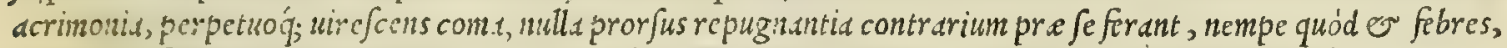
on alui pro, lunis oborisntur potius caloris primicne exuberantia (ut accidit deuoratis andcardijs) qudm bumorun putredine. Neq; preterca poteft nigredo illa à frigido pabulo in auicularum pennis fuboriri: nam fi frigiditate ni= grefcerent, illico perirent. Quindoquidem nimis excedens frigus baudquaquam nigredinem inducit, nifi menbris $f=$ mul confectis ac dcperditis. At non ita fit ea nigredo, que peruftis bumoribus gignitur, quemadmodum accidit Ae= thiopibus. Hec fane dixiffe uolumus, non ut quicquam tam celebratorum uirorum autboritati detraberem, ne $;$; etiä quód aufim temeré cormm fententijs refragari; fed ut meam in medium proferrem fententiam, atque ut bec à nobis

30 proponerentur alijs difcutienda, EN fudiofis diligentius aftimanda. Ceterim quoniam taxus N E R I V M, quod Grecirbododendrum, rbododaphnen uocant, Mauritani ueró oleandrum, mibi in mentem redegit, cum fciam fcripfiffe Galcnum, o ipfum fecutos, non modó brutis; fed etiam boninibus effe uenenum, cùnq́; co quàmplurimis in locis referta fit Italia, pretereundum non duxi, quin bic de Nerio aliquid dicerem. Et quanuis non abfque ratione fortaffe fcrip fertt Dio corides libro quarto, item'́; it buius prafatione, quod Nerij folid or flores, fi deuorentur, bo= minibus contra mortiferos ferpentium mor fus prefidia funt, atg; in bac re ideo poßit er fides adbiberi, quod etiam can

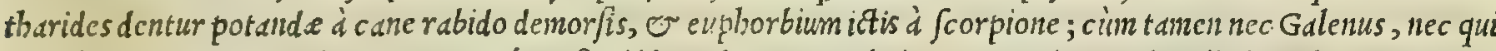

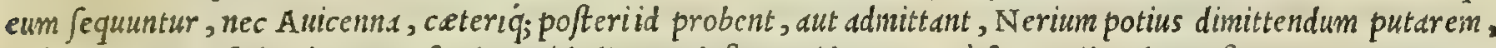
quim cuiquam exbibendum, prefertin quód alia non defint antidota, que ḋ ferpentibus demorfis magnopere opitu= lantur. Nerium igitur, Galeni 0 A uicenne teftimonio, tam potum, quim in cibis fumptum, quanuis non largius in=

- 4 geratur, bomines E quadrupedes interficit. Primum enim intolerabiles excitat anguftids, intume fcit inde aluus, er fub $\int$ equitur uniuerfi corporis inflammatio: quód temperamento calidum fit, er ficcum, diffecans, er exulcerais. $0 b$ id enim non tantum noxam corporibus infert, intra corpus fumptum; fed etian cos afficit, qui in eius umbra fubfede= rint, taxi ( ut anté diximus) modo. Quinetiam aqux fluuiorum, or lacuum, in quorum ripis Nerium cre fcit, unbra,

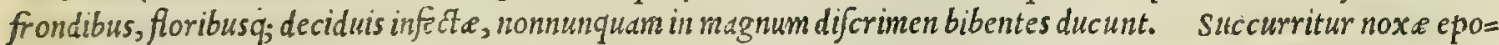
to fani grecidecocto, aut deuoratis palinulis, aut uiticis femine, aut frondibus, aut baufto borum decocto. Confe= runt $O$ carice ex melle, aut faccharo dut iulapio fumpte. Preterea defrutum, er pinguiá, er que craffum dant $a=$ limentum auxiliantur, non omißis tamen clyfteribus, or uonitionibus, ut in alijs omnibus fe penumero dictumeft. Conuenit $\sim$ diacaftoreum ( $1 t$ Conciliator eft author) potum duarum dracbmarum pondere. Profunt item iuniperi bacce codem pondere. Porró illa quoq; letbifera eft arbor, quam perperàn quidam sicomorum appellant, qux fru

so ctus profert loti arboris inftar, quorum oßiculis funiculo traiectis, fuas preces Deipar airgini numerant infima gés= tis mulicres, que illos uerticillos à monachis fepe dono accipiunt, quód in eor um monafterijs arbor ea frequens repe riatur. Hanc A uicenna uocat A Z A D R A C H T fen v 1. quarti uoluminis, fic inquiens: Folia Azadaracht, quent= adnodun or lignum, animalia necant. Tollitur noxa ijs medicamentis, que in uniuerfum omnibus fuccurrunt uene= nis. priuatin ueró ijs, quibus or nerij uis exitialis aufertur. Caueant itag; omnes, qui hanc arborem fuis in uiridarijs alunt, ne forté imprudenter $\int e$ ip $\int 0 s$, er domefticos omnes in perniciem agant. Sed fi aliquis for talfe dubitaret hanc arborem non elfe Azadaracht Auicenne, fidemillimanfeftam faciet Andreas Bellunen/is, qui in Arabicorum no= minum intereretatione, ita e Je aperté declarat.

Nerij ueneni curatio.

Azadarach arboris uenenum, \& reme dia. 


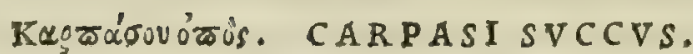

CA P. XIII.

E p O T v s carpafi fuccus foporem, citamqque ftrangulationem adducit. Adiuuantur autem qui hauferunt, epotæ cicutz remedijs.

Carpafr,8: o- QV O'D N A M bodie plante genus nobis Carpafum dici poßit, omnino fateor me ignorare : nee quenquam res pocarpafi cö- periri crediderin in Italia, qui plura quam nos de Carpafo referre poßit. Quandoquidem etf bic inter uenenatas fideratio. plantas illud defcripferit Diofcorides; nufquam tamen in precedentibus libris quicquam de Carpafo retulit, quemad= modum nec pofteritan Greci, quim Arabes, ex quo coniectari poßit, quidnam antiquis fuerit carpafum. Hoc Pau= lus Diofcoridem fecutus lib.v. carpefiam uocat. Quamobren credidere nonnullicarpafum, carpefiam, er carpefium, Vana quorŭ- de quo primolibro latius diximus, unam er candem effe plantam. Sed uanam prorfus borum fententiam effe arbidam opinio. tror. Siquidem à nemine posteritatis memoris proditum inuenitur, deleteriam uim ullan carpefio ineffe, uerim ean dem (ut Galenus, er Paulus teftantur) que ip/i plou, quinino ita aduerfus uenena commendari compertum eft, quod Quintus carpefium cinnamomi loco in theriacam addere non dubitauerit, quod tantum id prestare exiftimaucrit, quantum poteft laudatißima caßia. Verim fi quis fortaffe affereret opocalpafum, de quo foribit Galenus, dum pro= batißime inyrrhe notas expendit, libro primo de antidotis, Jo opocarpa fum boc loco ḋ Diofcoride def criptum unum or idem effe medicamentum, is meo quidem iudecio, rem (ut aiunt) acu tetigiffet, quód opocalpafum Galeno morti=

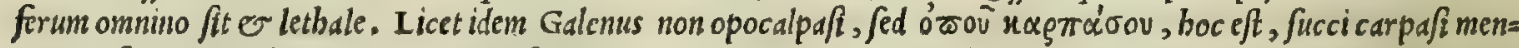
tionem faciat tum libro primo de compofitione medic. localium, ubiex Archigene ea recenfet medicamenta, qua capil= 20 los cripos reddunt: tum etiam lib. $v$, de compofitione eorundem in quodam molari emplaftro. Caterum cum buius $u$ us, or nottia apud ommes penitus exoleuerit, non eft cur alid à nobis frustrà de eo fit inftituenda curatio.

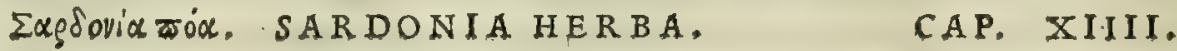

SAR D ONI A ranunculi herbx generi afsignatur, qux uefcentibus mentem adimit, \& quadam ner uorum diftentione labia in rictum contrahit, vt rifus fpeciem præbeant. à qua quidem affectione, de Sardonio rifu adagium in vulgus infaufto omine manauit. Poft uomitü peculiariter conuenit aqua mulfa \& lac, liberaliùs epota : irrigatio, perunctioq́ue à pínguibus medicamentis, totum corpus excalfacientibus : in calidam aquam, oleumq́ue defcendant, fed tum multum perfricare, $\&$ inungere ex. pedit. \& in fumma, curam omnem, qux conuulfioni neruorum adhibetur, exequi oportet.

Sardonix her QV o'D inter Ranunculi genera ea annumeretur planta, que à Sardinia, ubi plurima na fcitur, nonnullis uocdo bx uenenum, tur berba Sardonia, abunde docuit Diofcorides libro fecundo. Tradidit buiufce curationem Aëtius lib. $x: 1$ r. qui praz

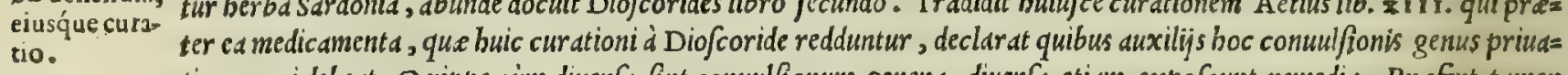
tim curari debeat. Quippe cüm diuer $\int_{a}$ fint conuulfionum gentera, diuerfa etiam expofcunt remedia. Prefert tamen caftoreum in puluerem contritum aut per fe, aut é dulci uino potum. Ceterim, ut Conciliator est author, adiuuantur qui hauferint Apium rifum ( $\{$ ic enim Sardoniam herbam appellauerunt Ma!ritani) uino dulci potentíg; adeó largè epo= to, ut inde ebrij factı diutius dormiant; item meliffopbylli fucco, ex aceto fumpto : is enim, ut idem ait, Sardonie her = be uerum ac fingulare eft antidotum. Sed quoniam ( ut Diofcorides prodidit) in hac cura, balnea, o laconica admor 40 dum profunt, ea utique paranda funt medicamentorum decoctis, quibus uis infit excalfaciens, tum ctiam deficcans, $\sigma^{\circ}$ qua propria facultate neruos tum roborent, tum iuuent. Cuiufmodi funt, ftrechas, byyfopum, faluid, ruta, betonica, chamepitys, amaracus, origanum, calamintha, pulegium, dictamnum, anthemis, fatureia, acorum, syriaca er Cele tica nardus, afarum, phu, cyperus, rofinarinus, $\mathrm{\sigma}$ id genus alia. Ad bec prestat inungere occipitium, cernicem, of -uniuer fam finalem medullam, fufino oleo, aut écaftoreo, aut é terreftribus lumbricis, aut é cofto, aut ex byperico, aut uulpino, aut unguento ar agone, aut agrippino, aut deniqg; alys his fimilibus,

$$
\text { Y'ooxíapos. HYOSCXAMTS. }
$$

CAP. XV.

H y o S C Y A M V M potum, aut comefum, fimílem ebrijs abalienationem mouet : fed facilè me- 50 dicamentis cedit. Auxiliatur aqua mulfa copiosè data, lacque, præfertim afininum : fi id defideratur, caprillum, uel bubulum, uel aridarum ficuum decoctum. Faciunt ad id etiam nuclei pinei, aut cucumis femen ex paffo fumptum, \& uinum falfum, cum adipe fuilla recenti, paffoq́ue : itidem urticæ femen, aut nitrum ex aqua, \& intubus erraticus, \& finapis, \& nafturtium, radix, cepa, \& allium: \& hæc fingula cum uino fumantur. Poftea finendi quiefcere, quemadmodum qui uinum biberunt, ut excoquant,

Hyofcyami S V C C V R R I T V R facilé Hyofcyani noxie, cuius biftoriam cum Diofcoride tradidimus libro quarto, ubie

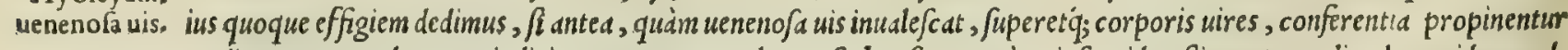
medicamenta. Sed prater indicia, que epoto, uel comefo byof cyamo à Diofcoride aßignantur, alia plurd eidem reds didit Ačtius libro x 1 1 1. nempe quód infequatur iactatio corporis cuin distortione; quibus fuccedic exolutio, animi 


\section{In Lib. fextum Diofcoridis.}

deliquio finilis, oculorum rubor, pruritus, deinde tremor : pratered omnino delirant agri, er putant fe flagris cor= pore cadi. Proinde meritó Ananienfes byof cyamum unlgó uocant Difturbio, utpote quod mentem, er omnes corpo= ris $\int e n f u s$ difturbat. Mcminit utriusq; byo fcyami inter deleteria pharm.tca etiam Auicenna, fic inquiens. Epoto byo= fcyamo albo, of Sium compagines luxantur, lingus in abfceffus tran/it, /punat os, caligant or rufe fcunt ocul, fpiritus difficulser redditur. Hinc fiunt ucrtigines, furditas, gingiuarum, or totius corporis pruritus : ebrietas, amentia, fu=

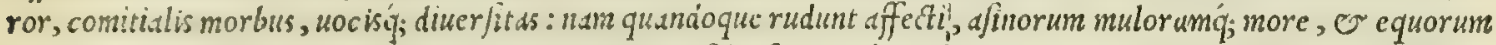
modo binniunt. A' nigro autem corporis extrema canfige cunt, obtencbrantur oculi, oboritur delirium, atq; adeó con/tringitw" pectus, ut impcdita prorfus refpiratione, fuffocentur, comucllantur'́; agrotantes. Veriun bec om= nia cicutan facere tradiderunt Diofcorides, er Paulus. Quo fit, ut fuppicariliceat, in boc cacutiffe, erraffe $\dot{q}_{;}$A uit=

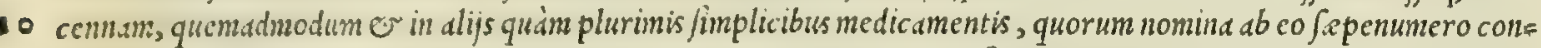
funduntur. Caterim in albi byofcymi curatione idcn Auccma prefirt ceteris medicamentis theriacam, $\mathcal{O}^{\sim} \mathrm{M} i$ thridatis antidotum. Scd ijs, qui mgrum hauferint, poft uomitum, or clyftcres, meracum prebet potandum: quin e. bubulum lac, ablinthium, caftoreum, rutam, laferis lacryman, baccas of folia lauri, dcfrutum, urtica fonen, magu= darim, c.trdamomum, o fiyr.scem: :ed que fingula ex uino fumantur. His preterca addit mori radic is decoctum, et opobaljanum cx lafe potum. Ad bec infuper farinam triticeam uino fubuctam, emplaftrimodo uentriculo utiliter imponi pronititit. Sunt porró cx recontioribus nomine preclaris, quilongum niper in boc magnopere cömendant, atque ctiam piftacia largius mandicato, cateris preferunt antidotis.

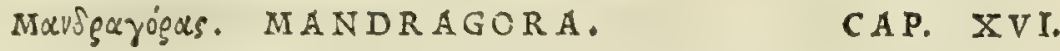

MA N D R A o R A fi bibatur, confeftim fopor infequitur, exolutio, ac uehemens ueternus, nihil temerc̀ diftans à lethargo. Cui, antequàm aliquid ex ijs accidat, uomitus \& aqua mulfa proderit: poltea nitrum, \& abfinthium, ex uino dulci, aut pafto fumantur . caput rofaceo, \& aceto perfundatul. Proficit excitatio, \& motus corporis, \& olfactus eupatorij, \& piperis, finapis, caltorij, \& rutæ, tritorum in aceto: \& liquidæ picjs, \& odor è lucernarum exuftione, \& extinctu. Quòd fi ægrè jj reuocentur, fternutamenta mouere, alijsque communibus auxilijs uti conuenict.

QV A N D O QV I D E M Mandragore hiftoriam latius profecutifuimus libro quarto, ubi utrunc; cius genus depinximus; ideo munc tantion indicia primum, of accidentia referam, que ab epotis uel deuoratis cius tum radice,

30 tum fructu euenire folent: deinde horum curationem aggrediar. quoniam fi diutius malefica uis ferpere, augeriq; ne gligenter dimittatur, nullis adhibitis remedijs, facile ij qui bauferint, emori poterunt. Quamobrcin dixerim, Aëtium fecutus, cam uix fallere bibentem, aut comedentem poffe, quód odore fit admodum graui, ac naufcabundo, amaro iniu cundó; guftu. Certa itidem copia, or menfura ad ledendum requiritur. De catero ueró moleftias quidem facit, $\int e d$ ferius interimit. Huius potu facile agrotantes ( $u t$ Diofcarides inquit) in ueternofum foporem delabuntur: quin $\sigma_{\text {r }}$ fegnes, o languidi, $\sim$ triftes, et exoluti fiunt, adeo ut clamoribus, ac torfionibus excitati, repenté rur fus tanquam amentes recidant. Remoueri noxam fcribunt, preter ca que Diofcoridi produntur, coriandri femine, aut pule= gio ex calida aqua, aut alui derectione cum deiectorto medicamento, quo ad ueternofos utimur. Qúdd fi ḋomitu, qui malè babent, non excitentur à fom no, origanum potandum ex frigida, tanquam expertißimum medicamentum offer = ri uolunt. Profunt item acria cly $\int \mathrm{mata}$, frictiones apperis linte aminibus in totum corpus exten $\int a$ : cucurbitula ignis

40 flamma appofita tü occipitio, tum fcapulis, tum etiam natibus: fibule extrema corporis membra torquentes : quin et fternutamenta, que ueratrialbi puluere naribus indito cienda funt: or feptica medicamenta ueficas excitantia, ut cantharides, er ranunculus, occipiti, et poft aures emplaftri modo impofita, maximopere auxiliantur. nanque bec omnia ualentißimé reuocant, que cerebro officiunt. Porró animaduertendum eft, quód iubet Diofcorides egro= tantium caput ad repellerdum uapores eo petentes, ro faceo, acetóg; perfundi. Id quod etiam Galenus lethargicis cö= mendaffe uidetur lib. X I I I. methodi medendi. Sed boc certé, fi quis rem accuraté cxpendat, rationi refragaride= prehenditur. Vnde nil mirum, fi Paulus, Aëtius, Alexander Trallianus, $\mathcal{O}$ alij, qui Galeni ueftigia fequnntur, cum recte nouiffent ueternum morbum à frigidis tantum humoribus prouenire, or rofaceum cum ace to illi baudquaquam connenire, quod magis refrigerare ualeant, caftorium, chamapityn, pulegium, calamintham, ferpyllum, thymbram, et thymum huic medicamento addiderint, ne eo folo admoto, morbum fouerent, atq; demum agris mortem adferrent.

so Verim enimuero putandum eft, Galenum rofaceum ex aceto tantum imponere, ubi frigidus bumor, quo ueternus ex= citatur, bili ( ut plerunque accidit) fuerit admiltus, que tamen bilis maxima ex parte in ipfo duntaxat morbi princi= pio uexare folet: nam cum tenuis fit, facile refoluitur, et fuperatur a frigido. Hinc itaq; quifq; expendere e cogno fcere poteft, an ijs, qui a deuor ata mandragora ueternofi fiunt, purum illud medicanentum ex rofaceo, $\sigma$ aceto ad= mouere liceat, nullis addit is excalfacientibus, cum (nifallor) ab affumpta mandragora caput nullo afficiatur calore. Ad hee tamet fi mandragor soma matura comedantur à nönullis detracto femine, citra ullam prorfus moleftiă; im= matura tamen, et cum femine deuorats, mortifera fané inferunt fymptomata. siquidem exoritur intolerabilis ardor, qui uniuer fan corporis Juperficiem adurit: lingua, er os are fcunt, quan ob caufam ore perpetuó biante cernuntur affecti, frigituin trabontes iërem. Quibus nifíllico Juccurratur, conuulfi pereunt: contrd ueró facilé liberantur, \{ ftatim baferint, aus opem ferre polfunt. Id autem commodé, of efficaciter preftat Andromachi theriaca, ex aqua pota : quippe bac fola momenio omnem aufert moleftiam. Curantur (ut Conciliator inquit) quibuiufce radiccm, uel pomum, ucl liccum fumperint: mius tantum dici inedia, fi tamen fubinde preftantifunimmeracum vinum largius

Q7 2 bibant

Mandragorx uenefica natura.

uicennę erratum.

Hyofcyami utriufyue ruratio.

Mandragore noxæ reme dia.

Rofaceum vtrum hic con ueniat. 


\section{And. Matthiolı Comm.}

bibani agri, or acetum olfaciant, cui admifum fit caftoreum. Sed horum omnium peculiare fcribit effe antidotum Metellarú nu doncfticaradix triduo cumpane, e fale deuorata. Ceterum cum mandragorce poma METELLAS NVCES cü ueneficiü, quas uocu'tt, mihi in memoriam reuocauerint, quarum hiftoriam fuperius libro primo defcripf, fciuerimí,; non mos \& remedia. dó, fi edantur, fuapte natura canes necare, fed etiam homines, cum nibil de bis, quod extet, pofteritatis memorie pro diderit Diofcorides, nec antiquorum cateri, non alienum duxi boc loco earum indiciarefirre, atq; etiam medicamen= ta commcmorare, qua barum ue neno opitulantur. Ex nuces igitur cim intus in corpus fumuntur, uertigines, er fa= ciei ruborem induc unt : quin o oculorum caligines, temulentiam, inexpugnabilemó; fomnum : pofremó oboritur fri gidus fudor, uicine mortis prefagiun. Auxiliatur noxe excitatus pluries uomitus aqua calida, $v$ oleo: poft uomi= tum datur conuenientißime butyrum, or uinum meracum copiof un, additis pipere, pyretbro, lauribaccis, cinnamo= mo, $\sigma$ caftoreo. Prodeft, $\sim$ agrotantium extremas corporis partes, nempe manus, o pedes callda aqua fouere, dc inde frictionibus rudi linteamine fact is calorem in uniuer fun corpus excitare: cum eo tanen, ut fubind balanino, aut costino olco perung antur affecti. Preftat item exercitatio, proinde ad celcren greffun cogendifunt, ut uniuer fun corpus incale $\int a t:$ o pinguibus poftea cibis, dulciǵ; uino refocillandi. In funna OO his ca maximé conueniet cu ratio, quam epotum requirit opium, de quo proxima commentatione differemus.

MHห̧́very, MECONIVM,

CAP. XVII.

E p о т o papaueris fucco, quem meconion tocant, confequitur veternus cum perfrictione, \& pruritu uehementi, ita ut fepe inualefcente ueneno, tanta erumpat prurigo, ut hominem excitet: corpus id medicamentum olet. Poft citatam oleo uomitionem, acres clyfteres auxiliantur, acetumq́ue mulfum cum fale potum, aut mel cum rofaceo calido : merum cum abfinthio aut cinnamomo copiofum, aut calidum per fefe acetum : nitrum ex aqua, \& origanum cum lixiuia aut paffo: \& rutæ fylueftris femen cum pipere, vino, \& panace: piperque cum caltorio, \& aceto mulfo, vel cum fatureiæa at origani decocto cum uino. Hi olfactilibus excitandi : \& ob enatam pruriginem in balneas defcendant, $\&$ foueantur. Poft lauacrum prodeft iurium pinguium vfus, cum uino, aut paffo: medulla etiam ex oleo pota.

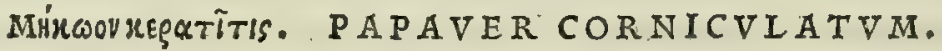

CAP, XVIII.

Qy o D corniculatum papauer appellant, \& potu, \& cibo eadem inferre confueuit, quax papa30 ueri fuccus : nec alijs expugnatur auxilijs .

Opij uenefica. I N G R A T V S Opijodor, perinde atque mandragore, facilé obftat, ne in cibis, aut medicamentis inferi pofs natura. fit, quin ueneficium pateat guftantibus, prefertim cùm necem non inferat, nifi certa quadam fumatur quantitate. Quamobrem raró contingit, ut homines uenefici opio utantur, ubi quenquam ueneno tollere uolunt, nimirum ueri= ti ne fraus odoris grauitate deprehendatur. Tametfi quandoque accidat, aut forté medicorum imperitie, aut phar= macopolarum negligentia, ut ebibitis medicamentis, quibus opium admiftum fit largius quàm par fit, fumentes in ea iucurrant difcrimina, quorum meminit Diofcorides, Atq; illa quoque fequantur, qua in fuis alexipharmacis Nican= der ijs uerbis reprafentauit. Animaduerte, inquit, $\dot{e}$ fumpto papaueris in capite fuo femina gerentis liquorc dor = mientes: nam illi in funma corporis cute frigent: nec oculi eis aperiuntur, fed enim palpebra corum immobiliter colligantur, éq; labore eo, odoratus fudor diftillat und collectus, adeoó; ip fum corpus palle fcit ac labia ardent, eq́; genis nexus demittunt, id eft flaccide maxille funt. Langudus item $\mathcal{N}$ frigidus é gutture anhelitus expirat: Sape o liuidus unguis, uel obtortus nafus mortem non procul abeffe nunciant, ipfí,; oculorum, qui in caua recefferunt. radij. Nicandro fubfcribit Aëtius lib. x I I I ubi fic inquit. Quando uoluntarie meconium aliqui biberint, fiue id ma= nifeftare uoluerint, fiue uolentes non poßint, bis cognofcentur indicijs. Sequitur enim eos, qui opium acceperunt, in fomnum grauem collapfio cum frigiditate or pruritu intenfo, ut aliquando ob ipfum excitentur : odor q́; opij per totum corpus effertur, e exhalat: inferior maxilla laxatur, tume fcunt labra, irruit finguitus, diftorqwetur nafus, pallor adeft, liuor unguium, precordiorum diullio, reffiratio parud, 0 frigida, oculorum offufcatio, er ad po=

Opij ueneni ftremum mortifera conuulfio. Hac de notis, que opium fumptum confequuntur. Quibus ualentifimé illa remedia curatio. auxiliantur, quorum bic meminit Diofcorides. neq; enim plura apud pofteriores Grecos reperi. Auicenna autem prefert laferpitij lacrymam, or caftoreum. Sed preftantißimum dicit effe medicamentum, theriacam, fagaze= neam, o Mitbridatis antidotum ex uino potum. Excitandi etiámnum funt agrotantes fternutamentis, fibulis, fri $i$ ctionibus, odoramentis, nempe mofcho, caftoreo, lafere, ambaro, naribus inditts, quin e fulphuris fumo. Succurs vitur conuul/ioni, , fi uniuerfum corpus perungatur fu/ino oleo, ac etidm coftino, alijsó;; remedijs, quorum in prece= denti capite meminimus. Verim longe onnium potentifime proficit antidotus noftri ufus, fcilicet quinta effentia the riacalis, de qua Juperius in prafationis commentatione diximus, quód prafentaneo remedio non modó his omnibus. opituletur; fed etiam omnibus in uniuerfum uenenis, que frigiditate nimia interimunt. Nec aliter curantur, qui con niculatum papauer deworauerint. 


\section{In Lib. fextum Diofcoridis.}

CAP. XIX.

Qvo D Pharicon uocant, fapore fyluefre nardum imitatur. Refolutionem neruorum potum adfert, cum conuulfione \& delirio. Oportet autem poft uacuationes vinum ablinthiten potui dare, cum cinnamomo, aut myrrha, aut nardo gallico, quod ferinen aliqui uocauerunt: aut fipica nardi duas drachmas, \& myrrhe totidem obolos, cum paffo : aut irim cum croco ex uino : derafünque caput illinire hordeacea farina cum aceto, \& trita ruta.

o N O N equidem battenus apud quenquam fcriptorem confequi potui, quid Pbaricum antiquis fuerit, an fim=

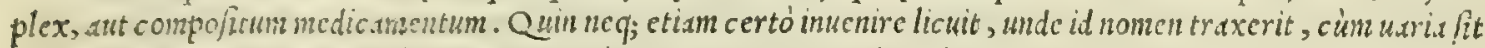
de nombire cius apud authores fontcistia. Porró is, qui in Nicandrialexipharmaca fcholid foripfit, hec protulit. Pra $x a g$ or as memorie prodic phatricum Lethalc medicamentum fic uocatum a Pharico uencfico quodam Creten/i, qui boc reperit. Sunt qui primm Pharis Arcadia repertum uclint: appellant autem ctiam MIedicum. Nec defunt qui in Theffalis in Pleris, alij Lacedemone, quod ibi fortaffe proueniat. bx cille. Caterum cim iam id neritó deperdetum

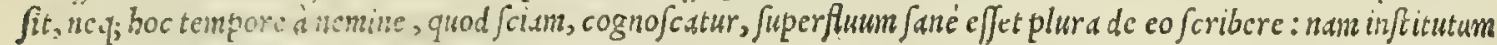
nofrum non c, in in re incerta diutius immorari.

Tokiroiv: TOXICVM.

CAP. XX.

T o x I C V M ex eo nominari viderur, quòd barbarorum fagittæe ea illinebantur. Qui biberint, labiorum, \& lingux inflummatione tarquentur. Incoërcitus furar varias ijs imagines obuerfat: quare uix medicinx locus eft, raroğue qui haufcrunt, cuadent. Vinculis ergo cohibendi, aut vinum dulce cum rofaceo bibere, $\$$ reuomere cogantur : rapi femen bibendum cum uino. Priuatim ijs conuenit quinquefolij radix, \& hircinus fanguis, aut caprillus, codem modo fumptus : roboris, fagi, aut ilicis cortex cum lacte tritus : malaq́ue cotonea trita effe, aut cum pulegio, \& aqua bibere, conuenict: amomum \& balfami femen ex vino. Sed qui periculis defuncti funt, diu lecticis deçumbunt: \& vbi furrexere, ftupidi reliquum uitæ tempus degunt

30 Q I D antiquis fuerit Toxicum, quo Barbarifagittds inficiebant, ut ijs uutneratos inimicos baud dubie perde= rent, nec à Diofcoride, nec ab alio aut Graces, aut Arabice familice autbore memorie prodetume efe, mbibi bactenus compertum eft. Ideo ó; difficile admodun fuerit decernere an Toxicum hodie fit, uel cognofcatur in Europa, cum pro prié bi Barbari antiquis dicantur, qui Troglodyticam Aethiopie regionem incolvut, apud quos fortaffe tantiun na= fcitur. Verum crimuero putauerunt quidam, ut Manardus Ferrarienfis uir noftre atatis celebris, id antiquis fuif= fe Toxicrm, qiod A rabes Napellum uocant. Cure quidem fententia non oinnino ijs uidetur refellenda, qui plura de Toxico non inucftigarunt. quandoquidem ( ut Auicenna eft author) non defuere, qui fagittas napello inficerent:

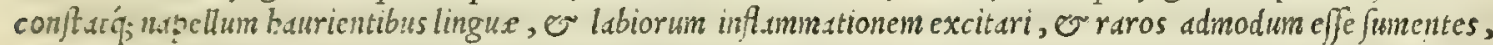
qui cudd ant: id quat omnes Greci toxico adf cribunt. Ad bec cim afferat Auicemna, quód fiqua cura toxico adbibe= ripoßit, es fixt uomitionibus, baufto dhtex rapi femine, o funptus fubinde glandium putaminibus, hoc omnino illo=

40 rum opinionein alget. siquidem Diofcorides quoque ijs, qui toxicuin hauferunt, rapi femen ad ciendum uomitum ex uino potandum prebet, ac deinde quercus, fagi, alt ilic is corticem, arborum nimirum, que omnes glandes prafe= runt. Qune fané onmia facilé ad credendum trahunt Grecoruin toxicuin, or A rabuin napelluin unum er idem effe werenum. Sed diligenter rem expendentibus contrarie profectó fe fe offerunt rationes. etfi enin ex notis predictis toxicun, $\widetilde{N}$ Napellum unum $v$ idem effe wideantur; tot tamen alie bxbentur note, que alterum ab altero difcri= minant, o contrarium argumnt, ut aliter exiftinandum non fit, quim quodd deleteria bec medicanenta plurimùn inter fe dißidesnt. Namnufquam, quod legerin, tradidere Mauritani eos, qui Napellum bauferint, in tantum fu= rorem agi, ut uinculis fint coèrcendi, quemadmodum eos, qui toxicum deuorauerint. Equidem illud pro certo teft d=

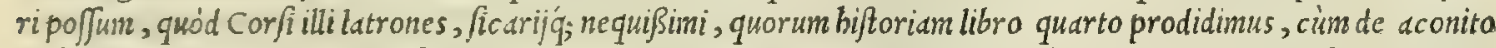
differeremus, quanquam ab affunpto Napello ed omma dederint indicia, que $a b$ A uicenna napello aßignantur; in so nullum tamen furorem adductifuere, neq; ullum etiam fenfere delirium. Pretered Auicenns, noftróq; teftimonio, qui experimentum uidimus, epoto Napello, oculi exterius prominent, oboriuntur uertigines, animi defictus, o in= gens crurium imbecillitas. 2uorum tamen fymptomatum nhil de toxico agens meminit Diofcorides. Quinetiam (ut ipfe perbibet Auicenna) qui Napellipericula etwadunt, plerung; aut ad beciicam febrent, aut ad tabem, aut ad comi= tialem morbum de fciscunt. id quod Toxicum fumentibus non euenit : borum fiquidem qui fuperuixerint, ftupidi tan= tùm reliquum uite tempus ducunt. Ex bis itaq; ommibus liquidó apparet, quod hec inter $\int e$ maximé differunt. Lon= gé enim feuiora funt Toxici incominoda, qudin Napelli, ut abunde conftat ex Nicandro in alexipharmacis, ubi To= xicum defcripfit is notis. Protenus etiain lethalis toxici dolorem, o malun abigere difcas, quando fuis cruciati= bus bominem comprebenderit. Lingux eius, qui Toxicunz baufert, infernécraßjior redditur. Scd labia intumefcen= tia, os plané pondcre fuo degrauant, ac aridum prorfus $\beta$ putum regerit, inferioriq́; parte gingiue diff unduitur, or $\dot{e}$ fuis ftationibus mouentur. Sepe etian cordiftuporem iniecit, oninisq; fes fus confternatus eft, fontico ifto mulo pes= turbatus. Aclaborans co, e balat, or mugit, innumeras nugas fabulasqg; pres infania edens: ac fine intermifione Toxici notx

Toxici confi deratio.

Manardi opinio reprob. ex Nican. 


\section{And. MatthioliComm.}

dolens, uebementer uociferatur, inftar bominis, cui caput, totum corpus compingens, enfe amputandum fit. Vel quemadmodun cratcrifera facras res tractans ip $\int a \mathrm{R}$ be $\int$ acerdos, nona inenfis publico appropinquans itineri, lon= gun ore fuo rumorem, o clamorem edit, quem horrendum in montanis latratum audientes fibi metuunt. Sic ille rd= bie, mente fua turbatus errans eiulat, ac lupi inftar fugittie' ululat, obliquisq́; pupillis taurino more inpiciens, al= bum dentem acuit, dentibusq́; fuis depumat. bactenus Nicander. Caterim differunt toxicum, or napellus in cu= randiquoque ratione. Toxicum nanque Diofcoridi curatur rofaceo ex paffo poto, quinquefolij radicibus, caprillo, o bircino fanguine, cotoneis malis, amomo, o balfami firctu. Auicenna ueró Napello fuccurrit cum uimi potu, bu= tyro, mof cho, capparis radice, o co deniq; mure, qui napelli ipfius radices depafcitur . que utiq; medicamcnta o= mnia ab ijs admodum difcrepant, qux in Toxicicuratione commemorauit Diofcorides: qucm tamen pené ad uer= bum reddidit Auccenna in cateris uentenorum auxilijs. Hac igitur apertijßime oftendunt, conuincunt $\dot{y}_{\text {; }}$ Napellumet 20 Toxscum effe diuerfa uenena. Nec illa obftant fententice noftra, qua fuperius in Manardifauorem adduximus. quan doqueden: (ut facilé colligi poteft ex uniuerfa buiufce libri materia) alia etiant babentur ucnena, que quód eaden excitent accidentia, o paribus curentur antidotis, uidentur unam, o candem rem effe, cium tamen longé diuer $\int a$ cernantur : cuiufmodi funt mandragord, opium, byofcyamus, cornculatum papauer, e id genus alia. Sed ut iams de Toxico meam in medium profer am fententian, eum haudquaquam fallicrediderin, qui dixerit, id effe Auiccnn.e Toxicum, quod idem $\mathrm{T} u$ fom appellat. Nempe quodd affer at eo epoto labra, o linguam inflammari, fequi delirium, o incoërcitum furorem. qua propria toxici junt indicta. Attamen hoc uidetur illi omnino fuiffe incognitum. quod nec minus fortafe Diofcoridem latuit. Nam î toxicum nouiffet Diofcorides, eius certé hiftoriam libro quarto filcn= tio non difimulafet, ubi de cateris mortiferis differuit medicamentis. Illud porró indicium quodammodo facit, Mau= ritanorum tufoin cffe Diofcoridis toxicum, quód nomen illius licet corrupté, ab hoc Arabes traxiffe uideantur, quafi 20

Napelli uene toxicon tufoin nominauerint. Verim cuim toxicum de N A P E L L o loquendi nobis occafionem dederit, non a= num, eiusąue licnum fuerit, ut noftrum fequamur inftitutum, boc loco cius tum uenenum, tum remedia defcribere, prefertim cüm remedia. nafcatur in Italia. Napellus itaque, ut Maurit:norum teftantur monumenta, o noftra adfipulatur experientia, $\mathbb{f}$ potu uel cibo in corpus ingeratur, faud ftation adfert difcrimina : nempe illico labia inflammantur, o adeo intume fcit lingua, ut exeri cxtra dentes, $\mathcal{E}$ oris amplitudine capi non poßit: oculi item pariter intume $\int c u n t$, ita ut promine=

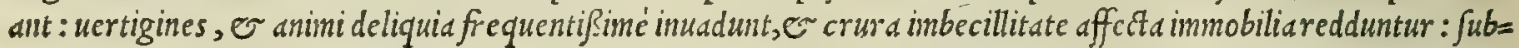

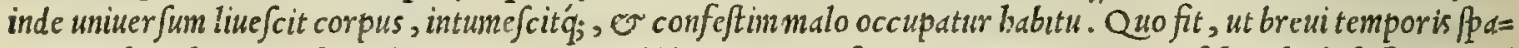
tio, qui fumpferint, miferabiliter intereant. Sed id mirum non eft: quippe quonidm tanta eft buiufce le thiferi ueneni uis, ut nifi ftatim proprijs antidot is fuccurratur, null is fubinde cxpugnatur medicamemtis. Imó quanuis etiam in ip= fo principio valentior d dentur remedia; pauci tamen fuperuiuunt, qui aut bectica febri (ut diximus) aut tabe, aut co= 30 mitiali morbo tandem non conficiantur. Succurrendum igitur illico fuerit, excitatis prius nomitibus (ut Auicenna inquit) ) epoto rapi, aut napi femine. Prodeft deinde butyrumbubulum coctum, oo fape ac largé cum uino fumptum: item glandium putaninum decoț ex exino potum. Auxiliatur diambari, o dianofchi puluis : quin potius amba=

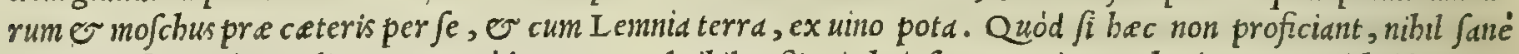
praterea perandum relinquitur, quod parum, uel nibil poßint in buiufce ueneni noxa theriaca, er Mitlbidatis an= tidotus. Proinde dicebat Auicenna, theriacam Napello non prodeffe, nifi certo tempore, er termino. Faciunt ad hoc o capparum radices, quód dixerint quidam antiquorum, has uerum Napelli effe antidotum. Conciliator fma= ragdi puluerem duarum drachmarum pondere magno remedio ex uino potandum pollicetur. Sed boc dari tantùm poteft Pontificibus, Imperatoribus, Regibus, alijs $q_{\text {; }}$ opulentis principibus. quandoquidem parua, uel nulla eft ad = bibenda fides pretioforum lapidum fragmentis, quibus hac atate feplafid utuntur. Ad hac recentiores feré omnes, 40

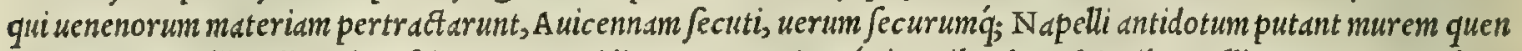
dam, qui Napelli radices depa fcitur. Hunc uidimus nos, cepimusq; in quibusdam altioribus uallis Ananie montibus. sed non omnibus datur ipfum inueniendi, uenandiǵ; modus: ad hoc nanque multa patientia, o uigilantia opus eft. Quamobrem mibi snirum non eft, quód fcripferit quidam recentiorum clarißimus, magnificum quendä uirum ac prin cipem, philofophum tasnen, or medicum, cum diu bos mures quefiuiffet, neq; eos inuenire potuiffet, ut demum fuum conficeret antidotum, horum uice magnas quasdam cepiffe mufcas, quas folijs, of foribus Napelli uictitare obferua= werat . Eo autem antidoto, quod conftabat ex predict is muf is numero uigintiquatuor, uncijs duabus Lemnix Pphra= gidis, e pari pondere baccarum lauri, atq; Mitlsidatis antidoto, omnibus oleo 0 melle fufficienti exceptis, admi= randos fecit effectus, non folum aduer fus Napelli uenenum, quod ut periculum faceret, diuer/is dederat animalibus, o ipfemet experiundi antidotigratia fumpjerat; fed etiam in omni alio ueneno. Sed quid dicam ( fi tamen licet fine uitio fud quenq; laudibus efferre) de admir anda ui olei noftri de fcorpionibus, cuius componendi rationem tradidi= mus in prefationis buius libri commentatione, cùm à tam Sauo exitialiq;; ueneno, qui biberint, breui admodum tem= pore liberentur, eo tantum exterius inuncti nibil certé alud, nifí quód aduer $\int u s$ boc uenenum, er catera que vifce = ra non erodant, ficut er uenenoforum omnium morfus e ictus, inter omnia remedia (pace aliorum dixerim) id prie mum fibi locum uendicat. Vbi enim uebementißıma, ferociaq, fuerint uenend, fingulis horis inungi poftulat: ubi ue=

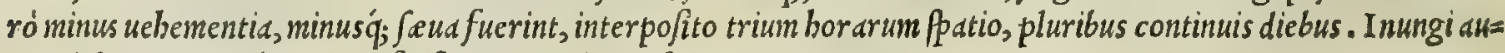
tem debet non modó cordi ad finiftram mamillam; fed temporum quoque, manuum, o pedum arterijs. 


\section{In Lib. fextum Diofcoridis.}

\section{I'gुas. IXIA.}

\section{CAP. XXI.}

I x I A, qux vlophonon appellatur, inter potandum aliquid ocimo fimile guftu \& odore redolet : vehementem linguæ inflammationem excitat:mentem mouet: omnes excrementorum exitus fupprimit: ftrepitum cum animi deliquio ciet : ijsq́ue inteftina latrant, nec egeritur quicquam. Poft uomitionem aluu mq́; refolutam, auxilium praftat aqua, in qua abfinthium maduerit, ex uino largiore, aut aceto mulfo pota : rutæá; fylueftris femen, aut laferis radix. item tragorigani decoctum, cum aliquo fupradictorum, aut lacte, aut refina terebinthina, aut nardo, aut caftorio, aut laferpitio, quo-

20 rum finguli oboli conueniunt quin \& nuces inglandes ex uino, cum refina, caftorio, \& ruta tritx, ita ut lingula drachmæ pondus rquent. Itidem chamelæx, aut thapfix, aut abfinthij fucci ficilicus cum aqua mulra, \& accrum calidum potum.

I I I A, wt fuperius libro tertio retulimus, lenta, o vifcimodo tenax eft lacryma, que in chamelconis albi ra = Ixix uene fea dicibus agglutinat. reperitur. Hec (ut Nicander, quem Diofcorides eft fecutus, in alexipharmacis inquit) guftatd natura. ocimo fimlcm faporem pre bet: baufta extresnun lingue tractum exapperat, interiora adurens . quinetià corde fuo turbatur ad infanian usque quifunp $\int e r i t$, ac linguam penitus dentibus lacerat. Porró mente attonitus redditur, al=

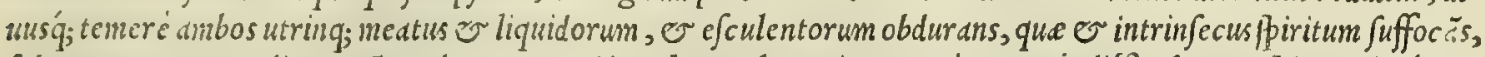
fubmurmurat, ac modico traitu nolutatur. Qui item hoc malo angitur, egré magnaq; difficultate repirat, adeóq; ue=

20 nenatd illa ixix potio protenus excrementa eijcit okorum fimilitudine. bactenus Nicander. Caterum Mauritani ixiam aldabsc uocant, quod proprié uifcun fignificat. Cuius nimirum incommodis in primis fuccurrunt, Auicenua tefte, excititte uomitiones, o infufi clyjteres, qui ijs maximopere auxiliantur: :ed mitiores leniores $q_{\text {; }}$ effe oportet. Proftant deinde auxilium theriaca, o Mitbridat is antidotus, ex abfintbij Romani, aut fantonici decocto pota. Pro= funt item epithemata, que cordis imbecillitati dicantur: quin e utriusque bugloßiflores faccharo afferuati, addetis margaritis, corallijs, pretioforum lapidum fragmentis, mofcho, ambaro, or alijs qua cordi opem ferunt. Conuenit infuper rofaceum aceto admiltum, or fincipiti ubi futurs interfecat, linteis illitum. Quxe fané remedia non modò re= morantur, frangüt'q; ueneni uim; fed omnibus etiam incommodis ab co excitatis mirificéfubueniunt. Porró cùm in frequenti reccntiorum medicorum ufu fit albi chameleonis radix ad arcendam peftilentiam, or ad interaneorü tineas necand as; ideo caueanc qui ea utuntur, ne agglutinatam lacrymam, /i qua forte fortund inba ferit, probeant deuor an=

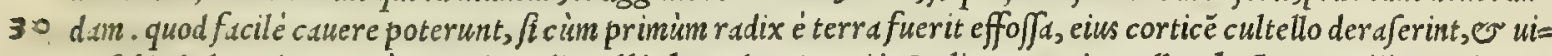
no fubinde lauerint. Verum ego in radice albi chameleonis, qui in I talia prouenit, nullam bactenus Ixiä reperi. At $t=$ tamen quidă Creten/is rei herbarie ftudiofus mibi pro certo afjirmauit, é carline unlgó uocate radice in Creta Ixiä ab ijs colligi, qui fagittas conficiunt, ut pennas fagittis conglutinent. Nec modó eam reperiri mibiretulit in eo carli= ne genere caule uiduo; fed etiam quandoq; in altero, fed rurius. Que certé omnia opinionem auxerüt, ut hoc obiter dicamus, carlinas uocatas Diofcoridis effe chamaleones. Quód auté plus ueneni infit C H A M AE L E O N I ni= gro, quàn albo, ut Galenus fcriptum reliquit, or poft ipfum $\mathrm{P}$ aulus, o Aëtius eius doctrinam fecuti (de qua re fu= perius libro tertio differuimus) non ita facilé crediderim, cum albo tantü Ixiam innafci fcribat Diofcorides. Non ob id tamen preteribo, quin boc loco ea refer ant, qux de Chameleonis nigri ueneno, ov eius remedijs memorix prodide= runt Paulus, of Aëtius : ira enim fcribunt. A chameleonis nigri potu mor $\int u s$ uentris,

40 bus inteftinorum equitur : facies diftorquetur, o uomitus $p$ pumofus, tremores, concußiones, $\sigma$ totius corporis con= uulfiones, ac uoc is interceptio concoinitantur. Ceterum curantur ex bis, qua ad fungos funt relata. Datur eis er thlapios, $O$ bete fuccus, $\mathcal{G}$ triticee ptifane cremor ex paffo, abfintbij dilutum, $\sigma$ nitrum cum aceto mulfo. vbi

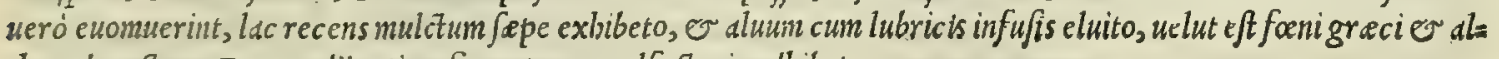
thes decoctun. Precordijs etiam fonenta, ac calfactoria adhibeto.

$$
\text { Yupuitrov. CERVSSA. CAP. XXII. }
$$

C E R V'S S A fuocolore proditur: fumpta enim, mox palatum, gingiux, lingua, \& commiffurædentium, candore quodam inficiuntur: fingultus, tufsim, ac lingux ariditatem excitat: ijs extreso ma frigefcunt, mens labat, membra torpefcunt. Quibus dare conuenit aquam mulfam, aut ficuum, aut maluæ decoctum, aut lac calidum, aut fefamam ex uino tritam, uel lixiuiam ex farmentis factam, amaracinum oleum, aut irinum, perficorum offa cum hordei decocto : columbina oua cum thure, aut hordei decocto, aut prunis: aut gummi, quod ulmus plorauit : aut bumor, quem ulmea folia reddiderunt, cum tepida aqua : fed tum quoq̨; uomant. Conuenit etiam thapfiæ fuccus, aut fcammonix, cum aqua mulfa potus.

CE R V S SAE faciunde rationem tradidimus fuperiore libro. Hec tametfi ad ulcerum medicamenta, que ex= terius illinuncur, falubre plerung; fit medicamentum; ;i tamen fumatur intus in corpus, interficit, quemadinodun ce = tera deleteria pharmacd, de quibus iam plura retulimus. Epote ceruffe incómoda pluribus notis, quàm fecerit Dio= fcorides, eleganter carminibus reddidit in alexipharmacis Nicander, quorum carminum hec erit paraphrafis. Ce=

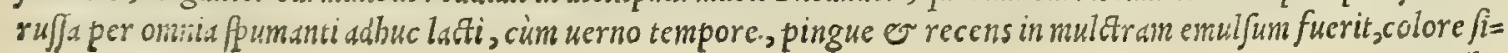

Ceruffe letha lis natura. 


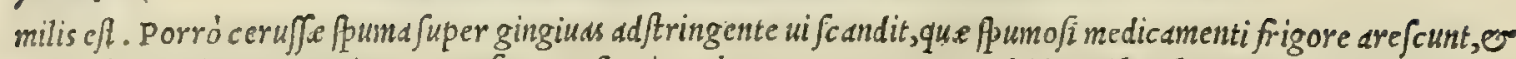
contrabuntur in rugas. Lingus, es fauces apperitate languent. Vexantur ob id, qui baufcrint, arida tußi, oculisq́; nutantes gratutate, dum crebros ruftus egerunt, non fine labefactione fui opplentur. Hinc fit, ut capite non parum turbentur : quine tiam animo fuo naufeabundi pre triftilabore gemunt. At fepißiné in ipfa luce uanum phantafma,

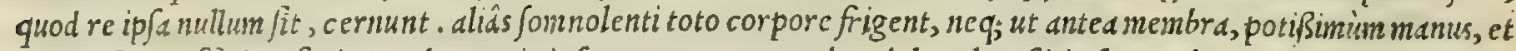
pedes, fum of ficiun faciunt, adeo ut ni eis fuccurratur, eo tandem dolore lace Biti, fuccumbant pereantóf. . hactenus Nicander. Catcrum A uicenne teftimonio ceruffam haurientibus alia adueniunt incommoda, nempe animi deliquium, faucium apperitas, uentriculi, alui coinpun tiones, precordiorun ten/io, anhelitus difficultas, prefocatio pirituü, Ceruffe mali $\sim$ albedo totius corporis : quin $\widetilde{\sim}$ urina modo nigra, modó cruenta redditur. His auxilium preftant (ut ipfe, er auxilia.

Aëtius tradidere) Scammonium cx mul] a potum, aliá; medicantenta, qux fuapte natura urinam ualenter pellunt. Post hec clyfteribus uticouncniet, ac fubinde prouidere, ne dormiant affecti, fed uigilantes sepius euontat poto prius bydromelice, filino, or narcisino oleo admiltis. Preferunt quidam uomitiones ab atriplicis, o rapi femine concita= tas: item clyfteres ex braficx decocto cum olco, absque fale: infuper theriacam ex uino, o Mitbridatis antidotuin, or albunn meracum uinum largius potum.

\section{MUкห่TES: FVNGI,}

\section{CAP. XXIII.}

F v N G O R V M alij genere, alij copia lædunt: omnes tamen ftrangulatus fufpendio fimiles concitant. Quibus confeftim fuccurrendum : communiter ex oleo uomere cogendi : mirificè iuuat lixiuia ex farmentis, aut pyraftrifurculis, epota cum fale, pofca, \& nitro. Fructus, aut folia pyraftri 20 cum fungis decoeta, ftrangulantem illam uim auferunt, efitataq́uc eisdem auxiliantur. Aduerfus fun gos gallinacea oua cum pofca proficiunt, adiecta ariftolochix drachma : item abfinthium cum uino melleque fumptum, \& ex aqua potum : apiaftrum ex nitro: panacis radix, \& femen in uino: fex uini cremata, cum aqua : ațramentum futorium ex aceto: radix, uel finapis, aut nafturtium efu profunt.

Fügorum ve- . No N modó nocent in uniuerfum Fungi, quod in corum genere aliqui habeantur lethales, $\sigma$ fudpte natura ue= nefica natura. neno imbuti; fed etiam quód ex bis, qui perniciofi non funt, plus quam uentriculi robur ferre poßsit, quando ;; ingerd= tur, ita ut tunc non malefica ui : fed copia ledant. Quippe cim natura bumidiadinodum, er frigidi fint, es lentore non modico fcatednt, fuperato fua quantitate corporis calorc fuffocant, Atrangulant, er denicy; interimunt, nifi citius remedijs fuccurratur. Cognof cuntur qui mortifirifunt (ut fuperus libro quarto tradidimus) fi frangantur, quod 30 illico uarios mutent colores, flatimq; computrefcant. Proinde dicebat Auicenna, in fungorum genere cos effe letha= les, qui uirides, or cesij deprebendütur. Sed certé magnopere admirari licet, quód tanta in hominibus inualuerit gula libido, ut etfi friant fungos effe plerunque necis bopitium; tamen fui ipfius obliti, magno fané apparatu eos in

Fungorŭ prę cibis auidijimé deuorent. Verün poftquaim tantam cum palato fungi iniere gratiam, ut ab bis abftirere bomines paratio. non poßint, faltem difcant uelim, ut fe ipfos à morte uindicent, fungos nunquam effe fumendos, nifi prius cum $15 l u e=$ fribus pyris decocti fuerint. Quód / fylueftria pyra defiderentur, ex domefticis ea fupplere poterunt, que ceter is aufteriora babentur. in quem ufum adbiberi poffunt tam recentia, quàm fole ficcata. Praftant idem arboris tam fo= lia, quim cortex, pra fertimí; fylueftris : fiquidem fungorum antidotum pyra funt. Diofcorides libro quarto prater medicamenta bic ad fungos aßignata, practulit origani, or fatureix decoctum, gallinaceorum fimum, ex aceto aut melle potum : quod tamen ( ut Pbildgrius explicat) album effe oportet. Sed primum medicamentis fapius enarratis 40 cliciendus eft uomitus, of fubinde acria infundenda cly/mata, ut extra corpus trabatur uirus. Caterim ignoran= dum non eft, cos incommoda afferre longé maiora, qui propria natur a uenenati nafcuntur .quandoquidem non modo fuffocant, ftrangulantó; camedentes; fed etiam inteftina exulcerant, uentriculum inflant, fingultum, or puntiones excitant, corpori uniuerfo pallorem inducunt, er urinam remorantur. Prater bec alia uerenda, $\mathrm{O}$ letbifera oriun= tur fymptomata, nempe frigus, tremor, interceptio arteriarum, animi deliquium, perfrigidus fudor, or mors ad po=

Fungorŭ ue- fremum immatura. "His primùm auxiliantur uomitiones omni celeritate excitata : quibus etiam conuenit epotus neni remedia. domeftici raphani fuccus, aut deuorata rute folia, aut origanum, aut mel. Prodeft deinde mirum in modum theriaca, Or Mitbridatis antidotus ex acerrimo aceto pota, aut ex oxymelite, aut ex aqua uite uocata . quamobrem quinta ef= fentia noftra theriacalis, in bis fungor ü malis mirificam fert opem. Pretulit ad hac A uicenna calida quacunq; aro= mata: cuiusmodi funt diapipereos, diacyminum, diagalanga, dyamofchum. Conciliator potandum exbibet magno iu= so uamento uinum optimum, in quo conferbuerit piper, offert'́; fubinde allium crudun deuorandum. Id quod facit uni. uer fa feré rufticorum turba, qui ( ut Galenus inquit) allio theriaca uice plerunque utuntur.

\section{rúfos. GYPSVM.}

\section{CAP. XXIIII.}

L A P I D E S C E N S gypfum ftrangulationem creat. Quare eadem proferenda funt, qux manfis fungis, auxilia: \& ad hæc malux decoctum, quod etiam olei uicem penfat: vtpotecùm pingue fit, euomendo lubricas uias, \& faciles reddit, deradique corpora non finit . quod vbi duratur in lapidê, gypfum efficit. Quinetiam prodeft oleum ex aqua mulfa, aut ficorum decofto : \& lixiuia è ficulneo cinere, aut farmentis facta, cum vino copiofiore pota: \& origanum, aut thymum cum lixiuia, aut aceto, aut paffo : hiquue decocto malux proluendi. 


\section{In Lib, fextum Diofcoridis.}

G Y P S V M omnibus notum, fi bibatur, aut comedatur, frangulat ( $u t$ Diofcoridcs inquit) quód repirationis meatus uslenter adlbingat, $\mathrm{O}$ obltruat. Neminit huius inter uenenata medicanenta Auicenna, fic inquiens. Eadc. funt gyp/indicis, que $\mathcal{C}^{-}$ccruffe, preterquim quód illud citius, or atrocius frangulat. quanobrcm ijs, qui baus= ferint, ca comenume medicanc nta, que cerufJe, o fungis opitulari diximus. Poftea lubrica dand a funt, cuiusmodi cft malue, alth ce forni graci, c linifiminis decoctum. Conciliator cgelidan aquan cum butyro primum patandam iubct, or dcinde tomitum excitwdum, i womitu calidan itcm cum molle prebet, ut iterum uomant: pof remo Nithri= datis antidotum wino mer.tco mifl um, drachnarun duarum pondere. Quód fi aluus ab boc adftrita fuerit, citctur o=

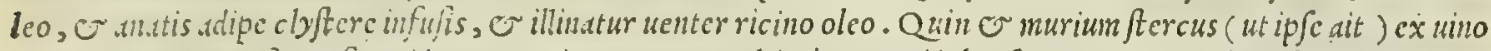
potum, propriun c/t gyp $\sqrt{i}$ antitotun. Auiccnna autcm ultino purgari iubet $\int$ cammonio, 0 alijs plarmacis, que

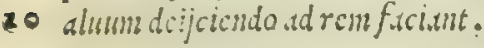

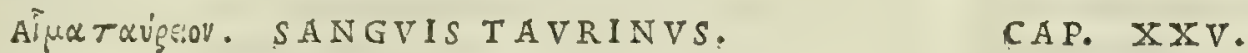

T A I I recensiugulati fanguis epotus, fpirandi difficultatem, ftrangulatumáue concitat: fiucium, tonlillarumq́ue meatus cum neruorum diftentione præcludit: lingua rubefcit : dentes inficiuntur, \& quadam concretifanguinis ueftigia, inter eorum commiffuras reftant. Quare uomitum vitabimus : fanguinis enim globi attractu illo in fublime relati, magis gulæ inculcantur. Dari ergo opus eft qux concretum fanguincm difcutiunt, \& aluum fubducunt. Grofsi lacteo fucco turgentes ex pofia, \& nitrum perféf, auxiliantur: nec fecus coagulum omne cum aceto, \& la ferpitij radice, 20 aut lafere: itidem \& brafsicæ femen, \& c̀ cinere ficulneo lixiuia : conyzæ folia cum pipere, \& rubi fuccus ex accto . aluus refoluenda. Tis qui feruantur, ftercorofa, \& fluida per fedem egeri confueuefunt. Stomachum, aluumqú hordeacea farinaex aqua mulfa perungere oportet .

NE 11 o tauri funguinem clim potandum exhibere poteft: nam unufquifq; fane mentis fanguincm cognofcet. quare, mea quidem ententis, fieri non poteft, ut uenefici eo quenquam decipiant: quippe nifi largius bibatur, er ad=, buc calens ab ip/is defluens uenis, anted quàm concre $\int$ cat, noxam non infert, dut leuen. Quo fit, ut cos tantim tau= rino anguine interire crediderin, qui aut atra bile tentati, aut cacodemonibus irritati, uel ut aliquod feum mortis ge nus ab legibus pro fuorum facinorum poend luenda inftitutum cffugiant, uel ut immedic abiles or grauißimos morbo= rum crsciatus finiant uitam pertefi (quod Plinius lib. X X.cap. X V I I I. feciffe ait epoto opio Licinij Cecinne pa= 30. trcm ciuem Romanum) morten fibi uoluntariam confcifcunt. Proinde fcité Nicander in alexipharmacis ita fcriptü rcliquit. Si ex infipientia quifpiam atrum taurifanguinem hauferit, moerore adeó ingemit, ut nimio cruciatu tandcm conficiatur . quando cordi appropinquans fanguis ille condenfatur, ac in medio alui receptaculo in grunos coagu= latur : binc E meatus pirituun obdurantur, er balitus fuffocatur impleto gutture. Atquitractibus, or fingulti= bus ifte afflutus, crebró bumi puma coinquinatus palpitat. bec ille. Caterum fi forté fortuna euenerit, ut quis tauri funguincm potatuerit, $\odot$ ad eum domeftici, quibus factum conftet, medicos aduocent, tunc medici ijs uti poterunt re= medijs, qi!orum bic abunde meminit Dio fcorides. Scd quonian taurinus fanguis menftruun fanginem mibi in men= tem redegit, atq; etian bic nobis oc urrit fel pardi, uipera, or canis pifcis: item cerebrum felis, quem Graci alurum uocant, ceric cxrema cauda, quorundam quadrupedum fudor, or malum denique improbatum ; $_{\text {; }}$ caforeuin, que onnis liner letbslis medicamenta annumerdntur, cumbec à Diofcoride in boc uenenorum cenfu pretermiffa depre=

40 hendaitur, et nobis propofitum fit, fingulorum uires maleficas, edrum $\dot{q}$; auxilia de fribere, bic locus opportunus ui= fus eft, in quo de ijs differeremus, er noftrum inftitutum, quantumpofjumus exequeremur. Sanguis itaq; $\mathrm{M} N=$ $S$ T R V V S mulierü, prefertimǵ; biliofarum, o facilé rixantium potus, adeó bibentes effafcinat, or inficit, ut lu= naticos $\%$ ancntes eficiat. Id auten deteftabilis facinoris quandoque perpetrant malefica uenefic áq; mulieres ca= codenonibus ducte ip pun exhibendo proprijsmaritis, uel alijs, quos odio profequntur. Huius tamen noxe fuc= curritur contritis margaritis drachme pondere ex meliffophylli aqua potis : auxiliatur er tepida balneum. Confert ad bec (ut Conciliator inquit, fi tamen id abfg; diuine legis iniuria fieri poßit) ut affecti bilari frequentió; mulierum confortio letentur, cun eisq; coësnt, precipue cum iuuenibus, que raró nuptias celebrent. Prodeft er theriaca dra chme pondere ex fun arix aqua quotidie pota. Profunt or uiperei paftllif crupuli pondere, additis tum margaritis, tum theriaca codem pondere. Epoto autem P A R D I felle excitatur uomitus, ceu aloés amarore, os er nares

so inficiens: poft uonitum uniuerfum corpus flauefcit, ictericorun modo: poftremó ea omnia confequuntur incommo=

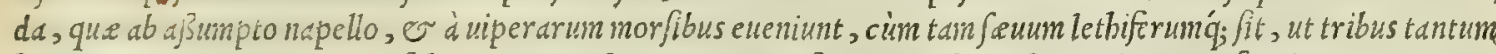
boris potantes perimat. quod/i boc temporis pationon interficit, prorfus deperandum non fuerit. Expugnatur, priminz somitionibus illico excitatis, fubinde ijs utiq; antidotis, que napello, uel uipere morfu infictis opitulantur. Auicenus buic ueneno peculiarem conficit theriacan cx Lemnie terre, er lauri baccarum, fingulorum drachma una: caprcoli coszuli drachnis quatwor : myrrhe, o ruta feninis, cuiusq; femidrachna . qus omnia melle excipit. Hanc lirglandis qusn:itate exlibet, excitatis demde uomitionibus, duct is q́; demum labor antibus in calida aque bal= neum, cui inferbuerint odoratcmedicamenta. Sed V I P E R AE fel adeó perniciofum exiftit, ut ftatim anini de= liquium adferat: quare rarifime antidotis fuccurri potef, quód nullum detur ea praparandi patium. Veruntanch
fi quid eft, quod tan breui teinporis momento quicquan opis ferat, id erit quan celerrimé excutatus uomitus, epoto fi quid eft, quod tam breui teinporis momento quicquan opis ferat, id erit quam celerrimé excutatus uomitus, epoto
prius cofto butyro, igne colliguato: quo womitiones iterum, atq; iterum noucre oportet. Pof uomitus nibil falu= brims, quam theriaca, or IIthridatis aitidotum, nofchus, ambarum, of eorum compofitamedicamenta, qux dia=

Sanguinis tau rivenenata na tura.

Sanguinis mé Arui uenenú, eiusq́ue cura to.

Pardi fellis ue nenum, eiusque remedia

Viperx fellis uenefica uis, \& auxilia. 


\section{And. Matthioli Comm.}

mofchum, or diambarum appellantur. vbi autem animi deliquia perfeuterant, or corporis unituerfi anguftia, uinum quidem offerendum eft, aut capporum, or gallinarum carnium fuccus ex aque feruentis balneo in uafe uitreo diftillax tus. Huic equidem noxa crediderim magnifice aducrfarioleum noftrum de fcorpionibus, cuius componendiratio nem tradidimus in buius libri praf fationis commentatione : itidem $\sigma$ quintam effentiam noftram, quód itu oculi fuis Canis pifcis perquàm tenvißimis partibus in totum deferatur corpus. Porrófel, quod à C A N E pifce eximitur, lethiferum felıs uenenū, eft.quippe quiod potum, uel efitatum lentis rantum quantitate, feptenis diebus interficiat. Curantur tamen qui baufe= \& cura. rint, epoto bubulo butyro cum gentiane radice, cinnamomo, ev leporis coagulo. Prodeft $\sigma$ corpus uniuer $\int u m$ odo Felis cerebri ratisoleisillinire, or uictu tenuißimo uti. Ceterim qui F E L I S C E R E B R V M in cibis ederint, crebris affis maleficiū, \& ciuntur uertiginibus, fiuntóq; fubinde ftolidi, $\sigma$ amentes. Quibus etfi fubueniri poßit, id tamen non nifî temporis tra= remedia.

ctu, $\sigma$ admodum difficulter fieri poteft. His danda cft L emnex $\beta$ bragis, $\sigma$ uomitiones inde funt excitande, fieriq́; id oportet ter, aut quater in menfe. Preflat item auxilium, fi quotidie mane fumant cgrididmo fchi confictionem, tri= bus uel quatuor boris ante cibum. Quninimo mofchus per $\int e \int e$ fufficienter auxiliatur: nang; ut quidam tradiderunt, mofchus tantium huiufce cerebri proprium eft antidotum, $f$ dimidij fcrupuli pondere ex uino bibatur. Sed illud non eft ignorandum, quód non modó Feles dcuorato eorum cerebro bomines inficere pofjunt; fed pilis quoq; reßiratione, or oculorum intuitu. Nam etfi pili onnes imprudenter in cibis fumpli, prefocare poßint, anbelitus meatus obftruen=1 tes; tamen filium priuatim exitiales cenfentur. Eorum praterea piritus tabifico quodain ueneno infectu depreben= ditur. Etemim noui ego quofdam, qui cùm felibus ddeò delectarentur, ut nunquam fine ipfis dormitum peterent, attra $=$ cto inde diutius aëris uebiculo corum piritu, in tábem, o marafmum incidere. quibus poftremó confecti diem fuum - bierunt. Nec diu eft, quòd in quodam monachorum conobio uniuer $\int a$ perït familia', magno felium numero, er con= tubernio. Ladunt item fuo (ut diximus) oculorum intuitu, adeó ut quidam reperiantur, qui bis uifis, aut auditis, pa= 20 uore quodain illico capiantur, terreanturq'; maximé, quód non modó ex eorum ueneno prouenire exiftimauerim; fed ctiam propria corum Hatura, qui cos uel intuentur, uel audiunt. quandoquidem ij fua natura talem à coelo qualitaté influxam babent, que nunquam ad proprism mouetur actionem, nifi obijclatur id, quod natura fibi contrarium fue= rit. Horum plures in Germania duntaxat uidimus, o quofdam ex ea natione Goritie commorantes. Qưod autem uerum fit id aliunde euenire non poffe, quàm à congenita qualitate, qu.e paucis admodum ineft, aperté fané oftendes gunt corum aliqui. Cuippe cum buius gentis quidam byemis tempore in bypocauftum nobifcum candturus intrafs fet, quó plurium amicorum fodalitas conuenerat, mulier quadam buius uiri nature confcia, ne is, vifo felis catulo, quem educauerant, iratus difcederet, illum in arcula quadam eodem in coenaculo cöcluferat. Sed quanuis nec uidiffet ille, nec audiffet catulum, cum pauco póft tempore dërem fel is balitu infectum inpiraffet, irritat a fatim ea tempera= menti qualitate feliun inimica, emiffo fudore, pallida admodum facie, omnibus fane admirantibus, tremebundus con= 30

Caudx cerui clamare capit, bic aliquo in angulo latet frlis. His autem eadem ofem ferre putauerim, qua cerebrum comedenti= uenenum, \& bus remedio effe diximus. Inuenitur etiämnum in C A V D A E C E R V I extremis partibus porraceus quidam, eius curatio. humor fellea bili admodum fimilis, qui fi fortè deuoretur, prefentanetm eft uenenum. Adfert enim illico intolerabiles anguftids, anini deliquia, o omnia tandem fymptomata, que epotum napellum confequuntur. Succurritur his, ut cateris, primùm uomitionibus, epoto butyro excitatis. Pofted dandus Smaragdi puluis ex uino dimidij fcrupuli pon= dere. Quin o piftacia profunt, or pontica nuces in cibis largius fumpta. Ad hac uniuerfum corpus inungi proa Sudoris ani- ftat, oleo é citri femine expreffo. Item theriaca proficit ex uino pota duarum draclsmarum pondere. Magna quoqs malü uirus, infert incommoda quadrupedum quorundam s V D o R, prefertim equi, afini, $\odot$ muli, quanuis ctiam caterorum fit ix remedia. malus. Is igitur potus uiridem tumidang q; reddit faciem: fudorem foetidum in uniuerfum excitat corpus, prefertim fuh alis . Perturbat preterea tum uentriculum, tum aluum uniuer $\int a m$, genitis excitatisq́; flatibus in inteftinis. Quód 40 fi bibatur ex uino, delirium facit. His tepidam largius prebendam fcribunt, ut concitato inde uomitu puluerulentus fudor reijciatur. Poft uomitü confert uinum cum rofaceo potum : item rbabarbarum femidracbme pondere fumptü, addito fo Bitij falis momento . tamet/i propria buiufce fudoris antidotus ea fit theriaca ( ut Auicenna eft author) que ex Lemnia phragide, o lauribaccis conficitur, cuius componende rationem paulo fuperius retulimus, de Pardifele Caftorei viru differentes. Venenofum aqué ac lethiferum aiunt effe etiam C A S T O R E V M, quod iam putredine nigredinem lëra uis,\& cu- contraxit, uel illud potius, quod é Ponto fuerit allatum. Hoc enim (ut strabo inquit) uenento fum est propria fui na= ratio. tura. Animaduertant igitur tum feplafiarï, tum medici, cum plurimi ufus fit medicamentum, ne malum exhibentes caftoreum, aliquem interimant. Quandoquidem non modó furore aguntur, quiboc medicamentum bauferint; jed es tiam intume fcentem linguä exerunt, atq; tam faud febre corripiuntur, ut uno tantium feré die intereant. Aduerfus boc uenenum mirum in modum iunant uomitiones, quas toties butyro, o bydromelite epotis citare conuenit, quod nullun ea, qua reijciuntur, caftorei odorem referant. Poft uomitiones conducit diamuron potum, aut limonum, aut citrei mali fuccus faccharo admiftus. Verim peculiariter buiufce caftorei antidotum eft coriandri fennen toftum, drase chmarum duarum pondere fumptum.

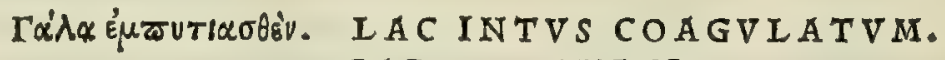 CAP. XXVI.}

Eos, Qvi coagulatum lac hauferunt, frequens illico ftrangulatio inuadit, quòd in globulos quofdam lac coalefcat. Quibus iuuandis pro antidoto, coagulum ex aceto damus, \& bibere fæpius cogimus. Damus \& calaminthæ folia arida, item fuccum : aut laferpitij radicem, aut lafer cum pofca: thymumq́ue ex vino, \& cum luto fuo lixiuiam. Sed nulla falfilago obijciatur : quoniam magis 


\section{In Lib. fextum Diofcoridis.}

lac coiret,$\&$ in cafeum denfaretur. Neque illos vomere conuenit: fiquidem concretum lac fefe in gula angultias infinuans, ftrangulas.

C R E D I D E R E quid.m Diofcoridisinterpretes, authorem boc in loco de eo codgulato lacte differere, quo Lactis coagu frequenter in cibis utimur. E' quorum numero fuere $R$ uellius, $\odot$ Mandrdus Ferrarien is ca epiftola, in qua uniuer = lati confidefan Marcelli interpretationen corrigit. Sed ij alioqui uiri cruditisimi, in boc haud dubié falluntur, meo indicio ratio. Siquidem lac ea ratione coagulutmin, nutrit, non autcin ftrangulat, ut onnes in uniuerfum homines teftari poffunt, fcd Qunorundam prafertim ij qui in montibus degunt, cum Muio, or I zmio menfibus buiufcemodil lactis plurimü deuorent. Idco nil a= ror. Fiud nobis al] ircndun effe putaucrim, quim quód de co tantim lafte intellexerit Diofcorides, quod cum adinifto cod=

20 gulo bibitur, antequdim coalcfcat, ita ut intus, non extrè codgulatum fit. Quo factun eft, ut in boc à Ruellij inter= pretatione in aliam dejcimerimus or bic, o in buius libri prafatione prope calcem. Magis enim Diofcoridis fenten= tiam exprimi cenfemus, fi lac intus coagulatum, uel (ut Marcellus) lac cui coagulum admiftum fit, uertantur uerba

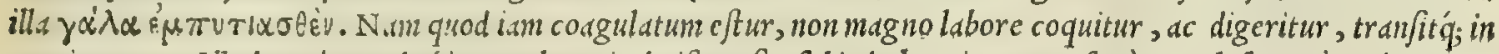

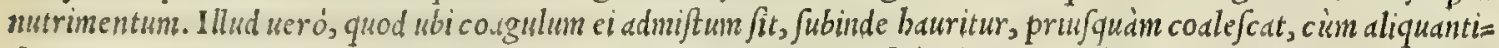
Pper in uentriculo re fcderit, ui admifti codguli illico inibi concre fcit, fit ǵ; concostrici facultati dé contumax, ut fu= perato caloris robore ftrangulet, non fecks ac taurinus fanguis. Proinde afferit Diofcorides, tauri fanguinem mini= mé Juffocare, nifi reccus caliduśg, é iugulati tauri uenis defluxus bibatur, antequàm concrefcat. quandoquidem is nö enecat aliqua propria ucncni facultate, fed concretione tantüm, quam in uëtriculo confequitur. Id quod euidentißi= mum cst in epoto lacte, rui admiftum fit coagulum : aut in eo quoq;, quod fine coagulo bibitur, er per fe aliis de cau=

2o fis in uentriculo coale fait. Eue nit enint quandog; boc, cum lac bibitum craßius fuerit, o uentriculi, er iccoris tem= peratura caldda, er ficca nimis. Namingens borum uifcerum tum caliditas, tum ficcitas, confumpta breui lact is bu= miditate, reliquun, quod crafjun eft, facilé cogit, $\odot$ cỗßpißat. Quinetiam illud idem ingentifit frigiditate : nimirum expreffo ab ea, quod tenuium eft partium, reliqum, craßioris fubft antic facilé congelafcit, baud fecus quàn de gla= cie, o nime fierilibro quarto meteororum tradidit Ariftoteles, Cumabrem eft Galeni confilium libro tertio de ali= mentorum facultatibus, ut nemo lac potaturus ipfum bibat, nifi mellis, aut falis tantillum prius admifceat, ne in uen= triculo concre fat . Sed non propterea mirarilicet, quodd Diofcorides fcripferit, lac concretum in uentriculo haben= tibus wibil falis falsiue effe offerendum. Quippe quemadmodum coagulum primó lac coagulat, contrariumó; deinde efficit, fi iam cöcreto lacti juperappergatur; ita fal prius lacti commiltum, id concrefcere probibet, mox contrarium rffectum prabet, fi iant concreto appergatur . recens enim cafeus fale relperfus, illico duritiem contrabit. Sed ian

30 ad curationem accedamus. Eddem autem erit lactis in uentriculo codgulati curandi ratio, qua fanguinis tauri, quan= do ijs t sntim fit utendum medicamentis, que fuapte natura concreta liquant, o difcutiunt. Qua in re auxiliu pre = ftant ipfa coxgula, acetum, prefertimíf; fcillinum, lixiuium, o ed omnia, que incidunt, e difgregant. Porró

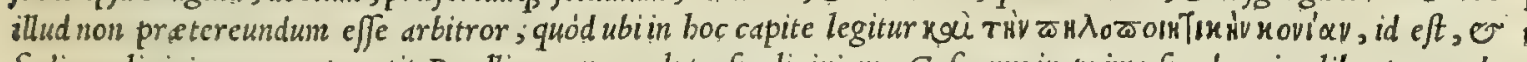
figlinam lixiuiam, non ut uertit Ruellius, $\sigma$ cum luto fuo lixiuiam, Gefnerus in primo fuo de animalibus tomo, de

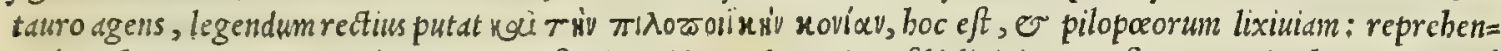
ditó; inhoc Cornarium, quòd putauerit figulos ad lutum lauandum fibi lixiuiam conficere. Sed mibi, ut ingenuè dicaim, magis placet Gefneri, quàm Cornarij opinio. Siquidem cium figlinum lutum nunquam lixiuia lauari aut pd= rari audiucrim, uidcrin, aut legerim, ueritati confonum non udetur, ut de figlina lixuia intellexerit Diofcorides: fed de ea potius, qua ad lanam expurgandam, ut infecture magis idonea reddatur, utuntur pilopoi, bi funt, qui pi-

40 leos conficiunt. Eorum nanq; lixiuia, quód é combufta uini fece plerunq; fiat, ea qua ad caput capillosq; abluendos communiter paratur, acrior, fortior'; efficitur: e proinde ad lac diffoluendum in uentriculo codgulatum, eft lon= gé ualentior. Error pretere a facilis effe potuit librariorü, ex unius duntaxat litere uariatione, $\mathrm{N}$ pro i cribentium.

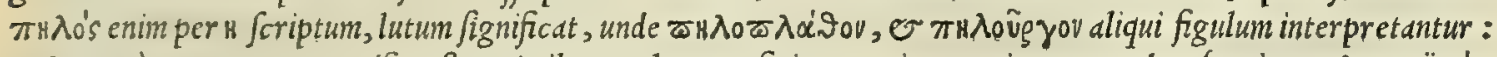

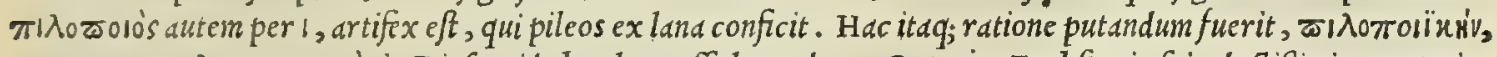

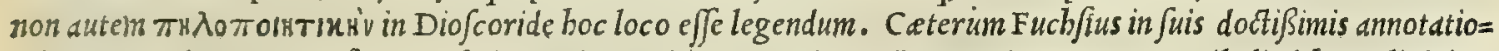
nibus in Nicolaum Myrepficume eafectione, in qua de unguentis tractat, capite $\mathrm{x} x$ v I I I, nil dliud banc lixiuiam efe putat, quàin aquam qua lutum lauerit, uel per lutum tranfierit, non autem cum cinere, or calce factam. Sed cum figlinum lutum potius adftringat, contrabatq́, , quàm laxet, ac digerat, nefciuerim profectí , qua ratione is eă lixiuim é tali luto confectam, ijs potandam daret, quibus lac in uentriçulo concreuifjet.

so
Atix́grugos.
ARGENTI SPVMA.
CAP. XXVII,

S p v м $~$ argenti pota, ftomacho, uentri, \& interaneis grauitatem cum magnis torminibus adfert, \& nonnunquă pondere fuo inteftina vulnerat, urinamq́ue fupprimit : corpus intumet, plumbeamq́ue deformitatem concipit. Quibus fubuenit fecundum uomitionem, potum fylueftris hormini femen, myrrhæ drach mx octo, abfinthium, hyffopum, apij femen, aut piper, aut liguftri flos ex uino: aridum palumbis fimum, cum nardo $\&$ uino.

P о т A argenti Puma, cuius hiftoriam libro quinto tradidimus, lethiferd ( $u$ t Diofcorides inquit) adfert incom= moda. Sed preter brec, Aëtio, $\subset$ Auiceind autboribus, alia etiam eueniunt mala , nempe compaginum, ơ articu=

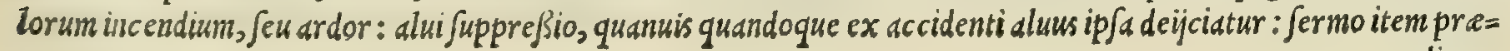

Iactis in uen triculo coagu lati curatio.

Diofcoridis lectio caltiga ta. 
peditur, er fedis inteftinum prominct: poftrenò inuale fcente malo agrifuffocati moriuntur. Nicandro ueró in alce xipharmacis authore, ijs qui argenti pumä fumpferint, alui moleftia accedit: quin $\sigma$ flatus fe fe reuoluentes per me= dium uentrem, o iuxia unbilicum murmurant, inftar torminum curatudifficiliorum, qux hominem afflictant du= ris eum cruciatibus impetentes. Nec iam urine eijcienda patet exitus: membra totius paßim corporis ardent, pla= néq; iam plumbeum, feu liuidum colorem induerunt. hec ille. Ceterim illud auimaduertendum eft, quód ubi in hoc capite legitur, dandam effe myrrbam octo dracbinarum pondere, non deeft fufpicio, quin ea lectio fit deprauata, quód bec myrrbe mmia uidedtur eße quantitas. Auget fupicionem $\mathrm{Nic}$ ander, qui duos tantum myrrbe obolos exhibet, Spumæargen totidem exhibet Aëtius, Auicenna ueró tres drachmas non excedit. Curatio in uniuer fum fit citatis primiın uomi= ti curatio. tibus, $\sigma$ infufis deinde cly fmatibus (ut Conciliator tradit) ex bydromelite, gallinarum, er anatum adipe. Poft hec prodeft amygdalinum oleum potum é dulcibus nucibus expreffum. Conferunt item carica in cibis fumpte: preterea so ucntriculum apij fucco, or aluum butyro illinire utile eft. Proprium ueró buinfec ue neni antidotum (ut idem dit) eft lathyris femen duarum draclsmarum pondere potum. Veruntamen cim hoc facultatis admodum deiectorix fit medi= Plübi fcobis camentum, dracbmam ego non excederem. Eadem quoq;infert mald P L V M B I $S$ C O B s tenuißimé contrita, noxa, \& curatio.

Ferri fcobis, e ijsdem pariter curatur medicamentis. siquidem argenti \$uma nil alind eft, quàm plumbü argenti,aut aris recre= mento commiftum. Nec deleteria ui uacant ( $u t$ author eft Auicenna) FERR I tum fcobs, tum fquama, tum fquamx, \& re recrementum . tametfi omnia bec prius diutius aceto macerata nulla prorfus moleftia in medic um ueniant ufum, den= crementi no- turq́; potanda dy fentericis, mulieribus uteri defluxione tentatis, o in eclegmate ad lienis infarctus, item $\dot{q}_{j}$ ad ente= xa, \& cura. rocelas. Sed de bis uel non infienatis, ucl plufquàm par fit fumptis, fortaffe intelligit Auicëns. Itaq; excitatur ab bis inteftinorum cruciatus, oris $\mathcal{O}$ linguce $\int$ cabrities, aftuatio univerfi corporis, capitis dolor, marafmus, $\sigma$ membro= rum onnium arefactio. Succurritur nox a potu lactis recenter mulfi, ac fubinde datis aluü ualenter foluentibus medi= 20 canentis. fecundum qua butyrun tandiu potandum dare oportet, donec inteftinorum dolores amoue antur. Hac dum funt, perfundatur corum caput oleo rofaceo, uiolaceo, e é nymp bex floribus parato. Tollitur deinde adueniens marafini intemperies, ov corporis uniuerfi arefactio, demerfis in balneo laborantibus, in quo teftudines, rane, or malu.e folia inferbuerint: quinetian clyfteribus ex pedum bedorum iure, aut althea radicum decocto: item butyro Iargius in cibis Jumpto, or epotis pinguium carnium iuribus. Sed (ut idem Auicenna fcribit) proprium buiufce fer= rei pharmaci antidotum, eft lapis magnes dracbma pondere potus, ex mercurialis, uel beta fucco. Veruntamen boc haudquaquam fieri poffe uidetur absq; manifefto fumentium difcrimine, quădoquidem etfi magnes fuapte natura fir= rum trabat; non tainen affirmauerim, quód banc ob caufam eius quog; deftruat facultates, er impediat noxam, fed potius quod eam augedt crediderim. Quippe cum is ferrum ad $\int e$ traxerit, id fané diutius in uentriculo retinebit, ex Magnetis ue- quo noxafouebitur. Adde preterea, quíd cum $\odot$ ip $\int e$ M G N E s deleteria fit facultatis, adeó ut eos, quibau= nefica uis, \& ferint, lunaticos, or melancholicos efficiat, eum baudquaquam ore fumendum effe duxerim. His itaq; qui Magnctem auxilia. jumpjerint, commendant quidam auri tenuißimam fcobem ex uino potain, of finaragdor um ramenta codem pondere. Laudant etian clyfteres ex lacte, or dulcium amygdalarum oleo infufos. Sed cater is praferunt fmardgdum ter no= Squamæ æris $11 \mathrm{~cm}$ diebus potum, tribus femper intermißis dicbus. Lethifira e non parum formidanda eft etian AE $\mathbf{R} I S$. lethifera uis, S QV A M A E uis. Ea fíquidem pota, intolerabiles alui defluxiones mouet, aut noxias uomitiones concitat, obor= \& remedia. tis inde moleftißimis alui, or uentriculi punctionibus. His :ailiantur citate primim uomitiones: deinde egri in bal= neum mittendi funt, in quo bircor um conferbuerint capita, aut ingens cochlearum numerus. Prodeft er menthe fuc cus potui datus : infuper aluum, os wentriculum calido rofaceo perungere expedit. Verü ad boc pre cateris pol= lent acori radices trium drachmarum pondere pote, aut carum fucci tantundem. Sed nobis acori fuccum dare per= difficle fuerit, cum legitimum in noftris non proueniat regionibus, nec nifificcum afferatur. Lituani tamen, $\mathrm{Cr}_{\mathrm{T}}^{\mathrm{T}}$ are ofo rari eo abundant, ut fuperius libro primo prodidimus.

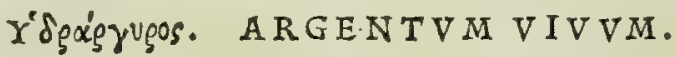

\section{CAP, XXVIII.}

A R G E N T V M viuum potum eadem quæ fpuma argenti infert,eidemq́ue utendum auxilijs. Lac copiosè potum auxiliari conftat: fed poftea euomant, qui hauferunt.

Argenti uiui V E R A M omnino er exquifitam argenti uiui cognitionem non babuife Diofcoridem er Galenum, illud maximo pernicialis na indicio effe uidetur, quód bic paucis, ille ueró perplexé cius biftorian, er facultates tractauerit. Hoc, ut in prafa= turs. tionis buiufce uoluminis commentario tradidimus, intcrimit, fi largius bibatur, exceffu fumme frigido or bumido. $\mathrm{p}$ utrefacit enim boc fuo exuperante temperamento innatum cordis lizumorem, ac. Jubinde congelat fanguinem, uit ales piritus, o ipfam denif; cordis fubftantiam . quandoquidem id medicis experientia compertum eft, ut Conciliator te= ftatum reliquit. Nam cum feplafiarius quidam ardentißuma febre correptus, fiti intolerabili uexaretur, o delirio oberrans in pharmacopolium defcendiffet, ut aliquid ad potandum inueniret, forte fortuna in argenti uiui uas incidit, multumíg ex co potauit, aque fortaffe uice : poftcaftatim in fuum cubiculum fe recepit, ubi paucis póft boris conge= latus interijt. At cum cius domeftici fub cadauere magnam argéti uiui quantitatě inueniffent, iam per fedem egre $\beta i$, aduocarunt medicos, ut eius rei, quam miraculum exiftinabant, diligenter caufan inueftigarent. I $i$ ftatim ex phars macopolio argenti uiui uas adferri iufferunt, quod ubi feré uacuum reperiffent, rem uti fe babuerat deprebenderunt: auxit'; fidem, quód evifcerato homine, adhuc argenti uiui libram in eius uentrıculo inuenerunt: quin er fanguinem circa cor concretum. Quo argumento palàm fit, magno admodum receffu frigidum effe argentum uiuum. Verüm enimure in eius curatione illud inquirendum eft, an purum jit quod potunt fuerit, an faliud aliónc liquore extinctum, 


\section{In Lib. fextum Diofcoridis.}

at accrrints aqua, qua chymifte utuntur, aut per fe tantiun precipitatum, aut una cum an fenico, uel chalcantho fu= blimatum . cim enin aliud alio perniciofiss babcatur, proprium quodlibet cxigit remedium. Pcrnicialius c/t fubli=

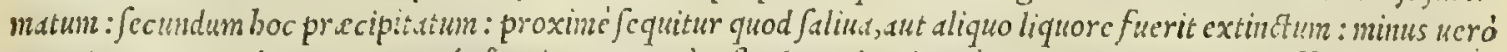
cateris nocet, quod purum, wiulion; fuerit: utpote cimfluidum admodum /it, or ponderofum, non difficultcr clyfte = ribus extrabitur. Id quod ceteris generibus non enenit, que cum uentriculo inhscresn:, illum facilé erodunt, or ex= ulcerant. Argento uiwo puro, aut cxtincto, aut precipitato cpotis, eaden confequntur fymptomata, qua argenti Apuma potw infert, fed cum mugno anbelitws fatore, quen or ij refipiunt, qui Gallica lue affectico illinuntur. Quod maximum prebet indicum, quod fuat exupcrantc humiditute, omnes humores, qui uentriculo alijs q́; circumfanribus p.rtibus beferini, computrcjecrc fuciat. Ceterim cpoto fublinato, illico lingud, o fauces non aliter exaperätur,

- quìn fi quis inmaturorum forborum fuccum baufiffet. Quod fanć incönodun nullo lenientiun gargarizatu,nifí dif=

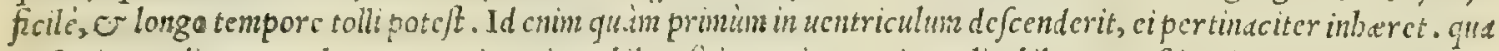
re stutin eradit, or exulcer.ti : tuin inextingmbilcm fitim excitat, e inexplicabilcm anguftian inducit. His fuccedit

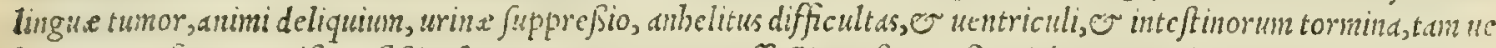

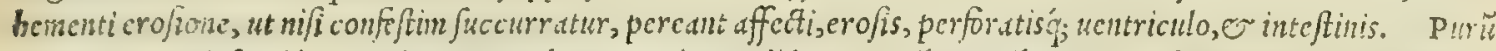
curatur ("ut Diofcorides, Aerius, or Paulus memorie prodidere) auxiijs, quibus argentifpuma: nam nifi copiofins

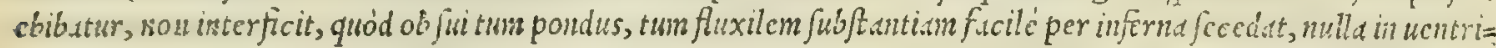

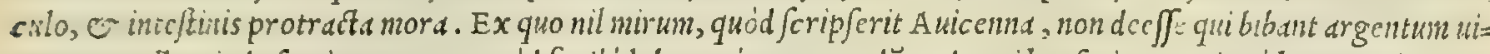
uum, er nullus inde fontiant noxam, quód facilé labatur é corpore, dünodo qui ha!nferint, continué buc atq; illuc dc= anbulcnt. Goriticnjes mulieres agre parturientibus ultino renedio, argentum uium potandum prebent, fcrupuli

so pondere. Nec defunt qui ad interimendas alui timeas, pueris ctiant propinent, ad duorum granarum milij quantitatẽ, citra nullas yolcftiam. In alior um autem curatione alia requiruntur remedia, nempe clyfteres, womitiones, pin= gnis in potu frumpta: Or ut in uniuer fun dicam, bis opem fermnt omnia medicamenta, que nenenis erodentibus conue

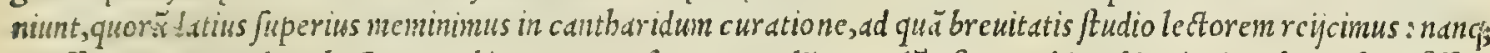
ijs cfficsciara non plur a baf?enus nobis comperta funt. Nec alijs utendü eft remedijs, ubi quis cinnabarin fump/iffet.

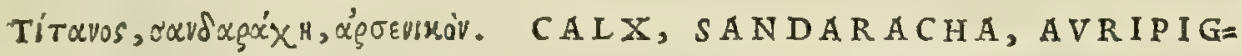 MENTVM. CAP. XXIX.}

C. I. $x$, fandaracha, \& auripigmentum, pota aluum, \& inteftina cum vehementi erofione ex30 cruciant. Pribenda cuncta, quæ fuo admiftu illorum acrimoniam hebetant, ac foluunt, \& facilem lubricamq́ue aluum reddunt, cuiufmodi ibifci, \& maluæ fuccus eft : natura enim vtrique peŗlubrica. Dundum decoctum feminis lini, vel femen tragi herbæ, vel oryzæ, lacq́ue cum aqua mulfa copiofum, iura pinguia, $\&$ boni fucci.

$\mathrm{N}$ o $\mathrm{N}$ modó Calx, sandaracha, $\approx$ A uripignentum, quorum biftorian fupcriore libro tradidimus, baufta ue= bementifimos wentriculi, erintefinorun cruciatus, or erofiones excitant, ut Diofcorides inquit ; fed etian fitim in= explebilcm, faucium, or guls aperitatcm, tußim, fpirainu difficultatem, urina fuppreßionem, or dy enteriam. Ca terum hec onnia adimuantur (ut feité docet Diofcorides) pinguibus acrimoniam obtundentibus, Or potionibus lenien

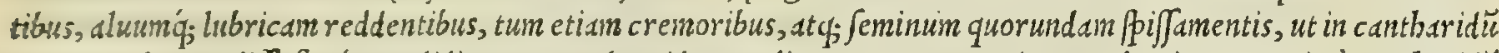

-4 curatione latius, diffufuśg prodidinus. quandoquidem medicamentorum omnium erodentium curatio à cantharidiu

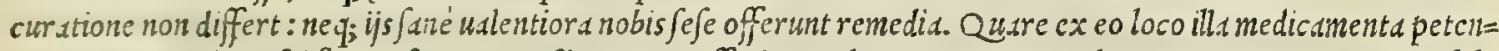
da erant ijs, quibus ufuifutura funt. Eofdem quoq; effectus malos, or noxios prabent A R S E N I V M Jub= limatum, Aerugo, er quod ofjecine Rifagallun appellant: quin er Saponis lixiuium,quód uulgó uocant Itali la mae

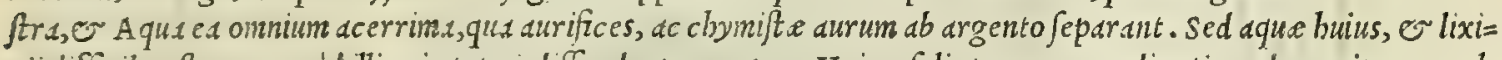
uij difficilis cft cura, quód illico in totum diffundantur corpus. Vniuerfalis tamen curandiratio eadem erit, que cal= cis, Oo auripigmenti: tamet/falterum alteio fit uebementius, of erodentius. Qui autem priuatim Arfenicum $\int u b=$ limatum bauferunt, cos frequenter uomere oportet, poto femper prius butyro, aut per $\int e$ tantuin, aut addito rapife= minis decotto. Profunt bis or clyfteres ex pingui iure, aut ptifane alic cúc cremore, aut piffanentis ex pfyllij, mal= ux, $\sigma$ cydoniorum femine factis. Auxiliatur amygdalimum oleum, ov ius pinguium gallinarun in cibis fumptum. In

so preftantißimum ueró antidotun cen etur foßile cryftallum, in tenuißimum puluerem contritum dracbmx pondere, ex dulci amygdalino oleo potum. Porró A E R v G o, preter alid eius mala anté dicta, adeó pirandi meatus oc $=$ cludit, ut magno impetu fuffocet affectos. Succurritur noxe crebris cumbutyro, o calida excitatis uomitibus, ut in arfenico, e infufis fubinde clyfteribus ex afinino latte, er dulci amygdalino oleo. Prodeft er Lemnia fphragis dra=

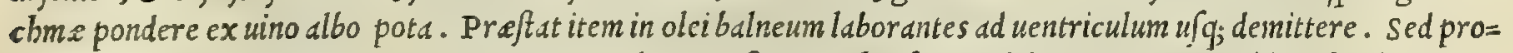
prium huiufce pharmaci antidotum ( ut ait Conciliator) eft, ut qui hauferint, bibant ex uino corallia rubra in tenucm puluerem contrita fenorum frupulorum pondere. Ceterim R I S A A L L o uulgó difto, quód quidam Real= Rifagalli cugal appellant, cim maximé extreméq; ficcet, e neruos contrabat, non alia conuenit cur atio, quìm que argento ui= ratio. uo, E arfenico fublimatis, or arugini adbibetur . quanquam priuatim non obfcuré iuuat univerfun corpus dulci $d=$ mygdalino illinire, er uiolaceo iulapio, o ptifana bordeaced fitin extingucre. Froficit 0 pinorum nucleorum $0=$ Ieum, aut è magnis nucibus, que ex India adue huntir, expreffum, fernilibra pondere potum. In Jumns ea omnia cf= ficaciter adhibentur, que cantharidibus conferre diximus.

Calcis, fundarache, \& auripigmentive nefica uis, $\&$ curatio.

Arfenicifublimati,\&alio= rum quorundā venenum.

Arfenici fublimati cura tio.

Aeruginis ve neni remedia.

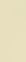
(1)

$$
\text { Rr nagos's }
$$




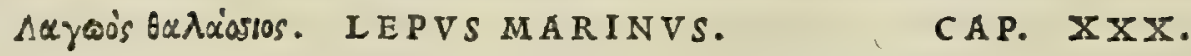

Qv I leporem marinum biberunt, pifcium uirus olent: procedente tempore, aluus dolore afficitur, \& vrina fifticur: et fi quando eam reddere contingat, purpureum colorem referet . omne pifcis genus auerfantur, \& odio habent: fœetido, ac graui fudore manant: biliofus vomitus, interdum fanguini promifcuus, fubfequitur. His dandum lac afininum, vel paffum continuè, aut radicis maluæ folioru mq́ue decoßtum, aut trita cyclamini radix cum vino, aut ueratri nigri, aut fammonij fucci drachma, cum aqua mulfa, puniciq́ue mali acinis. Cedria contrita cum vino efficax elt : anferinus fanguis, vt tepebit, potus. Sed cùm pifces omnes refpuant, afpernenturq́ue, folis fluuiatilibus can- 10 cris vefci poffunt, bibuntq́ue eos admifto vino, adiutiq́ue ab his percoquunt . cùmq́ue appetere $\&$ comeffe pifces cœeperint, fux falutis indicium habent.

Leporis mari ni veneni figna.

D I $x$ I $\mathrm{m}$ v $s$ de Lepore marino libro fecundo, de quo ita fcribit Nicander in alexipharmacis. sin marini lepo ris male perdentis potionem deprebenderis, perniciem afferentem, odorem eius fenties, qualis eft $\int q u a m a r u m, ~ o \sigma ~ p i=$ fcium purgamenti. Porró guftus, $\mathcal{O}$ fapor eius pifcofus eft, qualis putrefactorum pifcium effe folet : uel cum non= dum ablutorum fquame polluunt corpus. Sequitur buiufce potionem uiridis fellis fuffufio, cum obtenebratione uifus: $\mathcal{E}$ caro paulatim in homine contabe ccit. Accedit his ciborum omnium abominatio, malus babitus, $\sigma$ talorum ardor: oculi in concaum occultantur, o gene dc maxille florido colore rubent. Vrina egerrimé redditur : que tamet/í reddatur, purpurea apparet, o plus aquo fanguinea. Ad bec fi pifces agris offerantur, eos illico naufe abundi exe = crantur. bec ille. Cui Jubfcribunt Aëtius, $\odot$ Auicenna, qui preter relatd indicia, alia adbuc le pori martno epoto a)ignant, his uerbis. Marinus lepus adeó iđterum inducit, ut totius corporis habitus croceo admodum colore inficid= tur. Poftea facies liuens intume $\int c i t$, pedum plante incenduntur, adeft pirandidifficultas, pectoris $\sigma$ pulmonis an= guftia, ruffecuntó; oculi . Debinc tußis emergit ficca, Butus cruentus, renum dolor, uirilium q́; inflammatio, adeò ut perpauci eudant, qui non labantur in tabem. Quare Galenus libro de theriaca ad Pifonem, proprium marinilepo= ris effe ait, ut pulmonem exulceret, 0 erodat. Succurritur noxe (ut Diofcorides inquit) afinino lacte ex paffo poto, o malua decocto. Neq; id aliam ob caufam, ut Aëtius declarat, quàm ad eliciendum uomitum, o ueneni acui= tatem retundendam, quemadmodum elleborum, cyclaminum, o fcammoniü exhibet, partim ad citandas uomitiones, partim ad aluum deijciendam. Catera ueró, ut incommodis fubueniatur, que internis infert particulis. Prefertur quibufdam aduer fus boc malum humanus fanguis calens é uenis potus : humanum item lac, ab ip fis uberibus exuctum, 30 $\mathcal{O}$ uulpis caro inafata : quin $\mathbb{O}$ theriaca diate Jeron tribus diebus pota.

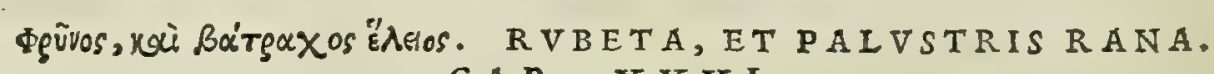 CA P. XXXI.}

R V B E T A, aut rana paluftris affumpta tumores ciet: pallor corpus vehementer decolorat, ut pla nè buxeum fpeftetur: fpirandi difficultas torquet: \& grauis halitus oris, fingultusq́; , inuita interdú geniturx profufio confequitur. Adiuuantur fecundum uomitionem multo meri potu, \& arundinis radicis binis drachmis, aut cyperi totidem . Breuiter, cogendi funt, ut vehementi ambulationi \& cur fui fe credant, ob torporem, quo corripiuntur . quinetiam quotidie lauandi funt.

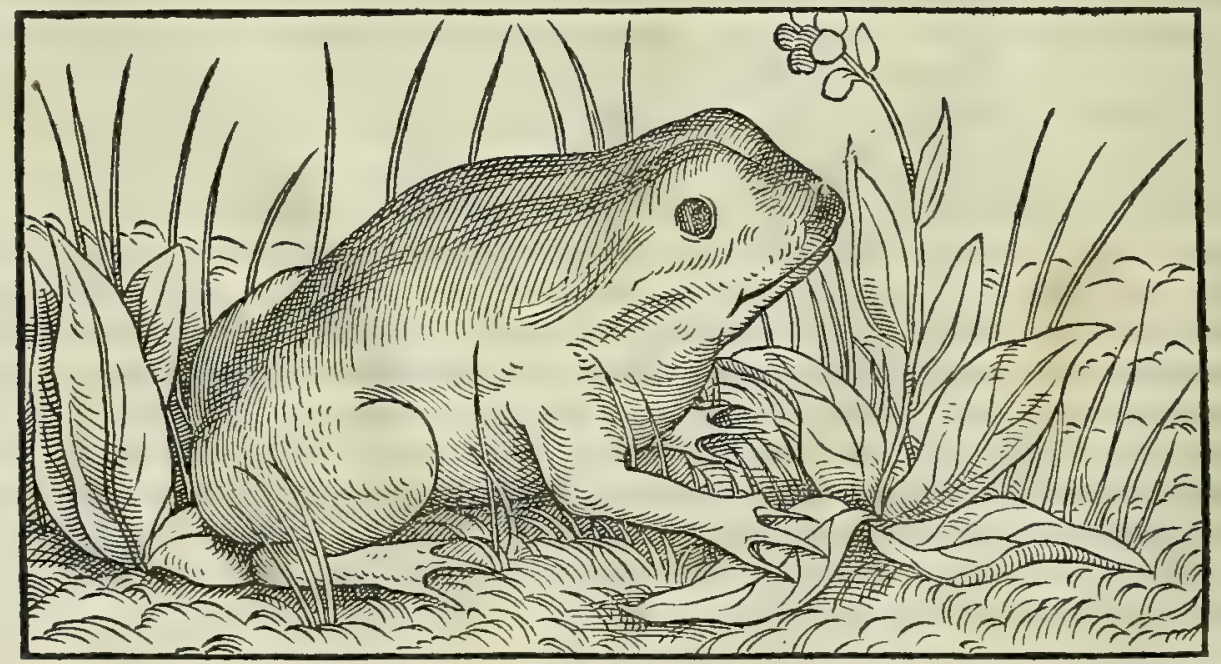

Rubetz, palu Itrisque rana
R V B E T A E Ranx, quam quidam bufonem uocant, diuerfa reperiuntur genera. Terreftris tumell, qua Gre = cis phrynos dicitur, Latinis ueró rubeta, quód in frutetis e fepibus inter rubos degat, nocentior, magis q́; lethifer a eft, quàm que in paludibus, er aquofis fcrobibus uiuit (id quod inon recté, meo iudicio, intellexit A loy fius Mundella, brixianus octaua fui uoluminis epiftold.) tantóg. magis noxia, lethiferág. fuerit terreftris, quăto in opacioribus, fris gidioribusq́; 
gidioribusq;; locis uitam duxerit. Quamobrem in boc genere ex onnum peßime creduntur, que in umbrofis conuale

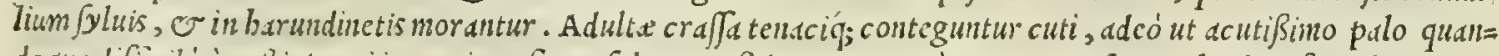
doque dificile i rulticis, qui ita eas interficere folent, perfodantur. Ha cum circumnafcentes berbas, fiuc aliquod de= pafcens dumbl, wencno inficcre uolunt, conts absut fe fe in tunoren, ut ucnenum per urinan longius eiuculcntur in plantar, or circumfiantes quadrupedes. Qudre admirari non licet, $f i$ nommunquam repenté int crimant bonincs, qui

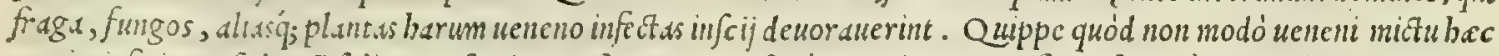

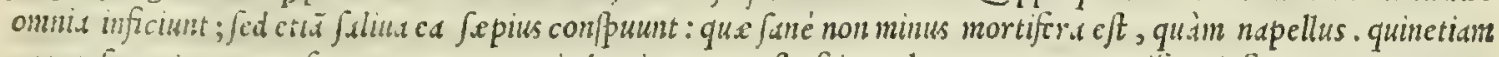

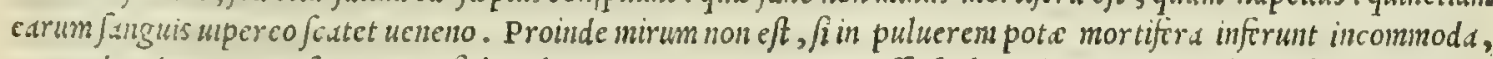
quenadmodun or morfu. Nane ctfi dentubus careant; tamen compreffa fabris ginginis particula, or fubinde ingref

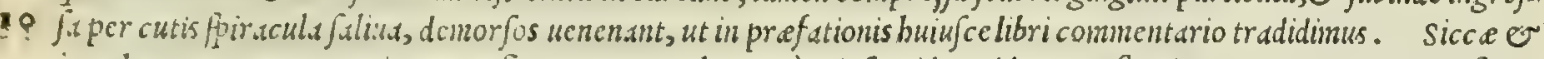
in puluerem pose, ut Auicenna refert, preter mala que à Diofcoride redduntur, faucium, er gutturis tum inflam= mutionem, twm ficciatcm excitant: itcm oculorun caliginem, ucrtigines, conuul/iones, dy fenteriam, faftidium, uomi= tus, animi deliquium, delisium, anentium, o plerunque cdentulos faciunt bomines, quanuis cuadant, qui bauferint. Nec minora cham pericula atferunt fructus, o berbe carum uene no infedte, er epotus carunden fanguis. Curan= tur ijs malis affecti theriaca, uel sithridat is antidoto tribus continuis diebus ex uino potis. Idem pr.eftat teftudinis marmx fanguis, additis cumu, leporis codgulo, or uino. Datur potanda prefentaneo remedio quinta effentia no= frat theriacalis. Quin or oleun noftrum de fcorpionibus exterius commodé inungitur. Prefert Conciliator finaragdi pulucrcm cx uno potum frupuli pondere, cum co tamen, ut fubinde intret ager nudus in mulum recenter cxenterd=

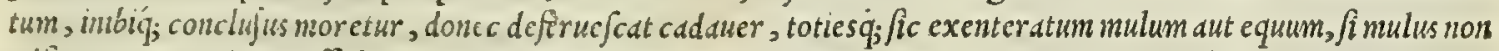

20 adjit, permutet, donec cffulo diutius fudore cedat noxa. Aétius mulis, er equis parcens, in clibano, quantum toleras ri pojit, calidisuno affectos, uel alio in loco arte calefacto detinendos ad fudandum iubet, quemadmodum curantur.

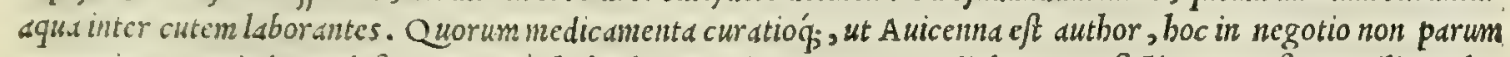
conucniunt. Proind prodef ijs maxmé rbabarbarum, diacurcume, or dialacce confectio : tamet $f i$ Conciliator la= pidem bis onmibus preferat, qui in earum capite reperirifolet.

\section{$B \delta\{1 \lambda \lambda \alpha$. HIRVDO.}

\section{CAP. XXXII.}

DE V O A T AE cum aqua hirudines, fi ori uentriculi adhærent, tractione partium, nonnullam fuctionis imaginem præbent: eo enim argumento haufta hirudo deprehenditur. Has nuria forbiti: one exicutre, \& Cyrenaicus fuccus, aut laferpitij folia, aut betæ, cum aceto, aut pota niuis glebula, cum polca. nitrum exaqua gargarizatur, aut atramentum futorium aceto dilutum. Si faucibus hæreant, in a quam calidam ingrefsis, a qua frigida ore contineatur, \& ad eam hirudines cxilient .

H I R V D I N E S raró in alijs aquis inueniuntur, quàm in paluftribus, lacuftribus, or ftagnantibus: quando=

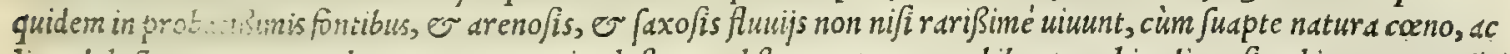

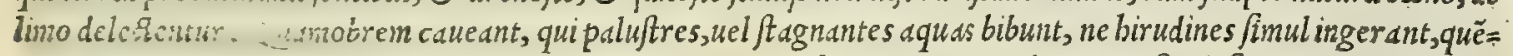
admodun irexpe:... silutoribus nonnunquam euenit . nanque aftatis tempore calore, o fiti defatigati, dum aquam,

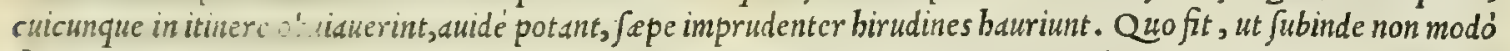
fibi Janguinem exugifenume ( ut tradidit Diofcorides;) Jed etiam ( ut Auicenna inquit) cruenta expuant, ac pret $t=$ 40 more melancholicifiant. Verim anteaqudim aliquod offeratur medicamentum, inueftigandum eft, an aninal ori uentriculi, an gule adhe eferit, an ip is faucibus. Id quod facile intelligi poteft ex eorum, quibirudines haufcrint, relatio= ne : quonism ubi fütionem fentiunt, nimirum ibi hirudinem fixain effe fignificatur. Quód/i ori uentriculi affixa fue= rit, auxiliun preft at murialeniter epota, foettd a item laferpitij lacryina, quin o lixiuium cum fale ov ace to aut ra= phani domeftici fuccus cum ace to, d!! oleum crudum bauftum, quod per fe tantim bac interficit aninalia . conferunt infuper ed omnia, que alui tineds, "iumbricos necant. si uerò guttur inediun ab birudine obfideatur, proderit acre lixiuim gargarizare, aut aquă, in qua alumen cum aceto inferbuerint, uel calcbanthum, aut murian cum lixiuio, accto, o finapi fimul comin: fis. Sed fi ea faucium ambitui bareat, opem mirificam feret (ut Diof corides docet) $c a=$ lidx balneum, aqua frigida in ore contenta. Siquidem birudo ab aque calore propul ata, ad frigidan in ore conten= tam decurrens, facile und cum ip $\int a$ aqua expuetur. Interdum contingit, quód ftatim fub lingue radicibus, uel in prie 50. mis faucium partibus adhare fcit, ita ut depreffa lingua uideri poßit : tunc roftratis forcipibus faculé extrahl poterit, uel quóuis alio inftrumento, quod cuique in promptu fuerit.

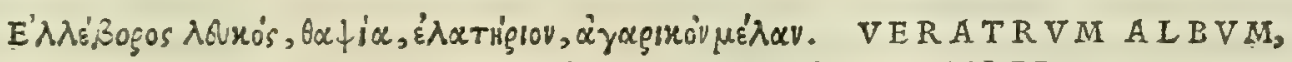 THAPSIA, ELATERIVM, AGARICVM NIGRVM. \\ CAP. XXXIII.}

PROVIDEND V M etiamijs, qux etfi ferendiauxilij gratia tradantur; non minoratamen cæteris venenis pericula fæpius adferunt. Qualia funt album veratrum, thapfia, elaterium, agaricum nigrum : liquidem ea ftrangulatus concitant, aut immodicas deiectiones mouent. Quibus ea medentur, qux in fungorum mentione, \& fimilibus retulimus. Nimios autem deiectionum impetus, medicamentis, quæ excrementa fupprimunt, coërcebimus. Neq; negligenda quæ parum qui-

Hirudinum deuoratarum noxa.

Hirudinum curatio.

Ranx malefcæ figna, \& cu ratio.

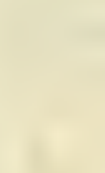

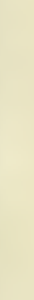




\section{8}

dem nocere uidentur, interim verò vitam in difcrimina agunt. Quo in numero funt fylueftris ruta, gith, noux glacics, pappi recentes : Hores autem funt eius fpinx qua cactos dicitur. Eos qui fumprerint, fola uomitio recreat.

Diuifio capitis caltigata.

\section{E X T A N T quimplurini}

garico nigro, d precedentı capite feiunctum non legitur. Verim cum antiquißimus manu fcriptus codex, hac proc
prio, o peculiari capiti dicauerit, uideatur' '; abfurdum de bis differuiffe Diofcoridem und cumbirudinibus, cum qui= bus nullam labent cognationem, neque ijsden curantur remedijs, non temer é facturos duximus, fill $₫$ ḋ nobis feor=

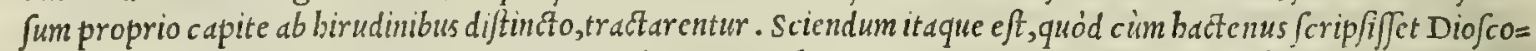
rides omnium uenenor un indicia, que pota, uel deuorata, bomines necant, uel faltem agros cfficiunt, quin er uni= uerfalia e particularia antidota tradidiffct, quibusillorum uis frangi, ac deftrui poßit, cim pretcrea fcirct aliqua in medicum u um haberi medic amenta alü̈ duccntia, qux fimpliciter pota, $\mathcal{O}$ nullis antidotis infranata, uel maiori menfura, uel pondere, quàm par fit Jumpta, non minus homines interimunt, quàm qua proprie uenend uocantur, medicos tllud boc loco admoncre uoluit, quód in propinandis bifce medicamentis minimé cacutiant, fed in boc onne fuum ftudium, omnemí; diligentiam impendant. Verim quanuis, inter éd omnia, qux in medicun ufum ucniunt, pau= corum tantim meminerit, nempe thapfia, albi ueratri, elaterij, 0 agaricinigri; non tamen ob id fuerit in fimulan= dus, quód nefciuerit preter haec, alia plura effe medıcamenta, que noxä inferre poffunt, autmaiorem quam illa, aut equalem. Quippe quod illi fatis uifum fit, fi tantim horum cxemplo imperitos medicos difcrimen, noxam'́; docuif= fet, que onmia in uniuerfum medicamenta aluum cum labore ducentia plerung; fumentibus adferunt, cum (ut modo diximus ) uel largius quàm deceat, uel fuis antidot is exuta fumuntur. Sed ut barum rerum ftudio is in omnibus, quan= 20 tum polfumus, fat isfaciamus, prater ea qua à Diofcoride tradita funt, nos alia quoq; plura addere decreuimus, quibus quotidie paßsim utuntur medici. Cuiufmodifunt cyclaminus, ueratrum nigrum, euphorbium, turpetum, tithymali omne genus, frammonium, colocyntbis, bryonia, latbyris, ricinus, thymelad, or chameled. Quandoquidem cium bec omnia medicis in frequentißimo int $u$ u, ad corporis excrementa exigenda, or ad uomitum quandoque ciendum, in quism plurimis bominum affectibus, mibifane negligentix adfcribi poffet, fi bec prorfus filentio inuolutfen, prefertin cion fepius eueniat quorundam circunforaneorum imperitia, ac temeritate ( pharmacopolas nunc preterco, quód cortm

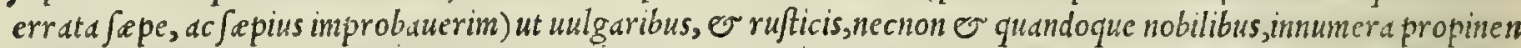
tur pharmaca aluum ducentia, qua plerung; Jumentes in magnum difcrimen ducunt, quoniam nec medicamenta pon= derant, nec infrenata exbibent, nec ad egrotătium temperaturam, étatem, fexum, confuctudincmó; refpiciunt. Qu fit, ut agrotantes, qui in eorum manus incidunt, precipué ï qui natura funt imbecilles, màgnis nnonunquam affi= 30 ciantur incommodis, quibus nifi periti propris fuccurrerent remedijs, faclé interirent. Albi itaque Veratri potio=

Albi ueratri, aliorumq́; no xa, \& auxilia.

$$
\text { to }
$$
, frangulationes, er repirationis anguftia. quibus dehinc tanta Juccedit principum facultatum imbecillit ds, ut paruo temporis momento egri animi deliquio corripiantur, grauiter pirent, ov frigido fudore made fant. Po= fremó, nifi citius fuccurratur, oborto fingultu, illico uel fuffocati, uel conúulfi intereunt. His primim auxiliantur uomitiones (ut multoties diximus) crebró concitate, or infufa cly fmata, quorum fapißiné fuperius meminimus. Poft bec remedio funt antidota, qua in uniuerfum omnibus aduerfantur uenenis, prefertimć; theriaca, cui (ut Galenus pluribus in locis teft atur) uis peculiaris ine ft, modo adulterio uacet, ut fumpta poft medicamenta deiectoria, adeó eo ruin fuperet uires, ut nibil per aluum exigant. Ceterim priuatim Albo ueratro confert aqua mulfa largius fumpta, or nymphee flores duarun drachmarum pondere poti, ucl deuorati, tradunt'́; bec propria alli ueratri effe antido= ta. Cyclamino deinde conducunt lauribacce, duarum drachmarum pondere, fed propria facultate nigrum piper in puluerem contritum, er codem pondere potum. Elaterio preterea opem fert Andromachi theriaca ex baccarum lauri decocto, aut melle pota fenum fcrupulorum pondere : uerum proprium eius remediun eft mentha fuccus. That= pfie deniq; er nigri agarici noxa tollitur, ijs medicanentis, quibus albo ueratro fubuenimus, cim eadem fint buius, Nigri ueretri que illorum incommoda. Fiunt quoq; d N I G R o ueratro ( ut fcribut Auicenna) interdum borrenda fympto= noxa, \& cura. mata, nempe intolerabiles aluifluxiones, fuffocationes, conuulfiones, animi deliquia, palpitatio cordis, lingua arefas Atio, dentium confrictio, frequentißimi ructus, or uniucrfi corporis inflammatio: $\Theta$ nifillico fuccurratur, tre= mor confequitur, uniuer fum occupans corpus, cum quo poftremó commortuntur egri. His auxilium praftat abfin=

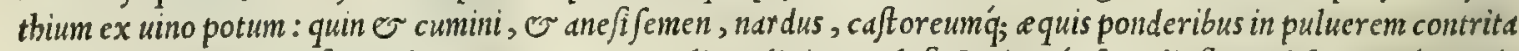
or ex uino pota: appofitis, ubi intumuert uenter, linteolis igne calefactis, item $q_{;}$facculis flatus difcutientibus. Ci= 50 band autem funt egri recenti cafeo, melle, butyro tan crudo quàm cocto, pinguium carnium iuribus, ac etiam palfo. sed non propterea parcĕdum fuerit antidotis in uniuerfun iuuantibus, nec etiam nymphace floribus, utpote qui non Euphorbij, modó albi ueratri uires demoliantur; fed etiam nigri. Porró E V P H O R B I V M fauces, $\sigma$ guttur uebementi \& quorüdam admodum incendio vexat. Corpus uniuerfum inflammat, uentriculum, or inteftina magno dolore erodit, fingultum aliorum vene excitat, O continuas aluifluxiones. Que itidem omnia mala inducunt T V R P E T V M, Scammonium, Colocyns nata potio.

this, Bryonia, Titbymali omnes, Latbyris, O Ricinus. quanquam non tam acriter nocent, ueluti euphorbum. $A^{\prime}$ T H Y M E L A E A autem, er Chamelea pituitof \& pumanteśq; excitantur iomitiones, alui profluuia, intolerabiles inteftinor un, or uentriculi erofiones, anguftia, inflammationes, et uniuerfic corporis cruciatus : quin $\odot$ fitis impla

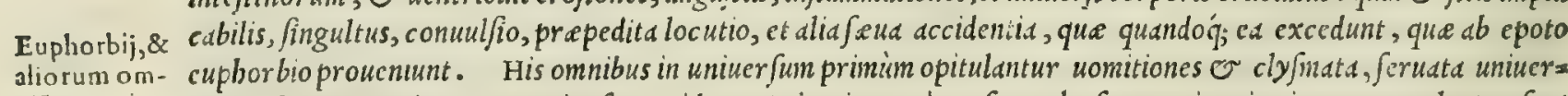
niŭ curatio. Salimetbodo, ac etiam communis ufus antidota. Priuatim weró profunt oleofa, dc pinguia: item que ualenter funt 


\section{In Lib. fextum Diof coridis.}

frigida, ut hec ingentcin feruorem extinguant, illa uero' ut exupcrantem acrimoniam obtundant. Proinde pratulit Auc enna acidum lac, caphuram ex rofacea aqua potam, punicorum aufterorum uinum, angurie, cucumeris, cu= curbit.x, $\sigma$ acidorum malor um fuccum : itcm bordei ptifanam niue, uel glacic refiigcratan. Sed proprium (ut aiüt) cuphorbij antidotum eft citrifenten ex uino, in quo belenij radix inferbuerit potum. Scammonij ueró lac, à quo dem= ptum fuerit butyrum, inalorum, cotoncorum, rhois, vibisó; fuccus. Colocynthidis deinde antidotum fuerit fané bu= bulum lac, o butyrum recens, Lemnia $\beta$ bragis, o finar.tgdipuluis, pluries pota. Turpetipraterca, $\in$ Titby= malorum omnium, Andromachi theriaca cx uno pota, in quo Cretenfe ditammum incortum fucrit: item mumia $\int e=$ pulcrorum in puluerem ex wino meraco pota drachme pondere. Bryonice porró, theriaca ex uino baufta, in quo be= leniun conferbuerit, itemiq; nigrum piper contritum. Latbyris ad bec, $\mathcal{G}$ Ricmi proprium antidotum eft byperici

io fuccus, aut berb́a ip fa in pulucrem pota. Thymelae deniq; o chamele a rofaceum ferapium, ex bordei ptifana po= tum, of fubinde orig anum Crctenfe igni toftum. Sed hec omnia praftant tantim ad fupradictorum medicamentorum uim deleteria fuperandam. Caterim cum plerung; cueniat, ut bac, que modum excedunt medicamenta, uaria ac diuer $\int a$ adfer.unt incommoda, que ctiam ob fuirepentinam uchementiam prä fentanea expof cunt remedia, nempe cö= tinentes womitus, perpetua alui proflunia tam ceteronum bumorum, quam purifanguinis, cum uaforum of cula uene= ni ui re forantur, conuulfiones, pr.efócationes, animi deliquium, or uirium omnium imbecillitatem; idcirco non modó attendendum fuerit, ut medicanenti uis antidot is fuperetur; fed etiam ut ip/is graubus fymptomatis omni diligentia fuccurratur. Quandoquidem hec fe pius tantifunt ponderis, ut maiorem, celeriorem $\dot{q}_{\text {; }}$ expetant curationem, quàm catera. I thibcutur itdq; uomitus modum cxcedentes ( $f$ tamen medicamentum cum bumoribus reiectum fit) adfrin= gentibus medicamentis, que uentriculum roborant, exterius prefertim illitis : quin er uinculis, ac fibulis, extremis 2o membris obtortis. Faciunt ad boc in corpus fumpta flaud myrobalana, tam ficca, qudm faccharo afferuata: item nu= ces cum putaminibus faccharo fimiliter condite, diacytonites, faccharum rofaceum diutius inueteratum, addita Le= mnia phragide : pretcrea cydoniorum, e punicorum malorum uinum, fylucftrium prunorum fuccus, myrtibacca, rhus, rofa ficca, fylucf triun ro farum femen, cornu ceruimum combuftum, fantald, corallia, omphacium, acetum, er id gemus alia. Sed corum que exterius illita profunt, bec fe fe offerunt, Indica uidelicet, or Celtica nardus, mentha, glandes, lentifcind, refina, thus, flaua myrobaland, myrtifolia, o bacce, rhus, melinum, ntardinum, lentifcinum, er myrtinum oleun. Nec tantim pollent hee ad uomitiones compefcendas; fed etiam parifacultate ualent ad fiftendas

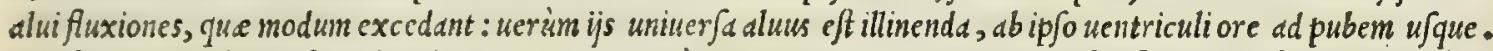
Preftat $0 \sim$ brachia ab fapulis ad manus, or crura à coxendicis articulo ad pedes $u f q ;$ fafcijs confringere, offufis fubinde auftcris plantarum fuccis. Confret item fudoris excitatio, aut detentis agris in calido cubili, aut laconicis 30. arte calefatis, in quibus agros caput emittere oportet, aut brachijs, er cruribus, in calide balnco demer/is. Ab bis dare conuenit, que adftring unt, or roborant. Principes in uniuer fum facultates roborant odorata medicamenta, $c k=$ iufmodi funt ro $\int e$ ficca, caphura, garyophylla, agallochum, ftyrax, laferpitij lacryma, iuniperi bacca, fantala om= nia, or id genus plura. Pretulit in buiufcemodi alui fluxionibus Auicenna nafturtij femen toftum, trium drachma= rum pondere, ac fubinde in lacte decoctum, quoufq; lac concreuerit, er poftremó potum. si uerio bac non profue= rint, foporiferis utilicebit, nimirum Philonis medic amento, atbanafia, requie, ev alijs quibufcunq; que opium, dut meconium exceperint. Namet fi hec quoq; $10 x a$ haud uacent; tantum tamen adferunt iuuamenti ( $f$ tamen recta $r d=$ tione exbibeantur) ut ijs tutó in tam inagno difcrimine medici uti poßsint. In fumma fi optimam haberemus theriacă. que ex adulterinis $\mathcal{\sigma}$ Juppofititijs non effet confecta inedicanentis, omnibus preponeretur antidotis in fuperanda uimedicanentorum aluum ducentium. Siquidem teftatur Galenus (ut pauló fuperius diximus) pluribus in locis,

40 fuis in libris de theriaca ad Pifonem, ef Pamphilianum, illud optime theriace indicium effe, ut à prefumpto deie= Atorio pharmaco potabumorum deiectionem impediat, citra ullan egrotantium noxam. Id quod nobis experiens tia compertum eft preftariab antidoto noftro, cuius defcriptionem tradidimus in pr fationis buius libri commen= tario. Prodeft non parum prater hac uomitionibus, $v$ fluxionibus pradictis ctiam uiltus regimen ex adftringens tibus $\odot$ aufteris inftitutum, que deinde niue uel glacie refrigerari conuenit, aut in altum aquse puteum fune fus pendi. Adiuuantur conuulfiones, qu.e ab ingentibus, laboriojis $q_{\text {; }}$ alui proftuuijs eueniunt, ijs duntaxat cibis, qui= bus ad refocillanda exinanita corpora, uiresó; roborandas utuntur medici. Quo in negotio prefertur bumanum lac ab ip/is exuctum uberibus: quin $\mathcal{O}^{\mathrm{d}}$ dulciun amygdalarum cremor, er carum pariter oleum, ciborun condimentis adniftum. Profunt e nuclei pinei, pistacia, Indica nuces, o melopeponum femen, omnia in mortario contufa, or caporum iure colliquata, addito candidiorifaccharo. Opem fimiliter fert caporum, or phafianorum exenterato= So rum carnium eliquatus fuccus, carnibus ip/is tenuiter incifis, uitreo uafe conclufis, $\sigma$ in aqua balneum codem in uafe decoctis, quousq; uniuer fus ab bis exudauerit fuccus. is nanq; frequenter potus cocblearis menfura ( ut libello de uiribus cordis predidit Aucenna) magis fuccurrit imbecillitatı cordis, quàm alius quiuis cibus. Conducunt pres. terea recentium ouorum uitellicarnium iuribus admisti, of faccharo reperfi: infuper caporum, phafianorum, per= dicum, or attagenarum pulpa in mortario contu $\int a$, or iure, ev faccharo temperata. Prafocationibus porró $\int u b u e=$ nimus jisdem tun auxilijs, tum medicamentis, quorum fuperius mentionem fecimus, cisn de mortiferis fungis differex remus. Caterim meminit hoc capite Diofcorides preter predicta, melanthij, fylueftris rute, e carum plantarum lanuginis, que in aculeatarum genere quibusdam cacti uocantur. Quorum omnium bistorias, $\sigma$ facultates fupe= rius proprijs locis tradidimus, qux tamen non femper nocent. At fi noceant, curantur excitatis uomitionis, ebibi= to prixs malue decoto, aut late, aut recenti crudo butyro. Poft que proficiunt pinguia iura, or catera, que al= utun emolliunt. Dent igirur operain, diligenter ; animaduertant feplafiartj probi, ac fideles, ne in ponderandis bifce medicanentis, abiatusu aut oculis imprudenter decipiantur. Qunetiam eos admonitos uelim, ut imperitos, ac teme=

Remedia ad varia fympto mata.

Remedia ad cóuulfiones. 
rarios cireunfor aneos a pharmacopolijs fuis excludant, reprehendant, or miffos faciant: ac fi opus fuerit, protomes dicis er rectoribus ciuitatum eos denuncient, ne mifelli agrotantes fub publica omnium fide ab boc improbo ac pejici. mo honinum genere prodantur, atq; in perniciem agantur.

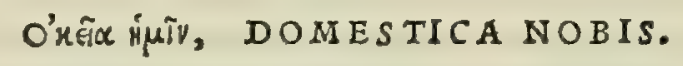

\section{CAP. $\mathrm{XXXIIII}$}

A Qv A frigida abunde pota,aut meracum uinum liberaliùs epotum, aut paffum, præfertim à balneo, aut curfu, aut vehementi exercitatione, ftrăgulatus, \& dolores infert. In quibus fanguinis mifsio protinus, \& vacuatio, imminentia foluunt pericula. Sed de notis veneficiorum, ac remedijs, \& cauen di modo, hactenus dicta fint . Subiungeremus etiă antidota neceffaria, qux præclarè a uxiliantur,qui- * * bus utimur,quale Mithridatium eft præfertim,\& quod fanguine, \& quod fcinco temperatur. Verùm quoniam alijs in locis diligentifsimè fcripta funt, hîc ab corum defcriptione fuperfedemus.

Rerum dome

$\mathrm{N}$ o $\mathrm{N}$ modó aqua frigida, or uinum meracum, aut paffum inter ed, que nobis domeftica funt, or quotidiano ufu. ficarú noxa. alimentum prebent in humane uita fubfidium, co modo pota, quo Diofcorides fcribit, maxima adferunt difcrimina; fed etiam carnes, 0 pifces. Etenim hec utraq; cocta, E adbuc feruentia bumidis locis diutius afferuata, fubindé frigida deuorata, cosdem malos pariunt effectus, quos à malefic is fungis creari tradidimus : tamet $f$ quandoque non nifi duobus, aut tribus póft diebus appareat noxa. Tofte preterea carnes, uenenatorum fubeunt naturam, fi calidas inter duas fuffocentur patinss, obuoluantur'́; linteis, ne exbalare poßint. Eadem etiánnum mala inferunt mortici=

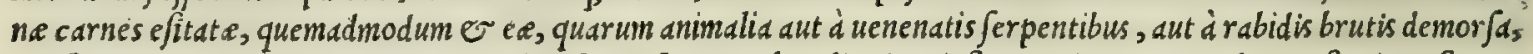
aut fulmine ista interiere. Quandoquidem sepius barum efu coli oritur inflammatio, maeror, alui proflunium, furor, obliuio, ueternus morbus, $\mathcal{E}$ ad poftremun mors infequitur. Quamobrem bec fane negligenda non funt, quin po= tius fumma cur a uitanda. quippe aliquos noui, qui bis deuoratis nullo medicamento adiuti, intume fcente inde toto con pore, tandem uitan miferé finiuerunt. Nec minus euitare oportet oua barbi pifcis: nam adeó uenenata funt, ut fi lar

Píciú, \& carnui noxa remedia. gius fumantur, cosqui bafererint, in magnum periculum adducant. Pifcium curatio eadem eft, que fungorum. quanquam non exiftimat Conciliator, ut pifcibus ficut mortiferis fungis conueniant fylue fria pyra. Carnium uero. fuffocatarum malis fuccurritur excitatis prius uomitionibus, of infu/is clyftcribus: mox uini optimi er odorati pos tu, admifto cydoniorum malor um fucco. Praftat à uomitu L emniam Phragidem bibere, unà cum agallocho, $\mathcal{O}$ ma= fiche . quanuis eadem fit harum cura, qua coli affectibus adbibetur.

\section{De venenatis animalibus.}

CAP. XXXV.

$\mathrm{D}$ E B E S T I I S, quæ virus eiaculantur, \& exitialibus venenis, ideo fcribere aggredimur, ve tota curationis remediorumq́ue ratio ad umbilicum perducatur. Siquidem pars hæc non minus quàm cxter $x$ aliæ, neceffaria eft ijs, qui artem medicam exercent, vtpote cùm adminiculo eorum; quæ inibi traduntur, doloribus, periculis, \& cruciatibus, plurimisque alijs malis homines liberari conueniat. Hæc autem in fumma faftigia duo, ficuti ab initio relatum eft, diftribuitur. Nam qui de 40 feris virus infpuentibus fermo differit, theriacus dici folet: qui verò de amoliendis ueneficijs, alexipharmacus : quo prius tradito, fimul quæ fequi figna confueuerunt, præmonftrabimus : tú quæ nonnihilauxilij ferunt. Omnia autem in promptu, \& ad manum haberc artificem oportet, propter urgentem frpenumero necefsitatem . Siquidẽ pauca è uenenis \& virulentis animantıbus, tarda \& graffantia fenfim pericula cient, ita ut dilationem admittant : pleraq; verò præfentaneam perniciem afferunt. Hominum autem partim malè alijs cogitantes, ingenita prauitate maleficium ita temperant, ve fpatium curanti liberum non relinquant : partim fceleris admifsi confcientia, aut trifti aliquo euentu opprefsi, haufto fponte ueneno, mortem fibi confcifcere conantur . qui poftea deprehenfi, aut refipientes, \& vitæ cupidi, præfentaneam opem pofcunt. Non defunt qui hoftiles fagitras illinentes, aut fontes aquasq́; puteanas hac labe polluentes, certam \& ineuitabilem aduerfarijs perniciem moliun- $s q$ tur. In quibus ipfis etfi maleficium non fubitò, fed aliquantò pòft graflari natura fua comparatum eft; tamen nifi primo quoque tempore coërceatur, \& remedijs fubinde excipiatur, fruftrà tandem fuccurritur, occupatis iam corporibus exitiali vi ueneni . Proinde non vulgari induftria diligentiaq́; in ea re utendum eft, vt quod in alijs incommodis ars confueuit, in his quoque falutem mortalibus præbeat. Quin \& apud prifcos genus hoc vnum exiftimabatur effe eius partis, quæ medicamentis pu gnat: fed recentiores id ip fum difcreuerunt, nominantes præcautionem, \& modum precauentem, fa lubris fanantisq́; medium ftatuentes, parua \& leui fupra m odum perfuafione decepti. Siquidem tres in humanis corporibus conftitutiones effe cōtendunt . vnam, qua fani degimus : alteram, qua finiftra ualetudine corpora laborant : tertiam, quæ medium inter vt rafq; locum isbi uendicat. In qua pofiti, fanitatem fpecie mentiuntur, facileq́; in morbos \& pericula concidunt, ob uim corruptricê, quæ corporibus noftris incumbit : quemadmodum in ijs videre licet, quos excandefcens rabie canis momor deric, 


\section{In Lib. fextum Diofcoridis.}

derit; necdum tamen aquam horrent : in ijs quoque qui cantharidas hauferunt, fed nondum urinx tormento cruciantur. Tripartitò igitur artem digeri, tripliciq́ue corporis confututioni meritò refpondere tradunt. Salubrem partem effe uolunt, quæ fanitatem tuetur : præcauentem, eandemq́ue prohibentem, qux obftat, quo minus in morbos incidant: \& fanantem, qua uitia diccutiuntur. Quibus ita refponderi poteft, quòd primùm ex ifta ratiocinatione non tres corporis tancùm, fed quatuor haberi conftitutiones fatendum effet. quippe vt aliqui funt, qui recdum morbo liborant, morbo tamen maximè ob impendentem caufam funt obnoxij : ita funt, qui iam priore morbo defuncti, nondum tamen fecundx ualetudini reftituti funt. id quod in ijs qui à morbo proximè fefe recolligunt, cernere licet, qui turium recreationem \& robur defiderant. Sed quemadmodum curand ratio

xo ad partem medicamentariam pertinet; ita pracautionem eidem fubijci par eft. Ad arcendas enim ua = letudines uehementibus utimur auxilijs, altiore fcariticatu, uftionibus, amputatione, derodenubus epithematis, potionibus perniciei occurrentibus, \& plerisque alijs . Verùm enimuero funt ufque eò rudes nonnulli, ve ne remedia quidem appellent, qua morbos arceant . Cuius fententia inire ratio nem haud promptum eft : etenim cum uerbum ipfum, præcaucre, tum agendi modus, omnino auxiliarem remediariamq́ue uim præ fe ferunt. Mirum uerò nifi etiam fua illa diftributione partium eos complectuntur, qui in peltilentis coli ftatu morbo nondum correpti funt: pelti tamen, propter obuerfantes aëris occafioncm, opportuni, \& in morbum proni redduntur. Dicere forfitan quis poffet, fulubris inftitutionis præcepta non aliud effe, quàm arcendorum morborum rationem : quippe cùm firma reddere corpora, \& minus uitijs obnoxia nitamur, vt inoffenfa ualetudine degant, nec

20. morbis conflictentur. Neque id filentio prætereundum, quòd maximè præcipuum, \& tanquam caput rei eft, non oporterc medicinx partium diftributionem, totidem corporis conftitutionibus refpondere, fed naturas lingulorum fuis notis feorfum fcrutari, ac explorare, ut fuis locis oftendimus. Cum ijs igitur non pluribus agendum. Illud magis adnotare conuenit, affectus, qui à uirulentis ani malibus, uenenisq́ue contrahuntur, uocari cæcos, id eft, quorum ratio minimè iniri poteft. Quin \& ea, qux cisdé auxiliantur, nulli pariter funt addiata caufæ. quapropter quæftionibus obferuatoriæe artis, \& eius qux ratione fulciatur, annumerari folent. Neque prorfus uerum deprehenditur, affectus huiufmodi cæcos effe. nam quod femper fe protrahit, \& nullum in quibufdam neceffarijs ufum. exhibet, haud facili coniectura colligi potelt : ctfi naturæ proprietate prorfus cæecos cos aflectus concedimus, qui ab exitialibus uenenis, \& animantibus, quæ uirulento morfu fæuiunt, contrahuntur.

30 Nam quod ad opus nonnullum ufum præbet, datq́ue medendi occafionem, neque imperceptibile, neque cæcum, nullíve cauf obnoxium reputatur : fed magis ab ipfo quis impulfus, demonftrationem fe habere, \& opinionem de abditorum cognitione confirmare poterit. Nam etfi fxpe minora funt, quàm ut fenfibus percipiantur; euidenter tamen ex ipfis inter fe collatis deprehenduntur. Diocles autem in eo commentario, quem Pliftarcho dicauit, fatis modos perftrinxit, ad verbum ita fcribens. Noffe quis hoc poteft cùm in alijs non paucis, tum in uiperis, \& fcorpionibus, \& reliquis id genus, fecum animo reputans, vt quanuis exiguo fint corpore, vixq́ue confpeEtui fubijciantur; magnorum tamen difcriminum ac dolorum caufas inferunt: quorum nihil præter quandam corporis exiguitatem, uimq́ue præcæeteris animantibus datam illis, facile fuerit fpectare . Quanta enim ea moles corporis eft, quxà fcorpij iđtu, \& aliorum id genus uenenatorum, quæ nos morfu conficiunt, 40 attingitur? quorum aliqua uehementes cruciatus excitant, alia erodunt, \& putredines cient, nec defunt qux præfentaneam perniciem moliantur. Aut quantulum elt quod à phalangij morfu ingeritur, \& uniuerfum corpus excruciatur? neque enim quis magnitudinem ipforum deprehendere poffet, cùm prorfus exigua mole conftent. Ergo quòd hæc ad affectus referantur, conftitit inter omnes. Verùm quòd exactè deprehenfum lit, vim quandam ipfis ineffe mortiferam, quæi infinuata corporibus, moleftiarum, qua exoriuntur, nobis caufa fit, in confeffo eft, \& omnium confenfu perfuafum. Nec quisquam inuenietur usqueadeò contentionis fudio flagrans, qui aliunde exoriri moleftras affeucret, quàm à materia mortifera partem corporis attingente. Porrò id erat, quod inter utilia artis opera in omni opere dicere oportuit, qúxnam res opus hoc efficiat, vt nihil prorfus nos lædat, incomprehenfa communis caufx qux proprijs ineft ratio : quandoquidem tum euidenter indicari pof-

so fit, cùm deprehenfa eft. Ideo Erafiftratus empiricorum pertinaciam graui cauillatione inceflens, cæcis affectibus caufas afsignauit, inficiatus his communem, \& fupremam morborum caufam incomprehenfibilem effe: \& hanc in co, quem de caufis fcripfit, commentario aptifsimè prodidit,candido fignatam lapillo. Nec ferendos eos effe cenfuit, qui fe dicant in quibusdam, ut in uenenis, ferpentium jąibus, \& cæteris id genus trita medendi ratione contentos effe. neque fatisfacturam fibi obferuationem eam, qux à caufarum comprehenfione feparata eft : primùm enim genere comprehendi facilè poffunt. Quod autem fit lethifera uis, corporaque permutans, ita ut perimat, ex ijs qua pergenus, non perfpeciem uagantur, curationem indicat, qua hæc hebetare, \& protfus expugnare liceat. Cùm uerò fubiungit. Ad aquam dulcem, \& potui idoneam uenit quis, \& ante obferuationé ad uomitum, ad vulneris dilatationem, ad demorfe partis fuctum, cucurbitulas adfixit, partem incîdit, urentia medicamenta, aut ea qux vim eandem adipifcuntur, admouit, poftremò partem amputauit: fecum reputauit medicamina, quæ per fummam cutim ferre, \& applicari folita, immiffx ad 
intima perniciei repugnarent. Hæc itaque, qux differuit Erafiftratus, ueritati confentanea funt, nec arti refragantur. Sed methodicos demirari licet, qui mortiferam vim corporibus illapfam, negotiorum, quæ ipfa facefsit, effe caufam diffiteantur : verùm rudiufculè nomini attendunt. Nam apud

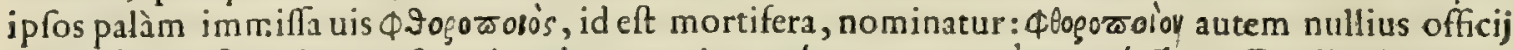

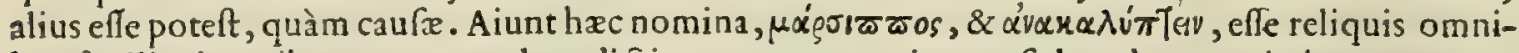
bus fimilia, in quibus partes quædam dictionum non pro uirtute, fed nuda enunciatione compre-

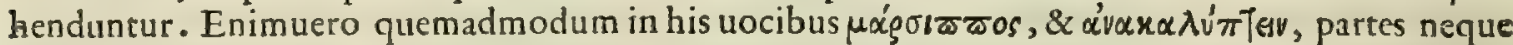

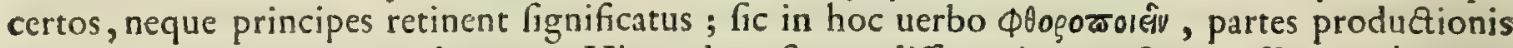
gratia, non pro uirtute coalucrunt. Hinc ad caufarum differentias tranfeunt, affirmantque caulfrom aliquas euidentes effe, quæ dum aduerfam ualetudinem crearunt, feparantur: cuiusmodi funt frigus, labor, $x$ ftus, \& fimilia . quasdam continentes, quæ permanent, poftquàm morbum excitarunt, hoc eft, quibus præfentibus, \& effectus eorum adfunt: increfcentibus, affectus augentur : decrefcentibus, minuntur : $\&$ cùm definunt, ijdem finiuntur : quibus folis ac per fe manentibus, $\in f-$ fectus quoque ipfi manent. Talia quidem receptifsina funt caufarum difcrimina, quorum nulli phthoropœon fubijci poteft. Euidens enim caufa non eft, quoniam morbus ipfe permanet, nec ipfa a corpore feparatur. Nec continens caufa dici poteft, cùm magna ex parte hic adfit : quemadmodum accidit ijs, qui à rabiofo cane funt demorfi. Quòd fi neque euidens caufa, neque continens fuerit, neque per $f e$, neque alterius confortio caufa erit. Quòd fi à nulla caufarum differentia phthoropceon deducere poffumus, confequitur, vt neq; caufam effe fateamur. Quòd autem afferunt, uocabula qux$\mathrm{dam}$ in fe non habere partes rerum fignificatrices, fed nuda \& fimplici pronunciatione ficta effe, fareri neceffe elt. Verùm non om nia, fed perpauca talem nancifci conditionem exiftimandum eft: ne-

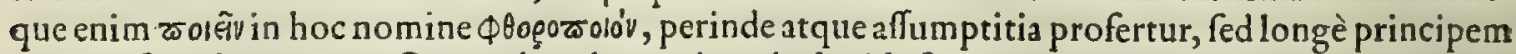
obtinet fignificationem. Quemadmodum enim $\phi \log \tilde{x}_{s}$, id ef corruptionis, nomen mutationem in

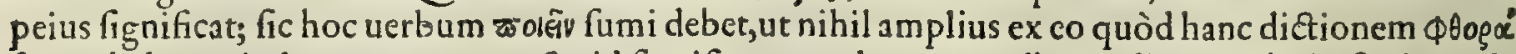
fecum habeat, declaret. neque prorfus id fignificat, quod omnes palàm audiunt, \& huic fimile red-

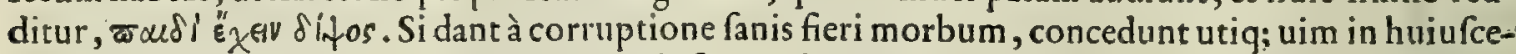
modi uerbo ๘oเ̂̄ fubeffe: fiquidem aliquid eft, quod corruptionem efficiat . Omne autem quod aliquid efficit, oftenditur per fingulas caufas, quæ corporibus fubijciuntur, idque tam in lethalibus uenenis, quàm in ijs quæ corporibus ingeruntur. Verùm nonnihil fubiacere caufarum differentijs produnt. Quinetiam aberrarunt, non exactam diuifionem affumentes . Qui verò fe dogmaticos profitentur, caufam effe partim præparantem, partim continentem afferunt, vt inguinum vlcus, \& inguinariam febrim, \& quæ effectui tú afsiftat, tum etiă feparetur, vt à fract is pracipitatio. In fumma quoties quidpiam fuapre natura caufa fuerit, nec ulla diuifione comprehenditur, uitiofum eft, neq; cauf $x$ adfcribitur, corum qux idem genus fortiuntur. Sed quod phthoropœon caufa fit, nomen ipfum argumento eft, $\&$ in ijs quæ contingunt, apertius oftenditur. Quid aliud cauf $\not 2$ arbitrantur effo poft impreffum a ferpentibus ictum, quàm ex animante uim, \& illapfum in corpora uirus? Neque enim frigus, neque $x$ Itum, neque fectionem corporis, neque cruditatem, neq; aliud quicquam fimile caufari poffunt. Verùm quoniam caufarum differentijs gaudent, \& aliquas continentes, alias euidentes appellant, ipfis dicendum, utroque iftorum modorum euidentem quidem caufam effe, quod affectú præcedit, \& quod corporis fubftantiam præoccupat: continentem uerò, quod morbis præfenti- 40 bus adeft, qua feparata recedunt, qux cum ipfa euenerant. Sed de ijs hactenus. Statuendum itaque mortiferam uim intrinfecus manifeftifsimam effe caufam, ipfamq́; principem facere fcopum oportet. Et antequàm ad ima decumbant morbi, uarijs modis eft certandum, donec uis tota corporibus excutiatur. Modò enim reuocari debet ea parte, qua peftis intrauerit : modò aliqua alia, præfertim principatum non obtinente, antè coërceatur, quàm altius irrepens uifcera tangat : aut eius pernicies eluatur, retundaturq́ue, cùm iam membratim peruagatura eft. Itaque uenena fi haufta fint, crebris uomitionibus : fi morfu impreffa, fcarificatione, affixis cucurbitulis, exuctu, carnis circumfcriptione, nonnunquă amputatione extremæ partis, euocantur. Retinentur uerò infufione, \& impofitu medicamétorum acrium cohibentur. hæc fimul utig; arcere uirus, \& eluere poffunt . Reftinguuntur, $\&$ euincuntur meraciore potu, aut paflo nulla aqua diluto, uel contrariorŭ efu, qux acrimonia fint pradita. Poftremò deiectio alui, euocatus fudor, $\&$ alia quædam in commune, qux membratim demóftrabimus, auxiliantur. Verùm enimuero non lethiferam modò materiam; fed \& magnitudinem, \& tempus, pro fcopo confiderare oportet . etenim ab iis remedia quàm plurimum difcrimen capeffunt. A'magnitudine quidem, cùm nonnulla ex uenenis, \& uirofis animalibus pericula minantur: alia putredines altas, aut exteriores excitant : alia vehementifsimos dolores, aut cæcos cient : alia uix medicamétis cedunt, \& magis minúsve moleftias excitant. Oportet auten ea qux pericula ferunt, peruicacioribus auxilijs expugnari : \& minus infefta, mitioribus . Quippe abfurdum fuerit in grauioribus, fegnioribus medicamentis homines in difcrimen adducerc: in minoribus uerò, uehementium auxiliorum iniuria corpus lacefferc . Finitio à temporibus in promptu eft : hoc enim fubitò in pericula, \& prafentes mcleftias adducit: illud verò fenfim, \& dilatas in diem longam, aut breuiorem producit . Itaq; in acutis quidem confettim multa fimul auxilia repræfentari oportet: reliquis, pau= latim. Hxc quadam at tis formula breuiter dcfinita fint. Iam membratim rem profequamur. 


\section{In Lib. fextum Diofcoridis.}

$\mathrm{C}$ v M bafenus tradiderit Diofcorides de bis priuatim ucnenis, qua cpota aut in cibis fumpta, corpora noftra permutant, corrumpunt, deftruunt, e deniq; in perniciem agunt, wt bac in re nibl amplius defideraripoffet, ftatuit deinceps de bis ctian fibi cffe differendum, quxe uirulcnta animalia itfu, ucl morfu relinquknt. Quód utiq; probé fci= ret, hac non minora: qusm illa reprafentare difcrimina, imó etian maiora: quandoquidem cucniant liec ex tempo=

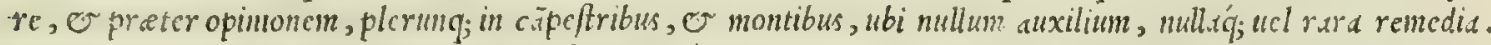
Qunuobrm de bis non mimus dligenter differuic, quin de alijs, qua corporibus ingeruntur, aigumento fat is mani=

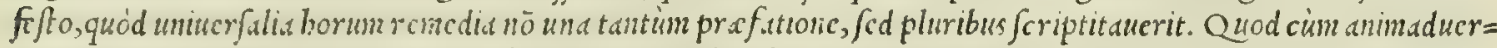
terint recentiorum quid.m, haud dubié exiftinarunt, hoc fextum wolumen in quatuor libros cffe diuide ndumi, nempe in fextum, feptimum, oct aumu, en nonum. Veruntancn ij mibi non recté (pace femper crudutorun dixcrim) cacx=

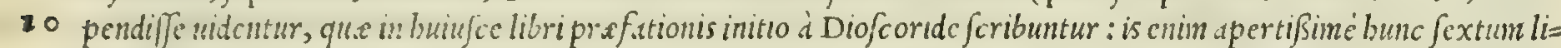
brum totius operis ultimum declar.mit. Quapropter ipfe Diofcoridem fecutus relictis aliorum opinionibus, afferere non dubitucrim, buis uniucr fun de ucnenis, or uencnatis animalibus tractatï, unum tantim, non plures cffe libros:

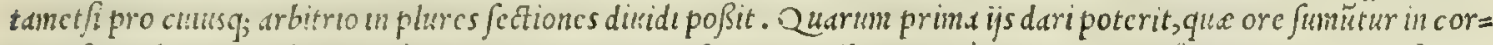
pus: fecunda canis rabidi inor/ibus : tertia indicijs ac fompiomatibus, qua a ucncnatis morfilus oriuntur : poft rema ueró corum curationi. Verün eninuero cimbec diutus cxaminauerim, ut Diofcorides doctrina ad maius onmum commdem in unum congeratur, or ne tot buius librifunt fectiones, uenenoforum animalium tum indicia, tum acci= dentia, qux proprijs capiribus tradidit Diofcorides, ijs coniunximus, quibus ip $\int e$ cgit de eorundem curatione, $c$ resnedijs, ut un! qquifq; iunctim nulla temporis iactura, uno tantum capite indicia, accidentia, $\odot$ curationem conf $c=$ quatur. Quod or ip/e fecit Diofcorides, wbi fuperiks de uene nis differuit, que in corpus fumuntur. Ibi enim indicia 20 d curationbus nondifinxit. Nam fin uno tractatu indicid, in altero ueró curationcs quaerantur, maius tempor is dipendium fict, maior'; menti moleftix inferctm; quaim fi hac omnia in unum redacta legentibus $\int e$ e offerant. Nec; boc nobis uitio adfcribcndun cffc putanks, quando res è nugis placerc folcant, quó commodiusfieri pofjunt, cum practeresillud (ut aiunt) fruftra fiat per plura, quod ficri potcft per pauciora. Neq; etiam ob id quis calumniari po= tcrit, quod Diofcoridis codiccm allqua ex parte deprauauerim : quód nufquam à me deprauatum, fid tantum in me lorem formam, o ad priorem authoris doctrinam ip fun redactum, of reftitutum putem. Porró non aliud fuper bac prefatione nobis dicendun uidetur (que multis uicllectu difficilis extitit, ut Marcellus ipfe fatetur, quód fortaf= $\int c$ Dulcticam ignoratuerit ) nfít quod aliud fane bee prefatio non fit, quàm Diofcoridis Ariftotelem fecuti difcepta= tio, aducrfus cos ommes, qui fuperficie tenus in medica facultate, Juper nuda ac fimplici uoc abulorum interpretatione altercantur, eorum '; prefertim, qux̉ ex uarijs, ac duerfis uocibus componuntur. Quandoquidem bec interpreta= 30. tionis uocabulorum diftractio, potius ad fophiftas, e nugatores attinet, quàm ad expertos, et probatos medicos, ut facile uidere eft in pluribus irrcprebenfibilibus uocabulorü exemplis ex pluribus uocabulis compofitorum, que in lib. peribermenias ab Ariftotcle aßignätur. Quippe quoniam nouerat ip $\int e$ Diofcorides, quéd tam metbodicorum, quain dogmaticorum qudam in ip is compofitis uoc abulis declar andis expertorum, exercitatorumq́; medicorum fententiă, proprijs uocabulis denominatan, baudquaquam fecuti fuerant. Cateriun o eos non parum reprebendit, qui abfque alıqu Dialectice fundame nto, diuifiones in caulis facere audent. nam cum in diuifionibus errorem committant, in ijs quoq; que fequuntur, errent neceffe eft. Proinde qui bec latius uberiusq́; nofcere cupunt, Ariftotelcm con fulant li bro fecundo play/icorum : illis fiquidem inibl amplißime fatisfiet. Potuiffemus quidem or nos rem banc pluribus proz fequi: :ed cum noftrum inftitutum non fit, nunc in aliam materiam digredi, bxc filentio pretereunda duximus.

Nours ordo huius libri. 


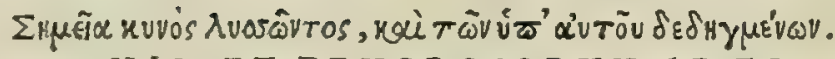
NIS, ET DEMOROSORVMAB EO.

\section{SIGNA RABIOSI CA=}

CAP. $\mathrm{XXXVI}$.

D E R A B I OS I canis morfu fermonem alijs præpofuimus, quòd id animal domefticum,ac frequens effe confueuit, \& in rabiem fxpius agitur, ac perit, ab eoq́ue caueri difficile. inde periculum ineuitabile hominem manet, nif multis vtatur auxilijs. Canis plerunque flagrantifsimis æxtibus in rabiem efferatur: interdum quoties frigora incefferunt. Rabiofus autem potum \& efcam auerfatur: largam fpumantemq́ue pituitam naribus, $\&$ ore proijcit : toruè $\&$ folito triftius intuetur $:$ in omnes palsim finelatratu irruit, \& æquè feras hominesq́ue, tam familiares, quàm ignotos mordet: nec protinus infeßtum quicquam infligit, nifi, ve vulnus, dolorem : exinde morbus ille, qui ab aquæ metu hydrophobicus Graia eft voce appellatus, contrahitur . Euenit autem cum diftentione neruorum, totiusq́ue corporis rubore, præfertim faciei, cum fudore, \& languore quodam. Aliqui auræ fplendorem fugiunt: alij fine vlla doloris intercapedine vexantur. Sunt etiam qui canum more latratus $x$ dant, \& obuiam factos morfu adoriuntur, ac mordendo fimili vitio labefactant. Proinde ex ijs, qui hoc vitium fenferint, neminem feruatum vidimus, nifi forfitan ex hiftoria vnum aut alternm euafiffeaudianus. fiquidem Eudemus fuperaffe quendam affirmat. Themifonem aliqui demorfum in hunc furorem incidiffe, \& euafiffe fatentur. Alij ipfum cùm amico aquam expauefcenti morem gereret, \& officium exhiberet, quadam naturarum concordia, fimilem contraxiffe affectum : fed poft multos tandem cruciatus feruatum extitiffe. Moleftifsimum itaque genus morbi, à quo multos, an- 20 teaquàm ipfum experirentur, vindicauimus, \& complures ab alijs medicis feruatos nouimus.

Conis rabiofi uenefica natu ra, \& figna.

canes quibus caufis rabie exagitentur.

$\mathrm{N} \vee \mathrm{L} \mathrm{L} \mathrm{V} \mathrm{M}$ in uniuer fum animal homini tam domefticum, familiarég; reperitur, nullumí; quod tam multiplici, uarióq; genere conftet, quàm canis. Hinc eft, quód uiri, mulieres, ac pueri ijs magis deléfantur, quàm ceteris ani= malibus, que in domibus noftris aluntur, tanta quidem intercedit canibus cum bomine focietas. Qui tamcn in rabiem acti, quos momorderint, in maximum difcrimen plerunq; deducunt. Cim itaq; canes à continuo bominum confortio nunquam abfint, quipropterea illorum morfibus magis fubijciuntur, quain cxterorum, que morju pariter, uel ictu uenenum eiaculantur; ideo merito quidem de bis prius, qudim de reliquis beftijs uenenat is tradidut Diofcorides. CRF terim quanquam ipse caufas non fcribit, cur magis aftate Canic ula ardoribus, itidem hyeme frigoribus uebementißi= mis in rabiem aguntur, qudm reliquis anni temporibus; cum tamen palan fit, canum rabiem non aliunde prouenire, 3 quain ab atrabiliarijs excrementis, facilé cognofci poteft, id aftate euenire perufto a caloribus eorum fanguine, bye= me ueró frigoribus concreto. Rabidicanis indicia defcribut Galenus lubro de theriaca ad Pifonem ( $/ 2$ tamen liber is Galeni legitimus eft ) bis uerbis. Si audieris canem, qui aliquem momorderit, gracilem corpore, $\mathcal{O}$ ficcum, oculis ru= bentibus, cauda demiff, puma ex ore fluente, praterea lingua fords porrecta, or tanquam bile colorata obuiü, quen= quam infilijfe, citraq́; rationem cucurrifee, deinde rur fus fubito confiftentem cum ird quadan mag is furenti non ip/h prauifos momordiffe, hac inquam fi in eo fic habere audieris, ftatim rabiofum canem fuiffe intelligas. hec ille. Ince dunt preterea ( ut quidam afferunt) lento gradu, demißis auribus, abfciffa uoce, ft upido capite, er obuios non modó bomines nullo delectu; fed $\mathcal{O}$ beftias deniordent. Nec mirun fi propriuin mordeant dominum, alios $q_{;}$domefticos $0=$ mnes, nullius habito dif crimine, uel ratione. fiquidem cum proprium atr a bulis fit fenfus omres inficere, omnium er fui ipfius obliti, domefticos ip fos cognofcere nequeunt. Id quod etiam pluribus bommibus accidit, qui melanclsolici

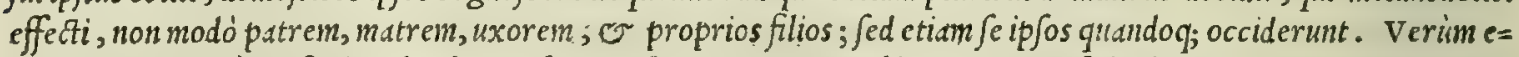
nimuero non tantiun aftiuis caloribus, er byemis frigore canes in rabiem aguntur, fca ctiam morticinarum, putrida= rum, uermibus q́; fcatentium carnium efu: quin or marce fcentis earum fanguinis. Quod fif fuerint ba carnes eorum animalium, que peftilentia, aut ictu fulminis, aut ucnenoforum morfibus interierint, có facilius maiorió; afficiuntur rabie. Qua etidm excitari folet computre fcentibus aquis fiequentius ebibitis, quod bae ommia atrabiliarios fuccos augeant, or putredine corrumpant. Eoó; mag is bis de caufis in rabiem aguntur, quantó alter altero fuapte natura magis atre bili obnoxius fuerit. Aduertant praterea nobiles mulieres, ne fuis catellis, quos in delicijs babent, or qui bus maximé oblectantur, cibun uel iufculun edendum prebeant, quibus aromata, prafertin' ; piper er gingiber, fue= rint admifta. Quippe cum bec caliditatis, ficcitatisq;; modum excedant, eadem ratione, qua ingens ceftatis feruor, $c$ a = nes rabidos efficiunt. Caueant ideo eas libenter moneo, ne ipfis forte fortuna id mali accidat, quod Tridenti cueniffe fcimus clarißimo Baldo utriufq; legis doctori. Is fiquidem inter lidĕdum cum quodă fuo catello iam rabıe affecto, le= uiter in inferiorl labio demorfus fuit. Sed ipfe buius rei ignarus quarto póft menfe rabidus factus, $\sigma$ tandem bydro= phobicus miferabiliter mortem obijt, nullo adiutus medicamento. Ad hec fcicndum eft, quód nö canes tantim (quan=

Animalia alia rabie tentantur. quam ij magis,quàm catera animalia in rabiem agantur) rabidi fiunt; (ed etiam alia pleraq; animalia,nempe uulpes, muftele, uiuerre, martes, fimix, er id genus alis. Quapropter ne ciucrim, quo argumcnto dixerit Galenus libro fexto de locis affectis, folum canem inter ceter a aninalia corripi rabie : nifi uolucrit dicere (ut equidem reor) canes ceteris animantibus rabiei magis e fe obnoxios. Refert Ariftotcles libro octauo de biftoria animalium, camelos etiä, er equos in rabicm agi. Id quod ego quoq; afferere polfum : etcnim memini, cum ruri degerem, me uidiffe equum ras bie furentem, qui fracto capiftro obuiam quandam uetulam per capitis, or crinium uittam morfu comprebenfain, de= cem plures⿱宀; pasfus à terra fupen fam pertulit, nullo tamen unlnere illato, fed magno fané ter ore. Hoc affectu ca= piuntur (ut Auicenna eft author) etiam muli, qui fuis aliquando morfibus dominos, $\mathcal{O}$ frabularios rabidos, $\mathcal{O}$ uclu= 


\section{In Lib. fextum Diofcoridis.}

ti arrepticios redididannt. Verim huiufmodi animalia non nifi raró, ucl nunquan per fe rabie tentantur; quando= quide in feré femper id ills eucniat, cun à canibus, feu lupis, aut unlpibus rabidis mordentur. Cxterim (ut ipfe Dio= fcorides inquit) rabioforum canum morfus infeftum quicquam protimus non infligit, nifi, ut unl inus, dolorem. Sed ne= glect a curstione, demorfi aliquo póft tempore rabidifunt, or aquan expauefcunt . quod etiun futetur Galemus li= bro de therisca ad Pifonem, alijsí;; in locis. Idcirco diligenter aducrtant, qui à canibus mordentur, $f \mathfrak{l}$ aliqua $\int e \int e$ of $=$ ferant inácia, quibus comijci poßıt, cancm, qui momorderit, rabic laboraf)e . siquidem neglectis remedijs (ut modó diximus) in id difcriminis denorfi adducütur, ut nullus fubinde relinquatur falutis locus. Tradidere oribafius, $p_{\text {atu }}$

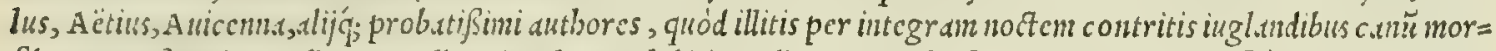

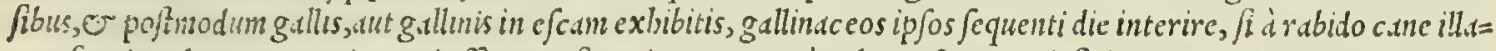

10 tum fuevit unluus. Sunt ctian qui afferant, fi panis emanante è uuluere fanguine inficiatur, or cuicunque caniquan= tünuis fanclico offeratur, cancm non modó illum non mandere; fed nec olfacere quidem. Attamen bis tantium expe= rimentis ( nteo cojilio) non plané fidendum fuerit: quanquam ca à probatifimis prodantur authoribus. quapropter ali. indicis iam dita diligenter fucrint perquirenda. Cum autem rabidorum canum mor fus negligütur, poft aliquod temporis /patiun demorfi practer morem cogitabundi funt, edq́; mente reuoluunt, que illis infuet. funt, quod iam ue= neni uis in cerebrum repens in.tginatriccm occupet facultatcm. Si ueró adbuc in longum protrabuntur nullis reme=

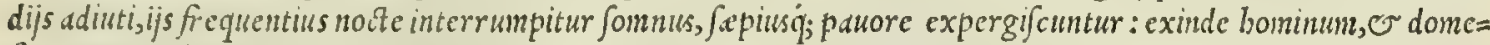
fticorum confortu witant, or cumb ferino quodan apectu fecum fubmurmurant: folitudinem deligunt, lucem er can= did omnis odire maximé, rubent quando q; facie, ijsq;; extremarum partium nerui conuelluntur : po/tremó có dedu= cuntur, ut aquam expauefcant. Quod certißumum mortis, ơ incxpugnabilis ueneni prabet indicium. Proinde di=

20 cebat Diofcorides exijs, qui boc uitium fenferint, neminem feruaripoffe. Allata itaq; in corum confpectu aqua, cu= ius potu facilé Sandrentur, fi tanen bibcre polfent, ingentißinis clamoribus, et canü latratu aftantes terrent. Quód fi diutius ante cos aqua ip $\int a$ dimittatur, tremunt, fudant, deficiunt animo, delirant, pauoréq; concutiuntur, ac fi in $i=$ gnem illico fe proijcicndos cernerent. Id ueró accidit, quód melancholici ffecti, corruptis, infectisq́; inde animalibus facultatibus, recufant mifelli, metuunt'́; aquam, qua fold fanari poffunt. Nec alia de caufa id euenire cenfent medici, quam buiufce inexpuguabilis ucneni prauitate. Nam cim hunorum omnium, er totius corporis principalium facul=

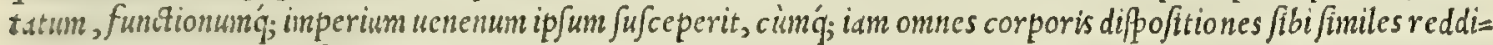
derit, mouentur uniuerfi corporis uires, irruint क् contra id, quod fibi contrarium exiftimant, boc eft, contra ipfam aquam, fi ca in medium afferatur. Quocirca Galenus libro de theriaca ad Pifonem, ita fribit. Non enim corpus duntaxat ip/is inurefcit, 0 conuethitur interdum, febriq́; acri intus uritur, fed animus etiam delirat, or grauißimï

30 ip/is affert fymptom.t. Quippe aquam timent, ac propter multam ficcitatem bumidi tenentur defiderio, er à potu abfinent, quia mente alienati, id quod auxiliari poßit, non confiderant. Fugientes enim aquam, pauentes'́; mifer= rimo mortis genere intereüt. hafenus Galenus. Ha itaq; rationabiles funt caufe, quibus in aque timorem deueniunt. Veruntamen quidam tefantur, ut Aëtius, Pofidonius, $\mathcal{O} \mathrm{R} u f u s$, id etiam accidere poffe, quód rabidi canis imaginé widere in aquis inaginentur, cuius pecicm rccolentes, protinus ingenti terrore corripiuntur . quod quidem nimiam ob ficcitstem perpetiuntur. Nam philo fophus quidan ( ut Ä́tius refert) mor fus à cane rabido, $\sigma$ egregia animi uir= tute affection refiftens, dum phantafticicanis imago fibi obuer faretur in balneo (ea enim ip/i quoque quemadmo= dum $\approx$ rcliquis eodem morbo affectis apparebat) diu intra $\int e$ neditatus, ecquid tandem inquit commune eft canic $\tilde{u}$ balneo s quod fffatus balneum intrauit, $\mathcal{O}$ imperterritus bibit, at $q_{;}$ita morbum fuperauit, $\mathcal{O}$ incolumis euafit. Vn= de poftex in proucrbium manauit, quid cani cum balneo. Refert Auicenna quód fí quis à cane rabido demorfus, aquă

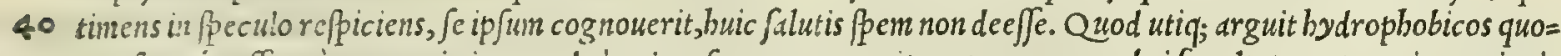
que fanari poffe, cim ueneni uis non adeo uniuer fum occupauerit corpus, er cerebrifacultates, ut omnino ratioci= natrix facultus ablata fit. Quamobrem mirum non $f f, f i$ philo $\int$ ophusille, cuius biftoriam refert Aëtius, curatus eud= ferit, cum m.unfeftó appareat cius ratiocinatricem facultatem parum fuiffe affectă. Ad hac fcribit Auicenna euenire interdusu, ut a cane rabido demorfi quedam frufta carnisingenti cum dolore mingant, que forma propé canes paruulos referant. quod etiam ab alijs recentioribus accepimus, quin er ab ijs, quibuiufmodi catulos $\int_{e}$ minxiffe $f_{d}=$ tentur. Ceteriun cum hoc potius fabulofum, quàm rationi confentaneum uideatur, atq; ab ipfa natura penitus alie num, fi qui id uermu effe rationibus, $c$ autboritatibus comprobatum uidere cupiunt, Gentilem Fulginatem confulăt Auicemne interpretem : item Conciliatorem differentia 79 . Quandoquidem ex ijs nimirum intelligent, quo patto hec preter naturs inf:itutum quandoq; eueniant. Poftremo afferit in boc capite Diofcorides fateri aliquos Themi= so forem, cim amico aquam expaue fcentı morem gereret, $\mathcal{O}$ officium exbiberet, quadam naturarum concordia fimi= lem contraxiffe affectunn. Sed id potius ego euentyfe crediderim, quód Themifon medicus amicum laborantem excitan

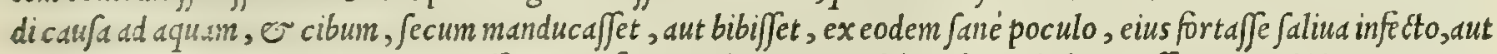
alio quóuis modo oris $\beta$ umam contigife. Nam $\tilde{f}$, ut Galenus tradit libro fexto de loc is affectis, rabidorum canum faliua, nud. corporis membra contingens, non aliter homines rabidos efficit, quàm $f i$ demorderětur, quid mirum, $f$

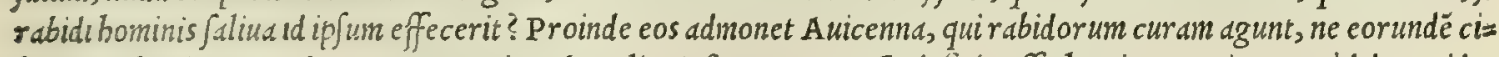
borum reliquias comedant. Nec paruipendat aliquis punte contactu infici polfe bomines: quippe quód duos uide= rim ego, qui ipuma tantim perfufi, nullo quidem ex morfu accepto uulnere, rabiem contraxerunt. Legitur in Ari= ftotele lib. V I I I. cap. X X I I. de hiftoria animalium, quód omnia animalia à cane rabido demor fa rabiunt, excepto homine. Que tumen fententia aperté falfa deprebenditur, ut millies experimento compertum eft. Quamobrem po= tius adducor, ut credam Ariftotelis codicem eo in loco deprauatum effe, quám ut in re clara, $\mathcal{O}$ ommibus cognita, ip Jum A riftotelem ignorantix accufare uclim.

Neglecti mor fus difcrimina, \& caufx.
Salutis indiciunn. 


\title{
$75^{6}$
}

\section{And. Matthioli Comm.}

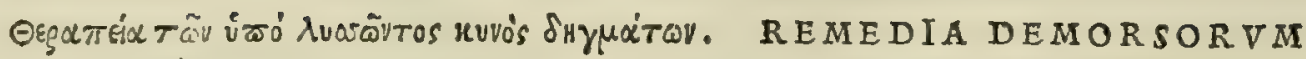 \\ A' CANE RABIOSO. \\ CAP. XXXVII.
}

R A I I o medendi duplex . vna communis, qua utendum in omnes morfus, quos uirulentx animantes imprefferunt: alia peculiaris priuataque, eorum duntaxat quos rabiofi canes momorderint: quæ nonnullis quidem fummam opem ferre confueuit : alijs uerò inutilis, maximè qui ex multo iam tempore ictum acceperunt. Qux ad hanc pertinent, primùm exponemus, deinde curfim perftringemus, quæ ad communem medendi rationem pertinent. Cancros itaque fluuiatiles in farmentis albæ uitis cremare oportet, \& cinerem corum, quàm minutifsimè tritum habere reconditum : itidem gentianx radicem tufam, cribratamq́; reponere. Quoties autem canis rabiofus morfum intulerit, in quaternos cyathos meraci uini, bina cineris cancrorú cochlearia, unumq́; gentianæ conijciantur : hæc in polentæ dilutioris modum fubacta, quatriduo bibantur . Inter principia medicamentum hoc modo detur. Atqui fr ab illato morfu bini terníve dies fluxerint, curationé aufpicabimur à triplicato pódere, fupra id quodab initio retulimus. Optimum hoc aduerfus rabioforum morfus auxilium, quod \& plerisque unum fatisfecit, coćue cum fiducia uti licet. Sed ut alijs etiámnum auxiliis contra ineuitabile periculum muniamur, nihil cæteris uti prohibet. Satius autem multò fuerit, etiamfi in vanum recidat, medicamentorum in humanos tolerare cruciatus, quàm per inertiam, ac defidiam in difcrimen adduci. Nec ita in demorfis à rabiofu animali maiora vulnera uereri oportet, vti minora , \& ulcufculis cutis fimilia : quippe maiori vulnere confertim copiofus fanguis emanans, poteft $x$ nonnihil virulenti liquoris exhaurire: quod in minoribus non accidit. quin à maioribus abfcedentes carnes hinc auferre, \& labia acie fcalpelli circunfcribere, \& prehenfam hamulo aut vulfella carné amputare oportet . In vtrisq; circunftantia loca altioribus vlcufculis fcarificanda, ut copiofior fanguinis uacuatio arceat, ne uenenum membratim infinuetur. Cucurbitulx cum multa flamma agglutinatæ id iuuamenti præftant, ut ueneni uis extrahatur.

Curatio demorforum à riens, ut mibi fuperuacuume efe uideatur quicquain adderc. Verum ut noftrum fequamur inftitutü, ut

T A M accuraté exquifitég; tradidit boc capite Diofcorides rabidicanis curationem, nibil plané fol entio pretex ctoribus fiat fatis, qui nouis femper rebus inhiant, non alienum fuerit bic nomind a commenorare, qua multos for = taffe delectabunt, quód ea in hac re non inutilia, neq; fcitu iniucunda putem. In primis itaq; illud animaducrendü eft, quód alia utiq; ratione căcrorum flusiatilium cincrem pra parabat Galenus, quàm Diof corides, ut conft ut aperté ex uerbis ipfius Galeni lib. X $\mathrm{x}$. fimp. medicamentorun, ubi ita fcriptum reliquit. At fiuniatilium cancrorim cinis, quin quam fimiliter predictis exiccatorius eft; fubftantie tamen totius proprietate, mirificé contra rabioforwm morfor $\vec{s}$ efficax eft, isq́; tum folus, tum cum gentiana $\mathcal{O}$ thure moltó praflantior. Thuris fane partem effe unain oportet, quinque autem gentians, porró cancrorum deccm. Et raró equidem aliter illis uftis nos fumus ufí : celerìn dì eum modum plerunque, quo utebatur Aefchrion empiricus, medicamentorum peritißimus fenex, concinis, ac preces ptor meus. Patella erat aris rubri, in quam impofitos cancros uiuentes, bactenus urebat, donec in cincrem redige= rentur, ut facilé ad leuorem redigi pofent. Hic Aefchrion fic paratum promptum femper in editus hoc babcbat medicamen, tëpore aftiuo urens cancros ipfos poft ortum Canis, quando fol in Leonem tranfiffet, lin a decins octa= ua. Porró bibendum boc medicanen ijs, qui à cane rabido fuifent mor $i$, prebebat quotidie usque ad diem quadrage $=40$ fimum men $\int u r a$ cochlearij fatis magni, aque infper fum. At $f i$ non protinus ab initio, ucrün aliquot pof dies à mor $f u$ curam capiffet demorfi, tunc quotidie duo cocblearia aque injpergebat. Ad ipfum ueró uulnus emplasticum appli= cabat medicamentum, quod ex pice brutia, o opopanace, acctoó; conficitur, habens picis libram unam, unum ace= Multorum ti acerrimi fextarium Italicum, opopanacis ueró uncias tres. hec Galenus. Caterün fciendum eft, eos nuaximé,
error.
meo iudicio, ballucinari (ut latius librofecundo prodidimus) qui gamnaros Latinis uocatos, cancrorum fuusatilium erros. loco, à cane rabido denorfis potui exbibent. Nanque aliud Grecis aninal effe cenfemus rapreivoy, aliud ueró a's $\alpha=$

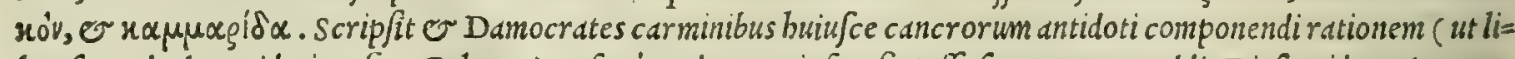
bro fecundo de antidotis refert Galenus) eo fane modo, quo ipfum fortalfe fecutus eam reddit Diofcorides. Attamen antiquorum quidam refinam terebmtbinam impofuerunt thuris uice, quod Aefchrion Galeni preceptor huic femper inferuit medicamento. In fumma huius antidoti uires miris laudibus $a b$ autboribus celebrantur, adeó ut fcripferit $\mathrm{G} a=$ lenus, neminem unquam mortuum effe, qui hoc antidoto recté fuerit ufus. His non dißimiles uires ueteres aßignant Alyffo, fi ficcum quadraginta dicbus continuis detur ex bydromelite potandum: fed à prind ftatin die incipiendum erit. Huius experimenti meminit Galenus libro fecundo de antidotis, ubi alia quoq; ualentiora remedia ad rabidorum morfus ex Afclepiade retulit. Verïm nobis difficile admodun fuerit decernere, qùsenam bodie planta fit, que uete= rum Alyffon reprefentet, ita ut potius de hoc diuinandun effet, quim aliquid certiftatuendum, ut latius fuperius li=

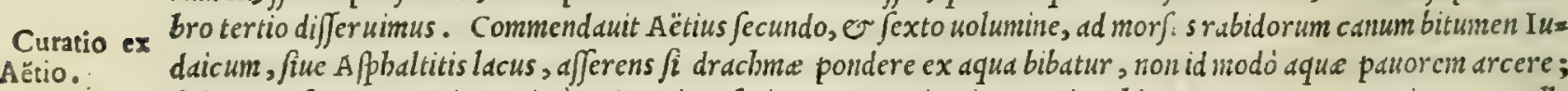
Aétio. fed e cos fanare, quos iam primum timor inuaferit. Memoravit ctiam marinos bippocampos ex aceto nigro er melle fubactos, tam potu hauftos, quim uulneri illitos. Confert praterea his maximé acutus rumex : quare idcm forip it fe nouiffe fenem quendam, qui demorfos à cane rabido hoc folo rumice curabat. Prinó cnim ulcus cius decocto fouebat: deinde herbam ipfam illinebat , candemq́; potandam exhibcbat. quod quidem medicanentum tanquuan cfficacißimum 


\section{In Lib. fextum Diofcoridis.}

fummopere conmendabat. Plurima autem, or turbulenta qui illam affumpforint, mingcre folcnt: id quod maximé bac in curatione confert. 2uo fortaffe argumento extulit Auicenix propri.t qued sm medicamentu, que canthuridas

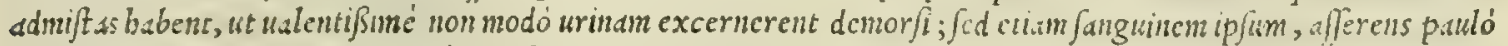
pojtfecurü elfe falutis indicium, cum poft medicamenta fanguinem minguni affecti. Porró Galcnus libro de theris= ca ad pilonem, theriacam prefert tam intus in corpus fumptam, quam extcrius fupra morfusillitum. Sca' chim bee,

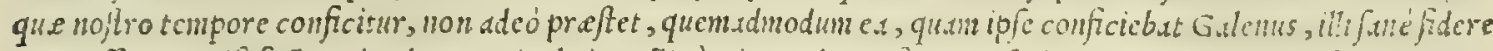
non poffumus, nifi facto prius de ca periculo in gallis a uipera demor/is, ut ip/e docet Galenus. Protejt item pota=

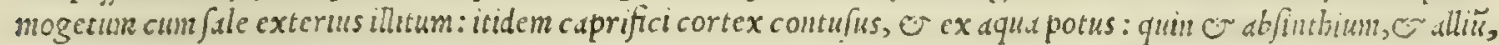
misus centaurum, arifolochia, artemifia, fcordim, chamadrys, bryonia, pulegium, or lafir, tam cxterius tllita,

- guim interius fumpts. Sunt qui credant fecurißimum c/fe remedium ipfius rabudi canis, qui momordert, iccur to=

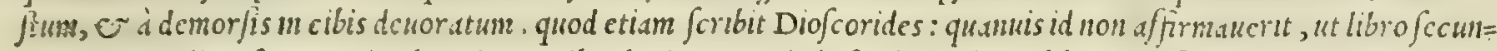
do cupite de diuer forum animulum iccinoribus legitur. Proinde forbit Galcnus libro $\mathrm{x}$ 1. fireplicium medicanento= rum, iecur canis rabicntis alijs ualentioribus antidotis admitum quàm plurimos janaffe, fed cos tamen !nteriiffe, qui folum nullis alijs adiectis medicamentis illud cfitarunt. Sunt etiannum qui credant, ut loco anté citato tradut Diof coF rides, arceriaque pawores dente eo, qui canimus dicitur, fi is i cant, qui monorderit, cxemptus, or folliculo mdutus, pro amuleso biachio adnectatur. Scd nemini bis fidendsm cffe perfiuferin, ut in noftrabuius fexilibri pref atione de pretioforum lspillorum Juppenfione diximus : fatius enun cffe femper exiltimaul certis ac tutis uti medicanentis. Cexterün carationis fumma in:numm maximé opcran expofcit. Quandoquidem uulnus diducere oportet, lanatamiq; per ambitum carnem refenderc : ita cnim latior fit ueneni exterius euocandi aditus, demitur quod tabefactü ch, os 20 cx funguinis fluore ab excidentibus cultris excitato, repens affectio non parun reuellitur. Quod etlam facere expe= dit jcalpdilo circunquag; profindius adudto, or fubmde appofitis fcalpto loco cucurbitulis fanguinem firtiter extr.t= benubus, aut liruduibus. Nedic sment:t autem, que aluum citant, e bunores deijciunt, in principio amnino uitun=

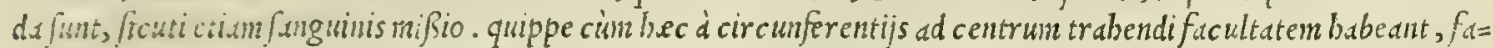
cile $x$ gros in moris tr bherent difcrimen. Tumetfí in curationis proce fa, or ubi prefertim medicorum negligentia cirius quim expetat ratio conclusum fuerit uulmus, irrepferit'; uenenum (ut poftea dicetur) medic anenta aluun du=

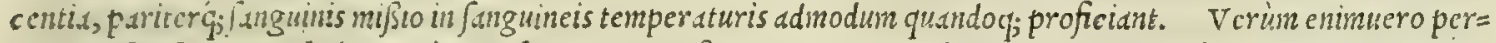

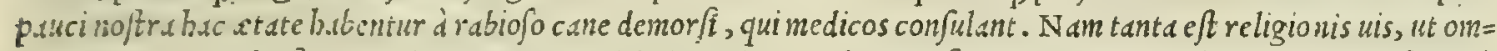
nes, quos canes rabiofi momorderint, partim ad diui Donin templum confugiant, partim ueró ad diui Bellini facellü, ub: quibusdan exorcijinis, or panibus characteribus obfignatis à facerdotibus perquin facile curantur, ut pluri= 3. morum teftumonio equidem fateri pofjum. Sed cogitanti mibi quónam pacto boc tam facilé eweniat, nonnulle fefe obtulerunt rationcs, quas liberé dicam. Haud dubié in primis diuina auxiliatur gratia :quippe cum non parum mos

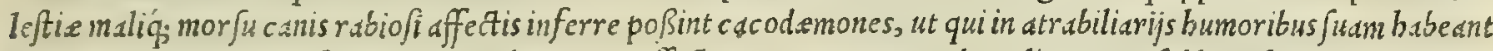
Sedem, i| quidem cxorcifiais cedentes abeunt, $\sigma$ afflctorum corpora munda relinquunt, fublato fecum uenena. il= lud pretcres addiderin, quid fortaffe faccrdoces ipfi aliquod nobis occultum babent antidotum, quod panibus this admijecutes, agris deuorandum : vel id aliquo in potu bibendum exbibent. His deniq; accedit magna laborantium fl $=$ des, quam fujcipit Deus optimus maximus, cuius folius munere omnia noftra delentur incommoda, atque omnes all= feruntur agritudines.

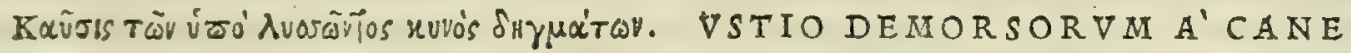
RABIOSO. CAP. XXXVIII.

Remedia fiSpéta.
Auxilium religiolum.

C O N T R A virulentos iftus, uftio expeditifsimum eft auxilium, utpote cùm ignis catera uiribus praftet, fimul quòd uirus domet, \& ferri penitius non patiatur: fimul quòd pars ignem experta, poftea non vulgare fundamentum curationi futuræ præbeat, manente diutius exulceratione. Animaduertendum ex eo tempore, cùm cruftæ decident, ne ulceris oræ coalefcant, \& cicatrice induantur, fed fi fieri potelt ad multum, idq́ue præfitutum tempus, vlcerationes, \& fordidas adhuc \& inflammationem minantes prorogari conuenit. Quod inditum ijs falfamentum cptimè præftabit, \& fylueftre allium detritum, item cepæ, fucçúsve, præfertim Cyrenaicus, aut qui Medicus, aut Parthicus appellatur. Iritici grana tam manfa, quàm non manfa imponantur: fiquidem fubacta pifáve à so perfufione vulnera dilatant. Sunt qui à mandentium ieiunio, fibi aliquid afcifcere arbitrentur, quod fuapte natura refiftat: verùm id certum non eft. caterùm rempeftiuus eorum ufus minimè eft contemnendus. Si verò, quod perfxe accidit, ante dies prafinitos cicatrices coirent, committeréturá; , manum poltulabunt: nanque eas diducere, carnemq́ue fcalpello circinare, aut iterum inurere expediet. Vbi verò propolitum tempus præteriit, vlcus ad cicatricem ducendum, \& emplaftro, quod è fa libus conficitur, locus comprehendendus : nec multò pòft finapifmo vtendum.

C A V I E R I V M, quod ferro igne candenti, aut auro, aut argento fit, non modó falutiferum eft ad rabidica= nis morlum; fed ctiam aliorum quor uncunq; animaliun uirus eiaculantium, quin or ad alios infanabiles feré morbos. Proinde mirum non eft, quod hoc loco dixerit Diofcorides uftionem, fiue cauterium contra uirulentos ittus aut mor =

VAtionis, five cauterij vtiliJus expeditisimum effe auxilium. Fiat itaq; cauterium intrepidé, tantæé; amplitudinis, ut ulceris cicatrices breui cö= mittinon pofint. Qüd fitmidus quifpiam uftionem ignis terrore recufet, $\int$ epticis e exulcerantibus medicamentis 


\section{$75^{8}$

utendum erit. Qua in re cateris preftat, quod uocant argentun fublimatusy . admifcetur id unguentis refrigerantibus, ut minus doloris inferat. Probatur boc, quod non modó ualentißimé inurat; fed quód ctiam exafta ab eo caro, obductíg; crufta duobus tantum diebus póft decidat, fi tamen rccenti butyro aßsdú illinatur. id quod in aliorum exu. ftrone non euenit, nifi longiore temporis traftu. Quod fi igne, aut adurenti medicanzen to ( $u$ t multis de carfis quan= dog; accidit ) id effici nequeat, diligenter prouidendum eft, ne uulnus coёat, fed diutius maneat diductum 0 apertü, fuperimpofitis emplaftris ualidé attrabentibus, cuiufmodi funt qux é brutia pice, refinis, uario gummi genere, or id genus alijs parantur. Si ueró cauteria fiant, diligenter procurandum, ut relicta quaim primim excidat crufta,quó ueneno pateat exitus. quippe ea diu in uulnere retenta, omnes obducit meatus magno agrorum detrincnto. Porró non magno quidem negotio decidet appofita continué liquida uernice oui uitello, er recenti butyro permifta: quin

Prxeipitati o butyro folo igni liquato, or madefactis in co Pplenijs fupcrimpofito: praftat enimboc cateris. Vbi ueró $\dot{0}$ vocati vis, uulnere crufta deciderit, falutiferum quidem fucrit remedium plage quotidı puluerem pracipttati (fic enim uocant chymif te argentum uiuum in puluerem rubicundum conflatum ) infpergere : fiquidem id eximium prefiantißimumí; medicamentum, preter id quod uulnus occludi probibet, diu'q; patens feruat, attrabit etiámnum ex alto ad fuperfix ciem potenter uenenum. Qua in re catera buiufe facultatis precellit medicamenta. Commodé etiam, nec minus efficaciter idem puluis attractorijs emplaștris, fiue unguentis admifceri,e fubinde uulneri admoueri poteft . ctentm iandudum certior fum, in uniuer fa medice facultatis materia, nullum baberi medicamentum, quod ualentius ab alto reuocet extrabat'; uirus, quàm pracitatum dictum. Ad hec tamet $f$ ( $u t$ omnibus feré placet) in quadragefimum diem apertum uulnus dimittere fit fatis; non tamen errauerit, qui diutius prorogauerit, ut quicquid mali refiduum fuerit, exhariatur.

\section{هíuT RABIOSI CANIS. \\ CAP. XXXIX.}

QV AE A D partem iCtam pertinent prælidia, ita fe habent. Cxterùm ui.tus rationem ex ijs, qux ueneno aduerfantur, coniectura quadam colligere oportet, fimul ut aeneni uires hebetet reftinguatq́ue, fimul vt arceat, quò minus ad intima pernicies illabatur. Etenim affumpta perniciofarum virium penetrationi refiltunt. Quorum utrunque præftare poteft uini meracioris, pa $\int_{s i}, \&$ lactis potus . quippe qui hæc omnia capiunt ad curam, nonnihil veneno obijciunt, quod omnem cius acrimo niam obtundat. Simili modo alliorum, porrorum, ceparumq́ue cibus : quòd ea difficulter confician tur, vixq́ue aboleantur. Nam multos dies huius cibi qualitates remanent,quo tempore nec euincuntur, nec permutantur à mortifera vi, fed contrarijs illa uis expugnatur. Cui rei antidotorum vfus accommodatur, \& theriaces, Mithridatij, \& eius quad eupatorio temperatur, deniq; omnium quæ ma gnam aromatum partem fibi vendicant. quippe aromata omnia uiribus \& fubftantijs æegrè permutantur: quare in corporibus euincunt. Victus ratio hoc modo fe habet. Noffe convenit, pauorem aqux non ftato, definitoq́ue tempore exoriri : plurimum tamen ad quadragefimum ufque diem neglectis differri confueuit : poft femeftre etiam nonnullos inuadit: quendam poit annum aquam horruiffe conftat. quæ nobis vifu comperta fuere. Narrant \& aliquos poft feptennium aquæ metu fuiffe tentatos. Inter principia demorforum à cane rabiofo curandi ratio talis eft . Verùm cnimuero fi ea quæ retulimus auxilia, primis diebus prætermiffa fuerint, nec fcalpro carnem circinare, nec uftionem experiri operæpretium eft. non cnim quod pertranfiit, fatis enacare poffent. Nulla utiq; iftius rei occafio aut utilitas, fed in caffum corpora doloribus fternentur. Alter uerò curationis modus accedat . Deiętio magnum præbet iuuamentum, utpote cùm mouendo, corporis habitú tranfmutet: $\&$ qux colocynthidem recipit hiera . item lac fchiftum, quod fimul deiectionem moueat, \& venenum doma re pofsit cibi acres, \& meraculi potus, quibus uis ueneni uehementer retunditur, quotidie fumi debent . Caterùm fudores ante cibos, \& polt etiam ciendi . Dropacifmi finapifmić; alternatim per cor pus totum adijciendi. Sed longè omnium efficacifsimum auxilium helleborifmus cognofcitur: quo cum fiducia non femel atque iterum, fed frequentius ante quadragefimum diem, vel poft hoc tempus uti licet. Tantam enim uehementiam hoc auxilium habere fertur, ut quidam qui iam aquæ mecum fentirent, fumpto helleboro, fimul ac primum morbi impetum experirentur, fuerint feruati . nam $\& x$ $\mathrm{j}$ m uitio tentạtos nemo unquam feruare poteft. Itaque primùm curam contra rabiofi canis morfus breui fermone expofuimus. iam ad alia, qua uenenatis morfibus fruire confueuerunt, tranfeúdum. Notas uno contextu, deinde communem medendi locum, qui omnibus conuenire pofsit, explicabimus. Curfim deinceps fubiungemus ea, quæ fua proprietate nonnullis auxilium præftare poffunt. Poltremò fubnectentur etiam uenenata, qua nullis cedunt remedijs.

Ratio viqus

I N S T I T V E N D A demorfis à cane rabiofo diligenter eft ratio uifus, nec ea tantiun regula, cuius bic memi demorfis à ca nit Diofcorides; fed etiam ut ea fit ciborum quantttas, que iss recté conueniat. siquidem buiufce curationis regimen ne rabıofo in tenuem uictum non expedit, ficuti nec pleniorem, ut Aëtius eft author libro v 1 .ubi fic inquit. In uictu indigentia, er fatietas euitanda, mag is tamen indigentia : bec enim fuccorum prauitatem adauget, quod nequaquam expedit malefi= coulceri. Ergo alimentum moderari oportet, ut E recté conficiatur, E optimum fuccum corpori prabeat. Nec minus egeftioni, or urinarum prouocdtioni studendum. quod quidem tum ed, que prediximus, tum foniculum, or 


\section{InLib. fextum Diofcoridis.}

'fculdix comcfs efficiunt. Plus ueró finul or alum, or urindm ducit . ac cichorium agrefte crudun oblatumftomd cho confert, quem nonnulli ferim, nonmulli ab amstrudine picrim appellunt. Profunt O brofica cine, or paluftris

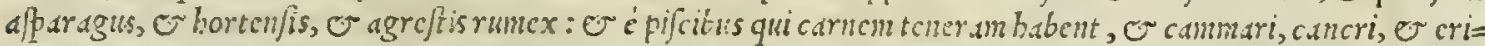

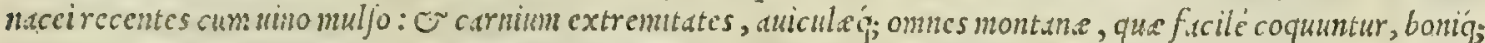
fint fucci. Vimum album tenue, neq; nalde antiqum. bxc ille. Ex quibus conijci poteft, batc in curatione ca pluri=

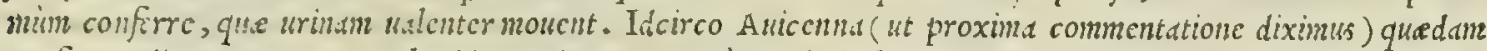
profert medicanient.s, que canthuridus cxcipiunt, ut uni cum lotio funguis ctian reddatur. proinde mirum non eft, fi quando q; preculcus natur, per inftrumentum urine, magno cum dolore parua uclutiliquide carnis frufta catu= lorum forma, ucncum propellat. His itaq; ca uiaus ratione wtilicebit, qua urinan agré exccrnentibus à medicis in=

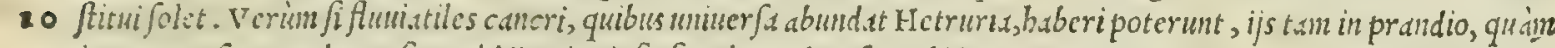

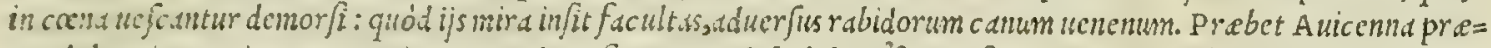
ter dulce winum etian aquan, in qua candens ferrum, uel chalybs reftind a fucrint. Catcrim noffe conuenit (ut fcribit Diofcorides) aqux pauorem non ftato definitog; tempore exoriri: plurinim tamen ad quadrage finum ufq; dicn neglect is differriconfueuit: poft feneftre etian nonmullos inuadit: quendan poft annum aquan borruife con= fiat. que nobis ufu comperta fuere. Narrant er aliquos poft feptemium aque metu fuiffe tcritatos. Sed cogitanti mibi unde id cueniat, mulla func alia batcenus fe fe obtulit ratio, quàm qux ex dentorforum temperamento, ac uiribus fumi potef. Qundoquidem nommlih babentur, qui wivibus uxlidesinis preftant: quddan qui debiles, er infirmi funt: alij qui corporis me.tus angufftßimos habent, alij ueró contra' quidan fyncerißsimis referti funt bumoribus, nonnul* liueró fuccis ichoribus fattentibus, ac facile putredini obnoxijs. Ex quo fit, ut in bis citius, in illis ucro ferius bac 20 appareant fymptonasta. In Hetruria abfinent demorfi per integrun annü à quorundan lignorum contactu, profer $=$ tin corni arboris, o fanguinex uirge uocat s . Siquiden (ut teftantur ij,quirem experimento compertam babent) fi barum arborum uirge tandu mambus teneantur, quousq; concale fcant, illico demorfi rabie exagitantur. Quod cuiquan minine fubulo um videri debet: etenin mcminime uidife in ciuiatc noftra Ilicinenfi amicu quendam meum rabic correptum, quód corni arboris uirgis (dabat cnim lanificio operam) landm diu excußiffet, qui corum oblitus, quibus fibi a medicis interdictum erat, rabidus interijt. Poftremó fciendum eft, aqua pauorem baudquaquam cu= rari pofe, cum ueneni uis ommes corporis occupauerit facultates: quanuis in ip fo patuoris initio, aut anteaquàm ue= nenum illap fum fucrit in winiver fum corpus, aliqui curati euxferint, ut philofopbus ille, cuius biftoriam fuperius e= narrauinus . prefertin cim pro uiribus in morbum nituntur male affecti, $\sigma$ qui corum curationem agunt. His ad= fipulari uidctur Diofcorides: quippe qui quosdam afferit, qui iam aque metum fentiebant, fumpto cum fiducia belle= 30 borifno non fomel atque iterum, fed frequentius ante quadrage fimum diem uel poft, furfe ferndtos. Proinde feribit Auicenna cos, qui aquam expauefcunt, deploratos non effe, quousq; in peculo intuentes feip fos cognofcunt, argu= mento quod non adbuc uene num uniuer fas infecerit cerebrifacultates. Hoc igitur tempore medicamentis utendum ef deiettorijs, $\mathcal{O}$ fi nibil obftet, fanguinis mißio non apernanda. Ex medicamentis autem in boc cateris praftat al bun uel nigrum ucratrum, ijs adect is, que eorum infienant feruorem. Conucnit etiam epithymum, fend, fumaria, myrobaland, elateriun, agaricum, rhabarbarum, centaurium minus, genife femen, thapfia, confectio Amech, e bie ra colocynthidis, o Armenius lapis: fiquidem bec in atra bile deijcienda principem tenent locum. Proderititem

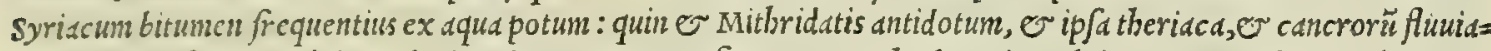
tilium combuftorum puluis, Galeni modo paratus. Confert preterea bis leporis, uulpis, or capreoli coagulum. Sed femper in primis omniftudio curandum, ut aquam malé affecti bibant. Verum ne ip am intuentes pauor inuadat, lone

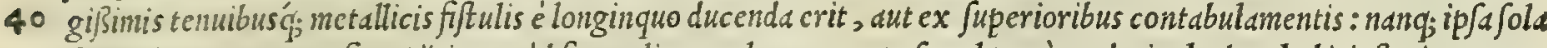
ferusri poterunt. Refert Aëtius, quod fi catuli codgulum ex aceto femel tantùm ederint bydrophobici, ftatim cos cas pit potus aque cupiditas, er bibunt: ob id đ́, medicamentum hoc miris latdibus extulit. Sunt quinigruin cicer aque incoquendum effe uelint: fic enin aqua claritatem anittit, nigráq; efficitur: o prater id quód baurientibus pauorë non udfert, qucmadinodun qua fyncerd, pcllucida q́; peEtutur, urinam ualenter ducit. Nec defunt qui fuddeant uren tia cataplafinata occipiti effe apponenda, pariter'q́; poft aures. Que et $\sqrt{i}$ ad rem facere non uide antur, quód ualene tißsmté exiccent; ubi tamen deploratifunt egri, ualentişinis etiam medicamentis uti lic ebit.

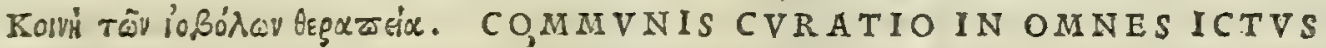 VIRVLENTOS. CAP. XL.}

A D VER S S quidem omnem animalis ictum, quod venenum vibrat, oris fucio conuenit. Sugentem verò oportet ieiunum non effe, fed \& cibum fumpfilfe, ir uino os abluiffe: poftea exigurum olei in ore continens plagam exugat. Locus iple fpongia fouendus, deinde fcarificandus : fed vlcufcula altius imprimere expedir, quò virofa materies profundo euocetur. Circinatio autem carnis, \& fectio, farificatione longè potentius opitulantur : nanq; ab ijs duo peculiaria præfidia fiunt . vnum, quòd uirus è loco tollitur : alterum, quòd eius ueneni pars, qua ad interiora graffatur, cum multo copioloq́ue fanguine excernitur. Quòd fi locus fectionem non admittat, cucurbitula cum largiori flamma adfigenda funt. Sed iam de vitione fuprà in rabioforŭ morfu differuimus. Si verò icta pars, utfote extrema, cam fectionem commodè non refpuat, præfertim in omnibus ferpentium ictibus, ut afpidis, cerafte, fimiliumque, procul dubio amputanda eft. Conuenientiona fuprà dictis auxilia fudt, qua epithemata uocant. Imponatur farmentitius cinis, aut ficulnus, cum lixiuio ftillatitio

qux pauor dquod $v$ fq iépusexoriatur. 


\section{And. Matthiols Comm.}

fubactus, garo, \& acri falfamento : porri, серx, \& allia modò minutifsimè contrita illinuntur, modò cremata vulncribus inijciuntur. Quinetiam diffecti gallinarum pulli, cùm maxinsè tepent, percuffo loco applicentur. Nee defunt qui hifce tanquam difcordia quadam naturali pugnantibus vtantur: verùm huius rationem inire facillimum fuerit. Gallinæ en im calida natura præditæe funt, argumento, quòd deuoratum infigne virus conficiunt, \& aridifsima quxque femina confumunt:item nonnunquam arenas Japillosqueingluuie fua deuoratos, diffoluunt. Itaque animantis admoticalore adiutus fpiritus, ab i\&ta parte impetum capeffens exiliensq́ue ftcum venenum exigit. Nec me fugit, quid in Aegypto fieri foleat. Cùm fpicas Aegyptij metunt, ollam picis paratam habent, \& appenfam fafciam : tunc enim maximè ferpentium iniurias expauefcunt, tum proptcr fpicilegij tempus, tum quòd opacis fimul abditæ fpeluncis, \& cauernis, denfoque aruorum cefpite delitefcuñ. Moleftifsima enim animalia , \& virus eructantia, Aegyptus in campis ferre confueuit. Vbi ergo aut in pedem, aut partem aliam, morfum intulerunt, qui adfunt, fafciam in ollam picis conijciunt, \& femel aut iterum brachium aut crus paulùm fupra vulnus obligant, \& arctifsimè duo è præéfentibus diftringunt, locumque fecantes qua circumactus eft laqueus, picem inftillant: cùm que fatis vulnus excepiffe videtur, laqueum refoluunt, \& cepis alijsq́ue fuprà memoratis illinunt. Præterea pix liquida cum fale trito \& feruente illita, præfentaneo eft auxilio, fi iugiter innouetur. Conuenit \& cedria, \& fimum caprarum ex vino decoetum. Locum aceto calido, calamintha in lotio, maris aqua, aut acida muria decocła, foueri falutare eft. Quinetiam non defunt emplaftra vehementifsima, \& calidifsima, quæ venenum elicere, expugnare, $₫$ difcutere poflunt. Cuiufmodi funt qux ex fale, aut nitro, finapi, \& cachrye componuntur, de quibus confequenter erit tractandum. Erafiftratus za autem non iniufta reprehenfione eos incefsit, qui incognitas ad hunc vfum facultates confcripferunt, vt elephanti fel, crocodilíve fanguinem, ouaque teftudinis, \& confimilia. Nam cùm iunantia quædam literis tradidiffe uidentur, planè in hæc fola incidentibus impofuerunt. Quare talia deuitanda funt, cùm difficilè, nifi regia facultate, perueftigari pofsint: neque, quò noftra fides ijs obftringatur, frequenti obferuatione, fufficiens experimentum præftiterint. Qux autem ad communem omnium vfum pertinent, quæq́ue facilè fuppeditari, 8 omnibus à ferpente percufsis auxilium ferre queunt, fubiungenda videntur. Intubus itaque, \& erica, \& aftragalus, cum acero pota, contra omnes ferpentium morfus auxiliantur. Item bitumen, \& uirentes platani pilulæ in vino diluto co¿t $x$, \& paliuri decoetum : radix ariftolochix, \& eryngij : decoctx etiam lauri baccx, \& deuorat $x$, piperq́ue largiùs efitatum, ruta, anethum, \& cyclaminus : coma porrorum priutim ex pane, aut al- a lium, aut cepæ, falfamentaq́ue quàm acerrima : origani decoctum cum vino potum, foeniculi, pulegij, calaminthæ, porrorumq́ue fuccus cum melle deforptus. hæc quidem à plantis conquiruntur. $\mathrm{Ab}$ animantibus verò quædam utiliter peti folent, gallinaceorum cerebella in cibo, leporinum eoagulum cum uino, itidem caftorei fextans : teftes marinx teftudinis fumpti multum prodeffe traduntur: muftela fale inueterata inter auxiliaria medicamenta eft. Commendatur in primis exenterata; quæ fale ficcefcens jnueteratur: ex qua binas drachmas cum uino bibiffe fatis eft. Sed de fimplicibus; quæx dari folent, hactenus. Percufsis à ferpente prodeft alui deiectio, diffuens fudor, vrina copiosè reddita. Sunt $\&$ compofitæ quædam potiones, qux mira remedia polliceri traduntur, ut $\&$ opij $\&$. myrrh $x$ finguli oboli, piperis ficilicum : ea melle excipiuntur, \& inftar Aegyptix fabx dantur cum uino. Itidem fylueftris rutæ feminis, gith, cumini Aethiopici, ariftolochix, galbani, fingulorum pa- 40 res portiones tritæ, \& cum erucæ fucco fubactæ; digeruntur in paftillos, qui drachmæ pondus æquét. dantur ex ijs terni cyathi cum uino. Hæc habui de communibus auxilijs quæ dicerem. De peculiaribus remedijs contra beltias, quæ venena uibrant, confequenter eft dicendum.

Ordinis Diofcoridıs ímutati ratio.
VE N E N O S O R V M animalium ictus, morfusq; doctrindm, curandiq; rationem, duabus fectionibus tradidit Diofcorides. In quarum alterd cuiufcung; ittus indicia expofuit : in altera ueró curationes diligentilimé confcris pitit. Caterum prefationem hanc illi fectioni prepofuit, que curandirationem docet : in qua prafatione omnium ui= rulentorum ictuum curationem in uniuerfum profecutus eft. Verìm quoniam ( ut fuperius diximus in commentatio= ne, quam in caput $\mathrm{x} \times \mathrm{x} v$. buius libri confcripfimus) rati fumus illud non parum legenti negotium faceffere, quid ex

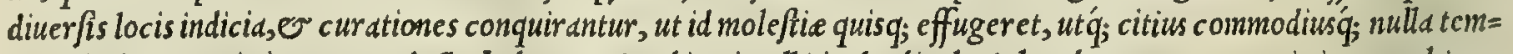
poris idctura omnia in unum redacta baberentur, ubi prius illd in duobus locis legebantur, nos omnia in unum locum congeßimus, atq; ex duobus capitibus unum tantùn fecimus, fingulis uirulentorum ictibus fua peculiaria remedia $\int u \neq$ bijcientes. Hanc ueró Diofcoridis prefationem prefiximus, in qua tamet $f$ adeó exacté doctéq; tradiderit is uniuer $\int_{a}$ lem uirulentor um omnium animalium ictibus medendi methodum, ut nihil plané addi poßit; tamen ne ab inftituto no: ftrodefeciffe uideamur, in eorum gratiam, qui femper plura proferri expectant, nonnulla modó differam, quse, ut

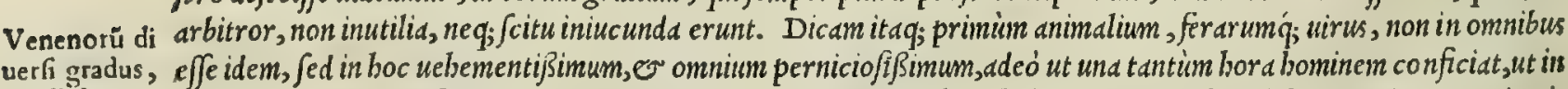
\& efeétus. appide, cerafte, e bafilifco : in alio ueró minus uebemens minus q́; letbale, uno uel duobus diebus interimens, ut in ui pera : in alio deniq; bis longe imbecillius, ut in fcorpione, $\sim$ phalangio, longiore tempore necans. Veriun quanquam id plerunq; eue nit, quòd animalia que mordent, uel icunt, diuerforum /int generum, o proinde diuerfa etiam eorum uenena; accidit tamell, ut ab apide, uel uipera demorfi quandoque tribus tantim horis,nterdum uno duntaxat dic 


\section{In Lib. fextum Diolcoridis .}

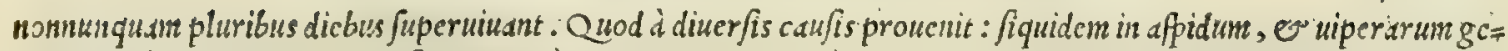
nere longé pernicialiores funt fresnne quàn mares, iunenes quim fenes (quanuis non defint, qui contrarium putent)

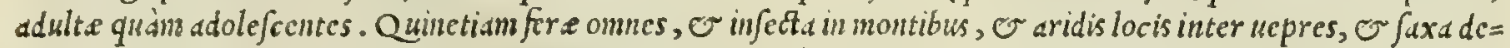
gentes, ijs citius bominem perdunt, que paluftrcs, uligino fosq́; traifus incolunt. Citus praterea necant, qua orien= talem, on meridionalem inbabitant plagum, quam que feptentrionslent. Ad bec fanelice depaftis nocentiores funt,

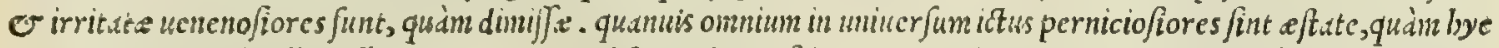
me. He itad; caufe effe poffunt, cur citius, uel ferius demorfintereant. Id tamen ctiam plerung, fit ex fortiori, uet imbecilliori demor forum temperamento, aut uaforum latitudine, uel anguftix. quandoquidem (ut fuperius pluribus in locis diximus) ueneno non tam facilis parebit aditus, ubi uafa fuatete nutura angufta fuerint, quàm ubt latiora.

10 Caterime errant, Auicenne tefrimonio, qui ferpentium uencinum frigidum effe ftatunnt, quód ab ijs demorfíllico frigidi fint, quod q; ferpentes ip fi, ut frigoris impatientes, appetente bycine in fubterraneis cauernis latitent, uel fub Japidibus, fub quibus priustin fe condunt uipere, ubi nomunquam adcó frigore correpte reperiuntur, ut ftupide o immobiles reddite, tanquam congelate perfiftant. Frigiditas enim toti corpori ex ictu uel mor fu adue niens, non utiq, enenit ex ueneni frigiditate; fed quód innatus calor ab extremis, o ultimis corporis partibus ad cor fe confe= Yat, quód 'f; etian uencno fuperetur, o extinguatur. Nec eo argumento frigidi temperamento ferpentes funt iudi= c.undi, quòd foilicet byeme immobiles, o feré exanimes fuis in cauernis reperiantur . quippe nulla alia de caufa id il

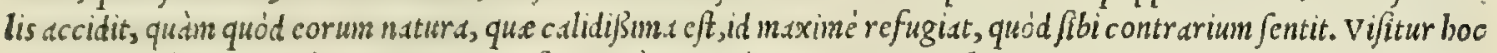
pariter in pifcibus, qui cimn frigidi natura fint, quim primum ex aqua cxtrabuntur, ä̈ris calore necantur. Quin er uefpe, que temperamento calide funt, o ficce, eadcm ratione byeme conficiuntur, nifi calidißinis recondantur lo.

:0 cis. Sed iasn iftuum, uel morfuum uirulentorum curationem aggrediamur. In qua Diofcoridem, Paulum, Aëtium, or alios seterni nominis fcriptore imitati, dicimus efficacisimum effe remedium, morfu uel ictu illatum unlnus con= tinuc ore fugere ( fugentem tamen prius prepar atum effe oportet) O fubinde uenenum, uel uenenatum fanguinem expuere. Veruntamtentid opus, nteo quidem iudicio, perfici non poteft, absq; magno fugentis difcrimine. Nam fi in

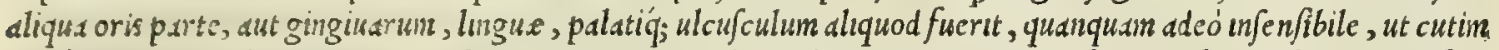
tantim occupet, ubi zenenum in os fuatione renocatum ulceris lockin contigerit, $\mathbb{E}$ fanguini fe admifcuerit, qui for= ti futione facilé é gingiuis per dentium connexus inanat, dubitandum non eft, quin illico fugenti perniciem inferat: itaqf fiat, ut qui alteri mederi velit, fibi ip/e necem paret. Quin nec minus periculi immineret, fi uenenate faliue tan tillum inftomachun de fenderet. Neq, temteré bxe dicimus. etenin iam nos uidimus (ut fuperius in noftra in primă,

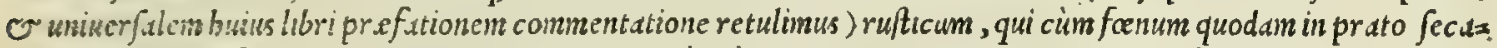

to ret, fortéfortuns falce mediam fecuit uiperams: o cuin à truntco, quem manu imprudens fuftulerat, in digito mor= fus effet, os uulneriftatim admouit, o uenenat un exuxit fanguinem. quo facto repenté mortuus concidit. Proinde fcite admonet Aëtuls, ut callexnt, qui fugunt, ne os babeant ulceratum. Porró ad bxc uitanda difcrimind, recentio

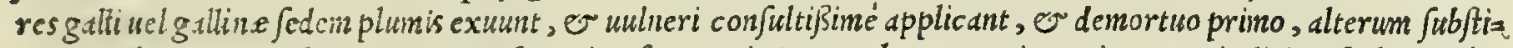
tunnt, idq́; tandiu profequnntur, quoufo; uniuer $\int$ a ueneni uis extrahatur. Cuius rcicertum indicium habent, ckims gallus poftremó appofitus non moritur. Aëtius Diofcorident fecutus, non modó gallinaceos, gallinasóq uimentes dilfe etas, of adluc palpitantes lis morfibus connodé applicari tradidit; ;ed etiam quodlibet uolatiliun genus, item inue= mun, tencllorumiqg; quadruped́lin. Debinc idem iubet, excitatis calide aque potu uomitibus, ualentiora dari antido= ta, nempe theriacam, o Mitbridatis antidotum. Mirificam uim in bac curatione babent, quantum equidem experien tia comperi,quinta noftra effentix, pariter ; oleun de fcorponebus, quorum parandi rationem in prefationis buius

40 libri commentario tradidimus: fiquidem his tantum antidotis, imó nonnunquain folo oleo, nonnullos à uiperis demor= fos fanaumus, paucis admodum boris, qui cimn nullum uite fignum preberent, tanquam deplorati iacebant. Nam tan, ta eft borum partium tenuitas, ui momento uniuer fum corpus percurrant, 0 fubinde omise fuperent venenum. Pro= tulit Aëtius farmentorun, or ficulne cinteris uice, cam que è laurinis conficitur lignis. Cuius fententiam magis pro= bandan cenfemus, quòd hec arbor fuapte natur a polleat aduerfus uenena. Vbi ueró ueneni uis cötumax reperiatur; o non mifi longo tempore euinci poßit, eft diligenter animaduertendum, ne itti unquam die ac noctu dormire finalt= tur, donec ueneni wis cutinuerit . quippe qròd fomnus ( $u t$ alijs in locis fuperius dictum eft) uenenum inaximé ad cor, $\mathcal{O}$ cerebrum ducat, o fecum trabat. Multa prater hec habentur remedia uulneri illinenda, ut calx uiud, oleo o melle fubatta . hec enim (ut Aëtius efs author) omnibus uenenatis morfibus opem fert, praterquàm ab appide illatis: Sunt e qui nigri ueratri recentein radicem in winus figendan confulant: quód bec (ut equidem me experientia co 50 gnowffe fateri poffum ) uirus ualentißimé extrabat. Qümobrem Tridentina rur a cim iumentum aliquod à ferpente icitur, faxtim pirfor ato ibidem corio, preftantißimo remedio ellebori nigri radices in uulnus inferüt. Profunt etiáms

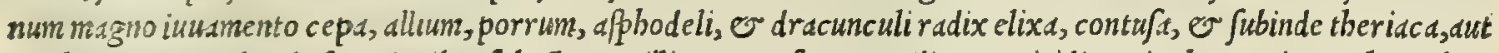
Mitlorddatio, er oleo de fcorpionibus fubatta, $\sim \sim$ illita. Non fecus auxiliantur , iridis, ari, phu, utriusq; chameleio

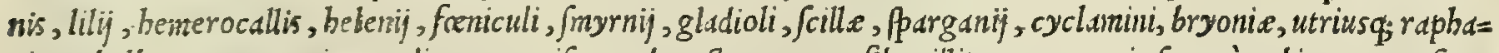
ni, E bulbaceorum omniwn radices, concife, ac decocte, o mor fibus illite : que omnia $\int_{x p e}$ à nobis experta funt. Conferunt pretereabdellium, syriacum bitumen, pix liquida, caftoreum, montanarun caprarum fimum, euphor= bium, fulphur urins admiftum, $\int a l$, nitrum, taurinum fel , oleracce eruce, utrung; la fer, galbanum, fagapenum, panacis lacrynta, erica, by foopum, origani omne genus, dictamnum Cretenfe, er I talicum, calamintba, conyzd om=

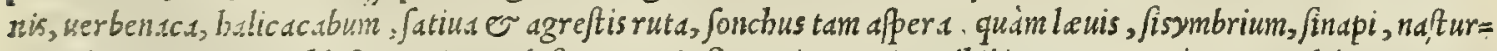
tium, lepidium, iberis, thlapi, aut in esnplaflris, aut in fomentis exterius adbibita. Que ueró pota, uel deuorata ud=

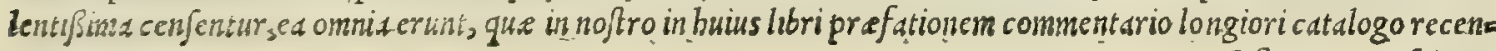

Quorundam opi. explora.

Virulểrorum istuú,vel mor fuú curatio. 


\section{2 \\ And. Matthioli Comm.}

fuimus . tametif priustim ad uenenatos iffus preferantur Medica mald, 0 corum femen: quin o ecbij, o uiticis, o liguftci, or peonix, or byacintbi: pretered uirides platani penfiles pilule, iuniperi bacca, conzzs, chame= drys, fcordium, chamepitys, echiniterreftris caro, gallinaceorum or gallinarum cerebrum, leporis o equi coagls lum ex uino potum, marine teftudinis fanguis cum cymino, porrifuccus ex melle, nlafturtium, maloris ccintaurij, gens= tiane, albi dictamni, o fuperior gladioli radix, thlapi, pulegium, Cretenfe dictamnum, elichryfi coma, rane oleo incodte, ov fale conjerfe, earundem ius, oleo of fale adiectis, or cerui genitale ficcum, o in puluerem potum. Mia rificum sc fingulare remedium praftat illius her be radix, quam Goritienfes, ex eo quód ferpentium morfibus celerie ter, o efficaciter medeatur, serpentinam uocant, cuius biforiam defcripfimus libro fecundo in coronopi mentione: bec fiquidem in puluerem ex uino baufta cocblearis menfura, à uenenofo quöus ferpente demorfos breui tempore fas nat: neque ea folum ualet aduer fus uirulentos ictus; fed etiam contra cpota uenenat. Its feré uiribus pollent (ut quidam recentiores fatentur) flo fculi illi fyluestres rofeo colore micantes, quos nonnulli fylueftres garyoplyllos uocant.

Theriacalau-

Porró Galenus librode theriacd ad Pifonem, ceteris antidotis tam fimplicibus, quam compofitis ad uirulentorum dibus à Gale- mor/us Andromachi theridcam pretulit bis uerbis. Theriace eft procul dubio apud uniuerfos bomines celebratifimum no celebtata. antidotum, tum quod pollicito neminem fruftretur, tum ob ipfius attionis efficaciam. Siquidem null lum unquam a $f e$ ris, que hominem folent interimere, commorfum, hac ftatim epota perijffe memorie eft proditum. Nullus eadem prafumpta haud multó póft morfu impetitus, bellus ueneno ceu illam fuperante interijt. Quod fubinde nonnulli pres= tores etiam, penes quos uite, or necis potestas eft, experiuntur: atque medicamentum probare uolentes, an quod pros mittat preftare quoque poßit, in ommibus iam ob praud quedam, $v$ illegitima facinora ad mortem iudicatis, de ipfa faciunt experimentum. Nos autem cum in bominibus id non poßsinus, in alijs quibusdam animantibus idem facientes, ueram medicamenti probationem inuenire conemur. Nanque gallis, qui domi non enutriti, neque nobis funt contuber $=20$ nales, fed potius agrestibus, $\mathcal{O}$ ficciore preditis temperamento, captis, feras obijcimus, $\mathcal{\sigma}$ qui inter illos non biberint ex medicamento, protinus intereunt : qui ueró biberint, conudefcunt, $\odot \sim$ d morfu uitam retinent. Interdum uerà medicamentum num adulteratum fit, hoc quoque modo probare conuenit. Si epota theriaca, non purgetur, qui pura gans fumpfit medicamentum, hoc ipfo iudicamus antidotum effe preftaniifsimum, quoniam purgationem, ei qui medi= camento ufus fit purgante, impedierit, ut tali experimento d ueri medicaminis inuentione nunquam aberraucrimus. $h a=$ ctenus Galenus. Cuius nimirum atate qui pretorium in facinorofos exercebant iudicium, facilé probare poterant num theriaca probata effet facultatis, an adulterina. Nanque pluribus in locis qui ob fua facinora mortis fupplicio damnabantur, non femper capite, aut laqueo, aut quóuis alio poens genere necabantur, prout leges ftatuebant: Fed fepius in theatrum ducti, ut mitiori fupplicio é medio tollerentur, afpidibus, $\sigma$ uiperis offerebantur demordendi. Huius rei teftis est Galenus eodem libro ad $\mathrm{P} i$ onem, ubi post enarratum Cleopatra interitum fic inquit. Pluries in 30 magna Alexandria fum contemplatus, quàm celeriter afpides bomines perimant. Cùm enim altquem bac pene lege damnatum, bumaniter, citóque uolunt occidere, adycientes ipfius pectori feram, iubentésque paululum ambulare, ita fine mora bominem tollunt è weedio. Probanda igitur fuerit theriaca, prefertim que fit hoc tcmpore, antequam ema= tur, uel alicui propinetur, in gallis agrestibus à feris fepius enarratis demorfis, ut docet Galenus, aut in alio quóuis animali : etenim in fimiis (ut opinor) tutius or certius id experiri poffent, quodd fimie magis cateris bominem refe= Gentes tutęà rant. Narrant quidam antiquitus fuiffe gentes in pluribus orbis partıbus, que fuapte natura cum ferpentibus deferpêtibus,eo gebant, tractabántque manibus, nullo unquam ab his morfu accepto. Cuius rei testis es? Plinius libro vir. cap: 11. rumá;; iđabus ubi ita fcriptum reliquit. Crates Pergamenus in Hellepponto circa Parium genus bominum fuiffe tradit, quos oplio= genes uocat, ferpentum itfus contactu leuare folitos, o manu impoftta uenena extrabere corpori. Varro etiam nunc c) $\int e$ paucos ibi, quorum faliue contra ifus ferpentum medeantur. Similis er in Aplorica genus $\mathrm{P} f y$ llorum fuit, ut $A=49$ gatharchides fcribit, $\dot{A} \mathrm{P} f y$ llo rege dicta. Horum corpori ingenitum fuit uirus exitiale ferpentibus, ex cuius odore fos pirent eas. Mos uerò liberos genitos protinus obijciendi fauißimis earum . cóque genere pudicitian coniugum expe= riendi, non profugientibus adulterino fanguine natos ferpentibus. Hac gens ip $\int_{a}$ quidem propé interemptione fubla= ta eft d $\mathrm{Naffomontbus,} \mathrm{qui} \mathrm{nunc} \mathrm{eas} \mathrm{tenent} \mathrm{fedes.} \mathrm{Genus} \mathrm{tamen} \mathrm{bominum} \mathrm{ex} \mathrm{bis,} \mathrm{qui} \mathrm{prof} \mathrm{ugerant,} \mathrm{out} \mathrm{cum} \mathrm{pugnatum}$ est, abfuerant, bodiéque remanet in paucis. Simile $\sigma$ in 1 talia $\mathrm{M}$ arforum gente durat, quos a Circes filio ortos fex runt, o ideo ineffe ijs suim naturalem edm. hec Plinius. Veruntamen, ut author eft Galenus libro de theriaca ad Pifo= nem, Marfi qui fuo tempore extabant, contra ferpentiun uenend mullam utique propriam babebant facultatem: Sed fraude quadam uniuerfam decipiebant plebeculam. Ipfe enim loco citato ita fcribit. Circulatores bi nunquam congruo tempore uiperas uenantur, fed multó poft uernationem, cim non amp̈tius uigent. Captas autem ipfas crcbró fibi ipfis affuefaciunt, $\sigma$ cibis non folitis enutriunt, imó carnes ipfis permittentes, $\mathcal{O}$ continue nordere cogentes, ut uirus ex 5 ? earum ore wacuetur efficiunt . quinetiam mazas quafdam obiyciunt, qua dentium for amina obftruant. A tque bac ratio: ne morfus fiunt imbecilles, ut uidentibus magnum fit miraculum, talis ipforum ad fraudem parandam artificij imperis

Fraus circunforaneorum, qui diui Pauli flispem mentiuntur. tis. hec Galenus. Ceterim id fradis doliue genus, nostro etiam tempore locum babet, in bis prefertim circulatos ribus, er circunforaneis, qui ex diui Pauli sirirpe (quod tamen plane mentiuntur) fe prognatos predicant. Quippe quód ferè omnes Apuli fint ex Leccia urbe oriundi, aut ex circumftantibus locis. quanquam factle poffunt originem duxiffe d Marfis eorum uicinis, qui fexcentenis, aut fortaffe millenis annis ante duum Paulum extitere. Cauendum igitur fuerit ab corusn nugis: nam quicquid loquuntur, pollicenturq; , id omne fraudulenter, $\mathcal{E}$ dolose agunt. Cas piunt enim uiperas abeunte iam byeme, o ut magis ab earum morfibus fe tutentur, manus fibt perquàm deligenter inun. gunt quodam unguento hac in uenatione ab ip/is experto. Vnguentum illud conficitur ex oleo fylueftris raphani femine expreffo, dracunculi radicis, 0 a aphodeli fucco, leporis cerebro, fabine folijs, lauri baccis, $\mathcal{E}$ alïs quibusdam ade.

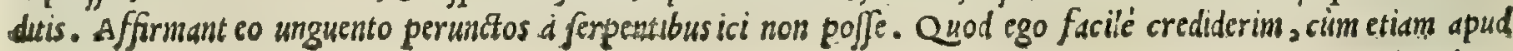




\section{In Lib. fextum Diofcoridis.}

Nicandrum in theridc is unguentum repererim, quo quifuerit perunctus, d feris icinon poßit. Nicandri uerba fubij= ciam, qux foluta oratione ita redduntur. Quódfi in triuijs mift treptilia ian recens generantia fefe, or rem fecum babentia, in ollam mitias, repones aduerfim perniciofas noxas remedium. Inijcies autem in ollam illam cerebri, feu medull cerui recens cxfi drachmas triginta: cotylas quatuor rofacei, cuius prinam, mediam, er tertiam expreßio= nem unguenturij practpuas, or folas numerant. Olci fplendentis crudi totidem coiylas infunde, $\mathcal{O}$ colylam cere unan, atc; bee in rotundo uafe ccleriter calcfacito, doncc liquefacte ferpcutium fquame molle cant. pofted arte pa= ratare molan recipies, or bec onmia in unum mif a turbabis, teresíf; cum ferpentibus. Longé autem pinas fepara: quandoquidè malcficum illis uenenum adbereat. Omnia porró membra ex boc unguéto inunge, tumqु; uel in quámuis wiam, wel grabatum etiam te tutó conferes, ucl cim arentis aftatis tempore ad area opera cinctus, tridentibus pro=

to fundum m.nipulorum acerum difquifiueris. bec ille. Capiunt igitur qui Marfosfe faciunt, uiperas, aliud'q; quód= uis ferpentium genus hoc modo: captisq; ftatin caput faliua perfundunt, cuius contactu non parum uile fcunt, er ue= nemferitatem deponunt, quod hominis faliua facultate fit illis prorfus contraria. Cum autem in foro, ut miraculo= Jum de $\int e \beta p e c t$.culum prabeant, $a b$ bis mullo neneni incommodo demordi fe facere uolunt, oblato prius illis dure car= nis frufto, id dentibus dilaniare cogunt, ut uirus,quod prope dentes quosdum ueficulis continetur, in manfam effunda= tur carnem. Non defunt tamen qui etiam ueficulas illas forcipibus ab findant, ne amplius ueneno repleantur. I taque bac fraude uniuer an gentem decipiunt. Veriun pulcherrimé borum fiaus quandoq; detegitur, cum fimul in eodem foro plures eiusdem praui generis bomines contendunt, ut alter alteri primum locum preripiat, $O N$ fummam apud populum authoritaten confequatur. Nam ij, ut quisq; fe legitimé ex diui Pali familia ortum oftendat, uiperis, qui= bus uenerum exemptum non fit, feinuicem dilacerăt, profumptis tamen fuis fallacibus antidotis : quibus tandem fru= 20 ftrati, d ueneno uiftirelictis uexillis, tanquam moribundi, fuis é pulpitis in terram cadunt. Et certe nififtatim periti medici illis opcin ferrent, mortem fepe immaturam oppeterent : licet etiam interdum occumbant, er animam caco= demonib:is, corpora ueró $\int$ is serpentibus deuoranda relinquant. Equidem memini, cum effem Perusijs, me duos hu= iufce gener is circunforaneos uidiffe in foro, qui in tribus corporis partibus à uiperis demorfi erant: $\mathcal{O}^{\circ}$ ij fane ambo perij]ent, nifi Carauitus ille Bononienfis chirurgicus, o precetor meus, oleo noftro de fcorpionibus eos inunxiffet: nec fus illis profuiffec lapis, quem uendunt, er ommibus prafirunt, aduerfus omnia uenena. Quemadmodum idem non profuit ijs, qui Tridenti inuicem in foro demor $i$, es ueluti mortui in bopitium delati, predicto oleo fanitati re fituti fucre, magno quidem amborum difcrimine, ac dede zore. Sunt qui dicant eum lapidem, uel potius terră obfigna= tam $\dot{a}$ Nelitc infula allatam, quam omnibus preponunt antidotis, uim omnino aduerfus ferpentium uenena efficacem babere, quenatinodum o ea, que à Lemno infula Lemnia nocatur. Veruntamen ubi ab apide, uel uipera quis fue 30 rit demorfus, parum uel nibil proficit. quamobrem credendum minimé fuerit, panem uel uinum, quibus fuas ij ad= murmurant cantilenas, cos qui fump $\int e r i n t$, tutos à ferpentibus, or alijs id genus uenenum eiaculdntibus, ad integrum ufq; annum feruare poffe. Quandoquidem nouimus nos, qui boc pane deworato fe tutos à ferpentibus exiftimantes, ferpentium uenationife dedere: $\int e d$ ab ijstandem demorfi buius admurmurati panis opinione falfi interiere. Non tamen eam inficias, quin aliqui reperiantur, quibus quedam ea d̀ colo facultas tributa eft, ut à ferpentibus non mor= deantur. siquidem noui ego plures, qui fimpliciter, nulloq; artificio aut uerbis apides, or uiperas quotidie capiebăt, nec unquam ab ijs itti fuere. quanuis ferpentes ab ijs modo pedibus calcati, modó manibus compreßifuerint, ac diu= tius in mudo co:um finu gestati. Eeq; preterea negauerim, ferpentes non poffe carminibus, $\sigma^{\circ}$ incantationibus com= pelli, quód plurinis id conftet experimentis. Ceterim, ut nibil quod ad curationem ił uum uirulentorum facere polsit, d nobis pretermittatur, qui omnia que fcimus, ingenué docemus, non uerebor prodere memoria (etfid fciä 40 ad meślicos non pectare, neq; ab ip/is recipi) quónam pacto in Romano agro fenex quidam eremita amicus meus, a

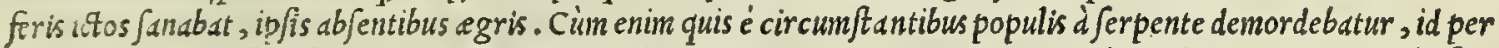
nuncium eremite fignificabant: tum is interrogabat nuncium, an medic amentum icti loco ebibere uellet. Quod fi id fe faqurun: reffondebst, iubebat ille, ut dextrum pedem calceo denudatum folo fifteret, er cultello totius pedis uefti= gio lineam circunducebat: deinde iubebat pedem auferri, o intra patium line $x$ fignate cultellic upide hec uerba in fcribebat. CARO CARVZE, SANVM REDVCE, REPVTA SANVM, EMANVEL P A R A C I E T V S. mox terră eodem gladio abradebat, ita ut omnes abolerentur characteres: abrafum pulue: rem fictili quodam paruo dqua pleno excipiebat, ibió; tantiper dimittebat, donec terra fubfideret: demum nuncij interula aquam percolabat, or cruce fignatam illi bibendam prabebat. Sed certé mirum eft, quód eadem bora ictus fanabatur, qua muncius potıonem illam fump $\int e{ }^{3} a t$, ut mihi plané compertum es, er omnibus illius regionis incolis :

so Hec eft cirratio in uirulentos ictus, qua utebaturille eremita qui mibi fepius dixit, boc effe maius fecretum, efficda cius gु; rerzedium, quod babeant ij, qui fuam originem in diui Paulifamiliam falsó referunt.

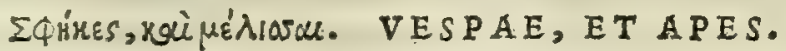

\section{CA. X. XI.}

IN T E R ferientium venenatorum notas, nihil de vefpis, \& apibus articulatim digefsimus, quòd confpicuze omnibus fint, \& nihil excellens, aut notatu dignum in his obferuetur : inter remedia tamen earum meminiffe non fuit alienum. Igitur aduerfus vtrarunque ictus prodelt illita malua, \& hordeacea farina cum aceto, ficulneum lac in vulnus inftillatum, \& muriæ, aut aquæ marinæ fotus.

E T S I ueparum, er apum ictus nemini unquam attulerit necem; cum tamen dolores moleftißimi inde quando

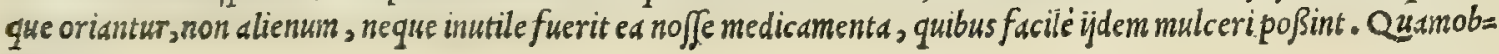

Vefparun, \& apurn iEtus, \&z remedia. 


\section{And.Matthioli Comm.}

rem iam dictis ä Diofcoride remedijs ea addenda duximus, qua priuatim fcribit Aëtius lib. $x$ I I . fic inquiens. Si quis

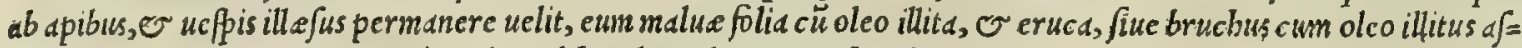
feruabunt. Quandoquiden uerö quidam ab his clanculum percußi, ob doloren perturbantur, putant q $_{;}$fe ḋ maligno aliquo animante petitos effe, neceffarium exiftimo prius oftendere qua figna borum iftus conitentur. Hos itaq; , qui $a b$ apibus punguntur, dolor ittus confequitur, er rubor loci, cum tumore partium in anbitu fitarum: ftimulus alks tem omnino in percuffo loco reperietur. Exdem etiam hos, quos ueßa pupugit, concomitantur, fed intenfirord: ue rìm ftimulum uepa in percuffo loco non relinquit. Auxilium autem utrig; ferunt luto, aut ftercore bubulo eis illito cum pofca : aut malue folijs impofitis cum pofca: aut cinsolia cum malua $\mathcal{\sigma}$ pofca : aut fe fano cum pofca. Naturalis ter auten opitulatur uenerand d, or uiuifica ftrombi conchylij imago in figillo ferreo exculpta, or loco ictus appref: fa : non enim permittit anplius inflammationem generari. In potu praterea ip/is foliorum lauri tenerorum dracbmis is duas cum uino auftero prábeto . hec Aëtius. Ceterum compertum eft, dolorem ftatim feddri illitis nusufcis prius contritis. Id quod fimiliter preftant thymbra, meli 3 ophyllum, $\odot$ fisymbrium.

\section{$\Phi \alpha A x^{\prime} \gamma \gamma l \alpha$. PHALANGIA,}

CAP. XIII.

DEM OR S I s à phalangijs locus quidem ipfe, quafiab impafto aculeo rubet, non intumefcens, nec per ambitum calidus eft, fed mediocriter humefcit : vbi verò contrariorum oceurfu refrixit, confequitur corpore toto tremor, diftentiones poplitum, $\&$ inguinum, conuulfionibus non difsimiles . in lumbis collectio exoritur, \& perpetua vrinæ libido lacefsit, multaque reddendis excrementis colluctatio . vniuerfa cute frigidus fudor emanat, collacry mant oculi, offufisq́ue nebulis caligant. Horum ictibus ficulneum cinerem adiecto fale trito, \& vino imponere oportet : aut radicem fylueAtris punicæ quàm tenuifs imè tritam : aut ariftolochiam cum hordei farina, \& aceto fubactam. V1cera aquæ maris proluenda, aut apiaftri decocto, foliaq́ue eiufdem illinenda. Lauacris perpetim utẽdum, \& propinandum abrotoni femen, anifum, ariftolochiam, cicer fylueftre, cuminum Aethiopicum, cedrides tritas, platani corticem, \& trifolix herbæ femen : priuatim autem, fingulorum ex ijs binas drachmas dare cum uini hemina conuenit . item myricæ fructus, \& chamæpityos, \& uiridium cuprefsi pılularum deco\&tum, admifto uino. Sunt qui fluuiatilis cancri exprefsi fuccum cum. lacte, affumpto apij femine, confeftim moleftijs liberare prodant .

Phalågiorum generaex Aë น้อ.

P H A L A N G I O R M generd quanquam plura ḋueteribus defcribuntur; tamen Aëtio libro X I I I.cap. 30 $\mathrm{x}$ v I I I. Cex tantum numerantitr, his uerbis. In pbalangiorum genere primum quidem rbagium, alterum lupum, ter $=$ tiun formicarium, quartum cranocolaptes, quintum fclerocephalum, fextum fcolecium appellant. Ac primum qui= dem $\mathrm{R}$ bagium, id eft, acineum, figura rotundum eft, colore ueró nigrum, acini une nigre finilitudine, unde etiam ap=. pellationem accepit : $\sigma^{\circ}$ os quidem iuxta medium uentrem babet, pedes veró ex utraque parte quàm breuißunos. Alterum uerò L upus appellatum, mufcas perdit, eisf́; pafcitur : ac corpus quidem babet latum, or uolubile, partes uerò circa collum ipfis incife funt: amplius autem er os eius eminentias tres babet. Tertium autem Myrmecium, hoc eft, formicarium dictum, formice maxime aßsinilatur, colore fuliginofo: corpus ueró cius uelut aftris quibufdam infignitum eft, maximé circa dor fum. Quartum deinde Cranocolaptes, fublongum eft, er uiride, ftimulum'́; iuxta collum babet, at $\phi_{;} / i$ in quem irruat, locos circa caput petit. Quintü Sclerocephalum diqum, caput babet $\int a x e \tilde{u}$, or obduratum: lineamenta ueró per omne corpus fimilia animalibus illis, que circumuolitant noctu lucernas. Sextum q0 autem Scolecium fiue uermicarium appellatum, fublongum eft, o fubmaculofum, maximé circa caput. Atque he. quidem pecies phalangiorum enumerantur. bactenus Aëtius. Quitamen cuiufcunque phalangij notas, or indicia feorfum non deferipfit ( genus enim diuer fum diuer fa quoq; parit fymptomata) fed omnia in commune fimul collegit. Quamobrem fi particulatin cuiusque phalangij indicia per fe fcire cupimus, Nicandrun confulamus. Is fiquidem Phalăg.genera, \& morfus notxe ex $\mathrm{Ni}-$
candro. in theriacis preter id quód plura, quàm fecerit Aëtius, phalangiorum genera reddit, fingulorum etiam priuatim in: dicia defcribit fuis uerfibus, qui ita paraphrafticé in Latinum uertuntur. Operd iam nunc noxij confidera phalans gij, fignaq; cius uorfus. Primus ita q; ßlendidus R hox appellatur, niger plane, accumulatis pedibus prorepens, mez dium uentrem ore, $\mathcal{O}$ dentibus feptum babens. Cui ab boc inflictum fuerit uulnus, perinde corpore apparet atque ft nihil quicquam fauciatus foret: oculi ueró inferioriparte rubefcunt, frigus iuxtd in corpore adberet, infigitur, ftd= timq́; color, or membra bominis à fupernis ad ima uergere videntur : neque penis femine unidus demittitur, fed lum= bos occupans ita frigus genumm nexus diffoluit. Afterion iam fecundum obferua, in ckius dorfo pinguia quadam re= lucent, ac lucide in corpore uirgule. Percuffum ab boc inexpectatus borror cum flamine quodam adoritur, caput

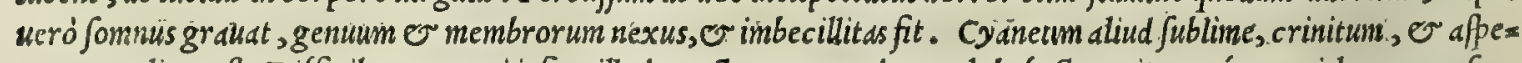
rum equaliter eft. Difficilem corpori infert illud puncturam, quodcunq; labefastauterit, corq́; graui languore fuc

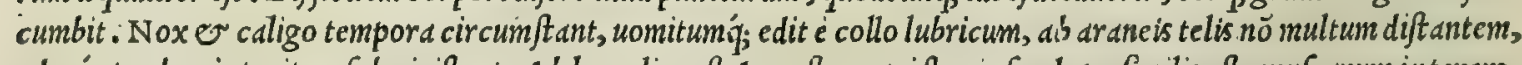
adeóg; tandem interitum fubminiftrat. Ab boc alius eft Agroftes, qui fpecie fua lupo finilis eft, mufcarum interems ptori, qui apum obferuator eft, culicum qui p fenes dicuntur, of aftrorum, o onmiun qua ad telam ipfius peruene rint. Hic imbelle plagan, er uanum uulnus homini infligit. Cuod autem Dyfderi, fiue. pheceum appellant, rutilum fatis, ue $\beta$ e crudis ue $\int c e n t i$ perfimile. Hic fi quempiam uulnerarit, ingens é uulnerc tumor erigitur : morbi etiam qui dam ad $z$ cnud, alias etiam neruorum cordis, $\mathrm{\sigma}$ uellarum languentium trepidatio, alids uirium deftitutio, ut percuf =

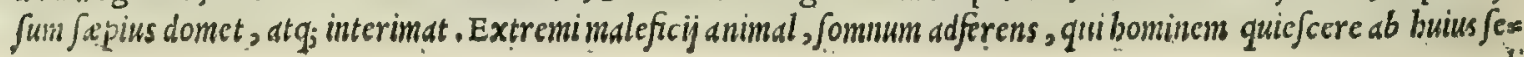




\section{In Lib. fextum Diofcoridis.}

culi laboribus facidt: Eft pretered Formicarium dictum, quod formicis planc fimile fit, collo quiden rutilum, reli= quun corpus nigredini ex putredine fact $x$, par eft, undique latum, ftcllatum dorfum,punctis q́; diftindun gercns, cui fubcinericiun tempus ad modicam ceruicen attollitur. Atque ex boc pladingio dolores priorum finiles uenenatorä ueniunt. Sunt or alia parua phalangia fcarabeis fimilia, que in agris inter legumina fua carpunt pafcita. Horun cirs cacruciantem mor fun tubercula, o pultule exurgunt, cor obcrins furit, lingua incondité obmurmurat, oculi etiam fubuertuntur. Educatur in Aegypto in perfex folijs, quem Cranocolapten dicunt, plalanx finilis, qua cir= cumlucernas cum impetu uolitat nocte. Eius borribile femper caput inceffanter nutat, uterus autĕ grauatur. Hic ubi cuipiam ftimulum infixerit, qucm ecruice tenus gerit, facile fane citra onnem laborcm ad interitum ducit. hac Ni= cander. A' quo tsmen in boc diffentit Aëtius, quod fclerocephalum ijs finile fecrit bcftiolis, que noctu lucernds

1. circumuolitunt, Nicander ueró buic cranocolapten comparauerit. Sediam ea profe quamur, qua de phalangioruan iffibus tradidit Aëtius, qui loco fuperius citato fic babet. Qire percuffos à balangijs concomit.ntur, communia funt iuxta magnitudinem, o paruitatem difcreta. Norfius porró tenuis eft, ut uix confpici poßsit: tumor autem liuidus, quibufdan ctiam rubicundus: frigiditas adeft circagenu, lumbos, or fcapulas, nonunnquam ueró totum corpus ag= granatur . amplius or dolor aßsduus adeft, tremor, pallor, uigtia. Q uibusdan ueró pudendi tentigo, or circa caput pruritus, aliquando etiam circa furas: oculi humecti, or lacrymantes, ac caui, or uentcr inequaliter eleuatur. In= tumefcit autem uniuer fum corpus, faciesq; , $\mathcal{O}$ maxime circa linguam partes, adeó ut impedito fermonc balbutiant demorfi. Quibufdan ueró urime eınittenda dificult.s adcft, cum pudendi tentigine, er dolore. si ueró minxerint, aquofe ip forwn funt urine, quedam aranedrum tel is finilia in fe babentes, e womitus quoq; fimilis. aliquando ueró o per uomitum, o per uentren talia cxcernuntur. Caterim in calidam aquan demißsi, dolore lcuati fibi uidentur:

2o póft ueró é balneo egredientibus intentun dolet pudendum. Senioribus uero pudendun plurinim laxatur, ac mini= mé intenditur. Atque hec quidem communitev ad omnium iftus fequntur. Si ueró cranocolaptes aliquem percufe= rit, caput magis dolet, $\mathcal{O}$ uertigines confequntur, frigus continens, delirium, corporis iactatio, or uentriculi pune ctiones. Omues autem à phalangijs percußi iuuantur aßiduis balneis: ictus etiam locus ex trifolij bituminofi decocto, cum oleo proluatur, totusn ueró corpus ex cerato liquidißimo pinguefiat. Iuuantur etiam fomento pongiarum in ca lido ace to tinctarum, o plage continué adbibitarum. Cataplafmata autem eis conueniunt : bulbi, fanguinaria, por $=$ rtm, furfures accto incocti, bordeaced farind incoctis cum ea in uino aut melle laurifolijs, rutd, großi, caprinum fercus cum uino, amaracus cum aceto, fylueftris ruta cum ace to, or cyperus . bactenus Aëtius. Caterum Diofco $=$ rides uarij in locis huius totius operis de medica materia plura alia medicamenta intus in corpus fumenda aduerfus phalangiorum morfus comnemorauit, preter ea que hoc capite peciatim retulit. Ea autem funt, is funnatim colli= 30 gantur, myrti baccarum fuccus ex uino potus, fuccus item foliorum mori cydthi menfura, lixinium é fici uel caprifici cinere paratum, ap aragiradicum decoctum, agreft is lactuca, coris femen, bedera fuccus ex aceto potus, ruta ex uino haufta, bicracium, daucifemen, melanthium drachme pondere ex aqua potum, aparine, melißophyllum, $\mathbb{O}^{\circ}$, phalangium berba ex uina pota, pentaphyllum, byacinthi radix, or fedum minus. Qua ueró ad idem exterius illi= renda commendauit, bec funt, mullus pifcis diffectus, malue decoctum, aqua marind, or marinorum iuncorum te= nella folla. Nec defunt compofita medicamenta ab authoribus tradita qua fi quis uidere or habere cupit, Galenum confulat libro fecundo de antidot is, ubi ualentißina de fcribuntur antidota ad plsalangiorum ictus, è pluribus ueterum clarißinor un medicorum monumentis excerpta. In funma tamen legitima theriacd, o Mithridatium contrapha $=$ langiorum uenenum ceteris preftantiora cenfentur. Sunt etiámnum in phalangiorum genere recenfenda, que no= bis in Hetruria T A R A N T V L A E Hocantur. Qudrun biftoriam, $\sigma$ admiranda jymptomata fuperius libro fe= 40 cundo abundé retulimus, cum de phalangijs differeremus. Quinetiam iniói docuimus, quo modo ab j̈s icti curentur, muficis inftrumentis, ductis q́; quàm longißinis tripudijs. quare có fe conferre poterunt, qui hac fcire defiderant.

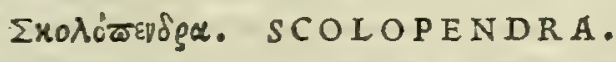

CAP. XLIII.

S I S C O I O P E N R A, aut dicta ophioctene, morfum intulit, locus per ambitum liuore fugillatur, \& computrefcit : interdumq́ue, licet rarò, fæculentus, atque ruber cernitur . A' morfu ipfo exulcerari locus incipit,ulcusq́ue id negotium exhibet, ferè remedijs inuictum : præterea toto corpore prurigo fentitur. Hxc ubi morfum inf̧xit, fal quàm lcuifsimè tritus, ex aceto uulneri infpargédus, aut ruta fylueftris fuperponenda. Locus acida muria foucndus, \& danda in potu arifolochia. so cum uino, aut ferpyllum, aut calamintha, aut ruta fylueftris.

T E R R E S T R E S Scolopendras Hetrufci centipedas uocant. Sunt enin in Hetrurid omnibus uulgaris noti= tie uermes, innumeris utrinque pedibus referta, colore fubrufo : diuerfo quoq; genere conftant. Caterùm ed tantùm. itu uerenumrelirquunt, que quod morfu ferpentes interficiant, ophioctone appellantur, quarum tantum exiftema= Scolopendr $x$ uenenolę cófideratio. mus hoc loco meminife Diofcoridem. Veruntamen que in uniuerfo genere ex fint bactenus compertum non babeo. Quibufdain in regionibus tanta copia increuere fcolopendra, ut fugate ab eis populi, proprios deferuerint lares. quod Arerietis contigiffe feribit Theophraftus. Progreditur fcolopendra tam in anteriorem, quadm in pofteriorem partem. Idcirco fcribit Ariftoteles lib. I I I I. cap. v I I. de hiftoria animalium, quód diffecta Scolopendra altera parte in caput, alter a in caudam mouetur, o erpit. Vnde uidetur exiftimaffe Nicander, hanc bicipitem e efe, ut eius uerba in theriacis innuunt, cum inquit. Modica'g; pemphredon, biceps';; fcolopendra. Cuius eunt is ale, ut remi nauis, fftinant. Non inepta quidem. Nicandri comparatto : nam fcolopendre pedum multitudine uelocí; motu triremem 


\section{6}

\section{And. Matthioli Comm.}

Scolopendre reprefentant. Harum morfibus (ut Diofcorides dit) auxiliantur aßphodeli fenen, o fores ex uino poti: Quinetia morfus secse (ut fcribit Ä̈tiks) ed omnia fcolopendre ittibus medentur, que priuatim muris aranei mor fibus conueniunt, de quoa
dia. rum curatione palilo inferius dicemus. Preferunt antiquorum nonnulli cinerem aceto fubactum, or uulneri illitum, item foillă : preterea palegium, rutam, er mentham ex uino potam. De marinis scolopendris tradidimus fuperius libro fecundo. Nec tamen mibi compertum eff, aliam noxam ab ijs inferri, quìm ingentem pruritum ijs tantim par= tibus, quibus inheferint ( ut fcribit Ariftoteles, $\approx$ Diofcorides ) earum erucarum more, que pilis horrent, e que prasertim in pinu uitam agunt.

Exogrios. SCORPIO.

\section{CAP. XIIIII.}

S C O R P I O N I morfu inflammari ftatim incipit locus, \& indurefcit, ac intentus rubet, viciffimq́ue dolore premitur : modò fiquidem exæfuat, modò frigore occupatur. Labor repentè fatigat, \& aliquando meliufculè habet, aliquando recrudefcic . Confequitur fudor, horroris fenfus, \& tremor. Extremæ corporis partes refrigefcunt, inguina extolluntur, per fedem flatus exeunt, capilli eriguntur, pallor membra decolorat, \& dolor, tanquam ex pungente acu, per vniuerfam cutem fentitur. Percufsis præfenti eft auxilio ficulneum lac in vulnus inftillatum. Scorpius ip $\int e$, qui ictum vibrauit, tritus, \& percuffo loco impofitus, fuæ plagæ rcmedium eft, ob cæcam quandam naturarü (vt conftat) difcordiam, quæ antipathia appellatur. Præterea tritus, \& impofitus cum fale, lini femine, \& althæa, fcorpius conuenit. Sulphur ignem nors expertum, refina terebinthina exceptum, \& emplaftri modo adiętum, auxiliatur. Itideın galbanum ad fplenij formam duetum, \& calamin- 20 tha, qux trita illinatur, \& farina hordei in vino parata, in decocto rutæ. Semen trifoliæ herbæ tritum, \& vulneri iniectum opitulatur. Hæc ad affectum locum pertinent. Poft hæc quàm effica= cifsimis potionibus utendum, cuiufmodi funt ariftolochiæ, præfertim corticis binæ drachmæ cum vino, tufa gentiana, \& pulegium decoctum, \& baccælauri pauco numero tritæ, \& calamintha cum pofca, in qua magnopere difcoqui debet: cupreffus cum vino, \& ruta, nec fecus ficulneum lac: laferpitium, fi adfit: fin defideretur, peucedani fucco utendum . efficas eft potum trifolij, \& ocimi femen. Horum autem omnium uicem penfatiugis lauacri vfus, euocatus fudor, \& dilutæ vini potiones.

Scorpionum genera ex Ni candro.

P L V R A, ac udria antiquis numerantur Scorpionum generd, ut latius libro fectundo diximus, gitorum alij mul $=30$ tum, alijparum fuo itu officiunt .'Porró Nicander in theriacis fcribit corum octo reperirigenera, bis uerbis. Age= dum aculeo dolorifico armatum forpionent canam, eiusq́; tetricum gemus. Quorum primus albicans, neque fonti= cus, neque lethalis eft. Sed cuirutile gene micant, calorem flagrantemó; mortalibus furorem inc ußit, quo malo bo= mines horrore concutiuntur, or frigore, perinde ac qui febre diuexantur, or acri fiti incenduntur. Qui lividus eft, maldm trepidationem, $\sigma$ motionem tribuit hominibus, quos percufferit, qui ceu attoniti, $\mathbb{e}$ uani, e ftultiris dent. Alius uiridante colore, qui finul ac corpus bominis concußerit, tremores, e frigora illico admittit, acrisq; grando talibus uidetur circum/tare, etiam fi fol ardentißimé radijs fuis flagret. Talis tantáque cius ftimuli afflictio, cuius uertebra nouem (lego feptem, cum non piures frorpionum caudis ineffe comperiantur) iuncturis connexe api=

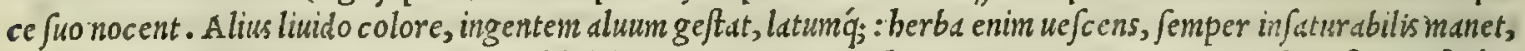
corpus etiam hominis exedens, inguini infolubili iftu nocens: tam uebemens eius genis, er ori morfus infitus, infixis= que eft. Deprebendes itidem fimilem fcorpione litor ali feu marino caricro, qu albentes algas fuctumí; nuris decer= pit pafcendo. Alij rurfus incuruis aquales plané paguris uidentur, corpore grandes, chelis, o forcipibus aquéfo= lidi, atque pag uri, qui in $\int a x o f i s$ cauernis demorantes fibi timent . quinetidin e paguris tales $\int$ corpiones, genus er or = tum fuum dicunt. Nam ckim rupes, ienuesó; multum ftrepentis maris reliquerint algas, cos ex mari ine $f$ cantes pifca= tores extrabunt. At pagurife peti ea wenatione entientes, murium rimas, or nidos fubeunt, ubi prolem perditricen babent, ibió; é mortuis tandem paguris fcorpij nocentes per foramina ifta generantur. Poftremó melichlorus tibi animaduertendus, cuius fummun uerticillum prenigrum cft, inextinctamó; noxam infigit, bominibus certé infenfif $=$ fimus ille obliquo greffu corpus flamme fimile commouens : pueris ueró, o natu minoribus celerem interitum ad=

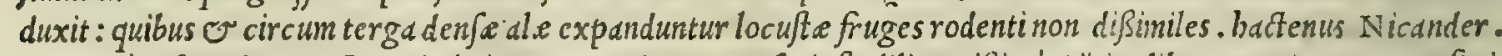

Scorpionum

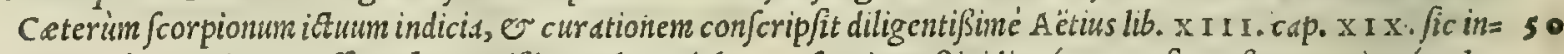
ietus, \& cura tio ex Ac̈tio.

quiens. A' Scorpio percufos uebementißimus plage dolor confequitur, frigiditas q́ ac tenfio, et flupor : circá; pla = $\mathrm{gam}, \mathrm{O}$ totum corpus frigidus fudor: $\widetilde{\sigma}$ bis, qui iuxta infernas partes percußi funt, inguina excitantur, ac intume= fcunt: qui ueró circa fupernas, locus fub alis. Et hec quiden leviter percußis adfunt. Validius autem ict is ardor cir: ca plagam adeft, quemadmodum in ambuftis, or uerrucarum inftar formicarum eruptio circa labra, ov totum corpus, ut grandine $\int e$ impeti putent. Facies difforquetur, fordes circa oculos ad funt glutinofe, o lacryme vifcom $f_{a}$ : durities articulorum, anusq́; procidit, cum egerendi cupiditate: ppuma circd os eft, et womitus largus, fingultus, conuulfitones opifthotonicis fimiles. Hisigitur ferpyllum, althax rddicen, $\sim$ elaphobofcum bibendum prebeto. preter opinionem autem facit elaphobof cus, tum uiridis comefta, tum ficca pota. Cochleam item hortulanam ma ximé accipito, edm'́; und cum opcrimento tritam, plag e imponito, e confflim fedabis dolorem. Idem etiam uermes terreni faccre dicuntur. Prodeft pretered fiuiditilis cancer tritus, addito lafere, in uino potus. Confert verbenaca

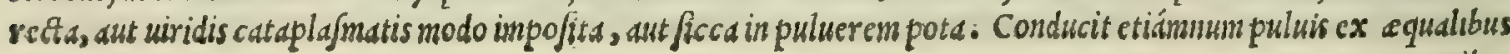




\section{In Lib. fextum Diofcoridis.}

partibus cumini, melanthij, el uiticis f cminis confectus, ero dracbms pondere ex uino potus. Datur, or paftinaca fe=

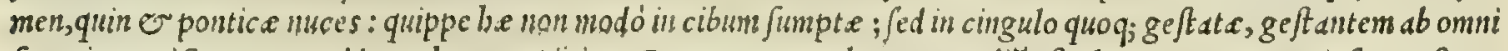
fcorpionum iftu tutum reddunt. hec ex Aëtio. Conmune o unlg tre remediü eff plagam perungere ip forum for = pionum olco. Proinde oleum noftrum de fcorpionibus, cuius anted fepenumero me ntionem ficinus, bac in curatione maximopere conueniet. Scorpionun ítibus Diof corides preter ç medicamẽta, quor um boc capite meminit, bee Remedia alia

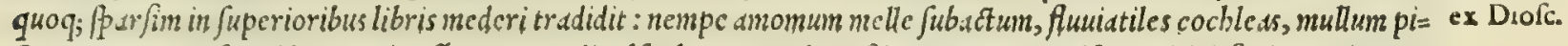
feem recentem, Jmaridem muria a Jeruatum, diuulfas lacertas, domeficos mures concifos, tritici farinam uino aut

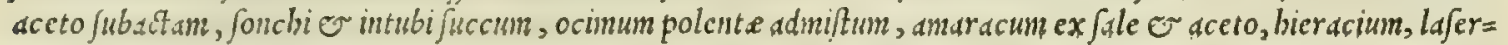
pitij lacry:n:m, melijophyllum, chamepityn : uerbafci illius folia, quod tantim aureum florem gcrit, leucoij aurei so femen: or polcmonie radiccn, cui tantam uint contra fcorpiones ineffe quidam tradunt, ut ij ab bis nö feriantur, qui cam geftucrint: quos, fi forté percufifucrint, witil tane moleftipaffuros affirmant. Et bac omuia profunt tan= tim unlneri illita. Que ueró pota, uel dcuorata auxilium preftant, eiusdem teftimonio, boec crunt : fluuiatiles can= critriti, or cum a/inino late poti : dinorum or cquorum, qui in pafcuis degunt, fimum liquatum in uino, or potum: oxylapathi, er oxalidis femen cx uno aut ex aqua potum, agreftis lactuca : abrotoni hortenfis, paftinaca, byacin= thi, o urtic:e femen : guin or olufatrum, o beliotropium, ov cardamomum, or myrrba, or myrti baccarum ui= num. E' quibus ommibus cum plur a poßint confici antidota, pro uaria medicorum intentione, non operapretium pu= to, nos las in re longiorem moram ducere, ut que potius peritißsmi cuius $q$; indicio fit relinquenda.

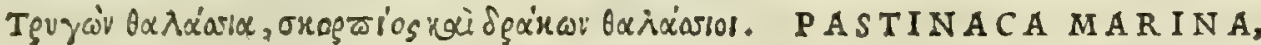 SCORPIO ET DRACO MARINI. CAP. XLV.}

S I M A R I A paftinaca percufsit,protinus accidunt moleftidolores,afsidux conuulfiones, laffitudo, \& imbecillitas, mens percursis labat, poftea obmutefcunt : oculi caligant. Percuffus autem locus in a mbitu cum uicinis partibus denigratur, \& ita obftupefçit,ut tangentem non fentiat. hunc fi quis premat, atra fanies, craffa, \& malè olens excernitur. Ei qui marina paftinaca icitur, omnia, qux de uiperarum morfu paulò pòłt referemus, fimili modo conueniunt. Peculiariter autem ictus à marino fcorpione, \& dracone inferuntur, qui moleltos cruciatus cient: interdum autem, fed rarò, nomas excitant. Quibus abfinthij, faluire, aut fulphuris ex aceto triti potio fubuenit, Ipfi etiam diffeAti, vulneribusq́ue impofiti, fui cuịufque ictus remedio funt .

Q v I dimarind Paftinaca pcrcußi funt ( ut teftatum reliquit Aëtius) bis uulneris locus maniffté apparet. Se= Paftinacr ma quitur autem dolor pertinax, er totius corporis ftupor. A cutum enim, or firmum babet aculeum, quo uebementif= fima ui in altum impulfo, nerui faciantur. quapropter in aliquibus mors derepenté totum conuellés corpus comita= tur. Narrant quidam, quód $f \mathfrak{i}$ quis caudam pastinace, que itum intulit, aufer at, or in arborem maximé quercum, fupendat ac figat, ip fam quidem arborem are fcere, egrum autem fanari, atque id iuxta contrarie affectionis, e re = medij rationem contingere. Id quod etiam afferit Nicander in theriacis, his plané uerbis. Trygonem, boc eft, pafti= nacam, itidcm maleficum, maréq; waftătem draconem arcere noui. Dolore autem fic hominem afficit trygon, cum ob=

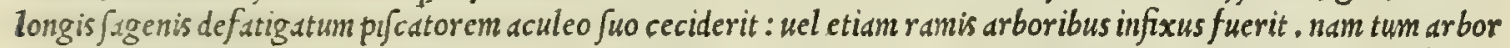
eafit obfcurior, ignobilior q́; . Siquidem ab buius mor $\int u$, ceu folis $\& f t u$, eius er radices perdite unà cum folijs flacci=

-4 de redduntur, $\mathcal{O}$ are $\int$ cunt: homini ueró caro putredine imminuitur . bec Nicander. Ceterum auxilium fentiunt percußji, ut Aëtius inquit, ubiftupor, o refrigeratio totius corporis confequatur, ex calidis illitionibus, $\sigma$. confimi= libus cataplafinatis. Proprié autem furfures aceto incocti, o procataplafinate impofiti cis auxiliantur, or ipfum adco acetum pro fotu affuJum maxiné prodeft. Magis autem conueniunt eis attractoria, or qua tenuium partium funt, ac calida. quo nimir um per attraftoriam facultatem uenenum ex profundo attrabatur, er per calorem frigix ditas mitigctur, er qua tenuium funt partium, in altum proreptent. Ad banc igitur rem in promptu babebis apta, fulphur uisum ur ina ueteri fuba.4 um, narrubium, laurifolia, ecbium, radicem panacis, falsiam, o fimilia. At uero fi hec defiderentur, fermentum acidum cum liquida pice emollitum imponito: mirabiliter enim auxiliatur. Dato iten lauri decocture, aut fuccum Cyrenaicum cum myrba magnitudine faba, ac modico pipere terito, ac dato cum uino: aut fil phium, aut lajer ex uino: aut fuccifici guttas quinque, cun tribus ferpylligranis bibendas prabe. Hec Aëtius so aduerfus paftinace marine iftus auxilia reddidit. Ad quos praterea commendatur faluix decoctum continué pluri=

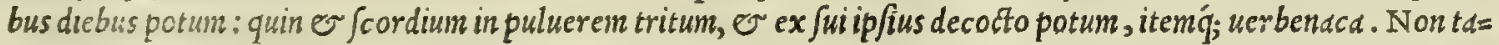
men ob id pretermittenda eft theriaca, aut Mitbridatis antidotus, aut quinta noftra effentid, cuius ian fxpe memini= mus. Porrò Nicaider quoq; nonnula remedia protulit, qua bec funt. Anchufa folia, quinquefolium, rubiflores, arctium, oxalis, lycopfis, ordilum, chamepitys, fagi cortex, agreftis paftinace femen, terebinthi fructus, phycus marinus, adiantum, $\int$ myrnium, eryngium, libanotis, cachry, er utrunque papauer.

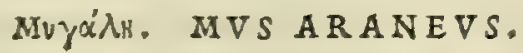

\section{CAP, XLVI.}

A' M V R E araneo percufsis, circa morfum in orbem inflammatio exoritur, nigraq́ue puftula, diluta fanie turgens, exurgit: proximx partes liuent. Rupta pultula, depafcens ulcus, non ei diffimite, quod ferpit, occupat. Inteftinorum quoque tormina, difficultas urinæ, \& frigidxafperginis of- 
fufro confequuntur. Huius morfibus auxiliatur ex galbano fplenium, per fe vulneri exterius impofitum, ve medicamenti modo accto tritum, \& hordeacea farina cum aceto mulfo illita. Q uinctiam mus ipfe, qui morfum intulit, fi diffęus apponatur, ictus fui veneficia luit. Refiftunt quoque acini dulcis punici decocti, \& illiti : item porri, \& allia contrita, necnon aquæcalidæ fotus : fed hæe ad locum pertinent. Prodelt potum abrotoni decoctum, maximè fi in uino detur .prxterea ferpyllum, \& galbanum, \& eruca vinu madefacta : recentes cuprefsi pilulæcum aceto, \& cyclaminus ex aceto mulfo, \& pyrethrum cum vino, \& chamæleonis herbæradix. Nec defunt, quiliterarum monumétis tradiderunt, tritum murem araneum contra fuos i\&tus commodè bibi. Quam hiftoriam apudalios inuentam, dignam duntaxat cenfuimus, quæ adnotaretur. Alij affeuerant, demorfum non aliâs exulcerari, nifi prægnans mus araneus fuerit : tum fanè auxiliari ferunt .

Qv A N Q v A м Mus araneus, qui, quòd colore muftele fit fintilis, Grecis $\mu v \gamma \alpha \dot{\lambda} \lambda$ dicitur, ab onnibus in= ter uenenata numeratur; attamen in agro Tridentino is nullam morfu infertnoxam, quemadmodum nec fcorpio. Hi= Muris aranei ftoriam cius fuperius libro fecundo retulimus. quare iam ad eius morfus notas, ev remedia progrediamer. Demor= morfus notę, fis itaq; ab eo ( ut Aetius inquit) uulnera manifefta fiunt: quadrifido enim ordine illata unlnera conjpiciuntur : $\sigma^{\circ}$ \& curatio. Fanguis quidem primùn purus promanat, pauló póft uerò faniofus. animal enim ip fum putre factione occidit. Confue= uerunt etiam bulle infurgere, quas fi quis difrumpat, carnem fubiacentem feculcntam offendet, 0 fiß Inflatio autem fequitur demorfos. Caterìm boc animal frequentius ad teftes infilire folet, eosq́; uerbere inpetcre, 100 bominis modó; fed cuiusque etiam bruti animantis. Auxilium autem ferunt cüm ob putrefactionem pericliantur de= morfi, poft predicta communia remedia, lauri tenella folia, unius aut duarum drachmarum pondere, tritw or ex ui= no pota. Conueniunt etiam ipfis omnia communia uenenorum remedia é uino dulci in potu fumpta. In pecortbus ueró ¿ iumentis illa ipfa cum aqua trita, naribus infunde : eft enim ipfis prefens remedium. Vnde etiam bowinibus fimi=

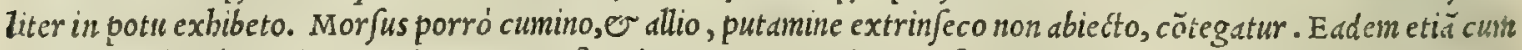
oleo trita aßidué ac diligenter locis circumfitis illinantur. Si ueró rupta fuerint bulle, er ulcera oborta, acida muria proluatur locus, appergaturǵ; fubinde ufti bordei puluere. Verùm non rumpentur, nifi pregnans fuerit mus ard= neus, qui mor fun infixit. Quód fi exulcerentur, mali punicidulcis putamen coctum tritum erit imponendum, 6 ulcera ex eodem decoçto, aut magis myrti decocto proluenda, fouenda $q_{\text {; }}$. Strato ueró inquit, in muris aranei mory primin fcalpello, circunquaq; unlnerandum effe locum, er murem fubinde araneum uftum cum ace to imponendum, aut finapi tritum, $\sigma$ ace to exceptum. In potu ueró opem ferunt panax, eruca, capparis cortex, gentiane radix, $\odot$ yecta uerbenaca, omnia ex uino pota, aut in cataplafinate conformata, or morfibus illita. Profunt er malue folia 30 impofita, or magna antidota potui data.

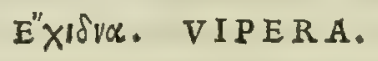

CAP. XLVII.

S I V I P E R A momordit, corpus intumet, uehementer arefcit, fubalbidumq́uc colorem concipit. Sanies à vulnere profunditur, primùm fubpinguis, mox cruenta . puftulæ aduftis fimiles erumpunt: \& antea depafcens ulcus, quod in proxima repens, non fumma modò corporis; fed intima quoque corripit. Gingiuæ ijs cruore fuffunduntur: inflammatio circa iecur erumpit: torm ina, $\&$ biliofi vomitus fequuntur. Sopor, tremor, \& urinæ difficultas accedit, \& frigidus fudor offunditur. Vbi uerò uipera morfum imprefsit, fimum caprinum cum uino, ftudiosè im pofitum opitulatur. item laurus \& abrotonum, \& galbanum fplenij loco fuperiectum, \& origanum uiride inditum - pulli gallinarum difcerpti, \& confeftim admoti : crui farina vino fubacta : radicis cortex usque eò tufus, vt in puluerem folutus abeat, \& fcilla tolta : detritum chamæmelum, hordeacex farin $x$ cataplafma in aceto mulfo præparatum, fed locus antè eo calido foueatur. hæc loco imponuntur. Contra uiperinos ictus rubus cum uino prodeft. Aliqui anchufam tenui folio conftantem auxiliari produnt. Leporini coaguli in vino terni oboli bibuntur, \& porracei fucc hemina in mero, \& foliorum apiaftri fuccus, \& fylueftris ruta . hæc in vino potari debent. Vinum frequenter bibendum, allia mandenda, \& cepæ \& porri recentes, falfamenta acerrima, \& opipara . fimplicia hæc funt: Percufsis à vipera pręclarè auxiliatur medicamentum, quod myrrhæ, piperis, caftorij, floris portulacæ feminisque, dimidio acetabulo conftat: hæc omnia in Cretico paffo teruntur, aut in alio pro- so

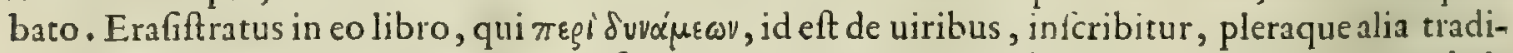
dit,quæ ictis à vipera auxilium ferre poffunt : inter quæ talia maximè laudantur. Gallinacea cerebella cum vino pota, femen fatiuæ brafsicx tritum, \& acetabuli menfura cum uino potum. Quinetiam bonum eft digitum in liquidam picem intingere, deinde vinum, quo digitus fuerit elutus, bibere. Hæc funt quæ contra viperæ ictus auxiliantur.

Viperarun VI P E R A R V M biftoriam exactius, ut puto, latiusq́; libro fecundo tradidimus, quàm ut operapretium fit mortus indi- lice candem repetere, uel plura nobis fuperfint addenda. Quare tantum reliqumn eft, ut iam de earum mor fus indi= ci2. cijs, or remedijs differamus. Reperiuntur itag; in eis (ut Aetius memoria prodidit) quos uipera mas momórdit, uu ine ra in loco bina : in bis ueró qui à foemina demorfif funt, quaterna. Primim autem ex eis excernitur $\int a n g u i s$, dez inde fanics funguinolenia, er oleofa. Adeft tumor biliofus, feruidus, bullojus, Jubruber, deinde linidus, denigras 
tus, or proferpens. siccitas uehemens ineft ori,ardor, exolutio, o frigidi horroris infulius, aliquädo b bilis uomitus,

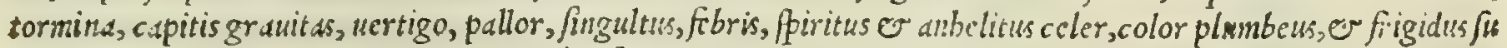
dor. Mors in horis feptem, aut ut longißinc abfit, tertia die, in bis qui non feruantur, or maximé bis, qui i uipera fxe

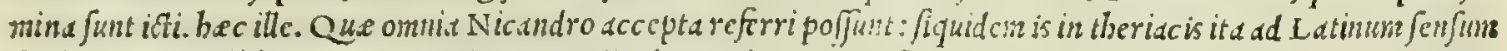
fcribit. Hinc luctü a wipera mananté uiatores diuulgant: duos crimn inftur ncrui acutos mafculi dentes in ore fuo uirus cruct antes, oftentant: wipera ueró femin femper plures excrit, perniciofo fuo ore infultans. A tqui in carne ifi fa $=$ cilé latos dentes perpendas. Porró é uipcra inflita plaga fanies aliâs pingucdini finilis, aliâs cruenta, interdum fin. ne ullo colore confpicitur. Sed que ulcus ip fun curo circundat, germinans graui offert $\int e f e$ tumore : interdum rubés,

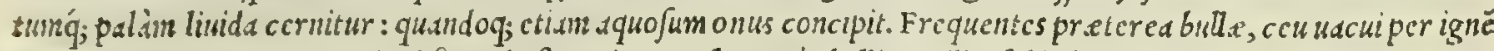

10 tumores, perinde ac corpus ignifit anbuftum, in cute fupcrne ebulliunt. illic fubinde putrednes circumcirca accur= runt, alie quidem feorfum à uulnere, alie circa plagam ueneno non dißinilem mortem edentes. Apera itaguc no= $x a$, sebementer $\dot{q}_{;}$ignef ccns totum corpus exedit : bic per guttur, atque coliun coc̈untes fonitus, agminatimftrepüt: quinetiam oculorkin ucrtigine nocret. Illico q; mcmbris grauans inbecillitas, o lumbis anxictas uenit: at in capite caliginofum onus confiftit. Atqui laborans ille altâs fitiaridun guttur fum cxiccat, fepeq ; ex unguibus cum figus tenet. Hyberna autem niuc exuber.tns grando, omnia membra degrauat. Crebró etian biliofos ucntris fui tumores expuit, toto cor pore psllens, ac bumens circd membra fudor niuis idefu frigidior circunfunditur. Colorem interd $u$ liuidi plumbi gerit, alix̂s obfcurum, mox floribus fimilis eft eris. bxtenus Nicander. Preftat igitur (ut Aëtius author cft ) priksquim crucnta prodeat wrin, allij p!wimum de uorare, or uinum meracun copiofum bibcre, exci= tat is fubind uomibus. Eficucifimum enin cis remediun eft allij f fus, ac meracior uini potio, inquit Archigenes,

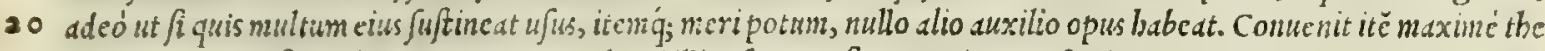

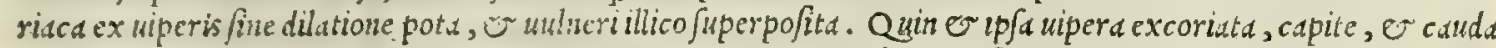

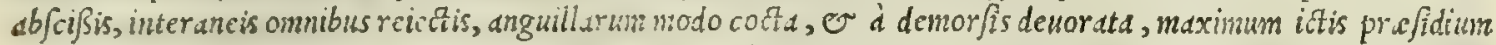

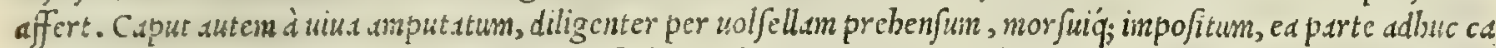
lente, que ceruicem contigit, uenenum id inirifice extrabit. Conducit or diffectan gallinam adbuc interné calentent morfui imponere, id'q; alijs pariter diffect is, frequenter, or aßsidue repetere. Oportet etiam fcalpello per anbitum demorjum locum circuncidere, or cucurbitulas fubinde admonere. A' cucurbitulis foliorum fraxini fuccus in potu exbibendus eft, er expreffa dे fucco folia uhineri illinenda: eft enim ualde effic ax ad uiperarum morfus fr axinus ar= bor. Meliffopbylli item folia, e fuecus tum ex uino potus, tum uulneri exterius illitus, euidens auxilium confert, $e=$ tiamfis iam imoriatur ager. Aiunt praterea, fi quis melantbij draclsmas quatuor edat, non moriturü. similiter etiam 30 melapbroditos herba efficax cft, er cancrifluuiales cum lacte triti, or poti, or uulneri adbibiti. Magnifice etiam

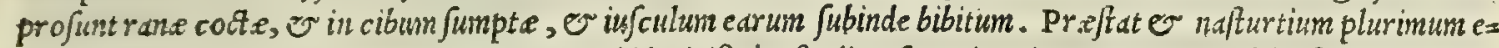

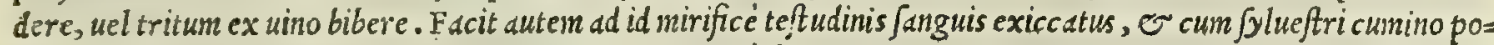
tus. Vtendum etiam omnibus communibus remedijs, fuprà fapius relatis ; quippe fuperuacaneum fucrit eadem tam fe pe repetere. Maxinn ucró utendun ef anchufe radice, o beliotropio cum uino. dandus $\sigma$ bematites lapis. Aux xiliantur 0 raphani in cibo accepti, o deinde uomitu reiceti, exbibitaftatim ḋ uomitu Andromacbi theriaca. Poft fcarificationem, or gallinurum inpofitionen, uulnus ex trifolij bituminofi decocto calido, diu proluendum ac fouens. dum eft : nam fi pasco id tempore fiat, demorfi peius afficiuntur. Deinde porrum wూ panem cum fale illini conuenit, aut allium cum ace to, aut ip fius exusti, aut fraxini cinerem, aut alium quémuis cum aceto, aut haftula regie, aut $f_{y=}$ comorifolia cum pane : aut lauri tenellis folijs, coctis er cum oleo tritis integatur locus, aut caprino ftercore, prius

40 quim claudatw. Cater um, ut libro de theriaca ad Pifonem author eft Galenus, non modó è uiperarum morfibus res

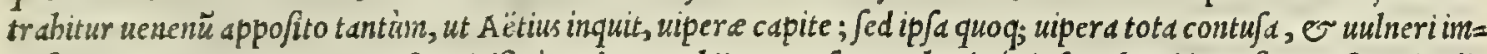
pofita. Contra uiperarum mor fius snirifice medetur ecbij epotus fuccus, berbá; ip $\int a$ uulneri impofita, ut fuperius li= bro quar to prodidimus, Illius Alcibij biftorian referentes, à quo echium Alcibiadis cognomentum accepit. quando= quidem planta bec (ut ip $\int$ e Diofcorides teftatur) facultatibus adeó preftantibus infignitur, ut epota eius radix ex aimo, non percußis modó a ferpentibus opituletur; fed eos quoq; qui antea biberint, feriri non patiatur. Commen= dauit etiámnum aduer fus uiperar um morfus Diofcorides parfin in fuis de medica materia libris, prater ea que boc capite retulit, alia preftantißima fimplicia medicamenta, partim exterius applicanda, partim bibenda, uel comeden= da, quorum nonnulla bic Jubijciam. Vulneri igitur exterius illita conferunt, iuniperi, o fraxinifolia, triticifurfu= res ex rute decocto incocta, erui farina uino materata, fcilla ex aceto fruefacta, perfonats, ebuli, er fambuci ras

so dices in uino clixat 2 , farmentitius cinis ace to fubattus, alia ; complura, que breuitatiffudentes nunc filentio inuol = uimus. Pota ueró profunt caßia odorata, coftum, myric e femen, piftacia, ceruigenitale exiccatum, tritum er po= tum, chondrylla, anag allidis fuccus, ferule medull, aparine, rubie radicis, or terreftris tribuli fuccus : auxiliatur etiam bryonie radix. Admirandos in uper prebet effectus radix illa, quam Goritien fes ab auxiliari cius ui serpenti= nam uocant, cuius hiftoriam, pariteŕ, ufus rationem fuperius libro fecundo tradidinus. Verum prater bec prafen taneo remedio fandt noftra quinta effentia, cocblearis menfura pluries eodem die pota: item oleum noftrum de fcors pionibus, de quo etiam $\int e$ pius diftum eft, edratione inuntum, quam fuperius ipfius confictendi modum def cribentes retulimus. In viperarum quoque genere ed nimirum immanis ferarecenferipoteft, quam $\triangle M M O D \perp T E N$ uocant, cuius et fi nusquam, quod extet, meminerit Diofcorides; minime tamen filentio pretercundum e/t, quin hec eiusq; ueneni remedis de criósntur. siquidem Ammodite, meo iudicio, in pluribus Italix of Illyrix locis reperiun= tur, prefertim in Gorttienfi comitatu, $\sigma$ Iapidix montibus. Eft enim fera hec uipere omnino fimilis, preterquàn quod capite fit ampliore, ec maxilis latioribus, quod'́, ultimo roftro fuperiori parte eminentiam quandain babeat, 


\section{And.Matthiolı Comm.}

acutí ucrruce fimilem. Vnde circunforanei, qui ferpentes eorumíg; ueneni remedia profitentur, hanc fer drin uulgo: appell.nt Afpido del corno, hoc efl, Apiden cornutum. Neq; fane ineptum illi nomen indiderunt: nang; non minor: cum uclocitate interficit, quain apis. Scinus cnim quosdam ab his inopinaté demorfos, tribus tantim boris morte. occubuiffe. Proinde fcité libro x I I I. cap. x x v. de eo ita friptum reliquit Aëtius. Ammodites m.gnitudine quia: dem cubitalis eft (maior enim non pingitur, neg; fcribitur) colore ueró arenofus, per corpus autem maculis nigris infignitus: caudain babct preduran, fuperné difciffam. A' quibusdan ueró Cenchrias, boc eft miliaris, ob caude. inftar milij duritiem, appellatus eft. Latiores autem maxillas, quàm uiperababet, cimm; in inultis, aliäs ei finilis. A mmoditz fit, colore magis difcerni poteft: uipera enim fubflaud eft. Caterum ab Ammodite percufos feftina ut plurimiun morlus figna, mors fequitur . qui ueró tasn breui non pereunt, his fanguis é uulnere manat, $\mathcal{O}$ uulnus intumefcit: fed pauló póft \& curatıo. Sanies effertur, fequitur $q_{\text {; }}$ capitis grauitas, 0 animi deliquium. Qui ueró optiné difpofiti funt, or robufti, in tri $=$ duo intereunt : quanquam reperti funt, qui in feptimum $u \int q u e$ diem durarint. Celerius ueró mors aduenit bis, qui dे famina fauciantur. Auxilium porró er ij ferunt, primìm quidem à communibus remedijs, utpote ab adfixis cucurs: bitulis, circuncifo prius per ambttum uulneris loco, e fuperioribus partibus arctifimis uinculis cóstrifis: quin $a b=$

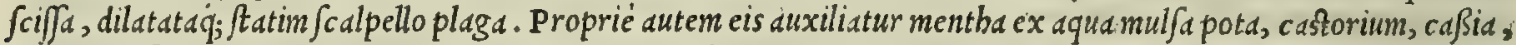
e artemifia fuccus cum aqua. Danda etiam in potu theriace, necron uulneri eadem illinenda. Vtendum er empla: Sepis fere có- fris attractorijs, or fubinde cataplafmata, que ad nomas fiue ulcera ferpentia conducunt, imponenda: Viper Gderatio. preterea fimilis, ut quidam tradunt, ea etiam fer a fuerit, quam s E P A nominant, cuius biftoriasn fuperius libro fecundo retulimus. quanquam inibi Diofcorides sepein lacerte generi aßignauit, unde or eam lacertam Cbalcidi= cam à quibufdam uocari tradidit. Itag; cim uaria fit apud authores sepis biftoria, facilé adducơr, tit credam, sepa reperiri non modó in lacertarum; fed etiam in mortiferarum ferpentium, é uiperärum genere . Qüod fané uidetur 20 afferere Nicander in theriacis fuis. Siquidem cim inquit primo', Preterea niualis, ov afper admodum mons Othrys

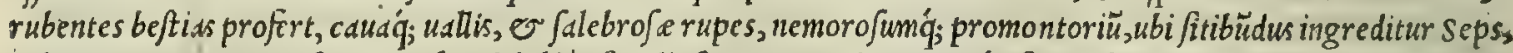
colore nunquam uno uifus, oc. baud dubie oftendit ferpentem, immanemq́; feram fe reprefentare; non autem la= certam. Cùm ueró fecundó ait, sepem item corpore demiffo, exiguis haud dißimilem lacertis, declinabis; nulli du= bium eft, quin eam defcripferit, quam Chalcidicam lacertam uocant. Nicandro fubfcribit Diofcorides, quippe qui etf libro fecundo ea ratione sepa ftatim poft lacertas reddiderit, quod lacertis corpore, er forma fit finilis; attanen lic bro quinto, sepa uiperarum generi adfcrip/it, ubi de aceti mulfi uiribus differens, inquit. Acctümul fum contra mor fum eius uipera, quan fepa uocant, bauftum meconium, ixiámuc auxilio eft. Aëtius tamen' eius sepis tantùn inemi= nit, qua inter mortiferos ferpentes, uel uipere genera recenfetur, bis uertis. Serpens, qui seps appellatur, longitu= dine quidem duorum cubitorĭ reperitur : ex craffo autem in te nuem abit : rectà ueró ac tardé proferpit. Caput babct 30 latum, os acutum: uniuer fum autem corpus multis albis notis reperfum. Sed aliter de scpis forma, magnitudine, Sepis morfus greffu tradidit $\mathrm{P}$ aufanias, ut fuperius libro fecundo fuo loco adnotatum reliquimus. 'Cxeterim ab ea percußis (ut

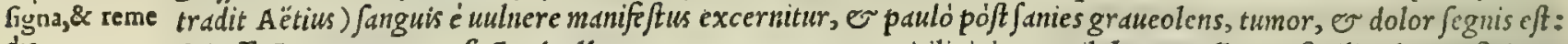
dia. fed affecta partes putrefacte dealbantur, or totum corpus uitiligini, que alphos appellatur, fimili colore inficitur. pili, capilliq; é toto corpore defluunt, atq; intra tres, aut quatuor dies icti pereunt. Porró opem e hi fentiunt ex ijsdem rebus, qua in uipere, $\mathcal{O}^{\sim}$ cerafte, $\mathcal{O}$ ammodite morfu relate funt. Exbibenda eft preterea portulaca pluri= ma in cibo, $v$ uinum bibendum myrtites meracius. Conueniet item pongiam calido ace to imbutam, morfui impone. re, er ex butyro cum melle locumillinire, aut milium cum melle, aut paleas und cum terra, que eis adheret, exus= Atas imponere . bec. Aëtius. Ex qubus facilé conijci poteft, cum ambe be fere è uiperarum fint genere, ijs tutó an= Acontix bi- tidotis earum uenenum fuperari poffe, quibus uipereum frangitur, or enincitur. Sed quoniam hec bumane uite to foria, mor - tam inimica animalia aliam admodum pernicio fam feram mibi in mentem reuocarunt, qua Grecis ideo A $C O N T \mathrm{~T}$ fus notx, \& appellatur, quód iaculi, uel fagitte modo in bominem profiliat, cum nibil de ea à Diofcoride memoria proditum fit, cura.

fciuerimq; 0 banc in Italia reperiri, non alienum duxi de eius biftoria ac ueneni curatione ea boc loco commemo= rare, que ex probatis authoribus excerpfi. Hanc itaq; defcribens Galenus libro de theriaca ad Pifonem, inquit. Acontias ferpens, ubi fe multum extenderit, ceu iaculum quoddam corporibus infiliens, fic perimit. Hac, ut $A \ddot{e}=$ tius fcriptis tradidit, $\int e r p e n s$ eft duorum cubitorum magnitudine, figura autem craffa in tenuem abeunte, colore uiridi, prefertim iuxta uentrem, ut milium colore referat, unde er cenchrias, boc eft miliaris, appellatur. Aiunt hanc fortiorem fieri, çim milium floret. Porró ubi fe ad ledendum parat, extendit fe ipfam, ac ueluti iaculum ui= bratum corporibus inuolat, dt;; boc modo uerberat. Ab buius morfu omnia, qua de uipera dicta funt, fequuntur accidentia, atq; etiam grauiora, adeó ut etiam putrefactiones er carnium defluxus confequantur, ac grauior item so mors fuccedat. Caterim remedia fimiliter eadem, que ad uipere morfum bis conducunt. Eft qui referat inter re $=$ centiores non obfcurus author, quod cum paftor quidam inifellus, fub cuiufdam arboris umbra xftate media quietem fomnumq; caperet, cuius focij non procul oues pafcebant, ab Acontia, que in arborem afcenderat, ita percuffus fuit in finiftram mamillam, ut illico perierit. At focij audito percußionis fonitu, uifo ferpente, quem nouerant, fuper defuncti pectus, relicto grege in propinquum rus, pauore territi, aufugerunt. Reperitur boc fenißimi ferpentis ge nus, ut quidam mibi retulerunt, in quibusdam Calabria, or sicilie tocis, ubi ipfum incole à fagitta Sattone uer= naculo nomine appellant. 


\section{In Lib. fextum Diofcoridis.}

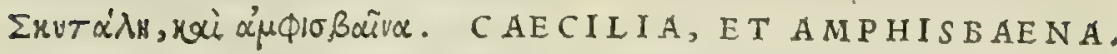 C A P. XLVIII.}

CoNS I M I L I A fuprì ditis in vipera eueniunt ijs, qui ̀े crcilia nomine, \& amphisbæna demorfi funt, eademq́ue ferc̀auxiliantur. quare hoc venenum priuatam defcriptionem fortitum non eft, neque vifum eft dignum, quod alio genere comprehendatur. De ijs autem mentionem hoc loco fecimus, quoniam ferè remedijs ad uipcras foriptis, perculsi ab eis adruturi foleant .

10 No N defunt, quifcripferint, Amphisbendm prater naturue inftitutum duobus cum capitibus gigni, que utran= que erpentis cxtremitatem occupent : fierif; ob id putent, ut fir in utrang; parten repat. Quod tamen fabulofun

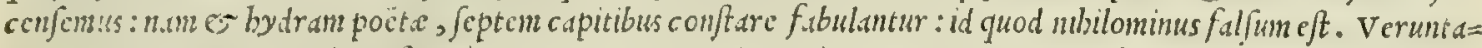
men nonnegatucin cgo id monftrose, $\sigma$ pretcr nature intentioncm cuenire non poffe in ommi ferpentium ouipa= rorum gencre, quem.dinodun $O$ wolutilium. Siquiden pluries compertum eft, ex uno tantum ono duobus uitellis re= ferto, mici pullum modó babenten quatuor alds, modó totiden crura, totidem ; pedes : atq; ctiam lacerta uifa funt aliquando becipites. Sed bae non utiq; fatumt, baberi aliquod ferpentium genus natura biceps. Hoc fcitißmé, er apertijincé confirmat Ariftoteles libro, or cap. I I I. de gencratione anmalim, fic inquiens. Monftra raró admo= dum funt in ijs, que fingulos pariunt, fed crebrims in iis, quorumpartus ef nuntrofus, $\mathcal{O}$ precipue in auium ge= nere, ponsimun'; in gallinis. Iis enint partus numcrofus, non modó quód lepe pariant, ut columba; uerum etian

20 quód mulros fimul conceptus intra fe contincant,e tcmporibus omnibus coëant. Hinc gemind etian pariunt plura: colserent enm conceptus, quoniam in propinquo alter alteri eft, quomodo interdum fructus arborum complures. Quód li witell. diftinguuntur membran.t, gcmini pulli difcreti fine ulla fuperuacua parte generantur. Sed fi uitclla contimumtw", nec wll. intcric $t a$ membrana difterminantur, pulli ex ijs monfrifici prodeunt, corpore, Er capite wno, cruribus quaternis, alis toridem . quoniam fuperiora ex albumine generantur, er prius: ( uitellum enim cibo ijs eft ) pars autem inferior pol?ca inftituitur . quanquan cibus idem, indifcretusq́; fuppeditatur. I am ferpens etiam bi= ceps uifus eff, uidelicet eaden de caufa: nam id quo ; genus oua parit, o multa numero. bec Ariftoteles. Qux fa= né mibi facilé perfuadent, ut credam, omnino fallum effe, quód Ampbisbena ex fui generis natura biccps perpetuó na featur. Verim quandoquidem hoc ferpentis genus terreftrium lumbricorum modo utrisq; extremitatibus, capite fci= licet $\sigma$ cauda, acuminatis gignitur, adeo ut difficilimé poßit caput à cauda difcerni, exiftinauere quidam banc fe= 30 ram duobus conftare capitibus. Proinde Aëtius lib. x I I I. cap. X x v I I. fcribit, Scytalam (banc alij Cacilian in= terpretantur ) $\widetilde{\sigma}$ Amplisbenam animalia effe inter fe fimilia. Non enim, inquit, ex craßis in caudan tenuem abeüt, fed equalis cra Bitudinis in uniker fum exiftunt, ut neq; cognofcant uidentes ea, iuxta utram partem caput aut cauda fint fita. Quod equidem tum in terrenis or alui tineis, tum in erucis quibusdam, tum etiam in birudinibus conpici= tur. Differi autem, ut idem tradit, amplisbend a fytala, quod illd ex utraq; parte progrediatur, unde d Gracis illi nomen unditum eft. Galenus porró libro de theriaca ad Pifonem, Ampbisbanam bicipitem effe exiftimat ( $f \mathrm{t}$ tamen liber is adfcripttius non eft) ut bxc uerba, que in co leguntur, aperté of endunt. Amphisbena (eft autem animal biceps, quemadmodun fanc $\sigma$ natigis utrinque proram habentia, cui natura ex fuperfluo fubfantia bina capita eft largita) hoc inquam animal, aiunt, fi mulier grauida fupergreffa fuerit, male abortum facit. hacille. Cate= rium, ut ip $\int e$ Aëtius fcriptum reliquit, ab utraf; demorfis contingit morfum obfcurum effe, ac uix apparere, uelut

40 funt mufcarum iqus. quapropter etianfi mordeant, non enecant tamen, fed inflammationem excitant, ut apum er ueparum ftimulus. Quare transferantur ad bos quoq; que de illis funt relata, uerum facultate intenfiore. Ex bis etian Aërij uerbis conijcipoteft, cum horum animalium iqus admodun tenuis, or obfcurus fit, A mphisbene caput inelle terrenis uermbbus, uel alui tine is perfimile: ac proinde adeó etian caude amulum, ut alterü ab altera non nifz dificilé drfcerni poßit. Caciliam autem Hetrufci uulgó appellant Lucignola. Amphisbane corium, authore Nican dro, oleaftribaculo circumueftitum, finanibus frigore torpentibus tractetur, calorem ftatin adfert, articulorumíg. nexus diffoluit.

$$
\triangle \text { güívos. DRYINVS. }
$$

CAP. XIIX.

5o A' D R Y I N o morfis puftulx, moleftique dolores incidunt, præertim quà dilutæ faniei emifTarium fubelt: quinetiam erofio, torminaque confequuntur. Ab co ictis conuenit ariftolochia cum uino pota, trifolium herba, radix haltulæ regiæ fimiliter affumpta, \& fructus ex omni glandiferarum arborum genere: \& tufx ilicis radices, \& illitæ parti i£t auxiliantur .

D R Y I N v s, ut in theriacis teftatum reliquit Nicander, in quercubus latebras parat, aut alicubi in concauis $f a g$ is, $m$ montibus uerfatur. Appellant eum alio nomine etiam bydrum, fed $\sigma$ alij chelydrum, qui relict is bryis, $p a=$

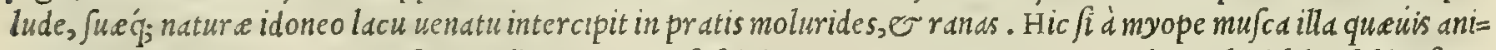
mantis prouocante, petatur, in fuetum illum impetum fufcipiens, cum concaus quercus robur celeri faltu fubit, fru= cto fibi in imo cepite cublli. Candet tergo, caput illi aquale, adeó́; bydro finile: grauis autem foetor à corpore cius cuaporat. Quemadmodunt quaní incurux, necnon abrafa corij prefegmina fub ter etibus ferramentis circa bumen= tes equorum exuuias, e pelles lument. Si quempiam is uel in talum, uel pedis plantam percuferit, à corpore ittibo=

Amphisbenx', ¿x cæcilix confider.

Amphisbęna biceps nöeft.

Vtriufq; mor fus figna, \& curatio.
Dryinihiftoria, \& eius ICtus notx ex Nican. 
minis difficilis odor parfus fertter, atq; circa idum niger in acutum furgit tumor, mentemq́; merentis angor, or tri= fitia, qubus detinetur, ob curant. Species nimio dolore conflaccefcit, E perit : cutis cum corporc ámodum malẻ

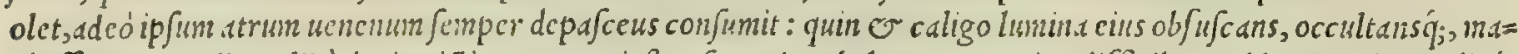
$l \dot{e}$ affectum perdit. Alij à dryino ifti caprarum inftar fcu ouium balant, ac onnino difficilcs redduntur, impcnáio $\dot{q}_{;}$ cruciantur. Vrina eis decutitur, o palle fcit. Ip/i ueró dormitantes ftertunt, frequentibus fingultibus correpti,allis

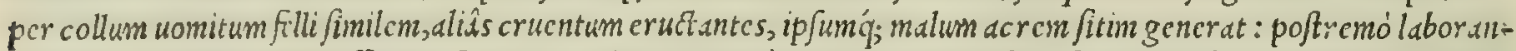
tibus membris tremorem effundit. bee Nicander. Ceterim Dryini nomen buic fere mortifere inditum cft, quod in qucrcuum caucrnis, qux prope radices funt, ftabuletur. Grecis cnim quercus $\delta$ is dicitur. Proinde Galcnus libro de theriaca ad Pifoncm, de dryino ita foribit. Dryinus ferpens fic nominatus, quód in radicibus qucrcuum uitut, $t$ um malignus ad perdendum proditur, ut eius, qui fupergiediur imprudens, cuits à pedibus excorictur, totacrura ad= $\mathbf{2} 0$ modum intunc $f$ ant, $\sigma$ quod magis mirificum eft, menus quoque ep $\int e$ curantium codcm modo periclitentur. Si als= tem quis aggrediatur eum perimere, olfactu adeo muld ari aiunt, ut quemlibet gratü odorem praunm effe exiftimet, Dryini defcri nec alterius preterea rei queat fentire. bactenus Galcnus. Dryino, ut Ac̈tiusinquit, abundat Helleppontus. Is la= ptio, \& mor- tibula in quercuum radicibus babet, atque adeo fatidus cft, ut etiamfi quis eum non uideat, fretore loci cognofcatur. tus curatio. Eft autcm cubitorum duorum longitudine, obefus, ac aperrimis fquammis circa uniuerfum corpus munitus. Porró qui, ab eo percutiuntur, bis tumor infurgit nigricans, dolor uchemens, nome, delirium, corporis ficcitas, fingultus, biliofus uomitus, aut omnino fimplex, urine fuppreßjio, tremor, interceptio nocis, ftupor, fcifura, or mortufica $=$ tio percufforum locorum: plurimi ctiam intercunt. Porró or hi quoq; ex ijs, que in uipere mor fu difa funt, opem fentiunt :item '́; ex communibus remedijs iuxta confequentium acceßionum proportionem adlibitis.

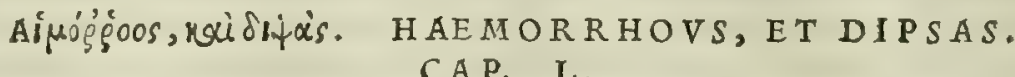

A B H AE M ORRH O O ictis vehementes cruciatus accidunt, qui angufta, contract aq́ue corpara ex continuo dolore reddunt. Ex plaga copiofus fudor cftuir; \& quacunque parte corporis cicatrix ulla fuerit, ea fanguine manat. Excrementa per aluum cruenta ejjciuntur, profluensque fanguis in globo coit. $A^{\prime}$ pulmone fanguinem extufsiunt, $\&$ in uomitiones effufi fine remedio commoriuntur. Quos uerò dipfas percufsit, folutus ac non confrictus tumor premit, fitisq́ue usque eò pertinax, ut fatiari non pofsit, ac fine ulla intercapedine excruciet : \& fi potum plcno ore affatim trahant, illico in eandem fitim relabuntur : proinde toto habitu fimiles funt ijs, qui antea potus nihil hauferint . quare propter continuam fitim, \& prefter, \& caufon, aut dipfas appellatur. Hemorrhoi, dipfadisque morfus uelut immedicabiles à plerisque maiorum doplorati relinquebantur . quare fi peculiaribus contra dipfadem rcmedijs egeamus, communia experiri operæpretium erit. Protinus autem farificatione uti, uftionem facere, \& filocus patiatur, extremorum amputatione opus erit: confequenter quàm acerrima cataplafmata admouere, de quibus fapenumcro diximus. Nec me fugit, acres cibos, maximè à falfamentis, utilcs effe. Meraca potioncs, \& latacra profunt, qux fubinde interiefto breui fpatio affumenda funt, priusquàm morbi genus emerferit . quo femel erumpente opem ferre non poteft ulla medici opera. In ietu hamorrhoi cadeni profunt. Infuper quæ in commune opitulantur, ut farificationes, uft iones, acres cibi, meraci potus, \& qux nunc in dipfade definiuimus . Quinetiam decocta uitis folia, \& cum melle trita.

Hxmorrhoi perniciofusiEus, \& hiltotia.

H AE M O R R H O V $s$, e Hamorrbois, authore Galeno in libro de theriacd ad Pifonem, fuis ipforum nomi= nibus fimilem hominibus perniciem inferunt . quippe percußi, fanguine per os, er nares, totoq́; corpore effufo, inte= reunt. Hic (ut in theriacis cecinit Nicander) petrofas rimas a Biduó incolit, afperum. Jupinum, o modice pendens tem lectum illic fumens, ubi tractum fuum babeat, deinde pabulo fatur fiat. Longitudo ciks pedis ueftigio aqualis: caterim quod ad latitudinem attinet, d̀ capite adusque caudan totus or fubtilis, er minutus cft. Aliâs colore igneo, aliâs rur fun candens. Collo fatis conftricto cft, gracilis cauda necefjario in arctum contracta, extenta eff angulté, o tenuiter. supra eius frigidos, o niuales oculos, duo cornua fronti funt infufa: alborc luminum fuorum, locu= fis uel fylueftribus apibus par. Infuper horribile, or aperum ei caput horret, obliqué modico corpore fuo inftar cerafte claudicans. Ex medio etiam dor fo paruum nauigium femper appellit, ad terram uentrem fium atterens: fquamis ueró o itinere parüfubftrepit, perinde ac arundinis copiam tranfeat. Poft ictum ftatim decolor fpecies ac: currit, nigra nimirum, cor'q; ipfum dolore circumangitur : uenter aqua refertus effluit. Quin o prima nocte fanguis cùm ex naribus, tum collo, $\mathcal{O}$ auribus falit, recens biliofo ue neno coinquinatus : lotumi item rubens accurrit . queé; in corpore funt uulnera, $\mathcal{O}$ plag a, bemorrboi rumpuntur aperiuntur'; : cutes cnim fuligine contr abuntur. Caueas itag; in primis, ne in te foemind hemorrbois uirus fuum idculetur. Nam fi cui morfum illd inflixerit, eigingiue fimul ignefcunt, peritusq; ; unguibns fanguis cum impetu procurrit. Dentes cttain ex ea cade gracolentes, feu bumen= tes molunt. hac ex Nicandro. Cui fubfcribit Ac̈tius, fic inquiens. Aninulia bec (hemorrhoum, o hemorrhoida intellige ) colore quidem funt arenofo, magnitudine autem tres palmos aquant, e in temem caudan angusa figura paulatin de finunt. Sunt autem igneo oculorum fulgore, rcet.óg, Cr tardé proreptant. Per corpus weró imultis notis albis, of nigris uariegata funt, ơ apperioribus fquamis obfit.1: quapropter dum ferpunt, fonus auditur. Et foemina quidem uentri incumbens, per terram reptat, e gref]um inferné circa caudam firmat: : mas ucró circa uentrcm in 


\section{InLib.fextum Diofcoridis. $\quad 773$}

greffu nititur, or collum ferpendo extendit. Conf cquitur horm norfun color iti loci cruentus, coloris tetri, or

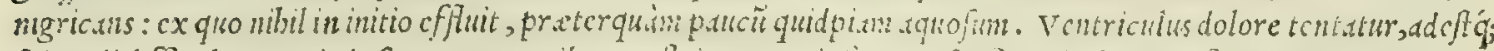

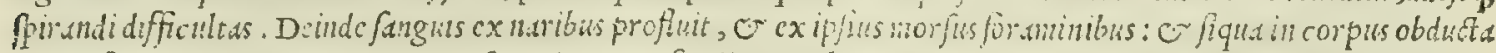

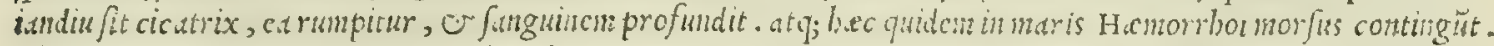

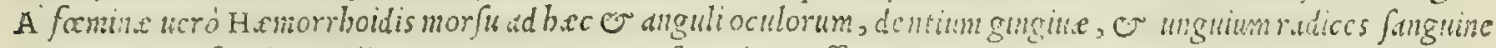

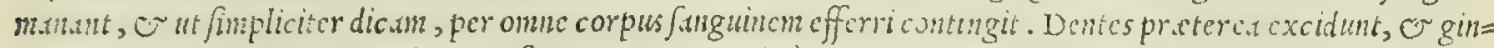

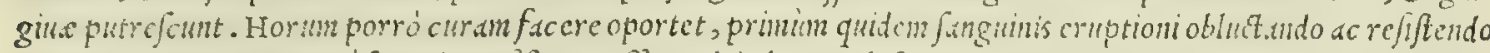

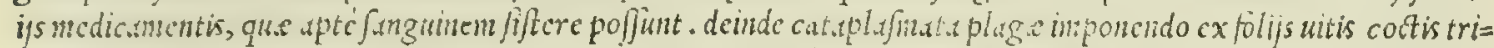

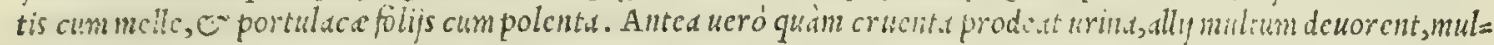

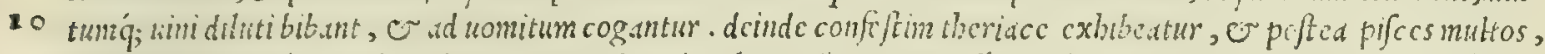

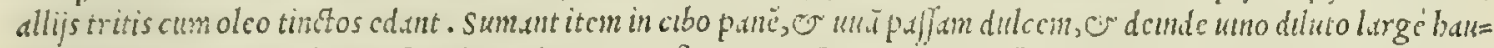
fto womant. Plaga ucró aquafrigida proluatur : uefica autcm fpongijs calidis foucurtur. Sediande Dipfade diffe= ramus, que fic à Gr.ccis dict eft, quòd continuan, $\sigma$ incxtinguibilen fitin excitct. Huius mentioncm fecit Galenus

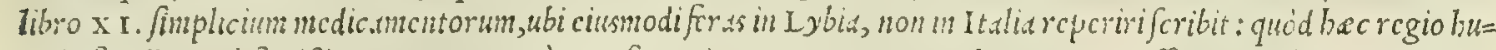

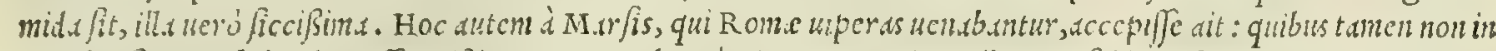
omnibus fidem albibcndsm cffe exifinat. Quare longe minus nos ijs circunfor anc is fide preftarc debcmus, qui Mar=

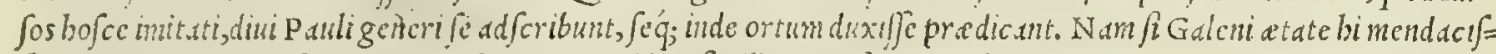

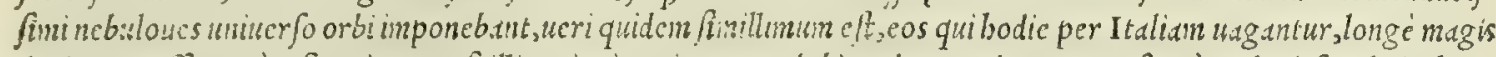
decipere polfe, quàm feccrint Nirfílli antiqui. quippe non dubitandum, quin corum aftus à Galeni feculo in bune

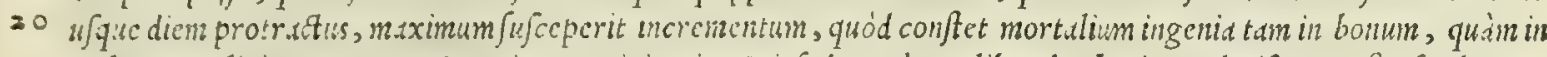
m.lum procliui, atate magis acmi. Neminit etian Dipfadis Galenus libro de theriaca ad Pifonem, fic fcribens.

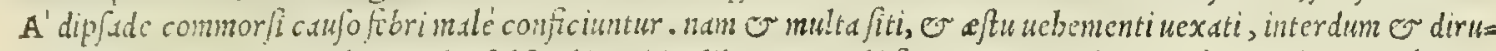

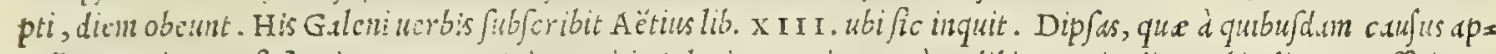

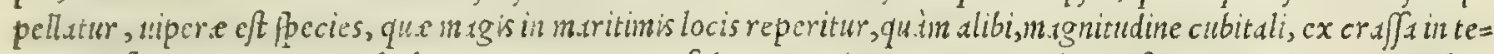
nuem definens : not xs autem habe: par omne corpus fuluxs, or nigras : caput ueró angufius. Sequitur autem ab ed denorfos, preter ca que de uipcr. dicta funt, o fitus intolerabilis plane, adeo ut ctiam/i multus potus eis adbibed= tur, fitis non fedctur: or tamen neque per urinas, neque per uomitum, neq; per fudores quic quam excernitur. Duo= bus igitur perewist modis, aut ob imultan fitin exufi, ji potum non funant : aut ob muliam potus repletionem diften= tus rumitur wenter, ucl inferné circa inguina, uel circa imum uentrem, ut in a flua inter cutem fepius enenit. Catex

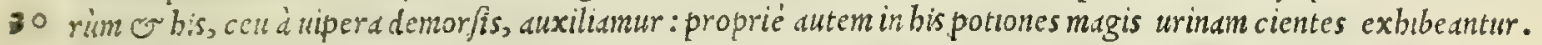
Aluus item per infufum eluatur, or oleo cum decoat is exhibito, ad uomitum cogendi funt male affecti. Ad plagx ue= ró locum, poft exuctionem, circuncifionem circunquaque falpello factam, cucurbituldrum affixionem, er delfect as gallinas admotas, calx uiua cum oleo imponitur, o cmplaftra attractoria, o theriacd illinuntur. Porró Dipfadis priuatim nemiat Aclianus lib. I x. de biftoria aninulium, fic inquiens. Dip $\int a s$, cuius uin, er naturam eius,nomen nobis declarat, inferior quidem eft magnitudine, quàm uipera, fed tamen in occidendo quàn celerrimé fuperior. Cu=

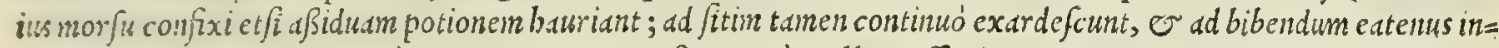
famnal:tur, quo.rd celerriné runpantur. Eam Softratus cum albam effe ait, tum duas in cauda lineas nigras babe. re. Et ficut audio, uario, multipliciq́; nomine nuncupatur: quidam prefterem uocant, alij caufonem, alij anomba= ten, à quibusdam melanurus appellarifertur. Cum in Apbrica, tum magis in Arabia nafcitur. hec Aclianus. Ex Leoniceni er

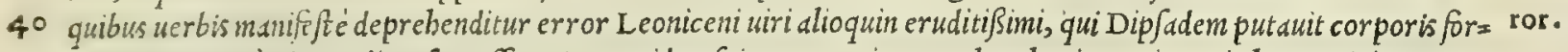
man nullis not is à upera diuerfam effe. Nec equidem fcio, qua ratione, uel authoritate nixus, in banc opinionem uea nerit, in eág; perfiterit.

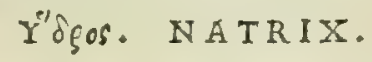

\section{CAP. II.}

A в X A T R I E demorfisvlcus dilatatur, \& liuidum, acingens euadit. Sanies ex co multa, \& atra, \& malè olens, non fecus atque ijs quæ ferpunt vlceribus, expuitur. Si ergo morfum natrix adegit, prodeft origanum tritum, \& aqua fuka \&um : lixiuia cum oleo indita, aut ariftolochix cortex, aut querna radix minutim contrita, \& hordei farina cum aqua, \& melle colliquata. Bibuntur etiam

so binæ ariftolochix drachmæ in potione pofcx cyathis duobus, deinceps marrubij fuccus, vel decoEtum alterius cum vino. faums recens datur in aceto.

H Y D R V s anguis in aquis plerunque degit, à quibus nomen fibiuendicauit. Sunt or qui Natricem, quód d= quis innatet, uocent. Hic fir relictis aquis, terras inbabitet, longé nocentior euadit, uocaturq; tunc cherfydrus. Dif= fert tamen is à dryino, qui ( ut fuperius diximus) Nicandro bydrus etiam appellatur. Siquiden ip fe de Hydro, cuius nunc buftoriam, morfus difcrimina, or remedia profequimur, differuit fub cher jydri nomine in theriacis, fic carmine in profam wer $\int 0$ cribens. Age itaque cher $\int y d r i$, qui apidi conformis eft, figuram aqualem recita. Sed plugam eius malefica, $\sigma$ peßtma anéfigna equuntur. Tota cutis circa carnem arida, or abominabilis expaffa ab internis par" tibus, bumentem icfum fatis certó indicat, putredine fathifcens. Quinetiam dolores immenfí ig ne fcentes, bominem tandem unterimunt . mox etiam per membra pufule finguntur, alie ex alia parte inuicem turbantes agrum. A tqui cher fydrus iam antea in unido, Seu parum aqua habentilacu, irreconciliabilem ranis iram adfert. Enimuero ubifole 
aqun exiccaid fucrit, adeog; ariditas in findo extiterit lacus, tumbic ferpens in terra fe fe continet, er fquallidus; $\checkmark$ deformis in fole tetrum corp:us fum refocillans: in femitis autem, lingud fua aflando fitibundus fulcos exedit. hac

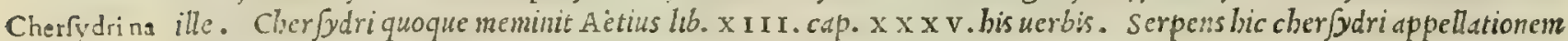
tura, morfus, iide habet, quod in pruscipio quidem in aquofis degit loc is, er bydrus appellatur ab ipfis aquis, hoc eft natrix. pofted \& curatio. ueróficcos incolit locos, o ex compofitione locorum, cherfydri, id eft natricis terreftris, nomen inucnit. In bume $=$ Et is qudem locis, ex humido vitu ex atiatus, non purum uenenum babet: ciun autem terreftris fit, nocentius id ac= quirit. Caterum forma, paruam terieftrem apiden refert, preterquàn quód ceruicem non ita latam babet : boc $e=$ nim infigne folum apides pre bis habcnt. Qui igitur ab hoc mor fi funt, eis communiter eadem accidunt, que in allo= rum ferpentiun mor $\int u$, ueluti eft tumor, continuus dolor ardens, liuidus locus, E feculentus, uertigo oculorum, exolutio, uomirus bllio Jus, ac fretidus. Proprié autem motus tolius corporis inordinatus, ut et per uentré quadam in= ordinaté ferantur : mors autem intra tres dies. Porró cx comnunibus remedijs etian bi opem ferunt, or ex theria= cis antidotis. Priuatim ueró coni cupreßt drachmam unam, et myrtibaccarum itidem unam, tcrito, $\sigma$ cusn melle ro= facio, aut uino mulfo in potu exbibcto. Iuxta ueró affectum locum calcem uiuan, or fimulia, cum oleo imponito.

\section{KérXgos. CENCHRVS. CAP. III.}

C E N C H R I morfum, quiviperino istui fimilis eft, putridum vlcustequitur.'carnes antea, vt in aqua inter cutem, prætumidæ defluunt. lethargo corripiuntur, \& veterno prefsi fomnos captant. Erafiftratus eos iecinore, inteftino ieiuno, coloq́ue conflictari author eft quippe diffectis ipfis, omnes ferè partes corruptæ reperiuntur. Morlis à cếchro auxiliatur lactuca fruetus cum lini femine illitus, \& fatureia trita, \& fylueftris ruta, \& ferpyllum, cum duabus haftula regix drachmis, \& tribus vini cyathis, aut ariftolochiæ radix, item cardamomum, \& gentiana.

Cenchri con QV A V I s Aëtius appellatuit Cenchrum ammoditen, or acontiam cenchriten; non tamen propterea cen $\int e n=$ fideratio. dum elt Cenchrum, de quo bic differit Diofcorides, ammoditen, aut acontiam effe: quód bic nullan cum illis babedt cognationem, nec fimilitudinem. Ea autem de caufa Cencbrus diatus eft, quód maculis perquàm minmis ( $u t \mathrm{~L} u c d=$ nus eft author) milij magnitudine, or colore, uniuerfum eius corpus repperfum appareat. Auicenna cenchrum fa= mojum appellat.

\section{Kegóshs. CERASTES.}

CAP. LIII.

A' C E R A S T E percufsis locus attollitur, cum duritia puftulofus è plaça fanies profluit, modò atra, modò pallidió : fed toto concretu varicofus intumefcit : genitale intenditur, mens labat, \& oculorum caligo exoritur : denique rigore neruorum diftenti commoriuntur. Siceraftes percufferit, cita partis amputatio fuffragatur . quare fine mora ictam partem amputare, aut falpro confeftim circuncidere, \& ijs fimilia profequi oportet. Vrentia infuper reliquijs admouenda: fiquidem virus hoc veneno bafilifci fimile eft.

Ceraftx mor C E RA S T AE, quorundam probatißimorum autborum tefimonio, in Apbrica duobus in capite cornibus cos fus exitralis, chlearum inftar oriuntur, ḋ quibus cerafte, boc eft cornuti, nomen inuenerunt. Horum mor fus lethal is feré femper 40 \& auxulia. fuerit, nifi (ut Diofcorides inquit) demorfum membrum ftatin d̀ reliquo corpore abfcindatur, amputetur'q;, dut fal= tem illico omnis caro, que demorfum ambit locum, circuncidatur. Immanis bec fera (ut refert Aẹtius) cubitalis eft longitudinis, longißina duorum eft cubitorum, corpore ueró areno $\sqrt{a}$, ev iuxta caudam de quamata. Eminentias babet in capitc duas, cornuum fimilitudine : partes ueró circa ue ntrem ex ordine fquamis obfite funt . quapropter in ferpendo fonum fibilo finulem edit : per obliquun autem, non reità proreptat. Ceterum percußis abea, cleudtio ac tumor plage capitis claui fimilitudine infurgit, e fanics profluit uini colore, aut nigricans, er maximé per am= bitum, uelut in cruentatis ac Jugillatis altâs fieri confueuit. Reliqua item, que in uipera morfu dicta funt, ctiam bis fuccedunt, cum intenfione uehementiori. Vt plurimim ueró $u \int q$; ad nonum diem fuperfunt. Remedia autem eadem, que morfis à uipera conferunt . hec Aëtius.

$$
\text { A'oris. ASPIS. }
$$

CAP. LIIII.

A B A S P I D E ictis vulnus exiguum prorfus, quafi ab adacta acu citra tumorem confpicitur: fanguis exiguus ille quidem, fed ater diftillat: caligo uelox oculos obnubit: labor in totum corpus multiplex, omnino lcuis, \& non fine uoluptate confequitur. Ideo Nicander perpulchrè cecinit. At uir perit abfque labore, virens, atq; difcolor. mediocris ftomachi dolor afficit : frons perpetuò reuellitur: genx contremilcunt, quafi fine fenfu in fomno uacillent . hos mors tollit, ad diei trientem non dilata. Cxterùm ijs, qui ab afpide feriuntur, quæ de cerafte fcripta funt, auxilia dari debent. Nam uenenum hoc, yuemadmodum bafilifci, aut fanguis bubulus, celer rimè in arterijs fanguinem cogit. 


\section{In Lib. fextum Diofcoridis.}

- R E P R I O apud cos authores, qui animaliü bifiorias trudunt, tria Apidum genera confitui, $\odot$ ununquod= que, ubi bominem norfu comprehenderit, cclerrme mortem inferre : quippe tanta eft carum ueneni uis in hominum necen, ut rarifine ferucntur, qui ab cis percußi fuerint. De bis foribcns Galenus libro de theriacs ad Pifonem, /ic inquit. Inter spides nominats piyss collum exporrigens, ov patii metita longitudine, perinde ac fi tunc rationslis

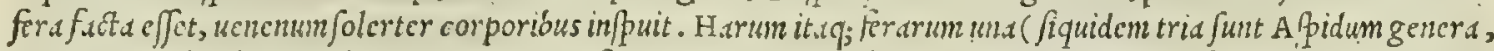

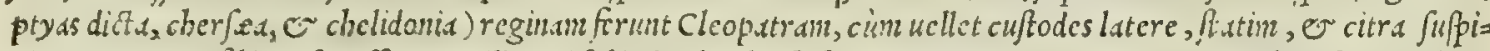
cionem mortem /jbi confciuifec. Hxc ille, qui fubinde pluribus biftorian enarrauit tam inuiti animi buiufce moribun= due regine. Cetcrum cbelidonian uocat.m, id nominis fibi cont araffe nolunt, quód birundinü modo dorfo nigricet,

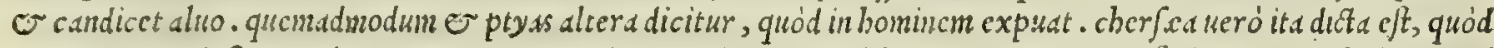

a in mediterrancis. fomper degat. Harum omnium meminit Actius libro x 1 I $1 . c a p . x \times$. fic inquiens. A pidum apud ferarum friptores tres pipecies reperiuntur . quedam enim ex eis terreftres appellantur : quedan ueró chelidonie, que circa flumiorum rip.1s, prafertim Nili, latibula babent: alie ueró ptyades nominantur. Terreftres quidem igi= tur maiores funt, o quandoque usq; ad quinque cubitorum longitudinem reperiuntur. Maxime ucró piyades, cine=

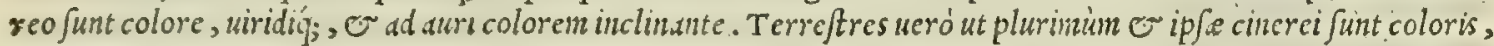
quanquam $\sigma$ fubuirides reperiantur. Caterum acceßsiones, 0 figna comnunia funt in bis, quos apides momorde= runt. Vulnera enim in demorfo loco, ueluti ab acupunct inucnuntur : bina quidem ex maris imorfu, ex fomelle ue= rò quatuor citra magnum dolorem, à quibus wibil cffluit, nifi uiolentum animal fit, quod mor fun inflixit. Confequi= tur autem ft: por, pallor, fiontis refigeratio, aßidui biatus, palpebrarumnictationes, colli inclinatio, capitis graui= tas, fegnicics, 6 collap/io in fomnum profundum, ad finem uero er conulfio. Mors autem in tribus ad fummum bo:

so ris ex terreftris mor $\int u$ equitur : in chelidonia ueró ictuprefentißima adeft. Porró bis, qui à ptyade confuuntur, caligo oculorum fuccedit, e cordis dolor, facici tumor, ac auditus corruptio : tardius autem mors confequitur. Au= xilium autem ab apide morfi ferunt, or prafertim quos ptyas momordit; ex acerrimi aceti potu : dandum aútcm eft, quoufque aceti qualitatem circa dextram pracordiorum partem perceptent. bepar enin in morfis ab afpide pri= mum aiunt fenfupriuari. Caterim ad prenotionem, an uicturus fit percufJus, centaurium cum uino tritum biben= dum prebent: fiquiden enim etsomet pharmacum, morietur, finon, uiuet. Quo uéró ueneni in corpus diftributi uis probé ekomatur, allia trita cum zytho exhibenda funt, donec naufeabundus reddatur malé affectus. aut opopanax cum uino diluto detur, $\odot$ confeftim enomet. Numius autem inquit. Origanum uirıdem, aut aridam pro agri uiribus cum uno dato. Poft uomitum antidotis theriacis utendum, or communibus remedijs predictis. Vtiliter autem ad pla gam imponuntur poft cucurbitarum adbibitionem, ẽ fcarificationem, centaurium cum myrrba, e modico opio.

30 Rumex autem fi catapla jmatis modo imponatur, nibil ladetur. Preter opinionem ueró auxiliatur theriace tum pla= ge impo/ita, tum pota. Profunt autem et aßidue excitationes cum euulfionibus, et plagis, et uniuerfi corporis mo= tus, of aqua marina calida pro fomento apper $\sqrt{a}$. hatenus de apidibus Aëtius. Efficacißimum porró, oo omnium, quantum equidem expertus fum, preftantißimum antidotum contra uenenofum ictum apiduin, quas furdds dicunt, que in I talia pluribus in loc is reperiuntur, efț noftra quinta effentia, ex aqua uite et antidoto noftro confecta. Quippe cim tenuium admodum fit partium, iqu oculi in uniuer fum corpus diffunditur, uenas, et arterias confeftimper= means. Vnde probibet, ne fanguis et piritus in uafis refrigerati cogantur : atque aucto calore innato, ueneni uim ar= cet potentißimé, id'q juperat citißimé.

\section{BณбiAioros. BASILISCVS. CAP. LV.}

ERAS I R R T V S in libro, quem de medicaminibus, \& venenis condidt, de vocato baflifco ficitè ita refert. Cùm bafilifcus momorderit, vulnus ad auri colorem efflauefcit . Itaq; in plurimis, quæ virus eiaculantur, comites notæ ita fe habent. Adbafilifi morfum, vt idem Erafiftratus aua thor eft, auxiliatur caftorij drachma in vino pota: item papaueris fuccus. Ictuum remedia ita fe habent.

M V L T I P L E X uariá;; eft apud frarum fcriptores Bdfilifcibistorid, quem Latini Regulum uocant. Sunt enim qui fribant tante perniciei anmal effe Bafilifcum, ut folo oculorum intuitu, alij fibilo tantum, alij balitu, alij
uerómorfu, homines fatim interimat. Nec defunt qui uulgi opinionem fecuti, ex antiquigalli ouo banc fauißiman

so fram nafciputant. Ex hac itaque hiftorix uarietate, ac inconftantia facilé adducor, ut credan, plerofque biftoriá bafilijci, ut fabularem, difcripfiffe. Id quod etiam probé Diofcorides $\int e n f i \iint e$ atq; adeó noftro iudicio adftipulari ui= detur. Siquiden is ne cum alijs accufaretur, Erafiftratum citauit, authoremq́; biftorix buius fecit. Bafilifcimeminit Galenus libro de theriaca ad Pifonem (fintanen liber itle inter legitimos cen ctur) ubi fic inquit. Bafilif cus bellua fub= flatu, $\sim$ triplici frontis apice munita, tantummodo confectus, $\odot$ quando fibilat auditus, uidentes $\int e, \approx \sigma$ audientes necat: at w; fi quod aliud aninal illum etiam mortuum attingit, ftatim moritur. Hinc diunt omne aliud reptiliï genus cauere, ne balilifco uicinum babitet. Libro ueró x. cap. primo de fimpliciun medicamentorum facultatibus idem contra Xenocratein fcribens, non omnino Zafilifcibiftoriam comprobare widciur, fic inquiens. Nambcftiam feu fe=

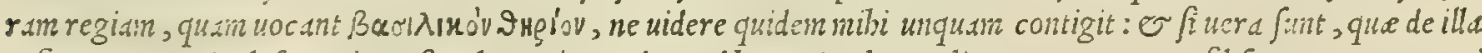
referuntur, periculofum etiam eft uel propé accedere ad boc animal. Aclianus pratered Bafilicum tanta ueneni acuitate, ct immanitate pollere ait, ut quanuis magnitudine dodrantale non excedat inenfuram; ferpentes tamen cris nes etian ingentes Jwo duntaxat halitu extinguat, adeó ut uirga quoque é longinquo contakius, illico tangentem

Bafilifci varia hultoria.

Afpidum hiforra, it? no ix, \& cura.

,...

... 


\section{6 \\ And. Matthioli Comm.}

conficiat. Huiusitem borrendißime fra hiftoriam tradidit Plinius lib. v I I I. cap. X X I. ubi itd friptum reliquit. Apud Heperios Aethiopas fons eft Nigris, ut plerique exiftimauere, Nilicaput, ut argumenta, que diximus, per =

Catoblepas. Juadent. Iuxta bunc fera appellatur Catoblepas, modica alioquin, caterisq́; mcmbris iners, caput tantum pragra ue agréfrens: id deictum femper in terram. Aliâs internecio bumanigeneris, omnibus, qui oculos cius uidere, confrftim expirantibus. Eadem er Bafilifeiferpentis eft uis. Cyrenaica bunc generat prouincid, duodecim non amplius digitorum magnitudine, candida in capite macula, ut quodam diademate infigni. Sibilo omnes fugat ferpentes: nec flexu multiplici, nec ut reliqua, corpus impellit, fed celfus or erectus in medio incedens. Necat frutices non contas cos modó, uerime afflatos: cxurit berbas, rumpit faxa. Talis uis malo eft. Creditum quondam ex equo occifo hafta, or per edm fubeunte ui non cquitem modó, fed equum quoque abfumptum. Huic tali monfro ( epe enim ene= ctum concupiuere reges uidere) muftelarĭ uirus cxitio eft: adeónature nibil placuit effe fine pari. Inijciunt eas ca= uernis, facilé cognitis fola tabe. Necant ille fimul odore, moriuntur q́;, er nature pugnam conficiunt. Hec de bafi= Plura fabulo- lifco Plinius. Quem tamen plura cim alijs fabulofa narraffe putamus. Nam fi tantun oculorum intuitu, fibilo, aut fa in Balilici halitu hominem interficit, non equidem uideo; quomodo factum fit, ut ij qui ip $\int u m$ uiderunt, ciusq́; facien adnotds h.toris. $\quad$ runt, ex quorum poftea relatione huius feré biftoriam plerique defcripferunt, incolumes cuaferint: prefertint cùm tam paruum fit animal, ut nifi é propinquo loco conpici poßsit. Atque adeó bine mibi impoßibile uidetur, quin ipfe apicientes non uiderit, cim ( $u t$ Plinius refert) non multiplici flexu inceddt, ut reliqua fer , fed celfus, er cre ctus: uel quòd ex infecto circumftante đëre, qui uiderunt non perierint. Caterum cum Erafiftratus bis fabulis nul= lam fortaffe fidem adhiberet, certo $\dot{q}_{j}$ fciret Bafilifcum morfu tantù, ut alic fer c, bomines interimere, eius dun= taxat morfus curationem inftituit. Verim quandoquidem buiufce ueneni uis adeò uchemens, or immanis exiftit, ut expugnari non poßit, non eft cur plura bic referam, quam ex Erafiftrato memoria prodidit Dio fcorides. Quem dus 20 cem er authorem fecuti, ut ip $\int e$ Juis de medica materia libris boc fexto finem impofuit; itanos noftris in eos commentarijs, quos ad noftram communemí; rei medica fudioforum utilitatem conf crip/imus, iam ex= tremain manum imponemus. Non obliti immen as gratias agere D E o optimo maximo, cui or omnia accepta referimns, $\sigma$ bonorem ac gloriam tribuimus

fempiternam.

LIBRISEXTIET VLTIMIFINIS.

\section{Venetiis, In Officina Erafmiana,}

Vincentij Valgrifij . 


\section{Petri Andrex \\ M A T T H I O L I \\ S E N E N S I S}

Serenifsimi Principis Ferdinandi

\section{Archiducis Auftrix \&c. \\ Medici,}

A P O L O G I A

ADVERSVS AMATHVM LVSITANVM

Cum Cenfura in eiufdem enarrationes.

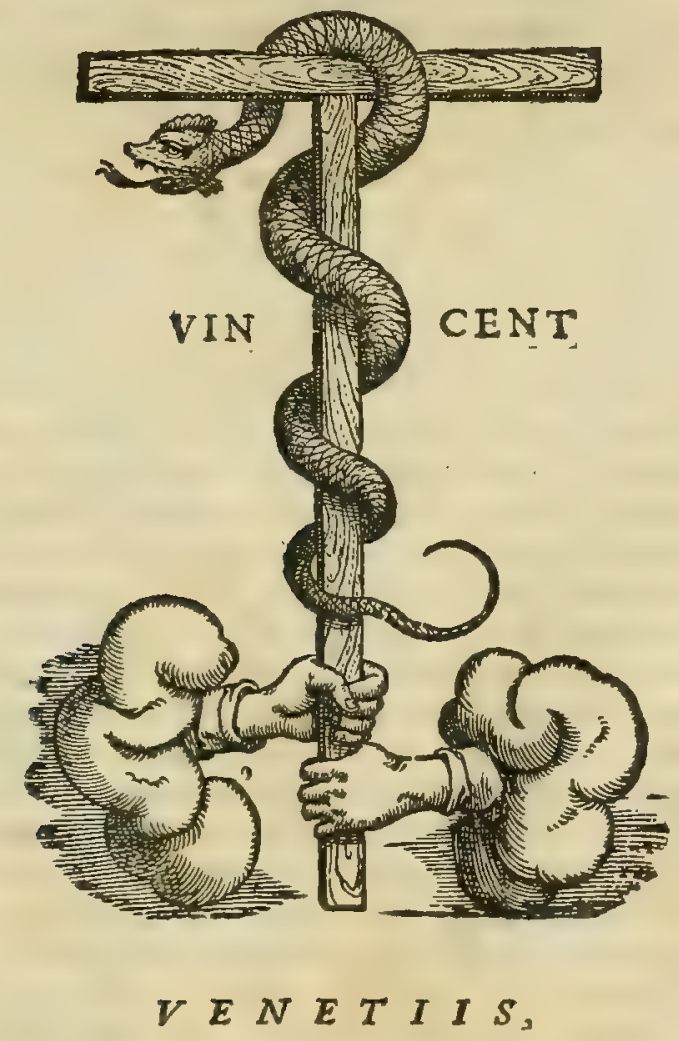

Ex Officina Erafmiana, Vincentij Valgrifij.

$M$ D L VIII。 


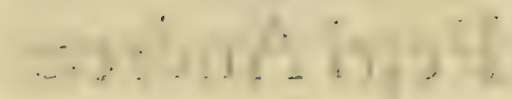

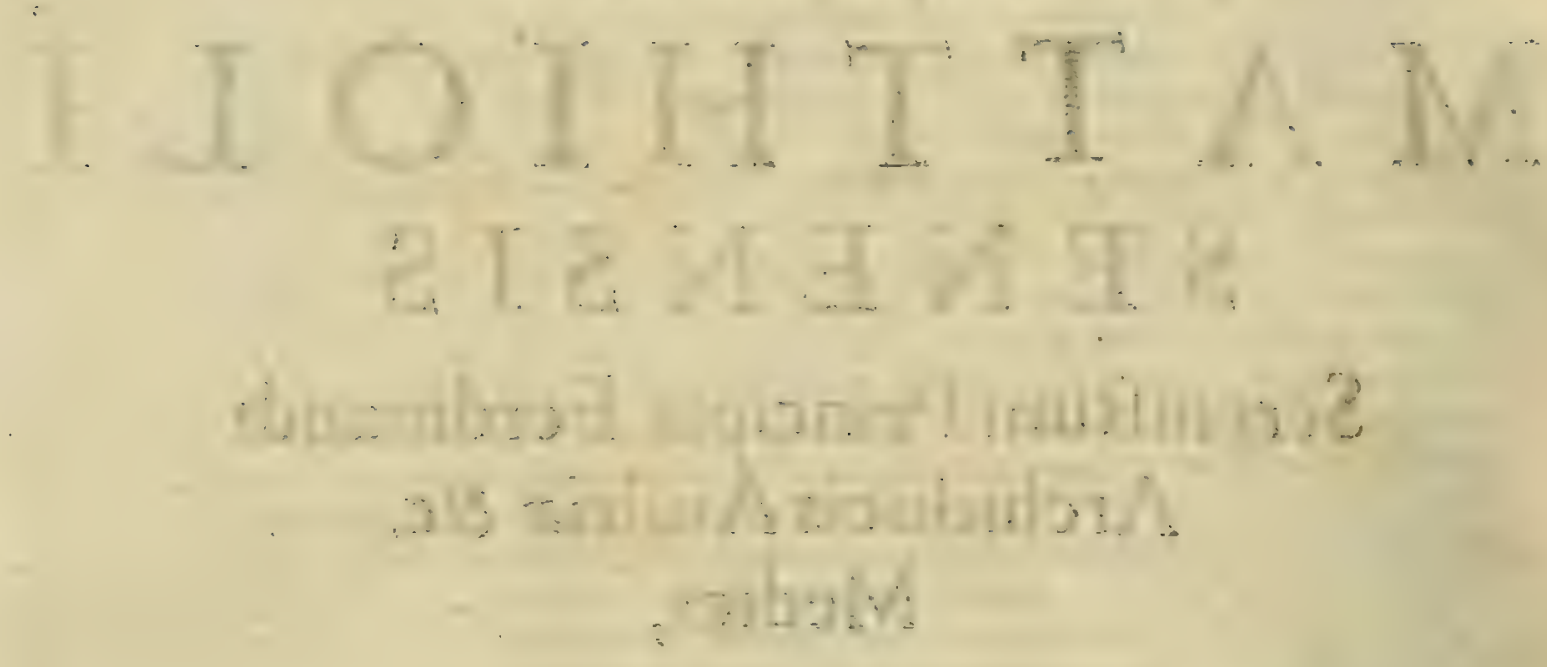

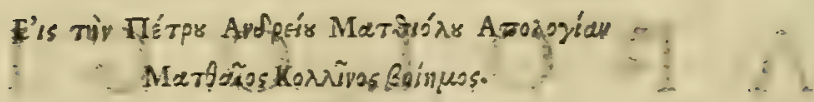

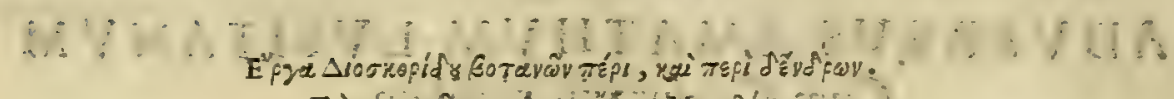

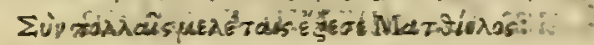

O

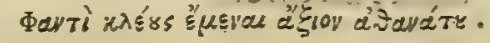

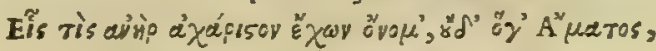

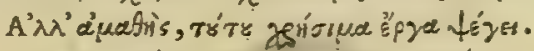

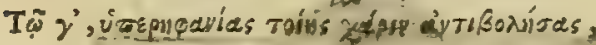

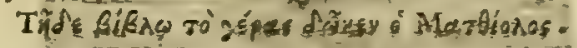

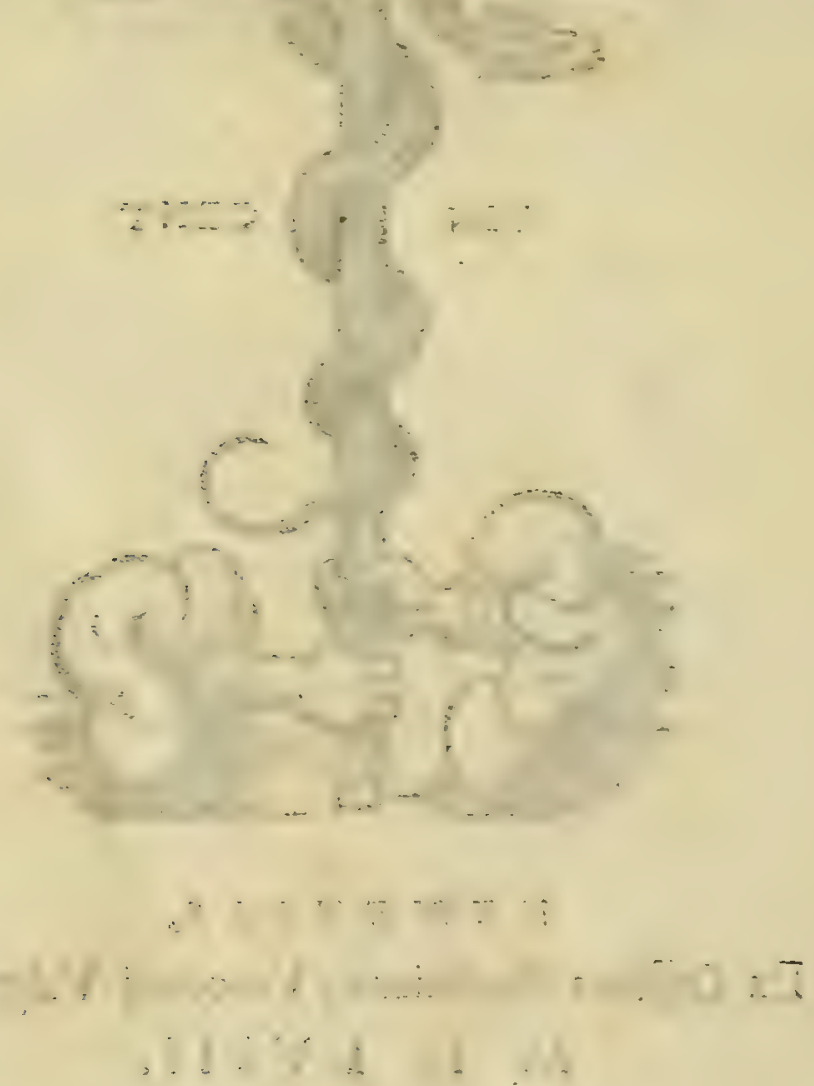




\title{
FRANCISCVS PARTHINVS
}

\section{$\begin{array}{llllllllllll}R & O & B & O & R & E & T & A & N & V & S\end{array}$ \\ Serenifsimi MaximilianiRegis Bohemix}

\author{
MEDICVS PETRO ANDREAE MATTHIOLO
}

PRAECLARISSIMO MEDICO.S. P. D.

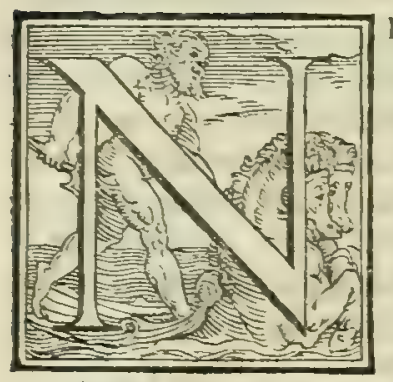

E M I N I boc unquam mortalium bactenus conceßum fuife uideo ( prestantißime Natthiole) quantuncunque in quatis precelleret facultate, ut in tanta $p_{a} \beta_{t m}$ indicios run, ,ententiarunǵ; ustietaie, omnium defiderid, or omnium aninos aqualitcr exples ret. Atque in bac communi mortalum quidem infelicitate nefcio quomodo placatiores, o longe plus femper moder atos fe exbibent boni uiri, in quibus or uirtutis, ac fingularis

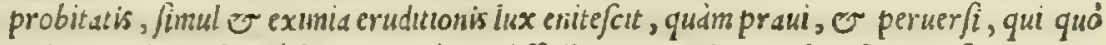
masorsimplicatifunt infcitia, tantó $\sigma$ difficiliores, 0 in omnibus fe morofiores prebent. Vt quod ignaula, uel mentis bebetudine, fiue fuo quodam infortunio non ualuerint adipifci, id fus imperitix tenebrls in alys obruere contendant. Quorum quum molefta,

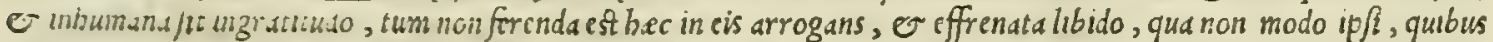
mhil bonum, or cimnatum placere potift, in opumis faftudunt, jed o ed prorumpunt, ut etiam cateris omne tollant emolumentum, $\mathbb{C}$ oneni doctrma fructu, $\odot$ utditate polient. Ac quamuis ea fit in te conftantia, ea morun grauitas, ut parum, aut nibi! cur andam, or onninó negligendam tibi arbitreris A mathi cuiufdam Lufltani boninis ingratıßumi, or

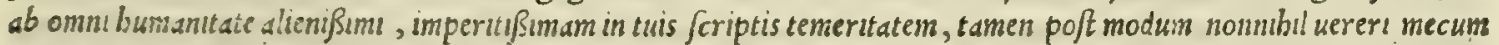
capi, ne hac animi tu magnitudo long is quam parfit, euadat. Nam quum iam frequenter ad me delatum foret, te Apologiam, quann contra bunc ineptum hominem iibstituer as, pariter o cenfur as in eius grakißsima errata pene ad finem perduxiffe; non minus tua, quàm omnü reliquorum caufa, capiebam animo non mediocrem uoluptatem; quód has definfionis partes per neminem commodus fubiri, nec per ullum facilus, o clarius buius infanam uecordian, quàm per te ipfum retegi poffe extstimarem. Nunc autem quo confilio, quáue mentis altitudine te aut tedeat, aut pudeat publicé $f_{d-}^{\prime}$ cefere aliquid negotij cum ifto nugatore, nefcio laudem an (quod mihi certé potius uidetur) ) tuum bac in re nonmbil uiz

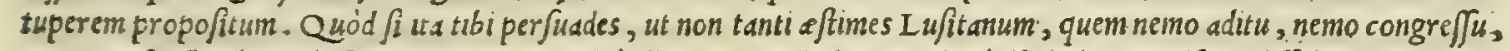
nemo confpectu aliquo doctorum utrorum meritó dignatur, $u t$ indignum plané tibs iudices, ut istam diffolutam, $\odot$ prescopttem loquacitatem irretitam retundas, magis tuam eruditionem, quam funmam eße nullus dubitat, quam reliquorum confulis udicium. An quo. fingulari doctrine lumine facilé tu huius falfitatem animaduertis, idem quoque de onnibus cenfes? Erras profecto ini erudutißume Mattbole. Quot erunt, qui cafu in bunc hominem incident, quos iş̧us falfitas di ueritatis ftudio impediat: Quot ille nondum facis inftruttos, O in hac facultuteroboratos fuis calumnijs à tuis puls cherrimis operibus auertet? Qui quò infirmiores adhuc circa buius fcientie ty rocinia adherefcunt, aut nec dum tua dos Et/sıma scripta expenderint, tanto periculofius ab boc ueteratore inducentur. Qui adeo perfrifte fronis est homo in aliena reprebendendo, in fuas fabulas intrudendo, adeo perfidiofus in alienis fcriptis violandis ev (quu imperitorum mos ef e folet ) ateó prochuis est ur fus constituenda fententia, ut uel mediocriter doctos nonnibul forté commoueat. Huius ins= pudentie tu non occurres? Eam quum tu fine omni tua molestia comprimere ualeas, cum omnium reliquor un detrimen= to Lbidmosé grafJaripaticris? Dicam id, quod fentio Mattbiole, non tam, ut ceteris in bac nostra medica difciplina prestantißumis uris aliquid derogem, qui pro fua bumanitate fumma omnia tibi tribunnt, quàm ne tui oblitus effe uideagis. Quis hac noftra atate doctus in bac medica facultate elaborauit? Quis utilus, of luculentius hanc nobis maiori diligentua, o eruittone illuftrauit? Vt excellentßuni ubique uiri, quos maria, terre, itinerum immen fitas diuidunt à tuo confpectu, bi animo, formonibus, fcriptis, literarum mißione ( ut tu optimé nofti) certatim uelut ingentes, o immortales tibigratlas agant. Ego quidem ( ut de me priuatim ingenue fatear) bis tuis amplißimis comnunibus beneficijs fic me tibi deuncitum, of adstrictum cognofco, ut nubul tui caufa detrectare nec debeam, nec uelim. Quisita fit mbumanus, que in quoquam tant a fit uamanutos, ut tuis pulcherrumis, of fruttuofißimis elucubrationtbus adiutus, bis fruens, his quotidie fe oblectans, non dico ingr atitudinis uel minimum inditium ostendat, fed hos tuos preclarißumos fudores immortalttatts, fi poßit (id quod fore non ambigo) glaria non compenfet? non omnibus monumentis decorandos cos putet? licet nulda glorle cupiditas ad hoc te simularit, qua maior est tuus animus, nec ea te buc impulit, fed folus communis, of publice utilitatis amor, quo incredibititer flagras, te inflammauit, ut omnes gravißimos fufciperes labores. Tane täne fut in Lufitano ingratitudo, eáne inbumanitas, ut nibil iftorum recordetur? Non quòd ull tantum largiar homi ni, ut tantam ei uindrcem excellentian, quafi nil omnino in eo deprehende ualeat, quod non leuiter aliquem offendat, quod non tenuem aliquam apud alios mereatur reprebenfionem. Nec tantum tu tibl afferis, ut ( $f i$ quidem id fecißet) emendatum te i L ufitano dolere queas. Vfque adeo ne hominem effe immoder alum? Ita in aliorum labores impudentem? Sic ubique in alienıs repellendis imperitum? Et quod ad te attenet, minus equidem fum follicitus de ea modestia, pietate, gratitudine, quam ille umpertifisinus homo tue preftare debuerat humanitati. Non tantl ef? id incommodum, ut corri-

$\mathrm{A}=\mathrm{gi}, \mathrm{O}$ 
gi, or refarciri poffet d quamplurimis doct Jimis, or gratuißimis uiris dubitem. Nam ut innumeros hoc nostro preter muttam tempore, erudutısmos, or plenos leporis; uenuftatis, bumanitatssq; utros, qu quo fint ingènij cultu, quo fia-

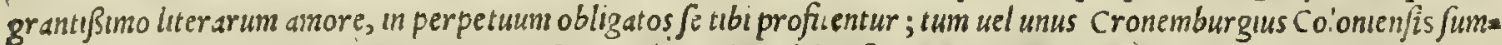

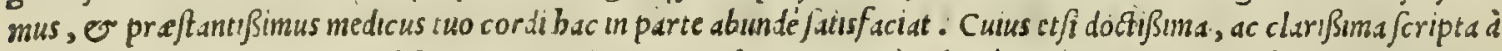
te uerfata non ignorem, audi obfecro qua gractitudine, authoritate, quàin docté, quadm luculenter in fuo de compofitios ne medicamentorum libro breuter fuum in te intrmum affectum declaret; o Lufitani illius nequitiam, o indoctian in: probitatem redarguat, ac perstringat. AM A T HV S, I N $\mathrm{V} I T$, L V I I A NV S frequcnter odiofa confidentia wis

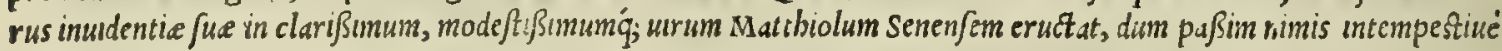
buius doctrinam fuper commentarys in Diogcoridem edits coargutt, ac tnfectatur : quibus probatc fidei bominbus nil alud, quam malignum animum, o perniciofam inuidiam oftentat; tpfe interim infintis modis dignus, qui ob inagnam stirpium imperittam, atque improbam in fe translatam operam alienam (quod crinen eft longé omnium turpisumum) uelut é fubimi doct is ueniar deridendus. Eequid etenim enarrationibus fuis inferuit, quod non iuftifimo titulo uni Mats: thiolo acceptum referre debeat? A quo dum amulandi ftudio diffentit, in grantes, manifeftos'́; errores imprudens bonro prolabitur. Cuiufmode exemplum tum in bac planta, tum in Acanthio, tum Coronopo, tum Elchry $f 0$, ac in plerisque alyjs nifitur. Mulío fatius fuerat, quó doctiorem fe eftimaret, é quoque modestiorem prestare, quod ingenumun Fbilo=

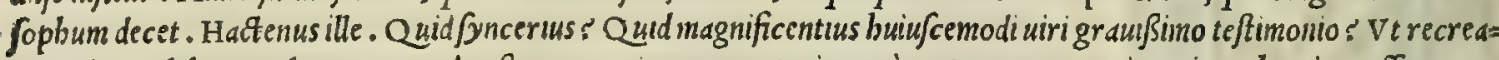
re potius te debeant tal um, ov tot clarißımorum uirorum centurie, quàm ut te moueat unicum inter bomines effe porten tum, quod omnem comitatem, gratitudinem, beneuolentiam, o ipfam bumanitatis naturam exuerit. Si monftriboc fit fimile talem in lucem effe editum, $v$ in commune bumanum confortium furfe productum buiufcemodi hominem, qui es rodat, laceret, conuellat, in ea infaniat, of debacchetur, de qubus bumaniter pares agere gratias nunquam poterat; minime tamen reformido, quin parum multifint futuri, qui fua inodeftia iftius intemperantian conuincant, qui fua grats titudine, $\sigma$ candore, illius infolentem malignitatem, $\mathcal{\sigma}$ infaniam fuperent. Quorum fynceritas, boneftas, probitas, non te plus reuocent, ac confolentur, quam iftius barbaries te deijciat. Abfit, ut non multó plus eruditißimorum uiros rum iudicia ualeant, quàm importunitas unius I ufitame. Hoc porró multó magis me affligit, quód quun tu ipfe per to commodé, es opportunißumé confutare poßis hanc audaciam, id per te fieri nolis. An aliorum patrocinia expectas? Quum alios non animus, fed ingenuus pudor ab hac dehortetur moleftia cum ifto fubeunda bomine. Alij fuis impediti nes= gotijs, aliena difficulter fe fubijciant falci. Ceteris aut non innotut Amathus, aut (quod mibi est uerifimillimum) tibi banc referuant prouinciam. Indignum fe arbitrantur de eius difceptare mente, $\mathcal{E}$ iudicio cum aliena temeritate, eo ins columi, o adbuc fuperftite, cuuus labores fint attentati, cui Jua eruditio optimé fit cognita, o exploriata, qui optime fe ipfum intelligat. Non decere id onus in cateros reiyci, quod ab eo fit accerfium, qui e id facilé fer at, o matora por tarit. Neminem altena cenfent tutius, diligentius. fiaelius protecturum, quam jua isfits, in qubus fuus honor, fua laus?

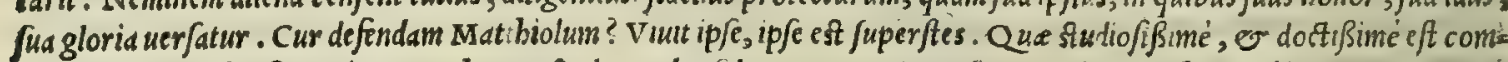
mentatus, ea nobis feruet integra, bec custodiat nobis falud, contra peruerfor um calumnias baec nobis thedtur. Quare tue fit prudentia excellent! Sime Mattb:ole, ut quid hic te facere conueniat, fedulo proficicias. Et quid opus ef magids

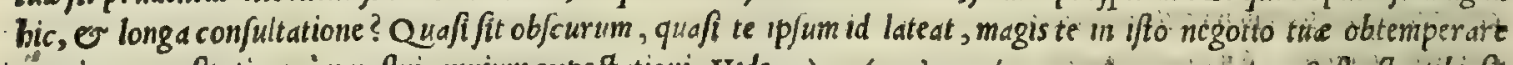

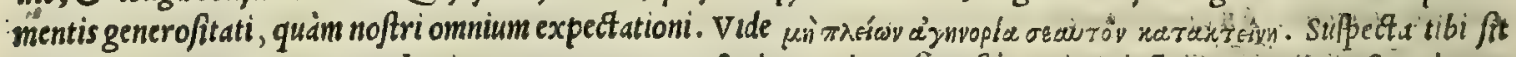

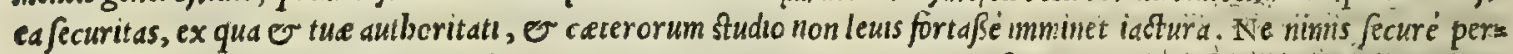

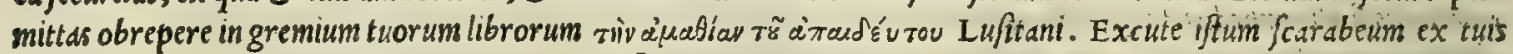
floribus, nec finas, ut fuis molestißimes fufuxris, et foetore iśta contaminet, ex qubbus optima, et rof fidd mimellid reliqui fe con fecturos perant. Hic labor (et quis labor!) mifi ad cetera tua preftantißima monumenta, uelut cirmulis accedat, eit nos à te accepiße cognofcemus beneficld, que fuerint inchoata, non absoluta, 那lendidé adumbrats, non exprefa. Quid? Vereor Matthiole, ne qui fint futuri, qui ftuc tuum filentium molefté, ac ádso ferant acerbé, quii ex prioruin amplifimorum beneficiorum pantuiffe tc dicant, cum tanti ea non ducas, ut ea nobis ab hac contagionie liberes. Pros pulfa nobis hanc moiestiam, declina, obtunde omnem improbitatem, ut tutó nos in tuis luculentißimis operibus fciamus poffe uerfari. Si te mortuo (quod Deus Opt. Max. auertat) L ufitanus ita nequiter tua inuafißet opera, implor andus, $\mathcal{O}$ excitandus ( credo ) nobis eras, ut omn ignominia, macula, omni uel tenuißima afperfa labecula, tua nitidißıma nobis restitueres opera. Nunc quid uiuus ceffas? Quod tunc à mortuo nos obtinere non poffe pené iniquum putaremus, quan= tó id erit deploratius, quantó miquius à uino non impetraße? Quid illud? Nibil'ne te boc mouebit, quód uictus, of tho 'iudicio, quod grauißimum est, fuper atus manum conferere cum ifto imbelli transfuga abnuere cenféberis ? O ea iam tat cité condemnare, ob que caterifue foelcitati cum primis gratulantur ‘ Scimus iam banc operam à te increptam, plus increbuit bic rumor, quod latius, o liberius bunc calcographus dissuparit. Vt hac quoque opere fuas bibliothecas dow ct. Simi complures locupletandas expectent. Hanc ßpem comprehenfan, or mentibus nostris infixam, $\mathbb{f}$ tua prestan= tia defraudet, quid cogitabimus, cur ab incoepto desttteris? Cur non id perfeceris, qiood tu ipfe inchoaris? An cedere te poffe quirquam credat I ufitani ineptiys? aut iure te reprebenfum ab ifto imperitisumo calumniatore fateberis? Nulla uel tenulßsma irrepat huufcemodi fuppicio. Da quod di te magnifice expectamus. Exhibe quod lectu, ov uifu iucundißst: mum erit omnibus. Emitte quod iam penes te babes paratum. Quid abdis, quod non in lucem dare tue derogat exiffis mationi, Iufitani inanem auget confidentiam? Quid dicet calumniator profligatißimus? Scripfi contra Matthios lum, rapui, fuffuratus, depredatusfum, qua uolui. viuit Matthiolus, nil contradicit. Adeo noinnunquam plus inuat perfricare frontem, qudm omnia tribuere doctrina . Vici nil repugnantem. Cedit Matthiolus Amatho. Hacine profua impudentia, ff non effutiet, fecum uolutabit? Noli tantum locum dare buius amentie. Nobis nibil erit incundius tus existmatione, nil dignius, nil contra buius furorem uebementius, quam quod ex tue eris ditionis 


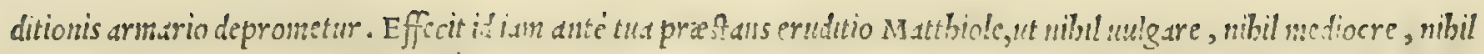

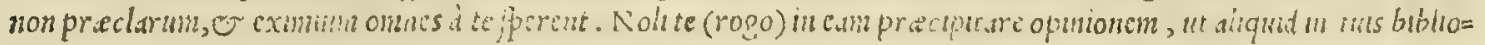

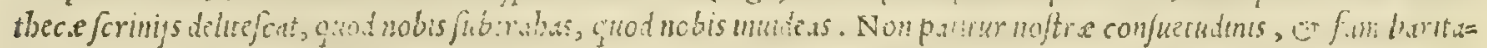

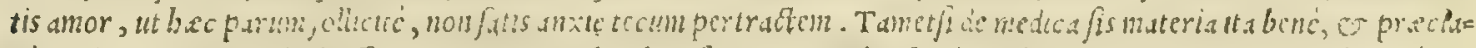

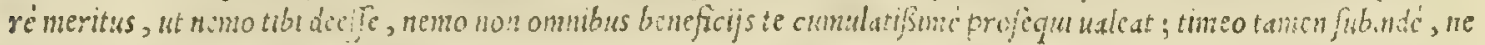

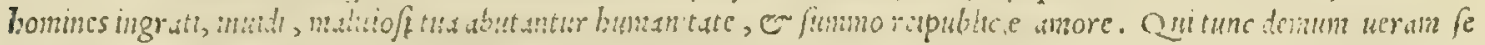

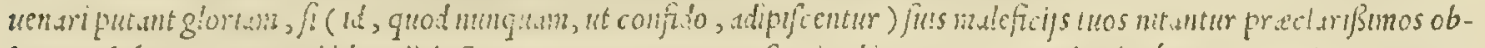

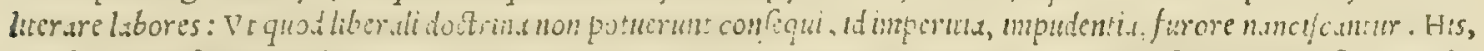

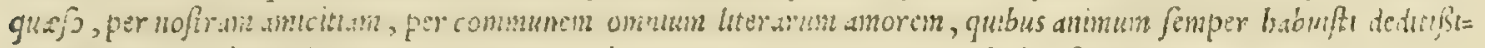

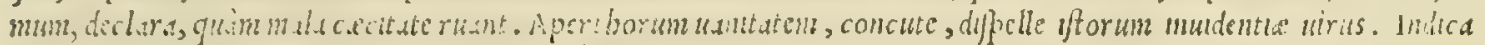

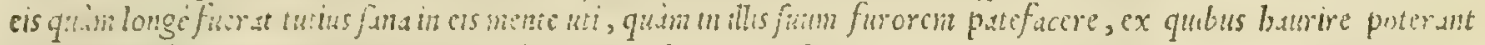

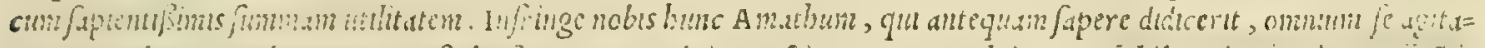

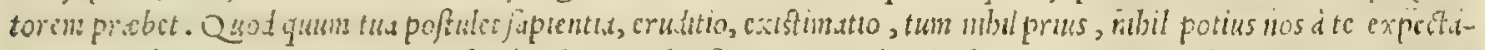

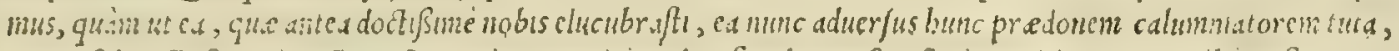

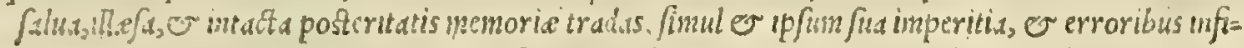
mut ornis. Vae mi crudtuß me Matho'c, er quancelerrimé noftre fatis=

facias omminm exp:ctationi. Vicime Aufile Qusuto

Nonas Srptembris. 1557. 


\title{
MAGNIFICO, AC CLARISSIMO D.Petro Cannizero Serenifsimi
} Regis Romanorum \&c. Archiatro

\author{
PETRVSA A $N D R E \mathscr{A} S M A T T H I O L V S$
}

SENENSIS MEDICVS. S. P. D.

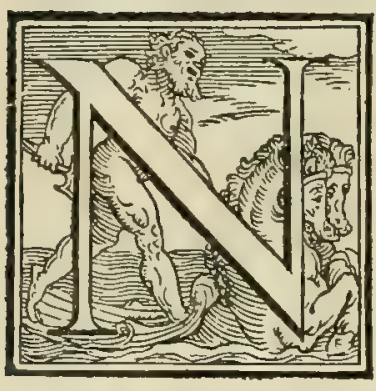

E SC I O quo pacto id ferè Jemper v/u venire animaduertamus (clarijime vir) fummos, \&o preftantißimos viros, quò magis excellunt, \&o quant oqu cue ceris bo nis, ac eruditis viris magis fatisfacunt, tanto importunius improborum nequitia, et calumnüs imperi, ac laceßi. Quo minus mihi dolendum cenfeo, fi ego quoque (quamuis in me quidem, Eo in hoc meo amore fatis acripublice vtulitatis non id prestantia culmen videam, quod cos fummoperè offendat ) poft tot confumptos labores, horum improbitatem, inuidiam, \&o irritos morfus euadere non potuerim. Quod quidem ueutiquam in huiufce aui improbitatem ( at quidam fortaßè putant) Sed in impiorum hominum impudentiam rë̈ciendum arbitror. Qund tomet $\sqrt{2}$ minus fit noum, minus inufitatum, vt ab honeftißimo quenquam impediat insitutu, tamen miferum eft, of certè deplorandum; quum vià cum ipfa virtute nata fit inuidia, liwor cum primordiys emerferit, \&o hac omni tempore fusm exer cuerint improbitatem. Insidia verò virus improbitatis fue nunquam in obfcuros, ignaros, abieclosq́; exercere folet, fed in eos plurimum, qui ceteris vel doctrina, vel fapientia, vel alijs quibufcunque animi, vel fortune dotibus preclariores, eminentioresq́; ena erunt.V tpoté qua cum è loci ewehi non poßsit, quo praclari viri pro pric zirtute peruenerunt, fraudibus tantum of technis fe extollere nituntur. Nec idcirco mirum videri debet, fi quo magis quis inclare fcat, è vehementius in illum hac fe iaculetur vipera, Go feuiat tigris. A dhec sutem quum quandoque animaduertiffem, \& labores, conatusq́; nostros ab inuidis dilacerari comperiffem, gaudebam fanè, \& mex propè cuiufdam foelicitatis effe ducebam (licet nunguam mihi tantum tribuerim) a clerißinorum hominum communi fortuna me non fegregari. Ob idq́; decreueram potius inuidorum rabiem falentiv extinguere, quim fcriptis refpondendo palim facere corum latratus mihi negotium faceffere; prafertim cim in omni vita precipuos comites mearum actionum, confiliorum, voluntatum, pudorem, modestiam,

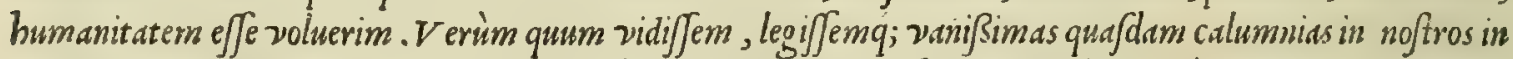
Diofcoridem commentarios editas ab Amatho quodam Lufitano homine fanè non folim, vt eius fort nomenclatio, apprimè indocto, fed etiam, quantìm ex eius fcriptis colligi potest, omnium arrog.antißimu: quumq́; pr.eter id comperiffem hunc quamplurima ex commentarys nostris furtim in fuas tranftulijfe enarrationes, $\mathcal{G}$ in illis innumeros commififfe errores, qui ret herbaric studiofis magno fuiffent detrimento ( hoc enim pre cateris me maxime angebat) nifi ï a nobis paldim refellerentur; pietate potius, quaim cupiditate aliqua contendendi, à qua maximéfum alienus, excitatus patifanè non potui ( etf aliter mecum prius ftatueram) quin foriptis in publicum editis eius calumnias contunderem, errata reprehenderem, imposturas concuterem, furta parefacerem. Quod quum tandem feciffem, dubius fubindè diftrahebatur animus, an quam confeceram. Apulogiam, $\nu$ nà cum Cenfurs in eius deliramenta in lucem proferrem, an verò diutius domi nof tre premerem. Siquidem tamet f non verebar binc aliquam me reportaturum victoriam, non tamen ducebam eam mibi fore gloriofam,è quod cum homine nullius ferif frugis, \&o pauce admodum exiftimationis in certamen defcenderem. Ob idq́; confultius videbatur fripta illa iam adornata in aliquem tenebricofum angulum abdere, quàm in lucem eurlgare. Ad hoc accedebat, quod audivem, of iam etiam viderem quamplurimos doctigimos \&o honefisimos viros (quos nunquam nouimus) non tam nostra, quàm veritatis caufa patrocininm fufcepi]fe, ac iam tündem pro me tullfe fententiam, Amathum vero caufa cecidiffe. Verim diwerfum fuadebat genius meus, fubindè velut infufurrans indignum fore fo meos partus tanta iniuria affectos hac tantum ratione destituiffem. I d'q; eo magis mihi faciendum fuade bat, quo iam in promptu effent, qui fuis fcriptis ad hoc muneris exequendum me phamimum compelterent. Dum itaque anceps in his verfor opinionibus, \& in alrera mihi animus repugnat, in altera verò confcientia, \&o ipfius hominis damno/a imperitia me admonet, \&N vbi potius nego- 


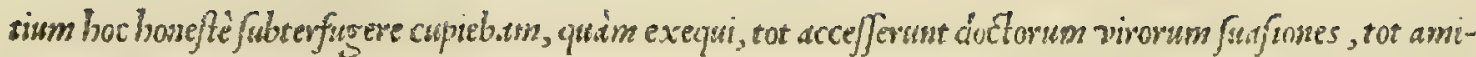
corum liter e, tot calcographi nof tripreces, tot quorundam allatse rationes, ut tandem (quariqum foic inuisus ) decreserim eorsum potius fequi fententuam, quàm meam. Atqui inter rot fur lores, amicos ef studiofos

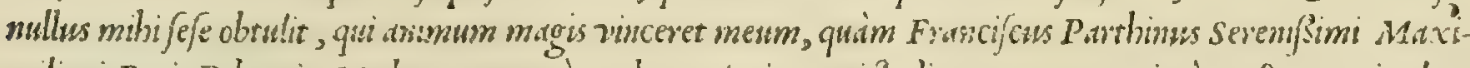

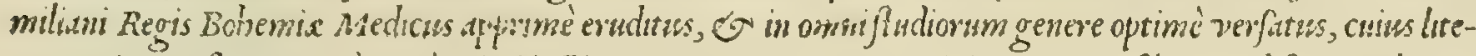
re omnium poftreme adeo me à prioni instituto revocurust, vt ens opinion, of conflio, quod emper plurimi

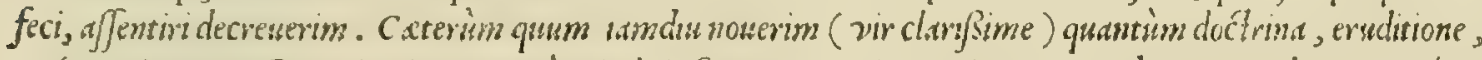

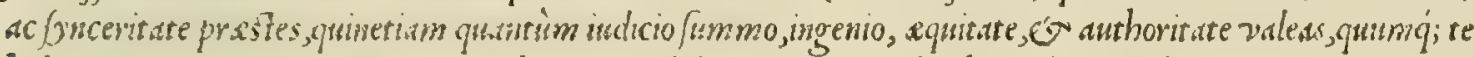

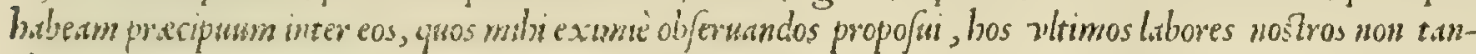
tum nubi legendos, videndosq; mirtere decreu, fed eriam muscupari volui. Nec (mihicrede) eo animo, w

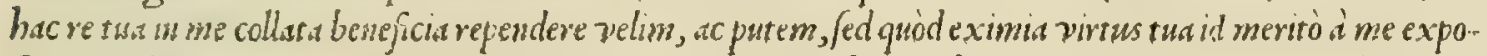

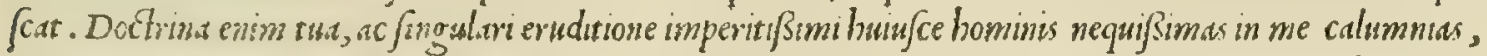

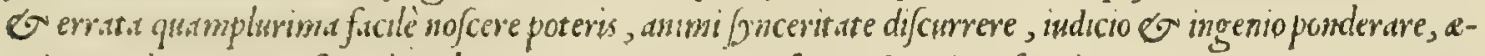

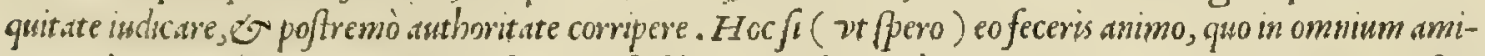
corum, bonorumq́; virorum negotijs femper effe foles, vevendum mibi non est, quin tuis etiam preconïs noftra augeantur prafidia. Nam vol videris hac onsmia partim in me falso effe collara, partim in rei medicat uostrx, of ftudioforwm, tymunculorumq; diforimen effe deprompta, tu, qui omui pietate duceres, ntutiquam te continere poteris, quin ommbus modis labores noftrostuearis. Vale. Praga Quarto

Calend. Septembris. 



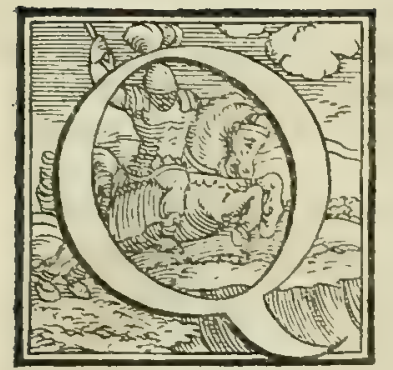

V V M N o $\mathrm{N}$ Sine magno labore, magnaque induftria Commentarios in Diofcoridem edidiffem, quemadmodum doetis quàmplurimis, præclarifque materix medicx ftudiofis hofce labores noftros non ingratos fore fpe rabam, fic neminem tàm peruerfum, inuidum, improbumá; fore iudicaui, qui non potius optimi confuleret ( $v t$ ingenuè fatear) candidos noftros, \& fynceros conatus, quàm iniquius quidpiam de his exiltimaret. Etcnim quŭ fimper me admodum delectauerit medica materia , \& temporis 3 ftudij illi tantum impenderim, vt aliquid qnoque noftrum in hac facultate valere iudicium crediderim, ingenui honeftió; uirj munus effe putaui, fua induftra, $\mathbf{S}$ labore parta, ne Reipublicx inuidere videretur, in commune omnium ftudioforum vfum in publicū promere. Hanc itaq; ob cau fam hoc mihi ingenuum, honeftumć; videbatur, vt id quod vnufquifq; in quolibet fcientia gencre,vel ingenio, vel doetrina, vel longa, diu turnaq́; lucubratione, obferuantiaq̣; libi priuatim, \& non quali priuatum, \& fibi proprium fuerit affequutus, cótineat, fed in com mune tocius reipublicix emolumentum proviribus libenter effundat. Hoc cùm iampridem à me effet factum, non line fructu fortafsè, nec ( vtaudio) abfque magna multorum præclariffimorum uirorum laude, quibus mex elucubrationes placuerunt, tametfi ij nec me noucrint, nec viderint unquam; non leuiter fum excitatus, vt libentius, \& alacrius nouum fufciperem laborem, vt cæ augercntur, plantarum imaginibus decorarentur, \& latino fermone cuderentur. At dum acriori, intentioriq́ue, quàm hatenus in hac verfor opinione, $\&$ iam opus prelis Erafmian is fubeffer, frequentibus amicorum literis ad aures meas peruenit incredibilis Amathi cujufdan Lufitani intemperantia. Id quod non parum fortafis ab hoc meo me diuertiffer inftituto, nifi ab hoc vno contemni, \& arrodi audiuiffem, quę tot præftantifimorum authorum iudicia comprobarent. Verumtamen non adcò horum tot hom inum iudicio ftare volui, quin \& ille Lufitanus, quem immodeftiffimè in meos inuehi com mentarios audieram, nonnihil me commoueret. Non enim arbitrabar hominem illum tanta poffe duci temeritate, vt ea, quæ paflim abomnibus penè probarentur, fine magna ratione, \& confilio tonuellere, \& lacerare auderet. Quamobrem curaui fedulò, vt eius libri ad me deferrentur,non alio profectò animo, quàm quòd philofophi munus, \& mex modeftiæ femper duxi, non ea peruicacia proprijs affigi, vt corum improbaretur opinio, qui melius \& fanius aliquid fentirent. Equidem pu tabam quòd cum Lufitanus ille omnium vltimus Diofcoridis codicem expendiffet, adeò omna cribraffet, \& excuffiffet, vt nullus reliquus fuerit ambigendi locus. Mouebat quoque iftius Centurionis nomen, quem centurias quafdam digeffiffe aiebant. Sed vbi primùm eius enarrationes intueri ce peram, longè aliter quàm putaram, eueniffe cognoui. Quandoquidem præter calumnias mihi falsò afcriptas, nil aliud quàm inuidentiffimum animum, acloquacem, \& ineptum hominem obferuare potui. Nefcio profectò magis'ne me offenderit hominis imperitia, qui nullo iudicio,nulla ratióe alie na praceps \& infanifimè damnet, an improbitas, \& infignis nequitia, quòd tam impudenter ex his ipfis, quæ in alios calumniatur, fuas agit prædas, \& tanquam fua quali vindicat. Verùm vt fuam agnolcat infcitiam, nec fuis calumnijs quicquàm noftræ detrahat authoritati, aut publicæ vtilitati, quin \& ne in pofterum fortè honeftiflimum noftrum, vel aliorum impediat curfum, cogor fanè eius ineptias aperire, ne videar id mali ad pofteros relegare, fi præfentibus culpis ignofcerem. Licebic itaq; nobis noftra pro virili defendere, \& ex omni parte tueri, ne fi hæc filentio diffimularem, quis deindè modeftiam noftram in confcientiam duceret. Et primò ne aliqua iniuria, aut fraude hic qui tam improbè nos laceffiuit, fecum agi putet, ac etiam vt candidus lèetor facilius deprehêdat, \& æa quilfimè difcernat veriufque controuerfiam, antea eius verba ob oculos ponam, ad qux fingulatim mihi refpondendum meminero.

A T Videte obfecro, quàm grauiter, anvehementer me primum adoriatur Lufitanus, non quafi de herba fibi fit certamen, fed quafi mecum de rcligione contendat, quam homo inconftans iam pri dem turpiflimè, ac impudentiflimè deferuit. Nec enim(inquit) veritas ipfa occultanda eft hac de rio Meum in Italia non reperiri,fed plura fanè effe fcribo,qux me ancipitem reddiderunt, an Meum, quod nunc pro genuino fumitur, legitimum fuerit. A Lulitano iąmpridem non didici in Iralia quod-

Commentarij in Diofco ride magno labore func edici.

Ingenui uiri inแuนs.

Quã ob callfam Commé tarij in Diof. latinc fint editi, \& planta rum imagini bus illuttrats.

\section{Cur edita} hxc fit Apologia.

Calúnia prima de Meo. , quem fequutus poftea Marcellus Vergilius vir alioqui doctiffimus, rei tamen herbarix non admo um peritus, dixit,nunc, quod fciam, nullum Italiæ Meum eft. Ob quæ verba Matthiolus Senerifis in Italia quoque Meum non reperiri clamat, immò contra Patres Mefues interpretatores acriter agit, qu in Ca!zbria, \& Nurfix montibus Meum nafci affirmant. Quod ita effe crediderim, cum apud Bo noniam quoque nafcatur, vt teftes funt Nicolaus Nicoluccius pharmacopola Ferraricnfis, \& Gafpar de Gabriclıs nobilis Paiauinus harum rerum maximus indagator. Accufandus ıgitur Matthiolus eft potius, cum magis ncgligens in inquirenda hac herba fuerit, quàm diligentiffimi Patres, qui defudantes Nurlix montes, vt eam indè eradicarent, afcenderunt. Sed fruftra me tanta acerbitate perfequednupprogenuinofumitur lagitimum
Calumniare fellisur. 


\section{0 \\ Petri And.Matth. Apologia}

Mei confidesatio.

dam circumferri Meum, cum ante ipfum hoc fciuerim. In hanc tamen inclinari me dixiopinionem, illud á genuino ac vero Meo mihi videri longè diffimile. Hoc etfi fimpliciter à me effet dictum, vt meam hac in parte folum exponerem fententiam, nefcio tamen cur accufandus magis illi videar quàm leniter admonendus. At quòd in hanc venerim opinionem, illud in caufa fuit, quòd plures huius rei mihi conftarent rationes. Etenim eft in prımis quòd viderim noftratis Mci radices longè craffiores, uegetioresq́; quàm genuini cxpetat hiftoria : quippè longas, \& tenues radices Meo reddidit Diofco Meum, quod rides. Elt deindè quòdexdem grauiter potius, quàm fuauiter oleant, quum tamen Diofcoridi Mco circüfertur à radices requirantur odoratæ non graucolentes. Elt præterea quòd manfæ parum om ninò acrimonię genusu diffidet refipiant. At quum, Galeno authore, Meum tertio exceffu excalfaciat, cur non illud genuinum a-

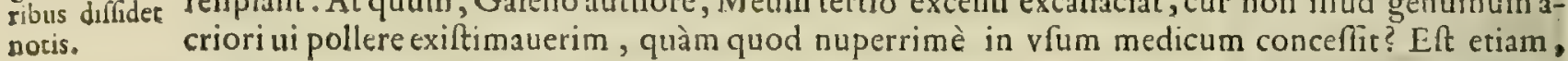
quòd extent manufcripti Diofcoridis codices, qui Meum non Anethi, fed Anifi folijs, conferant. Quod \& idem refert Plinius, quem licet reijciat Amathus, non tamen fine ratione eft adductus, vt fcriberet non nafci in Italia Meum. Nam cum non nifi à medicis, ijsq́: admodum paucis jpfum feratur, magnum \& euidens eft argumentum non ibidem fua fponte progigni. Quorfum velut peregrinum à medicis excolebatur, fi ubique in Italia nunc illud excrefcere uidemus? His itaque palàm eft,vt non ab re in cenfendo Meo mihi plurimùm fuerit ambigendum. Etenim mihi perpetuò decrctum volui, non ita facilè de rebus dubijs affirmare, ne id arrogantiæ potius, temeritatiq́;, quàm doctrinẹ, $\&$ diligentiæ nobis afcriberetur. Verumtamen nolui ob id prætermittere, quin huiufce Mei imaginem appingerem, non tamen, vt hoc tantùm argumento fateri uiderer illam genuinum referre Meú, fed ut lllud nobis antea non ignoratum (ut opinari videtur Lufitanus) oftenderem. Quam ob caufam non modò illos mihi femper deteftandos propofui, qui tam fiscilè de incertis fententiam ferunt, fed \& eos longè magis, qui, ubi fatear, hanc uel illam me non vidıffe, nec nouiffe ftirpem, mox clami tant, \& erroris me arguunt . Equidem femper optimi uiri munus effe credidi, ignota, uel dubia potius filentio inuoluere, \& nihil de illis determinare, quàm in polteritatis difcrimen, falfa pra ueris Vulpina Lufi defcribere, \& dubia pro certis afferere. Quod quandoque feciffe Monachos illos, quos, uulpina qua tani religio. dam religione, patres Lufitanus appellat, non ambigimus. Sed fanè mirum uidetur, quum noftram, \& fuam religioné omni flagitio polluerit, dedccore maculauerit, fcelere obligıuerit, \& eam tantùm ob caufam è fua exulauerit Lufitania, quòd hic tam acriter proMonach is illis depugnet, qui Iudeorum omne genus maximè perfequuntur. Sed \& illud etiam mirandum nobis fefe offert, quòd hic me tantoperè laceffiuerit, quòd in eos hæc fcripferim, quum tamen ipfe pluries Monachos illos aliàs damCalumnia fe net. Id quod etiam cum Plinio feciffe conftat. A T I A M H O M I N I $S$ videte inconftantem feuecunda. ritatem, qui \& fi paulò antè ( puto enim me aliter inuadere non potuiffe) Plinium ipfum, \& alios gra uiffimos authores expladere, ac damnare non eft ueritus, me tamen quafi rigidus patruus feuerè increpat, quod à Plinio non nihil in Iridis mentione difcefferim, ea ratione adductus, quòd is prater Diofcoridis fententiam, candidam Iridem rufxe prætulerit his uerbis. Illyrica quoque duorum gene rum eft. Raphanitis à fimilitudine, quæ \& melior : Rhizotomos fubrufa. Nouam hic quandaun ex- , Calúnix con cogitat Lufitanus artem, qua me adoriri poffe putat. Nam quum idem Plinius alıbi fcripferiti Iridis $^{2}$ futatio. radicem cæteris præftarc, quæ rufo fuerit colore, ne ulla in tanto uiro obferuari poffit diffenfio, eam inuenit defenfionem fidus patronus, qua haud fcio an defendi fe uelit ipfe Plinius. Atqui Lufitanus priorem claufulam diffoluens ita legit. Illyrica quoque duorum generum eft, Raphanitis à fimilitu dine, Reliqua quæ fequuntur in unum coercet cum relatiuo, Qux \& melior Rhizotomos fubrufa. $O$ infignem Palæmonem. Non equidem rogabo Amathe, ut dicas, in quo codice tales uideris interpunctiones, cum certò fciam in nullo inueniri . At afferatur iam in medium Frobeniana editio,quam tibi patrocinari putas. Afferatur (inquam) ut ftatim confufus fileas. An non te pudet editionem hanc uocare in iudicium, ut illicò palàm fiat, quàm grammaticorum omnium iudicio, E T particulam, pro e T r am ibi fumi? Qux ifta connexio? Qux etiam melior, Rhizotomos fubrufa. Nimis $\sqrt{a}_{2}$ nè multa nobis affers de uerbo, cuius fenfus cuilibet tegenti fole lucidius apparet. Iftis grammatica confufis legibus nolit (me hercule) defendi Plinius. Malit is communi; obliuionis quodam errore ( quod \& doctifímis $\&$ fummis uiris inter multa quandoque contingit negotia) lapfus uideri, quàm Plinium qua huic grammatico fua fubijci opera. Id'ne nouum tibi eft in Plinio, ut aliquoties fibi non fatis cundoq; non fa- Pter? Mihi quidem \& Atudiofis le toribus nequaquam. Etenim de Caltore fcribens Plinius libro tis fibicon octauo, capit.3 o.caftores affirmat dentibus fibi teftes abfcindere, quum uenatu urgentur, ob hoc fe ftare. peti gnaros, id quod poltea lib.32.cap.3.apertifímè negauit, \& tanquàm fabulofum cxplofit. De Po pulo autem agens lib. $26 . c a p .23$. nullum hanc florem, nullumq́; fructum edere ait, quorum oblitus lib. 2 3.cap.8.eandem Populum dixit, \& uuas, \& femen gignere; hoc comitialibus, illas ad unguenta præferens. Quid igitur mirum, quod fcelus id erit, fi \& in Iride, \& fibi, \& Diofcoridi Plinius re= pugnaffe dicatur? Equidem id flagitium non dico in Plinio fummo utiq; authore, fi in tanto opere, \& tam uaria lectione aliquando memorix fragilitate fit prolapfus, præfertim cùm is potius alienam recitet hiltoriam, quàm propriam. Te potius miror Amathe, qui quod tibi lubet,idem cæereris,quú tamen iufta id ratio fuadeat, non licere cenfeas. Nos ueritatem ubique fequimur, eam nulla hominum authoritate, quoad poflumus, patimur obfufcari. Non tanti (mihi crede) eft æftimandus in Pli-
Animaduerfio in Lufitanum. 


\section{Aduerfus Amathum Lufitanum.}

nio aliquis memorix lapfus, quanti eam, quam de laboribus noftris agis, rapinam xftimandam cenfemus. Quid enim turpius, impudentius, deteftabiliusq́; quàm furtiuam frugem ex aliena meffe in fuum tranfierre horreum? Quid deinde inhumanius, quàm quem expoliaueris, gladio \& conuitijs adoriri? Optimorum'nc hxc funt hominum? Graffatorum, prædonumq́ue potius mihi uidentur, quos tu maximè fequutus uideris. Quo fit ut mirum non fit, fi primùm è Lutitania pulfus, ac dcindè è Germania in Italım reičtzus, iam inde etiam profugus aberras, adeò ut folum ferè non inuentas, ubi iam tutus effe pollis. Porrò hxe mihi de Lufitano illo dixiffe liceat, non ut uidear cum homi ne pugnare, quem non cft ut timeam, neque ctiam ut odio profequar aliquo, præfertim cum mihil fui pollideat, ubi polfim poften rcfici, ubt uicerim ; fed tantum medicx materix uindicand $x$, \& honoris noftri fuftunendi caufa.Potuifem quidem Amathum hunc acriori, uehementioriǵue fermone reprehendere, primùm quiòd tam temẹ è laborcs nolt tros depradatus fit , deindè quòd falfillimas, fri uolasq́; calumnias in me cxcogitauerit. Poftremò quòd ubi aliquid fuo marte cudit, in grauifimos, frequentesque labatur errores. At qqui quum probi, ac candidi hominis non tit munus conuitijs ac maledict is, fed propria uirtute pugnare, ea uiar in dicendo modeftia, quam animi noftri fynceritas, \& eius infolentia expofcere uidebuntur. Quòd fi quancioque pietate fumma adductus, uel calumniarum iniquitate fauciatus, pauca qux dam acerbiora fortaffe in hunc deprompfero, rogo atque etiam obfecro, ne quis id mihi uitio uertat. Scio quidem in refpondendo me magnam non habere expecta tionem, quòd nemo iam lit, qui eius legerit libros, quin prius nouerit non modò hominis imperi-

" tiam, fed etiam temeritatem. A MEO I V I T Anvs de Amomo hac in me confert.At Matthiolus Se"nenfís cum nos uero carcre Amomo fciret, ut illum tamen habeamus, in Lufitaniam nos remittit,ubi " ex India nunc delatum contendit : mea tamen fententia fallitur', cum hucufque Amomum uerum in" compertum fít. Hrc ille. Sed planè falsò, cum plura me dixiffe fcribat, quàm rei ueritas expofcat. Quandoquidem cùm nunquam meis foriptis aftirmarim Amomum ex India in Lufitaniam conuehi, nec eò quem quam remiferim, ut ille fomniaffe uidetur, dum meas mentitur lucubrationes, \& eas ( quæ illius eft liberalitas) fuis uerbis amplificat. Scripfi quidem me ̀̀ quibufdam non fpernendæ fidei medicis accepiffe iam primùm ex India in Lufitaniă afferri Amomum, nec fanè plura, quàm hxc. Cærerùm cum eorum fententiam nec probauerim, nec damnauerim, cur hac in réme adeò uellicer, conijcere quidem non poffum, nifi quıs fortaffè in eius maleuolum animum hæc reijciàt, Quod autem ille perperàm meam acceperit mentem, id argumento effe poteft, quòd in commentarijs noftris " latino fermone editis, nihil huiufce fabulx meminerim. A D C A L A M V M Odoratum meniamus, " ubi ille grauiores, ficut ipfe putat, in me admouet machinas, quas idcircò non magno fanè negotio à "nobis amoliemur, quòd non aliquo confilio, non aliqua prudentia, aut ratione fed fuo mole ( propè dixeram moria ) id in nos moliri contendat, Arguit me, quod nixus Theophrafti, \& Plinij tefti2. monio certò affirmauerim radicem, qua paffim Odorati Calami uice utuntur Seplafıx, legitimum, "genuinumq́; effe Acorum : quin \& quod lccripferim Calamum Odoratum harundinem effé, non radi" cem,quibus refragatur his uerbis . At mea fententia decipitur Matthiolus, cùm licet Theophraftus, " \& Plinius in Calamo Odorato calamum, \& non radicem laudare uideantur,alibi tamen Calami Odo " rati radicem defiderant, \& eam cateris calami partibus anteferunt, vt apud Plinium eft legere lib. 24. " cap. 2 z.in quo cum Calami Odorati iu uamentr enumerat fic inquit. Efficaciffima autem in omni ha" rundine, qux proxima radici : efficaciflima, \& genicula. Per quæ uerba manifeftè percipitur, quòd " in omni calamo, fiue harundine, radix efficacior eft pars. Qua de caufa Calami Odorati radix potius, " quàm calamus in opus trahenda eft, ut meritò hactenus pharmacopolx hac preciofa , \& exotica radi " cepro vero, ac genuino Calamo Odorato ufi funt. Quantùm verò ad J̦iofcoridem attinet, fi quis \% introfpiciens eum accuratius expenderit, inueniet illum de radice potius loqui, quàm de calamo,çùm "radix geniculata dicitur , calamus uerò potius nodis cinctus. His'ne tam ftolidè me putat concludi "Lufitanus? Sed audiat ipfe non quàm Matthiolus, qui hæc accuratius priufquàm fcripferit, penfitauit, fed quàm turpiter jpfe potius decipiatur, quippè qui temerè Plinij, \& Diofcoridis grauiffimorum authorum abutitur teftimonijs. In primis enim ut eius argumenta difloluam, \& tanquàm inania, \& irrita monltrem, non vereor, ne Plinius, aut Theophraftus Calami Odorati radices adeò de 9) fiderarint, vt nufquam ẹarum fecerint mentionem. Nam quòd Plinius ait,efficaciffimam in omni ha "rundine eam effe partem, qux radici proxima, quis fuerit Plinianx lectionis, latiniqúue fermonis adeò imperitus, vt non uideat de harundine non de radicibus intellexiffe Plinium. Namq; examinatu rus quæ nam partes in uniuerfo calamo cæteris præftent, næ non radices, ut Lufitanus fua quadam malitia, vel forta $\int s e ̀$ imperitia in me diftorquet, fed partes radicibus proximas cæeteris præftare inquit: quod facilè prudens animaduertet lector. Nec enim aliam ob caufam putat Plinius maiori ui pollere eas calami partes, quæ propè radices habentur, quàm eædem ibi craffiores, uegetiores, robuftiorefque in omni harundinum genere reperiantur, quàm in cæteris earundem locis ; quo fit, ut etiam calami ipfus genicula efficaciora pariter jpfe exiftimauerit Plinius. Quippè \& genicula robuftiora funt; \& crafiora. Quam ob caufam Calamum illum prætulit Diofcorides, qui densè fuerit genniculatus . Sed iam ip fum quafo intueamur locum, quem ille quafi uiolentum quoddam telum in me uibrat.At fo ulla in eo fit prudentia, fil leuius \& confideratius uerba Diofcoridis mecum perpenderit, non folum 
deponet hanc iracundiam, fed fortafsè etiam nofcet, quàm magno ducatur errore. Nam quòd Calamum, non radices defcribat Diofcorides, apertè quidem conftat, cùm ait. Calamus Odoratus in In= dia nafcitur, melior eft fuluus, densè geniculatus, \& qui affulosè frangitur, plena araneorum fiftula. Hácille. Qux tamen perperàm Lulitanus intelligit. Quippè calamus in primis harundinem defignat,non radicem. Præterea proprium harundinis eft plurıbus conftare geniculis, \& affulosè frangi. Deinde fiftula, in qua quoddam aranex telæ fimile concludicur, calamo tantum debetur, non radici, qux folida, dura, lignofa, \& vbique occlufa fpectatur in omni harundinum genere. Ad hre fuluus color calamo fanè debctur, non radici. Quippè quòd radix in harundine perpetuò albicet. Ad jd autem quod proprium fit radicis ( ut ille contendit) ut ipfa geniculata dicatur, calamus uerò potius nodis cinctus, Diofcorides ipfe refpondet. Quandoquidem is non modò quarundam plantarum radices geniculatas facit, fed etiam caules, \& calamos nonnullarum ftirpım reddidic geniculatos, vt facilè quis certior fieri poterit, qui eius codicem legerit in Hydropipcre, in altera Cyclamino, in Gentiana, in Panace Afclepio, in Liguftico, in Elaphobofco, in Crareogono, in Gramine, in Equi feto, in Cicuta, in Pityufa, in Ebulo, alijsç; nonnullis. Sed relinquamus hæc (inquam) quæ legere non vacauit Lufitano, \& alios confulamus authores. Plinius tritici culmis genicula quaterna, farris fena, hordei ottona tribuit. Hinc libro de fenectute Culmo geniculato inquit Cicero. Hxc fi animaduertiflet Amathus, aut fi non tam negligenter \& ofcitáter Diofcoridis codicem legiffet; tam non fuiffet infulfus. Illud tamen maximè in hoc homine ridiculum uideri debet, quòd quum tam excelJentem fe haberi uelit medicum, reiq́; herbariæ peritiffimum, cius fententiæ, quam damnat, nullam foluat rationem, \& omnia relinquat intacta argumenta. Porrò ego in illum tam uecors non ero, ut hominem potius, quàm opinionem parum ualidam nulla ueritatis imagine fultam uidear perfequi . Solus feuerus hic iudex in nos ex al to tribunali fert fententiam, damnat noftra. Tantum fibi temporis fupereffe non putat, ut uel aliquid probabilius afferat, uel rationes noltras diffoluat: ut non ueritatem, cui à quouis prolatæ femper fui addictiffimus, fed folam fuam fequi maleuolentiam fe monftret. Nos (quod præcipuum fanè nobis eft ftudium) ne calumniatores potius, quàm ueritatis pute mur indagatores, multa habemus, cur Amathi huiulce nobis difpliceat opinio. Primum quòd nufquam uifa fit radix inter ualdè admodum innumeras, quas ille falsò genuini Calami effe cenfet, qure fecum uel minimum harundinis trunculum cacumini adnexum deferat: ficuti quamplurimæ uifunk tur, quæ ab ipfo cacumine folia emittunt Iridis, ut quifque facilè certior fieri poterit, qui diligenter

Calamus $\mathrm{O}$. hafce radices explorauerit. Conftat præterea hafce radices ex Lituanie, \& Tartariæ finibus, quin etiam doratus com ex Ponto, ubi paffim ferè proueniunt, ad nos conuehi. Qiod maximo cuique argumento effe poteft, munis ufus eos prorfus hallucinari, qui eas ip fas radices Calami Odorati effe contendunt, quòd nullus extet auunde atterat. thor ( quod uiderim ) qui fcripferit Odoratum Calamum alibi prouenire, quàm in India, \& $S y$ ria . Quin \& illud in noftram concedere fententiam Lufitanum fortafsè monebit, quod à Galeno dictum eft, quippè qui fcripferit Calami Odorati partium effentiam effe in caliditaris, frigiditatisq́; coniugatione temperatam, $\&$ minimum habere acrimonix, cùm tamen guftantibus palàm fit, radicem hanc non obfcurè effe acrem, pariter \& amaram, id quod Odorato Calamo minimè tribuit Galenus. Hifce itaq́; fatis iam comprobatum cenfemùs fua in fententia hic hallucinari Lufitanum: nec pluribus eft hæc noftra defendenda caufa. In fequentibus tamen \& rationibus, \& authoritatibus oftende-

Calumnia quinta de Aipalatho.

\section{Calünia re -} tunditur.

Rhodium Oleastrum non effe Afpala thum. mus, radices has legitimi effe Acori. NEC MINVS FA L I T V R, quæ de Afpalatho contra nos affert. Eft uerò Afpalathus (ut Ruellius teftatur, \& recentiores Graci confirmant) lignum, quod à Rho-, diorum infula affertur, \& illud, lignum Aloës, Rhodiorum officinæ appellant, ex quo coronæad is fundendas preculas Deo parantur. Nec enim Matthiolus, qui hoc tanquàm fallum euertere conten-" dit, audiendus eft, quum revera lignum hoc, ex quo coronæ parantur, ex arbufcula humili crebris " fpinis aculeata in infulis $R$ hodiorum , \& alijs Græciæ locis ceditur, non uerò ex oliuæ fpeciem refe- . " rente arbore. Vidimus enim nos apud Thomam Lucenfem infignem apud Ferrarienfes pharmacopolam huiufce ligni frufum brachialis craffitudinis, folidum, graue, multis interceptü nodis, quod ." à Græcis hominibus fub nomine Afpalathi acceperat. Erat enim lignum coloris fubrufi, cui fimile $n$ in Hifpania apud Taraconenfes, \& Valentinos magna in copia reperitur. Hactenus ille. O folicem ", difcipulum, qui ubique magiftros habet pharmacopolas, à quibus fic inftitutus difcedit, quafi ab Apollinis, aut Aefculapij reuertatur oraculis. Sed uenit mihi in mentem, ne quoque iniuriam his fa ciat, quibus præceptoribus fe toties ufum iactitat. Verùm feu ab ijs hæc fit edoctus, feu ipfe fuo ingenio hæc excogitauerit ( malo enim non à me hæc agitari teftimonia, quàm ad hæc inueftiganda tan tum fruftrà fufcipi laboris ) ego prołectò R hodium illud lignum multùm diftare ab Afpalatho certò fcio: quòd primum illud corrice tenus rubens non fit, fed potius albicans. Afpalathus enim Diofco ridı detracto cortice adeò rubet, ut purpuram penè referat. Quo argumento credidere quidam Santa lum rubrum legitimum efle Afpalathum, quanquàm \& illi aberrauerint. Sed \& id clariffimè demon ftrat, Rhodium lignum nullam cum $A$ fpalatho habere cognationem, quòd fribat Galenus, qui legi timum in Græcia fortafsè pluries deguftauit, hunc guftu effe acri, \& fimul adfringenti ui præditum: $I d$, quod minimè in hoc $R$ hodio ligno reperitur, quemadmodum nec præualens amaritudo, quam illireddidit Diofcorides. Quòd autem huiufceligui planta fit Oleaftri fpecies, Id maximè fatentur Rhodij, 


\section{Aduerfus Amathum Lufitanum.}

Rhodij, 'qui cius hiftoriam ex Mclita infula ad me feripferunt his verbis. Lignum ex quo torno glo Rhodij Olea buli fiunt ad fundendas preces, truncus eft arboris longitudine hominis metam non excedentis. Na"fcitur arido, \& faxolo tractu, fronde perpetua olcattri amula, foribus albicantibus, baccis nigal"cantibus, paruis, caudice breui contracto, brachij inftar craffo, à quo rami prodeunt rari, fpinis ferè nullis, aut admodum paucis, albicante toto cortice. Ligni matcries cortice tenus candicat, medullitus uerò nigricat . Radicibus niticur firmis albicantibus . Quibus palàm effe arbitror R hodium hoc lignum ab Afpalatho admodum effe diucrfum : \& Lufitanum unà cum Ruellio in codem uerfari errore. Quippè ( ut pramilimus) Af́palathus tantùm cortice tenus, non ut ille exiftimaffe uidetur, in tota lignt lubltantia, adcò fíturatc ruféfcit, ut purpureus appareat. Quinetiam cùm Afpalathus in Rhodo proueniens frutex fic furculolus (ut teftis eft Diofcorides) non arbor procera, rationi confo num non elt , ut ad brachialem crallitudincm adolefcat. Cæterùm quòd de re incerta non modò con tendai, fed tam facilè audcat affirmare, deteftandum mihi uidetur. Quippè nil tam temerarium,tamq́ue indignum fapicntis grauitate crediderim, quàm aut falfưm fcutire, aut quod non fatıs exploratè perceptum fit, \& cognitum, line ulla dubitatione defendere.

H I N C A D HELE N I M venio, in quo quum Lufitanus exiftimet, me pluribus modis allucinatum, adeò vt nullis poflim me defendere rationibus, acriori morfu in nos inuehitur his uerbis. Confirmat Marcellus Vergilius fe fic in antiquiflimo Diofcoridis codice legiffe. Caulem ex fe mitrit "Hulenium, craftum, hirfutum, cubitalem, \& aliquandò maiorem, angulofumq́; , flores luteos, \& in " jjs lemen Verbafco limile, tactu pruritum faciens. Vnde facile credere eft, ut hæc peruerfa, \& immu "tata fuere, ita quoque pars hre ad amaritudinem attinens: quanquàm eam quoque à Plinio prætermifam animaducrto. Vnde Matthiolus Senenfis hic falsò admodum Plinium adducit libro x I x. "cap.v. qui ulirà quòd in co capite nullam penitus de Helenio mentionem faciat, libio tamen $\mathrm{x}$ x $\mathrm{I}$. "cap. x . vbi Helenij meminit, non de hac loquitur, fed potius de Aegyptia, cui Diofcorides in hoc capite ex mente Crateuæ herbarij ramulos Scrpylli modo humi fparios tribuit, folia uerò Lenti fimi"lia: cui quoque to in loco nullam tribuit amaritudinem. Immò in defcribenda hac herba Plinius à "Diofcoride uariat, cum Diofcorides folia Lentis, \& ramulos Serpylli per terram fparfos Aegyptiam "Inulam habere tradat. Ille uerò non Lentis folia, fed Serpylli potius poffidere dicit. Accedunt ad " hæc, quòd cap. x x I . eiufdem libri, ubi medicamenta Helenij pertractat, dulcem effe afferit, non amaram : ut liquidò conftet Plinium de illa tantùm dulci Aegyptia. Inula memoriam feciffe, non ue"rò de hac à nobis a mara tractata. Proindè Matthiolus, fi Plinij authoritatem in hac parte fubticuif" fet, prudentius dubio procul feciffet, ac non ita duplici errore hallucinaretur. Primùm cùm credat; "Plinium de hac Inula prima mentionem feciffe, quum ( ut diximus) potius de fecunda Aegyptia agat. "Secundò cùm dicat Plinium illi amaritudinem tribuere, cùm re uera illi dulcedinem condonet, \& non "2maritudinem, ut cuiq; legenti notum erit.

HAE C I T A QVE SVN T, qux in me fpicula mittit Lufitanus. Sciat igitur uelim, culpam, qua me accufat, non in me, fed in Ty pographum effe reijciendam, quippè qui imprudenter meam peruer terit fententiam oblitis quibufdam lineis, in quibus Plinij ucrba adnotaueram, qux de Helenio primi generis ab eo fcribuntur(præter Lufitani opinionem, quod hunc Plinij locum femidormiens pertranfiuerit) libro x v III. cap. v. \& quibufdam alijs lineis priorum loco acceptis ex decimo uigefimi primi libricapite, qux poftea in medium adduxeram de altero Helenij genere, quod in Aegypto pro uenit. Facilis enim ac lubricus fuit lapfus, quippè quum propè eflent dux illæx Plinianx authoritates, Typographus, qui è codice noftro manufcripto hæc in fuum transferebat typum, oculi imprudentia deceptus primum Plinij locum tanquam dormiens preterijt, \& fecundum in eius locum repo fuit, quod ad alterum fpectauerat Helenium . Cuius erroris illud femper omnibus fuerit argumentum (ne furtafsè quis putet me id totum fubdolè in Typographum reijcere) quòd non modò in com mentarijs noftris Latinis factis pluribus antea annis in lucem editis, id erroris fuerit expurgatum, fed quòd ca quoque Plinij uerba per Ty pographum eò tranflata libro $\mathrm{x}$ I x . cap. v. ibi afcriptis non le= gantur, fed libro X X I . cap. x. ubi de Aegyptio Helenio is egit. Quin \& illud de innocentia noftra maximè teltari poterit, quòd illa per Ty pographum tranfpofita authoritas, nil penitus ad rem no: ftram faciat, neque concludat, ut priores Italicæ editiones noftræ unumquem q; certiorem reddent : Non enim putet uelim Lufitanus quòd adeò fim excors, ut tam indecenter, tamq́; fatuè Pliniana illa uerba, quæ nihil pro fententia noftra concludunt, in prædictorum fulcimentum attulerim. Quando quidem fi æquo animo is accuratius perpenderit, quæ Plinius de Helenio uerba fecerit libro decimo nono, capite quinto, à me eo loco citatis, nec ofcitanter Plinium relegerit, me omni culpa uacare compulfus ueritate fatebitur. Ipfe enim Plinius ibi fic habet. Siferis fatus menfibus Februario, "Martio, Aprili, Augufto, Septembri, Octobri, breuior is eft, fed torofior, amariorq́ue. Inula per

" fe ftomacho inimiciflima, eadem dulcibus mifta faluberrima : pluribus modis aufteritate iuncta "gratiam inuenit. Hactenus ille. Hxc itaque funt à Typrographo oblita, qux ad probanda ea, " quæ diximus, afferebamus ex quinto capite decimi noni libri. Cærerùm, ut luam Lufitano detegam negligentiam, uel fortafsè imprudentiam, dicat fanè cur tam aperta fronte negaucrit, Plinum

Calúnia vт. de Helenio.

Calumnia re tunditur.
Lufitani imprudentia. 
libro decimo nono, cap. v. Helenij frue Inulx, de qua primò fcribit Diofcorides, nihil penitus me miniffe, cùm tamen ea omnia, ac etiam perplura ibı habeantur, quæ hic his perpaucis lineis in mediam attulimus. Quibus etiam uidere poterit, qua ratione negaverit reperiri apud Plinium Inulam effe amaram. Hifce igitur de caufis iamprimùm Lufitanus conijcere poterit id, quod in me reprehen dit, tantùm quidem à ucritate diftare, ut potius fibi ipli, quàm mihi iniuriam inferre uideatur. At in= fignem $\&$ arrogantem hominis temeriratem audiamus, qui quò magis præceps elt in rebus maximè

Calumnia vIr.in ungué to Sampfuchi no.

Calumnia confutatio. ambiguis, hoc manifeftius fuam prodit infcitiam. SE D I A M fe fe offerunt recriminanda, qux in unguento Sampfuchino aduerfum me feribit, tametfi longè magis ipfum accufent : quòd ea; qua nullis argumentis probari poffunt, falsò probare contendat, \& qux pluribus fanè modis proba ta funt, nullis in contrarium allatis rationibus, inani quadam arrogantia, improbare nitatur, fic inquiens. Etli apud Theophraftum, vel Plinium, nonnullosq́; alios celebres uiros Sam pfuchus cadem \# cum Amaraco, fiue Maiorana herba fit, apud Diofcoridem tamen, \& Galenum, ac Paulum Aegine- " tam multùm inter fe diffcrunt, cùm Sa nofuchus Maiorana herba hodie in fictilibus \& uafculis repo- " fita ad feneftras pro delitijs habita fit . A maracus uerò Parthenium eft, qux an Matricaria officinarum " fit,tertio dicemus libro. Hanc uerò animaduertentes inter utraque difierentiam Galenus, \& Paulus, " diuerfa capita tanquam de rebus diuerfis fecerunt, uidelicet de Sampfucho, \& A maraco, quam prius ", nofcens Diofcorides uigilantiflimus, oleum Sampfuchinum ab oleo Amaracino, tanquam rem diuer " fam diftinxit. Nam Amaracus Galeni, \& Pauli proculdubiò apud Diofcoridem Parthenium eft, ut " tertio libro facilè quis comprehendere poterit, cùm ibi Parthenium A maracum effe dicat. Quii uerò ", Amaracum Galeni, \& Pauli Marum: Diofcoridis effe opinantur, miro modo cœcutiunt; nam etfi ue ", rum fit, quòd Galenus, \& Paulus in libris de facultatibus medicamentorum fimplicium de Maro nul " lam faciant mentionem, non proindě Amaracum illorum Diofcoridis Marum ob nominis uicinita- " tem effe dicere debent: \& eò magis quia Galenus in lıbris de Antidotis, \& Amaraci, \& Mari tanquam \# rerum diuerfarum meminit. Qüare Matthiolus Senenfis, fi hæc animaduertiffet, non fic facilè cefpi ", taffet, nec hæc fic confufa reliquiffet. Hactenus ille. Sed cur hæc Amathe? Tu id mihi turpè ducis ho " mo præceps, quòd in rebus dubijs meam fufpenderim fententiam? an uclis tu potius, ut præcipiti quadam arrogantia in iftam tuam incurram uecordiam? nifi incredibili ardercs libidine noftros oppugnandi labores, tu tam effes inter hos fcopulos præceps? adeò temerè de his decernercs? Nos fanè longè aliter fentimus. Etenim malo cæteris ueritatis indagandæ apertam relinquere uiam, quàm no ua temeritate eos hinc auertere, prafertim cùm non defint clariffimi uiri, qui hac Galeni lectione plurimùm hęfitarunt. Siquidem non defunt rationes, quæ oftendant Amaracum Galeno \& Paulo tam Parthenium, quàm Marum poffe defignare. Quam ob rem nec hanc, nec illam opinionem pro bare, uel improbare libuit. At aliquid in re difficili \& fufpecta afferere liceat, quod neutiquam in tan ta antiquitate nouum effe debet; magis in hoc inclinor, ut librariorum negligentia hunc. Galenilocum corruptum putem, ac hoc errore Mari titulum in Amaracum effe tranllatum. In qua re tameti authorum certa defint teftimonia, non tamen huius rei abfunt indicia, qux Amaracum Galeno, \& Paulo Marum defignare præ fe ferant. Siquidem cùm fit $G$ aleni proprium inftitutum fimplicium me dicamentorum uircs ex Diofcoride defcribere, idque prafertim feruare in his, quæ uiribus non nulgaribus præftant, neutiquam crediderim, fi Amaracum Galeno Parthenium delignaffer, quin fcripfiffet ex Diofcoride id Epithymi modo bilem atram, \& pituitam detrahere, furpiriofos \& melancholicos iuuare, calculofos expedire, anhelofis liberam fpirandi facultatem reddere, quin \& eius de= cozto infidentibus fominis uteri duritias emollire, $\&$ inflammationes arcere; illitu verò ignem facrum extinguere, collectionesć; confumere. Quạndoquidem tam raras, utilesq́ue facultates haudquaquam putarem filentio inuoluiffe Galenum, fi de Parthenio eo capite egiffet. Verùm cùm Maro nil aliud uirium tribuerit Diofcorides, quàm quòd illitu ferpentia ulcera fiftat, \& quòd in unguentis addatur, mirum fanè non eft, fi de Maro tractaturus Galenus libro fexto de fimplicium medicamentorum facultatibus, ubi fortafsè depravata lectione de Amaraco legitur; de eius viribus fobriè admodum tractauerit, paucisq́ue perftrinxerit, nec plura dixerit, quàm quòd fui ui excalfaceret, \& ficcaret. Id quod etiam egit fortafsè lubens, quòd latius de co fcribere ftatuiffet libro primo de antidotis in Hedichroi compofitione. Hæc nobis dicta uelim, non aftirmandæ tantùm huiufce opinionis caufa, fed tux refellendx temeritatis, ac impudentix. Quamobrem cos mihi impugnare non libuit, quorum tu opinionem fequeris. Nimirum quòd in obfcuris, incerrisq́; nufquam foleam in aliquem uerba facere, nec quicquam agerè, cuius nequiuerim caufam prohabilem reddere, coq́ue præfertim quòd fciuerim ijs effe etiam rationes, quibus fe tueri poffint, nempè Serapionis teftimonium, qui id tantùm quod Galcnus de Amaraco fcripfit, Matricariæ tribuit. Sed hæc etiam poffet deftrui authoritas. Hxc itaque fi rectè, fincereque perpendiffes, non modò te ipfum nouiffes, fed $\&$ fortafsè puduiffet ita te iniurià in me confpiraffe. Reliquum nunc eft, utiam tibi tua detegam errata, ne alios in pofterum ducas in errores. Inquis tu Lufitane, apud Diofcoridem, Galenum \& Pau Jum Sampfuchưm, \& Amaracum admodum inter fe differre. Id, quod effe falfum, \& a neritate alienú, illiçò probari potelt ex ipfo Diofcoride, quip pè qui libro tertio de Samplucho agens, ícriptú relique- 


\section{Aduerfus AmathumLufitanum.}

rit, Sampfuchum à Siculis, \& Cyzicenis, apud quos laudatiffimum prouenit, Amaracum uocari. " Hoc idem facilè uidetur probare crian Galenus. Ipte enim libro primo de antidocis, Amaraci pluri" mum in Cyzico nafci ferrbit, \& Amaracinum unguentum in Cyzico parari ait libro fecundo cap.pri " mo de compolicione medicamentorum fecundùm locos. Id quod omnibus palàm facit, nil aliud $\mathrm{Ga}$ leno delignare Amaracum, quàm Sampluchum. Etenim cùm Cyziceni Sampluchun Amaracum appellent, quis nam fuerit ille tam amens, excors, obtufiq́; ingenij homo, qui non noucrit Amaraci num unguentum in Cyzico paratum è Samplucho fieris His fub foribit etiam Plinius libro x x I. ca" pi. X I. Sic inquiens. Amaracum Diocles medicus, \& Sicula gens appellauerc, quod Aegyptus, \&e * Syria Sampfuchum. \& cap.XX xI. ciufdem libri, Sampfuchum (inquit) fiue Amaracum in Cypro , laudatifimum, \&iodoratiffmum. Fit cx en oleum, quod Sampfuchinum uocant, five A maracinum , ad excalfaciendos, emolliendos q̧; neruos, \& uuluas. Quibus palàm eft, quàm imprudenter hæc affe rat Lufitanus. Nec obltat quòd in quibufdam Diofcoridis codicibus legatur Parthenium etiam altquibus Amaracum uocari . Siquidem hoc non tuetur huius unituerfalem ncgationem. Adde quòd illa verba Diofcoridi fpuria à quìm plurimis rei plantarix ftudiofis nor ab re iudicantur. Nimirum extant Graci codices antiquifimi manufcripti, in quibus non legitur in Parthenij capite particula illa

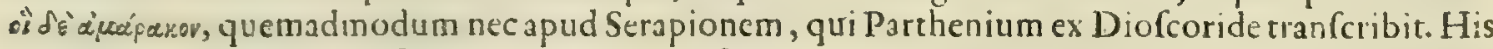
acceditaliud ltolidum Lufitani erratum, quod facilè quis intueri poterit, quum afferat is Amaracinum unguentum odore iucundifimo redolens paraffe antiquos non è Sampfucho, quod Cyzicenis, qui illud olim preftantiflimum parabant, Amaracum dicitur, fed ex Parthenio, quod etiam falsò eam effe plantam exiftimat,quam obodoris urrus Seplafire merito Cotulam fortidam uocant. Sed quantùm in Amaracino unguento, quod odoris fragrantia plurimùm preftaffe fcribit antiquitas, hæc feercns planta conueniat, ij cerrò iudicare poterunt, quibus longè magis, quàm illi res medica cordi fuerit . Et quidem fitetur Galenus libro primo de Antidotis, ac alijs etiam locis in Cyzico, quemadmodum in uniuerfa minori Alia, Mari \& Amaraci oriri plurimum, parum uerò in alijs regionibus, præfertimq́; in Iraliz. Id quod Lufitanum hiç'maximè hallucinatum palàm facit. Quandoquidem nul lo magis herbarum genere ubiquè abundat Italia, quàm Cotula fnetida dicta. Ea enim ubique fcatent campi, horti, arex, platex, femitx, ac colles, adeò ut nullus in Italia fit locus, ubi hæc herba non proueniat. Adde quòd cùm dicat Galenus in Cyzico Amaraci nafci plurimum, vbi Amaracinum unguentum omnium odofatifimum parabatur, \& nobis iam comprobatum fit Sampfuchum à Cyzice nis Amaraci nomine appellari, fatis comprobatum effe putamus, Lufitanum medicx materix ignarum, \& tam Diofcoridi, quàm Galeno idem effe Sampfuchum, quod Amaracuın. Dcmum an Diofcoridis Partherium Cotula fœtida fit itauulgò uocata (ut Lufitanus certò fibi perfuader) is poftea audiet. DE I A S M ENO V N G VENT O multùm quoque mecum contendit, \& ex ijs foribus pa rari Iafmenum, quos Itali uulgò appellant Gelímini, cùm tamen id nullis rationibus comprobet, fed tantùm fuis nitatur verbis, non eft cur multis cum illo agam. Sat enim mihi effe exiftimo, cùm fcribat Diofcorides parari Iafmenum (ideft Violaceum unguentum) è floribus albæ Violæ, nullo pacto fieri poffe, ut ex alijs paretur floribus, \& ex ijs præfertim, quorum apud Diofcoridem, \& antiquos nulla prorfus habetur hiftoria. Quin \& fuperuacaneam hic omnem uerbofitatem effe cĕfeo, cò quòd in commentarijs noftris fatis, fuperq́; comprobatum fit, eos proculdubiò decipi, quos I_u fitanus fịbi imitandos propofuit. Prætereà cùm is rationibus argumentisć; noftris, nullis prorfus obftet uer bis, nec ulla dicendi facultate ( $f$ philofophum medicumá; ut audio fe putat) non uereor, quin facilè fcire poffit, me ad fuas non teneri obiectiones, nifi primùm ad noftra refponderit argumenta. Quibus nulla alia de caufa illum nihil in contrarium adduxiffe putamus, quàm quòd is longè magis defen dendæ pertinaci $x$, quàm ueritati fuerit addictus.

I N P I No autem vt Theophraftum defendere uideatur, fic mecum agit Lufitanus. Longum 2 profectò, nec minus diffscile effet omnes Pini fpecies percurrere. Illius tamen ( Theophrafto authore "Syluetris uerò in Ideam, \& Maritimam partitur. Nam idea, ideft montana rectior, celfior, mate"riæá; cralfior elt; fed maritima folio ornatur tenuiori, imbecilliori, \& cortice læuiori ad coria utili, " in qua nux confpicitur rotunda, breuić; dehifcens. In Idea uerò tanquam nux fylueftrior, oblon" gior $\in \mathbb{f}$, uiridis, minusq́; hifcens. Hæc ad Theophrafti mentem, quæ uera effe nullus hucufquè in dubium traxit,præter unum Matthiolum Senenfem, qui omninò hæc fuo tantùm iudicio fultus euer tere conatur, dicens, fe in fylucftri maritima Pino obferuaffe nuces non quidem rotundas, fed oblon gas, potius folidas, difficulter dehifcentes; in montana uerò non oblongas, fed breues, \& ad aperiendú taciles. At nos reuera Theophraftú uerum uniuerfaliter dixiffe obferuauimus, ac Matthiolum aut non rectè apprehendiffe, aut potius, ut noui aliquid aljis dixiffe uideretur, in medium hæc afferre uoluiffe:

HAEC ILIIVS SVNT VERBA. Cæteruman uera, uel falfa, fyncerè, uel fubdolè prolata, can didifimus quifque lector, qui noftros legerit commentarios facile conijcere poterit. Explodenda.n. deteftandaq́; funt Lufitani figmenta, qux hic aduerfum me habet.Siquidem ego recitata Theophrafti hiltoria,nec eum hallucinatum, nec delufum afferui, fed id tantùm Theophralto repugnare dixi, quod utriufá; Pinaltrı ftrobilus ịn noftro climate teftatur. Quòd aüt uera, non fiẹta, nec fabulofa fcripferim

Scolidum La Grani. ecrací.

Calumnia viii. de Iafmeno ungué ro. Depulfio. 
16 Petri And.Matth. Apologia

(ut ex fe ipfo fortafsè me iudicat Lufitanus) is proculdubiò fateri poterit, qui in agro Tridentino Ideam, in Senenfi, ac Pifano maritimam obferuaueric Pinaftrum. Quippè in maritimis hilce locis dưo habentur Pinaftri genera, quọrum alterum ftrobilos profert fpithama longiores, alzerum uerò breuiores paulò, compactili duritic conclufos, nec per fe fucilè dehifcentes. In Tridentinis uerò montibus quemądmodum, \& in Bohemia, qux Pinu vbicunque fyluefcit, Pinaftri nuces in vniuer fum vifuntur longè maritimis breuiores, infirmioresq́; , quæ cum primùm inaruerint, illicò dehifcunt, \& ab arbore decidunt. At fiquis ad viuas, virentesq́ huiufce Pinorum plantas fe conferre nequiuerit, nouas Pinorum imagines poftrem $x$ commentariorum noftrorum editioni appictas intueri poterit. Quod fi fyncero animi affectu fecerit, non uerem ur, quin facilè conijciat, noltram in plan tarum hiftoria fidem falsò à Lufitano improbatam : \& fubindè etiam nofcet magnam illius imperitiam, \& apertam in nos inuidentiam. Ego quidem nunquam putaui hæc in Theophraftum reijcere, fed noftro climati caufam aflignaui. Quamobrem non poffum non admirari Lufitanum, quippè qui non fit ueritus tam euidentes in me afferre calumnias. Equidem nunquàm negaucrim Pinaftros, que in Ida monte proueniunt, quin \& eas, quæ in Graciæ maritimis crefcunt, in nucibus edendis contra rio modo forfican fe habere, cxli, folić; illius immutata natura.

Calumniax. in Hippocampo.

Iufitani opinio necrefel licur, necpro batur.

Calínia. $\times x$. defatiuo $\mathrm{Cu}$ cumere.
VE N I O A D Hippocampum, cuius hiftoriam à nemine defcriptam hactenus reperi: Quo fit, ut difticilè admodum fit abfque ulla dubitatione affirmare, quod nobis fit pifcium genus, quod Hippocampum appellaueric antiquitas. Nec difplicerer Lufitani opinio, quam longè antea audieram à Luca Ghino medico clariffimo, quòd Grxcis rectè idem fonet Hippocampus, quòd latinis flexuofus equus, li quo probari poflit, effet ad manus. Verumtamen cùm nulla extet Hippocampi hiftoria,cur eius opinionem accipiam, fanè non habeo: quin nec etiam cur refellam. Plinius lib. $\mathrm{x} x \mathrm{x} v \mathrm{r} . \mathrm{cap} . \mathrm{v}$. " dum Praxitelis admiranda percurrit marmora, uideri feribit in maxima dignatione Gn. Domitij de- " lubro in circo Flammịnio Neptumnum, Thetim, atque Achillem, Nereidasạ́; fupra delphinos, \& " hippocampos. Qıx quanquam demontrant Hippocampos equorum effigiem præ fe ferse, non ta-, mẹn hac Plinij authoritate quis unquam rectè aftirmare poterit, Hippocampos, quorum ille meminit, eos effe pif́ciculos Equi uel Draçunculi formam habentes, quos quidam ueros effe Hippocampos non ambigunt. Qiındoquidem Plinijuerba luce clarius demonftrant Hippocampos paruos nó effe pifces, fed ingentes fortalsè beluas, corporis mole Delphinis minimè inferjores. Nifi hæc potius fabulofa cenfeamus, quàm uera. Nos autem cum iamdiu non ignorauerimus non decfle rei medicx ftudiolos, qui Equiculos illos, uel marinos Dracunculos ueros effe Hippocampos putarent, non abs re effe duximus horum Equiculorum imagines commentarijs noftris adiungere, non ea tantùm caufa, ut horum placitis fubfcriberem, fed ut unumquemq́; , prafertimq́; Zoilos admonerem, me hæc prius non ignoraffe. Verum non ob id abfurda vocari expedit (ut Lufitanus putat) quæ de Hippocampo antea fcriplimus, doetiflimos Diofcoridis interpretes, \& Græci fermonis peritiflimos fecuti, quorum non defunt, qui afferant in Locuftarum genere haberi Hippocampum . Quibus fubfcribere uidetur Plinius libro $x$ x x I1. cap. XI. At cum inter Locultas nulla fpeftetur, quæ magis flexuofo dorfoerucas, quas Græci xajutas uocant referat, quàm ea, quæ ibi pariter picta fpectari potelt, nefas fanè fuerit tam petulanti ore affirmare, noltram, \& aliorum opinionem, tanquam abfurdam effe fpernendam, cùm tamen rationibus, \& authoritatibus comprobatam unufquifque facilè cernat.

M Y LT A IIAM CONTRA Nos de fatiuo Cucumere effundit Lufitanus procacius magis, quàm uerè, fic inquiens. Cucumer non ubique fatiuus reperitur, qua de caufa multi non fine ingenti erro re Citrulum, quem Peponem effe certò fimus Cucumerem appellant, uulgarium forfitan uqce fe- " ducti, qui in Italia ferè uniuerfa \& Flandria , ac Germania Citrulum Cucumerem uocant; fed, ut di- , $x^{i}$,non fine magno, ne dicam pudendo errore; inter quos nouifimus extat Matthiolus Senenfis in fuo Diofcoride Hetrufca lingua confeeto. Eft igitur Græcorum Cucumer, fue Cucumis dictus fic (ut , Varroni placet) quia facilè curuatur baculi craflitudine, colore uiridi, longitudine cubitalı, \& maio , ri, præfertim fị in flore exiftens in fiftulam mittatur. Tunç enim (ut tradit Plinius libro x I X.cap.v.) " mira longitudine, \& ad fiftulx complementum crefcit, \& hac de caufa Columella Anguinum Cucumerem eum appellat, quia oblongus, craffus, atque inftar anguis flexuofus fit. Nafcitur enim in fi- , mili planta, qua Cucumis fylueftris oritur. Rarò in Lufitania Cucumer uidetur, fecus autem in alte, ra parte Hifpaniæ præcipuè apud Salmaticenfes, ubi in magna cernitur copia hirfutus, colore omninò uiridi, longitudine cubitali, \& curua. At Pepo is eft, quem Officinx ob colorem Citri in maturi "

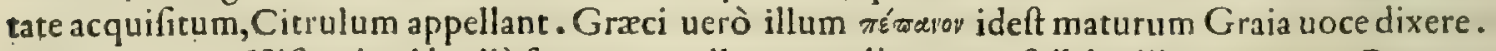

Quam uocem Hifpani uel hodiè feruantes nulla mutata litera, aut fyllaba illum quoque Pepanum uocant: \& eius fupremam partem concifam fronti $x$ ftus hora, in qua illum plerunque comedinus, tanquàm refrigerantem admouemus. Quod olim quoque à Gracis ficri Diofcorides innuere uidetur. Vefcimur enim Pepone hifpani, dum uiret, nam poftquàm maturuit, \& colorem luteum Citri maturi contraxit, tanquam cibo inutilem rejjcimus. Siquid tamen illius comedendum frt, eius fu, prema, \& cartilaginea pars tantùm pro ui\&tu, reiecta eius medullari parte, accipienda eft, ut apud in feriores Germanos plerunque fit, qui Peponibus jjs non nifi maturis contra Hifpanorum confuetu, dinem in uiftu utuntur : quorum medullarem, \& interiorem partem in qua femen continetur, tan= 


\section{Aduerfus Amathum Lufitanum.}

" quam improbam \& malam reijciunt, fupecma \& cartilaginea illa, crebris uerrucis ornata parte contenti.Qui mos apud Grxcos quoquè fuit, ut ex Galeno deprchenditur libro fecundo, de Alimentp"rum facultatibus, ubi inquit. Huc accedit quòd in Peponibus homines à carne intima,in quo femen

"habetur, abftinent. Sed hiec ignorans Matrhiolus, nil in hoc capite facit, quàm uellicare alios. Sed audias Amathe. Solus'ne inter tot eruditifimos uiros, quibus eaden placuic opinio, à te reprehendor? Solum inter innumeros alios Matthiolum infectaris? Quapropter? non alia opinor caufa, nifi ut tuam malitiofam inuidentiam in eius tantum uidearis monumenta efludiffe, ex quibus tu opima Spolia congefilti. Egregiam certè hominis in furando prudentiam, ut tacitè ijs fecum gaudeat, qux publicè criminari putecur. Iccircò, homo uaferrime, tot hæc contra me conftruuntur hic uerba? Sed audiat ipfe Lufitanus quàm hic toto aberrauerit cælo. Etenim fententix noftræ haudquaquam ob= ftare, fed plurimum aftipulari cenlemus, quòd dixerit Varro Cucumim à curuore effe dictum. Quip pè quòd Cucumeres, qui paflim in Italia proueniunt, \& quos falsò Lufitanus Pepones effe conten= dit, plerunquè incurui fpectantur, ut æltate tota uidere quis poteft in clarifimarum urbium plateis, ubi innumeri ucnduntur. Porrò fi hxc ignorat Lufitanus, non medicos confulat, fed olitores. Nam ij oftenfis incuruorum cucuminum millenarijs, facilè craffam hanc caliginem ab ipfius oculis detergent. Pretereà uulgarem Cucumim, quo pafim utimur, uerum \& genuinum effe manifeftò com" probat Plinius libro X I x.cap.v. his uerbis. Particulatim Cucumis floret, fibi ipfi fuperflorefens, " candida lanugine obductus, magisq́; cùm crefcit. Hxc ille; quibus palàm eft Cucumeres noftri ufus legitimos effe. Quippè fi Lufitanus (ut prædiximus) olicores adibit, $\&$ ad eorum hortos fæpè fecon tulerit, uniuerfos uidebit cucumeres, illos fcilicet, qui nuper emerferunt, \& iam primùm ad iuglan dium quantitatem intumuerunt, fibi ipfis in cacumine fuperflorefcere, 8 alba quadam contegi lanu gine. Ad hac fententiam noftram, ac quamplurimorum clarifimorum fcriptorum à Lufitano falsò improbatam illud lanè luce clarius oftendit, quòd fatiuus, ac uulgaris Cucumis fructu tantùm ab er ratico differat. Vtrique enim eadem funt folia, ijdem flores, exdem uiticulæ, \& eadem in uniuerfum deniquè facies, ur libro quarto teftatur Diofcorides, \& libio vi I.cap.vi.de hiftoria plantarum poftè ritatis memoriæ prodidit Theophraftus. Tanta enim inter hafce plantas intercedit fimilitudo cogna tioq; , ut ii fimul lerantur, uel alter alteri conferatur, nulla ferè differentia dignofcantur. Nec propte reà negauerim, quòd cucumis ille, qui fua longitudine ferpentis fpeciem refert, \& quem Hetruria fal sò Melonem uocat, inter Cucuminum genera non fuerit recipiendus, cùm \& ipleolitorum mangonio, è uulgaribus noftris in eam formam fucrit redactus :id quod Hippocrati primùm, dein Plinio,

3) \& Palladio referunt acceptum, quippè qui fcripferint flore in fiftula, uel harundine demiffo, Cucu-

" mim indè miralongitudine crefcere, \& omni alia, qua coguntur, forma : id quod etiam de Cucurbi

") tis tradidit Columella. Hinc itaque fuam traxit originem illud Cucuminum genus, quodita pralon gum fe diffundit, \& anguium modo contorquetur. Quippè fato fubindè feminc, quod exemptum fit ex hifce pralongis mangonio illo paratis, in poiterum per fefe eadem forma proueniunt, ut \& no's experimento comprobatum fcimus, non folum in Cucumeribus, fed etiam in Cucurbitis, præfertimq́; in ijs, quas Indicas uocant. Id quod ctiam Plinius affirmat loco prius citato. Nam cùm maximè compertum haberet in Campania oriri Cucumeres mali Cotonei effigie (ij autem ut Lufitani fert opinio prælongi non erant) \& huiufce formx caufam reddere uellet, Fortè (inquit) primò natum

"ita audio unum, mox feminc ex illo genus factum. His itaque palàm fit (ut Lufitani illius uerbis utar)

" in quàm magno, ac pudendo is uerfetur errore. Quippè fi ( ut idem falsò contendit Lufitanus) uniuerfum Cucuminum genus fponte fua ita pralongum proueviret, ftolidum fanè effet id arte ueI man gonjo moliri. Sed Cucumeres fui natura non effe adeò in longitudinem protenfos manifêtè demon Itrat Plinius, quippè qui fcribat Cucumeres in Italia, effe quàm minimos, in prouincijs quàm maxi mos. Nam fi fponte fua ea effent forma ( ut Lufitanus fomniaffe uidetur) fcripfiffet quidem nafci Cu cumeres in Italia quàm breuiffimos in prouincijs quàm longiffimos. Adde quod etiam experimento conftat (ut ego mihi teftis effe poffum . Aquod Cucumeres fic Italis uocati in fuppolitam aquam defcendere nitantur appenfi ; \& contrà refugiant, \& unci modo recuruentur, ubi uas oleo plenum fupponaturapertum. Id quod proprium effe Cucumeris affrmant praclarifsimi rei rufticæ, plantariæque fcriptores. Præter id fi guftum confulas nulla penitus faporis, vel odoris differentia inter prælongos Cucumeres illos, \& vulgares noftros cognofci poteft. Adhæc cùm tria Theophrafto, \& Plinio fint Cucumerum genera Laconicum, Scytalum, Bcoticumq́ue, hoc maximè etiam Lufitano aduerfatur, quòd unum tantùm Cucumerum genus ftatuerit. Adid autem, quod Columellatcfimonio afferit Lufitanus fatiuum Cucumim Anguinum vocari, quòd forma anguium referat fpeciem, nil aliud nobis refpondendum fefc offert, praterquàm quod falsò id Columellæacceptum referat. Conftat enim Anguinum Cucumim nilaliud fuiffe Latinis, quàm Cucumim fylueltrem, quemadmodum fylueftre Allium Diofcoridi Anguinum vocatur, non quòd forma referat angues, fed quòd in fylueftribus nafcatur locis, vbi facilè ftabulantur angues. Catcrùm quòd Anguinus Cucumis fylueftris fit, non fatiuus, teftatur in primis Lucius Apuleius fuo de fimplicium medicamentorum libro, capite proprio de fylueftri Cucumere; quin \& quidam Diofcoridis codices, vt Hermolaus \& Marcellus legunt, quibus etiam fubfcribit Phnius libro xx. cap. II .

Amathus fuas enatrationes in Diof. ex Mathio. lo crálicripfit.

Calumniare fellicur.

Cucurbite,
\& cucumeres
olitorí man-
gonio tuarias
indunt formas. . . 
Iufitanus fui Sed cur hoc nitar tantorum virorum teftimanijs comprobare, cùm Lufitanus ipfe capite de Agrefti ipfius laqueo captus.

Lufitanus më das.

Crucumere fui ipfíus oblitus id apertè fateatur, \& fuo fe iugulauerit gladio? Seà quod falsò Columella teltimonio fuerit is vfus, prater id quod nufquam ab iplo hoc fcriptum effe fcimus, teftem habeo

Hermolaum virum fanè praclarifsimum, qui in fuo Corolario Lufitanum mendacio redarguit his verbis. Cucumeres in fiftula apud Hippocratem demiffo flore mira longitudine quafi anguina fpe-, cie prouenịunt, quanquam Anguinus cucumis idem videtur effe, qui Syluctris, multò anfra magni- ", tudinem fatiui, Erraticus \& Angueus Columellæappellatus à fatiuo penitus differens. Hsetenus, Hẹrmolaus. At lit ita : demus huiç bono viro à fua forma longiores illos cucumeres ab aliquibus Anguinos vocari, At non intelligit quàm non cohærentia, quàm in fe ipfum repugnantia dicat? nunquid non uidet homo mifer, quòd non aliam ob caufam hæ differenția plantis addi folent, quàm quòd a reliquis carundem generis diftinguantur? Non'ne ftatim ob hoc fequitur effe etiam alia cucumerum genera? Refipiat mifer, \& fua iam recognofcat errata . Refipiat, inquam, cum fignis omni luçe clarioribus vincatur à teftibus, \& propria confefsione vrgeatur. Comprobat etiam cucumerem noftratem non effe Peponem, cum in primis fapor, tum deindè facultas. Sapor quidem, quòd cùm fcribat Symeon Sethi Græcus author Pepones fapore effe dulces, nulla fanè ratione fiẹri potelt, vt cucumeres nofțri vfus fuerint pepones, quippè qui eò magis amarelcunt, quò maturiores euadunt, vt Theophraftus feribit lib. v I. cap. x I I I I. de Plantarun caufis. Prxterea fi Peponum facultas expendatur, conftabit fanè ex Galeni fententia, quòd deuorati biliofos excitant morbos, quin \& vomitiones, \& id quidem (vt Symeon ille afferit)fua dulcedine efficiunt, præfertim cùm in biliofum inciderint ventriculum. Ad hac confricata Peponum caro (vt Galenus ait) vitia cutis in facie, nempè alphos, lentigines, ephẹlidasq́; abftergit dulci, quo imbuitur, fucco. Id quod ex noftratis cucumeris affrictu nunquàm confequeris. Nec obitat quòd Hifpani cucumerem noftrum (ut Lufitanus inquit ) Pepanü uocent. Quippè cù $m$ Itali à Latinis originem ducant, omninò credendum uide

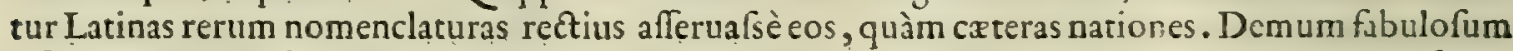
ęffe fcimus, \& Lufitani figmentŭ, quod Flandri uulgares Cucumeres edant, cum penitus confenue

Iufitani fig= mentü explo fum. rint. Sunt enim domi nolțræ Flandri, qui nobis fẹruiunt, \& qui Flandriam, \& Germaniam ferè totam peragrarunt, ịd penitus deteftantes. Nec obftat fcripfiffe Galenum à Peponum carne intima, quar femen continet, abftinere homines, quum id fiat potius in Peponibus noftris, quàm in Cucumeribus, quorum feminibus unà cum carne uefcimur. His itaque poterit Lufitanus fortafsè nofcere, quàm in cenfenda Cucumeris hiftoria fuerir hallucinatus, \& fubindèpalinodiam meditari . Nam fi fecus fecerit, quum fcribat Plinius Cucumeres in Italia quàmminimos, in prouincijs vero quammaximos prouenire, cumq́; Lufitanorum regio, qua fe orjundum facit,ad vltimas Europæ oras habeatur, \& ob id caxteris fortafsè magis ab Italia diftet, verendum fanè eft, ne rei medicæ ftudiofi, qui hxc perl egent Cucumerem Lufitano maiorem nufquam fe vidiffe aftirment. Sed nimis fortafsè prolixè Cucumeris caufam egi . Equidem hæc nimia effẹ fateor in re minimè obfcura. Veruntamen vt huius calumnix \& maledicta aliquando ceffent, omnis eius eft obtundenda verbora importunitas; ne li for tè breuior frm,iure fibi cedi putet, minusq́; fibi a nobis fatisfactum clamitet, \&, qua eft inani arrogantia,non filentio, vel difsimulatione vanè fe victorem glorietur.

Calúnia xij. IA M D E CA R P E S I o pauca ei refpondeo, de quo agens Lulitanus capite de Pipere, poltquä de Carpefio. ibi de Caryophyllis egit, noftrum ibi ordinem, \& doctrinam quemadmodum in cæteris fequutus, ita aduerius nos fcribens comminifcitur. Caryophyllis Carpefium proximum eft, quod Cubeba Officinis dicitur, vt libro primo meminimus, \& Aetuarius confirmat. Non enim Carpefium Zcdoaria, fiue Zurumbet Arabum êt, vt Matthiolus augurat, quum potius, vt dicimus, Carpefium Cubeba fit. Hæc falsò Lufitanus. F A L s o', inq'uam, quòd nobis nufquam fcriptum fit Zedoariam, fiue Zurumbet effe Carpefium. Quis ergò non miretur hominis impudentiam,infidelitatem,

Lufitanus im pudentia \& mendacio no cantur.

Calúniaxiij. in Artemifia. mendaçemq́; locutionem? Quis non deteftetur huiufcemodi hominum genus, qui tam cuidentibus calumnijs, ac ımpofturis candidifsimos quofque lacerant? Huic adhibenda fides? huic credendum? huic affentiendnm? Ncquaquam. In confeffo enim eft omnibus hominis huiufce fcripta fui ipfius efle figmenta, mendacia, vanitates, adeò vt iam omnibus stomachum commouerint. Sed quantùm hallucinetur mifer, dum fibi perfuadet Zedoariam, \& Zurumbetum Mauritanis nihil inter fe differre, poftea audiet, cum innumeros illius errores promulgauero.

S E QV I T V R, V T quid de Artemifia dicas, videamus. Artemifia duplex eft, altera latifolia hortenfis, odore acuto, fapore verò amaro ; altera verò Matricaria dicta tenuifolia, à Grxcis Leptophyllos appellata. Nec enim in eam imus fententiam, quòd Matricaria hæc Parthenịum fit, vt Matthiolus contra omnes grauifsimos mẹdicas contendit, quum re vera tenuifolia Artemifia vuulgaris Matricaria eft. Nam Parthenium, Brufaculum, Herba foetida Chamomilla fimilis eft, vt fuo dicemus loco. Hæc illius ad vnguem funt verba. Inania tamen, nihilq; ponderis referentia. Quum enim Lufitanus argumentis, rationibus, \& authorum teftimonijs, quibus fatis, luperq́; nobis cumprobațum eft, Matricariam vulgò vocatam, alteram non effẹ Arțemifiam, nihil relponderit, nec fubindè vllis indicijs, ac rationibus contra fententiam noftram feriplerit, fed fua tantum talia opinione duçus, pon eft fanè cur cum illo pluribus agam: fed illum in fe ipfum latrantem relinquam. Verum
Amathum in re ipfum datrare. 


\section{Aduerfus Amathum Lufitanum.}

vt huiufce hominis imperitiam pluribus detegam, \& procacitaté compefcam, libebit fanc̀ nobis nonnulla in contrarium afferre. Scribic it?que Lufitanus Aremifiam duorum effe generum, alteram $1 \mathrm{~d}-$ tifoliam, hortenfemq́; , altẹram Matricariam tcuuifoliam disłam, quibus illicò dcprehenditur, quà. an ofçitanter Diofcoridem legerit. Qui etfi fcripferit alterum Artemilix genus folio efle renui, non ta-

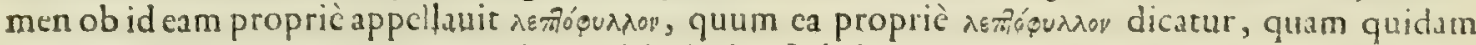

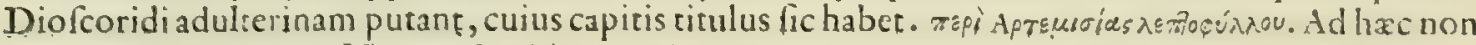
reperio vfquam fcriptiffe Diofcoridem, quin nec etiam Plinium, primi generis Artemifiam hortenfem effe plantam, fed quòd in maritimis fpontè, \& per fe proueniat, vt ille, ve fibi aliquid arroget, fatetur. Adhre duo funt argumenta, quibus refragari nemo poteft, quæ maximè obftant Matricariam non efle lecundi generis Artcmiliam. Alterum quod hac flore lit paruo, tenui, in vniuerfum candido : id quod fanè in Matricaria non vifitur, quum flos illi infit Artemifiæ maioris dccuplo major, frmus, non tenuis, non in vniuerfum candidus, fcd vmbilicotenus aurcus, candidis foliolis circumfeptus, vt in Anthemide. Alıcrum, quòd plantạ fit ad manus pumila, ac tenuior, qux adcò maiorem Arthemifram xmulatur, adeoq́; illı congener eft, ( vt fatecur etiam Brafauolus) vt ambigendun non fit , quin ip fạ fit altera Artemiliạ . Adde quòd cum Matriçaria folijs, caule, Horibus, fäpore, odoreq́; plurimùm à prima Artemịfra diffcrat, non eft fanè cenfendum, quin cius differentias, ac notas filentio inuoluiflct Diofcorides; fcd cùm inter primum, \& altẹrum Artemifix genus nulla intercedat diffẹrentia, præterquàm magnitudinis, crafsiçudinisq́;, vt ipfemet apertifsimè tatetur Diofcorides, non fuit illi opus, alterius Artemifix notas pluribus explicare. Demum \& illud vni cuique contra Lulitani fententiam verum poteft cfe argumentum, quòd antiquorum nullus fcriptú reliquerit, Artemiliam alteram nec etiam primam ẹfe amaram, quemadmodum reperitur vulgaris Matricaria, quæ amaro aḍmodùm guftu fentitur, adeò vt parum ab Abfinthio differat. Quod etiam argumentum prabet, in caliditate, \& ficcitate hanc longè magis exçedere, quàm ip fa Galeni teftimo nio excedat Artemilią. Hæac itaque fr quis rętè perpenderit, nobis quidem minimè verendum fuerit, quin Lufitani infcitiam, \& iudicij vanitatem facile deprehenderit . Quòd autem Matricaria non fit Parthenium, \& quòd ea planta Parthenium fit, quam vulgari appellatione Cotulam foctidam dicunt,nos penitus deteftamu r,quippe fi Cotula forida Diofcoridi Parthenium effet, quum hac omni ex parte Anthemidẹ adeò referat, vt tantú ferè odoris diuerfitate altera ab altera digno fcatur, quis nă dubitauerit, quin Diofcorides Parthenio Anthemidis folia reddidiffet,nó Coriandri? Coriandri folia Cotula fœtida profectò non habet, fẹ Antemidis, Matricaria verò contrà. At fi forțe obiẹcerıt Lufita nus cùm ad fummum vfque Coriandrum adoleuẹrit, \& fuum iam edidẹrit fẹmen, quæ in fummitatibus funt folia, adeò parua tẹnuiaq́; i peetari, vt Autemidis łolia quadantenus referant ; quumq́; dicat Diofcorides, Parthenium foljjs effe Coriandri tenuibus, is ad minura tantùm folia refpexit, non ad maiora. Vide quàm hoc ego argumentum propulfabo facile. Siquidem cùm neque Oribafius ex Diofcoride à quo verbum ex verbo trạnfcribit, neque Serapio, qui eandem feruat regulam, legat particulam illam $\lambda \varepsilon \pi \alpha_{\alpha}$,arbitrandum fanè eft, particulam $\lambda$ s rum incurịa, vel potius temeritate, præf́rtim cùm plantarum comparationes rectius, exactiusç; fieri debeant, cùm plantx ipfra adolefcunt, vel confiftut; quoniam hoc tempore foliorum, ac caulium no tæapertislimè confpici poffunt; non autem cùm primùm oriuntur, vel cùm confenuerint, quo tempore genuina foliorum forma videri non poteft. Quin \& illud contra Lufitanum maximè pugnat, quòd cùm Cotula forida longè acrior fit, quàm amara, adeò vt ea fedem abftergentibus ardorem non obfcurum inferat, ob idq́; vulgò Ferrarienfibus ( ve Brafauolus inquit) dicatur Brufciaculo: Parthenium effe non poteft. Quandoquidem Diofcoridi Parthenium nulla faporis açredine commendatur, fed tantùm amaritudine, qux in Matricaria manifeftò percipitur fine acredinis tantillo. Poftremò cùm fexcenties iam expertum fit Matricariạm ea omnia præftare, qux Parthenio a frribuntur, palàm fanè eft, maximẹ deludi eos, qui contrą fententiam noftram friuolis quibufdam argumentis, ac captiunculis machinanțur. Sed veinam tam facilè vera inueniri poffent, quàm falfa conuinci. C A ET E R V M quum anteà fcripferim in mel̆s commentạijs italico fermone primùm in lucem editis Symphytum Petræum à me hactenus non uifum, quafi me negligentiæ inertiæá́; accufare uelit Lufi 9, tanus, hæc fuo more aduerfum me fcribit. Ex herbis, quas Toannncs Falconeriłs Anglus fecum affere " bat,Symphytum Petræum erat, quod Confolidam nonnulli appellant, quæ (ut teftatur Ruellius) " familiaris Gallis admodum eft, \& eam fua lingua Buglam uocant. In Italia quoque nafçi cum Paulo "Caftiliono medico affirmamus, quanquàm Matthiolus eam nụnquam fẹ uidiffe tradat.

H I S I V S I T A N V ș Non tantùm in me inuehitur, ut putaram, noftrxaccufandæ gratia negli Confuratio. gentix, fed etiam fux extollendæ glorix, quippè qui fẹ nobis rei medicæ peritiorem oftenderce ambierit. Verum fi (ut folertes decet (criptores) Italica eadẹm commentaria fecundò edita anno ì C H R I S T O Nato. M. D. L. perlegiffet, comperiffet quidem Symphytum Petræum me per me met adinueniffe. Id quod is nunquam per fefe, uel per alios fortafse feciffet, ni Falconerius ille ( $f_{i}$ ta menuera refert ) id illi oftendiflet. Non enim una die uniuerfa feges in horreum congregari poteft. Quno fit, ut accufari iure non poffim, ubi quandoque faftus fuerim, me hanc uel illam non nouife ftirpem. Præftabat quidem tunc mihi Symphy tum Petraum nunquam me uidiffẹ fateri, quàm men- 


\section{Pet.And. Matth. Apologia}

tiri, vt doctior, diligentiorq́; uiderer,quo nibil deteftabilius, exccrabiliusq́; dici poteff.

Calünia Ir. A D S P A R A I V M veniamus, in quo ita me taxat. Sparganium fiue Xiphidion Officina. De Sparga - rüm Spatula foetida eft, cùm inter fe maximè conueniant. Vndè Matthiolum Senenfem hic errare nio.

certum eft, qui Sparganium non effe Spatulam fœtidam contendit, \& cò magis, quia in Spatula fœtida pilulas non comperiri, in quibus femen claudatur, dicat: quod fallifsimum effe, qui Spatula for, tidx mediocrem habent notítiam, noruite . Proindè Sparganium Spatulam fotidam effe certum eft.

Calumnia cố Hactenus ille. Demiror fanè tam perfrictam hominis frontem, qui quafi omnium rerum naturam, धunditur. plantarum omnium intimam notitiam perdidicerit, ac imbiberit, adeò audacter hos graues inihi im ponit errores, confeltim me errare accufat. Cognofcitis, vt opinor, hominis eruditionem, \& vitxe confuetudinem. Porrò non modò omnibus rei herbariæ ftudiofis (vnum tantùm Ruellium excipio) fed \& cxteris omnibus, quibus aliqua fit ftirpium cognitio in conteffo eft, nil aliud effe Spatulam Spatula forti- foetidam vulgò appellatam, quàm Xy ridem . Xy ris enim præter id, quòd omnibus noris, Sparulam da eft Xyris, foetidam referat, foliorum odore facilè indicat nomenclationis occafionem, quippè quoniam fi. dinon Sparga - gitis confricentur, foetidum admodum odorem fundunt, undè illi nomen, adeò vt Tirefia,vel $T$ alpa
nium. cæcior fit, qui non uiderit, Spatulam fotidam uocatam omnibus fanè notis Xyridem referre. Hane à nemine defcriptam reperio, præterquàm à Mattheo Syluatico Pandectarum authore, oui eam Iridi fimilem reddidit. Id quod Lufitani petulantiam palàm facit. Siquidem nulla extat planta, qux magis Iridem referat, quàm Xyris, adeò vt fcripferit Oribafius appellari aliquibus Sylueftrem Iridem, à quo quantùm diftet Sparganium, eos iudices velim, qui in materia medica indaganda plus

Calünia xvj. operis, ac laboris, quàm Lufitanus impenderunt. NE C P L V R I B V s verbis ea refellam, qux,

De Siderite. de Siderite obijcis, in quam magis, ac magis tuam detegis rei plantariæ infcitiam, cum ita memoras . Confpicitur Sideritis hæc in nonnullis vallibus folic afpero Saluiæ magnitudine tanquàm Marrubij albicante, \& per circuitum tanquàm Quercus dentato, quod fricatum ex fe odorem, qualem ex Cy "s donijs optimè maturis oriri videmus, emittit, quem Diofcorıdes fubintelligit, cùm dicit guftu non \# iniucundo, cum aditrictione aliqua. Hanc verò Fuchfius in fuo herbario nouiffe videtur, quanquàm ", Matthiolus oppofitum contendat. Sed re vera Matthiolus eam nunquam vidit, quia fi eam cogno- „, uiffet, illius odorem fuauifsimum nunquam prxtermififfet. Hæc eius funt verba : fed quàm omni

Sui ipfus nu- fucco inania,ipfe videat. Quòd enim de Sidcrite prima, quam fe in doctisfimi viri Fuch fij herbario gis confudi - narrat inueniffe, fuas proferat commentitias nugas, hic facilè demonftrat, quòd eius folia non mo tur Lufitanus. dò non (pectentur Quercus inftar.finuata, fed nec per ambitum nulla parte laciniata, tametfi Lufitanus, vt potius fuam tueretur opinionem, quàm veritatem, id non fit veritus affirmare. Ip fa en im $F u$ chfij piEtura de Lufitani fide maximè teftatur. In primis enim flores oftendit fpicatos in cauliü fummitatibus crumpentes, non autem in ipfis caulibus orbiculatx vertebræ inftar, vt in Marrubio, per interftitia difpofitos. Prætereà folia nulla ex parte correfpondent, nec pomortum Cydoniorum odor, quem folus Lufitanus illi tribuit. Diofcorides enim Cydoniorum odore, nec quouis alio Sideritem hanc commendauit, fed guftu non iniucundo ; multa enim habentur, quæ odore maximè placeant, \& fapore difpliceant. Sed mihi fatis verendum eft, an Lufitanus Cydoniorum odorê huic plantæ tribuerit, ut uera fateretur, an fortafsè fuæ fuftinendæ opinionis caufa. Quippè Fuchfius hu iufce odoris non meminit, nec nobis periculum facientibus percipi potuit. Non enim hanc ftirpem ignoramus, vt fua potius temeritate, quàm fcientia cxiftimat Lufitanus. Sed non fortafsè à fcopo aberraret, qui dicer et Lufitanum Fuchsij Sideritcm nufquam vidiffe, nifi appictam, quod falsò fcribat, Sideritem hanc in vallibus nafci, vbi plerunque folum vliginofum effe folet, Fuchfius verò perindè, Calúniaxvij. ac Diofcorides in afperis, petrofiss, ac incultis locis. M I N v s acerbèaliquantò patior, cùm de Tra De Trago. go noftram ftudet emendare opinionem, vbi Lufitanus ita fuam exorditur calumniam. Non prætermittendus quoque eft Ruellius, qui proculdubiò in dignofcenda herba ifta multùm hallucinatus eft, qui Tragum Iunci fpeciem effe crediderit, cui quoque Matthiolus Senenfis fubfcribit nulla fultus ratione, cùm è directo Tragum herba fit, ex qua uitrum conficitur. Atqui.inter omnia, quæ haAtenus nobis obiecta funt a Lufitano, \& fatis dilucidè, vt arbitror, refutata, nihil iuftius, nihil $x$ quius fateor, vnquam in nobis eft calumıiatus, quàm qux de Trago hic recitat. Hoc modò fi cauere potuiffet, dum nimis fe follicitum exhibet circa exiguam in nobis labeculam, non ipfe pluribus fe maculis contaminaret. Equidem fateor,olim in Tragi hiftoria ancipitem me habuiffe opinioné, quanquàm inclinaret quandoque animus ad credendum, nil aliud Tragum effe, quàm quoddă humilis Iunci genus in maritimis proueniens, cui femen acinofum in cacumine nafcitur rubrum, adftringenti fapore. Eram enim tretus hoc argumento, quòd fcilicet fcripfiffet Diofcorides,nafci Tra gum fine folijs, pufillis circùm ramos acinis, rufis, multis, magnitudine tritici, acuto' cacumine,

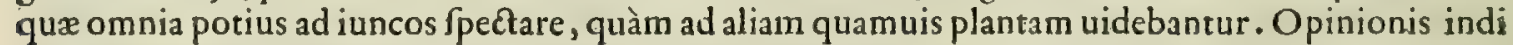
tia fubindè augebat, quòd fequenti ftatim capite idem Diofcorides de Iuncis uulgaribus egerit. Verùm quod \& fummis, \& præclariffimis contingit ingenijs, ut temporis proceflu plura quoque inue nerint, ir diligentius examinauerint, id mihi accidiffe fateor. Re nanque in pofterum exactius agita ta, ac perpenfa, melioribus adinuentis, minimè puduit priorem dcponere opinionem. Etenim cùm animaduerterem apud Theophraftum, \& Plinium, quorum etiam iudicium in noftris Lati- 


\section{Aduerfus Amathum Luficanum.}

nis commentarijs fecuti fumus, Tragun utrifque Scorpionem appellatum, quemadmodum \& Dio fcoridi aculeatam in uniuerfum effe plantam, priorem, qux in animo verfabatur, opinionem diutius " fequi non libuit. De hac enim planta fcribés Theophraltus lib. v I. cap. r. de Plantarum hiftoria on

"Aculestarum, inquit, alis ex toto acu lei funt, vt Cortuda \& Scorpius. Hxc enim nullum, præter a" culeum, folium gerunt. Id quod poftea reperijt tertio eiufdem libri capite his verbis. Inter ea verò " diftincta genera plurimum qux aculeato folio côftant, nimirum dixerim, quod ex toto fpinofum in" fpiciatur, exiguo eft numero, quemadmodum diximus, \& difficile quicquam fermè inuenies, præ:" ter Corrudam, \& Scorpium, qux poft Aequinoctium Autumni florefcunt. Scorpius enim florem " in carne extuberante fuh extremo aculci profert, initio cardidum, polteal leuiter accedentem ad pus " puram, \& fingulari radice, eademq́; breui adhatet. Hxc ille. cui fubrcribit Plinius libro x x x.cap. " $x$ v. fic inquiens. Spinofarum multa fpecies . In totum fpina eft ACparagus, Scorpio . Nullum enim folium habet. Quibus palàm eft Tragum, quem Diofcorides etiam Scorpioncm vocat, nullıs pro" uenire folijs, fed licatere tantùm aculeis. Id quod etiam videtur fateri Diolcorides, quòd dixerit, Tra" gum, quem alij Scorpion vocant, fine folijs oriri, acutis tantùm circa ramos adnatis granis . Quamobrem libenter hac in re poftea meam correxi fententiam, quam Lufitano difplicuiffe fummoperè gauderem, fi quid hac mea dubitatione melius, ac certius aliquid deprompfiffer, fed quod vfu uenire nimiæ temeritati pleruncque folet, dum nim is in me excandefcens maius aliquid affeuerare nititur, longè turpifsimè labitur, quòd eam velit plantam legitimum effe Tragum, quæ Mauritanis Kali, \& Alliali appellatur, nobis verò Hetrufcis Soda, cuiusq́; imaginem vltima huic editioni addidimus libro fecundo inter Atriplices ad viuum expreffam. Quandoquidem planta hæc, ex qua alumen con ficiunt, quo vitrarij vtuntur, Catinum appellatum, quin \& fal, quod à planta Alkali vocant, folijs non vacat, quum admodum fit foliofa, nec vllis penitus riget aculejs. Ip fa enim cum primùm emergit, folijs profilit minori Sedo æmulis, quæ tractu temporis dodrantali ferè longitudine augentur, ge niculatimá; protrahuntur. Cum verò iam adoleuerint, prodeunt è geniculis folia pinguia, crallạ̣;, incurua, ex lata origine in acutum definentia. Vbi verò a! fummum conftiterint, in caulium cacuminibus longè minora, exilioraq́; fpectantur rufo colore, à quorum exortu parux, rotundxá; prodeunt pilulx, in quibus minutum femen concludirur, vt videre eft extra Tergefti mœnią, ijs præfertim locis, quibus falinarum areæcircundantur. Quæ Tragi notis prorfus repugnant. Adde quòd Kali fapore fit admodum falfo, Tragus uerò non falfo, fed adftringente, Qux omnia citra controuerfiam atteftantur, quòd legitımum Tragum nunquam viderit, nec notrerit Lufitanus. Qui tam excors, obliuiofusq́; deprehenditur, vt eandem herbam legitimum Tragum effe affirmet, qüam prius afferuit effe Anthyllidem, vi poltea differam. Cæterùm eam conftat plantam genuinum effe Tragum, quam nos fuo luoco appinximus. Quippè ea fola, Corruda excepta, tota fpinofa vifirur, nullis circundatur folijs, \& in maritimis tantùm nafcitur, fruticofa, humilis, humi accumbens, innumeris triangulis, quadrangulísue, tritici magnitudine vbique fcatens, in quorum medio (vt Theophra ftus inquit) poft Autumni Aequinoctium flos emicat albus, qui paruo temporis tractu purpureus euadit, adftringenti fapore, perindè ac tota planta, adeò ve nihil repugnet, quin hæc genuinum Tra gum dici queat. Hanc inueni ego primus in Tergeftino folo in Hadriatici littore, vbi frequentisfima,copiofaq́; oritur. Nec immeritò Scorpium eam appellauere antiqui, quippe quòd auelli non poffit, nifi ictis ab ea manibus, vt ego mihi teftis effe poffum. Tantùm igitur abeft, vi celari uelim mea, ficubi funt errata, ut es etiam i ple non uerear emendare, gaudeoq́; hæc à cæteris aperiri, modò ifta femper adhibeatur moderatio, vt potius veritas exquiri videatur, quàm improbx calumnix, qux in optima quaque inuehuntur, inftrui fentiantur. Etenim id longè honeftus arbitramur, vbi quis fe lapfum nouerit ( quum proprium fit hominum labi) fe hallucinatum aliquandò agnofcere; quàm, quod extremæeft pertinacix, ac uecordiæ, quod femel arripueris mordicus adeò tenere, ut ullinc auelli non confentias. Ac fanè in jjs commentarijs, qux anteà Italico euulgaui fermone, nonnullạ poftmodum deprehendi, quæ minus quàm decreueram à nobis enucleatè, exacteq́; effent fcripta . Quorum \& eo ipfo tempore non eram nefcius. Verebar quidem fxpè ne tanti operis feftinatio inter tot alia, quibus in dies diftinebar, iudicij fortè extremam maturitatem in aliquibus peruerteret. Quod fanè peccatum leue (vt credo) \& in paucisfim is repertum, quamuis reliquorum utilitate, tùm facilè compenfari, tùm rectè obfcurari poffe cenferem, fciebam tamen prauos, ac maleuolos homines minimè defuturos, qui etiam reftifsimè à nobis dicta lacerare, \& caninis dentibus arrodere non ceffarent; \& qui citius reliquorum omnium fru氏tu fe expoliari mallent, quàm ụt leuisfimum alicui condonarent erratum. Sed quid? Tot amicorum erant interpellationes, qui boç opus à me quotidıè flagitarent, \& propè fuo iure poftularent, ne hoc meorum ftudiorum partu eos diutiuss defraudarem, \& fufpenfos tenerem; ut improborum, inuidorumq́; iniquis morf̧bus me intempeftiuis obijci maluerim, quàm horum refiftere uoluntati. Emifi tandem opus non tam maturum, quàm amicorum precibus, \& obfecrationibus efflagitatum . Qurorum defiderijs fatisfactum à nobis plurimùm gaudeo. Si qua verò erant nimis accelerata, ea fanè longè accuratius in Latinis noftris commentarijs agitata funt, \& difcuffa. Id quod tunc me maximè folabatur. Qux fi ante me ita deprehendiffet Lufițanus, vt nullam in me oftentâfet acerbitatem, nullas in optimè munita, firmataq́; fuas ingesfiffet

Kali,\& Alka

li Arabum.

Kalihiftoria.

(1) .

Lufirani inconftantia.

Tragum ge nuilsum.

Author Tragun primus inuenit.

calumnias, 
calumnias, \& non fua infidelitate in alienas poffesfiones irruınperet, gratias ei profectò agesem; quòd fuo ftudio, \& fynceritate hifce nos fubleuaffet laboribus. Iam verò opti ma quæq; fuedisfimè lacesfit, a ònuellit, diripit, $\&$ in quibus aliquam veniam mereri poterat eius calumnia, hæc maiori offu fcat fal.

Lufitani abjectio in Ama rantho. dendusLufica nierror. chfius à Lufi tani calünia vindicantur.

Calúniaxviij. de minoriSe do.

Iufitanus reprehenditur.

Calumniare fellitur, \& Amathum hallucinatum ef fe altéditur. cortice læui, \& fucco plena ad multa expetita. Quæ in uniuerfum notx, fi cum minoris Sedi hiforia comparentur, clarisfimè demonftrabunt tantumab illo differre Fabariam, quantum à lufcinia coruus. Non enim aliam ob caufam Semperuiuum tam maius, quàm minus id fibi nominis a ciuit, quàm quòd perpetuò anno toto virefcat, ac viuat. Id quod teftatur Theophraftus libro vir. cap. X I I I r.de hiftoria Plantarum, quin \& Plinius loco nuper citato. Idem prætereà affirmat plantæ ipfius nomenclatio Græca, A'é\}̧wov enim Græcis fempiternum defignat. Sd hoc naturæ donum Fabariæ minimè largitum videtur, quum autumno pereat tota $a_{2} \&$ in vniuerfum arcfcat, nec indè celerius repullulet, quàm Vere medio. Quod autem Vermicularis dicta, quæ Semperuiuum minus nulla reclamante nota repræfentat, fapore fit acris, deteftantur vniuerfi materiæ medicæ ftudiofi, cùm nullo alio fit fapore, quàm acido. Sed cùm fortafsè Lufitanus fyncero careat guftu, perindè ac iudicio, mirandum fanè non eft, fi inter acidum, \& acrem nullam fecerit differentiam. D E C I R s I o hxc Calüniz xix. habet. Adeò Cirfíon noftræ vulgatæ Bugloffx refpondet, vt omninò fatendum fit eandem effe her- , de Cirfio. bam, cuius fèntentix Ruellius quoque patrocinatur, \& meritò quia videmus Bugloffam aliquandò " triquetrum habere caulem fpinofum, ex cuius floribus nefcio quid, vt animaduertenti notum eua det, euanefcit, nam in cæteris ita inter fe refpondent, vt fpectanti nulla dubitandi maneat occafio . Proinde Matthiolum in hac re minus benè dixiffe crediderim, cum Cirfum alteram herbam à BuCalunania di gloffo effe contendat . Sic Lufitanus ille. Cæterùm cùm uulgari Bugloffo caulis fit rotundus, non triluitur. $\quad$ angulus, ut fortafsè per fomnium vidit Lufitanus, nec foliola ab imo cernantur, quæ vllam rof fpeciem præ fe frant, fed fpithamalongiora, quin \& quòd caulis cacumen orbiculatum non fit, nec ibi capitula purpurea, qux in pappos euanefcant, videantur, vulgaris vfus Bugloffum Cirlium effe non poteft, cui caulem reddidit Diofcorides perpetuò triquetrum non aliquandò tantùm, \& angulos ip- 


\section{Aduerfus Amathum Lufitanum.}

fos folum aculeatos voluit, \& per interualla molles, quibus profetò notis vulgare Bugloftum prorfus deftituitur. Caule cnim att, ve diximus, tereti, qui ubique tenuifsmis aculeis rigent. Adh.ec Cirlio capitula requiruntur purpura, ve etiam præer Dioforidem fatetur Plinius libro x x va! cap. v I I I. qux in lanugincm dchifome. A cùm vulgare Bugloffum nulla vnquam capitula preserat, qux tandem lanuginem vlla m contrahant, fed flores tantù purpureos, nullam prex féfentes capituli formam, nec unquam lanuginem contrahentem, non uideo, cur ita folidè ctediderun villyare Buglofum legitimum afle Cirfum, in quo cenfendo decepti funt Rucllius, \& cum fequutus Lulitanus, qui cum feripleric è vulgaris Buglofsi thoribus necio quid euanefecre, fuam iptius vanitatem declaiat. Cirsij (vt opinamur) genumi imaginem quis uidere poterit in commentarijs noftris, qua viuum legitimumgi; refirat. Bugloflum enim quod pasfun concesfit in vfum, vel Echij tpecies eft, vel potius fortas is ipla Lycoplis, vt aliàs latius cxplicabimus. RE. L I Qv v M eft, ut ad ca refpon " deam, quibus me falso in Ellcboro accufit Lufitaus his verbis. Ex iunioribus quoque Matchiolus "Senenfis nigrum Illeborum albo periculofiorem facit, quia tta experientia deprehondit, quum ta-

" men hodie boni pratici nigro correpto tanquam Duagredio utantur. His in nos ille. Sed an iure, vel iniuria ens iudiccs ut lim, qus accuratius, quàm ille ea perlegerunt, qux in commentarijs noftris de utriusq́; Ellebori uiribus fortplimus, quibusq;; in animo femper eft non mentiri. Siquidem ij, ubi nufquam à me feriptum reperentnt, nigrum Veratrum albo effe validius, pernicioliusq́; ( ve Lufitanus (omniaffe uidetur) minimè mihi verendum eft, quin illum temeritate, ac mendacio accufaturi fint. Scripli quidem, fcriptis commendaffe Pliniuen libro x x v. cap. v. Nigrum boues, equos, fuesq́; necare, cùm tamen Albo nullo incommodo depafcantur. Quno fit, vt iniurià in me rececerit Lufitanus, qux non noftræ, fed Plinianx funt lectionis. At quum is ad noftros perdendos labores inuidentia, ac liuore fe totum accinxerit, cò cœcitatis, amentix, infolentiæq́; procesfit, ut etiam aliorum crrata in nos remiferit, urporè, qui mentiri nunquam erubıcrit; non alia opinor caufa, quàm quòd uoluerit monimentum feelcris, atque audacia fux effe in confpectu omnium. Hacterus Amathe tuis ineptisfimis calumnijs lacis, fuperq́; puto à nobis cffe refponfum, atque ita clarè, tantaq́; luce cas me diluiffe nunc arbitror, ut fi vlla in te fuerit ratio, fi qua probitas, fi quod etiam fcientix veftigium, fácilè feu in me, fcu in alios iftam fis polthac depoliturus temeritatem. Elt quidem, vt difcas, quid dofit fentiant, priufquàm tam arroganter, $t a n$ temerc̀ in corum labores infolefcas. Quinetian quo pąo eorum fudoribus potius candidè \& gratanter fruar is, quàm ut cos imperitè laceflas, \& tuis calumnijs obruas. Etenim non iccircò has vigilias libentisfimo animo fufcepimus, vt tu eas obfcures tua inuidentia, ac etiam imperitia. Etcnim fi noftras has lucubrationes tibi vfui effe nolis, cur ralem clandeftinum furem te exhibes, ut folùm tua furta commendata alijs effe uelis; cæetera uerò, quæ tua libido fibi non uendicarit, ea malitiofa ttudeas opprimere inuidentia? Patcfaciam in alijs tuum infidelem in meis ferinijs animum. Nunc fatis mihi eft, fi tuas contuderim calumnias; quibus fi tuo quoque iudicio à me eft fatisfactum, uehementer tua caufa gaudeo; fin is maneas, ac perfereres, qualem te effe prædicant, certè non omnium iudicium, candor, ac æquabilitas ex vna tua indocta, \& præcipiti pendebit maleuolentia. Narrat vetufta gentulitas eos, qui fe intulifent magnæ Dex facrificijs, confeftim excœcari, quam quidem cæcitatem illi non tam ad oculos, quàm ad mentem refurebant. At ego Amathe non te ideo ccecum dico ductus hac gentilium fuperftirione, quòd Cibeles alicuius te inferueris facris, fed ca tantum ratione, ac fententia (vt tu ipfe iampridem in te experiris) quòd à Deo immortali perfidisfimè defcifcas. Etenim cum (ut audio) nunc noftr religionis te ipfum facias, nunc Iudaicis legibus, fuperftitionibusq́; te totum addicas, \& ita non folùm in homines, fed in ipfum Deum Optimum Maximum infolelcas, minimè id eft mirum, fi à te ipfo quoque deficias, \& omni ftatu mentis dimouearis. Vt non modò in te nulla vigeat pietas, nulla religio, verùm \& in ipfa medica facultate, quam immeritò profiteris, plurimùm cocutias. Hinc ego fieri arbitror, vt non folùm tibi, fed \& cæateris om nibus moleftifsimum, ac infeftislimum te exhibeas: \& tumultuofifsimis mentis furijs impulfus modò huc modò illuc agiteris : quin etiam ut tu, qui tamdiu tua impietate in diuina cocutis veritate, nunc nec alios, nec te ipfum in ipfa medica facultate intelligas. Quare nulla mouebor admiratione, fi tuam obftinatam detrectes exuere uefaniam. Non id iam animo mecum proponebam, non iccircò tuam reprimere fum conatus infanabilem ( vt timeo) libidinem, vt te tuæaliquandò in tanta veritatis luce pœniteat infaniæ, fed id magis elaboraui, ne tyrones, \& buiufce medicæ materiæ Atudiofos tuæ fortè impedırent calumniæ. Nihil tuam Amathe moror Cenfură . Iudicabunt fyncerius docti, ac præclari homines, utrùm tu iuftius me inuaferis, an ego majori ui te in me temerè irruentem declinauerim, penitusć; profligauerim. Quapropter aut cefla Amathe poft-

hac calumniari, aut tam quæfo non fis futilis, \& inanis, vt quum reliquorum labores \& feripta explodas, tu nihil melius afferas; aut, quod vltimum eft, caue, ne apud eruditos , \& æquisfimos lectores, ac iudices, qui nunquam deerunt, tua inuidia, \& calumnia noftrum augeant, \& amplificent honorem.

Caltuia $x \times$. de Elleboro.

Exploditur Lulicani calu mnia.

Lufrani inuidentia deregi tur.

Animaduerfio in Amathi deliraméra in fcitianq̣;

Lufiranus Sc miiudxus. Hi fpanitales Ma ranos vecant, quos maximè deceitantur. CurAmathus tanta labore cocitate.

Cur Author hanc cunfece ric Apologiä. 


\section{P E T R I A N D R E AE M A T T H I O L I I}

0

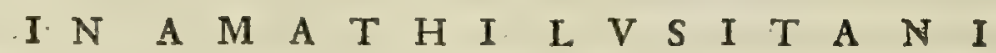

E N

C E N S V R A.

Prxfatio in Cenfuras.

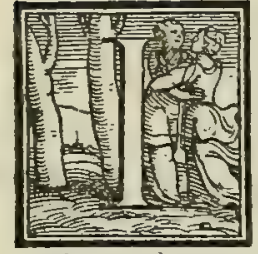

A M M I N v S vereri debeo, ne quis potius glorix captandx cupiditate me putet adductum, vt homini impudenti \& rerum omnium imperito, fuos patefaciam errores, quàm ad id vera, rectaq́; duci ratione. Quòd fi liberius in hominem petulan: tem adeò importunè lacefsitus inueherer, quis probus non id mihi iure concedat? In Amathum, inquam, qui fuis iniquisfimis calumnijs, non modò honeftisfimos labores noftros opprimere nititur, fed $\&$, quantùm in ipfo eft, fua imperitia, \& impudentıstima confidentıa rem medicam obfcurare conatur uniuerfam. Nec fanè aliud fibi quis de eo perfuadere poteft, qui aliorum fcripta à quàm plurimis comprobata, fatisq́; communita, fus temeritate incefsit, \& violare molitur. Hoc fi impunè, \& tacitè fit improbis permittendum, vt fuo tantùm. iudicio audacter reprehendant, ac contaminent omnia, quò nam omnium præetantisfimarum facultatum cultus deueniet? Quis pofthac iftorum fe obiectet ingratitudini? Verùm ut \& ipfum, fi qua adhuc in eo viget ratio, pœnitear iftius calumniandi infanjsfimæ licentiæ, \& non folùm ex alijs, uerùm ex fe ipfo fuam cognofcat omnium rerum infcitiam; infringenda eft hæe nimis arrogans, \& effrenis audacia . Non arbitrabar quemquam tam perfricte frontis effe poffe, qui ibi tam feuera in alios cenforia utatur uirga, vbi ipfe tot vbique fcateat erratis. Moleftum, friuolumq́; penè credidiffem grauioribus impeditus negotijs, vt cum huiufce hominis difceptarem ineptijs, nifi ipfum in me tam petulanter infultare à pluribus audiuiffem. Nunc autem eadem moleftia, qua iftius impetum, \& uanam incurfionem à me prohibui, ne quis iftius feueri cenforis impellatur iudicio, vt ftatim approbet, quæab ifto viderit proferri : Audiat bonus, \& egregius vir, quantò tutius fortafsè fuerat honeftè tacere, quàm eo pacto contra cæteros infanè oblatrare. Atqui hac in re ea neutiquam vtar vanitate, qua ille contra nos; \& ne hominem potius perfequi, quàm veritatis ftudiofi videamur, nihil nobis erit negotij cum Amatho. Etenim eius errata fic in lucem producam, vt fi uel ipfe met aliquid ha beat, quo ijs, quæà nobis afferuntur contradicere valeat, doctorum judiciolongè libentius acquiefcam, quàm vt aliqua pertinacia reliquorum ftudia retardem. Idem qui hoc promitto, hoc quod eft xquifsimum, fi non ab Amatho, quem rediturum vix ad mentem fpero, faltem ab erudito lectore id peto, ac poftulo, ne qua mora, ne quod impedimentum rerum, \& medicinæ fiat candidatis, vt tum demum de utroque noftrum fuam ferat fententiam, vbi noftras rationes diligenter expenderit,ac péfitarit. Amathus non nifi quadam præcipiti dementia noftros inuafit labores, conuulfit, diftraxit, nullam huiufce facti afferens rationem, nifi quod fux authoritati, hoc eft Itultisfimæ libidini, tantùm putauerit ubique conceffum. Ego fanè, qux in ifto reprehendo, nifr apertisfimis, \& ipfa luce clarioribus argumentis inductus videar, cupio me eiufdem argui temeritatis, ftultítix, ignorantix, quam de fe prodidit ille. Atque ficut candidus lector, qui hæc in manus fump ferit, facilè difcernet, ita fore arbitror, vt minimè eum pœniteat eius lectionis, ubi non tantùm iftius teterrimos lap fus, fed $\&$ non fine noftro labore, rerum plurimarum cernet explanatas naruras. Ideoq́; hæc, quò maiori cum facili tate, \& emolumento diftinctius ab omnibus legerentur, in certa hæc digefsimus capita, ac iam tandcm alijs innumeris filentio inuolutis, ad ea, quæ funt præcipua, in quibus ille turpifsimè offendit, veniamus.

\section{A C O R V M.}

DeAcoro Cé DE ACOR O fuumipfus, quod olim tenuit, reprehendit iudicium, fed quantò prxftiterat à fura j. priori non difcedere fententia, ipfe videat, qui vegetiorem Galangam nihil ab Acoro difcrepare puGalangx $C_{y}$ tat, cuius error multus patet rationibus, is indicijs. Nimirum quòd neutrum Galangx genus folia perifolia. proferat Iridis (vt qui uiderunt teftantur) fed Cyperi, quo fit (Lufitano etiam ita teftante) !t non defint, qui Galangam ipfam Cyperum Babylonicum vocent. Tum quòd vegetioris Galangæe radix cum Iride nihil habeat cognationis, nec illius faciem vlla ex parte referat; adde quòd radix hæc rufefcat potius, quàm fubalbicet. Praterea Galanga nufquam reperta eft, quæ guftu fuerit fubamaro, ut de Acoro fatetur Galenus, fed tantùm acri . Quocircà non immeritò Serapioni, qui inter Arabas in enarranda fimplicium medicamentorum hiftoria primas tenet, aliud eft Galanga, aliud uerò Acorum. Ob eandem quoquè caufäm inter græcos Actuarius, \& Nicolaus Myrepficus in paranda Aurea Alexandri antidoto, \& Acorum \& Galangam imponunt, tanquam medicamenta inter fe diuerfa. Q1ii bus luce clarius quis intueri poterit, Galangam, \& Acorum pluribus fanè notis differre. Acoro enim folia non debentur Cyperi, fed Iridis, quin \& radices Iridi proxim $x$, geniculis interceptx, fubalbicantes, ṇon fubrufefcentes, \& ( ut Plinius inquit, cui \& Lufitanus fubfcribit) ruptu faciles, non 


\section{In AmathiLulitani Enarrationes.}

ut in Galanga, utraque fractu contumaces, quibus perfpicuum, fatisq́; comprobatum cen fonus,ne, trum Galung: genus cfe Acorum. Nec profętò incellexerim unq̨uan (vt aliàs meminimus) quo pa Eto, quáue metamorphofi factum lit, ve Galanga illa, qua ab alia non genere, nec uiribus, fed tantùm magnitudine differt, quum primùm ad nos è Syria, vel Memphi aducêa ett, in Acorum fe con mutauerit : neli quis fortalsè dixerit, eueniffe hoc magicis praftigijs, quò fuam tueręur opinionem. Ac cùm ad noftra penitus obmutefar argumenta, quibus in hac re fumus ufi, illud fanè fufpicari libet, hec potius retractaffe Luficanum, uc Brafauolum à nobis reprehenfum (illi enim ubique plurimùm uidetur addictus) (uı immemor defonderet, quàm ut ueritatem, quam prius facebatur, futtineret. At Fuchlius vir profectò clarifsimus, \& qui pocius philofophum fe exiftimat, quàm ut pertinax fic authos, erfi iam pridem in Brafauoli concefferit fententiam, vifis fortafsè Conmentarijs no ftris, ac pariter argumentıs, quibus corum deteftamur opiniones, qui exiltimant,maiorem Galangá effe Acorum, honelta quadam dicendi ferie, qua fuam tuetur exiftimationem, poftremo quem edidit,de compofitione medicamentorum libro, à priori opinione non parùm uidetur abcffe. Quod fertafsè feciflet etiam Brafauolus, nifi immatura morte fuiffet prxucntus. Porrò Acorum non mea tantùm, fed plurimorum fententia, qui in re mẹdıca multùm praftiterunt, ca fanè crit radix, quam perperam Cahamum Aromaticum appellast. Ipfa enim fi primùn refo oculorum incuitu cxpendatur, ac deinde fyncero ruminetur guftu, nulli dubium effe opinamur, quin adeò fingulas Acori notas fit reprafentatura, ut is meritôftupidus appellari debeat, qui aliter fenferit . Quo fit, ut ridendum uideatur Lufitani argumentum, quo ducitur, ut credat Galangam eam ob facultatem, qua ad ue nerea præltare fatentur Mauritani, gentunum effe Acorum : quoniam Apuleius Acorum Veneream herbam quibuldam uocari fcribat. Quandoquidem cùm nullam explicauerit ille rationem, qua illi Venere: herbæ nomen accefferit, non tanti nobis fuerit A pulei authoritas : præfertim cum plurim $x$ alix preter Galangam habeantur radices, qux hac polleant facultate. Cum enim anciquorum nullus frriptis commendauerit Acorum ad Venerea præftare, facilè quis opinari poterit Latinis(vt audio) Veneream herbam uocari, quòd fortafsè ob plantæ pulchritudinem, amœnitatem, \& odoris fragran tiam Vencri illam dicauerıt antiquitas, quemadmodum \& Myrtum. Plures enim habentur plante, qux Venerea appellantur nomenclatione, nempè Venereuin labrum, Vcnercum pecten, Venerëus capillus, Venereuș vmbilicus . quin etiam Thymum, \& Sty rax, quòd fuauiter fpirent, Venercx di cuntur plante. Adhæc in Acori hiftoria parùm quidem Apuleio adftipulandum niderur, quippè qui non fatis conftanter de Acoro fcripferit. Primùm enim nafci Acorum fcribir in locis: cultis, hortis; ac pratis contra omnium penitus fententiam, deindè uerò illicò afferit idem inuentu rarum, nec inueriri, ncc fciri polfe, nificum flofculum emiferit. Qů omnia fi cum ijs conferantur quà à grauifsimis fcriptoribus de Acoro fcripta funt, facilè fabulofa deprehendi poterunt. Nec minus inlipidum uideturaliud Lufitani argumentum, quòd eam ob caufam velit Galangam effe Acorum, quoniam à Plinio dictum fit libro x x v. cap. x I II. Acorum nigras habere radices; quandoquidem crassioris Galangæ radices nigræ nufquam repertæ funt, fed fubrufefcentes. Atqui illi uenia danda eft : quippè quòd (vt aiunt) de coloribus cæci non iudicant. Cxterùm extant apud nos Pliniani codices mendis ultimo loco expurgati, ac reftituti, qui non nigras, fed fubnigraś legant Acoro effe radices. Quam quidem lectionem magis probamus, quòd fcripferit is paulò infrà, Creticas Acori radices effe Ponticis candidiores : quinetiam quòd hæc lećtio Diofcoridi adflipuletur, qui Acoro radices tribuit fubal bicantes. Subalbus enim color is (mea fententia fuerit) qui ex nigro albicat; fubniger uerò qui ex albo nigricat, adeò ut fubalbus, \& fubniger color parùm inter fe differant. Talis autem uifitur color jjs in radicibus, quibus pafsim utimur Calami Odorati uice.

\section{A R D A M O M V M.}

N E C fanè minus in Cardamomo cæcutit Lufitanus, utpotè qui putauerit Cardamomum quo ufi funt ántiqui, lignum fuiffe, non femen. Fatet non leuis error, quòd, effe plenum, frangenti contumıx, occlufum, far tuumq́; , porius feminis fit proprium, quàm ligni. Sed Cardamomum antiquis fuiffe femen, non lignum, teftatur apertifsimè grauifsimus author Galenus libro primo de Antidotis capite quinto, ubi fic habet. Fructus autem, qui unà cum uirgultis, folijs, calicibus, ac floribus in Theriacam mittuntur, ij funt, Scordij, Nepitæ, Marrubij, Stœechadis, Dičamni, Polij, Chamxdiyos, Chamæpityos, Hyperici, Centaurij. Radices autem hæ. Zinziberis, Iridis, Rhei, Quinquefolij, Cofti, Nardi Indicæ, Nardi Celticæ, Gentianæ, Mẹi, Athamantici, Phu, Ariftolochiæ tenuis. Semina uerò hæc. Napi, Petrofelini, Thlafpis, A mcos, Anethi, Fæniculi, Dauci, Cardamomi. Hæc ille.Recenfuit etiam inter femina Cardamomum fenior ille Andromachus, ubi carmine de Theriaca fcripfit his uerfibus .

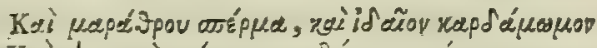

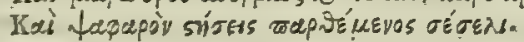

Hæc Andromachus, \& Ealenus aduerfus Lufitanum ante tot fecula fcripta teliquerunt. 


\section{NIGELLA CITRINA.}

Cenfura iij. de Nigella Cit.ina.

E R R A T Lufitanus, quòd recentiores quofdam fortè fequutus fibi perfuaferit Nigellam Citrinam (liceat mihi nunc pharmacopœorum vti uocabulis) Maius Mauritanorum effe Cardamomum; " Minus uerò id, quod Meleghetam uocant . Quandoquidem Serapioni Maius Cardamomum femen " eft, quod oblongis quiburdam concluditur capitibus, ijs ferè fimilibus, qux è Rofis prodeunt, granis " fubnigris, rotund is, in quibus minuta continentur femına angulofa, fareta, $\&$ odorata. Id quod ma * nifeftò a rguit Nigellam hanc, qux Melanthij eft fpecies ( vt nobis aliàs fätis, fuperḉ; oftenfum arbitramur) Maius Mauritanorum Cardamomum effe nequaquam. Adde quòd Nigellæ calix nullum intra fe habeat granum, quod ipfum femen excipiat, fed parua femina tantùm intercurfantibus mem branis papaueris modo. Prxter id cùm fui Cardamomi colorem fubnigrum fecerint Arabes, non uideo cur Nigella Citrina uocata, quæ colore fpeetatur Citrei mali à quo illi nomen, Maius illorum Cardamomum appellari posfit.

\section{E L E G H E T.A.}

Cenfura iiij. Qvo'D prætereà Melegheta, Minus Mauritanorum Cardamomum non fit, quís facilè conijde Meleghe- cere poterit; quippè cùm hoc femen calice quodam, Melanthij inftar concludatur', Cardamomum tis. uerò Minus (ut Serapio inquit) fuum ferat femen nullis occlufum capitibus, colore Maiori æmulo. Qui tamen color fubniger Meleghetis minimè eft afsimilis; eò quòd hx colore frit fubrufo Indici Milij inftar, quod TufciSaginam uocant, Infubres uerò Melegam, unde fortafsè accesfit his feminibus Meleghetæ nomen. Adhæc cùm Meleghetæ femen longè maius habeatur; quàm Nigella Citrina, non uideo fanè cur confentaneum fuerit id Minus uocari Cardamomum.

\section{CVBEBA, CARPESIVM.}

Cenfurav.de I N C V B E B I $s$, \& Carpefio cenfendis quantùm aberrat, quòd Cubebas uelit, quibus palfim Cubebis \& Carpefio. utuntur Officinæ, tum ueras Arabum effe Cubebas, tum etiam legitimun Galeni Carpefium. Verùm, ut apud Arabas nullus habetur, qui fcripferit ufquam Cubebas effe baccas, uiel femen, ita neo apud Græcos ullus extat author, qui Carpefium fateatur effe femeti. Galeno enim Carpefium te- »s nues funt feftucæ, fiue farmenta parua, Cinnamomi virgultıs fimilia . Quare quum Mauritanis idem: 》 fit Cubeba, quod Græcis Carpefium, nullo pacto ficri poffe putamus, ut vulgaris Cubeba, quæ baccarum generibus afcribenda eft inter feftucas, \& tenuia uirgulta, Carpefum effe poffit,ac debeat, quin etiam nec genuina Mauritanorum Cubeba : vt pluribus rem hanc in commentarijs noftris explicatam habemus.

\section{S A L I V N C A.}

Céfura vj. de Saliunca.

M v L T o verò apertius fuam declarat infcitiam in Saliunca, quam eandem arbitratur effe plan. tam, quam Itali Spico, recentiores quidam Pfeudonardum appellant; ad qund quoque genus refer tur, quæ pafsim uulgò uocatur Lauendula : in quo certè miror maximam hominis nefcio imperi-1. tiam, an ftuporem dixero. Etenim quid alienius? quum manifeftè Plinius Saliüncam foliofam affe-" " rat effe plantam adeò breuem, utnecti non posfit, quin \& herba uerius, quàm flos, denfa ueluti ma-." " nu prefla, radice numerofx cohærens. Quantùm ab hac differt Pfeudonardus? quum planta eft fru- " ticofa, lignofaq́; Rorifmarini Coronarii inftar non breuis, fed bicubitalis, \& flos verius quàm herba, \& quæ in corollis facilè necti posfit. Florum enim longiores pediculi iunceo ferè lentore præftant. Prætereà Pfeudonardus numerofis radicibus non cohæret, nec adcò densè fruticat, ut folia tam pertinaciter fibi ipfis inhæreant, ut tanquam manu preffa cernantur. Adde quòd in Pannonia, \& in Noricorum Alpium apricis locis, nufquam 1 -feudonardus proueniat, vbi Plinio ipfo tefte, numerofa prouenit Saliunca. Humilis autem \& breuis Saliunca herbula eft, non bicubitalis \& $\mathrm{P}$ feudonardi modo frutico $\mathrm{F}$, ac lignofa, quamobrem in Buccolicis poeta cecinit.

Puniceis humilis cedit Saliunca rofetis.

Tantum difcrimen inter Saliuncam \& Pfcudonardum non cernit Lufitanus, ut humillimam herbam à bicubitali non diftinguat frutice. Timendum, nifi hanc oculorum curet caliginem, ne culicem pro cane, uel fortafsè etiam equo accipiat.

\section{I N N A M O M V M:}

Cenfura vij. de Cinnamo mo.
R E D I E O in gratiam aliquandò cum hoc homine, qui alicnis (vtinam tam uerè) nos locupletet diuitijs, \& optimo Cinnamomo capfis (ut ille inquit) cannella refertis, qux ab India deferuntur Antuerpiam, nos abundare iactat, \& contra omnium preclarisfimorum authorum fententiam fibi perfuader, Cinnamomum effe corticem rantùm fux arboris non lignum. Nouitatis anidus nouum credo aliqquid afferre ftuduit. Fidem idcircò fux authoritati adhibendam minus dubitauit, quòd iam tama 
increbueritapud omnes Lutitanos, peragratis Africa \& Indix regionibus, Aromatum multagenera effe aduecta. Miror cur non fe in his quoque partibus fuiffe fingar, ue maiorem huius conmenti faciat fidem. Sed cùm nec iple iỏ a Alerat, nec Lulitani, qui naugijs iftas terras petierunt vilam huilys rei afferant hiftoriam, nos Lutiano in iftis commentitijs inuentis aftipulemur? Prefertin cum non define probarisimorun fcric corum teftimonia, qui repellentes has nugas apertifsimè fatcantur Cin namomum virgultum effe pumilx arboris non corticem tantùm. Id enim in prim is teftatur Diofco3ides, fic inquiens. In Cine amomi Mofy'litei uocati generé preftat recens nigrum, ex vunoto in ci-

" nerem uergens, lixuc, tenuibus ramulis, ac frequentibus nodis cinctum, perquàm iucundè olens. Quibus palàm fit Cinnamomum virgultum effe tenue nodis pluribus conftans. Huic fubfcribit (iat "Lenus libro primo de Antidot is his uerbis . Quæuis autem Cinnamomi fpecies ab una radice, ceu fru" tex q̨uidam paruus conturgit, cmittirģ; hæc fex, illa feptem virgulta, uel paulò plura, paucioráue; " non æquali tamen onnia longitudine funt; Verùm quod maximum eft, pedis Romani dimidium " non cxcedit. hrec ille. Adeft adhec liber de fimplicibus medicamentis ad Paternianum (Baleno afcri" ptus, qui etiam ac Cinnamomo lic habet . Cinnamomum funt rami ferè, ac uirgulta, quæab una ra " dice plura excrelcune, recta $\&$ minuta, bieuiasq́; colore fubrufo, \& cortice extenfo non rugofo, qui " cortex non ita facilè ungue à ligno abraditur: nodulos plures, \& interualla habent, \& in medio lr" ues habentur. Si nerò fíangantur, quafi pulnerem emittunt, odore omnia uincentem. Ferè enim. " hæc maxima probatio Cinnamomi eft, quod fit umnium rerum odoratifsimum. Quibus grauifsi" mus accedens author Ariftoteles Cinnamonum furculum effe teftatur libro I x. cap. x I I I. de hifto " ria Animalium, fic inquiens. In Arabia \& A Ais C.innamomus appellata, quam furculos Cinnamomi " portare, \& nidum ex his conficere aimnt. Nidificat excelfis arboribus, \& ramis, fed incola fagittis. "plumbatis nidum petunt, atque ita difcufo in terram, Cinnamomum legunt. Adhrc Cinnamo" mum furculaceum efé uirgultum fatetur Galenus loco fuperius citato, vbi ait plura apud Im perato" res extare Cinnamomi genera, quorum nullım ueluti truncus in ramos plures diuifum multùm at" tollebatur, fed Hellebori figuram præ fe ferebat, ucl potius Damafonij . Quibus palàm eft Cinnamo mi virgulta adcò tenuia haberi, vt Hellebori, uel Damafonij radices non excedant. Adde quòd quú ipfe dicar Galenus ramuiculos accepilfe Cinnamomi, non cortices ex eo quod à Traiano, \& Hadriano imperatoribus repofitum, fuerat, vel cos quidem ramufculos apud fe feruaffe, facilè conftabit omnibus Cinnamoni uirgultum effe tenue; \& non folùm in jpfo cortice, fed in ligno cdoratam reperiri facultatem. Quandoquidem fi Cinnamomum cortice tantùm præftitiffet, cur prætulerit Diofcorides ramulos, quemadmodum ix Galenus, fanènon uideo. Quamobrem Lufítano fabula hano ego tantùm acceptam referam, prafertim cum præter asfignata teftimonia nemo fit, Lufitano excepto, qui Venetijs, quò uulgare Cinnamomum ex India affertur, perindè ac. Antuerpiam, vnquam uiderit, repereritq́; Cinnamomi virgultum, quod genuinum repræentauerit. Nimis quoque vana eft opinio, qua credit Galeni tempore non eam fuiffe Cinnamomi.penuriam, qualem recentiores quidam exiftimant. Id quod Galeni iphus teftimonio falfum effe conuincitur. Ip fe enim libro prj" mode Antidotis, vbi Cafiam expendit, fic inquit. Hæc'aduerfus Quinti dictum obiecta fint, eò " quòd mihi reijciendum omninò non uidetur corum praceptum, qui pro Cinnamomo duplum Ca" fræ imponendum cenfent; quanquàm ego femper Cinnamomum impofuerim : Nam quibus ègo " Romæantidoros compofui, cùm uel Imperatorum amici, uel diuites effent, facilè fuit illis Cinna" momuma à Regibus petere, jjs uerò Cinnamomum emere. Hæc itaque Galeni funt verba ; quibus facilè quis certior fieri poterit, an Galeni tempore tanta fuerit Cin namomi copia, quantam Lufia: nus defcribit, vt fuam tueatur fabulam. Non enim fuiffet opus medicis alijs pluribus, qui Romr Galeni ætate florebant, fuis in theriacis modò Cafiæ duplum, modò Carpefium (vt Quintus) Cinnamomi loco fubftituere, fi genuini confequendi Cinnamomi illis tam ampla fuiffet facultas.

\section{LACCA ARABVM.}

C oN S V L T Y M longèmelius ( Inea quidem fentertia) fuiffet Lufitano, fi poeticx porius quàm medicæ facultati fe totum addixiffet; nam qui eo in effingendis fabulis aptior, promptiorq́; fe præftiterit; uideo profectò neminem. Id enim omnibus palàm fiet diu in re medica uerfatis, qui diligenter iftius intuebuntur Centurias, in quibus innumera fe fe offerunt figmenta, adeò rem feriam præ fe ferentia, ut ea quis difficillimè fabulas effe nofcat, nifi medica facultatis fuerit rectè peritus. Verùm cùm ad hoc ill um natura pepererit, mirandum fanè non eft, fi à fabulandi făcultate difcedere nequeat, fed potius illi uenia danda : quippè qui id propria agat natura, qua in præfentia ductus de Mau ritanorum Lacca fcripturus euadere non potuit, quin fabulofi aliquid admifceret his verbis. Qui ग) huc ufque Cancamum Laccam effe putarunt, miro errore deprehenduntur, cùm Cancamum Gum3. mi odoriferum fit, Lacca verò fiue manfa, fiue fuffimentis explorata inodora percipitur. Quam ho") die Lufitani ex India a ferunt rubram, translucidam, tincturis præcipuè deferuientem, \& ex ea Of" ficinæ compofitionem quandam præparant, Dialaccam appellatam, quæ (vt certò fcimus) non gum" mi, aut arboris, plantæe ue alicuius gutta eft, fed potius formicarum alatarum ftercus, fauagoq́; uelut ris.

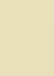

Cinnamomi virgulta tenuia Hellebori radicú modo.

Lufitani opi nio uama.

Cinnamonum Galeni tempore etiam rarum . Ceffura viii. de I.acca Arabuna.

Lufitani cen turix fabulo $f x$

Lufitani Lac cx hiftoria fabulola.

C 2 cura 
cera apum. In regno igitur Pegu di̊to apud Indos cùm terra, vel pluuia, uel arte plus iulto irrigatur, " formic $x$ pradicta ligna quxdam fubtilıa ab incolıs fic difpolita in altum afcendunt, in quibus Lac- ", ram generant, \& hac de caufa in Lacca ligna ipla percipimus, qux dubio procul arboris non funt " Lufitåi fabu Laccam ferentis, ut hucusq́; omnes ferè crediderunt. Hæc illius elt fabula. Atqui illi maximè refraga " Ia explodi - tur Ludouicus ille Romanus libro fexto fuæ nauigationis, ubi de his agit aromatis, ac mercimonijs, qux Sumatra infula, fiue Taprobana mittit, fic inquiens. Mittit etiam ea regio Laccam, unde conficiunt rutilum colorem. Gignitur hæc in arbore iuglandibus noftris haudabfimili. Hæc ille. Cui fubfcribit lofeph Indus cap. CX LI. vbi fatetur in Cambaia Laccam uberius nafci, quàm alibi gentium, non autem fieri, gigníue formicis, aut fcarabæis, ut læpidius \& facetius quàm uerius fabulatur Lufitanus. Prætereà cùm duplex fit Lacca, quæ Alexandria Aegypti Venetias comportatur, altera. lignis quibufdam inhærens Sumatri à Sumatra fortafsè infula nuncupata, altera Cambaiti à Cambaia denominata in glebas Myrrhæ inftar concrcta, nulli inhærens ligno, non eft, cur Lufitani fabulam, hiftoriam putem. Siquidem gleba illa fole clarius palàm facit, Laccam gummi effe arboris, non quidem, ut per fomnium uidit Lufitanus, formicarum alatarum ftercus, quibus etfi ubique fcateat tota Europæ regio, nufquam tamen uifx funt alatæ formicæ, quæ Laccam, aut fimile aliud excernerent. Cæterùm quum fatis fuperq́; nobis comprobatum fit in Commentarijs in Diofcoridem editis Mauritanorum Laccam, \& Græcorum Cancamum effe idem, adeò ut pluribus id comprobare teltimonijs non fitopus,cadit, peritạ́; Lufitani fententis,quam fequi nemo debet.

\section{E I AE O M E L I.}

Cenfura ix. TR I P I I C I fe pariter implicat errori in Elxomele, quod ipfum defluere fuo more fingat è Pal de Elxome- marum caudicibus. Tum quòd hinc duo liquorum genera putet apud Diofcoridem defluere, nố ule. num tantùm, Mel nimirum per fe \& Oleum ex eadem arbore manantia. Prætereà ut noui femper ali quid apportet, quòd hunc liquorem ex Indica nuce credat diftillare. Deprehenditur in primis error ex ipfiusmet Diofcoridis uerbis, qui Elæomelis hiftoriam ita præfatur. In Palmyris Syriæ,quod E- »» lxomeli uocant ex quodam caudice manat oleum melle crafsius, fapore dulci. Quibus palàm eft de $\#$ uno tantùm liquore fcripfiffe Diofcoridem, nempè de Oleo, quod ob melleam dulcedinem uno uer

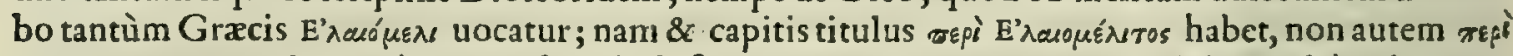

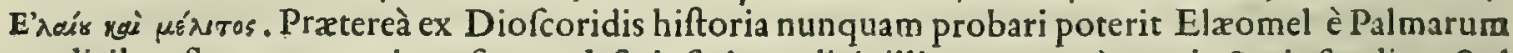
caudicibus fluere, quum is nufquam defcripferit caudicis illius nomen, à quo in Syria funditur. Sed effe talfum palmas liquorem hunc fundere manifefto fatetur Plinius libro x x I I I. cap. I I I I. ubi ex Olearum quarundam truncis, non ex Palmis fluere Elæomel affirmat . Quòd autem ex Indica nuce Elæomel manare non crediderim, id fanè mihi licere perfuaferim, quòd huius hiftorix neminem habeam authorem præter Lufitanum.

\section{A C E R.}

Céfura x. de ConT EN D I T maximè Lufitanus, utpote qui femper falfa tueri nititur, Macim, quo MyriMacere. Aticæ nuces prætextus inftar conteguntur,\& Græcorum Macerem nihil inter fe differre. Cui nifi quis aftipuletur, illum feuerus iudex contumacem declarat : tantá fibi arrogat authoritatem, ut certò putct unumquenque fuis debere aftipulari deliramentis. Verum quum id nulla afferat ratione, uel authoritate, ipfe meritò non modò contumax fuerit declarandus, fed infolens, uecors, ac delirus. Quip

Lufitani info pè qui potius errori patrocinari uoltuerit, nihil perpendens, \& aliorum fubferibere ineptijs, quàm lentiz. ueritatem ampletti, ac tueri. Atqui quum nobis in Commentarijs noftris in Diofcoridem editis,abundè comprobatum fit, cum Græcorum, tum etiam Mauritanorum teftimonijs, horum Macim My rifticæ nucis effe tegumentum, ut ipfo oculorum intuitu unufquifque uidere poteft, illorum ucrò Macerem corticcm effe radicis magnæ (vt apertisfimè libro x I I. cap. v I I I. teftatur Plinius) non eft ut hic pluribus iftius Centurionis infolentiam, \& infcitiam redarguam . Eò itaque fe conferre poterunt, qui hafce differentias hactenus non confiderarunt.

\section{E R I C A.}

Cenfura zj. de Erica.

N E C minus in Erica hunc deceptum reperio, quippè qui neget cọntra omnium doctisfimorum uirorum fententiam eam plantam, è qua uniuerfa ferè Hetruria ad mundandas ædes fcopas fibi parat, ullo pacto effe Ericam; hoc tantùm inani argumento fretus, quòd hæc femel tantùm in anno flore at, quum tamen Erica Theophrafti teftimonio bis in anno Horere debeat. At quàm decipitur? cùm Erica bis in non nobis tantùm, fed alijs quàm plurimis obferuatum fit plantam, quam Ericam uocamus bis in annu floret. anno nempè uerno, \& autumnali tempore fine ulla controuerfia forefcere. At cùm libro tertio fcribat Diofcorides Corim herbam Ericæ folijs prouenire, conftetó; id Ericam noftram per omnia referre, palàm fit omnibus hanc legitimam effe Ericam. 


\title{
In Amathi Lufitani Enarrationes.
}

\author{
A C A C A I I S.
}

A CA C A I I M nafci furibit apud fux gentis Olyfiponá Lufitanici regni metropolim fruęu ẩbo, pufillis margaritis fimili, cx planta quadam inter My ricam \& Ericam media. Sed quòd ad fabu las redeat, palàm faci: Diolicorides, qui fcriplic Acacalim femen haheri Aegyptij fruticis Myricx feminc fimili, non auten Acacalın fruticem effe Myricx fimilem. Cxterùm cùm duo fint Myricæ ge nera,alterum fructum gerens quali florem compage mufcofum, alterum uerò Gallx fimilcns; videãe obfecro, qui rcm medicam profitencur, quàm negligenter Diofcoridem legerit Lufitanus, quin \& qua auchoritate, vel ratione ductus aftirmare aufus fic Acacalis femen pufillis margaritis non effe abfimile : quum antiquorum quisiam (quod fciam) nufquam id fcriptis commendauerit.

\section{P A L I V R V S.}

IN PA I I V R o confundens hiftoriam pede prolabitur, fiquidem putat Diofcoridis Paliurum \&. eam, de qua libro I Ix. cap. x vi I. de hiftoria Plantarum tradidit Theophraftus, \& Galenus octauo de fimplicium medicamentorum facultatibus, illam effe arborem, quam Agrifolium vulgò uocamus, folio lauri, per ambitum aculeato, craffo, perpctuoq́; fructu Rufci modo rubente. At tam Diofcoridi, quàm Theophrafto citato loco Paliurus frutex eft, non arbor, \& femen in filiquis profert, fuliginofum, manfu lentorem rclinquens, feminis lini modo. Id quod in Agrifolio nufquam fpectaripoteft,cum baccifcra fic arbor: Nec proptereà negauerim Agrifolium aliud effe Paliuri genus, quod (vc jple quoque Thcophraltus inquit libro \& cap. II I I. de hiftoria Plantarum) in Africa nafcitur, quum notis omnibus illam referat. Vcrùm non ob id affirmauerim Agrifolium alterum illud effe genus, quod liliquas profert. Scd cùm Lufitanus fortafsè audierit Agrifolium inter Paliuri genera haberi, nec unquam legerit Paliuri differentias apud Theophraftum, nulla adhibita diftin\&tione pro omni Paliuro Agrifolium adducit. Qv I N \& in hoc decipitur, quòd certò crediderit Pahurum à Flinio defcriptum libro x I I I.cap. x I x.\& à Theophraftolibro \& capite quarto effe Diofcoridis Paliurum. Error fanè per fe patet, quòd Diolcoridi Paliurus femen in filiquis ferat; Theophrafto verò \& Plinio citatis locis fructum ferat rubrum filiquis nullis infertum. Nam tametfi filiquarum non meminerit Diofcorides, fed tantùm feminis, quum tamen rara in arboribus fint femina, qux filiquis, uel uafculis quibuslibet non afferuentur, non temerè cenferi poteft filiquas prætermififfe Diofroridem. Nam fi de Africana Paliurp fcripfiffet is, fruetus meminiffet non feminis. Adhæc quum Theophraftus Paliuro filiquas ferenti eafdem tribuerit tum uires, tum qualitates, quas fuo reddidit Diolcorides, ambigenduın fanè non eft, quin Diofcoridis Paliurus femen in filiquis ferat.

\section{R I.B E S.}

MA V R I I A N O R V M Ribem vulgi opinionem fequutus eam arbufculam cenfet hortis, \& uiridarijs familiarem, qux folio exit uitigineo, paruo, albæ Populo æmulo, ramulis lentis, obfequiofis ą:, topiarijs aptisfimis, è quibus tructus racematim dependent, acinis magnitudine piperis, ru

" bentibus, fapore fubacido. Sed manifeftè refellit eum Serapio ('Ribes enim Arabica planta eft) Ri" bem afferens effe arborem capreolos proferentem colore viridi rubefcente, folijs latis, magnis, ro" tundisq́; : quæ quidem notæ in noftra Ribe omnes defiderantur. Vulgaris enim Ribes nec fert capreolos, nec lata, nec magna, necrotunda folis, fed parua, uitiginea, \& diuifuris per ambitum laciniata.

\section{ROSAE DAMASCENAE.}

Qvo in altum magis in hoc turbulento mari vela facio, eò flagrantius ad portum aliquem me receptum uelim. Tædet profectò cum intis ineptijs me diutius ad naufeam vfque conflictari. Sed quid agam? In portu erat refipilcendum, nunc danda vela,quæcunque fe offerat moleftia. Maximè cùm ita diluantur ipfius nugæ, ut hinc ad feria reuocemur. Audite quæfolepidam hominis peritiam. De Rofis enim fcribens, quas Damafcenas appellat, quasq́ue vulgus Mofchettas vocat, quod odoris fortafsè fragrantia Mofcum refipiant, non folùm has non minori ui deieftoria pollere exiftimet, quàm Scammonia, fed exitiofs fimum effe medicamentum pariter contendit. Hoc vt confirmat,ani"lem prorfus huic fubtexit fabulam, quòd Venetijs viderit (liceat mihi nunc fuo uti teftimonio)no " bilis fimam quandar fux gentis mulicrcm Beatricem à Luna uocatam, quæ quum femel tantùm fac" charum ex hifce Rofis paratum à medico quodam Veneto tanquam medicamentŭ quod nullo incó" modo aluum cieret, deguftaffet, ftatim faucium \& lingnæ defquam mationé, quin \& uentriculi erofio " nem contraxit. Nihil ad meattinet de illa, quam adducit, muliercula. Primùm ( ut ego mihi teft is effe pofum ) id contra Lufitani fententiam maximè pugnat, quum fepius ipfe met id fumpferim meCenfura xvi:

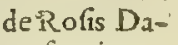

Cenfuraxiij. de Paliuro.

Céfura xiiij. in eodem $\mathrm{Pa}$ liuro.

Cenfura sv. in Ribem.

Ribis legitima hiltoria. mafcenis. 
dicamentum, alijsq́; frequenter dederim fine ullo prorfus incommodo, adeò ut qu ulandoque pueris fe Iuf́ani iudi- licifsimè propinauerim. Prætercà non magno negotio deprehendi potceft Lufitani iudicium effe falcium falfum: fum, quòd manfa hæc rofánullam penitus guftui relinquat acredincm, fed tantùm fe oftendat tum adfitringentem, tum etiam fubamaram. Id quod manifeftè indicat, ut nulla facium, aut linguæ erofio, inflămatioúc hinc deguftantibus accedere pofsit. Mihi enim hafce rofas fæpè mandenti, ut quan doque adftrictam excitarem aluum, nihil erofionis, inflammationisć; accefsit. Quo fit, ut quis rectè opinari pofsit, fuo inconftanti iudicio delufum effe Lufitanum, ut potè qui huiufce medicamenti fa cultatis penitus ignarus, fy mptomatis illius caufam in illud perperam reiecerit. Cùm potilis creden dum fịt id ab acrium, falforumq́; fuccorum defluxu proueniffe, qui fortè fortuna eo tempore, quo rofaceum illud faccharum mulier illa fumpfit, à capice in eas partes labi cœpit. Nce putauerim unquam mẹdicum illum Venetum, quem tạmen nominare non audet Lufítanus, adeò excordem, impru dentem, negligentem q́; fuiffe, ut tam nobili , ac diuiti mulieri mcdicamentum præbuerit,cuius igno rauerit uires, præfortim cùm ad huiufmodi ditilfimos ægrotantes ij plerınque accedant medici, qui

Lufitani in re medica eui dens imperitia.

Iuftani i Teleniabin in = fcitia.

Rorx Perficx qux apud Auicennam: in Palmx In nolucro.

Palma Elate Diofcoridi quid.

Palmx Elares hulto ria:

Galeno Elates duo gene ra. Quinctiá \& Diolcoridi. primas in ciuitatibus tenent. Atqui magis fanè demiror hominis imperitiam, quòd tam acriter dam. nauerit has Damafcenąs Rofas odore per quàm fuau fragrantes, è quibus clementifimum illud paratur medicamentum nullo penitus incommodo aluum ducens. Contrà uerò tam magnis laudibus prætulerit ad eandem exoluendam Perfici a boris flores; quin \& fyrupum ex corundem diluto paratum. Quandoquidem (ut iam fexcenties obferuauimus) Perficiarboris flores ad ducendam aluum deuorati, incommodis quàm plurimis fumentes aficiunt, nempè crebris uomitionibus, uentriculi \& inteftinorum torminibus, animi deliquio, \& crebris alıi deictionibus; qux omnia plerunque fe quitur frigidus fudor, aftuatıo, uirium amiffo, \& corporis uniuerfi imbecillitas. Prater id, quis

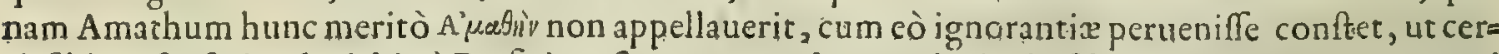
tò fibi perfuaferit Ieleniabin è Perficis rofis paratum, de quo pluries in febrium curatione, \& uentri culi dolore meminit Auicenna, ex Perfici arboris floribus parari debere? Sed quàm falfa, ac ridenda teneatur opinione, luce clarius oftendit ipfa medicamenti nomenclatio, quippè Ieleniabin Mauritanis omnium preclariffmorum medicorum confenfu nil aliud delignat, quàm Mel Rofaceum. Sed quonam pacto Rofaceum Mel è floribus Perfici arboris parari pofsit ( $a h$, ah, ah pra rifu fcribere fe rè nequimus ) qui fciunt, doceant; quum id hactenus nec uiderim, noc legerim ufquam. Conftat enim per Rofas Perficas nil aliud uoluiffe Auicennam, quàm Puniccas. Siquidem libro quinto, ubi is de compofitione medicamentorum omnium egit, de quibus in uniuerfo meminit volumine, Ieleniabin ad febres, \& uentriculi dolores parari iubet è Rubeis Rofis, non autem (ut Lufitani uana fert opinio) ex Pcrfici arboris floribus. Id quod manifefte indicats nil aliud Perficas Rofas Auicennæ de fignare, quàm Puniceas, Perficas ille fortafsè uocatas, quod à Perfis in fuas uenerint regiones. Nam \& nos Damafcenas uocam us eas, de quibus diximus, qquòd è Đamafco Syriæ primò ad nos peruenęrint ?

\section{PALMAE INVOLVCRVM.}

F A L L I T V R Præter id Lufitanus in ea examinanda palma, quam Græci énátur uocant. Is enim

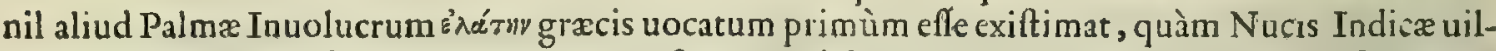
lofum tegumentum, hoc tamen argumento fretus, quòd Nux Indica uocata ab arbore proferatur(ut referunt qui in Indiam peregrinantur) Palmæ fimili. Deinde uerò fua fortấsè inconftantia ductus, in eiufdem capitis proceflu, reuocata priori fententia, (qui talium puerorum eft mos) nil aliud tandem affirmat apud Diofçoridem effe Elaten, quàm Palmæe germen, quod Græcis Encephalos dicitur; ea ratione innixus, quòd feripferit Galenus libro octauo de fimplicium mẹdicamentorum facul tatibus, id rectè Elaten uocari. Sed gemino hic fe implicat errore. Quandoquidem Diofcoridi Palma Elate nil aliudeft, quàm fiuctus Palmarum adhuc forefcentium inuolucrum, calixć;,non nucis alicuius tegumentum, nec germen. Indicæ enim Nucis nufquàm meminit Diofcorides, nec (quod fciuerim, legerim'ue ) antiquorum aliquis. Quo fit, ut csnfendum fit, huiufce Nucis inuolucrum nunquam antiquis, innotuifie. Porrò Palma arbor, qua dactylos profert (id quod penitus ignorare L.!fitanum non ambigimus ) primò inuolucrum magnum edit foliculi cuiufdam inftar, in qua quàm plưrimi flores includuntur, quii longo pediculo ferie quadam pendentes racematim cohæerent. Id tractu temporis dehifcit, emerguntq́; flores. Carpitur deinde inuolucrum ad plura utile, idque eft, quod Diofcoridi Elate appellatur: qux fi non ignoraffet Lulitanus, non ita fortafsè facilè, dum duabus uult infidere fellis, duabus hinc parietibus caput impegiffet. Nec nobis fanè obftat Galeni authoritas, qua nititur Lufitanus. Siquidem Galenus loco fuperius citato, duo facit Elates genera, unum quod germen eft ipfius Palmæ, aliud uerò tegumentum, de quo tantùm fcribit Diofcorides, cui etiam Elates duo produntur genera; quorum unum illud eft, de quo diximus, aliud uerò id totum, quod inuolucro illo concluditur; quorum nullum Nucis Indicæ tegumentum, nec GaleniEn cephalon effe poteft. Caterùm ut fortafsè probet Elaten plura apud antiquos defignare, Plinium in medium affert, quippè qui fcripferit libro duodecimo feçundo, cap.vltimo, arborem quandam efle Abietem uocatam unguentis cxpetitam, quam alij. Elaten uocant, aljj Palmam alj Spathen. Id quod 


\section{In Amathi Lufitani Enarrationes.}

maximè palàm facit,quàm imprudenter uelit Lufitanus aliorum errorum infcitia fuam tueri opinionem. Siquidem Plinius non latis aptè locutus deprehenditur uocabulorum fimilitudine deceptus .

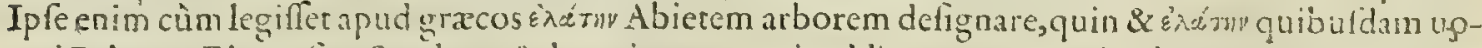
cari Palmam Elaten fiue Sparhen, $\&$ hanc in unguentis addi; magno ac pudendo errore putauir, idem effe Abietem arborem, \& Horefcentium dactylorum Inuolucrum, quod ad unguenta fpiffanda cxpetebatantiquitas.

\section{PERSE A A R B O R.}

RE PRE HEN D I T Aliorum opinionem, ut uanam, qui Perfeam arborem exiftimant à Perfico noftrate differre. Sed quàm ille totus fit ụanus, \& quàm magno ducatur errore, facilè quis añimaduerter ex probatiffmorum authorum teftimonijs. Nam (ut Theophraftus memorix prodidit "libro quarto, capite fecundo, de Plantarum hiftoria) Perfea arbor eft Aegypti afpectu magna, for" mofaç; folio, fore, ramo, totaq́; figura potifimum Pyro proxima, nıfi quòd altera folio perpetuo, " altera deciduo eft. Fructum abunde parit, omniq́; tempore perficit. Nouus anniculum femper oc" cupat, maturitas anniuerfariorum afflatu conficitur, rcliquam crudiorem auferurit, atque recon" dunt. Fruetus eft magnitudine Pyri figura oblongus, Amygdalæ modo colore herbidus, nucem in" tus habet, ut Prunum, uerùm longè minorem, molliorem q́; . Caro eius fuauis, ac prædulcis mandi " tur, concoetuq́; facilis, \& innocua eriam largiore cibo fumpta. Radice arbor exuperat tum longitu" dine, tùm etiam crafítudine, multitudineq́;. Materie conftat robufta, dura, uifuq́; decora, neluti "Lotus, quapropter ex ea, \& fimulacra, \& lectulos, \& menfas, \& reliqua fimilia fabricant. Hactenus Theophraftus. Cæterùm fì Perfex Aegy ptiæ notæ cùm Perfico noftrate conferantur, qua uniucrfus farter orbis, liquidò conftabir has plantas nihilò minus infter fe diftare, quàm à Quercu Salicem. Perficus enim arbor, qux noftris in hortis, uiridarijs, ac uinetis paffim frequentifsima uifitur, procera, magna, formofaq́; nufquam uifitur, nilhilq́; cum Pyro cognationis habet; fed potius per omnia Amygdalum refert. Quin nec fronde perpetuò uiret, nec fructum omni temporeperficit, nec oblongus is eft Amygdale intar, fed orbiculatum in fpheræ modum, colore minimè herbido; fed cùm maturuerit, aut fubpallido, aut fubcandicante, aut rubente, aut flauo. Hujc officulum prieter id Pruno minus non uifitur, fed quandoque duplo, ttiploq́; maius, nec illi figura fimile, quin nec fractu facilius, fed longè contumacius : Adhæc noftratis Perfici fruetus guftu prædulci non percipitur, fed potius fubauftero, aut uinofo. Adde quòd uulgaris Perfici fructus maximè damnauerit GaJenus libro fecundo de Alimentorum facultatibus, ut praui fucci alimentum, \& qui facilè corrumpá tur, \& noxam uentriculo inferat . Contrà uerò qui ex Aegyptia Perfea proueniunt. Poftremó Pérficus noftràs radice nititur breui non longa, tenui non craffa, rara non multiplici, \& proindè rariffi mè annofa reperitur. Contabefcit, peritq́; facilè, quòd imbiccillibus admodum fuftentetur radicibus. Ob idá; ligni materies illi rara, fungofaq́; cernitur, nec nifi ad ignem apta; quum tamen Aegyptix Perfex folida, compacta, pulcherrimaç; f pectetur, tit potè qux in multiplices ueniat ufus, Quo fit, ut omninò A matho amẹtior, \& Lufitano lufciofior fuerit, qui non nouerit Perfeam Aegy ptı ar borem à uulgari Perfico plurimùm, atque plurimùm differre. Id quod etiam com probatur Plinij te-

"Atimonio, qui libro $x$ v. cap. $x$ I I I . fic fcriptum reliquit. Nam Perficæ arbores fero, ' 8 cum difficul

" tate tranfiere, ut qux in Rhodo nihil ferant, quod primum ab Aegypto eorum fuerat hofpitium.

2) Falfum eft uenenata cìm cruciatu in Perfis gigni, \& pænarum caula à Regibus tranflata in Aegyptí,

" \& terra mitigata. Id enim de Perfea diligentiores tradunt, qux in totum alia eft, nec extra orientem

" nafci uolunt. Eam quoque negauerunt eruditiores ex Perfide propter fupplicia tranflatam, fed à Per

" feo Memphi fatam, \& ob id Alexandrum illa coronari uictores ibi inftituiffe in honorem ataui fui .

"? Semper autem folia habet, \& poma, fubnafcentibus alijs. Hæc Plinitus . Verùm non modò hic $\&$ pa riter Theophraftus deftruunt Lufitani euanidam fententiam, fed etiam grauifsimus author Galenus, qui libro fecundo de compofitione medizamentorum fecŭdum,locos, manifeftè teftatur in nulla alia Romanis fubdita gente uidiffe Perfeam arborem, præterquàm in Alexandria Aegypti.Sed ubi rerum' reftimonia adfunt, quid opus eft uerbis? Hoc tamen tantừm addam, quòd cùm per longas ante Gale num ætates Perficus, uulgaris notitix arbor, uniuerfam occupauẹrit Græciam, Italiam, ac alias paffim regiones; fi Perficus noftràs ab Aegy ptia non differret Perfea, nullo pacto credendum eft, eò dementiæ perueniffe Galenum, ut pofteritatis memorix commendauerit, nufquam gentium uidiffe Perfeam, nifi tantùm in fola Alexandria.

\section{F L V V I A T I L E S C A N C R I :}

Qv v M Lufitanum de Fluuiatilibus Cancris differentem legerem, tenere me non potui, quin in uehementem foluerer cachinum. Siquidem illum eò inlcitix perueniffe offendi in hifce cenfendis, ut A quatiles Teftudines Cancrorum affirmauerit effe genus eò grauifsimo argumento impulfus, quòd ${ }_{\text {Ridenda }}^{\text {Lu- }}$
hecticis, \& lenta febre laborantibus maximè commendentur, O lepidum caput; fine helleboro tibi fitani amencerebium tia.

Cenfura $x \nabla_{-}$ II I. de Perfea. Perfex arboris hiftoria ex Theophra Ato.

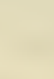

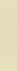


cerebrum demulceam $m$ Serióne hæc dicuntur ab Amatho? an rifum fua uccordia mouereftudet? Nimirum adducor, ut credam ( fi id feriò fatear, quòd fentio) aliquo amentix genere illum quandoq́; uexari, \& proindè tunc temporis non nifi huiufmodi deliramenta defcribere. Nam \& Ranæ, \&Coclex in Cancrario genere erunt, quòd hecticis maximè conferant, fi potius Lufitani delirio addicimur, quàm ueritati.

\section{A R I N V S C O R P I O.}

Cenfura xx. M A R I N V M Scorpionem paruulum quoddam putat effe animalculum, quod ex Cancrario gene de Marino re exiltimauerim (uidimus. $n$. illud fxpè in Hadriatici littore tanquam inutile à Pifcatoribus reieScorpione. ctum)longis, ac tenuibus cruribus, corporis forma terreftri fcorpioni fimili, chelis pariter tenuif fim is , cauda nulla, \& omni penitus pulpa carens. Gulielmus Rondoletus libro x v I I I. cap. X X I r. de Marinis pifcibus animalculum hoc Cancrum Bpaxaxíney uocat. Verum Ariftoteli, Hicefio, Galeno, Athrnco, Plinio, Aelianoq́; Scorpius pelagius eft pifcis, \& inter nullos afellos, lacertos, cernuas, \& quot quot funt,alios duræ carnis recenfetur, non autem in Cancrario genere. Quum autem eius hiftoriam in commentarijs noftris in Diofcoridem pluribus defcripferim, \&z ueram Scorpionis imaginem appinxerim, eò feconferre poterit Lufitanus, fi cæcitatis fux remedium non neglexerit.

\section{R A N A E.}

Céfura xxi: VB I Ranarum uires expendit Lufitanus, proculdubiò aberrat, quòd omnes in uniuerfum Rade Ranis. nas uenenofas cenfeat, adeò ut in Aetium inuehatur, quòd is libro I I $\mathbf{~}$. cap. $\mathbf{L} \mathbf{V} \cdot$ paluftres ranas in ter uenenata recenfeat, \& tamen libro fecundo earum ius tanquam alexipharmacum pratulerit ad uenenatorum reptilium i¿tus. Error nimis eft manifeftus, quòd quotannis infinitus ranarum nume rus Italis in cibum ueniat ex his, qux in paludibus, \& fcrobibus morantur, \& nullo tamen incommodo comedentes afficiunt. Nam fi (ut Lufitanus inquit) Ranæ omnes uenenof effent, nulli dubium eft, quin quàm plurimi earum efu interirent:quum non defint homines innumeri, qui ijs tantùm fapius fatientur, nulla ob id accedente noxa. Nec fanè fententix noftræ obftat, quòd Galenus lib . de Cibis boni \& mali fucci fcriptum reliquerit, à Ranis effe abftinendum . quippè is Ranas non deteftatur, quòd ueneno aliquo fint infectæ, fed quòd malum in corpore fuccum procreent, perindè ac pifces in ftagnis \& paludibus degentes. Quippè fi Galenus putaffet uenenofas effe Ranas, nunquam

Iufitani Re- eas inter cibos retuliffet. Sed magis fortafsè Lufitanus credo lege percitus Mofaica, quàm ueritatis ligio. fuftinendx defiderio in Aetium inuectus eft, quem ( pace eius dixerim) non intellexit. Ip fe enim libro fecundo de Viribus animalium agens, qux in ufum medicum ueniunt, ubi deuenit ad paluftres Kanas, qux paffim ab omnibus eduntur, Ranæ paluftres (inquit) in aqua elixæ, faleq́ue \& modica oleo conditæ, uenenoforum reptilium ictus, fi ius earum bibatur, magnum præfiđium afferunt. Id quod ex Diofcoride deprompfit, qui pariter de his egit ijfdem uerbis. Quibus manifertè fuffragatur Plinius libro x x x I I. capite quinto,ubi non modò Ranarum ius prætulit contra ferpentium ietus, fed etiam ad Marini Leporis uenenum, haufta uenena, deuoratam Rubetan, Salamandramq́; ijs laudibús prætulit. Nec ob id uelim fortafsè putet Lufitanus Aetium fibi ipfi repugnaffe. Quippè qui di xerit libro X I I $\mathrm{I}$. quòd deuorata paluftris Rana tanquam uenenofa uarijs, ac multis uexet incommo dis. Quandoquidem ibi de paluftribus Ranis non egit, qux in cibum veniunt, fed de uenenofis, qux è Bufonum funt genere, $\&$ in paludibus præfertim fæetidis morantur. Ipfe enim cùm proximo capite de Rubetis Ranis egiffet, quas Bufones alij appellant, uoluit de aquaticis etiam Bufonibus, quos Græ ci fub Ranx paluftris nomine comprehenderunt, uerba facere; quoniam fciuerat Bufones, \& terreftres, \& aquatiles reperiri, ut unumquemq; compertum habere non ambigimus, qui diligentius, accuratiusq́; materiæ medicæ operam nauarit, quàm fecerit Lufitanus. Id quod manifeltè declarat libri illius titulus, qui de Noxiorum animalium morfu, \& de beftijs uirus eiaculantibus infcribitur. Nam. \& idem legitur apud Diofcoridem; quippè qui libro fecundo de Ranis, qux in cibum ueniunt, egit; fexto uerç,ubi peculiariter de Venenis, \& Venenatis animalibus tractauit, de Rubetæ, \& paluftris Ra-

Lufitano in næcuratione caput proprium edidit. Adeò ut iam nobis fateri liceat, neutiquam in re medica Lufitare medica nó no effe aftipulandum.
effe aftipulan

dum.

\section{G A L L I N AE.}

Céfura xxIr de Gallinis.

A T Q V I nulla mihi amplius eft contentio cum Medico, optime lętor, uerùm cùm folertifsimo deguftatore, vel coquo potius, quo plurimùm recreatur officio regalium epularum. Gallinas inferioris Germaniæ prænimia algoris inclementia carnes habere fcribit hircinis, vel caprinis deteriores , \& proindè malum, uitiofum'ue præbere alimentum; quin \& rarò ibidem homines idcircò uefci gallinis. $\mathrm{O}$ indagatorem omnium eduliorum. Patere id me te percontari. Quis amabò te abidem Prin ceps fux præfecit culinx, ut iftis eum fpoliares delitijs: Id quum ego mecum admiratus Flandris qui-. 


\section{In AmathiLufitani Enarrationes.}

bufdam exponerem, fabulam effe aiebant. Quippè quòd non minus in eorum regionibus carnium probitate, faporisć; iucunditate praftent gallinx, quàm alibi. Adhæc pariter fabulofum effe fatentur, quòd raro gallinis ibidem uefcantur incolx, ea ratione innixi, quòd earum cibus reprobum generet alimentum ; fed quòd multi fortafsè à gallinis abltineant fumptui parcentes. Quòd autem prater rationem ij medici agane (ut ait Lufitanus) qui poft exactam purgationem ad uentriculum abfter gendum ab inhærente medicamento fimplex gallinarum ius exhibent, fanè non improbamus; féd qui fint lij prorfus ignoramus, quum in communi omnium medicorum ufu perpetuò effe fciuerim, ius illud hoc in negotio nunquam exhiberi, nifi faccharum admifceant rubeum. Nec id temerè factum putaucrim, quum non ambigam ius ita paratum non modò abftergere, fed etiam poffe roborare. Id quod à purgarione plurimùm præftat.

\section{A C S C I S S I L E.}

L A c s C I s S I L E Nil aliud effe ccnfet, quàm lac ipfum fimplex per fe acefcens . Conuincitur " iplius Diofcoridis teftimonio, qui huiufce parandi lactis rationem fcribit his uerbis. Ex omni lacte " fit, quod Scifsile appellant, hoc modo. Lac fictili nouo feruet, ramoǵ; ficulneo recenti mouetur, in" fparlis, poftquam bis uel ter efferbuerit, totidem aceti mulfi cyathis, quot funt lactis heminx. Ita " enım ferefcens liquidum ab co diuiditur, quod in cafeum concreuit; fed cùm feruet, ne fuperfunda" tur, conueniet fpongia ex frigida continuò fictilis labrum detergere, fextariumq́; argenteum frigidx " aquæ plenum demittcre. Hxc ille. Diofcoridi fubfcribit Galenus libro decimo, de fimplicium medicamentorú facultatibus, ubi de Canino ftercore egit : quin \& Paulus libro primo cap. L x x x v I I I. Non poflum fatis cogitarc, quæ fuerit in homine tanta imprudentia, aut fomnolentia, quòd cùm tam fplendidis enarrationibus cxplanandum Diofcoridem fufceperit, adeò graui labafcat negligentia.

\section{O L Y R A.}

IN SRVMENT A CE O genere eam magno errore Olyram cenfet Lufitanus, quam nos Secală, \& Plinius Secalem, \& Farraginem appellat, è qua ruftici panem conficiunt nigrum triticeo longè de terriorem. Sed cadit Lufitani opinio, quòd Galeno primo de alimentorum facultatibus Olyra colore fit albo, adeò ut dixerit Plinius libro decimo octauo, cap.octauo, effe, quilob Oly ra candorem, il„ lam Orizam effe putarent. Praterea fcribit idem Plinius ex Oly ra dulcem confici panem, id quod cx " pane ex Secale confecto minimè percipitur, cùm potius quodammodo amarorem refipiat. Adhæc Se cala ita uulgò uocata, cùm in area flagell is decutitur, illicò omnem exuit tunicam, \& tritici modo nu da colligitur : fed aliter Oly ræ euenire fatetur Galenus loco fuperius citato, dum Oly rinos expendit " panes, lic inquiens. Habet autem Typh $x$ femen extrinfecus corticem, ueluti Oly ra, \& Hordeum, " uerùm decorticatum in panes congeritur: \& paulò inferius ait. Ex nobilifsima Olyra, cùm, ut decet, 3) fuerit decorticata, nominatum Tragum conficiunt, quo plerique utuntur. Quibus planè conftae Olyram decorticari in area non poffe Alagellis, quemadmodum nec Hordeum, nec Zea, nce Auena, dum in area concutitur; fed opus effe, ut in pilis pinfentur, ut etiam hoc wuo moris eft apud omnes,

\section{C $H O N D R$ D.}

E X E A fruge parari Chondrum exiftimat, quam quidam in Italia, ut in Tridentino agro, Scan dellam uocant : quod meritò redarguit omnium agricolarum confenfus, qui dicunt hanc efle Hordei genus, non Zex. Hordei enim plura habentur genera, ut quis ex Theophrafto noffe poteft libro octauo capite quarto de plantarum hiftoria. Quæ fi rectè expendantur, nil aliud Scandella erit, quàm Hordeum minus, qux binis tantum uerfibus fpicam gerit, rotundiore etiam grano. Nam præter id, quòd per omnia nempè facie, \& uiribus Fordeum referat, conftat non effe Zeam, quam Dicoccon appellant, quòd nunquam Scandella reperta fit, qux Zex illius modo in geminis putaminibus coniunctum femen habeat. Quo fit, ut nullo pacto Scandella inter Zeas recenferi pofsit. Zea autem Dicocco abundat Goritienfis ager, \& Foroiulienfia arua, ibiq́; uulgo Pirra Farra dicitur, quòd Zea ibi $a b$ incolis in uniterfum Pirra uocetur. Cæterùm quia ex hoc Zeæ genere Halicam, fiue Chondrum fibi parant, quam ipfi Far appellant, licet falsò ( differt enim ab Halica Far) ideò eadem Pirra Farra nominatur à ruricolis. Huic alius eius affinis eft error, quòd fcrip ferit, putaueritq́; Far ab Halica ni hil differre, idq́; ex Scandella parari, quam Zeam Dicoccon cenfet. At Plinij tcttimonio Far nil aliud eft, quàm frumenti, uel tritici genus Adoreum uocatum. Ille enim libro x V I I I. cap. v I I . it n) friptum reliquit. Frumenti genera non eadem ubique, neque ubi eadem funt, ijfdem nominibus . "Vulgarisfimum Far, quod Adoreum ueteres appellauere. Item eodem capite, ut palàm faceret aliud " efle Zeam, è qua fit Halica, aliud verò Far, Qui Zea vtuntur, inquit, non habent Far. Item cap. vi I. 2) eiufdem libri, populum Romanum, ait, Farre tantùm è frumento trecentis annis ufum. Verrius 2. Cribit, Quo tempore Romanis nullus fuit Halicx ufus, ut ipfe met teftatur Plinius libro Xx II.

Cenfura $\times x-$ IIIr. de Oly ra.
Cenfura $\mathrm{xx}$ Ir.de fcifsi lilacte.

Lactis Scifsilis parandera tio. 
cap. x x v. cùm inquit. Halica res Romana eft, \& non pridem excogitata, neque arbitror Pompei " magni atate in ufu fuiffe. His accedit Afclepiadis, \& Galeni authoritas libro feptimo de compofitio " nę medicamentorum fecundùm locos in quodam cclegmate ad cruenta fputa, ubi fic habet. Farris Clu " fini appellati fextarij dımidium, decocti Marrubij uirdis fextarium unum. Hxc in uas uitreum con" iecta per diem \& noxtem macerari finito , fequenti die pharmacum molito, quemadmodum Hali- ") cam maceramus. Hæc Galenus; quibus palàm eft à Farre differre Halicam. Galeno fubfcribit Aetius " libro I x. cap. X L v. his uerbis. Q nod uerò latinè in regionibus Romx uicinis Far appellant, hoc mo " do paratur. Frumentum modico tempore aqua madefacito, indéque extractum, ac in pilam conie- " Etum, ucluti Ptifanam à cortice repurgato, ubi uerò corticem exuerit tollito, atque in fole ficcato, de " inde manibus tritum, "donec penitus à cortice fuerit mundatum, crafsifsimè 'molito, ita ut granum " unum in quatuor aut quinque partes redigatur, \& ficcum afferuato. Vfus autem tempore Halic $x$ o" do coquitur, \& à fanis in cibum fumitur. "Hæc ille; ad quæ certè pertingere debuerat ille magnarum " centuriarum conftructor.

\section{P H A E O L V S.}

Cenfura $x x-$ vir. de Phareolo.

Cenfurax $x-$ virt. in Dolicho.

Célura $x x-$ Ix.de Rumice.
PH A S O L V M, Siue Phafiolum, non paruam illam, \& uulgarem, quam Galenus Ochron ap pcllat, fed magnam effe Eruiliam falsò contendit. Quandoquidem Eruilia illa maior latinis Pifum di citur, non autem Phafeolus.Differre autem Phafeolum ab omni Eruilia \& Pifo teftis eft Plinius libro x VI I . cap. vII. fic inquiens. Frumentis folium harundinaceum, Fabretundum, \& magnæ legu " minum parti . Longiora Eruilix, \& Pifo. Phafeolis uenofa. Quibus palàm cft, nec Eruiliæ genus, ", nec Pifum effe Phafeolum. Conftat præterea Eruilix cuiufque generis, uel Pifi filiquas clixas in cibis à nemine mandi, quòd adcò dura fint cartilagine, ut nullo manfu dentibus confici qucant. Contrà uerò uulgaribus, genuinisq́; Phafcolis accidit. Id quod idem fatetur Plinius cap. x I I. eiufdem libri, ubi fic habet. Siliqux rotundæ Ciceri, cæteris lcguminum longæ, Pifo cilindriacæ , Phafeolorum " cum ip fis manduntur granis: id quod noftris Phafeolis uulgaribus accidit. Nam tencllas corum fili. ”, quas fuis granis refertas, modò in acetarijs Afparagorum modo, nunc unà cum brafficis elixas ; ante maturitatem æltate comedimus; quod tamen nulli alij leguminum generi à natura datum effe compe rimus. His itaque palàm eft Phafeolum Diofcoridi nullam effe Eruiliam, fed uulgaris ufus Phafeolum, qui pafsim in campis feritur. Quippè non tantùm folia illi infunt (ut Plinius inquit) uenofa, fed ( ut Diofcorides ait) deuoratus inflat, fpiritus ciet, \& ægrè concoquitur. Quin etiam uirjdis cum filiqua fumptus aluum emollit. An non in idem cadit erratum, quum Eruiliam, quam confundebat cum Phafeolo, Dolichum à Theophrafto credit appellari? quum Dolichum ille teftetur apertè adaEto longo palo confurgere. Id'quod maximè denotat, Dolichum nil aliud effe, quàm uarium Phafeolumillum, qui Diofcoridi Hortenfis Smilax dicitur. Quippè in primis hiclongifsimos afcendit palos, quibus Lupi Salictarij modo fe circumuoluit, nec alibi, quàm in hortis feritur . Quinetiam eius filiquæ fimul cum granis, perinde ac aliorum Phafeolorum manduntur in cibis. Id quod in præfatio ne fecundi libri de Alimentorum facultatibus teftatur Galenus, \& Paulus Aegineta libro primo. Atqui fi pluribus inanem fuam uelitfententiam confutari, commentarios noftros in Diofcoridem confulat. Plura enim ibi reperiet, quæ hic filentio prætermittenda duximus, ne plantarum potius hifto riam fcribere, quod in alijs uberius exequuti fumus, quàm iftius temerarij hominis imperitiam, ac negligentiam uideamur aperire; quod iam noftrum eft inftitutum, fed id breuiter : ne, fi omninò tacuerimus, ille fua temeritate in cæteris noftra abutatur modeftia; fin copiofius, ne iuftum excedamus modum.

\section{I.APATHVM, SIVE RVMEX.}

A C I A M Propemodum uereor, ne quis eruditus tandem faftidiat in audiendis innumeris, 8 tur pifsimis iftius hominis erratis. Qux fi nuda in medio ponelem, cui non ifta ftomachum moueant? Nunc ita uniufcuiufque occurrere ftudeo prudentix, ut non parum hoc quemque confolari debeat quòd in huius refrenanda audacia plura interim à nobis afferuntur non infrugifera, \& ( nifi me fpes fallit) non indigna eruditis auribus. Id unum fiquidem hic ubique laboro, ut \& Lufitani, qui tam infidè, ac improbè aliorum uerfat fcripta, patefiat audax infcitia, \& ueritas fimul in his tencbris non fiv ne lectoris emolumento elucefcat. Verùm fic à nobis utrunque eft peragendum, ut plura, \& abfolutius nos aliàs de his acturos meminerimus, utć; contra Lufitani infultus, ac imperitiam non parum hinc quoq; roboris, \& lucis accedat. Quarè ( quod in cæteris fum facturus) iam accedam ad ea, qua de Spinachio, feu Rumice ille profert. Nam quòd hortenfe olus Spinachium nobis pafsim uocatum; Satiuum Lapathum effe afferat, meo certè iudicio longifsimè aberrat; quòd Spinachium cum Rumi ce, uel Lapatho nihil habeat cognationis; fiquidem nec folio, nec caule, nec flore, nec femine, nec radice $S$ pinachium Lapatho fimile cernitur, quemadmodum nec guftu, nec uiribus. Conftat item Galenum ( \& fi contrarium fortafsè fomniauerit Lufitanus) Spinachij, quin nec Hortenfis Lapathi meminiffe inter olera, fed tantùm fylueftris Lapathi, cum inquit. Licet cuiuis (utante diximus) "

Lapathum 


\section{In AmathiLufitani Enarrationes.}

"Lapathum appellare Betam agreftem, ut quod non guftu modò, fed uiribus etiam Betx Hortenfi eft " adlimilc. Verùm cùm Beta Lapatho fit fuauior, iccircò nemo éft, qui non ipfa libencius uefcatur. Haztenus Galenus. Quibus palàn eी Spinachium Lapathum efle non poffe; nam præter id, quod spinachium Spinachrum nihsl cum Lapatho habeat fimilitudinis, fylueftre olus non elt, fed horrenfe. Quno fit, ut nó elie inter fylueft ris Beta eciam appellari nequeat. Adde quòd Spinachium fuauius, \& cibo gratıus ol us lit, quấ Lapathi ge =Beta; v A N E' idem fibi pcrfuadet Lapathum communis ufus nunquam in ciborum ufum concefsiffe, cùm Galenus loco iam citato, ubi fylueftre Rapum inter olera, qux comcduntur, recenfuic, \& Vana Lufita fylueftrem appelfarit Betam. Quinetiam \& Tridentina, \& Goritienfia rura, totiusq́; ferè Iralix agre ni perfuáro * fites homines id maximè comprobant, cùm uere Sylueftris Lapathi plurimùm manducent, quòd eo tempore tenella habcat folia.

\section{H.O N D R Y L L A.}

CH OND R Y L A Diofcoridicaulem, flores, \& folia habet Cichorio frmilia, adeò ut inter Ci chorij lpecies ueniat numeranda, tenuior tamen tota Cichorio eft. At Lufitanus, qui in Diofcoridis leatione maximè uerfatum fe ubique cenfet, Chondryllam folio effe hortenfi Intybo minus rectè fcribit. Id quod proculdubiò oftendit Chondryllx ftirpem aliquam nunquam uidife Lufitanum.

\section{G I N G I D I V M.}

N E c Errore uacat, qux de Gingidio cenfet, quippè qui uelit recentiores quofdam fequutus nil aliud græcıs efle Gingidium, quàm uulgare illud Olus, quod Cherophyllum, uel Cherofolium uo cant. Arqui Cheroph ylli folia, pariter ac radices nihil amaroris, adfrtrićtionisq́; mandentibus rclinquunt, fed potius dulcedinis, \& acuitatis tantillum refipiunt; quam tamen Diofcoridis, \& Galeni te " ftimonio Gingidium herba fit adftrictionis, \& amaritudinis non obifcưræ, adeò ut fit etiam Sylue"Atri Paftinaca amarior, \& ob id ( ut Galenus inquit libro fecundo de Alimentorum facultatibus) potius fuerit hæc herba medicamentum, quàm alimentum. Adde quòd Galeno libro de Cibis boni, \& " mali fucci capite oftauo, \&e de Attenuante uictus ratione cap. I 1 r. Gingidium herba fit fylueftris, con trà uerò Cherophyllum, quod palsim in hortis feritur', ad obfonia.

\section{S C A N D I X.}

N E C Minus improbari debet, quòd fenferit legitimam Scandicem eam effe herbam, quae in fegetibus nafitur, plerunque in agrorum extremitatibus Chcrophyllo fimilis, flore albo, mucronatis in cacumine corniculis, Geranij æmulis, in quibus conditur femen; quandoquidem hæc herba nec amara eft, nec fubacri guftu deprehenditur. Id quod in Scandice Galeni teftimonio non obfcurê per cipitur, adeò vt hanc ille rctulerit inter ea medicamenta, quæ fecundo ordine intenfo, uel tertio inci piente excalfaciunt. Prætereà quum Scandicis hiftoriam ( quod uiderim, legerimǵ;) neno fcrip ferit antiquorum, arduum fanè uidetur, uel potius temerarium decernere, \& pro certo affirmare hanc uel illam plantam efe radicem. Quippè hæc, quam alios fequutus Scandicem appellat Lufitanus (ut rei herbarix periti exiftimant) eam maximè refert plantam, qux Plinio Veneris Pectenappellatur, ut la: tius in commentarijs noltris feriptum reliquimus.

\section{H I R C I B A R B V L A.}

QVAN T V'M in cenfenda Hircibarbula fallatur Lufitanus, ij facilè nofcent, quifin re herbaria eius legcrint enarrationes. Ille enim, ut noui aliquid atferre uideatur, fi uera defint, fabulofa afferre non ambigit. Scribit is duas Tragopugoni effe fpecies, alteram flore purpureo, alteram luteo; fed utrique radicem effe paruam, bulbofam aliquantulùm oblongam, Auellanæ nucis magnitudine,dulcem, \& efui aptam, quam pueri in Hifpania in campis eradicantes à fimilitudine paruarum nucum Nuccllas appellant, \& illarum efu maximè delectantur. Sed aberraffe deprchenditur, quòd non folùm Jiofcorides, fed \& Theophraftus, \& Plinius feriptum reliquerint Tragopogono radicem effe longam, ac dulcem. Id quod fole clarius uifitur in genuina Hirci barbula; non autem bulbofam Nucis Pontice magnitudine. Quibus palàm eft, quàm diligenter, quàmq́ue accuratè diligens enucleator legerit Diofcoridem (ut Theophraftum, \& Plinium præteream) quem enarrandum fufcepit. Is enim ( quantùm uidco) eam plantam Tragopogonum putat,quam Fuchfio in Commentarijs de Stirpium natura A pios admentitur. Planta hæc in Bohemia frequens non in agris tantùm, fed etiam in uineis. Germani Terræ Nucem appellant. Sed quàm habeat cùm Tragopogono cognationcm, ego fanè nullam uideo.

Cenfura $\mathrm{xxx}$. de Chondryl la.

Cenfura $x \times-$ $x$ r.de Gingidio.

(1)

\section{Cenfura xx- II.de Scan- dice.}

Cenfura xsxirr.de His ci barbula.

\section{Iufitanitum}

non legiffe Diofcoridem nifi ofcitäter. 


\title{
Petri And. Matth. Cenfura
}

\author{
S M I L A X H O R TENSIS,
}

Cenfura $x x-$ IIIII. de Hortëfi Smi lace.

Cenfurarsxv.de Thla: Spi.

Cenfura $x x$ xvi.de Zedoaria.

Serapiőis interpreris laplus.

Cenfura $x \mathrm{x}$ xvir.de Seru thio.

Cenfura $x x$ Xvir.in Lu firani fabulä

Cenfura $x x-$ xix.de alcera Cyclami220.

Lufitanus ina niter Matthi olum citat.

No N P A R V o profectò etiam errore notatur Lufitanus, ut Diofcoridem de Hortenfi Smilace diferentem, de omni Phafeclorum genere fub Smilacis illus nomine fcripfiffe arbitretur, cùm uulgares Phafeoli, quibus paffim in cibis uefcimur, dum fati in campis uirent, non repant, nec adeò frutices confcendant, ut Smilacis modo topiarias fcænas inumbrare queant. Prxtereà quum uulgaris Phafeolus pafiim in campis feratur, cæterorum leyuminum more, quo pacto, quáue ratione Hortenfis Smilax uocari pofsit, profectò nefcio. Sed quoniam hæc longè plurịbus nobis comproba ta funt in commentarijs noftrịs in Diofçoridem, eò Lulitanụm remittimus,

\section{T H L A S P I.}

N E C minus decipitur Lufitanus in expendendo Thlafpi, quòd dixerit in eo latum percepiffe femen, \& folia in cacumine diuifa. Ac fi ex uerbis eịus coniecturam facère licet ( quod tamen pace eius dixerim ) nunquam uidit Thlafpi. Non enim Thlafpi fẹmen latum eft, ut Galenus teftatur, fed rotundum, firnile milio, \& aliquandò longiufculum; \& proindè rectè fcripfit Diofcorides, Thlafpi fe men efle Nafturtio fimile. Latus quidem foliculus eft, qui femen ipfum includit, fed qui foliculum dicant effe femen, neminem habeo præter vnum Lufitanum. Cæterùm Thlafpi folia (ut intuentibus facilè patebit ) nufquam in cacumine diuifa fpectantur, fed foliculi,qui femen concludunt, ut in com mentarjjs noftris quis legere poterit, ubi hunc Diofcoridis locum reftituimus.

\section{Z E D O A R I A.}

Qv o D Zedoaria \& Zurumbetum Mauritanis idem non fint, aduerfus Lufitanum reclamat Sera pio,qui de his diuerfis capitibus diuerfam feribit hiftoriam. Deindè quòd Zedoaria radix fit herbæ, Zurumbetum uerò arbor procera, infrugifcraq́; citreum odorem fipirans, folio Salicis colore ex uiri di in luteum langucicente, ut idem Serapio fcriptum reliquit. Zurumbetum Paulo Arnabo appellatur. Actius tamen utriufque meminit, Zedoariæ, fcilicet \& Arnabonis uarijs in locis, tanquam de me dicamentis inter fe differencibus. Sed Lufitano perindè ac alijs quibufdam errandi anfam dedit Serapionis interpres, qui cap. C L X XII. Zcdoariam falsò Zurumbetum eppellat. Patet interpretis error Serapionis ipfius teftimonio, quipłè qui cap.c c L XX X. de Zurumbeto egerit,\& longè aliudà Zedoaria fecerit.

\section{S T R V T H I V M.}

S T R V T H I V M, fiue Radiculam, fiue Lanariam herbam magno fanè errore nihil à uulgaribus Saponarijs differre putat Lufitanus. Quippè quod harum nulla fpinofo proueniat folio, quum tamen Theophrafto, ac Plinio Struthium aculeata fit planta, \& caulem proferat fœnilaceum, qui talis ijs Sa ponarijs, de quibus meminifti, non uifitur. Adde quòd neutrum Saponariæ genus fternutamenta cie re ualeat. Ad fabulam autem maximè ridenda $m, \&$ potius longo cachino explodendam, quàm uerbis refellendam, quam narrat Lufitanus de herba illa in eius caftelli moenijs nafcente, à quo fe oriundumi facit, qux flore fit Pafferculi effigie, eò ģuòd ibi pafferes quàm plurimi nidificent, \& femine in coitu eiaculato herbæ radices refpergant; nil aliud dicendum cenfemus, nifi quòd hic fuis delirament is co lophonem addiderit Lufitanus. Caterùm fi propè nidificantes pafferculos, nafcentes plantæo ob id flores pafferculorum illorum formam proferant, quòd earum radices eorum fpermate madefant,cur fiar igitur quòd plurimorum animantium formas, qui in campettribus, \& fyluis morantur, in quàm plurimis non reperiantur herbis, quotidiè eorum femine perfufis, Lufitanus ipfe dicat, qui fua fingulari amentia nouam hanc philofophiam excogitauit; ir qua fi fortafsè perfeuerandum ftatuerit, dif́cat etiam à circulatoribus fcribere Mandragoras ex humani feminis profufione oriri: quin \& Antirrhinum ex bubulo, quod ẹius fernen uafculıs includatur, qux uitulina referunt capita .

\section{Y C L A M I N V S A L T E R A.}

GRAVE, \& permoleftum mihieft, quòd in Cyclamino fui erroris me faciat authorem, cùm di cat Matthiolum Senenfem alteram Cyclaminum à fe confpectam affirmare, radice parua Auellanx perfimili, tametfi hactenus ille nunquam uiderit . Quibus conijcere quis rectè poterit, quàm ille ofcitanter commentarios noftros legerit, \& inaniter me citauerit; quandoquidem nobis nufquam diEtum eft Cyclaminum Alteram, cui fuperuacuam radicem affignat Diofcorides, radice conftare parua, Nucis Ponticæ magnitudine, quum ibi rectè affirmauerim Cyclaminum hanc me nufquam uidilfe in Italia. 


\section{In Amathi Lufitani Enarrationes.}

N v I V M difcrimen cernit diligens, \& folertiffimus rerum infpector inter Efculentum Bulbum, \& Alcalonicum Ciepe, quod nos uulgò uocamus Scalogna. At quantum diftant Afcalonicum enim Cape inter Cxparum genera antiquis recenfetur, non autem inter Bulbos. Lufitano refragatur maximè Theophraftus, quippè qui libro v I I.cap.I I I I.de Plantarum hiftoria, Afcalonicum Cæpe, ac alterum ciufdem generis Fîsile appellatum inter Cæeparum genera recenfuit, non inter Bulbos,de quibus fpeciatim egit cap. X I I I eiufdem libri, cui fubfcribit Plinius libro x I X. cap.vI.fic inquiens . "Allium, Cxpasq́; inter Deos iure iurando habet Aegyptus. Genera apud Græcos plura. Sardia, Sa" mothracia, Alfidena, Setama, Schift, A fcalonia ab oppido Iudeæ nominata. Demum Galenus libro " vr.de fimplicium medicamentorum facultatibus Efculentos Bulbos amarofos, ac pariter adftringen " tes facit. Id quod rurfus repetijt libro fecundo, de Alimentorum facultatibus. Quæ tamen qualitates in Afcalonica Ciepa non reperiuntur. Ip fa enim acris eft ualdè perindè, ac cætera Cæparum genera, nec quicquam ei ineft amarofi faporis. Equidem putabam hæc non ignoraffe Lufitanum, quum illum compertum habeam oriundum à locis quibufdam non procul ab Afcalone Iudea.

\section{A R G E M N E A L T E R A.}

A L T E R A M Argemonem Diofcoridi adulterinam effe non ambigimus, ut in Commentarijs no ftris diffulius diximus; fed hoc fortafsè nefciens Lufitanus, ne huius plantæ uideretur ignarus, Argemonem alteram eam plantam effe cenfet, qux recentioribus quibufdam Argentina dicitur, non alia (utopinor) ratione, quàm quòd Argentina folia gerat uulgari Agrimonio fimilia, quæ quantùm cum Sylueltri Papauerc habeant cognationis, fimilitudinis'ue (talia enim Argemoni alteri requiruntur folia) ij iudices erunt, qui plantarum hiftorias diligentifsimè explorauerunt, \& Lufitani imperitiam norunt. Quicùm fortafsis fibi perfuaferit, eam ob caufam Eupatorio Argemonij nomen ac cefsiffe, quòd folijs \& facie Argemonem hanc referret, nomenclationibus magis innixus, quàm plan sarum ipfarum notis, hic etiam mifer fe deridendum dedit.

\section{T E L E P H I V M.}

Qv A ง T v'M in cenfura Telephij hallucinetur; qui uult Telephium Diofcoridi nil aliud effe, quàm tertium semperuiuum, illud fanè ftatim oftendit, quòd Diofcorides de Telephio libro fecúdo, $\&$ de Semperuiuo illo libro quarto fcripferit, \& quòd nec nobis fcriptum reliquerit Diofcorides tertit:m Semperuiuum quibufdam Telephium uocari.Siquidem. Diofcorıdes has nomenclaturas non re cipit, fied tantìm adducit, quamobrem non eft propterea dicendum tertium Semperuiuum effe Telephium; quemadmodum (exempli gratia) nec Helfine, quam Parthenium quofdă appellaffe Diofco: rides feribit, Parthenium eft, nec A farum Bacchar eft, nec Afplenum Hemionium, nec Gingidiū Lepi dium : tamet fi hrec omnia aliarum plantarum nomine quibufam appellentur. Nam fi Diofcoridi idế effet T tephium, \& tertium hoc Semperuiui genus, non fuiffet illi opus de altero per fe fecundo libro fcribere, de altero uerò libro tertio inter Semperuiui genera, ut etiam compertum habemus feciffe Pli nium, qui lib. x x v I I.cap. X I I I.de Telephio egit, libro uerò x x v.de tertio Semperuiuo,poftquàm de alijs duobus generibus diferuit.Adhæc fi Telephij facultates apud Diofcoridem, \& Pliniú expendantur, Telephium uidemus uitiligines fanare, quinetiam uulnera, \& finus; hoc uerò Semperuiuum ftrumas tantùm difcutere.

\section{A G A R I C V M.}

L O NG E' ab omni fcopo eos medicos aberrare fcribit Lufitanus, qui Agarico in paftillis conformato pafsim utuntur, noua fua quadam opinione ductus, quòd Agaricum cótritum nullo pacto diu fuas uires feruare pofsit. At nos illum errore fanè lŏgè maiori procul dubio duci cenfemus, eoq́; præ fertim quòd nullam afferat rationem, nec probatiflimorum fcriptorum authoritaté, qua fuam fulciat fententiam. Porrò Mefues clarifsimus inter Arabąs,\& qui in componendis medicamentis primas tenet, Agaricum in paftillos redigi fuadet, ut unà cum ijs, quibus excipitur, medicamentis tractu tempo ris debitam acquirat mixtionem : id quod expedit omnibus compofitis medicamentis. Nec uideo cur tam facile quicquid tenuium partium in eo extiterit ( ut friuolis admodum uerbis contendit Lufitanus ) euanefcere pofsit . Siquidem cum Mefui paftilli de Agarico, Salem forsilem, Gingiber, \& Oxymel excipiant, non fanè conftat cur tam facile tenuior Agarici pars in auram refolui pofsit, cùm mellis proprium fit in fuo uigore admifta diutius afferuare, Salis uerò \& Gingıberis huic medicamento facultatem augere. Fruftrà quidem tot catapotiorum maffas, quæ Agaricum excipiunt, Seplafiæ confectas afferuarent, quin \& electaria aluum ducentia, $f_{1}$ Agaricum in puluerem ijs additum fuas ftatim deperderet uires; fruftraq́; illud in Theriaca addidiffet Andromachus . Quamobrem omninò explo-

D denda

Cenfura xlj. de Altera As gemone.

Cenfuraslij. de Telephio,

Cenfura sliij de Agarico. 


\section{Pet. And. Matth. Cenfura}

denda erit Lufitani fententia, qui præter omnium clarifsimorum uirorum placita folus iubeat Agaricum ea ipfa hora effe contundendum, ac alijs addendum medicamentis, qua expedit illo uti .

\section{R H A B A R B A V M.}

Cenfu.xliiij. de Rhabarba ro.

Rhabarbarú totum dyfentericis maximè conuenire.

Iufieani infcitia in cenfendo Auicë$n x$ Rhabarba ro.

CAET E R V'M de Rhabarbaro fcribens Lufitanus, medicos illos magno teneri errore contendit, qui toftum,uel uftum Rhabarbarum dyfentericis propinant,ea ratione adductus, quòd omnia qua igni torrentur ob contractam acredinem abradant. Quarè fuadet, ut à R habarbaro in dy fentericis om ninò abttineant medici. Atqui fi Rhabarbarum dari Jibear, non uftum, neque affum effe propinandū, fed crudum, hac tamen condicione, ut prius auferantur $a b$ en tenuiores partes. Id quod facilè (ut ipfe ") ait ) effici poteft, fi ex aqua Plantaginis, uel Rofarum maceretur.Verùm Lufitano maximè refragatur " Mefues, ubi Rhabarbari uires expendit his uerbis. Rhabarbarum toftum dyfentericis probè confert. "2 Et paulò fuperius ait, Quòd fi poft hafce functiones uifcera adftrictione roborante egerint, ip fum qui "》 dem Rhabarbarum in puluerem contritum exhibendum fuerit. At illud, quod igne torrefcit, uehe- " menter operatur, ac etiam uehementius id, quod comburitur. Hæc Mefues. Sed audiat etiam Gale num, qui libro nono de Compofitione medicamentorum fecundum locos combufta, torrefactaq́ue medicamenta dy fentericis dare fuader, nempè Cochleas, Cornu Ceruinum, Opium, Gallas, Mali- " corium, Pini corticem, Hyofciamum, Acaciam, \& alia plura uino nigro excepta. Prætereà x I. de $"$ Simplicium medicamentorum facultatibus, exuftas etiam Cochleas cum Galla, \& Pipere dy fenteri- " cis commendat. Quibus fanè patet non modò ho cin medicamento fpernere Galenum Coclearum, \& \& Gallarum combultarum acredinem, fed etiam addere Piper acerrimum medicamentum. Huiufmudi medicamentis nulla dubitatione utuntur etiam pofteriores Græci, Paulus (inquam ) Oribafius, Aetius, Alexander. Adde quòd ubi inteftina ulceribus fuerint affęta, Auripigmentum, Sandaracham, Alumen, Calcem, Aeris fquammam, \& alia plura erodentia medicamenta clyfteribus infundunt. His itaque palam eft,combufta,toftaq́; medicamenta non modò nullo prorfus incommodo dyfentericis dari poffe, fed magno fanè iuuamento, quòd crudis longè magis exiccent, ac etiam adftringant. At $f \mathbf{i}$ ufta, \& in cintres uerfa dy fentericis tutò exhibere fuadent tot grauilfimi authores, cur illis toftum Rhabarbarum interdicat Lufitanus, conijcere nequeo. Nam fi, Medicorum omnium confenfu, dyfenteria affectiali debent affatis uolatilium carnibus, ouorum uittellis ignitis tcgulis toftis, \& alijs quàm plurim is alimentis frixis, torrefacțisq́; ; cur igitür à-R habarbaro illo fuerit ab̂tinendum, nulla penitus ( ni fallor) fe fe offert ratio. Porrò ad aliud Lufitani fgmentum, quo fretus ait, plures uidiffe Lufitanos fui generis hamines dy fenteria affectos ufti $R$ habarbari potu interijffe, nil aliud refponden dum in præfentia fuccurrit, quàm quòd nobis minimè fịt approbandum, cùm fexcentos homines ad uitam reuocatos fciamus tofti $R$ habarbari potu, Equidem non poffum non mirari Lufitanum,quòd fux'tantùm gentis Lufitanos Rhabarbari ufti potu interemptos in exemplú adducat,ac fi illis tantùm fuerit lctale medicamentum, cùm tamen is (ut ipfius teftantur fcripta) toto ferè ætatis fuæ decurfu apud inferiores Germanos primùm, \& dẹindè apud Italos fuam exercuerit medicinam. Demiror itê,, quòd ita temerè quafi diuinıtus edoctus affirmare non fit ueritus potius ex Rhabarbari ufti potu interijffe eos, quàm ex morbi natura, quum hæc fciri non poffint. PIæter id, mihi nunquam perfuafum uelim, longè magis dy fentericis $\mathrm{R}$ habarbarum illud profuturum, quòd aqua Plantaginis uel Rofarum fuerit maceratum, quàm țoftum, uel uftum. Quandoquidem Galeni teftimonio affatio, uftioq́; plurimùm liccitatis,aduftionisq́; medicamentis confert; contrà uerò euenit ijs, quæ aquis macerantur. Sed hæc fortafsè in medium adducit Lufitanus Auicennæ teftimonio confifus, qui dyfentericis Rhabarbarum nullam uftionem, affationemq́; expertum ex Plantaginis aqua bibendum fuadet;quòd fortafsè nefciuerit Rhabarbarum nil aliud Auicennæ defignare interpretis lapfu, quàm Græcorum Rhaponticum. Quod quum nulla deiectoria ui polleat, citra uftionem, affationemq́; propinat Auicenna ex Plantaginis aqua, nec id macerat, ut fibi fingit Lufitanus.

\section{CHAMAELEO ALBVS, ET NIGER.}

Céfu. xlv. de Chamęleoni bus.
A c с v'M ille Chamalconem Album cenfet effe ftirpem fpinis undiq; horrentem, folio grandi, lactis quafi maculis interlito, quam quidam Carduum Marix, quidam à maculis Carduum Lactariü uocant, quidam Suarium, quòd eo fues pafcantur;quis eius opinionem probet?cùm Chamæleo albus nullum producat caulem Diofcoridi, fed è medio f pinas echinatas Cinaræ modo. Carduus autem La ctarius caulem profert bicubitalem, \& quandoq; maiorem adnatis pluribus refertum, iongis, prædurisḉ;. Radici nulla eft odoris præftantia,nec Chamæleonis facultas . Siquidem deuorata, Diofcoridis teftimonio canes, fues, muresq́; necat. Contrà uerò hrec fues non modò alit, fed etiam faginat, undè illi nomcn. Poltremò albo Chamæleoni, Theophrafti teftimonio, caput requiritur magnum Acano fimile, non autem paruum, quale in Lactario Carduo fpectatur. Sed qualem in albo, talem \& in nigro fedeclarat Chamæleone, exiftimans hunc inter illud Cardui genus, quodà Carduo Lactario nulla alia dignofcitur differentia, quàm quòd huic folia non fint laçteis illis maculis refperfa, fed po- 


\section{In AmathiLufitani Enarrationes.}

tius nigricantibus. Cui iftud comprobabitur? Spina hxe caulem non rubrum, nec dodrantalem, fedbicubitalem, ac colore uiridem eflert. Deindè huic flores non funt uerficolores, fed purpurci. Prætereà carduus hic radice nititur alba, integrạ́; non Chamælconis Nigri modo exterius nigra, in terius uerò flaua \& pluribus in locis cxela, non acri, fed potius fubamara. Adde quòd Diofcoridi Nigri Chamæleonis folia requiruntur rubro colore diftincta, non maculis infeeta nigricantibus . Quibus cortum facit omnibus, quanta iudicij maturitate in plantarum cenfura ducatur Lufitanus.

\section{R O C O D I L I V M.}

A T Q y A nec fuifeprxtat difimilem in Crocodilio? Eam hanc opinatur effe ftirpem, quam uulgus herbariorum Carlinam appellat, ea tantùm ductus ratione, quòd hæc non folùm in fyluis, fed etiam in arenofis (ut Plinius inquit) \& litientibus nafcatur locis. Sed coccutit non leuiter; quòd Carlina, qux caulem profert, adcò om nibus in uniuerfum notis nigrum Chamæleonem repræfentat, ut neuriquam quis prefuaderi poffit eam effe Crocodilium, præfertim cùm facto periculo, ijs fanè ui ribus non præftet, quibus prxltare Crocodiliurn Diofcorides, Galenus, Plinius, ac alij pleriq; pofte ritatis memorix prodiderunt. Crocodilij enim decoctum (horum omnium teftimonio) potui datum fanguinem copiofum per nares pellit. Quod fi prxtaret Carlinæ radix,magno admodum pretio xlt timaretur à Medicis. Adde quòd Crocodilio radix fit longa, læuis aliquantulum lata, odore, ut $\mathrm{Na}$ ftutij, acuto: Carlinæ uerò crafla, rotunda, afpera, inxqualis, exefaq́; , nullo Nafturtij odore predita. Adhxc Crocodilij remen Galeni teftimonio acre,odoratumq́; percipitur : qux facultates in Carli na proculdubiò defidẹantur.

\section{P O T E R I V M.}

PO T E R I V M cam uult efle arbufculam,quam Germani Schlehen, nos ucrò fylueftrem Prunum nominamus;quod idem cxiftimauit Cornarius uir alioqui infignis, cuius opinjonem magis hic fequi tur Luficanus, quàm genuini Poterij hiftoriam. Ego uerò nibil hic contra Cornarium dicam, quem uí clariffimus Fuchtius pluribus argumentis copiofiffimè refellit. Qüo circà his iam fuperfedemus, folùm, ut noftri memores infituti, dicimus utiunq; deceptum, \& plurimùm aberraffe Lufitanum; quòd tylueltris Prunus potius in frutiçofarum arborum recenferi debeat, quàm inter herbas, item quòd nulla penitus conueftiatur lanugine, quòd item ramulis non habeatur longis,ac tenuibus Tragacanthæ modo, fcd breuibus, folidis, duris, contortisq́; : quin nec fructuet acuto, nec odorato, fed inodoro, auftco, adfringenti admodum fucco: adeo ut qui dixerit fylueftrcm Prunum cffe Poterium (Cornarij, $\$$ illius pace dixerim) Tirefia cacior dici poffit, nel mente captus. Qno fit, ut mirarinon dubant Medici, fi clarifimus ille Fuchfius plura in Cornarium uberrimè confcripferit.

Cenfu. xlvi. de Crocodilia.

Crocodilij mira uis.

Cenfurax!vij. de Pozerio.

Cornarius re prehenditur. Fuchfij laus.

\section{E V C A C A N T H A.}

NEC A' 5 E ipfodiffentit, quòd etiam Leucacantham herbam eam effe arbufculam contendat, qux in fepibus, \& frutetis prouenit, folio Pyri, fructu in maturitate nigro, liguftrinis baccis non abfimili, è quibus elegantiffimum colorem uiridem parant pictores. Quandoquidem Diofcorides hoc loco de aculeatis herbis egit, non autem de arboribus. Adhæc arbufcula hxc, quam nos uncamus Spino Merlo, quiàam uerò Spino Zerbino Cyperi radices non habet, fed arboreas, ligno ras, longas, prædurasq́; auftero fapore, nulla admifta amaritudine, adcò ut nihil fucci in dè cxprimi polfit, etiam fi aretifimo prelo ftringeretur; quum tamen è Leucacanthæ radicibus fuccum exprimat Diofcorides ad rupta, \& conuulfa fananda.

\section{R E T E N S E D J, C TA M N M A L TER V M.}

C AE T E R'M \& dealtero Cretenf Dictamno cœcutiffe Lufitanum non ambigimus, quippè qui fcripfit uideri hoc non modò in hortis, fed etiam in fictilibus ad feneftras fiequenter reponi folio (ut illius uerbis utar) Crefonis, flore pulchro, purpureo, qui fricatus odorcm ex fe refert, qualem cx flore Narantij oriri uidemus. Sed quàm fibi ipfi imponit? primùm quòd hoc Diçamnum Theophrafti teftimonio in Creta tantùm proueniat. Id quod uidetur etiam fateri Diofcorides, cùm dicat, \& hoc ex Creta ad nos aduehi. Prxtereà quòd non fcripferit Diofcorides, quin etiam nec Theophraftus, nec Plinius Dictamum hoc folio efle Sify mbrij Aquatici,quod Lufitanus, uulgus fequutus, Ciefonem appellat; fed Sifymbrij abfolutè, quod indicat, hos preclariffimos authores de primo Sify m brijgenere intellexiffe. Sifymbrium enim primi generis folio eft Menthæ, rotundiore tamen, non autem Erucæ, qualia funt Crefoni folia, quæ an magis Dictamni folijs fint comparanda, quàm pri migeneris Sifymbrio, ij diiudicent, qui rem herbariam doctıffrmè profitentur. Hisaccedit, quòd Diofcoridi huiufce Diftamnifolia odorem ex fe mittunt medium inter Sifymbrium, \& Saluiam, à quo omninò eum diuerfum putamus, quem Arantiorum fores fuauiffmè fundunt.

Cenfuxiviij. de Leucacan ${ }^{b}$ tha. Cenfu. xlix. de altero Cre renfi Dictam no. 
C A L A M I N T H A.

Célura I. de Calamintha.

Cenfura lij . de rertio cala minth $x$ gene re.

E. O' quòd Ferrarienfes, \& Longobardı Gattariam herbam Neuedam (quafi Nepetam) uocent, magno eriore tibi perfualit Lufitanus Gattariam hanc effe fecundum Calaminthæ genus; fed aberraffe uidetur, quippè Diofcoridi Calamintha fecundo loco pofita, folio eft Pulegij, qucmadmodum \& fapore, non autem Apiaftri, uel Vrticæ, quibus Gattaria uocata maximè uifitur æmula. Nec minus jtem decipitur in cenfenda tertij generis Calamintha, quòd crediderit hanc eam effe, qua pafsim in Italia utuntur Scplafix. Patet crror, quòd hæc folia habeat Pulegio grandiora, rotundiorag̨ue, non autem prælonga Mentaftri modo, cui tertiam Calamintham fimilem fecit Diofcorides.

\section{S A M P S C H V S.}

Cenfura liij]. Qv. A N T a fit Lufitani inconftantia, quanta in nos inuehendi fraus, quantaque is fui ipfius ca. de Sampfu- piatur obliuione, is facilè intueri poterit, qui legerit eius enarrationes libro primo in Olei Sampfucho. chini confectione, \& libro tertio cap.proprio de Sampfucho. Quandoquidem libro primo apertifsi mè contendit aduerfus nos fcribens Diofcoridi Samp fuchum nuila ratione effe Amaracum, \& ob id plura ibi in nos machinatur, ut in A pologia fuperius præmifimus. Libro uerò tertio euidenter fatetur magno fuæ leuitatis dedecore nil aliud effe Sampfuchum, quàm Amaracum, uel Maioranam.

Lufíani leui Quare non modò fe ipfum euidenter confurat, \& grauifsimè uulnerat, fed etiam palàm declarat, non tas. aliam ob caufam noftram impugnaffe fententiam, quàm ut nobis aduerfaretur, \& quocunque modo fuum uirus in nos euomeret. Tanta in nos inflammatus rapitur cupiditate, qux mentem ei excacet, memoriam tollat, \& infano quodam modo fe ipfum deftruat, ac penè fubuertat.

\section{R V T A S Y L V E S T R I S.}

Cenfuraliiij. S Y I V E T R E M Rutam, quam Cappadocibus Molyn, Syris Befafa, quibufdam uerò alijs de Ruta Syl- Harmolam uocari Diofcorides inquit, eam effe plantam exiltimat Lufitanus, quam Caryophyllos ueftri. ultramarinos, uel Indicos uulgus appellat; fed manifeftè decipitur. Quandoquidem hæc herba preter id, quòd folia Rutæ non proferat, flores aureos gerit magnos, ad luteum uergentes, non, ut Ruta fylueltris, candidos. Quinetiam capita non prodeunt alterius Ruta modo, fed longa pluribus eminentibus coftis ftriata. Prætereà, nec femen ilh uifitur trianguli fpeciem referens, neq; fubrufum, fed longum, nigrumq́; nulla amaritudine præditum. Adde etiam quòd Galeni teftimonio Sylueftris hæc Ruta radicem proferat nigram; id quod in hifce Cariophyllorum Indorum plantis maximè defi. deratur.

\section{CVMINVM SYLVESTRE.}

Cëfuralv. de Sylueltri $\mathrm{Cu}$ mino.

Cenfura Ivj. de codem.

Cenfura lvij. de Coriandro.

Luficani infignis amentra
SY L VES IR E Cuminum quum non uiderit, nec nouerit Lufitanus, illud Officinis Rufticum Cuminum uocari ait, perindè ac fi adeò uulgaris notitix fuerit, ut nullo fit opus examine; quum tamen pauci (ne dicam nulli reperiantur Pharmacopœi, qui unum uel alterum Sylueftris Cumunige nus legitimè cognofant. Nam præter fatiuum, nullum aliud nouere Seplafix. At Amathus, ne ui. deatur id ignorare, Sylueftre Cuminum adeò uulgare facit, ut quis illud apud Myropolas intueri pofsit. Qưo fit, ut rectè intuentibus palàm fit, non modò Amathum Sylueftris Cumini hiftoriam confundere, fed quid fit Sylueftre Cuminum penitus nefcire, \& ignorata tanquam cognita, \& uulga . ria fateri . Duo enim Diofcoridi, quem nunquam accuratè legit Lufitanus, funt Cumini genera inter fe pluribus repugnantia: fed hæc negligens Amathus rem omnem confudit.Siquidem nulla generum habita differentia abfolutè protulit Sylueftre Cuminum Officinis Cuminum Rufticum uocari ; quú tamen non defint rei herbarix peritifsimi, qui hactenus de Sylueftris Cumini generibus nihil affirment.

\section{O R I A N D R V M.}

I N C E N S E N D o Coriandro quàm nun hallucinatur, non decipitur, fed penè delirat? quòd uul garis ufus Coriandrum fcribat, non effe antiquorum Coriandrum, fed illis Coriandrum fuiffe aliam plantam Cicutariam dictam, folio noítratis Coriandrifimili. Id quod tueri nititur hoc tantùm argumento, quòd Coriandri plantam Hifpani nullo incommodo olcraceis cibis admifceant. Quin \& quòd eius femen odoratum fit, \& eius pariter herba optimi fit odoris, uel faporis. Cæterùn hxc quum legiffem, mirari fanè defij, quòd alia etiam innumera deliramerta in medium adduxerit. Quis autem ( $D_{i j}$ boni) Lufitanum hunc nugantem, immò $\&$ r amentem ignoret, quum dicat Coriandriuul garis herbam odoris quidê foetidifsimi lectlilariorü cimicú inftar optimi effe odoris, ac faporise Equi dem cenf́cbam utero tantŭ gerentes mulieres citta, picać; corripi poffe.Sed (ut uideo)Amathus etiam eo morbo laborat, quòd forta $\int_{s c ̀}$ ob multam præftitam in re medica operam, \& ob magnas illas $C c n-$ turias adeò intumuerit, ut prægnanti fimilis euaferit: Vel quòd fortafsè Coriandri iantùm intel olera 


\section{In Amathi Lufitani Enarrationes. 4I}

olera efitauerit in Hifpania eius faporis,odorisq́i præftantia allętus, ut indè facilè amentiam contraxerit, quam facere Coriandrum Icribit Diofcorides, ubi largius affumatur in cibum. Quo poftca fa ctum elt, ut indè Amathi nomen fuerit confequutus. Prxtereà cur fuam probare pofsic Amathus ful titiam, quòd Coriandrum communis ufus ucterum Coriandrum non fit, quòd in cibo acceptum nil mali inferat, nihil fanè rarionis adduci poteft. Quandoquidem etiam Galeni tempore Coriandrum in obfoniorum uenerat ufun, ut ipfe teftatur Galenus libro fccundo, de Alimentorum facultatibus, \& libro de Attenuante uictus ratione. Quin \& Diofcorides non nifi à largiore Coriandri efu abftinere prohiber. Proindè mirum non eft, ficum alijs oleribus pro obfonio deuoratum nibil incommodi afturat, perindè ac Papauer.

\section{P E T R O S E L I N V M.}

G E N V I N v Gracorum Petrofelinum idem, quod Seplafix, \& Herbariorum uulgus pafsim Apium uocant, magno fanè lapfu effe credit Amathus, quòd hoc Paludapium fit in hortis träflatum, riguis, \& uliginofó folo gaudens. Contrà uerò Petrofelinum, quod Diofcoridis, \& Galeni teftimo nio in preruptis, \& faxeis montium locis, ut ipfa met indicat nomenclatio, tantùm proueniat, fenine Ammi odoratiore, fapore acri aroma olente. Id quod in communi Officinarum Apio nufquam percipitur.

\section{E L A P H O B O S C V M.}

E R R A R E in Elaphobofco non modò Amathum cenfemus, fed pro more etiam falfa narrare fci mus. Nam ut fe ipfum præclarum oftendat, ait in quxrendo Elaphobofco fibi adiunxiffe duos dofísimos uiros, quos ctiam nominat. At quum horum alter, cuius in commentarijs noftris pluries mcminimus ob prxfantifsimam cius doftrinam, integritatemq́ue, mihi pluries affirmauerit illum nec nouife, nec fortafsè uidiffe unquam, quod illi credam non habeo.

\section{O L L V T E A.}

Céfura lix.de Elaphobolco

Amathus infi delitatisargui tur.

C O I L V I E A quibufdam reiagrariæauthoribus Alburnum uocari affirmat, Italis uerò uulgò Cenfura lx. Aorno. Verùm quantùn ego legi, cùm Alburnum planta non fit, fed pars tantùm arboris, idem qui de Collutea. femper fuit deprchenditur Amathus, Plinij primùm teftimonio, qui libro x v I. cap. x v I I. de Al, burno hæc fcrsptis mandauit. Humor \& cortici arborum eft, qui fanguis earum intelligi debet. Pro "cute cortex elt. Proximi plerifque adipes. Ij uocantur à colore Alburnum, mollis, ac pefsima pars li" gni, etiam in robore facilè putrefcens, teredini obnoxia: quarè femper amputabitur. Hacille. Quibus facilè Amathi conuincicur ignorantı. At fi fortafsè, ut noftram effugiat cenfuram, dixerit, non dixffe Colluteam uocari Alburnum, fed Laburnum, \& id erroris in Typographum reiecerit, facilè refpondi poterit \& hoc effe falfum. Quandoquidem Laburnum, tcfte Plinio, Alpina tantùm eft arbor dura, \& candida materie, cuius florem cubiti longitudine apes non attingunt. Id quod in Collutea fanè celideraiur, quum hac Alpina non fit, fed ubique ferè proueniat, materie non alba, fed exterius buxea, medullitus nigra, flore non cubitilongitudine, fed breui, Genifta modo.

$$
S \text { E N A. }
$$

CAE T E R V'M magno etiam errore fcribit Senam herbamaluum exoluentem eam effe plantã ( ut Cenfura lxj. jp(e opinatur) qux Theophrafto Collytea appellatur. Nam cùm apud Theophraftü duplex fit Col-, de Sena. lytea,nec de qua intclligat explicet, nó folùm hallucinatus deprehenditur, fed \& cófufus, adeò ut quid fibi uelit nefcjat. Prætereà cùm Collytea utraq; Theophraltolib. I I 1.cap.x I I I I. \&.x vi I.de hiftoria plantarum arbor fit non herba, \& utriufq; meminerit inter arbores, minus conftare fibi uana Lufitani potętopinio.

$$
\text { G I A V C I V M. }
$$

N I s I alium præter fe teftem adduxerit Lufitanus, qui Glaucium herbamapud Louanienfes uim Cenfura lxij. derit, qux cum Diofcoridis hiftoria concordet, ego illi credam? Nam cùm illum tam fxpè hallucina de Glaucio. tum off́nderim, ac fabulofum, uitio mihi dandum non cenfeo, fi nifi dato pignore illi nố credidero.

\section{A L Y S S V M.}

N v I I A M conftituit differentiå inter Diofcoridis Alyffon,\& Plinianum.Sed quàm penitus neu Céfura iri: trum intellexit? Siquidé Diofcoridi Alyffum exiguus eft frutex unicaulis, fubafper, rotúdis folijs, fru- de Alyf Ê duplicium fcutorü effigie, quadantenus latú, in montibus, \& afperis locis emicans; qux fanè omnia in Sylueftri Rubia, qux Plinio Alyflum eft, defiderantur.Siquidem hæc non adeò exigua eft plăta, fec plerunq; bicubitalis, nọ uno tantü caule crefcens, fed pluribus, folijs minimè rotundis, fed ftcllẹ modo

D 3 decut- 


\section{2

decuffatis, femine rotundo non lato, nee duplicem, nec fimplicem fcutum referente. His accedit quòd Diofcorides de utraq́; Rubia maiori nempè, \& minon tradıdit uno, \& eodem capite. Id quad illum feciffe putandum non $\in f_{t}$, $f_{1}$ Sylueftrem Rubiam ab Alyflo diuerfam non iudicaffet, de quo prius dixe rat eodem libio.

\section{A T T R A C T Y L I S.}

Céfuralxiiij de Atrractyli

R E D I T aufterus \& imnitis cenfor; uirgam, ucl fuftem potius profert. Eijcitomnes ex medicoram, ideft ex fuo fenatu, \& grauifsimè hallucinari cos contendit, qui negant Attractylida alterum Syluettris Cnici effe genus, eo argumento innixus, quòd firibat Plinius, primam fylueftris Cnici fpe ciem Attractylida quibufdam uocari - fed, quantùm uidere, aut conijcere poffum, A mathus ipfe potius hallucinatur. Nam quamuis fcribat Plinius primi generis Sylueftre Cnicum quibufdam AttraEtylida nuncupari, non tamen affirmat, Cnicum illud effe Attractylida; nec eorum recipit fententiam, qui putant genuinum fylueftre Cnicum nihil ab Attractylide differre, quemadmodum fuperius diximus de Telephio diferentes, Tulephium non proptereà effe Semperuiuum minus, quòd hoc etiam Telephium (ut Diofcorides Icribit) quibufdam dicatur, nec Helfinem Parthenium, nec Afple num Hemionium: quoniam ijs etiam nominibus à nonnullis appellentur . Quamobrem Plinius ipfe eodem libro fpeciatim de Attractylide egit his uerbis. Acarna colore tantùm rufo à Scolimo diftin " guitur , \& pinguiore fucco. Idem erat Attractylis quoque, nifi candidior effet, \& nufi fanguineum fuc " cum funderet, qua de caufa Phonos uocatur à quibufdarn, odore etiam grauis . Quibus palàm eft Pli " nio Attractylida nullum fylueftris Cnici effe genus. Id quod maximè atteftatur Theophraftus libro v I. cap. I I I I. de plantarum hiftoria. Is enim poftquàm de omni Cnici genere diferuit, de Acarna, \&e Attraktylide fpeciatim egit. Adde quòd experimento etiam liquet, neutrum fylueftris Cnici genus fanguineum fuccum fundere. Vnde Amathı minus probari poteft fententia.

T E V C R I V M.

Cëluta Ixv. de Teucrio. tarijs addunt, Amathus Teucrium effe indicat. At in priftina fua uerfatur cœcitate, quippè quú fcri-
bat Diofcorides ' Teucrium herbam uirgæ cfígiem referre Trifaginis fimilitudine, facilè palàm fit in ter Teucrum, \& Sanguiforbam ma ximam intercedere differentiam. Siquidem hæc nobis Pimpinel la uocata iunceis conttat cauliculis, folijs utrinque pinnatis, nullam uirgx effigiem, nec Trifaginis Amathi opi- formam referentibus. Quòd uerò Pimpinella hoc nomine fit appellata, eò quồd odore fit Citruli, nio explofa. quem Hifpani Pipinum uocant, nobis probare non libet, quum compertum habeamus uocata fuiffe primùm Pimpincllam à bipinnatis cauliculis, undè poftea corrupta appellatione Pimpinella eft ap pellata. Nam cùm nullo Citruli odore, uel fapore fit prædita, cur Amathi fententiam probem non ui deo.

\section{Y C H N I S.}

Cenfura 1xvj Qv a e de Lychnidis uiridibus folijs fcribit Amathus, quòd fcilicet ea oleo illita igne flagrent, \& de Iychnide. indè nomen traxiffe ftirpen, fabulofa omninò uidentur; cùm re uera Lychnidis folia, non uiridia, fed ficca ad lucernarum ufum pro ely chnio ufurpauerit antiquitas, undè fibi nomen inuenit ; non quòd uiridia flagrent, ut Amathus putat. Quippè núxyov Græcis lucerna dicitur, sגúxvov funiculus, qui è gofipio lucernis inditur ad ignem excipiendum.Sunt enim Lychnidis folia admodum uillofa, tomentofaq́ue, \& proindè arefacta ignem facilè concipiunt,perindè ac illius Verbafci folia, quod Lychni te ab eodem effectu pariter appellatur.

\section{A R T A G V M.}

Cëlura Ixvij. de Martago.

M A R T A G v M flores edere Lilio albo fimiles, fed croceos affeuerat, \& proindè Martagú Plinio eam plantarr effe exiltımat, quam ipfe ab Hercule Petilium uocatam fcribit libro x X I.cap. v I I I. At demiror, ubi Lulitanus, qui tanto ufu, tanta omnium rerum peritia eft præditus, Martagum uiderit croceos emittens flores. Mihi enim ante hunc diem, id eft inaudıtum, cum flores proferat purpureos, rubentibus quibufdam punct is refperfos. Id quod manifeftè arguit Hemerocallem pro Martago accepiffe Lufitanum. Namque is fore conftat aureo Lilij tum facie, tum etiam magnitudine. Cærerùm an Marıgum, uel Hernerocallis Petilium fit à Plinio defcriptum, fateri fanè non aufim, quum Pecilium Plinij ipfius tettinonio autumnali tempore floreat inter uepres colore rofæ fylueftris, illa uerò cum alijs lilijs media floreant æftate.

\section{T R I F O L I V M.}

Cenfuralxviij.1: Irifon l.o.

Qv o’ D Bituminofum Trifoliŭ nunquă uiderit,noueritá; Lufitanus, hoc argumento facilè conjjci poteft, quòd afferat Pratenfe Trifoliú omnibus uulgò notú primò Rută olere, ubi uerò adoleuerit Bituminis 


\section{In Amathi Lufitani Enarrationes. $\quad 43$ \\ Bituminis odorem reddere. Atqui hoc falfum effe unicuique conftabit, qui Pratenfis Trifolij odo-}

rem olfactu explorauerit. Siquidem id nec $\mathbb{R} u t x$, nec Bituminis quicquam ullo tempore refipiet . Etenim aliud genus eft à communt Trifolio, quod Græci Afphaltite ab odore, nos Bituminofum uo " camus. Iccircò rectè fcripfit Plinius lib. x x I.cap. I x. Trifolij tria effe genera, Afphaltite aliud, aliud "Acutum, Minutum item aliud, quo prata ferè omnia fcatent. Hinc itaq; apertifsimè conftabit Pratenfe Trifolium longè ab Afphalcite diuerfum haberi, \& Lufitanum non paruo in errore uerfari.

\section{A M B R O S I A.}

A M B R OS I A M ait ille effe herbam, quam uulgo Tanacetum uocant Seplafix. Verùm patet eius non mediocris lapfus. Siquidem Ambrofia Diofcoridis teftimonio pufillus eft frutex, adeo ut trium palmorum longitudinem non excedat, folijs exiguis circa imum caulem, Rutam referentibus, cauliculis perindè quali racemulis grauidis, qui nunquam florent, odore uinofo, fuauiq́; , radice tenui fefquipedali, quxomnia in Tanaceto maximè defiderantur. Namq́ue Tanacctum bicubitales gerit caules, ac etiam quandoquc longiores, folia non Rutæ, fed Maioris Millefolij amaro fapore, flores aureos globuli modo, odore ( quod maximè refert) graui, ac ingrato. Nullos fert hæc planta racemos cauliculis appenfos, nullus ibi uinofus ador, nec aliàs fuauis. Illud etiam addi poteft, quòd Tanaceto nufquam uifa fit radix fefquipedalis, fed breuis, \& fuperuacua .

\section{G N A P H A L I V M.}

A D E O breuiter, perplexeć; Gnaphalij hiftoriam fcribit Diofcorides, quin etiam Plinius illum fequutus, ut;non decernas, qux nam planta ex his, quæ in ipfo naturæ uiridario coluntur genuinum Gnaphalium reprafentet. At Lufitanus, qui hæc quemadmodum \& cæetera leuiter admodum expen dit, quandam herbam Gnaphaliumeffe afferit, quæ Anconitanis Zigi appellatur, ea tantùm ratione ductus, quòd hre planta tenuibus fit folijs, mollibus, albicantibusq́;, quum tamen plura habeantur herbarum genera, quæ his notis in figniantur, perindè ac herba illa, quæ uulgaribus herbarijs Gnaphalij nomen mentitur. Etenim adeò Plinij Impiam repræfentat, ut poft hac ambigendum non fit, quin Impia nobis fit defideranda.

\section{OE N N T H E H E R B A.}

RE CEN T I OR E S quofdam fequutus Oenanthem eam uult effe plantam, quam Filipendulam uocant, cùm potius Oenanthe Diofcoridis teftimonio caulem craffum palmi longitudine gerat, femen quale in Atriplice fpe\&tatur, radicem magnam in multa rotunda capitula extuberantem ; nafcatu rq́; in petris. At longè aliter prouenit Filipendula. Etenim non in petris, fed in pratis, \& læto folo rafcitur, radice nufquam magna, quæ in rotunda capitula extuberet, fed fili modo tenuis pluribus appenfis globulis, non rotundis, fed potius glandium figura, ut in Pæonia, fed longè minoribus, undè illi nomen. Semen præterea Atriplicis illi non ineft, fed globuli inftar quadruplici apice mucronati, ut in Buxo: quin nec caulis illi uifitur craffus, fed tenuis, non palmari longitudine, fed bicubitali. Quibus palàm effe non ambigimus, Oenanthem à Filipendula quàm maximè abeffe.

P H Y L L V M.

D v M in Phyllo Ruellij fententiam improbat Lufitanus, fe ipfum ignorantix manifeftè accufat his uerbis. Hanc Rucllius Alteram Perficariam effe credit; quo uerò iudicio alij iudicent. Eft uerò hodic herbula quædam unico tantùm ornata folio, \& inde Vnifolium dicta. Semen racemofum ferpentis limilitudinem ferens. His herbam illam defcribere uidetur Lufitanus, quam quidem Ophiogloffum, id eft ferpentinam linguam uotauere. Sed plurimùm is à ucritatis fcopo, \& à ueris ipfius herbx delineamentis digreditur. Etenim preter id, quòd femen racemofum non proferat, id nullam ferpentis imaginem oftendic, fed ferpentis potius linguam imitatur. Id quod certò arguit, Lufitanŭ hanc plantam negligenter admodum examináffe. His accedit alius illius lapfus, quod affirmauerit Diofcoridis Phyllum effe Ophiogloffum, cùm nullis prorfus notis conueniant.

Cenfura Lx$x$ r.de Ocnäthe herba. de Graphalio. Ix. de Ambrofia. (n)

\section{H O R M I N V M.}

A I I o R V M quorundam infiftens ueftigia pro certo affeuerat Horminum eam effe, quam quidå Cenfura LxSclaream,alij Matrifaluiam, nonnulli herbam Sancti Iohannis uocant. Sed cùm Horminum Diofco- xin I I. de ridi plăta fit Marrubio fimilis,caule femicubitali,circa quem eminentix filiquarü forma prodeant ad Hormino. radicem fpcetantes, in quibus femen includitur oblongú, nigrumó;, neutiquam crediderim Sclaream ip fam, quę miro odore fragrat, efle Horminum.Quandoquidem hæc folio elt Verbafci, non Marrubij. 
caule bicubitali, nó femicubitali:Prætereà Sclareæ caulis ṇullis ue?titur filiquis, fed rami, qui ex caule ipfo prodeunt multi. Adhæe filiquulæ, in quibus femen concluditur, rotundum, non oblongum ad radicem non fpectat, fed ad uerticem. Adde etiam quòd nulla odaris præftancia Horminum commerdauit Diafcorides . Etenim illius odoris fragrantiam nunquam filentio inuoluiffet Diofcorides. Quo fit, ut cùm hæc non perpenderit Lufitanus, aliorum tạntùm opinione imprudens abductus errauerit unà cum illis, quorum fequițur errores.

\section{O N O S M A.}

Cifura lxxv. O N O S M A inter uulgares Rapunculos, quibus pafsim vtimur in acetarijs,nafci Lufitanus fcri de Onofima: bit: quin \& illis adeò Onolmam fimilem facit, ut difficilè ab ipfis dignofcatur. At quum Onofma folio fit Anchuæ Diofcoridis teltimonio, quæ non minus diftat à Rapunçulo, quàm equus à lepore, illicò friuolam, \& ftolidam nimis, ut cæteras omnes, opinionem induit Lufitanus. His accedit quòd Onorma non nifi in afperis nafcitur, radice fanguineum fuccum fundente: id quod maximè defiderari poteft in Pfeudorapunculo illo; quòd is radiçe fit alba, tenui, ac fuperuacua,nullo unquam tempore cruenta.

\section{A. N T Y. L L I S.}

Cëfura lxxvi Qv r N \& in Antyllide cenfenda plurimùm decipitur, cùm uelit, quinimò \& affirmauerit eam deAntyllide: legitimam, genuinamq́; effe Antyllidem, quæ Mauritanis Kali, fiue Alkali appellatur; cuius cinere utuntur ad conflanda uitra. Error non magno negotio deprehẹditur. Etenim cum Diofcoridi dur» » fint Antyllidis fpecies, altera qux Lenti fint fimillima, folijs mollibus, ramulis recti palmi altitudi- „a ne, altera uerò folijs Aiugæ hirfutioribus; non uideo, cur credam Alkalim Antyllidas utrafque refer re, quum nullis conueniat notis: quippè Alkali, cùm primùm è terra emerferit, folio eft tereti, pingui, Minori Sedo non abfimili, quod poftea in dod rantalem ferèlongitudinem adolefcit, geniculatimq́; protrahitur Equifeti mod̦o. Quum uerò iam adoleuerit (ut de Trago diferentes in Apologia fuperius diximus ) prodeunt è geniculis folia pinguia,craffaq́;, incurua, ex latz origine in acutum definentia. Vbi uerò ad fummum planta excreuerit, in caulium cacuminibus longè minora, exilioraq́; fpectantur rufo colore, à quorum exortu paruæ, rotundæć; pilulæ prodeunt, in quibus femen minutum concluditur. At quum huiufce plantx tam uarias mutationes non animaduerterit Lufitanus, proindè factum eft, ut ip fe crederet Alkali diuerfi effe generis; quorum unum altcram Antyllidem, aliud fecundam effe contendit. Sed cùm Alkali nullam cum Aiuga habeat fimilitudinem, cui alteram Antyllidem fimilem fecit Diofcorides, nec folijs unquam hirfutis fit uifa, nec ulla ex parte Lentis figuram referat, cui prior Antyllis eft æmula ; fateatur ex ueteri fuarum opinionum promptuario conLufitanus no itanter hæc fe proțuliffe Lufitanus. Adhæc cùm ipfe de Trago agens aflerat Alkalı effe Tragum,dedu tacur. cor in eam opinionem, ut credam Lufitanum Circx ueneficis incantationibus imbutum, unam, \& eandem plantam in uarias transmutare formas . Quod in Alliali factum uidemus, quam nunc Tragú nunc Anthyllidem facit

\section{IITHOSPERMVM,}

Cenf. lxxvij: de Lithorper: mo.
G E N V I N v M. Diofcoridis Lithofpermum eam memorat effe plantam, qux globulos illos (laçhrymas uocant) mittit, quibus utuntur funiculo traiectis ad numerandas preces. In quo manifeftè peccat, quoniam Diofcoridi Lithofpermum planta eft folijs Olex longioribus, latioribusá;, ac mol lioribus humi accubantibus ramulis, rectis, tenuibus, firmis, crasfitudine acuti iunci, lignofis, in quo rum cacumine bifidi exortus cauliculorum fpeciem exhibeant, foliis longis, interq́; paruum femen rotundum Erui parui (vt Oribafius \& Serapio ex ipfo Diofcoride tranfcribunt) magnitudine, nafcaturq́; in afperis. Quæ omnia in planta lachrymas 11 las ferente defiderantur. Siquidem hæc folia proferc harundinacea, quemadmodum \& culmos per interualla geniculatos, in quibus femen Orobo duplo grandius uifitur, quæ quantùm cum Lithofpermi notis habeant fimilitudinis, ipfe uideat . Adde etiam quòd Lithofpermum in editis, \& afperis locis per fe fponte nafcatur. Lachry ma uerò uo. cata non nifi fata proueniat, erectis omninò calanis non humi repentibus, ut fcribit Plinius.

\section{A L I S M. A.}

Cenf.lxxviij: C AE T E R v'M Alifmam herbam credit Lufitanus Ruellium \& Cordum fequutus eam effe plan de Alifma: tam, quam quidam Plantaginem Aquaticam, alii Barbam Syluanam uocant : fed faifum non obfcu rè liquet. Etenim Alifma folia fert Plantagini fimilia, fed anguftiora, in terram reflexa, laciniataq́; caule fimpliciter tenui, cubito altiore, capitibus Thyrfi, fore candido pallefcente. At plantagina Aquaticæ folia infunt Plantagine latiora, acuto cacumine, furfum fpectantia, neutiquam laciniofa, caule plurimo adnatis multis referto, nulla Thyrfi effigie,radice inodora,nec etiam acri, Quæ omnia palàm faciunt maximè deludi eos, qui unà cum Lufitano in hoc uerfanturerrore.

B R I- 


\title{
In Amathi LufitaniEnarrationes. 45
}

\author{
B R I T A N N I C A.
}

A I I O R V M jterum adhærefcens errori crẹdit nil aliud cffe Britannicam, quàm eam herbam, quæ palsim Suplafiis,ac uulgaribus herbarijs Biftorta dicitur, co tantùm forcalsè argumento ductús, quod hxc planta Rumicis fit folium. Verum mea fententia fallitur. Etenim quamuis Biftorta folio fit Lapathi, aut Rumicis nigriore, pilofiore tamen non uifịtur, fed glabriore, leuioreǵ, ruleeis intercurjantibus fibris, \& à terra quadantenus $\mathrm{C} \mathfrak{e}$ fio, qux onınia in Britannica maximè dcfiderantur.Adhæe Britannicx radix requiritur tenuis, ac breuis. Cuntra uerò alteri. Namq́; Biftortæ radix quandoque nobis uifa eft brachiali ferè crafsitudine, bipollicari autem fæepisfimè, colore in nigrum rufefcente, non (ut in Britannica fcribit Plinius) nigro. Preter id Britannicx radicibus tanquam breuibus, ac tenuibus, nihil uirium attribuit Diofcorides, fed tantùm foliorum fuccum ad medicamenta pratulit . At Biftorta contrario modo fe habet, cum tantùm radicibus præftet, \& nullus fit eius fofiorum ufus.

\section{ALTERA CLEMATIS.}

N E C minus in Altera decipitur Clematide, quippè qui cenfeat Flammulam uulgò appellatam, genuinam effe Diofroridis Clematidem Alteram. Clematis enim hæc Dinfcoridi per arbores repit, id quod in Flammula nufquam mihi uidere lıcuit, cùm planta fit ręti caulis. Legitimam Clematidé nos eam effe non ambigimus, cuius imaginem dedimus in Commentarijs noftris, quanquàm ob id haudquaquam negabo, Flammulam hanc Clematidis non elfe genus; fed non proptereà affirmaucrim unquam Clematidem Alteram effe Diofcoridis.

POLEMONIA.

N I M I v M addiąus Brafauoli uirialioqui eruditisfimi, non tam ut ueritatem videatur indagare, quàm ut pro fua fide, $\&$ antiqua confuetudine huius fatrocinetur fentencix, Polemoniam effe herbam contendit, quam quidam Rutam Caprariam, alij Galegain appellant . Multa porrò funt (ut in Commentarijs noftris oftendimus ) qux utriufque fententiam confutent. Primùm fi natale folum expendamus, id profectò tacilè indicabit Galegam non effe Polemoniam, quòd hæc in montibus, \& afperis proueniat, illa in campeftribus læto, \& uliginofo folo, adeò ut propè aquas, \& in fcrobium. aquarum marginibus plurimum oriri uideatur. Pratcreà nihil in fummis caulibus habet, quod corymbaceam effigiem referat, fed corniculos Fœnogræci, xmulos, in quibus femen occluditur rufefente colore; quod in Polemonia nigrum requiritur. Hæc itaque fi diligentius exploraffet Lufitanus, non ita fortafsè facilè in Brafauoli fententiam concesfiffet . Nec fanè uideo cur fibi tantùm arrogantiz afciuerit, ut tantùm Brafauoli tuendi caufa, Aloyfium Mundellam medicum huiufce tempeitatis eruditifsimum, \& medicæ materiæ ftudiofisfimum fua tantùm garrulitate fretus adeo temerè maledictis, conuitijsq́; laccesfinerit, præfertim quum, pro more, illius argumentis, quemadmodum \& noftris nihil refponderit. Obfecro dicas Amathe, quo furore agitaris? qua temeritate duceris? ut aufus fis, ubide Sorbis egiti, Mundellam ipfum uirum citra omnem controuerfiam clarisfimum Sycophantam appellare? Tu, mihi crede, potius Sycomoros appellandus fueris, cùm tantùm ad amen tias, \& fatuitates te procreauerit natura, illum uerò ad totius reipublicæ commodum. Depone iftam mentem, define impudentisfime, ifto modo doctisfimos viros laceffere. Omnes, qui iftam in te audient ingratam contumaciam, quamuis de facie te nunquam uiderint, quum tamen talem te audierint, non ne ftolidum, vecordem, infanum, $\&$ omni mentis ftatu dimotum te iudicabunt? Aliter jampridem nullus prudens de te exiftimat; hoc unum tibi patet refugium, fi iftius infanæ dementiæ infa mes uelis delere maculas, ut aliquandò te ad mentem reuoces, \& præftantisfimos viros optimè de lite ris meritos non tuo more fycophantas, fed modeftius nominare affuefcas .

\section{A G O P V .}

L A G O P V M magno errore eam plantam exiftimat Lufitanus, quxà triplici foliorum apice Tri nitas appellatur. Quandoquidem cùm Diofcorides, Plinius, et fi qui funt alij, qui Plantarum hifto- de Lagopo. riam fcribunt, nullis penitus notis Lagopum defcripferint, non uideo cur folus Lufitanus diuinare uelit, quafi oraculo quodam doztus, quæ nam planta antiquis fuerit Lagopus, Verùm quòd Trinitas Lagopus non fit, id argumento effe poteft, quòd ille Plinij \& Diofcoridis teftimonio inter fege tes nafcatur in campis, 1 lla uerò in frutetis iuxta fepes, \& in opacis proueniạt .

Cenfulxxxi. de Polemonia.

Arrogantia Amą̧hi.

Aloyfius Mï della à calum nia uindicaEur. deAlteraCle matide.
Cenfu.lxxix. de Britänica. 


\section{PetriAnd.Matth.Cenfura}

\section{Y P H I V M.}

Cenfirsxiij de Xyphio.

Qvo'n Plinius librox x v.cap. x I. per Xyphium intelligat Pfeudoacorum, quod in paludibus prouenit flore aureo Iridis æmulo, ut Lufitanus perperam intelligit, minimè probamus, non folùm ea ratione, quòd Xy phij hiftoriam Plinius accuratè, probeq́; defcribat, non Pfeudoacori ; fed quòd etiam genuinas eius facultates, quas Diofcoridi acceptas facilè referre poteft. Prætereà Pfeudoacoro radicem effe Iridis grandiorem nemo ambigit. At Plinius ibidem rectè Xyphio dixit effe radicem $\mathrm{Nu}$ cis Auellanæ figura. Nec obftat quòd fcriplerit is nafci Xyphion in aquofis, Diofcorides uerò in arvis, quum $\&$ in aruis, $\&$ in paluftribus locis magis quoque proueniat, ut perindè ac nos rei herbarix ftudiofos obferuaffe nó dubitamus. At Plinius, qui longè melius Xyphij natale folum explorauerat , quàm Lufitanus,non aliă ob caufam in humidis nafci dixit, quàm ut eorú refelleret opinioné,qui Lö chitim à feminis figura Xyphiú effe cenfebant. Hinc itaque is argumentum fumens, probat Lonchitim Xyphiŭ non effe, quòd illa in fitiétibus tantùm proueniat locis. His alius accedit Lufitani lapfus, quo facilè adducor, ut credă, ip fum nufquam uidiffe Xy phium, nimirùm quòd fcribat illi effe radıces Caninis tefticulis fimiles, quum nufquam Xyphium repertum fit, qui Cinoforchis modo radices gereret. Xyphij enim radices rotund $æ$ funt, \& compreflæ uerticilli modo, uel Ibifci feminis inftar, cui plurimùm aftipulatur, inuolucris fimul conclufi, ijs fimilibus, quibus Croci bulbus contegitur. Qux tamen de his fcripturus animaduertiffe debuerat Lufitanus.

\section{GRAMEN HAR VNDINACEVM.}

Céf.lxxxiiii. de Harundinaceo grami ne.

Cenf. Ixxsv. de Idęo Rubo. m
Cenf.luxxuvi.
de Chryfanthemo.

\section{L v S I T A N I opinionem de Harundinaceo Gramine ea ratione improbamus, quòd fcribat plan} tam effe vulgarifsimam ad Eridani ripas nafcentem,quin \& iumentis gratisfimum effe pabulum. Nă cùm ( Diofcoride tefte) hoc Graminis genus iuxta uias oriatur, non iuxta flumina, non magno mihi negotio credendum fuerit, Aquaticos Calamos, qui propè fluuiorum aquas nafci folent, pro Harun dinaceo Gramine accepiffe Lufitanum.

\section{R VBVS ID AEVS.}

T A M E T S I Idæum Rubum in Ida monte plurimùm nafci fcribat Diofcorides, \& frpius Idxum pro montano accipiatur, Lufitanus tamen ad Padi fluminis ripas oriri hunc Rubum affirmat. Sed C HRYSA N T H E M M.

Qv v M nufquam verum Chryfanthemum viderit Lufitanus, quo tamen abundat Italia,pafsimque omnibus fit notum; quum q́; ofcitanter eius hiftoriam examinaffet apud Diofcoridem, eam herbam Chry fanthemum effe putat,quàm herbariorŭ uulgus, quod unoquoque menfe floreat, Calendulam uocat. Apertè conuincitur error, quòd Chryfanthemum Diofcoridi folia gerat plurimis incifuris diuifa, id quod in Calědula uocata prorfus defideratur, quú illi Minoris Anchufx modo longa fpe Centur nullis prorfus incifuris laciniata.Sed id fortafsè illû in hanc opinionem adduxit, quòd habeátur aliqua Diofcoridis exemplaria, qua habeant Chryfanthemum quod alij Caltham uocant. \& \&. Nam quum non defint rei herbarix periti, qui Calendulam hanc non fine ratione Caltham effe exiftiment, llle nominis tantùm argumento fretus,neglecta penitus Chryfanthemi hiftoria, Calendu lam ipfam Chryfanthemum effc putauit. At fi in fimplicium facultate, ac hiftoria, ut illum fanè decebat,fe exercuiffet,\& uaria Diofcoridis exemplaria habuiffet ad manus, eaq́; præfertim, qux à doctisfimis uiris magno labore funt reftituta, uidiffet quidem in Chryfanthemo non legi wát $\lambda a$, fed $\chi a x x d s$.

\section{A S T R A G L V S.}

Cenfolxxxvii deAltragalo,

A S T R A G A L V M oriri radice rotunda, Raphani nıodo magna feribit Diofcorides. Quibus quis facilè coniicere potett Aftragalo radicem non effe rotundam in pilx modum, fed tereti forma,quum talis fit Raphani radix. Quamobrem in Aftragali cenfura inaniter Lufitanum hallucinari deprehendimus, quòd fcribat Inferioris Germanix incolas Aftragali radicibus uefci fub cineribus Caftanearum modo affatis; easq́, Iuglandium nucum figura, magnitudineq́; effe afferit albo intus colore, \& nigro exteríus cortice. Hinc itaque fufpicor ego Lufitanum pro Aftragalo eam plantam accepiffe, qux Fuchfio, \& recentiorum alijs Diofcoridis effe Apros, quæq́; Germanis Erdnuffen, id eft, Nux Terrx uocatur. Sed quàm magna inter has plantas interfit differentia Tirefia coecior fuerit, qui non uiderit. 


\section{In AmathiLufitanı Enarrationes.}

A C O N I T V M.

D V a in cenfendo primis generis Aconito Fuchfium uirum apprimè doctum accufat Lufitanụs, ille tamen longè grausus aberrat, quppè qui tanquan coecus iudicet de coloribus, \& nulla racione firibar Aconicum Pardalianchen in mul tis reperiri locis, radicibus nigris ad rubedincm declinantibus. Quibus facilè palàn clt, quàm fücrit ille negligens in explorandis, legendisq́; plantarum hiftorijs. Etunim Diofcorides primi gener is Aconito radicem facit Scorpionis caudam æmulantem \& Alabaftri modo fiplendentem. Verùm an A abaftrum colore lit nigro rufefcente, ftatuarij iudicent, \& lapicider, \& qui Kome columnas ex Alabaftro uiderint, ad Conltantini lauacrum propè facrum Laterancnfe, \& ad D. Agnetis xdes extra Viminalem portam.

\section{O L C H I C V M.}

QV A N o hichomo femel errandi faciet finem? yuoufque tot uitijs hic omnium cæterorum Cenf.lxxix. nos obtundet iudex? nufquam ne dabit breue aliquod fpatium in omnıbus paginis refpirandi? Vbi- deColchico. que (ut uerè fatear) ad naufeam ufque omnia pafsim Amathi fapiunt Officinam. Tædet omnia huc coaceruari, quibus illc fuum uolumen expoliuit. Tranfcurro innumera, \& ad finem ftrictim per omnia propero. Quid tamen buni de Colchico fentit? cùm hoc nihil refert difsidere ab Hermodactylo, de quo fcripfere Paulus, \& Serapio. Vcrùm nihil eft, que minus Lufitano meritò reluetemur, cŭ Paulus diverlis capitibus eodem libro de Colchico \& Hermodactylo tractauerit, hunc per fe, uel ex decoê o potum arthriticis commendans, illud ucrò quod letale fit ab ufu medico abigens. At Lufitancs, ue fuam tucatur fententiam, mirandum non effe dicit, quòd Paulus feorfum de Hermodactylo, tanquam à Colchico differentem fermonem habeat, alibi uerò de Colchico caput prætigat; quum id conlülò fecerit, uidens utique Colchicum non adeò uenenofum effe, praccipuè ubi Hermodactylus dicebatur, fed rei medicx potius conducibile. Qua de caufa de eo, ut venenofo cum cæteris Græcis caput conftituit, al ibi uerò tanquam de re fibi nouiter comperta, \& non admodum uenenofa fub Her modaciyli nomine. Verùm hæc Lufitani figmenta, cur fanè probem, non uideo. Siquidem fi Paulus hac fuiflet duetus opinione, credendum quidem non eft, quafi ille cò infania, furorisq́; perueniffer, ut Culchici nomen in Hermodactylum peruertiffet : quin etiam nec quòd in medicum afferret ufum mortiferum medicamentum, de quo paulò polt egit fex tantum intcriectis capitibus, proprio occultatc nomine, quum rettè fciuerit Paulus, uires \& facultates in plantis haberi, non in earum nomenclaturis. Nec pariter obftat alia Lufitani ratio, nimirum quod in uno loco de eo tanquam veneno fub Colchici nomine fcripferit Paulus, in altero tanquam medicamento fub Hermodactyli appellatione. Quandoquidem cùm Paulus libro quinto, inter cateras uenenofas ftirpes Colchici latius meminerit, non fuerat illi opus iterum de eo fcribcre libro feptimo, ubi de medicamentis falubribus, non de ueneris egit; nec tam horrendam facere metamorphofim, ut meicos deciperet. Nec item obftat Serapionis authoritas, quòd is Colchicum Diofcoridis HermodaAylum appellet. Quippè Serapionisla hoc in loco, ficuti in alijs nonnullis Colchicum, quod Hermodactylum uocat, cum genuino pfus. Hermodactylo, de quo fpeciatim egit Puulus, confundit. Etenim fcatere mendis Hermodactyli caput in Serapione quis facilè nouerit, quum ea, quæ Diofcoridi accepta referre debeat, Paulo afcribat; \& quæ Pauli funt in Hermodactylo, Galeno accepta referat . Quodd autem (vt Lufitanus putat)in fola Colchide Colchicum nafci ueneno fum, ac letale, alibi uerò minimè, non facilè probamus, cùm nulla huiuferei fit nobis ueterum authoritas . At quum Diofcorides libro quarto, ubi de Colchico fcripit, non Colchicos tantùm admoneat, ne huiufce plantx radicem deuorent cius dulcedine allecti, fed omnes in uniuerfum homines, maximo eft argumento, hanc plantam non tantùm apud Colchos, fed ubique nafci uencnofam.

\section{E P H E M E R V M.}

L v 5 I I A N v recentiores quofdam fequutus Lilium, quod Conuallium uocant, magno errore Ephemerum effe putar. Nam huic Lilio folia non infunt Lilij, quin nec radix longa,qux digiti fiecrasfitudine, fed tenuius in capillamenta definens. Prxtereà nec caulis illi uidetur Lilio fimilis, fed de Ephemegracilis, fiexilisq́; tenuisfimi iunci inftar . Adhæc nec credi par eft, Diofcoridem filentio inuoluiffe, quin eriam nec Galenum, qui eius quoque hiftoriam narrat; fuauisfimi odoris preftantiam, quo Lilium Conuallium fragrat, fi hoc illis Ephemerum effet. Quo fit, ut unà cum Lufitano cocutiant y qui hac ducuntur opinione.

\section{VMBILICVS VENERIS.}

V B I de Veneris Vmbilico fcribit Lufitanus, tam primùm quàm alterum parietibus hærere afferit, \& humectis nafci in locis folio craflo, rotundo, concauo, coxendicis figura; quibus palàm fit, quan-

Céf.Ixxxviij. de Aconito. 
tùm in re herbaria præftet, ualeatq́; Lufitanus, quippè qui hallucinatus exiftimauerit inter Veneris Vmbilicos nullam intercedere differentiam foliorum, radicum, ac etiam locorum, in quibus proueniunt. Quum tamen Diofcoridi Cotyledonis primú genus folia ferat Acetabuli figura, \& radicem Oliuæ modo rotundam. Altèrum uerò Maius referat Sedum, \& maiori nitatur radice. Adde etiam quiòd neutrum in humectis nafcatır locis, quum primum in tcctorum tegulis, \& collapfis ædificiorú parietibus proueniat, maritimis præfertim locis, ut Plinius inquit: Alterùm uerò inter ingentisfima faxa in montibus nafcatur.

\section{T A L I C T R V M.}

Cenfur. xcii. R V E L I I v s uir profectò clarisfimus, \& in firpium hiftoria non poltremus author Talictrü de Talictro, in Gallia nafci fcribit, ibiq́; appellari Argentinam, eò quòd eius Coriandrina folia argenteo fplendo re micent. Nos autem quòd hanc herbam nufquam uiderimus, Ruellij fententiam probare, nec improbare poffumus. At Lufitanus, qui nulla ratione omnes impugnare folet, ftatim id falsò fenfiffe Ruellium fcribit, tametfi eius Argentinam nec uiderit, nec noucrit unquam. Nec ualet Lufitanialgumentum, quòd Argentinam herbam, fic alijs uocatam à Talictro maximè diftinguat. Siquidem de hac Lufitani Argentina haudquaquam intelligit Ruellius. Hæc enim folijs non eft Coriandri, fed unico tantùm folio affurgit nullis lacinijs interfecto. Quo fit, ut ille meritò ueniat accufandus, quum ini urià alios accufet.

\section{P O T A M O G E T V M.}

Cenfu. xciij. dc Potamogeto.
ПOTAMOTEI'T $\Omega$ N fic dicta eft Grecis, quòd fluminibus fit uicina, aut in ipfis fluminibus nafcatur. Id quod clarisfimè demonftrat Diofcorides, quum inquit, Potamogetum folium Betæ fimile gerit hirfutum paulò fupereminens extra aquam. Id quod facilè comprobat eciam in hac planta hallucinari Lufitanum. Quippè qui Potamogetum eam herbam effe contendat, quam Seplafiæ Pulmonariam uocant. Siquidem hæc primùm in fluminibus non nafcitur, nec propè eorum alueos, fed fecus uias propter fepes, \& fruteta, præfertimq́; opacis locis, folio non Betæ, fed Buglosfi ; cuius faporem etiam adeò imitatur, ut eo ficut \& facie Bugloffum referat. Adde quòd huic maculæ quædam in folijs cernantur albo colore, de quibus nihil inuenio fcripfiffe eos, qui Potamogeti hiftoriam narrant.

\section{LOTVS VRBANA.}

Ceni. sciiij. deVrbanalo to.

$O^{\prime}$ Qv A'M vehementer decipitur Lufitanus in cenfenda Vrbana Loto. Conftat id, quòd nulla ratione nec authorum teftimonijs temerè affirmauerit eam effe Lotum Vrbanam, quam quidam Trifolium Acetofum, alij Panem Cuculum, nonnulli Alleluia uocant. Etenim legiffe apud antiquorum aliquem Lotum hanc fapore effe acetofo. Prætereà Plinio quis non uiderit aliud effe Satiuam Lotum,aliud Trifolium Acetofum, quod ipfe fpeciatim Oxyn à fapore meritò uocat, quòd nomine, \& uiribus differant? Siquidem ille Oxym ad enterocellas, \& diffolutum ftomachum præftare ait, id quod facilè quis guftu deprehendere poteft . Lotum uerò Satiuam ad difcutiendas oculorum cicatrices, argema, \& nubeculas ex Diofcoride propofuit, tanquam excufforium, deterforiumá; medicamé tum. Id quod nunquam Oxys præftare poterit.

\section{A NTIRRHINVM.}

Cenfur. xr.v. de Antirrhino.

I N exiftimando Antirrhino immeritò fanè Lufitanus Plinium criminatur, quòd Antirrhini plan tam lino fimilem fecerit, ac etiam quòd Lychnin Agriam appellauerit. Nec alia ratione Plınium 1mpugnat, quàm quòd non liceat (ut ipfe putat) Antirrhinum appellari Lychnin, quod florem habeat illi fimilem, \& magna fit inter has plantas differentia . Qua in re fanè quid arguat in Plinio nefcit. Cuius infcitiæ id in caufa effe putauerim, quòd Lufitanus Plinianæ lectionis, perinde ac aliorum authorum impatiens, \& rudis fucrit. Nam quanquàm Plinius libro x x v.cap. x. Antirrhinum Lychnin Agriam uocari fcribit; non tamen ob hoc affirmat, quòd Antirrhinum, \& Lychnis Agria una \& eadem fint planta; fed tantùm admonet, à quibufdam ita uocari Antirrhinum. Id quod etiam inucni-

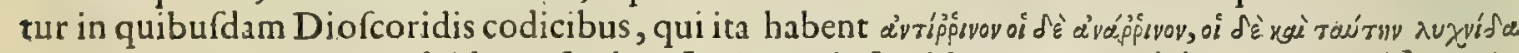

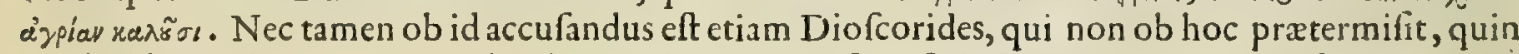
Lychnidis Agriæ meminerit, ubi libro tertio de Domeftica fcripfit. Aliàs enim nobis fuperius dictü eft , præfertimq́; de Telephio diferentes, non deeffe plantas, quæ aliarum etiam Plantarum nomenPlinits à ca- claturis appellentur, quum tamen nihil cum illis habeant cognationis. Prætereà cum plures hodiè ha lumnia uindi beantur Antirrhini fpecies, quarum alia, quæ inaior eft, folia gerit multifida, alia Lino fimilia, alia par catur. 


\section{In Amathi Lufitani Enarrationes. 49}

quem tamen miror accufare Lulitanum, quum is de Iride dıfercns, acriter me accufauerit; quòd ibi quadam in Plinium depromplerim.

P O L Y A L A.

POL Y C A A M. Ceribit Diofcorides ad palmialtitudinem adolcfere folijs Lenticula,guftuad-

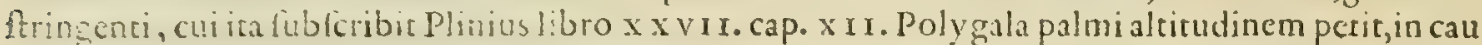
le lummo folijs Lenticul.e, gultu adltricto. Quibus tamen notis difficilc̀ admodum uidetur, ut quis herbam afferc postic, que lcgitimam Polygalam referat, quum horum neuter caulium, florum, radicitn, natalisq; loli huiufce plante meminerit. At Lufitanus, qui (quantùm uideo)longè potius Oedipum, quàm medicum protitecur, quandam plantam Polygalam elfe putar, qux uirgas Geniftx mittit, in quarum fum mitate Hores emicant, au rei, prxtanti odore, ex qua (ut ip fe ait) magna pars Italix fcopas parat. Quin \& hanc quoque plantam fcribit fapore effe amarifsmo. Veruntamen cum a nemine memoria piodicum fit Polygalam hifce nutis haberi, coniecturas, quas fe dicit habere Luftanus, prafertim quum ea fcribere non fit aufus, friuolas, ac inanes putamus. Adde quòd Diofcorides, Galenus, Plinius, Oribafius, \& quot quot funt alij grauifsimi authores, nufquam Polygalam fcripferuntefle amaram; fed adfringenti fapore. Pratereà Polygalæe planta tota, omnibus confentientibus, lac prouocat, non fores tantùm, quorum nemo meminit. Sed hoc ignorans Lufitanus pu tat hanc facultatem floribus tantùm deberi, quòd fuaui præitent odore, ac fi odorata omnia lacti provocando fint idonea .

\section{O C H R A.}

Pv т A T Lufitanus Rubricam, qua utuntur Pigmentarij, ac Sarcinatores, quaq́; ufi funt haftenus Myropolæ lapidis Hæmatitis uice, genuinam effe Ochram. Sed magno tenetur crrore. Ochra enim (ut Diofcorides fcribit) luteo eft colore, non rubro, ut propria indicat nomenclatio. $\Omega^{2} \chi^{p o s}$ enian Gixcis, pallor Latinis interpretatur. Id quod etiam fatetur Galenus Com. I I.in lib. Prognolticorum Hippocratis . Quæ fi legiffet Lufitanus, non ita fortafsè temerè de rebus fibi ignotis tam ridiculum protuliffet iudicium.

\section{E L A N T E R I A.}

ME L A T T R I A nafci in faucibus cuniculorum, in quibus xs foditur, falis modo concretam, quin \& in fumma facie corundem locorum, teltis eft Jiofcorides: quo fit, ut æris potius aliquid hanc continere crediderim, quàm argenti, ut fibi falsò perfuafit Lufitanus. Ipfa enim in argenti metallis non reperitur, fed in æris cunıculis, cuius facultates posfidet, perindè ac Chalcantum, Sori, Chalcitis,ac Mify : \& proindè rectè uim caufticam obtincre Melanteriam fcribit Dıof:orides, quã \& Mify. Argento enim nulla uis cauftrca ineft, fed æri quàmplurima.

\section{SOR Y}

In cenfendo Sory non minori ducitur errore, quòd pro certo crediderit, Chalcanthum factitiü, Céf.xcix. de quod Pharmacopœi Vitreolum Romanum uocant, genuinum efle Sory. Patet error, quòd Sory res Sory . fit effolla, non arte parata, tum etiam quòd Chalcanthum fiue fosfitium, fiue fit arte paratum à Sory omaium confenfu plurimum differat.

\section{A V R I P I G M N T V $M$.}

E D E M ferè tenetur errore etiam in Auripigmento, quòd pro more, temerè afferat id coctum Cëf.c. de Au effe. Error facilè palàm fit, quòd fcribat Diofcorides, Auripigmentum per fe gigni ijs in metallis, ripigmento. in quibus gignitur Sandaracha, non autem excuqui, \& arte parari. Crudum itaque eft Auripigmentum non cočum. Quippè fi coquatur, \& igne torreatur, magnoperè rufefcit, adeò ut Carbunculi fpetiem induat, \& pellucidum fiat.

\section{G A G A T E S.}

Q V I D de Gagate, tandem eius opinionem referam? quem nigrum illud Succini genus effearbitratur, quo imagines parantur eorum galeris aftigendæ, qui peregrè proficifcuntur uel ad D. Iacobiædes, uel adailas quafcunque. Nihil Lufitanum fui pænitet. Quantum illa inter fe diffonant? Quum Succinum hoc lapis non fit, fed potius, ut quidam putant, Bituminis, aut Piffafphalti genus . Gagatis deGagates porrò lapis eft bituminofus, non autem Bitumen ipfum, fquallidus, \& cruftofus; contrà feript:o . 
uerò illud, quum nullam lapidis fpeciem præfe ferat, nulloǵ; fquallore, cruftísue fit uitiatum. Genuino, ac uero Gagate utuntur Septentrionales quàm plurimæ regiones, qux lignis non admodum abundant, ad fouendum ignem. Plurimum Gagatis foditur in Leodienfi agro apud Flandros, Brobàndosq́; , qui plurimùm differt ab illo Succini genere. Sed præcidamus tand $m$ quæfo alia , quæ reftant innumera, ne uideamur pilos quofque carpere, qui ueritatis candorem impediunt, \& ne circa minutias caullari nos arbitretur Lulitanus. Mihi quidem ( ut ingenuè farear) non leue fuit incommodum cum huius friuolis ineptijs colluctari. Veruntamen tum iftius proteruitate lacestitus, tum multorum (ut prædiximus) honeftisfimorum uirorum precibus excitatus, id diligentius fàcere non fum coactus, quàm uel mex occupationes, uel iftius leuislima, kx imperitisfima temeritas à me exigebant . Simul \& commoncbat non mediocriter illius feuisfima authoritas, quam in omnibus tam temerè, tamq́ue uanè fibi uendicat. Cui tantùm cæteros cxiftimauit adhibituros fidei, ut ea quoque, Animaduer- quæ nulla confirmaret ratione, eodem mentis ftupore excepturos alios putarit. Hoc fi ucl temeritafio in Anathom. te, uel fortafsè fimplicitate, aut infcitia potius, quibus plurimum ualet, fecerit, agnofcat iam denique quàm ei periculofum fucrit aliorum carpere, $\&$ immodeftisfimè damnare labores, priulquàm fua taleat intelligere fodiffima errata, quibus omnia eius uolumina, \& præclaræ illæ Centuriæ ubique fcatent. Nunc cùm \& tela repulerim, quæ tam infipienter ille in me iecerat, \& pariter hominem ex fuis præfidijs citra omne negotium dimouerim, non ty ronibus modò, fed etiam doetis non ingratã me in hoc collocaffe operam arbitror. Nec uerò tanti mi hi crit, $\mathrm{fi}$ Lufitanus, quo eft furore, iniuftè fe argui clamitet . Quin \& hoc fingulare fux dementix dabit indicium, quo manifeftus nullss argumentis, nulla ratione, nulla ueritate fatisfieri poffe conqueratur. Equidem quantùm potui, hoc unicè fum conatus, ut non folùm te reprehendi doleat, $f$ d $\&$ fux confidentifsimæ imperitiæ ipfum 14

re pœniteat. Quin etiam ut fciat, ac nofcat fe crrorum Centurias fecifle, quemadmodum \& $x$ gritudinum. In quo quantùm profecerim Lectoris candidi , \& eruditifsimorum uirorum eritiudicium. 



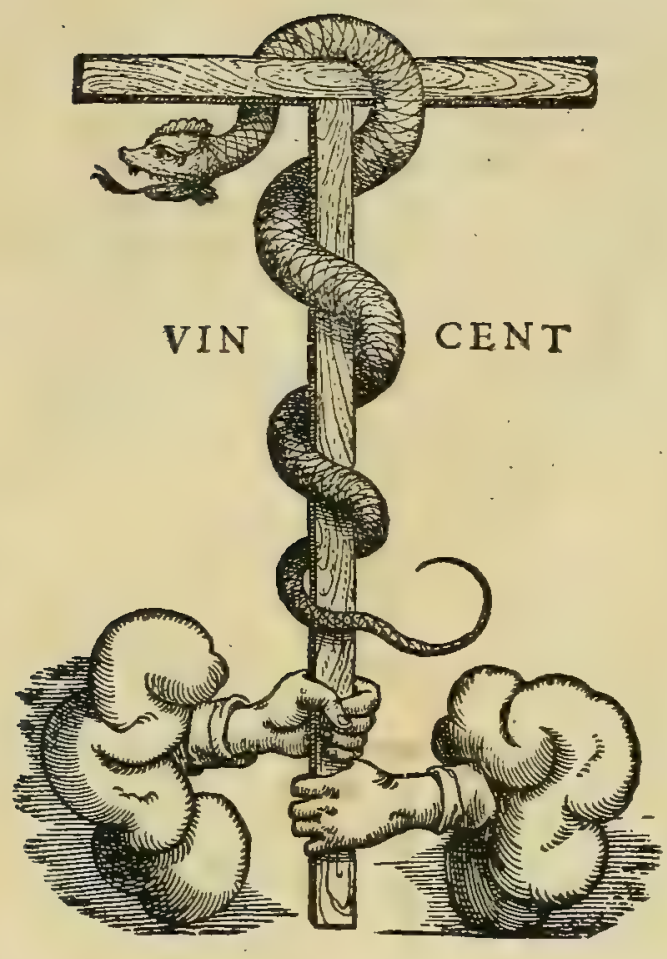




c

dical

agiol

COUNTWAY LIBRARY OF MEDICINE

$f \mathrm{QK}$

99

ML 32

1558 
210.0 vilo or 2.3

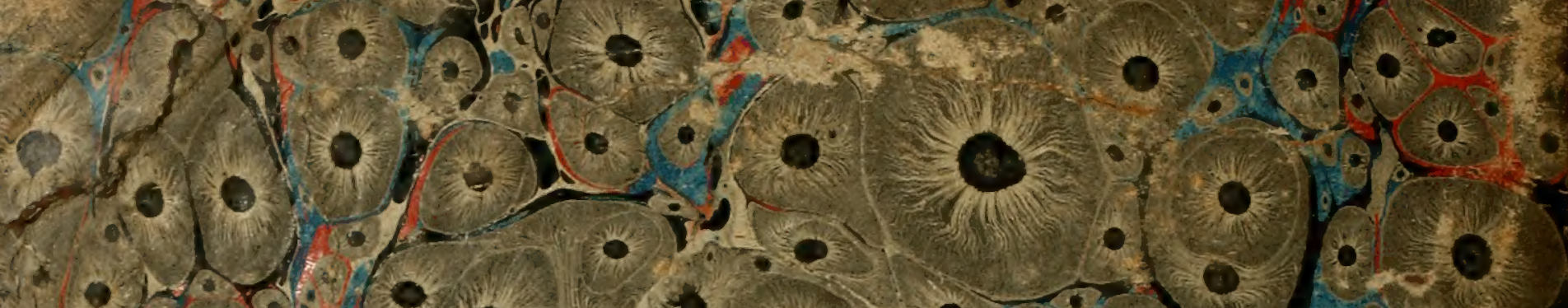

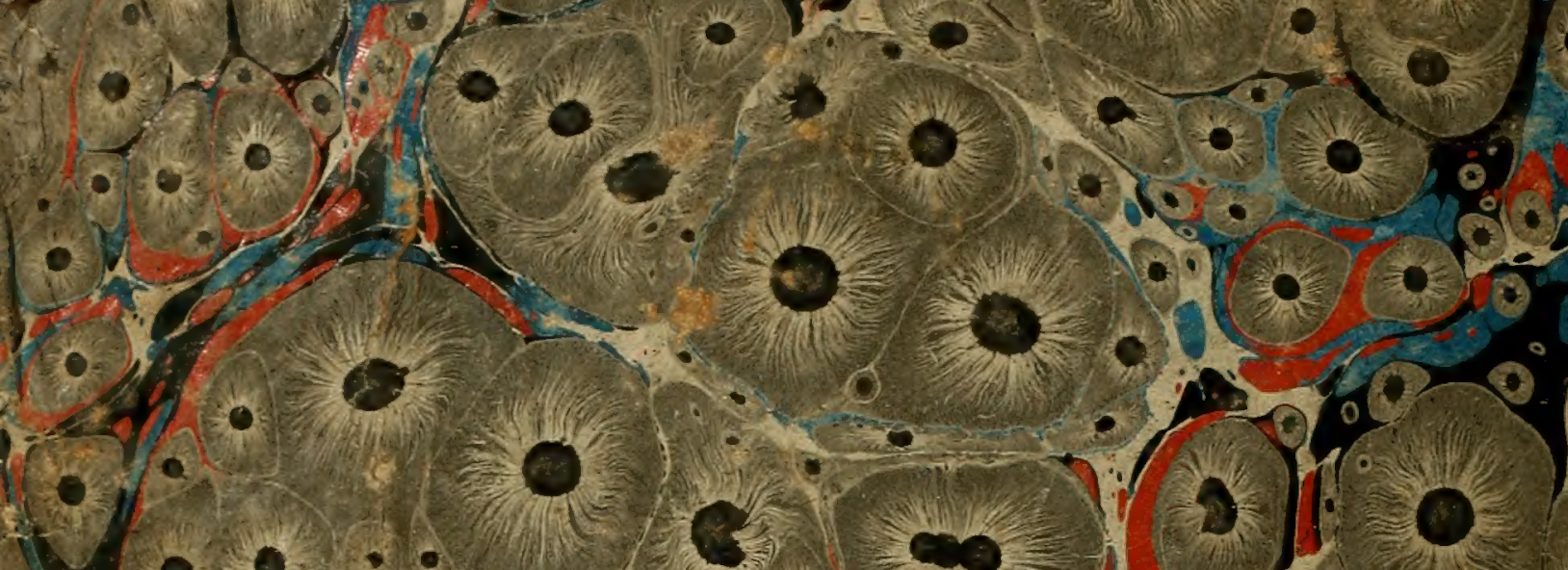

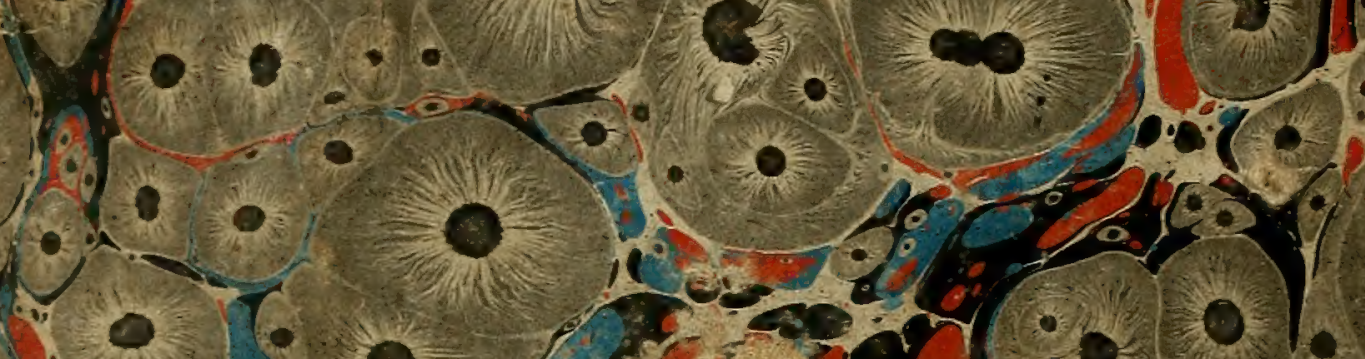

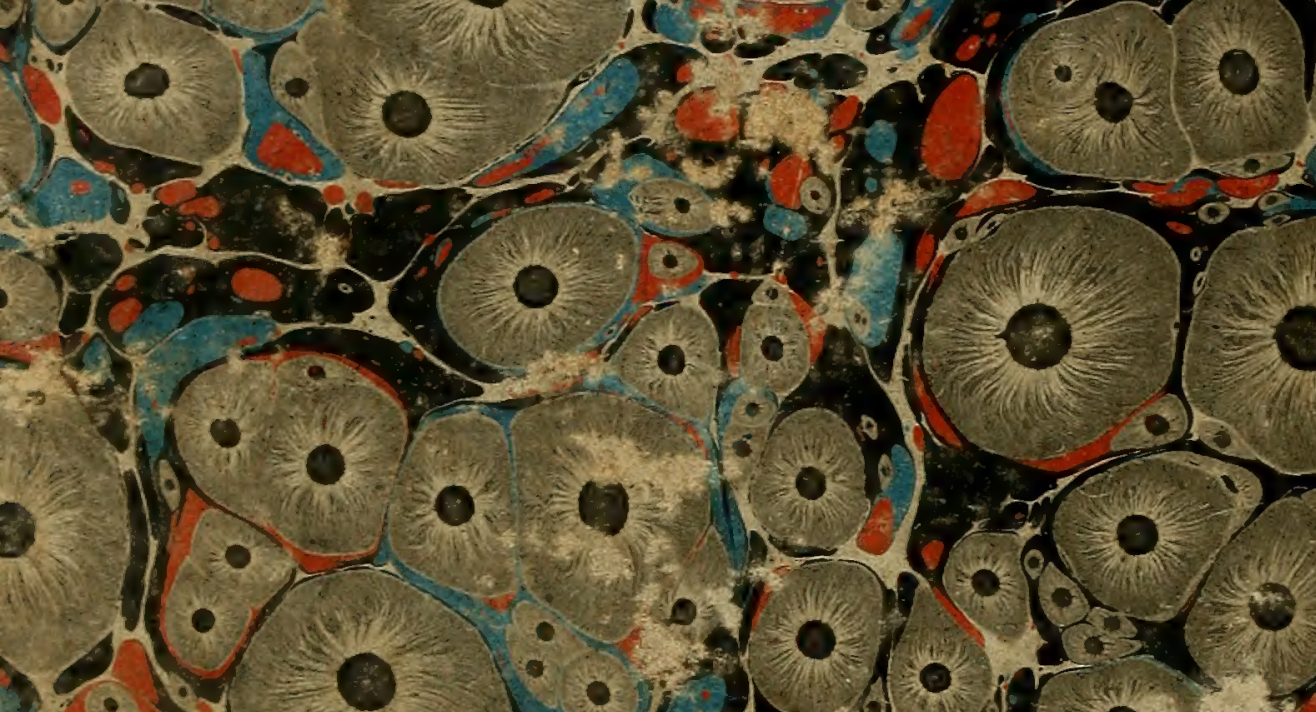

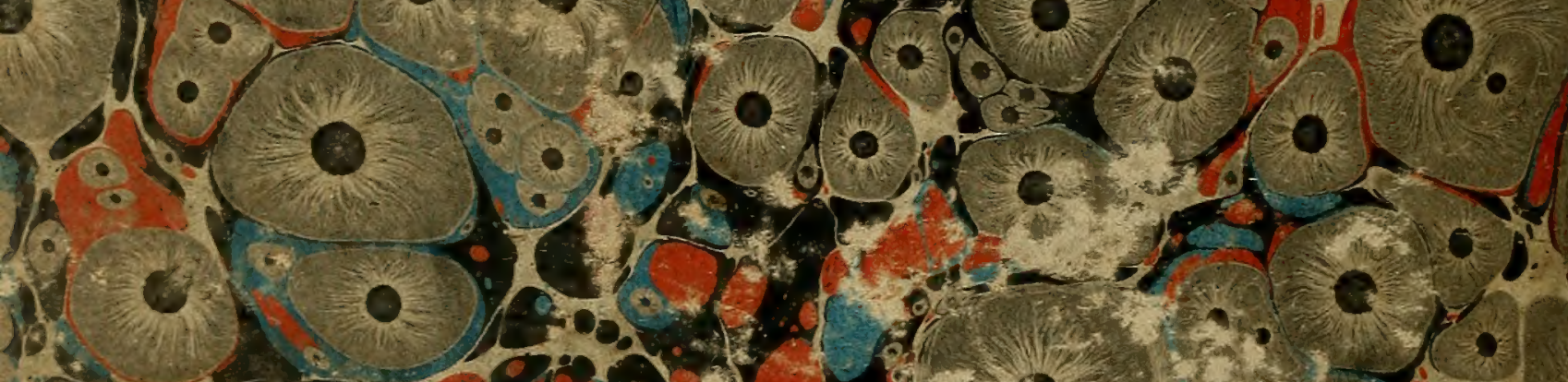

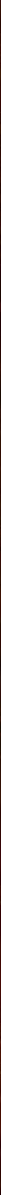

